\title{
Le Corbusier
}

50 años después

Congreso internacional. 18 al 20 de noviembre 2015

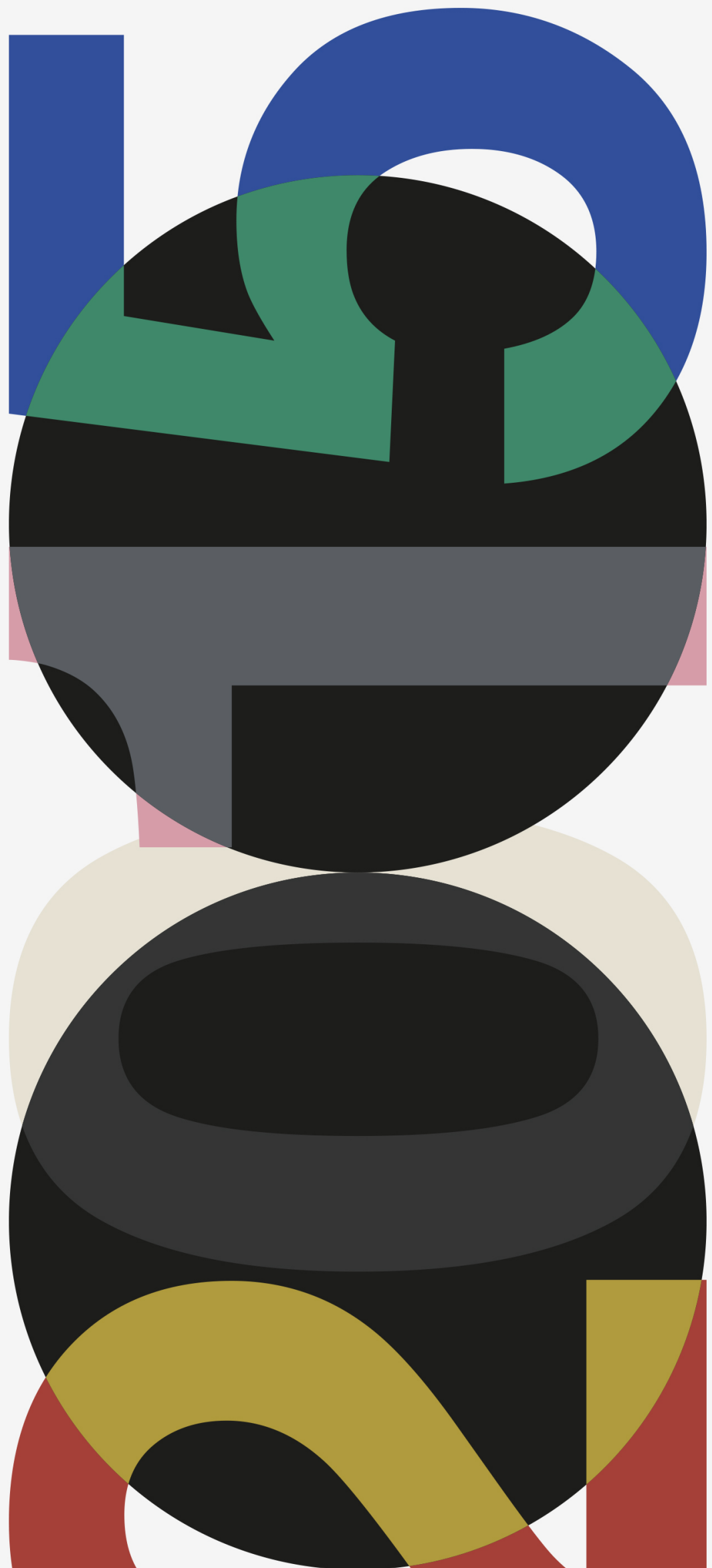






\section{Colección Congresos UPV}

Los contenidos de esta publicación han sido evaluados por el Comité Científico que en ella se relaciona y según el procedimiento que se recoge en http://cargocollective.com/lc2015

\section{Dirección}

Jorge Torres Cueco

\section{Coordinación}

Clara E. Mejía Vallejo

\section{Colaboración en la edición de las actas}

Francisco Martín López López

Juan María Songel González

\section{Diseño e imagen gráfica}

Alejandro Campos Uribe

(C) de los textos: los autores.

(c) de las ilustraciones: los autores.

(C) 2015, de la presente edición: Editorial Universitat Politècnica de València.

www.lalibreria.upv.es / Ref.: 6247_01_01_01

ISBN: 978-84-9048-373-2 (versión electrónica)

DOI: http://dx.doi.org/10.4995/LC2015.2015

\section{(c) $(1)(\Theta)$}

Le Corbusier, 50 years later. International Congress.

Se distribuye bajo una licencia de Creative Commons 4.0 Internacional.

Basada en una obra en http://ocs.editorial.upv.es/index.php/LC2015/LC2015 
ORGANIZACIÓN 



\section{COMITÉ CIENTÍFICO}

\section{COORDINADOR:}

JORGE TORRES CUECO.

Dr. Arquitecto. Catedrático y Director del Departamento de Proyectos Arquitectónicos en la Universidad Politécnica de Valencia.

\section{MIEMBROS DEL COMITÉ:}

\section{JOSÉ RAMÓN ALONSO PEREIRA}

Dr. Arquitecto. Catedrático de Historia de la Arquitectura y Urbanismo en la Escuela de Arquitectura de La Coruña.

\section{TIMOTHY BENTON}

Doctor y Profesor de Historia del Arte en la Open University de Cambridge. Miembro del Consejo de Administración de la Fondation le Corbusier.

\section{LUIS BURRIEL BIELZA}

Doctor Arquitecto. Profesor Asociado Théorie Et Pratique De La Conception Architectural et Urbaine. École Nationale Supérieure d'Architecture Paris-Belleville.

\section{JUAN CALATRAVA ESCOBAR}

Dr. en Filosofía y Letras. Catedrático de Historia de la Arquitectura en la Escuela Técnica Superior de Arquitectura de Granada.

\section{JUAN CALDUCH CERVERA}

Dr. Arquitecto. Catedrático de Composición Arquitectónica en la Escuela Politécnica Superior, Universitat d'Alacant.

\section{JEAN-LOUIS COHEN}

Dr. Arquitecto. Sheldon H. Solow Professor in the History of Architecture at New York University Institute of Fine Arts. Antiguo miembro del Consejo de Administración de la Fondation Le Corbusier.

\section{ARNAUD DERCELLES}

Máster en Literatura Contemporánea en la Universidad de París X Nanterre y Máster en Historia Contemporánea en la Universidad París I, Panthéon Sorbonne. Responsable del Centro de Documentación y de Investigación de la Fondation Le Corbusier.

\section{MARTA LLORENTE}

Dra. Arquitecta. Profesora Titular de Composición Arquitectónica. Escuela Técnica Superior de Arquitectura de Barcelona. Universitat Politècnica de Catalunya.

\section{XAVIER MONTEYS}

Dr. Arquitecto. Catedrático de Proyectos Arquitectónicos. Escuela Técnica Superior de Arquitectura de Barcelona. Universitat Politècnica de Catalunya.

\section{MARÍA CECILIA O'BYRNE OROZCO}

Dra. Arquitecta. Profesora del Departamento de Arquitectura. Universidad de Los Andes. Bogotá. (Colombia).

\section{ANTOINE PICON}

Dr. Arquitecto. Ingénieur Général des Ponts et Chaussées. Profesor en la Harvard University Graduate School of Design. Presidente de la Fondation Le Corbusier. 


\section{JOSEP QUETGLAS}

Dr. Arquitecto. Catedrático de Proyectos Arquitectónicos de la Universitat Politècnica de Catalunya. Miembro de la Fondation Le Corbusier.

\section{BRUNO REICHLIN}

Dr. Arquitecto. Profesor emérito de la Universidad de Genève. Antiguo miembro del Consejo de Administración de la Fondation Le Corbusier.

\section{ARTHUR RUËGG}

Dr. Arquitecto. Profesor de Arquitectura y Construcción en el Departamento de Arquitectura de la ETH Zurich. Miembro de la Fondation Le Corbusier.

MARTA SEQUEIRA.

Dra. Arquitecta. Profesora del Departamento de Arquitectura. Universidad de Évora (Portugal).

MARIA CANDELA SUAREZ

Dra. Arquitecta. Profesora Auxiliar Invitada Universidade Lusíada do Porto e Universidade Fernando Pessoa.

\section{MARGARETH DA SILVA PEREIRA}

Dra. Arquitecta. Profesora de la Faculdade de Arquitetura e Urbanismo, Universidade Federal do Rio de Janeiro.

MARIDA TALAMONA

Dra. Arquitecta. Profesora de Storia dell'architettura y Directora del Master europeo en Storia dell'architettura en la Università degli Studi Roma Tre (Italia). Miembro del Consejo de Administración de la Fondation Le Corbusier. 


\section{COMITÉ ORGANIZADOR}

\section{DIRECTOR:}

\section{JORGE TORRES CUECO.}

Dr. Arquitecto. Catedrático y Director del Departamento de Proyectos Arquitectónicos en la Universidad Politécnica de Valencia.

\section{SECRETARIA:}

CLARA E. MEJÍA VALLEJO

Dra. Arquitecta. Profesora del Departamento de Proyectos Arquitectónicos en la Universidad Politécnica de Valencia.

\section{VOCALES:}

\section{RAÚL CASTELLANOS GÓMEZ}

Dr. Arquitecto. Profesor del Departamento de Proyectos Arquitectónicos en la Universidad Politécnica de Valencia.

\section{JUAN DELTELL PASTOR}

Dr. Arquitecto. Profesor del Departamento de Proyectos Arquitectónicos en la Universidad Politécnica de Valencia.

JOSÉ RAMÓN LÓPEZ YESTE

Arquitecto. Profesor del Departamento de Proyectos Arquitectónicos en la Universidad Politécnica de Valencia.

\section{SALVADOR SANCHÍS GISBERT}

Arquitecto. Profesor del Departamento de Proyectos Arquitectónicos en la Universidad Politécnica de Valencia.

CARLA SENTIERI OMARREMENTERÍA

Dra. Arquitecta. Profesora del Departamento de Proyectos Arquitectónicos en la Universidad Politécnica de Valencia.

\section{JUAN MARÍA SONGEL GONZÁLEZ}

Dr. Arquitecto. Profesor Titular del Departamento de Composición Arquitectónica en la Universidad Politécnica de Valencia.

\section{ALEJANDRO CAMPOS URIBE}

Arquitecto. Doctorando del Departamento de Proyectos Arquitectónicos en la Universidad Politécnica de Valencia.

\section{PEDRO PONCE GREGORIO}

Arquitecto. Doctorando del Departamento de Proyectos Arquitectónicos en la Universidad Politécnica de Valencia. 



\section{PRESENTACIÓN}

En agosto de 1965 se produjo en las aguas del Mediterráneo el fallecimiento de Le Corbusier, reconocido como el arquitecto más importante del siglo XX. Con este motivo, el Departamento de Proyectos Arquitectónicos de la Universidad Politécnica de Valencia, con el apoyo de la Fondation Le Corbusier de París, promueve la realización de este congreso internacional en Valencia.

Tras el Congreso de Granada sobre Le Corbusier celebrado en dicha ciudad en el año 2007, de carácter nacional, tuvo lugar en la Universidad Politécnica de Valencia el evento Mise Au Point. Seminario Internacional sobre Investigación en Proyectos Arquitéctónicos- Workshop: Investigación sobre Le Corbusier, celebrado entre abril y mayo de 2011, casi como una preparación para este congreso internacional que se celebra otros cuatro años después y con la voluntad de reforzar este carácter internacional para glosar la figura de este arquitecto que ha tenido una absoluta transcendencia en la arquitectura moderna y contemporánea.

Le Corbusier fue uno de los arquitectos más fecundos en producir interrelaciones entre ideas e imágenes, entre disciplinas plásticas y arquitectura, entre historia y modernidad. El poder de sus ideas estaba continuamente siendo experimentado y corroborado por su obra arquitectónica. En sus proyectos, escritos, pinturas y esculturas va desengranando diferentes visiones de lo que debía corresponderse con la modernidad arquitectónica, que, en su persona, se nutrió de referencias ideológicas también heterogéneas. Si hay algo que se destaca en su trayectoria es la transversalidad en su labor creativa. Esta idea de transversalidad permite la apertura del congreso a artistas plásticos, historiadores, editores de libros, fotógrafos, pensadores y, por supuesto, arquitectos.

Además su obra no se circunscribe al ámbito de su país de adopción. Francia, sino que sus proyectos están presentes en todas las partes del mundo: desde París a Moscú, desde Alemania a Roma, en Suiza o Bélgica encontramos edificios de Le Corbusier. Pero también en Venecia, Túnez, Estados Unidos, Japón o la India, además de los planes de Estocolmo, Bogotá, Argel o Barcelona, por poner unos pocos ejemplos. Viajó varias veces por España y en 1928 visitó la ciudad de Valencia. Sus huellas están presentes en todas las partes del mundo. Fue el primer arquitecto global, de ahí el interés que suscita en todos estos lugares y la necesidad de la presencia internacional de ponentes e investigadores.

Pero si hay algo que debemos destacar es su relevancia en un determinado campo del oficio de arquitecto: la casa, la vivienda, la habitación. Toda su vida está marcada por una voluntad casi pedagógica de enseñar a habitar: "savoir habiter". Este era casi un lema irrenunciable y, de hecho, la vivienda constituye un objetivo primordial en su quehacer. De hecho, en 1952, en su "Declaración de principios sobre los deberes de la arquitectura moderna" escribe: "el deber que deben cumplir los arquitectos es, precisamente, poner en primer lugar la vivienda". Buena parte de los conjuntos residenciales actuales de cierto interés tienen sus raíces en las múltiples propuestas de viviendas que realiza desde la primera década del pasado siglo. Explorar sus permanencias en la arquitectura de hoy y cómo contribuir a una mejora del hábitat colectivo es, sin duda alguna, un asunto que será tratado en este congreso.

Su legado es casi inabarcable. Le Corbusier desveló incesantemente la sucesión de sus pensamientos recogidos en agendas, textos, entrevistas y artículos de prensa. Disponemos de la mayor parte de sus dibujos, bocetos y planos de proyecto, además de una inmensidad de textos críticos sobre su figura. Por tanto, es un personaje en el que caben múltiples modos de acercamiento. Pero además, su transcendencia es definitiva y sus epígonos múltiples y reconocidos. Arquitectos contemporáneos de renombre internacional reconocen sus deudas con el maestro franco-suizo: Rem Koolhaas, Toyo Ito, Alvaro Siza, Rafael Moneo, Luigi Snozzi, Peter Eisenman o Kenzo Tange, entre muchos otros. Reconocer y rastrear su influencia en nuestra arquitectura es un tributo necesario. 


\section{PRESENTATION}

En août de 1965 se produisit dans les eaux de la Méditerranée le décès de Le Corbusier qui, à ce moment là, était déjà reconnu comme l'architecte le plus important du XXème siècle. Cinquante années se sont écoulées depuis lors et à la vue de cet évènement le Département de Projets Architectoniques de l'Université Polytechnique de Valencia, avec le soutient de la Fondation Le Corbusier, a l'intention de promouvoir un Congrès International à Valencia.

Quatre ans après le Congrès de Grenade, célébré en 2007 et de caractère national, eu lieu à l'Université Polytechnique de Valencia la rencontre Mise au Point entre les mois d'avril et mai 2011. Celle-ci comprenait un Séminaire International abordant le thème de la recherche en Projets d'Architecture et un Workshop spécifiquement centré sur la recherche à propos de Le Corbusier. Autres quatre années sont passées depuis et le moment semble idéal pour célébrer un Congrès International ayant pour but revisiter le travail et la figure de Le Corbusier, architecte avec une transcendance absolue pour l'architecture moderne et contemporaine.

Le Corbusier a été un des architectes les plus féconds quant à la production d'interrelations entre idées et images, entre disciplines plastiques et architecture, entre histoire et modernité. La force de ses idées était constamment mise à l'épreuve et corroborée para son œuvre architecturale. Dans ses projets, écrits, peintures et sculptures il égraine progressivement des visions diverses de ce qui devrait se correspondre avec la modernité architecturale qui, en sa personne, se nourrissait de références idéologiques. Un aspect relevant de sa trajectoire réside dans la transversalité de son activité créatrice. Cette ouverture d'esprit qui le caractérisait, donne lieu à ce que le congrès soit susceptible de combler les inquiétudes tantôt des architectes, comme des artistes plastiques, des historiens, des éditeurs de livres, des photographes et des penseurs.

A l'universalité des domaines de connaissance abordés vient se joindre l'extension géographique considérable de son travail. La présence de son œuvre ne se limite pas au domaine de son pays d'adoption, la France, ayant réalisé des projets presque partout dans le monde. Depuis Paris jusqu'à Moscou, de Berlin jusqu'à Rome, en passant par Venise, la Suisse et la Belgique, il a embrassée la presque totalité du continent européen. Mais il a aussi réalisé des projets aux États Unis, en Amérique Latine, au Japon et en Inde, sans oublier les plans urbains qu'il a rédigé pour Stockholm, Bogotá, Alger ou Barcelone, pour ne citer que quelques exemples.

Il voyagea maintes fois en Espagne et en 1828 il visita la ville de Valencia. Son emprunte est présente partout dans le monde. Il a été le premier architecte global, d'où découle l'intérêt que son travail suscite dans un ample spectre international et la présence au niveau planétaire de chercheurs qui s'intéressent à sa production.

Il faut aussi souligner l'importance de sa contribution dans un certain domaine du travail de l'architecte: la maison, le logement, l'habitation. Toute sa vie a été marquée par une volonté quasi pédagogique d'enseigner à habiter : "savoir habiter ». Celle-ci était une devise quasi inébranlable, et de fait le logement constitue un des objectifs de plus clairs de son savoir faire. En 1955, dans sa "Déclaration de principes sur les devoirs de l'architecture moderne » il écrivit : «le devoir à accomplir par les architectes, c'est précisément de mettre au premier plan le logis ». Une grande partie des ensembles résidentiels construits jusqu'à nos jours, et qui présentent un certain intérêt, trouve ses racines dans les multiples projets résidentiels qu'il réalise depuis la première décennie du siècle dernier. Explorer ces permanences dans l'architecture d'aujourd'hui et aborder la réflexion sur la manière de contribuer à une amélioration de l'habitat collectif est sans aucun doute une affaire que sera traité dans ce Congrès.

Son legs est pratiquement inabordable. Le Corbusier dévoila incessamment la suite de ses pensées qui apparaissent recueillies dans des carnets, des textes, des interviews, et des articles de presse. Garce à la Fondation Le Corbusier, que lui même se chargea de promouvoir avant sa mort, il est possible de disposer 
aujourd'hui de la presque totalité de ses dessins, de ses exquises et d'innombrables plans des projets. En parallèle, au long des années se sont écris une énorme quantité de textes critiques sur lui et sur son travail. De la qu'il soit possible d'approcher le personnage depuis des sources multiples. Sa transcendance est définitive et ses épigones multiples et reconnus. Architectes contemporains de renommée internationale reconnaissent leurs dettes vis à vis du maitre franco- suisse : Rem Koolhaas, Toyo Ito, Alvaro Siza, Rafael Moneo, Luigo Snozzi, Peter Eisenmann ou Kenzo Tange, entre maintes autres. Reconnaître et suivre les traces de son influence dans notre architecture actuelle s'avère être un hommage toujours nécessaire. 


\section{INTRODUCTION}

In August 1965, Le Corbusier, recognized as the most important architect of the twentieth-century, passed away in the Mediterranean Sea waters. For this reason, the Architectural Design Department at the Polytechnic University of Valencia, with the support of the Le Corbusier Foundation in Paris, promotes this international conference in Valencia.

After a national conference on Le Corbusier took place in Granada (Spain) in 2007, the Polytechnic University of Valencia organized between April and May 2011 an event called Mise Au Point. International Seminar about Research on Architectural Projects - Workshop: Research on Le Corbusier, almost as a preparation for this international conference to be held in the same premises four years later, the intention now being to strengthen its international scope, in order to reassess this leading figure with an unquestionable significance in modern and contemporary architecture.

Le Corbusier was one of the most prolific architects in the creation of links between ideas and images, between visual arts and architecture, between history and modernity. The power of his ideas was continually being tested and confirmed by his architectural work. In his projects, writings, paintings and sculptures he worked out different visions of what should match architectural modernity, which drew on a personal background built upon diverse ideological references. If there is any outstanding feature in his career, it is the transversal condition of his creative work. This idea of transversality enables us to open this conference to artists, historians, book publishers, photographers, thinkers and, of course, architects.

Moreover, his work is not limited to France, his adopted country, as we can find his projects and buildings all over the world, from Paris to Moscow, from Germany to Rome, in Switzerland or Belgium, as well as in Venice, Tunisia, United States, Japan and India, in addition to the plans of Stockholm, Bogotá, Algiers or Barcelona, just to name a few examples. He travelled several times around Spain, visiting the city of Valencia in 1928. His seal is visible all over the world. He was the first global architect; hence the interest aroused in all these places and the importance of counting on the participation of international speakers and researchers.

Something to be particularly noted is his relevance in a specific field of the architect's task: the house, the dwelling, the room. All his life is marked by an almost pedagogical will, to teach how to live: "savoir habiter". This was an almost unavoidable motto, being housing a key target in his work. In fact, he states in 1952, in his "Declaration of principles concerning the duties of modern architecture": "the duty to be fulfilled by architects is, precisely, to give first priority to housing". A great amount of current housing developments with a certain degree of significance are based on the numerous housing proposals he worked out since the first decade of the last century. One of the aims of this conference is to explore the permanence of his proposals in current architecture and how to contribute to improve the quality of collective housing.

His legacy is extremely extensive. Le Corbusier never ceased to reveal the wealth of his thoughts, which were collected in notebooks, texts, interviews and newspaper articles. Most of his drawings, sketches and project drawings are available to us, in addition to an extensive range of critical texts about him. Therefore, his personality allows many different approaches. But on top of this, he exerted a far-reaching influence on many well-known heirs. Internationally renowned contemporary architects, such as Rem Koolhaas, Toyo Ito, Alvaro Siza, Rafael Moneo, Luigi Snozzi, Peter Eisenman and Kenzo Tange, among many others, acknowledge their debts to the French-Swiss master. To recognize and trace his influence on our architecture is a necessary tribute. 
ÍNDICE 

Le Corbusier's uncanny interiors

Tiziano Aglieri Rinella

Reconstrucción de una pirámide borrada. Análisis de la Capilla Mortuoria encargada por Lucie

Delgado Chalbaud en Caracas, Venezuela, 1951

José Javier Alayón González, Mariolly Dávila Cordido and Odart Graterol Prado

Les « Unités » Modulor dans la Philosophie de l'Espace de Gaston Bachelard Aurosa Alison

El espacio público en Le Corbusier. Evolución de su pensamiento y de sus estrategias formales Eusebio Alonso García

Estrellas sobre fondos cambiantes: convocando la luz Isabel Álvarez and Silvia Blanco

All of Paris, Darkly: Le Corbusier's Beistegui Apartment, 1929-1931 Ross J. Anderson

Le Corbusier y la Reorganización del hábitat rural David Arredondo Garrido

Le Corbusier et la main ouverte à Chandigarh. La genèse d'une œuvre Abdelmalek Arrouf and Nadia Berkane

Architecture as machine; Towards an architectural system for human well-being Paramita Atmodiwirjo and Yandi Andri Yatmo

La construcción de lo inefable Alfredo Baladrón Carrizo

Fotografías que seccionan una mirada a Le Corbusier Carlos Barberá Pastor

Une correspondance architecturale: Ionel Schein "enfant" de Le Corbusier Silvia Berselli

Vernacular Serbia Traced by Jeanneret, Yugoslav Modern Figured à la Corbusier Ljiljana Blagojevic

La Fábrica verde de la Ciudad lineal industrial: una propuesta de Le Corbusier para el trabajo del hombre en la "época maquinista" Silvia Bodei

Experimenting with prototypes: architectural research in Sweden after Le Corbusier's projects Ingrid Campo Ruiz.

Team10 out of CIAM: Sobre el papel de Le Corbusier. Identificación y legado.

Alejandro Campos Uribe

La Villa Savoye. Permanencias y transformaciones

Teresa Carrau Carbonell

F VAL. Feria Valencia y Guillermo Jullian de la Fuente. L'héritage de Le Corbusier Federico Carro Gil, Miguel Navarro Pérez and Marta Mompó García

Le Corbusier's Legacy: Modern experimentation in Mario Bonito's work Helder Casal Ribeiro

Ronchamp in the spotlight. The feature of a shocking building in the 50s journals Francisco Javier Casas Cobo 
El lugar del arte en arquitectura. Los "lieux porte-voix, porte-paroles, haut-parleurs" de Le

Corbusier en su discurso del Convegno Volta, 1936

José Luis Chacón

Le Corbusier et les relations avec le Brésil Silvia Raquel Chiarelli and Ruth Verde Zein

Le Corbusier's Musée à croissance illimitée: A Limitless Diagram for Museology Irene Chin

Le Corbusier and the mysterious "résidence du président d'un collège" Fabio Colonnese

Le Corbusier Roof-Spaces Alessandra Como, Isotta Forni and Luisa Smeragliuolo Perrotta

Des-montaje de la maqueta de la propuesta para el Palacio de los Soviets de Le Corbusier Miguel Ángel De la Cova Morillo

Le Corbusier y Charles Lasnon: De las maquetas blancas de los Salones de Otoño a los plan-reliefs del nuevo urbanismo Miguel Ángel De La Cova Morillo

Le Corbusier's Proposal for the Capital of Ethiopia: Fascism and Coercive Design of Imperial Identities Elisa Dainese

Le Corbusier y la construcción vertical del espacio estratificado Sonia Delgado Berrocal

Analyse architecturale, modélisation 3D et narration filmique: un regard original sur quelques objets corbuséens Denis Derycke and Véronique Joanne Boone

Le Corbusier's Cité de Refuge: historical \& technological performance of the air exacte Luis Manuel Díaz and Ryan Southall

Le Corbusier et la Belgique / Son Héritage

Marc Dubois

Machines à exposer

Cathérine Dumont d'Ayot

Learning from Le Corbusier

Laurent J. Duport

601

Georges Candilis (1913-1995) architecte pour le plus grand nombre Laurent J. Duport

Concevoir aujourd'hui un film sur la villa Savoye Anouchka Dyephart

Autour du pyjama de Le Corbusier. Le vêtement comme modèle de pensée fondateur Clotilde Félix Fromentin

Le Corbusier y Lúcio Costa. Diálogos sobre la síntesis de las artes Fernanda Fernandes da Silva

Listening and the League of Nations: Acoustics Are the Argument Sabine von Fischer 
Le Corbusier. Arquitectura urbana: Millowners Association Building y Carpenter Center María Pía Fontana and Miguel Y. Mayorga Cárdenas

Le Corbusier and Ariadne

Alessandro Fonti

Architecture and Art: La Ronchamp's symbiosis as a "total work of art" Sarah Frances Dias and Maria João Durão

Summer houses in Portugal: the legacy of the Exitenzminimum and the work of Le Corbusier Tiago Freitas

La Villa Sarabhai. La riqueza de lo ambiguo Andrea García González, Vicente Mas Llorens and José Santatecla Fayos

Influencias pintorescas de Le Corbusier en el Pabellón Brasileño de Osaka '70 Sergio García-Gascó Lominchar

Arquitectura y tapiz de Le Corbusier. La trama y la urdimbre de la casa nómada Antoni Gelabert Amengual

Génesis del proyecto de la Cité de Refuge de París Alejandro Gómez García

Le Corbusier: architecture, music, mathematics: longing for classicism? Clara Germana Gonçalves and Maria João Soares

Mirada objetiva y dimensión subjetiva del cine en Le Corbusier Josefina González Cubero

Memory and change through Le Corbusier. Fragments of urban views Fabiola Gorgeri

Captando la mirada. Publicidad y reclamo en el espacio expositivo de Le Corbusier Jerónimo Granados González.

The Baghdad Affair. How diplomacy supplanted one of the last major projects by Le Corbusier Nuno Grande

Bruno Zevi on Le Corbusier: another way to an "organic architecture" Luca Guido

Maestro y discípulos: Japón y el pabellón para la Exposición Internacional de París de 1937 Pablo Jesús Gutierrez Calderón

Le Corbusier between sketches. A graphic analysis of the Acropolis sketches Sebastian Harris

Le Corbusier Postwar Painterly Mythologies Geneviève Hendricks

El dibujo y la noción de horizonte en Le Corbusier Germán Hidalgo Hermosilla

Mapping the Stylistic Affiliations of Le Corbusier's Work Phoebus Ilias Panigyrakis

THE INEVITABLE ORDER: Revisiting the Calibrated Biomimetics of Le Corbusier's Modulor Rajini Itham Mahajan

On Diagonal Time in Le Corbusier's Visual Arts Center Michael Jasper 
Charles-Edouard Jeanneret miembro de 1'OEUVRE

Inmaculada Jiménez Caballero

Ratio and the Divine Proportions: Le Corbusier and Rudolf Wittkower

James Kirk Irwin

1081

« L'espace indicible »: conceptions et textualités

Mickaël Labbé

1093

Le Corbusier y Lilette Ripert. Les Maternelles vous parlent, hacia una pedagogía más humana Paula Lacomba Montes

Crónica de un desencuentro: Le Corbusier en las Américas

Alejandro Lapunzina

1132

Estrategias geométrico-matemáticas en la obra de Le Corbusier (1923-1933)

Teresa Larumbe Machín

From Impact to Legacy: Interpreting Critical Writing on Le Corbusier from the 1920s to the Present

Graham Livesey and Antony Moulis

La mirada de Pedro Vieira de Almeida a Le Corbusier: una visión desde Portugal en la segunda mitad del siglo XX

Tiago Lopes Dias

El epígono de El Modulor: La serie amarilla en las investigaciones de Rafael Leoz

Jesús López Díaz and José Antonio Ruiz Suaña

1198

La mediterraneidad en la obra de Le Corbusier. La bóveda catalana lecorbuseriana: Influencias y evolución

Esmeralda López García

La Ligne Claire de Le Corbusier. Time, Space, and Sequential Narratives

Luis M. Lus Arana

Le Corbusier's legacy in the tropics: modern architecture in Angola and Mozambique (1950-1970) Ana Magalhães

Le Corbusier, el punto de partida de Juan Borchers

Sandro Maino Ansaldo

Le Corbusier and the American Modulor Madalena Mameli

Maisons Jaoul, confort higrotérmico y su percepción en la arquitectura de tipología unifamiliar de Le Corbusier

Daniel V. Martín Fuentes

La casa y el recinto. Un proceso abierto a través del proyecto para la Residencia Peyrissac en una explotación agrícola en Argelia

Carmen Martínez Arroyo, Rodrigo Pemjean Muñoz and Juan Pedro Sanz Alarcón

Letter from the Basses-Pyrénées: An Unintended Trigger for a Site Exchange

Laura Martínez de Guereñu Elorza

El "hameau" vertical de Le Corbusier. Una alternativa residencial al bloque lineal

Yolanda Martínez Domingo and Josefina González Cubero

Le Corbusier -hombre y arquitecto- en Cap Martin

Anna Martínez Durán

1364 
Elogio del cuadrado: cuadrícula, cuadro, cuatro, cubo Andrés Martínez-Medina

Le Corbusier versus Sergei Eisenstein. La construcción de un sueño Elena Martínez Millana

Búsquedas para el establecimiento de una relación armónica con el paisaje. Dos exploraciones paralelas

Clara E. Mejía Vallejo and Juan Deltell Pastor

Global Architects: a dialogue between Le Corbusier and Fernando Távora on Architecture

Universality Susana Meleiro Lima

« Histoire d'une Fenêtre ». Le Corbusier y la construcción de la mirada Ricardo Merí de la Maza, Alfonso Díaz Segura and Bartolomé Serra Soriano

La Réaction Poétique of a Prepared Mind Matthew Mindrup

FLC 4932. Lo inesperado en la obra de Le Corbusier. Consideraciones en torno al origen de la promenade.

Roger Miralles Jori

Brise-soleil: principios y transformación en la obra de Le Corbusier Silvia Morel Correa, R. Anzolch and R. Pedrotti

L'Architecture Vivante y Le Corbusier María Pura Moreno Moreno

The Thematic Content of Le Corbusier's Musée Mondial: Nature and Perspectivity Dagmar Motycka Weston

Architecture in Translation: Le Corbusier's influence in Australia Antony Moulis

Le Corbusier and the "Lection of the gondola" Alioscia Mozzato

Le Corbusier in Berlin, 1958: the universal and the individual in the unbuilt city Mara Oliveira Eskinazi

Le Corbusier and The Americas: Affinities, Appropriations and Anthropophagy Daniela Ortiz Dos Santos

"Who is Le Corbusier?" According to Turkish Architecture Guliz Ozorhon and Ilker F Ozorhon

Chandigarh antes de Chandigarh (Cartografía de una idea) José del Carmen Palacios Aguilar

Páginas de un desencuentro: Le Corbusier y L'Architecture d'Aujourd'hui (1930-65) José Parra Martínez

Habitar el aire

Marta Pérez Rodríguez

Le Corbusier and São Paulo - 1929: Architecture and Landscape Guilherme Pianca

La forme du temps à Moscou

Pedro Ponce Gregorio 
Entre les lignes ou de bouche à l'oreille. Le Corbusier en roumain

Radu Tudor Ponta

Dattiers Andinos y la Búsqueda Paciente en Rue de Sèvres, 1948-1959

Ingrid Quintana Guerrero

The Philosophical Framework of Le Corbusier's Education: Schuré and German Idealism Armando Rabaça

Le Corbusier in Chandigarh: A Search for the Natural Order Aparma Ramesh

The mur neutralisant as an active thermal system: Saint Gobain tests (1931) versus CFD simulations (2015).

Cristina Ramírez-Balas, Juan José Sendra Salas, Rafael Suárez Medina, Enrique D. Fernández-Nieto and Gladys Narbona-Reina

Le Corbusier, Missenard et Le Climat Javier Redondo Morán

Construcciones ambientales en el hábitat moderno: Le Corbusier y André Missenard (1937-57) Ignacio Requena Ruiz and Daniel Siret

Notre Dame du Haut, Ronchamp, the shape of a listening. A whole other generative hypothesis Luca Ribichini

La lección del embalse. Le Corbusier y los aprovechamientos hidroeléctricos Antonio Santiago Río Vázquez.

Le Corbusier et le Brésil: une Synthèse des Arts Majeurs, et aussi des Arts Mineurs Cecilia Rodrigues Dos Santos

"L'emploi du quatrième mur sur le pan de verre". Apariciones del concepto de cuarta pared en los libros, textos y documentos de Le Corbusier José Antonio Rodríguez Casas

Le Corbusier en 'Líneas Simples': Toyo Ito Marta Rodríguez Fernández

Metáforas obsesivas e ideogramas (marcas del surrealismo en la construcción del discurso de Le Corbusier) Luis Rojo de Castro

Possibles liens avec le Monde Antique. La suggestion des ruines dans les œuvres de Le Corbusier: de l'architecture Romaine au bâtiment de la Haute-Cour de Justice de Chandigarh Chiara Roma

Le Corbusier y la autonomía de la arquitectura Alberto Rubio Garrido

Corbu's Hands Agnieszka Rumież and Witold Oleszak

Le Corbusier et Christian Zervos dans Cahiers d'art Maria Paola Sabella

CAPRICCI NO CAPRICHOSOS: copy_paste de Le Corbusier; o los inesperados saltos de la cabra Maurizio Salazar Valenzuela

Diagrama y Arquitectura. La Sintaxis Espacial en el Carpenter Center for the Visual Arts Juan Alejandro Saldarriaga Sierra 
Dibujando La Casa Peyrissac

Albertina Saseta Naranjo

Le Corbusier's early urban studies as source of experiential architectural knowledge

Cristoph Schnoor

Le Corbusier y el edificio del Ministerio de Educación y Salud Luciane Scottá

Garder mon aile dans ta main: The genesis of the Open Hand

Gabriel Sepe Camargo

Criterios de combinación de colores para la arquitectura en Salubra I: estudio de tonos Juan Serra, Jorge Llopis, Ana Torres and Manuel Giménez.

The Photo book as Symphony - Ronchamp as Sculpture: Re-composing Architectural Photography

Talette Simonsen

La poética del urbanismo de Le Corbusier: arte y función en la ciudad moderna Andrea Soler Machado and Emanoela Gehlen Bregolin

Complejidad y contradicción en Le Corbusier

Roger Such Sanmartín

Let's play with Le Corbusier

Barbara Świt-Jankowska

Visions "humaines" ou "infernales": les moyens de transport et la perception de la ville chez Le

Corbusier Simona Talenti

The eye of the architect. Le Corbusier and the photograph: demonstrate, learn, remember Annarita Teodosio

In Quest of Modernity: Le Corbusier's Project for the New Civic Hospital in Venice Inés Tolic

Copy-Paste: Le Corbusier en OMA/Rem Koolhaas

Raúl Del Valle González

Learning how to design architecture form the Villa Savoye design process Karel Vandenhende

Los dibujos para el Palacio

Victor Hugo Velásquez Hernández.

Bajo la Luz. Buscando la luz Ínigo de Viar Fraile

Rem Koolhaas: Le Corbusier through the Looking-Glass Beatriz Villanueva Cajide

Sobre una caracterización 'corbuseriana' del mobiliario moderno María Villanueva Fernández and Héctor García-Diego Villarías

El proyecto del Convento de Sainte Marie de la Tourette. De la celda al espacio inefable Alejandro Vírseda Aizpún

Le Corbusier's Secret Geometry: Speculations on Regulating Lines Hidden in Ronchamp Peter Wood

MONUMENTALIZING MODERN MOBILITY

Carlos Eduardo Comas 


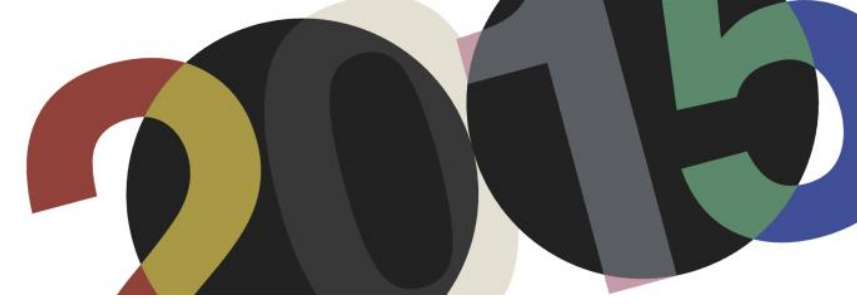

DOI: http://dx.doi.org/10.4995/LC2015.2015.708

\title{
Le Corbusier's uncanny interiors
}

\author{
T. Aglieri Rinella
}

Assistant professor of Architecture. Al Ghurair University, Dubai

\begin{abstract}
The reception of Le Corbusier's early buildings in Paris provoked an astonishing sensation of shock and estrangement in the public of the time. This troubling sensation of wonder is still alive today, after almost a century from their construction, and it is particularly vivid in some of the interiors, as we can notice from the photographic documentation of the time. Sigmund Freud, in his book "The interpretation of dreams", underlined the direct relation existing between the interior of the human psyche and the interior of the house a subject lives in. He defined the interior of each man's home as a sort of "diagnostic box" of the human mind, able to disclose the psyche of the individual, expressing his dreams, desires and obsessions. In his purist houses, Le Corbusier seems to have imposed his overwhelming personality on the clients, somehow expressing his own idealistic dream of the city of the future and foreseeing the visionary scenarios of a modernist utopia. This paper's goal is to present a psychoanalytic reading of Le Corbusier's buildings of the time, analyzing a number of significant examples in order to identify their uncanny effects, disclosing the hidden relations between cause and effect, and decoding the related composing technics used in the interior design.
\end{abstract}

Resumen: La recepción de los primeros edificios de Le Corbusier en París provocó una sensación asombrosa de shock y extrañamiento en el público de la época. Esta sensación inquietante de asombro sigue vivo hasta hoy, después de casi un siglo de su construcción, y es particularmente viva en algunos interiores, como podemos observar en la documentación fotográfica de la época. Sigmund Freud, en su libro "La interpretación de los sueños," subrayó la relación directa existente entre el interior de la psique humana y el interior de la casa donde un sujeto vive. Él definió el interior de la casa de cada hombre como una especie de "caja diagnóstica" de la mente humana, capaz de revelar la psique del individuo, expresando sus sueños, deseos y obsesiones. En sus casas puristas, Le Corbusier parece haber impuesto su personalidad arrolladora en los clientes, expresando de alguna manera su propio sueño idealista de la ciudad del futuro y previendo los escenarios visionarios de una utopía modernista. El objetivo de este trabajo es de presentar una lectura psicoanalítica de los edificios de Le Corbusier de la época, analizando una serie de ejemplos significativos con el fin de identificar sus efectos extraños, revelar las relaciones ocultas entre causa y efecto, y decodificando las relativas técnicas compositivas utilizadas en el diseño de los interiores.

Keywords: Le Corbusier; Interiors; Architecture; Uncanny; Freud; Surrealism.

Palabras clave: Le Corbusier; Interiores; Arquitectura; Perturbador; Freud; Surrealismo.

\section{Introduction}

As is known, the reception of Le Corbusier's early buildings in Paris in the 1920s provoked an astonishing sensation of shock and estrangement in the public of the time.

This troubling sensation of wonder is still alive today, after almost a century from their construction, and it is particularly vivid in some of the interiors, as we can notice from the photographic documentation of that period, often carefully set up and selected by Le Corbusier himself.

Le Corbusier's Purist houses are pervaded by a slightly uncanny atmosphere where ambiguity of space reading, ghostly presences, unexpected occurrences, seem to lend to the space an "estranging" aura. 
Regarding the interiors of the La Roche house, Tim Benton has spoken of "Unheimlich" («Uncanny» in English), claiming that the arcane sensation perceptible along its "architectural promenade" may be put in relation with the theories of K.A. Scherner and Sigmund Freud and explaining the psych-sensorial origin of these feelings with a comparison between oneiric sensations and the sensorial experience of the "promenade" .

According to Scherner, the oneiric fantasy had as a favorite symbolic representation the image of a house. Sigmund Freud, in his book "The interpretation of dreams", underlined the direct relation existing between the interior of the human psyche and the interior of the house that a person lives in. He defined the interior of each man's home as a sort of "diagnostic box" of the human mind, able to disclose the psyche of the individual, expressing his dreams, desires and obsessions ${ }^{2}$.

The concept of Unheimlich was described by Freud in a famous essay ${ }^{3}$. The term Unheimlich is the contrary of Heimlich $^{4}$, which means familiar, homely (the root heim means "home"). Unheimlich is therefore what, even if referring to a domestic environment, is not totally familiar to us, because we grasp something different and unusual that surprises and creates a sensation of "estrangement".

In other words, we feel the Unheimlich in architecture when we grasp something of anomalous, of unconventional, which more or less unconsciously strikes our feelings, in an interior domestic space which we should be accustomed to. It is the sudden revelation of these unexpected concealed elements, latent presences in our subconscious, which make us feel the vibrant Unheimlich sensation.

In architectural design, illusionistic expedients of any kind, decontextualizations, allusions, abrupt changes of architectural scale and dimensions, unexpected presences, mysterious solutions and surprise-effects, are all emotional devices able to immerge space users into an estranging and oneiric atmosphere.

Anthony Vidler, in his book The Architectural Uncanny ${ }^{5}$, has deeply investigated the concept of Unheimlich in architecture. Even if frequently associated with the frightening feelings of fear and mystery, according to Freud Unheimlich doesn't necessarily have a negative meaning. Unheimlich can be just something of new and unknown, and often what is new is scaring for most people. This may also partially explain the sense of shock (or even of refusal) often produced by Le Corbusier's early buildings in the Twenties.

In his purist houses, Le Corbusier imposed his overwhelming personality on the clients, somehow expressing his own ideal dream of the city of the future and foreseeing the visionary scenarios of a modernist utopia.

One can assume that the complex client-architect relation in many Le Corbusier's projects could be similar to a sort of psychoanalytic 'positive' transfert, in which the client unconsciously assign to the architect "passion" feelings in a way very similar to a process of "love" attraction. This is particularly relevant in residential projects, where the architect is appointed to design his client's "home" (so, according to Freud his "diagnostic box"). In these cases, the architect has to deep-dig into the clients' psyche, understanding and analyzing their

\footnotetext{
${ }^{1}$ Benton Tim, "Villa La Rocca, Die Planungs und Baugeschichte Der Villa La Roche”, in Ein Haus für den Kubismus, Die Sammlung Raoul La Roche. Basel: Kunstmuseum, 1998, pp. 227-243.

${ }^{2}$ Freud Sigmund, Die Traumdeutung, 1899. Italian ed.: L'interpretazione dei sogni. Turin: Bollati Boringhieri, 1973.

${ }^{3}$ Freud Sigmund, Das Unheimliche, 1919. Italian ed.: "Il perturbante" in Saggi sull'arte la letteratura e il linguaggio. Turin: Bollati Boringhieri, 1969.

${ }^{4}$ In German, a further meaning of the term Heimlich is also «secret, hidden», that could seem antithetical to the concept of «familiar» and «homely». Heimlich therefore presents a sort of ambiguity, in which the less used meaning (mysterious, hidden) is almost coincident with its opposite Unheimlich.

${ }^{5}$ Vidler Anthony, The Architectural Uncanny: Essays in the Modern Unhomely. Cambridge (Mass.)-London: The MIT Press, 1992.
} 
conscious and subconscious needs and desires, elaborating and mediating them through the architect's leading personality.

For Le Corbusier, this can be certainly true in some cases, such as for the project of Raoul La Roche's house, where the client, a banker and art collector, was totally fascinated by his architect's aesthetic sense and personality. The client completely agreed on his ideas, giving him maximum freedom in his house's design. This relation of total reliance between client and architect is quite rare. La Roche was a bachelor who lived alone. His only passion was contemporary art, into which his great friend Le Corbusier had initiated him. The project of his house was intended to "frame" his collection of paintings, including those of Le Corbusier himself (significantly hanged in the more private space of the bedroom). Their friendship lasted a whole lifetime always with equal strength. According to Freud's theories, one may assume that La Roche lived towards Le Corbusier a kind of 'positive' transfer, similar to a proper "love" attraction.

On the contrary, this is certainly not the case of the project for the eccentric millionaire Charles De Beistegui, where the kind of relation with the architect was more similar to a brief "infatuation" (with subsequent quick separation and psychological removal). Here the project was the result of a "match" between two overwhelming personalities, both with strong (even if different) views and ideas, which outcome was an extraordinary crossing of unexpected reciprocal affinities.

Considering the psychoanalytic implications, Tim Benton attempted to uncover both the stimuli, or "elements" of Le Corbusier's designs, and the process whereby the design components are transformed and distorted into a poetic architectural language ${ }^{6}$. A number of authors presented introspective analyses of some of Le Corbusier's buildings, revealing the presence of significant stimulating aspects related to horror vacui, symbolism, mnestic associations, voyeurism, transparency and "surrealist" illusionism.

All these features are evident in a lot of significant buildings, from the pre-Parisian villa Turque to the subsequent La Roche house, villas Church, Stein and Savoye, up to Charles de Beistegui's apartment.

In the present brief essay, I will attempt to present a psychoanalytic reading of some of Le Corbusier's most relevant buildings of the time, analyzing a number of significant examples in order to identify their uncanny effects, disclosing the hidden relations between cause and effect, and decoding the related composing technics used in the interior design.

\section{Horror Vacui, Sublime and oneiric sequences}

Horror Vacui literally means from its Latin origins «fear of empty space». In architecture, we feel this disturbing sensation when entering into a very large and empty space, coming from a smaller sized room. This is a peculiar recurrent characteristic of the architectural "Uncanny". Walter Benjamin ${ }^{7}$ observed that the Uncanny was generated by the appearance of modern large towns, with their huge empty spaces and the heterogeneous crowds flowing the Parisian boulevards. This originated the individual's alienation as a modern collective pathology. The metropolitan Uncanny is often expressed by phobias associated to the space's experience, such as agoraphobia, fear of large open spaces and of the void, which we find with different scales and characteristics in many of Le Corbusier's interiors, where the sudden occurrence of wide empty spaces is a recurrent feature.

\footnotetext{
${ }^{6}$ Tim Benton mentions the drawings used by Le Corbusier to illustrate his lectures in Argentina, where these processes of transformation of physical stimuli are described in terms of "digestion". Cf. Benton Tim, Villa La Rocca, op.cit.

${ }^{7}$ Benjamin Walter, "Uber einige Motive bei Baudelaire", in Gesammelte Schriften, vol. I. Frankfurt am Main: 1974. Italian ed.: "Di alcuni motivi in Baudelaire", in Angelus novus. Saggi e Frammenti, Einaudi. Turin: Einaudi, 1962, pp. 109-130.
} 
Galleries, overhead walkaways and balconies abruptly open to the void, generating a dizziness feeling that charges the environment with emotional tension.

The Uncanny has been also related to the more magnificent concept of Sublime ${ }^{8}$, even keeping significant differences. Edmund Burke assumed that one of the main causes of Sublime was terror (e.g. of the void, of the great dimension of the nature). In certain cases and contexts, Sublime and Uncanny can appear indistinguishable and similar. Shock is an estranging tool of contemporary art, and Freud himself acknowledged the Uncanny as an aesthetic category, existing within the traditional limits of Sublime, or rather in «all that generates anguish and terror» ${ }^{9}$. The Uncanny, however, can't be just considered as an expression of negative sensations, but as a variety of forms and aspects, able to provoke estrangement also as a consequence of positive emotions.

In Le Corbusier's architecture, the plan libre allowed by reinforced concrete structure creates fluid inner space interpenetrations through mezzanines, internal courtyards and double high spaces in a continuous sequence developed along the promenade. In Notes à la suite ${ }^{10}$ he defined these interpenetrations as the "enjambements" of modern architecture, particularly present in the hall of the La Roche house, where the promenade is a dreamlike path full of emotional tensions, leading the visitor through a succession of spaces, ramps, stairs, bridges and mezzanines open over the void. Tim Benton also compared the feelings provoked by this dramatic path to a Sublime sensation evoking a Piranesian scenario, imagining La Roche walking alone at night to reach his bedroom $^{11}$.

Since the entrance to the La Roche house, after an external approaching path, the visitor is obliged to pass through a narrow access door, a simple opening cut in a recessed wall located in the corner between two wings of the building. This entrance seems conceived as a "bottleneck" allowing the passage to the largest dimensions of the inner hall. Passing the threshold, the visitor is surprised by the ample dimensions of the hall, facing an impressive space developed in height on three floors. The light coming from the large glass span over the entrance floods the space fostering the sensation of vastness. The inner walls of this large empty space are totally in white, with a chromatic effect that amplifies its dimensions, and cut with openings and voids that further expand the space perception. After the "compression" experience of the entrance, the visitor is suddenly "decompressed" and plunged into a "horror vacui" feeling.

In the hall, the simultaneous presence of overlapped spaces and interpenetrations on the three floors, result of the previously mentioned architectural "enjambements", creates disorientation, lending Unheimlich qualities to this place. The visitor is overcome with astonishment, as the space is not immediately recognizable as a domestic space. It actually presents itself an enigma, which can be solved only climbing up through all its levels to reach the mezzanine of the library, lit by a skylight and visible as a target destination of the promenade.

The following emotional path is heralding of further surprises, climbing up the floors through stairs and ramps, in a mesmerizing dream-like sequence.

\footnotetext{
${ }^{8}$ Vidler Anthony, op. cit., p. 22

${ }^{9}$ Freud Sigmund, Das Unheimliche, p. 81.

${ }^{10}$ Le Corbusier, "Notes à la suite" in Cahier d'Art. March 1926, n.3. Paris: Editions A. Morancé, 1926

${ }^{11}$ Cf. Benton Tim, "Villa La Rocca", op.cit., p.235.
} 


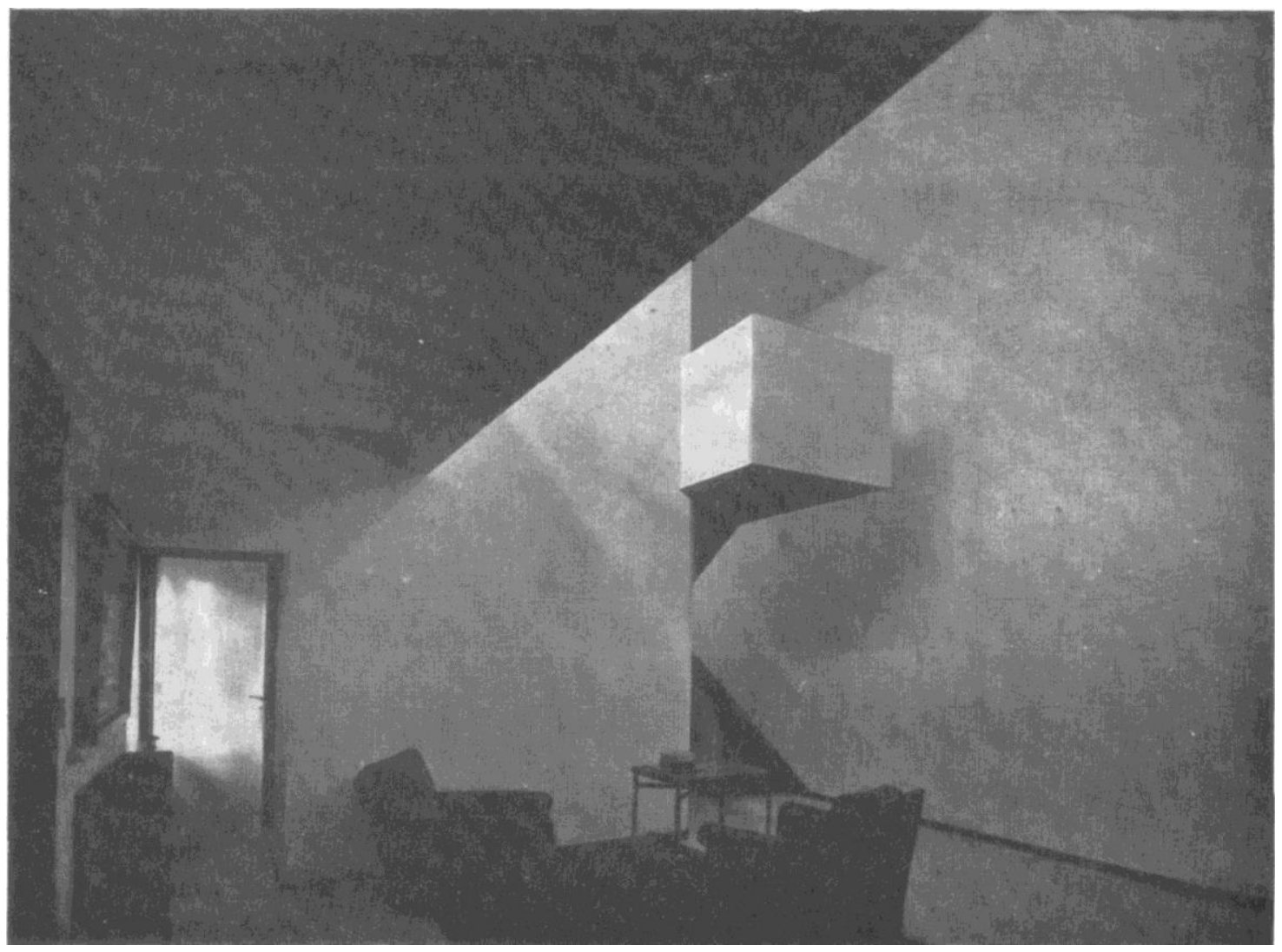

1. La Roche house, entrance hall, 1925 (photo Charles Gérard, FLC L2(12)73 @FLC-ADAGP).

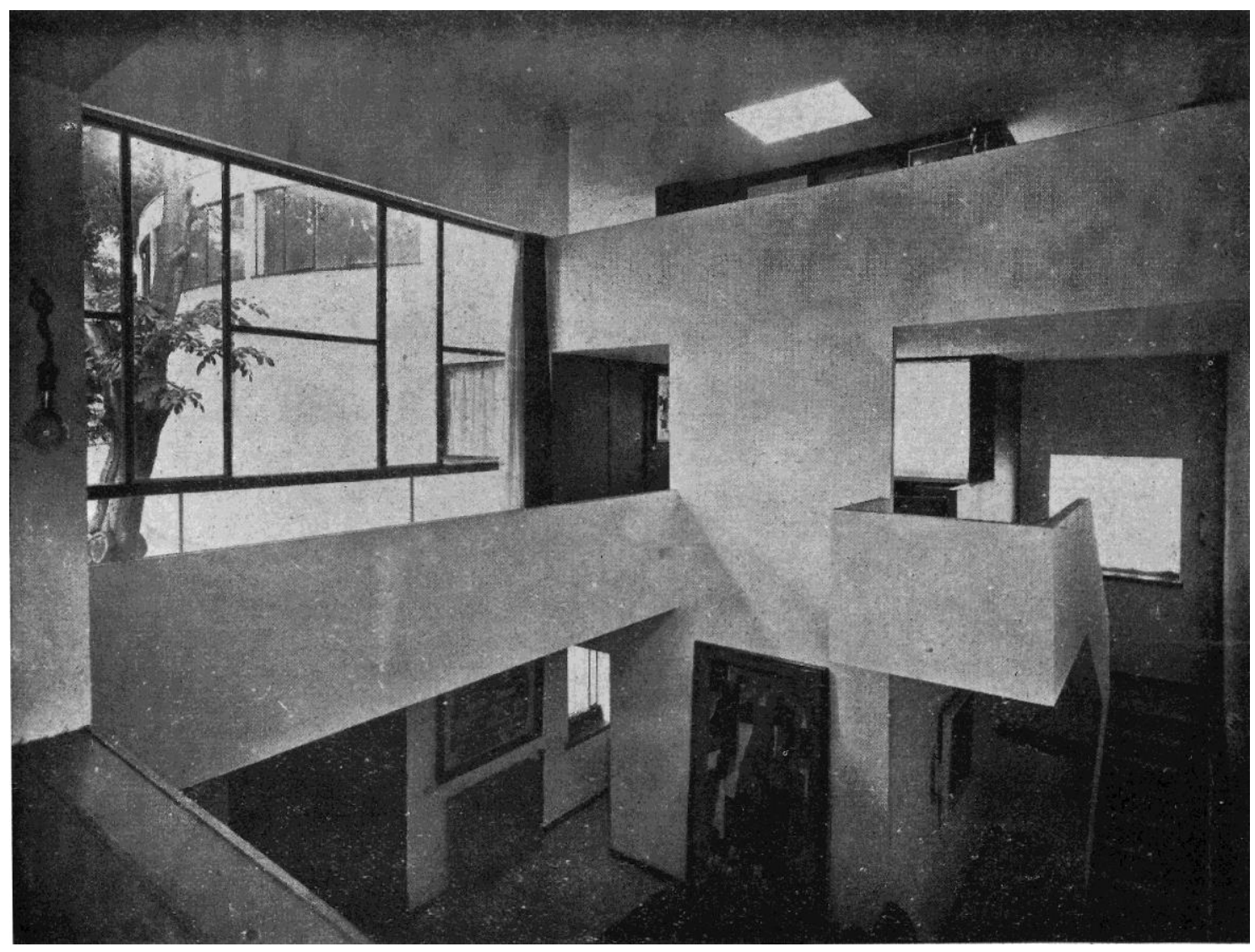

2. La Roche house, hall, 1925 (photo Fred Boissonnas, FLC L2(12)74 @FLC-ADAGP). 


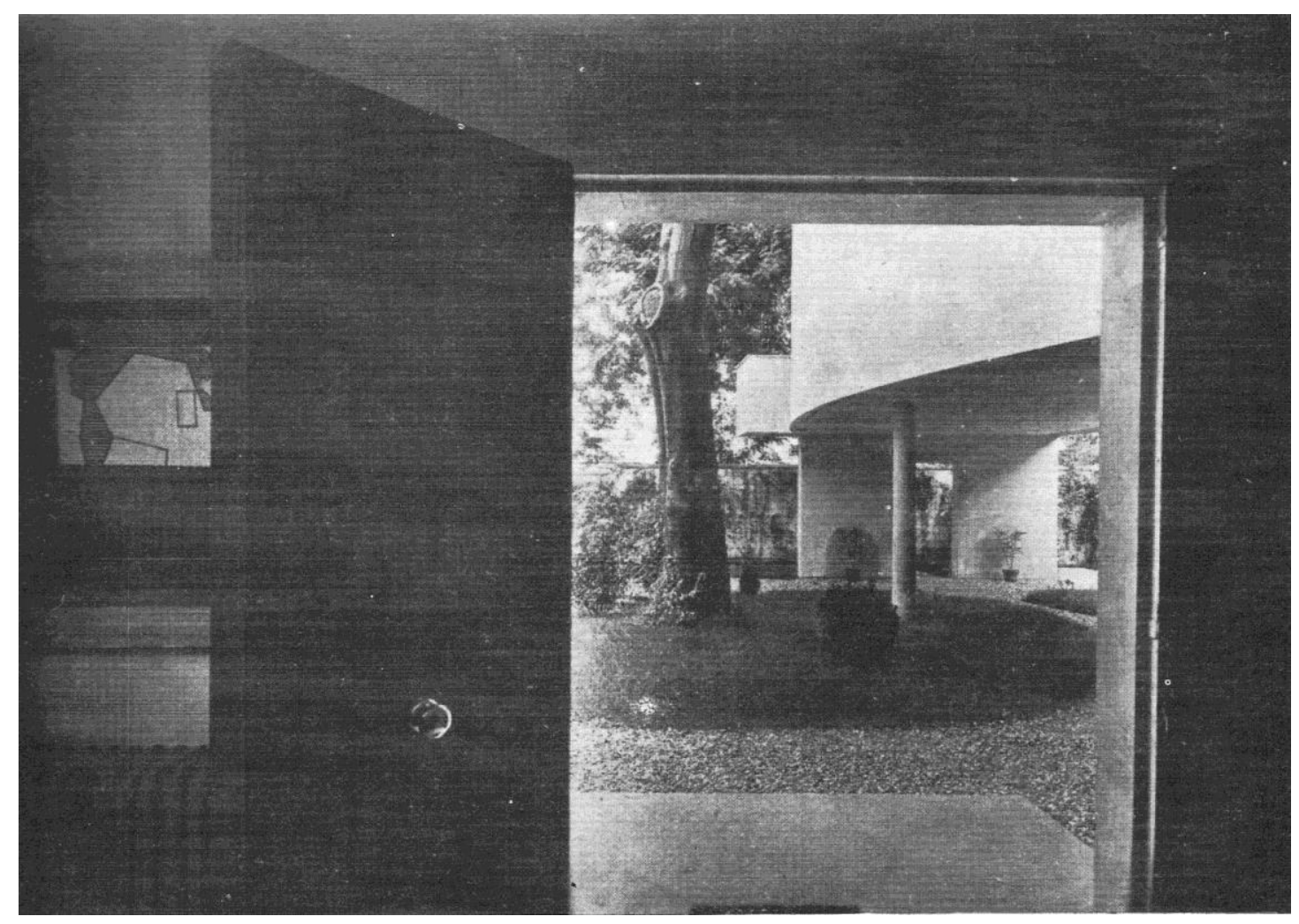

3. La Roche house, door open to the garden (photo Fred Boissonnas, FLC L2(12)71 @FLC-ADAGP).

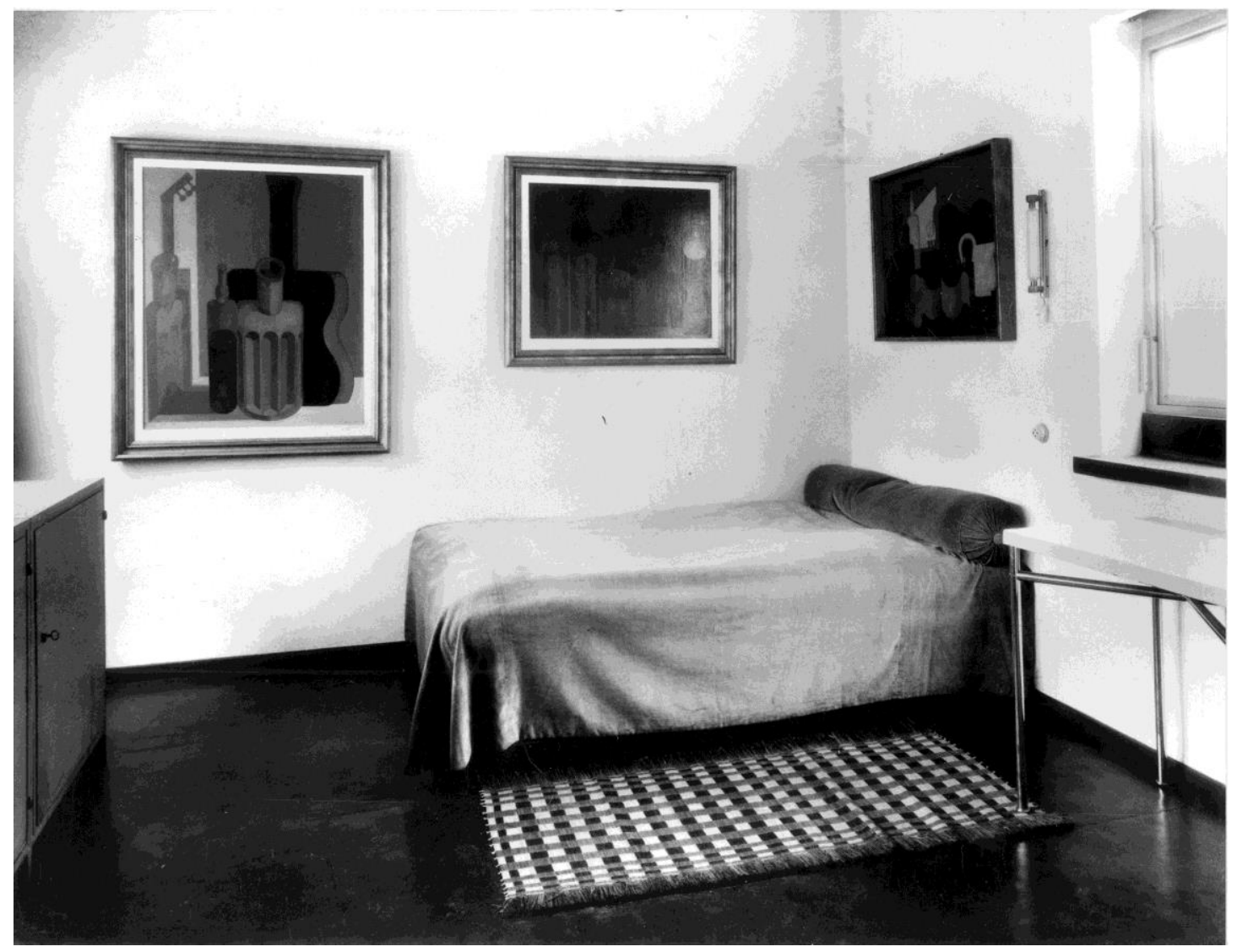

4. La Roche house, bedroom in 1926 (photo Fred Boissonnas, FLC L2-12-145 OFLC-ADAGP). 
In the superior levels, the void sensation is particularly significant in the open spaces surrounding and overlooking the hall. The narrow corridor giving access to the bedroom at the third level is separated from the hall's void only by a very low balustrade of $30 \mathrm{~cm}$ height, surmounted by a light and wide steel tube grid. Visitors walking in this tight space (especially those who are descending from the staircase) feel the frightening sensation of falling down in the empty space.

In his architectural promenades Le Corbusier often provides dynamic sequences alternating space "compression" and "decompression". Doors are treated as thresholds able to reveal the sudden show of the nature or unexpected changes of scale. In the La Roche house, the abstract inner environment generates contrasts with the external natural environment, which is suddenly discovered when opening some doors to disclose the presence of a tree or a garden, with a sort of Sublime surprise effect on the visitor.

In some cases, entryways lead to rooms with totally different space properties. For example, the La Roche's bedroom, accessible from the narrow corridor overlooking the frightening empty space of the hall, is a very small, essential and traditional simple room. Le Corbusier compared it to a monk's cell, and claimed that its small dimension and its cozy space proportions were properly fitting with this room's function, conceived just for sleeping. Furthermore, in this very private room, where La Roche arrived after a long path to finally find his bodily and psychical relaxations, only Purist paintings were hanging, in order to assure his full sensorial satisfaction $^{12}$.

In the La Roche house Le Corbusier treats domestic and public spaces in different ways. He features a more intimate and cozy atmosphere in the private spaces (e.g. bedroom and dining room), while giving a more representative and energizing character to public space like the entrance lobby. This hall performed the task of welcoming guests, with the cantilever balcony from which La Roche himself greeted visitors. According to Elisabeth Blum, this could wake mnestic associations with the ceremonial of baroque receptions and in this house one could find elements of baroque architecture mutated in new forms and functions, inspiring a sort of unconscious déjà vu. Although perhaps a more fitting reference was the balcony of Italian municipal palaces, from which the mayor gave his speeches to citizens.

A further similar feeling of horror vacui is somehow also present in the previous Le Corbusier's project of the villa for Anatole Schwob in La Chaux-de-Fonds. Here, a declared mnestic association is claimed since the villa's name, called "Turque", for its imaginary reference issued from Le Corbusier's memories of his travel to Turkey. The villa's features an inner square hall with a double high space of two floors. This void space presents analogies with the La Roche hall, with a large mezzanine at the upper level overlooking the hall empty space, amply lit by a large double-high glazed wall, that covers an entire side of the hall. Here again, the visitor is surprised to find this ample space vertically amplified, and he feels sucked into an estranging experience.

\section{Symbolism}

However, one of the most interesting aspects in the design of villa Turque is the noteworthy presence of ancestral geometric symbols used by Le Corbusier.

\footnotetext{
${ }^{12}$ We remember that La Roche reserved his bedroom to Purist painting also in his former Parisian apartment in rue Costantine. In a letter to Le Corbusier, La Roche writes "J'ai accroché votre grand tableau en face de mon lit; il est vraiment admirable et me cause un grand joie. La peinture puriste se trouve concentrée dans la chamber à coucher et constitue un ensemble presque plus parfait encore que le tableaux cubistes du salon". FLC E 2-7 (129), May 1923.
} 


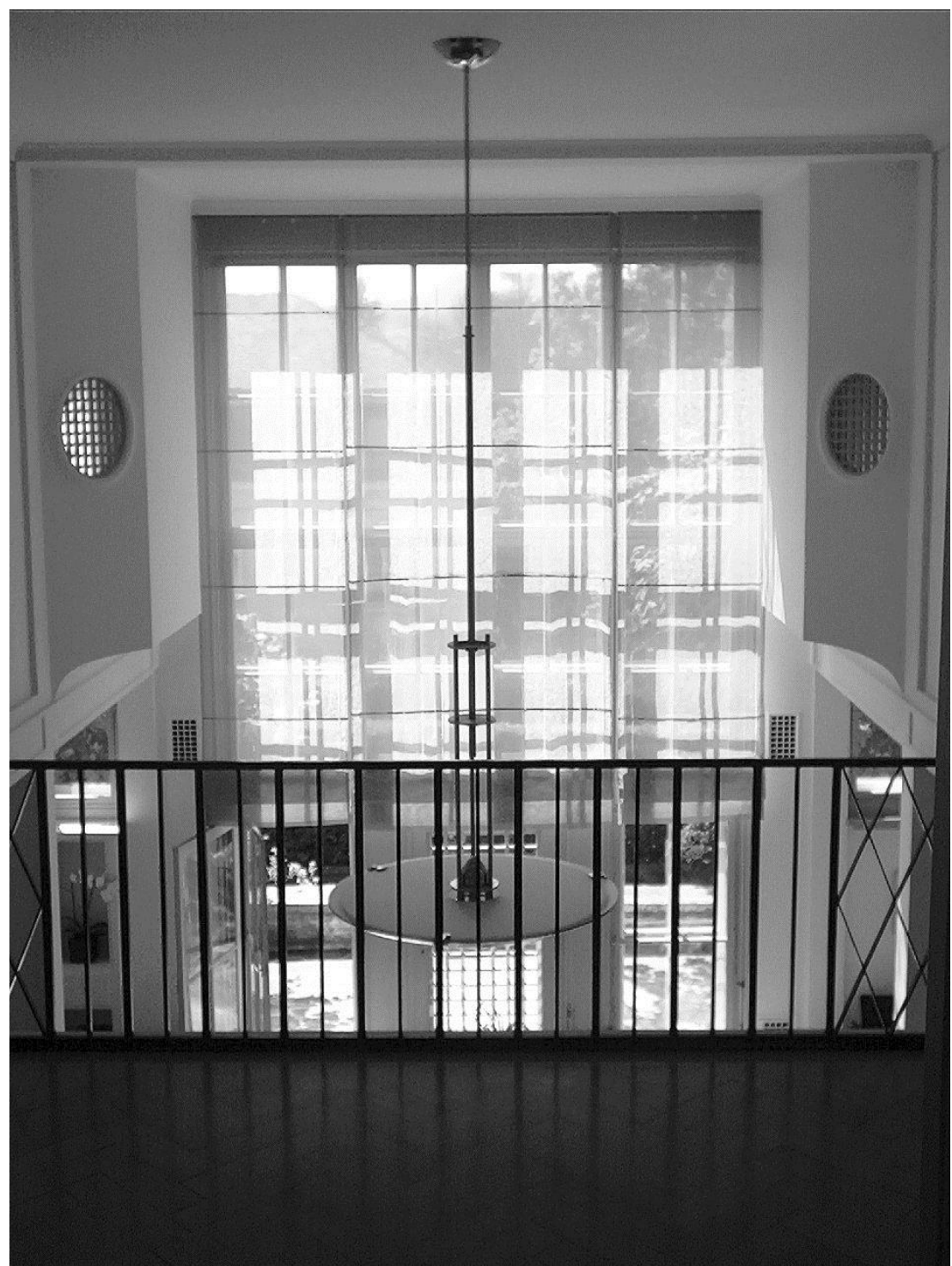

5. Villa Turque, view on the hall from the mezzanine (photo Tiziano Aglieri Rinella, 2003).

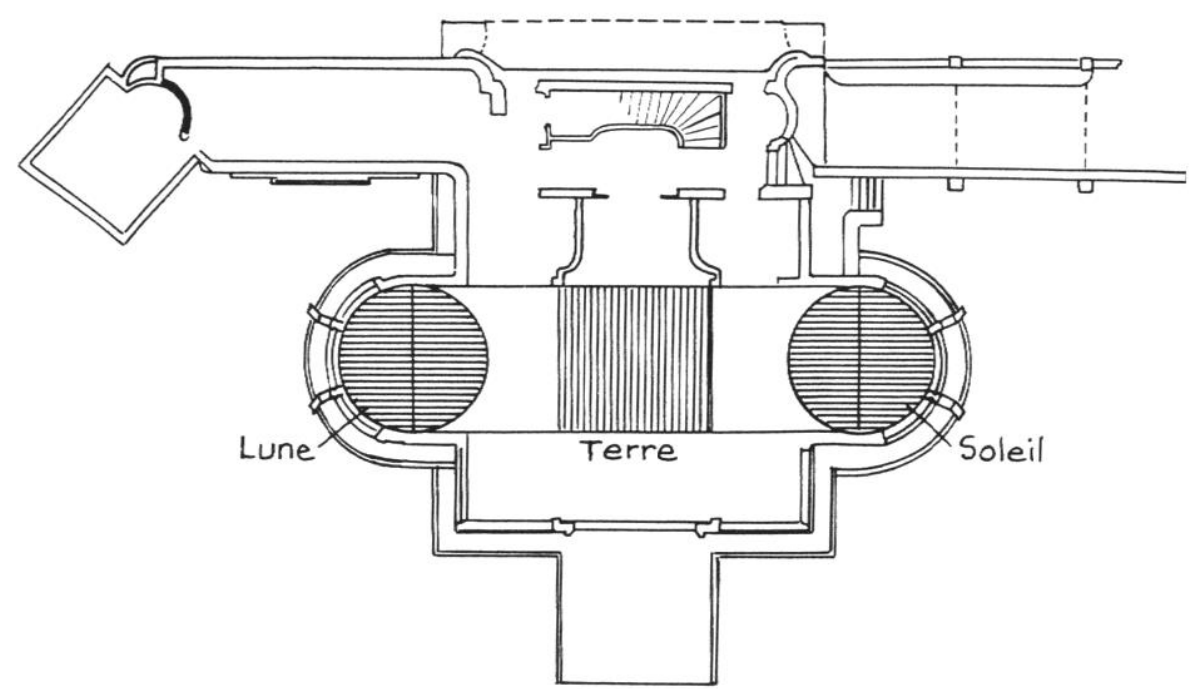

6. Villa Turque, plan (from: Garino Claude, Le Corbusier - La Villa Turque 1916-1917, Ebel, 1987). 
As he asserted in his Voyage d'Orient, he was literally obsessed by symbolism, claiming that "l'obsession du symbol est au fond de moi"13. This emotional attachment to the geometric shape was connected to his past places experience, to which he added a metaphysical ancestral meaning.

During his travel, at the arrival in Istanbul Le Corbusier will discovery the simple geometry of the mosques and domes scattered in the city. This will make him approaching Paul Cézanne's theory of «treating nature like a cube, a sphere, a cone». These ancestral symbols were deep-rooted in Le Corbusier's mind. Echoes and reminiscences of this journey's experience will affect the project for the villa, where we find plenty of geometric symbols. Le Corbusier himself associated the circle and the square to the villa's plan, according to the trilogy sun-earth-moon ${ }^{14}$.

The square is the first omnipresent symbol in the plan. It represents unity, the earth, and it symbolizes the number four ( 4 pillars x $4=16$ pillars, the total number of pillars in the villa). The circle is the symbol of the perfection and of the byzantine architecture, which associated with the square orients the temple according to the sun. The half-circle is present in the two side round elements, and symbolizes dualism and the moon.

Besides the large number of symbols presents in the building, referring to the deep assimilation of his journeys' stimuli, Le Corbusier carried out for this project a careful study of its geometric relations and proportions. In the elevations, he applies the aesthetic geometry of the Doric order, which links architecture to the symbolism of numbers. The strength of his past experiences emerged through these forms as sensorial flashbacks.

We find here the first samples of use of tracés régulateurs, later on further defined with the project of La Roche house. This system allows applying a mathematic rule to architecture, expressed through a geometrical logic. On a more metaphysic level, the tracés allowed to disclose the concealed order, revealing a portion of the universal order of the nature and therefore generating a sense of beauty.

According to Le Corbusier ${ }^{15}$, geometrical forms act on the human sensorial system, transmitting a sensation of balance and coherence. Thus, considering the psychological effects of form and perception (Gestaltpsychologie) applied to the architectural design, architecture becomes a tool to produce aesthetic emotions, a "machine à émouvoir".

\section{Voyeurism}

Another Le Corbusier's obsession, particularly recurring in his projects of the 1920's, is his compulsive interest for transparency, allowing a sort of architectural 'voyeurism'. Beatriz Colomina has underlined how Le Corbusier's buildings are crossed by continuous transparencies, where the look is directed both to the exterior (through framed views) and to interior spaces (terraces, roof-garden). Along the promenade of villa Savoye, we have a sequence of views that pass through the interiors to the framed landscape, favoring a voyeuristic practice.

In the photographs of the interiors, we have the impression that somebody just left the room, leaving some traces of its presence as a coat or a hat left on the table.

\footnotetext{
${ }^{13}$ Le Corbusier, Voyage d'Orient, 1911. In Von Moos Stanislaus (ed.) Le Corbusier, Voyage d'Orient: 1910-1911. Paris: Villette, 2012.

${ }^{14}$ Garino Claude (ed.), Le Corbusier - La Villa Turque 1916-1917. La Chaux-de-Fonds: Ebel, 1987

${ }^{15}$ For further deepening, CF. Aglieri Rinella Tiziano, Le Case La Roche-Jeanneret di Le Corbusier. Roma: Officina Edizioni, 2008, p.65-68.
} 


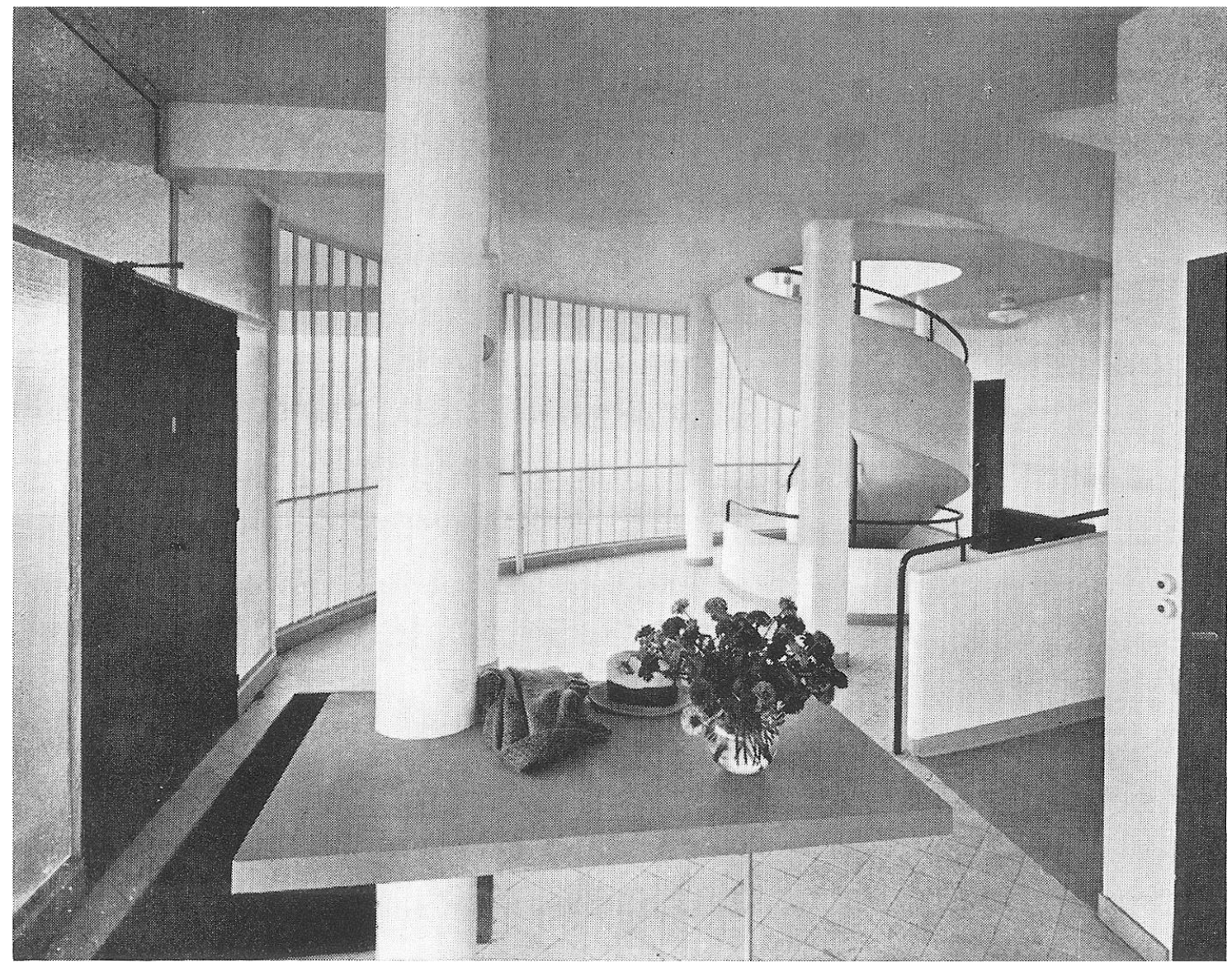

7. Villa Savoye, entrance (photo Marius Gravot, FLC L2(17)61 OFLC-ADAGP).

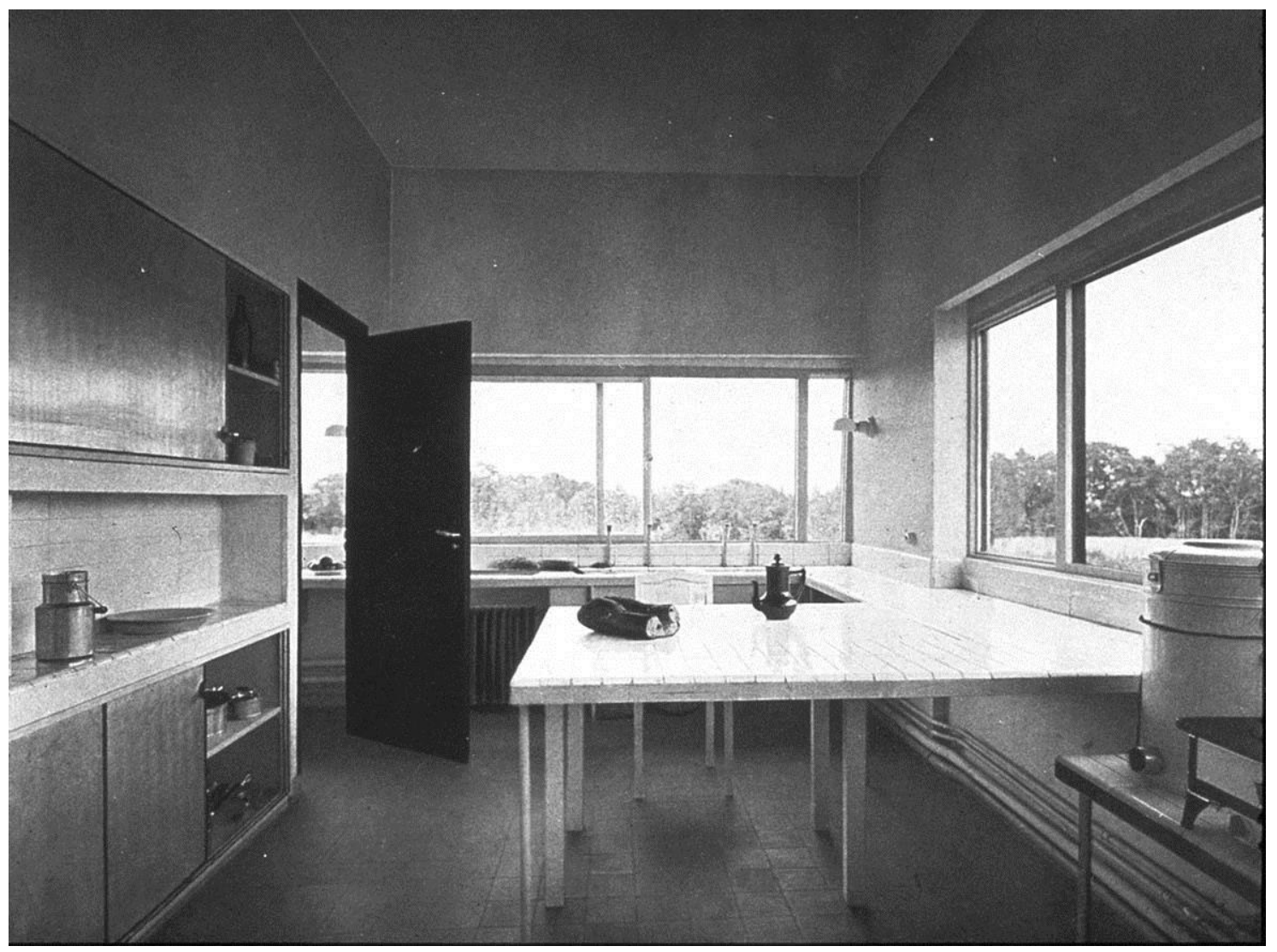

8. Villa Savoye, kitchen (photo Marius Gravot, FLC L2(17)176 OFLC-ADAGP). 


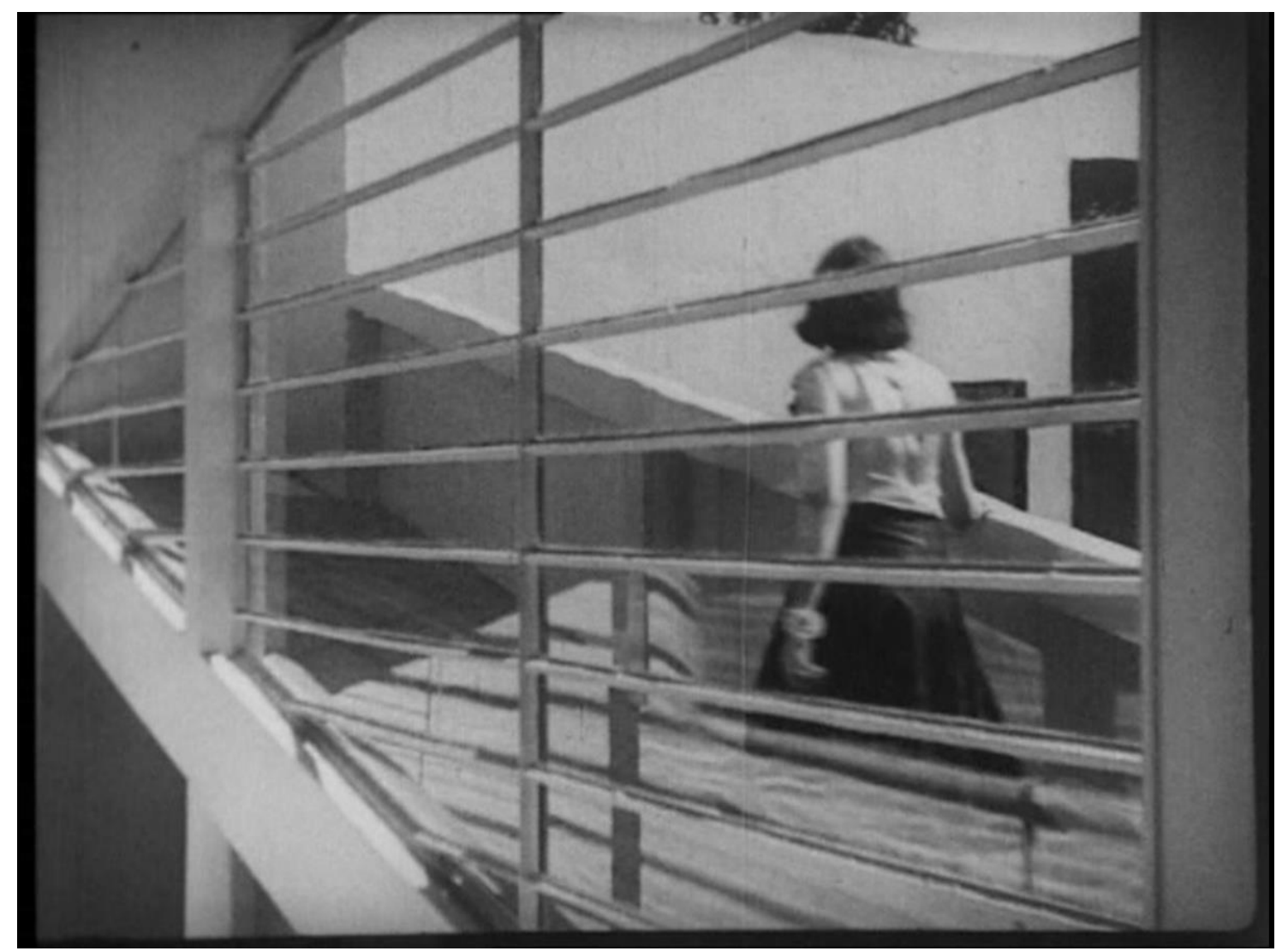

9. Villa Savoye, (shot from l'Architecture d'aujourd'hui, Pierre Chenal, 1930 OFLC-ADAGP).

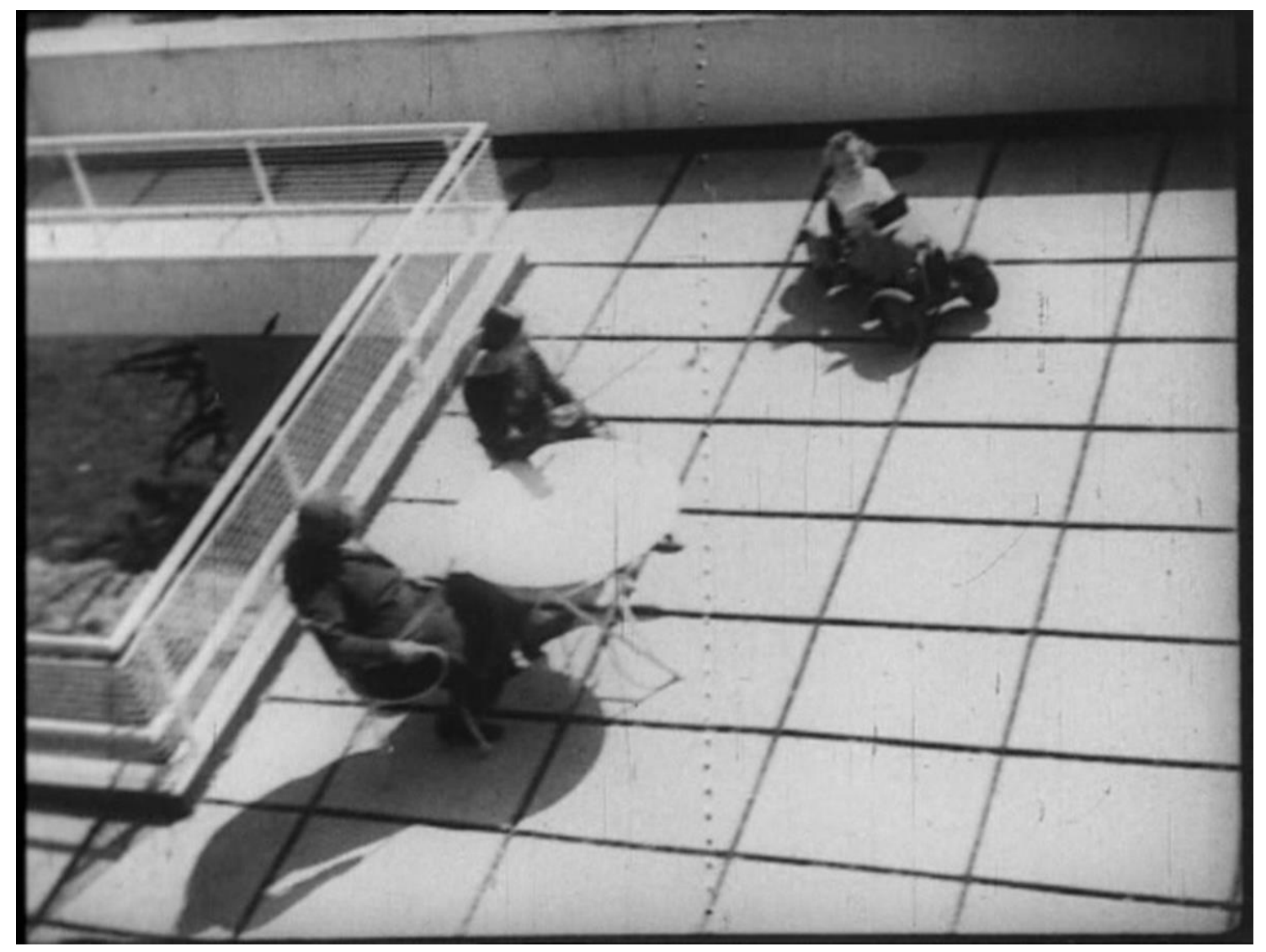

10. Villa Stein, (shot from l'Architecture d'aujourd'hui, Pierre Chenal, 1930 @FLC-ADAGP). 
This mysterious and Unheimlich presence is recurrent in many photos. The presence of objects in these images is functional to link the abstract modern architecture to the real world (represented by the presence of man) as its new aesthetic language is unfamiliar (thus uncanny) to the domestic imaginary of public. The human concealed presence, in this case, is a projection of Le Corbusier himself (a doppelgänger?) ${ }^{16}$, which leaves objects belonging to him (glasses, hat, ecc.) as clues of his presence.

Some photographs of the kitchen in villa Savoye are particularly interesting. A picture depicts some bread and a jug on the table, while the door is left open, suggesting the idea that somebody (a mysterious "intruder") just left the room. Colomina stated that the look in these pictures is a sort of "detective" look, a voyeuristic look where we are looking for somebody, a mysterious latent presence.

This is evident in many photographs but, as the perception occurs in motion, it is more tangible in the sequences of the short film Architecture d'aujourd'hui, directed by Le Corbusier and Pierre Chenal in 1930. Here, in a crossing view from interior to exterior, through the bars of a glazed surface, we can spy a women walking up the external ramp towards the roof garden of villa Savoye, or watching a family chilling out on the roof terrace of villa Stein. According to Colomina, these fleeting apparitions are grasped furtively, there is not any eye-contact between these people and the camera, and the point of view is the one of a voyeur spying their domestic life. In a reversal of roles, in this case we -the observer- are the "intruder", the disturbing Unheimlich presence into a domestic private environment.

A further point is the recurrent "frightening" sensation to be observed, that one can grasp inside many Le Corbusier's articulated interiors. The presence of enjambments and the space fluidity, increase this property that is present even in some of Le Corbusier's early buildings like the already mentioned villa Turque. Here, at the upper floor, the presence of inner grating windows overlooking the hall remember the gratings from which enclosed monks see in monasteries. The same mnestic association is present also in the La Roche house, misrepresented by means of hollow voids dug into the inner facades of the hall.

\section{Polychromies: mnestic associations and camouflage architecturale}

Le Corbusier asserted to use in his interior polychromies, beyond the natural physical effects, also psychological effects connected to the emersion of subconscious memories. Since the project for La Roche house, he uses interior polychromies as a tool to modify the spaces' perception, amplifying or compressing them according to the needs and to the light conditions. As explained in the first volume ${ }^{17}$ of the Oeuvre Complete, colors allowed the "camouflage architecturale", an illusionistic device able to emphasize certain volumes or to hide other ones.

In the use of color in architecture ${ }^{18}$, Le Corbusier treasures his experience as a painter. Regarding the psychological reactions generated by colors, in La Peinture Moderne, he states: «in addition to the immediate and purely physical reactions of the different colors, we associate also mental impressions: we associate to the blue color the specific sensations of aerial, liquid, remote, deep, memories of all that appears with that color in nature: water, sky, distant objects; brown is terrestrial, green suggests vegetation and so on» ${ }^{19}$. Therefore, the colors' physical and psychological effects will be used in architecture together with their perceptive effects.

\footnotetext{
${ }^{16}$ CF. Rank Otto, “Der Doppelgänger”, in Imago, III. 1914, pp.97-164. Italian ed.: Il doppio: uno studio psicoanalítico. Milano: Se, 2001

${ }^{17}$ Le Corbusier, Oeuvre complete 1910-1929, vol. 1, 1929. Basel: Birkhauser, 1995.

${ }^{18}$ CF. Le Corbusier, "Polychromie architecturale". In Arthur Ruegg, Polychromie architecturale, Basel: Birkhauser, 1998.

${ }^{19}$ Ozenfant and Jeanneret, La Peinture Moderne. Paris: Ed. Grès, 1925. Italian ed.: Sulla pittura moderna. Milano: Christian Marinotti Edizioni, 2004, p. 226-228.
} 
Colors with different properties and emotional values will be applied on the walls' surface according to the optical experience.

In Le Corbusier interiors' the choice of colors is influenced by his personal remote experience, as the result of subconscious reminiscences of his youth's experiences and flashbacks of his travels. Inhabitants (and architects) tend to re-create past place experiences they treasure in their homes (or projects). Psychological studies ${ }^{20}$ demonstrated that people form an emotional attachment to these places and they want them to be just as psychologically confortable as they are physically confortable. Therefore, we attempt to have our homes similar to other places that have been satisfying in our life, seeing the sort of colors we remember from these settings, and this makes our experience more pleasant through tiny sensory flashbacks.

\section{Surrealist influence and illusionism}

Some scholars have noticed the presence of recurrent surrealist elements in the architecture of Le Corbusier, although he never acknowledged any relation with the surrealist movement ${ }^{21}$.

In L'Art Décoratif D'Aujourd'hui, he had harshly criticized Surrealists, arguing that their poetics was based on "real" objects, products of the machine age, instead of surreal "oneiric" objects issued from our deep remote unconscious $^{22}$. Le Corbusier quoted De Chirico, that on the first issue of the magazine Révolution Surréaliste (December 1924) wrote: "they are like levers, irresistible as these powerful machines, these gigantic cranes lifting, on the tingling building sites, floating fortresses with heavy turrets, as breasts of antediluvian mammals ${ }^{223}$. This stunning description of machines in motions on a modern building site, and the comparison to a prehistoric monstrous "antediluvian" creature depicts an uncanny scenario with elements belonging to the aesthetics of the machine age.

Nevertheless, even if Surrealists extol a "dramatic" romanticism, they used always real "functional" objects. These real objects are the "magnificent fruit of the machine age, to which we are so little accustomed that they intertwine them with their dreams" muddle,24. Le Corbusier reaches the conclusion that "real" and "functional" objects, issued from the machine age, lead to a new concept of beauty, consequence of the Esprit de l'époque. According to Le Corbusier, Surrealists seem frightened by modernity, and refuse to abandon the certitudes of their aesthetic habits in their surrounding environment and in their homes' architecture.

\footnotetext{
${ }^{20}$ Augustin Sally, Place advantage. Applied Psycology for interior architecture. Hoboken (New Jersey): John Wiley and Sons, 2009, pp.169-170.

${ }^{21}$ CF. Gorlin Alexander, "The ghost in the machine", in Mical Thomas (ed.), Surrealism and architecture. New York Abingdon (UK): Routledge, 2005, pp. 103-118.

${ }^{22}$ Le Corbusier, L'Art Décoratif D 'Aujourd'hui. Paris: Ed. Grès, 1925. Paris: Flammarion, 1996, pp 189-190.

${ }^{23}$ Quoted by Le Corbusier in L'Art Décoratif D'Aujourd'hui, p.190 (translated by the author).

${ }^{24}$ Le Corbusier, Ibidem, p. 190.
} 


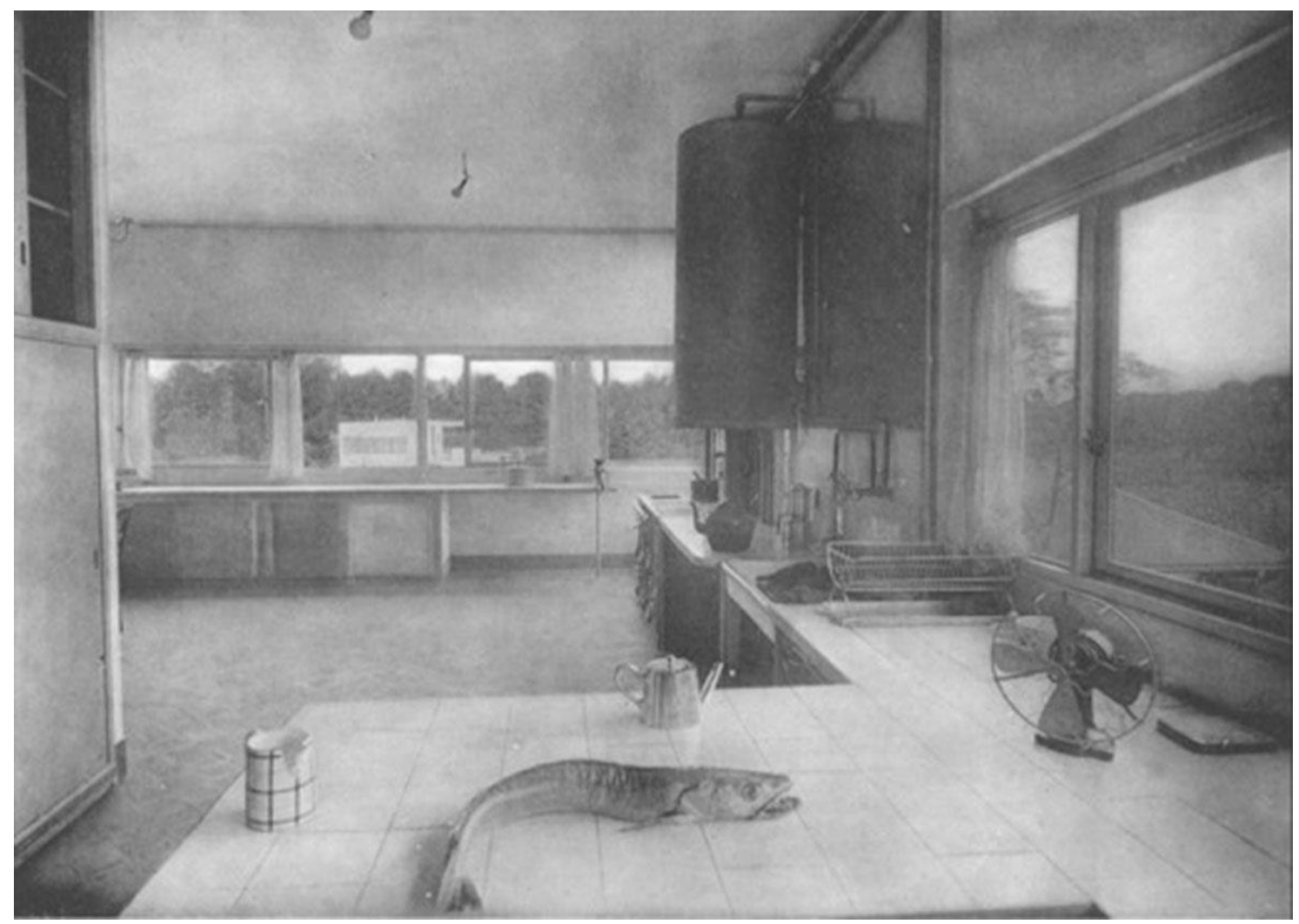

11. Villa Stein, kitchen (photo Georges Thiriet, FLC L1(10)53 OFLC-ADAGP).

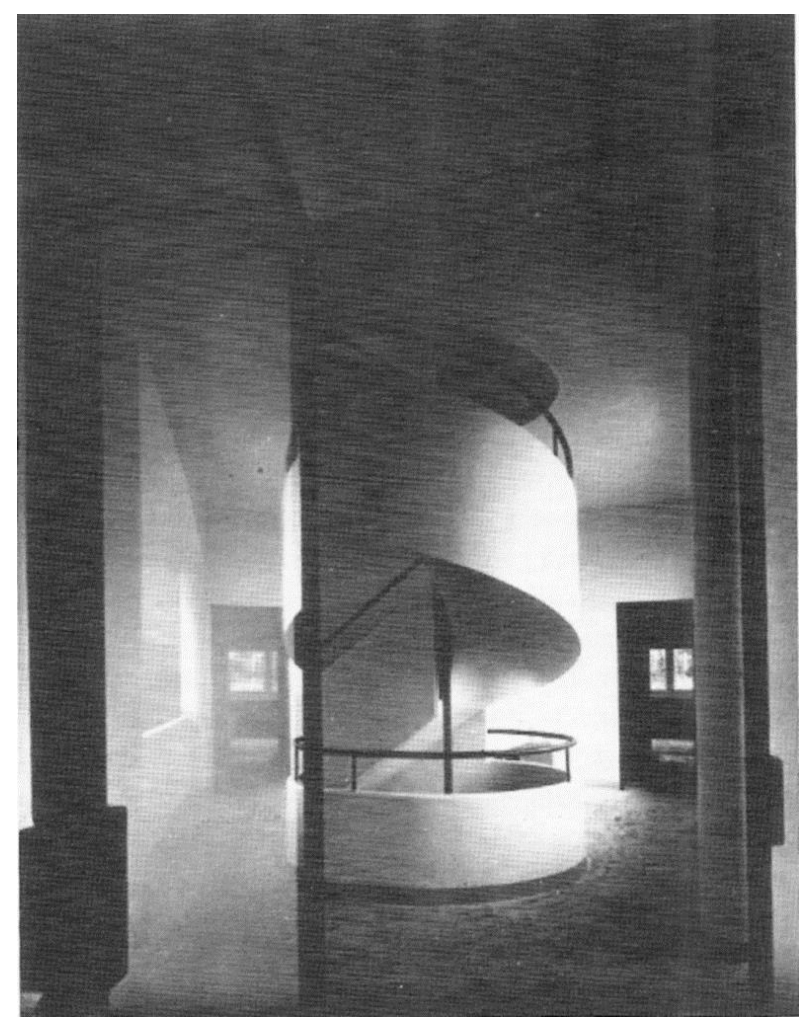

12. Villa Savoye, view on the staircase (photo Marius Gravot, FLC L2(17)139 CFLC-ADAGP). 
However, Le Corbusier had an intimate knowledge of the Surrealists' work, writing also in Surrealist magazines $^{25}$. Some views of his interiors, portrayed in photographs of the time, significantly look as proper surrealist stagings. As well as the Surrealists, Le Corbusier sought to jolt man's perception of the architectural space through the deliberate reversal of the expected. He also shared with them the goal of transcending the real, attempting to disclose the concealed order of the universe.

Optical illusionism and surrealistic effects are present, with different levels of ambiguity, both in Le Corbusier's architecture and in the photographs of his works. A surrealistic component is evident in many of the 1920s interiors photos, in which we often find unexpected presences. For instance, in a famous photo of the kitchen of villa Stein in Garches, there is a close up of a huge "uncanny" fish on the table, as a surrealistic objet-trouvé. The oversized dimension of the fish is further underlined by its isolation in the modernist abstract surrounding environment that amplifies his estranging power. Another photograph of the interior of villa Savoye, presents an intriguing illusionistic set up. This picture portrays a glazed door open on the inner staircase on the right. The glazed door reflects the corridor in front of it, giving the illusion of a virtual deeper space and amplifying its perception $^{26}$. Le Corbusier uses here photography as a tool to transcend (and distort) the space, producing a strong visual Unheimlich impact.

A particularly interesting case of "surrealist" illusionism is present in a photograph of the interiors of the pavilion of the $18^{\text {th }}$ century in villa Church in Ville d'Avray, transformed by Le Corbusier between 1928 an 1929.

In this building, Le Corbusier used the whole range of window typologies of his architectural language, from "pan de verre" to the single conventional opening. Bruno Reichlin focused his attention on a window of the first floor, a modern version of the traditional window "trou dans le mur"27.

Here Le Corbusier attempted to achieve not only the space qualities of the traditional window, limit between interior and exterior, but also its psychological effects and latent symbolic meanings. The goal of this interior setting seems to be the staging of these meanings and values.

This rectangular window is a recessed pivoting case surrounded by a white frame in concrete similar to a painting frame and has the traditional proportions of a painting. A mirror covers the wall surface around the frame. This generates an ambiguity of perception between real (the window view through the glass) and fiction (the reflection of the mirror).

In the photo, a camera set on a tripod is visible reflected in the mirror. This unusual presence, together with two open books on the table reveals an "uncanny" presence in the room. It seems that somebody has been here and just left the room, and the observer feels a sensation of estrangement ${ }^{28}$. In another photo published on the Oeuvre Complete, the horizontal shelves of the wall library are reflected in the mirror, amplifying the room's depth to infinity and widening the space.

\footnotetext{
${ }^{25}$ Le Corbusier reviewed a "madman's" drawings in the Surrealist magazine Minotaure. Cf. Le Corbusier, "Louis Sutter, L'inconnu de la Soixantaines", in Minotaure 9, 1936, pp. 62-65. Quoted by Gorlin Alexander, op. cit.

${ }^{26}$ CF. Fanelli Giovanni, "Le Corbusier”, in Fanelli Giovanni, Storia della fotografia di architettura. Bari: Laterza, 2009, p.428-437.

${ }^{27}$ CF. Reichlin Bruno, "Per un'iconografia della finestra nell'architettura di Le Corbusier", in PSICON n 2-3. Firenze: w/o.pub., 1975.

${ }^{28}$ CF. Colomina Beatriz, Privacy and Publicity: Modern Architecture as Mass Media. Cambridge (Mass.) and London: The Mit Press, 1996. P. 327.
} 
Le Corbusier uses the mirror as an illusionist tool, to create a fictional staging in the interior design. As for his interior polychromies, the mirror becomes a powerful tool of camouflage architecturale, able to dissolve the wall. The windows lose its constructive significance: it is no longer a "hole" in the wall, as there is no longer wall, its perception is cancelled. This window was conceived as a proper painting. The solid frame detaches the opening from the mirror, characterizing it as a framed painting. The framed view of the landscape becomes a painting.

Le Corbusier clearly expresses his vision about the role of the painting into an interior space in Notes à la Suite ${ }^{29}$ :

"I admit (...) the easel painting (...) because we paint this way a work free of any surrounding environment. Free of any architectural context, separated from its background by a frame, surrounded by a frame, closed by a frame, (...) The modern architecture, new and healthy, (...) initiates us to the eloquence of walls. She brings a serenity that can be severe or joyful. The painting will come, at the right moment and at the right place, to bring meditative pleasures. In this house, where centres of gravity, of attraction, (...) affirm themselves, a painting will be, in those places, as the clear crossing of the perfect accord.

(...) Let's listen to the walls. They are the new eloquence of architecture. (...) in some privileged places (...) a painting sharpen the intensity of a mathematic place of this space construction"

This clarifies the mirror's function: it dissolves the wall, leaving the window-painting on the threshold that divides the space in two parts: the real and the virtual one. This threshold becomes one of the centres of "gravity" and of "attraction" of the house.

As well as in the La Roche house-gallery the painting acted as a proper "metaphysic catalyst" into the interior space $^{30}$, establishing a transcendent relation art-architecture, in the pavilion in Ville d'Avray the window-mirror holds a similar property.

The ambiguity produced by the simultaneous perception of the two antithetic spaces extols the quality of the window view, which appears as detached from the surrounding environment and floating in the virtual space of the mirror, generating an "Uncanny" optical illusion

Significantly, to explain the estranging qualities of this interior space, Bruno Reichlin assumed the presence of analogies with surrealist painting ${ }^{31}$. The ambiguity of perception of the dualism real-reflection generated by the mirror was compared to Magritte's mural painting Le Domaine Enchanté for the Knokke Casino in Belgium (1952), while Le Corbusier's expedient to show enclosed in a "painting frame" a view of the real world was associated to the painting Le bon sens (1945-46), where a painting frame is used as a base tray for some real objects.

\footnotetext{
${ }^{29}$ Le Corbusier, "Notes à la suite", op.cit. (translated by the author).

${ }^{30}$ For further deepening on the relation art-architecture, CF. Aglieri Rinella Tiziano, Dal cubismo al Purismo, arte e architettura nell'allestimento della collezione La Roche. Roma: Kappa Edizioni, 2010. See also an English and Portuguese reduced text in: Aglieri Rinella Tiziano, "Do Cubismo ao Purismo: arte e moradia na casa galeria la roche", (From Cubism to Purism-art and architecture in the La Roche house) in ARQTEXTO. October 2012, n.19. Porto Alegre: Departamento de Arquitetura e PROPAR-UFRGS, 2012, pp.98-109.

${ }^{31} \mathrm{CF}$. Reichlin Bruno, "Per un'iconografia della finestra nell'architettura di Le Corbusier", op.cit.
} 


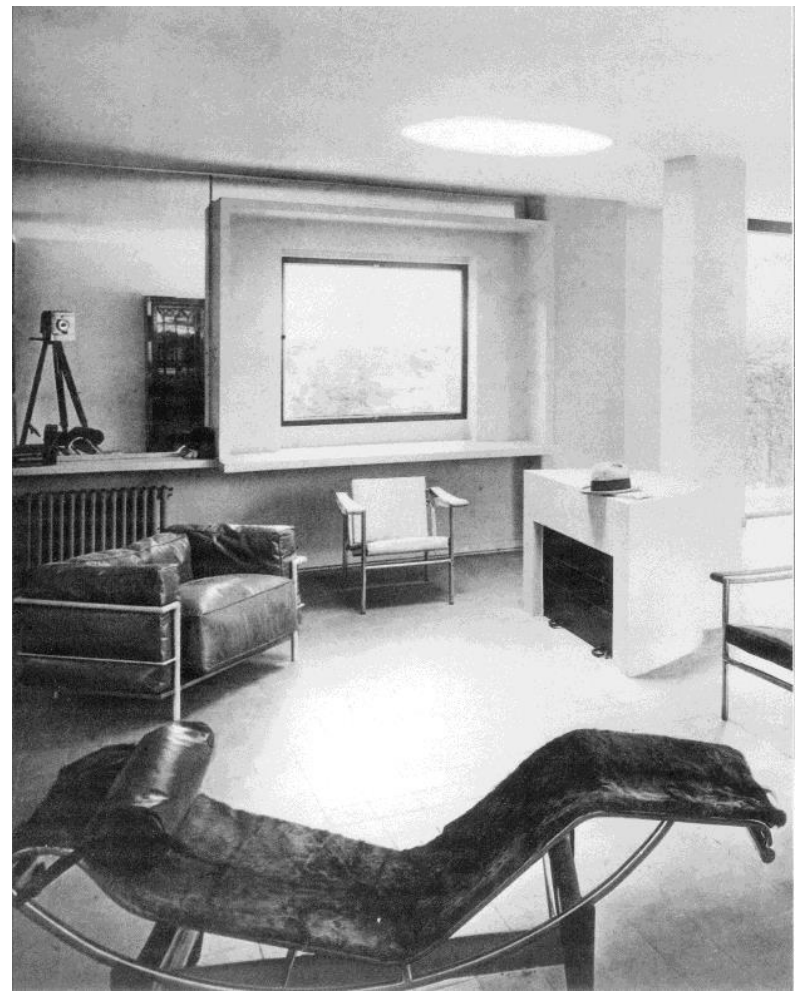

13. Villa Church in Ville d'Avray, living room (photo Georges Thiriet, FLC L3(7)89 CFLC-ADAGP).

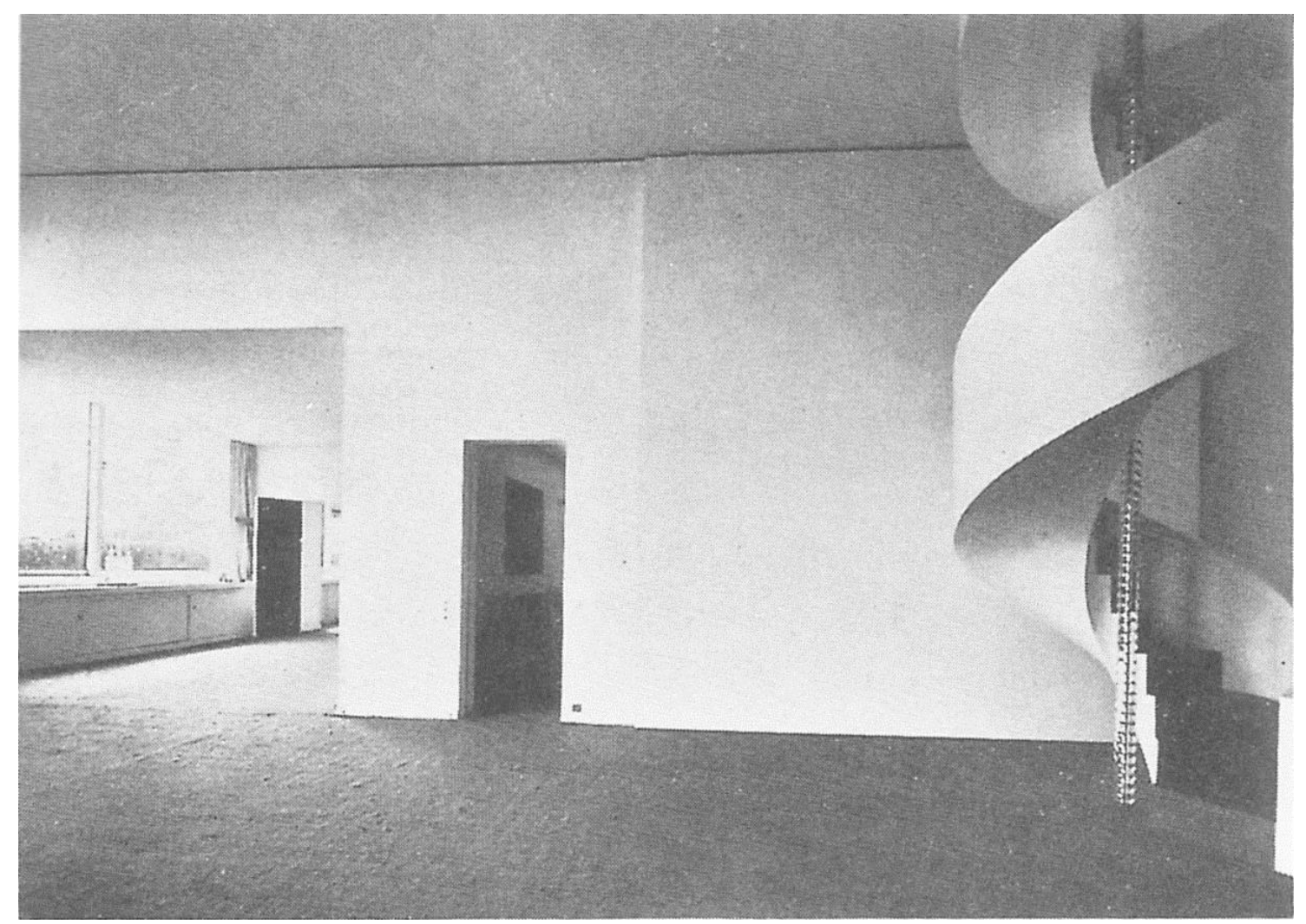

14. Penthouse for Charles de Beistegui, interior view (photo Marius Gravot, FLC L2(5)37 OFLC-ADAGP). 


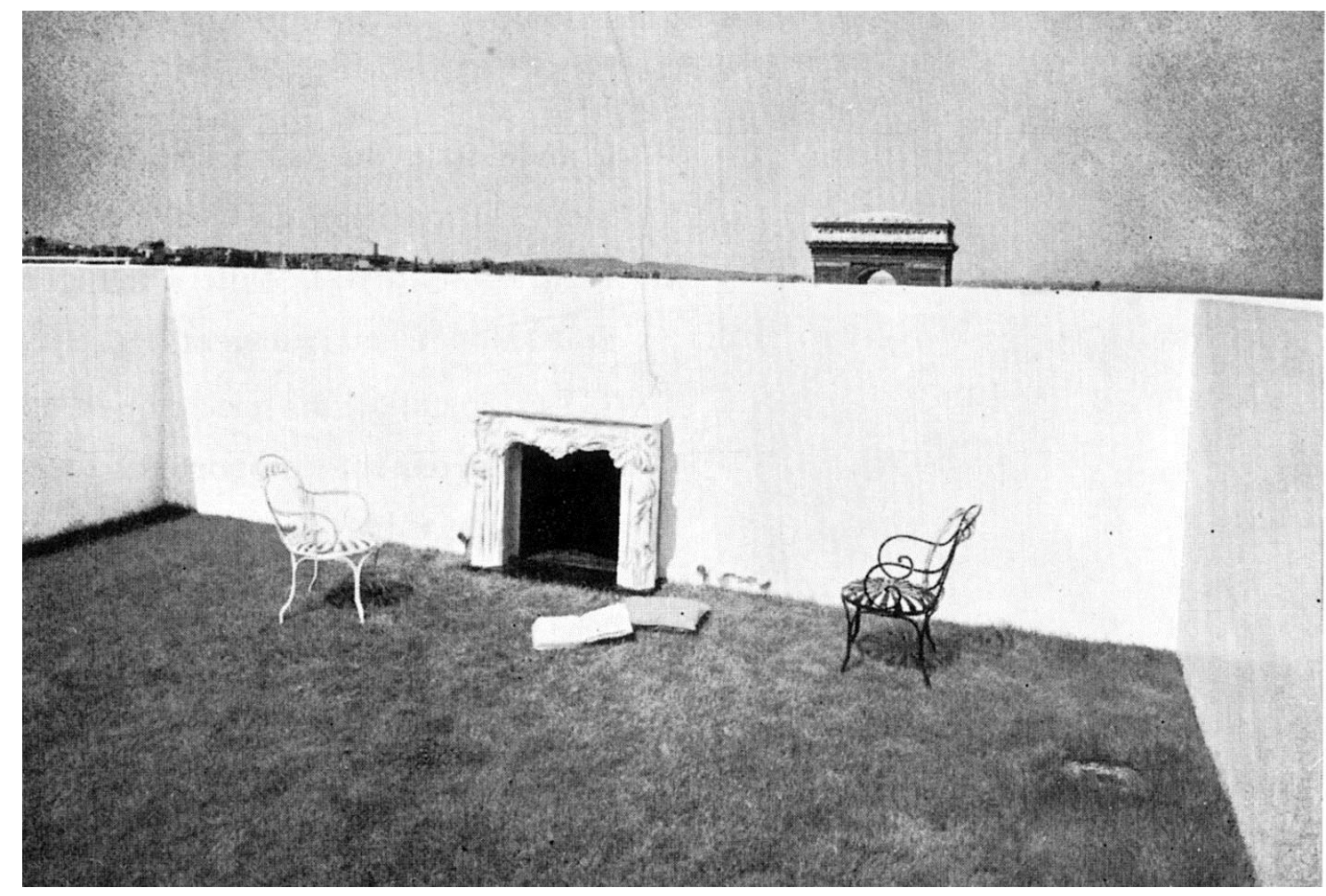

15. Penthouse for Charles de Beistegui, chambre à ciel ouvert, (photo Marius Gravot, FLC L2(5)23 @FLC-ADAGP).

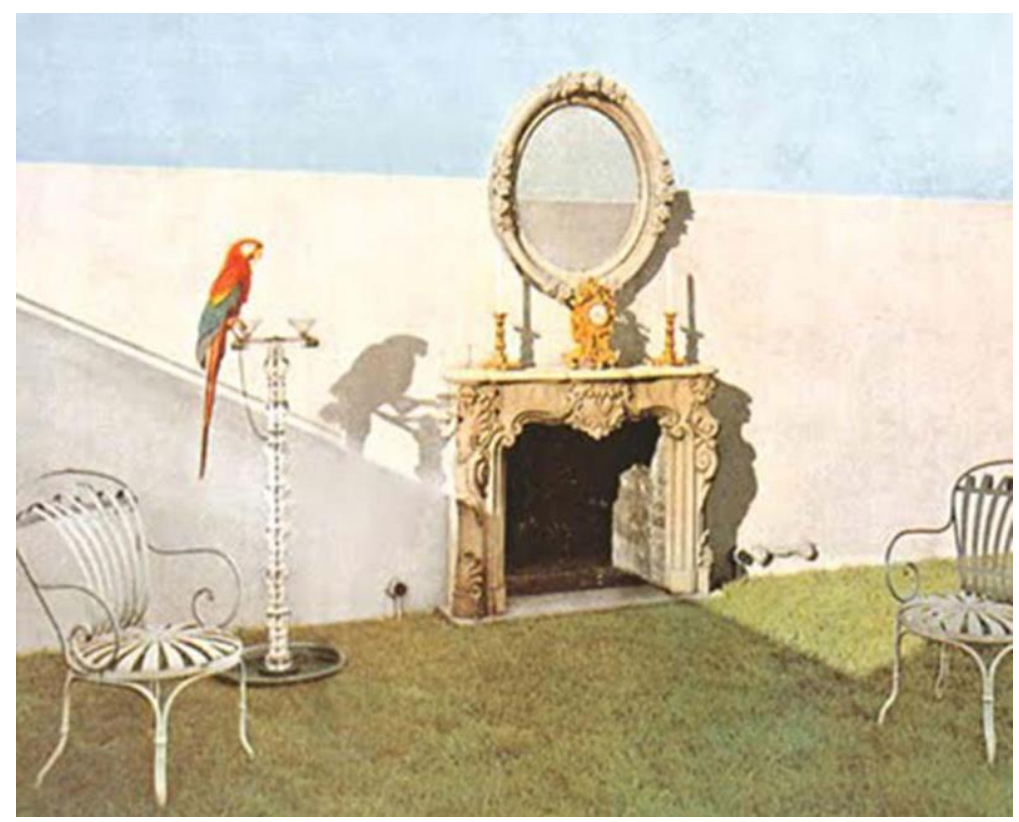

16. Penthouse for Charles de Beistegui, chambre à ciel ouvert, setting by Salvator Dalì (from «Plaisir de France», mars 1936 (CFLC-ADAGP). 
Le Corbusier will have a tangible opportunity to apply surrealistic devices to interior architecture with the project for the apartment of Charles de Beistegui, on the rooftop of a building on the Champs Elysées. Beistegui, a surrealist art collector, will have a fundamental role in the interior design and this decisive collaboration will produce the first proper surrealist work of architecture of the Modern Movement.

Unlike the projects previously analyzed, in the design of which Le Corbusier had the only preponderant main role, in the Beistegui apartment the final result is the consequence of the overlapping wills of two exceptional overwhelming personalities: the client and his architect.

Beistegui was an eccentric multi-millionaire who loved to organize memorable parties to which he invited many artists and celebrities of the time. The apartment was therefore not intended to be inhabited but to receive visitors and as a representative venue to host parties.

A first peculiarity was the absence of electric lighting in the apartment. The whole apartment was lit by candlelight. Electricity was used in the apartment, but only to move sliding walls and to open windows. Beistegui actually considered candlelight as the only "living" light. One could see in this choice a wish to create the characteristic cozy and spectacular flickering light of chandeliers in baroque banquets. Surrealists, and Beistegui, were obsessed by baroque theatricality and decorated furniture, and the overall atmosphere of the apartment during his parties had to be similar to the one pictured many years later by Stanley Kubrick in his famous movie Barry Lindon (1975, shot entirely by candlelight, without any additional artificial lighting). This reference to the baroque iconic imaginary is also evident in the surrealistic setting of the roof terrace, designed by Salvador Dalì upon request of Charles de Beistegui.

Clearly, in the Oeuvre Complete Le Corbusier portrayed the apartment without any furniture, which was chosen by Beistegui (who employed also Napoleon III chairs and Venetian chandeliers). Nevertheless, if the overdecorated styles were clearly in opposition to the abstract purist lecorbuserian architectural envelope, this estranging mixture produced an unusual environment, amplifying the objects' presence and underling the place's emotional tension.

The images of the chambre à ciel ouvert are particularly meaningful. Surrounded by white walls, the Parisian landscape disappears, except than for a few fragments of some "lieux sacrés de Paris" (the Arc de Triomphe, the Eiffel tower, the Sacré Cour), which tops appear over the walls. The abstract decontextualized space is enclosed between the sky and the grass floor. The fireplace doesn't have a real function, but its goal is just to "give a direction" to the space, focusing the attention on its presence. In the setting created by Dali, an oval mirror surmounts the fireplace, with an illusionistic effect similar to the one previously analysed in Le Corbusier's pavilion in Ville d'Avray: the mirror reflects the sky in his upper part (creating an ambiguity of perception between real sky and virtual reflection) and the top of the wall on his lower half (another ambiguity). Two traditional white chairs in wrought iron, a colorful parrot on a perch and some other objects complete the picture.

We don't consider Le Corbusier's opinion on this setting, which is certainly very far from his customs, but one should notice that the iron chairs are similar to the ones present in many roof-gardens designed by Le Corbusier, such as the ones of his personal apartment in rue Nungesser et Coli and of the Jeanneret-Raaf house.

Besides the settings personally arranged by Beisegui, the other photos of the terraces and of the (empty) interiors published by Le Corbusier in the Oeuvre Complete seem to express a latent metaphysic atmosphere, certainly accentuated by the absence of furniture. 


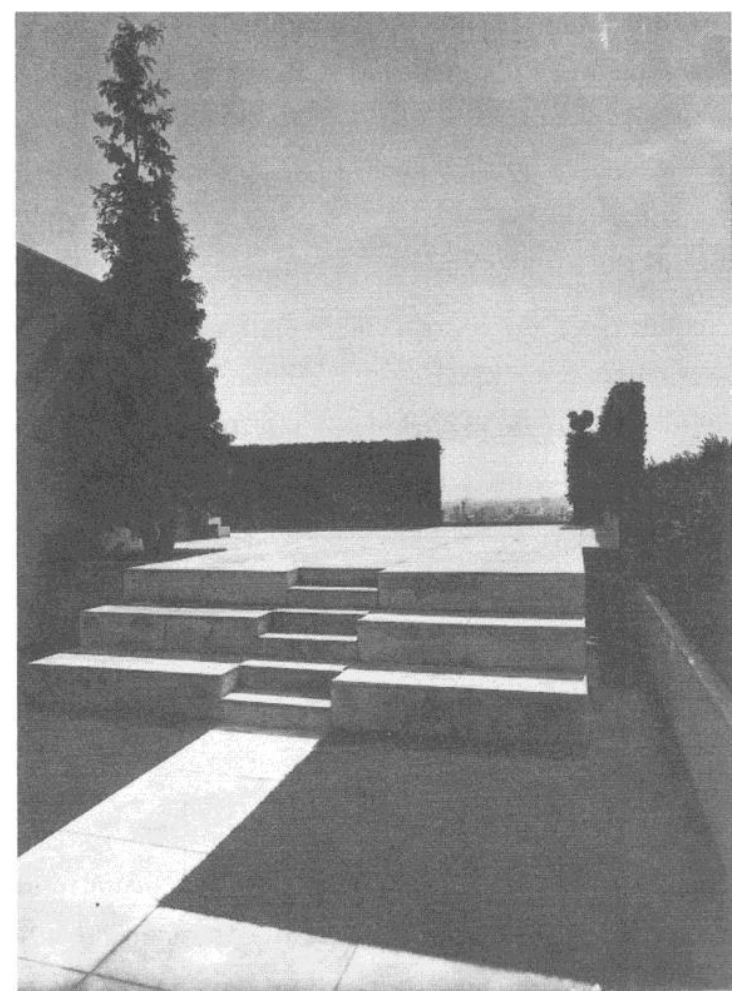

17. Penthouse for Charles de Beistegui, roof garden (photo Marius Gravot, FLC L2(5)21 CFLC-ADAGP).

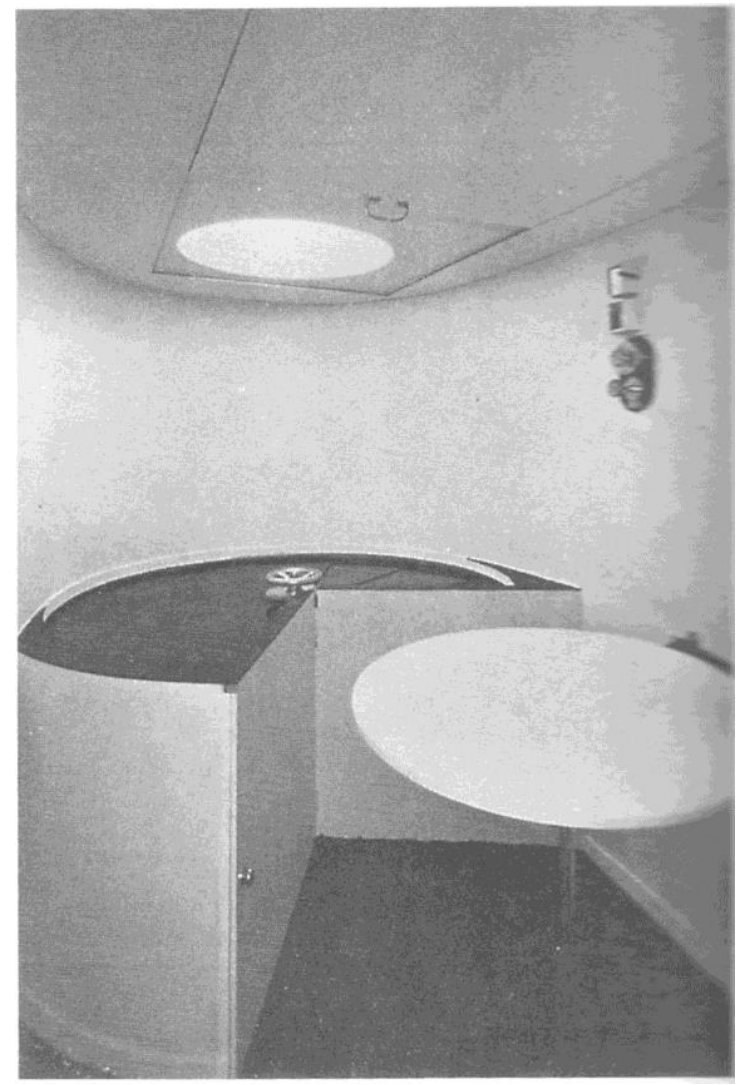

18. Penthouse for Charles de Beistegui, the camera obscura (photo Marius Gravot (FLC-ADAGP). 
Particularly interesting is the use of electric technology to slide partition walls, open doors and activate cinematographic devices (a projection screens automatically unfolds as the chandeliers rise up on pulleys). It is interesting to imagine the oneiric ambiance of this interior space, lit simultaneously both by low "living" candlelight and flickering cinematographic light, and its mesmerizing effect on the visitors.

As Colomina observed ${ }^{32}$, electricity was not used to illuminate, but as a technology of framing, to make visible or to hide landscape views. Le Corbusier's aim was to conceal the full panoramic view of Paris, offering instead framed views of its most representative elements. On one of the roof terraces, a hedge wall framed a view of Notre-Dame, isolated from its surrounding context. A button activated a sliding device to slip away the wall of greenery, revealing the hidden view of Paris.

In the interior space, the living room had two windows "framing" the Eiffel Tower to the south and Notre-Dame to the east. These views were treated as "pictures", in a way similar to the window-painting framing device used in the villa Church's pavilion.

Half of the south windows moved electrically, opening the view on the terrace where the Arc de Triomphe suddenly appeared. We can easily imagine the wonder of the visitors of the time, surprised by these unexpected discoveries and by the astonishing use of technology. The Apartment had multiple reframing devices, allowing visitors to experience amazing findings and revelations. This wish to surprise the visitor, to shock him with the unexpected, could be perhaps associated also to the eccentric personality of Beisteugi.

Le Corbusier however, had in this project the possibility to make use of the most advanced technologies of the time, for a very wealthy client. He applied these technologies to a space not intended to be a conventional "domestic" space, but rather a space for exclusive society events. Therefore, the whole project can be considered as a "frame" or a "stage" for the events organized by Beistegui. This explains the large use of theatrical (and even cinematographic) devices, which purpose was to surprise and excite guests.

By using framed views, Le Corbusier totally decontextualized the Parisian monuments, presenting them completely isolated as objets trouvées into an artificial environment. Their sudden discovery, as well as the subsequent revelation of the surrounding landscape (after opening the frames), had a powerful surprising effect on the visitors.

The place in which the decontextualization becomes absolute and the visitor plunged into an abstract immersive environment was the camera obscura with the periscope. Whereas the surrounding Parisian landscape was somehow denied on the roof terraces, hidden by high walls and greenery, here, in a closed darkened environment, the periscope projected the views of Paris on a glass table. As Tafuri asserted: "the distance interposed between the penthouse and a technological device, the periscope, secures the Parisian panorama. An 'innocent' reunification between the fragment and the whole is no longer possible; the intervention of artifice is necessary "33. Thus, with the periscope, Le Corbusier realizes a complete and radical decontextualization of the apartment from its surrounding city, settling a void distance between them. The house is suspended into an abstract space. The modern man is totally "estranged" and dissociated from its urban space, to which he no longer belongs. Le Corbusier seems here to consider the "uncanny" feeling associated by Walter Benjamin to the appearance of large modern towns, enclosing the wideness of the Parisian landscape into a small projection

\footnotetext{
${ }^{32}$ CF. Colomina Beatriz, op.cit., p. 301

${ }^{33}$ Tafuri Manfredo, "Machine et mémoire: The City in the work of Le Corbusier", in (Brooks Allen ed.) Le Corbusier. Princetown: Princetown University Press, 1987. Quoted by Colomina Beatriz, op.cit., p. 305-306.
} 
room. As Anthony Vidler observed ${ }^{34}$, "here, the privileged point of view (the one of the [...] observer that maintains a cautious distance from the market, looking at it from the 'cousin's window' with a telescope (...) is an attempt to preserve a feeling of individual security (...) in the apparent chaos of modern urban life ${ }^{\text {, } 35}$.

\section{Conclusions}

The domestic projects of the Twenties are significantly a projection of Le Corbusier's aspirations and dreams, in the heroic period of his ideological struggle for the modern architecture. Each house can be considered as a sort of "diagnostic box" of his psyche, able to reveal us his deep subconscious aesthetic dreams and obsessions.

Thus, the purist villas designed by Le Corbusier in this period are Unheimlich also because they show a vision of a possible future, as imagined by the mind of the most visionary architect of the XX century. Also, as Freud stated, often what is new is also worrying (thus «uncanny»). In the "pittoresque" articulation of volumes of the La Roche house and in the suspended pure volume of villa Savoye, there is perhaps an analogy with the imaginary future world envisaged by Fritz Lang in Metropolis, iconic science fiction film significantly issued in 1927, in the middle of Le Corbusier's purist period ${ }^{36}$. This comparison is particularly significant because both exemplify an ideal representation of a shared Zeitgeist, foreseeing new conceivable urban scenarios issued from the machine age.

I have tried to demonstrate, through a hermeneutic reading of some of Le Corbusier's major purist works that, being aware or not, he instinctively applied psychological devices to his architecture. This feature is more evident in interior spaces, as these places were often qualified as "abstract" environments, with different levels of decontextualization from their surrounding venue.

The minimalist setting of his interiors' photographs often provoke a horror vacui sensation that, according to the applied psychology, emphasizes the architectural value of the portrayed spaces and objects.

I analyzed a number of significant examples, focusing on their «Uncanny» qualities and attempting to disclose the emotional expedients used in the interior design.

Some of Le Corbusier's modernist interiors, from the La Roche house to villa Savoye, provoke to the visitors a strong sense of estrangement and disorientation, which Le Corbusier himself celebrated in the Precisions ${ }^{37}$ and that has been investigated by many scholars ${ }^{38}$.

These houses are not immediately recognizable as domestic interiors as, entering into them, there is no trace of the conventional familiar functions of human habitations.

The disorientation feeling is further intensified by the space interpenetration of solids and voids and by the elision of forms and functions, generated by the "enjambments" of modern architecture (issued from the pictorial tool of the marriage des contours). Thus, this composition of forms originated in a rational reflection on the

\footnotetext{
${ }^{34}$ Anthony Vidler, op.cit., p. 4.

${ }^{35}$ Walter Benjamin, "Uber einige Motive bei Baudelaire", op. cit., pp.605-53.

${ }^{36}$ I'm certainly not claiming of any direct relation between Lang and Le Corbusier, but I'm just underlining a sort of affinity of views in accord with the "esprit de l'époque".

${ }^{37}$ Le Corbusier, Precisions sur un état présent de l'architecture et de l'urbanisme. Paris: Ed. Grès, 1930. Paris: Altamira, 1994, p. 136.

${ }^{38}$ Beatriz Colomina has explored the sense of disorientation produced by Le Corbusier's modernist interiors. Cf. Colomina Beatriz, "Where are we?", in VV.AA., Architecture and Cubism, Cambridge (Mass.)- London: The MIT Press, 1997, pp.141166.
} 
modern world and conceived as a "spéculation plastique", is certainly the main feature that gives to these interiors astonishing visual power and disorienting "Uncanny" qualities.

Le Corbusier achieves in his interiors the abstraction of architecture, featuring a virtual place, a transcendental dimension suspended in time and space. On a more metaphysic level, in an endeavor to reveal a fragment of the concealed universal order of nature, he 'opened' a door towards the perception of the Unheimlich.

\section{Sources of images}

1. La Roche house, entrance hall, 1925 (photo Charles Gérard, FLC L2(12)73 OFLC-ADAGP).

2. La Roche house, hall, 1925 (photo Fred Boissonnas, FLC L2(12)74 (FLC-ADAGP).

3. La Roche house, door open to the garden (photo Fred Boissonnas, FLC L2(12)71 OFLC-ADAGP).

4. La Roche house, bedroom in 1926 (photo Fred Boissonnas, FLC L2-12-145 OFLC-ADAGP).

5. Villa Turque, view on the hall from the mezzanine (photo Tiziano Aglieri Rinella, 2003).

6. Villa Turque, plan (from: Garino Claude, Le Corbusier - La Villa Turque 1916-1917, Ebel, 1987).

7. Villa Savoye, entrance (photo Marius Gravot, FLC L2(17)61 OFLC-ADAGP).

8. Villa Savoye, kitchen (photo Marius Gravot, FLC L2(17)176 @FLC-ADAGP).

9. Villa Savoye (shot from l'Architecture d'aujourd'hui, Pierre Chenal, 1930 OFLC-ADAGP).

10. Villa Stein (shot from l'Architecture d'aujourd'hui, Pierre Chenal, 1930 @FLC-ADAGP).

11. Villa Stein, kitchen (photo Georges Thiriet, FLC L1(10)53 OFLC-ADAGP).

12. Villa Savoye, view on the staircase (photo Marius Gravot, FLC L2(17)139 @FLC-ADAGP).

13. Villa Church in Ville d'Avray, living room (photo Georges Thiriet, FLC L3(7)89 OFLC-ADAGP).

14. Penthouse for Charles de Beistegui, interior view (photo Marius Gravot, FLC L2(5)37 OFLC-ADAGP).

15. Penthouse for Charles de Beistegui, chambre à ciel ouvert, (photo Marius Gravot, FLC L2(5)23 OFLCADAGP).

16. Penthouse for Charles de Beistegui, chambre à ciel ouvert, setting by Salvator Dalì (from «Plaisir de France», mars 1936 OFLC-ADAGP).

17. Penthouse for Charles de Beistegui, roof garden (photo Marius Gravot, FLC L2(5)21 @FLC-ADAGP).

18. Penthouse for Charles de Beistegui, the camera obscura (photo Marius Gravot $\odot$ FLC-ADAGP).

\section{Bibliography}

Aglieri Rinella Tiziano, "Do Cubismo ao Purismo: arte e moradia na casa galeria la roche", (From Cubism to Purism-art and architecture in the La Roche house) in ARQTEXTO. October 2012, n.19. Text in English and Portuguese. Porto Alegre: Departemento de Arquitetura e PROPAR-UFRGS, 2012. pp.98-109.

Aglieri Rinella Tiziano, Dal cubismo al Purismo, arte e architettura nell'allestimento della collezione La Roche. Rome: Kappa Edizioni, 2010.

Aglieri Rinella Tiziano, Le Case La Roche-Jeanneret di Le Corbusier. Roma: Officina Edizioni, 2008, p.65-68.

Augustin Sally, Place advantage. Applied Psycology for interior architecture. Hoboken (New Jersey): John Wiley and Sons, 2009

Benjamin Walter, "Uber einige Motive bei Baudelaire", in Gesammelte Schriften, Vol. I. Frankfurt am Main: 1974. Italian ed.: "Di alcuni motivi in Baudelaire", in Angelus novus. Saggi e Frammenti. Turin: Einaudi, 1962 
Benton Tim, "Villa La Rocca, Die Planungs und Baugeschichte Der Villa La Roche". In Ein Haus für den Kubismus, Die Sammlung Raoul La Roche. Basel: Kunstmuseum, 1998.

Colomina Beatriz, "Where are we?”, in VV.AA., Architecture and Cubism. Cambridge (Mass.) - London: MIT Press, 1997

Colomina Beatriz, Privacy and Publicity: Modern Architecture as Mass Media. Cambridge (Mass.) - London: The Mit Press, 1996.

Fanelli Giovanni, “Le Corbusier”, in Fanelli Giovanni, Storia della fotografia di architettura. Bari: Laterza, 2009

Freud Sigmund, Das Unheimliche, 1919. Italian ed.: "Il perturbante" in Saggi sull'arte la letteratura e il linguaggio. Turin: Bollati Boringhieri, 1969.

Freud Sigmund, Die Traumdeutung, 1899. Italian ed.: L'interpretazione dei sogni. Turin: Bollati Boringhieri, 1973.

Garino Claude (Ed.), Le Corbusier - La Villa Turque 1916-1917. La Chaux-de-Fonds: Ebel, 1987

Gorlin Alexander, "The ghost in the machine", in Thomas Mical (ed.), Surrealism and architecture. New YorkAbingdon (UK), Routledge, 2005

Le Corbusier, "Louis Sutter, L’inconnu de la Soixantaines”, in Minotaure 9, 1936

Le Corbusier, "Notes à la suite" in Cahier d'Art. March 1926, n.3. Paris: Editions A. Morancé, 1926

Le Corbusier, L'Art Décoratif D'Aujourd'hui, Paris: Ed. Grès, 1925. Paris: Flammarion, 1996

Le Corbusier, Oeuvre complete 1910-1929, vol. 1, 1929. Basel: Birkhauser, 1995.

Le Corbusier, Precisions sur un état présent de l'architecture et de l'urbanisme. Paris: Ed. Grès, 1930. Paris: Altamira, 1994

Le Corbusier, Voyage d'Orient, 1911. In Von Moos Stanislaus (ed.) Le Corbusier, Voyage d'Orient: 1910-1911. Paris: Villette, 2012

Ozenfant and Jeanneret, La Peinture Moderne. Paris: Ed. Grès, 1925. Italian ed.: Sulla pittura moderna. Milan: Christian Marinotti Edizioni, 2004

Rank Otto, "Der Doppelgänger”, in Imago, III. 1914, pp.97-164. Italian ed.: Il doppio: uno studio psicoanalítico. Milano: Se, 2001

Reichlin Bruno, "Per un'iconografia della finestra nell'architettura di Le Corbusier", in PSICON n. 2-3. Firenze: w/o.pub., 1975.

Ruegg Arthur, Polychromie architecturale. Basel: Birkhauser, 1998

Tafuri Manfredo, "Machine et mémoire: The City in the work of Le Corbusier", in (Brooks Allen ed.) Le Corbusier. Princetown: Princetown University Press, 1987.

Vidler Anthony, The Architectural Uncanny: Essays in the Modern Unhomely. Cambridge (Mass.)-London: The MIT Press, 1992. 


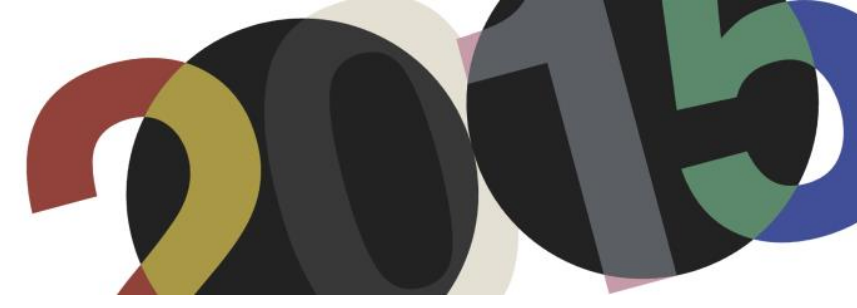

DOI: http://dx.doi.org/10.4995/LC2015.2015.1081

\title{
Reconstrucción de una pirámide borrada. Análisis de la Capilla Mortuoria encargada por Lucie Delgado-Chalbaud en Caracas, Venezuela, 1951
}

\author{
J. Alayón González, M. Dávila Cordido, O. Graterol Prado \\ Departamento de Diseño, Arquitectura y Artes Plásticas. Universidad Simón Bolívar
}

\begin{abstract}
Resumen: Este trabajo analiza, por diversos medios, el proyecto de la capilla mortuoria con dos tumbas para el expresidente militar Carlos Delgado-Chalbaud y su padre. El encargo, no realizado, fue el único que, tras varias tentativas, pudo ejecutarse en Caracas, Venezuela. Le Corbusier archivó este proyecto como un "Monument", y dentro de su trayectoria solo estuvo precedido por otro de carácter funerario dedicado al Mariscal F. Foch en la Porte Maillot de París y, posteriormente, diseñará su propia tumba en Cap Martin. Esto convierte al proyecto de Caracas, prácticamente desconocido, en un caso singular dentro de las tipologías funeraria y religiosa. La reconstrucción planteada se sustenta en la documentación conservada, el análisis histórico de las fuentes documentales, el empleo de la perspectiva clásica y las herramientas digitales para aportar precisiones y avances sobre estudios previos. En paralelo, la comparación con propuestas formales similares, enmarca el objeto de estudio dentro del legado del arquitecto. La pirámide ejemplifica la relación entre hombre y naturaleza, el "juego jugado por el hombre con los elementos cósmicos", el papel de la forma, y de las trazas reguladoras en un periodo en el que su racionalismo purista se abre a interpretaciones más expresivas de la forma. En el fondo de esta investigación subyace el interés por comprender el proceso proyectual de Le Corbusier y su idea de arquitectura en torno a los años 50, al tiempo que se reconstruye un proyecto prácticamente borrado.
\end{abstract}

Abstract: By several methods, this work analyzes the project for the mausoleum with two tombs for the former military president Carlos Delgado Chalbaud and his father. The unrealized commission was the only work that could have built in Caracas, Venezuela. Le Corbusier archive this project categorized as a "Monument" and in his career, it was only preceded by another funerary project dedicated to Mariscal F. Foch located in Porte Maillot in Paris, France. Only there was another funeral project: his own grave at Cap Martin. This makes this virtually unknown project in Caracas, a singular case framed within the funeral and religious categories. The proposed reconstruction is based on the preserved documentation, historical analysis of various documentary sources, the use of classical perspective and digital tools to provide clarifications and progress on previous studies. Parallel, comparisons with similar previous and subsequent formal proposals frames the object of study in its entire legacy. The pyramid illustrates the relationship between man and nature "the game played by the man with the cosmic elements", in a period in which his purist rationalism opens to a more expressive performances in form. In the background of this research lays an interest in understanding the design process of Le Corbusier and his idea of architecture around the 50's, while a virtually erased project is restored.

Palabras clave: Le Corbusier; capilla; Caracas; análisis; reconstrucción; pirámide. Keywords: Le Corbusier; mausoleum; Caracas; analysis; reconstruction; pyramid.

\section{Introducción. La pirámide borrada.}

Según explica Alejandro Lapunzina en su texto "La Pirámide y El Muro: notas preliminares sobre una obra inédita de Le Corbusier en Venezuela", el arquitecto suizo seleccionó el proyecto de capilla mortuoria en un borrador con el contenido del número 5 de su Euvre complète. Nombrado como "Monument Delgado Chalbaud", el proyecto de Caracas hubiese cerrado este volumen, que terminó recogiendo obras tan

\footnotetext{
${ }^{1}$ En Massilia. Anuario de estudios lecorbuserianos. Barcelona: Fundación Caja de Arquitectos, 2002, № 2002, pp. 148-161.
} 
significativas como la capilla de Ronchamp, la nueva ciudad de Chandigarh con sus edificios más representativos o la Unidad de Habitación de Marsella. También están incluidos el Modulor y su obra "Plástica y Poética" a través de pinturas, murales, esculturas y tapices. Sin embargo, nos parece más relevante el que hubiese compartido páginas con la casa del Dr. Curutchet —única obra en el subcontinente- y el "Plan de Urbanización de Bogotá", cuya finalización coincidió con el proyecto venezolano.

Las razones por las que fue finalmente descartada de la edición y que la copia del proyecto correspondiente a su taller haya desaparecido de su archivo se desconocen, pero la obsesión archivística de Le Corbusier alimenta diversas teorías basadas en causas más premeditadas que la perdida casual del material. No obstante, el hecho de que se conserve algo de ese proyecto descarta, a nuestro parecer, una acción consciente por eliminar u ocultar solo parte de la documentación.

Existe la posibilidad de que Jean-Claude Mazet, su ayudante en este proyecto y con quien sostuvo una tensa relación que desembocaría en un reclamo de honorarios mayor al pautado inicialmente, pudo haber sido quien conservara la copia del proyecto. Sin embargo, de haberse roto totalmente las relaciones entre ellos dos, parece poco probable que Le Corbusier hubiese incluido las observaciones que le hizo el arquitecto asistente sobre su Modulor, publicadas en su segundo volumen de $1955^{2}$. Otra hipótesis sostenida por Lapunzina, hace referencia a las confusas condiciones del asesinato del Coronel Carlos Delgado-Chalbaud, e incluso su reputación y trayectoria como político ${ }^{3}$.

Lo único seguro es que el material perdido lo constituyen 6 láminas -aunque Le Corbusier enumera 8 documentos - según la carta ${ }^{4}$ que anuncia a su cliente el envío, en correo aparte, de la carpeta del anteproyecto con la siguiente información:

DEL n ${ }^{\circ}$ 4344. Escala $5 \mathrm{~mm} / \mathrm{m}$. Plano de situación

DEL $\mathrm{n}^{\circ} 4345$. Escala $1 \mathrm{~cm} / \mathrm{m}$. Vista a vuelo de pájaro de la capilla y de su entorno.

DEL $\mathrm{n}^{\circ}$ 4346. Escala $1 \mathrm{~cm} / \mathrm{m}$. Planta baja con la disposición del altar y las tumbas.

DEL $\mathrm{n}^{\circ}$ 4347. Escala $1 \mathrm{~cm} / \mathrm{m}$. Alzado de la capilla y su entorno desde la vía de acceso.

$\operatorname{DEL~}^{\circ}$ 4348. Escala $1 \mathrm{~cm} / \mathrm{m}$. Vista de la capilla desde el otro camino y dentro del recinto.

DEL $\mathrm{n}^{\circ}$ 4349. Escala $1 \mathrm{~cm} / \mathrm{m}$. Perspectiva interior de la capilla sola.

DEL $\mathrm{n}^{\circ}$ 4350. Escala $1 \mathrm{~cm} / \mathrm{m}$. Perspectiva de la capilla en el interior del cercado.

$\operatorname{DEL~}^{\circ}$ 4351. Trazos reguladores que determinan la armonía del proyecto.

De estos planos solamente se conservan cuatro fotografías de la carpeta abierta mostrando las cuatro primeras láminas y dos dibujos que podrían corresponder al 4349 y 4350. De las dos vistas de la lámina 4348 y de los trazos reguladores que contendría la última, solamente quedó el boceto de preparación del documento 5 .

\footnotetext{
${ }^{2}$ El texto al que hacemos referencia dice: "El Sr. Jean-Claude Mazet, arquitecto, observa una grave falta debida a mi ignorancia (que, por desgracia, ise extiende a todos los dominios!)”, a continuación enumera las observaciones que le hace Mazart. Ver: Le Corbusier: El Modulor 2. Buenos Aires: Editorial Poseidón, 1962. pp. 40-41.

${ }^{3}$ Ver el apartado: "Carlos Delgado-Chalbaud y los acontecimiento que motivaron el proyecto", en: Lapunzina, Alejandro: "La Pirámide y El Muro" pp. 149-151.

${ }^{4}$ FLC I2-08 32.

${ }^{5}$ FLC I2(8)52. En otro documento, el FLC I2-08 34, Le Corbusier deja una nota para Mazet en donde le solicita: “Faire le dossier Delgado-Chalbaud en photostat avec spirales en 2 exemplaires : un pour l'atelier et un pour le client".
} 


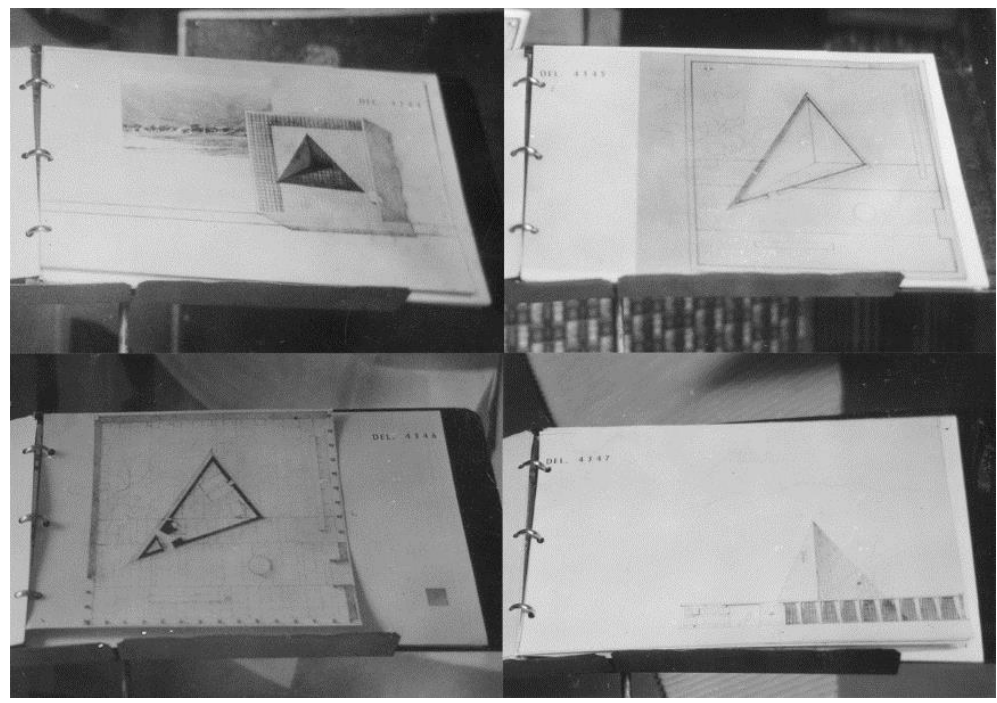

1. Fotografías de las cuatro primeras láminas del anteproyecto: DEL nº 4344, DEL nº 4345, DEL nº 4346, y DEL nº 4347. CFLC-ADAGP

Del lado venezolano es probable que un simple descuido o menosprecio haya llevado la carpeta que viajó a Venezuela, vía Nueva York ${ }^{6}$, al fondo de un basurero. Ni la familia Delgado-Chalbaud — que recientemente ha constituido una fundación_, ni el Archivo del Palacio de Miraflores (sede presidencial) ${ }^{7}$, ni la Biblioteca Nacional, ni el Archivo General de la Nación, todas instituciones consultadas para esta investigación, poseen dicha copia o noticia alguna al respecto. La poca tradición archivística venezolana y la destrucción accidental de parte de depósitos documentales tan importantes como el del Ministerio de Obras Públicas, nos dan pocas esperanzas de poder acceder a esa documentación que ha quedado perdida en el tiempo, entre París y Caracas.

El dossier I2-08 archivado en la Fondation Le Corbusier, conserva los documentos sobrevivientes ya mencionados, pero en su web tampoco enumera la capilla mortuoria entre la selección de sus obras no construidas (ver: Works $\rightarrow$ Architecture $\rightarrow$ Projects) ${ }^{8}$, pudiendo estar listada tras el "Plan Urbano de Bogotá" o los proyectos frustrados de Chandigarh de los años 50.

Nuestro estudio no pretende agotar el tema, pues los datos existentes solo permiten hacer algunas precisiones y ampliaciones sobre la "notas preliminares" de Lapunzina. Las hipótesis planteadas han tratado de demostrarse con distintos métodos y apoyándonos en el resto de la obra lecorbuseriana, buscando enfocar el borroso anteproyecto que el arquitecto dejó. El ejercicio de su reconstrucción se plantea en el marco de su arquitectura de posguerra, sin descuidar sus precedentes racionalistas, de los cuales la capilla tetraédrica es un ejemplo tardío que marca, justamente su transición de una concepción de la forma pura a una expresiva.

Intencional o casualmente, esta pirámide ha sido borrada, a pesar de ser uno más de los proyectos malogrados en el nuevo mundo. La capilla hubiese sido levantada en un espacio geográfico tropical, cerca del ecuador, a medio camino entre la argentina Casa Curutchet (1949-53) y el estadounidense Carpenter Center (1960-63), ambos

\footnotetext{
${ }^{6}$ Por intermediación de la Sra. Douce Correa, a cuya dirección en Nueva York hace el envío Le Corbusier.

${ }^{7}$ Durante el desarrollo de esta investigación, en el segundo trimestre de 2015, el Archivo del Palacio de Miraflores se está trasladando al Archivo General de la Nación por labores de conservación, no obstante, en consulta verbal realizada a su director, el Lic. Marcos Fuenmayor, el 29.04.2015, nos aseguró que en dos ocasiones anteriores había realizado la misma búsqueda sin éxito.

${ }^{8}$ Solo aparece en el apartado "Architecture-Alphabetical Index", en el bienio 1951-53, con los documentos 8 $\rightarrow 52$ bajo el nombre: "Caracas - Vénézuela. Chapelle commémorative pour les généraux Delgado et Chalbaud - 1951".
} 
extremos continentales y templados de sus dos obras americanas construidas. En cualquier caso, este trabajo redibuja y reconstruye la capilla para analizar el papel que tuvo en el contexto general de su obra, pues la pirámide caraqueña no fue ni la primera, ni la última que Le Corbusier diseñó.

\section{Las pirámides de Le Corbusier.}

\subsection{Arte.}

En sus pinturas de los años 20, los cuerpos geométricos simples que admiraba de la estética ingenieril los vemos representando botellas, vasos, copas, pipas, etc., conectados, superpuestos y, por supuesto exquisitamente calculados. Esas formas se organizan en base a relaciones geométricas que buscan una armonía perfecta. Las pirámides estaban en su lista de las grandes formas primarias, cuya imagen es "clara y tangible", por tanto, "formas bellas"10. No obstante, no aparecen de una manera explícita en los cuadros de esta época, solo las figuras cónicas son una aproximación. Nature morte du Pavillon de l'Esprit Nouveau, de 1924, o Trois bouteilles, de 1926, son dos pinturas en donde estas figuras aparecen en vista axonométrica evidenciando su base circular. Una representación frontal, sin profundidad ni sombra, podría confundirla con un triángulo o una pirámide.

En la década siguiente, en composiciones más planas como Adieu Von, 1932-1939-1957, pinta figuras triangulares, algunas de ellas contiguas, construyendo la imagen de un volumen piramidal irregular, también en proyección frontal. Pero es en la década del 50, coincidiendo con la construcción de las pirámides que estudiaremos, con obras como Taureau IX, de 1954 y Taureau X, de 1955, donde estas figuras se representan de modo más claro y, al mismo tiempo, complejo, debatiéndose entre agrupaciones de triángulos o pirámides, a veces vistas en planta o con caras sombreadas de colores distintos. El pintor Le Corbusier las representa como simples figuras de color plano o con gradaciones de colores distintos, ocasionalmente remarcadas por líneas negras que establecen claramente sus límites. Todavía en 1962, en Composition avec lignes géométriques jaunes, oranges, bleues, figuras similares definidas por estas líneas negras, son dibujadas superpuestas a otras triangulares de colores que no coinciden en todos sus lados. En soportes como la puerta de Ronchamp también son recurrentes estas formas y $\operatorname{trazos}^{11}$ y en los tapices para Chandigarh, la balanza de la justicia equilibra dos triángulos de distinto tamaño.

\subsection{Arquitectura.}

\subsubsection{Talleres de Arte. La Chaux-de-Fonds, Suiza.}

En un ejercicio temprano de búsqueda formal purista, los "Talleres de Arte" para su ciudad natal, CharlesEdouard Jeanneret empieza a materializar las influencias filosóficas y estéticas de Hippolyte Taine, quien defendía las formas clásicas como las más puras y simples. En este edificio que reuniría las enseñanzas de las artes y los oficios, el joven Le Corbusier persigue un equilibrio formal, absoluto y perfecto, en donde la pirámide es el centro de la composición escalonada. Algunos autores asocian el misticismo artístico de Le Corbusier con las lecturas de John Ruskin o el propio Taine y sitúan a "Los Grandes Iniciados" de Eduardo Schuré (1908),

\footnotetext{
${ }^{9}$ Le Corbusier: Hacia una arquitectura. $2^{\mathrm{a}}$ ed. Barcelona: Poseidón, 1977. p. 16.

${ }^{10}$ Ibíd.

${ }^{11}$ Fragmentos de estas obras pictóricas han sido reproducidas en algunos muebles del Pabellón Suizo, en la C.I.U.P.
} 
como obra fundamental en la formación del joven Jeanneret que vería los viajes iniciáticos y el legado pitagórico como el destino ineludible para afrontar un camino plagado de incomprensiones y de soledad en la búsqueda de la belleza. Probablemente en esas y otras lecturas sobre el arte antiguo, estaba el germen de su fascinación por la figura piramidal que brotaría en la década de los 50 con toda su carga histórica y simbólica.

\subsubsection{0 - 1955. Capilla Notre Dame du Haut. Ronchamp, Francia.}

El proyecto de esta capilla está íntimamente ligado al de Caracas, pues la venezolana se desarrolla en paralelo a la francesa, iniciada un año antes. Aunque la primera piedra en Ronchamp se coloca el 4 de abril de 1954, ya en los bocetos del carnet de Le Corbusier en su primera visita a la colina, durante la primavera de 1950, aparece el pozo lleno de volúmenes que recoge las aguas de la cubierta principal en la cara de poniente, por medio de una gárgola ubicada exactamente en el eje longitudinal del edificio ${ }^{12}$.

La relación más evidente es, precisamente, la utilización de dos pirámides, muy esbeltas, dentro del pozo ovoide y a nivel del suelo. A diferencia del resto de pirámides analizadas que se encuentran elevadas, en Ronchamp y en Caracas, las pirámides establecen relaciones claras de escala humana. Por la simultaneidad de los dos procesos de proyecto, Le Corbusier consulta al Padre Reverendo Couturière, de Ronchamp, sobre los aspectos rituales de la capilla tropical, y serán las "normas" del cura francés las que se tendrán en cuenta en los planos definitivos, que nunca llegaron a realizarse ${ }^{13}$.

Un tercer aspecto a considerar, sería el apilamiento en forma de zigurat, ordenado por Le Corbusier, con el excedente de piedras de la demolición de la antigua capilla de Ronchamp ${ }^{14}$. Aunque no se trate de una pirámide de cuatro o cinco caras es oportuno analizar su disposición en el conjunto de la colina de Ronchamp, pues no se encuentra dentro de un recinto claro como el resto de ejemplos.

Por último, Le Corbusier debió encontrar un sitio adecuado dentro del universo moderno y controlado para elementos que escapaban a su diseño en ambos casos. En Ronchamp, para la imagen tallada en madera de la Virgen de Notre Dame du Haut (finales del s. XVII) ${ }^{15}$, y en Caracas, para el vitral de Beauvais con la imagen figurativa de la Virgen de Coromoto que la Sra. Chalbaud poseía previamente y que pidió incluir en la capilla ${ }^{16}$.

\subsubsection{Capilla Mortuoria. Caracas, Venezuela.}

Así como el proyecto no llegó a concluirse, su nombre tampoco llegó a estar claro. Designaciones como Chapelle mortuaire, tal como definió el encargo Lucie Delgado-Chalbaud; Chapelle Funéraire, como aparece en los documentos del taller; Pyramide, como la llama Le Corbusier en su memoria, Monument Delgado Chalbaud, como se hubiese publicado en su Euvre Complète; o Chapelle commémorative pour les généraux

\footnotetext{
${ }^{12}$ Raramente se representan este pozo y sus cuerpos en los planos de la planta baja, mientras que suelen ser protagonistas de las imágenes tomadas a la fachada oeste, donde el sol de la tarde exalta el juego de estos volúmenes bajo la luz.

${ }^{13}$ Esta entrevista la menciona Le Corbusier en su carta a Lucie Delgado-Chalbaud del 26 de julio de 1951. FLC I2-08 33.

${ }^{14}$ Más tarde, terminaría convirtiéndose en monumento conmemorativo a los franceses caídos, y bautizada como "Pirámide de la Paz", para lo que Le Corbusier proyectó una columna con una paloma.

${ }^{15}$ Salvada por los zauvos antes de que los bombardeos de 1944 destruyeran la capilla original.

${ }^{16}$ Este tema pudo haber sido un motivo de desacuerdo entre arquitecto y cliente. De manera tangencial, Le Corbusier da a entender que él diseñará "el vitral solicitado", por lo que Lucie debe recordarle que el vitral existe y debe incorporarse a la capilla, dejando abierta la posibilidad de que él diseñe otros. FLC I2-08 33. Más adelante, Lucie le pregunta si cree que estos nuevos vitrales deberían representar los personajes difuntos, para lo que ofrece enviar fotografías de su padre y suegro, los cuales "podrían eventualmente ser estilizados". FLC I2-08-36.
} 
Delgado et Chalbaud, como lo lista la web de la Fondation Le Corbusier, son denominaciones para el mismo proyecto. Como sea, la de Caracas es una pirámide más de la tradición funeraria y una de las primeras del arquitecto suizo, quien acepta el encargo bajo la condición de que un arquitecto asistente, bajo su tutela, sea quien desarrolle el proyecto.

Como ya comentamos, Jean-Claude Mazet, arquitecto francés, que acababa de finalizar estudios de posgrado en la Universidad de Harvard, sería el encargado de delinear la tumba de los Delgado-Chalbaud. Al final, Le Corbusier, le hace saber a Lucie que se ha involucrado personalmente bastante en el proceso, aportándole "un cuidado extremo" 17 arrastrado por el entusiasmo que le causó el proyecto, afirmando "haber alcanzado una expresión arquitectural de notable dignidad" ${ }^{, 18}$, con la pirámide recubierta de cobre dentro de un recinto pétreo.

La solicitud de la Sra. Chalbaud fue recibida el 19 de marzo de 1951 y el 4 de abril siguiente Le Corbusier contesta que podría afrontar el proyecto si ella acepta las condiciones ya expuestas. Lucie da su visto bueno en carta fechada el 28 de ese mismo mes, correspondencia recibida en París el 9 de mayo. Sin embargo, pasan cuatro meses exactos desde la recepción del encargo hasta que Le Corbusier cita a Mazet para el jueves 19 de julio por carta enviada de su secretaria dos días antes ${ }^{19}$. Seguramente para ese momento Le Corbusier ya habría resuelto el diseño en sus grandes trazos. Así pues, al jueves siguiente, 26 de julio, el anteproyecto está listo para ser enviado a Caracas. Ese día, probablemente, haya sido el último que Le Corbusier le dedicó a la capilla venezolana ${ }^{20}$, pues en paralelo debía seguir pensando, entre otros proyectos, en Ronchamp y Chandigarh.

\subsubsection{Convento Sainte-Marie de la Tourette. Eveux-sur-l'Arbresle, Francia.}

En el caso del convento, la pirámide no se encuentra a ras de suelo, ni sobre la cubierta. El Oratorio de los Novicios, que es el espacio que cubre, es la suma de una estructura de dos pantallas intersectadas, en forma de cruz latina, sobre la que se apoya un cubo, y sobre éste, la pirámide. Aunque los tres niveles conforman una unidad — quizá evocando las torres románicas características de la arquitectura monacal, específicamente la de Le Thoronet que fue visitado por Le Corbusier expresamente-, cada elemento mantiene su identidad. Externamente, el arquitecto reduce la base de la pirámide para que se entienda la diferencia de los cuerpos geométricos y para disponer una canal que recoge las aguas de lluvia. Internamente, las cuatro paredes del cubo se prolongan en las caras de la pirámide que se juntan en la cúspide ligeramente inclinada hacia el centro del patio, en dirección suroeste. Ese desplazamiento del eje de la pirámide se ve compensado con el lucernario que se proyecta en la dirección contraria, buscando la luz indirecta del norte.

El Oratorio de los Novicios protagoniza el claustro del convento, aunque sin visuales claras sobre el mismo, salvo desde el balcón público de la portería. La torre cuadrada destaca en el paisaje de terrazas ajardinadas de distintos niveles de manera austera e incluso ligera a pesar de su solidez y opacidad, en un esfuerzo por tratar de elevarse hacia el cielo. También, como el lavatorio de Le Thoronet, la pirámide invade el espacio central y se puede ver, fraccionadamente, desde los pasillos del convento a través de los pans de verre ondulatoire.

\footnotetext{
${ }^{17}$ FLC I2-08 32.

${ }^{18}$ Ibíd.

${ }^{19}$ FLC I2-08 28.

${ }^{20}$ Meses más tarde intercambiaría las últimas cartas con la Sra. Chalbaud sobre la posibilidad de una posible demanda al gobierno, pero sin mencionar aspectos del diseño de la capilla.
} 
Sobre la cubierta del convento, la pirámide apenas despunta, interponiéndose a la línea del horizonte. En el interior, dos ventanas verticales, con vidrios de colores — amarillo a la derecha y rojo a la izquierda-, flanquean el altar que ocupa el centro, elevado sobre un podio de un escalón. El lucernario de la pirámide baña de luz el altar de frente, quedando de espalda al acceso.

\subsubsection{Palacio de la Asamblea. Chandigarh, India.}

En las primeras versiones del Palacio de la Asamblea, la cubierta es un plano deshabitado sobre el que, paulatinamente, irán apareciendo los volúmenes que terminarán conformando una de las imágenes más características de la nueva capital del Punjab. En una vista a vuelo de pájaro del palacio, fechada el 25 de agosto de $1955^{21}$, todavía la pirámide no es parte de la gran cubierta que brindaría la posibilidad de apreciar los fenómenos cósmicos, como la luna o el sol desde dentro del edificio. Su diseño debe producirse entre septiembre y octubre de ese año pues, los planos definitivos de la Asamblea fueron terminados en noviembre. No obstante, la idea de unos lucernarios estaba ya expresada en bocetos iniciales, justamente para explicar la conexión con el $\operatorname{cosmos}^{22}$.

La cubierta visitable, destinada a eventos, es una composición que funciona en dos escalas distintas: la del recinto de la cubierta y la del territorio circundante, sobre todo desde la explanada del Capitolio, en donde el observador puede entender el perfil claro de los volúmenes representativos de los dos niveles de la Asamblea (Cámara baja y alta) dispuestos sobre este gran techo. En la explanada, gran espacio conector de los poderes públicos, Le Corbusier construirá los "signos" y las relaciones que idearon la nueva ciudad: el Modulor, la espiral armónica, la torre de los cuatro horizontes, la Mano Abierta, etc., los cuales se ejecutarían en hormigón y "serían revestidos de color o de dorado según el caso, en madera revestida de hierro o de láminas de cobre",23, como en el caso precedente de Caracas.

La pirámide orientada al norte, cuya cara vertical y acristalada funciona como lucernario, se asienta sobre una base cuadrada que en realidad es el espacio cúbico de la Cámara del Consejo. Desde el exterior, esta base apenas más alta que el muro de fachada - al tiempo que queda escondida tras el muro perimetral permite elevar el volumen para que el arranque de la pirámide se pueda ver desde una distancia intermedia. De este recinto elevado que es la cubierta del parlamento solo emergen el casco hiperboloide de la sala de la Asamblea, la torre que da acceso al punto más bajo del casco, de manera tímida el prisma noroeste de uno de los dos accesos a la cubierta, y la pirámide que corona la Cámara del Consejo. Otros volúmenes quedan sumergidos.

\subsubsection{Museo Nacional de Arte Occidental. Tokio, Japón.}

En este último caso, Le Corbusier utiliza la pirámide también como un tragaluz que ilumina el espacio central del museo, una versión tardía de su modelo "Musée à spirale carrée". El volumen piramidal queda envuelto por otros cuatro lucernarios perimetrales que apenas permiten su visión desde fuera del edificio. Además, su ubicación en un lugar alto de la ciudad, dificulta que la pirámide pueda destacar y configurar la silueta de la caja arquitectónica y su reconocimiento desde distintos puntos de su entorno. Por el contrario, tiene un papel protagónico en el interior, en donde la pirámide vacía, llena de luz, corona la gran sala, que es el núcleo del museo. Aquí su base no cubre un espacio de dimensiones y forma similar, sino que se superpone, rotada, a la

\footnotetext{
${ }^{21}$ Publicada en: Le Corbusier: Euvre complète. Vol 6. Zurich: Les Editions d'Architecture, 1953. p. 95.

${ }^{22}$ Ver: Op. Cit. Vol. 5, p. 120.

${ }^{23}$ Ibíd. p. 153.
} 
ortogonalidad de los espacios, evidenciando el sistema estructural que queda a la vista bajo ella y potenciando el recorrido centrípeto del museo.

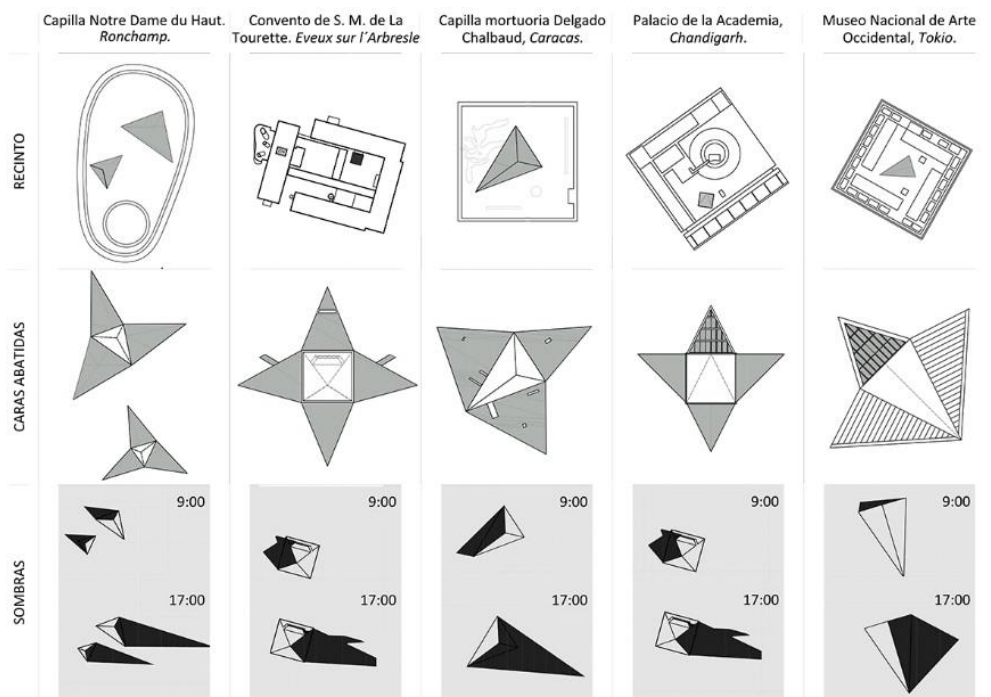

2. Cuadro comparativo de las pirámides proyectadas por Le Corbusier, mostrando: Recinto, Caras Abatidas, y Sombras de mañana y tarde respetando su latitud y longitud.
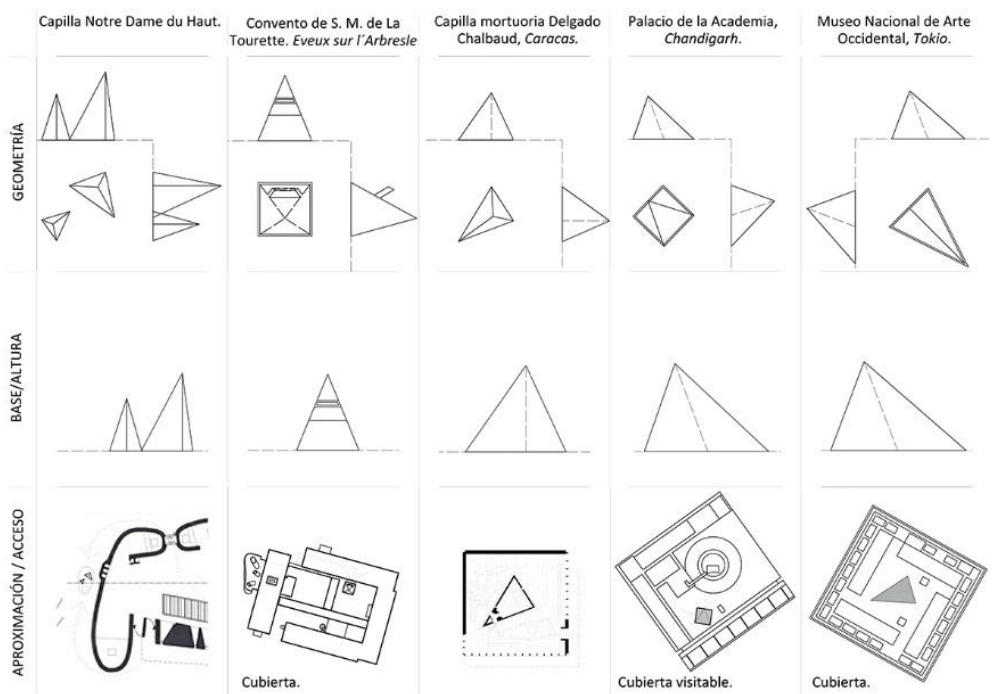

3. Cuadro comparativo de las pirámides proyectadas por Le Corbusier, mostrando: Geometría, relación Base/Altura, y Aproximación /Acceso.

\section{La pirámide reconstruida en su lugar.}

El nivel de anteproyecto en el que quedó la pirámide de Caracas nos obliga a establecer distintas hipótesis para aclarar, al menos, sus contradicciones e indefiniciones. La reconstrucción la iniciamos a partir de la documentación original conservada, es decir, las fotografías de las láminas del anteproyecto: la planta de ubicación, una planta baja, el alzado del acceso y la planta de cubierta. Una vez corregidas las deformaciones de las perspectivas de las imágenes y cuadrando la planta a una parcela de 20 x 20 metros, se delineó la misma. 
A pesar de su baja resolución, la fotografía de la planta permitió trazar con detalle el cerramiento de la parcela, el enlosado, el árbol y la planta de la pirámide. No obstante, la altura de corte horizontal no es única, ni estándar, y se superponen las proyecciones de las ventanas que están mucho más arriba, lo que dificulta el establecimiento exacto de estos vanos.

La planta redibujada certificaba que Le Corbusier, había establecido la cúspide de la pirámide en el centro geométrico de la parcela, solo nos falta determinar su altura. Para ello, escalamos la imagen del alzado hasta que el muro del recinto alcanzase los 2,26 $\mathrm{m}$ del Modulor, asumiendo que habría repetido la misma altura que en los umbrales de acceso - muy similares — de la casa Curutchet y de La Tourette. Con ello determinamos que la altura de la pirámide se aproximaba mucho a la 9,528 m —última medida de la serie roja lecorbuseriana ${ }^{24}$ — y así la fijamos. En paralelo, revertimos a su proyección cónica la perspectiva a mano alzada de Le Corbusier, asumiendo la misma altura de 2,26 para el muro, dando como resultado una altura de 20,28 m, lo que duplica nuestro otro dato. Descartada esta posibilidad, el resultado de esta comprobación revela la voluntad del arquitecto de proyectar una pirámide que se percibiera muy esbelta vista desde el lado sur.

Anclado ese punto central, la base de la pirámide empieza a definirse a partir de las trazas reguladoras que parten de las esquinas sur de la parcela y se cruzan en un punto sobre el eje norte-sur de la misma, a 2,26 m del muro norte. Los otros dos vértices son las medidas anterior y posterior en progresión aurea - tomadas perpendicularmente a sus linderos - en la escala Modulor. La forma resultante de estas trazas, es una pirámide irregular, pero matemáticamente definida, que apunta en su bisectriz mayor a la esquina suroeste del recinto, vértice que contiene la entrada a la capilla y el único visible desde la puerta del recinto.

Para el acceso a la capilla se repitió la altura estándar de 2,26 m, así como para los bancos 0,432 m. La mayoría de las medidas comprobables en la planta coinciden con algunas del sistema, como el tamaño de las losas de piedra del piso o los bajorrelieves de la fachada este. La forma, altura respecto del suelo y medida exacta de los vanos se definió cruzando la información de las perspectivas y la planimetría ya que solamente la ventana más alta es visible en el alzado conservado.

Comparando el despiece de todas las pirámides proyectadas por Le Corbusier, se puede observar que la de Caracas comparte con las de Ronchamp, su base triangular irregular. En el caso de Tokio, la base es un triángulo isósceles y su cara más pequeña se alza perpendicular con un ventanal, lucernario similar al de Chandigarh. Siempre que concibe los lucernarios como pirámides, éstos buscan la luz indirecta del norte, pero en Caracas, cerca del ecuador, el arquitecto abre vanos en las 3 caras de la capilla indistintamente, asumiendo además que facilitan la ventilación cruzada.

La breve descripción que envía Le Corbusier a la Sra. Chalbaud explica cómo se podría construir:

Le terrain de $20 \mathrm{~m} \times 20 \mathrm{~m}$. est entouré d'une cloture ajourée partiellement sur 2 faces, pleine sur la $3^{\circ}$ face et ajourée partiellement sur la $4^{o}$ face. Le dallage du sol est en pierre. Sur ce dallage se dresse la chapelle selon une pyramide à trois faces d'un tracé animé par les proportions et la mathématique, trace qui doit, à mon point de vue, conduire à une sensation rare et faire régner une harmonie.

Cette pyramide à trois faces permet de disposer l'autel et les tombeaux d'une façon subtile avec un éclairage efficace.

\footnotetext{
${ }^{24}$ En la tabla de medidas del Modulor del Atelier 35, de la Rue de Sèvres.
} 
J'ai eu un premier entretien au sujet des données rituelles de la chapelle avec le Révérend Père Couturier. Celui-ci examinera avec moi, dès mon retour de voyage, les plans d'après vos observations, les plans seront ainsi réalisés définitivement selon les règles.

Le sol et l'autel sont prévus en pierre. Les deux tombes seraient faites chacune d'une plaque de bronze fondue munie des inscriptions et symboles utiles (je dessinerai les plaques tombales). Les parois inclinées de la pyramide à l'intérieur seront de mosaïques noires et blanches; le vitrail demandé se trouvera au-dessus des tombeaux, je le dessinerai. La pyramide sera construite en béton mince de façon à éviter l'échauffement et la radiation sous l'effet du soleil. Cette pyramide serait revêtue de plaques de cuivre patinées vert de gris ; je pense que ce serait mieux ainsi (plutôt) que de faire dorer les plaques.

Sur l'espace déterminé par la clôture extérieure se trouvent deux bancs allongés de pierre et une plate-forme ronde à hauteur de siège pour s'asseoir.

Un arbre occupera une place justement désignée par les tracés. Je serais heureux de savoir quelle sorte d'arbre vous préférez de façon à donner à l'ensemble une présence vivante et amicale. En dehors de cet arbre, aucune plante ni fleurs, mais seule la simplicité du dallage de pierre du sol et l'accompagnement des montagnes que l'on voit fermer l'horizon au-dessus de la clôture prévue au projet. ${ }^{25}$

\section{La pirámide de Caracas: una sensación de armonía.}

La introducción del quinto volumen de sus obras completas ya mencionado, que resume su obra entre los años 1946 y 1952, está dedicada casi en su totalidad a su obra india y la escribió él mismo en marzo de 1953. El texto lo cierra reflexionando sobre los aspectos — como ya dijimos, él los define como signos—, "sobre los cuales son concebidos técnicamente el urbanismo y la arquitectura de Chandigarh" ${ }^{26}$ :

Ces signes sont les phases du jeu joué par l'homme avec les éléments cosmiques : homme et nature. Jeu des nombres, jeux du calendrier et de la journée solaires, jeu du soleil - sa lumière, son ombre, sa chaleur. Ce jeu fut précisément le travail de ma vie depuis toujours. Il gère, me semble-t-il, l'architecture et l'urbanisme.

Le cour ouvert, débordant, aux immensités intérieures de la réflexion, comme aussi à la grandeur toute maternelle du ciel, des plaines, des monts, des arbres, des plantes... notre univers tangible ${ }^{27}$.

Estos mismos signos son identificables en el proyecto de Caracas, cuando los edificios de Chandigarh todavía eran germinales. A través de nuestro análisis podremos evidenciar el juego de los números y del sol en torno a esta tumba, última morada y tránsito hacia el más allá, que sin embargo celebra "nuestro universo tangible". Como admite Le Corbusier, ese juego ha sido su búsqueda permanente, y si los signos — representación de algo - se potencian en los años 50, sus preocupaciones en los 20 por crear una arquitectura nueva "testimonio de un espíritu limpio" ${ }^{, 28}$, no desaparecen en su época madura. Por ello, Le Corbusier en el prefacio de la reedición de Hacia una arquitectura, en 1958, exige al editor mantener el texto original, sin cambiar nada, evidentemente para no transgredir un momento preciso de la historia pero, suponemos, también como reconocimiento a la vigencia de algunas de esas búsquedas prístinas.

\footnotetext{
${ }^{25}$ FLC. I2-08 33.

${ }^{26}$ Le Corbusier: Euvre complète 1946-1952. p.10. (Traducción de los autores)

${ }^{27}$ Ibíd.

${ }^{28}$ Le Corbusier: Hacia una Arquitectura. p. X.
} 
En la "Lección de Roma" de ese libro, Le Corbusier reproducía doblemente la Pirámide de Cayo Cestio (12 a.C.): por un lado, con una fotografía de la tumba del personaje romano atravesada por la muralla ${ }^{29}$, y por otro, su versión dibujada ${ }^{30}$, exenta, como una de las formas simples que desencadenan sensaciones constantes. Este monumento romano, por su carácter funerario ${ }^{31}$ y sus proporciones geométricas creemos que fue su principal referencia histórica para la capilla mortuoria de los Delgado-Chalbaud.

\subsection{La parcela.}

En carta escrita el 10 de marzo de 1951, sin preámbulos, Lucie Delgado-Chalbaud pregunta a Le Corbusier, si podría diseñar una capilla mortuoria con dos tumbas para su marido y suegro. El encargo es muy sencillo y concreto. La cliente solo especifica que el proyecto debe ser "sobrio y austero",32 para poder ofrecerlo como alternativa a otros "de mal gusto" ${ }^{\text {33 }}$ que el Gobierno está estudiando, por lo que considera este encargo como urgente. En la segunda carta, fechada el 28 de abril de ese mismo año, la Sra. Chalbaud acepta las condiciones del encargo, y envía una fotografía del terreno, especificando que sus dimensiones son de 20 x 20 metros, aunque su superficie no debería ser ocupada en su totalidad por la construcción de la capilla.

De esta imagen del Cementerio General del Sur de Caracas, solo se conserva la reproducción que acompañaba el "Plano de situación", en escala 1:200 de la lámina "DEL n4344". Se trata pues de la fotografía de una fotografía. En esta imagen, con muy poca definición, se intuye la parcela a través de dos sombras lineales que podrían ser el desnivel de la acera que conforman una esquina. En primer plano, todo está vacío y las pocas construcciones que se pueden adivinar se encuentran muy al fondo. Estas siluetas se recortan contra una masa vegetal, detrás de la cual una masa blanca asemeja un volumen horizontal con una torre.

\footnotetext{
${ }^{29}$ Ibíd. p. 24.

${ }^{30}$ Ibíd. p. 128.

${ }^{31}$ La larga tradición funeraria asociada a las pirámides es un argumento evidente en la elección de esta forma geométrica. Y dentro de esta tradición existen distintas versiones de la figura apuntada. La pirámide de Roma guarda una relación más estrecha — en sus proporciones_ - con las pirámides nubias de Meroe, al norte de Sudán o las egipcias de Deir el-Medina, que con las clásicas de Guiza. La pirámide de Caracas que Le Corbusier dibuja en sus perspectivas también persigue una esbeltez similar.

${ }^{32}$ FLC I2-08 17.

${ }^{33}$ Ibíd.
} 


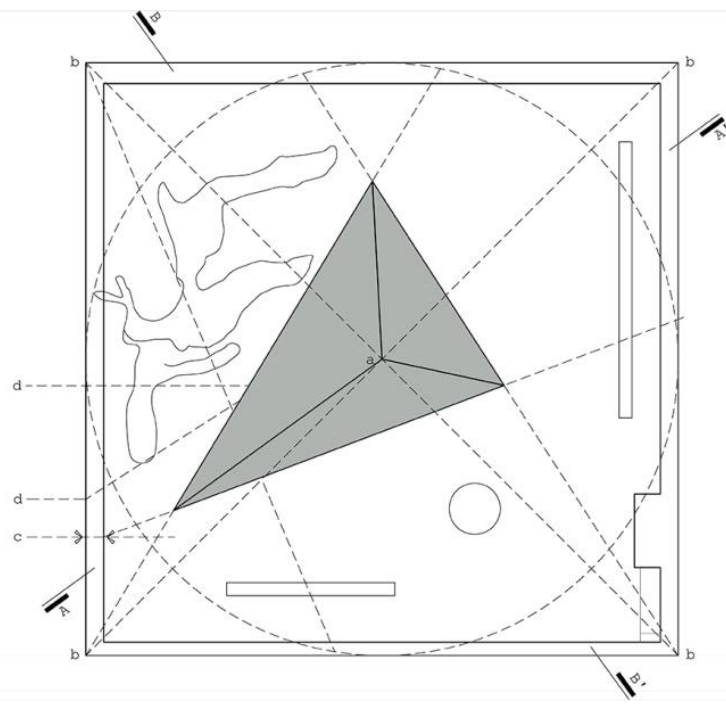

4. Planta de cubierta y trazas reguladoras.

En el plano de situación, el dibujo define solo una vía principal, con un ancho sin determinar, pero con una acera sobre la que se alinea una de las fachadas del recinto de la capilla. El acceso no está sobre esta acera sino en una cara perpendicular a ésta, en la esquina próxima a la vía que se asume como principal. No obstante, en el plano de la lámina "DEL n 4344", no se puede distinguir un acceso pavimentado. La sombra que arroja el muro de la parcela muestra un terreno irregular, sin construir y sin conformar el ángulo recto de una esquina.

Es difícil determinar si Le Corbusier obtuvo datos adicionales sobre la orientación de la parcela, pero la sombra proyectada en su plano de ubicación, generalmente representada al atardecer, nos hace concluir que la vía principal coincide con el lado sur. Otro dato que avala esta hipótesis es que justamente en el interior del vértice oriental de la pirámide, se encuentra el altar como dicta la tradición, convención que Le Corbusier ha respetado en Ronchamp, La Tourette y Firminy-Vert. Haya sido o no la orientación real de la parcela, Le Corbusier parece asumir estos puntos cardinales para su proyecto, en donde el sol de poniente proyecta una sombra que apunta al acceso del recinto y, al menos en ese momento del año, desde el acceso podrá verse el sol descender detrás de la cúspide de la capilla. Finalmente, aunque las dimensiones de la parcela donde se construyó el mausoleo aprobado por el Gobierno ${ }^{34}$, son distintas, su orientación es prácticamente la misma, por lo que no se descarta que se trate de la misma, aunque reducida ${ }^{35}$.

No se ha podido comprobar en los archivos del cementerio la titularidad inicial de esta parcela para establecer vínculos con alguna institución oficial que la haya podido ceder, ni un emplazamiento similar al de la foto. Por tanto, entre la correspondencia y documentos conservados no hay ningún dato objetivo que nos permita establecer con precisión la ubicación de la parcela dentro del cementerio más allá de lo ya argumentado. Le Corbusier asume la perfección geométrica del terreno descrito por su cliente para crear su propio universo interior determinado por la geometría.

\footnotetext{
${ }^{34}$ Proyecto del arquitecto venezolano Luís Malaussena.

${ }^{35} \mathrm{Si}$ bien el frente del mausoleo actual ronda los 20 metros de frente, su profundidad es aproximadamente 11 metros y en ninguno de sus lados existe un camino claro como para poder entender alguno de sus vértices como una parcela en esquina. Incluso, si se tratase de la parcela de la esquina más próxima de esa manzana, ésta tiene un ángulo agudo bastante acusado, descartándola como posible ubicación de la parcela cuadrada.
} 


\subsection{El recinto}

Coincidimos con Lapunzina en las referencias al templo primitivo publicado por el mismo Le Corbusier en "Hacia una arquitectura" como la primera fuente a la que acudir para entender esta capilla dentro de su propio recinto, su propio territorio. El arquitecto define este perímetro como una "clôture ajourée", una cerca calada que evoca más la presencia de un cerramiento ligero y transparente, que la del recinto amurallado que es, pese a presentar discontinuidades en algunos de los linderos.

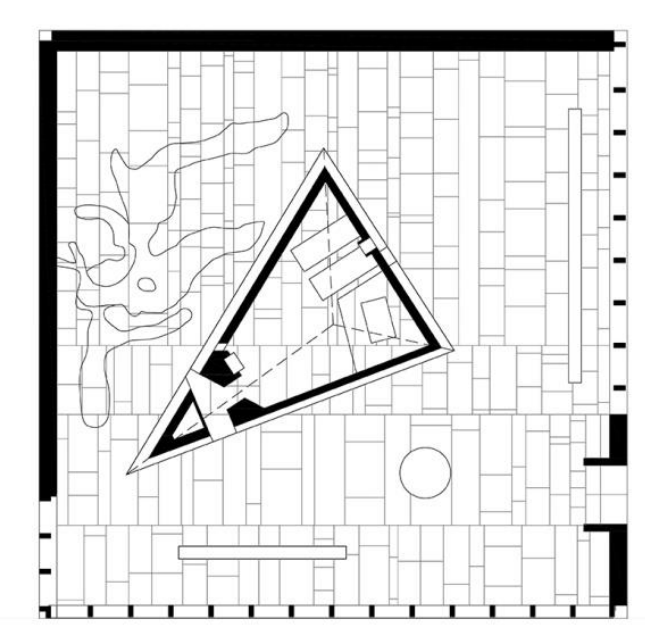

5. Planta baja de la capilla.
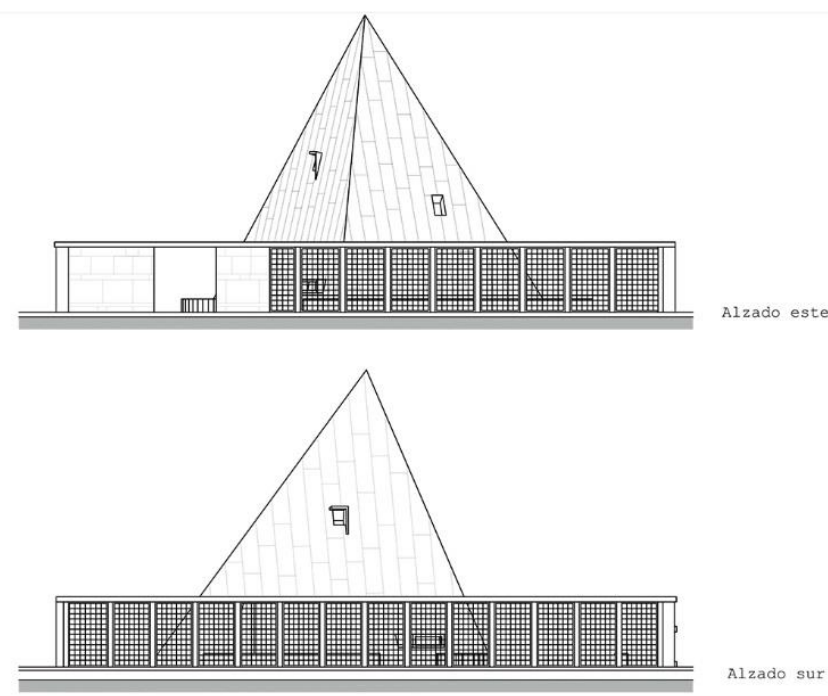

6. Alzados este y sur.

Volviendo sobre la borrosa foto de la parcela, la mayor certeza que podemos tener es que se trataba de un sector aun sin ocupar en sus inmediaciones. Un descampado sin más parámetros contextuales que las montañas que le rodean y el cielo. Y son precisamente esos dos elementos naturales los que Le Corbusier incorporará a su proyecto al no tener más detalles del lugar. 
El muro se convierte bajo estas condiciones en una primera operación arquitectónica, en la ocupación humana del entorno natural, en la materialización del encuentro entre el dentro y el afuera. Con ello, el arquitecto delimita un espacio, proyectado al cielo, en cuyo centro, según unos trazados reguladores levanta un volumen piramidal. La necesidad de dar una escala a la capilla mortuoria en un descampado, que con el tiempo se convertirá en un paisaje atiborrado de tumbas y mausoleos de las más variadas formas y tamaños, aísla al visitante del mundo terrenal, para introducirle en un espacio que se abre hacia arriba. Los bancos están dispuestos para que la pirámide siempre esté en primer término. Tras ella, el árbol, y tras él, el muro obliga a elevar la mirada hacia las montañas cercanas y al firmamento en último término.

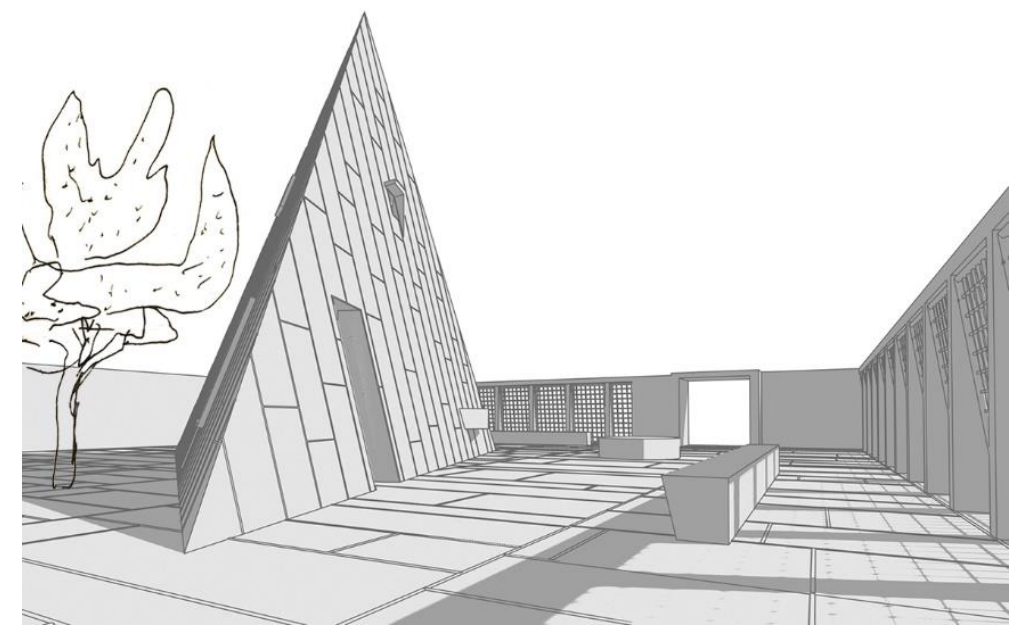

7. Vista de la capilla desde el oeste.

Aunque el recinto tiene una vocación cósmica, como en el caso de Chandigarh, el muro se comporta de manera distinta en sus cuatro costados. Al vaciar las esquinas exteriores, Le Corbusier mantiene la independencia de cada una de las caras. Hacia la vía principal, lugar donde no habría ninguna construcción próxima, es permeable y permite reconocer, a través de la cerca, la pirámide. Al naciente está el acceso, remarcado por un trozo de muro, mientras que el resto es igual que el sur: una sucesión de pilares rectangulares, cuyo intercolumnio lo ocupan vallas metálicas ${ }^{36}$ inclinadas hacia dentro. Sobre este trozo de muro una retícula de altos y bajorrelieves anuncian el vano que da acceso al recinto, a través de un umbral que marca de manera clara y dilatada el paso del exterior al interior. En el lado opuesto, el muro de poniente es el inverso, pues perfora la esquina próxima a la calle - abriendo la perspectiva sobre la vía principal - y el resto es un muro ciego, al igual que todo el lindero norte, evitando el futuro vecindario caótico de tumbas. De este modo, la diagonal que marca la dirección de la pirámide, queda reforzada por el fondo ciego que forman las caras norte y oeste, frente a las perforadas del sur y el este.

El enlosado en piedra natural define este espacio con líneas continuas norte-sur y líneas parciales este-oeste. Solamente dos trazas se interponen en sentido transversal generadas por el muro que contiene el acceso y que marcan una dirección, una especie de tapiz, que lleva hasta el acceso de la capilla. El volumen de la pirámide se asienta sobre esta trama sin interrumpirla, generando un gran dinamismo en su interior al no corresponder a ninguna de sus caras. Las líneas de las láminas de cobre que definen la superficie del volumen, paralelas entre sí

\footnotetext{
${ }^{36}$ Para la cerca perforada, Lucie comenta a Le Corbusier que al no haber mano de obra calificada, se podría, eventualmente, construir en Francia. FLC I2-08 36.
} 
y perpendiculares al suelo, refuerzan la esbeltez que perseguía Le Corbusier para su pirámide, al tiempo que su inclinación genera un contraste claro con la ortogonalidad del recinto.

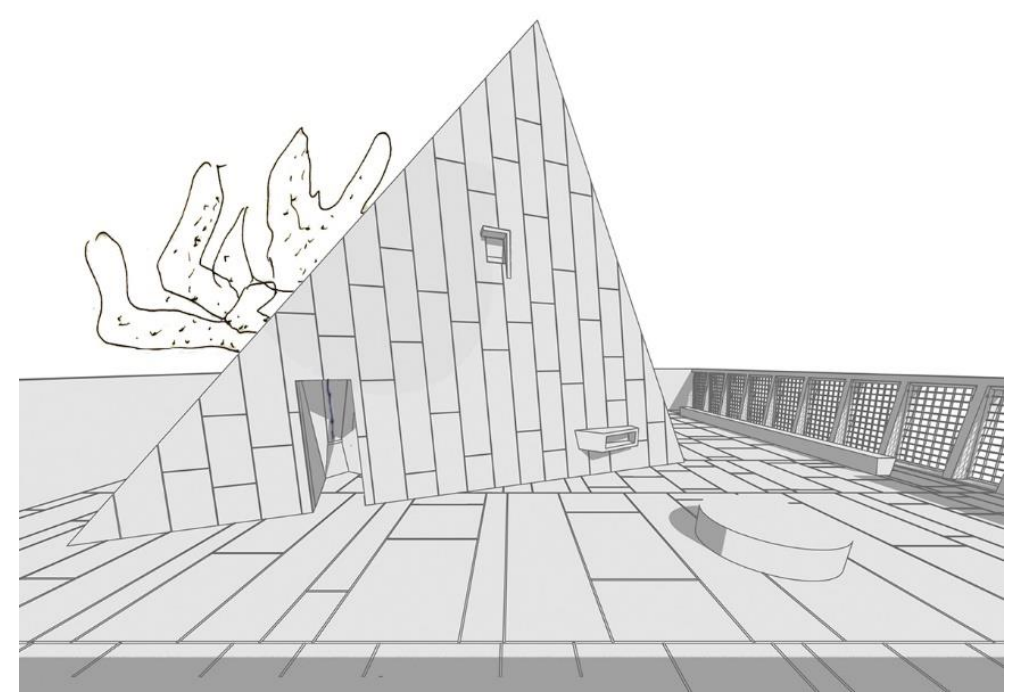

8. Vista de la capilla desde el sur.

\subsection{La pirámide}

La capilla tiene como base un triángulo escaleno, generador de un tetraedro irregular, sin ningún eje de simetría. Eje que sí tienen el resto de los ejemplos citados en este trabajo, salvo las escultóricas de Ronchamp. Esta figura irregular es, sin embargo, el resultado de unas trazas geométricas sobre el cuadrado perfecto de la parcela "que conducirán a una sensación rara y hará reinar la armonía"37. Al mismo tiempo, y aunque no lo explicita, el Modulor determina el resto de relaciones que Le Corbusier perseguía.

La respuesta sobria y austera del interior recuerda lo primitivo de la capilla paleocristiana de María in Cosmedin, recogida también en Hacia una arquitectura $^{38}$. La decoración se limita solo al uso de mosaicos —otra similitud con los primeros espacios católicos_- en grandes paños de color negro y blanco que buscan potenciar el efecto dramático de las entradas puntuales de luz. En ningún documento se menciona el uso de vidrios en estos vanos y menos si serían coloreados, como en el caso de Ronchamp. La capilla tiene seis huecos, dos con altura de una puerta - uno de éstos solo es una ranura para iluminar el acceso a la capilla —, y cuatro a distintas alturas que dejan pasar la luz controladamente al interior. Le Corbusier quería una iluminación precisa para marcar la presencia sutil de los elementos de la capilla: la entrada, las tumbas y el altar, manteniendo un ambiente en penumbra que invite a la reflexión y al recogimiento.

\footnotetext{
${ }^{37}$ FLC I2-08 33.

${ }^{38}$ Le Corbusier: Hacia una arquitectura. p. 129.
} 

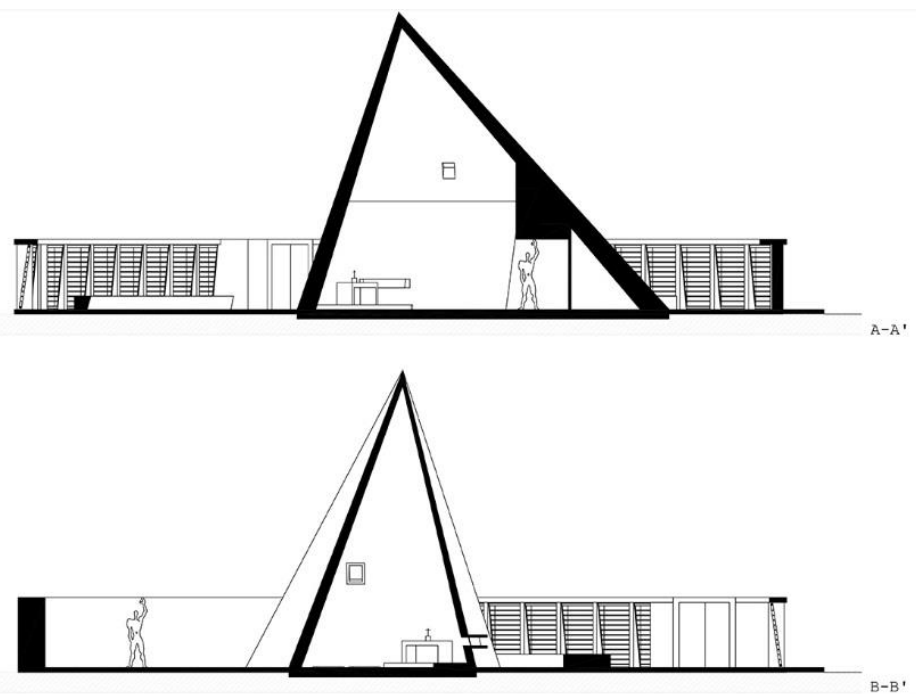

9. Secciones A y B.

El vano ubicado en la cara noreste contendría el vitral ${ }^{39}$, a 1/3 de la altura interior sobre las tumbas. A la izquierda de ésta, y a media altura aproximadamente, otro vano se abriría a la luz de poniente por la cara noroeste. En la cara sur, al costado del altar, una ventana baja y apaisada da claridad al lugar de celebración de la misa y un último hueco, a $2 / 3$ de la altura exterior, protegido del agua por una cornisa en forma de "L" invertida, cuela la luz por el punto más alto, al tiempo que evacúa el calor condensado en la parte alta de la pirámide ${ }^{40}$.

El ingreso se realiza a través del corte que secciona la punta suroeste de la pirámide. Ese espacio luminoso, dirigido a la contemplación del árbol, es sin embargo un espacio comprimido, de paso. A continuación, el espacio único, elevado y umbrío, se va revelando poco a poco, a medida que la retina se acostumbra a la poca cantidad de luz que traspasa los vanos. En la mañana, el vitral resplandecerá por el sol directo sobre su superficie de color. Por la tarde, el sol entrará por los huecos del lado oeste, pudiendo alcanzar las tumbas e incluso el altar. A la izquierda del acceso, una cavidad en el muro de gran espesor, nos hace pensar en la posibilidad de un asiento, o incluso un reclinatorio. El robusto altar reposa, como en La Tourette, sobre un escalón, mientras que las tumbas, con placas de cobre, se disponen rasantes con el suelo de piedra.

\subsection{El árbol}

Le Corbusier había dispuesto un árbol dentro del recinto, única presencia vegetal del conjunto —eliminando cualquier opción de otras plantas o flores-, el cual "daría al conjunto una presencia viva y amigable", pero dejaba la elección de la especie a la cliente. Ella expresaba su preferencia por el flamboyán (Delonix regia) y su espectacular floración naranja rojizo, pero admitía desconocer cuál sería el árbol más adecuado, tanto por su longevidad como por la leyenda asociada. Por esa razón, en carta del 15 de agosto de 1951, Lucie comenta a Le Corbusier que Carlos Raúl Villanueva le llevará a Francia en los próximos meses un libro sobre árboles venezolanos.

\footnotetext{
${ }^{39}$ Las dimensiones aproximadas que indica la Sra. Chalbaud son 40 x $50 \mathrm{~cm}$., pero la fotografía del mismo demuestra que se trata de una forma cuadrada.

${ }^{40}$ En el Oratorio de los Novicios de La Tourette, el vértice interior de la cúspide presenta problemas de humedades, pues la ventana queda muy por debajo de ese vértice oscuro y sin circulación de aire.

${ }^{41}$ FLC I2-08 33.
} 


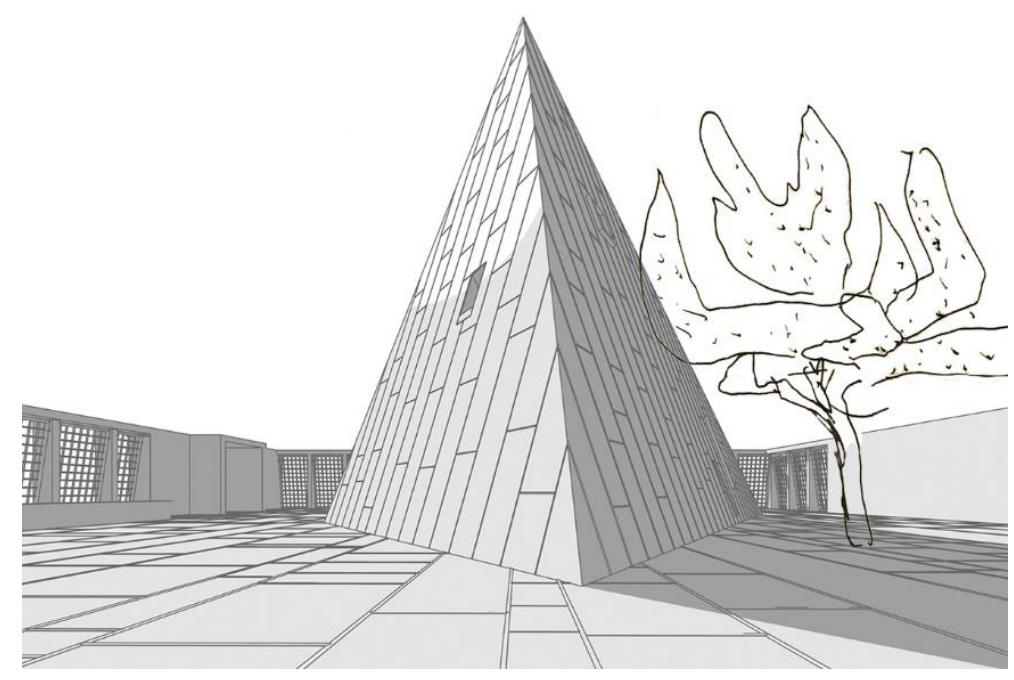

10. Vista de la capilla desde el norte.

El flamboyán propuesto, aunque posee el aspecto vivaz que interesaba al arquitecto, tiene forma de parasol, un tanto distinta a la copa con ramas ascendentes que dibuja Le Corbusier en la perspectiva ${ }^{42}$. A la postre, sus características morfológicas le habría hecho descartar esa especie, pues su desarrollo horizontal aéreo tocaría la pirámide dada su proximidad, y sus raíces superficiales e invasivas, tal como imaginó Alejo Carpentier en sus Pasos perdidos (1953), aprovecharían “...el descuido de canciones y siestas para arquear el lomo en todas partes, acabando en veinte días con la mejor voluntad funcional de Le Corbusier" 43 .

La posición de la única presencia natural del conjunto responde, por el contrario, a decisiones matemáticas, a un punto preciso dentro del campo espacial. Su tronco se vería a través del vano enfrentado al acceso de la pirámide, un corte en el volumen resultante de la línea que parte de la esquina noroccidental. Pero también hay otras razones estéticas y funcionales para situar el árbol en el lado oeste del recinto. La principal, proteger a la pirámide del sol de poniente, preocupación del arquitecto por el recalentamiento de la capilla. La otra, es su papel dentro del paisaje interior del recinto. Su vivacidad, es la cara opuesta de la muerte, de la severidad pétrea del muro, del suelo y de la pirámide. Es la forma natural que hace de fondo a la forma geométrica, que proyecta sombras orgánicas sobre el volumen afilado, metálico, escenificando el juego del sol y de los números, de la naturaleza y el hombre.

\section{Epitafio de formas y números}

La tumba de Le Corbusier e Ivonne, con el Mediterráneo al fondo, también es un cuadrado. Una base perfecta, sobre la que reposan dos cuerpos geométricos limpios, puros. Las letras escritas sobre la placa solo aportan datos, el verdadero epitafio son las formas y los números que las generaron. El sol hace hablar a esos números, revelando la belleza y claridad de los volúmenes.

Los trazados reguladores, decía Le Corbusier, son la solución al nacimiento fatal de la arquitectura. El pecado original del desorden, sería purificado por la matemática sensible, dotando a la arquitectura de euritmia, de

\footnotetext{
${ }^{42}$ FLC 33422. El cual usamos en las imágenes del modelo 3D: Figuras 7, 8 y 10

${ }^{43}$ Carpentier, Alejo, Los pasos perdidos. Madrid: Alianza Editorial, 2002. p.41.
} 
pulso, de vitalidad. La capilla mortuoria de Caracas, estuvo pensada y proyectada bajo esas premisas: formas y números capaces de convertirse en signos.

\section{Procedencia de las imágenes}

Fig. 1. Fotografías de las cuatro primeras láminas del anteproyecto. Archivo de la Fondation Le Corbusier. FLC I2(8)335-003 @FLC-ADAGP; FLC I2(8)335-002 CFLC-ADAGP; FLC I2(8)14 CFLC-ADAGP y FLC I2(8)13. CFLC-ADAGP.

Fig. 2. Cuadro comparativo de las pirámides proyectadas por Le Corbusier, mostrando: Recinto, Caras Abatidas, y Sombras de mañana y tarde respetando su latitud y longitud. Autores: Alayón, Dávila y Graterol.

Fig. 3. Cuadro comparativo de las pirámides proyectadas por Le Corbusier, mostrando: Geometría, relación Base/Altura, y Aproximación /Acceso. Autores: Alayón, Dávila y Graterol.

Fig. 4. Planta de cubierta y trazas reguladoras. Autores: Alayón, Dávila y Graterol.

Fig. 5. Planta baja de la capilla. Autores: Alayón, Dávila y Graterol.

Fig. 6. Alzados este y sur. Autores: Alayón, Dávila y Graterol.

Fig. 7. Vista de la capilla desde el oeste. Autores: Alayón, Dávila y Graterol.

Fig. 8. Vista de la capilla desde el sur. Autores: Alayón, Dávila y Graterol.

Fig. 9. Secciones A y B. Autores: Alayón, Dávila y Graterol.

Fig. 10. Vista de la capilla desde el norte. Autores: Alayón, Dávila y Graterol.

\section{Bibliografía}

Carpentier, Alejo: Los pasos perdidos. Madrid: Alianza Editorial, 2002.

Curtis, William: "Formas sagradas y connotaciones antiguas". En Le Corbusier: ideas y formas. Madrid: Hermann Blume, 1987.

Lapunzina, Alejandro: "La Pirámide y El Muro: notas preliminares sobre una obra inédita de Le Corbusier en Venezuela". Massilia: anuario de estudios lecorbusierianos. Barcelona: Fundación Caja de Arquitectos, 2002, $\mathrm{N}^{\circ} 2002$, pp. 148-161.

Le Corbusier: El Modulor 2. Barcelona: Editorial Poseidón, 1976.

Le Corbusier: Hacia una Arquitectura. 2ª Ed. Barcelona: Poséidon, 1977.

Le Corbusier: Euvre complète 1946-1952. Vol. V. Zurich: Les Editions d'Architecture, 1953. 


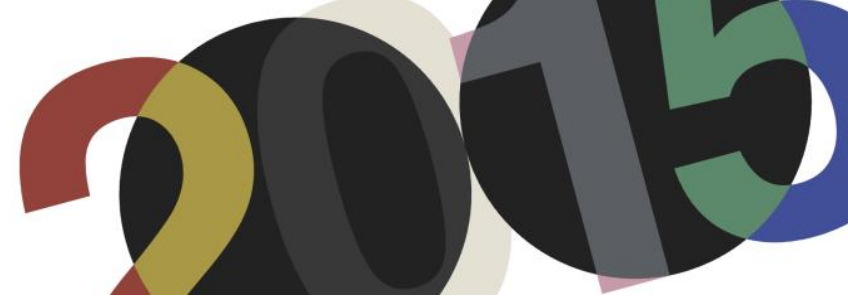

DOI: http://dx.doi.org/10.4995/LC2015.2015.1045

\title{
Les «Unités » Modulor dans la Philosophie de l’Espace de Gaston Bachelard
}

\author{
A. Alison
}

GerPhau, Paris, La Villette

\begin{abstract}
Résumé: Celui du Modulor est le premier exemple de la mesure humaine utilisée dans l'architecture. L'architecture de la moitié du vingtième siècle a été influencée par les projets de Le Corbusier. En même temps, la pensée de Gaston Bachelard s'évolue contextuellement au Mouvement Moderne et en 1957 le philosophe publie le célèbre ouvrage "La Poétique de l'espace ». Une bonne partie de sa pensée a été influencée par l'étude des quatre éléments naturels, par une conception de l'espace intime et par les différents développements de l'image de la maison. La description de la maison, dans les mots de Bachelard, correspond aux thèses principales de Carl Gustav Jung sur les différentes étapes de l'âme. Dans cette étude nous analysons les liaisons entre une conception intime de l'espace vécu et la pensée progressive de l'architecture moderne. A travers les exemples suggérés par l'Unité d'Habitation et par le Cabanon de Le Corbusier, nous voulons illustrer les dynamiques d'une philosophie de l'espace, émotionnelle, intime et secret.
\end{abstract}

Abstract: The Modulor is the first example of the human measure. The architecture of the second part of the twenty century was influenced by Le Corbusier works. The development of the thought of Gaston Bachelard is contextualized in the second half of the twentieth century too, he writhed the Poetic of the Space on 1957. His philosophy was influenced based on the study of the four natural elements, up to the conception of intimate space, namely that of the house. The Bachelard house description corresponds to the Carl Gustav Jung's theses about the soul life and the soul stadium. In this paper we analyse the correspondences between an intimate conception of the lived space and an architectural progressive thought. Throw the examples of Le Corbusier's Unité d'Habitation and of Le Corbusier's Cabanon we try to explain the emotional, intimate and secret dynamic of a current Space Philosophy.

Mots clés: Unités, Modulor, Architecture, Mouvement Moderne, Gaston Bachelard, Poétique de l'espace, Espace intime. Keywords: Unités, Modulor, Architecture, Gaston Bachelard, Space Philosophy, Intimate Space.

\section{Les mesures de l'homme.}

La mesure anthropocentrique du Modulor est énoncée pour la première fois en 1945. Après une longue gestation liée aux cordonnées de la Nature et du Cosmos, Le Corbusier nous présente sa nouvelle unité de dimension à travers ces mots : «Le Modulor est un outil de mesure issu de la stature humaine et de la mathématique. Unhomme-le bras-levé fournit aux points déterminants de l'occupation de l'espace, - le pied, le plexus solaire, la tête, l'extrémité des doigts le bras étant levé, - trois intervalles qui engendrent une série de section d'or, dite de Fibonaci. D'autre part la mathématique offre la variation la plus simple comme la plus forte d'une valeur : le simple, le double, les deux sections d'or ${ }^{1}$ ». Dans l'unité du Modulor nous avons la possibilité de voir comment s'établit un rapport entre les mathématiques et les dimensions humaines. L'exigence de Le Corbusier est celle de conjuguer l'importance de la présence humaine dans l'espace et celle de la construction d'un espace idéal pour un aménagement urbain à «dimension humaine ». La thèse principale du Modulor c'est que l'espace implique l'homme et vice-versa. C'est ainsi que tout l'espace peut être considéré à travers l'échelle de l'homme. Les étapes qui amènent à la construction de cette mesure, se basent sur le rapport qui implique l'homme à la Nature

\footnotetext{
${ }^{1}$ Le Corbusier, Le Modulor, Editions de l'Architecture d'Aujourd'hui, Paris, 1955, éd., Fondation Le Corbusier, 1983, page 55.
} 
et au Cosmos. Le rapport de l'homme avec son environnement nous suggère une comparaison théorique entre : les caractéristiques sociales et biologiques du Modulor et la pensée « $\operatorname{arché-cosmique~}^{2}$ » de la philosophie de Gaston Bachelard. Le Corbusier nous explique comment l'idée du Modulor naît par rapport à une exigence naturelle de la dimension humaine. Cela nous ramène aux thèses de Bachelard sur l'imagination matérielle ${ }^{3}$ et sur l'importance du rapport entre l'homme et les éléments naturels. Le Corbusier, dans ses premières architectures, mène une recherche des mesures-bases urbanistiques. Au cours de ses voyages en Europe il remarque dans les architectures harmonieuses des maisons des Balkans, des maison turques, des maisons grecques, tyroliennes, bavaroises, suisses, des vieilles maisons de bois du gothique français, et encore des petits appartements du faubourg Saint-Germain et du Petit Trianon, une hauteur de deux mètres entre plancher et plafond. Cela lui permet d'introduire dans ses études l'importance de la dimension humaine dans un espace habité. Dès ce moment Le Corbusier ne renonce pas à introduire cette hauteur «savoureuse » en se mettant même en contradiction avec les réglementations édilitaires. Un jour un des édiles d'une importante commune de Paris lui déclare : «Nous vous autorisons à transgresser parfois le règlement, car nous savons que vous travaillez pour le bien de l'homme ${ }^{4} »$. Le but de Le Corbusier est celui d'harmoniser le flux de la production mondiale. Cela nous permet de comprendre comment la figure du père de l'architecture moderne et puriste peut se rapprocher des thèses sur l'espace bachelardien ${ }^{5}$. Avec l'introduction de la dimension humaine, c'est-à-dire avec l'introduction d'un usage de l'espace intime et habité pour l'utilisation d'une échelle mondiale, Le Corbusier affirme son intérêt anthropocentrique. Le Modulor est donc un exemple de comment l'espace intérieur, l'espace profond, l'espace que Bachelard examine à travers la topoanalyse ${ }^{6}$, peut se projeter dans des exemples concrets.

\section{La philosophie de l'espace intime chez Gaston Bachelard.}

En analysant la position que l'architecture occupe dans la philosophie de Gaston Bachelard, nous voulons illustrer tout d'abord le concept de la dimension humaine comme fonction principale de l'habiter. C'est ainsi que le pouvoir de l'architecture s'inscrit dans les rapports de cause à effet de la dimension humaine. Si l'espace habité se développe autour du caractère de l'intimité, alors l'architecture est capable de reproduire l'unicité d'une dimension affective grâce à l'intimité qui s'en dégage. En tant que hic et nunc ${ }^{7}$ de l'espace, le caractère de l'intimité peut être utilisé comme une lecture afin d'avoir un cadre complet de ce que serait la contextualisation de la dimension humaine dans l'architecture de Le Corbusier. A cet égard la philosophie de l'espace de Gaston Bachelard caractérise le concept de l'habiter à travers une dimension humaine «matérielle » et «sensorielle ». C'est-à-dire qu'en utilisant la philosophie de Bachelard comme modèle d'analyse, on peut distinguer ce que signifie l'intimité et par conséquent le pouvoir que possède l'architecture pour la reproduire. En partant du corpus d'images de la maison, on peut tracer la ligne fondamentale de l'espace habité en tant qu'espace intime. Bachelard dans La Poétique de l'espace dit: «L'espace saisi par l'imagination ne peut rester l'espace

\footnotetext{
${ }^{2}$ Wunenburger, Jean-Jacques, Gaston Bachelard et la médiance des matières arché-cosmiques, [in] Chris Younès et Thierry Paquot (éd) Philosophie, Ville et architecture. La renaissance des quatre éléments, Paris, La Découverte, 2002, pp. $27,42$.

${ }^{3}$ Voir Gaston Bachelard, L'Eau et les rêves. Essai sur l'imagination de la matière, Paris, José Corti, 1942.

${ }^{4}$ Le Corbusier, Le Modulor, page 28.

5 Alison, Aurosa. Science et Poétique de l'Espace chez Gaston Bachelard. Directors Jean-Jacques Wunenburger, Université Jean Moulin Lyon III ; Etudes des systèmes ; Giulio Raio, Università degli Studi di Napoli l'Orientale, Filosofia \& Politica ; Napoli, 2014.

${ }^{6}$ Voir : Bachelard, Gaston L'Expérience de l'espace dans la physique contemporaine, Paris, Felix Alcan, 1937 ; Bachelard, Gaston, La Poétique de l'espace, Paris, Puf, 1957.

7 Benjamin, Walter, L'ceuvre d'art dans l'époque de sa reproductibilité technique, Allia, 2003, Paris ; Das Kunstwerk im Zeitalter seiner technischen Reproduzierbarkeit, 1955, Frankfurt.
} 
indifférent livré à la mesure et à la réflexion du géomètre. Il est vécu ${ }^{8} »$. Le philosophe traite les images de l'être intime à travers les structures qui traversent la quotidienneté de chaque individu et à travers les conditions primordiales que nous suggère la nature. Afin de parvenir à une conception de l'espace entier, nous utilisons l'image de la maison pour définir la façon d'habiter un espace intime. La maison « ... Maintient l'homme à travers les orages du ciel et les orages de la vie. Elle est corps et âme. Elle est le premier monde de l'être humain. Avant d'être "jeté au monde " comme le professent les métaphysiques rapides, l'homme est déposé dans le berceau de la maison. Et toujours, en nos rêveries, la maison est un grand berceau. Une métaphysique concrète ne peut laisser de côté ce fait, ce simple fait, d'autant que ce fait est une valeur, une grande valeur à laquelle nous revenons dans nos rêveries. L'être est tout de suite une valeur. La vie commence bien, elle commence enfermée, protégée, toute tiède dans le giron de la maison ${ }^{9}$ ». En effet, sans l'image de la maison, l'homme serait dispersé, il perdrait tous ses repères. C'est dedans la maison que l'être est accueilli et enveloppé par une chaleur presque maternelle. Dans la maison natale notre âme se développe à travers les valeurs d'intimité. Chaque fois que nous habitons une maison nos gestes, nos habitudes, sont déjà inscrits dans notre être

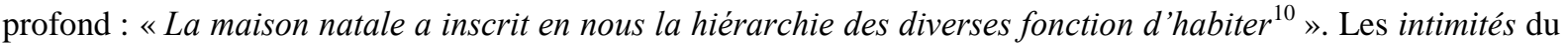
caché, du secret et du profond se relient dans la maison aux phénoménologies des immensités en dehors de nousmêmes. La valeur fondamentale de l'image de la maison se trouve essentiellement dans son universalité. A ce propos la maison se base sur une dialectique du dehors-dedans dans la mesure où elle représente la manière du bien-être. C'est ainsi que l'image de la maison pour Bachelard se constitue d'un univers dialectique en se développant tout au long d'un axe vertical entre les polarisations du haut et du bas. De la cave au grenier la maison nous fournit la «carte géographique » de notre âme, une fonction fondamentale que le philosophe appelle topoanalyse $e^{11}$. A travers la topo-analyse nous pouvons réellement comprendre quel est le fondement principal d'une fonction d'habiter : c'est-à-dire d'un logement intime dans un espace heureux.

La maison représente à travers toutes ses nuances un univers dialectique. Dans la maison on rêve, on est protégé, on y retrouve l'abri primordial. Bachelard nous illustre deux dialectiques dans La Poétique de l'Espace, celle du dedans-dehors et celle de l'immensité intime, avec le but de tracer une caractérisation qui ne réside pas seulement dans les limites géométriques mais aussi dans une façon de l'être à la base de notre volonté d'habiter le monde : «Le philosophe, avec le dedans et le dehors pense l'être et le non être ${ }^{12}$ ». L'être là ou bien L'être ici correspondent à une prise de conscience ontologique, où l'être est à la base d'une dialectique spatiale constitutive. C'est ainsi qu'à travers les indications de la maison habitée nous pouvons saisir l'espace entier. C'est dans la maison que l'homme apprend à habiter. «Il ne s'agit pas de décrire des maisons, d'en détailler les aspects pittoresques et d'en analyser les raisons de confort. Il faut, tout au contraire, dépasser les problèmes de la description - que cette description soit objective ou subjective, c'est-à-dire qu'elle dise des faits ou des impressions - pour atteindre les vertus premières, celles où se révèle une adhésion, en quelque manière, native à la fonction première d'habiter ${ }^{13}$ ». L'homme à travers la structure de la maison actualise la découverte de sa propre âme et sa conscience de centralité se développe grâce aux fonctions intimes de l'habiter. Bachelard dans sa recherche sur les fonctions de l'habiter ajoute une focalisation importante sur les activités intimes. En effet, pour vivre un espace, quel qu'il soit, il faut comprendre comment y adhérer. La dimension de l'immensité intime

\footnotetext{
${ }^{8}$ Bachelard, Gaston, La poétique de l'espace, Puf, Paris 1957 ; 9 ème édition 2005, page 17.

${ }^{9}$ Bachelard, Gaston, La poétique de l'espace, page 26.

${ }^{10}$ Ivi, page 32 .

${ }^{11}$ Voir Wunenburger, Jean-Jacques, Gaston Bachelard et la topoanalyse poétique, en, Les territoire des philosophes, sous la direction de Thierry Paquot et Chris Younès, La Découverte, 2009, pages 47-72.

${ }^{12}$ Bachelard, Gaston, La poétique de l'espace, page, 191.

${ }^{13}$ Bachelard, Gaston, La poétique de l'espace, 191.
} 
nous rapproche d'une façon d'être dans l'espace et en même temps nous aide à contextualiser nos intimités à l'extérieur de nous-mêmes. C'est-à-dire qu'à travers les immensités poétiques l'être atteint une intimité ancestrale et primordiale. Tout en restant dans le cadre du bien-être l'immensité est une dimension qui nous amène à sa contemplation. A travers cette faculté l'être acquiert une tranquillité constitutive qui se répète dans le temps. La forme que nous avons trouvée avec la spirale du dehors-dedans à travers la dimension de l'immensité intime se déploie dans un infini de la contemplation. Que signifie alors pour Bachelard contempler l'immensité ? «L'immensité est en nous. Elle est rattachée à une sorte d'expansion d'être que la vie refrène, que la prudence arrête, mais reprend dans la solitude. Dès que nous sommes immobiles, nous sommes ailleurs; nous rêvons dans un monde immense ${ }^{14} \gg$. Bachelard nous parle donc d'une immensité intime, d'une immensité intériorisée. L'immensité ne sera pas celle analysée par le géographe mais plutôt celle qui témoigne de notre implication intime avec le reste du monde. L'immensité intensifie notre regard, la tranquillité qu'elle dégage est le juste repos de notre âme. A travers la contemplation de l'Univers nous retrouvons toutes les profondeurs vécues et perdues de notre être. Le regard sur le monde nous projette dans le monde même. A travers ce regard nous sommes renvoyés à une primitivité radicale. Dans l'espace intime et dans les immensités intimes nous retrouvons toujours notre être. Caché, protégé, défendu, livré, l'être dans l'espace exprime toute son homogénéité, toute son naturel spontané. A travers les fonctions d'habiter de la maison bachelardienne, nous avons la démonstration de comment l'être s'étend et s'intensifie dans le monde tout comme chez soi.

\section{L’intimité spatiale chez Le Corbusier : Le Modulor, Une échelle pour le mesurage harmonique de l'espace.}

Dans le cadre d'un rapport intime avec le monde et avec l'espace, nous voulons d'abord illustrer les caractéristiques «humaines» du Modulor. Les équilibres que Le Corbusier va atteindre afin de rétablir un rapport fusionnel entre l'homme et ses besoins sociaux, se basent sur un terrain utile tant pour l'individu que pour une collectivité. Son œuvre, que nous pouvons qualifier de sociale, représente le bouleversement du rapport entre homme et habitat. A partir de la parution des thèses argumentées dans le Modulor «Essai sur une mesure harmonique à l'échelle humaine applicable universellement à l'architecture et à la mécanique » en 1950, ce sera en définitive l'habitat qui consolidera les mesures de l'homme et non pas le contraire. C'est ainsi que dans la «philosophie » de Le Corbusier nous pouvons percevoir une approche totalisante de l'architecte dans l'espace, où qu'il soit. Dans ce cas, la dimension intime se projette à travers la manifestation d'une nouvelle pensée d'aménagement urbanistique. Dans le langage de Le Corbusier nous retrouvons souvent des mots comme: fonction, ouverture, unité et homme. De la maison à la ville, les facteurs fondamentaux restent ceux du paysage, de l'environnement, du vert et surtout des phénomènes biologiques. "On parle ici d'outillage, d'outils d'habitation mis entre les mains d'êtres vivants et fondés sur des constantes psycho-physiologiques dûment reconnues, inventoriées par des gens compétents (biologiques, médecins, physiciens et chimistes, sociologues et poètes $^{15}{ }$. Cette théorie nous ramène au fait que l'homme, tout comme l'architecte, dépend de l'espace et l'espace de l'homme. L'homme, le sujet, l'individu biologique est en rapport avec l'espace d'un point de vue subjectif, sensible, presque spirituel. L'être de l'homme est une spirale qui n'a ni début ni fin, ni dedans, ni dehors, il constitue et contient l'espace. L'architecture urbaine de Le Corbusier, divisée en unités sociales, se théorise dans une architecture du dedans et du dehors, où l'environnement naturel concourt à faire partie du projet et par conséquent de la construction. « La nature intervient en façon substantielle dans la fonction de vivre qui est celle de l'habiter ${ }^{16}{ }^{\prime}$. C'est ainsi que l'habitation doit se relier à des conditions d'ordre cosmique,

\footnotetext{
${ }^{14}$ Ivi, page 169.

${ }^{15}$ Le Corbusier, Manière de penser l'urbanisme, $2^{\text {ème }}$ édition Editions Gonthier, 1966, page 59.

${ }^{16}$ Le Corbusier, Manière de penser l'urbanisme, page 82.
} 
basées sur des lois naturelles et des dimensions humaines. A partir de la dimension du Modulor, le but de Le Corbusier est celui de fournir la caractérisation fondamentale de l'harmonie. En soulignant l'importance d'une destination humaine, l'architecte doit se refaire à une conception métrique qui assure le bien-être en tant que conception d'espace intime, d'espace protégé. "S'agissant de construire des objets d'usage domestique, industriel ou commerciale, fabricables, voyageables et achetables en tous lieux du monde, la société moderne manque de la mesure commune capable d'ordonner les dimensions des contenants et des contenus, capable, par conséquent, de provoquer des offres ou des demandes assurées de sécurité. Ici, s'attache notre effort. C'est sa

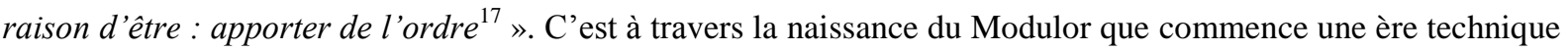
qui prévoit dans le domaine de la mesure, l'échelle de l'homme : «The Humanisation of Space ».

«Prendre possession de l'espace est le geste premier des vivants, des hommes et des bêtes, des plantes et des nuages, manifestation fondamentale d'équilibre et de durée. La preuve première d'existence c'est d'occuper l'espace $^{18} »$. A travers cette citation Le Corbusier introduit le rapport entre l'homme et l'espace à travers l'implication corporelle sous la forme de l'occupation de l'espace. C'est-à-dire qu'en suivant les thématiques basilaires de l'espace bachelardien en tant qu'espace de l'intimité, nous pouvons trouver des similitudes intéressantes entre l'espace bachelardien et celui que le Modulor de Le Corbusier nous illustre. Comment, alors, est née l'idée du Modulor? Sur quelles bases s'érige sa caractérisation anthropologique ? «Il faut bien qu'une découverte se soit servie un jour de la tête, de l'œil, de la main d'une personne: conditions favorables d'ambiance et de milieu, circonstances ayant permis le déroulement positif de la recherche et sa conclusion. Proposer l'emploi d'une mesure nouvelle destinée à compléter un jour le mètre ou le pied-pouce apparaît une prétention excessive. On l'admettrait plus facilement si telle était l'offre d'un concile ou d'un congrès à l'issue de leurs travaux. L'idée est apparue à un homme courant, pas même chercheur de profession, issu toutefois, d'un milieu particulier et ayant bénéficié de l'ambiance utile ou, à l'occasion, l'ayant créée. L'homme mis ici en question est architecte et peintre, pratiquant depuis quarante-cinq années un art où tout est mesure ${ }^{19}{ }^{\prime}$. Le Corbusier nous explique comment l'idée du Modulor naît par rapport à une exigence naturelle de la dimension humaine. Cela nous relie aux thèses de Bachelard sur l'imagination matérielle et sur l'importance du rapport entre l'homme et les éléments naturels. A cet égard, Le Corbusier continue à expliquer comment le Modulor se développe par rapport à son étude de la mesure. Le but de Le Corbusier est celui d'agir sur les dimensions standards et de les transformer selon les dimensions humaines. "La nécessité d'architecturer à l'échelle de l'homme l'avait conduit à dessiner au mur de son atelier une échelle métrique de quatre mètres de haut afin de s'y confronter lui-même, d'y opposer sa propre stature, d'y inscrire en travers un jeu de mesures vraies, mesures d'appui, de siège, de passage, etc... Cette expérience montrait que le mètre n'est qu'un chiffre, heureusement soumis au système décimal, un chiffre abstrait, incapable en architecture de qualifier un intervalle (une mesure). Outil dangereux même, si partant de son abstraite conformation numérique, on se laisse aller, par insouciance ou paresse, à le matérialiser en des mesures commodes! Le mètre, le demi-mètre, le quart de mètre, le décimètre, etc... ; évolution qui s'est accomplie petit à petit au cours du siècle, aveulissant l'architecture ${ }^{20}{ }$.

Le rapport entre dimensions mathématiques et dimensions humaines pour Le Corbusier se concrétise d'un point de vue scientifique en 1933 avec l'obtention du grade de Docteur Honoris Causa en philosophie mathématique. Les recherches de Le Corbusier, sur l'organisation des formes dans l'espace vont être reconnues par l'Université de Zurich. En 1946, onze ans plus tard, notre architecte reçoit une reconnaissance encore plus importante pour

\footnotetext{
${ }^{17}$ Ivi, pages 20,21 .

${ }^{18}$ Ivi, page 31.

${ }^{19}$ Le Corbusier, Le Modulor, page 25.

${ }^{20}$ Ivi, page 33 .
} 
ses recherches de la part de Albert Einstein. «Le $1^{\text {er }}$ mai 1946, je prenais l'avion de New-York, mandaté par la France aux Nations Unies pour y défendre l'architecture moderne à l'occasion de la construction du siège de l'O.N.U aux U.S.A. J'eus le plaisir de m'entretenir assez longuement du "Modulor » avec le professeur Albert Einstein à Princeton. J'en étais à la période de grande incertitude, d'anxiété; je m'expliquais mal, je l'expliquais mal, j'étais empêtré dans les « causes et effets »... A un moment, Einstein prit un crayon et calcula. Stupidement je l'interrompis, la conversation dévia, les calculs demeurent en panne. L'ami qui m'avait amené était navré. Gentiment le soir même, Einstein, parlant du "Modulor», m'écrivait: "C'est une gamme de proportions qui rend le mal difficile et le bien facile. " Certains estiment que cette appréciation manque d'allure scientifique. Quant à moi, je pense qu'elle est extraordinairement clairvoyante. C'est un geste amical qu'un grand savant fait à nous autres qui ne sommes point des savants mais des soldats sur le champ de bataille. Le savant nous dit: "Cette arme dit juste : en matière de dimensionnement, donc de proportion, elle rend votre tâche plus assurée ${ }^{21} »$. Les bases sur lesquelles se fonde Le Modulor sont la solution du rapport entre les valeurs anglo-saxonnes du pied et du pouce. En se référant sur une base de six pieds $(182,88 \mathrm{~cm})$ Le Modulor résout automatiquement le différend qui sépare les usagers du mètre des usagers du pied-pouce. C'est ainsi que les dimensions humaines rentrent dans les paramètres du calcul mathématique. «Pendant que roule et tangue durement le navire, je dresse une échelle de chiffres: Ces chiffres engagent la stature humaine, les points décisifs d'encombrement de l'espace. Ils sont donc anthropocentriques. Occupent-ils une situation mathématique particulière, caractéristique, voire privilégiée ? On peut dès lors affirmer que cette règle engage le corps humain dans ses points essentiels d'occupation de l'espace et qu'elle fait état de la plus simple et essentielle évolution mathématique d'une valeur, à savoir : l'unité, son double et les deux sections d'or, ajoutées ou retranchées. Nous voici singulièrement plus affirmatif et avancé qu'au moment de la simple insertion favorable, au lieu de l'ange droit, d'un troisième carré contigu, égaux tous les trois entre eux ${ }^{22}{ }^{2}$.

Le but de Le Corbusier, à propos d'une intimité spatiale, a été celui d'harmoniser le flux de la production mondiale: «La promesse, vérifiée, d'être toujours harmonieux, divers, élégant, au lieu d'être banal, monotone et disgracieux. Et encore réduire l'obstacle né des mesures inconciliables mètre et pied-pouce ${ }^{23} »$. Avec l'introduction de la dimension humaine, c'est-à-dire avec l'introduction d'un usage de l'espace intime et habité pour l'utilisation d'une échelle mondiale, Le Corbusier affirme son intérêt anthropocentrique. Le Modulor est donc un exemple de comment l'espace intérieur, l'espace profond, l'espace que Bachelard examine à travers la topoanalyse, peut être illustré à travers des exemples concrets.

\subsection{L'Unité d'habitations de Marseille.}

Le Corbusier réussit à illustrer le principe fondamental de l'harmonie naturelle sous forme de dimension humaine. La perception de cette perfection objective est relancée par la Nature qui nous entoure. En reprenant Gaston Bachelard et une philosophie de l'espace, nous pouvons fournir un exemple évident: celui du coquillage. Bachelard dédie dans La Poétique de l'espace un chapitre entier à l'image de l'abri primordial à travers l'image de la coquille : «A la coquille correspond un concept si net, si sûr, si dur que faute de pouvoir simplement la dessiner, le poète, réduit à en parler, est d'abord en déficit d'images. Il est arrêté dans son évasion vers les valeurs rêvées par la réalité géométrique des formes. Et les formes sont si nombreuses, souvent, si nouvelles, que de l'examen positif du monde des coquilles, l'imagination est vaincue par la réalité. Ici, la nature imagine et

\footnotetext{
${ }^{21}$ Ivi, page 59 .

${ }^{22}$ Le Corbusier, Le Modulor, page 51.

${ }^{23}$ Ivi, page 109.
} 
la nature est savante. Il suffira de regarder un album d'ammonites pour reconnaître que, dès l'époque secondaire, les mollusques construisaient leur coquille en suivant les leçons de la géométrie transcendante. Les ammonites faisaient leur demeure sur l'axe d'une spirale logarithmique ${ }^{24}$ ». A cet égard la tâche de la Nature est une base fondamentale pour une phénoménologie architecturale. C'est ainsi que la forme de l'espace intime se manifeste sous sa forme universelle à travers la volumétrie du Modulor et Le Corbusier utilise l'image de la coquille pour l'illustrer : «Le volume bâti est la coquille de l'escargot; le statut du terrain, c'est le potager où notre homme-escargot trouve ses nourritures matérielles et spirituelles. L'homme et son milieu. Et, ce faisant, unir l'architecture à l'urbanisme; plus exactement encore : arracher l'urbanisme à sa figure actuelle à deux dimensions (néfaste outil mis entre les mains d'agents-voyers) et lui conférer la troisième dimension, seule capable de rassembler les données du problème dans leur unité, leur solidarité, leur ensemble ${ }^{25}$. C'est en respectant les lois de l'harmonie naturelle que le plan général de l'Unité d'Habitation de Marseille au Boulevard Michelet est une construction pour 1600 habitants comprenant 26 services en commun. Il s'agit d'un immeuble de 140 mètres de long, 24 mètres de large et 56 mètres de haut. Le Corbusier établit la nomenclature de toutes les mesures employées dans les dessins préparatoires. C'est ainsi que son atelier prépare quinze mesures illustrées de la façon suivante: «J'imaginai une stèle de béton coloré de rouge et de bleu et qui par des chiffres de bronze incrustés mettrait ces choses en évidence. On dressera cette stèle sous les pilotis près de la porte du hall ; elle aura quatre faces. Trois bonhommes en filigrane de bronze : un bras levé, les deux autres superposés affirmeront la règle $e^{26}$ ». L'âme du bâtiment nous ramène à la recherche bachelardienne de l'âme intime dans l'espace. Nous pouvons affirmer que Le Corbusier utilise les règles basilaires de la topoanalyse au sein de son projet pour l'Unité d'Habitation de Marseille. Un dernier exemple d'aménagement topo-analytique et anthropocentrique réside dans l'organisation même des espaces individuels et privés. Le Corbusier en disant «Tous objets étant à portée de mains et répondant aux positions assis ou debout ${ }^{27}$ », crée, à travers la dimension du Modulor, un état d'agrégation unitaire qu'on peut qualifier de «texturique ». Les volumes qui naissent grâce aux différentes compositions du Modulor peuvent s'inscrire à la fois dans les domaines des façades urbaines et dans les aménagements d'intérieurs. C'est ainsi que l'introduction du Modulor dans L'Unité d'habitation de Marseille permet la création de milieux (bureaux, maisons, édifices, topographies, sculptures) où nous retrouvons une homogénéité «textile» à la fois architecturale et artistique. «Mon travail architectures et peintures, est depuis plus de trente années nourri de sève mathématique. (Je précise que je fus en cancre à l'école en matière de calcul qui ne m'inspirait qu'angoisse et répugnance. L'introduction du Modulor (premièrement baptisé «grille de proportions» dans mon labeur ne prit donc aucunement l'allure révolutionnaire; elle manifestait simplement le constant émerveillement d'un homme -d'un ingénu- jamais embarrassé d'académisme devant l'illumination des infinies ordonnances. Jours après jour, cet ingénu mesure que son art est conduit par une règle. Il reconnaît la règle, la salue avec respect et avec joie ; étant tenu de transmettre sa pensée par le truchement des mains et des têtes de vingt dessinateurs, il s'aperçoit avec toujours plus d'évidence, qu'ayant passé la porte des miracles, sa bonne chance l'a conduit dans un jardin où fleurissent les nombres ${ }^{28} »$. L'utilisation du Modulor en tant qu'outil de mesure harmonique peut se retrouver dans les Unités d'habitation de Marseille où le Modulor s'applique dans les différentes parties de la structure. Cela veut dire que nous avons un exemple objectif de comment la projection de l'espace intime trouve sa dimension et se manifeste à travers l'utilisation des espaces individuels, collectifs, structurels et environnementaux. Le Corbusier

\footnotetext{
${ }^{24}$ Bachelard, Gaston, La Poétique de l'espace, page 105.

${ }^{25}$ Le Corbusier, Entretien avec les étudiants des Ecoles d'architectures, Les Editions de Minuit, 1957, Paris.

${ }^{26}$ Le Corbusier, Le Modulor, page 142.

${ }^{27}$ Le Corbusier, Le Modulor, 144.

${ }^{28}$ Ivi, page 131.
} 
organise l'espace des habitations à travers les dimensions du Modulor. A savoir que même l'espace urbain est aménagé selon des règles géométriques-antrhopocentriques et géométriques-naturelles.

\section{2 «Tout prés de l'homme», Le Cabanon.}

«Le 30 décembre 1951, sur un coin de table dans un petit «casse-crôute » de la Côte d'Azur j'ai dessiné, pour en faire cadeau à ma femme pour son anniversaire, les plans d'un " cabanon " que je construisis l'année suivante sur un bout de rocher battu par les flots. Ces plans (les miens) ont été faits en 3/4 d'heure. Ils sont définitifs, ; rien n'a été changé ; le cabanon a été réalisé sur une mise au propre de ces dessins. Grâce au Modulor, la sécurité de la démarche fut totale ${ }^{29} 》$. Le Cabanon, caractérisé par le thématisme de l'espace « vécu », a été idéalisé et réalisé par Le Corbusier pour sa vie privée. Un «buen retiro » projeté tout d'abord comme cadeau à sa femme et ensuite comme le refuge d'une vie. La structure du Cabanon, représente les conditions idéales du projet architectonique. C'est-à-dire que sa structure synthétise l'idéalisation et l'usage personnel. Dans le Cababon, à Cap-Martin, il y a un jeu continu de dedans et dehors entre les modules qui l'occupent et qui le composent. A l'intérieur de cet objet à réaction poétique, Le Corbusier engage Le Modulor afin d'illustrer la forte cohésion entre la fonctionnalité essentielle et une esthétique pure. Deux lits en bois, une table-bureau, des tabourets, une armoire, une librairie et un wc font de la superficialité une nécessité. Le jeu de la réduction proposé par Le Corbusier inspire une composition cartésienne qui se relie à une plasticité libre, conséquence de l'art cubiste et des tendances puristes. Ce carré de 366x366 cm mesure exactement 14 mètres carrés qui correspondent encore une fois à une éthique humaine persistante dans la vie de l'architecte. En 1929 à travers les standards fixés par la loi Flecheur en France et destinés aux édifices populaires et à travers les résultats de l'existence-minimum du Congrès du CIAM, Le Corbusier commence à travailler sur un redimensionnement des mesures essentielles du Modulor jusqu'à arriver à la mesure de 14 métres carrés, destinée aux plus pauvres. C'est ainsi qu'à travers le Cabanon, notre architecte, notre homme social, remet à l'architecture le pouvoir de construire l'espace pour toutes les typologies d'hommes en se détachant totalement de toutes interprétations sociales ou politiques. "L'homme heureux, est l'homme qui réalise toutes les fonctions d'une vie domestique, où il lit, où il étudie, où il reçoit les amis dans 15 métres carrés ${ }^{30} »$. La forte résonnance humaine du Cabanon ${ }^{31}$ nous renvoie à l'importance d'un espace intime non seulement dans la structure architectonique mais aussi dans le concept d'un espace vécu. L'harmonie des couleurs et des sensations du paysage extérieur, dans lequel nous retrouvons ce «nid », se répètent dans une richesse désarmante qui se trouve à l'intérieur. En regardant le paysage de la Méditérannée qui protège et entoure le Cabanon, on aperçoit des phénomènes de composition complexes qui se relient aux solutions illustrées par Le Corbusier. La matière plastique correspond à une formalisation de l'esprit et de la connaissance des simples gestes quotidiens qui nous ramène à un fort existentialisme spatial.

C'est ainsi, qu'à travers les normes de la topoanalyse suggérées par Gaston Bachelard, nous avons constaté comment l'organisation de l'espace à travers le Modulor permet encore aujourd'hui de se sentir chez soi dans la ville tout comme dans la maison. C'est ainsi que la division à l'échelle humaine n'est pas seulement réalisable mais aussi de grande actualité. Le message que nous laisse actuellement Le Corbusier, cinquante ans après sa mort, est celui de vouloir sauvegarder surtout l'âme de l'habiter à travers la dimension humaine du Modulor : la plus simple, la plus organique et la plus poétique surtout.

\footnotetext{
${ }^{29}$ Ivi, page 252.

${ }^{30}$ Le Corbusier, Vers une architecture, Ed. Crès, Paris, 1923, page 154.

31 Alison, Filippo, L'interno del Cabanon. Interior of the Cabanon, Triennale Electa, Milano, 2006.
} 


\section{Bibliographie}

Alison, Aurosa, Science et Poétique de l'Espace chez Gaston Bachelard. Directors Jean-Jacques Wunenburger, Université Jean Moulin Lyon III ; Etudes des systèmes; Giulio Raio, Università degli Studi di Napoli l’Orientale, Filosofia \& Politica ; Napoli, 2014.

Alison, Filippo, L'interno del Cabanon. Interior of the Cabanon, curated by, Triennale Electa, Milano, 2006.

Bachelard, Gaston L'Expérience de l'espace dans la physique contemporaine, Paris, Felix Alcan, 1937.

Bachelard, Gaston, La Poétique de l'espace, cit.

Bachelard, Gaston, La Poétique de l'espace, Puf, Paris 1957 ; $9^{\text {ème }}$ édition, Puf, Paris, 2005.

Bachelard, Gaston, L'Eau et les rêves. Essai sur l'imagination de la matière, Paris, 1942, José Corti.

Bachelard, Gaston, La Poétique de l'espace, cit.

Bachelard, Gaston, La poétique de l'espace, cit.

Bachelard, Gaston, La poétique de l'espace, cit.

Bachelard, Gaston, La poétique de l'espace, cit.

Bachelard, Gaston, La poétique de l'espace, cit.

Bachelard, Gaston, La Poétique de l'espace, Paris, Puf, 1957.

Benjamin, Walter, Das Kunstwerk im Zeitalter seiner technischen Reproduzierbarkeit, Frankfurt, 1955.

Le Corbusier, Entretien avec les étudiants des Ecoles d'architectures, Les Editions de Minuit, Paris, 1957.

Le Corbusier, Le Modulor, cit.

Le Corbusier, Le Modulor, cit.

Le Corbusier, Le Modulor, cit.

Le Corbusier, Le Modulor, cit.

Le Corbusier, Le Modulor, cit.

Le Corbusier, Le Modulor, cit.

Le Corbusier, Le Modulor, cit.

Le Corbusier, Le Modulor, cit.

Le Corbusier, Le Modulor, cit.

Le Corbusier, Le Modulor, cit.

Le Corbusier, Le Modulor, Editions de l'Architecture d'Aujourd'hui, Paris, 1955, éd. Fondation Le Corbusier, 1983.

Le Corbusier, Manière de penser l'urbanisme, cit.

Le Corbusier, Manière de penser l'urbanisme, cit.

Le Corbusier, Manière de penser l'urbanisme, cit.

Le Corbusier, Manière de penser l'urbanisme, Editions de l'architecture aujourd'hui, Paris, $1946 ; 2^{\text {ème }}$ éd. Editions Gonthier, 1966.

Le Corbusier, Vers une architecture, Ed. Crès, Paris, 1923

Wunenburger, Jean-Jacques, « Gaston Bachelard et la topoanalyse poétique ». Thierry Paquot et Chris Younès, Les territoire des philosophes, La Découverte, 2009, pages 47-72. 


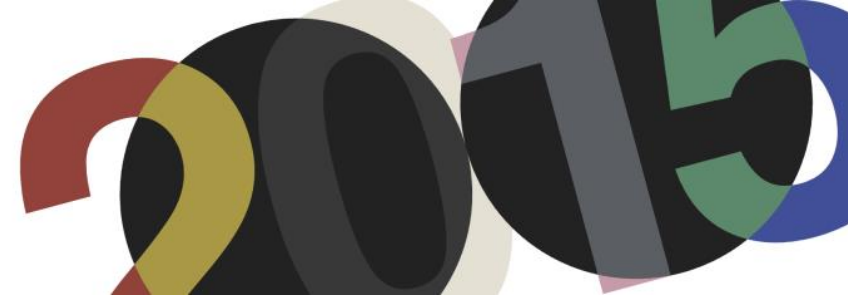

DOI: http://dx.doi.org/10.4995/LC2015.2015.1012

\title{
El espacio público en Le Corbusier. Evolución de su pensamiento y de sus estrategias formales
}

\author{
E. Alonso García
}

Escuela Técnica Superior de Arquitectura de Valladolid

\begin{abstract}
Resumen: Se analiza el papel del espacio público en diferentes obras de Le Corbusier, en sus diferentes categorías -paisaje, espacio urbano, colectivo, comunitario, de encuentro y relación, social, circulatorio, etc. - y en su implicación en las estrategias formales y espaciales. Articularemos estas reflexiones en tres apartados. El primero incidirá en la relación o identificación que se produce entre paisaje y espacio público en sus propuestas urbanísticas en las décadas de los años veinte y treinta. En el segundo apartado contrastaremos las diferencias y similitudes entre dos proyectos, UHM y Ronchamp, entendidos a veces como contradictorios pero en cuya solución proyectual resulta determinante el diseño y ubicación de los espacios colectivos de encuentro y relación de la comunidad; y ello a pesar de sus diferencias programáticas. En el tercer apartado veremos la interacción con el paisaje urbano que establece la dialéctica entre arquitectura y ciudad en dos proyectos de los últimos años, Centro de Artes Visuales Carpenter y Hospital de Venecia. Esta breve selección de edificios y proyectos, dentro de la dilatada producción de Le Corbusier, permitirá, por su adscripción temática y cronológica, establecer una adecuada perspectiva temporal en la compresión del tema y su evolución.
\end{abstract}

\begin{abstract}
It is analysed the role of the public space in different works of Le Corbusier, in their different categories landscape, urban space, collective, community, meeting and relationship, social, circulatory, etc. - and their involvement in formal and spatial strategies. We are going to distribute these reflections into three sections. The first will affect the relationship or identification that occurs between landscape and public space in its urban planning proposals in the decades of the 1920s and 1930s. In the second section, we will contrast the differences and similarities between two projects, UHM y Ronchamp, sometimes understood like contradictory but in whose design solution is determining the design and location of collective spaces of encounter and relationship of the community; and it occurs despite their functional differences. In the third section we will see the interaction with the urban landscape that the dialectic between architecture and town sets in two projects of last years, Carpenter Visuals Arts Center and Venice Hospital. This brief selection of buildings and projects, within the extensive production of Le Corbusier, will allow, by its thematic and chronological affiliation, to establish a suitable temporal perspective in the understanding of the subject and its evolution.
\end{abstract}

Palabras clave: espacio público; interrelación; paisaje; infraestructura; contexto; ciudad. Keywords: public space; interface; landscape; infrastructure; context; town.

\section{Introducción. Espacio público, paisaje y mecanización.}

El espacio público en sus diferentes categorías - espacio urbano, colectivo, comunitario, de encuentro y relación, social, circulatorio, etc. - es hoy un campo de trabajo muy presente en cualquier debate arquitectónico, cuya importancia trasciende la propia disciplina: “... lo cierto es que si se toman algunas de las obras clásicas del pensamiento urbano procuradas en las décadas de los años sesenta, setenta e incluso ochenta, el valor 'espacio público' apenas aparece o, si lo hace, ... le habrían convenido otros conceptos como "espacio social”, espacio común”, espacio compartido", espacio colectivo", etc."1 y, aunque no siempre fue así, suele implicar o ir asociado a otro concepto con diferentes acepciones y paradojas, el de paisaje - paisaje natural, cultural, urbano,

\footnotetext{
${ }^{1}$ Delgado, Manuel, El espacio público como ideología. Madrid: Catarata, 2011, p. 16.
} 
interior, virtual, etc.-. La reciente exposición sobre la obra de Le Corbusier, An Atlas of Modern Landscapes ${ }^{2}$, organizada por el MOMA (2013) y que pasó por España en 2014 subrayó esta relación entre arquitectura y paisaje y la interrelación que se produce entre espacio público y espacio privado, incorporando con ello un ineludible debate ideológico en la búsqueda de las estrategias formales del proyecto.

La obra de Le Corbusier se desarrolla entre los planteamientos urbanos utopistas de finales del siglo XIX y principios del XX -Fourier, Sant'Elia, Tony Garnier- y los estudios de antropólogos, geógrafos y sociólogos cuyos textos a partir de los años de las décadas de los cincuenta y sesenta revitalizan algunas de estas cuestiones.

Estas reflexiones sobre el espacio público en Le Corbusier ilustran, por un lado, la evolución del problema en su pensamiento, el diferente protagonismo que adquiere en diversos proyectos, con escalas, programas y ubicaciones distintas, y, por otro lado, el constructo que el propio Le Corbusier va articulando en su trayectoria durante los dos primeros tercios del complejo siglo XX. Realiza muy tempranamente propuestas urbanísticas de gran escala donde el paisaje figura como el espacio público de la ciudad; son propuestas abstractas e idealizadas pero abordará también proyectos de menor tamaño con una actitud más fenoménica y contingente.

Desde el punto de vista de la fortuna crítica, en general y sobre Le Corbusier en particular, es oportuno señalar dos cuestiones: la primera se refiere al modo en que determinados logros del pensamiento quedan a veces fijados en el tiempo por más que evoluciones posteriores resulten críticas con ese momento particular y permitan elaboraciones de mayor complejidad; abordaremos a continuación las similitudes y diferencias entre estas propuestas urbanísticas realizadas entre principios y la mitad de los años veinte y sus otras propuestas de principios de los años treinta como las realizadas para Argel y Sudamérica. La segunda se refiere a la sesgada percepción de excesiva originalidad de cualquier aportación artística e intelectual por desconocimiento u ocultación de sus antecedentes. Dos responsabilidades convergen aquí para el caso que tratamos; una es el propio Le Corbusier en su afán de apropiarse de avances ajenos y rebautizarlos como nuevas invenciones ${ }^{3}$ y la otra, que afecta de modo particular al siglo XX, recae sobre la omisión de críticos y estudiosos, tendentes en ocasiones demasiado fácilmente a recrearse en la condición de invención y originalidad. En las últimas décadas, la producción de estudios atentos y rigurosos va confirmando para el caso Le Corbusier aquello que Frampton

afirmaba para la arquitectura del siglo XX, en general, en términos de "continuidad e inflexión más que en términos de originalidad como fin en sí mismo" ${ }^{\text {. }}$.

Le Corbusier, como tantos otros en los inicios del siglo XX, confía en la ciencia y en la técnica como remedio y salvación de tantos males que aquejan a la sociedad en general y, en particular, a las ciudades y al problema de la vivienda $^{5}$; habrán de pasar algunas décadas para comprender la carga ideológica que ambas representan. En 1941 el propio Le Corbusier recoge el sentimiento de decepción ${ }^{6}$ :

\footnotetext{
${ }^{2}$ Cohen, Jean-Louis, Le Corbusier: an atlas of modern landscapes, New York: MOMA, 2013.

${ }^{3}$ Tafuri, Manfredo. "Machine et mémoire. The City in the Work of Le Corbusier". En Brooks, H. Allen. Le Corbusier. Princeton: Princeton University Press. 1997, p. 204; a propósito de "la formulación teórica de la casa como máquina de habitar en un escrito de 1853 de Adolphe Lance”; también cfr. Moos, Stanislaus von. Le Corbusier. Barcelona: Lumen. 1977 (1968) $1^{\text {a }}$ ed. p. 93.

${ }^{4}$ Frampton, Kenneth. "Rappel à l Ordre: The Case for the Tectonic". En Frampton, Kenneth, Labour, work and architecture. Collected Essays on Architecture and Design. New York: Phaidon, 1987. p. 92.

5 Torres Cueco, Jorge. Le Corbusier: visiones de la técnica en cinco tiempos. Barcelona: Fundación Caja de Arquitectos. 2004.

${ }^{6}$ Esta reflexión de Le Corbusier aparece en el libro Sur les Quatres Routes de 1941 y encabeza el artículo de Frampton, Kenneth "The Other Le Corbusier: Primitive Form and the Linear City, 1929-52". En Frampton, Kenneth, op. cit., p. 219.
} 
"La sociedad contemporánea sufre una devastadora enfermedad. La Mecanización, que debería haber sido un remedio para todos sus males, ha sido desplazada. Nos permitimos derramar (despreciar, desaprovechar) nuestros tradicionales modos de vida, siendo imposible llegar a un acuerdo. A pesar de milagros aislados, la era de la máquina no ha conseguido todavía sus avances. No ha sido capaz de conseguir sus propios retos ni aprendió a saltar en el vacío y establecer una nueva tradición de la felicidad humana. Así, lo que debería haber sido un laborioso recurso de la humanidad para la libertad ha llegado a ser considerado por muchos poco menos que una calamidad”.
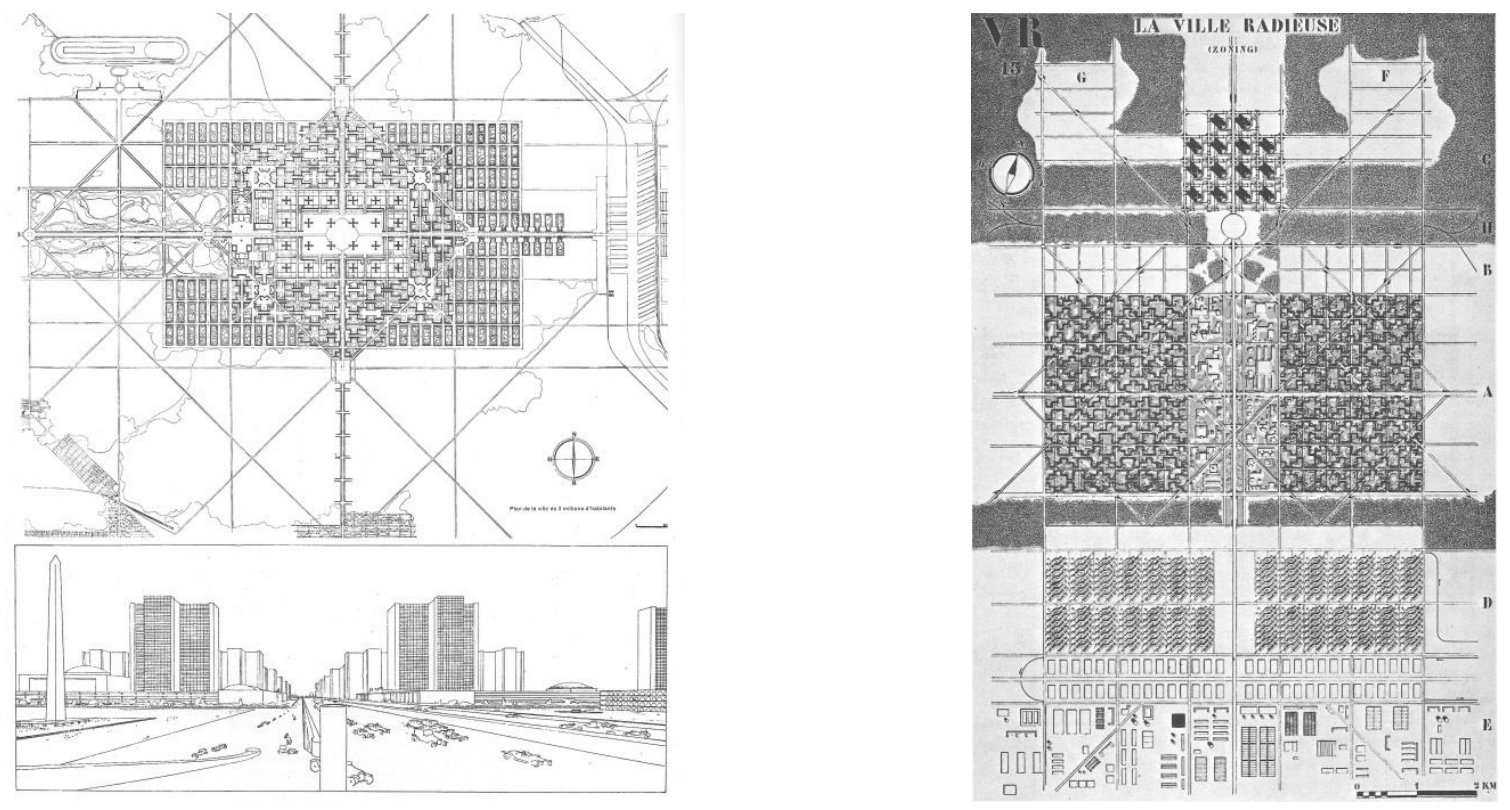

1. LC: Ville Contemporaine. Ciudad para 3 millones de habitantes, 1922. @FLC-ADAGP

2. LC: Ville Radieuse, 1925. (OFLC-ADAGP

Articularemos estas reflexiones en tres apartados. El primero incidirá en la relación o identificación que se produce entre paisaje y espacio público en sus propuestas urbanísticas en las décadas de los años veinte y treinta.. En el segundo apartado contrastaremos las diferencias y similitudes entre dos proyectos entendidos a veces como contradictorios pero en cuya solución proyectual resulta determinante el diseño y ubicación de los espacios colectivos de encuentro y relación de la comunidad; y ello a pesar de sus diferencias programáticas. En el tercer apartado veremos la interacción con el paisaje urbano que establece la dialéctica entre arquitectura y ciudad en dos proyectos de los últimos años. Esta breve selección de edificios y proyectos, dentro de la dilatada producción de Le Corbusier, permitirán, por su adscripción temática y cronológica, establecer una adecuada perspectiva temporal en la compresión del tema y su evolución. 


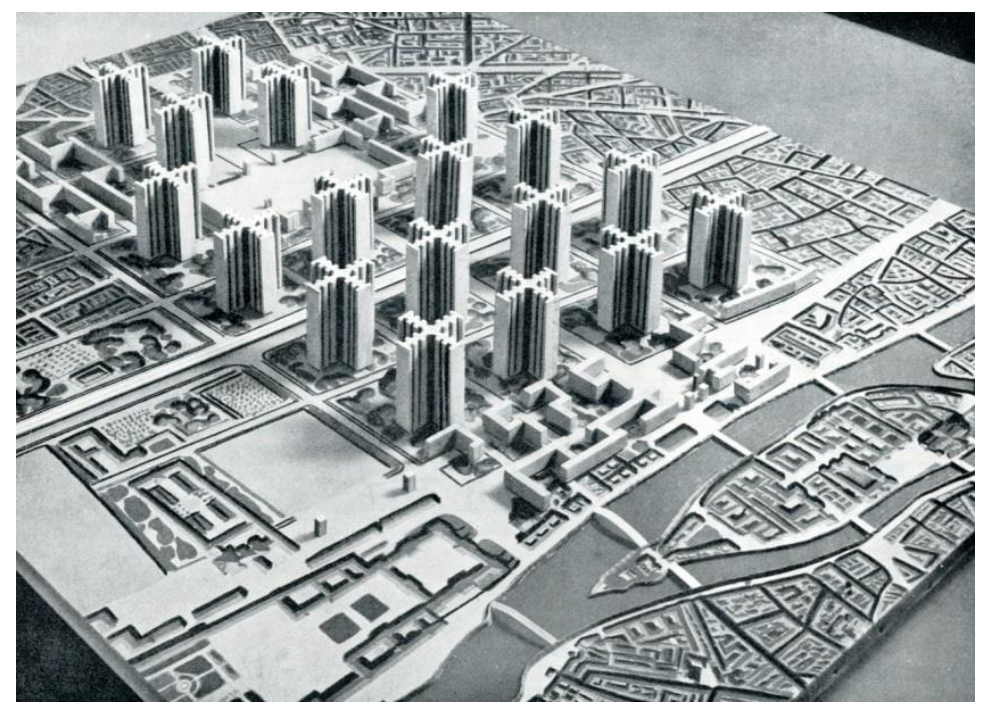

3. LC: Plan Voisin 1925. Detalle del centro (LC, Oeuvre Complète. CFLC-ADAGP)

\section{Paisaje y espacio público en las propuestas urbanas de los años 20 y 30}

Bien formado y conocedor de las teorías utopistas del siglo $\mathrm{XIX}^{7}$ sobre las teorías y propuestas urbanas para una nueva sociedad, Le Corbusier filtró pronto y reinterpretó su aprendizaje en sus propuestas urbanísticas de los años 20. Son propuestas que en su gran escala resultan necesariamente genéricas pero en donde emerge el descubrimiento de la naturaleza entendida como paisaje, con sus propias leyes compositivas y en su doble función de acoger la arquitectura, constituyéndose en su fondo natural, y para ser contemplada desde ella, dotando a la naturaleza de condición plástica y objeto experiencia artística: "la naturaleza sobre la que se asienta la ciudad de los modelos teóricos no es silvestre porque no existe ningún paisaje circundante; es un parque, una arquitectura vegetal con la que se manufactura el paisaje urbano",.

La Exposición de Artes Decorativas de 1925 consolidó la imagen vanguardista de Le Corbusier, no sólo por el propio Pabellón de l'Esprit Nouveau sino por la documentación relativa a algunas de las propuestas urbanísticas que hasta entonces había desarrollado -Plan Voisin, Ville Contemporaine-. Esta imagen quedó reforzada con la ejecución de sus obras puristas más insignes -villas Stein, Savoie,...- a finales de la década de los años veinte al tiempo que, no obstante, el propio Le Corbusier abordaba en aquellos años reflexiones bastante más críticas -las conferencias de Sudamérica, 1929, las propuestas de Argel, 1931-33, por citar algunas- con aquellos postulados que le posicionaron como uno de los máximos representantes de la modernidad mecanicista.

\footnotetext{
${ }^{7}$ Bergdoll, Berry, "París: más allá de la ciudad del siglo XX". En AV Monografías. Le Corbusier. An Altas of Landscapes. Madrid: Arquitectura Viva, 2015, 176. p. 44.

${ }^{8}$ González Cubero, Josefina. "Sesión continua: nómadas en el jardín. Ville Contemporaine y Ville Radieuse". En Monteys, Xavier. Massilia: anuario de estudios lecorbuserianos. Le Corbusier y el paisaje. Sant Cugat del Vallés, 2004. p. 75.
} 


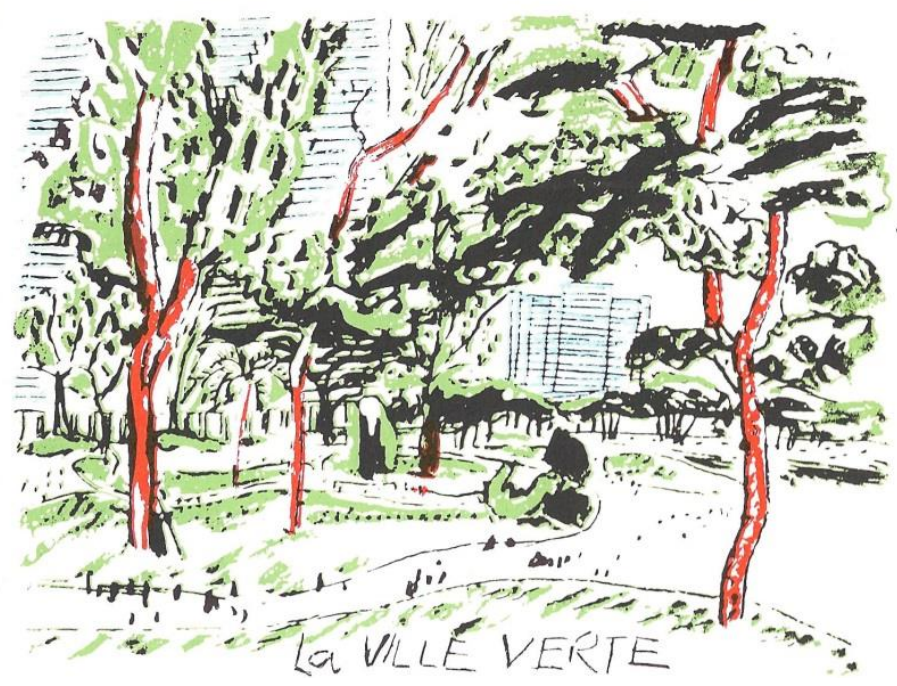

4. LC: Ville Verte (LC, Precisiones, Fig 156. OFLC-ADAGP)

Libertad, felicidad humana, salvación moral, etc., son términos y aspiraciones que el arquitecto ha recogido de los utopistas del siglo XIX y que están presentes en sus investigaciones sobre el problema de la vivienda y de la ciudad durante las primeras décadas -viviendas Dom-Ino ${ }^{9}$, Inmuebles Villas ${ }^{10}$ - en las que sobresalen dos aspectos clave, la relación de la casa con la vegetación y la naturaleza y los espacios colectivos que surgen de los mecanismos de agrupación de las viviendas. Son experiencias de pequeña escala que aluden ya a una conciencia de lo público y de las relaciones sociales cuyo marco ideal de desarrollo será en medio de un paisaje natural y lejos de los centros congestionados de la ciudad industrial.

\subsection{Paisajes habitados: la ciudad en el parque.}

$\mathrm{Al}$ abordar escalas mayores como el diseño de la Ville Contemporaine, una Ciudad para tres millones de habitantes, el paisaje natural, el parque, es el gran espacio público, la alfombra de verdor ${ }^{11}$, en cuyos dominios se insertan los edificios, a partir del cual se despliegan en sus diferentes escalas los diversos espacios públicos, colectivos, comunitarios, de encuentro y relación junto a la diversidad de tipologías edificatorias. Casa y ciudad insertadas en la naturaleza. Este protagonismo del paisaje natural en su relación con la arquitectura es la aportación significativa de Le Corbusier al proyecto de la ciudad contemporánea que recoge de la tradición pintoresca del siglo XIX, que le es transmitida en primera instancia por L`Eplattenier, su profesor en La Chauxde-Fonds ${ }^{12}$.

\footnotetext{
${ }^{9}$ Los espacios públicos y arbolados que resultan de la ordenación zigzagueante de los bloques Dom-Ino evocan La ciudad Industrial de Tony Garnier. Moos, Stanislaus von. Le Corbusier, op. cit. pp. 58-59.

${ }^{10}$ La calle corredor elevada en los diferentes niveles de acceso a las viviendas, que aparecerá posteriormente en los Redents y en las Unités, recuerda los corredores de los falansterios de Fourier.

${ }^{11}$ Curtis, Williams. Le Corbusier. Ideas y formas. Madrid: Blume. 1986. p. 61.

12 Ábalos, Iñaki. Atlas pintoresco. Vol. 2: los viajes. Barcelona: GG. 2008. pp.120 y ss. Analiza las influencias en Le Corbusier de los pintorescos del siglo XIX, como Frederick Law Olmsted, cuyo Central Park le impactará especialmente en su viaje a NY en 1935, junto al Rockefeller Center.
} 


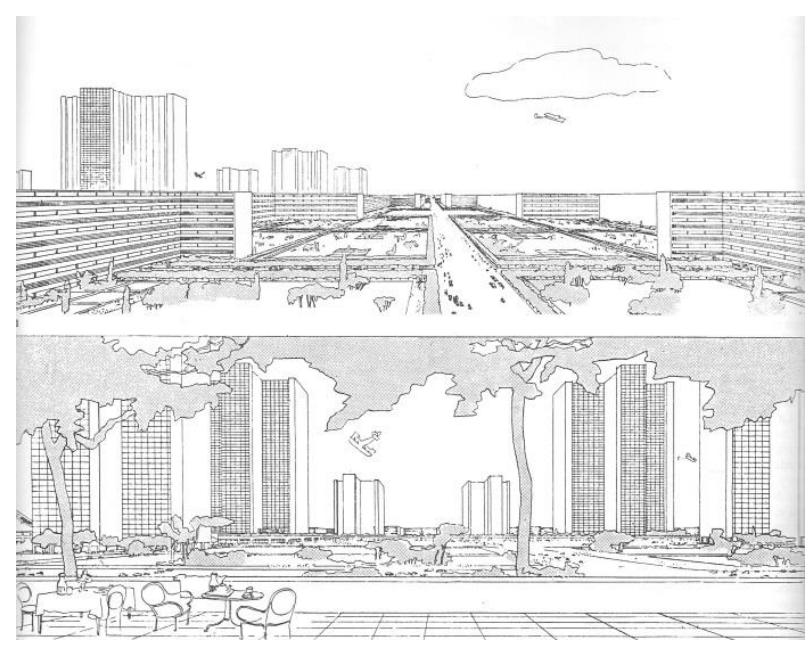

5. LC: Ville Contemporaine. Ciudad para 3 millones de habitantes, 1922. Bloques à Redents de la periferia y rascacielos del centro frente al aeropuerto (LC, Oeuvre Complète. OFLC-ADAGP)

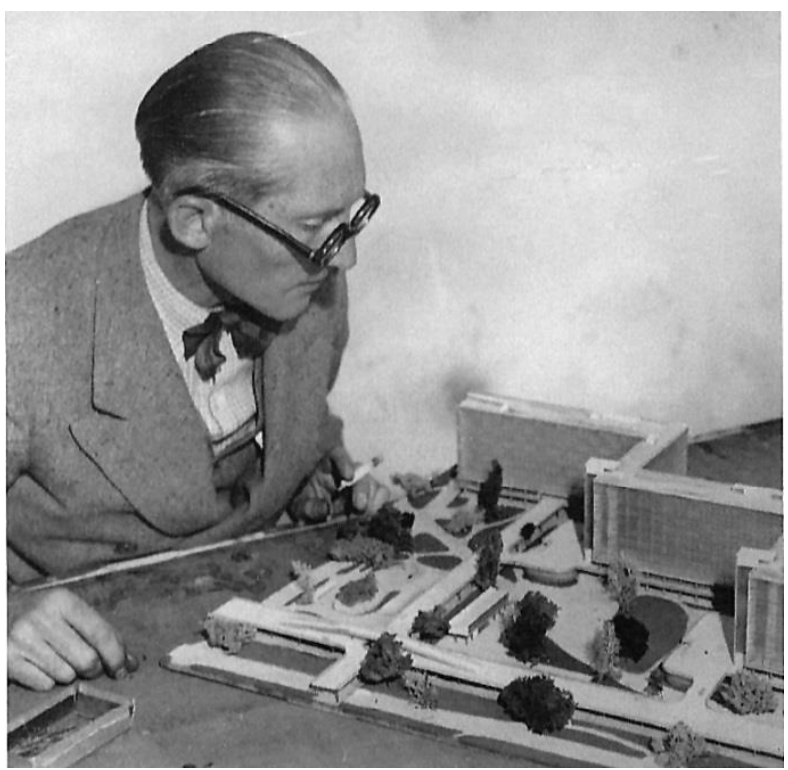

6. LC: ante la maqueta de los Bloques à Redents (LC Oeuvre Compléte. CFLC-ADAGP)

La Ville Contemporaine (1922) y su actualización posterior, la Ville Radieuse (1930-33), son sus aportaciones teóricas a partir de la crítica moderna de la ciudad congestionada, obsoleta, insalubre, heredada del siglo XIX. Junto a un predominio compositivo de la planta que recoge mecanismos geométricos de jardines de los diseñadores franceses de los siglos XVIII y XIX $^{13}$, se recogen las ambiciones utopistas de la vida en la naturaleza y a través del protagonismo "de la naturaleza en la construcción del espacio público de la ciudad"14, la gran máquina de la ciudad moderna de Le Corbusier ${ }^{15}$ adopta el espacio exterior y verde como característica determinante de sus estrategias formales.

Con diferencias en su composición y en sus trazados geométricos, ambas se asemejan en su entendimiento de articular el gran jardín como un plan urbano. La Ville Contemporaine presenta un esquema centralizado y una

\footnotetext{
${ }^{13}$ González Cubero, Josefina, op. cit. pp. 72-73.

${ }^{14}$ Ábalos, Iñaki, op. cit. p.123.

${ }^{15}$ Monteys, Xavier. La gran máquina. La ciudad en Le Corbusier. Barcelona: COAC. 1996.
} 
organización concéntrica en la secuencia tipológica que, desde el centro a la periferia, distribuye rascacielos cruciformes, bloques à redents e inmuebles-villas. Estos tres elementos básicos, que son objeto de diversas experimentaciones en proyectos específicos durante aquellos años, constituyen también la base tipológica de la Ville Radieuse que organiza con una serie de bandas paralelas, diferenciadas por usos y tipologías, y cosidas por una espina central que concluye en la agrupación de los rascacielos de oficinas, configurando una composición antropomórfica.

El Plan Voisin (1925), que arrasaba buena parte del centro de París situado al norte del Sena, representa una concreción mayor con el lugar y una menor idealización que las anteriores, adecuándose al menos a la continuidad de las calles del entorno y manteneniendo dentro de su perímetro algunos edificios preexistentes. Esta mediación, que en este caso establece la corona más exterior de los inmuebles-villas en su encuentro con las edificaciones del viejo París, sería más difícil con la propuesta Ville Radieuse. No obstante, la defensa que el propio Le Corbusier hace en Buenos Aires del Plan Voisin como "máquina de finanzas: la época maquinista ha creado una mina de diamantes en el centro de París" ${ }^{\prime 6}$, deja expuestas las razones para concitar una crítica sobre el carácter de herramienta de producción de la ciudad liberal que este tipo de planes urbanísticos contiene ${ }^{17}$.

Le Corbusier proyecta para el centro de la Ville Contemporaine siete niveles de circulación superpuestos ${ }^{18}$ que albergarían, enunciados desde abajo hasta el nivel superior: estaciones de grandes líneas, recorridos de cercanías, el metro, circulación de peatones, cruces de tránsito ligero y, finalmente, el aeropuerto. Además, la superposición de niveles, con calles elevadas para el tráfico rápido de coches, permitía la continuidad ininterrumpida de tránsitos peatonales y los recorridos sinuosos a pie entre la vegetación que explicita el dibujo de la Ville Verte ${ }^{19}$. Si en la Ville Contemporaine estas calles elevadas sobre pilotis para el tráfico se limitaban a los ejes principales, en la Ville Radieuse aparecen en mayor número y complejidad.

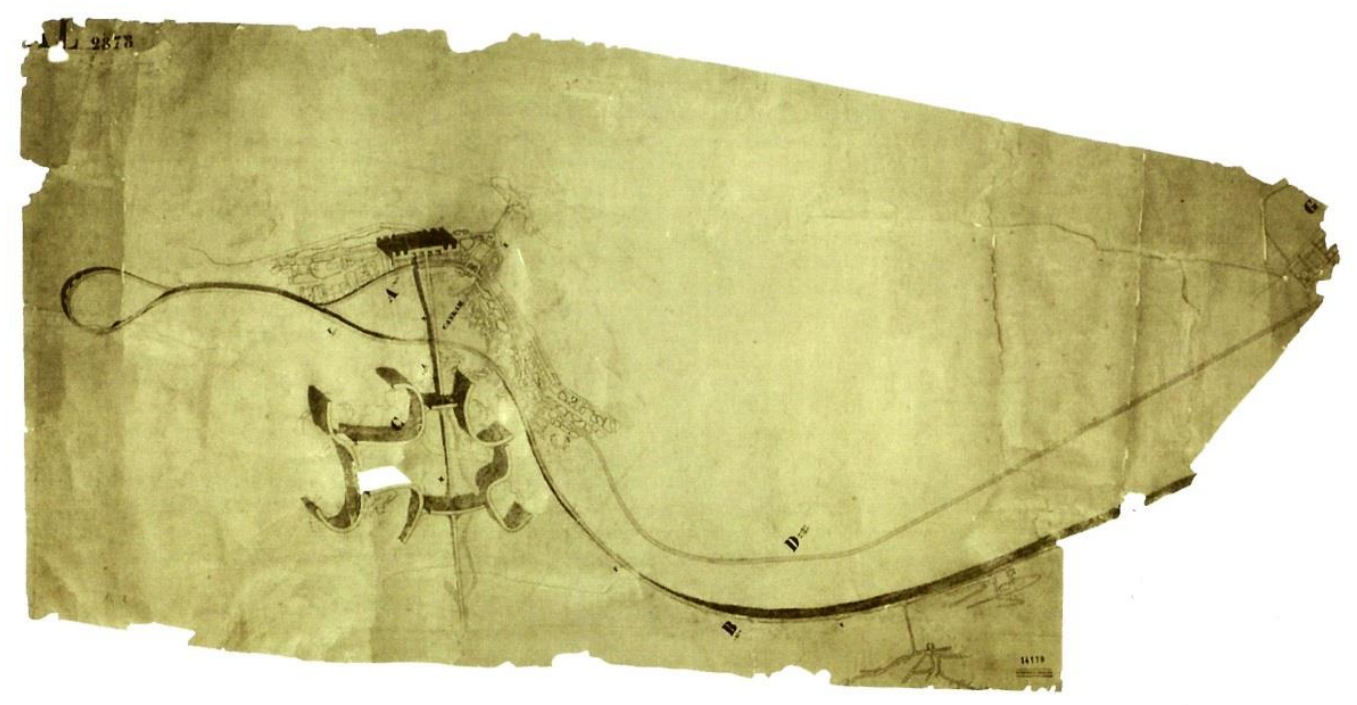

7. LC: Plan Obús para Argel (1932-34). Planta. FLC 14118. @FLC-ADAGP.

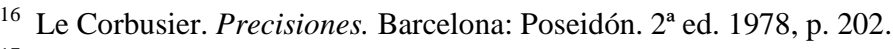

${ }^{17}$ Tafuri, Manfredo, op. cit., p. 214.

${ }^{18}$ Moos, Stanislaus von, op. cit., p. 202.

${ }^{19}$ Le Corbusier, Op. cit., p. 179.
} 


\subsection{Argel: infraestructura habitada y acústica visual.}

Las vías elevadas para el tráfico de automóviles de los modelos teóricos representan, por un lado, la reconciliación de la ciencia -el tráfico rápido sin interrupción- y la naturaleza -posibilidad de recorrer a pie, también sin interrupción, los senderos peatonales entre los árboles-; supone la convivencia de la civilización maquinista con la naturaleza ${ }^{20}$; por otra parte, estas vías rápidas elevadas vinculan el mito de la velocidad y una especial percepción del paisaje; no por casualidad, las perspectivas que muestran la contemplación del paisaje desde esta posición privilegiada mientras se conduce subrayan su predisposición al deleite en la casi total ausencia de tráfico. Es una plasmación más de las estrategias de le Corbusier en torno a la idea de una visión en movimiento ${ }^{21}$.

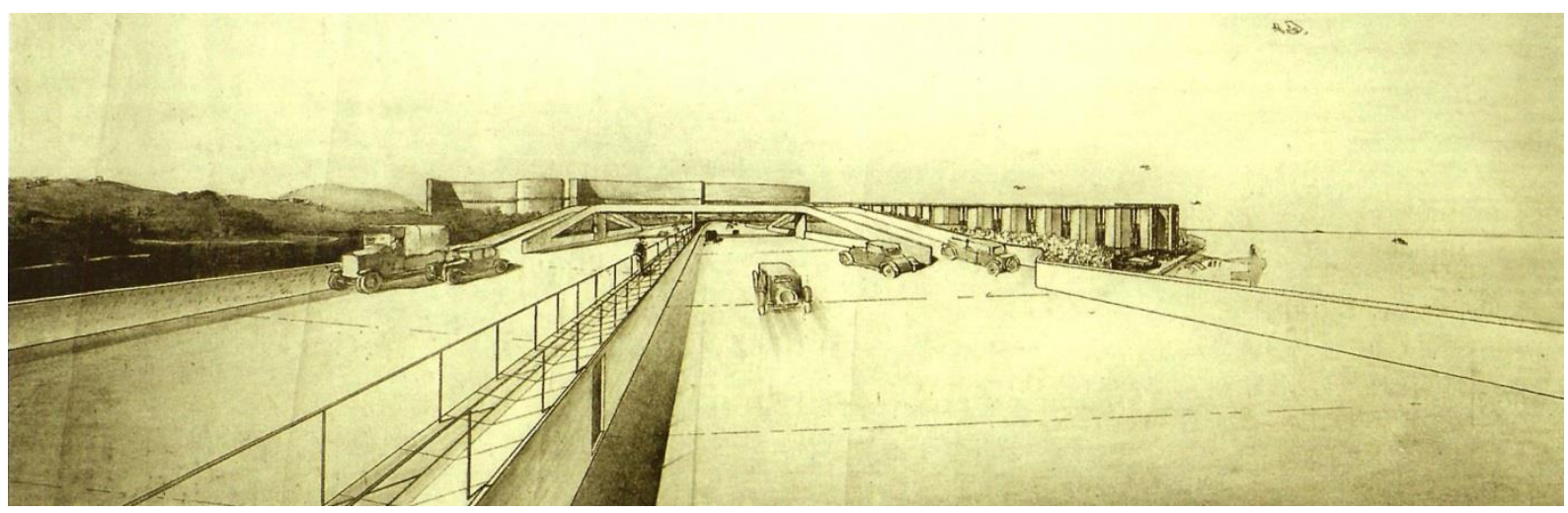

8. LC: Plan Obús para Argel (1932-34). Percepción desde el viaducto habitado mientras conducimos (Versión B. CFLC-

\section{ADAGP)}

En el proyecto Obús para Argel (1932-34) el mito de la velocidad sigue presente pero entra en juego la acusada topografía y emergen dos aspectos que anclan la propuesta al lugar con tanta radicalidad visual como significación cultural y ello se produce desde una mayor concreción y relación dialéctica con el sitio; en Argel propone construir un viaducto habitado, elevado 100 metros y bajo el cual se construirán las viviendas. Un edificio puente que recorre en paralelo la bahía, siguiendo la geometría curva de la costa. Este particular modo de responder a la topografía ya había aparecido en algunas propuestas para Sudamérica -Sao Paulo, Río de Janeiro, Montevideo- con ocasión del viaje de 1929, a la vuelta del cual escribirá durante el viaje de regreso sus Precisiones respecto a un estado actual de la arquitectura y del urbanismo. a diferencia de los modelos teóricos que hemos visto, donde los edificios residenciales construían un nuevo horizonte, ahora son esos viaductos los nuevos horizontes que referencian el lugar. La topografía provoca una reacción poética ${ }^{22}$ y, en el caso de Argel, "las curvas de la carretera evocaban el vaivén de las caderas de las mujeres y el contorno de sus cuerpos tendidos $^{23}$; el trazado sinuoso del viaducto y de los bloques à redents, situados estos sobre el promontorio de Fort L`Empereur y destinados a la vivienda de la población europea, recuerda los trazados de los desnudos de mujeres de sus dibujos y pinturas y la geometría de la caligrafía árabe. En Argel aparece también el concepto de acústica visual que Le Corbusier recuerda haber sentido por primera vez frente al Partenón en 1910 y que va a

\footnotetext{
${ }^{20}$ Picon, Antoine."Argel: ciudad, infraestructura y paisaje”. En AV Monografías, Le Corbusier. An Altas of Landscapes, op. cit. pp. 64 y ss.

${ }^{21}$ Cohen, Jean-Louis. "En defensa del paisaje”. En AV Monografías. Le Corbusier. An Altas of Landscapes, ibídem, p. 10.

${ }^{22}$ Frampton, Kenneth, "The Rise and Fall of the Radiant City: Le Corbusier 1928-1960”. En Oppositions. Le Corbusier 1923-1960. 1980, 19-20. Cambridge: MIT Press, p. 3

${ }^{23}$ Picon, Antoine, op. cit., p. 66; Macleod, Mary. "Le Corbusier and Algiers" .En Oppositions, 1980, 19-20, op. cit., pp. 5585; Moos, Stanislaus von, "Le Corbusier As Painter". En Oppositions, 1980, 19-20, ibídem, pp. 89-107.
} 
ser un argumento importante en su justificación del proyecto de Ronchamp: "El Plan Obús para Argel, inmediatamente posterior a sus vuelos americanos, será su primera gran composición de acústica visual”,24.

\section{Espacios colectivos: espacios de encuentro y relación para la comunidad.}

El juego de dualidades contrapuestas y la confrontación de fenómenos dispares es un procedimiento proyectual muy utilizado por Le Corbusier ${ }^{25}$. En la Unidad de Habitación de Marsella y en Ronchamp están también presentes pero la comparación entre ambas obras, tan cercanas en el tiempo de su ejecución y tan distantes en la fortuna crítica inicial, puede resultar estimulante. A pesar de su diferente programa, residencial y religioso, ambas atienden el desarrollo de una vida social y colectiva en un lugar determinado -recorrido, acceso, ascensión, reunión, comunicabilidad,...-. Son dos proyectos que de modo distinto privilegian los espacios colectivos de encuentro y conexión de sus respectivas comunidades.

\subsection{UHM y Ronchamp: fenómenos duales}

La Unidad de Habitación de Marsella (1947-52) y la capilla de Nôtre Dame du Haut de Ronchamp (1950-54) representan el final de una etapa, la primera, y el principio de otra, la segunda. Todavía hoy, vistas juntas, configuran una imagen ambivalente que las hace parecer cosas diversas; buena parte de la crítica asumió sin más que, abandonando las proclamas maquinistas de las décadas anteriores que prepararon la construcción de la Unidad de Habitación, Le Corbusier se sumergió en una experimentación plástica motivada por el programa religioso. Abstracción formal en la primera y empatía en la segunda expresan claramente sus diferencias y los cambios vitales.

Marsella y Ronchamp parecen dos caras contrapuestas de la reflexión sobre la relación entre técnica y arquitectura que constituye a su vez un debate permanente en la historia del arte y de la arquitectura. La primera

unidad de habitación que construyó -también la más completa de programa colectivo y más elaborada en su construcción- y la iglesia de Nôtre Dame du Haut representan dos imágenes y dos sistemas formales tan contrapuestos a priori, como sendas caras de La Gorgona que el propio Le Corbusier publicara en 1942, una figura ambivalente donde el rostro del sol, que significa vida, alude a la nueva arquitectura y la medusa Gorgona, que a quien miraba convertía en piedra, es símbolo de muerte y de la Academia ${ }^{26}$, de la dualidad entre ciencia y $\operatorname{arte}^{27}$. James Stirling expresó tempranamente en primera persona la perplejidad que gran parte de la crítica experimentó ante la dualidad contrapuesta que el propio Le Corbusier asumió al concluir dos obras casi en el mismo tiempo como Ronchamp y las casas Jaoul, apenas posteriores a la finalización de la Unidad de Habitación de Marsella. Al analizar la experiencia que Le Corbusier había recorrido en su arquitectura doméstica desde la segunda década del siglo XX hasta sus casas más brutalistas advertía que "Le Corbusier, yendo de lo general a lo particular, ha producido una obra maestra de un orden excepcional pero completamente personal" $y$ subraya cómo Garches y Jaoul “... representan los dos extremos de su vocabulario..." 28.

\footnotetext{
${ }^{24}$ Quetglas, Josep. "Ronchamp: un paisaje de acústica visual”. En AV Monografías. Le Corbusier. An Altas of Landscapes, op. cit., p. 56.

${ }^{25}$ Menin, Sarah; Samuel, Flora. Nature and Space: Aalto and Le Corbusier. London-New York: Routledge. 2003, p. 23; Curtis, Williams. Le Corbusier, op. cit., p. 11.

${ }^{26}$ Pierrefeu, François de, Le Corbusier, La maison de l’ homme, París: Plon, 1942, p. 204. La ilustración se publicó también en el cuarto volumen de la Oeuvre complète, 1965.

${ }^{27}$ Torres Cueco, Jorge, op. cit., p. 225. cfr. Frampton, Kenneth, Le Corbusier, Madrid: Akal, 2000 (Hazan, 1997), p. 96.

${ }^{28}$ Stirling, James, De Garches a Jaoul, en AR, 1955; Stirling, James, Ronchamp. La capilla de Le Corbusier y la crisis del racionalismo, en AR, 1956.
} 

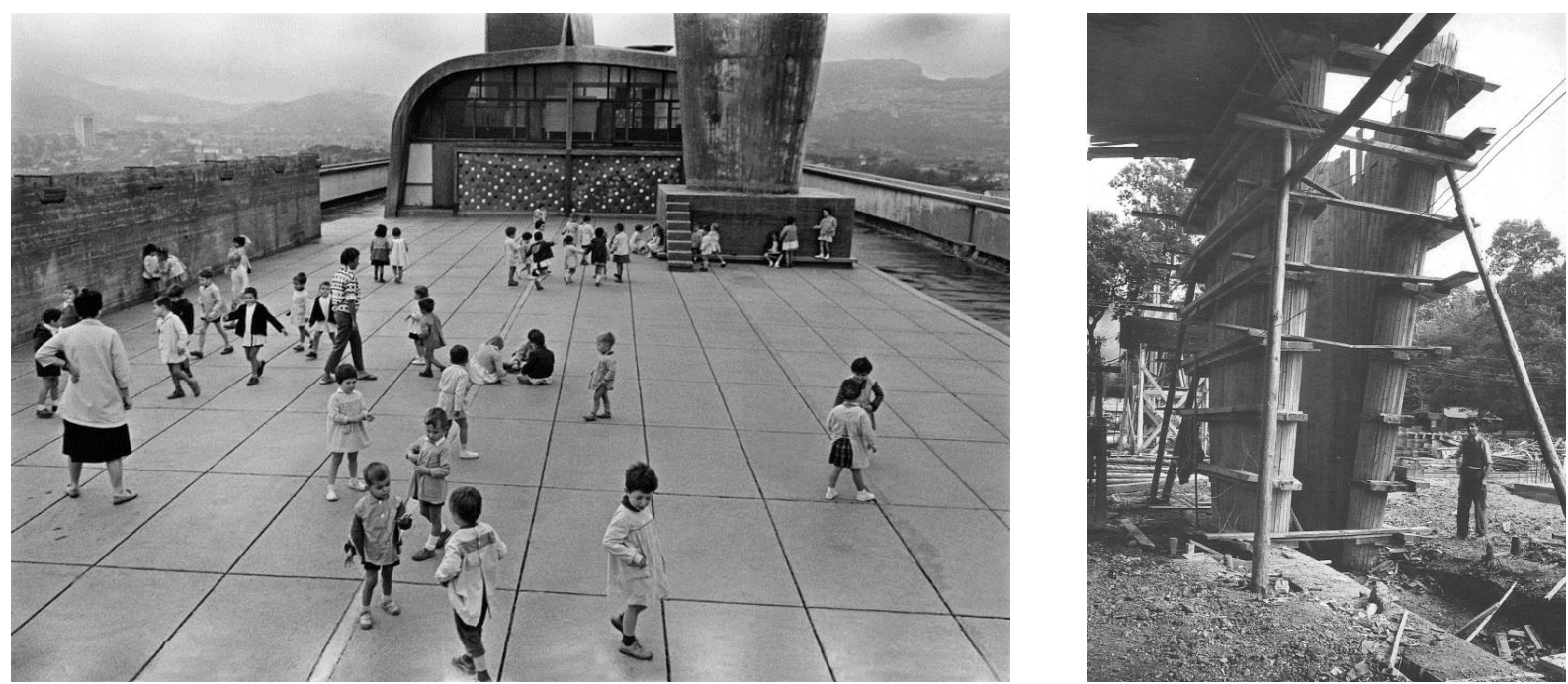

9. LC: UHM: el espacio público de la cubierta; lugar de encuentro colectivo y observatorio del paisaje. OFLC-ADAGP

\section{LC: UHM: pilotis de planta baja (FLC, L1.13.102. (FLC-ADAGP)}

No obstante esta dialéctica no es cerrada y en ambos casos se interpretan y transfieren valores de uno de ambos sistemas (maquinista y fenomenológico) en el otro. Aunque, como el propio Stirling detecta, cabe identificar claramente un cambio filosófico de actitud entre el sistema formal de la Unidad de Habitación y el de la capilla de Ronchamp, el debate contiene mayor complejidad, pues si en el contexto social es posible datar en torno a 1950 este cambio $^{29}$, también es fácil identificar ejemplos de esa actitud fenoménica con anterioridad ${ }^{30} \mathrm{y}$, a su vez, el eco de estrategias enunciadas anteriormente en las obras posteriores.

La actitud brutalista de las casas Jaoul está presente en el hormigonado en bruto de los pilotis de Marsella, cuya marcada textura de la tablazón del encofrado -que el propio arquitecto prefería frente al relamido acabado de los pilotis de Berlín- recuerda la materia de que están hechos y el trabajo artesanal de su ejecución; una actitud, que teniendo episodios anteriores, convive en Marsella con el montaje en seco de elementos prefabricados ${ }^{31}$.

\footnotetext{
${ }^{29}$ Judt, Tony, Post-guerra. Una historia de Europa desde 1945. Madrid: Santillana, 2005, p. 24.

${ }^{30}$ Frampton, Kenneth. "The other Le Corbusier: Primitive Form and the Linear City, 1929-52". En Frampton, Kenneth, Labour, work and architecture, op. cit., p. 218-225; Monteys, Xavier. "Le Plan Paralysé. Revisando los cinco puntos". En Quetglas, Josep. Massilia 2002: anuario de estudios lecorbuserianos. Barcelona: Fundación Caja de Arquitectos. 2002, pp. 141-147.

${ }^{31}$ Frampton, Kenneth, Le Corbusier, op. cit. pp. 112-146
} 


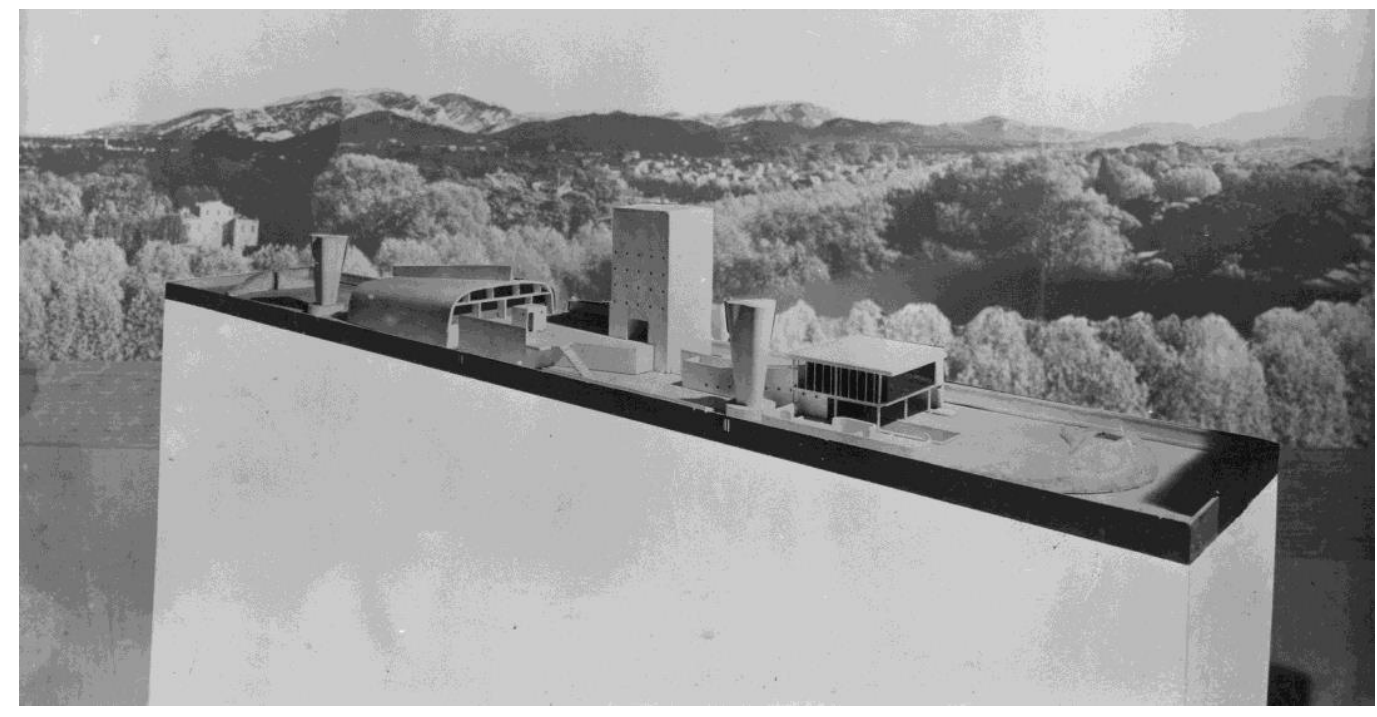

11. LC: UHM: maqueta de la cubierta (FLC, L1.12.38. (FLC-ADAGP)

\subsection{Los espacios públicos de la UHM. La soledad de las unités. Identidad y significación de la terraza comunitaria}

La imagen de jaula tridimensional del botellero es la imagen que construye la fachada del edificio como imagen alveolar, como suma de espacios o vacíos entre planos huecos que albergan la estructura y las instalaciones. El edificio consolida la imagen de esta pequeña ciudad como suma de unidades o alvéolos articulados por tres elementos de escala colectiva: la calle comercial que se ubica en niveles intermedios y los ya mencionados equipamientos y espacios de encuentro de la cubierta y de la planta baja. Su escala monumental está en consonancia con la 'grandeur conforme ${ }^{32}$ que buscaba Le Corbusier y que es el catalizador de la reinterpretación operada sobre los cinco puntos de su arquitectura. En este sentido, la Unidad de habitación de Marsella no es sólo el epígono de una época sino que se presenta como una experiencia cargada de futuro, no tanto en la traslación literal de hallazgos formales, sino en la maduración conceptual llevada a cabo sobre el papel que los aspectos técnicos van a desempeñar en la estrategia formal. Las 'unidades de habitación' conforman una ciudad vertical que alberga entre 300 y 400 familias, superponiendo sobre un desarrollo de planta común los usos privados y colectivos, circunstancia que no queda enunciada en los inicios del proyecto de Marsella pero que se alcanza en etapas sucesivas. Su carácter microurbano y acumulativo se sustancia en la autonomía formal de cada parte, significando con claridad el juego vibrante de vida -apartamentos y espacios de tránsito y relación- y azaroso juego de escalas en la combinación de usos y medidas; con la excepción de la forzada inclusión de todo el programa en la volumetría prismática, cabría advertir la traslación al proyecto de una contingencia procesual que es característica notable en Ronchamp y otras obras; de hecho, frente al resto de las unidades ejecutadas, los pilotis de Marsella denotan esta cualidad fenomenológica en su geometría y materialidad, explotando la condición 'matérica' del hormigón bruto ${ }^{33}$. Esta visualización y puesta en escena del proceso de transformación de los pilotis de Marsella -al igual que en muchas de las piezas de la cubierta: gimnasio, chimeneas de

\footnotetext{
${ }^{32}$ Banham, Reyner, "Fórmulas de vivienda colectiva. La maison des hommes y la misère des villes", en Le Corbusier (II), AV,10, Madrid, 1987, pp. 24-35; Curtis, William, Le Corbusier, op. cit., pp. 162-174; Moos, Stanislaus von, Le Corbusier, op. cit. pp. 234 y ss.; Calafell, Eduard, Las unités d’habitation de Le Corbusier, Barcelona: Fundación Caja de Arquitectos, 2000, pp. 14-35.

${ }^{33}$ Gargiani, Roberto, Rosellini, Anna. Béton Brut and Ineffable Space, 1940-1965. New York-Oxford: Routledge, EPFL Press, 2011, pp. 3 y ss.
} 
ventilación, las rocas junto a la piscina, etc, cuyas geometrías explotan las posibilidades plásticas de la ejecución del hormigón bruto anticipan mecanismos de proyecto que va a experimentar a partir de Ronchamp.

La terraza en la cubierta de la UHM representa, mejor que en ninguna de las otras cuatro unités construidas ${ }^{34}$, que fueron progresivamente simplificándose, la necesidad de dotar de sentido y significado a los espacios públicos de estas ciudades verticales; la fotografía de la maqueta de la terraza, con todos sus edificios y espacios comunitarios en detalle, frente al absoluto desdibujado de todos los pisos inferiores -relegados a constituir un mero basamento de realce de esos espacios públicos de la comunidad- nos parece suficientemente expresiva de la intencionalidad significante: "Se trata del lugar que Le Corbusier denominaba toit-terrasse, que alberga una serie de instalaciones destinadas al uso colectivo, a la cultura del cuerpo y del espíritu-gimnasio, solario, sala de juegos de la guardería, teatro, piscina- y cuya formalización y disposición contrasta fuertemente con la regularidad y repetición que son una constante en el cuerpo del edificio" ${ }^{35}$. La terraza que corona el edificio acoge el desplazamiento de casi todos los equipamientos que requiere la comunidad que, a excepción de una zona comercial ubicada en plantas intermedias, son deslocalizados de la habitual cota del suelo en planta baja y reubicados en la cubierta del edificio mediante una estrategia bastante frecuente en Le Corbusier, consistente en trastocar las localizaciones habituales del programa dentro del propio edificio ${ }^{36}$. Esta cota privilegiada de la cubierta se convierte en un mirador urbano sobre el paisaje, una infraestructura clave de este edificio-ciudad, a la que complementa el suelo elevado sobre pilotis que alberga las instalaciones. El uso colectivo de la cubierta estaba ya presente en los inmuebles villas de los años veinte y en los redents de la Ville Contemporaine, pero sin la fuerte carga simbólica que la estrategia formal de estos usos comunitarios le añaden.

La soledad de una única unité lastra en buena medida la idea de la ciudad en el parque, la idea del paisaje como espacio público y la posibilidad de contemplar el cruce de senderos peatonales que se despliega en la Ville Verte. Este era el planteamiento inicial de estas pequeñas ordenaciones y así sucede en el proyecto donde por primera vez aparece el tipo edificatorio de la unité, el proyecto de dieciocho unités en Némours (1934), conectadas por una red de circulaciones con geometría romboidal para adaptarse a la topografía.

\footnotetext{
${ }^{34}$ Sbriglio, Jacques. Le Corbusier: l'Unitéd habitation de Marseille. Marseille: Parenthèses, 1992.

${ }^{35}$ Sequeira, Marta. "Toit-civique. Le Corbusier y el espacio público a 50 metros del suelo". En PC: proyecto y ciudad: revista de temas de arquitectura, 2012, $n^{\circ}$ 3. Cartagena: Universidad, p. 21; Sequeira, Marta. "A Concepçâo da cobertura da Unitéd'habitation de Marselha: três invariáveis". En Quetglas, Josep et altri. Massilia 2005: anuario de estudios lecorbuserianos. San Cugat del Vallés: Centre d`investigacions estétiques. 2005, pp. 132-155.

${ }^{36}$ Alonso García, Eusebio. "Estrategias alucinatorias en el último Le Corbusier”. En Actas, Critic/All. Madrid: Critic/All Press. 2014, pp. 55-73.
} 


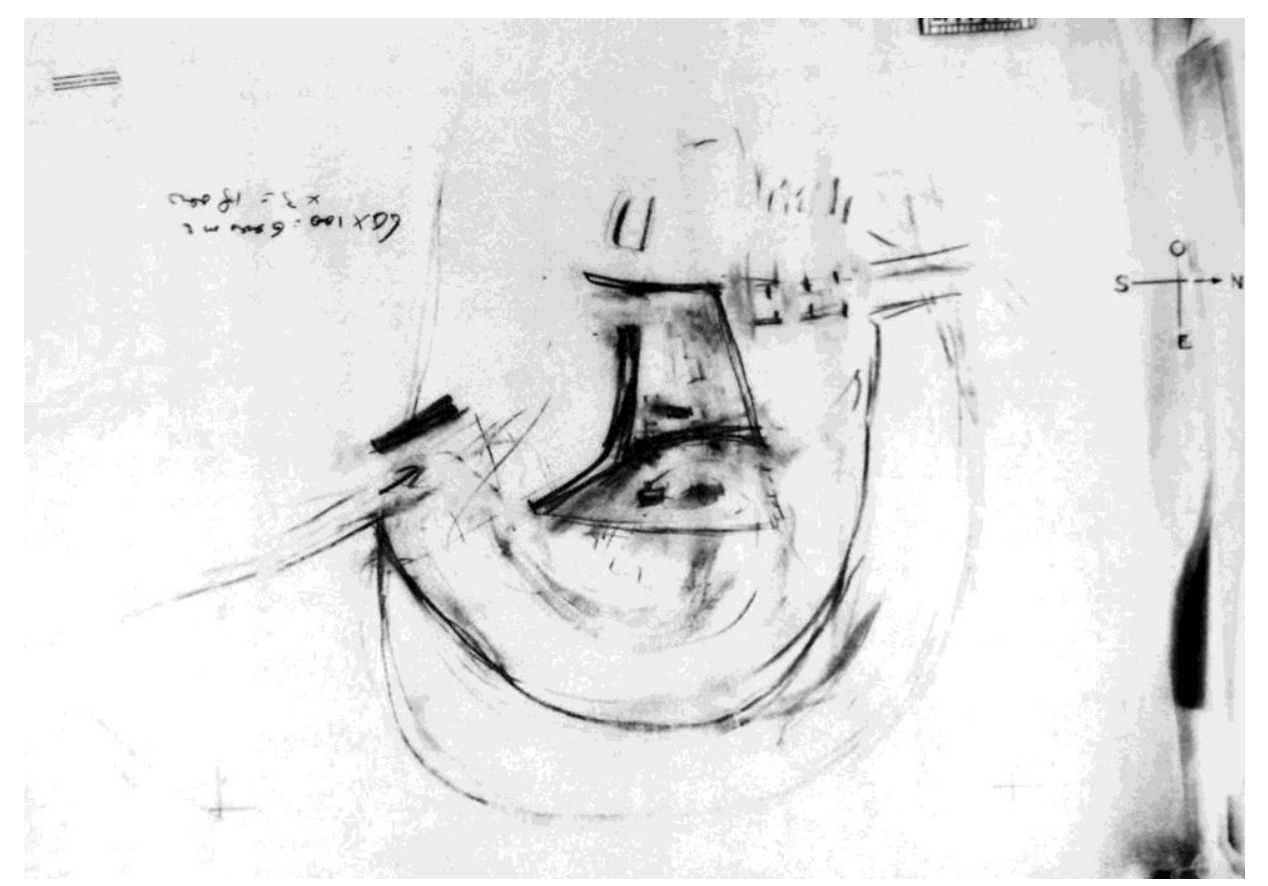

12. LC: primer diseño de Ronchamp (FLC 7470. @FLC-ADAGP) donde aparece la cávea que encinta la iglesia exterior

\subsection{La capilla de Ronchamp: identidad, memoria, significado}

La iglesia de Ronchamp protagoniza una lista de proyectos y edificios de tema religioso del que tan sólo tenía dos precedentes que no pasaron de las primeros bocetos: Le Tremblay (1929), donde una rampa exterior accede al volumen vertical y ortodoxamente prismático; la iglesia excavada en la montaña de la Sainte Baume (1948), la evocación del espacio excavado; el Convento de la Tourette (1956), donde la iglesia cierra el claustro en el lado norte y en el convento el programa de usos se superpone en diferentes niveles, ocupando los superiores las habitaciones; Firminy (1961-63 y 2003-2006); este proyecto quedó inconcluso a su muerte, en 2003 apenas estaba ejecutado parte del zócalo inferior y la iglesia ha sido recientemente concluida. Ronchamp (1950-55) es un espacio críptico y evocador, cuya forma es el resultado de un proceso altamente sensible, cuyas reglas no resultan obvias ${ }^{37}$.

Ya no es tan fácil individualizar los volúmenes platónicos que el arquitecto descubrió en la Roma clásica; estos han sufrido a lo largo del proceso de proyecto una transformación. El propio arquitecto reconoce en esos últimos años el carácter biológico de su arquitectura. Su complejidad y sus anamorfosis le acercan a los procesos formales de arquitectos barrocos como Borromini -con quien compartía también el gusto por coleccionar objects trouvés, entre ellos, conchas, caracolas-, o a la evolución formativa de los organismos biológicos que enseñó D’Arcy Thompson por primera vez en 1917 y que volvió a publicar en 1942. Alan Coulquhoun constata la “necesidad de introducir 'intención' en el proceso de diseño" ante la imposibilidad de la pura objetividad tras la entrevista con Xenakis en la que éste relata cómo en el proceso de diseño del Pabellón Philips (1958), junto a Le Corbusier (otra versión no cúbica de la boîte des mîracles): "utilizó procedimientos matemáticos para determinar la forma característica de la estructura ... el cálculo determinó la forma característica de la

\footnotetext{
${ }^{37}$ Eardley, Anthony, Le Corbusier's Firminy Church, NY: IAUS, Rizzoli International, 1981; Teresa Trillo, Enrique de, Tránsitos de la forma, Barcelona: Fundación Caja de Arquitectos, 2009; Burriel Bielza, Luis, 2010, "El altar y la puerta en la iglesia parroquial de Saint-Pierre de Firminy-Vert”, RA nº 12, junio 2010, Universidad de Navarra; Alonso García, Eusebio, "La iglesia de Firminy y la machine à émouvoir de Le Corbusier", en Actas, Porto: CEAA/Centro de Estudios Arnaldo Araújo, , 2012, pp 61-68
} 
estructura, pero después de esto la lógica deja de actuar y la organización compositiva tiene que ser decidida basada en la intuición”; y concluye que "una doctrina puramente teleológica de las formas técnico-estéticas resulta insostenible ${ }^{, 38}$.

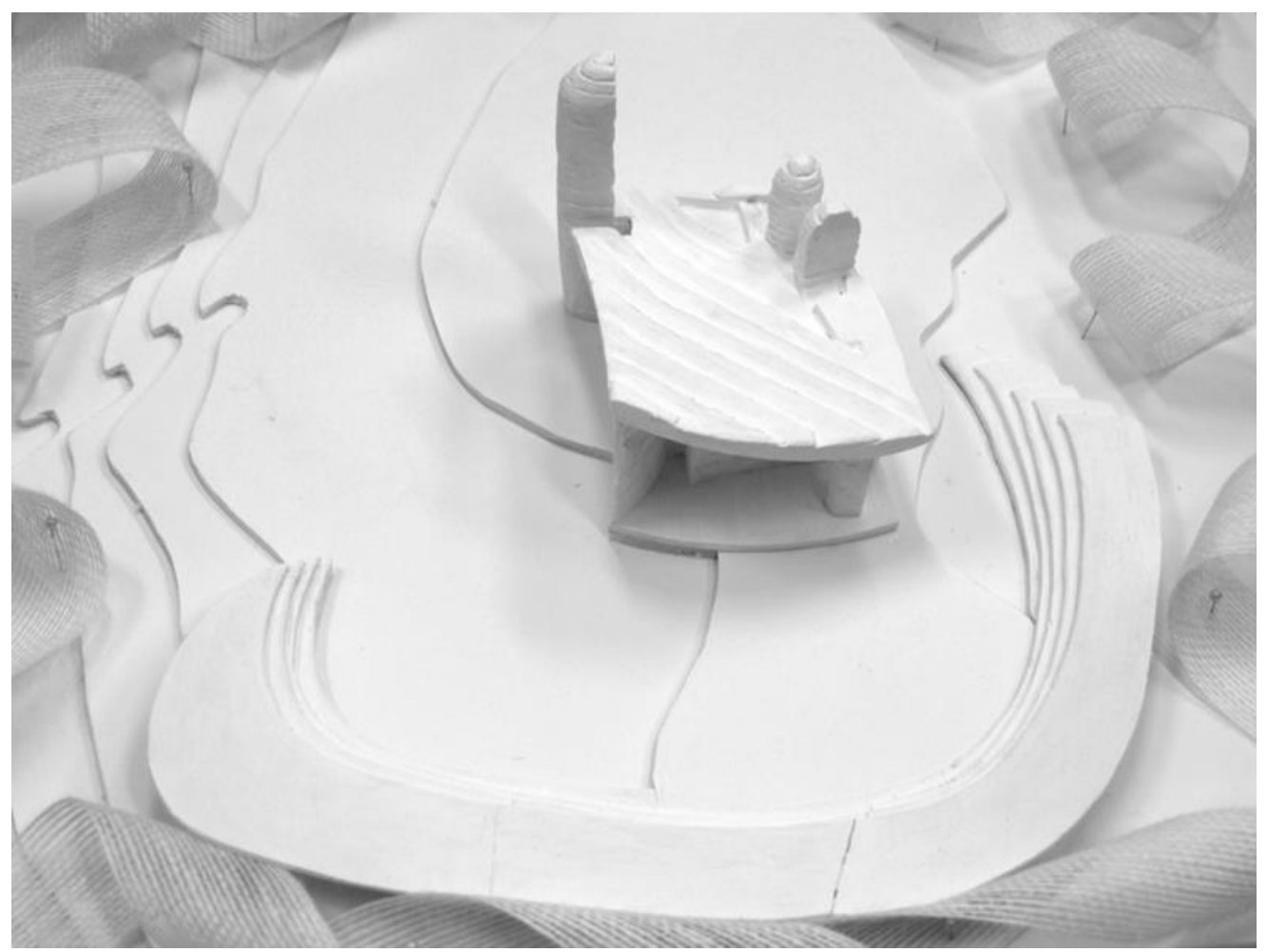

13. LC, Ronchamp. Hipótesis de maqueta según los primeros diseños de Ronchamp (@Eusebio Alonso García) donde aparece la cávea que encinta la iglesia exterior.

Aldo van Eyck defendió la idea de que la arquitectura, más allá ser funcional, debía ser portadora de significado ${ }^{39}$. Definió la arquitectura como construcción significante en una clara crítica hacia el funcionalismo e investigó en los mecanismos de accesibilidad al nivel emocional: "Van Eyck reconoció 'el lugar' en tanto que cualidad universal fundada en todas las formas de la arquitectura urbana pre-industrial, como 'espacio abierto', como 'espacio hecho accesible', tanto emocional como institucional, como un espacio concreto que es conquistado por el lenguaje urbano desde el vacío neutral del espacio Newtoniano y cargado con potencial especifico de la experiencia "40. Para Reyner Banham, la capacidad de conmover es una de las características del nuevo brutalismo; inicialmente le asignaba tres características: la legibilidad formal de la planta, clara exhibición de la estructura y valoración de los materiales por sus cualidades inherentes; posteriormente, siguiendo los proyectos de los Smithson, reemplazó el primer punto por “memorabilidad como imagen”, subrayando la relevancia de la imagen por sí misma y explicaba que su valor reside en la capacidad de conmover a quien la contempla $^{41}$.

\footnotetext{
${ }^{38}$ Coulquhoun, Alan, “Tipología y método de diseño”, en Jencks, Charles, Bird, G, El significado en arquitectura. Madrid: Blume, 1975 (1969), p. 302.

${ }^{39}$ Strauven, Francis, Aldo van Eyck. The Shape of Relativity, Amsterdam: Architectura and Natura, 1998.

${ }^{40}$ Strauven, Francis, "The urban conjugation of functionalism architecture", en VV.AA., Aldo van Eyck, Amsterdam: Stichting Wonen, 1982, p. 101.

${ }^{41}$ Nernández Villalobos, Nieves, Utopías domésticas. La casa del futuro de Alison y Peter Smithson, Barcelona: Fundación Caja de Arquitectos, 2012, p. 23.
} 


\subsection{Comunicabilidad: La machine à émouvoir}

"La percepción ... funciona de una forma que es esencialmente distinta del análisis científico. La experiencia posee una naturaleza "sintética", comprende conjuntos complejos cuyos componentes, aún sin tener una relación lógica, aparecen, sin embargo, totalmente integrados. En nuestro caso es especialmente importante el amplio grupo de sistemas simbólicos conocido como arte. El arte no nos proporciona descripciones sino expresiones directas de ciertos aspectos de la realidad",42.

Le Corbusier apreció en sus viajes esta máquina de conmover; en el capítulo dedicado a 'arquitectura pura, creación del espíritu': “... Voici la machine à émouvoir. Nous entrons dans l'implacable de la mécanique [...] ces formes provoquent des sensations catégoriques ...Le sentiment d'une fatalité extra-humaine vous saisit. Le Parthénon, terrible machine, broie et domine ${ }^{, 43}$. La estrategia formal de Ronchamp trasciende lo razonable y constituye el paradigma de lo que le Corbusier definió como el 'espacio indecible ${ }^{44}$, algo de lo que es difícil hablar porque asistimos a una visión repentina de un proceso que ya no es mera combinatoria sino el resultado de transformaciones sucesivas que, como afirma el propio arquitecto: “... es una aventura que se desarrolla en tres tiempos: 1. integrarse en el sitio. 2. Nacimiento 'espontáneo' (después de incubación) de la totalidad de la obra, de una vez, de un golpe. 3. Lenta ejecución de los dibujos, de los diseños, de los planos y de la construcción misma y 4. Acabada la obra, la vida está implicada en la obra, totalmente encajada en una síntesis de sentimientos y de medios materiales de realización ",45.

Un diseño temprano de la planta de Ronchamp, dibujado en formato grande y en una sola sesión, conteniendo algunas correcciones, es un buen ejemplo de esto. Aunque faltan todavía piezas claves del programa como las capillas-torre, elementos fundamentales en la estabilidad del edificio, la estrategia formal está definida con claridad, conteniendo desde estos inicios las dos iglesias, la interior y la exterior de la que se ocupará en posteriores diseños y de la que finalmente no se llegará a construir la cávea que sí queda aquí recogida y aparece en numerosos diseños (un elemento éste de la cávea que acompaña a muchas de las boîte à miracles de su producción). Están ya aquí identificadas las claves de la 'acústica visual' del lugar.

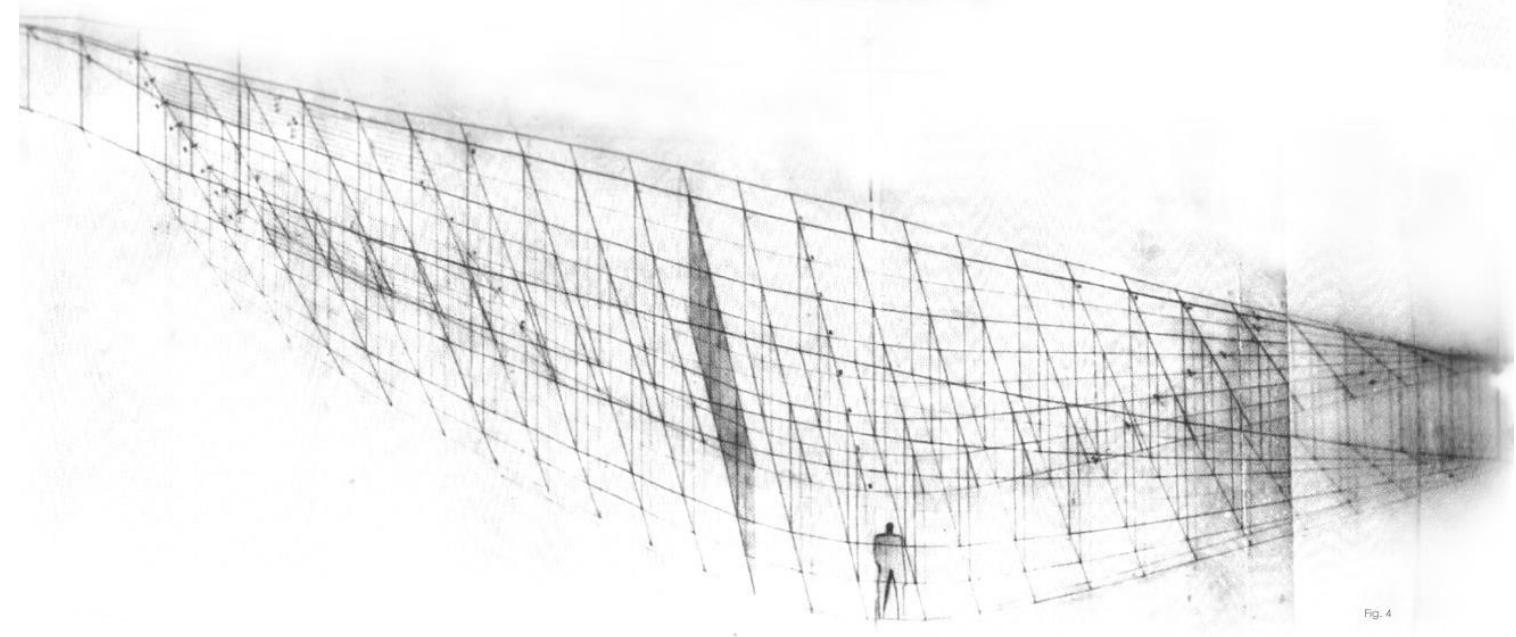

14. LC: Ronchamp. Estructura de la cubierta con las costillas de hormigón. Diseño FLC 7250. CFLC-ADAGP

\footnotetext{
${ }^{42}$ Norberg-Schulz, Christian, "El significado en arquitectura" (1966), en Jencks, Charles, op. cit., p. 242-243.

${ }^{43}$ Le Corbusier, Vers une architecture, París: Crés, 1923, p. 173.

44 "El espacio inefable": Le Corbusier, "L'espace indicible”, en L'Architecture d'Aujourd'hui, n. hors-série, “Art”, 1946, pp. 9-17

${ }^{45}$ Petit, Jean, Le livre de Ronchamp. Le Corbusier. París: Editec, 1961, p. 17.
} 
Es éste un diseño enigmático, 'como surgido de golpe', donde queda reflejada desde sus trazas iniciales la diferente función de los muros sur y este; ambos se reúnen en la esquina que habrá de recibir a los peregrinos en su acceso al sitio y cuyo encuentro con la cubierta configura una de las imágenes más crípticas y conmovedoras de la arquitectura moderna a la vez que ha generado, como advirtiera Stirling, uno de los cuestionamientos más duros a la misma. El edificio contiene todos los elementos necesarios para la liturgia, con el altar situado al este y en cuyo extremo opuesto se ubica la gran gárgola que evacua las aguas de la cubierta sobre la cisterna exterior; queda marcado así un eje este oeste que con otro transversal, que liga las dos capillas más orientales, dibuja un cruz en el pavimento interior, dispuesto con ligera pendiente hacia el altar principal, resuelto con inclinación contraria a la que adopta en el mismo eje el techo, abriendo la perspectiva y activando el terreno de la colina donde se ubica; al igual que en la iglesia exterior, la propia topografía participa en la iglesia interior.

\subsection{Ceci n'est pas une voûte}

Al igual que cuando nos aproximamos al exterior, en el interior de la iglesia 'la machine à émouvoir' actúa con eficacia y junto a la sorpresa entra en juego la memoria: reconocemos formas y mensajes, un espacio abovedado, gruesos muros y vidrieras, aunque, parafraseando a Magritte, tendríamos que decir que 'ceci n'est pas une voûte', pues lo que vemos no es una bóveda sino un gran arquitrabe con un perfil de sección en permanente variación y el muro que parece más grueso, por la geometría de sus ventanales abocinados y no coincidentes, es precisamente el muro más ligero de toda la construcción, pues es un 'muro hueco' que se construye con delgadas pantallas de hormigón armado, arriostradas horizontalmente a diferentes alturas, en concordancia con la distribución de ventanas, y sobre las que se fijaron mallas metálicas para recibir el hormigón proyectado que conforma el acabado de la pared que vemos; toda la cubierta se construyó con delgadas láminas de hormigón que exigieron un encofrado con precisión puntual para cada caso pero con un trabajo sistematizado. La técnica es sofisticada en su planteamiento y callada en su presentación, permitiendo 'activar' el espacio en la intención deseada.

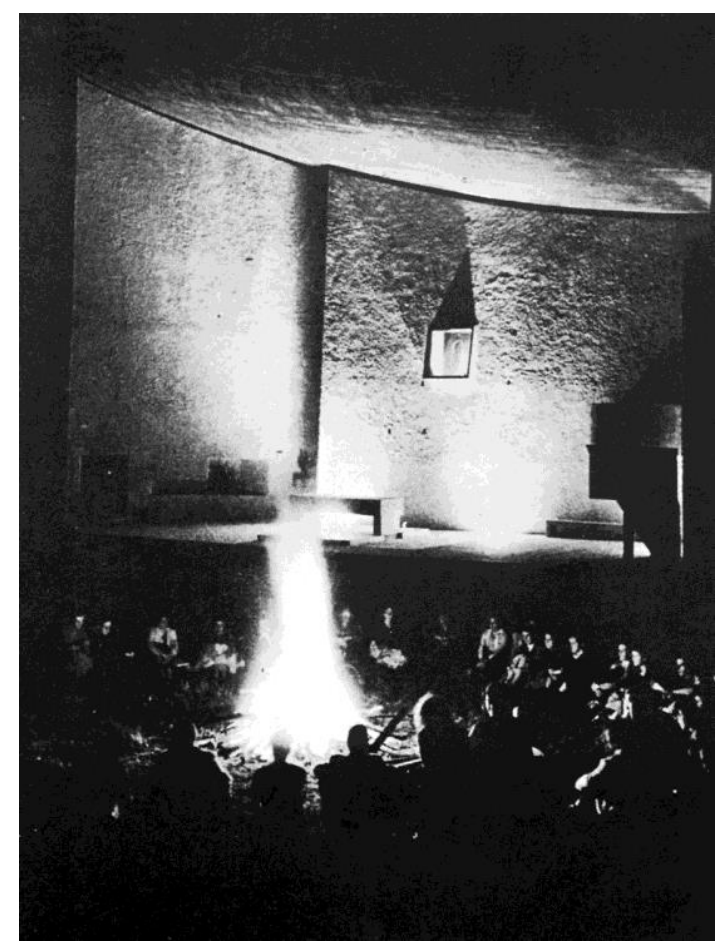

15. LC Ronchamp. Reunión de la comunidad en la explanada de la iglesia exterior (procedencia: J. Petit, Le livre de Ronchamp. (OFLC-ADAGP) 
Ronchamp es ante todo espacio interior; lo era incluso la iglesia exterior con su altar específico y su cávea envolvente $^{46}$ y nos recuerda por ello el mecanismo de la 'boîte à miracles' -no cúbica, en este caso- tal como la describió el propio Le Corbusier: “... el arquitecto puede concebir los edificios que os serán más útiles, porque posee el más alto grado de conocimiento de lo volumétrico. Puede, de hecho, crear una caja mágica que encierre todo lo que podéis desear. Desde la estancia en juego de la 'Caja de los Milagros' escena y actores se materializarán: la 'Caja de los Milagros' es un cubo; en ella se dan todas las cosas necesarias para la fabricación de los milagros, levitación, manipulación, distracción, etc. "47.

La experiencia anterior a Ronchamp fue la frustrada iglesia excavada en la montaña de la Sainte Baume y esta condición de espacio excavado y moldeado está presente en Ronchamp, no sólo por lo que respecta a la 'aparente bóveda invertida', sino por la superficie reglada de la pared del muro sur, o las capillas que alberga el espacio-estructura -en la tradición francesa del poché- de las tres torres. Todo el juego de luces, la que resbala desde lo alto de las torres, la que entra por la grieta entre los muros sur y este y la 'bóveda' es el 'juego sabio 'para activar estas sensaciones. Con obras como la iglesia de Firminy o el Pabellón Philips en la Expo de Bruselas (1958) aprendimos que la 'caja de los milagros' no tiene que ser necesariamente cúbica como si lo es, entre otras obras, en la Tourette o en el Hospital de Venecia.

Función, estructura y símbolo es un breve texto de Kenzo Tange (1966) donde aparecen estas preocupaciones, relativas a la arquitectura, al espacio urbano y a los planes urbanísticos que denotan la preocupación por estas cuestiones en la época: “Creo poder afirmar que tenemos necesidad de un concepto simbólico de la arquitectura y del espacio urbano, a fin de asegurar al hombre la significación y el valor humanos. Si hacemos corresponder una forma característica a una función característica ésta resulta perceptible de inmediato y posee su propia identidad. Desarrollando esta noción, se comprueba que a través de la forma se puede expresar no sólo una función física del espacio, sino también su significación metafísica. ... El pensamiento simbólico entra también en el proceso de estructuración. Es práctico dar una significación simbólica a la propia estructura para elaborar los planes y favorecer su comprensión por la gente" 48 .

\section{Arquitectura y ciudad. Interacciones con el paisaje urbano. De Harvard a Venecia}

Los dos últimos años de su vida Le Corbusier trabajó en el Hospital de Venecia, que finalmente no se llegará a realizar, potenciando con ello el carácter mítico y testamentario que contribuirá a ampliar la resonancia y validez de las posibilidades que el proyecto contiene, cuestión programática inherente a su propio planteamiento, pues en él se aborda no sólo la solución a determinados problemas enunciados sino la cuestión de la flexibilidad frente a la aparición de problemas futuros. Entendiendo que "Las ciudades son caleidoscópicas, metamórficas y caóticas y lo son necesariamente ${ }^{\text {,49 }}$, incorpora en la estrategia formal del proyecto la lógica formativa de la propia ciudad de Venecia. Apenas unos años antes, su intervención en la Harvard extrude la volumetría del edificio a partir a partir de interpretar cuál debe ser la relación de éste con el espacio público. En sendos casos, los espacios públicos de tránsitos y circulaciones no sólo son determinantes en la organización espacial del programa, sino

\footnotetext{
${ }^{46}$ Le Corbusier incorporó un dibujo de este espacio escénico en un diseño para un plato conmemorativo. Sobre la cualidad escénica del espacio de la iglesia exterior y su inclusión en el discurso de un "teatro en serie”, cfr. QUETGLAS, Josep, "Mise en scène de Ronchamp". En RICHARD, Michel, La boîte à miracles. Le Corbusier et le théâtre. Massilia 2012. París: FLC, Editions Imbernon, 2012, pp. 108-109.

${ }^{47}$ Lámina 11, Proyecto del Museo del Siglo XX, en Le Corbusier, Oeuvre Complète, Zurich: Artemis, 1965, Volumen 7, p. 170 .

${ }^{48}$ Tange, Kenzo, "Función, estructura, símbolo”, en Kultermann, Udo, Kenzo Tange 1946-1969, Barcelona: GG, 1970, p. 225; Lin, Zhongjie, KenzoTange and the Metabolism Movement, London-NY: Routledge, 2010, pp. 172 ss.

${ }^{49}$ Eyck, Aldo van, La interioridad del tiempo, en Jencks, Charles, op. cit., p. 201.
} 
que aparecen, como veíamos en el caso de la epifanía que representa el diseño FLC 7470 de Ronchamp, con clarividencia desde el inicio. Más allá de la idea de promenade architecturale -mecanismo que será negado en Venecia- es la idea de circulación y tránsito, de enlaces y conexiones lo que encuentra renovados argumentos de proyectos: "la calle como máquina de circular" había expresado años antes Le Corbusier".

\subsection{La ciudad atraviesa la casa: el Centro de Artes Visuales Carpenter.}

Edificio con una mayor implicación urbana, que anticipa planteamientos del Hospital de Venecia; lo público y lo privado, lo individual y lo colectivo conviven simultáneamente: "En tanto que forma, lo urbano lleva un nombre; es simultaneidad ${ }^{51}$... Simultaneidad de percepciones, de acontecimientos, espacio por tanto de hipersocialización, puesto que es la forma concreta que adopta el encuentro y la reunión de todos los elementos que constituyen la vida social ${ }^{p 2}$.

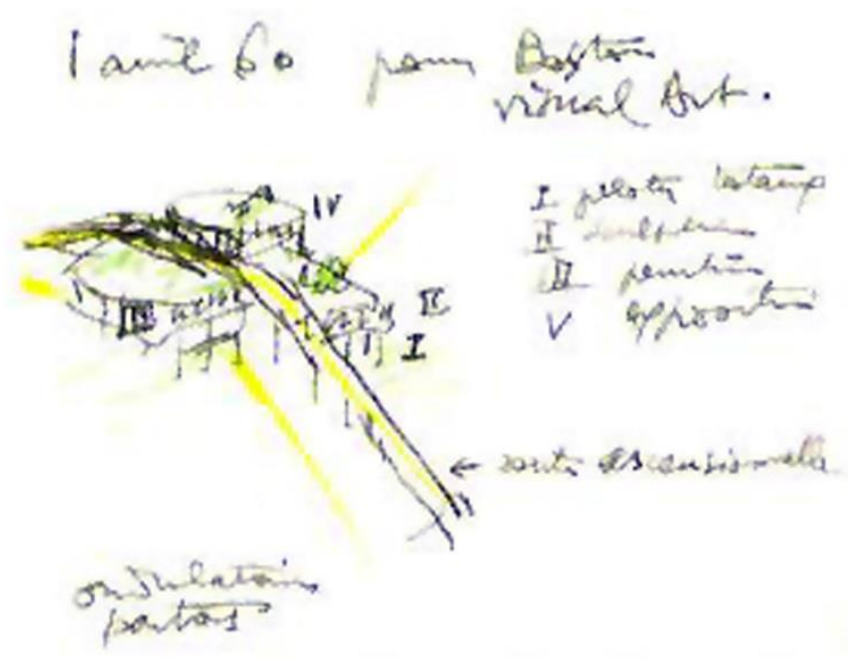

16. LC: Centro de Artes Visuales Carpenter, Universidad de Harvard (1960-63). Croquis carnet P60. OFLC-ADAGP

Sobre la base de la multitud de caminos que atravesaban diagonalmente las diferentes parcelas en el entorno de La Yarda de Harvard y sobre la idea de mantener este recorrido, al parecer existente sobre la propia parcela y con anterioridad a la construcción del centro de artes, Le Corbusier ensaya desde el inicio del proyecto esta visión de un camino que atraviesa en diagonal la parcela ${ }^{53}$; en un diseño muy temprano este recorrido parece describir un bucle sobre lo que habrá de ser el edificio, menos definido y vuelve a salir por el lado opuesto. Como en otros proyectos que hemos visto, esta intuición poética y poderosa supone un anclaje al lugar, entendido de un determinada forma o, mejor dicho, percibido de una determinada forma, pero también al programa; la idea de una calle que atraviesa el edificio satisface también el requisito de flexibilidad y el de potenciar la accesibilidad de los estudiantes de los diferentes centros del entorno a la escuela de artes, anticipándose así a la introducción de la ciudad en la casa que será tema específico en Venecia. Le Corbusier

\footnotetext{
${ }^{50}$ Torres Cueco, Jorge. "La arquitectura es la circulación”. En Torres Cueco, Jorge. Le Corbusier: mise au point. Valencia: Universidad. 2012, p.214.

${ }^{51}$ Lefebvre, Henri, El derecho a la ciudad, Barcelona: Península, 1978 (1968), p. 68.

${ }^{52}$ Lefebvre, ibidem, p. 99

${ }^{53}$ Sekler, Eduard Franz, Le Corbusier at work: the genesis of the Carpenter Center for the Visual Arts. Cambridge: Harvard University, 1978.
} 
interpreta y actualiza la relación con el espacio público de la Yarda, pero cabe reconocer también el eco de este mecanismo circulatorio en la Villa Savoya ${ }^{54}$.

Pero aquí las consecuencias son diferentes, entre otros motivos porque no se impone en ningún momento enrasar la volumetría ni por arriba ni por ningún lado; al contrario, la evolución del proyecto documenta que, definida la calle, ésta extrude el volumen que se ve paulatinamente sometido a diferentes estrategias formales que caminan en la misma dirección (desdoblamiento, escisión, deslizamiento, fragmentación); en definitiva, la calle que se eleva hasta el tercer nivel para volver a descender después de atravesar el edificio es el elemento formalmente más estable. A pesar de la pequeña dimensión, la oportunidad para desplazar el enfoque del problema arquitectónico hacia lo urbano y el espacio colectivo sitúa este proyecto en una imagen memorable gracias a esta 'calle extra' que reclamaba por aquellos años Jane Jacobs como solución a tantos problemas urbanos ${ }^{55}$.

\subsection{Hospital de Venecia: Infraestructura urbana; construir sin construir; saltando sobre la ciudad, flotando sobre el agua.}

\subsubsection{La ciudad como metáfora y analogía. Saltando sobre la ciudad y sobre el canal}

En el Hospital de Venecia, Le Corbusier asume la condición mutable del propio programa sanitario y plantea la idea de flexibilidad en su organización como mecanismo más idóneo para poder adaptarse a las situaciones diferentes. Entre estas circunstancias cambiantes, sus posibilidades de crecimiento estaban entre las más importantes, dotando al edificio de una condición de "inacabado”: “... la especificidad de la sección del ático codifica genéticamente el crecimiento del Hospital... El modo en que el crecimiento queda controlado representa todavía uno de sus avances más significativos " ${ }^{, 56}$ :

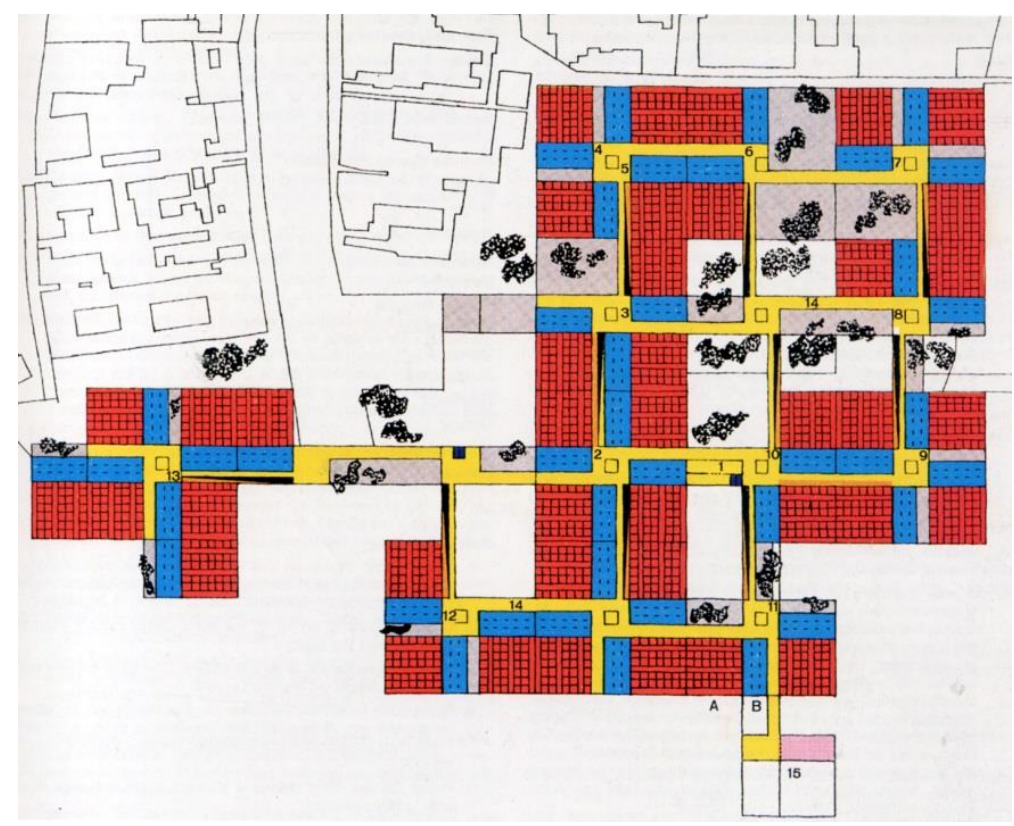

17. LC: Hospital de Venecia, 1964-65. Diseño original de LC y Jullian de la Fuente: Primer proyecto, 1964, planta 3 (procedencia: LC, Oeuvre Complète, vol. 7. OFLC-ADAGP)

\footnotetext{
${ }^{54}$ Benton, Tim. "Le Corbusier y la promenade architecturale”. En Arquitectura, 264-265. Madrid: COAM. 1987, p. 46.

${ }^{55}$ Jacobs, Jane, Muerte y vida de las grandes ciudades, Madrid: Capitán Swing Libros, 2011 (1961), p. 214.

${ }^{56}$ Sarkis, Hashim, "La paradójica promesa de la flexibilidad”. En Sarkis, Hashim, Le Corbusier's Venice Hospital and the mat building revival, Munich-London-NY: Harvard Design School, 2001.
} 
La idea de la posibilidad de crecimiento es experimentada de modos diversos en relación a cada parte distinta del casco de Venecia, de tal modo que el perímetro del hospital asume desde el proyecto las mayores condiciones de incertidumbre que cabe advertir o, lo que viene a ser lo mismo, el sistema de organización inherente y su estrategia de implantación permite resolver de forma diferente situaciones diversas; esto es, asume con naturalidad las singularidades del sistema. El Hospital de Venecia plantea un sistema sintáctico de partes iguales entre sí estableciendo múltiples enlaces en su periferia con el casco de la ciudad. El proyecto se desarrolla horizontalmente — matbuilding o edificio estera - por medio de una acumulación lógica basada en una cuidada casuística. La unidad básica del programa o 'unité de batissé, la unidad de cuidados formada por 28 camas, se repite hasta el final. La composición rotatoria de las unidades, establece conexiones y vínculos entre un pabellón y otro, mientras su desplazamiento produce la aparición de vacíos en el campo horizontal del hospital. Es la forma de esta unidad básica y el modo preciso en que son articuladas lo que acaba por configurar la forma global del edificio ${ }^{57}$.

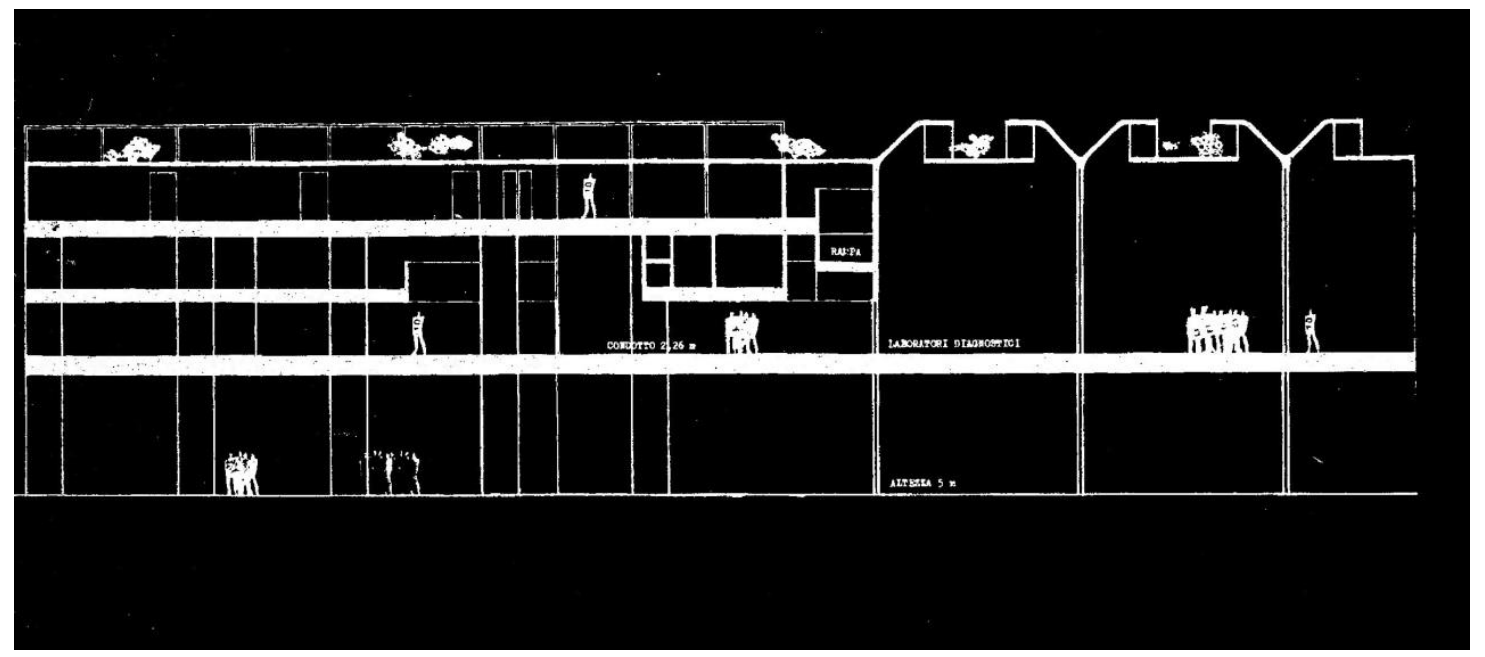

18. LC: Hospital de Venecia, 1964-65. Detalle de la sección, incluyendo laboratorios, conduits y rampas de conexión entre niveles superiores (procedencia: Hashim Sarkis, p. 4. Archivo Guillermo Jullian de la Fuente)

Si en Ronchamp resultaban determinantes los mecanismos evocadores de la memoria y el diálogo con el lugar para dotarla de significado, el Hospital de Venecia aúna en sí el hecho de ser posiblemente el proyecto más contextual de Le Corbusier y de recurrir para ello a los sistemas de crecimiento más abstractos que estaban utilizando los arquitectos del Team X, junto al abandono de la promenade architecturale, según relata el propio colaborador de Le Corbusier, Jullian de la Fuente: "Desde 1963 con el proyecto de la Olivetti empezamos a plantearnos como estructurar los diferentes espacios sin usar 'la promenade architecturalé como medio para conectarlo. El orfanato de Aldo van Eyck y sus escritos en Forum fueron una de las llamadas de atención en ese momento. La idea de un proyecto como una pequeña ciudad o parte de una ciudad fue confrontada con el proyecto del Hospital de Venecia (...). La idea de 'dual phenomena' u opuestos fue explorada y, después de mi presencia en la reunión del Team X de Royaumont, confirmado por la discusión sobre el proyecto utópico de Blom para una ciudad. Le Corbusier estuvo de acuerdo: con su proyecto de apartamentos universitarios de 1925 como modelo, añadimos nuestra capacidad para producir una conjunción de solicitaciones y variaciones que crearon la estructura, permanencia y provocación del proyecto del Hospital de Venecia de Le Corbusier ",58.

\footnotetext{
${ }^{57}$ Cfr. Allen, Stan, “Distribuciones, Combinaciones, Campos”, en BAU, 14, 1996, pp. 68-75.

${ }^{58}$ Strauven, Francis, Aldo van Eyck's Orphanage. A Modern Monument, Amsterdam: NAI, 1996, p. 50
} 


\subsubsection{Construir sin construir}

Curiosamente en el Hospital de Venecia Le Corbusier adoptó, a favor de la flexibilidad del espacio y de la posibilidad de asumir posibles cambios internos y externos, un mecanismo basado en reglas sumamente abstractas y al mismo tiempo incorporó en su organización las claves del sistema urbano del propio lugar en el que surge el edificio: "La ciudad de Venecia está allí y yo la he continuado. No he inventado nada. He proyectado un complejo hospitalario que puede nacer, vivir y expandirse como una mano abierta: es un edificio "abierto", sin una sola fachada definitiva, en el cual se entra desde abajo, es decir, desde dentro, como en otros lugares de esta ciudad"59.

Le Corbusier traslada al edificio la lógica del contexto veneciano —calles, plazuelas, puentes, etc.—. Por ello su forma es "abierta", ni cerrada ni inmutable. Su imagen no es definitiva: no sólo conceptualmente, sino que también espacialmente es posible modificarla, cambiarla, extender esta estructura, sin que por ello se altere su principio generador y su concepción arquitectónica global. Esto significa, como ha subrayado Petrilli, "construir sin construir".
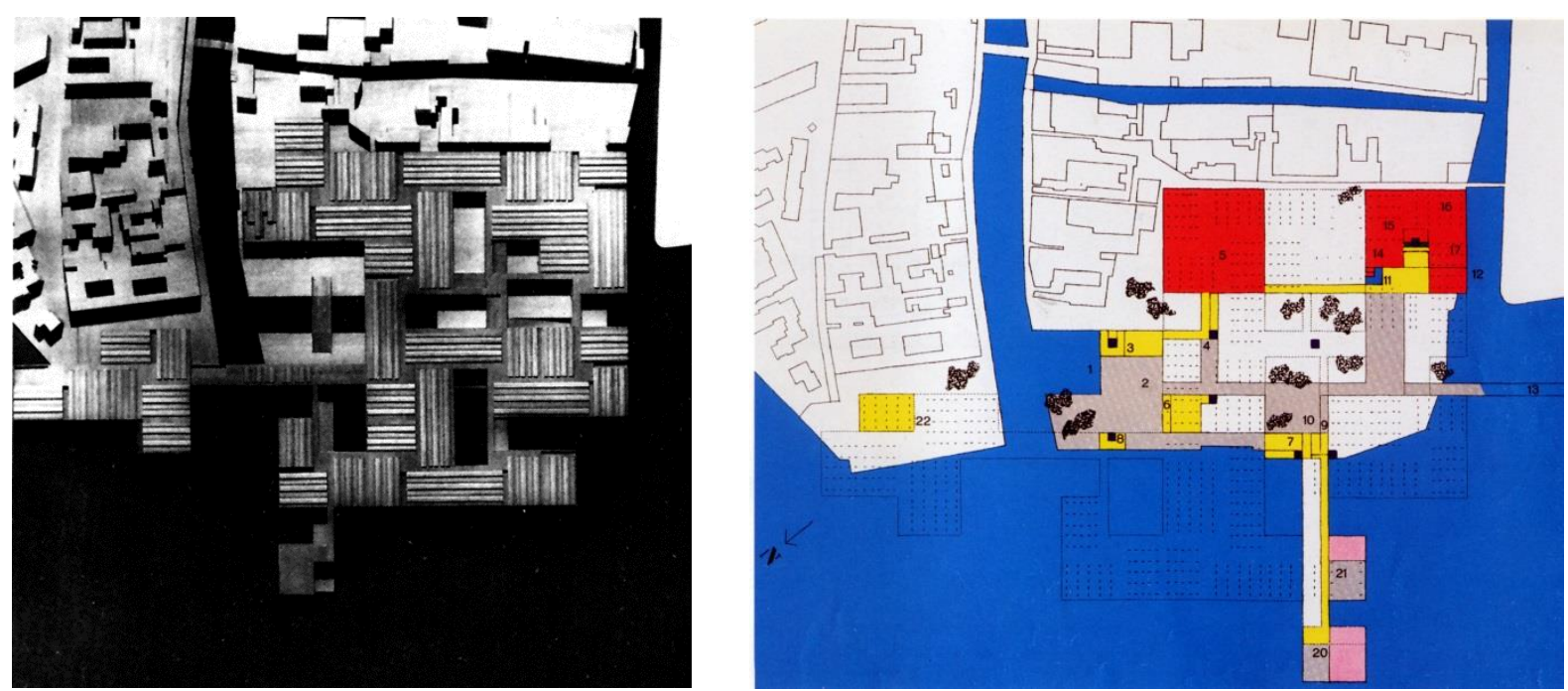

19. LC: Hospital de Venecia; maqueta del $2^{\circ}$ proyecto, 1965, vista cenital (LC, Oeuvre Complète, vol 7. OFLC-ADAGP).

20. LC: Hospital de Venecia, 1964-65. Diseño original de LC y Jullian de la Fuente: Primer proyecto, planta 1 (LC, Oeuvre Complète. (FLC-ADAGP)

La idea de generar un sistema de relaciones, de construir una infraestructura espacial que permita desarrollar el programa y contemplar sus variaciones a la vez que configurar espacios colectivos de relación evoca los sistemas de relaciones complejas de los “mat building", en los que el proyecto es entendido en términos de organizaciones topológicas abiertas y variables ${ }^{60}$.

En Venecia la abstracción deriva de un entendimiento del problema en términos de infraestructura y logística. La estrategia formal del edificio, superponiendo en altura los diferentes usos, con las camas en el más elevado, se basa en la organización de las diferentes circulaciones, saltando sobre los campos, plazas y canales de la ciudad. Con el programa y la geometría diferentes de Ronchamp, las torres capillas, que inicialmente no están presentes

\footnotetext{
${ }^{59}$ Petrilli, Amedeo. Il testamento di Le Corbusier. Il progetto per l'Ospedale di Venezia, Venecia: Marsilio, 1999, p. 49.

${ }^{60}$ Cortés Vázquez de Parga, Juan Antonio, Historia de la retícula en el siglo XX. De la estructura Dom-ino a los comienzos de los años setenta, Valladolid: Universidad de Valladolid, 2013, pp.43 y ss.
} 
en el primer croquis de la iglesia y sucesivos, van progresivamente apareciendo $^{61}$, transfiriendo esta condición procesual a la propia obra a partir de una relación dialéctica y evocadora con la memoria del lugar y del programa. En Venecia esta contingencia se alimenta al proyectar un edificio con los mecanismos urbanos de la ciudad. La relación entre el edificio del hospital y el espacio público ya no es la convencional y mucho menos la relación con el suelo ${ }^{62}$. En esa década de los años 60 , tal anhelo coincidirá con la reivindicación de lo público y la cualificación de espacio urbano y colectivo.

\section{A modo de conclusión: una perspectiva en el tiempo}

Estas reflexiones sobre algunas obras de Le Corbusier a partir de la idea del espacio público y del modo en que este tema incide en sus estrategias formales en torno a la arquitectura, la ciudad y el paisaje nos permite despejar una perspectiva temporal y una idea de continuidad en el modo de abordar los problemas y en el modo de concitar ideas y reacciones entre épocas, proyectos y lugares diversos. Desde la inicial vinculación a las influencias utopistas y al paisaje, de una anhelada e idealizada naturaleza, por un lado, y a la técnica, por otro, al compromiso dialéctico con el contexto urbano de Harvard o Venecia, se abre un camino de aprendizaje y confrontación con culturas y topografías que estimulan la reacción poética y la capacidad de entender el sentido y significado de los nuevos lugares. Vemos como a medida que el idealizado mito de la velocidad va sosegándose, la idea de circulación, de movimiento y de conexiones, alimenta la estrategia de proyecto con una diversidad de respuestas en las relaciones entre espacio público y espacio privado, entre arquitectura y ciudad, rica y conmovedora.

\section{Bibliografía}

ÁBALOS, Iñaki. Atlas pintoresco. Vol. 2: los viajes. Barcelona: GG. 2008.

ALLEN ,Stan, “Distribuciones, Combinaciones, Campos”, en BAU, 14, 1996.

ALONSO GARCÍA, Eusebio, La iglesia de Firminy y la machine à émouvoir de Le Corbusier, en Actas, Reapropiaciones del Movimiento Moderno. Porto: CEAA/Centro de Estudios Arnaldo Araújo, 2012.

ALONSO GARCÍA, Eusebio, Paulo Mendes Da Rocha. Constructor de horizontales en el aire, en Barcelona: DPA 30, 2014, pp. 40-49.

ALONSO GARCÍA, Eusebio, Estrategias alucinatorias en el último Le Corbusier, en Actas, Madrid: Critic/All Press, 2014, pp. 55-73.

ARENDT, Hannah, La condición humana, Barcelona: Paidós, 1993 (1958).

BANHAM, Reyner, "Fórmulas de vivienda colectiva. La maison des hommes y la misère des villes", en Le Corbusier (II), AV,10, Madrid, 1987.

BERGDOLL, Berry, "París: más allá de la ciudad del siglo XX”. En AV Monografías. Le Corbusier. An Altas of

\footnotetext{
61 "El acto de creación en sí mismo tiene mucha más importancia que el objeto creado y éste gana en significación en la medida en que muestra las señales del trabajo que lo ha engendrado y no está perfectamente acabado”. Así se expresaban los miembros del Grupo COBRA (1948-51), incorporados luego a la Internacional Situacionista (1957). VV.AA, Situacionistas. Arte, política, urbanismo. Barcelona: ACTAR, 1996.

“... la acción sustituyó en el siglo XVII a la contemplación, acontecimiento radical que conlleva la conciencia del carácter procesual' de cualquier experiencia, incluso la real experiencia humana... El concepto central de las dos ciencias nuevas de la Época Moderna, las naturales no menos que las históricas, es el de proceso, y la real experiencia humana subyacente es acción”. Arendt, Hannah., La condición humana. Barcelona: Paidós, 1993 (1958). p. 316

${ }^{62}$ Alonso, Eusebio, Paulo Mendes Da Rocha. Constructor de horizontales en el aire. En Barcelona: DPA 30, 2014, pp. 4049. pp. 40-49.
} 
Landscapes. Madrid: Arquitectura Viva, 2015, 176.

CALAFELL, Eduard, Las unités d'habitation de Le Corbusier, Barcelona: Fundación Caja de Arquitectos, 2000.

COHEN, Jean-Louis. "En defensa del paisaje”. En AV Monografías. Le Corbusier. An Altas of Landscapes. Madrid: Arquitectura Viva, 2015, 176.

COHEN, Jean-Louis, Le Corbusier: an atlas of modern landscapes, New York: MOMA, 2013.

CORTÉS VÁZQUEZ DE PARGA, Juan Antonio, Historia de la retícula en el siglo XX. De la estructura Domino a los comienzos de los años setenta, Valladolid: Universidad de Valladolid, 2013.

COULQUHOUN, Alan, “Tipología y método de diseño”, en JENCKS, Charles, BIRD, G, El significado en arquitectura. Madrid: Blume, 1975 (1969).

CURTIS, Williams, Le Corbusier. Ideas y formas. Madrid: Blume. 1986.

DELGADO, Manuel, El espacio público como ideología. Madrid: Catarata, 2011.

EARDLEY, Anthony, Le Corbusier's Firminy Church, NY: IAUS, Rizzoli International, 1981.

FERNÁNDEZ VILLALOBOS, Nieves, Utopías domésticas. La casa del futuro de Alison y Peter Smithson, Barcelona: Fundación Caja de Arquitectos, 2012.

FRAMPTON, Kenneth, Labour, work and architecture. Collected Essays on Architecture and Design. New York: Phaidon, 1987.

FRAMPTON, Kenneth, Le Corbusier, Akal: Madrid, 2000.

FRAMPTON, Kenneth, "The Rise and Fall of the Radiant City: Le Corbusier 1928-1960". En Oppositions. Le Corbusier 1923-1960. 1980, 19-20. Cambridge: MIT Press, 1980.

GARGIANI, Roberto, ROSELLINI, Anna. Béton Brut and Ineffable Space, 1940-1965. New York-Oxford: Routledge, EPFL Press, 2011.

GONZÁLEZ CUBERO, Josefina. "Sesión continua: nómadas en el jardín. Ville Contemporaine y Ville Radieuse". En Monteys, Xavier. Massilia: anuario de estudios lecorbuserianos. Le Corbusier y el paisaje. Sant Cugat del Vallés, 2004.

JACOBS, Jane, Muerte y vida de las grandes ciudades, Madrid: Capitán Swing Libros, 2011 (1961).

JENCKS, Charles, BIRD, G, El significado en arquitectura, Madrid: Blume, 1975 (1969).

JUDT, Tony, Post-guerra. Una historia de Europa desde 1945, Madrid: Santillana, 2005.

LE CORBUSIER, “L'espace indicible”,en L'Architecture d'Aujourd'hui, n. hors-série, “Art”, 1946, pp. 9-17.

LE CORBUSIER, Oeuvre Complète, Zurich: Artemis, 1965.

LE CORBUSIER. Precisiones. Barcelona: Poseidón. 2a ed. 1978 (1930).

LE CORBUSIER, Vers une architecture, París: Crés, 1923.

LEFEBVRE, Henri, El derecho a la ciudad, Barcelona: Península, 1978 (1968).

LIN, Zhongjie, Kenzo Tange and the Metabolism Movement. Urban Utopias of Modern Japan, London-NY: Routledge, 2010.

MACLEOD, Mary. "Le Corbusier and Algiers". En Oppositions. Le Corbusier 1923-1960. 1980, 19-20. Cambridge: MIT Press, 1980.

MENIN, Sarah; SAMUEL, Flora. Nature and Space: Aalto and Le Corbusier. London-New York: Routledge. 2003.

MONTEYS, Xavier. La gran máquina. La ciudad en Le Corbusier. Barcelona: COAC. 1996. 
MONTEYS, Xavier. "Le Plan Paralysé. Revisando los cinco puntos". En QUETGLAS, Josep. Massilia 2002: anuario de estudios lecorbuserianos. Barcelona: Fundación Caja de Arquitectos. 2002.

MOOS, Stanislaus von. Le Corbusier. Barcelona: Lumen. 1977 (1968) 1ª ed.

MOOS, Stanislaus von, "Le Corbusier As Painter". En Oppositions. Le Corbusier 1923-1960. 1980, 19-20. Cambridge: MIT Press, 1980.

NORBERG-SCHULZ, Christian, "El significado en arquitectura" (1966), en JENCKS, Charles, BIRD, G, El significado en arquitectura. Madrid: Blume, 1975 (1969).

O’BYRNE OROZCO, Mª Cecilia, El proyecto para el Hospital de Venecia de Le Corbusier, Tesis Doctoral, Barcelona: ETSA UPC, 2007.

PETIT, Jean, Le livre de Ronchamp. Le Corbusier, Editec, 1961.

PETRILLI, Amedeo, Il testamento di Le Corbusier. Il progetto per l'Ospedale di Venezia, Venecia: Marsilio, 1999.

PICON, Antoine."Argel: ciudad, infraestructura y paisaje”. En AV Monografías, Le Corbusier. An Altas of Landscapes, Madrid: Arquitectura Viva, 2015, 176.

PIERREFEU, François de, LE CORBUSIER, La maison de l’ homme, París: Plon, 1942.

QUETGLAS, Josep. "Ronchamp: un paisaje de acústica visual". En AV Monografias. Le Corbusier. An Altas of Landscapes, Madrid: Arquitectura Viva, 2015, 176.

QUETGLAS, Josep, "Mise en scène de Ronchamp". En RICHARD, Michel, La boîte à miracles. Le Corbusier et le théâtre. Massilia 2012. París: FLC, Editions Imbernon, 2012, pp. 98-111.

SARKIS, Hashim, "La paradójica promesa de la flexibilidad", en TRANSFER-, diciembre 2002; también Le Corbusier's Venice Hospital and the mat building revival, Munich,-London-NY: Harvard Design School, 2001.

SBRIGLIO, Jacques. Le Corbusier: l'Unitéd habitation de Marseille. Marseille: Parenthèses, 1992.

SEKLER, Eduard Franz, Le Corbusier at work: the genesis of the Carpenter Center for the Visual Arts, Cambridge: Harvard University, 1978.

SEQUEIRA, Marta. "Toit-civique. Le Corbusier y el espacio público a 50 metros del suelo". En PC: proyecto y ciudad: revista de temas de arquitectura, 2012, $\mathrm{n}^{\circ}$ 3. Cartagena: Universidad, 2012.

SEQUEIRA, Marta. "A Concepçâo da cobertura da Unitéd'habitation de Marselha: três invariáveis". En QUETGLAS, Josep et altri. Massilia 2005: anuario de estudios lecorbuserianos. San Cugat del Vallés: Centre d’investigacions estétiques. 2005.

STIRLING, James, De Garches a Jaoul. Le Corbusier como arquitecto doméstico en 1927 y 1953, en Architectural Review, septiembre 1955. (Traducción en castellano en Anales de Arquitectura, Departamento de Teoría de la Arquitectura y Proyectos Arquitectónicos, Valladolid: Universidad de Valladolid, n 5, 1993/94, pp.208-213).

STIRLING, James, Ronchamp. La capilla de Le Corbusier y la crisis del racionalismo, en Architectural Review, marzo 1956. (Traducción en castellano en Anales de Arquitectura, Departamento de Teoría de la Arquitectura y Proyectos Arquitectónicos, Valladolid: Universidad de Valladolid, nº 5, 1993/94, pp. 215-219).

STRAUVEN, Francis, "The urban conjugation of functionalism architecture", en VV.AA., Aldo van Eyck, Amsterdam: Stichting Wonen, 1982.

STRAUVEN, Francis, Aldo van Eyck. The Shape of Relativity, Amsterdam: Architectura and Natura, , 1998.

STRAUVEN, Francis, Aldo van Eyck's Orphanage. A Modern Monument, Amsterdam: NAI, 1996.

TAFURI, Manfredo. "Machine et mémoire. The City in the Work of Le Corbusier". En Brooks, H. Allen. Le Corbusier. Princeton: Princeton University Press. 1997. 
TANGE, Kenzo, Función, estructura, símbolo (1966), en KULTERMANN, Udo, Kenzo Tange 1946-1969, Barcelona: GG, 1970.

TERESA TRILLO, Enrique de, Tránsitos de la forma, Barcelona: Fundación Caja de Arquitectos, 2009.

TORRES CUECO, Jorge. Le Corbusier: visiones de la técnica en cinco tiempos. Barcelona: Fundación Caja de Arquitectos. 2004.

TORRES CUECO, Jorge. "La arquitectura es la circulación”. En TORRES CUECO, Jorge. Le Corbusier: mise au point. Valencia: Universidad. 2012.

VV.AA, Situacionistas. Arte, política, urbanismo, Barcelona: ACTAR, 1996. 


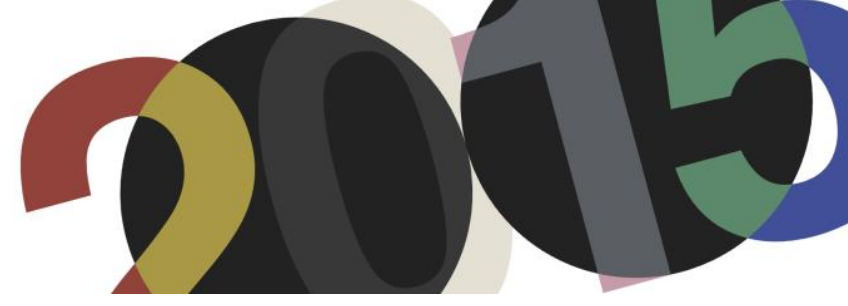

DOI: http://dx.doi.org/10.4995/LC2015.2015.980

\title{
Estrellas sobre fondos cambiantes: convocando la luz
}

\author{
I. Álvarez Gallego*, S. Blanco Agüeira** \\ * University College Dublin \\ ** Cesuga-University College Dublin
}

\begin{abstract}
Resumen: Tras crear y desarrollar durante siete años diecinueve poemas manuscritos, que hoy en día son considerados síntesis de su pensamiento, Le Corbusier publicó en 1955 su Poème de l'Angle Droit. Al estudiar este poema reconocemos en él los principales temas presentes en su trayectoria, así como algunos elementos - la espada, la nube y la estrella-que aparecen en su obra pictórica y arquitectónica. La presente comunicación pretende desvelar las conexiones que se establecen entre uno de estos elementos en concreto, como es la imagen de la estrella, y su incorporación al proceso de proyecto lecorbusieriano. Se trata de analizar cómo este tema, que se repite de forma obsesiva, configura imágenes que permanecen en las estrategias arquitectónicas que llevó a cabo el maestro suizo. La estrella habla de faro, de guía, de motor dentro de un proceso de viaje. Es el elemento que representa la movilidad del cosmos, que rige ese carácter de repetición ligado al arte; una señal que guía al viajero y define el itinerario que deben seguir sus pasos, que nos hace pensar en una brillante luz y en la distancia entre lo real y lo imaginado. Y, sobre todo, es la referencia presente en edificios, que condensaban así reflexiones que daban coherencia y unidad a las distintas opciones del proyecto.
\end{abstract}

Abstract: Following a seven year period dedicated to the creation and development of nineteen manuscript poems, which today are considered a synthesis of his thinking, in 1955 Le Corbusier published his Poème de l'Angle Droit. The study of this poem reveals the principal themes that dominated his trajectory, as well as a series of elements, namely the sword, the cloud and the star, which appear in his pictorial and architectural work. This paper aims to shed light on the connections established between one of these elements in particular — the star-and its incorporation into Lecorbuserian method of architectural design. It seeks to analyse how this item is repeated obsessively, forming images which remain rooted in the architectural strategies developed by the Swiss architect. The star speaks of a lighthouse, a guide, a driving force that spurs on the journey. It is the element that represents the mobility of the cosmos, which governs the nature of repetition linked to art; a signal that guides the traveler and traces the route their steps must take them, leading us to think of a bright light and the distance that separates the real and the imagined. And above all, it is the reference in those buildings that condensed the reflections that gave coherence and unity to the various project options.

Palabras clave: estrella; cosmos; proyecto; mirada; símbolo; proceso creativo.

Keywords: star; cosmos; project; gaze, symbol; creative process.

\section{Introducción}

Sostenía el literato francés Georges Perec ${ }^{1}$ que escribir supone tratar meticulosamente de retener algo, de evitar su olvido o abandono, dejando en alguna parte un rastro, una marca o algunos signos de nuestras obsesiones. Lo suficiente para conseguir que las palabras se conviertan en una extensión de la memoria y de la imaginación. O mejor aún, que los textos sean capaces de dotar de profundidad a ese imaginario al que los arquitectos recurrimos cada vez que proyectamos. Ese lugar racional y subjetivo que alimentará el proceso creativo, nutriéndolo de

\footnotetext{
${ }^{1}$ Perec, Georges: Especies de espacios. 5ª edición. Barcelona: Montesinos, 2007.
} 
experiencias personales, vivencias, inquietudes, lecturas o viajes, dispuestos a saltar en cualquier momento al proceso de proyecto.

Para poder aproximarnos a esos territorios imaginarios sobre los que se asienta la actividad creativa de Le Corbusier, es obligado recurrir a El Viaje de Oriente. En dicho diario, el maestro suizo parece indicar que lo evidente esconde siempre un secreto, que detrás de cada banalidad se esconde una oportunidad de arquitectura. Saberlo le llevó años: las más de cinco décadas transcurridas entre su redacción y su publicación definitiva. Descubrirlo le permitió encontrar el sentido y la dirección a su trayectoria, encontrar significados a la descripción de un viaje, reconocer ese material acumulado en sus propios trabajos. Recuerdos almacenados, imágenes cargadas de sentimientos, sueños evocadores que nos permiten dar forma a ese universo personal: "Después, esas horas de la noche durante las cuales, inmóvil, simulaba dormir para, con los ojos abiertos, ver sin cesar las estrellas y, las orejas atentas, sentir cómo se adormece todo vestigio de vida y toma gloria el silencio. Así he vivido intensamente esas horas más felices y ellas ha dejado en mí, después de tres años, su despótico recuerdo" ${ }^{\prime 2}$.

Las referencias a la estrella, al símbolo sobre el iconostasio, son constantes en el diario de viaje. Pero también ocuparán un lugar destacado en su Poème de l'Angle Droit, un trabajo que se extendió a lo largo de varios años y que facilita una mayor comprensión de las claves y de los signos preferentes utilizados por Le Corbusier. De hecho, sobre el tablero a partir del cual se organizan las distintas lecturas e interpretaciones del Poema, se dispusieron verticalmente tres emblemas, la espada, la nube y la estrella. Tres iconos que ayudan a reflexionar sobre aspectos relativos a la creación arquitectónica, a la síntesis de su pensamiento, así como al fondo mismo de su obra construida y de su pintura. "Cinco años fueron consagrados a este trabajo en el cual yo deseaba incluir un orden de pensamientos que la actividad cotidiana no permite generalmente exteriorizar. Estas no están tan solo en el fondo de mi carácter sino también al fondo mismo de mi obra construida y de mi pintura ${ }^{\prime 3}$.

Así pues, podemos considerar la estrella como uno de los elementos claves que conforman ese sustrato en el que se apoya tanto la labor pictórica como arquitectónica de Le Corbusier. La presente comunicación pretende mostrar cómo su actividad creativa estaba ampliamente ligada a un carácter autobiográfico, de manera que determinados aspectos de su obra solo puedan ser entendidos a través de este cuerpo celeste, un polígono estrellado que se presenta como un exponente claro de la proporción áurea. Con todo, se intentará evitar una interpretación que centre en este icono un sistema de referencias demasiado amplio. Rastrear su significado y su aparición en la obra plástica y arquitectónica es un reto posible. La clave de esta estrategia de investigación la da el propio arquitecto, cuando en 1963 escribe lo siguiente: "La clé c'est: regarder, observer, voir, imaginer, inventer, créer" ${ }^{4}$ [La clave es: mirar, observar, ver, imaginar, inventar, crear].

Pero no sólo la presencia de este polígono estrellado encierra un significado oculto tan trascendente, pues el fondo sobre el que queda representado también es relevante. En este sentido, será objetivo de la investigación el hecho de interpretar, desde una perspectiva personal, ese juego de conexiones, ese tejido de imágenes y datos que, procedentes de distintos ámbitos y disciplinas, sirvió de fundamento al universo imaginario del maestro, rigiendo así toda su actividad creativa.

\footnotetext{
2 Jeanneret, Charles-Edouard: El Viaje de Oriente. Murcia: Colegio Oficial de Aparejadores y Arquitectos Técnicos de Murcia, 1984, p. 142.

${ }^{3}$ Alba Dorado, María Isabel: Intersecciones en la creación arquitectónica. Reflexiones acerca del proyecto de arquitectura y su docencia. Sevilla: Secretariado de Publicaciones de la Universidad de Sevilla, 2010, p. 131.

${ }^{4}$ Cap Martin, 1963. (Carnet T70, $n^{\circ} 1038$ ).
} 


\section{La mirada instrumental}

En octubre de 1925 Le Corbusier envió una sugerente e ilustrada carta a la señora Meyer con el objetivo de persuadirla acerca de las bondades de la villa que pretendía construirle en el centro de París. Entre las numerosas virtudes expuestas destacaban las posibilidades de la cubierta: "Le ciel est dessus: avec les murs, autour personne ne vous voit. Le soir on voit les étoiles et la masse sombre des arbres de la Folie St James" ${ }^{\prime 5}$. La tranquila contemplación de esos objetos astronómicos que brillaban con luz propia fue un tema recurrente en su imaginario personal, una referencia que salpicaba sus textos, una evidencia del dinamismo continuo que suponían los esquemas de rotación y de traslación de la Tierra alrededor del Sol. No es de extrañar pues que uno de los epígrafes de El Viaje de Oriente se remate recurriendo a la noche infinita: ";Entra la noche, negra y dulce en los campos de nuestra visión, el Athos ha desparecido, pero hay tantas estrellas!" 6 .

En las dos citas anteriores, podemos comprobar cómo la estrella, el astro que nace y se oculta, las esferas luminosas presentes desde tiempos inmemoriales, ejercen de guías conductoras del proceso proyectual y al mismo tiempo suponen elementos en brazos de los cuales el arquitecto se abandona sin aparente rumbo fijo. Su presencia constante en el Poème de l'Angle Droit nos permite arrojar luz sobre el entramado del pensamiento de su autor. Las ciento cincuenta y cinco páginas litografiadas, que contienen diecinueve poemas manuscritos, permiten revelar los territorios imaginarios coincidentes con una época en la que Le Corbusier estaba materializando alguno de los referentes arquitectónicos del siglo XX. Fueron la cristalización de varias décadas de búsquedas pictóricas, de un esfuerzo teórico y plástico. Pero también se convirtieron en la manera de dar forma a ese mapa biográfico que se había ido gestando a lo largo de los años, pasiones e ideas rumiadas desde antiguo; en definitiva, la experiencia de la vida, la cual "se encuentra en el espesor de este libro, deliberadamente puesto a resguardo del tumulto, del desorden y también de la mediocridad e incluso de la necedad" ${ }^{\prime}$.

La obra, realizada entre 1947 y 1953, y publicada finalmente en 1955, convierte en transparente el mundo personal del que nacieron sus propuestas arquitectónicas y artísticas. A través de ella es posible entender esas constantes que se repiten, como son el sol, el mar, la presencia de la mujer o la mano abierta, entre otras. Todas ellas pasaron a formar parte del sustrato subjetivo y personal del que surge el proceso de creación. El propio arquitecto afirmaba que la base de su investigación y producción intelectual, la fuente de su libertad de espíritu y la posibilidad de desarrollo descansaban sobre episodios de creación pura, sin aparente finalidad práctica, y que ejecutó durante gran parte de vida desde las ocho de la mañana hasta la una de la tarde, tal como el mismo relataba. "Esos momentos han sido la llave de mi producción artística y los medios para que se pueda comprender mi arquitectura" ${ }^{\prime 8}$.

\footnotetext{
5 "El cielo está arriba: con los muros alrededor nadie la contemplará. Por la noche se ven las estrellas y la masa oscura de los árboles del Folie St. James". Boesiger, Willy (ed.): Le Corbusier. Oeuvre Complète 1910-1929. Zurich: Girsberger, 1964, p. 89.

${ }^{6}$ Jeanneret, Charles-Edouard: El Viaje de Oriente. Murcia: Colegio Oficial de Aparejadores y Arquitectos Técnicos de Murcia, 1984, p. 168.

${ }^{7}$ Calatrava Escobar, Juan Antonio: "Le Corbusier y Le Poème de l’Angle Droit: Un poema habitable, una casa poética". En Calatrava Escobar, Juan Antonio (Coord.): Le Corbusier y la síntesis de las artes: El poema del ángulo recto. Madrid: Fondation Le Corbusier-Círculo de Bellas Artes-Caja Duero Obra Social, 2006, p. 19.

${ }^{8}$ Le Corbusier, 1953, citado en Juárez Chicote, Antonio: "El secreto de la forma. Una geometría aproximativa". En Calatrava Escobar, Juan Antonio (Coord.): Le Corbusier y la síntesis de las artes: El poema del ángulo recto. Madrid: Fondation Le Corbusier-Círculo de Bellas Artes-Caja Duero Obra Social, 2006, p. 79.
} 
De este modo, el Poema se presenta como una compleja maraña que conecta obras, dibujos y pensamientos, una especie de tablero de juego con profusión de datos e imágenes, pero con algunos referentes claros. Así, las secciones que lo estructuran se disponen según una combinación de letras, colores e imágenes. Siete filas de iconos, identificados con las siete primeras letras del alfabeto, configuran un eje vertical que guarda paralelismo con el iconostasio de los templos ortodoxos, a través del cual se exhiben los siete temas principales: A: Medio (verde); B: Espíritu (azul); C. Carne (violeta); D: Fusión (rojo); E: Caracteres (blanco); F: Ofrenda (amarillo); G: Instrumento (púrpura). Representadas en horizontal aparecen imágenes en un número variable, que nos indican las ilustraciones de los diecinueve poemas contenidos. Con todo, lo más interesante son los tres signos que se emplazan en la parte superior de ese elemento religioso oriental: la espada, la nube y la estrella (Imagen 1). Tres herramientas gracias a las cuales nos podemos asomar a esos mundos imaginarios que despertaban su invención.

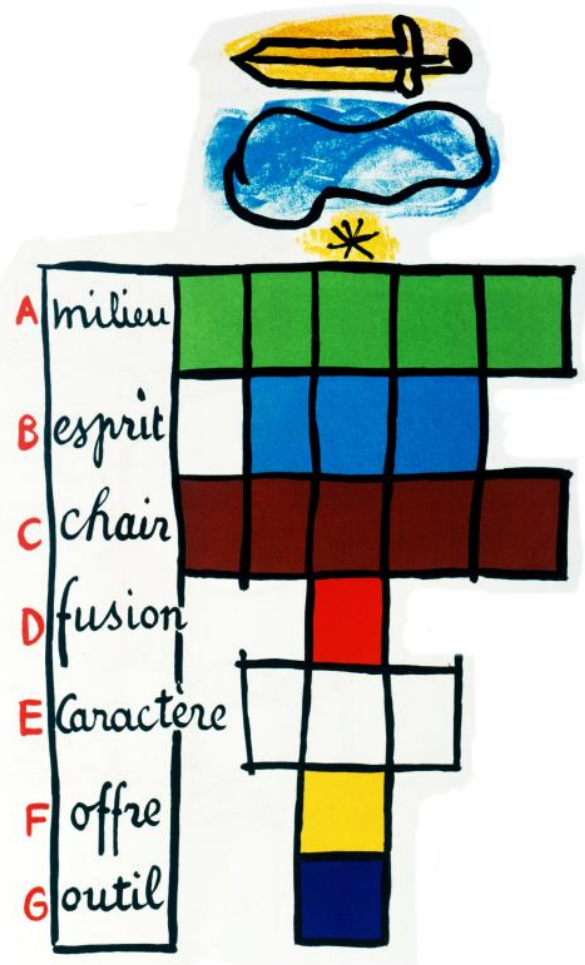

1. Le Corbusier. Le Poème de l'Angle Droit. Iconostasis. Fuente: Calatrava Escobar, Juan Antonio (Coord.): Le Corbusier y la síntesis de las artes: El poema del ángulo recto. Madrid: Fondation Le Corbusier-Círculo de Bellas Artes-Caja Duero Obra Social, 2006. OFLC-ADAGP.

La espada nos conduce a esa lucha que se libra en toda creación artística entre opuestos: entre lo real y lo imaginado, entre lo racional y lo irracional. Es el instrumento con el cual combatir las fuerzas oscuras y "materializar la poesía que anima nuestra existencia"". El segundo de los símbolos, la nube, es entendida como el espacio vaporoso e inefable que se ubica en un mundo intermedio entre lo formal y lo informal ${ }^{10}$. Y si Le

\footnotetext{
${ }^{9}$ Burriel Bielza, Luis. Saint-Pierre de Firminy-Vert: el edificio como objet-à-réaction-émouvante. Director: Ignacio Vicens y Hualde. Tesis doctoral. Universidad Politécnica de Madrid, Departamento de Proyectos, 2010, p. 163.

${ }^{10} \mathrm{Ib}$.
} 
Corbusier decidió acercarse a esas masas móviles y difusas, también se aproximaría a las estrellas, esos focos luminosos que intentó atrapar y convocar en sus arquitecturas.

\section{Cerca de las estrellas}

Le Corbusier sobrevoló el cielo, atravesó nubes y se dejó guiar por las estrellas, en compañía incluso de la persona que posiblemente más cerca deseó estar de ellas. Y es que existen circunstancias dentro de una trayectoria profesional que semejan insignificantes, carentes de calado o achacables al azar, pero que conforme pasa el tiempo activan procedimientos que conquistan otros territorios. Es el caso de uno de los viajes emprendidos por Le Corbusier tras haber recalado en 1929 en la ciudad de Buenos Aires. Allí aceptó la invitación de la compañía Aeroposta para participar en uno de los vuelos que inauguraban el transporte de viajeros entre la capital argentina y Asunción, en Paraguay, lo que le permitió entrar en contacto con dos pilotos experimentados, Jean Mermoz y Antoine de Saint-Exupéry. El segundo, con menor antigüedad en la línea aeropostal, ejerció de copiloto, formando parte del reducido pasaje del Latécoère 28 que se dirigía a la capital paraguaya. La excesiva duración del viaje, que comenzó en plena noche y se alargó durante ocho horas, sirvió seguramente para que el arquitecto y el aviador francés reparasen en las mismas estrellas, extrayendo del acto de volar enseñanzas aplicables a sus respectivas creaciones artísticas ${ }^{11}$. En este sentido, el propio piloto de guerra describía la atmósfera que se respiraba en el interior de aquellos aparatos: "Nueve pasajeros, arrebujados en sus mantas de viaje, apoyaban la frente en su ventanilla, como en un escaparate lleno de joyas, pues las pequeñas ciudades de Argentina desgranaban ya en la noche todo su oro bajo el oro más pálido de las ciudades de estrellas" 12 .

Saint-Exupéry explicaba asimismo las claves de su actividad como piloto, permitiéndonos comprender mejor las limitaciones de observación terrestre: "Se está en contacto con el viento, con las estrellas, con la noche, con la arena, con el mar. Se bandea uno astutamente con las fuerzas naturales. Se espera la escala como una tierra prometida y uno busca su verdad en las estrellas" ${ }^{\prime 13}$. No es de extrañar pues, que una de las grandes novelas del aviador francés, Tierra de hombres, se titulase en inglés "Wind, Sand and Stars", esto es, Viento, arena y estrellas, albergando citas como la anterior, que demostraban cómo para el autor la experiencia de volar se acercaba más al ámbito de los objetos astronómicos que al plano sobre el que debía aterrizar. Aupado a esa misma zona elevada del suelo, Le Corbusier observó fascinado los vastos paisajes argentinos y, en definitiva, el mundo, así como la mejor forma de planearlo. Se encontraba ante una nueva forma de ver, que le obligó a pensar seriamente en la relación entre la construcción y el paisaje humano, reparando en el espectáculo descubierto bajo sus pies ${ }^{14}$. Inspirado por aquellas vistas desde las alturas trazó bocetos y planes para Montevideo y Sao Paulo, pero también bosquejó rascacielos bonaerenses rodeados por un cielo estrellado que se reflejaba en la superficie del agua (Imagen 2), certificando el potencial del nuevo medio de transporte como instrumento óptimo de análisis.

\footnotetext{
${ }^{11}$ Tras este episodio, dichos personajes podrían haber compartido otras vivencias e impresiones debido a que ambos se alojaban en el mismo hotel bonaerense. Pico Valimaña, Ramón: "Octubre de 1929, un paseo por los cielos". En Zarch. "Las trazas del lugar". Octubre 2013, № 1. Zaragoza: Arquitectura Unizar, p. 168.

${ }^{12}$ Saint-Exupéry, Antoine de: Vuelo Nocturno. Madrid: Anaya, 2003, p. 115.

${ }^{13}$ Saint-Exupéry, Antoine de: Tierra de hombres. Buenos Aires: Troquel, 1972, p. 70.

${ }^{14}$ Schiff, Stacy: Saint-Exupéry: A Biography. London: Random House, 2011, p. 168.
} 


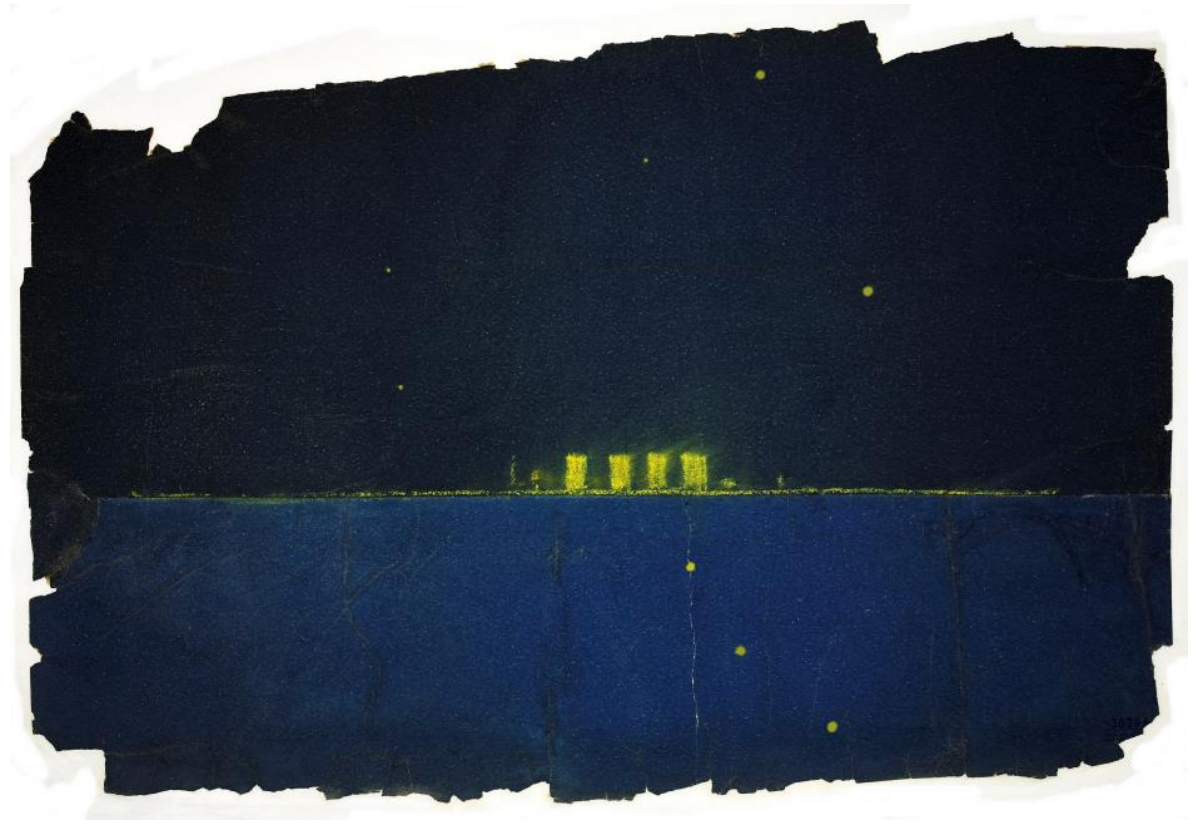

2. Le Corbusier. Croquis de rascacielos sobre el Río de la Plata, en Buenos Aires (Argentina), 1929. CFLC-ADAGP.

Desde esa distancia cercana a las estrellas, el arquitecto conoció los asentamientos, los ríos, las llanuras y los paisajes de la frontera argentina. El espectáculo fue calificado como cósmico, en una descripción que no se alejaba demasiado de lo manifestado por Saint-Exupéry años después, cuando afirmaba que el avión había permitido aprender la línea recta: "Henos aquí, por consiguiente, juzgando al hombre según la escala cósmica, observándolo a través de nuestras ventanillas como a través de instrumentos de estudio. Henos aquí releyendo nuestra historia ${ }^{\prime 15}$. Le Corbusier recordaba incluso la puntualización realizada por el que luego sería piloto de guerra acerca de las poderosas ventajas de los aeroplanos, entre las cuales destacaba la posibilidad de poder ver la superficie terrestre a treinta mil pies de altura ${ }^{16}$. Se le dotaba así al pasajero de una nueva mirada que se sentía atraída por la inmensidad y por el abismo: una nueva forma de percepción basada en la vista aérea, alejada de las "infernales visiones" obtenidas desde el automóvil o desde el tren ${ }^{17}$. Una forma de mirar que invitaba a soñar y sobre la que fundamentaría Le Corbusier una parte importante de su discurso. De hecho, la propia concepción del Poema del Ángulo Recto, su testamento vital y artístico, no sería posible sin el avión, ese artefacto que "incitaba a una larga y sombría meditación"18, ese vehículo propulsado "que nos lo había mostrado todo, y lo que nos había revelado enseñaba una inmensa lección" ${ }^{19}$. El reconocimiento aéreo le supondría a partir de ese momento un mecanismo imprescindible para planear las intervenciones en la ciudad, para alcanzar la debida distancia con el mundo de los hombres, y para crear ese imaginario que dirigiese su creación arquitectónica, mezcla de fuerzas pertenecientes a lo racional y de otras que emanan de la conciencia y se cultivan fructificando solamente con el efecto de un trabajo interior ${ }^{20}$.

\footnotetext{
${ }^{15}$ Saint-Exupéry, Antoine de: Tierra de hombres. Buenos Aires: Troquel, 1972, p. 49.

16 "Be prepared M. Le Corbusier; the airplane has now endowed man with an eye that can look down from 12,000, from 30,000 feet above the ground". Citado en Bridge, Gary; Watson, Sophie (Ed.): A Companion to the City. Massachusetts: Blackwell, 2003, p. 39.

${ }^{17}$ Le Corbusier: Précisions sur un état présent de l'architecture et de l'urbanisme. París: Vincent, Fréal et Cie, 1930, pp. 4-7.

${ }^{18}$ Le Corbusier: Aircraft. London: Studio Publications, 1935, p. 123.

${ }^{19} I d$., p. 12.

${ }^{20}$ Le Corbusier: Mensaje a los estudiantes de arquitectura. Buenos Aires: Infinito, 1959, p. 56.
} 
$\mathrm{Al}$ arquitecto, esa experiencia sobre los cielos americanos le permitió adquirir una forma de conocimiento que alimentase sus estrategias urbanas a través de una mirada fascinada, sorprendida, propia de quien ve algo por primera vez. Porque aquel viaje a Asunción le ayudó a Le Corbusier descubrir una visión diáfana de la realidad y liberada de obstáculos, mientras que para Saint-Exupéry supuso otra experiencia necesaria para el acopio de material vital que nutriese los mundos que habitaban en su cabeza y que, a la postre, le ayudaron a ilustrar más de una década después esa celebérrima novela corta que es El Principito, en la cual es posible contemplar un paisaje configurado por apenas un par de líneas y una estrella en el cielo.

\section{Convocando la luz}

El vuelo de 1929 debió de producir en Le Corbusier una notable sacudida emocional, pues a partir de entonces la mirada entre nubes y estrellas se apoderó de su campo visual. Además de poder explorar el paisaje y de planificar el territorio, ideando infraestructuras y reprogramando dimensiones, pudo también acceder en las alturas a una región flotante que le acercaba al territorio de los sueños, de la libertad y de la reflexión tranquila. Una región que parecía disfrutar especialmente, si atendemos a los diarios de movimientos por el mundo ${ }^{21}$, en los que se mostraba a menudo extasiado y lírico, y en los que dejó constancia de las nuevas percepciones que dichos desplazamientos generaban. Precisamente, en esa zona intermedia entre el suelo y el cielo, entre lo de arriba y lo de abajo, se situaban las esquemáticas estrellas que comparecían en sus trabajos de tapicería (Imagen 3). Y no sólo en sus murales nómadas surgió este elemento en una posición más o menos flotante, sino que también se hizo presente en el estrato central de la cara exterior de la puerta de acceso principal a la ermita de Ronchamp (Imagen 4), uno de los iconos arquitectónicos de la centuria pasada.

Sobre las láminas metálicas pintadas a mano, y luego esmaltadas de dicha puerta, es posible apreciar cómo este elemento se sitúa en un estadio intermedio entre un cielo por el que navegan nubes y una tierra definida por planos sobre los que serpenteaba un meandro. En la cara interior, ambos pentágonos —el convexo y el estrellado - se sitúan en el mismo eje vertical que una mancha vaporosa y flotante, remitiéndonos de nuevo a un mundo misterioso, en el que razón, memoria, circunstancias vitales, pensamiento y poesía se funden, adquiriendo un papel racionalizador ${ }^{22}$. Un ámbito propicio para la revelación, para sacar a la luz aspectos que permanecen velados e incorporarlos a la acción de pensar. Una oportunidad para poner en marcha el pensamiento asociativo y completar el conocimiento de una realidad a partir de datos ya manejados y de la intuición. En este sentido, es posible descubrir cómo en el muro este de la ermita surgen unas diminutas perforaciones que contribuyen a dotar de dramatismo el interior (Imagen 5). Con la urna de la Virgen convertida en un foco luminoso de gran potencia, una constelación se despliega en torno a ella, atrapando las estrellas en el muro tras el altar.

\footnotetext{
${ }^{21}$ Colomina, Beatriz: "Towards a global architect". En Pozo Municio, José Manuel (Coord.): Viajes en la transición de la arquitectura española hacia la modernidad. Pamplona: T6: 2010, p. 44.

${ }^{22}$ También en la colorida puerta principal del Palacio de la Asamblea de Chandigarh, cuerpos celestes aparecen a ambos lados de la línea del horizonte, trazada hacia la mitad de la composición.
} 


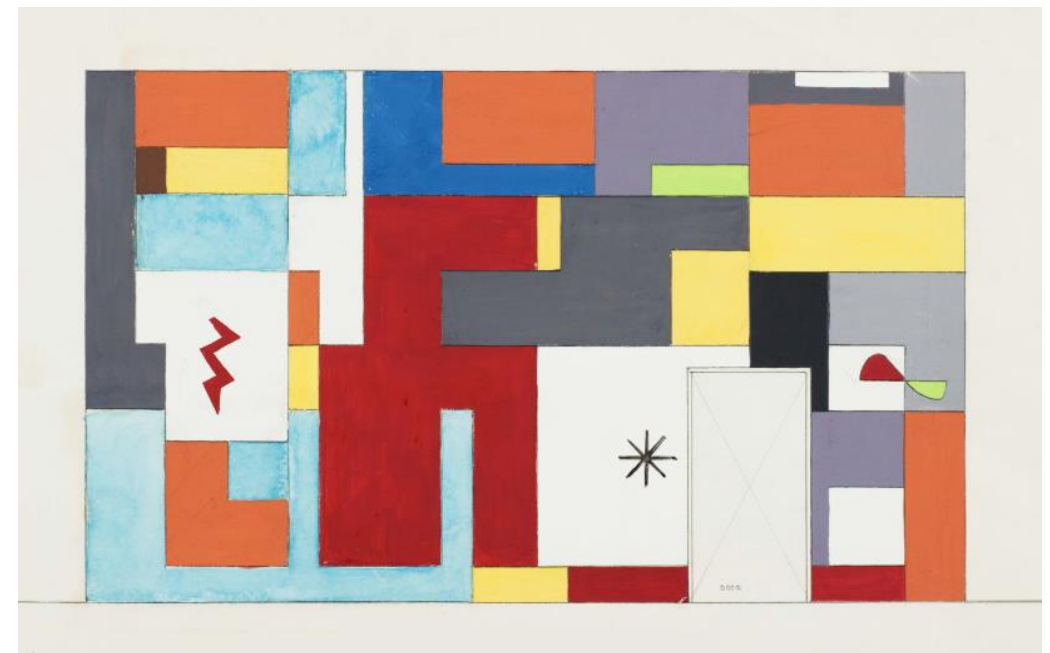

3. Le Corbusier. Estudio de tapiz para la Corte de Justicia (sala 4), Chandigarh (India), 1954. CFLC-ADAGP.

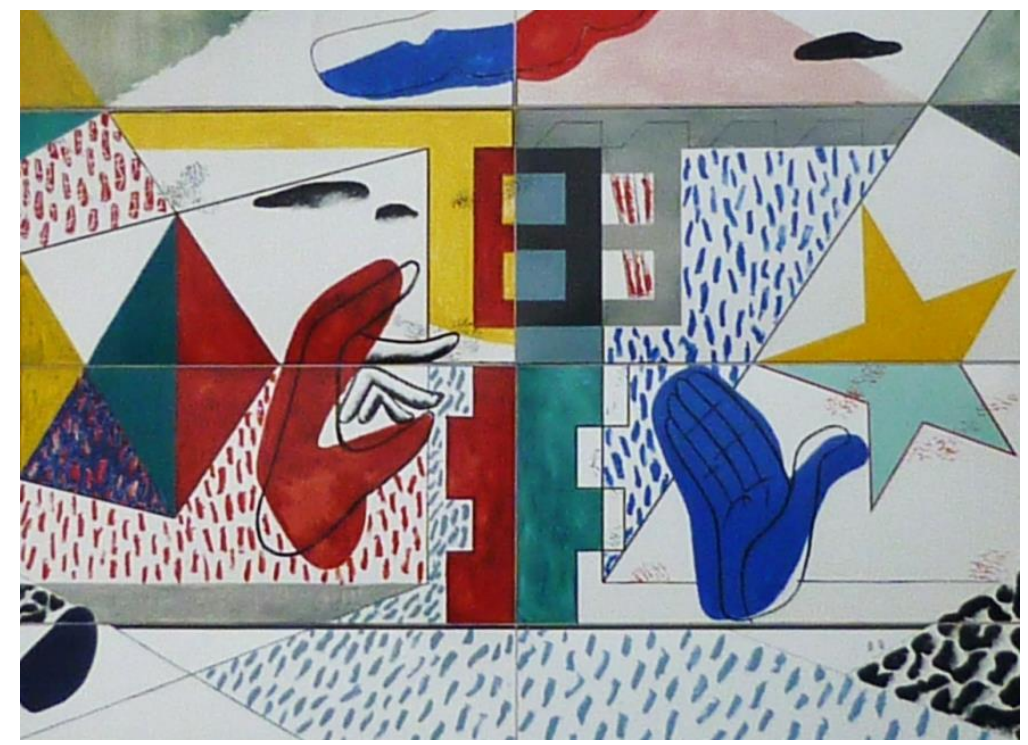

4. Le Corbusier. Ermita de "Notre-Dame-du-Haut", Ronchamp (Francia), 1950/55. Detalle de la puerta. Fotografía de las autoras. 


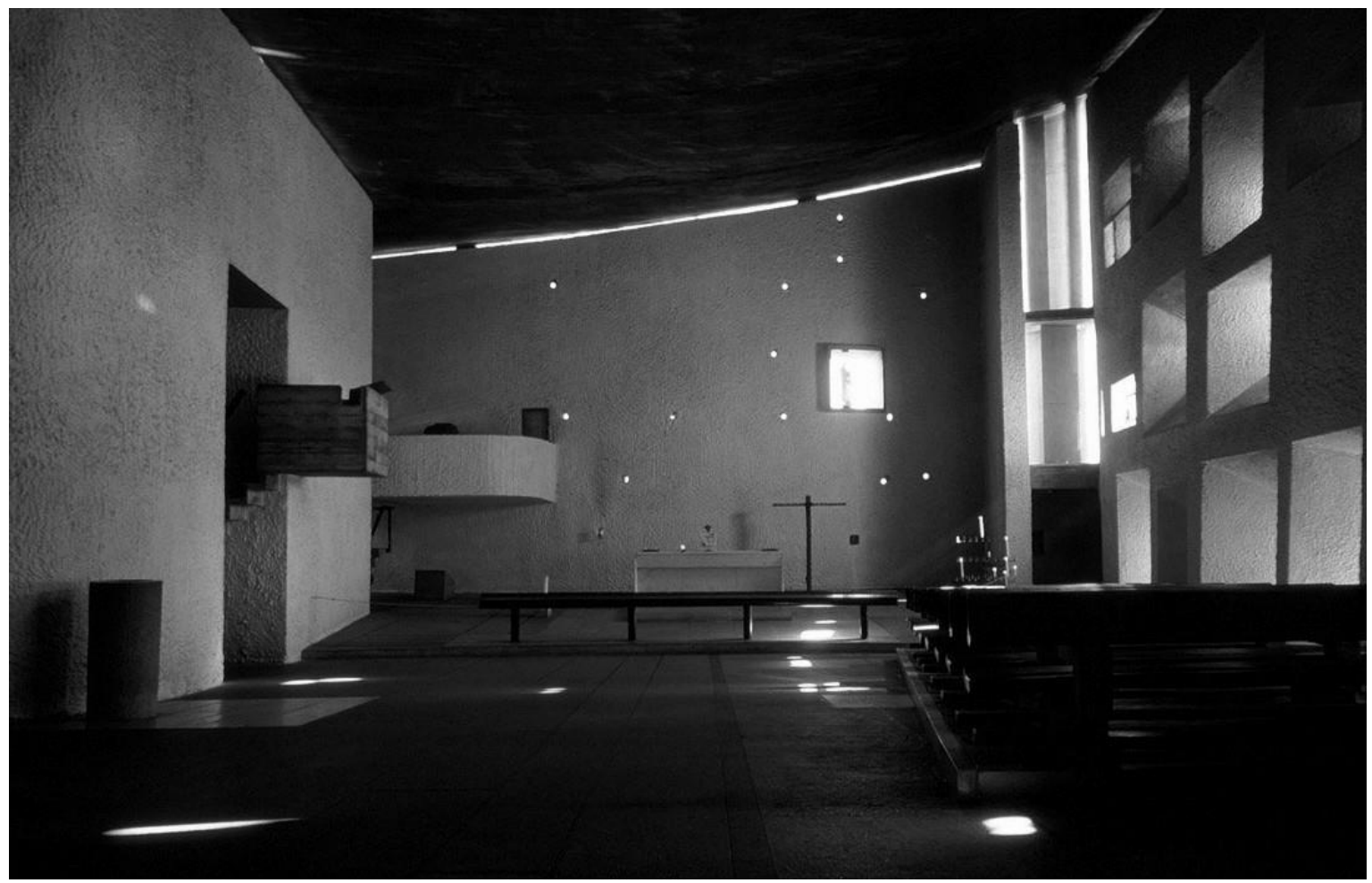

5. Le Corbusier. Ermita de "Notre-Dame-du-Haut", Ronchamp (Francia), 1950/55. Vista del muro este. Fotografía de las autoras.

No fue la ermita de Notre Dame du Haut el único interior en el que Le Corbusier convocó ceremonias celestiales. En el pabellón Philips para la Exposición Universal de Bruselas de 1958, las superficies regladas fueron perforadas en algunos puntos para crear una caja mágica. El recinto efímero, compuesto de distintos ambientes y equipado con proyectores de nubes y astros, albergaba un espectáculo por medio del cual los cuerpos celestes podían chispear en la caverna interior (Imagen 6). En el caso de la sala de la Asambleas del Palacio de Chandigarh, esta se vio rodeada de un halo de columnas dispuestas de forma radial. Rayos que partiendo de un elemento central abierto al sol y a las estrellas se dispersaron en una planta que puede ser leída como una reflexión sobre la contracción y expansión de las fuerzas cósmicas (Imagen 7). Y no solo la planta, pues en el esquema de la sección dibujado por el arquitecto en noviembre de 1951 también se congregan las dos fuentes de iluminación, de cuya intersección derivaron las trayectorias sobre las que se construyó el espacio del paraboloide hiperbólico. La ceremonia del sol y de la luna, que permanecen congelados en un mismo instante, se convierte así en la generadora del embudo de la sala, la pieza que arrastra todo cuerpo celeste a su interior (Imagen 8). El remate de la cubierta se transformó en un instrumento de medida del tiempo y de conexión con la naturaleza, de la misma manera que el óculo perforado sobre el presbiterio de la capilla del convento de Santa María de la Tourette sirvió para tensionar el espacio, elevando la vista hacia las alturas. Estancias ligadas al cielo, que no están completamente abiertas a la luz directa, pero que vibran con el paso de las nubes y del sol: "Entière en soi, faisant son affaire de tout sol, ouverte aux quatre horizons, elle prête sa toiture à la fréquentation des nuages ou de l'azur ou des étoiles" ${ }^{23}$

23 "Entera en sí, arreglándoselas en cualquier suelo, abierta a los cuatro horizontes, presta su techumbre a la visita de las nubes, o del azul o de las estrellas". Calatrava Escobar, Juan Antonio (Coord.): Le Corbusier y la síntesis..., Op. Cit., p. 58. 


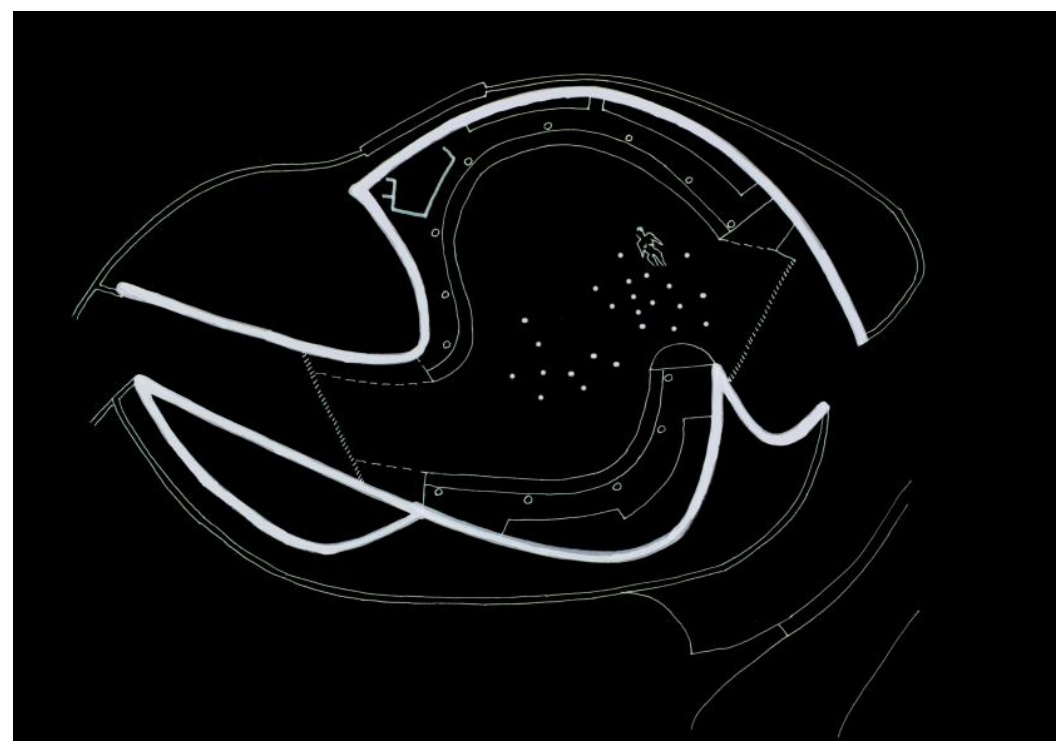

6. Le Corbusier. Pabellón Philips, Exposición Universal de Bruselas, 1958. Planta. Fuente: elaboración propia.
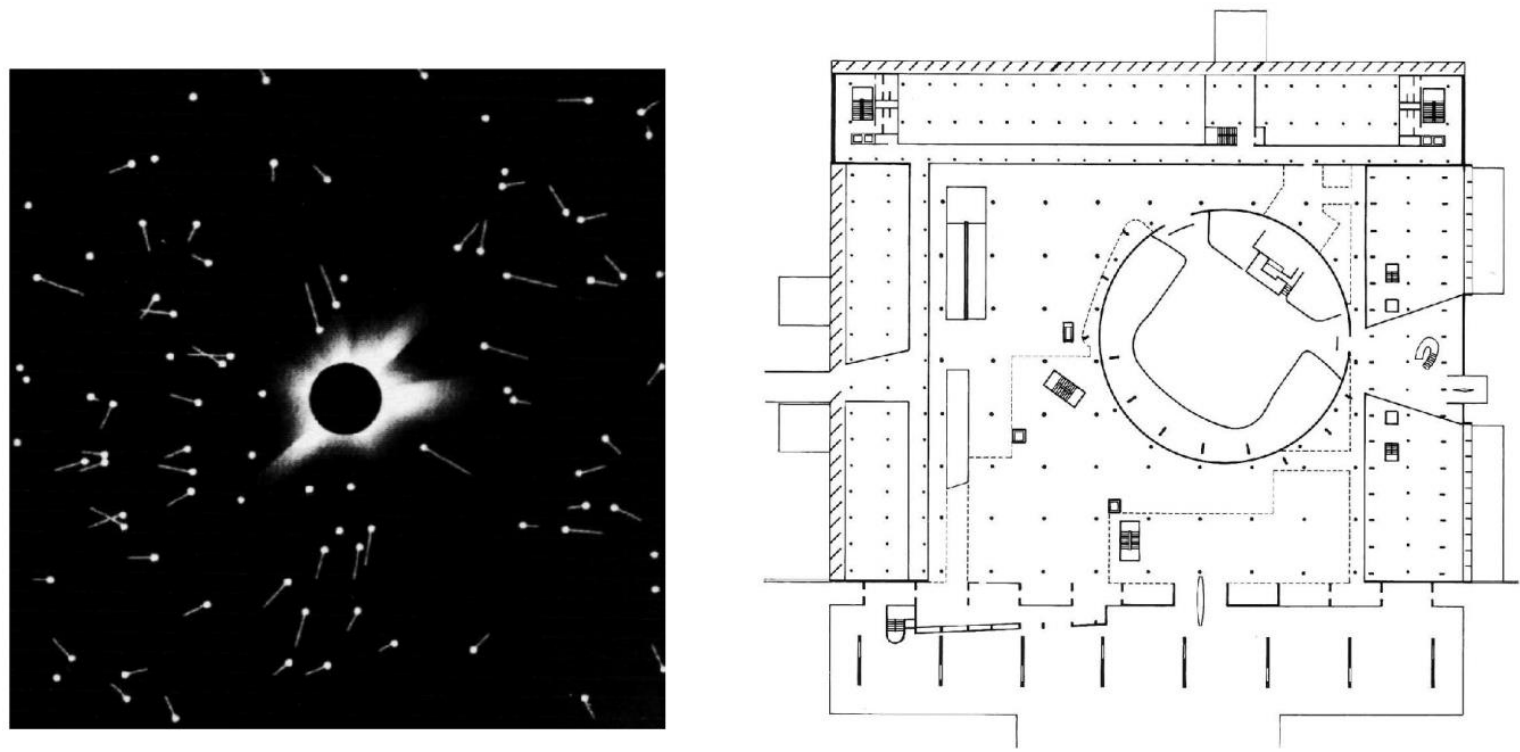

7. Le Corbusier. Planta del Palacio de la Asamblea de Chandigarh (India), 1951/65. Mundo de puntos flotantes y trayectorias de luz en comparación con un eclipse solar (izquierda). Fuente: elaboración propia. 


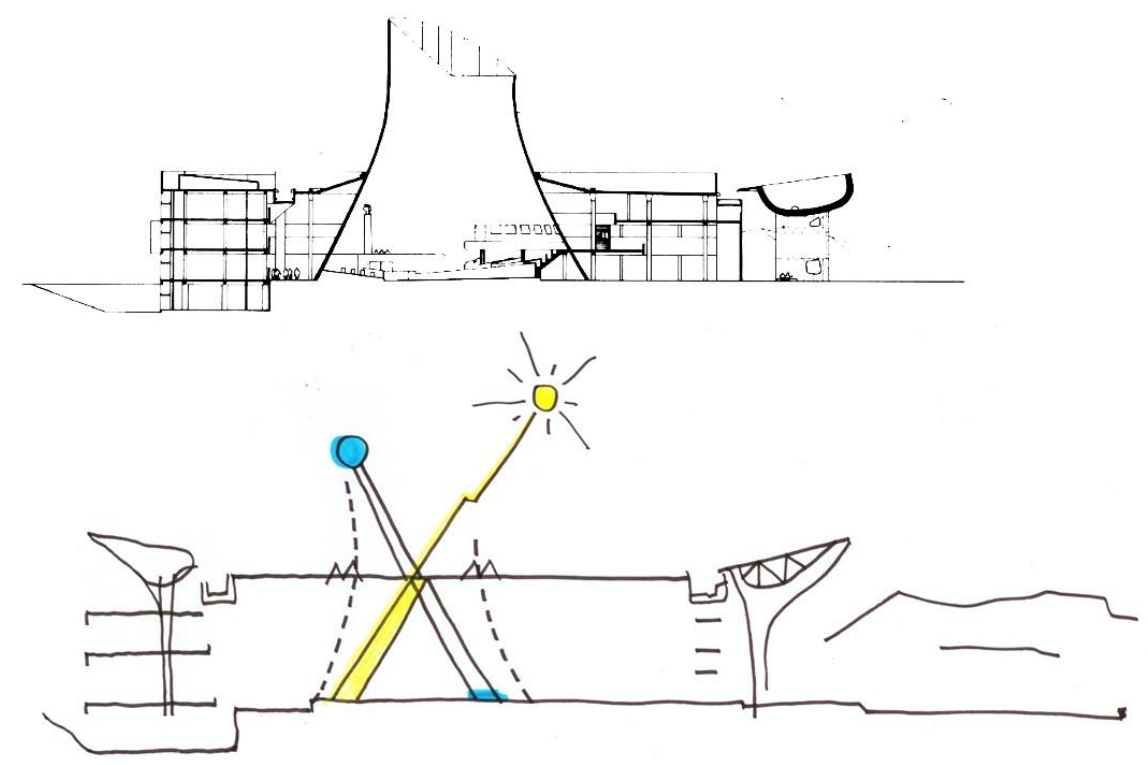

8. Le Corbusier. Sección (arriba) y esquema (abajo) del Palacio de la Asamblea. Fuente: elaboración propia.

El detalle de representar las estrellas en el muro se repetiría en su obra póstuma, la iglesia de Saint-Pierre, en Firminy. Algo lógico, si tenemos en cuenta las referencias previas manejadas por el arquitecto: el monumento megalítico de Stonehenge y el interior de Santa Sofía ${ }^{24}$. Del primero le atraía su marco cósmico, su relación con el curso del sol y del movimiento de las estrellas. Del segundo le fascinaba la notable ligereza de la cúpula, en contraste con la masa externa. De aquel viaje a Oriente realizado en 1911, que tan fuertes emociones arquitectónicas le había aportado, perduraba un dibujo de la antigua basílica ortodoxa, así como descripciones de las mezquitas relativas a la desmaterialización del espacio que Le Corbusier percibía al observar como un "techo de estrellas se extendía, formado por zonas concéntricas, sobre la gente en oración" ${ }^{\prime 25}$. Sobre esta base, José Oubrerie trabajó para configurar un espacio oscuro, abierto al cielo, y perforado sobre el altar. Aparecen así cuerpos que irradian luz al espacio, pequeños puntos luminosos sobre la superficie inclinada de hormigón que resaltan en el sombrío interior (Imagen 9). Un sustrato duro y masivo sobre el que toma forma una constelación de pequeñas estrellas que no hacen sino recordarnos la experiencia vivida por Le Corbusier en el monasterio griego de Yviron, cuando arrastrado al interior del santuario, se vio sumergido en una atmósfera irreal: "Estos cuatro o cinco que siguen obstinadamente el canto, uniforme, testarudo, gritando de pasión, vuelven sus caras convulsas hacia el negro de la cúpula, apuntalados sobre los brazos de las sillas del coro. Una paz inmensa nos rodea, nosotros los inmensamente afligidos; la noche, el mar, el monte; nosotros, las cúpulas asfixiadas por los humos de cera e incienso, el gran clamor del grito de angustiosa llamada. Cerrando los ojos por fin, tengo la visión de un sudario negro, tamizado de estrellas de oro ${ }^{\prime 26}$.

\footnotetext{
${ }^{24}$ Oubrerie, José: "La iglesia de Saint-Pierre en Firminy, de José Oubrerie y Le Corbusier". En Fernández Cobián, Esteban (Ed.): Arquitecturas de lo sagrado: memoria y proyecto. A Coruña: Netbiblo, 2009, p. 164.

${ }^{25}$ Jeanneret, Charles-Edouard: El Viaje de Oriente. Murcia: Colegio Oficial de Aparejadores y Arquitectos Técnicos de Murcia, 1984, p. 91.

${ }^{26} I d$., p. 150.
} 


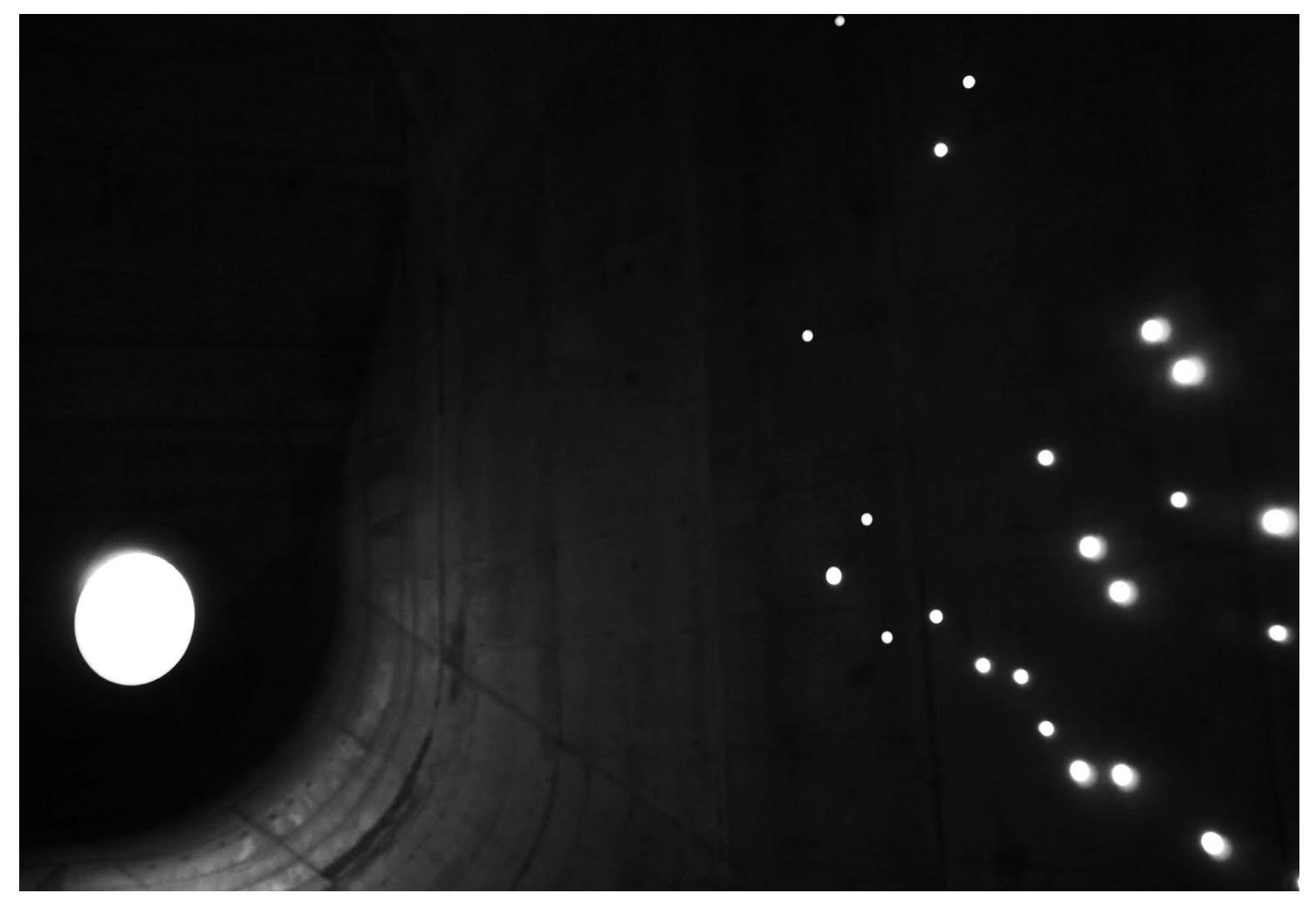

9. Le Corbusier y José Oubrerie. Iglesia de Saint-Pierre en Firminy (Francia), 1961/2006. Detalle del interior. Fotografía de las autoras.

\section{Conclusiones}

Operar en ese territorio escurridizo que emplea las vivencias personales, la biografía y la memoria visual, sin rehuir lo aleatorio, y lo irracional, es la principal aportación de este trabajo. Discernir unas figuras particularmente propensas a revelarse, a mostrarse, a imponerse en los mecanismos de proyecto. Desentrañar aspectos que saltan a la vista en bocetos, apuntes y circunstancias biográficas, aunque el propio autor no se molestase en explicarlas con detalle. Proponer mediante un ciclo dinámico basado en la experiencia y en la reflexión del arquitecto una serie de estrategias proyectuales concentradas en el manejo de los mecanismos mentales y emocionales que acaban determinando puntos de luz, rayos blanquecinos o campos estrellados que se superponen sobre fondos cambiantes: papel, cartón, lienzo, tapices, esmaltes, piedra u hormigón.

Numerosos proyectos de Le Corbusier albergan esos símbolos que no desempeñan por sí solos ningún rol en la configuración de respuestas arquitectónicas concretas, que pertenecen al mundo irracional o subjetivo, pero que iluminan decisiones, matices y geometrías a través de infinitas intersecciones y conexiones en el proceso de creación.

Al dibujar la estrella, Le Corbusier se enfrentaba con aquello con lo que se involucraba, se situaba frente al objeto al mismo tiempo que desarrollaba una reflexión sobre las opciones del proyecto. Dibujar la estrella de varias puntas suponía materializar sus ideas, pensar sobre ellas y volver a realizarlas (Imagen 10). Si consideramos que nuestras manos son órganos para el pensamiento, tal como propuso Martin Heidegger, podremos considerar que para el maestro suizo estas se convirtieron en el instrumento indispensable para concretar la acción, la mirada. Son las manos con las que trazó el último de los tres elementos situados sobre el iconostasio. La estrella que sube y baja en el horizonte. Un sol que sale, se pone y vuelve a salir. 

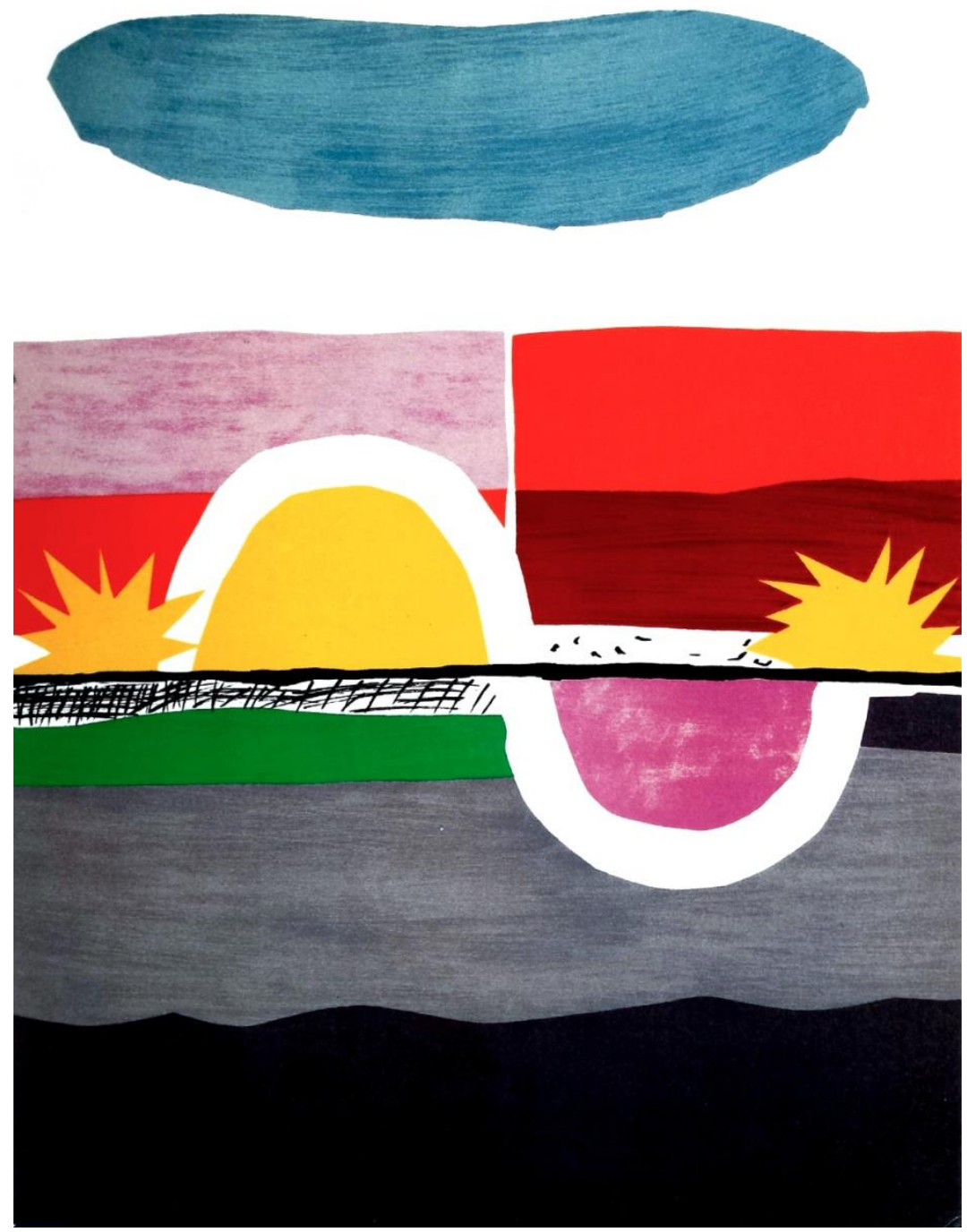

10. Le Corbusier. Papier collé preparatorio para Le Poème de l'Angle Droit. Fuente: Calatrava Escobar, Juan Antonio (Coord.): Le Corbusier y la síntesis de las artes: El poema del ángulo recto. Madrid: Fondation Le Corbusier-Círculo de Bellas Artes-Caja Duero Obra Social, 2006. OFLC-ADAGP.

\section{Bibliografía}

Alba Dorado, María Isabel: Intersecciones en la creación arquitectónica. Reflexiones acerca del proyecto de arquitectura y su docencia. Sevilla: Secretariado de Publicaciones de la Universidad de Sevilla, 2010.

Boesiger, Willy (ed.): Le Corbusier. Oeuvre Complète 1910-1929. Zurich: Girsberger, 1964.

Bridge, Gary; Watson, Sophie (Ed.): A Companion to the City. Massachusetts: Blackwell, 2003.

Burriel Bielza, Luis. Saint-Pierre de Firminy-Vert: el edificio como objet-à-réaction-émouvante. Director: Ignacio Vicens y Hualde. Tesis doctoral. Universidad Politécnica de Madrid, Departamento de Proyectos, 2010.

Calatrava Escobar, Juan Antonio (Coord.): Le Corbusier y la síntesis de las artes: El poema del ángulo recto. Madrid: Fondation Le Corbusier-Círculo de Bellas Artes-Caja Duero Obra Social, 2006.

Colomina, Beatriz: "Towards a global architect". En Pozo Municio, José Manuel (Coord.): Viajes en la transición de la arquitectura española hacia la modernidad. Pamplona: T6: 2010, pp. 41-48. 
Jeanneret, Charles-Edouard: El Viaje de Oriente. Murcia: Colegio Oficial de Aparejadores y Arquitectos Técnicos de Murcia, 1984.

Le Corbusier: Précisions sur un état présent de l'architecture et de l'urbanisme. París: Vincent, Fréal et Cie, 1930.

Le Corbusier: Aircraft. London: Studio Publications, 1935.

Le Corbusier: Mensaje a los estudiantes de arquitectura. Buenos Aires: Infinito, 1959.

Oubrerie, José: "La iglesia de Saint-Pierre en Firminy, de José Oubrerie y Le Corbusier". En Fernández Cobián, Esteban (Ed.): Arquitecturas de lo sagrado: memoria y proyecto. A Coruña: Netbiblo, 2009, pp. 162-177.

Perec, Georges: Especies de espacios. 5ª edición. Barcelona: Montesinos, 2007.

Pico Valimaña, Ramón: "Octubre de 1929, un paseo por los cielos". En Zarch. "Las trazas del lugar". Octubre 2013, N 1. Zaragoza: Arquitectura Unizar, pp. 168-179.

Saint-Exupéry, Antoine de: Tierra de hombres. Buenos Aires: Troquel, 1972.

Saint-Exupéry, Antoine de: Vuelo Nocturno. Madrid: Anaya, 2003.

Schiff, Stacy: Saint-Exupéry: A Biography. London: Random House, 2011. 
It seeks to correct some inherited errors of fact, particularly in relation to the contents of the primary drawings by Le Corbusier ${ }^{4}$. It identifies, for example, that there is an axonometric drawing is in circulation that clearly depicts both the camera obscura periscope and the famous fireplace in the chambre à ciel ouvert. It is drawn in accord with the distinct series of 1:50 axonometric drawings that Le Corbusier produced during the course of the design of the Beistegui Apartment, and the implication is that it concludes the series. However, Le Corbusier did not actually produce such a drawing. Both the camera obscura periscope and the fireplace appeared late in the process of design and were only properly drafted in plan, elevation and section drawings ${ }^{5}$ (figs. 2,3 and 4 ).

The client for the apartment, Charles de Beistegui, has been described as an eccentric multimillionaire with an extravagant personal style of excessive neoclassical eclecticism, who "seized every opportunity to throw parties and banquets in his many (self-decorated) residences ... with friends from aristocratic, moneyed and artistic circles"6. In early 1929 Beistegui determined to realise a décor de fête as a rite of entry to the circles of the Parisian haute bohème. He shortlisted a number of prominent Modernist architects who might help him to realise his aim, these being Gabriel Guevrekian, André Lurçat, and Le Corbusier with Pierre Jeanneret, ${ }^{7}$. Each was solicited to produce a proposition for the apartment depicted in a suite of orthographic drawings and in a single axonometric drawing at 1:50 scale, without the knowledge of the others. Together with an initial estimate of cost, the drawings were required by the beginning of June 1929. Le Corbusier was, somewhat surprisingly, awarded the commission in mid-July 1929. He must have been challenged, if not chastened, by the fact that Beistegui had apparently been more roused by the other two architects' proposals ${ }^{8}$, but his enthusiasm for the project was

Rizzoli, 1988, pp. 32-51; Sylvain Malfroy, "Der Aussenraum ist immer ein Innenraum [The Exterior is Always an Interior]," Werk, Bauen + Wohnen 81, 1994, pp 36-41; Benton, The Villas of Le Corbusier 1920-1930; van den Bergh, "Charles Beistegui: Autobiography and Patronage", pp. 17-40; Anthony Vidler, "Paris: Beistegui Apartment, Or Horizons Deferred" in Jean-Louis Cohen, ed., Le Corbusier: An Atlas of Modern Landscapes, New York: The Museum of Modern Art, 2013, pp. 274-79.

${ }^{4}$ The primary drawings by Le Corbusier that were consulted for this paper are those that were reproduced in H. Allen Brooks, ed. The Le Corbusier Archive, Vol VIII: Appartement de Beistegui, Cité Univérsitaire - Pavillon Suisse, Ville Radieuse, and Other Buildings and Projects, 1930, New York: Garland and Fondation Le Corbusier, 1982.

${ }^{5}$ This axonometric drawing appears in Reichlin, "L’Esprit de Paris", p. 50; van den Bergh, "Charles Beistegui: Autobiography and Patronage", p. 36; and in Benton, The Villas of Le Corbusier and Pierre Jeanneret 1920-1930, p. 208. Benton suggest that this drawing is "based upon drawings in the le Corbusier office, c. May 1930", identifying FLC 17490 as the source. FLC 17490 is a plan drawing at the terrace level and the camera obscura periscope is not even depicted on it. Note also that the plan drawing that Benton includes on the same page as the axonometric is also incorrectly labeled as having been based upon FLC 17490. Not only does it depict the camera obscura periscope, it is a roof plan rather than a plan at the terrace level. The plan drawing on which it was based must have been FLC 29863.

${ }^{6}$ van den Bergh, "Charles Beistegui: Autobiography and Patronage", p. 17. It is important to note here the contribution of the interior designer Emilio Terry, who furnished Beistegui’s dwellings, including the Beistegui Apartment. See Pierre ArizzoliClémentel, Emilio Terry, 1890-1969: architecte et décorateur, Montreuil, France: Gourcuff Gradenigo, 2013.

${ }^{7}$ Note that Robert Mallet-Stevens was a conspicuous omission from this list. He had recently completed houses for some of Beistegui's friends, and was evidently considered to be no longer 'original'. One of these houses was the Villa Paul Poiret (1921-23) and the second was the Villa Noailles (1923-28). Both houses are worth mentioning in that they had common features that would also appear in the Beistegui Apartment, namely the concept of the chambre à ciel ouvert, and the way that the vertical access to the rooftop terrace culminated in a protuberant observation post from which one enjoyed a controlled view of the surrounding landscape.

${ }^{8}$ Whilst Le Corbusier's proposal of the $3^{\text {rd }}-4^{\text {th }}$ June 1929 had a 'classic simplicity' (see FLC 17431, 17434-5), Beistegui evidently enjoyed the surprising promenades of follies in both Guevrekian's and Lurçat's proposals, along which he would be able to lead his guests. Le Corbusier's final design owes much to the proposals of the other two architects, although it is to be noted that he did not unthinkingly adopt any elements from them. Rather, he creatively transfigured particular architectural moments. For example, Guevrekian's table tennis table was transformed first into a croquet court and finally into the famous chambre à ciel ouvert. Guevrekian's and Lurçat's proposals are reproduced in van den Bergh, "Charles Beistegui: Autobiography and Patronage", p. 31. 
evident. In a letter to Beistegui he enthusiastically referred to the project as a programme vedette (stellar program) that would offer a "solution to the roofs of Paris".

Whilst much discussion on the Beistegui Apartment has understandably been in reference to Surrealism ${ }^{10}$, it will likely be more profitable to speak more particularly of the 'modern fragment', as thoughtfully and expansively addressed by Dalibor Vesely. Vesely wrote of the "situational meaning of individual fragments", identifying that in the early development of collage the creative process depended on a few critical points of reference that were usually fragments of a familiar reality, which were transformed through a sequence of steps into a more complex configuration that opened up the metaphorical possibilities of sameness and difference in reference to the "context of a world opened up by the main theme" ". He identified the metaphoricity of fragment as being not only relevant in the domain of the arts, but also potentially as the progenitor of " $a$ new restorative power relevant to our culture as a whole" ${ }^{, 12}$.

Vesely asserted that Le Corbusier was the first architect to consistently use fragment as part of a positive vision, and that in his interiors "the juxtaposition of elements and the overall layering of space are motivated entirely by situational criteria" "13. He made particular reference to the chambre à ciel ouvert atop the Beistegui Apartment, which is treated simultaneously as an open space and a closed interior: "The situation is open to a series of readings in which individual elements play the role of metaphorical fragments, revealing the situational character of the dwelling in the context of a room, city and nature" ${ }^{\prime 14}$. Vesely identified that the tool that permits us to navigate through the potentially infinite "forest of symbols and indices" is analogy, which has the capacity to reveal the deep relations between distant realities that nevertheless share a common latent world, which is "where our imagination and its organizing power have their source" ${ }^{\prime 15}$. The chambre à ciel ouvert contrives a series of analogical relationships: between the Arc de Triomphe and an ornate fireplace, between tended grass and carpet, and between the ceiling of a room and the sky ${ }^{16}$ (fig. 5). Peter Carl has, on many occasions, recognised the fecundity of Le Corbusier's analogical imagination. Of relevance to the current discussion is his recognition that the English word Chimney harbours only a portion of the French la cheminée, which also "directly refers to the fireplace, the fireside and to the mantelpiece-and is therefore another term for foyer within Corbusian iconography" $"$. That is, there is a depth to the associations that transcends matters of form and iconography.

Whilst the remarkable chambre à ciel ouvert has understandably attracted the most scholarly attention, it is to be noted that the preparatory sequence of spatial situations that Le Corbusier contrived for Beistegui's guests to

\footnotetext{
${ }^{9}$ Le Corbusier, cited in Vidler, "Paris: Beistegui Apartment, Or Horizons Deferred”, p. 275.

${ }^{10}$ See for example Alexander Gorlin, "The Ghost in the Machine: Surrealism in the Work of Le Corbusier", Perspecta 18, 1982, pp. 50-65

${ }^{11}$ Dalibor Vesely, "Architecture and the Ambiguity of Fragment" in Robin Middleton, ed., The Idea of the City, Cambridge, Mass.: MIT Press, 1996, p. 115.

${ }^{12}$ Ibid., p. 116.

${ }^{13}$ Ibid., p. 118. See also Vesely, "Surrealism, Myth and Modernity", AD Profiles 11, 1978, pp. 87-95; and Vesely, Architecture in the Age of Divided Representation: The Question of Creativity in the Shadow of Production, Cambridge, Mass.: MIT Press, 2004.

${ }^{14}$ Ibid., 118. Vesely was more buoyant about the genuine architectural contribution of the chambre à ciel ouvert than others have been. Benton wrote that, as completed, "this open room, with its lawn carpet and working fireplace, mocked the simple pleasures of the early schemes". Benton, The Villas of Le Corbusier and Pierre Jeanneret 1920-1930, p. 208.

${ }^{15}$ Vesely, "Architecture and the Ambiguity of Fragment", p. 117.

${ }^{16}$ Note that Le Corbusier had often asserted his conviction that "the exterior is always an interior." See for example a subsection of the chapter "Architecture II: The Illusion of Plans" entitled 'The Exterior is Always an Interior' in Le Corbusier, Towards a New Architecture, trans. Frederick Etchells, London: J. Rodker, 1931, pp. 191-194.

${ }^{17}$ Peter Carl, “Le Corbusier's Penthouse in Paris, 24 Rue Nungesser-Et-coli,” Daidalos 28, June 1988, p. 72.
} 
arrive at the outdoor room comprises an equally rich medley of 'metaphorical fragments'. The sequence begins with the corkscrew-like spiral staircase that ascended from the large open entertainment room below (fig. 6). Architecturally, the spiral staircase was 'set adrift' in the entertainment room. It did not in any way nestle, accord, align or converse with any other elements of the architecture, and it touched the ground very tenuously. The dark-coloured treads were extremely narrow, and could certainly have only been ascended one person at a time. In all, the staircase had something of the character of a ladder that conceptually had either been temporarily set in place from the room below or cast down from the circular hole in the base of the camera obscura pavilion. Peter Carl wrote of the spiral staircase to the roof garden in Le Corbusier's own apartment in similar terms, identifying it thematically with the Jacob's ladder that was later published in the architect's Poésie sur Alger, 1950, which ascended from a region of water "to arrive at the meeting-point of sea-horizon and heavens" 18 . He further drew a comparison between Le Corbusier's Jacob's ladder and the well-known example from Robert Fludd's Utriusque Cosmi ... Historia [The Origin and Structure of the Cosmos], 1619, which depicts "an ascent from dark matter to luminous spirit, from sensus to verbum" "19. Carl suggested that the spiral staircase in Le Corbusier's apartment was structured to allow the inhabitant to re-enact the eternal drama that he provisionally termed "an awakening to creativity" 20 . A vertical handrail served as the axis of revolution around which the spatial transformation was to be enacted: "One's left hand rises in a vertical line while the body performs a spiral ascent around it" 21 . An identical situation occurred in the Beistegui Apartment. The guest stepped up from the vast dark carpeted floor (conceptually a region of water), with their left hand on the central vertical handrail and ascended in a spiral to the camera obscura pavilion that served as a vestibule between the actual everyday city of Paris and the "rooftop fantasy" 22 of the city above.

At the top of the spiral staircase the guest arrived, singly, in the small and necessarily dark camera obscura pavilion $^{23}$ (fig. 4). While the decision to include the camera obscura periscope in the pavilion was very likely made after the plans for the apartment were agreed upon in June $1930^{24}$, and there is debate as to whether its presence is to be attributed to Le Corbusier or Beistegui ${ }^{25}$, it can be read as the transformed fulfilment of an ambition that was present in the original schemes by Guevrekian and Lurçat, but that, interestingly enough, did not appear in Le Corbusier's original scheme. The two architects had each included a sundial in an open belvedere on the rooftop, which can only have been in response to the brief supplied by Beistegui. A sundial 'apprehends' the fundamental universal condition of time. A camera obscura is similarly acquisitive. Latin for

\footnotetext{
${ }^{18}$ Ibid., p. 73.

${ }^{19}$ Ibid., p. 73. Carl identified that "the goal of such ascents is the attainment of the pneumatikos, the spiritual man reconciled with the cosmos."

${ }^{20}$ Ibid., p. 71.

${ }^{21}$ Ibid., p. 72.

${ }^{22}$ Vidler, "Paris: Beistegui Apartment, Or Horizons Deferred",p. 277.

${ }^{23}$ Vidler referred to the pavilion as "small oval cabin ... windowless hut", Benton as a "free-standing oval projection on the roof terrace" and Malfroy as "a little house (Häuschen)". Vidler, "Paris: Beistegui Apartment, Or Horizons Deferred", p. 277; Benton, The Villas of Le Corbusier and Pierre Jeanneret 1920-1930, p. 206; and Malfroy, "Der Aussenraum ist immer ein Innenraum," p. 40. Unless otherwise noted all translations from German are by the author.

24 "One of the causes of the extra cost [of the apartment] was the provision of immensely costly changes caused by the piercing of the concrete slabs in order to fit the revolving periscope with its tall chimney like protuberance (April-July 1932)." Benton, The Villas of Le Corbusier and Pierre Jeanneret 1920-1930, pp. 206-208. Vidler similarly noted that "The periscope seems to have been conceived at the very last minute-requiring the demolition of the already completed reinforced concrete roof to the spiral stair." Vidler, "Paris: Beistegui Apartment, Or Horizons Deferred", p. 277.

${ }^{25}$ Reichlin has suggested that although it is impossible to know whether the periscope can be attributed to Le Corbusier or Charles de Beistegui, it was more likely to be de Beistegui's invention, since its construction demanded many alterations to the spiral staircase. He concludes that in any case, "it is certainly an idea that came at the end [of the design process]." Reichlin, "L’Esprit de Paris", p. 56.
} 
'darkened chamber', a camera obscura is a pre-photographic optical instrument producing an exact yet inverted re-production of an external scene in a darkened room as light passes through a small aperture ${ }^{26}$. Whilst the principle was known in antiquity, having been mentioned by Aristotle and others, it was first properly articulated by the Italian polymath Giambattista della Porta in his Magia Naturalis, $1558^{27}$. He described the effect as very pleasant for "great men and scholars and ingenious persons to behold" 28 . The camera obscura is a dark, quiet and slow phenomenon, in part due to the physiological requirement of a period of time for the eyes to adjust to the abrupt change in illumination upon entering $\mathrm{it}^{29}$. The image slowly revealed in the small dark pavilion in the Beistegui Apartment was an acquired vista of Paris that took in the full living city, not only the four emblems of the "imperishable heritage" ${ }^{, 30}$ of Paris that were privileged in the chambre à ciel ouvert. The strangeness of this apparition of the city would have lent the interior of the diminutive camera obscura periscope cabin an aura of the uncanny, which is what Sigmund Freud defined as the simultaneously familiar and foreign ${ }^{31}$.

The German for uncanny, unheimlich, literally 'un-homely', is a much more evocative and accurate rendering of the notion. Freud wrote that the word heimlich is ambiguous since "on the one hand it means that which is familiar and congenial, and on the other, that which is concealed and kept out of sight... Thus heimlich is a word the meaning of which develops towards an ambivalence, until it finally coincides with its opposite, unheimlich" ${ }^{32}$. In this case, the unheimlich would have been engendered by the revelation that perhaps the room itself, autonomous of the architect or client's determination, enjoyed a secret intercourse with the 'other'-the city of Paris that it faced silently every day. The conditions of the room into which the scene is projected affects its reception, whether or not it is consciously manipulated or is simply left to stand in its unaltered state. So, whilst the images re-produced by cameras obscura are 'objective', that is, they are unmediated by technology, every installation is never merely receptive. It is, to some degree, transformative. The transformative context was, in the case of the Beistegui Apartment, a small lozenge-shaped pavilion within a specific building on the Champs-Elysée that was in turn tied-in to the particular historical and urban context of the city of Paris, which mattered so much to Le Corbusier, and to the Surrealists ${ }^{33}$.

Paris possessed, for Le Corbusier, an inimitable 'esprit' that was expressed architecturally in the distinctive profile of the horizon of the city. In a renowned sequence of drawings explaining his Plan Voisin of 1925, to an audience in Buenos Aires in 1929, the architect traced the historical development of this horizon in five steps:

\footnotetext{
${ }^{26}$ For a concise history of the camera obscura see John H. Hammond, The Camera Obscura, Bristol: Adam Hilger, 1981.

${ }^{27}$ Giambattista della Porta, Magia Naturalis, Naples: Cancer, 1558. Published in English as Natural Magick by John Baptista Porta, a Neapolitane: In Twenty Books: Wherein are Set Forth all the Riches and Delights of the Natural Sciences, London: Thomas Young \& Samuel Speed, 1658.

${ }^{28}$ Porta, Natural Magick, p. 364.

${ }^{29}$ As Porta wrote, "when men walk in the Sun, if they come into the dark, that affection continues, that we can see nothing, or very scantly; because the affection made by the light, is still in our eyes; and when that is gone by degrees, we see clearly in dark places." Porta, Natural Magick, p. 363.

${ }^{30}$ These architectural icons were the Arc de Triomphe, Sacré-Coeur, Notre Dame and the Eiffel Tower. See Le Corbusier, The City of Tomorrow [Urbanisme, 1924], trans. Frederick Etchells, Cambridge, Mass.: MIT Press, 1929, pp. $271,281$.

${ }^{31}$ Sigmund Freud, "Das Unheimliche", Imago, Bd. V., 1919. Published in English as "The "Uncanny"” in The Complete Psychological Works, Vol. XVII, London: Hogarth Press 1955, pp. 217-56. For recent treatments of the uncanny in contemporary architectural discourse see Vidler, The Architectural Uncanny, Cambridge, Mass.: MIT Press, 1992; and Vidler, "Fantasy, The Uncanny and Surrealist Theories of Architecture" Papers of Surrealism 1, Winter 2003.

${ }^{32}$ Freud, "The 'Uncanny", pp. 222-223.

${ }^{33}$ In 1929, the same year that Le Corbusier began working on the Beistegui Apartment, Walter Benjamin wrote that for the Surrealists, at the "centre of this world of things stands the most dreamed-of of their objects, the city of Paris itself." And further that for the Surrealists' Paris was "a little universe." Walter Benjamin, "Surrealism: The Last Snapshot of the European Intelligentsia" [Der Sürrealismus: Die letzte Momentaufnahme der europäischen Intelligenz, 1929] in One-Way Street, London: Verso, 1979, p. 231.
} 
beginning with the medieval city with its focal Notre Dame; the classical city with its Louvre; Neoclassical Paris with its Pantheon; modern Paris with its Arc de Triomphe, Basilique due Sacré Coeur, and the Eiffel Tower; and finally, the Paris of Le Corbusier's imagination - entirely redeveloped according to his Plan Voisin. It is this point that it is possible to address the ways that Le Corbusier 'staged' the city of Paris in the Beistegui Apartment. Peter Carl has recognised that the main effect of the contrivances on the rooftop of the apartment was to mask out all of Paris but certain cultural monuments, "a vision of Paris analogous to that of the Plan Voisin of 1925 "34. Reichlin has also written that "what makes the roof garden [chambre à ciel ouvert] interesting is the way that Le Corbusier staged the city" 35 , and Sylvain Malfroy has noted that in the apartment the view of Paris was "transformed through a subtle staging, and the model for this staging, as invented by the theatre of the $19^{\text {th }}$ century, would appear to owe much to the typological schema of the panorama" 36 . This recognition prompts consideration of the relevance of Le Corbusier's Pavillon de l'Esprit Nouveau at the International Exposition of Modern Decorative and Industrial Arts of 1925 in Paris, to the Beistegui Apartment. The main pavilion was a full-scale prototype of an ideal urban apartment. An exhibition annex that comprised large twin exedra-like rooms was constructed as a counterpoint to this single dwelling (fig. 7). It hosted dioramas ${ }^{37}$ of two of Le Corbusier's comprehensive urban schemes - the ideal Ville Contemporaine [Contemporary City for Three Million Inhabitants], 1922, and the Plan Voisin, 1925, which proposed demolishing much of the centre of Paris. As Richard Difford noted in his focused study of the building, "in the case of the dioramas, the existing city, which surrounds the pavilion and which is the subject of Le Corbusier's criticism, is explicitly shut out in favour of the artificially simulated alternative" ${ }^{, 38}$. This echoed the nineteenth-century inclination for dioramas to depict the city in which they were actually situated, rather than exotic alternative locations, revealing a "desire to present the city back to itself" 39 . Sylvain Malfroy recognised that in Le Corbusier's hands "the panorama is made into an instrument of anticipation. The public is challenged to experience in a direct and unmediated way the likeliness of the architectonic and urban propositions, and in fact to partake in the happiness of a completely transformed world" ${ }^{\prime 0}$. There is a clear intention to coax, if not convert, the visitor to a point of view. As with the original nineteenth-century examples, there is a clear sense that the dioramas are "associated with mastery over the city and of collective space"

The Beistegui Apartment was conceived 4 years after the Pavillon de l'Esprit Nouveau exhibition. Le Corbusier's hopes for the realisation of his hugely ambitious urban schemes can only have been tempered by that time. Vidler has put forward the hypothesis that the Beistegui Apartment was a "poignant response" to the refusal of his proposals, and that Le Corbusier may have sought to "create the illusion of a city erased", coupled with a "panoramic, didactic" view of the city, demanding its re-planning ${ }^{42}$. The role of the high-walled chambre à ciel ouvert was to judiciously remove from sight the "Pack-Donkey" streets of the everyday city, conferring

\footnotetext{
${ }^{34}$ Carl, "Le Corbusier's Penthouse", p. 67.

${ }^{35}$ Reichlin, "L’Esprit de Paris", p. 56.

${ }^{36}$ Malfroy, "Der Aussenraum ist immer ein Innenraum," p. 37.

${ }^{37}$ The word 'diorama' was coined in 1823 by the French photographer and scenographer Louis Daguerre. He fashioned the term from the Greek 'di-orama', to 'see through'. See Helmut and Alison Gernsheim, L. J. M. Daguerre: The History of the Diorama and the Daguerreotype, London: Secker \& Warburg, 1956, pp. 13-18.

${ }^{38}$ Richard Difford, "Infinite Horizons: Le Corbusier, the Pavilion De L'Esprit Nouveau Dioramas and the Science of Visual Distance," The Journal of Architecture 14:3, 2009, p. 304.

${ }^{39}$ Ibid., p. 304.

${ }^{40}$ Malfroy, "Der Aussenraum ist immer ein Innenraum," p. 37.

${ }^{41}$ Difford, "Infinite Horizons", pp. 304-305.

${ }^{42}$ Vidler, "Paris: Beistegui Apartment, Or Horizons Deferred", p. 275, p. 279.
} 
views only of four emblems of the "imperishable heritage" of Paris ${ }^{43}$ : the Arc de Triomphe, Sacré-Coeur, Notre Dame and the Eiffel Tower.

The intentions of the curious camera obscura pavilion are less self-evident than those of the chambre à ciel ouvert, but are potentially no less profound. The following tantalising hypothesis would, in a concrete way, couple Le Corbusier's thinking on the city of Paris with the diminutive pavilion. It hinges on Le Corbusier's familiarity with the symbolism traditionally attached to particular geometric figures. In this case, the figure is one that originated in Euclid's ancient epoch-making 13-book treatise on mathematics and geometry The Elements. The very first laconic proposition in the first book of The Elements reads as follows: "On a given finite straight line to construct an equilateral triangle" ${ }^{\text {"44 }}$. The ensuing sequence of geometric operations that can be carried out using a compass and straight edge arrive at a configuration of two circles whose centre points lie on the circumference of the other and on the common 'given finite straight line', creating an almond-shaped overlap (fig. 8). ${ }^{45}$ This figure at the centre of the composition is subsidiary to Euclid's geometrical proposition, but it later became invested with mystical significance in the cultural context of early Christianity, and became codified as a central Christian symbol in the medieval period. ${ }^{46}$ Coming to be known as the vesica piscis (fish bladder), it represented an opening and appearance of the divine, appearing most prominently in the West Façade of Chartres Cathedral (ca. 1145-55), where Christ is centrally situated in a vesica piscis shaped aureola in the central tympanum.

Le Corbusier was certainly familiar with the architecture of the Middle Ages, and he purported to be acquainted with the working methods, and 'secrets' of the masons who achieved the cathedrals. In When the Cathedrals Were White, 1937, he wrote that in the Middle Ages "the law of numbers was transmitted from mouth to mouth among initiates, after the exchange of secret signs" harmony are complicated, delicate. To understand the reason in them you have to have a spirit of some sensibility. Speak of them openly? That would be to put them in danger of errors of fact and of understanding" ${ }^{" 48}$. In the same year that the book was published, Le Corbusier installed a photomontage entitled L'Esprit de Paris in his Pavilion des Temps Nouveaux at the 1937 World Exposition (fig. 9). On the right hand side of this photomontage the medieval cathedral of Notre Dame de Paris is highlighted inside a clearly delineated vesica piscis form. A thin horizon line extends to the left of the vesica piscis, locating the top of the Arc de Triomphe and the base of the Panthéon.

Turning now to the form of the camera obscura pavilion, it can be revealed that the ground plan was determined geometrically by the vesica piscis configuration. And further that, when the plan of the pavilion is overlaid with

\footnotetext{
${ }^{43}$ Le Corbusier, The City of Tomorrow, p. 271, p. 281.

${ }^{44}$ Euclid, The Thirteen Books of the Elements. Vol. 1 (Introduction and Books I and II), New York: Dover, 1956, p. 241.

${ }^{45}$ The geometrical proof proceeds via the inscription of a circle that has its centre at Point A on one end of a 'given finite straight line' A-B, and a circumference that passes through Point B. A second circle of equal radius that has its centre at Point $\mathrm{B}$ is then inscribed, passing through Point A. The centres of the circles are then joined to the point of intersection of the two circles, Point $\mathrm{C}$, to create an equilateral triangle A-B-C.

${ }^{46}$ Note that Euclid became a venerated figure in operative stonemasonry, which is a craft driven by geometry. It is written in The Constitutions of Stonemasonry that “... all science lives only by the science of geometry... There is no tool to work with that has no proportion. And proportion is measure, and the tool or the instrument is earth. And geometry is... the measure of the earth, wherefore I may say that all men live by geometry... You shall understand that among all the crafts of the world... masonry has the most notability and most part of its science is geometry." The Constitutions of Masonry (ca. 1450, British Museum, M.S. 23198), ed. Matthew Cooke, London: R. Spencer, 1861.

${ }^{47}$ Le Corbusier, When the Cathedrals Were White [Quand les cathédrales étaient blanches, 1937], New York: McGraw-Hill, 1964 , p. 6.

${ }^{48}$ Ibid., p. 6.
} 
Euclid's original geometric demonstration and with the L'Esprit de Paris montage (fig. 10), some striking correspondences are exposed. Notre Dame de Paris, one of the icons of the 'imperishable heritage' of Paris is central to the configuration. The Arc de Triomphe, another of the icons, appears to the left of the image, in the exact location that it would have appeared when viewed through the camera obscura periscope. ${ }^{49}$ The horizon line of the photomontage lies on the 'given finite straight line' of Euclid's geometric construction, emphasising the motif of 'horizon' that is persistent in Le Corbusier's architecture and his art. Peter Carl goes as far as to say that "it is difficult to find a painting of Le Corbusier in which the theme of the horizon does not appear" Malfroy also identifies a metaphorical assertion of the horizon in the Beistegui Apartment, particularly in respect to the camera obscura pavilion where: "on the periscope table one can read the ocean of the roofs of Paris or the desert of its walls" and further that the search is "no longer for the vertigo inducing altitude, rather it is for the aesthetic of the horizontal view: an aesthetic that had been communicated in the diorama that was exhibited in 1925 in the Pavillon de l'Esprit Nouveau" ${ }^{, 51}$. The image of the city projected down onto the small round table in the darkened camera obscura pavilion on the Champs-Elysée would never have the audacious profile of the Plan Voisin, but it captured the real Paris-the city of Le Corbusier's imagination.

\footnotetext{
${ }^{49}$ Note that in Le Corbusier's drawings the periscope is almost always drawn facing in the direction of the Arc de Triomphe and its location is often noted in annotations.

${ }^{50}$ Carl, "Le Corbusier's Penthouse in Paris", p. 67.

${ }^{51}$ Malfroy, "Der Aussenraum ist immer ein Innenraum," p. 39, p. 41.
} 


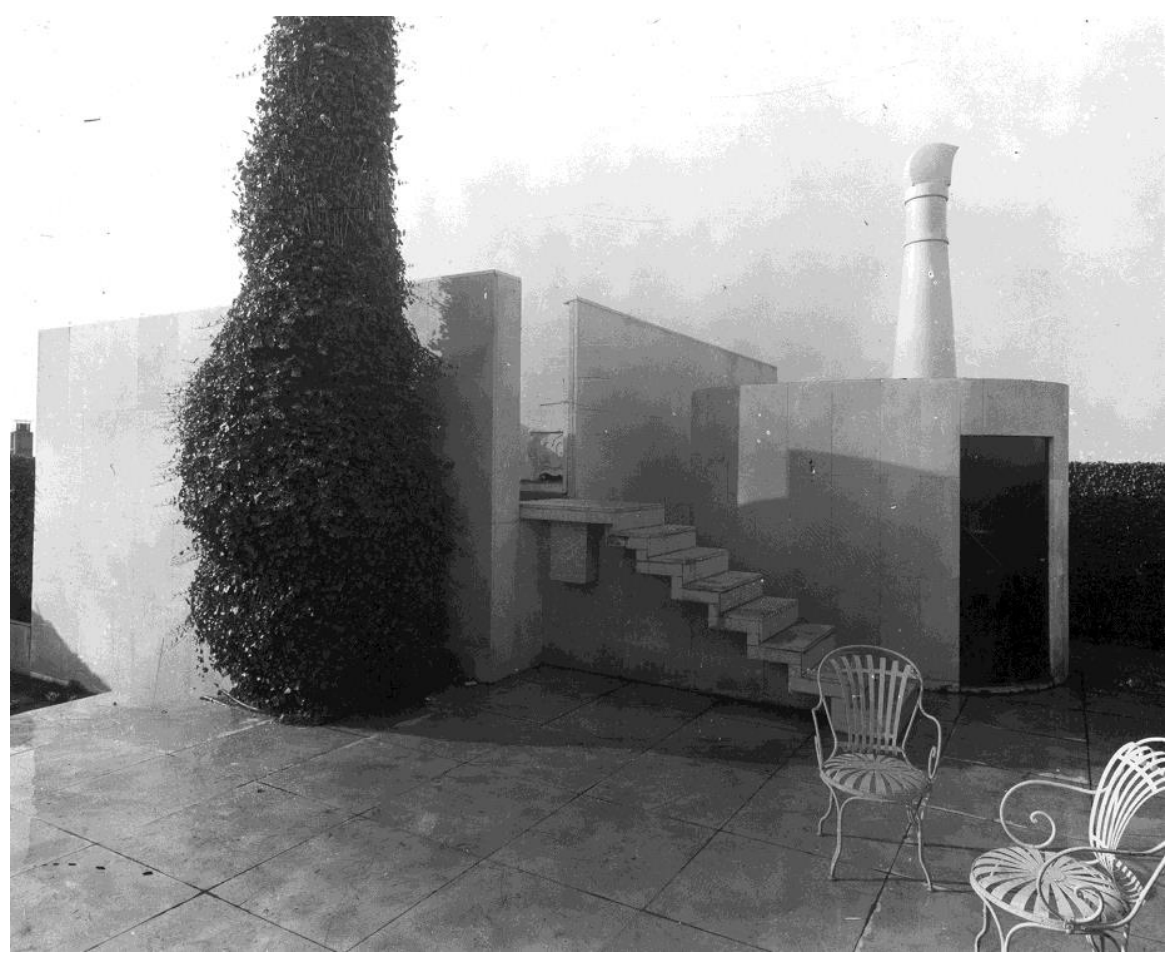

1. View of the camera obscura pavilion on the rooftop of the Beistegui Apartment (FLC L2-5-16 CFLC-ADAGP).

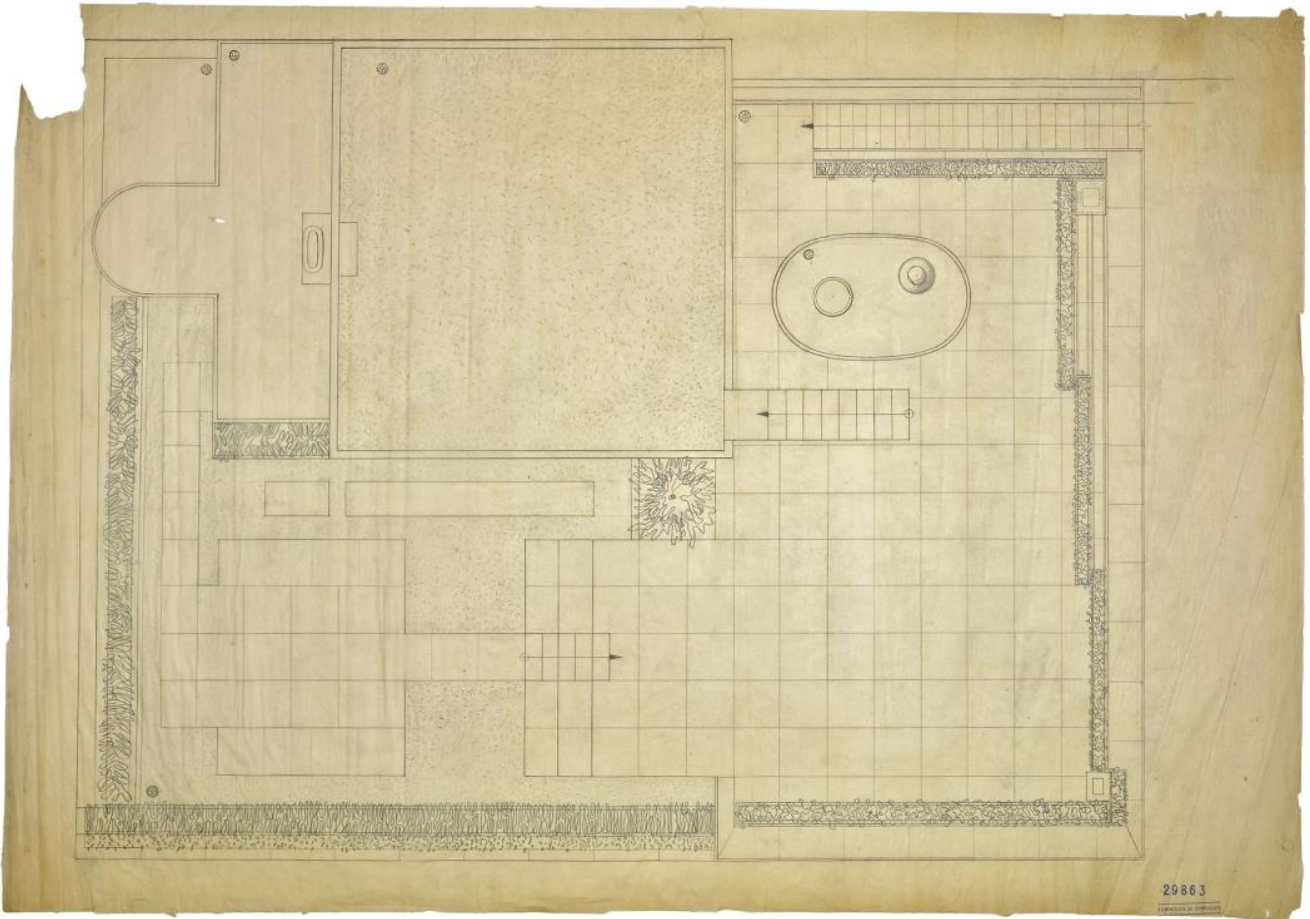

2. Final as built roof plan drawing of the Beistegui Apartment (FLC 29863 CFLC-ADAGP). 


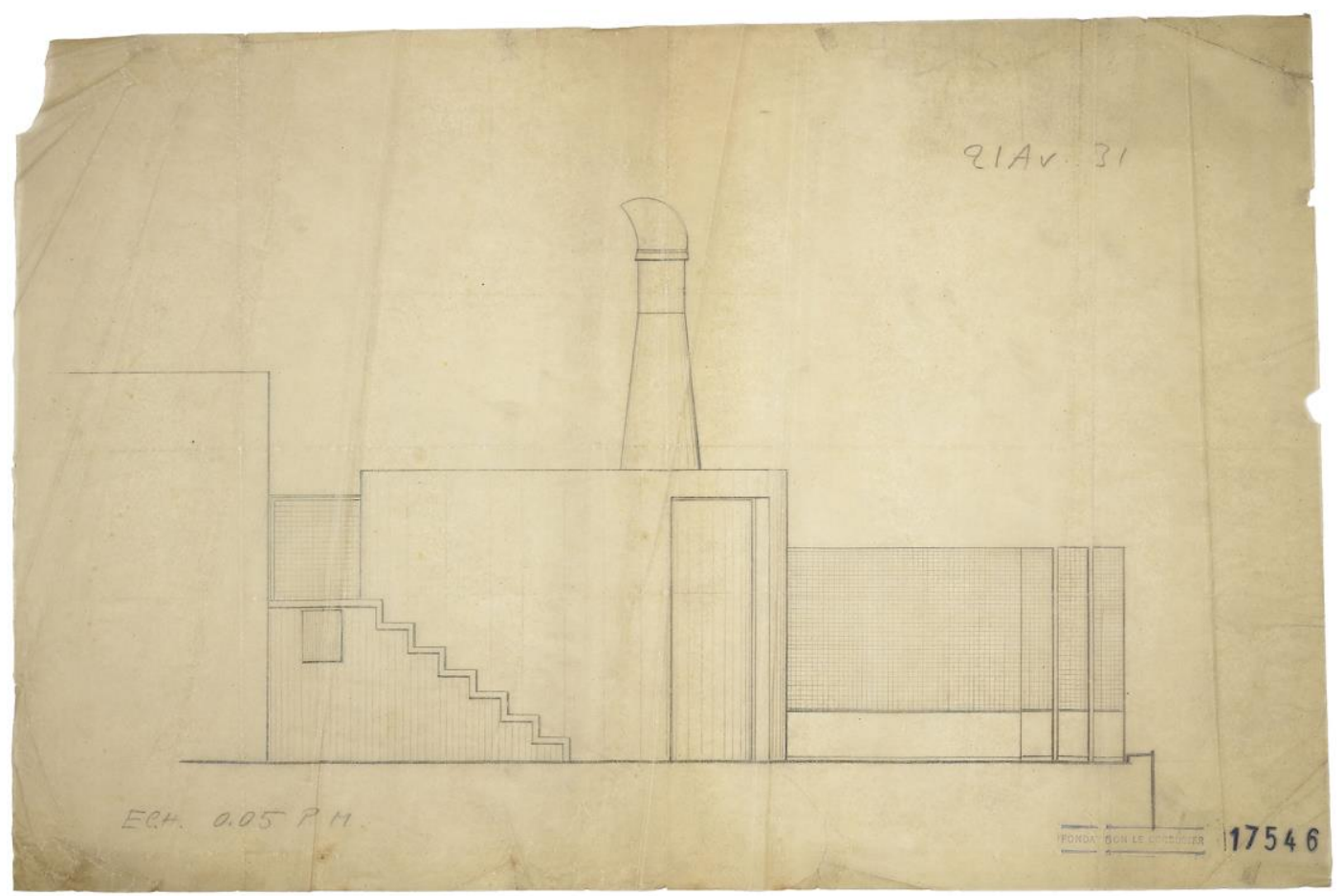

3. Elevation drawing of the camera obscura pavilion, $21^{\text {st }}$ April, 1931 (FLC 17546 OFLC-ADAGP).

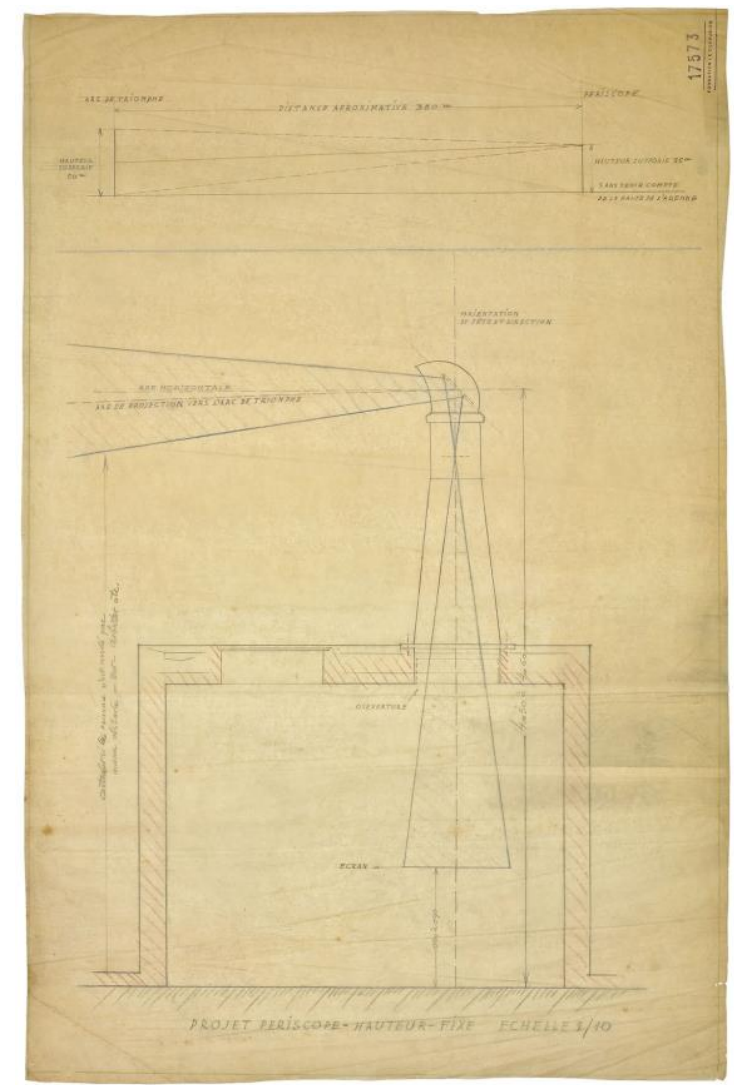

4. Section drawing of the camera obscura pavilion (FLC 17573 OFLC-ADAGP). 


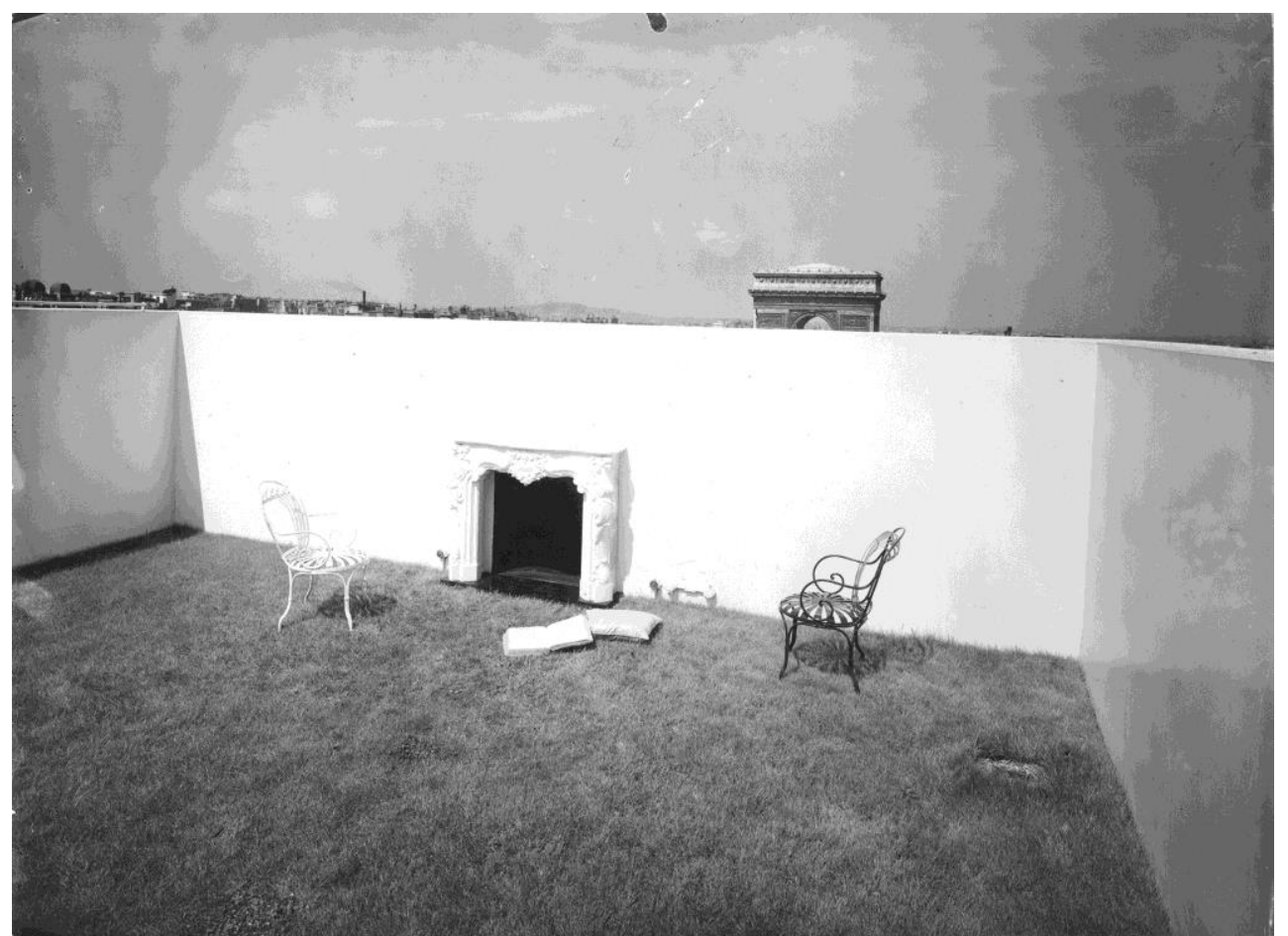

5. View of the fireplace in the chambre à ciel ouvert, with the Arc de Triomphe in the background (Photograph by Marius Gravot, FLC L2-5-23 (OFLC-ADAGP).

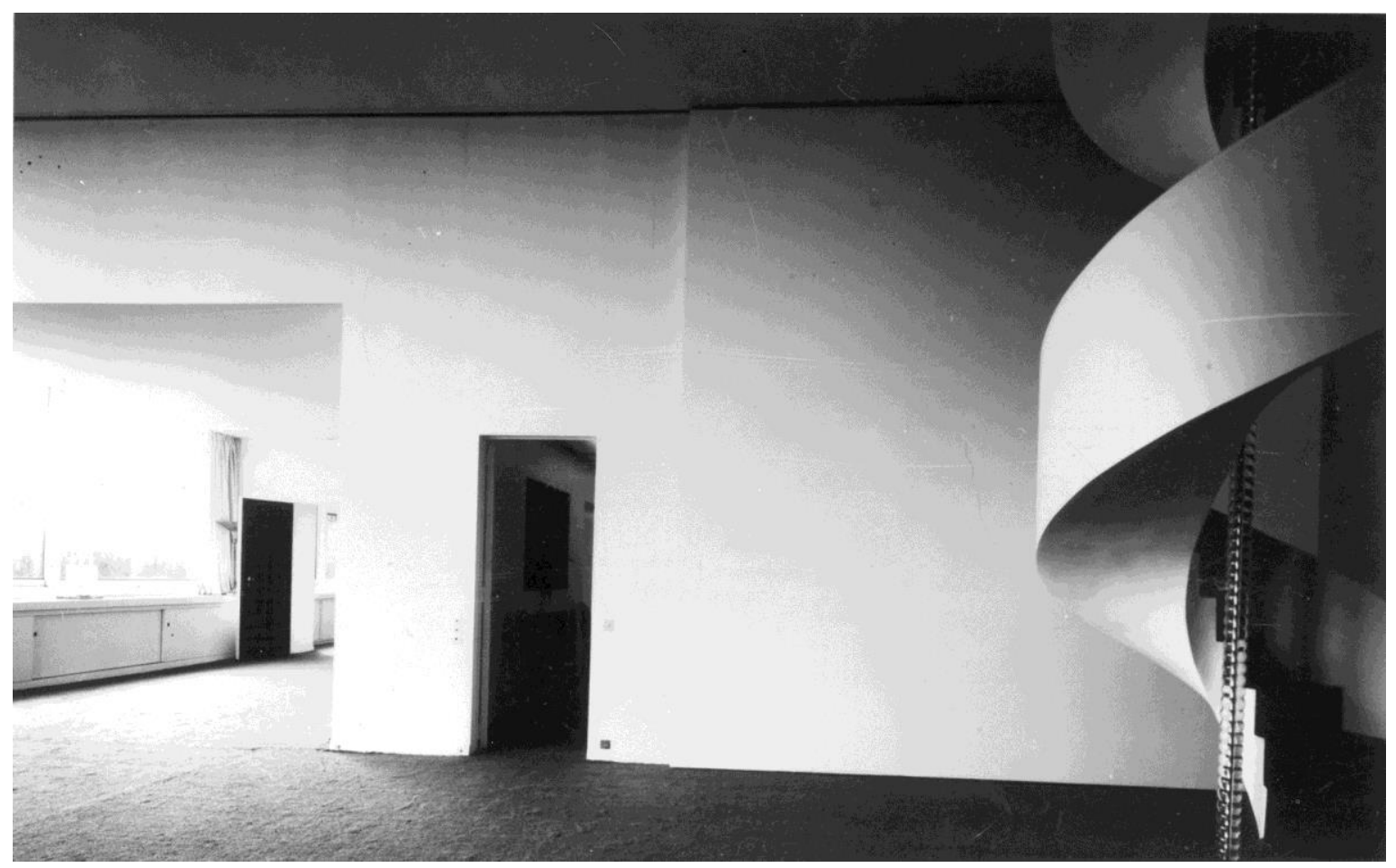

6. Interior view of the entertainment room, with the spiral staircase that arrives in the camera obscura pavilion (Photograph by Marius Gravot, FLC L2-5-37 (FLC-ADAGP). 

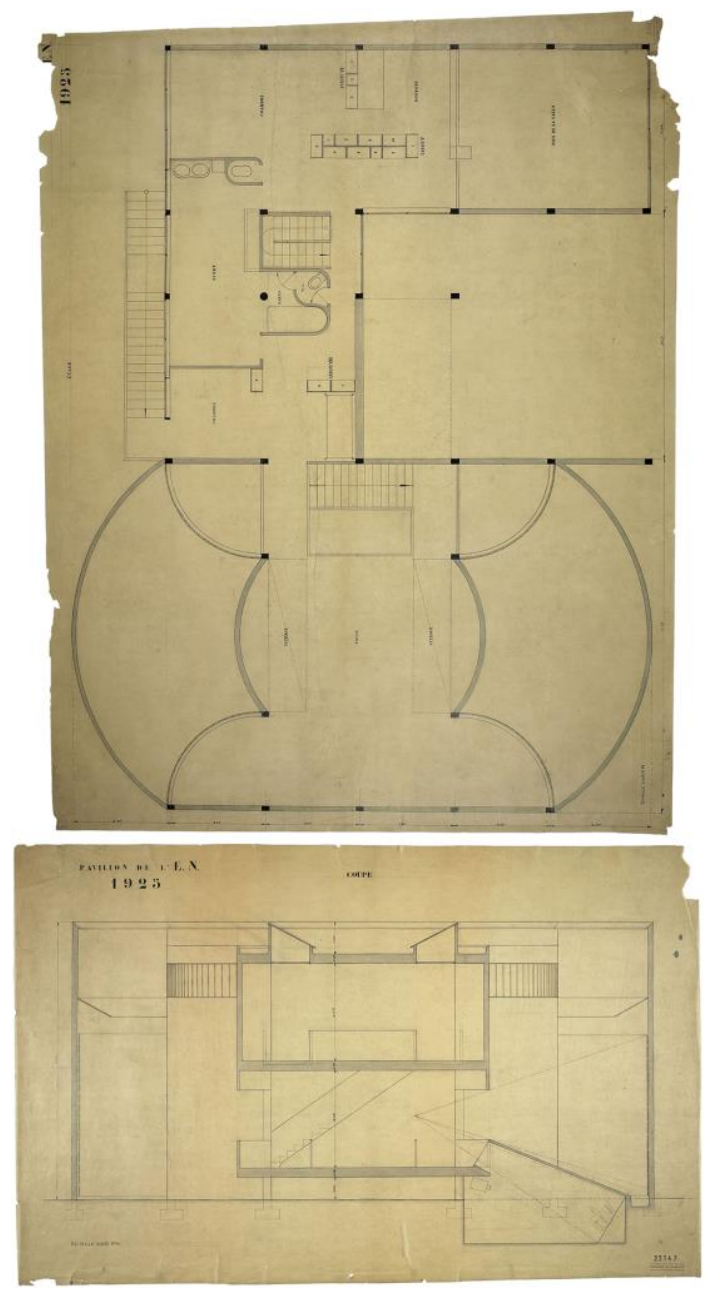

7. Plan and section drawings of the Pavillon de l'Esprit Nouveau at the International Exposition of Modern Decorative and Industrial Arts, Paris, 1925 (FLC 23132 and FLC 23147 OFLC-ADAGP).

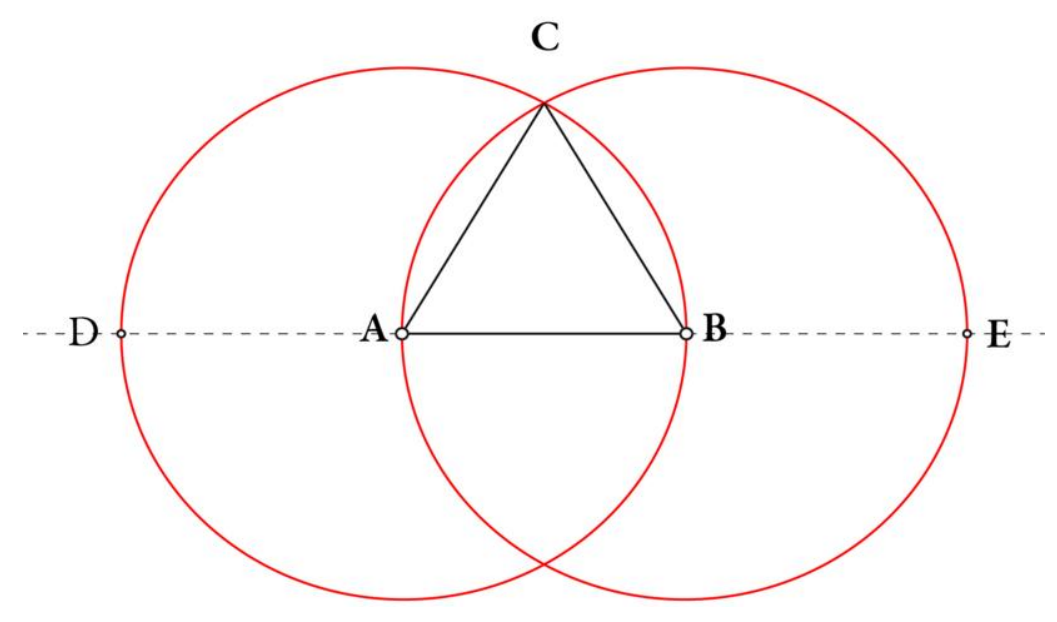

8. The geometrical proof of Euclid's first proposition in Book 1 of The Elements: "On a given finite straight line to construct an equilateral triangle." 


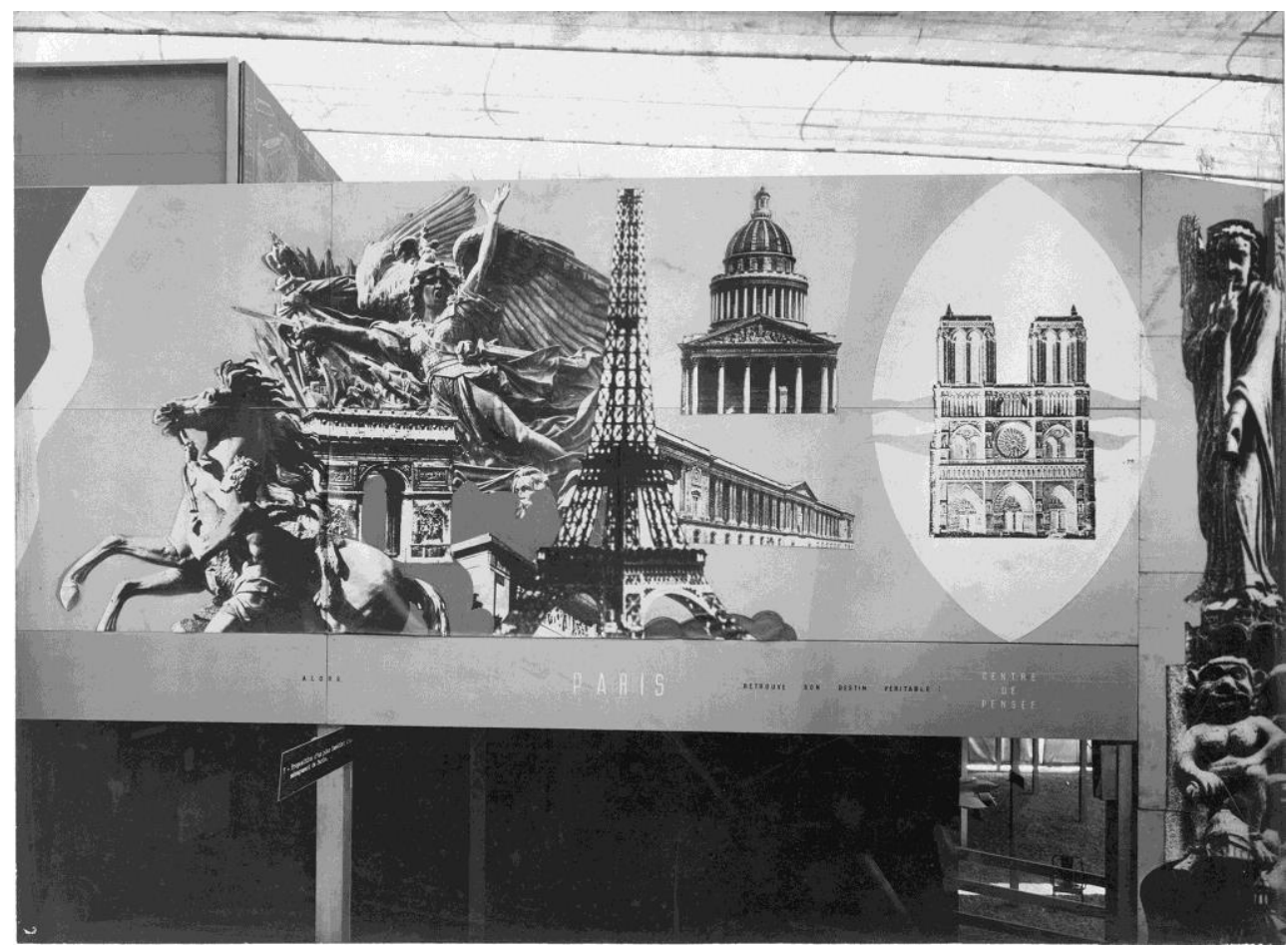

9. Le Corbusier's L'Esprit de Paris photomontage in his Pavilion des Temps Nouveaux at the 1937 World Exposition (Photograph by A. Salaün, FLC L2-13-109 OFLC-ADAGP).

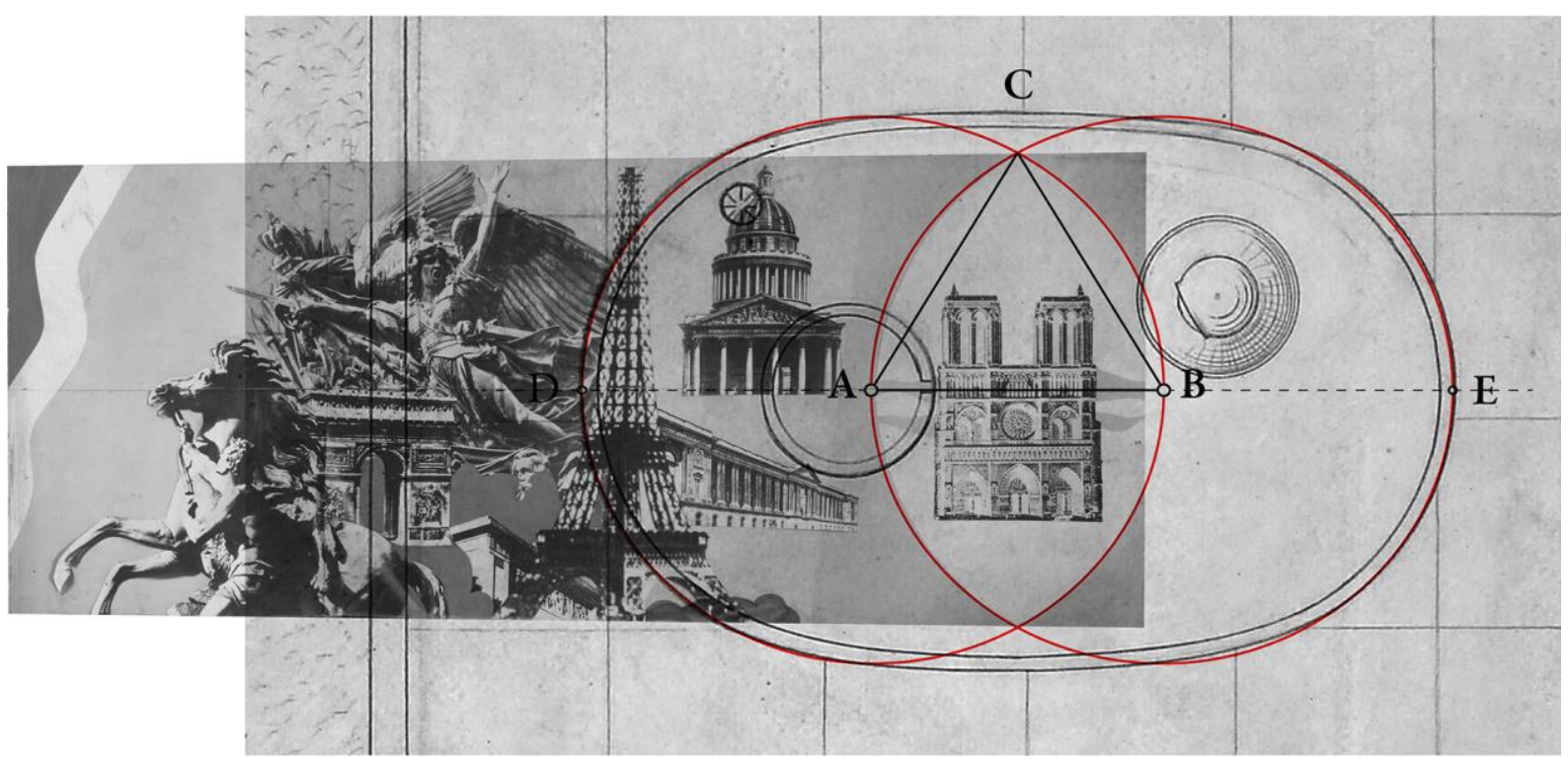

10. Composite image by the author that superimposes the roof plan of the camera obscura pavilion (FLC 29863, detail. CFLC-ADAGP) with the geometric figure of the vesica piscis, and with the L'Esprit de Paris photomontage (Photograph by A. Salaün, FLC L2-13-109 (FLC-ADAGP). 


\section{Bibliography}

Arizzoli-Clémentel, Pierre. Emilio Terry, 1890-1969: architecte et décorateur, Montreuil, France: Gourcuff Gradenigo, 2013.

Benjamin, Walter. "Surrealism: The Last Snapshot of the European Intelligentsia" [Der Sürrealismus. Die letzte Momentaufnahme der europäischen Intelligenz, 1929] in One-Way Street, London: Verso, 1979. pp. 225-39.

Benton, Tim. The Villas of Le Corbusier 1920-1930, Basel: Birkhäuser, 2007.

Bergdoll, Barry. "Paris: Le Corbusier and the Nineteenth-Century City" in Jean-Louis Cohen, ed., Le Corbusier: An Atlas of Modern Landscapes, New York: The Museum of Modern Art, 2012. pp. 246-49.

Bergh, Wim van den. "Charles Beistegui: Autobiography and Patronage" OASE 83 Commissioning Architecture, December 2010. pp. 17-40.

Boesiger, Willy. Le Corbusier et Pierre Jeanneret: Euvre complete, 1929-1934, Zurich: Girsberger, 1934.

Brooks, H. Allen, ed. The Le Corbusier Archive, Vol. II: Cité Frugès and Other Buildings and Projects 19231927, New York: Garland and Fondation Le Corbusier, 1983.

Brooks, H. Allen, ed. The Le Corbusier Archive, Vol VIII: Appartement de Beistegui, Cité Univérsitaire Pavillon Suisse, Ville Radieuse, and Other Buildings and Projects, 1930, New York: Garland and Fondation Le Corbusier, 1982.

Carl, Peter, “Le Corbusier's Penthouse in Paris, 24 Rue Nungesser-Et-coli,” Daidalos 28, June 1988. pp. 65-75.

Colomina, Beatriz, "The Split Wall: Domestic Voyeurism" in Max Risselada, ed. Raumplan Versus Plan Libre, New York: Rizzoli, 1988. pp. 32-51.

Conrads, Ulrich. ed. Programs and Manifestoes on $20^{\text {th }}$-century Architecture trans. Michael Bullock, Cambridge, Mass.: MIT Press, 1999.

Difford, Richard. "Infinite Horizons: Le Corbusier, the Pavilion De L'Esprit Nouveau Dioramas and the Science of Visual Distance,” The Journal of Architecture 14:3, 2009. pp. 295-323.

Euclid, The Thirteen Books of the Elements. Vol. 1 (Introduction and Books I and II), 2nd ed., New York: Dover, 1956.

Freud, Sigmund. "The 'Uncanny"” [Das Unheimliche, 1919] in The Complete Psychological Works, Vol. XVII, London: Hogarth Press 1955. pp. 217-56.

Gernsheim, Helmut and Alison Gernsheim, L. J. M. Daguerre: The History of the Diorama and the Daguerreotype, London: Secker \& Warburg, 1956.

Gorlin, Alexander. "The Ghost in the Machine: Surrealism in the Work of Le Corbusier", Perspecta 18, 1982. pp. $50-65$.

Hammond, John H. The Camera Obscura, Bristol: Adam Hilger, 1981.

Le Corbusier, The City of Tomorrow [Urbanisme, 1924], trans. Frederick Etchells, Cambridge, Mass.: MIT Press, 1929.

Le Corbusier, Towards a New Architecture [Vers une Architecture, 1923], trans. Frederick Etchells, London: J. Rodker, 1931.

Le Corbusier, When the Cathedrals Were White [Quand les cathédrales étaient blanches, 1937], New York: McGraw-Hill, 1964.

Lefèvre, Wolfgang. ed., Inside the Camera Obscura: Optics and Art under the Spell of the Projected Image, Max Planck Institute for the History of Science, 2007.

Lucan, Jacques Le Corbusier: une encyclopédie, Paris: Centre Georges Pompidou, 1987. pp. 68-71.

Malfroy, Sylvain “Der Aussenraum ist immer ein Innenraum," Werk, Bauen + Wohnen 81, 1994. pp. 36-41. 
Melis, Paolo. “Il 'cadavere squisito' di Le Corbusier: Pierre Jeanneret e Charles Bestegui”, Controspazio 9, no. 3, 1977. pp. 36-37.

Porta, Giambattista della. Natural Magick by John Baptista Porta, a Neapolitane: In Twenty Books: Wherein are Set Forth all the Riches and Delights of the Natural Sciences [Magia Naturalis, 1558], London: Thomas Young \& Samuel Speed, 1658.

Saddy, Pierre. "Le Corbusier Chez Les Riches, L'appartement De Beistegui," Architecture, Mouvement, Continuité 49, 1979. pp. 55-70.

Tafuri, Manfredo. “The City in the Work of Le Corbusier” in H. Allen Brooks, ed., Le Corbusier, Princeton, NJ: Princeton University Press, 1987. pp. 203-218.

Vesely, Dalibor. Architecture in the Age of Divided Representation: The Question of Creativity in the Shadow of Production, Cambridge, Mass.: MIT Press, 2004.

Vesely, Dalibor. "Architecture and the Ambiguity of Fragment" in Robin Middleton, ed., The Idea of the City, Cambridge, Mass.: MIT Press, 1996. pp. 108-21.

Vesely, Dalibor. "Surrealism, Myth and Modernity", AD Profiles 11, 1978. pp. 87-95.

Vidler, Anthony. "Fantasy, The Uncanny and Surrealist Theories of Architecture" Papers of Surrealism 1, Winter 2003.

Vidler, Anthony. "Paris: Beistegui Apartment, Or Horizons Deferred" in Jean-Louis Cohen, ed., Le Corbusier: An Atlas of Modern Landscapes, New York: The Museum of Modern Art, 2013. pp. 274-79.

Vidler, Anthony. The Architectural Uncanny, Cambridge, Mass.: MIT Press, 1992. 


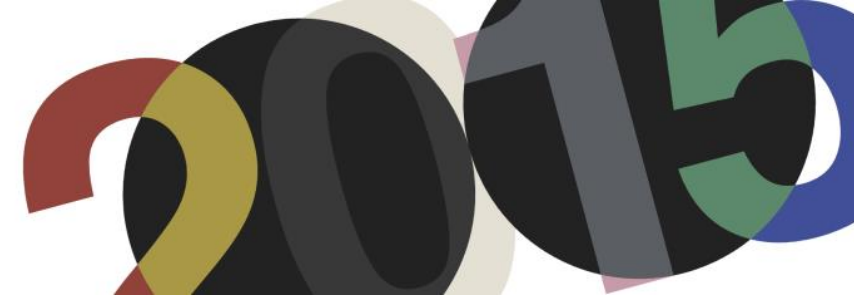

DOI: http://dx.doi.org/10.4995/LC2015.2015.713

\title{
Le Corbusier y la Reorganización del hábitat rural
}

\author{
D. Arredondo Garrido
}

Escuela Técnica Superior de Arquitectura de Granada

\begin{abstract}
Resumen: El conjunto de proyectos de reorganización del hábitat rural desarrollados por Le Corbusier en la década de los treinta supusieron una nueva mirada sobre un sector de la sociedad que aún no se había sumado a la modernidad. A través de la Ferme Radieuse y el Village Radieux, combinados en la Unité d'explotation agricole, Le Corbusier elaboró una teoría de desarrollo territorial que incorporaba la tecnología, mejoraba la habitabilidad y aumentaba la inclusión social de los agricultores, sin perder la esencia del contacto con la naturaleza. Planteó un modelo de reforma agraria basado en el mantenimiento de la propiedad y la constitución de cooperativas de propietarios-trabajadores agrícolas, organizado por medio de una exhaustiva conectividad entre funciones y materializado gracias al uso de técnicas y sistemas constructivos contemporáneos. Una reorganización que entendemos merece una relectura contemporánea, que profundice en estos proyectos gestados desde la modernidad más avanzada, con una mirada universal buscando el desarrollo completo de un "homme réel" conectado con el territorio.
\end{abstract}

Abstract: Le Corbusier's rural reorganization developed in the thirties compromised a new approach to a sector of the society that had not yet joined modernity. Through the Ferme Radieuse and the Village Radieux, combined in the Unité d'explotation agricole, Le Corbusier designed a theory of territorial development that included technology, improved habitability and increased social inclusion of farmers, without losing the essence of contact with nature. He created a model of agrarian reform based on the maintenance of the property and the establishment of land owner-workers cooperatives. It was organized by a comprehensive connectivity between functions and materialized through the use of contemporary techniques and building systems. A reorganization that deserves a contemporary reinterpretation to deepen in these projects, which were created from the most advanced modernity, with a universal point of view, seeking for a full development of a "homme reel" connected to the land.

Palabras clave: Reorganización rural; años 30; Ferme Radieuse; Village Radieux; Unité d'explotation agricole. Keywords: Rural reorganization; thirties; Ferme Radieuse; Village Radieux; Unité d'explotation agricole.

\section{Introducción}

Durante el primer tercio del siglo XX se desarrollaron un conjunto de proyectos que propusieron una reconciliación entre los impulsos de las metrópolis industriales y las condiciones sociales, culturales y naturales de los asentamientos agrícolas, aspirando a conseguir un "urbanismo agrario". Como la mayoría de los proyectos de utopías urbanas ${ }^{2}$, no concluyeron en objetos construidos, aunque podemos estudiarlos gracias a sus espléndidas representaciones. En ellas son presentados como asentamientos ideales, exentos de los problemas de las grandes metrópolis de la primera mitad del siglo XX. Sin embargo, no deben verse únicamente como ensoñaciones, sino que se constituyen en interesantísimas críticas a la sociedad del momento, respondiendo a sus

\footnotetext{
1 Waldheim, Charles: "Notes Toward a History of Agrarian Urbanism" en Bracket 1: On Farming, White, Mason; Przybylski, Maya (Eds.). Barcelona: Actar, 2010. pp. 18-24.

${ }^{2}$ Este tema ha sido ampliamente estudiado en la tesis doctoral, David Arredondo Garrido: Agricultura en la ciudad. De la utopía a la conciencia de lugar. Directores: Juan Calatrava y Juan Manuel Barrios. Universidad de Granada, 2013.
} 
problemas sociales, económicos o medioambientales. Se sitúan, por tanto, en plena consonancia con las corrientes de renovación arquitectónica que constituyeron el Movimiento Moderno.

Como ejemplos más relevantes podríamos destacar la propuesta de ciudades disueltas en la naturaleza que hizo Bruno Taut $^{3}$ tras la Primera Guerra Mundial; la ciudad lineal propuesta por Moise Ginzburg ${ }^{4}$ a finales de los 20; el desarrollo de una ciudad dispersa hasta el infinito en las praderas americanas de Frank Lloyd Wright ${ }^{5}$; la organización de un plan agrícola territorial que planteó Ludwig Hillberseimer ${ }^{6}$; y finalmente, la Reorganización Rural que diseñó Le Corbusier entre la década de los 30 y comienzos de los 40.

El enfoque de estas propuestas de "urbanismo agrario" fue esencialmente funcionalista, entendiendo que la correcta distribución de las actividades humanas en el territorio permitiría una mejora de la sociedad. En ellas lo agrario estaba claramente presente, siendo, más que uno de los ejes sobre los que se apoyaba su diseño, el elemento estructurante de las sociedades ideadas.

\section{Objetivos}

Este artículo pretende un conocimiento más profundo de los citados proyectos de Le Corbusier. Entendemos que merecen una relectura contemporánea, en un momento en el que se están considerando nuevos modos de interacción entre lo urbano y lo rural. Son numerosos los proyectos actuales que pretenden diseñar una conexión más sana y justa entre la vida en las ciudades y los valores naturales, culturales y alimentarios de lo agrario. Una mirada que, incluyendo lo paisajístico y medioambiental, añade la perspectiva de la seguridad alimentaria y la cohesión social de los territorios.

Los proyectos de reorganización del hábitat rural diseñados por Le Corbusier incluían ya un análisis complejo de esta situación, poniendo en conexión directa la funcionalidad de estos territorios, su valor cultural y paisajístico, así como su interrelación con el resto de sectores de la vida contemporánea. Así, se han estudiado los proyectos originales publicados por el propio autor, documentación del archivo de su fundación, revisiones y reediciones de estas obras, así como las investigaciones más relevantes sobre este conjunto de proyectos. Este artículo irá analizando las diferentes fases del desarrollo mediante un relato cronológico para llegar a un mejor entendimiento de sus influencias, conexiones e intenciones, y avanzar en el conocimiento de estos proyectos.

\section{Contexto}

El conjunto de proyectos formado por la Ferme radieuse ${ }^{7}$, el Village radieux ${ }^{8}$ y la posterior implementación de ambos como Unité d'explotation agricole en la teoría urbanística de Les Trois Établissements Humains ${ }^{9}$, puede

\footnotetext{
${ }^{3}$ Taut, Bruno: Die Auflösung der Städte. Die Erde eine gute Wohnung, der Weg zur alpinen Architektur. Hagen: Folkwang, 1920. Recogido en castellano en: Taut, Bruno: Escritos, 1919-1920, Iñaki Ábalos (Ed.). Madrid: Croquis, 1997.

${ }^{4}$ Ginzburg, Moisei; Barshch, Mikhail: "Zelenyj Gorod”. SA Sovremennaya Arkhitektura. 1930, № 1-2. p. 22.

${ }^{5}$ Este proyecto se encuentra en diferentes fases de desarrollo en: Wright, Frank Lloyd: The Disappearing City. New York: W. F. Payson, 1932; Wright, Frank Lloyd: When Democracy Builds. Chicago: University of Chicago Press, 1945; y Wright, Frank Lloyd: The Living City. New York: Horizon Press, 1958.

${ }^{6}$ Hilberseimer, Ludwig: The New Regional Pattern: Industries and Gardens, Workshops and Farms. Chicago: P. Theobald, 1949.

${ }^{7}$ El proyecto de Ferme Radieuse se desarrolló entre 1933 y 1934. Archivo en Fondation Le Corbusier (FLC) H3-16 y L3-20.

${ }^{8}$ El proyecto del Village Radieux se desarrolló entre 1934 y 1937, ver: FLC H3-16 y L3-20.

${ }^{9}$ Edición original, Le Corbusier: Les Trois Établissements Humains. Paris: Éditions Denoël, Collection ASCORAL, 1945; posteriormente en Le Corbusier: L’urbanisme des trois établissements humains. Paris: Ed. de Minuit, 1959. Versión en
} 
entenderse como una auténtica propuesta de reorganización del hábitat rural. Este conjunto de ideas estuvieron presentes en el pensamiento de Le Corbusier desde mediados del año 1933 hasta sus últimos días. Así quedó reflejado en su obra testimonio, Mise au Point ${ }^{10}$, en donde dedicó una parte importante del texto a recordar y reformular este modelo de organización territorial, ampliamente cribado a lo largo de tres décadas.

El desarrollo de estos proyectos se llevó a cabo en una década, los años 30 del siglo XX, en donde la habitual y probablemente ya superada, división bipartita de la obra de Le Corbusier dificulta su catalogación. Durante estos años, pese a mantener una actitud cercana al determinismo tecnológico, su interés por el lugar y la concepción orgánica o bilógica de los proyectos estaba ya patente. En un período no muy amplio de tiempo se sucedieron manifestaciones que demuestran una evolución en su pensamiento que también afecta a su relación con el mundo rural, objeto de esta investigación. De manera que en los textos del proyecto de 1925 de Ville Contemporaine pour Trois Millions d'Habitants, Le Corbusier calificaba las actividades de jardinería y horticultura en las viviendas para obreros a las afueras de la ciudad como "ejercicio sano (..) algo estúpido, inefectivo y a veces peligroso" $^{\prime 11}$. Y en 1931, en la revista Plans, y sobre la foto aérea de una superficie agrícola de la Alsacia altamente subdividida en parcelas, declaraba que "vivimos en la era de la máquina pero las máquinas no puede ser usadas aquí"12.

Sin embargo a partir de 1933, en paralelo al reconocimiento de las singularidades territoriales, geográficas y culturales que demostró tras sus viajes y proyectos en Sudamérica y el norte de África, Le Corbusier estaba estableciendo un orden orgánico en su arquitectura. Un orden nuevo (ordre nouveau) que se conseguiría por medio de la defensa del medio natural así como de los derechos biológicos universales del hombre real (homme réel), como escribió en la Ville Radieuse:

“(...) el sol en el alojamiento, el cielo a través de los cristales de la vivienda, los árboles bajo los ojos (...) tocan lo más profundo del ser fisiológico y del ser psicológico. Nos ponen en armonía con nuestro profundo destino natural ${ }^{, 13}$.

Y en 1934 incluiría ya la siguiente reflexión en sus Euvre Complète:

"No es posible pensar en urbanizar las ciudades modernas si no pensamos en desarrollar el campo. Algunos de los habitantes de la ciudad volverán al campo. Pero si éste sigue siendo lo que es hoy, nadie querrá volver. Para ello es necesaria la reordenación del suelo, la construcción de poblados de cooperación y establecer un nuevo tipo de granja, utilizando la maquinaria de la cultura moderna"14.

Mary Mcleod ${ }^{15}$ defiende que, en paralelo a esta evolución, la mayor influencia de su interés por lo agrario se debió al contacto con el sindicalismo regional. Un movimiento político de amplio espectro en el que Le

castellano Le Corbusier: El Urbanismo de los Tres Establecimientos Humanos, Junyent, Albert (Tr.). Barcelona: Poseidón, 1981.

${ }^{10}$ Edición facsímil en castellano de la obra original de 1966, Le Corbusier: Mise au point. Torres Cueco, Jorge (Ed.). Madrid: Abada Editores, 2014. Incluye el ensayo, Torres Cueco, Jorge: Pensar la Arquitectura: 'Mise au point' de Le Corbusier. Madrid: Abada Editores, 2014.

${ }^{11}$ Le Corbusier: The City of To-Morrow and Its Planning (1925). New York: Dover, 1987. pp. 202-03. Citado por McLeod, Mary: “Le Ferme Radieuse. Le Village Radieux," en Le Corbusier et La Nature. Paris: Fondation Le Corbusier - Editions de la Villette, 2004. p. 130. (Traducción desde el inglés por autor).

${ }^{12}$ Le Corbusier: "Décisions". Plans, Diciembre 1931, № 10. (Traducción desde el frances por autor).

${ }^{13}$ Citado en Torres Cueco, Jorge: Pensar la Arquitectura (...). op. cit. pp. 105-6. Original en Le Corbusier: La Ville Radieuse. Boulogne-sur-Seine: Editions d'Architecture d'Aujourd'hui, 1935. p. 14 y p. 43.

${ }^{14}$ Le Corbusier: Euvre Complète 1929-1934. Zurich: Girsberger, 1935. p. 186. (Traducción desde el francés por autor).

${ }^{15}$ McLeod, Mary: “Urbanism and Utopia: Le Corbusier from Regional Syndicalism to Vichy”. Princeton University, 1985. 
Corbusier participó como editor y autor de artículos en varias de sus revistas. En las páginas de Plans (1931-32), Prèlude (1933-36) y L'Homme Rèel (1934) aparecieron artículos en los que el grupo propugnaba una descentralización tecnicista del gobierno. Jeanne Walter, Philippe Lamour, Hubert Lagardelle participaban, junto a Le Corbusier y otros, en estas publicaciones que ansiaban una planificación social dirigida por tecnócratas ${ }^{16}$. Frente a la improductividad e incapacidad de las instituciones democráticas, preferían una autoridad que procediera de la capacitación técnica ${ }^{17}$, una acción directa frente al capitalismo por medio de la intervención económica y la descentralización progresiva del gobierno ${ }^{18}$.

La intención final era el desarrollo completo del ser humano en una sociedad orgánica. Para ello, uno de los puntos destacados en sus propuestas políticas fue la reforma agraria. Reforma que debía producirse por la aplicación científica de las innovaciones técnicas y sociales. Y que entendía el trabajo en un sentido antropológico, como un intercambio con la naturaleza, un control del hombre sobre el medio ${ }^{19}$.

En el seno de este grupo se produjo el encuentro con el agricultor y activista sindical Norbert Bézard. Por intermediación del Doctor Peter Winter y de Philippe Lamour ${ }^{20}$, Bézard comenzó una correspondencia con Le Corbusier que sería el germen de sus proyectos rurales. En su carta de 1933, que el propio arquitecto suizo reprodujo en el capítulo 7 de La Ville Radieuse ${ }^{21}$, Bézard le pedía:

"Le Corbusier, ¡no te quedes en la ciudad; ¿Piensas que nosotros leemos con ojos indiferentes las descripciones de vuestra Ciudad Radiante? ¿Quieres ocuparte un poco de nosotros, acordarte de nuestras campiñas, nuestras granjas, nuestros campos, nuestros pueblos (...) Corbusier [sic], danos la Granja Radiante, el Pueblo Radiante $^{, 22}$.

Durante el año 1933 Bézard introdujo a Le Corbusier en el mundo rural a través de "una larga, paciente y meticulosa asimilación" $"$. A lo largo de sus visitas a la campiña de la región de Sarthe, en el noroeste de Francia, y de sus reuniones con los agricultores ${ }^{24}$, Le Corbusier apreció una general mala organización y un atraso en las viviendas e infraestructuras de los agricultores. Este nuevo interés le animó a la lectura de geógrafos e historiadores rurales como L' Histoire de la Campagne Française de Gaston Ruopnel, La Terre au Paysan de Henri Pitaud y Questions de Charles Ferdinad Ramuz ${ }^{25}$. Así, en el futuro trabajo sobre Les Trois Établissement Humains, recogería unas frase de Gaston Roupnel abogando por la bondad del trabajo cooperativo en el campo: "Los pueblos deberán transformarse en una asociación de trabajadores y en una cooperativa de producción.

\footnotetext{
${ }^{16}$ Ragot, Gilles: "La Ferme et le Village Radieux de Le Corbusier. Nouvelle déclinaison du principe d'équilibre entre l'individuel et le collectif'. In Situ. Revue des patrimoines, julio 2013, № 21.

${ }^{17}$ Lourau, René: El Estado y el inconsciente: ensayo de sociología política. Barcelona: Kairós, 1980. p. 164.

${ }^{18}$ Ragot, Gilles: "La Ferme et le Village radieux de Le Corbusier (...)”. op. cit.

${ }^{19}$ Thilo Hilpert, “La Maison des Hommes: Leçons Possibles de L'anthropocentrisme de Le Corbusier," en Le Corbusier et la Nature. Paris: Fondation Le Corbusier - Editions de la Villette, 2004. p. 23.

${ }^{20}$ Ragot, Gilles: "La Ferme et le Village radieux de Le Corbusier (...)". op. cit.

${ }^{21}$ Le Corbusier: "Réorganisation Rurale," en La Ville Radieuse. Paris: Vincent Fréal and Cie., 1964. pp. 319-36. Y antes de ello en Prèlude. 1934, No 4.

${ }^{22}$ Ibíd., 321. (Traducción desde el francés por autor).

${ }^{23}$ Ibíd., 324.

${ }^{24}$ Por ejemplo la que llevó a cabo con 50 agricultores en la ciudad de Le Mans, ver: Mary McLeod, "Piacé: Ferme Radieuse and Village Radieux," en Le Corbusier: An Atlas of Modern Landscapes, Cohen, Jean-Louis (Ed.). New York: Museum of Modern Art, 2013. p. 188.

${ }^{25}$ McLeod, Mary: "Le Ferme Radieuse. Le Village Radieux". op. cit. p. 136.
} 
Volverán los tiempos de la explotación colectiva; volverán los tiempos originales en los que cada uno estaba al servicio de todos ${ }^{, 26}$.

El conocimiento de primera mano, tanto práctico como teórico, de la situación de la región hizo que Le Corbusier se cuestionara cómo exportar las ideas del planeamiento racionalista al mundo rural. Pese a que en esos años se estaban imponiendo proyectos de reforma agraria de explotación extensiva, a gran escala y de gestión gubernamental $^{27}$, la idea de Le Corbusier era la modernización de las producciones agrícolas familiares, la mejora de su competitividad y de las condiciones sociales de sus habitantes sin perder los valores naturales. Por ello sus propuestas no exigen la disolución de la propiedad privada, ni la gestión gubernamental, sino que parten de un cooperativismo ${ }^{28}$ cercano al añorado por Roupnel, en donde la propiedad permanece en el campesinado y las cooperativas tienen un peso importante en la gestión.

\section{Ferme Radieuse}

La organización rural propuesta por Le Corbusier partía de la reordenación de un trabajo familiar cooperativo en las granjas. Por lo tanto, el primero de los proyectos a desarrollar debía ser el de un nuevo modelo de granja: la Ferme Radieuse. Éste apareció por primera vez en el número 14 de la revista Prèlude en noviembre de $1934^{29}$. Poco después se publicó en el número 4 de la revista L'Homme Réel ${ }^{30}$ y luego dentro de la Ville Radieuse ${ }^{31}$.

Se trata de una explotación agrícola de $20 \mathrm{Ha}$ gestionadas por una sola familia. Consta de una vivienda y una serie de construcciones que albergan los usos necesarios para la explotación agrícola y ganadera de la propiedad. El tamaño y la estructura fue el resultado de la adaptación del proyecto a la zona de Piacé, de donde procedía Bézard, que sirvió de emplazamiento teórico de la propuesta. Esta influencia se aprecia fundamentalmente en la elección de un tamaño de explotación medio, que correspondía a un territorio de bocage ${ }^{32}$, como se denomina en la región a la zona con suaves pendientes, subdividida en parcelas, en donde se alternan pastos y bosques. Pese al emplazamiento elegido, el modelo es claramente teórico y según el propio autor, debería adaptarse a los diferentes regímenes climáticos y condiciones topográficas.

Le Corbusier entendió desde el inicio la granja como “(...) una biología, un organismo, un ser. (...) Incorpora la tierra, el territorio, la naturaleza y el trabajo humano. ¡Está viva!”33. Este organismo tendría las mismas partes que el ser humano: “órganos de decisión, de locomoción, de manipulación y de almacenamiento”34. De manera que una vía central permite la ordenación interna de las diversas construcciones funcionales de la granja y su conexión con los pastos.

\footnotetext{
${ }^{26}$ Le Corbusier: Les Trois Établissements Humains. op. cit. pp. 77-78. (Traducción desde el francés por autor).

${ }^{27}$ Por ejemplo en la URSS. Ver más en McLeod, Mary: "Radiant Farm and Village: Le Corbusier's Agricultural Utopia, 1933-1942". Dumbarton Oaks, Washington: D. O. Garden and Landscape Studies. 2012.

${ }^{28}$ McLeod, Mary: "Piacé: Ferme Radieuse and Village Radieux". op. cit. p. 187.

${ }^{29}$ Le Corbusier: "Ferme Radieuse, Village Radieux". Prélude. op. cit.

${ }^{30}$ Le Corbusier: "Village Radieux, Ferme Radieuse". L’Homme Réel. 1934, № 4. pp. 54-59.

${ }^{31}$ Le Corbusier: "Réorganisation Rurale". op. cit.

${ }^{32}$ Así define Bézard el territorio de Piacé a Le Corbusier en la carta recogida en Ibíd., p. 322. y en el dibujo incluido en incluido en En Bézard, Norbert: "Rapport: L’Urbanisme Rural”, En 5 Congrés de Paris 'Logis et Loisirs'. Boulogne-surSeine: Editions d'Architecture d'Aujourd'hui, 1938. p. 15.

${ }^{33}$ Le Corbusier: "Réorganisation Rurale". op. cit. p. 325. (Traducción desde el francés por autor).

${ }^{34}$ Le Corbusier: La Ville Radieuse. op. cit. p. 82. Cita recogida en castellano por García-Germán, Javier: "De la Ville Verte a la Geoarquitertura," Massilia. Annuaire d'Etudes Corbuseennes. 2008, № 7. p. 197.
} 
La vivienda se emplaza separada del espacio de trabajo, en una edificación independiente en el corazón de la explotación. Su posición central y elevada sobre pilotis, permite el control visual de las cosechas extensivas para alimento de los animales, del huerto de frutales, de la granja de aves y de los establos en el patio de trabajo. El uso de pilotis permite evitar la humedad en la vivienda ${ }^{35}$ y facilita el contacto directo desde la planta baja abierta hacia el jardín de recreo y el huerto de vegetales junto a la residencia. La planta alta se organiza a partir de una gran sala que alberga la cocina y el salón, completada por tres dormitorios y dos baños. La construcción se haría con elementos prefabricados sobre una estructura metálica, consiguiendo grandes ventanales, cerramiento de paneles y cubierta plana recubierta de tierra.

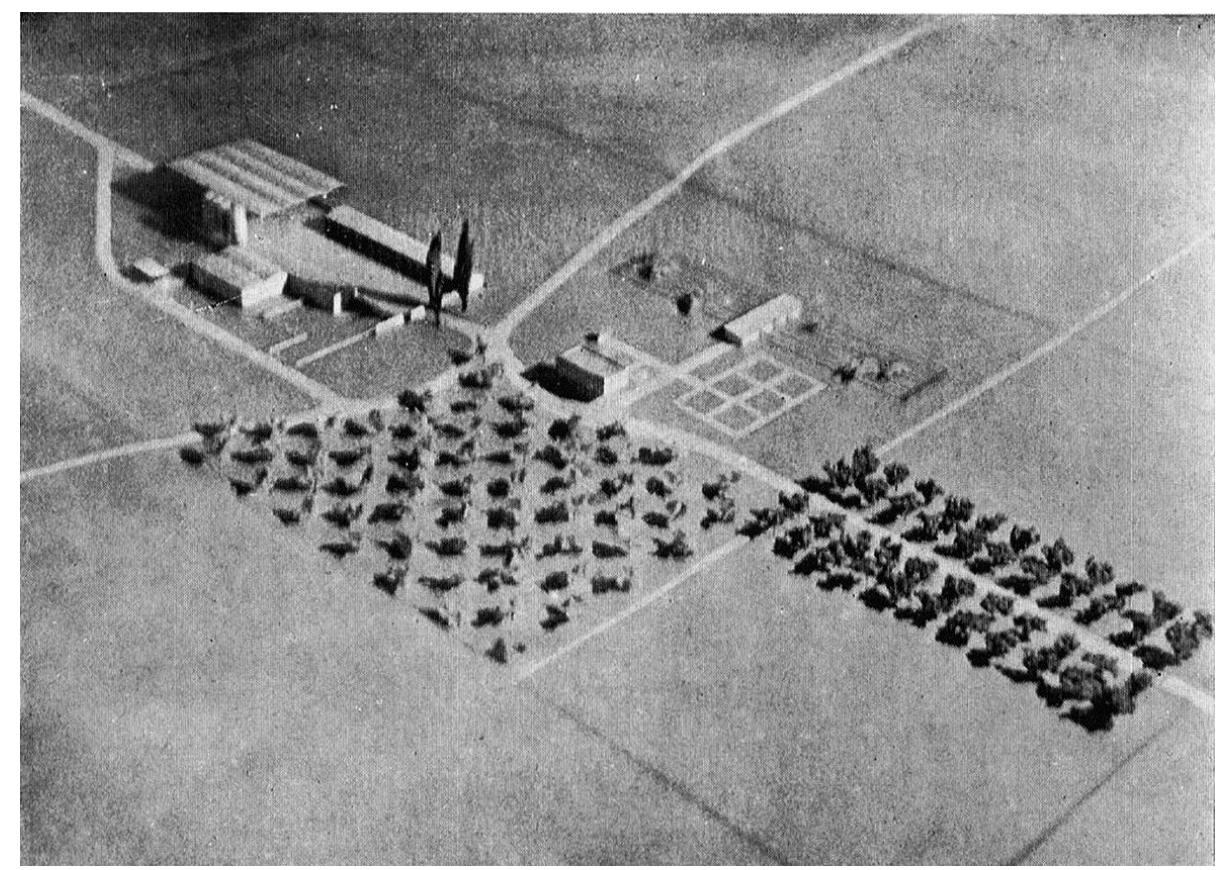

1. Maqueta de la Ferme Radieuse publicada en Le Corbusier: Euvre Complète 1929-1934. Zurich: Girsberger, 1935. p. 188.
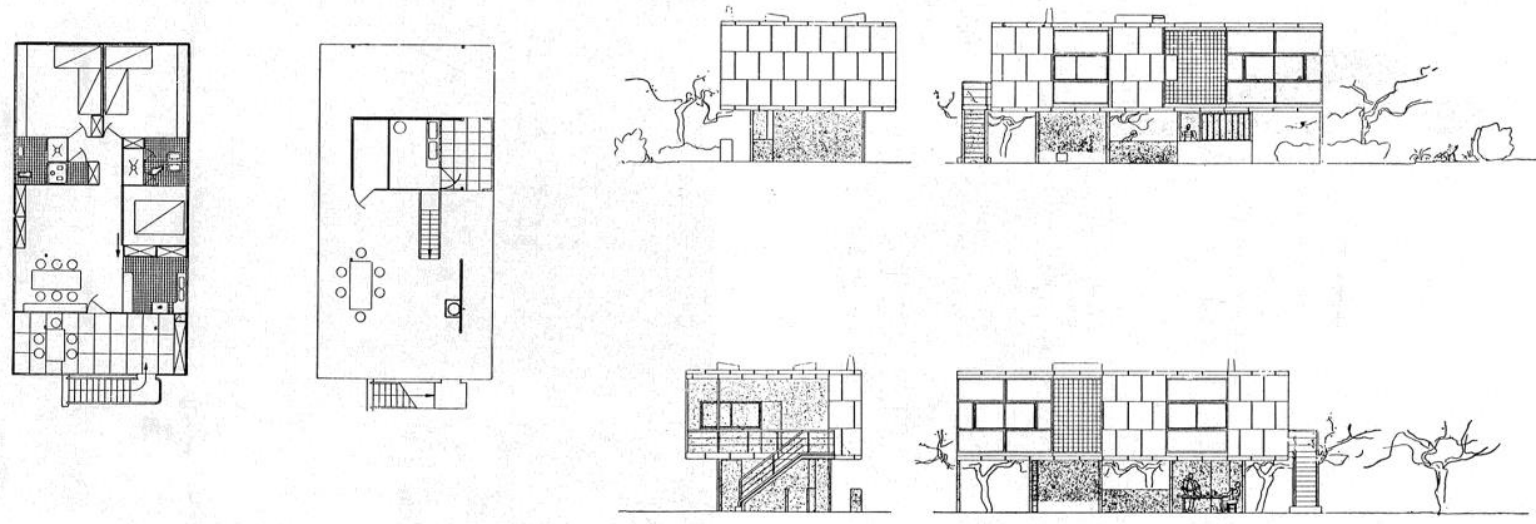

2. Planimetría de la vivienda, Ferme Radieuse, Le Corbusier: Euvre Complète 1929-1934. Zurich: Girsberger, 1935. p. 187.

${ }^{35}$ Le Corbusier: "Réorganisation Rurale". op. cit. p. 325. 
Este proyecto no supuso el diseño de nuevo modelo de vivienda desde cero, sino que fue una reutilización de sus

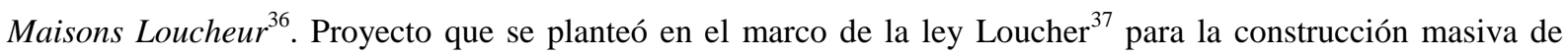
vivienda barata a finales de la década de los 20. Por tanto debía ser una construcción económica, prefabricada y de rápido montaje que además siguiera las tendencias del momento respecto a la vivienda mínima. A diferencia de las Maisons Loucheur, la casa para la Ferme Radieuse no era pareada, eliminando el muro medianero de piedra, convirtiéndose en una vivienda independiente y, si cabe, más técnica, al estar construida en su totalidad en seco con elementos prefabricados.

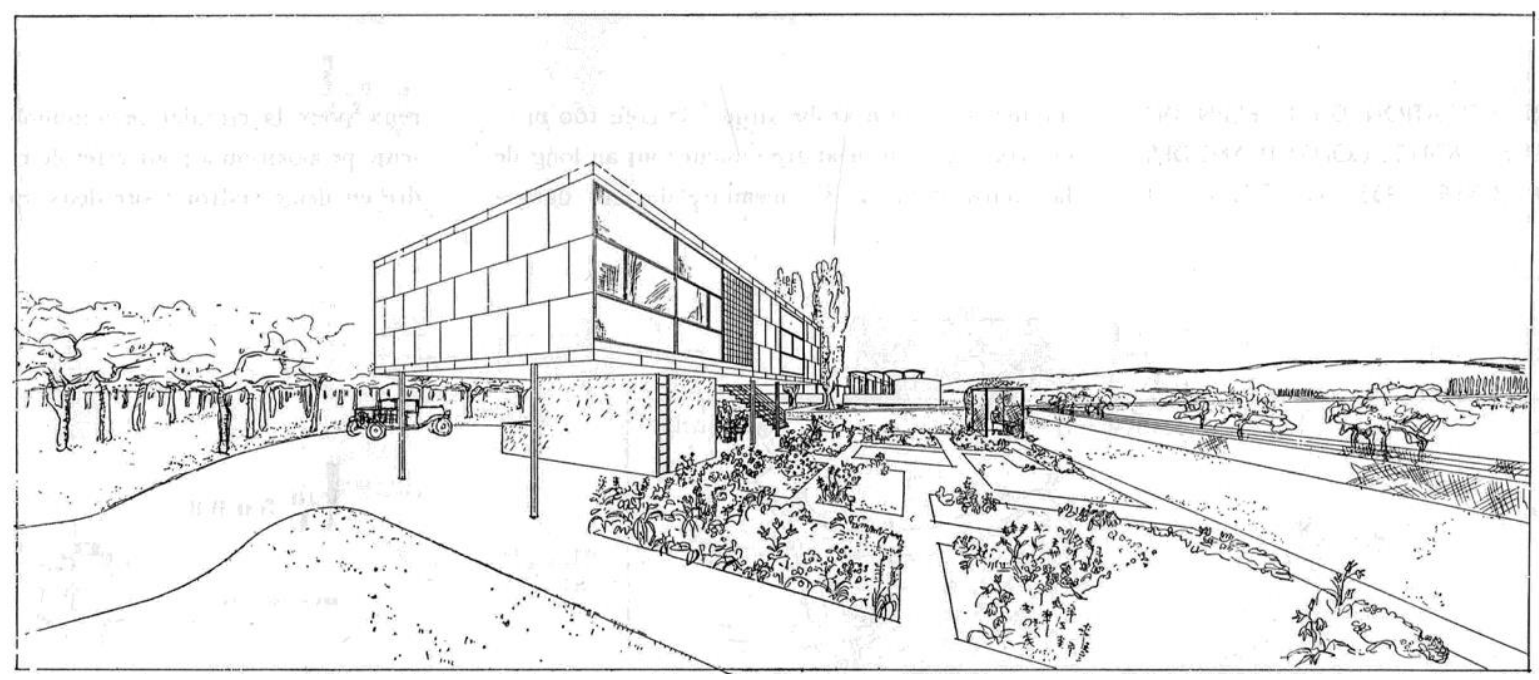

3. Exterior de la vivienda, Ferme Radieuse, Le Corbusier: Euvre Complète 1929-1934. Zurich: Girsberger, 1935. p. 191.

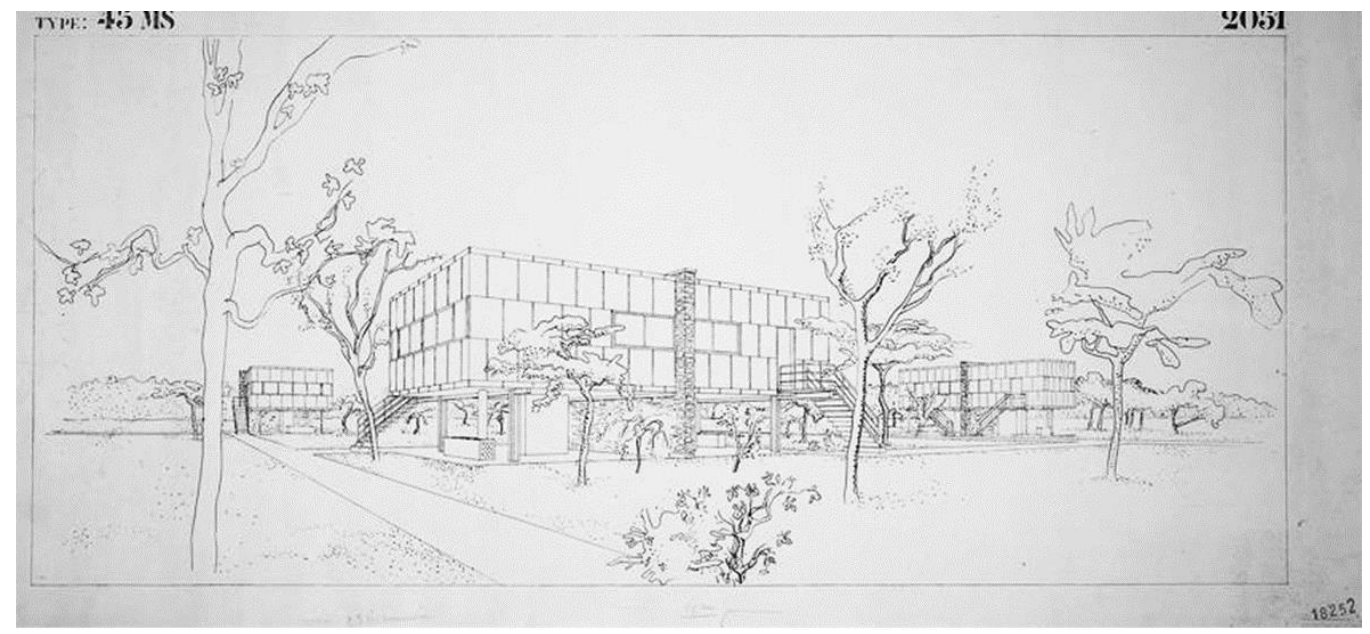

4. Vista exterior del proyecto de las Maisons Loucheur. FLC 18252.

Al fondo del camino central se ubica el patio de trabajo. Se organiza como un espacio abierto delimitado por muros exteriores, con suelo hormigonado modelado para que evacuen las aguas y proteja a los trabajadores de la humedad y del barro. En torno al patio se dispone una serie de naves construidas a partir de la suma pórticos de acero en módulos de 6 metros que soportan bóvedas rebajadas prefabricadas de hormigón protegidas con un manto de tierra. Estas naves se organizan en una zona para almacenaje de materiales, otra para el granero y otra

\footnotetext{
${ }^{36}$ Le Corbusier: Euvre Complète 1910-1929. Zurich: Girsberger, 1935. p. 199.

${ }^{37}$ Ver más en Benton, Tim: "La Réponse de Le Corbusier à la Loi Loucheur," en Le Corbusier. Une Encyclopédie, Lucan, Jacques (Ed.). Paris: Éditions du Centre Pompidou - CCI, 1987. p. 237.
} 
para los animales. El movimiento del grano y del alimento para el ganado se produce mediante un sistema mecánico similar al de un ferrocarril a pequeña escala suspendido del techo. Éste tiene como objetivo optimizar las labores de separación, selección y almacenaje del grano, así como el cebado del animal y retirada del estiércol para devolverlo al campo. Desde la zona trasera del granero arranca el camino que permite la entrada directa de los productos agrícolas y la salida del estiércol.

En todo el proyecto se aprecia un interés claro por generar un organismo constituido por circuitos funcionales que conecten las actividades humanas, las de los animales y la naturaleza; un "único organismo con un metabolismo interno coherente" ${ }^{38}$. Un artefacto humano, industrial y tecnológico, cuyo objetivo es optimizar los intercambios energéticos entre el territorio, los animales y las personas, una suerte de funcionalismo biológico que busca la armonía entre todos sus componentes.

Una vez finalizado el diseño y publicado en diversos medios, Le Corbusier buscó su materialización, pero la disolución de su grupo sindicalista no lo facilitó. Pese a ello se esforzó en intentar construirlo desde 1934 hasta 1942, incluso en otros países, como en Italia. Durante sus visitas al país transalpino y sus intentos de entrevistarse con Mussolini, Le Corbusier se interesó por las propuestas de recuperación agrícola en la zona del Agro Pontino. Llegó a afirmar que Sabaudia estaba hecha con gusto y llena de buenas intenciones pero no era sino "una imitación artística de los pueblos bonitos de cualquier sitio" 39 , a diferencia de su granja radiante que era "una herramienta pura, eficaz, necesaria y suficiente, con una función rigurosa y útil" 40 . Por ello, ya desde París, le propuso por carta al Duce que construyera 1400 granjas radiantes en el espacio agrícola recuperado en las Lagunas Pontinas ${ }^{41}$. Estos proyectos, sin embargo, no eran adecuados para ese territorio, de gran extensión, completamente plano y dedicado casi exclusivamente al cereal en explotación extensiva; dinámicas diferentes a las del territorio de bocage en el Sarthe francés. Además, frente al corporativismo fascista con alta intervención del estado ${ }^{42}$, el regionalismo sindical implícito en su proyecto requería de una gestión descentralizada y la implicación de los sindicatos.

\section{Village Radieux}

El trabajo de la granja radiante fue presentado posteriormente a George Monnet, ministro socialista de agricultura, que no lo consideró pero, al menos, permitió mostrarlo en la sección de agricultura del Pavillon des temps nouveaux en la Exposición Internacional de París de $1937^{43}$. Aquí, con el título de Reorganisation Agraire, Le Corbusier mostró con dibujos, maquetas y textos el proyecto de la granja radiante y, también, el de un centro cooperativo ${ }^{44}$. En ellos expuso:

"Reorganización agraria, planeamiento rural para volver a la tierra, no hay urbanización para las ciudades sin desarrollo del campo, la industria aportará el equipamiento.

\footnotetext{
${ }^{38}$ García-Germán, Javier: "De la Ville Verte a la Geoarquitertura”. op. cit. p. 198. (cita recogida en castellano).

${ }^{39}$ Le Corbusier: "Réorganisation Rurale". op. cit. p. 336. (Traducción desde el francés por el autor).

40 Ídem.

${ }^{41}$ McLeod, Mary: "Piacé: Ferme Radieuse and Village Radieux”. op. cit. p. 190.

${ }^{42}$ McLeod, Mary: "Le Ferme Radieuse. Le Village Radieux". op. cit. p. 132.

${ }^{43}$ El Pavillon des temps nouveaux de la Exposición Internacional de Arte y Técnicas en París de 1937 fue diseñado por Le Corbusier.

${ }^{44}$ El proyecto de centro-poblado cooperativo se recoge en Le Corbusier: Euvre Complète 1934-1938. Zurich: Girsberger, 1939. pp. 104-110.
} 
Es la tierra (el tipo de suelo y las estaciones) la que decide, no la gente. La generalización en la agricultura es una receta para el fracaso: primero deben definirse las regiones.

Debe crearse una municipalidad rural: Granjas familiares trabajan la tierra, el poblado como comunidad de servicios compartidos, una empresa cooperativa.

Proyecto de consolidación del campo para una región claramente definida: La vuelta al campo es posible únicamente a través de granjas familiares apoyadas en recursos colectivos (métodos y equipamiento). ",45
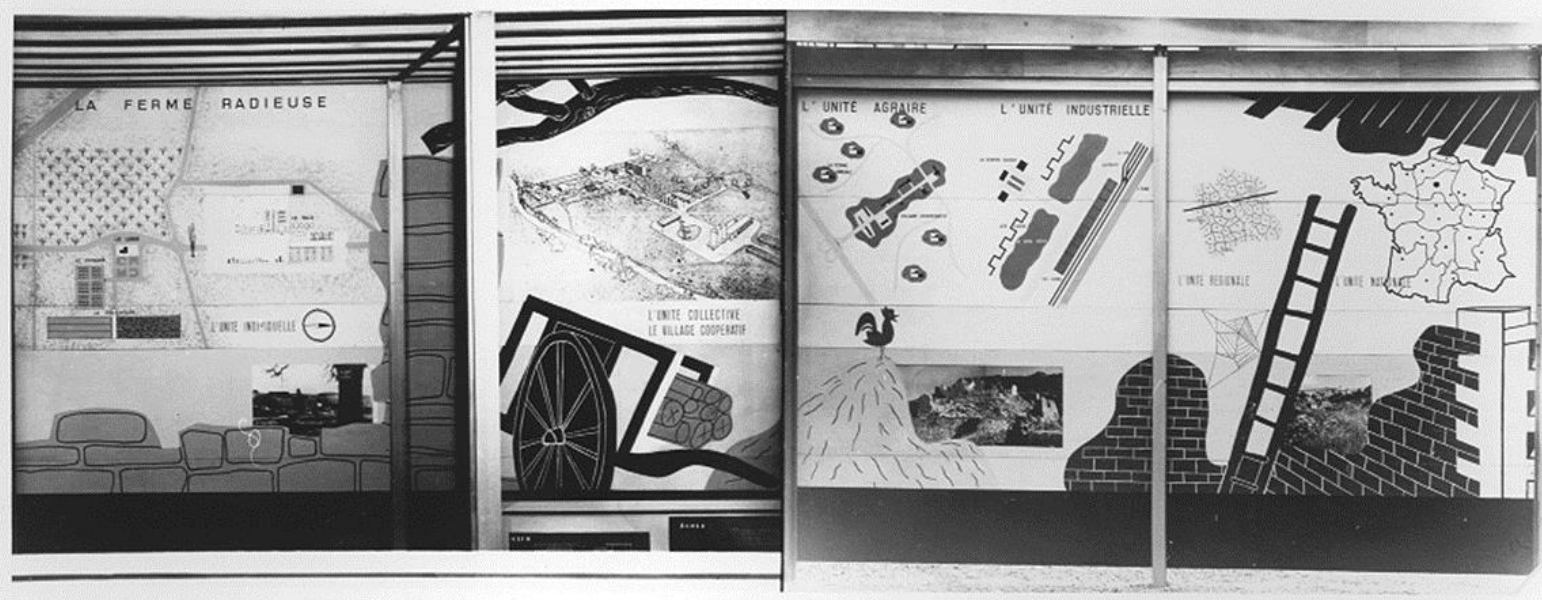

5. Panel sobre la Reforme Agraire en el Pavillon des temps nouveaux en la Exposición de París 1937. FLC L2(13)148.

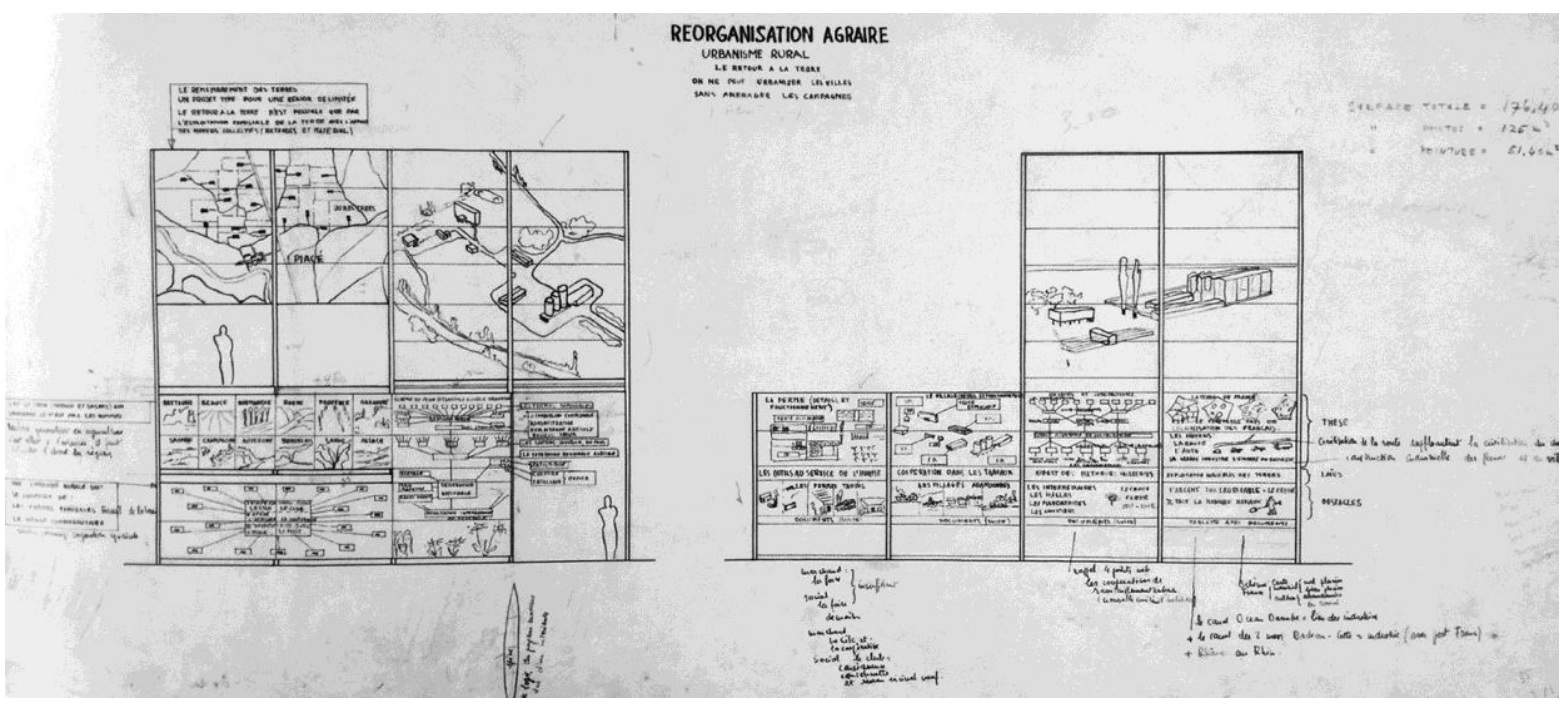

6. Boceto del panel a exponer en el Pavillon des temps nouveaux en la Exposición de París de 1937. FLC 00681.

\footnotetext{
${ }^{45}$ Panel original reproducido en: Cohen, Jean-Louis; Benton, Tim; Tittensor, John (Eds.): Le Corbusier Le Grand. Londres Nueva York: Phaidon, 2014. p. 311. (Traducción desde el francés por autor).
} 


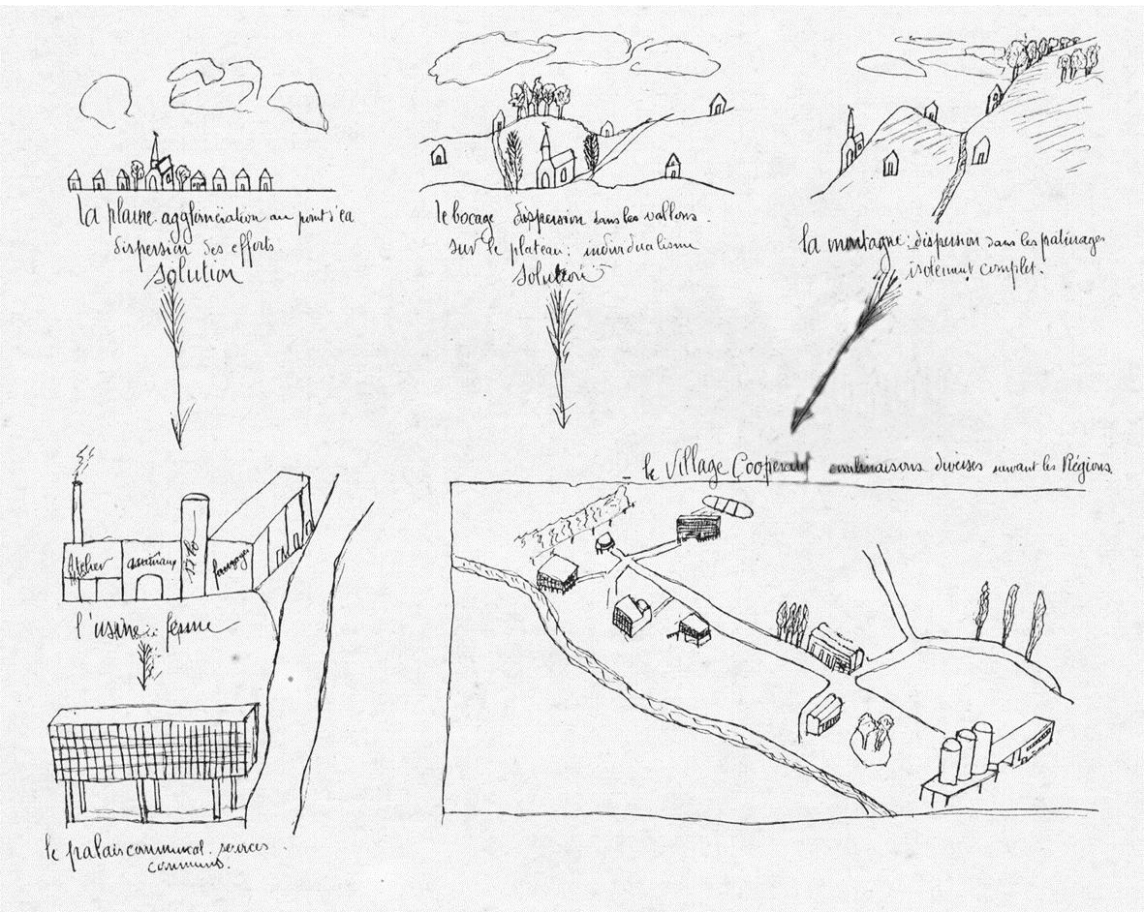

7. Bocetos de Norbert Bézard sobre el territorio de Piacé y el tipo de poblado cooperativo adecuado. En Bézard, Norbert: "Rapport: L’Urbanisme Rural", En 5 Congrés de Paris 'Logis et Loisirs'. Boulogne-sur-Seine: Editions d'Architecture d'Aujourd'hui, 1938. p. 15.

En esta exposición se mostraba por primera vez una versión elaborada del poblado radiante o centro cooperativo $^{46}$. En las publicaciones anteriores aparecieron esquemas que no pasaban de ser bocetos inspirados en las ideas de Bézard. El diseño definitivo al que llega Le Corbusier en 1937 obviaba la propuesta de emplazarlo sobre una colina que controlara el territorio ${ }^{47}$ y se sitúa en un lugar teóricamente plano y bien comunicado. Partía de una organización similar a la de la granja, por lo que una espina central distribuía el conjunto y conectaba el poblado, no ya con los campos, sino con una vía rodada de alta capacidad. Se percibe, de una manera más clara, el deseo de incorporar a la vida rural, condiciones socioeconómicas comparables a las de las ciudades.

Según este modelo, los propietarios de granjas radiantes se asociarían formando comunas de producción, cuyo centro sería un Village Radieux. Éste se presenta en disposición abierta e integrada en el medio, con funciones que van desde las netamente agrarias, a las de contacto social, pasando por las industriales o las de servicio. Se desarrollarían en un conjunto de construcciones dispersas en un entorno verde, materializadas por medio de estructuras prefabricadas de acero y cubiertas con bóvedas rebajadas de hormigón. Los interiores y los remates no serían prefabricados, sino que se harían por obreros locales usando técnicas de la zona.

La organización de las funciones comienzan, desde el acceso, por las agrarias. El silo cooperativo, el "vientre" 48 del proyecto, funciona como marca de la comunidad en el territorio. Su importancia radica tanto en su función real, recipiente de almacenaje y centro de gestión de la producción, como en su dimensión simbólica, elemento de gran potencia en el paisaje que transmite a los campesinos la seguridad de que sus cosechas están protegidas y a salvo de la especulación. Tras este primer conjunto aparece una serie de instalaciones para las actividades industriales, en donde se producirían piezas para la gran industria y se transformarían in situ los productos

\footnotetext{
${ }^{46} \mathrm{Al}$ año siguiente apareció el proyecto reflejado en Le Corbusier: "La Réforme Agraire, Le Village Radieux," en Des Canons, Des Munitions? Merci! Des Logis... SVP. Boulogne-sur-Seine: Editions d'Architecture d'Aujourd'hui, 1938. pp. $114-137$.

${ }^{47}$ McLeod, Mary: "Piacé: Ferme Radieuse and Village Radieux". op. cit. p. 189.

${ }^{48}$ Le Corbusier: El Urbanismo de los tres establecimientos humanos. op. cit. p. 80.
} 
cosechados, evitando la desaparición de las artesanías populares. Junto a ello se emplaza el almacén de distribución y venta de productos agropecuarios, además de la cooperativa de abastecimiento, que permitiría el acceso a productos que habitualmente no pasaban de los centros de más demanda.

Avanzando por el eje central aparecen equipamientos de servicios (correo postal), residenciales (bloque de viviendas en régimen de alquiler con usos comunitarios), educativos (escuela) y de ocio (club). El club, de clara influencia soviética y denominado por Le Corbusier la "cabeza" del poblado, funcionaría como el principal punto de encuentro comunitario. El esquema quedaría presidido por el edificio administrativo, sede del ayuntamiento y del sindicato, al fondo de la vía central.

Los servicios ofrecidos y la conectividad regional permitida, hacían que Le Corbusier entendiera el poblado como un "dispositivo técnico portador de seguridad y esperanza en el mundo campesino" "49, permitiendo a la comunidad dar el salto desde su universo inmediato y conocido de los $4 \mathrm{~km} / \mathrm{h}$, al abierto y desconocido de los 50 $100 \mathrm{~km} / \mathrm{h}^{50}$. Resolviendo en su conjunto los tres problemas básicos planteados de inicio, los de "circulación, almacenamiento y manipulación" ${ }^{\prime 51}$. Además, materializaba otra de sus inquietudes, la armonía entre el individuo y el colectivo, entre la célula y el organismo. Y es que, junto con las ideas centrales de reorganización del suelo, el modelo cooperativo aseguraba esta armonía por medio de unos usos (club, escuela, talleres, oficinas) considerados como extensiones del hábitat, inseparables de cualquier proyecto residencial, tanto en la ciudad como en el campo.

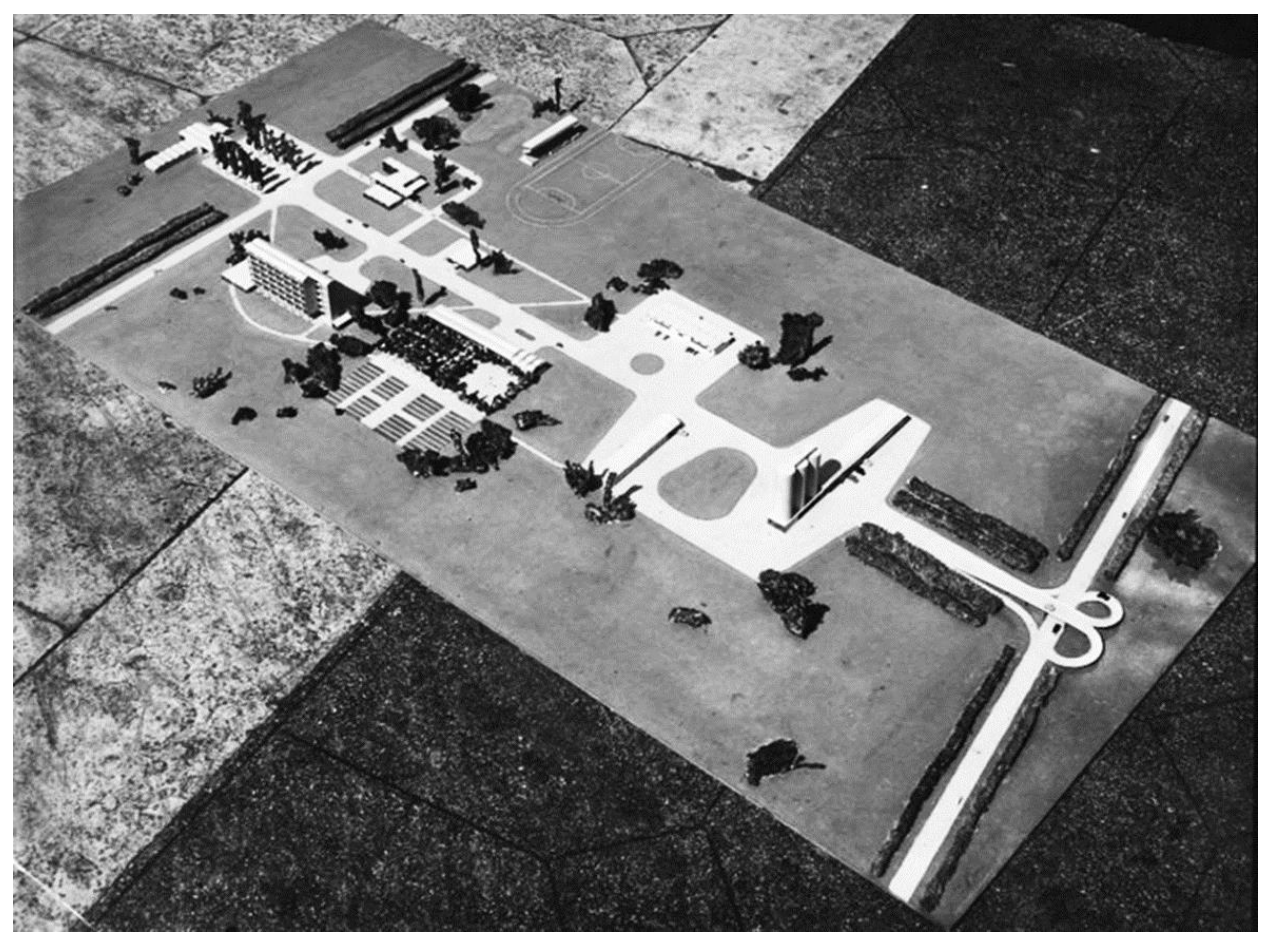

8. Fotografía de la maqueta del Village Radieux. FLC L3(20)61.

La exposición de la reforma agraria en el pabellón de 1937 permitió a Le Corbusier contar con un material de gran calidad para seguir mostrando su proyecto, y así lo hizo inmediatamente en el V congreso del CIAM. Este fue probablemente el foro que aportó mayor repercusión a la propuesta, al darse a conocer a los más relevantes

\footnotetext{
49 Ídem.

${ }^{50}$ Ibíd., p. 74.

${ }^{51}$ Le Corbusier: "Réorganisation Rurale". op. cit. p. 327.
} 
arquitectos del momento. Sin embargo, recibió la crítica, entre otros, de los arquitectos holandeses cercanos al socialismo. Estos atacaron fuertemente la idea de regionalismo y el modelo de agricultura de pequeña escala en la que los agricultores mantenían la propiedad, opuesto a sistema intervencionista y extensivo que defendían ${ }^{52}$.

La poca aceptación en el Congreso de París no fue óbice para que Le Corbusier continuara madurando estas ideas; así lo reflejan las referencias que hizo a ellas en 1939 tanto en la revista Sillons ${ }^{53}$ como en el manuscrito Sur les 4 Routes $^{54}$; o los comentarios que incluyó en la Maison des Hommes ${ }^{55}$. En 1940 elaboró otro manuscrito que firmó junto a Bézard titulado La Ferme radieuse et le Centre Coopératif. Reorganisation Agraire. Programme de la grande industrie ${ }^{56}$, donde cambió el nombre de "village" por "centre" y "radieux" por "coopératif", enfatizando así en el modelo de gestión. Posteriormente, Le Corbusier intentó trasladar estos proyectos al Gobierno de Vichy e incluso se han recogido propuestas de implantación en los Estados Unidos ${ }^{57}$, que llegaron a tener impacto en las políticas de construcción de vivienda social en el oeste del país, especialmente por medio de la oficina de San Francisco de la Farm Security Administration ${ }^{58}$.

\section{Unité d'explotation agricole}

La fundación en 1942 del grupo ASCORAL permitió a Le Corbusier contar con un equipo para afrontar esquemas organizativos a escala territorial. Aujame, Hanning, Dubreuil o el propio Bézard colaboraron en las investigaciones que se recogieron en la publicación de 1945 Les Trois Établissements Humains ${ }^{59}$. Los Tres Establecimientos Humanos puede considerarse su última gran propuesta urbanística a escala territorial, la cual defenderá hasta el final de su vida.

La unidad de explotación agrícola, junto con la ciudad lineal industrial y la ciudad radiocéntrica de intercambios, conformarían la tríada de asentamientos funcionales que constituyen el modelo territorial propuesto. Se trataba, por tanto, de un nivel más en su trabajo sobre la reorganización del hábitat rural, pasando del diseño de unos modelos de granja y de poblado cooperativo a su implementación en una teoría completa de ordenación del territorio.

En este modelo, la superficie delimitada por la red de ciudades industriales lineales se colmataría por medio de una malla de explotaciones de planta poligonal, maximizando la utilización productiva de los recursos naturales. Estructura territorial de enorme similitud con la propuesta de Walter Christaller ${ }^{60}$ en 1933 para el territorio agrícola del sur de Alemania, sobre la que Le Corbusier podría haber tenido conocimiento en algún momento ${ }^{61}$. En el diseño de cada explotación agrícola poligonal, Le Corbusier pasa del modelo aislado que mostró en la década anterior a una mayor concreción espacial. A partir de la existencia de una serie de aldeas, procede a la

${ }^{52}$ CIAM: 5 Congrés de Paris “Logis et Loisirs”. Boulogne-sur-Seine: Editions d'Architecture d'Aujourd'hui, 1938. pp. 1078 .

${ }^{53}$ Le Corbusier: "Renaissance de la Vie Paysanne". Sillons. 1939, № 1.

${ }^{54}$ Se publicó dos años después en Le Corbusier: Sur les 4 Routes. París: Éditions Gallimard, 1941.

${ }^{55}$ Le Corbusier; de Pierrefeu, François: Maison des Hommes. París: Éditions Plon, 1942. p. 121.

${ }^{56}$ Manuscrito recientemente publicado en Francia: Le Corbusier; Bézard, Norbert: La ferme radieuse et le centre coopératif., Benoît Hérisson (Ed.). Piacé: Piacé le radieux, 2015.

${ }^{57}$ Bacon, Mardges: Le Corbusier in America: Travels in the Land of the Timid. Cambridge, Mass.: MIT Press, 2001. p. 288.

${ }^{58}$ Ver los proyectos Rural Community en Woodville y Agricultural Workers' Community en Chandler recogidos en: Mock, Elizabeth: Built in USA: A Survey of Contemporary American Architecture. Nueva York: MoMA, 1945.

${ }^{59}$ Le Corbusier: Les Trois Établissements Humains. op. cit.

${ }^{60}$ Christaller, Walter: Die zentralen Orte in Süddeutschland (1933). Darmstadt: Wissenschaftliche Buchgesellschaft, 1968.

${ }^{61}$ Frampton, Kenneth: Le Corbusier. Madrid: Ediciones Akal, 2001. p. 111. 
ordenación funcionalista del territorio. En una posición central, y cercana a la vía de comunicación nacional o regional que atraviese la zona, se ubica el poblado cooperativo. En el espacio inmediatamente anexo a él, se sitúan los cultivos intensivos de hortalizas y frutales para consumo local o venta. En un segundo anillo se desarrollan los cultivos extensivos de cereales, tubérculos y viñas, entre los cuales se reservan espacios para la cría de la ganadería. Dispersas por este segundo anillo se disponen las granjas radiantes.

Las vías ya existentes se refuerzan y, junto con otras de nueva construcción, permiten la conectividad entre los poblados, el centro cooperativo, las granjas y los espacios de cultivo. El proyecto incluye la definición pormenorizada del poblado cooperativo, repitiendo el modelo de 1937 con leves modificaciones en cuanto a la ubicación del club, y la ordenación de la granja radiante, sin cambios respecto a la original.
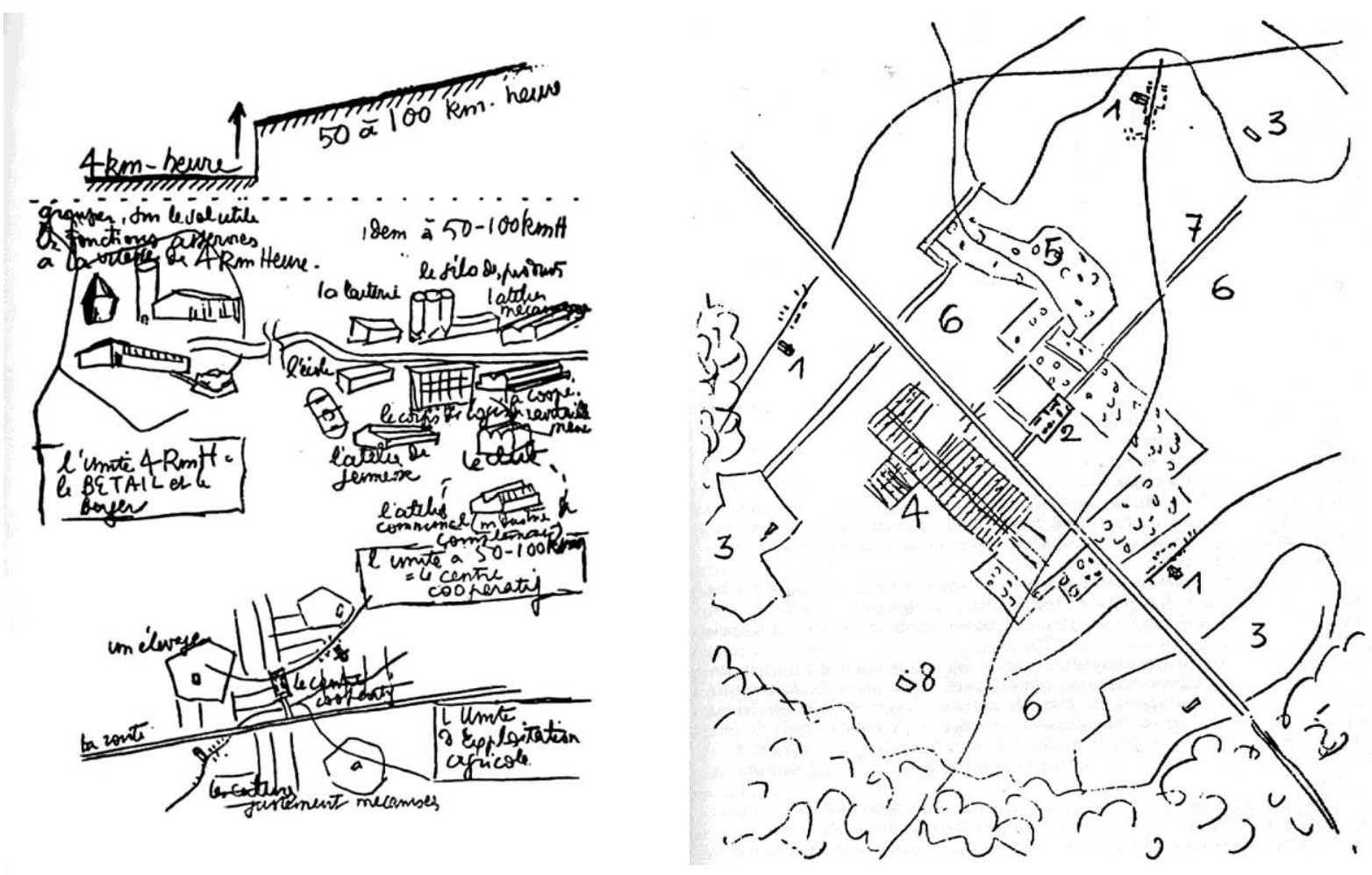

9 y 10. Esquemas sobre Les Trois Établissements Humains, y la Unité d'Explotation Agricole, en Le Corbusier: L' urbanisme des Trois Établissements Humains. París: Ed. de Minuit, 1959. p. 75 y p. 77.

La modernización de la organización propuesta no sólo beneficiaría al funcionamiento de la tierra, sino que permitiría incluso la promoción de industrias específicas, tales como manufacturas y enlatados de verduras y frutas, producción de leche y derivados, industria maderera, caza, etc. Una industria que podría llegar a ser "brillante y optimista, plena de intensidad y belleza"62 gracias a su conexión con el resto de asentamientos humanos. Las ciudades industriales lineales mejorarían y protegerían el campo ya que aseguraban que la industria se desarrollara en lugares concretos y no invadiera el territorio de manera incontrolada. Además, permitían a las zonas agrícolas conectarse con los flujos económicos y culturales, dignificando e intensificando el campo sin perder su esencia agraria. Para Le Corbusier, éste era algo más que un modelo territorial, era la solución a la sociabilidad humana, la única manera de establecer una ocupación "conforme" del territorio ${ }^{63}$ frente a la progresiva desnaturalización de la vida humana.

\footnotetext{
${ }^{62}$ Dubois, Gilles: "Le Corbusier, L’agriculture et L’urbanisme”. op. cit. (Traducción desde el francés por el autor).

${ }^{63}$ Torres Cueco, Jorge: Pensar la Arquitectura (...).op. cit. p. 98.
} 
Pese al convencimiento del maestro suizo, ningún gobierno puso en marcha su modelo territorial. Ya después de la Segunda Guerra Mundial, en el año 1956, propuso la idea a un antiguo miembro de la revista Prèludes, Philippe Lamour, encargado del desarrollo de la zona del Bajo Ródano-Languedoc ${ }^{64}$. Al igual que pasara en Italia, las diferencias del territorio con respecto al que se había utilizado como modelo de estudio, hicieron inviable su implementación. Pero la idea siguió en la mente de Le Corbusier hasta el final. Como ya se ha comentado, en su última obra teórica Mise au Point, este modelo de reorganización territorial ocupó una parte importante de su discurso, lo que demuestra la continuidad en el pensamiento de Le Corbusier, que nunca dio etapas por cerradas sino que trabajó cribando y perfeccionando sus proyectos hasta el extremo.

\section{Conclusiones}

La granja y el poblado radiantes surgieron como soluciones al problema de una sociedad rural aislada. El progreso industrial había provocado una tremenda desconexión entre lo urbano y lo rural, que se encontraban en mundos diferentes. Frente a ello, la unidad de explotación agrícola, junto con los otros modelos de asentamiento humano, intentaría maximizar la productividad y facilitar la conectividad, lo que reduciría los desequilibrios territoriales existentes.

El diseño concreto de las explotaciones agrícolas se realiza entendiéndolas como asentamientos humanos de primer nivel, en los que se llevan a cabo actividades que deben tener condiciones y servicios de calidad, similares a los que se disfrutan en el medio urbano. Además de su comunicación con las redes territoriales, se les dota de servicios comunitarios que fomenten el encuentro y el intercambio, y se utilizan materiales, técnicas y estándares de confort contemporáneos. En definitiva, se busca conseguir condiciones óptimas de comodidad en la residencia, de eficiencia y productividad en el trabajo y una interesante oferta de ocio y cultura que rompan la marginación del mundo rural.

La novedad de la propuesta lecorbusierana es, por tanto, el diseño de una conectividad funcional. Pese a su independencia física, el funcionamiento de los asentamientos depende de los flujos de encuentro y retroalimentación; del intercambio de productos, servicios y suministros que se producirían en los puntos de contacto. Esta visión contemporánea, está posibilitada por las novedades técnicas procedentes del mundo de los transportes y de la construcción. Utilizándose conceptos urbanísticos como el zoning o la conectividad entre redes, y arquitectónicos, como la construcción modular, el uso de estructuras porticadas, la disposición elevada de las viviendas sobre pilotis, la abstracción volumétrica de las piezas, etc.

Por otro lado, también es novedosa la propuesta cooperativista. Un modelo de reforma agraria no basada en una apropiación estatal de la tierra si no en la constitución de cooperativas de propietarios-trabajadores agrícolas que servirían de intermediarias para la gestión comunitaria de sus recursos y productos. Frente al individualismo antiurbano imperante en propuestas teóricas como la de Wright, o el intervencionismo estatal soviético de la propuesta de Ginzburg, en la de Le Corbusier prima una adecuada combinación entre individuo y sociedad. Un modelo que mantiene la independencia de la propiedad pero colectiviza aquellos elementos que cada agricultor individualmente no podría conseguir, tanto materiales como inmateriales.

\footnotetext{
${ }^{64}$ McLeod, Mary: "Piacé: Ferme Radieuse and Village Radieux". op. cit. p. 191.
} 
De manera que Le Corbusier no cae en estos proyectos en un "romanticismo campesino", sino que mantiene una mirada universal, moderna y funcional que conseguiría la integridad biológica del ser humano. Actitud que, por otro lado, demuestra una distancia teórica con respecto al problema real. Le Corbusier siempre defendió que la granja era como un tractor o una cosechadora por lo que debía "ser complementada con la experiencia de un campesino, sin cuya sabiduría resultaría fallida su integración en el metabolismo de la granja y en la ecología del lugar" ${ }^{\text {, }}$. Por lo que es claro que no se concibió como una solución de aplicación literal, sino como un modelo o prototipo que debería adaptarse a las diferentes zonas y saberes populares. Sin embargo, la realidad es que en tres décadas nunca adaptó ni modificó el proyecto, paso que probablemente hubiera dado en el caso de su construcción.

Este inmovilismo demuestra que la perspectiva desde la que se enfocó el problema fue técnica, científica y urbana. Tanto la granja, como el poblado y la unidad de explotación agrícola se diseñaron estableciendo ejes de organización, creando anillos según usos, generando distribuciones homogéneas, etc. Lo cual podría entenderse como la implementación de una visión tecnicista, en lugar de una renovación alcanzada a través de las reclamaciones de los usuarios reales. Una ordenación mecánica, propia de la época, sobre un medio que probablemente debiera haber sido entendido en su mayor complejidad, teniendo en cuenta las singularidades y ritmos del mundo agrario.

Si situamos el proyecto de Le Corbusier en su contexto, entendemos que entronca con las propuestas de Taut, Wright, Hilberseimer o Ginzburg relatadas al inicio del artículo. Plantearon un enfoque global hasta entonces nunca realizado: el diseño de modelos agrarios perfectamente conectados con el resto de los sectores económicos, materializados con una arquitectura contemporánea. Demostraron un enorme interés por mejorar las condiciones de los agricultores, grupo social que aún no se había sumado a la modernidad, mediante la incorporación de la tecnología, la mejora de la habitabilidad y la inclusión social, sin perder las bondades del contacto con la naturaleza y con la producción de alimentos. Un conjunto de propuestas de enorme valor que representan la manera de entender la planificación del territorio en esta década de los 30, tan necesitada de renovación. Miradas urbanas, funcionales y técnicas que para su materialización hubieran necesitado de cambios profundos que superaban las posibilidades del planeamiento.

\section{Bibliografía}

Arredondo Garrido, David: “Agricultura en la ciudad. De la Utopía a la Conciencia de Lugar”. Directores: Juan Calatrava Escobar y Juan Manuel Barrios Rozúa. Universidad de Granada, 2013.

Bacon, Mardges: Le Corbusier in America: Travels in the Land of the Timid. Cambridge, Mass.: MIT Press, 2001.

Benton, Tim: "La Réponse de Le Corbusier à la Loi Loucheur" en Le Corbusier. Une Encyclopédie, Lucan, Jacques (Ed.). Paris: Éditions du Centre Pompidou - CCI, 1987. p. 237.

Bézard, Norbert: "Rapport: L’Urbanisme Rural”. En 5 Congrés de Paris 'Logis et Loisirs'. Boulogne-sur-Seine: Editions d'Architecture d'Aujourd'hui, 1938. pp. 3-16.

Christaller, Walter: Die zentralen Orte in Süddeutschland. Darmstadt: Wissenschaftliche Buchgesellschaft, 1968.

Congreso Internacional de Arquitectura Moderna (CIAM): 5 Congrés de Paris 'Logis et Loisirs'. Boulogne-surSeine: Editions d'Architecture d'Aujourd'hui, 1938.

\footnotetext{
${ }^{65}$ García-Germán, Javier: "De la Ville Verte a la Geoarquitertura”. op. cit. p. 205.
} 
Cohen, Jean-Louis; Benton, Tim; Tittensor, John (Eds.): Le Corbusier Le Grand. Londres - Nueva York: Phaidon, 2014.

Dubois, Jacques: “Le Corbusier, L'agriculture et L'urbanisme”. Habitation: Revue Trimestrielle de La Section Romande de l'Association Suisse Pour l'Habitat. 1957, No 29.

Frampton, Kenneth: Le Corbusier. Madrid: Ediciones Akal, 2001.

García-Germán, Javier: "De la Ville Verte a la Geoarquitertura". Massilia. Annuaire d'Etudes Corbuseennes. 2008, No 7. pp. 196-209.

Ginzburg, Moisei; Barshch, Mikhail: “Zelenyj Gorod.” SA Sovremennaya Arkhitektura. 1930, No 1-2. p. 22.

Hilberseimer, Ludwig: The New Regional Pattern; Industries and Gardens, Workshops and Farms. Chicago: P. Theobald, 1949.

Hilpert, Thilo: "La Maison des Hommes: Leçons Possibles de L'anthropocentrisme de Le Corbusier." en Le Corbusier et La Nature. Paris: Fondation Le Corbusier - Editions de la Villette, 2004. pp. 21-32.

Le Corbusier: "Décisions". Plans. Diciembre 1931, №10.

—. El Urbanismo de los tres establecimientos humanos. Junyent, Albert (Tr). Barcelona: Poseidón, 1981.

—. "Ferme Radieuse, Village Radieux". Prélude. 1934, Nº 14.

_. La Ville Radieuse. Boulogne-sur-Seine: Editions d'Architecture d'Aujourd'hui, 1935.

. "La Réforme Agraire, Le Village Radieux" en Des Canons, Des Munitions? Merci! Des Logis... SVP. Boulogne-sur-Seine: Editions d'Architecture d'Aujourd'hui, 1938. pp. 114-37.

—. Les Trois Établissements Humains. Paris: Éditions Denoël, Collection ASCORAL, 1945.

—. Logis et Loisirs. Boulogne-sur-Seine: Editions d'Architecture d'Aujourd'hui, 1938.

—. L’ Urbanisme des Trois Établissements Humains. Paris: Ed. de Minuit, 1959.

—. Mise au point. Torres Cueco, Jorge (Ed.). Madrid: Abada Editores, 2014.

_. Euvre Complète 1910-1929. Zurich: Girsberger, 1935.

—. Euvre Complète 1929-1934. Zurich: Girsberger, 1935.

—. Euvre Complète 1934-1938. Zurich: Girsberger, 1939.

_. "Renaissance de la Vie Paysanne." Sillons. 1939, № 1.

_. "Réorganisation Rurale” en La Ville Radieuse, Paris: Vincent Fréal and Cie., 1964. pp. 319-36.

_. Sur les 4 Routes. París: Éditions Gallimard, 1941.

—. The City of To-Morrow and Its Planning. New York: Dover, 1987.

_. "Village Radieux, Ferme Radieuse". L'Homme Réel. 1934, № 4. pp. 54-59.

Le Corbusier; Bézard, Norbert: La Ferme Radieuse et le Centre Coopératif. Hérisson, Benoît (Ed.). Piacé: Piacé le radieux, 2015.

Le Corbusier; de Pierrefeu, François: Maison des Hommes. París: Éditions Plon, 1942.

Lourau, René: El Estado y el inconsciente: ensayo de sociología política. Barcelona: Kairós, 1980.

McLeod, Mary: “Le Ferme Radieuse. Le Village Radieux” en Le Corbusier et La Nature. Paris: Fondation Le Corbusier - Editions de la Villette, 2004. pp. 129-50.

- "Piacé: Ferme Radieuse and Village Radieux" en Le Corbusier: An Atlas of Modern Landscapes, Cohen, Jean-Louis (Ed.). New York: Museum of Modern Art, 2013. pp. 185-92. 
—. "Radiant Farm and Village: Le Corbusier's Agricultural Utopia, 1933-1942." Dumbarton Oaks, Washington: Dumbarton Oaks Garden and Landscape Studies, 2012.

"Urbanism and Utopia: Le Corbusier from Regional Syndicalism to Vichy.” Princeton University, 1985

Mock, Elizabeth: Built in USA: A Survey of Contemporary American Architecture. Nueva York: MoMA, 1945.

Ragot, Gilles: "La Ferme et le Village radieux de Le Corbusier. Nouvelle déclinaison du principe d'équilibre entre l'individuel et le collectif”. In Situ. Revue des patrimoines. Julio 2013, No 12.

Taut, Bruno. Die Auflösung der Städte. Die Erde eine gute Wohnung, der Weg zur alpinen Architektur. Hagen: Folkwang, 1920.

—. Escritos, 1919-1920. Iñaki Ábalos (Ed.). Madrid: Croquis, 1997.

Torres Cueco, Jorge: Pensar la Arquitectura: 'Mise au point' de Le Corbusier. Madrid: Abada Editores, 2014.

Waldheim, Charles: "Notes Toward a History of Agrarian Urbanism." en Bracket 1: On Farming, White, Mason; Przybylski, Maya (Eds.). Barcelona: Actar, 2010. pp. 18-24.

Wright, Frank Lloyd. The Disappearing City. New York: W. F. Payson, 1932.

. The Living City. New York: Horizon Press, 1958.

When Democracy Builds. Chicago: University of Chicago Press, 1945. 


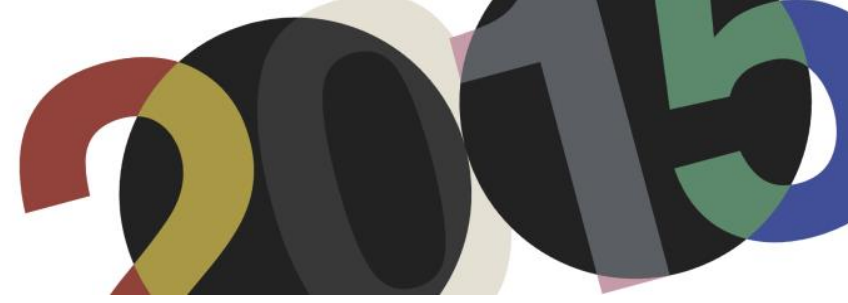

DOI: http://dx.doi.org/10.4995/LC2015.2015.1006

\title{
LE CORBUSIER ET LA MAIN OUVERTE À CHANDIGARH.
}

\section{La genèse d'une œuvre}

\author{
A. Arrouf, N. Berkane \\ Laboratoire d'Etude et de Modélisation des Phénomènes Architecturaux et Urbains, de l'idée à l'usage \\ (LEMPAU), Département d'architecture, Université El Hadj Lakhder Batna, Algérie
}

\begin{abstract}
Résumé: En décembre 1950, Le Corbusier est associé à la conception de la nouvelle capitale du Pendjab indien. En complément du projet, il intégra le monument de la main ouverte élevée au dessus de la fosse de la considération. Le Corbusier déclare d'emblée que le monument de la Main Ouverte est un "complément» au programme de Chandigarh, fourni par "l'autorité ». Il est une "contribution personnelle " qui n'a pas de commanditaire. Il est de fait un élément " inattendu». Un élément inhabituel qui n'a d'autres raisons d'être que celles propres à son architecte.

Mais justement quelles sont-elles ces raisons? Pourquoi Le Corbusier a-t-il ressenti le besoin de rajouter un monument au programme de Chandigarh? A quelle fin ? A la gloire de qui ? En vue de quelle symbolique ? Pourquoi lui-a-t-il donné cette forme? Pourquoi l'a-t-il fait mobile? Et pourquoi l'a-t-il placé sur cette esplanade qui relie les bâtiments de l'assemblée et de la justice? Le travail de recherche ici présenté tente de répondre à toutes ces questions. Il adopte, pour ce faire, une approche génétique qui cherche à comprendre comment se fait la genèse de l'œuvre.
\end{abstract}

Resumen: En diciembre de 1950, se involucra Le Corbusier en el diseño de Chandigarh, la que sería nueva capital del Punjab indio. Como un complemento del proyecto, Le Corbusier integra el monumento de la mano abierta, situado sobre el pozo de la contemplación. Le Corbusier declara, desde el principio, que el monumento de las mano abierta es un "complemento" al programa de Chandigarh, facilitado por "las autoridades". Se trata de una "contribución personal" que nadie ha solicitado. De hecho, es un elemento "inesperado". Un elemento inusual cuya razón de ser obedece al propio arquitecto.

Pero cuáles son esas razones? ¿Por qué Le Corbusier sentía la necesidad de añadir un monumento al proyecto de Chandigarh? ¿Con qué fin? Para la gloria de quién? En vista de qué simbolismo? ¿Por qué darle esta forma? ¿Por qué lo hizo móvil? ¿Y por qué razón lo ha

colocado en esta plaza que conecta los edificios de la asamblea y de la justicia?

Este trabajo de investigación que vamos a presentar trata de responder a todas estas preguntas. Adopta, para ello, un enfoque "genético", en la medida que busca comprender la génesis de la obra.

Mots-clés: Main ouverte ; approche génétique ; monument ; archives.

Palabras clave: Mano abierta; Enfoque genético; Monumento.

\section{Introduction}

Il y a de cela presque vingt ans, Christian de Portzamparc ${ }^{1}$ disait déjà, à l'occasion d'un colloque ${ }^{2}$ qui traitait de monuments et de monumentalité que la nature de l'architecture est double.

Il affirmait que même si l'architecture moderne, « depuis qu'elle existe est fondée sur le rejet du monument, sur la dénégation de ce qu'on pourrait appeler : les origines monumentales de l'architecture »; même si les écrits fondateurs ont essayé de faire disparaître la dimension symbolique de l'architecture ; même si le mot monument

\footnotetext{
${ }^{1}$ Christian de Portzamparc, 1986, p.21.

${ }^{2}$ Premier colloque international organisé par l'association Ville et Projets, les 30 novembre et $1^{\text {er }}$ décembre 1985, à l'Abbaye de Royaumont autour du thème « Ville, Symbolique, Forme, Pouvoir, Projets ».
} 
y figure comme «mot tout à fait dérogatoire, comme l'insulte primaire (avec le mot académique) », l'architecture reste à la fois utilitaire et symbolique.

Il est clair que la modernité dans son attitude anti-monumentale non seulement architecturale mais aussi et surtout intellectuelle et philosophique ${ }^{4}$, n'a pu empêcher certaines de ses œuvres les plus en vogue d'être, ou du moins de devenir, des monuments.

Mais ce «devenir monument » d'œuvres ordinaires, jamais conçues en tant que monuments, montre l'impact de la modernité sur l'acception même des concepts «monument » et «monumentalité ». Une notion moderne du monument s'est formée, qui autorise Christian de Portzamparc à classer dans la même catégorie-monument la tour de Tatline et les œuvres de Le Corbusier à Chandigarh et permet à Joseph Rykwert d'y joindre la villa Savoie.

Cette situation paradoxale qui réunit ce «qui fût et n'est plus » à ce «qui est et ne fût point », nous pousse à nous poser un certain nombre de questions :

- qu'est-ce donc qu'un monument? qu'est-ce qui est monument et qu'est-ce qui ne l'est pas ?

- Qu'est-ce qui devient monument combien même il n'a jamais été conçu en tant que tel et qu'est-ce qui n'en sera jamais un même s'il a été voulu tel ?

- Pourquoi construit-on des monuments ?

- Qu'est-ce que la notion moderne de monument?

\section{Mais qu'est-ce donc qu'un monument?}

Hegel $^{5}$, affirme que l'architecture est née pour symboliser. Sa fonction première est de représenter un fait humain : «Le but de l'art, son besoin originel, c'est de produire aux regards une représentation, une conception née de l'esprit. » Le rôle de «l'architecture indépendante » ${ }^{6}$ est en somme de donner aux idées « une existence sensible qui leur corresponde » et les œuvres d'art « offertes aux sens doivent renfermer en soi un contenu ». Ce contenu doit par ailleurs être représenté de telle sorte qu'il ne soit pas possible de prendre l'œuvre pour « un objet réel de la nature », mais bien de la percevoir comme «un produit de la représentation et de l'activité artistiques de l'esprit».

L'exemple le plus remarquable nous en est offert par la tour de Baal. Hegel la décrit substantiellement comme étant « une tour, non creusée à l'intérieur, mais massive, de la longueur et de la largeur d'un stade. Sur cette tour s'en élève une seconde, puis une troisième, et ainsi jusqu'à huit tours superposées. Un chemin en fait le tour, conduit jusqu'au sommet (...). Mais, sur la dernière tour est un grand temple (...). Cependant il n'y a point de statue élevée dans le temple (...). Néanmoins, nous ne pouvons assimiler cette construction gigantesque aux temples dans le sens grec ou moderne ; car les sept premières assises sont entièrement massives et la huitième, la plus élevée, est la seule où séjourne le dieu invisible, qui ne reçoit là aucune prière. La statue était au dessous, en

\footnotetext{
${ }^{3}$ Joseph Rykwert, 1986, p.136.

4 «Cette attitude de déni du monument n'est pas seulement architecturale, elle fait probablement partie de tout un travail de l'époque moderne à l'avènement de l'ère industrielle: une sorte de travail de déconstruction du mythe, le rêve d'une transparence intellectuelle, d'une transparence instrumentale du monde, un moyen de le connaître mieux. Evidemment cela commence avec les lumières, c'est présent dans le positivisme, dans l'essor du rationalisme, de la science. » (Portzamparc, 1986, p.22).

${ }^{5}$ Esthétique, au chapitre «L'architecture art symbolique », p.21.

${ }^{6}$ Ibid., p.23.
} 
dehors de l'édifice. Ainsi, l'ouvrage entier s'élève indépendant, pour lui-même, sans rapport à un autre but, sans rapport au culte et au service divin (...). La forme, reste encore ici abandonnée au hasard et à l'accidentel. Elle est déterminée seulement par le principe matériel de la solidité : la forme d'un cube. » ${ }^{7}$

Si l'on en juge par cette description, la tour n'avait pas de fonction utilitaire. Elle était pleine. Elle avait une présence artificielle, elle offrait aux sens une œuvre différente de tous les objets de la nature.

Nous avons là, la définition de l'un des «grands pôles originels au sens du monumental. » ${ }^{8}$ Un premier paradigme de ce qu'est le monument : Un corps artificiel expression d'une pensée conceptuelle. Il est plein, massif, de forme géométrique différente de toutes celles qui existent dans la nature et sans autre fonction que celle de sa présence propre.

Ce premier paradigme Hégélien, s'attache à la vision de l'architecture comme masse, matière et construction. Il s'appuie sur les objets archétypes de l'orient : la tour de Babel, les pyramides ou l'obélisque et néglige tous ces monuments bâtis autour de l'autre caractéristique essentielle de l'architecture, à savoir l'espace et les espacements.

Les temples de Carnac, le grand cercle de Stonehenge, sont des exemples originels de « cette notion de vide qui pourrait constituer un second pole ${ }^{9}$. Les alignements, les tracés géométriques et la volonté d'inscrire une spatialité, sont dans cette catégorie de monuments, les instruments de l'acte architectural. Grâce à eux, l'esprit humain a pu se transmettre sans être en cela semblable à l'action naturelle. Un deuxième paradigme qui complète le premier est né. Le monument est désormais, une organisation artificielle faite de masse et d'espace. Elle exprime une pensée conceptuelle. Elle est de forme géométrique spécifique sans commune ressemblance avec toutes celles qui existent dans la nature. Elle n'a d'autre fonction que celle de sa présence propre.

Des objets tels que la tour de Tatline et la tour Eiffel sont une parfaite expression de ce deuxième paradigme. Les deux tours sont faites de masse et d'espace, elles sont même des masses vidées qui s'inscrivent dans l'espace et créent leur propre espace. Elles se situent en somme, aux antipodes des masses monumentales hégéliennes et elles n'arrivent à être telles que par la réintroduction de la dimension constructive hégélienne. Le besoin du vide a autorisé l'émergence d'une nouvelle acception de la dimension constructive hégélienne. La construction qui permet de tenir est délaissée pour celle qui permet d'alléger. L'architecture et ses monuments se sont petit à petit affranchis de leurs préoccupations de pesanteur dans un processus qui a commencé il y a fort longtemps ${ }^{10}$ et qui a conduit à considérer monument tout objet architectural qui présente de grandes prouesses techniques et constructives.

A partir de là, le monument est devenu l'objet qui sort de l'ordinaire. C'est le paradigme de l'inhabituel, de l'exception qui fait dire à Françoise Divorne ${ }^{11}$ que «dans la monumentalité contemporaine, ce qui démarquera

\footnotetext{
${ }^{7}$ Ibid., p.24.

${ }^{8}$ Ch. De Portzamparc, Op. Cit., p.23.

${ }^{9}$ Ibid., p.26.

${ }^{10}$ «La pyramide est le signe de la mort. Bien clairement par leur forme qui est celle des montagnes. Laissez agir la pesanteur, et le tas de pierres se disposera selon la forme pyramidale. Cette forme est donc le tombeau de tout édifice; mais l'effrayant est que l'architecte a bâti volontairement selon la mort, cherchant la durée par là, comme si la vie était une courte perturbation, (...); mais la pyramide est une image bien plus parfaite de l'éternelle inaction; ainsi elle annonce au spectateur l'imperceptible et introuvable momie.

(...). Le Temple grec est le signe de la vie. Tout est entrepris et dressé contre la pesanteur. La colonne, par ses proportions, et par toutes ses parties, signifie qu'elle supporte ; et l'angle droit règne ici, qui est le signe du maçon (...)» (Alain, 1962, pp.7-8). Et comme pour faire écho à cette pensée, nous retrouvons cette autre de Le Corbusier : "La loi de l'éboulement des terres fixe à jamais le destin des pyramides : une pente de 45 degrès, impeccable. » (Le Corbusier, 1937, p.33)

${ }^{11}$ Françoise Divorne, 1986, pp.17-19.
} 
un bâtiment monumental, c'est la manière dont il contraste avec les autres bâtiments dans son traitement architectural, que ce soit par ses dimensions, son mouvement, sa forme ou sa grandeur. (...) Beau ou laid, il échappe à l'esthétique. Un monument devrait en effet se rapprocher de l'exceptionnel... ».

C'est en vertu de ce paradigme que le mouvement moderne a fini par créer ses monuments propres. Des monuments qui sont devenus tels parce qu'ils créent une situation équivoque qui met en scène à la fois le paradigme de l'exception et celui du modèle. C'est ainsi que la villa Savoie est classée monument par Rykwert. Elle est devenue «la maison-emblème, maison-exemple, maison-monument. » ${ }^{12}$ Elle est emblème de la modernité parce que placée dans l'environnement pré-moderne, elle fait exception. Elle est non seulement l'exemple de ce que devraient être les maisons modernes mais elle constitue un précipité de tous les concepts modernistes de la maison, elle en est l'archétype même, elle en est le modèle et le symbole. Elle donne une expression visuelle aux idées constitutives de la modernité et à la structure sociale de la communauté que celle-ci voudrait voir se constituer ${ }^{13}$ et c'est ainsi qu'elle est devenue monument.

Si ce paradigme moderne du monument permet d'expliquer pourquoi autant d'objets architecturaux aussi différents que le sont le couvent de la Tourette, la chapelle de Ronchamp, la glass-house, la maison à la cascade, le palais de l'assemblée d'Islamabad ou la villa Savoie, sont devenus monuments alors même qu'il n'ont jamais été édifiés dans tel objectif, il reste cependant incapable d'expliquer la raison d'être d'objets tels que la tour de Tatline, le monument à Paul Vaillant-Couturier, la tour d'ombre et la main ouverte à Chandigarh de Le Corbusier, le monument aux victimes de la manifestation de mars 1920 de Walter Gropius ou encore le monument à Karl Liebknecht et Rosa Luxemburg de Mies Van der Rohe.

Parce qu'en fait la question mérite d'être posée. Pourquoi la modernité a-t-elle produit des objets qui sont loin d'être aussi utilitaires que le voudraient sa tradition et ses doctrines ? pourquoi a-t-elle produit des entités aussi symboliques ? bref, pourquoi a -t-elle produit des monuments, qui sont depuis le départ conçus et édifiés en tant que tels ? et en agissant ainsi, les architectes auteurs de tels objets ont-ils ou pas remis en cause les idées fondatrices de l'architecture moderne et le paradigme moderne du monument?

Le Dictionnaire Hachette Encyclopédique de 1998 définit ainsi le concept monument :

«Ouvrage d'architecture ou de sculpture édifié pour conserver la mémoire d'un homme illustre ou d'un grand événement. »

«Ouvrage considéré pour sa grandeur, sa valeur ou sa signification. »

« Euvre considérable par ses dimensions ou ses qualités. »

Dans cette banale définition de dictionnaire est énoncée une partie de la réponse. Les deux dernières catégories rejoignent de toute évidence le paradigme de l'exception et du contraste tandis que la première introduit une nouvelle donnée. Elle définit une fonction pour l'objet monument. Il n'est plus purement symbolique et édifié pour lui-même sans autre but que son être, tel que le voulait Hegel, mais il sert à « conserver une mémoire » et à «marquer un événement». Il est l'objet qu'on édifie pour faire durer la trace de quelqu'un ou de quelque événement jugés importants. Le monument perpétue le souvenir. Il rappelle. Il transforme l'éphémère en éternel. Il crée la durée.

\footnotetext{
${ }^{12}$ Rykwert, Op. Cit., p.135.

${ }^{13}$ Cf. Ch. Norberg-Schulz, 1998, p.15.
} 
Mais cette fonction n'a pas toujours été telle. Les monuments pré-modernes ${ }^{14}$ étaient d'abord édifiés pour glorifier, pour légitimer, pour faire perdurer et pour rendre continuellement présent un pouvoir, une religion, une idéologie et un prince : l'Arc de Triomphe romain élevé à la gloire de Rome, du vainqueur et souvent de l'empereur, Les monuments élevés par Albert Speer à la gloire de Hitler, les Cathédrales Gothiques élevées à la gloire de l'Eglise, les pyramides élevées pour la gloire du pharaon-dieu fils de dieu, etc.

Le monument ne pouvait être perçu en tant qu'objet autonome, il était surchargé de connotations négatives et c'est pourquoi la modernité dans son élan humaniste, a fini par le rejeter, mais pas définitivement. Elle l'a remplacé par une conception plus démocratique du monument qui s'inscrit en droite lignée du paradigme de l'exception et du modèle.

Le monument à Paul Vaillant-Couturier (fig.1) est l'expression même de cette nouvelle vision des choses.

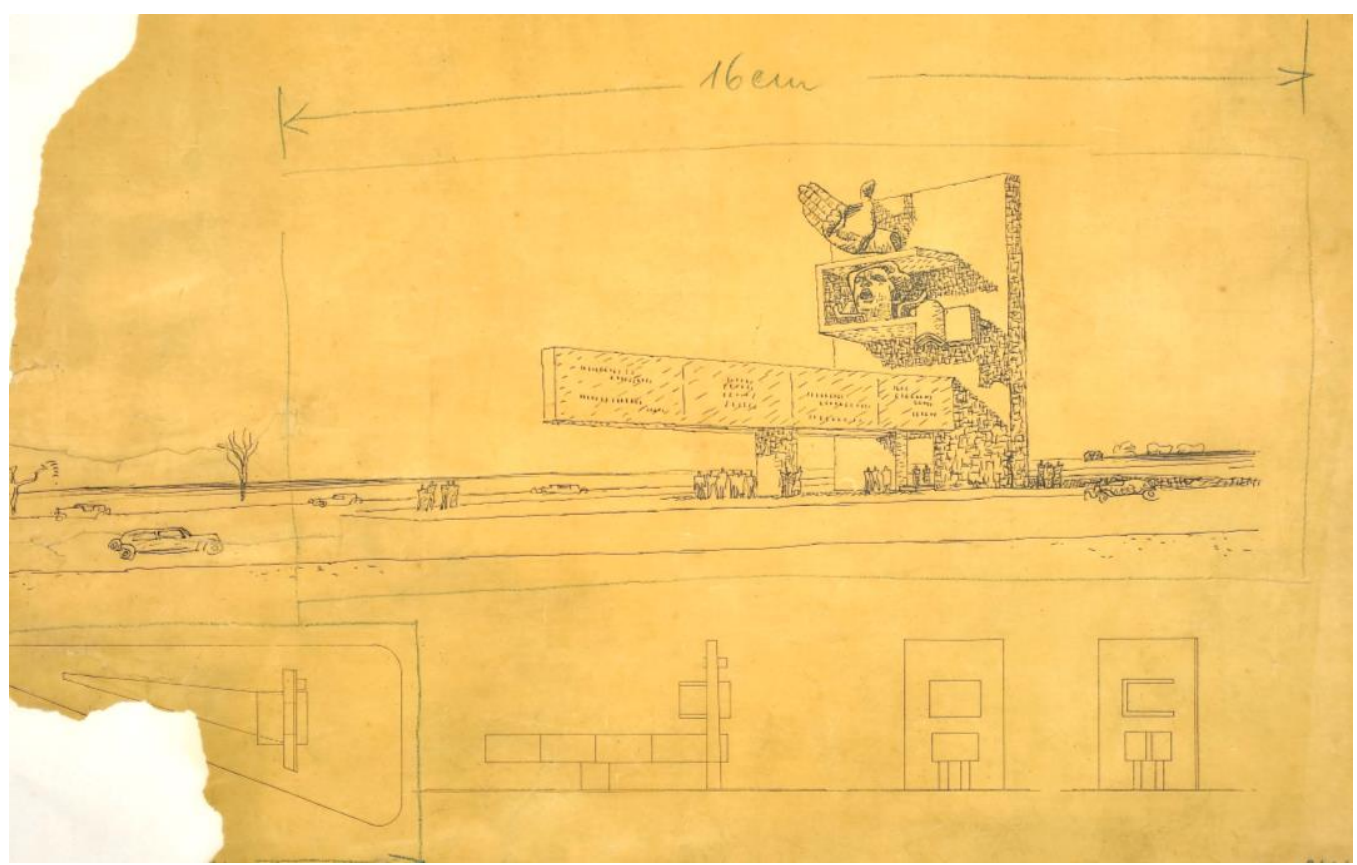

1. Projet de monument à Paul Vaillant-Couturier. Villejuif, France, 1937. Fondation Le Corbusier, OFLC-ADAGP.

Son architecture mise à part, la commande du monument et les clients qui l'ont passée ainsi que la personnalité à qui il est dédié sont autant d'éléments du paradigme en question.

En effet, ce monument est dédié à Paul Vaillant-Couturier, journaliste éditeur de «L'Humanité », politicien et personnalité phare de la gauche française. Il n'est pas mort en martyr, ni en étant au pouvoir. Mais on lui a dédié un monument pour ses qualités personnelles exceptionnelles et susceptibles de servir de modèle à d'autres. La commande du monument n'est l'œuvre d'aucun pouvoir ou clergé mais elle est l'idée d'un comité indépendant qui comptait entre autres le cinéaste Jean Renoir et le monument est le résultat d'un concours architectural dont le lauréat fut Le Corbusier que certains différends idéologiques opposaient pourtant à Vaillant-Couturier ${ }^{15}$.

C'est ainsi que furent conçus les monuments modernes sur la base du paradigme de l'exception et du modèle : ils sont des objets architecturaux exceptionnels qui symbolisent des événements et des personnalités non seulement exceptionnels mais aussi susceptibles de servir de modèle.

\footnotetext{
${ }^{14}$ Quoique ce genre de monuments continue à exister de nos jours dans tous les pays totalitaires.

${ }^{15}$ Alexander Tzonis, 2002, p.129.
} 
Cette règle compte cependant au moins une exception, qui loin de confirmer la règle aurait plutôt tendance à la faire évoluer. Il s'agit en l'occurrence du monument de la Main Ouverte à Chandigarh de Le Corbusier.

\section{Le monument de la main ouverte à Chandigarh}

En décembre 1950, Le Corbusier est associé à la conception de la nouvelle capitale du Pendjab indien. En complément du projet, il intégra le monument de la main ouverte élevé au dessus de la fosse de la considération (fig.2).

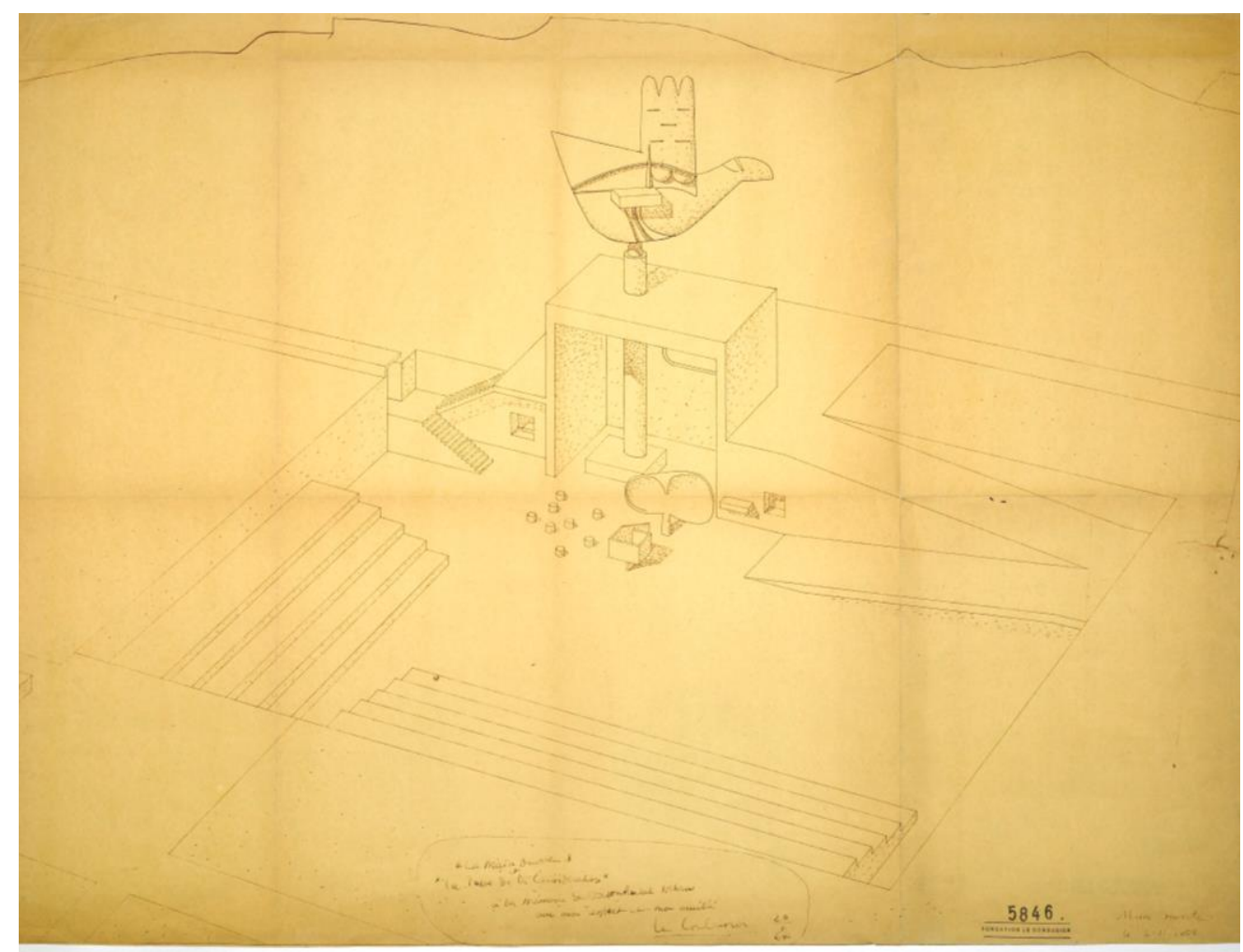

2. La Main Ouverte et la Fosse de la Considération. Fondation Le Corbusier 5846, @FLC-ADAGP.

En introduction à ses Euvres Complètes 1946-52, Le Corbusier, en parle ainsi :

«En complément du programme de Chandigarh, capitale du Punjab, j'ai apporté, en creusant dans la terre, une petite contribution personnelle, baptisée drôlement : «La Fosse de la Considération ». Il s'agit d'un trou carré dans le sol, de 4.79 mètres de profondeur et de 25.07 mètres de coté. Des gens s'y réuniront, ceux qui parleront et ceux qui écouteront, debout ou assis: ils ne verront que le ciel posé sur les quatre bords de la fosse et la "Main Ouverte » haute de 16 mètres, de fer pur martelé et riveté sur une charpente de bois et tournant au vent sur un roulement à billes : «la Main » s'orientera selon le vent du jour. (...) Cet élément inattendu d'urbanisme a été spontanément, simplement et sans le moindre débat, appelé là-bas «le monument du Capitol » » ${ }^{16}$.

A travers cet énoncé, Le Corbusier commence par confirmer notre définition du concept moderne du monument et va même au-delà.

Il annonce de premier abord que le monument est «une contribution personnelle». Il n'est commandé par aucune autorité. Bien au contraire, le monument est décrit comme «complément » du programme qui lui a été

${ }^{16}$ Le Corbusier, Oeuvres complètes, 1946-52. 
fourni par les autorités indiennes et qu'il juge être insuffisant et à la limite de la banalité, même s'il a constitué pour lui en tant qu'architecte, l'occasion d'imaginer et d'inventer :

«Mais le programme dressé par l'autorité est un programme banal, conformiste, tant en ce qui concerne l'habitation qu'en ce qui concerne les éléments institutionnels de la ville ${ }^{17}$. »

Le monument vient donc clarifier, énoncer et disculper. Il clarifie la position de l'architecte vis-à-vis du projet de la ville de Chandigarh : je suis responsable de la conception mais pas du programme. Il énonce ce que le concepteur pense du programme, de la ville, de ce qu'elle devrait être et de ce qu'elle devrait devenir et le disculpe face à ce qu'est cette ville sur le plan des institutions et de l'habitat.

La raison d'être du monument est ainsi établie. Il n'est fait ni pour glorifier, ni pour évoquer un quelconque événement, pouvoir ou personne. Le monument est créé pour éclaircir, rappeler et répondre à un besoin personnel de démarcation. Il est enfanté par une préoccupation d'éthique. Même si en étant ainsi, le monument marque une idéologie, cette idéologie reste personnelle. Elle est celle de l'architecte, qu'il juge en toute sincérité être celle du devenir du genre humain et de ses villes. Idéologie qui devrait caractériser une ère, une période, celle du machinisme. C'est d'ailleurs ce qui est énoncé par le contexte dans lequel est posée la critique du programme de Chandigarh :

"Quelle est la fenêtre ouverte sur demain? Personne ne l'a encore désignée, personne encore n'a réussi à l'ouvrir; l'horizon du monde est bouché. On ne sait pas de quoi demain sera fait. Plus de cent années ont rassemblé les éléments du jeu. Quel sera le jeu? Quelles sont ou seront les règles du jeu?

Je pose une simple question incidente, une question d'architecture : que deviendront nos villes : New York, Londres, Paris atteintes dans leur masse gigantesque faussée, écrasée d'erreurs récentes ou déjà accumulées, brûlées par le souffle de l'ère machiniste?

La parole est à demain.

(...) Nulle part au monde le problème n'est encore foncièrement posé - fait d'économie, de sociologie et d'éthique -. Et l'homme prétend d'être le conducteur de sa civilisation ${ }^{18}$. »

Le paradigme moderne du monument est ainsi poussé à l'extrême : l'architecte monumentalise pour son compte. Il exprime ses propres idées et sa façon de voir les choses; bref, sa liberté de pensée. Mais en voulant se démarquer de ce qu'il n'aimait pas, de ce qu'il n'admettait pas, il se devait de symboliser aussi sa part de responsabilité dans la ville de Chandigarh et la Main Ouverte exprime sa façon de faire les choses et c'est exactement ce qui transparaît à travers la suite de sa description de cette œuvre :

«Au long de l'esplanade de 400 mètres qui relie le Bâtiment de l'Assemblée à celui de la Justice, se dresseront les signes sur lesquels sont conçus techniquement l'urbanisme et l'architecture de Chandigarh ${ }^{19}{ }^{1}$.

Telle est donc définie la mission de la Main ouverte avec les mots mêmes de son créateur. Mais cette définition quoiqu'elle énonce les raisons de son etre $^{20}$, ne permet nullement de comprendre la raison de sa forme :

\footnotetext{
${ }^{17}$ Le Corbusier, 1953,

${ }^{18}$ p.10. Ibid.

19 Ibid
} 
«pourquoi une main?», ni celle de son état: «pourquoi une main ouverte et verticale ? », ni celle de son lieu d'édification : «Pourquoi l'esplanade du bâtiment de l'Assemblée ? ». Tout comme elle n'explique point les idées qui ont été à l'origine de la composition dans sa totalité : «Pourquoi une fosse et pourquoi une telle appellation : la fosse de la considération ? » ni « Pourquoi une main qui tourne ? ».

Bien sur, tant que ces questions restent sans réponse, l'appartenance au paradigme énoncé, ne peut être vérifiée. C'est pourquoi, nous tenterons d'y répondre et pour y arriver, nous adopterons une « approche génétique ».

\section{L'approche génétique}

L'approche génétique est une démarche théorique qui a pris naissance dans l'environnement littéraire et textuel. Elle porte depuis une trentaine d'années le nom de «critique génétique » et remonte à une longue tradition philologique $^{21}$.

Le propre de cette approche, tel que son nom l'indique, est d'essayer de comprendre la manière dont se fait la genèse de l'œuvre littéraire. A l'opposé de la longue tradition philologique qui approchait le sens par la médiation de l'archive, l'approche génétique est parvenu à renouveler la connaissance des textes grâce à « un véritable renversement opéré en déplaçant l'interrogation critique de l'auteur vers l'écrivain, de l'écrit vers

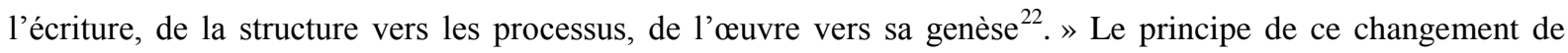
l'approche critique, est le constat que toute œuvre littéraire dans son état définitif est le résultat d'un travail, et donc «d'une élaboration progressive » au cours de laquelle l'auteur a préparé, conçu, produit, transformé, rédigé, révisé et corrigé son texte avant de le présenter dans sa forme finale. L'approche génétique se donne pour objet cet intervalle temporel du «devenir-texte ». Partant de l'hypothèse que le texte final est le résultat, l'aboutissement et la mémoire de ses propres changements, variations et mutations, elle tente de comprendre, à travers l'étude des « traces » laissées par l'auteur de son travail de création, la genèse de l'œuvre.

Les «traces», dans le domaine littéraire sont «les manuscrits de l'œuvre ». Elles sont le «pré-texte » qui raconte l'histoire de l'œuvre, de sa réalisation depuis le moment où l'auteur a entrevu l'idée première de son projet de texte, jusqu'à son état final de texte imprimé.

A concrètement parler, les traces en question sont constitués par tous les documents de travail de l'écrivain : « carnets, plans, scénarios, notes et documentations préparatoires, ébauches, brouillons, mises au net, épreuves corrigées $^{23}$.»

Le passage de la critique génétique du texte à une approche génétique de l'architecture a été rendu possible par l'évolution des préoccupations théoriques en architecture. C'est seulement au moment où l'œuvre finie, donnée à voir pour ce qu'elle est, c'est-à-dire, comme un objet architectural dont la réalité est assimilée à celle d'un objet naturel donné-là et dont l'extériorité au processus de conception est comparée à celle de l'objet naturel vis-à-vis des processus naturels, a cessé d'être le point focal de toutes les recherches théoriques en architecture, qu'un tel rapprochement est devenu possible.

\footnotetext{
${ }^{20}$ Cette façon de faire est habituelle chez Le Corbusier : rappelons-nous le monument dédié au modulor élevé au pied de l'unité d'habitation de Marseille, à travers lequel l'architecte rappelait l'utilisation de son système de mesure dans tout le projet.

${ }^{21}$ Cf. Pierre-Marc De Biasi, 2000 (a).

22 Ibid, p. 17.

${ }^{23}$ Ibid, p. 18.
} 
C'est à ce moment précis que « les coulisses de la création, le secret de fabrication ${ }^{24} »$, de l'objet architectural sont devenus objet de connaissance et qu'il est devenu possible de s'intéresser à la genèse des œuvres, aux processus qui y ont conduit et aux conditions de leur naissance.

Essayer de comprendre les processus créatifs et le travail de conception de l'architecte, ont ainsi accédé à un statut de légitimité et l'approche génétique est venue naturellement répondre aux besoins nouvellement identifiés, avec pour avantages, à la différence des autres chemins théoriques, une vision archivistique systémique, qui ne rejette aucune des composantes du travail de l'architecte de quelque nature soient-elles: graphique, verbale, picturale, textuelle ou autre. En s'intéressant aux traces laissées par l'architecte concepteur entrain de concevoir son œuvre, en prenant en charge la «pré-œuvre », l'approche génétique de l'architecture permet à la fois de :

Situer l'œuvre dans son contexte de création et en donner une lecture plus complète.

Comprendre le mode de travail de l'architecte considéré à l'occasion d'un projet donné avec la possibilité de retrouver son mode de travail global qui pourrait être établi à partir de l'étude génétique d'un certain nombre de ses œuvres..

Comprendre le processus de production et de conception de chaque œuvre, considérée individuellement.

Comprendre les raisons d'être de l'état final de l'œuvre : les motivations des divers choix et décisions prises par l'architecte.

Notre objectif étant ici la compréhension des raisons d'être de l'état final de la «Main Ouverte» de Le Corbusier, une approche génétique de ce travail semble être toute indiquée. Toutefois, nous ne nous en tiendrons pas à une application classique. Parce qu'en fait, l'étude des seuls documents qui ont servi à la conception de l'œuvre ne nous apprendra pas tout ce que nous voudrons savoir, dans ce cas précis. C'est pourquoi, nous utiliserons d'autres documents de l'architecte, même si parfois ils ne portent pas de références directes à l'œuvre en question. Tout comme nous aurons recours à des documents qui n'appartiennent pas directement à l'architecte mais à ses collaborateurs ou à des personnes qui l'ont directement connu ou étudié. Ces documents, cette nouvelle forme plus complexe de «traces » comportera des éléments de natures très diverses. Nous nous intéresserons aux peintures de l'architecte qui pourraient receler des préoccupations communes avec le projet en question. Nous porterons également notre attention sur ses textes écrits qu'ils se rapportent de manière directe au projet considéré ou qu'ils soient d'un ordre plus global, plus générique avec l'intention de comprendre certaines de ses positions philosophiques et théoriques susceptibles de porter un éclairage nouveau sur sa façon de faire.

Il y a également ses carnets de notes ou «carnets d'idées, qui jouent le rôle de «mains courantes » pour l'enregistrement en vrac de « choses vues » (...), ce sont des réserves, des « garde-penser » où l'on emmagasine des images, des croquis et des notes par provision, pour l'avenir généralement sans finalité immédiate ${ }^{25}$.»

Les carnets de voyage « pleins de dessins-mémoires ${ }^{26}$ » sont également une pièce maitresse du puzzle. Tout comme le sont les entretiens verbaux accordés par l'architecte qu'ils concernent directement l'œuvre en question ou des préoccupations qui lui sont contingentes.

\footnotetext{
${ }^{24}$ Pierre-Marc de Biasi, 2000 (b), p.8.

${ }^{25}$ Op. Cit., 2000 (a), p.45.

${ }^{26}$ Ibid.
} 


\section{Analyse de l'œuvre}

Le monument est placé au long de l'esplanade de 400 mètres qui relie le Bâtiment de l'Assemblée à celui de la justice. Il est placé au cœur de la ville de Chandigarh. Il se compose de deux parties essentielles : la Fosse de la Considération profonde de 4.79 mètres et large de 25.07 mètres au dessus de laquelle « se dresse » la Main Ouverte, haute de 16 mètres.

L'emplacement est à première vue classique : quoi de plus normal qu'un monument au centre de la ville ? Mais telle n'est peut-être pas la seule raison. Parce qu'en fait, cette partie terrestre ou devrai-je dire terrienne du monument: la Fosse de la Considération, a une fonction. Elle est le lieu de regroupement dans lequel les citoyens peuvent «débattre de la chose publique ». Elle est l'équivalent des deux bâtiments qu'elle prolonge. Sans en posséder la formalité, elle en a la fonction. Elle est la représentation du pouvoir citoyen censé contrebalancer l'autorité officielle des deux autres pouvoirs. Elle est l'agora grecque ou le forum romain réinterprétés et revisités.

Dans son appellation même, la Fosse est l'expression de la restitution du pouvoir aux citoyens. Elle est la Fosse de la Considération : considération des couches populaires et de ce qu'elles pensent.

Quand on connaît la constitution hiérarchisée de la société indienne, la fosse est aussi le lieu de la considération de l'autre : «Des gens s'y réuniront, ceux qui parleront et ceux qui écouteront, debout ou assis (...) ${ }^{27}$ »

Elle est le lieu dans lequel et par lequel, «l'homme devient le conducteur de sa civilisation ${ }^{28}{ }$.

La forme de la fosse de la considération est, à un détail près, similaire à celle des autres bâtiments qu'elle prolonge. Elle est comme eux de forme géométrique pure mais alors qu'ils sont élevés au dessus du sol, elle y est creusée, enfoncée.

Elle en est le négatif.

Elle est l'espace et ils sont le bâti, elle est le vide et ils sont le plein, elle en est le contre-poids.

Le Corbusier a opéré un «déplacement de concepts » si complexe que la fosse de la considération est devenue à la fois l'équivalent du Bâtiment de l'Assemblée qu'elle prolonge et l'expression de ces vieux lieux publics euxmêmes consacrés au débat de la chose publique, que sont l'Agora et le Forum. En faisant jouer ses facultés de réinterprétation et ses stratégies d'innovation par adaptation et réinterprétation de ce qui existe dans la tradition, décrites par Colquhoun ${ }^{29}$, l'architecte a réussi à recréer le lieu public par excellence, mais en l'insérant dans le sol, lui donnant ainsi, comme à la recherche d'une touche personnelle : « une petite contribution personnelle ${ }^{30}$ ", une spatialité différente. Le lieu devient particulier, spécifique, unique. Il n'est pas la place publique, représentée elle par l'esplanade. Ni exactement le Forum ou l'Agora, situés eux au ras du sol, ni le bâtiment de l'Assemblée édifié et élevé au dessus du sol. La fosse de la considération est enfouie dans le sol mais aussi ouverte au ciel. Elle est à la fois intérieure et extérieure. Elle est aussi profonde que l'est la civilisation indienne ${ }^{31}$, mais en étant

\footnotetext{
${ }^{27}$ Le Corbusier, 1953, p.10.

${ }^{28}$ Ibid.

${ }^{29}$ Alain Colquhoun, Recueil d'essais critiques, OPU, Alger, 1985, p.59.

${ }^{30}$ Le Corbusier, op. cit., 1953.

${ }^{31}$ Le Corbusier était profondément conscient de cette réalité et il l'a noté à plusieurs reprises, comme ici dans ce Passage tiré d'une lettre adressée par Le Corbusier à M. Nehru et intitulée "La Main Ouverte », écrite à Chandigarh, le 26-27 novembre 1954 : «Mais l'Inde n'est point un pays tout neuf; elle a vécu les plus hautes et les plus anciennes civilisations. Elle possède une intelligence, une éthique et une conscience. »
} 
abaissée par rapport au sol, elle exprimerait peut-être aussi bien l'état d'une démocratie indienne encore titubante, qui reste à faire (fig.3).

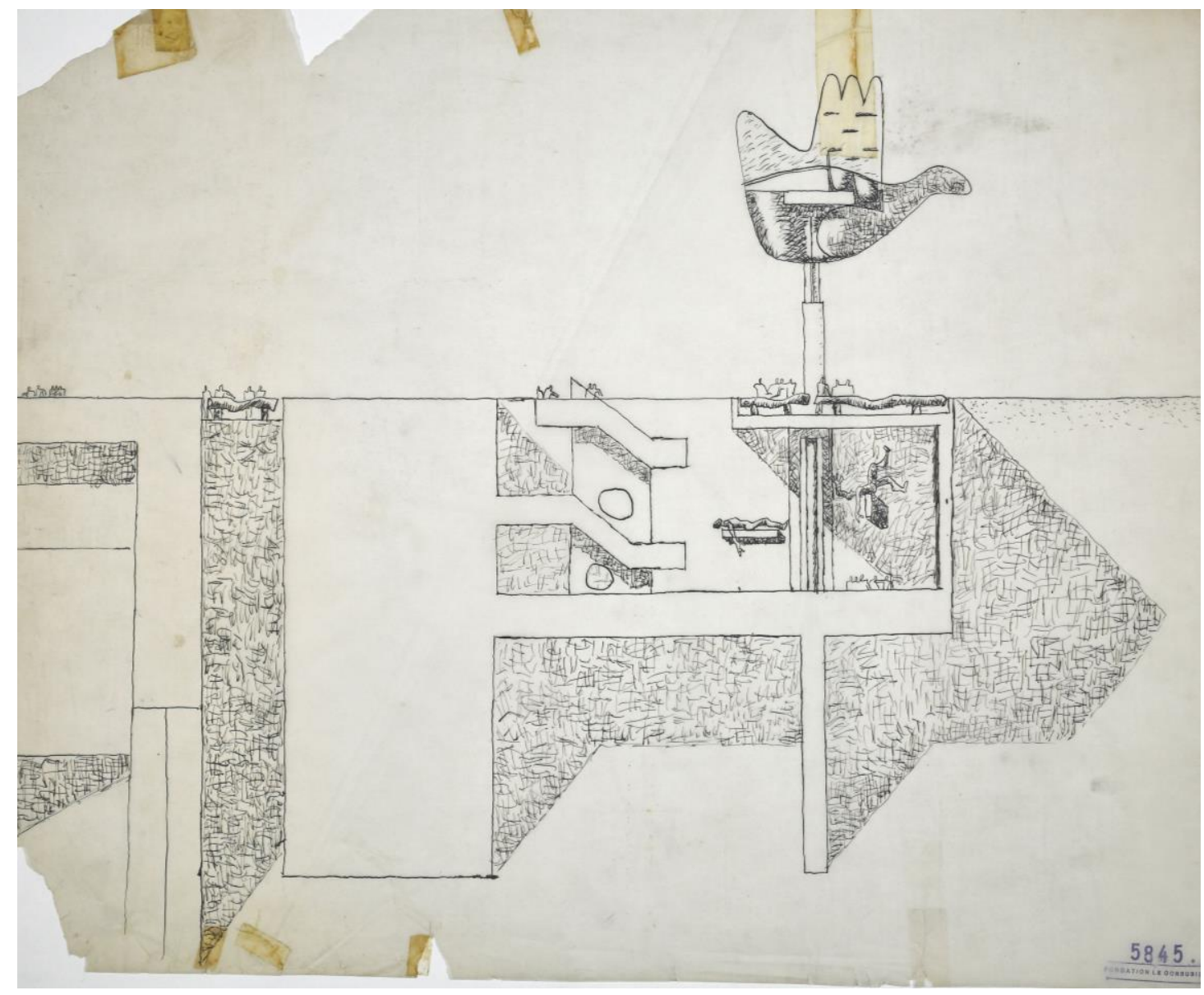

3. Coupe sur la fosse et la main ouverte. Fondation Le Corbusier 5845, @FLC-ADAGP.

Le paradoxe créé par cet enfouissement dans le sol marié au nom de « Fosse de la Considération » est peut-être ce qui fait dire à Le Corbusier qu'il s'agit d'un «drôle de baptême ${ }^{32}$ ».

Les gens placés dans la fosse sont protégés des influences du pouvoir et de l'autorité. Ils ne sont dirigés que par leur souhait d'évoluer et de progresser.

L'ouverture vers le ciel leur rappelle un devoir d'ascendance et la Main Ouverte placée au dessus de la fosse, au dessus d'eux en somme, leur montre le chemin ascendant, elle leur rappelle qu'ils sont maitres de leurs destin : « ils ne verront que le ciel posé sur les quatre bords de la fosse et «la Main Ouverte » haute de 16 mètres ${ }^{33}$. »

L'importance du lieu choisi pour le monument ne s'arrête pas là. Elle n'est pas uniquement bi-dimensionnelle. Elle est surtout tri-dimensionnelle et spatiale. Elle n'est pas uniquement horizontale mais elle reprend le complément naturel de l'horizontalité qu'est la verticale. Parce qu'à cette première relation organique que ce lieu crée entre la fosse et son environnement se superpose une deuxième relation aussi importante qui relie la Main Ouverte, la partie verticale du monument aux éléments naturels du site : «Le Milieu » : l'Himalaya, le ciel, le

\footnotetext{
${ }^{32}$ Le Corbusier, 1953.

${ }^{33}$ Ibid.
} 
soleil et tout ce qui constitue l'horizon (fig.4). La ligne horizontale qui complète la verticale du monument et s'y oppose. Ainsi sont matérialisés les signes sur lesquels sont techniquement conçus l'urbanisme et l'architecture de Chandigarh : «Ces signes sont les phases du jeu joué par l'homme avec les éléments cosmiques : homme et nature. Jeu des nombres, jeux du calendrier et de la journée solaires, jeu du soleil - sa lumière, son ombre, sa chaleur $^{34}$ » et ce sont ces signes qui sont encadré par cette ouverture dans le cube de béton évidé qui supporte la Main.

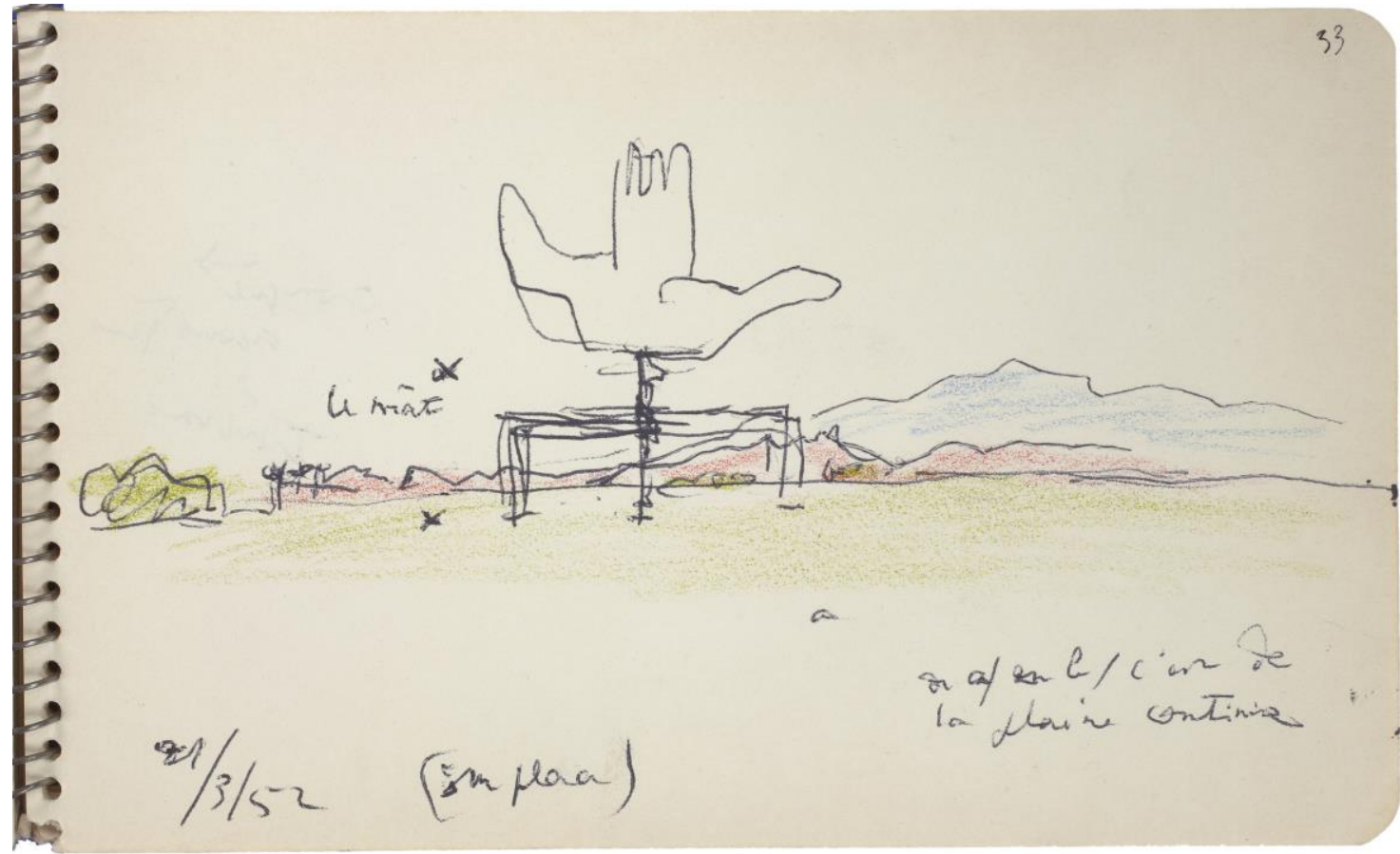

4. La Main Ouverte dans son environnement. Croquis d'étude de Le Corbusier, Carnet F-24, Fondation Le Corbusier, OFLCADAGP.

Partout la relation au milieu est mise en jeu, mise en évidence, et mise en scène : «Me voici parti à la recherche de vérités architecturales plus vastes. Je perçois que l'œuvre que nous élevons n'est ni seule, ni isolée; que l'atmosphère en constitue d'autres parois, d'autres sols, d'autres plafonds, que l'harmonie qui m'a arrêté net devant le rocher de Bretagne existe, peut exister partout ailleurs, toujours. L'œuvre n'est plus faite seulement d'elle-même : le dehors existe. le dehors m'enferme dans un tout qui est comme une chambre ${ }^{35}$. »

Mais ces signes ne sont pas les seuls. Ils en comptent aussi un autre, celui de l'angle droit. Un angle droit qui est partout présent: entre les lignes de la fosse et le mat de la Main, mais aussi entre celui-ci et la ligne des montagnes et celle de l'horizon.

Il est également présent au sein de la fosse carrée et cubique et au sein du cube de béton évidé qui supporte la main et entre ces deux cubes l'un vertical et l'autre horizontal, mais aussi entre le mat et le cube de béton. L'angle droit est également dans le cadre qui traverse le cube de béton pour montrer les éléments naturels en arrière plan, comme pour montrer une forme de relation de l'architecture au milieu.

Mais pourquoi donc l'angle droit?

Poser cette question reviendrait implicitement à se demander pourquoi ces signes ? Et de là à se demander si la main en tant que telle fait partie de ces signes ? Et aussi comment ces signes expriment-ils l'architecture et

\footnotetext{
${ }^{34}$ Ibid.

${ }^{35}$ Ibid.
} 
l'urbanisme de Chandigarh ? Et en poussant le questionnement jusqu'au bout comment ces signes en viennentils à exprimer la façon de faire de Le Corbusier du moment qu'il énonce que le jeu de ces signes synthétise sa façon de voir et de faire l'architecture et l'urbanisme : «Ces signes sont les phases du jeu joué par l'homme avec les éléments cosmiques (...). Ce jeu fut précisément le travail de ma vie depuis toujours. Il gère, me semble-t-il, l'architecture et l'urbanisme ${ }^{36}$.»

\section{L'angle droit}

L'angle droit est pour Le Corbusier l'expression même de l'architecture. Mais bien au-delà, il est la synthèse du monde et de la vie des hommes.

Il est pour l'architecture le lieu de toutes les mesures, la référence suprême et essentielle (fig.5) : «Alors je dessine par deux traits seulement ce lieu de toutes les mesures, et je dis, ayant comparé dans mon esprit nombre d'œuvres humaines, je dis « voici, cela suffit". »

Pour l'architecte, il est un outil. Pour Le Corbusier, il est l'outil par excellence, il est son signe et son choix. Il le classe à l'occasion du « Poème de l'Angle Droit », sous le chapitre «Outil », qui est le dernier chapitre du livre, comme pour en faire une sorte de testament, de legs universel et de manifeste qu'il énonce ainsi :

«On $a$

Avec un charbon

Tracé l'angle droit

le signe

il est la réponse et le guide

le fait

une réponse

un choix

il est simple et nu

mais saisissable

Les savants discuteront

de la relativité de sa rigueur

Mais la conscience

en a fait un signe

Il est la réponse et le guide

le fait

ma réponse

mon choix ${ }^{38}$.»

L'angle droit est pour Le Corbusier «la base de sa pensée architecturale. (...) L'angle droit n'est pas seulement géométrie, mais symbole. Il est chargé de valeur mystique ${ }^{39}$. »

\footnotetext{
${ }^{36}$ Ibid.

${ }^{37}$ Le Corbusier, 1930.

${ }^{38}$ Le Corbusier, 1955.

${ }^{39}$ Wogensky, 1979.
} 
Pour l'homme, l'angle droit est l'expression de sa vie toute entière et de sa mort. Il est le symbole de la station debout qui sert à voir et à agir et de la position horizontale qui sert à dormir et à mourir ${ }^{40}$. Il est le garant de sa relation à la nature et à la vie.

«L'univers de nos yeux repose

sur un plateau bordé d'horizon

La face tournée vers le ciel

considérons l'espace inconcevable

jusqu'ici insaisi.

Reposer s'étendre dormir mourir

Le dos au sol.

Mais je me suis mis Debout!

Puisque tu es Droit

te voilà propre aux actes.

Droit sur le plateau terrestre

des choses saisissables tu

contractes avec la nature Un

pacte de solidarité : c'est l'angle droit

Debout devant la mer vertical

te voilà sur tes jambes ${ }^{41}$. »

\section{La main}

Existerait-il un angle droit sans l'homme ? Sans l'homme y aurait-il possibilité de géométrie ? Il semblerait que non $^{42}$, et Le Corbusier l'a confirmé.

La main est donc tout d'abord symbole de l'homme. Elle est le moyen, l'outil, l'intermédiaire qui relie l'homme à l'univers. Elle permet non seulement d'agir, mais aussi de connaître et de rentrer en contact avec l'univers, avec la nature et avec les choses qui nous entourent.

La main prend, la main perçoit, la main saisit :

«Tendresse!

Coquillage la Mer n'a cessé

de nous en jeter les épaves de

riante harmonie sur les grèves.

Main pétrit main caresse

Main glisse. La main et

la coquille s'aiment ${ }^{43}$.»

\footnotetext{
40 « La mort est la porte de sortie de chacun de nous. Je ne sais pourquoi on veut la rendre atroce. Elle est l'horizontale de la verticale, complémentaire et naturelle. » Lettre de condoléances adressée par Le Corbusier à André Wogensky à l'occasion du décès de son père, in Wogensky, Rome, 1979.

${ }^{41}$ Le Corbusier, op. cit., 1955.

${ }^{42}$ Cf. Serres, 1993.

${ }^{43}$ Le Corbusier, op. cit., 1955.
} 


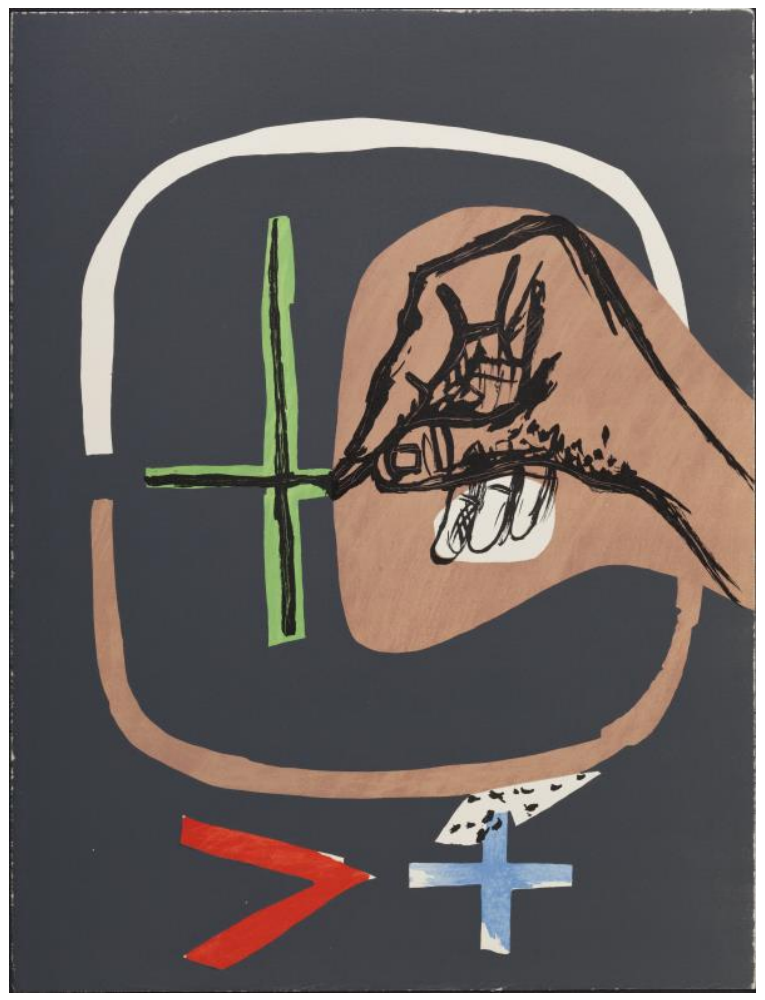

5. L'angle droit. Source : Le Corbusier, 1989, p. 151, OFLC-ADAGP.

La main dessine, la main découvre: la main reçoit. (fig.6)

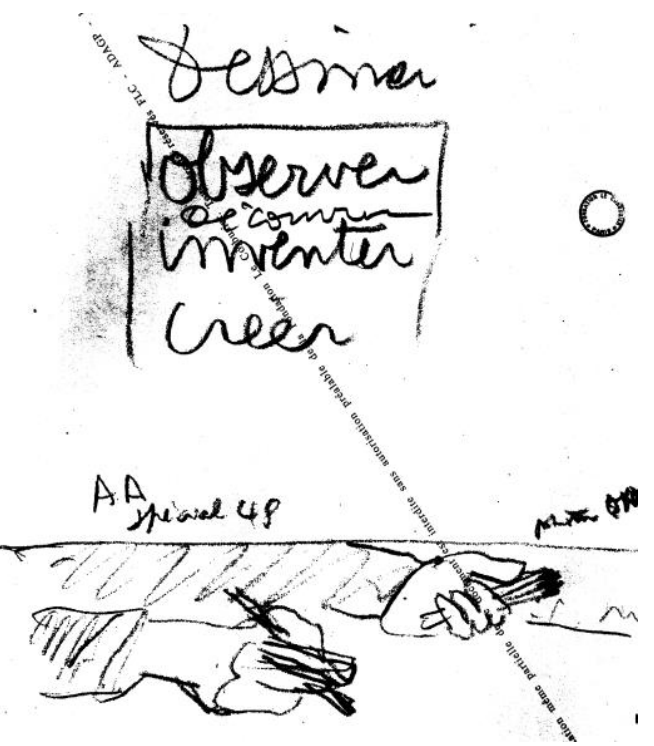

6. La main dessine : elle aide à observer et à découvrir mais aussi à inventer et à créer. Source : Fondation Le Corbusier, CFLC-ADAGP.

La main transmet, la main agit, la main donne : la main offre.

Telle est la main de Le Corbusier, elle est symbole de l'action. L'action de l'homme sur le milieu, sur lui-même, sur le propre de l'homme pour les hommes. La main se saisit, à travers le toucher et le dessin de ce qui existe et le transforme en vue d'offrir à l'humanité une invention nouvelle, différente et unique.

La main est gestes. Elle est geste de déclamation dans le monument à Vaillant-Couturier), mais elle est aussi geste de bénédiction dans la porte de notre Dame de Ronchamp, elle est geste de conciliation dans ce dessin des 
«deux mains gauche et droite aux doigts entrecroisés ${ }^{44}$ », elle est geste de protection, elle est geste de connaissance, elle est geste de création et d'invention, elle est geste de reconnaissance, elle est geste de rencontre et de paix.

«Les mains nous expriment. Les mains dessinent. Les mains palpent la forme. Les mains forment l'objet. Les mains développent ${ }^{45}$.»

C'est pour toutes ces raisons que la main a toujours fasciné Le Corbusier. Il suffit pour cela de faire un tour du coté de ses tableaux et de ses dessins pour voir combien cet organe l'habite (fig. 7, 8,9 et 10). Son livre « Le poème de l'angle droit » est à lui seul un empilement extraordinaire de dessins de mains dans diverses positions.

La main ouverte est en quelque sorte l'aboutissement de cette intense préoccupation. La main quand elle est ouverte est geste de réception et d'offrande.

Elle est la porte de l'esprit (fig.11). Elle permet d'y entrer et d'en sortir. Elle reçoit de partout, de tout et de tous et en donne à tous.

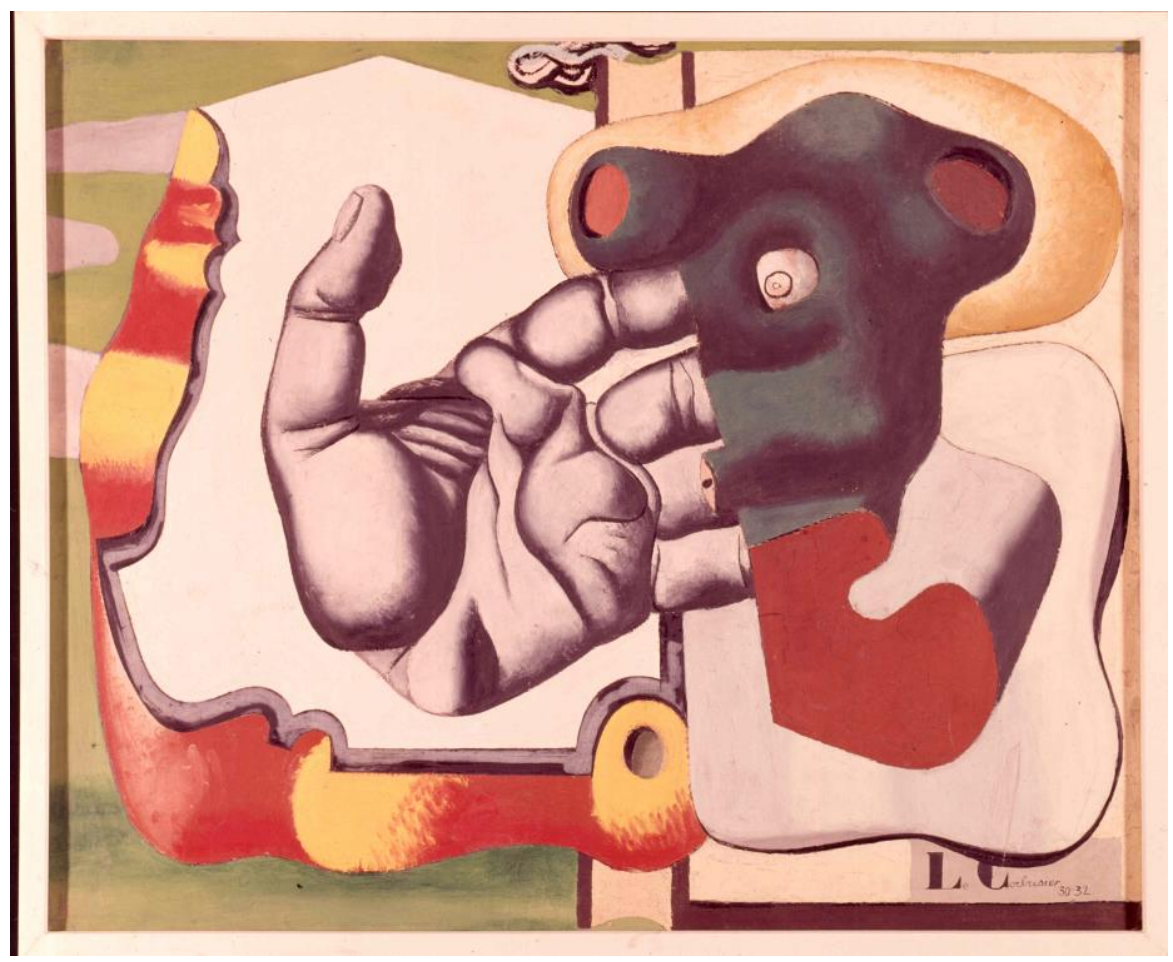

7. La main rouge, 1932, CFLC-ADAGP.

\footnotetext{
${ }^{44}$ Ibid.

${ }^{45}$ Wogensky, 1987.
} 


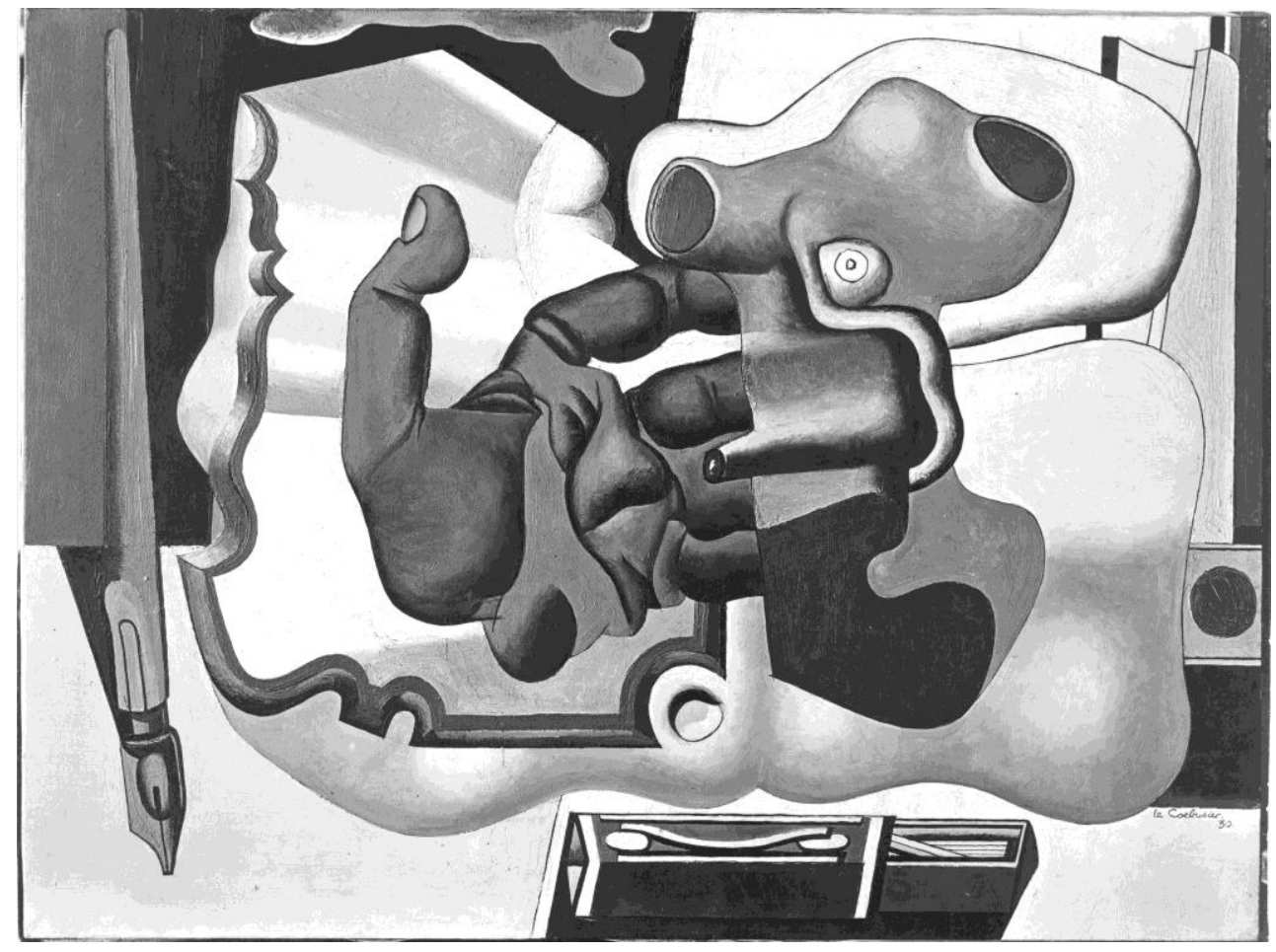

8. La main et le silex, 1943, OFLC-ADAGP.

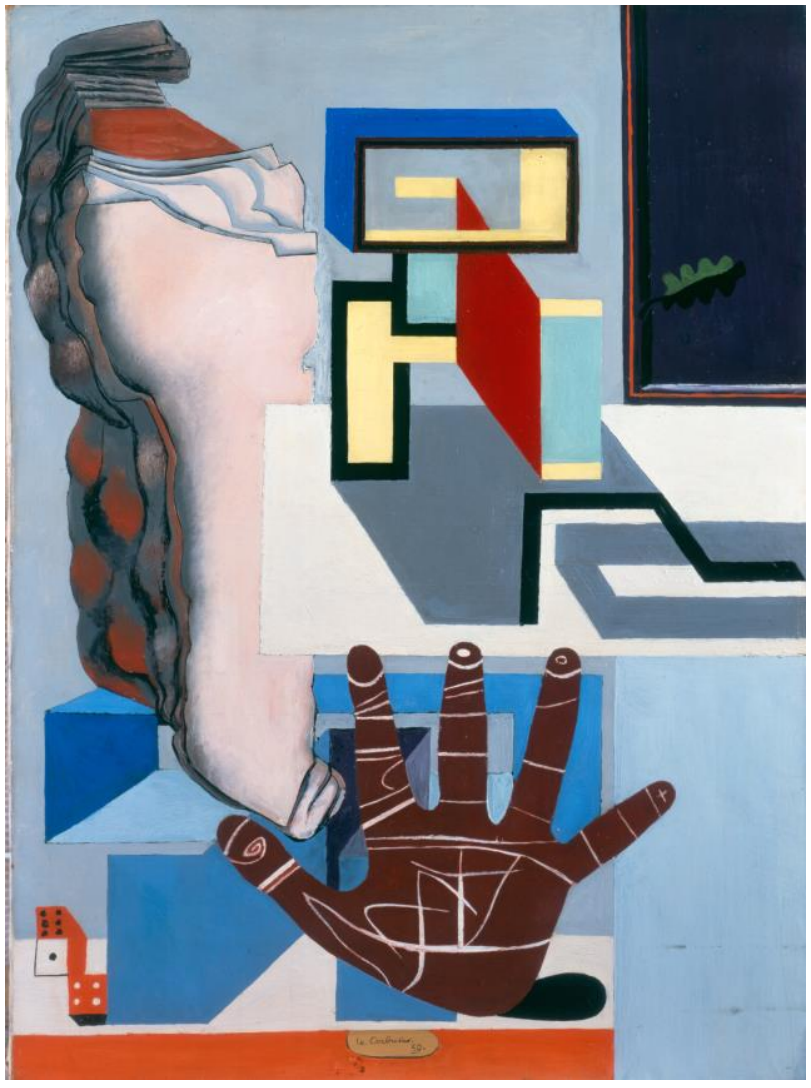

9. Lignes de la main, 1930, (FLC-ADAGP. 


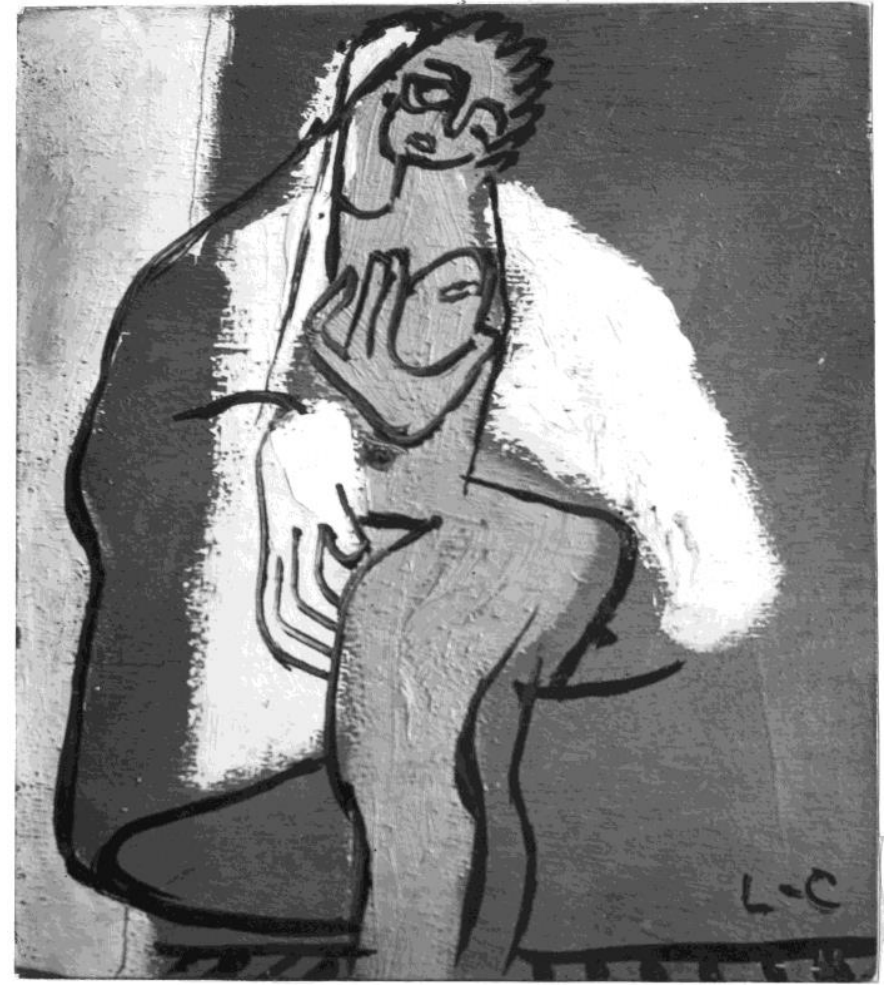

10. Cœur sur la main, 1943, OFLC-ADAGP.

Telle est la main de Chandigarh :

«Ouverte pour recevoir

Ouverte aussi pour que chacun

y vienne prendre

Les eaux ruissellent

le soleil illumine

Les complexités ont tissé

leur trame

les fluides sont partout.

Les outils dans la main

Les caresses de la main

La vie que l'on goûte par

le pétrissement des mains

La vue qui est dans la

\section{Palpation}

Pleine main j'ai reçu

pleine main je donne ${ }^{46}$ »

Symbole aussi d'une Inde dont la main est «ouverte pour recevoir les richesses créées, ouverte pour les distribuer à son peuple et aux autres ... » ${ }^{47}$.

\footnotetext{
${ }^{46}$ Le Corbusier, op. cit., 1955.

${ }^{47}$ Le Corbusier, lettre à Nehru, Chandigarh, 26-27 novembre 1954, p.2.
} 


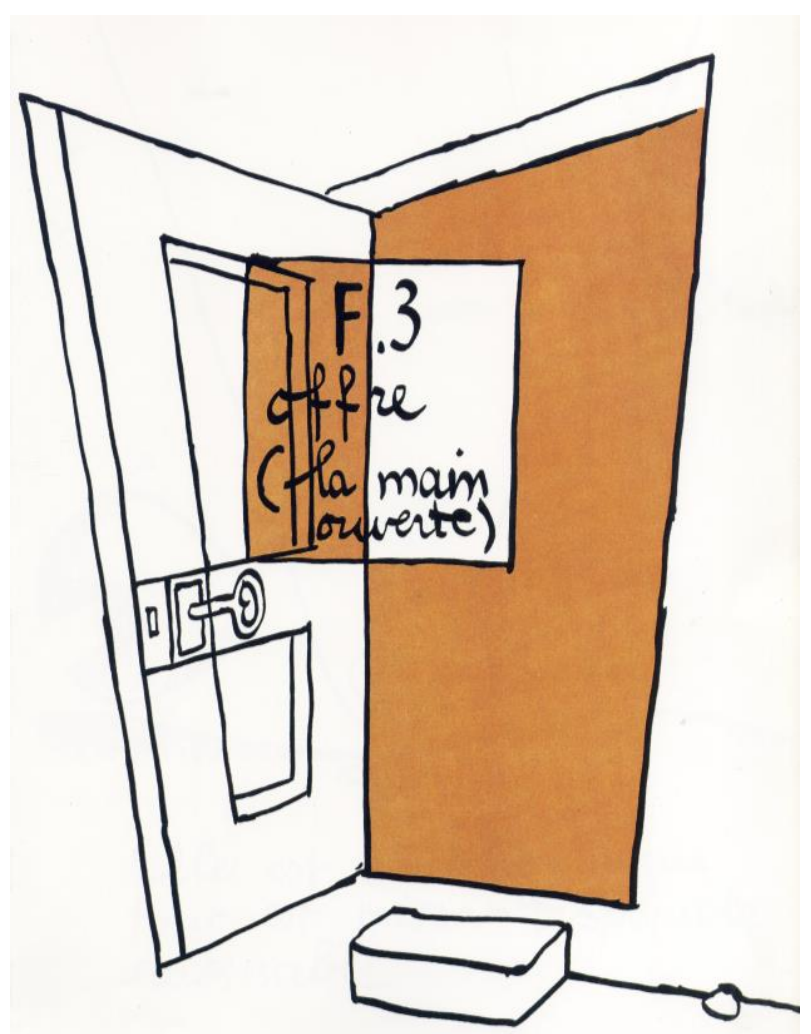

11. la main ouverte, la main offre. Elle est porte de l'esprit. Source : Le Corbusier, 1989, p.141. OFLC-ADAGP.

Son histoire a commencé en 1948, tel que le dit Le Corbusier dans les notes qu'il a faite de sa première rencontre avec Nehru: «J'ajoute depuis 1948, je suis obsédé par le symbole de la main ouverte j'aimerai pouvoir le placer au bout du capitol devant l'Himalaya. (...) J'ai pensé qu'au moment où le monde moderne jaillit en illimitées richesses intellectuelles et matérielles, il fallait ouvrir la main pour recevoir et pour donner ${ }^{48} . »$

Son idée en tant qu'œuvre architecturale est «née à Paris, spontanément, ou plus exactement comme suite à des préoccupations et à des débats intérieurs venus du sentiment angoissant des désharmonies qui séparent les hommes si souvent et en font des ennemis. Un premier croquis apparaît, spontanément-une espèce de coquille flottant au dessus de l'horizon: mais des doigts écartés montrent une main ouverte comme une vaste conque. Plus tard, l'année suivante, dans un hôtel de la Cordillère des Andes, l'idée revient, prenant une forme différente ; ce n'est plus une conque, mais un écran, une silhouette ${ }^{49}$.»

C'est ainsi qu'est venu au monde le projet de la Main Ouverte de Chandigarh. Une silhouette de main ouverte, inscrite dans un carré (fig.12), placée au dessus d'un autre carré que creuse un carré et qui est lui-même posé au dessus d'un carré enfoncé dans le sol. Vue de dessus, elle rappelle un autre symbole si cher à Le Corbusier qu'est le bateau et vue de face, elle rappellerait presque une colombe (fig. 13).

\footnotetext{
${ }^{48}$ Le Corbusier, extrait du carnet de notes : Première entrevue avec M. Nehru

${ }^{49}$ Le Corbusier, op. cit., 1953.
} 


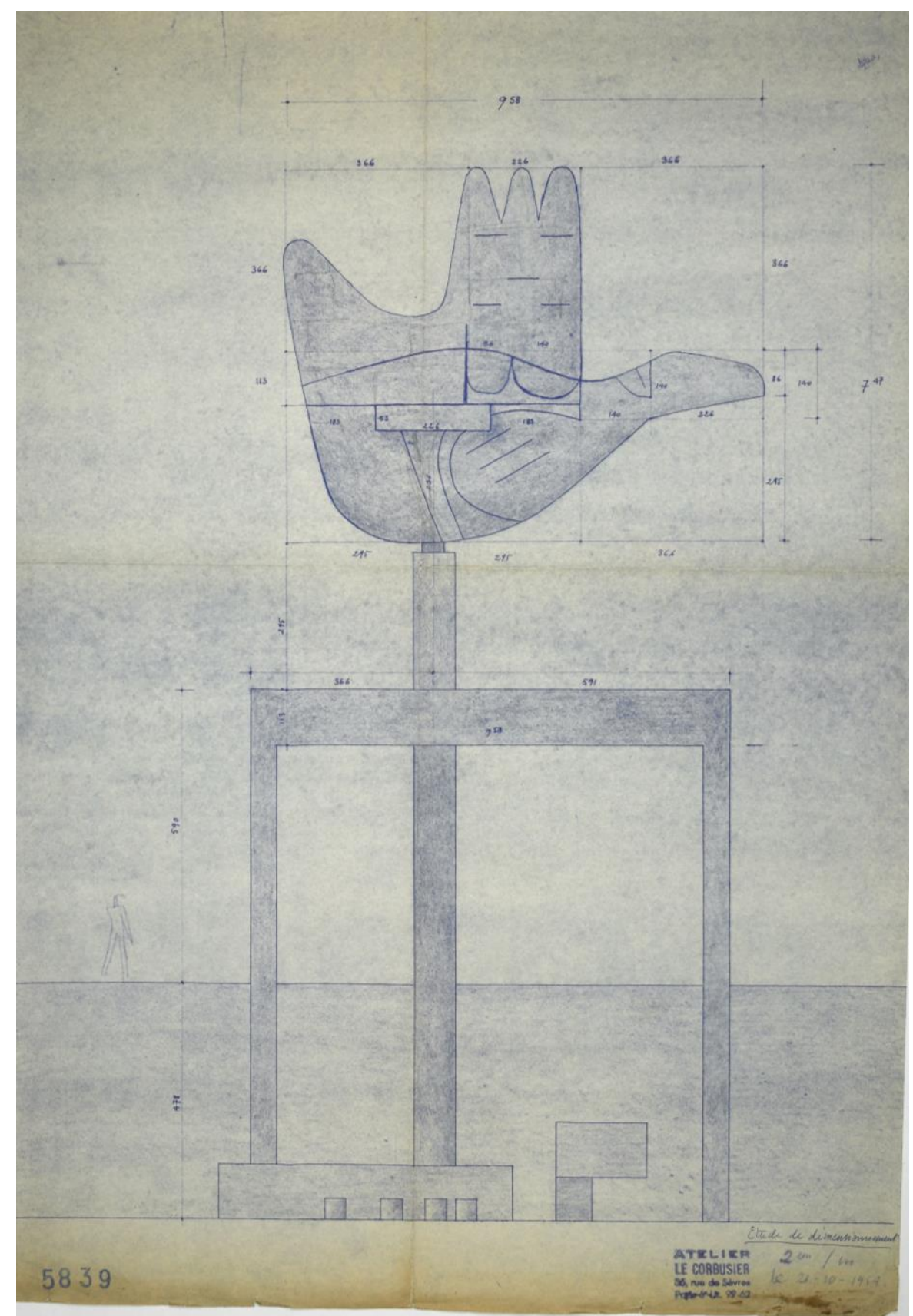

12. La main inscrite dans le carré, Fondation Le Corbusier, 5839, OFLC-ADAGP.

Mais tout ceci reste secondaire.

Ce qui est cependant important, c'est que cette main faite de fer pur martelé monté sur une charpente de bois, «tel qu'il est employé par les Indiens en dinanderie pour la confection des cruches contenant l'eau des puits. Art habile et ferme de rivetage et de soudure des plaques de $\mathrm{fer}^{50}{ }$, tourne aux vents sur un roulement à billes. « «la Main» s'orientera selon le vent du jour. Attitude qui ne symbolise pas la girouette opportuniste. Au contraire : symbole de la prise en considération des faits de la réalité quotidienne ${ }^{51}$. »

\footnotetext{
${ }^{50}$ Ibid.

${ }^{51}$ Ibid.
} 
Le Corbusier a intégré le mouvement dans son monument. Par ce geste il a intégré le temps et le changement au sein même de l'être architectural. Il a fourni à l'architecture la seule dimension qui lui manquait jusque là. D'une préoccupation fort ancienne déjà

exprimée à travers le monument à Vaillant-Couturier conçu en fonction d'une perception séquentielle, il a fait une réalité architecturale. Avec cette création, l'architecture cesse d'être un simple témoin du temps pour se «mouvoir » en un acteur du temps, à part entière.

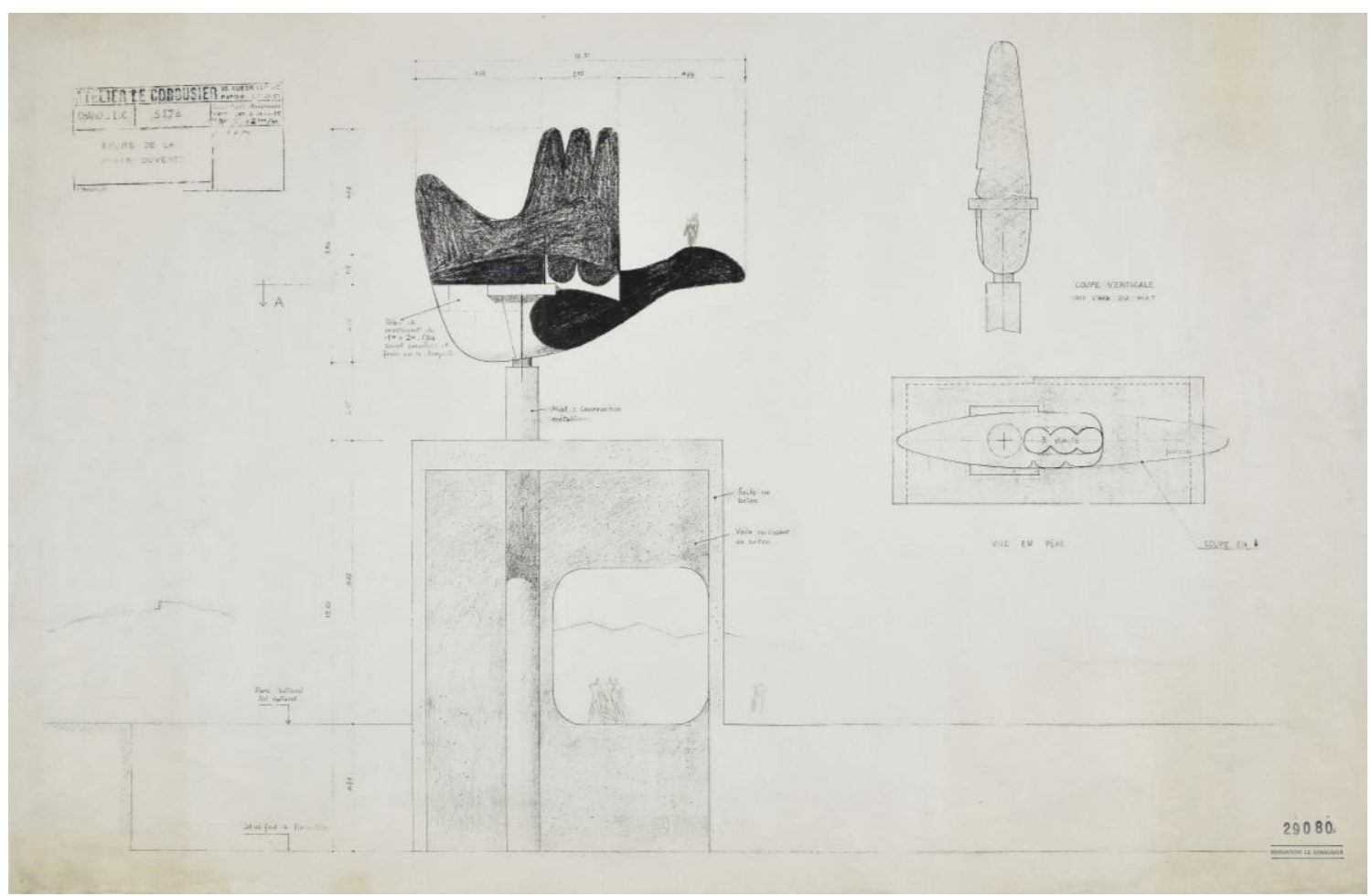

13. La main ouverte vue de face et de dessus. Fondation Le Corbusier 29080, OFLC-ADAGP.

\section{Conclusion}

La «Main Ouverte » a non seulement intégré toutes les données du paradigme moderne de la modernité : absence de commande officielle, réinterprétation de la dimension constructive, dissolution des masses, géométrisation et spatialisation, mais elle l'a surtout poussé jusqu’à son apogée.

A travers la main Ouverte, Le Corbusier est retourné aux origines de l'architecture humaine et en a bouclé la boucle: «Finalement l'enclos du trou et le signe dressé sur la plaine sont les deux modes fondamentaux qui définissent un espace : le totem et la clairière, l'objet focal et le vide ceint (...). Ils sont ici réunis en un seul anneau construit de la géométrie pure ${ }^{52}$. »

Le Corbusier a monumentalisé pour lui-même en s'efforçant de créer une synthèse pour l'œuvre de sa vie, mais il a également et surtout monumentalisé à la gloire du genre humain et des hommes qui travaillent, qui innovent, qui inventent et qui créent pour le plaisir des autres, tels des acrobates.

${ }^{52}$ Ch. De Portzamparc, 1987. 


\section{ACROBATE}

«Un acrobate n'est pas un pantin

Il consacre son existence à une activité

par laquelle en danger de mort permanent,

il réalise des gestes hors série, aux limites

de la difficulté, et de la rigueur

de l'exactitude, de la ponctualité ... quitte

à se rompre le cou, à se briser les os, à

s'assommer.

Personne ne l'en a chargé

Personne ne lui doit gratitude quelconque

Mais, lui, il est entré dans un

univers hors série, celui de l'acrobatie.

Résultat : bien sûr! Il fait des choses

que les autres ne peuvent faire.

Résultat : Pourquoi fait-il cela? se

demande autrui : c'est un prétentieux, c'est

un anormal ; il nous fait peur; il nous fait pitié ;

il nous embête ${ }^{53}$ ! »

\section{Remerciements}

Les auteurs tiennent à remercier la Fondation Le Corbusier pour les avoir autorisé à faire usage, à titre gracieux, des images ici introduites.

\section{Bibliographie}

Colquhoun, Alain, Recueil de textes choisis. Alger : OPU, 1985.

De Biasi, Pierre-Marc (a), Pour une approche génétique de l'architecture, in Genesis, №14, 2000. Montréal : Centre Canadien d'Architecture (CCA), pp.13-64.

De Biasi, Pierre-Marc (b), La clarté des archives, in Genesis, $\mathrm{N}^{\circ} 14,2000$. Montréal : Centre Canadien d'Architecture (CCA), pp.7-12.

De Portzamparc, Christian, in Pierre Mardaga (Ed.), CORBU vu Par, 1987. Liège.

De Portzamparc, Christian, L'architecture est d'essence mythique, in actes du colloque Ville, forme, symbolique, pouvoirs, projets. Liège : Editions Pierre Mardaga, 1986.

Divorne, Françoise, Entre événement et mémoire : la monumentalité contemporaine, in actes du colloque Ville forme symbolique pouvoirs projets. Liège : Editions Pierre Mardaga, 1986.

Hegel, Esthétique. Textes choisis. Paris : PUF, 1953.

Le Corbusier, «La Main Ouverte », lettre à Nehru, Chandigarh, 26-27 novembre 1954. Paris : Fondation Le Corbusier.

Le Corbusier, Carnet F-24. Paris : Fondation Le Corbusier.

${ }^{53}$ Le Corbusier, 1948. 
Le Corbusier, Le poème de l'angle droit, 1955, réédition 1989. Paris : Fondation Le Corbusier et éditions Connivences.

Le Corbusier, Euvres complètes 1946-52. Zurich : Editions d'architecture (Artemis), 1953, $7^{\text {th }}$ ed., 1976.

Le Corbusier, Précisions sur un état présent de l'architecture et de l'urbanisme, collection de l'Esprit Nouveau. Paris : Editions G. Grès et Cie, 1930.

Le Corbusier, Quand les cathédrales étaient blanches. Paris : Plon, 1937.

Rykwert, Joseph, Construction du corps et souvenir de la ville, in actes du colloque Ville forme symbolique pouvoirs projets. Liège : Editions Pierre Mardaga, 1986.

Serres, Michel, Les origines de la géométrie, Collection Champs. Paris : Editions Flammarion, 1993.

Tzonis, Alexander, Le Corbusier. Poétique, machines et symboles. Royaume Uni : Editions Hazan, 2001.

Wogensky, André, in Pierre Mardaga (Ed.), CORBU vu Par, 1987. Liège. 


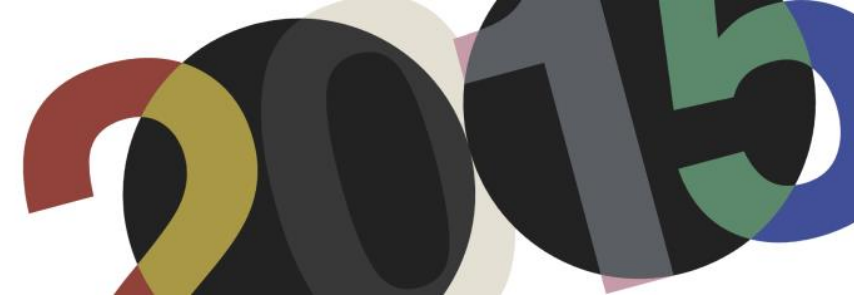

DOI: http://dx.doi.org/10.4995/LC2015.2015.679

\title{
Architecture as machine; Towards an architectural system for human well-being
}

\author{
P. Atmodiwirjo, Y. A. Yatmo
}

Department of Architecture, Faculty of Engineering, Universitas Indonesia

\begin{abstract}
Le Corbusier's well-known phrase 'The house is a machine for living in' suggested a kind of machinic aesthetic that became an important concept behind the functionality, standardization and rational order that together laid the foundation of modern architecture. This paper attempts to expand on Le Corbusier's idea of machine by particularly examining architecture as a machinic system and how it could potentially depict spatial qualities that fulfill their functional purpose for human well-being. The idea of machine became a way to introduce scientific and logical reasoning as the basis of designing architecture through the establishment of standards. There were, however, some criticisms against the idea of machine since it tends to dehumanize, by assuming that human being had the same basic needs that could be standardized. This paper attempts to highlight that the establishment of standard becomes necessary, not in generating standard architectural forms but in defining the performance standard of architecture for human well-being.
\end{abstract}

Resumen: Conocida frase de Le Corbusier 'The house is a machine for living in'sugiere una especie de estética maquínica que se convirtió en un concepto importante detrás de la funcionalidad, la normalización y el orden racional que juntos sentó las bases de la arquitectura moderna. En este trabajo se intenta ampliar la idea de Le Corbusier de máquina en particular examinar la arquitectura como un sistema maquínico y cómo se podría llegar a representar cualidades espaciales que cumplan su propósito funcional para el bienestar humano. La idea de la máquina se convirtió en una forma de introducir el razonamiento científico y lógico como base de diseño la arquitectura a través del establecimiento de normas. Hubo, sin embargo, algunas críticas contra la idea de la máquina, ya que tiende a deshumanizar, asumiendo que el ser humano tenía las mismas necesidades básicas que podrían ser estandarizados. Este trabajo trata de poner de relieve que el establecimiento de la norma hace necesario , no en la generación de formas arquitectónicas estándar, pero en la definición de la norma de rendimiento de la arquitectura para el bienestar humano.

Keywords: machine; system; standard; well-being; users.

Palabras clave: máquina; sistema; norma; bienestar; usuarios.

\section{Introduction}

The idea of architecture as machine was proposed by Le Corbusier particularly through his well-known statement 'The house is a machine for living in.' This phrase appeared in his writing Toward A New Architecture $^{1}$ to illustrate his argument that architecture should be designed in a way that refers to the engineers' working methods in problem solving and that it should be designed in accordance to standards. The idea that house should be designed following the same logic as the machine has led to the establishment of standardization in architecture, which Le Corbusier then also further extended into the standardization at the city scale. ${ }^{2}$ This paper attempts to expand on Le Corbusier's idea of machine by particularly examining how it could potentially depict the way architecture fulfills its functional purpose for human well-being.

\footnotetext{
${ }^{1}$ Le Corbusier. Towards a new architecture, New York: Dover Publication, 1986, p. 107

${ }^{2}$ Evenson, Norma. Le Corbusier: The machine and the grand design, London: Studio Vista, 1969
} 
The idea of machine was not exclusively proposed by Le Corbusier. Various works in architecture and other related disciplines has addressed both the abstract and concrete meanings of the machinic concepts, such as Guattari's desiring machine ${ }^{3}$ and Daniel Libeskind's reading, memory and writing machines ${ }^{4}$. Some works took further the idea of machine in architecture through the concepts such as mechanics and appliances, such as Nicholson's appliance house ${ }^{5}$ and Banham's idea of house as an ensemble of mechanical gadgetry ${ }^{6}$. These works suggest that the idea of machine involves the mechanisms of interface, complexity and causality, and therefore it provokes some critical ways of comprehending the relationship between elements involved in a system. To compare these ideas of machine with Le Corbusier's statement regarding architecture as machine is of course beyond the scope of this paper. Nevertheless these examples suggest the continuous attempts to think of architecture in a metaphoric way by referring to various properties associated with the machine.

Architecture as a machine could be understood as an assemblage of elements, as constituting different parts that together make up the whole system, as described in the following: 'To see dwelling as a machine in the manner of Deleuze and Guattari would also be essentially to make the same point as Le Corbusier: it would be an assemblage of elements coming together in a consistency, namely, the boundary of a dwelling. ... The house is something that is made up of a collection of elements which become significant when made into a whole. ...Both these notions of the machine, therefore, imply a form of determinism based on the material, of the machine as a limiting and containing form, which imposes an order and an organisation forced by the coming together of its constituent elements. ${ }^{7}$

This paper intends to further examine how Le Corbusier's idea of machine could explain how architecture is developed and realized as a working system, particularly to cater for the needs of its users. The relationship between the users and architecture incorporates complex relations that involve various bodily aspects of spatial experience, comfort and ergonomics as well as human desire and emotion. These are the bodily aspects that to some extent determine the well-being of the inhabitants. This paper argues that the idea of machine becomes a way to introduce scientific and rational approach as a basis of designing architecture through the establishment of standards, especially in designing domestic living space. The establishment of standard will be discussed by taking reference to some of Le Corbusier's writing and works, particularly The Manual of the Dwelling ${ }^{8}$ that indicate the importance of standard in responding to the basic needs of human being. Meanwhile, there are some criticisms that the establishment of standard tends to assume that human being has the same basic needs that could be standardized. The paper will conclude that the establishment of standard becomes necessary, not in generating standard architectural forms but in defining the performance standard of architecture, which is eventually to promote the well-being of the users.

\footnotetext{
${ }^{3}$ Guattari, Felix. "On machines". Journal of Philosophy and the Visual Arts, 1995, vol. 6, pp. 8-12

${ }^{4}$ Ioannidou, Ersi. "Humanist machines: Daniel Libeskind's 'Three lessons in architecture”". In Bandyopadhyay, Soumyen et al (Eds.) The humanities in architectural design: A contemporary and historical perspective. Routledge: London, 2010, pp. 81-90

${ }^{5}$ Nicholson, Ben. Appliance house. MIT Press, 1990

${ }^{6}$ Banham, Reyner. "A home is not a house". Art in America, 1965, vol. 2, pp. 70-79

${ }^{7}$ King, Peter. In dwelling: Implacability, exclusion and acceptance. Hampshire, Ashgate, 2008, p. 50

${ }^{8}$ Le Corbusier. Towards a new architecture, New York: Dover Publication, 1986, p. 107
} 


\section{The establishment of architectural standard}

For Le Corbusier, the machine is a metaphor for architecture, through which the idea of functionality was established. The purpose of creating architecture as a machine for living is achieved by establishing a standard, with the primary goal to create order in human life and living space. 'The key modern principle for Le Corbusier was function, and this is where the machine metaphor is so important. The idea of the house as a machine is that it fulfills a specific function. ${ }^{, 9}$ In relation to architecture, Le Corbusier emphasized that in order to fulfill its functions, architecture should be consistently guided by certain standard. The establishment of standard is considered important because it would allow human to live better in a more orderly way, thus it becomes an important foundation from which good architecture could emerge.

The basis of defining the standard was the functionality. The idea of architecture as a machine indicated the importance of science and logic as a basis of designing architecture. Le Corbusier referred to the way engineers work in creating airplanes, automobiles and other machines; each problem was stated explicitly, and thus could be responded appropriately and correctly by the solutions. There was a logical process that existed beyond the creation of engineering products; 'the lesson of the airplanes lies in the logic that governed the enunciation of the problem and which led to its successful realization. When a problem is properly stated, in our epoch, it inevitably finds a solution. ${ }^{10}$ This is the way architecture should be created - through logical reasoning and establishment of standards. The standards were not established arbitrarily but through logical and scientific reasoning. 'A standard is established on sure bases, not capriciously but with the surety of something intentional and of a logic controlled by analysis and experiments... The establishment of standard involves exhausting every practical and reasonable possibility..."11 The above statement suggested a scientific way of thinking and its importance in the design process of architecture.

The idea of standard in architecture was developed by Le Corbusier through his project Maison Citrohan. The name Citrohan referred to Citroên, suggesting the idea that the house should be designed and produced as automobiles. ${ }^{12}$ Maison Citrohan was produced as a prototype of housing with standard building elements (Figure 1). The windows, doors and other elements should follow certain dimensions. The idea of standardization was further realized in many other projects such as the housing at Pessac, where the standardization of building elements became a method to achieve cheap and quick production of houses. All the dimensions of the doors, metal windows, roller blinds, staircases and fittings were all standardized and incorporated into the modular design process. ${ }^{13}$

\footnotetext{
${ }^{9}$ Ibid, p. 48

${ }^{10}$ Le Corbusier, Towards a new architecture, p. 110

${ }^{11}$ Ibid, p. 136

${ }^{12}$ Von Moos, Stanislaus, Le Corbusier: Elements of a synthesis, Rotterdam: 010 Publishers, 2009

${ }^{13}$ Tim Benton, 'Pessac and Lege revisited: Standards, dimensions, and failures." In B. B. Taylor (ed.), Le Corbusier et Pessac, Paris: Fondation Le Corbusier, 1972
} 

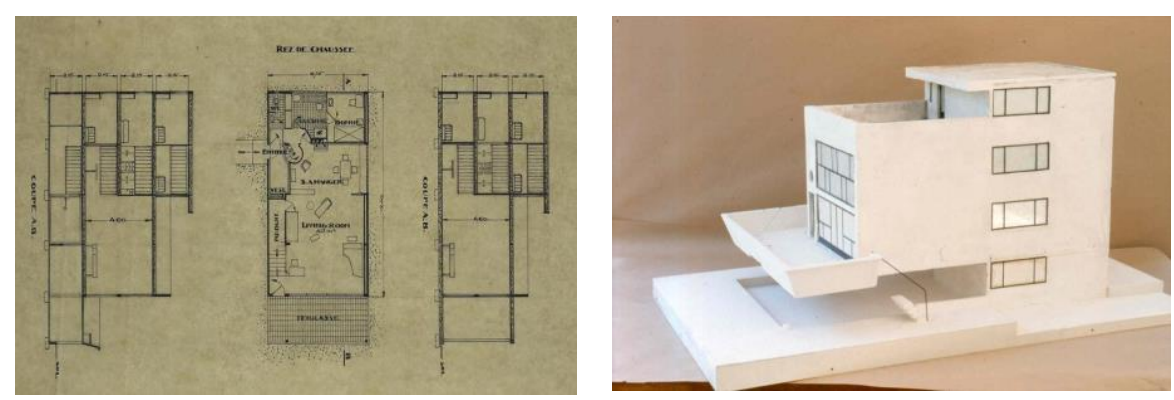

1. The model and plans of Maison Citrohan (Fondation Le Corbusier, image no. 20711 @ FLC-ADAGP).

The importance of such standards was further elaborated by Le Corbusier in the 'Manual of the Dwelling. ${ }^{, 14}$ In this manual, he listed the requirements of the house so that it could cater for the functional, everyday needs of the inhabitants. The manual was emerged from his criticism against inefficiency, uselessness of elements and other design mistakes that he observed in many of the houses at that period of time. He argues that the houses were not designed appropriately for modern living. As he stated: 'The existing plan of the dwelling-house takes no account of man and conceived as furniture store ${ }^{, 15}$ and thus a manual of dwelling is desperately needed. Included in this manual were the requirements and the elements that should be demanded by the house inhabitants, from the space requirements of the bedroom, bathroom, kitchen and living room, the needed household elements and furniture, and some other requirements.

The list was somewhat arbitrary, since it appears as 'a strange combination of functions, outcomes and aesthetic qualities. ${ }^{16}$ This arbitrarily could be observes in a portion of the following manual texts: 'If you can, put the kitchen at the top of the house to avoid smells. Demand concealed or diffuse lighting. Demand a vacuum cleaner. Buy only practical furniture and never buy "decorative” pieces. If you want to see bad taste, go into the houses of the rich. Put only a few pictures on your walls and none but the good ones. ${ }^{17}$ In this example, 'to avoid smells' suggested the desirable condition for certain space, while 'demand concealed or diffuse lighting' referred to certain kind of lighting that is preferable - there was further explanation of why this kind of lighting was preferable somewhere else in the book. The suggestion 'demand a vacuum cleaner' had nothing to do with the design of the house but more on the needs for daily maintenance for cleanliness. Meanwhile the suggestion on the furniture and decoration refers to his disapproval against 'the house of the rich' which was usually full of decorative pieces with the walls full of pictures.

Observing the whole manual, we could observe that the list included the space requirements as well as suggestions of how to arrange the spaces: it included the desirable condition of the space as well as the suggestion of elements that should be provided. Nevertheless the manual had illustrated the importance of various functions that should be fulfilled by the dwelling in order to perform appropriately as human living space. Through the manual, Le Corbusier demonstrated how programmatic functionality became the main consideration from where the standardized requirements were derived and then used to design a proper house for living. This programmatic functionality incorporated the requirements for the space and the interior elements, the

\footnotetext{
${ }^{14}$ Le Corbusier, Towards a new architecture, pp. 122-123

${ }^{15}$ Ibid, p. 122

${ }^{16} \mathrm{King}$, In dwelling: Implacability, exclusion and acceptance, p. 49

${ }^{17}$ Le Corbusier, Towards a new architecture, p. 123
} 
standards for use and maintenance, as well as the economic propriety, which altogether defined what Le Corbusier conceived as the proper way of living for the modern era. ${ }^{18}$

\section{Standard for comfort and health}

Le Corbusier argued that the establishment of standard was a logical way to address the problem. Each of the requirements that were demanded in the Manual of the Dwelling illustrated an aspect of the dwelling space, and it was established for logical reasons and to address certain problems. The major problems identified by Le Corbusier, as he further explained, were primarily related to comfort and health. The demands for physical comfort constantly appeared in his works, especially in the established requirements for an open plan design which allowed for light and air to come through. It also appeared in the Manual of the Dwelling: 'the house is only habitable when it is full of light and air. ${ }^{19}$ Such openness as spatial properties was then developed into what was called the form language of modern architecture: 'One of the more important attributes of modern architecture style was the freedom it gave architects to plan the interior areas of buildings without regard to the previous conventions... With the new style, architects could open whole wall surfaces to light and air. ${ }^{20}$ The introduction of modern materials that allowed for larger span of space also meant possibility to have more open space design, which was open to light and air that functioned to provide comfort for the inhabitants.

The establishment of the standard for comfort was also developed in relation to the ergonomics of the furniture design. The idea of architecture as machine for living was extended to the furniture - 'Chairs are made to sit in. ${ }^{21}$ Le Corbusier emphasized the importance that chair should be appropriate for human body sitting on it, and he criticized the existing chairs in the houses, which did not give the best position for sitting. He attempted to understand different types of chairs in relation to human body ergonomics, ${ }^{22}$ and came up with a prototype of chair which he defined as appropriate - with attachment to hold a coffee cup, with a footrest, and with the body of chair adjustable to different positions depending on the sitting purpose. His works on furniture design indicated his attempts to state the problem of comfort in sitting and then to develop a logical solution to respond to such needs of comfort.

The establishment of architecture as machine with many standardized requirements was related not only to individual bodily comfort but also related to the wider issues of healthy living. 'Le Corbusier's famous machine a habiter was not only a machine for living in, but a technologically enhanced medical machine for healthier living. ${ }^{23}$ Many of the standards were necessary to be established in order to create architecture for healthy living. Architecture was considered essentially as a machine that could provide human with a new, hygienic environment for living. ${ }^{24}$ Awareness of how the climatic surrounding may affect the space became important. This was demonstrated for example in the works of Le Corbusier that incorporated the solarium to capture the

\footnotetext{
${ }^{18}$ Klingman, Anna. "Eyes, which do not see: Liners, airplanes, automobiles", Architectural Theory Review, vol. 9 no. 1 , 2004, pp. 19-35

${ }^{19}$ Ibid, p. 123

${ }^{20}$ Newman, Oscar. “Whose failure is modern architecture?” In Mikellides, Byron (Ed.), Architecture for people, New York: Holt. Rinehart \& Winston, 1980, p. 46

${ }^{21}$ Le Corbusier, Towards a new architecture, p. 117

${ }^{22}$ Benton, Charlotte, "Le Corbusier: Furniture and the interior". Journal of Design History, vol. 3, no. 2/3, 1990, p. 113

${ }^{23}$ Rault, Jasmine. Eileen Gray and the design of sapphic modernity: Staying in. Surrey, England: Ashgate, 2011, p. 34

${ }^{24}$ Smith, Wally \& Lewi, Hannah. "The magic of machines in the house," The Journal of Architecture, vol. 13, no. 5, pp. 633-660
} 
health benefits of sunshine, ${ }^{25}$ and those that explored the solar geometry in relation to the orientation of the design to capture the benefit of the light and air. ${ }^{26}$ Some of the spatial ideas of modern architecture were assumed to have been associated with the attempts to combat tuberculosis at that time, by providing access to light, air and sun through various architectural features: flat roofs, terraces, balconies, summer houses and reclining chairs. ${ }^{27}$ Some analytical diagrams were produced to indicate his concern towards the importance to establish the architectural system that could work to promote human comfort and healthy living.

It becomes clear that one of the main purposes in establishing the standard for architecture was to set criteria for architecture to function or perform appropriately to achieve human comfort and health and hygiene. The logical reasoning that became the basis of functional thinking was very useful in defining the problems and developing solutions as logical responses to the problems. Le Corbusier had demonstrated such scientific way of thinking in solving the problem of the dwelling at that time, and he attempted to create new modern living spaces which were governed by standards in order to achieve comfort, health and ergonomics of human as the users of architecture. Architecture as machine provided an idea of how architectural elements could become parts of a machinic system that responded to the problems of bodily comfort, ergonomics and health. However, it also raised a more fundamental question on the extent to which machinic properties of standardization could intersect with bodily-related purposes of architecture, in order to promote the role of architecture for human well-being, and we will turn to this issue in the following section.

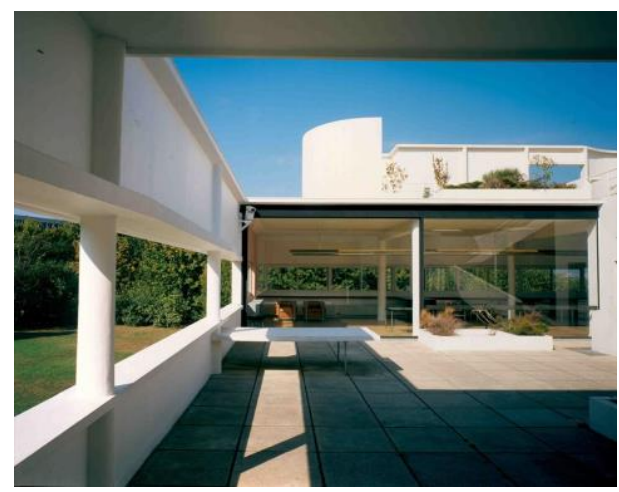

2. Some features of modern architecture that promote human comfort and health (Photo by Paul Kozlowski, Fondation Le Corbusier @FLC-ADAGP).

\footnotetext{
${ }^{25}$ Sully, Nicole. "Modern architecture and complaints about the weather, or, 'Dear Monsieur Le Corbusier, It is still raining in our garage...." M/C Journal, Vol. 12, No. 4, 2009

${ }^{26}$ Mackenzie, Christopher. "Le Corbusier in the sun", The Architectural Review, June 2011

${ }^{27}$ Campbell, Margaret. "What tuberculosis did for modernism: The Influence of a curative environment on modernist design and architecture, Medical History, vol. 49, 2005, pp. 463-488
} 

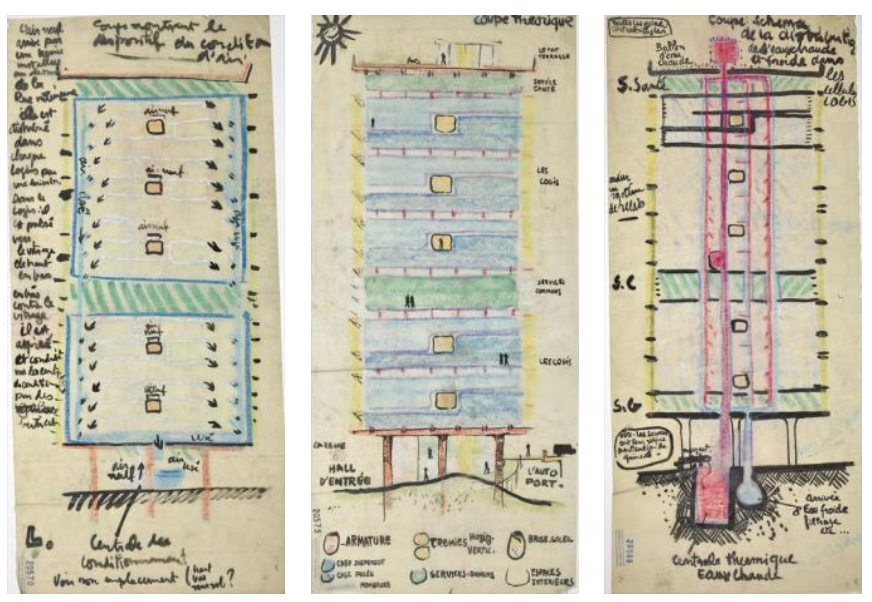

3. Analytical diagrams of Unite d'Habitation showing concern towards human comfort (Fondation Le Corbusier, image no. 20570, 20575 and 20586 @FLC-ADAGP).

\section{Standard for architectural performance for well-being}

Further debates in architectural theories and practices have extensively questioned and criticized the approach of modern architecture that was mainly directed by standards and functional order, while human inhabitants have different social, cultural and behavioral needs and characteristics. 'The effect, as well as the aim, of this machinic metaphor is to denigrate the human subject. In Le Corbusier's work it is about stressing uniformity, regularity and function. ${ }^{28}$ There is a danger that such standardization may result in the ignorance of many humanistic aspect of architecture. The idea of architecture of machine was led to several generalizations: 'firstly, that a wellstated problem naturally finds its solution; secondly, that since all men have the same biological organization, they all have the same basic needs; and thirdly, that architecture, like machinery, should be a product of competitive selection applied to standards which, in turn, should be determined by logical analysis and experimentation. ${ }^{29}$

This criticism on the generalization embedded in the machine idea, however, was also countered by some arguments such as: 'modern architecture becomes a subject of humanism. ... Based upon the expression of rational conditions and functional needs, it became as independent, free and even emotional as any work ever created by man - therefore approachable from the humanistic point of view. ${ }^{30}$ This argument suggested the possibility to consider the position of architecture as machine from humanistic approach, rather than simply taking into account its mechanistic and standardized aspects. Understanding humanistic side of architecture becomes very important since the architecture and design also needs to have a role as an instrument of "social engineering" that could impact on the improvement of the society and human behavior. ${ }^{31}$

This paper attempts to argue that within Le Corbusier's idea of architecture as machine, manifested through standardization, it is possible to situate the human body as an integral part of architecture as the machine for

\footnotetext{
${ }^{28} \mathrm{King}$, In dwelling: Implacability, exclusion and acceptance, p. 50

${ }^{29}$ Collins, Paul. Changing ideals in modern architecture 1750-1950. London: Faber and Faber, 1965, p. 165

${ }^{30}$ Zucker, Paul. "The humanistic approach to modern architecture," The Journal of Aesthetics and Art Criticism, vol. 2, no. 7, 1943, p. 26

${ }^{31}$ Abel, Chris. Architecture, technology and process. London: Routledge, 2004, p. 63
} 
living. There seemed to be a relational interaction between human body and architecture beyond the standardized requirements of the dwelling. Le Corbusier clearly emphasized that the ultimate goal of the standards was to achieve human well-being: 'Where order reigns, well-being begins. ${ }^{32}$ The form language of modern architecture was essentially the attempts to link the expression of materiality of architecture with the well being of the buildings users. ${ }^{33}$ This was manifested mainly through formal language that emphasized on the spatial qualities that were conducive to human comfort, ergonomics and health. In other words, the standards became the way to guarantee the performance of architecture in functioning for human well-being.

The most often criticism against the idea of architecture as machine is that of the tendency of the machine to dehumanize. This is particularly attributed to the standards that tend to assume the same needs for every human. Standardization of architecture would lead to the standardization of human life. '...standardization became a way of life, where not only products and work processes were standardized for the first time but also people's daily routines, desires, and leisure activities. ...it failed to include the individual expression of consumers. ${ }^{34}$ In establishing the standards, Le Corbusier took position in understanding human needs within the context of modern life. This was done mainly by criticizing the spatial qualities that according to him were not appropriate to the modern living. He argued that the old way of living was no longer appropriate: 'the modern world we live in which has changed the whole manner in which humans should relate to the built environment. ${ }^{35}$ Thus architecture should also be designed in accordance to the new way of living, which Le Corbusier defined as the way of living that was more efficient and healthier.

It becomes necessary to address the issue of whether standardization of architecture could be assumed to fulfill the various needs of human. It is possible to examine whether there are any components of the dwelling that could be deemed as basic and general - thus assumed to be the same for all human being. There were some basic necessities that needed to be satisfied for all human organisms in order to survive, and these eventually led to the needs for controlling the environmental condition to fulfill these basic needs. ${ }^{36}$ Some requirements existed on how the dwelling should fulfill human needs at the most basic level of physiological comfort and health. Physiological comfort and health is something that could be explained scientifically, by referring to certain physical conditions of architecture that match the needs of comfort and health. Some examples in Le Corbusier's Manual of the Dwelling were: 'One wall to be entirely glazed, opening if possible on to a balcony for sun baths' and 'Demand ventilation panes to the windows in every room. ${ }^{37}$ These recommendations suggested the elements of architecture that were crucial to maintain physiological comfort and health of the inhabitants.

Thus the idea of human basic needs which Le Corbusier responded to by establishing the standards referred to human basic needs that could be assumed the same for every organisms - those that were related to basic physiological needs of comfort and health. This is where the standardization of architecture could play its important role, in defining the spatial quality that could not be compromised. Establishment of standards becomes possible (and also necessary) for certain aspects of architecture. These basic human needs are those that

\footnotetext{
${ }^{32}$ Le Corbusier, Towards a new architecture, p. 54

${ }^{33}$ Newman, "Whose failure is modern architecture?" p. 58

${ }^{34}$ Klingman, "Eyes, which do not see: Liners, airplanes, automobiles", pp. 29-30

${ }^{35} \mathrm{King}$, In dwelling: Implacability, exclusion and acceptance, p. 48

${ }^{36}$ Broadbent, Geoffrey. Design in architecture: Architecture and the human sciences. London: David Fulton Publishers, 1988, p. 138-154.

${ }^{37}$ Le Corbusier, Towards a new architecture, p. 123
} 
are inevitable requirements towards human well-being, since they become the prerequisite before the other needs - that are more psychological, social, or cultural - could be fulfilled.

Le Corbusier, however, also established standards that were more relevant to the needs other than the basic physiological needs. For example, he recommended certain way of orderly living with no clutter and certain taste of art and aesthetics: 'Put only a few pictures and none but the good ones. Keep your odds and ends in drawers or cabinets. The gramophone or the pianola or the wireless will give you exact interpretation of first-rate music... ${ }^{38}$ These recommendations had different nature from those that intended to establish standards for physiological comfort and health. These seemed to be the standards that could be easily criticized since every human may have different understanding of what was orderly living and had different aesthetical taste. It is important to address this kind of recommendation wisely in order to leave enough rooms for individual aspiration, which is also important for human well-being.

The establishment of standards that became the important aspect in the idea of architecture as machine could be understood as Le Corbusier's attempts to generate architecture as a system to fulfill the functional needs of human being. Standards are necessary for some aspects of architecture that could not be compromised, especially those related to human physiological comfort, ergonomics and health, which were also a prerequisite for human well-being. Architecture as machine becomes a system that could promote the interaction between human body and architecture, through the establishment of standards. Standards were established not merely to achieve generalization or uniformity of architectural forms or to achieve cheap and quick production, but to ensure the performance of architecture that promotes human comfort, ergonomics and health. Architecture as machine is essentially a standardized systems of architecture, which were established for the ultimate purpose for the wellbeing of its inhabitants.

\section{Acknowledgements}

This paper was supported by the funding from Cluster Research Grant, Universitas Indonesia, 2015.

\section{Bibliography}

Abel, Chris: Architecture, technology and process. London: Routledge, 2004.

Banham, Reyner: "A home is not a house". Art in America, vol. 2, 1965. pp. 70-79.

Broadbent, Geoffrey: Design in architecture: Architecture and the human sciences. London: David Fulton Publishers, 1988.

Benton, Charlotte: "Le Corbusier: Furniture and the interior," Journal of Design History, vol. 3, no. 2/3, 1990. pp. 103-124.

Campbell, Margaret: "What tuberculosis did for modernism: The Influence of a curative environment on modernist design and architecture," Medical History, vol. 49, 2005. pp. 463-488

Collins, Paul: Changing ideals in modern architecture 1750-1950. London: Faber and Faber, 1965.

Evenson, Norma: Le Corbusier: The machine and the grand design. London: Studio Vista, 1969.

Guattari, Felix: "On machines". Journal of Philosophy and the Visual Arts, vol. 6, 1995. pp. 8-12.

\footnotetext{
${ }^{38}$ Le Corbusier, Towards a new architecture, p. 123
} 
Ioannidou, Ersi. "Humanist machines: Daniel Libeskind's 'Three lessons in architecture'”. In Bandyopadhyay, Soumyen et al (Eds.) The humanities in architectural design: A contemporary and historical perspective. Routledge: London, 2010. pp. 81-90.

King, Peter: In dwelling: Implacability, exclusion and acceptance. Hampshire: Ashgate, 2008.

Le Corbusier: Towards a new architecture. New York: Dover Publication, 1986.

Mackenzie, Christopher: "Le Corbusier in the sun”, The Architectural Review, June 2011.

Newman, Oscar: "Whose failure is modern architecture?" In Mikellides, Byron (Ed.): Architecture for people. New York: Holt. Rinehart \& Winston, 1980. pp. 44-58.

Nicholson, Ben: Appliance house. MIT Press, 1990.

Rault, Jasmine: Eileen Gray and the design of sapphic modernity: Staying in. Surrey, England: Ashgate, 2011.

Smith, Wally \& Lewi, Hannah: "The magic of machines in the house," The Journal of Architecture, vol. 13, no. 5, pp. 633-660.

Tim Benton: "Pessac and Lege revisited: Standards, dimensions, and failures.” In B. B. Taylor (ed.), Le Corbusier et Pessac. Paris: Fondation Le Corbusier, 1972.

Sully, Nicole: "Modern architecture and complaints about the weather, or, 'Dear Monsieur Le Corbusier, It is still raining in our garage...." M/C Journal, vol. 12, no. 4, 2009.

Von Moos, Stanislaus: Le Corbusier: Elements of a synthesis, Rotterdam: 010 Publishers, 2009.

Zucker, Paul: "The humanistic approach to modern architecture," The Journal of Aesthetics and Art Criticism, vol. 2, no. 7, 1943. pp. 21-26. 


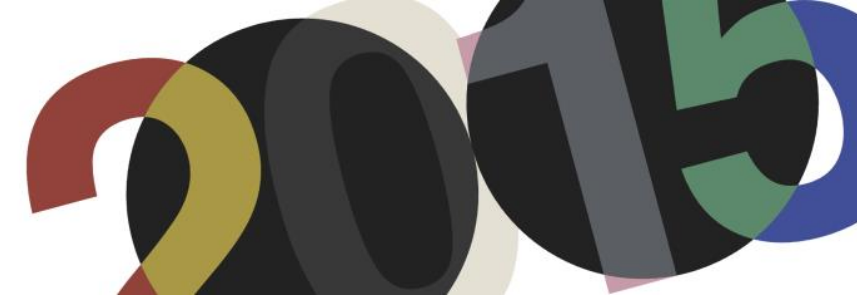

DOI: http://dx.doi.org/10.4995/LC2015.2015.674

\section{La construcción de lo inefable}

\section{A. Baladrón Carrizo}

Escuela Técnica Superior de Arquitectura de la Universidad Politécnica de Madrid

Resumen: La caja B3-7 de la Fondation Le Corbusier recibe el nombre de "Ouvrage: L'Espace indicible”, y contiene los documentos relativos a un libro, nunca publicado, sobre el que Le Corbusier estuvo trabajando desde 1953 hasta 1961. Ante una nueva era que comenzaba tras la II Guerra Mundial, expresaba la voluntad de una nueva forma de apropiación del espacio por medio de la Síntesis de las Artes en búsqueda de la emoción estética. La búsqueda de lo inefable se convirtió en el objetivo común del proceso creativo de todas las disciplinas artísticas que practicó. Un concepto que va más allá del formulado en los "Cinco puntos para una nueva arquitectura», y que hace necesario el conocimiento del mismo para completar la comprensión de su obra. Pero, ¿cómo explicar aquello que no puede ser contado por medio de la palabra? Esto solo es posible a través de su forma de entender el Arte, la 'manière de faire', cuyo fin es provocar una emoción inexpresable.

En este artículo se pretende mostrar la relevancia del concepto de espacio inefable en la obra de Le Corbusier mediante un análisis de los documentos de la caja FLC B3-7, así como de la obra arquitectónica y plástica en la época en la que trabajó sobre este concepto. Se establecerá un diálogo entre los procesos técnicos (tekné) y los procesos del pensamiento (logos) de este periodo para exponer los elementos que utilizó para construir lo inefable.

Abstract: The box B3-7 at the Fondation Le Corbusier is named "Ouvrage: L'Espace indicible". It contains several documents related to an unpublished book that Le Corbusier was working out since 1953 until 1961. After the Second World War, he shows a new way of taking possession of space throughout the Synthesis of the Arts, and looking for the aesthetical emotion. The search for the ineffable became the common target of the creative process of different art disciplines. A new concept of space beyond the one generated by the "Five points for a new architecture", that it is necessary to know to understand his work. But, how to explain something that it is not possible to be describe by words? This is only possible by his understanding of the Art, 'la manière de faire', which its goal is to provoke an inexpressible emotion.

This article try to show the relevance of the concept of ineffable space in the work of Le Corbusier by the analysis of the documents of the box FLC B3-7, as well as the architectural and plastic work that treats this concept. It will be established a dialogue between technical processes (tekné) and thinking processes (logos) during this period to expose the elements used by him to build the ineffable.

Palabras clave: Le Corbusier; inefable; emoción; arte; espacio; Síntesis.

Keywords: Le Corbusier; ineffable; emotion; art; space; Synthesis. 


\section{Introducción}

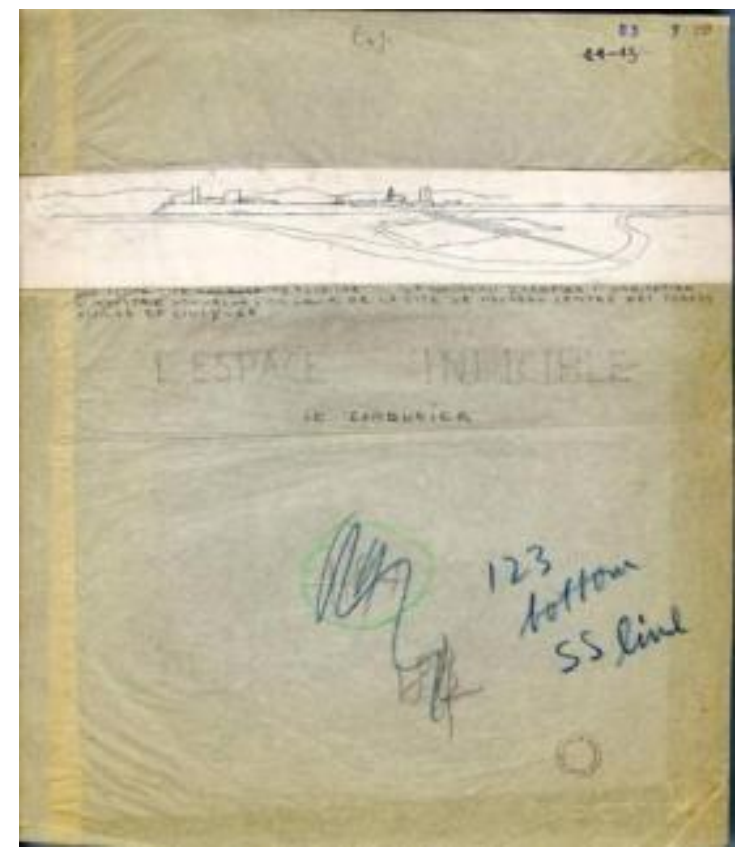

1. Borrador de la portada del artículo L'Espace indicible. B3(7)99 @FLC-ADAGP.

El 13 de septiembre de 1945, apenas un mes después de la finalización de la II Guerra Mundial, Le Corbusier escribe el primer manuscrito para un artículo que sería publicado en Abril de 1946 en el número especial Art de la revista L'Architecture d'Aujourd'hui. El título de este artículo fue ' $L$ 'Espace indicible", . Aunque el primer título del texto, el cual aparece tachado en los manuscritos iniciales fue 'Tomar posesión del espacio'. Lo que en el artículo se dice esencialmente es que la clave de la emoción estética es una función espacial común a todas las expresiones artísticas, la Arquitectura, la Pintura y la Escultura. Es una llamada hacia la Síntesis de la Artes.

"El texto debe ser situado por el lector en su justo lugar",2. Así comienza el encabezamiento del texto. Durante el periodo posterior a la II Guerra Mundial se da la paradoja de que la humanidad tiene el deseo y la necesidad de fundar nuevas ciudades, como no había ocurrido desde el siglo XIII, pero por el contrario, los hechos acontecidos durante la guerra, hacen que ella misma tome conciencia de que puede autodestruirse. Por ello, existe un consenso universal en el deber de restaurar los valores perdidos: la escala humana, los derechos del individuo y la seguridad más rudimentaria del movimiento dentro de la ciudad ${ }^{3}$. Esta civilización tiene en común una concepción del espacio que forma parte de su actitud, tanto emocional como espiritual. El objetivo de la arquitectura era entonces la organización de formas en el espacio: la nueva concepción del espacio-tiempo. Esta concepción del espacio había sido transformada por las vanguardias pictóricas a principios de siglo mediante la introducción de la cuarta dimensión, el tiempo. En el artículo se contradicen las tesis planteadas durante la época

\footnotetext{
${ }^{1}$ Le Corbusier, "L’Espace indicible”, en L'Architecture d'aujourd'hui, número especial “Art”. París: 1946. pp.9-17; También en Le Corbusier, manuscrito, 13 Septiembre 1945, FLC, B3.7.210-224; mecanografiado, FLC, B3.7.239-246; mecanografiado con notas manuscritas, FLC, B3.7.507-511 y mecanografiado, FLC, B3.7.255-274.

${ }^{2}$ Le Corbusier, L'Espace indicible, idem.

${ }^{3}$ Giedion, Sigfried: Espacio, tiempo y arquitectura: origen y desarrollo de una nueva tradición. Cambridge (Massachussetts): Harvard University Press, 1969. Barcelona: Ed. Reverté 2009. p. 18.
} 
purista en la que Le Corbusier se cuestionaba la existencia de esta cuarta dimensión ${ }^{4}$. Por aquel entonces, calificaba de absurdo pretender expresar otras dimensiones que las que perciben nuestros sentidos. Sin embargo, en el artículo reconoce que su vida, consagrada al arte y a la búsqueda de la armonía, le ha permitido observar el fenómeno a través de la práctica de las tres artes: arquitectura, escultura y pintura.

“Apropiarse del espacio es el primer gesto de los seres vivos, de los hombres y de las bestias, de las plantas y de las nubes, una manifestación fundamental de equilibrio y de vida. La primera prueba de la existencia consiste en habitar el espacio.

La flor, la planta, el árbol, la montaña están en pie, viven en un medio. Si un día nos dejamos atraer por su actitud verdaderamente tranquila y soberana es porque, aunque separados de su contenido, provocan resonancias a su alrededor. Sensibles a tanta unión natural, nos detenemos y contemplamos, emocionados por todas las concordancias que orquestan tal cantidad de espacio. Entonces advertimos lo deslumbrante que es todo lo que vemos.

La arquitectura, la escultura y la pintura dependen específicamente del espacio y están ligadas a la necesidad de gestionarlo, cada una mediante sus propias herramientas. Lo que aquí se dirá es, esencialmente, que la clave de la emoción estética es una función espacial.

Acción de la obra (arquitectura, escultura o pintura) sobre su entorno: ondas, gritos o clamores (el Partenón en la Acrópolis de Atenas), los trazos que brotan como por radiación, como accionados por un explosivo; el lugar, próximo o lejano, se ve sacudido, afectado, dominado, acariciado.

Reacción del medio: los muros de la obra, sus dimensiones, el lugar con el peso diverso de sus fachadas, las extensiones o las pendientes del paisaje y hasta los horizontes desnudos de la llanura o los crispados de las montañas, todo el ambiente influye sobre ese lugar donde se halla la obra de arte, signo de una voluntad humana, a la que impone sus profundidades o sus salientes, sus densidades severas o vagas, sus violencias y sus suavidades. Se presenta un fenómeno de concordancia, exacto como una matemática, verdadera manifestación de acústica plástica, si se nos permite denominar así uno de los órdenes de fenómenos más sutiles, portador de alegría (la música) o de opresión (el estruendo).

Sin la menor pretensión, hago una advertencia relativa a la «magnificación» del espacio que los artistas de mi generación abordaron siguiendo el impulso tan prodigiosamente creador del cubismo, hacia 1910. Hablaron de la cuarta dimensión, con mayor o menor intuición y clarividencia, poco importa. Una vida consagrada al arte y, particularmente, a la búsqueda de una armonía, me ha permitido observar a mi vez el fenómeno a través de la práctica de las tres artes: arquitectura, escultura y pintura.

La cuarta dimensión parece ser un momento de evasión ilimitada, producida por una consonancia excepcionalmente justa de los medios plásticos empleados y desencadenada por ellos.

No es un efecto del tema elegido, sino una victoria de la proporción en todas las cosas, tanto en los aspectos físicos de la obra como en la eficiencia de las intenciones, reguladas o no, aprehendidas o inaprensibles y, no obstante, existentes y deudoras de la intuición, milagro catalizador de saberes adquiridos, asimilados aunque tal vez olvidados. Pues en una obra concluida con éxito hay masas intencionales ocultas, un verdadero mundo que revela su significado a quien tiene derecho, es decir, a quien lo merece.

Se abre entonces una profundidad sin límites que borra los muros, expulsa las presencias contingentes y realiza el milagro del espacio inefable.

\footnotetext{
${ }^{4}$ Le Corbusier y Ozenfant, A. Aprés le Cubisme, edition des Commentaires. París, Octubre 1918. Traducido en Ozenfant/Le Corbusier. Acerca del cubismo. Escritos 1918/1926. El Croquis Editorial, col. Biblioteca de Arquitectura. Madrid, 1993. pp15-16.
} 
Ignoro el milagro de la fe, pero vivo a menudo el del espacio inefable, cúspide de la emoción plástica.

En calidad de investigador, he sido autorizado a hablar en estos apuntes de mis experiencias personales en las artes mayores, desgraciadamente disociadas o desunidas entre sí desde hace un siglo. Pero el paso del tiempo y de los acontecimientos conducen ahora, indudablemente, hacia una síntesis entre arquitectura, escultura y pintura.

Quien aborda la arquitectura (esa que nosotros entendemos y no la de las academias) debe ser un artista plástico impecable y un conocedor viviente y vivaz de las artes. Hoy en día, cuando el arquitecto ha devuelto al ingeniero una parte de su trabajo y de su responsabilidad, el acceso a la profesión sólo debería consentirse a personas debidamente dotadas del sentido del espacio, una facultad que el método sintético de diagnóstico de la personalidad tiene la responsabilidad de revelar.

Privado de este sentido, el arquitecto pierde su razón de ser y su derecho a existir. Por lo tanto, es una cuestión de higiene social mantener a ese tipo de candidatos alejados del mundo de la construcción.

Las imágenes que inspiran estos apuntes muestran el deseo incesante de apropiarse del espacio mediante arquitecturas y urbanismos, esculturas y pinturas, todas ellas susceptibles de lograrlo bajo la infatigable presión de una invención permanente.

Tras el largo trayecto de una profunda evolución que nos ha separado de los tiempos pretéritos, descubrimos una verdad esencial: la de la síntesis, hoy posible, de las artes mayores, arquitectura, escultura y pintura, en el reino del espacio. Las perspectivas «a la italiana» no lo consiguen: lo que está sucediendo aquí es algo distinto. A este «algo» lo hemos bautizado cuarta dimensión; ¿por qué no?, si, al fin y al cabo, es subjetiva y de naturaleza irrefutable pero indefinible y no euclidiana. Un descubrimiento que será criticado con afirmaciones apresuradas y superficiales, muy a la moda, como, por ejemplo, que la pintura no debe horadar la pared, que la escultura debe estar fijada al suelo...

Creo que no existe ninguna obra de arte que no tenga una profundidad inaprensible, que no se desarraigue de su punto de apoyo. El arte es ciencia espacial por excelencia. Picasso, Braque, Léger, Brancussi, Laurens, Giacometti, Lipchitz, pintores o escultores, todos ellos se han dedicado a la misma conquista.

Ahora comprendemos el matrimonio que pueden celebrar las artes mayores ligadas a la arquitectura: el de una unidad construida tan sólidamente como un Cézanne.

Flotan en el ambiente unas posibilidades extraordinarias, embriagadoras, estimulantes; un encuentro de la Puerta Dorada de las artes mayores. Ayudándose las unas a las otras, disiparán las neblinas que ennegrecen tanto las ideas como a los artistas, depositando sobre ellos poses heredadas (y no discutidas): las metopas, los frontones, los tímpanos, los entrepaños de la tradición. Su alianza será diferente. El urbanismo dispondrá, la arquitectura dará forma, la escultura y la pintura dirigirán las palabras selectas que son su razón de ser.

Resulta singular darse cuenta de que son los acontecimientos los que se han puesto en marcha, mientras los hombres, estupefactos, los miran pasar, olvidando tomar el coche y acudir puntuales a la cita.

La cita es hoy fundamental, en un mundo que cambia de piel para acoger a una sociedad maquinista que está liquidando las existencias de su primer establecimiento y que arde en deseos de instalarse para actuar, para sentir y para reinar. "5

\footnotetext{
${ }^{5}$ Le Corbusier, "El espacio inefable” en Minerva número 2.06, 2006. Texto original traducido al castellano por Marisa Pérez Molina.
} 


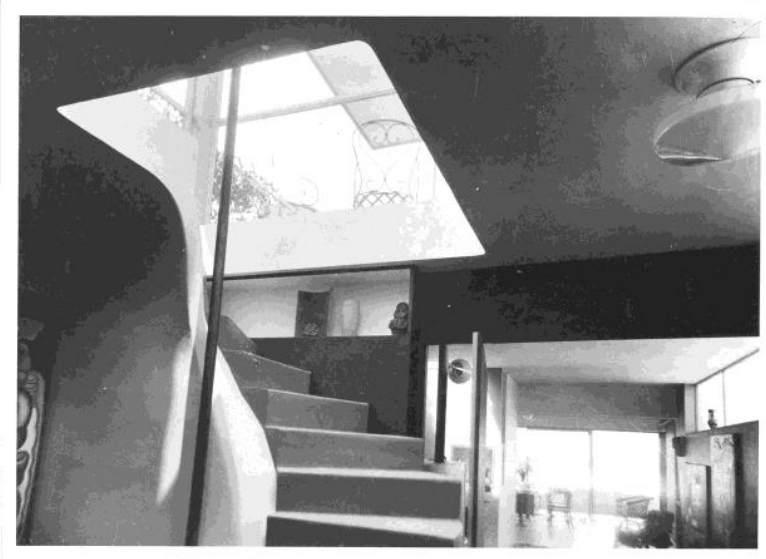

2. Apartamento de la rue Nungesser et-Coli. Ilustración seleccionada de la caja B3.7. B3(7)416 CFLC-ADAGP.

El cuerpo principal de este artículo es citado e incluido numerosas veces en posteriores publicaciones, lo que evidencia la importancia del texto y del concepto en él expuesto. En 1948 aparece en Architecture et l'esprit mathématique ${ }^{6}$. Ese mismo año, sirve también para la introducción del libro New World of Space ${ }^{7}$ que acompaña a la exposición itinerante sobre su obra en Estados Unidos. Poco después, a modo de versión francesa de ese libro, aparece un nuevo número especial de la revista L'Architecture d'Aujourd'hui, cuyo título es Unité. Fragmentos íntegros del texto se repiten en Le Modulor en 1948 y Modulor 2 en 1955 ${ }^{9}$. Otras declaraciones y afirmaciones del propio Le Corbusier a lo largo de los años posteriores se suman a los aspectos esenciales señalados en el artículo de 1946. En 1961, escribe de nuevo en un número especial de L'Architecture d'Aujourd'hui dedicado a la arquitectura sacra:

"Soy el inventor de la expresión espacio inefable, que es una realidad que descubrí a lo largo del camino. Cuando una obra ha alcanzado su máxima intensidad, en proporción, en calidad de ejecución y perfección, un fenómeno de espacio inefable se produce: los lugares empiezan a irradiar, irradian físicamente. Ellos determinan lo que yo llamo espacio inefable, en otras palabras, no dependen de las dimensiones sino de la calidad de la perfección; este es el dominio de lo inefable ${ }^{\text {,lo }}$.

Según explica Le Corbusier en su libro Modulor 2, el concepto de espacio inefable es fruto de su experiencia en el apartamento de la calle Nungesser-et-Coli (Fig.2):

"Estas palabras son fruto de una experiencia. En mi casa hay un vestíbulo, dos metros cuadrados. Un muro es iluminado por una gran ventanal orientado al norte y situado en el jardín de la cubierta. Este muro está entonces, bajo una constante -y casi ideal- luz. Es el único muro iluminado de esta manera, el piso está diseñado con orientación este y oeste.

\footnotetext{
${ }^{6}$ Les grands courants de la pensé mathématique, presented by F. Le Lionnai, 1948, new edition, 1962 (p. 480 ff.) citado por Krustrup, Mogens. "Det Uudsigelige Rum = the Ineffable Space [Le Corbusier]". En Arkitekturtidsskriftet B, -01-01, no. 50. pp. [54] avery. Århus, Dinamarca, 1993.

${ }^{7}$ Le Corbusier, New World of Space, 1948 p.7 y sig.

${ }^{8}$ Le Corbusier, “Unité”. Número especial de L'Architecture d'Aujourd'hui, París, 1948. p. 5 a 58.

${ }^{9}$ Le Corbusier, Modulor, 1948, p.30 y sig. Modulor 2, 1955, p.25-27; p.148 y sig.; p.207 y sig.

${ }^{10}$ Le Corbusier, "Conversación registrada en la Tourette", en L'Architecture d'Aujourd'hui, Número especial sobre arquitectura religiosa, junio-julio 1961. p. 3. Citado por Krustrup, Mogens, op.cit. Traducción del autor.
} 
Me había habituado a usar este muro como un banco de pruebas para mis pinturas mientras estaba trabajando en ellas, tanto pequeñas como muy grandes.

Un día -en un preciso momento- vi cómo un inexpresable espacio aparecía enfrente de mis ojos: el muro, con su pintura, perdió sus límites: se transformó en ilimitado.

Lo probé con mis amigos y visitas. Después de que la pintura hubiera estado colgada, de repente la retiré. Allí seguía el pequeño muro de dos metros de largo: una pequeña pared.

Todo esto me hizo pensar.",ll

La relevancia que el concepto de espacio inefable tuvo en el proceso creativo y en la labor diaria del taller de la rue de Sèvres 35 viene señalado por las veces que este tema fue objeto de conversación entre ellos y Le Corbusier. Así lo atestiguan Jerzy Soltan ${ }^{12}$ y André Wogenscky que señalaba que "para Le Corbusier el objetivo era conseguir y crear un 'espace indicible',, 13

Bastan estos ejemplos para señalar la gran importancia que para Le Corbusier tuvo el concepto de espacio inefable como búsqueda de la emoción plástica común a todas las disciplinas artísticas. Resulta pues fundamental entender de qué manera se realizó esa búsqueda y como se transformó en obras para comprender mejor su obra, especialmente en el periodo posterior a la II Guerra Mundial.

\section{Metodología y desarrollo de la investigación}

Para desarrollar esta hipótesis se plantea un método de investigación mediante la observación de fuentes directas, así como de investigaciones posteriores. En primer lugar, se analiza la documentación existente en la Fondation Le Corbusier. La caja FLC B3.7 L'Espace indicible contiene los manuscritos originales, cartas, notas, dibujos y la maqueta del libro que nunca llegó a ser publicado. En segundo lugar, se realiza un análisis de las obras construidas durante la época en la que se desarrolló el concepto de espacio inefable. Este análisis se realizará contrastando la información procedente de los cuadernos de notas, croquis, planos y fotografías, con su obra plástica. Los resultados de la investigación aquí mostrados pertenecen a una parte del desarrollo de una tesis doctoral.

\footnotetext{
${ }^{11}$ Le Corbusier, Modulor 2. Paris, 1955, p. 27. Traducción del autor.

${ }^{12}$ Samuel, Flora. Le Corbusier in Detail. Amsterdam: Elsevier, 2007. p.122

${ }^{13}$ Wogenscky, André. Le Corbusier's Hands. París, 1987 p.81. Traducción del autor.
} 


\subsection{La caja B3.7}
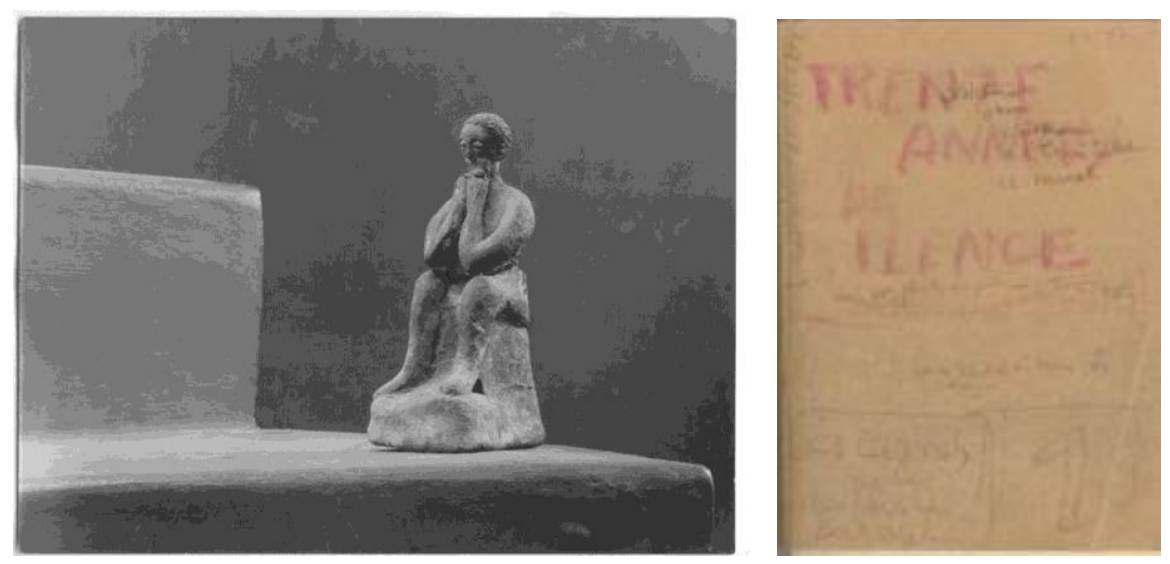

3. Imagen de una estatuilla.B3(7)413@FLC-ADAGP.

4. Portada de la maqueta manuscrita. B3(7)566-001 @FLC-ADAGP.

En la introducción del Volumen $n^{\circ} 6$ de su Obra Completa ${ }^{14}$, que comprende la obra realizada en el periodo entre 1952 y 1957, Le Corbusier hace referencia a la inminente publicación de tres libros que, sin embargo, nunca llegarían a ver la luz:

\section{Fin d'un Monde: Délivrance \\ 2. Le Fond du sac \\ 3. L'Espace indicible}

Junto a estos tres títulos define su obra como una síntesis de las artes. Arquitectura, urbanismo, pintura y escultura, son para él un evento plástico e incluso poético. Un evento cuya semilla fue sembrada mucho tiempo atrás pero que sólo ha dado su fruto tras el paso del tiempo, tras una vida consagrada al arte. Arte entendido como «la manera de hacer», cuyo objetivo es provocar una emoción tan intensa, tan poderosa, que podría calificarse de inefable, una palabra que, según Le Corbusier, describe uno de los caminos a la felicidad.

"Ignoro el milagro de la fe, pero vivo a menudo el del espacio inefable, cúspide de la emoción plástica",15 Según señala Catherine de Smet, de los tres títulos anunciados en el volumen n 6 de la Obra Completa, $L^{\prime}$ Espace indicible es el más elaborado ${ }^{16}$. El nombre que tuvo inicialmente el proyecto de libro fue Trente années de silence, en referencia al libro de André Malraux Voix du silence, y a los años en los que Le Corbusier, voluntariamente, decide no exponer su obra plástica (1923-1953). Tras haber propuesto esta obra a Albert Camus y a Jean Paulhan, finalmente acuerda con Jérôme Lindon, de "Les Editions de Minuit", llevar a cabo la edición de lo que sería el primero de los Cuadernos de la búsqueda paciente. En una carta agradeciendo a Le Corbusier su consentimiento, Lindon escribe: “Pienso que "L'Espace Indicible”, podría, de alguna manera, llegar a ser el gran libro teórico que se espera de usted impacientemente, y que podría obtener una gran difusión” ${ }^{17}$. El libro sería un volumen ilustrado sobre su obra plástica, fruto de la exposición organizada por Jean Cassou en el Museo

\footnotetext{
${ }^{14}$ Le Corbusier, Le Corbusier: Euvre Complète. Vol.6, pp. 11.

${ }^{15}$ Le Corbusier, L'Espace indicible, idem.

${ }^{16}$ Smet, Catherine de., Vers une architecture du livre, 2007, pp.212 y ss.

${ }^{17}$ Carta de Jérôme Lindon de 1 de diciembre de 1953. FLC, B3.7.1. Citado por Krustrup, Mogens, op.cit. Traducción del autor.
} 
Nacional de Arte Moderno de París en noviembre de 1953. Finalmente, la génesis de la obra se prolongó más allá de 1960 y el título del mismo fue cambiado al de L'Espace indicible.

La caja B3.7 de la Fondation Le Corbusier, en París, recibe el nombre de "Ouvrage: l'Espace Indicible". Esta caja contiene todos los documentos preparatorios, la correspondencia, una selección de imágenes e incluso un borrador manuscrito de más de 150 hojas. El contenido de la caja está dividido en seis partes:

- $\quad$ Notas y documentos preparativos

- Maqueta manuscrita

- Textos manuscritos y dactilográficos

- Ilustraciones

- Leyendas de las ilustraciones y citas

- Correspondencia 1946-1959

\subsubsection{Notas y Documentos Preparativos}

Esta primera parte está estructurada de acuerdo a cinco capítulos que contienen notas y dibujos que hacen referencia a imágenes de sus obras, pinturas o esculturas que acompañarían al texto. A cada capítulo le corresponde un símbolo diferente:

- Temps Nouveaux

- Opinion ou 30 Années de Silence

- L'Explication-Les "Clefs"

- L'Art est la manière de faire

- Le Caractère apparaît á l'usure du temps

Temps Nouveaux, está organizado en diecinueve apartados. Le Corbusier utiliza la imagen del acróbata para definirse a sí mismo. Se ve como un provocador de formas que abre la puerta hacia una nueva estética y plástica arquitectónica. Los viajes y las experiencias vividas son las fuentes de las que se alimentan muchas de sus reflexiones. Como muestra de ello plantea paralelismos entre su experiencia del Acrópolis en 1911, su primer cuadro La cheminée de 1918 y la cubierta de la Unidad de Habitación de Marsella (Fig.5). En este apartado también se aborda el origen del significado de indicible. Este proviene de Rabelais, y de los filósofos Plotin o Anaxágoras.

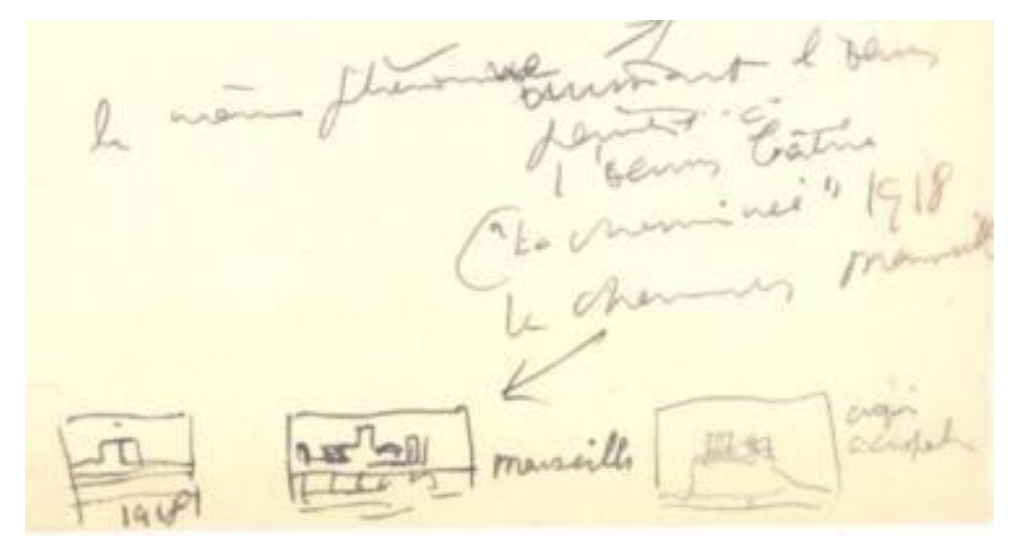

5. B3(7)30 @FLC-ADAGP. 
Opinion ou 30 Années de Silence, ofrece una autobiografía resaltando su relación con otras artes y como se fue generando un proceso de pensamiento hasta llegar al planteamiento de la "Síntesis de las Artes". Un proceso voluntario en el que fue eliminando los límites entre las distintas disciplinas artísticas, haciendo de la mano su campo de libertad.

L'Explication - Les "Clefs" con las que estructura su obra corresponden a las etapas de su pintura desde 1918 hasta 1955:
a) vidrios y botellas
b) los objetos de reacción poética
c) la figura humana
d) el bestiario
e) los dibujos automáticos

Lo que se dice en este punto es que el espacio inefable interviene mediante transferencia de objetos concretos a conceptos evocadores, transmisores y provocadores de espacio, para seguir con un "fenómeno acústico al servicio de las formas". Un momento de emoción y de concordancia que se encuentra en la intimidad de la obra.

En L'Art est la manière de faire, se señalan cómo los trazados del cuadro St. Sulpice se transforman en la fachada del rascacielos de Alger y se cuenta el proceso de construcción de la fachada de la Unidad de Habitación de Marsella, consistente en inventar, conocer el problema, buscar la solución y transmitir órdenes precisas. En este caso fueron necesarias 4000 órdenes para construir esta fachada. Bastaron, dice, quince minutos de visita de obra y sin embargo fueron necesarios cuarenta años de investigación previa.

Le Caractère apparaît á l'usure du temps. Señala como el libro, de carácter introspectivo, rompe el silencio de 30 años y abre la puerta de la búsqueda paciente.

\subsubsection{Maqueta Manuscrita}

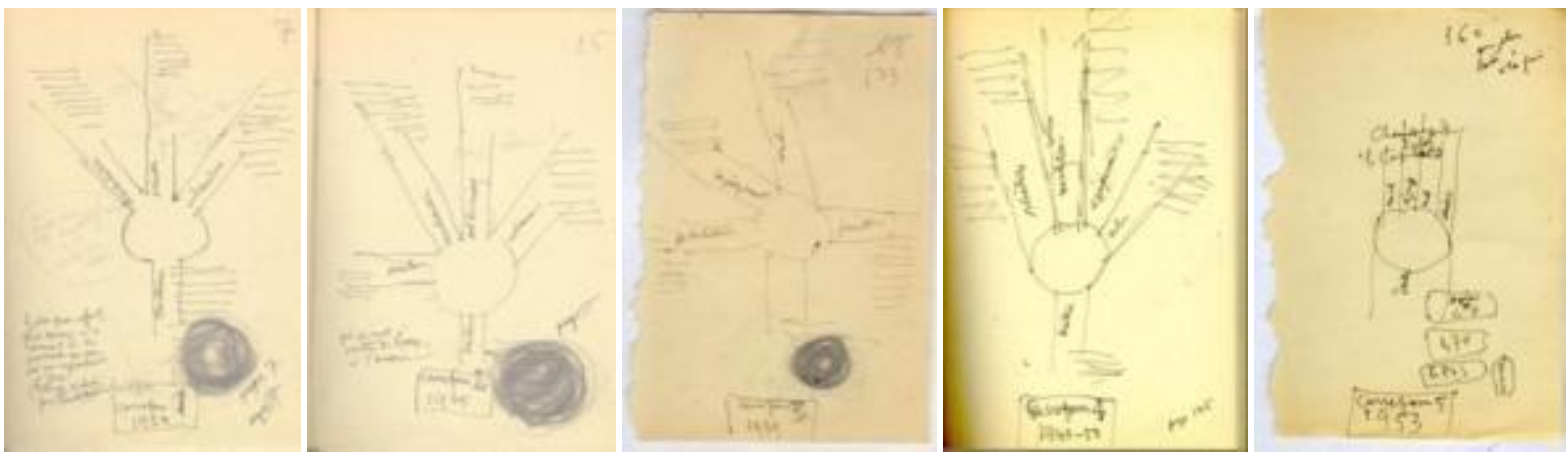

6. Portadas de los capítulos de la maqueta manuscrita. B3(7)566.009/017/126/151 y 166 @FLC-ADAGP.

La maqueta manuscrita contiene el borrador de más de 150 hojas encuadernadas que conformarían el libro. El libro se divide en cinco capítulos. Cada capítulo tiene una fecha asignada y un diagrama (Fig.6). Los capítulos están ordenados cronológicamente. Carrefour 1 - 1922; Carrefour 2 - 1925; Carrefour 3 - 1939; Carrefour 4 1940-50; Carrefour 5 - 1953. El diagrama muestra un círculo central en el que confluyen tres o cuatro ramas en 
la parte superior. Cada una de estas ramas corresponden con las diferentes disciplinas, arquitectura, pintura, escultura y urbanismo. Hacia la parte inferior sale una nueva rama con el nombre de 'doctrina'.

Significativamente, en el último capítulo, aparecen sobrescritas las palabras 'Chandigarh' y 'le Capitolio' señalando estos proyectos como aquellos en los que se fusionan todas las disciplinas, la Síntesis. También hay referencias a otros libros como Le Poême de l'Angle Droit, Le Fond du Sac o el Sistema de las 7 vías.

\subsubsection{Textos manuscritos y dactilográficos}

Artículo original fechado en Septiembre de 1945 y posteriores documentos preparatorios del artículo de la revista Art de 1946.

\subsubsection{Ilustraciones y citas}

Selección de imágenes y dibujos entre los que cabe señalar los vinculados con la geometría de las formas orgánicas y naturales, sus relaciones geométricas y sus proporciones. También se incluyen imágenes de esculturas, detalles de obra o incluso bocetos que muestran procesos de ensamblaje y configuración de formas a partir de objetos sencillos como unas cerillas(Fig.7).

\subsubsection{Correspondencia}

Correspondencia comprendida entre 1946 y 1959 con Reynal et Hitchcock Inc., Mourlot, Vriant, Parodi, Brandon, Sweeney, Claudius Petit, Camus, Paulhan, Gropius, Vienot (Institut d'Esthétique Industrielle), Dubreuil, Perry (Télé Radio Coproduction), Lindon, Duval y Vieilleville.
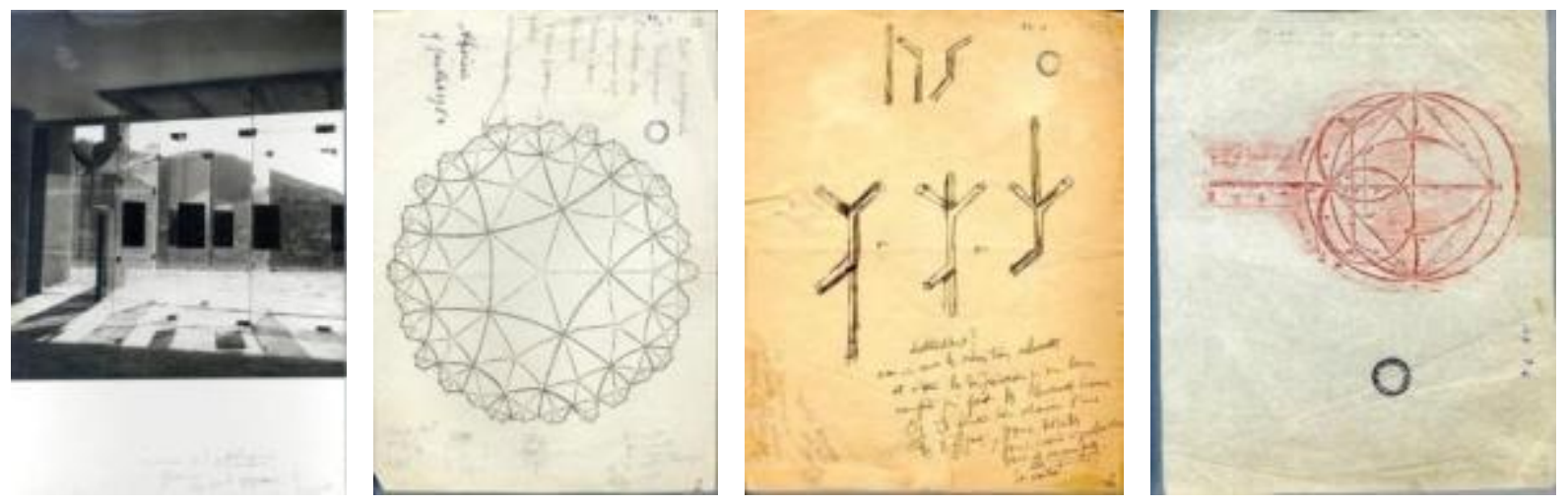

7. Ilustraciones pertenecientes a la caja B3.7. B3(7)9/78/136 y 297@FLC-ADAGP.

\section{Resultados}

\subsection{Una nueva concepción del espacio urbano}

En los años cuarenta, paralelamente a los escritos de Le Corbusier sobre el espacio inefable, Sigfried Giedion señala en su libro Espacio, Tiempo y Arquitectura ${ }^{18}$, que los maestros de la pintura moderna habían puesto en

\footnotetext{
${ }^{18}$ Giedion, Sigfried, Espacio, Tiempo y Arquitectura, p.28.
} 
valor la concepción del espacio de civilizaciones arcaicas como la Egipcia o la Griega. Al contrario de la civilización Romana, en la cual el espacio arquitectónico era sinónimo de cavidad, las primeras civilizaciones planteaban relaciones de volúmenes en el espacio, cuya interacción ofrecía una composición casi musical. Muestras de esta concepción son las pirámides de Guiza o la Acrópolis de Atenas. Según Giedion, la conciencia contemporánea vuelve a ser sensible al poder de la disposición de volúmenes en el espacio. Este señala cómo Alberto Giacometti experimentó durante veinte años con la interacción de formas primitivas hasta que diseñó $L a$ plaza de la ciudad (1948), un grupo de cuerpos de bronce, desmaterializados al máximo, pero formados y colocados de tal modo que llenan el espacio que hay entre ellos y más allá de ellos. En la Arquitectura, la disposición de volúmenes del proyecto para el centro de Saint-Dié (1945) son muestras de estas primeras relaciones de volúmenes en el espacio concebidas intencionalmente para un proyecto urbano.

"Hablando claro: el plan de Saint-Dié 1945, desde mi sensibilidad, está en relación directa con la música. Ritmo y tono se conjugan; dando la impresión de una composición sonora: tiempo y espacio, ritmo y melodía. Tiempo y espacio, lo propio de la arquitectura y el urbanismo. Música y arquitectura comparten un mismo registro de la sensibilidad",19 (Fig.8)
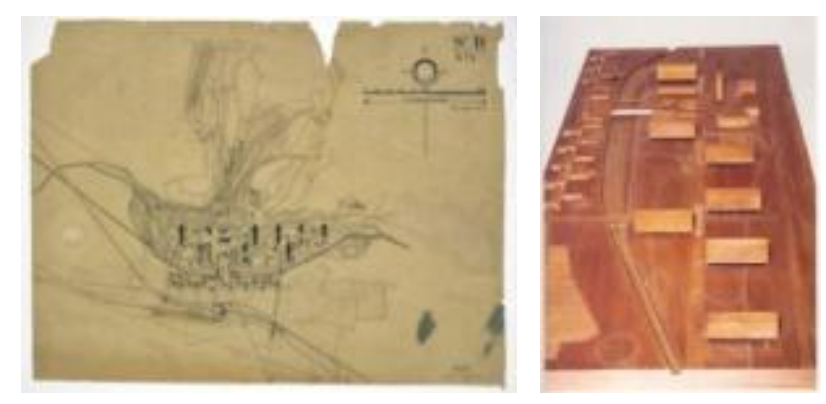

8. Urbanización Saint-Dié. Plano (09497A @FLC-ADAGP.) y maqueta (Saint-Dié - Centre civique @FLC-ADAGP.)

Le Corbusier, al describir el espacio inefable, establece una relación directa entre la arquitectura y la música. Un fenómeno de concordancia, exacto como una matemática, que describe como "acoustique plastique" y que experimenta por primera vez en la Acrópolis, uno de los órdenes de fenómenos más sutiles, portador de alegría (la música) o de opresión (la cacofonía). Ya en 1936, en la conferencia de Volta en Roma ${ }^{20}$, expone el paralelismo entre música y arquitectura equiparando el proyecto arquitectónico a una sinfonía musical. La arquitectura, dice, es "el juego sabio, correcto y magnífico de las formas bajo la luz". Un juego arquitectónico de combinación de formas cuyo éxito radica en la correcta proporción. Una relación similar a una "sinfonía musical: la diversidad, la cadencia, el silencio, la dulzura o el clamor y la fuerza" ${ }^{21}$.

El proyecto de Saint-Dié presenta una nueva clase de relaciones espaciales, muy relacionadas con aquellas que observó en sus viajes de juventud. A modo de esculturas contemporáneas, los volúmenes vacían, llenan y modelan los espacios. Cada uno desprende su propia atmósfera y a su vez mantiene la relación con el conjunto,

\footnotetext{
${ }^{19}$ Le Corbusier, "Unité, p.22. Traducción del autor.

${ }^{20}$ Le Corbusier, "Les tendances de l'architecture rationaliste en rapport avec la collaboration de la peinture et de la sculpture”, Rome, Reale Accademia d'Italia, 1936, p.12. En Le Corbusier - Savina, dessins et sculptures. Fondation Le Corbusier, Philippe Sers éditeur. Paris, 1984.

${ }^{21}$ La familia de Le Corbusier tenía una fuerte relación con la música. Su madre era profesora de piano y su hermano un músico, por lo que se puede comprender mejor esta relación. Gargiani, Roberto; and Rosellini, Anna. Le Corbusier: Béton Brut and Ineffable Space, 1940-1965 : Surface Materials and Psychophysiology of Vision. Londres: Routledge, 2011. Traducción del autor.
} 
generando experiencias espaciales continuamente cambiantes. Los proyectos urbanos que diseñó Le Corbusier durante estos años comparten estos principios de disposición de volúmenes en el espacio y podría decirse que eran abordados como esculturas. En Chandigarh, el único proyecto urbano llevado a cabo, halló una nueva definición del espacio inefable:

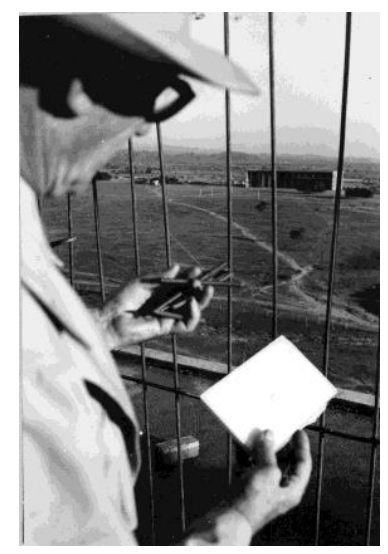

9. Imagen de Le Corbusier observando el Palacio de Justicia desde las obras del edificio de los Ministerios. Chandigarh. L4(3)89-10 @FLC-ADAGP

"Espacio inefable, el Palacio de Justicia desde 1000 metros de distancia aproximadamente, eso es precisamente la presencia del término: 'espace indicible'. Imposible de medir. Los Himalayas están detrás, las montañas, las colinas, el lugar...¿aplastante?. De ningún modo: el sitio unido por lo inexpresable, lo imperceptible, lo inexplicable. Digo esto con orgullo. Finalmente aquí, a los 67 años de edad y alejado de todas las disputas profesionales y políticas, y otras rivalidades, fui capaz de crear una arquitectura que cumple las funciones diarias pero que simultáneamente lleva a una alegría jubilosa",22. (Fig.9)

\subsection{Espacios cóncavos y convexos}
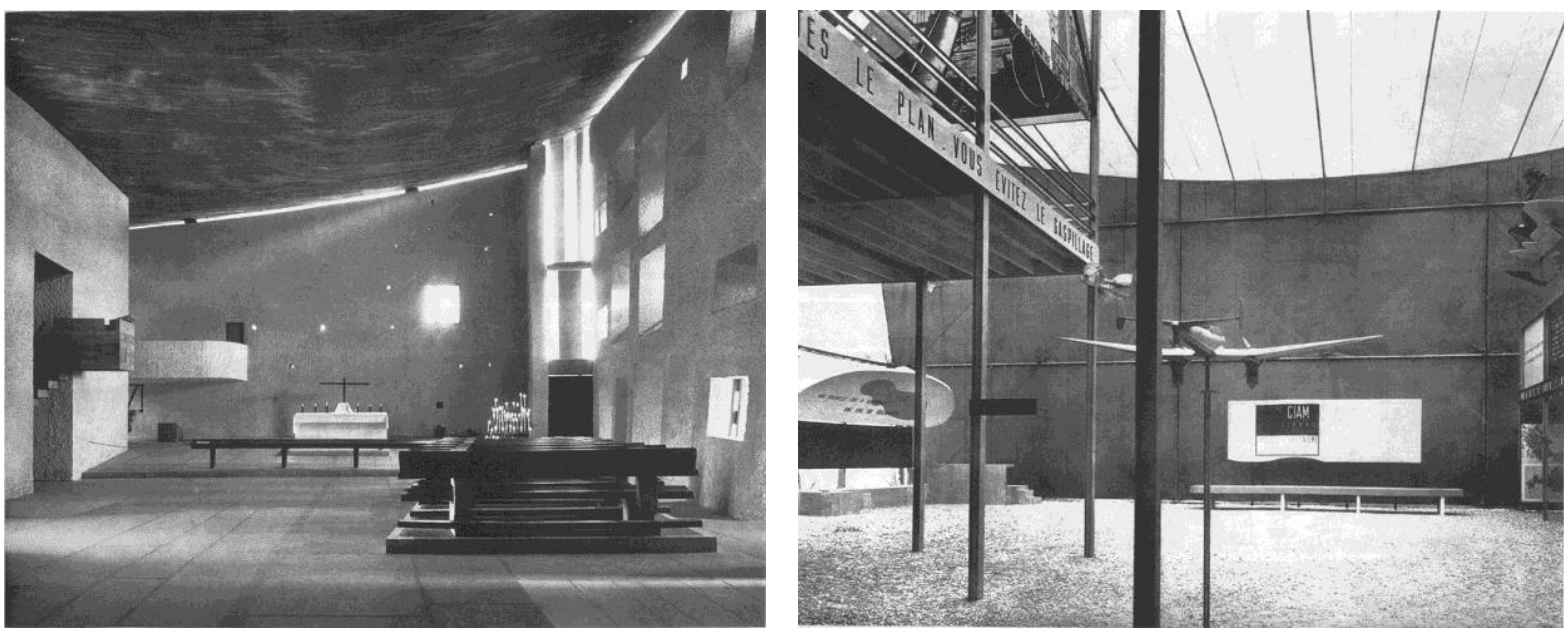

10a. Imagen interior de Ronchamp. (1950-55). OC vol6 p.33 OFLC-ADAGP.

10b. Imagen interior del Pabellón de los Tiempos Nuevos (1937). OC vol3 p.163 @FLC-ADAGP.

${ }^{22}$ Le Corbusier, Carnets 3. 190, (sobre el Palacio de Justicia). Nota fechada el 19 de Noviembre de 1954. Citado por Krustrup, Mogens, op.cit. Traducción del autor. 
Cada periodo histórico ha creado su propia forma de abovedamiento interior: romano, bizantino, románico, gótico, renacentista y barroco. Puede decirse entonces que cada forma específica de abovedamiento se ha convertido casi en el símbolo de su época. Los nuevos materiales y técnicas de construcción contribuyen a la transformación de los espacios. La utilización de este tipo de espacio abovedado y su evolución a lo largo de los años en la obra de Le Corbusier merece especial atención por su relación con la escultura y las reacciones psicológicas que las superficies cóncavas y convexas tienen en la experiencia del espacio.

El desarrollo de las técnicas constructivas de las bóvedas laminares de hormigón permitieron que los techos pudieran volverse convexos, y desplazar su centro al punto más bajo, como sucede en la Capilla de Ronchamp. Esto resulta significativo desde el punto de vista psicológico. El techo convexo se eleva hasta los muros circundantes e indica que no se detiene allí, sino que se extiende todavía más. En Ronchamp este efecto se enfatiza por medio de la rendija de vidrio que separa el techo del muro. Esta estructura tridimensional del paraboloide hiperbólico ofrece un nuevo punto de partida para la imaginación espacial. El equilibrio siempre está incluido en su propia configuración, y la impresión de estar suspendido deriva de su construcción interna.

La rendija que recorre las fachadas sur y este introduce la luz resbalando por la superficie del techo. Este efecto hace que el techo recuerde a la estructura de una tienda, lo que muestra la gran influencia que Gottfried Semper tuvo sobre Le Corbusier. La imagen tipo de la tienda en Le Corbusier sirvió como base para muchos de sus proyectos. Uno de los primeros ejemplos es el Pabellón de los Tiempos Nuevos (Fig.10b), cuyas imágenes interiores ofrecen una similitud evidente con la capilla de Ronchamp(Fig.10a). También el proyecto para el Pabellón para la Síntesis de las Artes en la Porte Maillot, fruto del Congreso CIAM VII de 1949 en Bérgamo y de la creación de la Association pour une Synthèse des Arts Plastiques ${ }^{23}$, presidida por Matisse y cuyos miembros principales son Le Corbusier y André Bloc. Este edificio estaría dividido en cuatro partes bajo una estructura tipo "paraguas" para cada una. Las cuatro partes que compondrían este centro acogerían un Museo Experimental del Arte de París, un Laboratorio Permanente con talleres, una Exposición permanente de la búsqueda plástica, arquitectónica y urbanística, y, finalmente un Espacio de entrada y recepción. Este proyecto nunca sería ejecutado, pero sí que fue utilizado en otros proyectos como un pabellón en Lieja, o los que finalmente serían ejecutado como el de Chandigarh, o el Pabellón del Hombre en Zúrich. (Fig.11).
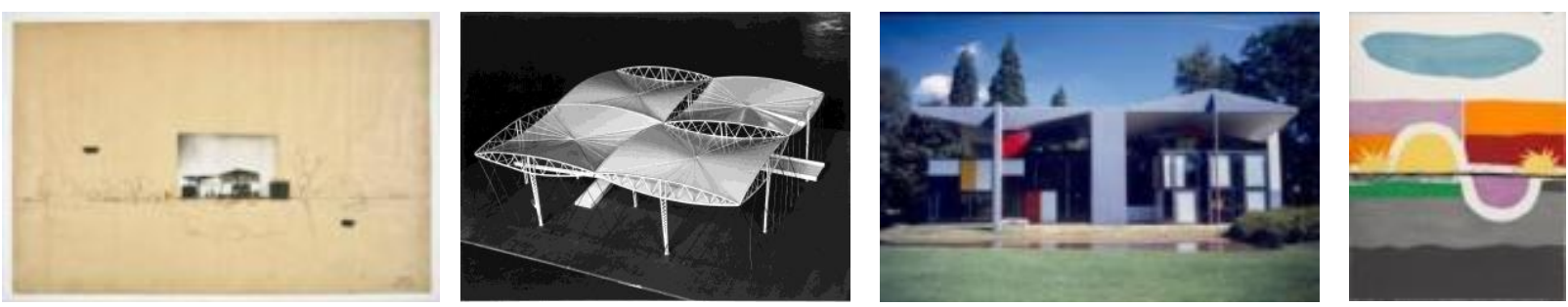

11a. Pabellón de la Síntesis de las Artes Mayores en Porte Molitor, París. (1950). 18154 @FLC-ADAGP. 11b. Maqueta del Pabellón de Francia en la Exposición del Agua en Lieja, Bélgica (1937). L1(3)109 @FLC-ADAGP. 11c. Pabellón de Exposición ZHLC (Maison de l'Homme), Zurich, Suiza. (1963). L3(18)72 @FLC-ADAGP. 11d. El Poema del Ángulo Recto. PAD_p.17 OFLC-ADAGP.

Si bien Le Corbusier, a partir de mitad de los años 30, parece haber perseguido esta tipología de edificio con una gran cubierta y pocos puntos de apoyo, que permitían una planta completamente libre, es también importante señalar los proyectos de finales de los años 20 en los que utilizó recurrentemente la bóveda suspendida como

${ }^{23}$ FLC, J1-5 
concha acústica. Este es el caso del Palacio de la Sociedad de Naciones en Ginebra (1927) (Fig.12a), o del Palacio de los Soviets en Moscú (1931) (Fig.12b). Un tipo de solución similar a la que fue utilizada por Le Corbusier, unos años más tarde, en el proyecto para el edificio de Naciones Unidas en Nueva York (1947). Tal vez influido por la propuesta del escultor Naum Gabo en el concurso del Palacio de los Soviets, proponía un suelo y un techo reflejos de ellos mismos, a modo de conchas de mejillones, para conformar la sala de las asambleas. Un espacio que según Giedion hubiera constituido uno de los espacios interiores más emocionantes de aquel periodo ${ }^{24}$.
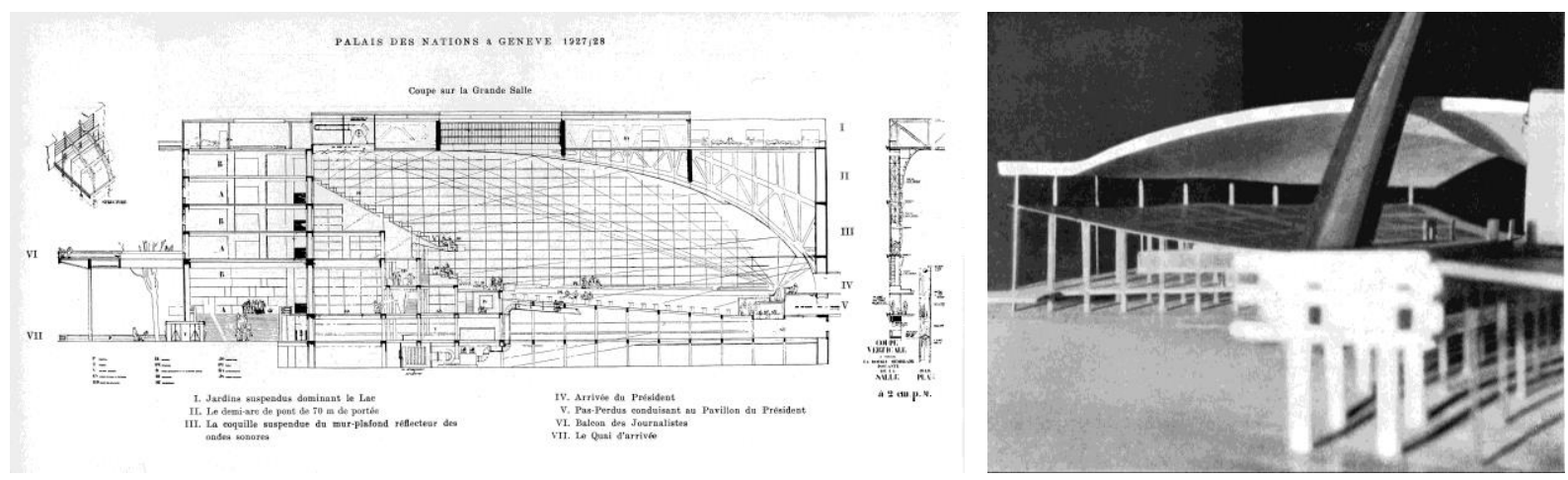

12a. Sección y detalles de la Gran Sala del Palacio de la Liga de Naciones de Ginebra. (1927).

OC vol1 p.166 @FLC-ADAGP

12b. Maqueta de la Sala de Asambleas del Palacio de los Soviets, Moscú. (1931). OC vol2 p.126 OFLC-ADAGP.

${ }^{24}$ Ver Giedion, Espacio, Tiempo y Arquitectura, p.32. 


\subsection{El pilar}
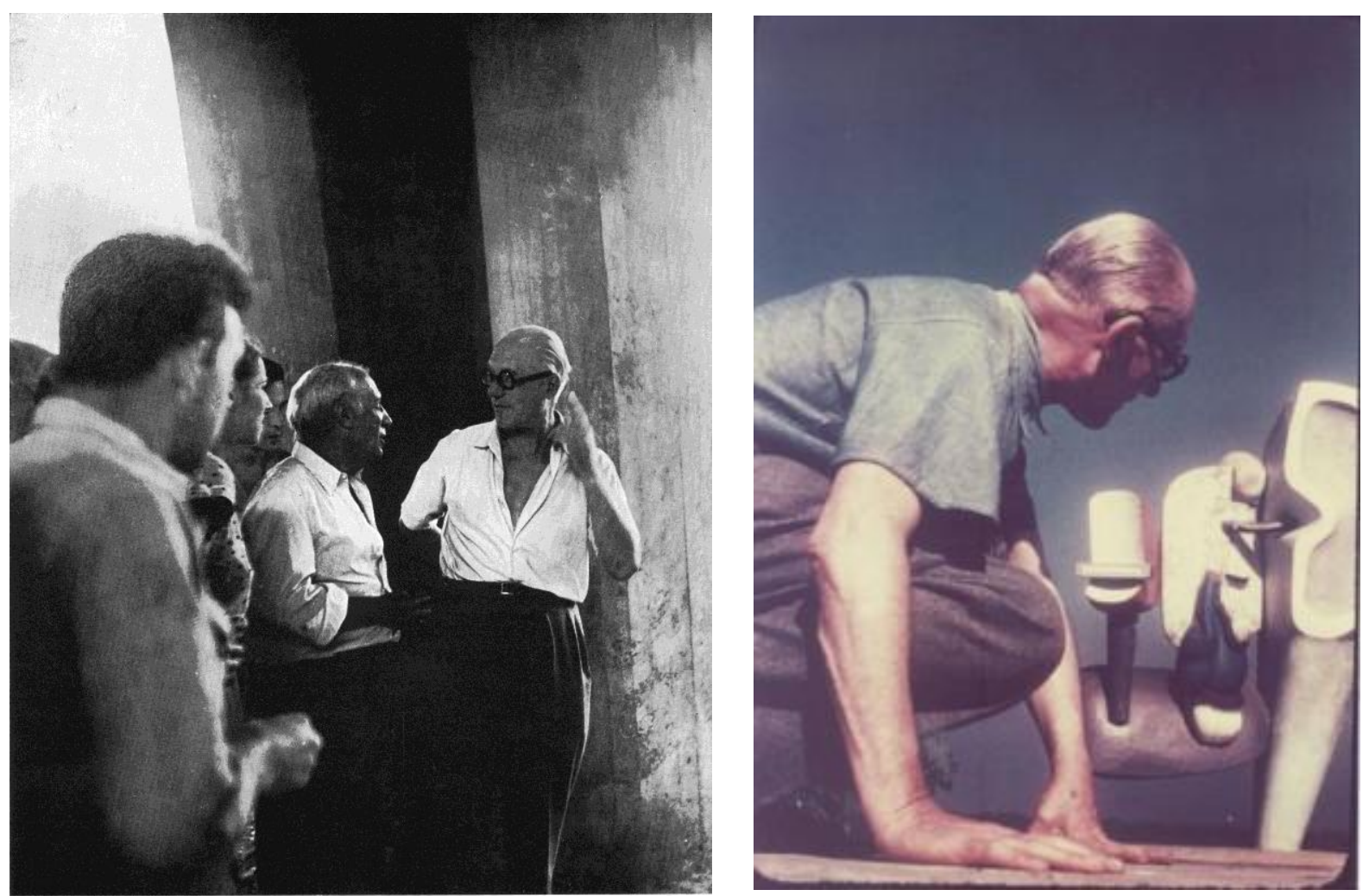

13. Picasso y Le Corbusier en la Unidad de Habitación de Marsella. OC vol5 p.9 @FLC-ADAGP.

14. Le Corbusier y la escultura Ozón. L4(9)114 @FLC-ADAGP.

De todas las imágenes que se tomaron el día que Picasso visitó las obras de la Unidad de Habitación de Marsella, Le Corbusier seleccionó una en concreto para incluirla en las primeras páginas del volumen 5 de su Euvre Complète $^{25}$ (Fig.13). La fotografía fue tomada entorno a 1950. Ésta muestra a Picasso en el centro de la imagen dirigiéndose a un Le Corbusier cuyo dedo apunta hacia arriba, hacia uno de los pilotis de hormigón de la Unidad. A la izquierda de la imagen aparecen sus colaboradores, con gesto impaciente, tal vez por saber si su jefe pasará el test a los ojos del reconocido artista plástico.

Precisamente el pilar es el primero de los cinco puntos para una nueva arquitectura que proponía Le Corbusier en los años 20. Aquel pilar tubular de la villa Savoye, se había transformado en un elemento plástico que evocaba alguna de sus primeras esculturas con Joseph Savina (Ozon) (Fig.14). Estos enormes pilares de hormigón ya habían sido utilizados anteriormente en el Pabellón Suizo de la Ciudad Universitaria de París (1931-1933). Le Corbusier no permanecía ajeno a los avances del ingeniero Robert Maillart en sus estructuras de hormigón $\operatorname{armado}^{26}$. Su perfecto conocimiento del material le llevó a emplear métodos constructivos que eliminaban todo aquello que no fuese funcional, evitando masas pasivas o pesos excesivos y aproximándose a la forma orgánica. La relación entre los pilares de sus puentes y los de las unidades de habitación son evidentes. La idea principal que perseguía Le Corbusier era que este espacio no resultase un muro que impidiese que el espacio verde fluyera por debajo de su edificio.

\footnotetext{
${ }^{25}$ Le Corbusier, Euvre Complète 1952-1957, 5, p.9.

${ }^{26}$ Robert Maillart fue el ingeniero de la obra de Le Corbusier en Ginebra, Immeuble-Clarté (1930-1932).
} 

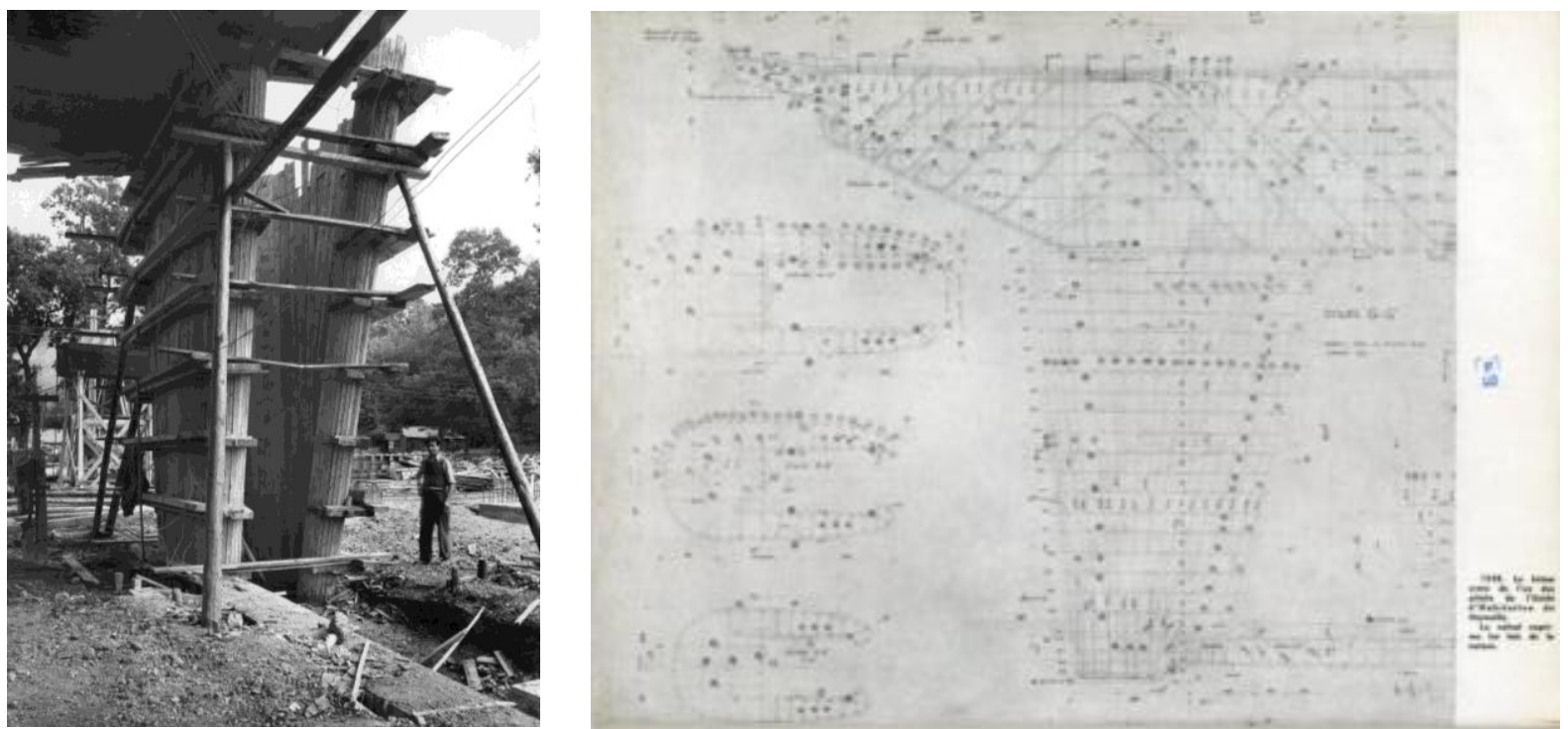

15. Encofrado de pilotis en el extremo sur del segundo sector de la Unidad de Habitación de Marsella. L1(13)1026 CFLC-ADAGP.

16. Planos del armado de los pilotis de la Unidad de Habitación en la revista 'Unité'. Architecture d'Aujourd'hui-p.54 OFLC-ADAGP.

Además, el propio material sirvió para reforzar las intenciones plásticas. El hormigón en bruto (béton brut) adoptaba rasgos de roca natural. La ingenuidad de Le Corbusier permitió no alisar las marcas ni las huellas accidentales del encofrado, tampoco los defectos de la mala ejecución que - como declaró en su discurso de inauguración - "estallaban por todas partes en la obra”. Los dibujos de los encofrados de madera revelan la intencionalidad plástica de la solución (Fig.15), como en el dibujo de espina de pez de los enormes pilotis portantes o en las superficies rugosas de las torres de ventilación y de los ascensores. Cualquier cambio de la intensa luz mediterránea actúa con una fuerza peculiar, contribuyendo a transformar estos objetos utilitarios en estimulantes elementos plásticos ${ }^{27}$. En el número especial 'Unité' de la revista L'Architecture d'Aujourd'hui (1948), se incluye un dibujo de los armados de estos pilotis entre las ilustraciones del texto (Fig.16). Este dibujo ocupa una página completa en la parte final del artículo, junto a las conclusiones. Todas las imágenes finales son dibujos preparatorios de esculturas y pinturas murales salvo este. De nuevo una solución técnica pasa a ser una decidida expresión artística ${ }^{28}$.

\footnotetext{
${ }^{27}$ Giedion, idem, p.534.

${ }^{28}$ Le Corbusier, “Unité”, 1948, p. 47 y 54.
} 


\subsection{La Fachada}
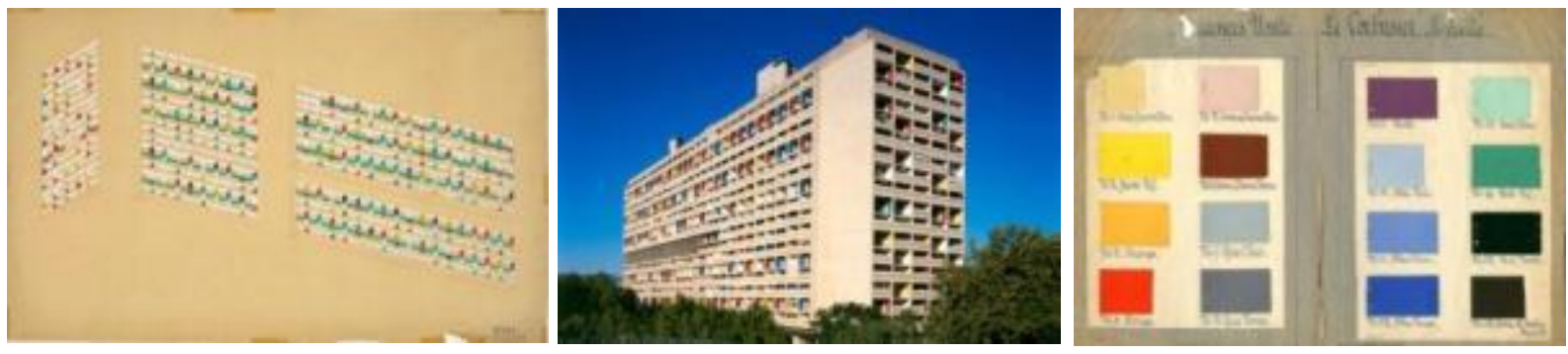

17a. Estudio de la composición de colores de las logias de la Unidad de Habitación de Marsella. 27096 @FLC-ADAGP.

17b. Fachada Oeste y Sur. Colores prevalentes azul y rojo respectivamente. Marseille1 @FLC-ADAGP.

17c. Carta de colores. O5(10)249 @FLC-ADAGP.

"Después de veinticinco años de investigación, un nuevo elemento arquitectónico (aunque de esencia tradicional) puede, tal vez, unir definitivamente la arquitectura del acero, el cemento y el vidrio: el brise-soleil que, de hecho, introduce una técnica nueva: el control del sol (iluminación y deslumbramiento).

El acero o el cemento armado nos liberaron de Vignola y de los prejuicios, llevándonos al plan libre; el plan libre nos condujo a la fachada libre; la fachada libre al pan-de-verre. Evolución natural, irrefutable. "29

La aplicación del pan-de-verre en sus proyectos mediterráneos (Carthage (1928), Barcelona (1933), Alger (1930, 1933, 1938 y 1939) le llevó a incluir un dispositivo regulado por el curso cotidiano del sol: el brise-soleil. Además, el pan-de-verre impone servidumbres delicadas de limpieza difíciles de mantener por un grupo de 2000 personas, y un grado extraordinario de desorden debido al uso individual del sistema (ventanas, cortinas, toldos, estores, etc.). El origen de esta solución constructiva es la reinterpretación del espacio loggia que había visto a menudo en sus viajes. Una solución utilizada a lo largo de la historia tanto en la arquitectura opulenta como en la más sencilla. Una solución técnica se convertía, una vez más, en un aporte plástico extraordinario. ${ }^{30}$

En un pasaje de Hacia una Arquitectura, Le Corbusier habla sobre la relación entre el interior y el exterior de un edificio: "Un edificio es como una burbuja de jabón -esta burbuja es perfecta y armoniosa si el aire ha sido distribuido y regulado desde el interior. El exterior es el resultado del interior." 31

En la Unidad de Habitación de Marsella (1947-1952) se hizo realidad el modelado plástico de los muros. Las superficies se entretejen con ritmos de horizontalidad y verticalidad a gran escala. Las paredes de vidrio de las fachadas se retranquean detrás de la pantalla perforada. Se aplican diferentes colores a los laterales de los brisesoleil pero no en los frentes, consiguiendo enfatizar el efecto plástico (Fig.17).

En el edificio de los ministerios de Chandigarh (1952-1957), la revitalización del muro alcanzó la expresión más poderosa gracias al uso escultórico de los elementos constructivos, como los parapetos verticales y los brisesoleil horizontales. La fachada de $254 \mathrm{~m}$ de largo se divide en cuatro partes. Una de ellas, la zona de los ministros, se diferencia del resto gracias a la diferenciación y variación plástica. Por delante de la fachada, un

\footnotetext{
${ }^{29}$ Le Corbusier, "Unité”, p.49. Traducción del autor.

${ }^{30}$ Le Corbusier, "Unité”, p.52.

${ }^{31}$ Le Corbusier, Hacia una arquitectura, p. 146.
} 
cuerpo que alberga la rampa de 40 metros de altura, sale hacia delante en ángulo agudo generando una interesante tensión.

En la composición de los edificios se dan procesos similares a los experimentados en las esculturas. La aplicación del color para enfatizar o el ensamblaje de elementos son algunos ejemplos. El análisis de la obra arquitectónica, pictórica y escultórica de Le Corbusier muestra una traslación continua entre las diferentes disciplinas (Fig.18). En las notas para el libro L'Espace Indicible y en Le Modulor (p.216) señala que el trazado regulador en el cuadro Saint-Sulpice (1933), constituye la base del rascacielos de Alger. En el marco de este cuadro se encuentra una inscripción que dice "Eglise Tremblay Architecture 1929-1931", que hace referencia al primer proyecto para un espacio religioso, una iglesia en Tremblay (1929). Además, también fue motivo de una escultura Cathédrale en 1964, así como de la pintura mural del Pabellón Suizo de París y de la litografía análoga en L'poème de l'angle droit (p.139) que ilustra la frase: "Soy el constructor de casas y palacios"32.

Finalmente, podría decirse que el proyecto de Tremblay guarda relación con la iglesia de Firminy. Tal vez este proyecto represente la concepción del espacio sagrado moderno que tenía Le Corbusier. Preguntado por ello, decía que haría que una torre alta se alzase desde el centro y que levantaría una serie de vigas cruciformes de hormigón, una encima de otra, de modo que la visión hacia arriba pareciese extenderse hacia el infinito. ${ }^{33}$
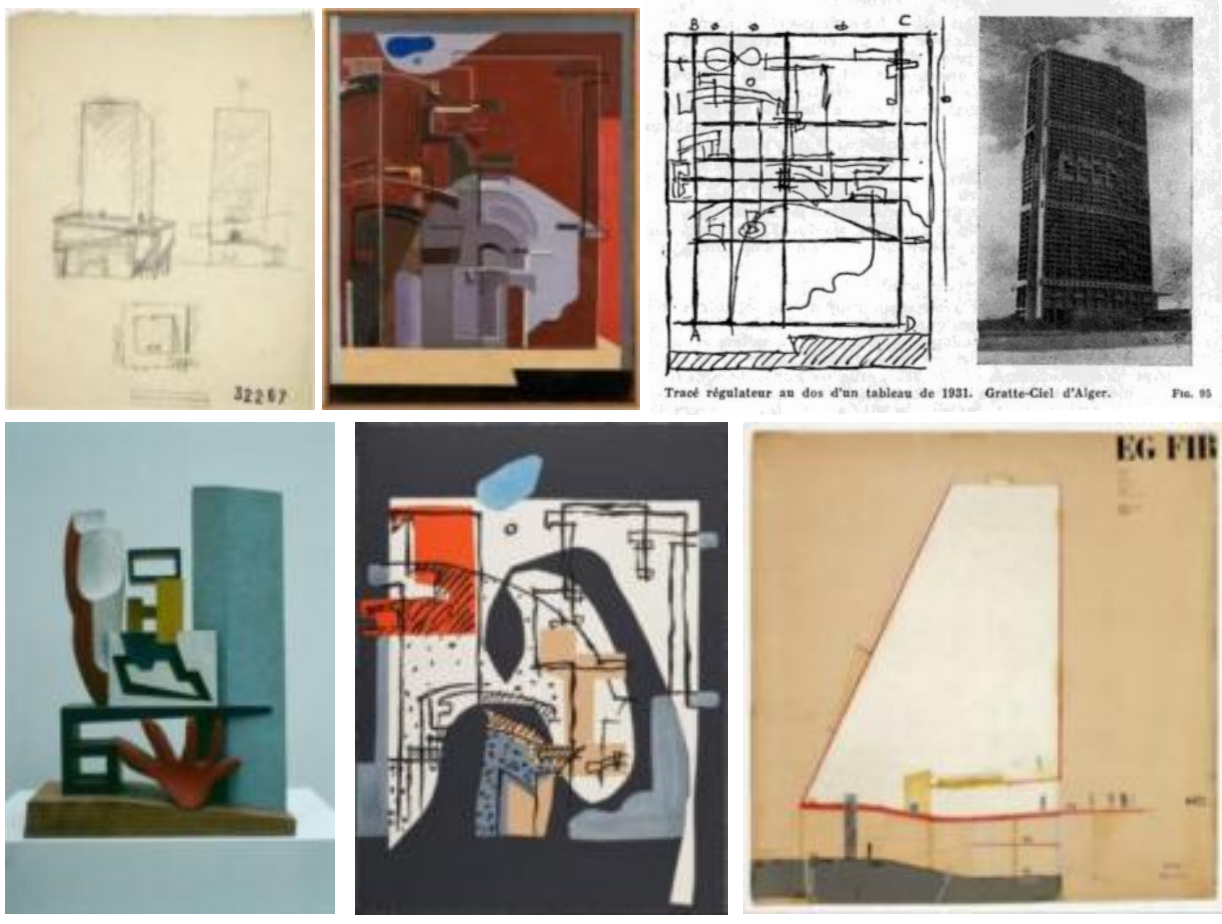

18a. Iglesia de Tremblay (1929), 32267 OFLC-ADAGP; 18b. Pintura Saint Sulpice (1933), Peinture FLC 96 OFLC-ADAGP; 18c. Le Modulor p.217 OFLC-ADAGP; 18d. Escultura Cathédrale (1964), Sculpture FLC 43 OFLC-ADAGP ; 18e. El Poema del Ángulo Recto, PAD_p.139 OFLC-ADAGP; 18f. Firminy, 32234 OFLC-ADAGP

\footnotetext{
${ }^{32}$ Le Corbusier, Le poeme de L'Angle Droit. Ed. Círculo de Bellas Artes \& Fondation Le Corbusier. Madrid, 2006. p.138. Original. Ed. Verve. París, septiembre 1955.

${ }^{33}$ Giedion. ídem, p. 553.
} 


\section{Conclusiones}

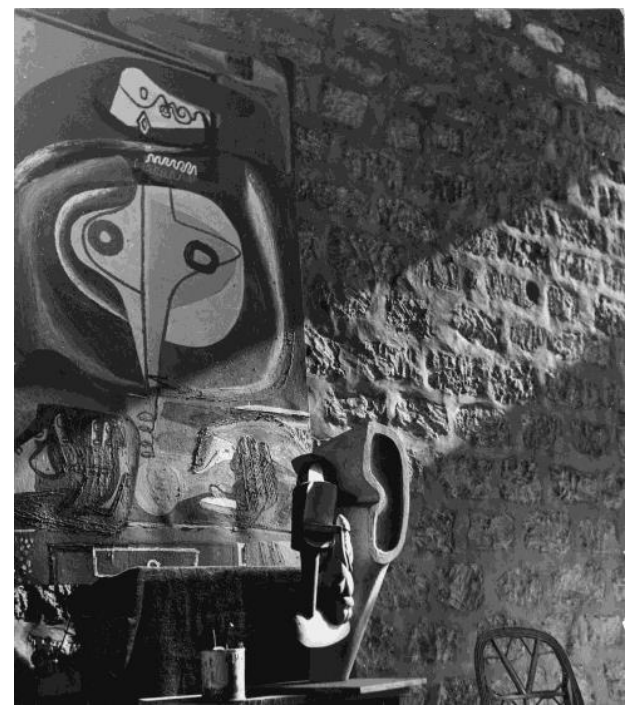

19. Imagen de pintura y escultura sobre el fondo del muro del taller de la búsqueda paciente, Nungesser-et-Coli 24. L2(10)68 CFLC-ADAGP.

Si en alguna cosa se diferencia Le Corbusier de otros maestros de la arquitectura contemporánea es su destacado trabajo en las tres principales artes plásticas, arquitectura, escultura y pintura, y principalmente que el límite entre las tres disciplinas desaparece. Como han señalado Stanislaus von Moos, Alan Coulquhoun, o F. Sekler, hay evidencias que nos hacen pensar en un desplazamiento de conceptos ${ }^{34}$ entre la obra plástica y la obra arquitectónica y urbanística de Le Corbusier. Desde muy pronto destacó que su práctica de las artes le servía como un laboratorio morfológico de arquitectura, un laboratorio de búsqueda paciente. Su interés estaba centrado en establecer diálogos consigo mismo más que con otros artistas. Las translaciones morfológicas se empezaron a mostrar en los años treinta, pero es después de la II Guerra Mundial cuando estas transgresiones entre las diferentes disciplinas llegan a ser el tema principal de su obra. Un tema cuyo fin es la búsqueda de la emoción plástica. No importa el tamaño de la obra arquitectónica o el plan urbano, la pintura o la escultura. Es tan solo una cuestión de armonía. Una armonía a la cual se llega mediante el perfecto conocimiento de la técnica y la manera de hacer. Una búsqueda de la Venustas tras el cumplimiento perfecto de la Utilitas y de la Firmitas. Un encuentro con un objeto evocador, transmisor y provocador que hace que el tiempo se detenga por un instante.

No sabemos si la publicación del libro L'Espace indicible, que se quedó a nivel de proyecto, habría confirmado las esperanzas en este gran libro teórico. Solo nos quedan algunas notas y el plan de obra organizado de forma similar al artículo inicial. Un texto teórico acompañado de una serie de fotos y diseños cuidadosamente presentados. Del borrador de la obra y de los numerosos artículos relativos al espacio inefable se puede deducir que lo que Le Corbusier intenta mostrar no es la "no-decibilidad" de un espacio, sino más bien el proceso por el cual las ideas devienen en cosas - el sentido mismo de la Arquitectura. Ahora bien, todo libro que trata de describir este procedimiento no puede más que darnos sus principios. Sus logros, las obras que aparecen junto a los textos, forman un discurso independiente. No son formas a imitar, tan solo evidencias de un pensamiento.

${ }^{34}$ Von Moos, Stanislaus, Le Corbusier. Elements of a Synthesis, p.266 
Cabe entonces preguntarse cual fue el verdadero motivo por el cual este libro nunca llegó a ver la luz, ¿fue a causa de larga prolongación en el tiempo y el consiguiente hastío de la editorial? ¿o más bien, fue la voluntad de Le Corbusier en no querer mostrar algo que había pertenecido a su yo más profundo?

\section{Agradecimientos}

Quisiera manifestar mi agradecimiento a la Fondation Le Corbusier por permitirme trabajar en sus archivos así como por su colaboración y disponibilidad, en especial a Arnaud Dercelles y a Isabelle Godineau.

A mi director de tesis, Luis Martínez Santa-María, por sus siempre acertados comentarios que me ayudan a seguir avanzando.

Por último, a mi mujer, Marta, y a mis hijos, Martín y Julia, por su paciencia, su tiempo y su comprensión.

\section{Bibliografía}

Calatrava, Juan. Doblando El Ángulo Recto: Siete Ensayos En Torno a Le Corbusier. Madrid: Área de Edición del Círculo de Bellas Artes, 2009.

Cohen, Jean-Louis. Le Corbusier: An Atlas of Modern Landscapes. London: Thames \& Hudson, 2013.

Frampton, Kenneth; Calatrava, Juan. Le Corbusier. Tres Cantos: Akal, 2000.

Gargiani, Roberto; Rosellini, Anna. Le Corbusier: Béton Brut and Ineffable Space, 1940-1965 : Surface Materials and Psychophysiology of Vision. London: Routledge, 2011.

Giedion, Sigfried; Sainz Avia, Jorge. Espacio, Tiempo y Arquitectura: Origen y Desarrollo De Una Nueva Tradición. Barcelona: Reverté, 2009.

Hervé, Lucien; Joray, Marcel. Le Corbusier: L'Artiste Et l'Écrivain. Neuchatel: Éditions du Griffon, 1970.

Krustrup, Mogens. "Det Uudsigelige Rum = the Ineffable Space [Le Corbusier]". Arkitekturtidsskriftet B, -0101, no. 50. pp. [52] avery. Århus (Dinamarca): 1993.

Le Corbusier y Ozenfant, A. Aprés le Cubisme, edition des Commentaires. París, Octubre 1918. Traducido en Ozenfant/Le Corbusier. Acerca del cubismo. Escritos 1918/1926. Colección Biblioteca de Arquitectura. Madrid:

El Croquis Editorial, 1993.

Le Corbusier, "El espacio inefable” en Minerva número 2.06. Madrid: Área de Edición del Círculo de Bellas Artes, 2006.

Le Corbusier, "L'Espace indicible”, en L'Architecture d'Aujourd'hui, número especial “Art". pp. 9-17. París: Editions de l'Architectura d'aujourd'hui, 1946.

Le Corbusier, "Unité", en L'Architecture d'Aujourd'hui, número especial. París: Editions de l'Architectura d'aujourd'hui, 1948.

Le Corbusier, “L'Espace indicible”, FLC, B3.7.

Le Corbusier, Le poeme de L'Angle Droit. Madrid: Ed. Círculo de Bellas Artes \& Fondation Le Corbusier, 2006. Original. París: Ed. Verve, 1955.

Le Corbusier, "Les tendances de l'architecture rationaliste en rapport avec la collaboration de la peinture et de la sculpture", Rome, Reale Accademia d'Italia, 1936, p.12. En "Le Corbusier - Savina, dessins et sculptures". París: Philippe Sers éditeur, 1984.

Le Corbusier. El Viaje De Oriente. Barcelona: Laertes, 2005.

Le Corbusier. Hacia Una Arquitectura. Madrid: Apóstrofe, 1998.

Le Corbusier. El Modulor y Modulor 2. Barcelona: Poseidon, 1980. 
Le Corbusier. Mensaje a Los Estudiantes De Arquitectura. Buenos Aires: Infinito, 1961.

Le Corbusier. Manière De Penser l'Urbanisme. Editions de l'Architectura d'aujourd'hui, 1946.

Le Corbusier, et al. Le Corbusier: Euvre Complète. Zurich: Editions d'Architecture Artemis, 1995.

Le Corbusier; Cohen, Jean-Louis and Ahrenberg, Staffan. Le Corbusier's Secret Laboratory: From Painting to Architecture. Ostfildern: Hatje Cantz, 2013.

Le Corbusier; and Lucan, Jacques. Le Corbusier: Une Encyclopédie. Paris: Centre Georges Pompidou, 1987.

Le Corbusier; Ozenfant, Amédée and Olmo, Carlo. Après Le Cubisme. Torino: Bottega d'Erasmo, 1975.

Le Corbusier, et al. Le Corbusier Et La Question Du Brutalisme: LC Au J1. Marseille: Parenthèses, 2013.

Moos, Stanislaus v.; and Heer, Jan d. Le Corbusier: Elements of a Synthesis. Rotterdam: 010 Publishers, 2009.

Samuel, Flora. Le Corbusier in Detail. Amsterdam: Elsevier, 2007.

Sbriglio, Jacques, et al. Le Corbusier \& Lucien Hervé: The Architect \& the Photographer, a Dialogue. London: Thames \& Hudson, 2011.

Smet, Catherine d. Le Corbusier, Architect of Books. Baden: Lars Müller Publishers, 2007.

Smet, Catherine d., Vers Une Architecture Du Livre : Le Corbusier : Édition Et Mise En Pages, 1912-1965. Baden, Switzerland: Lars Müller Publishers, 2007.

Torres, Jorge, Pensar la Arquitectura: «Mise au Point» de Le Corbusier. Madrid: Abada Editores, 2014.

Wogenscky, André; Le Corbusier. Le Corbusier's Hands. Cambridge: MIT Press, 2006. 


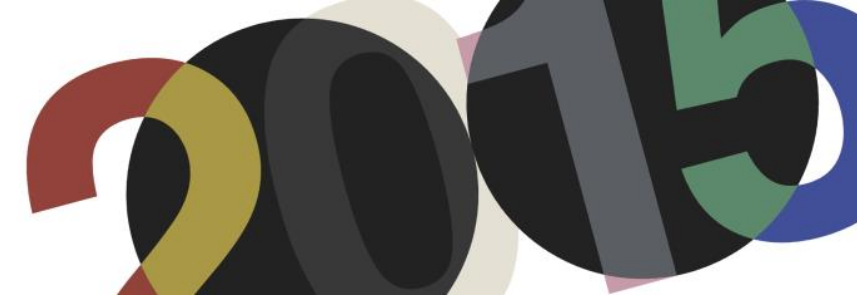

DOI: http://dx.doi.org/10.4995/LC2015.2015.681

\title{
Fotografías que seccionan una mirada a Le Corbusier
}

\author{
C. Barberá Pastor
}

Escuela Politécnica Superior. Universidad de Alicante

\begin{abstract}
Resumen: El texto, titulado Fotografias que seccionan una mirada a Le Corbusier, analiza algunas imágenes de casas construidas de Le Corbusier y Pierre Jeanneret. Las fotografias tienen características comunes que nos presentan un plano en dos dimensiones, el marco de un hueco, y un espacio en tres dimensiones, el de la habitación representada. Las fotografias, al mostrar un hueco y un espacio, incitan a pensar que se están refiriéndose a la experiencia arquitectónica de traspasar un vano. Interpretaciones sobre el uso y la actividad en el interior del espacio doméstico en relación con el espacio público componen el resto del escrito.
\end{abstract}

Abstract: The text, entitled Photographs that severed a look at Le Corbusier, analyzes some pictures to houses built by Le Corbusier and Pierre Jeanneret. The photographs have common characteristics that lead to the interpretation that we have a plan in two dimensions within a hole, and three-dimensional space, the room represented. The photographs, showing a hole and a space, incite to think that they are referring to the architectural experience of crossing a vain. Interpretations on the use and activity within the domestic space in relation to the public space make up the rest of the writing.

Palabras clave: Le Corbusier, Iglesia, Savoye, Cook, Planeix, Ozenfant.

Keywords: Le Corbusier; Church; Savoye; Cook; Planeix; Ozenfant.

\section{Comentarios sobre la mirada a una fotografía.}

La finalidad de la fotografía no está en mostrar lo figurativo. El propósito de cualquier fotógrafo está en hacer ver lo que la apariencia de las cosas no puede manifestar por si misma. Aunque pueda parecer contradictorio, la fotografía no es el medio para representar lo aparente de aquello que vemos. Más bien, una fotografía, nos presenta un modo de ver, que trasmite aquello que rodea al fotógrafo según una manera de entender el mundo ${ }^{1}$. La excepcionalidad de la fotografía viene por la capacidad para comunicar lo que se ve desde un punto de vista, pero a partir de quien mira a través del diafragma. Cuando se pulsa el "click" y se trasmite aquello que está frente al fotógrafo, la relación que se establece está llena de incertidumbre. Entre los límites del espacio que uno ve y la posición del observador, o entre la diferencia de lo que se ve desde un lado u otro, hay un intento por acercar una distancia que nos separa de lo que vemos. En esta distancia se escapa cualquier intencionalidad premeditada. Lo tridimensional, al pasar al plano bi-dimensional, al quitarle una dimensión al espacio, el fotógrafo se ubica en un ámbito entre dos categorías, en algunos casos contrapuestas, por la dualidad que hay entre el intento por acercarse a algo, eliminando la dimensión que nos distancia de aquello.

La fotografía, como representación del espacio, es la imagen de las condiciones donde se llevan a cabo lo que puede acontecer. Esto no quiere decir que aquello que se da en el espacio quede caracterizado -una fotografía no es la representación de los acontecimientos-, una fotografía es, en cierta medida, la caracterización de una condición, es la representación de las posibilidades para que algo suceda. De la misma manera que un modo de

\footnotetext{
1 “Aunque en cierto sentido la cámara sí captura la realidad y no sólo la interpreta, las fotografías son una interpretación del mundo tanto como las pinturas y los dibujos.” Sontag, Susan. Sobre la fotografía, Edhasa, Barcelona, 1981, p.67.
} 
ver es una posibilidad para entender el mundo, las condiciones del entorno son la posibilidad para que un acontecimiento pueda darse. Este texto es como la fotografía misma: una representación de unas condiciones. Con esto se evidencia una dualidad que nos acerca y aleja entre dos aspectos, lo que vemos y el modo de verlo, y aunque en cierta manera, van parejos: en la medida que se distancia uno, se puede presentar con más claridad el otro; ya que entre lo que vemos y el modo de verlo está la representación y la posibilidad. La manera en la que nos refiramos a ellos nos acercará a que un acontecimiento pueda darse. Sobre esta dualidad va el presente escrito.

Cuando por primera vez una persona se sitúa en un punto del espacio físico en el que nunca nadie había logrado ubicarse, este punto, principalmente, adquiere un protagonismo que se intensifica por la nueva condición del observador. Esta trascendencia no viene dada por alcanzarse por primera vez una posición, un lugar en el espacio, sino por presentarse a la visión aquello que nunca alguien había percibido con anterioridad. En estas condiciones, en el estado en el cual se descubre una mirada primeriza, es cuando puede presenciarse una nueva visión del mundo. La primera vez que una persona subió en globo, recreado por Andrei Tarkovsky en la película Andrei Rubliev, a todos aquellos que estaban en tierra y veían desde abajo como un cuerpo se elevaba por los aires sin apenas esfuerzo, podría sorprenderles presenciar algo que no habían visto nunca. No obstante, lo realmente impactante, lo más inquietante de toda esta proeza, debieron ser las sensaciones que causaban las imágenes contempladas por los ojos de quien volaba, que entre gritos y sollozos mostraba las sensaciones de quien realizaba la aventura representada en el film.

Los fotógrafos, pintores, cineastas y arquitectos, adoptan y plantean nuevos puntos de vista en el espacio para intentar establecer una nueva manera de ver aquello que les rodea. Le Corbusier, a partir de la pintura y la arquitectura, trató de presentarlo en los dos espacios en los que mejor se desenvolvía, el espacio bi-dimensional y el espacio tridimensional. A partir de algunas fotografías a sus casas, es donde vamos a establecer relaciones: entre las dos y tres dimensiones, entre la fotografía y la arquitectura, entre el espacio proyectado desde un razonamiento y un razonamiento al espacio construido, entre la imagen desde un punto de vista y aquello que se ve, entre la representación del espacio y el espacio sentido a partir de la experiencia, o entre lo que vemos y el modo de verlo. Todo ello a partir de una manera de entender las fotografías a las casas ${ }^{2}$.

\section{Una representación del espacio. Fotografías a unas casas de Le Corbusier.}

En algunas de las ilustraciones a las casas construidas por Le Corbusier el punto de vista se ubica tan cerca de los paramentos que delimitan el espacio que aquello que se fotografía parece estar refiriéndose a otras cuestiones. Cuestiones más referidas a la arquitectura de su autor que a una representación de las casas. Da la sensación que, el punto de vista está tan concienzudamente estudiado que, esta condición, nos genera una lectura a la fotografía por un lado y la arquitectura fotografiada por otro.

La imagen del estudio Ozenfant (figura 1), tomada desde una de las esquinas del desván, ilustra el espacio interior del taller (figura 2). La posición, en el momento de sacar la fotografía, define una imagen un tanto forzada, al estar el punto de vista tan cerca de la pared y el techo. Se corresponde con la situación de una persona en el altillo, casi en el muro medianero. La imagen nos muestra la puerta enfrentada, de la biblioteca, junto al ventanal y el tragaluz superior del interior del taller. El hecho de que se vea luz entrando por la pequeña ventana a través de la puerta, a la que se accede por la escalera que se ve al fondo de la imagen, nos hace entender que la

\footnotetext{
2 "Veremos pues que la fotografía solo expresa lo accidental. Lo que hace falta materializar no es el objeto en sí , la sensación bruta de la belleza, sino la emoción que provoca." Ozenfant/Le Corbusier. Por donde va la pintura, Acerca del purismo, El Croquis editorial, Madrid, 2000, p.33.
} 
posición del fotógrafo se sitúa casi tocando el muro. Es una imagen que nos muestra la intención de acercarse al mismo borde de la sala. Esta situación plantea un desafío al propio espacio. Provoca una tentativa a salir de sus límites.

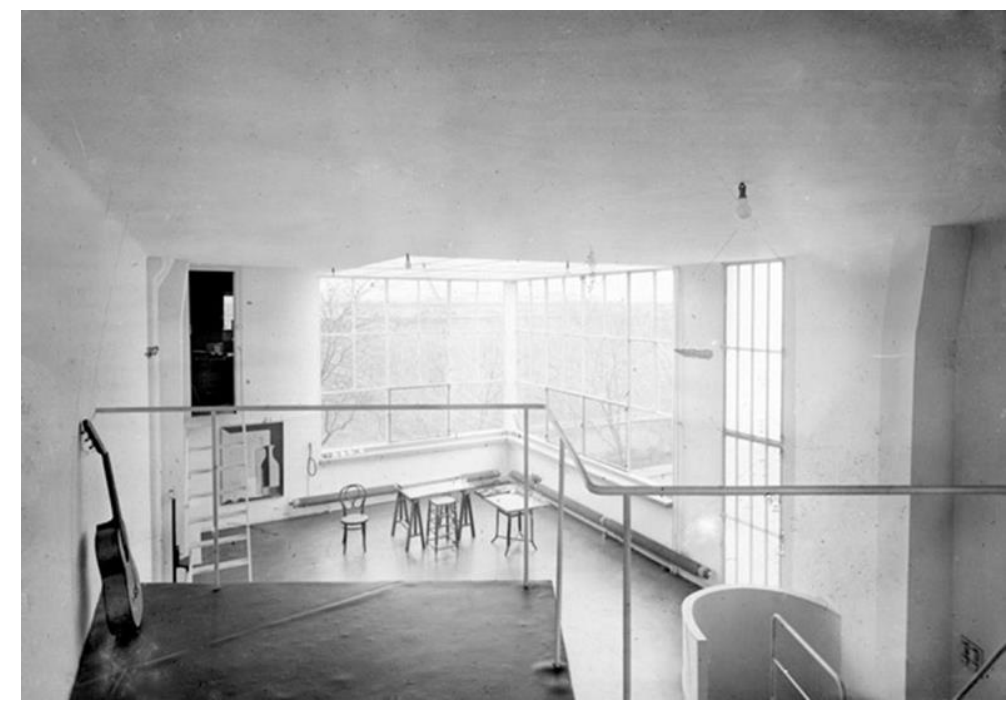

1. Casa estudio del pintor Ozenfant. París 1922. Fotografía de Charles Gérard, FLC L2(13)7. Vista tomada desde el altillo hacia la biblioteca.

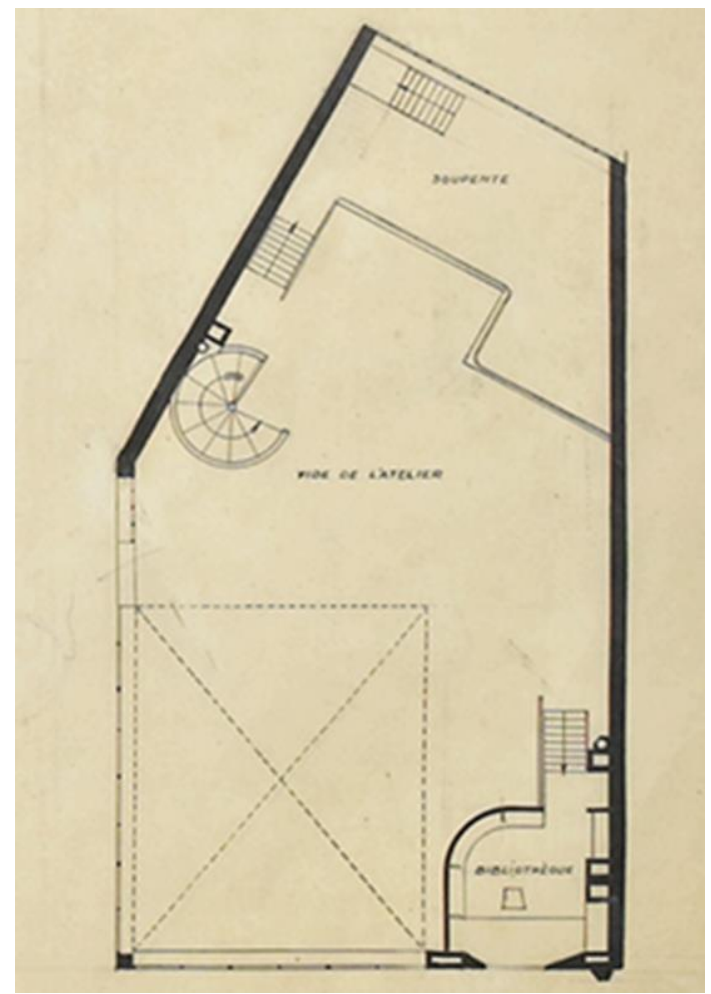

2. Casa-estudio del pintor Ozenfant. París 1922. Planta del Altillo y Biblioteca. Plano FLC 7826.

Tomada desde el interior de la sala de otra casa, la maison Planeix (figura 3), muestra la ubicación del fotógrafo muy cerca de la fachada que da al patio ajardinado. La dirección de la mirada es hacia los libros de la estantería en el lado izquierdo de la imagen, el tragaluz en el techo, y la esquina opuesta hacia las dos puertas. Una está 
abierta, da a la terraza. La otra, cerrada y de vidrio, permite la visión hacia el Boulevard Massena. En el interior se cruzan las aristas del techo que conforman el espacio según la vidriera en zig-zag. Por debajo, sobre el suelo, se encuentra parte del mobiliario interior conformado por unos caballetes y un tablero, muy parecido al que se encuentra en la fotografía de l'atelier Ozenfant (figura 1). La vista, aunque con orientación contraria -la anterior mira hacia el norte y ésta hacia el sur- se direcciona hacia los dos tragaluces del techo que inundan de luz el espacio de los dos talleres.

Otra fotografía, tomada en la misma casa (figura 4), ubica el punto de vista en la pasarela, en la misma planta que l'atelier, a la que se accede desde la escalera ubicada en el jardín. Parece una imagen simétrica a la anterior, separada por la fachada del patio. Sin embargo está tomada más cerca del muro medianero, que se ubica detrás. El motivo es que al distanciarse del muro frontal que vemos al fondo de la pasarela, la imagen permite ver las aristas del espacio de l'Atelier a través de la ventana corredera que se encuentra abierta (figura 4).

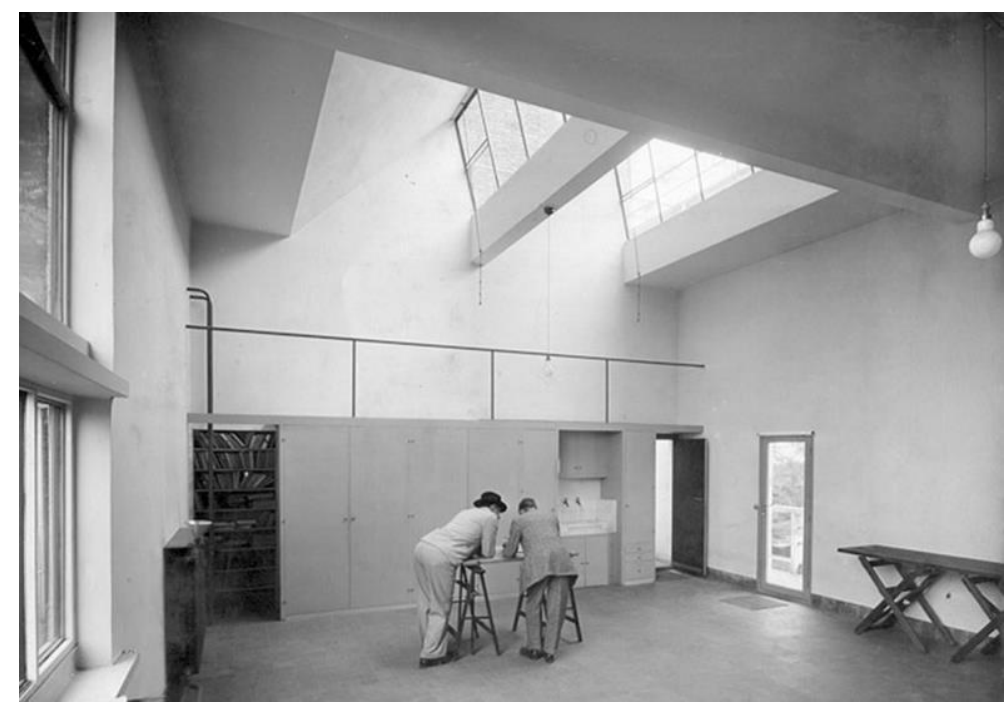

3. Casa Planeix. París 1924. Fotografía de Georges Thiriet, FLC L2(14)22. Vista tomada desde L'Atelier hacia el altillo.

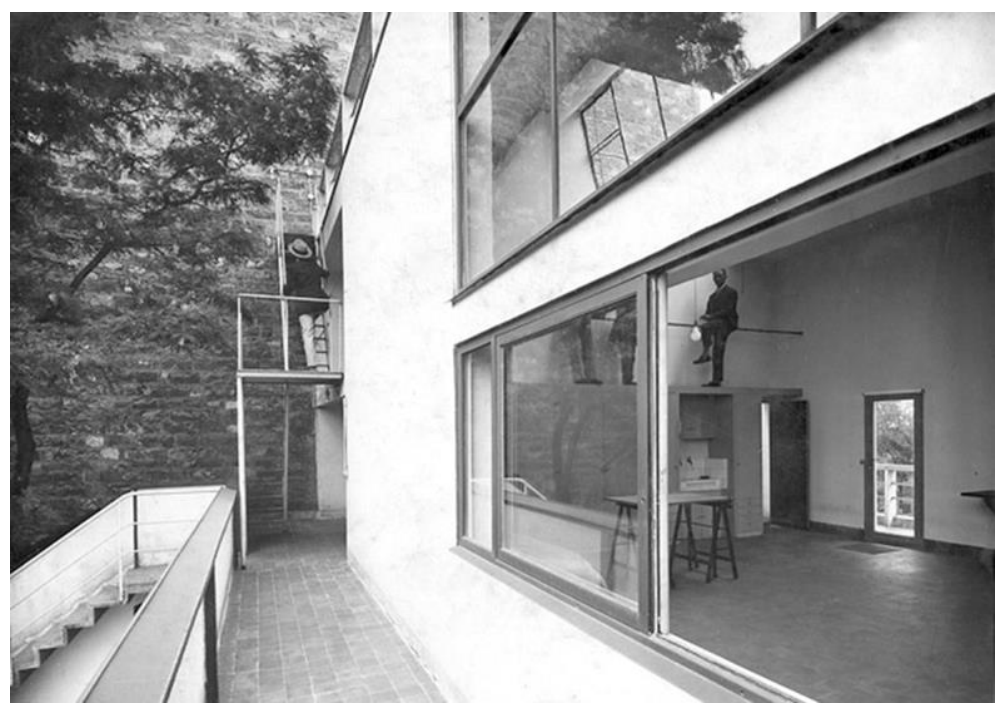

4. Casa Planeix. París 1924. Fotografía de Georges Thiriet, FLC L2(14)16. Vista tomada desde la terraza hacia la escalera exterior. 


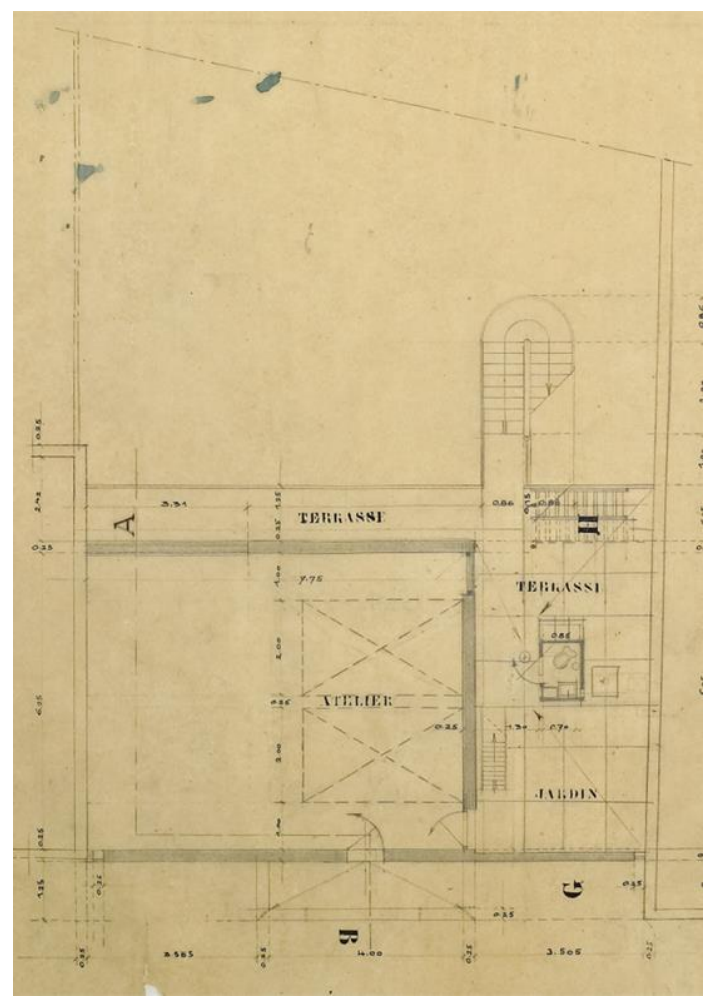

5. Casa Planeix. París 1927. Planta de L’Atelier y Terraza. Plano FLC 8902.

En la fotografía de la villa Cook (figura 6) vemos que la imagen está tomada desde la biblioteca, en dirección hacia la terraza. El fotógrafo se ubica muy cerca del borde de la barandilla que da al salón, junto a la escalera de acceso (figura 7). La fotografía muestra una mirada a tres espacios diferenciados. A la derecha, el salón a doble altura se relaciona con la biblioteca mediante la escalera y la barandilla que se ve en primer plano. A través de la escalinata se permite llegar a la terraza desde la planta inferior. Las puertas abiertas sugieren la facilidad a traspasar con el cuerpo los vanos que diferencian las salas. Es como si mediante la ubicación del punto de vista, entre las dos habitaciones y por las puertas de la terraza abiertas hacia fuera se estuviera incitando a traspasar estos espacios, a franquear sus límites.

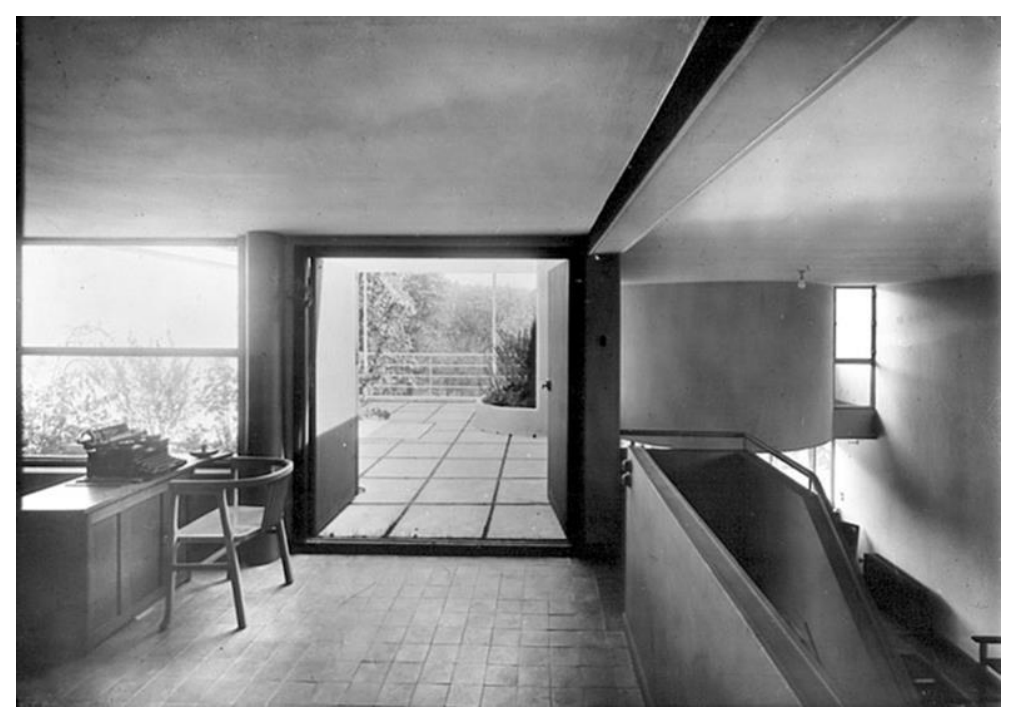

6. Casa Cook. Boulogne-sur-Seine, 1926. Fotografía de Charles Gérard, FLC L1(6)11. Vista tomada desde la biblioteca hacia la terraza. 


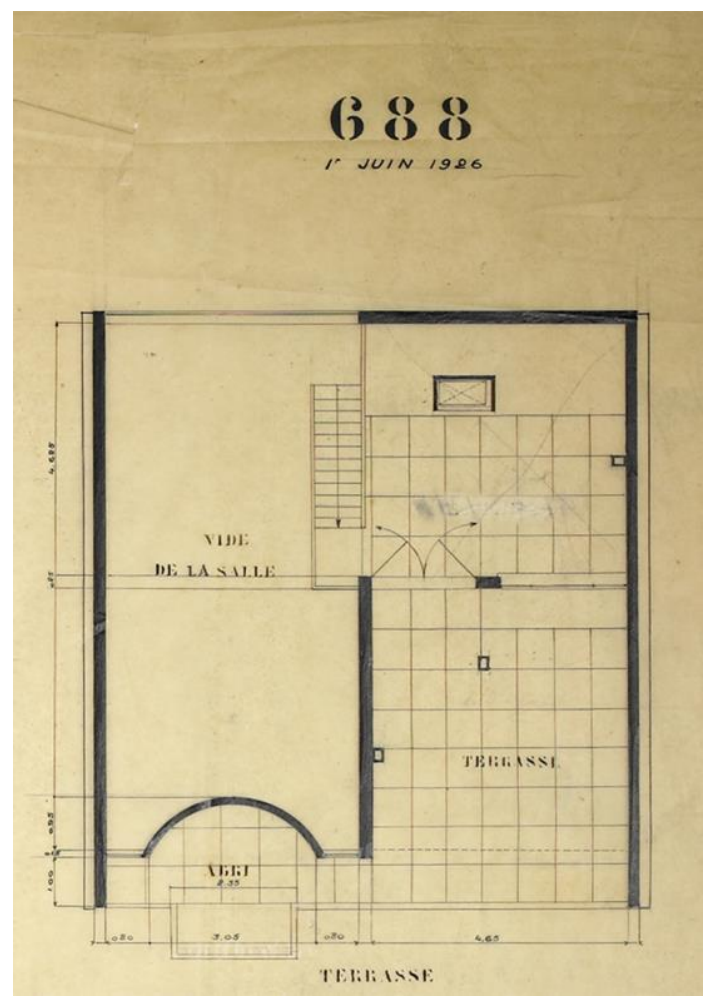

7. Casa Cook, Boulogne-sur-Seine, 1926. Planta de la biblioteca y la terraza. Plano FLC 8292.

En la villa Savoye (figura 8), una fotografía que ilustra los límites que diferencian dos estancias, la terraza y el salón, nos expone la ubicación del fotógrafo enfrentado a la puerta que da al distribuidor, también abierta. La posición del punto de vista, casi en el borde de la puerta corredera que permite acceder al salón, desde la terraza, nos descubre dos aspectos diferenciados: una estancia al aire libre y otra techada y limitada por cuatro paredes. El punto de vista del observador incita, de nuevo, a moverse desde la terraza hacia adentro, en diagonal, hacia la esquina noroeste de la casa.

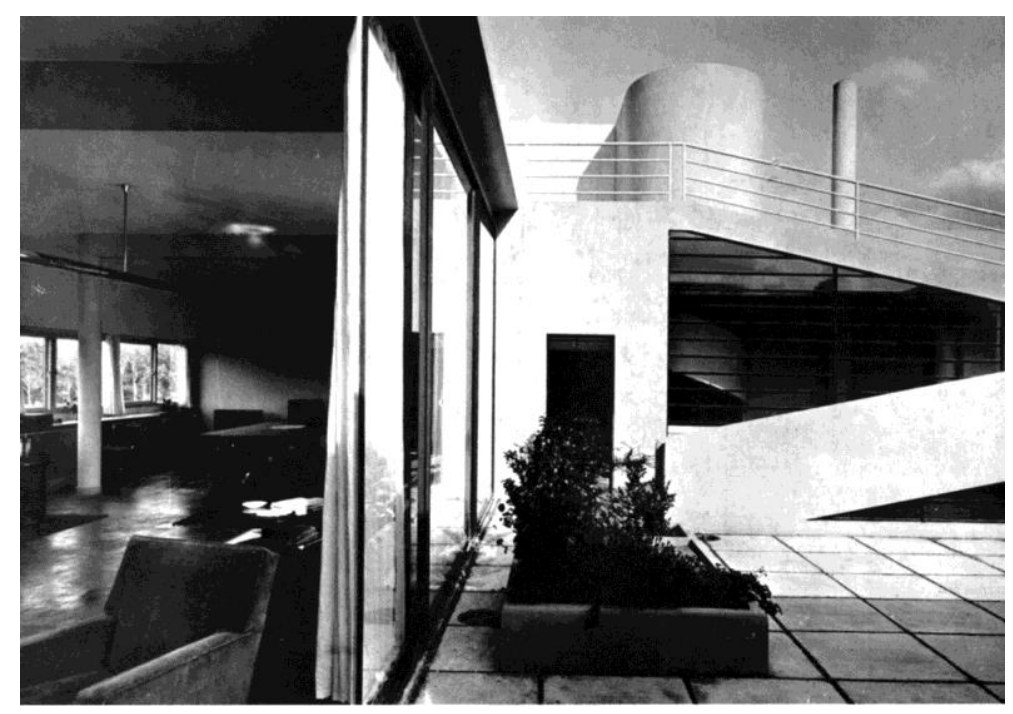

8. Villa Savoye. Poissy, 1928. Fotografía de Marius Gravot, FLC L2(17)49. Vista tomada desde la terraza hacia el distribuidor y el salón. 


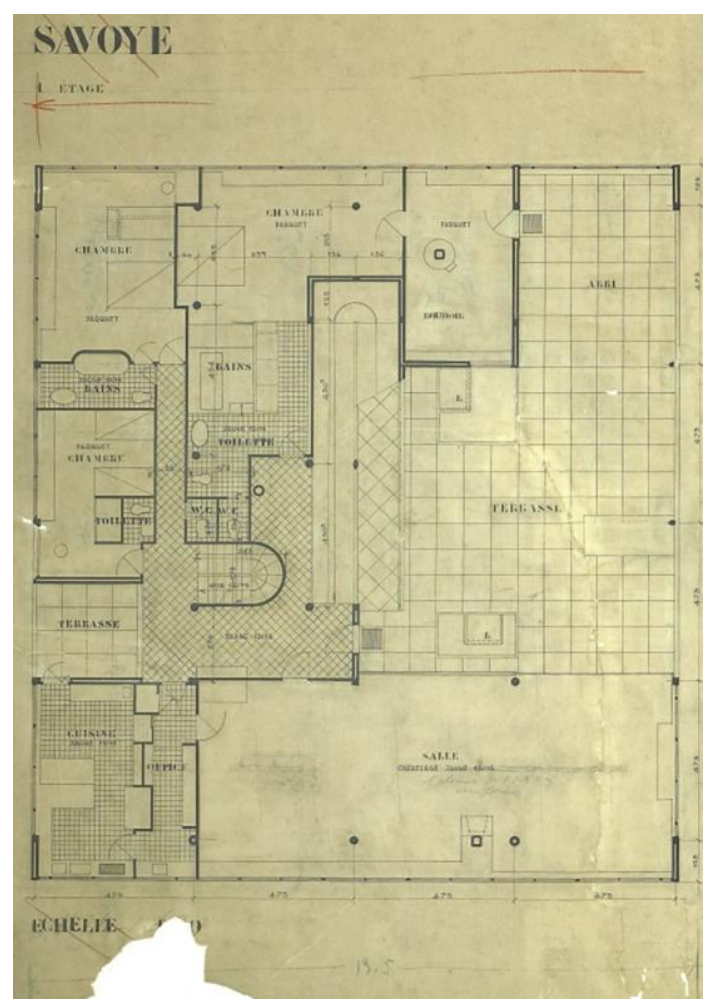

9. Villa Savoye, Poissy, 1928. Planta del primer piso, con la terraza, el salón, y el distribuidor. Plano FLC 19440.

En la última de las seis fotografías, esta vez a la Villa Church (figura 10), vemos que el punto de vista se ubica muy cerca del pasamanos del peto de la terraza, situando al fotógrafo en una posición muy cerca del propio límite del espacio abierto en última planta. La imagen muestra, otra vez, la relación entre distintas estancias, no solo vinculadas entre ellas en el interior de las salas sino también en la terraza, en relación con el cielo, acercando al observador y relacionándolo con las partes más altas de la casa (figura 11).

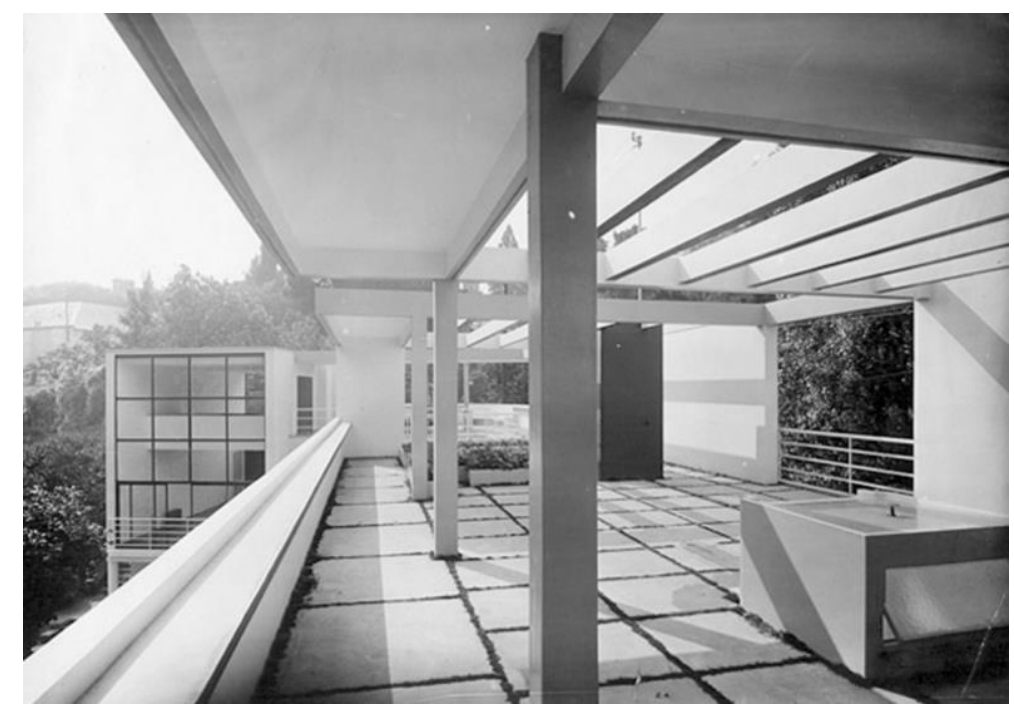

10. Villa Church. Ville d'Avray, 1927 . Fotografía de Georges Thiriet. Vista tomada desde la terraza. FLC L3(7)102. 


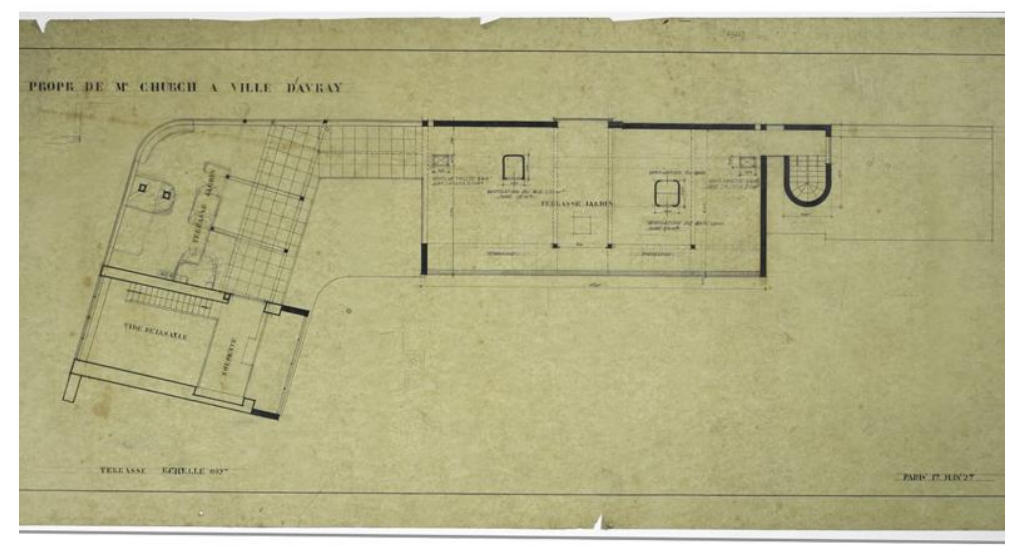

11. Villa Church. Ville d'Avray, 1927. Planta de la terraza. Plano FLC 8122.

Si nos fijamos en las seis imágenes comentadas sobre las cinco casas de Le Corbusier, vemos ciertas cuestiones comunes que nos permiten hablar de ellas de una manera parecida. Ya sea en el lado izquierdo o el derecho de la imagen enmarcada, uno de los paramentos que define el espacio representado se nos viene encima. Ya sea la pared de l'atelier Ozenfant o la pared de la casa Planeix, la barandilla de la biblioteca de la casa Cook o la barandilla de la terraza de la villa Church, o la misma ventana de la Villa Savoye; el punto de vista del fotógrafo, al ubicarse tan cerca del límite de las salas que representan, parece forzar el espacio. Provoca una tentación por salir de la habitación.

\section{Una fotografía como marco para salir del espacio geométrico.}

Salir de una habitación, a partir de una fotografía, adquiere un sentido sintáctico, y muy probablemente ontológico, que nos lleva a pensar en el espacio: la primera cuestión que el arquitecto afronta cuando proyecta un edificio.

La posición de una persona cuando abandona un recinto es, justamente, la de acercase a las paredes. El punto de vista, mientras nos movemos, hace que los bordes del espacio se transformen. La imagen adquiere distintas perspectivas, y según donde nos situemos, los perfiles que definen el interior se deforman constantemente hasta el mismo momento en el que se sale de la sala. Una vez se deja la estancia y se entra en el espacio contiguo, los paramentos de la primera habitación dejan de apreciarse. Sin embargo esto no significa que abandonemos su caracterización. Salir de un espacio no significa no tenerlo en cuenta, al revés, un alejamiento puede significar acercarse. Tomar distancia es una manera de entender aquello que nos rodea, y no sólo puede definirse como una característica del espacio sino más bien como una cualidad del mismo. El modo por el cual se llega a entender un espacio no es estando en él, desde una posición fija, sino al moverse. El espacio son distancias evidenciadas por el movimiento. Sentir un espacio es recorrerlo, es mover el aire, acercarse, alejarse de sus paramentos, entrar y salir de él.

El espacio, como "interior de un límite", adquiere un carácter geométrico y acotado, se define a partir de dimensiones, texturas y materiales que conforman los paramentos que diferencian una habitación de otra. La experiencia de traspasar el vano entre dos habitaciones es percibido por los sentidos, y al dejar una sala, el cuerpo se separa de los paramentos que lo envuelven. Sin embargo, en otro ámbito, las connotaciones que adquiere pensar el espacio, plantea conformar un discurso caracterizándolo entre lo geométrico y lo 
fenomenológico. Es una complejidad transmitirlo mediante el lenguaje escrito ${ }^{3}$. Según Jose Luis Pardo, la acción "comienza a ser", no desde lo fenomenológico o desde la experiencia en el espacio, sino en un intento por acceder desde otro ámbito, distinto a aquel que una fotografía trata de expresar desde lo que aparenta visualmente. Esta cuestión puede dar un sentido distinto a la imagen fotográfica, justamente porque estas fotografías plantean alejarse del espacio geométrico, plantean traspasar sus límites, no para entrar en otro espacio físico, parecido al que representa, sino para entrar en otro tipo de espacio.

Cuando salimos del espacio de una sala, éste queda impreso en el cerebro. La memoria es lo que permite construirlo y es quizás, la acción de salir de él, lo que nos permite caracterizarlo. Cuando se abandona un espacio, el medio para alcanzar un punto de vista insólito, que permita descubrir a éste en su esencia es el recuerdo y la memoria, que es lo que permite construir el alma. ${ }^{4}$ Este escrito es un intento por entrar en una dimensión del espacio. Es un intento por definirlo. No obstante, en este afán no podemos entrar por mero capricho, por ser íntimo, inalcanzable, interno y por tanto carente de representatividad. No puede mostrarse ni exhibirse.

Salir de un espacio, en todos sus aspectos, siempre va a suponer entrar en otro. No obstante si hablamos de una fotografía ¿a qué espacio estaríamos refiriéndonos? $?^{5}$

A las fotografías vamos a dotarles de un sentido en dos aspectos diferenciados. Uno como representación del espacio tridimensional, y por tanto desde una cuestión propia de la imagen y del espacio geométrico. En otro aspecto, menos evidente, la fotografía va a disponerse como espacio interpretable. No quedará definida por lo que representa, sino más bien, por aquello que no es mostrado a simple vista ${ }^{6}$.

Para interpretar una imagen, la relación entre aquello que se ve y el lugar en el que uno se ubica puede ser tan

${ }^{3}$ El modo de expresar una experiencia del espacio tiene una complejidad que no está propiamente en el lenguaje sino en la propia experiencia. Jose Luis Pardo lo define en el subcapítulo "4.2. La experiencia de los límites de la experiencia" cuando dice: "Si la experiencia de(l) ser puede ser descrita como una experiencia de los "límites en los que ser deviene sentido"; tales límites constituyen pues, las condiciones de posibilidad de la sensibilidad y de la sensatez, aquellos entornos en los cuales es posible sentir (el ser, la naturaleza) y que llamamos los Espacios (9). De nuevo es Heidegger (1951) quien nos recuerda que "un espacio (Raum) es algo que está despejado (eingeräum), liberado, es decir, en el interior de un límite, en griego, péras. El límite no señala el cese de una cosa, sino más bien, como ya observarán los griegos, aquello que a partir de lo cual algo comienza a ser (sein Wesen beginnt). Un espacio es un lugar para la manifestación de la physis, para el devenir sentido del ser. Pero, ¿Devenir sentido no es acaso aparecer? ¿No sería redundante hablar, como aquí hacemnos, del "devenir sentido del ser"? Si el ser, en la experiencia, se reduce a su aparecer, decir "el devenir sentido del ser", ¿no es acaso como decir "el ser del ser"? (...) es un modo de decir que "ser es devenir"; y devenir (sería fatal decir el devenir) es forzosamente ilimitado (Deleuze-Guatari: 1980), devenir es devenir, o sea, no puede cesar lo que es, no puede dejar de devenir, más allá de todo límite; ser deviene sentido dentro de ciertos límites, pero el mismo devenir sentido dentro de ciertos límites no puede tener límite.” Pardo, Jose Luis. Las formas de la exterioridad, Pretextos, Valencia, 1992, p.123-124.

4 "No recordamos porque tengamos alma: tenemos alma porque recordamos, y sólo en la medida en que olvidamos (nuestra alma es más grande cuando más grande sea el alcance de nuestra memoria); y no olvidamos porque tengamos cuerpo: tenemos carne porque olvidamos, y sólo en la medida en que olvidamos (nuestro cuerpo crece con nuestro olvido, y un alma que lo ha olvidado todo ya es sólo cuerpo-cadáver)." Pardo, Jose Luis. Las formas de la exterioridad, Pretextos, Valencia, 1992, p.64.

${ }^{5}$ Hablar de una fotografía no es lo mismo que hablar del espacio que representa. Mientras que en uno su caracterización es por disponer de dos dimensiones, en el otro, el espacio representado se caracteriza por disponer de tres. El discurso, de un espacio o de otro, nunca puede estar contextualizado de una misma manera.

6 "Merece la pena detenerse un instante en la razón en que se apoya Kant para sostener que la representación del espacio no es (y no puede ser) un concepto: el espacio es pensado como si encerrase una multitud infinita de representaciones, y ningún concepto puede ser pensado así. "Espacio y tiempo son quanta ilimitadamente infinitos, negativamente infinitos... de un tipo tal que sólo puede ser representado como parte de un todo aún mayor y, por tanto, como infinito" (Transición..., XXII, 19)" Pardo, Jose Luis. Las formas de la exterioridad, Pretextos, Valencia, 1992, p.278. 
distante que quizás el sentido de la imagen representada podría tener más relación con aquello que no se ve en la imagen que con lo que la imagen nos presenta a la vista en su carácter figurativo. Es aquí donde la fotografía adquiere un sentido, es cuando alcanzamos a ver qué quiere trasmitir fuera de lo eminentemente aparente. Estos dos aspectos plantean concebir el espacio representado desde distintas dimensiones que van a permitir interpretar las fotografías, desde una cuestión representativa por un lado o desde lo que no puede representarse y que no se trasmite de forma directa ${ }^{7}$, por otro.

Cuando a partir de una fotografía se platea hacer ver lo que no puede mostrarse, la imagen fotográfica queda referida directamente a su imposibilidad por describir con palabras el sentido de aquello que aparece meramente representado ${ }^{8}$. Para descifrarlo tendremos que interpretar las fotografías, intentando ver lo oculto de ellas, lo que no se trasmite desde lo visible. Esta interpretación de las ilustraciones nos sitúa entre dos conceptos opuestos: la representación del espacio y lo aparente, por un lado, y lo que la propia fotografía no puede representar, por su propia limitación como medio. Para ello, el punto de vista en el que nos tenemos que situar no es el mismo que el del fotógrafo, por encontrarse el propio fotógrafo en el lugar de lo representado.

El espacio geométrico, por sus particularidades físicas, por sus límites construidos o por el hecho de ubicarnos mediante el cuerpo entre los paramentos y objetos que lo definen, nos lleva a definirlo desde sus dimensiones, a partir de la materia y desde la condición de ser representado mediante una fotografía, las plantas de un proyecto, o mediante un dibujo en perspectiva Pero si atendemos a alcanzar un punto de vista insólito, en el que nadie se hubiera situado con anterioridad, de manera que desde ese punto se puedan interpretar cuestiones ajenas a aquellas que el punto de vista nos permite mostrar únicamente desde la imagen, habría que ubicarse en otro espacio y concebir al anterior desde un ámbito que permita caracterizarlo para hacer del lugar un espacio propio, inalcanzable por cualquier punto de vista representado mediante una fotografía.

Para llegar a alcanzar el sentido de la posición tan cerca de los límites del espacio en el que se encuentra la cámara que fotografía las casas de Le Corbusier, deberíamos intentar, más que tratar de ver qué es lo que podemos interpretar viendo la imagen, intentar lo contrario: proponernos ver qué es lo que nos aleja de esa misma imagen. Estando tan cerca de los límites del espacio, el lugar al que nos acercamos es al de la materia, a lo físico y tangible, a la realidad física relacionada con lo visible. Pero si hablamos de entrar en lo contrario, si miramos la imagen que muestra la fotografía para alejarse, nos separamos de lo figurativo que muestra la imagen. Nos acercamos, justamente, a lo que no puede representarse. Es aquello que queda referido a los sentidos, a la experiencia sensible, a las vivencias de los acontecimientos dados en la experiencia arquitectónica; que aunque una fotografía no pueda ser capaz de presentar puede aludir a ello y quizás sea el modo para entrar en un espacio distinto al representado. Por tanto habrá que referirlo a la acción de un movimiento que nos permita salir del espacio geométrico que representan las fotografías.

\footnotetext{
7 "La fotografía implica que sabemos algo del mundo si lo aceptamos tal como la cámara lo registra. Pero esto es lo opuesto a la comprensión, que empieza cuando no se acepta el mundo por su apariencia. Toda capacidad de comprensión arraiga en la capacidad de decir no.” Sontag, Susan. Sobre la fotografía, Edhasa, Barcelona, 1981, p.33.

8 "Pintar no es reflejar lo visible (pues algo llega a sólo a ser visible porque está pintado, porque constituye un "alimento para el ojo") sino hacer visible lo invisible y, por tanto solo puede suceder a partir del des-cubrimiento de lo invisible, de lo nunca visto o jamás pintado: des-cubrir las cosas es romper su caparazón externo de sentido, de imágenes, de sonidos o de signos y pensamientos, des-oir su voz y volverse ciego a su brillo, abstraerlas de los espacios, para encontrar así la "verdad" bajo el disfraz del sentido, una verdad que sólo puede aparecer, entonces, como ausencia absoluta de sentido, página-en-blanco sobre la que escribir." Pardo, Jose Luis. Las formas de la exterioridad, Pretextos, Valencia, 1992, p.140. (quizás debería ir en otro sitio esta cita)
} 


\section{Salir de un espacio, entrar en otro, ubicarse.}

Uno de los misterios más sorprendentes de la experiencia arquitectónica es traspasar un vano. Esta práctica que permite salir de un espacio para entrar en otro es una acción muy cotidiana, que aunque pasa desapercibida, no deja de tener un carácter misterioso. Esta cualidad no la caracteriza el nuevo espacio al que uno se enfrenta sino el acontecimiento que supone pasar del espacio tridimensional, el de la arquitectura, para entrar al plano bidimensional, el de la pintura ${ }^{9}$. Estos dos mundos, imprescindibles para experimentar mediante los sentidos la arquitectura, es propio de las fotografías a las casas. También de la propuesta pictórica y arquitectónica de Le Corbusier.

Viendo las fotografías, podemos ver que tienen características comunes todas ellas. Nos llevan a pensar que el espacio que representan es concebido de una misma manera. Si las repasamos hay dos componentes que podríamos caracterizar consecutivos. Dos partes se presentan en cada una de las imágenes mostradas. Nos indican una sucesión. A partir del movimiento, propio del acontecer arquitectónico, una de las componentes de la imagen va a ir consecuentemente detrás de otra, en la acción que supone traspasar un vano.

En la imagen de l'atelier Ozenfant (figura 12), una puerta abierta en uno de los lados, el de arriba de la escalera que permite el acceso a la biblioteca, nos incita a traspasar con la mirada el tabique que delimita el rectángulo. A través de ella se ve la luz que proviene del exterior de la sala, la misma que se ve si dirigimos la mirada hacia el lado derecho de la fotografía-. Consecuentemente, la mirada va a ir dirigida a la derecha, donde se encuentra el espacio, el de l'atelier, representado por las aristas del techo y el suelo, y la esquina vertical entre los dos ventanales que dan a la "Avenue Reille". Son dos partes que incitan a mirar correlativamente, por el contraste que presentan entre ellas, y por el conjunto que nos muestra la propia imagen. La oscuridad, por un lado, define el hueco del paño y establece un espacio ilimitado. Se traduce en la curiosidad por saber qué hay detrás del hueco. Después la mirada irá dirigida a la sala. Una secuencia que se repite en una y otra de las imágenes.

Las dos componentes, la del vano y el espacio, que caracterizan la fotografía, plantean compararlos. Tienden a verse desde una coexistencia. Una tras otra. Forman parte de una composición que podríamos establecer como frontal y diagonal. Aunque la puerta no se ubica en el centro de la fotografía, el punto de vista, al situarse en uno de los límites del espacio, hace que el observador quede enfrentado a ella, como si tuviéramos que traspasar la imagen.

Sin embargo, la comparación, va a quedar determinada por una secuencia de dos miradas. Están originada desde una sucesión ordenada en dos partes: el marco y el espacio. Desde una cuestión propia de la experiencia arquitectónica, sobre esta secuencia, ¿qué podemos interpretar? Si nos fijamos en lo que nos enfrentamos después de pasar un vano, ¿no es el nuevo espacio lo que nos aparece y por lo el cual nos adentramos en él? Los

\footnotetext{
9 “Sin duda esa ventana es un radical -o irónico- desarrollo y subversión de las teorías y prácticas cubistas. La experiencia de la pintura, desde el impresionismo hasta el cubismo, había ido reduciendo progresivamente la distancia entre la tela y el motivo representado. Si el cuadro trataba de captar el mundo como a través de una ventana, la profundidad a que abría esa ventana iba siendo cada vez más reducida, hasta llegar a coincidir imagen y motivo sobre el mismo marco, en la misma tela, con el collage cubista: ahí la realidad se adhería a la tela y lo representado coincidía con su representación. La ventana de Poissy no es sino un estricto y radical collage, donde Le Corbusier no engancha un trozo de papel de periódico, de tela o de madera, sino un fragmento mismo de naturaleza. Pero, así haciendo, hace regresar inesperadamente a la pintura hacia su lejana y tradicional definición como imagen a través de una ventana, vuelve a posiciones performistas, sin dejar, sin embargo, de ser un puro ready-made, montado escogiendo un producto previo, la misma naturaleza, y convirtiéndola, sin manipularla, por la simple selección de su encuadre y de la mirada que la capta, en paisaje, en "obra". Quetglas, Josep. Le heures claires. Proyecto y arquitectura en la Villa Savoye de Le Corbusier y Pierre Jeanneret, Associació d'idees. Centre d'Investigacions Estétiques, Barcelona, 2009, p. 595,596.
} 
marcos del hueco es un cerco que diferencian dos estancias y hasta que no lo traspasamos con el cuerpo no puede alcanzarse el nuevo espacio. ¿No estará definiendo la propia fotografía una secuencia que se refiere al movimiento, al hecho de traspasar una pared para dejar atrás un espacio y entrar en otro? Sobre esto va la indagación que plantea salir del espacio geométrico para entrar en un nuevo espacio. Veamos las otras imágenes.

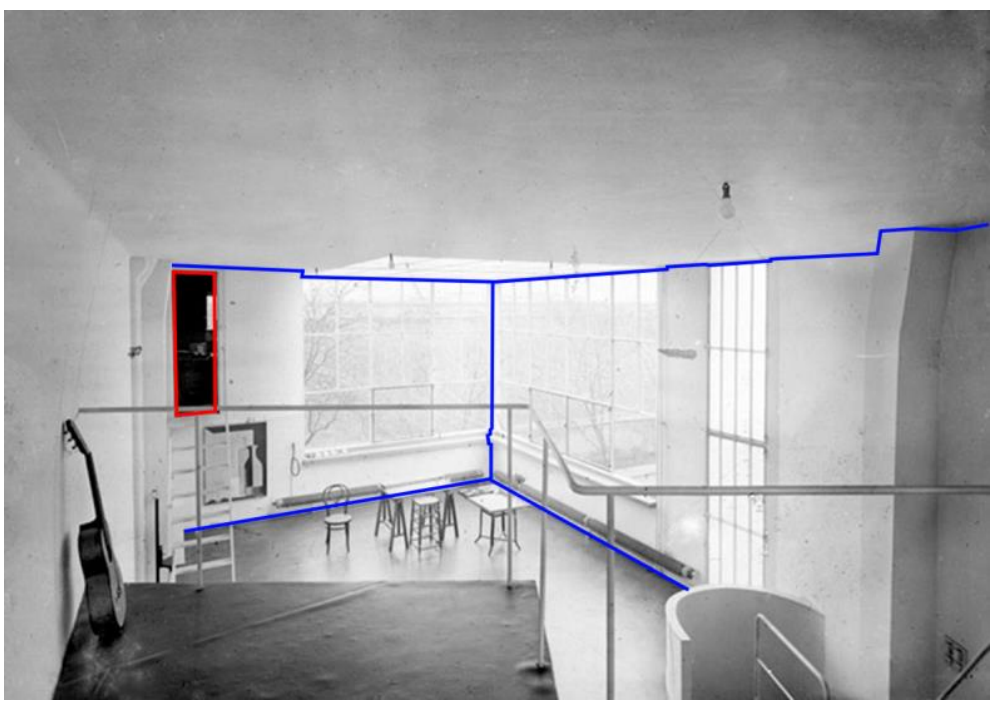

12. Casa estudio del pintor Ozenfant. París 1922. Fotografía de Charles Gérard, FLC L2(13)7. Vista tomada desde el altillo hacia la biblioteca. Una interpretación sobre el vano y el espacio de la sala remarcado por el autor.

En la Villa Cook (figura 13), otro de los vanos que identificamos, como en el resto de las fotografías, es el de la salida a la terraza. Se sale a través del marco de un hueco que va desde el suelo hasta el techo. Este hueco permite acceder desde la biblioteca al jardín de la última planta. El punto de vista, en este caso, se ubica enfrentado al plano que conforma las cuatro esquinas del hueco. De nuevo invita a traspasarlo. Las dos puertas abiertas, de par en par, hacia afuera, nos incita a salir del espacio de la biblioteca para entrar a otro espacio. Pero viendo la imagen, por lo que podemos observar en la fotografía, ¿a qué espacio podríamos entrar, con la mirada, tras pasar el marco de las dos puertas abiertas? ¿Al de la terraza? Realmente, el espacio de fuera no queda definido en la imagen. Únicamente, una barandilla y el plano del suelo alude a un lugar que es exterior, al cual no podemos entrar por no quedar mínimamente definido y delimitado. No disponemos de información para poder entrar en él. Obviamente, la consecuente mirada, ha de ser hacia el espacio que controlamos: el definido por los paños que se nos presentan a la vista. La mirada, se traslada en diagonal, hacia la derecha de la imagen, al espacio representado por las aristas del suelo y la pared; y la del techo, entre las ventanas y el muro curvo. Las dos componentes de la imagen muestran una sucesión tras dos miradas a la fotografía, una consecución referida a un espacio y el siguiente que, de nuevo, aluden a la acción de traspasar un vano. 


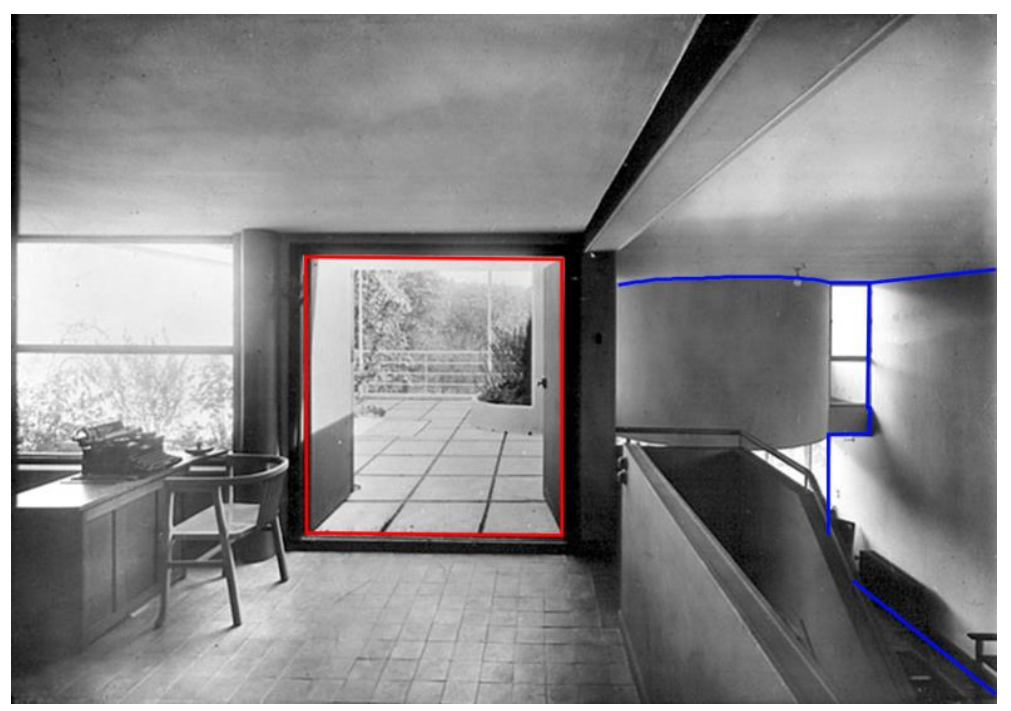

13. Casa Cook. Boulogne-sur-Seine, 1926. Fotografía de Charles Gérard, FLC L1(6)11. Vista tomada desde la biblioteca hacia la terraza. Una interpretación sobre el vano y el espacio de la sala remarcado por el autor.

Con esta insinuación al movimiento, las fotografías sugieren referirse a una experiencia fenomenológica que simboliza dos tiempos consecutivos: el de traspasar un vano, para salir de un espacio, y el de acceder a uno nuevo. La característica de esta secuencia es que ocurre en el plano de la fotografía ${ }^{10}$. La serie de imágenes, que identifican este acontecimiento transcurre en el plano bi-dimensional. De esta manera, y con más razón, si vemos una fotografía tras otra, el orden de los fenómenos que se suceden en el espacio y en el tiempo, quedan descompasados. Aluden a un tiempo que no se liga propiamente con el espacio geométrico que representan las imágenes ${ }^{11}$. Con esto, salir del espacio, no es una acción referida meramente al espacio geométrico, al espacio físico y por tanto medible. El espacio de la imagen fotográfica nos incita a salir de una sala, el de la habitación representada, y nos incita a salir del espacio geométrico para entrar en otro espacio. Aunque las fotografías representen distintas salas, vamos a tratar, viendo estas imágenes, de encontrar cuestiones comunes que se refieran a ese nuevo espacio al que poder entrar.

\footnotetext{
10 "Y todo ello adquiere un aspecto bastante paradójico si uno se pregunta qué clase de fenómenos son el espacio y el tiempo o de qué modo aparecen." Pardo, Jose Luis. Las formas de la exterioridad, Pretextos, Valencia, 1992, p.26.

11 "La física actual descubre que, bajo ciertas condiciones, algo escapa al tiempo y al espacio, pero ello no anula el hecho de que, al mismo tiempo nosotros estamos, indiscutiblemente, en el tiempo y en espacio./ No podemos reconciliar esas dos ideas ¿Debemos aceptarlas como tales? La aceptación de la complejidad es la aceptación de una contradicción, es la idea de que no podemos escamotear las contradicciones con una visión eufórica del mundo./ Bien entendido nuestro mundo incluye a la armonía, pero esa armonía está ligada a la disarmonía, es exactamente lo que decía Heráclito: hay armonía en la disarmonía y viceversa.” Morin, Edgar. Introducción al pensamiento complejo, Barcelona Gedisa, 1996, p.95.
} 


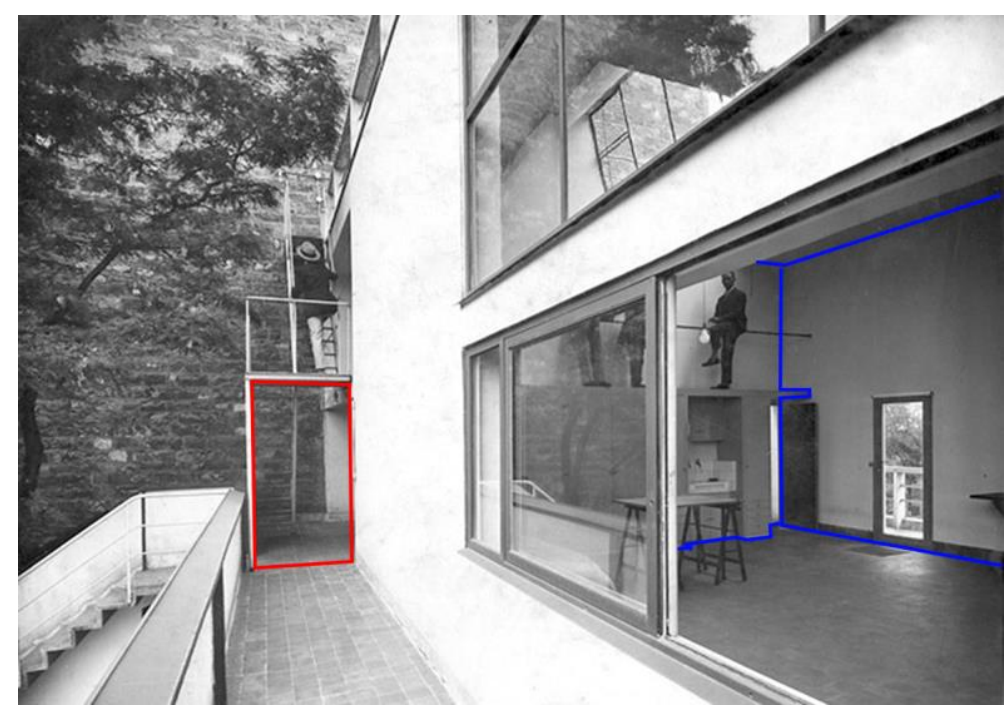

14. Casa Planeix. París 1924. Fotografía de Georges Thiriet, FLC L2(14)16. Vista tomada desde la terraza hacia la escalera exterior. Una interpretación sobre el vano y el espacio de la sala remarcado por el autor.

Si atendemos esta misma cuestión viendo cada una de las fotografías vemos que esta sucesión se repite en cada una de las imágenes. En la de la maison Planeix (figura 14), aparece la pasarela de acceso a l'atelier. Se presenta de nuevo el marco de un vano y el espacio de una sala en la misma secuencia. El marco de la escalera que sube a la cubierta nos muestra el hueco a traspasar. La frontalidad de éste queda enfatizada por el punto de fuga entre los límites del suelo, la barandilla y la fachada. Indican una primera dirección de la mirada hacia el recuadro conformado por el soporte de la escalera metálica, el descansillo, el suelo y la arista del muro de la fachada. Otra vez definen un plano. Después, una mirada hacia la derecha, una segunda mirada hacia la ventana que aparece en uno de los lados, nos permite descubrir repentinamente el espacio. Desde esta misma consecución, la sala, delimitada por los paramentos entre la arista del techo, la arista vertical de las paredes y la arista del suelo, muestra el interior de l'atelier. L'atelier se descubre después de traspasar el vano, como objeto de una primera mirada. Es una secuencia que nos manifiesta una manera de mirar las fotografías, un modo que nos va a cambiar también la manera de interpretarlas. Una vez estos dos elementos característicos de las imágenes se presentan: el vano conformado por un plano y el espacio de la sala, adquieren un protagonismo cada vez que se mira la imagen. Siempre aparecen, a pesar de que nos fijemos en otras características de la fotografía. Ocurre en cada una de las distintas imágenes.

Si miramos la otra imagen de la misma casa (figura 15), la tomada desde el interior de l'atelier, el umbral, marcado por la librería enfrentada al punto de vista del fotógrafo, nos marca una primera visión de la imagen. Su contraste con las puertas de armario del mismo tono que las paredes, ejercen una secuencia parecida al l'atelier Ozenfant (figura 1). Nos enfrenta al umbral para, de forma previa, mostrarnos el espacio que vamos a encontrar con otra mirada en diagonal; que representada por las aristas del taller nos devuelve al espacio que muestra la fotografía. Secuencialmente, presenciamos de nuevo estos desarrollos en dos golpes de vista. Están marcados por una perspectiva casi frontal y otra diagonal. Esta consecución, además de quedar definida por un orden, se va a caracterizar también por la dirección de las dos miradas. 


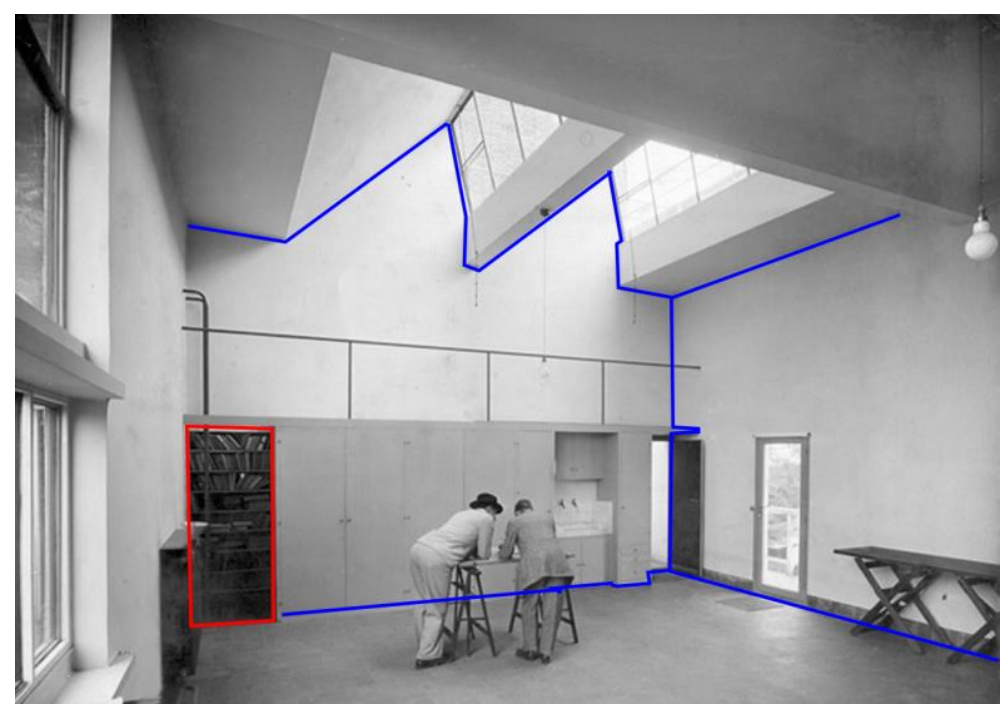

15. Casa Planeix. París 1924. Fotografía de Georges Thiriet, FLC L2(14)22. Vista tomada desde L'Atelier hacia el altillo. Una interpretación sobre el vano y el espacio de la sala remarcado por el autor.

Un espacio, cuando nos lo encontramos después de traspasar un vano, pocas veces lo descubrimos de forma frontal. La imagen que vamos a encontrar al entrar a una nueva sala, la mayoría de las veces, va a ser una imagen diagonal. Mientras que a un vano nos enfrentamos frontalmente ${ }^{12}$, la dirección siempre suele ser perpendicular al plano que traspasamos. En el espacio siempre será al contrario. Se nos presenta en oblicuo, caracterizado por las aristas que mediante la mirada descubrimos la máxima distancia de un recinto, en diagonal. Para conocer un espacio no podemos quedarnos con una imagen, la que nos encontramos al traspasar el hueco que descubrimos de forma frontal. La mirada ha de recorrer los rincones, en todas direcciones, hacia los lados que disponemos a derecha e izquierda. Cuando esto ocurre, mediante miradas transversales y en distintas trayectorias, es cuando uno se ubica en el propio espacio en el que se encuentra.

En la Savoye (figura 15), la puerta que accede al distribuidor desde la terraza en la planta primera, enfrentada a la mirada del fotógrafo, prevalece a la mirada al salón de la izquierda. El vano nos impone una mirada primeriza, mediante un golpe, por ubicarse el punto de vista de la imagen frente a la puerta. Ésta, de nuevo, nos incita a entrar al espacio contiguo, pero esta vez al de la izquierda. Nos muestra la sala en dirección trasversal, que al presentar la arista más alejada de la habitación, entre la pared del fondo y la ventana rasgada de la fachada noroeste, muestra una característica de la imagen diagonal.

\footnotetext{
${ }^{12} \mathrm{Al}$ igual que los miembros de un edificio son colocados frontalmente en relación con sus ejes principales también nos colocamos nosotros mismos frontalmente con respecto a esos miembros.” P. Frankl, Arquitectura Gótica, Cátedra, Madrid, 2002 , p. 85.
} 


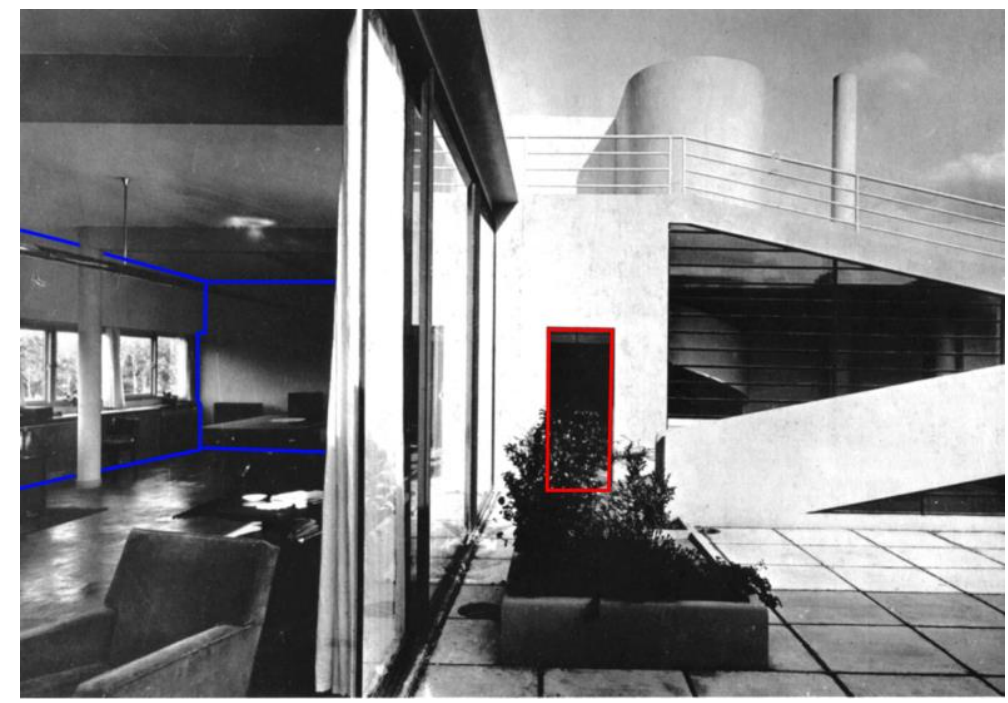

16. Villa Savoye. Poissy, 1928. Fotografía de Marius Gravot, FLC L2(17)49. Vista tomada desde la terraza hacia el distribuidor y el salón. Una interpretación sobre el vano y el espacio de la sala remarcado por el autor.

En la última de las imágenes, a la Villa Church (figura 17), la terraza está protagonizada por el final de una perspectiva frontal, marcada por las líneas del suelo, los pilares, la barandilla y la pérgola. Este punto de vista se contrapone al espacio del salón, que aparece a la izquierda en el final de la imagen, por encima del borde que delimita el pasamanos de la cubierta.

Si repasamos todas las imágenes, nos plantean una cuestión común: juntas nos definen una serie. Son fotografías tomadas en lugares y momentos distintos y aunque representen espacios y tiempos distintos, propio de la mirada a cada imagen, en la secuencia establecen una misma relación. En el momento que son miradas las imágenes la manera para referirse al espacio al que aluden son comunes. Sin embargo la serie nos presenta un modo de ver que podríamos definir contrapuesto. Las propias imágenes, que representan construcciones distintas, plantean adentrarse a un lugar que no se corresponde con los limites geométricos del espacio que representan. Un espacio al que podemos acceder en el tiempo que dura la mirada a las fotografías. Ya sea la mirada a una u otra, se trata de una misma dimensión del espacio, al cual se entra, convirtiendo "al lugar en un espacio de más de cuatro dimensiones, donde la quinta es tanto la memoria como el delirio asociativo"13. Así define Josep Quetglas el espacio de la villa Savoye.

\footnotetext{
${ }^{13}$ Quetglas, Josep. Le heures claires. Proyecto y arquitectura en la Villa Savoye de Le Corbusier y Pierre Jeanneret, Associació d'idees. Centre d'Investigacions Estétiques, Barcelona, 2009. p. 564.
} 


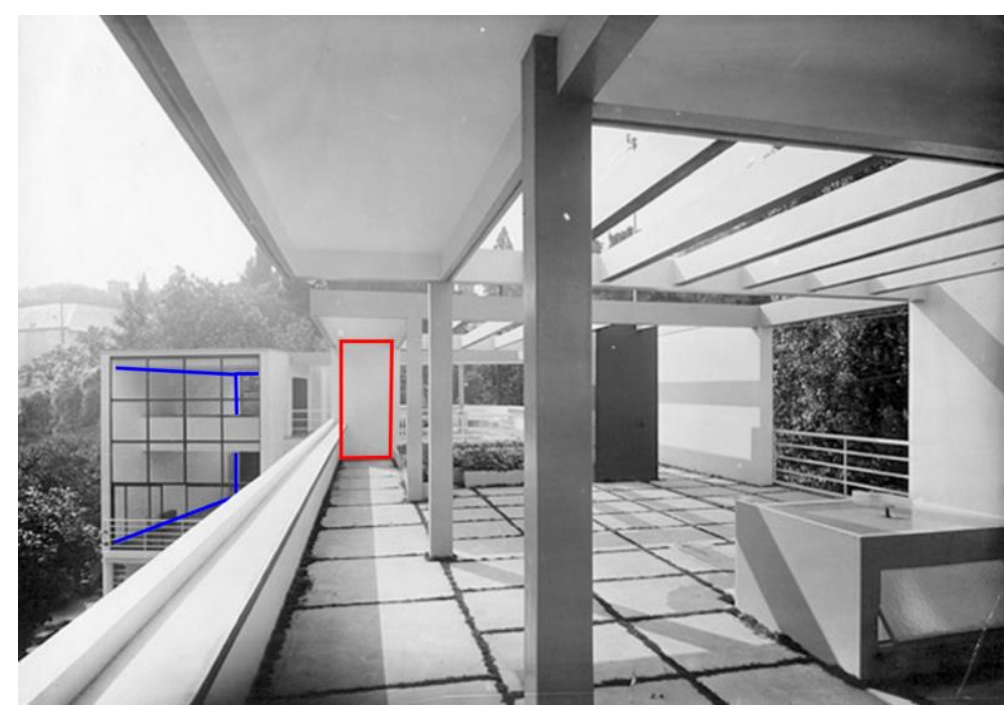

17. Villa Church. Vista tomada desde la terraza. Una interpretación sobre el plano y el espacio de la sala.

El recorrido que plantean las fotografías, para traspasar un vano y acceder a un nuevo espacio, se establece una ruptura del binomio espacio-tiempo ${ }^{14}$ al referirlo a la experiencia fenomenológica. Esto tiene una consecución lógica por el hecho de concebir, las fotografías, un espacio que se encuentra fuera del espacio físico. La coexistencia que supone traspasar un vano mediante una imagen fotográfica, va a quedar referenciada a una sucesión temporal que no tiene que ver con el espacio representado en planta. Viendo los planos de cualquiera de las casas fotografiadas, por ejemplo el de l'atelier Ozenfant (figura 2), la consecución de espacios que se suceden, al traspasar la puerta de la biblioteca, no se corresponde con el espacio que vemos desde la sucesión de las miradas a la fotografía. Traspasar un vano no va a quedar referido al consecuente espacio en su sentido físico. Lo que nos muestra la fotografía es una consecución de la mirada a un vano que nos incita a traspasarlo. Después, la mirada a la sala en la que nos encontramos es vista en un instante después. Esta coexistencia no es un encadenamiento de espacios. La coexistencia queda ligada exclusivamente al tiempo, y en un instante, es el tiempo quien nos va a devolver al espacio en el que nos ubicamos, o más bien, al espacio en el que se encuentra el punto de vista que muestra la fotografía. Esta consecución nos presenta un modo de ver las imágenes referido a espacios no consecutivos, -que no se refiere a dos espacios distantes sino que, el espacio al que nos trasladamos es el mismo en el que nos encontramos-.

¿Qué plantean pues, las fotografías, cuando nos incitan a salir de un espacio para devolvernos al mismo espacio en el que nos encontramos? Volver a un mismo espacio, cuando el sentido que expresa la imagen es salir de él, significa dar protagonismo al tiempo, ya que es el tiempo el modo de plantear la coexistencia de las cosas. Pero, ¿A qué acontecimiento que ocurre en el tiempo deberíamos aludir para concebir el movimiento de traspasar un

\footnotetext{
14 "Para percibir que se trata de una sucesión de tres notas, es necesario que, al oír la primera, yo la retenga para poder añadirla a la segunda cuando ésta se produce, y así en cada caso. De otro modo, no cabría hablar de nota primera o segunda porque, sin tal facultad retentiva, cada nota sería siempre la primera y la única y, de este modo, de acuerdo con el argumento, jamás adquiriría yo la idea de tiempo. Así pues, esta idea exige de hecho la coexistencia de las tres notas: una coexistencia que no se da "en la naturaleza" sino "en el espíritu" (en la Memoria). Este hecho favorece aún más la tesis de que la idea de tiempo tiene un origen meramente "subjetivo", y que no afecta para nada a la relación de las cosas (o impresiones) " en sí mismas", y dificulta la hipótesis leibniziana de una cronológica apoyada en bases metafísicas. Pero si es cierto que la sucesión temporal implica la coexistencia, también lo es que dicha coexistencia nada tiene de "espacial" o, dicho de otro modo, que la noción de coexistencia no parece tener nada que ver con le espacio". Pardo, Jose Luis. Las formas de la exterioridad, Pretextos, Valencia, 1992, p.32-33.
} 
vano mediante una fotografía? Obviamente al tiempo de la memoria. Los acontecimientos que se han ido sucedido es a lo que se refiere una vuelta al espacio. Volver al espacio en el que nos encontramos es repetir, en la mente, lo realizado, admirar lo acontecido. Meditar sobre aquello que ha transcurrido es considerar, de nuevo, los eventos.

Este planteamiento nos lleva a pensar sobre lo que ocurre en una casa, sobre sus espacios, sobre el programa doméstico, las actividades y acciones que se suceden constantemente.

\section{Pensar el espacio proyectado. Pensar el espacio construido.}

El motivo que lleva, durante el proyecto, a pensar sobre lo que ha de producirse en el interior de un espacio es la consideración de los modos de relación entre personas que ocupan el espacio construido. El espacio, antes de ser usado, antes incluso de ser proyectado y definido, ha de ser pensado como tal. No en el sentido de su ejecución para cumplir una determinada función, para servir a una cuestión práctica, sino desde la atención que requiere para el habitar, para el hecho de concebir sus consecuencias.

Si comparamos las fotografías con los planos del proyecto, aquello que podemos ver en las fotografías como representación del lugar donde se suceden los acontecimientos, lo vemos también en el proyecto. Viendo el alzado del proyecto de la Villa Planeix (figura 18), y comparado con la fotografía sacada desde el exterior (figura 19), la relación que plantean establece concebir la representación del espacio como acontecimiento. Estos dos momentos, cuando se está dibujando la propuesta y cuando es retratado el edificio construido, establecen vínculos. El vínculo entre el acontecimiento representado, mediante una imagen, y el hecho de pensar el espacio adquiere un sentido sobre el acontecer antes de que nada haya acontecido. El proyecto no es el proyecto de un edificio donde se sucederán actividades propias de un programa sino que es un proyecto de acontecimientos.

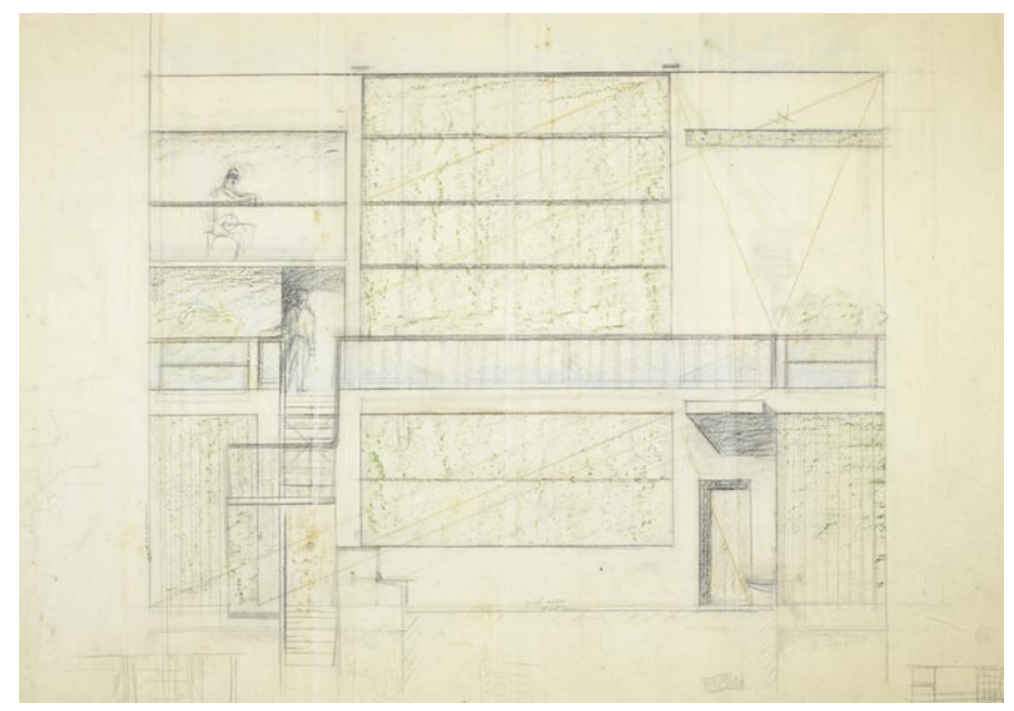

18. Casa Planeix. París 1927. Alzado patio interior. Plano FLC 08932

En la figuración de las personas que aparecen en el alzado de la villa Planeix (figura 18), probablemente dibujado por Pierre Jeanneret, vemos como estas personas dibujadas ocupan el interior del alzado. Están ubicadas concretamente en el umbral del acceso a l'atelier y en el altillo, donde se ve el boceto de un hombre sentado (figura 20). Adquieren una trascendencia, no solo por la posición que adoptan, al representar unos 
acontecimientos en el momento que se redacta el proyecto del edificio, sino por la comparación a la fotografía del edificio construido. Las personas dibujadas son las mismas que las personas fotografiadas ${ }^{15}$. Si los planos del proyecto aluden a los acontecimientos en el momento se dibujan los planos, ¿no se referirán las fotografías hechas al edificio construido a esa misma cuestión? ${ }^{16}$ Los bocetos, no tratan de ser una figuración de las personas, sino más bien aluden a unos sucesos por los esbozos que indican el movimiento propio de una acción. Tanto la cabeza, como los brazos de la persona sentada en la silla (figura 20) indican que la persona no alude únicamente a una figura. Parece que esté moviendo el brazo. Por otro lado, en el otro boceto, las piernas parecen señalar un giro, y podría parecer que está mirando al dibujante. Las imágenes hacen hincapié a una misma cuestión referida a los sucesos: el fin último de la arquitectura cuando un proyecto es elaborado.

Una relación de este tipo, entre dos procesos tan distanciados entre el proyecto y el edificio construido, cabe referirlo a un acercamiento. Bien desde un intento por llevar el proyecto a un acontecimiento, al hecho de consumar un designio, o bien, al contrario, al hecho de llevar un edificio construido a un proyecto, proponen relacionar dibujo y fotografía. Si vemos la fotografía (figura 19), las personas que ocupan el espacio de la sala, no dejan el rastro propio de un acontecimiento desarrollado en el taller. Señalan una pose, como lo hace un modelo en una sesión fotográfica que trata de mostrar una acción sin consumar. Un proyecto es un designio no consumado, algo que está por suceder. Al fin y al cabo, las dos ilustraciones son un intento por trasladar al papel una imposibilidad, la de consumar una propuesta que no ha podido llevarse a cabo. ¿De qué posibilidad se trata? $\mathrm{Si}$ volvemos a las fotografías aludiendo a los dos temas principales del escrito, la actividad y los acontecimientos; la acción de salir de una sala se relaciona con dos ámbitos del espacio representado, lo bidimensional y lo tridimensional. La interpretación a las fotografías plantean llevar a cabo un deseo que va más allá del suceso que acontece en un espacio, porque el motivo no es la representación de la acción propiamente, sino más bien, el hecho de trasladarla a otro sitio mediante la memoria.

\footnotetext{
15 "Dibujo un personaje. Lo hago entrar en la casa; descubre su volumen, tal forma de habitación y sobre todo tal cantidad de luz que entra por la ventana o el panel de cristales. Avanza: otro volumen, otra llegada de luz. Más lejos, otra fuente luminosa; más lejos aún, inundación de luz y penumbra al lado.” Le Corbusier, Precisiones, Apóstrofe, Barcelona, 1999, p. 154.

${ }^{16}$ Otra de las alusiones que relaciona fotografía y proyecto es referido por Josep Quetglas en; Quetglas, Josep. Le heures claires. Proyecto y arquitectura en la Villa Savoye de Le Corbusier y Pierre Jeanneret, Associació d'idees. Centre d'Investigacions Estétiques, Barcelona, 2009; cuando dice: "La similitud entre FLC 19425 y la foto sin pie muestra que también el plano de la ventana del lado suroeste de la terraza-jardín es pensado por Le Corbusier como uno de esos espejos virtuales que permiten, colocados de canto, tener como ángulo de visión un escenario contrapuesto: la naturaleza, hundida hacia el suelo, expandida, a un lado; la construcción, elevada, definida, al otro lado." Hay una relación que vincula la manera de realizar las fotografías con los proyectos desarrollados y pensados en el estudio.
} 

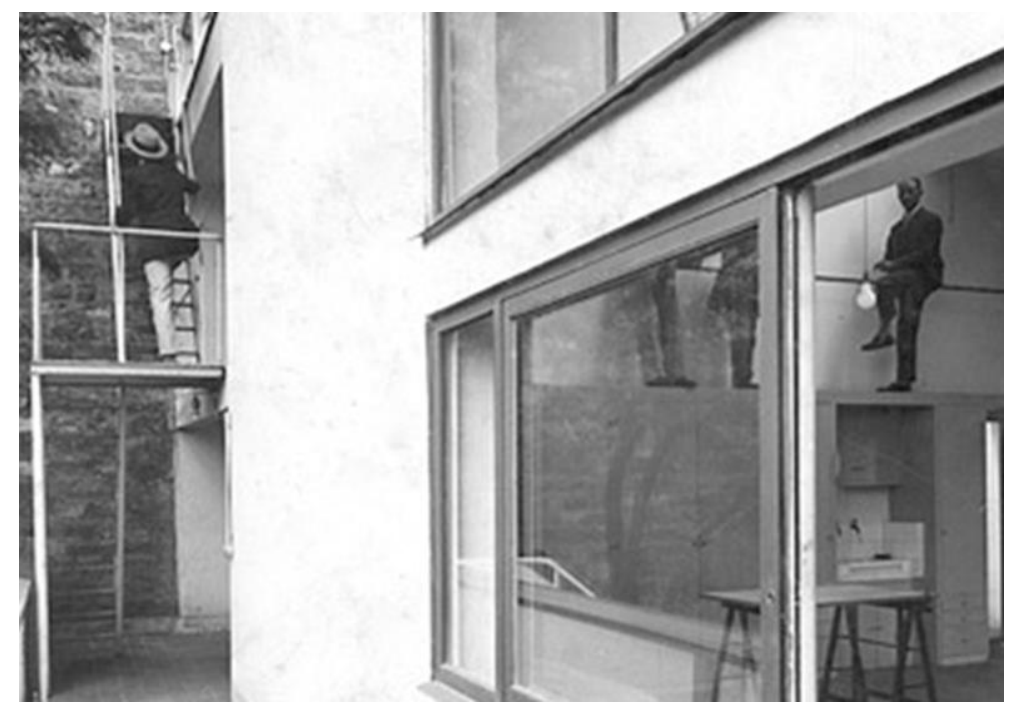

19. Casa Planeix. París 1924. Fotografía de Georges Thiriet, FLC L2(14)16. Vista tomada desde la terraza hacia la escalera exterior. Detalle.

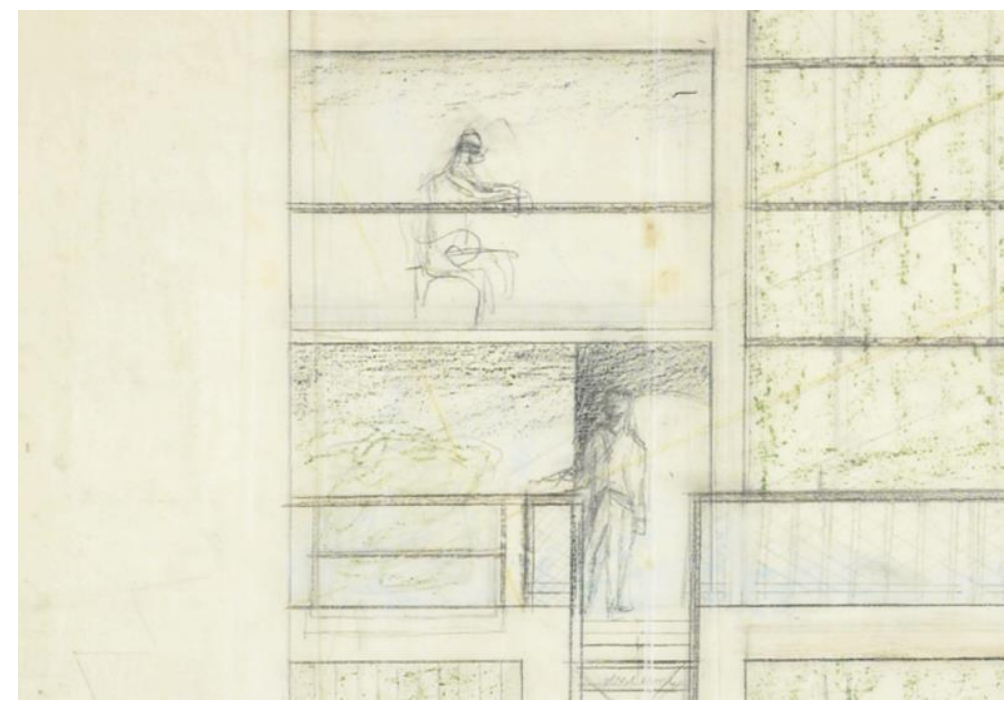

20. Casa Planeix. París 1927. Alzado patio interior. Plano FLC 08932. Detalle.

\section{Un acontecimiento en el interior de las fotografías.}

Atendiendo al programa de las casas proyectadas tienen la particularidad de referirse a un uso eminentemente planteado para el trabajo artístico ${ }^{17}$. "The clients can be divided into artists (Ozenfant, Lipchitz, Miestchaninoff), the musician (Ternisien, Planeix), amateurs and collectors (La Roche, Stein, Cook)". ${ }^{18}$ La particularidad de las

17 "Y, si entramos en casa para trabajar, la sensación es mucho más formal, porque afecta al hombre todavía más de cerca. Ahora, que, gracias a nuestras herramientas, hemos podido organizar nuestro trabajo, nos hemos editado de útiles también adaptados a su función que son como miembros nuevos.” Ozenfant/Le Corbusier, De la pintura de las cavernas a la pintura de hoy, Acerca del purismo, El Croquis editorial, Madrid, 2000, p149.

${ }^{18}$ Benton, Tim. The villas of Le Corbusier and Pierre Jeanneret. 1920 1930, Birkhäuser Verlag AG, 2007, p. 13. 
casas, dispuestas para una actividad para la música, la pintura, la escultura, la poesía o la literatura, lleva a reflexionar sobre el hecho de salir del espacio para estudiar la distinción entre el interior y el exterior como sucesos que posibilita el espacio construido. Las fotografías, al plantear salir de la sala para rememorar aquello que ha acontecido en él ¿no plantean el designio de trasladar al exterior de la casa el tiempo de un acontecimiento, el que se da en el interior de sus habitaciones? El contenido, caracterizado por los usos, dota al espacio de una acción, que al salir, relaciona la actividad artística cuando se da en dos lugares distintos. La actividad sale del taller para presentarse a la ciudad. Realmente, el planteamiento, los contenidos que se dan en la casa, proponen el inicio de una actividad que pasa a ser pública, pero que se configura en el espacio doméstico. El programa de la casa, queda caracterizado por una actividad que va a presentarse a la ciudad. La relevancia de estos sucesos se halla en el inicio de las acciones, que proponen presentarse en el espacio público a partir de un espacio íntimo. Las fotografías muestran la intencionalidad de sacar del espacio de una sala los acontecimientos que se dan en el espacio propio para que sean mostrados. No para llevar a cabo una relación entre interior y exterior desde lo figurativo, sino para extraer los acontecimientos que se desarrollan en sus espacios. Una de las cuestiones más relevantes que plantean las casas en el entorno urbano es la relación que posibilitan entre las actividades y los usos, desde lo íntimo y lo sensible, y a partir de los programas planteados en dos espacios habitados en la ciudad, el de la vivienda y el de la calle.

Las fotografías no plantean exclusivamente un vínculo entre el espacio exterior que entra en la casa desde lo visual sino, más bien, es un planteamiento arquitectónico que vincula intimidades desde el origen de un trabajo artístico y la expresión de ese trabajo trasmitido al tejido urbano. Este planteamiento es roto, la mayoría de las veces, cuando las instituciones establecen los programas públicos, cuando el estado define y configura las actividades que han de darse en los edificios para la música, la danza, la pintura, o la escultura. Por el hecho de estructurar las actividades quedan truncadas las posibilidades de trasmitir el sentido de lo eminentemente propio.

Como dice Jose Luis Pardo:

\begin{abstract}
"En esta antigua leyenda hay algo que se opone a la sensación, a saber, el arrepentimiento del caballero que surge de su corazón afligido. Se trata, en fin, de una especie de anti-sensación, un "movimiento del alma" que no procede de la exterioridad, que tiene su origen en la interioridad misma, un sentimiento. Y ese sentimiento es la base sobre la que se edifica una base interior del alma que ya no requiere, para subsistir, del impulso que le proporciona la exterioridad a través de la sensación. Con el tiempo, la casa, el hogar, el espacio doméstico o familiar se convertirá en el templo de los sentimientos que la fachada exterior (tendida hacia la vida pública) no deja traslucir, y en la cual el individuo (única sede legítima de tales sentimientos incomunicables) se disuelve entre la muchedumbre anónima y urbana que, o bien apaga y extingue los sentimientos, o bien los amplifica hasta convertirse en la turba exterior que destruye los espacios y detiene el tiempo. De hecho, la casa y la calle se oponen como la unidad y la muchedumbre, y el crecimiento de la calle, el desarrollo de la ciudad, se percibe siempre como el aumento de volumen del rumor de la multitud, el crecimiento de la muchedumbre, el desbordamiento de las masas. "Las masas buscan disipación, pero el arte reclama recogimiento... quien se recoge ante una obra de arte se sumerge en ella... por el contrario, la masa dispersa sumerge en sí misma a la obra de arte."19
\end{abstract}

\footnotetext{
${ }^{19}$ Pardo, Jose Luis. Las formas de la exterioridad, Pretextos, Valencia, 1992, p.210.
} 


\section{Una conclusión interpretada.}

En algunas obras de teatro representadas en Pompeya ${ }^{20}$, un pequeño telón, definido por un lienzo rectangular, enmarcaba de fondo las acciones de actores. Mediante mimo protagonizaban las escenas al final de las obras de teatro o entremedio de ellas, en el "intermezzi", que servían para representar escenas, alguna de ellas obscenas. Mientras, se preparaban los actos en el escenario que quedaba tapado. Estas acciones, fueron tomando forma de drama mímico, en el que, en años anteriores, esta misma representación había sido ocupada mediante la fábula. El lienzo, la tela de fondo que enmarcaba la acción de los actores, servía para enfatizar la acción representada, servía para enmarcar y dar protagonismo al acontecimiento que era representado entre escena y escena. Estos actos, desarrollados mediante cortinas, que servían de marco, ensalzaban la apariencia de una representación en la que los movimientos de las figuras adquirían todo el sentido, al encontrarse excluidos de la palabra. Estas acciones llegaron a sostenerse por si mismas, y llegaron a ser asociados a festividades que se desarrollaban en muchas ciudades, tanto de Oriente como de Occidente. Con el tiempo todos los actos públicos desarrollados en tales festividades fueron motivo de entretenimiento en, también, algunas casas. Eran compromisos para cenas y fiestas en el interior de viviendas pompeyanas donde las representaciones salían del teatro para montarse en el interior de habitaciones privadas. En ellas también llegaban a construirse estructuras para las representaciones mímicas. La Casa degli Amorini Dorati, en Pompeya, fue testigo de numerosas actuaciones teatrales de mimo ${ }^{21}$.

Este trozo de tela unido a un marco de madera, relacionándolo a las imágenes de las casas comentadas ¿a qué elemento podríamos vincularlo?; por configurar un plano, por enmarcar mediante su opuesto de tela un rectángulo, ¿no podría relacionarse con el marco de las puertas que definen cada una de las imágenes enfrentadas al punto de vista? Por su forma, siendo uno el opuesto del otro, podrían quedar emparentados, no por ser uno el vano y el otro el lienzo, sino por ser la tela el fondo de lo representativo, por ser ésta quien ensalza la apariencia del acontecimiento. Al contrario, el vano no permite la representación, se escapa mediante el propio hueco, que la omite para aludir al acontecimiento y presentarlo en la acción propia de, por ejemplo, traspasar una puerta, como comentábamos al analizar las fotografías.

"La arquitectura de Le Corbusier pudo ser objeto de interés por parte de algunos arquitectos y críticos norteamericanos de las décadas de los setenta y ochenta. Pero, mientras la obra de los verbalmente más interesados muestra una absoluta ceguera, es John Hejduk, aparentemente más alejado, quien mejor ha seguido y desarrollado uno de los puntos básicos de la arquitectura de Le Corbusier" ${ }^{\prime 2}$. Uno de los arquitectos que mejor conoce a Le Corbusier ha mostrado, justamente, mediante su arquitectura, una posibilidad a las relaciones más intensas entre las almas de las personas. John Hejduk al sacar del espacio doméstico las actividades para vincularlas al espacio público, a través de un proceso que ha durado 25 años, con un planteamiento de casas donde las salas en las que se plantea el programa de la vivienda, se va separando hasta quedar en el espacio público, propone una posibilidad de relacionar de manera íntima los acontecimientos. A través del contenido que establecen mediante el objeto-sujeto, sus propuestas arquitectónicas han pasado del espacio doméstico al espacio urbano. El planteamiento de John Hejduk establece un nexo que cicatriza una escisión en el desarrollo de la historia del programa arquitectónico. John Hejduk dice: "en la Inglaterra isabelina, el encargo más valorado y más buscado por un arquitecto consistía en la Masque, en la mascarada. Consistía en una estructura que se

\footnotetext{
20 “es Pompeya, donde Jeanneret pasa seis días, desde el 8 al 13 de octubre de 1911, lo que cierra con un episodio intensísimo su Viaje de Oriente." Quetglas, Josep. Le heures claires. Proyecto y arquitectura en la Villa Savoye de Le Corbusier y Pierre Jeanneret, Associació d'idees. Centre d'Investigacions Estétiques, Barcelona, 2009. p.535.

${ }^{21}$ Allardyce Nicoll, N. A., Masks, Mimes and Miracles, Cooper Square Publicers INC, New York, 1964.

${ }^{22}$ Quetglas, Josep. Dos charlas sobre John Hejduk. Esquemas, John Hejduk. House for a poet, Edicions UPC, Barcelona, 2000, p.28.
} 
situaba en un edificio ya existente. La sección era así. Una estructura que mantenía una fachada y los actores se situaban enfrente de la fachada, mediante mimo actuaban en silencio. El público podría venir y participar en la pantomima siempre que estuvieran callados. La mascarada llegó a Italia y a Francia. En Inglaterra desapareció con la introducción de las ejecuciones públicas. ${ }^{23}$

Dedicado a Cecilio Sánchez-Robles Beltrán.

\section{Imágenes}

1. Maison-atelier du peintre Amédée Ozenfant, Paris, 1922 - Photo Charles Gérard, FLC L2(13)7.

2. Plan FLC 7826. Maison-Atelier du peintre Ozenfant, Paris, 1922. Plan de l'étage.

3. Maison Planeix, Paris, 1924. Photo Georges Thiriet, FLC L2(14)22.

4. Maison Planeix, Paris, 1924 - Photo Georges Thiriet, FLC L2(14)16.

5. Plan FLC 8902. Villa Planeix, Paris, 1927. Plan de l'étage, atelier.

6. Maison Cook, Boulogne-sur-Seine, 1926 - Photo Charles Gérard, FLC L1(6)11.

7. Plan FLC 8292. Villa Cook, Boulogne-sur-Seine, 1926. Plan de la terrasse.

8. Villa Savoye, Poissy, 1928 - Photo Marius Gravot, FLC L2(17)49.

9. Plan FLC 19440. Villa Savoye, Poissy, 1928. Plan du 1er étage

10. Villa Church, Ville-d'Avray, 1927 - Photo Georges Thiriet, FLC L3(7)102.

11. Plan FLC 8122. Villa Church, Ville d'Avray, 1928. Plan au niveau de la terrasse.

12. Maison-atelier du peintre Amédée Ozenfant, Paris, 1922 - Photo Charles Gérard, FLC L2(13)7. Remarcado realizado por el autor.

13. Maison Cook, Boulogne-sur-Seine, 1926 - Photo Charles Gérard, FLC L1(6)11. Remarcado realizado por el autor.

14. Maison Planeix, Paris, 1924 - Photo Georges Thiriet, FLC L2(14)16. Remarcado realizado por el autor.

15. Maison Planeix, Paris, 1924. Photo Georges Thiriet, FLC L2(14)22. Remarcado realizado por el autor.

16. Villa Savoye, Poissy, 1928 - Photo Marius Gravot, FLC L2(17)49. Remarcado realizado por el autor.

17. Villa Church, Ville-d'Avray, 1927 - Photo Georges Thiriet, FLC L3(7)102. Remarcado realizado por el autor.

18. Plan FLC 8932. Villa Planeix, Paris, 1927. Elévation de façade.

19. Maison Planeix, Paris, 1924 - Photo Georges Thiriet, FLC L2(14)16. Detalle.

20. Plan FLC 8932. Villa Planeix, Paris, 1927. Elévation de façade. Detalle.

\footnotetext{
${ }^{23}$ Sánchez, Cecilio, (et al) (Ed.), John Hejduk. Dos conferencias, Ediciones Generales de la Construcción, Valencia, 2001, p.42.
} 


\section{Bibliografía/referencias}

AA VV. Le Corbusier. Plans. 1905-1926, Echelle, Tokyo, 2005.

AA VV. Le Corbusier. Plans. 1925-1928, Echelle, Tokyo, 2005.

Allardyce Nicoll, N. A., Masks, Mimes and Miracles, Cooper Square Publicers INC, New York, 1964.

Benton, Tim. The villas of Le Corbusier and Pierre Jeanneret. 1920 1930, Birkhäuser Verlag AG, 2007.

Le Corbusier, Precisiones, Apóstrofe, Barcelona, 1999.

Morin, Edgar. Introducción al pensamiento complejo, Barcelona Gedisa, 1996.

Ozenfant/Le Corbusier. Acerca del purismo, El Croquis editorial, Madrid, 2000.

Pardo, Jose Luis. Las formas de la exterioridad, Pretextos, Valencia, 1992.

Quetglas, Josep. Le heures claires. Proyecto y arquitectura en la Villa Savoye de Le Corbusier y Pierre Jeanneret, Associació d'idees. Centre d'Investigacions Estétiques, Barcelona, 2009.

Sánchez, Cecilio, (et al) (Ed.), John Hejduk. Dos conferencias, Ediciones Generales de la Construcción, Valencia, 2001.

Sontag, Susan. Sobre la fotografía, Edhasa, Barcelona, 1981. 


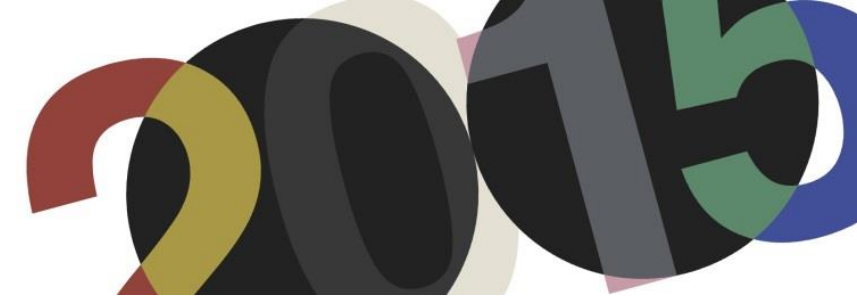

DOI: http://dx.doi.org/10.4995/LC2015.2015.1042

\title{
Une correspondance architecturale: Ionel Schein "enfant" de Le Corbusier
}

\author{
S. Berselli \\ Istituto di storia e teoria dell'arte e dell'architettura (ISA) \\ Accademia di architettura di Mendrisio - Università della Svizzera Italiana (USI)
}

\begin{abstract}
Résumé: Pour la génération d'architectes, tels Ionel Schein, qui se forment à Paris après la guerre, Le Corbusier représente le seul antidote à l'académisme "bozartien". La filiation corbuséenne se fait d'abord en clandestinité, à travers les livres et les projets, puis avec le contact direct ou par lettre, et représente un bassin inépuisable pour l'éducation permanente des jeunes à l'architecture. Les rencontres et la correspondance, ponctuée de divertissements intellectuels, permettent à Schein d'absorber le lexique corbuséen comme une nouvelle langue maternelle, jusqu'à la formation de son propre vocabulaire d'architecture. A la mort du maître, contré pendant toute sa vie par les institutions, Schein est dégoûté par la suite grotesque d'honneurs posthumes mise en scène: sa fidélité au message de Le Corbusier survit aux apparences et dans ses obituaires sans couronnes de lauriers on trouve le sens profond d'un héritage tant discuté et imposant.
\end{abstract}

Resumen: Para la generación de arquitectos que, como Ionel Schein, se forman en París después de la guerra, Le Corbusier es el único antídoto contra el academicismo de la Escuela de Bellas Artes. La filiación corbuseana se hace primero clandestinamente, a través de los libros y de los proyectos, y en seguida con el contacto directo o por carta, y representa una reserva inagotable por la educación de los jóvenes a la arquitectura. Las reuniones y la correspondencia, punteada de entretenimientos intelectuales, permiten a Schein de absorber el léxico corbuseano como una nueva lengua materna, hasta la formación de su propio vocabulario arquitectónico. A la muerte del maestro, Schein crítica duramente la serie grotesca de honores póstumos enscenada por las instituciones que lo obstaculizaron por toda su vida. Su fidelidad al mensaje de Le Corbusier sobrevive a las apariencias y en sus obituarios sin coronas de laurel se encuentra el significado más profundo de un legado tan discutido e imponente.

Mots clés: Ionel Schein; Claude Parent; Atelier 35 rue de Sèvres; Scuola CIAM Venezia 1952; CIAM IX 1953; correspondance.

Palabras clave: Ionel Schein; Claude Parent; Atelier 35 rue de Sèvres; Escuela CIAM Venecia 1952; CIAM IX 1953; correspondencia.

\section{Introduction Objectifs, méthode, résultats}

Des nombreux écrits critiques que Ionel Schein (1927-2004) a dédié à Le Corbusier ${ }^{1}$ descends une filiation que jusqu'aujourd'hui a été peu étudiée, et seulement du côté du maître. Pendant mes recherches doctorales, dirigées par Prof. Carlo Olmo dès 2007, j'ai analysé l'œuvre d'Ionel Schein, architecturale et écrite. Cet étude dans un archive inexploré, intégré par la visite aux bâtiments réalisés et les entretiens aux protagonistes, a permis d'identifier des thématiques constantes dans la pensée et la production des deux non-architectes. Ma thèse doctorale vient de paraitre en italien, avec le titre Ionel Schein. Dall'habitat evolutivo all'architecture populaire ${ }^{2}$.

\footnotetext{
${ }^{1}$ Voir la Bibliographie, au point 6.

${ }^{2}$ Berselli, Silvia: Ionel Schein. Dall'habitat evolutivo all'architecture populaire. Mendrisio: Mendrisio Academy Press Cinisello Balsamo: Silvana Editoriale, 2015.
} 
Ma proposition pour le Congrès LC2015 a comme objectif la reconstruction d'une filiation qui commence avec la lecture des livres du maître et le pèlerinage de visite à ses bâtiments, se concrétise en 1952, quand Ionel Schein est chargé d'accueillir Le Corbusier à Venise, et termine seulement avec la mort de ce dernier. Le fonds Schein conservé au Frac Centre d'Orléans et l'archive de la Fondation Le Corbusier à Paris présentent plusieurs documents inédits ${ }^{3}$ qui témoignent l'intensité de la correspondance entre les deux : envois de textes polémiques ou programmatiques, commentaires sur chantiers et projets récents ou du passé, réflexions, congratulations pour chaque succès ou un petit mot de soutien pour les échecs. Tout ça, bien sûr, de la part de Schein ; mais il reçoit toujours une réponse positive, soit qu'il nécessite quelques dessins pour une publication ou bien pour une exposition, soit qu'il demande la production d'un texte original à donner aux jeunes étudiants ou la présence à une signature de livres.

L'étude de cette relation permet de mieux comprendre l'influence de Le Corbusier sur la génération des jeunes architectes qui bâtissent pendant la reconstruction, après la promulgation du Plan Courant. Déçus par l'Académie des Beaux-Arts, les institutions, les CIAM, ils trouvent une nouvelle énergie vitale dans l'atelier de Le Corbusier, qui ne leur empêche pas de choisir, après, de différents chemins, en devenant par exemple architectes radicales (Guy Rottier), engagés politiquement (Ionel Schein) ou plasticiens (Claude Parent). Les journaux de commentaires personnels que Schein écrit à Venise et à Aix-en-Provence représentent une critique ponctuelle, motivée et anti-héroïque de cette saison de renouvellement des CIAM, vue de l'intérieur. Le stage à l'atelier de la rue de Sèvres en 1953 permet à Schein de travailler aux dessins de l'Unité de Nantes-Rezé et de concentrer son attention sur le thème privilégié de l'architecture pour le plus grand nombre, sujet central du débat de l'après-guerre et de la riche production architecturale bâtie par Schein.

\section{Nous étions des clandestins}

\section{La leçon corbuséenne comme antidote à l'académisme "bozartien"}

Après avoir quitté la Roumanie en 1948, Ionel Schein déménage avec sa famille à Paris, où il s'inscrit à l'Ecole Nationale Supérieure des Beaux-Arts pour poursuivre ses études d'architecture, commencés après la guerre à l'Université de Bucarest. Pour comprendre le climat de l'Ecole, on peut se référer à l'autobiographie de Claude Parent, compagnon d'étude et de travail d'Ionel Schein du 1949 au 1955 : "En ce temps-là, déjà, l'école ne vivait plus que sur un faux prestige et des traditions défuntes. Divisée en atelier dirigés chacun par un «patron» choisi par les élèves, elle entretenait un climat de compétition artificielle entre les étudiants. D'atelier à atelier la lutte était féroce. Tous les coups étaient bons pour obtenir, dans chaque "écurie" pourrait-on dire, le plus possible de récompenses scolaires destinées non pas à préparer les jeunes à l'exercice correct de leur future profession, mais à tresser des couronnes de laurier aux architectes patrons les plus débrouillards, et les plus forts en gueule au jury, en réalité les plus compromis et pistonnés, complices volontaires de la léthargie d'une administration croupissante et veule ${ }^{\prime 4}$. Comme en témoigne Claude Parent, les années Quarante et Cinquante montrent une phase de déclin graduel de l'Ecole ${ }^{5}$ et les nombreux projets de réforme de l'institution sont contestés et jamais appliqués ${ }^{6}$.

\footnotetext{
${ }^{3}$ Je remercie les archives suivantes : Fondation Le Corbusier, Paris (dorénavant abrégée FLC) ; Fonds Schein, FRAC Centre, Orléans (abrégé FRAC) ; Archive CIAM, GTA Archives, Zurich (abrégé GTA).

${ }^{4}$ Parent, Claude: Claude Parent Architecte. Paris: Laffont, 1975, pp. 17-18.

${ }^{5}$ Epron, Jean-Pierre (édité par): Architecture: une anthologie. Tome 2: les architectes et le projet. Liège: Pierre Mardaga, 1992, p. 135.

${ }^{6}$ Seulement en 1962 la réforme Querrien a été approuvée, mais le projet de loi est tardif, n'entre pas en vigueur et ne peut pas arrêter la dissolution des ateliers et la capitulation de l'institution avec les manifestations étudiantes de mai 1968.
} 
Au début des années Cinquante, André Gutton appelle Le Corbusier "le grand publiciste", le nom de ce "monsieur", considéré comme "le diable soi-même fait non-architecte”, , est interdit par l'Ecole et, si jamais il est prononcé, cela provoque des rires moqueurs parmi les étudiants et les professeurs ${ }^{9}$. Pendant cette période, la figure de Le Corbusier détermine la limite entre orthodoxie et révolution au sein de l'Ecole et son œuvre interdite est un liant exceptionnel, capable de cimenter un partenariat fructueux entre les jeunes rebelles, fatigués de respirer la poussière des institutions (Figures 1 et 2).
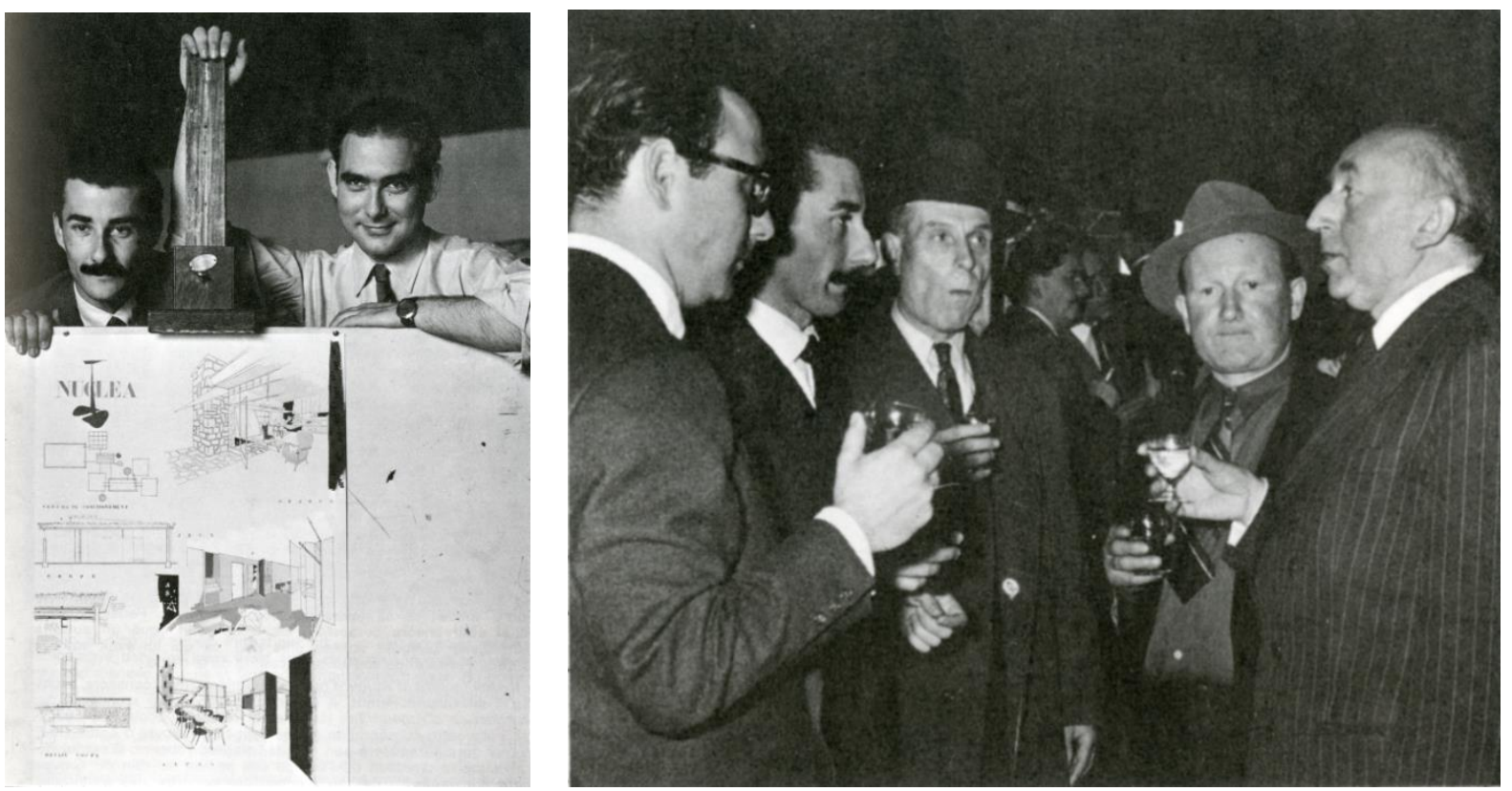

1. Claude Parent (à gauche) et Ionel Schein (à droite) avec le projet gagnant pour le concours «La Maison Française», 1952 (dans Ragon, Michel: Claude Parent. Monographie critique d'un architecte. Paris: Dunod, 1982, p. 33).

2. Concours national "La Maison Française", 1952. De gauche à droite : Ionel Schein, Claude Parent, les deux directeurs de l'ENSBA et Pierre Sonrel (ibidem, p. 32).

Ionel Schein et Claude Parent s'opposent à l'enseignement académique en produisant des textes polémiques adressés $A$ nos ainés...les jeunes ${ }^{10}$. La rébellion les unit de plus en plus, au point que Nicolas Schöffer se souvient d'eux "comme des jumeaux"111; cette complicité les fortifie jusqu'à trouver le courage de citer publiquement, et pour la première fois dans l'histoire de l'Ecole, Le Corbusier: "Sur un projet nous avions mis une citation de Le Corbusier, avec son nom. C'était la première fois que le nom de Le Corbusier apparaissait dans les ateliers. Le scandale a été énorme. Gutton a dit en amphi : «Parmi vous il y a un provocateur mal élevé». Mais plus tard nous avons eu de très bons échanges avec Gutton, qui nous a fait admettre à l'Ordre,

\footnotetext{
${ }^{7}$ Cfr. Ragon, Michel: Monographie critique d'un architecte: Claude Parent. Paris: Dunod, 1982, p. 27.

8 "...j'avais lu, dès quinze ans, les livres de Le Corbusier, où je me régalais des formes utiles d'avions et de bateaux, et accessoirement de quelques habitations et immeubles jetés dans la verdure. Mais il était interdit de parler alors de ce "monsieur » à l'école, car on le considérait comme le diable soi-même fait non-architecte", dans Parent, Claude 1975, p. 19.

9 "Non seulement l'enseignement qui lui est donné quai Malaquais ne ressemble en rien à Vers une architecture, mais le nom seul de Le Corbusier provoque alors la plus franche rigolade aussi bien parmi les élèves que parmi les professeurs", dans Ragon, Michel 1982, p. 13.

${ }^{10}$ Parent, Claude; Schein, Ionel : A nos ainés...les jeunes, document inédit daté 25 février 1953. FRAC.

11 "J'ai rencontré Claude Parent grâce à André Bloc et au Groupe Espace. Parent et Schein, qui étaient alors comme des jumeaux, m'ont invité dans leur atelier du boulevard Suchet. Ils étaient très jeunes, très sympathiques, deux jeunes loups qui rouaient dans les brancards". Entretien avec Nicholas Schöffer, juin 1980, dans Ragon, Michel 1982, p. 127.
} 
Parent et $\mathrm{moi}^{\prime \prime 2}$. En 1966, c'est bien Gutton qui favorise l'admission de Schein et Parent à l'Ordre des Architectes sur présentation d'un “dossier d'œuvres”. Il s'agit d'un procédé exceptionnel et rare utilisé en précédence pour l'admission de professionnels non diplômés, mais reconnus pour la qualité des œuvres, notamment Auguste Perret et Le Corbusier ${ }^{13}$.

Les années de la collaboration représentent pour Schein et Parent la période de formation à l'architecture, un processus d'apprentissage qui se déroule simultanément sur de différents niveaux, tout d'abord avec la critique de l'enseignement traditionnel, puis avec la fréquentation des protagonistes de l'avant-garde artistique. Dans cette période, ils produisent des projets résidentiels cohérents avec les prescriptions du Ministère de la Reconstruction et de l'Urbanisme (MRU) et ils publient leurs conceptions au même temps sur les pages des revues spécialisées et dans les hebdomadaires populaires, comme "Elle" et "La Maison Française" ${ }^{14}$. La nature de cette collaboration a été reconstruite par Schein dans le texte Nous étions des clandestins : "A l'Ecole des Beaux-Arts nous étions des clandestins; les deux seuls ou les deux rares à avoir manifesté notre marginalité, notre opposition au système "bozartien". Nous avons refusé de faire le diplôme, c'est-à-dire de reconnaître le système, alors que nous avions les valeurs et le temps pour le faire. Nous sommes restés une dizaine d'années aux Beaux-Arts, tout en entrant dans la profession par effraction"15.

\section{La main du maître forçant la nôtre}

\section{La filiation corbuséenne comme éducation permanente à l'architecture}

Dans le vaste réseau de relations professionnelles tissé par Ionel Schein, se démarque par sa continuité chronologique et son intensité le lien établi avec Le Corbusier. Le jeune Schein manifeste très tôt son admiration pour les écrits et les œuvres de Le Corbusier, et peut-être encore plus pour son charisme en tant que professionnel pas diplômé, contré par les institutions académiques et au même temps adoré par les avant-gardes. En ces quelques mots, Claude Parent reconstruit la filiation corbuséenne de sa formation, et de celle d'Ionel Schein, à l'architecture : "Enfant de Le Corbusier je l'ai été, je vous l'ai dit, avant même de savoir ce qu'était l'architecture. Enfants de Le Corbusier, nous les fumes, Ionel Schein et moi, quand nous avons construit nos trois premières maisons après celle du concours. Les maisons Morpain, Le Jeannic, Hardy, petites cabanes de béton, sont venues au monde avec la main du maître forçant la nôtre ${ }^{\prime 16}$.

Le premier contact avec l'Atelier de la rue de Sèvres se fait par une lettre qu'Ionel Schein et Claude Parent écrivent aux délégués nationaux des CIAM ${ }^{17}$. La lettre, datée du 7 janvier $1952^{18}$, exhorte les délégués des CIAM à coordonner les efforts des étudiants des écoles d'architecture et d'urbanisme pour créer dans chaque

\footnotetext{
${ }^{12}$ Schein, Ionel: Nous étions des clandestins, dans Ragon, Michel 1982, p. 190.

13 "...en 1966, selon une enquête du Monde, avait obtenu le privilège de figurer parmi le huit professionnels inscrits à l'Ordre sans posséder de diplôme...", dans Ragon, Michel 1982, p. 18. Claude Parent indique l'année 1974 comme date de l'enquête, dans Parent, Claude 1975, p. 60.

${ }^{14}$ Cfr. par exemple : Schein, Ionel; Parent, Claude: Maison Française 1953. La Maison Française. № 69, juillet 1953, pp. 3 14. Raimond, Anne-Marie: Un toit pour chaque français (1 et 2). Elle. $\mathrm{N}^{\circ}$ 399, 27 juillet 1953, pp. 24-29; Elle. $\mathrm{N}^{\circ} 400,3$ aout 1953, pp. 26-29. Schein, Ionel; Parent, Claude: Essai pour un habitat individuel évolutif et Habitation à Ville d'Avray. L'Architecture d'Aujourd'hui. N 49, octobre 1953, pp. 4-5 et pp. 10-13.

${ }^{15}$ Schein, Ionel: Nous étions des clandestins. Ragon, Michel 1982, pp. 190-192.

${ }^{16}$ Parent, Claude 1975, p. 28.

${ }^{17}$ Ils déclarent avoir trouvé les adresses dans les dernières pages du livre : Giedion, Siegfried: A Decade of New Architecture - Dix ans d'Architecture Contemporaine. Zurich: Girsberger, 1951, pp. 231-232.

${ }^{18}$ La copie envoyée à Le Corbusier est à la FLC, D2-20-333 ; celle de Siegfried Giedion est au GTA, 42-SG-40-509. Les deux lettres sont identiques.
} 
pays un groupe de jeunes. Ils exigent une investiture officielle, de façon que ces représentants des étudiants puissent collaborer avec les membres du Congrès et transmettre leur message dans les universités.

La lettre reçoit plusieurs réponses, de la part de Candilis, Emery, Giedion ${ }^{19}$, Lods, Neutra, Roth, Sert, Le Corbusier e Wogenscky ${ }^{20}$, comme spécifié par Schein et Parent en juin 1952 dans Présences ${ }^{21}$. Ce texte fait partie des Documents de Sigtuna 1952 et renouvelle l'appel aux délégués CIAM fait par lettre. Les auteurs demandent une investiture officielle des groupes des jeunes, mais surtout ils exigent une prise de position, de la part des membres des CIAM, au sujet de la formation en architecture. Dans ses textes, et encore dans ses dernières lettres à Le Corbusier, Schein dénonce à plusieurs reprises le problème de l'enseignement de l'architecture en France et menace le fantôme de la chute dans un "nouvel académisme", au point que ses mots semblent parfois prévoir les événements du Mai '68.

En cherchant une alternative à l'Académie, Ionel Schein participe à l'école d'été CIAM, tenue du 10 Septembre au 9 Octobre 1952 à l'IUAV de Venise, sous la direction de Franco Albini, Ignazio Gardella, Ernesto Nathan Rogers et Giuseppe Samonà. Pour mieux garder le souvenir de cette expérience, il écrit, pendant toute la durée de l'école, un journal qui représente un témoignage exceptionnel du climat tendu, parfois asphyxiante, des débats menés dans la ville lagunaire. Entre conférences répétitives et balades trop touristiques, Schein se montre critique et ennuyé, ne pouvant plus supporter les contraintes de la "mise en grille", jusqu'à se demander : "Quo vadis CIAM ?"22. Pendant cette période, Venise accueille aussi le Congrès Unesco et la Conférence internationale des Artistes $^{23}$, dont Le Corbusier est l'un des créateurs. Le jour 21 Septembre, Schein est chargé d'accueillir Le Corbusier à la gare de Venise et il note dans son journal : "Dimanche. Repos. Réception ridicule de L.C. à la gare, comme de petits enfants... marche à pied avec lui à travers Venise. Remarques ridicules et artificieuses $^{\prime 24}$. Deux jours plus tard, Le Corbusier donne une conférence que Schein considère entre les expériences les plus importantes de l'école d'été : "deux heures, mais des choses nouvelles et intéressantes : les Indes surtout" ${ }^{\prime 25}$. Selon Schein, le nouvel "organicisme" de Le Corbusier, descends de la "destruction de la machine par la machine" et porte à la construction d'un nouveau "microcosme",26.

Déçu par l'école CIAM et par ses pairs, Schein se rapproche progressivement de la figure qui constitue dans cette période de formation sa référence principale : Le Corbusier. Avec Parent, il fait un stage à l'Atelier de la rue de Sèvres en 1953, on ne peut pas déterminer si avant ou après le CIAM IX. À la Fondation Le Corbusier ils n'existent pas de traces du passage des jeunes à l'Atelier, tandis que le FRAC d'Orléans conserve une note de payement pour le "dessinateur" Ionel Schein ${ }^{27}$. Claude Parent raconte que ce stage a été bref, quelques mois, et consacré à la production de dessins pour le rez-de-chaussée de l'Unité d'Habitation de Nantes-Rézé, sous la

\footnotetext{
${ }^{19}$ Lettre de Siegfried Giedion à Claude Parent et Ionel Schein du 19 janvier 1952. GTA, 42-SG-40-508.

${ }^{20}$ Lettre d'André Wogenscky à Claude Parent et Ionel Schein du 14 janvier 1952. FLC, D2-20-334.

${ }^{21}$ Schein, Ionel; Parent, Claude: Présences, 23 juin 1952, dans Les documents de Sigtuna 1952, reçu par A. Roth le jour 20 aout 1952. GTA.

$22 \ll 30 / 9$ Mise en grille... ceci veut dire... je me le demande. Enfin, puisqu'ils l'ont demandé soyons des élèves consciencieux... Quo vadis CIAM?» dans Schein, Ionel: Journal de l'Ecole d'été CIAM, manuscrit, 1952. FRAC.

${ }^{23}$ Les documents sont au FRAC et à la FLC, U3-7, 317-321.

${ }^{24}$ Schein, Ionel: Journal de l'Ecole d'été CIAM, manuscrit, 1952. FRAC.

${ }^{25}$ Ibidem.

${ }^{26}$ Ibidem.

27 "Atelier Le Corbusier, 29 jan 1954. Salaires et Rétributions payés pendant l'année 1953. Monsieur SCHEIN Yonel, Dessinateur. 22, Av. De Versailles - Paris $\left(X V I^{\circ}\right)$. Soixante-quatorze mille trois cent vingt francs (74.320 Frs.) Somme que nous avons déclarée aux Contributions Directes au titre de vos revenus pour l'année 1953". FRAC.
} 
direction de Iannis Xenakis. Le caractère impossible de ce dernier aurait été la cause du départ de Schein, suivi un mois plus tard par Claude Parent ${ }^{28}$.

En peu de temps après la première lettre aux délégués CIAM, les deux étudiants ont gagné considération auprès d'André Wogenscky, qui charge Claude Parent de se rendre à Aix-en-Provence pour l'organisation du CIAM $\mathrm{IX}^{29}$. Le Groupe CIAM-Jeunes se constitue à Paris ${ }^{30}$, sous la direction de Wogenscky et avec la collaboration de Georges Candilis ; la question à l'ordre du jour est l'habitat et les deux jeunes sont bientôt impliqués dans un débat auquel vont participer les protagonistes de la scène architecturale internationale ${ }^{31}$.

Le CIAM IX d'Aix-en-Provence se pose comme objectif la définition d'une Charte de l'Habitat, qui puisse jouer en architecture le rôle détenu par la Charte d'Athènes en urbanisme. Ce document univoque ne verra jamais le jour, en raison des différences de pensée irréconciliables au sein du Congrès. Le CIAM d'Aix marque une fracture $^{32}$ et registre la montée d'une nouvelle génération (les Smithson, Candilis et Bakema), qui remet en question le fonctionnalisme de la Charte d'Athènes.

Ionel Schein participe au Congrès et publie son compte-rendu sur «L'Architecture d'Aujourd'hui», juste après celui du directeur de la revue, André Bloc ${ }^{33}$. Dans son article, le jeune architecte d'origine roumaine utilise un lexique spécifique, appris au Congrès et bientôt assimilé, avec mots et locutions comme habitat, logis, taudis, prolongements du logis, le plus grand nombre, cadre de vie, aménagement du territoire. Pendant toute sa vie, Schein utilise ce vocabulaire, qui oriente sa réflexion vers la définition du thème centrale de sa production, l'architecture populaire ${ }^{34}$, sa version personnelle de la Charte de l'Habitat. Le CIAM IX instille dans le jeune architecte la graine de la réflexion sur le logement social, un sujet qui ensuite l'anime pendant toute sa production. Son premier manifeste pour un habitat individuel évolutif ${ }^{35}$ représente un trait-d'union linguistique avec les CIAM et germine parmi les papiers de notes du Congrès d'Aix-en-Provence : "Fonction habiter : varie suivant l'évolution de la société. Ce que l'homme construit pour habiter doit pouvoir perpétuellement $\underline{\text { changer }}^{\prime \prime 36}$. Cette prise de conscience amène Schein à abandonner les plans-types en vogue pour repenser le problème de la résidence avec un point de vue plus large, soit avec un plan d'“aménagement du territoire" dans lequel les "prolongements du logis" permettent le développement de la vie des hommes à l'intérieur et à l'extérieur du logement.

\footnotetext{
${ }^{28}$ Entretien avec Claude Parent recueilli par Silvia Berselli en novembre 2008.

${ }^{29}$ Lettre d'André Wogenscky et R. Andreini à Claude Parent du 12 décembre 1952. Wogenscky et Andreini envoient à Claude Parent un chèque pour le remboursement des frais de voyage. FLC, D3-02-72.

30 “...nous avons constitué, sous la direction de Mr. André Wogenscky, un groupe d'étude qui constitue en France le premier noyau du Groupe CIAM-Jeunes. Le premier sujet proposé par Mr. Wogenscky étant l' «Habitat», nous serions très heureux de pouvoir donner, dès le Congrès de Stockholm, une première relation de nos travaux d'études" dans la lettre de Claude Parent et Ionel Schein à Siegfried Giedion du 24 mars 1952. GTA, 42-SG-40-506.

31 "Monsieur Wogenscky a donné une première impulsion à cette idée [CIAM Jeunes], en réunissant dans une série de causeries sur l'Habitat, un premier groupe d'étudiants" dans Schein, Ionel; Parent, Claude: Présences, 23 juin 1952. GTA.

${ }^{32}$ Cfr. Bonillo, Jean-Lucien; Massu, Claude; Pinson, Daniel (édité par): La modernité critique, autour du CIAM 9 d'Aix-enProvence - 1953. Marseille: Imbernon, 2006.

${ }^{33}$ Schein, Ionel; Parent, Claude: Premières conclusions du Congrès. L’Architecture d’Aujourd'hui. №48, 1953, p. V. Parent n'ayant pas participé au Congrès, l'article a été écrit par Ionel Schein (voir le manuscrit de 3 pages au FRAC). L'article est présent en 2 copies à la FLC : D3-02-492/ D3-02-494 ; D3-02-500/ D3-02-504.

${ }^{34}$ Schein, Ionel: Peuple et architecture populaire. Architecture. N³8, 1961, pp. 672-678

${ }^{35}$ Schein, Ionel; Parent, Claude: Essai 1953.

${ }^{36}$ Schein, Ionel: CIAM 9, manuscrit, s.d. FRAC.
} 


\section{Où diable pêchez-vous votre jargon, vous autres, les jeunes? Formation d'un vocabulaire d'architecture à réaction sociale}

La correspondance entre Schein et Le Corbusier est ponctuée d'envoi d'articles, manifestes, idées, à partir du déjà cité compte-rendu du CIAM IX. Vers la fin des années Cinquante, Schein joue le rôle de correspondant de Paris pour plusieurs revues italiennes, suisses et allemandes d'architecture. Cette affectation lui est attribuée en raison de sa connaissance des langues étrangères et de sa renommée internationale après le succès de la Maison en Plastique en 1956. Sur les pages de la zevienne "L'architettura. Cronache e storia" il publie une série d'articles consacrés à l'architecture moderne dans la capitale française. La troisième Lettre de Paris ${ }^{37}$ est dédiée à Georges Candilis et Le Corbusier écrit à Schein: "J'avais pris connaissance de votre article dans la revue "Architettura" que je reçois. Je suis très content de voir que les anciens de la rue de Sèvres font de bonnes choses et que vous appréciez les travaux de Candilis et de Woods. Merci de la sympathie que vous avez pour mon travail ; j'ai déjà eu l'occasion de l'apprécier" ${ }^{\prime \prime 3}$. C'est Le Corbusier lui-même à souligner une différence en se référant à Candilis et Woods comme à des anciens dans la lettre adressée à Schein. Mais cette lettre révèle aussi une affinité, un lien plus ou moins évident, entre les différentes générations d'architectes qui se forment à l'atelier Le Corbusier, qu'il s'agit d' "enfants de Le Corbusier",39, comme Parent et Schein, ou bien d' "anciens de la rue de Sèvres ${ }^{\prime \prime 40}$.

Correspondant pour "Baukunst+Werkform", Ionel Schein est chargé de la rédaction d'un numéro monographique de la revue sur l'architecture contemporaine à Paris. La curatelle du projet est le moteur pour la préparation d'une exposition itinérante ${ }^{41}$ inaugurée à Hannover à l'occasion de la publication, en décembre $1959^{42}$ (Figures 3 et 4 ).
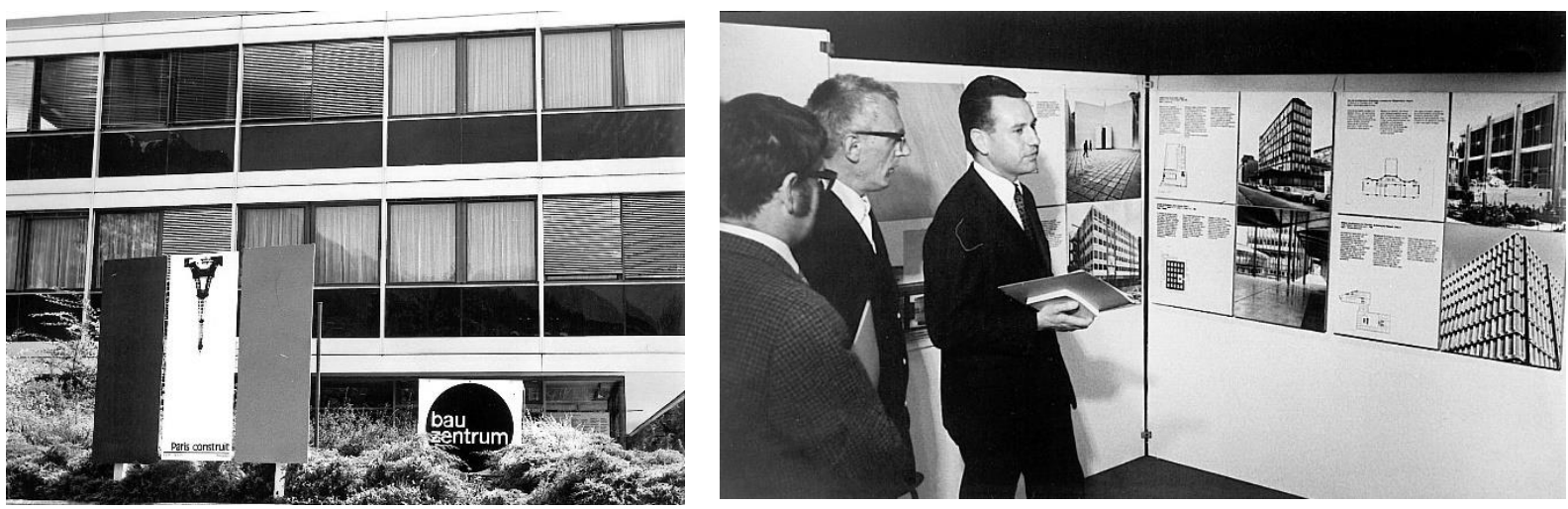

3. - 4. Ionel Schein (édité par), Exposition itinérante Paris baut/Paris construit, Hannover, 1959. Fonds Schein, FRAC Centre, Orléans.

\footnotetext{
${ }^{37}$ Schein, Ionel: Lettre de Paris: l'architecte Georges Candilis (3). L’architettura. Cronache e storia. №33, juillet 1958, pp. 167-175.

${ }^{38}$ Lettre de Le Corbusier à Ionel Schein du 28 juillet 1958, FLC R3-03-61.

39 "Enfants de Le Corbusier, nous les fumes, Ionel Schein et moi..." dans Parent, Claude 1975, p. 28.

40 "Je suis très content de voir que les anciens de la rue de Sèvres font de bonnes choses et que vous appréciez les travaux de Candilis et de Woods". Lettre de Le Corbusier à Ionel Schein du 28 juillet 1958, FLC R3-03-61.

${ }^{41}$ Quelques étapes de 1'exposition Paris baut/Paris construit présentée à Hannover, Allemagne (11 décembre 1959-11 janvier 1960), Musée des Arts Décoratifs, Paris (1960), Libano et Cipre (1965), Pavillon Baltard, Paris (1970), Kunstgewerbmuseum, Zurich (1972).

${ }^{42}$ Schein, Ionel: Paris baut. Baukunst+Werkform. Décembre 1959.
} 
L'exposition est indépendante d'aucun organisme, fondation culturelle ou parrainage français, afin de maintenir une position neutre dans la sélection et la présentation des projets. Les photographies sont réalisées par le suisse Thomas Cugini et par Ionel Schein, qui est l'auteur des textes.

La "sympathie" "43 (dans le sens étymologique du terme) pour l'œuvre de Le Corbusier conduit Schein à présenter plusieurs bâtiments du maître dans son Paris baut, devenu deux ans plus tard une guide multilingue en format de poche au titre Paris construit (Figure 5).

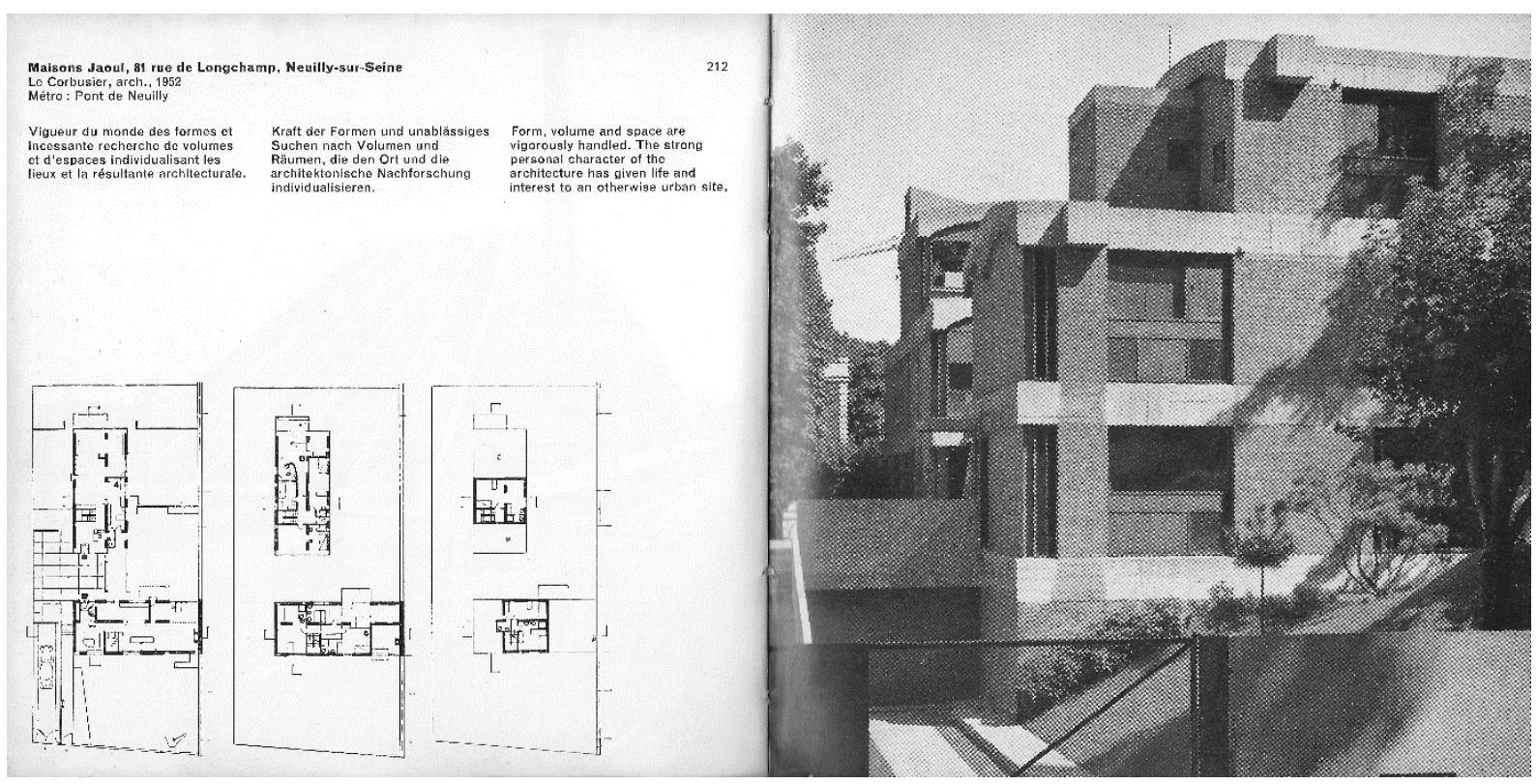

5. Ionel Schein, Paris construit, deux pages du guide dédiés aux Maisons Jaoul, photographiés par Ionel Schein. Dans Schein, Ionel: Paris construit. Guide de l'architecture contemporaine. Paris: Vincent Fréal et Cie, 1961, pp. 72-73; $1970\left(2^{\mathrm{e}}\right.$ ed. augmentée), pp. 212-213.

Schein demande à Le Corbusier les plans de la Maison du Brésil, que l'éditeur Girsberger est en train de redessiner pour l'Euvre complète ${ }^{44}$. Il reçoit les dessins le jour 7 novembre $1959^{45}$ : le plan publié dans Paris construit (première édition de $1961^{46}$ et deuxième augmentée de $1970^{47}$ ) est celui de l'Euvre complète ${ }^{48}$, tandis que dans "Baukunst+Werkform" on trouve des dessins différents, probablement de la main de Schein.

Dans la revue, l'œuvre théorique de Le Corbusier prends une grande place, tandis que ce rôle est redimensionné dans le guide. L'introduction de "Baukunst+Werkform" est illustrée par un croquis du Plan Voisin ${ }^{49}$ et suivie par

\footnotetext{
${ }^{43}$ Lettre de Le Corbusier à Ionel Schein du 28 juillet 1958, FLC R3-03-61.

44 "Cher Monsieur, réponse à votre lettre du 1.9.1959, je regrette vivement mais je n'ai pas à disposition les documents graphiques que vous me réclamez. Les dessins sont faits au crayon; ils sont nombreux, successifs et rectificatifs. Je crois savoir que les Editions Ginsberger font une mise au net de ces dessins pour une publication. J'essaierai de me renseigner et de savoir si je pourrais obtenir pour vous une épreuve graphique utile" dans la lettre de Le Corbusier à Ionel Schein du 7 septembre 1959, FLC R3-03-65.

45 "Donné tout à Schein le 7 novembre 1959", note manuscrite sur la lettre de Ionel Schein à Le Corbusier du 14 septembre 1959, FLC R303-66.

${ }^{46}$ Schein, Ionel: Paris construit. Guide de l'architecture contemporaine. Paris: Vincent Fréal et Cie, 1961, p. 38.

${ }^{47}$ Schein, Ionel: Paris construit. Guide de l'architecture contemporaine, introduction par Max Querrien. Paris: Vincent Fréal et Cie, 1970 ( $2^{\mathrm{e}}$ ed. augmentée), p. 74.

${ }^{48}$ Le Corbusier; Boesinger, W. (édité par): Euvre complète 1957-65. Bâle: Birkhäuser, 2006, p. 192 (ed. or. Zürich: Éditions d'architecture, 1965).

${ }^{49}$ Republié dans Le Corbusier: Les Plans de Paris: 1956-1922. Paris: Éditions de Minuit, 1956, pp. 5, 137.
} 
l'essai Continuer! ${ }^{50}$, signé par Le Corbusier. Ce texte est accompagné par les dessins de la capitale française déjà publiés dans Précisions sur un état présent de l'architecture et de l'urbanisme ${ }^{51}$ et dans Les Plans de Paris : 1956-1922 $2^{52}$. La postface est aussi signée par Le Corbusier, qui propose une réflexion originale ${ }^{53}$ sur l'Unité de Nantes-Rézé, en soutenant la thèse de l'haute densité en architecture. Schein remercie chaleureusement Le Corbusier pour sa collaboration : "Cher Monsieur, je vous dois des remerciements sincères et frénétiques pour les documents que vous avez mis à ma disposition - et pour celui que vous m'avez donné. L'exposition "Paris Baut" sera présentée à Paris aussi et votre écriture, et vos idées et aussi quatre de vos réalisations (Pav. Suisse, Pav. Brésil, Rue Nungesser et Coli, Maisons Jaoul). Et je pense aussi ... à cet immense désir que j'ai (après avoir travaillé trois mois chez vous il y a six ans) de pouvoir parler avec vous, un soir, un matin, n'importe d'architecture, donc de tout. Ne me renvoyez pas à vos livres ; je les possède tous, et je les ai tous lu" ${ }^{\prime 54}$. Dès ce moment les contacts et les visites au Molitor sont plus fréquents et Schein invite Le Corbusier au vernissage de l'exposition Paris construit, qui rejoint finalement la capitale le 11 mars 1960 au Musée des Arts Décoratifs.

Les lettres de Schein sont souvent accompagnées par des articles publiés, mais aussi par des programmes inédits, des manifestes, des essais critiques. Le 25 juin 1960, Le Corbusier reçoit un texte de la part de Schein et il lui répond comme à un enfant: "J'ai lu avec vif intérêt votre papier : «Notes pour une attitude actuelle concernant l'Architecture». Vous avez parfaitement raison d'un but à l'autre. Vous êtes sur la piste depuis quelques années ; j'y suis depuis cinquante années ${ }^{\prime 55}$. Le ton bourru ne décourage pas Schein, qui continue à envoyer au maître ses textes, comme Pour Paris du 1962. La réponse ne tarde pas, avec un post scriptum ironique : "Où diable pêchez-vous votre jargon, vous autres, les jeunes? Est-ce de la littérature de l'Est?" ${ }^{\prime 56}$.

L'indulgence qui accompagne le langage des jeunes suit également leurs gestes : pendant l'été 1960, Schein visite plusieurs architectures corbuséennes, y compris le pavillon caché de Roquebrune-Cap Martin et le chantier de l'Etoile de Mer. Les regards se croisent, mais la rencontre se fait en silence : Schein craint d'être chassé, tandis que Le Corbusier a peur que les gens découvrent et violent son retrait secret. Le même jour $1^{\text {er }}$ septembre $1960^{57}$, les deux s'écrivent pour se rassurer réciproquement et se remercier pour ce silence complice.

Au contact de l'architecture corbuséenne (la Tourette surtout), la prose de Schein acquiert des tons lyriques: "Et d'où que l'on regarde, le couvent prend et garde l'aspect d'un tout - d'une sorte de miracle voulu, prévu, accompli. L'Homme de partout devrait, ici comme à Ronchamp, comme sur le toit de Marseille, comme à Nantes, comprendre que le beau est la vie ${ }^{\prime \prime 58}$. Le secret de Roquebrune renforce le lien et Le Corbusier participe à plusieurs évents organisés par Schein, comme la signature de son L'Atelier de la recherche patiente chez Vincent et Fréal. A cette occasion Le Corbusier rencontre les étudiants du cours tenu par Schein à l'École des Arts Décoratifs et c'est tout à fait l'occasion de boucler la boucle, par rapport à l'époque de la formation du

\footnotetext{
${ }^{50}$ Le Corbusier: Continuer!, dans Schein, Ionel: Paris baut, 1959, pp. 668-669.

${ }^{51}$ Le Corbusier: Précisions sur un état présent de l'architecture et de l'urbanisme. Paris: Éditions Crès, Collection de "L'Esprit Nouveau", 1930.

${ }^{52}$ Le Corbusier: Les Plans de Paris: 1956-1922. Paris: Éditions de Minuit, 1956, pp. 126-127.

53 "Das nebenstehende Blatt gab uns Le Corbusier als seinen Beitrag zu dem vorliegenden Heft und zur Ausstellung Paris Baut". Le Corbusier, Kleines Manifest zum Thema "Unité d'Habitation”, dans Schein, Ionel: Paris baut. 1959, pp. 706-707.

${ }^{54}$ Lettre de Ionel Schein à Le Corbusier du 3 décembre 1959, FLC R3-03-68.

${ }^{55}$ Lettre de Le Corbusier à Ionel Schein du 30 juin 1960, FLC R3-03-80. Cfr. Le Corbusier; Jenger, Jean (édité par): Choix de lettres. Bâle: Birkhäuser, 2002, pp. 453-454.

${ }^{56}$ Ibidem.

${ }^{57}$ Lettre de Le Corbusier à Ionel Schein du $1^{\text {er }}$ septembre 1960, FLC R3-03-81. Lettre d'Ionel Schein à Le Corbusier du $1^{\text {er }}$ septembre 1960, FLC R3-03-82.

${ }^{58}$ Lettre d'Ionel Schein à Le Corbusier du $1^{\text {er }}$ septembre 1960, FLC R3-03-82.
} 
jeune, quand le nom de ce «monsieur » était interdit. Pour les étudiants des cours de Schein, Le Corbusier écrit le texte L'urbanisme est l'expression de l'activité d'une époque. L'architecture est l'expression de l'esprit d'une époque ${ }^{59}$, destiné à être lu pendant la projection des diapositives de ses projets et dessins.

Lors que Le Corbusier est chargé du projet pour l'Hôpital de Venise, Schein lui envoie une note de félicitations avec le dessin de la place Saint Marc. Le Corbusier fait ses corrections au dessin (Figure 6), qu'il renvoie à Schein en photocopie, avec la lettre: "Cher Monsieur, merci de vos «Très sincères félicitations» du 16.11.1963. Je vous signale que la piazetta [sic] de Venise possède deux colonnes entre le Palais Ducal et l'autre Palais et qu'entre ces deux colonnes on aperçoit le Campanile et le fronton de l'île St Georges Majeur et qu'à Venise l'horizon est beaucoup plus bas que vous ne l'indiquez. Par ailleurs, les gondoles ne sont jamais mises à quai parallèlement mais transversalement et je vous signale, encore, que le Palais Ducal a un dessin de façade en marbre rose et blanc en losange et que les chapiteaux de la colonnade de ce Palais sont à la naissance des arcs. Bien cordialement à vous. Le Corbusier. P.J.: 1 photo-copie ${ }^{, 60}$.

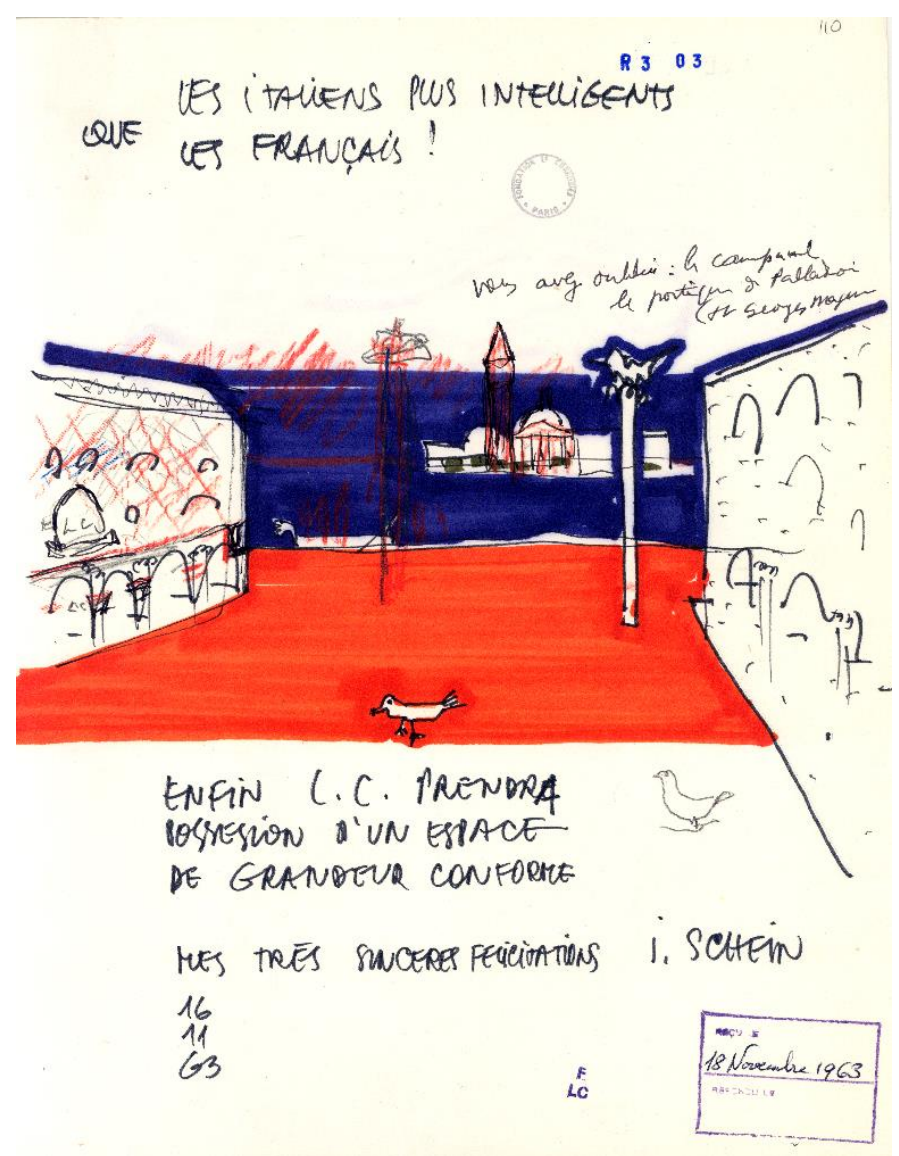

6. Note de félicitations de Ionel Schein à Le Corbusier du 16 novembre 1963. Corrections faites par Le Corbusier. Fondation Le Corbusier, Paris.

La publication d'une sélection de la correspondance corbuséenne Choix de lettres ${ }^{61}$, par Jean Jenger, reproduit cette lettre à Schein, mais l'éditeur coupe le texte après la signature, en oubliant le "par joint" et le dessin. La

\footnotetext{
${ }^{59}$ Lettre de Le Corbusier à Ionel Schein du 17 mai 1962, FLC R3-03-98. Cfr. Le Corbusier; Jenger, Jean (édité par): Choix de lettres. Bâle: Birkhäuser, 2002, pp. 478-479.

${ }^{60}$ Lettre de Le Corbusier à Ionel Schein du 2 décembre 1963, FLC R3-03-109-001. Dessin: FLC R3-03-109-002.

${ }^{61}$ Le Corbusier; Jenger, Jean (édité par): Choix de lettres. Bâle: Birkhäuser, 2002, p. 492.
} 
lettre devient ainsi un épanchement injustifiable et perd son caractère de divertissement intellectuel entre élève et enseignant, typique de leur correspondance. Le dessin de Venise est la synthèse parfaite de ce rapport, qui commence à l'école CIAM de 1952 et se termine dans la ville lagunaire, où les deux se rencontrent, probablement pour la dernière fois, en avril $1965^{62}$.

Schein a l'opportunité de connaitre, ou bien la capacité de faire ressortir, un Le Corbusier qui se plie volontiers à corriger les mots et les dessins de ses petits-enfants. Comme un grand-père bourru et imposant, il suit, avec une touche de fierté, leur pas sur le chemin qu'il a ouvert.

\section{Le cadavre rêvé Une suite grotesque d'honneurs posthumes}

Ionel Schein a dédié de nombreux écrits à la mémoire de Le Corbusier, publiés juste après sa mort en 1965 ou bien quelques années plus $\operatorname{tard}^{63}$. Le premier obituaire, publié sur "Architecture 65" en septembre-octobre, présente un caractère plus passionné et est partagé en deux sections. Tout d'abord La Mort, description du rituel funèbre qui met en scène, "machiavéliquement, la "perte" du "génial" et du "grand" Le Corbusier"164 ; ensuite La Vie, célébration de l'héritage de celui qui "fut philosophe - et plus : bâtisseur de sociétés ; car il est indéniable qu'avant toute chose Le Corbusier est un des grands "structurateurs sociaux" de son temps" ${ }^{\prime 65}$. Les célèbres portraits de Le Corbusier aux lunettes noires qui accompagnent l'article sont faits par Thomas Cugini, le photographe de Paris construit, sur indication de Schein (Figure 7). Le croquis Venise: la cité à l'échelle humaine (Figure 8) a probablement été donné à Schein pendant leur rencontre dans la ville lagunaire en 1964, et constitue une réponse graphique au dessin de la Place Saint Marc que les deux s'étaient renvoyé l'année auparavant (Figure 6).

\footnotetext{
62 «L-C a vu Schein à Venise (8-14 Avril 65)» note manuscrite sur la lettre d'Ionel Schein à Le Corbusier du 3 Mars 1965 , FLC R3-03-119.

${ }^{63}$ Voir, par exemple, les nombreux obituaires : Schein, Ionel: Le Corbusier, bâtisseur de sociétés. Architecture 65. № 66, septembre-octobre 1965; Id., Le Corbusier, bâtisseur de sociétés. Le Monde. 1 février 1967; Id., Le Corbusier pas mort. Un bâtisseur de sociétés. Le quotidien de Paris. 3 septembre 1975; Id., Ils étaient tous là... Architecture. Novembre 1981.

${ }^{64}$ Schein, Ionel: Le Corbusier, bâtisseur de sociétés. Architecture 65. №66, septembre-octobre 1965

${ }^{65}$ Ibidem.
} 

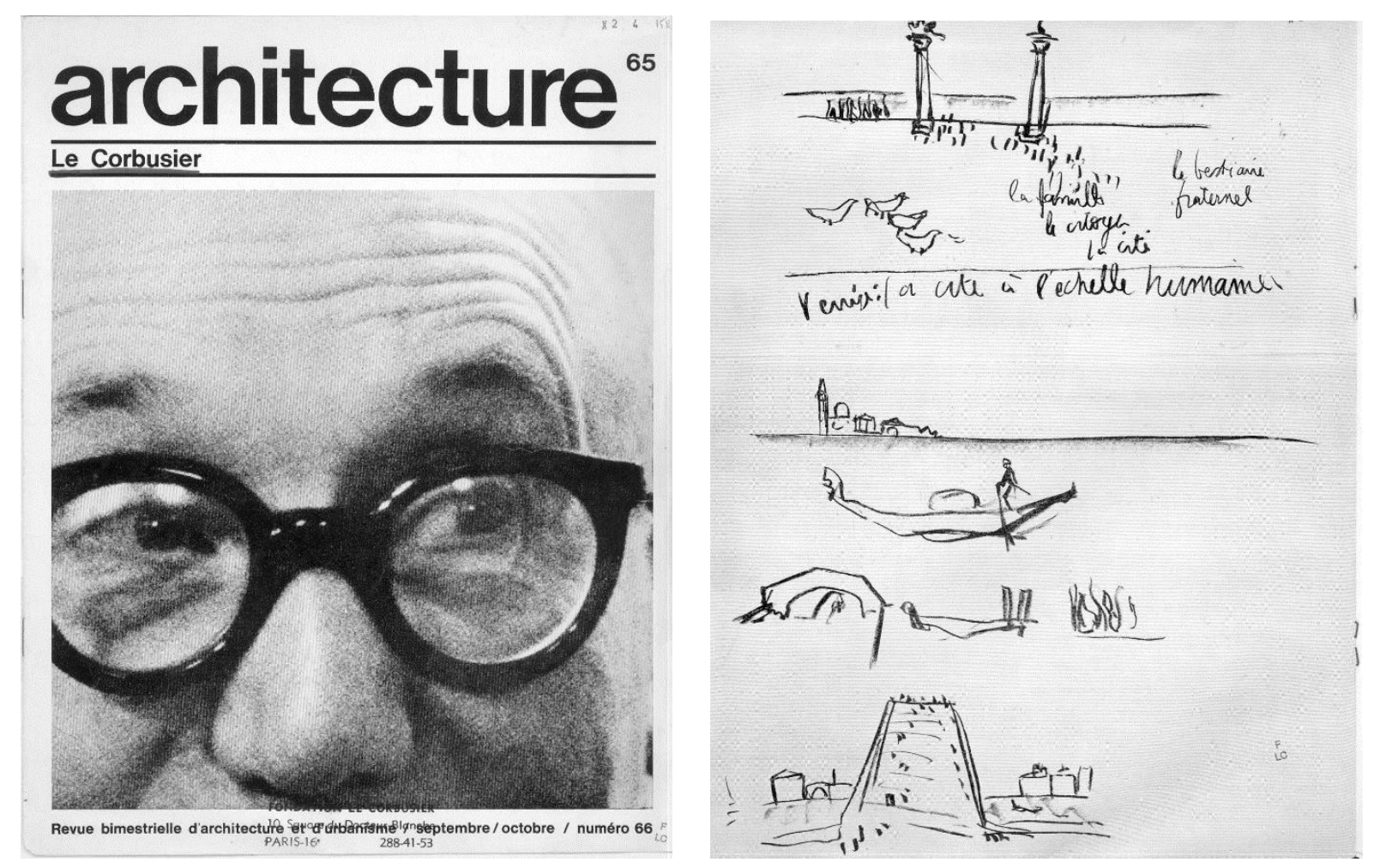

7. Le Corbusier, Couverture de l'édition monographique commémorative de la revue Architecture 65, septembre-octobre 1966. Portrait par Thomas Cugini.

8. Croquis de Le Corbusier Venise : la cité à l'échelle humaine, publié dans la même revue, Architecture 65, septembreoctobre 1966.

Les funérailles somptueuses réservées à Le Corbusier arrachent à Schein de considérations pleines de résignation : "... en France cartésienne, les hommes de valeur n'acquièrent leur grandeur aux yeux de ceux qui les ont humiliés durant leur vie, qu'après leur mort. Ce besoin de «disparition » est indispensable à ceux qui, à la tête des affaires du pays, ont recours aux alibis sécurisants: Le Corbusier était par son caractère intransigeant, sa vie austère et sa mort subite, pour cette besogne, le cadavre rêvé"t66.

En conclusion on pourrait relire, cinquante ans après la mort de Le Corbusier, les mots que Schein a écrit dix ans après cette même date. Dans une époque actuelle de polémique intense, on oublie trop souvent que "L'actualité de Le Corbusier réside dans son esprit imaginatif et inventif, innovant; dans la poursuite incessante et sans faille d'un même combat farouche, celui pour l'architecture, dans l'absence de tout compromis. Dans l'histoire de l'architecture contemporaine sa place n'est pas encore prise ; il vit toujours ${ }^{\prime 67}$.

\section{Bibliographie}

Berselli, Silvia: Ionel Schein. Dall'habitat evolutivo all'architecture populaire. Mendrisio: Mendrisio Academy Press - Cinisello Balsamo: Silvana Editoriale, 2015

Bonillo, Jean-Lucien; Massu, Claude; Pinson, Daniel (édité par): La modernité critique, autour du CIAM 9 d'Aix-en-Provence 1953. Marseille: Imbernon, 2006

\footnotetext{
${ }^{66}$ Ionel Schein, Le Corbusier pas mort. Un bâtisseur de sociétés. Le quotidien de Paris. 3 septembre 1975.

${ }^{67}$ Ionel Schein, Le Corbusier pas mort. Un bâtisseur de sociétés. Le quotidien de Paris. 3 septembre 1975.
} 
Epron, Jean-Pierre (édité par): Architecture: une anthologie. Tome 2: les architectes et le projet. Liège: Pierre Mardaga, 1992

Giedion, Siegfried: A Decade of New Architecture - Dix ans d'Architecture Contemporaine. Zurich: Girsberger, 1951

Le Corbusier: Précisions sur un état présent de l'architecture et de l'urbanisme. Paris: Éditions Crès, Collection de "L'Esprit Nouveau", 1930

Le Corbusier: Les Plans de Paris: 1956-1922. Paris: Éditions de Minuit, 1956

Le Corbusier; Boesinger, W. (édité par): Euvre complète 1957-65. Bâle: Birkhäuser, 2006 (éd. or. Zürich:

Éditions d'architecture, 1965)

Le Corbusier; Jenger, Jean (édité par): Choix de lettres. Bâle: Birkhäuser, 2002

Parent, Claude: Claude Parent Architecte. Paris: Laffont, 1975

Ragon, Michel: Monographie critique d'un architecte: Claude Parent. Paris: Dunod, 1982

Raimond, Anne-Marie: Un toit pour chaque français (1 et 2). Elle. № 399, 27 juillet 1953, pp. 24-29; Elle. $\mathrm{N}^{\circ}$ 400, 3 aout 1953, pp. 26-29

Schein, Ionel; Parent, Claude: Maison Française 1953. La Maison Française. № 69, juillet 1953, pp. 3-14

Schein, Ionel; Parent, Claude: Premières conclusions du Congrès. L’Architecture d'Aujourd'hui. N48, 1953, p. V

Schein, Ionel; Parent, Claude: Essai pour un habitat individuel évolutif et Habitation à Ville d'Avray.

L'Architecture d'Aujourd'hui. N 49, octobre 1953, pp. 4-5 et pp. 10-13

Schein, Ionel: Lettre de Paris: l'architecte Georges Candilis (3). L'architettura. Cronache e storia. $\mathrm{N}^{\circ} 33$, juillet 1958, pp. 167-175

Schein, Ionel: Paris baut. Baukunst+Werkform. Décembre 1959

Schein, Ionel: Peuple et architecture populaire. Architecture. N³8, 1961, pp. 672-678

Schein, Ionel: Paris construit. Guide de l'architecture contemporaine. Paris : Vincent Fréal et Cie, 1961 (1e éd). 1970 (2e éd. augmentée)

Schein, Ionel: Le Corbusier, bâtisseur de sociétés. Architecture 65. №66, septembre-octobre 1965

Schein, Ionel: Le Corbusier, bâtisseur de sociétés. Le Monde. 1 février 1967

Schein, Ionel: Le Corbusier pas mort. Un bâtisseur de sociétés. Le quotidien de Paris. 3 septembre 1975

Schein, Ionel: Ils étaient tous là.... Architecture. Novembre 1981 


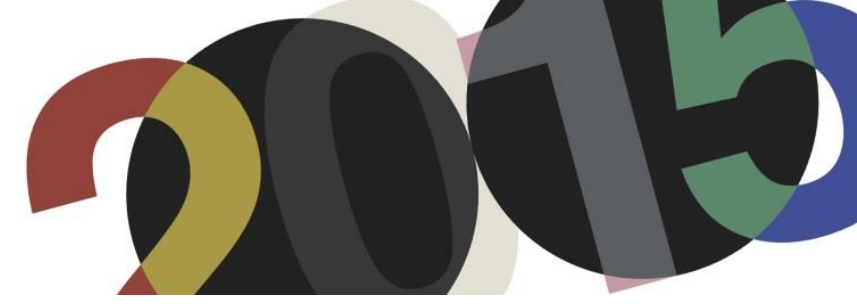

DOI: http://dx.doi.org/10.4995/LC2015.2015.565

\title{
Vernacular Serbia Traced by Jeanneret, Yugoslav Modern Figured à la Corbusier
}

\author{
Lj. Blagojević \\ University of Belgrade - Faculty of Architecture
}

\begin{abstract}
The paper examines correlations of architectural culture in Serbia with modern ideas of the twentieth century that were engendered through engagement with concepts originated by Le Corbusier. Based on analysis of primary sources, the paper examines the dichotomy vernacular - modern as a critical point of this correlation. For instance, what was the significance of vernacular or folklore heritage, that Charles-Édouard Jeanneret traced in Serbia in 1911, and how did its value became part of the foundational discourse of the modern movement? What kind of relation to Le Corbusier's doctrines were forged by modern architects in Serbia of the interwar years, and which lessons learned in his Parisian atelier by collaborators from the late 1930s had been transmitted far and wide in socialist Yugoslavia's urban planning? This paper focuses on comparative analysis of direct material evidence of sources on the one side and interpretations on the other, with the aim to show more clearly a two-way working of sources, reception and selective transmission through architectural thinking and design process. In sum, the argumentation will aim to elucidate the processes of acknowledgment, emulation, idealization, analytical probing, dogmatization, critique and annihilation of Le Corbusier's ideas in the long march of modernism's emancipation and decline in Serbia over the course of the twentieth century.
\end{abstract}

Resumen: El artículo examina las correlaciones de la cultura arquitectónica en Serbia con ideas modernas del siglo XX que se generaron a través de los conceptos originados por Le Corbusier. Basado en el análisis de fuentes primarias, el artículo examina la dicotomía vernácula - moderna como un punto crítico de esta correlación. Por ejemplo, ¿cuál fue la importancia del patrimonio vernáculo o folclore, que Charles-Édouard Jeanneret trazó en Serbia en 1911, y cómo se convirtió su valor en una parte del discurso fundamental del movimiento moderno? ¿Qué tipo de relación con las doctrinas de Le Corbusier se forjaron por los arquitectos modernos en Serbia de los años de entreguerras, y qué lecciones aprendidas en su taller parisino por los colaboradores de la década de 1930 habían sido transmitidas en la planificación urbana de Yugoslavia socialista? Por un lado, este documento se centra en el análisis comparativo de pruebas materiales directas de fuentes, y por el otro lado de la interpretación, con el objetivo de mostrar más claramente dos maneras de trabajo de las fuentes, la recepción y transmisión selectiva a través del pensamiento arquitectónico y proceso de diseño. En síntesis, la argumentación tratará de dilucidar los procesos de reconocimiento, la emulación, la idealización, la investigación analítica, dogmatización, la crítica y la aniquilación de las ideas de Le Corbusier en la larga marcha de la emancipación de la modernidad y el declive de la misma en Serbia en el transcurso del siglo XX.

Keywords: Le Corbusier; Serbia; vernacular; purism; socialist modernism; New Belgrade.

Palabras clave: Le Corbusier; Serbia; vernácula; purismo; modernismo socialista; Nuevo Belgrado.

\section{Introduction}

The paper follows two principle lines in its inquiry of correlations of architectural culture in Serbia with modern ideas that were engendered through engagement with concepts originated by Le Corbusier: the first identifies vernacular art and its milieu that had been seen by the eyes of Charles-Édouard Jeanneret when he visited Serbia in 1911, and the second concerns modern ideas that were seen by the eyes of young architects from Yugoslavia collaborating in his rue de Sèvres atelier in the 1930s. In simple terms, the research is not about the question of influence, rather the opposite, it looks at a two-way working of sources. Ch.-É. Jeanneret traced out vernacular artistry in Serbia and interpreted its qualities which seem to me to be relevant for his budding interests in the theory of purism. Conversely, Le Corbusier's artistry that was traced out at source in his atelier by his 
collaborators, had manifold interpretations, themselves changing over the course of the twentieth century, including those by architects from the former Yugoslavia, which are explored in this paper. In that sense, I would argue that seeds of Le Corbusier's theory of purism, to be precise, what he calls "objets-types répondant à des besoins-types" (Le Corbusier 1925, p. III), were already present in sketches and photographs he made in June 1911 at the Belgrade Ethnographic Museum and towns in the Eastern Serbia. Also, I would argue, that his planning theory, particularly that of the Radiant City, formed the basis of rethinking modern city and housing in the post war socialist Yugoslavia.

The glaring radiance of Le Corbusier's lines, whether spoken, drawn or built, all too easily blinds the eyes, leaving mythical traces and uneasy issues in the murky shadows of its dazzling light. Recent research, thus, aims to elucidate zones left in the shadow, by careful reconstruction of context and through finding new historical evidence (e.g., Amirante and others, 2013). Alternatively, authors read his work through more theoretical lenses, hypothesising it through referencing to philosophical discourse, such as seeing "transgression and ekphrasis" (Korolija Fontana-Giusti 2015) in the Serbian itinerary of the Voyage d'Orient. ${ }^{1}$ The present paper focuses on comparative analysis of direct material evidence of sources on the one side and interpretations on the other, aiming to examine a two-way working of sources, reception and selective transmission through architectural thinking and design process. In the first section, the paper offers a comparative view at original objects beheld by Ch.-É. Jeanneret and his drawing interpretations of those same objects. In the second section, the paper explores output of some of the most notable Yugoslav architects in the decades after they had collaborated in Le Corbusier's atelier. My aim is to discern more clearly between questions of sources, impressions and inspirations, doctrine or dogma, and transformations through design process.

\section{Vernacular Serbia Traced by Charles-Édouard Jeanneret: besoins-types}

The first ethnographic exhibition in Belgrade opened on September 20,1904, as the permanent collection of the Ethnographic Museum, part of the Museum of Serbian Lands, also consisting of the Museum of Natural History of Serbia. Thereafter, the exhibition was open for locals on Thursdays and Sundays, while travellers, that is foreigners and those visiting from provincial Serbia, could visit any day at any hour (Bižić-Omčikus 2002, p. 47). One such foreign visitor, Charles-Édouard Jeanneret writes in June 1911: "In a quiet corner of the city there is an exquisite ethnographic museum, with carpets, clothing, and ... pots, beautiful Serbian pots of the kind we will go looking for in the highlands of the Balkans" (Le Corbusier 1989, p. 43). The first research question here, thus, asks what was it exactly that made the ethnographic museum earn its quality of being exquisite in Jeanneret's discerning eyes, when it is known only too well that he qualified the city itself as "a ridiculous capital, worse even: a dishonest city, dirty and disorganized" (Le Corbusier 1989, p. 43), saved only by its admirable position.

The museum's modest historicist architecture emulating neo-Renaissance elements on its façade could hardly have impressed the visitor. Two stories high urban mansion with a back garden built ca. 1860, bequeathed to the state by its former owner, the prominent liberal politician Stevča Mihailović (1806-1888), was reconstructed at the beginning of the twentieth century to fit the museum purposes. ${ }^{2}$ At the outset, its ground floor was dedicated

\footnotetext{
${ }^{1}$ References to propositions by Roland Barthes, Georges Bataille, Wilhelm Worringer, Michel Foucault, Jacques Derrida, and Gilles Deleuze and Felix Guattari (Korolija Fontana-Giusti 2015, pp. 73-5).

2 Original house was designed by architect Andrija Vuković (1812-1884), reconstructed ca. 1900 into museum by architect Milorad Ruvidić (1863-1914).
} 
to the department of natural history, while the ethnographic department exhibited in four or five rooms of ca. 150-200 sq. $m$ on the first floor, and expanded to six rooms at the time when Ch.-É. Jeanneret visited.

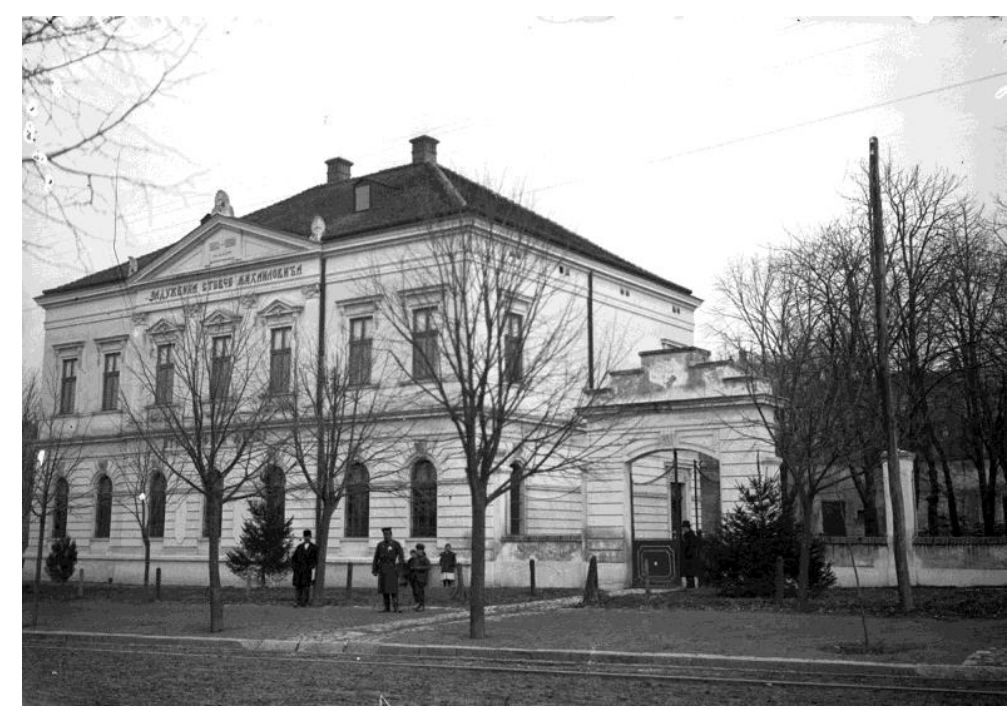

1. The Ethnographic Museum in Belgrade - Bequest of Stevča Mihailović, photograph ca. 1905 by Nikola Zega.

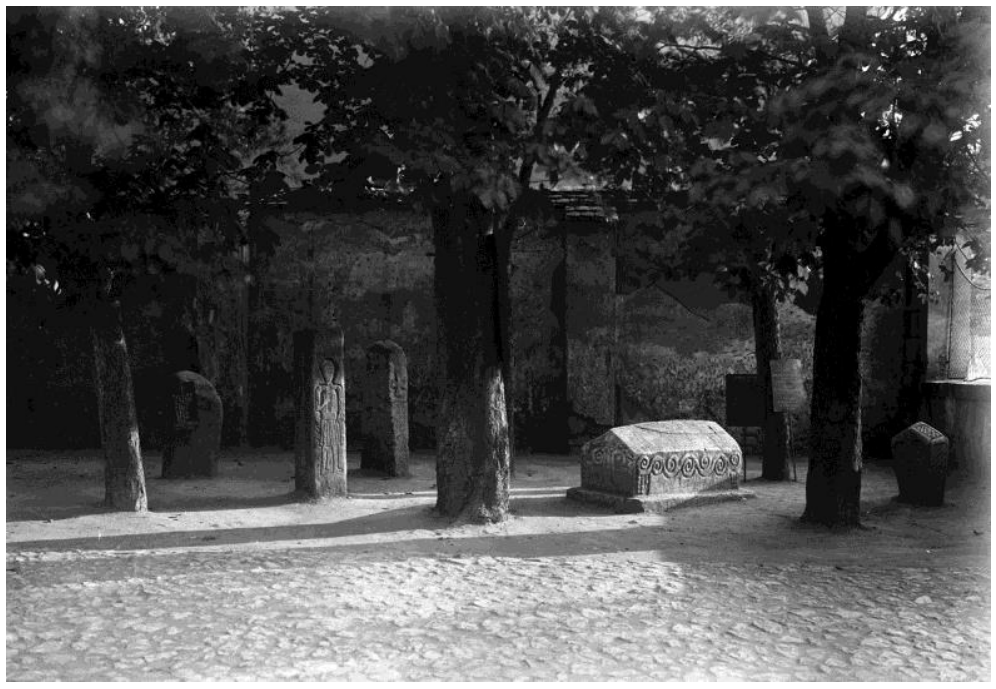

2. Lapidarium in the courtyard of the Ethnographic Museum in Belgrade, photograph ca. 1905 by Nikola Zega.

In the garden and courtyard, the lapidarium comprised dozen stone tombs, three cult monuments and four stone baths alongside a collection of wooden objects including a large boat hull and models of vernacular timber huts. (Vlahović 1951, pp. 15-16). Particularly notable exhibits in the lapidarium were the bogomil tombs (stećak, Serbo-Croat) which were placed in the yard among greenery and trees. Two explanatory boards were mounted next to them. One board, annotated in Serbian, English and French, read: Epitaph of the Serb Paulician Church of the XII ${ }^{\text {th }}$ Century, i.e., Épitaphe de la secte des Cathares ou Albigeois serbes - XII siècle. The other one mapped the sites of stećak tombs in Serbia, that were mostly located in the Western part along the river Drina and the border with Bosnia. In a recent publication, Danilo Udovički-Selb (2013, pp. 214-7) argues the relevance of bogomil tombs as one of the knots in the complex web of sources from the voyage d'Orient. Originating from Bulgaria, probably of ancient Persian decent, the bogomils migrated over centuries (X-XII c.) through Byzantine territories of Serbia and Bosnia, further west to Dalmatia, across the Adriatic Sea to Northern Italy and, eventually, to Languedoc in southern France where they are called les cathares (Fr.). Udovički-Selb discusses 
the bogomil tombs, that Jeanneret photographed in the Belgrade Museum's yard, ${ }^{3}$ as one of the inspirations for the Modulor, expanding on previous research on Ch.-É. Jeanneret's early education by Paul V. Turner (2001, p. 49), which pointed to the young man's keen interest for the cathares history as related to his family origins and, later, the name Le Corbusier. But, Turner also points to an etymological link of cathares being called the Pure, and of Jeanneret's familiarity from his childhood with their history (Turner 2001, p. 94). The bogomil tombs in Belgrade, I would suggest, can be read as a source of manifold significance, including that of a strong affective response of the traveller in appreciation of an elemental order of a transhistoric and transpatial quality of their pure form.

Objects on show in the ethnographic exhibition also caught the attention of the young traveller. The museum's collection grew out of the initial accumulation at the ethnographic department of the National Museum of Serbia, numbering ca. 1,000 items (clothing and shoes, jewellery, crockery and cookery, pottery, music instruments, photographs, etc.), enlarged in 1903 by 111 new objects, 5,000 Easter eggs and 544 items of lace and embroidery. ${ }^{4}$ By the time of Ch.-É. Jeanneret's visit, the collection grew as result of state funded new acquisitions presented at the Exposition Universelle et Internationale de Liège (1905), Bucharest Jubilee Exhibition (1906), Balkan States Exhibition in London (1907), and exhibition of Serbian women's craft in Prague (1910), as well as through private donation by "Velimirijanum" trust in 1909.

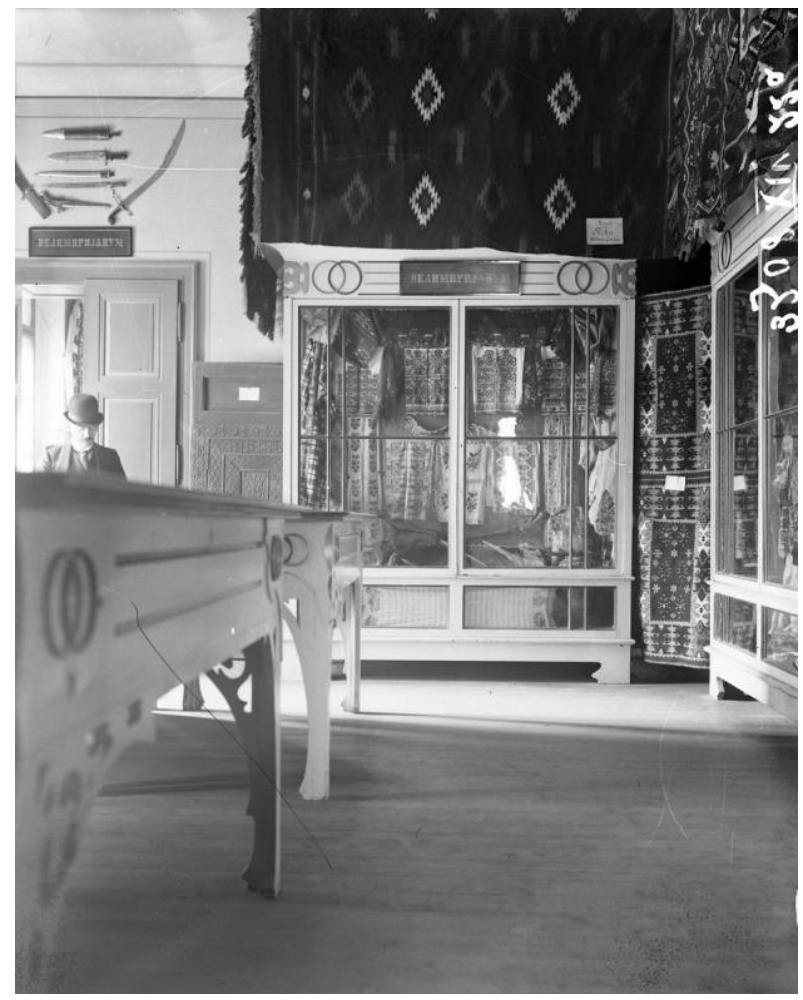

3. Vitrines in the first exhibition of the Ethnographic Museum in Belgrade, 1907

\footnotetext{
${ }^{3}$ Udovički-Selb 2013, p. 217

${ }^{4}$ Beginnings of ethnography in Serbia were connected with preparations of the Serbian section at the All Russian Ethnographic Exhibition and Pan-Slavic Meeting in Moscow in 1867. For the purposes of this exhibition, the Serbian Learned Society amassed the first selection comprising six full folk costumes, ca. 100 photographs and 20 paintings as well as a number of other objects, subsequently donated to Rumyantsev Museum in Moscow (Румянцевский музе́й) for the then planned all-Slavic collection. See: Vlahović 1951, p. 13.
} 
In the Museum of Serbian Lands, the exhibition was arranged in new white Art Nouveau vitrines containing lace, fine embroidery, mannequins dressed in full costumes and jewellery, and delicate small objects such as Easter eggs. Metal objects, armoury, pictures and carpets were hung on walls, and some sets with scripted scenes with mannequins dressed in folk costumes were arranged in the exhibition space: baby in a crib, coachman for hire with a stuffed horse, traditional Muslim room interior and the like, as depicted in the period photographs by the museum's first custodian Nikola Zega.

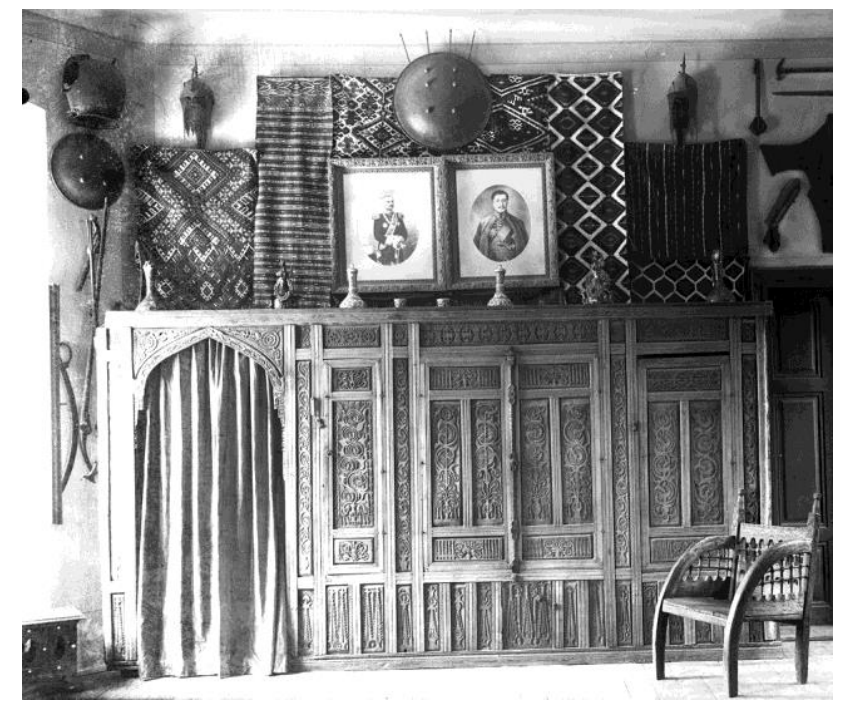

4. Musandra (Turkish) - wood carved closet panelling, the first exhibition of the Ethnographic Museum in Belgrade, 1905

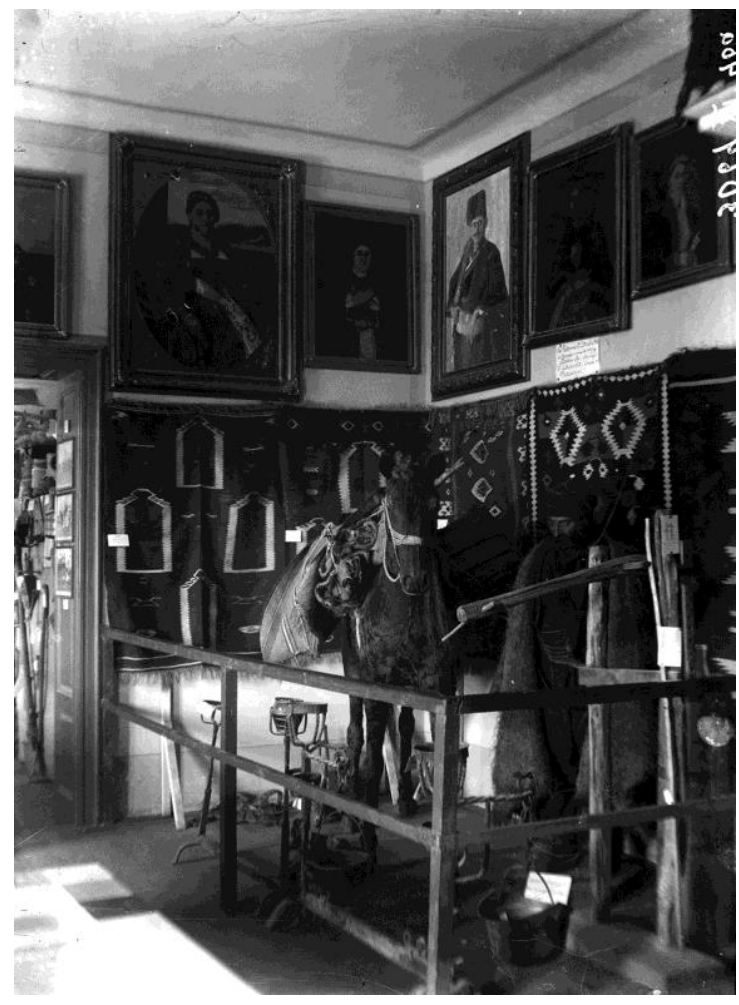

5. Kiraci (Turkish) - coachman for hire, the first exhibition of the Ethnographic Museum in Belgrade, 1904 
Yet, in records of his visit, Ch.-É. Jeanneret paid little attention to the exhibition arrangements photographed by the local custodian. He notes discrete exhibits only, such as killim rugs from the famous traditional workshops in the Serbian town Pirot - jotting down in his sketchbook the word in German "Pirottenteppiche". ${ }^{5} \mathrm{He}$ also sketches only a selection of exhibits: sundry pottery and the traditional single string wooden instruments including one named gusle, the instrument used to accompany epic recitals of oral poetry (Blagojević 2003, p. 5). ${ }^{6}$ The sketches do not depict the richness of the exhibition setting, instead, they show discreet pots or instruments floating on paper with no support or base. I would argue these early subtractive sketches may be seen as seeds of abstract thinking about typology of objects which will inform the theory of purism.
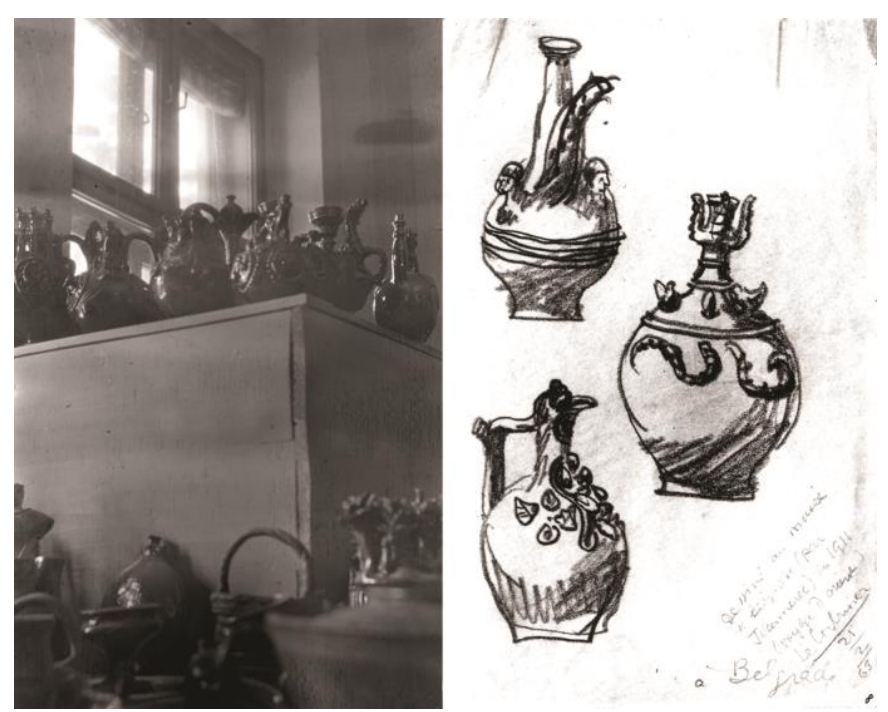

6. Pottery exhibited at the Ethnographic Museum in Belgrade, photographed in 1907 by Nikola Zega; Ch-É. Jeanneret, drawing of Serbian pottery from the Ethnographic Museum in Belgrade, 1911

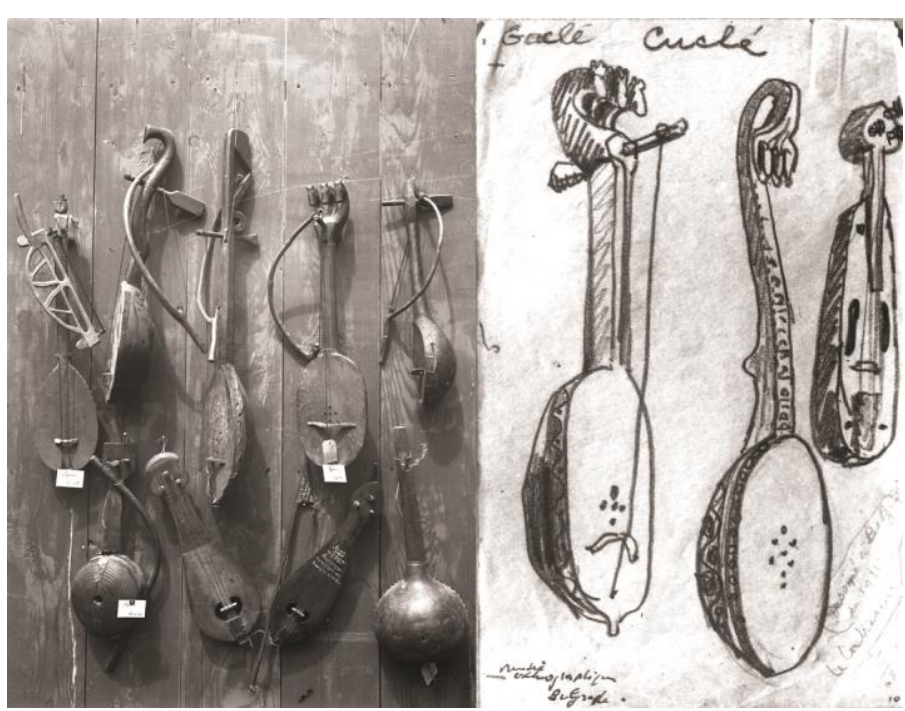

7. String music instruments from the collection of the Ethnographic Museum in Belgrade, photographed in 1907 by Nikola Zega; Ch-É. Jeanneret, drawing of gusle from the Ethnographic Museum in Belgrade, 1911

\footnotetext{
${ }^{5}$ Sketch "Pottery from the Balkans (courtesy Fondation Le Corbusier)", reproduced in: Le Corbusier 1989, p. 17. The year 1910 noted on the sketch is erroneous, it should read 1911, cf. Editor's note: Op. cit., p. 43.

${ }^{6}$ In 1963, Le Corbusier donated to the National Museum in Belgrade two pencil drawings that he had sketched in the city's Ethnographic Museum, with handwritten annotations to that effect (Blagojević 2003, pp. 232-3 n. 4).
} 
Le Corbusier held pottery in high regard. In his L'Art décoratif d'aujourd'hui (1925, pp. 34-35), he published two consecutive full page photographs of pottery, an earthenware jug from Serbia decorated with the figure of the winged horse Pegasus from the Greek mythology and the other pot from Spain with delicate profiled concentric horizontal lines. As he himself recounted twenty five years later to the Belgrade architect Milorad Pantović, ${ }^{7}$ collaborator in the rue de Sèvres atelier in 1936-37, he had found the Pegasus jug in the town of Knjaževac, in Eastern Serbia near the border with Bulgaria, and had it shipped to Switzerland to his mother, who kept it in the family house and, latter, at the Villa "Le Lac" (Pantović 1965, p. 81). Le Corbusier spoke very fondly about his travels through Eastern Serbia and the towns Knjaževac, Negotin and Zaječar. ${ }^{8}$ The maittre, Pantović noted, spoke of the appreciation of good humour and shrewdness of the people from the region that he called "bon type Danubien" (Pantović 1965, p. 81), and also recounted an anecdote of him stopping a peasant on a Belgrade street to buy off him a pretty folk woven woollen sack the man had carried on his shoulder, for five francs, and sent it to his mother.

The Serbian jug with Pegasus can be seen in a photograph from ca. 1919, with Charles-Édouard holding it above his head, posing in a picture together with Albert Jeanneret and Amédée Ozenfant in the Villa Jeanneret-Perret in La Chaux-de-Fonds. ${ }^{9}$ The killim covered cushion behind his back, and another jug on the window sill to the left, presumably, trace back to the same Balkan itinerary.

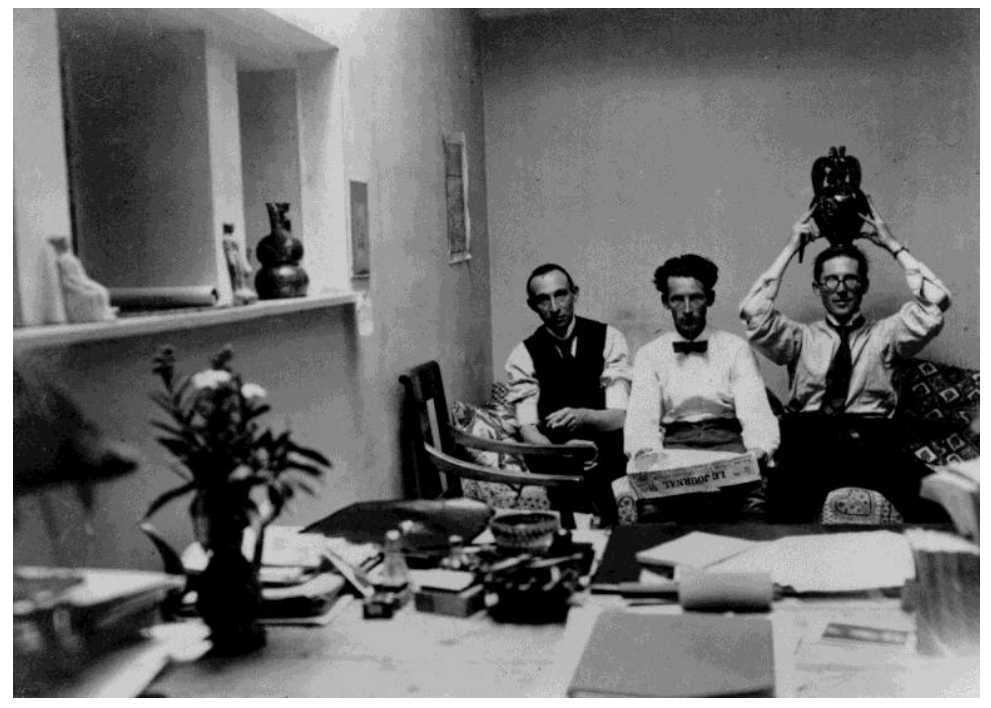

8. Charles-Édouard Jeanneret (right), Albert Jeanneret (centre), and Amédée Ozenfant (left), ca. 1919. OFLC L3(16)36 (25)

Another colour pencils sketch of a very similar jug with Pegasus, originating also from Knjaževac, annotated and signed by Le Corbusier, shows a variation of the Greek mythical motif and other decorative elements. This sketch was presented in 1959 as a gift to Radenko Mišević (1920-1995), painter and Professor of Arts Academy in Belgrade and Sarajevo. Incidentally, the painter's sister, Seka Mišević-Mijatović was an avid collector of ethnographic art, including a large number of earthenware pots and jugs from Serbia and Bosnia, and might have been a point of contact between the two men. ${ }^{10}$ In the caption to the photograph of the Pegasus jug, Le Corbusier

\footnotetext{
${ }^{7}$ On Pantović's career, projects and travels, see Blagojević 2008

${ }^{8}$ Pantović himself originated from the same region, his paternal family of old from Zaječar.

${ }^{9}$ Image published in Blagojevic 2003, p. 7. Dating and location of picture noted on the copy of the photograph supplied by the FLC (more recently, Korolija Fontana-Giusti 2015, p. 65, dates the same picture in 1922, and locates it in the Paris workshop in rue d'Astorg, but with no reference to FLC inventory no.)

${ }^{10}$ She donated her entire collection of some 800 objects to the Ethnographic Museum in Belgrade in 1993. See: Reljić, ed. 1994
} 
writes of its predicament: "Le folklore dans sa puissance lyrique. A travers les siècles, on retrouverait Pégase. La rivière, l'arbre, les fleurs sont transcrits en formes essentielles. L'exubérance du sentiment poétique dont les expressions sont fixées depuis des siècles, fait de ce vase un object d'exception. Le potier serbe qui fit ce vase vers 1900 l'avait relégué avec maints autres dans son grenier. Il était le dernier à en avoir fait, il n'y croyait plus. Chez lui des vaisselles de commerce vulgairement ornées à la machine occupaient ses étagères. D'un coup brutal, le 'progrès' avait fait tomber des traditions millénaires.” (Le Corbusier 1925, p. 34).
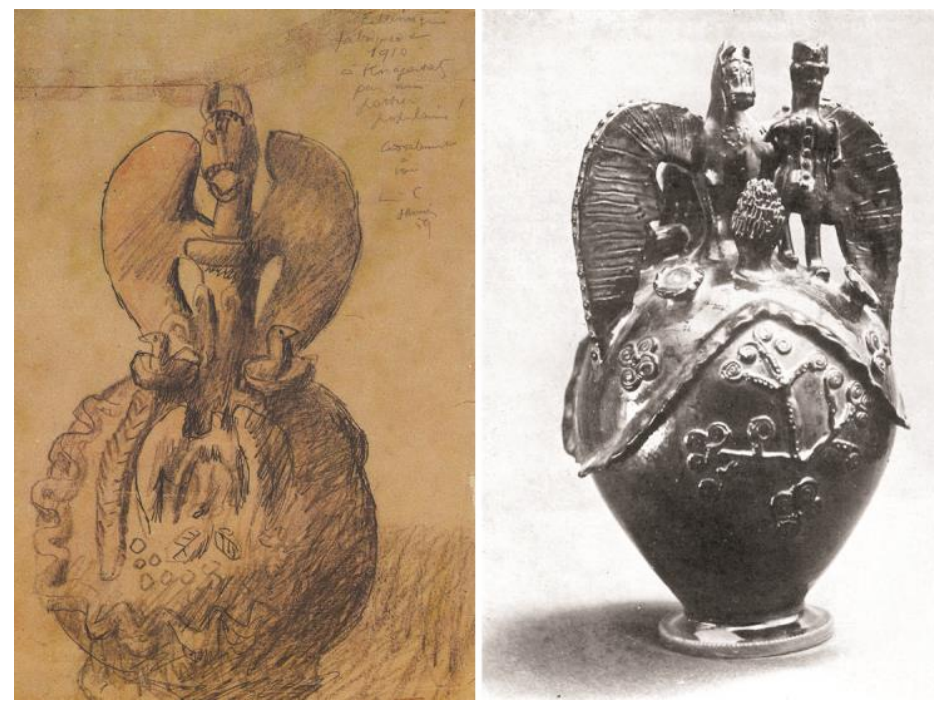

9. Ch.-É. Jeanneret, drawing of the jug with Pegasus from Knjaževac, dated 1910, in fact 1911, (left); the jug with Pegasus (right), reproduced in Le Corbusier's L'Art décoratif d'aujourd'hui (1925)

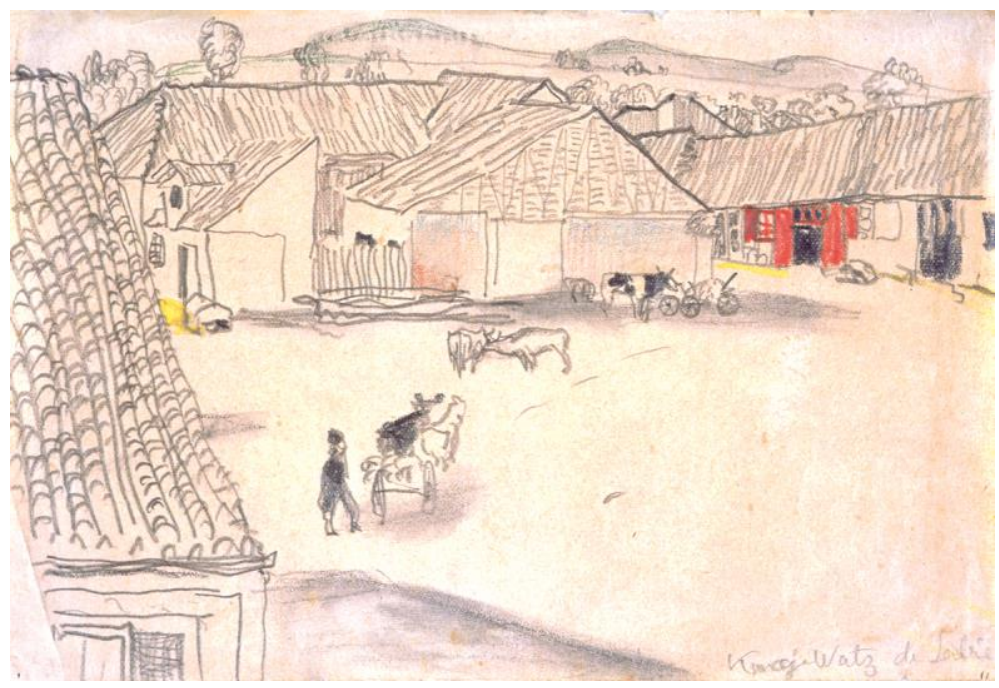

10. Ch-É. Jeanneret, Knajewatz de Serbie (Knjaževac in Serbia), 1911

After Belgrade, Ch.-É. Jeanneret followed the trail of the earthenware pots, heading east, downstream the Danube, as noted in a letter to William Ritter, who largely inspired the Balkan itineraries: "J'en suis encore à Belgrade et au petit chemin de fer belge vers l'intérieur" (Dumont 2013, p. 60). In Negotin, he writes of the local ruby-red wine originating from Bordelais, divine music played by the "tziganes" and the town's "quintessential" (Le Corbusier 1989, p. 45) cemetery. There, he was apparently taken by symbolic and decorative properties of carved grave stones reminiscent of the ones he saw in the Belgrade museum, although those in Negotin are dating form mid-eighteenth to mid-twentieth century. The rural milieu of Eastern Serbia is recorded in his colour pencils drawing with a handwritten annotation "Knajewatz de Serbie", showing a slightly 
elevated view of a village common surrounded by sundry farm houses, with a peasant directing an oxen pulled cart and few cattle grazing in the foreground, and a rolling landscape sketched lightly in the background. ${ }^{11}$ In Knjaževac and Zaječar he stays for two days, June 13-14, 1911, before leaving Serbia never to return.

In sketches and photographs he had taken in Serbia, Jeanneret's appreciation of the folklore is evident, even without his words to that effect. Modern Serbia on the trail of, as he himself called it, "invading and dirty 'Europeanization'” (Le Corbusier 1989, p. 15), fared rather differently. When in 1958 the Serbian architect Jovan Krunić, another collaborator from the 1930s, visited the master in Paris and showed him the then recent publication on Belgrade architecture, it is noted, "[h] is comment was, as ever, unforgiving: «My God, how ugly it is.»" (Krunić quoted in: Blagojević 2003, p. 8). The dichotomy of the Balkans in general, and Serbia and Belgrade in particular, persisted, at least in Le Corbusier's eyes: beauty in the perishable works of the natural man, the noble savage if you will, and horror in the works of the moderns.

In the decade following the end of First World War, the architects in Serbia took to their own journeys, alternating between exploring vernacular heritage, medieval urban, religious and military buildings and sites, and experimenting with the modern idiom. One instance is indicative, in that sense: at the First Salon of Architecture in 1929, organised by the Group of Architects of Modern Movement in Belgrade, the architect Branislav Kojić (1899-1987), one of the Group's founders and prominent interwar modernist, exhibited a selection of his works which included both architectural survey of Balkan vernacular architecture, and two drawings entitled Interior «à la Corbusier».

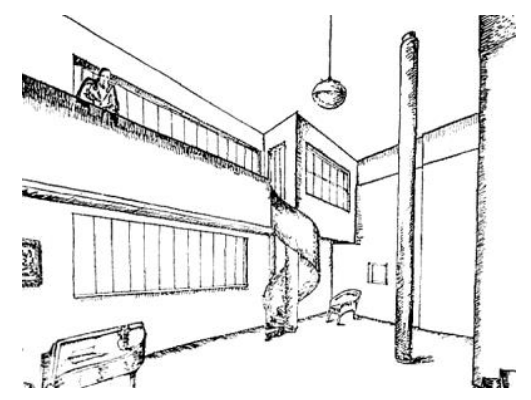

11. Branislav Kojić, Interior «à la Corbusier», 1929

Except in odd cases, such as this interior which serves as a motif in the title of this paper and occasional competition projects that will be mentioned in the next section, Le Corbusier's discourse had marginal impact on interwar modernism in Serbia. It was only in the changed socio-political context of socialism, that his work was publically exhibited in a comprehensive way for the first time in $1952,{ }^{12}$ and that his theory, especially, planning theory became extremely relevant for the urbanization processes set in motion after the Second World War. As I aim to explore in the sequel, the driving force for the introduction of Le Corbusier's ideas were young architects from Yugoslavia who collaborated in his Paris atelier as interns in the 1930s. Yet, the legacy of these

\footnotetext{
11 This drawing originates from the collection of Erich Chlomovitch (Erih Šlomović, 1915-1942), associate and personal assistant of Ambroise Vollard in his gallery in rue Lafitte, in 1936-39. According to some sources, after Vollard's death in 1939, Chlomovitch inherited one part of the collection, recently contested, mainly consisting of drawings, books and graphics, which came into possession of the National Museum after the Second World War, as a donation by the collector's mother.

${ }^{12}$ Originally organized by the Institute of Contemporary Art in Boston in 1948, the exhibition travelled around the U. S. and Brazil before it crossed over and toured Europe, from Berlin and Munich, to Stockholm, Belgrade, Milano, Rome, Vienna, Oslo, and other major cities. For lack of gallery space in Belgrade, the exhibition of some 100 exhibits including paintings, sculptures and projects, was mounted in a school building and it lasted only twelve days in 1952-53 over the New Year's holidays (Corbusier 1952, cf. Blagojević 2010).
} 
relationships with Le Corbusier, as it will be discussed, was neither straightforward linear nor conceptually uncontested.

\section{Les Temps Nouveaux and Modernism in Yugoslavia}

Five architects from the Kingdom of Yugoslavia collaborated in the office of Le Corbusier in 1937, working on the preparations of the exhibition in the Pavillon des Temps Nouveaux at L'Exposition Internationale des Arts et Techniques dans la Vie Moderne in Paris, namely: Xenija Grisogono (1909-1997), Juraj Neidhardt (1901-1979), Milorad Pantović (1910-1986), Branko Petričić (1911-1984) and Ernest Weissmann (1903-1985). ${ }^{13}$ In the next decades, all five were to advance their own trajectories and very specific modern concepts that marked the post Second World War architectural culture in Paris, Zagreb and Sarajevo, Belgrade and New York. I will sketch out a few nodes in the complex web of contacts, exchanges and activities of these five architects, that are argued relevant for the topic at hand. ${ }^{14}$

At the time of working on Pavillon des Temps Nouveaux, outside their office time, both Neidhardt and Pantović entered the competition for the urban regularization of Novi Sad, medium size city (ca. 75,000 inhabitants) in Vojvodina province of Serbia. Even though their projects earned only commissions, rather than awards, $2^{\text {nd }}$ commission for Neidhardt and $7^{\text {th }}$, special mention for project outside the rules, for Pantović and his team, their respective entries can be regarded as cornerstones of modern planning in Yugoslavia (Blagojević 2007, pp. 31 42). Juraj Neidhardt, graduate from Akademie der bildenden Künste der Meisterschule für Architektur in Wien, collaborator of Peter Behrens in Berlin in 1930-32, and of Le Corbusier in 1933-37, based his plan of Novi Sad on macro-level three-dimensional modelling of the city and traffic scheme of concentric rings: outer ring of satellites (Trabanten, Ger.), dirty periphery ring, clean periphery ring, green pedestrian ring and city core ring. On micro-level planning he devised a scheme of diverse neighbourhoods, with traffic and circulation analogous to tree branching and diverse residential typologies (Grabrijan 1937, p. 145-148).

\footnotetext{
${ }^{13}$ Grisogono, Pantović and Weissmann had several connection points; all three participated in a the group exhibition of Yugoslav artists and architects in the Parisian gallery in rue du Faubourg Saint-Honoré in April 1937; after Paris, Grisogono, ran Weismann's office in Belgrade at some point in 1938 (information related to me by Tamara Bjažić Klarin, for which I am thankful); all three were in New York for the World Exhibition in 1939, Weissmann designed the Yugoslav section at the exhibition and decided to stay in the U.S. after the show, Grisogono and Pantović returned to Belgrade and continued to collaborate on several projects until 1950s, when Grisogono who emigrated to Paris and subsequently worked on designs for La Défense in 1960s and 1970s (Chabard 2011, p. 85). Collaborators from the former Yugoslavia in 1938-39 include Plečnik's students Edvard Ravnikar (1907-1993), Marjan Tepina (1913-2004), Jovan Krunić (1915-2001) and others. All of them, except Grisogono who lived in Paris, were to hold prominent positions in academia and the profession in the socialist Yugoslavia after the Second World War.

${ }^{14}$ That is, the scope is scaled for the format of the conference paper, with many aspects of comprehensive and exhaustive inquiry of the topic left for further research.
} 


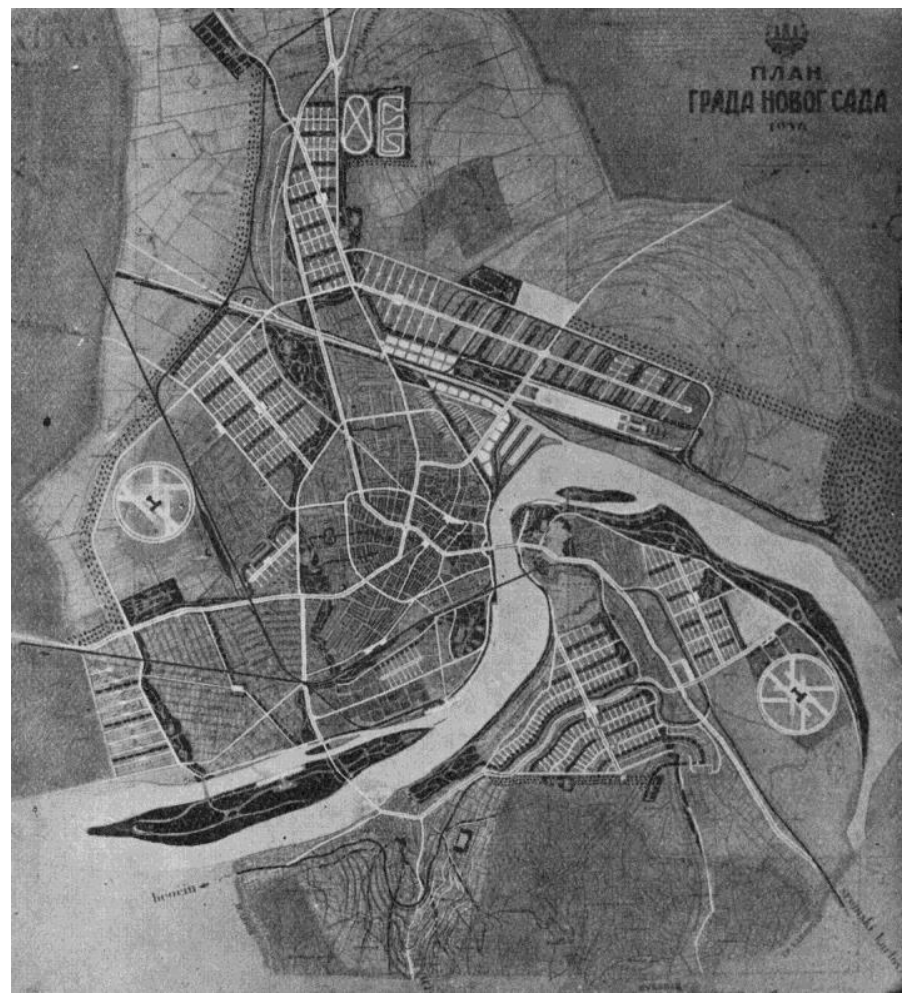

12. Juraj Neidhardt, Competition entry for Urban planning of Novi Sad, 1937

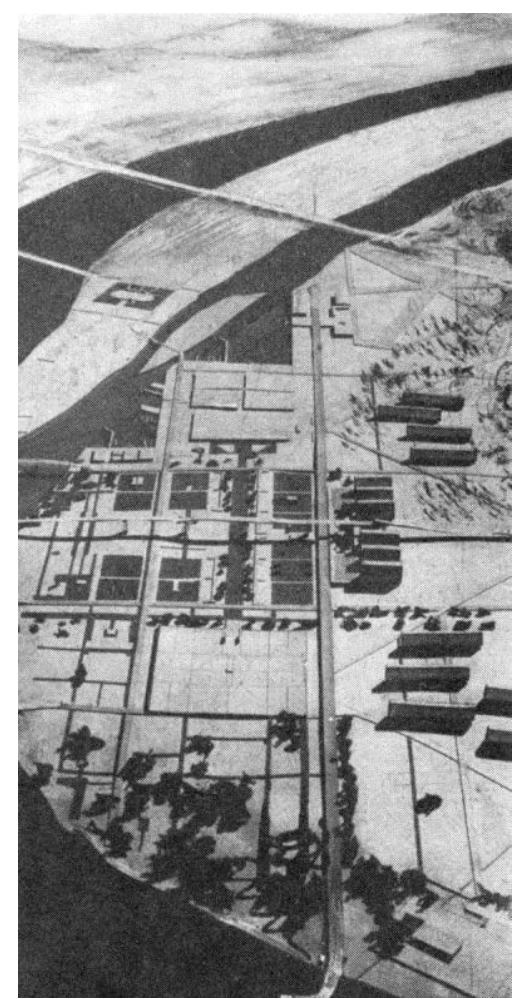

13. Milorad Pantović, Jean Bossu, Otto Clauss and G.T.J. Kuiper, Competition entry for Urban planning of Novi Sad, 1937

Milorad Pantović teamed up with colleagues from Le Corbusier's office, namely Frenchman Jean Bossu, Swiss Otto Clauss and Dutch G.T.J. Kuiper. Their plan envisaged the enlargement of the city up to 250,000 inhabitants, as a polycentric new town organized on the principle of maximum 15 minutes walk between work and habitation 
with recreation and leisure included in the zone of housing. Such poly-functional modern urban quarters of 6,000-7000 inhabitants with density of 200 inhabitants per hectare, were planned next to the historical core along the Danube waterfront. In an article about this project and the ways of collaboration, published in the Dutch journal De 8 en OPBOUW, Kuiper (1938, p. 38) writes about the atmosphere of confusion, freedom, discussion and exchange in Le Corbusier's office which bred great enthusiasm in young collaborators hardly understanding each other speaking in many tongues, who often teamed up to do competitions and in that way circulated the ideas they learned at source.

Of all collaborators from Yugoslavia most widely known is the global role played by the architect Ernest Weissmann, University of Zagreb graduate, collaborator in rue de Sèvres atelier between 1927-30, and member of Congrès Internationaux d'Architecture Moderne (CIAM) and Comité International pour la Résolution des Problèmes de l'Architecture Contemporaine (CIPRAC) in the interwar period. ${ }^{15}$ After emigrating to the U.S. in 1939, Weissmann briefly collaborated with Josep Lluís Sert on the project "East River Crescent" in New York City as well as on Sert's book Can Our Cities Survive, ${ }^{16}$ and was a member of the design team for the U.N. Headquarters in New York. From 1944, he joined the United Nations Relief and Rehabilitation Administration (UNRRA), in the 1950s and 1960s, he headed the housing, building and planning activities of the UN and edited the related bulletin. Global impact of Weissmann's work is not directly related to the present theme, thus, not discussed here. ${ }^{17}$ His impact on modern architecture and planning in Yugoslavia, however, directly relates to the question of sources from Le Corbusier's atelier. I would single out Weissmann's catalyst role in devising modern planning methodology for CIAM 4, the city analysis of Zagreb carried out by Radna grupa Zagreb (RGZ), the working group he had founded as CIAM's national group for Yugoslavia (Bjažić Klarin 2014).

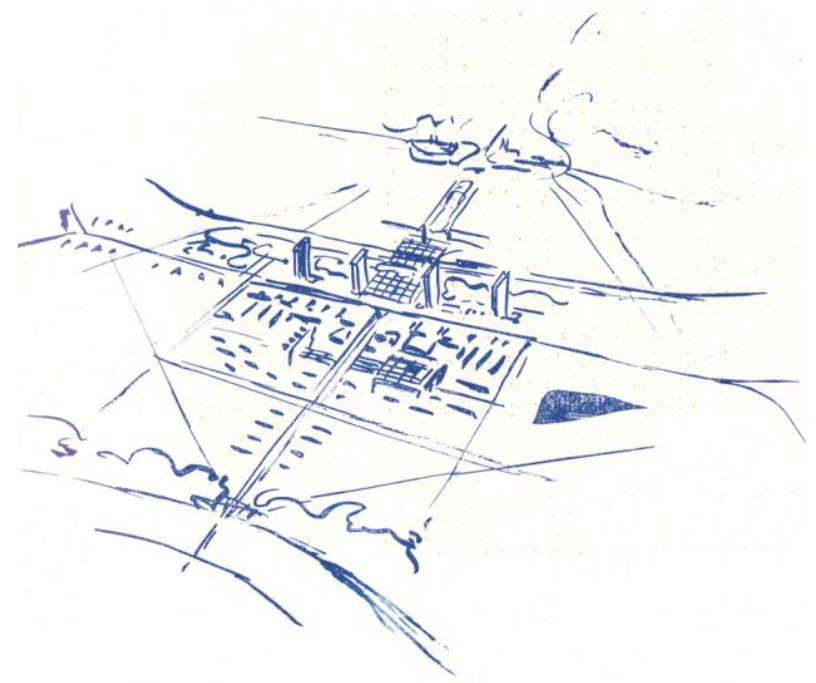

14. Vladimir Antolić, Plan for New Zagreb (1949)

\footnotetext{
${ }^{15}$ On Weissmann's role in the CIAM, see: Mumford 2002, passim

${ }^{16}$ See unpublished version of book cover, reproduced in Weissmann 1984-85, p. 189

${ }^{17}$ Weissmann's role in "exchanges between architects across the Cold War divide" (Stanek 2012, p. 301), is gaining attention in global research, such as in doctoral research (e.g., Muzaffar 2007), and wider academic discussions, such as recent talk "United Nations Urbanism: Architects and Cold-War Politics of Development Aid", at the International Seminar "Morphologies and Power: Architecture, planning and urban design", held at Departimento di Archittetura e Studi Urbani, Politecnico di Milano, January 14, 2015, given by Tom Avermaete.
} 
Continuity of the CIAM concepts devised by RGZ in the 1930s is evident in plans for New Belgrade (Seissel 1947, p. 21) and New Zagreb (1949) by Vladimir Antolić, ${ }^{18}$ Weismann's associate in CIAM and RGZ member. More to the point, I would point to the significance of the text Weissmann wrote not long before his death, in which he gives a valuable personal testimony about CIAM, its "failed revolution" (Weissmann 1984-85, p. 33), his own role at CIAM 4, and his latter attempts to forge a collaboration of CIAM and UNRRA. The text titled "We had another version of the Charter", documents plurality of positions advocated by CIAM actors at the time and as such it deserves a translation into major languages and inclusion into the wider knowledge base on the history of the modern movement.

Planning and construction of New Belgrade had been one of the central projects of the post Second World War urbanization in the former Yugoslavia. Envisaged as a modern socialist city of some 250,000 inhabitants, with the seats of the Federal government and ministries, the Communist Party Central Committee Headquarters, Museum of Revolution, Museum of Contemporary Art and related public squares, zones for parks and recreation, industry and shipbuilding, New Belgrade offered fertile ground for experimentation in modernist planning including multiple interpretations of Le Corbusier's ideas, concepts and doctrines. ${ }^{19}$ As noted by Edvard Ravnikar, prominent Slovenian architect and planner, and Le Corbusier's collaborator in 1939: “Our planning culture (in Yugoslavia, that is), of which we can only speak as a potentiality, would not be as it is without, should I say, familial relations (with Le Corbusier) from the early days of his great inventions in urbanism" (Ravnikar 1965, p. 82, comments in parenthesis by author). Ravnikar himself demonstrated this relation in his planning proposal for New Belgrade in 1947. In form, his plan replicates the Radiant City scheme, if only at $1 / 4$ of the original scale. To be precise, Ville Radieuse - VR 15 synthetic diagram (Le Corbusier 1935, p. 171) is scaled to fit the area of marshland between the rivers Danube on top of scheme and Sava at its bottom, amounting to $2,8 \mathrm{~km}$ distance.

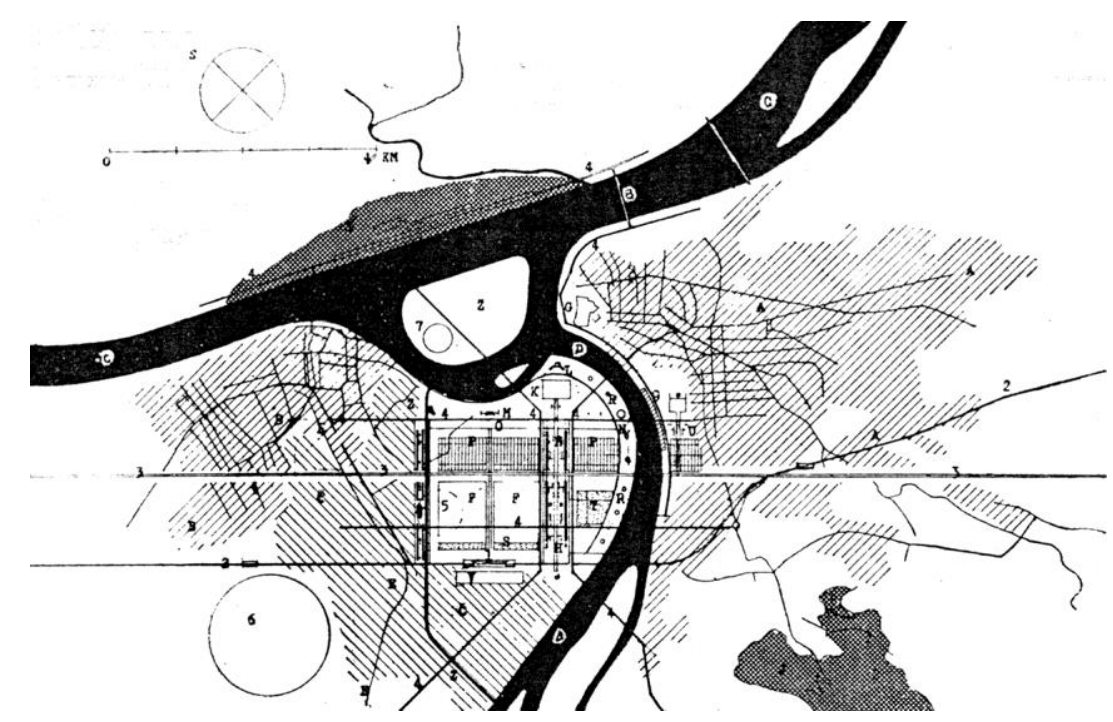

15. Edvard Ravnikar, Plan for Greater Belgrade, 1947

A closer look shows that Le Corbusier's plan is taken only as an icon, a pattern rather than programme. When compared, differences between theory of the VR and practice of the socialist planning are striking: la cité d'affaires is reprogrammed into the great square in front of the state and party institutions - the domineering Central Committee tower at the apex, Presidency of Federal Government and Federal Parliament flanking it on

\footnotetext{
${ }^{18}$ Projects first published in Seissel 1947; and Antolić 1949

${ }^{19}$ On New Belgrade planning history, see: Blagojević 2007, 2012
} 
each side - 24 federal ministries buildings substitute for the housing, embassies and residential quarter for diplomats in place of les manufactures and so on. This plan marks the culminating point of the socialist realist period in planning of New Belgrade.

Soon thereafter, the planning and infrastructure construction in New Belgrade were suspended due to the socioeconomic crisis following Yugoslavia's leader Tito's break with Stalin and USSR led politics of the Warsaw Pact, and consequent expulsion of Yugoslavia from the Cominform in 1948. Some ten years later, when New Belgrade planning was resumed, Le Corbusier's ideas came alive again, this time in a different context of a decentralised country on the path of self-management socialism. Proposal for the new city's master plan drawn in 1957 demonstrates a version of the Radiant City different to that proposed by Ravnikar in 1947. Here, the Ville verte theoretical diagram - VR 7 (Le Corbusier 1935, p. 163), is most literally transferred in plan to the same scale to the marchland of New Belgrade to form the pattern of housing blocks in the central zone of the new city. The architect in charge of the plan and newly appointed director of the Urban Planning Bureau of Belgrade was Branko Petričić, University of Belgrade graduate in 1935, who worked as an intern in Le Corbusier's office in the period $1^{\text {st }}$ February $-1^{\text {st }}$ August 1937, as a bursary of the Ministry of Construction of the Kingdom of Yugoslavia. In the Parisian atelier, Petričić collaborated on the project Plan de l'Ilot Insalubre $N^{\circ} 6$ (Le Corbusier 1937, p. 67), which was itself elaboration of the theoretical model of the housing quarter from the Radiant City (cf. Le Corbusier 1937, p. 74). The ideal plan model, however, had to be adjusted to realpolitics of planning, under-developed technology and socialist economy of construction in New Belgrade (Petričić 1957). Thus reduced, the New Belgrade master plan proposal based on Ville verte concept, not only lost any sophistication of the original source or l'Ilot $n^{\circ}$. 6, but it had not overcome the basic naïveté of direct transmission of theory into practice. Consequently the plan was vehemently criticized by the architect, University of Belgrade professor Nikola Dobrović (1897-1967), one of the most prominent modernists in Yugoslavia and the first post-war planner of New Belgrade. Dobrović grounded his critique on scrutiny of solutions for the major territorial waters, but above all on the plan lacking meaning and symbolic power and it being based on ideas stuck in a past (Dobrović 1957, p. 210-1). Thus denounced, the master plan, which eventually did get adopted in 1958, albeit as an amended compromise version of the first proposal, was revoked before long.

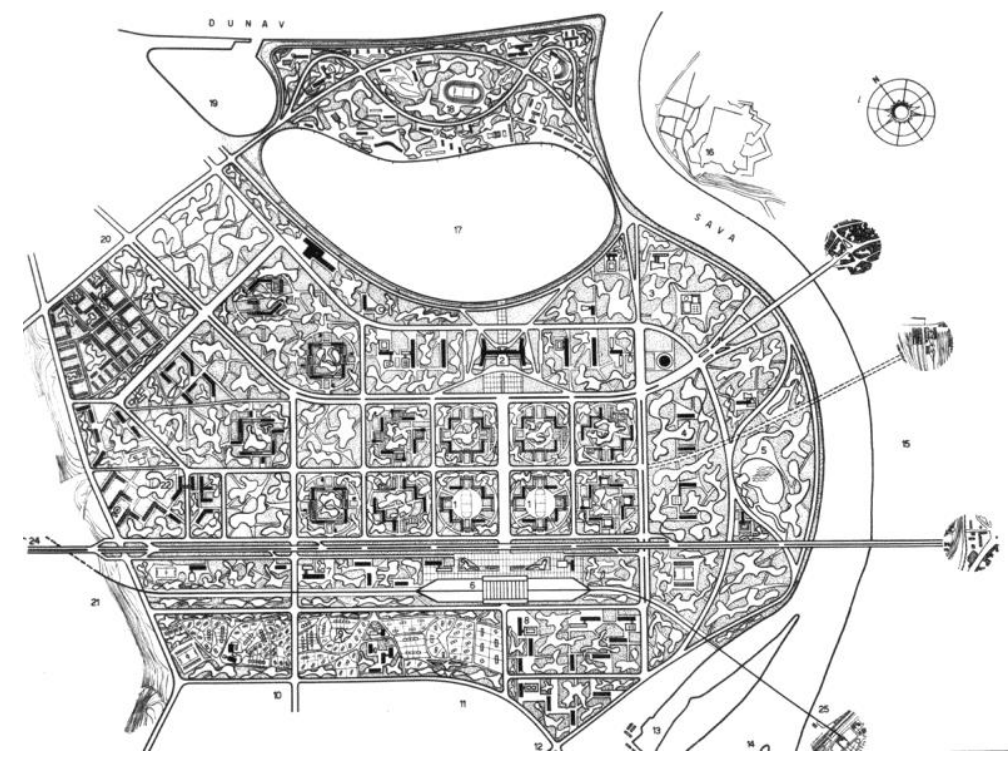

16. Branko Petričić, New Belgrade master plan proposal, 1957 
The final Plan of Central Zone of New Belgrade (1960), which had stood the test of time as the basis for construction of housing blocks in the central zone of the new city until early 1980s, can also be seen as interpretation of the legacy of Le Corbusier's planning theory. The appropriation of modernism in this period was largely marked by the CIAM's concept of functional city. The dogmatic rigorousness of The Athens Charter was additionally burdened and inhibited by the political and ideological limitations of a socialist-communist mono-structure. The plan in question proposed strict separation of functions, monumental centre with public and commercial buildings vs. six housing open form mega-blocks $(4,000-10,000$ inhabitants each) with recreation and social services (Novi Beograd 1961). In practice, while housing was finalized as planned in 1960s and 1970s, the whole central area remained undeveloped well into the 1980 s.

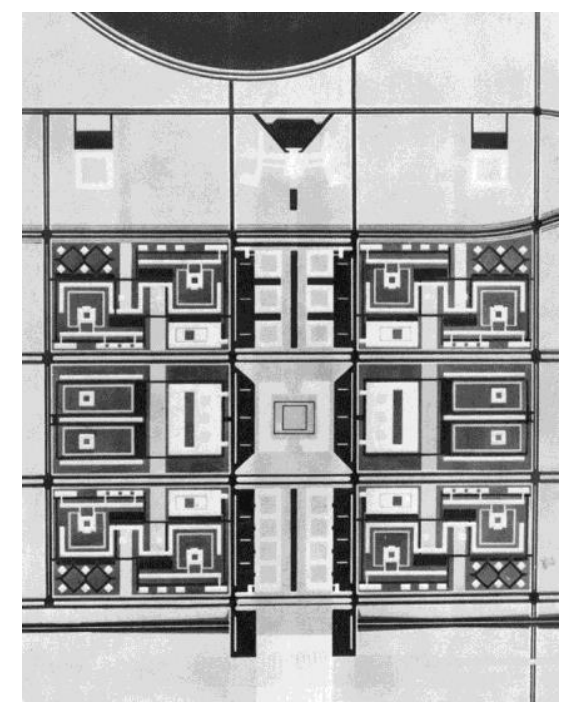

17. Leonid Lenarčič, Milutin Glavički, Milosav Mitić, Dušan Milenković and Uroš Martinović, Final Plan of Central Zone of New Belgrade, 1960.

Indeed, the mid 1980s were marked by criticisms and calling into question the principles of the functional city. The theoretical basis of the critique itself and subsequent concepts of densification was provided by the "Research into Alternative Urban Models", and "Study for the Reconstruction of the Central Part of New Belgrade and the Sava Amphitheatre", which were carried out by the Urban Planning Bureau in the period from 1979 to 1984, and published in 1985, in a book entitled Lessons of the Past (Perović 1985). The book offers the most extreme criticism of the functional city and by extension of the modern socialist city of New Belgrade, regarding its unfinished open plan as an economic, social and physical void. In 1986, an international competition affirmed post-modernist concepts of densification and return to anti-Corbusian principles such as reintroducing corridor street and perimeter urban blocks right into the structure of the modern plan. The final curtain fell on the modern city with the breakdown of socialism as a system and the breakdown of the system of planning which left the unfinished modern city wide open to haphazard reclaiming of free, open, public, and green under-urbanized space, mostly for commercial purposes. ${ }^{20}$

\section{Concluding notes}

To sum up, the making of modernism as predicted by Le Corbusier, betrayed the great folklore traditions. One architect in Yugoslavia that played modern in line with the dichotomy vernacular - modern in the Corbusian

\footnotetext{
${ }^{20}$ On spatial processes in New Belgrade in the post-socialist period, see Blagojević 2014
} 
sense was Juraj Neidhardt, especially in his post-Second World War work in Bosnia. The seminal book entitled Architecture of Bosnia and the Way to Modernity by himself and Dušan Grabrian (1957), illustrated by Neidhardt's projects and drawings and pictures of vernacular artistry and buildings and sites, with Preface by Le Corbusier, recently received a fitting reappraisal. Udovički-Selb (2013, pp. 208-11) compares its methodological approach to that of what he sees as Le Corbusier's method, that is, interpreting Balkan sources as cornerstones in the genesis of the "Cinq points de l'architecture». I would add that Neidhardt's architectural research of the dichotomy vernacular - modern, that resulted in a rare version of a modernism in sync with the complex climatic and cultural contexts of multiethnic and multiconfessional, simultaneously traditional and contemporary socialist society of Bosnia, came closest to what Ch.-É. Jeanneret might have had hoped for the Balkans. Permanence, as Neidhardt writes, of "a common spirit of forms, regardless of nationality, religion, place and time (is) our own path in the modern architecture, organic, vital, and not an imported one, to some extent analogously to what had happened in our Mediterranean region where the architecture has already assumed the characters of the autonomous contemporary style” (Neidhardt 1970, p. 59).

In the context of urban planning, the transfer of ideas, concepts and theory changed pace over time and in different socio-political contexts. Unmediated transference of essential Corbusian thinking in the planning of Novi Sad resulted in two distinct visions of a democratic city - historic centre surrounded by satellite neighbourhoods in Neidhardt's scheme and polycentric city by Pantović, Bossu and others. Neidhardt persisted in his vision, continuing and transforming it over forty years well into the 1970s, when he wrote: "the great epoch of the 'neighbourhood cult', which as an ethical norm, can be consciously accepted also in the modern town-planning" (Neidhardt 1970, p. 59).
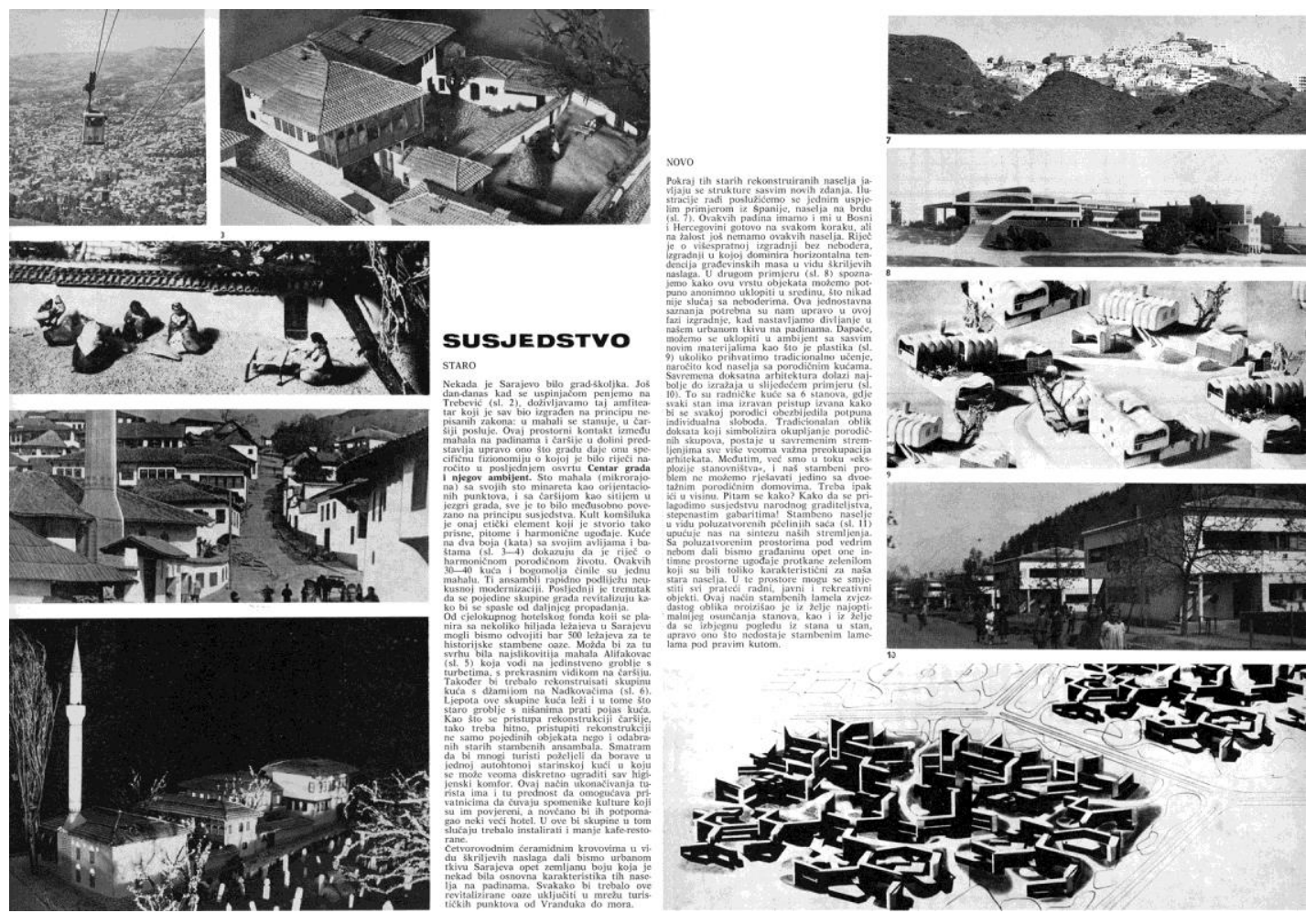

18. Juraj Najdhardt, 'Neighbourhood' collage and text, 1971

On the other extremity stood crafty manipulation of Ville Radieuse, such as in dogmatic readings of the Socialist-Realism, e.g., government city of strict hierarchy with Communist Party as the head of scheme, in the plan of New Belgrade by Edvard Ravnikar in 1947. Ten years earlier, Milorad Pantović and his colleagues from 
Le Corbusier's office opposed such an utopian socialist "collectivist city" (Pantović 1937, p. 253), as well as the populist garden city concept of "slavery individualism (and) sterile isolation" (Ibid.), offering their vision of a city based on just communal policy which assumes balance of collective and individual interest, public and private property. Without such a balance, as it turned out in real-socialism city planning and, for that matter, in current processes of post-socialist socio-political transition in Serbia, the legacy of Le Corbusier was made null and void, even if the urban landscape seem to have been marked strongly by modernist architecture and town planning. In resume, the encounter between architecture culture in Serbia and Le Corbusier thus might best be called asymptotic, that is a near meeting, postponed or missed. In other words, such an asymptotic correlation, which most evidently existed in formal and nominal terms and modes, amounted to little discursive exchange.

Finally, to make a full circle: sixty years after Ch.-É. Jeanneret saw bogomils stećak in the yard of the Belgrade Ethnographic Museum, Juraj Neidhardt re-actualizes the question of folk art as object-type by using the photograph of an Ottoman grave stone nišan (Serbo-Croat) on the cover of the article entitled "Value of Permanency", that he wrote and designed for the special issue of the Belgrade architectural journal published for the occasion of the congress of International Federation for Housing and Planning (IFHP). ${ }^{21}$

"This case indicates us to study our folk art in another direction, too, with regard to the third dimension", writes Neidhardt (1971, p. 59), arguing, as Le Corbusier had before him, for autochthonous way of searching.

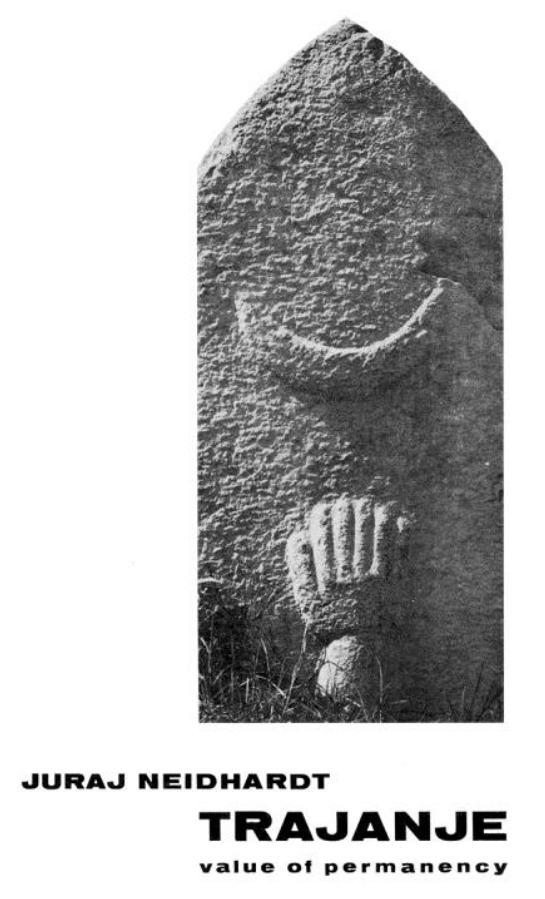

19. Juraj Neidhardt, "Value of Permanency", photograph by Ranko Rosić, 1971 ${ }^{21}$ IFHP Congress "New and Traditional in the Same Town", held in Belgrade June 6-12, 1971. Arhitektura urbanizam, no.
$64-65,1971$ 


\section{Sources of images}

Image 1. Ethnographic Museum, Belgrade, inventory no. 3450

Image 2. Ethnographic Museum, Belgrade, inventory no. 21853

Image 3. Ethnographic Museum, Belgrade, inventory no. 3308

Image 4. Ethnographic Museum, Belgrade, inventory no. 3078

Image 5. Ethnographic Museum, Belgrade, inventory no. 3064

Image 6. Ethnographic Museum, Belgrade, inventory no. 4243 (left); National Museum, Belgrade (right)

Image 7. Ethnographic Museum, Belgrade, inventory no. 3094 (left); National Museum, Belgrade (right)

Image 8. Fondation Le Corbusier, Paris

Image 9. Reljić 1994, p. 8 (left); Le Corbusier 1925, p. 34 (right)

Image 10. National Museum, Belgrade

Image 11. Museum of Science and Technology, Belgrade

Image 12. Grabrijan 1937, p. 145.

Image 13. Pantović 1937, p. 258.

Image 14. Antolić 1949, p. 25

Image 15. Ravnikar 1947, p. 455

Image 16. Private collection, courtesy Vesna Petričić-Tomić

Image 17. Novi Beograd 1961, p. 33

Image 18. Neidhardt 1971, pp. 50-51.

Image 19. Neidhardt 1971, p. 47.

\section{Bibliography/references}

Amirante, Roberta and others. (Direction scientifique): L'invention d'un architecte: Le voyage en Orient de Le Corbusier. Paris: Éditions de la Villette, 2013

Antolić, Vlado: Regulacioni plan i direktivna regulaciona osnova Zagreba”. Arhitektura, no. 18-22, 1949, pp. 529.

Bižić-Omčikus, Vesna: "Dr Sima Trojanović - život i rad". In Bižić-Omčikus, Vesna. (Ed.): Na početku. Dr Sima Trojanović: Istraživač, naučnik i prvi čuvar Etnografskog muzeja. Belgrade: Etnografski muzej Srbije, 2002. pp. 7-82. [Serbian Cyrillic]

Bjažić Klarin, Tamara: "Yugoslavia: Home and Life; or, How Do People Live in Zagreb". In Van Es, Evelien and others. (Eds.): Atlas of the Functional City. Bussum: THOTH Publishers - Zürich: gta Verlag, 2014. pp. $412-425$.

Blagojević, Ljiljana: Modernism in Serbia: The Elusive Margins of Belgrade Architecture, 1919-1941. Cambridge, Mass.: The MIT Press in association with the Harvard University Graduate School of Design, 2003

Blagojević, Ljiljana: Novi Beograd: osporeni modernizam. Belgrade: Zavod za udžbenike, Arhitektonski fakultet and Zavod za zaštitu spomenika, 2007 [Serbian Cyrillic]

Blagojević, Ljiljana: "Voyage to the Occident, City Break in the Orient". Perspecta, The Yale Architecture Journal, no. 41.2008, pp. 65-71.

Blagojević, Ljiljana: "Pariz - Beograd via Njujork. Priča o dve izložbe arhitekture". Zbornik Narodnog muzeja Beograd, Istorija umetnosti, XIX/2, 2010, pp. 607-625. [Serbian Cyrillic] 
Blagojević, Ljiljana: "The Residence as a Decisive Factor: Modern Housing in the Central Zone of New Belgrade". Architektúra \& urbanizmus, no. 3-4, 2012, pp. 228-249.

Blagojević, Ljiljana: "Novi Beograd: Reinventing Utopia”. In Stanek, Lukasz; Schmid, Christian; Moravánszky, Ákos. (Eds.): Urban Revolution Now: Henri Lefebvre in Social Research and Architecture. Farnham, London: Ashgate, 2014, pp. 301-318.

Chabard, Pierre: "La Défense / Zone B (1953-91): Light and Shadows of the French Welfare State". Footprint, vol. 5, no. 2, 2011, pp. 71-86.

Corbusier: izložba. Beograd: Savez društava arhitekata Jugoslavije, 1952

Le Corbusier: L'Art décoratif d'aujourd'hui. Paris: Les Éditions G. Crès et C', Collection de "L'Esprit Nouveau", 1925

Le Corbusier: La Ville Radieuse. Réimpression en 1964. Paris: Vincent Fréal \& Cie, Collection de l'équipement de la civilisation machiniste, 1935

Le Corbusier: Des canons, des munitions? Merci! Des logis ... S.V.P. Boulogne: Éditions de L'Architecture d'aujourd'hui, 1937

Le Corbusier: Journey to the East. Edited and annotated by Ivan Žaknić, translated by Ivan Žaknić in collaboration with Nicole Pertuiset. Cambridge, Mass.: The MIT Press, 1989

Dobrović, Nikola: "Novi Beograd kao gradotvorački poduhvat; njegov lik i simbolika iz perspective 1957 godine". Tehnika, vol. XII, no. 10, 1957, pp. 209-211.

Dumont, Marie-Jeanne: "William Ritter, inspirateur caché du Voyage d'Orient". Dans Amirante, Roberta and others. (Direction scientifique): L'invention d'un architecte: Le voyage en Orient de Le Corbusier. Paris: Éditions de la Villette, 2013. pp. 49-65.

Grabrijan, Dušan: "Natječaj za regulaciju Novog Sada, kratki grafičko analitički prikaz natječajnog projekta "Atina"”. Građevinski vjesnik, no. 10, 1937, pp. 145-148.

Grabrijan, Dušan; Neidhardt, Juraj: Arhitektura Bosne i put u suvremeno. Ljubljana: Državna založba Slovenije, 1957

Korolija Fontana-Giusti, Gordana: “Transgression and ekphrasis in Le Corbusier's Journey to the East”. In Rice, Louis; Littlefield David. (Eds.): Transgression: Toward an Expanded Field of Architecture. London: Routledge, 2015. pp. 57-75.

Kuiper, G.T.J.: “Stage te Parijs". De 8 en OPBOUW, no. 4, 1938, pp. 38-39.

Mumford, Eric: The CIAM Discourse on Urbanism, 1928-1941. Cambridge, Mass.: MIT Press, 2002

Muzaffar, Ijlal M.: The Periphery Within: Modern Architecture and the Making of the Third World. Advisor Mark Jarzombek. Massachusetts Institute of Technology, Department of Architecture, 2007

Neidhardt, Juraj: “Trajanje / Value of Permanency”. Arhitektura urbanizam, no. 64-65, 1971, pp. 47-59.

Novi Beograd. Belgrade: Direkcija za izgradnju Novog Beograda, 1961

Pantović, Milorad: “Jesu li dosadašnji urbanski sistemi negativni?”. Savremena opština, no. 11-12, 1937, pp. 253-260 [Serbian Cyrillic].

Pantović, Milorad: “Atelje L.C. - Rue de Sèvres 35”. Arhitektura urbanizam, no. 35-36, 1965. pp. 80-81.

Perović, Miloš R.: Iskustva prošlosti / Lessons of the Past. Belgrade: Zavod za planiranje razvoja grada Beograd, 1985

Petričić, Branko: Faktori gustine i struktura grada (uz projekat Novog Beograda). Habilitation Thesis. University of Belgrade - Faculty of Forestry, 1957

Ravnikar, Edvard: "Veliki Beograd”. Obzornik, no. 11-12, 1947, pp. 451-456 
Ravnikar, Edvard: “Le Corbusier (1887-1965)”. Arhitektura urbanizam, no. 35-36, 1965. pp. 81-82.

Reljić, Ljubomir. (Ed.): Poklon zbirka Seke Mišević Mijatović. Belgrade: Etnografski muzej Srbije, 1994.

Seissel, Josip: “Konkurs za urbanistički plan Novog Beograda”. Arhitektura, no. 3, 1947, pp. 18-22.

Stanek, Łukasz: "Introduction: the Second World's architecture and planning in the Third World". The Journal of Architecture, vol. 17, no. 3, 2012. pp. 299-307.

Turner, Paul V.: La formazione di Le Corbusier. Idealismo e movimento moderno. Translated into Italian by Chiara Guarnieri. Milano: Jaca Books, 2001

Udovički-Selb, Danilo François: "Les Balkans, genèse des «Cinq points de l'architecture». Dans Amirante, Roberta and others. (Direction scientifique): L'invention d'un architecte: Le voyage en Orient de Le Corbusier. Paris: Éditions de la Villette, 2013. pp. 207-217.

Vlahović, Mitar: “Etnografski muzej NR Srbije”. In Zbornik Etnografskog muzeja u Beogradu, 1901-1951. Belgrade: Naučna knjiga, 1953. pp. 11-22.

Weissmann, Ernest: “Imali smo drugu verziju povelje”. Arhitektura, no. 189-195, 1984-85, pp. 32-37. 
particular el trabajo obrero, a las condiciones naturales lo lleva a imaginar y dar forma a una nueva ciudad para para la "civilización maquinista".

Con el grupo del ASCORAL, asociación multidisciplinar fundada en el 1943 en París, elabora en 1945 el nuevo modelo urbano, que aspira a la armonía y sintonía con el ritmo "natural" de la vida. En la base de su estructura coloca los "Establecimiento humanos", formados por tres unidades: la "Unidad de explotación agrícola", donde se desarrolla el trabajo campesino, la "Ciudad lineal industrial", destinada al trabajo obrero, y la "Ciudad radioconcéntrica de intercambio" de los comercios y servicios (1). Cada actividad tiene sus propias exigencias y peculiaridades, y existe una substancial diferenciación entre las distintas tipologías de empleos. La urbanística, por lo tanto, debe mirar de delinear un "orden" en el territorio, "una biología que tome en cuenta la naturaleza de la tierra donde surgen [los establecimientos humanos] y la naturaleza de los hombres que la habitarán. [...] Quedará conquistada una línea general de conducta aplicada a una civilización de trabajo que entra, después del tumulto de la presente crisis, en su segundo ciclo, el que debe inaugurar una era de armonía"2

La Ciudad lineal industrial se desarrolla a lo largo de las vías de comunicación, para insertarse más fácilmente dentro del movimiento rápido de la circulación de los productos, mientras la fábrica, puesta a mitad de camino entre ciudad y campo, se transforma en Fabrica verde, porqué es capaz de recrear en su interior un ambiente "saludable", gracias a la presencia de "sol, espacio y verde" que "proporcionan aquí, como en los barrios residenciales, las influencias cósmicas, la respuesta a las pulsaciones del pulmón, la virtud del aire, así como la presencia de aquel medio natural que presidió la lenta y minuciosa elaboración del ser humano"3 (2).

\section{La Fábrica verde}

Le Corbusier describe la Fábrica verde como un edificio organizado según "una biología de las circulaciones, de la composición de los edificios y de la eficiencia", que "reinstala de nuevo las 'condiciones de naturaleza' alrededor del trabajo", se contrapone de esta forma a la "Fabrica negra [...] de los primeros cien años de la

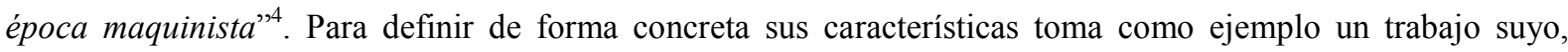
encargado por el Ministro del Armamento Raoul Dautry: el proyecto de un establecimiento para tres mil obreros, destinado a la producción de armas de guerra, en Mountiers-Rozeille, cerca de Aubusson, cuya construcción apenas empezada, fue interrumpida después del armisticio franco-alemán del 22 de junio.

Le Corbusier hasta aquel momento había construido solo pocos proyectos destinados a edificios industriales, sin embrago ya en el 1910 entró en contacto con el mundo de la industria en el estudio de Peter Behrens en Berlín, después colaborando con la compañía A.E.G. entre el 1917 y el 1920 como administrador de la fábrica de ladrillos en hormigón en Alfortville cerca de París. Entre sus trabajos de aquellos años encontramos un proyecto de tres mataderos (1918) en el campo francés, una pequeña industria de tapices para el industrial Henry Frugès

\footnotetext{
${ }^{2}$ Ivi, p.68.

${ }^{3}$ Ivi, p. 102 .

${ }^{4}$ Ibidem.
} 
en Pessac (1925) y el proyecto de la editorial Draeger ${ }^{5}$ (1929).

Son experiencias aisladas que ya lo habían invitado a reflexionar sobre los nuevos mecanismos industriales y los consecuentes problemas relacionados con la organización de los ambientes de trabajo. Todos estos temas son retomados a la hora de redactar el proyecto para la fábrica de armas en Aubusson (1940), donde podemos encontrar, entre los dibujos, una interesante perspectiva del edificio, con las diferentes volumetrías en medio del verde y con la vista majestuosa de los Alpes al fondo, enseñando el contexto en el cual la fábrica tenía que ser edificada: fuera de la ciudad, en "zonas verdes seleccionadas por la orientación y el paisaje"6 (3). La imagen compositiva del dibujo se presenta a nuestra mirada como un eco de otras obras de Le Corbusier, en particular los proyectos y los numerosos croquis realizados durante sus viajes, cuando con atención observaba y tomaba nota de la realidad que había alrededor. Ya desde el viaje a Oriente (1911) el joven Jeanneret había dibujado en su cuaderno monumentos, edificios y ruinas, como volúmenes insertados en sus paisajes particulares; así durante su visita en Delfos dibuja un croquis del "Iskegaon", detrás del templo de Apolo, representado por tres paralelepípedos de piedra, marcados con acanaladuras, incluyendo las imponentes montañas del monte Parnaso en el fondo (4). La mirada del arquitecto-observador quería remarcar en el dibujo la "resonancia" compositiva que se establece entre los tres volúmenes geométricos del monumento, contrapuestos al perfil irregular y majestuoso de las montañas en el horizonte. El mismo croquis se encuentra sucesivamente en capítulo Thèse del libro Une maison, un palais (1928), elegido para explicar el poder del orden de la geometría sobre la naturaleza circundante en la arquitectura. Sobre esto escribe: “dominan los golfos y los valles, en Delfos, estos tres cubos de piedra, testimonios violentos y puros, hablan del sublime. Es sobre la geometría que surgirán los templos y los palacios: es en esta que se encuentran las pruebas de la voluntad, el poder. Los curas y los tiranos enseñaran su fuerza poniendo como base de la arquitectura la geometría" 7 . En este caso, el "eco" que se recrea entre los elementos de la composición, genera unidad, y la geometría de la arquitectura en primera plana se contrapone y relaciona con el perfil irregular de la topografía circundante.

Esto sucede también en el diseño de la Fabrica verde de Aubusson, donde las volumetrías cuadrangulares, formadas por cuerpos de fabricación paralelepípedos, dispuestos en paralelo y cerrados con una cubierta shed, se confrontan con el perfil sinuoso de las montañas en una relación directa entre "artificial" y paisaje "natural", para que la naturaleza se integre así con el espacio arquitectónico y se convierta en el elemento que ayude a volver los ambientes de trabajo más confortables y a medida de hombre (5). Este sistema compositivo que se articula con volúmenes en paralelo recuerda otros proyectos sucesivos del arquitecto suizo, en los cuales utiliza el sistema de la bóveda para recrear una particular relación con el paisaje alrededor. En la residencia de la Cherchell (1942), por ejemplo, el edificio puesto sobre una roca con vistas al mar y la bahía, está pensado dentro de un recinto de planta rectangular, donde los volúmenes se alternan a los espacios abiertos de los jardines en un "juego de llenos y vacios" y se presenta "integrado con el paisaje, manteniendo la amplitud de la roca, la

\footnotetext{
${ }^{5}$ Después de la segunda guerra mundial se dedicará también a la reconstrucción del edificio de la Manufactura Duval en StDié (1946-51).

${ }^{6}$ Le Corbusier : L'urbanisme des trois établissements humains, cit. (trad. esp., cit., p. 60).

${ }^{7}$ Le Corbusier : Une maison, un palais. Paris : Collection de L'Esprit Nouveau, 1928, p.15.
} 
soledad de los lugares, y el tamaño de los horizontes" $"$. Esta solución viene a ser adoptada unos años después en el proyecto de la basílica de Sainte-Baume (1948), donde, en un "terreno absolutamente inculto y árido" sobre una montaña, piensa realizar cerca de un santuario un conjunto residencial formado por la agregación de unidades habitadas de dos o tres plantas, hospedadas dentro de un volumen paralelepípedo, cubierto con dos bóvedas rebajadas. Con este proyecto, escribe Le Corbusier, "empieza el largo camino hacia la investigación de una arquitectura y una urbanística capaces de valorar el glorioso paisaje", 9 como sucede también en el conjunto residencial de Roq et Rob (1949) de Cap Martin, puesto en un terreno con un fuerte desnivel hacia el mar y construido a partir de la agregación de módulos habitables estándar ("volume habitable alvéolaire") con bóveda rebajada, que se alternan con espacios abiertos y recorridos $(6,7,8)$.

Para la fábrica de la Ciudad lineal industrial Le Corbusier explica en efecto que "los edificios están dispuestos según las necesidades del terreno y las exigencias de la fabricación [...] se abrirán grandes ventanales sobre perspectivas panorámicas juiciosamente preservadas o conseguidas. Los espacios entre edificios constituirán conjuntos armoniosos con vastas extensiones del cielo y perspectivas a la distancia"10 (9). La circulación interior de la fábrica está proyectada de forma que los diferentes flujos de material y personas no interfieran entre sí. Le Corbusier aprovecha de esta manera el desnivel del terreno, entre rio y montaña, y crea una entrada al edificio más alta y una pasarela sobrepuesta a la cubierta de las oficinas, para la circulación del personal, diferenciándola del recorrido de entrada y salida de la planta baja del material y productos. El circuito de fabricación se subdivide pues en diferentes ramificaciones según las zonas y las fases de producción (V1, V2 y V3), creando un sistema continúo que "reproduce la fase de un circuito sanguíneo"11. A escala urbana se planea que el establecimiento tenga que estar cerca de las viviendas de los obreros, y posicionado en un sistema que se desarrolle linealmente a lo largo de las vías de comunicación principales y las vías de comunicación de la materias primas (por agua, tierra o ferrocarril), facilitando la cadena productiva y los desplazamientos de los mismos obreros durante el día, entre casa, trabajo y ocio ${ }^{12}$. Habiendo eliminado por lo tanto los puntos de ruptura del ciclo de producción y montaje, en la fábrica verde de Aubusson se hace más ágil el funcionamiento del todo el mecanismo y la circulación de los obreros, puesto que "estas circulaciones expresan la más estricta economía. Proceden de adentro a afuera, con disciplina igual a la de la vida"13 (10).

\section{Los modelos urbanos para el trabajo del hombre}

La Fábrica verde está concebida a partir de una estructura eficiente y funcional para la producción, a la vez que es capaz de acoger los trabajadores y acompañarlos en sus ritmos vitales durante las veinticuatro horas, mitigando y/o rompiendo así el duro y determinístico sistema de producción fordista y taylorista. Este aspecto es

\footnotetext{
${ }^{8}$ Le Corbusier : Euvre complète 1938-1946. Zurich : Girsberger, 1946, p. 116.

${ }^{9}$ Le Corbusier : CEuvre complète 1946-1952, Girsberger, Zurich 1952, p. 24.

${ }^{10}$ Le Corbusier : L'urbanisme des trois établissements humains, cit. (trad. esp., cit., p. 108).

${ }^{11}$ Ivi, p. 105.

${ }^{12}$ Le Corbusier había desarrollado un proyecto parecido en el 1935, por un encargo del industrial Jan Bat'a para el Plan urbanístico del Valle de Zlín en Checoslovaquia, donde estaba ya presente la articulación de las fábricas en el territorio a lo largo de las tres principales infraestructuras viarias y siguiendo la topografía.

${ }^{13}$ Ivi, p. 106.
} 
importante, ya que destaca algunos de los temas cruciales del pensamiento social de principios del siglo XX y sobre los cuales Le Corbusier ha trabajado con insistencia para crear nuevas soluciones arquitectónicas y urbanísticas. En un capítulo de Les trois établissements humains, titulado Une éthique du travail, escrito por Hyacinthe Dubreuil (1883-1971), sindicalista-obrero, Le Corbusier subraya:

"Cuando un hombre- o con mayor precisión, un trabajador- se encuentra en la posición de ejercer una actividad sin que su inteligencia sea llamada a asociarse a sus actos, esta inteligencia 'tiene hambre"14.

Tanto para Le Corbusier como para los integrantes del ASCORAL, el ejercicio del intelecto y el "impulso creativo" tienen que ser parte esencial del trabajo, sobre todo del obrero. Dentro del establecimiento industrial urge crear las condiciones favorables para mantener en equilibrio el ritmo biológico natural de los trabajadores. La vitalidad y la naturaleza humana están en crisis debido a los mecanismos repetitivos de producción, introducidos por la organización "científica" del trabajo. El taylorismo y el fordismo trasforman el cuerpo del trabajador en un instrumento especializado, completamente dependiente de la máquina, divisible y utilizable en sus diferentes partes según las tareas del ciclo productivo. Para estas líneas de pensamiento, una cuestión importante a la cual enfrentarse es la redefinición del papel del trabajo en la vida del hombre, en relación al diseño del territorio, de la ciudad y de la arquitectura.

Estos son temas muy valorados por Le Corbusier y presentes desde los años '20 en sus obras y en sus escritos. En su ensayo Urbanisme (1925) imagina la Ville Contemporaine como un modelo de ciudad integrada dentro de la organización taylorista, con la idea que esta pueda convivir con los ritmos biológicos del hombre, articulados en las veinticuatro horas por el movimiento continuo entre residencia, trabajo, y tiempo libre. El arquitectourbanista intenta enfrentarse al problema poniendo el acento sobre la cuestión del trabajo, porque la ciudad nace desde la residencia, pero a su vez tiene que estar coordinada con el lugar de trabajo de cada ciudadano; de esta forma queda implícito el "horario de trabajo", que tiende a prolongarse, si los medios de transportes no son suficientes y/o las distancias son excesivas (11). En esta ciudad, pensada con una planta radio-concéntrica, el trabajo administrativo e "intelectual" se desarrolla en los rascacielos de la Cité d'affaires, ubicados en el centro, mientras el obrero se localiza dentro de los establecimientos industriales periféricos, puestos entre el centro urbano y la Cité jardín. La población en cambio, es clasificada según la ubicación del lugar de trabajo y de la vivienda, definiéndose como urbana o suburbana, según viva y trabaje en el centro o en la periferia, y finalmente mixta, si trabaja en el centro y reside en la Cité jardin. La solución posible es la de "disminuir la distancias y concentrar el trabajo acelerando su ritmo" ${ }^{\text {, }}$, explica Le Corbusier, porqué de esta manera aumenta la productividad, ritmada por las maquinas (de la cadena de montaje y también de los transportes), y se salvaguarda mejor el ritmo biológico del trabajador. Introduciendo ideas ya muy difundidas en los ambientes intelectuales y científicos de los años '20 y '30, precisa que el tiempo antes gastado en los desplazamientos puede ser así utilizado para el "descanso" y el "deporte", importantes porqué son necesarias: "ocho horas de descanso. El urbanista tiene que responder a esta exigencia. El ejercicio del deporte tiene que ser accesible a cada habitante

\footnotetext{
${ }^{14}$ Ivi, p.56.

${ }^{15}$ Le Corbusier : Urbanisme. Paris : Crès, 1925, p. 182.
} 
de la ciudad. El deporte tiene que poderse realizar debajo de casa “"16.

"La salud fisica es la base de la salud mental, base de toda actividad equilibrada, de toda la producción, en todo los campos y también en el arte como en todo los otros" afirmaba también el médico y amigo de Le Corbusier Pierre Winter, en el artículo "Le Corps Nouveaux" de la revista L'Esprit Nouveaux".

La propuesta de la Ville Contemporaine (1925) es una idea de armonía "orgánica", que unos años después será articulada en la Ville Radieuse (1930) como un nuevo modelo de ciudad en el cual "la esencia es la vivienda" proyectada en la llamada Ville Verte residencial (12). En este nuevo modelo "el terreno para el deporte se encuentra debajo de la vivienda", y los lugares del trabajo, fácilmente accesibles con el transporte público, están en los bordes de la ciudad: de un lado la Cité d'affaires, cerca de las Villes satellites destinadas a la administración y al gobierno, y en el extremo opuesto, la zona industrial para las manufacturas, empresas e industrias pesadas. "Nosotros trabajamos para vivir. No vivimos para trabajar", escribe Le Corbusier en este ensayo, añadiendo: "y tendremos unas horas libres"19. El mismo Pierre Winter retoma el tema subrayando que "una vida natural primitiva se sustituye por una vida artificial cada vez más complicada que ha determinado otras maneras de vivir y trabajar [...] Nuestra mayor preocupación es devolver al trabajo su verdadero sentido. Cuando declaramos que queremos liberar el trabajo es porqué sabemos bien que hoy es sumiso e inhumano. El trabajo, a nuestro entender, es la actividad del hombre considerada en su conjunto, con un horario armoniosamente planteado, de trabajo utilitario y de trabajo desinteresado, con alternancia de trabajo disciplinado, aceptado, consentido y tiempo libre elegido según fantasía y libertad" ${ }^{20}$

En estos años Le Corbusier entra en contacto con el sindicalista Hyacinthe Dubreuil que desde hace años se ocupa de estos temas, y profundiza la amistad con él cuando viene invitado precisamente en Zlín para colaborar con el industrial checo Jan A. Bat'a, es una empresa considerada en aquellos años un importante ejemplo de fordismo en Europa, cuyo funcionamiento es objeto de estudio por parte de Dubreuil. El interés de Le Corbusier por los estudios del sindicalista, así como la clara influencia de los mismos en sus reflexiones teóricas, quedan evidenciados por el hallazgo de ocho ensayos de Dubreuil en su biblioteca personal, seis de los cuales contienen una dedicatoria por parte del autor ${ }^{21}$.

El sindicalista percibe inicialmente de manera positiva la nueva organización de la fábrica y apoya fuertemente los elementos de progreso. El nuevo tipo de organización productiva es, sin embargo, un tema muy discutido y no siempre aceptado por la nueva clase obrera y por los sindicalistas. El primer ensayo publicado por Dubreuil,

\footnotetext{
${ }^{16}$ Ivi, p. 191.

${ }^{17}$ Winter, Pierre : ' Le corps nouveau '’. En L'Esprit Nouveaux» 1921, N. 15, p. 175.

${ }^{18}$ Le Corbusier : La Ville Radieuse, éléments d'une doctrine d'urbanisme pour l'équipement de la civilisation machiniste, Paris : Éditions Vincent Fréal, 1935, cit., p. 168.

${ }^{19}$ Ivi, p. 115.

${ }^{20}$ Winter, Pierre, 'Travail et sport'. En Plans, 1932, N .13, pp. 20-25.

${ }^{21}$ Dubreuil, Hyacinthe : Standards. Le travail américain vu par un ouvrier, Paris : Grasset, 1929. Id., Nouveaux Standards. Les sources de la productivité et de la joie. Paris : Grasset, 1931. .; Id., A chacun sa chance. L'organisation du travail fondée sur la liberté. Pari: Grasset, 1935; Id., L'Exemple Bat'a. La libération des initiatives individuelles dans une entreprise géante. Paris : Grasset, 1936; Id. L'Équipe et le ballon. L'ouvrier libre dans l'entreprise organisée. Paris : Le Portulan 1948; Id., Le Compagnonnage. Paris : Acad. Des Sciences Morales et Politiques, 1956. Id., E. Rimalho, Deux hommes parlent du travail. Paris : Grasset, 1939.
} 
titulado Standards. Le travail américain vu par un ouvrier français (1929), termina siendo un best-seller en Francia (se venden 30.000 ejemplares traducidos en diferentes idiomas), y por otro lado será duramente criticado por el sindicato CGT, del cual formaba parte el mismo autor, ya que será recibido como un documento a favor de la cadena de montaje y del uso de máquinas en el trabajo obrero. Luego, Dubreuil se traslada a Estados Unidos por un periodo de quince meses para trabajar como obrero en algunas fábricas, entre las cuales se encuentran los establecimientos de Detroit. El sindicalista estudia la forma de introducir en Europa el "método norteamericano", actualiza el sistema "estandarizado" y propone la búsqueda de la "armonía" para los trabajadores, integrando las teorías de Ford con las utopías del falansterio de Fourier.

Dubreuil trata ulteriormente la exigencia de armonía en el lugar de trabajo en su ensayo sucesivo Nouveaux Standards. Les sources de la productivité et de la joie (1931), que Le Corbusier lee atentamente subrayando en lápiz párrafos enteros del texto. En este nuevo escrito, Dubreuil advierte que la cuestión importante del cambio inminente es "considerar el trabajo moderno, con su organización y su procedimientos técnicos, como el resultado del trabajo de la ciencia y de la experiencia práctica, y describir los medios adecuados a introducir los elementos que puedan rendir la vida digna de ser vivida, o sea la alegría, la poesía y la belleza"22. El "factor humano" está en el centro de su discurso, junto con la idea que el trabajador pueda llegar a "la alegría y la felicidad" en la fábrica y durante su vida cotidiana, de forma que también su intelecto sea satisfecho. Le Corbusier parece compartir completamente este análisis subrayando en su libro estas partes del texto y tomando nota con comentarios de aprobación (“très bien", “voilà", etc.) las paginas en las cuales están insertadas. Estos temas vienen profundizados también en la obra sucesiva, que el autor regala a Le Corbusier con la dedicatoria: “A mi amigo Le Corbusier que reconoce haber aplicado en otro plano estas ideas de la 'biología' urbanística"23.

El ensayo A chacun sa chance. L'organisation du travail fondée sur la liberté (1935), Dubreuil introduce de hecho el concepto de organización « orgánica » de la fábrica, porqué el «problema real », explica el autor superando la visión taylorista e fordista, "es aquello de transformar la naturaleza de las relaciones que los hombres tienen entre ellos y no la relaciones del hombre con el proprio medio. Ocurre que estas relaciones van desde el aspecto mecánico hacia el aspecto orgánico"24. La idea es crear "empresas colectivas", inspiradas a las contemporáneas "empresas cooperativas" italianas, organizadas y gestionadas directamente por los obreros y en consecuencia, desde su punto de vista, devolver positividad a la vida de la fábrica con el trabajo experimentado. Como dice en su libro una organización armónica del trabajo: "No puede ser tan irracional pensar que las relaciones entre seres humanos - a esto se reduce en efecto la vida interior de una empresa - deberán poder ser establecidas según reglas en analogía con la biología. [...] No es utópico imaginar que vendrán un día probablemente lejano- en el cual reinará dentro de un grupo, y en los organismos superiores formados por grupos, una armonía parecida al ser viviente" 25.

Este concepto viene ulteriormente analizado en L'Équipe et le ballon. L'ouvrier libre dans l'entreprise organisée (1948), donde Dubreuil habla de una verdadera "revolución" en la cual los obreros deben actuar desde abajo

\footnotetext{
${ }^{22}$ H. Dubreuil, Nouveaux Standards. Les sources de la productivité et de la joie, cit., p. 160.

${ }^{23}$ Id., A chacun sa chance. L'organisation du travail fondée sur la liberté, cit.

${ }^{24}$ Ivi, p. 14.

${ }^{25}$ Ivi, pp. 131-132.
} 
para reformar la estructura de la empresa-fabrica y llegar a decidir sobre su organización. Una frase, subrayada en lápiz en el texto de Le Corbusier, señala que "este pensamiento, apropiado de la biología, está destinado a modificar por entero nuestra concepción de la vida y de la organización de la empresa"26.

La biología es la ciencia que puede ayudar el hombre a curar su cuerpo en el trabajo y en la vida, y a lo mejor, a sanear muchos de los problemas causados por la nueva "civilización maquinista". Será el mismo Dubreuil, siempre en Les trois établissements humains, quien va a explicar:

"Los músculos, el cerebro y los sentidos están hechos para funcionar, y no para una vida vegetativa. Pero eso no es todo: están hechos para funcionar en armonía con toda la naturaleza, y en particular con este gran regulador de toda la vida que es el sol"27.

En los mismos años serán establecidas la cuatros principales funciones del "organismo urbano" (habitar, trabajar, cultivar la mente y el cuerpo, y circular), por parte del CIAM en La Charte de Athènes (1943) que, como subraya Le Corbusier, reúnen en la ciudad "lo que el desarrollo del fenómeno maquinista había separado y desnaturalizado" ${ }^{28}$.

Es en la Ciudad lineal industrial de Les trois établissements humains ( 1945 ) que finalmente la fábrica se hace Fábrica verde, donde el verde, el paisaje, la circulación y los espacios tienen que ser enlazados y puestos en relación con el funcionamiento "biológico" del trabajo, lejos de los ritmos mecánicos de la cadena de producción. Una concepción a la cual Le Corbusier llega después de un largo recorrido de estudio y de proyecto, alimentado por referencias culturales y arquitectónicas, en particular el pensamiento de su amigo Dubreuil, que finalmente el arquitecto traduce en lenguaje arquitectónico en Aubusson, un establecimiento que vuelve a estructuras compositivas fluidas y "orgánicas" más que mecánicas.

Casi vente años después, en el desarrollo del proyecto para el Centro de cálculo electrónico en Rho-Milán (196064), la innovadora fábrica de calculadores electrónicos, encargada por la Sociedad Olivetti y nunca realizada, Le Corbusier, fiel a su modelo de Fábrica verde, y por esto muy atento a los aspectos relacionados con la salubridad del aire, luz y verde en el interior, pensará un edificio industrial "a medida de hombre". Las soluciones formales y compositivas, y el conjunto arquitectónico en sí mismo, serán diseñados como un gran organismo integrado en el paisaje, porque "reconocer la existencia de una civilización del trabajo y querer conferirle los signos más altos de la calificación, es delinear un camino natural capaz de aportar en el trazado y en la realización de los establecimientos humanos lo ritual, lo sagrado, lo fraterno leal y lo constructivo, todos aquellos elementos de un método profundamente basado ente todo en priorizar, dentro de la armonía y el equilibrio, la trilogía: hombrenaturaleza-cosmos" 29 .

\section{Bibliografía}

ASCORAL (dirigé par Le Corbusier), Les trois établissements humains. Paris : Denoël, 1945

\footnotetext{
${ }^{26}$ Ivi, pp. 84-85.

${ }^{27}$ Le Corbusier : L'urbanisme des trois établissements humains, cit. (trad. esp., cit., p. 57).

${ }^{28}$ Ibid (trad.. it. cit., p. 88).

${ }^{29}$ Ivi, p.66.
} 
Dubreuil, Hyacinthe : Standards. Le travail américain vu par un ouvrier, Paris : Grasset, 1929.

Dubreuil, Hyacinthe : Nouveaux Standards. Les sources de la productivité et de la joie. Paris : Grasset, 1931.

Dubreuil, Hyacinthe : A chacun sa chance. L'organisation du travail fondée sur la liberté. Pari : Grasset, 1935

Dubreuil, Hyacinthe : L'Exemple Bat'a. La libération des initiatives individuelles dans une entreprise géante. Paris : Grasset, 1936

Dubreuil, Hyacinthe : L'Équipe et le ballon. L'ouvrier libre dans l'entreprise organisée. Paris : Le Portulan 1948

Dubreuil, Hyacinthe : Le Compagnonnage. Paris : Acad. Des Sciences Morales et Politiques, 1956.

Dubreuil, Hyacinthe : E. Rimalho, Deux hommes parlent du travail. Paris : Grasset, 1939.

Le Corbusier: La Ville Radieuse, éléments d'une doctrine d'urbanisme pour l'équipement de la civilisation machiniste, Paris : Éditions Vincent Fréal, 1935, cit., p. 168.

Le Corbusier, L’urbanisme des trois établissements humains. Paris : Édition de Minuit, 1959

Le Corbusier, Une maison, un palais. Paris : Collection de L'Esprit Nouveau, 1928

Le Corbusier, Euvre complète 1938-1946. Zurich : Girsberger, 1946.

Le Corbusier, Euvre complète 1946-1952, Girsberger, Zurich 1952.

Winter, Pierre : ' Le corps nouveau “'. En L'Esprit Nouveaux» 1921, N. 15, p. 175.

Winter, Pierre, 'Travail et sport'. En Plans, 1932, N .13, pp. 20-25. 


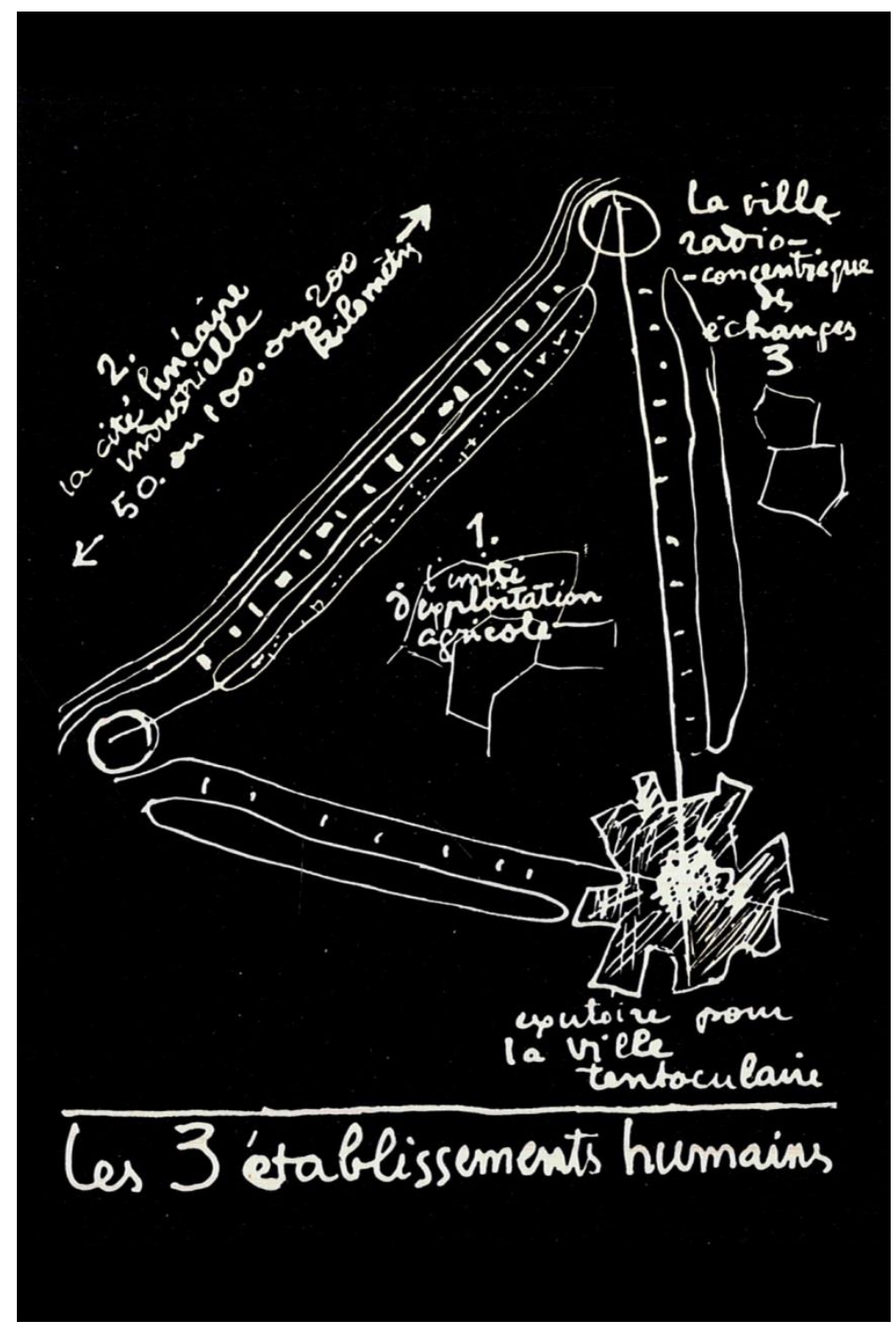

1. Los tres establecimientos humanos. L'Urbanisme des trois établissements humains, ed. del 1959. CFLC-ADAGP 


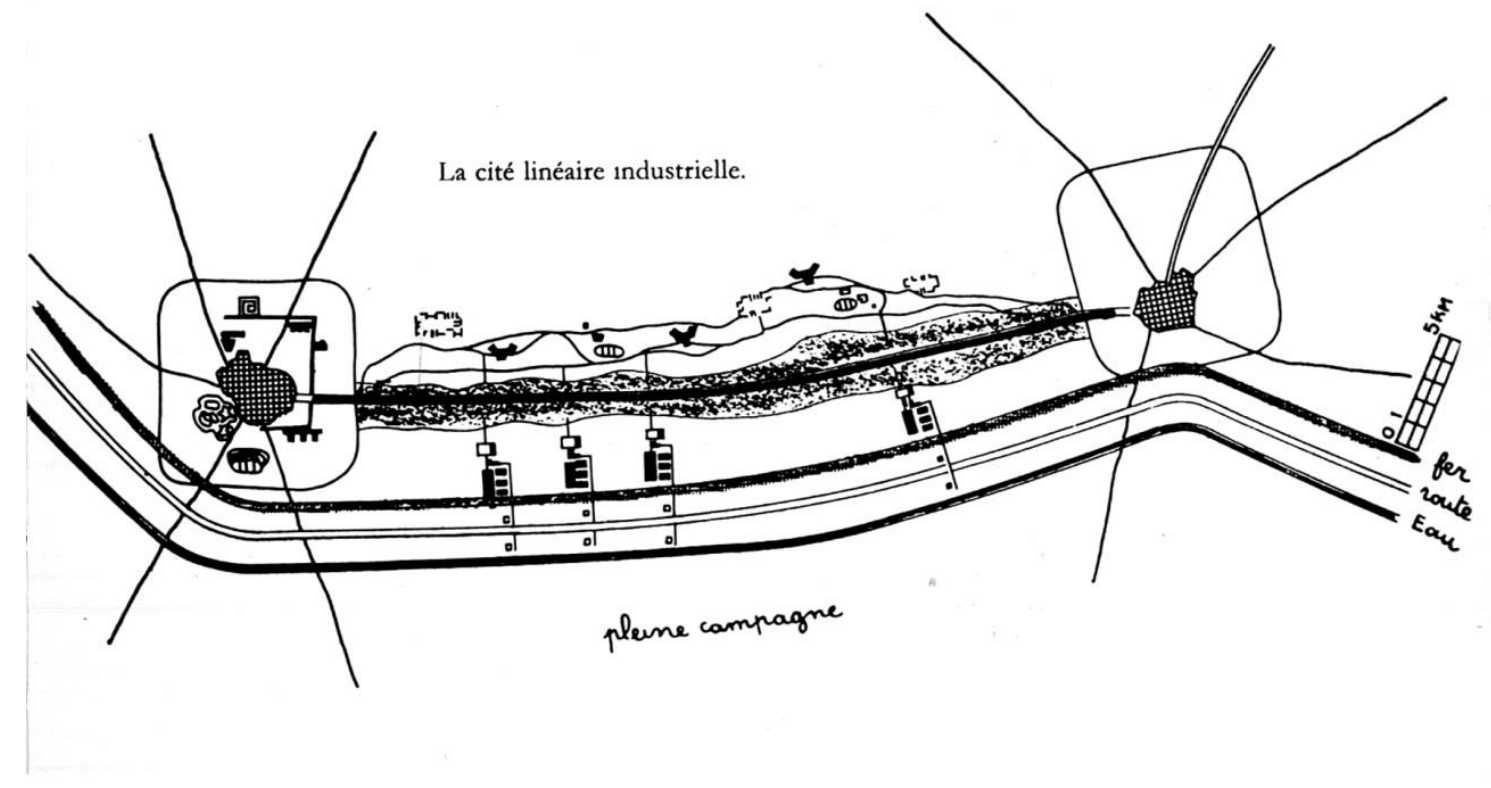

2. La ciudad lineal industrial. L'Urbanisme des trois établissements humains, ed. del 1959 CFLC-ADAGP

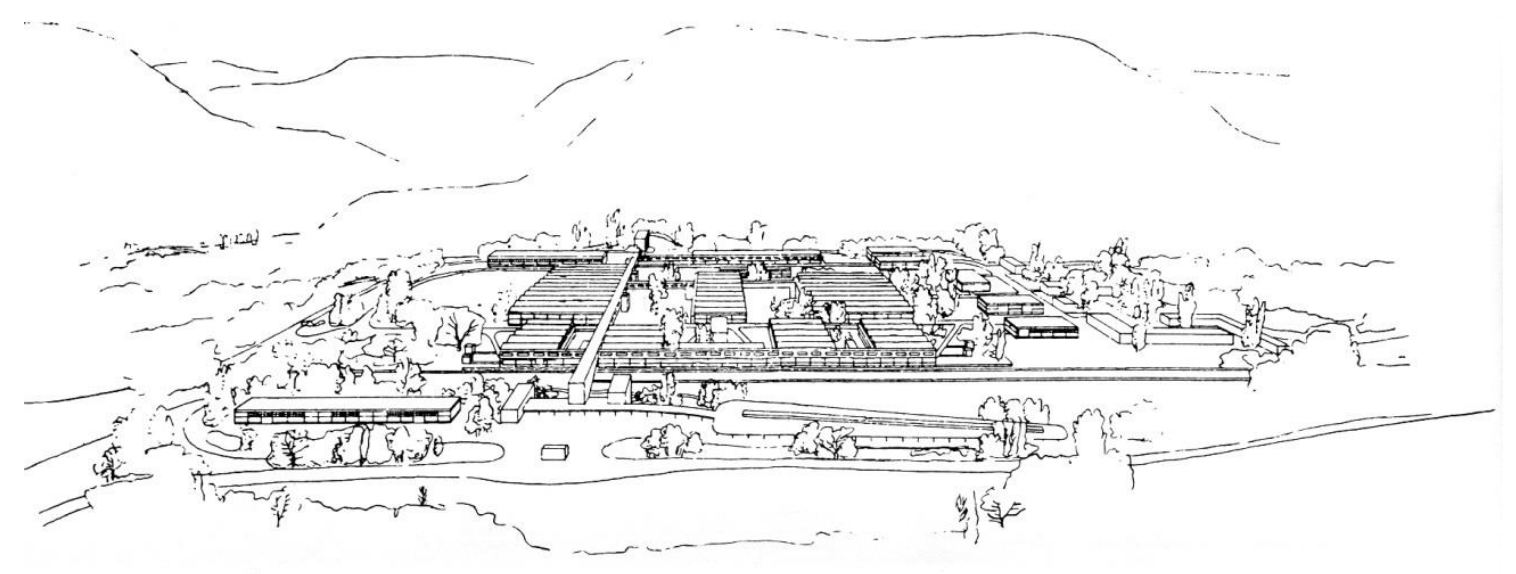

3. Vista de la Fábrica verde. Euvre complète 1938-1946. OFLC-ADAGP 


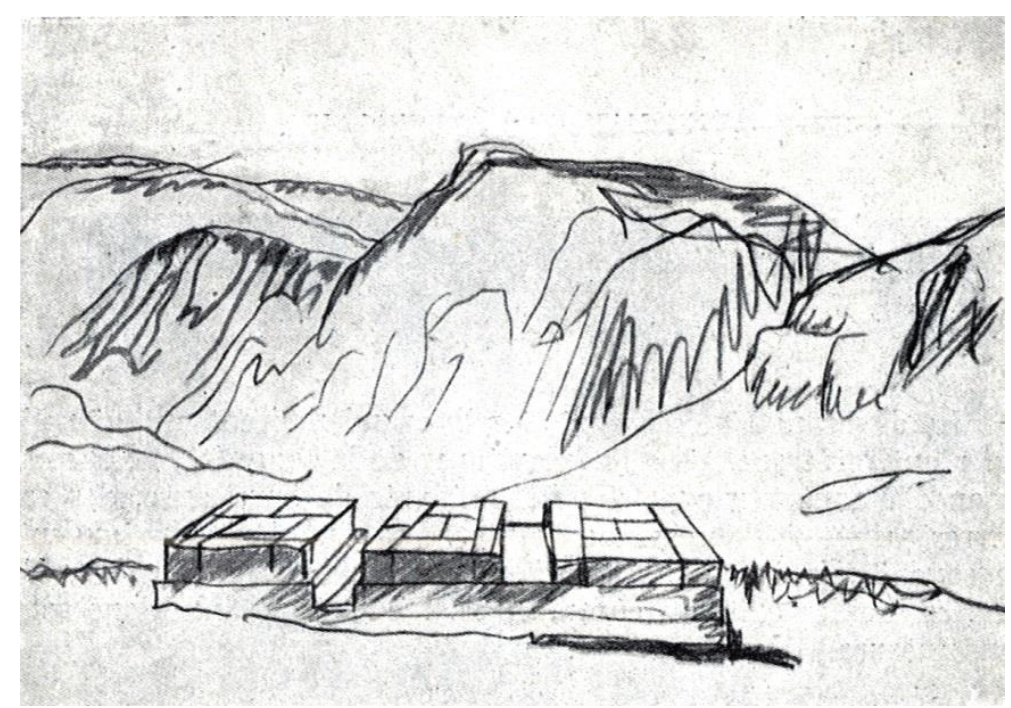

4. Dibujo de Le Corbusier en Delfos (1911). Le Corbusier, Une maison, un palais, 1928. OFLC-ADAGP

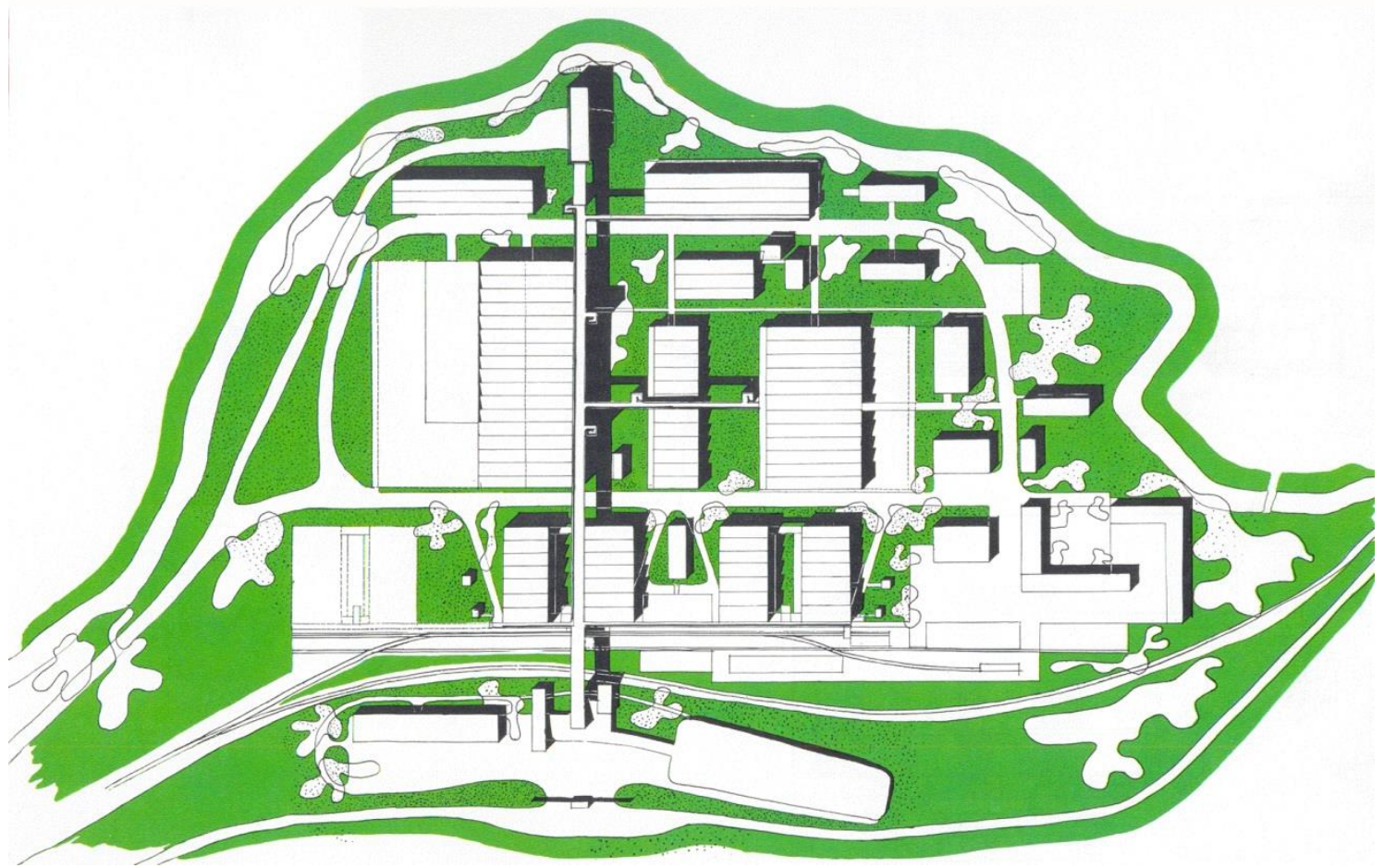

5. Planta de cubierta de la Fábrica verde en Aubusson. Euvre complète 1938-1946. CFLC-ADAGP 


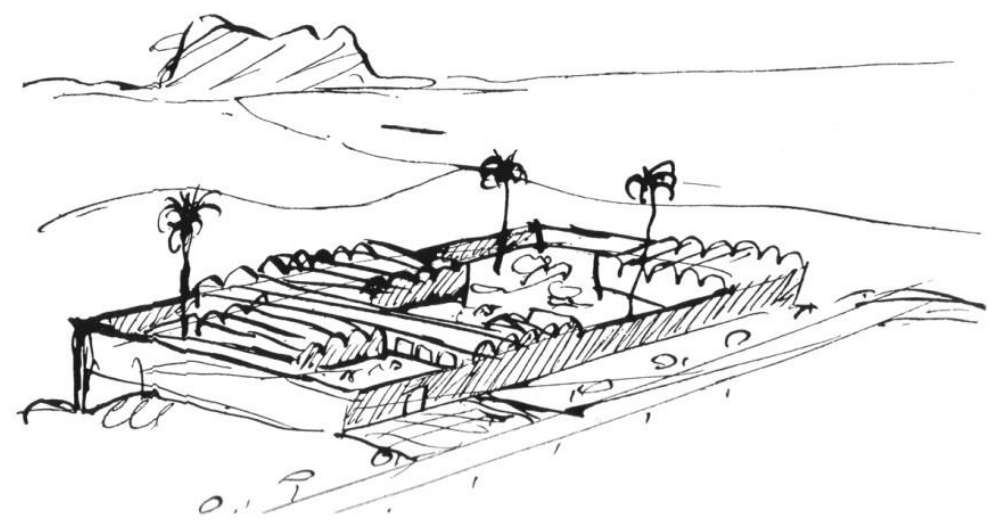

6. Dibujo de la residencia rural de la Cherchell (1942). Euvre complète 1938-1946. OFLC-ADAGP

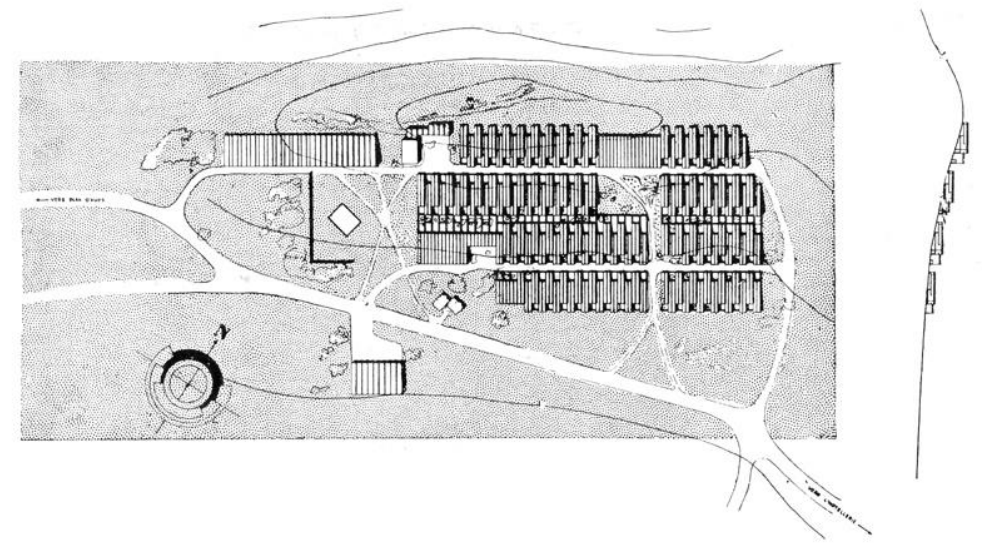

7. Proyecto para las residencias de la basílica de Sainte-Baume (1948). Euvre complète 1946-1952. CFLC-ADAGP 


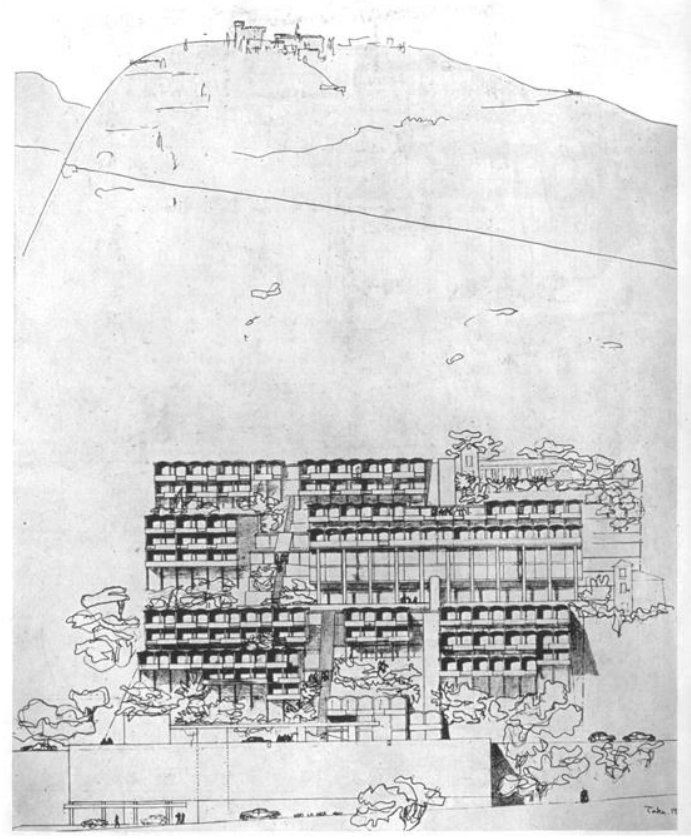

8. Proyecto para las residencias de Roq et Rob a Cap Martin(1949). Euvre complète 1946-1952. CFLC-ADAGP

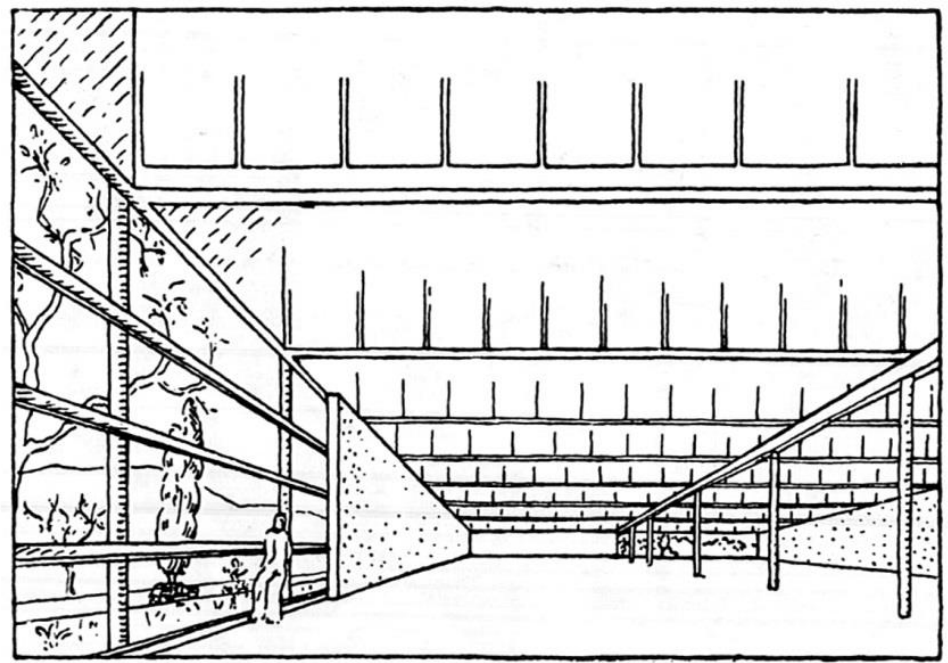

9. Vista desde el interior de la Fábrica verde. Cuvre complète 1938-1946. OFLC-ADAGP 

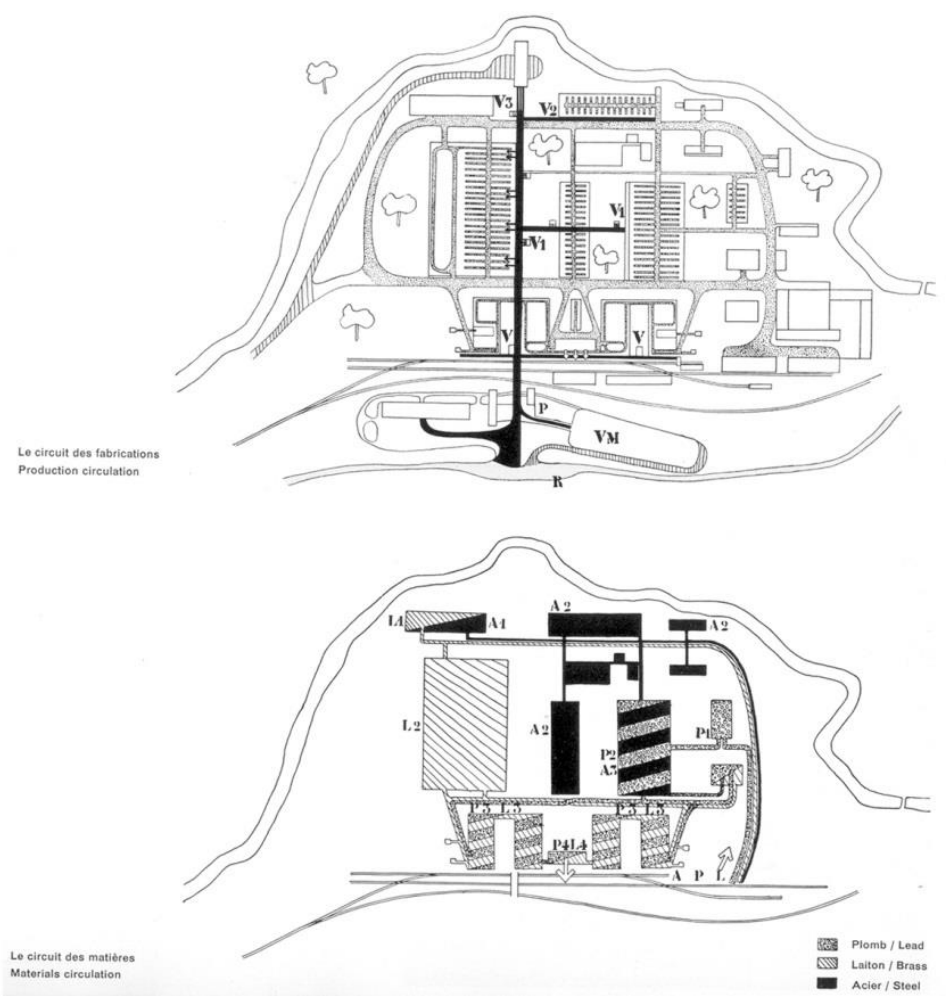

10. Los circuitos de las fabricaciones y de los materiales en la Fábrica verde de Aubusson. CEuvre complète 1938-1946. CFLC-ADAGP
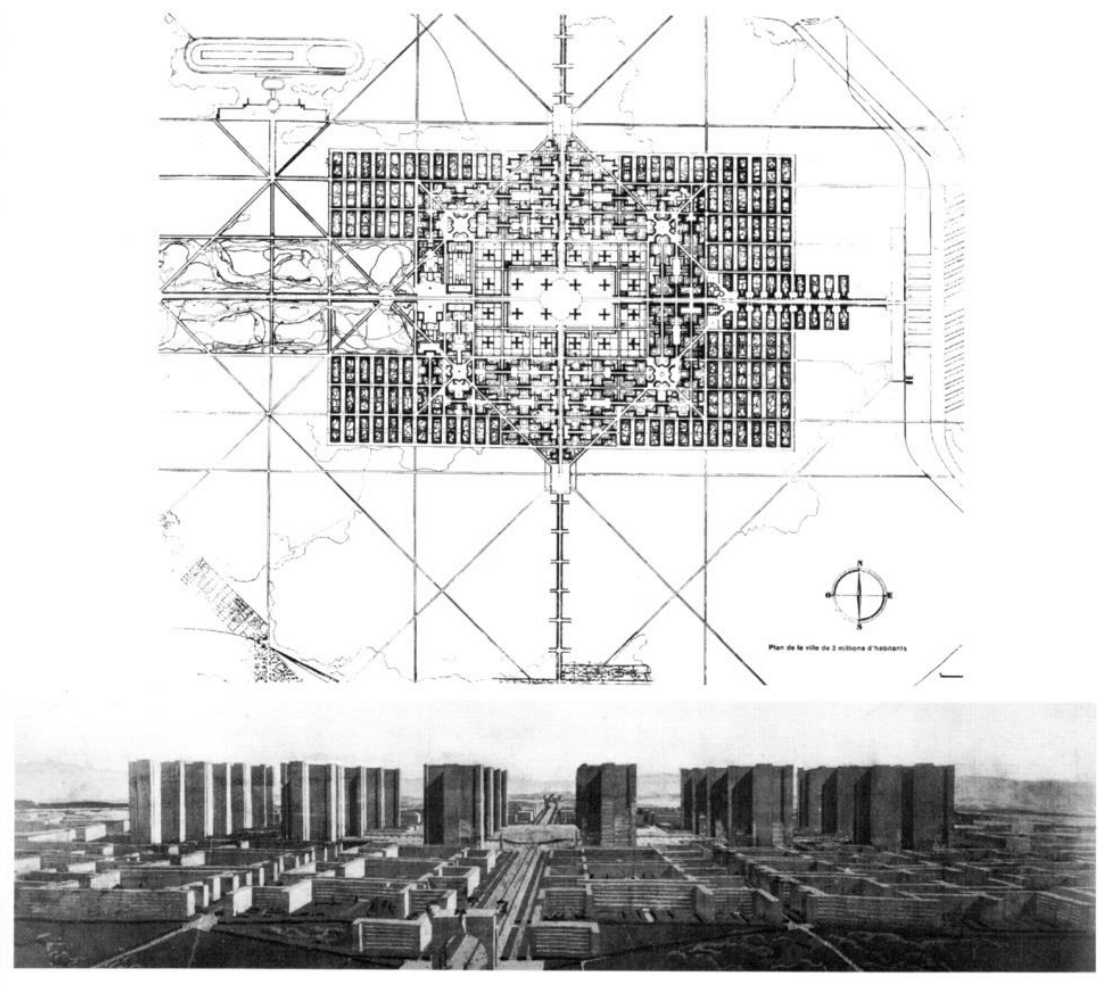

11. La Ville Contemporaine (1922). Urbanisme, 1925. CFLC-ADAGP 


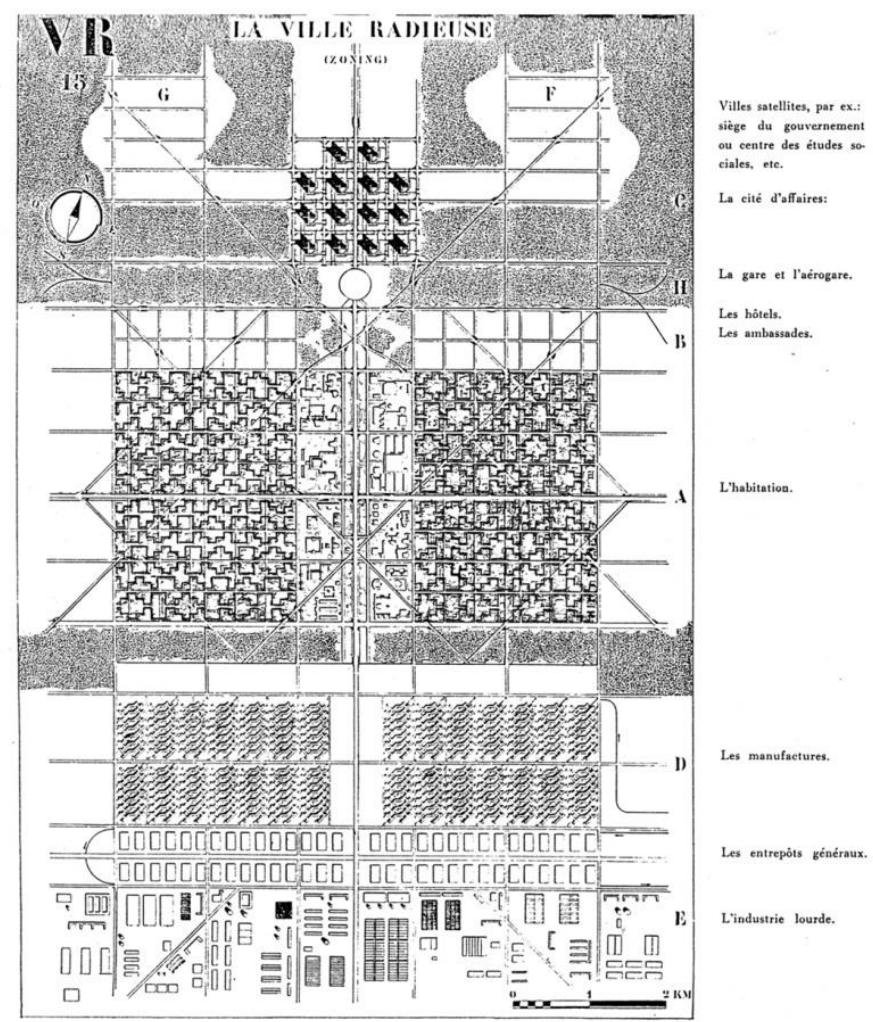

12. La Ville Radieuse (1930). Ville Radieuse, 1935. CFLC-ADAGP 


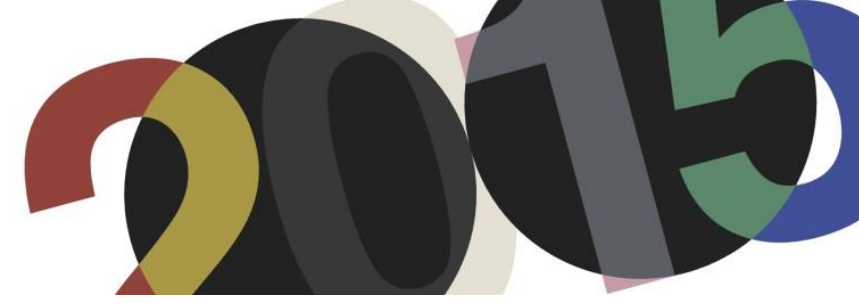

DOI: http://dx.doi.org/10.4995/LC2015.2015.893

\title{
Experimenting with prototypes: architectural research in Sweden after Le Corbusier's projects
}

\section{Campo-Ruiz}

\section{Escuela Técnica Superior de Arquitectura de Madrid, Universidad Politécnica de Madrid}

\begin{abstract}
Le Corbusier's architectural production throughout the twentieth century served as a reference for subsequent developments in architecture and urban planning in Sweden. Some of the buildings and urban plans subsequently developed in Sweden and influenced by Le Corbusier's ideas and projects also impacted on the international architectural scene. This research analyses how the study of Le Corbusier's works affected projects in Sweden from the 1920s to the 1970s and how they also became an international standard. Le Corbusier's works provided a kind of prototype, with which Swedish architects experimented in alternative ways. During the 1920s, Le Corbusier's Pavilion de l'Esprit Nouveau and the Stuttgart Weissenhofsiedlung impressed influential Swedish architect, including Uno Åhrén, Gunnar Asplund and Sven Markelius, who later became proponents of modernism in Sweden. The 1930 Stockholm Exhibition marked a breakthrough for functionalism in Sweden. After 1930, urban plans for Stockholm and its suburbs reflected some of Le Corbusier's ideas, such as the urban plan by Sven Markelius, and Vällingby's town centre by Leif Reinius and Sven Backström. After 1950, Léonie Geisendorf, Ralph Erskine, Sigurd Lewerentz and Peter Celsing placed considerable emphasis on rough texture in poured concrete. Lewerentz, who admired the works of Le Corbusier, designed the churches of Markuskyrkan in 1956 and St Peter's in Klippan in 1966, with a wider international impact. Reyner Banham included several works by Le Corbusier and also Markuskyrkan Church by Lewerentz in his book The New Brutalism: Ethic or Aesthetic? in 1966.
\end{abstract}

Keywords: Sweden, twentieth-century architecture, urban planning, prototype, architectural experiment, functionalism.

\section{Introduction}

"If you are going to see beautiful churches in Europe, there are three you should not miss: St Peter's Basilica in Rome, Nôtre Dame in Paris and Västerort Church in Vällingby!" A statement by Le Corbusier after his 1958 visit to this little church in Sweden on the outskirts of Stockholm, designed by Carl Nyrén and Bertil Engstrand and completed two years before. Le Corbusier praised this building, while some architects in Sweden also paid close attention to Le Corbusier's projects.

Le Corbusier's architectural production throughout the twentieth century served as a reference for subsequent developments in architecture and urban planning in Sweden. Some of the buildings and urban plans developed in Sweden and influenced by Le Corbusier's ideas and projects also impacted on the international architectural scene. This research analyses how the study of Le Corbusier's works affected projects in Sweden from the 1920s to the 1970s and how they turn became a benchmark for the international architectural arena. Le Corbusier's works became a kind of prototype, with which Swedish architects experimented in alternative ways.

\footnotetext{
${ }^{1}$ Brandão Jönsson, Henrik: Fantasiön: ett reportage från Brasiliens hjärta. Stockholm: Atlas, 2010. p. 273.
} 
Many forms proposed by Le Corbusier were adopted in Sweden and adapted to the emerging needs of a society that increasingly demanded equality at all levels, as reflected in the Social Democratic government that came into power in 1932, and embraced environmental design as a means to achieve higher living standards. Current socially inclusive designs may find a resource in these Swedish experiments.

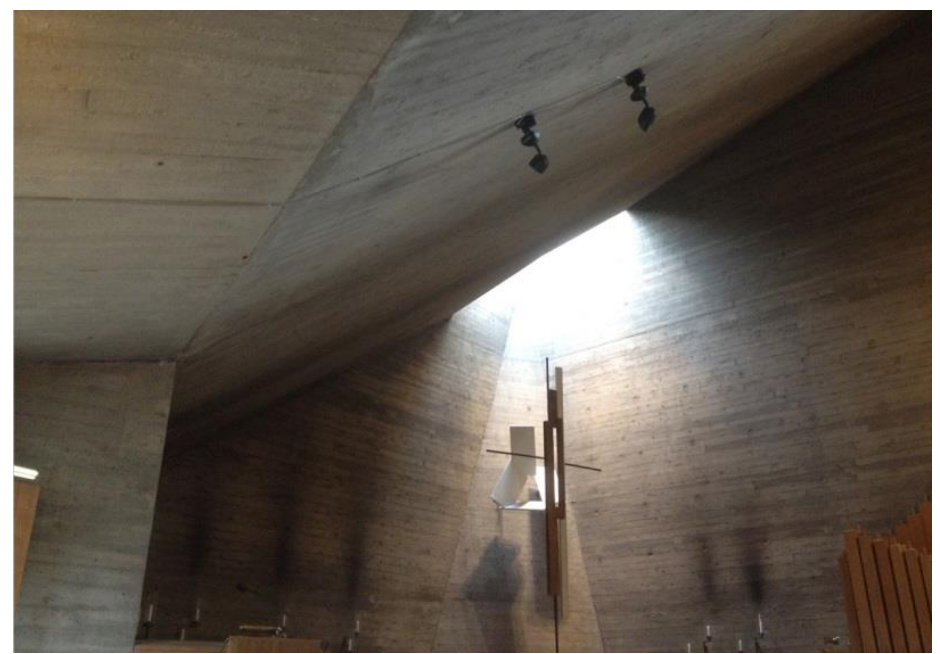

1. Interior of Västerort Church in Vällingby designed by Carl Nyrén and Bertil Engstrand, 1956.

\section{From 1920s to the mid-1930s. L' Esprit Nouveau as a springboard for experimentation at the Stockholm Exhibition}

In 1930, the Swedish Society for Crafts and Design (Svenska Sjöjdföreningen) organised the Stockholm Exhibition of applied art, industrial design, handicrafts, domestic craft, dwellings and other objects. The art historian Gregor Paulsson (1889-1977), Director of this society since 1924, and Gunnar Asplund (1885-1940), Chief Architect, started working on the new exhibition master plans and major buildings in 1927. Asplund began by drafting sketches of the buildings following Classical aesthetics. ${ }^{2}$

However, Asplund and Paulsson's 1928 trip to Brno and Stuttgart to visit Le Corbusier's work may have played a key role in Asplund's evolution towards functionalism, reflected in his drawings for the exhibition. ${ }^{3}$ In 1919 , Paulsson had published a polemic pamphlet, Better Things for Everyday Life, in which he advocated that industrial and rational design should benefit social progress. ${ }^{4}$ Indeed, in many of Le Corbusier's modernist forms, Paulsson now saw an opportunity to render architecture and design more accessible to all.

Additionally, a number of well-known Swedish architects who contributed to the Stockholm Exhibition were aware of some Le Corbusier's works: Uno Åhrén (1897-1977), Sven Markelius (1889-1972), Osvald Almqvist (1884-1950) and Sigurd Lewerentz (1885-1975), among others. Lewerentz designed the exhibition's logo, the posters, the Green Point café, the advertising mast, several stands, furniture and a bus for General Motors.

\footnotetext{
${ }^{2}$ Rudberg, Eva: “The Stockholm Exhibition 1930”. In Manuel López-Peláez, José; Fernández Elorza, Héctor; Rudberg, Eva (Ed.): Exposición Universal de Estocolmo 1930. Madrid: Editorial Rueda, 2004. p. 27.

${ }^{3}$ Rudberg, Eva: “The Stockholm Exhibition 1930”. In Manuel López-Peláez, José; Fernández Elorza, Héctor; Rudberg, Eva (Ed.): Exposición Universal de Estocolmo 1930. Madrid: Editorial Rueda, 2004. pp. 25-39. Also Hakon Ahlberg and Uno Åhrén.

${ }^{4}$ Kåberg, Helena: “An Introduction to Gregor Paulsson's Better Things for Everyday Life.” In Creagh, Lucy; Kåberg, Helena; Miller Lane, Barbara (Ed.): Modern Swedish Design. New York: The Museum of Modern Art, 2008. pp. 59-71.
} 
Osvald Almqvist focused on the standardisation of kitchens and contributed to the housing section. He had already developed a pioneering work on Taylorist studies in kitchen use as early as $1920 .^{5}$

Uno Åhrén visited Le Corbusier house at the Weissenhofsiedlung Exhibition. ${ }^{6}$ Le Corbusier and Pierre Jeanneret had built there a Citrohan house and an adjacent double house, where they tested solutions for minimal housing conditions. ${ }^{7}$ Supporting Stuttgart's project, Le Corbusier launched one of his bluntest manifestos in which he formulated the Five Points of a New Architecture. The success of the Stuttgart Exhibition led to the creation in 1928 of the Congrès Internationaux d'Architecture Moderne (CIAM) at La Sarraz Castle. Le Corbusier played a key role in the first meeting and his ideas strongly influenced subsequent congresses in Frankfurt, Brussels, Athens and Paris dedicated to minimal housing conditions and the functional city. ${ }^{8}$

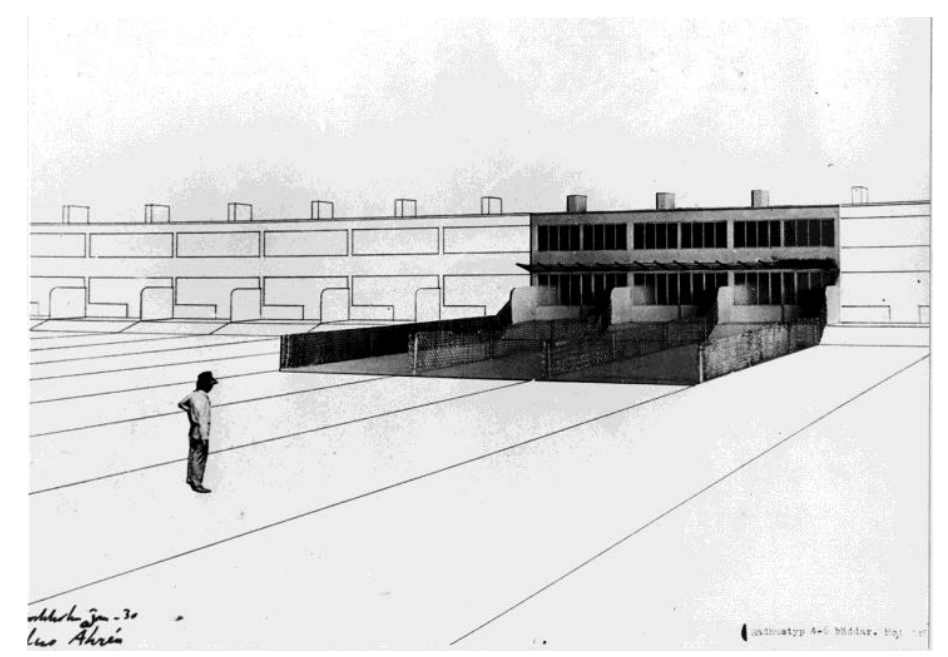

2. One of Åhrén's proposal of dwellings for the 1930 Stockholm Exhibition, a project for a single house, photomontage.

At the Stockholm Exhibition, Åhrén revealed his research on functional dwellings for the housing section, the Hall of Apartments, a terrace house, a one-family house, furniture and a small pavilion. Despite the palpable similarities between Åhrén's work and some of Le Corbusier's ideas, Åhrén critiqued Le Corbusier's contributions at the Weissenhofsiedlung for his preference of the play of formal over functional qualities and considered that the whole exhibition had failed in this aspect, with the exception of Oud and Gropius. ${ }^{9}$ Although Åhrén had previously defended Le Corbusier's L'Esprit Nouveau pavilion and emphasised the functions of the designs, he found Le Corbusier's project for Stuttgart too luxurious. ${ }^{10}$ Curiously enough, Åhrén used similar panoramic windows and white-washed surfaces to those of Le Corbusier's project at the Weissenhofsiedlung to materialise some of his principles and opposition to Le Corbusier's luxuries. Åhrén challenged personal

\footnotetext{
${ }^{5}$ Gasterland-Gustafsson, Grechen: Design for Living: German and Swedish Design in the Early Twentieth Century. Doctoral Thesis. Supervisor: Jochen Schulte-Sasse. University of Minnesota, 2008. p.163.

${ }^{6}$ Mattson, Helena; Wallenstein, Sven-Olov: Swedish Modernism: Architecture, Consumption and the Welfare State. London: Black Dog Publishing, 2010. p. 18.

${ }^{7}$ Cohen, Jean-Louis: Le Corbusier, 1887-1965. Köln: Taschen, 2004. p.35.

${ }^{8}$ Cohen, Jean-Louis: Le Corbusier, 1887-1965. Köln: Taschen, 2004. p. 36.

${ }^{9}$ Gasterland-Gustafsson, Grechen: Design for Living: German and Swedish Design in the Early Twentieth Century. Doctoral Thesis. Supervisor: Jochen Schulte-Sasse. University of Minnesota, 2008. p.163.

${ }^{10}$ Eriksson, Eva: "Rationalism and Classicism 1915-30.” In Cladenby, Claes; Lindvall, Jöran; Wang, Wilfried (Ed.): Sweden 20th Century Architecture. Munich-New York: Prestel, 1998. p. 73.
} 
expression in favour of rational decisions for a collective interest in numerous controversial articles. ${ }^{11}$ Åhrén claimed that "the future or decline of Western culture depends on whether it is possible to be modern in a deeply human and fruitful sense" $"$. Åhrén posited that building costs challenged affordable housing with minimum quality standards, revealing the political implication at stake. ${ }^{13}$ Two years after the Stockholm Exhibition, Åhrén became a member of the CIAM and joined its media department, where he concentrated on the political and propagandistic effects of architectural work. ${ }^{14}$

For the Stockholm Exhibition, Sven Markelius designed the hospital section, a flat, a one-family house and furniture. As a young student, Markelius had travelled to Germany where he met Gropius, visited his Siedlung Dessau-Törten project, followed by the Weissenhof Siedlung and, in France, Ville Savoye, still under construction. ${ }^{15}$ In 1929, Markelius had recently become a member of the CIAM, taking part in meetings in Frankfurt and Berlin in in 1929 and 1931, respectively.

The Stockholm Exhibition was constructed from late 1929 to early 1930. Most of the buildings had timber frames covered by asbestos-cement sheets, although a few buildings were built with steel frames. The exhibition attracted 4 million visitors and a broad analysis from international and domestic media. ${ }^{16}$ According to Sigfried Gideon, International Secretary of the CIAM, "There's been no exhibition to rival this one for overall effect!" 17

One year after the exhibition, several architects published the manifesto acceptera, which Lorenzo Capbianco believes to have been influenced by Le Corbusier. ${ }^{18}$ Authored by Åhrén, Paulsson, Asplund, Markelius, Walter Gahn (1890-1985) and Eskil Sundahl (1890-1974), the manifesto aimed to break with the architectural thinking that had dominated Swedish discourse until then, criticising historical eclecticism and advocating unadorned surfaces. ${ }^{19}$

\footnotetext{
${ }^{11}$ Creagh, Lucy: "An Introduction to acceptera”. En Creagh, Lucy; Kåberg, Helena; Miller Lane, Barbara (Ed.): Modern Swedish Design. New York: The Museum of Modern Art, 2008. p. 131.

${ }^{12}$ Eriksson, Eva: "Rationalism and Classicism 1915-30." In Cladenby, Claes; Lindvall, Jöran; Wang, Wilfried (Ed.): Sweden 20th Century Architecture. Munich-New York: Prestel, 1998. p. 74.

${ }^{13}$ Rudberg, Eva: “Early Functionalism 1930-40.” En Cladenby, Claes; Lindvall, Jöran; Wang, Wilfried (Ed.): Sweden 20th Century Architecture. Munich-New York: Prestel, 1998. p. 91.

${ }^{14}$ Mattson, Helena; Wallenstein, Sven-Olov: Swedish Modernism: Architecture, Consumption and the Welfare Stat. London: Black Dog Publishing, 2010. p. 18.

${ }^{15}$ Rudberg, Eva: “The Stockholm Exhibition 1930”. In Manuel López-Peláez, José; Fernández Elorza, Héctor; Rudberg, Eva (Ed.): Exposición Universal de Estocolmo 1930. Madrid: Editorial Rueda, 2004. p. 45.

${ }^{16}$ Rudberg, Eva: “The Stockholm Exhibition 1930”. In Manuel López-Peláez, José; Fernández Elorza, Héctor; Rudberg, Eva (Ed.): Exposición Universal de Estocolmo 1930. Madrid: Editorial Rueda, 2004. p. 26.

${ }^{17}$ Rudberg, Eva: “The Stockholm Exhibition 1930”. In Manuel López-Peláez, José; Fernández Elorza, Héctor; Rudberg, Eva (Ed.): Exposición Universal de Estocolmo 1930. Madrid: Editorial Rueda, 2004. p. 25

${ }^{18}$ Rudberg, Eva: “The Stockholm Exhibition 1930”. In Manuel López-Peláez, José; Fernández Elorza, Héctor; Rudberg, Eva (Ed.): Exposición Universal de Estocolmo 1930. Madrid: Editorial Rueda, 2004. p. 15.

${ }^{19}$ Creagh, Lucy: "An Introduction to acceptera". En Creagh, Lucy; Kåberg, Helena; Miller Lane, Barbara (Ed.): Modern Swedish Design. New York: The Museum of Modern Art, 2008. p. 127.
} 


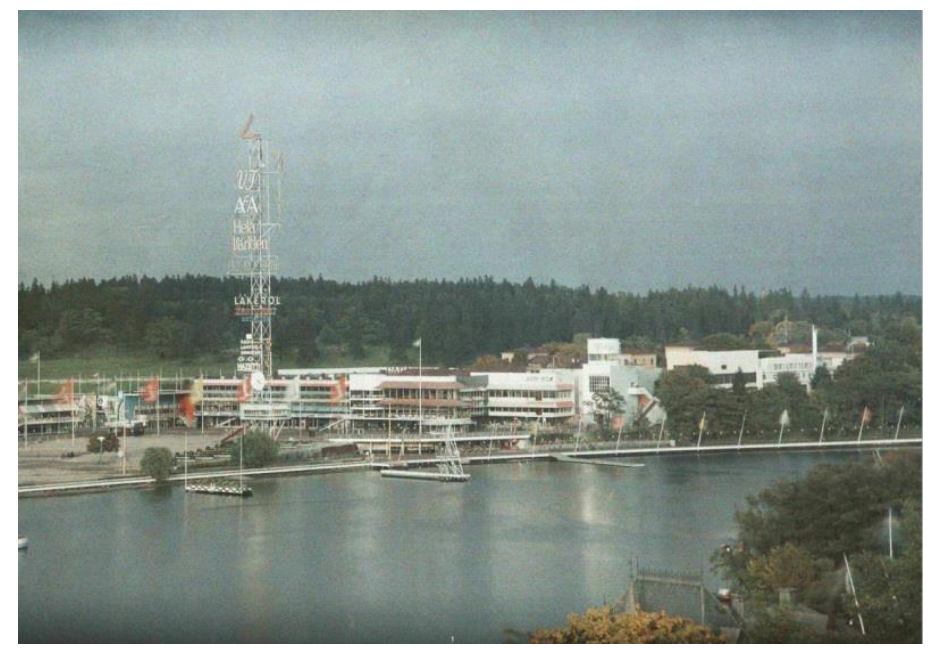

3. The Stockholm Exhibition of 1930, director Gregor Paulsson and Chief architect, Gunnar Asplund.

The works developed for the Stockholm Exhibition uncovered an adaptation of functionalism in Sweden that triggered further international interest. Henry-Russell Hitchcock and Philip Johnson showed the pavilions for the Stockholm Exhibition in the International Modern Architecture Exhibition at New York's MOMA in $1932 .{ }^{20}$ Hitchcock and Johnson subsequently published the celebrated book The International Style: Architecture since 1922, featuring Asplund's works at the Stockholm Exhibition, with a lakeside axonometric of the site and a photograph of the area between the Mass-produced Furniture and The Noble Metals pavilions. ${ }^{21}$ This book also featured the Flamman Theatre Auditorium in Stockholm by Uno Åhrén.

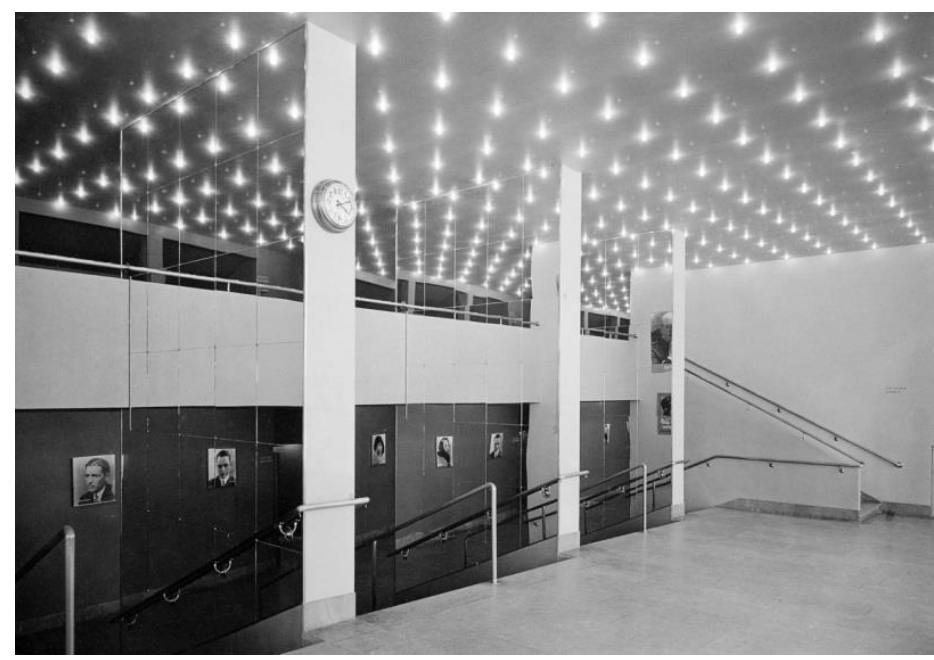

4. Åhrén's Flamman Theatre, 1929-1930.

Asplund was the focus of heavy criticism from Hakon Ahlberg, an influential architect in Sweden at that time: "it was Asplund, but it was also somebody else, somebody stronger who was behind his work. Aladdin had

\footnotetext{
${ }^{20}$ López-Peláez, José Manuel: “Asplund's Maturity”. En López-Peláez, José Manuel; Fernández Elorza, Héctor; Rudberg, Eva (Comp.): Exposición Universal de Estocolmo 1930. Madrid: Editorial Rueda, 2004. p.41.

${ }^{21}$ López-Peláez, José Manuel: “Asplund's Maturity”. En López-Peláez, José Manuel; Fernández Elorza, Héctor; Rudberg, Eva (Comp.): Exposición Universal de Estocolmo 1930. Madrid: Editorial Rueda, 2004. p.41.
} 
rubbed his lamp and the castle in the air was there, made of shiny material. However, the genie of the lamp was Le Corbusier: without his help, this work would not have existed"22.

However, in the words of Kenneth Frampton, "in no way can we regard the Stockholm Exhibition as being a Neo-Corbusian from a formal point of view, since, apart from the steel stanchions, the ubiquitous strip window and the general use of flush planar surfaces, none of the Corbusian Five Points of a New Architecture are strictly in evidence at Stockholm"23. Instead, Frampton claims that the exhibition was under the influence of the Russian Constructivists.

In fact, many of the works shown at the Stockholm Exhibition embraced some of Le Corbusier's forms, adapting them in order to connect with the emerging spirit of collective welfare, announcing the upcoming establishment of Swedish Social-Democracy. 'Architecture or revolution', the title of the final chapter in Le Corbusier's Vers une architecture (1923) presents architecture as a tool for the regeneration of "an organic social hole" avoiding revolution, in the words of Helena Mattsson and Sven-Olov Wallenstein. This proposition found some similarities in the Swedish debate around the 1920s, when "home' was seen as a salvation from an impending Bolshevik revolution and the dwelling became the place where a concrete politicizing of architecture must take place" $^{\text {24 }}$. Elin Wägner, an influential political writer of the time, pointed out that the upcoming exhibition was a "revolution from below", a transformative force of the production processes and the way of living. ${ }^{25}$

\section{The mid-1930s to the 1950s. Urban planning in Stockholm and suburbs. Le Corbusier's point blocks as a model and a point of departure}

After 1930, urban planners in Sweden began experimenting with housing, bearing in mind Le Corbusier's principles. During the interwar period, Swedish living conditions were poor, to the point of being considered among the worst housing standards in 1930's Europe. ${ }^{26}$ At that time, the recently elected Social Democratic government focused on housing issues. The new policies in urban planning ran parallel to changes in the social sphere demanding greater equality. "Because of the success of the housing programme and the comparative lack of public opposition to the new architecture," in the words of Alan Colquhoun "the Modern Movement in Sweden was completely lacking in the Jacobinism of the French and German movements"27.

In central Stockholm, the urban planner Albert Lilienberg devised a competition in 1932 for the extension of the major Sveavägen Road down to Gustav Adolfs Torg Square, located in Nedre Norrmalm district. However, the municipal administration eventually refocused this competition on whether to extend this road or not. ${ }^{28}$ The competition committee, which included architects, politicians and foreign experts, observed that the existing street grids and buildings in the neighbourhood were not suitable for the effective functioning of the city and that

\footnotetext{
${ }^{22}$ López-Peláez, José Manuel: “Asplund’s Maturity”. En López-Peláez, José Manuel; Fernández Elorza, Héctor; Rudberg, Eva (Comp.): Exposición Universal de Estocolmo 1930. Madrid: Editorial Rueda, 2004. p.45.

${ }^{23}$ Frampton, Kenneth: "Stockholm 1930, Asplund and the legacy of funkis". In Caldenby, Claes; Hultin, Olof; Asplund: a book. New York: Ginko Press, 1985. p. 35.

${ }^{24}$ Mattson, Helena; Wallenstein, Sven-Olov: Swedish Modernism: Architecture, Consumption and the Welfare Stat. London: Black Dog Publishing, 2010. p. 17.

${ }^{25}$ Mattson, Helena; Wallenstein, Sven-Olov: Swedish Modernism: Architecture, Consumption and the Welfare Stat. London: Black Dog Publishing, 2010. p. 17.

${ }^{26}$ Nyström, Louise; Lundström, Mats Johan: "Sweden: The Life and Death and Life of Great Neighbourhood Centres ”. In Built Environment. 2006, № 32/1. pp. 34.

${ }^{27}$ Colquhoun, Alan: Modern Architecture. Oxford-New York: Oxford University Press, 2002. p.195.

${ }^{28}$ Hall, Thomas: Stockholm: The making of a Metropolis. New York: Routledge, 2009. p.118.
} 
proposals should aim to give "a clear and logical expression to the role of the district as a commercial centre," encouraging the opening of Gustav Adolf Torg Square northwards. ${ }^{29}$

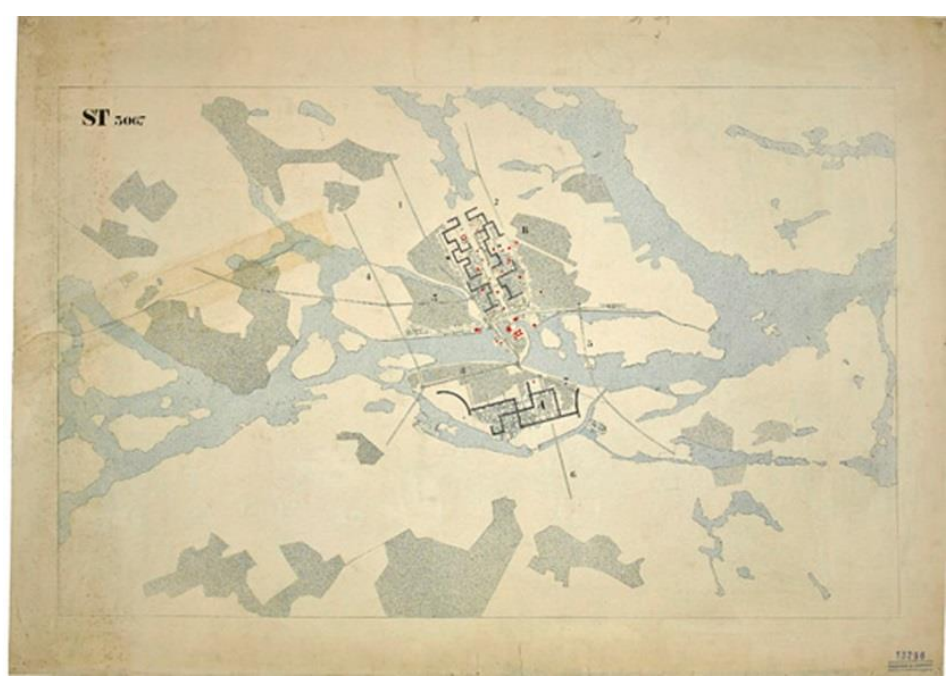

5. Le Corbusier's urban plan of Stockholm for the Nedre Norrmalm competition of 1933.

The competition attracted 350 entries, with many foreign participants. ${ }^{30}$ Alvar Aalto proposed free-standing slab blocks. Le Corbusier's entry replaced older buildings with modern point blocks. In the opinion of Thomas Hall, Le Corbusier's entry was "no doubt intended to provoke debate"31. In fact, Le Corbusier had asked Rudolf Cronstedt, a draughtsman who had worked in his atelier in Rue de Sèvres, to arrange a series of lectures in Stockholm as early as January $1933 .^{32}$

In an article published in 1934, architect and urban planner Sven Markelius considered that the problem with this competition had been that most entries were utopian and out of touch with the reality of things, including Le Corbusier's project. ${ }^{33}$ Le Corbusier's entry was never officially developed, and yet, after a long process culminating in 1957 , the urban plan reflects some of his ideas.

Markelius had been Director of Town Planning in Stockholm since 1944 and had directed post-war urban development in the city, after building the Swedish pavilion for the New York Exhibition in 1939. His contributions to the United Nations complex with Le Corbusier and Oscar Niemeyer had brought him international recognition. For Stockholm, Markelius planned to demolish the downtown almost in its entirety and replace older buildings with open public spaces, parks and high-rise towers. The eventual construction of highrise buildings and a large open space in the centre of Stockholm was in many ways similar to Le Corbusier's 1922 project "a contemporary city for three million inhabitants". Le Corbusier had aimed to make space and light available to all within the city centre, to avoid wasting land elsewhere. ${ }^{34}$

\footnotetext{
${ }^{29}$ Hall, Thomas: Stockholm: The making of a Metropolis. New York: Routledge, 2009. p.118.

${ }^{30}$ Hall, Thomas: Stockholm: The making of a Metropolis. New York: Routledge, 2009. p. 118.

${ }^{31}$ Hall, Thomas: Stockholm: The making of a Metropolis. New York: Routledge, 2009. p. 120.

${ }^{32}$ Linton, Johan: Le Corbusier's Plan for the Urbanization of Stockholm. Stockholm: Moderna Museet, 2013. p.2.

${ }^{33}$ Capobianco, Lorenzo: Sven Markelius, Architettura e città. Napoli: Electa Napoli, 2006. p.17.

${ }^{34}$ Curtis, William J R: Le Corbusier, Ideas and Forms. London-New York: Phaidon, 1986 (2015). p. 110.
} 


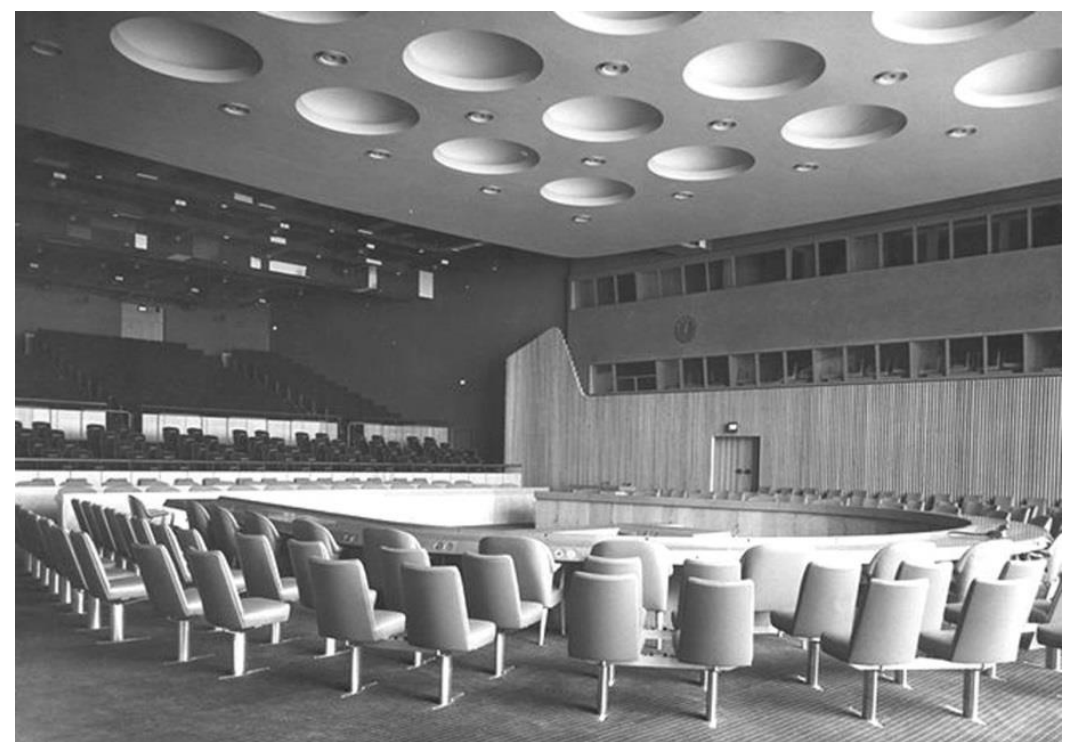

6. Sven Markelius' meeting room for United Nations, 1947-52.

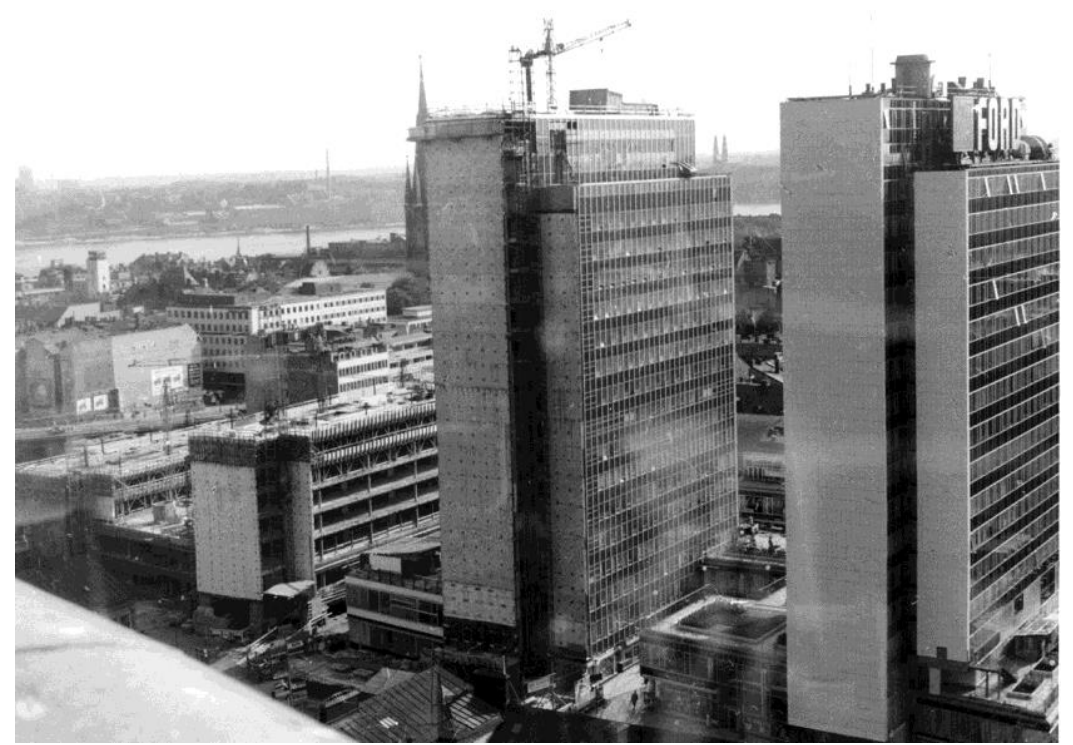

7. Sven Markelius' urban plan of Stockholm devised the demolition of the pre-existing blocks to build high-rise towers. Hötorgscity and Sergels Torg, 1952-1956.

Stockholm's modernisation project triggered numerous demolitions in Stockholm's city centre, most of the Renaissance blocks being replaced, as well as part of the surrounding eighteenth- and nineteenth-century buildings, ${ }^{35}$ to become, in the words of Swedish architect Thordis Arrhenius, "one of the most ambitious and costly urban projects in postwar Europe" ${ }^{\text {} 36}$. Former housing was replaced with large-scale city blocks of offices, commercial units and a new cultural complex, Kulturhuset (1971-74) designed by architect Peter Celsing (192074), in a process that was completed in the late 1970 s.

\footnotetext{
${ }^{35}$ Arrhenius, Thordis: "Preservation and Protest, Counterculture and Heritage in 1970s Sweden." In Future Anterior. 2010, $\mathrm{N}^{\mathrm{o}} 7 / 2$. pp. 110 .

${ }^{36}$ Arrhenius, Thordis: "Preservation and Protest, Counterculture and Heritage in 1970s Sweden." In Future Anterior. 2010, $\mathrm{N}^{\mathrm{o}} 7 / 2$. pp. 111 .
} 
Parallel to these developments, the Social Democratic government appointed a parliamentary commission on housing, which included some of the most progressive architects, such as Uno Åhrén and Sven Wallander, and the economist, sociologist and politician Gunnar Myrdal. ${ }^{37}$ Their 1946 report lay the foundations for a new housing policy and a new Building Act in 1947. Lewis Mumford's book The Culture of Cities, translated into Swedish in 1942, and the Greater London Plan of 1944 were also important influences. The Stockholm Exhibition had been the big break-through for Swedish modernism and over the following years, various suburbs of three-storey, light-coloured apartment buildings were developed. However, some critiques were raised regarding the lack of socially-minded spaces in these new approaches.

Just one year before, Markelius had launched his vision of neighbourhood planning as the new way of developing Stockholm, as published in a booklet co-authored with Göran Sidenbladh. ${ }^{38}$ Markelius and Sidenbladh's plan laid new suburban clusters of about 10,000 inhabitants along the recently established underground system. Each cluster followed the idea of the $\mathrm{ABC}$ town: Arbete (work), Bostäder (housing) and Centre (commercial and public services at its centre).

Based on the ABC premises, Markelius planned Vällingby in the suburbs of Stockholm in 1952, thereafter a reference for urban planners worldwide. Vällingby was planned as the largest suburban neighbourhood in Sweden, including a variety of houses and informal groupings. Blocks of flats were built around the centre and single-family houses further away, with the aim of highlighting pedestrian walkways. Vällingby Centre is surrounded by the Greater Vällingby area, which consists of five districts for around 80,000 inhabitants.

Additionally, Vällingby Centre was designed by Leif Reinius (1907-1995) and Sven Backström (1903-1992), who had worked with Le Corbusier between 1932 and 1933. The project became so important that Vällingby Centre was inaugurated in 1954 in the presence of the Royal Family, several members of the Swedish Government and the Parliament, as well as other politicians and decision-makers, and several surrounding housing areas were completed within the following year. Le Corbusier visited Vällingby in 1958.

\footnotetext{
${ }^{37}$ Nyström, Louise; Lundström, Mats Johan: “Sweden: The Life and Death and Life of Great Neighbourhood Centres”. In Built Environment. 2006, № 32/1. pp. 33.

${ }^{38}$ Nyström, Louise; Lundström, Mats Johan: "Sweden: The Life and Death and Life of Great Neighbourhood Centres". In Built Environment. 2006, № 32/1. pp. 34.
} 


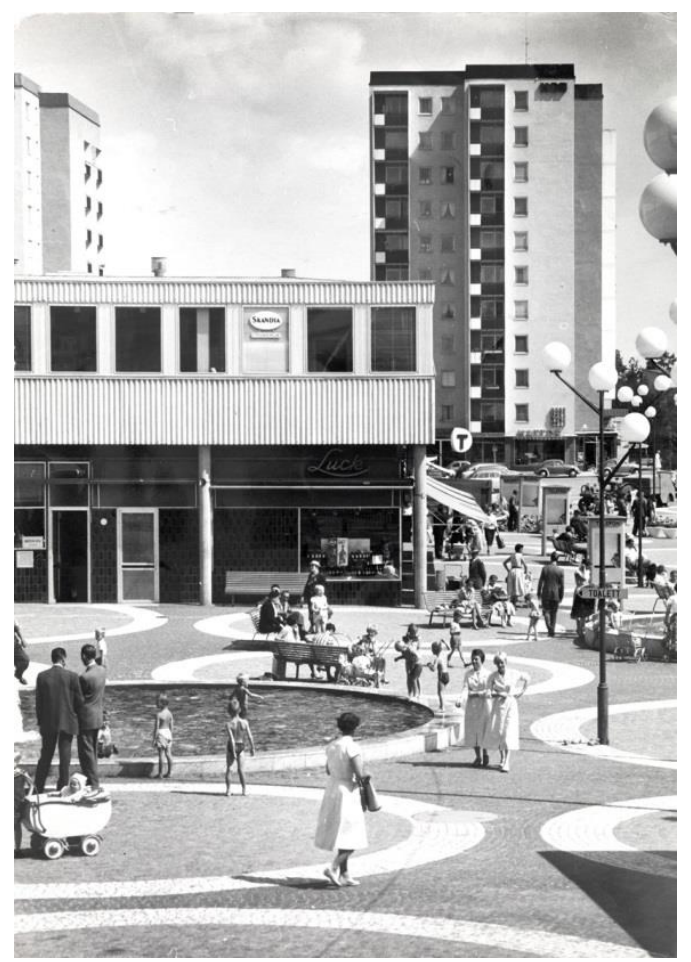

8. Vällingby Centre was designed by Leif Reinius (1907-1995) and Sven Backström (1903-1992)

Vällingby has drawn both strong appraisals and critiques. It became a benchmark for urban planners and the materialisation of many ideas about new towns of that time. It also relied mainly on commercial activity, becoming somewhat unsustainable in social terms. ${ }^{39}$ Vällingby enhanced a close relationship between the individual, everyday life and the landscape.

\section{The 1950s-1970s. Béton brut - Brutalism}

After 1950, many works in Sweden began to emphasise the texture of material, and Le Corbusier's use of concrete became a benchmark. Léonie Geisendorf (1914-), a Swiss architect who had worked for Le Corbusier, designed with her husband St Görans Gymnasium in Stockholm, in the 1950s, and Villa Delin; both works made profuse use of rough concrete. She had helped Le Corbusier with Le Pavilion des Temps Nouveaux for the 1937 Paris Exposition. ${ }^{40}$

\footnotetext{
${ }^{39}$ Ingersoll, Richard: "Second Nature: On the Social Bond of Ecology and Architecture". En Dutton, Thomas; Hurst Mann, Lian (Ed.): Reconstructing Architecture: Critical Discourses and Social Practices. Minneapolis, MN: University of Minnesota Press, 1996. p. 134.

${ }^{40}$ Hallemar, Dan; Lauri, Tomas; Svensson, Julia; Lundqvist, Marianne; Berving, Tobias, Upwind Geisendorf 2014. Stockholm: Arkitektur- och designcentrum, 2014. p. 12.
} 


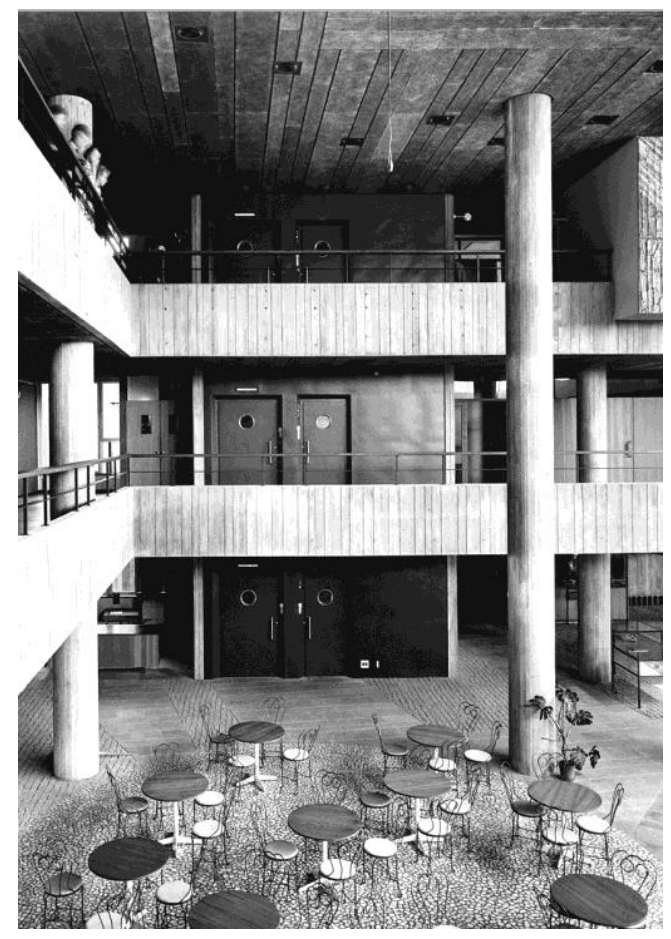

9. St Görans Gymnasium in Stockholm by Léonie and Charles-Edouard Geisendorf, 1956-1973.

A close friend of Geisendorf's, ${ }^{41}$ Ralph Erskine, completed the housing, school and commercial centre in Gyttorp in 1955, both works emphasising the rough texture in the poured concrete. By contrast, Erskine's criticism of modernism aligned with the ideas of Team X, with which he had contacts. ${ }^{42}$ Erskine was particularly receptive to human behaviour and community dynamics. ${ }^{43}$ According to Erskine: "zoning is a misunderstanding of functionalism ${ }^{\text {,44. }}$.

Sigurd Lewerentz, who admired the works of Le Corbusier, designed the churches of Markuskyrkan in 1956 and St Peter's in Klippan in 1966, with a wider international impact. Peter Celsing completed St Thomas' Church in 1959 and most notably, his building of the Filmhuset (completed in 1970) could be regarded as influenced by Le Corbusier's works, such as La Tourette. In his 1966 book The New Brutalism: Ethic or Aesthetic?, Reyner Banham included several works by Le Corbusier, as well as Lewerentz's Markuskyrkan Church.

${ }^{41}$ Hallemar, Dan; Lauri, Tomas; Svensson, Julia; Lundqvist, Marianne; Berving, Tobias, Upwind Geisendorf 2014. Stockholm: Arkitektur- och designcentrum, 2014. p. 15.

${ }^{42}$ Caldenby, Claes: “The Time of the Large Programmes 1960-75.” En Cladenby, Claes; Lindvall, Jöran; Wang, Wilfried (Ed.): Sweden 20th Century Architecture. Munich-New York: Prestel, 1998. p.146.

${ }^{43}$ Walters, David; Brown, Linda. Design First. Oxford: Architectural Press, 2004. P. 17.

${ }^{44}$ Caldenby, Claes: "The Time of the Large Programmes 1960-75." En Cladenby, Claes; Lindvall, Jöran; Wang, Wilfried (Ed.): Sweden 20th Century Architecture. Munich-New York: Prestel, 1998. p.146. 


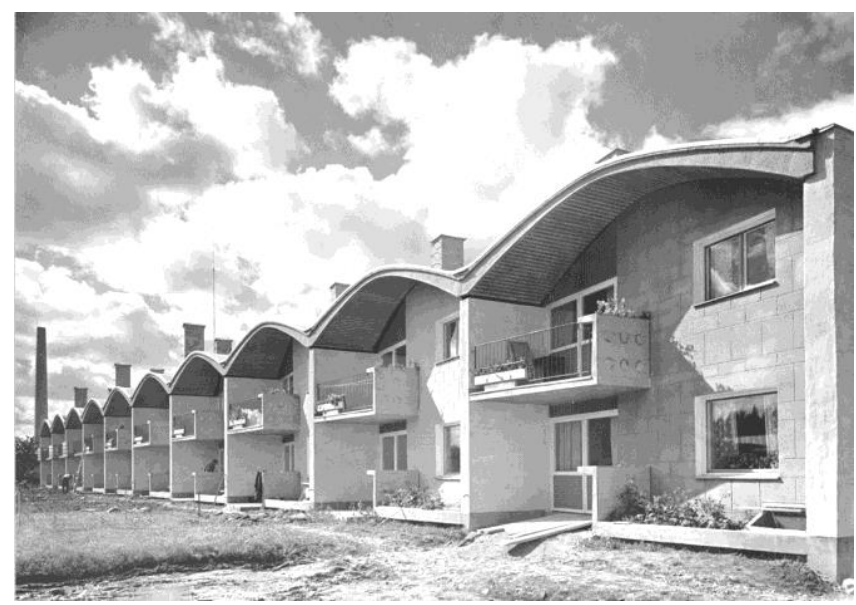

10. Ralph Erskine, row-houses in Gyttorp, 1945-55.

\section{Conclusions}

An analysis of Swedish adaptation and transformation of elements from Le Corbusier's projects shows how Swedish architects developed innovative designs by exploring new applications of Le Corbusier's forms and materials. They transformed his approaches into alternative uses, adapting them to place and the social conditions specific to Scandinavia.

Some of Le Corbusier's construction methods served to materialise ideas that, in principle, seemed very different, if not opposing, such as Åhrén and Erskine's. These subversive results reflect not only the complexity of Le Corbusier's legacy, but also the adaptation of new, similar forms for different identities. Swedish adaptation of Le Corbusier's elements became a resource for producing novel designs, which in turn impacted on the international arena.

\section{Acknowledgements}

I am grateful to the Swedish Design Centre for Architecture and Design in Stockholm and Fondation Le Corbusier for their help.

\section{Source of images}

Figure 1. Photograph by the Author.

Figure 2. The Swedish Centre for Architecture and Design. Photographer unknown.

Figure 3. The Swedish Centre for Architecture and Design. Photographer Gustaf W:son Cronquist.

Figure 4. The Swedish Centre for Architecture and Design. Photographer C. G. Rosenberg.

Figure 5. Le Corbusier/BUS 2012.

Figure 6. The Swedish Centre for Architecture and Design. Photographer unknown.

Figure 7. The Swedish Centre for Architecture and Design. Photographer unknown.

Figure 8. The Swedish Centre for Architecture and Design. Lennart Olson.

Figure 9. The Swedish Centre for Architecture and Design. Photographer Sune Sundahl.

Figure 10. The Swedish Centre for Architecture and Design. Photographer Sune Sundahl. 


\section{References}

Arrhenius, Thordis: "Preservation and Protest, Counterculture and Heritage in 1970s Sweden." In Future Anterior. 2010, No 7/2. pp. 106-123.

Brandão Jönsson, Henrik. Fantasiön: ett reportage från Brasiliens hjärta. Stockholm: Atlas, 2010.

Caldenby, Claes: “The Time of the Large Programmes 1960-75.” En Cladenby, Claes; Lindvall, Jöran; Wang, Wilfried (Ed.): Sweden 20th Century Architecture. Munich-New York: Prestel, 1998.

Capobianco, Lorenzo: Sven Markelius, Architettura e città. Napoli: Electa Napoli, 2006.

Cohen, Jean-Louis: Le Corbusier, 1887-1965. Köln: Taschen, 2004.

Colquhoun, Alan: Modern Architecture. Oxford-New York: Oxford University Press, 2002.

Creagh, Lucy: “An Introduction to acceptera”. En Creagh, Lucy; Kåberg, Helena; Miller Lane, Barbara (Ed.): Modern Swedish Design. New York: The Museum of Modern Art, 2008.

Curtis, William J R: Le Corbusier, Ideas and Forms. London-New York: Phaidon, 1986 (2015).

Eriksson, Eva: "Rationalism and Classicism 1915-30.” In Cladenby, Claes; Lindvall, Jöran; Wang, Wilfried (Ed.): Sweden 20th Century Architecture. Munich-New York: Prestel, 1998.

Frampton, Kenneth: "Stockholm 1930, Asplund and the legacy of funkis". In Caldenby, Claes; Hultin, Olof; Asplund: a book. New York: Ginko Press, 1985. pp. 35-39.

Gasterland-Gustafsson, Grechen: Design for Living: German and Swedish Design in the Early Twentieth Century. Doctoral Thesis. Supervisor: Jochen Schulte-Sasse. University of Minnesota, 2008.

Hall, Thomas: Stockholm: The making of a Metropolis. New York: Routledge, 2009.

Hallemar, Dan; Lauri, Tomas; Svensson, Julia; Lundqvist, Marianne; Berving, Tobias, Upwind Geisendorf 2014. Stockholm: Arkitektur- och designcentrum, 2014.

Ingersoll, Richard: "Second Nature: On the Social Bond of Ecology and Architecture". En Dutton, Thomas; Hurst Mann, Lian (Ed.): Reconstructing Architecture: Critical Discourses and Social Practices. Minneapolis, MN: University of Minnesota Press, 1996.

Kåberg, Helena: “An Introduction to Gregor Paulsson's Better Things for Everyday Life.” In Creagh, Lucy; Kåberg, Helena; Miller Lane, Barbara (Ed.): Modern Swedish Design. New York: The Museum of Modern Art, 2008.

Linton, Johan: Le Corbusier's Plan for the Urbanization of Stockholm. Stockholm: Moderna Museet, 2013.

López-Peláez, José Manuel: “Asplund’s Maturity”. En López-Peláez, José Manuel; Fernández Elorza, Héctor; Rudberg, Eva (Comp.): Exposición Universal de Estocolmo 1930. Madrid: Editorial Rueda, 2004. pp. 41-51.

Mattson, Helena; Wallenstein, Sven-Olov: Swedish Modernism: Architecture, Consumption and the Welfare State. London: Black Dog Publishing, 2010.

Nyström, Louise; Lundström, Mats Johan: "Sweden: The Life and Death and Life of Great Neighbourhood Centres”. In Built Environment. 2006, No 32/1. pp. 32-52.

Rudberg, Eva: "Early Functionalism 1930-40.” En Cladenby, Claes; Lindvall, Jöran; Wang, Wilfried (Ed.): Sweden 20th Century Architecture. Munich-New York: Prestel, 1998.

Rudberg, Eva: “The Stockholm Exhibition 1930”. In López-Peláez, José Manuel; Fernández Elorza, Héctor; Rudberg, Eva (Comp.): Exposición Universal de Estocolmo 1930. Madrid: Editorial Rueda, 2004. pp. 25-39.

Walters, David; Brown, Linda. Design First. Oxford: Architectural Press, 2004. 


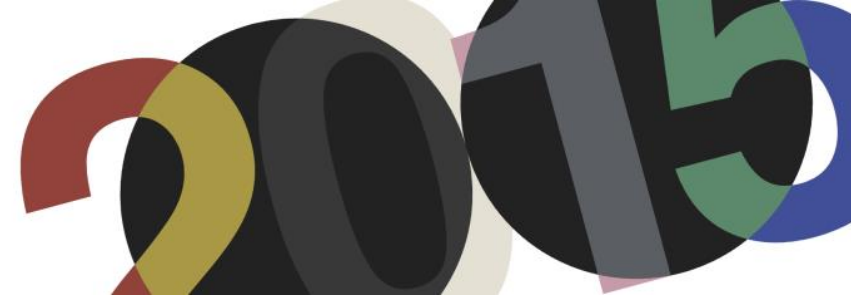

DOI: http://dx.doi.org/10.4995/LC2015.2015.642

\title{
Team10 out of CIAM: Sobre el papel de Le Corbusier. Identificación y legado
}

\author{
A. Campos Uribe
}

Escuela Técnica Superior de Arquitectura de Valencia

\begin{abstract}
Resumen: Aunque existen diversas versiones sobre el nacimiento del Team10 y la disolución de los CIAM, todas coinciden en el carácter de ruptura. Frente a la versión canónica que explica el fin de los CIAM como confrontación, este artículo muestra, a través del estudio de los documentos que pasaron por el estudio de Le Corbusier, que muchas de las ideas del grupo ya existían en el interior de los CIAM, y que la creación del Team10 contó con el apoyo de los miembros fundadores. Es especialmente importante el apoyo personal de Le Corbusier que a través de cartas y dibujos entendió muy pronto que era el momento de apartarse y dejar paso a la nueva generación; hasta el punto de constatar que sin su apoyo es posible que el Team10 nunca hubiera sido creado. Le Corbusier, como figura y ejemplo de los jóvenes que supo, generosamente, dar el relevo a tiempo.
\end{abstract}

Abstract: Albeit different versions of Team 10 birth and dissolution of CIAM exist, all of them coincide in its disruptive nature. This article tries to prove, far from the canonical representation of the end of CIAM and by studying the documents that went through Le Corbusier's atelier in Paris; that many of the ideas of Team 10 were already present inside CIAM and that Team 10's creation had the support of several of CIAM's founding members. It is especially important Le Corbusier's personal backing. Le Corbusier, who through letters and drawings understood very soon that it was the time to step aside and give way to the new generation. In fact, it was vital to the creation of Team 10, without whom it would not have been possible.

Palabras Clave: CIAM; Team 10; Le Corbusier; Aix-en-Provence; Dubrovnik; Smithson, Bakema.

Keywords: CIAM; Team 10; Le Corbusier; Aix-en-Provence; Dubrovnik; Smithson, Bakema.

\section{Introducción}

Aunque existen diversas versiones sobre el nacimiento del Team10, la mayoría coinciden en su carácter de ruptura. En los CIAM de post-guerra la metodología reflejada en la Charte d'Athènes, comenzaba a levantar críticas de las generaciones más jóvenes. Un inesperado dogmatismo se imponían entre los miembros de la segunda generación, alineados con la interpretación exhaustiva de la carta en cuanto a la separación de funciones y el enfoque analítico; mientras los miembros fundadores, verdaderos propulsores del espíritu de los CIAM, iban abandonando progresivamente su participación activa en los congresos. La tercera generación se nutriría de multitud de ideas que habían comenzado a surgir bajo el paraguas del CIAMVI en Bridgwater (1947) y que representaban un nuevo enfoque en el que la importancia se trasladaba a la imaginación y la síntesis, al concepto de identidad, y en particular a las relaciones entre funciones más que las funciones en sí mismas.

Como explica Annie Pedret en su trabajo titulado "CIAM and the emergence of Team10 thinking", en realidad el pensamiento del Team10 tiene un marcado carácter de continuidad con las ideas que habían nacido en los últimos congresos. Pedret conecta las propuestas teóricas del Team10 con conceptos promovidos desde 1947 por los grupos holandeses (Opbouw y de 8) e inglés (Mars), pero también por personas como Alfred Roth o Sigfrid

\footnotetext{
${ }^{1}$ Pedret, Annie. CIAM and the emergence of Team 10 thinking 1945-1959, Tesis Inédita defendida el 06/2001 en el Massachusetts Institute of Tecnhology (A partir de ahora AP)
} 
Giedion, o el grupo italiano del que destaca Ernesto N. Rogers; demostrando que los conceptos de identity, doorstep, the art of living, el visual group o el cluster, el change and growth y en general la apuesta por una arquitectura de relaciones, no son patrimonio del Team10. El trabajo nos permite entender el grupo como la continuación, que no ruptura, de los CIAM aunque con un nombre distinto, y comprender que ese cambio de nombre fue en realidad un acontecimiento casual forzado por personas como Peter Smithson o John Voelcker, que nunca creyeron que en la misma organización fuera posible dar un verdadero giro de ideas.

Resulta muy interesante preguntarse por el papel de Le Corbusier durante los últimos congresos, y en particular por su relación con los actores que posteriormente formaron el Team10. En un primer momento Le Corbusier trató de monopolizar el pensamiento de los CIAM2, pero tras la guerra y ante las reinvindicaciones en el seno de la organización entendió que era hora de dejar paso a la generación de los jóvenes para que "apoyados sobre las espaldas" de los miembros fundadores emprendieran su propio camino. A partir de ese momento Le Corbusier resultó ser uno de los más importantes aliados de la nueva generación y en numerosas ocasiones intervino para otorgarles su confianza; hasta el punto de poder afirmar que el nacimiento del Team10 y su "ruptura" con los CIAM no hubiera sido posible sin su apoyo explícito y enormemente generoso.

Aunque hay una versión distinta del nacimiento del Team10 contada por cada uno de sus miembros, mediante el análisis de los documentos que circularon por el estudio de Le Corbusier podremos ponerlas a prueba para encontrar el verdadero papel que tuvo en la creación del grupo.

\section{El futuro de CIAM: los jóvenes toman el relevo}

A lo largo de los años de guerra, el pensamiento de los CIAM se había desarrollado en direcciones contrarias. Por una parte Le Corbusier y Sert promovían el urbanismo de la "Charte d'Athènes", mientras Giedion y Alfred Roth asentaban las bases de un "post-funcionalismo" regional, social y cultural. En su libro New Architecture ${ }^{3}$, que influenció mucho a la nueva generación ${ }^{4}$, Roth aportaba ideas nuevas: la historia como herramienta para comprender el presente e inventar el futuro, el valor de las relaciones humanas en la arquitectura o la importancia de la imaginación. Giedion, en Space, Time, and Architecture ${ }^{5}$, incidía también en la importancia de las "relaciones entre cosas" y de la historia, reforzando la necesidad de acercamiento a las culturas regionales. En esa misma línea se movía el pensamiento de los grupos holandeses Opbouw y De 8 de los que Jaap Bakema y Aldo van Eyck eran miembros, y del inglés Mars Group al que pertenecían los Smithson, Voelcker y Howell.

En el primer congreso tras la guerra, el CIAM VI en Bridgewater, ambos grupos realizan una importante contribución que sin embargo no sería recogida en los informes del congreso. En particular Aldo van Eyck, que había vivido en Suiza durante la guerra y compartía muchas ideas con Giedion, hace un alegato en contra de la tiranía del sentido común ${ }^{6}$, y a favor de un cambio de dirección en el enfoque excesivamente analítico y

\footnotetext{
${ }^{2}$ En muchas ocasiones Le Corbusier se encargó de elaborar el discurso oficial haciendo caso omiso de las verdaderas discusiones que se producían en los CIAM. Cambió en varias ocasiones el Consejo, nombrando a amigos como Sert o Giedion, asegurándose así el control de lo que sucedía

${ }^{3}$ Roth, Alfred. The New Architecture. Zurich: Les Editions A'Akrchitecture, 1940

${ }^{4}$ Según declaraciones de Peter y Alison Smithson, Giancarlo de Carlo, Aldo van Eyck y Ernesto Rogers

${ }^{5}$ Roth, Alfred. The New Architecture. Zurich: Les Editions A'Akrchitecture, 1940

${ }^{6}$ Entre sus palabras podemos encontrar por ejemplo la idea de que "a new consciuosness has begun to permeate mankind" $o$

"imagination is the essence of existence". También menciones a Giedion o a los logros de Le Corbusier, Mondrian o Brancusi como ejemplos para la nueva dirección en los CIAM.
} 
deductivo de los CIAM que había llevado a una separación entre la arquitectura y las personas a las que finalmente servía. Las discusiones alrededor del término habitat son constantes dentro de CIAM, y los nuevos miembros apoyan una definición mucho más extensa e inclusiva, mientras que los veteranos son reacios a cambiar la teoría construida a lo largo de los CIAM previos a la guerra. En sucesivos congresos y encuentros, la joven generación no cesa de proponer nuevas ideas para una arquitectura y un urbanismo más humanos, y sin embargo los informes de resultados de las reuniones seguirían ignorando sus reivindicaciones hasta 1952.

En la reunión del consejo de los CIAM de mayo del 52 $2^{7}$, en la que están presentes Candilis, Gropius, Rogers y Giedion, se produce la primera mención directa de Le Corbusier a los jóvenes. La reunión se realiza con el objetivo de decidir el futuro de los CIAM y el tipo de participación de los jeunes en la organización. Le Corbusier afirma que los fundadores ya son demasiado viejos y no tienen la flexibilidad necesaria para responder a los nuevos requerimientos. Sin embargo, está de acuerdo con Gropius en que una salida de los anciens ahora sería muy teatral, y a la vista de que los jóvenes únicamente piden una mayor participación ("les jeunes ne se sentent pas prêts à agir seuls”), se decide darles un papel más activo en el próximo congreso en Aix-enProvence. Ya en 1952 había planes para dar el relevo a los jeunes, y fueron Gropius y Le Corbusier los que propusieron al CIAM Council que se hicieran cargo de la organización del décimo congreso.

Es especialmente esclarecedora la carta que envía Sert a Le Corbusier ${ }^{8}$ en la que explica su punto vista sobre el futuro de los CIAM. Propone que no haya diferenciación alguna entre jóvenes o viejos, pues la tarea de los CIAM no es de una generación sino que debería continuarse en la siguiente. "Nous avons aussi passé beaucoup de temps à des controverses philosophiques. Aujourd'hui nous devons agir, faire face aux réalités”. Hace además una serie de sugerencias para la reorganización de los Congresos: limitar el número de miembros, restaurar la estructura anterior a la guerra (CIRPAC) y celebrar un congreso cada dos años dando la responsabilidad de su organización a los jóvenes. Estas propuestas, nacidas de una empatía especial de Sert por los jeunes, serán en su mayoría llevadas a cabo en el período de tiempo desde esa primera reunión en el 52 hasta la disolución definitiva de los CIAM en 1959.

En Aix-en-Provence los grupos participan más que nunca ${ }^{9}$ y se crea un comité de transferencia (Fig1). Aix-enProvence será el primer congreso al que asisten los Smithson, y en el que presentan su conocido "Urban ReIdentification Grid", introduciendo la idea de las escalas de asociación o la de "doorstep", y será la primera ocasión en la que un grupo de jóvenes encuentra una misma manera de trabajar que los unirá hasta 1981 bajo el nombre de Team10. En Aix se reconoce un salto generacional para algunos irreconciliable y de que los CIAM, como organización, es incapaz de evolucionar.

(pg 32-43) Van Eyck, Aldo. Collected Articles and Other Writings 1947-1998. Amsterdam: Vincent Ligtelijn y Francis Strauven, SUN Publishers, 2008

${ }^{7}$ Conseil CIAM Mai 1952. (Fondation Le Corbusier - FLC D3-1 2-8)

${ }^{8}$ J.L. Sert 26/10/1952 a Le Corbusier. (FLC D3-1 538-543)

${ }^{9}$ J.L-Sert 14/07/1952 (FLC D3-1 553) 


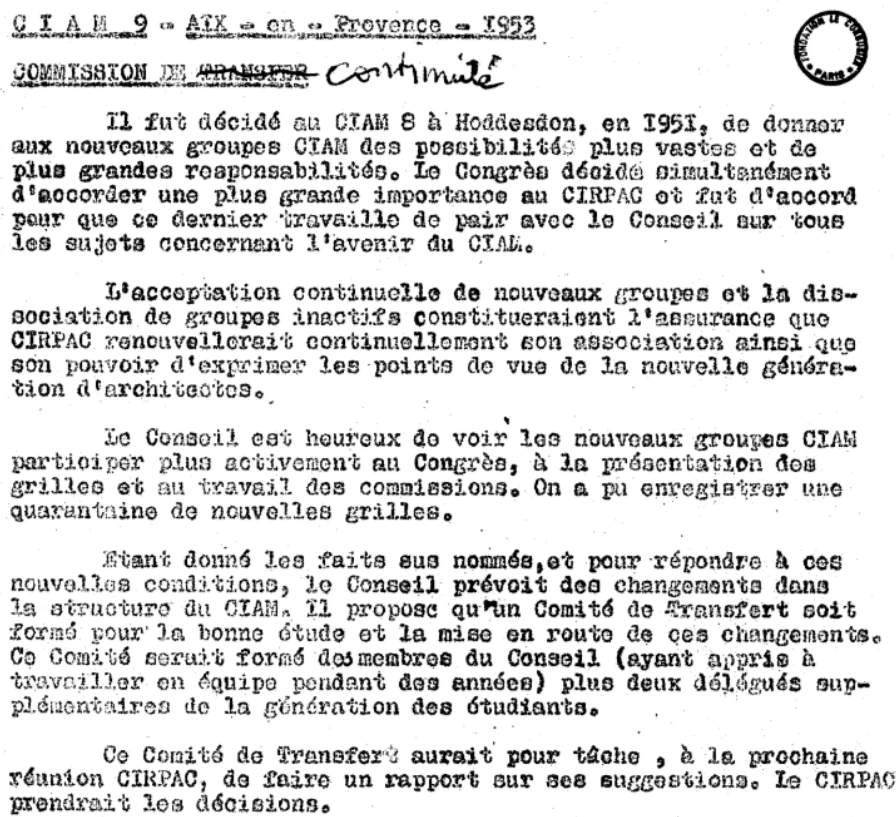

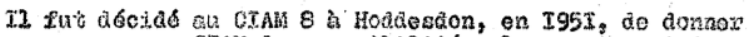
aux nouveaux groupes CTAll des pobsibilitus plus vastos et do

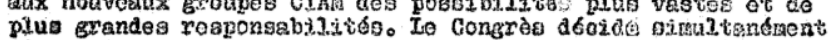

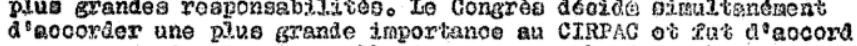

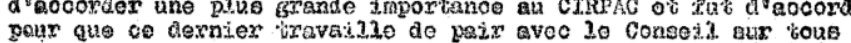

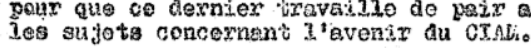

Toaccoptation continuello de nouveaux grounes ot in dissociation de groupes inactiss constitueraiont $\lambda^{2}$ eseucance que

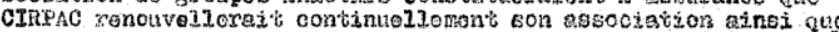
son pouvoir d texprines les points de vue de Ia nouvelzo gentration a'archituotes.

is Conseily ear houroux do voir' 103 nouveaur grouges CIAH partiojpor plus activenent au Congrès, ì 3.2 mósertation dor grijles et au travaj? des comalgsions. On a pu omregistres une quarantino de nouve?les erilles.

fitant donna leo tajts gus nomines, ot pour répondre a ces

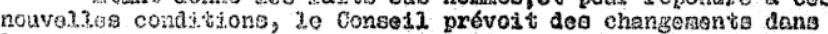

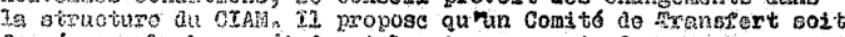
zorné your' 1 . bonne ótude ot la mise en routo de ces changenentso Co conitlé seruit' torns dos menbsor du Consoil. (ayant appris ì travoij3er on equipe pendant des années) plus deux dóĵ̣gués supplésentalres de la géneration des ótudianta.

Ce Conjté de Trengier's aurait poux thohe, è la prochajne rénion CIRPAC, do Taire un rapport sur ses stgegesiono. Io CTRPAC prondrait les d6́isions.

1. En la copia recibida por Le Corbusier, aparece cambiado Comission de Transfer por Comission de Continuité. Esto explica su postura al respecto. 24/07/1953 (FLC D3-1 553) OFLC-ADAGP

\section{El manifiesto de Doorn}

Tras el congreso, en la reunión de Doorn, los jóvenes alcanzan un acuerdo en torno al concepto de habitat. En la redacción del documento final, que se llamó "Statement on Habitat" aparece por primera vez el famoso diagrama de Geddes (Fig 2) y el concepto de "Scale of Association". Se constata el valor de la Carta de Atenas pero se reconocen sus limitaciones, proponiendo un método que libere el potencial acotado por las cuatro funciones; y se pasa a considerar cada comunidad como un caso concreto que hay que tratar con sus peculiaridades (particular total complex $)^{10}$. En esa misma reunión se habla de la organización de los CIAM. Bakema y Van Eyck están a favor de la continuidad (Fig3), y sugerieren al consejo que los jóvenes organicen CIAMX ${ }^{11}$.

En la reunión del Consejo y los delegados en $1954^{12}$, con Le Corbusier y la mayoría de los miembros del Team10 presentes, se observa una primera incursión de las nuevas ideas en la organización. Se puede extraer de la transcripción que los grupos Mars (Lasdun+Smithson+Voelcker), Opbouw (Bakema), Gamma (Candilis) y De 8 (Van Eyck) toman una parte muy activa en el encuentro. Se acuerda en la reunión que la preparación del CIAMX se encargará a un grupo pequeño de individuos (Bakema, Smithson, Candilis y Gutman), que el tema del congreso sería el habitat humano y por tanto el trabajo presentado reflejaría el habitat ideal teniendo en cuenta las condiciones climáticas y sociales (Mars Group), y que la síntesis era más importante que ampliar más el análisis (Van Eyck y Giedion).

\footnotetext{
${ }^{10}$ This method of work will induce a study of human association as a first principle, and of the four functions as aspects of each total problem. (FLC D2-8-13) El Statement on Habitat sería renombrado por Alison Smithson como The Doorn Manifesto, como base para el desarrollo teórico del Team10. Como constata Pedret, la redacción del documento fue manipulada por los Smithson para construir la idea de que ellos eran los autores (AP 56)

${ }^{11}$ Discussion on organizational maters Doorn 29/01/1954

(ET10 25-27) Smithson, Alison. The Emergence of Team 10 out of CIAM. London: Architectural Association, 1982

12 (FLC D2-8 142-144)
} 

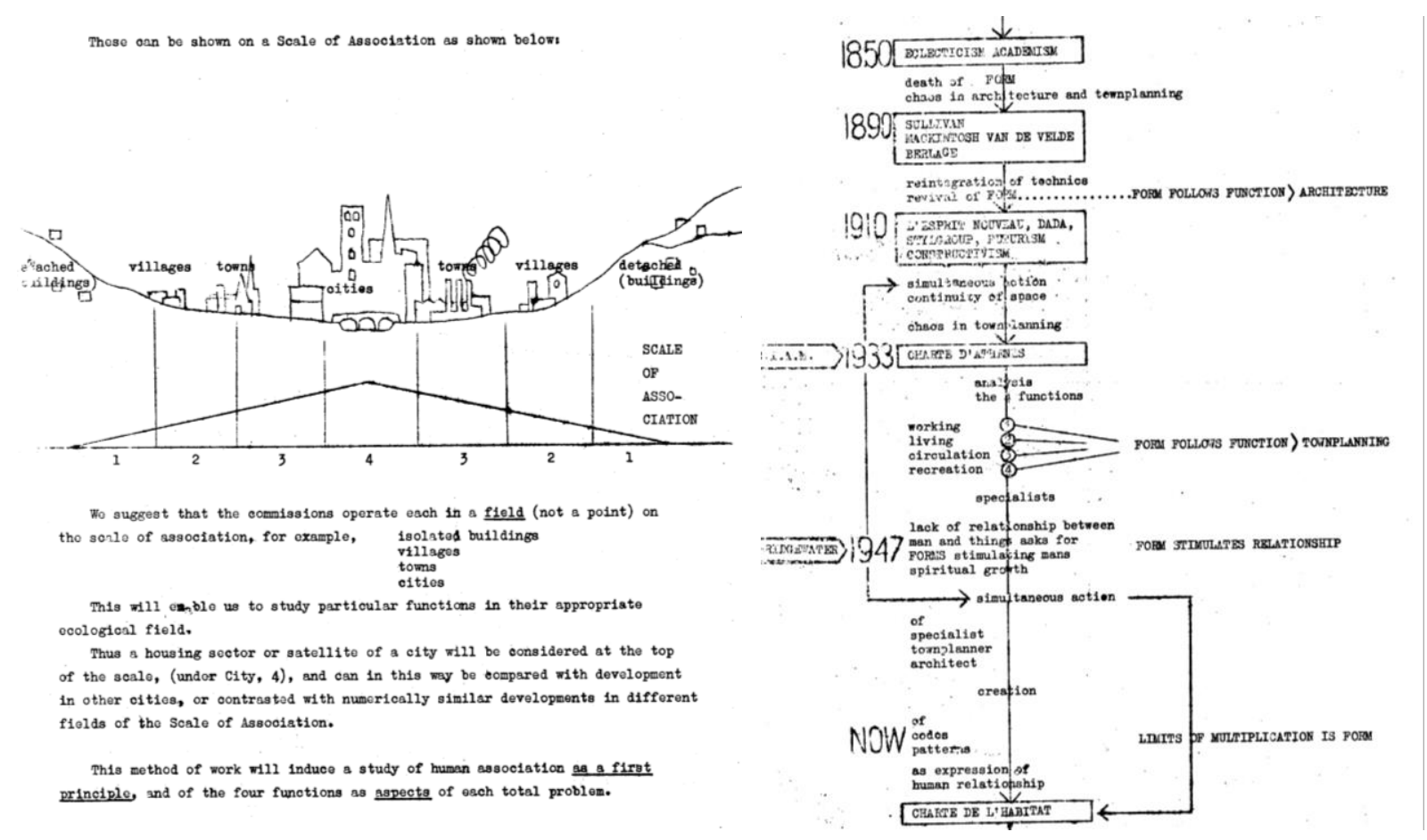

2. Fragmento del Statement on Habitat en Doorn, con su interpretación del diagrama de Geddes (FLC D2-8 15)

3. Esquema elaborado por Bakema (FLC D2-8 16) @FLC-ADAGP

\section{Crisis en el Team 10: "if you want to continue, continue in your own way"}

A lo largo de los primeros meses de preparación del congreso y discusión sobre el término habitat, se encuentran las primeras diferencias entre los jóvenes que a punto están de terminar con el grupo antes de haberse creado. Tras la reunión de Doorn, Peter Smithson es el encargado de redactar el marco del congreso y las instrucciones para los grupos. En el proceso de redacción, mediante sucesivas reuniones, se abandonan algunos de los acuerdos de Doorn y se modifican o añaden otros ${ }^{13}$. El resultado, según Sert, Gropius y Giedion, es un tanto ambiguo e impreciso, y critica duramente los logros previos de la organización ${ }^{14}$. Bakema hace una serie sugerencias para realizar modificaciones que son ignoradas ${ }^{15}$, y finalmente toma la decisión de redactar un

\footnotetext{
${ }^{13}$ El documento final presentado al consejo se conoce como Draft Framework 3. Instructions to groups. (FLC D2-8 36-39)

${ }^{14}$ Tres documentos muestran la preocupación por la falta de precisión. Una carta a Bakema (FLC D3-7 130) de Gropius, Giedion y Sert en la que exigen claridad ("we received a program that has many fine statements of a general type, but is lacking in precise directives") y muestran su enfado por la crítica ("it is not customary in our congress to start criticising past efforts"). Una carta de Giedion a Le Corbusier (FLC D3-7 128) "l'ataque injuste vis-à-vis de la Charte d'Athenes", "le manque de precision". El último, de Candilis, es una carta a Smithson y Bakema en la que afirma que Giedión está "terriblement inquiet au sujet de l'organisation spirituelle du Congrès" (FLC D3-7 135). Smithson responderá enfadado: "What do the Professors want?" (ET10 43)

${ }^{15}$ Carta de Bakema 22/09/1954, en la que atiende a las exigencias de los veteranos. Propone también incluir el concepto de "the art of living", el trabajo con especialistas diversos, el concepto de "identity" y el de "change and growth", la importancia de la búsqueda de nuevos patrones... Todos vitales para comprender el pensamiento del Team10, ya reivindicados por los holandeses. (FLC D2-8 43-45)
} 
documento que se conoce por Orientation ${ }^{16}$ y enviarlo a todos los miembros de los CIAM. Smithson, Howell y Voelcker responderán enfadados a Bakema ${ }^{17}$ e intentarán aclarar la situación, pero la diferencia de criterios llevará finalmente a la intervención de Le Corbusier y Sert.

En Orientation el Dutch Group ponía más énfasis en las relaciones ente personas y cosas, y marcaba cuatro ejes para organizar el congreso. "The Aesthetics of number", que pretende solucionar la monotonía producida por la estandarización y la repetición en grandes actuaciones. "Growth and change" (Bakema) el habitat no debe resistirse al desarrollo y cambio de aquellos a los que sirve. "The greater reality of the doorstep" (Van Eyck) que pretende desarrollar las relaciones "between man and man, between man and things", y superar las polaridades existentes (individual-colectivo, físico-espiritual, dentro-fuera, parte-todo), entendiendo que son "dualphenomenon" ( $\sin$ uno no existe el otro). Y por último "The ecological aproach", como síntesis de los tres anteriores, que trabaja sobre la Scale of Association mediante el estudio de proyectos concretos en su contexto. Se pretende establecer un marco teórico y posteriormente estudiar los proyectos bajo el diagrama de Geddes, por lo que no se abandona lo propuesto por Mars. El Mars Group, con su enfoque empírico, pretendía que ese marco teórico se desarrollara a través del estudio de proyectos, pues creían que proponerlo desde el principio supondría acotar las ideas. Todas las propuestas del Team10 en torno al término habitat tratan de dar respuesta a unas necesidades que ya no son para un ser humano abstracto sino concretas para cada comunidad y cada individuo.

El siguiente contacto se produce en el apartamento en París de Le Corbusier en septiembre de 1954. Como recuerda Alison Smithson ${ }^{18}$, la reunión tenía un doble motivo: por una parte conocer personalmente a Le Corbusier, que estaba dispuesto a pasar la dirección de los CIAM a los jóvenes sin problemas, y por otra discutir el marco del décimo congreso (base de todas las propuestas posteriores del Team10) que tenía como objetivo regenerar los CIAM. Le Corbusier apoya las inquietudes del comité ("if you want to continue, continue in your own way") ${ }^{19}$ e incluso afirma ser un miembro más del grupo pero sin el deseo de que su figura pese sobre ellos ${ }^{20}$.

\footnotetext{
${ }^{16}$ Redactado por Bakema 24/10/1954 con la ayuda de Van Eyck en el que proponen un marco específico para el congreso. Se organiza en dos grandes partes. En "Orientation" se hace una narración histórica del momento y se reconocen los logros de los CIAM, apoyando la continuidad. En "Organisation" se recoge el documento acordado en Doorn y se desarrolla de forma muy distinta al de los Smithson, más particularizada y concreta. Es un documento que permite entender el valor de las aportaciones del Dutch Group al pensamiento del Team10.

(FLC D2-8 47-55)

${ }^{17}$ En una carta a Bakema y firmada por Howell, A. and P. Smithson y Voelcker: "we are completely bewildered by the document of October 24th", "the author of the new sections has very largely missed the point of the last years work". En realidad, mediante el análisis de los documentos, no se encuentra un cambio sino más bien un desarrollo y concreción. (ET10 36-37)

${ }^{18}$ Smithson, Alison. Team Ten Meetings, 1953-1981. United States: Rizzoli International Publications, 1991

${ }^{19}$ Ibid

"According to Sandy van Ginkel, Le Corbusier said: 'If you want to continue, continue in your own way.,",

${ }^{20}$ Risselada, M. and Van den Heuvel, D. Team 10: in search of a Utopia of the present. Netherlands: NAI Publishers, 2006.

"Van Eyck: Team 10 started within CIAM, and there were people like Ernesto Rogers and Le Corbusier himself who were enthusiastic and supported us: some of our meetings took place at Le Corbusier's house, do you remember? So he was 'sur les épaules des autres', 'abbas les emmerdeurs' he wrote. Le Corbusier said: 'I am a member but I do not want to weigh on you', 'I belong to Team 10',"
} 
En los documentos de preparación para la reunión elaborados por Candilis se exponen las razones por las piensan que es necesario un cambio en los CIAM $^{21}$ y se menciona por primera vez el nombre "EquipeX",22, que será utilizado a partir de ese momento. En el apartamento de Le Corbusier ${ }^{23}$ se citan textualmente las palabras de Candilis pero se minimiza la crítica a los CIAM. Le Corbusier da su opinión sobre la idea de habitat en la que distingue entre "the dwelling as a container: le dedans, and the extension of the dwelling: le dehors", en contraposición a la idea mucho más inclusiva de los jóvenes. También afirma que "dans les reserches [...] la primauté est donnée à l'humain est non pas à la mechanisation" y sugiere que no se utilicen nombre comunes para las agrupaciones de edificios, haciendo alusión a las escalas del Scale of Association (isolate, village, town, city); en su lugar propone utilizar simplemente "the Habitat in isolation, in Small Communities...". En el documento Orientation Bakema responde a esa petición, frente a los documentos de Smithson-Howell-Voelcker que se niegan a abandonar la Scale of Association. La idea de Le Corbusier es pasar el relevo a los jóvenes y que los mayores recapitulen los 25 años de los CIAM, así como la elaboración de una "Chartre de l'Habitat" con los resultados del décimo congreso.

Si bien es cierto que había personajes como Le Corbusier que veían una clara diferenciación en función de la generación, otros como Ernesto N. Rogers pensaban que la idea de separar a jeunes y anciens solo llevaba a la división y no a la unión según la vitalidad del espíritu. Miembros del Team10 también mostrarían su aprecio por figuras como la de Le Corbusier ${ }^{24}$, entendiendo que él no era el problema; sin dar importancia al salto generacional sino más bien criticando la deriva producida por individuos sin vitalidad ni objetivos. No creían en una separación entre un old y un new $C I A M^{25}$, sino que lo veían como una organización que ya no era útil para solucionar los nuevos interrogantes.

En cartas a Bakema Le Corbusier muestra su simpatía (“faites mes amitiés à tous, spécialement à Van Eyck pour qui j'ai, comme pour vous, beaucoup d'estime"). Sin embargo, a lo largo de 1955 se suceden las muestras de decepción de personajes como Emery o Wogenscky ${ }^{26}$. Desde Cap Martin ${ }^{27}$ Le Corbusier muestra su molestia con

\footnotetext{
21 "Nous pensons, surtout après Aix, que le moment est venu de donner de l'eau de jouvence au mouvement CIAM". "La senilité, la fatigue, la mediocrité envahissent CIAM". "Les congrès deviennent avec le temps un lieu de rencontre" En el documento se constata que el acuerdo alrededor del Draft 3 no era tan extenso como Smithson afirmaba, pues Candilis expone muchas ideas que serán utilizadas en el documento "Orientation" como el carácter evolutivo del habitat y el concepto de "l'Habitat du grand nombre" demostrando que "Orientation" no era simplemente la opinión de los holandeses. (FLC D37 7-9)

${ }^{22}$ Team10 es el nombre que se da al grupo encargado de organizar CIAM X

${ }^{23}$ Meeting of Team X with the Vice-Presiden and Secretary General of CIAM.

Team X (Bakema, Van Eyck, Van Ginkel, Smithsons, Howells y Candilis), Le Corbusier y Giedion. (FLC D2-8 40-42)

${ }^{24}$ Encontramos menciones a Le Corbusier en muchas declaraciones del Team10.

Por ejemplo Van Eyck en su intervención en CIAMVI ("the achievement of men like Le Corbusier, Mondrian or Brancusi compels us to believe that we are indeed approaching a brighter era")

${ }^{25}$ Jaap Bakema y Giancarlo de Carlo hablan sobre Le Corbusier en Otterlo 1959

(Newman, Oscar, CIAM '59 in Otterlo. New York: Universe Books Inc, 1961)

Bakema: "I don't agree with those who speak of an old CIAM and a new CIAM. There can never be an old and a new: we simply go on"

La intervención de Giancarlo es especialmente interesante por analizar los CIAM subrayando la excepcionalidad de la figura de Le Corbusier. ("Le Corbusier, endowed with a boundless formal shrewdness and with an unrelenting technical earnestness, always managed to avoid the bottomless pit of academicism")

${ }^{26}$ En una carta del 6 de abril de 1955 de Wogenscky a Emery, copia enviada a Le Corbusier, Wog da su opinión y muestra su decepción ("je suis eidéré de voir la pauvreté, la partialité, l'aspect négatif et destucteur, l'absence de propositions concretes... qui caractérisent à mon avis le programme préparé par le groupe designé. C'est une déception car j'attendais
} 
los jóvenes y cree que hay una atmósfera equivocada ("les joueurs jouant"). Piensa que "les jeunes n'ont pas la force d'embrasser la térrible complexité du phénomène moderne", y cree que su tarea es "prouver par des oeuvres!" y la de los veteranos redactar la Charte de l'Habitat que ha de "servir aux jeunes, de règle, de consigne, d'arme d'attaque et de défense".

\section{La intervención de Le Corbusier}

Empujado por una carta personal de Giedion muy crítica con el Team $10^{28}$, en la que pedía su intervención directa, Le Corbusier se reunirá el 9 de mayo de $1955^{29}$ con Candilis, que aclara el punto de vista de los jóvenes.

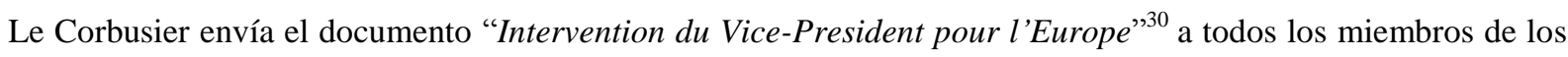
CIAM, defendiendo el enfoque y el trabajo realizado por el Team10. Esta intervención será vital como se constata en correspondencia entre Bakema y Smithson: "Pete. Corbu is okey, we did win the battle against professors!" 31 . La alegría por la intervención de Le Corbusier muestra la importancia que aún tenía su opinión dentro de los CIAM. En el documento Le Corbusier, que por fin ha entendido que CIAM se encuentra en un momento de cambio, afirma que "les éléments établis par le Team X sont raisonnables et parfaitement acceptables" y que "j'ai relevé ceci, c'est que (question de jeunesse et d'inexpérience) des termes sont souvent mal employés", refiriéndose al documento Draft 5 elaborado por Smithson y que incluía muchas reivindicaciones de Orientation $^{32}$. Giedion, que aún no confía en los jóvenes, escribirá: "Le Corbusier could not care a jot about CIAM $^{, 33}$.

La invitación al congreso la redactan Candilis y Le Corbusier ${ }^{34}$ según lo acordado. Se mantiene el método de trabajo propuesto por los Smithson (Scale of Association) y la idea principal del congreso es: "the function living becomes 'the habitat' when it is organically integrated in an environment"; ambos en la linea del Statement on Habitat de Doorn.

En la reunión previa al congreso, en septiembre de $1955^{35}$ se modifican las instrucciones redactadas por el Team10 en un "échange de vue entre les délégues des groupes et le Team X", eliminando la idea de Fields of Association (reacción molesta de Smithson) ${ }^{36}$. En segundo lugar, se decide el tema del CIAMX, que será "L'Habitat, Probleme de Relations. Premiere Propositions", como había sugerido Le Corbusier, y se cambia así

infiniment mieux de Bakema et de Van Eyck"). La carta aparece anotada a mano con la respuesta de Le Corbusier. (FLC D2-8 331-332)

${ }^{27}$ Ibid

${ }^{28}$ (FLC D3-7 128)

${ }^{29}$ (Candilis to Bakema, 9 May 1955)

${ }^{30}$ (FLC D3-7 30-33)

31 "Candilis told me that Corbusier was in complete agreement with our proposals for CIAM X" (ET10 44)

${ }^{32}$ El documento aprobado por Le Corbusier abandona la crítica a los CIAM y en su lugar incluye el relato histórico redactado en Orientation. Aunque no elimina la Scale of Association, sí que introduce las ideas de Change, Relationship between things, Doorstep y el Ecological Approach propuestas por el Dutch Group.

33 (CIAM 42-JT-13-463)

${ }^{34}$ (FLC D3-7 95-97)

35 (FLC D3-7 50-54)

${ }^{36}$ Circular a Sert y Team 10. "By the elimination of the 'Scale of Association', the emphasis on the community as an entity has disappeared, and with it the possibility of finding the key to Habitat which is the basic unifying belief of Team X". (ET10 54-56) 
el enfoque del diagrama de Geddes a la importancia de "las relaciones" como factor irrenunciable para una arquitectura más humana. También se pospone un año el congreso para desarrollar las instrucciones, y se modifica el lugar de celebración a Dubrovnik. "Les délégués présents sont unanimes pour remercier le Team X de sa contribution et du travail qu'il a fourni jusqu'ici'”.

La tarea para Dubrovnik era "to give form to the relations between functions, and to the more complex human structure of the agglomeration", y aunque el Team10 creía que esas relaciones solo se podrían definir tras el congreso $^{37}$, Giedion realiza una intervención en la que empatiza con las reivindicaciones de los jóvenes y da algunos ejemplos ${ }^{38}$. Entendiendo sus ideas, hace explícito su apoyo. Giedion habla de la necesidad de establecer relaciones entre funciones (algo que nunca había admitido) que serán más importantes que las funciones en sí mismas (calcado a las afirmaciones del Dutch Group). Se observa la inspiración de Giedion en el documento Orientation, y es evidente la simpatía de Giedion por Van Eyck, incluso en la manera de redactar y las expresiones utilizadas. Ha terminado por imponerse el enfoque de Orientation, y Smithson queda aún más alejado del núcleo de los CIAM.

Las preparaciones del congreso continuarán gracias a la intervención de Le Corbusier, no exentas de distintos puntos de vista, con los jóvenes intentando que sus ideas no desaparezcan de las instrucciones a los grupos y el consejo imponiendo elementos programáticos. Finalmente el congreso se organizará en cuatro sub-comisiones: clúster (tiene que ver con la idea de doorstep), mobility, change and growth, urbanism and habitat (the ecological aproach); similares a las propuestas por los holandeses.

\section{El mensaje de Le Corbusier: un problema de dos generaciones}

El 23 de Julio de 1956, poco antes de la celebración del décimo congreso, Le Corbusier redacta el "Message de Le Corbusier adressé au X Congrès CIAM à Duborvnik" ${ }^{39}$ y lo envía a Sert para que lo comparta con todos los presentes acompañada de una carta personal ${ }^{40}$ que resulta muy esclarecedora.

En la carta privada Le Corbusier sugiere que tras el congreso se disuelvan las comisiones creadas en Bérgamo y se modifiquen los estatutos que organizan los CIAM en grupos nacionales. Le Corbusier cree que el término nacional provoca "rivalité ou d'idées préconçues", y "conflits de préséance ou de jalousie"; y piensa que eliminándolo se abriría la organización a "la participation de nouvelles forces ou de nouvelles conceptions", grupos locales más diversos. La decisión de Bridgewater sirvió para distinguir "entre les travailleurs efectifs, et les verbeux, les éternels mécontents, les protestataires...", y ahora la metamorfosis debe operar sobre la base de la nueva generación. Para él los CIAM no son una cuestión de orden geográfico sino más bien de caracteres, de individuos "éminemment désintéressé" que asumen "les taches et n'ont jamais reserché des avantages

\footnotetext{
${ }^{37}$ (FLC D3-7 57-63)

${ }^{38}$ Giedion expone muchas de las ideas del Team 10, incluso de manera más clara: "the town is essentially relations, encounters, the coming together of you and me", "the age of compartmented specialization nears its end", "to study the new forms of human relations is the business of the architect, and it is the task of CIAM" (FLC D3-7 55-56)

${ }^{39}$ (FLC D3-7 121-127)

40 "le X Congrès doit dissoudre les commissions", "la métamorphose CIAM 1956 doit s'opérer sur la base de la nouvelle génération", "on n'atteindra à des buts pratiques que par ce désintéressement total, absolu, irréductible"

(FLC D3-7 118-120)
} 
personnels". Su opinión marcará la nueva dirección que toman los CIAM a partir de 1956, volviendo a ser una organización compuesta por individuos.

El mensaje público a los presentes en Dubrovnik es un precioso documento en el que Le Corbusier expresa su total apoyo a la nueva generación, tratando de definir su tarea. Se organiza en tres partes: “crise ou evolution? réponse: problème de générations", "la génération de 1928" y "la génération de 1956 va prendre le commandement".

I

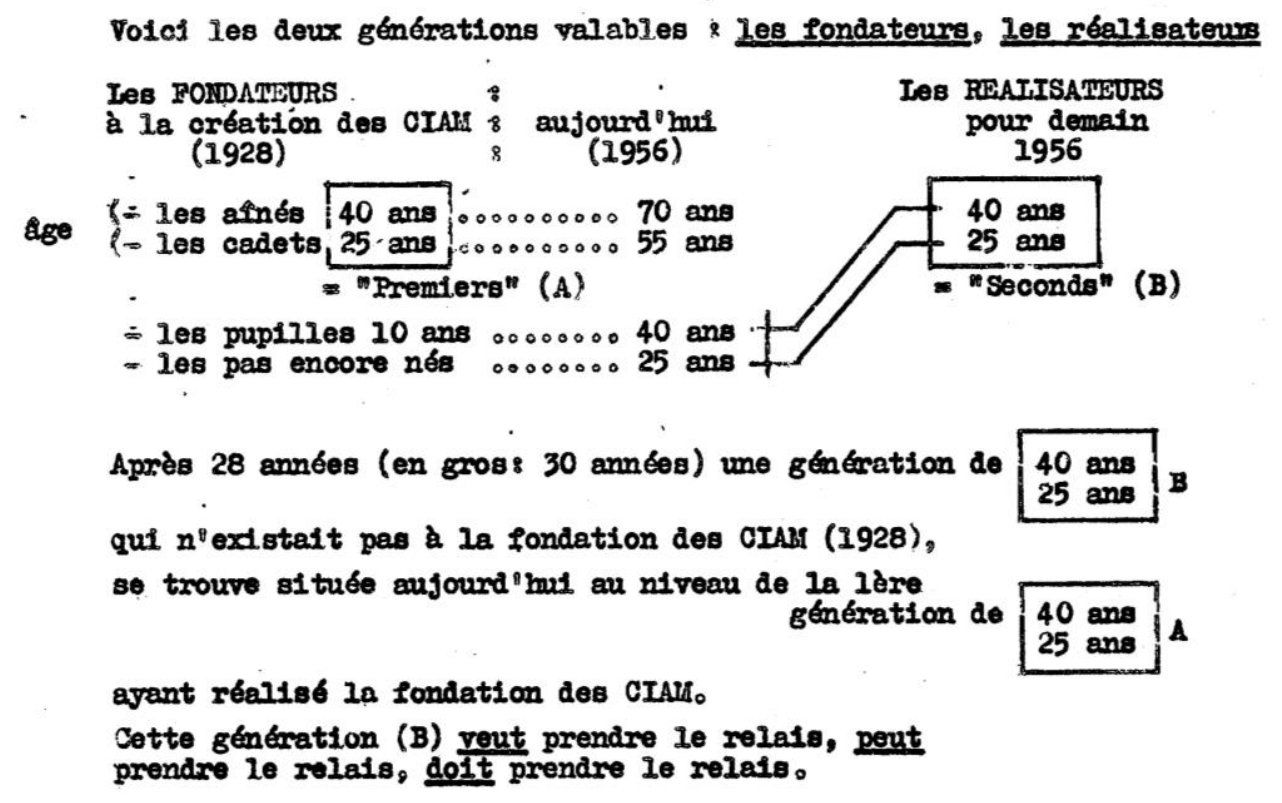

4. Fragmento del mensaje de Le Corbusier. OFLC-ADAGP

En la primera parte (Fig4) Le Corbusier resume el problema actual como un problema de generaciones: la de los fundadores, que son aquellos que en la fundación tenían 40-25 años (CIAM Premier); y la de los "realisateurs" que tienen ahora esa misma edad (CIAM Seconds). Es el momento de la nueva generación, que "veut prendre le relais, peur prende le relais, doit prende le relais". Le Corbusier no quiere eclipsarlos con su figura, “c'est pour cela que je ne suis pas à Dubrovnik", ya que la primera generación está "hors de l'ambiance de l'époque présente" mientras que la segunda generación se encuentra "ainsi en plein coeur de l'èpoque présente" $\mathrm{y}$ entiende los problemas actuales de la arquitectura. "Leus prédécesseurs n'y sont plus, ils en sont sortis, ils se trouvent hors des coups directs de la conjoncture".

En la segunda parte reitera el logro histórico de "les CIAM-PREMIERS", que han aportado "un programme cohérent du domaine bati, une doctrine" para que los CIAM Seconds la utilicen: las cuatro funciones (habitation, travail, loisirs y transport) y un método que tiene que ver con la estandarización y la normalización. Han instituido los CIAM, han enunciado los problemas de la arquitectura y el urbanismo, y han preparado la Carta de Atenas obteniendo reconocimiento mundial. La tarea de la segunda generación es "d'harmonisation", y esa armonización (habitat) se apoya sobre las ideas de los fundadores. 
1956. "Les CIAff=SECONDS" prennent te relais。

Deux graphiques valables peuvent résumer mon exposé :

Ier graphique :

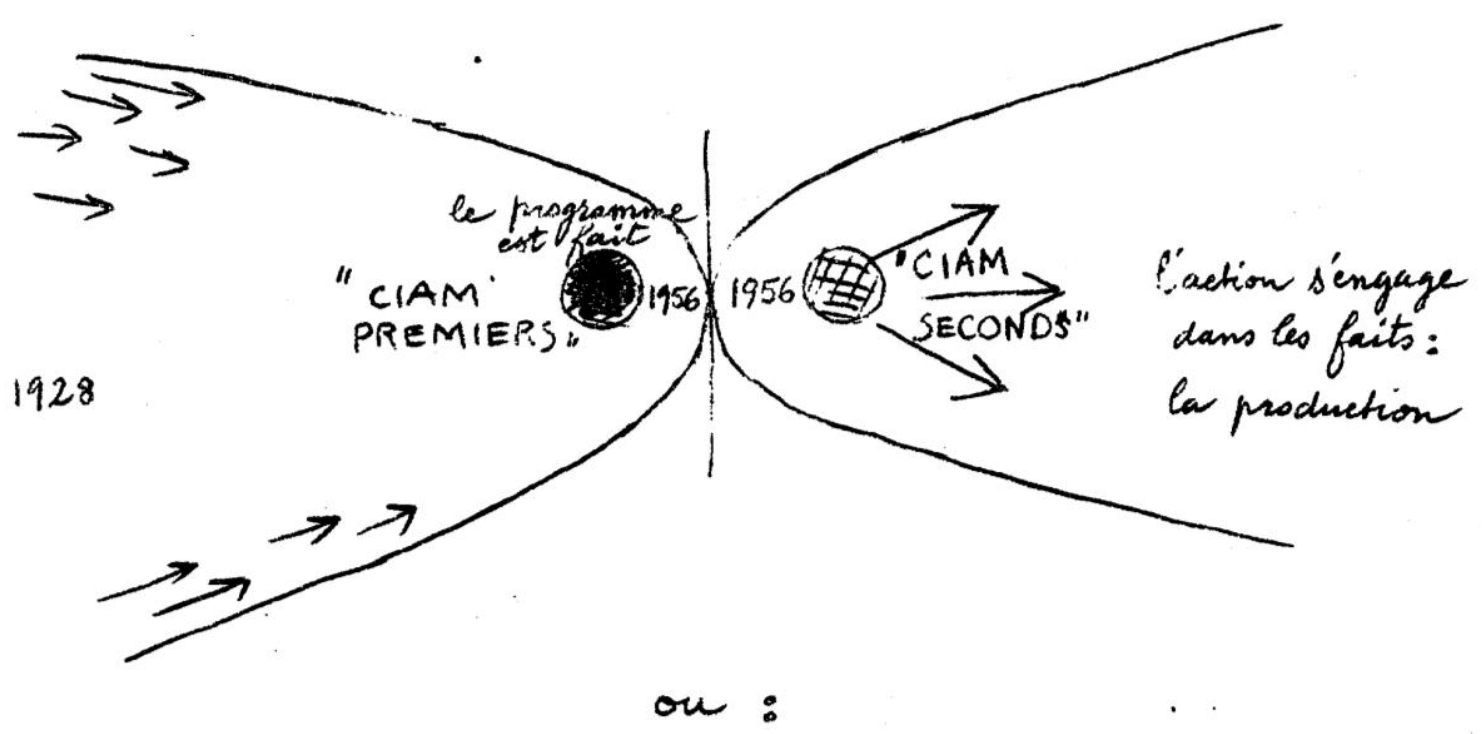

5. Fragmento del mensaje de Le Corbusier. CFLC-ADAGP

La tercera parte se resume en dos gráficos (Fig 5 y 6 ). En ellos Le Corbusier representa por primera vez de forma explícita el momento de inflexión en el que se encuentran los CIAM, demostrando que entiende la importancia de Dubrovnik. En el primer dibujo retoma la idea ya expresada: la primera generación construyó el programa y ahora la segunda generación debe demostrar con sus acciones (su tarea es la producción). En el segundo especifica: una doctrina de los CIAM Premiers que viene de lo social, la economía y la técnica (pone orden a la confusión), y una acción de los CIAM Seconds que buscará la armonización en esos mismos términos. 

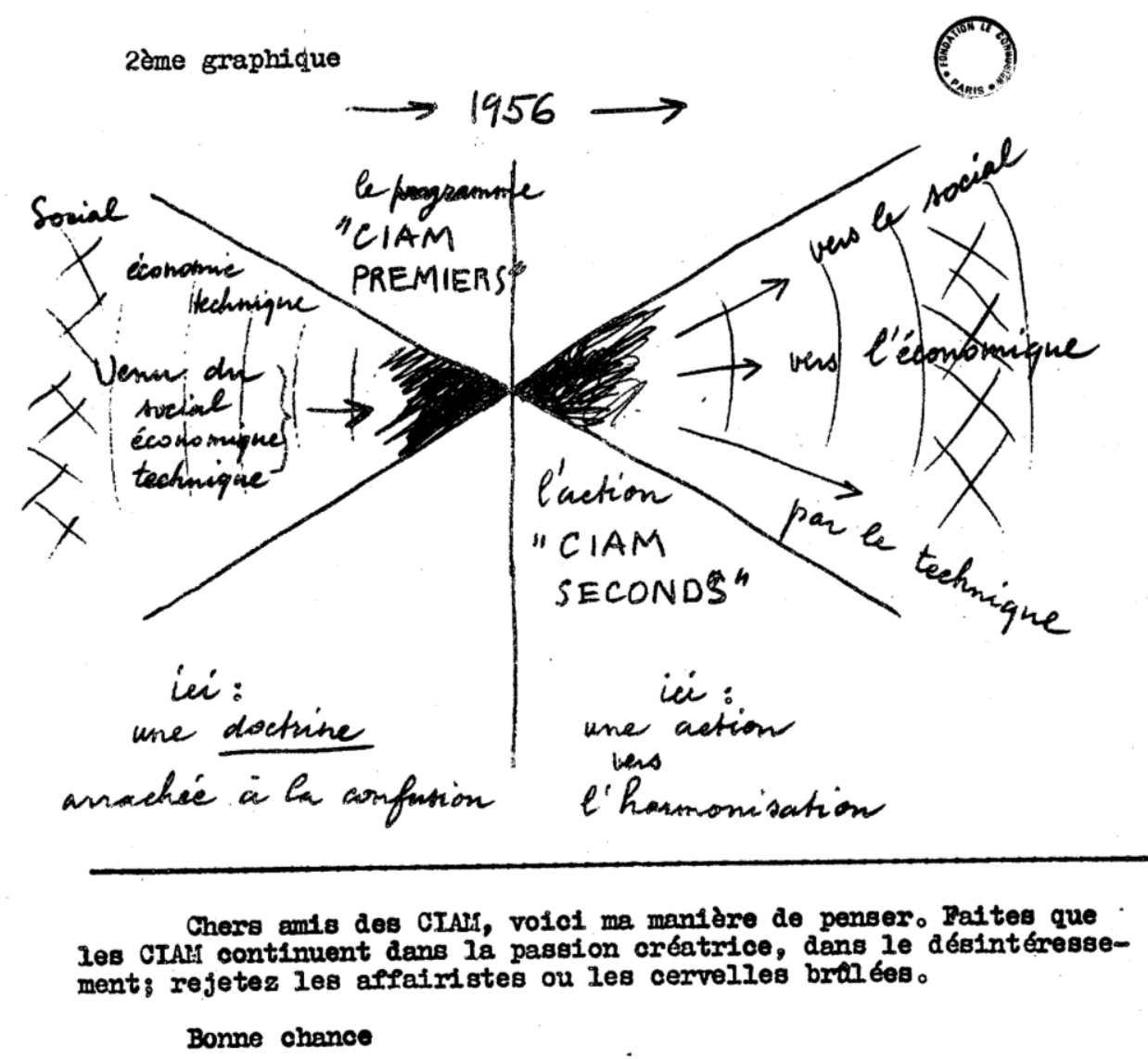

Vivent les CIAHR-SECONDS !

6. Fragmento del mensaje de Le Corbusier @FLC-ADAGP

El mensaje termina. "Chers amis des CIAM, voici ma manière de penser. Faites que les CIAM continuent dans la passion créatrice, dans le désintéressement; rejetez les affairistes ou les cervelles brulées. Bonne chance. Vivent les CIAM-SECONDS!". Le Corbusier no pretende comprender todas las propuestas de los jóvenes pero entiende lo fundamental: la importancia de armonizar, relacionar las funciones entre sí para construir una arquitectura y un urbanismo más solidarios, pero sobre todo que es el momento de dejar que construyan su camino.

En el anexo, Le Corbusier insiste en la necesidad de elaborar una carta del Habitat que debe ser tarea exclusiva de los CIAM Premiers y pide a los presentes que eviten la discusión en torno a las generaciones: "Chers amis, cessez cette controverse, je vous en supplie". Le Corbusier es el primero de los fundadores en apoyar a los jeunes, y su mensaje, junto a la renuncia de su papel principal en los congresos, desemboca en la asamblea en Dubrovnik en la que se decide el proceso de reorganización de los CIAM. A partir de este momento el papel de Le Corbusier será oficialmente secundario, aunque seguirá manteniendo correspondencia con miembros del Team10. No volverá a tomar parte en las reuniones. 


\section{La reorganización de los CIAM: "batalla" en Otterlo}

La asamblea general tras el congreso de Dubrovnik, el 10 de agosto de $1956^{41}$, acuerda la reorganización total de los CIAM en los términos planteados por Le Corbusier y encarga la tarea a Bakema, Emery, Howell, Rogers, Roth, Smithson y Woods. En enero se disolverían los grupos y los CIAM volverían a estar compuestos por individuos. Se envía un cuestionario a todos los delegados para que propongan a 30 individuos que formarán los CIAM. Muy pocos delegados responden al cuestionario, entre ellos Le Corbusier ${ }^{42}$. Giedion sugiere ${ }^{43}$ que se utilice otro nombre para la nueva etapa de los CIAM, pues es la única manera de conseguir una verdadera renovación.

También responde Bakema ${ }^{44}$ en nombre del Dutch Group, Candilis y Woods, que aprovecha para hacer una serie de propuestas. Cree que una organización como CIAM carece de sentido si los miembros no admiten que hay problemas imposibles de solucionar individualmente, y que los principios de la arquitectura moderna no se pueden desarrollar sin reconocer su relación con el "total human habitat" (diagrama de Geddes). Hace falta reconocer en el mismo proceso la investigación, el diseño, el uso, la realización y la eliminación. "Recognition of the totalness of this process can result in an architecture called total arquitecture as a further step to the expression of full life; life which is substituting the work 'to possess' by the word 'to use"'. Cree que los grupos deben tener especialistas de todo tipo y el contacto debe ser entre individuos. Las reuniones deben realizarse siempre en lugares en los que se puede visitar obras construidas (esta será una de las premisas de las reuniones del Team10). Sert, Gropius, Giedion y Tyrwhitt ${ }^{45}$, en su carta conjunta, proponen a Bakema como presidente del nuevo CIAM.

En el grupo inglés se han sucedido una serie de acontecimientos. Según P. Smithson ${ }^{46}$, el resultado más positivo del décimo congreso es que los miembros han empezado a dudar de la existencia de los CIAM. En Inglaterra supuso la disolución del Mars Group, y la posibilidad de construir un nuevo sistema de contactos desde cero sin arrastrar acuerdos pasados. En una carta a Bakema y Woods ${ }^{47}$, Smithson va un paso más allá afirmando que se opone completamente a la elección de 30 miembros sin que se decida en un congreso quién tiene el espíritu para formar parte de la nueva organización. En una carta el 9 de Diciembre ${ }^{48}$ al consejo de los CIAM, Alison y Peter Smithson se muestran claros en su postura: "We must make a complete break with the name CIAM". En su opinión el nombre representa una estética que está acabada y aunque creen en el objetivo de la organización, no creen en sus métodos (pensamiento diagramático, planeamientos cartesianos, propiedad pública del suelo...)

\footnotetext{
${ }^{41}$ Al finalizar CIAMX se reúne la asamblea como había sugerido Le Corbusier. En el documento hay una anotación a mano de Le Corbusier: "y mai pas sur le nom CIAM!". Puede que el nuevo CIAM no se llame CIAM, uno de los temas de mayor discusión durante el proceso de reorganización.

(FLC D3-19 67-68)

${ }^{42}$ (FLC D3-19 72-73)

${ }^{43}$ Carta de Giedion a P. Emery 24/12/1956.

"les groupes ont perdu l'intérêt et l'initiative", "il faut faire une nouvelle sélection très sévère, expulser sans compromis les membres inactifs et devenir de nouveau humble et restraint en nombre", "Corbu, Sert et moi ont demandé que la continuation des CIAM devait avoir soit un nouveau nom" (FLC D3-19 74-75)

${ }^{44}$ (FLC D3-19 81-83)

${ }^{45}$ (FLC D3-19 86-87)

46 (ET10 71-72)

47 (ET10 74)

${ }^{48}($ ET10 75-76)
} 
"It would be better to make CIAM history and start a new group". Frente al "CIAM de los 30" opinan que a cada reunión debe asistir un grupo de personas distinto.

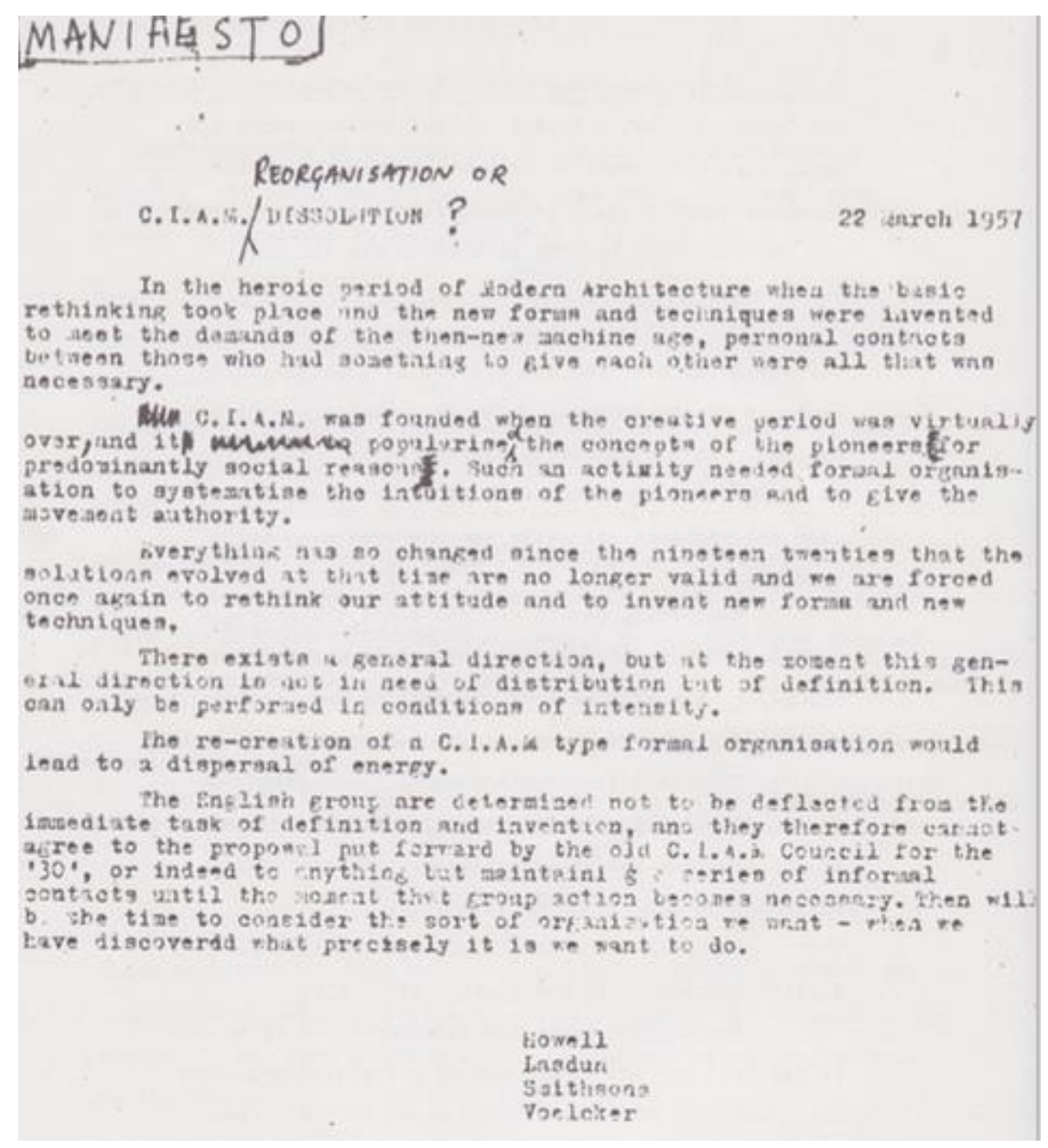

\section{CIAM Dissolution (ET10 77) OFLC-ADAGP}

Los comentarios son ignorados y los Smithson elaboran un documento titulado CIAM Dissolution (Fig7) en el que concretan su punto de vista: "the English group are determined not to be deflected from the immediate task of definition and invention, and they cannot agree to the proposals by the old CIAM Council, or indeed to anything but maintaining a series of informal contacts". El documento es firmado también por Howell, Lasdun y Voelcker ${ }^{49}$ pero fue elaborado por los Smithson como demuestran las distintas versiones.

En paralelo se suceden las propuestas de Bakema que queda en una posición intermedia ${ }^{50}$ y prefiere un enfoque constructivo, similar al de Candilis-Woods ${ }^{51}$ y Soltan $^{52}$. Sin embargo, la actitud destructiva de los ingleses

\footnotetext{
49 (ET10 78) (FLC D-3-19 118)

${ }^{50}$ Propone la organización de una reunión para tratar la disolución. Resume los puntos de vista: continuar; disolver y crear una red para contactos informales; o reorganizar (lista 30 miembros). Bakema apuesta por continuar con un espíritu de investigación e imaginación.
}

(FLC D3-19 106-107) 
provoca una respuesta contundente. En mayo de 1957, Sert, Gropius, Giedion y Tyrwhitt envían una carta a Le Corbusier $^{53}$ avisando de que circulan documentos que hablan de la disolución de los CIAM. Según su versión, en Dubrovnik se votó cómo sería el nuevo CIAM por amplia mayoría. "The persons who have made this statement may have forgotten this, though some were elected to the Reorganization' Committee". Saben que es tiempo para un cambio, pero creen que no se puede mantener una actitud destructiva cuando han tomado responsabilidades. "It is not a question of abandoning the old, but of supplementing and transcending it".

Cuando Bakema pide más tiempo para desarrollar las ideas del grupo y decidir la reorganización, el consejo responde enfadado: "the Reorganization Commitee has not carried out the committments",54, y sugieren una reunión para decidir el futuro de los CIAM que se celebrará en la Sarraz. Otros, como P. Emery, señalan directamente a Peter Smithson ${ }^{55}$ como el causante de la disputa y expresan su molestia por la intención destructiva de los ingleses que sin tener en cuenta la decisión mayoritaria en Dubrovnik dan publicidad a ideas desestimadas.

\section{La Sarraz 1957: “C'est bien!”}

En septiembre se celebra en La Sarraz una reunión para aclarar las distintas opiniones que se habían hecho públicas. Los Smithson, por carta $^{56}$, renuncian a asistir a la reunión para expresar su enfado: "one can only recreate what one loves by repudiating it". Adjuntan una propuesta en la que ya no hablan de disolución (cambian de idea gracias a Bakema) pero siguen rechazando la elección de 30 miembros. Proponen un nuevo nombre: CICON (CIam CONtinuity).

En La Sarraz ${ }^{57}$ se disuelven definitivamente los grupos. Como apuntaba Le Corbusier (y los jóvenes desde Doorn), era necesario restringir los CIAM a aquellos miembros que fueran activos. Se nombra un nuevo comité en el que se sustituye a Smithson y Howell por Voelcker y se adopta un nuevo nombre, "CIAM: Research Group for Social and Visual Relationships", en sintonía con las ideas del Dutch Group. La tarea del comité es designar los nuevos participantes en base a las recomendaciones de los grupos y organizar el próximo congreso en el que se decidirá el rumbo que toman los CIAM.

\footnotetext{
${ }^{51}$ CIAM no pude seguir siendo patrimonio de Le Corbusier, Giedion, Gropius... La tarea no consiste en distribuir las responsabilidades sino en hablar sobre los nuevos problemas y buscar soluciones. No importa el nombre sino la unión bajo el espíritu adecuado. "Dans tout les cas, nous continuerons à travailler dans l'esprit des CIAM, avec ou sans organisations". (FLC D3-19 122-124)

${ }^{52}$ Afirma que el nombre de la organización no tiene importancia. Pero una organización en la linea de CIAM debe existir para garantizar el contacto de arquitectos de todos los lugares.

(FLC D3-19 117)

53 (FLC D3-19 96-98)

${ }^{54}$ Carta de Giedion, Sert, Gropius y Tyrwhitt (FLC D3-19 100)

${ }^{55}$ P. Emery a Bakema el 25/06/1957

"Les réponses sont parfaitement encourageantes, à l'exception d'une seule, celle de SMITHSON qui, bien que membre du Comité, et ayant accepté les décisions de Dubrovnik, revient sur toutes ces décisions, et demande la dissolution". "Je pense que es faisant, HOWELL, LASDUN, SMITHSON et VOELCKER perdent toute qualité pour discuter de l'avenir des CIAM car on ne peut charger quelqu'un de crééer ou de protéger ce qu'il a formellement l'intention de détruire".

(FLC D3-19 101-103)

${ }^{56}$ (ET10 80-81)

${ }^{57}$ (FLC D3-19 125-127)
} 
Un mes después Bakema pide ${ }^{58}$ a todos los delegados que envíen la lista de nombres. En la carta menciona los objetivos del nuevo CIAM: la necesidad de desarrollar el arte de vivir (término que atribuye a Le Corbusier en carta de 1953) pues todas las actividades humanas se realizan en espacios; la importancia de introducir la arquitectura y el urbanismo como elementos activos dentro de la sociedad y la relación entre las funciones. La carta aparece anotada a mano por Le Corbusier (“C'est bien!") y él mismo contestará personalmente a Bakema $^{59}$. A partir de este momento Bakema informaría directamente a Le Corbusier con copias de los documentos anotadas ${ }^{60}$. Le Corbusier y el Team10 quedan así unidos (Fig8).

Le Corbusier a Bakema ${ }^{61}$ :

Merci de vos 'Directives pour la...

Tout cela me parait très bien. Il faut que la vie passe avant tout et les feuilles du printemps s'ouvrent devant les feuilles de l'automne de l'année précédente qui se replient tranquillement et parfois tombent,

Bon courage! et amicalement à vous

Anotación de Bakema en respuesta ${ }^{62}$ :

Merci pour votre encouragement poétique. J'espère que l'arbre que s'appelle Le Corbusier restera fort enfin que ses feuilles donneront encore longtemps beaucoup de protection.

Merci Jeanneret

Tras la reunión en La Sarraz el comité se vuelca en su tarea de organizar el congreso, que será celebrado en Otterlo en septiembre de 1959. Finalmente se amplía el número de invitados a 50 (Le Corbusier rechaza la invitación) y se propone que las discusiones filosóficas y abstractas se eviten. El congreso se basará en el análisis de proyectos construidos ${ }^{63}$. El objetivo de la reunión de Otterlo es descubrir si existen unas ideas comunes a los participantes y decidir la continuidad de los CIAM. El tema propuesto está en completa sintonía con el Team10: la manera de organizar las relaciones entre el hombre y su entorno físico, unas relaciones que no son estáticas, sino que están sujetas a la evolución perpetua y el crecimiento continuo de los individuos. Si existe afinidad en este punto, CIAM podrá continuar. En el último documento oficial previo a Otterlo encontramos un párrafo que ilustra la concepción de la arquitectura de los miembros del comité (Fig9)

\footnotetext{
58 (FLC D3-19 128-129)

59 "J'ai reçu votre document CIAM du 22 octobre 1957 et je l'ai annoté: C'est bien!. Amicalement à vous" (FLC D3-19 130)

${ }^{60}$ Son numerosas los mensajes a Le Corbusier en notas a mano (FLC D3-19 132, 138)

${ }^{61}$ (FLC D3-19 145)

62 (FLC D3-19 146)

${ }^{63}$ (FLC D3-19 132-137)
} 


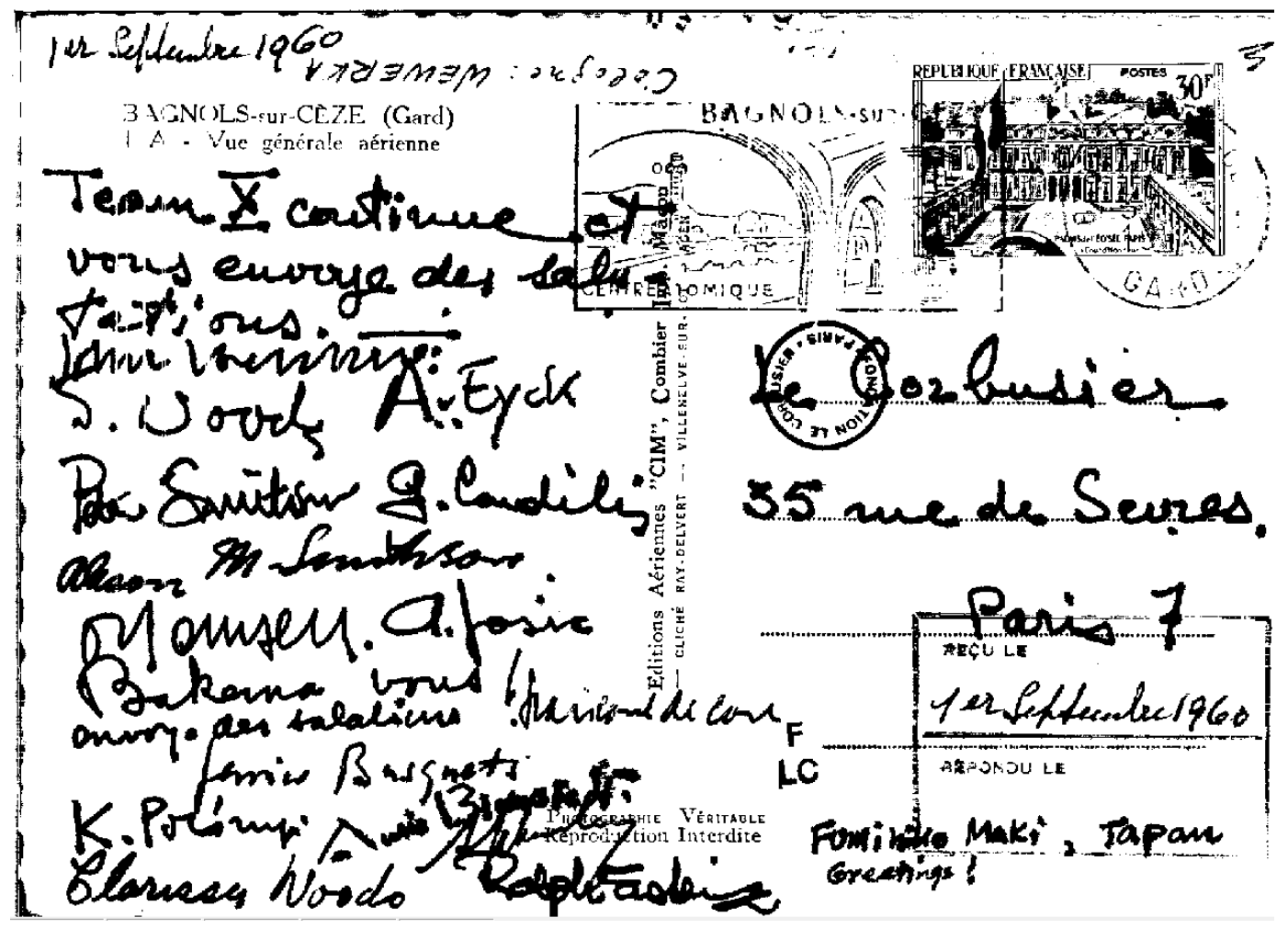

8. Postal de TeamX a Le Corbusier. (FLC D3-19 171-172) CFLC-ADAGP

2. That together with an explanation of their particular work, authors should give their general opinions on the present position of architecture and planning. Each author skould describe the factors which he considers to be fundamental Each author skould describe he is working. The co-ordinating group considers to the circumstances in which he is working. Tuthor could indicate how the it would be valuable if, in addition, each author could indicate how the itive annetion between people and their surroundings.

itive passive, (the new towns, restrictive legislation etc.) or are used irresponepassive, (the now towns, resing style etc.), at the present time. The force ils (stalin of architecture and and and bread.

If architects are no longer able to act through their building, their identity will be lost, they will become: industrial designers, decorators etc. Architecture should be life-enhancing.

3. That, if some affinity of approach is apparent at Otterlo, the co-ordinating group suggests that C.I.A.M. should become a simple centre for the exchange of ideas and research in architecture and planning.

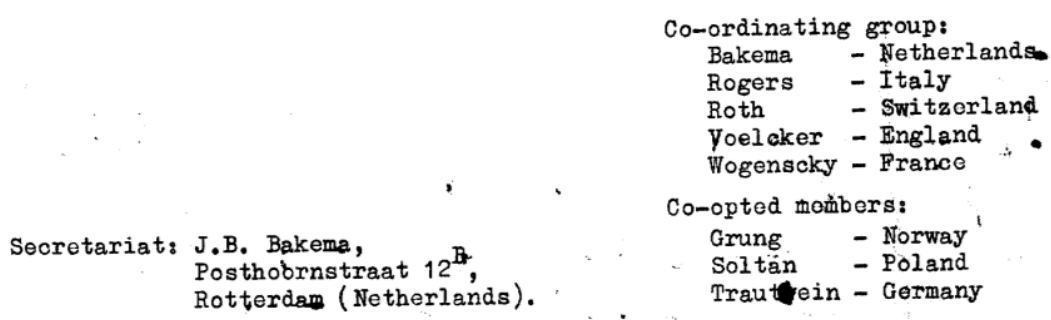




\section{La disolución de los CIAM: "pris la decision dans l'esprit de La Sarraz"}

Tras meses de preparación se celebra el primer congreso con la participación exclusiva de los jóvenes. Días antes Le Corbusier envía un telegrama (Fig10) a Bakema y le insta a tomar la decisión sobre el futuro de CIAM en el espíritu de la Sarraz (1928).

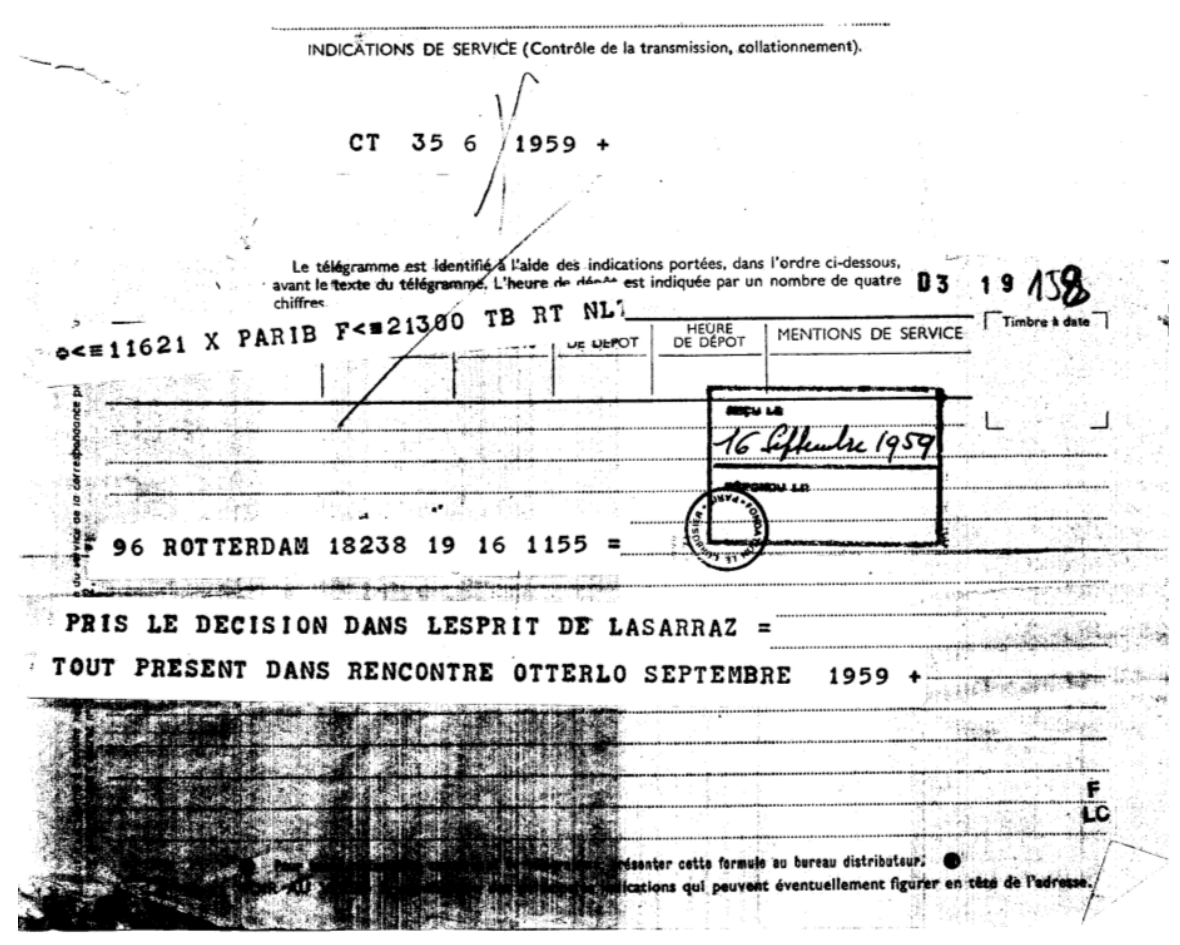

10. Telegrama de Le Corbusier a Bakema. (FLC D3-19 158) @FLC-ADAGP

Aunque podría pensarse que la disolución de los CIAM (Fig11) que se firmaría el último día del congreso fue un acto de "traición" de los jóvenes, la decisión se toma dans l'esprit de la Sarraz: construir a través de la unión de individuos un nuevo pensamiento para solucionar los problemas de la arquitectura. En el resumen de la reunión ${ }^{64}$ se constata la existencia de dos maneras de trabajar dentro de CIAM: una que se puede describir neutral y en la linea de las propuestas de CIAM desde 1928, y otra que puede considerarse agresiva, que intenta trabajar con cualidades individuales y sociales para desarrollar un nuevo lenguaje coherente con el comportamiento humano (la mayoría elaborados por miembros del Team10). Debido a la falta de coherencia en los planteamientos, se decide que "the name of CIAM will be used no more in relation to future activities of the participants", pero se constata el deseo de comparar el resultado de las actividades futuras y se crea el Post Box for the development of the Habitat del que se encarga Bakema (Fig12).

${ }^{64}$ (FLC D3-19 159-160) 


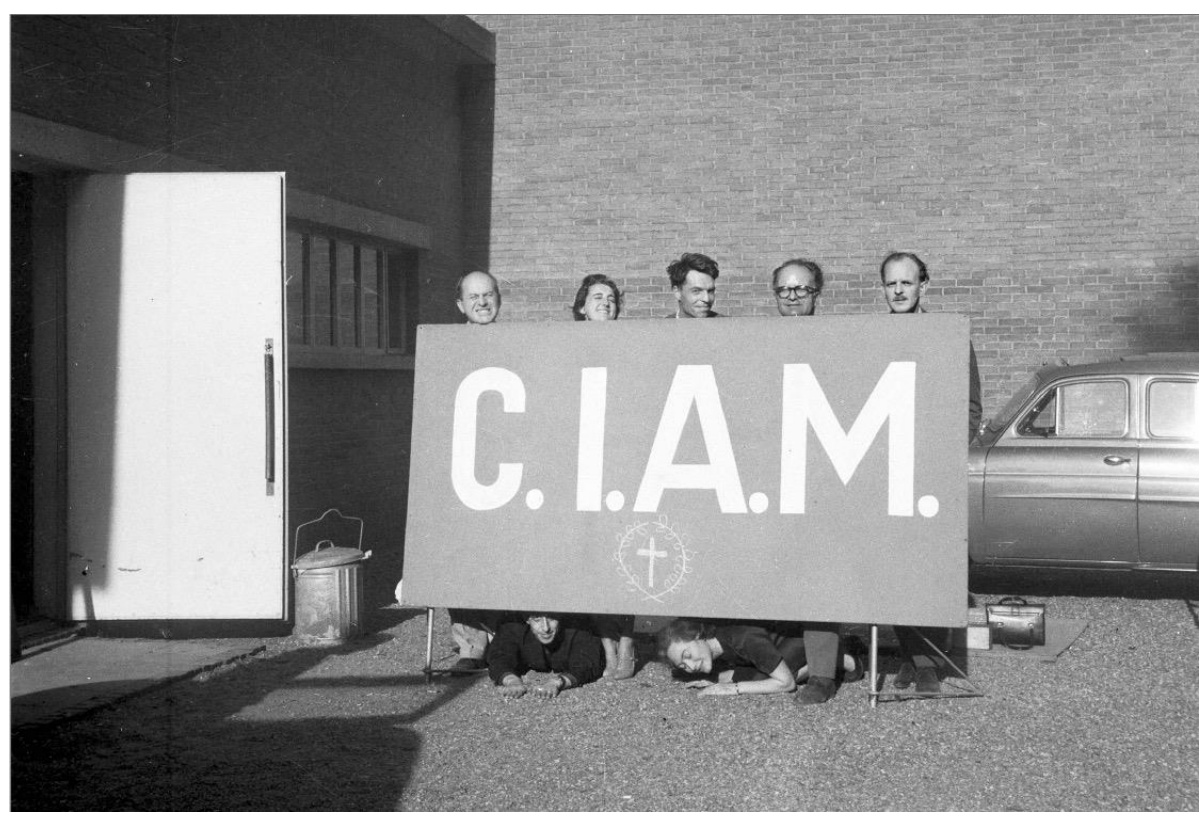

11. Fotografía de CIAM Otterlo. Alison und Peter Smithson Archiv Nederlands Architectuurinstituut

Esta decisión en ningún momento implica un rechazo de la tarea previa de los CIAM que en el mismo documento alaban. De hecho, la decisión implica simplemente asumir que la organización llamada CIAM ya no es útil para desarrollar la idea de habitat, pero los individuos del Team10 seguirán trabajando con el mismo espíritu. Habría que preguntarse si la decisión de romper con los CIAM no responde al afán de protagonismo de algunos participantes.

Now, I make the next propositions:

1. If you are confrontated with problems concerning Habitat and you like to confrontate them with other colleaques, who are working in research spirit, you send me plans, text and photos concerning this problem.

2. I shall prepare a folded illustrated communication paper with summeries of this information.

3. After a period there will be a meeting of those whorgve information, organized by themselves.

4. The name of thiscrichange centre will be :

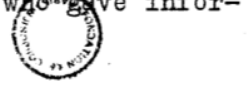

Post Box for the development of Habitat.(B.P.H.)

Borte Postale pour le developpement de l'Habitat.(B.P.H.)

Briefkasten für die Entwicklung von Habitat.(B.P.H.)

5. The aim will be to develop architecture and townplanning towards a language which can communicate about humain behaviour.

$$
\begin{aligned}
& \text { B.P.H. } \text { 20th. of September } \\
& \text { Rotterdam } \\
& \text { Posthoornstraat } 12^{B} \\
& \text { J.B. Bakema }
\end{aligned}
$$

12. Fragmento del comunicado que anunciaba la disolución (FLC D3-19 162) CFLC-ADAGP 


\section{Team 10: "To be alone, to be together"}

La ruptura de los CIAM no está exenta de polémica. En agosto de $1960^{65}$, tras la reunión en Otterlo, Giedion envía una carta a Le Corbusier firmada por Sert, Gropius, y Giedion. Comienza narrando la fundación de los CIAM y enumerando sus logros, pues los jóvenes estaban siendo muy injustos y no estaban agradeciendo el trabajo de los fundadores. Según su versión los fundadores decidieron apartarse en Aix para pasar el relevo a los jóvenes. Allí se presentaron varias posibilidades: abrir una nueva página, como proponía Le Corbusier (CIAM Seconds), o eliminar los CIAM como proponía Giedion. Se decidió por unanimidad continuar por insistencia del Team10. En Otterlo un grupo minoritario entregó a la prensa un comunicado en nombre de los CIAM (Fig10) en el que se decidía disolverlos sin haberlo discutido en común, por lo que no podía considerarse un consenso de la organización. "Repeated attacks on the leadership and policies of the previos CIAM" han causado esta ruptura. Aún así CIAM ya ha cumplido su tarea y depende de los jóvenes presentar una plataforma constructiva que siga atrayendo a arquitectos de todo el mundo.

Ante el silencio de Le Corbusier, Giedion vuelve a escribirle ${ }^{66}$ para publicar la carta con su nombre. Le Corbusier contestará finalmente con ironía y enfado, pues cree que los jóvenes han tomado la decisión correcta (Fig13). Aún así, la carta de Giedion/Sert/Gropius se publicará bajo la firma de Le Corbusier.

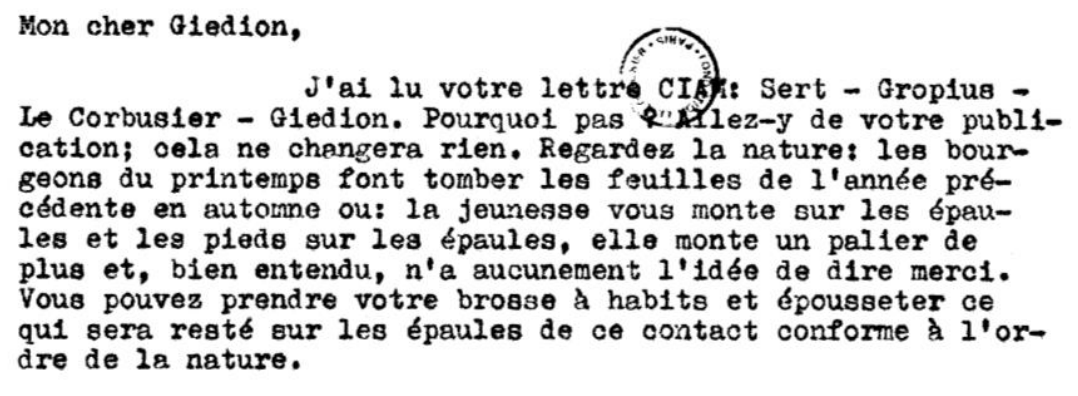

Bien cordialement à vous.

\section{LE CORBUSIER}

13. Respuesta de Le Corbusier a la carta de Giedion. (FLC D3-19 177) @FLC-ADAGP

Dolido por la misiva, Bakema contesta. El comunicado de Otterlo fue aceptado por todos los participantes en una discusión abierta la última jornada del congreso. En su opinión, aunque fuera cierto que Team10 anunció la disolución, no habría sido posible mientras quedasen miembros que quisieran continuar. Se decidió dejar de usar el nombre CIAM porque los objetivos de 1960 no son los mismos que los de 1920, y el nuevo nombre se elegirá

\footnotetext{
65 "there was an organized opposition against any positive statements about reorganization and continuity by a small group (Team10) whose basis attitude was negative" (FLC D3-19 172-175)

66 "Si vous ne répondez pas dans une quinzaine de jours, nous prenons la liberté de publier la lettre avec votre signature" (FLC D3-19 176)
} 
cuando los nuevos objetivos hayan sido definidos. En la copia que Bakema envía a Le Corbusier ${ }^{67}$, escribe una anotación a mano:

La vérité d' Otterlo n'est pas dans la lettre circulaire de Giedion.

Je crois qu'avec cette lettre l'histoire CIAM est compromis. Jamais une organisation ne peut faire de l'architecture. C'est l'architecture qui organise.

Bak

Para Bakema el Team10 no sustituye a los CIAM, sino que es uno de los grupos que decide trabajar de manera independiente, "perhaps others will follow". Si los CIAM deben o no continuar es una pregunta que deben hacerse sus miembros, y la decisión del Team10 no tiene nada que ver con su disolución, sino con la informalidad fundamental para su concepción como grupo creativo. Van Eyck y Bakema son tajantes ${ }^{68}$ :

The social responsibility which characterized the activities of CIAM's first years, formed its specific morality, but faded as the years went on. What had characterized CIAM in the beginning was all but lost. This fact was reflected in CIAM's static institutional form, in its arbitrary commissions and method of study...

We believe in architecture which can express human feelings of all kind.

To be alone, to be together, with technic, without tecnhic, under the trees, over the trees, on a hill or in a valley, to be child, to be old, above and below, soft and hard.

There is no hierarchy.

Our urban districts could surprise and stimulate again if the hidden potency of our new social structure (open society) should be expressed by building.

The architect would be indispensable again and architecture could be a function realizing everybody's right to full life.

Quizás no fuera tal la ruptura. Puede que en realidad siempre buscasen recuperar el espíritu de los primeros CIAM, y que la única forma fuera romper con una organización que se había vuelto dogmática y se había visto excesivamente jerarquizada. Con estas palabras comienza el camino del Team10 en solitario, en total sintonía con los primeros CIAM.

\footnotetext{
${ }^{67}$ Circular de Postbox (FLC D3-19 178-181)

${ }^{68}$ Extracto de circular: "Les informations du rencontre Otterloo données para un document, si que par vous. Gropius, Giedion, Sert ne sont pas juste"

(FLC D3-19 182-183)
} 


\section{El último mensaje de Le Corbusier}

El 5 de enero de 1961 los jóvenes publican el TeamX Statement, en el que rompen por completo con los CIAM y expresan su gratitud a los que han mantenido tantos años la plataforma. "Nous continuerons nos recherches et espérons de confronter les résultats avec les travaux des autres" ${ }^{69}$, dice Bakema a Le Corbusier.

Le Corbusier, generoso, enviará las últimas palabras de apoyo al grupo (Fig14), que serán muy bien recibidas y agradecidas por Bakema (Fig15).
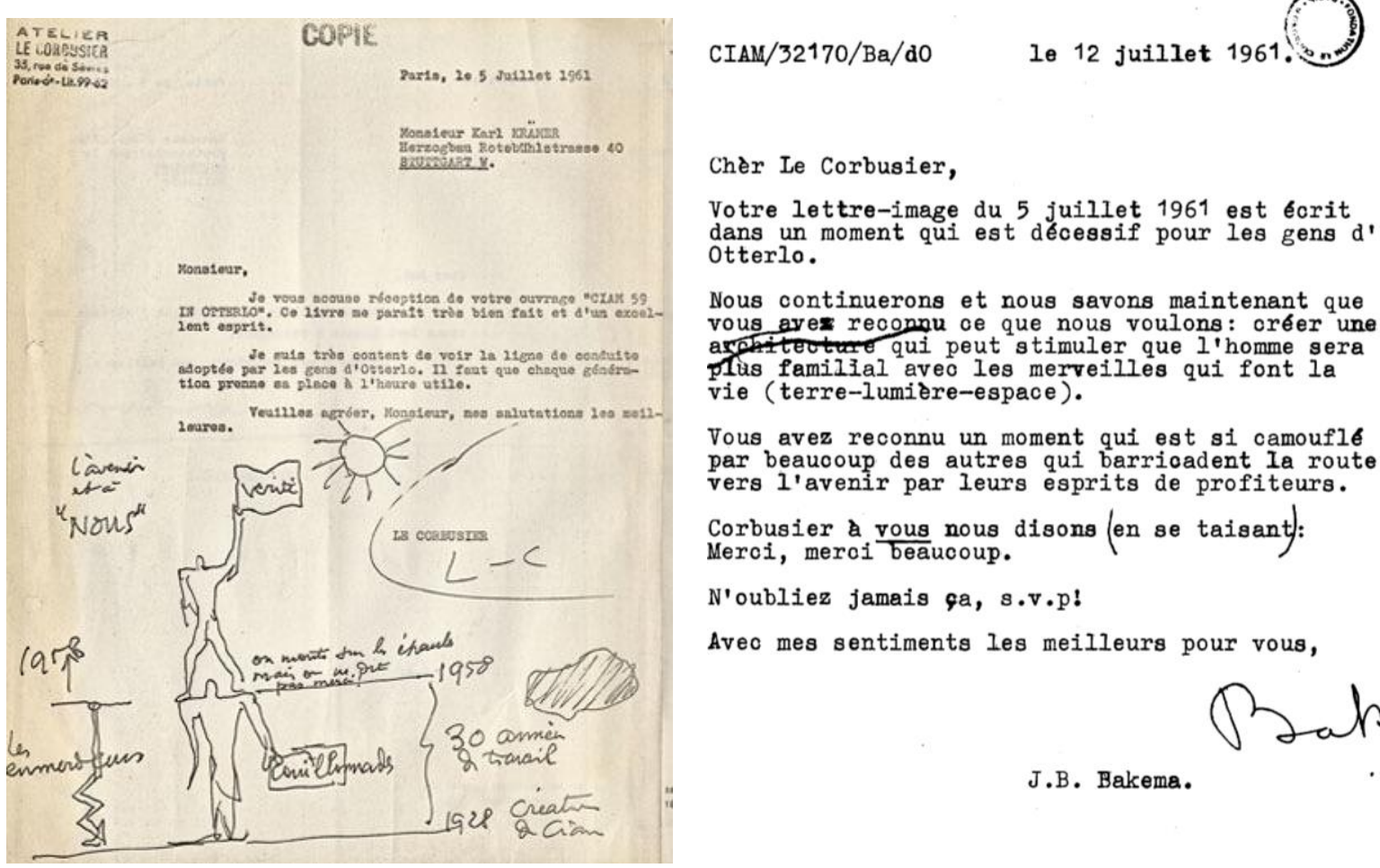

14. Dibujo de Le Corbusier enviado a Bakema. (FLC D3-19 186) CFLC-ADAGP

15. Agradecimiento de Bakema a Le Corbusier. (FLC D3-19 190) CFLC-ADAGP

Todos estos contactos a lo largo del tiempo muestran el importante papel de Le Corbusier en el nacimiento del Team 10, bien sea como espectador pasivo o como incitador de unas ideas menos dogmáticas; aunque finalmente fuera la inmovilidad de la segunda generación la que produjo la ruptura. Sin embargo, Aldo van Eyck recordaba también con admiración los encuentros en el apartamento de Le Corbusier, en los que el maestro participaba activamente conversando y dibujando con tiza y borrador, haciendo de moderador en las discusiones, y señalando, cuando la conversación se estancaba, otros puntos de vista que permitían continuar y enriquecían las conclusiones obtenidas. Bakema nos deja notas y cartas de agradecimiento sincero, y Candilis numerosas muestras de aprecio. Enormemente generoso en su actitud y tan inteligente para apartarse a tiempo y dejar paso a los que tenían la fuerza e ilusión de la juventud, que en su momento él también había tenido. Un preciso acto de identificación y legado.

${ }^{69}$ (FLC D3-19 181) 
En una de las más importantes reuniones del Team 10, en Royaumont 1962, los CIAM Seconds, que habían tomado el relevo, sintetizan en un mensaje a Le Corbusier el agradecimiento de toda una generación: "Nous Continuons, Merci". Ese agradecimiento que no puede expresarse de otra manera, sino únicamente diciendo: gracias, no te defraudaremos (Fig16).

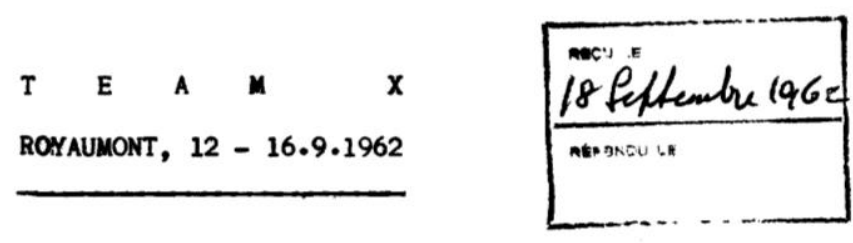

A L'ATTENTION DE M. LE CORBUSIER.-

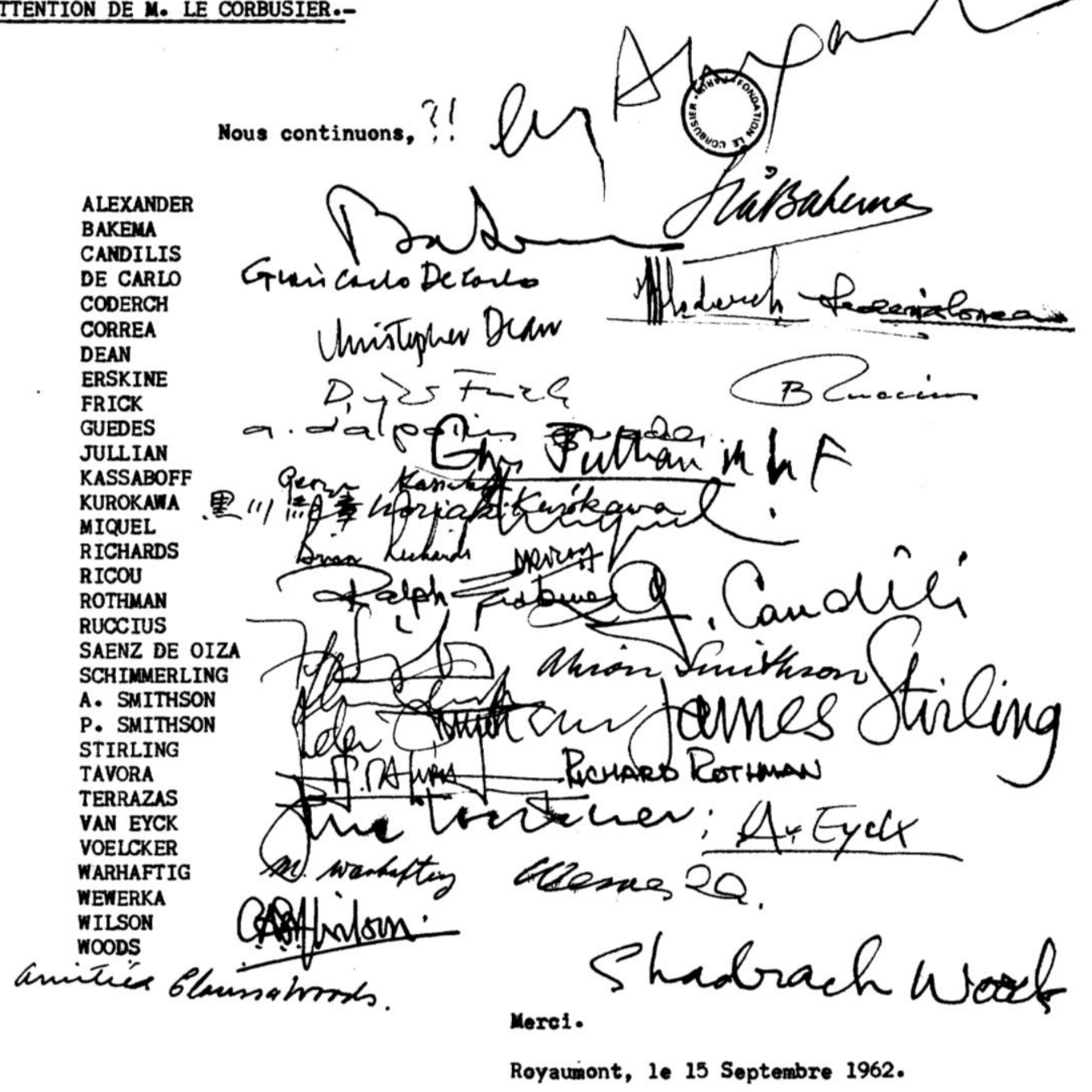

16. Carta de agradecimiento a Le Corbusier. (FLC D3-19 210) OFLC-ADAGP 


\section{Bibliografía}

Archivo: Fondation Le Corbusier, Paris.

Newman, Oscar, CIAM '59 in Otterlo. New York: Universe Books Inc, 1961

Pedret, Annie. CIAM and the emergence of Team 10 thinking 1945-1959. Director: Mark Jarzombek.

Massachusetts Institute of Tecnhology, Department of Architecture, 2001

Risselada, M. and Van den Heuvel, D. Team 10: in search of a Utopia of the present. Netherlands: NAI Publishers, 2006

Roth, Alfred. The New Architecture. Zurich: Les Editions A'Akrchitecture, 1940

Smithson, Alison. Team Ten Meetings, 1953-1981. United States: Rizzoli International Publications, 1991

Smithson, Alison. The Emergence of Team 10 out of CIAM. London: Architectural Association, 1982

Van Eyck, Aldo. Collected Articles and Other Writings 1947-1998. Amsterdam: Vincent Ligtelijn y Francis Strauven, SUN Publishers, 2008 


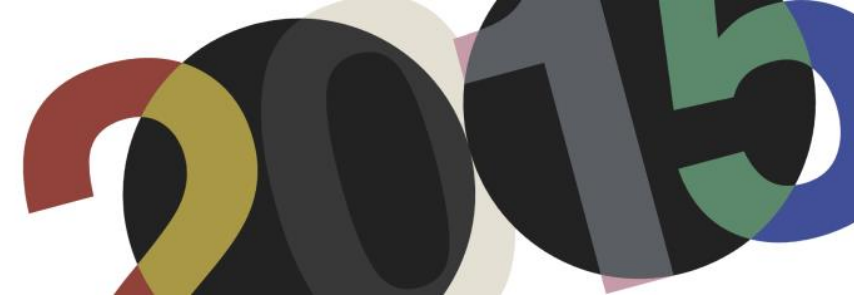

DOI: http://dx.doi.org/10.4995/LC2015.2015.523

\title{
La Villa Savoye. Permanencias y transformaciones
}

\author{
T. Carrau Carbonell
}

Escuela Técnica Superior de Arquitectura de Valencia

\begin{abstract}
Resumen: El Patrimonio del Movimiento Moderno y su conservación es un tema de actualidad, no solo desde el punto de vista teórico sino también desde el práctico, ya que la arquitectura de principios del s.XX lleva tiempo necesitando y asumiendo intervenciones para mantenerlas en pie. Se escoge como tema de estudio la vivienda, como arquetipo estudiado por los grandes del Movimiento Moderno y concretamente la villa Savoye como paradigma del Estilo Internacional. Así, con la investigación de este modelo se pretende sacar conclusiones para la conservación de la herencia de Le Corbusier asegurando su permanencia en las generaciones futuras. Se ha realizado un análisis de la villa Savoye por etapas de tiempo. Cada periodo se ha estudiado a través de unos parámetros comunes, obteniéndose una panorámica de la evolución de los elementos que la forman y de su globalidad. Los resultados de este análisis permiten hacer un estudio comparativo entre la villa original, la villa en sus distintas etapas y el estado actual, precisando qué es lo que realmente queda de la villa de 1930. De esta aportación surgen preguntas y reflexiones: ¿importa la conservación de la materia original en la permanencia de un hito? ¿es aceptable una máquina para habitar que no se puede habitar? ¿qué prevalece: la autenticidad arquitectónica o a la autenticidad histórica en la conservación de las obras de Le Corbusier?
\end{abstract}

Abstract: The Heritage of the Modern Movement and its conservation is a current topic, not only from the theoretical point of view but also from the practical, that is because the early twentieth century architecture has been needing and assuming interventions to keep up. It is chosen as a subject of study the housing, as well studied by the great archetype of the modern movement and specifically the Villa Savoye as a paradigm of the International Style. Thus, the investigation of this model is to draw conclusions for the preservation of the heritage of Le Corbusier ensuring its permanence in future generations. It has conducted an analysis of the Villa Savoye through stages of time. Each period has been studied through common parameters, giving an overview of the evolution of the elements that shape it and its entirety. The results of this analysis can make a comparative study between the original villa, the villa in its different stages and the current status, specifying what really remains of the villa of 1930. This contribution questions and thoughts arise: Does it matter the conservation of the original matter in the permanence of a milestone? Is it acceptable to inhabit a machine that you can not live in? Architectural authenticity prevails against the historical authenticity in the conservation of the works of Le Corbusier?

Palabras clave: Savoye; evolución; permanencia; intervención; patrimonio.

Keywords: Savoye; evolution; permanence; intervention; heritage.

\section{Una caja en el aire}

"La realidad en cuanto tal es desde sí misma constitutivamente abierta (...) Investigar lo que algo es en la realidad es faena inacabable, porque lo real mismo nunca está acabado". Son numerosas las publicaciones que se han realizado sobre la Villa Savoye; desde el inicio de la historia de la villa en 1931 con un artículo publicado en Architecture Vivante ${ }^{2}$, hasta hoy con la recién editada "Les Heures Claires de la Villa Savoye",3 de Jean-

\footnotetext{
${ }^{1}$ Zubiri, Xavier: ¿Qué es investigar?. Discurso en la entrega del Premio Ramon y Cajal. Octubre 1982

${ }^{2}$ Le Corbusier \& Jeanneret. P: "Maison Savoye, Poissy”. En Architecture Vivante vol. 16. Paris: Jean Bodovici, 1931

${ }^{3}$ Savoye, Jean-Marc; Delhomme, Jean-Philippe: Les Heures Claires de la Villa Savoye. Paris: Éditions des Quatre Chemins, 2015
} 
Philippe Delhomme y Jean-Marc Savoye donde se recogen una serie de originales ilustraciones que reflejan la vida de los Savoye en la Villa. Entre tanto, se han sucedido investigaciones en profundidad como la de Josep Quetglas recopilada en "Les Heures Claires. Proyecto y arquitectura en la Villa Savoye de Le Corbusier y Pierre Jeanneret"4 o la de Jacques Sbriglio "Le Corbusier. La Villa Savoye" y muchos otros que han sido imprescindibles en la elaboración del presente trabajo. A pesar de que todos son estudios sobre el mismo objeto, cada uno de ellos arroja nuevas luces sobre la obra de Le Corbusier, temática que resulta una inagotable fuente de conocimiento dada la brillantez del personaje.

La investigación que a continuación se resume tiene como objetivo conocer lo que queda hoy de la villa original y Porqué, descifrando el Qué y el Cómo de las distintas intervenciones y sucesos en ella ocurridos desde su construcción hasta la actualidad. ¿Ha sobrevivido la Villa Savoye a los avatares del tiempo? ¿Sigue existiendo hoy la casa que Le Corbusier proyectó y construyó en Poissy hace más de ocho décadas?

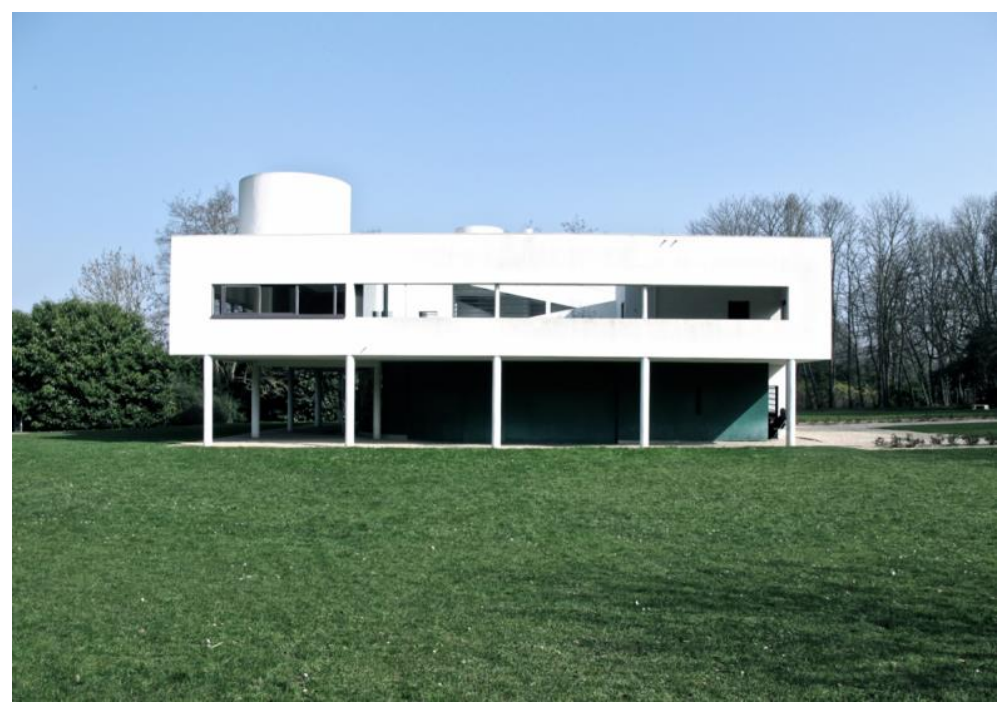

1. Imagen de la villa en 2014. Una caja en el aire.

\section{Evolución retrospectiva}

El análisis de la villa se ha realizado siguiendo una línea del tiempo; desde 1928 hasta 2014. La historia de la villa se ha estudiado por etapas. Cada etapa a través de siete parámetros: los personajes, el tiempo, el emplazamiento, la función, la envolvente, los espacios y recorridos y la materialidad. De este modo se obtiene una trayectoria en el tiempo de los elementos constituyentes de la villa. En cada uno de los periodos se ha recurrido a fuentes de la época que se analiza. Así, en la investigación de la villa de los años 30 ha sido de gran importancia el estudio de textos de Le Corbusier y en etapas posteriores la documentación de testigos de cada época. Una vez se ha pasado cada periodo por el tamiz de los parámetros, se ha hecho un análisis comparativo de los elementos que han pasado por la red, es decir, se han obtenido los elementos de la villa que han permanecido desde su construcción hasta hoy y los elementos que se han transformado, cuando y porqué.

\footnotetext{
${ }^{4}$ Quetglas, Josep: Les Heures Claires. Proyecto y arquitectura en la Villa Savoye de Le Corbusier y Pierre Jeanneret. Sant Cugat del Vallès : Associació d'Idees, Centre d'Investigacions Estètiques, 2008

${ }^{5}$ Sbriglio, Jacques: Le Corbusier. La Villa Savoye. Madrid: Abada editores, 2005
} 


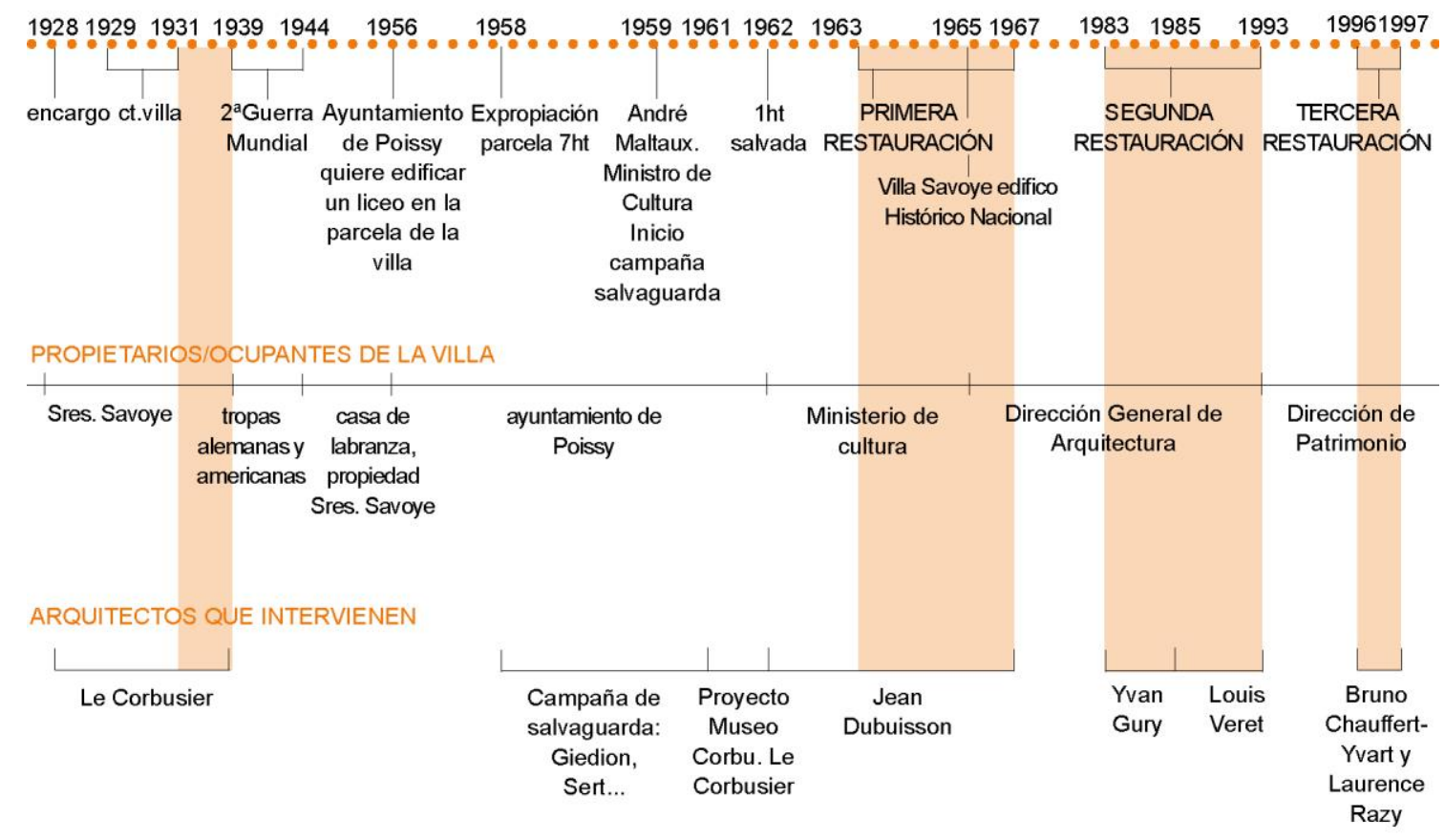

2. Línea del tiempo de la Villa Savoye.

\subsection{Una casa, una historia}

La historia de la villa comienza en 1928, cuando Pierre Savoye, director de una compañía de seguros, y su mujer Eugènie encargan a Le Corbusier una casa donde poder disfrutar los fines de semana lejos del ajetreo de la ciudad, en un amplio terreno a 30 km de París. A continuación, se señalan únicamente los aspectos o parámetros esenciales de cada periodo, necesarios para el entendimiento de su transformación en el tiempo y su estado actual.

\subsubsection{La Villa en 1931}

“La casa es una caja en el aire (...) debajo de la caja, pasando a través de los pilotes llega un camino de coches (...) del interior del vestíbulo arranca una rampa suave, que conduce casi sin darse cuenta, al primer piso, en donde transcurre la vida del habitante (....)"6. Con la villa recién construida, Le Corbusier describe la casa recorriéndola, plasmando esa preferencia por la arquitectura árabe en cuanto a que se aprecia en movimiento. De esta descripción se obtienen dos claves de la villa original: la caja y el recorrido.

“Arriba en el lado norte de este cuadrado, se perciben cuerpos cilíndricos, paredes con curvas libres...Estas

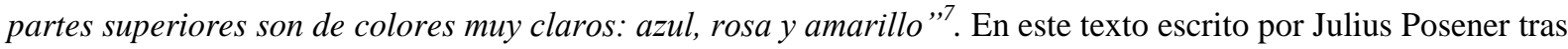
una visita a la villa en los años 30 , se encuentra otro aspecto esencial de la villa original; los colores de la envolvente.

\footnotetext{
${ }^{6}$ Le Corbusier: Precisiones respecto a un estado actual de la arquitectura y del urbanismo. Barcelona: Poseidón, 1978 p.p.158

${ }^{7}$ Posener, Julius: "La Maison Savoye à Poissy”. En Architecture d'Aujourd'hui No2, Paris:1930. p p. 20-21
} 


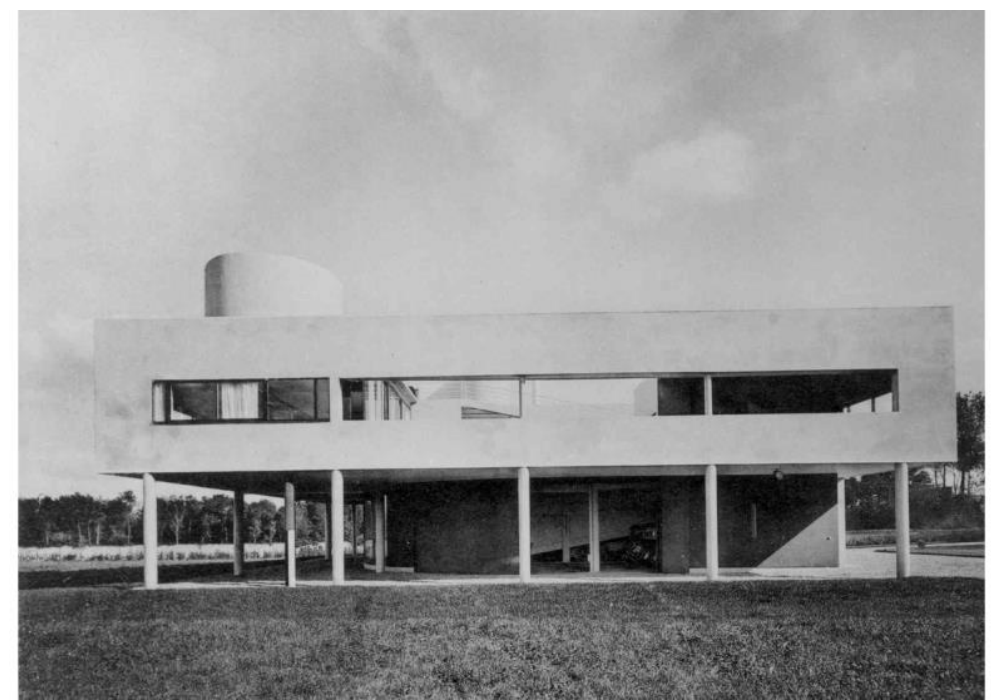

3. Imagen exterior de la villa en 1931. L2(17)4 @FLC-ADAGP

\subsubsection{Periodo de degradación 1938-1962}

Se trata de un periodo muy largo y cuyo comienzo está marcado por la Segunda Guerra Mundial, cuando los Sres. Savoye abandonan Paris. En este momento la villa pierde su FUNCIÓN de vivienda que ya nunca será recuperada. Durante la guerra fue ocupada por las tropas alemanas aprovechando su posición estratégica como punto de observación aéreo. Cuando finalizó la guerra la villa fue alquilada como casa de labranza para la explotación agrícola de los campos circundantes y en los últimos años de este periodo llegó a utilizarse como club de jóvenes antes de su clasificación como Monumento Histórico en el año 1962.

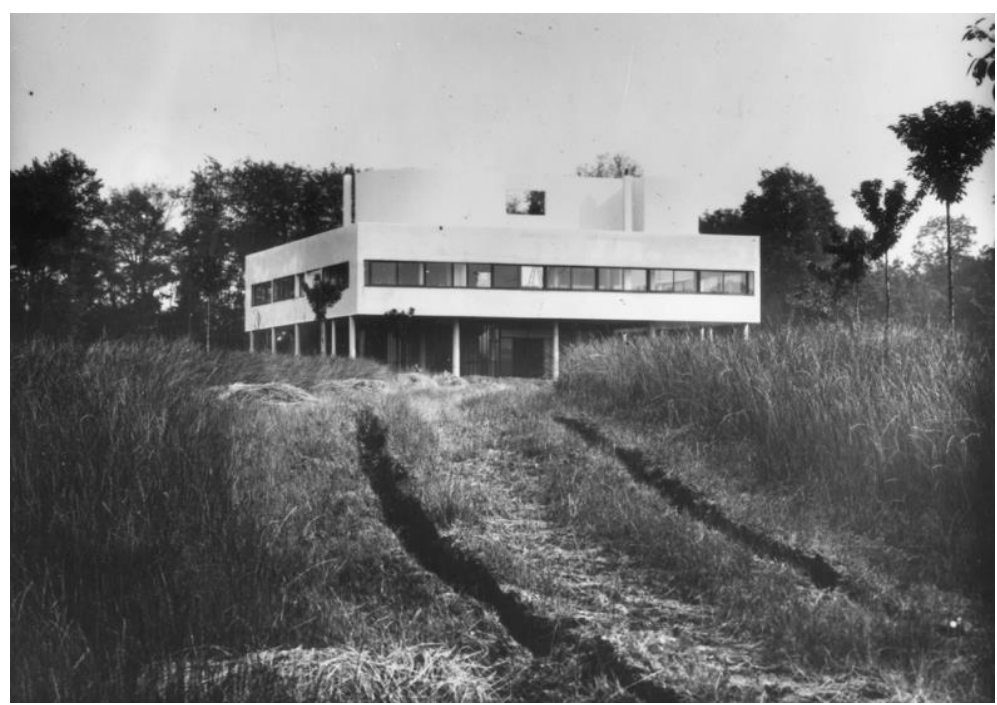

4. Villa en la década de los 50. L2(17)15. Fotógrafo: Marius Gravot. CFLC-ADAGP

A finales de los años 50, Poissy se convierte en una ciudad industrial motorizada por la industria del automóvil, con el consiguiente aumento demográfico. Esto significa que el vasto terreno que ocupa la parcela de la villa se convierte en un punto de mira para el Ayuntamiento de Poissy, que busca terreno donde construir los nuevos equipamientos. Tras un periodo de litigios entre los Savoye, el Ayuntamiento, Le Corbusier y grandes 
personalidades de la arquitectura, se expropian 6 hectáreas salvándose solo 1 hectárea en la que se encuentra la villa y la casa del jardinero. El resultado de este acontecimiento es la pérdida del entorno original de la villa, que a partir de este momento tendrá un liceo como vecino en lugar de amplias praderas y bosque.

"Tal vez, y tendría gracia la paradoja, los niños de la escuela cercana podrán pensar que se trata de la vivienda que han levantado, en su viaje a la Tierra, los habitantes de otro planeta, pues el optimismo progresista de Le Corbusier no se ha perdido, aunque la vivienda entera se haya convertido en una auténtica ruina" ${ }^{8}$. Respecto a la materialidad, este periodo significa el estado de máxima degradación de la villa siendo los acabados, "la carrocería" y las instalaciones, "el motor"10, las partes más afectadas, tal y como puede observarse en los esquemas de la imagen $n^{\circ} 5$.

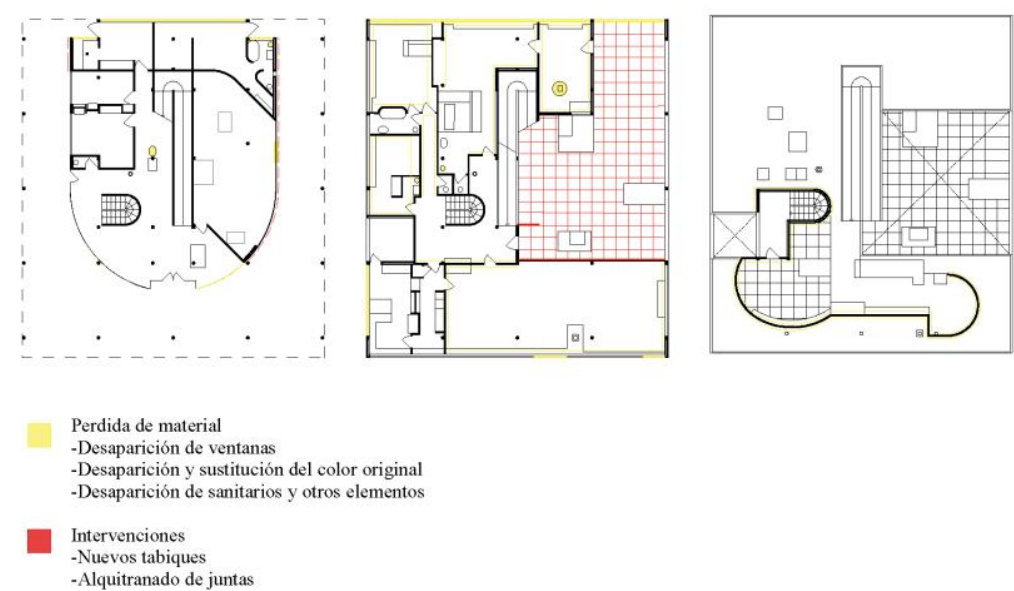

5. Estado de la Villa Savoye en la década de los sesenta, tras el periodo de degradación: enlucidos despegados del paramento, carpinterías e instalaciones rotas, elementos impropios, etc.

\subsubsection{Museo LC 1961-1965}

En los años 60 ante el deterioro de la villa, Le Corbusier insiste en la intervención inmediata para proteger a la villa de un empeoramiento material. Propone un nuevo uso como Museo Corbu, precisamente para protegerla y conservarla. Aunque este proyecto nunca se realizó por motivos burocráticos y económicos, es de gran interés porque supone lo que Le Corbusier hubiera hecho sobre su propia obra. Josep Quetglas dedica un capítulo en "Les Heures Claires" a este proyecto, en el que describe de forma detallada los cambios propuestos por Le Corbusier. Quizás el mas relevante es la nueva puerta de acceso pivotante y esmaltada que hubiera supuesto un gran resalte en fachada, adecuado para el nuevo programa de museo. Además, asumiendo que iban a construir un liceo a pocos metros de la villa, propone que los visitantes accedan a pie y en sentido contrario al original para dejar así el liceo a la espalda y tener como fondo de perspectiva la villa. Propone una nueva paleta de colores

\footnotetext{
${ }^{8}$ Moneo, Rafael: "Una visita a Poissy”. En Arquitectura. No74. Madrid: COAM, 1965. pp. 35-41

${ }^{9}$ Le Corbusier: "El plano de la casa moderna". En Precisiones respecto a un estado de la arquitectura y del urbanismo. Barcelona: Poseidón, 1978. pp. 146

${ }^{10}$ ídem.

${ }^{11}$ Quetglas, Josep: Les Heures Claires. Proyecto y arquitectura en la Villa Savoye de Le Corbusier y Pierre Jeanneret. Sant Cugat del Valdès: Associaciò d'idees. Centre d'Investigacions Estètiques, 2008
} 
para el interior y la sustitución de las carpinterías por otras metálicas mas sencillas; "He preparado la habitación interior de la Villa Savoye en Museo Corbu (sin mobiliario). Mi contratista de albañilería no puede trabajar a destajo porque es bricolaje (es un hombre de confianza). La calefacción y la instalación eléctrica (que fue arrancada por completo) son elementos nuevos, igual que las ventanas (que simplificaré mucho) ${ }^{\prime 12}$.

En definitiva, Le Corbusier introduce cambios en la villa que la actualizan y adaptan a las nuevas circunstancias, aunque conservando siempre la esencia del edificio. Le Corbusier muere en 1965 sin ver siquiera el comienzo de la primera restauración.

\subsubsection{Primera restauración 1963-1967}

El arquitecto encargado de la primera intervención en la villa es Jean Dubuisson, arquitecto jefe de Edificios Civiles y Palacios Nacionales en Francia. Aunque fue designado para la realización de este trabajo en 1963, el dossier con los trabajos pertinentes no se entregan hasta 1965, ejecutándose la obra entre 1965 y 1967.

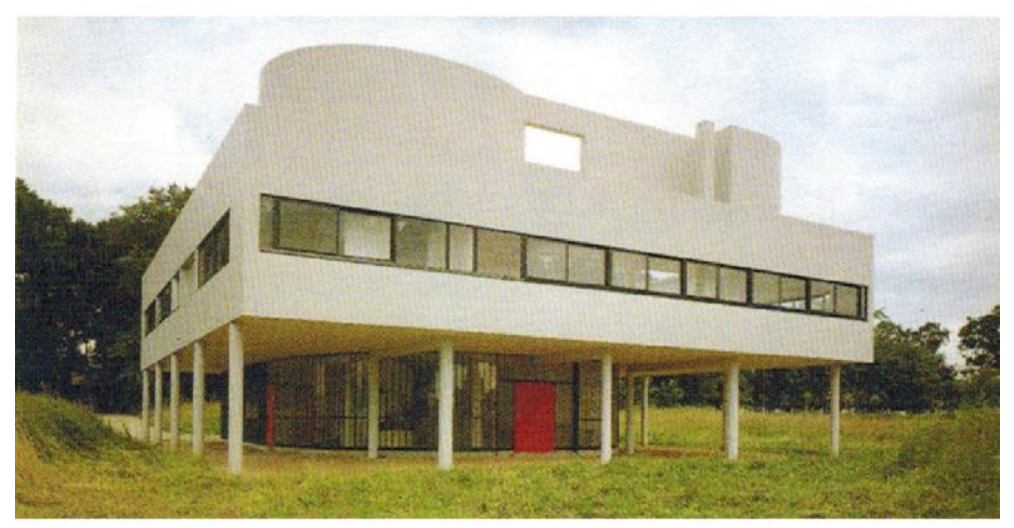

6. La villa Savoye tras la primera restauración

Tal y como se ve en la imagen $\mathrm{n}^{\circ} 6$, el resultado de la intervención es una villa con aspecto de nueva, en la que destacan dos elementos: el color blanco del solárium y la caja, y el color rojo de la puerta de acceso. Este último quizás represente la intención de hacer un guiño al proyecto de Museo Corbu, en que Le Corbusier resaltaba la puerta de acceso haciéndola pivotante y esmaltada.

\footnotetext{
${ }^{12}$ Carta de Le Corbusier a Claudius Petit, del 20 de junio de 1962. (FLC H1-12-24). En Quetglas, Josep: Le Corbusier y Pierre Jeanneret. Villa Savoye "Les Heures Claires" 1928-1962. Madrid: Ediorial Rueda S.L, 2004. Nota 30
} 

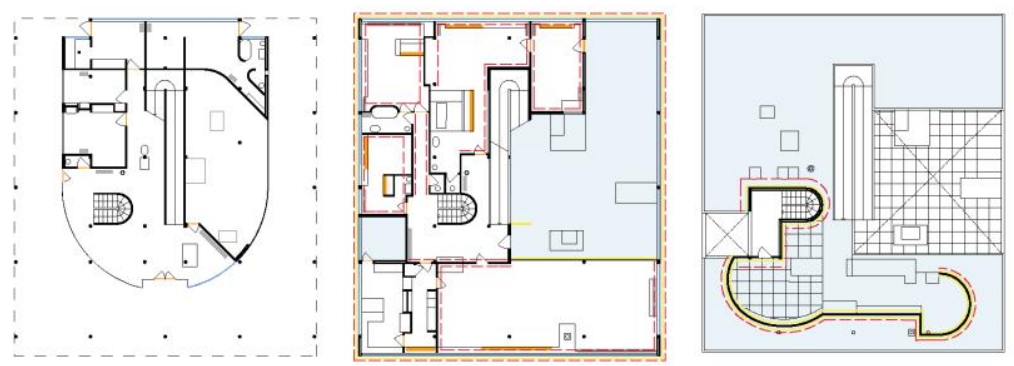

$$
\text { Demolición }
$$

-de tabiques

-del enlucido del solárium

Intervención

-pintura blanca en el exterio

-pinturas con tonos de la FLC en el interior

intervención en ventanas:

nuevas carpinterias metálicas

impermeabilización

reparación de puertas y armarios (madera)

cambio de instalaciones: calefacción y agua

7. Actuaciones durante la primera intervención global 1963-1967: impermeabilización de cubiertas, demolición de elementos impropios, sustitución por carpinterías metálicas, reparación de armarios y puertas, etc.

\subsubsection{Segunda restauración 1983-1993}

La falta de mantenimiento hizo necesaria una segunda intervención global. Algunos autores como T. Prudon afirman que ya desde 1977 se habían realizado algunos trabajos de mantenimiento, pero no es hasta 1983 cuando se plantea un trabajo de restauración global. En este caso, también el Arquitecto de Edificios Civiles y Palacios Nacionales del momento se encargó de la intervención.

Los objetivos eran dos: recuperar el esquema de color de la villa y resolver los problemas de impermeabilización. Para recuperar los colores se recurre a los tonos de la Fundación Le Corbusier sin reproducir los originales perdidos. En el comienzo de este periodo el solárium se pinta de tonos similares a los que describía Posener, aunque se acaba pintando de blanco. El mismo criterio se aplica a otros elementos desaparecidos como las luminarias; se escogen otras nuevas y distintas a las originales y se colocan en la misma posición que ocupaban en 1930. Las actuaciones abordadas en esta intervención se describen en la imagen n9.

En líneas generales, el resultado de esta actuación es la recuperación de la esencia de la villa; sus recorridos, transparencias y opacidades, sin hacer réplica de lo que falta. "Así, la Villa Savoye se ha convertido en un cuidado monumento histórico, inhabitado y por lo tanto no amueblado. Por eso, está bien protegido y accesible a los visitantes" ${ }^{\prime 13}$. Estas palabras de Alfred Roth publicadas en 1987, es una de las primeras impresiones de la villa recién abierta al público, en la que se intuye el olor a nuevo que debía tener la villa en ese momento. En 1993, la villa es asignada a la Dirección de Patrimonio y queda abierta al público en su totalidad.

\footnotetext{
${ }^{13}$ Roth, Alfred: "Bauherr war eine Baudame”. En Aktuelles Bauen Plan No9, 1987. pp. 30-33
} 

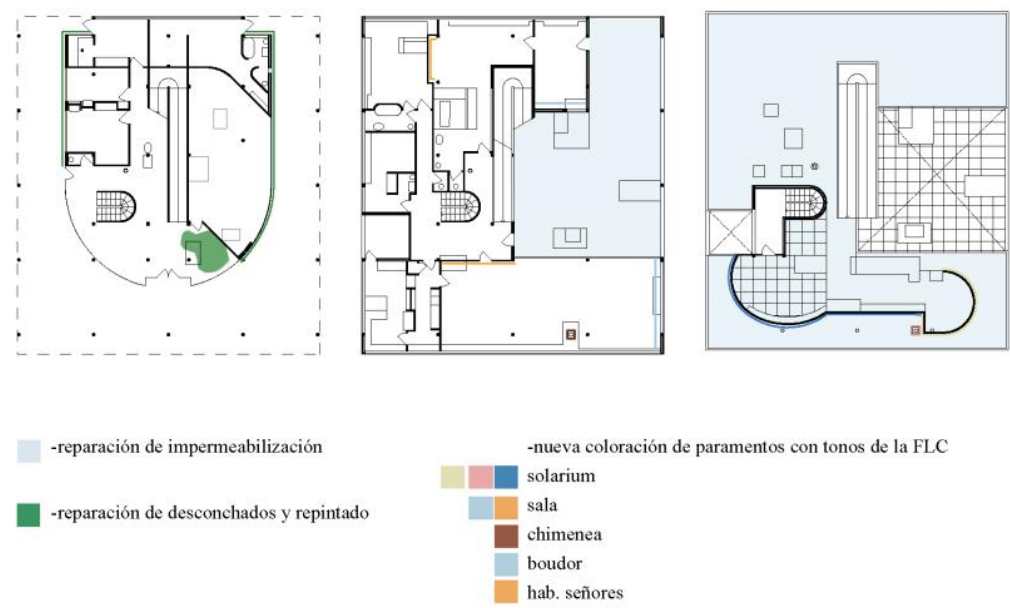

8. Actuaciones durante la segunda intervención global 1983-1993.

\subsubsection{Tercera restauración 1996-1997}

A finales de los 90 se propone una nueva intervención global con el objetivo de recuperar la atmósfera original de la villa y actualizarla en su uso como museo. Bruno Chauffert-Yvart y Laurence Razy son los encargados de esta actuación.

Para recuperar la atmósfera se recuperan los colores originales por medio de distintos estudios y catas con un criterio: solo se reproducen los colores de los que se tiene constancia, el resto se queda en blanco, tal y como describe Mourel Journel ${ }^{14}$ en la guía "Le Corbusier's Villa Savoye". Además, se reproducen los elementos originales perdidos en la etapa de degradación, como lámparas o interruptores, imitando los originales. Para adaptarla a su uso como museo, se sacrificaron algunas estancias quedando cerradas al público para uso de oficina o almacén, tal y como se grafía en los esquemas de planta de la imagen $n^{\circ} 10$. En los últimos años se han utilizado distintos recursos de merchandising que en algunos casos entorpecen la espacialidad de algunas salas.

\footnotetext{
${ }^{14}$ Morel-Journel, Guillemette; Ballot, Jean-Christophe: Le Corbusier's Villa Savoye. Paris: Editions du Patrimoine, 2000
} 

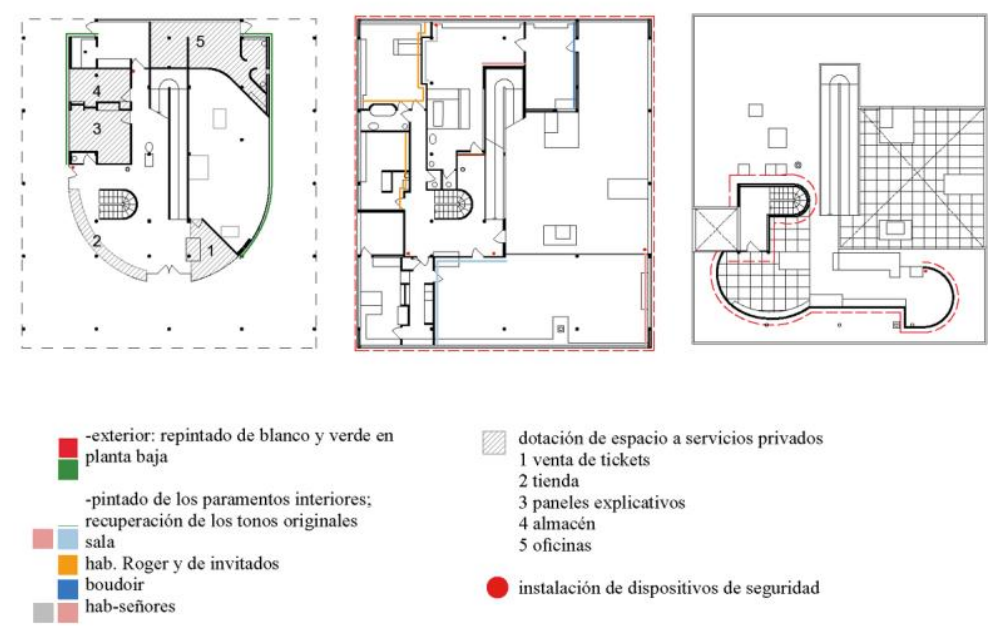

9. Actuaciones durante la tercera intervención global 1996-1997: recuperación de los colores originales y elementos desaparecidos.

\subsection{Paseo en el tiempo por la promenade architecturale}

Recogiendo todos los datos del análisis de la villa en sus distintos periodos: los personajes, el tiempo, el emplazamiento, la función, la envolvente, los espacios y recorridos y la materialidad, se hace un análisis comparativo de la villa entre las etapas clave, constatando e interpretando su evolución en el entorno, la envolvente y el interior. De esta comparativa se extraen los elementos que han permanecido y cuando se perdieron los que se transformaron.

\subsubsection{Situación en el entorno y el comienzo del paseo arquitectónico.}

"Otra cosa: la vista es muy bella, la hierba es una bella cosa y el bosque también: se les tocará lo menos posible. La casa se plantará en medio de la hierba como un objeto, sin dañar nada,"15. Le Corbusier proyecta una casa para una parcela de 7 hectáreas de extensión, rodeada de bosque. La ubicación en medio de la parcela está cuidada y estudiada. Le Corbusier insistió mucho en la preservación del espacio abierto alrededor de la villa "si el parque es retirado, todo está perdido" $"$.

El análisis de una foto aérea de 1930 y otra de la actualidad muestra los cambios significativos que han sucedido en entorno, como consecuencia principal del aumento demográfico de Poissy. En el origen, la villa y la casa del jardinero estaban solas, sin edificaciónes alrededor, una cerca limitaba las 7 hectáreas de parcela. Ahora una valla y unos metros de cerca en el lado sureste limitan la propiedad de 1 hectárea. Así mismo cambia la extensión de prado y bosque y con ello las vistas desde la villa. En el origen, estaba colocada dominando todo el terreno en todo su perímetro y hasta un horizonte lejano, libre de obstáculos. Actualmente ese radio se ha reducido de forma considerable, por lo que las vistas tienen un horizonte más cercano que puntualmente deja pasar el cordón de árboles llegando a ver el edificio vecino, como se plasma en la imagen nº 10 .

\footnotetext{
${ }^{15}$ Le Corbusier; Boesiger, Willy: Le Corbusier et Pierre Jeanneret. Oeuvre complète de 1929-1934. Zurich : Les Editions d'Architecture, 1973. P.p.24

${ }^{16}$ Le Corbusier: FLC H1-12-229 en Murphy, D. Kevin: "The Villa Savoye and the Modernist Historic Monument” . En Journal of the Society of Architectural Historians. Edición digital: University of California Press, 2002. P.p.76
} 
¿Qué hacer cuando el tiempo ha modificado de forma irreversible el entorno de una obra? ¿se pierde en cierto modo su originalidad? Este tipo de cambios, exigen la aceptación de los mismos y su uso como herramienta de evolución, igual que Le Corbusier hizo en su proyecto de Museo Corbu. En el conocimiento y la imaginación del arquitecto está la clave para hacer posible la preservación un obra del pasado, asegurando su permanencia en el fututo y acogiendo la realidad presente. "No hay permanencia sin transformación"
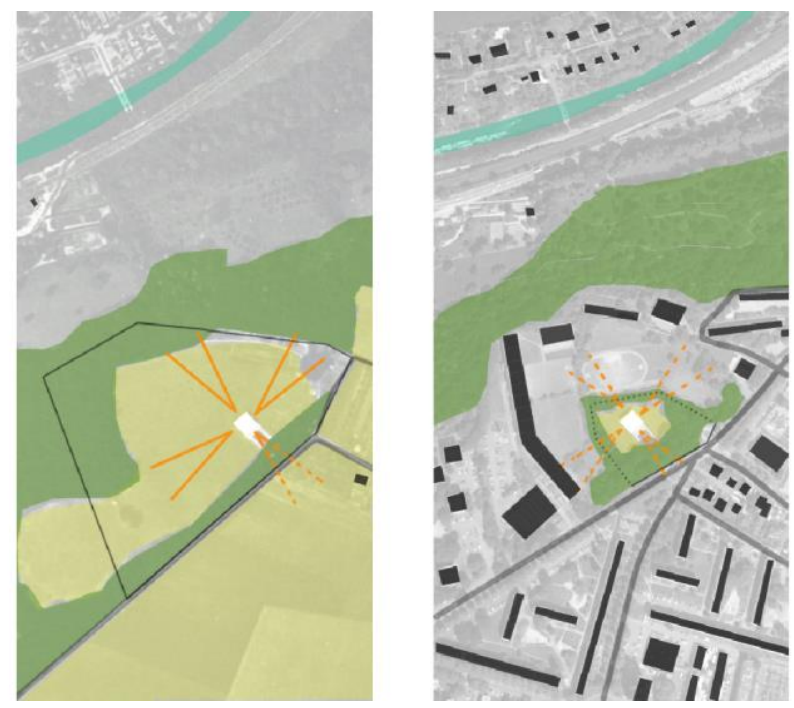

10. Esquema comparativo del entorno 1930 y 2014: se señala la extensión de prado, bosque y caminos, edificación y límites, vistas.

En el análisis del entorno próximo, donde comienza la promenade architecturale, se observa que con el paso del tiempo, o más bien de las intervenciones, la villa se aproxima cada vez más a la imagen original; una evolución retrospectiva. Aunque el contexto quedó definitivamente modificado con la expropiación del terreno, con la segunda intervención se consigue recuperar en cierto modo la sensación original de estar en un gran prado limitado por un bosque, mediante mecanismos de replantación de árboles a modo pantalla. De este modo, en cota 0 parece que la villa está implantada en un frondoso jardín sin rastro de edificios vecinos. Por otra parte, el original acceso para los coches en forma de horquilla, se perdió como tal al perderse la función de vivienda. En la última intervención este camino de grava se ha recuperado, replantando incluso el tipo de jardinería que le acompañaba en el origen, y aunque su uso ya no es rodado, el visitante actual puede hacer el recorrido original a pie.

\footnotetext{
${ }^{17}$ Bosch, Ignacio: extracto de la conferencia "La ruina como valor añadido". Valencia: 2014
} 

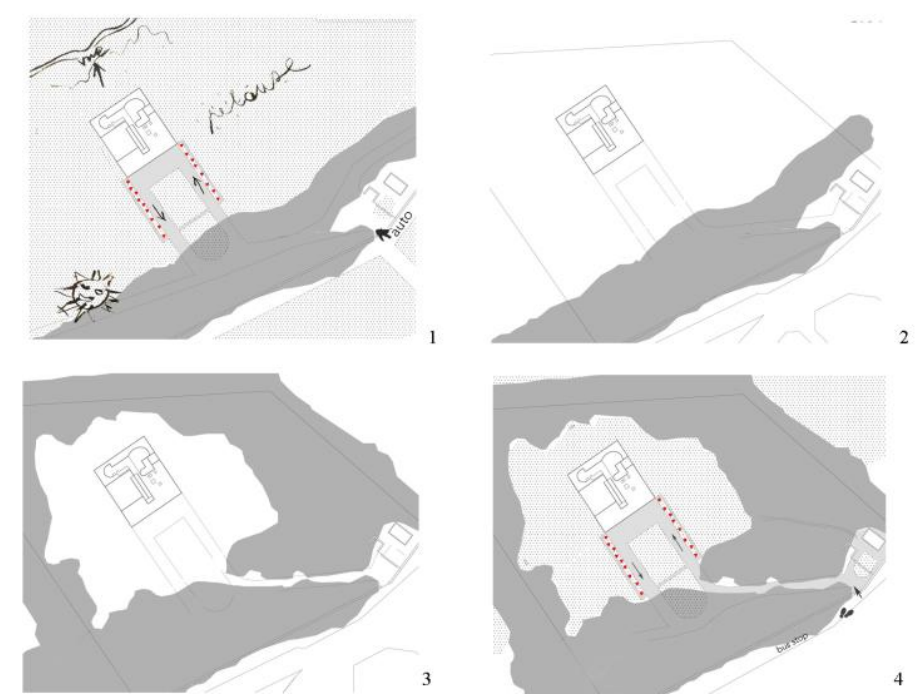

11. Esquema evolución del entorno próximo; 1: año 1930, 2: primera intervención, 3: segunda intervención, 4: tercera intervención: recuperación de la imagen idílica de la villa de 1930

Tras una visita a la villa Álvaro Siza escribió "Mucho del encanto de la Villa Savoye -de la Arquitectura- tiene su origen en una interrumpida y precaria complicidad entre los que la realizan: promotores, constructores, proyecto. Su continua degradación refleja la imposibilidad de mantener ese equilibrio encantador, sin dejar de buscarlo. No sabemos qué dioses la habitan. Como un templo Japonés, se recompone antes de resquebrajarse ${ }^{, 18}$

Quizás sea la captura del tiempo, lo que verdaderamente se busca en esta villa, como ocurre en otras intervenciones en obras del Movimiento Moderno ¿Cuál es el sentido de la búsqueda del origen y congelación en el tiempo, si el tiempo pasa irremediablemente?

\subsubsection{La envolvente}

El estudio de la envolvente conduce a la reflexionar sobre la evolución no retrospectiva de las fachadas, especialmente en lo que se refiere al solárium.

Le Corbusier pudo concebir el solárium como comienzo o fusión con el aire, las nubes y el cielo. El arquitecto describe la villa como una caja blanca flotando; por abajo flota sobre una sombra y por arriba el solárium desaparecería mediante el color; mediante tonos que podrían fundirse con los de un atardecer. Esta hipótesis estaría respaldada por los dibujos originales de las fachadas en los que Le Corbusier solo pinta de blanco la caja, por la descripción anteriormente comentada de Posener y por la maqueta original que guarda el MOMA, en la que el solárium es de tonos rojizos, azul y amarillo. Si bien, respecto a este último criterio, se han escrito hipótesis ${ }^{19}$ que apostarían por una villa blanca en su exterior.

\footnotetext{
${ }^{18}$ Siza, Álvaro: Textos. Madrid: Abada ediciones, 2014

${ }^{19}$ Quetglas, Josep: “Algo sobre el color de la arquitectura de Le Corbusier”. En Arquitectura №358. Madrid: COAM, 2009. pp.93-97: Josep Quetglas escribe entorno a algunas villas de la época purista de Le Corbusier: "Fuera, el edificio es inexpresivo, discreto, reservado, monocromo....En el interior, policromía imprevisible, sorprendente, impactante" Sobre la maqueta que Le Corbusier hace para la Exposición del MoMA de Nueva York con colores en el exterior "una maqueta es un objeto, no una arquitectura, no produce desplazamientos del observador"
} 
La dicotomía aparece revisando la historia de la villa, cuando en los años 60 se pica todo el revestimiento del solárium perdiéndose cualquier prueba del color que pudiera existir. Por otro lado, la posible persecución de una villa ideal, atendiendo el criterio de Viollet-Le-Duc de la unidad de estilo y restitución del objeto a un estado que quizás no haya existido nunca, puede llevar a pensar en un solárium blanco. Se trata de la casa que culmina la época purista de Le Corbusier, es el último eslabón de una serie de viviendas de fachada blanca.
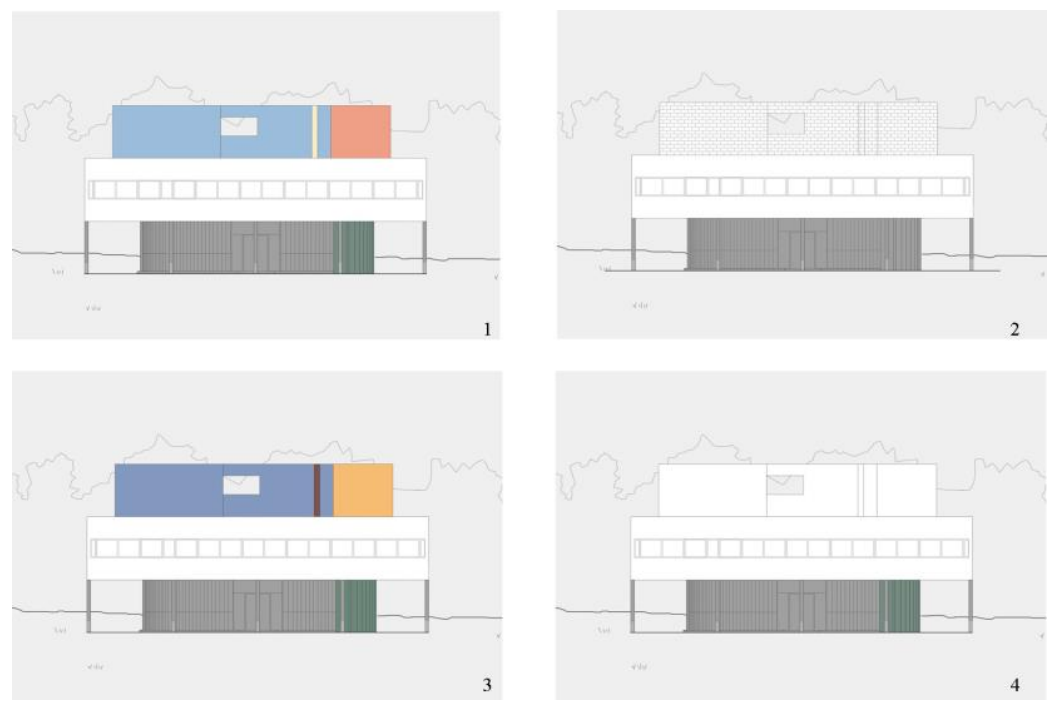

12. Esquemas evolución fachada noroeste; 1. año 1930, colores según maqueta original, 2. La villa durante la primera intervención sin enlucido en el solárium, 3. La villa tras la intervención de Ivan Gury a finales de los 70, 4 la villa tras la tercera intervención global.

\subsubsection{El interior}

Desde el punto de vista material, el interior de la villa ha evolucionado de forma similar al entorno; poco a poco se han borrado las huellas del tiempo. Durante la segunda intervención de principios de los 90 se actuó en la villa sin recurrir a la restauración en estilo; se utilizaron nuevos elementos para sustituir lo que se había perdido. Por ejemplo, en la sala, las paredes inicialmente rosa se pintan de color azul, la chimenea originalmente blanca se pinta de color terre hombre, se sustituyen las luminarias downlight de la entrada por uplight, etc. Esto levantó algunas polémicas entre los arquitectos conservacionistas como Lion $\mathrm{Krier}^{20}$, que vieron esta actuación como un ataque a la originalidad de la obra. Sin embargo, en la última intervención global hay un cambio de criterio; las paredes se han repintado con los tonos originales, las lámparas perdidas se han reproducido, etc. Se recurre, otra vez, a la restauración en estilo iniciada en el s.XIX con Violet-le-Duc, devolviendo la villa a lo que debió de ser. ¿Qué hubiera hecho Le Corbusier? La respuesta podría obtenerse en el Pabellón Suizo. El esquema de color original de los años 30 cambia por completo en la modificación que Le Corbusier hace en los años 50. Este y otros estudios de color están publicados en "The Architectonic Colour. Polychromy in the Purist Architecture of Le Corbusier" de Jan de $\mathrm{Heer}^{21}$. En ellos se observa que el arquitecto suizo actualizaba sus propias obras sin retenerlas o paralizarlas en un tiempo pasado. Le Corbusier valoraba su propia obra, como queda reflejado en sus escritos en la movilización mundial que organizó para el salvamento de la villa Savoye. Esto no es incompatible

\footnotetext{
${ }^{20}$ Krier, Lion: "SOS. Villa Savoye". En Architectural Design N5/6. London: 1992

${ }^{21}$ De Heer, Jan: The Architectonic Colour. Polychromy in the Purist Architecture of Le Corbusier. Rotterdam: 010 Publishers, 2009.
} 
con la evolución o actualización de su obra, como demostró en el Pabellón Suizo prescindiendo de la "Restauración en Estilo".
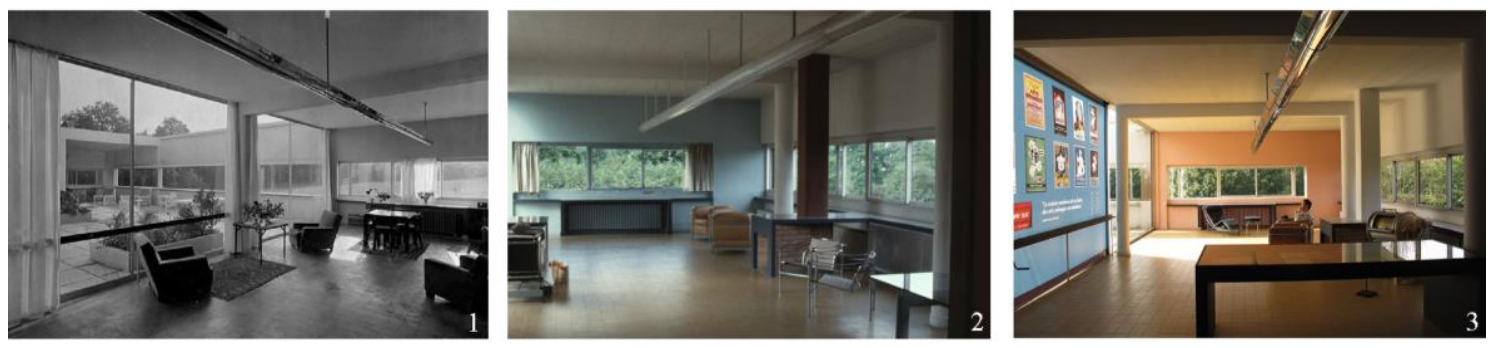

13. Evolución de la sala: 1 villa 1930. FLC L2(17)98. Fotógrafo: Marius Gravot. CFLC-ADAGP., 2. la sala en 1990, 3. La sala en 2014

\section{Villa Savoye ¿Indestructible?}

En una visita a Poissy hace menos de un año, me pude encontrar directamente con la Villa Savoye y preguntarme quien era. Tras recorrer el corto pero frondoso camino, entre árboles y vegetación y dejando atrás la casa del jardinero, la villa se aparece ante el visitante. La sensación es la de hallar una caja blanca atemporal. ¿Desde cuando estas aquí? El tiempo se detiene. Es un volumen tan limpio, que da igual que el enlucido esté sucio. Es limpia. Destila pureza, rotundidad.

Una vez dentro ya, todavía entre verdes y brillos, te encuentras con la rampa, empiezas a descubrir la arquitectura, comienzas la promenade architecturale, una arquitectura que se abarca paso a paso. Ya lo contó Giedion; "es imposible abarcar la Villa Savoye a primera vista, desde un solo punto de observación: es literalmente una construcción según el principio espacio-tiempo" ${ }^{22}$. En palabras de Sáez de Oiza, "la arquitectura es una secuencia de relaciones espaciales percibidas en función de las experiencias vividas y promesas de espacios por ver" ${ }^{23}$. Estas palabras se entienden bien hoy en la Villa Savoye, donde el espacio se construye con el tiempo, donde la arquitectura se entiende en movimiento tal y como prefería Le Corbusier.

"La arquitectura es el juego sabio, correcto y magnífico de los volúmenes bajo la luz" 24 . En la villa Savoye entendí, aprehendí la conocida frase de Le Corbusier. Allí estaba la luz correteando por las habitaciones, dibujando alfombras en el suelo, cambiando en cada instante, presentando a el Tiempo como su más fiel amigo. La emoción de la arquitectura que Le Corbusier pensó y proyectó para esta casa, están allí.

\footnotetext{
${ }^{22}$ Giedion, Siegfried: Espacio, Tiempo y Arquitectura. $5^{\mathrm{a}}$ ed. Barcelona: Científico-Médica S.A, 1979

${ }^{23}$ Sáenz de Oiza, Francisco Javier: Tres arquitecturas. Entrevista TVE. Noviembre, 1990

${ }^{24}$ Le Corbusier: Vers une archicteture. Buenos Aires: Poseidón, 1978. pp.16-17
} 


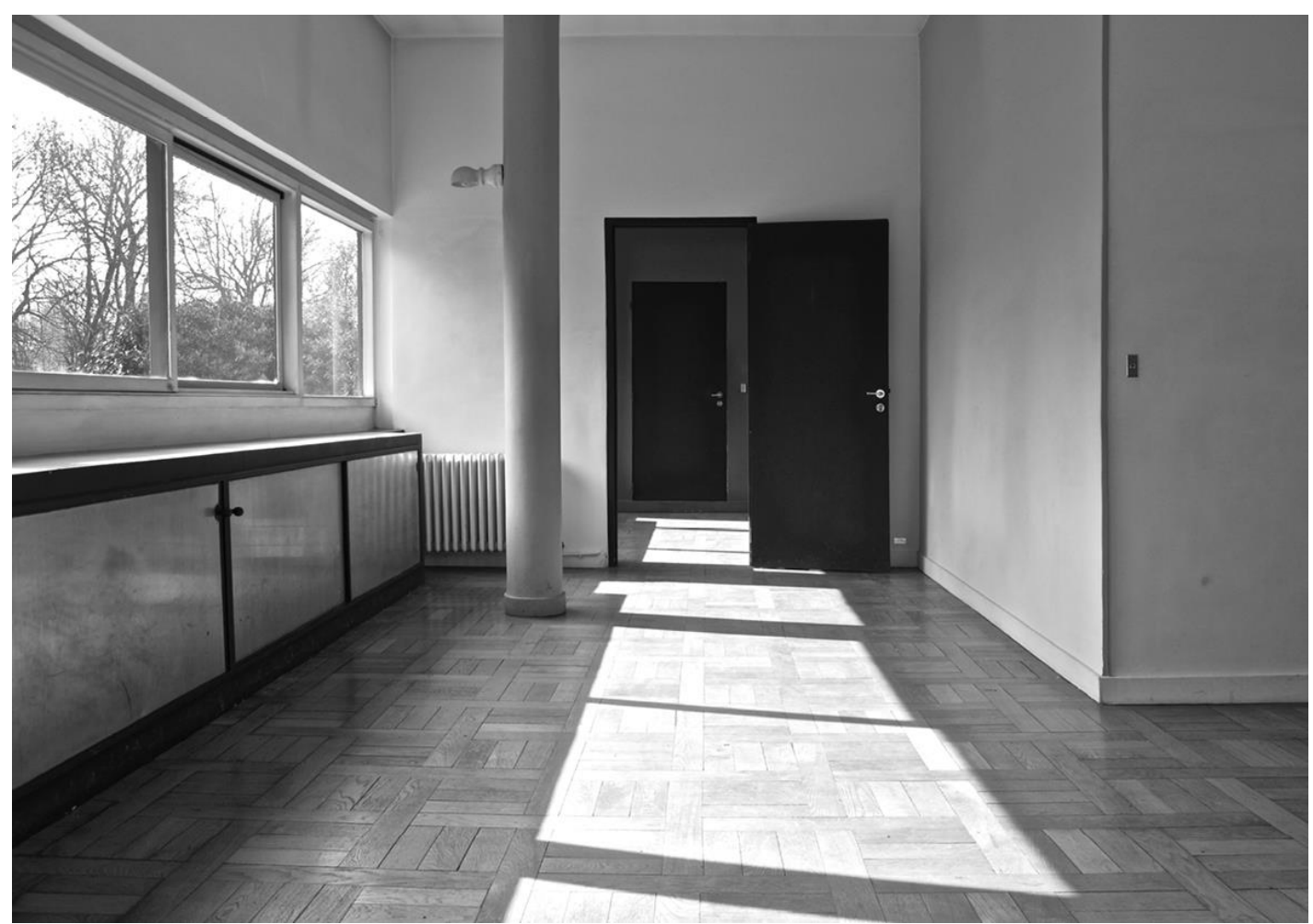

14. La Villa Savoye año 2014; juego de volúmenes bajo la luz.

Cada día el sol es atrapado por las rendijas de la villa Savoye. Se trata de una caja horadada en su cintura, por lo que recibe luz de norte, de sur, de este y de oeste. La luz de norte ilumina el espacio con luz difusa, y la de sur dibuja las horas en las estancias. Además, en la villa hay luz vertical, luz que entra desde el cielo solo a determinados espacios, como linternas apoyadas en el techo que hacen que te detengas y mires y busques. " $L a$ LUZ SÓLIDA en visible movimiento, danzando sobre una invisible LUZ DIFUSA en reposada quietud" ${ }^{25}$. La luz entra en vibración con el material que alumbra. En el interior, la luz juega con el blanco, lo vuelve gris, amarillo, lo vuelve de todos los colores. Algo así como el blanco de Sorolla, blanco que se pinta con gris, con azul, con rosa. Esta blancura coloreada la encontramos en la villa: "La blancura del blanco casi nunca es blanca: es casi siempre transformada por la luz y por lo que está cambiando: el cielo, las nubes, el sol y la luna" ${ }^{26}$.

\section{Conclusiones. La permanencia de un hito}

Teniendo como panorámica la evolución de la villa desde que se construyó hasta hoy, surgen una serie de reflexiones entorno al modo en que se ha conservado. La villa se ha mantenido más como imagen y concepto, que como testimonio material de una época ¿Es posible el mantenimiento de la herencia de Le Corbusier como testigo material fiel de construcción de principios del siglo XX, como parte de la historia? Según Wessel de Jonge, esto no es solo posible sino también necesario; "El Movimiento Moderno ha sido una inflexión fundamental en la historia de la edificación. Según mi punto de vista, fundiendo los conceptos sociales y

\footnotetext{
${ }^{25}$ Campo Baeza, Alberto: La idea construida. Buenos Aires: Editorial Nobuko, 2009. p.p 30

${ }^{26}$ Meier, Richard: publicación digital en www.richardmeier.com "White is the most wonderful color because within it you can see all the colors of the rainbow. The whiteness of White is never just White: it is almost always transformed by light and that which is changing; the sky, the clouds, the sun and the moon"
} 
tecnológicos de una época el Movimiento Moderno iguala la originalidad fundamental de la arquitectura romana y, según las publicaciones de Viollet-le-Duc, de la gótica. El segundo punto es que la arquitectura contemporánea perdería una parte esencial de su historia si no salvaguardamos algunos de estos edificios" 27. Andrés Martínez Medina también apoya la preservación de las huellas del tiempo en este tipo de arquitectura; "Borrar las huellas del tiempo de la arquitectura moderna impide que se las sitúe adecuadamente en el devenir del tiempo y de la historia. Acusar el tiempo no es volverse ruina. El tiempo debería reflejarse en las obras o las obras dejarán de ser de nuestro tiempo, habitarán una dimensión virtual"28. Sin embargo, teniendo como ejemplo la trayectoria de este Monumento, surge una pregunta; ¿importa el valor del Tiempo en una obra del Movimiento Moderno? ¿permiten los edificios del M.M mantener la pátina del tiempo como lo permiten las sólidas construcciones romanas? Se encuentra una posible respuesta a estas reflexiones en el entendimiento de la Villa Savoye como “machine à habiter”. Le Corbusier entendió en la máquina una nueva forma de proceder, " $E l$ paquebote es la primera etapa en la realización de un mundo organizado de acuerdo con el espíritu nuevo"29. Un máquina, para que funcione está en continuo cambio, una máquina no funciona siempre con las mismas piezas. La Savoye, como cualquier máquina requiere una constante renovación y mantenimiento de sus piezas para que funcione. Si por el contrario, se pretende conservar una máquina como reliquia, las piezas se arreglan y se reparan dejando el olor a viejo aunque esté implícita la pérdida de su función.
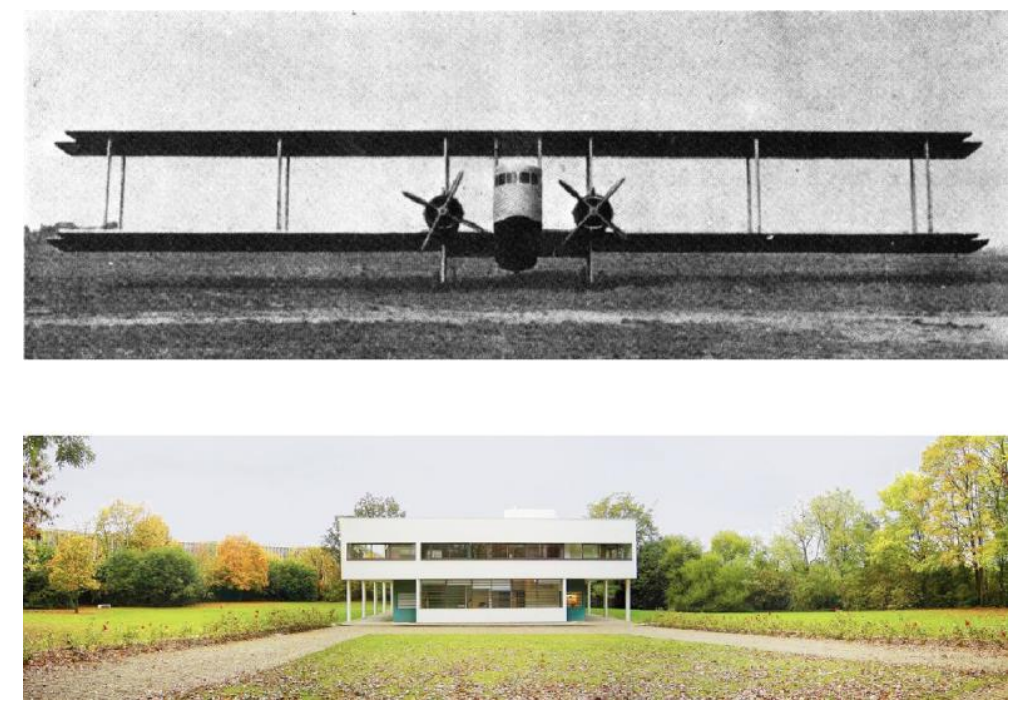

15. Le Corbusier: la máquina de volar y la máquina de habitar

Hoy pocos materiales originales quedan. A los problemas propios del abandono se suman las patologías originales de la obra. Le Corbusier investigó y experimentó en su obra. Esto explica la existencia de algunas "irregularidades" como goteras y otros problemas de humedad que tardaron en resolverse, haciéndose precisa la sustitución de algunos materiales originales. Además, las soluciones perecederas propias de la industrialización duran una serie de años, no una eternidad. A pesar de esta realidad, la Villa Savoye permanece hoy como modelo

\footnotetext{
${ }^{27}$ De Jonge, Wessel. En Ribera, David: Dios está en los detalles .Valencia: General de ediciones de arquitectura, 2012. p. $74-$ 75

${ }^{28}$ Martínez Medina, Andrés: "Las Huellas del tiempo en la arquitectura moderna intervenida”. En Conferencia Internacional CAH20thC. Criterios de Intervención en el Patrimonio Arquitectónico del Siglo XX. Madrid: Secretaría General Técnica, Ministerio de Cultura, 2011
} 
de una Nueva Arquitectura, como hito del Estilo Internacional. En la búsqueda del porqué, llego siempre a los mismos conceptos: "la Promenade", la Luz, el Tiempo. La villa Savoye se entiende tan bien hoy como ayer. "Los universales trascienden, crean un espacio regido solo por la geometría y la proporción, mas allá de todo lugar particular. Y trazan un tiempo eterno (...) Luz, Gravedad y Proporción significan Tiempo, Orden y Belleza. Se entiende, se experimenta que el valor no está en los materiales, en lo material, sino en los intangibles, en la idea, en lo espiritual" 30 escribe Alberto Burgos.

Esta reflexión bien puede plasmarse a través de una colección de lienzos pintados por Le Corbusier en los años veinte. Son una serie de cuadros, inspirados en aquella colección de Monet, en los que representa las mismas formas con distintas tonalidades y combinaciones de color. Se comprende bien la permanencia de la villa en el tiempo: son distintos los tonos de la paleta para cada cuadro, pero siempre dibujan las mismas formas. En la villa, son distintas las intervenciones, los acontecimientos que le hace pasar el tiempo, pero es siempre la misma Idea, es siempre la misma Villa. Quizás sea esto lo que de verdad importa, más el Qué y menos el Cómo: que las palabras de Le Corbusier sigan vivas en sus edificios, que sus obras sigan siendo una fiel representación de sus ideas: "Se utiliza la piedra, la madera, el cemento, y con esos materiales se levantan casas, palacios: eso es construcción, el ingenio trabaja. Pero, de pronto me conmovéis, me hacéis bien, soy dichoso y digo: es bello. Esto es arquitectura. El arte está aquí, ${ }^{31}$.
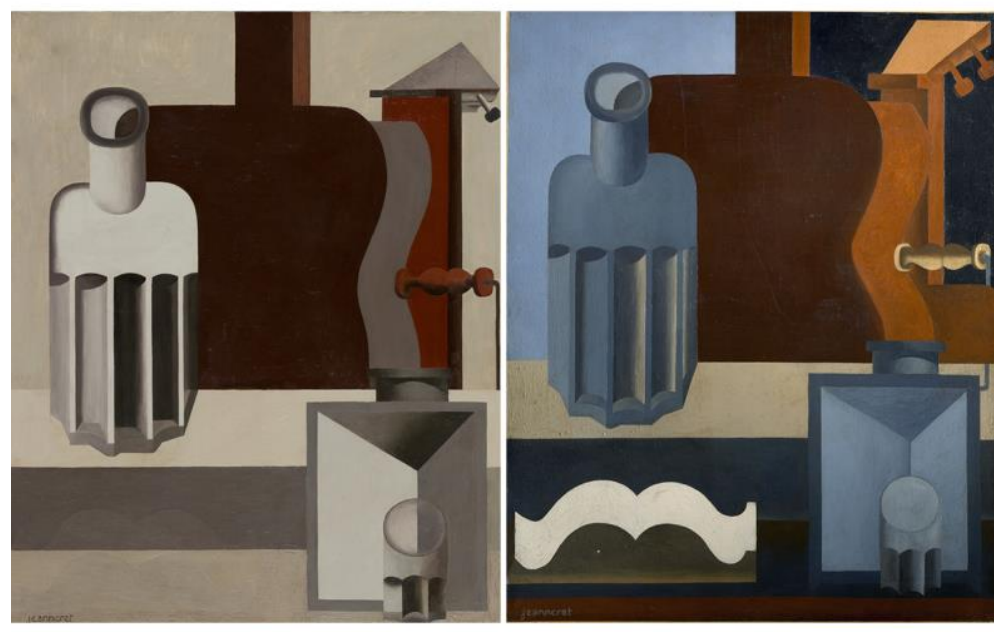

16. Guitarra vertical, 1920. Le Corbusier. Peinture FLC 138 @FLC-ADAGP. Peinture FLC 174 @FLC-ADAGP

\section{Agradecimientos}

A mis directores de tesis, así como a la Escuela Técnica Superior de Arquitectura de Valencia. A mi familia y amigos.

\section{Procedencia de imágenes}

$1,2,5,7,8,9,10,11,12,13.3,14$; realizadas por la autora del presente artículo.

${ }^{30}$ Burgos, Alberto: “Top. (desde 1992) Esencialidad. More with less”. En Campo Baeza, Alberto: Alberto Campo Baeza. Arquitectura 2001-2014. Valencia: Ed. General Ediciones de Arquitectura, 2014. p.p 11

${ }^{31}$ Le Corbusier: Vers une Architecture. Buenos Aires: Editorial Poseidón, 1978. pp.123 


\section{3; L2(17)4 @FLC-ADAGP. La Fondation Le Corbusier}

4; L2(17)15. Fotógrafo: Marius Gravot. OFLC-ADAGP. La Fondation Le Corbusier

6; Torres Cueco, Jorge; Le Corbusier mise au point. General de ediciones de arquitectura. Memorias Culturales. Valencia, 2012

13.1; FLC L2(17)98. Fotógrafo: Marius Gravot. OFLC-ADAGP. La Fondation Le Corbusier

13.2; Torres Cueco, Jorge: 1990

15; OFLC-ADAGP. Le Corbusier: Vers une Architecture. Buenos Aires: Editorial Poseidón, 1978, p.p 59 / Burgos, Alberto: fotografía panorámica de la Villa Savoye.

16; Peinture FLC 138 @FLC-ADAGP. Peinture FLC 174 @FLC-ADAGP. La Fondation Le Corbusier

\section{Bibliografía}

Boesiger, Willy; Le corbusier: Le Corbusier et Pierre Jeanneret. Oeuvre complète de 1929-1934. Zurich: Les Editions d'Architecture, 1973

Burgos, Alberto: “Top. (desde 1992) Esencialidad. More with less". En Campo Baeza, Alberto: Alberto Campo Baeza, Alberto; Arquitectura 2001-2014. Valencia: Ed. General Ediciones de Arquitectura, 2014

Campo Baeza, Alberto: La idea construida. Buenos Aires: Editorial Nobuko, 2009.

Curtis, William J.R; Ideas and forms. London: Phaidon, 1986

De Heer, Jan: The Architectonic Colour. Polychromy in the Purist Architecture of Le Corbusier. Rotterdam: 010 Publishers, 2009.

De Jonge, Wessel. En Ribera, David: Dios está en los detalles .Valencia: General de ediciones de arquitectura, 2012.

Frampton, Kenneth: Le Corbusier. Barcelona: Editorial Akal, 2001.

Giedion, Siegfried: Espacio, Tiempo y Arquitectura. $5^{\text {a }}$ ed. Barcelona: Científico-Médica S.A, 1979

Krier, Lion: "SOS. Villa Savoye". En Architectural Design N5/6. London: 1992

Le Corbusier: Precisiones respecto a un estado de la arquitectura y del urbanismo. Barcelona: Poseidón, 1978

Le Corbusier \& Jeanneret. P: "Maison Savoye, Poissy”. En Architecture Vivante vol. 16. Paris: Jean Bodovici, 1931

Le Corbusier: Vers une Architecture. Buenos Aires: Editorial Poseidón, 1978

Martínez Medina, Andrés: "Las Huellas del tiempo en la arquitectura moderna intervenida". En Conferencia Internacional CAH2OthC. Criterios de Intervención en el Patrimonio Arquitectónico del Siglo XX. Madrid: Secretaría General Técnica, Ministerio de Cultura, 2011

Moneo, Rafael: "Una visita a Poissy”. En Arquitectura. Nº74. Madrid: COAM, 1965.

Morel-Journel, Guillemette; BALLOT, Jean-Christophe: Le Corbusier's Villa Savoye. Paris: Editions du Patrimoine, 2000

Murphy, D. Kevin: "The Villa Savoye and the Modernist Historic Monument" . En Journal of the Society of Architectural Historians. Edición digital: University of California Press, 2002

Quetglas, Josep: “Algo sobre el color de la arquitectura de Le Corbusier". En Arquitectura №358. Madrid: COAM, 2009.

Quetglas, Josep: Le Corbusier y Pierre Jeanneret. Villa Savoye "Les Heures Claires" 1928-1962. Madrid: Ediorial Rueda S.L, 2004 
Quetglas, Josep: "Les Heures Claires. Proyecto y arquitectura en la Villa Savoye de Le Corbusier y Pierre Jeanneret". Sant Cugat del Valdès: Associaciò d'idees. Centre d'Investigacions Estètiques, 2008

Roth, Alfred: "Bauherr war eine Baudame”. En Aktuelles Bauen Plan N9, 1987.

Sáenz de Oiza, Francisco Javier: Tres arquitecturas. Entrevista TVE. Noviembre, 1990

Savoye, Jean-Marc; DELHOMME, Jean-Philippe: Les Heures Claires de la Villa Savoye. Paris: Éditions des Quatre Chemins, 2015

Siza, Álvaro: Textos. Madrid: Abada ediciones, 2014

Zevi, Bruno: Historia de la Arquitectura Moderna. $5^{\text {a }}$ Ed. Barcelona: Editorial Poseidón, 1980.

Zubiri, Xavier: ¿Qué es investigar?. Discurso en la entrega del Premio Ramón y Cajal. Octubre 1982 


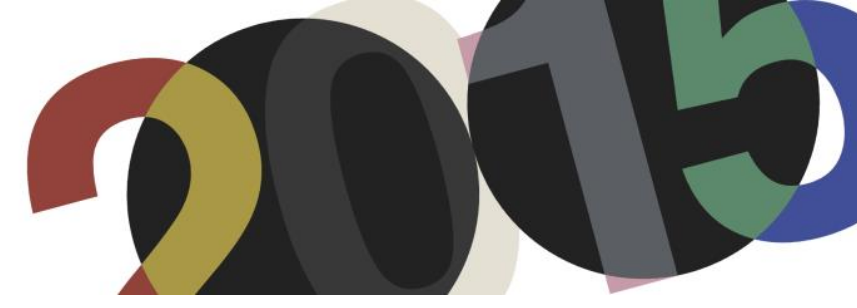

DOI: http://dx.doi.org/10.4995/LC2015.2015.630

\title{
F VAL. Feria Valencia y Guillermo Jullian de la Fuente. L'héritage de Le Corbusier
}

\author{
F. Carro Gil*, M. Navarro Pérez*, M. Mompó García** \\ *Universidad Politécnica de Madrid \\ **Escuela de Arquitectura de A Coruña
}

\begin{abstract}
Resumen: La Mezquita de Córdoba, el paradigma del Mat-Building y la invitación al juego, están detrás de una obra cuya pertenencia a la órbita lecorbuseriana debe ser plenamente reconocida: la Feria de Valencia (1967) de Guillermo Jullian de la Fuente.

Cincuenta años después de la muerte de Le Corbusier y desaparecido, también, quién en los últimos años de vida del maestro fue su principal colaborador, apenas queda nada de la única obra de los herederos del Atelier de la rue de Sèvres construida en España.

Tomando como idea el paradigma de "juego" pretendemos, con nuestro estudio, avanzar en el conocimiento de esta obra para encontrar su vinculación con ese modo de entender lo arquitectónico que Le Corbusier nos propone cuando afirma que, reunidos bajo la luz, de modo sabio, correcto y magnífico, los volúmenes (las formas arquitectónicas) juegan.
\end{abstract}

\begin{abstract}
The Mosque of Cordoba, the paradigm of Mat-Building and the invitation to the game, are behind a work whose membership lecorbuseriana orbit should be fully recognized: the Feria de Valencia (1967) of Guillermo Jullian de la Fuente. Fifty years after the death of Le Corbusier, and Guillermo dead too, who in the last years of the life of the Master was his main collaborator, there is nothing left of the unique work of the heirs of the Atelier de la rue de Sèvres built in Spain. On the idea to the paradigm of "play " we intend, in our study, to advance in the knowledge of this work to find its links to this way of understanding the architecture that Le Corbusier proposed to us when he states that, gathered under the light, so wise, correct and magnificent, the volumes (the architectural forms) play.
\end{abstract}

Palabras clave: Juego; Atelier; Venecia; Valencia.

Keywords: Game; Atelier; Venice; Valencia.

\section{Introducción}

Tratar de interpretar la Feria de Valencia al margen de la figura de Le Corbusier constituye un ejercicio ciertamente contradictorio ya que, con la misma seguridad con la que se puede afirmar que el proyecto no es del maestro, se debe afirmar que la Feria de Valencia es obra lecorbuseriana. Es más, de todos los proyectos que hace cincuenta años quedaron huérfanos sobre las mesas de dibujo del Atelier de la rue de Sèvres, la Feria de Valencia fue el que -con el impulso creativo de los herederos de aquel taller- consiguió recibir el testigo del ejercicio magistral de Charles-Edouard Jeanneret.

Sobre la base de esta idea, el objetivo de nuestro trabajo no se orienta pues a mediar en la controversia sobre la posible vinculación del maestro con el proyecto para Valencia. Nuestra intención pasa, sobre todo, por reorientar el debate dentro de sus auténticos límites: los que sitúan a la Feria de Valencia como verdadera obra del taller de Le Corbusier.

Si fue por casualidad, o no, cómo es que llegó a levantarse en Valencia una edificación tan directamente relacionada con el Atelier del Corbu, es algo que no afecta al fondo de esta investigación. Si fue por casualidad, 
fue sin duda un feliz suceso. Si, por el contrario, hubo la intención de vincular el proyecto del recinto ferial valenciano a los herederos espirituales de Le Corbusier, fue un feliz acierto. Pero ni una cosa ni la otra añaden o restan valor arquitectónico a los pabellones que en 1968 comenzaron a construirse a las afueras de Valencia siguiendo el proyecto del arquitecto chileno Guillermo Jullian de la Fuente.

La concreción con la que queremos abordar este estudio nos lleva a estructurar el trabajo en tres apartados concatenados. En el primero de ellos, unos apuntes sobre la figura de Jullian nos conducirán a la formulación de un paradigma directamente relacionado con esa tendencia al orden y a la articulación, que está en la esencia del proceso creativo de la proyectación arquitectónica: nos referimos a la idea de "juego".

A la luz de este paradigma nos acercaremos al proyecto de la Feria de Valencia para proponer -en un segundo apartado de nuestro estudio- su lectura en relación con una obra con la que comparte, no sólo rasgos de una misma arquitectura, sino también, y sobre todo, el participar de ese espíritu de juego que anima y explica gran parte de la obra lecorbuseriana. Nos referimos al proyecto del Hospital de Venecia cuya continuación, tras la muerte del maestro, se solapa en el tiempo con el proyecto para Valencia. Sólo una indagación orientada por esta idea nos permitirá establecer los vínculos entre ambas arquitecturas, más allá de las evidencias.

Cerraremos el estudio volviendo la vista atrás para indagar en el nacimiento de este proyecto, poner orden en los datos fragmentados que nos son conocidos, con el propósito de completar una base lo suficientemente firme en la que sustentar un juicio crítico sobre esta obra.

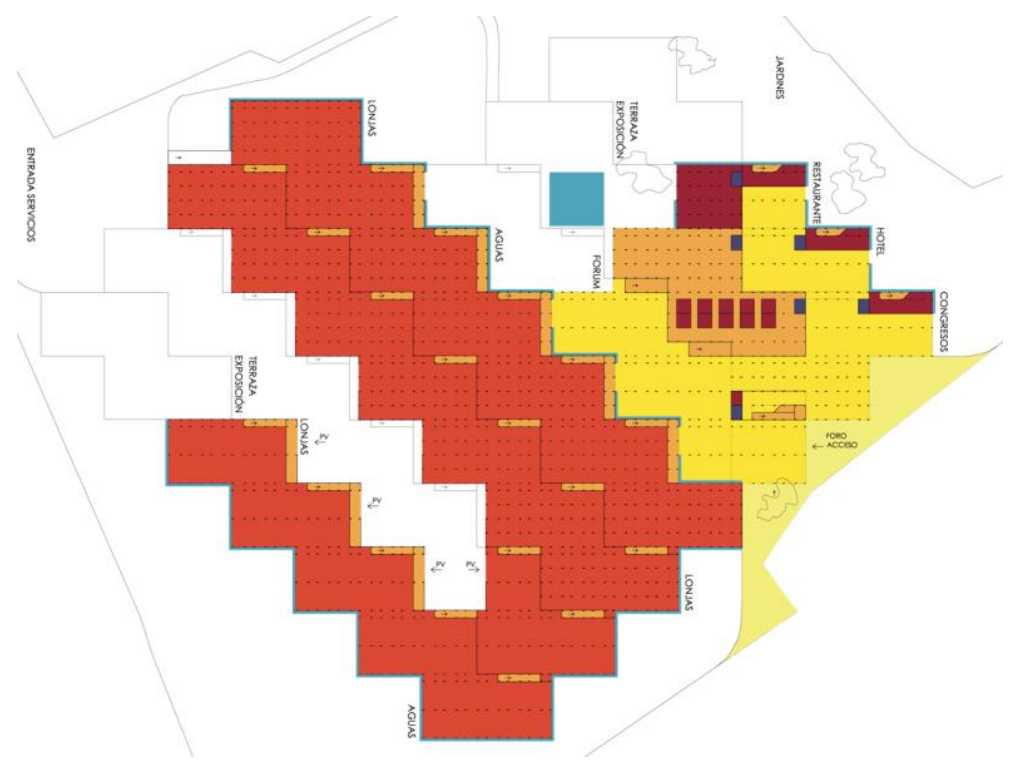

1. Plano canónico de la Feria de Valencia.

\section{El juego como paradigma}

Guillermo Jullian de la Fuente, nace en 1931 en Valparaíso (Chile) y se forma como arquitecto en la Escuela de Arquitectura de la Universidad Católica de esa ciudad. En 1958, apenas finalizada su formación académica, se embarca rumbo a Europa con el propósito de conocer a Le Corbusier y trabajar con él. Después de un tiempo visitando gran parte de su obra construida en el continente - una suerte de "peregrinaje" lecorbuseriano- en enero 
de 1959 escribe al maestro, solicitando formalmente un puesto en el Atelier: "Je viens vous demander si vous pouviez m'accepter comme un disciple de plus pour collaborer dans votre ouvre qui est déjà historie"1.

La respuesta, aunque negativa, dejaba abierta la puerta a colaborar de alguna manera. Poco después, una breve carta del maestro - esta vez en agradecimiento a unos apuntes de la Plaza de San Marcos de Venecia que Jullian le había hecho llegar- contiene una advertencia que, para un amante de la arquitectura como sin duda lo era Jullian, no estaba exenta de ironía y sarcasmo: "Le coup de crayón est une chose dangereuse chez les architectes"

No obstante la participación en la obra lecorbuseriana -si bien fuera del Atelier- da comienzo pronto, al entrar a trabajar para la ingeniería que estaba desarrollando el proyecto del Estadio de Bagdad. Y así, antes de finalizar el verano de 1959, una invitación a almorzar en casa del Corbu va a señalar el inicio de una colaboración que se prolongará a lo largo de seis intensos años, hasta la muerte del maestro.

Al evocar el ambiente que Jullian descubre en el laboratorio de Le Corbusier, recurre a una doble metáfora en la que se condensa un modo muy personal de entender el trabajo junto al maestro: "el atelier era una especie de caja de Pandora donde estaban todas las ideas de Le Corbusier, sus libros, sus viajes, sus obras, todo lo cual usábamos como base para trabajar nuevos proyectos. Todas las cosas que utilizábamos para trabajar estaban ahí, desde antes, nosotros jugábamos con ellas"3.

Esta alegoría a la creatividad del juego, entendido como la esperanza que ha quedado encerrada en la caja de Pandora, la queremos convertir en el hilo conductor del análisis de la Feria de Valencia. Jullian -como nos recuerda el profesor Claudio Vásquez en su introducción al número monográfico que la revista Massilia le dedica en 2007- al abandonar el Atelier de la rue de Sèvres era portador del tesoro de haber conocido la manera de trabajar de un maestro que, en muchos aspectos, había reformulado la arquitectura del siglo XX. Un modo de trabajar en consonancia con aquel universo poético que formaba parte de sus vivencias en la Escuela de Valparaíso ${ }^{4}$.

Para establecer el sentido que queremos imprimir al paradigma en torno al que va a girar el análisis de la Feria de Valencia, vamos a detenernos brevemente en el ensayo de Johan Huizinga Homo ludens, publicado por primera vez en 1938.

En esta obra, Huizinga aborda la realidad y el significado del juego como fenómeno cultural. Para el autor de este fundamental ensayo sobre la naturaleza lúdica de la cultura, la primera caracterización del juego tiene que ver con la libertad: "Todo juego es, antes que nada una actividad libre",.

\footnotetext{
${ }^{1}$ La carta enviada por Jullian a Le Corbusier se encuentra publicada en el “Anexo 1" de Massilia 2007.

${ }^{2}$ La respuesta del Corbu (fechada el 2 de marzo de 1959) esta publicada en: Pérez de Arce, Rodrigo. Guillermo Jullian. Obra abierta. p. 207. En esta misma obra se reproducen además los bocetos enviados por Jullian a Le Corbusier (p. 15).

${ }^{3}$ Jullian de la Fuente citado por: Vásquez, Claudio. "Conversación con Guillermo Jullian de la Fuente”. En Massilia 2007. p. 18. Esta referencia al juego y la caja de Pandora se encuentra también (expresada en términos muy parecidos) en la entrevista que Amedeo Petrilli le hace al arquitecto en 1998; publicada en: Petrilli, Amedeo. Il testamento di Le Corbusier: il progetto per l'Ospedale di Venezia. p. 120.

${ }^{4}$ A este respecto recomendamos la lectura del artículo de Pérez Oyarzún "Valparaíso y los años formativos", publicado en: Massilia 2007.

${ }^{5}$ Huizinga, Johan. Homo ludens. p. 20.
} 
Pero a esta primera característica, el juego incorpora, para Huizinga, otras relacionadas con ese alejamiento de la vida "corriente", ese "estar encerrado en sí mismo" -que supone el jugar- para refugiarse en una esfera de actividad que posee su propia tendencia. Un universo que determina, para el juego, sus límites de tiempo y de espacio, y dentro del cual el juego es orden: crea orden.

De este modo, esta aspiración del juego hacia el orden y la articulación, dibuja los límites de un paradigma interpretativo del hecho arquitectónico que trasciende el plano metafórico en el que el concepto suele quedar encerrado. Un paradigma que sirve así para interpretar el sentido que Jullian imprime a su propio modo de acercarse al proyecto. No es extraño, pues, que la añoranza del juego, modele su memoria cuando afirma: " $E l$ Atelier de la rue de Sèvres... siempre fue un lugar alegre porque Le Corbusier trabajaba como un niño"6.

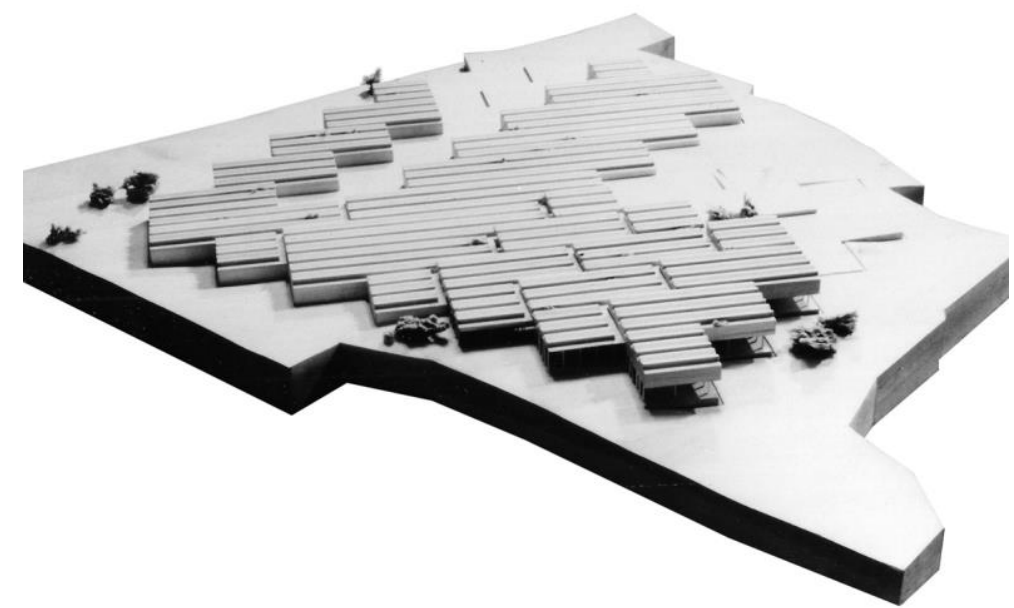

2. Vista de la Maqueta de Feria de Valencia.

\section{La esvástica y el dominó quebrado}

En el análisis de la Feria de Valencia, las referencias a la Gran Mezquita cordobesa así como el ejemplo del MatBuilding, constituyen acotaciones que, a pesar de haber sido abordadas en diferentes comentarios sobre el proyecto, deben sin embargo ser consideradas como parte de su interpretación.

A Córdoba -aunque de pasada- se refiere Jullian en la entrevista que Amedeo Petrilli le realiza en $1998^{7}$. En ella viene a señalar ese deseo de construir un espacio interpretado a partir de un orden de pilares -los pilotis lecorbuserianos- que, junto al manejo de la luz cenital, protagonizan el proyecto para Valencia. Asimismo la Mezquita, cuya grandiosa arquitectura estaba, muy probablemente, entre las intenciones del proyecto de la Feria, aparece como imagen iluminadora en un momento de la entrevista que, en 2006, le hace María Celia O’Byrne: "así es que [sic] está pensada la Feria de Valencia".

\footnotetext{
${ }^{6}$ Jullian de la Fuente citado por: Pérez de Arce, Rodrigo. Op. cit. p. 41.

${ }^{7}$ Petrilli, Amedeo. Op. cit. p. 121.

${ }^{8}$ O`Byrne Orozco, María Cecilia. “Entrevista a Guillermo Jullian de la Fuente”. En: El proyecto para el Hospital de Venecia de Le Corbusier. Director: Josep Quetglas. Universidad Politécnica de Cataluña - Escuela Técnica Superior de Arquitectura de Barcelona, 2007. Cuaderno V. p. 65.
} 
Por otra parte, el concepto de "Mat" - cuya traslación al español (estera) se queda lejos del significado arquitectónico alcanzado por el término inglés- constituye una referencia de carácter general a un tipo de edificación cuyas conexiones con la Feria de Valencia resultan evidentes.

En efecto, el Mat, expresaba una aspiración de la arquitectura moderna -y más concretamente de la arquitectura que estaba en discusión dentro del seno del Team 10- por alcanzar e interpretar ese "anónimo colectivo" en el que -como señala Alison Smithson en su transcendental ensayo sobre el significado y la caracterización del MatBuilding- las funciones venían a enriquecer lo construido y el individuo adquiría nuevas libertades de actuación favorecidas por un orden nuevo y cambiante, basado en la interconexión, los patrones de asociación compactos y las posibilidades de crecimiento, disminución y cambio ${ }^{9}$.

Aunque el concepto de Mat-Building aparece plenamente formulado casi una década después del proyecto de Jullian para la Feria de Valencia, la idea -como señala Smithson- fue tomando forma progresivamente y moldeándose a través de diferentes proyectos de los que el de la Universidad Libre de Berlín (1963), del equipo Candilis-Josic-Woods, terminará convirtiéndose -con su construcción- en el ejemplo paradigmático ${ }^{10}$.

Entre las arquitecturas que componen la mirada retrospectiva de Smithson sobre el Mat, aparece un proyecto que va a convertirse en el marco de referencia en el que podemos situar la Feria de Valencia: la propuesta de 1964 de Le Corbusier y Jullian para el Hospital de Venecia.

En efecto, la Feria de Valencia de Jullian de la Fuente, cuya gestación tiene lugar durante el desarrollo -ya sin Le Corbusier- del proyecto del Hospital de Venecia, mantiene con éste muchas similitudes: el grafismo, el manejo de la forma arquitectónica en la consecución de una edificación de carácter horizontal, el carácter secundario de las fachadas frente a la importancia del plano de cubierta y la solución concreta a la iluminación de los espacios interiores, señalan estos puntos en común. Pero más allá de estas circunstancias, es el espíritu de "juego" el que anima ambos proyectos. Si en Venecia, Jullian y Le Corbusier juegan con la rotación de las unités de soins en la conformación de una esvástica que resuelve la circulación horizontal dentro del edificio, en Valencia esas mismas piezas - convertidas ahora en lonjas- construyen una suerte de dominó quebrado, magistralmente adaptado a la topografía, cuya vocación es la de extenderse sobre el territorio desplegándose como un gigantesco mosaico.

Esvástica y dominó quebrado se convierten así en elementales mecanismos compositivos que explican ambos proyectos. Mecanismos en los que se encierran las claves para la creación de la obra. De este modo, al apoyándonos en la idea de "juego", el estudio se reorienta hacia la descomposición analítica del proyecto. Una descomposición que nos permite llegar, no sólo al conocimiento de los elementos que integran la totalidad, entendidos como principio constituyente de la forma arquitectónica, es decir: como origen y parte de ésta, sino también, y sobre todo, a la comprensión de las relaciones de orden que mantienen dentro de la misma.

Recorreremos, pues, un camino para ir de los hechos a la ley que los rige, tratando de expresar la constitución de la forma arquitectónica como síntesis de un proceso creador y unificador. El paradigma de juego será nuestra

\footnotetext{
${ }^{9}$ Smithson, Alison. "How to Recognise and Read Mat-Building: Mainstream Architecture as It Has Developed towards the Mat-Building”. En: Sarkis, Hashim (Ed.). Le Corbusier's Venice Hospital and the Mat Building Revival. p. 91. El artículo de Alison Smithson se publicó por primera vez en septiembre de 1974 en la revista Architectural Design.

${ }^{10}$ Ibid.
} 
apoyatura, y los maravillosos diagramas funcionales de la Feria de Valencia, publicados por Jullian en 1968 en la revista Lotus -a los que más adelante nos referiremos- indican que no vamos desencaminados.

\subsection{Venecia}

En Venecia, Le Corbusier y Jullian acometen la proyectación de un complejo orden horizontal, consecuente con la tipología y la trama de la ciudad, que implicaba la creación de una densa masa de edificación atravesada por patios. En la consecución de este orden, la creación de una unidad básica de edificación -la unité de bâtisseconstituye el germen del proyecto.

Esta parte elemental del conjunto se proyecta a partir del nivel superior de la edificación: la planta de las habitaciones - cellule- de los enfermos, que se va a convertir en el plano canónico del Hospital.

La unité de bâtisse conforma un cuadrado en el que desde un núcleo central -campiello- que conecta en vertical las distintas plantas del edificio, parten cuatro calles cuya disposición en esvástica imprime un orden rotacional a la unidad. Sobre este orden se va a apoyar la pieza secundaria del juego: la unidad de cuidados -unité de soinsque organiza la disposición de las habitaciones en torno a una serie de pasillos.

A través de la unité de bâtisse, circulación y función quedan dirigidas por un mismo engranaje -el de la rotaciónque termina por imponer sus reglas de juego a las unidades contiguas y, por extensión, a toda la planta.

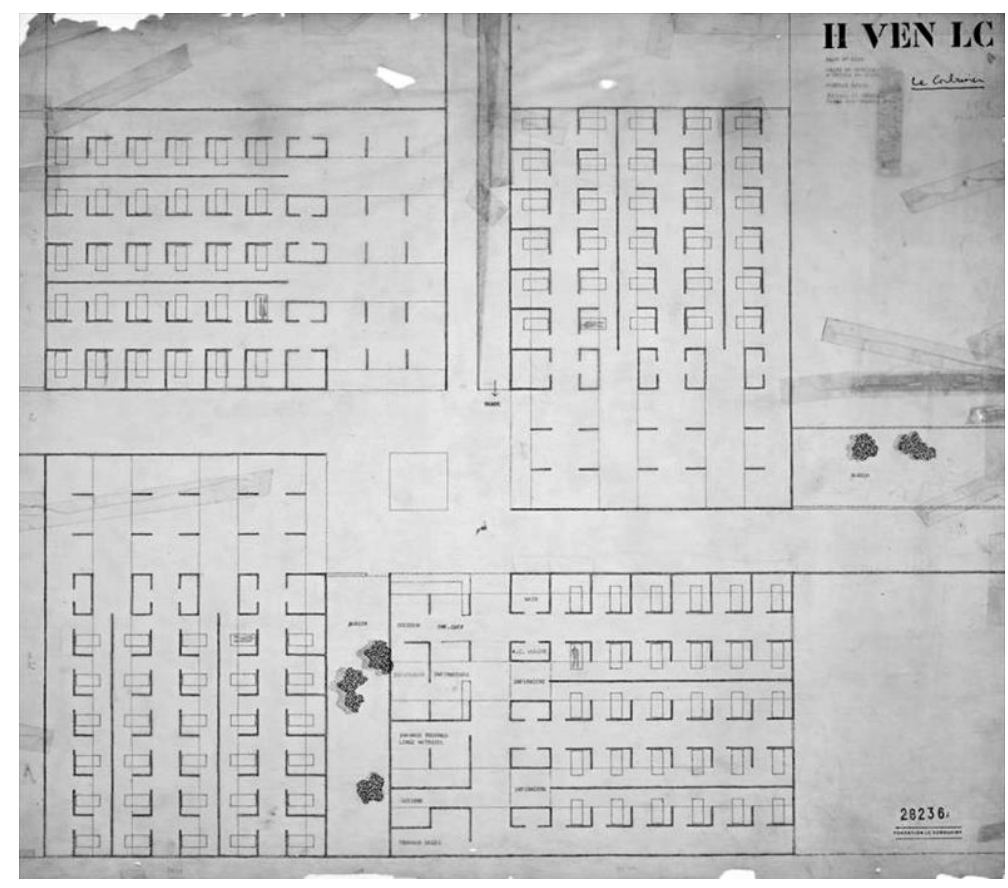

3. H VEN LC. Plano No 6286: "Unité de bâtisse - 4 Unités de soins" (escala 1:100, 1/10/1964) CFLC-ADAGP. 
En un ensayo aparecido por primera vez en 1966 en Architectural Design, Alan Colquhoun hace un análisis de dos de los últimos proyectos de Le Corbusier -el edificio de la Embajada de Francia en Brasilia y el Hospital de Venecia- en el que muy acertadamente examina las coincidencias entre ambas arquitecturas. Para Colquhoum, a pesar de las diferencias funcionales y organizativas entre una y otra propuesta, existe la evocación de una "respuesta compleja" en la que se superponen diversos niveles, pero en la que el recurso a un esquema fijo hace posible la descomposición analítica de su arquitectura. De este modo, la forma no se piensa como algo que emerge de la función, sino como algo basado en "esquemas ideales", y es en ese nivel en el que, para este autor, las funciones, libremente desplegadas, entablan con la forma un diálogo repleto de incidencias estéticas inesperadas $^{11}$. Su conclusión nos aporta una idea que estimamos clave para entender la conexión de estos proyectos -en los que de manera tan decisiva intervino Jullian de la Fuente- con el proyecto de la Feria de Valencia: "la impresión de complejidad, en Venecia, como en Brasilia, es el resultado del impacto de varios subsistemas heterogéneos sobre unos esquemas básicos que, en sí mismos, son extremadamente simples ${ }^{12}$.

Como veremos, la elementalidad del juego en esvástica que explica el orden complejo del Hospital de Venecia, se traducirá en un elemental juego en dominó quebrado que revela el orden complejo de la Feria de Valencia.

\subsection{Valencia}

En Valencia el juego de elementos que componen la unidad básica del proyecto se simplifica. Ésta ya no es tanto una pieza de piezas - como era el caso de la unité de bâtisse del Hospital de Venecia- como una unidad construida a partir de un módulo básico de edificación: la lonja.

Pero para entender el significado de este elemento del proyecto se debe prestar atención a una serie de láminas que constituyen el primer escalón conceptual del mismo. Nos referimos a un conjunto de diagramas que, bajo el título de "programa", fueron desarrollados por Jullian en colaboración con José Oubrerie y Fernando Domeyko ${ }^{13}$.

Se trata de un conjunto de dibujos fechados en París el 15 de febrero de 1967 en los que se investiga a cerca de la creación de una topología para el proyecto. El punto de partida para esta indagación lo constituyen los diferentes sistemas circulatorios a los que tiene que dar respuesta el conjunto de la Feria. En un primer grado de aproximación a la geometría del recorrido, la traza de éste se apoya en una retícula de tres por tres módulos cuadrados sobre la que se pueden dibujar diferentes circuitos construidos a partir del giro a 90 grados.

Con estos diagramas, Jullian parece ir un paso más allá de la creación de una simple traza lineal, reinterpretando la "grilla" y orientando la búsqueda a la consecución de una auténtica "textura". El entramado del proyecto va adquiriendo cada vez mayor complejidad, mediante operaciones de superposición de las circulaciones y la división y combinación de los diferentes sectores en los que se puede organizar el conjunto. De ahí que el último de estos diagramas se refiera, precisamente, a la creación de una "matriz" capaz de dar respuesta a la implantación de la Feria sobre un territorio todavía abstracto.

\footnotetext{
${ }^{11}$ Colquhoun, Alan. "Interacciones formales y funcionales. Un estudio de dos de los últimos proyectos de Le Corbusier”. En: Arquitectura moderna y cambio histórico: ensayos 1962-1976. p. 43. En ambos proyectos fue decisiva la participación de Jullian de la Fuente, hasta el punto de continuar con los trabajos tras la muerte de Le Corbusier.

${ }^{12}$ Ibid.

${ }^{13}$ Estas láminas fueron publicadas en la revista Lotus. № 5. 1968. pp. 36-37.
} 
Un segundo escalón conceptual, da comienzo cuando ese entramado básico de la matriz se superpone a la topografía del sitio, dando lugar a lo que, el profesor Rodrigo Pérez de Arce, interpreta como verdadero "campo de juego" 14 . Surgiendo de este modo la necesidad de definir la pieza esencial del mismo.

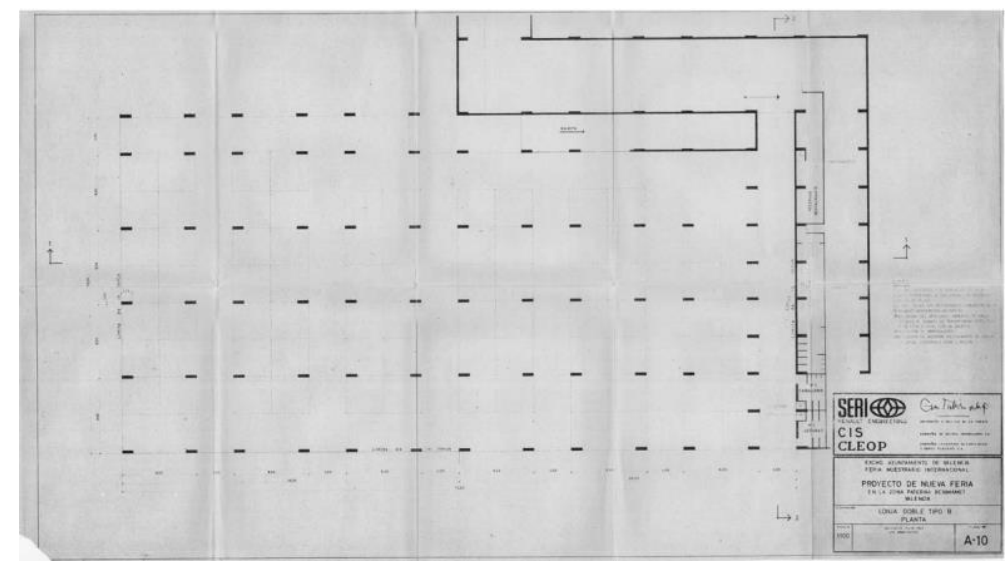

4. Planta de la lonja doble tipo B de la Feria de Valencia. Plano No A-10 (escala 1:100, Julio 1967).

Ésta nace de una unidad de construcción -la lonja de 36 x 36 m.- que se ajusta a la dimensión del módulo cuadrado de la parrilla y que básicamente corresponde a un espacio ordenado a partir de los pilares (pantallas) que sostienen un sistema de cubierta formado por una losa plegada en V, similar a la del Hospital de Venecia.

Cada lonja permite la creación de tres áreas de exposición de $8 \mathrm{~m}$. de anchura y $36 \mathrm{~m}$. de largo en las que las pantallas se disponen de tal forma que entre ellas se pueden organizar espacios expositivos basados en el módulo cuadrado de 4 × $4 \mathrm{~m}$. Entre estas áreas de exposición se generan pasillos transversales -también de $4 \mathrm{~m}$. de ancho- que conectan con la circulación de borde de la lonja, integrándose al sistema de recorridos dentro de la Feria.

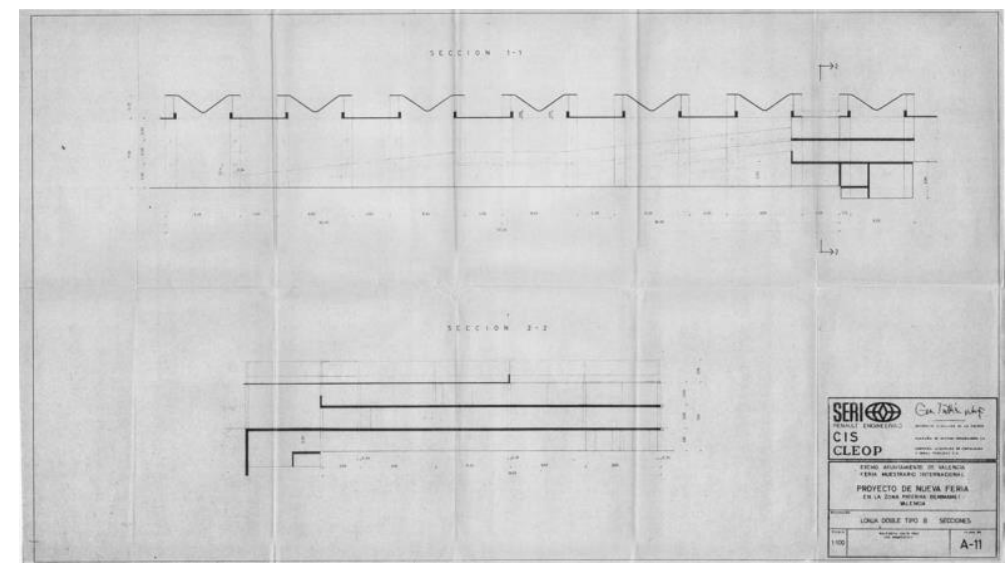

5. Secciones de la lonja doble tipo B de la Feria de Valencia. Plano No A-11 (escala 1:100, Julio 1967).

La pieza básica del proyecto se construye a partir de dos módulos contiguos de lonja, de los que uno de ellos resuelve con una rampa la diferencia de cota de nivel $(2,50 \mathrm{~m}$.) que conlleva la implantación de la trama sobre el

\footnotetext{
${ }^{14}$ Pérez de Arce, Rodrigo. Op. cit. p. 63. A este respecto debemos señalar que el binomio "arquitectura y juego" constituyese -para este autor- la primera de las seis claves temáticas que explican la obra de Jullian de la Fuente (ver pp. 20-47).
} 
terreno. Con esta pieza esencial del juego - en realidad una doble lonja- se produce el montaje de todo el conjunto de la Feria.

Comenzando en la cota inferior del terreno, el sistema semeja un dominó quebrado que va generando terrazas en zigzag. Estas plataformas se conectan entre sí mediante el sistema de rampas que, a su vez, generan ejes de circulación que las atraviesan en diagonal.

El juego con las diferentes alturas de las lonjas (5 m., 7,50 m. y 10 m.) permite -a nivel volumétrico- absorber las diferencias de cota entre las distintas plataformas, de manera que, combinando esas alturas, se consigue que la volumetría del conjunto de pabellones sólo presente un único escalonamiento para un interior que se desarrolla en cuatro plataformas con desniveles de 2,50 m. entre ellas. La edificación adquiere así un carácter horizontal, a pesar de las grandes diferencias topográficas.

En la zona superior del terreno se localiza la entrada general que sirve también al área de congresos, restaurante y hotel ${ }^{15}$, que forman una unidad dentro del proyecto. Su arquitectura se plantea siguiendo el mismo sistema estructural de los pabellones de exposición y constituye un magnífico ejemplo de integración de diferentes programas dentro de una misma construcción.

Con una pieza -la lonja-formalmente similar a la estructura de la unité de soins del Hospital de Venecia, Jullian crea un maravilloso juego de dominó que se va adaptando a las curvas de nivel del terreno para completar un mosaico bajo el que se cobija un espacio continuo pero diverso en el que tiene lugar la confluencia de las gentes.

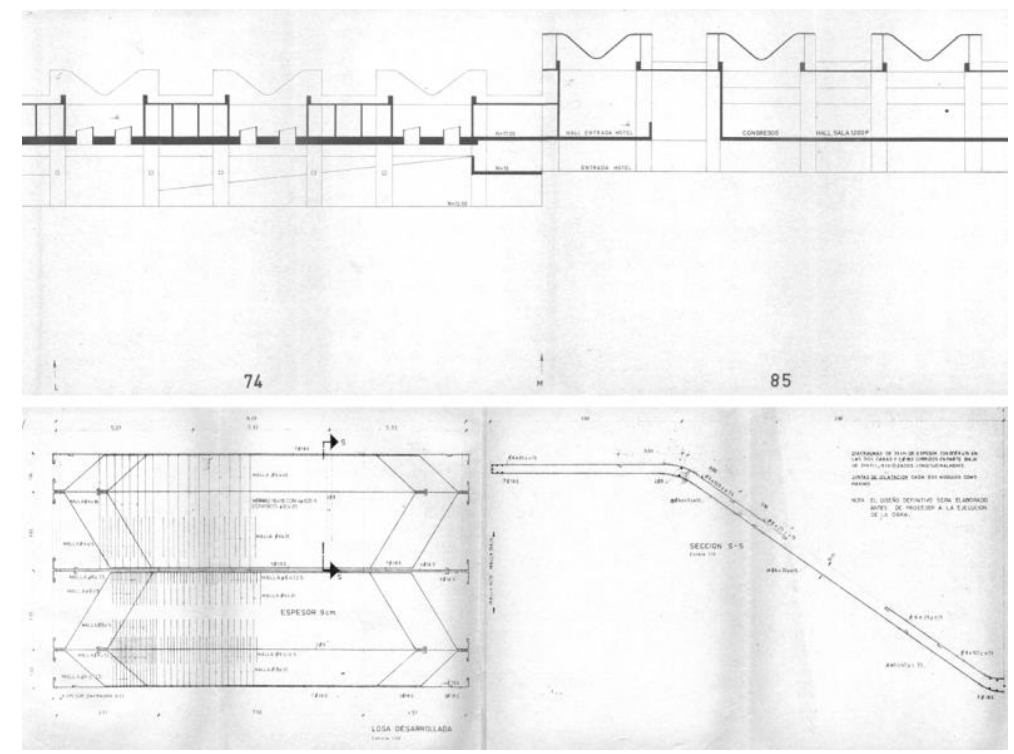

6. Detalle de la sección longitudinal 5, hotel y sala de congresos, Plano No A-26 (escala 1:100, Julio 1967). Armado de la losa en forma de V de 16 metros del proyecto original, Plano $\mathrm{N}^{\circ}$ E-17 (escala 1:50 y 1:10, Julio 1967).

\footnotetext{
${ }^{15}$ Este conjunto estaba previsto en una segunda fase de construcción que no llegó a realizarse.
} 


\section{Apuntes para una conclusión}

La seriedad, que no frivolidad, del juego, no debe ocultar un hecho al que no es ajeno nuestra ponencia: la Feria de Valencia lamentablemente ha desaparecido. Sólo un pequeño pabellón sobrevive absolutamente descontextualizado y sin protección patrimonial. Si desaparece, lo habrá hecho la única edificación en la que se ensayó a gran escala la construcción de las cubiertas del Hospital de Venecia ${ }^{16}$.

Se da la paradoja de que ambas obras - coetáneas en su desarrollo proyectual- sólo permanecerán en la memoria de la arquitectura moderna, así como en sus documentos, pero no como obra construida en la que se pueda experimentar la percepción del espacio, su escala, su luminosidad, el ambiente: la emoción de una arquitectura viva.

Como memoria, cabe destacar esa íntima relación que tiene el proyecto de Valencia con el del Hospital veneciano. Ambos pioneros y coetáneos respecto de aquel concepto arquitectónico del Mat-Building que, con evidente protagonismo de Shadrach Woods, había surgido en las reuniones del Team 10. Paradigma que -como ya hemos señalado- pondrá en valor Alison Smithson en su famoso artículo de $1974^{17}$, y de cuya filosofía proyectual se han realizado posteriormente diversos ejemplos.

A este respecto debemos señalar el artículo de Timothy Hyde "How to Construct an Architectural Genealogy", en el que, con una mirada hacia delante, hace un recorrido por la arquitectura moderna vista desde la óptica del Mat-Building. Los ejemplos destacado por Hyde van desde el barrio de Tuscolano de Libera (1951-54), hasta la propuesta de Reiser, Unemoto y Eisenman para Nueva York (1999). Un itinerario en el que -a diferencia de Smithson- el autor se detiene en el proyecto de Jullian para la Feria de Valencia: "from the Crystal Palace to Tange's plan for Osaka, provide further training in mat building... multiple programs and extensive circulation contained by comprehensive structure permit flexible use and movement within a legible system" ${ }^{\text {"18 }}$.

Cabe recordar que Jullian escribe a los Smithson en septiembre de 1.967 informándoles del inicio del proyecto de la embajada francesa en Brasilia y anticipándoles que les mostrará el proyecto de la Feria de Valencia, cuyos planos de desarrollo sabemos que están fechados en julio de ese año. También informa del proyecto a Mónica Pidgeon, editora de Architectural Design, en diciembre de ese mismo año ${ }^{19}$. Sin embargo la primera vez que aparece publicado el proyecto es con motivo del artículo, que en 1968, le dedica Giuseppe Mazzariol en la revista Lotus; cuya portada está protagonizada por un maravilloso boceto de la sección. Allí la Feria es presentada como el primer proyecto que -tras la muerte del maestro- acomete en solitario Jullian de la Fuente, su último hijo espiritual. El proyecto es contemplado, por Mazzariol, bajo el paradigma de un moderno y gigantesco "Bazar" en el que la experiencia de un recorrido no obligatorio y diverso adquiere todo el protagonismo ${ }^{20}$.

\footnotetext{
${ }^{16}$ Antes de la construcción de la Feria, Jullian ensayó, a pequeña escala, la construcción de este tipo de cubierta en un ático para oficinas en Lyon. Ver: Pérez de Arce, Rodrigo. Op. cit. pp. 114-115.

${ }^{17}$ Smithson, Alison. Op. cit.

${ }^{18}$ Hyde, Timothy. "How to Construct an Architectural Genealogy". En: Sarkis, Hashim (Ed.). Le Corbusier's Venice Hospital and the Mat Building Revival. p. 108

${ }^{19}$ La Facultad de Arquitectura, Diseño y Estudios Urbanos (FADEU) de la Pontificia Universidad Católica de Chile custodia actualmente el Fondo Documental Guillermo Jullian de la Fuente. La carta a los Smithson así como la enviada a Mónica Pigdeon tienen los códigos FGJ-C0269 y FGJ-C0278 respectivamente. Dichos documentos sólo puede ser consultados en la biblioteca de la FADEU. Conocemos su contenido por las fichas del catálogo redactadas por la archivista Paloma Parrini.

${ }^{20}$ Mazzariol, Giuseppe. "La Feria di Valencia di Guillermo Jullian”. En: Lotus. № 5. 1968. p 35.
} 
También la idea del recorrido preside el apartado que Pérez de Arce dedica a la Feria en su artículo de Massilia 2007. Bajo el encabezamiento "Valencia y los laberintos funcionales", el autor se detiene en aquellos diagramas topológicos que constituyen la primera aproximación conceptual al proyecto y en los que, como vimos, la idea de "juego" adquiría un papel destacado: "fuertemente polarizada, la idea de recorrido que emerge de estos esquemas parece querer iluminar los tránsitos y relaciones entre recintos y, al mismo tiempo, estimular la deriva de los pasos perdidos, operación que recuerda ciertos juegos figurativos" ${ }^{21}$.

Un importante apunte sobre esta presencia del juego en la obra de Jullian, lo encontramos en el comentario de Pablo Allard contenido dentro de su artículo "Bridge over Venice". Ensayo en el que queda clara esa cercanía entre el proyecto para Valencia y el Hospital veneciano. Hablando de cómo entiende Jullian el orden, dice Allard: "this incorporation of a dimension of play in constant dialogue with working rigor is more serious than its superficial reading, and it has been a persistent characteristic of Jullian's work"22.

Por último, Giuliano Gresleri, considera en su artículo: "La Chiesa in collina e l'atelier tra cielo e mare", que la Feria de Valencia constituye el desarrollo de los procedimientos agregativos del Hospital de Venecia y señala cómo el proyecto, a pesar de ser poco conocido, encontrará repercusión en la búsqueda arquitectónica de los años sucesivos; donde la idea de un espacio capaz de crecer armónicamente sin interrumpir la concepción espacial del módulo básico que lo compone, será recogida por el Atelier 5 y por Herman Hertzberger e influirá en el trabajo de muchos otros arquitectos ${ }^{23}$.

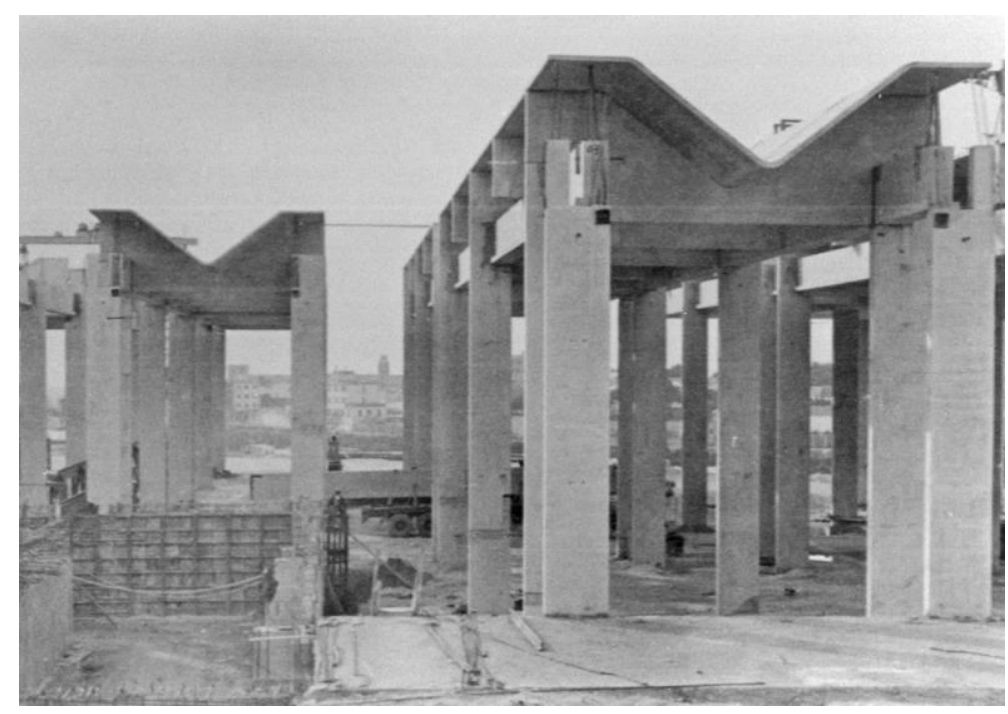

7. Construcción de las losas en V en Feria de Valencia.

${ }^{21}$ Pérez de Arce Antoncic, Rodrigo. "Entre el atajo y la promenade: recorridos en la obra de Guillermo Jullian". En: Massilia. 2007. p. 146. El autor ilustra esta idea con una lámina que recoge una poesía laberíntica cúbica dedicada al obispo de Oporto (c. 1600).

${ }^{22}$ Allard, Pablo. "Bridge over Venice. Speculations on Cross-fertilization of Ideas between Team 10 and Le Corbusier (after a Conversation with Guillermo Jullian de la Fuente)". En: Sarkis, Hashim (Ed.). Le Corbusier's Venice Hospital and the Mat Building Revival. pp. 18-35.

${ }^{23}$ Gresleri, Giuliano: "La Chiesa in collina e l'atelier tra cielo e mare”. En: Massilia. 2007. p. 40. 


\subsection{Aproximación a una cronología}

El proyecto para el Hospital de Venecia y el de la Feria de Valencia discurren por caminos muy diferentes. Mientras que el Hospital avanza siguiendo una línea continua, clara y documentada, la Feria transita por una ruta discontinua, borrosa y olvidada. De ahí que cuando estos caminos se acerquen lo hagan a veces en terrenos en los que se desdibujan las huellas que nos permiten reconocer el momento exacto de esa aproximación.

1917 señala, en la arquitectura del Corbu, la época que va de las Casas "Dom-ino" a las Casas "Citrohan". Pero en Valencia es el año en el que nace una institución que se convertirá con el tiempo en uno de los grandes instrumentos de proyección internacional de la ciudad: la Feria de Valencia.

Sin embargo, 1917 sólo constituye una anécdota dentro de esta cronología: la de situar en el horizonte la fecha de 1967 como la de la celebración del cincuenta aniversario del nacimiento de aquella institución. No es extraño pues, que en el ánimo de los promotores del nuevo recinto ferial estuviera la idea de señalar, con una gran obra de arquitectura, esa conmemoración ${ }^{24}$. Nuestra aproximación a esta fecha tan significativa requiere, por tanto, un gran salto en el tiempo.

1963

17 de diciembre. Le Corbusier escribe a Carlo Ottolenghi -presidente de los Ospedali Civili Riuniti di Veneziaaceptando hacerse cargo del proyecto de Hospital de Venecia y comprometiéndose a entregar una primera fase del mismo en mayo del año siguiente.

Es también el año de la fundación de la Feria Internacional del Mueble de Valencia: Fernando Mateu de Ros es su director y fundador.

1964

El Ayuntamiento de Valencia se hace con los terrenos del antiguo campo de tiro de Paterna -situado a las afueras de la ciudad- que serán destinados a albergar el nuevo recinto ferial.

1965

30 de marzo. La Embajada de España en París dirige una carta a Le Corbusier en la que le comunican el interés de una persona en España por entrevistarse con el maestro para: "exposer un projet espagnol d'urbanisation de la banlieue de Valence ${ }^{\text {} 25}$. El Agregado Cultural de la Embajada -Rafael F. Quintanilla- firma el documento. Le Corbusier incorporada a la carta una nota manuscrita que no hemos podido descifrar. Del contenido de la misiva se deduce que el maestro -aunque desconocía los detalles- estaba informado sobre el asunto.

1 de abril. La Secretaria de Le Corbusier remite una carta al Agregado Cultural de la Embajada española, en la que le comunica que el maestro "sera heureux de vous recevoir en mai ainsi que la personne venant d'Espagne qui doit lui donner les précisions utiles relatives à votre projet d'urbanisation. Toutefois il vous demande de bien vouloir le prévenir assez longtemps à l'avance de la date de ce rendez-vous car il doit s'absenter de Paris à plusieurs reprises" ${ }^{26}$.

\footnotetext{
${ }^{24}$ La feria se celebraba entonces en el entorno de Viveros, en pleno centro de la ciudad.

${ }^{25}$ Fundación Le Corbusier. Documento No 12-16-251.

${ }^{26}$ Fundación Le Corbusier. Documento No 12-16-252.
} 
8 de abril. Le Corbusier y Jullian de la Fuente viajan a Venecia para la entrega del proyecto del Hospital.

Mayo. Es el mes previsto para la cita con Le Corbusier. Sabemos -por testimonios familiares directos- que Fernando Mateu de Ros y Carlos Soria -arquitecto director de los servicios técnicos de Feria Muestrario de Valencia- viajaron a París para entrevistarse con el maestro. Sin embargo no es posible confirmar la fecha exacta de esa visita ya que no se han encontrado, por el momento, los documentos que la acrediten.

Agosto. Durante todo el mes Jullian está en Venecia trabajando en el proyecto del Hospital: concretando quien debe hacer los cálculos de la estructura de hormigón y quien debe pagarlos. El 27 de ese mes muere Le Corbusier en Cap Martin.

En el primer consejo de administración del hospital tras la muerte del Corbu se decide que sea su colaborador Jullian de la Fuente quien continúe con el proyecto en los términos contractuales.

Otoño-invierno. Se cierra el Atelier de la rue de Sèvres y Jullian, Oubrerie, Jeannette -la secretaria de Le Corbusier- y Andreini -el contable del Atelier- se trasladan a un pequeño estudio de pintor en la rue Daguerre del barrio de Montparnasse, que había pertenecido a Shadrach Woods.

1966

19 de febrero. Con motivo de la inauguración de la V Feria del Juguete de Valencia se presenta a la prensa la maqueta y planos de las nuevas instalaciones feriales. Se trata de un anteproyecto firmado por Carlos Soria y Román Giménez. El diario Levante lo recoge con estas palabras: "Los correspondientes proyectos han sido realizados por los arquitectos Carlos Soria y don Ramón [sic] Giménez. Ocuparán una superficie de unos cien mil metros cuadrados, y su coste se estima en unos seiscientos millones de pesetas... El proyecto es magnifico, ya que ofrece una espléndida perspectiva y amplios espacios para el montaje de estas ferias comerciales ${ }^{27}$.

28 de febrero. Jullian entrega en Venecia el proyecto titulado "H.VEN.LC - Variante à 800 lits" que lleva el sello de Le Corbusier.

1966-[1967]

Se abandona el proyecto de Soria y Giménez a favor del realizado por la ingeniería francesa SERI-Renault, para la que Jullian trabajaba como arquitecto asesor tras la muerte del $\mathrm{Corbu}^{28}$.

1967

Febrero-junio. El Atelier Jullian de la rue Daguerre trabaja en el proyecto para la Feria de Valencia (F VAL). Intervienen: Oubrerie, Andreini, Gabillar, Domeyko, Gambarin, Koszel y Jampen.

\footnotetext{
${ }^{27}$ Levante. Domingo, 20 de febrero de 1966. p. 7. El proyecto es muy diferente al realizado posteriormente por Jullian de la Fuente: un sistema de pabellones independientes se ordenan en torno a lo que parece ser una gran avenida central que actúa como eje de simetría que desemboca en un pabellón o plaza semicircular.

${ }^{28}$ En un reportaje publicado en El Mercantil Valenciano (Domingo, 30 de junio de 2002. p. 5), Román Jiménez comenta que fueron los problemas para financiar la obra los que dieron al traste con aquella propuesta y declara que fue SERI-Renault la que aportó la solución para el dinero, pero traían bajo el brazo su propio proyecto.
} 
Julio. SERI-Renault (Arquitecto: Jullian de la Fuente): "Proyecto de Nueva Feria en la zona de Paterna Benimàmet. Valencia".

Septiembre. El hijo de Carlos Soria se incorpora al Atelier Jullian de la rue Daguerre para colaborar en el proyecto de la Embajada de Francia en Brasilia, que Jullian había heredado del Corbu ${ }^{29}$.

1968

Dan comienzo las obras de la Feria de Valencia con el movimiento de tierras.

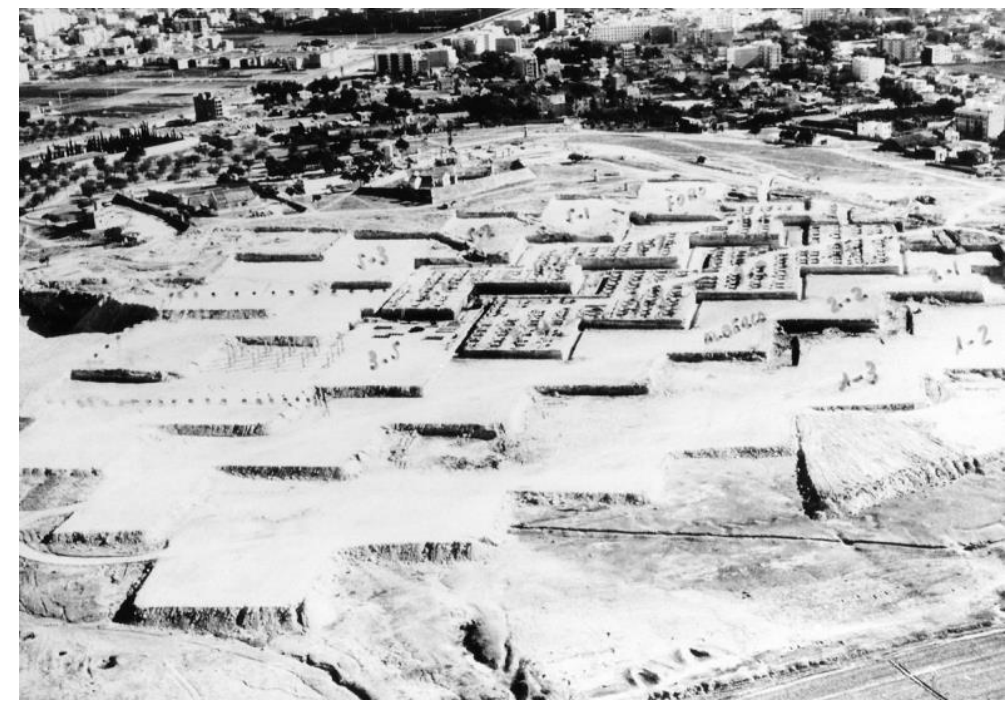

8. Explanación y aterrazamiento de los terrenos en los que se edificará Feria de Valencia.

1969

La construcción de la Feria de Valencia sigue adelante. El diario Levante recoge la noticia de la visita a las obras del alcalde de la ciudad con estas palabras: "Como técnico asesor de las autoridades figuraba el arquitecto municipal, director de las obras, don Román Giménez, coautor, con el arquitecto don Carlos Soria del proyecto de esta nueva Feria que se está levantando, desarrollando una idea del arquitecto francés Jullian de la Fuente, discípulo y seguidor del célebre Le Courbusier [sic]"30. La primera fase de edificación será inaugurada en octubre de este año.

\footnotetext{
${ }^{29}$ Destacamos este hecho para acercarnos al modo de trabajar del Atelier de la rue Daguerre. En conversación con Carlos Soria Giner (mayo-2015) sabemos que su llegada a París -tras haber acabado sus estudios de Arquitectura en la escuela de Barcelona- coincidió con la obra de reforma de aquel pequeño local. Tres días antes se había marchado Mario Botta, quien había estado trabajando durante un año en el desarrollo del proyecto para Venecia. Según su testimonio directo parece ser que Giuseppe Samoná estaba interesado en que en el Hospital interviniesen los hermanos Petrilli -alumnos suyos en la Escuela de Arquitectura de Venecia- por lo que Carlos dedicó su labor al proyecto de la Embajada. Soria Giner, comenta el hecho de que Guillermo Jullian y José Oubrerie heredaron el método de trabajo de Le Corbusier, así como los proyectos que estaban en marcha a la muerte del maestro: donde lo dibujado por el Corbu se mantenía hasta el final, mientras que en lo nuevo se permitían cierta flexibilidad. Recuerda que en el Atelier trabajaban con papel sulfurizado y dibujaban los detalles a escala 1:1 en hojas de papel continuo que se colgaban de las paredes. Posteriormente, el trabajo pasaba a la ingeniería SERI-Renault que se encargaba de realizar el proyecto de ejecución.

${ }^{30}$ Levante. Sábado, 12 de enero de 1969. p. 11.
} 


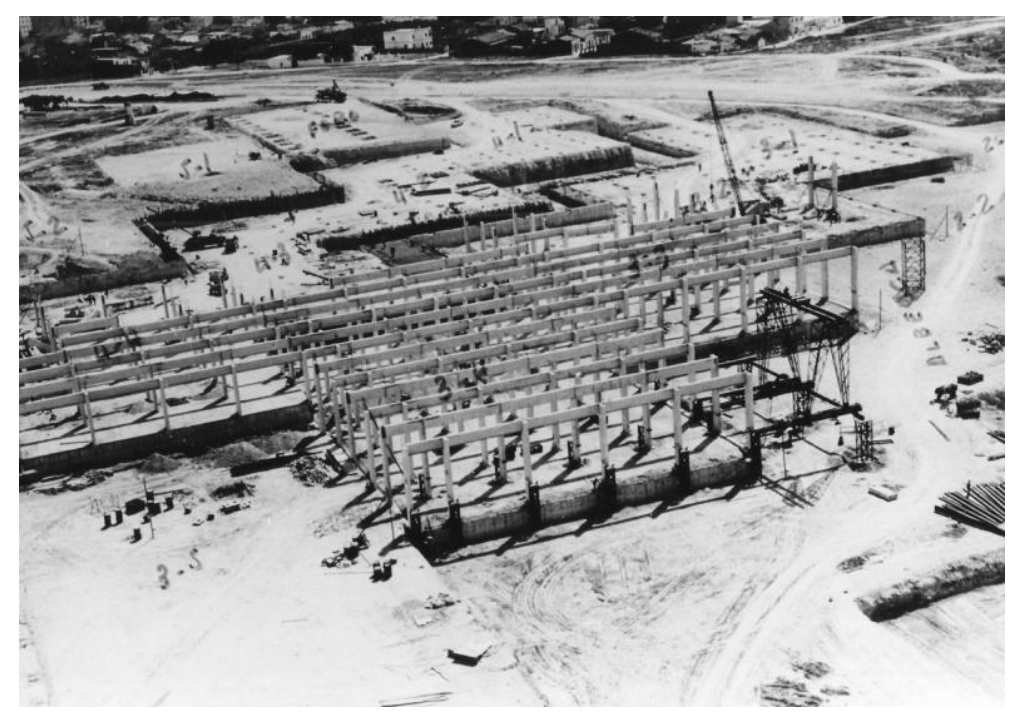

9. Construcción de la estructura de las lonjas de Feria de Valencia.

1970

Se abandona definitivamente la construcción del Hospital de Venecia, días antes de esa decisión se habían tomado las primeras muestras para la cimentación de los pilotis ${ }^{31}$.

La Feria de Valencia comienza su andadura. Casi treinta años después el edificio será demolido.

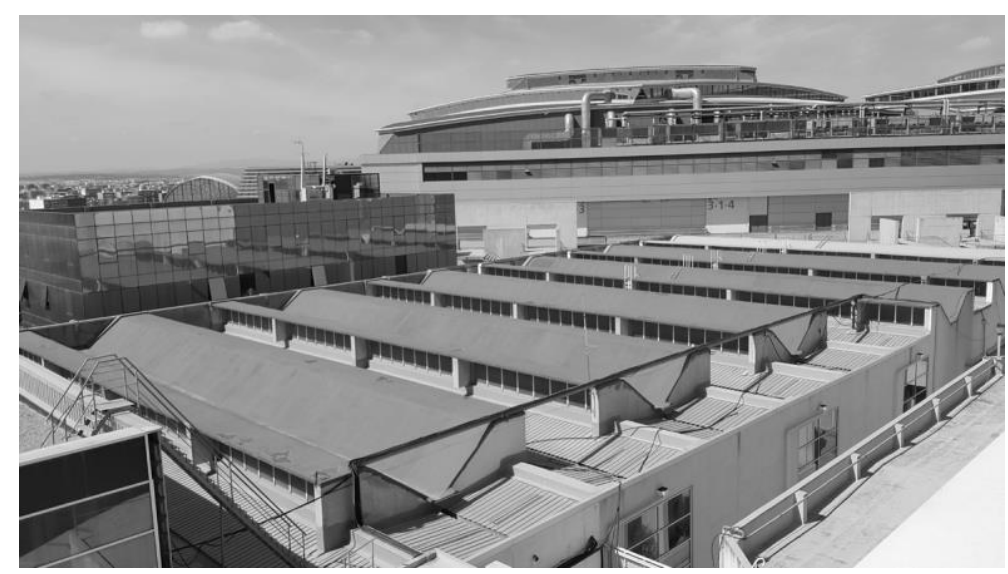

10. Cubierta del Foro Norte, única lonja existente.

\subsection{La Feria de Valencia: valor patrimonial}

A pesar de lo poco que queda del edificio y su absoluta descontextualización, entendemos el valor patrimonial que tiene la permanencia de la Feria Valencia de Jullian de la Fuente en la memoria arquitectónica de la ciudad. Quedan los documentos orales, escritos y gráficos que completan el recuerdo de haber transitado por sus lonjas sin la justa valoración de su importancia en la historia de la arquitectura moderna.

${ }^{31}$ Allard, Pablo. Op. cit. p. 27. 


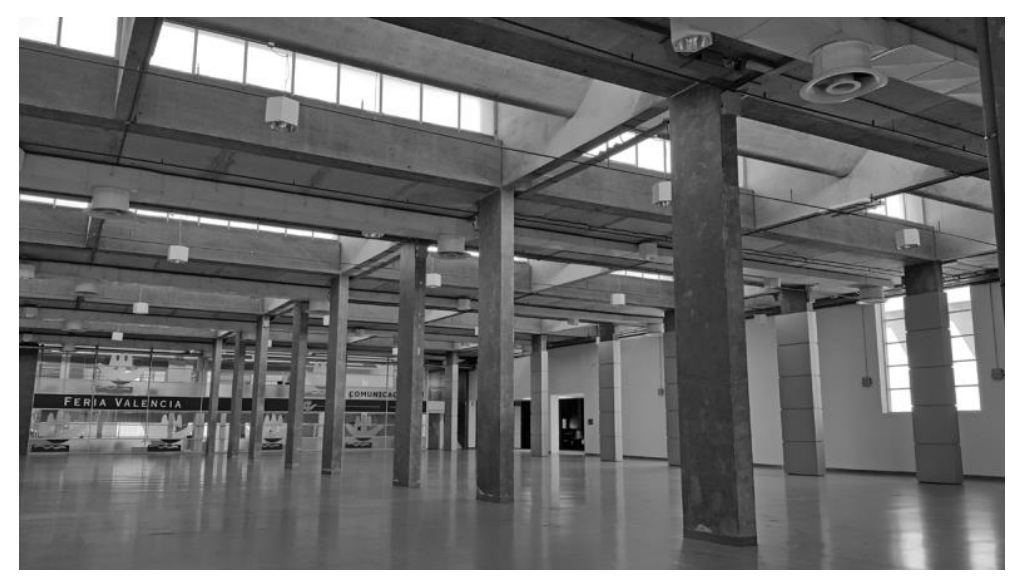

11. Espacio interior del Foro Norte.

Hay de inmediato que conseguir poner en valor lo poco que se conserva del conjunto. A la protección del bien inmueble hay que unir la protección de toda la documentación existente, la cual sabemos que está correctamente archivada y documentada en los originales depositados en la Facultad de Arquitectura, Diseño y Estudios Urbanos de la Pontificia Universidad Católica de Chile. Así como añadir una labor informativa sobre la íntima relación que existe entre el hecho compositivo recogido en el Mat-Building y los proyectos del Hospital de Venecia y la Feria de Valencia. Deber informativo del que el presente trabajo constituye un primer intento.

Es igualmente necesario proponer la inclusión del módulo de lonja que aún permanece en pie, dentro de una ficha de catálogo del DOCOMOMO IBERICO (Documentation and Conservation of buildings, sites and neighbourhoods of the Modern Movement- Sección Ibérica), ya que entendemos que es un registro abierto, y que -aunque en su primera fase se incluyeron los 166 edificios considerados más representativos del período comprendido entre 1.925 y 1.965 - se ha ido ampliando con obras coetáneas a la Feria de Valencia: como el edificio de la Confederación Hidrográfica del Júcar en Valencia (1.962-1.970) de Miguel Colomina, o las obras de Fernando Moreno Barberá de la Universidad Laboral de Cheste (1.965-1.969), la Facultad de Derecho (1.9591.968) y la de Filosofía y Letras (1.960-1.970) ambas en Valencia. Ficha que se documentaría con la descripción del proyecto original, el estado actual y los valores arquitectónicos de la pieza construida, como son: la fabricación in situ, el uso de la luz cenital, la materialidad del hormigón y el orden compositivo. Con una referencia clara como obra reconocida del Atelier de Le Corbusier e inscrita en el concepto Mat-Building.

Proponemos también la inclusión del módulo de lonja en el Catálogo de Espacios y Bienes Protegidos del Plan General de Ordenación Urbana de Valencia, con la categoría de Bien de Interés Cultural. Su inclusión en el Inventario General de Patrimonio Cultural Valenciano, según dispone en su artículo 15 la Ley 5/2.007 de Patrimonio Cultural Valenciano.

Esta protección y catalogación llevaría aparejada, pues, la colaboración entre administraciones públicas y, en este caso las instituciones locales - concretamente el Ayuntamiento de Valencia y Feria Valencia- para que adopten las medidas recogidas en la citada Ley en cuanto a conservación, protección, difusión y posibilidad de conocer el citado Bien. 


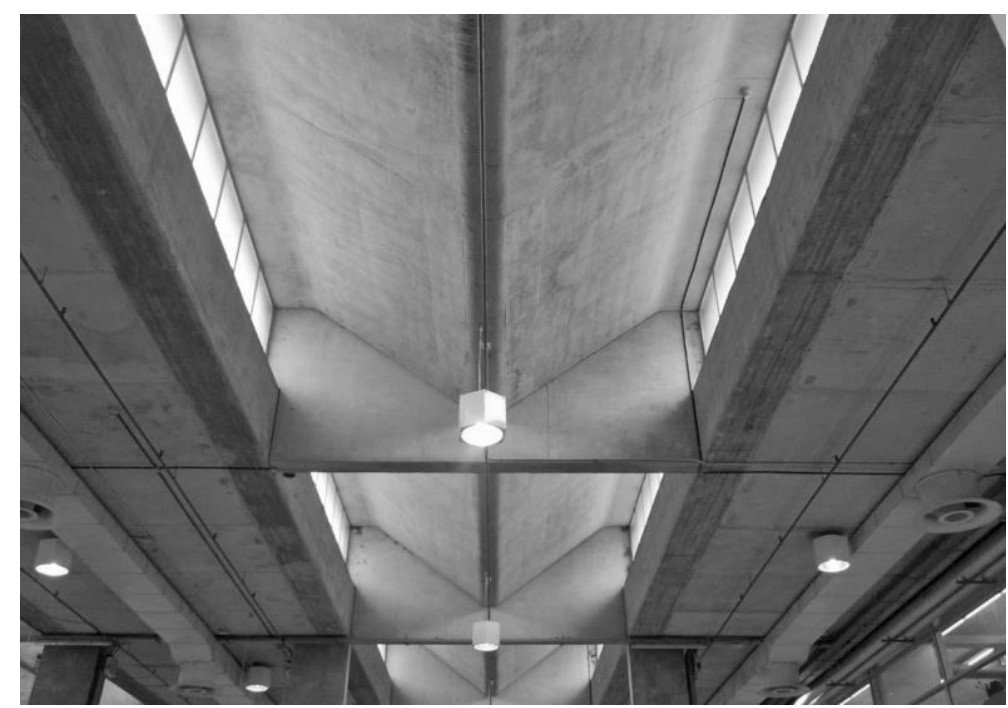

12. Detalle del lucernario, losa en $\mathrm{V}$ del Foro Norte.

\section{Conclusión}

Si algo queda claro en nuestra aproximación a la Feria de Valencia es la conexión directa de este proyecto con Le Corbusier y su Atelier.

En primer lugar porque el trabajo constituye, en realidad, una obra colectiva realizada -tras la muerte del maestro- por sus propios dibujantes con su Chef d'Atelier al frente. De la lectura del índice de bocetos y planos depositados en el Fondo Documental Guillermo Jullian de la Fuente, de la Pontificia Universidad Católica de Chile, se observa que muchos de ellos llevan la mano de Jullian, de José Oubrerie, Fernando Domeyko, Amedeo Petrilli y otros colaboradores del Atelier ${ }^{32}$.

En segundo lugar porque el proyecto para Valencia se superpone en el tiempo al desarrollo del Hospital de Venecia, que estaba a cargo de los mismos proyectistas. Una superposición que, no obstante, trasciende ese propio plano temporal para conectarse con los aspectos puramente arquitectónicos que vinculan ambas arquitecturas.

En tercer lugar porque de todos los proyectos que quedaron sobre las mesas de dibujo del Atelier de la rue de Sèvres tras la muerte de Le Corbusier; o bien no siguieron adelante -como en el caso del Museo del siglo XX en Nanterre- o bien se transformaron radicalmente por exigencias del promotor -como sucedió con la Embajada de Francia en Brasilia- o bien -como en el caso la iglesia de Firminy- se terminaron mucho tiempo después, pero siguiendo las ideas esbozadas por el Corbu. De manera qué, el único proyecto que podemos considerar de "nueva planta", pero conectado directamente con los modos de pensar y hacer de Le Corbusier, es la Feria de Valencia.

No podemos terminar esta investigación sin hacer referencia a un dato que no puede ser pasado por alto: la buena sintonía que debió establecerse entre Carlos Soria -arquitecto director de las obras- y Jullian de la Fuente, a raíz

\footnotetext{
${ }^{32}$ Conocemos estos datos por las fichas del catálogo redactadas por la archivista de la FADEU Paloma Parrini.
} 
del trabajo conjunto en la construcción de la Feria. Una afinidad que, sin duda, contribuyó a que en Valencia se hiciera realidad la construcción de una obra lecorbuseriana. Prueba de esta sintonía la tenemos en el dibujo que Jullian regala a Soria y que, aunque alejado del concepto arquitectónico que inspira el proyecto para Valencia, nos devuelve a aquel paradigma en el que nos hemos apoyado para articular nuestro análisis: la idea de juego en la composición arquitectónica.

Se trata de un boceto del alzado de la Casa del Hombre de Zurich (1963), que lleva las iniciales L C y la fecha 4/4/63. En el dibujo, dos elementos de cubierta - uno cóncavo y el otro convexo- se articulan entre sí para componer un paraguas bajo el que se cobija una construcción independiente ${ }^{33}$. Maravilloso ejemplo de ese modo de entender la arquitectura, como el juego sabio correcto y magnífico de los volúmenes reunidos bajo la luz.

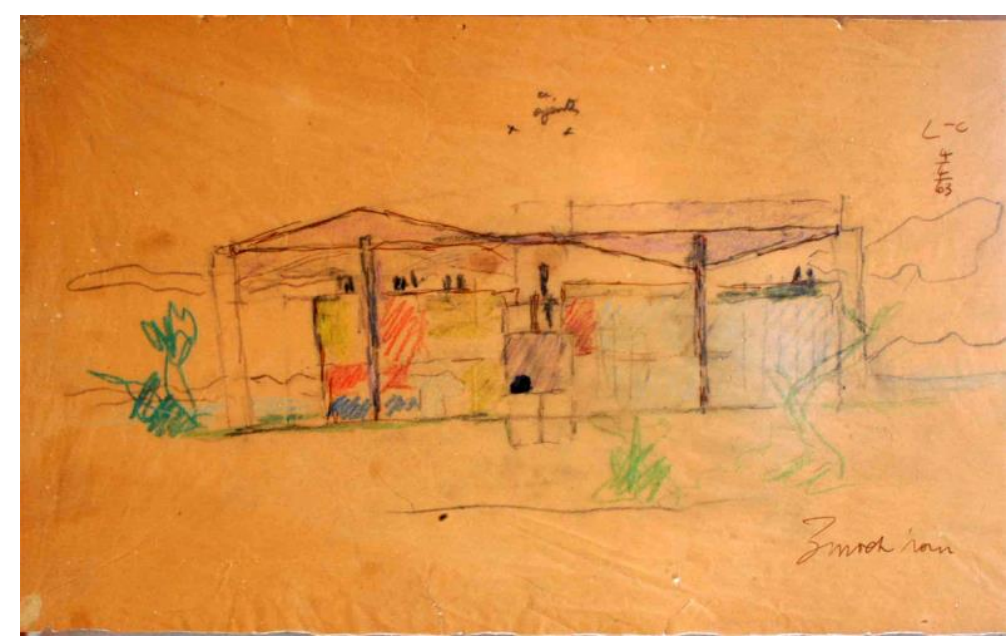

13. Boceto "Casa del Hombre" L-C 4/4/63, propiedad particular.

\section{Epílogo}

En un texto revisado a lo largo del tiempo y reescrito por última vez en julio de 1965 (Mise au point), Le Corbusier se refiere a la seriedad del juego y de los que juegan con estas palabras: "Il n'y a que ceux qui jouent qui soient des types sérieux! ... Les alpinistes, les rugbymen et les joueurs de cartes, et les joueurs de roulette sont des fumistes, car ils ne jouent pas ..."34.

Una seriedad que sujeta el juego a la disciplina de la regla, convertida así en la propia razón de su existencia. Y por eso añade: “Oui, la règle c'est le jeu ... Tout à l'intérieur de la règle! Rien hors de la règle! Sinon je n'ai plus de raison d'exister. Là est la clef. Raison d'exister: jouer le jeu"35.

\footnotetext{
${ }^{33}$ El dibujo lo conserva Mariano Soria Giner, quién nos ha facilitado su fotografía y otorgado el permiso para su publicación.

${ }^{34}$ Le Corbusier. Mise au point. En: Žaknić, Ivan. The Final Testament of Père Corbu. New Haven - Londres: Yale University Press, 1997. p. 114.

${ }^{35}$ Ibid. Existe traducción autorizada de este texto realizada por Jorge Torres, quién en el ensayo que la acompaña repasa algunas otras referencias a la idea del juego y sus reglas en diferentes textos del maestro. A este respecto ver: Torres, Jorge. Pensar la Arquitectura: "Mise au point" de Le Corbusier. pp. 91-92.
} 


\section{Agradecimientos}

Queremos agradecer a la Institución Ferial de Valencia así como al Archivo histórico del Ayuntamiento de Valencia las facilidades que nos han dado para acometer esta investigación. También expresamos nuestro agradecimiento a la familia de Fernando Mateu de Ros y, en especial, a sus hijos Fernando e Ignacio y a su nieto Fernando que tan amablemente nos han atendido. Asimismo expresamos nuestro agradecimiento a los hijos de Carlos Soria: Carlos, Mariano y Juan Luis Soria Giner por sus aportaciones a este trabajo, así como a la documentalista de la FADEU de la Pontificia Universidad Católica de Chile Paloma Parrini y a Delphine DS. Studer de la Fundación Le Corbusier. Por último agradecemos la ayuda que nos han prestado Tomás Roselló (arquitecto técnico e investigador) y nuestros compañeros José Luis Esparza y José Luis Ros.

\section{Procedencia de las imágenes}

Imagen_1. Autores de la ponencia: plano canónico de la Feria de Valencia.

Imagen_2. Feria de Valencia: vista de la maqueta.

Imagen_3. Fundación Le Corbusier : H VEN LC. Plano Nº 6286: "Unité de bâtisse - 4 Unités de soins" (FLC 28236) OFLC-ADAGP.

Imagen_4. Feria de Valencia: Planta lonja doble tipo B de la Feria de Valencia.

Imagen_5. Feria de Valencia: Secciones lonja doble tipo B de la Feria de Valencia.

Imagen_6. Feria de Valencia: Detalle sección longitudinal 5, hotel y sala de congresos. Armado de losa en forma de $\mathrm{V}$ de 16 metros.

Imagen_7. Feria de Valencia: Construcción de las losas en V.

Imagen_8. Feria de Valencia: Explanación y aterrazado de los terrenos.

Imagen_9. Feria de Valencia: Construcción de la estructura de las lonjas.

Imagen_10. Autores de la ponencia: Cubierta del Foro Norte, única lonja existente.

Imagen_11. Autores de la ponencia: Espacio interior del Foro Norte.

Imagen_12. Autores de la ponencia: Detalle del lucernario, losa en V del Foro Norte.

Imagen_13. Mariano Soria: Boceto "Casa del Hombre" L-C 4/4/63.

\section{Bibliografía}

Allard, Pablo. "Bridge over Venice. Speculations on Cross-fertilization of Ideas between Team 10 and Le Corbusier (after a Conversation with Guillermo Jullian de la Fuente)”. En: Sarkis, Hashim (Ed.). Le Corbusier's Venice Hospital and the Mat Building Revival. Múnich - Londres - Nueva York: Prestel, 2001. pp. 18-35.

Colquhoun, Alan. "Interacciones formales y funcionales. Un estudio de dos de los últimos proyectos de Le Corbusier". En: Arquitectura moderna y cambio histórico: ensayos 1962-1976. Barcelona: Gustavo Gili, 1978. pp. 34-44.

Gresleri, Giuliano: "La Chiesa in collina e l'atelier tra cielo e mare”. En: Massilia. 2007. pp. 32-42.

Huizinga, Johan. Homo ludens. Madrid: Alianza-Emecé, 6 ${ }^{\mathrm{a}}$ reimp., 2007.

Hyde, Timothy. "How to Construct an Architectural Genealogy". En: Sarkis, Hashim (Ed.). Le Corbusier's Venice Hospital and the Mat Building Revival. Múnich - Londres - Nueva York: Prestel, 2001. pp. 104-117.

Le Corbusier. Mise au point. En: Žaknić, Ivan. The Final Testament of Père Corbu. New Haven - Londres: Yale University Press, 1997. pp. 141-155.

Mazzariol, Giuseppe. "La Feria di Valencia di Guillermo Jullian”. En: Lotus. No 5. 1968. pp. 34-59. 
O’Byrne Orozco, María Cecilia. El proyecto para el Hospital de Venecia de Le Corbusier. Director: Josep Quetglas. Universidad Politécnica de Cataluña - Escuela Técnica Superior de Arquitectura de Barcelona, 2007.

Pérez de Arce Antoncic, Rodrigo. "Entre el atajo y la promenade: recorridos en la obra de Guillermo Jullian". En: Massilia. 2007. pp. 138-153.

Pérez de Arce, Rodrigo. Guillermo Jullian. Obra abierta. Santiago de Chile: ediciones ARQ-Pontificia Universidad Católica de Chile, 2000.

Pérez Oyarzún, Fernando. "Valparaíso y los años formativos”. En: Massilia 2007, pp. 54-67.

Petrilli, Amedeo. Il testamento di Le Corbusier: il progetto per l'Ospedale di Venezia. Venecia: Marsilio, 1999.

Smithson, Alison. "How to Recognise and Read Mat-Building: Mainstream Architecture as It Has Developed towards the Mat-Building". En: Sarkis, Hashim (Ed.). Le Corbusier's Venice Hospital and the Mat Building Revival. Múnich - Londres - Nueva York: Prestel, 2001. pp. 90-103.

Torres, Jorge. Pensar la Arquitectura: "Mise au point" de Le Corbusier. Madrid, Abada, 2014.

Vásquez, Claudio. "Conversación con Guillermo Jullian de la Fuente”. En: Massilia. 2007. pp. 18-31. 


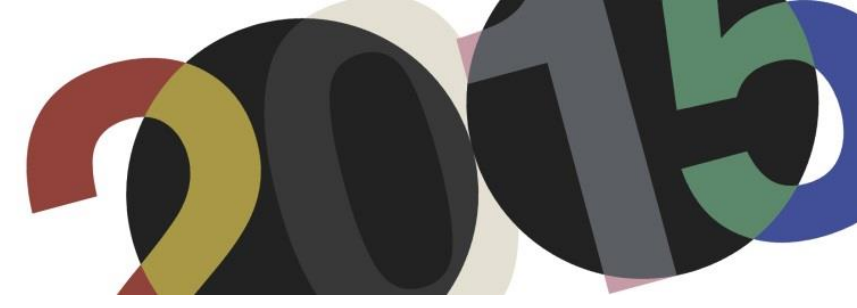

DOI: http://dx.doi.org/10.4995/LC2015.2015.1004

\title{
Le Corbusier's Legacy: Modern experimentation in Mario Bonito's work
}

\author{
H. Casal Ribeiro
}

Centro de Estudos de Arquitectura e Urbanismo, Faculdade de Arquitectura da Universidade do Porto

\begin{abstract}
This paper investigates the path of third generation Portuguese modern architect, Mário Bonito (1921/1976), in order to understand and clarify his contribution to the maturity process of portuguese modern architecture, that began at the end of the 1940s, strongly influenced by Le Corbusier. Through the understanding of his final academic work, CODA (Competition to Obtain the Architects Diploma), designated Pavilhão das Ilhas Adjacentes, located in Jardim do Palacio Cristal (Crystal Palace Gardens) in Porto, dated 1947/48, we intend to deepen his relationship with the modern premises of corbusier's architecture, framed by portuguese reality. However Le Corbusier's legacy in Mario Bonito's work is not formal but thematic, in understanding the main issues that guide the intent of progressive man in molding a modern and just society. The paper covers themes characteristic to Portuguese modernist architecture such as the dialogue between craftsmanship and technique, compositional rigor and rational design issues resulting from the systematization of the construction processes, with the search for standardization of architectural and constructional elements. This dialogue emphasizes the compromise between tradition and modernity that will be present in all of Mário Bonito's designed and written work, announcing the experimental temperament and formal coherence of his subsequent works.
\end{abstract}

Resumen: Este artículo investiga el camino de la tercera generación de arquitecto moderno portugués, Mário Bonito (1921/1976), a fin de comprender y aclarar su contribución al proceso de la madurez de la arquitectura moderna portuguesa, que se inició a finales de la década de 1940, fuertemente influenciado por Le Corbusier. A través de la comprensión de su obra académica final, CODA (Concurso para Obtenção do Diploma de Arquitecto), designado Pavilhão das Ilhas Adjacentes, ubicado en Jardim do Palacio de Cristal en Porto, con fecha de 1947 / 48, tenemos la intención de profundizar su relación con las premisas modernas de la arquitectura Corbusiana, encuadradas por la realidad portuguesa. Sin embargo el legado de Le Corbusier en el trabajo de Mario Bonito no es formal, sino temático, en la comprensión de los temas principales que guían la intención del hombre progresista en el moldeo de una sociedad moderna y justa. El artículo abarca temas como el diálogo entre la artesanía y la técnica, el rigor compositivo y problemas de diseño que resulten de la sistematización de los procesos de construcción, con la búsqueda de la normalización de los elementos arquitectónicos y constructivos. Este diálogo enfatiza el compromiso entre la tradición y la modernidad que estará presente en todo trabajo diseñado y escrito de Mario Bonito, anunciando el temperamento experimental y coherencia formal de sus obras posteriores.

Keywords: legacy; Mário Bonito; portuguese architecture; Porto; universality.

Palabras clave: legado; Mário Bonito; arquitectura portuguesa; Porto; universalidad.

\section{Introduction}

An observation of corbusier's contribution to the dissemination of modern architecture discloses two legacy conceptions - the works equivalent in formal plasticity reproduction and those inspired by the progressive social intent and composition notions/themes but free from formal restraints. Together, these two conditions are similar in notion but distinctly different in result; one, placing the issue on universality of architecture, the other universality in architecture.

This paper, admitting the possibility of both intakes, discusses the latter, as the one with more consequence to the understanding of contemporary architecture's possibilities, through Mario Bonito's final academic project, 
emphasizing the construction of a coherent narrative that identifies its main issues, through the eyes of corbusier's political and cultured universal man.

The present essay derives from a PhD thesis, Experimentação do Moderno na Obra de Mario Bonito, presented in 2013, at FAUP and a current investigation on the design process in Porto between the 1940s and 1960s, an experimental period in the portuguese modern architectural scene, integrated in Study Centre of Architecture and Urbanism (CEAU_FAUP); group: Atlas da Casa_Identity and transference.

To address the third generation of Portuguese modern architects ${ }^{1}$ we have to take into account framing Portuguese cultural and social context of Republican matrix, in the early $1900 \mathrm{~s}^{2}$, with their academic training period, during the thirties, based on the confirmation of a military dictatorship ${ }^{3}$ and respective validation of the Estado Novo ${ }^{4}$ political state. In the late forties, they will assert their professional practice conscious of the national circumstances, and in the next decade they will present unique architectural work in the implementation and dissemination of modern architecture, based on the ideas deepened and transmitted by CIAM.

Mario Bonito, born in 1921 on the east side of Porto, submits his admission exam at the School of Fine Arts of Porto (EBAP) in 1936 and terminates his academic studies in 1945, presenting his CODA in 1947, with the consequent architect's diploma in 1948.

His professional career is associated with the cities of Porto and Lisbon, at different times, 1921-1963 and 19641976, respectively. These cities represent two different phases, both in its architectural and artistic production, and in the knowledge and dissemination of his work.

Mario Bonito's path is strongly characterized by his vocation and multifaceted action in artistic, cultural and social activity, with a passionate relationship with life and with those who surrounded him.

His artistry, clearly inspired by the Bauhausian man, with direct influence of Carlos Ramos' approach to teaching architecture and the arts, enabled and encouraged him to engage in other artistic and social areas with the same relevance and quality he dedicated and manifested in the field of architecture.

"Identified with the principles of Athens Charter, in the complexity of his personality, Bonito was finding other identities and other passions. (...) The intellectual dimension of Mario Bonito did not run out, in his action as a planner and activist of a new idea of architecture. His wide knowledge and passion for the art of his time, as well as his civic sense, led him not only to expand his interests, but also to diversify his fields of intervention." 5

\footnotetext{
${ }^{1}$ The third generation corresponds to architects born between 1917 e 1927, to which Mario Bonito (1921/1976) is part. It's important to emphasize that in Portuguese architecture we consider the first generation between 1890 and 1907; second generation between 1907 and 1917.

${ }^{2}$ The first Portuguese Republic characterized by an elitist politician body with progressive socio-cultural policies, is a democratic regime that spans from 1910, after the fall of the monarchy, to 1926.

${ }^{3}$ On 28th May 1926, general Gomes da Costa's up rise in Braga will lead to the establishment of a military dictatorship (1926-1933). Ramos, Rui (Dir.): História de Portugal. Lisboa: A Esfera dos Livros, 2009, p. 862.

${ }^{4}$ On 11th April 1933 enters into play the new Political Constitution and on 29th August is created the Surveillance and State Defense police. Thus, Estado Novo regime is initiated, freezing all progressive ideas or social policies, spanning until 25th April 1974. Ramos, Rui (Dir.): História de Portugal. Lisboa: A Esfera dos Livros, 2009, p. 862.

${ }^{5}$ Costa, Alexandre Alves: Textos Datados. Coimbra: Edições do Departamento de Arquitectura da FCTUC, 2007, p. 87-88.
} 
The thematic versatility - architecture/art, theater and cinema ${ }^{6}$ - that Mario Bonito addresses and deepens, through writings and designs, is a preponderant factor to unveil his humanistic character and his intellectual restlessness on the need/search for progress in Portuguese society through the understanding of the modern movement masters, such as Le Corbusier.

His proposals will always be conceived in modern syntax vocabulary ${ }^{7}$, integrating progress and industry innovation through the use of abstract composition - geometric tracings and conceptual metric - reinterpreting his social relevance as an architect, i.e., the condition and the significance/meaning of universal man and notion of progressive habitat in the city's constructed landscape.

This modus operandi and understanding of the discipline of architecture will be shared with much of the architects in the defense of modern architecture in particular those who shared his daily routine at EBAP/ESBAP and formed ODAM group or participated in meetings of the UIA and CIAM-Porto group, led by Alfredo Viana Lima.

In Europe, the condition of modern architecture, inspired by the in-between wars experimentation, in the late forties and, specially, in the fifties, began to find growing opposition, with masters such as Le Corbusier, moving definitively away from the delicate white architecture to interpret the textures of new materials, resulting from the systematic construction and standardization of its constructive elements while maintaining the functional city premises in the urban structure. In Portugal the pursuit for these modernistic ideals, linked to European and Brazilian modern architecture, were much into play with the younger generation of architects, imposing on the political regime different public interventions. Thus, after the Second World War, Portuguese architecture finds itself in an anachronic position, due to the temporal discrepancy associated to the pursuit of these premises linked to 1920s experimentation, when Europe had started to question them, with particular emphasis to the CIAM meeting at Bridgewater (England) in $1947^{8}$.

In this evolutionary process, the term modern will be replaced over time, in different contexts by terms as alive or true that is, reinforcing the perception of architecture as a direct response to society's problems - reflection of the culture of its time, one of Le Corbusier's key premises. In fact, Mario Bonito wanted and believed in the transformation of his time, but only through the social responsibility of the/as an architect and citizen both in the ethical performance of his duties and as a daily experience.

\footnotetext{
${ }^{6}$ Mario Bonito has a strong connection to cinema,1949-1963, both in criticism/debate and dissemination, with a decisive role in the life of Portuguese Cinematography Club / Cineclube do Porto, from 1949 to 1963 and participates actively in the life of local theater company, Círculo de Cultura Teatral - Teatro Experimental do Porto, from 1962 to 1964 . He was invited, by Carlos Ramos, , with three other young architects, Fernando Tavora, Agostinho Ricca, Carlos Loureiro, to teach at ESBAP, from 1950 to 1957.

${ }^{7}$ Applying cobusier's modulor in his later works.

${ }^{8}$ The change of atmosphere of postwar CIAM 6, themed "the human community in modernist civilization", is clear for Kenneth Frampton: "The postwar reunion congress, that is to say CIAM 6, which took place in bucolic Bridgewater in Somerset, England, in September 1947, could hardly have been more removed from the radical political themes that had dominated CIAM, some eighteen years before. In first place, the common language of the congress momentarily shifted to English; in the second, despite the continued leading presence of both Giedion and Le Corbusier, the most dominant wing of CIAM, namely the MARS group (founded in 1933), was now not only the host but also the most active national contingent within the organization. (...) Thus CIAM 6 began to go beyond the four functional categories of 1933 Athens Charter as formulated by CIAM 4, affirming that «The aim of CIAM is to work for the creation of a physical environment that will satisfy man's emotional and material needs»." Frampton, Kenneth: "Foreword", Mumford, Eric: The CIAM Discourse on Urbanism, 1928-1960. Mass: MIT Press, 2002, p. xiii.
} 
The collective consciousness manifested in the formation of the two platforms ICAT (Iniciativas Culturais de Arte e Técnica) in Lisbon in 1946 and ODAM (Organização dos Arquitectos Modernos) in Porto in 1947, will reveal a common ground between the different architects, where the sharing of objectives will also be defended by Mario Bonito.

The Portuguese publication of the Athens Charter, in 1944, and Le Corbusier's Manière de Pensar l'Urbanisme, in the following year, with the disclosure of L'Architecture d'Aujourd'hui's special issue, October 1932, dedicated to the Perret brothers, Auguste and Gustave, and their aphorisms/architectural poem with the original title Contribution à une théorie de l'Architecture, first published in 1945 in the French magazine Techniques et Architecture, may also be considered primary influence or source for Mario Bonito.

Other important publications are the set of articles entitled The modern Dutch architecture that resulted from Francisco Keil do Amaral's trip to the Netherlands in 1936, for the monitoring of the construction of the Portugal Pavilion at the Paris Universal Exhibition of 1937. The way that various topics will be addressed in these texts, especially given that these publications correspond to Mario Bonito's initial formative years, will have two direct relationships with his thinking and future architectural research, i.e., the decisive trip to Europe (1950) that included the Spain, France, Netherlands and the knowledge of a fundamental reference for his project submitted to the CODA - Le Corbusier and Pierre Jeanneret's Des Temps Nouveaux Pavilion, conceived for that Universal Exhibition, with the objective to disseminate the ideas and experiences of Congrès Internationaux d'Architecture Moderne (CIAM).

Mário Bonito will publish an important set of 16 texts, from 1948 to 1971, that express his awareness and sense of modernity in the role play of a democratic and progressive society, with emphasizes to the two communications - Regionalism and tradition and The architect's tasks - presented at the First National Architecture Congress (1948), the main text in the ODAM exhibition catalogue (Porto, 1951), and manifest driven From Abstract Architecture to Realistic Architecture (1956), Universality in Architecture (1971) and You were saying... (1971).

In 1947, the proposal for the Ilhas Adjacentes Pavilion presented to the Competition to Obtain the Architect Diploma (CODA) begins to outline in an extremely clear way, the idea of architecture that Mario Bonito aims to support and develop.

The opportunity of drafting an ephemeral building inserted in an emblematic public garden is a rare occasion in Porto's urban landscape. The specific context of the Crystal Palace Garden and lack of programmatic complexity sets into play the relevance of temporary architecture as an experimental foreground and complementary themes/issues on the dialogue with the site/natural landscape, as an enriching interpretation of its significance and the established geometric relationships with preexisting elements in the construction of $a$ sense of place inhabited by corbusier's Universal Man and Perret's structural truth notion.

\section{Taking part of the modern intent}

Twenty-six year old Mário Bonito affirms with the Ilhas Adjacentes Pavilion an architectural notion that will accompany him throughout his professional practice: interpreting an architectural work as an object of art that seeks to reflect originality and counteracts false or preconceived assumptions, i.e. architecture as " $a$ mix of intuition and technical expertise""9.

\footnotetext{
${ }^{9}$ Bonito, Mário. "Pavilhão Ilhas Adjacentes”, technical description. EBAP, 1947.
} 
The option of developing a work like the Ilhas Adjacentes Pavilion, an ephemeral building with " $a$ three month reign - duration of the exposition" 10 , inserted in a public garden is not only a rare opportunity in Porto's urban landscape but also an uncommon programmatic theme in the proposals presented to ESAP's Competition to Obtain the Architect Diploma (CODA), but as Mario Bonito refers "it was a logical deduction, the conception of ephemeral architecture is rooted in the laws of definitive architecture" "11.

The choice of this project/theme can also be interpreted as a deliberate way to join the controversy surrounding the approval of Artur Andrade's modern proposal for the new Exhibition Palace, against the criticisms of public institutions and government agents, can be interpreted as Mário Bonito's first documented public manifestation, in the defense of modern architecture and the ethical practice of architect's profession.

Mario Bonito's proposal, respecting the exposition's proposed layout, will be drafted in parallel to the afflicted design process of Artur Andrade's (1946-48) Palácio de Exposições da Associação Industrial Portuense, called publicly into question for its architectural modernistic expression and subsequently will not be approved by authorities.

The first publication that addresses and disseminates the works presented to EBAP/ESBAP's CODA, the Ilhas Adjacentes Pavilion, together with over 21 examples $^{12}$ will be framed by a text entitled 40 Years: The ethics of aesthetics and the aesthetics of ethics, by Manuel Botelho.

The text, structured in four points, tests and explains, at first, the adversity of the forties towards architecture of modern premises and the affirmation of the official political agenda with the Portuguese World Exhibition (1940) - celebrates the fascist state ideals - concluding with the characterization of the circumstances surrounding the exercise of the architect's profession:

"Addicted interpretations of the past, combined with ideological ambiguities, difficult modernity and no wonder that the repression of the regime would combat modern architecture, as has happened in all political totalitarianism. The spirit of modern architecture is distorted and the architectural reflection, confined to mediocre content and debate on Portuguese national style, is guided by what we call aesthetic ethics"13.

However, the second point highlights the new conditions and paradigms that characterize this decade, especially in the post-war period, synthesizing them into four main ideas:

"To talk about modern architecture is inevitably to speak of a political problem. The First World War changed the socio-economic conditions in Europe, accelerating industrial development and bringing out new technologies. (...)

Architecture changes face: from the object builder architect we go to the architect urbanist and construction in series cannot occur outside the industrial technology.

(...) It was not so much about the renewal of architecture but the obtaining of a better world.

\footnotetext{
${ }^{10}$ Bonito, Mário. "Pavilhão Ilhas Adjacentes", technical description. EBAP, 1947.

${ }^{11}$ Bonito, Mário. "Pavilhão Ilhas Adjacentes", technical description. EBAP, 1947.

${ }^{12}$ The various cases are spread over thirteen public buildings of various themes, five detached houses, a multifamily building and a urban project. In this publication Mario Bonito's pavilion will be the only example to address the issue of ephemeral architecture, not only in the 40s, but also the next two decades.

${ }^{13}$ Botelho, Manuel: "A ética da estética e a estética da ética". rA Revista de Arquitectura. October 1987. Porto: FAUP, p. 7.
} 
(...) The conclusion of the war and the awakening of democracies provide a higher cultural upheaval climate, which makes the 40s particularly important reflection for modern architecture in Portugal"14.

The growing political awareness in Europe and the evolution of the construction industry and techniques, with their respective influence and incorporation into the creative and architectural process, will not have the corresponding echo in Portuguese reality, except for small groups of architects and students, who will in some cases, with the projects presented to the CODA, be their first manifestation against the architecture advocated by the Estado Novo regime. These projects can be considered the first reflections of Carlos Ramos at EBAP and the consequent attempt of pedagogical renewal proposing a modern education, within the existing Beaux-Arts curriculum.

In the late forties, some CODA projects begin to evoke a possible condition associated to industrial modernity, but other proposals continue to submit a response, based on operative conditions according to dominant taste and objective state commissions - emphasizing "eminently practical national modernism and the adoption of modern vocabulary used as an eclectic language"

The proposals, in the late forties, João Andresen (1948), Vasco Vieira da Costa (1949) and Luis Oliveira Martins (1950), reveal the search for a design that incorporates imported models, but its Delfim Amorim`s "My House" (1947), with two different interpretations of the same program, that reveals the ambiguity of the period, even for those who defended a new architecture.

Although Alfredo Viana de Lima's CODA (1941) already referenced Le Corbusier's work, be it versions of “Centrsoyus Moscow" (1928), "Palais de Nations" (1927/28) for Geneva, and "Palais de Soviets" in Moscow (1931) or even the proposals for the new capital of Punjab, Chandigarh, initiated in 1950, both in the fragmented solid-void dialectic plan draft, formal configuration and urban meaning expressing a solid-void dialectic. The example of "La cité de refuge of l'Armée du Salut" (1929-33) in Paris, will be another shining example of the building's fragmentation into several bodies, scale and varied geometry, with proportional settings and compositional balance promoting, through the configuration of diverse shapes, an architectural promenade which organizes and distributes the ensemble.

These corbusian experiences will also have a particular progress in Brazilian architecture, a constant reference to Portuguese reality, through Affonso Eduardo Reidy, Henrique Mindlin, Lucio Costa and Oscar Niemeyer, among others, with emphasis on plan and facade libre with modular grids and free form ramps and portico or canopies that unify the compositions.

However, despite these specific experiences and cultural unrest, the atmosphere was hostile to the Modern Movement architecture, as implied by Manuel Mendes:

"In 1948, Porto lived years of lead, brutishness with regard to the imposition of style rules/values coercive to free-circulation/exploration of the idea and the artistic practice of architecture"16.

\footnotetext{
${ }^{14}$ Botelho, Manuel: "A ética da estética e a estética da ética”. rA Revista de Arquitectura. October 1987. Porto: FAUP, p. 7.

${ }^{15}$ Coutinho, Bárbara: "Carlos Ramos, Comunicador e professor - Contributo para a afirmação e divulgação do Moderno", Tostões, Ana (Dir.) Arquitectura Moderna Portuguesa 1920-1970. Lisboa: IPPAR, 2004, p. 49.

${ }^{16}$ Mendes, Manuel: "Errância poética”, Jornal de Noticias, Outubro 2000. Porto: Porto 2001, Capital da Cultura.
} 
The opening of José Carlos Loureiro's technical description presented with his CODA, after the First National Architecture Congress 1948, expresses the difficulties and preconceptions existing in the architect's practice, as opposed to the pedagogical work encouraged by Carlos Ramos in CODA projects.

"The standardization does not exist in our country because it is dogmatically assumed that we should only use stone, tile, wood and in certain forms and principles. (...) It is time to make experimental buildings where technicians have, as well as freedom of design, analysis possibilities of new materials. But since it is known that the educational orientation in this school gives ample freedom and cherishes the attempts of renovation, it's beyond the scope of this CODA to deal with this external problem"17.

It's this search for concrete responses to problems or questions with the corresponding deepening of necessary free exploratory-circulation of ideas and the artistic practice of architecture, as manifested by Manuel Mendes, that the Ilhas Adjacentes Pavilion, presented to the CODA, six months before the First National architecture Congress, acquires importance and a specific space for reflection on modern Portuguese architecture.

Through the proposal's technical description we can formulate three key issues: the clarification of the significance of architecture as a creative act and social phenomenon, the interpretation of place in the formulation of a proposal and the meaning of form through construction systematization - structural truth.

The text structured in four parts presents, the first point, an introduction that discusses and defines the project's main theme - ephemeral architecture - framing the meaning of the permanent and provisional constructions; the second, an objective analysis of the program, with the presentation of a direct reference; in the third part, the form - "Which form to take?" 18 - fits an accurate reading of the site conditions with full explanation of the proposal's strategy and, in the fourth part, the materials and constructive solution explains the form's conformation with its respective spatial materialization.

The structure of the text tries to mirror the deductive methodology of the creative process deploying the presentation of the pavilion in successive reflections and conclusions until the final shaping of the building's ideas.

In the introduction Mario Bonito alerts, on the academic relevance of the chosen subject/theme for his CODA emphasizing that an architectural object "is not measured in length, but in depth, by the way it performs and by the emotion it arouses" ${ }^{19}$. The lack of programmatic complexity is evoked as a means to accentuate the meaning of feeling-poetics - in the creative process: "We agree that with the chosen theme some may struggle in the field of functional organization. But it also seems that, more than any it lets the imagination a wide range of resources, even a certain justifiable plasticity of forms. Starting from a formed and accepted concept that an exhibition should express itself in spectacular ways, we try not to forget and care for what in them must be unique and speculative"20.

He clearly states that there are points of contact between permanent and temporary architecture, with the first representing the greatness of a society through the wealth of their materials and constructive options and the

\footnotetext{
${ }^{17}$ Loureiro, José Carlos: “CODA”. rA Revista de Arquitectura. October 1987. Porto: FAUP, p. 33.

${ }^{18}$ Bonito, Mário. "Pavilhão Ilhas Adjacentes”, technical description. EBAP, 1947.

${ }^{19}$ Bonito, Mário. "Pavilhão Ilhas Adjacentes", technical description. EBAP, 1947.

${ }^{20}$ Bonito, Mário. "Pavilhão Ilhas Adjacentes”, technical description. EBAP, 1947.
} 
second, in this case, "by its own ephemerality, it must first translate the greatness of a show on which irreducibly the curtain shall close, ${ }^{, 21}$.

Hence, Mario Bonito sustains that shaping space or modeling form - architectural composition as the main response to the posed problems, regardless of the programmatic purpose, size, temporal durability or cost embodies a work of architecture.

"May the very spectacle created by the architecture's originality be the reason for their perpetuity"22.

This claim has a particular significance when framed by Auguste Perret's statement about the L'Esprit Nouveau Pavilion $^{23}$ reported by Le Corbusier, "there is no architecture here!"24; showing that the issue, even between modern architects, hasn't always been peacefully welcomed.

These prepositions place the proposal as a conceptual project, i.e. above all interested in arousing design issues or investigating/testing compositional principles.

The technical description focuses on the characteristics that portrait the Crystal Palace Gardens and the specific site settings, identifying the garden's geometric layout, natural elements - vegetation/trees, lake, walkways/paths, avenues - and relationship with existing or planned buildings for the Commemorative Exhibition. The identification and characterization of these various elements, with their respective architectural significance and sensorial interpretation, will not only be preponderant to the proposed general layout but will also play an essential part in the geometrical conception of the pavilion.

Mario Bonito considers the volumetric tension between Artur Andrade's Exhibition Palace and existing small chapel articulated by the lake's formal expressiveness and the path defined by the main Avenue as the four main compositional elements. The option to deploy the pavilion on the lake as a way to explore its sensorial attributes and the plasticity of a natural element is reinforced in the technical text: "only the placing on the water would create the right environment, by association of ideas; the reflection on the lake, the very sound of submerged aquatic gardens and fountains, would be a guaranteed successes of emotion",25.

Consequently, the volume of the pavilion is careful organized alongside the main avenue freeing the Exhibition Palace's glassed front permitting a broad view of the lake and the foreseen light fountain. The pavilion appears on the west side, as a natural backdrop to the lake framing the view from the new Exhibition Palace.

\footnotetext{
${ }^{21}$ Bonito, Mário. "Pavilhão Ilhas Adjacentes", technical description. EBAP, 1947.

${ }^{22}$ Bonito, Mário. "Pavilhão Ilhas Adjacentes", technical description. EBAP, 1947.

${ }^{23}$ The Pavilion integrated the Exposition des Arts Décoratifs, held in 1925, with Auguste Perret as vice-president of International Architectural Contributions Jury. "The exposition was planned by the organizing committee as an opportunity to demonstrate the emergence of truly modern architecture. They specified that there would be no copies, imitations, or counterfeits of past styles." Although the result of the exposition will oblige Perret to state, in the same year: "In 1900, it was the triumph of marconi, twirls and ornament. Now they have the air of suppressing ornament, but only the air. Nobody speaks of anything but straight lines, essentials and construction; but if one looks closely, it is obvious that ornament is still the only thing that matters, so that there are finally more useless things than ever before. These useless elements are so rigid and bare that the uninitiated assume them to be necessary; thus the error is all the more serious for being dissimulated, and there will have to be an earnest reaction if we are to get out of the rut in which we are being bogged down." Britton, Karla: Auguste Perret. London: Phaidon Press, 2001, p. 65.

${ }^{24}$ Le Corbusier: "Perret par Le Corbusier", L'Architecture d'Aujourd'hui, special number "Perret". October 1932, Paris. p. 9. This episode occurs with a large time frame nevertheless Auguste Perret is one of Bonito's main references.

${ }^{25}$ Bonito, Mário. "Pavilhão Ilhas Adjacentes”, technical description. EBAP, 1947.
} 
Thus the pavilion's siting, through the lake's sensorial interpretation, is directly displayed by the geometry of the lake, the limits of the existing chapel's platform and the parallelism of the main avenue, moving away, in terms of scale and composition, from the dominant volumes of the new Exhibition Palace. The pavilion is centered between the lake's boundary line, on the north, and the chapel's platform perimeter at the other end, allowing the reading of a geometric composition that defines a square with the pavilion's width and the main avenue. This composition drafts a complex system of regulating lines that draw successive circles that inscribe and set the pavilion's volume, defined by converging lines, linking and providing mediation space with the main avenue.

The center of the circles will be marked by the plasticity of a vertical element that announces the pavilion on the main avenue and inside the Crystal Palace garden.

These notions underline the placing of questions on interpretation of a context and its significance on the building's siting and its respective volumetric and spatial modulation through structural integrity and geometric composition - regulating lines and force vectors - emphasizing universality in architecture associated to the corbusian notion of primary mathematics governing architecture and site significance.

This notion is stressed in his toward an architecture: "There is no primitive man; there are primitive means. The idea is a constant, potential from the start.

Notice in these plans how a primary mathematics governs them. There are measurements here. In order to build well and distribute the labor properly, so as to assure solidity and utility of the work, «measurements» condition the whole ${ }^{, 26}$.

In relation to site significance the recent exhibition Le Corbusier, an atlas of modern landscapes, brings into light the question of landscape as a fundamental tool in thinking Corbusier's architecture. Jean-Louis Cohen stresses his relationship to landscape "which provided him with scenes to observe, stimulation for invention, horizons against which to set his projects, and a fertile field of metaphors ${ }^{\text {,27 }}$.

It appears that, in a context composed mainly of natural elements, the interwoven geometric layout and the proportional relationship of the different parts/elements that comprise the architectural composition is a design method that emphasizes Bonito's notion "the splendor of truth will lend beauty to the building" ${ }^{28}$.

We can consider that the evoked splendor of truth will be translated not only by the proposal's constructive and technical systemization but also by a symbolic interpretation of a structure representative of the project's main theme - a canvas cover, i.e., the tent.

The canvas cover principle, with its free forms coating the structural elements, that are apparent from the inside, characterized by their ties in constant tension, helps to strengthen the direct dialogue with the context's natural forms. Unlike the new Exhibition Palace and the existing chapel, the pavilion is not intended as a volume that imposes on the garden, but one that establishes a close dialogue with all its elements, complementing the composition in formal and symbolic terms. This metaphor - tent versus temporary structure - is also present in the project referenced for the distributive principle: Corbusier's Des Temps Nouveaux Pavilion.

The pavilion, structured by this conceptual idea, presents all its structural elements, coating surfaces or shapes that mold the interior space, avoiding being parallel or orthogonal to each other. The composition avoids

\footnotetext{
${ }^{26}$ Le Corbusier: Toward an Architecture. London: Frances Lincoln, 2008, pg. 133.

${ }^{27}$ Cohen, Jean-Louis: "In the Case of Landscape". Le Corbusier, an atlas of modern landscapes. London: Thames \& Hudson, 2013, pg. 23.

${ }^{28}$ Bonito, Mário. "Pavilhão Ilhas Adjacentes”, technical description. EBAP, 1947.
} 
orthogonality between the vertical and horizontal elements with the raised floor of the pavilion as two ramped surfaces in dialogue with the modulated structural arc, accelerating the perspective of the interior space. Through the cross section we can verify that the pavilion's composition presents a convergence track points, structured by an axis, creating a volume in constant tension in all viewpoints. The pavilion's volumetric modulation and plan settings reinforce this reading and interpretation in the molding of interior and exterior space with the same architectural intent.

On a closer analysis we can conclude that Corbusier's proposal for Des Temps Noveaux Pavilion will be decisive not only for the functional organization but also for the conceptual principle and the building's formal modulation. This project will have a strong ideological influence, i.e. it asserts its temporary condition modulated with a metal structure to support in tension a canvas that conforms an exhibition space with the programmatic objective to disclose, for the first time, the ideas and investigations undertaken by CIAM, since 1928.

Here we can also evoke Corbusier's volumetric and formal manifestations of the Ronchamp Chapel in the relationship with the landscape and the meaning of the programme - initially an informal settlement of prayer.

The fact that we can establish links to future corbusian works puts into play the notion that Mario Bonito understood his main themes/notions of design and applied them to different situations arriving to compositions with similar interpretations that will be explored in the future by Corbusier himself.

The recreational pathways will also be a main theme in the interwoven dialogue with the garden's functional layout and sensorial ambience. From the main avenue, which interconnects with the various natural and artificial elements, the two pathways enter the pavilion on the opposite side outlining a possible central path in the exhibition area inside.

This continuum, evoking once again another corbusian theme - architectural promenade - promotes a sensory experience of freedom in different indoor spaces and outdoor forms embodying the spirit of a small pavilion in the middle of nature, but nevertheless reaffirming the contemplative and festive character of the exhibition.

Complementarily, the response to the exhibition programme is based on the single vaulted space principle, with access on the opposite extreme, organized by movable exhibition furniture which would allow flexibility and spatial fluidity permitting a full reading of the interior volume at all times.

This organizational and expository layout/principle, according to Mario Bonito's technical description is directly linked to the ideas conveyed in the Des Temps Nouveaux Pavilion, determining the formulation and quantification of the programme. He emphasizes the Pavilion's characteristics as "a documentary proof" of the expression of an idea by a huge void organized through removable furniture - "light screens" - that allow " $a$ suggestive catalogue of industrial products to be exhibited" ${ }^{29}$.

Mario Bonito considered the Pavilion as a machine that transformed his visitors, educating them and exposing them to new ideas of urbanism and architecture, emphasizing that "it was, indeed, perfect in the art of developing and presenting a thesis ${ }^{30}$.

As mentioned, the importance of an Exposition Pavilion that not only discloses for the first time the message of CIAM, but also with an experimental structure imposing its modern language in the center of Paris, ${ }^{31}$ has an

\footnotetext{
${ }^{29}$ Bonito, Mário. "Pavilhão Ilhas Adjacentes”, technical description. EBAP, 1947.

${ }^{30}$ Bonito, Mário. "Pavilhão Ilhas Adjacentes", technical description. EBAP, 1947.
} 
huge ideological effect, particularly in the Portuguese political atmosphere, that may have been decisive for its direct quote in his text.

Hence, Mario Bonito proposes an elegant volume, with "slim and rhythmic support" on the water, whose shape is reduced to an intelligent organization of open spaces, built entirely of wood, as described in the technical description: "To satisfy all these requirements, and because the limited dimensions of the lake so advised, it imposed a construction on slender and rhythmic support, that would fall within the own wooded park environment" ${ }^{32}$.

The volume's configuration and interior space are modulated by the definition of a structural element - arched portico - which, through its formal individualization, is repeated modeling the interior space, deployed by a strict geometric composition articulated with a constant basic metric.

The visual complexity of the volume settings stems from a rigorous compositional layout based on a measurement systematization, which results as a harmony instrument of form and space.

The premise of structural integrity, defining and characterizing the inner space, is clear: "The bone that is to the building as the skeleton for the animal and it was our intention not hide (...)"33.

The structure's modulation - comprised of arched porticos - complies with the geometric and metric layout present in the building's general schematic layout. The geometric composition of the porticos will determine the modulation and proportion of the vaulted interior space. The drawing is based on the definition of several concentric circumferences that, as they multiply, they determine the alignment between the various architectural elements and define their respective positions within the symmetrical composition.

The center of the circles coincide with the lower node that, from this point, disciplines the compositional settings, including, relationships that do not participate directly in the volume's characterization or definition, like the setting of the structural foundation or the definition of the pavilion's distance to the lake's water line.

This composition has the same geometric design principle used in the pavilion's siting with all the relationships it establishes with the natural landscape and surrounding buildings/elements. This design, takes into account the general notion of the assembly to the detailed definition of the portico revealing rationality and precision that that will reflect the proposal's quality and consistency.

The wood as the dominant material will be crafted in all structural and plastic dimensions with different sections - associated, juxtaposed or individual - presenting a formal consistency in the detail, from general to particular situations.

"And the designed structure, would not be the only viable one but the most significant, under the preconception of the elements in play, the design process would push forward the solution" ${ }^{34}$.

\footnotetext{
${ }^{31}$ In a period of political unrest, before Second World War, Corbusier writes to his mother: "The Exhibition opened the first sunny day. Despite the despicable criticisms of all those bastards, it's marvelous to think that we've done this, in the hearth of Paris, and in the midst of a social revolution. It's very instructive. Everything's possible! You can create a new city right in the vigorous hearth of an ancient one, without wrecking its life, without halting its life. And you can do it while the biggest, most serious struggle between workers and bosses is starting. In the midst of a revolution. I hope the others do the same. There is amazing worker discipline here. A wisdom." Le Corbusier. "Architecture and Revolution: Pavillon des Temps Nouveaux, Le Corbusier and Pierre Jeanneret, 1937, International Exhibition in Paris " Catalogue (letter extract, dated 25th June 1937). USA: Columbia University, 2009.

${ }^{32}$ Bonito, Mário. "Pavilhão Ilhas Adjacentes", technical description. EBAP, 1947.

${ }^{33}$ Bonito, Mário. "Pavilhão Ilhas Adjacentes", technical description. EBAP, 1947.
} 
The definition of specific repetition elements introduces the issue of prefabrication - standardization of the constructive elements and its coating - despite the use of a material with traditional connotation, unlike concrete and iron with modern meaning. The first is excluded by the provisional nature of the construction; the second would introduce a complexity framed by the inefficiency of Portuguese technology or construction industry. However, this option is also associated with the dialogue between the site's characteristics and the desired rigorous and technical machine like expression associated to prefabrication.

The possibility of a single material for the design - structural/building system and the inner and outer lining - will be another determining factor in the equilibrium of such a complex structure, allowing a formal and plastic continuity between the various parts of the pavilion.

Mario Bonito with this double intake - material versus expression - associates the artisan craft with the idea of construction standardization and the systematization of technical solutions, which reveals the intentionality of his design in the transmission of a coherent and rigorous architectural idea.

\section{Conclusion}

Mario Bonito's proposal incorporates compositional principles and design processes that seek to explore new ways of industrial and constructive progress. References to Auguste Perret and Le Corbusier, in terms of architectural thinking and program interpretation, are emphasized in specific passages of the technical description. However, we may extend these influences to images of several works by Auguste Perret in Paris, where the autonomous concrete structure assume through its plasticity the characterization of space, such as the Studios-Olivier Metra, 1921/25, and the amazing interior of Esders factory in avenue Philippe Auguste, 1919, with elegant arches inscribed in the central voided space ${ }^{35}$.

The lifting of the pavilion, frees the bottom of the arched porticos, alluding pilotis, with several directions and geometries according to the viewing angle. This intent refers not only to one of Corbusier's five points, but reflects mostly the deepening of a formal freedom in the design. In this case, the pilotis' design and rhythm refers to a dialogue with nature, expressed in the technical description: "To satisfy all these requirements, and because the limited dimensions of the lake advised, it had to be a building on slender and rhythmic support what fine would fall within the own wooded park environment" ${ }^{36}$.

The formal pilotis principle experimentation will be present in Corbusier's work in an outstanding manner, exploring different configurations and scales, from which we can highlight, in this case, St. Marie Convent of La Tourette's structural design, in 1953/57. The apparent randomness of the structure/pilotis will also be explored by Corbusier, when faced with the need to place the building in dialogue with the natural landscape, in this case with the sharp topography and the distant woods.

For Mario Bonito, the purpose of an architectural object does not reside in the direct functional response but in the knowledge of immediate and future feelings that the object transmits to its user. The intention to endure the feeling is part of architecture's main condition, i.e. to (re)establish new architectural/cultural references to harmonize man's daily routine and qualify society culturally. "We want to be sincere. The splendor of truth will lend beauty to the building. And if, in closing of the curtain on the exhibition, perpetuates in everybody's

\footnotetext{
${ }^{34}$ Bonito, Mário. "Pavilhão Ilhas Adjacentes", technical description. EBAP, 1947.

${ }^{35}$ These two works are present in the magazine dedicated to the Perret brothers; L'Architecture d'Aujourd'hui, $\mathrm{n}^{\circ}$ VII, Outubro 1932, p. 54-56.

${ }^{36}$ Bonito, Mário. "Pavilhão Ilhas Adjacentes”, technical description. EBAP, 1947.
} 
memory a powerful emotion, we will have achieved our purpose, conquering through architecture the forgetfulness of man" ${ }^{37}$.

The process that searches for original sources as a basis for the formulation of an architectural culture will be fundamental to the sustainability of a response that is to be genuine and of its time.

In his writings, the defense of the architect's profession through social dimension with the identification and reading of "occasion" as a way to give an updated response to concrete social problems, far from the architect as "lyrical visionary able to conceive by grace, or by interference from an anonymous intuition" ${ }^{38}$. Mario Bonito asserts that "architects of our time reach different architectural solutions, because urban planning consents or imposes and because it's a reflection of his century's social climate, scientific and economic information" ${ }^{39}$.

"The Portuguese architect cannot waste time around easy and hollow plasticity and aesthetics, purely decorative" ${ }^{\prime \prime 0}$.

Therefore, "The past does not receive - gives. The present receives and transforms. The future will transform the legacy of the present. It's the chain" ${ }^{, 41}$.

It will be with this persistence that his willingness to seek the path of new architecture without losing, however, the sense of continuity in the reading of architectural history. This insight into the modern architecture's framework as a natural and evolutionary moment in the History of Art, will be highlighted in most of Mario Bonito's texts, and will be associated with Le Corbusier's Vers une Architecture, 1923, highlighting the approach of architecture through three themes "volume, surface and plan" and the chapter "architecture" with its "The Lesson of Rome", "The Illusion of the plan" and "Pure creation of the mind" with constant references to the forms of history and their meaning/significance.

Hence, for Mario Bonito this process transpires two key themes: the notion of place and of time as a vehicle for an educated/cultured position in response to society's everyday problems.

Place will always be the condition of Porto, of the country plunged in a regime, in a society that cultivates the mental and physical oppression, advocates cultural stagnation, revivals contrary to progress, i.e. that feeds people's ignorance and that of a nation.

Time will be a key to read, study and understand specific concerns, always through the apprehension and comprehension of the past, to better respond to the problems of the present.

Mário Bonito, the militant architect and participant citizen, believed that we can only provide a complete answer to today's problems with a full understanding of the options of the past, framed in a progressive perspective of a democratic society and a cultured man:

- an intellectual restlessness approach to architectural themes based on a collective attitude or social response - the aura of universal man;

\footnotetext{
${ }^{37}$ Bonito, Mário. "Pavilhão Ilhas Adjacentes", technical description. EBAP, 1947.

${ }^{38}$ Bonito, Mário: "Um arquitecto de luz e celulóide". Vértice - Revista de Cultura e Arte. № 83, Volume X, July 1950, p. 43.

${ }^{39}$ Bonito, Mário: "Palavras de introdução a uma exposição de arquitectura". Exposição de Arquitectura. Póvoa de Varzim: Tipografia Frasco, 1956.

${ }^{40}$ Bonito, Mário: “A universalidade na arquitectura”. Notícias da Amadora-Semanário Popular. No 505, May 1971.

${ }^{41}$ Bonito, Mário: "Palavras de introdução a uma exposição de arquitectura". Exposição de Arquitectura, Póvoa de Varzim. Póvoa de Varzim: Tipografia Frasco, 1956.
} 
- the intent to conceive not a universal architecture, like the international style - but to introduce/include universal themes in architecture associated with the interpretation of the conditions of place - universality in architecture and not universality of architecture;

- the proportions of the human body and the spiritual concerns of man as a fundamental condition on drafting and understanding spatial notions - a critical approach avoiding simplifications and transient options: sedimentation of an architectural poetics;

- the conceptual truth of the modern vocabulary and syntax through compositions that emphasize measurement, proportion, rhythm and tension between different elements - a search for a harmonious and coherent compositional whole through a complex process of thought;

- the pursuit of an individual creative work possessing a complex inner life refusing to fit into movements or obey the dictates of critical fashions - man in the centre of an artistic and social driven practice.

Understanding Mario Bonito's Ilhas Adjacentes Pavilion, permits us to recognize today how to transport, through an interpretative process, Le Corbusier's main design themes and architectural interpretations with a conceptual and formal consistency that strengthens the design process, through the identification of the posed problem and its respective formulation through an architectural concept/principle, based on a disciplined logic interpreted by the physical and symbolic conditions of the context, programme and commission.

Thus the work highlighted can be interpreted as an artistic practice about the importance of architecture and the evolution of a design process, with its respective sense of composition, formulating a proposal that questions and interprets a given reality - how to integrate modern architecture's premises with its respective heritage in today's conditions without losing its transforming and inspiring condition of a new future. 


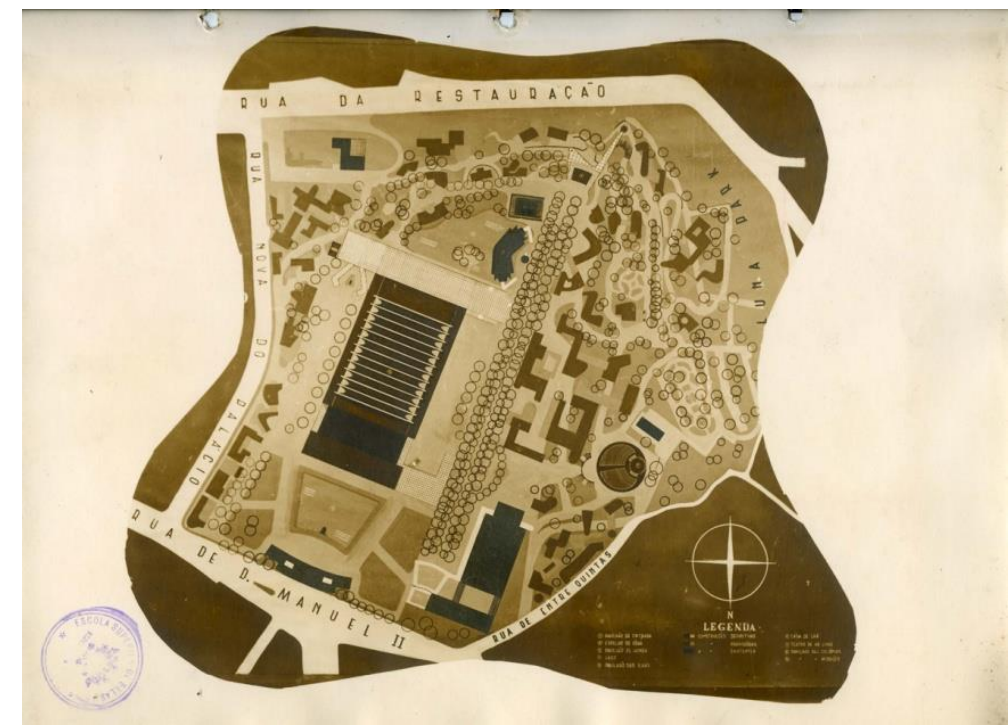

1. Original sheet with General layout plan, Pavilhão das Ilhas Adjacentes, CODA, 1947.

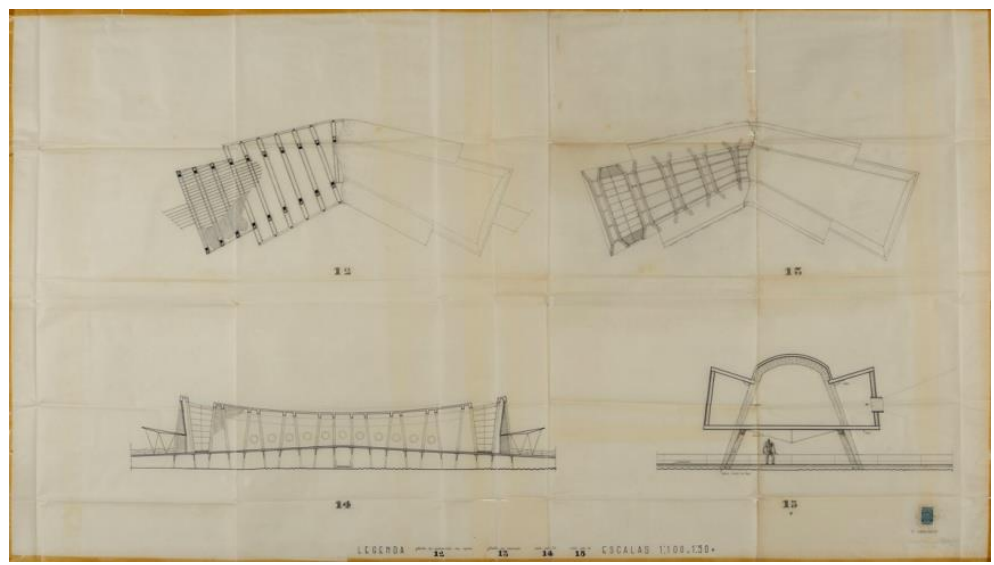

2. Original sheet with Plans and sections, Pavilhão das Ilhas Adjacentes, CODA, 1947.

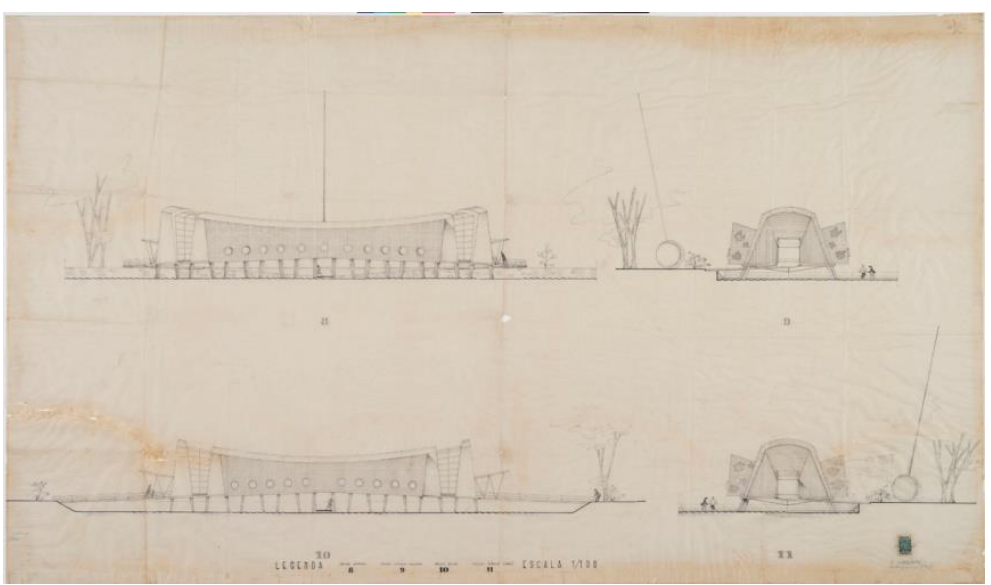

3. Original sheet with elevations and cross-sections, Pavilhão das Ilhas Adjacentes, CODA, 1947. 


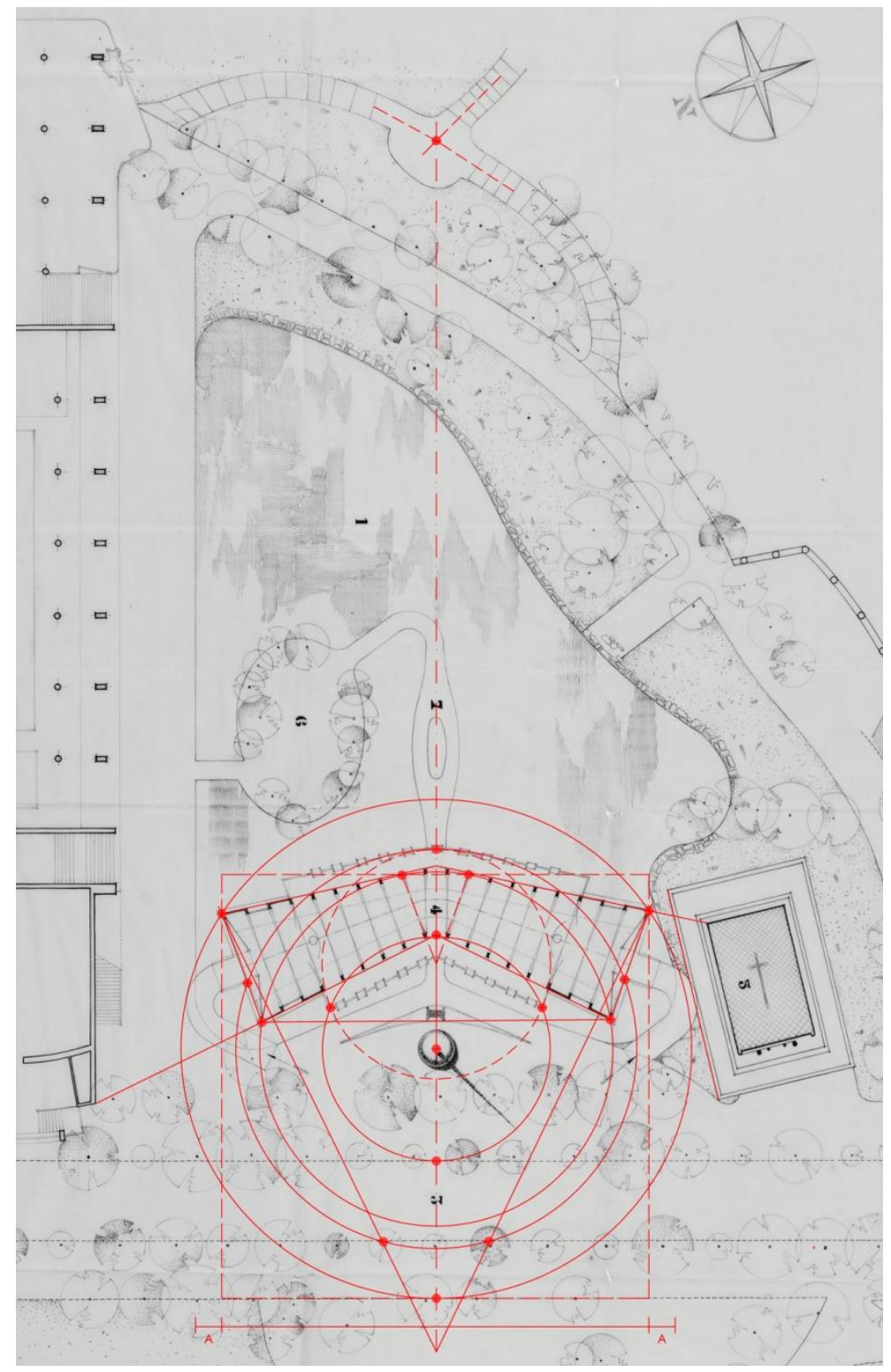

4. Juxtaposition of regulating lines/ force vectors on general site plan.

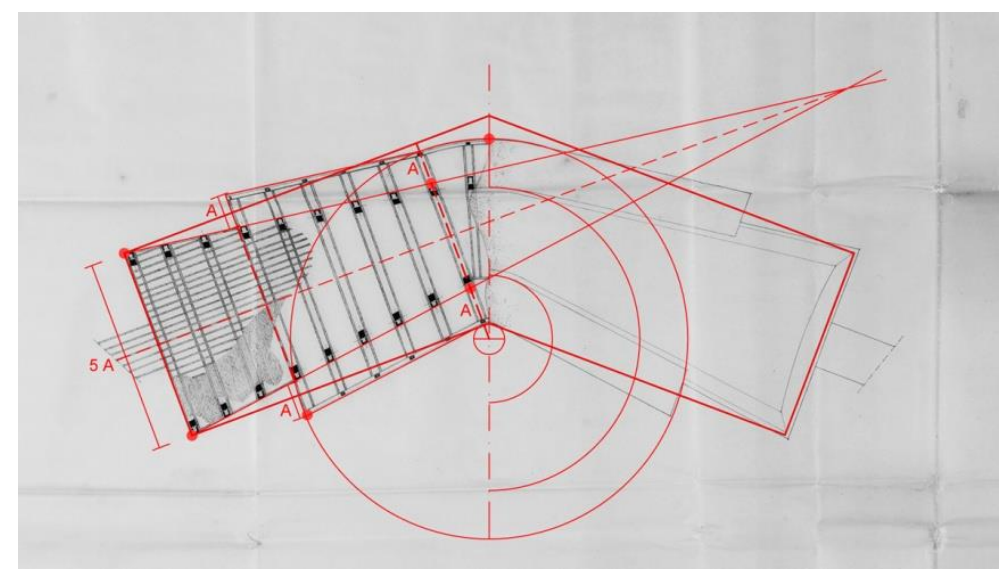

5. Juxtaposition of regulating lines/ force vectors on pavilion's floor plan. 


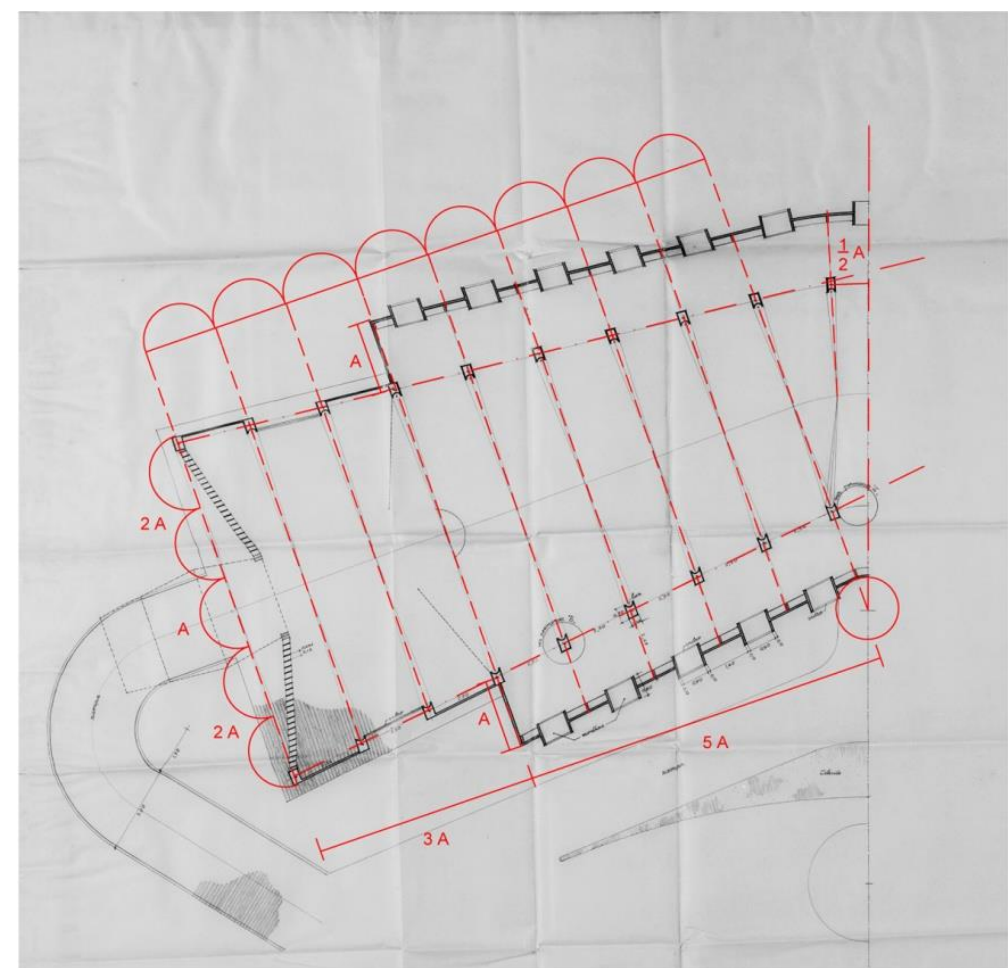

6. Juxtaposition of regulating metric composition on pavilion's floor plan (extract).

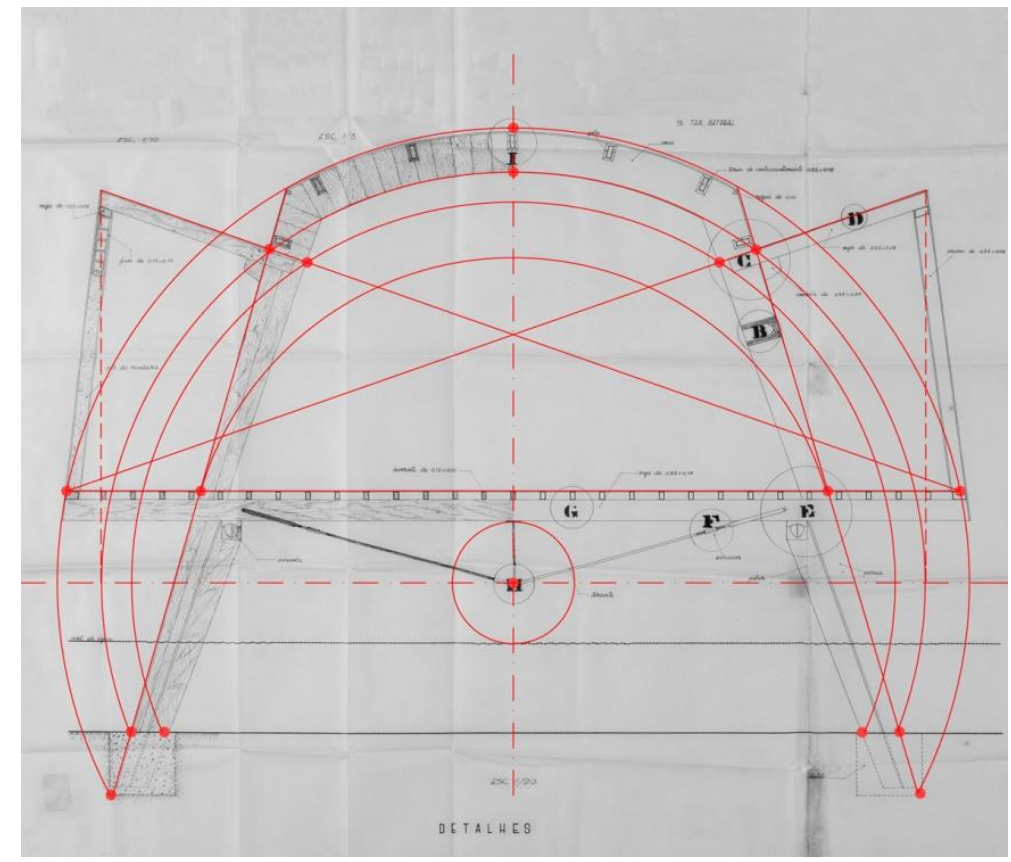

7. Juxtaposition of regulating lines on pavilion's longitudinal cross-section. 


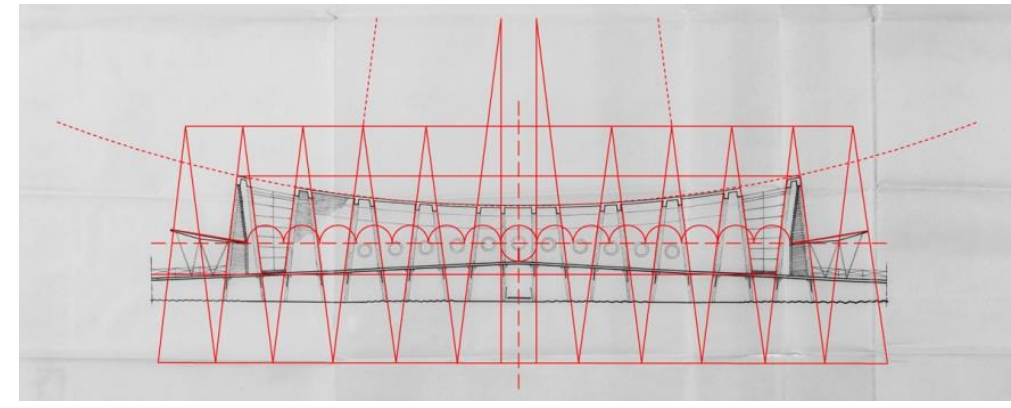

8. Juxtaposition of regulating lines on pavilion's cross-section - arched portico.

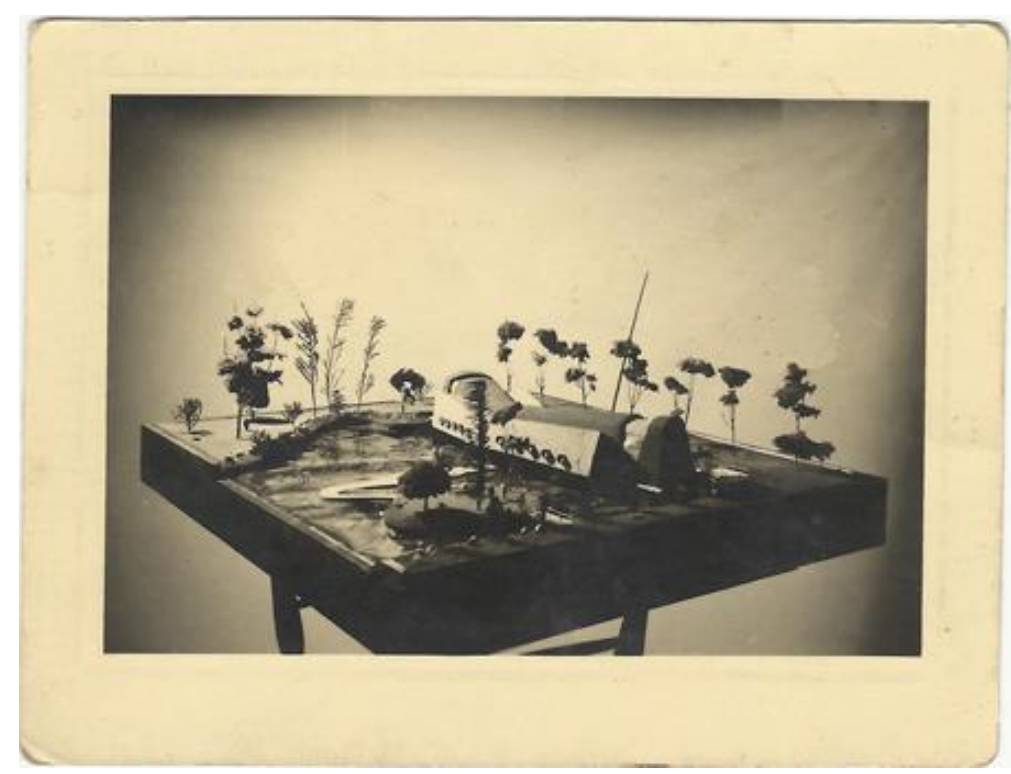

9. Photo of original model, Pavilhão das Ilhas Adjacentes, CODA, 1947.

\section{Source of images}

1/3 - Centro de Documentação da FAUP, Porto;

4/8 - Schemes by the author;

9 - Mario Bonito's Family archive.

\section{Bibliographical References}

Bonito, Mário: “A universalidade na arquitectura”. Notícias da Amadora - Semanário Popular. N 505, May 1971.

Bonito, Mário: "Palavras de introdução a uma exposição de arquitectura". Exposição de Arquitectura, Póvoa de Varzim. Catalogue. Póvoa de Varzim: Tipografia Frasco, 1956.

Bonito, Mário: "Pavilhão das Ilhas Adjacentes", technical description. EBAP, 1947.

Bonito, Mário: "Um arquitecto de luz e celulóide". Vértice - Revista de Cultura e Arte. № 83, Volume X, July 1950.

Britton, Karla: Auguste Perret. London: Phaidon Press, 2001.

Cohen, Jean-Louis: Le Corbusier, an atlas of modern landscapes. London: Thames \& Hudson, 2013. 
Costa, Alexandre Alves: Textos Datados. Coimbra: Edições do Departamento de Arquitectura da FCTUC, 2007. L'Architecture d'Aujourd'hui, special number "Perret". October 1932, Paris.

Le Corbusier. "Architecture and Revolution: Pavillon des Temps Nouveaux, Le Corbusier and Pierre Jeanneret, 1937, International Exhibition in Paris ” Catalogue. USA: Columbia University, 2009.

Le Corbusier: Toward an Architecture. London: Frances Lincoln, 2008

Mendes, Manuel: "Errância poética”, Jornal de Noticias, Outubro 2000. Porto: Porto 2001, Capital da Cultura.

Mumford, Eric: The CIAM Discourse on Urbanism, 1928-1960. Mass: MIT Press, 2002.

rA Revista de Arquitectura. October 1987. Porto: FAUP.

Ramos, Rui (Dir.): História de Portugal. Lisboa: A Esfera dos Livros, 2009.

Tostões, Ana (Dir.): Arquitectura Moderna Portuguesa 1920-1970. Lisboa: IPPAR, 2004. 


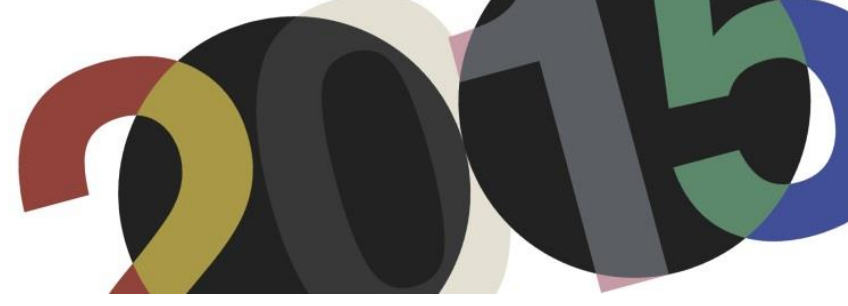

DOI: http://dx.doi.org/10.4995/LC2015.2015.942

\title{
Ronchamp in the spotlight. The feature of a shocking building in the 50s journals
}

\author{
F.J. Casas Cobo \\ College of Architecture and Digital Design, Dar Al Uloom University, Riyadh, Saudi Arabia \\ Escuela Técnica Superior de Arquitectura de Madrid
}

\begin{abstract}
Although currently it is largely accepted that Chapelle Notre-Dame du Haut at Ronchamp is one of the milestones in Le Corbusier's works, there is no less agreement in saying that it was one of the most controversial of his works and one turning point in modern architecture, not only in terms of digging a grave for functionalism but to opening a window to a wide bunch of architects and works that would have been excluded from history and maybe forever otherwise. In order to recall its importance, we must look back to how architectural journals featured Ronchamp in the mid fifties as, on one hand, Le Corbusier was not a young architect but a very well known and respected one with an international reputation and therefore, it was not easy to criticize his works and, on the other hand, Ronchamp was such a shocking building for many colleagues who had no choice but writing about it that somehow they were between the Devil and the deep blue sea.
\end{abstract}

Keywords: Ronchamp; debate; journals; historiography, contemporary; criticism.

\section{Introduction}

One of the most beautiful polemics arose when Ronchamp was completed was one due to Ernesto Nathan Rogers and Giulio Carlo Argan in Casabella in 1955. If Rogers supported the so called new trajectory of Le Corbusier's career, Argan criticized it upon a moral basis by pointing that Le Corbusier was an agnostic architect who, therefore and according to Argan, should have not accepted the commission to build a church. The moral issue shifted to a more cultural approach when Giancarlo di Carlo jumped in the debate in the pages of Casabella continuitá. Bruzo Zevi in L'architettura had joined the discussion previously contributing to reinforcing the idea of Ronchamp as consistent with modern architecture while James Stirling offered an explanation about it occupying a middle ground in The Architectural Review whereas Nikolaus Pevsner wrote a less benevolent text about the Chapelle.

Not only Casabella welcomed Ronchamp displaying it in its cover but also Architectural Forum and other journals such us Architectural Design or L'Architecture d'aujourd'hui gave significant room to the event. Even three years later in Arts\&Architecture, where few attention had been paid to Ronchamp as they were busy showcasing case studies and buildings related to industry manufactures, John Jacobus Jr. will review a book on Le Corbusier and months later Craig Ellwood himself will write "The Machine and Architecture" giving both texts new perspectives on the new path Ronchamp had already opened.

It is very unlikely that architects, historians or critiques change their minds and admit to having said something they regret afterwards. A rare example might be Robert Venturi, who apologized for his disdain towards Mies van der Rohe some twenty years later after writing his famous "Less is a bore" but not much can be said about those who openly criticized Le Corbusier's Ronchamp and eventually succumbed to stick to the most extended acceptance of this building as one, although conspicuous and consequence of a unique genius mind, still consistent with the variety of ideas supported and embraced by him. However, it can be tracked and it compones the skeleton of our more recent historiography if we follow up later books by Rogers or Zevi and those written 
by Drew, Jacobus or Joedicke in the $60 \mathrm{~s}$ and $70 \mathrm{~s}$ disembarking in the recent Tafuri, Frampton, Curtis, Colquhoun, Cohen and so on histories of modern architecture which homogeneously underline the importance of Ronchamp as part of the -otherwise imposible to frame- broad, varied and rich modern architecture.

\section{Ronchamp in the 50s journals}

As mentioned before, one of the most passionate debates was the one hold between Ernesto Nathan Rogers and Giulio Carlo Argan. All begun with the article "Il metodo di Le Corbusier e la forma nella "Chapelle de Ronchamp"', published in Casabella in 1955. In this somehow enthusiastic text, E. N. Rogers writes with great veneration towards Le Corbusier's last work. However, it can not be said that Rogers is only paying a tribute to him as there is some criticism in his text. In particular, Rogers is not very satisfied with the angle between north and east walls although he prays indulgence to that as if it was a very small failure from someone thought to be perfect, a tiny imperfection. More over, in the interior, the writer claims to dislike the use of the red color in fire wrapping the altar but these two details will be mostly the only ones to be pointed out as partially wrong whereas the rest of the text will be laudatory and in order to exalt Le Corbusier's work as a masterpiece.

In this sense, one of the most interesting themes that Rogers touches in the article is, of course, the apparent contradiction in Le Corbusier's trajectory as this was, to everybody's eyes, a work that would not fit in easily. Rogers does not bow his head and sanctions that Ronchamp can not be seen or understood as part of a linear process -an historic one- as it was of an irreductible originality and synthesized his individual and very original personality and history.

For Rogers, it does not represent any contradiction the fact that Le Corbusier had championed the machine and his approach to a new world where industry and machinist ideas commanded it. Even more, he challenges Le Corbusier's imitators to follow him from now onwards as Ronchamp was undoubtedly an almost unreachable model to imitate.

It was not a surprise how Rogers did not hesitate in applauding this controversial last work of Le Corbusier from the very beginning as this position was consistent with previous articles he wrote but although it can not be said that he was brave jumping in, it is true that his text was one of the most supportive ${ }^{1}$ and led to a fruitful debate afterwards.

Le Corbusier himself published a brief text following Rogers' pages. The author underlines the palimpsest nature of the chapel in a terrain where different constructions had been replacing others after successive wars and describes the building itself with some references to materials, construction, the four horizons and its determining character over the form of the building which is not the aim of its description as he wants to put the light on other aspects such us psychological sensations.

\footnotetext{
${ }^{1}$ Nor Architectural Forum nor Casabella was the first journal in publishing Ronchamp in September 1955; Architectural Design did it in July 1955. At the same time as Architectural Forum and Casabella, Architectural Review published "From Garches to Jaoul: Le Corbusier as Domestic Architect in 1927 and 1953”, the controversial article by James Stirling who, eventually some months later, would write on Le Corbusier's Ronchamp for Architectural Review in March 1956. Conspicuously, French L'Architecture d'aujourd'hui will not do likewise until April 1957 but Ronchamp would be front page.
} 
Very soon after, in the first issue of 1956, Casabella publishes Giulio Carlo Argan's response to Rogers in the first pages under the form of letter to the journal ${ }^{2}$ in which he does not only show his surprise (and disagreement) with Rogers but also with Bruno Zevi, who had posed himself in favor of Ronchamp through the pages of L'architettura, the journal he founded and directed since mid 1955. In "Verso un solo linguaggio", Zevi explains the inclusive journal's position with regard to rationalist trends and organicist proposals which included Italian examples but explained through a parallelism with international architecture and, in particular, with Alvar Aalto as leader of the organic European movement, according to Zevi, and Le Corbusier's Ronchamp, a building that, in his opinion, was not rationalist and did not follow any of the five points towards a new architecture but nevertheless was consistent with the natural evolution of rationalism and had adopted the demanding of internal space, articulated volumes and had enriched the figurative dictionary, being all of the previous ideas part of what the new organic movement demanded.

As in the case or Rogers, no one wast taken by surprise when Zevi supported Le Corbusier's surprising building though not him but Giuseppe Samonà would be the one who would sign a later article ${ }^{3}$ devoted to Ronchamp. Worth mention here that Zevi had been devising an inclusive discourse since the foundation of Associazione per l'Architettura Organica (A. P. A. O.) more than ten years before in 1944.

Continuing with Argan's reply to Rogers, Argan admits that he has not visited Ronchamp (Rogers had) and he had only seen what Casabella had featured but he did not expect his opinion may change as it was grounded in moral basis rather than formal. The truth is that, despite the extremely long letter to complain and argue against Rogers' article, this is the only regret anybody may stick with after all.

Argan accused Ronchamp of being insolently anti-historic, not in the sense of the history of religious architecture but with regard to the history of modern architecture. Needless to say at this point that the debate on history was on the table and Italian architects played a remarkable role on it. Following this debate, a new one involving again Ernesto Nathan Rogers would take place amid Architectural Review and Casabella on Neoliberty and the supportive attitude of Rogers to some Italian architects who outlined a revival on liberty style but, later on, Rogers (within his office BBPR) will build the astonishing Torre Velasca which would lead to further and fierce dispute reaching CIAM and its further dissolution. Argan teased Rogers' description of the way to the altar through soft ramps and uneven floor and compared architectural functionalism and machine-àhabiter with a "machine to worship and pray" in what might be a religious functionalism.

The central point of Argan's disagreement lied in Le Corbusier as figurehead of modern architecture turned into a kind of spiritual leader ${ }^{4}$ for the society and serving an anti-modern purpose as this was. Argan admitted that he was not against the idea of non religious architects working for religious institutions but, and this is the key of the question, to exalt the ideals of these institutions by designing a building which enabled to this great excitement being the author, Le Corbusier, a secular.

Some few months later, probably the minimum posible between the printing outs of the successive journals, Rogers would answer Argan's letter with another letter dated 16 February 1956. Rogers did not surrender to the argument of Argan with regard to the moral ground of modern architecture, which was something he always

\footnotetext{
2 Argan, Giulio Carlo: “Dibattito su alcuni argomenti moral dell'architettura”. In Casabella continuita, Nr. 209, JanuaryFebruary 1956, p. 1-4.

${ }^{3}$ Samoná, Giuseppe:'Lettura della Cappella a Ronchamp". In L'architettura, June 1956.

${ }^{4}$ Argan reminds the calvinist origins of Le Corbusier's family. Le Corbusier's indifference towards religion was not a secret as he claimed himself to be an agnostic but not as atheist and that, despite no small debate amid the clients, did not avoid him to get the commission to build the Chapel.
} 
agreed with, but waved a flag on Le Corbusier's creativity and extraordinary vitality to interprete different themes along all his career in an unbiased way.

Rogers will answer every and each of the many arguments thrown by Argan regardless they were historical, moral, ethical or stylist. It is not the aim of this paper to review all the parallelisms and deep analysis that Argan uses in an attempt to convince his colleague, or otherwise, as they are too many and include references as different as Mondrian, Baroque, Gothic, Gropius or Einstein. Nevertheless, the differentiation between functionalism and rationalism, an apparently overcome debate, is worthy to be explained. For Rogers, the functionalist architect does not operate amid the boundaries of pure logic but the one who incorporates the inherent vibrations of historical structures and translate those in a synthesis of utility and beauty with the symbols of his own and personal figurative language. This position was very closed to what Bruno Zevi and L'architettura were supporting and, needles to say, is a tailored ad hoc definition for Le Corbusier's last building.

In this sense, Rogers will be more explicit and enthusiastic and will place Le Corbusier in a position very close to nature, comparing him with Alvar Aalto and Frank Lloyd Wright, as he poses Le Corbusier wanted to merge architecture with nature reaching a complete fusion. It is true that Le Corbusier explained here and there his interest towards nature and the surroundings of the chapel, the idea of the four horizons, the collection of rain water and the way to approach the building from the countryside. However, it can not be said that this was his first concern always -as it was for other architects under the label of organic architecture- and thus Rogers seemed to be going further in this defense than what should be reasonable.

Another key contribution to the debate is the one made by James Stirling in The Architectural Review in March 1956. In "Le Corbusier's Chapel and the Crisis of Rationalism", Stirling relates a brief introduction where he points out the division between art and technology that has confronted the ideological base of Modern Movement since its origin, specifically when Art Nouveau was born and engineering was tackling new typologies at the end of 19th century. It is quite interesting that he bridges the gap between America and Europe explaining how functionalism is linked to construction and industrial processes in America whereas in Europe still stands the humanist essence related to the function. Thus, somehow, gives an explanation of the search of space and form that allows that something as awkward as Ronchamp occurs in Europe, something that Stirling will claim to "may possibly be the most plastic building ever erected in the name of modern architecture".

Stirling will not spend time addressing questions related to moral as Argan did and Rogers accepted to response. On the contrary, he analyzed why there was such few technology in Ronchamp, something that he attributed to the hesitation of Europe in embracing industry and technology as America had already done. Albeit this waving attitude, Stirling consents that there are some industrial products such as the handrails which are important. He goes back to Renaissance and Mannerist to draw a parallelism with the rationale of the modern movement and this so-called "conscious imperfectionism (sic)" of Ronchamp to eventually state that "Le Corbusier, proceeding from the general to the particular, has produced a masterpiece of a unique bust most personal order."

The debate on Ronchamp can not be restricted to Europe although Italian architects were the main characters in the fruitful discussion as it has been seen until now. The coverage given to Ronchamp was of different extent. From covers in some journals to, surprisingly, absolute silence, it is an evidence that Le Corbusier was a world wide leading figure but, unlike other coetaneous masters such us Mies van der Rohe or Walter Gropius whose presence in American made them more relevant and present in American press, Le Corbusier was a bit far from that. So, if Architectural Forum gave its front cover to Ronchamp in September 1955 and an illustrated article 
titled "Le Corbusier builds a church", Progressive Architecture, on the other hand, did not even mention Ronchamp in an extensive illustrated report about churches and temples in September 1956.

John M. Jacobus Jr. writes "Le Corbusier: Fantasy and the International Style" to be published in February 1958 in arts \& architecture American journal. Jacobus mentions one of the latest books on Le Corbusier, a volume on illustrations and manifestos covering 1952-57 period in which there are more images of built works than drawings and text, something that satisfies Jacobus as it is the statement of Le Corbusier building rather than just drawing or writing. He points out Ronchamp as one of the most notable recent works by Le Corbusier and questions if it is a building that can be, though barely, tagged as rationalist or as "old International Style" or, on the contrary, it is the last manipulation of space that Le Corbusier was challenging for the last twenty years, that is to say, it is not a question of form, again, but of internal space, as pointed out by Bruno Zevi, and thus there is no such inconsistency with rationalism nor with modern architecture as this building, Ronchamp, although odd formally, is embedded in the discourse of modern architecture in the new terms set by recent authors.

There will be another article in arts \& architecture in which the influence of Ronchamp is still discussed. In June 1958, Craig Ellwood wrote "The Machine and Architecture" in which he claims Ronchamp to be a deep manifesto against the machine and also denounces the existence of too many pseudo-Ronchamps among us, which may threaten the need -he continues- of re-examine our recent motivations and those related to the machine to find out a way to a new architecture, a meaningful architecture.

\section{Conclusions. A brief historiography of Ronchamp in the History of Modern Architecture}

The publication of Ronchamp can be considered as the celebration of an event which lead to these very relevant in the context of the 1950s debates and discussions. Nonetheless, other authors and historians kept on reviewing the facts, buildings, contexts and facts to distill and filter what, eventually, would shape the, still, vast and unmanageable core of history of modern architecture.

Perhaps it is fair to say that the debate between Ernesto Nathan Rogers and Giulio Carlo Argan, though exciting and even beautiful and unrepeatable, has not been considered a key moment in history of modern architecture. Not even the participation of Bruno Zevi was enough to consolidate it as such and this can happen because maybe not enough attention has been paid to the material that historical journals provide us with whereas focus is put in other more well known debates with a clear and recognizable structure as those held in the successive Congrès International d'Architecture Moderne where minutes and books are produced and immediately are part of the body of knowledge that will feed the future histories of architecture. Same may be applied to exhibitions catalogues but unfortunately not to journals as they remain a sometimes obscure material that only researches investigate and pour in doctoral researches that hardly reach other fields.

To sustain the previous, some books will be useful as examples. One of the most important recents histories of modern architectures are due to Kenneth Frampton for several reasons. Not only Frampton's is the first critical history of modern architecture as stated in the title but it has also been studied by generations of architects and even today is one of the most, although maybe not didactical wise, studied in schools of architecture. Frampton compares Mies van der Rohe and Le Corbusier approaches to monumentality which were about technique in the case of Mies, and vernacular in the case of Le Corbusier. Frampton lies on James Stirling's texts for Architectural Review (despite not mentioning the journal, only the author) and how, according to Stirling, the design of Maisons Jaoul had hurt sensibilities of those who thought that modern architecture was only about smooth surfaces machinist inspired and placed in an articulated structural frame. In Frampton's opinion, 
Ronchamp takes Le Corbusier back to the thirties and his shifted interest (after War World II) to vernacular rather than classic. There is no mention to Argan/Rogers/Zevi debate in the whole book.

William Curtis' Modern Architecture Since 1900 is one of the books that more clearly supports the thesis of Ronchamp as an icebreaker for the second half of the century. Curtis pays good attention to what critics said when Ronchamp was built and he starts by saying that "its completion in 1954 (...) shocked the critics who flocked to see it". He goes on mentioning Pevsner complaint of a retreat into "irrationality" and Stirling dismayed by "conscious imperfections and mannerism". Curtis does not elude to give an explanation to the burst of Ronchamp and he goes back to Le Corbusier's paintings, his wooden sculptures of late 1950s, his sketches of shells and boats of early 1930s and, of course, the Pavillon Suisse. Besides, he clarifies again the non-religious nature of Le Corbusier and his idealistic approach to architecture and society, not stressing at all Argan's concerns about a master of modern architecture serving religious purposes. Curtis goes on with more references to explain Le Corbusier's attitude. These can be found in the writings of Ruskin and Art Nouveau to summarize it in "forms capable of a divine and magical character" and something called "primitive animism" in an effort to close the debate and bridge a new path to this kind of less masters-based histories of architecture.

As time passes, the relevance of these debates may seem to vanish and other issues are raised. In his Modern Architecture, Alan Colquhoun does not make any reference to the debate, which may surprise no one, but shockingly, he does not even write about Ronchamp except through Michelucci and his indirect reference to it in a chapter devoted to rationalism and organicism. This history reaches the second half of 20st century and, of course, Le Corbusier is a central figure despite the many precautions and annotations to draw new, more inclusive and contextualized histories less focus on central figures and more interested in an open and less dogmatic description of modernism.

However, there is room for other debates like the one about Neoliberty between Reyner Banham and Ernesto Nathan Rogers and its final episode at CIAM being Torre Velasca and Rogers (BBPR to be more specific) the main characters are also mentioned in the book by Colquhoun. In this sense, it is difficult to explain how a debate that started due to the publication in Casabella of some Italian -let's say local- minor works may still have a place in some histories of architecture whereas the one on Ronchamp is completely missed. Actors are more or less the same (Rogers and Banham -Neoliberty- Rogers and Argan -Ronchamp-) but buildings had a minimum impact in one case whilst a huge one in the other. Reasons again can be found in (apart from the fact that Torre Velasca was presented in CIAM) in the englishness of Reyner Banham and Alan Colquhoun and also in the ideas discussed in both polemic debates but, if we look closely to these issues, we find that Ronchamp was not an stylistic debate but a debate about the deep roots of modern architecture and its commitment to change the world while Neoliberty was a polemic about style and history. Nonetheless, what was in play was more importante in the case of the polemic between Banham and Rogers as, somehow, despite the violence of the Ronchamp dispute, this building and the course of modern architecure has been sanctioned some time before by Bruno Zevi and other architects working in the same line as Le Corbusier, though with less shocking resultssupported the openness of modern architecture to new outcomes and investigations about space and -as a resultform overcoming the stiffness of modern movement and rigid functionalism.

More recently, Anthony Vidler would quote James Stirling's "Le Corbusier's chapel and the crisis of the rationalism" in his Histories of the immediate present. In particular, in the chapter devoted to a mannerist modern movement, Vidler uses Stirling to draw the attention back to pure poetry expression and the abandon of functionalism in a shift to plasticity and pure space, which resembles some ideas from Bruno Zevi as well. This only means that the debate is still open and, albeit is widely accepted that Ronchamp is part of the History of Modern Architecture, it is still unclear whether it was only a milestone in Le Corbusier's work or its impact was 
larger. To some authors, this is a question that remains open but even more, the debate on the moral ground of modern architecture between Rogers and Argan had been re-opened again in 21st century by Paolo Portoghesi who, on the occasion of the intervention of Renzo Piano in Ronchamp, stated that Le Corbusier had a secret and profound faith in the mystery of life and perhaps in the sacred.

Perhaps the only certainty -if so- that histories may certify is that Ronchamp was not a question of form but of space and there were other buildings challenging rationalism at the same time and calling for an organic architecture. This is not what matters now, it is the very essence of the Modern Movement and the possibility of an architecture which could actually lead the world and inspire the society to major and dramatic changes, and for that there are no evidences yet as it is still under construction.

\section{Bibliography/references}

Cohen, Jean-Louis. The Future of Architecture. Since 1889. London: Phaidon, 2012.

Cohen, Jean-Louis. Manières de penser Ronchamp: Hommage à Michel Kagan. Editions de La Villette, 2012.

Colquhoun, Alan. Modern Architecture. Oxford University Press, 200

Curtis, William. Modern architecture since 1900. Phaidon, 1982.

Forty, A. Words and Buildings: a Vocabulary of Modern Architecture. Thames \& Hudson

Frampton, Kenneth. Modern Architecture: A Critical History. London: Thames and Hudson, 1980.

Ockman, Joan. Architecture Culture 1943-68. A Documentary Anthology. New York: Columbia Books of Architecture / Rizzolli, 1993.

Pevsner, Nikolaus. Pioneers of Modern Design. From William Morris to Walter Gropius. London: Faber\&Faber 1936.

Tournikiotis, Panayotis. The Historiography of Modern Architecture. Cambridge, Massachusetts: Massachusetts Institute of Modern Architecture, 1999.

Vidler, Anthony. Histories of the immediate present. Inventing architectural modernism. Massachusetts: MIT Press, Cambridge, 2008. 


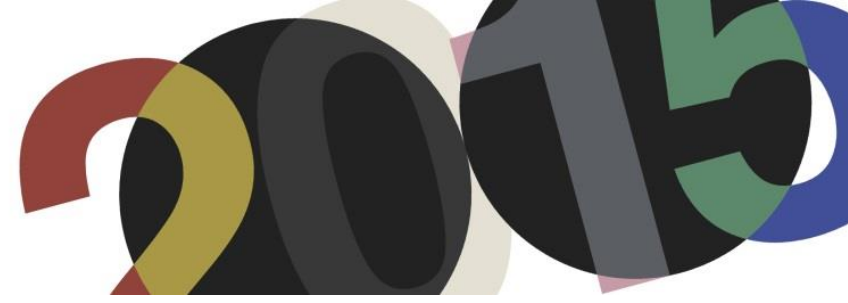

DOI: http://dx.doi.org/10.4995/LC2015.2015.810

\title{
El lugar del arte en arquitectura. Los "lieux porte-voix, porte-paroles, haut-parleurs" de Le Corbusier en su discurso del Convegno Volta, 1936
}

\section{J.L. Chacón R.}

Universidad de Los Andes. Mérida, Venezuela

\begin{abstract}
Resumen: En 1936 se celebró en Roma el Convegno Volta dedicado a la relación entre arquitectura y las artes figurativas. Entre los participantes estaba Le Corbusier quien presentó una ponencia donde claramente explica los fundamentos del lugar del arte en arquitectura, aspecto clave de su posterior Synthèse des arts.

Luego de un manifiesto sobre la Arquitectura Moderna, Le Corbusier afirma que en ocasiones excepcionales puede darse la "colaboración" entre arquitectura y arte con el fin de "aumentar el placer de los hombres". Dirige su atención a la pintura, la escultura y el diseño; y plantea como respuesta la policromía y los puntos "precisos y matemáticos" donde el artista "fuerte y digno" puede hablar y hacer sentir su discurso. Estos lugares del arte son comunicantes: "lieux porte-voix, porteparoles, haut-parleurs"; aun inexistentes entonces pero que se verán realizados años después, en la idea de la Synthèse des arts.
\end{abstract}

Abstract: In 1936 the Convegno Volta took place in Rome and it was dedicated to discuss the relationship between architecture and the figurative arts. Among the participants there was Le Corbusier, who presented a speech where he clearly establishes the fundamentals of the place of art in architecture, a key point in his later Synthèse des arts.

After a manifesto of Modern Architecture, Le Corbusier states that in certain exceptional cases there can be "collaboration" between architecture and art, with the scope of "increasing human pleasure". His attention is placed upon painting, sculpture and design; and as a response he proposes polychromy and "precise and mathematic points" where a "strong and worthy" artist can speak and let his discourse be felt. These places are communicative: "lieux porte-voix, porte-paroles, haut-parleurs". Although inexistent then, they will be materialized years later in the way of the idea of the Synthèse des arts.

Palabras clave: Arte, Arquitectura, Convegno Volta, Le Corbusier, Síntesis de las artes.

Keywords: Art, architecture, Convego Volta, Le Corbusier, Synthesis of the arts.

\section{El Convegno Volta: las relaciones de la arquitectura con las artes figurativas}

En 1936 en la Reale Accademia d'Italia de la ciudad de Roma fueron convocados artistas, arquitectos, historiadores y críticos para discutir el tema de las relaciones de la arquitectura con las artes figurativas al Convegno Volta ${ }^{1}$, evento organizado por Marcello Piacentini con el auspicio de la Fondazione Alessandro Volta. El discurso inaugural, por Romano Romanelli quien suplió a Piacentini por motivos de salud ${ }^{2}$, expresa la pretensión del congreso "el argumento [...] es muy querido a los pueblos que precian poseer una civilización" Romanelli. Haciendo referencia a la monumentalidad de Roma, antigua y -en aquel momento- fascista,

\footnotetext{
${ }^{1}$ El evento se tituló Convegno di Arti. Tema: Rapporti dell'architettura con le arti figurative, y se llevó a cabo del 25 al 31 de Octubre de 1936, en los espacios del Campidoglio de Roma.

${ }^{2}$ Piacentini intervendrá luego en el congreso con una ponencia titulada Le Tendenze dell'architettura racionalista in rapporto all'ausilio delle arti figuartive, justo antes de la de Le Corbusier. En ésta expondrá la importancia que ha tenido siempre la pintura en las edificaciones, y propone un retorno a la arquitectura monumental, la cual "exige la ayuda -para no permanecer estéril- de la pintura".

${ }^{3}$ Romanelli, Romano: "Discorso del Presidente del Convegno". En Fondazione Alessandro Volta: Convegno di Arti. Tema: Rapporti dell'architettura con le arti figurative. p.13.
} 
Romanelli sugiere el camino que deben emprender las artes luego de la crisis de finales del s.XIX; delinea así el objetivo principal de "establecer, en términos sobrios y precisos, cuales puedan ser los medios para volver a conferir eficacia a una verdadera y fecunda colaboración [entre las tres artes mayores]"4.

Entre los participantes del Convegno di Arti estuvieron José María Sert, Paul Bonatz, Marcel Denis, André Lhote, Filippo Marinetti, Mario Sironi, Gio Ponti, Ugo Ojetti, Giuseppe Pagano, entre otros. Le Corbusier fue también uno de ellos, quien participó con una ponencia titulada "Les tendance de l'architecture rationaliste en rapport avec la collaboration de la peinture et de la sculpture / L'œuvre d'art, présence insigne" generando grande polémica entre el público presente. Es un discurso donde claramente explica las razones que fundamentan el lugar del arte en arquitectura, aspecto clave para comprender su Synthèse des arts. En efecto, este discurso representa junto al artículo "Sainte Alliance des arts majeurs ou Le grand art en gésine" de 1935, los primeros textos de Le Corbusier que tratan sobre la idea de una síntesis de las artes, apoyado además en las premisas expresadas anteriormente en los años 20 en L'Esprit Nouveau ${ }^{5}$.

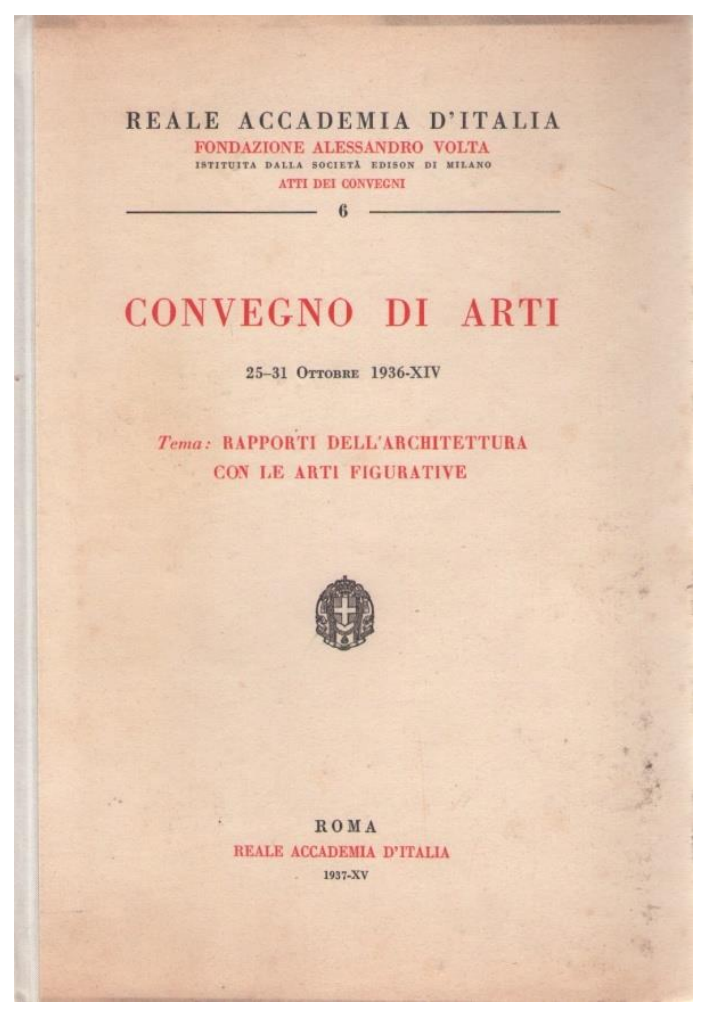

1. Portada del libro del Convegno Volta publicado por la Reale Accademia d'Italia en 1937.

Se plantea entonces realizar un análisis crítico de este discurso con el fin de resaltar tanto la valencia histórica como la estética de uno de los aspectos más importantes del pensamiento -en particular, estético- de Le Corbusier. Lo que constituyó una preocupación constante a lo largo de toda su carrera, la relación de la obra de arte en la arquitectura es un problema, aún poco tematizado por los historiadores de arquitectura y de arte en general, de gran belleza y de gran alcance, que necesita profundizarse e incluso promoverse.

\footnotetext{
${ }^{4}$ Ibidem. p.19.

${ }^{5}$ Cfr. Jornod, Naïma: "Le Corbusier ou la Synthèse des arts". En Jornod, J.P.; Jornod, N.; Sbriglio: Le Corbusier ou la synthèse des arts. p.16.
} 


\section{La Nueva Arquitectura}

La intervención de Le Corbusier en el Convegno Volta abre con la exposición de un manifiesto de la Arquitectura Moderna, en el cual se exaltan sus valores nuevos, y en especial el valor visual de la misma. Lo hace bajo el subtítulo "L'étude de la tendance qui règne au contraire dans l'architecture rationnelle d'exclure, en tant que superflu d'après une logique rigoureuse, le concours des arts figuratifs", y lo desarrolla en 23 puntos. Es un resumen sucinto de Vers une Architecture 6 , la obra insigne de promoción de la nueva Arquitectura Moderna, en la cual se muestran, según Jornod ${ }^{7}$, ya visos de la relación entre arte y arquitectura.

La pregunta con la cual introduce el problema es existencial: ornar o no ornar, decorar o no decorar, enriquecer o no enriquecer, ennoblecer o no ennoblecer; he allí el objeto que reúne arquitectos y artistas en tal evento. Su respuesta es claramente anti-académica, y contextualmente provocadora: "el olor que emana de los discursos, escritos y discusiones sobre este tema, es olor del pasado. Incienso quemado en algunas capillas" Le Corbusier $^{8}$. Ya su posición crítica -y de llamado de atención- ante el tema de discusión del congreso lo había manifestado en un telegrama que antecede su presentación oral ${ }^{9}$. Le Corbusier advierte en éste que la discusión no debe ser un retorno o un renacimiento del pasado, sino que debe más bien mirar a la nueva arquitectura, a la nueva sociedad, a la "era de la máquina".

"Es en la manifestación de las fuerzas humanas fundamentales, primarias, esenciales, que el-hombre- buscará el eje de sus verdades" Le Corbusier ${ }^{10}$. Este llamado a voltear la mirada sobre la esencia de los nuevos tiempos, permite superar un debate que se quede en "vanas decoraciones, intervenciones pictóricas o empastados plásticos". Por eso plantea la necesidad de un "examen profundo del fenómeno arquitectónico" que ayude a comprender las conquistas de los nuevos tiempos.

Para comprenderlas hay que observar a las "máquinas". Desde una pluma estilográfica hasta un dirigible Zeppelin (desde el cual escribió su intervención), todos son objetos, considerados como hechos arquitectónicos, en fin, "forrajes de los eventos sociales nuevos" $"$. De observar estos objetos (productos de la ingeniería y el diseño) "precisos, dramáticos, rigurosos" surge la nueva concepción de arquitectura, que Le Corbusier define en los términos de "formas bajo la luz" resultado de un "juego sapiente" $"$. Mirando lo que nadie miraba, descubre y expresa la nueva arquitectura como creación subjetiva e infinita.

Estas formas son concreciones de intensiones humanas, para ser recorridas por dentro y por fuera: "se entra, se camina, se mira; se mira procediendo mientras las formas se despliegan, se desarrollan, se combinan [...] se avecinan, se ven, nos interesan, nos paran, se aprecian, se giran alrededor, se descubre""13. He allí el "juego jugado" corbusereano: habitar la obra arquitectónica, desde y para el cuerpo humano. Este es, pues, el centro vital de la arquitectura.

\footnotetext{
${ }^{6}$ Llama la atención que este libro fuera dedicado a su amigo artista Amadeo Ozenfant, quien lo introdujo en la pintura.

${ }^{7}$ Jornod, Naïma, Op.cit. p.17.

${ }^{8}$ Le Corbusier: "Les tendance de l'architecture rationaliste en rapport avec la collaboration de la peinture et de la sculpture / L'œuvre d'art, présence insigne". En Fondazione Alessandro Volta: Convegno di Arti. Tema: Rapporti dell'architettura con le arti figurative. Roma. p. 107. Traducción del autor (así como las demás citas).

${ }^{9}$ En tal sentido ver las páginas 102 a 107 de su discurso.

${ }^{10}$ Le Corbusier, Op.cit., p.108.

${ }^{11}$ Ibidem, p. 110 .

${ }^{12}$ Estos son los mismos términos utilizados en Vers une architecture.

${ }^{13}$ Ibidem, p.111.
} 
En consecuencia, lo primordial en la obra arquitectónica son el volumen y el espacio, todo lo demás es secundario. Los medios para expresarlos son la planta y la sección, la luz y la proporción. En los primeros, Le Corbusier no se detiene a explicarlos; de la luz hace un manifiesto que desemboca en el último. Por una parte, "estamos a la merced - de la luz-del sol" porque ésta tiene un efecto potente y determinante sobre las emociones psico-fisiológicas del hombre ${ }^{14}$. Por otra, las proporciones, de igual manera, se determinan según medidas, conveniencias e intenciones, afirma Le Corbusier. "Yo entraré a esta habitación por esta parte, por cuanto la sorpresa se dará de acuerdo a la sinfonía ideada por mí. Y la luz solar entrará de una manera dada y no de otra" $^{, 15}$.

No son las formas en sí a lo que se refiere el maestro suizo, sino en cuanto que son percibidas por el espectador (de arquitectura), o habitante. En tal sentido, la luz y la proporción son comprendidas como pathos, como afecciones corporales en el espectador. Para esto no hacen falta ni decoraciones ni estilos ni calificativos señala Le Corbusier, solo el "juego sapiente, correcto y magnifico", que conlleva a combinar los elementos, de modo análogo a la música tal y como si fuera una sinfonía de volúmenes y espacios.

Le Corbusier concluye esta primera parte afirmando de manera prepotente que la arquitectura no tiene en efecto necesidad de las artes. "La arquitectura es una actividad que se extiende a cada construcción sujeta a las leyes de la visión" "16; es una actividad plástica que genera objetos. Por eso no ve la razón por la cual se le deban agregar las artes figurativas. Y sin embargo, luego de demostrar esto, paradójicamente procede a explicar la excepción de la regla: existen ciertas ocasiones donde la arquitectura puede "augmenter le plaisir des hommes par une collaboration exceptionnelle et magnifique avec les arts majeurs" ${ }^{\text {"17 }}$. Y así entra en escena la obra de arte, como "presencia" excepcional, poderosa y sobre todo "insigne", en la nueva arquitectura.

\section{Las "presences insignes"}

¿A qué se refiere entonces Le Corbusier con artes mayores? ¿Qué es arte para él? Las artes son géneros producidos por el "espíritu de perfección" del hombre, en tanto que generan "placer" hasta conmover el corazón. Así, la literatura, el teatro, la música, la arquitectura, la escultura y la pintura son artes, expresiones humanas que logran dicho fin. No así las artes decorativas, las cuales vienen señaladas despectivamente como consecuencias del "declive de una civilización". Bajo el subtítulo L'oeuvre d'art, présense insigne, Le Corbusier explica que más allá de una diversidad (de artes), el Arte es uno, humilde y potente. He aquí otro punto clave: sólo el Arte, solo y en mayúscula, es aquel capaz de aumentar el placer de los hombres, no el decorativo ni el aplicado; el Arte, expresado en una obra, es el único que puede entrar a jugar en una "colaboración" con la arquitectura.

En primer lugar, su preocupación principal la dirige hacia la pintura y los pintores. A tal respecto, la primera propuesta que lanza es la Policromía. Basado en el hecho que "el color es expresión inmediata, espontánea de la $v i d a " 18$. Le Corbusier expone que la policromía no es más que un elemento arquitectónico; por medio de colores (naturales) se expresa la fuerza de un muro, y se resalta. Por ello, el lugar para los colores, es decir para la pintura, son las superficies de los muros, al igual que de las puertas y ventanas.

\footnotetext{
${ }^{14}$ Cfr. Ibidem, p.112.

${ }^{15}$ Ibidem.

${ }^{16}$ Ibidem, p.113.

${ }^{17}$ Ibidem, p.114.

${ }^{18}$ Ibidem, p. 115.
} 
Pero esto lo afirma luego de haberse puesto el problema que este hecho representa. Para Le Corbusier el modo tradicional de asumir esto es paliativo: "andamos de inmediato a buscar a los pintores para hacer explotar los muros que nos dan fastidio" 19 . La pintura, tales y como los frescos y murales, esconde en realidad muros y paredes, restándole el protagonismo que éstos deben tener. Aún cuando pretendan respetar la arquitectura y ponerla en valor, el peligro de la pintura es lo opuesto, y es lo que sucede a menudo. En cambio, “la policromía arquitectónica no asesina los muros, puede más bien moverlos en profundidad y clasificarlos según su importancia" ${ }^{, 20}$. De esta manera, la policromía no es un agregado sino una respuesta adecuada, una herramienta arquitectónica de gran poder, un "elemento mismo de la planta y la sección”.

Aparte de los muros y paredes, Le Corbusier le presta también atención, pero sin detenerse en profundidad, a las "hojas móviles" (supuestamente de puertas y ventanas), por cuanto son elementos arquitectónicos que han servido como objetos de decoración. Al respecto, rechaza violentamente la tradicional operación del fresco (o la pintura aplicada), sugiriendo que estos elementos son idóneos para ser ocupados por "pintores verdaderos, dignos de la arquitectura",21.

Por consiguiente, el pintor que colabora con el arquitecto debe entender esto, debe ser pues ser "digno y fuerte". No cualquier pintor, ni siquiera cualquiera que esté formado para eso. En defensa de ese pintor ideal, Le Corbusier le reclama su rol ante la arquitectura: “Qui es-tu? [...] Que vas-tu dire?”. Solo entonces, en esas ocasiones "excepcionales" si cumple con las exigencias de la arquitectura, le permite una respuesta: "ici vous avez la parole; parlez!"22. Solo en dichos momentos, podrá la pintura tener lugar permanente y eterno en la arquitectura $^{23}$.

En un segundo plano está la preocupación por la escultura. Para Le Corbusier, ella tendrá cabida solo si se asimila igualmente a ser elemento arquitectónico como la policromía. En la discusión se toman por descontado los detalles en cuanto a los tipos de escultura o sus características, y señala los espacios en los cuales la estatuaria puede entrar y "hablar" en ciertos puntos del espacio arquitectónico. Por eso dice "autour de l'edifice, dedans l'edifice, il est des lieux précis, lieux mathématiques, qui intégrent l'ensemble et qui sont des tribunes d'oú la voix d'un discours trouvera son écho tout autour" ${ }^{24}$. En el juego sapiente de volúmenes bajo la luz, el lugar de la escultura ocupará sutil y precisamente un "lugar matemático", como por ejemplo, el foco de una parábola o un elipse, o bien el punto de intersección de varios planos. De allí que hable de una colaboración como operación tanto sutil como precisa. Si este objetivo se logra, igualmente como a los pintores, Le Corbusier increpa a los escultores: "s'il vaut la peine que ton discours soit tenu", entonces, "entre ici, sculpteur" 25. Y la escultura entrará para convertirse también en un elemento más de la arquitectura.

En paralelo al valor tridimensional de la escultura, Le Corbusier da importancia en su discurso a las molduras, por cuanto ocupan un lugar intermedio entre los muros y el espectador. Comprendidas como elementos que “diseñan los trazos de una superficie", las molduras permiten de hecho "exaltar a veces la matemática -de la

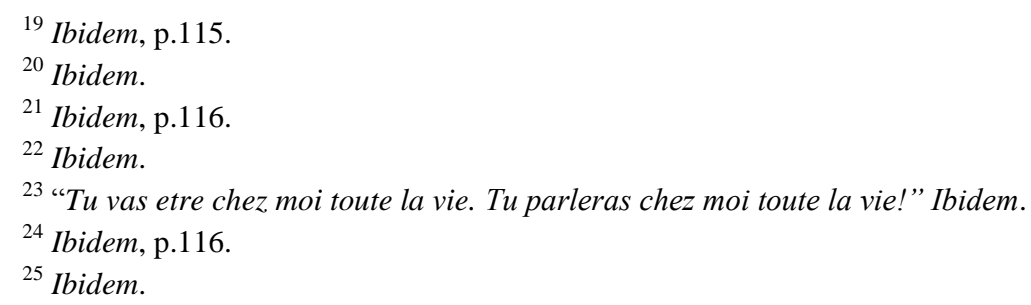


edificación- mediante el diseño riguroso con el cual se definen las superficies o volúmenes, o mediante los compartimientos a través de los cuales los multiplica"26.

\section{El lugar del Arte}

El lugar del Arte en la arquitectura, según Le Corbusier, está determinado por las intenciones arquitectónicas. En tanto que la obra de arte es una presencia insigne, ésta posee un poder particular que necesariamente dialoga, entra en sintonía, con el espacio para lograr un fin común: exaltar la percepción del espectador. Los lugares del arte en arquitectura son por tanto lugares comunicantes, "lieux porte-voix, porte-paroles, haut-parleurs" ${ }^{\text {"27 }}$. La capacidad de comunicar, para exaltar emociones, es el punto clave. De allí que Le Corbusier dirija su palabra a los pintores y les diga "Aquí tienes la palabra, ;habla!", y a los escultores "haz tu ingreso, oh escultor, si vale la pena que llegue a oírse tu voz"28. Por consiguiente, estos lugares portan y lanzan la voz, las palabras, insignes y dignas del artista y de su obra. Estos lugares potencian, no la obra en sí misma, sino las cualidades perceptivas de un espacio, resaltado por la misma. Si no es así, la obra engaña y oculta la arquitectura (y esto es precisamente lo que entiende Le Corbusier por decoración).

En esta afirmación, la arquitectura no se comprende ni como teatro, ni como fondo (inerte) que sostiene el arte; sino como fundamento geométrico y espacial de un todo. Los lugares del arte hacen parte de la matemática del plan arquitectónico. Por eso habla de ciertos puntos fijos, "puntos precisos, puntos matemáticos", en los cuales pueden aparecer las obras de arte, sean tridimensionales (esculturas o molduras) o bidimensionales (pinturas, muros policromados o paneles). Su ubicación depende del plano, es decir, de las intenciones arquitectónicas luego materializadas en el espacio. "Estos lugares matemáticos son la integral misma de la arquitectura de los tiempos nuevos, la cuya ley esencial es ser organismos palpitantes, exactos, eficaces, simples, armónicos, a efluvios lejanos, a ondas radiantes" ${ }^{29}$.

"La aventura arquitectónica de los tiempos modernos, de los nuevos tiempos es algo serio"30; por eso, la colaboración de los artistas no puede reducirse a una operación superficial. No hay cabida según Le Corbusier para los "viejos refritos" de la tradición, es decir, los frescos, los cuadros, las esculturas y las molduras ornamentales; el sentido que tuvieron antes, ya no lo tienen en los nuevos tiempos. Ni tampoco hay cabida para los 20.000 pintores y escultores desocupados de París (a los cuales se refiere constantemente), formados seguramente según la tradición Beaux Arts, como decoradores, y que no consiguen lugar en la nueva arquitectura. Su condición misma de pintor, le hace reclamar vigorosamente mayor profundidad, mayor comprensión, mayor dialogo.

Estos lugares en la arquitectura no existen para el Le Corbusier de 1936; ellos son parte de los tiempos nuevos, aún por crear, con inventiva y coraje más allá de las costumbres del pasado. Aunque ya en el pabellón del Esprit Nouveau de 1925 se asomaba una primera experimentación, será después de la segunda guerra donde desarrollará y materializará estas ideas en obra. Esta postura del año 36 está llena de optimismo, del mismo que lo acompañó siempre: "tout peut être raconté, montré, bâti en apparitions sensationelles du monde, de

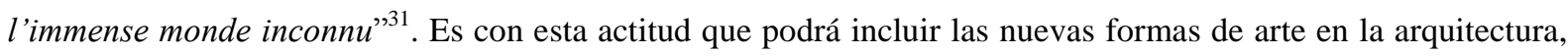

\footnotetext{
${ }^{26}$ Ibidem, p.117.

${ }^{27}$ Ibidem, p. 116.

${ }^{28}$ Ibidem, p.116-117.

${ }^{29}$ Ibidem, p. 116.

${ }^{30}$ Ibidem, p. 117 .

${ }^{31}$ Ibidem, p.118.
} 
como por ejemplo el cine o el fotomontaje. En el cine, dice Le Corbusier, "la Grande Nature est ouverte désormais" "32, el cual sustituye el "teatro de pose". El fotomontaje, ejecutado directamente sobre el muro, puede por otra parte "demostrar públicamente, probar, revelar, instruir". Son modalidades nuevas que brindan bondades y posibilidades que superan la imaginación de entonces.

\section{Comentarios y valorizaciones}

Luego de este breve e intenso manifiesto, Le Corbusier viene, en palabras de Giuseppe Pagano, discutido y adversado por dos arquitectos, mientras que es defendido por dos literatos; Pagano mismo se reparte entre las dos posiciones ${ }^{33}$. En realidad, Le Corbusier recibe la simpatía de la mayoría por su capacidad de "agudo y hábil propagandista del espíritu nuevo" Pagano ${ }^{34}$, pero es contestado por su visión radical de la arquitectura y en particular por la relación anti-académica con las artes.

Bonatz ${ }^{35}$ lo acusa de sugerir un "culto exagerado del individuo" aún cuando promulga "servir las necesidades de los usuarios". En cuanto a la unión de las artes con la arquitectura, afirma en oposición que "nunca jugaron el rol de ornamentos subordinados. Han sido siempre parejas iguales" ${ }^{\$ 6}$. Husarski ${ }^{37}$ lo señala de iconoclasta; y Hautecoeur $^{38}$ de abstraccionista (postula un ideal universal cuando la arquitectura es sumisa a condiciones contingentes). Severini ${ }^{39}$ es quien pone en tela de juicio sus afirmaciones "civilizatorias". Luego de hacer un breve bosquejo histórico de la relación entre arquitecto y artista, Severini asiente el hecho de estar ante una nueva época pero que el arte debe recomenzar "hacia nuevos destinos ligados sin embargo a la tradición" Dudok $^{41}$ critica la actitud de rechazar los logros obtenidos por artistas y arquitectos de antes, sugiriendo que ya, entre otras cosas, se ha logrado una síntesis de las artes. Igualmente Calza Bini ${ }^{42}$, en oposición a la propuesta corbusereana, reafirma "no renunciar nunca al aporte de luz y fuerza expresiva de las artes figurativas" ${ }^{43}$ tanto en Italia como en el resto del mundo.

\footnotetext{
${ }^{32}$ Ibidem.

${ }^{33}$ Cfr. Fondazione Alessandro Volta: Op.cit., p.143.

${ }^{34}$ Ibidem, p. 144.

${ }^{35}$ Paul Bonatz, arquitecto alemán, con diversas obras proyectadas principalmente en Stuttgart.

${ }^{36}$ Ibidem, pp. 130-131.

${ }^{37}$ Vaslav Husarki, pintor y decorador polaco, docente y editor de revista de arte.

${ }^{38}$ Louis Hatecoeur, conservador y académico francés, con cargos en el Museo del Louvre y de Luxemburgo, y con diversos escritos sobre Bellas Artes.

${ }^{39}$ Gino Severini, pintor italiano, fundador junto a Marinetti, Boccioni, Carrà y Balla del movimiento futurista.

${ }^{40}$ Ibidem, p. 136.

${ }^{41}$ Willem. H. Dudok, arquitecto holandés, con obras en Amsterdam y Rotterdam.

${ }^{42}$ Alberto Calza Bini, arquitecto y urbanista italiano, académico y líder del Fascismo, con obras en Roma, Bari, Bolzano, entre otras.

${ }^{43}$ Ibidem, p. 143.
} 


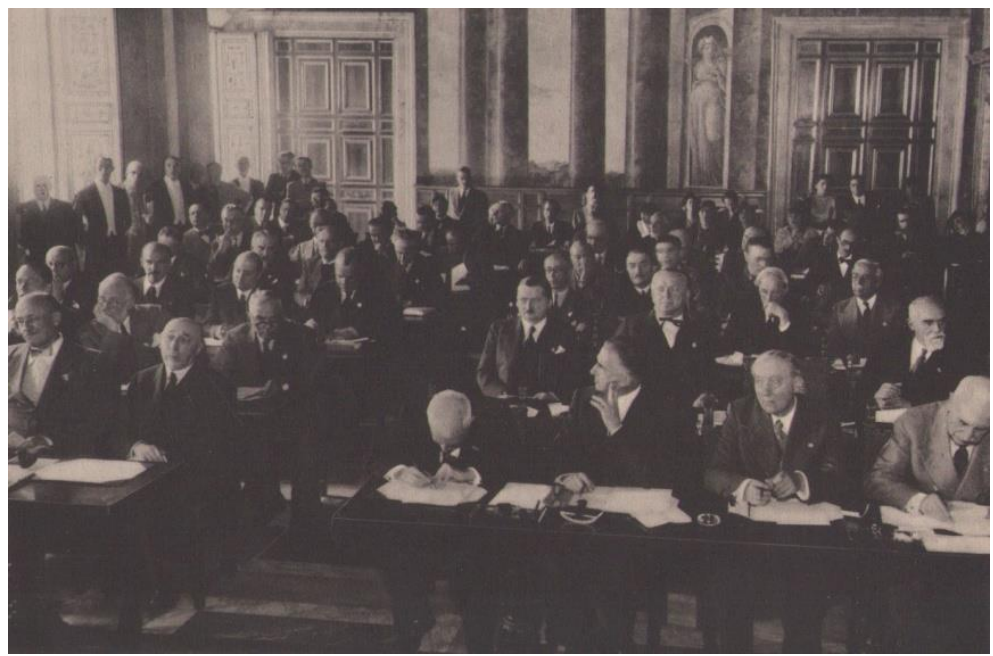

2. Fotografía del grupo de participantes en el Convegno Volta en 1936.

Históricamente, el tiempo le dará la razón al arquitecto Jeanneret. Éste se presenta pues como un visionario que irrumpe las intenciones del Convegno di Arti, aún ancladas en la tradición. Aún sin tener obras construidas que sustenten su pensamiento, Le Corbusier proyecta una mirada asombrosa, que se verá realizada muchos años después, en Chandigarh, Bruselas, Ronchamp y La Tourette, por ejemplo. Y conseguirá además una numerosa cantidad de adeptos, a través de los brazos comunicantes de los CIAM, que se adherirán a estas ideas y conformarán todo un movimiento ${ }^{44}$ que vendrá llamado Synthèse des arts. Ejemplo de ello se encuentran ubicados en todas partes del mundo, como en Italia, Francia, Brasil, Venezuela ${ }^{45}$, Estados Unidos, entre otros.

El concepto de Síntesis de las artes lo cautivará y usará más a menudo después de la guerra; vendrá divulgado y aplicado sobre todo por ese rasgo característico de multidisciplinariedad que le es propio. Según Jornod la síntesis de las artes de Le Corbusier "se presenta como una colaboración entre diversas disciplinas artísticas. Afirmando que el arte nunca decora, el considera de hecho que la obra de arte es una presencia que se compara a un 'huesped o visitante' dentro de una arquitectura que nos habla” Jornod ${ }^{46}$. En esta concepción, “cada obra tiene su rol", cada disciplina es autónoma y posee su propia fuerza. Aunque está anclada en los mismos intereses que perseguía el movimiento Arts \& Crafts de William Morris, e influenciada por los logros de las Vanguardias artísticas, tales y como el Neoplasticismo y el Constructivismo en particular, la posición corbusereana de síntesis es distinta a la integración "bauhaussiana", planteada por Gropius. Según von Moos "su problema era cómo lograr una consonancia básica entre las diversas manifestaciones de la creatividad y permitir que el edificio, la pintura y la escultura pudieran aún permanecer autónomos dentro de la totalidad" von Moos ${ }^{47}$. El objetivo de este ideal era lograr una "Unidad" en un producto procedente de diversas disciplinas; "un tal concepto -afirma de hecho Jornod- correspondería a un objetivo absoluto"48. La idea de "Unidad" por medio de la “colaboración”, además de poseer resonancias con la Gesamtkunstwerk, representa la inserción del carácter

\footnotetext{
${ }^{44}$ Más que movimiento fue una tendencia, la cual tuvo gran resonancia en Latinoamérica y en Norteamérica.

${ }^{45}$ Cabe mencionar la Ciudad Universitaria de Caracas (1949-1970), proyectada por Carlos Raúl Villanueva, la cual representa "uno de los ejemplos mejor realizados de la llamada Síntesis de las artes" Chacón.

${ }^{46}$ Jornod, Op.cit., p.19.

${ }^{47}$ von Moos, Stanislaus: Le Corbusier. Elements of a Synthesis, p. 280.

${ }^{48}$ Jornod, Op.cit., p. :18.
} 
“ideal”, propiamente moderno, en la relación histórica entre arte y arquitectura. La actitud moderna, como afirma una investigación del autor, se manifiesta en obras donde "el arte se integra como un ideal a priori a la arquitectura; la idea se coloca antes de la obra, siendo la integración una confirmación de la operación" Chacón ${ }^{49}$. Pero esta integración idealista pretendía ser "un modo de crear una sociedad nueva y radicalmente mejor de aquella precedente, ${ }^{, 50}$.

Aún cuando el ideal de Síntesis de las artes se agotó a finales de los años 60, se evidencian resonancias de la misma en obras contemporáneas, las cuales, lejos de estar adheridas a este ideal de síntesis, transitan por un mismo camino experimental de colaboración entre arte y arquitectura ${ }^{51}$.

Estéticamente, el lugar del arte que propone Le Corbusier en el Convegno Volta de 1936 se apoya en tres fundamentos interrelacionados entre sí: el juego, la disciplina y la investigación. O lo que sería en otras palabras, estos son los "puntos" teóricos que este discurso presenta, pero que a la larga fundamentarán la futura Synthèse des arts.

En primer lugar, la arquitectura para Le Corbusier es una actividad plástica, en la cual los volúmenes y la luz son los protagonistas de un "juego" intencional y libre. Por tanto, la arquitectura es en efecto Arte, así como son la pintura y la escultura. En este Arte, la obra de arte será considerada un elemento primordial, el cual ocupará un lugar esencial - "excepcional" decía el maestro- del juego arquitectónico. Ese lugar permitirá que la obra hable, grite, comunique su sentido y valor, para que pueda en fin lograr la exaltación emocional del habitante. La síntesis entre arte y arquitectura por medio del sapiente juego corbusereano generará entonces esos lugares "porte-voix, porte-paroles, haut-parleurs".

En segundo lugar, la arquitectura es una disciplina, es decir, un oficio que Le Corbusier ejercía diariamente, en estrecha relación con la pintura y la escritura. Es sabido que las mañanas de este "homme du letres" las dedicaba al ejercicio de la pintura, y las tardes a la arquitectura (las noches, tal vez a la escritura). "Aún cuando Le Corbusier había cultivado la imagen del artista como un ingeniero sensible, más tarde llegó a pensar su pintura como una actividad fundamentalmente privada - un dialogo intimo con los dramas de la forma y el color y una lucha con memorias, miedos y alegrías emergentes del subconsciente" von Moos ${ }^{52}$. Para él ambas disciplinas mantuvieron siempre su autonomía; se ve la diferencia entre el Le Corbusier-pintor y el Le Corbusier-arquitecto. Sin embargo, la experiencia de ambas demuestra una inter-relación entre ellas, la una se permea en la otra. Von Moos utiliza el término "displacement of concepts" para referirse a esta permeabilidad: "figuras individuales o formas de organizar las superficies eran probadas en un área y luego realizadas en otra",53. ¿Hubiese sido posible haber alcanzado tales logros sin esta capacidad multidisciplinaria? La idea de la Synthèse des arts es también la formulación existencial de un síntesis de vida, en este caso, de vida del hombre moderno.

Y en tercer lugar, toda la preocupación que tuvo Le Corbusier por la relación entre arte y arquitectura, se comprende como un intenso y extenso proceso de investigación. Desde sus inicios en el purismo, pasando por la formulación de los objets a reaction poétique, hasta sus obras maestras en Ronchamp o Chandigarh, se demuestra una constante reflexión que va de la práctica a la teoría, y viceversa. "Le Corbusier era un artista que creía en el dibujo y a quien gustaba presentar sus ideas en claras formulas gráficas” afirma von Moos; y tenía

\footnotetext{
${ }^{49}$ Chacón R., José Luis: Il rapporto tra arte e architettura: un «cerchio non chiuso». p.304.

${ }^{50}$ Ibidem.

51 Ver el Capítulo I, sección 1.1, de la Primera Parte APERTURA. UNO SGUARDO CONTEMPORANEO (ALLA

SOGLIA DEL SECONDO MILLENNIO), de la mencionada tesis del autor.

52 von Moos, Op.cit., p.282.

${ }^{53}$ Ibidem, p. 284.
} 
una obsesión por el dibujo "como el médium por medio del cual ver, medir, y entender su contexto" $" 54$. Su propuesta de "colaboración" entre arquitecto y artista, es pues un ideal surgido de la experiencia pero desarrollado como hecho ideológico, una práctica que se convierte en teoría y que luego vuelve otra vez a la práctica. Por consiguiente, "Les tendance de l'architecture rationaliste en rapport avec la collaboration de la peinture et de la sculpture / L'œuvre d'art, présence insigne" se comprende como parte de una investigación "proyectual" " : una teorización de las experiencias iniciales, que luego materializará en las obras maestras de su madurez. Este proceso de investigación resumido bajo el término Synthèse des arts es algo que Jeanneret lleva a cabo a lo largo de toda su carrera; es una verdadera y propia recherche patiente hacia una síntesis entre arquitectura, las artes y la vida.

No es difícil hacer por ultimo notar la correspondencia entre estos tres puntos y su vida. Desde los explosivos inicios hasta su misteriosa muerte, la vida de Le Corbusier transcurre como un verdadero "service de la poésie", dedicado a veces a la machine, otras al Angle droit, en algunas ocasiones como électroniqué, pero sobre todo, constantemente indicible. La fuerza de su poética, tanto desde la perspectiva histórica como estética, es aún inagotable.

"Art.

L'art: expressions de l'esprit, de la pensée, de la conscience [...]

Démarche urgente: reprise contact avec l'échelle humaine [...]

Les Artistes.

Médiums: Ils manifestent en signes synthétiques compréhensibles et beaux, le torrent des évènements: homme et nature, homme et destin, -l'âme humanine [...]

Durée: La grande eloquence peut être passagère ou éternelle. Nul ne peut le fixer d'avance. Ne será éternel que ce qui a d'abord été vivant, palpitant, vrai, d'aujourd'hui" Le Corbusier ${ }^{56}$.

Así contestaba, sintéticamente, el maestro suizo ante sus interlocutores del Convegno Volta, y se marchaba.

\footnotetext{
${ }^{54}$ Ibidem, p.296.

${ }^{55}$ Ver el artículo del autor "Bases teóricas del proyecto como investigación en la enseñanza universitaria de arquitectura. Propuesta y ejemplo de implementación en la Escuela de Arquitectura de la ULA“.

${ }^{56}$ Le Corbusier, Op.cit., p.146.
} 


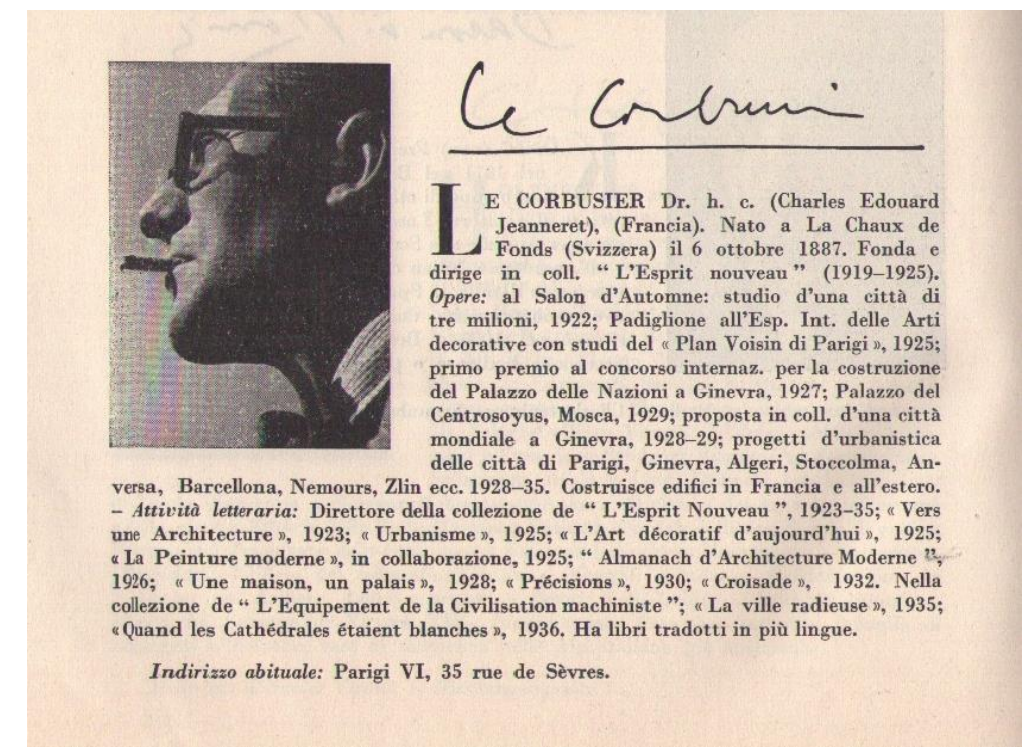

3. Ficha técnica de Le Corbusier así como aparece en la publicación.

\section{Agradecimiento}

Al Prof. Federico Brunetti, del Politecnico di Milano, por su constante apoyo, humano y académico.

\section{Créditos de las imágenes}

1 y 3. Libro propiedad del autor.

2. Fotografía en el libro, p.2.

\section{Referencias bibliográficas}

Chacón R., José Luis: Il rapporto tra arte e architettura: un «cerchio non chiuso». Tutor: Daniele Vitale. Tesis de doctorado. Milán: Politecnico di Milano, 2009.

: "Bases teóricas del proyecto como investigación en la enseñanza universitaria de arquitectura. Propuesta y ejemplo de implementación en la Escuela de Arquitectura de la ULA“. En Revista M. Volumen 10 $\mathrm{N}^{\circ}$ 2, Julio-Diciembre 2013. Bucaramanga, Colombia: Facultad de Arquitectura. Universidad Santo Tomás. pp. 6-21.

Fondazione Alessandro Volta: Convegno di Arti. Tema: Rapporti dell'architettura con le arti figurative. Roma: Reale Accademia d'Italia, 1937.

Jornod, J.P.; Jornod, N.; Sbriglio: Le Corbusier ou la synthèse des arts. Catálogo de la exposición. Milano: Skira Editore, 2006.

Le Corbusier: "Les tendance de l'architecture rationaliste en rapport avec la collaboration de la peinture et de la sculpture / L'œuvre d'art, présence insigne". En Fondazione Alessandro Volta: Convegno di Arti. Tema: Rapporti dell'architettura con le arti figurative. Roma: Reale Accademia d'Italia, 1937. pp. 107-119.

: Hacia una arquitectura. $2^{\circ}$ Edición. Traducción de Luis A. Romero. Buenos Aires: Edit. "El Distribuidor Americano", 1939.

von Moos, Stanislaus: Le Corbusier. Elements of a Synthesis. Cambridge, Massachusetts: The MIT Press, 1979. 


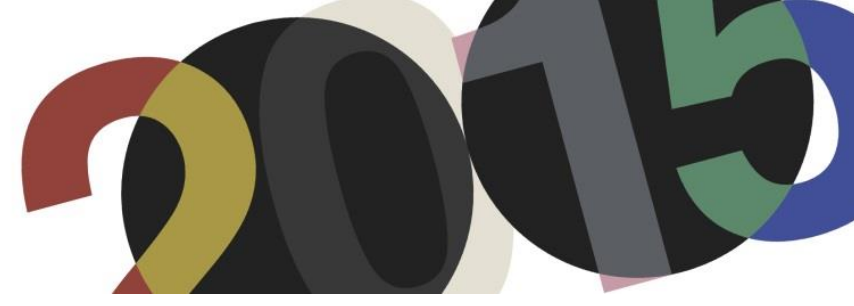

DOI: http://dx.doi.org/10.4995/LC2015.2015.285

\title{
Le Corbusier et les relations avec le Brésil ${ }^{1}$
}

\section{S.R. Chiarelli, R. Verde Zein}

Programme d'études supérieures de la Faculté d'Architecture et Urbanisme de l'Université Presbytérienne Mackenzie, Sao Paulo, Brésil

\begin{abstract}
Résumé: Les relations preofessionelles établies par l'architecte suisse-français Le Corbusier avec le Brésil ont été énormes et variées. Ayant été initiées dans les années 1920, elles ont été étendues jusqu'à sa mort en 1965, lorsque son projet de l'Ambassade de la France à Brasilia était en train de se développer (1964). Les informations disponibles sur l'ensemble des projets, des avres et des événements qui montrent la relation de Le Corbusier avec le Brésil ont été dispersés par plusieurs sources, et ils sont étudiés par plusieurs rechercheurs. Cet étude recueille et présente, de façon organisée et systématique, les informations clés sur les événements, en cherchant à élucider les cas où les informations soient différentes ou contradictoires, en présentant un résumé de ses informations sous une forme graphique compacte. L'article propose également une premiàre approche de l'étude d'un cas, celui du projet original de Le Corbusier pour l'Ambassade de la France au Brésil. Une des dernières æevres de l'architecte sera étudiée à la lumière de ses relations antérieures avec le Brésil, en tenant compte de sa position face aux relations stratégiques projectives proposées par l'architecte tout au long de son œuvre, et en considérant d'une façon spécifique mais pas exclusive, les projets realisés ou non, qui ont été élaborés par l'architecte au cours de sa dernière période créative dans les années 1960.
\end{abstract}

Abstract: The preofessionelles relationships established by Swiss-French architect Le Corbusier with Brazil was huge and varied. Having been initiated in the 1920s, they have been extended until his death in 1965, when the project of the Embassy of France in Brasilia was being developed (1964). The information available on all projects, works provided and events that show the relationship Le Corbusier with Brazil were dispersed by several sources, and they are studied by several rechercheurs. This study collects and presents an organized and systematic way, key information about events, seeking to clarify the cases where the information is different or contradictory, presenting a summary of information in a compact graphical form. The article also offers a premiere approach to the study of a case, that the original project by Le Corbusier for the Embassy of France in Brazil. One of the last works provided the architect will be studied in the light of its previous relationship with Brazil, taking into account its position to projective strategic relationship proposed by the architect throughout his work, and considering a specifically but not exclusively, realized or unrealized projects, which were developed by the architect during his last creative period in the 1960s.

Mots clés: Architecture moderne; Brésil; Ambassade de la France; Le Corbusier; æuvres; projets. Keywords: modern architecture; Brazil; Embassy of France; Le Corbusier; buildings; projects.

\section{Introduction}

L'architecte suisse-français Le Corbusier a établi des relations personnelles et professionnelles avec le Brésil depuis les années 1920, et le dernier travail qui l'a été commandé c'était le projet de l'ambassade de la France à Brasilia, la nouvelle capitale du pays. Plusieurs informations sur ces relations entre l'architecte suisse-français et

\footnotetext{
${ }^{1}$ Cet article fait partie de la recherche de doctorat en développement de Mlle Silvia Raquel Chiarelli, sous orientation de la Professeur Docteur Ruth Verde Zein, du programme d'études supérieuresde la Faculté d'Architecture et Urbanisme de l'Université Presbytérienne Mackenzie, et avec l'appui de la Fondation d'Aide à la Recherche de l'état de São Paulo (FAPESP).
} 
le Brésil ont été enregistrées dans les 8 volumes de L'œuvre Complète ${ }^{2}$ organisés par Le Corbusier, dans des lettres et des photographies disponibles sur le site officiel de la Fondation Le Corbusier ${ }^{3}$; dans les dessins et des notes prises dans ses cahiers de voyage ${ }^{4}$ pendant ses séjours en Amérique du Sud; et aussi dans les textes écrits et publiés par lui-même après une série de dix conférences à Buenos Aires, en Argentine, et à São Paulo et à Rio de Janeiro, au Brésil en 1929, lors de sa première visite à ce «nouveau territoire ». Voici les oeuvres: le livre Précisions: sur un état présent de l'architecture et de l'urbanisme ${ }^{5}$, dans lequel l'auteur raconte ses expériences dans le «nouveau territoire », ses discussions et les dessins qu'il a élaborés au cours de ses conférences; et le texte L'Esprit Sud Américain ${ }^{6}$, qu'il a écrit dans le bateau lors de son retour en France après son premier voyage à l'Amérique du Sud.

En plus des sources de l'architecte, plusieurs chercheurs ont mené des études importantes, globales ou spécifiques, sur ses relations. On peut mentionner le premier livre, Le Corbusier e o Brasil, écrit par les auteurs SANTOS, PEREIRA, PEREIRA et SILVA ${ }^{7}$, qui analyse une grande partie des relations de l'architecte avec le Brésil, en apportant un ensemble détaillé d'informations où sont inclus des dessins et des photographies et des dessins élaborés par l'architecte, et des correspondances échangées entre l'architecte et les brésiliens (Paulo Prado, Lúcio Costa, Oscar Niemeyer, d'entre autres), et entre l'architecte et des étrangers (Fernand Léger, Blaise Cendrars, d'entre autres), qui comme lui avaient aussi des liens avec le pays sud américain et, à cause de ça, ont enregistré des dialogues sur ce «nouveau territoire ».

La première publication d'un autre auteur à propos de ce sujet est probablement le livre Leitura Crítica de Le Corbusier, écrit par Pietro Maria Bardi, sous forme compacte, publé en 1950, à l'occasion de l'exposition itinérante de l'architecte (y inclus les peintures, les sculptures et les oeuvres d'architecture). L'exposition a eu lieu du 5 juillet 1950 au 5 mai de l'année suivante, environ deux ans après l'inauguration du Musée d'Art de São Paulo - MASP en 1948, où se trouvait à l'époque son premier siège, à la rue 7 de Abril, ayant pour titre « Nouveau Monde dans l'espace de Le Corbusier ». Bardi était le directeur du Musée d'Art de São Paulo et il connaissait déjà l'architecte suisse-français: les correspondances entre eux ont été publés plus tard dans le livre Lembranças de Le Corbusier: Atenas, Itália, Brasil. ${ }^{8}$

Les relations de Le Corbusier avec le Brésil sont aussi thème de l'interview que l'architecte Ítalo Campofiorito a donné à Hugo Segawa, quand Campofiorito ${ }^{9}$ raconte ses souvenirs de la visite de Le Corbusier à Brasilia et à Rio de Janeiro en 1962, qu'il a accompagné de très près, à la demande de Lucio Costa et Oscar Niemeyer.

\footnotetext{
${ }^{2}$ JEANNERET-GRIS, Charles-Édouard. Le Corbusier, œuvre complète 1910-1965. Zurich. Artemis, 1967, 8 volumes.

${ }^{3}$ Cf. www.fondationlecorbusier.fr, Accédé le 21 mai 2015.

${ }^{4}$ Le Corbusier Carnets. New York / Londres: The Architectural History Foundation / Dessin et Tolra, 1981-1982, 4 volumes, I. 1914-1948; 2. 1950-1954; 3. 1957-1964.

${ }^{5}$ LE CORBUSIER. Precisões : sobre um estado presente da arquitetura e urbanismo. Traduction: Carlos Eugênio Marcondes de Moura. São Paulo : Cosac Naify, 2004. (Éd. Orig. : Précisions : sur un état présent de l'architecture et de l'urbanisme, 1930).

${ }^{6}$ In : SANTOS, Cecília Rodrigues dos ; PEREIRA, Margareth Campos da Silva ; PEREIRA, Romão Veriano da Silva ; SILVA, Vasco Caldeira. Le Corbusier e o Brasil. São Paulo : Tessels, 1987, p. 68-71.

${ }^{7}$ SANTOS, Cecilia Rodrigues dos ; PEREIRA, Margareth Campos da Silva ; PEREIRA, Romão Veriano da Silva ; SILVA, Vasco Caldeira. Le Corbusier e o Brasil. São Paulo, Tessela, 1987.

${ }^{8}$ Livre et des documents correspondants consultés dans la collection du Centre de Photographies et de la Bibliothèque et Centre de Documentation du Musée d'Art de São Paulo.

${ }^{9}$ Interview de Italo Campofiorito à Hugo Segawa. A viagem de Le Corbusier ao Brasil em 1962. In : revista Projeto, une édition spéciale pour commémorer les 100 ans de Le Corbusier, São Paulo, n. 102, 1987, p. 113-116.
} 
D'entre les informations et enregistrements sur les relations entre l'architecte et l'Amérique du Sud ${ }^{10}$, dont le traitement est toujours en cours, on peut y inclure le livre Le Corbusier y Sudamérica: viajes y proyectos ${ }^{11}$ dans lequel les voyages de Le Corbusier vers le territoire sud américain sont mentionnés, y compris les trois fois qu'il a visité le Brésil, en 1929, 1936 et 1962.

Marcelo Puppi a publié un résumé de la vaste recherche ${ }^{12}$ qu'il a récemment terminé, dans laquelle il précise certaines informations importantes sur les relations entre le projet de Lúcio Costa et le projet de Le Corbusier et son studio pour la Maison du Brésil, dans la Cité Universitaire International de Paris (France) dans les années 1953-1956.

Pour le présent travail sont de majeure importance les études sur Le Corbusier qui sont en train d'être développées par l'architecte et professeur colombien à la Pontificia Universidad Católica de Chile (PUC-Chile) et qui sont faites par Ricardo Daza dans sa thèse de doctorat et aussi dans une recherche récente sur le voyage de l'architecte suisse-français à l'Est ${ }^{13}$. Ça a été d'un grand intérêt la façon dont cet auteur a travaillé les relations croisées entre les plusieurs projets et les dessins de Le Corbusier, lesquelles seront la base de cette proposition de recherche.

Cette étude a également éxaminé les informations sur d'autres recherches en cours, dont nous avons déjà pris la connaissance $^{14}$. Par exemple, le travail de l'architecte chilien et professeur de la Pontificia Universidad Católica de Chile (PUC-Chile), Dr. Francisco Chateau, qui étudie aussi le projet proposé par Le Corbusier pour l'Ambassade de France à Brasilia, et celui qui, en effet, a été réalisé, proposé par De La Fuente, mais avec une approche différente proposée par cette recherche ${ }^{15}$. Nous pouvons aussi faire référence aux recherches en cours dans la thèse de doctorat qui est menée au Brésil par l'architecte colombienne Ingrid Quintana Guerrero, sur les relations et les échanges entre Le Corbusier et ses collaborateurs de l'Amérique Latine qui ont eu lieu dans son bureau situé dans la Rue de Sèvres, à Paris ${ }^{16}$. Le cadre sera aussi révisé avec les données obtenues de la recherche de sources primaires, qui sont disponibles à partir de plusieurs sources, dont la principale c'est la collection de la Fondation Le Corbusier à Paris, en France; outre les archives de l'actuelle Ambassade de la France au Brésil ${ }^{17}$ et les archives du Ministère des Affaires Étrangères, les deux situés à Brasilia, qui permettront baser et complémenter les interpretations et les analyses proposées par cette recherche en cours.

A partir des références bibliographiques déjà consultées, une liste des oeuvres et des événements qui lient l'architecte au Brésil et qui, jusqu'à ce moment-là étaient dispersés dans plusieurs sources différentes, a été organisée de la manière la plus complète et systématique possible. Cette recherche préliminaire a constaté que,

\footnotetext{
${ }^{10}$ Les références mentionnées ci-dessus ont été soigneusement recherchées ; les prochaines références sont encore entrain d'être consultées et recherchées.

${ }^{11}$ OYARZÚN, Fernando Pérez, Le Corbusier y Sudamérica : viajes y proyectos. Santiago de Chili : Ediciones ARQ. 1991.

12 PUPPI, Marcelo. Espaços Inacabados: Le Corbusier, Lúcio Costa e a saga da Casa do Brasil, 1953-1956. Revue ARQTEXTO (PROPAR/UFRGS), Porto Alegre, n. 12, 2008, p. 160-203.

${ }^{13}$ Ricardo Daza est co-directeur de cette recherche et l'auteur de la thèse El viaje de Oriente. Charles-Édouard Jeanneret (Le Corbusier) y Auguste Klipstein, gagnante du concours de meilleure thèse d'Espagne 2011.

${ }^{14}$ Les contacts personnels avec ces auteurs ont été progressivement mis en place par les auteurs, qui prévoient des nouvelles visites sur le terrain au Chili.

${ }^{15}$ Francisco Chateau est professeur à Pontificia Universidad Católica de Chile, et il a écrit l'article « Yellow Peripherical Distinction. Guillermo Jullian en el encuentro del Team X en Berlim ». 1973, dans la revue Masillia 2007.

${ }^{16}$ Recherche de doctorat en cours à la Faculté d'Architecture et Urbanisme de l'Université de São Paulo (FAU-USP), sous l'orientation du professeur Dr. Paulo Bruna.

${ }^{17}$ Projetée, après le décès de Le Corbusier, par l'architecte chilien, et par son collaborateur dans son atelier Rue de Sèvres, Guillermo Jullien De La Fuente.
} 
bien que certaines de ses informations soient répétées et corroborent en deux ou plusieurs références, l'ensemble ne se produit pas en tant que telle dans toutes les sources. On a également constaté l'existence de quelques informations différentes, parfois contradictories, d'autres fois complémentaires, selon différentes sources. Finalement, on a noté que quelques informations sont perceptibles dans une référence, n'étant pas mentionnées par d'autres, ni même par les archives de la Fondation, et qui donc ont besoin de passer par une vérification ultérieure.

Toutes les informations obtenues juqu'à présent sur les relations personnelles et professionnelles entre Le Corbusier et le Brésil ont été collectées et consolidées. La chronologie des événements et une table ont été ellaborées avec des informations systématiques sur les relations professionneles (visites, projets, ordres, expositions, et etc.). Les deux pourront éventuellement être corrigées et complémentées par la recherche avec la vérification d'autres sources. Une table a été éllaboré par les auteurs avec des informations systématiques sur: a) le type de document (lettre, croquis, dessin, projet, texte, et etc.) où est mentionné le projet ou l'événement qui lie l'architecte suisse-français au Brésil; b) les pages dans lesquelles se trouvent les références de toutes les sources accedées; c) une brève description des informations contenues dans ces fichiers. Elle permet de vérifier brièvement quelles sources mentionnent chaque projet et/ou événement et quel type d'information apparaît dans chacune de ces sources.

La table s'est révélée un outil très utile pour recueillir et consolider les données déjà obtenues, et suggère que les aspects de la recherche doivent être approfondis pour vérifier et confirmer la pleine existence de ces informations. Il y a des données sur lesquelles très peu d'information a été trouvé dans les références et les fichiers consultés jusqu'à ce moment-là; il y a aussi d'autres avec des informations peu précises jusqu'à présent.

Une partie importante des données obtenues est trouvée seulement dans la liste des fichiers de l'architecture de l'index par ordre alphabétique disponible sur le site de la Fondation Le Corbusier ${ }^{18}$. Ces données ont été surlignés en rouge dans la table, et elles seront objet de recherche dans les archives de la Fondation.

Il y a des informations différentes ou divergentes à propos du même événement; ces cas sont surlignés en vert. C'est le cas, par exemple, de l'exposition des oeuvres de Le Corbusier au Musée d'Art de São Paulo - MASP en 1950. Sur la liste des expositions des oeuvres de l'architecte (expositions oeuvres L.C.) disponibles sur le site de la Fondation Le Corbusier on ne trouve que l'information que Le Corbusier aurait fait une exposition de ses peintures à São Paulo en 1950. Cependant, les livres écrits par SANTOS et alii (1987) et BARDI (1984) révèlent plus de détails sur l'exposition. Les deux informent qu'il s'agit de l'exposition « Nouveau Monde de l'Espace » (New World of Space), organisée par The Institute of Contemporary Art de Boston, États-Unis en 1948, et qui avait déjà passée par plusieurs musées disponibles sur le site de la Fondation Le Corbusier on ne trouve que l'information que Le Corbusier aurait fait une exposition de ses peintures à São Paulo en 1950. Cependant, les livres écrits par SANTOS et alii (1987) et BARDI (1984) révèlent plus de détails sur l'exposition.

Les deux informent qu'il s'agit de l'exposition «Nouveau Monde de l'Espace» (New World of Space), organisée par The Institute of Contemporary Art de Boston, États-Unis en 1948, et qui avait déjà passée par plusieurs musées américains et est arrivée au Masp en 1950.

Seulemente Bardi, e directeur du musée à l'époque, mentionne que l'exposition a été ouverte du 5 juillet 1950 au 5 mai de l'année suivante et qu'elle avait, en plus du titre, un sous-titre: «Some Day through Unanimous Effort Unity Will Reign Once More in the Major Arts: City Planning and Architecture, Sculpture, Painting », ce qui indique que l'exposition comprenait des oeuvres de peinture, sculpture et architecture de Le Corbusier. Il

${ }^{18}$ Cf. www.fondationlecorbusier.fr, Archives $\rightarrow$ Architecture $\rightarrow$ Index Alphabétique (recherche menée le 19 avril 2015). 
mentionne également la publication du catalogue «Lecture Critique de Le Corbusier » (1951), écrit par Bardi à l'occasion de l'exposition pour la divulguer. Seulement SANTOS et alii, dans Le Corbusier e o Brasil, ont inclus des annotations sur une liste de noms des tableaux qui étaient dans les boîtes débarqués au port de Santos, et qui apportaient le matériel à être exposé dans le Musée d 'Art de São Paulo. Ces informations, incluses dans les deux références bibliographiques, semblent se complémenter.

Afin de clarifier tous les doutes, quelques documents présents dans la collection du Centre de Photographie, dans la Bibliothèque et le Centre de Documentation du MASP ont été consultés. Les correspondances échangées entre Pietro Maria Bardi et The Institute of Contemporary Art de Boston ont été trouvés, datées des années entre 1948 et 1951, et qui ont enregistré les procedures nécessaires pour que l'exposition vienne au Brésil, en plus de documents fiscaux, des reçus, des tickets, des notes manuscrites écrites par Bardi, qui indiquent les oeuvres de chacune des boîtes livrés au MASP pour l'exposition de Le Corbusier. Les informations enregistrées sont d'accord avec celles publiées dans le livre Le Corbusier e o Brasil. Quelques autres documents consultés également confirment l'importation des oeuvres de l'exposition itinérante de Le Corbusier, envoyées par le musée Nord Américan au musée brésilien. Certaines de ces correspondances ont été sélectionnées pour être publiées dans son intégralité ici (Figures 2 à 4). Elles sont datées du 8 mai 1950, le 10 mai 1950 et le 18 mai 1950.

Les deux références bibliographiques mentionnent que l'architecte a refusé l'invitation de Bardi de venir au Brésil pour voir l'inauguration de sa propre exposition. Et aussi que, dans la lettre envoyée au directeur du musée, il se plaignait des brésiliens. Cependant, cette lettre n'a pas été trouvé parmi la collection du musée ${ }^{19}$. Le Corbusier faisait probablement allusion aux développements concernant ses attitudes envers les projets du Ministère de l'Éducation et de la Santé et de la Cité Universitaire, à Rio de Janeiro, qui étaient l'objet de sa visiteen 1936; et aussi sur l'exposition de l'architecture moderne brésilienne sponsorisée par l'Ambassade du Brésil à Paris.

Selon les auteurs SANTOS et alii :

«il (Le Corbusier) va plus loin quand il propose aussi (à Bardi) l'acquisition de sa toile 'Nature Morte Pleine de Lumière' de la part de MASP, comme une forme de lui compenser financièrement pour les injustices alleguées. L'idée est immédiatement acceptée par le critique italien et le tableau ira ainsi enrichir la collection du nouveau musée, après l'ouverture d'une action pour réunir des fonds nécessaires pour l'acquisition ». (1987: 222)

Cependant, il y a des désaccords sur l'étape finale du processus d'achat et de vente du tableau. Dans le texte cidessus SANTOS et alii (1987) ils impliquent a vendu le tableau pour le musée e que celui-ci est devenu une partie de la collection du musée. Par contre, BARDI (1984) révèle que, malgré les efforts du directeur, du groupe d'architectes et des entreprises prêtes à aider financièrement dans le procès d'acquisition, la toile n'aurait pas été acquise par le musée.

"On a essayé d'acheter une des peintures exposées, mais ça n'a pas été possible puisque la souscription lancé n'a pas réussi, malgré la participation de Rino Levi,

\footnotetext{
${ }^{19}$ Il n'en reste qu'à faire une recherche dans les arqchives personnels de Pietro Bardi, conservés par l'Institut Lina Bo et Pietro Maria Bardi, qui n'ont pas été systématisés que très récemment.
} 
Severo Gomes, Warchavchik, Jacques Pilon, Lina Bardi, Aldo Magnelli, Luis Medici, Henrique Mindlin, Lucjan Korngold et Marcelo Roberto (...)». 1984 :106) ${ }^{20}$

Les informations indiquées ci-dessus ne font référence que dans un cas en particulier. Il s'agit seulement d'une petite partie de ce processus complexe, en cours, de la recherche, vérification et consolidation des informations sur les interactions entre Le Corbusier et le Brésil, consideré comme la base indispensable pour la compréhension et lecture de la dernière de ses oeuvres brésiliennes: le projet, non réalisé, de l'Ambassade de la France à Brasilia.

\section{Le voyage de 1962 : la préparation du projet de l'Ambassade}

En décembre 1962 Le Corbusier visite le Brésil pour la troisième fois; plus précisement les villes de Rio de Janeiro et la nouvelle capitale du pays, inaugurée en 1960, la ville de Brasilia. Sa visite fut accompagnée par Lucio Costa, Oscar Niemeyer et, en spécial, par Italo Campofiorito. Une des raisons principales pour cette visite était de connaître le terrain destiné au projet de l'Ambassade de la France au Brésil. Il s'agit du dernier d'une série de projets et travaux, réalisés et non réalisés, conçue par architecte suisse-français pour le Brésil. Il s'agit également d'un des derniers projets de sa vie. Il a été ellaboré par Le Corbusier entre 1964 et 1965, après son dernier voyage au Brésil, et un peu avant de sa mort, au mois d'août 1965.

Sa visite au terrain, à Brasilia, où le projet de l'Ambassade serait construit, a été enregistrée par des dessins contenus dans un de ses «carnets de voyage », ce qui confirme que Le Corbusier avait l'habitude de les faire pendant tous ses voyages. Lors de cette visite il était accompagné de Italo Campofiorito, à l'époque chef du Service de l'Urbanisme Métropolitain de la ville de Brasilia.

Selon Campofiorito, lors de son interview à Hugo Segawa $(1987)^{21}$, il aurait été choisi par Oscar Niemeyer et Lucio Costa pour accompagner l'architecte étranger pendant son séjour dans notre pays. Dans ce texte, il remémore les moments pendant les visites au musée d'Art Moderne à Rio de Janeiro, conçu et construit par Alfonso Eduardo Reidy selon les doctrines du « maitre » suisse-français, et à la Maison des Canoës », d'Oscar Niemeyer, avec toutes les courbes et la délicatesse inhérentes à son « disciple » brésilien. Il se souvient aussi du moment où il a laissé l'architecte dans la compagnie de Lucio Costa, dans l'immeuble du Ministère de l'Éducation et de la Santé. Il s'agissait de la première fois que Le Corbusier visitait l'édifice après sa construction. Selon Campofiorito, Le Corbusier était fier de connaître cet édifice, qui n'avait pas été projeté exclusivement par lui parce que c'était le travail conjoint d'un group de jeunes architectes brésiliens qui se sentaient comme des «disciples » du «maitre » suisse-français et lesquels avaient, sur le point de vue de son «maître », réunit et construit leurs idées très bein, et bien avant qu'il même le faisait.

Selon Campofiorito, Le Corbusier a exprimé les mêmes sentiments lorsqu'il a connu Brasilia. Il s'agissait d'une ville qui avait été construite dans l'espace de trois ans, et dont la construction était surtout basée sur ses propres idées, datées de 40 ans auparavant, pour la "Ville contemporaine de trois millions d'habitants 》 (1922). Le Corbusier serait aussi surpris avec la construction de l'Université de Brasilia - UnB - plus spécifiquement avec le Centre de Planification Oscar Niemeyer - CEPLAN, construit en 1962 construit selon le projet d'Oscar Niemeyer, et dans lequel on a utilisé des matériaux pré-fabriqués. Pour Campofiorito, l'architecte a eu un regard

\footnotetext{
${ }^{20}$ Quelques documents existents dans la Bibliothèque et Centre de Documentation du MASP r'vèlent quelques parts du procès de vente de la toile de Le Corbusier (appelée dans la lettre comme « Nature morte pleine d'espace »).

${ }^{21}$ SEGAWA, Hugo. Entrevistas e Testemunhos :A viagem de Le Corbusier ao Brasil em 1962. In : Projet, São Paulo, n. 102 , 1987.
} 
d'admiration sur toute la ville et ses immeubles, où il a visualisé la maîtrise des jeunes architectes qui suivaent da doctrine. Selon les mots du propre Campofiorito, Le Corbusier aurait dit que:

«Je ne ferais pas comme ça parce que je suis dur, je suis lourd. Vous êtes marrants, vous les brésiliens. Vous êtes délicats, vous êtes presque féminins. Rodrigo (Melo Franco de Andrade), Lucio (Costa), Oscar (Niemeyer). Et même vous, Italo, vous êtes très délicat. Je suis un brute; ici ; je n'auras pas fait comme ça, je n'aurais pas fait ça de cette manière si délicate, les colonnes d'Oscar sont très délicates, le sol est très délicat. J'aurais fait construire la Place des Trois Pouvoirs avec des grandes dalles de béton et le long de l'asphalte, comme dans les aéroports ». SEGAWA, 1987 :113).

Campofiorito se souvient que, pendant la visite de Le Corbusier à Brasilia, le Ministre de la Culture à l'époque, Darcy Ribeiro aurait « commandé » à Le Corbusier les projets pour l'Ambassade de la France e aussi celui de la Maison de Culture Française; cependant, il n’y a aucun registre postérieur sur ce deuxième projet. Malgré la surprise de cette information (vue que le seul client avec le pouvoir de commander ce type de travail était le gouvernement français), les auteurs SANTOS et alii la mentionne aussi, et ils ajoutent qu'il y a eu également une mention d'un ordre pour les projets du Musée National de Brasilia, ou Centre National de Culture Brésilienne, ou Maison de Culture du Brésil. Selon eux, lors du voyage de 1962 Niemeyer aurait parlé à Le Corbusier sur cette probable commande, et sur le projet pour l'Ambassade de la France. D'après les auteurs, pendant ses derniers deux ans de vie, en Europe, Le Corbusier a été informé que ces trois projets ne seraient pas réalisés.

Quelques décennies plus tard, Pietro Maria Bardi, qui se prenait pour un ami de Le Corbusier, a publié dans son livre Lembranças de Le Corbusier: Atenas, Itália, Brasil, que l'architecte suisse-français avait visité, à Rio de Janeiro, le Ministère de l'Éducation et de la Santé, le Musée d'Art Moderne, l'Ensenble Pedregulho, les maisons de Sérgio Bernardes et celle de Jorge Moreira (1984 : 111 a 115), et qu'il aurait également visité Brasilia ayant l'intention de connaître la nouvelle capitale et le terrain où il allait projeter l'Ambassade de la France ${ }^{22}$.

Dans les livres Le Corbusier e o Brasil (1986) et aussi dans le livre de DI MATTEO et TIDORI (org.), Embaixada da França: Brasilia (2009), les auteurs parlent sur les efforts subis, à partir de 1955, dans le sens de lier son nom à la construction de la nouvelle capitale brésilienne. Les auteurs indiquent quelques parties des procédures de la commande du projet de l'Ambassade de France faite par le Ministère des Affaires Étrangères de la France à l'architecte; et ils relatent quelques difficultés qui ont conduit à prendre la décision finale de ne pas réaliser le projet après la mort soudaine de l'architecte. Ces informations se répètent partiellement dans les deus références bibliographiques cités, et les deux ont inclus d'autres détails qui se complétent mutuellement. La prise de décision de ne pas construire le projet du «maître » est traitée d'une façon plus détaillée dans le livre Embaixada da França: Brasilia, où sont révelés quelques faits qui se sont produits après la mort du «maître », jusqu'en 1970, quand un nouveau projet a été commandé par son « héritier » et bras droit dans la Rue bde Sèvres, l'architecte chilien Guillermo Jullian de La Fuente, et que ce fait se serait passé après la pression exercé par le gouvernement brésilien pour que le gouvernment français commence la construction de son ambassade dans la capitale déjà consolidée. Selon SANTOS et alii, le projet de Le Corbusier n'aurait pas été effectué parce que le gouvernement français «n'a jamais fait des efforts pour la réalisation de ce projet» (1987:255)

\footnotetext{
${ }^{22} \mathrm{Ni}$ Campofiorito ni Bardi avaient l'habitude de mentionner des faits de leur mémoires, une raison qui peut expliquer la différences dentre les informations. Celui-ce, et bien d'autres détails seront également vérifiés tout au long de la recherche.
} 
«Dans la lettre adressée à (André) Malraux (Ministre d'État de la France) juste après son retour du Brésil, l'architecte proteste amèrement à cause du mépris et du manque de reconnaissance de son travail de la part de la France, une complainte justifiée mais, d'une certaine manière, également prémonitoire vue que, après sa mort, même le contrat de construction de l'Ambassade de ce pays à Brasilia, le dernier projet qui, si on prend en considération la persévérance des suisses, pourrait être mis à jour, ce qui aurait couronner les efforts pour laisser une marque concrète du passage de l'architecte par le Brésil.» (1987 :259).

Il est intéressant de noter que le gouvernment suisse aurait commandé à Le Corbusier, en 1961, le projet de l'Ambassade de la Suisse à Brasilia. Un tel projet n'a jamais été éllaboré par le "maître », qui aurait refusé cette proposition en affirmant qu'il avait trop de travail à l'époque. Le projet de 1 'Ambassade de la Suisse est mentionné dans le livre de SANTOS etb alii, qui inclut la correspondence de Jacob Ott à Le Corbusier, datée du 20 janvier 1961 (1987 : 289); et fait partie aussi de la liste de projets non réalisés disponible sur le site de la Fondation Le Corbusier.

Pendant son séjour au Brésil, Le Corbusier n'a pas donné des interviews à aucun journal brésilien; cependant, avant de retourner en Europe, il a fait publier à la prsse brésilienne le texte suivant ${ }^{23}$ comme forme de remercier le pays qu'il a toujours consideré un « débiteur »:

«Le Corbusier dit que Brasilia est magnifique et qu'elle lui parle au coeur.

Le Corbusier, le fameux architecte français qui est venu au Brésil pour étudier et recueillir des éléments avec lesquels il veut projeter l'édifice de l'Ambassade de la France à Brasilia, a retourné samedi soir à Paris. Dans son message d'adieu, en s'adressant aux brésiliens, Le Corbusier a souligné : 'Pour ce grand voyageur que je suis, il y a dans le planisphère, entre les montagnes, sur les plaines et plateaux où les grandes rivières courrent vers la mer, des zones privilégiées. Le Brésil est un de ces endroits très chaleureux et généreux, qu'on aime appeler d'ami. Brasilia est construite. J'ai vu une ville déjà née. Elle est magnifique d'invention, de courage, d'optimisme; et elle me parle au coeur. C'est l'oeuvre de mes grands amis et (à travers les ans) de compagnons de lutte, Lucio Costa et Oscar Niemeyer. Dans le monde moderne, Brasilia est unique. A Rio, il y a le Ministère de 1936-45, il y a des oeuvres de Reidy, le monument en honneur aux morts de la guerre. Il ya beaucoup de témoignages. Ma voix est celle d'un voyageur de la terre et de la vie. Mes amis du Brésil : laissez-moi vou dire merci ${ }^{24}$

Dans ce texte, Le Corbusier ne fait aucune critique; au contraire, il remercie et fait des compliments au pays et aux brésiliens, et il se souvient de ses amis, sans créer des controverses. Ce message serait son dernier contact publique avec le pays. A cette époque, encore un de ses projets pour le pays, né également d'une commande idéalisée, mais pas clairement établie, n'aurait pas du succès non plus. A sentir l'optimisme de son ton, peut-être

\footnotetext{
${ }^{23}$ Texte aussi publié dans les livres: Le Corbusier e o Brasil (1986 : 292) et Embaixada da França: Brasilia (2009 : 13)

${ }^{24}$ Journal O Globo, le 31 décembre 1962. Disponible dans la collection de la Bibliothèque et Centre de Documentation du MASP.
} 
Le Corbusier croyait alors, en effet, que le panorama de frustrations serait finalement surmonté, et finalement une de ses oeuvres serait construite au Brésil.

Cependant, les termes de cette commande du projet de l'Ambassade de la France pour Le Corbusier continue à être peu défini par les sources consultés, et la responsabilité d'avoir des précisions sur ce thème est à la recherche, en cherchant des documents qui prouvent quels personnages y sont impliqués, et en menant également une investigation sur quelles raisons ont fait que le projet proposé par Le Corbusier n'ait pas été accepté. En outre, la recherche ira vérifier les questions relatives au projet lui-même: le programme, le site, les conditions, et comment éventuellement elles sont présentes dans la commande du client, et/ou ont été conçues par Le Corbusier à partir de ses propres idées. Pour cela, il est probable qu'il sera nécessaire de faire une comparaison avec le projet finalement éllaboré par Guillermo Jullian de La Fuente, construit entre 1972-1974 ${ }^{25}$, bien que ce fait ne soit pas l'objectif principal de la présente recherche, mais l'oeuvre Corbusienne.

\section{L'Ambassade de la France et d'autres œuvre}

Jusqu'à ce moment, la recherche a déjà organisé les bases sur lesquelles on a l'intention d'étudier de forme critique le projet pour l'Ambassade de la France, éllaboré par Le Corbusier, et qui englobe la reconnaissance de l'ensemble de son oeuvre, de forme à établir, ou proposer, des relations entre quelques unes de ses oeuvres, distribuées au long de toute sa carrière, et quelques unes de ses oeuvres, réalisées dans la même période, et qui ont été soigneusement étudiées et sélectionnées. On cherche, par conséquent, contribuer à la compréhension des présences constantes dans les solutions formelles, compositives et constructives de son oeuvre, et qu'elles aient de la signification pour la comprehénsion de celui qui est un des derniers projets de Le Corbusier: l'Ambassade de la France au Brésil.

La sélection des oeuvres à être considerées comme «significatif» pour l'étude présente a suivi les critères suivants:

a. Des oeuvres construites et non construites et les événements qui font une relation de l'architecte avec l'Amérique du Sud;

b. Des oeuvres construites et non construites et les événements qui font une relation de l'architecte avec le Brésil;

c. Des oeuvres internationales construites et non construites par l'architecte qui semblent présenter une relation avec le projet pour l'Ambassade de la France, sous le point de vue de la construction et de la composition architecturale.

Les oeuvres internationales en référence dans le dernier critère ont été sélectionnées à partir d'autres critères qui traitent de solutions architecturales (programmatique, constructive, compositive, et etc.) présentes dans le projet pour l'Ambassade de la France:

a. Projets d'ambassades;

b. Programme résidentiel;

c. Relation avec l'échelle urbaine;

d. Premières relations avec le Brésil;

e. Structure «dom-ino»;

${ }^{25}$ DI MATTEO, Colette, TIDORI, Jean-Martin (org.). Embaixada da França. L'Ambassade de la France. Brasilia. São Paulo: Imprensa Oficial do Estado de São Paulo, Instituto Totem Cultural, 2009. 
f. Présence des «brise-soleil »;

g. Présence de volumes cylindriques;

h. Présence de pied-droit double ou triple;

i. Accès par rampes / «promenade architecturale »;

j. Présence de dalles «perforées »/ des cours.

Ayant pour base ces critères, on a organisé un panneau d'oeuvres et d'événements (Figure 5) unis par une ligne du temps qui a, comme point de départ, la naissance de l'architecte et comme final l'année de sa mort.

Ensuite, les événements ont été exclus pour permettre de visualiser seulement les oeuvres qui semblent présenter quelque relation avec le projet pour l'Ambassade de la France, et on a divisé le panneau en suivant la même division par volumes présente dans L'Oeuvre Complète de Le Corbusier (Figure 6). Il faut expliquer qu'il n'y a pas d'oeuvres relatives aux volumes 4 (1938-1946) et 8 (1965-1969).

Il s'agit d'une première sélection qui devra être vérifiée point à point, de manière systématique et approfondie. Dans ce cas, quelques unes de ces oeuvres pourront être excluses et d'autres pourront être incluses à l'ensemble, selon le développement des recherches. De manière identique, l'ensemble de critères de sélection pourra être adapté. Étant donné que l'oeuvre de Le Corbusier est vaste, large et variée, il sera éventuellement nécessaire limiter l'analyse des références projectuelles, spécialement dans cet article, qui s'agit d'une recherche en développement, et ayant la considèration d'atteindre le plus grand nombre de critères de relation, listés ci$\operatorname{dessus}^{26}$.

Pour cet article, on a réalisé un exercice schématique pour vérifier quelles oeuvres peuvent atteindre le plus grand nombre de critères de relation entre le projet de l'ambassade, ce qui a resulté en une série d'autres panneaux (Figures 5 à 18). Un dernier panneau synthétise et se superpose toutes les analyses, pour vérifier lesquelles de ces oeuvres atteignent le plus grand nombre de critères de relation avec le projet de l'ambassade.

L'Ambassade de la France à Brasilia est la première et la seule ambassade projeté par Le Corbusier. Les dessins sont datés de 1964 à 1965, c'est-à-dire, ils ont été reálisés deux ans après le retour de son dernier voyage au Brésil en 1962, quand il aurait été « commandé ». Comme déjà mentionné, en 1961 l'architecte j’avait déjà été contacté par le gouvernment suisse pour projeter et construire son Ambassade à Brasilia; cependant, le projet n'a pas été développé par Le Corbusier, qui l'aurait refusé, probablement parce qu'il avait beaucoup d'autres travaux en cours à l'époque. Il n'y a donc pas un terme de comparaison, relatif à un programme, entre le projet pour l'Ambassade de la France au Brésil et les autres travaux de Le Corbusier.

Les dessin (plantes, coupures et élévations) et les photos de la maquette du projet de l'Ambassade de France montrent que le programme a été organisé en deux volumes de façon clairement différente: un prisme cubique avc quatre étages, destiné à la résidence de l'Ambassadeur; et un volume cylindrique avec sept étages, destiné à la Chancellerie. Les volumes sont indépendents et, d'une certaine manière, antagoniques: il compose, à la fois, une synthèse plastique-visuelle qui attendent, en séparé et très bien, les complexent questions du projet et des questions fonctionnelles du programme.

La plante circulaire pleine est une nouveauté dans l'oeuvre de Le Corbusier. Les plantes partiellemnt circulaires sont présentes en aspects, ou secteurs, des oeuvres antérieures de Le Corbusier: dans ses premiers projets, comme la Villa Schwob (1916) à Chaux-de-Fonds en Suisse, et dans la Cité du Refuge (1932) à Paris; et elles

\footnotetext{
${ }^{26}$ Dans des possibilités, les oeuvres sélectionnées seront visitées et photographiées, et dans chaque cas la bibliographie disponible et les recherches en dpeveloppement sur ces oeuvres seront vérifiées.
} 
sont de nouveau présentes dans ses dernières oeuvres, comme dans le Palais de L'Assemblée (1955) à Chandigarh en Inde. Un cas spécial est l'église Saint Pierre (1960) à Firminy-Vert en France où la tour cylindrique-conique de section circulaire est née de la transformation d'une plante carrée.

La connexion entre les deux volumes de l'Ambassade se produit à travers le plan rectangulaire. L'implantation définit les routes internes à travers un dessin sinueux et organique, qui traverse en diagonale le lot d'une extrémité à l'autre. Le Corbusier avait déjà conçu des routes et des rues internes et des rampes avec des formes sinueuses, reliant des volumes, dans ses œvres ultérieures, telles que: dans le Centre de Calculs Électroniques Olivetti (1963) à Rho-Milan, Italie; dans l'Unité d'Habitation et dans l'Église Saint Pierre (1960), tous les deux à Firminy-Vert, et dans le Palais des Congrès (1964) à Strasbourg, en France.

Des poches de parking sectorisées sont situées à côté de chaque volume; tout près de la Chancellerie il y a une deuxième poche afin de répondre à la hausse de la demande pour les véhicules des employés et des visiteurs de l'immeuble impliqués dans les activités administratives et les activités protocolaires.

Le volume cubique de la résidence est situé à l'arrière du terrain, profitant de la vue contemplative du paysage naturel du lac qui borde le bout du terrain; la maison et la piscine ont une position plus réservée et privée, et la piscine ne pourrait pas être vue par quelqu'un qui s'approchait du lieu. Le volume cylindrique de la chancellerie se trouve en face du terrain, à côté de l'accès et du contexte urbain.

Le volume prismatique de la résidence a ses plus grandes faces positionnées parallèlement à la face inférieure de la ligne de fond du terrain rectangulaire. Les deux plus grandes faces sont composées de panneaux de verre protégées par brises soleil de béton, tandis que les deux faces plus petites sont des pignons aveugles de béton armé. A l'intérieur du bâtiment il est possible d'envisager la vue sur la ville planifiée par Costa et Niemeyer, deux disciples de Le Corbusier.

Le volume cylindrique de la chancellerie est presque complètment entouré par une peau en verre protegée du soleil fort de la région par des brises soleil en béton donnant sur presque tous les alentours. Seule la zone pour les escaliers, les salles de bains et les ascenseurs forment un tour fermé en béton armé placé à l'avant du champ, c'est-à-dire, sur le côté sud du terrain, en face de la ville.

Dans les deux volumes les brises soleil indiquent une structure indépendante et déconnectée du volume, représentant une deuxième peau qui entoure chaquer bâtiment à côté de lui.

L'utilisation de la façade indépendante du reste du volume édifié et composé par des brises soleil a été d'abord utilisé par l'architecte dans la Maison du Docteur Curutchet (1949) à La Plata, en Argentine. Et les brises soleils sur les façades indépendantes ou non apparaisent dans des œuvres antérieures au projet de l'Ambassade, et qui sont liées à l'architecte comme, par exemple, le Ministère de l'Éducation et de la Santé (1936-1945) à Rio de Janeiro, au Brésil; dans la Villa Shodhan et le Palais des Filateurs (1951), les deux situés à Ahmedabad, en Inde; dans le Palais d'Assemblée (1955) à Chandigarh, en Inde; dans la Maison du Brésil (1957) à Paris, en France; dans le Visual Arts Center à l'Université de Harvard (1961) à Cambridge, aux États-Unis; dans le Centre des Calculs Électroniques Olivetti (1963) à Rho-Milan, en Italie, et dans le Palais des Congrès (1964) à Strasbourg, en France.

Une autre charactéristique commune aux deux volumes c'est l'utilisation de la structure dom-ino, équivalente au prototype de la Maison Dom-ino présenté par l'architecte pour la première fois en 1914. Cette même structure est également répandue dans d'autres travaux liés à l'architecte comme, par exemple, la Ville Savoye (1928) à Poissy, France; dans la Villa Baizeau (1928) à Carthage, en Tunisie; dans la Cité du Refuge (1932) à Paris, France; dans le Ministère de l'Éducation et de la Santé (1936-1945) à Rio de Janeiro, au Brésil; dans la Maison 
du Docteur Curutchet (1949) à La Plata, Argentine; dans la Villa Shodhan et le Palais des Filateurs (1951), à Ahmedabad, en Inde; dans le Palais d'Assemblée (1955) à Chandigarh, Inde; dans la Maison du Brésil (1957) à Paris, France; dans l'Église Saint Pierre (1960) à Firminy-Vert, France; dans le Visual Arts Center de l'Université de Harvard (1961) à Cambridge, aux États-Unis, dans le Centre des Calculs Électroniques Olivetti (1963) à Rho-Milan, en Italie, et aussi dans le Palais des Congrès (1964) à Strasbourg, en France.

Avec l'utilisation de la structure dom-ino, Le Corbusier peut concevoir la dalle de chaque étage librement, de sorte que parfois cela progresse et implique les pilotis ou parfois elle recule et crée des coupures qui génèrent des étages avec des pieds-droits doubles ou triples et des cours découverts dans le dernier étage. Par conséquent, l'usage de la structure, le plan et les façades sont liberés, comme nous pouvons observer par la position des divisions internes et par les panneaux en verre qui scèllent les deux immeubles.

Le pied-droit double ou triple est aussi représenté dans des œuvres antérieures liées à l'architecte, telles que le Ministère de l'Éducation et Santé (1936-1945) à Rio de Janeiro, Brésil; la Maison du Docteur Curutchet (1949) à La Plata, Argentine; Villa Shodhan et Palais des Filateurs (1951) à Ahmedabad, en Inde; le Palais d'Assemblée (1955) à Chandigarh, en Inde; l'Église Saint Pierre (1960) à Firminy-Vert, France; dans le Visual Arts Center de l'Université de Harvard (1961) à Cambridge, aux États-Unis, et le Palais des Congrès (1964) à Strasbourg, France.

Les cours intérieures avaient déjà apparus: dans la Villa Savoye (1928) à Poissy, France; dans la Villa Baizeau (1928) à Carthage, Tunisie et aussi dans un de ses derniers projets, l'Hôpital (1964) à Venise, Italie.

Un autre élément impotant du projet ce sont les deux rampes d'accès à la résidence de l'Ambassadeur. Chaque rampe est située perpendiculairement à chacune des plus grandes faces du prisme et sur des côtés opposés. Ces rampes rappellent celles projectées par Niemeyer pour le Congrès National à Brasilia. Les rampes projectées par l'architecte brésilien sont représentées par une feuille relativement mince de béton armé, desserrée du sol, et similaire à un tapis flotant. Par contre, les rampes de l'architecte suisse-français sont denses et lourdes, clouées au sol. Cette distinction entre le même élément projecté de manières différentes par les deux architectes fait que la phrase dite par Le Corbusier à Italo Campofiorito à l'occasion de sa visite à Brasilia - et qui fait référence à la délicatesse des formes des œuvres réalisées par les architectes brésiliens en comparaison avec les siennes, plus grossières - soit plus évidente et elle nous permet la réflexion que, à la fin de sa carrière, Le Corbusier serait probablement en train d'assimiler une part de la contribuition de ses disciples, même les brésiliens.

Les rampes intérieures qui composent une promenade architecturale et les rampes extérieures d'accès au volume avaient déjá été utilisées par l'architecte suisse-français dans ses œuvres antérieures comme, par exemple, dans la Villa Savoye (1928) à Poissy, France; dans la Villa Baizeau (1928) à Carthage, en Tunisie; dans la Maison du Docteur Curutchet (1949) à La Plata, Argentine; dans la Villa Shodhan et le Palais des Filateurs (1951) à Ahmedabad, en Inde; dans le Palais d'Assemblée (1955) à Chandigarh, Inde; dans l'Église Saint Pierre (1960) à Firminy-Vert, France; dans le Visual Arts Centre de l'Université de Harvard (1961) à Cambridge, aux États-Unis; dans le Centre des Calculs Électroniques Olivetti (1963) à Rho-Milan, en Italie et dans le Palais des Congrès (1964) à Strasbourg, en France.

Si on examine chaque volume de plus près on voit que, dans le cas du prisme, les séquences, c'est-à-dire, les axes des pilotis suivent toujours avec la même quantité: trois dans le sense longitudinal et quatre dans le sense transversal; toutefois, ce n'est pas le cas du cylindre. Dans le deuxième, il est possible de noter la variation dans les deux directions. Dans le sense longitudinal il y a une séquence, c'est-à-dire, un axe avec deux pilotis, et les suivants avec sept, cinq, quatre et trois, successivement. Dans la direction transversale (de gauche à droite): un, un, un, trois, quatre, quatre, quatre, un, un et un. C'est correcte en raison de la forme bidimensionelle du cercle 
qui ne permet pas la même quantité de pilotis au même rythme entre eux et c'est nécessaire diminuer au fur et à mesure qu'on se distancie de son centre.

Cette variation résulte aussi de l'emsemble composé par l'escalier, les ascenseurs et les salles de bains qui composent une structure en forme de «boîte » fermée qui fonctionne comme un grand pilier qui collabore, tout avec les pilotis, pour soutenir l'emsemble de la construction.

On peut noter aussi que Le Corbusier n'a pas suivi la même rigueur de rythme entre les pilotis du cylindre avec lequel il avait conçu le prisme. Pour le cylindre, Le Corbusier propose des rythmes différents donnant plus de liberté à celui-ci qu'au prisme et c'est pour cette raison qu'on aperçoit quatre pilotis « libérés » qui interrompent le rythme et traversent la façade indépendente des brises soleil. Cette variation ne serait pas perceptible pour l'utilisateur qui se trouve à l'intérieur de l'immeuble, au cas celui-ci aurait été construit. Cette variation peut seulement être notée par l'observateur de ses plans.

Selon la déclaration de l'architecte français OUBRERIE $(2007)^{27}$, les derniers projets de Le Corbusier marquent la transition vers une architecture plus libre et inventive et, paradoxalement, plus structurée.

Pour cet auteur, un exemple significatif de cette nouvelle phase serait le projet de l'Ambassade de France, qui présenterait une dichotomie entre la rigueur de la Résidence de l'Ambassadeur et la liberté et l'invention de la Tour de la Chancellerie.

«Les projets qui suivent - comme l'illustre le projet de l'Ambassade de Brasilia, qui montre une dichotomie entre la rigueur exprimée dans la Résidence de l'Ambassadeur et la liberté et l'invention de la Tour de la Chancellerie - sont déjà des projets de transition vers une architecture à la fois plus libre et inventive et paradoxalement plus structurée. » (2007: 51)

\section{Conclusions}

Ce travail présente des conclusions partielles d'une étude en cours ayant pour objectif les relations professionnelles entre Le Corbusier et le Brésil qui ont été collectées, vérifiées et systématisées et le propos de cette étude est le projet non accompli de Le Corbusier pour l'Ambassade de France au Brésil (1965-65), en lui considérant sous la lumière de toute l'œuvre corbusiènne, et plus spécifiquement de ses œuvres des années 1960. La comparaison entre l'œuvre de l'Ambassade du Brésil et les autres œuvres corbusiènnes a visé l'investigation et une compréhension plus ample des choix et des chemins cristallisés par la créativité et l’inventivité de cet architecte si expérimenté.

Bien que les analyses précédentes n'aient pas encore permis de conclure que ses dernières années de vie, quand Le Corbusier travaillait sur le projet pour l'Ambassade de France, démontrent une nouvelle phase de sa trajectoire créative, on peut cependant suggérer, en considérant cet œuvre à la lumière de toutes les autres antérieures, qu'il soit possible de la comprendre comme um moment de «synthèse », dans lequel l'architecte revisite et recombine les thèmes, les formes, les matériaux et les stratégies présentes dans les projets élaborés dans toutes ses phases précédentes (puriste, de cinq points, de matériaux naturels des années 1930, du

${ }^{27}$ OUBRERIE, Jose. Notes sur la contribution créative de Guillermo Jullian à l'atelier Le Corbusier. In : Massilia. Annuaire des Études Corbusiennes. ARQ Ediciones / PUC-Chile : Santiago, Chile, 2007, p. 50-53. 
brutalisme...). et, si au début de sa carrière Le Corbusier assimile et transforme la constribution de ses maîtres, à la fin il sera certainement en train d'assimiler quelque chose de la contribution de ses disciples, y inclus les brésiliens, en travaillant sur un bouillon de culture dense et complexe.

\section{Pièces jointes}

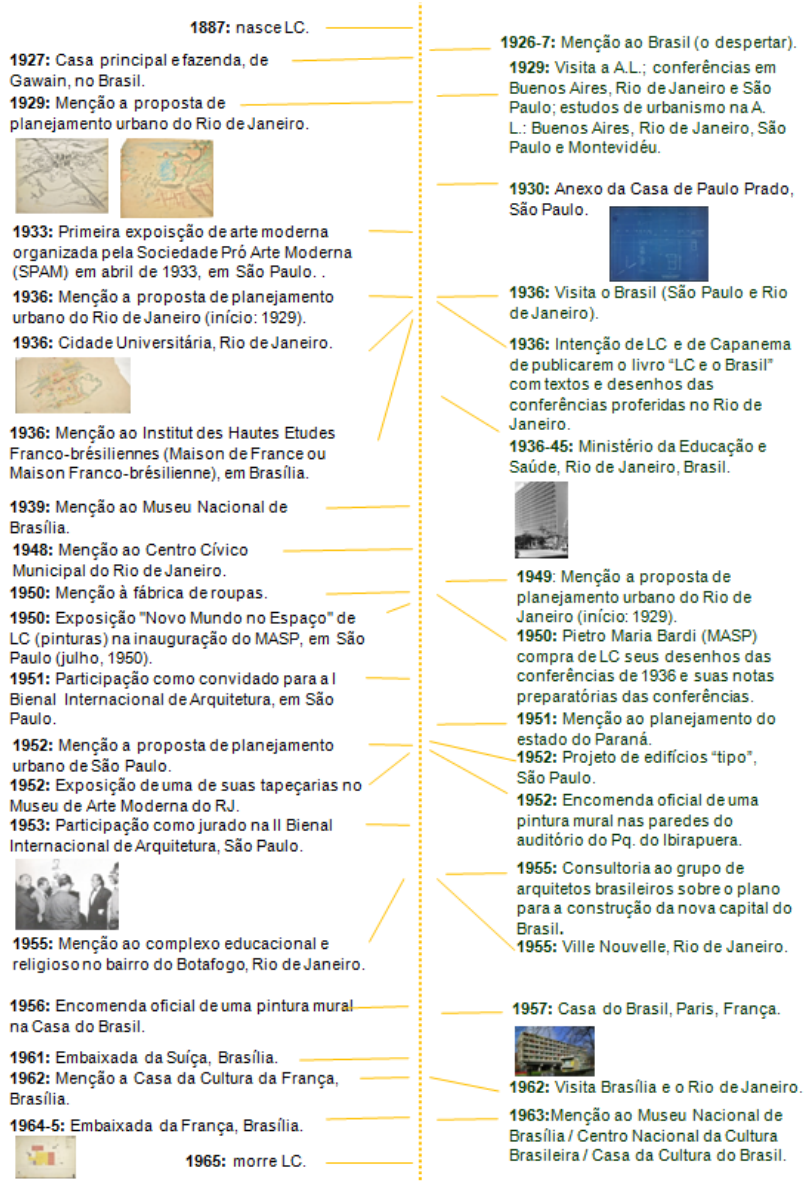

1. Chronologie. Source: Préparé par CHIARELLI basé sur les informations fournies dans les sources consultées par mai/2015. 
"São Paulo, mai 8, 1950.

Le Corbusier

35 rue de Sèvres

PARIS - Vlme.

Cher M. Le Corbusier :

Suite à votre lettre du 28 avril j'ai a vous communiquer le suivant concernant les deux idées posées.

$1^{o}$ - La question de la 'casa franco-bresilienne"’ à Rio il y a longtemps on n'en parle plus. Je ne sais pas bien si la question est completemente tombée ou à quel point elle se trouve, en tout cas je m'informerais à propos et j'aurai plaisir à vous écrire.

$2^{o}$ - Concernant les grands dessins éxecutés pendant vos conferences à Rio en 1936 je suis vraiment très interessé pour savoir à quel prix vous pourriez les céder au Musée. Cela nous interesse beaucoup et je crois bien qui ìls sont la clef même de l'architecture moderne brésilienne. Comme documentation et démonstration ces dessins nous seraint très utiles. Nous attendons votre proposition pour vous donner une réponse définitive.

$3^{\circ}$ - Votre exposition de Boston doit embarquer dans ces jours pour Santos. La salle dont elle sera exposé est prête. Je vous envoyerrai des photos quand elle sera monté pourque vous poussiez juger de la façon elle sera presenté. L'Instituto de Arte Moderna de Buenos Aires ne peut pas presenté l'exposition. Nous tacherons de contacté avec d'autres Musées.

A vous lire bientôt je vous pris de bien vouloir agréer mes salutation très amicales.

P. M. Bardi-directeur"

2. La lecture du contenu de la lettre de Pietro Maria Bardi pour Le Corbusier, 08/05/1950. Source: Bibliothèque et Centre de Documentation du MASP. 
“May 10, 1950

Mr. P. M. Bardi

Museu de Arte

Rua 7 de Abril No 216

São Paulo, Brasil

Dear Sir:

In reply to your kind letter of March 29th, we are glad to let you know that it will be agreeable to us to receive payment in French Francs for the paiting by Le Corbusier, 'Nature morte pleine d'espace', wich you wish to acquire from us.

The price of the picture is, as you know, one thousand dollars, and we would be pleased to received the equivalent in Francs.

We assume that you will take care of the cost of transportation, and we hope to receive soon pour shipping instructions.

Looking forward to hearing from you, we remain.

Sincerely yours,

A. P. ROSENBERG \& CO., INC.

Florence Walters"

3. La lecture du contenu de la lettre de Florence Walters pour Pietro Maria Bardi, 10/05/1950. Source: Bibliothèque et Centre de Documentation du MASP. 
"May 18, 1950

Mr. P. M. Bardi, Director

Museu de Arte

Rua 7 de Abril, 216

São Paulo, Brazil

Dear Mr. Bardi:

Your letter of May 10 enclosing your check in the amount of $\$ 1070$ arrived on May 17. The six cases comprising the Le Corbusier exhibition were delivered to the Moore-McCormack Lines today. The ship on which the exhibition will be coming to Santos is the "Moore-Mac-Surf"'; it is due to sail on Monday, May 22 from Boston, an unexplained delay of tree days.

Enclosed you will find a list of the cases and the material contained there in. You will note that be of help to you. In any case, on the back of every photographic panel, and every panel of text, is a diagram which shows the order of installation. I am including a description of our installation here.

Finally, enclosed here with is a copy of a letter from our Customs Brokers in regard to the necessity of your making a declaration before the American Consul on Form 204 in order to bring the material back to this country duty free.

May I take this opportunity to tell you how delight we are to send the Le Corbusier exhibition to São Paulo. We wish you every success for your showing at the Museu de Arte.

Most sincerely,

Natalie Marston

PS : The cases are marked as follows: M.A.S.P, Santos. We have also affixed labels bearing tha name and address of the Museu de Arte.'

4. La lecture du contenu de la lettre de Natalie Marston pour Pietro Maria Bardi, 18/05/1950. Source: Bibliothèque et Centre de Documetation du MASP. 


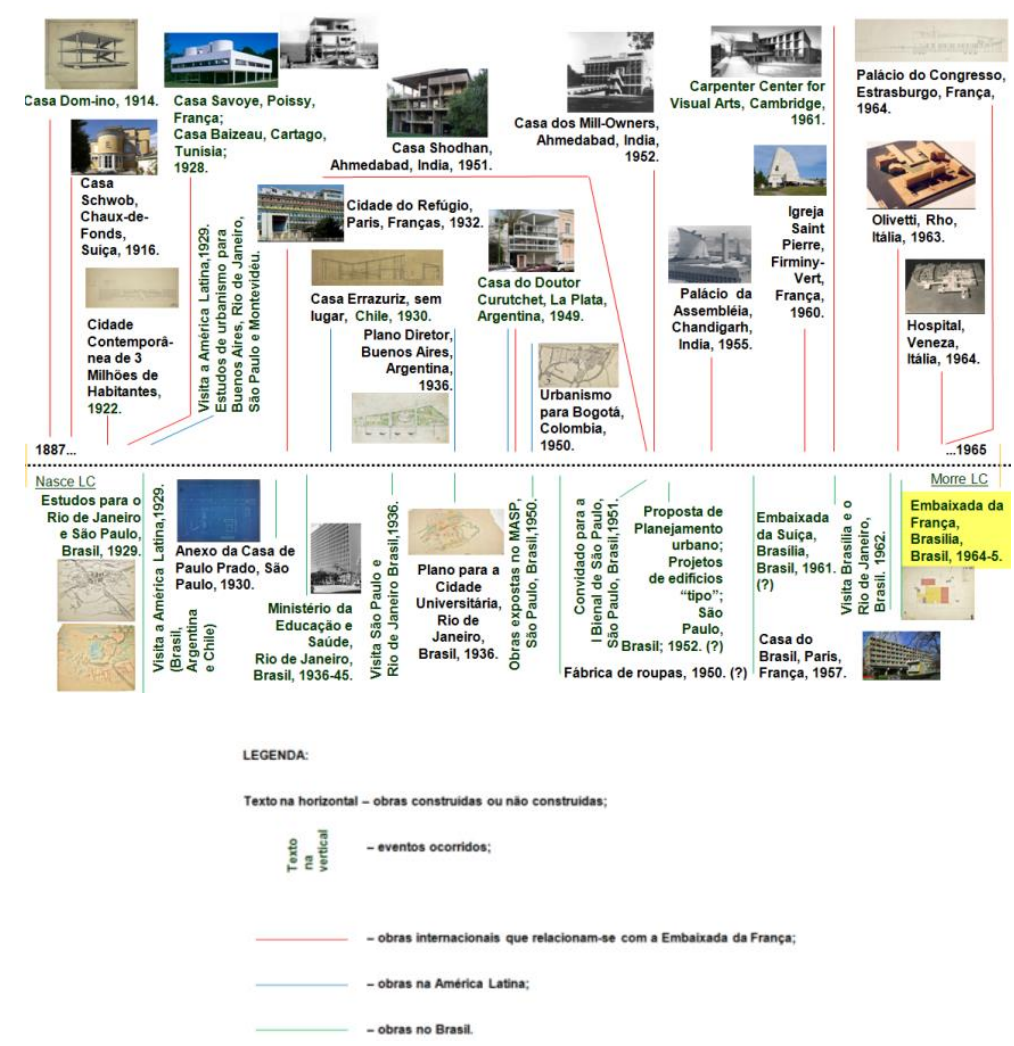

5. Travaux et événements. Source: Préparé par CHIARELLI basé sur les informations fournies dans les sources consultées par mai/2015.

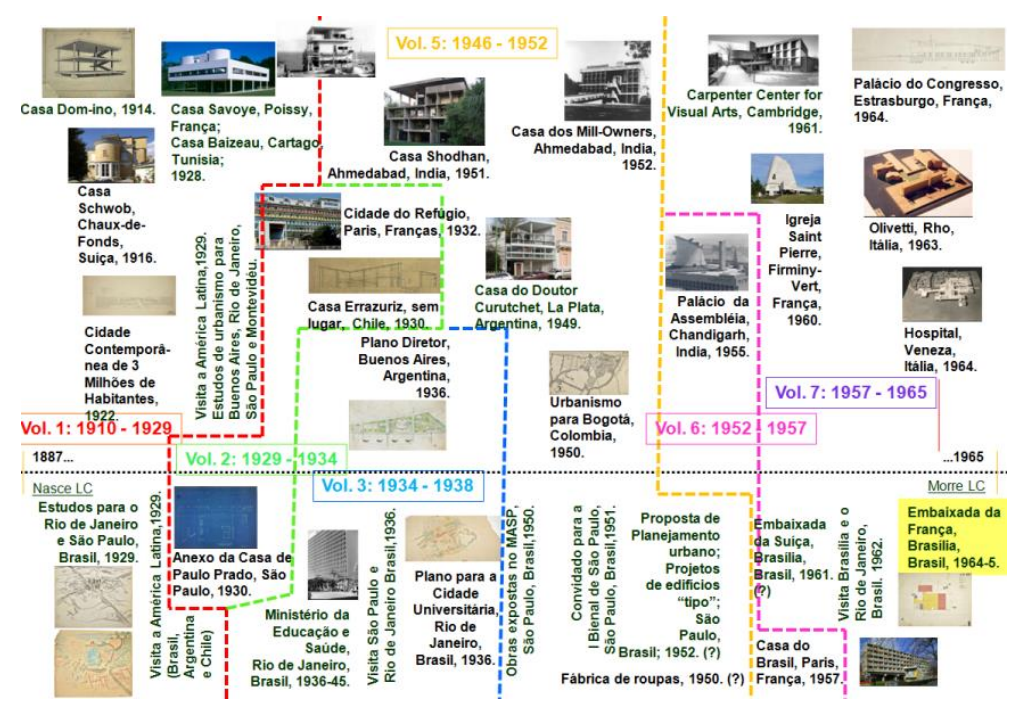

6. Travaux et événements divisés par les volumes . Source: Préparé par CHIARELLI basé sur les informations fournies dans les sources consultées par mai/2015. 


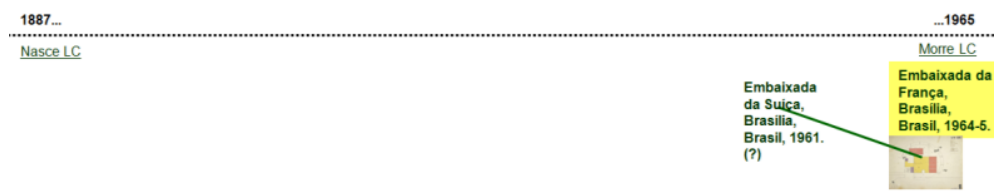

7. Ambassades projets. Source: Préparé par CHIARELLI basé sur les informations fournies dans les sources consultées par mai/2015.

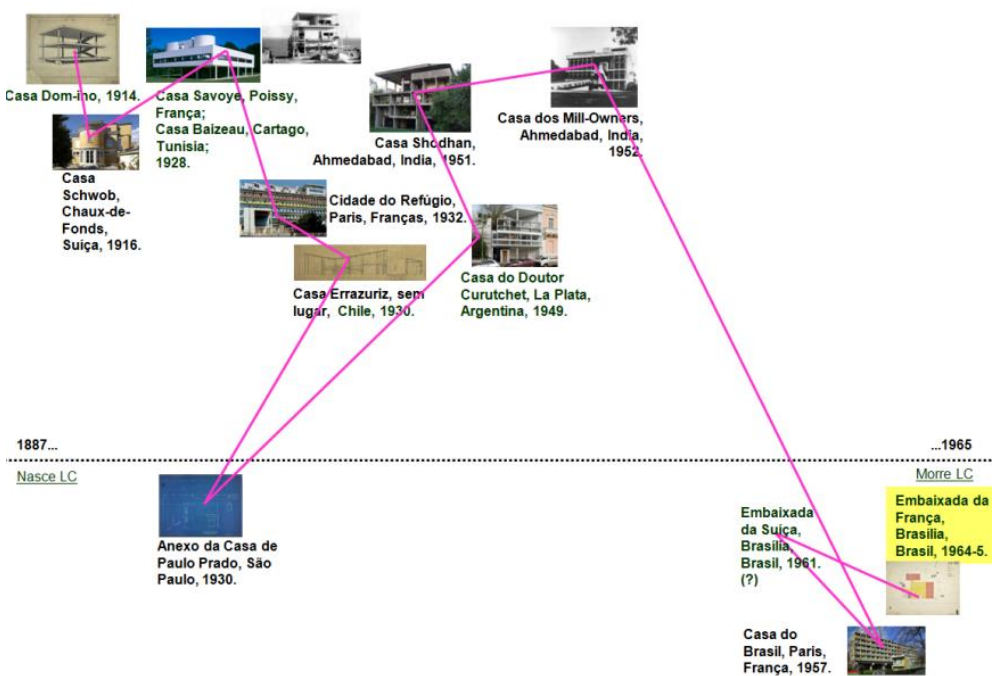

8. Programme résidentiel. Source: Préparé par CHIARELLI basé sur les informations fournies dans les sources consultées par mai/2015.

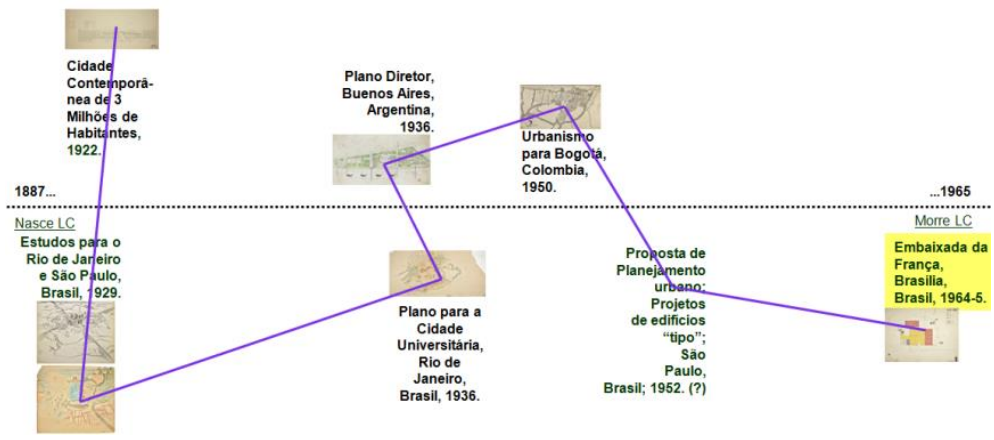

9. Relation à l'échelle humaine. Source: Préparé par CHIARELLI basé sur les informations fournies dans les sources consultées par mai/2015. 


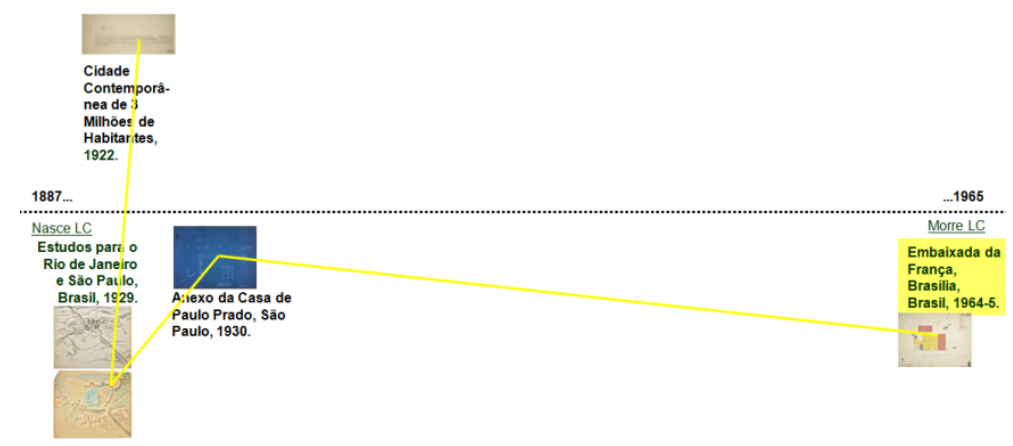

10. Premières relations avec le Brésil. Source: Préparé par CHIARELLI basé sur les informations fournies dans les sources consultées par mai/2015.

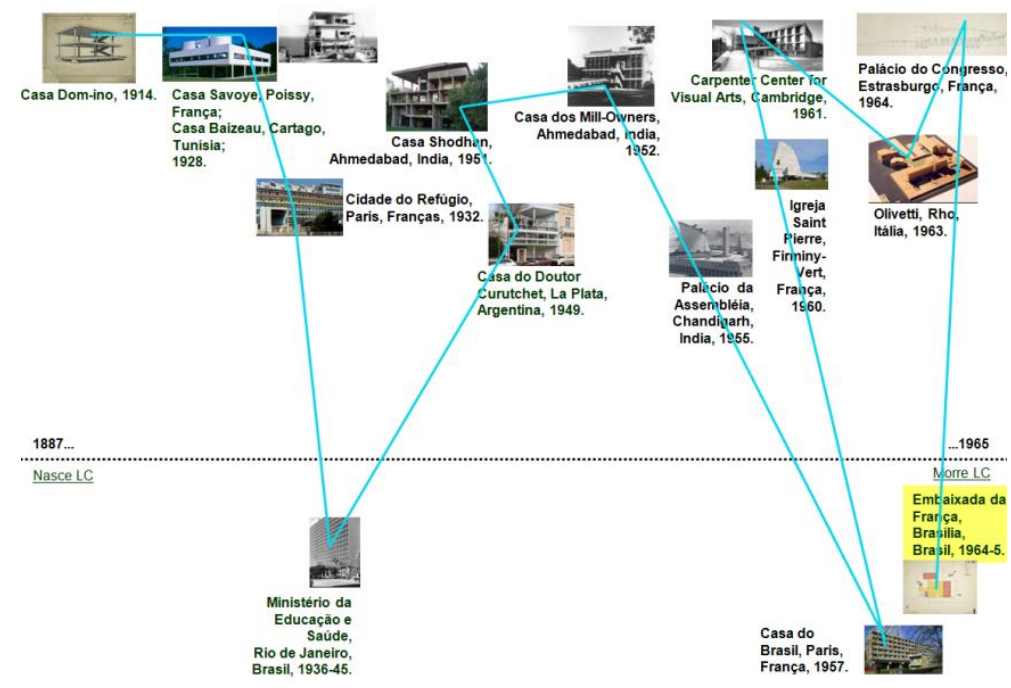

11. La estructure dom-ino. Source: Préparé par CHIARELLI basé sur les informations fournies dans les sources consultées par mai/2015.

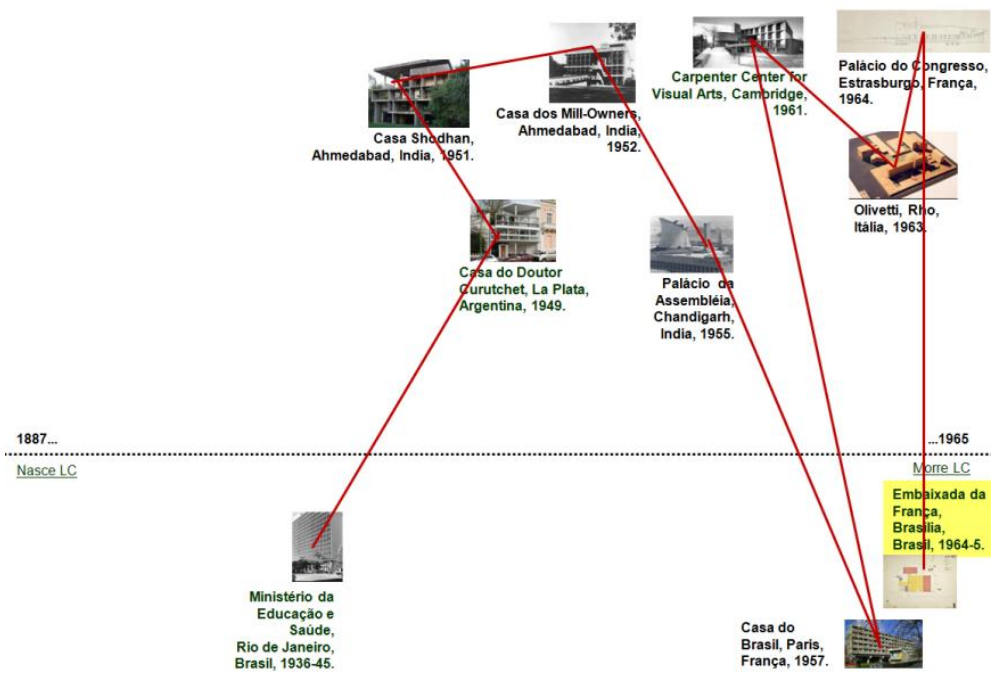

12. Présence des brises de soleil. Source: Préparé par CHIARELLI basé sur les informations fournies dans les sources consultées par mai/2015. 


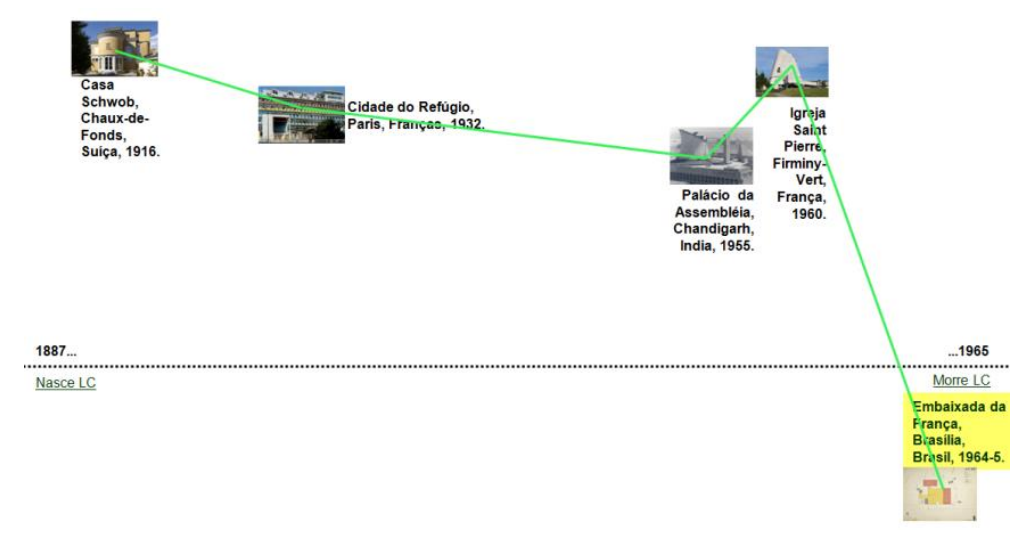

13. Présence de volumes avec plante circulaire. Source: Préparé par CHIARELLI basé sur les informations fournies dans les sources consultées par mai/2015.

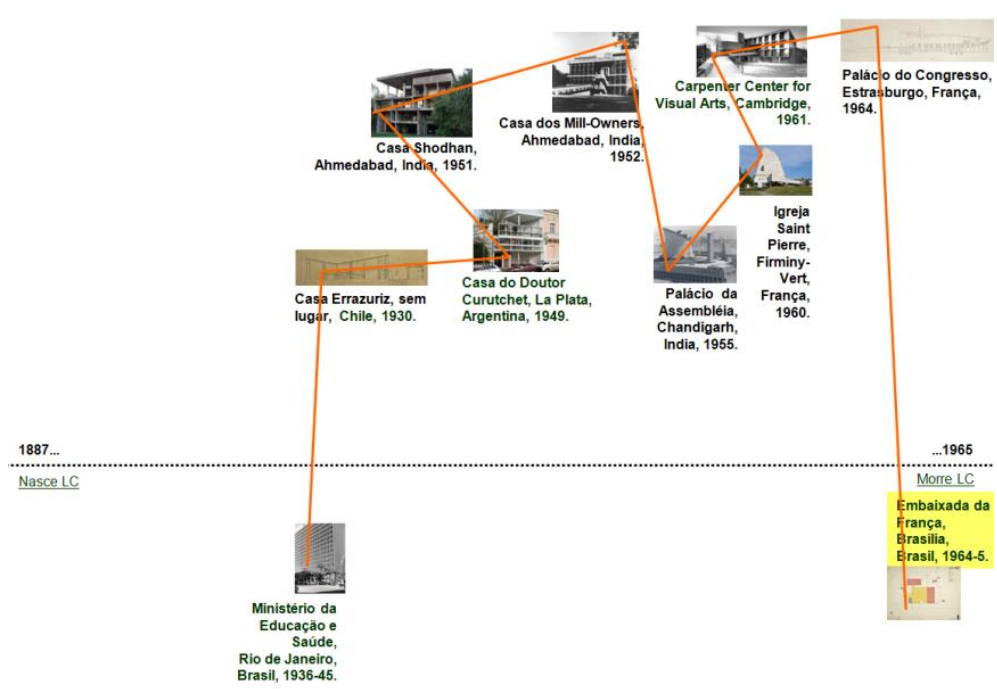

14. Présence de double hauteur ou triple. Source: Préparé par CHIARELLI basé sur les informations fournies dans les sources consultées par mai/2015.

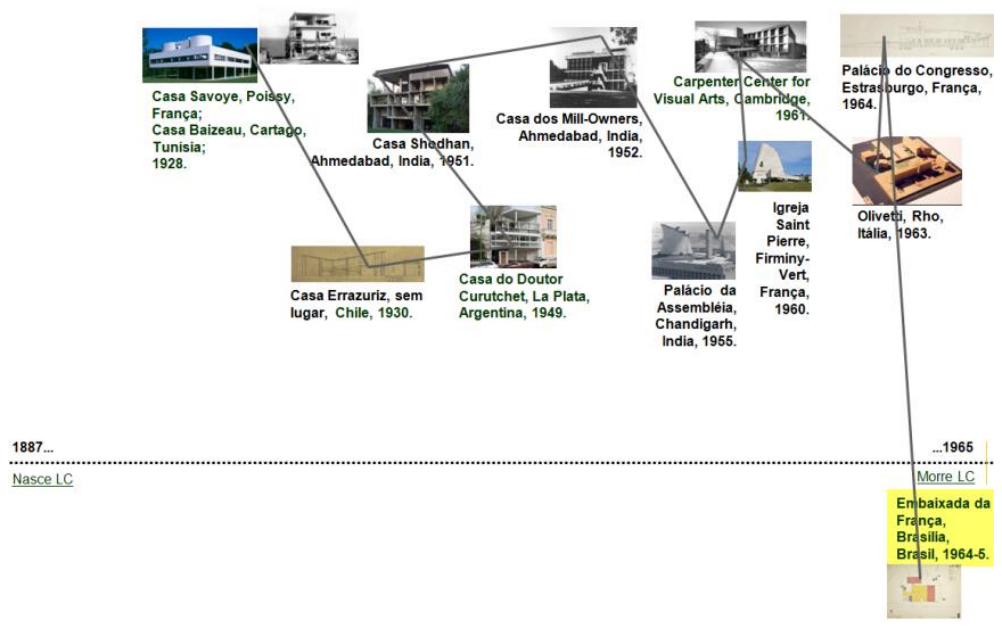

15. Rampes d'accès / Promenade architecturale. Source: Préparé par CHIARELLI basé sur les informations fournies dans les sources consultées par mai/2015. 


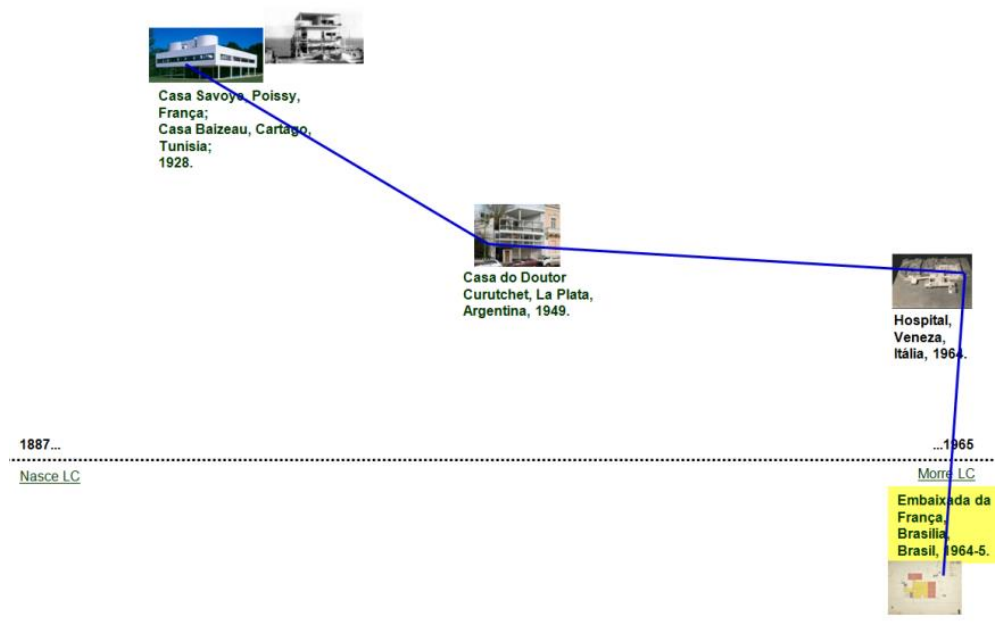

16. La présence de plaques perforées / patios dans l'interiur. Source: Préparé par CHIARELLI basé sur les informations fournies dans les sources consultées par mai/2015.

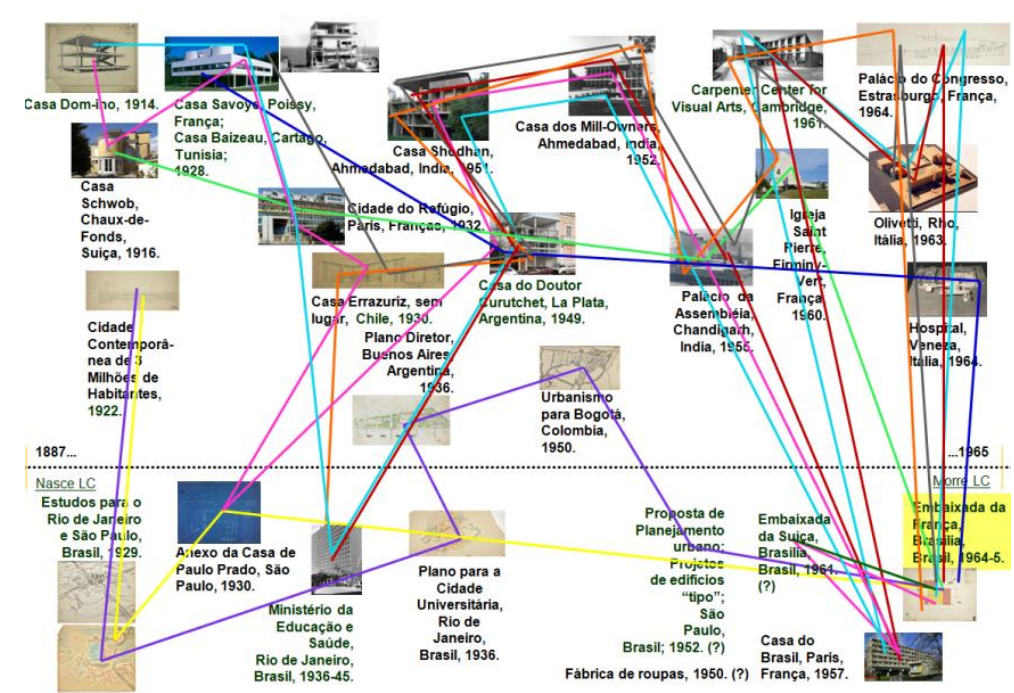

17. Résumé des analyses précédentes. Source: Préparé par CHIARELLI basé sur les informations fournies dans les sources consultées par mai/2015. 


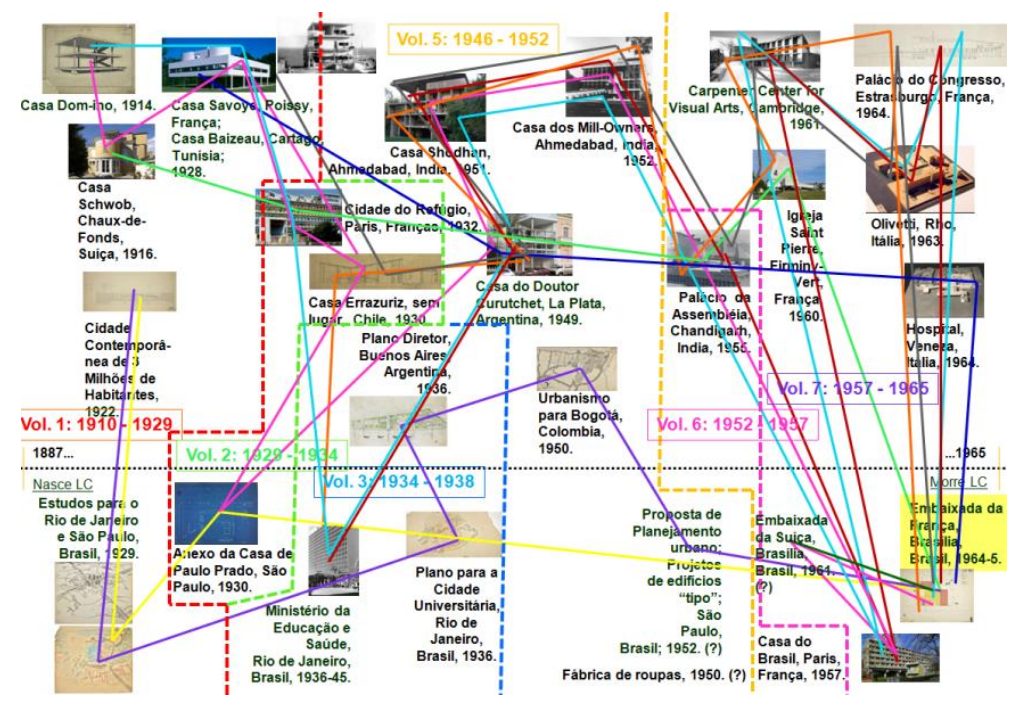

18. Résumé des analyses précédentes. Source: Préparé par CHIARELLI basé sur les informations fournies dans les sources consultées par mai/2015.

\section{Bibliographie / Références}

BARDI, Pietro Maria. Leitura crítica de Le Corbusier. Sao Paulo: Ed. Habitat, 1950.

CHATEAU, Francisco. Yellow Peripherical Distinction. Guillermo Jullian en el encuentro del Team X en Berlin, 1973. In: Massilia. Annuarie des L'Études Corbusiennes. ARQ Ediciones / PUC-Chile: Santiago, Chile, 2007, p. 76-89.

DI MATTEO, Colette; TIDORI, Jean-Martin (org.). Embaixada da França / L'Ambassade de France: Brasília. Sao Paulo: Imprensa Oficial do Estado de São Paulo, Instituto Totem Cultural, 2009.

GUERRERO, Ingrid Quintana. Filhos da Rue de Sèvres: relações e trocas dos colaboradores latino-americanos de Le Corbusier em Paris. Tese (PhD, em cours, dans l'Architecture et de l'Urbanisme), Université de Sao Paulo, Sao Paulo.

JEANNERET-GRIS, Charles-Edouard. Le Corbusier: oeuvre complète 1910-1965. Zurique: Artemis, 1967. 8 volumes.

LE CORBUSIER. Precisões: sobre um estado presente da arquitetura e do urbanismo. Tradução: Carlos Eugênio Marcondes de Moura. Sao Paulo: Cosac Naify, 2004. [Ed. orig., Précisions: sur un état présent de l'architecture et de l'urbanisme, 1930].

OUBRERIE, Jose. Notes sur la contribution crétive de Guillermo Jullian à l'atelier Le Corbusier. In: Massilia. Annuarie des L'Études Corbusiennes. ARQ Ediciones / PUC-Chile: Santiago, Chile, 2007, p. 50-53.

OYARZÚN, Fernando Pérez. Le Corbusier y Sudamérica: viajes y proyectos. Massilia. Santiago do Chile: Ediciones ARQ, 1991.

PUPPI, Marcelo. Espaços inacabados: Le Corbusier, Lúcio Costa e a saga da Casa do Brasil, 1953-1956. Magazine ARQTEXTO (PROPAR/UFRGS), Porto Alegre, № 12, 2008, p.160 - 203.

SANTOS, Cecília Rodrigues dos; PEREIRA, Margareth Campos da Silva; PEREIRA, Romão Veriano da Silva; SILVA, Vasco Caldeira. Le Corbusier e o Brasil. Sao Paulo: Tessela, 1987.

SEGAWA, Hugo. Entrevistas e depoimentos: A viagem de Le Corbusier ao Brasil, em 1962. In: Projeto, Sao Paulo, n. 102, 1987.

Collection du Centre de Documentation et Bibliothèque du Musée d'Art de Sao Paulo - MASP

Collection de la Fondation Le Corbusier

Adresse virtuelle: www.fondationlecorbusier.fr 


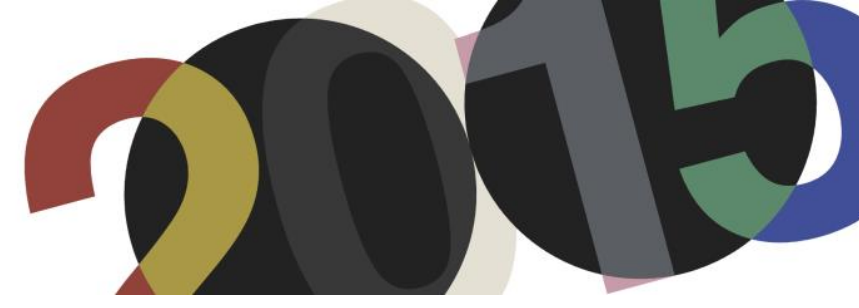

DOI: http://dx.doi.org/10.4995/LC2015.2015.584

\title{
Le Corbusier's Musée à croissance illimitée: A Limitless Diagram for Museology
}

\author{
I. Chin
}

\author{
Harvard Graduate School of Design
}

\begin{abstract}
Let us imagine a true museum, one that contained everything, one that could present a complete picture after the passage of time, after the destruction by time..." This paper considers La Musée à croissance illimitée, an unrealized proposal from 1939 by Le Corbusier in which a series of galleries elevated on pilotis and organized about a square courtyard would extend - infinitely. The paper unfolds as an analysis of the museum and its relationship to history and time, structured by the form of Le Corbusier's proposal. Four themes establish the parameters of the investigation - spatial organization, notions of monumentality, relationship to site, and ideas of growth - and Le Corbusier's resistant approach is considered as a method of criticality. Order-less, face-less, place-less, end-less. To categorize the Museum of Unlimited Growth as such is not to suppose conditions without, conditions of lack, or absence; but rather is a means to consider the proposal as an absolutea degree zero that subsumes and thus allows for conditions of possibility. The themes set up a dialectical reading of the project, as its negations are bound to the assertive, positivity of the idea of a limitless spiral. Perpetually unfolding and folding in on itself, the Musée resists the forces of time. It is the ur-museum, a concept that negates the historiography of museums before and proposes an impossible model for museums to come.
\end{abstract}

Keywords: museum; limitless; growth; spiral.

Palabras clave: museo; limites; crecimiento; espiral.

\section{Introduction}

"The museum is bad because it does not tell the whole story.

It misleads, it dissimulates, it deludes. It is a liar.",1

Le Corbusier was a harsh critic of the museum as institution. Published as a letter to the editor of Cahiers d'art, in 1931, his Musée a croissance illimitée, Museum of Unlimited Growth, was a radical proposal, for a seemingly contradictory architecture that is at once retrospective and projective. It is self-referential, and in its primitive form and oppositional approach, becomes myth and metaphor.

Each section in this paper opens with a direct quotation from the original proposal to consider the order-less, face-less, place-less, end-less, qualities of the project. These themes are presented as such to be polemical, as an interpretation of the Museum of Unlimited Growth as a counter-narrative to the typical museum as monument. Through these negations, the Musée stands as a degree-zero for architecture, a time-less symbol. The analysis attempts to interpret its complexities and paradoxes, in order to reveal a clearer picture of the museum as Le Corbusier envisioned. Within the proposal's text and drawings lies a discrete and continuous structure, a formal philosophy, a framework for architecture's relationship to history and time.

\footnotetext{
${ }^{1}$ Le Corbusier quoted in Calum Storrie, The Delirious Museum: A Journey from the Louvre to Las Vegas, London: I.B. Tauris, 2006.
} 


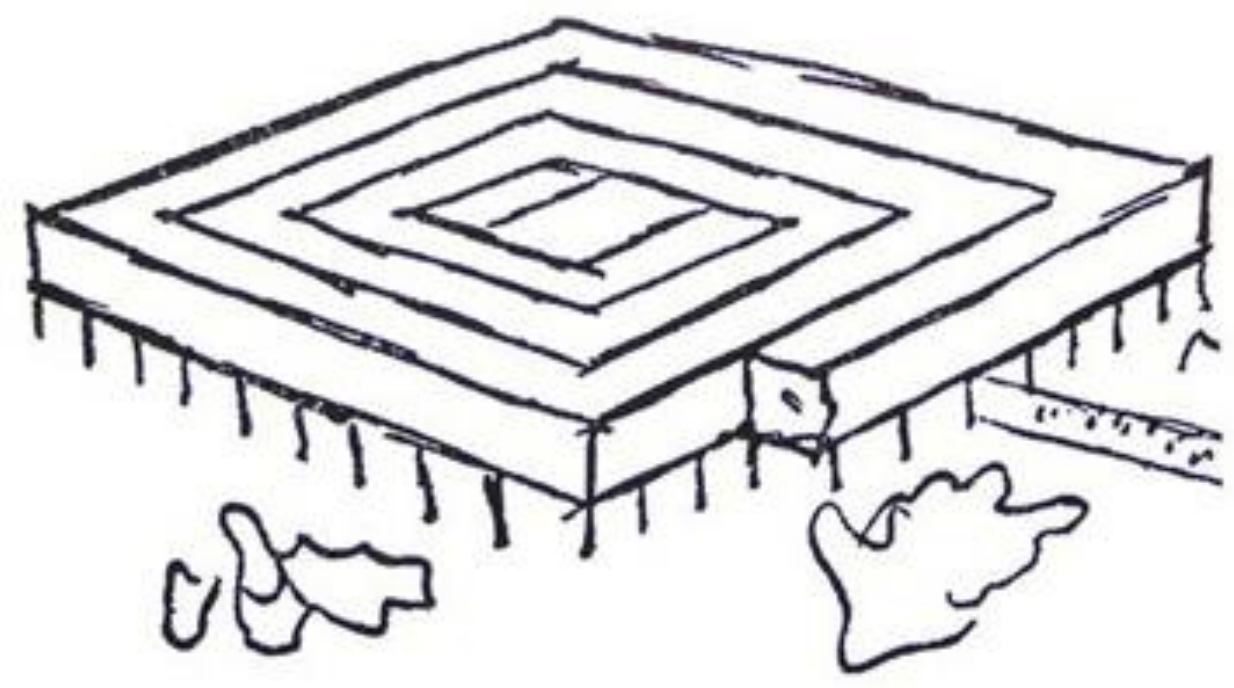

1. Musée à croissance illimitée, Euvre Complète. (C) FLC/ADAGP

\section{Order-less}

C'est un moyen d'arriver à faire construire à Paris un musée dans des conditions qui ne soient pas arbitraires, mais au contraire suivant des lois naturelles de croissance qui sont dans l'ordre selon lequel se manifeste la vie organique: un élément étant susceptible de s'ajouter dans l'harmonie, l'idée d'ensemble ayant précédé l'idée de la partie. $^{2}$

Le Corbusier would have been challenging the model of Jean Nicholas Louis Durand (1760-1834). In his Project for a Museum in 1803, Durand set the standard for the spatial representation of art history. Interpreted as abstract descendants of temples, early prototypes of museums were designed with a parti to describe a ritual of culturalization. Prominent elements of Beaux-Arts compositions ${ }^{3}$ would have included cour d'honneur (forecourt flanked by extended wings), corps de logis (main building), garden courts, and grand escalier. Monumental stairways and vestibules established thresholds of transition from external, profane space; while codified plans established a choreography through interior, sacred space. History unfolded along symmetrical axes, in sequential period rooms, with each branch of the major arts relegated to its own distinct quarter.

Le Corbusier's Museum of Unlimited Growth eschewed any of these elements and ideas of hierarchy. Its general form and massing can be seen through photographs of the maquette; and the master plan and logic of extension through drawings from the original article. The Musée opened from within a 14x14 meter square courtyard, and

\footnotetext{
${ }^{2}$ This is an approach to build a museum in Paris, not under arbitrary conditions, but one that follows laws of natural growth, in the order in which organic life manifests: an element contributing to harmony, this overarching concept precedes an idea of its parts. Le Corbusier and Pierre Jeanneret, "Pour la création a Paris d'un musée des artistes vivants," Cahiers d'art, année 6, no.1 (1931): 5-9.

${ }^{3}$ Helen Searing. New American Art Museums (New York, NY: Whitney Museum of American Art, 1982): 44.
} 
spiraled outward following a $7 \times 7$ meter grid. These galleries would extend incrementally, the museum growing along with its collection - an organic and harmonious architecture for the synthesis of arts.
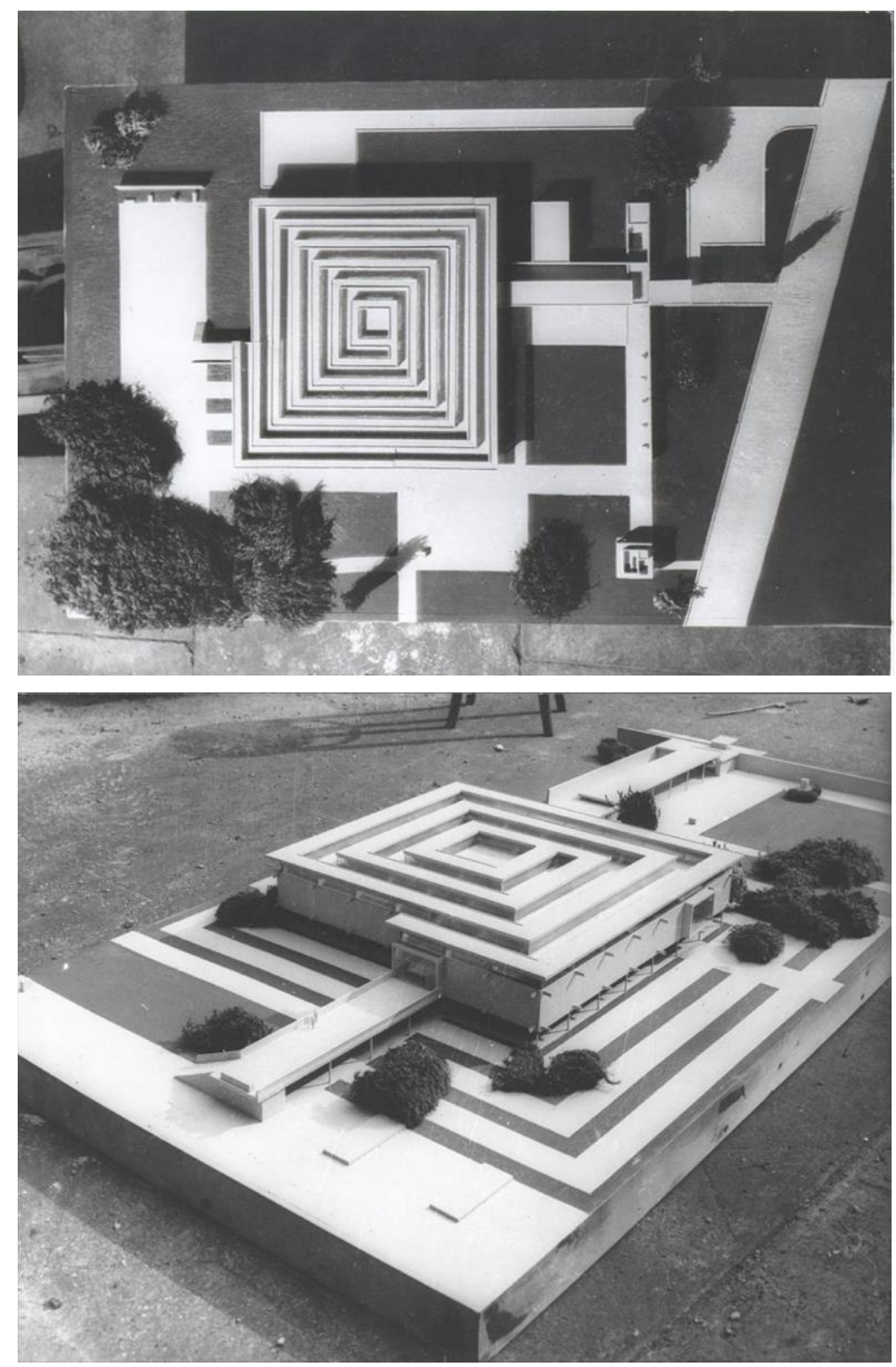

\section{2 - 3. Musée à croissance illimitée, maquette. ๑ FLC/ADAGP}

As an artist in his own right, from paintings, sculpture, tapestries, to murals, Le Corbusier produced artwork at massive scales. Having had exhibitions of his own and having had clients who were art collectors, he had experience with the complexities of display and was attune to scale and setting of art work. After participating in an exhibition at the National Museum of Modern Art in Paris, he would denounce the space to be inhuman "Legitimate works of art are tampered with in such a place losing their true relationship with man, for whom alone, when all is said and done, they are intended. ${ }^{44}$ Le Corbusier was therefore sensitive in addressing the relationship of the body to artwork. Although there are common standards for museums in terms of installation heights and spacing, in the total design of his museums Le Corbusier would describe the galleries to be multi-

\footnotetext{
${ }^{4}$ Le Corbusier. Le Modular II (Paris, 1948): 261.
} 
level and nuanced spaces with differentiated views. With interior details following the logic of the modular, Le Corbusier's museums were machines for viewing art.

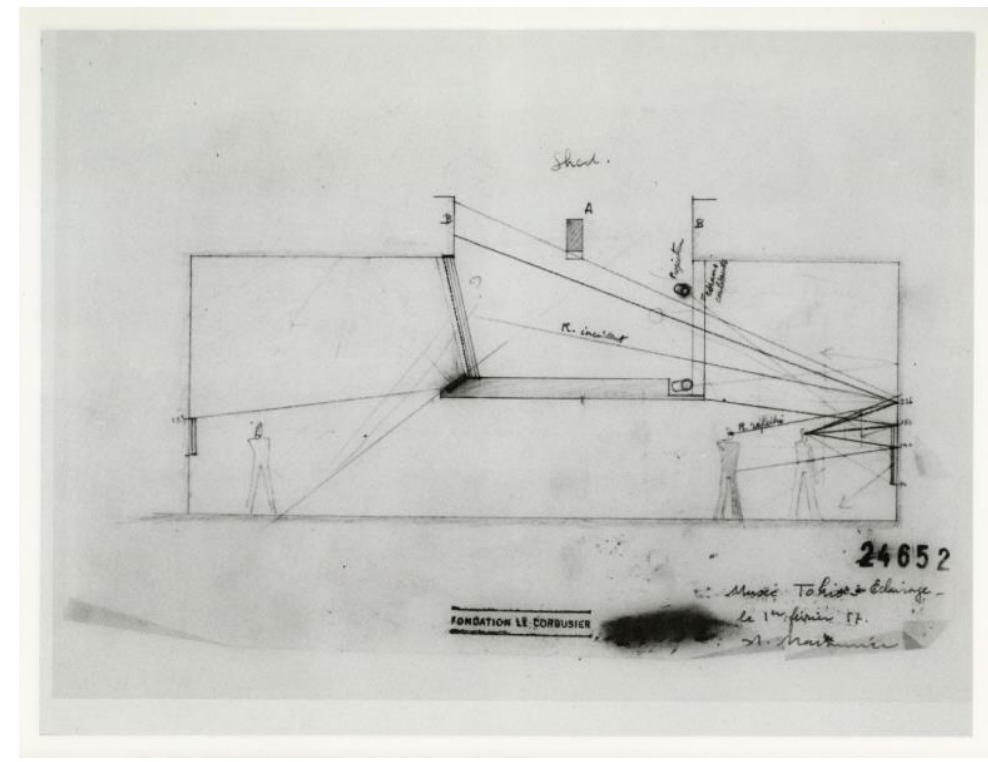

4. National Museum of Western Art, section. (C) FLC/ADAGP

There are three projects following Le Corbusier's concept for the Musée: the Sanskar Kendra Museum at Ahmedabad (1952-54), the Chandigarh Museum and Art Gallery (1947-1952), and the National Museum of Western Art in Tokyo (1957-59). These commissions came after several other attempted proposals, and were only built later in Le Corbusier's life. As with all utopian schemes, the resolution of the spiral plan varies in its realized iterations. Multiple entry/exit ways, auditoria, and landscape elements seen in plan violate the purity of the original drawing. However, despite the clarity in form of the Museum of Unlimited Growth, the project was always conceived as being part of a larger complex. Prescient of the evolution and demands of artistic practice, Le Corbusier understood the need for flexible performance spaces and planned areas for large scale sculptures. He was also aware that a cultural institution would need spaces for research and education. And before whitecube galleries or black-box theatres - there was Le Corbusier's box of miracles ${ }^{5}$ to accommodate various media and experiences. The square spiral museum would house permanent collections and there were to be pavilions for temporary exhibitions to supplement the greater narrative.

In terms of interior details, natural light would filter in through clerestories throughout the day and seasons, working in conjunction with multiple systems of artificial lighting. Whereas the sketches of the original proposal and the Indian museums have an open air courtyard, the National Museum of Western Art has unique skylights to create dramatic, yet functional gallery spaces. A model of the Museum of Unlimited Growth was included in Modular II as part of a series of projects (number eleven of twenty-three) ${ }^{6}$ illustrating the scope of Le Corbusier's mathematical ideas and how they can be carried across all scales, from the domestic object to the

\footnotetext{
5 "La boîte à miracles enclosing all that your heart desires. Scenes and actors materialize the moment the miracle box appears; the miracle box is a cube; with it comes everything that is needed to perform miracles, levitation, manipulation, distraction, etc. The interior of the cube is empty, but your inventive spirit will fill it with everything you dream of in the manner of performances of the old Commedia dell'Arte." Le Corbusier quoted in Massilia, La Bôtte à miracles - Le Corbusier et le théâtre : annuaire 2012 de la Fondation Le Corbusier (Paris: Fondation Le Corbusier; Marseille: Imbernon, 2012).

${ }^{6}$ Le Corbusier. Le Modular II, 176.
} 
very conception of a great city. Proportion and harmony create order to the experience of the museum, allowing art objects to speak for themselves. Architecture, here, supports a fluid unfolding narrative rather than an exacting art-historical structure. The curatorial challenge then, is to program the spaces of the museum according to the movement along the architectural promenade. ${ }^{7}$ The museum of unlimited growth presented a spatial reconfiguration for aesthetic experience. Robert Slutzky, painter and architectural theorist, has suggested "the ramp allows the observer to enter a building as the eye enters a painting, at the center of its spatial field, as opposed to the hierarchical stacking of a classical façade." ${ }^{\prime 8}$ The challenge that modern art posed to the viewer was a redefinition of perspective and relationship between the body and the art object. surface, and space. The human eye, in its investigations, is always on the move and the beholder himself is always turning right and left, and shifting about. He is interested in everything and is attracted towards the centre of gravity of the whole site. ${ }^{9}$

Unlike the circular dome which Durand's museum is fixed upon, the square figure at the center of Le Corbusier's museum is a dynamic field from which the museum opens. Painting, sculpture, and architecture meet, animated by the movement embedded within the architectural form of the Musée. With the absolute diagram of the spiral, Le Corbusier subverted preconceived notions of museological order and provided a space for the synthesis of arts. The spiral diagram which organized Le Corbusier's ideal museum, was therefore a framework for intellectual organization in the mind, rather than on the perceptual level of the eye.

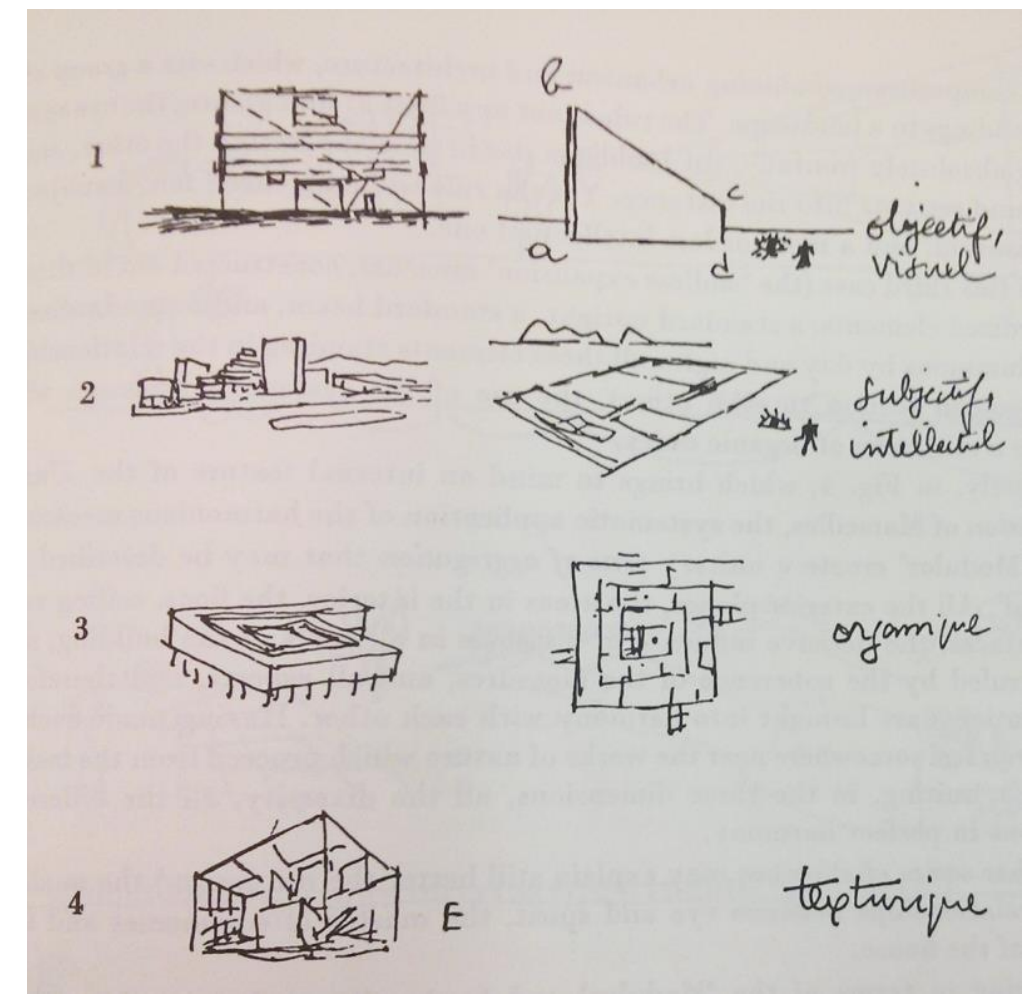

5. “organize," Modular II.

\footnotetext{
${ }^{7}$ Discussed extensively in Flora Samuel, Le Corbusier and the Architectural Promenade (Basel: Birkhäuser, 2010).

${ }^{8}$ Stanely Allen, "Le Corbusier and Modernist Movement," Any 1, no.5 (March 1994): 42.

${ }^{9}$ Le Corbusier. Vers une architecture (Paris: G. Crès et Cie, 1924): 191.
} 


\section{Face-less}

Le musée n'a pas de façade, le visiteur ne verra jamais de façade; il ne verra que l'intérieur du musée. ${ }^{10}$

While the structuring of this paper around oppositional terms is the product of my own extrapolation and analysis, face-less-ness is one idea that is directly legible in Le Corbusier's writing. He himself described his spiral museums as FRONTLESS ${ }^{11}$ in the retrospective monograph, Creation is a Patient Search. And in his original proposal, this idea is especially evident, emphasized through the repetitive use of negational terms. One would walk through the gate into a covered pathway, straight towards the center of the spiral without confronting any sort of monumental facade. Colin Rowe once said - "Face was never a preoccupation of modern architecture. ${ }^{, 12}$ However, this implies a inconsequential neglect, for the sake of emphasizing other, over-arching ideas. I will argue that in the case of the Museum of Unlimited Growth, the treatment of the building's elevation is loaded with intentionality and reflects a deliberate mode of resistance.

In Renaissance, humanist analogy, architecture is directly related to the body, and a building's façade is that body's face and means of expression. A perceptual understanding of a building is therefore understood visually via its elevation, as opposed to a conceptual plan diagram, perceived intellectually through spatial experience. Georg Simmel offers a similar reading within nineteenth century critical theory, of a building's façade as revealing of building's soul and personality, and by extension, the architect's soul and personality. The face of a building functions as an architectural representation of a contemporary historical moment. If a facial expression is a projection of an internal condition, in its allegorical role, a building's façade bound to its contents represents a moment of "cultural crystallization." ${ }^{13}$ Returning to Rowe's comment, however, there is a general sense in the twentieth century of a dissociation with these ideas and the role of "face" - where the monotony of glass towers is an expression of lightness and dematerialization, but signifies a social derealization and disembodiment. ${ }^{14}$

In the particular case of museums, architectural expression must negotiate with the artistic expression for which it is meant to support. Georges Bataille once noted, "one must take account of the fact that the rooms and objects of art are only a container the content of which is formed by the visitors." ${ }^{\prime \prime}$ Architects must reconcile opposing forces, museums' outward projection of civic iconicity, and inward tension between art object and functional space. Le Corbusier's Musée with its spiral order and face-less elevation subsumes and confronts this issue, challenging precedents which came before.

\footnotetext{
${ }^{10}$ The museum has no façade; the visitor will never see a façade; he will only see the interior of the museum.

${ }^{11}$ Le Corbusier. L'atelier de la recherche patiente (New York: Praeger, 1960): 97.

${ }^{12}$ Colin Rowe quoted in Anthony Vidler, "Losing Face: Notes on the Modern Museum," Assemblage no. 9 (June 1989 ): 41.

${ }^{13}$ A. Vidler, Warped Space: Art, Architecture, and Anxiety in Modern Culture (Cambridge, MA: MIT Press, 2000).

${ }^{14}$ Vidler, "Losing Face: Notes on the Modern Museum," 53.

${ }^{15}$ Georges Bataille quoted in Vidler, The Architectural Uncanny: Essays in the Modern Unhomely (Cambridge, MA: MIT Press, 1992): 98.
} 


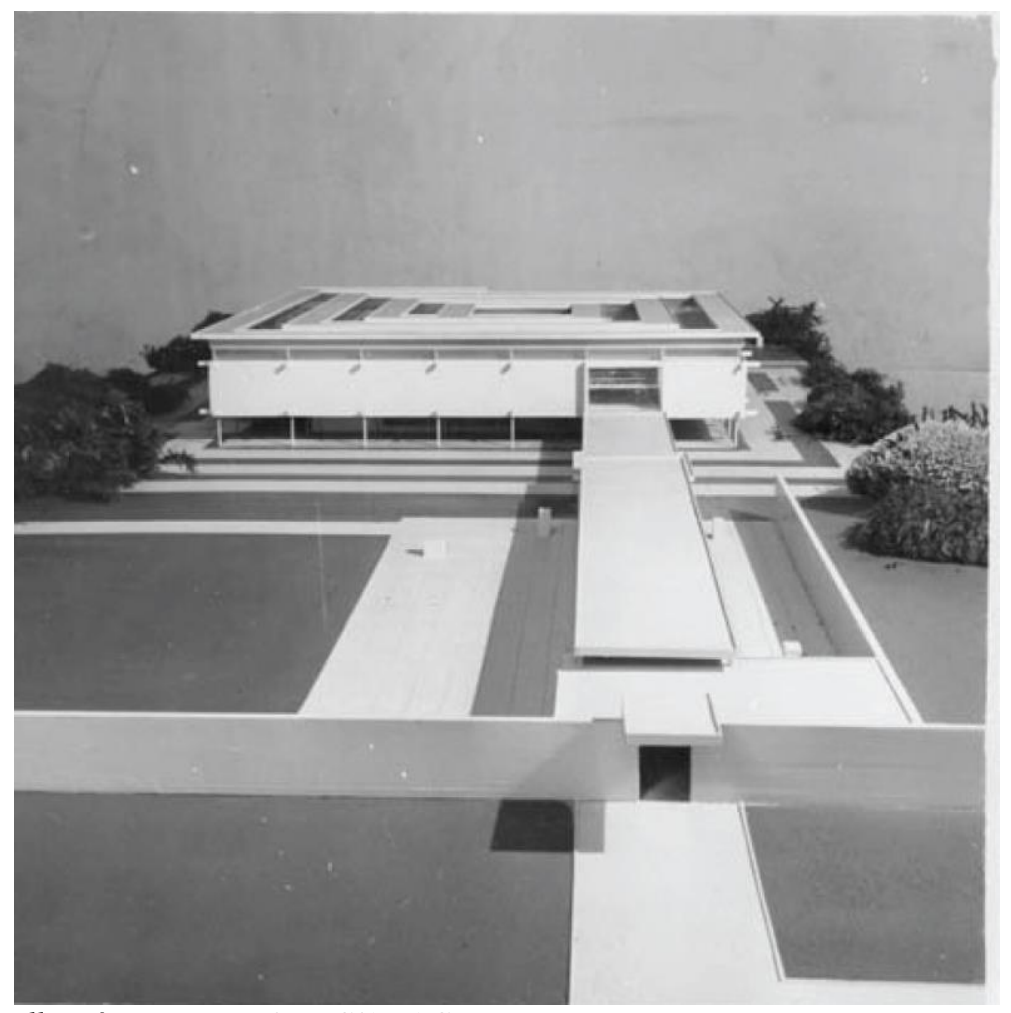

6. Musée à croissance illimitée, maquette. (C) FLC/ADAGP

Museums came to be expressions of nationalism after Napoleonic wars and cultural pillaging across Europe. This is best exemplified by Karl Friedrich Schinkel's Altes Museum. With its giant order of eighteen Ionic columns, the Altes Museum has a very deliberate face and connection to the city of Berlin. In the context of revolutionary Prussia, the other three sides of the building were modest brick surfaces with emphasis and investment on the monumental entry way, marked with: FRIDERICUS GUILELMUS III STUDIO ANTIQUITATIS OMNIGENIAE ET ARTIUM LIBERALIUM MUSEUM CONSTITUIT MDCCCXXVIII" ("Friedrich Wilhelm III dedicated this museum to the study of all antiquity and liberal arts in 1828") The inscription is significant in its projection of a national identity and pronouncement of the concept of bildung, or cultural and self-cultivation. Nineteenth century institutions would generally follow this classical model, creating sacred spaces, alluding to temples of antiquity, expressing transcendental aspirations and democratic, secular intentions. Twentieth century institutions, liberated from the role of symbols for nation-states or monuments for democracy and civic pride, then became icons of technological progress. In the post-modern era, architecture becomes image and spectacle ${ }^{16}$.

Tension emerges where architecture's function as frame, in relation to its autonomy as a self-serving art object, has become ambiguous. Architectural authority conflicts with artistic and curatorial intention. Hal Foster will call this the Art-Architecture Complex ${ }^{17}$ where spaces, under pressures and demands of consumer capitalism, have become a field in which structure, surface and symbol are collapsed and difficult to distinguish. Architectural practice has always found ways of expression through technology and materials but in modernity, this expression, as it has in artistic practice, has become pop image.

\footnotetext{
${ }^{16}$ Vidler, Architecture between Spectacle and Use (Williamstown, MA: Sterling and Francine Clark Art Institute, 2008).

${ }^{17}$ Hal Foster, The Art-Architecture Complex (London: Verso, 2011).
} 
Le Corbusier's free facade is not pictoral or superficial - that is, of the surface - but rather, volumetric and total. It is liberated from structural function but then resists any form of social function or cultural representation. Le Corbusier recommended that "a mason and a labourer be permanently employed in building this museum in an uninterrupted and perennial operation" ${ }^{\prime 18}$ - as the museum would be constantly under construction, a continuous wall unfolding and folding in on itself. As represented in the maquette, beams protrude from the wall in anticipation.

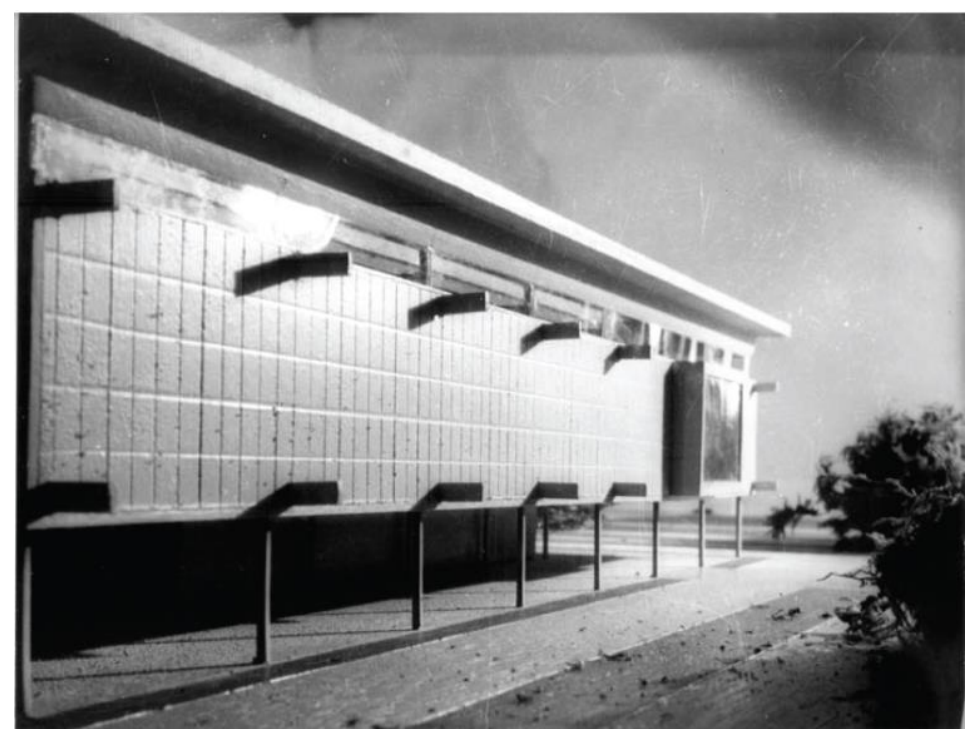

7. Musée à croissance illimitée, maquette. (C) FLC/ADAGP

The outer layer is only a temporary facade that will eventually become interior partitions. The spiraling future pattern of growth is marked on the ground around the box and the model shows the box covering 1,000 square meters and expanded to 3,000 square meters. Therefore, the museum is an ever-expanding interior without a definitive exterior. Beatriz Colomina has described the endless museum as "a machine for swallowing the outside. "19 The wall is more than a skin or surface for projected meanings or expressions, but a wholly active organ, an entity that carries with it the vitality of the entire project.

With regard to the power of the wall, Le Corbusier has said - A wall is beautiful, not only because of its plastic form, but because of the impressions it may evoke. It speaks of comfort, speaks of refinement; it speaks of power and of brutality; it is forbidding or it is hospitable; - it is mysterious. A wall calls forth emotions. ${ }^{20}$

And here, we can refer to the famous anecdote of the "poem of walls" which Le Corbusier created for his client in La Maison Roche. ${ }^{21}$ Raoul La Roche felt that the architectural expression of Le Corbusier's walls

\footnotetext{
${ }^{18}$ Le Corbusier et Pierre Jeanneret, "Pour la création a Paris d'un musée des artistes vivants," Cahiers d'art, année 6, no.1 (1931): 7

${ }^{19}$ Beatriz Colomina, "The Endless Museum: Le Corbusier and Mies van der Rohe," Log no. 15 (Winter 2009): 57.

${ }^{20}$ Le Corbusier quoted in A. Vidler, The Architectural Uncanny: Essays in the Modern Unhomely. (Cambridge, MA: MIT Press, 1992): 90.

21 "Remember the origin of my undertaking 'La Roche, when one owns as superb a collection of art as yours, one must build a house which is worthy of it.' And my answer: 'Very well, Jeanneret, build me that house.' But, what has happened? The house once finished was so beautiful that when I saw it, I cried out to myself: 'It's almost a crime to put paintings in it.' I put them in anyway. Could I have done anything but? Do I not have certain obligations to my painters, of whom you are one, by the way? I ordered a 'framework for my collection'. You made me a 'poem of walls'. Which of the two of us has been the
} 
overwhelmed the artistic expression of his collection. Perhaps, as one of Le Corbusier's seminal villa projects of the 1920s, this marks a critical point in his investigation of the surface of the wall. As discussed in the first section, I argue that the museum projects of the 1930s takes on an expanded perspective, and formal approach. Le Corbusier insists, here, on a subversion of face, although in the realized projects, there are nuances which respond to the specificities of the project sites.

In Tokyo, katsura-hama, green and grey pebbles, are embedded into the concrete of the National Museum of Western Art's exterior walls, and himeko-matsu pine wood grain of the formwork is imprinted on its round columns. In Ahmedabad and Chandigarh, local Indian bricks are vibrant red. However, these details serve more of a functional purpose than one of aesthetics. The window-less wall provides insulation. The prominent concrete guttering above the pilotis is intended to accommodate a particular kind of climbing plant which will shade the wall from the sun's heat. Mud-brick and stone are used in a rough manner as part of Indian vernacular. C'est le tabernacle de l'art moderne, mais il est pauvre comme une crêche. The museum is a temple of modern art, but it is poor like a manger. Beyond style or symbolism, without ostentation or signification, Le Corbusier's faceless museum was an anti-monument which Anthony Vidler describes as a method of criticality. "In these respects, then, the notion of an escape from or effacement of monumentality would seem to turn back on itself, implying the immediate absorption of the most "critical" vocabulary of references and the monumentalization of any institutional form, however veiled its "soul." The very eradication of the face that veils representation becomes symbolic in its own right, monumentalizing, despite itself, the most difficult contradictions in the debate over monumentality." 22 The neutrality of the Musée is taken as a method of resistance, which opens up the potential for signification, a degree zero of architectural expression.

\section{Place-less}

Le musée s'élève dans quelque banlieue ou grande banlieue de Paris. Il s'élève au milieu d'un champ de pommes de terre ou de betteraves. Si le site est magnifique, tant mieux. S'il est laid et attristé de pignons de lotissements ou de cheminées d'usines, ça ne fait rien. ${ }^{23}$

Although Le Corbusier's comment about the irrelevance of the beauty of the site was flippant, the mention of beets and potatoes relates to agriculture and cultivation, alluding to ideas of earth and the museum as a sacred space of cultural formation - grounds for the cultivation of the human spirit. The juxtaposition of an agricultural field with an industrial landscape, vastly different scenes, adds emphasis to his point that the Museum of Unlimited Growth can exist within any and all contexts.

Whereas the relationship between landscape, site, and building was significant for the domestic projects of Le Corbusier - the ribbon window establishing a connection between inside and outside through the wall - the museum was instead an introverted space, a continuous wall constantly unfolding and folding back onto itself. Pilotis would elevate the building, but unlike the way they were employed in his other projects, here they did not

most to blame?" Roche quoted in Stanislaus von Moos, Le Corbusier: Elements of a Synthesis (Cambridge: MIT Press, 1979): 266.

${ }^{22}$ Vidler, The Architectural Uncanny, 95.

${ }^{23}$ The museum rises in some suburb of Paris, set in the middle of a field of potatoes or beetroot. If the site is magnificent, so much the better. If it is ugly and saddened by sprocket-wheel developments or factory chimneys, it doesn't matter. 
serve to create circulation and public space on the ground level. Le Corbusier notes that this space below the galleries can serve as storage for the art, so the elevation of the building off the ground does have some functional reasoning. However, it is important to distinguish that in the case of the museum projects, the pilotis serve more of a symbolic purpose. By lifting the building from the earth, Le Corbusier removes the institution from its historical and cultural context. Place-less, the Museum of Unlimited Growth is unbound to nation or state, being of no-where and every-where.

Without delving too deeply into the political climate of Paris in 1931, (as scholarship on Le Corbusier's political values remains controversial and a divisive issue) it is worth acknowledging the relationship between museums and nationhood throughout history in brief, as it pertains to the discussion of architecture and place-making.

When early art collections from royal collections were made public to the general populace, they were still presented within princely palaces. The Louvre opened to the public in 1789 but the presence of the monarch, the body of the king, was very much part of the aura of the physical space of the gallery rooms. After the Napoleonic period, as nation states sought to reclaim and reassert their identity, the notion of site and place was of utmost importance, as an extension of power and authority. Architecture had the unique agency, apart from other major arts, to signify place. In a post-revolutionary context, colonial territories once emancipated would seek to cultivate their own sense of cultural legitimacy through the establishment of museums. Although the content within early American art museums would still be Euro-centric, architecture of the neo-classical order would serve to represent a young nation's cultural refinement. Through the collection and organization of objects, the exclusion of some, the appropriation of others, the space of the museum would establish a semblance of a collective history. Museums have therefore been critical in the projection of ideas of place, of borders, of territories.

The museum as a site has always confronted the problem of decontextualization, the removal of an art object from the artist's studio or a cultural artifact from its place of origin. Furthermore, the efficacy of cultural preservation through museums is arguable. However, the Sanskar Kendra Museum, Museum Director would defend his institution. "The modern museum that Le Corbusier created would bring about the active participation of people, instead of encouraging mere irresponsible contemplation of rare luxury objects torn from their contexts." ${ }^{24}$ His disciple Balkrishna V. Doshi would insist that, "Even as it addresses the Indian context, the city nevertheless remains international in carácter and gives us Le Corbusier's sense of the future not [a present] Indian life."25

The National Museum of Western Art in Tokyo is a complex scenario, in which issues of repatriation are involved. It was agreed upon that Le Corbusier would design the museum in order for the French government to return the Japanese collector's holdings after the Second World War. Despite the socio-political implications of these commissions, the architecture stands alone with its concepts of order-less-ness and face-less-ness contributing to a quality of unspecific, place-less-ness.

\footnotetext{
24 "Le Corbusier: Sanskar Kendra Museum, Ahmedabad, India 1957." A \& U: Architecture \& Urbanism no. 5 (May 2001): 45.

${ }^{25}$ Jon T. Lang, A Concise History of Modern Architecture in India (New Delhi: Permanent Black, 2002): 65.
} 
Beyond these three realized projects, Le Corbusier imagined Museums of Unlimited Growth for nations across the world - from France to Japan, Switzerland to Africa, Germany to India. The idea for a Museum of Unlimited Growth was refined over many iterations. First, in 1931 was the proposal for the Cahiers d'art, sans lieu; then a Centre d'esthétique contemporaine located in Paris, France in 1937; later an exploration for Philippeville, Africa in 1939; a decade after the three realized commissions, he would envision a Centre d'art international in Erlenbach, Germany located at the crossing of axes of Stockholm-Rome and Paris-Vienna-Belgrade-Bucarest in 1962; and a sketch for a Musée du Xxe siècle to be located in Nanterre, France would be his last drawing dated 29 June 1965. Perhaps he was envisioning a global network all along.

Transcultural and transnational, the original proposal and subsequent versions of the spiral museum captured the spirit of modernity. In a comparison of Mies van der Rohe and Le Corbusier's world views, Beatriz Colomina anecdotally points to how the former would rather travel by ocean liner or train, while the latter loved to fly. As it relates to the siting of their work, Mies's buildings, like the architect, can be seen as obstinate and steadfast; while Le Corbusier, in his mobility and hunger for travel, is expressive of a desire for his work to have equal reach, an architecture that can be nomadic and universal.

The idea for a World Museum actually preceded that of the Museum of Unlimited Growth. The Mundaneum was to be a global archive, a Roneo File Cabinet for the world and all of its knowledge. "Our desire is that in one place on the globe the total image and significance of the world should be visible and understood." 26 The Mundaneum from 1929 by Paul Otlet and Henri La Fontaine was the first instance of an attempt to spatialize a globally networked world, an attempt at internationalism. The Mundaneum was not just a project for a real building, but also an architectural metaphor of knowledge organization and dissemination on a global level, a building and a network ${ }^{27}$ - both a material and a virtual construction.

In The Delirious Museum, Storrie argues that in some ways, the theft of the Mona Lisa in 1911 from the Louvre marked the beginning of art's "ambivalent relationship" 28 with the museum. At that moment, the illusion of the authority of architecture and the authority of the museum was broken. Le Corbusier's design for the Musée and his explorations into traveling exhibition displays challenged the notion of artistic experience's relationship to place. As he describes - a Modular PREPARATION OF A TRAVELLING EXHIBITION (under the auspices of six major American museums). ${ }^{29}$ By the use of the Modulor the panels for the pictures were able to accommodate every imaginable shape and size. They were afterwards demounted and re-erected abroad. The permanent shelter offered by "project B" allowed sister-organizations abroad to come and exhibit in Paris. This type of metal parasol or umbrella could be adopted in Milan, London, Berlin, etc. So with Paris as a centre the circuit which would be set up would stimulate an intensification of the researches into the relationship of the Major Arts and architecture.

His architectural projects can be interpreted as a formal representation of his way of seeing and being in the world. The Athens Conference (1931) on restoration of historic buildings was organised by the International

\footnotetext{
${ }^{26}$ W. Boyd Rayward, "Visions of Xanadu: Paul Otlet (1868-1944) and Hypertext," Jasis 45 (1994): 235.

${ }^{27}$ Charles van den Heuvel, "Architectures of Global Knowledge: the Mundaneum and the World Wide Web," Volume no. 15 (2008): 49.

${ }^{28}$ Calum Storrie, The Delirious Museum: A Journey from the Louvre to Las Vegas (London: I.B. Tauris, 2006): 12.

${ }^{29}$ Le Corbusier, Modular I (Paris, 1948): 154.
} 
Museums Office, and the Athens Charter ${ }^{30}$ was drafted by Le Corbusier at the fourth Assembly of the International congresses on Modern Architecture (1933). Published in 1941, this reflected a growing consciousness among specialists all over the world, and introduced for the first time in history the concept of international heritage. As a project developed under these influences, the Museum of Unlimited Growth is an attempt at an autonomous architecture, beyond style or traditions. By subverting the notion of site, Le Corbusier achieved an architecture with authority over politics, undoing any obligation to cultural burdens. Place-less - the Museum of Unlimited Growth turns the visitor's attention and consciousness instead towards an inner, metaphysical space for the synthesis of knowledge and the arts.

\section{End-less}

Le musée est extensible à volonté: son plan est celui d'une spirale; véritable forme de croissance harmonieuse et régulière. ${ }^{31}$

Hannes Meyer famously said, "All things in the world are a product of the formula: Function times economy." Le Corbusier echoes this maxim, noting that successful architecture must be "inspired by the law of Economy and governed by mathematical calculation." 32 He understood very well the role of economic factors and issues of utility. To this end, he applies a modular, flexible wall system. Poteaux standard, cloisons-membranes fixes ou amovibles, plafonds standard. Économie maximum. He also acknowledges in the proposal that expansion would happen through private donorship. In the Museum of Unlimited Growth, a donor would attach his name not only to a work of art, but also to the very wall which would support the painting. That Le Corbusier would mention museum operations to this level of detail reveals that he was not naïve to the fact that architects' intellectual and artistic visions are influenced by matters of funding.

\footnotetext{
${ }^{30}$ Athens Charter for the Restoration of Historic Monuments Preservation, accessed through International Council on Monuments and Sites www.icomos.org.

${ }^{31}$ The museum is extendable at will: a plan which is that of a spiral; true form of harmonious and steady growth.

${ }^{32}$ Le Corbusier, Vers une architecture, 11.
} 


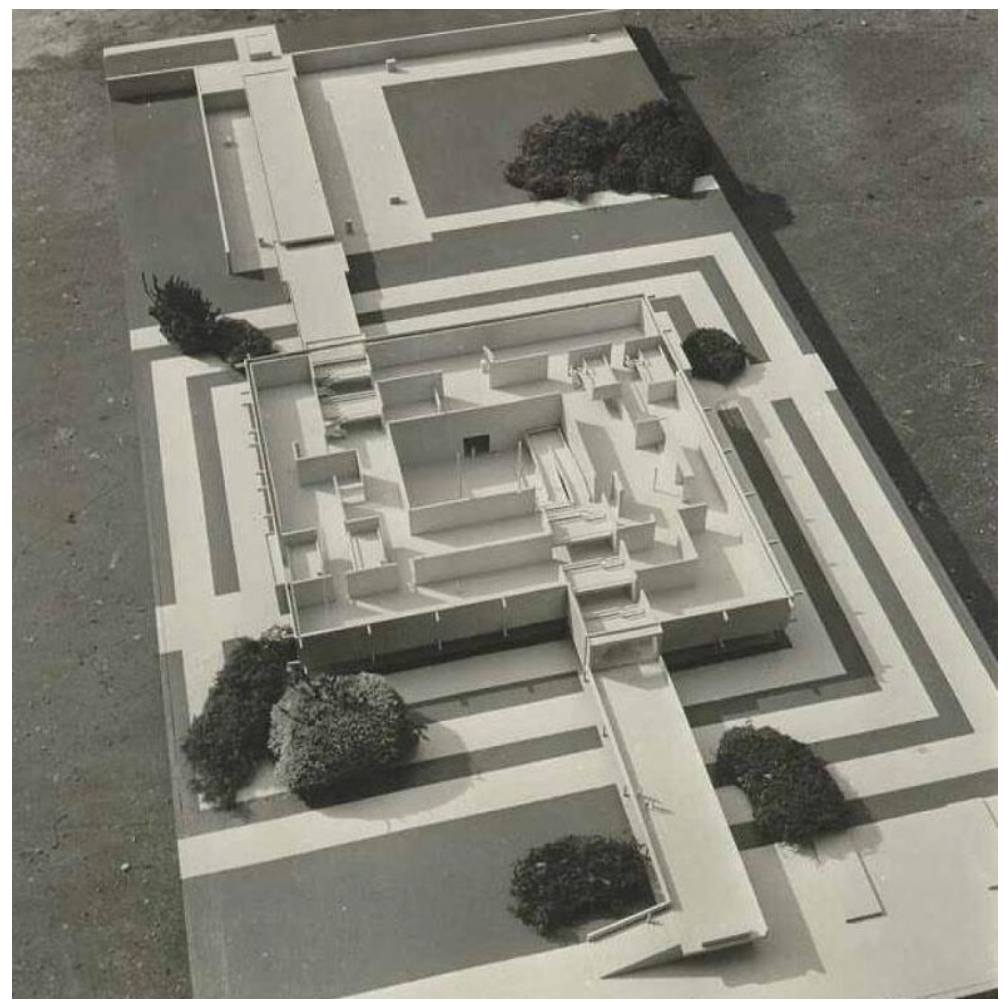

8. Musée à croissance illimitée, maquette. (C) FLC/ADAGP

Along with the bold scheme of unlimited growth, Le Corbusier's architecture trumps ideas of style or utility. The spiral is an end-less figure that allows for end-less representation and interpretation of culture. Le Corbusier argued that architecture - not fashion or technology - through concepts of order and harmony, becomes poetry that can be eternal: I have allowed a spiral staircase (very modern, and also timeless), spiral ramps (the same vertical circulation as the Tsentrosoiuz in Moscowvary modern and also very old!); I have allowed the museum of human creation to follow a spiral, not to be "the last word in fashion," but to assure, through this unique means, the absolute continuity of events in history. I cannot see any other way of doing it. ${ }^{33}$

Le Corbusier imagined that a modern museum, a true museum, would include the present day, the every day, the quotidian. In the Library of Babel (1941) Jorge Luis Borges imagined the universe as an infinite collection of books, a labyrinthian storehouse of knowledge. Gustave Flaubert's satire Bouvard et Pécuchet (1881) is a story about the pursuit, the impossibility and futility of attempting to build encyclopedic knowledge. Both stories attempt to illustrate theories of epistemology, about the complexities of collection and heterogenity. Nonetheless, Le Corbusier presented a provocation. "Let us imagine a true museum, one that contained everything, one that could present a complete picture after the passage of time, after the destruction by time (and how well it knows how to destroy! So well, so completely, that almost nothing remains except objects of great show, of great vanity, of great fancy). "34

Le Corbusier understood that there was a "cap" and realistically, the museum would not grow "infinitely." It is unclear how he envisioned the collection would develop after the museum reached its maximum dimension of

\footnotetext{
33 "In Defense of Architecture," republished in Oppositions Reader: Selected Essays 1973-1984 (New York: Princeton Architectural Press, 1998): 608.

${ }^{34}$ Le Corbusier, L'art décorative d'aujourd'hui (Paris: G. Crès et Cie, 1924): 16.
} 
nine thousand meters square. But it holds then, that beyond the ideas of physical growth is an idea of conceptual growth and that the projective and expansive form goes beyond built space to metaphysical space. The paradox of an endless museum allows one to contemplate the past while recognizing one's position in history, all the while conscious of the future to come.

\section{Conclusion (Time-less)}

The museum as a typology was a topic of patient research, contemplated over the course of Le Corbusier's entire career. His museums in India and Tokyo are versions of an impossible ideal, but through the analysis of the original proposal and subsequent iterations, we see the careful consideration of a means to synthesize art and architecture. Perhaps the concepts which have structured my argument can also be taken as the very qualities for which modernism is criticized: the order-less museum can be interpreted as determinist and monolithic; the faceless building has no poetry or soul; place-less, the project is anonymous, insensitive in fact; and end-less, the architecture becomes relentless and oppressive. However, one can argue that these aspects of the museum of unlimited growth allows it to literally project from its physical footprint and figuratively extend beyond its own moment in history. In its radical form, the spiral figure enframes an understanding of time - by resisting the forces of time.

It is a daunting task to engage with the many facets of Le Corbusier's body of work. From analyses of his villas as machines for living, to discussions of his urban projects to the study of the poetics of Ronchamp's primitive sculptural forms - scholarship on Le Corbusier's œuvre has largely overshadowed and overlooked the spiral museum projects. Yet, in the minimal spiral plan museum one can trace the development of a distinct position regarding the relationship of space and time. In his brief 1931 letter to Zervos, he laid the seeds for an obscure, yet meaningful project, one concerned pure potentiality and the limits of architecture.

\section{Source of Images}

(C) FLC/ADAGP Fondation Le Corbusier/Société des Auteurs dans les Arts Graphiques et Plastique.

\section{Bibliography}

Brooks, H. Allen, eds. Le Corbusier. New York, NY: Princeton University Press 1987.

Colomina, Beatriz. "The Endless Museum: Le Corbusier and Mies van der Rohe." Log no. 15 (Winter 2009): 5568.

Crimp, Douglas. On the Museum's Ruins. Cambridge, MA: MIT Press, 1993.

Foster, H. The Art-Architecture Complex. London: Verso, 2011.

Hays, K. Michael. Oppositions Reader: Selected Readings from a Journal for Ideas and Criticism in Architecture, 1973-1984. New York, NY: Princeton Architectural Press, 1998.

Heuvel, Charles van den. "Architectures of Global Knowledge: the Mundaneum and the World Wide Web." Volume no. 15 (2008): 48-53.

Kokuritsu Seiyō Bijutsukan. Thirty Years of the National Museum of Western Art Tokyo: 1959-1989. Tokyo: 国 立西洋美術館, 1989.

Lang, Jon T. A Concise History of Modern Architecture in India. New Delhi: Permanent Black, 2002.

"Le Corbusier: Sanskar Kendra Museum, Ahmedabad, India 1957." A \& U: Architecture \& Urbanism no. 5 
(May 2001): 42-49.

Le Corbusier et Pierre Jeanneret. "Pour la création a Paris d'un musée des artistes vivants." Cahiers d'art, année 6, no.1 (1931): 5-9.

Le Corbusier.

Vers une architecture. Paris: G. Crès et Cie, 1924.

L'art décorative d'aujourd'hui. Paris: G. Crès et Cie, 1924.

Le Modulor. Paris, 1948.

Le Modulor II. Paris, 1950.

L'atelier de la recherche patiente.Translated by James Palmes. New York: Praeger, 1960. 1930-71

Euvre Complètes, 1910-65, pubished in 8 volumes, edited by Willy Boesiger. Zurich, Girsberger,

The Le Corbusier Archive, in 32 volumes, edited by Allen H. Brooks. New York, NY:

Garland Architectural Archives, 1982-84.

Moos, Stanislaus von. Le Corbusier: Elements of a Synthesis. Translated by Beatrice Mock, Joseph Stein, and Maureen Oberil. Cambridge: MIT Press, 1979.

Rayward, W. Boyd, "Visions of Xanadu: Paul Otlet (1868-1944) and Hypertext." Jasis 45 (1994): 235-50.

Samuel, Flora. Le Corbusier and the Architectural Promenade. Basel: Birkhäuser, 2010.

Searing, Helen. New American Art Museums. New York, NY: Whitney Museum of American Art, 1982.

Serenyi, Peter. “Timeless but of Its Time: Le Corbusier's Architecture in India.” Perspecta vol. 20 (1983): 91 118.

Storrie, Calum. The Delirious Museum: A Journey from the Louvre to Las Vegas. London: I.B. Tauris, 2006.

Vidler, Anthony. Architecture between Spectacle and Use. Williamstown, MA: Sterling and Francine Clark Art Institute, 2008.

Vidler, A. "Losing Face: Notes on the Modern Museum." Assemblage no. 9 (June 1989): 40-57.

Vidler, A. Warped Space: Art, Architecture, and Anxiety in Modern Culture. Cambridge, MA: MIT Press, 2000.

Vidler, A. The Architectural Uncanny: Essays in the Modern Unhomely. Cambridge, MA: MIT Press, 1992. 


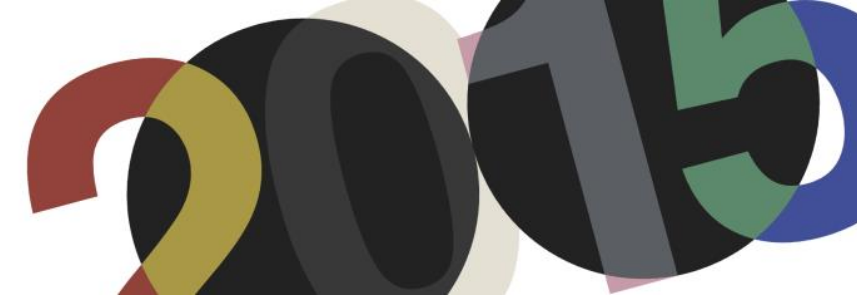

DOI: http://dx.doi.org/10.4995/LC2015.2015.774

\title{
Le Corbusier and the mysterious "résidence du président d'un collège"
}

\author{
F. Colonnese
}

Sapienza University of Rome

\begin{abstract}
At the very end of his travel to United States, Le Corbusier conceived and designed a modern villa that he lately inserted in the third volume of his Oeuvre Complete with the title 'Résidence du président d'un college près Chicago' and few words below describing it. He interpreted a simple request for suggestions by Joseph Brewer, the president of the Olivet College, Michigan, into an actual commission for a new house that responded to the kind of works he expected from his American admirers. He possibly designed it in a few hours'time from Kalamazoo to Chicago but the autograph hand-drafted plans and bird's-eye perspective view in the Oeuvre Complete congruently describe a well-thought project showing a number of affinities with his most celebrated European houses. The villa can be considered as an aware modular assemblage of parts that he had previously designed or even built, tied together by a long and suggestive promenade architecturale, to offer the "timid" American people a sort of full scale model to introduce them to his vision of modern life.

By analyzing Le Corbusier's sketches and conjecturing both dimensions and missing elements from previous designs, a threedimensional digital model has been elaborated to virtually visit the résidence and understand its fictive and educational value.
\end{abstract}

Keywords: Le Corbusier; Joseph Brewer; Olivet College; Promenade architecturale; Intertextuality; Digital Model.

\section{America calling}

“Un président de collège, imbu d'idées modernes, a désiré présenter à son comité les plans d'une maison dans laquelle il puisse recevoir ses élèves dans une ambiance favorable. La maison est nettement classée, au premier étage, en un salon - bibliothèque - terrasse et rampe descendant au jardin. Dans la soupente, un lieu intime: le cabinet de travail avec un jardin clos. Au rez-de-chaussée : la chambre à coucher du président; trois chambres d'hôtes, une communication direct avec l'entrée et, d'autre part, avec le bain de soleil à l'étage." Le Corbusier ${ }^{1}$

The résidence du président d'un collège is the only project designed by Le Corbusier during his journey to the US from October, 21 to November, 28 1935. The notebooks with his travel notes were lost, as evidenced by the gap between the carnets of Algiers of 1933 and those of Rio de Janeiro in $1936^{2}$ and the only known drawings can be found on When the cathedrals were white ${ }^{3}$, the book that sums up his American experience.

References to United States, the vertical city, its innovative production criteria, Fordism and, more generally, to the promises of a young and enterprising land, were present in the writings of Edouard Jeanneret since the time of L'Esprit Nouveau: in their geometric sincerity American industrial architectures had offered the young architect some of the most effective images to groom the anachronistic European academicism with. These ideas were obviously affected by the phenomenon of the so-called French Americanism that in the twenties conveyed

\footnotetext{
${ }^{1}$ Bill, Max: Le Corbusier. Oeuvre Complète. Volume 3. 1934-38. 14 ${ }^{\text {th }}$ edition, Basel - Boston - Berlin: Birkhäuser Publishers, 2006, p. 133.

${ }^{2}$ See: Le Corbusier Sketchbooks, New York - Cambridge (Mass.): Architectural History Foundation and the MIT Press, 1981-1982, vol. 1, pp. 29-31.

${ }^{3}$ Le Corbusier: Quand les cathédrales étaient blanches, voyage au pays des timides. Paris: Plon, 1937.
} 
the idea of an implicit superiority of European culture, contributing indirectly to the prejudices that marked negatively Le Corbusier's experience in America ${ }^{4}$.

America gradually discovered Le Corbusier through his urban projects, his first villas and books published between 1923 and 245. The Architecture League of New York, led by Raymond Hood, tried to invite him in 1929 by offering a contribution between 2000 and 3000 \$, but the Swiss architect was already busy with his tour in South America and responded too late. In the same years he had been contacted by the American entrepreneur Melville Easterday and cultivated for some time hope to build an office building and a house in Oklahoma City ${ }^{6}$. In 1930-31 his cachet had risen to \$ 3,000 for a conference in New York and \$ 500-600 for conferences in other cities, far beyond the possibilities of the League. As the director of Columbia University's School of Architecture, Joseph Hudnut promoted in 1933 a third attempt at inviting Le Corbusier but it also failed despite the support offered by MOMA ${ }^{7}$. Next year a fourth initiative involved Albert Frey and Carl Schniewind, a couple of Le Corbusier's friends, and it was the prelude to his trip in the fall of 1935. After the crisis of 1929 economic conditions were difficult both in Europe and in America and the payments he was offered were always lower than expected, but they could be balanced both by limiting the speaking tour to a few cities and by the opportunity to build something in America.

\subsection{Sailing to USA}

On October 16, 1935 Le Corbusier sailed from the port of Le Havre with a first-class ticket on the Normandie. He had three kinds of purposes before him: to be known through his lectures; to get commissions to build in America; to document US cities and factories in order to arrange further publications. The cruise did not offer him the same entertainment and emotions of his previous journey to Rio de Janeiro, but on October 21, when he arrived at New York, he found Marguerite Tjader Harris waiting for him. He had met the writer in Vevey, in his mother's home and had designed a villa for her in a plot nearby (FLC 9375). Mother of a child and divorced from her husband Overton Harris, Marguerite was muse and discrete confidant of Le Corbusier during his stay in the US. Despite her occult and uncomfortable role, "Marguerite can be fully appreciated as the person who enabled Le Corbusier to experience the realities of modern life and culture in America that would validate his Radiant City thesis." "In her company, New York appeared to Le Corbusier "overwhelming, amazing, exciting, violently alive - a wilderness of stupendous experiment toward the new order that replaces the current tumult"?. Marguerite showed him New York metropolitan life and opened her home in Darien, Connecticut, and her shack on the island of Pratt, Long Island as a safe haven: their happy days in the Baraque - that's the way Le Corbusier nicknamed it - were possibly the cause of the famous Cabanon in Cap Martin. Moreover, their relationship

\footnotetext{
${ }^{4}$ Hitchcock, Henry-Russell: "Le Corbusier and the United States”. In Zodiac. 1966, N 16, pp. 6-23; Bacon, Mardges: Le Corbusier in America. Travels in the Land of the Timid. Cambridge (Mass.) - London: The MIT Press, 2001.

${ }^{5}$ Pond, Irving: "From Foreign Shores". In Journal of the American Institute of Architects, December 1923, N¹1, p. 475; March 1924, $\mathrm{N}^{\circ}$ 12, p. 122.

${ }^{6}$ Fondation Le Corbusier conserves seven letters testifying these contacts. Bacon, op. cit., p. 330, note 182.

${ }^{7}$ After the success of the exhibition Modern Architecture: International Exhibition curated by Philip Johnson and HenryRussell Hitchcock (February 9 to March 23, 1932), MoMA was interested in inviting one of the leaders of European Rationalism to New York.

${ }^{8}$ Bacon, op.cit., p. 57.

${ }^{9}$ Le Corbusier: When the Cathedrals Were White: A Journey to the Country of Timid People. New York: Reynal and Hitchcock, 1947, p. 45.
} 
probably influenced his decision to stay at Gotham Hotel in New York even after finishing his local lectures, deleting all his commitments on the West Coast ${ }^{10}$.

\subsection{Le Corbusier in the Midwest}

While New York had offered Le Corbusier the opportunity to experience and study a metropolis, especially from its taller skyscrapers, East Coast cultural centers opened the doors of the liberal establishment, showing all the contradictions of the "new world". In the lectures he presented in his first month in America, Le Corbusier faced the cultural elite of Hartford, the uninhibited female students of Vasar Collage and the anachronistic Beaux-Arts atmosphere at MIT, where his presence proved decisive for the modernist breakthrough of the school of architecture $^{11}$.

After mid-November he began to visit the hinterland and, in particular, the Midwest. He moved to Detroit, Bloomfield Hills, Kalamazoo, Chicago, Madison, and finally, again Chicago ${ }^{12}$. In this territory dotted with those factories and barns that had fuelled some of his earlier speculations on industrial architecture, his attention turned away from journalists and academics to focus on entrepreneurs and industrialists while the topics of his lectures focused on production processes and their social consequences in urban areas. Those days were marked by the favorable reception Saarinen offered him in Cranbrook as well as the experience of the Ford assembly line in Detroit that convinced him to claim that "Houses of future will be made in factories"13.

On November 22nd, on the way to Kalamazoo Joseph Brewer suggested to Le Corbusier to stop briefly at Olivet College, where he was president. Accompanied by some members of the academic staff, he proposed to Le Corbusier the possibility of designing a new house of the president, since years before a fire had burnt down the old one. Le Corbusier considered Brewer a reliable interlocutor. During the years Brewer had worked as an editor and publisher in New York (1925-33), he had edited the American editions of Le Corbusier's books ${ }^{14}$ and had early contracted with him about a book on American Architecture to be published after his travel. He had been a member of a circle supporting MoMA's activities in favor of modern architecture and "under the presidency of Joseph Brewer, Olivet College had an extraordinary life as center of education in the arts" 15 . Brewer himself revealed about their quick inspection into the college and the nature of his proposal. "I took him up to the site and asked if he would be interested to do a quick sketch for a new house. I explained that the College had no money, that a gift would have to be sought, and I could give no assurances of anything ... he made some notes of the requirements as I saw them and said he would think about it" ${ }^{\text {"16 }}$. To Brewer Le Corbusier

\footnotetext{
${ }^{10}$ Bacon, op.cit., p. 87.

${ }^{11}$ Gordon Bunshaft revealed that after that lecture, "Corbu's books became our bible. What counted more in those books were the drawings, illustrations, and plans, not the written word". Quoted in Bacon, op.cit., p. 97.

${ }^{12}$ Program of lectures of the last part of travel consisted in: November 21, Cranbrook University; 22: Kalamazoo Institute of Arts, 25: Arts Club of Chicago and Renaissance Society, both in Chicago; 26: Memorial Union, University of Wisconsin, Madison; 27: Illinois Society of Architects and American Institute of Architects, both in Chicago. From Bacon, op. cit., p. 314.

${ }^{13}$ Quoted in Bacon, op. cit., p. 105.

${ }^{14}$ Brewer \& Warren had published Towards a New Architecture in 1927, from the $13^{\text {th }}$ edition of Vers une Architecture and City of Tomorrow and Its Planning in 1929 from the $8^{\text {th }}$ edition of Urbanisme.

${ }^{15}$ Robie Maculay, quoted in Saunders, Max: Ford Madox Ford: A Dual Life. Volume II: The After-War World. Oxford: Oxford University Press, 1996, p. 504.

${ }^{16}$ Quoted in Bacon, op. cit., p. 108.
} 
seemed elusive and inscrutable. "He looked around the place, chatted affably enough but was critical and slightly aloof (in fact, rather Swiss!) and clearly wanted to get on"17.

Two days later, on November 24, 1935 - exactly 80 years ago! - Le Corbusier produced a design that surprised Brewer, for he did not expect any project but just suggestions. "I was surprised when I got the drawing. He sent it to me from Chicago. He might have done it on the train"18. Brewer's proposal was exactly the kind of commission Le Corbusier hoped to receive during his American journey. It had arrived at the very end of his travel and, as often happened, was emphasized by his ambitions up to take on the characteristics of an architectural manifesto.

\footnotetext{
${ }^{17}$ Ibidem.

${ }^{18}$ Ibidem.
} 


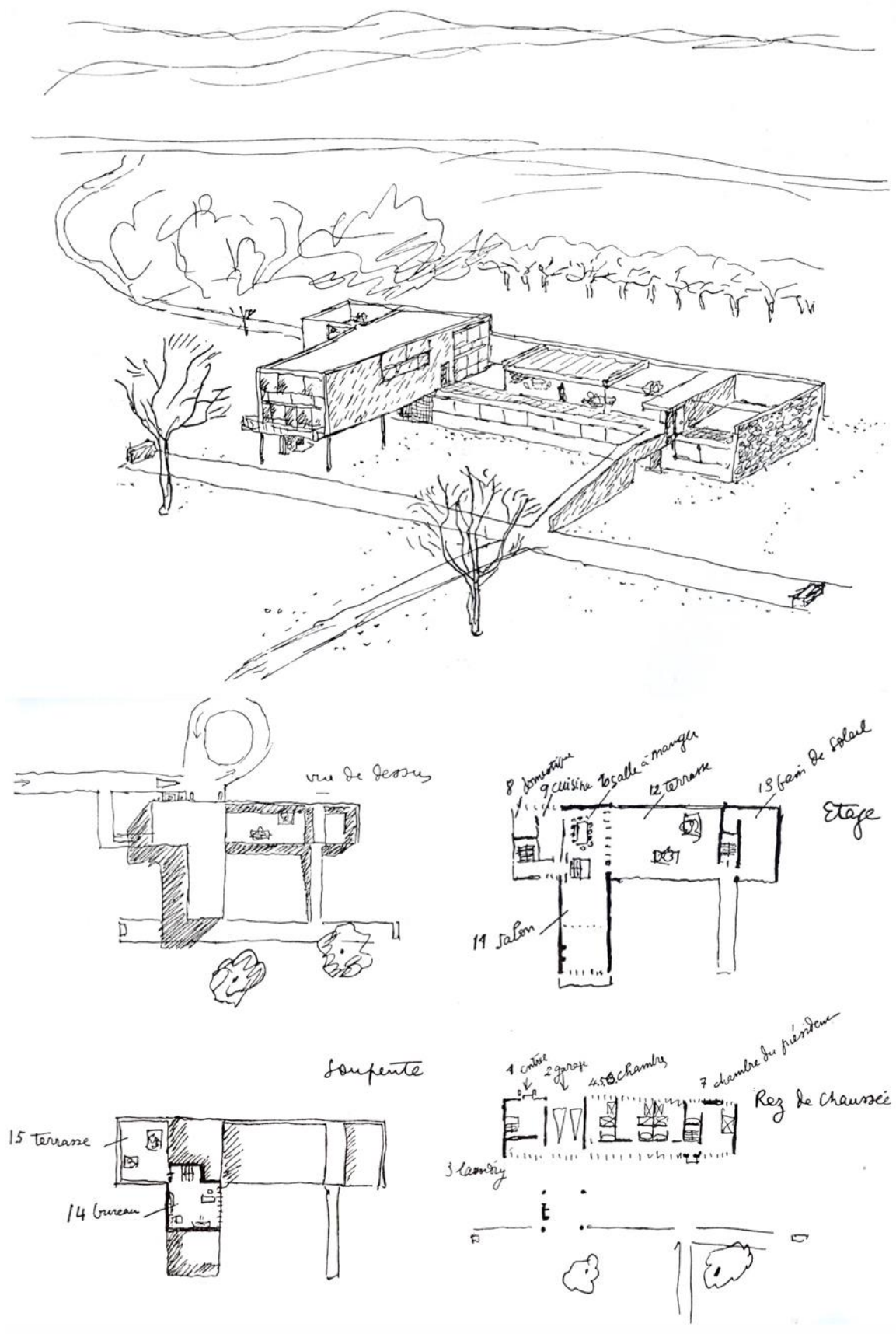

1. Le Corbusier, Bird's eye view and plans for la 'résidence du président d'un college', 1935 (Le Corbusier; Jeanneret, Pierre: Oeuvre Complète. Volume 3. 1934-38, (OFLC-ADAGP). 


\section{The President's House}

The two sheets Le Corbusier published years later in the third volume of his Oeuvre Complete, show sketches of the four plans (ground floor, first floor, entresol and roof) with shadows and numbered captions of the functions and a bird's eye view of the house. From these few elements emerge, however, a coherent project for a villa designed for the campus of Olivet College, Michigan (fig.1).

The site suggested by Brewer should be in the south-west part of the campus, close to the old Main Street (US 27) on a low hill overlooking the neighboring valleys (fig.2). This hypothesis is confirmed by two different sources ${ }^{19}$ but I am quite skeptical about it. Rooms position seems inconsistent with such a site as the bed-rooms windows would face west and the two large windows of the first floor would face north - the dining room - and east - the living room. A different site, on the east side of the campus, just before a little stream, would instead fit properly with rooms and windows position as well as the other elements recognizable in the sketches.

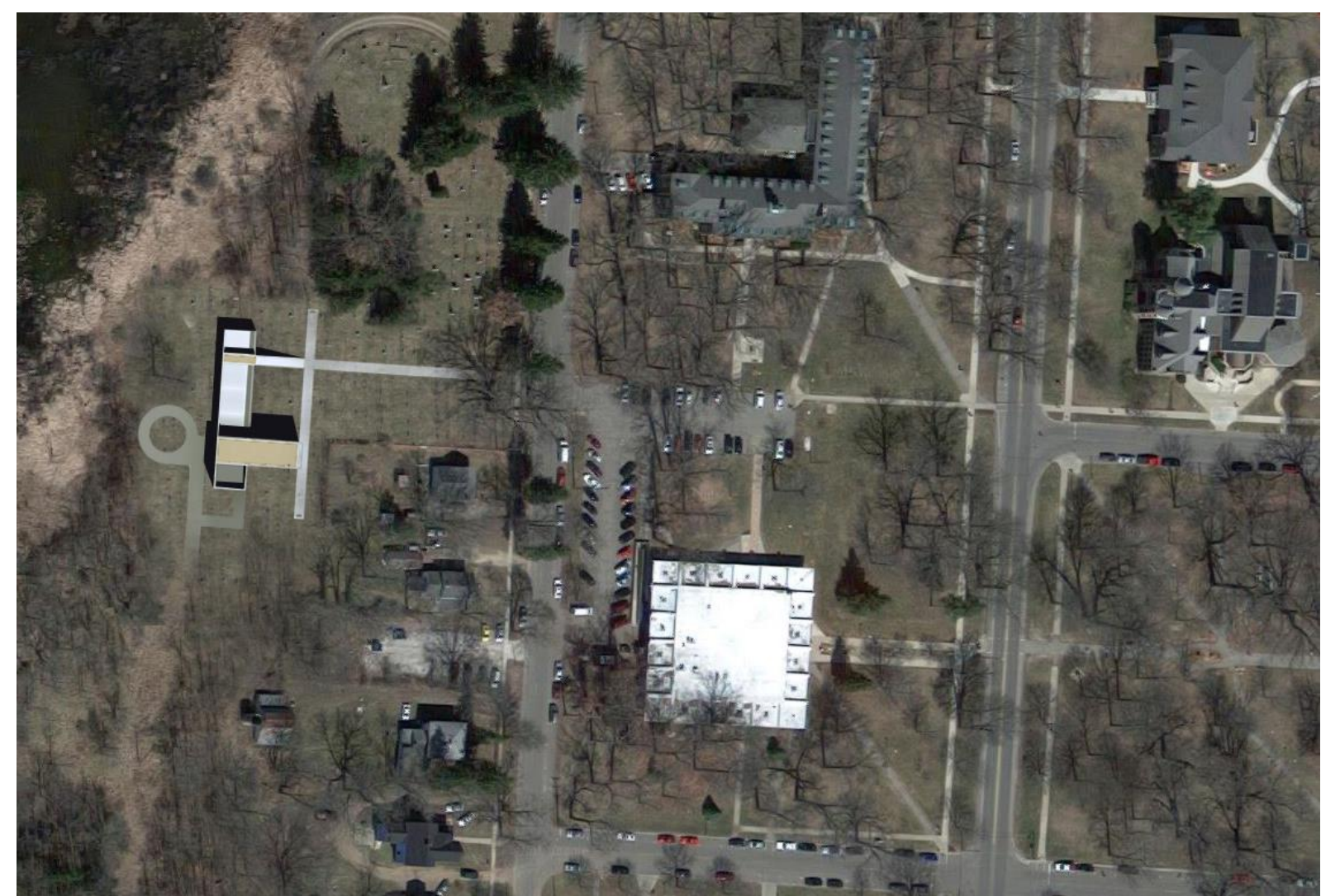

2. Photomontage of the President's House in an hypothetical SW site at the Olivet College (Image source: Googlemap; elaboration by F. Colonnese).

The architect took on the existing network of paths as a Cartesian reference to collocate the rectangle plan of the house. He conceived the house as a barrier to physically demarcate the edge of the campus; thus he placed the public functions of the house on its campus side and the private ones on the other side. He accordingly ordered the circulation flows: he placed a main entrance in the back façade, near the garage, where the street ended with a roundabout to facilitate cars movement while a second door is on the public side, hidden under the ramp leading directly on the étage. Then he organized the functions on three levels. In the ground floor, besides the

${ }^{19}$ Bacon, op. cit., p. 348 , note 185. 
entrance hall and the garage, he placed the four bedrooms with bathrooms served by a long corridor that isolated them from the campus. On the upper floor Le Corbusier arranged a roof garden and a private solarium, divided by the volume containing the staircase raising from the ground floor. A long parallelepiped, reachable both by the internal staircase and through the external route along the ramp and the garden, contained the double-height dining room and a living room while a kitchen and service room were in the adjacent volume. Another staircase by the entrance led to the central mezzanine where Le Corbusier placed the president's studio with an exit leading to a secret patio.

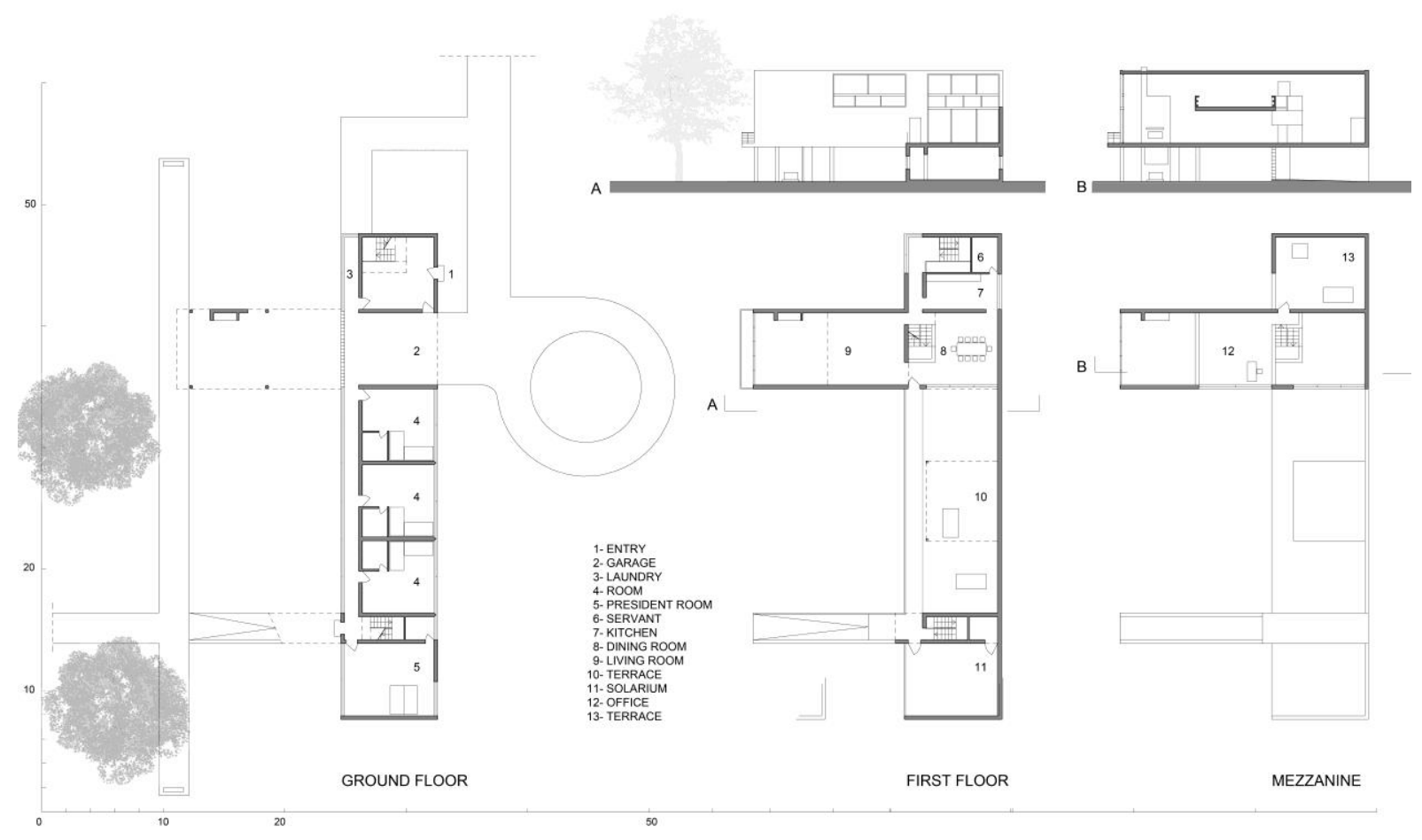

3. Reconstruction of the President's House: plans and sections (drawing by F. Colonnese).

\subsection{Modeling the house}

A reconstructive digital model has been elaborated by the author together with the engineer Silvia Gioja after Le Corbusier's sketches, supported by the evidence that only little inconsistencies can be found between plans and perspective, like the door in the solarium missing in the latter sketch or the jardin clos missing in the roof plan. The model bases on a modular re-organization of the plans drawn by the architect and corrected through what can be deduced from the perspective as well as an accurate constructive analysis. A previous attempt at reconstructing the house project had been proposed by Masuishi and Ando in $2001^{20}$, through 1:200 scale plans and a cardboard model, and we sincerely owe part of this first phase to their proposal, but further hypotheses have been formulated to develop the sketches into a coherent three-dimensional model showing both exteriors and interiors at a 1:50 scale average definition. For example the sketches do not explain clearly the form of the staircase separating the living from the dining room. The solution proposed took inspiration from the pulpits along the staircase of Maison La Roche. In absence of sections, each floor is assumed as $270 \mathrm{~cm}$ high, like Villa

\footnotetext{
${ }^{20}$ Masuishi, Shinichi; Ando, Tadao: Le Corbusier. Houses. Tokio: TOTO, 2001, pp. 250-252.
} 
Stein ground floor: this choice allowed the author to give the main volume a square vertical section. Some elements have been detailed in relation to Le Corbusier's architectural production, like the glass wall of the garage inspired by the ground floor of Villa Savoye, while others have been added as a logical conclusion to what can be seen in the sketches. Thus fireplaces have been designed according to renewal project for Villa Stein Le Corbusier was working on in the same months while a (short) chimney has been added on the roof. The back elevation has been designed mostly imitating the main one, with strip windows for all the rooms; both the shorter side walls were supposed to be in masonry. Finally a Villa Stein-like metal banister has been added on the ramp and the toit jardin.

Apart an exception, the views after the digital model have been generally rendered in greyscale to avoid hazardous hypothesis about the colors of the walls both for Le Corbusier used to decide the polychromie architecturale only in the final stages of the building and to let the reader focus primarily on the light and space effects.

\subsection{Early considerations}

As evidenced by the reconstructive model, the structure appears a reworking of the Maison Citrohan model through the experience of Parisian villas but rigidly organized in modules (fig.4), according to a policy that dates back at least to the studies of the working-class district of Pessac a decade before. Even the sketched plans evidence the division into cells and semi-cells, to which double heights and stairs accorded. In the house Le Corbusier had designed for Marguerite Tjader Harris five years before, he had demonstrated his ability to build a villa with standardized structures on the steep slope of Vevey where a forest of pilotis supported three rectangular volumes mutually orthogonal and hinged on the staircase tower. Perhaps his attendance of the woman combined with both the direct experience of the Ford's assembly line and the short time to design the house, convinced him to follow such a way.

What does this project means as part of Le Corbusier's travel to United States? It might look like a manifesto drawn up for the benefit of American people but certainly cannot be considered as a perfect application of his five points. Pilotis are still supporting the main volume but, at the same time, the bird's eye view (fig.5) reveals that the end wall is in masonry, as already experienced in the Swiss Pavilion and the houses in Les Mathes, for example. There is no trace of the free plan, although during the lectures he highlighted its importance, emphasizing even the use of mobile partitions ${ }^{21}$. On the other hand, the fenetre-en-longueur still reminds the gains of the free façade as well as the principle of the roof-garden is applied extensively, well beyond the actual possibilities of using open spaces with the climate of Michigan.

The house is rather the expression of a moment of transition between the idealism of the heroic period and local contingencies, in response to both changing economic conditions and his growing interest towards local building techniques and materials. It appears as a malicious synthesis of regionalism, vernacular, purism, avant-garde and the International Style, which was intended to educate timid or convert the infidels.

\footnotetext{
21 “When I do a house, I use les cloisons mobiles, movable partitions ... by a free plan”. Quoted in Bacon, op. cit., p. 89.
} 

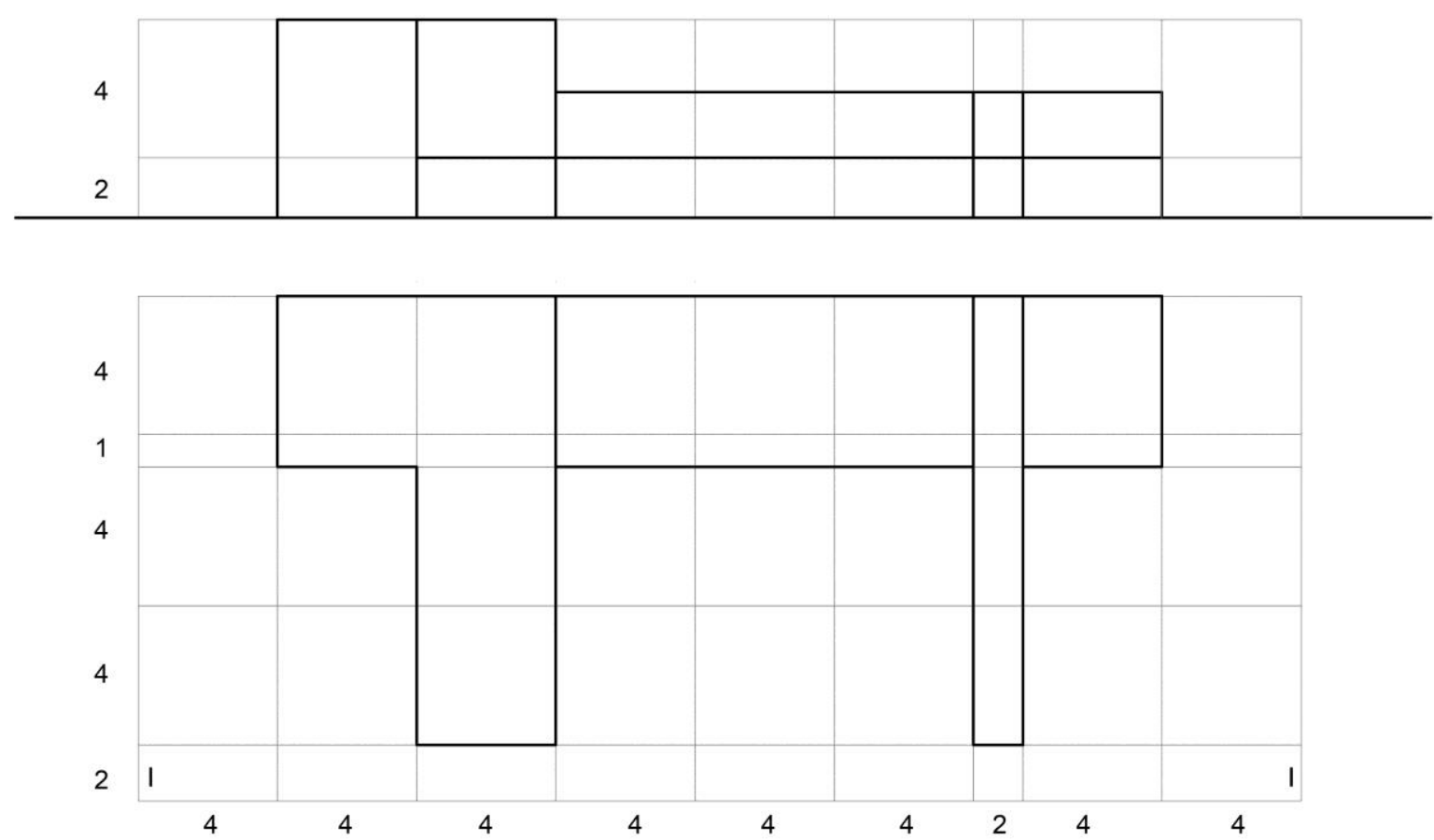

4. Modular scheme of plan and section of the President's House reconstruction model (drawing by F. Colonnese).

\section{The House as an aesthetic machine}

Apart the ordinary functions related to domestic life that can be only imagined from Le Corbusier's sketches, the house for Joseph Brewer is conceived to play at least four aesthetic functions at the same time: it is a model, a symbol, a theater, and a machine to (teach how to) see.

First, the house is a model to satisfy the US conditions of production and commissions and to direct the construction criteria towards standardization and prefabrication. Its volume was a direct expression of its modular skeleton but plastered surfaces diluted the effect of repetition of forms. The pillars and the larger windows manifest the module while the uprights of windows and balustrades exhibit sub-themes and rhythmic variations. The building appears as a villa specifically designed for a client and, at the same time, it suggests the implicit potential of other combinations of the same constituent elements, like a full-scale model useful to experiment the new architecture potentials and to convey both the process that generated it and its alternative outcomes.

The house of the president was the building of the highest authority of the campus, which is inevitably an architectural symbol. The archetype (unconsciously?) chosen by Le Corbusier is the Acropolis on which reside the deity in charge of the government of men. The basement becomes a podium partially clad in stone, as if it were part of the ground, and the parallelepiped transfigures into a temple supported by slender columns and deputed to administration and control. Consistently its windows look like open eyes to watch literally and metaphorically on campus life. Interpreting the window as a face, the entire volume of the building might well suggest an animal guarding the campus by turning its long neck in the same direction of the ramp / tail. But of course the whole composition could be interpreted as an architectural allegory of the cultural superiority of Europe over America, with the white perfect monolith left onto the altar by the priest of the new architecture for a new knowledge, not too differently from Stanley Kubrick's black monolith in 2001: A Space Odyssey. 


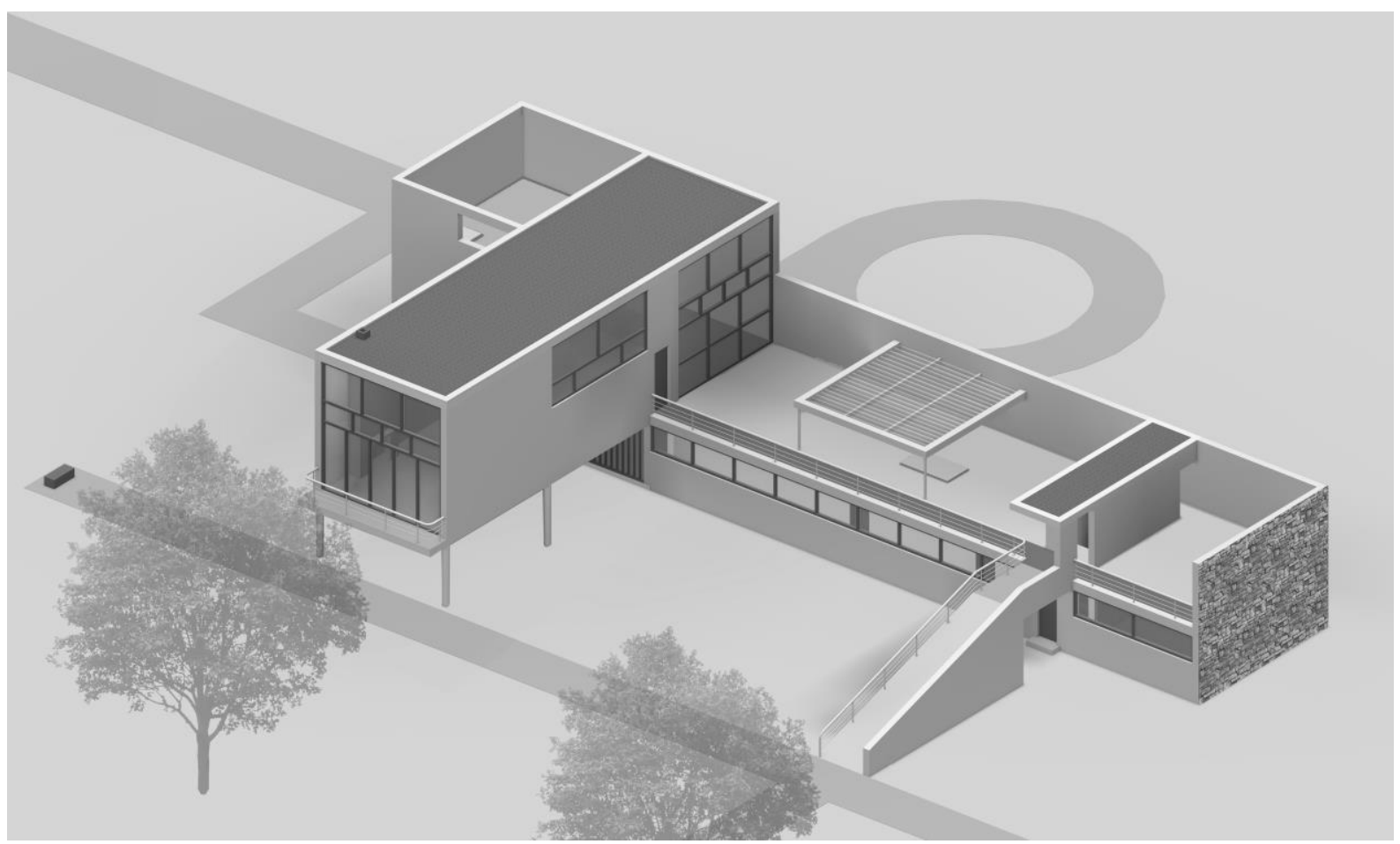

5. Axonometric view from the President's House digital model (picture by F. Colonnese and S. Gioja).

The house was also the place where students could meet the president. Thus the basement not only provided a physical limit to the campus, but appeared as a large stage on which the students' ritual ascension to the president could come to life and theatrically manifest. The back tall wall was obviously conceived for protecting people and plants from the wind but also to define a scenic box and emphasize the movements of the students / actors on the stage while a light textile structure, like a canopy, fixed the focus of the scene. Obviously the rite was choreographed by the elements of the promenade architecturale. Students would indeed walk the ramp, direct continuation of the campus avenue, up to the level of the roof garden and then would follow a transversal path, remaining in sight until they enter the parallelepiped.

Such a mise-en-scene of a procession along ramps and terraces, which partially replicated the route of the Cité de Refuge, will emerge again in highest spiritual content projects, such as the church of Saint Pierre at Firminy, the Palais des Assemblées at Chandigarh ${ }^{22}$ or the Convent of La Tourette, in which sentiers aériens would favor the "vision of monks in filing along the ramp, chanting psalms right up to the cloister in a spectacular staging of liturgical life", representation of community life (or perhaps even a parody in the form of an assembly line...). After reappearing behind the square window projected on campus, students would be framed by the enclosure, looking like acting in a floating theater box or one of those television sets that began to be commercialized in the same years.

${ }^{22}$ Curtis, William J.R.: “Abstractions and representations. Le Capitol de Chandigahr, paysage de symboles”. In Le Cahiers de la recherche architecturale et urbaine. "Le Corbusier. L'atelier intérieur". Février 2008, $\mathrm{N}^{\circ} 22 / 23$. Paris: Editions du patrimoine/Centre du monuments nationaux, 2008, pp. 151-176.

${ }^{23}$ Potie, Philippe: Le Corbusier: Le Couvent Sainte Marie de la Tourette. Basel - Boston - Berlin: Birkhäuser; Paris: Fondation Le Corbusier, 2001, p. 102. Le Corbusier's second sketch for La Tourette (FLC 1149 of 25.05.1954), rejected by the religious, entirely focused on the idea of a monumental ramp to integrate the cross central distribution to set up a system of sentiers aériens. 
Observing the plants, it is clear that if only Le Corbusier had wanted, he could have solved the public access to the President's House in a much quicker and unnoticeable way. Instead he chose to put a ramp far from the box in order to lengthen the access path and turn it into a theatrical event. The house for Le Corbusier was a place of action: his boxes were containers for dramas, a stage for the comedy of modern life ${ }^{24}$, where to see and be seen in constant motion. Something like that happened in the same years in the houses Adolf Loos designed for Möller, Tzara and Müller ${ }^{25}$, with the dining room in form of raised stage with a curtain but this aspect was never at the expense of family intimacy. Le Corbusier rather neglected often his customers' requests for privacy. He used to design houses with a theatrical and voyeuristic quality, according to a sort of mediatized domesticity as coined by Charles Rice ${ }^{26}$, with whom Le Corbusier tried to respond to the changing sentimental needs of a bored society. A letter of 1937 in which Emilie Savoye expressed to Le Corbusier his opposition to the people the architect sent constantly to visit the villa, reveals that he considered the houses he had designed like a public building or, at least, open to his both actual and potential clients, with the result that dwellers were reduced to actors for the benefit of their (unwanted) guests ${ }^{27}$, like in a concept art event.

\section{The Promenade Architecturale}

The idea of promenade architecturale Le Corbusier arranged since the days of the house-atelier for the painter Ozenfant $^{28}$, can be defined as an aesthetic kinematic device to explore space and architectural surfaces as well as to unveil the landscape through the architectural frame. After Princeton and Vesser, also his lectures in Kalamazoo and Chicago focused on this concept. After quoting graphically basic geometric solids on the long sheets hanged on the wall, Le Corbusier analyzed the issue of perception of a viewer moving in space by drawing a double sinusoid touching a number of polygons. This schematic plan view of an undulating route that crosses various rooms is the trace of the promenade: "the Bonhome, the visitor, drawn in silhouette, is the true subject and actor of the architectural experience; the route [is] the instrument through which the visitor experiences the situations that affect his senses, from the plastic forms that crosses his eyes" ${ }^{\prime 29}$. Below, a section of three rooms of different height and proportion exemplified the question of relativity of spatial experience as dependent on the direction of walk and the crossing sequence. On the right Le Corbusier summed up in six cases the relationship between the human body and different ground lines, while three perspective sketches showed the way the size and position of the openings affect the perception of interiors.

Place, spatial sequence, landform, views, epiphany of space through light, architectural experience: in a few diagrams Le Corbusier synthesized the ingredients of his architecture conceived in form of promenade. The President's House for Joseph Brewer seems to be a sort of compendium of this idea that can be appreciated only by walking it, albeit virtually.

\footnotetext{
${ }^{24}$ Damisch, Hubert: "I teatrini della vita moderna”. In Le Corbusier. Enciclopedia. Milano: Electa, 1987, pp. 292-308.

${ }^{25}$ Colomina, Beatriz: "Intimacy and Spectacle: the Interiors of Adolf Loos". In AA Files, Autumn 1990, N ${ }^{\circ}$ 20, pp. 5-15; “The Split Wall: Domestic Voyeurism”. In Colomina, Beatriz (Ed.): Sexuality and Space. New York: Princeton Architectural Press, 1992, pp. 73-130; Colonnese, Fabio: “Ornamento, delitto e colore”. In Rossi, Maurizio (Ed.): Colore e colorimetria. Contributi Multidisciplinari, vol. VII A. Roma: Maggioli Editore, 2011, pp. 207-214.

${ }^{26}$ Rice, Charles: The emergence of interior. Architecture, Modernity, Domesticity. New York: Routledge, 2007, p. 112.

${ }^{27}$ Colomina, Beatriz: "Vers une architecture médiatique". In Le Corbusier - The Art of Architecture. Weil-am-Rhein: Vitra Design Museum, 2007, p. 261.

${ }^{28}$ Benton, Tim: The villas of Le Corbusier and Pierre Jeanneret 1920-1930. Basel; Boston; Berlin: Birkhäuser, 2007, pp. 3542.

${ }^{29}$ Quetglas, Josep: “Con el publico en sùspenso". In Circo. "El corazòn del tempo". No 91, 2001, p. 6 (translated by the author).
} 


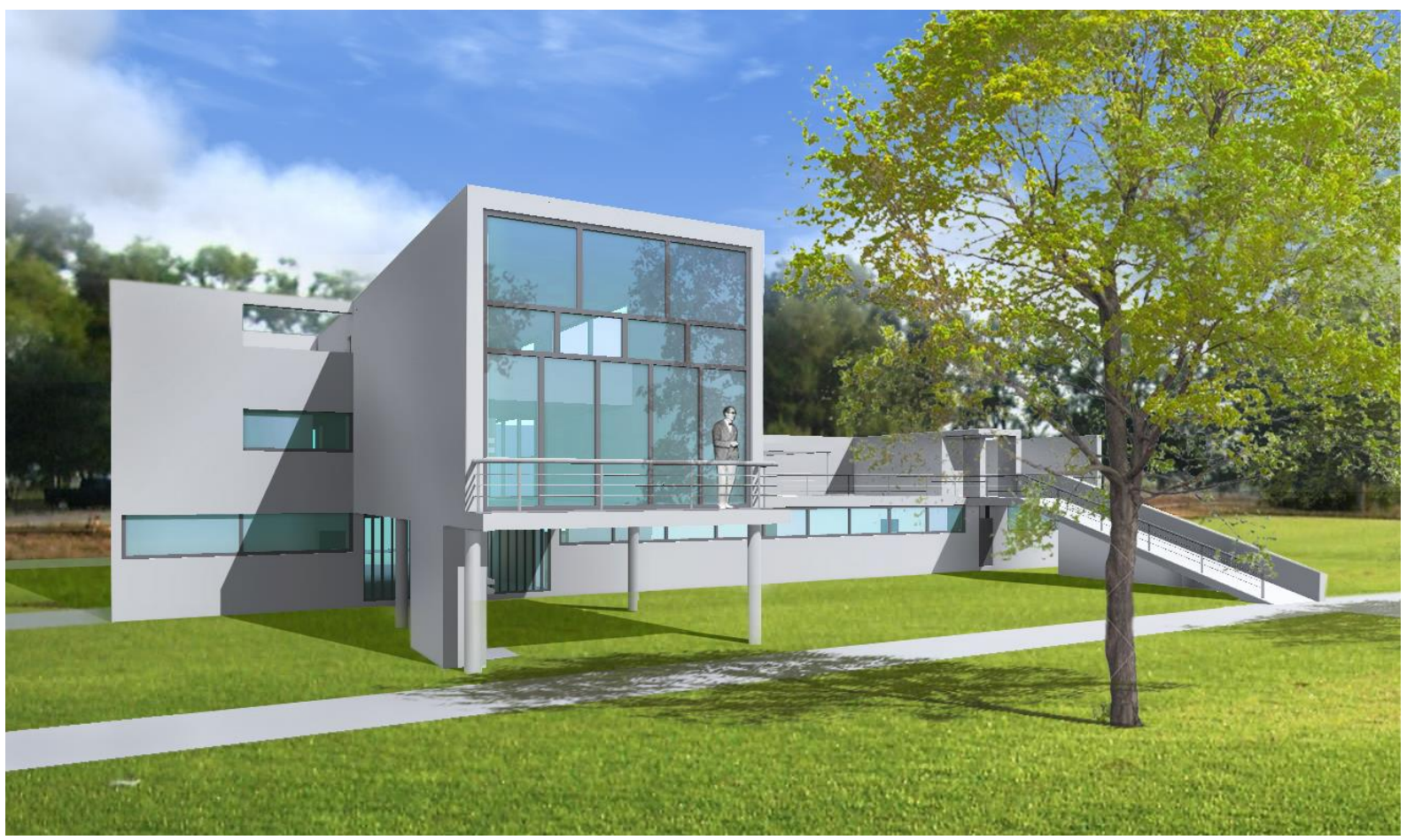

6. Rendered view from the President's House digital model with hypothetical chromatic effect (picture by F. Colonnese).

While the students approach the house, it looks like an architectural unit, but the eccentric position of the avenue to the ramp produces a virtual rotation of the long jutting volume. Before arriving at the ramp, a last transversal street cross the avenue but it looks blocked by barriers that seem to have the task of constraining the visual domain from which the building can be observed (fig.6). The ramp, which Le Corbusier often placed parallel to the body of his buildings, appears here placed perpendicularly to it. In this way, before appearing as a sign indicating the way to ascent, it is a connection, a piece of soil raising to join two levels together. The small volume containing the stair to solarium, constitutes the first enigmatic focus at the end of the ramp. Like many picturesque $^{30}$ gardens, the whole promenade is indeed organized in tranches animated by specific visual foci that are revealed at every passage and change of direction, passing by degrees from the monumental tone of the cantilevered volume to intimate atmosphere of the jardin clos (fig.7).

${ }^{30}$ About the picturesque heritage in Le Corbusier's concept of Promenade Architecturale, see: Etlin, Richard A.: The Romantic Legacy. Frank Lloyd Wright and Le Corbusier. Manchester: Manchester University Press, 1994; Macarthur, John: The Picturesque: Architecture, Disgust and other Irregularities. New York: Routledge, 2007; Bois, Yve-Alain; Shepley, John: "A Picturesque Stroll around 'Clara-Clara'”. In October, Summer 1984, N²9, pp. 32-62. Cambridge (Mass.): The MIT Press, 1984. DOI: 10.2307/778306; Colonnese, Fabio: Movimento Percorso Rappresentazione. Fenomenologia e codici dell'architettura in movimento. Roma: Officina Edizioni, 2012. 


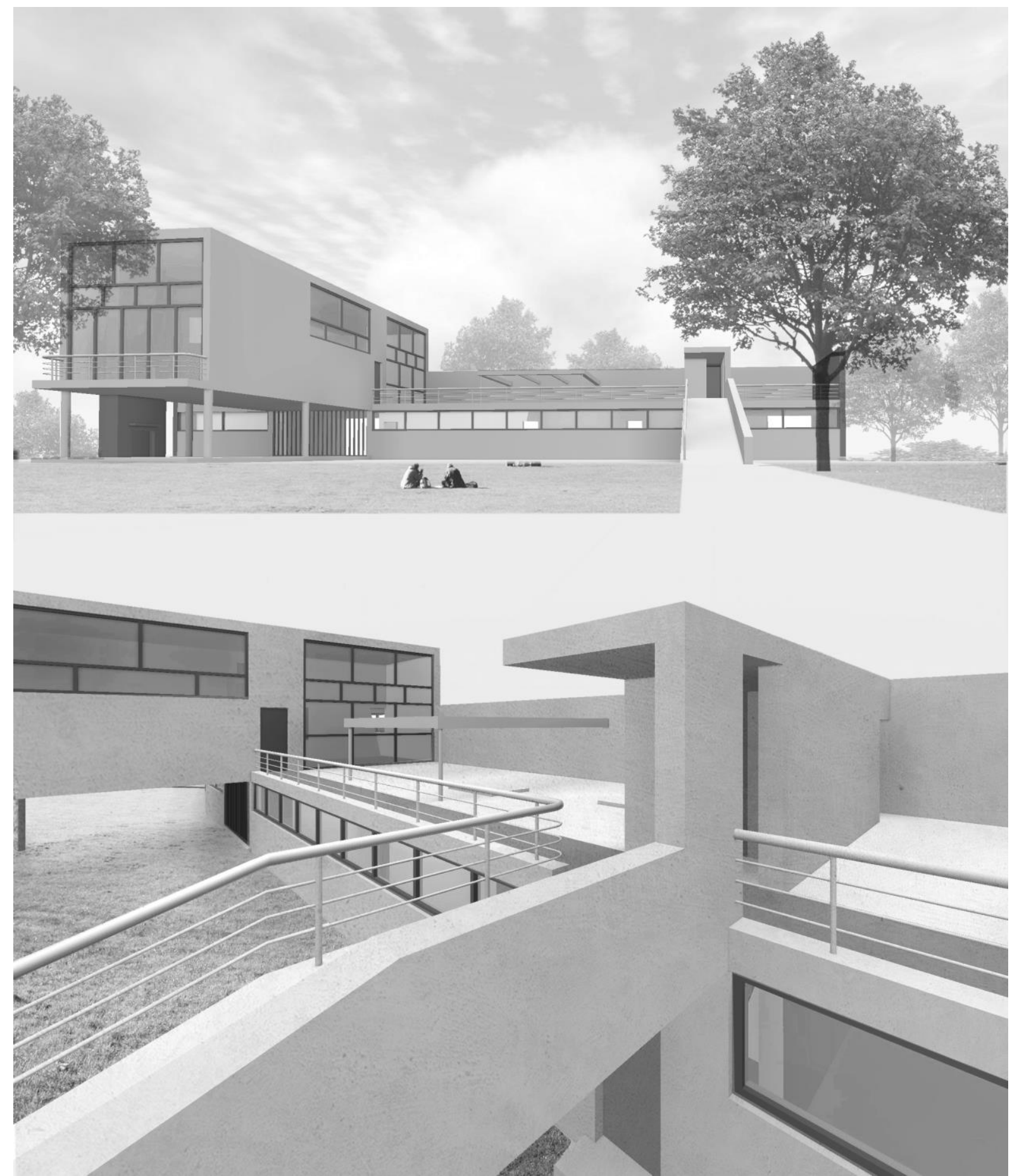

7. Rendered views from the President's House digital model along the promenade (picture by F. Colonnese).

The ramp is quite steep ${ }^{31}$ and abruptly slows the students, altering their pacing. They are then invited to direct their gaze around, focusing on what appears virtually moving without the fear of falling, like on a stair. A few steps later, as their eyes pass over the floor level of the étage, the roof garden appears to them as an unexpected revelation of a new world to be explored.

\footnotetext{
${ }^{31}$ The reconstruction revealed that the ramp would have an inclination of almost $30^{\circ}$, steeper than both that of Villa Savoye $\left(17^{\circ}\right)$ and that of Maison La Roche $\left(27^{\circ}\right)$.
} 
At its top the ramp turns into a short horizontal bridge: it leads under a shaded canopy that seems appositely designed to frame the long parallelepiped and indicate the new direction of the route (fig. 8). From here on the long slab looks like a two-dimensional plane that occupies the whole field of view of the students. Following the tall garden wall advancing gazes penetrate the large square windows into the dining room; then the eyes slide up, to decipher the role of the upper studio window and discovering the existence of an additional floor which becomes the new goal to reach, although it is not yet clear how. Until now the gaze anticipated and addressed the body along an ascending anti-clockwise trajectory that appears a version wider than the one that can be experienced either in Maison La Roche or Villa Savoye.

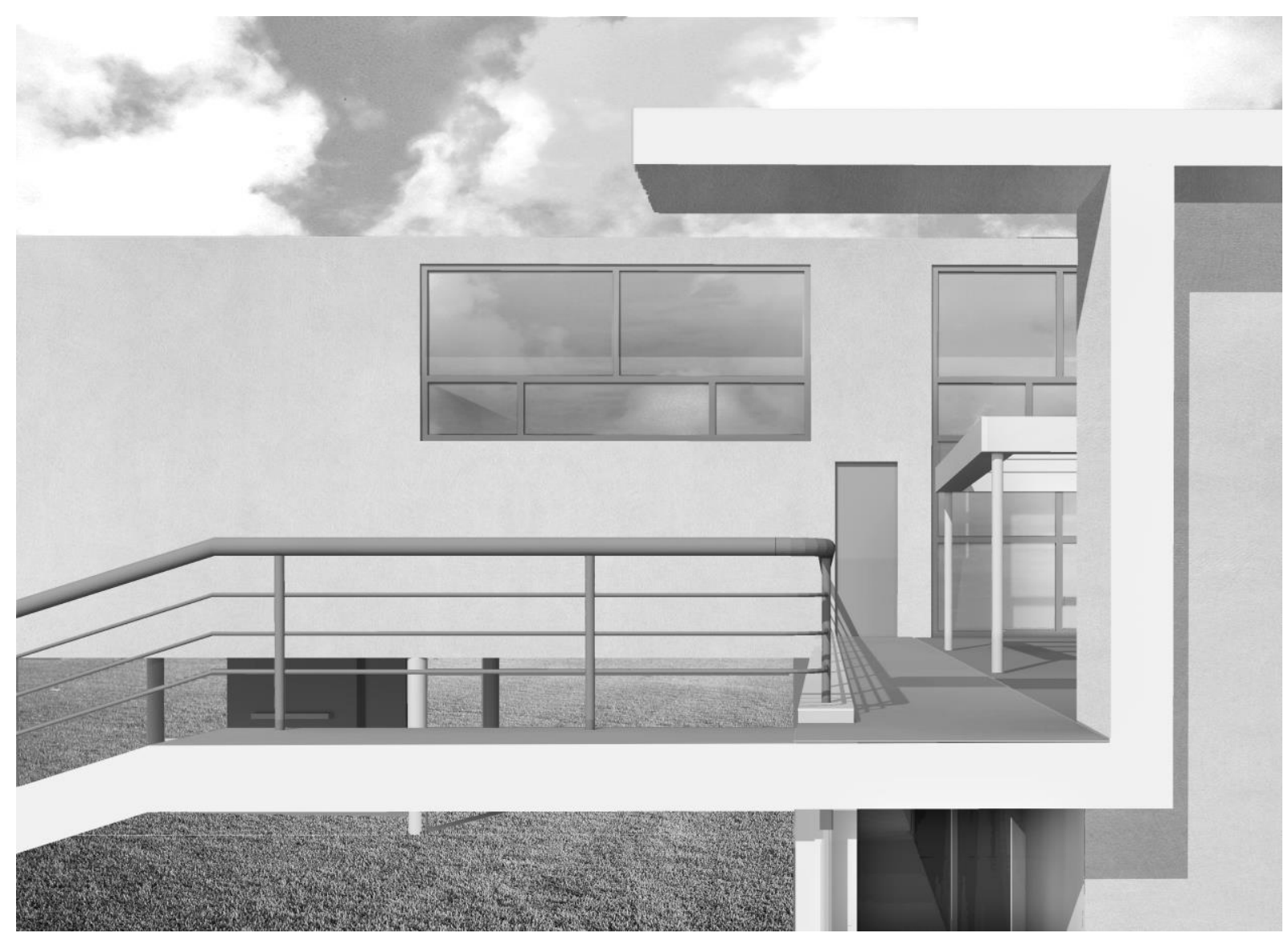

8. Rendered sectioned view from the President's House digital model along the promenade (picture by F. Colonnese and S. Gioja).

The door opens at the connection point between the dining room and the living room, revealing the existence of a staircase (fig.9) and the mezzanine predicted from the outside ${ }^{32}$. Here the path forks: the students are oriented to the left, called by the light coming from the large window that frames the campus. Friends and colleagues of the president instead have access to the stair that on the way up provides pulpits for looking over the dining room and discerning the roof garden design. From the study of the president one can finally appreciate and review all the way walked up to this point and enjoy a vantage point over the campus, with a floating sensation amplified by the distance between the railing of the mezzanine and the window glass plane. Only after watching the

\footnotetext{
${ }^{32}$ Perhaps an high window would have revealed the existence of the jardin clos from the sale à manger, like in Maison Cook, but there is no clue of it in the sketches.
} 
landscape through the architectural frame and becoming aware of the promenade, one can access the final chambre a ciel ouvert with only one unfiltered window to the horizon line.

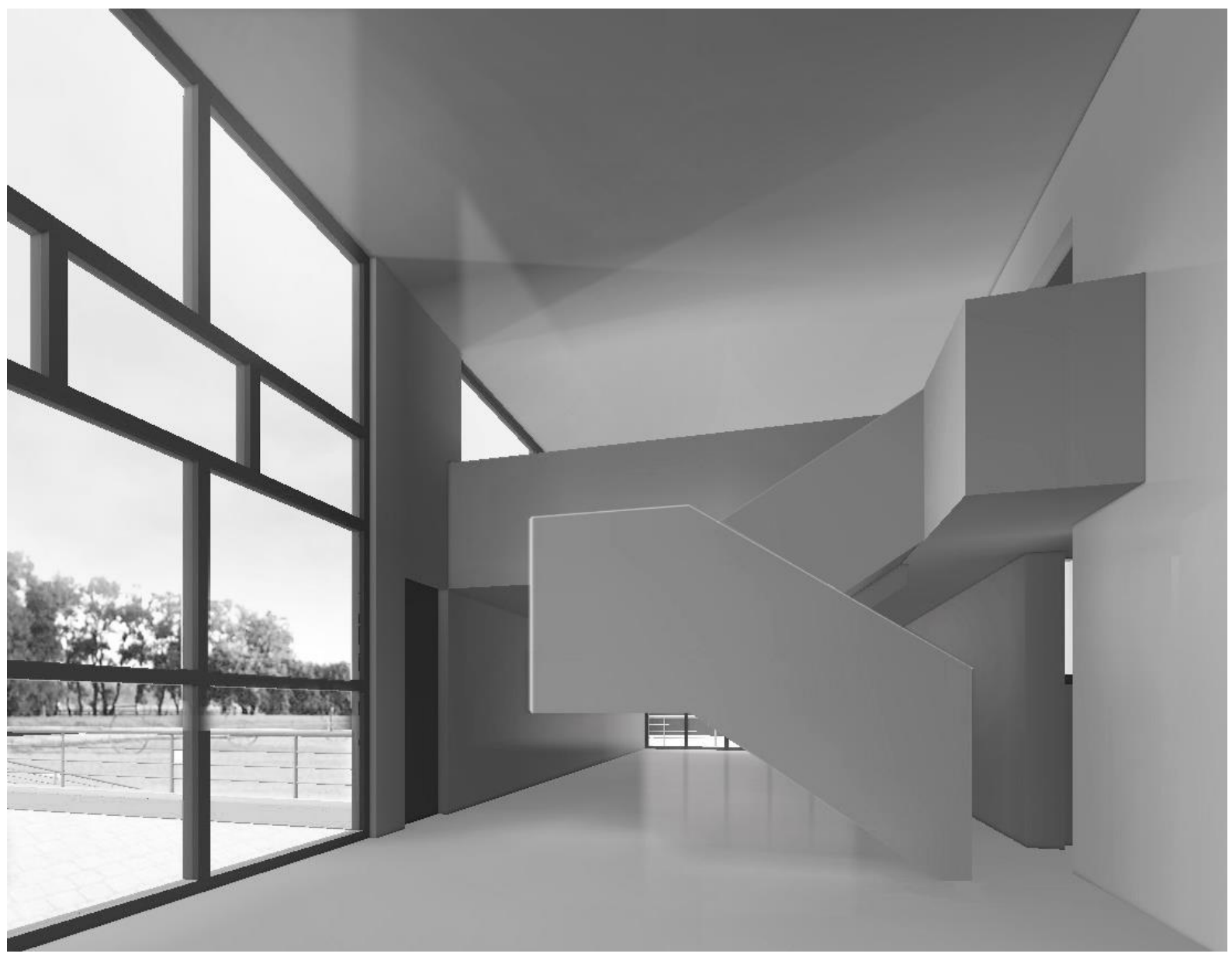

9. Rendered view of the Salle à manger from the President's House digital model (picture by F. Colonnese).

\subsection{Representation, Montage and Intertextuality}

The virtual exploration of the house highlights two aspects that could be qualified by the same term: assemblage. Not only the house is designed as an assemblage of pre-established parts but the promenade architecturale unveils it by following the principle of the montage as theorized by Sergej Eisenstein ${ }^{33}$. Several elements confirm the cinematic conception of this architecture: the existence of precise visual stations along the route; constraints and barriers aimed at defining the unit of space; partitions and window frames designed to suggest a unity of time; the use of the ramp that allows the eye to move rather freely flowing on surfaces apart and staring, a moment later, at close details; the opacity designed to contain the visual field and, on the contrary, the transparency to let the eye penetrate from outside to inside and vice versa. Although the body is not allowed that a linear route, the eye is invited to enrich it with come off, zoom and wide shots that increase the fictive quality and associate precise visual values to bodily sensations, enhancing the spatial experience. As Le Corbusier wrote

\footnotetext{
${ }^{33}$ See: Bois, Yve-Alain, Glenny, Michael: "Montage and Architecture”. In Assemblage, 1989, №10.
} 
in Urbanisme, "The eye should not always be stimulated in the same manner, or it becomes tired; but give it the necessary 'rotation' and change of scene and your walks will be neither tiring nor drowsy" 34 . But there is more:

"Behind the eye is that agile and generous, fecund, imaginative, logical and noble thing: the mind" 35 .

Le Corbusier's pictorial experiences with purist and cubist space gave him not only a peculiar sensibility toward the representation in and of motion ${ }^{36}$ but also a further mental level of reading of architecture itself. As observed by Reichlin, in a number of the paintings he depicted in twenties, objects seem to have been extracted from spaces following different modes of representation and then assembled in the same view. A similar ambiguity can be experienced in his architecture, by considering it as an assemblage of parts viewed with different perspective laws and assembled along the architectural promenade which Reichlin properly defined as the "guide to the reading of a work" 37 .

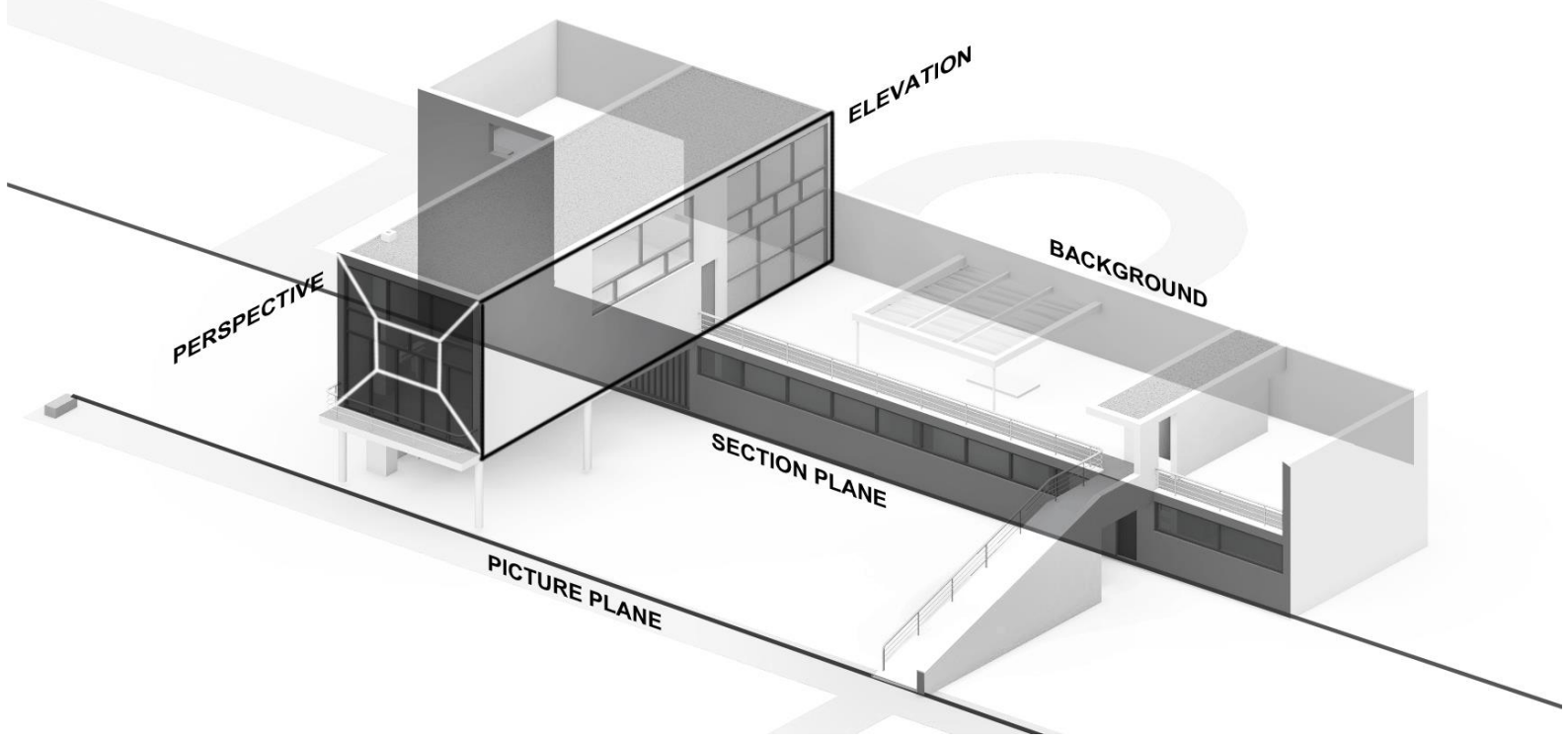

10. The house as a representation set (picture by F. Colonnese).

The abstraction of its forms announces this fictive character of the house. From a distance the composition reminds Adolphe Appia's geometric scenes Le Corbusier could appreciate during his travel to Hellerau in $1910^{38}$ as well as one of those descriptive geometry exercises showing shaded solids onto plinths and inclined planes. The transversal path along the approaching route signs the trace of the ideal perspective plane: by crossing this invisible threshold one leaves the reality and move into the representation arranged by the architect (fig.10). From this moment on everything starts to appear flat, consisting of two-dimensional planes: even the volume of the house can no longer be seen but in a frontal way. The basement appears instead the result of a vertical section in which the part closer to the viewer has been deleted and four thin pillars have been added to support the long parallelepiped. Such a volume looks like a real declaration of independence from gravity and, therefore, from

\footnotetext{
${ }^{34}$ Le Corbusier: The City of Tomorrow and Its Planning. New York: Dover, 1987, p. 62.

${ }^{35}$ Ibidem

${ }^{36}$ See: Colonnese, Fabio: "Note su alcuni disegni “panoramici” di Le Corbusier”. In Disegnare Idee Immagini. 2012, N 43, pp. 26-35.

37 Reichlin, Bruno: "Jeanneret-Le Corbusier, pittore-architetto". In Bardati, Flaminia; Rossellini, Anna (Eds.): Arte e architettura. Le cornici della storia. Milano: Bruno Mondadori, 2007, pp. 195-196.

${ }^{38}$ See: De Simone, Rosario: Ch. E. Jeanneret-Le Corbusier: viaggio in Germania 1910-1911. Roma: Officina Edizioni, 1989. p. 110.
} 
reality. It is virtually reduced to an elevation, to a flat representation of the modules and geometries that regulate its dimensions and proportions. After a few steps toward it, the large window on the dining room restores the third dimension to the long rectangle but always as an image behind the glass, this time literally.

The front door leads into a different dimension, like passing behind the scene of a theatre and invokes an impossible panoramic overview of the long transverse volume, similar to what can be experienced by entering the church of the Monastery of La Tourette. The viewer is thus forced to rotate his/her gaze and can grasp only parts of the interior space engulfed by the upper soupente. The double height not only serves to direct the field of view but also to offer an aesthetic and pedagogical experience ${ }^{39}$. Only beyond the lower ceiling perspective view is fully back and one might exclaim: "the four oblique lines of a perspective! The room is installed in front of the site. The whole landscape enters the room" ${ }^{40}$ under a generous portion of the sky. Paraphrasing Reichlin's words for the preliminary design of Villa Stein, "by following the path of the promenade the visitor catches then, from time to time or simultaneously, the vertical cross-section, the horizontal section, the interior, the exterior, the volume, etc. the terrasse jardin - namely, the constant and invariant features of the architectural object ${ }^{\circ 1}$. But even this view is still a representation, however, divided into an altarpiece or in a comic book panel by the window mullions. To definitely escape from the fictive world of the Brewer House one would need to go out on the balcony: in fact the vertical glass coincides with the perspective plane before the ramp and by trespassing it the viewer gets back literally and metaphorically the freedom to move and observe without filters but having learned to see.

Of course, such a metamorphic transfiguration of physical things into pictures and then images is part of a mental journey that needs the contribution of the spectator, as specifically required by Le Corbusier himself: "We can create symphonies. To be soothed by certain forms, to realize how they were conceived, by what relationships they were brought together, how they answer to a need which has become articulate, how they rank in one's personal scheme of chosen images. To measure, to compare indeed; to share with their creator his raptures and his torments..."42. He clearly asked the spectator to become an actor, to measure and compare with his/her body, and invoked personal imagery to give sense to the work. Thus such an assemblage house performs also an intertextual action: it is a text speaking of and to other texts.

Through the abstraction of its forms, the house works as a representation to involve the mind and the body of the spectator; despite the abstraction of its forms, there are always elements that explicitly refer to the monuments of the past Le Corbusier sketched on his early notebooks. From this point of view, many of his houses could be included in the category collection as intended by Charles Moore ${ }^{43}$ to describe the gardens that have the ambition to gather models of faraway places. Some historical references of the Brewer project have already been mentioned, and others could be more or less arbitrarily cited as the sanctuary at Palestrina, the Vatican Belvedere, the Charterhouse of Ema, the walls of Vesuvian villas with tree tops sprouting above them, the ramps of the Roman palaces, etc. But while in his earlier works the relations appear direct and sincere to the limits of

\footnotetext{
${ }^{39}$ As confidentially suggested by Le Corbusier's follower Henri Ciriani, it is important to offer those who grew up in a home the experience of different points of view to frame things, physically and consequently, mentally. Henri Ciriani, interview with the author, April 4, 2007.

${ }^{40}$ Gresleri, Giuliano; de Pierrefeu, Francois, Le Corbusier: La casa degli uomini. Milano: Jaca Books, 1985, p. 97. Le Corbusier's words actually commented his famous sketch of Rio de Janeiro.

${ }^{41}$ Reichlin, op. cit., p. 194 (Italic in the text).

${ }^{42}$ Le Corbusier, The City of Tomorrow, op. cit., p. 62.

${ }^{43}$ Moore, Charles W.; Mitchell, William J.; Turnbull, William, Jr.: Poetics of Gardens. Paperback edition. Cambridge: MIT Press, 1993, p. 79.
} 
the unconsciousness, in the President's House they appear mischievously mediated by solutions developed in his previous works. Of course, this is a project developed within a few hours and he could not help picking up prepared solutions from his repertory: almost the result of an automatic design / drawing session that indirectly reveals the continuous underground metamorphic process affecting his previous designs ${ }^{44}$. For example, the basement reminds the attic of Villa Stein, the ramp is reminiscent of the Maison de Week-end at Rambouillet while the double-height living room slavishly follows the interior of Pavilion de L'Esprit Nouveau, at the time generally acclaimed by American critics ${ }^{45}$. This process testifies not only an instinctive form of economy as a way to recover or recycle solutions from the repertory but a form of aware mannerism that here seems to turn into a self-quoting propaganda by densifying the network of formal relationships between his works in order to increase his fame.

The house is consequently primarily an intertextual ${ }^{46}$ work, which implicitly relies on a "cooperative interpretation" ${ }^{\prime 47}$ by the viewer to complete and give sense to its parts. The same choice to present the project in the form of sketches on the Oeuvre Complete emphasizes not only the importance Le Corbusier attributed to this design, even for possible future applications, but that implicitly the rough or missing elements could be reconstructed by the reader by referring to the repertoire of drawings and photographs in the previous pages. Even this apparently innocent choice has the indirect consequence to confuse the threshold between actual and virtual, between real and representation, like in many other parts of his books ${ }^{48}$.

\section{Conclusions}

Le Corbusier's travel to United States was quite a total fiasco and the project offered to Brewer was not realized as well as generally ignored by critics. Yet it is a significant event for both the special conditions in which it was designed and the architectural and even urban values it expresses. The theme of the house for the president of a college must have appeared to Le Corbusier in fact as an extraordinary opportunity to combine intensive studies on contemporary house with the idea of an initiatic and educational architecture inside a micro-urban community.

The house both is and looks like a Le Corbusier's house and, despite the original volumetric configuration, it establishes close relationships with his earlier works, especially with single-family residences of the twenties. Its role can be further clarified by the comparison with an episode of his travel to Latin America. During one of his public meetings, he proposed a design for a housing development to be completed by 17 replicas of Villa Savoye $^{49}$. In that case he had chosen to turn his most famous work - the result of a sophisticated tailoring design to the needs of the Savoye family - into a prototype for an housing development, offering his potential clients an already finished product to be sold. With the house for Joseph Brewer Le Corbusier changed his approach: he

\footnotetext{
${ }^{44}$ Quetglas noted that during the Princeton lecture Le Corbusier had drawn a plan of Villa Savoye differing from the built version, as if the architect had not stopped its formal development. Quetglas, op. cit.

${ }^{45}$ A New York Times anonymous reporter suggested a direct relationship between the "modern villa" full of "light, air and space", and the "American engineering". "Art of the Day in Many Galleries". In New York Times, 16 March 07, 1926.

${ }^{46}$ See: "Le Corbusier. L'atelier intérieur". Le Cahiers de la recherche architecturale et urbaine , février 2008, n. 22/23.

Paris: Editions du patrimoine - Centre du monuments nationaux, 2008.

${ }^{47}$ The definition comes from Eco, Umberto: Lector in Fabula. La cooperazione interpretativa nei testi narrativi. Milano: Bompiani, 1979.

${ }^{48}$ See: Naegele, Daniel: “Savoye Space. The Sensation of the Object”. In Harvard Design Magazine. 2001, № 15.

${ }^{49}$ Project d'adaptation de cette type de maison pour l'Argentine, aux environs de Buenos Aires... Le Corbusier; Jeanneret, Pierre. Oeuvre Compléte. Volume 2. 1929-1934. 15th edition. Basel - Boston - Berlin: Birkhäuser Publishers, 2006, p. 28.
} 
did not offer any more a post-Palladian monolith valid for any geographical and settlement condition but designed a building to respond both to functional and environmental requests of the college; moreover he conceived its form as the result of an assemblage of modular parts and solutions previously tested. More than a product Le Corbusier therefore offered a process and validated his proposal by citing recognizable elements out of his repertoire, as the floating box, the ramp, the strip window and the double height living-room: a process to convert with the "timid" American people to his own idea of modern life by revealing the potential of their own production processes and maliciously requiring their collaboration for deciphering all the layered meanings of his work. The house is therefore a sort of full-scale model and this fictitious atmosphere is declined throughout the promenade architecturale regulating the space exploration and turning the building into an educational device for the students and intellectuals who would follow the occult choreography of the Swiss master.

\section{Bibliography/references}

Bacon, Mardges: Le Corbusier in America. Travels in the Land of the Timid. Cambridge (Mass.) - London: The MIT Press, 2001

Bois, Yve-Alain, Glenny, Michael: “Montage and Architecture”. In Assemblage, December 1989, №10

Bois, Yve-Alain; Shepley, John: “A Picturesque Stroll around 'Clara-Clara”'. In October, Summer 1984, N2 29, pp. 32-62. Cambridge (Mass.): The MIT Press, 1984. DOI: $10.2307 / 778306$

Colonnese, Fabio: “Note su alcuni disegni ‘panoramici’ di Le Corbusier”. In Disegnare Idee Immagini. 2012, ${ }^{\circ}$ 43 , pp. $26-35$

Colonnese, Fabio: Movimento Percorso Rappresentazione. Fenomenologia e codici dell'architettura in movimento. Roma: Officina Edizioni, 2012

Etlin, Richard A.: The Romantic Legacy. Frank Lloyd Wright and Le Corbusier. Manchester: Manchester University Press, 1994

Gresleri, Giuliano; de Pierrefeu, Francois, Le Corbusier: La casa degli uomini. Milano: Jaca Books, 1985

Hitchcock, Henry-Russell: “Le Corbusier and the United States”. In Zodiac. 1966, N 16, pp. 6-23

Le Cahiers de la recherche architecturale et urbaine. "Le Corbusier. L'atelier intérieur". Février 2008, $\mathrm{N}^{\circ}$ 22/23. Paris: Editions du patrimoine/Centre du monuments nationaux, 2008

Le Corbusier Sketchbooks. New York - Cambridge (Mass.): Architectural History Foundation and the MIT Press, 1981-1982

Le Corbusier: When the Cathedrals Were White: A Journey to the Country of Timid People. New York: Reynal and Hitchcock, 1947

Le Corbusier; Jeanneret, Pierre. Oeuvre Compléte. Volume 2. 1929-1934. 15th edition. Basel - Boston - Berlin: Birkhäuser Publishers, 2006.

Le Corbusier; Jeanneret, Pierre: Oeuvre Complète. Volume 3. 1934-38. 14th edition, Basel - Boston - Berlin: Birkhäuser Publishers, 2006.

Macarthur, John: The Picturesque: Architecture, Disgust and other Irregularities. New York: Routledge, 2007

Masuishi, Shinichi; Ando, Tadao: Le Corbusier. Houses. Tokio: TOTO, 2001

Potie, Philippe: Le Corbusier: Le Couvent Sainte Marie de la Tourette. Basel - Boston - Berlin: Birkhäuser; Paris: Fondation Le Corbusier, 2001

Rice, Charles: The emergence of interior. Architecture, Modernity, Domesticity. New York: Routledge, 2007 


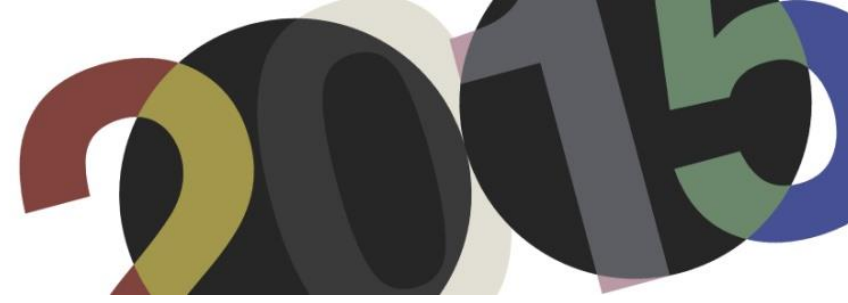

DOI: http://dx.doi.org/10.4995/LC2015.2015.960

\title{
Le Corbusier Roof-Spaces
}

\section{A. Como, I. Forni, L. Smeragliuolo Perrotta}

University of Salerno, Italy

\begin{abstract}
From technical solution, the roof-garden became a key spatial theme within Le Corbusier's work and creativity, evolving to become a fundamental component of his vision for the contemporary city. The roof garden is an open space in which to cultivate both the mind and body, and to experience a direct relationship with nature; through plants, the sky, and the sun, the urban and the natural world are combined together in the surroundings. This article follows the principal steps of Le Corbusier's research, starting with his initial experimentation in his own apartment studio in rue Nungesser-et-Coli, through to the complex development at the Unité. It follows how the roof garden becomes an optical device toward the horizon and a strong evocative instrument. The relationship with the nature and the horizon are the key of readings of several selected design projects which demonstrate at the same time the continuity of the research and the richness of the variations on the theme itself. The roof garden is one of the most fertile topics of Le Corbusier's legacy, evident in contemporary architectural developments.
\end{abstract}

Resumen: A partir de una solución técnica, el roof-garden se convierte en el tema central del trabajo y de la poética de Le Corbusier, evolucionando para convertirse en un componente fundamental de su visión de la ciudad contemporánea. El roofgarden es un espacio abierto en el que el hombre puede cultivar la mente y el cuerpo, donde se puede experimentar una relación directa con la naturaleza -la vegetación, a través de las plantas, el cielo, el sol, el urbano -y el mundo natural se combinan juntos en los alrededores. Este texto sigue los pasos principales de la investigación de Le Corbusier, partiendo de las experimentaciones iniciales -en su apartamento-estudio en la rue Nungesser-et-Coli-hasta el complejo desarrollado en la Unité. El texto sigue como el roof garden se convierte en un dispositivo óptico hacia el horizonte y en un gran instrumento evocativo. La relación con la naturaleza y el horizonte son las claves de lectura de varios proyectos seleccionados que muestran a la vez la continuidad de la investigación y la riqueza de las variaciones sobre el tema. El roof garden es uno de los temas más vivos del legado de Le Corbusier, también de gran importancia hoy en la arquitectura contemporánea.

Keywords: Roof-garden; Nature; View; Horizon; Landscape.

Palabras clave: Roof-garden; Naturaleza; Vista; Horizonte; Paisaje. 


\section{Introduction}

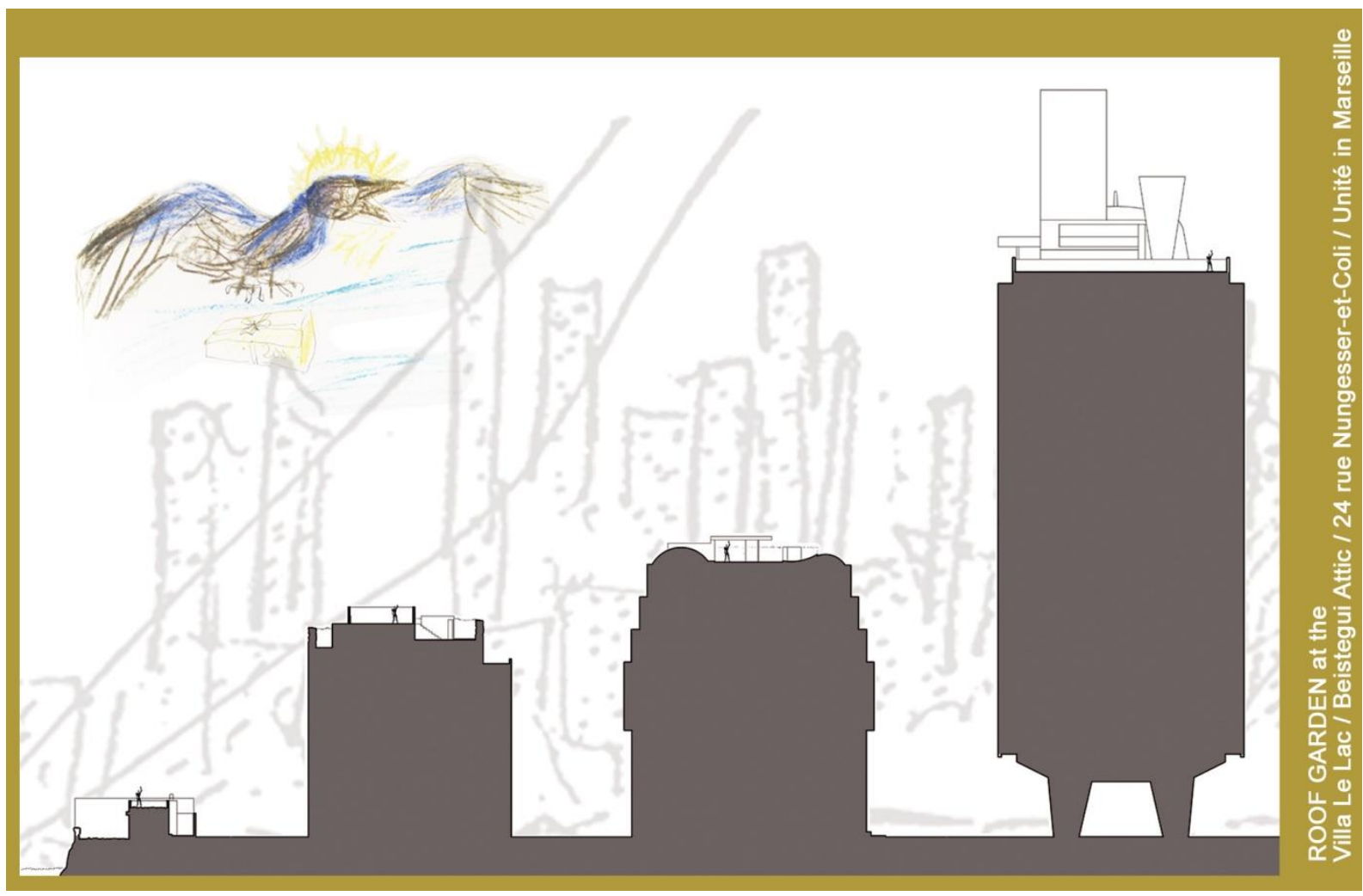

1. Collage by the authors.

Within Le Corbusier research, the roof-garden is not just one of the famous five points of a new architecture, but a totally new and fundamental spatial topic that explores the relationship between architecture and nature. Rather than observing the roof as the crowing element of architecture - a topic which would also involve many ideas and suggestions in Le Corbusier work - this paper examines it as an open-air architectural and urban space in direct connection with the natural world, conceived as an optical device which is focused on the horizon. The roof-garden space is a spatial theme criss-crossing through a variety of projects, a 'fil rouge' which becomes a narrative and interpretative thread throughout his work. Analysing the roof-garden as autonomous form distinct from the building that carries it, one can see the evolution of a theme with continual development and variation through the selected case-studies. The Le Corbusier roof-garden gradually grows both in its dimension and significance, amplifying its relevance and relationships.

Among the four essential functions of the Le Corbusier urbanism - inhabiting, working, circulating, and cultivating the body and the spirit - Le Corbusier assigns the roof-garden the role of responding to the last of these needs. The roof-garden offers a place to enjoy the sun and open-air, to exercise and to contemplate nature and the landscape, either alone or with friends. Nature on the roof-garden is not just an ornament nor frame for the landscape, but is to be physically experienced. The sky, sun and wind, the natural flora, and mountains and sea, are the main characters of Le Corbusier descriptions arising from his personal experience of these elements and forms. Looking from a high up vantage point towards the distant horizon is a leit-motiv connected with his first visual experiences: "All the years of my childhood were spent with my friends amongst nature [...] We were 
always on the mountain peaks; the vast horizon was an everyday view. When the sea of fog below extended to infinity, it looked like the real sea which I had never seen." I
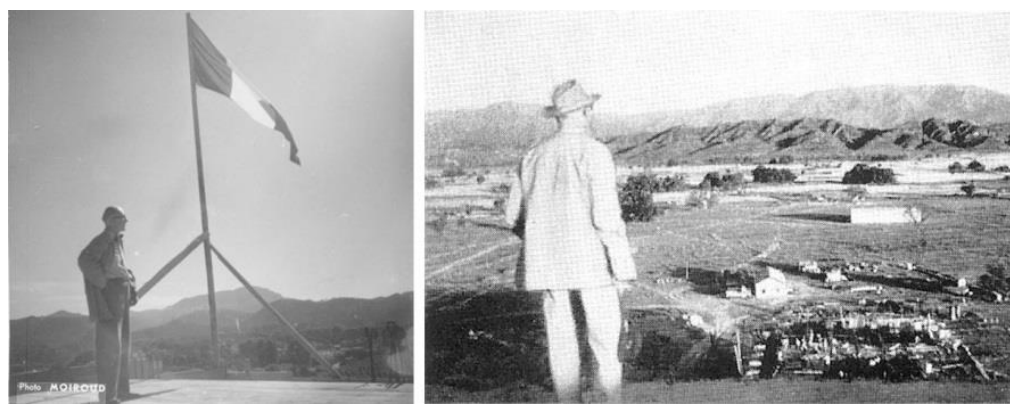

2. a. Le Corbusier on the roof of the Unite d'Habitation in Marseille; b. Le Corbusier on the roof of the Secretariat in Chandigarh.

We will follow Le Corbusier in the act of seeing - through the reading of his texts and visual descriptions, within his design projects and through drawings, film and photography shots. To explain the topic visually, each section of this text is accompanied by a collage, created using Le Corbusier materials. Photographic images have also been selected to communicate conceptual issues rather than provide a comprehensive description of each work. Assembled in sequence, as through a film clip, they show the continuity of the theme within the architectural oeuvre.

We start with the roof-terrace at 24 Nungesser-et-Coli, Paris because Le Corbusier uses it as a case-study in his comment on the roof-garden within the Complete Works. From his own roof-garden an investigation begins on the meaning of nature in the 'natural state' and also involves other projects, such as the Villa Le Lac. The Nungesser-et-Coli roof-garden is also the place where he experiments with visual techniques, testified in Le Corbusier films and photographs. We could consider this experimentation as the basis for future design process, through which he transfers his visual analysis into strategies for composition, crucially involving the horizon and the reshaping of the landscape into a series of scenes. The relationship with nature and the process of selecting a composition of views through the control of the horizon are the two main topics within Le Corbusier roof-garden projects, variously developed in each project. They become the key of reading of our selection of case-studies.

The Beistegui attic, in Paris, focuses on the process of vision. Other design projects, mainly villas, rather than commented in detail, construct a thematic anthology through descriptions and images, conveying the richness of the solutions and the experience of the roof-garden. Then, when designing Marseille Unite roof-garden the process of creating a composite of horizon determined views becomes defined, and in turn shapes the architecture and the open spaces. Le Corbusier's view of the city from the height of his roof-terraces seems to find continuity in the contemporary scenario and he appears, rather than a visionary, an architect capable of visions.

\section{The Roof-Terrace Nature}

Le Corbusier's roof terrace at 24 Nungesser-et-Coli becomes a paradigm, and is included as a case study in Report on a Roof-garden in the Complete Works ${ }^{2}$.

\footnotetext{
${ }^{1}$ Le Corbusier: L'Art décoratif d'aujourd 'hui. Paris: G. Crès \& Cie, 1925. Translation by authors.
} 
From a technical point of view Le Corbusier considers the roof-garden as the "model protector of the roof". Technical issues had already been explained within the $1^{\text {st }}$ volume: the flat roof is a consequence of the reinforced concrete construction; a consistent humidity on the roof is ensured by the presence of the earth and plants, decreasing problems of expansion and contraction of the reinforced concrete. Apart from these technical reasons, the roof-garden is an opportunity for recovery of the built-up area. Furthermore, "The city roofs could also become places of poetry". It is therefore a combination of several reasons, involving "technique, economy, comfort, and sentiment", 3 , which lead to development of the roof-garden.

Whilst these are his motivations for adopting the roof-garden theme, what is the garden's essence and how was it established? Rather than being built, it is created from nature itself: "Instead of 'digging my own garden', I let it grow". The photograph of the Nungesser-et-Coli roof-garden illustrates this concept: "A roof-garden established in 1932 on the eight floor of a block of flats in Paris, left in its natural state since 1940: ivy, cythise, lilacs, euonymus, box, plane (false sycamore), dog roses, thuya, lavender, lilies, lilies-of-the-valley, iris, and several bushy plants, grass", says the caption.

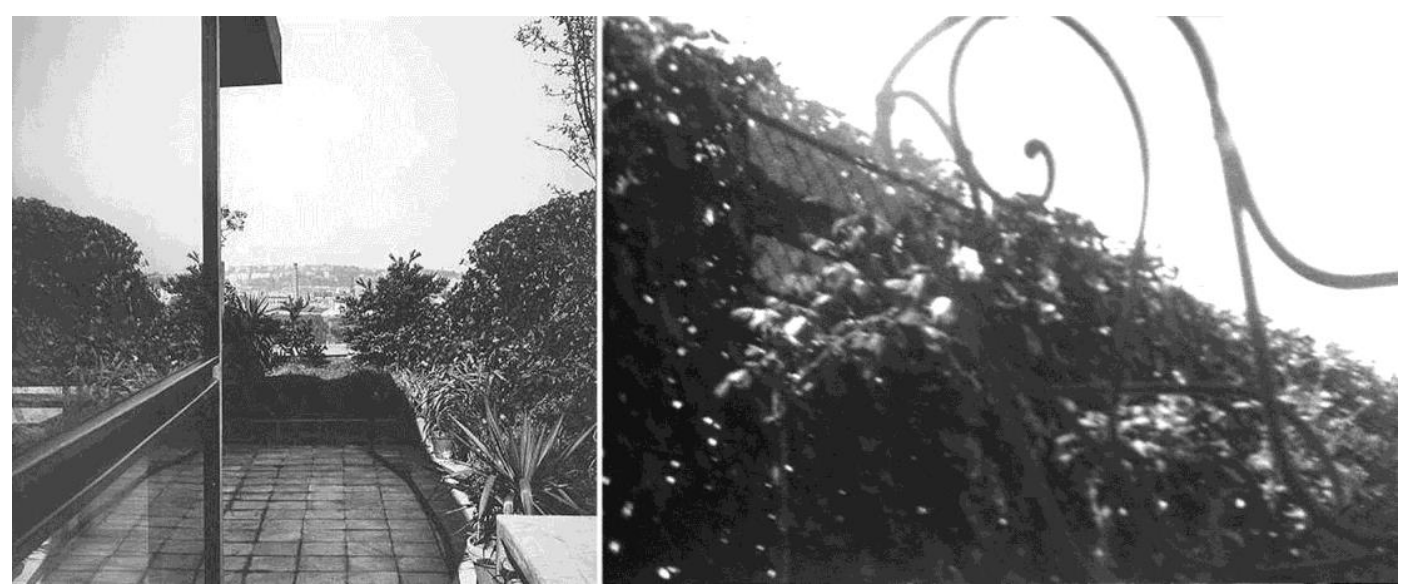

3. Roof-garden at 24 rue Nungesser-et-Coli, Paris.

Le Corbusier follows the idea gained from a head gardener: "Don't worry, let it be, nature will look after it". The roof-garden is the place where nature "regains its rights", where the natural elements are the ones to dictate its development: "The sun rules, the wind (above there) rules”. In the Report Le Corbusier describes the sensory aspect of the garden - the power of the sun and of the wind, the beauty of nature. He specifies the plant species of his garden: "The roses have gone wild and become magnificent Eglantines; the lavender twigs have become large bushes. The turf has become long grass; white, pink and yellow clover appear according to the Seasons". Here Le Corbusier rather than a planner becomes an observer; he follows the development of that natural state, the growth of the planted seeds, as well as of those brought by the wind, assisting a continuous evolutionary process. "A sycamore seed arrived on a stormy day: I am watching this latest arrival which threatens to become a giant. A bird brought a cythise seed, and in the spring the dense yellow flowers jostle the near-by lilacs. Ten years ago I planted a sprig of lily-of-the-valley, now a hundreds of lilies-of-the-valley open each first of May".

2 "Report on a Roof-Garden". In Le Corbusier: Oeuvre complète 1938-46. Volume 4. Boesiger, Willy (Ed.). Zurich: Girsberger, 1977. 7th ed. p. 140. All the following paragraph notes, unless stated, will refer to the same text.

3 “Les 5 Points d'une Architecture Nouvelle". In Le Corbusier: Oeuvre complète 1910-29. Volume 1. Boesiger, Willy (Ed.). Zurich: Girsberger, 1984. 11th ed. pp. 128-129. 
The space on the roof which can be recovered in modern cities, the cities made of reinforced concrete, is therefore a place of nature. Here nature has been separated from architecture, yet they live side by side, each one with its own laws. Le Corbusier gives space to the untamed and to the sensory and physical levels, aspects which are not often highlighted in the literature in his work, but clearly illustrated in his published text and images.

\subsection{The roof space in rue Nungesser-et-Coli}

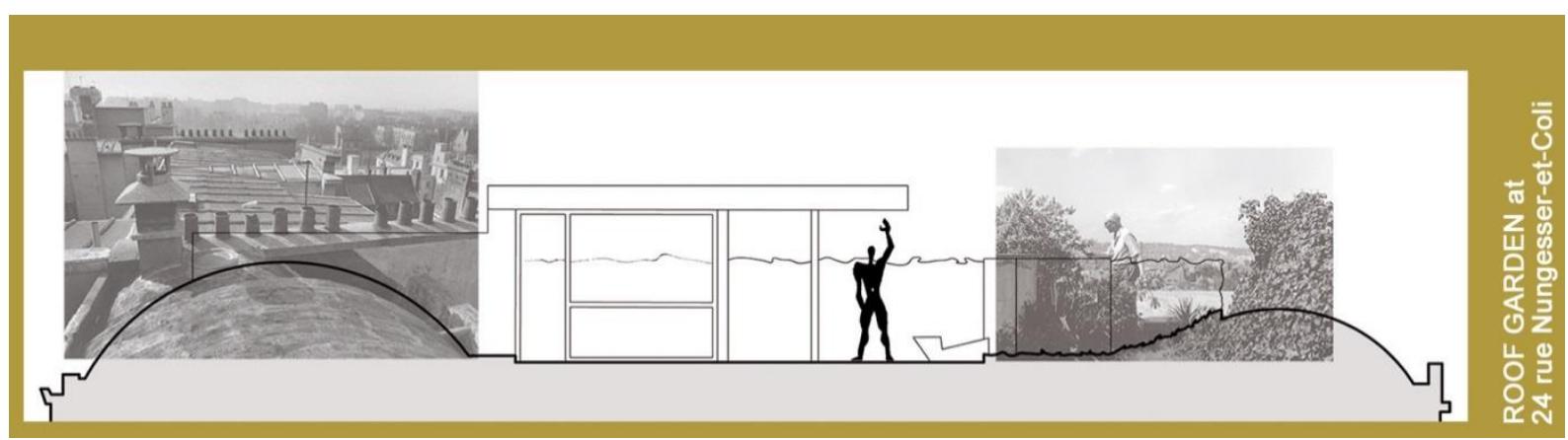

4. Collage by the authors.

The roof-garden at 24 rue Nungesser-et-Coli is the crowning element of the apartment/atelier on the seventh floor of the housing block, designed by Le Corbusier and Pierre Jeanneret between 1931 and 1934 in the Porte Molitor district. The apartment and painting studio occupy the entire seventh floor in open plan; the living area facing west towards the Bois de Boulogne and the area which at the time was countryside around Paris. The studio faced the stadium of Jean-Bouin, towards the east.

One reaches the roof space by a staircase - without a handrail - in plastic form, wrapped around an iron post. The entrance to the terrace is glazed on three sides, like a lantern, and is covered by a reinforced concrete cantilevered slab. From the lower level of the apartment one can see the leaves and the sky. The roof-terrace is a contained space, dominated by vegetation. The boundaries are defined on east and west by the extradoses of the vaults covering the apartment and studio below, and to the north and south by vegetation growing around simple iron espaliers. The plants also grow on earthed areas that partially cover the vault to the east, overhead of the apartment. From the garden one can see the city roofs, the park and the countryside. "You see Paris" is the opening sentence of Report on a Roof Terrace in the Complete Works. A sectional drawing, dated 7 August 1932 (FLC 13413), shows raised spaces designed into the top of the vaults - accessed by metal steps - achieving even higher level vantage points.

Le Corbusier designs both the roof terrace and the apartment through the control of the views and the relationship with the horizon, using some "architectural stratagems" 4 . The curvilinear surfaces of the vaults limit the view of the immediate surrounding, leading the eye towards the far away views. Le Corbusier comments on the sight in a letter to his mother: "Really, it's magnificent. There's a view over the countryside with so sense of being perched up on the 7th or 8th floor, thanks to architectural stratagems. No giddiness that way. The garden a poem. Lawn, lilac, roses, and more, and what a horizon!" 5.

\footnotetext{
${ }^{4}$ Letter by Le Corbusier to his mother, 29 April 1934. In Cohen, Jean-Louis: Le Corbusier Le Grand. New York: Phaidon Press Limited, 2014. p. 286.

${ }^{5}$ Ibid.
} 


\subsection{Experimentations on the roof space}

In his small roof-terrace of rue Nungesser-et-Coli, Le Corbusier experiments with his ideas about nature and the control of the views. The films made by Le Corbusier in 1936-38 ${ }^{6}$, using professional equipment ${ }^{7}$, contain selected frames and photographs of these years, and include sequences filmed at his apartment and its roof garden. One sequence filmed from the apartment balcony, starts from the paving below, then rises up along the plane of the shelf from where the city appears, framed in a pan that shows a progression from the urban towards the park and the surrounding countryside. The edge of the balcony parapet becomes the horizontal plane that defines from where the landscape is read.

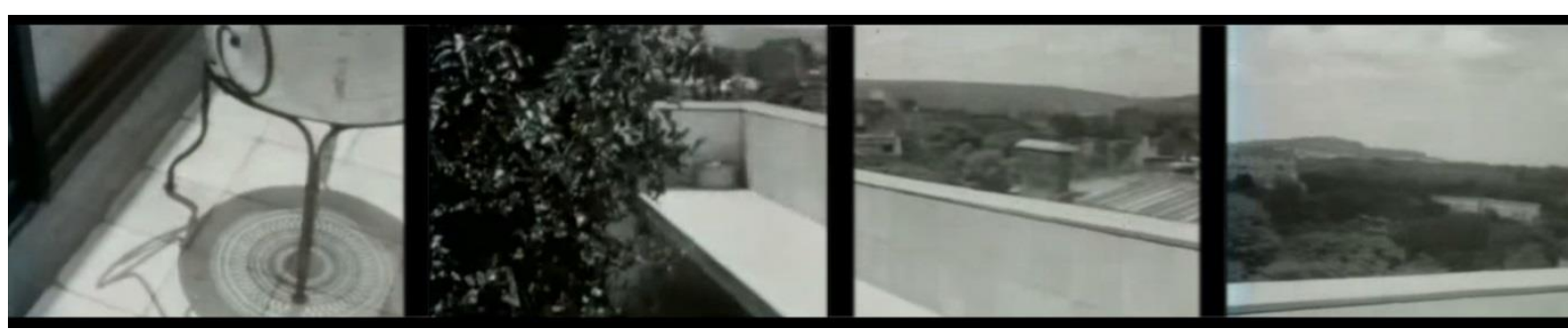

5. Stills from Le Corbusier 1936-38 film. Montage by the authors.

Another sequence in this film includes the roof garden. The shots start bottom-up, showing the view of the leaves and the sky from the staircase. When the camera arrives in the roof garden, it stays at a very low height, around the base of the vegetation.

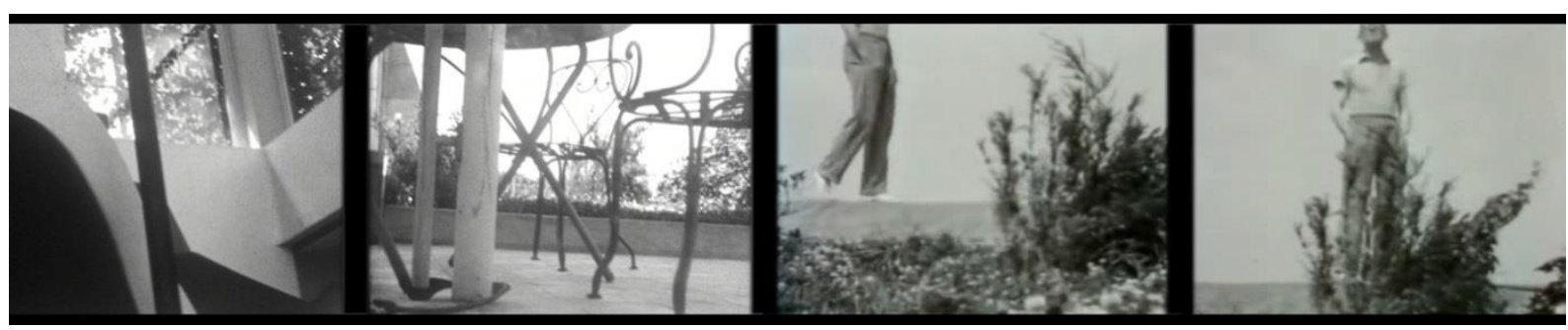

6. Stills from Le Corbusier 1936-38 film. Montage by the authors.

A series of close up frames, show the roof garden plants; consistent in their natural image with Le Corbusier's description of a wild and untamed garden in Report on a Roof-Garden. The vegetation is the main character, initially shown in isolation and then in a relationship with human figures - Le Corbusier, on the curvilinear surface of the vault, and his mother, gardening.

All these images are carefully studied and create a relation among planes: the ground, the upper edge of the vault, the mass of the vegetation. The shots, seen from bottom-up, exalt and even appear to falsify, these dimensional relationships. Le Corbusier films, and the visual frames he creates within the garden, should be considered visual reflections and studies on the landscape. As in his notebook drawings and annotations, Le Corbusier marks down - here at a visual level - the techniques used in connection with landscape and ideas here tested in his own space. Films and photographs, rather describing and representing, become a means of capturing a reflection on landscape issues and suggest spatial architectural solutions to adopt. Le Corbusier experiments with the relationship between the foreground and background, between close and the far, observing the

\footnotetext{
${ }^{6}$ «Films de Le Corbusier» (C) FLC-ADAGP, Paris: Fondation Le Corbusier.

${ }^{7}$ Benton, Tim: "Le Corbusier Secret Photographer". In Sbriglio, Jacques : Le Corbusier. Aventures photographiques. Paris: Éditions de la Villette, 2014. pp. 46-69.
} 
relationships between masses. He highlights the distant view by cutting out less meaningful parts; he selects views and studies the sequence of planes, depths, and the relationship with light and shadow, thereby creating a sequence of views as a montage. Created within places of his private life, around elements of his personal landscape, these images become a paradigm of his design concepts connected with visual fields and the horizon line.

\subsection{Landscape experimentations at the villa Le Lac}

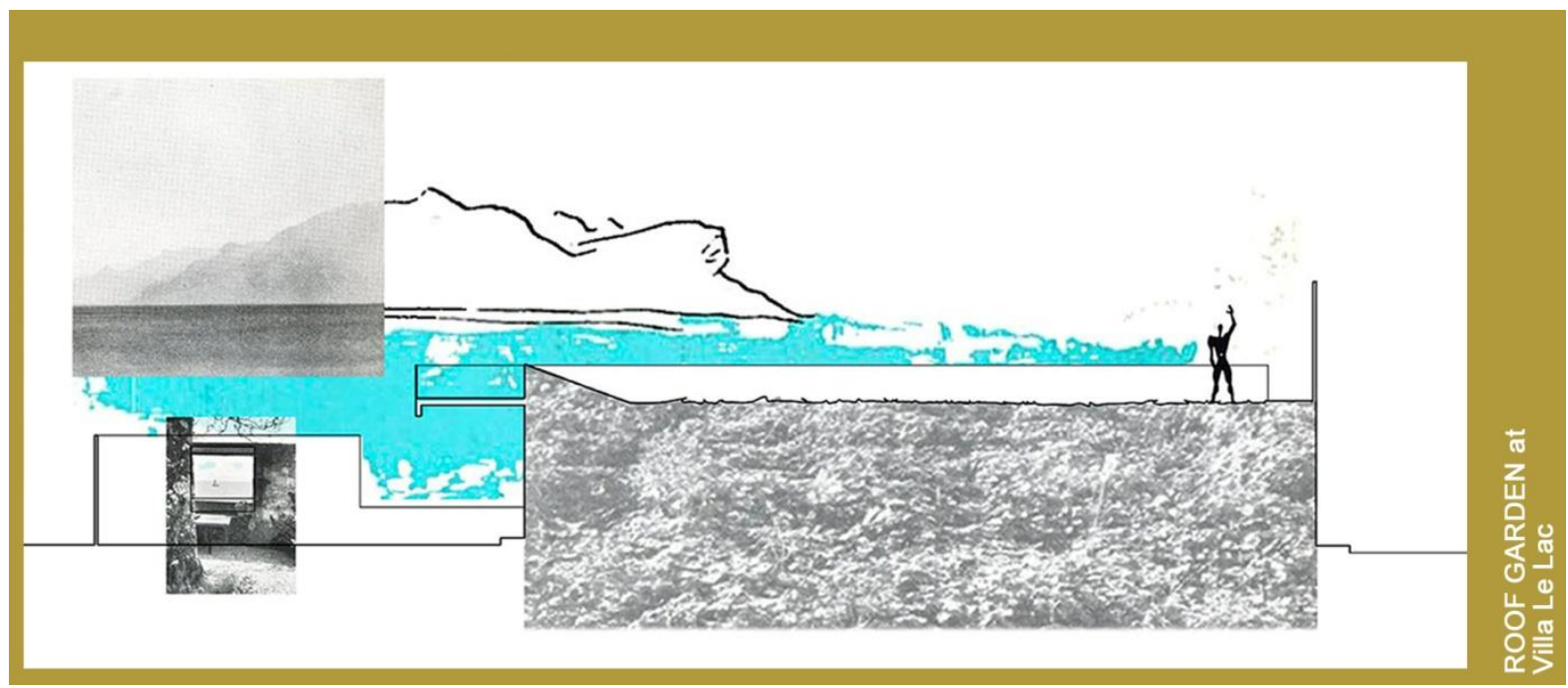

7. Collage by the authors.

As for his apartment in Paris, in the Villa Le Lac, designed for his parents, Le Corbusier realizes photographic and filmic shots ${ }^{8}$ which display similar studies about nature and landscape. The shots go either from the house to the lake or from the lake to the house, revealing a predominant interest on the relationship between architecture and nature. More than the house itself with the interior spaces, the film highlights the open spaces and the surroundings. The attention is focused on the horizon line. The greenery, luxuriant and protagonist of the scenes, is observed both in distance and close by.

In some frames, there is Le Corbusier himself, seated on the parapet along the lake, with the pipe, who seems in the act of explaining the place and the distant views.

The film narrative will be later developed in the form of a text, Une Petite Maison ${ }^{9}$, testifying once again that Le Corbusier camera fixes notes on visual topics. In the book the Villa Le Lac roof is narrated as the arrival of an almost curvilinear route which goes from the street, to the courtyard, to the inside of the house itself, and then outside again. The roof garden, "a pleasure known to some civilizations in former centuries", is a discovery: "here we are on the top!". Both in the film and within the text Le Corbusier constructs a visual plot through a montage of scenes; he modulates anticipations, interests, and surprises, as a cinema director.

\footnotetext{
${ }^{8}$ «Films de Le Corbusier» () FLC-ADAGP, Paris: Fondation Le Corbusier.

9 Le Corbusier: Une Petit Maison 1923. Zurich: Aux Édition d'Architecture, 1954. All following quotes in this sub-section are extracted from this text.
} 


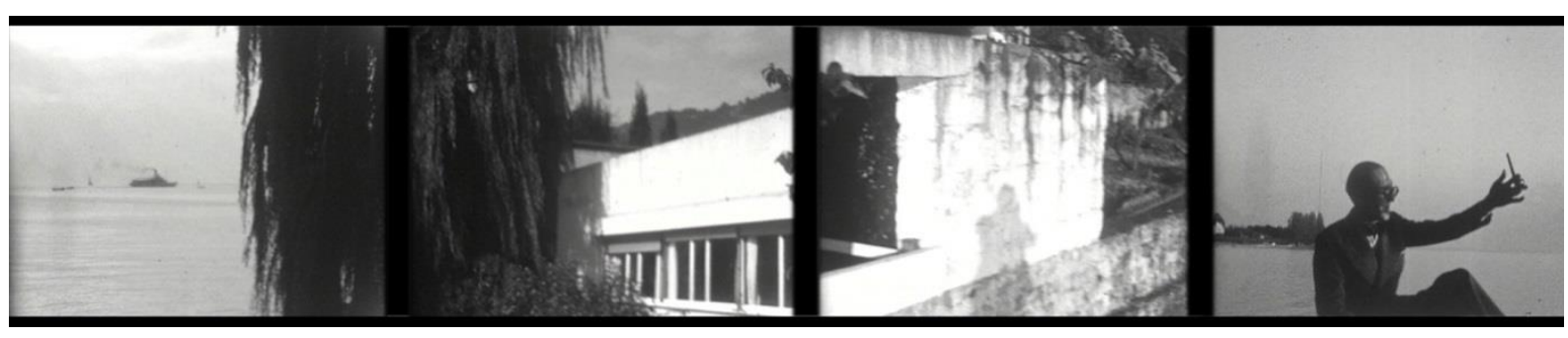

8. Stills from Le Corbusier 1936-38 film. Montage by the authors.

The space of the roof is then described through the same interpretations of the roof garden in rue Nungesser. First it is explained from a technical point of view - the roof garden regulates the temperature - and then it comments on the natural state of the nature. "Pay attention! It is towards the end of September. The autumn flowers are blossoming and the roof is green once more, for a thick carpet of wild geraniums has overgrown everything. It is a wonderful sight. In spring the young grass sprouts up with its wild flowers; in summer it is high and luxuriant. The roof garden lives independently, tended by the sun, the rain, the winds and the birds which bring the seeds. (Latest news, April 1954): the roof is completely blue with forgetme-nots. No one knows how they arrived". The raised view is an extraordinary condition comparable to the sight from the deck of a ship: "Is it a ship's rail or the wall of a roof we are leaning on? (A boat passing on the lake was also shown in the film). While the sight at the lower open spaces is confined by walls or framed by windows, on the roofgarden it finally spreads out on the open horizon.

The roof garden in Villa Le Lac, in particular its character of a place where nature grows according to its natural cycle, is a solution - both technical and suggestive - that recurs in other projects. Through the description on the convent of La Tourette, Le Corbusier highlights the continuity of his research. "The roof of the convent itself, like that of the church, will be covered with a thin layer of earth left to the vicissitudes of the wind, birds and other carriers of seeds, assuring both water-tightness and isothermic protection. (The roofs of the small house on Lake Léman, constructed thirty years ago, the apartment house at 24 Rue Nungesser et Coli and various buildings in India are similarly constructed) ${ }^{, 10}$.

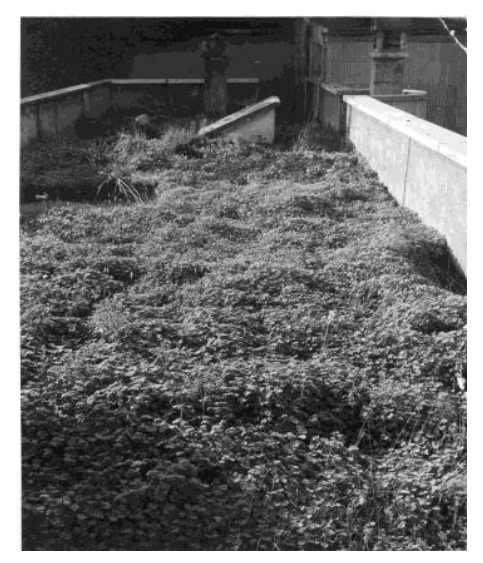

9. Roof-garden at Villa Le Lac.

\footnotetext{
10 “The Convent of La Tourette”. In Le Corbusier: Oeuvre complète 1952-1957. Volume 6. Boesiger, Willy (Ed.). Zurich: Girsberger, 1985. 7th ed. p.42.
} 


\section{Screening and Seeing}

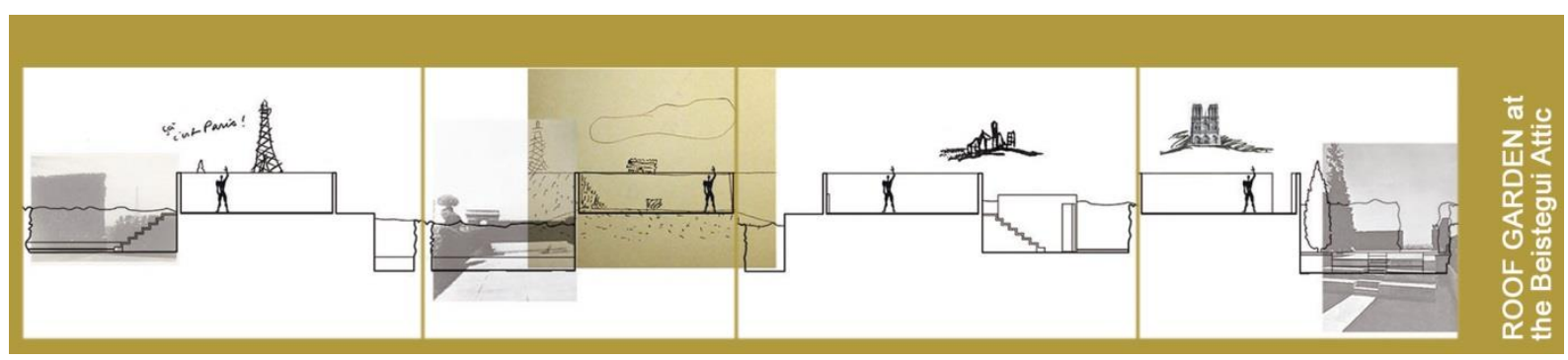

10. Collage by the authors.

Opposite to the Villa Le Lac condition, where the sight is initially enclosed and framed and then it conquers the possibility to space out on the roof, within the Beistegui Attic the view is gradually compressed along the ascending path leading to the solarium, which becomes a room without ceiling.

In a letter addressed to the client, Le Corbusier declares his immense interest in the attic development "because it offers a solution for the roofs of Paris, that I have been talking about 15 years" $"$.

With the design project of the Beistegui Attic, Le Corbusier "places Paris on a stage" 12. The space of the roof captures the landscape, with views cut out through the act of screening. The screens are made of stone or natural walls are created, for example, with an ivy hedge that, through mechanical stratagems, unfolds the view, "revealing Paris" ${ }^{13}$. Within this space so markedly surreal, also nature radically changes becoming, from untamed and natural, now artificially designed and even mechanised and man-made.

"The architectural solution to this problem is, in some way, an act of devotion to Paris. Let us explain: from this belvedere, Paris is visible on all its horizons: both in the most admirable places and in the dark desert of the roofs and the chimneys. The choice was to suppress that panoramic view and to create another architectural centre of stones, gardens and sky, completely isolated from the turbulence of the panorama, and to offer, in precise points, some exciting prospects of four of the things, visible from the place, that make the prestige of Paris: the Arc-de-Triomphe, at point-blank, the Tourre Eiffel, the Sacré-Coeur, and finally the mass of greenery overflowing from the Champs-Elysée to the Tuileires and which falls in the rivers, with Notre-Dame that stands out as an outline on a milky horizon. This concerns the architectural landscape proposed for all the rooms, both interior and exterior, on different terraces built on four successive levels"14.

Designing becomes an operation of selecting within the urban landscape. The Paris which is shown isn't the real city - with the people, the buildings, the streets - but the idea of Paris, the mental construction of the city. Le Corbusier rewrites the city through his selective process.

The Beistegui Attic is composed of a sequence of spaces, following a route from the lower gardens to the white room at the highest level; the sequence builds the city as it flows, like a cinematographic view ${ }^{15}$. By deliberately

\footnotetext{
${ }^{11}$ Tafuri, Manfredo: “ 'Machine et memoire': The City in the Work of Le Corbusier”. Santarelli, Stephen (Trans.). In Brooks, H. Allen (Ed.): Le Corbusier. Princeton: Princeton University Press, 1987. p. 203.

${ }^{12}$ Reichlin, Bruno: “L’Esprit de Paris”. In Casabella. January/February 1987, № 531/532. Milano: Electa. p. 55.

${ }^{13}$ Le Corbusier: "L'Arc-de-Triomphe a bruciapelo". In Casabella, January/February 1987. op. cit. p. 60.

${ }^{14}$ Ibid.

15 “A Geography of the Moving Image”. In Bruno, Giuliana: Atlas of Emotion: Journeys in Art, Architecture, and Film. New York: Verso Books, 2007. pp. 55-71.
} 
controlling and restricting elements of the view, the architectural space opens up at different levels to reveal different parts of the city.

"The fourth terrace is a few steps further above: it encircles the building: we pass the steps and arrive at a door made of a stone slab: this door slowly opens and shows a completely white ambient, entirely carpeted with a grassy cloak. The door closes again: it is the silence. You don't see any other that the sky and the play of the clouds and the patch of blue; it is a sensation of breath, of open ocean. Near the grassy carpet, a fireplace to light a fire, during the coolest evenings. [...] Only a yew breaks a corner of sky" ${ }^{\prime 6}$.

The visual path over the city of Paris is set up in the first three levels of the roof-garden and culminates in the last terrace: the solarium, an open-air room. Contrasting with the experience in lower levels, the space here has no stones, only a synthetic grass carpet enclosed by high walls enveloping the space within an intimate and surreal atmosphere. Here silence and introspection prevail, together with the detachment from the city. The Paris spectacle, selected and mise-in-scene by the architect at the lower levels of the garden, becomes even more selective at the solarium level. Standing on the attic one sees hardly anything of the city. The experience is all in the privileged contact among man, sky and the grass cloak covering the paving. "The city is banished from the sight in the highest terrace, and hence receives the highest tribute to the limit" ${ }^{17}$.

\section{The experience of the roof-garden}

Le Corbusier experiments with a variety of spatial conditions for the roof garden: it can be an elevated space with vegetation within the heart of the building; it can be a terraced garden, external to the building; it can be a solarium, at the top. For some projects Le Corbusier proposes a sequence of roof gardens, at different levels or terraces, which create new spatial and visual relations. The relationship with nature and the landscape, which are the main topics, is developed in a variety of ways. The roof walls cut the views on the city and frame landscape portions; in other cases, the nature enters into the composition as a scene.

Besides the different spatial conditions characterising the roof garden, there are common themes, illustrated through our selection of photographs and anthology of descriptive texts, in order to convey the experience of the Le Corbusier roof garden. Read in succession, these extracts in our montage of texts and images narrate the space of the roof in Le Corbusier work. "This villa has a story",18.

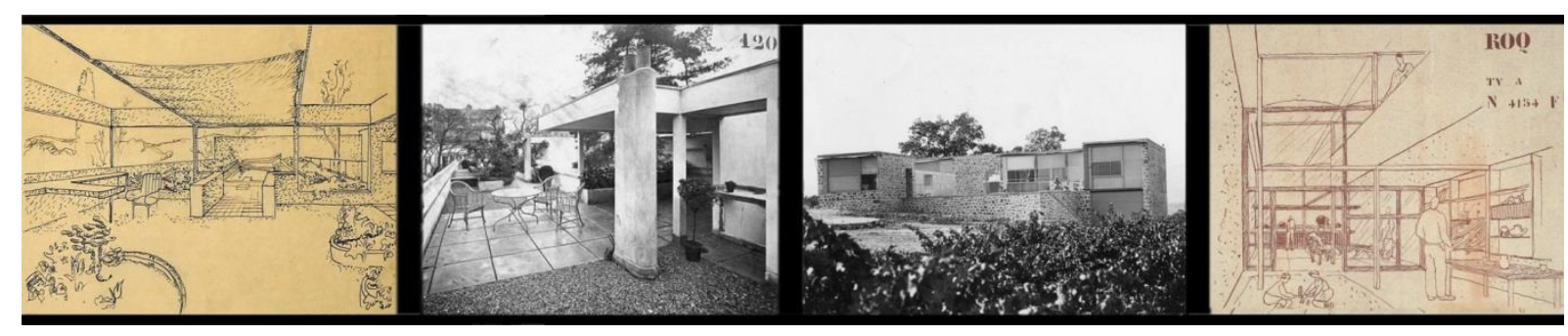

11. a. Villa Meyer; b. Maison La Roche; c. Villa de $\mathrm{M}^{\mathrm{me}}$ H. De Mandrot; d. Roq et Rob.

From a technical point of view by "establishing the garden on the roof, one protects the concrete slabs from expansion during summer. During winter, the garden insulates from the cold. The garden is the logic

\footnotetext{
${ }^{16}$ Le Corbusier: "L'Arc-de-Triomphe a bruciapelo". op. cit. p. 61.

${ }^{17}$ Reichlin, Bruno: "L’Esprit de Paris". op.cit. p. 55. Authors' translation.

18 “Villa Shodhan", incipit description. In Le Corbusier: Oeuvre complète 1952-1957. Volume 6. op. cit. p.134.
} 
complement of the flat roof" ${ }^{19}$, the roof-garden becomes "...an authentic architectural event, carrier of charme and poetry, a magnificent free luxury ${ }^{, 20}$.

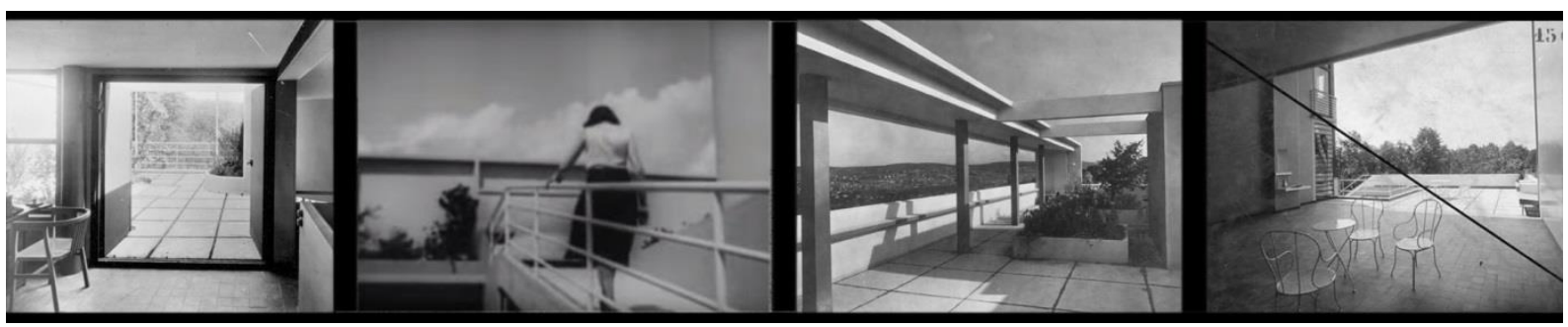

12. a. Maison Cook; b. Ville Savoye; c. Maisons Weissenhof; d. Villa Stein.

From the elevated space of the roof garden, there's a new relationship with the city. "The entrance is at the top of the house. One goes directly on the roof-garden from where one dominates the vast plantation of the Bois de Boulogne: one is no longer in Paris, it is like being in the country"2l.

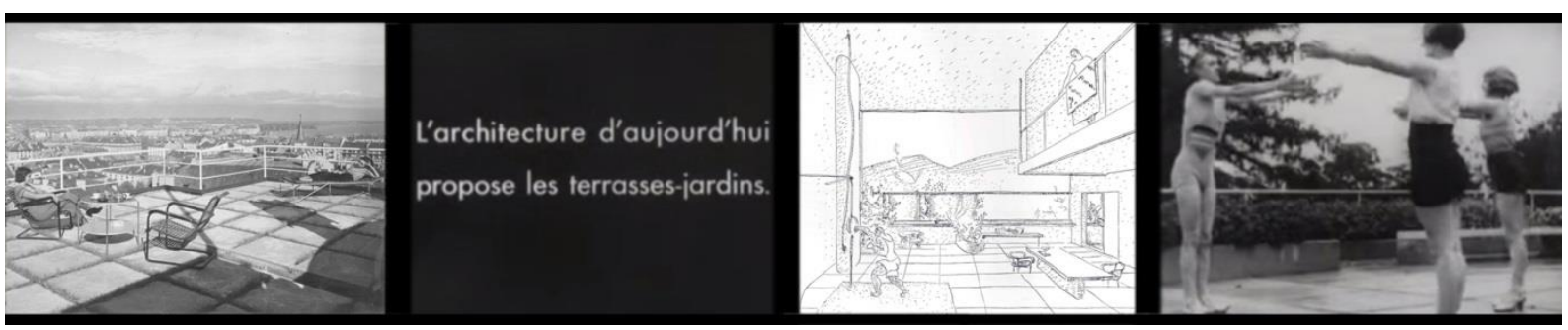

13. a. Immeuble Clarté; b. frame by Architecture d'aujourd'hui; c. Immeuble Wanner; d. Ville d'Avray.

At a short distance but at the same time quite far away, the city can be contemplated from a new vantage point. "From the boudoir you go out onto the roof, where there are no tiles, no slates, but instead a solarium and a swimming pool, with grass growing between the paving stones. Above is the sky: The walls mean that nobody roundabout can see you. In the evening you see the stars and the dark shape of the Folie St- James. Sliding screens offer total privacy. [...]This isn't a classic French garden, but a wild copse where, thanks to the woodland of the Parc St-James, you'd think you're miles from Paris",22.

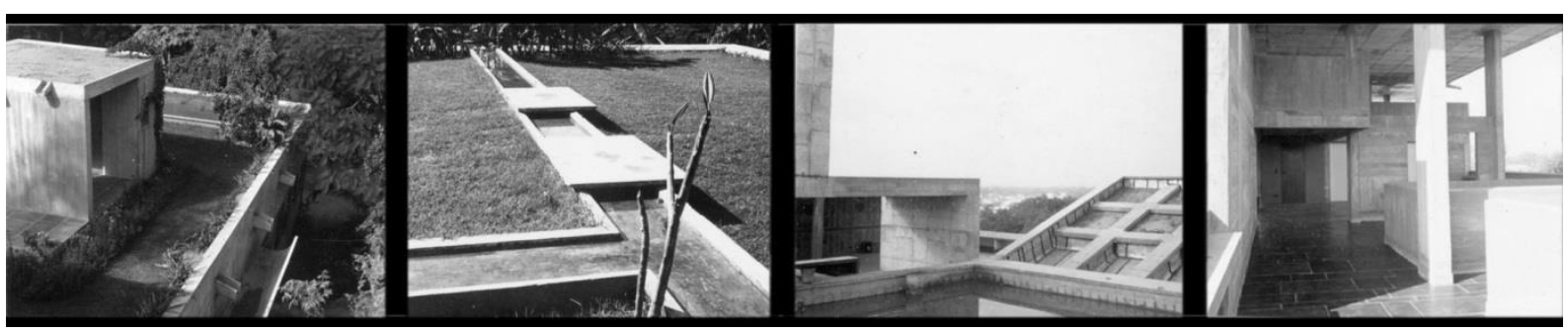

14. a. and b. Villa Sarabhai; c. Ahmedabad Millowners; d. Villa Shodhan.

Nature therefore becomes an essential element of the roof-garden and the surrounding landscape, integral to its composition: "The composition is organised through the landscape. The house occupies a small promontory

19 “Villa à Garches”. In Le Corbusier: Oeuvre complète 1910-1929. Volume 1. op. cit. p.145.

20 "Deux Maison construites pour la Ville de Stuttgart dans la colonie de Weissenhot". In Le Corbusier: Oeuvre complète 1910-1929. Volume 1. op. cit. p.150.

21 "Petit hotel particulier à Boulogne-Sur-Seine (Cook) 1926". In Le Corbusier: Oeuvre complète 1910-1929. Volume 1. op. cit. p.130. Authors' translation.

22 "Villa Meyer. Paris 1925. (1 ${ }^{\text {er }}$ Project)". In Le Corbusier: Oeuvre complète 1910-1929. Volume 1. op. cit. p.89. 
overlooking the plane behind Toulon, which is closed off by the beautiful outline of the mountains [...] it is forerun by a suspended garden which serves as first level and which links the habitation to the Pavilion reserved for the friends" ${ }^{23}$. The roof-garden is the place of socialisation: "the roof is used together with the bar for evening entertainment" ${ }^{24}$. The privileged contact with nature also makes the roof-garden an ideal place to take care of the body: "A bit of exercise before departing to the city. The pavilion is a bit further in the park: architecture and nature are mutually enhanced $d^{25}$.

Architecture and nature merge in the space of the roof-garden: "Grass sprouts out among the joints of the slabs; some snails move quietly; some tree were planted: tujas, cypresses, charcoals, okubas, China laurels, privet, tamarindas, etc. Six years have passed, the greenery is more beautiful than in any garden: the roof-garden is a bit like the conditions of a greenhouse (because the air is pure, the light intense, and the roots are in a hot and humid soil). The owner of the house said this spring: 'Come and see my lilac on my roof; it has more than one hundred of flowers bunches!' Family life takes place in the upper part of the house"26.

The succession of roof-gardens at different levels creates a new architectural space with a continuous landscape: "Above, the accommodations are disposed in the space of a "hanging garden", on several levels, constituting three apartments, separate and yet in contact with one another" ${ }^{27}$.

\footnotetext{
23 “"Villa de $\mathrm{M}^{\mathrm{me}} \mathrm{H}$. De Mandrot, 1930-31". In Le Corbusier: Oeuvre complète 1929-34. Volume 2. Boesiger, Willy (Ed.). Zurich: Girsberger, 1984, p.59.

${ }^{24}$ "Ahmedabad Millowners' Association Building Ahmedabad 1954". In Le Corbusier: Oeuvre complète 1952-1957. Volume 6. op. cit. p. 144.

${ }^{25}$ Decription text of Ville d'Avray extracted from the film Architecture d'Aujourd'hui. Directed by Pierre Chenal. Script by Pierre Chenal and Le Corbusier. Texts by Le Corbusier. Music by Albert Jeanneret. Produced by the review Architecture d'Aujourd'hui, $35 \mathrm{~mm}$, b\&w, time $18 \mathrm{~min}$. 1930. Translation by the authors.

26 “Maison La Roche - Janneret 1923. Le Jardin sur le toit". In Le Corbusier: Oeuvre complète 1910-1929. Volume 1, op. cit. p.65. Translation by the authors.

27 “Villa Shodhan". op. cit.
} 


\section{The stone roof-garden of the Unité of Marseille}

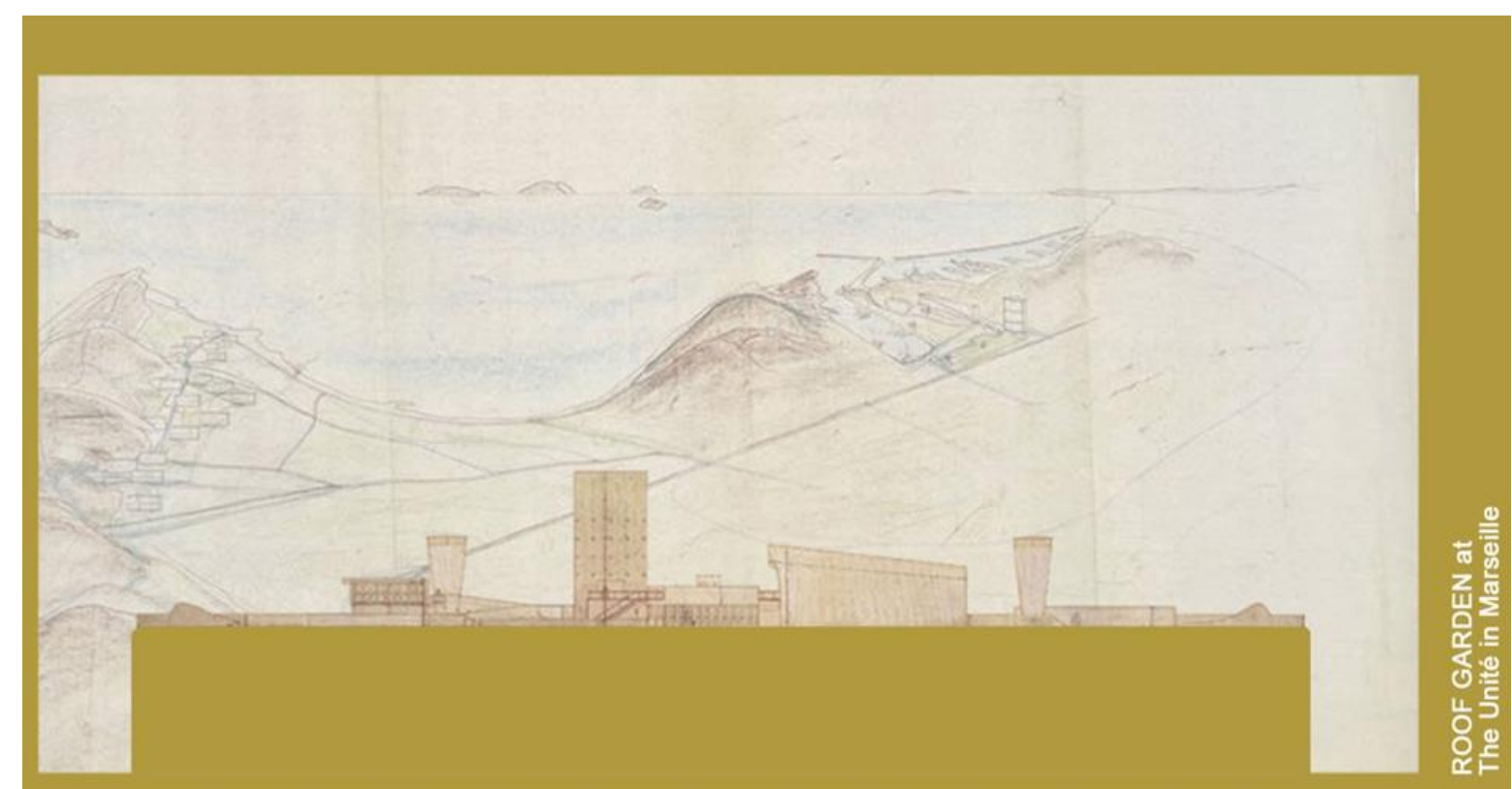

15. Collage by the authors.

Within the space Le Corbusier dedicated to writing about this complex and fundamental oeuvre - the Unité - in the $5^{\text {th }}$ volume of the Complete Works - (published when the building had just been completed) - the description of its roof space, is very notable ${ }^{28}$. It immediately strikes the reader that here there are no traces of untamed nature, nor any attempt to insulate and protect the béton from expansion and contraction, nor walls shielding against the city. Here Le Corbusier opens his research to new design and artistic experimentations.

Both in the Complete Works text and through the famous photomontage, the Unite roof space is described as an autonomous element, detached from the remainder of the building. It is as the whole building is nothing other than a powerful substructure for the dominating horizontal plane and articulated set of forms placed on top, all immersed within the profile of the horizon.

This corresponds to Le Corbusier Acropolis description in his travelling sketches. When the writing "Architecture is the correct and magnificent play of masses brought together in light" ${ }^{29}$ is placed alongside one of the photographs of the Marseille roof, on the Complete Works, there is a direct parallel between this oeuvre and the celebrated reference of Vers une architetture. ${ }^{30}$

The Marseille roof is, at the same time, the manifestation of an idea, a model which takes shape, and a prototype of subsequent developments. It is a "city within the city" 31 , a complex and dense space, dense for both functional programme and compositional strategies.

28 "L'Unité d'Habitation in Marseille". In Le Corbusier: Oeuvre complète 1946-1952. Volume 5. Boesiger Willy (Ed.). Zurich: Girsberger, 1985. 8th ed. pp.189-223.

${ }^{29}$ Ibid. p.222.

${ }^{30}$ Le Corbusier: Vers une architetture. Paris: G. Crès \& Cie, 1923.

${ }^{31}$ Moos, Stanislaus von: "Machine et nature: notes à propos de l'Unité d'habitation de Marseille". In Prelorenzo, Claude (Ed.): Le Corbusier. La Nature. Paris: Éditions de la Villette, 2005. pp. 43-54. 
Le Corbusier organises the roof-garden with one part reserved for the children with a small pool connected directly with a nursery and a primary school at the lower level, and with a gymnasium, a gathering space for open-air exercise, a solarium, a 300 m running track, buffet-bar, and service elements.

This roof is the public space par excellence of Le Corbusier's vertical village: a pedestrian elevated square at 56 $\mathrm{m}$ off the ground, a vast open space uncommonly elongated - 164 × $24 \mathrm{~m}$, conceived as a space for both body and spirit.

It is a garden suspended in the sky: a stone garden inhabited by a variety and fragmented set of forms rigorously in béton armé, where Le Corbusier adopts organic and plastic shapes inspired by botany and nature, in stark contrast to the rigorous and stereometric geometry of the housing block.

Ultimately this is a belvedere stretching toward its splendid horizon, a place for contemplation and meditation: "Up above, at $56 \mathrm{~m}$ from the ground, there's the most impressive and moving view of the world: the sea and the islands, the mountain range of Saint Cyr and the Tete of Puget, the Sainte-Baume, the mountain of SaincteVictorie, Marseille-la-Ville and Notre-Dame-de-le-Garde, l'Estaque. [...] This roof will be part of the landscape of Marseille. Its outline must be eloquent, a varied and soft discourse". ${ }^{32}$

The Unite roof-garden is a public space recalling suggestions of the Pompeii Forum and the Athens Acropolis, as well as the upper deck of an ocean liner.

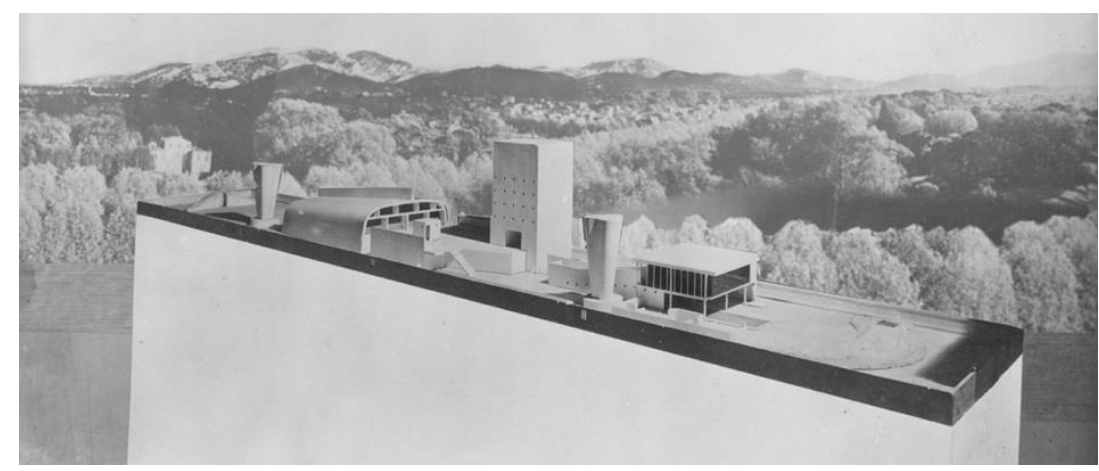

16. View of the model of the roof terrace in the Unite d'Habitation in Marseille.

\subsection{Composing sequences on the horizon line}

Buildings, plastic forms, open-air spaces are all composed in an intense dialogue with the line of the horizon. The parapet is solid and high, signed by the projection of the crowning corbel just below the eye level $(1,60 \mathrm{~m})$ : it restrains rather and doesn't invite you to look out, only narrow gaps, at structural joints, permit any view. Along the whole perimeter, the running track runs steady, without start or end points. Like a rut, it separates and distances the plastic composition from the urban surroundings. The main architectural elements are all gathered on the central platform, where vision reads the forms in a direct and dynamic relation with the mountains, sea and sky. As is for the Acropolis, "The equilibrium [...] is determined by the famous landscape which stretches

\footnotetext{
${ }^{32}$ Le Corbusier: Il Modulor + Modulor 2. Saggio su una misura armonica a scala umana universalmente applicabile all'architettura e alla meccanica. Saurwein, Emanuele (Ed). Mendrisio: Gabriele Cappelli editore, 2004. Volume "Il Modulor". p. 150.
} 
from the Piraeus to Mount Pentelicus". ${ }^{33}$ So too, on this roof terrace, it is the impressive horizon, with the sea, hills and islands, that influences the arrangement and shaping of component structures.

The main buildings -gymnasium, lift tower with water tank, and nursery - are in the centre of the platform, creating an outdoor tripartition of this city fragment. The first and central area, gathers all access to the terrace, with ramp and lifts, and is open to the view of the sea and the far away islands on the West side. The second, the children's garden on the South side, is oriented toward the view of the beautiful mountains; the third is fitness platform on the North side, almost isolated by the gymnasium, and faces the port of the Joliette.
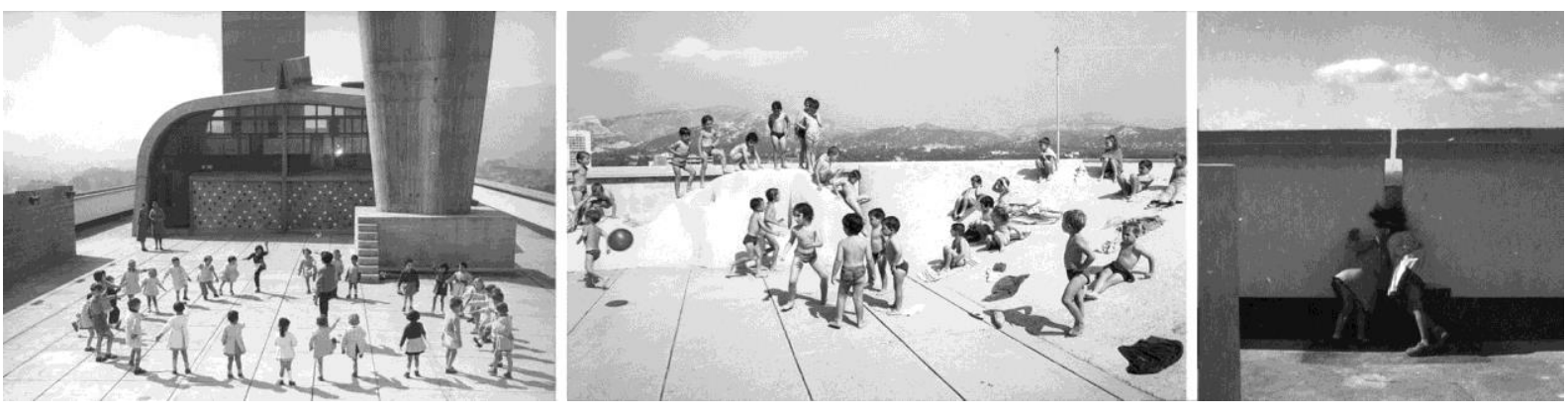

17. Roof terrace at the Unité d'Habitation in Marseille.

On the Marseille belvedere the composition envisages, that rather than have continuous boundary edges, it is defined by obstacles, accents and pauses, all capable of interacting with the horizon. These features include an inclined wall, windbreaks walls, a remarkably long and deep flower box and a funnel shaped ventilation stack which rather than cutting out or framing the landscape, takes on a dialectic relation with the natural elements.

The articulated profile of the mountains and the rectilinear profile of sea become the materials of the project. Where "the space is too vast, or the horizon isn't interesting, a wall is created on the right, three steps down there. From now on the theatre festivals can happen here, in summer, without the need of an additional scene".34 At the other end, where the horizon line is rich and indented (toward south), the symphony of forms reach the "biggest intensity at the most essential point (which is at the base of the mountains on the horizon)". 35

On this side, the articulated composition of pure volumes and plastic forms, together with the partitions of the children's garden, is always kept within the height of the solid parapet. The only emerging element is a column shaft, which offers an additional reference to the Acropolis. The powerful inclined plane - separating the children's garden from the running track - links the paving to the horizontal line of the parapet, and thus becomes the base to the mountains setting.

\footnotetext{
${ }^{33}$ Le Corbusier: Verso una architettura. Cerri, Pierluigi; Nicolin, Pierluigi (Eds.). Milano: Longanesi \&C, 1989. p. 39

34 “L’Unité d'Habitation in Marseille”, op. cit. p. 222. Authors' translation.

${ }^{35}$ Ibid. p. 221. Authors' translation.
} 

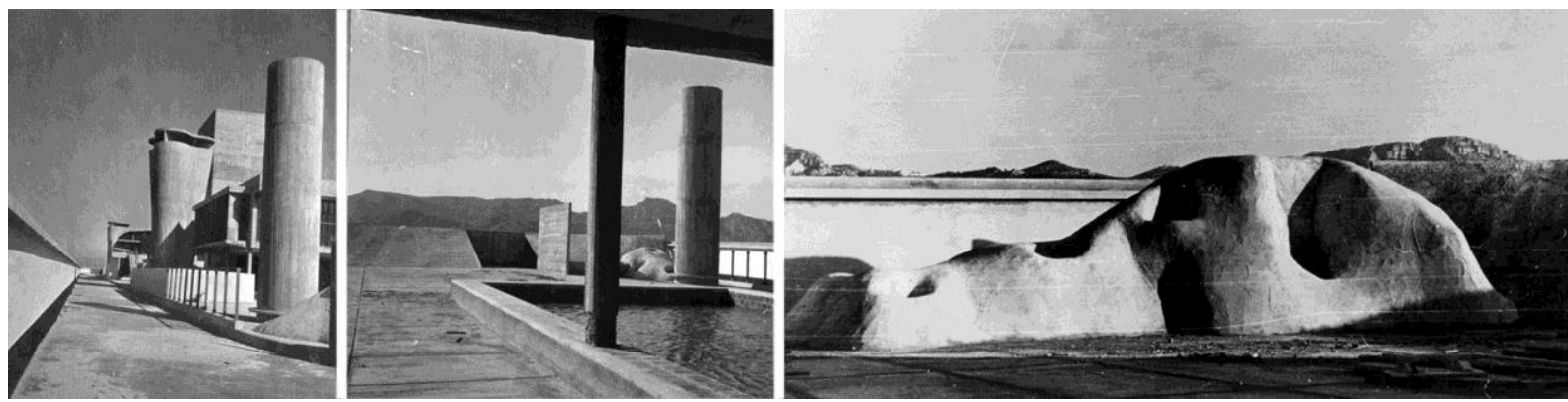

18. Roof terrace at the Unité d'Habitation in Marseille.

The compositional strategy adopted by Le Corbusier in this particular area of the roof garden, rather than recall the Parisian Beistegui Attic, seems to anticipate his visions for Chandigarh, India. Using the solution of the boundary banks around the Capitol- with a technique analogous to a cinematographical montage - the middle ground is removed from view and the foreground becomes directly connected to the background. ${ }^{36}$

The stone roof garden of Marseille, again as with the Acropolis, and this time through the reading of Eisenstein 37 ,"turns the inhabitant of space into a consumer of views". 38 "In my work I have the impression of thinking as Eisenstein does in his films" affirms Le Corbusier" ${ }^{39}$, who also writes in his notepad: "invite a film maker onto Marseille roof; extraordinary".

The varied fragments are constructed into a coherent whole, through the succession of the views, which one experiences within the experience of the site. Not univocally connected with a pre-definite path, as it happens somewhere else with the promenade architecturale, the succession is here left to the free choice of the stroller. It is perhaps for this reason that, as a director in the montage work, Le Corbusier feels the need of marking down in his notepad: "to envisage a touristic circuit with various strategic points (the visitor should not interrupt but to look from a point of view) exercise / restaurant / nursery / children clubs / hall". ${ }^{40}$

\subsection{The Marseille roof-terrace Nature}

Architectural artefacts, and protective structural elements are variously sculptured in béton before being assembled and juxtaposed. They become the occasion to celebrate a plasticity in composition, a symphony of forms, which as for his sculptures carry a kind of "acoustic nature - that projects far the effect of their forms and, conversely also receive the pressure of the surrounding spaces". 41

The whole set is very fragmented but articulated: pure prisms pulled together with organic forms evoking the natural world, whilst others return to the metaphor of the ocean liner - chimneys for ventilation, a boat keel for the gymnasium roof. For all of these, one unique material béton brut is chosen which, according to Le Corbusier

\footnotetext{
${ }^{36}$ Costant, Carolin: "From the Virgilian Dream to Chandigarh: Le Corbusier and the Modern Landscape". In Wrede, Stuart; Adams, William Hower (Eds.): Denatured Vision. Lanscape and culture in the twentieth century. New York: The Museum of Modern Art, 1991. pp 79-93.

37 "Metropolitan Montage. The City as Film in Kracauer, Benjamin, and Eisenstein". In Vidler, Anthony: Warped Space. Art, Architecture, and Anxiety in Modern Culture. Cambridge Mass.: The MIT Press, 2000. pp. 111-122 .

${ }^{38}$ Bruno, Giuliana: Atlas of Emotion, op. cit. p. 58.

${ }^{39}$ Cohen, Jean-Louis: Le Corbusier and the Mystique of the USSR. Princeton: Princeton University Press, 1992. p. 49.

${ }^{40}$ Le Corbusier: Carnet vol IV. Paris: Herscher, Dessain et Tolra, 1981. p. 295.

41 “Le Corbusier et Savina”. In Le Corbusier: Oeuvre complète 1946-1952. Volume 5, op. cit. p. 240. Authors' translation.
} 
is "a natural material of the same rank as stone, wood or terracotta"42 and reveals infinite expressive potentialities, such that the Unité could be regarded as a treatise on reinforced concrete. ${ }^{43}$

Any fault, or blemish in the concrete, is considered natural because it is human, it is an expressive opportunity so there is no attempt to correct or conceal it: "I will find its complement and establish a play between crudity and finesse, between the dull and the intense, between precision and accident. [...] Exposed concrete shows the least incidents of the shuttering, the joint of the planks, the fibres and knots of the wood, etc. But these are magnificent to look at, they are interesting to observe, to those who have a little of imagination they add a certain richness" $" 4$.

This imaginative capability is revealed by Le Corbusier when filming on the shores of Arcachon and Rio. Le Corbusier repeatedly films, again and again, the artefacts which capture his attention on the shore - shells, branches, fossils and traces stamped on the sand, with a rich texture and intricacy of reliefs, randomly produced by the sea and the sand. The camera zooms on the fragments, detaches them from their context, then offers up casts, concretions, sculptural oeuvres; it catches their visual and tactile qualities, marking them down in Le Corbusier poetic imaginary, to later reveal them in the plastic oeuvres. The films recapture Le Corbusier observations on the natural and urban landscape and reveal sources for his inspiration.

Nature - in the sense of the natural and untamed, of the grass and wild flowers - is completely absent on this roof, except for few paltry details of flower boxes and artificial mounds, originally designed in grass and plants, but actually built in beton brut. Nature, though, returns powerfully in these string objects à reaction poetique.

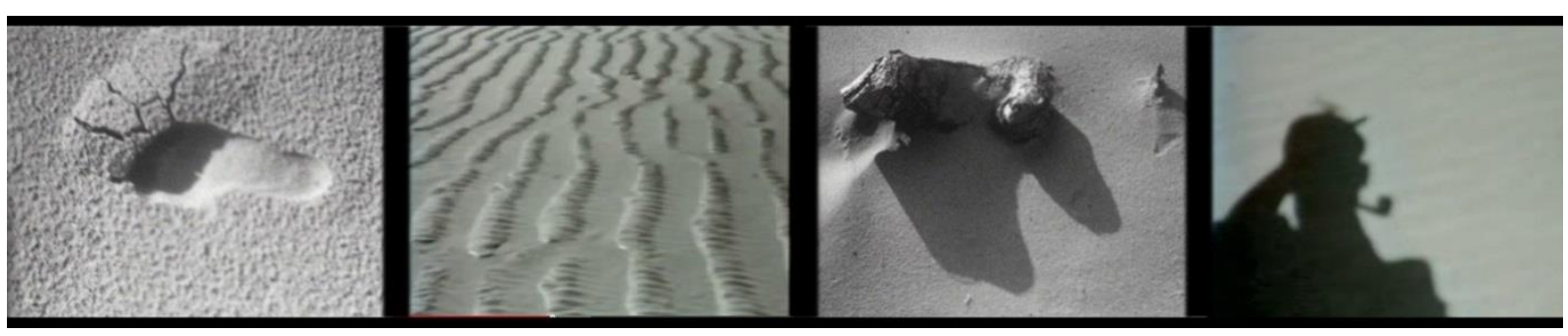

19. Stills from Le Corbusier 1936-38 film. Montage by the authors.

\section{Visions}

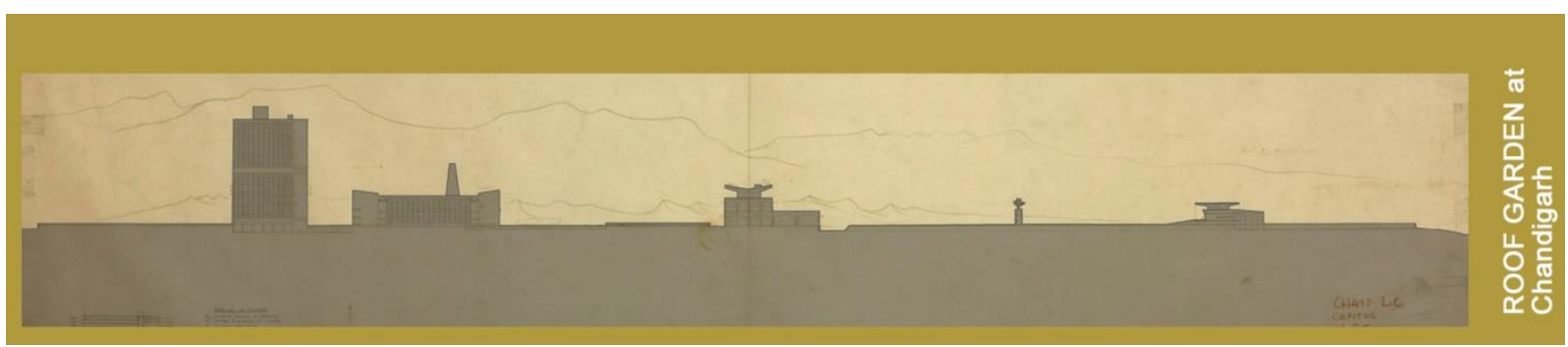

20. Collage by the authors.

\footnotetext{
42 “L’Unité d'Habitation in Marseille”, op. cit. p. 191.

${ }^{43}$ Von Moos, Stanislaus: "Machine et nature: notes à propos de l'Unité d'habitation de Marseille", op. cit.

44 “L’Unité d'Habitation in Marseille”, op. cit. p. 191.
} 
Within the technical evolutions related to the new material of reinforced concrete, Le Corbusier was able to discover new potential for the space of the roof garden and for the architecture and the modern city, developing it from the domestic to an urban scale. Both in rue Nungesser-et-Coli and at the Unité, Le Corbusier outlined the coordinates of contemporary research onto the urban landscape.

From the urban dimension of the Marseille solution, the roof-garden topic finds a territorial measure in Chandigarh. Because of the climate, the roof, together with the brise-soleil, becomes the characterizing theme for both the building and its overall setting. The roof is developed in a variety of ways so that we find the roofbasin, the roof-hat, the roof-terrace, the roof-garden. Here, where all is roof, Le Corbusier feels the need to represent the ground and the articulated outlines of the buildings as part of a single body offered to the horizon of the Himalayas. A continuous trace describes the unified profile of the buildings, it descends to the ground and excavates hollows and banks, or it raises hills, platforms, and podiums in order to articulate the strong horizontal definition of the plain.

The relationship with nature acquires a new cosmic dimension: the sun, the stars, the earth, the rain, the wind, are now primary forces shaping the architecture volumes, they pass through them and fill them, giving meaning to their forms.

Visionary and forward-looking, the view of Le Corbusier on the city and its landscape, from the high perspective of his roofs-gardens, still appears rich in suggestions today.

His ideas about nature in the natural state that were introduced on the roof garden in rue Nungesser-et-Coli and in Villa Le Lac, intertwine strong relations with the studies of the landscape by Gilles Clement - the third landscape, the moving garden and the untamed. Le Corbusier's concept of the roof garden as an urban public space is now being adopted in many roof- top projects all over the world, transforming the urban landscape and modernising traditional ideas of the city. The upper parts of buildings are being transformed into public squares or sky gardens, testifying the collective need to rediscover a direct relationship with nature within the big cities, starting from the roofs.

\section{Acknowledgements}

Fondation Le Corbusier, for support.

\section{Source of images}

Courtesy Fondation Le Corbusier:

FLC Plan 31514: 11.a; FLC Plan 18758: 11.d; FLC L1(10)46: 12.d; FLC L1(12)38: 16; FLC L1(15)103: 18.c; stills from Le Corbusier films «Films de Le Corbusier» (C) FLC-ADAGP: 3.b; 5; 6; 8.

Photograph by Henri-Paul Boissonnas, (C) Bibliothèque de Genève: FLC L3(18)48: 13.a.

Photograph by Marius Car: FLC L2(19)15: 11.c.

Photograph by Charles Gérard: FLC L1(6)11: 12.a; FLC L2(15)55: 11.b.

Photograph by Lucien Hervé: (C J. Paul Getty Trust. The Getty Research Institute, Los Angeles (2002.R.41):

FLC L2(10)135: 3.left; FLC L3(8)134-23: 14.a; FLC L3(8)137-51: 14.b; FLC L3(8)36-119: 14.c; FLC L3(9)42131: 14.d; FLC L2(1)34-184: 17.c; FLC L2(1)32-167: 18.a; FLC L2(1)59-643: 18.b.

Photograph by Dr Losen \& Co: FLC L1(2)67: 12.c.

Photograph by Melle Meyer: FLC L3(17)138: 9.

Photograph by Moiroud, FLC L4(2)6: 2.a. 
Photograph by Louis Sciarli: FLC L1(11)1: 17.a; FLC L1(11)42: 17.b.

Photograph by Peter Willi: FLC L2(17)42: 12.b.

Extract from Le Corbusier: Oeuvre complète 1910-29. Volume 1. W. Boesiger (Ed.). Zurich: Girsberger, 1984. 11th ed. p.182, (Immeuble Wanner): 13.c.

Extract from Le Corbusier: Oeuvre complète 1952-1957. Volume 6. W. Boesiger (Ed.). Zurich: Girsberger, 1985. 7th ed. p.50: 2.b.

Stills from Architecture d'Aujourd'hui. Directed by Pierre Chenal. Script by Pierre Chenal and Le Corbusier. Texts by Le Corbusier. Music by Albert Jeanneret. Produced by the review Architecture d'Aujourd'hui, 35 mm, b\&w, time 18 min. 1930: 13.b; 13.d.

Still from Le Corbusier. Film by Barsac, Jacques. Produced by Barsac, Jacques and Archambeaud, Christian. Distributed by Cine Service Technique, Film in 3 parts, 176 min., 1987: 19.

\section{Bibliography}

Le Corbusier: Vers une architetture. Paris: G. Crès \& Cie, 1923. Italian edition: Le Corbusier: Verso una architettura. Cerri, Pierluigi; Nicolin, Pierluigi (Eds.). Milano: Longanesi \&C, 1989.

L'Art décoratif d'aujourd'hui. Paris: G. Crès \& Cie, 1925.

Une Petit Maison 1923. Zurich: Aux Édition d'Architecture, 1954.

Carnet vol IV. Paris: Herscher, Dessain et Tolra, 1981.

Oeuvre complète. Boesiger, Willy (Ed.), vols. 1, 2, 4-8; Bill, Max (Ed.), vol. 3. Zurich: Girsberger, 1977, $1984-$ 1986.

“L’Arc-de-Triomphe a bruciapelo”. In Casabella, January/February 1987, № 531/532. Milano: Electa.

Il Modulor + Modulor 2. Saggio su una misura armonica a scala umana universalmente applicabile all'architettura e alla meccanica. Saurwein, Emanuele (Ed). Mendrisio: Gabriele Cappelli editore, 2004.

Brooks, H. Allen (Ed.): Le Corbusier. Princeton: Princeton University Press, 1987.

Bruno, Giuliana: Atlas of Emotion: Journeys in Art, Architecture, and Film. New York: Verso Books, 2007.

Cohen, Jean-Louis: Le Corbusier and the Mystique of the USSR. Princeton: Princeton University Press, 1992.

Le Corbusier. Le Grand. New York: Phaidon Press Limited, 2014.

Costant, Carolin: "From the Virgilian Dream to Chandigarh: Le Corbusier and the Modern Landscape". In

Reichlin, Bruno: “L’Esprit de Paris”. In Casabella. January/February 1987, № 531/532. Milano: Electa. pp. $52-$ 55 .

Moos, Stanislaus von: "Machine et nature: notes à propos de l'Unité d'habitation de Marseille". In Prelorenzo, Claude (Ed): Le Corbusier. La Nature. Paris: Éditions de la Villette, 2005.

Sbriglio, Jacques : Le Corbusier. Aventures photographiques. Paris: Éditions de la Villette, 2014.

Vidler, Anthony: Warped Space. Art, Architecture, and Anxiety in Modern Culture. Cambridge Mass.: The MIT Press, 2000.

Wrede, Stuart; Adam, William Hower (Eds.): Denatured Vision. Lanscape and culture in the twentieth century. New York: The Museum of Modern Art, 1991.

Films:

«Films de Le Corbusier» (C FLC-ADAGP. Paris: Fondation Le Corbusier. 
Architecture d'Aujourd'hui. Film directed by Pierre Chenal. Script by Pierre Chenal and Le Corbusier. Texts by Le Corbusier. Music by Albert Jeanneret. Produced by the review Architecture d'Aujourd'hui, 35 mm, b\&w, time 18 min. 1930.

Le Corbusier. Film by Barsac, Jacques. Produced by Barsac, Jacques and Archambeaud, Christian. Distributed by Cine Service Technique, Film in 3 parts, 176 min., 1987. 
Desde finales del siglo XIX, las Escuelas de Beaux-arts profundizan sobre el estudio de la anatomía y la fisionomía. A los "écorchés" que estudiara L'Eplattenier bajo la tutela de su maestro Mathias Duval se les sumarán los estudios de Marey, Muybridge y Richer en torno a la fotografía secuencial del cuerpo en movimiento (figura 1). Este avance, innegablemente unido a los estudios fisionómicos anteriores, supondrá un referente fundamental para las teorías de principios de siglo en torno al cuerpo y las artes, tales como la danza, el teatro, la pintura y la arquitectura.

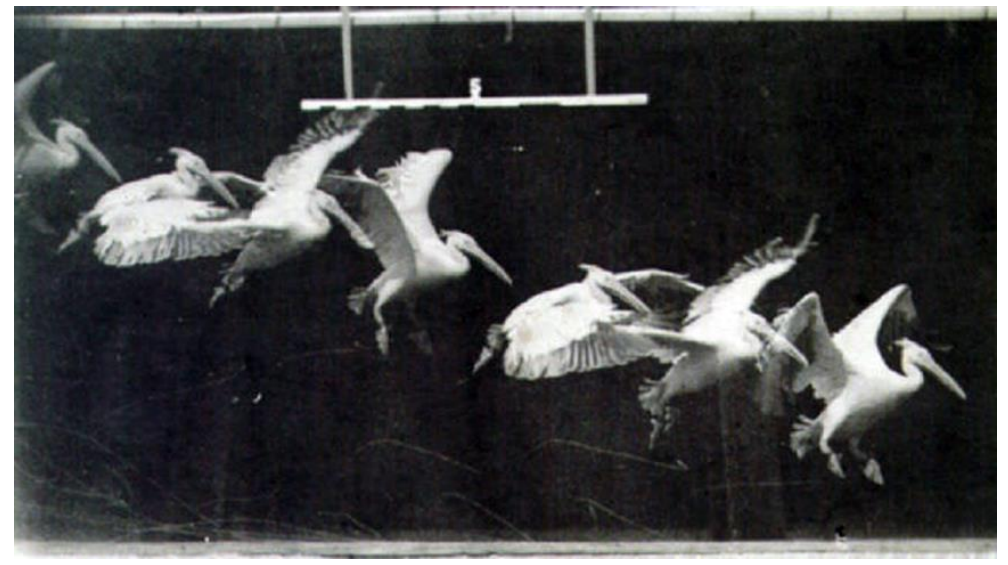

1. Vuelo del Pelicano. Ettiene-Jules Marey. 1887.

Un caso significativo será el "Método Dalcroze". Albert Jeanneret, discípulo directo de Émile-Jacques Dalcroze, dedicará dos artículos de L'Esprit Nouveau a las enseñanzas de su maestro, bajo el título "La Rythmique", en los que expondrá los principios que establecen la relación entre cuerpo, ritmo y movimiento (figura 2):

"le rythme musical est le régulateur (...) du mouvement corporel dans l'enseignement de la rythmique : le corps s'appuie sur cet élément éminemment suggestif qu'est la sonorité (...) rythmer les valeurs en mesures, assembler les mesures en phrases et les phrases en périodes (...) L'étude expérimentale de la langue plastique et établir ses rapports avec la langue musicale." ${ }^{2}$

Afín a estos planteamientos, Elie Faure será uno de los visionarios de esta nueva plástica. En su artículo de 1922 "De la cinéplastique", expondrá la epifanía del nuevo arte, en el que la plástica del objeto fijo viene a ser superada por la interpenetración de movimientos y ritmos, aliados con la música, para construir un "espace musical" cuyas concomitancias con la "architecture acoustique" son evidentes:

"La plastique est l'art d'exprimer la forme au repos ou en mouvement (...)les mouvements rythmés d'un groupe de gymnastes, d'un défilé processionnel, touchent de bien plus près à l'esprit de l'art plastique (...)puisqu'un rythme vivant et sa répétition dans la durée la caractérisent, la cinéplastique tend et tendra chaque jour davantage à se rapprocher de la musique. De la danse aussi" ${ }^{3}$.

Una "cineplástica " consistente en incorporar el tiempo como una dimensión más del espacio, que encuentra en el cine un medio perfecto:

"Le cinéma incorpore le temps à l'espace. Mieux. Le temps, par lui, devient réellement une dimension de l'espace.(...) La notion de la durée entrant comme élément constitutif dans la notion de l'espace, nous imaginerons facilement un art cinéplastique épanoui qui ne soit plus qu'une architecture idéale"4.

\footnotetext{
${ }^{2}$ Jeanneret, Albert. "La rythmique" en L'Esprit Nouveau. № 2. Paris: Freal, 1920, pp. 183-189.

${ }^{3}$ Faure, Eli. "De la cineplastique", en L'Arbre d'Éden. Paris: Cres, 1922, pp. 287 y ss.

${ }^{4}$ Idem.
} 
Un nuevo arte dispuesto para la educación del cuerpo y la mente, que encontrará su mejor soporte, el más directo por su uso cotidiano, en la arquitectura:

J'imagine que l'architecture en sera l'expression principale, une architecture d'apparence d'ailleurs difficile à définir, peut-être la construction industrielle mobilière, navires, trains,(...). La cinéplastique, sans doute, en sera l'ornement spirituel le plus unanimement recherché (...) $)^{5}$.

Objetos todos, más allá de su tamaño, construidos por ensamblajes que procuran una acción con el sujeto que interactúa con ellas, desplazándolo de las situaciones estáticas, ofreciendo un soporte para un tiempo moderno.

¿Cómo se construirá este nuevo cuerpo de escenario, de danzas y músicas precisas?, ¿cómo representar esa nueva arquitectura? .

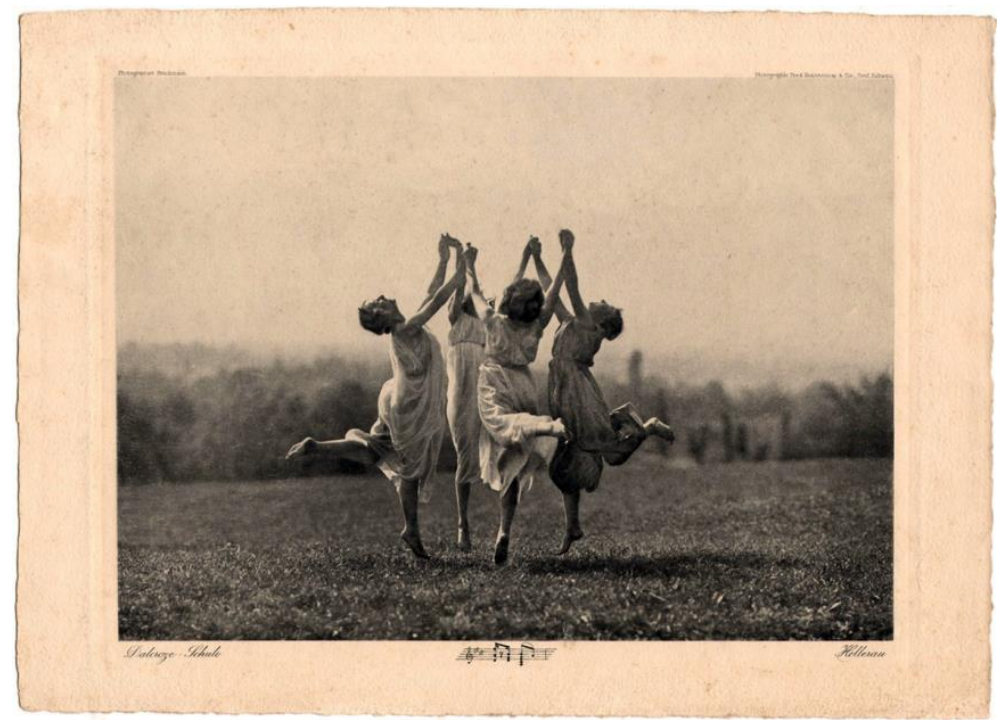

2. Dalcroze-Schule (Four Dancers in Flight), Foto de Frédéric Boissonnas, 1913.

\section{Las maquetas de Chenal.}

"J'ai lu votre livre. C'est vraiment bien, objectif, viable en cinéma, c'est du cinéma et il y a de la vision cinématique. Je vous en félicite. Je l'ai fait voir à Léger qui après l'avoir parcouru, l'a trouvé très bien". ${ }^{6}$

En 1930, Pierre Chenal realiza dos pequeños documentales por encargo de André Bloc, director de L'Architecture d'aujourd'hui, con el objeto de difundir los nuevos métodos de construcción moderna. Chenal conocerá a Le Corbusier al pedirle los convenientes permisos para filmar su obra ${ }^{7}$. El arquitecto no perderá la oportunidad de sacar mayor rédito a esta experiencia fílmica y desarrollará junto a él los scripts de ambos títulos, incorporando a su hermano Albert Jeanneret para la partitura que debía acompañar la cadencia de imágenes.

El interés de Le Corbusier por Chenal va más allá de la oportunidad publicitaria que supone la grabación de los dos documentales no sólo para su obra sino para él mismo como actor u hombre cinético, mezcla de mecánico y cirujano que manipula las anatomías de sus arquitecturas a través de las maquetas. Sin duda, la carta de Le Corbusier a Chenal demuestra el interés por la parte más reflexiva de la actividad cinematográfica. No por

\footnotetext{
${ }^{5}$ Idem.

${ }^{6}$ FLC B3-5-457-002. Carta de Le Corbusier a Pierre Chenal. 22 de octubre de 1930.

${ }^{7}$ Le Corbusier. Deux films de Pierre Chenal. Bâtir et Architecture. FLC B3-5-380." je ne connaissais pas Pierre Chenal. Un jour de 1930, il vint me demander l'autorisation de filmer quelques unes des maisons que nous avions construites".
} 
casualidad, el arquitecto comparte el libro del que Chenal es autor -"Drames sur celluloid"8 - con Léger, y el subrayado al "très" indica una indudable concordancia en las ideas de los tres personajes sobre el asunto que los reúne: "la vision cinématique".

"Drames sur celluloid" forma parte de lo que se ha denominado "cine-verse" ${ }^{9}$, consistente en la superposición o ensamblaje de versos que provocan una idea de movimiento resultado de "montar" diversas escenas cinéticas, representadas por cada uno de los 24 poemas del libro. Esta técnica está presente en los dos filmes de Chenal: las imágenes encadenadas necesitan ser puestas en relación -he ahí el interés de la música por parte de Le Corbusier, actuando de colágeno acústico- para transmitir no tanto una historia lineal, apenas existente en los dos filmes, como la experiencia de la nueva arquitectura.

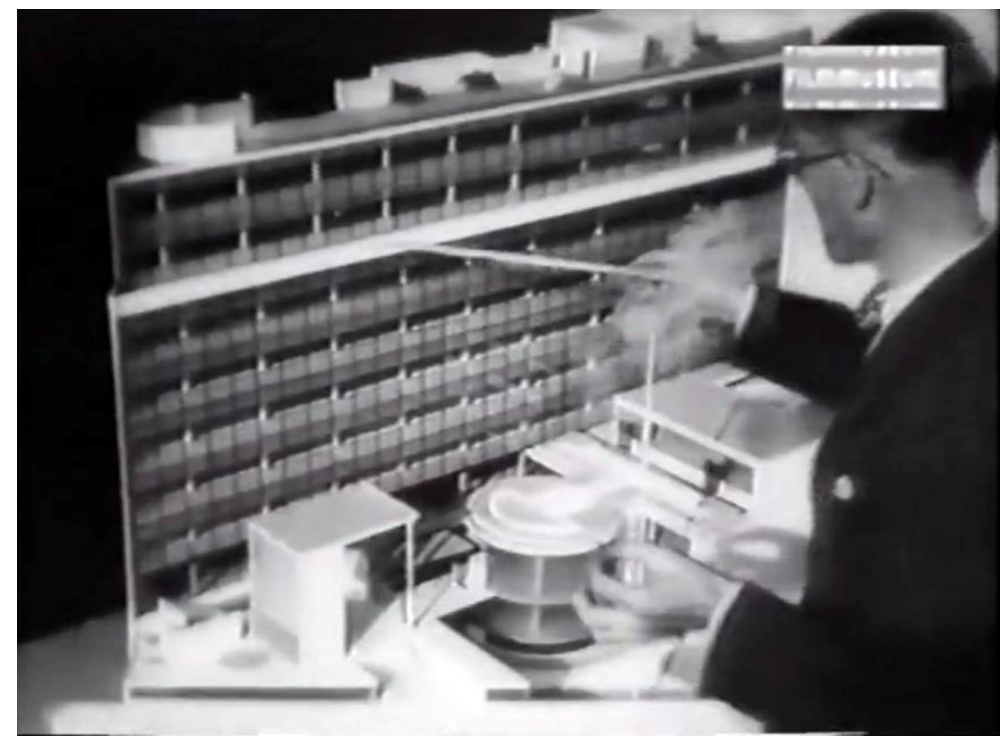

3. Fotograma de "Batir". Le Corbusier explica las nuevas anatomías arquitectónicas.

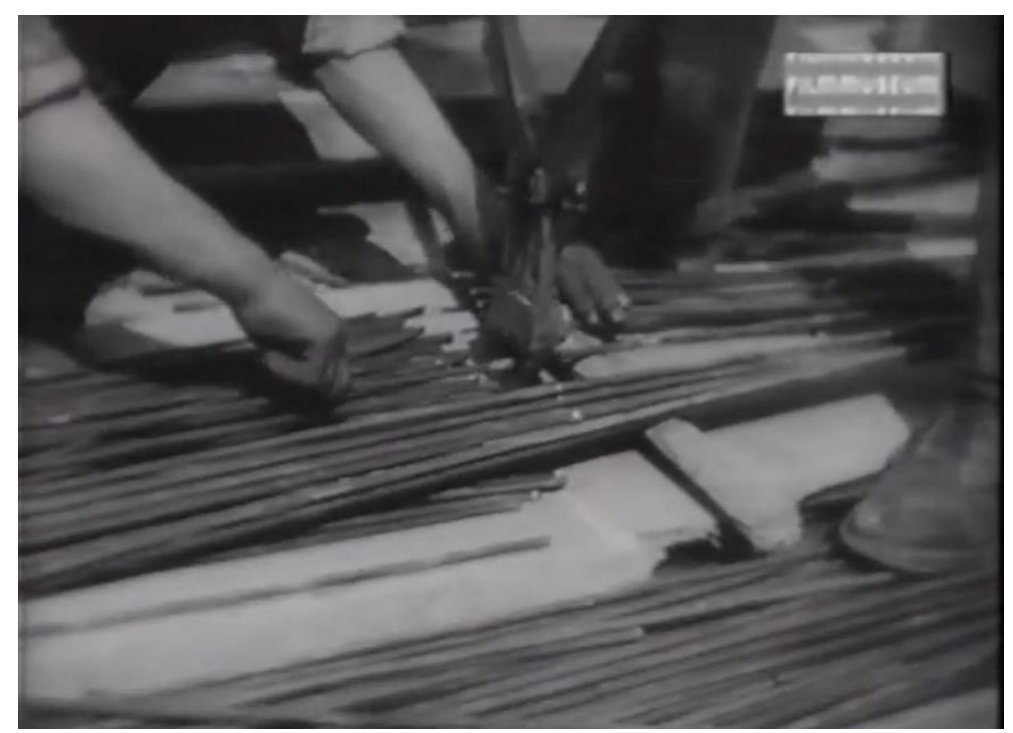

4. Fotograma de Batir. 1930. Obreros manipulan nuevos materiales de construcción.

\footnotetext{
${ }^{8}$ Chenal, Pierre. Drames sur cellulö̈. Paris: Ed. Les Persepectives, 1929.

${ }^{9}$ Cfr: Epstein, Jean. "Le phénomène littéraire" en L'Esprit Nouveau N. 8, mai 1921.Paris: Freal, 1921. pp. 856-860.
} 
A las obras realizadas por Le Corbusier se le sumarán la utilización de cuatro maquetas ${ }^{10}$, ejecutadas para el documental. En el caso del "Plan Voisin", las características que así lo señalan son el uso de colores y trompes d'oeil, más pensados para la cámara que para una exhibición ante el público ${ }^{11}$. En el caso de las restantes, existen una serie de aspectos que hacen pensar en una ejecución premeditada para la cámara. Las tres maquetas proponen elementos imitadores del vidrio, lo que permite un doble recurso al director y su colaborador: la transparencia y el reflejo ${ }^{12}$.

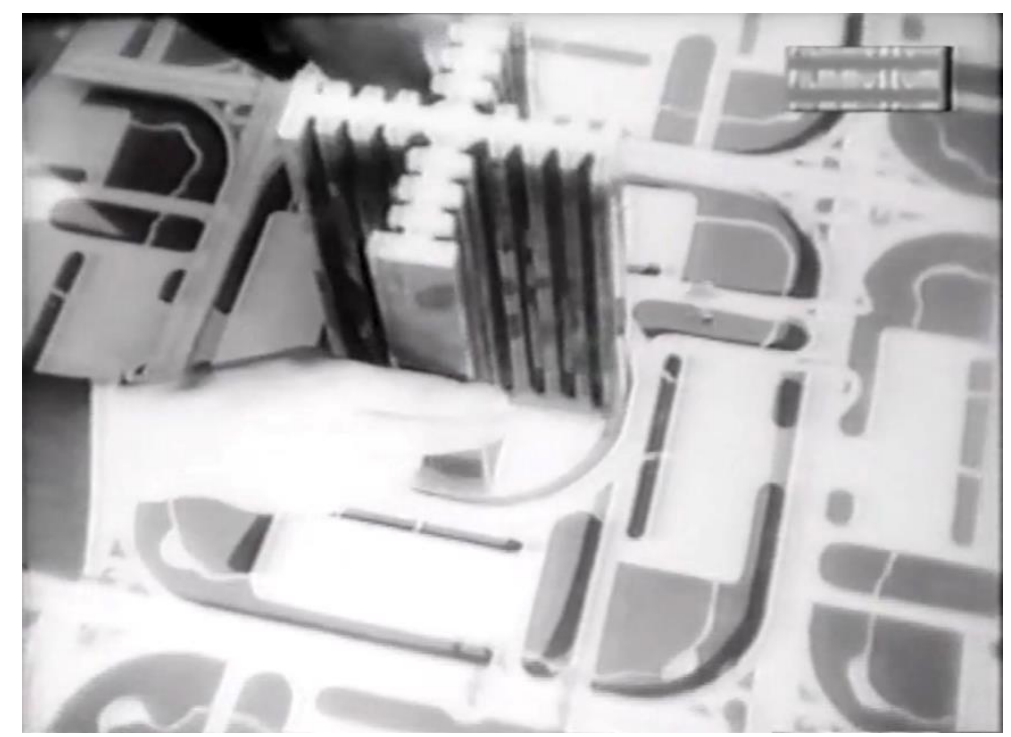

5. Fotograma de "Batir". 1930. Le Corbusier manipula un rascacielos del Plan Paris.

Más allá de algunas imágenes en las que los modelos actúan como representación del edificio en posiciones cercanas a la perspectiva tradicional, Le Corbusier crea relaciones escalares ilusorias, al irrumpir con la presencia de su propio cuerpo en movimiento alrededor del objeto: el humo de su cigarro, la mano que sobrevuela la ciudad o aquella que mantiene en el aire un edificio (fig. 3). Este recurso reverbera en el resto del film, donde son continuos los planos en los que el obrero interactúa con la máquina -con sus engranajes y bielaspara construir la nueva arquitectura (fig. 4). El montaje de imágenes de la Cité Refuge en construcción precedida de una toma de la maqueta desde idéntico punto de vista permite, en un abrir y cerrar de ojos, ver el edificio terminado, manipulando así los procesos de tiempo y construcción. Por tanto, la maqueta se convierte en un instrumento-máquina que el arquitecto utiliza para su oficio, alternativa de cartón a las llaves y tenazas de acero de la construcción a escala real (fig. 5). Ambos procesos montados encadenadamente en el filme dan el resultado deseado:

"Par son documentaire "Batir", Pierre Chenal a subitement pris contact avec ces réalités nouvelles pour lui; celles de l'acier et du ciment arme, celles de la machine des chantiers (...) il empoigne tous ces phénomènes nouveaux dans l'enroulement de sa camera, mais surtout, il se sent le gout de l 'exprimer a ceux qui $n$ 'ont pas eu

\footnotetext{
10 "Plan Voisin" y "Plan Paris" en "L'Architecture d'aujourd'hui" y "Cité Refuge" y "Gratteciel cartesien" en "Batir".

${ }^{11}$ Carta de Le Corbusier a Chenal. FLC B3-5-457-002. 22/10/1930 "Veuillez me faire savoir d'urgence de quelle couleur il faut peindre le plan en trompe l'oeil et les gratte-ciels en maquette, pour que cela soit photogénique".

${ }^{12}$ Cfr.: Rowe, Colin; Slutzky, Robert "Transparencia: literal y fenoménica", en Rowe, Colin Manierismo y arquitectura moderna y otros ensayos. Barcelona : Gustavo Gili, 1999. $1^{\circ}$ ed. Perspecta, 1963.
} 
l'occasion de faire sa découverte, et devant l'écran, par la logique de l'enchainement et la création poétique du film, le spectateur découvre a son tour la nouvelle épopée des chantiers moderne" ${ }^{13}$.

La fotografía del interior de una pequeña habitación -probablemente el despacho de Le Corbusier antes de su reforma tras la Segunda Guerra- muestra todas las maquetas utilizadas en el film, junto a un proyector eléctrico y, en primer plano, un cenicero sin usar y una jarrón de vidrio sin flor, posiblemente materiales de construcción (fig. 6).

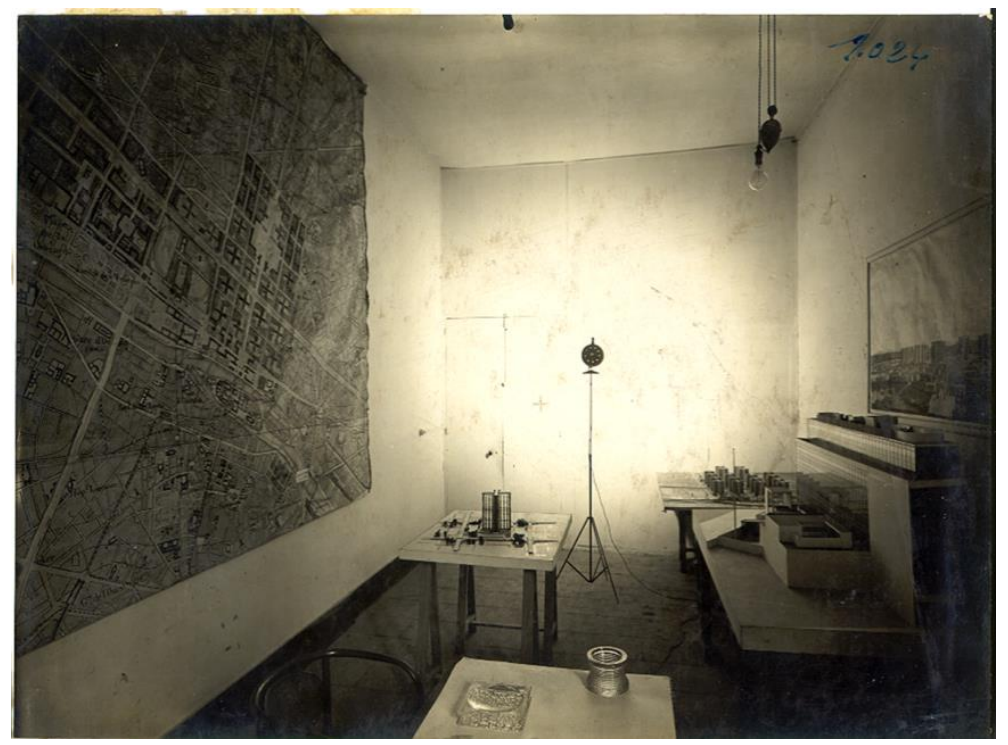

6. Despacho de Le Corbusier con todas las maquetas aparecidas en los filmes de Pierre Chenal. 1930.

Se muestran ante el objetivo fotográfico con sus sugerentes transparencias y los reflejos, producidos por la luz del foco rebotada contra la pared. La habitación se presenta así como un espacio imaginario. Su condición de bodegón purista a base de la acumulación de escalas, transparencias y reflejos funciona como una caja de resonancia ${ }^{14}$, donde conviven en un solo espacio el arquitecto como persona, su memoria -a través de los objetos que le sirven de inspiración- y su creación -a través de la presencia física de las maquetas. La puerta cerrada y las propias paredes, sustentando planimetrías como únicas ventanas de la estancia, insisten aún más en el carácter clausurado y reverberante de ese espacio, en el que la luz, sin la referencia solar, abunda aún más en dicha cualidad especulativa. A pesar de su imagen estática, no cabe la menor duda que al más mínimo movimiento de la cámara, brillos, reflejos y transparencias serán otros. Bastará un instante.

\footnotetext{
${ }^{13}$ Le Corbusier. Op.cit. nota 7.

${ }^{14}$ Beltramini, Guido y Croiset, Alain. Juan Navarro Baldeweg: risonanze di Soane. Entrevista J.J. Lahuerta y J.N Baldeweg. Vicenza: Centro Andrea Palladio, 2000. Baldeweg utiliza este término para referirse a la sala de maquetas de Soane
} 


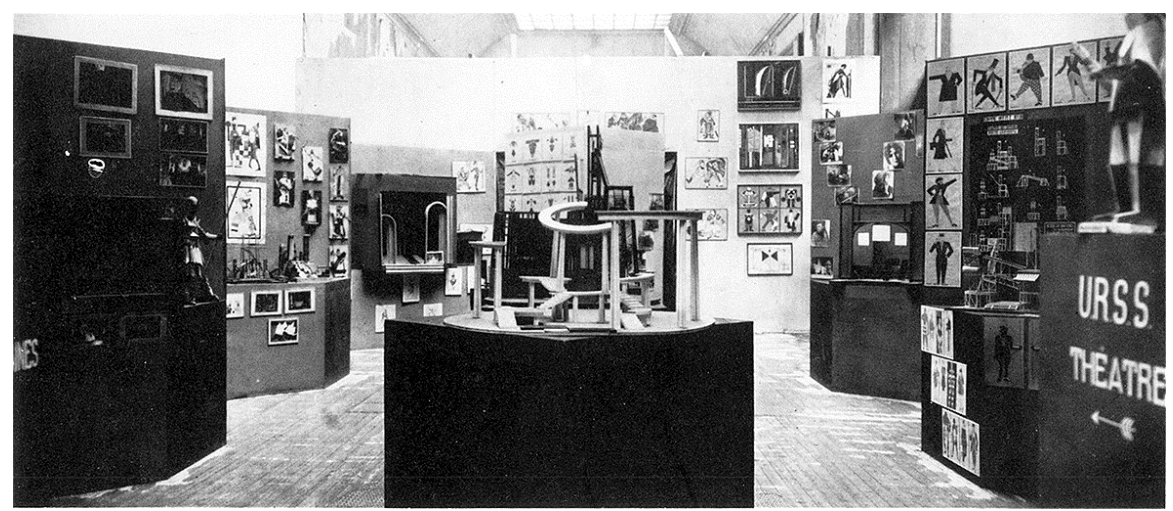

7. Imagen de L'Exposition d'Arts Decoratifs en Paris, 1925. Sala sobre el Teatro Ruso.

\section{Montages. Las maquetas rusas.}

Who would guess that its plan is a bas-relief incorporating elements of African sculpture in the manner of Picasso and Lipchitz? ${ }^{15}$

Los trabajos de Popova, Rodchenko, Vesnin, Exter o Stepanova, compendiados en la Exposición 5x5=25 realizada en 1921 en Moscú, propondrán diversas opciones de montajes teatrales para obras de Meyerhold mediante maquetas (fig.7). El material viajará a l'Exposition d'Arts Decoratifs de 1925 en París, donde llaman la atención de Le Corbusier, al igual que la maqueta del Monumento a la Tercera Internacional, diseñada por Tatlin . Dichas maquetas son realizadas como homotecias de los trabajos de escenografía, utilizando los recursos de una carpintería experta, enseñada tanto en los VKHUTEMAS como en las propias clases de escenografía del GVTM de Meyerhold ${ }^{16}$, señalando como protagonista principal a los procesos constructivos, más que a una plástica maquillada del resultado definitivo.

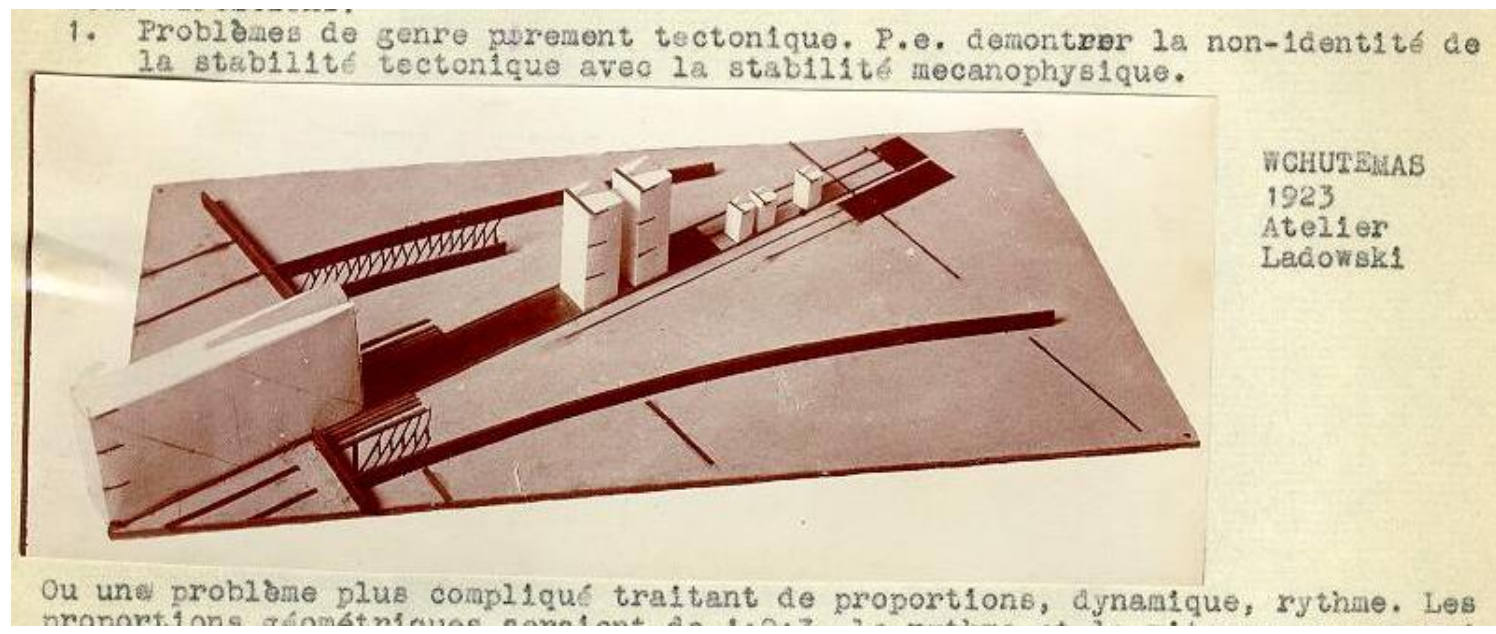

8. Imagen de maquetas del Taller Ladowski incluida en el envío del artículo "SSSR" de El Lissitzky a Le Corbusier.

\footnotetext{
${ }^{15}$ Drexler, Arthur. "Engineer's Architecture: Truth and Its Consequences", en Drexler, Arthur The Architecture of the Ecole des Beaux-arts. Boston: The Museum of Modern Art, MIT Press, 1977; pp. 13-26

${ }^{16}$ Cfr. Cohen, Jean-Louis [et al.] Constructivismo ruso : sobre la arquitectura en las vanguardias ruso-soviéticas hacia 1917. Barcelona: Ediciones del Serbal, 1994.
} 
Acompañando a Rodchenko ${ }^{17}$, son las maquetas en la Exposición de $1925^{18}$, relacionadas con la escenografía teatral, los primeros objetos que a Le Corbusier le permiten al fin palpar la nueva arquitectura rusa. A ella se le añade el conocimiento que, un año antes, tendrá del pensamiento y acción de El Lissitzky, a través del artículo $\mathrm{SSSR}^{19}$, que irá acompañado de varias ilustraciones. Texto e imagen recogen el interés del arquitecto, en ese momento vinculado a los VKHUTEMAS, por el uso de la maqueta, no sólo como medio de expresión de la arquitectura sino como sistema de enseñanza (fig. 8):

En 1921 un groupe de jeunes professeurs (Ladowski, Krinskl, Docutchajeff, Eflmoff) réussit à constituer une section autonome de la faculté d'architecture a l'académie (WCHUTEMAS) de Moscou.(...). Au lieu d'une salle de dessin on voulait un champ d'essai, au lieu de dessiner sur du papier dans la mesure 1 : 100. on voulait composer directement dans la mesure 1:1. En attendant chaque travail est exécuté en modèle".

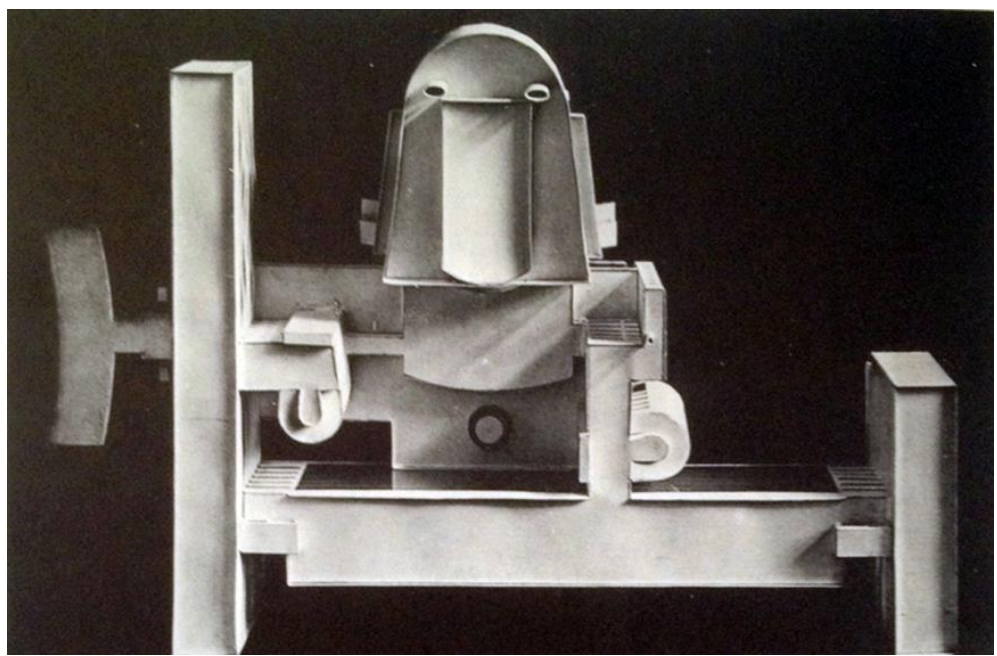

9. La maqueta del Centrosoyus fotografiada como un bas-relief. 1929.

Si el PROUN es "la estación de tránsito de la pintura a la arquitectura" ${ }^{20}$, las maquetas parecen ser la primera vía para entrar en contacto con la materia, superando una pura concepción retiniana, un camino que habrá de recorrer Le Corbusier en su periplo soviético. La maqueta del CentreSoyus será la estación de partida, aquella que Drexler vinculaba, no casualmente, con Picasso y Lipchitz, los dos artistas presentes el día que Tatlin descubrió una nueva cultura de lo material, venida también de $\operatorname{lejos}^{21}$. (fig 9)

${ }^{17}$ González Cubero, Josefina. "Hilos de teatro: La puesta en escena del Palacio de los Soviets de Le Corbusier". En Proyecto, Progreso, Arquitectura $\mathrm{n}^{\circ}$ 7. Sevilla: Ed. Universidad de Sevilla, 2012.

${ }^{18}$ Cohen, Jean-Louis. Le Corbusier and the Mystique of the USSR : Theories and Projects for Moscow : 1928-1936. Princeton, N.J.: Princeton University Press, 1992. p. 4.

${ }^{19}$ Lisstizky, El. SSSR. Referencia FLC D1-7-68-001 a 009. Sobre el desencuentro entre Lisstizky y Le Corbusier a raíz de este artículo. Cfr. ibídem, pp. 109 y ss.

${ }^{20}$ Lisstizky, El. "Interrelaciones entre las Artes". en 1929. La Reconstrucción de la Arquitectura de la URSS.. Barcelona Ed. GG. 1970. p. 9-10.

${ }^{21}$ En 1912, Tatlin descubre los collages de Picasso -precursores de sus "contrarelieves"- en el estudio del pintor, presentado por Lipchitz. Todos ellos mostraban en ese momento, un interés por el Art Négre. 


\section{La maqueta del Palacio de los Soviets.}

Evidenciar la síntesis entre lo técnico y lo artístico, que El Lisstizky atribuía a la maqueta del Monumento a la Tercera Internacional ${ }^{22}$, es el objeto del modelo a escala de la propuesta para el Palacio de los Soviets que se realizará en el Atelier de la Rue de Sevres durante el invierno del 1931-32.

Construida en la última fase del concurso, ya fuera de plazo de entrega, sus objetivos son dos. El primero, narrado por el propio Le Corbusier en la Oeuvre Complète, comprobar la calidad acústica del auditorio central, mediante un ocurrente sistema luminoso; el segundo, mejorar la presentación ante el jurado que examinaba los trabajos, pero no enviando fotografías o el modelo del edificio , como si ocurrirá en el caso del Centresoyus, sino haciéndo llegar una película de 100 metros de filme, lamentablemente perdida, en la que la maqueta servía de soporte para mostrar el proceso de ensamblaje de las distintas partes que lo conformaban, fusionando interior y exterior del edificio. Que la filmación sea posterior a los documentales de Chenal no es un hecho casual, como no lo es el interés creciente de Le Corbusier con el mundo del cine, ampliado gracias al conocimiento y amistad que entablará con Sergei Eisenstein. El realizador soviético del film, de nombre M'Ekk ${ }^{23}$, hubo de estar familiarizado con las teorías del montaje del famoso cineasta.

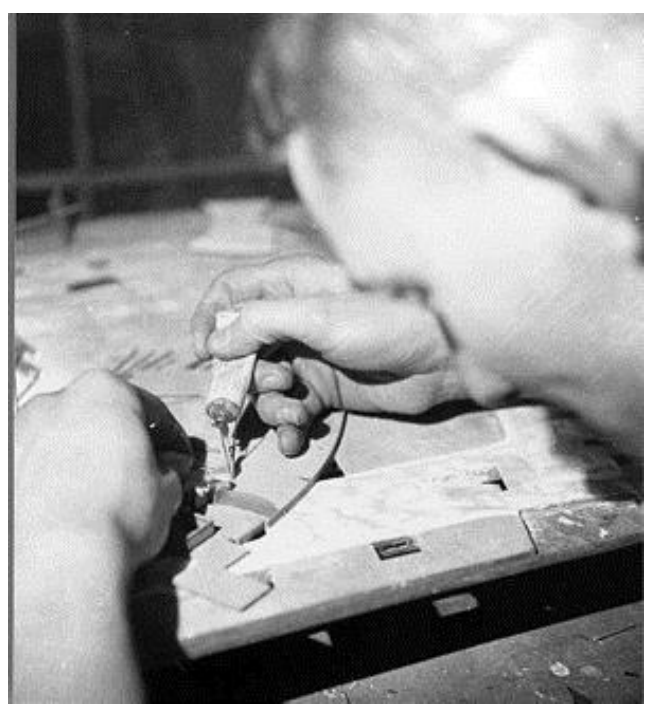

10. Uno de los colaboradores, Sanders posiblemente, montando la maqueta. El pegamento es novedad en 1932.

Eisenstein comenzará su carrera artística en el teatro Meyerhold. Pronto se dará cuenta que las teorías biomecánicas del director -muy presentes en su cine- no son suficientes como método de expresión de la comunión entre público y mensaje, por lo que dirigirá sus intereses a la pantalla, buscando la repercusión del mensaje en la masa. La monumentalidad de las fiestas soviéticas, de los grandes actos públicos de números exagerados, será la primera alternativa que los Soviets propondrán como representación del nuevo Estado. La propuesta de Le Corbusier se establece como un soporte tecnificado de estos actos públicos, a caballo entre el teatro Zon de Meyerhold y los grandes vacíos o espacios públicos en los que se desarrollan festivales y

\footnotetext{
${ }^{22}$ El Lissitzky. Op.cit n.19." (Tatlin) ejecutó esta obra sin específicos conocimientos técnicos-constructivos o estáticos y probó lo fundado por crear una síntesis entre lo <técnico> y lo <artístico>".

${ }^{23}$ El realizador "soviético" es referido en una carta de Le Corbusier a Gustave Lyon. FLC I2-5-188. Pudo compartir formación con Eisenstein en el VGIK (Insituto Gerasimov) fundado en 1919 por el gobierno soviético.
} 
procesiones con escenografías de Altman, Fomin, Duplitsky, Popova o Vesnin, en las que el recinto urbano y su skyline eran transformados para la ocasión ${ }^{24}$.

Ya ha sido señalada la influencia de Meyerhold en la propuesta de Le Corbusier para el Palacio de los Soviets ${ }^{25}$ y su relación con el kabuki japonés. Tanto el director de cine como el de teatro, poseen un conocimiento atento de la cultura nipona, que encauzan a sus actividades artísticas, pareciendo alejarse así de la escena teatral europea. No obstante, las concomitancias de las euritmias del método Dalcroze -e incluso influencias ${ }^{26}$ - con las biomecánicas de Meyerhold, o la idea de montaje de Eisenstein, son evidentes por sus puntos en común en torno al movimiento del cuerpo. Esta nueva presencia del cuerpo requiere el abandono de la representación de la estampa: la escenografía deja atrás su carácter bidimensional, se libera del fondo perspectivo para dejar a la vista aquello que mantenía en pie los lienzos ilusorios tradicionales. El resultado será el armazón, reflejo del acto purificador del constructivismo que "limpiaba el teatro para la representación del actor" ${ }^{27}$. Este mismo proceso se realiza homotéticamente en las maquetas, tradicionalmente utilizadas como sistema de preparación de la escenografía, presentadas dentro de una caja abierta por una cara correspondiente al marco del proscenio. Así, el umbral ilusorio del teatro burgués queda demolido por el nuevo teatro y lo que ofrece la maqueta no es ya una estampa, sino "pura construcción", llena de "lógica arquitectónica"28. Un ejemplo paradigmático será la maqueta realizada por Lissitzky para "I want a child", en la que se muestran todos estos atributos a través de la identificación que realizará el propio Meyerhold con la cultura del circo (fig. 10). El modelo, de dimensiones lo suficientemente considerables como para permitir a Lissitzky introducir su cabeza en él, responde a la perfección a los principios constructivistas de su deseo por realizar un espacio tridimensional cinético ${ }^{29}$.

La incapacidad creativa en las tres dimensiones será una de las armas más lacerantes que Lissitzky utilizará contra Le Corbusier en los albores de los concursos del Palacio de los Soviets, al señalar su querencia a recurrir a la ilusión tridimensional del espacio pictórico para realizar su arquitectura, toda una andanada mortal a un Le Corbusier que está pretendiendo poco a poco alejar de sí el aura de pintor para optar por una posición firme de arquitecto mundialmente reconocido:

"Le Corbusier is a classicist (...). Within this framework he manipulates, with a high degree of sensitivity, the spatial relations that he creates by means of explicit intersections between the three dimensions. (...) Yet if there is a single rule, one that is borrowed from history, it is that of the Golden Section, although this cannot be consistently applied to space-it is absolutely precise in two dimensions, but becomes meaningless in three. In the work of Le Corbusier, the eye of the painter is everywhere present (.... ${ }^{\prime 30}$.

La maqueta del Palacio de los Soviets parece ser la respuesta más contundente que pudiera realizar Le Corbusier a los ataques recibidos. Sin duda, hubo de influir en la decisión de realizar una maqueta, no solicitada por las

\footnotetext{
${ }^{24}$ Ziada, Hazem. Gregarious espace, Uncertain grounds, undisciplined bodies. The Soviet Avant-Garde and the 'Crowd' Design Problem. Phd. Georgia Institute of Technology, May 2011 p. 125 y ss.

${ }^{25}$ González Cubero, J. Op.cit. nota 16.

${ }^{26}$ Bowlt, John. "El constructivismo en el teatro". En Ortega, Carlos (dir). El Teatro de los pintores en la Europa de las Vanguardias. Madrid: Ed. Museo Reina Sofía, 2000. "El método de la biomecánica de Meierkhold, deudor de los principios de Emile-Jacques Dalcroze (...) y del teatro japonés, era el elemento principal del concepto constructivista del intérprete".

${ }^{27}$ Ibídem p.223,224.

${ }^{28}$ Ibídem p.230. "Por muy primitiva, por muy sencilla que sea su decoración, el esqueleto, su estructura básica (construcción) debe tener una lógica arquitectónica".

${ }^{29}$ Este objetivo también lo será de Le Corbusier en su propuesta de la Sala B del Palacio de los Soviets, donde idea un sistema de tramoyas que permite el uso de escenarios "á ronde bosse". Cfr. Boesiger. W (ed). Le Corbusier. CEuvre complète vol. 2. Basel: Ed. Birkhäuser, 1935 ( $\left.1^{\circ} \mathrm{ed}\right)$, p.124.

${ }^{30}$ ibídem. p. 109.
} 
bases del concurso, la exposición de 15 proyectos para un Palacio de los Soviets, aún sin lugar predeterminado, realizados por Ladovsky, Rozenblyum, el grupo ASNOVA, el Grupo ARU, entre otros y que fueron presentadas al público mediante maquetas ${ }^{31}$. Esta mejora en la representación no sólo la realizará Le Corbusier: Lubetkin, Storonov, Poelzig, Mendelshon y el grupo VASI (Vesnin) o Gabo también recurrirán a dicho instrumento. Pero desde luego, el franco-suizo marca una diferencia respecto al resto de propuestas, especialmente en el sistema de representación utilizado. La película será el último envío de material desde la Rue de Sevres, por lo que se enfatiza así la fidelidad de la maqueta a lo dibujado. Así, a la construcción del modelo a escala se le otorga una exactitud cercana a la de la obra, ya que en tanto no está totalmente resuelta la forma compleja del techo calculado por Gustave Lyon, la maqueta no puede ser terminada ${ }^{32}$, una espera necesaria para comprobar las características técnicas -no plásticas- de la propuesta (fig. 11):

"Sur la maquette actuellement en construction, nous avons procédé à une vérification de la répartition des ondes sonores, en nous basant sur l'unité de principe de la réfraction des ondes lumineuses. L'expérience a été concluante. En effet, nous avons, à l'intérieur de la maquette, installé une lampe à l'emplacement prévu pour le haut-parleur. Nous avons allumé la lampe, et les rayons se sont dirigés vers la coupole de la salle, ils s'y sont brisés suivant les lois de l'incidence identiques à celles du son: l'amphithéâtre des spectateurs s'est trouvé entièrement éclairé d'une matière uniforme, de même équivalence au premier rang qu'au dernier" ${ }^{33}$.

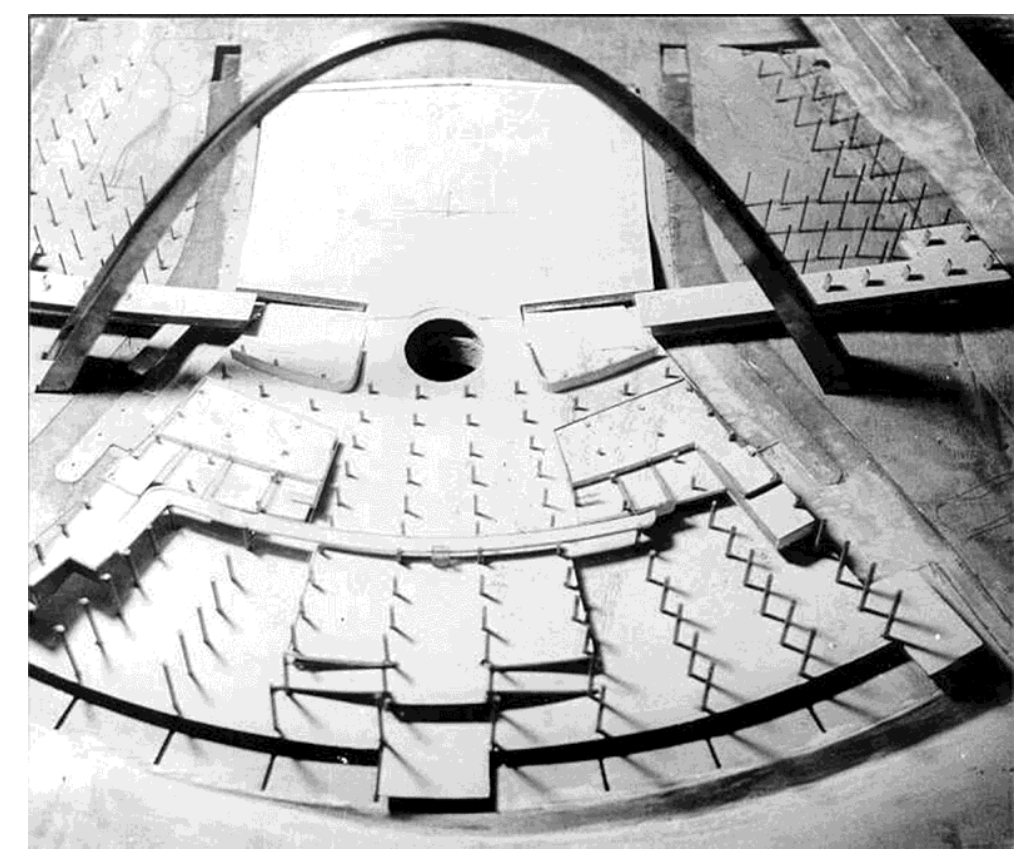

11. El agujero para la localización de la bombilla cuya luz imita el reparto del sonido.

Por fechas anteriores cercanas, ingenieros alemanes como Spandock o Hellmholtz ${ }^{34}$ están utilizando sistemas similares, con unas técnicas realmente novedosas (fig. 12). El propio Lyon ya haría algo similar para la maqueta

\footnotetext{
31 ibídem. pp. 186,187.

${ }^{32}$ Los últimos cálculos de Lyon se envían algunas semanas antes de la finalización de la maqueta. Cfr. Quetglas, J. Marza, F. "Palais des Soviets" en DVD Plans, vol. 4. Paris: Échelle-1, 2010.

${ }^{33}$ Boesiger. W (ed). Le Corbusier. Euvre complète vol. 2. Basel: Ed. Birkhäuser, 1935 (1ºd), p.124.

${ }^{34}$ Rindel, Jens Holger. "Modelling in auditorium acoustics. From ripple tank and scale models to computer simulations" en Revista de Acústica. Vol. 32.3 y 4. Madrid: S. Esp. Acústica. 2002. "In the early 1930s some german acousticians used rays of light in three-dimensional models of theatres to study the path taken by sound waves, but such models gave no help in investigating different frequencies of sound (...) Acoustic design was still largely a subjective art at this time".
} 
que realizara de la Sala Pleyel en 1923, cuyo siguiente relato periodístico bien pudiera aplicarse a la de los Soviets:

"Je me rappelle l'impression de stupeur que l'on éprouvait il y a trois ou quatre ans, lorsque M. Gustave Lyon nous invitait à contempler dans son cabinet de travail une vaste maquette en carton de la future salle. Les murs au lieu de s'élancer verticalement, s'incurvaient bizarrement, le plafond au lieu de présenter aux yeux une surface plane ou une coupole, figurait une sorte de gigantesque escalier renversé" ${ }^{35}$.

En definitiva, la maqueta es todo un instrumento de comprobación acústica, un recurso de ingeniero para el que las formas responden más bien a leyes matemáticas y a comprobaciones calibradas y no al "orden arquitectónico" ${ }^{36}$. El desmontaje del edificio en diversas partes, permitía estudiar por separado la sala principal, como en una biopsia, y observar el reflejo luminoso a través de la transparencia de sus laterales. (fig. 13).

Pero más allá de su efectividad como modelo de comprobación técnica, las relaciones entre la concha de la "Sala A" principal y la espacialidad luminosa que propone la bombilla bien pudieran ser una de las primeras experiencias de esa arquitectura acústica que Le Corbusier formulará en años posteriores. No se ha de olvidar que las primeras vinculaciones de la arquitectura con la acústica provienen de su visita al Partenón, en un espacio exterior, en un paisaje ${ }^{37}$. El efecto de la luz atravesando las vidrieras laterales y la fachada oeste del edificio hacen incluir a la ciudad dentro del proyecto, inundar de ondas la explanada de la antigua Iglesia del Salvador y reflejarse en las aguas del Río Moskva (fig. 14). Si Meyerhold podía meter la cabeza dentro de su espacio teatral tridimensional, Le Corbusier contemplaba, en la noche laboriosa de su estudio de Paris ${ }^{38}$, la luz reflectada sobre el techo de la concha, escapando a la ciudad por los costados y entre las costillas brillantes de las grandes ménsulas metálicas, al igual que el flexo que rebotaba la luz contra la pared en el bodegón purista de las maquetas de Chenal. Bien pudiera decirse que la cúpula paraboloide gravita sobre la ciudad, la acoge bajo ella, en los mismos términos que lo hace el Duomo de Pisa, como él mismo recogerá en sus dibujos preparatorios.

\footnotetext{
${ }^{35}$ Prunières, Henry. "Inauguration de la Salle Pleyel". en La Revue Musicale. n 1, 1 novembre 1927, p. 59-62.

${ }^{36}$ Le Corbusier. Cuando las catedrales eran blancas. Barcelona: Apóstrofe, 2007. p. 38. "Con la Sala Pleyel (Lyon) había expulsado a la Academia de la arquitectura. Desde ese día, ninguna sala, en el mundo entero, se proyecta de acuerdo con el esquema de las escuelas oficiales; todas tienen que referirse a esa lección de acústica y ortofonía".

${ }^{37}$ Quetglas, Josep. Op.cit.n.32."Since his visit to the Acropolis, Le Corbusier had named "acoustic" as one of the characteristics of architecture, which gathers and concentrates, to then spill and amplify, the landscape (...). If Brunelleschi had made devices to teach the Florentines to see their city "in perspective", Le Corbusier did the same thing with (...) this model of the Palais des Soviets, a piece halfway between Marcel Duchamp and Baldeweg, where Gordon Matta-Clark could enter, leaving the saw at the door."

${ }^{38}$ Boesiger, Will. Op.cit.n.33, p.124. El propio Le Corbusier relata la nocturnidad del trabajo.
} 


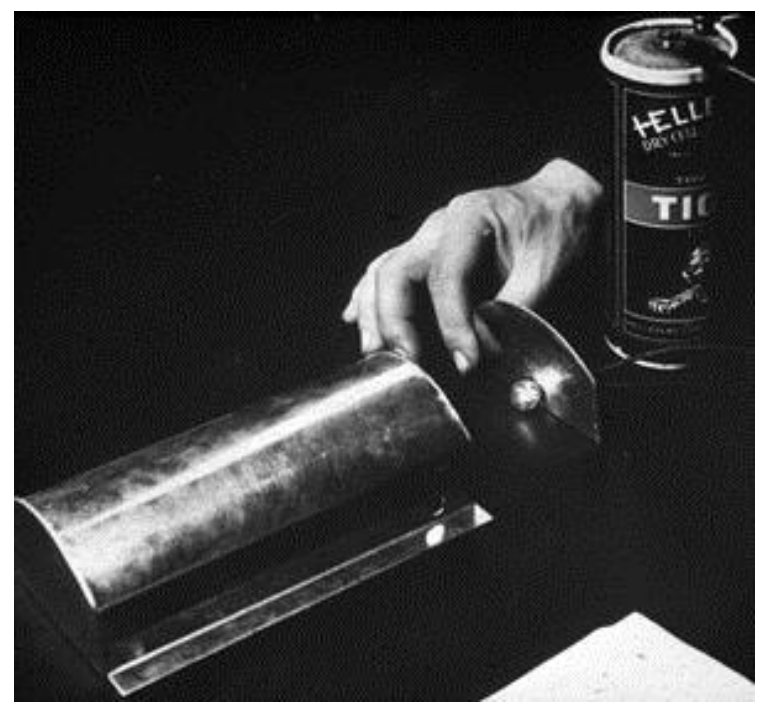

12. Sistema luminoso de comprobación. La batería alimenta una luz que se introduce en la bóveda metálica.

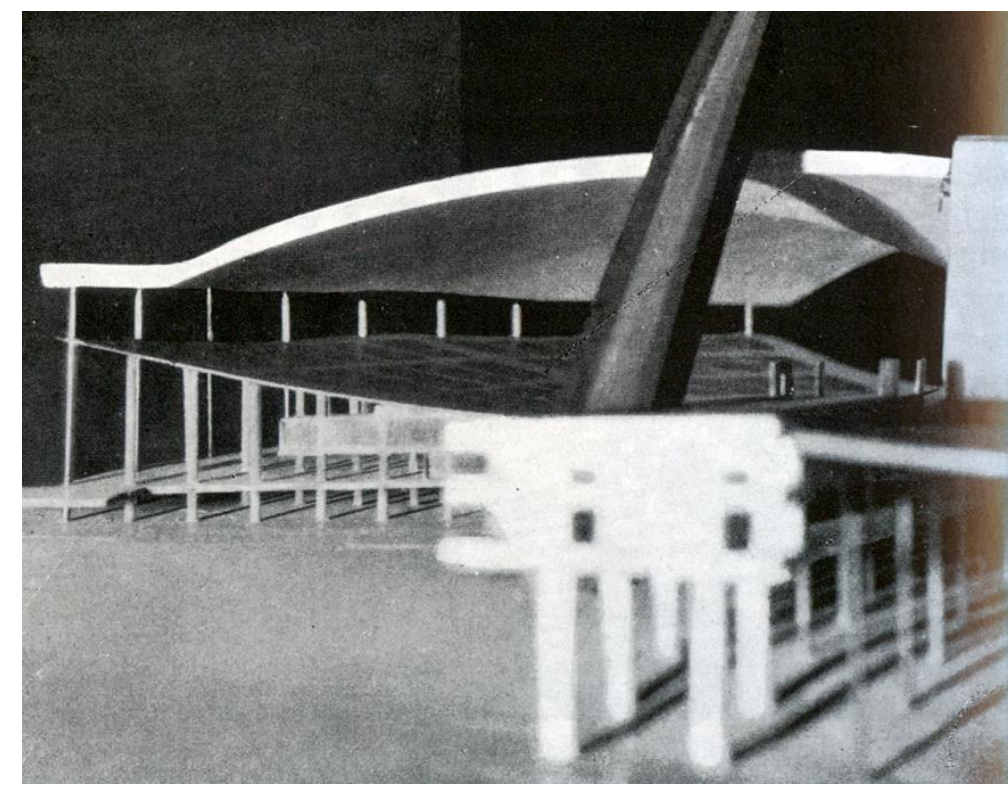

13. Detalle del techo. Por ese lateral había de corroborarse el experimento luminoso-acústico. 


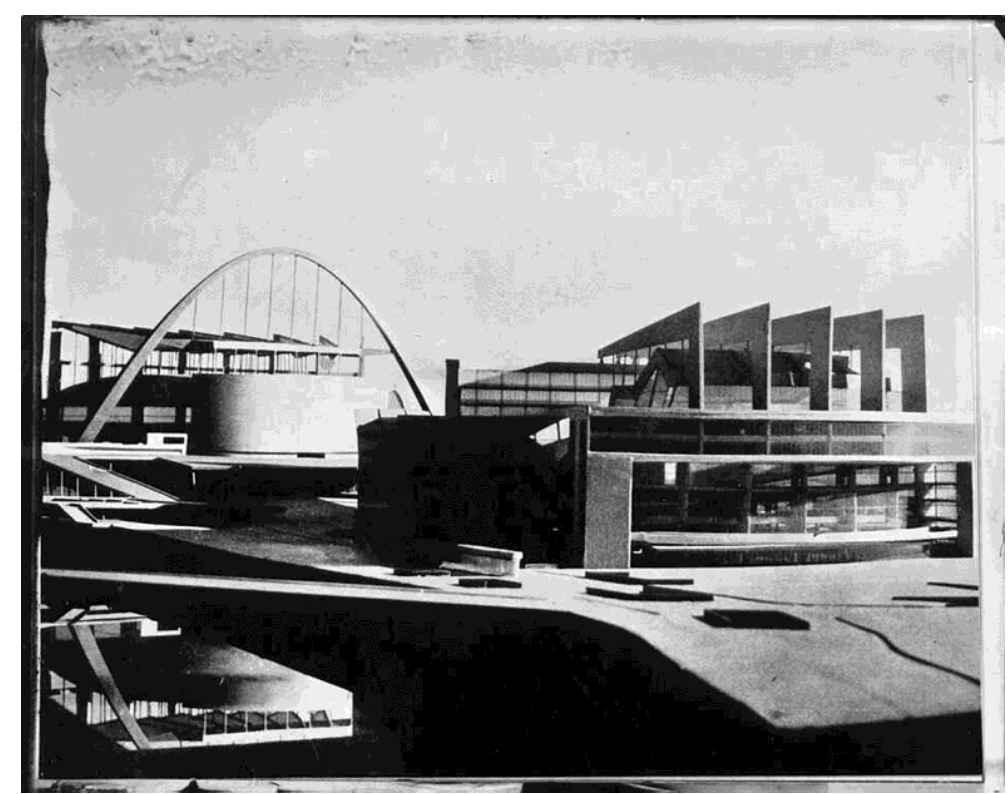

14. Fotograma del filme, con el edificio reflejado en las aguas del Mockba.

Por otra parte, la maqueta permitía un montaje de su conjunto, hecho que de seguro encontraba uno de sus leitmotiv en la película perdida. No cabe duda que las secuencias de construcción de las películas de Chenal, en las que las diversas escenas iban mostrando el proceso de construcción de los edificios, pudieron influenciar en este recurso, transmitiendo un mensaje de efectividad tecnológica. Pero esta posibilidad que ofrecía la maqueta desmontable también permitía explotar y explorar las posibilidades del proyecto, mediante un proceso didáctico muy cercano al de una clase de anatomía, frente al ecorché de este nuevo cuerpo soviético.

Las imágenes de la maqueta que han pervivido muestran distintos estadios. El primero en el proceso de construcción -de los últimos en el filme del desmontaje hipotético- corresponde a toda la plataforma con los pilares de la primera planta, y el arco paraboloide, representado por una pieza de metal moldeado, cuyos brillos hacen recordar a aquellos que producían las maquetas radiantes, o los trabajos de Naum Gabo o Moholy-Nagy (fig. 15). La materialidad de las jácenas y arco son representadas en la maqueta ${ }^{39}$ en metal, tal como lo recogen los dibujos técnicos del proyecto ${ }^{40}$ : nada de hormigón, es el magnífico acero soviético - de ahí el apodo de "stalin=hombre de acero"- el encargado de soportar el nuevo cielo que acoge a los Soviets .

Volviendo a la película perdida, la gran plataforma del solar ${ }^{41}$ de seguro hubo de ser objeto de atención. Según Cohen, una serie de tomas aéreas ${ }^{42}$ bien podrían haber dado cuenta de la gran plataforma y su esqueleto. Los fotogramas existentes, presentan una topografía urbana, en la que la ausencia de techo insiste aún más en la idea de un espacio público y, desde luego, un posicionamiento fiel a los procederes socialistas, basados en la cohesión social ${ }^{43}$ de masas que se mueven entre el interior y el exterior del edificio, evidenciados gracias al desmontaje de la maqueta (fig. 16).

\footnotetext{
${ }^{39}$ Ibídem p. 136. "Disposition de suspension de la salle par une ossature métallique".

${ }^{40}$ FLC 27847.

${ }^{41}$ Cfr. Cohen, Jean-Louis, op.cit.n.17 y Hoisington, Sona. "Ever Higher": The Evolution of the Project for the Palace of Soviets" en Slavic Review, Vol. 62, No. 1 (Spring, 2003), pp. 41-68.

${ }^{42}$ Cohen, J.L. op.cit. n.17. p.186. "aerial views".

${ }^{43}$ Ziada, H. Op.cit. n.24. "the problem of the Kinesthetic Conception of Space seeks to describe how the rhythmic choreographies evokes spatial conceptions and social cohesiveness, and thus demands architectural response.(...) Soviet
} 


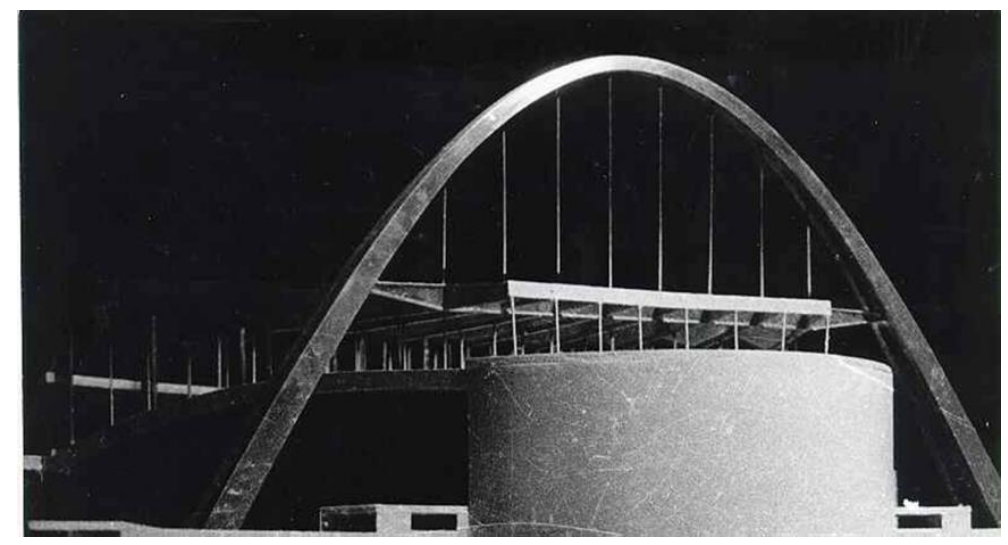

15. El gran arco de acero brilla contra un cielo negro. Posible recreación nocturna del filme.

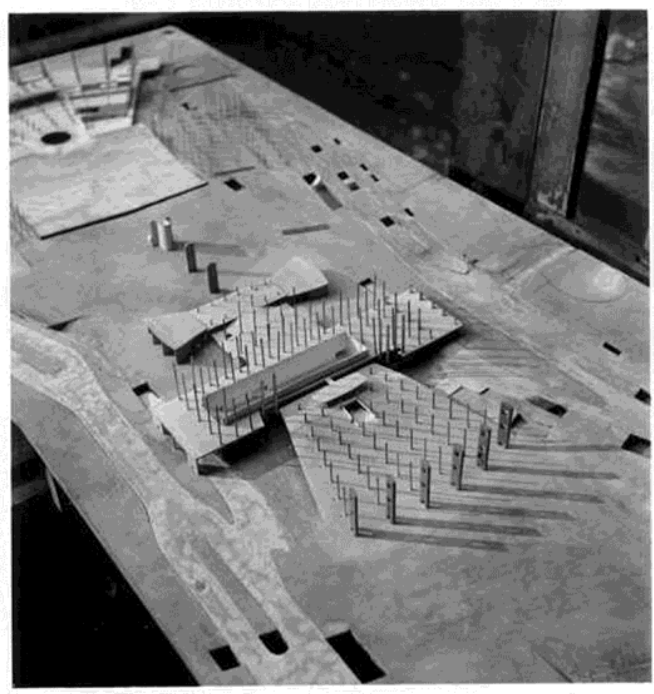

16. Vista aérea de la maqueta mostrando solo las cotas cero del proyecto.

Otras secuencias presentan la sala A y la sala B como dos órganos prácticamente independientes (fig. 17) cuya estructura y organización, aunque similares, permiten realizar una suerte de comparativa cercana a la que se acostumbra en la anatomía, entre órganos similares. Los ejes que las relacionan en las planimetrías no responden a la experiencia dinámica del objeto-edificio, cuyo resultado espacial es una multi-perspectiva sin jerarquías, que Tafuri relaciona con las Carceri de Piranesi. La maqueta permite, por su propia condición de ensamblaje de piezas este tipo de experiencia, en la que los límites son continuamente disueltos. A su vez, el uso de la superposición de imágenes mediante el montaje cinematográfico, gracias a la técnica de las "back projections" ${ }^{\text {"4 }}$, insiste en la transparencia de los cerramientos de la maqueta, representando el paradigma de la visualización del interior, de una sociedad sin secretos, que será tratada por Eisenstein en su proyecto no realizado "The Glass

architects were challenged with particular conceptions of such kinesthetic space, from Meyerhold's Biomechanics but also from the mass festivities of the day".

${ }^{44}$ Cohen, J.L. Op.cit. n.17; p.186. " and back projections, made possible by the fact that the sides of the model were transparent". 
House", bocetado entre 1926 y 1930, donde se propone una espacialidad cinemática a caballo entre la utopía y la distopía $^{45}$.

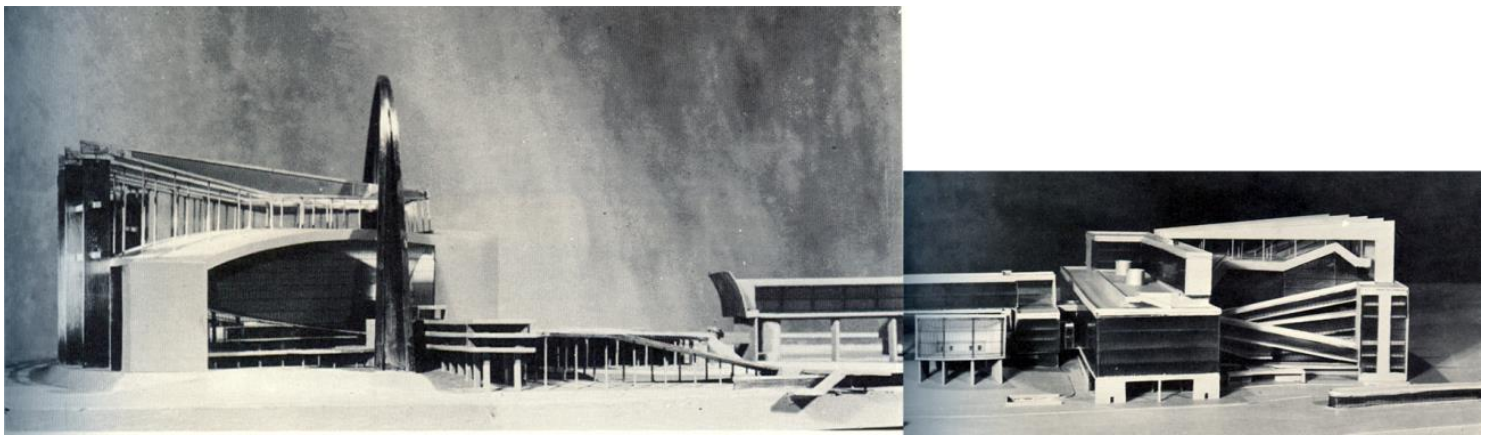

17. Montaje del autor del texto, recreando el dolly-shot del filme a lo largo del edificio, a partir de dos imágenes originales.

La relación con Eisenstein y los conocimientos e interés de Le Corbusier, como se ha expuesto, ante el nuevo arte, explica las transferencias entre los planteamientos del director y el arquitecto. En ese sentido, y en relación con el filme perdido de la maqueta, Eisenstein proponía como estrategia de expresión lo que él denominaba "montaje como conflicto". Basado en las superposiciones significantes de los ideogramas y los haikai de la cultura nipona, Eisenstein propone la construcción del significado por "choque" de conceptos:

"Conflicto de direcciones gráficas. (Líneas, ya sea estáticas o dinámicas)/ Conflicto de escalas. Conflicto de volúmenes. Conflicto de masas.(Volúmenes llenados con diversas intensidades de luz) Conflicto de profundidades. Y los conflictos siguientes, que sólo requieren de un impulso extra de intensificación antes de salir volando en pares dé trozos antagónicos: Planos cercanos y lejanos. Trozos de direcciones gráficas diversas. Trozos resueltos en volumen, con trozos resueltos en área. Trozos de oscuridad y trozos de luminosidad. Y, por último, hay conflictos inesperados como: Conflictos entre un objeto y su dimensión; y conflictos entre un evento y su duración" ${ }^{\prime 46}$.

Estos términos bien ilustran la experiencia del montaje de la maqueta del Palacio de los Soviets. El marriage des contours con aires constructivistas de la maqueta del Centrosoyus ha quedado completamente transmutado en una experiencia dinámica basada en el puro hecho de ensamblar o montar. Más allá de los contrastes plásticos de la maqueta terminada -brillos y sombras, fragmentación de los planos de cercanía y lejanía, rupturas de líneas (curva-quebrada)...- lo realmente común con el principio de Eisenstein es que esto se realiza con "trozos" que se ensamblan entre sí. Este proceso de montaje hubo de ser muy palpable en la película, en la que la deconstrucción de la maqueta, paso a paso, produciría una secuencia similar a los gestos de un actor biomecánico, forzando y marcando cada una de los distintos momentos de la acción, un recurso que el propio Eisenstein atribuía al teatro Kabuki o al cine de Epstein, manipulaciones del tiempo-espacio que el director ruso definía así:

La intensidad de la percepción aumenta a medida que el proceso didáctico de la identificación ocurre con más facilidad a lo largo de una acción desintegrada ${ }^{47}$.

A cada una de esas secuencias-objetos se le añade la manipulación de la escala, o en el lenguaje de Einsenstein "conflictos entre un objeto y su dimensión". Este recurso no es nuevo para Le Corbusier, un juego que permite

\footnotetext{
${ }^{45}$ Somaini, Antonio. "Utopies et dystopies de la transparence. Eisenstein, Glass House, et le cinématisme de l'architecture de verre." en Revue Appareil, nº 7. 2011.

${ }^{46}$ Eisenstein, Sergei. "El principio cinematográfico y el ideograma. 1929". En Eisenstein, S. La forma del Cine. Madrid: Ed. Siglo XXI editores, 1986.

${ }^{47}$ Idem.
} 
ver una casa en una botella, un aparejo de asno en un arco de 200 metros de altura, o un gorro caucásico como edificio $^{48}$.

Al igual que el cine de Eisenstein, lo que se pretende con ello es un proceso didáctico revolucionario: el espectador, tras observar el conjunto completamente montado, ha de ir completando su entendimiento de toda esa arquitectura que se va desplegando ante sí, cuya última imagen será el vacío del solar.

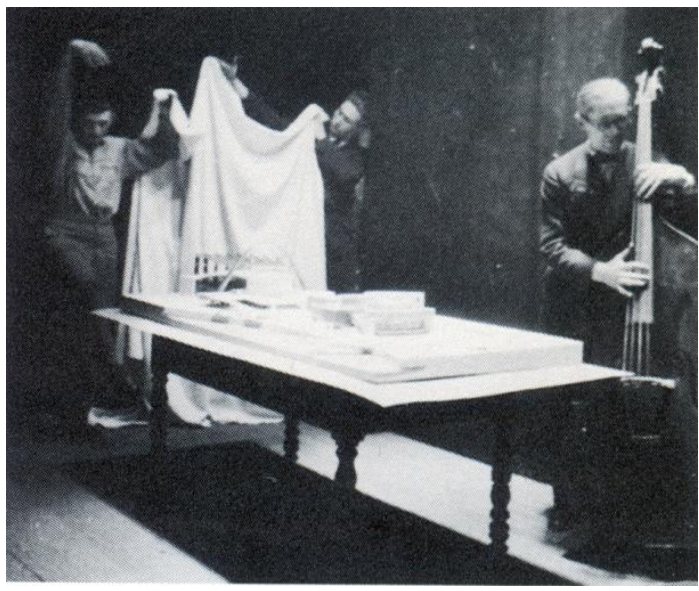

18. El descubrimiento de la maqueta.

La que bien pudo ser la primera secuencia del filme muestra una estampa ya no tan misteriosa. Le Corbusier pone música con un violón a la película, como hiciera su hermano con las de Chenal, o su primo Louis Soutter ${ }^{49}$ tocando en directo en salas de cine mudo acompañado por el mismo instrumento (fig.18). Los ayudantes retiran la sábana con un gesto posiblemente natural pero que, detenido en la imagen, presenta una teatralidad digna de una actuación biomecánica o del método Dalcroze. Se muestra así el ecorché sobre la mesa de estudio. Lo que sigue hay que imaginarlo. El cuerpo es auscultado por la cámara, que realiza unos dolly-shots por sus laterales ${ }^{50}$, familiarizando al observador con su forma, abundando en sus transparencias. Luego, la cámara sobrevuela el conjunto, como si se tratara de un avión pilotado por Shestakov, que guarda el Palacio del Pueblo. Una toma nocturna muestra el edificio iluminando el Moskva, derramando sus ondas a la ciudad. Luego empieza el desmontaje del edificio. Van desapareciendo -gracias a la técnica fílmica- las diversas partes, que pasan a ser auscultadas por la cámara mediante close-ups. Primero el edificio de la Sala B. Luego los laterales de la sala A, para mostrar la sección de acceso por los vestidores. A continuación se elimina la cúpula acústica y las costillas que la sostienen, para mostrar el anfiteatro y su continuidad con la explanada de las manifestaciones. Finalmente, queda la cota cero, la gran plataforma que oculta el Metro de Moscú presidida por el gran arco de acero.

\section{Epílogo.}

La maqueta trasladada para la exposición del MOMA de 1935 será expuesta en diversas ciudades de los Estados Unidos. Debido a las penurias de la guerra, Le Corbusier la malvenderá a la institución e intentará recuperarla

\footnotetext{
${ }^{48}$ Cfr. Cohen, Jean-Louis. Op.cit. n. 17; pp. 202-203.

${ }^{49}$ Le Corbusier. "Louis Soutter, l'inconnu de la soixantaine". en Revue Minotaure nº 9. Paris: Albert Skira, 1936, pp. 62-65. "Années désorbités de petite ville en petite ville. Le cinéma n'est pas sonore encore. Dans le noir des salles, au pied de l'écran, on a employé ce 'premier violon'".

${ }^{50}$ Cohen. Op.cit. n. 23; p.186.
} 
posteriormente, lo que producirá una profusa y agria correspondencia entre Paris y New York ${ }^{51}$. En cualquier caso, la maqueta que vieron aquellos americanos interesados por la modern architecture -y actualmente todo aquel que pueda contemplarla en una exposición- no era más que un objeto estático, terminado en sí mismo. Una imagen del modelo desmontado en el taller del $\mathrm{MOMA}^{52}$, antes de su desgraciada reparación que el propio Le Corbusier lamentará, transmite aún la complejidad cinética que posee el montaje de la maqueta del Palacio de los Soviets, cautiva desde entonces dentro de una vitrina.

\section{Procedencia de las imágenes.}

1. Ettiene-Jules Marey ref 3 PV 259. Archives College de France.

2."Boissonnas, Frederick. Dalcroze-Schule (Four dancers in flight)". http://photoseed.com/collection/single/dalcroze-schule-four-dancers-in-flight/

3. https://vimeo.com/67792107. Dir. Pierre Chenal. Film "Batir". 1930.

4. idem.

5. idem.

6. FLC. L2-14-48-001. Fotógrafo: Lucien Hervé.

7. http://thecharnelhouse.org/2013/08/03. Original en Catálogo Oficial de la Exposición. Paris: Vaugirad 1925.

8. FLC D1-7-68-006.

9. L'Architecture Vivante. Primtemps 1930. Paris: Ed. Albert Morance, 1930.

10. FLC L3-19-45-001.

11. FLC L3-19-46-001. Fotógrafo: Lucien Hervé.

12. Rindel, Jens Holger. "Modelling in auditorium acoustics. From ripple tank and scale models to computer simulations" en Revista de Acústica. Vol. 32. 3 y 4. Madrid: S. Esp. Acústica. 2002

13. Boesiger. W (ed). Le Corbusier. Cuvre complète vol. 2. Basel: Ed. Birkhausser, 1935 (1ºd), p.126.

14. FLC L3-19-42-001

15. FLC L3-19-56-001

16. FLC L3-19-59-001. Fotógrafo: Jean-Michel Bossu.

17. Boesiger. W (ed). Le Corbusier. Euvre complète vol. 2. Basel: Ed. Birkhausser, 1935 (1ºd), p.128

18. Cohen, Jean-Louis. Le Corbusier and the Mystique of the USSR : Theories and Projects for Moscow : 19281936. Princeton, N.J.: Princeton University Press, 1992. p.165.

\section{Bibliografía.}

Beltramini, Guido y Croiset, Alain. Juan Navarro Baldeweg: risonanze di Soane. Entrevista J.J. Lahuerta y J.N Baldeweg. Vicenza: Centro Andrea Palladio, 2000.

Boessiger. W (ed). Le Corbusier. Oeuvre Complete vol. 2. Basel: Ed. Birkhausser, 1935 (1 ed).

Bowlt, John. "El constructivismo en el teatro". En Ortega, Carlos (dir).El Teatro de los pintores en la Europa de las Vanguardias. Madrid: Ed. Museo Reina Sofía, 2000.

Chenal, Pierre. Drames sur celluloid. Paris: Ed. Les Persepectives, 1929.

\footnotetext{
${ }^{51}$ Cfr. múltiples cartas en la FLC, bajo los epígrafes C2-7 y C2-20.

${ }^{52}$ La imagen se encuentra en: Cohen, Jean-Louis (dir.). An atlas of Modern Landscapes. Londres: Thames\&Hudson, 2013. p. 169.
} 
Cohen, Jean-Louis [et al.] Constructivismo ruso : sobre la arquitectura en las vanguardias ruso-soviéticas hacia 1917. Barcelona: Ediciones del Serbal, 1994.

Cohen, Jean-Louis. Le Corbusier and the Mystique of the USSR : Theories and Projects for Moscow : 19281936. Princeton, N.J.: Princeton University Press, 1992.

Drexler, Arthur. "Engineer's Architecture: Truth and Its Consequences", en Drexler, Arthur The Architecture of the Ecole des Beaux-Arts. Boston: The Museum of Modern Art, MIT Press, 1977.

Eisenstein.Sergei. "El principio cinematográfico y el ideograma. 1929". En Eisenstein, S. La forma del Cine. Madrid: Ed. Siglo XXI editores, 1986.

Epstein, Jean. "Le phénomène littéraire" en L'Esprit Nouveau N. 8, mai 1921.Paris: Freal, 1921.

Faure, Eli. "De la cineplastique", en L'Arbre d'Éden. Paris: Cres, 1922.

Hoisington, Sona. Ever Higher": The Evolution of the Project for the Palace of Soviets en "Slavic Review", Vol. 62, No. 1 (Spring, 2003).

Jeanneret, Albert. "La rythmique" en L'Esprit Nouveau. № 2. Paris: Freal, 1920.

Le Corbusier. "Louis Soutter, l'inconnu de la soixantaine". en Revue Minotaure n 9. Paris: Albert Skira, 1936.

Le Corbusier. Cuando las catedrales eran blancas. Barcelona: Apóstrofe, 2007.

Le Corbusier. Deux films de Pierre Chenal. Batir et Architecture. FLC B3-5-380.

Lisstizky, El. "Interrelaciones entre las Artes". en 1929. La Reconstrucción de la Arquitectura de la URSS.. Barcelona Ed. GG. 1970.

Lisstizky, El. SSSR. Referencia FLC D1-7-68-001.

López Cubero, Josefina. "Hilos de teatro: La puesta en escena del Palacio de los Soviets de Le Corbusier". En Proyecto, Progreso, Arquitectura n ${ }^{\circ}$ 7. Sevilla: Ed. Universidad de Sevilla, 2012.

Prunières, Henry. "Inauguration de la Salle Pleyel". en La Revue Musicale. n 1, 1 novembre 1927.

Quetglas, J. Marza, F. "Palais des Soviets" en DVD Plans, vol. 4. Paris: Échelle-1, 2010.

Rindel, Jens Holger. "Modelling in auditorium acoustics. From ripple tank and scale models to computer simulations" en Revista de Acústica. Vol. 32. 3 y 4. Madrid: S. Esp. Acústica. 2002.

Rowe, Colin; Slutzky, Robert "Transparencia: literal y fenoménica", en Rowe, Colin Manierismo y arquitectura moderna y otros ensayos. Barcelona : Gustavo Gili, 1999. 1º ed. Perspecta, 1963

Soliña Barrerio, María. "Epistemología de la imagen mecánica en los años 20... " en Catalá, Josep Mª El cine de pensamiento. Formas de la imaginación Tecno-estética. Valencia: Universitat de Valencia, 2014.

Somaini, Antonio. "Utopies et dystopies de la transparence. Eisenstein, Glass House, et le cinématisme de l'architecture de verre." en Revue Appareil, nº7. 2011.

Ziada, Hazem. Gregarious espace, Uncertain grounds, undisciplined bodies. The Soviet Avant-Garde and the 'Crowd' Design Problem. Phd. Georgia Institute of Technology, May 2011. 
El prestigio de Lasnon, y en general del gremio de "mouleurs" es acorde al papel de estos artesanos en el Paris de principios de siglo, cuyas habilidades son reclamadas para tareas de orden decorativo y ornamental, así como para las labores de apoyo en el manejo del yeso a la numerosa colonia artística parisina. La publicidad del taller Lasnon recoge junto a los trabajos tradicionales del oficio, nuevas producciones a las que migran las habilidades seculares, tales como las copias de esculturas con carácter divulgativo, maquetas arquitectónicas, así como globos terráqueos, mapamundis y "carte-reliefs" 3 . Estos cruces entre arte, copia y artesanía refleja la vinculación de los oficios consolidados durante el siglo XIX con las expresiones de la nueva sensibilidad moderna, nacida de la reproductibilidad de objetos e imágenes, de cuyos cruces quedarán impregnadas las Vanguardias.

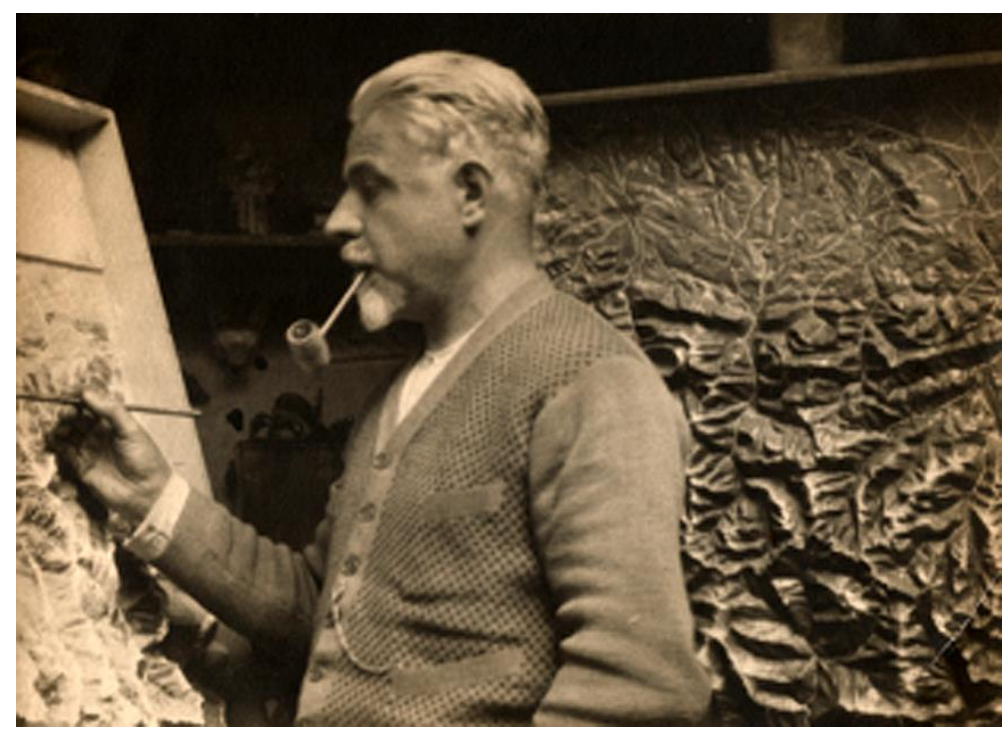

1. Charles Augustin Lasnon-Dussaussay trabajando en algunos cartes-reliefs. (circa 1930) Foto cedida por la familia Lasnon-Dussaussay.

Lasnon realizará varias maquetas para Le Corbusier, desde 1922 a 1937, englobables en dos categorías en las que la temática arquitectónica coincide con una técnica de trabajo del yeso: las viviendas, representadas mediante la técnica del "moulage de ronde-bosse" y las propuestas urbanísticas plasmadas mediante el "basrelief'. Estas dos técnicas poseen una fuerte presencia en artistas cercanos a L'Esprit Nouveau como Laurens, Archipenko o Lipchitz, conocidas referencias plásticas para Le Corbusier. Lasnon será un personaje destacado especialmente en los plan-reliefs, pues su vinculación al Service Geographique de l'Armée le permitirá estar al día en las nuevas técnicas de representación topográfica, habilidad que pondrá al servicio de su cliente Le Corbusier. En lo que se refiere a las maquetas de las "villas blancas", su mayor aportación fue la del paciente oficio necesario para ayudar a construir los primeros volúmenes de unas arquitecturas aún por venir, deviniendo así el práctico que realizara bustos solemnes ${ }^{4}$, en maquetista de la nueva arquitectura.

\footnotetext{
3 "Annuaire industriel. Répertoire général de la production française". Diversos anuncios de Lasnon. 1925: "Chambre Syndicale patronale des mouleurs statuaires de Paris. Président Trésorier: Augustin Lasnon,26, av. Villemain, Paris"; 1935 : "models et plans en relief pour l'ensseigment LASNON(C.-A.), 26, av. Villemin.Paris, 14"; 1938: "LASNON(C.-A.), 26, av. Villemin.Paris, 14" Mouleur-statuaire, maquettes et plans en relief".

${ }^{4}$ Destaca el busto del Mariscal Foch. Dato ofrecido por la familia Lasnon-Dussaussay.
} 


\section{El manifiesto estético arquitectónico. La representación de una nueva arquitectura.}

"Ejemplo: si muestro una forma primaria cúbica, desencadeno en cada individuo la misma sensación primaria del cubo; pero si dispongo sobre este cubo manchas geométricas negras, inmediatamente desencadenaré en el hombre civilizado una idea de dado para jugar, con todas las asociaciones que puedan derivarse.

Un papú solo vería en ello un ornamento. ${ }^{, 5} \mathrm{El}$ uso de la maqueta para divulgar la producción arquitectónica en los Salones y Ferias será un hecho común en los años 20. Los catálogos de preciosistas dibujos en perspectiva irán siendo complementados con maquetas, cuya facilidad de entendimiento por parte del gran público ${ }^{6}$ alimentaba la curiosidad por el funcionamiento o la ejecución del objeto representado. Muchas de estas maquetas serán realizadas con yeso, material barato y de labor fácil para el detalle y la aplicación del color, valores útiles en diversos campos del conocimiento, de la arqueología hasta la antropología ${ }^{7}$. Los programas de las Écoles de Beaux-arts propiciarán la transferencia a la arquitectura del método escultórico de modelos de prueba en yeso, anteriores a la obra definitiva e incluso escalados en muchos casos. Estos primeros "ébauches" arquitectónicos heredan también el valor artístico perecedero vinculado a la enseñanza y a la investigación de sus parientes, los vaciados escultóricos. Así, los alumnos de Mallet-Stevens mostrarán todo su "struggle for life" "8 a través de estos objetos fotogénicos y de plástica sugerente en blanco y negro. Estos valores no escapan a Le Corbusier cuando

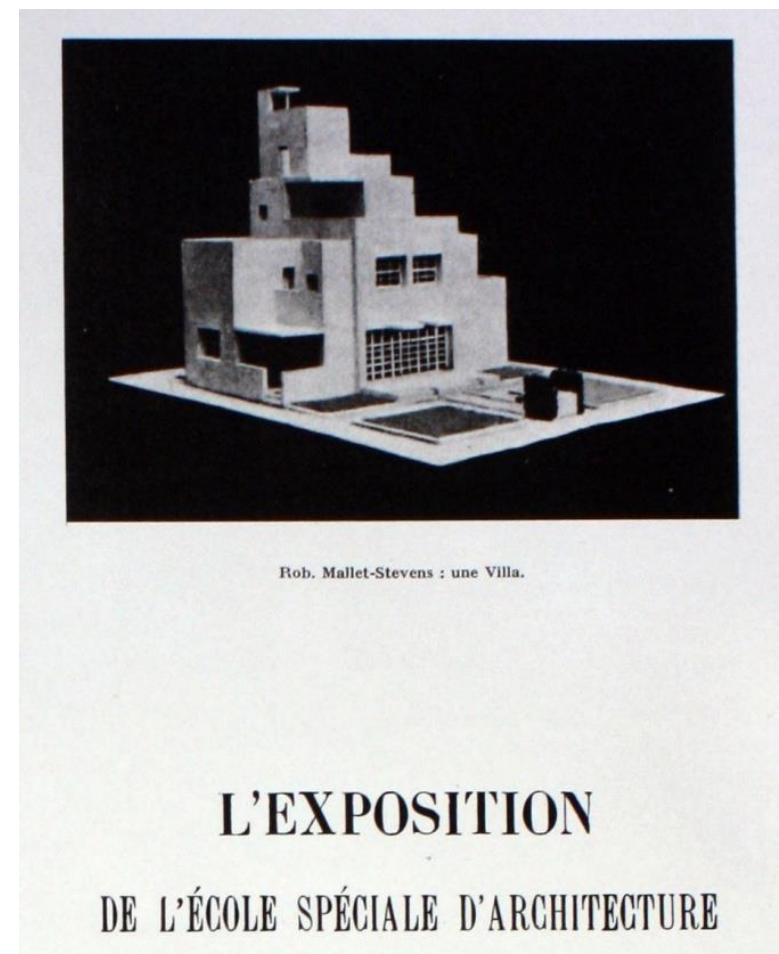

2. Maqueta de Mallet-Stevens, precedida por los trabajos de sus alumnos en. "L'Exposition de L'Ecole Spéciale d'Architecture" de 1923.

\footnotetext{
${ }^{5}$ Ozenfant, A.; Jeanneret Ch.E. Acerca del Purismo. Escritos 1918-1926. Madrid: El Croquis. 1994. p. 70.

${ }^{6}$ Rambosson, Y. "Le Mouvement des Arts Appliques. Les architectes modernes au Salon des decorateurs" en $L$ 'Amour de l'art, n. 6, junio 1923, p. 598: "le visiteur passe avec indifférence en face de plancher plans que le droit avec difficulté, mais dans une approche passionnée démonstrations pratiques, y compris il ya toujours quelqu'un capable de l'éveil juste lui esquissé dans un rêve.."

${ }^{7}$ Lasnon realizará reconstrucciones antropológicas prestigiosas como el "Hombre de la Quina".

${ }^{8}$ Le Corbusier. "L'Exposition de L'Ecole Spéciale d'Architecture". en L'Esprit Nouveau. no 23, mayo. Paris: V. Freal. 1924.
} 
manda realizar a Charles Lasnon sus maquetas para los Salones de Otoño de 1922 y 1923, luego retratados por fotógrafos de la talla de Albin Salaün, autor de algunas de las primeras instantáneas de su obra construida(figura 2). Pero, si bien de yeso, sus maquetas serán otras.

\subsection{La maqueta de la Maison Citrohan.}

Le Corbusier recurrirá por primera vez a Lasnon para realizar la maqueta de la Maison Citrohan a exponer en el Salon d'Automne de 1922. El modelo realizado a 1:20 ofrecía una experiencia al espectador opuesta y complementaria al diorama de la Ville Contemporaine de trois millions d'habitants, pues el visitante rodea el objeto expuesto, en vez de estar envuelto en él. Por su tridimensionalidad, la maqueta de la Maison Citrohan será la primera muestra volumétrica de las teorías de Le Corbusier, no sólo para el gran público, sino también para los colegas de profesión (figura 3). La descripción de L'Humanité refleja elocuentemente la novedad del lenguaje plástico que se pretende trasmitir:

"Le groupe LC expose aussi un modèle de maison sériée á charpentes en ciment armé, destiné aux cites-jardins: c'est un bloc blanc qui, avec des terrasses, rappelle les maison orientales mais qui a las avantages de technique modernes. Porte sur des soubassement largement aères il semble s'élever d'une sorte de bassin que permet de circuler autour, et forme une première terrasse $" ~ " 9$.

El leitmotiv de la maqueta queda cubierto: la necesidad de explicar la nueva arquitectura mediante medios más didácticos que los técnicos dibujos. Este recurso también será utilizado por otros arquitectos, pero de todas las maquetas expuestas, ninguna producirá en la prensa un rechazo tan caustico como la de Le Corbusier. En los otros modelos ${ }^{10}$ existe un afán porque la maqueta sea un objeto de representación del edificio: las aperturas de los huecos, cierto preciosismo en su terminación y el uso del color o texturas distan de la abstracción un tanto desasosegadora que produce ese gran cubo opaco, pura masa, apenas surcado por unos alambres negros que sustentan unas suertes de vidrios ${ }^{11}$ pegados como un parche sobre el yeso ciego. El comentario de prensa, que califica la maqueta como "villa aquarium cubique posée sur un plateau de cage à serins: c'est triste à pleurer" $^{\prime \prime 2}$, da buena cuenta de ello. Otros distintos a agradar son los objetivos.

La sección dedicada a la arquitectura en el Salon d'Automne tiene ya una reputada fama como espacio de presentación de la arquitectura parisina, ampliando la consolidada en el resto de las artes plásticas. La prensa especializada -no sin cierto tono banal- es capaz de reunirlos a todas bajo una misma idea, la de los paralelismos entre escultura y arquitectura, sin duda animados por la presencia de las maquetas:

"Il est curieux et agréable de constater l'influence des architectes sur les sculptures et réciproquement des sculpteurs sur les architectes. Leurs conception sont les mêmes.(...) Quand les frères Perret, quand Tony Garnier, quand Jeanneret, quand Van Doesburg construisent, ils édifient géantes sculptures, la lumière joue sur de vastes surfaces comme elle éclaire une pierre de Laurens ou un bas-relief en métal de Miklos » ${ }^{13}$.

\footnotetext{
${ }^{9}$ Mesnil, Jacques. "Au Salon d'Automne". En L'Humanité. 11/11/1922.

${ }^{10}$ Mallet-Stevens, Loos, Perret, Luçart, etc.

${ }^{11}$ Janneau, Guillaume. "L'Exposition des arts techniques de 1925. Que sera demain le logis?" en Le Bulletin de la vie artistique n. 11, 1 junio 1923. "II y aura désormais un salon de l'architecture. On y verra, outre des plans, des maquettes: le grand public n'a point le goût de l'abstrait et préfère au dessin une réalisation concrète, qui lui paraît plus expressive : il a tort, attendu l'altération des effets qu'entraîne une réduction d'échelle."

12 "Les arts decoratifs au Salon d'Automne" en Le Journal . 19/11/1922. Referencia FLC X1-2-71.

13 "Construira-t-on des cites-tour et des gratte-ciel sur l'emplacement des fortifications?" en Excelsior. 28/02/1923. Referencia FLC X1-3-27,
} 
La nota de prensa parece darle la razón a Auguste Perret, que criticará la excesiva voluntad plástica de los jóvenes arquitectos:

"Les jeunes architectes, affirme Perret, commettent au nom du volume et de la surface les mêmes fautes qu'on commettait dans un récent passé au nom de la symétrie, de la colonnade ou de l'arcade (...). Le volume les hypnotise, ils ne pensent qu'à ça et, dans un déplorable esprit de système, s'attachent à créer leurs combinaisons de lignes sans se préoccuper du reste; or ce reste est important; c'est l'a b c du métier qu'ils oublient: construire avant tout une maison habitable ${ }^{14}$.

A los ojos expertos de Perret, no hubieron de pasar desapercibidos los problemas constructivos que la maqueta presenta. Pero, por más posibles problemas que pudieran detectarse en esta versión de Citrohan II, en la maqueta se observan elementos que buscan atajar problemas constructivos, o acercarse a su definición. Es difícil imaginar que no fuera Le Corbusier, o Pierre, los que indicasen a Lasnon las soluciones ${ }^{15}$, tomando decisiones sobre la maqueta, como si de una dirección de obra, minúscula, se tratara.

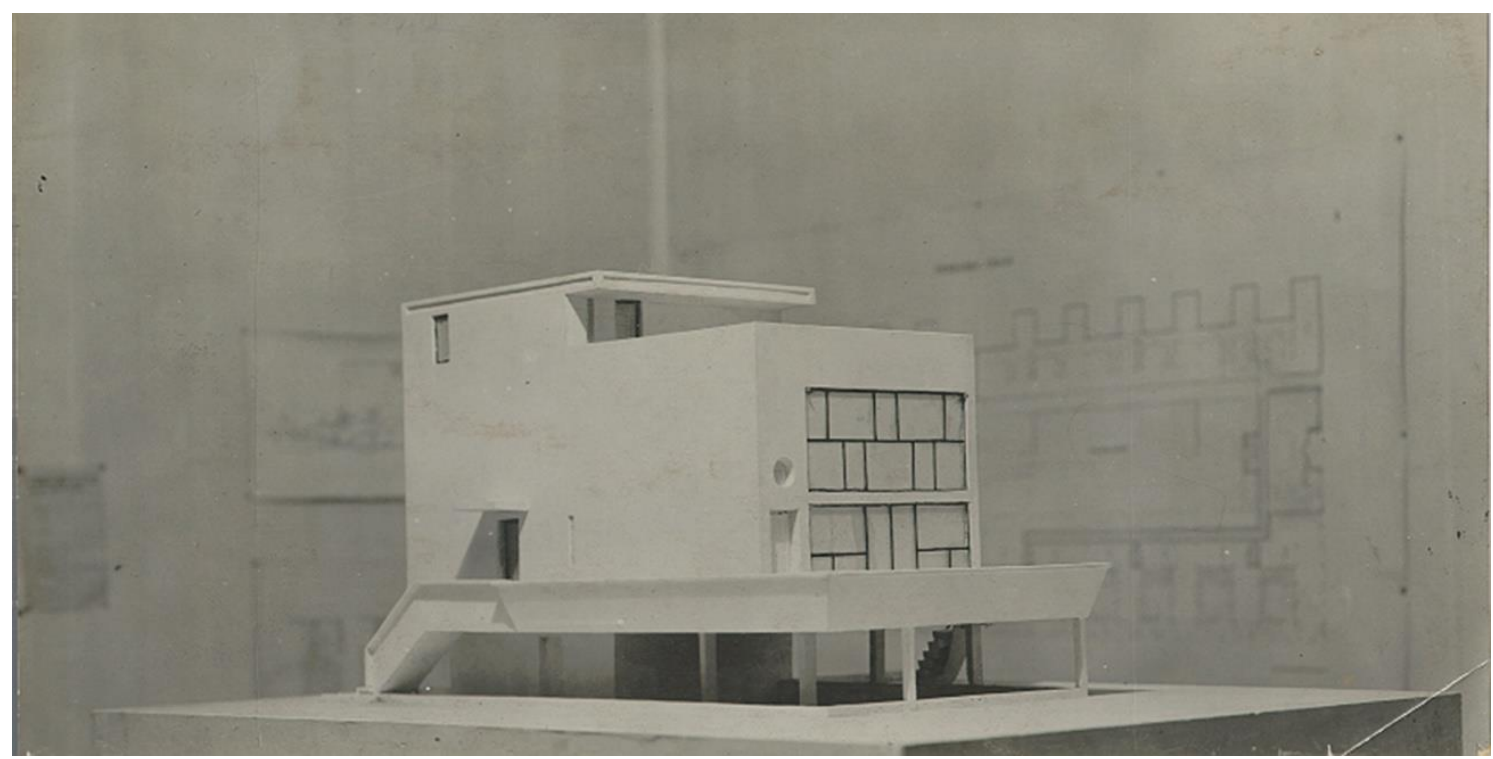

3. Maqueta de la Maison Citrohan en el Salón de Otoño de 1922 en Paris.

\subsection{Las maquetas del Salón de 1923.}

"Les nombreuses maquettes présentées par MM. Le Corbusier et Jeanneret ont surtout soulevé les discussions, ces architectes ayant une technique très neuve qui bouscule toutes les traditions"16.

En los casos de la maison Ribot, la Villa Niestle y la maison La Roche, los planos parecen haber sido realizados para que Lasnon preparase sus moulages a exponer en el Salón de Otoño de 1923. Sólo en el caso de la Villa Besnus, también expuesta, el desarrollo en firme del encargo y la existencia de un proyecto en toda regla permiten cumplir la promesa que Le Corbusier hará a su cliente:

"De plus, la maquette qui sera faite vous permettra de vous rendre un compte absolument exact de la construction"17.

\footnotetext{
${ }^{14}$ Baderre, Guillaume. "M. Auguste Perret nous parle de l'architecture au Salon d'Automne" en Paris Journal.01/12/1923.

${ }^{15}$ Dentro de las planimetrías de la maison Citrohan, existen algunos dibujos a escala 1:20, pero ninguno de alzados.

${ }^{16}$ Barderre, G. Op.cit. nota 9.

${ }^{17}$ Carta de Le Corbusier a M. Besnus. 7 de marzo de 1923. Ref. FLC H1-9-10.
} 
Sin duda, para las maquetas del Salon de 1923, la experiencia de la Villa Besnus ${ }^{18}$ hubo de servir de base y referente para ciertas soluciones constructivas ya representadas en ésta, superando las indefiniciones de la Citrohan (figura 4). Sin embargo, persisten en el modelo los atributos de escala, opacidad, soluciones de elementos de carpintería en negro y uso del yeso en su color (f40). La escala de la maqueta es objeto de comentario por parte del propio Le Corbusier en la Oeuvre Compléte:

"Plusieurs maquettes en plâtre sont exposées à l'échelle de $5 \mathrm{~cm}$ pour mètre; c'est une échelle qui permet vraiment de voir ce qu'on fait. Maquettes des maisons d'Auteil, de la maison de Vaucresson, et de cette villa pour weekend á Rambouillet. Cette exposition de grandes maquettes permet de poser, devant l'opinion, le problème de l'esthétique architecturale du ciment armé" ${ }^{\prime 19}$.

La elección de la escala 1:20 busca acentuar aún más la presencia de estos objetos, acercarlos a verdaderas esculturas $^{20}$, en su aspecto y en su observación. Sin detalles ni interiores en los que detenerse, que hubieran sido de fácil ejecución a dicha escala, estos objetos obligan a moverse en torno a ellos e indagar todas sus posibles facetas. Se insiste, en definitiva, en la matriz tridimensional del volumen, tan propio del moulage, y aunque huecos en su interior ${ }^{21}$, su presencia es más cercana a un “yeso" de Lipchitz que a una casa de muñecas.

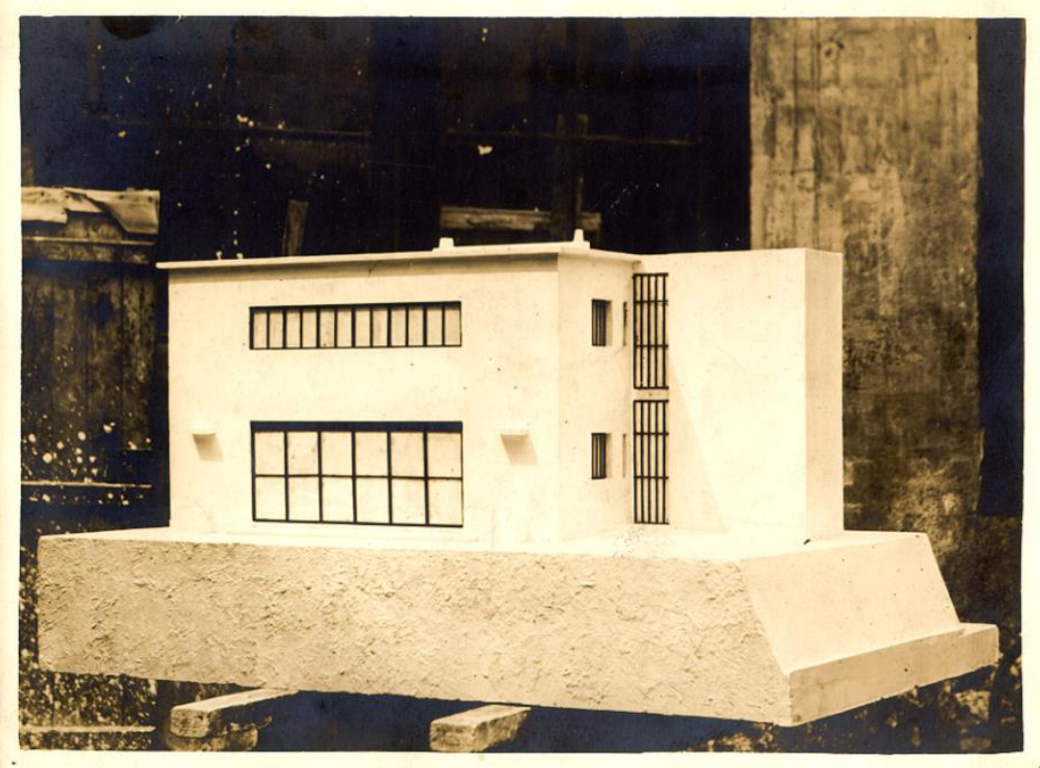

4. Maqueta de Villa Besnus, fotografiada posiblemente en el Taller de Lasnon. 1923

\footnotetext{
${ }^{18}$ La maqueta de la Besnus es, de todas, la única realizada en fechas anteriores a la exposición y dirigida al cliente, aunque es evidente que Le Corbusier tiene a la vista el evento de otoño.

${ }^{19}$ Boesiger. W; Storonov O. (eds.) Le Corbusier et Pierre Jeanneret. CEuvre Complète. 1910-1929. Basel: Birkhäuser. 1929 (1ºd.). p. 52.

${ }^{20}$ Los tamaños de las maquetas aún existentes son 985X605X605 para la villa Besnus, 133X81X82 para la Citrohan y 104,5X54,5X64,5 para la Ribot. La maqueta de Rambouillet hubo de alcanzar casi los dos metros de largo.

${ }^{21}$ Lasnon utiliza la construcción mediante placas de yesos de $1 \mathrm{~cm}$ de espesor $-20 \mathrm{cms}$ representados- que son ensambladas para conformar las cajas. Previamente, habrían de realizarse los moldes de cada una de los distintos alzados, en un proceso de bajorrelieve muy similar a ciertas concepciones puristas que ensamblan planta o alzado y sección del objeto representado.
} 
Otro motivo por la que la escala de la maqueta es la que permite "ver verdaderamente lo que se hace" es la posibilidad de observarlas en conjunto como si de una serie se tratara. La utilización de las mismas soluciones de carpinterías, portajes, vuelos y pilares están presentando un lenguaje arquitectónico nuevo, nada de juegos:

"Comme vous, je suis parfaitement d'accord que cette maquette est un joujou bien cher et bien encombrant, mais je vous disant que vous avez une maison (en plâtre!); et si nous avons le plaisir de passer a une construction plus sérieuse, il y aura entre deux peu á changer et le travail en sera bien facilité" ${ }^{\prime 22}$.

Primeras construcciones de yeso que son el tránsito de un lenguaje pictórico que se "arquitecturiza", en la que la construcción "en yeso" no deja de ser un paso hacia la definitiva del edificio, un puente entre la plástica y la arquitectura construida (figura 5).

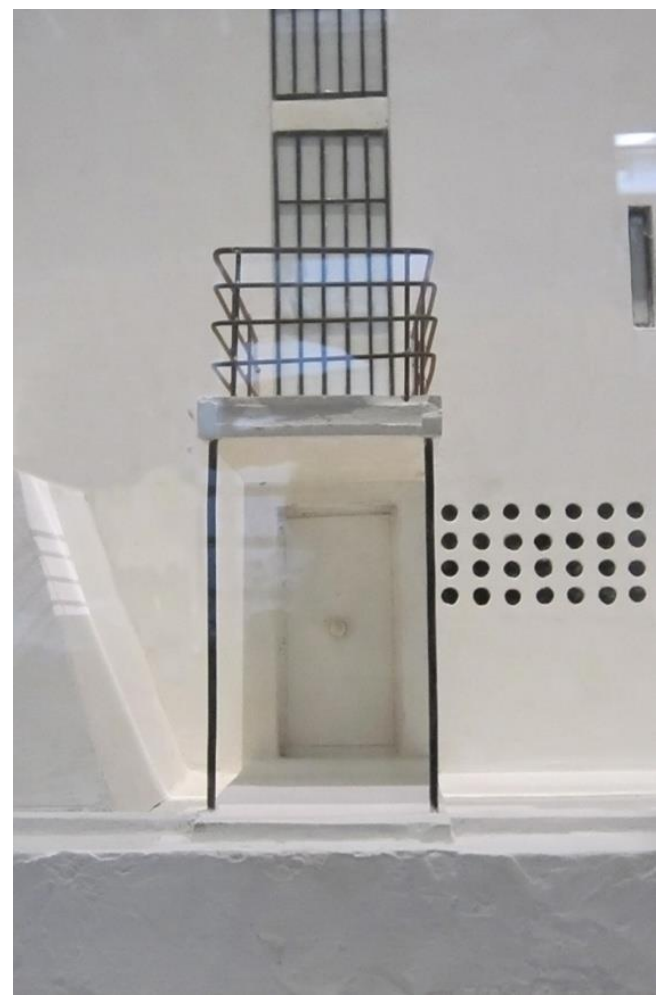

5. Maqueta de Villa Besnus, fotografia actual detalle acceso del acceso.

${ }^{22}$ Carta de Pierre Jeanneret a M. Niestle de 14 de Enero de 1924. Ref. FLC. I2-14-8. 


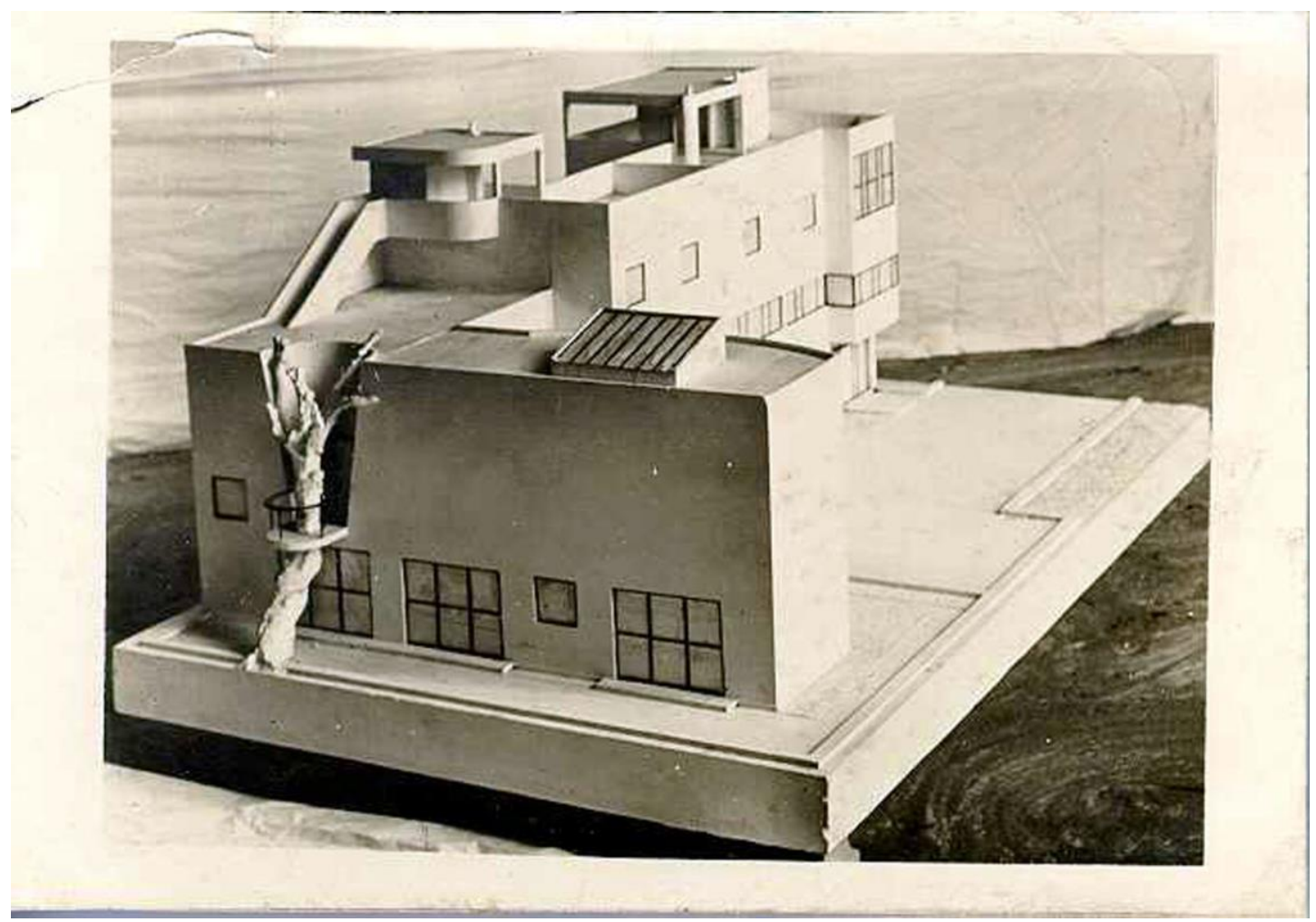

6. Maqueta de la Maison La Roche-Jeanneret. 1923.

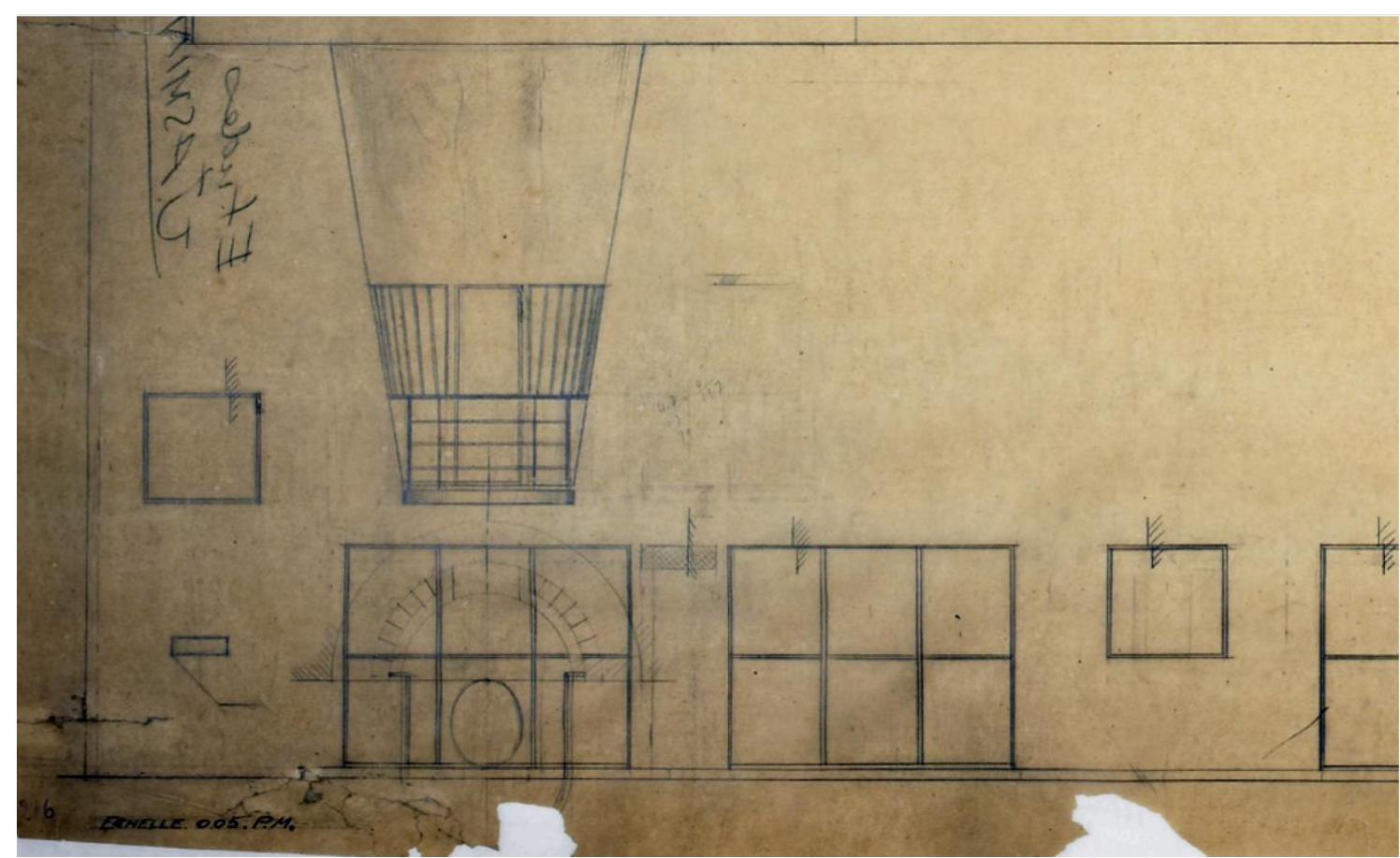

7. Planimetría FLC 15216. Obsérvese el dibujo en sección para las profundidades de casa hueco y el balcón en planta.

\subsubsection{La maqueta de las maisons d'Auteil.}

La maqueta de la Maison La Roche está presentando un nuevo estadio, de mayor complejidad dentro del discurso purista que sus compañeras, hijas de la producción en serie y moldeadas como si de piezas mecánicas se 
$\operatorname{tratasen}^{23}$. La complejidad de los elementos primarios que la componen, incluyendo la rama del árbol de tintes surrealistas, redunda en los valores escultóricos de la propuesta, algo capaz de admirar el culto cliente La Roche, que sucumbe a su vez a su condición representativa de un porvenir y al deseo de poseerla:

Je reviens du salon où j'ai été admirer encore une fois vos différentes maquettes. Elles sont vraiment remarquables, et je me réjouis d'ores et déjà de pouvoir bientôt habiter un maison construite par vous. ${ }^{24}$

Las fechas de creación de la maqueta y las fases de dibujo del proyecto corroboran un proceso calificable como escultórico (figura 6). Ya el 18 de Septiembre, Le Corbusier ha reservado un sitio "remarcable" para la maqueta de la maison double, "bajo la cúpula del Grand Palais" y el 22 de Octubre, la maqueta está finalizada, pagada a Lasnon y lista para estar expuesta, del 1 de Noviembre al 16 de Diciembre, junto al resto de hotels particulieres $^{25}$. El 22 de septiembre comienza Le Corbusier a trabajar en los bocetos de la versión definitiva del conjunto, tras la reducción drástica del solar ${ }^{26}$. A pesar de las múltiples variantes abiertas aún en el proyecto, un plano a 1:20 -escala de la maqueta- correspondiente a la fachada ${ }^{27}$ defendería la existencia de unas planimetrías lo suficientemente precisas para la realización del objeto en yeso. El plano recoge las profundidades existentes entre el plano de fachada y las ventanas dentro del mismo dibujo, así como de la forma troncocónica en torno a la acacia (figura 7). La ausencia de detalles más técnicos que requirieran de dicha escala señalan la misma hipótesis. La horquilla temporal en la que se mueven dibujos y maquetas no deja dudas de su interacción: realizada mediante el mismo sistema que sus antecesoras - placas de yeso previamente moldeadas y unidas entre sí- el modelo hubiera podido permitir perfectamente diversos ajustes ${ }^{28}$ o pruebas.

Estas esculturas monocromas representan las nuevas máquinas de habitar, sorprendentemente realizadas en el académico yeso, y no mediante tensores, chapas y bielas. El yeso, como los revocos blancos de los que sospechaba Perret al ver la obra construida de su antiguo discípulo, buscan la plástica de estos prismas, olvidando tras ellos la construcción gris del hormigón y el ladrillo.

\footnotetext{
${ }^{23}$.Todas estas viviendas se planteaban como viviendas a realizar en serie.

${ }^{24}$ Carta de La Roche a Le Corbusier, 4 de noviembre de 1923. Ref. FLC p5-1-154. Es evidente que el objetivo de estos modelos no se limitaba a la presentación del cliente -quien pagaba a Lasnon- sino además a su uso de su exposición en los Salon d'Automne, o en general la divulgación de la obra, a través de fotos y exposiciones.

${ }^{25}$ Expresión que se recoge en el Catálogo del Salon de Automne de 1923.

${ }^{26}$ El 14 de agosto, Se comunica a Le Corbusier la compra de parte del conjunto. Este hecho conducirá a la reducción del $n^{\circ}$ de viviendas. Cfr.: Benton, Tim. Les Villas parisiennes de Le Corbusier 1920-1930. Paris: Ed. de la Villette. 2007.

${ }^{27}$ FLC 15216. Cfr.: Reichlin, Bruno. Le Corbusier vs.De Stijl. Cuadernos de La Roche. FLC.

$28 \mathrm{El}$ precio de la maqueta es de 500 francos, frente a los 300 francos de Niestle. Si Albert Jeanneret pagó o no su parte de la maqueta es desconocido, pero parecería razonable pensar que sí. Un montante así haría pensar que el trabajo hubo de ser laborioso. Ver Ref. FLC: P5-1-6 y p5-1-155.
} 


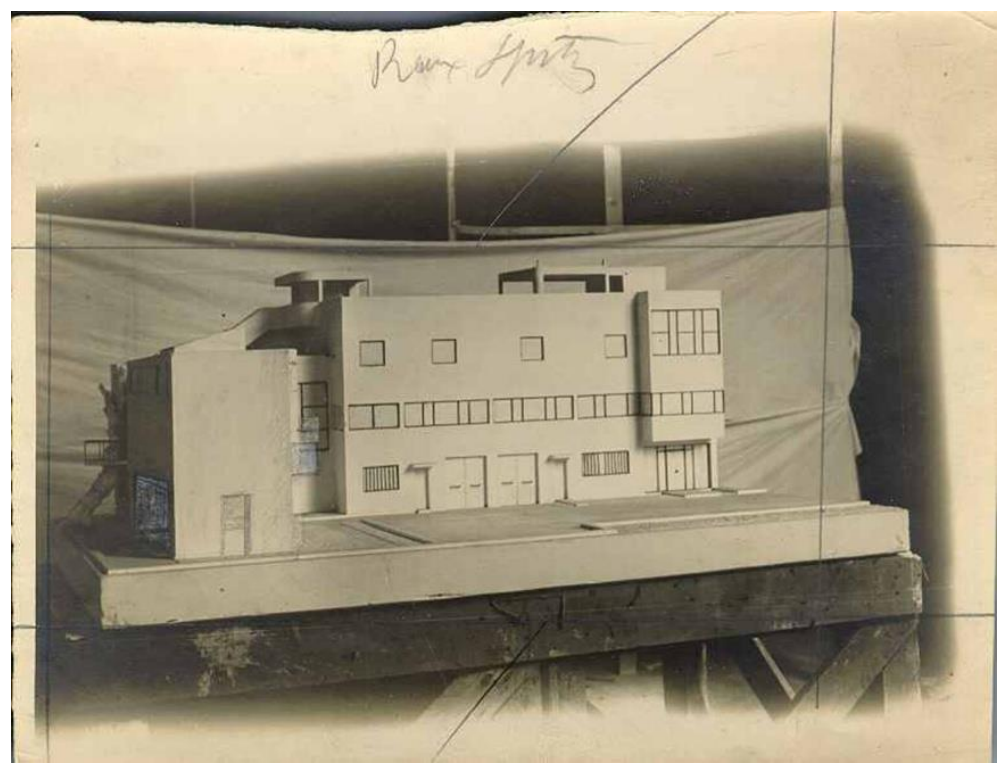

8. Maison La Roche-Jeanneret. La foto sirve de base para tantear la opción de elevar el cuerpo de la sala de exposiciones

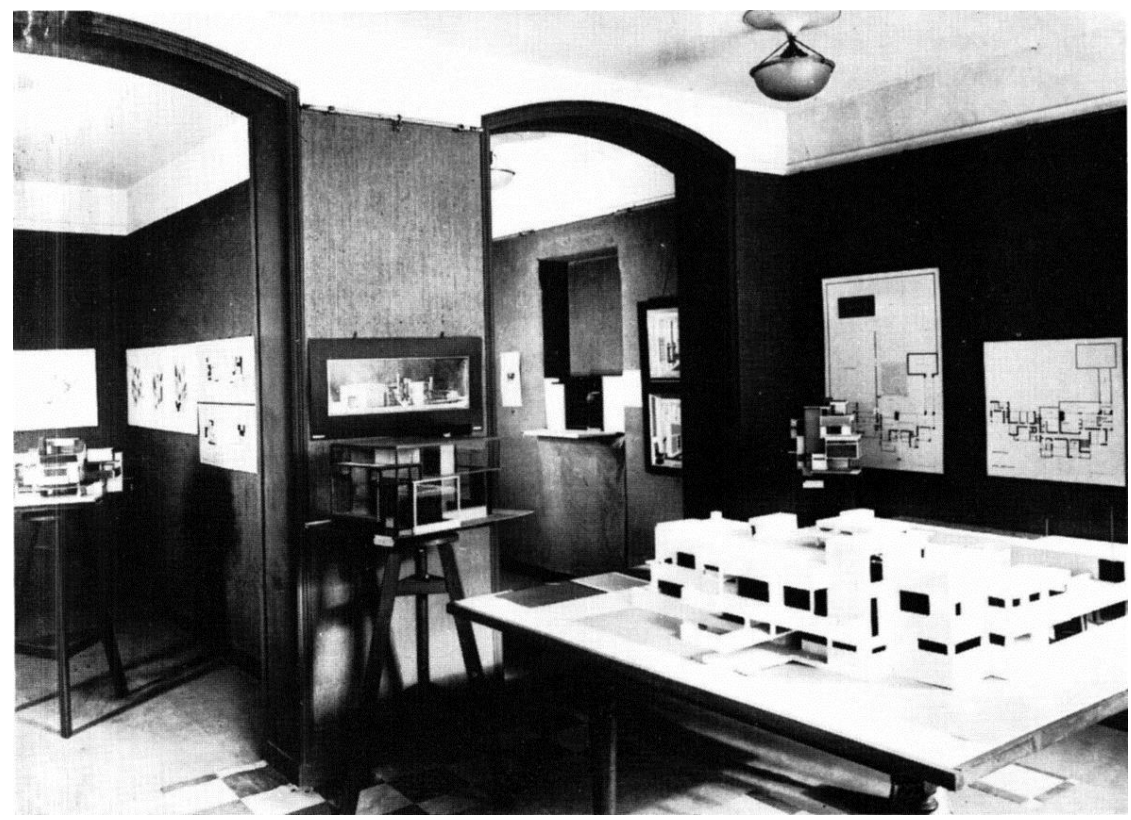

9. Exposición de De Stijl en la sala L'Effort Moderne. Paris 1923. La exposición coincide con la del salón de Otoño. Las maquetas son realizadas por Rietveld y Huszar, ambos con experiencia en carpintería.

La manipulación de una de las fotos de la maqueta La Roche detecta un nuevo avance (figura 8). La estable figura curvada de la composición purista ahora pretende elevarse, hacerse aérea. Otra nueva plástica va a ser presentada en las mismas fechas en la galería L'Effort Moderne (figura 9). La ligereza de sus maquetas, la vinculación de exterior con interior, el uso de los colores, produce una huella indiscutible en Le Corbusier, que apenas si ha finalizado una obra purista propiamente dicha, y para el cual los modelos a escala son su campo natural de investigación plástica. Pero estas maquetas holandesas las realizará un ebanista, no un mouleur. 


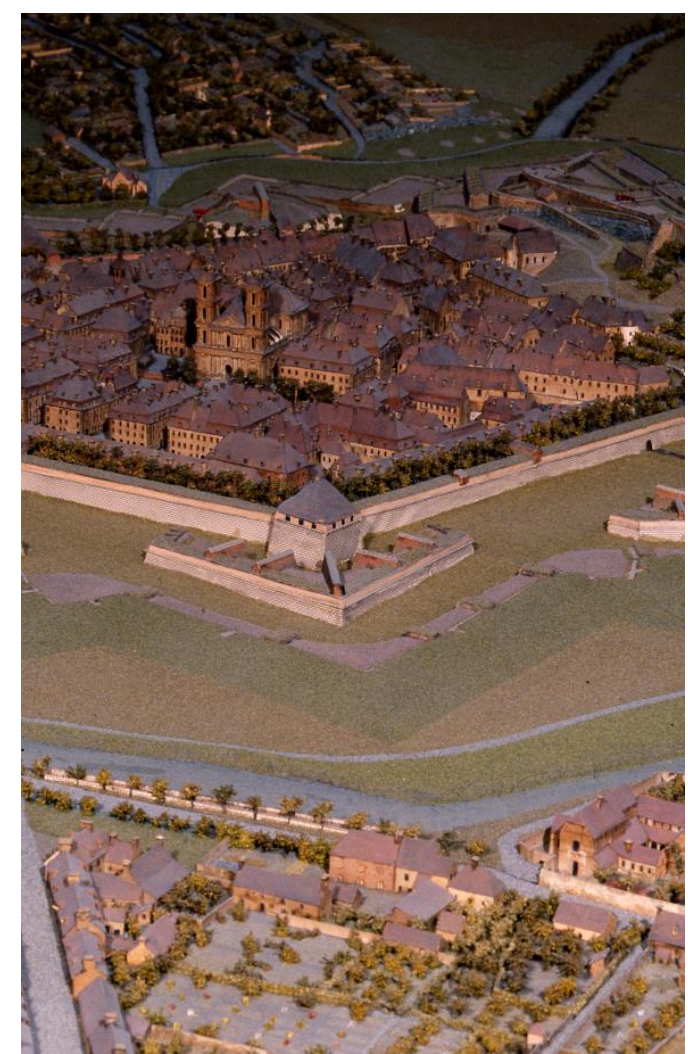

0. Plan-relief realizado bajo la supervisión del Mariscal de Vauban perteneciente a la Collection de Plan-reliefs conservada en el Musée des Invalides.

\section{Plan-reliefs. El urbanismo en tres dimensiones.}

"El aeroplano, en el cielo, transporta nuestros corazones por encima de todo lo mediocre. El avión nos ha dado la mirada a vista de pájaro. Cuando los ojos ven claramente, la mente puede decidir con claridad. "29

A partir de la Primera Guerra Mundial, se producirá una transferencia tecnológica de las técnicas de reconocimiento aéreo militar a la sociedad civil, en especial al planeamiento urbano, la arqueología, la botánica, etc. ${ }^{30}$. Los avances en geodesia y la aplicación de la estereoscopia se suman a las mejoras tecnológicas de las cámaras fotográficas y los sistemas de traslación de las tomas al mapa, con aparatos tales como el appareil de redressement, encargados de ejecutar las cartas cartográficas por estereofotogrametría.

En Francia será el Service Geographique de la Armée (SGA) el encargado de realizar las cartografías oficiales ${ }^{31}$. Compuesto de personal militar y civil, las tareas del estudio del territorio del SGA ilustran a la perfección las reflexiones aéreas de Le Corbusier, en las que se conjugan la geometría y la emoción plástica. Pero además de todo esto, el SGA tenía un cometido más, bien significativo:

\footnotetext{
${ }^{29}$ Le Corbusier. Aircraft. Madrid : Abada Editores, 2003. (1 $1^{\circ}$ ed. 1935). p.13.

${ }^{30}$ Cfr. Saint-Amour, Paul K. Applied Modernism: Military and Civilian Uses of the Aerial Photomosaic. Nottingham University. 2012.

${ }^{31}$ de Martonne, Enmanuel. "Photogrammétrie et photographie aérienne. À propos du congrès et de l'exposition internationale de photogrammétrie". En Annales de Géographie. Paris (s.e) 1935, t. 44, n²47. pp. 65-70. "Le Service Géographique de l'Armée est en France le principal usager de la photogrammétrie. Après avoir poursuivi pendant un certain nombre d'années des expériences minutieuses (...) il a commencé en 1912 à utiliser la photogrammétrie terrestre, et, en 1931, la photogrammétrie aérienne ".
} 
A ce rôle primordial, le Service géographique joint quelques missions annexes : nivellement de précision en Algérie et au Levant; mise au point et fabrication des instruments de géodésie (...) et de réglage de tir utiles à l'Armée; dotation des corps et unités en matériel de projection cinématographique(...). Enfin, il est chargé de la conservation du musée des Plans-reliefs des places fortes, installé aux Invalides, et, dans une école spéciale, il instruit les dessinateurs géographes destinés à ses ateliers et sections. ${ }^{32}$

Los Plans-reliefs, la gran empresa emprendida por el Mariscal de Vauban por encargo de Luis XIV están a la salvaguarda y mantenimiento del mismo servicio que realiza las planimetrías aéreas de toda la costa argelina expuestas en 1931 en la Exposition Coloniale de Vicennes ${ }^{33}$. El ejecutor de estas maquetas es “Ch-A. Lasnon” el mouleur-sculpteur encargado de realizar las maquetas de las villas puristas de Le Corbusier y Jeanneret para los Salons d'Automne de 1922 y 1923. Sus colaboraciones con el SGA hubieron de permitirle el acceso al mundo de las reproducciones en relieve cartográficas, a partir de unas bases geométricas de alta precisión, estudios que hubieron de hacer las delicias de Le Corbusier, amante de los vehículos y estudioso de las rutas, en cuya biblioteca personal se encuentra el catálogo de la Exposición ${ }^{34}$.

La relación de Le Corbusier con Lasnon, a cargo de los Plans-reliefs, sumada a su reconocimiento a la obra y pensamiento de Luis XIV y su pasión por el Hôtel des Invalides, donde se encuentran almacenadas estas maquetas, deja pocas dudas de que el arquitecto hubo de conocer bien estas representaciones del paisaje nacidas del control de una geometría inserta dentro de un territorio. La claridad geométrica de Vauban, seguramente admirada a través de los Plans-Reliefs, no pasará desapercibida para Le Corbusier (figura 10):

"Vauban a tracé ces bastions géométriques parce qu'il était un militaire... Organiser, c'est faire de la géométrie; faire de la géométrie dans la nature ou dans le magma «naturellement» issu du groupement des hommes en agglomérations urbaines, c'est faire de la chirurgie". ${ }^{35}$

Coinciden así la observación del plan-relief con la mirada del aeronauta. No es de extrañar por tanto que 1931 sea el año de la Exposition Coloniale en la que el SGA va a mostrar, gracias a las habilidades del oficio secular de Lasnon, que desde el aire el control preciso de un territorio es posible y tangible al gran público, pero también -y a la vista está que no es casualidad- es el año en el que Le Corbusier comienza la batalla de Argel, cuyas estrategias se ensayarán a través de las maquetas.

\subsection{Las maquetas ante la Autorité. La maqueta de Argel.}

"La réglage du tir viendra ensuite. Mon projet était un projet obus. Son but était de fixer la direction. „36

\footnotetext{
32 "Le Service géographique de l'Armée". En L'information géographique. Volume 2 n.5, 1937. pp. 206-207. Cfr. Warmoes, Isabelle. Maquettes historiques de Villes fortifiés. Paris: Musées Nationaux, 1997. "Le changement de nature de son activité entraîne le rattachement de la galerie de Plans-reliefs au Service Géographique de l'Armée (...). ce service accomplit principalement des travaux topographiques en Algérie et révisé la carte de France"

33 "L'Exposition colonniale de Vicennes". En Annales de geographie. Paris (s.e.)1931. nº 227. 15 sept 1931. p. 450. Este plan relief será referido en múltiples publicaciones. "Quant à la carte à $1: 200000$, qui comprend 82 feuilles, on n'en trouvera pas d'échantillon. Mais elle a servi de base à la Carte en relief de L'Algérie, d'une étendue impressionnante (4 m. sur 5 m.502), avec hauteurs surélevées quatre fois, exécutée par Ch. A. Lasnon, sculpteur à Paris, et exposée au centre du Palais de l'Algérie ".

${ }^{34}$ Nicoll, Edna L. A travers l'Exposition coloniale. Paris : E.L. Nicoll, 1931. (FLC V 130).

${ }^{35}$ Le Corbusier. Urbanisme .Paris: Editions G. Cress \& Cía. 1927. p.277.

36 "Lettre à une maire". L'Architecture d'Aujourd'hui. nº 10. FLC B3-5-137.
} 


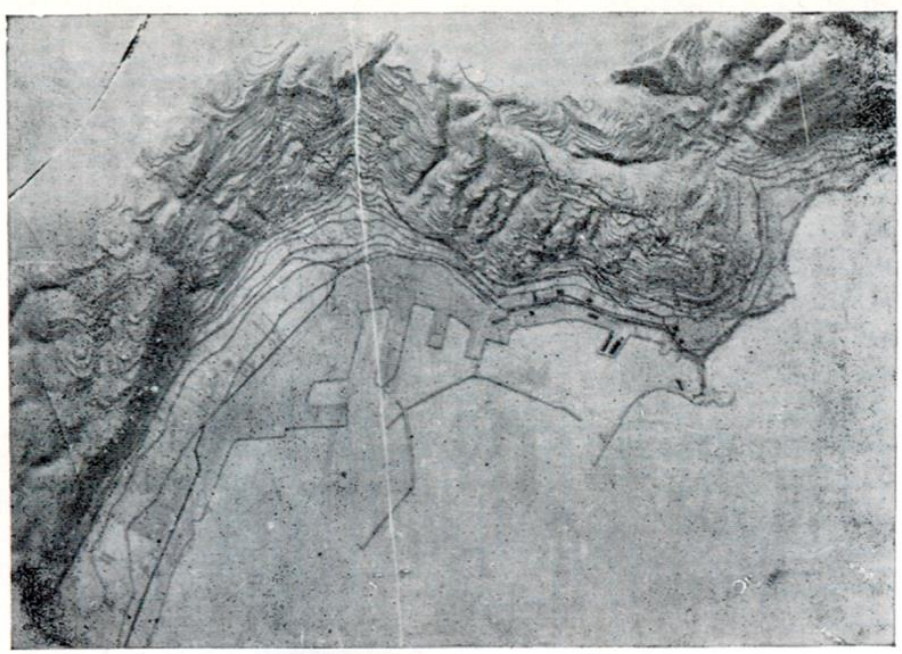

11. Plan-relief realizado por Emery y Breuillot de la topografía de Argel. Publicado en "La Ville Radieuse". 1932.

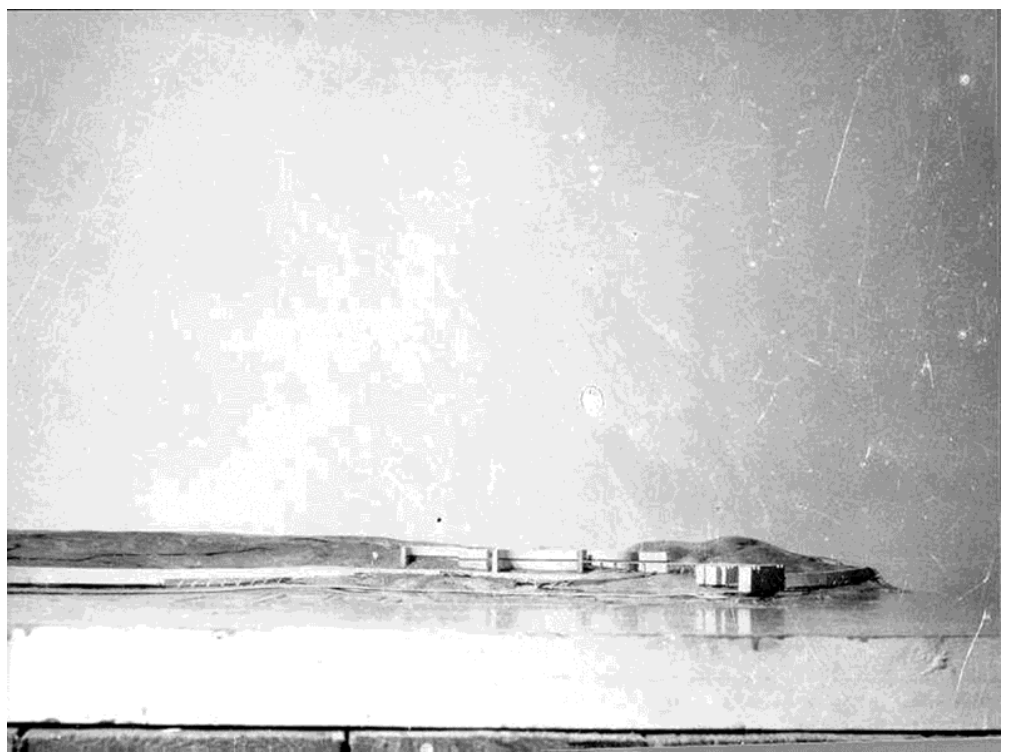

12. Vista de la maqueta realizada por Lasnon de la Propuesta de Le Corbusier, vista desde el mar. 1932.

Le Corbusier llega a Argel invitado por sus antiguos colaboradores del atelier, Pierre André Emery y Charles H. Breuillot, En sus conferencias en la capital aventurará algunos análisis sobre la ciudad, un "outillage urbanistique":

"la topographie de la ville est remarquable (...)Je ne vois pas à Alger des gratte-ciels démesurés, mais des bâtiments très longs, d'une seul tenant, perpendiculaires à l'horizontale de la ville ${ }^{\prime \prime 37}$.

Estos datos son relevantes a la hora de entender la aparición de las maquetas que se realizarán durante el siguiente año. Si bien es cierto que el recurso de la topografía como clave de resolución de un plan urbanístico posee un claro referente anterior en sus dibujos de Rio de Janeiro, dicha propuesta no desarrolla una documentación técnica suficiente como para comprobar su efectividad, sí alcanzada en Alger ${ }^{38}$. Entre la

\footnotetext{
${ }^{37}$ Giordani, Jean-Pierre "Le Corbusier et les projets pour la Ville d'Argel".Paris 1987. (tesis doctoral). p.84.

${ }^{38}$ Urbanistas del SFU, tales como Agache o Jaussely, recibirán encargos en Brasil y Sudamérica. Los movimientos de Le Corbusier siguen la estela de sus competidores y lo establecido en la Loi Cornudet para todos los territorios de la República Francesa.
} 
documentación que requiere a sus colaboradores para comenzar a desarrollar la propuesta se encuentra una maqueta donde se recoja la topografía del lugar:

"Emery et Breuillot prépareront une maquette du relief d'Alger et devront lui envoyer tous les documents officiels des projets en cours qu'ils pourron" ${ }^{\prime 39}$.

Dicho modelo será el que aparezca en 1933 ilustrando el capítulo de La Ville Radieuse dedicado a Argel (fig 11):

"La falaise d'Alger.- Nous avons, les premiers, établi ce relief du territoire d'Alger. Je dis qu'un édile qui regarde ce relief doit admettre qu'il ne copiera plus dorénavant ni Paris, ni Berlin, ni Londres (...).

Un tel relief devrait être placé dans chacun des bureaux attachés à l'urbanisation de la ville. On se limite à étudier sur papier, sur surface plane dans le rébus des courbes de niveau... "A0.

Texto e imagen se alían para presentar un mensaje nítido: la maqueta es el instrumento de planeamiento del nuevo urbanismo "à trois dimensions" en el que controlar los edificios en altura, el tráfico a diversos niveles, el ajuste a la topografía y el soleamiento incluso. Si las dos primeras valencias pueden tipificarse y cuantificarse, la topografía y la luz componen la carga poética, que encuentran también en la maqueta un instrumento de transmisión y comprobación idóneo.

Le Corbusier realizará, durante el invierno y la primavera de $1932^{41}$ la maqueta de la propuesta. A las conocidas instantáneas de vistas a vuelo del avión se les añaden las tomas desde el mar que comprueban los primeros esbozos realizados en agosto a bordo del Gouverneur-General-Chanzy (figura 12). Todas las imágenes de la maqueta presentan la convivencia abrupta del proyecto con la pre-existencia de un paisaje urbano y territorial, la crisis de las utopías urbanas nihilistas, que señala Tafuri: máquina y memoria son dos realidades que se confrontan $^{42}$ sobre el yeso.

La maqueta de la propuesta se ejecutará a partir de la enviada por los colaboradores argelinos realizada mediante el apilamiento de curvas de nivel. Con la ayuda de Lasnon se realizara un molde de ésta, donde la evidencia del trazado de las curvas de nivel es atemperado por unos suaves modelados tocados con cierto color. El conocimiento adquirido -gracias a Chenal- en la maqueta del Plan Voisin sobre los cromatismos más apropiados para ser filmados, hubo de estar presente en la elección de los sombreados de la maqueta, sin renunciar a representar los tonos reales del lugar. De hecho Le Corbusier intenta que el director haga un film sobre el edificio, sin conseguirlo ${ }^{43}$ (figura 13).

La calidad de la ejecución de los cuerpos de edificación delatan un proceso de tanteo de la forma ${ }^{44}$, si bien el modelo parte del rigor de las planimetrías del Service Geographique. Una comprobación de las planimetrías existentes y la maqueta permite observar la apenas existencia de planos en los que se desarrolle con precisión la forma del viaducto de viviendas.

\footnotetext{
${ }^{39}$ Giordani, Jean Pierre. Op. cit. nota 37. p. 84.

${ }^{40}$ Le Corbusier. La Ville Radieuse: eléments d'une doctrine d'urbanisme pour l'équipement de la civilisation machiniste. Paris: Vincent Fréal \& Cie, 1964 (1 ed. 1935) p. 234.

${ }^{41}$ La carta de principios de junio de 1932 de Charles Brunel datan la maqueta ya realizada en esa fecha. Aún no ha sido publicada en ningún medio. Ref. FLC I1-2-458.

${ }^{42}$ Tafuri, Manfredo. " Machine et memoire". En Lucan, Jacques (dir.) Le Corbusier. Une Encyclopedie. Paris: Pompidou, 1987.:"d'une parte la machine parfaite et d'autre la Casbah, ·temoin silenceux d'une autre temps- soigneusement préservée."

${ }^{43}$ Giordani, Jean Pierre. Op. cit. nota 37. pp 215.

${ }^{44}$ Giordani, Jean-Pierre " Le Plan Obus, 1931-1932: du sublime aux realités" en Jean-Lucien Bonillo (dir) Le Corbusier. Visions d'Alger. Paris: Fondation Le Corbusier, 2012. p.103-127
} 


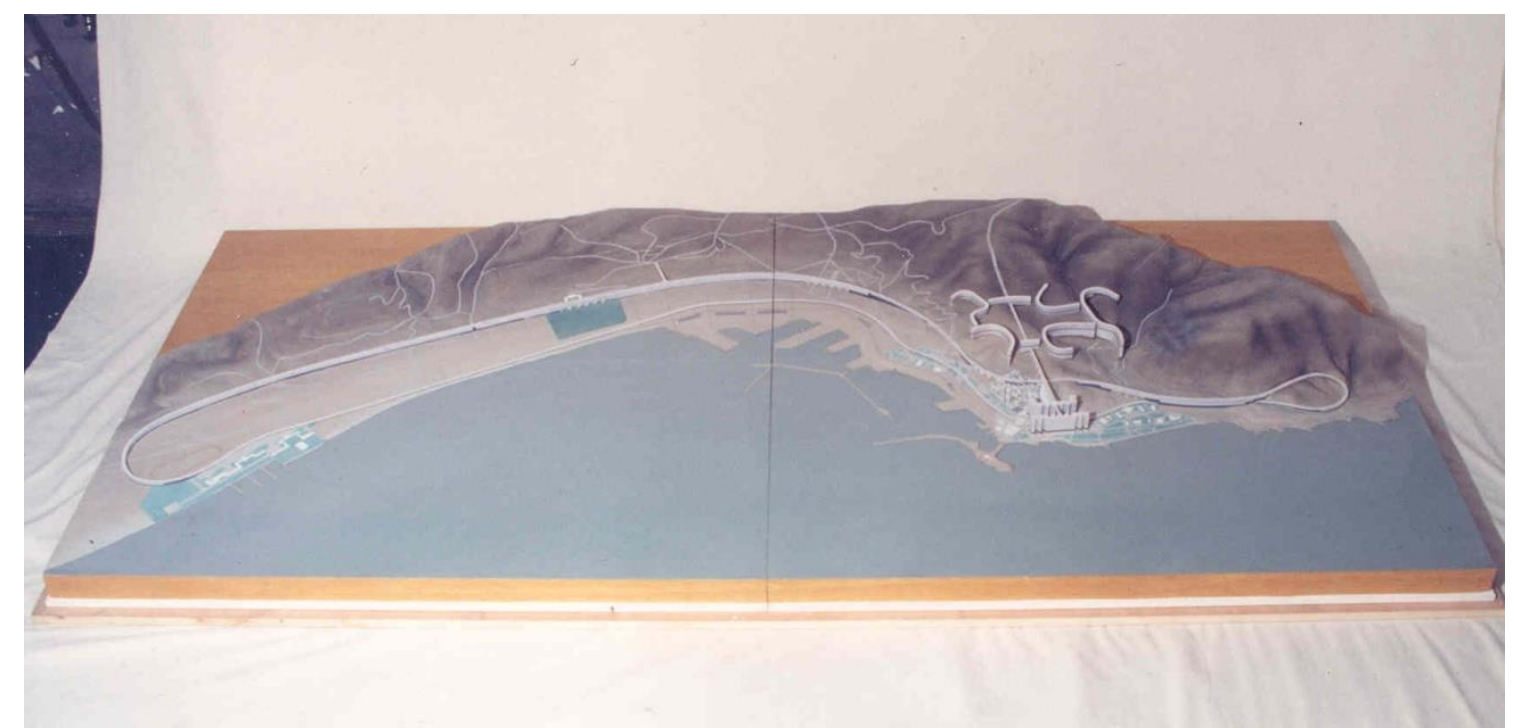

13. Estado original de la maqueta donde se observa el colorido aplicado por Lasnon. El descuadre entre base y el plan-relief ejecutado que se observa se debe a que los límites del plan-relief responden a los formatos del SGA.

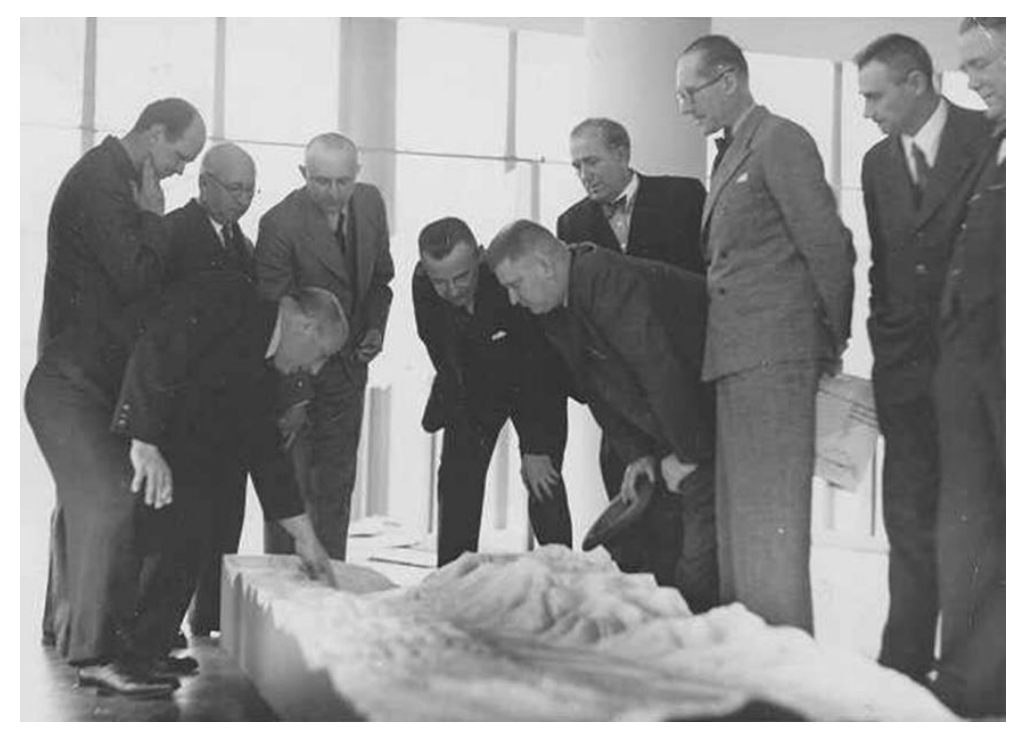

14. Bata y otros dirigentes se acercan a escudriñar la maqueta de la propuesta del Valle de Zlin. La postura corporal de Le Corbusier ilustra otra forma de mirar. 1935.

Así mismo, la mayoría de las planimetrías del "plan A" desarrollan aspectos secuenciales del proyecto. Pareciera que corresponde a la maqueta el reunir cada una de las realidades estudiadas mediante el dibujo.

Le Corbusier presentará la maqueta al alcalde, al igual que hará ante Bata en Zlin, como si de un Mariscal ante plan-relief del campo de batalla se tratara, sacando partido a las relaciones entre escala y poder que establece toda maqueta (figura 14). A pesar del esfuerzo, la visita de Charles Brunel al atelier de la Rue de Sevres en junio del 32 para observar la maqueta no tuvo el efecto deseado. Brunel, natural de Argel, hubo de imaginar de otro modo aquello que se le presentaba, más allá del extraño objeto en bajorrelieve que tenía ante sí, entre correa y músculo. A pesar del esfuerzo de Le Corbusier por tratar "avec soin" la Casbah, y utilizar recursos que ya estaban, de otro modo, presentes en la ciudad, los ojos del alcalde no debieron ver mucho más que unos toscos tarugos de formas sinuosas (fig 15). Su opinión sería cuanto menos similar a la expresada al recibir la propuesta C: 
"La Autorité requise pour décréter la démolition complète d'une agglomération de 300.000 habitants (...) ne pourrait être qu'une dictature absolue ${ }^{\prime 45}$.

¿Ojos que no ven?.

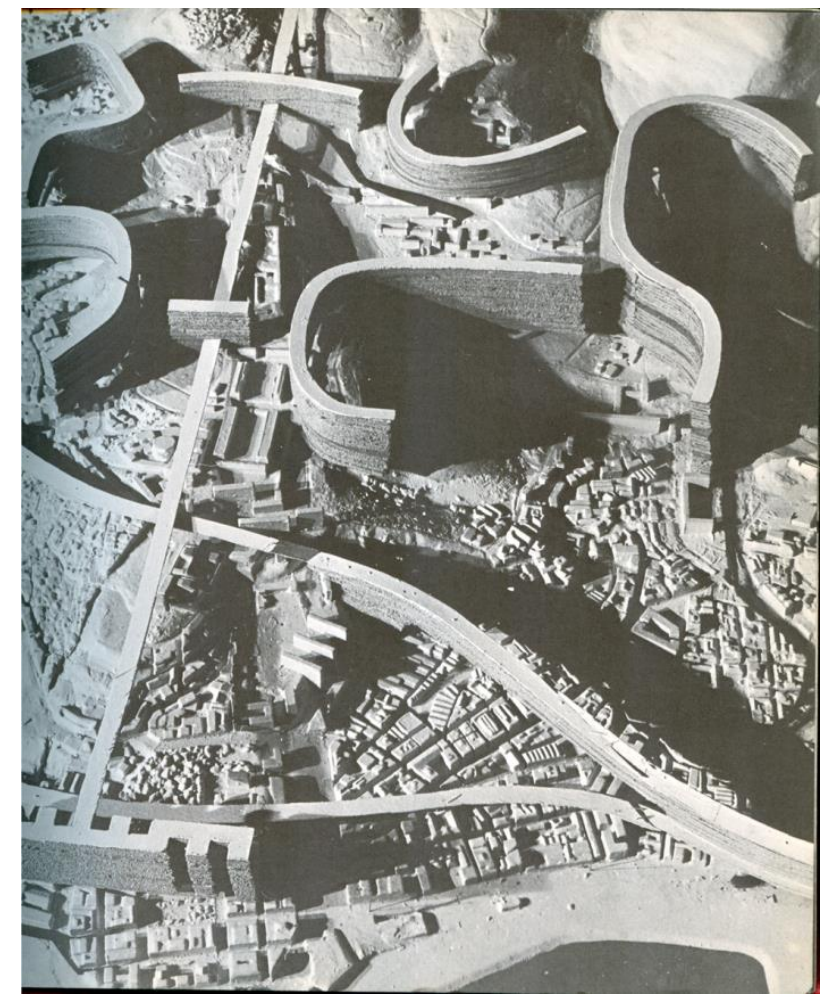

15. Detalle de la maqueta de Argel con los Crescent de Fort-L'Empereur sobre la Casbah.

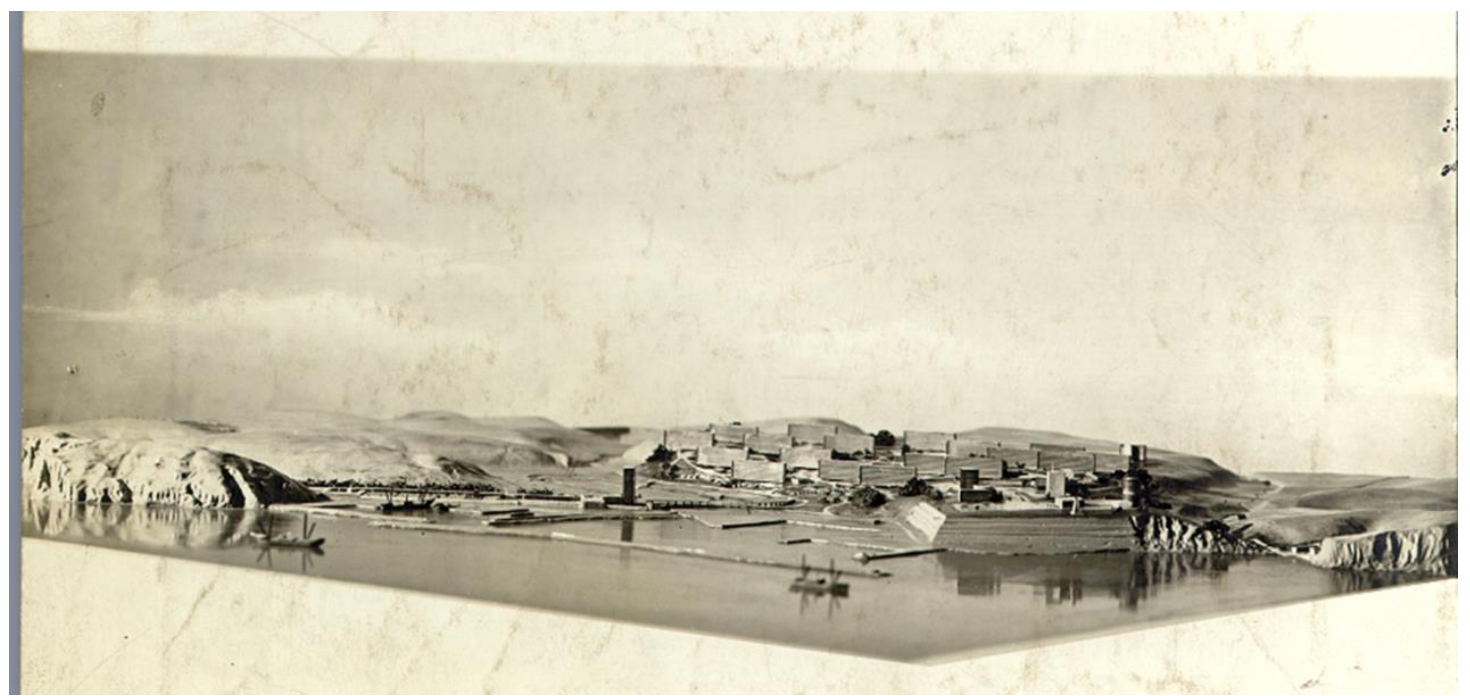

16. Detalle de la maqueta Nemours vista desde el mar. Se observan los macizos calcáreos, originales o manipulados

\footnotetext{
${ }^{45}$ Giordani, Jean Pierre "Alger. Urbanisme A".Le Corbusier Plans. DVD Collection. Vol. 1. Tokyo: Echelle-1. FLC. 2010
} 


\subsection{Nemours: piedras y jardines.}

Si el Plan Obus ya supuso un salto respecto a las teorías del Plan Voisin, el caso de Nemours aportará un mayor apego a la cota cero, al contacto con la realidad física del lugar: en la propuesta de la actual Ghazaouet se observa un acercamiento exhaustivo al paisaje existente ${ }^{46}$. Las planimetrías presentadas a la municipalidad en octubre de 1934 por el equipo de arquitectos aportan una documentación severa y científica, que ejemplifican la "Urbanisation de la Ville Functionelle" ${ }^{, 47}$ tratada en el Congreso de Atenas. Frente a la documentación gráfica y escrita, centrada en ilustrar los principios del nuevo urbanismo, la maqueta, de la misma escala que las planimetrías presentadas, permite discernir una atención cuidadosa al paisaje existente dejando en un segundo plano, incluso sustituyendo a la batería teórica (f. 16).

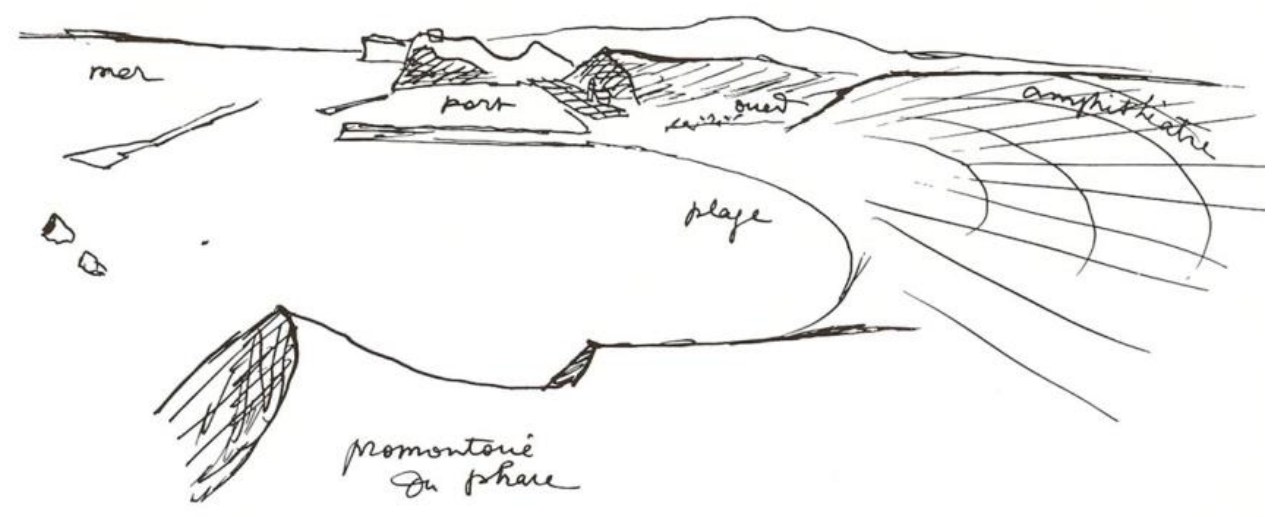

17. Croquis de Le Corbusier en su visita a Nemours.

La visita que realizará Le Corbusier a Nemours en Julio de 1934 le permitirá traerse consigo algunas imágenes del lugar. Dos realidades físicas se convierten rápidamente en objets à reaction poétique del proyecto. Un croquis de Le Corbusier marca con claridad toda la ladera a nordeste que se abre sobre el puerto, un espacio en concha que calificará como anfiteatro, flanqueado por dos riscos de terreno calcáreo (f17). En el mismo dibujo, puede observarse el segundo objet: en las aguas de la bahía, aparecen dos promontorios denominados "Les deux fréres" que conforman la entrada navegable al puerto natural de Nemours. Las dos rocas centran la atención visual del enclave, tal como muestran las postal de época adquirida y guardada por Le Corbusier (f18).

El trabajo de Lasnon resulta tan impecable y riguroso como el resto de la documentación. A partir de la documentación de la SGA, se observa la protuberancia de las dos piedras en el último malecón del puerto (f.18). El molde principal, realizado en yeso, presenta una decidida policromía, utilizando elementos metálicos -de perfiles nítidos- para las edificaciones (f 19). El área residencial presenta con verdadera pulcritud la madeja de

\footnotetext{
${ }^{46}$ La localidad fronteriza con Marruecos, de 3000 habitantes, está en ese momento acogiendo una serie de infraestructuras ferroviarias y rodadas, a las que se suma la construcción de un nuevo puerto que engarza con todo el conjunto. El plan Maestro se les encarga a Pierre-André Emery y Charles Henri Breuillot, que forman consorcio con Le Corbusier-Jeanneret y François de Pierrefeu, al cargo de las infraestructuras hidráulicas. Ver Giordani, JP. "Urbanisme. Nemours" en Le Corbusier DVD Plans V.6. Paris. Echelle-1, 2010.

${ }^{47}$ Le Corbusier. Op.cit. nota 40. pp. 311-317.
} 
viarios de diversas escalas, sobre un sorprendente tono verdoso, que se degrada hasta su desaparición en los confines de la ciudad. En la maqueta se hallan, por tanto, los dos elementos del lugar a partir de los cuales nace

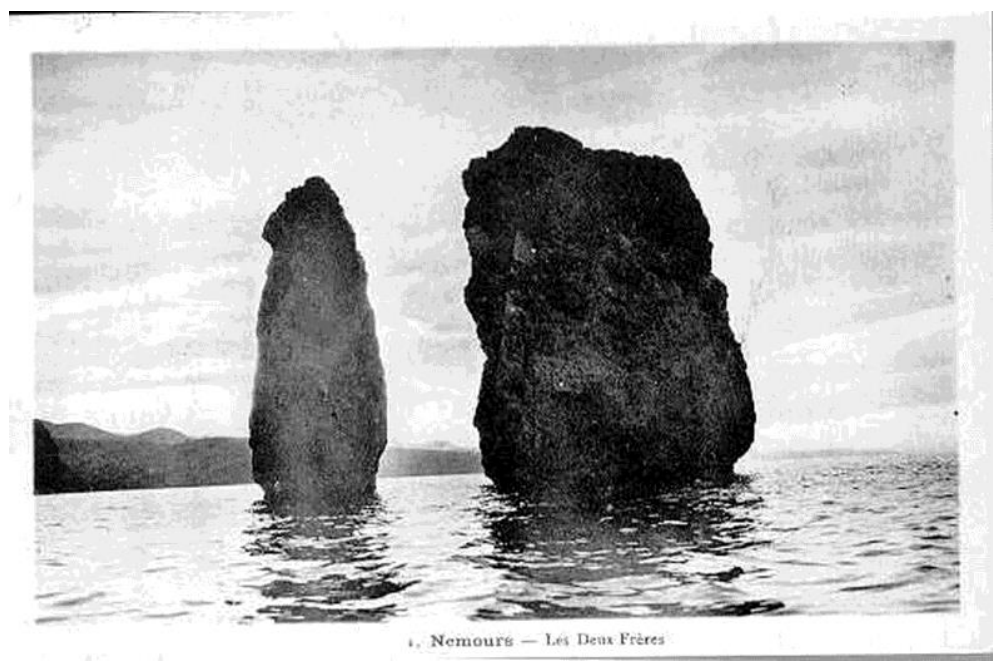

18. Postal de Nemours adquirida por Le Corbusier de "Les deux Frères".

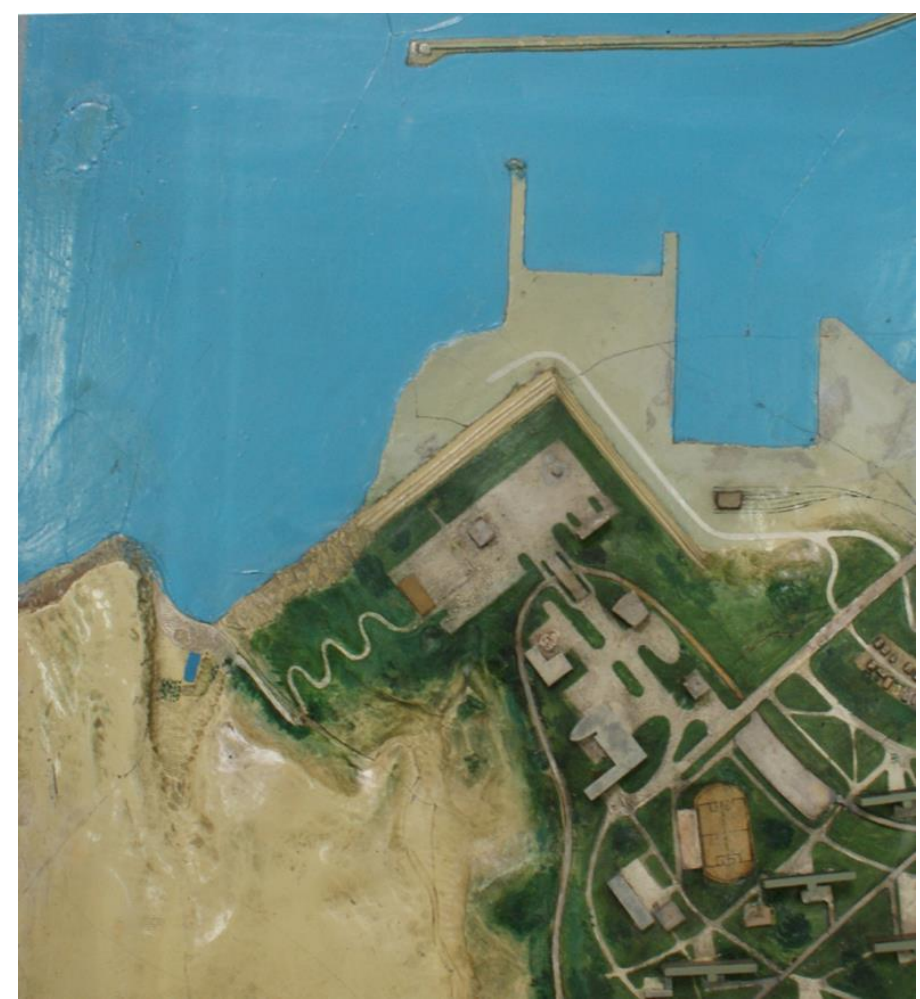

19. Maqueta Urbanisation Nemours. Le Corbusier. 1935. Detalle del esculpido en la roca en forma de atalaya y las "deux frères" al borde del malecón

la propuesta. "Les deux fréres" se conforman en charnela entre la componente poética de la propuesta y la funcionalidad de las infraestructuras. La ampliación portuaria utiliza la referencia de las dos rocas como cierre de la ganancia al mar para la ejecución de las nuevos muelles y playas a los pies del escarpe rocoso. Es esa nueva escala proveniente de la manipulación de las aguas la que crea el nuevo paisaje de Nemours desde el mar. Así, los dos islotes se convierten en una suerte de monumento que señala la entrada al puerto: las dos piedras seguirían liderando un paisaje modificado por el progreso, en la línea de las propuestas de Soergel, pero sin renunciar a la poética de la llegada en barco a un puerto. 
Por otro lado, el segundo aspecto que origina el proyecto se centra sobre la ladera-anfiteatro:

La zona de viviendas se hubiera levantado en un anfiteatro admirablemente expuesto al sol, vientos y panoramas y que actualmente es una extensión de arena y rocas donde ni un cordero encontraría pasto. Este terreno, bueno para 10.000 viviendas, no valía dos reales (...) Por el momento, todo era tierra desierta de África, donde se podrían plantar los más bellos jardines. ${ }^{48}$

Efectivamente, en la maqueta este área aparece cubierta de color verde, de una vegetación que el lugar original no posee. La reproducción de las fotografías en blanco y negro de la maqueta harían pasar a un segundo término este aspecto, dejando el protagonismo al trazado "a la francesa" de los caminos curvos y la jerarquía de viarios de la Carta de Atenas ${ }^{49}$ bellamente ilustrado en este ejemplo de "Urbanisme a trois dimensions". La obtención de "los más bellos jardines" se obtendría gracias al conocimiento del terreno calcáreo, inestable ante las escorrentías, lo que da como resultado acantilados, cortes y laderas peladas de vegetación, pero también fáciles de modelar. Le Corbusier ha de saber esto cuando propone la reconversión a paralelepípedo del irregular risco nordeste, sobre el que sitúa el hotel y el área militar. Una colina de estas características es lo que se encontró Gaudí al realizar el Park Güell, lugar que volvió a visitar Le Corbusier en su visita a la ciudad para los trabajos del Plan Maciá, en marzo de 1932, poco antes de Nemours. Los denominadores comunes no debieron pasar desapercibidos. Gaudí recurre a un sistema complejo de caminos curvos alrededor de la colina que hacen de viaductos de las aguas pluviales, un sistema parecido a los "terre vivante" de Forestier. A través de los elementos arquitectónicos que lo conforman va irrigando el terreno de la colina de una manera homogénea, con la consecuente creación de vegetación ${ }^{50}$.

$\mathrm{Al}$ cantero de Barcelona ${ }^{51}$ le precederán los moulages de Le Corbusier, nuevas estereotomías a través del betonbrut. Trabajos con las manos y la geometría, al fin y al cabo, sea cual fuere su escala.

\section{Entre la representación y la presencia.}

"Si algo caracteriza hoy las relaciones entre arte y fotografía, ese algo será la tensión sin dirimir que aparece entre ambos a causa de la fotografía de las obras artísticas" ${ }^{152}$.

Más allá de su aparición dentro de una molesta urna para dotar alguna exposición de mayor atractivo ${ }^{53}$, la presencia de estas maquetas en las investigaciones sobre la obra de Le Corbusier son las instantáneas realizadas por los fotógrafos del arquitecto, seleccionadas por él mismo para sus publicaciones. Sin duda, las claves representativas de dicho material, su condición divulgativa, es tan incontestable como la voluntad publicitaria de las teorías del arquitecto. Pero otros colaboradores vinculados a las artesanías, como Lasnon, permiten pensar en

\footnotetext{
${ }^{48}$ Le Corbusier. Por las cuatro rutas. Barcelona: Gustavo Gili,1972. p. 92,93

${ }^{49}$ Op. cit. nota 40. pp. 311-317. "A raíz de esto, recibimos el encargo de realizar el plan de la nueva Nemours. Una vez publicado y discutido, este plan fue considerado por los C.I.A.M. como la más pura expresión de la Carta de Atenas".

${ }^{50}$ Cfr: Cuchí, Albert; Silvia, Claudio." La Estrategia hídrica del Park Güell". En Ramos, Amadeo; Añón, Rosa (dir). Propuestas para Sevilla: de la Huerta de la Reina al Polígono Sur. Sevilla: UNIA, 2009.

${ }^{51}$ Le Corbusier, Gomis J., Prat Valles, J. Gaudi. Barcelona. Polígrafa, 1967 (1ºd. original 1958). " un hombre de una fuerza (...)manifestadas durante toda una vida de cantero; de un hombre que hacía tallar las piedras ante sus ojos sobre trazas verdaderamente muy pensadas. Gaudi es "el constructor" del 1900, el hombre de oficio, constructor en piedra, hierro o en ladrillo"

${ }^{52}$ Benjamin, Walter. Breve historia de la fotografía. Madrid: Casimiro libros. 2011. (ed. original: 1931).

${ }^{53}$ Sobre el uso de maquetas de arquitectura en exposiciones, cfr. Patteeuw, Veronique "Miniature temptations" en revista OASE "Models Maquettes", nº 84. Rotterdam: NAI Publishers, 2011, pp. 123-133.
} 
otra "vida de las formas" y en el "elogio de la mano" 54 a la hora de estudiar la obra de Le Corbusier. Estos modelos de yeso, revisitados, abren de nuevo la puerta al interior de la disciplina a través de la presencia física de la arquitectura, latente en su representación. Incluso en la era digital ${ }^{55}$.

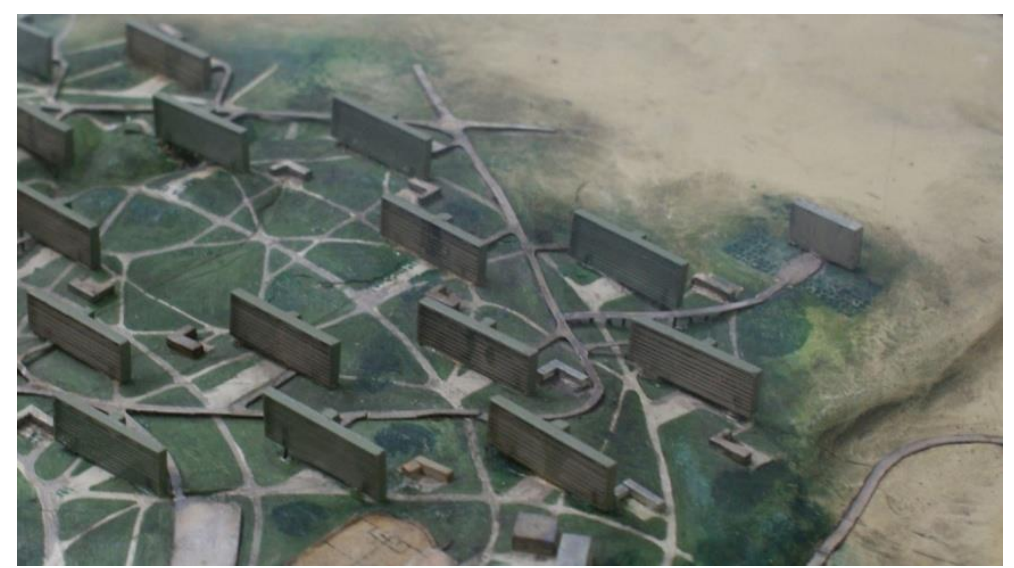

20. Maqueta Urbanisation Nemours. Le Corbusier. 1935. Detalle de los espacios verdes irrigados gracias al trazado sinuoso de los caminos.

\section{Agradecimientos.}

Agradecimientos a la "Fondation Le Corbusier" y su personal, en especial a Isabelle Godineau y Arnaud Dercelles por haber facilitado, en la medida de lo posible, el acceso a las maquetas en propiedad de la FLC y la ADAGP, así como al material de biblioteca y archivo. A la familia Lasnon-Dussaussay y en particular a Florence por su búsqueda de datos sobre su antecesor. A Isabelle Warmoes por su información sobre la Colección de Plan-reliefs.

\section{Procedencia de las imágenes.}

1. Foto cedida por la familia Lasnon-Dussaussay.

2. Encabezado de Le Corbusier. "L'Exposition de L'Ecole Spéciale d'Architecture". en L'Esprit Nouveau. $\mathrm{n}^{\circ}$ 23, mayo. Paris: V. Freal. 1924. p.

3. FLC. L3-20-9-001.

4. FLC. L3-7-45-001.

5. Fotografía del autor.

6. FLC. L2-12-1-001. Fondation Le Corbusier.

7. FLC 15216. Le Corbusier DVD Plans. Vol. 1. Paris: Echelle-1. 2010.

8. FLC. L2-12-4-001. Fondation Le Corbusier.

9. http://vaneesterenmuseum.nl/van-eesteren/vroeg-werk/

10. (c) Musée des Plans-reliefs, Paris. Photo. Ch. Carlet. Ville de Belfort.

\footnotetext{
${ }^{54}$ Focillon, Henri. La vida de las formas y Elogio de la mano. Barcelona: Xarait Ed. 1983. (ed. original: 1934). Le Corbusier conocía bien el libro y al autor.

${ }^{55}$ Sobre la actualidad de un pensamiento y acción basado en lo físico, cfr. Sennet, Richard. El Artesano. Barcelona: Anagrama, 2009.
} 
11. Le Corbusier. La Ville Radieuse: eléments d'une doctrine d'urbanisme pour l'équipement de la civilisation machiniste. Paris: Vincent Fréal \& Cie, 1964 (1ºd. 1935) p. 234.

12. FLC L1-1-69-001. Fondation Le Corbusier.

13. Fotografía de inventariado cedida por Fondation Le Corbusier.

14. www.fondationlecorbusier

15. Petit, Jean. Le Corbusier lui-même. Genève : Rousseau, 1970. p. 209.

16. Referencia FLC L1-1-103-001. Fondation Le Corbusier.

17. Boesiger, Willy (Ed.) Le Corbusier. Euvre Compléte . volume 3. p. 27 . Basel: Birkhäuser. 1939 (1ºd.).

18. Referencia FLC L5-3-53-001. Fondation Le Corbusier.

19. Fotografía del autor.

20. Fotografía del autor.

\section{Bibliografía.}

"Annuaire industriel. Répertoire général de la production française". Diversos años. www.gallica.fr.

"Construira-t-on des cites-tour et des gratte-ciel sur l'emplacement des fortifications?" en Excelsior. 28/02/1923.

"Le Service géographique de l'Armée". En L'information géographique. Volume 2 n.5, 1937. pp. $206-207$.

"Les arts decoratifs au Salon d'Automne" en Le Journal . 19/11/1922.

"L'Exposition colonniale de Vicennes". En Annales de geographie. Paris (s.e.)1931. no 227.15 sept 1931.

Baderre, Guillaume. "M. Auguste Perret nous parle de l'architecture au Salon d'Automne" en Paris Journal.01/12/1923.

Benjamin, Walter. Breve historia de la fotografía. Madrid: Casimiro libros. 2011. (ed. original: 1931).

Benton, Tim. Les Villas parisiennes de Le Corbusier 1920-1930. Paris: Ed. de la Villette. 2007.

Boesiger. W; Storonov O. (eds.) Le Corbusier et Pierre Jeanneret. Euvre Complète. 1910-1929. Basel: Birkhäuser. 1929(1ºd.).

Cuchí, Albert; Silvia, Claudio." La Estrategia hídrica del Park Güell". En Ramos, Amadeo; Añón, Rosa (dir). Propuestas para Sevilla: de la Huerta de la Reina al Polígono Sur. Sevilla: UNIA, 2009.

de Martonne, Emmanuel. "Photogrammétrie et photographie aérienne. À propos du congrès et de l'exposition internationale de photogrammétrie". En Annales de Géographie. Paris (s.e) 1935, t. 44, n²47.

Focillon, Henri. La vida de las formas y Elogio de la mano. Barcelona: Xarait Ed. 1983. (ed. original: 1934).

Giordani, Jean Pierre "Alger. Urbanisme A" en Le Corbusier. DVD Plans vol. 6. Paris: Echelle-1, 2010

Giordani, Jean-Pierre " Le Plan Obus, 1931-1932: du sublime aux realités" en Jean-Lucien Bonillo (dir) Le Corbusier. Visions d'Alger. Paris: Fondation Le Corbusier, 2012.

Giordani, Jean-Pierre. Le Corbusier et les projets pour la Ville d'Argel. Paris 1987. (tesis doctoral)

Giordani, JP. "Urbanisme. Nemours" en Le Corbusier. DVD Plans vol.6. Paris. Echelle-1, 2010.

Janneau, Guillaume. "L'Exposition des arts techniques de 1925. Que sera demain le logis?" en Le Bulletin de la vie artistique n. 11, 1 junio 1923.

Le Corbusier, Gomis J., Prat Valles, J. Gaudi. Barcelona. Polígrafa, 1967 (1ºd. original 1958). 
Le Corbusier. Por las cuatro rutas. Barcelona: Gustavo Gili,1972.

Le Corbusier. "L'Exposition de L'Ecole Spéciale d'Architecture". en L'Esprit Nouveau. no 23, mayo. Paris: V. Freal. 1924.

Le Corbusier. Aircraft. Madrid : Abada Editores, 2003. (1ºd. 1935).

Le Corbusier. La Ville Radieuse: eléments d'une doctrine d'urbanisme pour l'équipement de la civilisation machiniste. Paris: Vincent Fréal \& Cie, 1964 ( $1^{\circ}$ ed. 1935)

Le Corbusier. Urbanisme .Paris: Editions G. Cress \& Cía. 1927.

Mesnil, Jacques. "Au Salon d'Automne". En L'Humanité. 11/11/1922.

Nicoll, Edna L. A travers l'Exposition coloniale. Paris : E.L. Nicoll, 1931

Ozenfant, A.; Jeanneret Ch.E. Acerca del Purismo. Escritos 1918-1926. Madrid: El Croquis. 1994.

Patteeuw, Veronique "Miniature temptations" en revista OASE "Models Maquettes", no 84. Rotterdam: NAI Publishers, 2011.

Rambosson, Y. "Le Mouvement des Arts Appliques. Les architectes modernes au Salon des decorateurs" en L'Amour de l'art, n. 6, junio 1923.

Reichlin, Bruno. Le Corbusier vs.De Stijl. Cuadernos de La Roche. FLC.

Saint-Amour, Paul K. Applied Modernism: Military and Civilian Uses of the Aerial Photomosaic. Nottingham University. 2012.

Sennet, Richard. El Artesano. Barcelona: Anagrama, 2009.

Tafuri, Manfredo. " Machine et memoire". En Lucan, Jacques (dir.) Le Corbusier. Une Encyclopedie. Paris: Pompidou, 1987.

Warmoes, Isabelle. Maquettes historiques de Villes fortifiés. Paris: Musées Nationaux, 1997. 


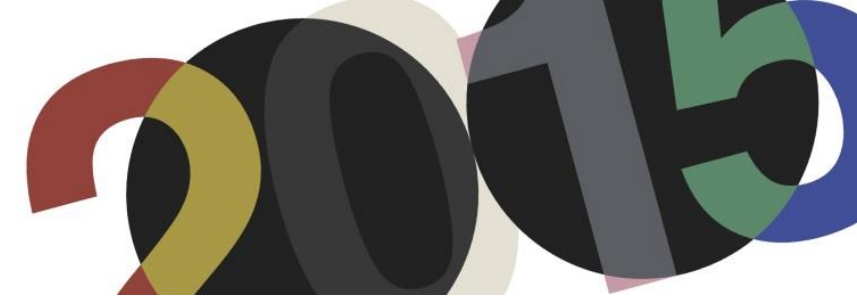

DOI: http://dx.doi.org/10.4995/LC2015.2015.838

\title{
Le Corbusier's Proposal for the Capital of Ethiopia: Fascism and Coercive Design of Imperial Identities
}

\author{
E. Dainese \\ University of Pennsylvania, History of Art Department
}

\begin{abstract}
In 1936, immediately after the Italian conquest of the Ethiopian territories, the Fascist government initiated a competition to prepare the plan of Addis Ababa. Shortly, the new capital of the Italian empire in East Africa became the center of the Fascist debate on colonial planning and the core of the architectural discussion on the design for the control of African people. Taking into consideration the proposal for Addis Ababa designed by Le Corbusier, this paper reveals his perception of Europe's role of supremacy in the colonial history of the 1930s. Le Corbusier admired the achievements of European colonialism in North Africa, especially the work of Prost and Lyautey, and appreciated the results of French domination in the continent. As architect and planner, he shared the Eurocentric assumption that considered overseas colonies as natural extension of European countries, and believed that the separation of indigenous and European quarters led to a more efficient control of the colonial city. In Addis Ababa he worked within the limit of the Italian colonial framework and, in the urgencies of the construction of the Fascist colonial empire, he participated in the coercive construction of imperial identities.
\end{abstract}

Keywords: Le Corbusier; Addis Ababa; colonial city; Fascist architecture; racial separation; Eurocentrism.

\section{Introduction}

Located in the Horn of Africa, Ethiopia has a unique cultural heritage. It was the home of the civilization of the ancient Aksumite kingdom from the first to the eighth centuries AD, as well as the center of the Ethiopian Orthodox Church, one of the oldest Christian churches. ${ }^{1}$ As the twentieth century approached, together with the young Republic of Liberia on the West coast, Ethiopia became the only African countries not colonized by European powers after 1884-85 and the Berlin Conference. The relationship between Ethiopia and Italy dated back to this moment culminating with the battle of Adowa, in 1896, and the defeat of the Italian army. In 1922, the unexpected ascendance of Benito Mussolini, leader of the National Fascist Party, exacerbated the Italian desire to redeem the humiliation of Adowa and easily revived the colonial project of unification of the East African territories - Ethiopia, Eritrea, and Somalia - in one greater Italian colonial region. On October 3rd, 1935, without any declaration of war, the Italian air force bombed civilians in the Ethiopian towns of Adowa and Adigrat. The invading forces took Addis Ababa after five months of war: the Ethiopian ruler, Haile Selassie, was forced to leave Ethiopia, while in Rome Mussolini proclaimed the Italian East African empire.

As part of its ambitious plan for African colonies, the Italian government initiated a competition to build the new capital of Ethiopia. Several Italian architects involved in the design of overseas territories developed schemes for Addis Ababa, among them Marcello Piacentini, Enrico Del Debbio, Giuseppe Vaccaro, Ignazio Guidi, and

\footnotetext{
${ }^{1}$ For the history of Addis Ababa see: Gebremedhin, N.: "A tale of Three Highland Cities". In Adjaye, D. (ed.): African Metropolitan Architecture. New York: Rizzoli, 2011, pp.31-34; Garretson, P.P.: A History of Addis Abäba from Its Foundation in 1886 to 1910. Wiesbaden: Harrassowitz, 2000; Pankhurst, R.: History of Ethiopian Towns. Wiesbaden: Steiner, 1982.
} 
Cesare Valle. Even the Swiss-French architect Le Corbusier, fascinated by the idea of designing the new capital of the Italian empire in Africa, sent a proposal based on the ideal Ville Radieuse.

Taking into consideration the plan for Addis Ababa designed by Le Corbusier, this article reveals his perception of Europe's role of supremacy in the colonial history of the 1930s and his Eurocentric assumption that considered overseas colonies as natural extension of European countries. Furthermore, this study opens up to the wider topic of racial policies in the Italian colonies and the Fascist building of the Italian empire in Africa. In particular, the article focuses on Le Corbusier's approach to Ethiopian architectural tradition, his fascination with Fascist central authority, and his desire to participate in the coercive construction of imperial identities.

\section{The visit to Rome}

Italy had always been a fundamental source of inspiration for Le Corbusier. He traveled extensively throughout the country studying its cultural heritage and history, and he was frequently in touch with numerous Italian architects and planners with whom he shared his thoughts on architecture and the utopian city. During the Fascist regime, Italy became also a place where, with the favor of Mussolini, the naturalized French architect hoped to finally realize the radical utopia of the Ville Radieuse. Beginning in the late 1931, the architect tried tenaciously to obtain an official invitation to visit Italy by the Fascist regime. ${ }^{2}$ He lobbied his Italian friends in contact with the regime about the request. At his suggestion, in October 1931, Sigfried Giedion, renowned art historian and founder of Congrès Internationaux d'Architecture Moderne (CIAM), asked Gino Pollini and his Italian group to work "for the execution of Le Corbusier's plans in collaboration with the young Italian (Swiss and French) architects.",

Despite his efforts, Le Corbusier visited the country only in 1934. That February, the editors of the magazine Quadrante, Pietro Maria Bardi and Massimo Bontempelli, sent him an official invitation to exhibit his work in Rome. Several witnesses and scholars analyzed Le Corbusier's work during and immediately after his stay in Italy. ${ }^{4}$ Talamona's study of the carnet titled "commencé le 3 juin 1934" and other Italian documents gave detailed descriptions of Le Corbusier's activities. ${ }^{5}$ In Rome from June 4th to $22 \mathrm{nd}$, the architect met with colleagues and experts, gave talks, and organized the display of his projects. Most importantly, he experienced the Italian debate on the most suitable architectural style to be adopted by the Fascist regime first-hand. Shortly before Le Corbusier's arrival, Mussolini had expressed his preference for modern architecture and his desire that Italian modernism could build the new Fascist nation. He finally preferred Italian rationalists instead of older architectural schools and styles. It is not surprising that Italian modernists saw Le Corbusier's visit to Rome as a blessing and that his visit produced great expectations and ferment. Motivated by the general enthusiasm for his work and for modern architecture in general, Le Corbusier hoped to discuss his ideas for the Fascist regime and a proposal for Rome (the Banlieue de Rome, 1934) personally with Mussolini during his visit. However, the meeting would never occur. On June $14^{\text {th }}$, only ten days after Le Corbusier's arrival, the Italian leader left the

\footnotetext{
${ }^{2}$ Ciucci, G.: “A Roma con Bottai”. In Rassegna. Vol.2, no.3, July 1980, pp.66-71.

${ }^{3}$ Giedion, S.: "Letter to Gino Pollini." October 29th, 1931, FLC I2 (3), pp.25-26 as quoted in Talamona, M.: "Roma 1934". In Talamona, M. (ed.): L'Italia Di Le Corbusier. Rome, Milano: MAXXI, Museo Nazionale Delle Arti Del XXI Secolo; Electa, 2012, p.245.

${ }^{4}$ See, for example: Bardi, P.M.: "Le Corbusier a Roma." In Quadrante. No.13, xii, May 1934, p.5; Talamona, M.: "Roma 1934". In Talamona, M.: L'Italia Di Le Corbusier. Rome, Milano: MAXXI, Museo Nazionale Delle Arti Del XXI Secolo; Electa, 2012, p.241.

5 Talamona, M.: "Roma 1934". In Talamona, M.: L'Italia Di Le Corbusier. Rome, Milano: MAXXI, Museo Nazionale Delle Arti Del XXI Secolo; Electa, 2012, pp.241-261.
} 
capital to meet Adolf Hitler. ${ }^{6}$ Mussolini, focused on his first meeting with the German leader, was not interested in discussing architectural topics, nor Le Corbusier's ideas on Rome and the utopian Ville Radieuse. With no prospects for future collaborations with the Fascist establishment, the French architect returned to Paris. However, he continued working secretly on his idea for Rome and Fascism, still hoping to discuss them personally with Mussolini during a future visit. Le Corbusier viewed the favor of the Italian dictator as the key to actualize the modern utopian Ville Radieuse. He believed that Fascism could help to fulfill his desire to "rebuild cities" and substitute their old structure with new urban forms, in Italy, France, and later Ethiopia. ${ }^{7}$ In the context of Mussolini's ambitions and under Fascist rule, Le Corbusier envisioned the complete redesign of the urban habitat and the beginning of a new civilization.

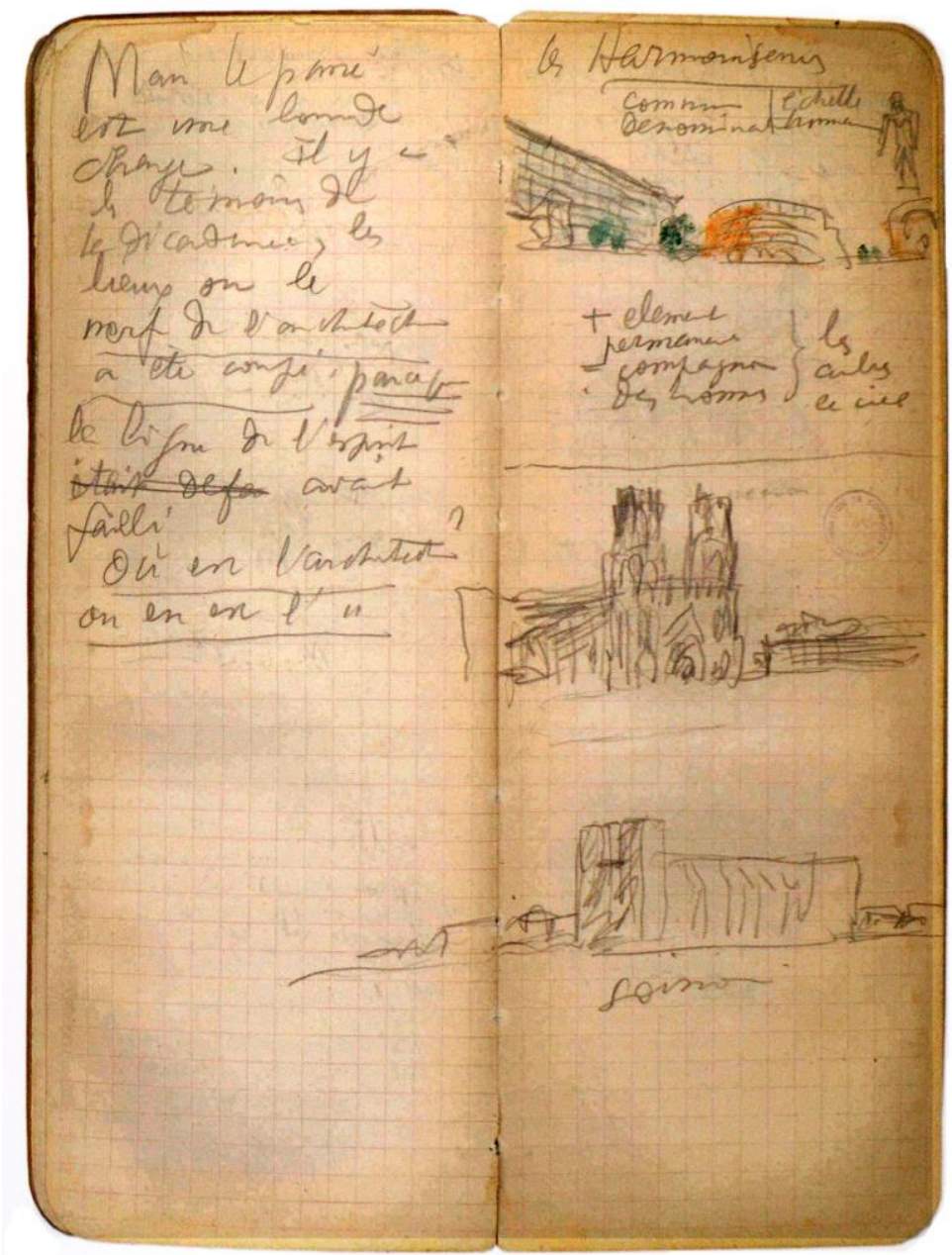

1. Les Harmoniseurs, Le Corbusier, Carnet de notes, 1934. (FLC-ADAGP.

\footnotetext{
${ }^{6}$ Mussolini and Hitler met in Piazza San Marco, Venice, on June 15th, 1934. All national and international newspapers published a picture of the event. Even Le Corbusier included the photograph in his book on La Ville Radieuse. Le Corbusier: La Ville Radieuse. Editions de L'Architecture d'aujourd'hui, Boulogne: Seine, 1935, p.340.

${ }^{7}$ Le Corbusier: La Ville Radieuse. Editions de L'Architecture d'aujourd'hui, Boulogne: Seine, 1935, p.150.
} 


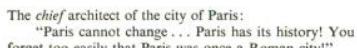

"Paris cannot change ... Paris has its history! Yo
(t) easily that Paris was once a Roman city"."

"Bravo! And where is this Parisian Rome today?"

(A hole and four collapsing walls in the middle of a
garden. The whole thing more or less buried in ivy.)

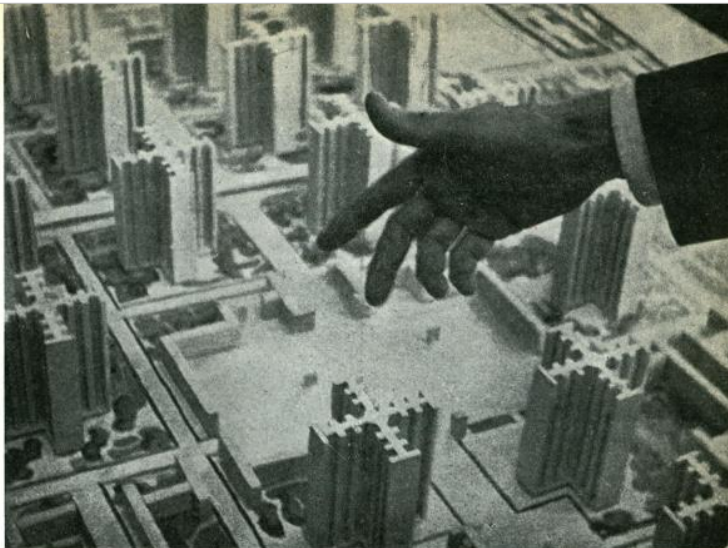

A friend of mine from Moscow, a technician whose job it is to solve a variety of Soviet city-planning problems, objected to my plans for the Radiant City when they were exhibited in our studio because they do not comply with present Soviet theory: "Large cities are an expression of capitalist rule; they are monstrosities intended as prisons for millions of suffering beings. All great cities ought to be split up, dispersed, scattered throughout the national territory in urban units of 50,000 inhabitants.. moment $\left({ }^{2}\right.$.

A few days later, my friend Paolo Prado, the coffee king of Brazil, told me the story of Augusto and his misfortunes. Augusto is his cook. Augusto's wife is a good-naturec, rather simple, fat matron. Paramount, the American movie company, have very recently built some of their enchanted palaces in Såo Paolo, and the films to be seen in them are also enchantments. Augusto's swife has ditched her husband and gone off to Hollywood: serving lunch "Well Augusto, what have you been up to in there?" "A A Senhor," the cook replied in tears, "as I stood there stirring my macaronis in the saucepan. I was seeing my wife's face again!"'

1. The Russian language employs the French word.
3. 1930 .

\section{A NEW CITY TO REPLACE THE OLD}

Cities are magnetic fields; the area over which they exert their pull can vary, and according to the composition of this pull, according to the qualitative differences of its components, so attitudes, attractive power, function within a national context, property The word city indispurom city to city. the natural center of gravity for a given producing area. But it also signifies, because of sometimes immense, spiritual hinterland.

2. A new city to replace the old. Page published in Le Corbusier: The Radiant City. New York: Orion Press, 1967, p.135. CFLC-ADAGP.

\section{Addis Ababa}

Disappointed but undeterred by Mussolini's initial disinterest in discussing his proposals, Le Corbusier organized another visit to Rome to participate in the annual Conference held by the Alessandro Volta Foundation on October 1936. On September $19^{\text {th }}$, 1936, only some months later the Fascist conquest of Ethiopia, the architect sent Bottai, Italian governor of Addis Ababa, a proposal for the Ethiopian capital accompanied with sketches. In a letter he sent along with the plan, Le Corbusier expressed his interest in the construction of the newly proclaimed Fascist empire in Africa. In place of Rome, Addis Ababa became Le Corbusier's object of interest in the construction of his ideal city. In his role of acknowledged leader of the modern movement, Le Corbusier sought to guide the architectural and urban development of the new Roman empire. From his perspective, the design of Addis Ababa was the perfect "architectural playground" for the urban revolution of the Ville Radieuse, and it could transform in the concrete possibility of leading the design and planning of the Fascist empire. ${ }^{8}$

\footnotetext{
${ }^{8}$ For Le Corbusier's understanding of Addis Ababa as an "architectural playground" see: Woudstra R.: "Le Corbusier's visions for Fascist Addis Ababa". October 9, 2014, http://www.failedarchitecture.com/le-corbusiers-visions-for-fascist-addisababa/. We must remember that Le Corbusier ignored the topographical situation of Addis Ababa. This is evident in the comment written on his plan: "solution théorique en absence complete de documentation regionale". See figure 6.
} 


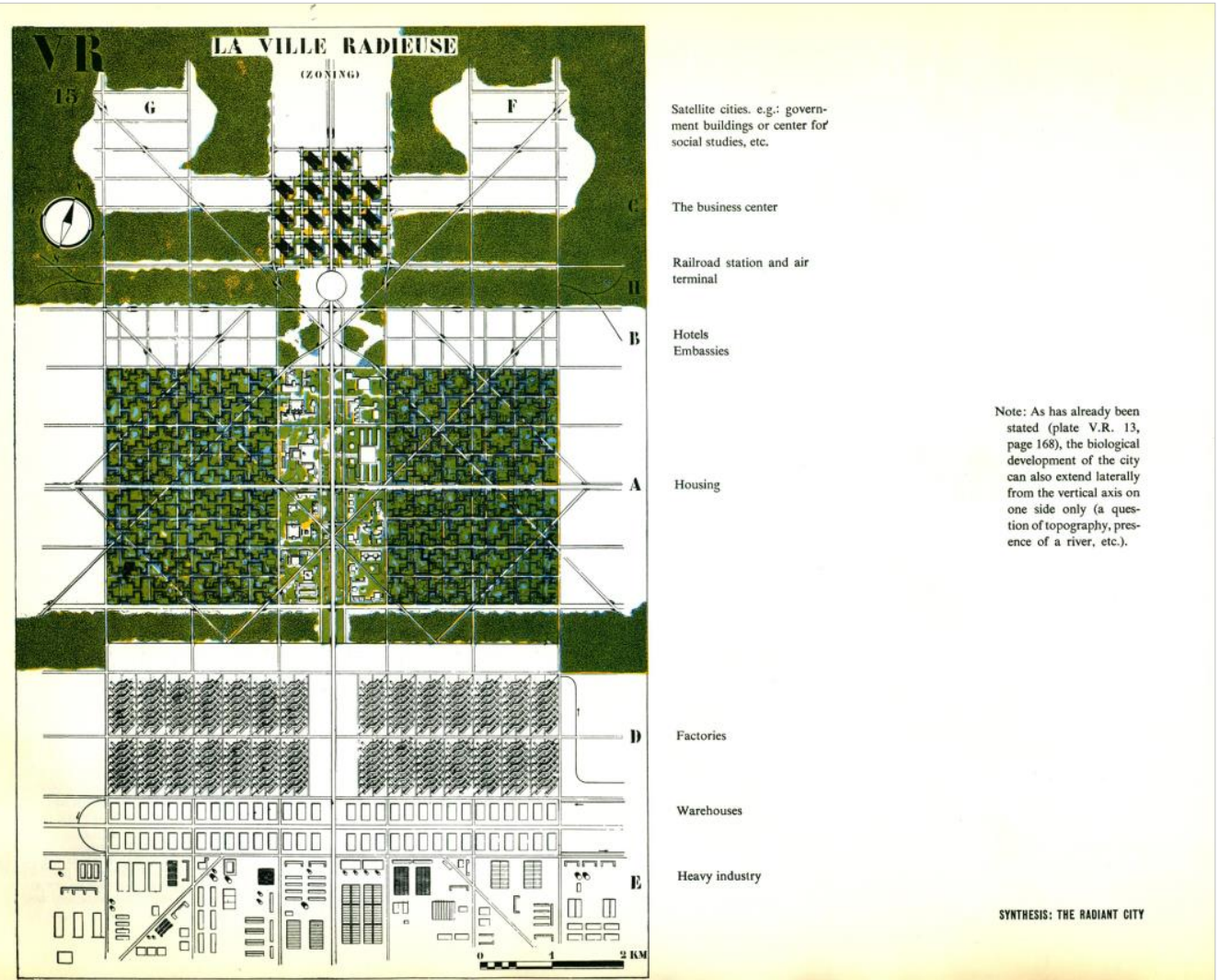

3. La Ville Radieuse, plan, Le Corbusier, 1931. Published in Le Corbusier: The Radiant City. New York: Orion Press, 1967, p.170. OFLC-ADAGP.

In his letter to Fascist authority, the French architect offered his technical services and criticized the garden city project of Ignazio Guidi and Cesare Valle, two Italian architects selected by the government to work on the capital in the summer 1936. According to Le Corbusier, as designed by Guidi and Valle the plan would have been "a disaster, a regression to dangerous concessions, to the death of capitalism." ${ }^{\prime}$ Le Corbusier did not share the interest in the garden city; unlike Guidi and Valle's proposal, his plan rejected the model of centralized city, introducing the limitless concept of the zoning system in parallel bands. According to Le Corbusier, the division in zones allowed infinite expansion and easy access to surrounding areas. Moreover, it permitted a heavy population density of 600-800 inhabitants per hectare in the residential area; the ground surface was rendered as a continuous park in which pedestrians could walk, participate in leisure activities, and enjoy the landscape. In his book La Ville Radieuse he wrote: "To a healthy body, to a mind kept in a continual state of activity and optimism by daily physical exercise, the city, if the right measures are taken, can also provide healthy mental activity." "Similar concepts were expressed in the plan of the utopian Ville Radieuse and Antwerp, in Belgium (1933), where a pragmatic approach outlined the idea of a high-density city thriving within greenery.

\footnotetext{
${ }^{9}$ Le Corbusier: Letter to Giuseppe Cantalupo. Paris, September 19, 1936, in FLC. As quoted in Gresleri, G.: "'La Nuova Roma della Scioa" e l'improbabile Architettura dell'Impero". In Gresleri, G. (ed.): Architettura Italiana D'oltremare 18701940. Galleria D'Arte Moderna Bologna, 26 Settembre 1993 - 10 Gennaio 1994. Venezia: Marsilio, 1993, p.170 (author's translation).

${ }^{10}$ Le Corbusier: La Ville Radieuse. Editions de L'Architecture d'aujourd'hui, Boulogne: Seine, 1935, p.67.
} 


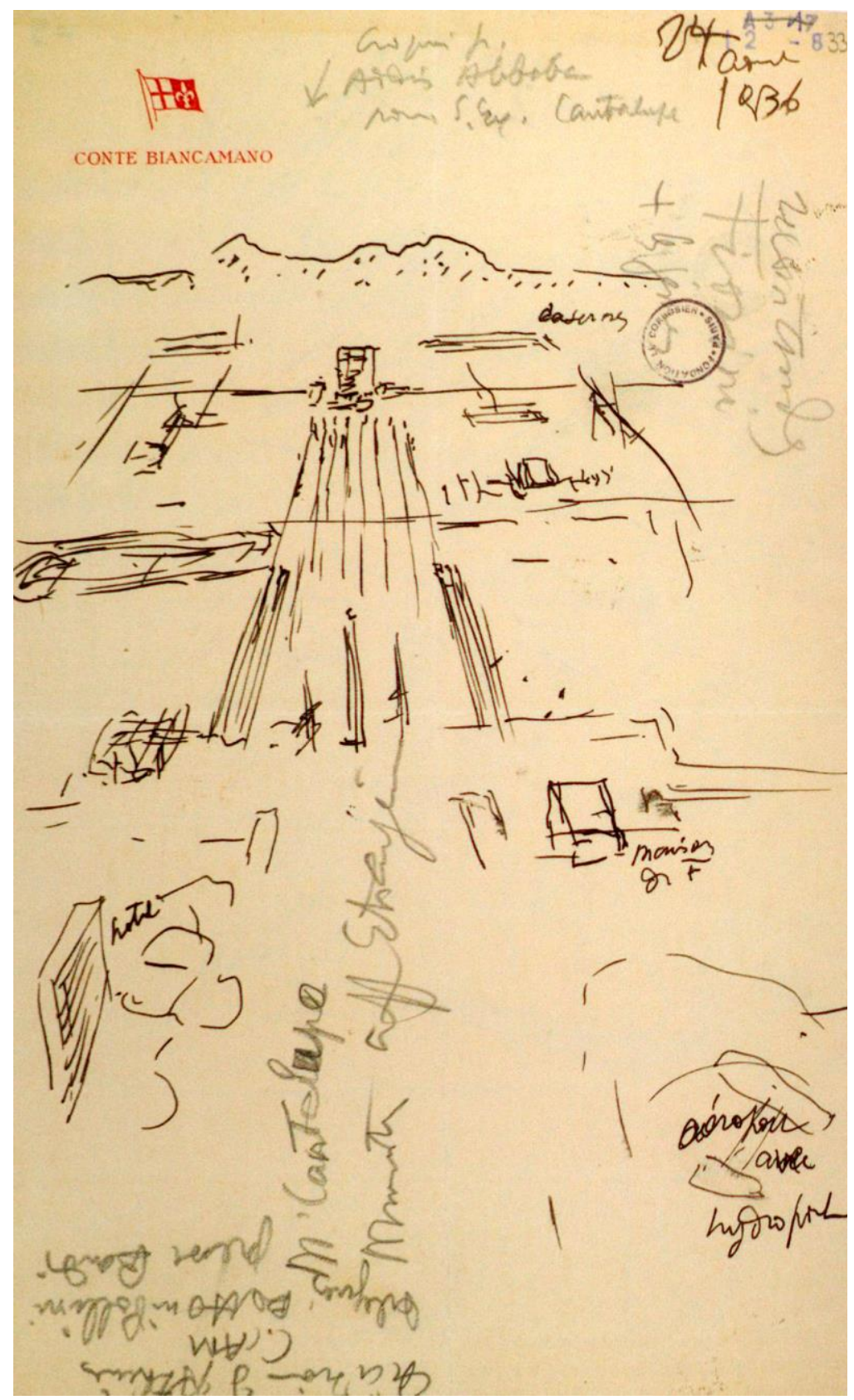

4. Perspective view, plan for Addis Ababa, Croquis p. Addis Abeba pour S. Ex. Cantalupo, Le Corbusier, August 24th 1936. CFLC-ADAGP.

Le Corbusier reproduced his radiant model in the European residential quarter of Addis Ababa by means of 50m high buildings. Located on the Western side of the wide and central boulevard, the buildings for Europeans settled according to a grid street network of 400m spacing. The sector could host 2,000-4,000 inhabitants per group of buildings, similarly to what Le Corbusier proposed in his sketches for the area around Rome. The proportion between built-up area and available land followed the capacity fixed in the Ville Radieuse - $12 \%$ built-up and $88 \%$ for parks and other open spaces. However, unlike his plan for the Ville Radieuse with 15-story serpentine blacks "a redents," the type chosen for the Ethiopian skyscrapers was more similar to the version proposed for Antwerp, the Banlieue de Rome, and the Urbanisation d'Hellocourt (1935), with non-cruciform slabs standing as a hybrid of the Ville Radieuse type and the later-developed free-standing 20-story slab block of Marseilles (1946). 

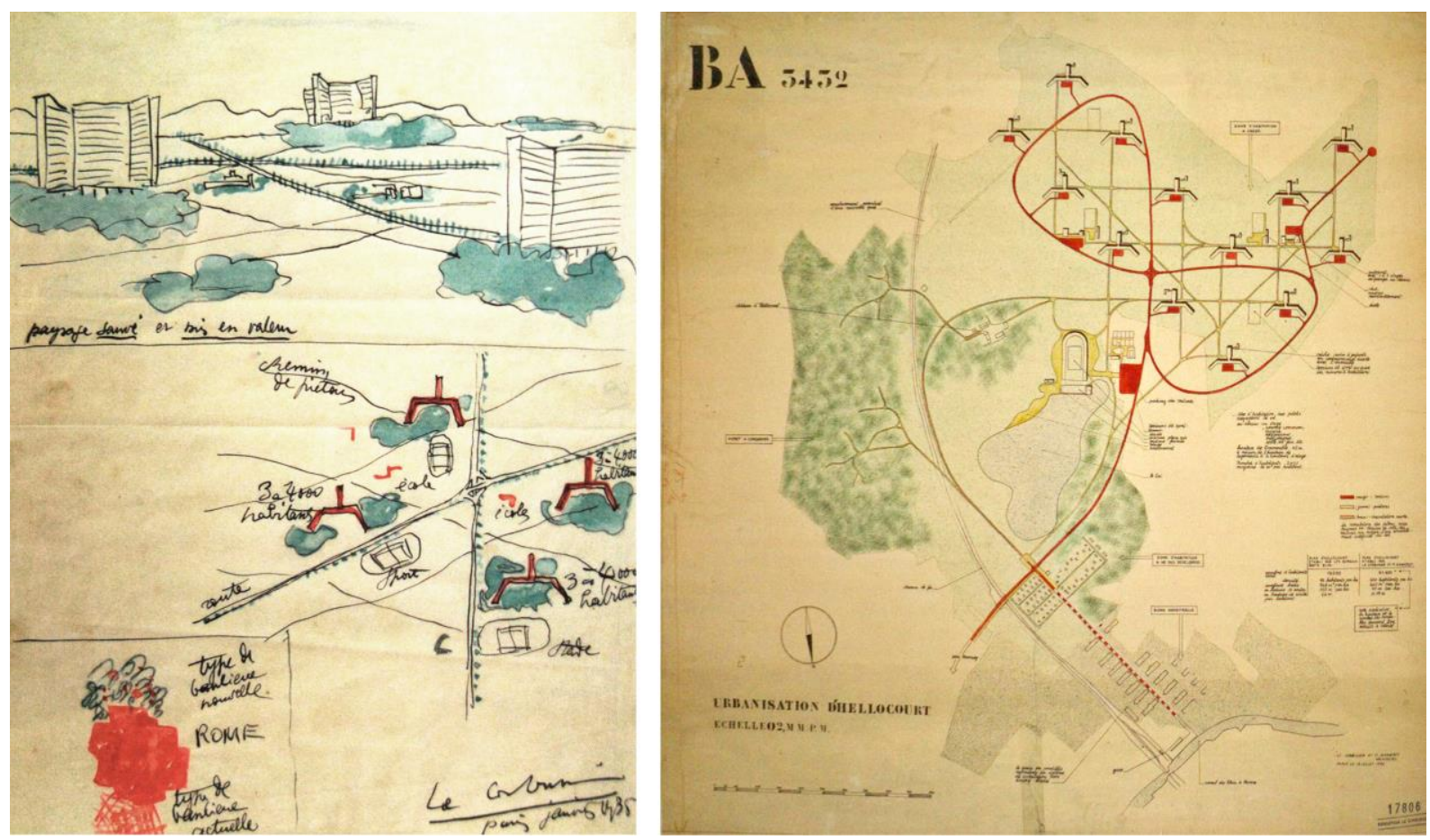

5. On the left: Suburb of Rome, Le Corbusier, 1934. Published in Le Corbusier: The Radiant City. New York: Orion Press, 1967, p.304, OFLC-ADAGP. On the right: Urbanisation d'Hellocourt 1935 (Usine francaise Bat'a en Lorraine), Le Corbusier, 1935, OFLC-ADAGP.

To obtain Mussolini's approval of the plan, Le Corbusier developed the city as expression of Fascist power. In contrast to Guidi and Valle's project, he proposed the design of a modern monumental capital traversed from North to South by a grand boulevard. At the Northern end of the artery, the military centre symbolized the head of the city as in the anthropomorphic metaphor of the Ville Radieuse. By positioning the military headquarter in this prominent position, Le Corbusier articulated the colonial city as an instrument of command, government and grandeur in the hands of the Italian colonizer. At the other end of the grand boulevard, Le Corbusier designed the industrial area, the sector devoted to produce goods and riches for the empire and its capital. The foro, in the center of the plan, symbolized the heart of the capital and the core of his political activities, where the Fascist regime organized indigenous population control and performed his propaganda through marches and military processions. This center was located between two halves or "lungs," as in the scheme for the Ville Radieuse. In the case of Addis Ababa the two halves housed the European residential zone, on the West, and the indigenous sector, on the East. Three skyscrapers dominated the plan. They hosted the "military government" on the North, the "civil administration" and the "indigenous affairs" in the center of the city. According to Le Corbusier, these towers represented three indispensable functions that the capital city of Italian colonial dominion must possess to guarantee the development of the great and prosperous Fascist empire. ${ }^{11}$

\footnotetext{
${ }^{11}$ Le Corbusier defined them the "moral maneuver of colonization." From the sketch drew by Le Corbusier for the plan of Addis Ababa. See figure 6.
} 


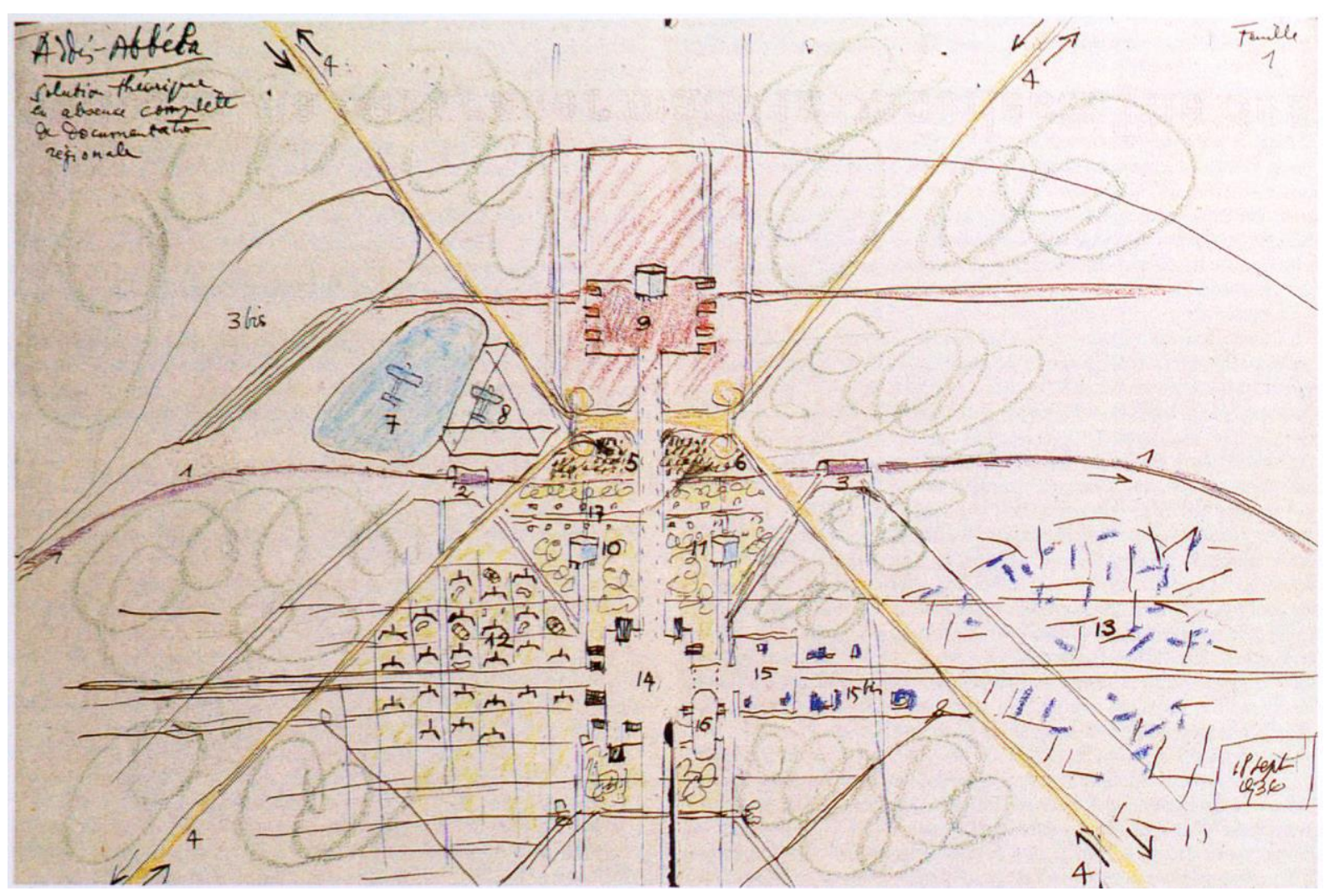

6. Addis Abeba: Solution Théorique en absence compléte de documentation régionale, Le Corbusier, September 18th 1936. CFLC-ADAGP.

\section{The Fascist empire in Africa}

Le Corbusier's arguments and design for Addis Ababa did not persuade Mussolini's Fascist government, more inclined to assign the planning and designing of Addis Ababa to Italian rationalists. Far from being a thoughtless political move, Mussolini's preference for national experts was part of a strategy that needs to be contextualized within the political situation of colonial Ethiopia, Fascist propaganda, and the Italian framework of Fascist power in the African country. ${ }^{12}$ Italy had entered very late into the era of European colonialism, always trying to "catch up" with France and Britain. Essentially for reasons of prestige and grandeur, often justified as the vital need for space, the Fascist regime looked with great interest at overseas countries. As David Rifkind clearly explains, the situation was complex; "the military adventure, the resettlement (and reform) of unemployed urban Italians as farmers in East Africa, the stabilization of African subjects under colonial rule, the cultivation of the Ethiopian highlands to supply Italy with needed agricultural products" were all aspects of the Italian interest in the country, together with the idea that migration to East Africa could contain Italian emigration abroad (i.e. in the United States) and sustain the economic development of the Italian firms growing in the African continent. ${ }^{13}$

Within the propaganda machine fine-tuned by Mussolini, the conquest of the African territory quickly became a cohesive motif of domestic consensus. Fascist indoctrination produced a patriotic popular front that the Italian regime exploited to increase public support for its supremacy. As part of this sophisticated propaganda machine,

\footnotetext{
${ }^{12}$ For the relationship between Le Corbusier and Fascism, see: De Jarcy, X.: Le Corbusier, Un Fascisme Français. Paris: Éditions Albín Michel, 2015.

${ }^{13}$ Rifkind, D.: “Gondar”. In JSAH. Vol.70, no. 4, December 2011, p.494.
} 
the Italian government called several architects and planners to build the physical structure of the colonial domination in Africa and the "image" of Fascist domain abroad, its power and grandeur. In the 1930s, Addis Ababa, the modern capital of the new Fascist empire, became the most important emblem of Fascist construction. Mussolini sought a monumental "Roman" capital, with new symbols connected to the magnificence of the Fascist empire and new sectors for Europeans and Italian inhabitants. Although Addis Ababa had a long history as a renowned urban center of East Africa, Mussolini asked his architects to build a completely new city in what was erroneously depicted as a virgin territory. The government aimed to establish a brand-new "feudal" system where the indigenous lived as "peasants around their king" - the Italian Emperor of Ethiopia. ${ }^{14}$ In his eagerness to obtain Mussolini's approval, even Le Corbusier followed these guidelines, designing his colonial city from a tabula rasa. He replaced Ethiopian emblems with new symbols of Fascist and military power and developed modern residential sectors for Italian emigrants separated from the indigenous residents.

\section{Le Corbusier's idea of colonialism}

On the title page of La Ville Radieuse, Le Corbusier described urban plans as "the rational and poetic monument set up in the midst of contingencies." According to him "contingencies" were the environmental features to which the plan would adopt, including place, people, culture, topography and climate. Accordingly, in Addis Ababa he worked on the plan within the possibilities and limits of the Italian cultural framework and, in order to obtain Mussolini's approval, developed the proposal of a modern imperial capital to build the image of a strong Fascist empire.

This approach was informed by nineteenth-century French discourse on colonialism and the "Orient." 15 As French architect, Le Corbusier admired the achievements of European colonialism and credited French domination for its remarkable urban architecture: "The soldiers of the French Conquest drew up handsome plans for the city. They knew how to plan." 16 His project for Mussolini must be understood within the legacy of two of the major representatives of French urban planning in North Africa, Marshal Hubert Lyautey, governor of Morocco from 1912 to 1925, and Henri Prost, Lyautey's architect and urban planner. ${ }^{17}$ As resident-general of the new protectorate of Morocco, Lyautey believed in the "dual city" concept, that is, the division of the city into two settlements, the European and the indigenous one, by a zone where construction was forbidden. ${ }^{18}$ In Casablanca, Rabat, Fez, Marrakesh, and Meknes, Lyautey and Prost strictly preserved ancient artifacts, mosques, street fronts, and other Arab details, while building entirely new quarters for Europeans. They regulated new constructions in the old Moroccan quarters and protected existing traditional buildings. As Gwendolyn Wright explains: "from the West came the clean lines and strict design guidelines for buildings, the spacious

\footnotetext{
${ }^{14}$ For the idea of Addis Ababa as a tabula rasa (or blank slate) see: Fuller, M.: Moderns Abroad : Architecture, Cities and Italian Imperialism. London, New York: Routledge, 2007, pp.197-198. For the quote see: Poggiali, C.: "La nuova Addis Ababa". In Gli Annali dell'Africa Italiana. Vol.1, no. 2, 1938, pp.455-489.

15 For a discussion about ethnographic surrealism, see Clifford, J.: The Predicament of Culture: Twentieth-Century Ethnography, Literature, and Art. Cambridge, Mass.: Harvard University Press, 1988, pp.117-51.

${ }^{16}$ Le Corbusier: La Ville Radieuse. Editions de L'Architecture d'aujourd'hui, Boulogne: Seine, 1935, p.233.

${ }^{17}$ For Lyautey's urban policies see: Taylor, B. B.: "Planned Discontinuity: Modern Colonial Cities in Morocco". In Lotus International. Vol. 36 (1979), pp.52-66. On Lyautey's work see: Abu-Lughod, J. L.: Rabat: Urban Apartheid in Morocco. Princeton: Princeton University Press, 1980.

${ }^{18}$ On Lyautey, Prost, and French overseas urban planning, see: Wright, G.: "Tradition in the Service of Modernity: Architecture and Urbanism in French Colonial Policy, 1900-1930”. In Cooper F., Stoler A.L.: Tensions of Empire, Colonial Cultures in a Bourgeois World. Berkeley: University of California Press, pp.322-345.
} 
thoroughfares and zoning regulations; from Morocco, local ornamental motifs in porcelain mosaics and cedar, together with architectural adaptations to the climate."19

Lyautey, Prost, and Le Corbusier shared a fascination with traditional and vernacular North Africa, and believed that modern city planning and urbanism could supplant older colonial frameworks based on military force. ${ }^{20}$ In particular, Lyautey and Prost admitted that, built as health precautions, the so-called "sanitary corridors" dividing European and indigenous sectors existed also for military reasons, allowing the rapid mobilization of French troops. They believed that the barriers between the European and Arab city marked the distinctions not only between two parts of a city, but also between two races. In accordance and responding to what Maynard Swanson referred as the "sanitation syndrome," Le Corbusier's project for Addis Ababa provided an indigenous separated sector, while promoting the idea of a European "city of modern times." The plan created a rigid division between Italians and Ethiopians, a phenomenon that Janet Abu-Lughod has called "urban apartheid" in reference to Moroccan cities. ${ }^{21}$ Like his French predecessors, Le Corbusier believed that the isolation of the indigenous population led to a more efficient control of the colonial city and could guide the development of a flourishing and healthy imperial capital. With the aim of promoting the control of population, he divided the plan for Addis Ababa into two parts that were symmetrical to the central axis of the great boulevard. If in the utopian Ville Radieuse the design in bands allowed specific functions according to different zones (i.e. education, business, transportation, and residential areas), in Addis Ababa every use was twin and separated. Le Corbusier designed two residential areas, two railway stations, two bus stations, and two squares. The West part of the city was for European people, the East one for the natives. The plan presented only one stadium. Yet even this structure had two separate zones, one for Italians and one for Africans.

As explained, Le Corbusier respected and supported French colonial policies and work in Africa, and his plan for Addis Ababa shows that he sustained also Italian colonialism in the country. For Le Corbusier, architecture and urbanism in North Africa showed the results of the French civilizing mission on the continent. Similarly, in Addis Ababa Le Corbusier celebrated the Italian and Fascist campaign of education in the country. Indeed, he considered Fascist authority the only power able to command and organize natives' life in Ethiopia - which he considered otherwise chaotic and promiscuous. In the 1936 letter to Mussolini, he declared: "Colonization - in particular the city before the indigenous population - must be a proof of order, strength and modern spirit." $22 \mathrm{Le}$ Corbusier's understanding of Addis Ababa human and physical realm developed from a common Eurocentric assumption that he shared with the majority of his contemporaries: the perception of Europe's role of supremacy in the colonial history of the 1930s. In the plan for Addis Ababa, the foro for military marches and the military

\footnotetext{
${ }^{19}$ Wright, G.: "Tradition in the Service of Modernity: Architecture and Urbanism in French Colonial Policy, 1900-1930". In Cooper F., Stoler A.L.: Tensions of Empire, Colonial Cultures in a Bourgeois World. Berkeley: University of California Press, p.330.

${ }^{20}$ Çelik, Z.: "Le Corbusier, Orientalism, Colonialism". In Assemblage. 17, April, 1992, p.66.

${ }^{21}$ For the "sanitation syndrome" see: Swanson, M. W.: "The Sanitation Syndrome: Bubonic Plague and Urban Native Policy in the Cape Colony, 1900-1909". In The Journal of African History. Vol. 18, No. 3, 1977, pp. 387-410. For Le Corbusier's quote, see: Le Corbusier: Letter to Giuseppe Cantalupo. Paris, September 19, 1936, in FLC. As quoted in Gresleri, G.: “'La Nuova Roma della Scioa" e l'improbabile Architettura dell'Impero". In Gresleri, G. (ed): Architettura Italiana D'oltremare 1870-1940. Galleria D'Arte Moderna Bologna, 26 Settembre 1993 - 10 Gennaio 1994. Venezia: Marsilio, 1993, p.170 (author's translation). On urban apartheid in Morocco, see: Abu-Lughod, J. L.: Rabat: Urban Apartheid in Morocco. Princeton: Princeton University Press, 1980.

${ }^{22}$ Le Corbusier: Letter to Giuseppe Cantalupo. Paris, September 19, 1936, in FLC. As quoted in Gresleri, G.: "'La Nuova Roma della Scioa" e l'improbabile Architettura dell'Impero". In Gresleri G.: Architettura Italiana D'oltremare 1870-1940. Galleria D'Arte Moderna Bologna, 26 Settembre 1993 - 10 Gennaio 1994. Venezia: Marsilio, 1993, p.170 (author's translation).
} 
skyscraper on the North illustrate his idea of colonial power as the ultimate force able to plan not only the physical world of Africa, but also its society. As several of his drawings of the French dominion explain, Le Corbusier recognized overseas colonies as natural extension of European countries. Similarly, he considered Ethiopia and its capital a constituent part of the Fascist transcontinental domination. Unified under his modern architecture and urbanism, Fascist control included Italy, North, and East Africa.

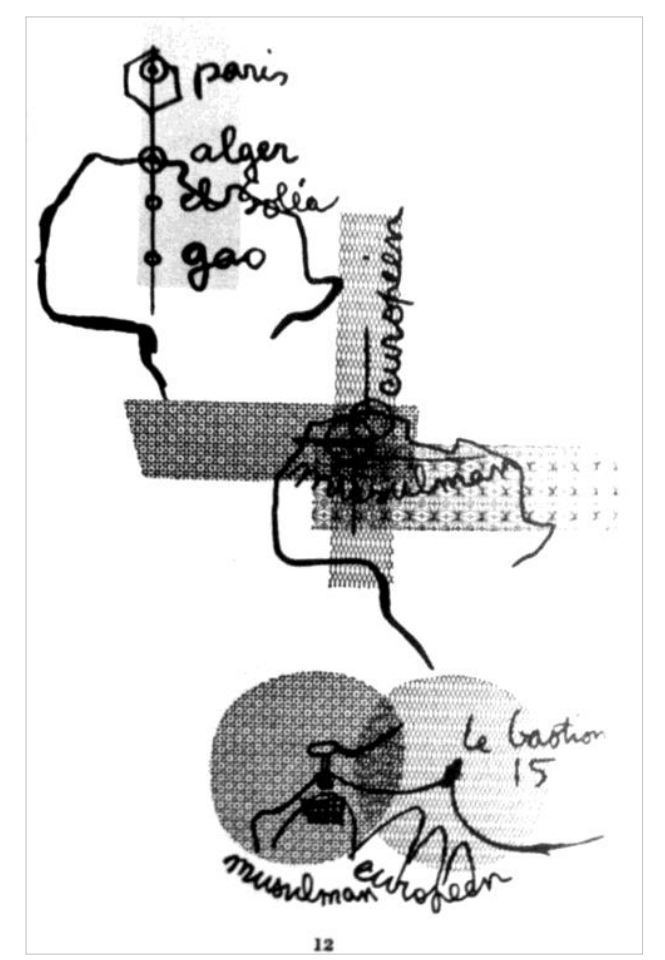

7. Diagrammatic maps showing geographical axes between France and Africa, Le Corbusier. CFLC-ADAGP.

\section{Ethiopian tradition: a non-valid alternative}

As Zeynep Çelik explains, Le Corbusier's interest in Africa was important to his broader questioning of Western cultures and search for valid alternatives in non-Western traditions. ${ }^{23}$ After his shift away from Purist abstraction and toward sensuously figurative compositions in the late 1920s, Le Corbusier became interested in the vernacular, as architect, artist, and planner. ${ }^{24}$ In 1929, before finalizing the Ville Radieuse, he visited South America where he had a stimulating experience surveying the tropical landscape from the airplane. ${ }^{25}$ Rio de Janeiro and its landscape suggested the idea of the viaduct city that later inspired his proposals for Algiers, the center of Le Corbusier's urban preoccupations from 1931 to 1942 and one of his most interesting plans and interpretations of African tradition.

\footnotetext{
${ }^{23}$ Çelik, Z.: "Le Corbusier, Orientalism, Colonialism”. In Assemblage, 17, April, 1992, pp.58-77. Describing Algiers, Le Corbusier declared "Inspiring image! [...] The [Algerian] street is only the bed for the rushing stream of passer-by." Le Corbusier: La Ville Radieuse. Editions de L'Architecture d'aujourd'hui, Boulogne: Seine, 1935, p.230.

${ }^{24}$ On this topic see Frampton, K.: "The Rise and Fall of the Radiant City: Le Corbusier 1928-1960". In Oppositions. 19-20 (Winter-Spring), 1980, pp.2-25.

${ }^{25}$ Dainese, E.: "Le Corbusier, Marcel Griaule, and the Modern Movement: exploring the habitat from the airplane". In Morello, E., Piga, E. A. B. (eds.): EAEA11 2013. Envisioning Architecture: Design, Evaluation, Communication. Roma: Edizioni Nuova Cultura, pp. 413-418.
} 


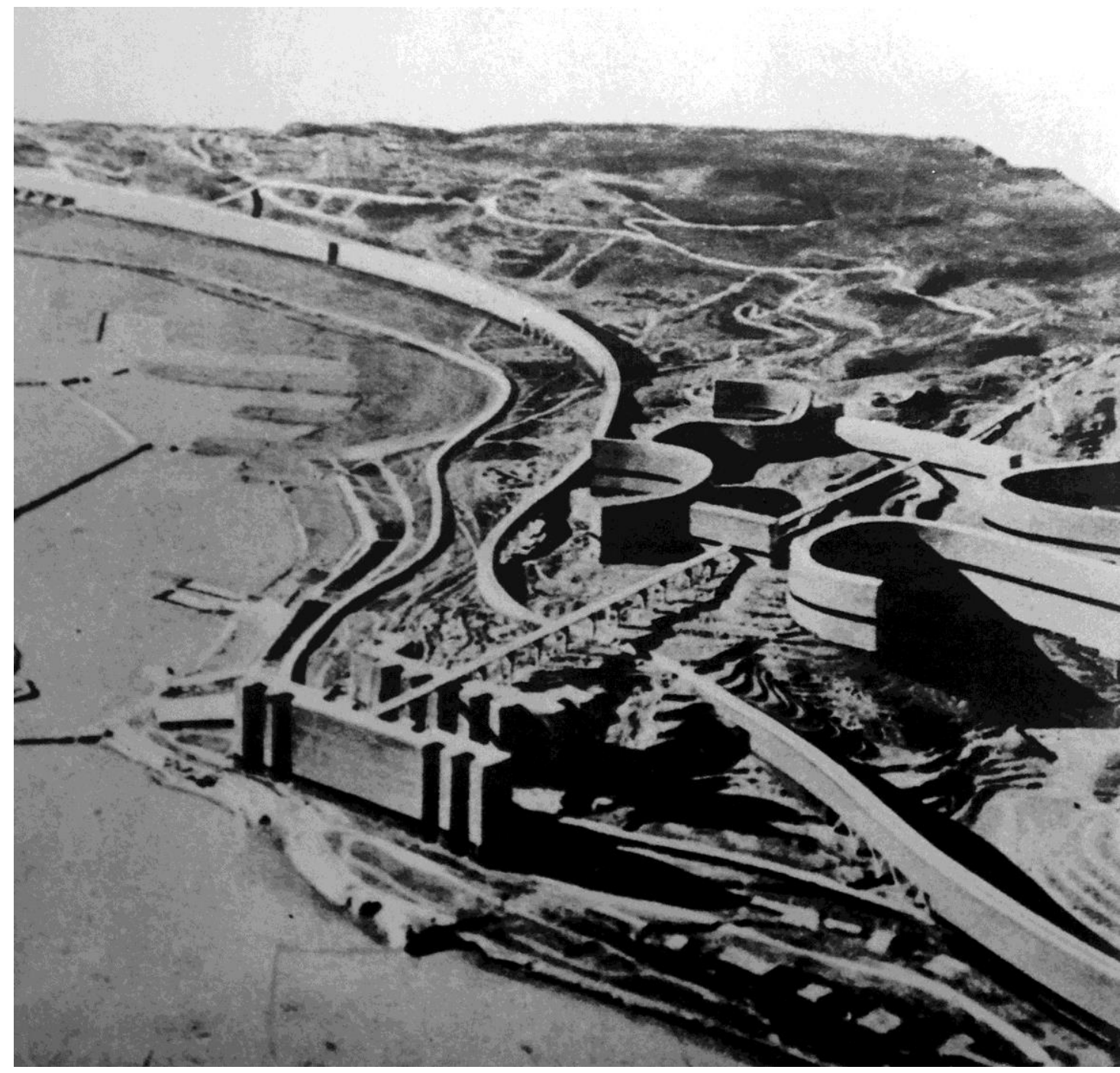

8. Obus A, Algiers, Le Corbusier, 1932. OFLC-ADAGP.

Algiers and the Muslim tradition informed Le Corbusier's project for Mussolini, and, of all the projects of the 1930s, it most clearly illustrates his attempt to define an African architectural ideal that expressed the relationship between traditional and colonial architecture. ${ }^{26}$ In the plan for Algiers, Le Corbusier proposed arabesque and sensuous forms, results of his understanding and interpretation of the Mediterranean and Arab world. Seduced by North Africa, which he visited in 1931, the French architect designed a great coastal viaduct, the housing redents, and an elevated highway. The project fundamentally challenged the static Cartesian plans of his previous utopian cities - the Ville Contemporaine and the Plan Voisin - and, like the Ville Radieuse, included the possibility of an infinite urban expansion along the highway. However, compared to Addis Ababa, the treatment of Algerian vernacular shows a fascination for traditional African architecture absent in his Addis Ababa plan. For the Ethiopian capital, Le Corbusier did not propose organic and sensuous forms, nor livable viaduct infrastructures. If Algiers had a universally recognized heritage, at the frontier linking Europe and Africa, in between Muslim and European tradition, traditional Addis Ababa was meanwhile the place of the

${ }^{26}$ For Algiers see Çelik, Z.: "Le Corbusier, Orientalism, Colonialism”. In Assemblage. 17, April, 1992, pp.58-77. See also William Curtis who mentions the "blatant colonialism" of the project: Curtis, W.: Modern Architecture since 1900. Englewood Cliffs, N.J.: Prentice Hall, 1990, p.209. Mary McLeod provides a background to the issue of colonial assimilation. See: McLeod, M.: "Le Corbusier and Algiers". In Oppositions. 19-20 (Winter-Spring), 1980, pp.54-85. 
unknown, unable to catch and captivate Le Corbusier's attention. As a result, he abandoned the lyricism of archaic Algerian references in favor of a doctrinaire and less sophisticated program, which he considered more suitable for the development of a military empire such as the Roman one.

As this study has described, in Addis Ababa, Le Corbusier's extreme pragmatism was expressed in the design of two completely separated cities, the European and the indigenous one, illuminating his preference for racial division in the colonial city. The French architect adopted a similar approach in Algiers, where he preserved the old traditional quarter and replaced the existing European one with the lyrical vision of the livable elevated highway marking "the hierarchical social order onto the urban image, with the dominating above and the dominated below." ${ }^{27}$ In the design for Addis Ababa, indigenous-European separation is defined horizontally as East-West division in sectors with no organic integration with the infrastructure system. Although present in the plan, the native sector lacked a specific program, as it was not considered a valid alternative to Western cultures. Unlike Algiers, in Addis Ababa there was no poetic rereading of the indigenous villages and no commitment to the mutual understanding between colonial and traditional cultures. Le Corbusier's attention was concentrated on the design of the Fascist-controlled city with no provisions to ameliorate the poverty and misfortune that most Ethiopians faced. By promoting social and racial restrictions through urban organization, the French architect established the urban conditions under which Fascist control could be fulfilled. Unplanned and relegated in a powerless position on the East, the indigenous area symbolized Ethiopian controlled existence and Fascist colonial inhumanity and cruelty in replacing local cultures.

\section{Conclusion}

In the first decades of the twentieth century, together with his interest in the Soviet Union and his relationship with Stalin, Addis Ababa, the Fascist empire, and Mussolini symbolized for Le Corbusier the most antithetical but tangible possibilities to build the utopian Ville Radieuse. Although Le Corbusier's knowledge of Ethiopia and sub-Saharan Africa was scarce - he never traveled to the country and he had no access to topographical maps of the region to complete his design - and although he faced enormous obstacles acquiring the support of the Italian government, the capital of Ethiopia was a crucial instrument for him to reflect on his utopia and its practical realization. As Mary McLeod explains, Le Corbusier projects of the thirties were "critical not only as precursors of later works, but also as new orientations which challenge the basic postulates - formal and social - of the Modern Movement." ${ }^{28}$ Indeed, the design for Addis Ababa was not simply the plan of a modernist colonial city in Africa, and it would be incorrect to dismiss Le Corbusier's interest in Ethiopia as political opportunism. Le Corbusier's enthusiasm for the plan extended both to the nature of his political choices, his constant search for central authorities, and the role of architecture itself as social object able to separate existing societies and superimpose new ones.

Despite Mussolini's indifference to Le Corbusier's proposal, the French architect worked with great determination, tremendous ambitions and perseverance within the Fascist framework. As in the case of the project for Algiers developed in order to celebrate the centennial of French occupation in Algeria and to become the capital of French Africa, his plan for Addis Ababa celebrated the Italian conquer of East Africa and the development of a new imperial capital. However, Le Corbusier's efforts did not meet Mussolini's favor and the proposal became the architect's last attempt to reach Fascist authority and build the utopian Ville Radieuse. As for Rome, Le Corbusier did not receive any reply from the Fascist regime. From Mussolini's point of view, he

\footnotetext{
${ }^{27}$ Çelik, Z.: "Le Corbusier, Orientalism, Colonialism”. In Assemblage. 17, April, 1992, p.69.

${ }^{28}$ McLeod, M.: "Le Corbusier and Algiers". In Oppositions. 19-20 (Winter-Spring), 1980, p.55.
} 
was a French and "communist" architect. ${ }^{29}$ The Italian prime minister could not allow a foreigner to work on the prestigious capital of his empire. Le Corbusier's visits to Russia between 1928 and 1930 had brought him into contact with the international Left proving that he was a Bolshevik. His political position was irreconcilable with the role of chief architect of the Fascist dominion in Africa. Disillusioned by Mussolini's refusal to meet and by the rejection of the proposal for Addis Ababa, the architect abandoned the project. Had Le Corbusier's sketch for Addis Ababa been realized, he would have probably never shifted to the more dynamic system focused on the megalopolis, and we would doubtless remember him as the architect of the Fascist coercive empire. ${ }^{30}$

\section{Acknowledgments}

The basic research for this study was carried out under the People Program (Marie Curie Actions) of the European Union's 7FP (FP/2007-2013, REA grant agreement n. 327261), which I gratefully acknowledge.

\section{Source of images}

1. Les Harmoniseurs, Le Corbusier, Carnet de notes, 1934. CFLC-ADAGP.

2. A new city to replace the old. Published in Le Corbusier: The Radiant City. New York: Orion Press, 1967, p.135. CFLC-ADAGP.

3. La Ville Radieuse, plan, Le Corbusier, 1931. Published in Le Corbusier: The Radiant City. New York: Orion Press, 1967, p.170. CFLC-ADAGP.

4. Perspective view, plan for Addis Ababa, Croquis p. Addis Abeba pour S. Ex. Cantalupo, Le Corbusier, August 24th 1936, OFLC-ADAGP.

5. On the left: Suburb of Rome, Le Corbusier, 1934. Published in Le Corbusier: The Radiant City. New York: Orion Press, 1967, p.304, OFLC-ADAGP. On the right: Urbanisation d'Hellocourt 1935 (Usine francaise Bat'a en Lorraine), Le Corbusier, 1935, (CFLC-ADAGP.

6. Addis Abeba: Solution Théorique en absence compléte de documentation régionale, Le Corbusier, September 18th 1936. CFLC-ADAGP.

7. Diagrammatic maps showing geographical axes between France and Africa, Le Corbusier. CFLC-ADAGP.

8. Obus A, Algiers, Le Corbusier, 1932. CFLC-ADAGP.

\section{Bibliography}

Abu-Lughod, J. L.: Rabat: Urban Apartheid in Morocco. Princeton: Princeton University Press, 1980.

Bardi, P.M.: “Le Corbusier a Roma”. In Quadrante. No.13, xii, May 1934, p.5.

Çelik, Z.: “Le Corbusier, Orientalism, Colonialism”. In Assemblage. 17, April, 1992, pp.58-77.

Ciucci, G.: “A Roma con Bottai”. In Rassegna. Vol.2, no.3, July 1980, pp.66-71.

Clifford, J.: The Predicament of Culture: Twentieth-Century Ethnography, Literature, and Art. Cambridge. Mass.: Harvard University Press, 1988.

\footnotetext{
${ }^{29}$ Di Marzio, C.: Letter to the Italian Foreign Minister. February 13th 1933, ASMAE, Fondo Affari Politici - Francia, b.10, 1933. As quoted in Talamona, M.: "Roma 1934". In Talamona, M.: L'Italia Di Le Corbusier. Rome, Milano: MAXXI, Museo Nazionale Delle Arti Del XXI Secolo; Electa, 2012, p.245 (author's translation).

${ }^{30}$ For Le Corbusier's gradual change toward the study of the megalopolis see Frampton, K.: "The Other Le Corbusier". In Raeburn (ed.): Le Corbusier, Architect of the Century, Hayward Gallery, London, 1987, A Centenary Exhibition, Paris. London: Council, 1987, pp.29-34.
} 
Curtis, W.: Modern Architecture since 1900. Englewood Cliffs, N.J.: Prentice Hall, 1990.

Dainese, E.: "Le Corbusier, Marcel Griaule, and the Modern Movement: exploring the habitat from the airplane". In Morello, E., Piga, E. A. B. (eds.): EAEA11 2013. Envisioning Architecture: Design, Evaluation, Communication. Roma: Edizioni Nuova Cultura, pp. 413-418.

De Jarcy, X.: Le Corbusier, Un Fascisme Français. Paris: Éditions Albín Michel, 2015.

Frampton, K.: “The Other Le Corbusier". In Raeburn (ed.): Le Corbusier, Architect of the Century, Hayward Gallery, London, 1987, A Centenary Exhibition, Paris. London: Council, 1987, pp.29-34.

Frampton, K.: “The Rise and Fall of the Radiant City: Le Corbusier 1928-1960”. In Oppositions. 19-20 (WinterSpring), 1980, pp.2-25.

Fuller, M.: Moderns Abroad : Architecture, Cities and Italian Imperialism. London; New York: Routledge, 2007.

Garretson, P.P.: A History of Addis Abäba from Its Foundation in 1886 to 1910. Wiesbaden: Harrassowitz, 2000.

Gebremedhin, N.: “A tale of Three Highland Cities”. In Adjaye, D. (ed.): African Metropolitan Architecture. New York: Rizzoli, 2011.

Gresleri, G. (ed.): Architettura Italiana D'oltremare 1870-1940. Galleria D'Arte Moderna Bologna, 26 Settembre 1993 - 10 Gennaio 1994. Venezia: Marsilio, 1993.

Le Corbusier: La Ville Radieuse. Editions de L’Architecture d'aujourd'hui, Boulogne: Seine, 1935.

McLeod, M.: “Le Corbusier and Algiers”. In Oppositions. 19-20 (Winter-Spring), 1980, pp.54-85.

Pankhurst, R.: History of Ethiopian Towns. Wiesbaden: Steiner, 1982.

Poggiali, C.: “La nuova Addis Ababa”. In Gli Annali dell’Africa Italiana. Vol.1, no. 2, 1938, pp.455-489.

Rifkind, D.: “Gondar”. In JSAH. Vol.70, no. 4, December 2011.

Swanson, M. W.: "The Sanitation Syndrome: Bubonic Plague and Urban Native Policy in the Cape Colony, 1900-1909”. In The Journal of African History. Vol. 18, No. 3, 1977, pp. 387-410.

Talamona, M.: L'Italia Di Le Corbusier. Rome: Milano: MAXXI, Museo Nazionale Delle Arti Del XXI Secolo; Electa, 2012.

Taylor, B.B.: "Planned Discontinuity: Modern Colonial Cities in Morocco". In Lotus International. Vol. 36, 1979, pp.52-66.

Woudstra, R.: "Le Corbusier's visions for Fascist Addis Ababa". October 9, 2014, http://www.failedarchitecture.com/le-corbusiers-visions-for-fascist-addis-ababa/.

Wright, G.: "Tradition in the Service of Modernity: Architecture and Urbanism in French Colonial Policy, 19001930”. In Cooper, F., Stoler, A.L.: Tensions of Empire, Colonial Cultures in a Bourgeois World. Berkeley: University of California Press, pp.322-345. 


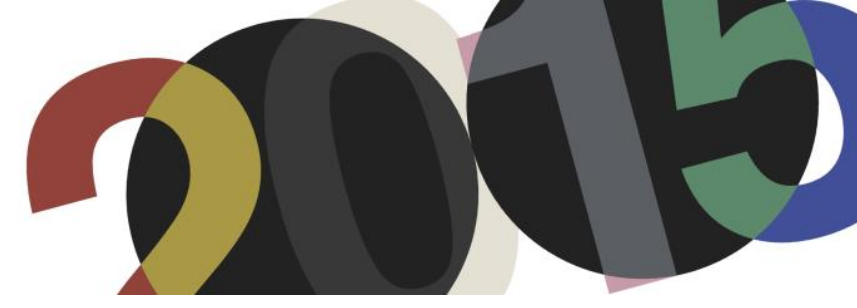

DOI: http://dx.doi.org/10.4995/LC2015.2015.690

\title{
Le Corbusier y la construcción vertical del espacio estratificado
}

\author{
S. Delgado Berrocal
}

\author{
Escuela Superior de Arquitectura de Madrid
}

\begin{abstract}
Resumen: La construcción del espacio mediante la superposición de planos verticales paralelos y franjas espaciales fue empleada por Le Corbusier tanto en sus obras pictóricas como arquitectónicas, tal y como manifestaron Colin Rowe y Robert Slutzky, en 1955-1956, al descomponer y analizar la "transparencia fenoménica" de la Villa Stein en Garches, 1926, $y$ del cuadro Nature morte à la pile d'assiettes, 1920, de Le Corbusier. Un sistema de estratificación espacial vertical mediante superficies opacas, derivado del cubismo, que genera una profundidad bidimensional donde la plástica expresa la plenitud de un volumen sin recurrir a la perspectiva. Una investigación sobre como Le Corbusier emplea la superposición de estratos verticales o de elementos autónomos y espaciados, es decir, de fragmentos de experiencias discontinuas en posiciones relativas, pero fuertemente vinculados entre sí para asegurar la coherencia estable de los resultados prefigurados, pre-determinados, pre-estabilizados. Un recurso donde el uso de relaciones formales directas, y el posicionamiento del objeto, es más importante que la representación del propio objeto. En base a lo cual, la presente comunicación pretende indagar sobre como ocasionar múltiples lecturas de esa nueva espacialidad plana -ampliando los puntos de vista multifocales y las partes independientes, pero manteniendo la unidad compositiva-; y sobre el paso de procesos de transmisión directa de relaciones formales a transformaciones ilegibles que provoquen nuevas emociones.
\end{abstract}

Abstract: The construction of space by overlapping parallel vertical planes and space bands was used by Le Corbusier both in his paintings and architectural projects, just as stated Colin Rowe and Robert Slutzky, in 1955-1956, to break down and analyze the "transparency phenomenal" to the Villa Stein in Garches, 1926, and the painting Nature morte à la pile d'assiettes, 1920, by Le Corbusier. A vertical spatial layering system by opaque surfaces, derivative of cubism, which generates a two-dimensional depth, where the composition expresses the fullness of a volume without resorting to perspective. An investigation about how Le Corbusier employs overlapping vertical layers or autonomous and spaced elements, that is to say, fragments of discontinuous experiences in relative positions, but strongly linked together to ensure stable consistency of the results pre-figured, pre-certain, pre-stabilized. A resource where the use of direct formal relations, and the positioning of the object, is more important than the representation of the object itself. Based on which, the present communication aims to investigate about how to cause multiple readings from this new flat spatiality-increasing multifocal viewpoints and independent parts, while maintaining the compositional unit-; and about the passage from direct transmission processes of formal relations to illegible transformations that cause new emotions.

Palabras clave: Espacio; Estratificación; Transparencia fenoménica; Profundidad bidimensional; Le Corbusier. Keywords: Space; Stratification; Transparency phenomenal; Two-dimensional depth; Le Corbusier.

\section{Superposición de estratos verticales. El espacio en profundidad bidimensional.}

Durante la segunda mitad del s. XX, los arquitectos Colin Rowe y Robert Slutzky, en su escrito Transparency: Literal and Phenomenal ${ }^{l}$, emplearon el concepto de "estratificación" para nombrar un recurso formal de

\footnotetext{
${ }^{1}$ Véase Rowe, Colin y Slutzky, Robert: “Transparency: Literal and Phenomenal.” Escrito en 1955-1956 en colaboración con Robert Slutzky y publicado por primera vez en Perspecta n.8, Yale Architectural Journal, 1963, pp.45-54. Reeditado en Rowe, Colin: Manierismo y arquitectura moderna y otros ensayos, Barcelona: Gustavo Gili, 1978.
} 
"construcción del espacio", basado en los estudios ópticos y las asociaciones provenientes del cubismo, que lograba alcanzar una transparencia fenoménica, es decir, tal y como manifestaban los citados autores, el uso de:

"Estratificaciones: recursos por medio de los cuales el espacio queda construido, substancial, y articulado, son la esencia de aquella transparencia fenomenal [léase fenoménica] que hemos observado como característica central de la tradición poscubista.",2

Un recurso formal relacionado con una nueva concepción del espacio profundo sin recurrir a la perspectiva. Un mecanismo de creación de la profundidad desde un sistema bidimensional, donde, al igual que en los cuadros cubistas, los objetos opacos y aplanados -situados en diversos planos paralelos que los contienen- se superponen y articulan, generando un efecto de transparencia no literal (denominada por Rowe y Slutzky: transparencia fenoménica). Una transparencia no fundamentada en el material del objeto o su condición cristalina -lo que se ve a través-, sino en la lectura o proceso mental de relaciones formales entre objetos opacos -lo que se lee--

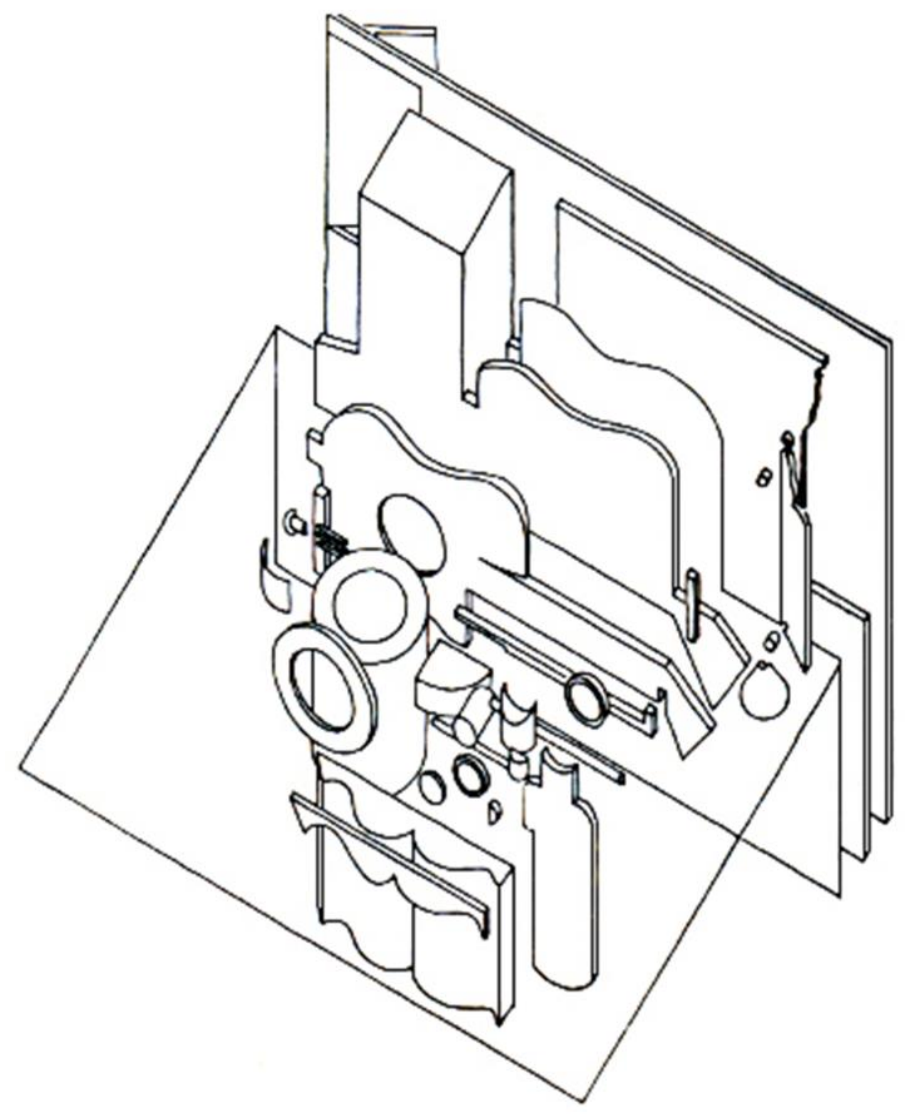

1. Colin Rowe y Robert Slutzky: Descomposición, en una serie de planos paralelos, del cuadro Nature morte à la pile d'assiettes, 1920, de Le Corbusier.

\footnotetext{
${ }^{2}$ Op. cit.: Rowe, C. y Slutzky, R.: Perspecta, p.53. Texto original: "These stratifications, devices by means of which space becomes constructed, substantial, and articulate, are the essence of that phenomenal transparency witch has been noticed as characteristic of the central postcubist tradition."
} 

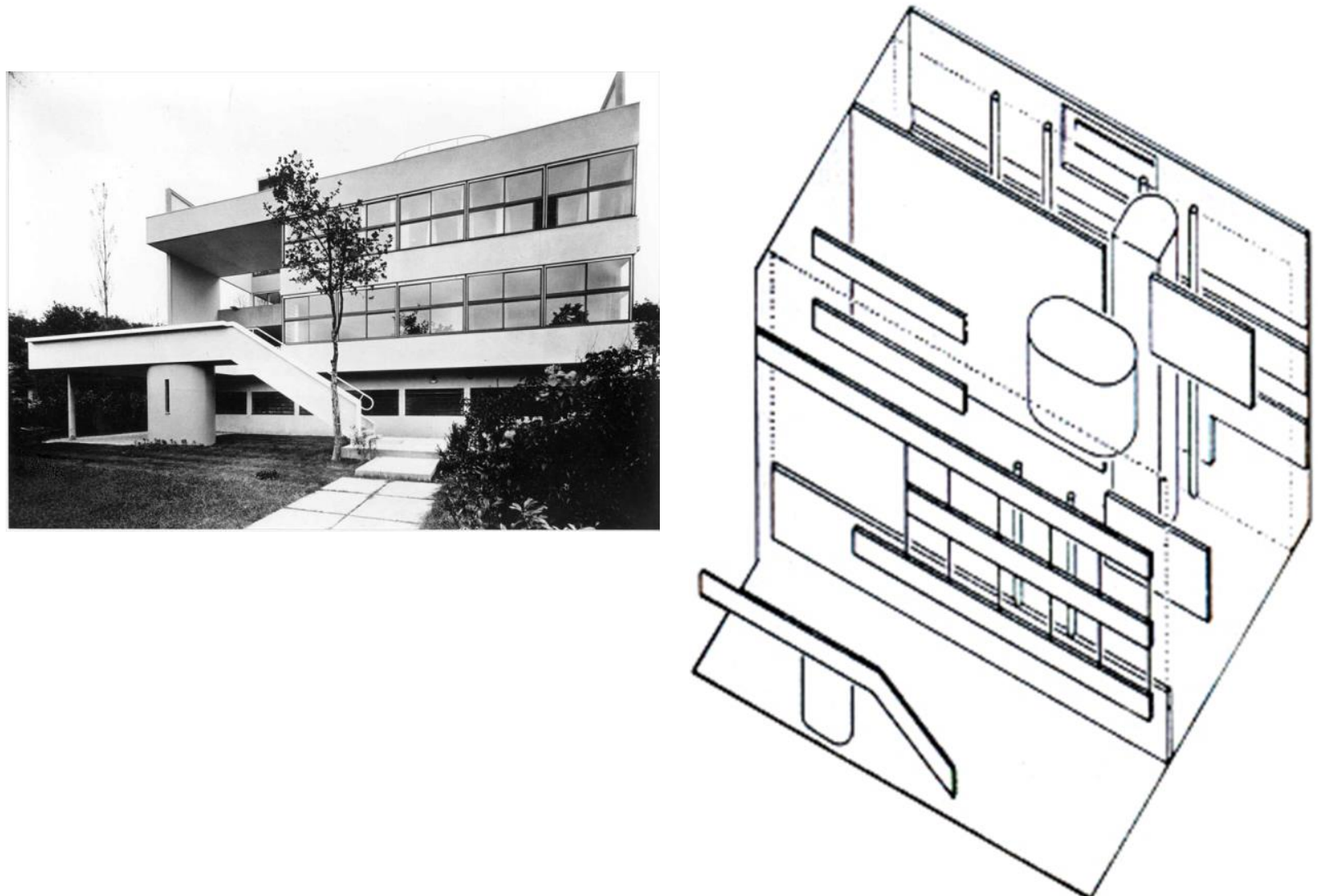

2. Le Corbusier: Villa Stein-de-Monzie, “Les Terrasses”, Garches (Vaucresson), France, 1926. @ FLC/ADAGP

3. Colin Rowe y Robert Slutzky: Descomposición vertical, en una serie de planos paralelos, de la Villa Garches, 1926, de Le Corbusier.

Por consiguiente, se trata de un conjunto de planos paralelos colocados en posiciones relativas siguiendo una estructura lineal, ordenada y legible que organiza una composición unificada, como se puede apreciar en el análisis llevado a cabo por Rowe y Slutzky del cuadro Nature morte à la pile d'assiettes, 1920, (fig.1), y de la Villa Stein en Garches, 1926, (fig.2 y 3), de Le Corbusier.

Unas descomposiciones sobre las que Rowe y Slutzky señalarán:

"Cada uno de estos planos es incompleto en sí mismo o quizás fragmentario; sin embargo la fachada se organiza tomando estos planos paralelos como puntos de referencia, y la implicación total es una estratificación vertical en capas del espacio interior del edificio, una sucesión de espacios que se extienden lateralmente recorriendo uno tras otro. Este sistema de estratificación espacial es lo que relaciona la fachada de Le Corbusier con el cuadro de Léger. "3

\footnotetext{
${ }^{3}$ Op. cit.: Rowe, C. y Slutzky, R.: Perspecta, p.50. Texto original: "Each of these planes is incomplete in itself or perhaps even fragmentary; yet it is with these parallel planes as points of reference that the façade is organized, and the implication of all is of a vertical, layerlike stratification of the interior space of the building, a succession of laterally extended spaces traveling one behind the other. This system of spatial stratification brings Le Corbusier's façade into the closest relationship with the Léger."
} 
Le Corbusier, al igual que Léger en sus cuadros, emplea un método de lectura equívoca de la tridimensionalidad, conseguido mediante un sistema de estratificación espacial.

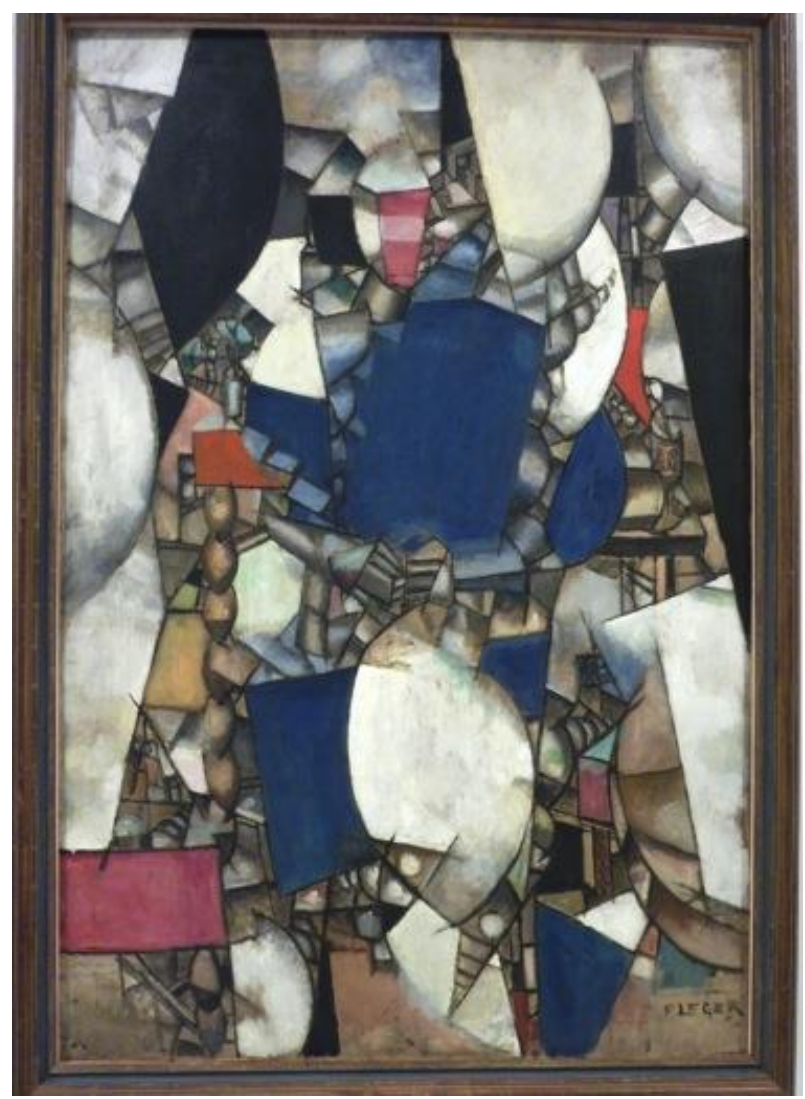

4. Fernand Léger: La mujer de azul, 1912.

En este sentido, Léger intensifica la tensión entre figura y espacio a través de las superposiciones, logrando que la mirada experimente una inacabable serie de organizaciones dentro del todo (fig.4). Para ello articula diversos objetos en un espacio poco profundo y abstracto. Unas superposiciones que proporcionan otra dimensión espacial y llevan a continuas fluctuaciones de la interpretación al no poder abarcarse todos los objetos en una sola mirada.

Asimismo, en los cuadros de Le Corbusier (fig.5), el espacio poco profundo, llano y extendido va adquiriendo poco a poco profundidad, gracias a las superficies paralelas superpuestas que se interpenetran sin la destrucción óptica de los objetos. Tal y como cita George Kepes:

"La representación de la superposición indica profundidad. Crea un sentido al espacio. Cada figura aparece paralelamente al plano gráfico y tiende a establecer una relación espacial de retroceso. "4

Del mismo modo, en la obra arquitectónica de Le Corbusier, se busca la ausencia de volumen, pero no de profundidad - una contradicción entre lo bi- y tri-dimensional-. Se provoca una sensación volumétrica de la fachada -superficie plana-, sugerida mediante la sucesión estratificada de planos abstractos, paralelos, y superpuestos, que dividen verticalmente el espacio (aumentando la extensión interior y persiguiendo la

\footnotetext{
${ }^{4}$ Kepes, Gyorgy: El lenguaje de la visión. Buenos Aires: Infinito, 1969, p.112. (Language of vision. Chicago: Paul Theobald, 1944).
} 
continuidad espacial). La creación de una "función estructural dinámica" con la que se consigue oscilar entre planos autónomos - colocados secuencialmente de forma lineal-, o lo que es lo mismo, donde cada plano actúa como una dirección dinámica independiente que lleva a otro plano, que a su vez lleva a otro, y así consecutivamente hasta la compresión íntegra del conjunto.

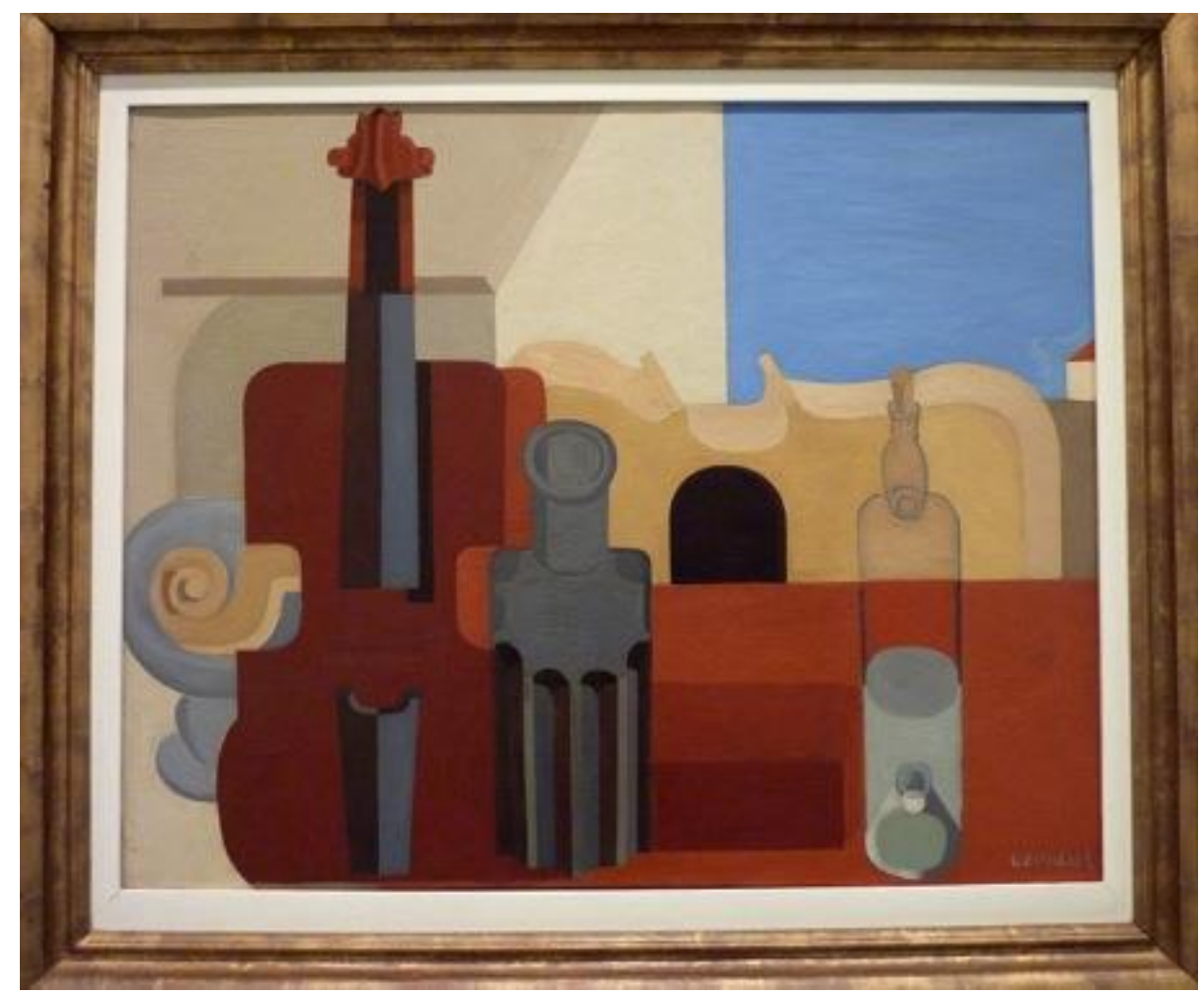

5. Amédée Ozenfant: Botella, frasco y violines 1920.

Una estructuración geométrica legible donde el observador-receptor, con un control visual sobre el conjunto, dota de significado a la obra, articulando las apariciones individuales mediante relaciones métricas y posicionales - un proceso puro con una lógica intrínseca intencionada, cuyas cualidades se envisten de una transparencia fenoménica (no literal)-. Unas interferencias entre el espacio profundo y el espacio superficial que siempre ocasionan múltiples lecturas -todavía desde la estabilidad y el orden- y que activan la experiencia de lo formal del sujeto receptor.

\section{Sistema relacional.}

En la construcción del espacio mediante la estratificación, no importa el objeto en sí -abstraído, sin perspectiva, cotidiano, puro, primario-, sino las relaciones o asociaciones entre elementos independientes que construyen un todo unitario. Unos estudios en los que, según afirma Le Corbusier: "la relación de los elementos [se produce] con vistas a crear en el cuadro un objeto único."

\footnotetext{
${ }^{5}$ Ozenfant, Amédée \& Jeanneret, Charles-Edouard: La peinture moderne. Paris: Les Éditions G. Crés \& Cie., 1925, p.168. (Traducción propia). Texto original: "La liaison des éléments en vue de créer dans le tableau un objet unique.”. Véase también Ozenfant \& Jeanneret: Après le Cubisme, Paris: Éditions des Commentaires, 1918.
} 
Desde esta óptica, George Kepes analizará la posición-organización de los elementos en ese tipo de construcciones gráficas, señalando:

"El extremo inferior del plano gráfico ha representado el punto visual más próximo; en consecuencia, el grado de elevación de las unidades visuales indicaba posiciones espaciales de retroceso. "6

Y, al mismo tiempo, los variados objetos superpuestos se identifican con el plano que los contiene ayudando a establecer la relación espacial por su transparencia, según Kepes:

"Cuando contemplamos figuras superpuestas, reconocemos que la primera, o sea la superior, tiene dos significados espaciales, a saber, el de ella misma y el de detrás de ella misma. [...] Experimentamos las diferencias espaciales o profundidad.",

Se presenta un espacio estratificado de objetos independientes dentro de la unidad, y las relaciones entre ellos por medio de enlaces ópticos-mentales provocados por la transparencia y superposición de los planos paralelos en posiciones relativas que exploran una lógica de combinaciones posibles. Multiplicidad, simultaneidad y multifocalidad de recorridos visuales, desde una posición estática del observador-receptor, que pretende evocar una legibilidad mental, considerando que:

"El purismo parte del elemento formal primario y geométrico, porque sus reacciones sobre nuestro físico son relativamente simples, comparado al mundo de las asociaciones (...) es la sinfonía de las asociaciones provocadas por ellas quien mueve nuestra cenestesia y nuestro yo consciente. Hablando por lo tanto de elementos formales y coloridos y considerándolos como excitantes de una acción específica determinada, podemos crear el cuadro como una máquina. El cuadro es un dispositivo destinado a emocionarnos. Esta noción es fundamental en el Purismo. " Ozenfant \& Jeanneret ${ }^{8}$

La unión entre la precisión (de la máquina) y la experiencia estética (excitación), entre la razón y la sensibilidad. Una emoción de orden intelectual provocada por la asociación de elementos que experimenta el sujeto receptor.

\footnotetext{
${ }^{6}$ Op. cit.: Kepes, G.: El lenguaje de la visión, p.111.

${ }^{7}$ Op. cit.: Kepes, G.: El lenguaje de la visión, p.112.

${ }^{8}$ Ozenfant \& Jeanneret: La peinture moderne. Paris: Les Éditions G. Crés \& Cie., 1925, pp.166-167. (Trad. propia). Texto original: "Le purisme part de l'élément formel primaire et géométrique, parce que ses réactions sur notre physique sont relativement simples, comparées au monde des associations (...) c'est la symphonie des associations provoquée per celles-ci qui émeut notre cénesthésie et notre moi conscient. Parlant donc des éléments formels et colorés et les considérant comme des excitants à action spécifique déterminée, on peut créer le tableau comme une machine. Le tableau est un dispositif destiné à nous émouvoir. Cette notion est fondamentale dans le purisme.”
} 

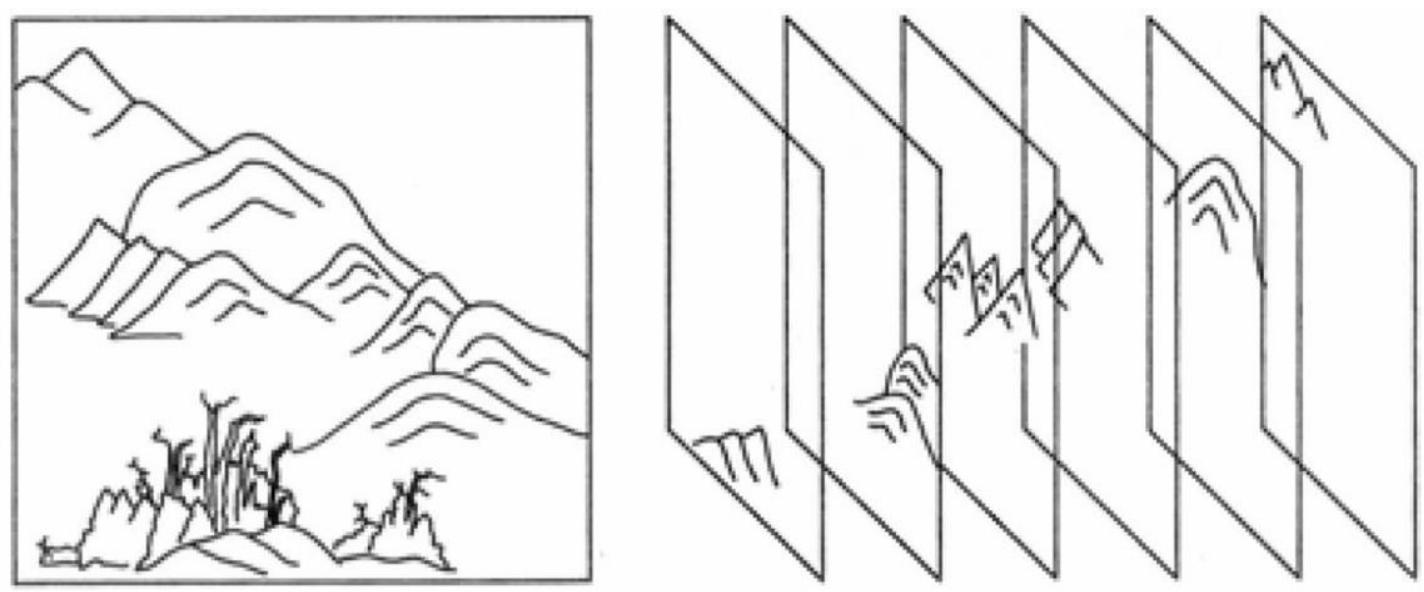

6. Diagramas de la superposición de montañas de la pintura de Li-Sheng, Dream Journey through the Xiao and Xiang Rivers, (ca.1170).

En comparación, el empleo de "planos paralelos" para la construcción del espacio (fig.6), iniciando el recorrido con pluralidad de puntos de vista, hasta obtener la sensación de que el espectador está ubicado en un lugar indeterminado, aéreo, desde el que contempla casi a vista de pájaro el panorama representado, conectando al observador con la elevación espiritual, lanzando la mirada hacia el paisaje lejano y extenso, es un fenómeno de la pintura china denominado shen yuan o "distancia profunda". Una técnica proveniente de los bajorrelieves chinos en los que se suceden y superponen diversas capas, con diferentes objetos opacos -sin transparencia literal- hasta crear el espacio. Tal y como se observa en el diagrama obtenido a partir de la pintura titulada Dream Journey through the Xiao and Xiang Rivers ${ }^{9}$.

Representaciones de la escena paisajística mediante la "acumulación" de "planos", siempre con una visión no geométrica ni limitada del espacio pictórico (tan característica de la perspectiva occidental). Todo ello en virtud de una mayor expresividad, más allá de la realidad, al ser reproducida una cualidad espiritual -vista por el ojo de la mente- y el espacio idealista habitado por otras realidades, por el eterno Qi o por el Tao.

Asimismo, este sistema de posicionamiento de los objetos, para dar sensación de profundidad sin límites (sin la utilización de la perspectiva), también puede observarse en los dibujos infantiles, donde, a falta de recursos conocidos para explicar lo que desea representar, el niño utiliza diversos aspectos visuales, tales como el fusionado del mundo tridimensional con el del plano gráfico bidimensional o el manejo de la combinación de planta y elevación. Aspectos similares a la multiplicidad de puntos de vista creados en los cuadros cubistas, que se alejan de la perspectiva única buscando la profundidad plana. Un recurso que también empleó Rem Koolhaas en la elevación-planta realizada para el concurso del Parque de la Villette, 1982 (una representación bidimensional de la elevación de cada franja de la planta del parque, con la que simula un gráfico tridimensional heterogéneo y simultáneo).

\footnotetext{
${ }^{9}$ Smith, Judith G., y Wen C. Fong (eds.): Issues of Authenticity in Chinese Painting. Nueva York: Department of Asian Art, The Metropolitan Museum of Art, 1999, p.273. La pintura original de Li, de la que se obtiene el presente diagrama, se encuentra en Tokyo National Museum.
} 


\section{Visión dinámica, experiencia narrativa espacio-temporal.}

El espacio se construye a través de la "estratificación", de la superposición de franjas verticales paralelas que avanzan y retroceden, englobándose y excluyéndose mutuamente en una relación de profundidad donde la mirada experimenta movimiento y tensiones desde una posición estática del observador.

La misma figura se ve como la más próxima o como la más alejada, es decir fluctúa, al concentrarse varias perspectivas espaciales divergentes en una sola captación visual; tal y como reconoce George Kepes:

"La transparencia representa una percepción simultánea de diferentes posiciones espaciales. El espacio no sólo retrocede sino que fluctúa en continua actividad. ${ }^{, 10}$

Si bien, a diferencia de la posición de Rowe y Slutzky que mantienen al observador estático e alejado, Sigfried Giedion propone un espacio relacional activo. Tal y como apunta Detlef Mertins:

"Para ellos [Rowe y Slutzky], la transparencia se basó en un observador colocado en el eje de un plano bidimensional (un cuadro o la fachada de un edificio), inmóvil y desprovisto de pensamiento y acción. Sin embargo, para Giedion y sus colegas constructivistas, era la función de una espacialidad en cuatro dimensiones activada por un sujeto móvil y participativo. Giedion describió esto como un espacio "relacional" en lugar de un espacio de objetos." $"$ ll

La visión múltiple -multifocal- supera la fijación estática de la perspectiva lineal -afocal o bifocal-. Una visión relativa -secuencial- y descentrada en una realidad estable, en la cual el espacio profundo se opone constantemente a la inferencia del espacio superficial, creando una tensión resultante que obliga a efectuar siempre nuevas interpretaciones de estructuras formales dentro de un todo, manteniendo la independencia de los objetos. Y a su vez, se van introduciendo actitudes dinámicas -no meramente contemplativas- que dan paso a la experimentación. Tal y como describe el propio Giedion al referirse a la transparencia literal de los planos del edificio de la Bauhaus:

"Hay una agrupación vertical y flotante de planos que satisface nuestra sensibilidad en favor de un espacio relacional, y hay una amplia transparencia [literal] que permite ver el interior y el exterior simultáneamente, de frente y de perfil, como en La arlesiana de Picasso, de 1911-1912: variedad de niveles de referencia, o de puntos de referencia, y simultaneidad; en resumen, la concesión del espacio-tiempo. ",2

Una percepción que será experimentada de modo narrativo en la arquitectura del movimiento moderno, como por ejemplo durante el recorrido de ascenso por la rampa ${ }^{13}$ (hasta el encuadre final del paisaje en la llegada a cubierta) de la villa Savoye, 1928, de Le Corbusier. Una secuencia sucesiva de planos o encuadres que se relacionan con el lenguaje cinematográfico y las técnicas de montaje, como capas enlazadas hasta obtener un significado global.

\footnotetext{
${ }^{10}$ Op. cit.: Kepes, G.: El lenguaje de la visión, p.114.

${ }^{11}$ Mertins, Detlef: Modernity Unbound: Other Histories of Architectural Modernity. Londres: Architectural Association AA Publications, 2011, pp.11 y 12. (Trad. propia) Texto original: "For them [Rowe y Slutzky], transparency relied on an observer stationed on axis with a two-dimensional plane (a painting or the façade of a building), immobile and devoid of thought and action. Yet for Giedion and his constructivist colleagues, it was a function of a four-dimensional spatiality activated by a mobile and participatory subject. Giedion described this as a "relational" space rather than a space of objects."

${ }^{12}$ Giedion, Sigfried: Espacio, tiempo y arquitectura : origen y desarrollo de una nueva tradición. Trad. y edición Jorge Sainz. Barcelona: Reverté, 2009, p.485. (Space, time and architecture : the growth of a new tradition. Cambridge: Harvard University Press, 1941).

${ }^{13}$ Una relectura de la promenade arquitectónica.
} 


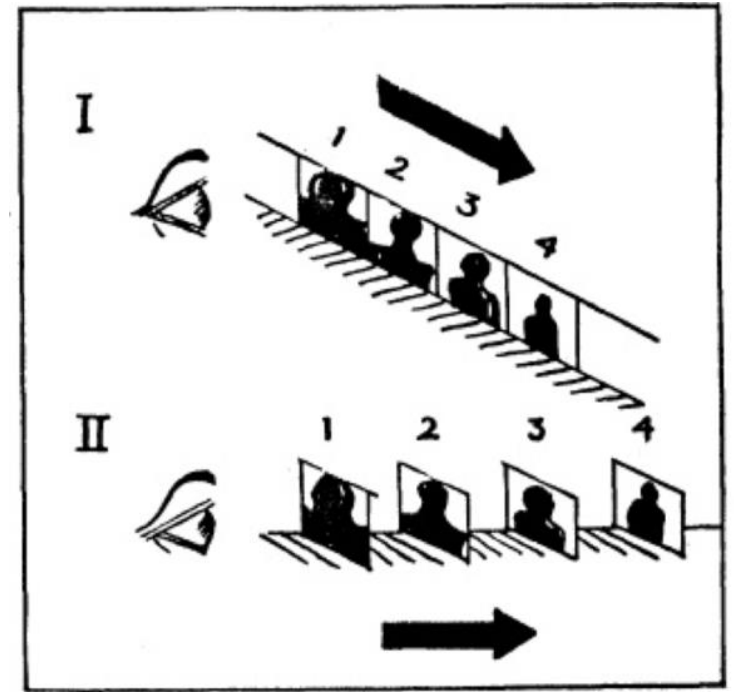

7. Eisenstein, Sergei: Esquema de percepción sobre la profundidad.

Tal y como esquematiza y argumenta Sergei Eisenstein (fig.7), en su libro El sentido del cine, para lograr la profundidad de una imagen:

"La vista puede disciplinarse, no para unir un cuadro a otro, como en nuestro fragmento [fig. I], sino para colocar uno sobre otro en capas. Esto produciría la sensación de ser arrojado dentro de una profundidad o la sensación de cuadros que se abalanzaran hacia el espectador. Imaginemos, por ejemplo, una serie de cuatro primeros planos de tamaño creciente, cada uno de una persona distinta y colocado en el centro de la toma. Una percepción natural de esta serie de cuadros no podría representarse en el diagrama superior sino en el inferior (fig. II)." 14

Una serie o secuencia de planos o capas superpuestas en continuidad, un establecimiento de discontinuidades físicas y enlaces psíquicos como en el montaje arquitectónico.

$\mathrm{Al}$ respecto, tal y como se sugiere, ante análisis actuales de la escena de la rampa:

"es posible que Le Corbusier tuviera la idea de tratar de insertar un montaje del tipo Eisenstein dentro de un corte clásico, si bien es extremadamente raro asociar estas dos gramáticas en una misma secuencia." [...] "Por lo tanto podemos suponer que estas referencias a las teorías de montaje de Eisenstein -teorías inspiradas en la lección de Choisy - constituyen un enlace tangible al concepto del paseo arquitectónico con la Acrópolis. ",15

\footnotetext{
${ }^{14}$ Eisenstein, Sergei: El sentido del cine. México: ed. siglo XXI S.A., 1974, p.148. (The film sense. New York: Harcourt, Brace and Co., 1942).

${ }^{15}$ Fondation Le Corbusier: L'invention d'un architecte. Le voyage en Orient de Le Corbusier. Francia: ediciones de la Villette, 2013. (Trad. propia). Textos originales: "Il est aussi possible que Le Corbusier ait eu l'idée d'expérimenter l'insertion d'un montage de type Eisensteinien à l'intérieur du découpage classique, bien qu'il soit extrêmement rare d'associer ces deux grammaires dans una même séquence." p.411. "On peut donc supposer que ces références aux théories de montage d'Eisentein -théories inspirées par la leçon de Choisy- constituent un lien tangible du concept de la promenade architecturale avec l'Acropole." p.413.
} 

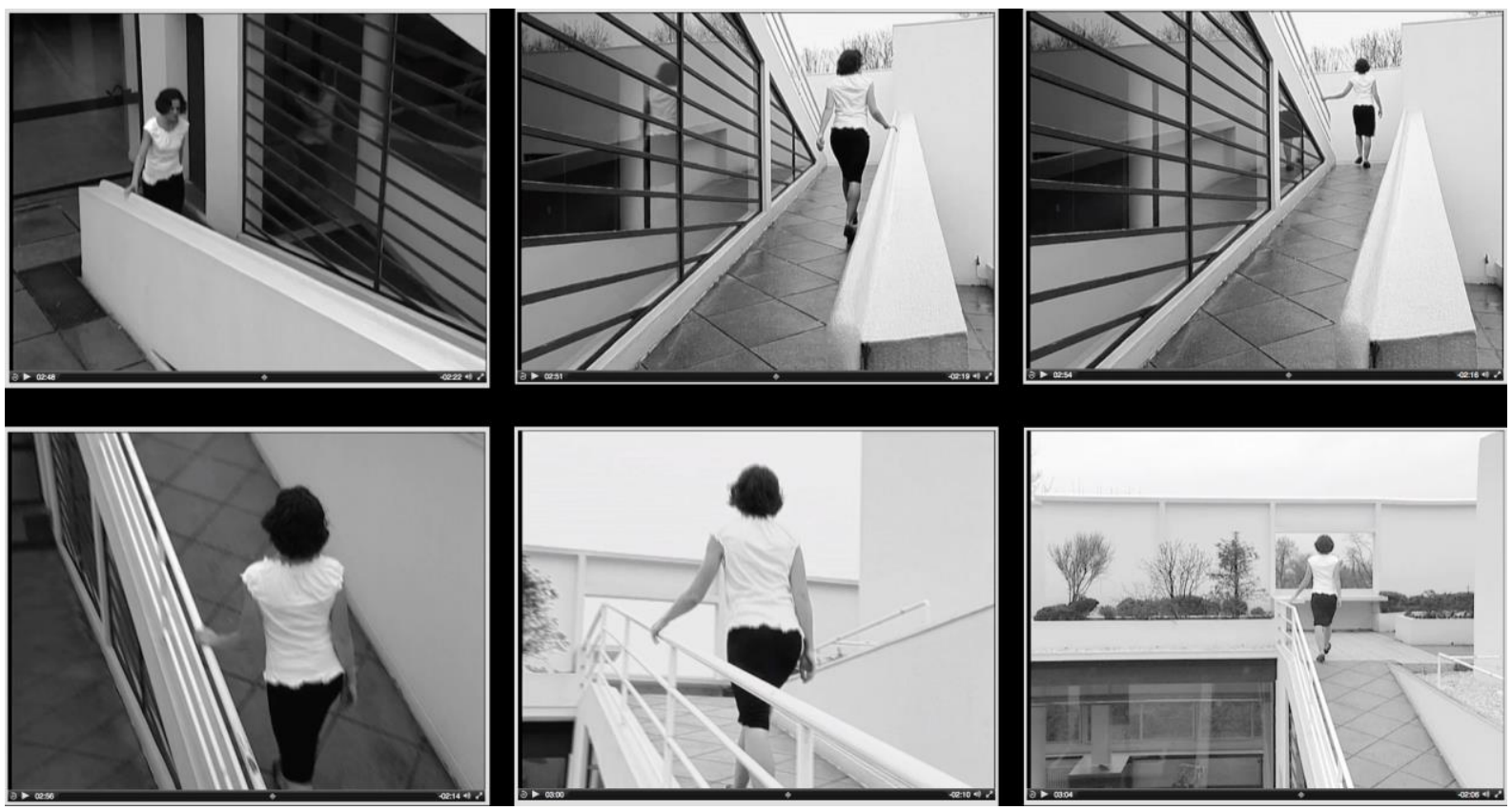

8. Selección de planos de la escena de la promenade arquitectónica del video de Matthew Roman titulado Savoye, 2004.

Un paseo que, en el nuevo montaje de la reinterpretación de la escena de la promenade arquitectónica de Matthew Roman ${ }^{16}$ (fig.8), transgrede el ángulo de 90 grados, definiendo la progresión ascendente de una mujer (subiendo por la rampa) utilizando una estructura diagonal, dando así un efecto cinematográfico que no es absolutamente bidimensional ni tridimensional.

En consecuencia, la construcción del espacio mediante la superposición de planos independientes, logra obtener una profundidad bidimensional y la multiplicidad de puntos de vista que, de modo similar a algunas vanguardias pictóricas del siglo XX, trata de introducir el tiempo en su definición plástica. Se genera, por tanto, una "ficción" de realidad volumétrica, y tal y como apuntaba Colin Rowe:

"El tiempo se convierte en el metrónomo del progreso y a sus aspectos seriales se les otorga una presencia acumulativa y dinámica, en tanto que, por otra, aunque secuencia y cronología se reconocen como los hechos que son, el tiempo, privado según esquemas experimentales. "17

El tiempo comienza a formar parte del espacio, es la cuarta dimensión. El tiempo antes absoluto, compacto, continuo, cuyo intervalo entre dos sucesos es homogéneo y separado del espacio -defendido por Aristóteles o Newton-, se transforma en un tiempo relativo, fragmentado, discontinuo -enunciado por Einstein en su "teoría de la relatividad"-. Y con ello, esta influencia de las teorías científicas de Einstein romperá con la composición estática, de centro único y punto de vista privilegiado clásico, dando paso a la posición relativa, donde cada "unidad" se concebiría como un centro independiente dentro de un espacio "relativista", de un espacio-tiempo referencial.

\footnotetext{
16 Véase video Savoye, 2004, de Matthew Roman, en el archivo de video-estudio digital de Cinematic Mapping of Cambridge. http://expressivespace.org/CMC/DIGIS-VE-22.html

${ }^{17}$ Rowe, Colin y Koetter, Fred: Ciudad Collage, Barcelona: Gustavo Gili, 1981, p.140. Texto original: "On the one hand time becomes the metronome of progress, its serial aspects are given cumulative and dynamic presence; while, on the other, though sequence and chronology are recognized for the facts which they are, time, deprived of some of its linear imperatives.” Rowe, Colin y Koetter, Fred: Collage City. Cambridge, Massachusetts: MIT Press, 1978, pp.143-144.
} 
Le Corbusier empleó la superposición de estratos, de elementos "autónomos" y "espaciados", fragmentos de experiencias discontinuas en posiciones relativas, manteniendo la unidad compositiva, y ampliando los puntos de vista, tanto en el plano vertical (como se ha visto anteriormente) como horizontal, siendo el modelo configurado mediante el empleo de un sistema de plantas libres, o forjados de hormigón armado, extendidas verticalmente mediante superposición, denominado Estructura Dom-ino -palabra formada por domus (casa) e innovation (innovación)-, de 1914, uno de los primeros acercamientos de referencia de Le Corbusier a la producción de una "teoría sistemática de composición arquitectónica de posición relativa" vinculada al concepto de "superposición" como "estratificación".

La cohesión y continuidad clásicas - cuyas partes remiten al todo perdiendo autonomía o independencia-, pasan a la fragmentación y discontinuidad modernas -cuyos elementos desde su posición relativa hacen presente la autonomía de las partes articuladas que constituyen la unidad-.

Cada planta libre, o plano horizontal independiente, será un elemento sujeto a la fuerza de vectores verticales que mantendrá una organización fija dentro del conjunto, posibilitando la compresión de la arquitectura en términos tradicionales como orden y geometría elemental -racional-, y al mismo tiempo, una definición espacial "abstracta" y "depurada", propia de la arquitectura del movimiento moderno, si bien en el caso de Estructura Dom-ino, la carencia de enlaces entre los planos horizontales provocará la rigidez de su sección, y tal como citará Federico Soriano "A la planta libre le falta profundidad"18. Una cuestión que Le Corbusier resolverá mediante la ruptura de los suelos abstractos y neutrales -con la inclusión de nuevos elementos o mecanismos, como la doble altura o la rampa, que enlazaba los espacios con un concepto lineal y narrativo del tiempo- y, posteriormente, - con figuras orgánicas que cualificaban el espacio moderno con tensiones específicas-.

\footnotetext{
${ }^{18}$ Soriano, Federico: "Planta fluctuante". Fisuras de la cultura contemporánea, n.3 1/3, 1995, p.67. Véase también en "Hacia una definición de la planta profunda, de la planta anamórfica, y la planta fluctuante.”, El Croquis, n.81-82, 1996, p.7.
} 


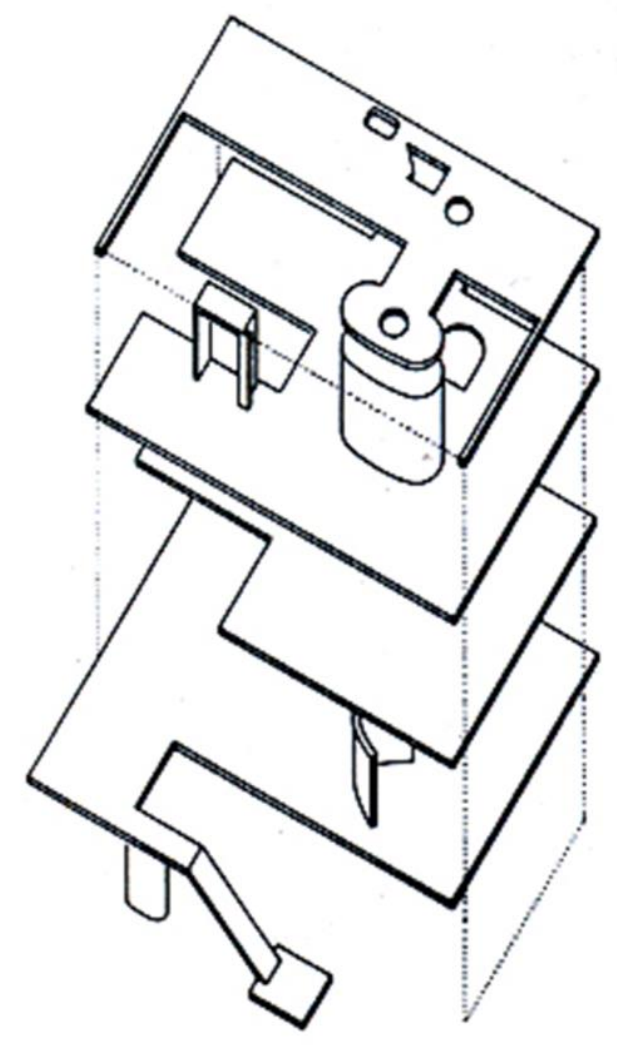

9. Colin Rowe y Robert Slutzky: Descomposición horizontal, en una serie de planos paralelos, de la Villa Garches, 1926, de Le Corbusier.

Así, los planos horizontales -suelos- serán operados hasta conseguir aumentar la dimensión espacial, de la 3D a la 4D, introduciendo el espacio-tiempo. Una planimetría referencial de experiencias fragmentadas -no compacta sino discontinua-, posiciones vinculantes con una voluntad estabilizadora y de control, una superposición visual de distintos planos que desintegran virtualmente la caja. Evocar "l'espace indicible"19 de Le Corbusier, aquel provocado por el espíritu y que no se puede describir con palabras, donde la plástica expresa la plenitud de un volumen según las exigencias del espíritu. Tal y como expresaba Le Corbusier:

"Entonces surge una profundidad sin límites, que borra los muros, ahuyenta las presencias contingentes: realiza el milagro del espacio indecible. "20

Una nueva "espacialidad plana" donde la arquitectura se expande hacia nuevas dimensiones, hacia un espacio continuo. Así, el movimiento de la mirada, y la sucesión o secuencia de espacios, es conducido también por un recorrido arquitectónico narrativo, bien sea físicamente por ejemplo al desplazarnos por la rampa, o virtualmente mediante la visión dinámica generada por la superposición y transparencia de los planos separados temporalmente y sus relaciones geométricas inestables.

${ }^{19}$ Le Corbusier: "L'espace indicible" escrito en 1945, publicado en L'Architecture d'Aujourd'hui, n. especial "Art", 1946, pp.9-17. ("El espacio indecible”. Trad. Fernando Álvarez, corrección Carlota Socías, DC Revista de crítica arquitectónica, n.1, 1998).

${ }^{20}$ Ibíd.: Le Corbusier: "El espacio indecible”, p.47; Texto original: "Alors une profondeur sans bornes s'ouvre, efface les murs, chasse les présences contingentes, accomplit le miracle de l'espace indicible." 


\section{Hacia el impacto emocional.}

Estos mecanismos formales, expuestos precedentemente, -que en sus orígenes fueron controlados, claros en la exposición de sus relaciones y de lectura correcta- (experimentados por Le Corbusier y posteriormente redirigidos por Rowe y Slutzky en atracción y defensa de las propiedades formales de obras arquitectónicas y pictóricas), acabaran transformándose en recursos manipulables, deformables, e ilegibles (utilizados por Peter Eisenman). En este sentido, tal y como cita Jeffrey Kipnis en su artículo P-Tr's Progress:

"A efectos prácticos, todas las intervenciones formales de Eisenman derivan del tratamiento que Rowe/Slutzky hacen de la Transparencia Fenomenológica.", 21

Ambos buscarán la experimentación de lo formal como acto que provoque una emoción de orden intelectualafectivo en el sujeto receptor -estático o dinámico-, si bien, en los tiempos actuales, se añadirá la complejidad en su lectura -rozando o alcanzando lo ilegible-, turbándose las asociaciones entre elementos, pero manteniendo mecanismos como la superposición, estratificación, articulación, etc. En cierto modo, la transparencia se convierte en traslucidez o borrosidad, y la lectura en afecto. Tal y como explica Peter Eisenman:

"Afectar tiene que ver con el modo en que formas particulares de efectos arquitectónicos, tropos, retórica, pueden desplazar nuestra experiencia convencional o esperada del espacio. "22

De lo que se deriva que, la liberación de la legibilidad -hacia lo topológico- conduce a procesos sin un sentido direccional preciso, sin transmisión directa de las relaciones, y repletos de secuencias ambivalentes. Extraños seccionados y combinaciones delirantes que promueven las experiencias inusuales (sensaciones imprevistas, no entendibles o no intencionadas) frente a experiencias inteligibles (lecturas formales, claras, leíbles). Efectos formales cada vez más complejos y avanzados, y no por ello menos interesantes o propositivos que sus antecesores.

\section{Procedencia de imágenes}

1, 3 y 9. Rowe, Colin y Slutzky, Robert en Transparency, 1955-1956; 2. Fondation Le Corbusier (C) FLC/ADAGP; 4 y 5. Fotografías propias. Kunstmuseum Basel; 6. Autor desconocido en Issues of Authenticity in Chinese Painting; 7. Sergei Eisenstein en The film sense, 1942; 8. Montaje propio sacado del video de Matthew Roman publicado en http://expressivespace.org/CMC/DIGIS-VE-22.html

\section{Bibliografía/referencias}

Benjamin, Andrew (et al.): Blurred zones: investigations of the interstitial. Eisenman Architects, 1988-1998. Nueva York: Monacelli Press, 2002.

Eisenstein, Sergei: The film sense. New York: Harcourt, Brace and Co., 1942.

Fondation Le Corbusier: L'invention d'un architecte. Le voyage en Orient de Le Corbusier. Francia: ediciones de la Villette, 2013.

\footnotetext{
${ }^{21}$ Kipnis, Jeffrey: “P-Tr’s Progress”. En El Croquis, n.83, "Peter Eisenman 1990-1997”. Madrid: ed. El Croquis, 1997, p.38.

${ }^{22}$ Eisenman, Peter en Benjamin, Andrew (et al.): Blurred zones: investigations of the interstitial. Eisenman Architects, 1988 1998. Nueva York: Monacelli Press, 2002, p. 6. Texto original: "Affect is concerned with the way particular forms of architectural effects, tropes, rethoric, can displace our conventional or expected experience of space.”.
} 
Giedion, Sigfried: Space, time and architecture : the growth of a new tradition. Cambridge: Harvard University Press, 1941.

Kepes, Gyorgy: Language of vision. Chicago: Paul Theobald, 1944.

Kipnis, Jeffrey: “P-Tr's Progress”. En El Croquis, n.83, “Peter Eisenman 1990-1997”. Madrid: ed. El Croquis, 1997.

Le Corbusier: “L’espace indicible” 1945. En L'Architecture d'Aujourd'hui, n. especial “Art”, 1946.

Mertins, Detlef: Modernity Unbound: Other Histories of Architectural Modernity. Londres: Architectural Association AA Publications, 2011.

Ozenfant \& Jeanneret: La peinture moderne. Paris: Les Éditions G. Crés \& Cie., 1925.

Ozenfant \& Jeanneret: Après le Cubisme, Paris: Éditions des Commentaires, 1918.

Rowe, Colin y Slutzky, Robert: “Transparency: Literal and Phenomenal”, 1955-1956. En Perspecta n.8, Yale Architectural Journal, 1963.

Rowe, Colin y Koetter, Fred: Collage City. Cambridge, Massachusetts: MIT Press, 1978.

Smith, Judith G., y Wen C. Fong (eds.): Issues of Authenticity in Chinese Painting. Nueva York: Department of Asian Art, The Metropolitan Museum of Art, 1999.

Soriano, Federico: "Planta fluctuante". En Fisuras de la cultura contemporánea, n.3 1/3, 1995. 


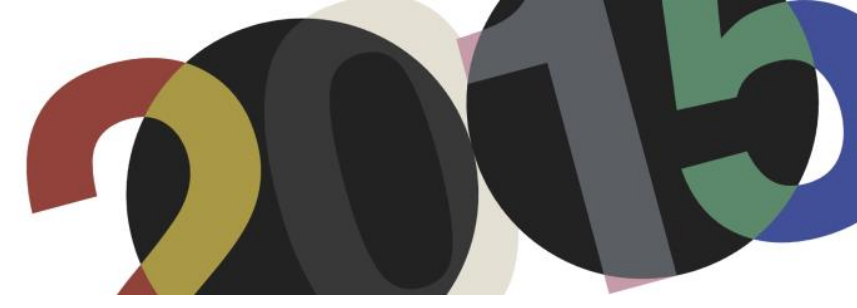

DOI: http://dx.doi.org/10.4995/LC2015.2015.764

\title{
Analyse architecturale, modélisation 3D et narration filmique : un regard original sur quelques objets corbuséens
}

\author{
D. Derycke*, V. Boone ** \\ * ULB, Bruxelles, Faculté d'architecture, CLARA/AlICe \\ ** ULB, Bruxelles, Faculté d'architecture, CLARA/hortence; ENSAP Lille, LACTH
}

\begin{abstract}
To analyze Le Corbusier's work through 3D digital modeling constitutes an important issue for the dissemination of the legacy of this major architect. During an analytical process, a relevant use of contemporary graphic means associated to an understanding of the codes of architectural representation allows to reveal new issues, or new points of view. When linking the graphic production of such process to film narrative and to the codes of documentary film, one obtain singular documents: short-movies based on computer generated images that support an analytical and critical thought, but also present projects under a new visual expression; didactic and descriptive. Those documents become particularly interesting when it comes to highlighting obscure architectural heritage, or to give body to projects remained on paper. With the support of the Fondation Le Corbusier, some Master architecture students investigated Belgian projects of the work of Le Corbusier, from which only two were built and no more than one remains. Through precise methodological issues, this paper accounts for the knowledge that such productions can offer on sometimes less-known architectural objects from the Swiss master.
\end{abstract}

Resumen: Analizar las obras arquitectónicas de Le Corbusier, a través la modelización 3D, constituye un desafio importante de difusión del legado de este gran arquitecto. Mediante el proceso analítico, un uso pertinente de los medios contemporáneos de representación gráfica asociados a una comprensión de los códigos de representación arquitecturales permite de establecer nuevas perspectivas y problemáticas poco tratadas. Cuando acoplamos la producción gráfica, creada por este tipo de proceso analítico, a la narración cinematográfica y a los códigos del cine documental, obtenemos documentos singulares : cortometrajes dentro de imágenes digitales que sostienen un propósito analítico y critico, pero que su vez presentan también los proyectos arquitectónicos bajo una nueva expresión visual, didáctica y descriptiva. Estos documentos pueden revelarse particularmente interesantes cuando se trata de valorizar un patrimonio arquitectural desconocido, o de ofrecer un cuerpo solido a los proyectos yacidos en hojas de papel. Con el apoyo de la Fundación Le Corbusier, los estudiantes de Master de arquitectura se interesaron a los proyectos belgas de los trabajos diseñados por Le Corbusier, de los cuales solo dos han sido construidos y solo uno permanece en pie. Mediante cuestionamientos metodológicos precisos, este articulo relata el conocimiento que este tipo de producciones pueden ofrecer sobre los objetos arquitectónicos menos conocidos del gran maestro suizo.

Keywords: Le Corbusier, architectural analysis, 3D modelisation, photography, short film, Belgium.

Palabras clave: Le Corbusier, análisis arquitectónico, modelización 3D, fotografía, cortometrajes, Bélgica.

\section{Introduction}

Le laboratoire AlICe de la Faculté d'Architecture de l'ULB s'intéresse depuis plus de 20 ans à l'analyse architecturale par la représentation graphique. Un des exercices proposé à des étudiants de Master consiste à analyser et à modéliser en 3D un objet d'architecture, puis à traduire cette analyse en un court-métrage en images de synthèse, en tenant un discours à la fois didactique et critique sur le bâtiment étudié. Ce travail permet aux étudiants de développer leur capacité à lire l'architecture d'une part, et d'autre part d'apprendre à construire, structurer et communiquer un propos précis à travers un média particulier (images de synthèse enrichies de prises de vues filmées, images d'archives, musiques, voix off,...). Cette approche pédagogique permet de mêler 
l'histoire et la théorie de l'architecture à la compréhension de la représentation graphique et de ses codes, anciens et nouveaux, avec comme objectif final un possibilité de diffusion du savoir architectural par les réseaux médiatiques contemporains. Souvent prétexte à des partenariats avec des institutions extérieures en charge de la gestion de patrimoine architectural, cet exercice prend une tournure particulièrement intéressante lorsqu'il s'agit de valoriser des fonds d'archives, des projets non-construits, ou encore des bâtiments disparus ou fortement altérés. Dans le cas de projets non-réalisés ou disparus, la maquette 3D permet de dépasser la simple question volumétrique contenue dans les documents originaux ou subsistants, et d'introduire pleinement la question de la spatialité, souvent cantonnée à quelques croquis ou photographies de maquettes. En outre, des informations parfois contradictoires provenant des documents sources doivent faire l'objet d'interprétations justifiées afin de cohabiter dans un même espace de représentation. Il résulte de ce processus des objets graphiques singuliers, qui soulèvent non seulement des enjeux de recherches, mais qui ont également un impact dans le domaine didactique et de la communication.

Pour commémorer le cinquantenaire du décès de Le Corbusier, le laboratoire AlICe a choisi de s'intéresser aux six projets de l'oeuvre belge de l'architecte, avec le support de la Fondation Le Corbusier à Paris. Pour plusieurs de ces projets, il s'agit d'une première modélisation numérique, ce qui permettra de mieux faire connaître auprès d'un large public les projets de papier, souvent assez avancés, et d'avoir une source complémentaire dans l'étude de ces projets. D'autres projets ont, en revanche, déjà fait l'objet de nombreuses études. Il s'agit alors de trouver de nouveaux angles d'attaque, de nouveaux points de vue, ou de proposer une synthèse de la connaissance existante qui pourra trouver dans le média numérique une nouvelle forme de diffusion. Après une brève présentation des six projets belges de Le Corbusier, cet article propose de relater quelques enjeux méthodologiques précis de l'analyse architecturale par les moyens graphiques qui anticipent la création d'un court-métrage, et de mettre en évidence la connaissance que ce processus est susceptible d'apporter sur l'oeuvre belge du grand architecte.

\section{Le Corbusier et la Belgique}

Outre la maison Guiette (1926), seule réalisation de Le Corbusier encore présente sur le sol belge, l'œuvre corbuséenne en Belgique est surtout marquée par sa participation à l'exposition universelle de 1958de Bruxelles, avec le Pavillon Philips et le spectacle multimédia Le Poème Electronique, de lui-même et d'Edgar Varèse ${ }^{1}$. L'œuvre sera détruite après l'exposition. C'est d'ailleurs le seul projet après-guerre de Le Corbusier en Belgique. Les autres manifestations de son travail belge concernent l'architecture domestique, l'architecture et le mobilier d'exposition, et un plan d'urbanisme. Ces projets se compressent en une décennie, entre 1929 et 1939. Il s'agit de la maison Canneel à Bruxelles (1929), le plan pour la rive gauche à Anvers (1933), le pavillon du jeune homme pour l'exposition à Bruxelles en 1935, et le Pavillon de l'eau pour l'exposition de l'eau à Liège (1939). Ces quatre projets ne sont pas réalisés, et les informations d'archives pour ces projets diffèrent profondément d'un projet à l'autre.

Quelques années après la réalisation de la maison Guiette à Anvers, Jean-Jacques Canneel lui confie le projet d'une maison à Bruxelles, signalée dans le premier tome de L'œuvre complète comme « Maison pour M. X à Bruxelles $»^{2}$. Le projet de la maison reste au stade de l'avant-projet, et a fait l'objet d'une étude de Marc Dubois

\footnotetext{
1 Petit, Jean (Ed.): Le Poème Electronique - Le Corbusier. Paris : Editions de Minuit, 1958. ; Treib, Marc: Space calculated in seconds. New Jersey : Princeton University Press, 1996.

2 Boesiger, Willy; Storonov, Oscar: Le Corbusier et Pierre Jeanneret. Oeuvre Complète. 1910 - 1929. Zürich: Editions Girsberger, 1943. pp. 204-205.
} 
dans le cadre du projet réalisé sur une autre parcelle, en 1931, avec L.H. De Koninck ${ }^{3}$ (bâtiment démoli en 1969). Les documents d'archives disponibles sont surtout les plans, coupes et façades de l'avant-projet, ainsi que les croquis des espaces intérieurs et extérieurs. Presque tous ces documents se retrouvent dans L'œuvre complète. Il s'agit d'une maison avec une typologie très belge de parcelle peu large et très profonde, dans un nouveau quartier bruxellois, qui imposait de construire en hauteur. Le programme initial souhaité par Jean Canneel décrit des espaces de vie au rez-de-chaussée, en interaction avec le jardin, une chambre à coucher, et une bibliothèquebureau en relation avec le toit-terrasse. Or, le projet de Le Corbusier néglige complètement ces demandes, en proposants des espaces de vie traversants, et, au deuxième étage, en ajoutant une piscine en relation avec la chambre à coucher du premier étage. Les espaces domestiques se trouvent également au premier étage, côté rue. Contrairement à l'escalier conçu pour la Maison Guiette à Anvers, Le Corbusier prévoit un double escalier en forme d'amande en plan, séparant ainsi domestique et propriétaires, mais créant également un objet sculptural qui devient la colonne vertébrale de la maison. Le projet a donc tout intérêt à être étudié de plus près, ce qui lui permet d'être inséré dans les études de l'évolution des projets domestiques et des maisons type Citrohan de Le Corbusier à cette période.

La maison Guiette, quant à elle, a été conçue en 1926, et a fait l'objet d'une minutieuse restauration par Georges Baines en 1987, parallèlement à la construction par ce dernier d'une extension à gauche de la maison. Suite à la restauration de la maison et à l'exposition sur Le Corbusier à Anvers cette même année, et aussi grâce à la renommée de son propriétaire le peintre René Guiette, la maison, ses principes, et l'historique de conception, sont bien documentés et discutés ${ }^{4}$. Révéler un autre point de vue que celui issu des approches et du matériel photographique existants, comme les photographies canoniques utilisées par Le Corbusier et les photographies de famille de René Guiette, toutes en noir et blanc, était donc nécessaire. La polychromie de la restauration étant inaccessible étant donné le statut privé de la maison, il était intéressant de restituer en 3D cette polychromie, en particulier pour rendre compte du vécu de la maison par la famille Guiette perceptible dans cette série de photos. Plus qu'une restitution des intérieurs des années 1940, il s'agit de donner des clefs de lecture pour une compréhension des aménagements des espaces, en incluant évidemment les choix de peintures de René Guiette pour sa propre maison.

Le plan de la rive gauche d'Anvers, réalisé pour le concours Imalso en 1933, est d'une part une application parfaite de la Ville Radieuse de Le Corbusier, comme lui-même en témoigne dans la publication homonyme de 1931, et d'autre part une remise en question de certains principes de ce plan de la Ville Radieuse, suite à l'apport extérieur de Huib Hoste et Fé Louquet, collaborateurs depuis la Belgique pour le concours. Ce concours fut l'objet de plusieurs publications, où le projet de Le Corbusier est, malgré l'accueil mitigé qu'il a reçu du jury, largement étudié ${ }^{5}$. Ces études ont pour objet la mise en contexte historique du concours, l'inscription du plan

3 Dubois, Marc: "Le Corbusier \& Louis Herman De Koninck. La maison Canneel 1929-1931". In Burniat, Patrick (Ed.): Le Corbusier et la Belgique (Les Rencontres de la Fondation Le Corbusier). Bruxelles : CFC-Editions, 1997. pp.63-78.

4 Baines, Georges; Spitaels, Els: Le Corbusier te Antwerpen : De Woning Guiette. Antwerpen : Hoger Architectuurinstituut van het rijk-stad Antwerpen, 1987. ; Schraenen, Guy: Les Peupliers. Maison Guiette = Huis Guiette. Le Corbusier 1926. Brussel : Sint-Lukasarchief, 1987.; Malliet, Anne: "Le Corbusier huis Guiette gerestaureerd". En $M \& L$. Novemberdecember 1987, N6, 1987. pp. 49-60. ; Prelorenzo, Claude (Ed.): La conservation de l'œuvre construite de Le Corbusier (Rencontres de la Fondation Le Corbusier). Paris : Fondation Le Corbusier, 1990.; Burniat, Patrick (Ed.): Le Corbusier et la Belgique, op. cit.; De Heer, Jan: The Architectonic Colour: Polychromy in the Purist Architecture of Le Corbusier. Rotterdam: Nai010 Publishers, 2009. ; Baines, Georges: “Du « système Dom-Ino » au «type Citrohan » : la maison Guiette à Anvers ”, En Massilia, 2011. pp. 50-81.

5 Commers, Ronald; Lombaerde, Piet: Le Corbusier en de Linkeroever te Antwerpen. Antwerpen: Hoger Architectuurinstituut van het Rijk (H.A.I.R.), 1987. ; Lombaerde, Piet: "Les projets pour la Rive Gauche d'Anvers, ou la Ville Radieuse en question”. In Burniat, Patrick (Ed.): Le Corbusier et la Belgique, op. cit. pp. 149-174. 
pour la rive gauche dans les plans urbanistiques de Le Corbusier, et l'apport des architectes belges dans le processus d'élaboration du plan.

La moitié des projets conçus pour la Belgique sont des projets de pavillons d'exposition. Pour l'exposition internationale à Bruxelles en 1935, Charlotte Perriand, René Herbst et Louis Sognot réalisent l'espace d'habitation d'un jeune homme. Le Corbusier et Pierre Jeanneret n'interviennent que partiellement pour le dessin de certains éléments de mobilier. Quelques plans dans les archives de la Fondation Le Corbusier témoignent cependant d'une étape architecturale réflexive sur le projet.

Ensuite, en 1939, l'architecte dessinera le pavillon de la France à l'Exposition de l'eau à Liège, également appelé le Pavillon de l'eau. Ce projet se caractérise par une structure en pylônes et cadres d'acier. Dans les quatre carrés des cadres se trouve une toile tendue en paraboloïde hyperbolique. La manière de tendre la toile fait référence au Pavillon des Temps Nouveaux de l'exposition universelle à Paris de 1937, et, comme le notent la plupart des études, il s'y trouve les prémisses du pavillon de Zurich pour Heidi Weber conçu en 1963 et achevé après la mort de Le Corbusier en $1967^{6}$. Différentes versions du projet du pavillon de l'eau existent, mais les informations restent très parcellaires et ne permettent pas de dépasser le stade d'un projet-croquis. Par contre, la plupart des documents d'archives sont des documents graphiques et non pas techniques, ce qui conduit à établir un propos analytique en concordance avec ce type de documents, en assumant les incertitudes.

Le dernier projet de Le Corbusier pour la Belgique, réalisé celui-ci, mais ensuite démoli, est le Pavillon Philips de l'Exposition universelle de Bruxelles en 1958. C'est aussi le dernier projet de pavillon de l'architecte.

Cette exposition est la première du genre à avoir lieu après la seconde guerre mondiale. Cette particularité, ainsi que la spécificité de l'œuvre conçue par Le Corbusier en collaboration avec Iannis Xenakis pour le pavillon, et Edgar Varèse pour le spectacle multimédia Le Poème Electronique, confère à l'objet un intérêt particulier dont témoignent plusieurs études monographiques qui se focalisent autant sur l'aspect audiovisuel, la conception et l'exécution de la structure, que sur la présence du bâtiment au sein de l'Exposition ${ }^{7}$. Le projet VEP (Virtual Electronic Poem) propose, par la réalité virtuelle, une reconstitution visuelle et auditive convaincante de l'expérience sensorielle du l'intérieur du pavillon ${ }^{8}$. Ce projet donne ainsi lieu à une expérience nouvelle, différente du film officiel tourné en 1958, et se situe plutôt en résonance avec les photographies d'époque de Lucien Hervé qui présentent les têtes des visiteurs faces aux grandes projections sur les murs courbes du pavillon. Un travail effectué par des étudiants ne peut prétendre rivaliser avec un projet d'une telle ampleur. L'approche sera donc plutôt celle de la synthèse rigoureuse mais didactique.

6 Baiwir, Jean-Claude: “Liège 1939: d'un pavillon d'exposition à l'autre” In Burniat, Patrick (Ed.): Le Corbusier et la Belgique, op. cit. pp. 199-210. ; Dumont D’ayot, Catherine; Benton, Tim: Le pavillon de Le Corbusier pour Zurich : modèles et prototype d'un espace d'exposition idéal. Zurich: Lars Müller Publishers, 2013.

7 Petit, Jean (Ed.): Le Poème Electronique, op. cit.. ; Treib, Marc: Space calculated in seconds. New Jersey : Princeton University Press, 1996.; Sterken, Sven: Iannis Xenakis, ingénieur et architecte. Director: Bart Verschaefel. Gent Universiteit, 2004. ; Devos, Rika: Modern at Expo 58. Discussions on post-war architectural representation. Director: Mil De Kooning. Gent Universiteit, 2008.

8 Lombardo, Vicenzo and others: "A Virtual-Reality Reconstruction of Poème Electronique Based on Philological Research”. En Computer Music Journal. “A Virtual Poème”. Summer 2009, №2. Cambridge Ma: MIT Press, 2009. pp. 2447. 


\section{Confrontation des sources au sein d'espaces graphiques communs : instauration d'hypothèses}

La recherche effectuée par les étudiants se base d'abord sur une étude bibliographique, sur le fond de plans numérisés ${ }^{9}$ ainsi que sur les archives de la Fondation Le Corbusier à Paris auxquelles ils ont eu accès. De ces documents de nature diverses (étude monographique, travaux de recherche, photos anciennes, plans de diverses étapes du projet, croquis, maquettes, archives écrites comme la correspondance ou des procès-verbaux de réunion, etc.) peut être extraite une description de taille et d'importance variables d'une partie ou de l'ensemble du projet étudié. Le premier enjeu d'une analyse par les moyens graphiques est de confronter les informations contenues dans ces différentes sources de façon à esquisser une ou plusieurs instances hypothétiques de la géométrie de l'objet étudié, correspondant à une époque ou plusieurs époques définies. Les sources bibliographiques et archivistiques sont donc triées, hiérarchisées, et classées suivant différents critères, puis sont confrontées au sein d'espaces graphiques ${ }^{10}$ communs de plus en plus détaillés : d'abord des vues géométrales et des dessins axonométriques, ensuite des maquettes d'étude, et enfin des modèles 3D numériques. Cette mise en commun des informations présentes dans diverses sources nécessite de résoudre toute une série de contradictions ou d'incohérences que ces sources mettent en exergue une fois qu'on les confronte. Certains détails doivent être interprétés parce que les documents d'archives n'en permettent qu'une compréhension parcellaire, d'autres - la plupart du temps les détails techniques - doivent être simplifiés lorsque leur description originale est trop précise pour que le niveau de détail du modèle soit cohérent et homogène. Enfin, certaines parties doivent être inventées car leur description est manquante, mais pour assurer l'harmonie visuelle et géométrique de l'ensemble, il y a nécessité de «combler les trous ». Cette invention se base néanmoins sur la compréhension de la totalité du projet étudié, et constitue une extrapolation de principes récurrents de l'architecture de Le Corbusier à des époques similaires. Des références peuvent donc être trouvées dans d'autres projets et transposées sur le bâtiment en question. Par exemple, l'étude portant sur la Maison Canneel (1929) propose une hypothèse de mise en couleurs des murs intérieurs qu'aucun document d'archives spécifique au projet ne permet d'étayer. Néanmoins, la compréhension des modes de mise en couleurs des maisons de type Citrohan est bien documentée ${ }^{11}$. La Maison Canneel étant apparentée à cette famille de projets, des principes de coloration peuvent en être extraits et transposés au projet bruxellois. Il en résulte une proposition dont on assume le statut extrêmement hypothétique, mais qui comporte une dimension exploratoire intéressante (1).

9 Le Corbusier. Plans. 4 coffrets de 4 DVD Echelle-1 Fondation Le Corbusier

10 Nous proposons de définir un espace graphique comme étant un univers représentationnel homogène, dans lequel coexistent une ou plusieurs figures caractérisées par un même mode projectif (géométral, perspectif, axonométrique), une même échelle, une même technique d'expression, et un même support matériel ou numérique. Un espace graphique peut être bidimensionnel (les modes projectifs) ou tridimensionnel (les maquettes). La mise en place de tels espaces permet de rassembler les informations géométriques issues de sources hétérogènes dans un document homogène, et ce à des fins de comparaison.

11 Le Corbusier: Salubra, Claviers de couleur. Bâle, Editions Salubra, 1931. ; Schraenen, Guy: Les Peupliers. Maison Guiette = Huis Guiette, op cit. ; Prelorenzo, Claude: Le Corbusier et la couleur (Rencontres de la Fondation Le Corbusier). Paris: Fondation Le Corbusier, 1992. ; De Heer, Jan: The Architectonic Colour: Polychromy in the Purist Architecture, op. cit. 


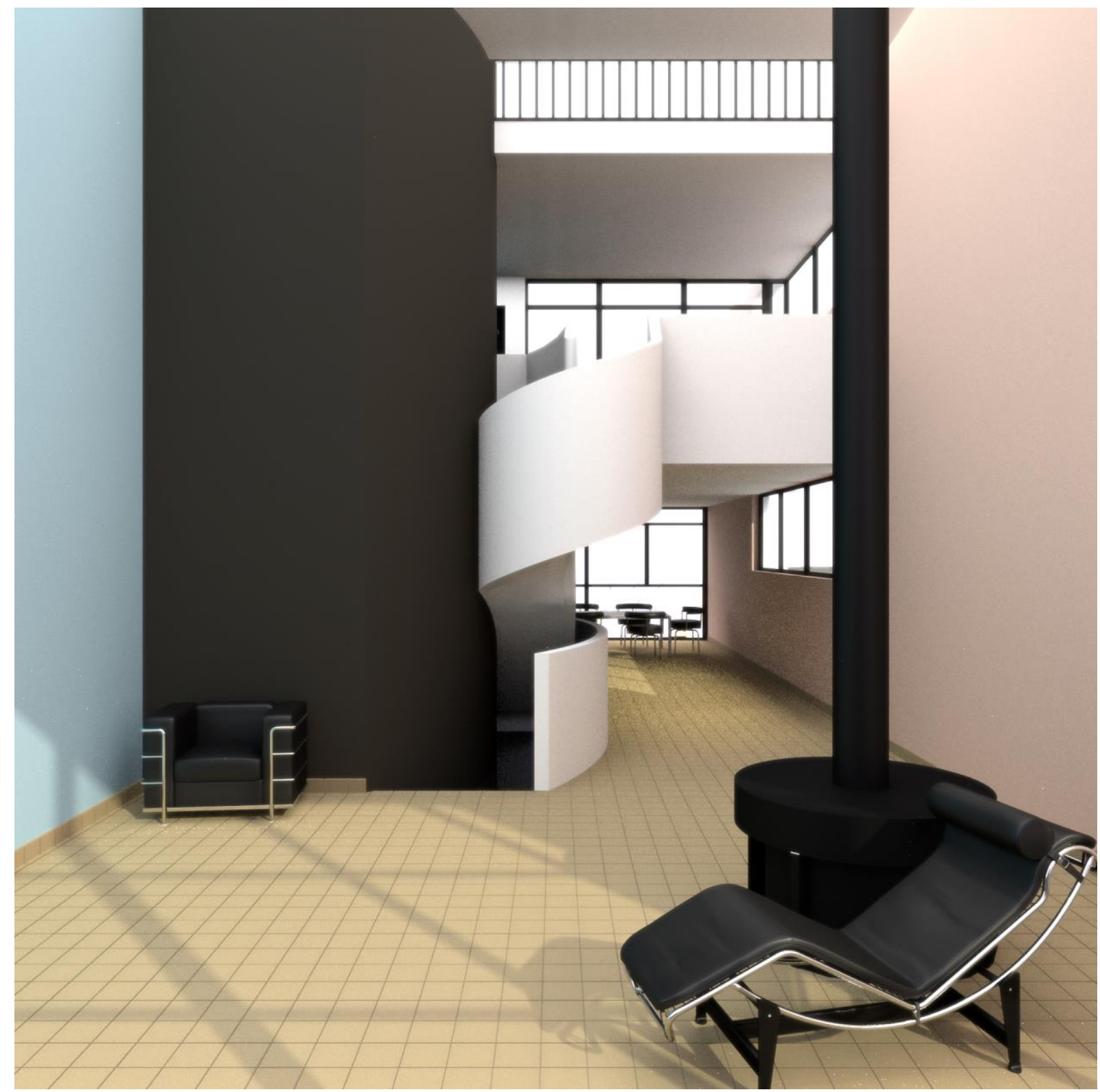

1. Maison Canneel (1929). Hypothèse de restitution, vue du salon et de la cage d'escalier.

L'interprétation ou l'invention sont également rendues nécessaires par l'incohérence fréquente des documents d'archives entre eux : certains éléments en plan, en coupe, en axonométrie, ou en maquette, sont différents, car issus de différentes étapes de la réalisation du projet, étapes parfois difficilement identifiables. Le modèle 3D entreprend alors de « résoudre » ces incohérences, tout en renseignant les choix effectués dans les documents du processus d'élaboration de l'analyse. Tout cela amène nécessairement à produire des objets graphiques ${ }^{12}$ singuliers et interprétatifs, mais dont le processus d'élaboration reste traçable. Par conséquent, le modèle 3D issu du processus analytique propose seulement une ou plusieurs hypothèses ; plutôt que de prétendre se substituer à une réalité potentielle ou disparue, il se contente de relater un état de connaissance sur un projet dans un contexte particulier, et sur base de sources précises et identifiables.

12 Nous proposons également de définir un objet graphique comme étant une figure d'un espace graphique, reprenant intégralement les caractéristiques de ce dernier. 
Cette démarche de confrontation des sources peut être observée dans l'analyse menée sur la Maison Canneel : les plans des différents niveaux sont ceux d'un avant-projet datant de 1929. Ils ne correspondent pas parfaitement entre eux lorsqu'on les superpose, et ne permettent pas réellement de reconstituer précisément les détails complexes et l'enchevêtrement spatial généré par la double circulation verticale et les courbes de la cage d'escalier, objet dominant et structurant dans la composition de la maison. Mis à part son registre formel extravagant, cette cage d'escalier se réfère à une typologie de circulation verticale et à un mode d'organisation du plan typiquement bruxellois, adapté à des parcelles étroites et profondes qui caractérisent le tissus urbain de la capitale belge. Bien que peu d'escaliers de projets de Le Corbusier semblent avoir une telle complexité formelle, certains projets sont clairement liés au projet Canneel; notons par exemple la double cage d'escalier de la Maison Cook à Boulogne-Billancourt (1926), le simple escalier de la Villa Stein-de Monzie (1927), et le pan de verre d'entrée de la villa Savoye (1929), dont le projet était à ce moment en cours. Plusieurs investigations dans divers espaces graphiques seront entrepris pour comprendre cet élément d'articulation de la Maison Canneel (2). Il en résultera un modèle $3 \mathrm{D}$ hypothétique qui se distance légèrement des sources originales, mais qui est tectoniquement cohérent.

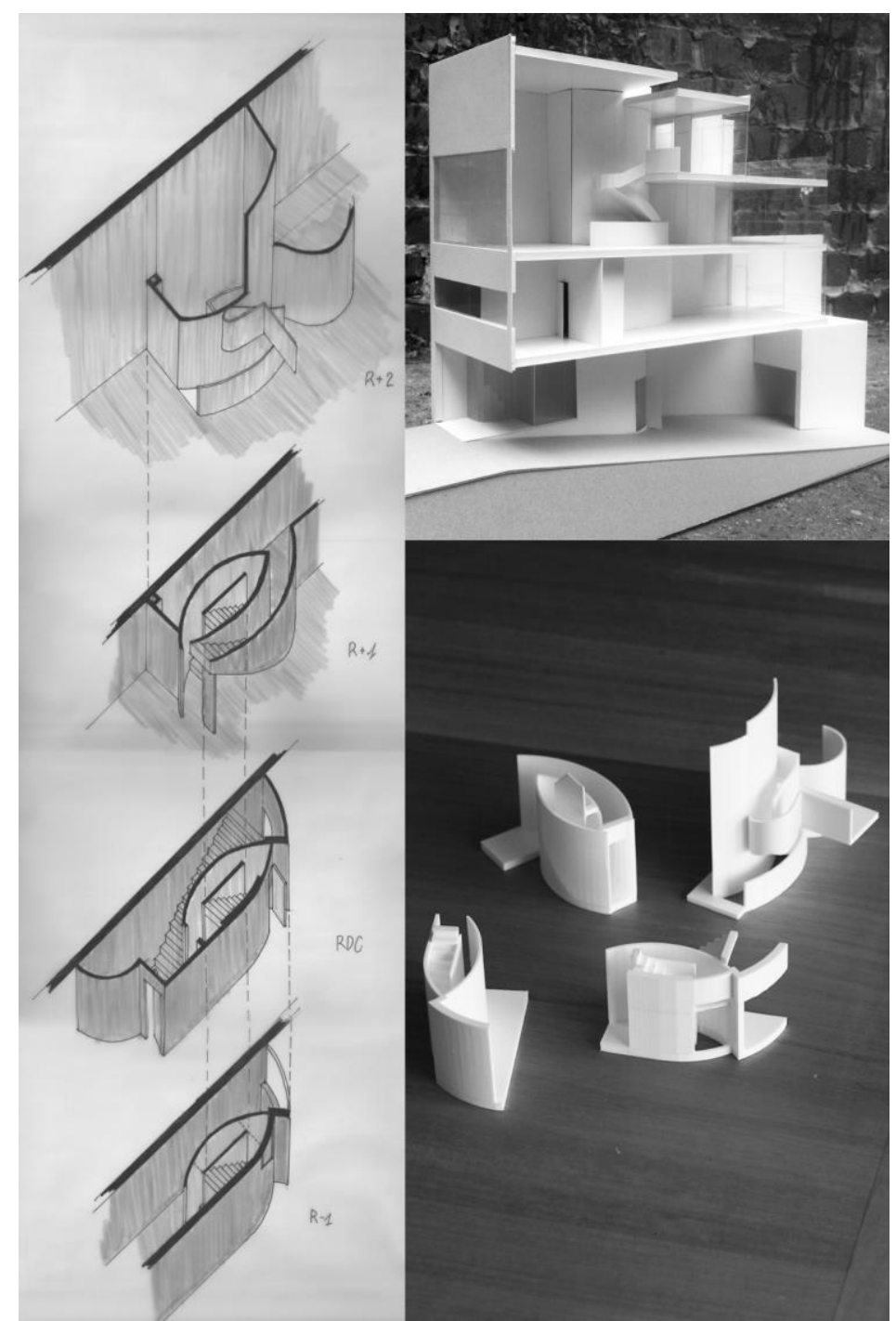

2. Maison Canneel (1929). Documents d'analyse graphique : maquette d'étude en carton et décomposition analytique de la cage d'escalier par l'axonométrie et l'impression 3D. 
Les archives relatives au Pavillon de l'Exposition de l'eau (1937) sont elles aussi très parcellaires et issues de versions du projet qui présentent des variations formelles et structurelles assez importantes. Les références bibliographiques sont également restreintes, le projet ayant fait l'objet de peu d'études. Il est donc nécessaire de comprendre l'approche de Le Corbusier dans d'autres projets de pavillons précédents, comme le Pavillon Nestlé (1928), contemporains comme le Pavillon des Temps Nouveaux (1937), ou ultérieurs comme le Pavillon de Zurich (1963), qui semble dériver directement du projet du Pavillon de l'eau ${ }^{13}$. Le modèle 3D résultant du processus analytique est hautement hypothétique et se contente d'évoquer les grands principes du projet, et seulement quelques détails de diverses versions de la structure avec un degré de certitude très relatif. Mais l'hypothèse inclut néanmoins une dimension exploratoire qui permet de suggérer l'univers spatial qu'aurait engendré le projet (3).

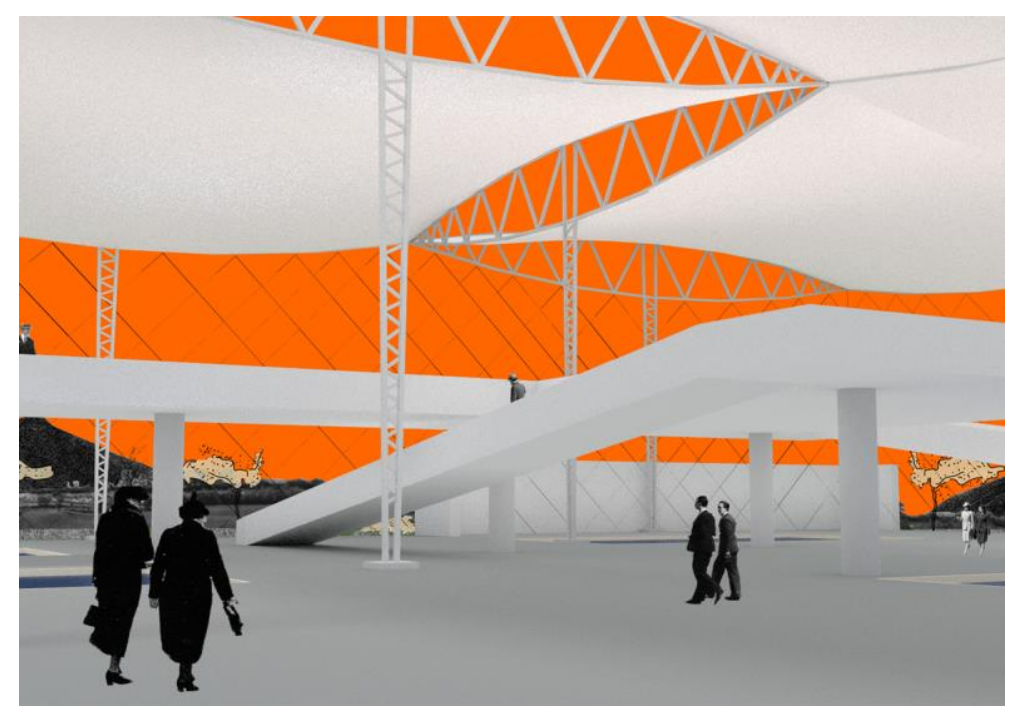

3. Pavillon de l'Exposition de l'eau (1939). Hypothèse de restitution de la spatialité intérieure du projet.

La Maison Guiette (1926) est le seul projet de Le Corbusier subsistant encore actuellement sur le sol belge, mais le bâtiment a subi des transformations importantes ainsi qu'une rénovation. Les étudiants se sont intéressés à l'intérieur de la maison tel qu'il est présenté dans une série de photographies datant approximativement de 1940, et ont tenté de restituer le projet tel qu'il était alors, avec la mise en couleurs des murs et le mobilier d'époque. Dans ce cas-ci, le bâtiment lui-même est source d'informations. L'hypothèse de restitution envisagée ici propose donc de confronter l'état actuel de la maison aux quelques photos dites officielles de Le Corbusier, devenues des vues canoniques, ainsi qu'aux photographies de famille réalisées par le peintre René Guiette lui-même. Bien que toutes ces photographies soient en noir et blanc, elles nous livrent des indications sur la manière dont la maison était vécue, sur l'ameublement, et sur les choix de tableaux exposés sur les murs dont Guiette était l'auteur. Dans l'étude de couleurs, la restitution des œuvres de ce peintre dans l'espace couleur corbuséen ${ }^{14}$ nous offre également des indications sur le choix de tableaux par rapport aux murs neutres et non-neutres. Le fait que

13 Dumont d'Ayot, Catherine; Benton, Tim: Le pavillon de Le Corbusier pour Zurich : modèles et prototype d'un espace d'exposition idéal. Zurich: Lars Müller Publishers, 2013.

14 En ce qui concerne la relation entre l'espace et les couleurs corbuséennes en tant que réceptacle d'une collection d'art, un parallèle peut être établi avec la Villa La Roche. La même année que la réception de la Maison Guiette a lieu la réception de la Villa La Roche. A cette occasion, Raoul La Roche note : "Je vous avais commandé un « cadre pour ma collection". Vous me fournissez un «poème en murs ». Qui de nous deux a été le plus fautif ?” (FLC, doc 506 bis, 24 mai 1926). 
l'artiste soit lui même intervenu dans le choix des couleurs effectué par Le Corbusier donne de bonnes indications sur la manière dont le peintre envisageait les teintes de sa maison en concordance avec son travail ${ }^{15}$. Les informations issues du bâtiment lui-même, celles issues des diverses photographies, ainsi que les études relatives aux couleurs des espaces corbuséens sont confrontées dans un même modèle 3D. Le document graphique ainsi obtenu propose une hypothèse de restitution en images de synthèse qui permet de se déplacer dans l'espace tel qu'il était supposé être aménagé à l'époque, en partant des points de vue identiques à ceux des photographies iconiques de 1940 (4 et 5).

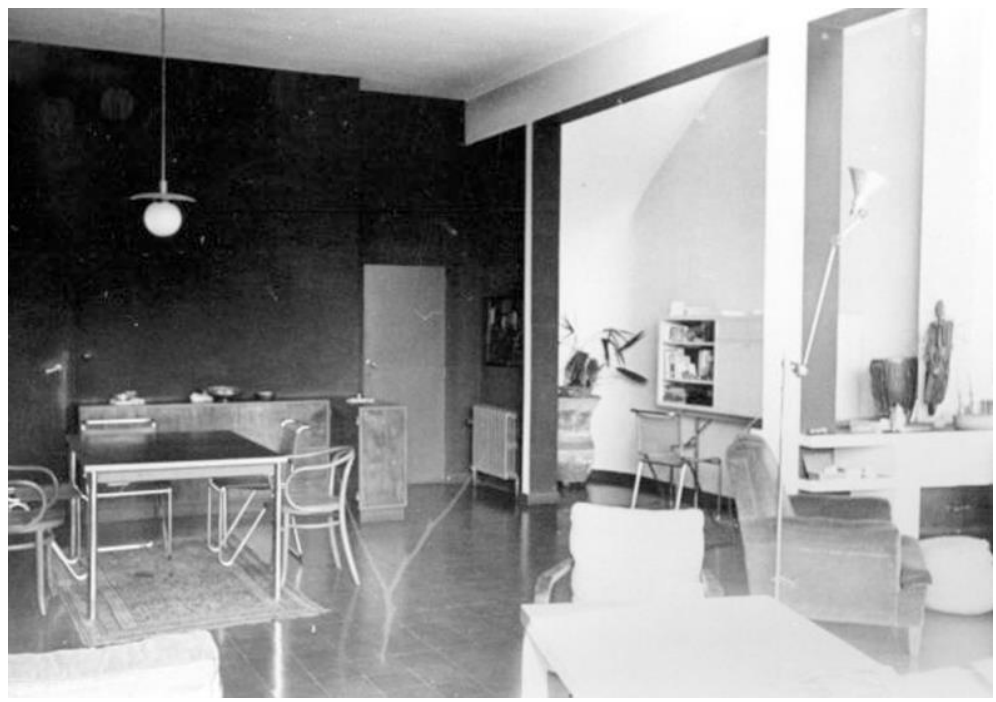

4. Maison Guiette (1926). Vue de la salle à manger vers 1940.

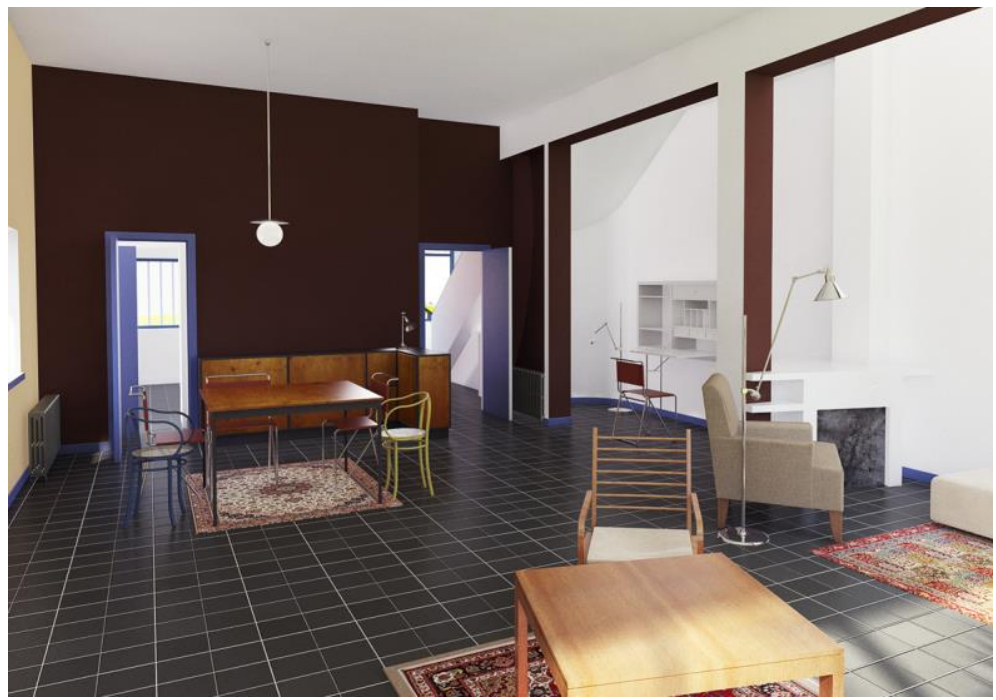

5. Maison Guiette (1926). Hypothèse de restitution colorisée de l'espace de la salle à manger aux alentours de 1940.

15 De Kerckhove d'Ousselghem, Manoela; Goyens de Heusch, Serge: René Guiette. Antwerpen: Mercatorfonds, 1991. ; Schraenen, Guy: Les Peupliers. Maison Guiette = Huis Guiette, op. cit. ; De Heer, Jan: The Architectonic Colour: Polychromy in the Purist Architecture, op. cit. 


\section{Analyse architecturale par hybridation des techniques graphiques}

La compréhension analytique et critique du contexte historique, théorique, social et politique est une composante fondamentale pour la connaissance d'un bâtiment, ainsi que pour charpenter le propos d'un court-métrage architectural. Néanmoins, cette problématique ne sera pas abordée ici, ce type d'étude ne procédant pas par les moyens graphiques qui sont le sujet du présent article. La conception architecturale quant à elle, s'élabore bel et bien par les moyens graphiques. Comme l'a remarqué Robin Evans, l'architecte ne manipule l'objet de sa création que par l'intermédiaire de représentations graphiques, à l'inverse des peintres et des sculpteurs qui sont en contact direct avec l'objet de leur création ${ }^{16}$. Ceci confère aux techniques graphiques un énorme potentiel génératif. Lors du processus de conception, les informations voyagent d'un document à l'autre en s'adaptant à diverses techniques de représentation. Lors de ces transferts successifs, des éléments s'évanouissent et d'autres apparaissent, ce qui a pour conséquence de faire évoluer l'objet architectural traité ${ }^{17}$. L'évolution du processus de conception architecturale par les moyens graphiques, la transformation du propos par le dialogue entre les artefacts médiateurs, peuvent également être pris en compte lors du processus d'analyse formelle d'un bâtiment. En effet, tant la conception que l'analyse visent à établir un discours architectural par une décomposition et une recomposition successives des formes, et ce dans le but de manipuler la géométrie dans des espaces graphiques abstraits. Dès lors, l'analyse peut être comprise comme une forme de rétro-conception, qui opère par un dialogue de moyens de représentation similaires à ceux de la conception ${ }^{18}$, et pour laquelle l'usage de techniques graphiques variées relève de la même capacité générative que celle décrite par Evans. L'analyse par les moyens graphiques se focalise donc sur les aspects formels, spatiaux et tectoniques. Pour investiguer tel ou tel autre aspect de l'objet architectural, il s'agit d'utiliser chaque média, traditionnel ou numérique, chaque mode de projection canonique, en fonction de ses spécificités. Ensuite, il convient de faire dialoguer entre eux les objets graphiques hétérogènes ainsi obtenus. Les informations contenues dans un document d'un type de média particulier vont soulever de nouvelles questions lorsque l'on décide de les transposer dans un autre média, et ainsi de suite ${ }^{19}$. Lors du passage d'un média bidimensionnel à un média tridimensionnel, certaines informations apparaissent - ou doivent être inventées pour assurer la cohérence visuelle et géométrique de l'ensemble (voir le point 3 du présent texte) - ce qui a pour conséquence d'enrichir la connaissance géométrique de l'objet étudié. A l'inverse, lors du passage d'un média tridimensionnel à un média bidimensionnel, certaines informations sont perdues, mais à l'avantage d'une plus grande clarté de lecture d'un concept particulier ${ }^{20}$. Finalement, la construction générale du court-métrage fait également appel aux techniques graphiques : le storyboard est un document de synthèse sujet à de nombreuses modifications. Il reprend des schémas simplifiés des vues mises au point dans le processus analytique, les articule entre elles et les combine aux autres médias qui composeront le

16 Evans, Robin: “Translations from Drawing to Building”. En Translations from Drawing to Building and Other Essays. London: Architectural Association Publications, 1997. p.156.

17 Ce caractère sériel inhérent à la représentation architecturale - aussi appelé propriété de secondarité - a également été étudié par Philippe Boudon et Frédéric Pousin dans Boudon, Philippe; Pousin, Frédéric: Figures de la conception architecturale: manuel de figuration graphique. Paris: Editions Dunod, 1988.

18 A propos de la dimension active et exploratoire de l'analyse architecturale par les moyens graphiques, voir Jenkins, Eric J: Drawn to Design. Analysing Architecture Through Freehand Drawing. Basel: Birkhäuser, 2013.

19 Les enjeux méthodologiques d'une telle approche sont développés plus exhaustivement dans Derycke, Denis; Lo Buglio, David: "Education in Architectural Analysis through Hybrid Graphical Means: A Setup for Critical Thinking". En Design \& Graphic Palimpsest. Atlanta GA: Southern Polytechnic State University, 2014. pp. 306-12.

20 En réaction à la trop grande densité d'informations simultanées imposée par les modèles 3D numériques, Joël Sakarovitch souligne la capacité d'énonciation des modes projectifs traditionnels : "parfois en dire peu c'est en dire beaucoup". Dans Sakarovitch, Joël: Épures d'architecture: de la coupe des pierres à la géométrie descriptive XVIe-XIXe siècles. Basel: Birkhäuser, 1998. 
film. Il rassemble un maximum d'informations pour anticiper la création du film, permet de rendre le processus traçable et aussi d'identifier les sources (6).

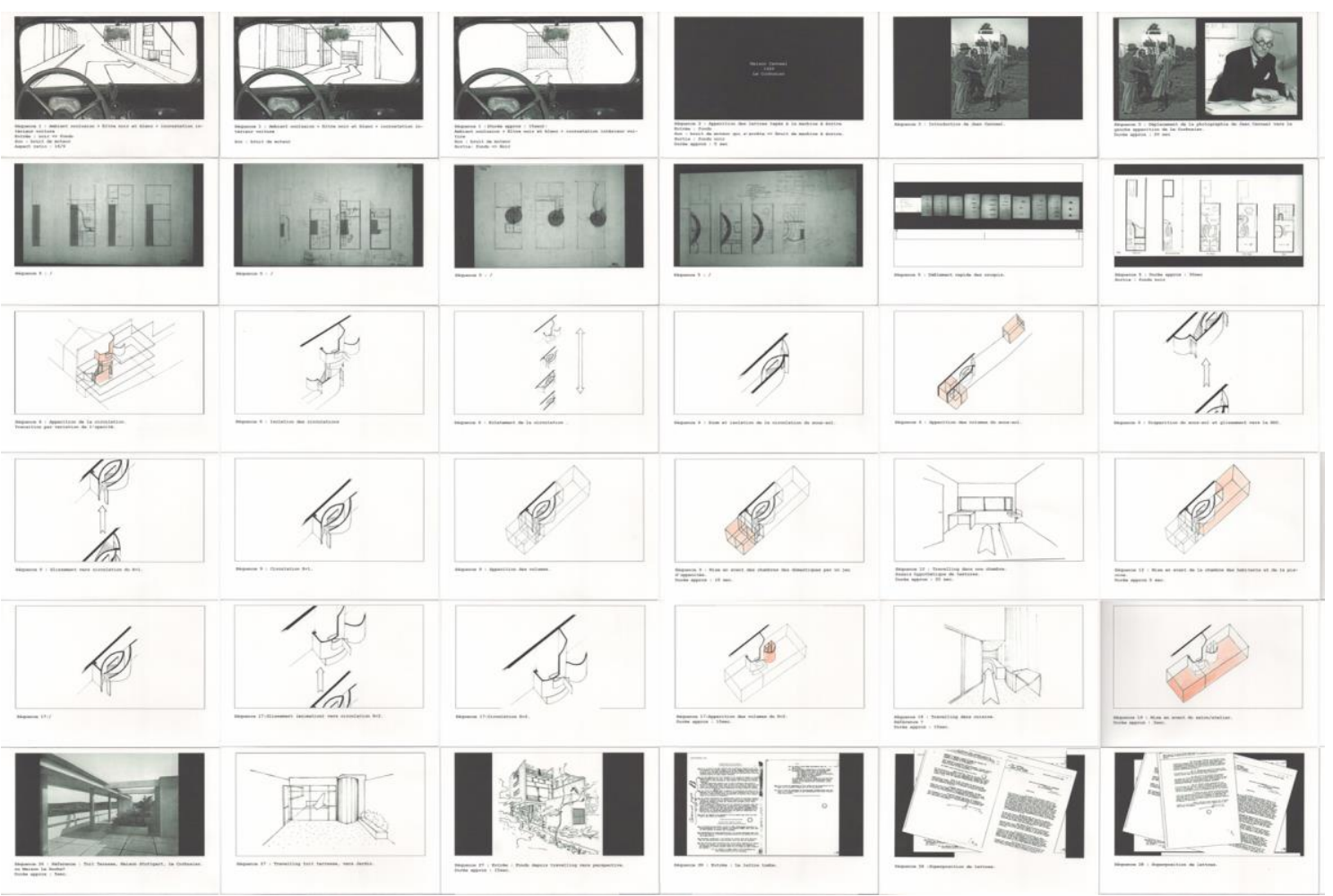

6. Maison Canneel (1929). Transcription du propos analytique dans un storyboard anticipant la création d'un court-métrage.

Si les techniques graphiques ont une influence évidente sur les concepts architecturaux manipulés, cette influence peut parfois devenir problématique lors de l'utilisation de logiciels sophistiqués dédiés à la conception architecturale. En effet, ces logiciels dits «métier» “contiennent une théorie implicite de la conception, jamais d'ailleurs explicitée ${ }^{, 21}$. Pour profiter des apports des logiciels 3D tout en conservant une réflexion architecturale relativement autonome, les études par modélisations 3D sont systématiquement effectuées sur des programmes indépendants du domaine de l'architecture, comme par exemple le logiciel open source Blender $^{22}$.

L'apport de connaissances d'une analyse par hybridation des techniques graphiques apparait de manière assez évidente dans le travail effectué sur la Maison Canneel. L'investigation commence par une compréhension rapide de l'objet et de sa volumétrie par une maquette d'étude en carton à a $1 / 50^{\text {ème }}$ (2). La maquette permet de dégrossir rapidement la composition et les articulations formelles globales, tout en évitant certaines questions géométriques trop précises face auxquelles le modèle 3D force à se positionner. Parallèlement, des croquis axonométriques décomposent et analysent l'élément complexe caractérisant le projet : la cage d'escalier (2). Le travail est ensuite affiné par la modélisation 3D qui permet, dans un second temps, un travail plus précis et plus détaillé que les médias traditionnels, ainsi que la possibilité de tester facilement des variantes sur certaines hypothèses. Pour chaque niveau, les éléments de la cage d'escalier sont extraits du modèle 3D de manière à

21 Michel Léglise se basant sur une étude de Ronald Hamel dans Léglise, Michel: “Ordinateurs dans l'apprentissage de la conception : mental et instrumental”. En Computerised Craftsmanship. Paris: eCAADe Conference Proceedings, 1998. p.139.

22 http://www.blender.org/ (consulté le 07 juin 2015). 
correspondre à ceux étudiés dans les croquis axonométriques, puis imprimés en 3D, étage par étage, et enfin assemblés (2). Revenir du modèle 3D ou des modes projectifs traditionnels vers les moyens de représentation tactiles permet une compréhension plus approfondie de certains éléments que les modes projectifs ne suffisent pas toujours à décrire clairement et efficacement. L'impression 3D s'avère particulièrement appropriée dans ce genre de démarche. Cette représentation de la cage d'escalier de la Maison Canneel, ainsi extraite de son contexte, prend une dimension sculpturale et constitue un regard analytique, didactique, mais aussi interprétatif de l'oeuvre. De la même manière que les axonométries plafonnantes d'Auguste Choisy créaient un univers fictionnel éloigné de l'objet auquel elles se référaient ${ }^{23}$, l'objet-sculpture résultant de l'impression en 3D de la cage d'escalier «raconte » la maison Canneel d'une autre manière. Partant d'une base analytique et objective, l'objet ne montre plus directement le projet mais évoque plutôt la richesse du registre formel de Le Corbusier (7).

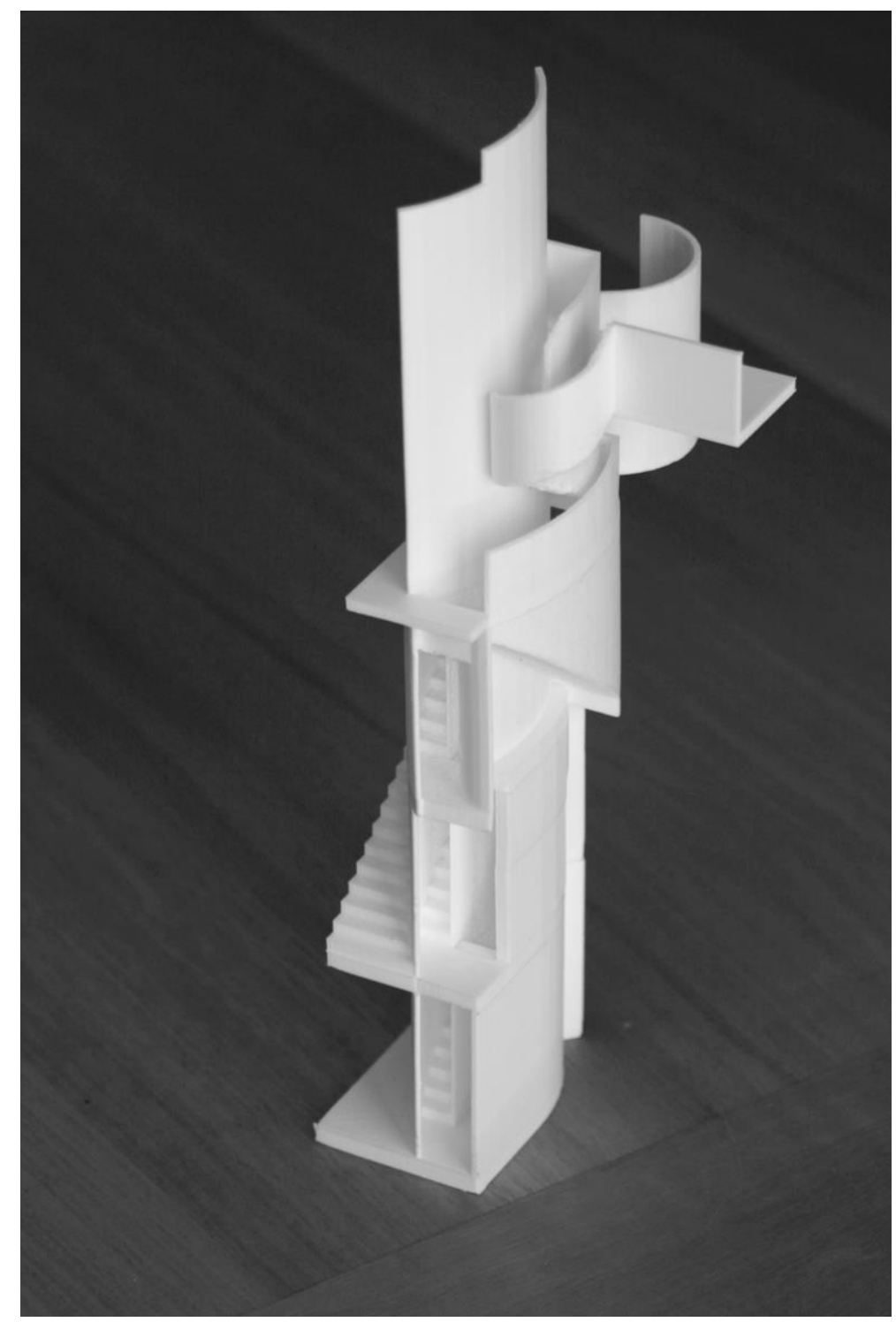

7. Maison Canneel (1929). Analyse et hypothèse de restitution de la cage d'escalier par l'impression 3D.

23 Mandoul, Thierry: “Une histoire dessinée". En Entre raison et utopie. L'Histoire de l'Architecture d'Auguste Choisy. Wavre: Mardaga Editions, 2008. pp. 111-162. 


\section{Choix de représentation graphique et qualification des hypothèses}

Comme expliqué précédemment, un choix pertinent des moyens de représentation graphique permet d'appuyer le processus analytique et exploratoire d'un bâtiment. Cette compréhension de la représentation architecturale se poursuit dans la manière d'exprimer les concepts analysés en vue de la production des images du court-métrage. Le niveau de détail, l'échelle, la couleur, le mode projectif, l'univers graphique, etc., participent à l'élaboration du message. Malgré l'extraordinaire diversification récente des moyens d'expression à la disposition des architectes, la compréhension des codes de la représentation en vigueur depuis des siècles reste un canevas de référence incontournable. Par exemple, il est important de transposer dans le média numérique 3D une différence cognitive de base que l'utilisation des programmes a tendance à masquer : la perspective informe sur ce que l'on perçoit d'un objet et l'axonométrie nous informe sur ce que l'on sait d'un objet ${ }^{24}$. Parce qu'elle évacue la question de l'observateur incarné, l'axonométrie est appropriée pour une expression analytique et décontextualisée de l'objet. La perspective conique, qui cherche l'osmose avec la perception visuelle, convient bien pour proposer des hypothèses de la perception spatiale que pouvait avoir un observateur se déplaçant dans l'espace intérieur ou extérieur du bâtiment étudié. Les choix de représentation qualifient également le niveau de certitude qu l'on peut avoir par rapport aux hypothèses de restitution que l'on propose. Les modèles 3D et l'image de synthèse contemporains permettent d'obtenir des rendus photoréalistes qui peuvent donner l'illusion d'une expérience spatiale vécue d'un projet, la différence entre des images filmées et des images numériques devenant presque impossible à établir. Si ce mode de rendu peut s'avérer approprié dans certains cas, il peut également créer des ambiguïtés, notamment lorsque le niveau de connaissances sur l'objet étudié ne permet pas de créer le substitut de réalité devenu accessible à l'aide des images de synthèse actuelles. Dès lors, des modes de représentation plus symboliques sont appropriés, utilisant à bon escient les codes de la représentation architecturale, puisant dans des registres expressifs variés, et cherchant plus à évoquer un univers possible qu'à se substituer à une réalité par trop hypothétique. Comme le rappelle Antoine Picon, "le projet n'est jamais une configuration fermée"25, et ajoutant ensuite: "le dessin d'architecture a toujours été au moins autant destiné à évoquer un espace de possibles que voué à la fixation de la morphologie du projet ${ }^{\text {"26 }}$. Ceci se vérifie lorsqu'on s'intéresse à des projets dont l'existence se cantonne à quelques planches dans un fond d'archives. Dans ce cas, des telles considérations doivent guider tant la compréhension que l'on peut avoir des dessins que l'on observe que l'élaboration des représentations que l'on produit pour exprimer ces observations. En laissant une place pleinement assumée à une interprétation qui est clairement comprise comme telle, la dimension exploratoire des nouvelles représentations permettent de faire émerger un nouveau questionnement. Le degré de certitude des informations présentées est accessible une fois que l'on confronte les représentations produites aux diverses sources que ces représentations tentent de rassembler au sein d'un même objet graphique.

24 Schneider, Bernhard: "Perspective Refers to the Viewer, Axonometry Refers to the Object". En Drawing as Medium of Abstraction. Daidalos - Berlin Architectural Journal, September 1981, №1. Berlin: Wilhem Krümpelmann, 1981. pp. 81-95. 25 Picon, Antoine: “Architecture et mémoire numérique”. En Archigraphy. Paris: Infolio, 2007. p.61.

26 Id. 
La Maison Canneel, restée au stade de l'avant-projet, soulève des questions de représentation intéressantes lorsqu'il s'agit d'en exprimer une hypothèse de restitution par l'image numérique 3D. Deux dessins originaux de Le Corbusier, l'un du rez-de-chaussée de la façade avant et l'autre présentant le bâtiment tel que vu depuis l'intérieur de lî̂lot, ont été réinterprétés lors de la réalisation du court-métrage sur ce projet. Le premier apport de l'image numérique est de donner une matérialité plus consistante à l'objet étudié par la simulation de la lumière sur les volumes puristes de la maison. Ensuite, le projet est situé à l'endroit où il était supposé voir le jour, et entouré d'un environnement bâti schématique, tel qu'il pouvait être aux alentours de 1940. Les informations disponibles ne permettant pas d'aller beaucoup plus loin dans l'hypothèse, l'environnement végétal dessiné par Le Corbusier est extrait des dessins et transposé tel quel dans le modèle 3D. Cette démarche vise à souligner le statut intermédiaire de ces images : un supplément de connaissance est apporté à l'objet tel qu'il se trouve décrit dans les archives, tout en manifestant le statut hypothétique des propositions, et en ne se détachant que partiellement des vues originales (8 à 11).

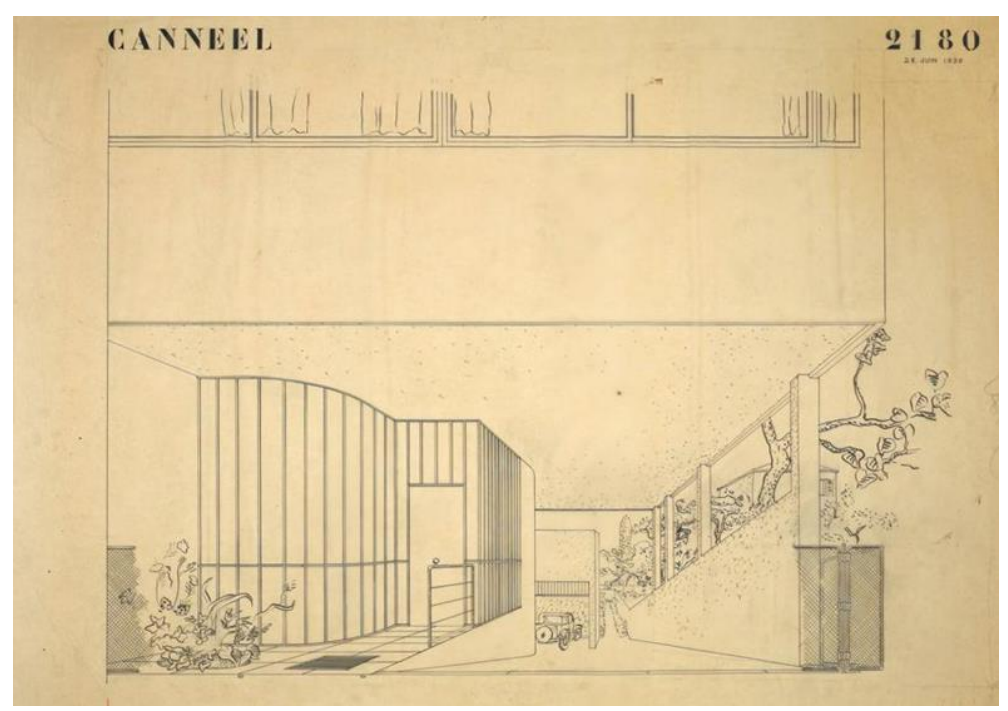

8. Maison Canneel (1929). Perspective de l'entrée et du rez-de-chaussée.

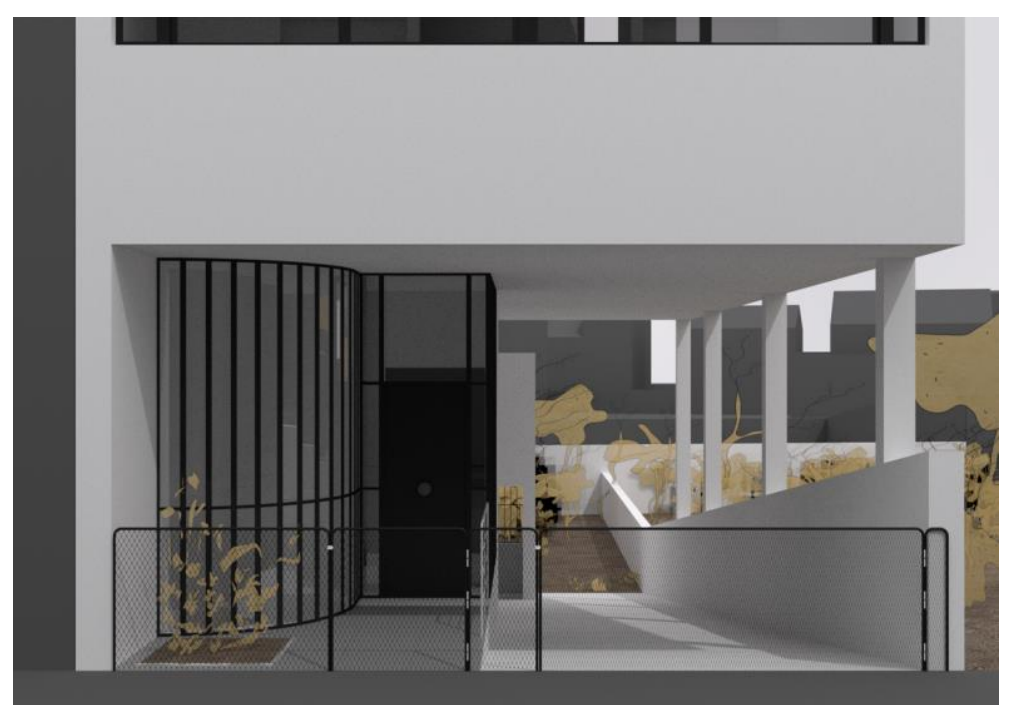

9. Maison Canneel (1929). Hypothèse de restitution de la perspective de l'entrée et du rez-de-chaussée. 


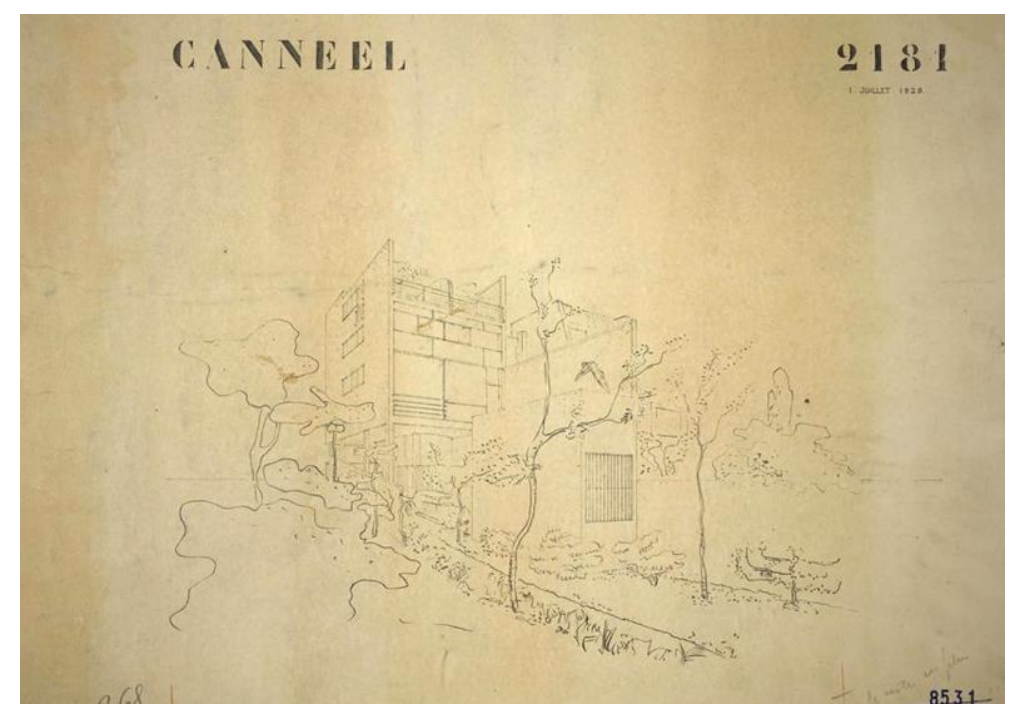

10. Maison Canneel (1929). Perspective de la maison depuis l'intérieur de l'îlot.

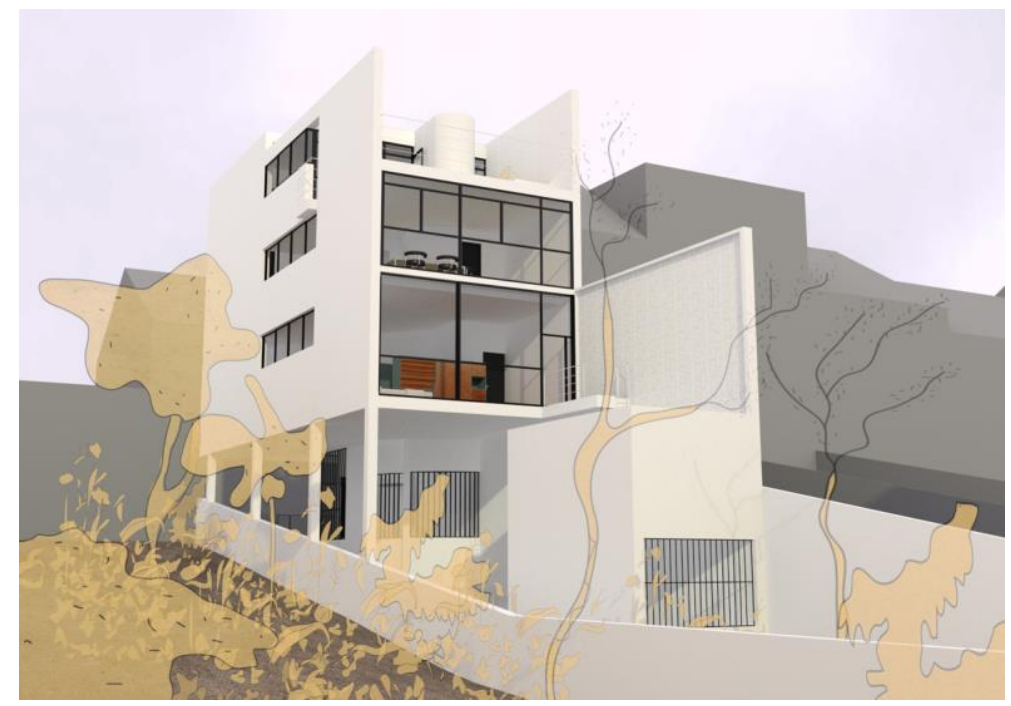

11. Maison Canneel (1929). Hypothèse de restitution de la perspective de la maison depuis l'intérieur de l'îlot.

Pour le dessin représentant la vue du salon et la cage d'escalier sculpturale, la démarche est similaire, tout en s'autorisant une légère incursion dans le domaine du réalisme. Les archives ne contiennent aucune indication concernant les matériaux de sol, les finitions et les couleurs des murs, sujet pourtant très important dans le travail de l'architecte à cette époque. Sur base du travail de Jan de $\mathrm{Heer}^{27}$, une hypothèse de mise en couleurs est alors proposée (1), et signalée comme telle dans le film. Dans le dessin original (12) apparaissent par contre des éléments de mobilier dessinés par Le Corbusier et Charlotte Perriand. Ces meubles sont modélisés en 3D et replacés dans l'espace aux mêmes endroits que sur les croquis. L'image numérique résultante donne à l'espace une impression de matérialité plus importante, mais son faible niveau de détail général la met hors de toute ambiguïté. Ces trois dessins de Le Corbusier, une fois réinterprétés en images numériques, servent de point de départ à trois travellings qui permettent de profiter pleinement de la spatialité proposée par l'hypothèse de restitution.

27 De Heer, Jan: The Architectonic Colour: Polychromy in the Purist Architecture, op. cit. 


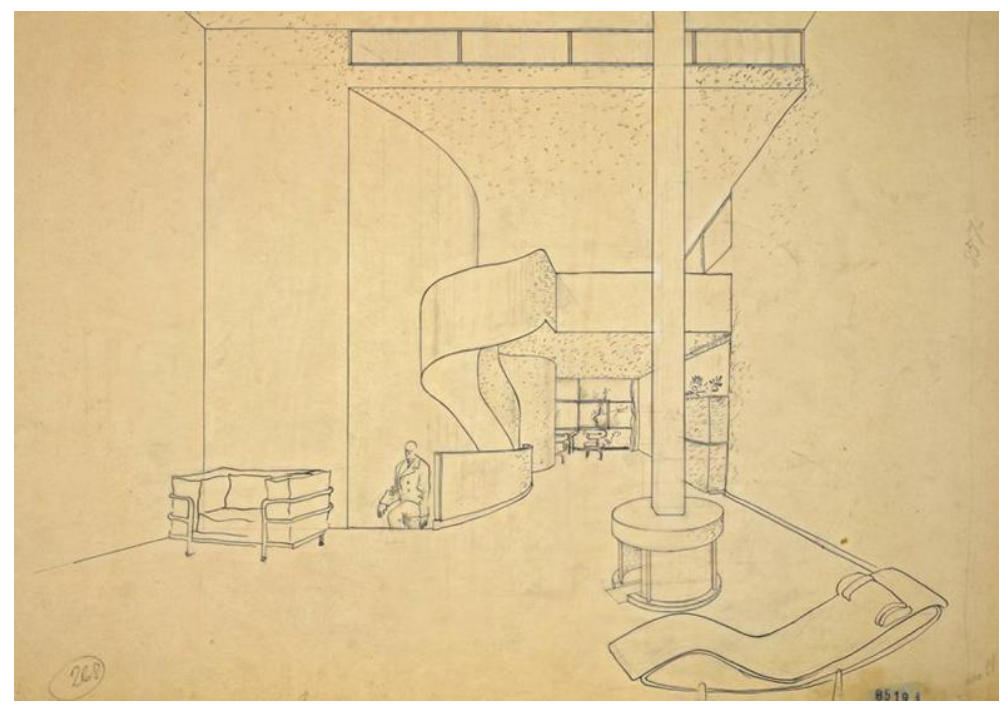

12. Maison Canneel (1929). Vue du salon et de la cage d'escalier.

A l'inverse, la richesse et la certitude des informations disponibles sur la Maison Guiette autorisent un mode d'expression beaucoup plus réaliste de l'hypothèse de restitution des couleurs et de l'aménagement mobilier aux alentours de 1940. Comme exposé précédemment dans cet article, la démarche de regroupement des informations au sein du modèle 3D tend vers un degré de certitude élevé. L'espace de la maison trouve alors son expression dans une simulation d'images numériques photo-réaliste, qui, une fois animées, permettent de profiter pleinement de la spatialité engendrée par l'hypothèse proposée (5).

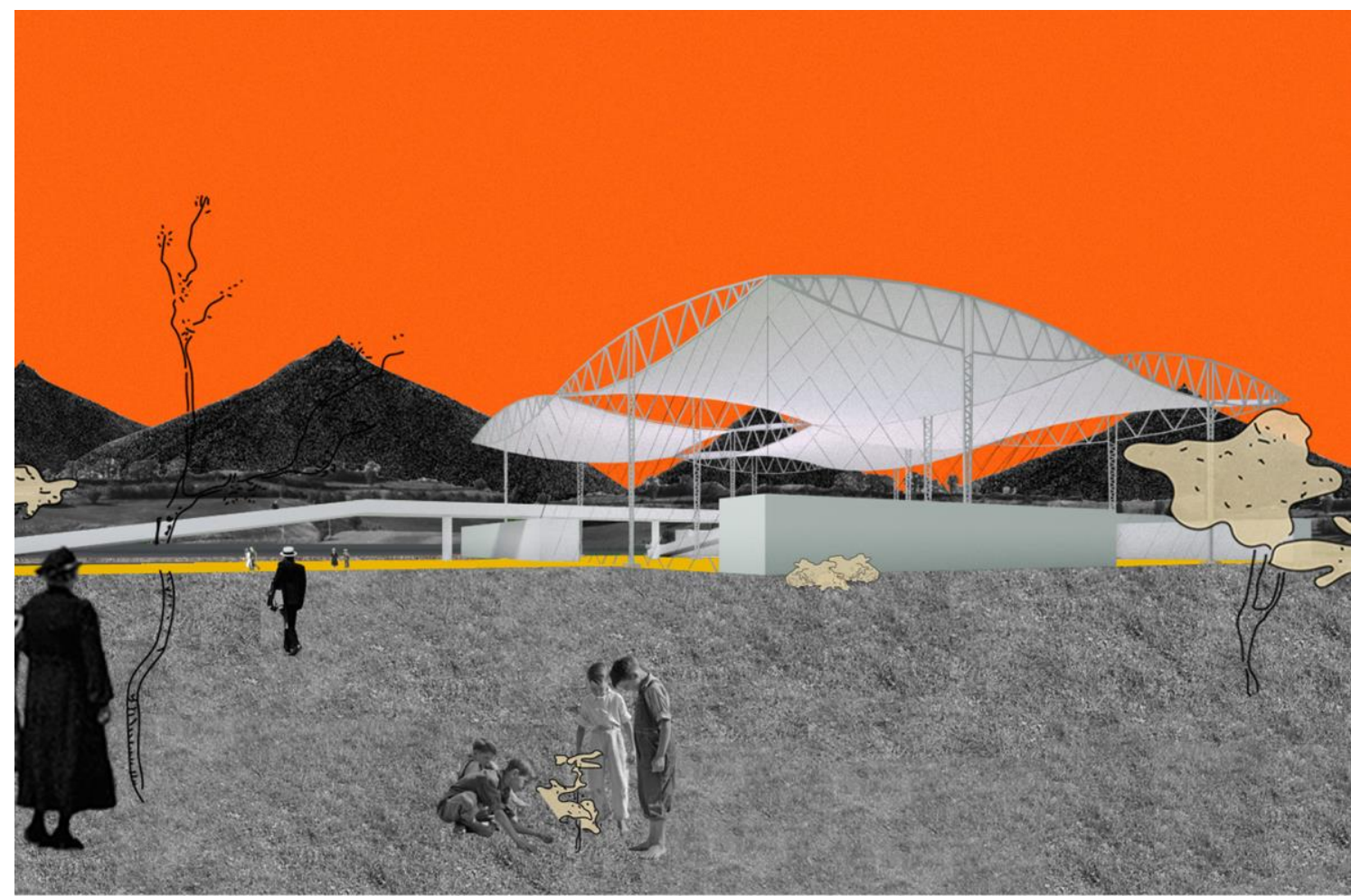

13. Pavillon de l'Exposition de l'eau (1939). Hypothèse de restitution d'une vue extérieure du projet.

Le peu d'informations disponibles ainsi que les diverses versions du projet Pavillon de l'Exposition de l'eau ont également déjà été abordées dans ce texte. Le modèle 3D regroupant les informations sur le projet, bien que très hypothétique, doit néanmoins trouver une manière d'être représenté en ne laissant aucune ambiguïté par rapport 
au niveau de connaissances que l'on a du projet. Un travail a donc été effectué sur une forme de représentation faisant la part belle au lyrisme et à l'aspect symbolique de la représentation architecturale. L'univers graphique coloré issus des dessins de l'architecte moderniste belge Renaat Braem (1910-2001) a servi de source d'inspiration pour suggérer les grands principes du projet et lui conférer une certaine matérialité, tout en restant résolument évasif et imprécis (13).

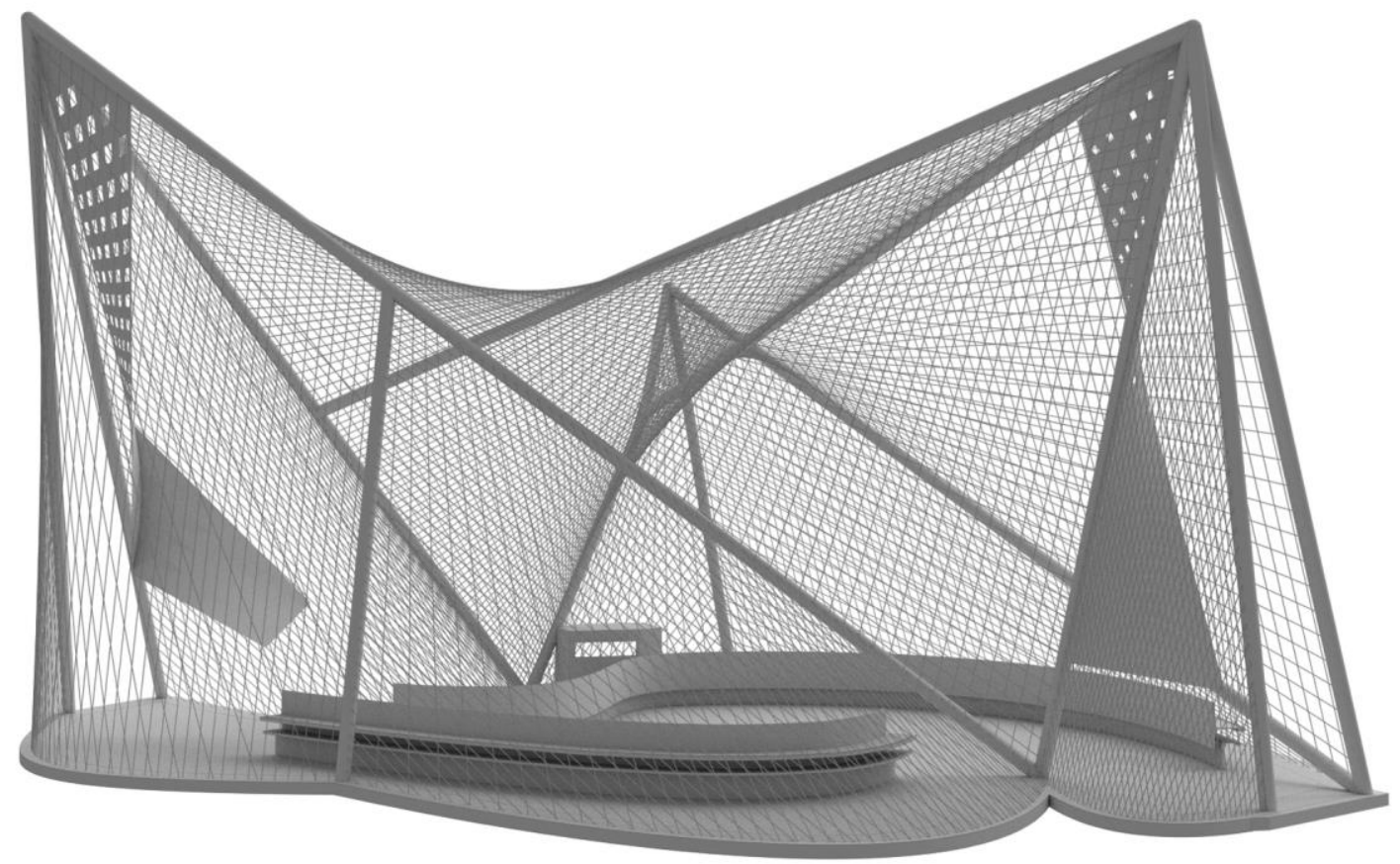

14. Pavillon Philips (1958). Hypothèse de restitution, développement didactique des principes structurels.

Le Pavillon Philips a déjà fait l'objet de plusieurs études - certaines très récentes ${ }^{28}$ - dont plusieurs travaux de modélisation 3D et de restitution par images de synthèse, notamment en ce qui concerne l'expérience sensorielle complète du Poème électronique qui était projeté à l'intérieur (Le projet VEP). Le travail des étudiants sur l'hypothèse de restitution 3D du pavillon Philips ne cherche donc pas à concurrencer des réalisations déjà très abouties, mais vise plutôt à proposer un document de synthèse, explicatif et didactique, depuis la commande du pavillon jusqu'à sa destruction, en passant par les divers épisodes de sa conception. En mêlant images d'archives et maquette 3D numérique, le court-métrage tend à décoder les différents composants de cet objet complexe, des poutres à la coque en béton avec les armatures extérieures, en utilisant avantageusement le modèle numérique pour rendre explicite la construction et le fonctionnement particulier de cet édifice. Le Poème électronique est aussi évoqué. Une reconstitution en est proposée, mais qui ne prétend nullement à l'exactitude précédemment atteinte. A la place, par une succession lancinante de points de vue grand angle depuis des endroits inaccessibles, le film propose une visite extatique et rêveuse du Poème. Afin de garder le propos clair et simple, le processus analytique du film utilise un mode d'expression qui renvoie à la maquette de concept : un objet dépourvu de détails reçoit une lumière neutre au milieu d'un contexte immaculé (14). Par contre, le court-métrage propose un

28 Wever, Peter: Inside Le Corbusier's Philips Pavilion. A Multimedial Space at the 1958 Brussels World's Fair. Rotterdam : Nai010 Publishers, 2015. 
rendu plus réaliste de la peinture métallisée recouvrant l'extérieur de la coque en béton, l'extérieur du pavillon ayant été traité de manière plus simple dans les reconstitutions 3D existantes.

\section{Conclusion}

Comme nous l'avons exposé, notre laboratoire encourage une réflexion sur les moyens de représentation numériques dans un contexte analytique plutôt que dans un contexte de conception, pour la simple raison que l'analyse architecturale peut être considérée comme une forme de rétro-conception, mais vierge - dans une certaine mesure - d'idéologies architecturales. Il est dès lors possible de se focaliser uniquement sur l'objet à étudier, sur les intermédiaires graphiques qui permettent sa manipulation, de comprendre les codes intrinsèques de la représentation graphique, et d'ensuite imaginer comment transposer ces derniers dans le média numérique animé. Dans le cas de l'étude de l'oeuvre belge de Le Corbusier, la plus-value apportée par ce type de travaux est d'ordres divers. Dans le cas de projet non-réalisés et relativement peu documentés comme le Pavillon de l'Exposition de l'eau ou la Maison Canneel, les documents graphiques produits ont un statut hypothétique et exploratoire qui leur confère une certaine singularité : plutôt qu'une représentation exacte du projet, ils sont plutôt un regard ou une interprétation, qui relève plus d'un état de connaissances sur le projet dans un contexte particulier, que de l'énonciation illusoire d'une vérité absolue. Dans le cas du Pavillon Philips ou de la Maison Canneel, l'apport concerne également la mise en évidence explicite de questions compositionnelles ou constructives complexes. La contribution à la connaissance sur la Maison Guiette est plus ténue étant donné la documentation déjà abondante sur le bâtiment. Le travail cherche dès lors à explorer des questions de détail en exploitant la richesse des ouvrages et des archives existantes. Dans tous les cas, un des apports notables de ces restitutions par le modèle 3D et l'image numérique, c'est de proposer une expérience cinétique de la spatialité hypothétique du projet.

Pour produire le média que constitue un court-métrage analytique, il y a nécessité de produire de nombreux autres médias, de nombreux autres objets graphiques. Le film, une fois terminé, est bien plus qu'un fichier numérique animé diffusable. Il est surtout caractérisé par son processus de création qui contient bien plus de connaissances sur l'objet étudié que le document final. Ce processus est traçable car archivé et référencé. En outre, la modélisation 3D d'une architecture est indissociable d'une compréhension exhaustive de l'objet étudié. Dans un processus de modélisation, une décomposition de l'architecture est nécessairement suivie d'une recomposition, d'un encodage méthodique. Ainsi, au-delà de la géométrie, le modèle 3D devient une base de connaissances sémantiques, une nouvelle source d'étude sur l'objet qu'il représente. Si les méthodes d'élaboration passent successivement et sans apriori des méthodes traditionnelles aux médias numériques, le résultat final est lui résolument contemporain : il profite d'Internet et des réseaux sociaux ${ }^{29}$ pour diffuser le savoir architectural.

\section{Sources des images}

1, 2, 6, 7, 9, 11. AlICe (ULB), 2015. Tom Pariente, Jérémy Moreau.

3, 13. AlICe (ULB), 2015. Marine Serrette.

4. René Guiette.

5. AlICe (ULB), 2015. Quoc Anh Bach, Correntin Werrie.

$8,10,12$. Archives de la Fondation Le Corbusier, ADAGP.

14, 15. AlICe (ULB), 2015. Benoit Capel, Jonathan Van Saet, Geoffrey Minne.

29 Les productions du laboratoires sont accessibles par le site http://www.alicelab.be/ et par le réseau d'échange de contenu video Vimeo : http://www.vimeo.com/alicelab/. 


\section{Bibliographie}

Baines, Georges: "Du «système Dom-Ino » au «type Citrohan » : la maison Guiette à Anvers ", En Massilia, 2011. pp. 50-81.

Baines, Georges; Spitaels, Els: Le Corbusier te Antwerpen: De Woning Guiette. Antwerpen : Hoger Architectuurinstituut van het rijk-stad Antwerpen, 1987.

Boesiger, Willy; Storonov, Oscar: Le Corbusier et Pierre Jeanneret. Oeuvre Complète. 1910 - 1929. Zürich: Editions Girsberger, 1943.

Boudon, Philippe; Pousin, Frédéric: Figures de la conception architecturale: manuel de figuration graphique. Paris: Editions Dunod, 1988.

Burniat, Patrick (Ed.): Le Corbusier et la Belgique (Les Rencontres de la Fondation Le Corbusier). Bruxelles: CFC-Editions, 1997.

Commers, Ronald; Lombaerde, Piet: Le Corbusier en de Linkeroever te Antwerpen. Antwerpen: Hoger Architectuurinstituut van het Rijk (H.A.I.R.), 1987.

De Heer, Jan: The Architectonic Colour: Polychromy in the Purist Architecture of Le Corbusier. Rotterdam: Nai010 Publishers, 2009.

De Kerckhove d'Ousselghem, Manoela; Goyens de Heusch, Serge: René Guiette. Antwerpen: Mercatorfonds, 1991.

Derycke, Denis; Lo Buglio, David: "Education in Architectural Analysis through Hybrid Graphical Means: A Setup for Critical Thinking". En Design \& Graphic Palimpsest. Atlanta GA: Southern Polytechnic State University, 2014. pp. 306-12.

Devos, Rika: Modern at Expo 58. Discussions on post-war architectural representation. Director: Mil De Kooning. Gent Universiteit, 2008.

Dumont d'Ayot, Catherine; Benton, Tim: Le pavillon de Le Corbusier pour Zurich : modèles et prototype d'un espace d'exposition idéal. Zurich: Lars Müller Publishers, 2013.

Evans, Robin: "Translations from Drawing to Building". En Translations from Drawing to Building and Other Essays. London: Architectural Association Publications, 1997. pp. 153-193.

Jenkins, Eric J: Drawn to Design. Analysing Architecture Through Freehand Drawing. Basel: Birkhäuser, 2013.

Le Corbusier: Salubra, Claviers de couleur. Bâle, Editions Salubra, 1931.

Léglise, Michel: "Ordinateurs dans l'apprentissage de la conception : mental et instrumental”. En Computerised Craftsmanship. Paris: eCAADe Conference Proceedings, 1998. pp. 138-145.

Lombardo, Vicenzo and others: "A Virtual-Reality Reconstruction of Poème Electronique Based on Philological Research”. En Computer Music Journal. "A Virtual Poème”. Summer 2009, №2. Cambridge Ma: MIT Press, 2009. pp. 24-47.

Malliet, Anne: "Le Corbusier huis Guiette gerestaureerd". En $M \& L$. November-december 1987, №6, 1987. pp. 49-60.

Mandoul, Thierry: "Une histoire dessinée". En Entre raison et utopie. L'Histoire de l'Architecture d'Auguste Choisy. Wavre: Mardaga Editions, 2008. pp. 111-162.

Petit, Jean (Ed.): Le Poème Electronique - Le Corbusier. Paris : Editions de Minuit, 1958.

Picon, Antoine: “Architecture et mémoire numérique”. En Archigraphy. Paris: Infolio, 2007. pp. 55-63.

Prelorenzo, Claude (Ed.): La conservation de l'œuvre construite de Le Corbusier (Rencontres de la Fondation Le Corbusier). Paris : Fondation Le Corbusier, 1990. 
Prelorenzo, Claude: Le Corbusier et la couleur (Rencontres de la Fondation Le Corbusier). Paris: Fondation Le Corbusier, 1992.

Sakarovitch, Joël: Épures d'architecture: de la coupe des pierres à la géométrie descriptive XVIe-XIXe siècles. Basel: Birkhäuser, 1998.

Schneider, Bernhard: "Perspective Refers to the Viewer, Axonometry Refers to the Object". En Drawing as Medium of Abstraction. Daidalos - Berlin Architectural Journal, September 1981, Nº1. Berlin: Wilhem Krümpelmann, 1981. pp. 81-95.

Schraenen, Guy: Les Peupliers. Maison Guiette = Huis Guiette. Le Corbusier 1926. Brussel : Sint-Lukasarchief, 1987.

Sterken, Sven: Iannis Xenakis, ingénieur et architecte. Director: Bart Verschaefel. Gent Universiteit, 2004.

Treib, Marc: Space calculated in seconds. New Jersey : Princeton University Press, 1996.

Wever, Peter: Inside Le Corbusier's Philips Pavilion. A Multimedial Space at the 1958 Brussels World's Fair. Rotterdam: Nai010 Publishers, 2015. 


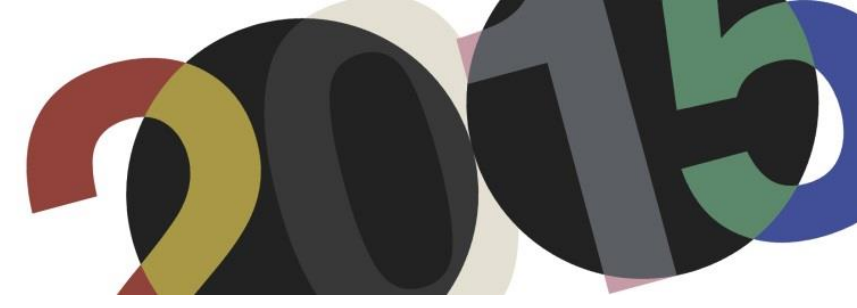

DOI: http://dx.doi.org/10.4995/LC2015.2015.796

\title{
Le Corbusier's Cité de Refuge: historical \& technological performance of the air exacte
}

\author{
L.M. Diaz, R. Southall
}

School of Arts, Design and Media, University of Brighton

\begin{abstract}
Despite a number of attempts by Le Corbusier to implement the combination of 'respiration exacte' with the 'mur neutralisant' he was never able to test the viability of his environmental concepts in a realised building. The Cité de Refuge, which was built with a more conventional heating system and single glazed facade, is however unique in that unlike the other potential candidates for the implementation of these systems, the building, as built, retained a key design feature, i.e. the hermetically sealed skin, which ultimately contributed to the building's now infamous failure. It is commonly argued that Le Corbusier, however, abandoned these comprehensive technical solutions in favour of a more passive approach, but it is less well understood to what extent technical failures influenced this shift. If these failures were one of the drivers for this change, how the building may have performed with the 'respiration exacte' and 'mur neutralisant' systems becomes of interest. Indeed, how their performance may have been improved with Le Corbusier's later modification of a brise-soleil offers an alternative hypothetical narrative for his relationship to technical and passive design methodologies.
\end{abstract}

Keywords: environment, technology, performance, history, Cité de Refuge.

\section{Introduction}

There are two technical building concepts that represent, perhaps more than any others Le Corbusier's early drive to find comprehensive and exclusively mechanical approaches to the heating and ventilation of modern buildings: a) the mur neutralisant, a double-skin glazed wall with conditioned air circulated within the cavity to moderate heat exchange between the interior and exterior, and b) the respiration exacte, a mechanical ventilation system for providing conditioned air to interior spaces at a constant temperature of $18^{\circ} \mathrm{C}$. The two are complementary and often considered in terms of one combined system; air exact.

The mur neutralisant was very much Le Corbusier's concept, and as early as 1916 he developed a forerunner for the Villa Schwob, La Chaux-de-Fonds, featuring heating ducts placed at the bottom of a double glazed cavity to create a thermal barrier ${ }^{1}$. It was not, however, until 1927 that Le Corbusier had the opportunity to engage with complex glazing again, but did so with two separate projects. The house in Stuttgart, built for the weissenhofsiedlung housing exhibition, featured a double-skinned glazing system, although there is no evidence of the cavity being mechanically treated (a number of Le Corbusier's drawings show the cavity being used for planting rather than active environmental $\operatorname{control}^{2}$ ). The second project was for the League of Nations competition entry (unbuilt) which proposed a double-skinned glazing system designed in collaboration with Gustave Lyon.

\footnotetext{
${ }^{1}$ Urbano Gutierrez, Rosa. "Pierre, Revoir Tout Le Systeme Fenetres: Le Corbusier and the Invention of the Mur Neutralisant (1928-1935)," International Journal of the Construction History Society, no. 27. Cambridge, 2012. p.109.

${ }^{2}$ Brooks, H. Allen. (ed.), Le Corbusier Archive, 32 vols. New York: Garland Publishing - Paris: Fondation Le Corbusier, 1982.
} 
Lyon would develop this into an air conditioning system ('a ration ponctuelle') for the Salle Pleyel in Paris $(1927)^{3}$, which Le Corbusier then adopted as the respiration exacte system. A further collaboration between the two on the design of the Centrosoyus building $(1928)^{4}$ eventually gave rise to the first proposed combination of mur neutralisant and respiration exacte (or air exact). Although the Centrosoyus project was eventually built with a double-skin façade, it was not mechanically ventilated, and the respiration exacte was omitted. Another opportunity to incorporate both systems came in 1931, again in the Soviet Union, with the competition for the Palace of the Soviets (unbuilt).

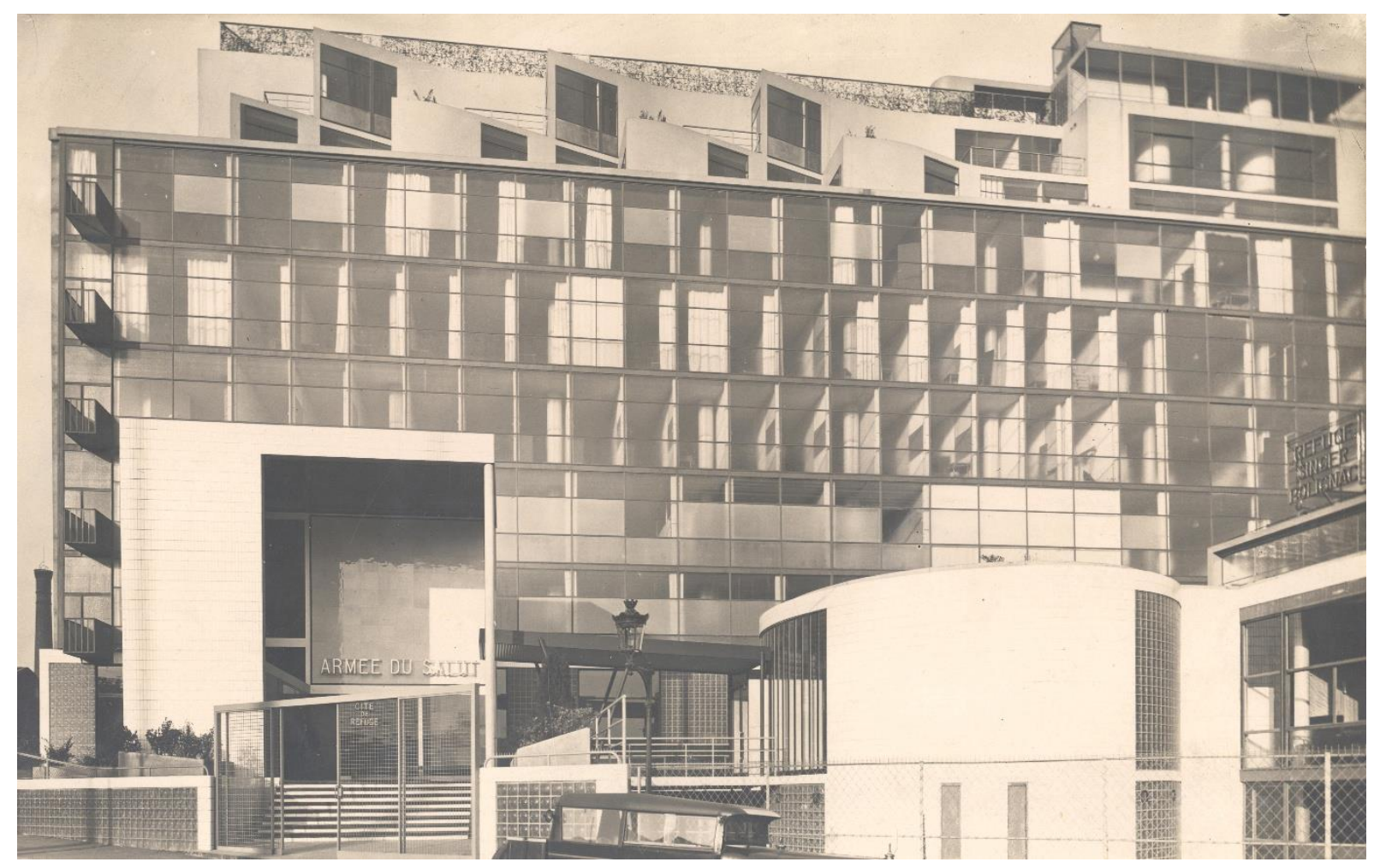

1. Cite de Refuge after completion @FLC-ADAGP

The Cité de Refuge, completed in December 1933, was Le Corbusier's last significant attempt to implement both systems $^{5}$. Due to financial constraints the building was eventually constructed with a single layer pan de verre (fully glazed curtain wall) instead of a mur neutralisant, with the respiration exacte relegated to a simple air heating system. Crucially, one feature was maintained due to high levels of pollution; the hermetically sealed skin. Almost immediately, complaints started to emerge of poor indoor air quality, and in the following summer of very high internal air temperatures, that eventually marked the building out as an early and notable building physics failure. The building was eventually retro-fitted with a passive external shading device, a brise-soleil, in 1952.

\footnotetext{
${ }^{3}$ Ramirez-Balas, C.; Suarez, R.; Sendra, J.J. "Future Technologies in Le Corbusier's Environmental Conditioning Systems: City of Refuge in Paris," Sustainably Architecture for a Renewable Future, PLEA2013 - 29th Conference, Munich, 10-12 September 2013; Urbano Gutierrez, "Pierre, Revoir Tout Le Systeme Fenetres: Le Corbusier and the Invention of the Mur Neutralisant (1928-1935)," p. 109.

${ }^{4}$ Urbano Gutierrez. "Pierre, Revoir Tout Le Systeme Fenetres: Le Corbusier and the Invention of the Mur Neutralisant (1928-1935)."

${ }^{5}$ After the Cite de Refuge, Le Corbusier continued to propose the mur neutralisant when he could (Immeuble Locatif and Immeuble Rentenanstalt, both in Zurich). Ibid. p. 123.
} 
The building's reception has oscillated between relative obscurity in the oeuvre of Le Corbusier and notoriety for its technical failure. Kenneth Frampton ${ }^{6}$ and Vincent Scully ${ }^{7}$ make no mention of the building in their histories of modern architecture while Manfredo Tafuri ${ }^{8}$ ignores the technical aspects of the building in his history of modern architecture. William Curtis' acknowledgement is fleeting: “...the new solution [fully glazed curtain wall] brought its own problems: lack of privacy, leaks, heat loss, and heat gain".

Other academic studies have tended to be straightforward in their declaration of the Cité de Refuge façade's failure. Yet, it is often tempered by reference to Le Corbusier's invention of the brise-soleil as a solution to its solar heat gain problems ${ }^{10}$. This cause-effect scenario, where the failure of a technical approach inspired a turn to vernacular and primitive technologies has become a common trope in explaining the change between the early and late modernist work of Le Corbusier, particularly among historians. Stanislaus von Moos, for example, writes:

“After his brief enthusiasm for 'international scientific techniques' as premises of a truly international architecture, he seems to have quickly returned to the more elementary techniques of environmental control... ${ }^{11}$

This narrative has been repeated by Curtis ${ }^{12}$ and others ${ }^{13}$ and has only recently been challenged. Rosa Urbano Gutierrez suggests a more subtle interpretation arguing that while Le Corbusier adjusted his approach it was not an abandonment of, or loss of faith in, technology ${ }^{14}$. Although there is an obvious difference between Le Corbusier's early designs and his later work, the change-over was not as dramatic as is often suggested. His designs in the 'purist' and technologically centred vein (Centrosoyus, 1928; Immeuble Clarté, 1930; Cité de Refuge, 1929; Nungessor-et-Coli, 1931) overlapped with projects that utilised stone, vaults and other traditional building techniques (Maisons Loucher, stone walls, 1929; Villa in Carthage, overhanging floor plates for shading, 1928; Pavillon Suisse, curved stone wall, 1930; House in Le Mathes, stone walls, 1935). This suggests a plausible scenario where Le Corbusier might have combined his early interest in l'air exact with his later brisesoleil.

Although the Cité de Refuge's façade system, as built, failed, it is the complaints and the ensuing, welldocumented $^{15}$ controversy, which in part makes the Cité de Refuge such a suitable candidate for performance analysis. Anecdotal and measured data generated at the time in the tussle between Le Corbusier and the Salvation Army provide the essential information concerning the original performance of the building required

\footnotetext{
${ }^{6}$ Frampton, Kenneth. Modern Architecture: A Critical History, 3rd ed. London: Thames \& Hudson, 1992.

${ }^{7}$ Scully Jr., Vincent. Modern Architecture, New York: G. Braziller, 1961.

${ }^{8}$ Tafuri, Manfredo. Modern Architecture, 2 vols. Milan: Electa, 1976.

${ }^{9}$ Curtis, William. Modern Architecture since 1900, New Jersey: Prentice-Hall, 1983, p. 203.

${ }^{10}$ See for example: Butera, F.M. "Glass Architecture: Is It Sustainable?," in Passive and Low Energy Cooling for the Built Environment, Santorini, 2005, pp. 161-68; Arnold, David. "The Evolution of Modern Office Buildings and Air Conditioning," ASHRAE Journal, Atlanta, June 1999, pp. 40-54; Requena Ruiz, Ignacio. "An Approach to Environment and Modernity Through Le Corbusier's Drawing," Revista de EGA, Valencia, no. 20, October 2012, p. 246.

${ }^{11}$ Von Moos, Stanislaus. Le Corbusier, Elements of a Synthesis, Cambridge, Mass.: MIT Press, 1979, p. 93.

${ }^{12}$ Curtis, William. Le Corbusier, New York: Rizzoli, 1986, p. 208.

${ }^{13}$ See for example, Sobin, Harris. "From l'Air Exact to l'Aerateur: Ventilation and Its Evolution in the Architectural Work of Le Corbusier," in The Green Braid, London: Routledge, 2007, pp. 140-52; Walden, Russell (ed.). The Open Hand: Essays on Le Corbusier, Cambridge: M.I.T. Press, 1977; Winter, John. "Le Corbusier's Technological Dilemna," in The Open Hand, pp. 322-47.

${ }^{14}$ Urbano Gutierrez. "Pierre, Revoir Tout Le Systeme Fenetres: Le Corbusier and the Invention of the Mur Neutralisant (1928-1935)," pp. 124-25.

${ }^{15}$ Taylor, Brian Brace. Le Corbusier, The City of Refuge, Paris 1929/33, Chicago - London: University of Chicago Press, 1987, chap. 4.
} 
for the validation of a simulation model. This data, coupled with existing documentation regarding the proposed air exact system and the eventual installation of a brise-soleil, makes the Cite de Refuge the perfect template to investigate this building's failure, but also to analyse the potential performance of Le Corbusier's intended ideal and of a hypothetical version combining technical and passive aspects of his design thinking.

Three simulation models (as built, as intended, as a hypothetical combination of systems) have been used to generate data concerning the environmental and energy performance of the three scenarios. The first model is used to both verify the simulation approach and establish a benchmark. The second model provides us with a snapshot of how Le Corbusier's original conception would have performed. The speculative aspect of the third model will allow us to understand the combined effects and importance of Le Corbusier's varied experiments. In total, this examination will suggest an alternative narrative concerning Le Corbusier's perceived abandonment of technology in favour of more primitive and vernacular models for environmental control.

\section{Methodology}

\subsection{Simulation methodology}

The free and open-source EnergyPlus ${ }^{16}$ building performance simulation tool is used here to simulate the thermal and ventilation performance of the Cité de Refuge. EnergyPlus is a well validated and comprehensive tool capable of simulating complex construction and mechanical ventilation regimes. EnergyPlus itself does not have a user interface for the construction and specification of a building model so a software tool developed in-house, called the VI-Suite (http://arts.brighton.ac.uk/projects/vi-suite), has been used. The VI-Suite functions as a plugin for the 3D content creation suite Blender, which allows EnergyPlus geometry import/creation and the specification of construction and ventilation elements. Once the building has been characterised, the VI-Suite runs EnergyPlus and exports the results for plotting and analysis. The geometry for the Cité de Refuge was initially created in Auto CAD from detailed plans and sections of the completed building ${ }^{17}$ before being imported into Blender.

\subsection{Cité de Refuge as built}

The construction of the realised single glazed facades has been well documented, consisting of toughened glass with a thickness of $7 \mathrm{~mm}^{18}$. This glass has been used for all glazed sections of the Southerly, Easterly and Northerly facades. Floors and internal walls have also been well documented and modelled accordingly.

The insulating walls, situated on the North, East and West facades, were installed to protect the building from the cold winter Northerly winds, and were reported to be constructed from an outer 110mm layer of terracotta brick, followed by a $20 \mathrm{~mm}$ air gap and $50 \mathrm{~mm}$ of internal pressed straw insulation ${ }^{19}$. Although the exact nature of the straw panels is not known, contemporary reports suggesting the wall had the same thermal insulation as a $1 \mathrm{~m}$

16 Crawley, Drury B, et al. "EnergyPlus: Energy Simulation Program,” ASHRAE Journal 42, Atlanta, no. 4, April 2000 pp. 49-56.

${ }^{17}$ Taylor. The City of Refuge, Appendix.

${ }^{18}$ Ramirez-Balas, Suarez, and Sendra. "Future Technologies in Le Corbusier's Environmental Conditioning Systems: City of Refuge in Paris," n.p.

${ }^{19}$ Taylor. The City of Refuge, p. 82. 
thickness of stone wall ${ }^{20}$ made it possible to deduce that their thermal performance is similar to Stramit compressed straw panels which were released onto the market in 1933.

Le Corbusier was aware that a large glazed facade such as the one realised in the Cite de Refuge, which did not incorporate the mur neutralisant, would require shading to reduce solar heat gains ${ }^{21}$. In the Cité de Refuge userconfigurable screens were installed on the inside of the facade. They are assumed here to have a solar reflectivity of $60 \%$, corresponding to the off-white colour seen in contemporary photos.

In terms of ventilation and heating, the solution used consisted of a relatively simple steam boiler-based heating system that delivered heated air in winter, and supplied untreated air brought down from roof level in summer. The smaller individual rooms were ventilated with vents above the door supplied in turn by ceiling conduits in the corridors. Air left the rooms under the door and was extracted through plumbing pipes and vents placed at strategic points. Larger rooms were supplied by blowers at critical points within the building. The ventilation capacity was reported to be 1 air change per hour $(\mathrm{ACH})$ in winter and $2-3.5$ in summer, figures very much in line with modern conceptions of ventilation. Originally the ventilation system was to have eight independently controlled zones, but only four were ultimately installed due to cost overruns on the foundations ${ }^{22}$. It is not known which portions of the building were serviced by each of these four independent systems.

\subsection{EneryPlus models}

The existence of contemporary reports of occupant dissatisfaction in the Cité de Refuge are extremely useful data for a building performance simulation, as they provide validation data and guidance. These reports centred on the mother $\&$ baby roomettes on the $4^{\text {th }}$ floor and the playroom and child's dormitory of the child care centre on the $5^{\text {th }}$ floor. All three zones have a strong relationship with the main, southerly facing, single glazed facade. The men's dormitory on the $5^{\text {th }}$ floor has also been modelled due to its high occupancy and weak relationship with the main glazed facade to provide some contrast. The modelled zones, within the context of the $4^{\text {th }}$ and $5^{\text {th }}$ floors, are shown in figure 2.

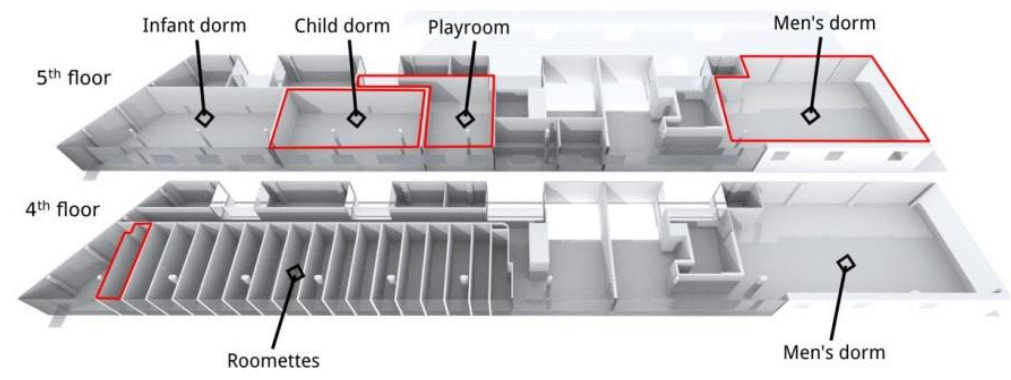

2. Overview of the modelled zones (highlighted in red). Source: Ryan Southall.

\footnotetext{
${ }^{20}$ Ibid.

${ }^{21}$ Ramirez-Balas, Suarez, and Sendra. "Future Technologies in Le Corbusier's Environmental Conditioning Systems: City of Refuge in Paris," n.p.

${ }^{22}$ Fernandez, Vanessa; Gallo, Emmanuelle. "A Factory for Well-Bing: Innovations in the Heating System and the CurtainWall in Le Corbusier's Salvation Army's City of Refuge," Proceedings of the 11th DOCOMOMO International Conference, Mexico City, 20-25 August 2010, n.p.
} 
After the zones of interest have been identified, the occupancy levels need to be determined for these spaces to understand the influence they will have on internal temperatures and internal $\mathrm{CO}_{2}$ levels. Plans of the completed Cité de Refuge building clearly indicate the number of beds in each of the dormitory zones, and these beds have been used to determine the maximum occupancy for each of these spaces. The play room was designed for a maximum occupancy of $60^{23}$. It is rather unlikely however that this level would have been reached on a consistent basis as the floor area of the space is only $52 \mathrm{~m}^{2}$, so maximum occupancy equivalent to the neighbouring dormitory space (31) has been used here. These occupancy levels, along with the assumed occupied periods and occupant metabolic rate in Watts per person (which defines occupant internal heat gains and $\mathrm{CO}_{2}$ production) are shown in table 1.

\begin{tabular}{|c|c|c|c|}
\hline Space & Occupant number $(\max )$ & Period & Metabolic rate (Wpp) \\
\hline \hline Men's dorm & 35 & $22: 00-08: 00$ & 90 \\
\hline Roomette & 1 & $22: 00-08: 00$ & 80 \\
\hline Play room & 31 & $08: 00-20: 00$ & 66 \\
\hline Child's dorm & 31 & $20: 00-08: 00$ & 57 \\
\hline
\end{tabular}

Table 1. Occupancy Parameters. Source: Ryan Southall.

As some important variables relating to the operation of the building are not known, an initial modelling phase was used to confirm some of the anecdotal data that is available for certain key areas of the building.

For example, contemporary complaints suggested that the ventilation system was turned off at night, and measurements taken at the time showed that $\mathrm{CO}_{2}$ levels in the $4^{\text {th }}$ floor roomette reached 2720 parts per million (ppm). Le Corbusier responded that these rooms were receiving $35 \mathrm{~m}^{3} / \mathrm{hr}$ in winter and 80 in summer. With this data, and by adjusting the period of ventilation provision within the model, it was possible to replicate these peak $\mathrm{CO}_{2}$ levels (simulated $2700 \mathrm{ppm}$ ) with a ventilation system in operation from 6 am to $11 \mathrm{pm}$.

Applying this ventilation regime to the large men's dormitory on the $5^{\text {th }}$ floor results in peak $\mathrm{CO}_{2}$ levels of around 10,000 ppm. Although not dangerous these levels would definitely support the reports of extremely poor air quality and stuffiness. For the as-built case the ventilation regime has subsequently been assumed to be in operation from 6 am to $11 \mathrm{pm}$.

\section{Results}

\subsection{Cité de Refuge as built (1933)}

The daily maximum and minimum temperatures for one of the $4^{\text {th }}$ floor mother $\&$ baby roomettes are shown in figure 3 .

\footnotetext{
${ }^{23}$ Taylor. The City of Refuge, p. 98.
} 


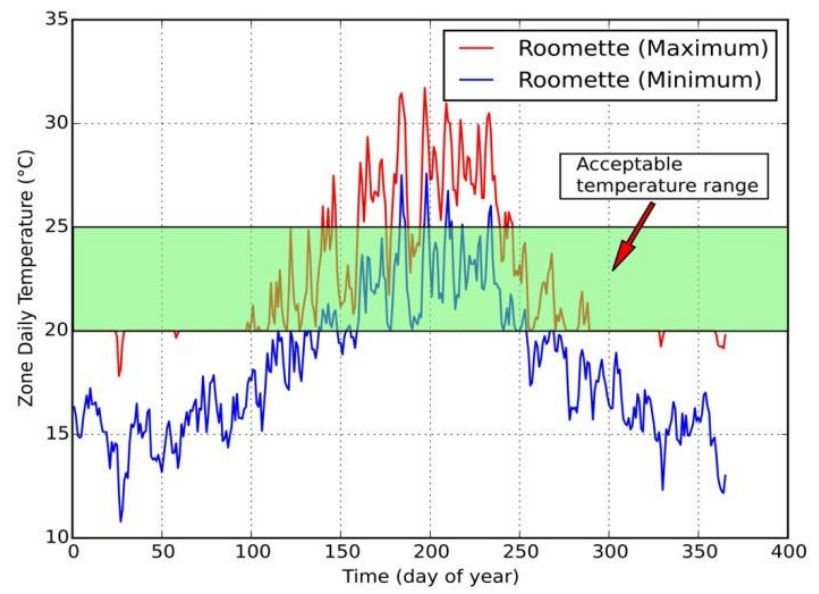

3. Mother \& baby roomette temperatures. Source: Ryan Southall.

It is clear from figure 3 that the space does not provide acceptable indoor temperatures. Maximum and minimum daily temperatures only fall within the desired temperature range in the spring and autumn. Minimum winter temperatures regularly fall below $20^{\circ} \mathrm{C}$ (minimum $11^{\circ} \mathrm{C}$ ) and summer temperatures regularly peak well above $25^{\circ} \mathrm{C}$ (maximum $32^{\circ} \mathrm{C}$ ). Cooler temperatures in a dormitory space such as this one are not necessarily an issue as occupants are generally in bed, but a minimum of $11^{\circ} \mathrm{C}$ is too low even in this context. Modelling the shading screens inside the facade as fully closed, summer temperatures still peak at $27^{\circ} \mathrm{C}$, and a combination of these two scenarios support the contemporary reports of temperatures peaking above $28^{\circ} \mathrm{C}^{24}$. Table 2 shows a breakdown of the thermal performance of the modelled zones.

\begin{tabular}{|c|c|c|c|c|c|}
\hline Space & $\%$ hours $<20^{\circ} \mathrm{C}$ & $\%$ occ hours $<20^{\circ} \mathrm{C}$ & $\%$ hours $>25^{\circ} \mathrm{C}$ & $\%$ occ. hours $>25^{\circ} \mathrm{C}$ & Peak ${ }^{\circ} \mathrm{C}$ \\
\hline \hline Men's dorm & 9 & 21 & 20 & 24 & 30 \\
\hline Roomette & 62 & 65 & $12(2)$ & $11(2)$ & $32(27)$ \\
\hline Play room & 17 & 0 & $30(15)$ & $37(24)$ & $37(32)$ \\
\hline Child's dorm & 7 & 14 & $30(14)$ & $33(17)$ & $40(32)$ \\
\hline
\end{tabular}

Table 2. Zone thermal performance (results with shading in brackets). Source: Ryan Southall.

It is clear from table 2 that all zones experience serious thermal issues. Both the play room and the children's dorm experience peak temperatures of $32^{\circ} \mathrm{C}$ even with the shading screens fully deployed (this corresponds with contemporary reports of temperatures in these spaces reaching $30-33^{\circ} \mathrm{C}$ ). Both these spaces spend approximately a third of the occupied hours below $20^{\circ} \mathrm{C}$, and a third above $25^{\circ} \mathrm{C}$, leaving only the remaining third as comfortable. The roomette is predominantly too cold as the heating system and low occupancy gains cannot counteract heat losses from the single glazed facade when there are no significant solar gains. The men's dorm does perform slightly better as its periphery is not dominated by the single glazed pan de verre, and this provides an early indication of where the problems with the building lie.

From a modern building physics perspective the reasons for the thermal failure of the building is fairly selfexplanatory. High solar gains coupled with no active cooling during the daytime, and high heat losses through the single glazed facade coupled with no heating during the night-time, result in extremes of temperature that often fall outside acceptable parameters. It's possible that the situation at night could have been improved if the building had had the planned eight independently controlled zones allowing the dormitory areas to be heated or ventilated at night. However, the overheating issues would have remained as the modelled ventilation system operates at the designed capacity in all spaces during the day.

${ }^{24}$ Ibid. p. 113. 
From an energy consumption perspective the heating loads for the four spaces are shown in table 3 . These figures only pertain to heating, as there is no active cooling employed, and does not include losses, inefficiencies or fan power, and simply represent the raw heating energy required to supply air at the reported flow rates at $18^{\circ} \mathrm{C}$. Actual figures would therefore be higher than reported here. Figures are presented in terms of annual kWh consumption and the common modern metric of annual kWh consumption by floor area.

\begin{tabular}{|c|c|c|}
\hline Space & Annual $\mathrm{kWh}$ & Annual $\mathrm{kWh} / \mathrm{m}^{2}$ \\
\hline \hline Men's dorm & 11269 & 78 \\
\hline Roomette & 626 & 57 \\
\hline Play room & 2561 & 49 \\
\hline Child's dorm & 4820 & 62 \\
\hline
\end{tabular}

Table 3. Heating Energy Requirements. Source: Ryan Southall.

The trade-off for very poor thermal performance is the energy consumption, which is modest and even rather good compared to current standards. It is interesting to note however that even with the relative efficiency of the system Le Corbusier suspected that the system was being shut off by the building operators to save energy ${ }^{25}$.

It has been claimed that the thermal comfort problems exhibited by the building are a result of the mur neutralisant and respiration exacte systems not being implemented ${ }^{26}$, and the responsibility for the failure of the building has been shifted from Le Corbusier to the client and their budgetary constraints. It is therefore of interest to test this assumption, and Le Corbusier's technical design intentions, with a thermo-physical model that incorporates both these systems.

\subsection{Cité de Refuge as envisioned with mur neutralisant and respiration exacte}

For this new analysis, the majority of the building simulation model remains the same as in the previous section. The only changes made are to the ventilation system (respiration exacte) and the facade (mur neutralisant).

The respiration exacte system developed and patented by Gustav Lyon as aeration ponctuelle and adopted by Le Corbusier was, in effect, an air-conditioning system that supplied the occupied areas with a constant ventilation flow rate delivered at $18^{\circ} \mathrm{C}$. Lyon's choice of a slightly lower temperature than would normally be considered comfortable i.e. $20^{\circ} \mathrm{C}$, suggests that he appreciated that internal occupancy and solar heat gains would make up the difference, and this was explicitly noted by Le Corbusier ${ }^{27}$. A noteworthy characteristic of Lyon's system was the very low flow rate supplied; 80 litres/minute/person, which equates to only 1.3 litres/second/person (lsp). This is far lower than typical modern standards of 8-10 lsp, which are designed to remove smells and moisture as well as providing a breathable environment. This flow rate was however predicated on the idea that the supply air would be heavily oxygenated by using ozone, a dubious proposition especially now that ozone has been identified as a health hazard.

\footnotetext{
${ }^{25}$ Gallo, Emmanuelle. "The Importance of Introducing the Study of Original Technical Devices in the 20th Century Architectural Heritage, for a Well-Reasoned Conservation Approach," International Conference Intervention Approaches for the 20th Century Architectural Heritage, Madrid, 14-16 June 2011, p. 3.

${ }^{26}$ See for example: Fernandez and Gallo. "A Factory for Well-Bing: Innovations in the Heating System and the Curtain-Wall in Le Corbusier's Salvation Army's City of Refuge"; Taylor, The City of Refuge; Jordan, Robert Furneaux. Le Corbusier, 1st Ed. New York: Lawrence Hill \& Co., 1972; Sobin, "From l'Air Exact to l'Aerateur: Ventilation and Its Evolution in the Architectural Work of Le Corbusier."

${ }^{27}$ Taylor. The City of Refuge, p. 20.
} 
Le Corbusier had, however, already received information that these flow rates were too low, and indeed that the use of ozone constituted a health risk $^{28}$. In an attempt to convince the clients for a previous project - Centrosoyus - of the efficacy of the system, Le Corbusier commissioned a report by the American Blower Company (ABC) to validate the approach. The report was however not very supportive, explicitly warning about the use of ozone and criticising the low flow rate and recommended a flow rate of 10 times $^{29}$ that proposed, i.e. 13 lsp, to maintain internal air quality in this type of program, figures much more in line with modern ideas of ventilation. A second report by $\mathrm{ABC}$ was also commissioned by Le Corbusier for the Cité de Refuge, but no record of the contents of this report exist, perhaps reflecting their negative attitude once again to the formulation of the system.

The mur neutralisant facade, as originally conceived by Le Corbusier, consisted of two single skins of glass between which was circulated conditioned air. This conditioned air would in theory moderate the temperature of the inner skin of glass, improving thermal comfort within the neighbouring room, reducing heat losses from the room to the outside on cold days, and reducing heat gain through the facade on hot days. Statements made by Le Corbusier indicate that he also considered the system to be able to deal with solar heat gains ${ }^{30}$. Although a mur neutralisant was never built, testing conducted by Le Braz, and overseen by Gustav Lyon, at the Saint-Gobain laboratories $^{31}$, in preparation for the Cité de Refuge do offer some clues into the detailed operation of the system, and plans drawn up for the Centrosoyus project offer some insight into its form. In the tests Le Braz circulated up to $150 \mathrm{l} / \mathrm{s}$ of air at a temperature of $15^{\circ} \mathrm{C}$ for summer operation and $30^{\circ} \mathrm{C}$ for winter operation through a glazed facade section $1.34 \mathrm{~m}$ in width and with cavities of various depths. The preparatory work for the Centrosoyus building indicated an all glass mur neutralisant with an internal $2.5 \mathrm{~mm}$ layer of frosted glass, a $200 \mathrm{~mm}$ air cavity with a $9 \mathrm{~mm}$ clear external glass layer. The cavity width is supported by Le Braz who concluded that the air cavity should be larger than $100 \mathrm{~mm}$ to reduce the air speeds within it.

There are two obvious problems with this version of the mur neutralisant: two clear glazing layers do not significantly reduce solar heat gain, and circulating conditioned air within a cavity only separated from the outside by a single pane of glass will incur significant heat losses in winter - a point also made in the earlier report by $\mathrm{ABC}$. Le Braz made some recommendations to address these weaknesses. He suggested an extra pane of glass on the outside of the ventilated layer to reduce heat losses to the outside ${ }^{32}$ and even suggested an external shading device to reduce solar gains, although the concept of the brise-soleil as such did not yet exist.

The air exact system as originally envisaged by Le Corbusier and Gustav Lyon would not only have delivered harmful ozone into the building but when simulated demonstrated thermal performance even worse than that seen in the as-built case. Subsequent analyses in this section therefore incorporate the recommendations made by Le Braz (a third layer of façade glazing) and ABC (increase in respiration exacte flow rate). The parameters used in the EnergyPlus model are therefore:

\footnotetext{
${ }^{28}$ Urbano Gutierrez, Rosa. "Le Pan de Verre Scientifique: Le Corbusier and the Saint-Gobain Glass Laboratory Experiments (1931-1932)," Architectural Research Quarterly 17, no. 1, Cambridge, 2013, n.p.

${ }^{29}$ Urbano Gutierrez. "Pierre, Revoir Tout Le Systeme Fenetres: Le Corbusier and the Invention of the Mur Neutralisant (1928-1935)," p. 115.

${ }^{30}$ Le Corbusier; Boesiger, Willy. Le Corbusier: Oeuvre Complet 1938-1946, vol. 4, Zurich: Editions d'Architecture, 1977, p. 115 .

${ }^{31}$ Urbano Gutierrez. "Le Pan de Verre Scientifique: Le Corbusier and the Saint-Gobain Glass Laboratory Experiments (1931-1932)."

${ }^{32}$ Ibid. p. 68.
} 
- The ventilation rate of the respiration exacte has been set to 13 lsp based on the maximum occupancy of the space.

- respiration exacte supply temperature is a constant $18^{\circ} \mathrm{C}$

- The construction of the mur neutralisant is $2.5 \mathrm{~mm}$ internal glass layer with a $200 \mathrm{~mm}$ ventilated cavity, $2.5 \mathrm{~mm}$ glass layer, $14 \mathrm{~mm}$ closed air gap and $9 \mathrm{~mm}$ external glass layer.

- The ventilation rate within the mur neutralisant is up to $150 / 1.341 / \mathrm{s}$ per metre of facade section to match the rate used in Le Braz's testing.

- The temperature of the air supply to the mur neutralisant is $30^{\circ} \mathrm{C}$ in winter, $15^{\circ} \mathrm{C}$ in summer and supplied up to the maximum flow rate to maintain a cavity temperature of $18^{\circ} \mathrm{C}$.

It should be noted that at 13 lsp there were no simulated air quality issues (in terms of $\mathrm{CO}_{2}$ concentration) in any of the modelled spaces, and for brevity these results have not been included here.

\subsubsection{Simulation Results}

Daily maximum and minimum temperatures for a $4^{\text {th }}$ floor mother $\&$ baby roomette are shown in figure 4.

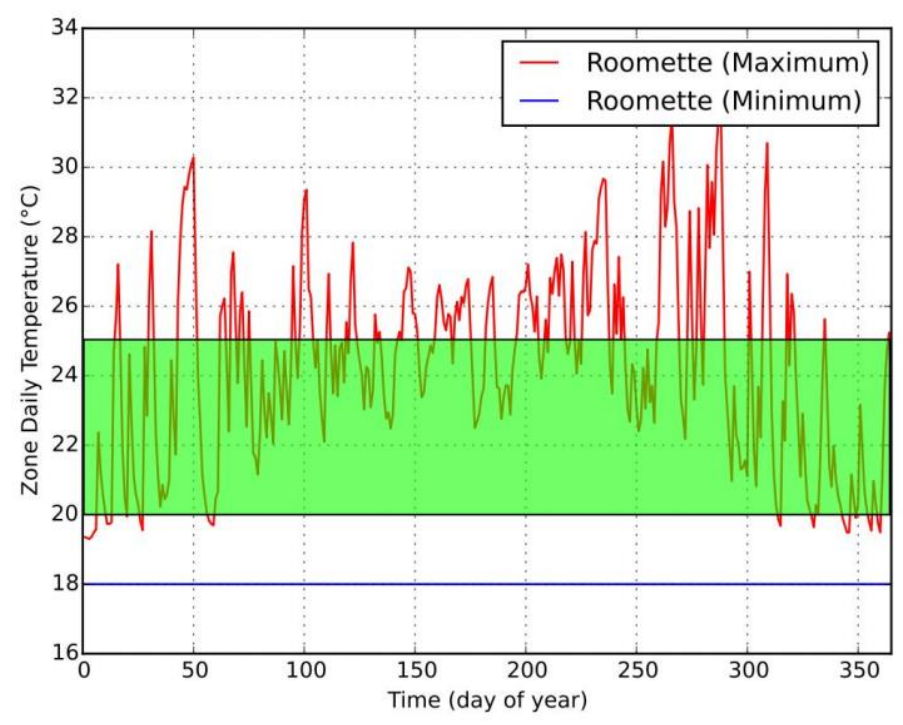

4. Roomette temperatures with air exact. Source: Ryan Southall.

As the rooms are heavily exposed to the glazed facade, and the flow rate of the moderating respiration exacte is low due to the low occupancy, the rooms still suffer from significant overheating issues with peak temperatures still reaching $31^{\circ} \mathrm{C}$. The three glazing layers and the moderated temperature of the mur neutralisant do however reduce heat losses to the outside and temperatures do not go below the respiration exacte supply temperature of $18^{\circ} \mathrm{C}$. This lower temperature is unlikely however to have generated significant user complaint as occupants are in bed at night and indeed temperatures slightly below $20^{\circ} \mathrm{C}$ may, in this context, be considered perfectly acceptable.

Temperatures within the other zones exhibit reduced peak temperatures as the greater occupancy means greater respiration exacte flow rates, and no other zone now experiences any significant period of time above $25^{\circ} \mathrm{C}$. The children's dorm does see peak temperatures of $27^{\circ} \mathrm{C}$, albeit rarely and not during the occupied hours. It is a 
testament to $\mathrm{ABC}$ and the greater American experience of air-conditioning at the time that the flow rates recommended by them are generally able to provide comfortable conditions and, with the exception of the roomettes, keep upper temperatures within the desired range.

The men's dorm does see significant occupied time with minimum temperatures below $20^{\circ} \mathrm{C}$ but as once again the occupants are generally in bed, and the lowest temperature exhibited by the space is $17^{\circ} \mathrm{C}$, this is unlikely to cause major discomfort.

A summary of the thermal performance of the modelled zones is shown in table 4 .

\begin{tabular}{|c|c|c|c|c|c|}
\hline Space & \% hours <20C & \% occ hours < 20C & \% hours > 25C & \% occ. hours > 25C & Peak \\
\hline \hline Men's dorm & 65 & 58 & 0 & 0 & 24 \\
\hline Roomette & 13 & 12 & 18 & 10 & 32 \\
\hline Play room & 25 & 0 & 0 & 0 & 25 \\
\hline Child's dorm & 9 & 0 & 1 & 0 & 27 \\
\hline
\end{tabular}

Table 4. air exact zone thermal performance. Source: Ryan Southall.

In summary, the thermal performance of the air exact system would have been much improved compared to the as-built case if the recommendations of Le Braz and ABC had been implemented. The energy consumption figures do however tell a very different story. Total energy consumption for heating and cooling are shown in table 5. These figures, where appropriate, also include the heating/cooling consumption of the mur neutralisant associated with a particular space.

\begin{tabular}{|c|c|c|c|}
\hline Space & Annual $\mathrm{kWh}$ & Annual $\mathrm{kWh} / \mathrm{m}^{2}$ & $\%$ change \\
\hline \hline Men's dorm & 9805 & 68 & -13 \\
\hline Roomette & 2319 & 211 & 370 \\
\hline Play room & 13236 & 254 & 518 \\
\hline Child's dorm & 22277 & 284 & 458 \\
\hline
\end{tabular}

Table 5. air exact heating/cooling energy requirement. Source: Ryan Southall.

Energy requirements have increased significantly with the exception of the men's dormitory, which is not heavily exposed to the mur neutralisant. The roomette, play room and children's dorm do however experience energy consumption increases of $370 \%, 518 \%$ and $458 \%$ respectively, which is the trade-off for better thermal comfort performance in these spaces.

It's maybe worth considering the context within which $\mathrm{ABC}$ made the recommendations in their report. At the time, air-conditioning in the US was largely considered for heavily glazed commercial developments underwritten by wealthy clients. The Cité de Refuge, run and operated by a charity, represents a very different client and if Le Corbusier was correct in his suspicion that the Salvation Army were turning off the implemented system to save money, it is safe to say that the energy consumption figures presented here for the air exact would have caused quite some concern. It does seem quite possible that if the air exact system had been realised complaints from the building owner would still have occurred, and although still fundamentally in part a result of high solar gains ( $85 \%$ of the energy consumption figures above are required for cooling), the bulk of these complaints would have focused on energy consumption rather than thermal comfort and air quality.

Considering that in the period between the construction of the Cité de Refuge and the post-war retro-fit of the brise-soleil Le Corbusier was toying with the idea of combining the brise-soleil and mur neutralisant ${ }^{33}$, and that complaints from the building owner could still have been generated by high solar gains, it is conceivable that Le

\footnotetext{
${ }^{33}$ Ibid. n.p.
} 
Corbusier would also have retro-fitted a brise-soleil to the air exact version of the Cité de Refuge. The following details the theoretical performance of such a combination.

\subsection{Cité de Refuge: hypothetical combination of air exact and brise-soleil}

Fundamentally, from a performance perspective, the brise-soleil is an external shading device that limits the range of incident solar angles that can penetrate a building, usually allowing winter daytime solar penetration whilst limiting high summer sun penetration. As such it can be considered part of a passive solar design methodology.

According to the simulations in the previous sections, it is in part high solar gain, especially in the summer months, that results in serious issues for the building: poor thermal comfort and poor energy performance. It would therefore appear that the moderation of the incoming solar radiation with a brise-soleil would be a very suitable approach to dealing with the deficiencies of both scenarios.

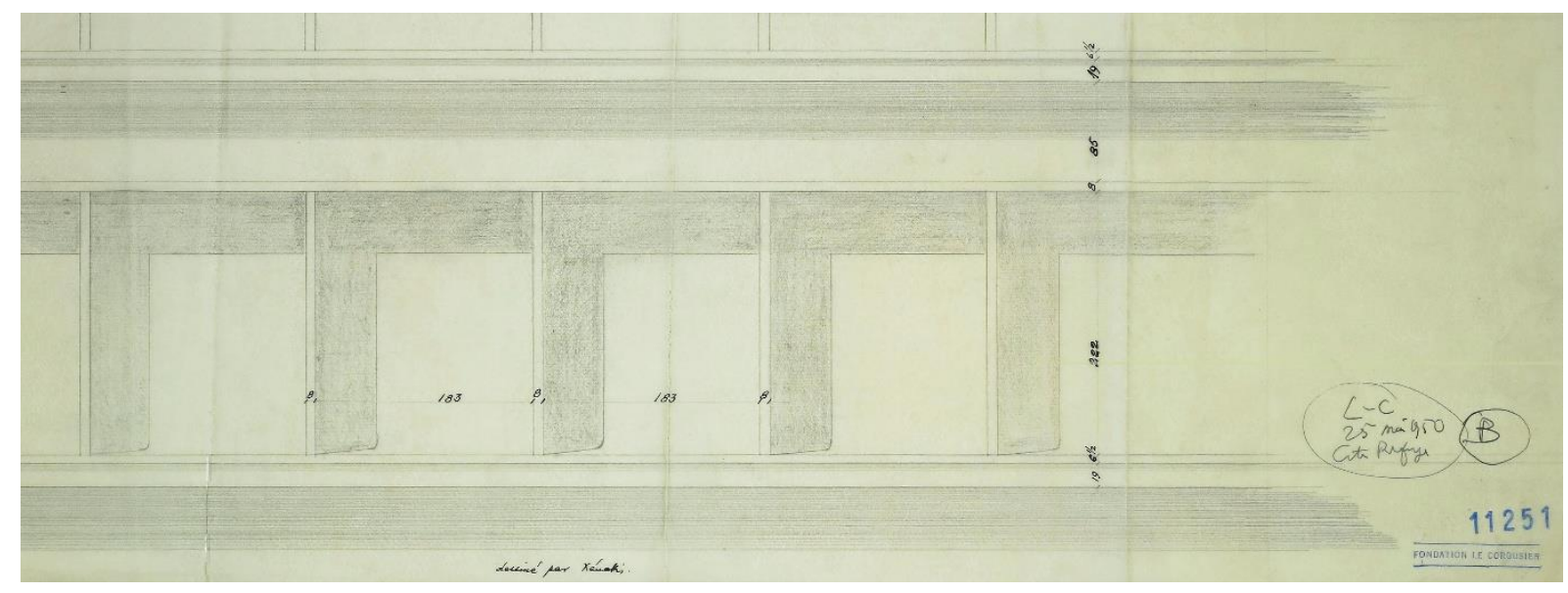

5. Drawing of brise-soleil by Xenakis, from Brooks, Le Corbusier Archive. 32 vols. OFLC-ADAGP

Possibly due to ongoing concerns about high summer temperatures in the building the Salvation Army insisted that any façade modifications include making the bottom third at each level opaque ${ }^{34}$. This has been incorporated into the simulation model. The subsequent design of the brise-soleil, drawn up by the engineer Bodiansky and the designer Xenakis ${ }^{35}$, proved to be very effective at preventing high summer sun from directly entering the building though the upper two transparent sections. Taking the brise-soleil geometry from Xenakis' original drawings ${ }^{36}$ (fig. 5) the rendering in figure 7 of the internal illumination of the $5^{\text {th }}$ floor at noon in midsummer demonstrates that sunlight is effectively eliminated, with only skylight allowed to enter the space.

\footnotetext{
${ }^{34}$ Taylor. The City of Refuge, pp. 117-121.

${ }^{35}$ Ibid. p. 121.

${ }^{36}$ Brooks. Le Corbusier Archive, 241 Vol. 6, drawing no. 11251, dated 25 May 1950.
} 


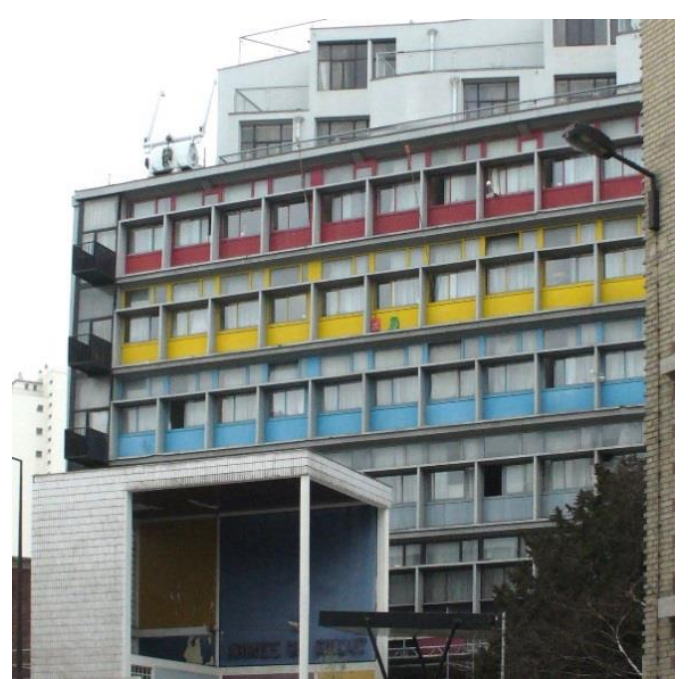

6. Cité de Refuge with brise-soleil.

Source: Luis Diaz

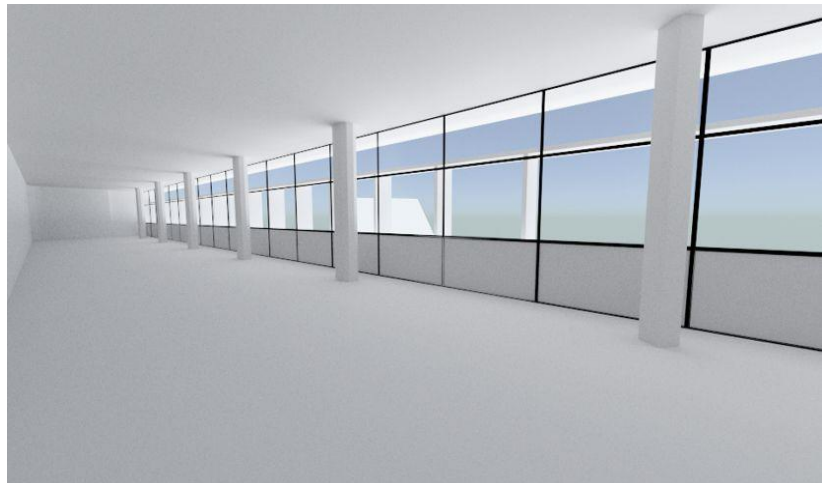

7. Rendering of internal illumination on $5^{\text {th }}$ floor. Source: Ryan Southall.

\subsubsection{Simulation Results}

The daily minimum and maximum temperatures of the roomette are shown in figure 8 and present a very different picture to the previous analyses. Overheating has now been completely eliminated and minimum temperatures, at over $17^{\circ} \mathrm{C}$, would be unlikely to cause problems for sleeping occupants.

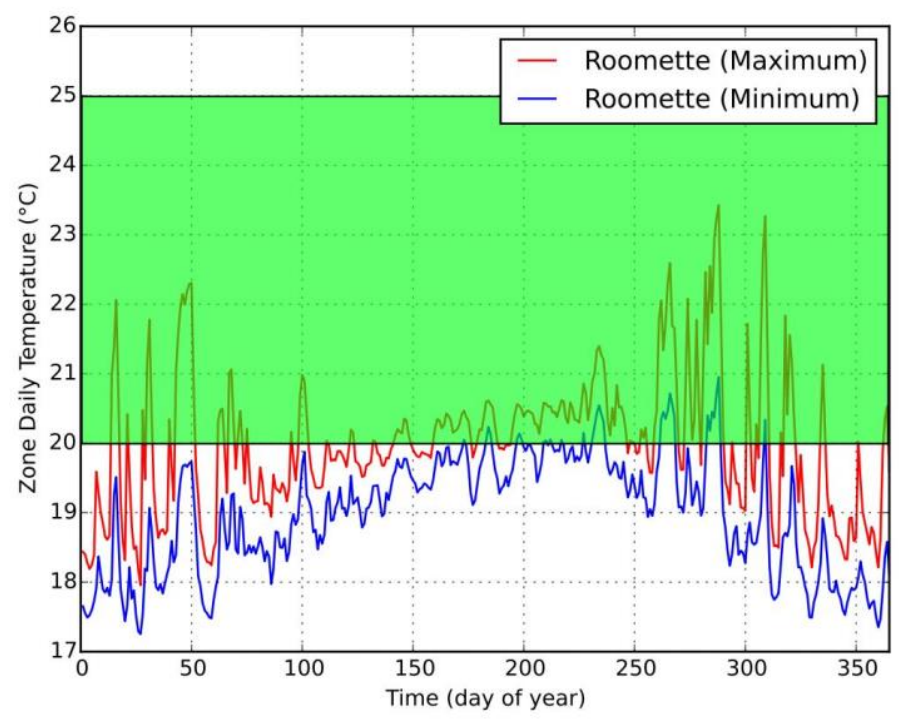

8. Roomette temperatures with brise-soleil. Source: Ryan Southall.

The thermal results are summarised in table 6 . Of note is that fact that none of the spaces now see any overheating, either in the occupied or non-occupied periods. Peak temperatures are now well below the upper value of $25^{\circ} \mathrm{C}$ specified in Le Braz's testing, creating, in summer time, what could be considered quite a cool, pleasant environment. Also of note is the high percentage of the time that the rooms experience temperatures below the lower threshold of $20^{\circ} \mathrm{C}$. Now that internal solar gains have been reduced the respiration exacte system supply temperature of $18^{\circ} \mathrm{C}$ often delivers temperatures between 18 and $20^{\circ} \mathrm{C}$. In the dormitory spaces this is not of major concern as occupants are generally in bed. In the play room, where occupants are not in bed, these low 
temperatures only exist for $12 \%$ of the occupied time and the absolute minimum during these times is a respectable $17^{\circ} \mathrm{C}$. All things considered the thermal performance of the building can now be considered to be very good, and indeed offer some leeway in the way the building is operated. Somewhat lower respiration exacte flow rates would for example still not lead to overheating.

\begin{tabular}{|c|c|c|c|c|c|}
\hline Space & \% hours < 20C & \% occ hours < 20C & \% hours > 25C & \% occ. hours > 25C & Peak \\
\hline \hline Men's dorm & 65 & 58 & 0 & 0 & 24 \\
\hline Roomette & 69 & 67 & 0 & 0 & 23 \\
\hline Play room & 60 & 22 & 0 & 0 & 23 \\
\hline Child's dorm & 51 & 12 & 0 & 0 & 22 \\
\hline
\end{tabular}

Table 6. air exact with brise-soleil thermal performance. Source: Ryan Southall.

Energy consumption figures are shown in table 7 along with the percentage reduction compared to the simple air exact case. In the roomette, for example, the significant reduction in internal temperature has led to an energy consumption reduction of $65 \%$, to a very reasonable $73 \mathrm{kWh} / \mathrm{m}^{2}$. In the childcare centre rooms, which have higher occupancies and higher respiration exacte flow rates, the consumption is higher but still $38-52 \%$ lower than without the brise-soleil. The absolute figures for the childcare centre are slightly high by modern energy efficiency standards but about as low as could be expected in an air-conditioned building with high occupancy levels. Further improvements could be achieved by more intelligently controlling the respiration exacte system in response to occupancy rates, especially as there is now some leeway in terms of peak temperatures.

\begin{tabular}{|c|c|c|c|}
\hline Space & Annual $\mathrm{kWh}$ & Annual $\mathrm{kWh} / \mathrm{m}^{2}$ & $\%$ reduction \\
\hline \hline Men's dorm & 9816 & 68 & N/A \\
\hline Roomette & 798 & 73 & 65 \\
\hline Play room & 8183 & 157 & 38 \\
\hline Child's dorm & 10814 & 137 & 52 \\
\hline
\end{tabular}

Table 7. respiration exacte heating/cooling energy requirement. Source: Ryan Southall.

\subsection{Conclusions}

Historical accounts make a compelling case, despite Le Corbusier's protestations at the time, for considering the building as built a technical failure. The simulations confirm this verdict and replicate the poor air quality and very high internal temperatures experienced by the occupants. The failure was largely a result of the hermetically sealed skin, kept as part of the original proposal for air exact and motivated by Le Corbusier's drive to keep out external pollutants, and the high solar gains combined with no active cooling system.

Historians have been more ambivalent on the question of Le Corbusier's proposed system of air exact while some academics have been unequivocally positive about $i^{37}$. The very low respiration exacte flow rates originally proposed by Lyon would, however, have delivered performance even worse than the built version. Even when considering the improvements suggested by ABC and Le Braz, the system does not eliminate thermal problems completely, even with the significantly increased energy consumption. Both performance issues are

\footnotetext{
${ }^{37}$ Ramirez-Balas, Suarez, and Sendra. "Future Technologies in Le Corbusier's Environmental Conditioning Systems: City of Refuge in Paris," n.p. "The City of Refuge...did not manage to convince with the innovations which he had hoped would provide a solution to temperature control problems. This was mostly due to the obstacles encountered in the building, which prevented the execution of one of the most brilliant technological innovations proposed by Le Corbusier: the combination of the mur neutralisant and the respiration exacte."
} 
again in part due to the high solar heat gains, but while the approach may have been conceptually naive it was not due to a lack of awareness on Le Corbusier's part of the potential problems associated with solar gains ${ }^{38}$.

If the client for the Cite de Refuge had been wealthy and less concerned with running costs, as with most clients of air-conditioning systems at the time, this hypothetical narrative could have ended there, and Le Corbusier could have carried on believing that the air exact system obviated the need for any external shading. It is clear however that the Salvation Army were pressed $^{39}$ to afford the capital investment in these technologies and it is not a stretch to suggest that it would have been crippling had they been faced with the operating costs associated with the air exact. Coupled with the persistent thermal issues in the roomettes, it is very possible that Le Corbusier would have found himself in a very similar situation to one he faced in reality; a very unhappy client whose dissatisfaction was partly derived from high solar heat gains. Knowing that in real life Le Braz recommended external shading, and bearing in mind evidence that Le Corbusier himself, in the period after the Cité was built, experimented with the idea of combining the brise-soleil and mur neutralisant ${ }^{40}$, it is reasonable to speculate that he would also have employed a brise-soleil in this hypothetical Cite when the opportunity arose after the war. The simulation of this combination indicates good thermal performance at a much reduced energy cost and suggests that Le Corbusier could have realised in 1952 a combination of his active and passive technical design thinking that would have performed very well. This model not only performs at levels comparable to present standards, including in terms of energy use, but also prefigures the common use of passive shading integrated with double skin glass façades that is ubiquitous today. This combination of a mechanical ventilation system with passive solar shading also represents an imagined and hypothetical shift in Le Corbusier's work. Yet, this invented trajectory isn't far from Le Corbusier's own approach in some of his last works such as the Carpenter Center in Boston and Heidi Webber Pavilion in Zurich. In the development of Le Corbusier's attitude to the mur neutralisant, from a system that could eliminate the appreciated problem of solar heat gains, to one that could be used in combination with external shading one can maybe read his attitude to technology more generally; an attitude that evolves ideas rather than displaces them. As Gutierrez has argued, the perceived 'rejection of technologies' post the Cité de Refuge, oversimplifies what is a more complex history. The hypothetical Cité de Refuge can be seen to represent a compressed body of knowledge about propositions and actual constructions from which Le Corbusier drew on and which prefigures some of his later projects. This suggests an interpretation of the Cité de Refuge that sees it less as a watershed project and more as part of a continual process of thinking about architecture and its relationship to various kinds of technologies. The shift in Le Corbusier's work can be seen to revolve less around an abandonment of technology and more an evolution away from reductive and idealistic expectations placed on a single technological system. If, in 1952, he had successfully realised a combination of distinct active and passive systems it could be expected that this interpretation of the development of his technical thinking would be more prevalent today.

\footnotetext{
${ }^{38}$ Le Corbusier and Boesiger. Le Corbusier: Oeuvre Complet 1938-1946, vol. 4, p. 115. "The curtain wall should have been a 'neutralizing wall'. But the authorities modified the idea, installing conventional central heating with radiators, leaving pending the problem of summer sun. In its present state, the solution would be to equip the glass wall of this building with a sun-breaker!"

${ }^{39}$ Taylor. The City of Refuge, p. 17; Urbano Gutierrez, "Pierre, Revoir Tout Le Systeme Fenetres: Le Corbusier and the Invention of the Mur Neutralisant (1928-1935),” p. 116.

${ }^{40}$ For example, this was proposed for the UN Building. Urbano Gutierrez. "Pierre, Revoir Tout Le Systeme Fenetres: Le Corbusier and the Invention of the Mur Neutralisant (1928-1935).”
} 


\section{Acknowledgements}

The authors would like to thank the following: University of Brighton Conference Support Fund and School for Arts, Design and Media for providing funding; the Office for Spatial Research, University of Brighton.

\section{Bibliography}

Arnold, David. "The Evolution of Modern Office Buildings and Air Conditioning." ASHRAE Journal, Atlanta, June 1999, pp. 40-54.

Brooks, H. Allen (ed.). Le Corbusier Archive. 32 vols. New York: Garland Pub. - Paris: Fondation Le Corbusier, 1982.

Butera, F.M. "Glass Architecture: Is It Sustainable?" In Passive and Low Energy Cooling for the Built Environment, 161-68. Santorini, 2005.

Crawley, Drury B, Linda K Lawrie, Curtis O Pedersen, and Frederick C Winkelmann. "EnergyPlus: Energy Simulation Program." ASHRAE Journal 42, no. 4, Atlanta, April 2000, p.p. 49-56.

Curtis, William. Le Corbusier. New York: Rizzoli, 1986.

Modern Architecture since 1900. New Jersey: Prentice-Hall, 1983.

Fernandez, Vanessa, and Emmanuelle Gallo. "A Factory for Well-Bing: Innovations in the Heating System and the Curtain-Wall in Le Corbusier's Salvation Army's City of Refuge." Proceedings of the 11th DOCOMOMO International Conference, Mexico City, 20-25 August 2010.

Frampton, Kenneth. Modern Architecture: A Critical History. 3rd ed. London: Thames \& Hudson, 1992.

Gallo, Emmanuelle. "The Importance of Introducing the Study of Original Technical Devices in the 20th Century Architectural Heritage, for a Well-Reasoned Conservation Approach." Intervention Approaches for the 20th Century Architectural Heritage, Madrid, 14-16 June 2011.

Jordan, Robert Furneaux. Le Corbusier. First Edition. New York: Lawrence Hill \& Co., 1972.

Le Corbusier, and Willy Boesiger. Le Corbusier: Oeuvre Complet 1938-1946. Vol. 4., 8 vols. Zurich: Editions d'Architecture, 1977.

Ramirez-Balas, C., R. Suarez, and J.J. Sendra. "Future Technologies in Le Corbusier's Environmental Conditioning Systems: City of Refuge in Paris." Sustainably Architecture for a Renewable Future, PLEA2013 29th Conference, Munich, 10-12 September 2013.

Ruiz, Ignacio Requena. "An Approach to Environment and Modernity Through Le Corbusier's Drawing." Revista de EGA, no. 20, Valencia, October 2012, p. 246.

Scully Jr., Vincent. Modern Architecture. New York: G. Braziller, 1961.

Sobin, Harris. "From l'Air Exact to l'Aerateur: Ventilation and Its Evolution in the Architectural Work of Le Corbusier." In The Green Braid, pp. 140-52. London: Routledge, 2007.

Tafuri, Manfredo. Modern Architecture. 2 vols. Milan: Electa, 1976.

Taylor, Brian Brace. Le Corbusier, The City of Refuge, Paris 1929/33. Chicago - London: University of Chicago Press, 1987.

Urbano Gutierrez, Rosa. "Le Pan de Verre Scientifique: Le Corbusier and the Saint-Gobain Glass Laboratory Experiments (1931-1932).” Architectural Research Quarterly 17, no. 1, Cambridge, 2013, pp. 63-71.

"Pierre, Revoir Tout Le Systeme Fenetres: Le Corbusier and the Invention of the Mur Neutralisant (1928-1935)." International Journal of the Construction History Society, no. 27, Cambridge, 2012, pp. 107-28.

Von Moos, Stanislaus. Le Corbusier, Elements of a Synthesis. Cambridge, Mass.: MIT Press, 1979. 
Walden, Russell. The Open Hand: Essays on Le Corbusier. Cambridge: M.I.T. Press, 1977.

Winter, John. "Le Corbusier's Technological Dilemna" in The Open Hand: Essays on Le Corbusier, pp. 322-47. Cambridge, Mass.: M.I.T. Press, 1977. 
M. X à Bruxelles ». ${ }^{3}$ Ceci est le dernier projet que LC cite dans son premier volume de 'Oeuvre complète', paru en 1929. À cause du krach de 1929, le futur beau-père de Canneel fait faillite et la maison mitoyenne à trois façades ne se construit pas. En 1931, Canneel choisit l'architecte belge Louis Herman De Koninck avec la permission de Le Corbusier.

En novembre 1930, LC est présent dans le Palais des Beaux-Arts (BOZAR) pour la réunion de la CIAM. Avec Huib Hoste et Loquet, il a pris part en 1933 au concours international de la Rive Gauche d'Anvers. ${ }^{4}$ Dans ce projet, il introduit le concept de sa 'Ville Radieuse' et il combine cela avec une proposition pour le Mundaneum de Paul Otlet. De ce projet ont été réalisé plusieurs perspectives magnifiques. Compte tenu de la crise économique, les projets pour la Rive Gauche arrivent dans les archives. À la demande de Hoste, le projet est remanié en 1939 par Le Corbusier.

Une partie de la participation française à 'l'Exposition Universelle et Internationale' à Bruxelles en 1935, a été conçue par Charlotte Perriand en collaboration avec Réne Herbst et Louis Sognot. Dans son "appartement du jeune homme" elle introduit des meubles qu'elle a conçus en tant que co-auteur avec Pierre Jeanneret et LC. ${ }^{5}$

Après Bruxelles en 1935, L'exposition de l'Eau se tient à Liège, à la veille de la Seconde Guerre mondiale. La réunion du CIAM, prévue dans le cadre de cet événement, a été annulée. En 1938, L'Équerre, un groupe de jeunes architectes liègeois, propose à Le Corbusier de coopérer au plan d'urbanisme pour cette exposition sur les deux rives de la Meuse. LC espère également se qualifier pour le pavillon français. Finalement, aucun des deux projets ne sera réalisé. ${ }^{6}$

LC est présent à l'exposition Universelle de Bruxelles 1958 avec un pavillon exceptionnel pour Philips. ${ }^{7}$ Le projet est une collaboration entre Le Corbusier et le musicien Edgard Varèse. Dans le bureau de LC travaillait à cette époque le jeune architecte et musicien Iannis Xenakis qui a eu une très grande influence sur le concept. Le bâtiment qui apparaît comme audacieux et très moderne est construit de façon traditionnelle et artisanale. À la fermeture de l'Exposition, ce pavillon a été démoli en raison de la méthode de construction. Alors que de nombreux pavillons ont été vendus et déplacés, le bâtiment Philips ne pouvait qu"être démoli. Tous ces projets de LC en Belgique ont été étudiés et publiés en détail au cours des années. ${ }^{10}$

\footnotetext{
3 DUBOIS, M., La maison Canneel / The Canneel house, In: Louis Herman De Koninck / Architecte des Années Modernes Architect of Modern Times. Bruxelles, Archives d'Architecture Moderne, 1989, pp.138-163.

DUBOIS, M., La virtuosité individualiste de Le Corbusier - Le fonctionnalisme parfait de De Koninck, In: Le Corbusier et le mouvement moderne en Belgique 1920-1940. Liège Saint Luc,1988, pp.55-65.

${ }^{4}$ COMMERS, R., LOMBAERDE, P., Le Corbusier te Antwerpen / De Linkeroever. Antwerpen H.A.I.R., 1987.

${ }^{5}$ RÜEGG, A., Le Corbusier - Furniture and interiors 1905-1965. Paris, Zürich, Fondation Le Corbusier \& Scheidegger \& Spiess, 2012, p.312-313.

${ }^{6}$ BAIWIR, J.-C., D'un pavillon d'exposition à l'autre, In: Le Corbusier et le mouvement moderne en Belgique 1920-1940. Liège, Saint Luc ,1988, pp.81- 87.

DUBOIS, M., Exposition de l' Eau / Tweemaal Le Corbusier, In: ARCHIS, nr.7,1990, pp.25-30.

${ }^{7}$ LOOTSMA, B., Poème Electronique : Le Corbusier, Xenakis, Varèse, In : Synthèse des Arts -Aspekte des Spätwerks 19451965. Karlsruhe, 1986, pp. 111-147.

TREVISIOL, R., Le pavillon Philips de Le Corbusier et Xenakis, In: Le Corbusier \& La Belgique.Paris - Bruxelles, Fondation Le Corbusier / CFC Éditions, 1997, pp.225-252.

WEVER, P., Inside Le Corbusier's Philips Pavillion /A Multimedial Space at the 1958 Brussels World's Fair. Rotterdam, NAi010 Publishers, 2015.
} 


\section{Son influence est très importante}

Depuis 1987, centième anniversaire de sa naissance, jusqu'en 2015, une énorme quantité d'études et d'analyses ont mis l'accent sur les différents aspects de sa vie et de son œuvre. Dans certaines études, l'influence de Le Corbusier pour les générations futures est examinée. L'impact de ses idées et de ses projets est impressionnant et il reste encore beaucoup de recherches à effectuer. En ce qui concerne la Belgique, son influence a été très importante, surtout dans les années 1920/1930 pour la jeune génération d'architectes comme Victor Bourgeois, Louis Herman De Koninck, Gaston Eysselinck, Léon Stynen, Renaat Braem, Maxime Brunfaut et Emile Goffay. ${ }^{8}$ Même après 1945, son influence reste grande, en particulier avec le projet de Marseille.

\section{L'œuvre de Léon Stynen}

L'œuvre de l'architecte Léon Stynen (1899-1990) et de son associé depuis 1949, l'architecte Paul De Meyer (1922-2011) n'est presque pas connue en dehors de la Belgique. ${ }^{9}$ Stynen a étudié à l'Académie d'Anvers où il a obtenu son diplôme en 1922. Comme beaucoup d'architectes en Flandre, ses premiers projets dans les années 1920 étaient fortement influencés par l'œuvre de l'architecte H.P. Berlage et par l'architecture des Pays-Bas en général.

En 1930, la Belgique fait la fête avec une grande exposition internationale à Anvers. Le jeune Stynen y construit deux pavillons. La même année, le nouveau casino à Knokke est inauguré, un bâtiment avec une façade entièrement en verre, dirigé vers la mer. ${ }^{10}$ Le casino, avec son langage formel moderniste, est un des bâtiments publics les plus importants à ce moment-là. Stynen construit sa propre maison en 1933-1934. Dans le secteur de l'habitat sa grande commande est l'immeuble d'appartements Elsdonck à Wilrijk, une commune verte aux bords de la ville d'Anvers. ${ }^{11}$ Ce complexe isolé à six étages contient de grands appartements pour la riche bourgeoisie. Stynen devra attendre les années 1960 avant de pouvoir construire un projet comparable. Il continue à suivre les développements dans l'œuvre de le Corbusier via des publications. Les projets de Stynen entre 1932 et 1934 montrent son habilité pour assimiler les influences du grand maître. Comme LC introduit la pierre naturelle dans l'architecture, Stynen suit la même voie vers une autre matérialité. Pour la maison Van Thillo à Ekeren (1936-

\footnotetext{
${ }^{8}$ CONDE-REIS, G., BASYN,J.-M., e.a., Brunfaut's Progressive Architecture - Fernand, Gaston, Maxime Brunfaut, A family of Modernist Architects / une famille d'architectes modernistes / Een familie van modernistische architecten. Brussels, CFC Editions - Atomium Editions, 2013.

DUBOIS, M., L' influence de Le Corbusier dans l'œuvre de Gaston Eysselinck, In: Le Corbusier \& La Belgique. Paris Bruxelles, Fondation Le Corbusier / CFC Éditions, 1997, pp.79-94.

SMETS, Marcel, Huib Hoste, voorvechter van een vernieuwde architectuur, Brussel, Nationale Confederatie van het Bouwbedrijf, 1972.

AVERMAETE, Tom, PROVO, Bregje (red.). Huib Hoste : 1881-1957. Antwerpen, CVAa, 2005.

STRAUVEN, Iwan, CULOT, Maurice, De gebroeders Bourgeois: architectuur en plastique pure, Bruxelles, AAM Uitgave, 2005.

STRAUVEN, F., Renaat Braem. Bruxelles, AAM, 1985.

BRAEKEN, J. (red.), Renaat Braem 1910-2001. Bruxelles, VIOE \& ASA Publishers, 2010.

${ }^{9}$ BONTRIDDER,A., La raison révoltée, Léon Stynen, sa vie et son œuvre. Anvers, Comité Léon Stynen, 1979.

BEKAERT, G., DE MEYER,R., Léon Stynen een architect. Antwerpen, deSingel, 1990.

LAUREYS, D. (red.), Léon Stynen, In: Bouwen in Beeld - De collectie van het Architectuurarchief van de Provincie Antwerpen, Antwerpen, 2004, pp. 262-271.

${ }^{10}$ Stynen construit le Casino de Knokke en collaboration avec des architectes anversois plus âgés: Jan Van Hoenacker (1875-1958) et François Dens (1880-1968).

${ }^{11}$ MALLIET, A., Résidence Elsdonck, een opmerkelijk en kleurig appartementsgebouw, oorspronkelijk in het groen, In: Monumenten \& Landschappen , nr.4, 1996, pp.23-34.
} 
1938), avec une façade en pierre naturelle, il reçoit en 1939 le prix d'architecture Van de Ven, la distinction la plus importante en Belgique. Il a utilisé les mêmes matériaux pour la construction du casino de Chaudfontaine (1937-1938). En 1939, Stynen collabore avec Henry van de Velde pour le projet du pavillon belge pour l'exposition mondiale à New York. En 1937, Stynen devient professeur à l'Académie Royale à Anvers. Il donne cours à son futur compagnon Paul De Meyer. En 1949, il devient le directeur du département d'architecture à Anvers. L'année après, il devient le directeur de La Cambre à Bruxelles, l'école qui était fondée par Henry van de Velde vers la fin des années 1920.

La personnalité de Stynen était tout à fait différente de celle de Le Corbusier. Dans l'œuvre de Stynen, l'influence de l'architecture classique est toujours visible. Il assimilait le langage formel moderniste et prenait clairement moins de risques techniques en construction en comparaison avec les architectes avant-gardistes comme Bourgeois ou Eysselinck. Pour sa propre maison, il décide d'utiliser de la maçonnerie traditionnelle au lieu du stucco plus fragile. Stynen était un aristocrate, qui pouvait toujours compter sur le soutien de la riche bourgeoisie. Il a construit trois casinos (à Knokke, à Chaudfontaine et à Ostende), des projets complètement différents des projets de logement social! C'est remarquable qu'il commence à préférer, à partir de 1945, une composition de façade en béton plutôt que des façades-rideaux lisses qui sont à la mode après le succès du Lever building à New York.

\section{Collaboration avec Paul De Meyer}

De Meyer, fils d'un architecte, est né en 1922 à Lier. Il a 18 ans lorsque la guerre éclate. ${ }^{12}$ Il fait ses études à l'Académie Royale d'Anvers et obtient son diplôme en 1944 avec son projet pour une auberge de jeunesse à Lier. Stynen était un de ses professeurs. Le langage formel de son projet final est moderniste, une construction sur pilotis avec une toiture plate. Après ses études, il commence sa pratique indépendante à Lier. Après la guerre, Stynen gagne la compétition pour le nouveau casino à Ostende. Il comprend très bien qu'il doit organiser son bureau d'une autre manière et qu'il a besoin de son "bras droit" fidèle dans son atelier. Grâce à cette décision, Stynen peut également ambitionner d'autres fonctions, comme le poste de directeur à La Cambre (Bruxelles) et la présidence de l'Ordre des Architectes. De Meyer devient son compagnon à partir de 1947, et il le sera jusqu'à ce que Stynen ferme son bureau à la fin de sa vie.

L'atelier de Le Corbusier à la Rue de Sèvres, où Pierre Jeanneret assurait la 'permanence', était probablement un exemple pour Stynen. Il avait également l'ambition d'embaucher de jeunes architectes talentueux, comme Walter Bresseleers et Paul Meekels, qui auront plus tard leur propre bureau d'architecture.

De Meyer commence directement avec un grand projet, le casino d'Ostende (1948-1953). Grâce au réseau de contacts de Stynen, le bureau reçoit un grand nombre de demandes de construction. Le bureau peut également collaborer au projet le plus grand en Belgique après la Deuxième Guerre Mondiale, l'exposition mondiale de 1958 à Bruxelles. Le pavillon pour l'industrie pétrolière est un projet intéressant. Surtout pendant les "Golden Sixties", le bureau reçoit différents grands projets. Un des grands clients est la famille néerlandaise Brenninkmeyer, propriétaire du groupe industriel de textile C\&A, qui demande de construire des magasins dans

12 Architect Bernard De Meyer (1883-1979).

LAUREYS, D. (red.), Bernard De Meyer, In: Bouwen in Beeld - De collectie van het Architectuurarchief van de Provincie Antwerpen. Antwerpen, 2004, pp. 183-186.

DELAHAYE, R., Architectenbureau Stynen \& De Meyer: Een kritische kijk op het werk tijdens en na de Tweede wereldoorlog. Gent, Vakgroep Architectuur \& Stedenbouw, 2003. 
les villes belges les plus importantes. ${ }^{13}$ Stynen \& De Meyer prêtent surtout attention à la façade en béton: ils essaient de trouvent une variation pour le 'brise-soleil'. Pour leur composition, les architectes font appel au section d'or et au Modulor de Le Corbusier. Cette attention particulière pour la façade est également visible dans un projet pour une grande école Peter Pan à Saint-Gilles (Bruxelles, 1956-1969). L'église pour la Sainte Rita à Harelbeke (1959-1962) est un exemple dans lequel le projet de Le Corbusier pour Firminy est utilisé mais pas copié.

Le projet avec lequel le bureau parvient à la reconnaissance internationale est le BP Building à Anvers (1961), un des premiers immeubles de bureaux dans lequel la façade et les dalles sont suspendues à la cage en béton centrale, où les ascenseurs et les escaliers sont situés. Le chef-d'œuvre est le Conservatoire Royal à Anvers, maintenant le centre culturel deSingel. Le concept avec une cour extérieure comme à l'Abbaye de la Tourette inspire très fort Stynen \& De Meyer. Aussi les formes organiques des fenêtres à l'entrés, un clin d'œil à LC et son projet à Chandigarh, et la recherche sur les brise-soleil sont présentes. Après la mort de LC, Stynen entre en contact avec l' architecte André Wogenscky dans le but de construire à Anvers le Musée à croissance illimitée, projet qui n'aboutira pas.

\section{Riverside Tower de Stynen \& De Meyer (1969-1972)}

Après la proposition de construire le Mundaneum à Genève (1928), LC fait une deuxième tentative pour introduire le concept de Paul Otlet dans sa proposition de la rive gauche à Anvers (1933). Ce concours international a été lancé par IMALSO, une société intercommunale. Principalement en raison de la crise économique, toutes les propositions ont été mises dans des boîtes d'archives.

Précisément ce lieu, situé à la large boucle de l'Escaut, sera réservé à la construction de trois tours d'appartements d'environ vingt étages. La première d'entre elles, conçue par Stynen et De Meyer est Riverside Tower (1966 à 1972). ${ }^{14}$ Le maître d'ouvrage est la famille Brachfeld (les frères Harry et Marcel), active dans le secteur du diamant. Le terrain d'IMALSO a été acheté à la fin de 1965 et en 1966 les architectes ont reçu la commande. ${ }^{15}$ Le but de Brachfeld était de vendre une partie des appartements, et d'en louer certains pour un court laps de temps, à des personnes employées par des sociétés internationales telles que Alcatel. Stynen et De Meyer avaient une grande appréciation pour le travail de Le Corbusier. Comme beaucoup d'autres jeunes architectes, De Meyer visite Ronchamp et Marseille avec Stynen dans la seconde moitié des années 50. La visite de La Cité Radieuse fait grande impression. En particulier la volumétrie du toit,, l'ouverture du rez-dechaussée, les types de duplex et la plasticité du pilotis de Marseille auront une influence sur le projet River Tower.

À la fin de 1966, on commence à faire les avant-projets de ce complexe de grands appartements. En automne 1967, les plans ont été établis pour le permis de construire. Le bâtiment de la tour de vingt étages plus penthouse dispose d'une superficie au sol de 40,50 mètres sur 15,50 mètres. Par étage, il y a quatre appartements spacieux et deux cages d'ascenseur avec des escaliers. Déjà, dès le départ, les architectes ont choisi une trame de 3,34 m. Au début de la construction en novembre 1968, un petit livre-guide est imprimé par CBS Riverside Tower pour

\footnotetext{
${ }^{13}$ Les projets pour C\&A en Belgique: Antwerpen (1963), Brussel / Bruxelles (1964), Charleroi (1968), Kortrijk (1968), Gent (1968), Sint Lambrechts Woluwe (1968), Namur (1969), Brugge \& Hasselt.

${ }^{14}$ Les deux autres tours: "Panorama" (1968) en "Habitim" (1974).

${ }^{15}$ Information dans la lettre de IMALSO à C.B.S. Tower p.v.b.a. du 30 octobre 1972. Les premiers dessins datent de novembre 1966. Le terrain est situé à l'angle Esmoreitlaan en Bouvaertlaan.
} 
informer les futurs propriétaires-acheteurs. Il contient un certain nombre de données spécifiques et fait l'éloge de la qualité du projet. Pour le positionnement du volume du bâtiment, il a été décidé d'orienter les chambres vers l'est, la salle de séjour vers l'ouest. Le complexe dispose d'une petite maison de gardien sur le côté ouest.

Tous les appartements disposent d'un garage souterrain (80 places) pour préserver la zone verte autour de l'immeuble. Il y a une salle séparée, équipée pour laver la voiture et aussi un espace avec des machines automatiques pour le lavage des textiles. Les débarras ne sont pas prévus dans le sous-sol, mais sur tout un étage au-dessus de la base à double hauteur du bâtiment. Toute humidité dans l'espace de stockage est ainsi bannie. Cette solution a également permis de regrouper les conduites verticales à l'horizontale pour libérer ainsi le socle du bâtiment de toute tuyauterie.

La façade se compose de béton blanc / gris avec un haut degré de finition. L'option d'un mur-rideau vitré est définitivement rejeté dans le texte. Il n'était pas souhaitable de prévoir de grandes terrasses. En revanche, les pièces ont de très larges fenêtres en aluminium pivotant à la verticale au milieu. Le bâtiment a deux cages d'ascenseurs, équipées par OTIS. Dans un des deux ascenseurs, la largeur de 1,75 m peut être élargie à 2,10 mètres pour faciliter le transport de meubles. Les appartements ont une hauteur sous plafond de 2,76 mètres au lieu de la hauteur alors courante de 2,60 mètres. En ce qui concerne le chauffage, tous les radiateurs sont incorporés. En bas de la notice d'information se trouvent quelques références des architectes ainsi qu' une liste des bureaux d'études. ${ }^{16}$

Cependant, l'orientation est-ouest mentionnée est pas correcte. Le volume construit est implanté plus nord-est / sud-ouest pour avoir une meilleure vue sur le vieux centre-ville. Il est remarquable pour cette tour que la vue depuis le salon est la boucle de l'Escaut et le port et non la ville d'Anvers, un choix que nous pouvons à peine comprendre aujourd'hui. D'une part, il y avait la vision urbanistique de l'implantation du gratte-ciel. D'autre part, il y avait dans les années soixante peu d'intérêt pour le centre historique de cette ville qui se trouvait dans un état parfois déplorable. Le futur n'était pas là, mais bien dans le port, la route vers la mer du Nord. Plus tard, une seconde, plus belle brochure promotionnelle a été publiée où les avantages et surtout la vue sur les environs verdoyants et sur la ville sont mis en évidence. ${ }^{17}$

\section{Travail patient}

Entre l'avant-projet de la tour et la finition du penthouse, il y a plus de quatre ans. Les plans de coffrage pour le penthouse ont été faites seulement au début de 1972; le déménagement de la famille De Meyer de Lier au nouvel appartement a eu lieu à la fin de juin 1973. Cette période a donné l'occasion à De Meyer de concevoir sa maison avec grand soin. Il y a eu un processus de travail patient, qui a pu être reconstruit grâce à ses nombreux croquis et photos. Dans les archives De Meyer ne se trouve aucune note écrite!

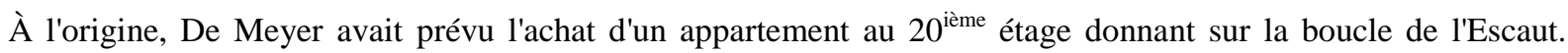
Quelques croquis montrent ses études pour rejoindre l'étage technique, le toit plat, par un petit escalier en

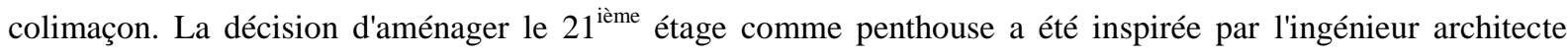
Léopold Hendrickx, directeur général de l' urbanisme en Belgique, qui s'était plaint du gâchis sur les toits des tours résidentielles où se trouvent des cages d'ascenseur et des cheminées de ventilation. Il voulait que De Meyer

\footnotetext{
16 Tous des projets à Anvers: BP Building, la Bourse aux Diamants, Conservatoire Royal de Musique et le bâtiment C.B.S. Building. Les bureaux d'études: Constructor (étude béton), Ing. Varendonck (chauffage), Ing. Van Haren (Électricité), acoustique (E.R.V.A.).

${ }^{17}$ Information sur le dépliant: les deux promoteurs: C.B.S. Building (entreprise de la famille Brachfeld) en P.V.B.A. Laureyssens, entrepreneur à Zoersel.
} 
profite de l'occasion pour montrer qu'il pouvait faire mieux. ${ }^{18}$ Une autre raison pour laquelle il a renoncé au $20^{\text {ième }}$ étage est probablement la construction d'une deuxième tour "Panorama", qui masquait partiellement la vue sur la boucle de l'Escaut.

L'idée de couronner la tour d'un appartement avec un toit jardin était pour De Meyer presque la réalisation d'un rêve, de l'ambition des idées de la modernité. Un 'toit jardin' comme cinquième façade d'un immeuble, cela a toujours été défendu par son maître admiré Le Corbusier dans les «Cinq points de l'architecture moderne ". C'est sans aucun doute le penthouse que LC a construit pour Charles de Beistegui (1930-1931) qui a inspiré très fort De Meyer. Toutefois, Le Corbusier a conçu pour ce multimillionnaire un décor de fête et non une résidence permanente. ${ }^{19}$ Dans la bibliothèque de De Meyer se trouve la deuxième partie de l'Éuvre complète où ce projet à Paris a été documenté. ${ }^{20}$ Les terrasses à Paris ont différents niveaux et il y aussi des escaliers. La façon dont De Meyer a dessiné les escaliers entre la petite terrasse à côté de la chambre à coucher principale et le jardin supérieur possède une nette affinité avec la solution de LC.

Les différentes phases du projet peuvent être reconstruites grâce aux nombreux dessins et aux photos des deux maquettes réalisées pour Brachfeld. Les photos de la première version montrent déjà un socle très ouvert où les pilotis sont conçus comme des disques qui s'élargissent vers le bas. Dès le début, le terrain a été remodelé grâce à une différence de hauteur. La zone verte côté Esmoreitlaan sous laquelle se situe le garage souterrain est plus haute que la partie de l'entrée et de l'accès au garage. Cette différence de niveau se voit dans le socle de l'édifice. La vue dégagée depuis le couloir qui relie les deux cages d'ascenseur est remarquable et la continuité de intérieur vers extérieur est renforcée par un mur de verre continu sans profils.

La relation entre l'entrée et l'accès au garage a un concept plus classique mais en même temps très fonctionnel. Les voitures peuvent s'arrêter sous la canopée pour laisser descendre les gens, et ensuite continuer vers le garage souterrain. L'idée de relier l'intérieur à l'extérieur est accentuée par l'utilisation du matériau sur le sol où un tapis de "Pirelli" était prévu. Cette solution n'a pas été réalisée dans la phase finale.

Dans le premier modèle, l'entrée n'est pas accentuée et il n'est pas encore question d'un penthouse. La composition des façades indique déjà que les étages sont pas tous semblables. Ainsi, au $13^{\text {ème }}$ étage, il y a l'accès

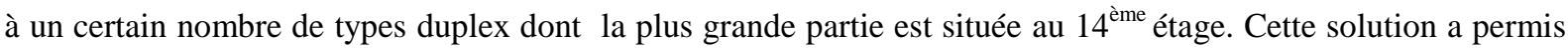
d'intégrer au $13^{\text {ème }}$ étage quatre petits studios (de 78,52 $\mathrm{m}^{2}$ à un petit studio de $38 \mathrm{~m}^{2}$ ).

Dans le second modèle, le socle reçoit une autre solution. Les "disques-pilotis" sont remplacés par des colonnes légèrement coniques vers l'intérieur. ${ }^{21}$ La hauteur du socle est de six mètres. Au-dessus du couloir entre les deux cages d'ascenseur il y a un passage ouvert, qui est indiqué sur les dessins comme "wandelterras" (terrasse promenade). L'entrée de la maison du gardien se trouve à ce niveau de 3,13 mètres. Grâce à cette solution, le concierge a l'occasion d'utiliser le second ascenseur. Cette 'terrasse-promenade' a peu de sens, et déjà pendant la phase de construction, une proposition a été élaborée côté Esmoreitlaan pour réduire l'espace ouvert du socle en introduisant une paroi en verre supplémentaire. Les plans indiquent le mot 'Kunsthandelaar', un espace

\footnotetext{
${ }^{18}$ Interview avec Paul De Meyer le 29 juillet 2004.

19 VAN DEN BERGH, W. , Beistegui avant Le Corbusier. Paris, Éditions B2, 2015.

${ }^{20}$ LE CORBUSIER, JEANNERET, P., Oeuvre Complète de 1929-1934. Zürich, Les Éditions d'Architecture Erlenbach, 1946, pp.53-57.

${ }^{21}$ Les colonnes dans le socle du bâtiment ont une forme conique : $130 \mathrm{~cm}$ (extérieur), $90 \mathrm{~cm}$ (intérieur), l'épaisseur $70 \mathrm{~cm}$. Cette forme est reprise dans les façades.
} 
d'exposition. Le petit escalier menant à la passerelle qui pouvait servir comme zone de bureau pour un marchand d'art n'a pas été réalisé. ${ }^{22}$

\section{Penthouse et "toit-jardin"}

Le plus gros problème pour De Meyer dans la conception de son appartement a été l'intégration de la deuxième cage d'ascenseur qui devait rester accessible pour l'entretien. Aussi pour les tuyaux de ventilation verticale, il fallait trouver une solution. Sur le second modèle, fabriqué en bois de balsa, on voit déjà la première version du penthouse. Le plancher technique situé à 67,48 mètres est simplement marqué sur les dessins comme zone de stockage et pour l'installation de la ventilation. Le penthouse dispose de deux niveaux: 69.16 mètres à l'entrée et 70.09 mètres à la salle de séjour. Une petite pente relie les deux zones. Sur la photo du second modèle, la zone de la pente a des fenêtres rondes. On peut supposer que, étant donné la large vue, il élimina ces petites ouvertures. Derrière la cheminé était prévu un petit espace de bureau. Un petit escalier permet la connexion entre l'étage technique et la surface du toit.

Sur le plan de la toiture est indiqué qu'il y aurait un petit bassin, un élément qui restera dans le projet final. De Meyer fait des recherches pour ne pas se limiter au toits plats, la pente et la forme du toit courbé sont adoptés et restent dans le projet final. De Meyer opte pour une forme de toit courbé tant pour le hall d'entrée avec vestiaire que pour une partie du plancher technique et pour le débarras du jardin. Ceci n'est pas étonnant quand on parcourt l'œuvre de LC où il utilise ces différents types de toiture. Sans aucun doute, les nombreuses publications des maisons Jaoul à Neuilly de LC ont convaincu De Meyer que la modernité ne correspond pas à l'usage exclusif des toits plats. Il est remarquable que, dans cette phase, sur le plan on ne trouve pas les mots chambres mais à plusieurs reprises débarras. Il est clair qu'il veut intégrer une grande partie du plancher technique dans son penthouse, mais que le résultat à ce stade n'est pas encore satisfaisant pour lui.

Dans un dessin non daté, il cherche à intégrer la cage d'ascenseur dans un volume elliptique. Dans cette proposition, le jardin du $21^{\text {ième }}$ est situé autour de la cage d'ascenseur et sur le côté ouest. Les terrasses donnent sur le côté nord et le côté sud. Il quittera définitivement l'idée d'une terrasse sur le côté nord, étant donné les conditions de vent à cette hauteur! De Meyer quitte la solution de la cage d'ascenseur elliptique dans ses nouvelles propositions, peut-être parce que elle ressemble trop au volume sur le toit de l'appartement de Charles de Beistegui. En fin de compte, la forme de base de la cage d'ascenseur sera prolongée jusqu'au $21^{\text {ème }}$ étage.

Dans la phase suivante, De Meyer cherche davantage comment ces deux niveaux peuvent être mieux connectés. Il va utiliser la coupe verticale pour intégrer à gauche et à droite de la cage d'ascenseur une partie de son penthouse. Au lieu d'un plan incliné unique, il y en aura quatre dans le projet final, dont un à l'extérieur. Les petits escaliers dans la phase précédente sont éliminés et remplacés par des pentes. C'est un moyen de relier différents niveaux que LC a utilisé dans beaucoup de ses projets.

Au niveau de l'étage technique, côté nord-ouest, il y a quatre chambres avec la toiture en pente. Au milieu, deux petites chambres pour les enfants dont les fenêtres sont orientées vers le nord, la troisième chambre donne sur le jardin supérieur. ${ }^{23}$ La chambre principale pour les parents avec une orientation ouest donne sur une terrasse qui

\footnotetext{
${ }^{22}$ En 1988 cette idée d'extension du socle est reprise quand le bureau Stynen / De Meyer a mis fin à ses activités. De Meyer va utiliser la passerelle comme bureau.

${ }^{23}$ Cette pièce avec la lumière du nord, De Meyer va l'utiliser pendent les dernières années de sa vie comme espace pour dessiner et faire des aquarelles.
} 
est reliée par un escalier au jardin devant. Dans la phase de conception, il y a des croquis dans lesquels il cherche des solutions pour connecter le salon directement avec la chambre des parents avec un petit escalier en colimaçon. Finalement, il laisse tomber cette solution et il déplace l'escalier sur le côté sud, de sorte à obtenir une petite surface de travail avec la bibliothèque, plus une salle de stockage au niveau de l'espace technique.

Une partie de la bibliothèque comporte une paroi courbe qui se prolonge sur le toit. Outre la bibliothèque, il $\mathrm{y} a$ un petit bureau en face de la fenêtre avec une vue sur les tours d'Anvers. Entre la fenêtre et la vue se trouve une partie du jardin. Celui qui regarde attentivement le haut de la façade de la tour peut trouver cette ouverture rectangulaire qui pourtant ne figure pas sur la deuxième version de la maquette. Pour De Meyer, ce fut un espace intime, le lieu de travail et dessin, entouré de ses livres. La vue sur Anvers est comme une peinture.

Il y a deux petits modèles en bois de balsa préservés qui illustrent bien les derniers ajustements. Le hall d'entrée avec vestiaire et toilette était trop petit par rapport à la superficie totale. Cette partie a été agrandie et dotée d'un deuxième salon avec bar à l' une atmosphère totalement différente que celle du salon. Pour cette zone de réception il a choisi un sol en marbre blanc et des sièges blancs. Le plan s'améliore systématiquement et offre une meilleure vue sur le jardin. Même à partir du lavabo près du vestiaire, on peut voir l'herbe et les arbres. Au printemps 1972, le penthouse est réalisé. Jusqu'au dernier moment, De Meyer apporte de petits changements et tous les détails sont étroitement dessinés et surveillés pendant la construction.

La hauteur du plafond dans les appartements de la tour est de 2,70 mètres. Dans le penthouse, il va utiliser des mesures différentes afin de ne pas créer une hauteur trop élevé. Pour le salon, il choisit de $2,75 \mathrm{~cm}$ tandis que le couloir qui relie la chambre à coucher a seulement 2,20 mètres de haut. Cette variation de hauteur améliore l'atmosphère de la perception du penthouse. La superficie du penthouse est de $272,28 \mathrm{~m}^{2}{ }^{24}$

\section{Unité entre l'espace intérieur et le mobilier.}

De Meyer a acheté de nouveaux meubles et des lampes qui ont créé une unité. À gauche de l'entrée, il y a un coin bar avec une vue imprenable sur la skyline d'Anvers. Les sièges en cuir blanc forment une unité un avec le beau sol en marbre blanc. Pour cet espace, De Meyer a choisi l'élégante lampe blanche Pipistrello conçue par Gae Aulenti en 1966. Les sièges en cuir dans le living sont de deSede, modèle DS 76. La table FESTO et les chaises empilables sont dessinées par Achille Castiglioni et produites par Zanotta. Au-dessus de la table il y a une lampe conçue par Jo Colombo pour la société Oluce. De Meyer a également acheté des lampes en forme de grands cailloux de différents formats. Ils sont conçus par le designer français André Cazenave.

Contrairement à LC qui a opté pour un béton brut, De Meyer exigeait une grande perfection. Pour améliorer l'acoustique, il choisit une moquette épaisse. Le long mur du salon est peint en noir. On y a fixé un système d'étagères conçu par le designer suédois, l'architecte et le producteur Nils Strinning. Ce concept "String" est composé de supports métalliques verticaux entre lesquels on mettait des planches ou des modules armoires. Ce système, conçu en 1949, a connu en Europe un énorme succès. Pour la bibliothèque, il a choisi le système conçu par le designer danois Poul Cadovius (1911-2011). ${ }^{25}$

De Meyer a attaché beaucoup d'importance à la cuisine. Il l'élabore dans tous les détails. L'île de cuisson se dresse au milieu de la pièce. Il y a une fenêtre horizontale avec vue sur la zone du port, de l'autre côté se trouve une paroi pliante en bois du sol au plafond. Pour le plafond suspendu, il utilise des lamelles en aluminium

\footnotetext{
${ }^{24}$ Lettre de C.B.S. Tower p.v.b.a. à IMALSO, le 2 février 1973: 272,28 m².

${ }^{25}$ Ce système de rayons est produit par Royal System A/S et avait un importateur à Bruxelles. L' architecte Poul Cadovius a reçu un "Gold medal" à Bruxelles en 1961 pour cette invention.
} 
(Luxalon), fabriquées par Hunter Douglas. Au-dessus des lamelles tout est peint en noir et une hotte est présente mais invisible. ${ }^{26}$

De l'entrée, une rampe part en direction du salon et une autre vers les quatre chambres à coucher. Entre la salle à manger et le salon se trouve feu ouvert autonome, une solution qui divise l'espace, tout en le laissant ouvert. De la salle à manger, une troisième rampe mène à la terrasse extérieure. Une quatrième rampe vers le toit se termine par une haute paroi courbe.

\section{Le toit Jardin}

Ce jardin avec ses niveaux différents et ses arbres était un des principaux objectifs de l'architecte. Ce lieu extérieur est une oasis de tranquillité protégée par des murs de différentes hauteurs. Le jardin a été créé en 1973. L'épaisseur du sol est de $60 \mathrm{~cm}$. On peut s'y promener du nord à l'ouest. Dans les archives, il y a également deux dessins pour une paroi en céramique probablement prévue sur l'un des murs de la toiture. Une de ces parois est un hommage à Le Corbusier avec un accent sur la main ouverte. Aucune de ces deux propositions n'a été effectuée.

Après la mort de l'architecte, j'ai reçu en 2014 tous les documents pour mes recherches concernant un des immeubles les plus réussis en Belgique. ${ }^{27}$ De Meyer a toujours refusé de publier ce lieu privé. Depuis cette année, il y a un nouveau propriétaire. L'unité entre l'intérieur et l'ameublement a disparu. In extremis, l'ensemble a pu être photographié par Filip Dujardin.

Avec ce penthouse, De Meyer montre son intelligence de transformer de façon créative l'héritage de Le Corbusier sans tomber dans la copie formelle. Cette étude essaie de retracer le processus créatif d'un architecte qui admirait Le Corbusier et montre en même temps le pouvoir de De Meyer d'assimilation personnelle de l'héritage du grand maitre.

\footnotetext{
${ }^{26}$ La cuisine est produite par l'entreprise Wielandts à base des dessins de De Meyer.

${ }^{27}$ Les documents se trouvent maintenant dans APA, Archief Provincie Antwerpen.
} 


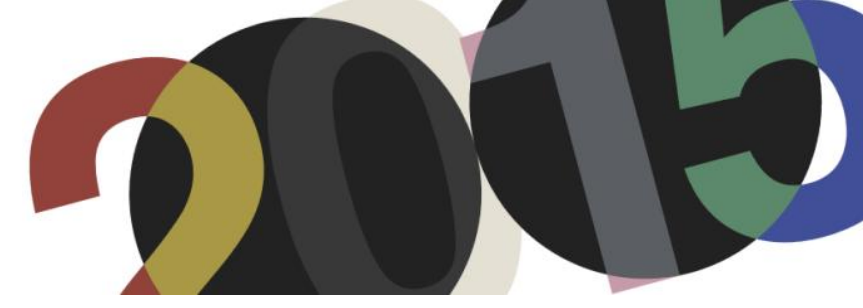

DOI: http://dx.doi.org/10.4995/LC2015.2015.1025

\title{
Machines à exposer
}

\author{
C. Dumont d'Ayot
}

Institut für Denkmalpflege und Bauforschung, ETH Zurich

Résumé: Ateliers d'artistes, appartements et villas de collectionneurs, pavillons, scénographies et musées : l'exposition est un fil rouge de l'œuvre de Le Corbusier. Le rapport que l'homme entretient à l'œuvre d'art et les modalités de ce rapport sont des éléments fondateurs de son architecture et occupent une position primordiale dans sa vision de la ville. De la ziggourat du Musée mondial en 1929, jusqu'aux projets des années 1960 comme le Centre d'Art international à Erlenbach ou le Musée du XXe siècle pour Nanterre, les musées sont des pièces incontournables des ses grands plans d'urbanisme. Les projets de musées et de pavillons d'exposition entre 1929 et 1965 et les concepts des différentes expositions qu'il organise évoluent en parallèle de sa manière d'envisager le rapport à l'œuvre, que ce soit celui de l'artiste, du spectateur initié ou du novice. Les esquisses préparatoires des différents projets de musées et de pavillons retracent cette évolution. La critique du projet du Mundaneum par Karel Teige assume un rôle clé dans la transformation décisive du concept du musée qui a lieu entre le Musée Mondial en 1929 et le projet de Le Corbusier pour le Musée à croissance illimitée en 1930. C'est un changement séminal qui est décisif pour les projets futurs. L'architecture et la relation à l'œuvre d'art ne sont plus déterminées par le recours à une forme, mais par un mécanisme fonctionnel et organique: la croissance, à la fois image et symbole de l'évolution positiviste de l'humanité.

Abstract: Exhibitions, museums, pavilions, artist ateliers, apartments and collectors'villas: exposition runs like a red thread through Le Corbusier's work. Man's relationship to art is a fundamental element of architectural dispositifs. Art influences his vision of society as a whole, and museums are central to his major urban plans, from the ziggurat of the Musée Mondial in Geneva, to the museums in Ahmadabad, Tokyo or Chandigarh, to projects he realized in the late 1960s, such as the Museum of the 20th Century in Nanterre. The evolution of museum design between 1929 and 1965 and of the concepts Le Corbusier developed for the different exhibitions of his own ceuvre are in keeping with his way of understanding the relationship to works of art, whether by the artist, a knowledgeable public or those encountering art for the first time. The sketches for the different museums and pavilions retrace this evolution. Karel Teige's critique of the Mundaneum project assumes a key role in the transformation of the museum concept that occurred between the Musée Mondial of 1929 and Le Corbusier's first designs for a Museum with Unlimited Growth in 1930. The architecture and the place for art in society are no longer determined by the use of a form but through a functional mechanism. Growth is understood as an image of the positive evolution of mankind. This seminal change is a key to the later projects.

Mots clés: musée, exposition, fonctionnalisme.

Keywords: museum, exhibition, functionalism. 
Ateliers d'artistes, appartements et villas de collectionneurs, pavillons, scénographies et musées : l'exposition est un fil rouge de l'œuvre de Le Corbusier. Le rapport que l'homme entretient à l'œuvre d'art et les modalités de ce rapport sont des éléments fondateurs de son architecture et occupent une position primordiale dans sa vision de la ville. Les musées sont des pièces incontournables des ses grands plans d'urbanisme ou sont investis de rôles majeurs. De la ziggourat du Musée mondial en 1929 au projet du musée à croissance illimitée au début des années 1930 avec ses variantes successives, du plan de reconstruction de Saint-Dié à la construction des musées d'Ahmedabad, de Tokyo et de Chandigarh après la Seconde Guerre mondiale, jusqu'aux projets des années 1960, avec le Centre d'Art international à Erlenbach ou le Musée du XX $\mathrm{XX}^{\mathrm{e}}$ siècle pour Nanterre ${ }^{1}$, l'évolution des projets de musées entre 1929 et 1965 et des concepts des différentes expositions qu'il organise ou qui lui sont consacrées est parallèle à celle de sa manière d'envisager le rapport à l'œuvre, que ce soit celui de l'artiste, du spectateur initié ou du novice. Les esquisses préparatoires des différents projets de musées et de pavillons d'expositions retracent cette évolution. La critique du projet du Mundaneum de Karel Teige assume un rôle clé dans la transformation décisive du concept du musée qui a lieu entre le Musée Mondial en 1929 et le premier projet de Le Corbusier pour le Musée à croissance illimité en 1930. L'architecture et la relation à l'œuvre d'art ne sont plus déterminées par le recours à une forme, mais par un mécanisme fonctionnel. La croissance est l'image de l'évolution positiviste de l'humanité. Ce changement séminal est décisif pour les projets futurs.

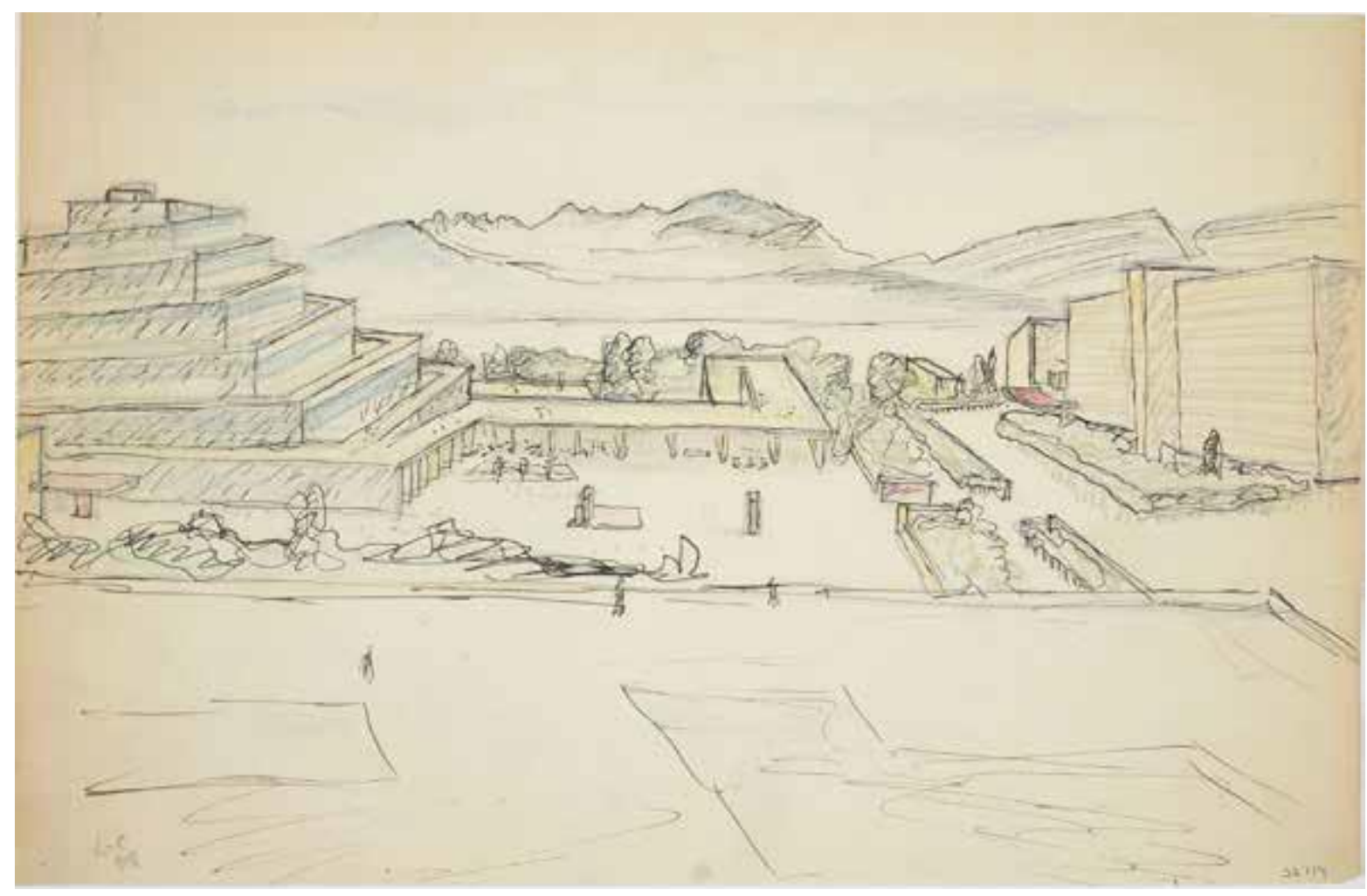

1. Le Corbusier et Pierre Jeanneret, Mundaneum, perspective de Le Corbusier montrant le panorama vers le lac Léman et le Mont-Blanc, FLC 32114.

\footnotetext{
${ }^{1}$ Sur les musées, voir Mory, Pascal : "Le Corbusier and the Syndrome of the Museum”. In Cohen, Jean-Louis ; Ahrenberg, Staffan (dir.), Le Corbusier's Secret Laboratory. From Painting to Architecture, Ostfildern : Hatje Cantz, 2013. pp. 256-281.
} 


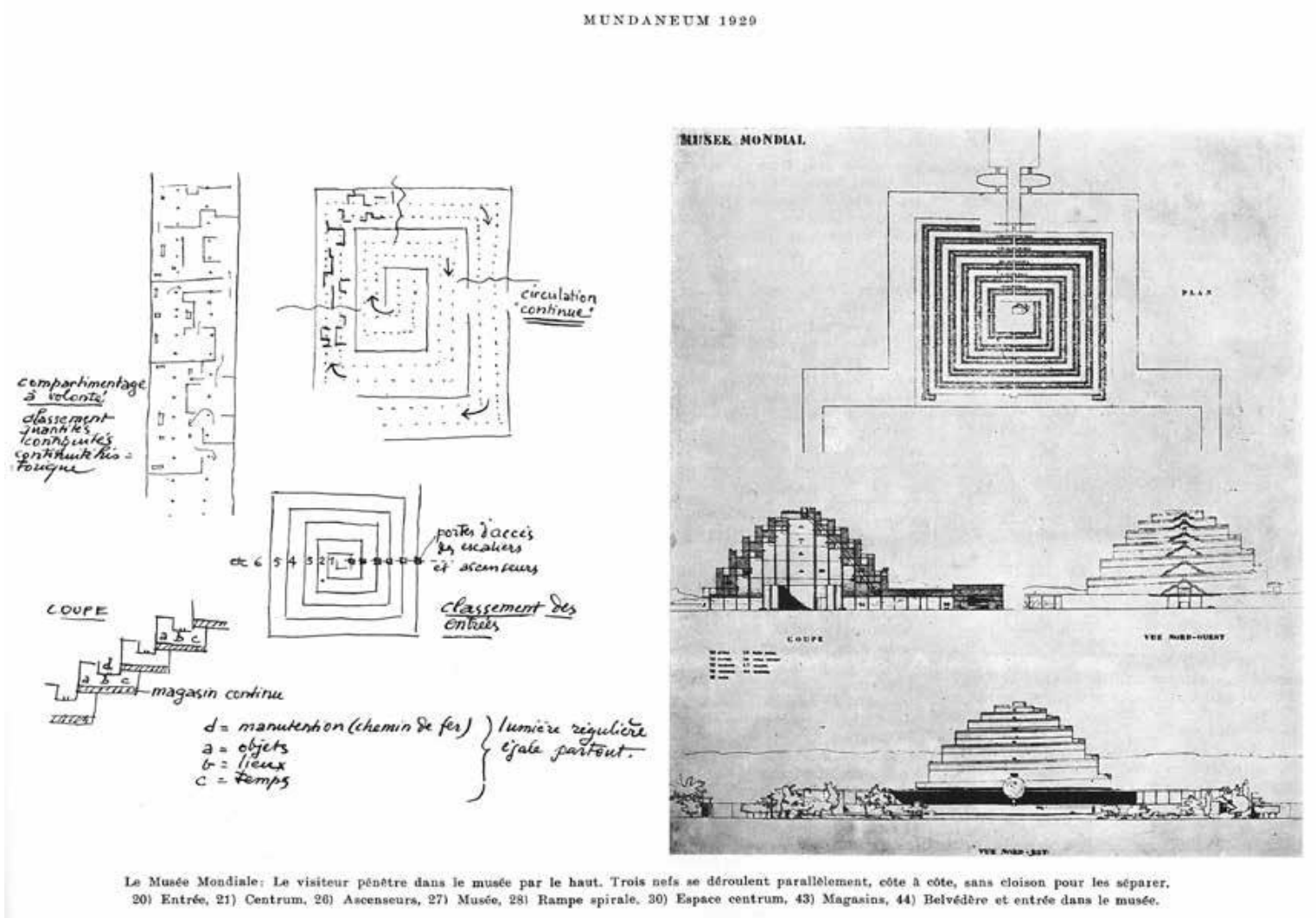

2. Le Corbusier et Pierre Jeanneret, Mundaneum, le Musée mondial, schéma montrant le fonctionnement de la circulation en spirale descendante et des trois nefs destinées aux objets (a), lieux (b) et temps (c) et le chemin de fer qui dessert le magasin continu (d), In Boesiger, Willy ; Storonov, Oscar (dir.) : Le Corbusier et Pierre Jeanneret, OEuvre complète.1910-1929. Zurich : Gisberger, 1937. Vol. 1, p. 193.

\section{Le Musée mondial, 1928-1929, le musée comme monument à la culture}

Le premier musée dessiné par Le Corbusier et Pierre Jeanneret en 1928-1929 est le Musée mondial ou "musée de la connaissance humaine" ${ }^{2}$. Le programme, qui dépasse largement celui d'un musée d'art au sens habituel, est le lieu symbolique majeur de la Cité mondiale, le Mundaneum. Ce projet de créer une structure supranationale dédiée à la paix porte la marque des utopies universalistes de la fin du XIX ${ }^{\mathrm{e}}$ siècle. Son ambition était de rassembler toutes les structures associatives existantes et de les intégrer dans un grand centre organisé autour de pôles culturels : la bibliothèque, l'université et, occupant le centre, le musée. Blaise Cendrars $^{3}$ avait organisé la rencontre de Le Corbusier avec Paul Otlet, figure visionnaire du mouvement pacifiste et instigateur du projet en 1927, au moment du concours pour le siège du Palais des Nations. Otlet avait établi dès les années 1910 un programme complet avec un organigramme détaillé de la Cité mondiale et du Mundaneum, un musée à visée universaliste et à haute charge symbolique qui aurait témoigné de l'essence des civilisations humaines.

\footnotetext{
${ }^{2}$ Voir Courtiau, Catherine : "La Cité internationale" et Gresleri, Giuliano : "Le Mundaneum. Lecture d'un projet”. In Charollais, Isabelle ; Ducret, André (dir.). Le Corbusier à Genève 1922-1932. Projets et réalisations, catalogue d'exposition, Lausanne : Payot, 1987. pp. 53-69 et pp. 70-78. Voir aussi Gresleri, Giuliano : “Mundaneum ”. In Lucan, Jacques (dir.), Le Corbusier, une encyclopédie. Paris : Éditions du Centre Pompidou, 1987. pp. 261-293.

${ }^{3}$ Blaise Cendrars est né à la Chaux-de-Fonds en 1887, la même année que Le Corbusier.
} 
Le Corbusier connaissait bien le site, une pente douce inclinée vers le lac Léman avec un panorama magnifique sur le mont Blanc et les Alpes d'un côté et le Jura de l'autre. Sur cet emplacement exceptionnel, la dimension paysagère est mise au cœur du dispositif urbain et architectural. La beauté du paysage, magnifiée par une scénographie grandiose, doit être garante de l'image universaliste que les institutions cherchent à se donner. Le Musée mondial est disposé à 45 degrés par rapport aux points cardinaux, suivant la trame du plan directeur de la Cité mondiale, il est ainsi adossé contre le Jura et orienté vers le lac, dans l'axe du mont Blanc. Sa forme monumentale marquée en fait le pivot de la composition de la Cité mondiale, l'élément d'ancrage dans le paysage lémanique. Ce paysage sert de coulisse à un parcours initiatique divisé en deux temps. Le visiteur doit entreprendre la longue ascension la pyramide en empruntant la rampe panoramique avant de pénétrer dans le musée par le haut. La rampe, longue de plus de 2,5 km implique une ascension d'au moins une demi-heure couronnée par la terrasse panoramique. Elle est l'instrument du conditionnement physique et mental nécessaire à la visite du musée, en créant à la fois un espace et un temps de transition pour le visiteur. Une fois à l'intérieur, il entame la descente de la spirale en suivant le parcours initiatique qui se déroule à travers les trois nefs contiguës présentant “L’homme dans le temps et dans le lieu. Exactement l'œuvre humaine reportée à l'époque de sa création et dans les lieux qui l'ont vu naître. L'ouvre. Le temps. Le lieu. ${ }^{4}$ ", une transposition littérale du programme de Paul Otlet. Les bords de la spirale sont fermés par des parois, la muséographie est basée sur l'organisation en trois nefs parallèles. Les schémas publiés dans l' Euvre complète montrent que le parcours à l'intérieur de la spirale n'était pourtant pas exclusivement linéaire. Les nefs sont matérialisées par des poteaux et le parcours est organisé par des cimaises librement disposées qui permettent de créer des ensembles et des espaces de dimensions variées selon les besoins. L'attention du spectateur est focalisée sur l'exposition, aucune ouverture ne vient le distraire de la contemplation des œuvres et du parcours de l'exposition : seules subsistent les œuvres et le fil narratif de l'exposition. Son parcours terminé, il sort sur l'esplanade de la Cité après avoir traversé le Sacrarium et se trouve devant le Globe, maquette du globe terrestre dans laquelle il peut entrer pour contempler la voûte céleste.

Le Corbusier restitue mieux que personne le lyrisme du projet: “ À chaque tournant, un horizon neuf; à chaque spirale une vue plus dégagée. Le site grandit à mesure. Au sommet, le site est là tout entier, panoramique : les Alpes les plus altières, le lac le plus suave, la ville tapie au fond; au pied de ses rochers horizontaux, le Rhône, ce grand fleuve du monde, qui s'enfonce vers la mer... Alors il pénètre dans le musée par le haut. Il voit les tableaux de la gestation du monde: les nébuleuses qui se forment en soleil ; le mécanisme des planètes, la séparation de l'air, de l'eau et de la terre. [... $]^{5}$ " Le parcours initiatique doit provoquer l'empathie du spectateur et accompagner un cheminement intérieur. Giuliano Gresleri a analysé l'importance et la signification de ce parcours qui, contrairement aux ziggourats antiques ou à la tour de Babel, ne suit pas un mouvement ascendant, allant vers le divin. Il note que : "Malgré l'émotion que Le Corbusier réussit à nous transmettre, la descente “impossible” - qui aurait duré trois à quatre heures échappait ainsi à l'idée, chère à la tradition de l'expressionnisme, d'un itinéraire mystique vers le sacré, d'une montagne ou d'un escalier à gravir. Par contre, elle devenait le chemin de la rationalité, du savoir, tous deux saisis à travers l'histoire même de l'homme. ${ }^{6}$ ",

\footnotetext{
${ }^{4}$ Le Corbusier : “Mundaneum, 1929 ”. In Boesiger, Willy ; Storonov, Oscar (dir.) : Le Corbusier et Pierre Jeanneret. Euvre 1929-1910 .complète. Zurich : Gisberger, 1937. $2^{\mathrm{e}}$ édition. Vol. 1. p. 194.

${ }^{5}$ Le Corbusier, cité par Gresleri, Giuliano : “Le Mundaneum. Lecture d'un projet”. In Charollais, Isabelle; Ducret, André (dir.) : Le Corbusier à Genève 1922-1932. Projets et réalisations, catalogue d'exposition. Lausanne : Payot, 1987. pp. 70-78, citation page 76 .

${ }^{6}$ Gresleri, Giuliano : “Le Mundaneum. Lecture d'un projet”. In Charollais, Isabelle; Ducret, André (dir.) : Le Corbusier à Genève 1922-1932. Projets et réalisations, catalogue d'exposition. Lausanne : Payot, 1987, p. 77.
} 


\section{La critique de Karel Teige}

La monumentalité affirmée du projet déclenche incompréhension et critiques dans le camp même des Modernes, en particulier de la part de Karel Teige ${ }^{7}$. Dans les pages de Stavba ${ }^{8}$, il publie un long article composé d'une description détaillée du projet suivi d'une critique attentive. Dans ce fameux texte dans lequel il pointe l'absence de légitimité du recours à des formes historiques et le "romantisme " inhérent à l'emploi d'une "section d'or ", il se livre en premier lieu à une analyse sévère du programme: "Where do the roots of the non-modern, and in fact archaic character of Le Corbusier's Mundaneum lie? To what should we attribute this architectural error and delusion? Actually, in our view, the first root of this misconception of the program lies in the program, the idea and the theory of the Mundaneum. This idea is not alive, it doesn't originate from a vibrant, felt need; it's the fruit of the abstract and rarified speculation of intellectual coteries within the League of Nations. "Il critique ensuite durement les illusions et la naïveté de Otlet et d'Andersen, avant de revenir sur le terrain de l'architecture : "It is an oft-repeated and confirmed experience that the architectural investigation of problems and programs which are ideologically unclear, falsely stated, or moribund, cannot produce works of elemenatary clarity and purity. " Puis il rappelle l'indissociable relation qui, à ses yeux, unit l'architecture moderne au fonctionnalisme: "Modern architecture was born not from abstract speculation, but from actual need, from the dictates of life, not the patronage of some academy or official group. Real need furnished programs: factories, bridges, railway stations, offices, housing for workers, schools, hospitals, hotels and apartments; from a fundamental understanding and shaping of these problems pure modern architecture was born. "Et il conclut sans appel sur l'échec programmé de toute autre tentative: "Examples of concrete and utilitarian architecture, as well as omens of a new metaphysical, monumental architecture both show clearly that, at the present time, architecture will fail in so far as it is not dictated by the actual needs of social and economic life. The only aim and scope of modern architecture is the scientific solution of exact tasks of rational construction. "

Le Corbusier dans sa tout aussi fameuse "Défense de l'architecture" " répond point par point aux attaques sur l'emploi de la forme de la pyramide, sur celui du nombre d'or, se saisissant magistralement de l'occasion pour asseoir les bases de son discours théorique, se refusant à réduire l'architecture à la seule expression d'une fonction et se ralliant au mot d'ordre "L'utile n'est pas le beau ". Par contre, à aucun moment, il n'argumente sur la question du programme, ni ne cherche à légitimer sa validité ou son actualité, il reste muet sur ce point. Il est toujours en pourparlers avec Paul Otlet, à qui il remettra la dernière étude pour la Cité mondiale sur la rive gauche d'Anvers en 1933 et ne tient sans doute pas à remettre en question les positions d'un client. Mais il est ici possible de faire l'hypothèse que sur ce point, la critique de Teige a atteint son but: malgré quelques ressemblances formelles évidentes, le projet du Musée d'art contemporain pour Paris sur lequel il travaille dès l'année suivante montre en effet un spectaculaire retournement des paradigmes et des choix projectuels qui avaient présidé à la composition du Musée mondial.

\footnotetext{
${ }^{7}$ Sur cette question voir Cohen, Jean-Louis : "Le Corbusier et les théories de l'avant-garde soviétique ". In Cohen, JeanLouis : Le Corbusier et la mystique de l'URSS. Bruxelles: Mardaga, 1987. pp. 142-150 et Reichlin, Bruno: "Solution élégante ”. In Lucan, Jacques (dir.) : Le Corbusier, une encyclopédie. Paris : Édition du Centre Pompidou, 1987. pp. 369-377. ${ }^{8}$ Teige, Karel “Mundaneum ”. In Stavba. Avril 1929. ํ⒑ pp. 145-155. La traduction anglaise parue dans Opposition. Octobre 1974. $\mathrm{N}^{\circ}$ 4. pp. 80-90.

${ }^{9}$ Le Corbusier : “Défense de l'architecture”. In L'Architecture d'aujourd'hui. 1933. № 10. pp. 38-61. L'article initialement écrit en 1929 pour la revue Stavba a été publié en tchèque dans Musaion. 1931, N 2, pp. 27-52. Sur l'importance de ce texte voir Reichlin, Bruno: "Solution élégante”. In Lucan, Jacques (dir.) : Le Corbusier, une encyclopédie. Paris : Édition du Centre Pompidou, 1987. pp. 369-377.
} 


\section{Le Musée d'art contemporain, 1930-1931, la première occurrence du Musée à croissance illimitée}

Le projet pour le Musée d'art contemporain prend la forme d'un envoi adressé à une figure tutélaire de l'avant-garde artistique, Christian Zervos, directeur des Cahiers d'art, et destiné à être publié dans cette revue $^{10}$. C'est un exercice que l'architecte se pose en l'absence d'une commande concrète, pratique à laquelle il recourt souvent. Il s'inscrit dans le contexte français de l'époque et dans une réflexion sur le rôle des musées qui fait écho au manque d'engagement des institutions face aux avant-gardes, peu présentes dans les collections publiques, et leur manque de réactivité par rapport aux débats artistiques contemporains. Auguste Perret avait publié en 1929 dans la revue Mouseion ${ }^{11}$, l'organe de l'Office international des musées, un texte intitulé "Le musée moderne " exposant sa conception d'un "édifice qui serait à la fois un lieu de délectation et de fête et un lieu d'étude ", une rotonde et un espace central destinés à l'exposition des chefs d'œuvre et, ouvertes sur cet espace central, des "galeries de classement et d'études", disposées comme un magasin de réserve, qui permettrait l'accès au visiteur. L'article, illustré d'un plan et d'une perspective à main levée, traite principalement de questions techniques, des avantages du béton, de la justesse de l'éclairage et de l'adaptation aux différentes œuvres exposées, peinture ou sculpture, ou encore au climat, mais n'engage pas vraiment un débat de fond et n'est pas destiné à la présentation concrète d'un projet. Le Corbusier de son côté cherche à asseoir sa position comme interlocuteur incontournable sur la question des programmes muséaux et propose un modèle prêt à l'emploi, "brevetable ", et surtout reproductible. Son choix de le publier dans les Cahiers d'art, donc dans une revue d'art, n'est pas un hasard. Sigfried Giedion y tient régulièrement une chronique sélective sur l'architecture et y a publié ses projets. L'architecte côtoie dans les pages de la revue les figures marquantes de l'avant-garde, bénéficiant ainsi ipso facto de leur caution.

\footnotetext{
${ }^{10}$ Le Corbusier et Jeanneret, Pierre : “Pour la création à Paris d'un musée des artistes vivants”, In Cahiers d'art. 1931. №1, p. 9.

${ }^{11}$ Perret, Auguste: “Le musée moderne ”. In Mouseion. Décembre 1929. № 9. pp. 225-235. La revue est créée en 1927, un an après la fondation de Office international des musées, ancêtre de l'ICOM, organisme dépendant de la Société des nations. La revue dont le siège est à Paris est très proche de l'OIM et joue un rôle pionnier dans les débats sur la muséographie, abordant des questions allant de la conservation des œuvres, au patrimoine monumental, au développement de nouveaux programmes comme les musées paysans ou les musées de plein-air, à l'architecture des musées et des expositions. Voir le résumé de la thèse de Marie Caillot : http://theses.enc.sorbonne.fr/2011/caillot.
} 

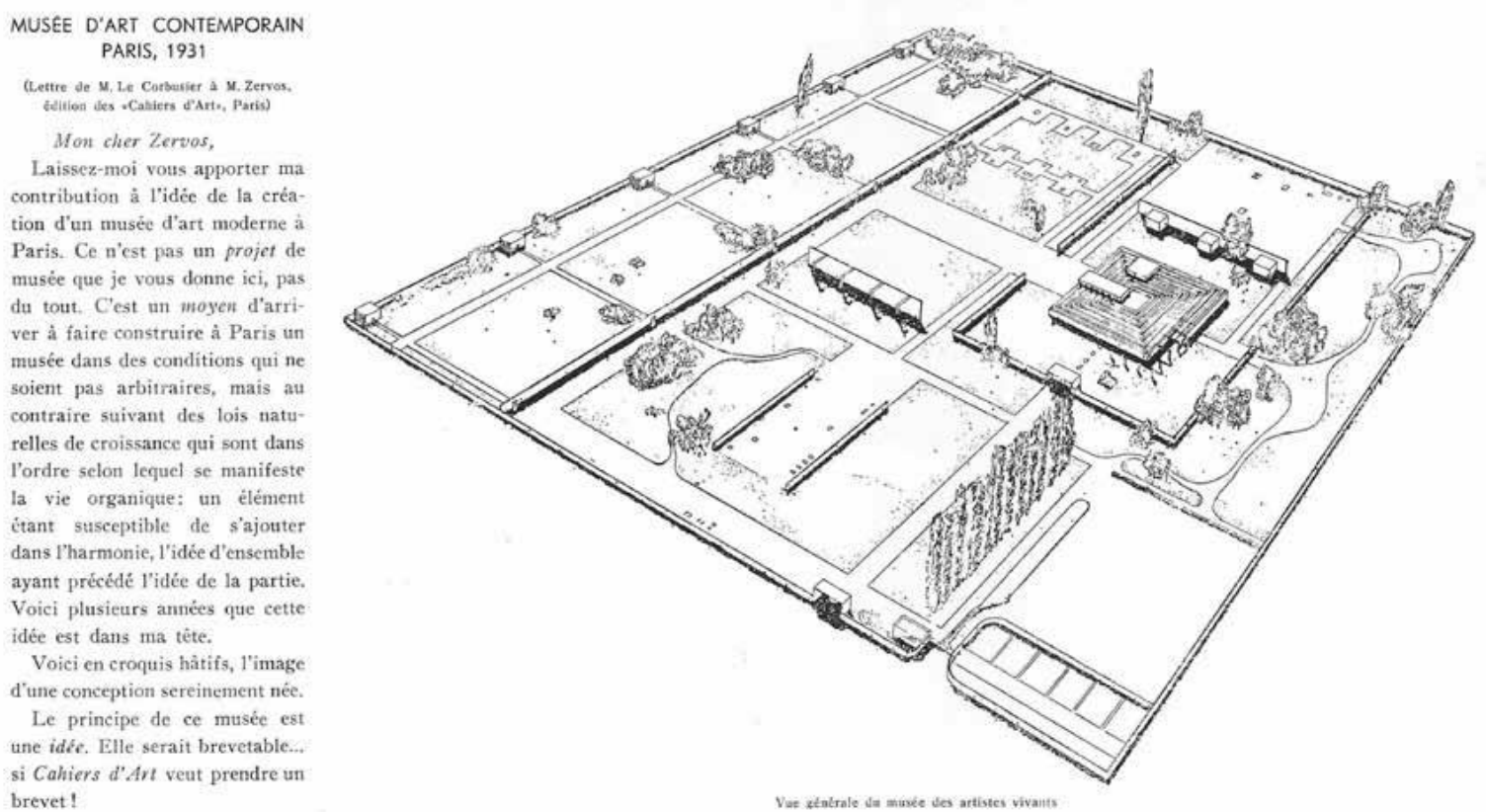

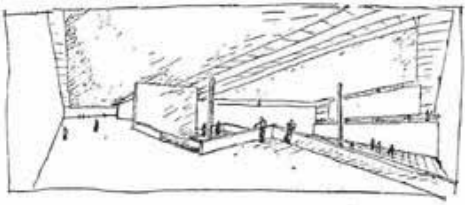

Aspect de la premitre salle entourte de la premile nef de la sire

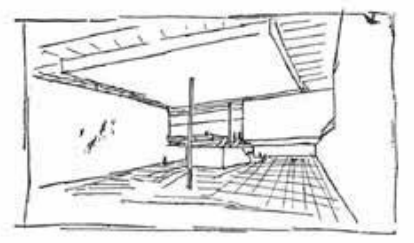

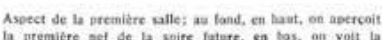

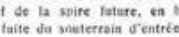

3. Le Corbusier et Pierre Jeanneret, Musée d'art contemporain, Paris, 1930, perspective aérienne. In Boesiger, Willy (dir.) : Le Corbusier et Pierre Jeanneret, OEuvre complète. 1929-1934. Zurich : Gisberger, 1935. vol. 2. p. 72.
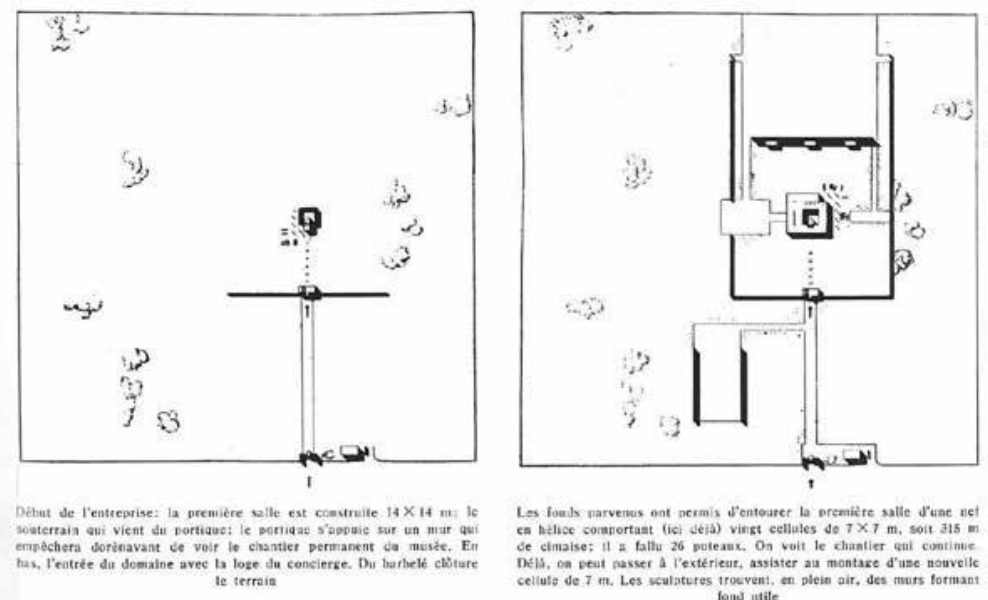

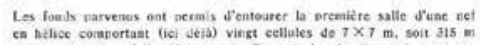

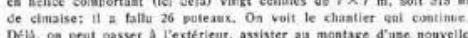
celluto de $7 \mathrm{~m}$. Les sculastutes troevem, en plein gir, des murs tormant

te terrain

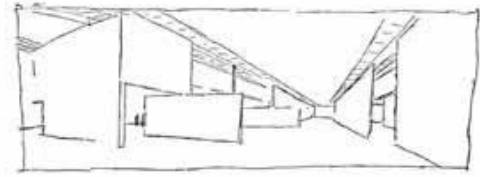

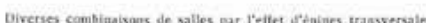

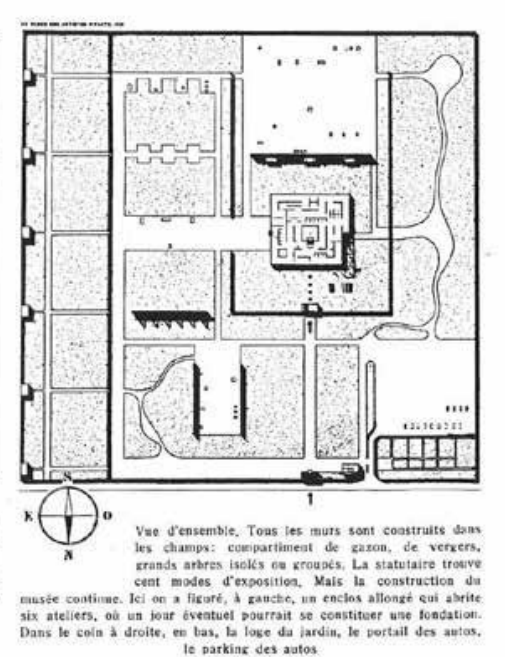

4. Le Corbusier et Pierre Jeanneret, Musée d'art contemporain, Paris, 1930, principe de croissance. In Boesiger, Willy (dir.): Le Corbusier et Pierre Jeanneret, OEuvre complète. 1929-1934. Zurich : Gisberger, 1935. vol. 2. p. 73. 


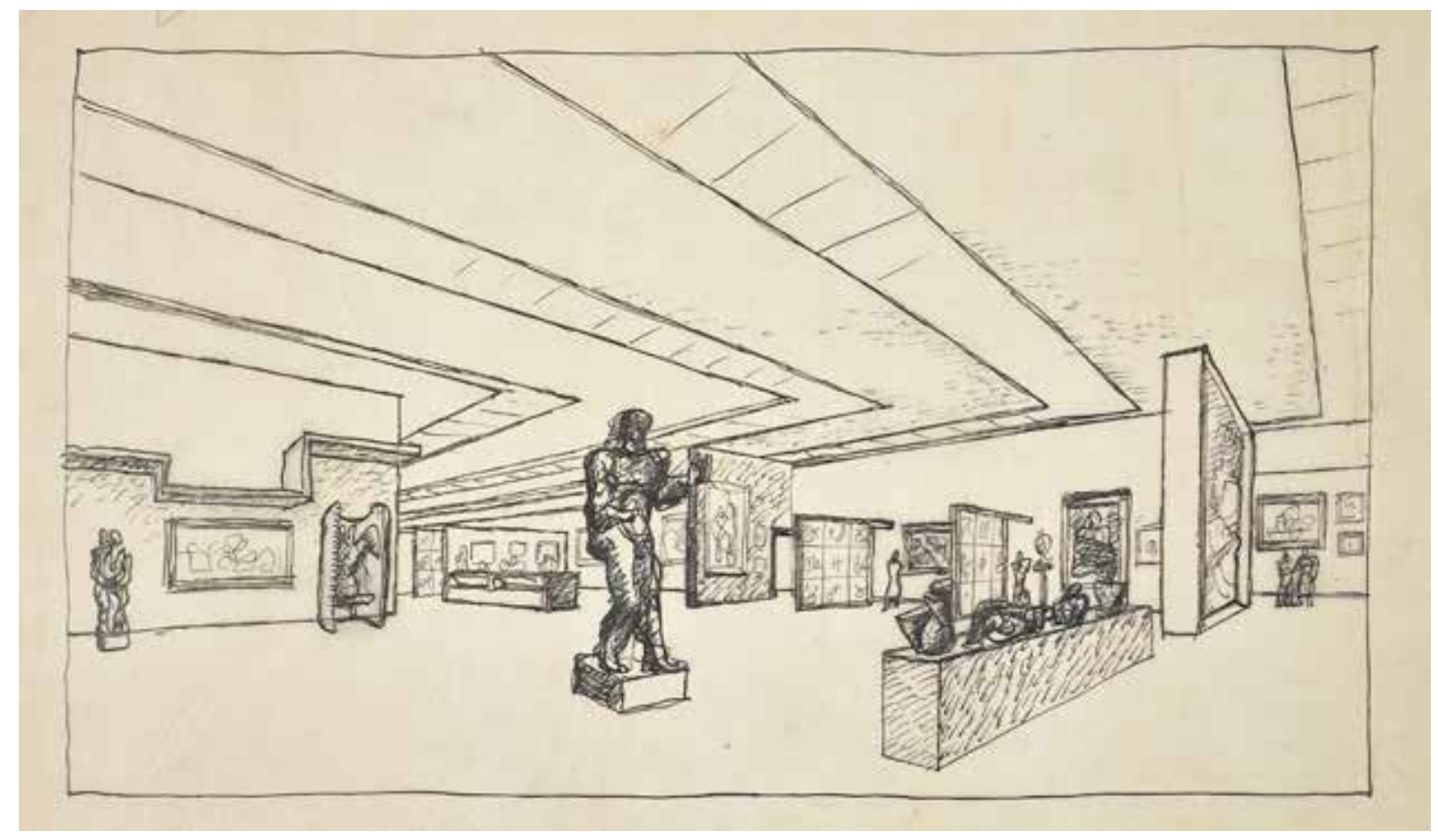

5. Le Corbusier et Pierre Jeanneret, Musée d'art contemporain, Paris, 1930, perspective, FLC 30037.

Au premier coup d'œil, le Musée d'art contemporain avec son iconique spirale carrée semble directement inspiré du projet du Mundaneum; pourtant le projet et les dessins préparatoires montrent une césure spectaculaire. La ziggourat a disparu, le parcours est désormais organisé dans un seul plan, la forme de la spirale maintenant aplatie autorisant un accroissement lent et continu de la surface du musée impossible dans le projet de 1929. C'est la première occurrence du musée à croissance illimitée. Le Corbusier cherche à le promouvoir en tant qu'idée et non en tant que projet, il écrit à Christian Zervos : “Ce n'est pas un projet que je vous donne ici, pas du tout. C'est un moyen d'arriver à faire construire à Paris un musée dans des conditions qui ne soient pas arbitraires, mais au contraire suivant les lois naturelles de croissance qui sont dans l'ordre selon lequel se manifeste la vie organique: un élément étant susceptible de s'ajouter dans l'harmonie, l'idée de l'ensemble ayant précédé l'idée de la partie. [...] Le principe de ce musée est une idée. Elle serait brevetable... ${ }^{12}$ " Mais un autre pas est franchi, le bâtiment, extensible, ne possède plus de forme fixée dans la durée: "Le musée n'a pas de façade; le visiteur ne verra jamais de façade; il ne verra que l'intérieur du musée. ${ }^{13}$ ". Le rapport au site, ville ou paysage, est mis à distance, voir indifférent : "Le musée s'élève dans quelque banlieue ou grande banliene de Paris. Il s'élève au milieu d'un champ de pommes de terre ou de betteraves. Si le site est magnifique, tant mieux. S'il est laid et attristé de pignons de lotissements ou de cheminées d'usine, ça ne fait rien [... $]^{14}$ ". Le mécanisme d'agrandissement du bâtiment implique un abandon de la façade en tant qu'enveloppe possédant un forme durable et qu'élément distinctif de l'image du bâtiment. La démonstration de ce non-conformisme programmatique se retrouve affiché jusque dans le détail de la clôture du terrain qui est prévue en barbelés. Le Corbusier cherche à se délester d'un ensemble de contraintes constructives, stylistiques et formelles pour se concentrer sur un principe fondateur qui guide la conception architecturale. La forme est la démonstration du principe directeur, ici le principe de croissance.

\footnotetext{
${ }^{12}$ Le Corbusier: "Musée d'art contemporain”, Paris, 1932. In Boesiger, Willy (dir.) : Le Corbusier et Pierre Jeanneret, Euvre complète. 1929-1934. Zurich : Gisberger, 1935. Vol. 2. pp. 72-73.

${ }^{13}$ Ibid.

${ }^{14}$ Ibid.
} 
La publication ne fournit que peu d'informations sur les choix muséographiques, quelques perspectives à main levée donnent une idée de l'atmosphère intérieure, montrant la salle centrale et le système d'éclairage zénithal. C'est une machine nue qui est livrée prête à l'emploi. L'accès par le centre prévu pour le Mundaneum persiste, de même que la trame dimensionnelle, un carré central de $14 x 14 \mathrm{~m}$, qui s'agrandit par l'ajout de modules de $7 \times 7 \mathrm{~m}$. Les cloisons-membranes prévues à l'intérieur peuvent être déplacées et laissent toute liberté au discours scénographique. Le parallélisme des trois nefs présentant corollairement les trois récits - objets lieux et temps - a disparu, et avec lui, l'hypothèse d'une narration simple de l'évolution. Les perspectives intérieures montrent une architecture qui se met en retrait, quelques plans abstraits qui servent de support aux œuvres et un système d'éclairage zénithal, la forme cherche à être neutre, le sens naît maintenant de la relation entre les œuvres elles-mêmes.

\section{Le Musée de la Ville et de l'État, 1934}

Le Corbusier et Pierre Jeanneret ont la possibilité de prendre part au concours pour la construction d'un bâtiment réunissant le Musée des artistes vivants, situé alors dans l'Orangerie du Palais du Luxembourg, et le Musée de la Ville, concours qui aboutira à la construction du Palais de Chaillot. Leur contribution présente certaines similarités avec le projet du Musée d'art contemporain, mais il reprend certains éléments de la scénographie muséale du Mundaneum. C'est une forme hybride qui inclut certains éléments des deux projets précédents. La forte pente du terrain et la densité du programme impliquent de nouveau le recours à un empilement des galeries. La parcelle est entièrement utilisée, et la question d'une extension ou d'un phasage ne se pose pas. Deux demi-spirales carrées, l'une s'évasant, l'autre se rétrécissant, sont collées dos à dos de manière à produire une structure en $\mathrm{H}$ ouverte d'un côté vers la Seine, de l'autre vers l'avenue du Président Wilson, exprimant ainsi visiblement la division entre les deux musées qui composent le programme. Le vide intérieur devient ainsi un espace public ouvert, profitant du site magnifique au centre de Paris. La scénographie urbaine est exposée avec des termes qui renvoient directement à une toile de fond plus paysagère qu'urbaine: "La promenade des visiteurs est nette comme une route de montagne ouvrant à gauche et à droite sur des vallées successives. Ce trajet direct constitue la visite touristique. Chaque vallée, c'est une section muséographique déterminée, mais chacune se dédouble et se triple en une galerie latérale d'étude (où sont des ouvres momentanément reconnues moins démonstratives que celles exposées dans la piste touristique) et une galerie intérieure de stocks (où chaque section muséographique installe son stock dans un étalage et une lumière déjà parfaitement suffisante). ${ }^{15}$ " Il convient de noter le dispositif de la galerie intérieure de stocks éclairée, prémisse d'une discussion sur l'accessibilité plus large des réserves pour un public spécialisé.

\footnotetext{
${ }^{15}$ Le Corbusier : “Plans pour les musées de la Ville et de l'Etat à Paris ”, Paris, 1932. In Bill, Max (dir.) : Le Corbusier et Pierre Jeanneret, Euvre complète. 1934-1938. Zurich : Gisberger, 1953. Vol. 3. pp. 82-89.
} 


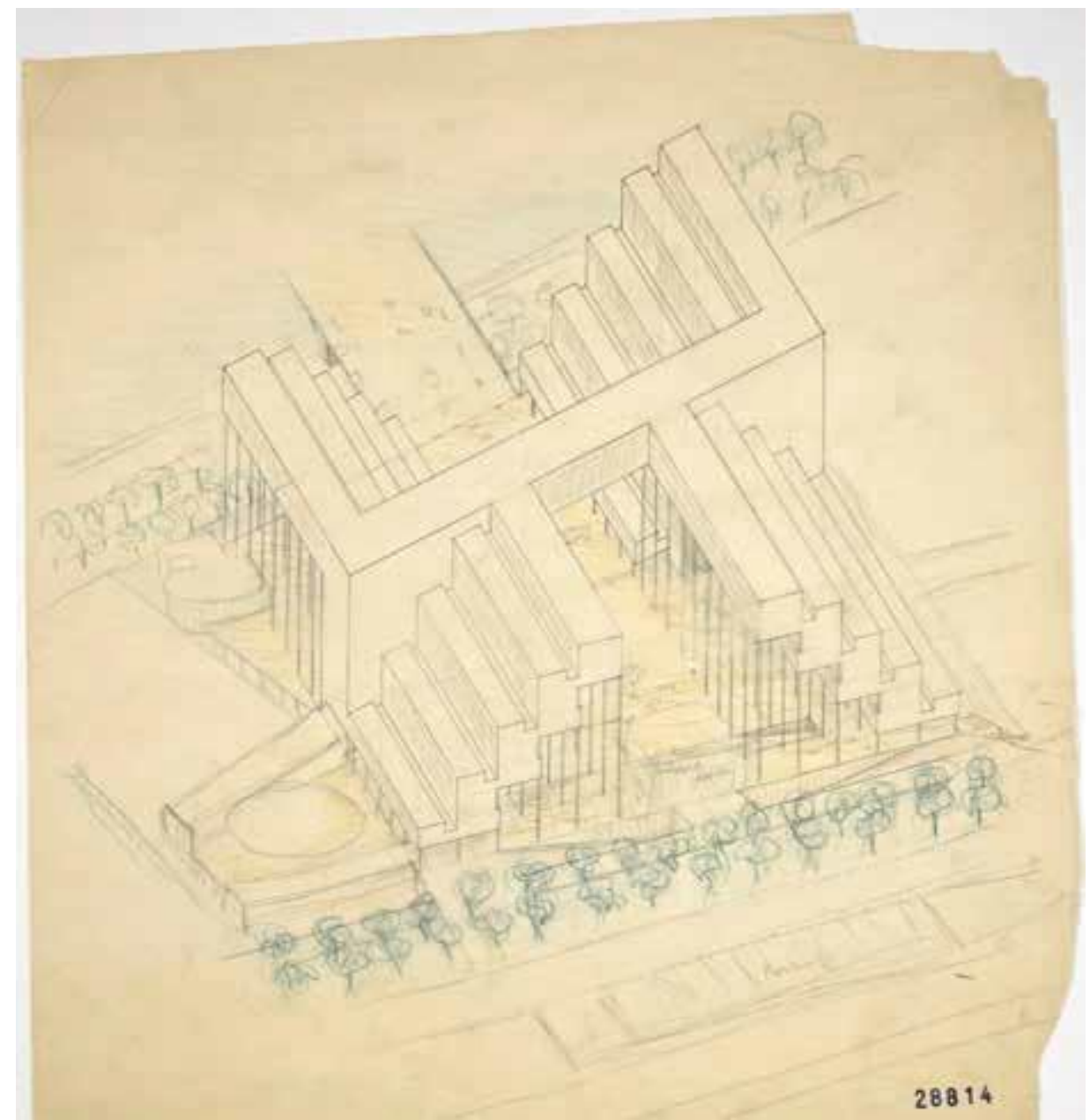

6. Le Corbusier et Pierre Jeanneret, Musée de la ville et de l'état, Paris, 1934, perspective, FLC 28814.

\section{Le projet $C$ pour l'exposition de 1937, le Centre d'esthétique contemporaine}

Les projets consécutifs réalisés en vue de l'Exposition internationale de Paris en 1937 sont le prochain laboratoire d'expérimentation pour les structures d'exposition. Après diverses tentatives infructueuses de construire un musée permanent, Le Corbusier et Jeanneret travaillent à partir de 1936 sur le projet C, une occurrence du musée à croissance illimitée dont ils définissent eux-mêmes le programme, une structure dont ils maitriseraient à la fois le contenant et le contenu. Cette situation privilégiée les conduit à étudier très en détail les relations et les interactions possibles entre les espaces générés par la spirale, la dynamique du parcours et les contenus. Les schémas FLC 705 et FLC 713 montrent la superposition de la trame constructive suivant les entraxes de 7 mètres et d'un parcours muséographique interdisciplinaire du type "musée de la connaissance ". Le parcours commence au centre par 1" "interdépendance des choses et de la culture " puis traverse l' " âge de la pierre " avant de traverser les différentes disciplines scientifiques - sociologie, éthique, philosophie -, puis les sciences physiques - biologie, astronomie -, continuant vers les inventions et les techniques, placées juste avant les mathématiques qui clôturent le parcours. Le plan FLC 675 montre la manière de concilier la flexibilité du dispositif spatial avec le contrôle du cheminement et de la progression dans l'exposition. Cette gestion d'un plan libéré de tout cloisonnement vertical fixe est désormais la constante de tous les projets ultérieurs. L'éclairage zénithal est le seul indicateur spatial qui impose certaines règles dans la façon de subdiviser l'intérieur. 


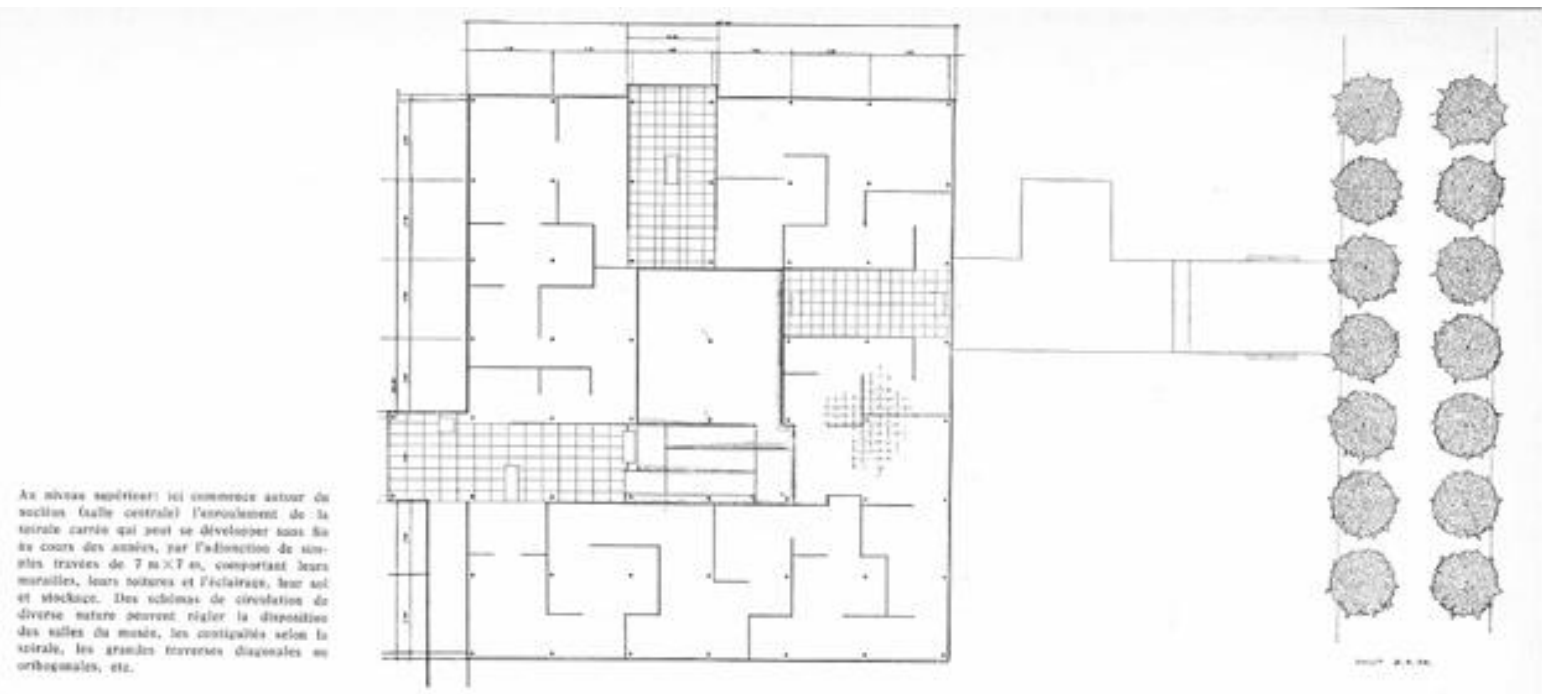

7. Le Corbusier et Pierre Jeanneret, Expo 37, Projet C, plan et élévation. In Boesiger, Willy (dir.) : Le Corbusier et Pierre Jeanneret, OEuvre complète. 1934-1938. Zurich : Gisberger, 1938. Vol. 3. p. 155.

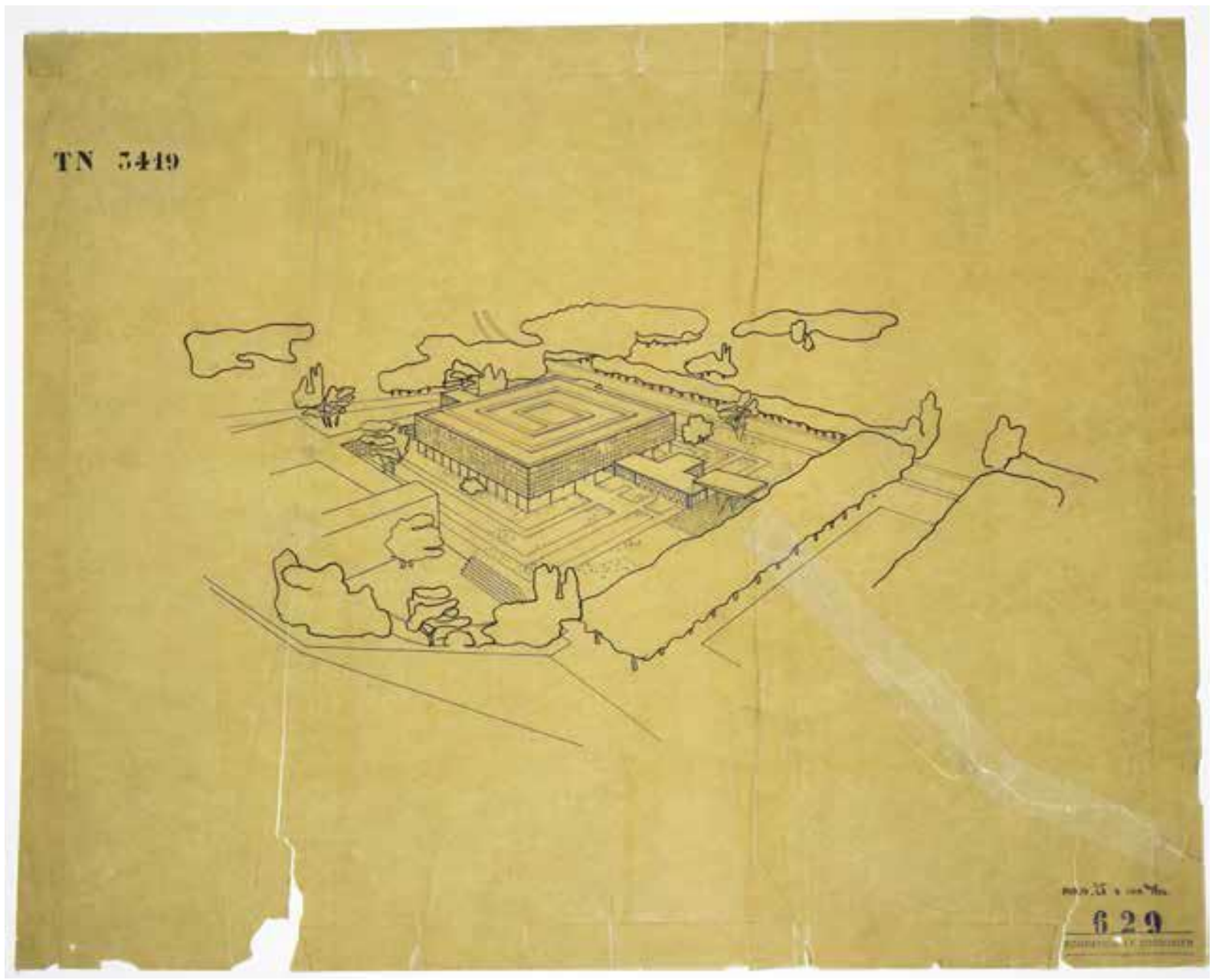

8. Le Corbusier et Pierre Jeanneret, Expo 37, Projet C, perspective à vol d'oiseau, FLC 626. 


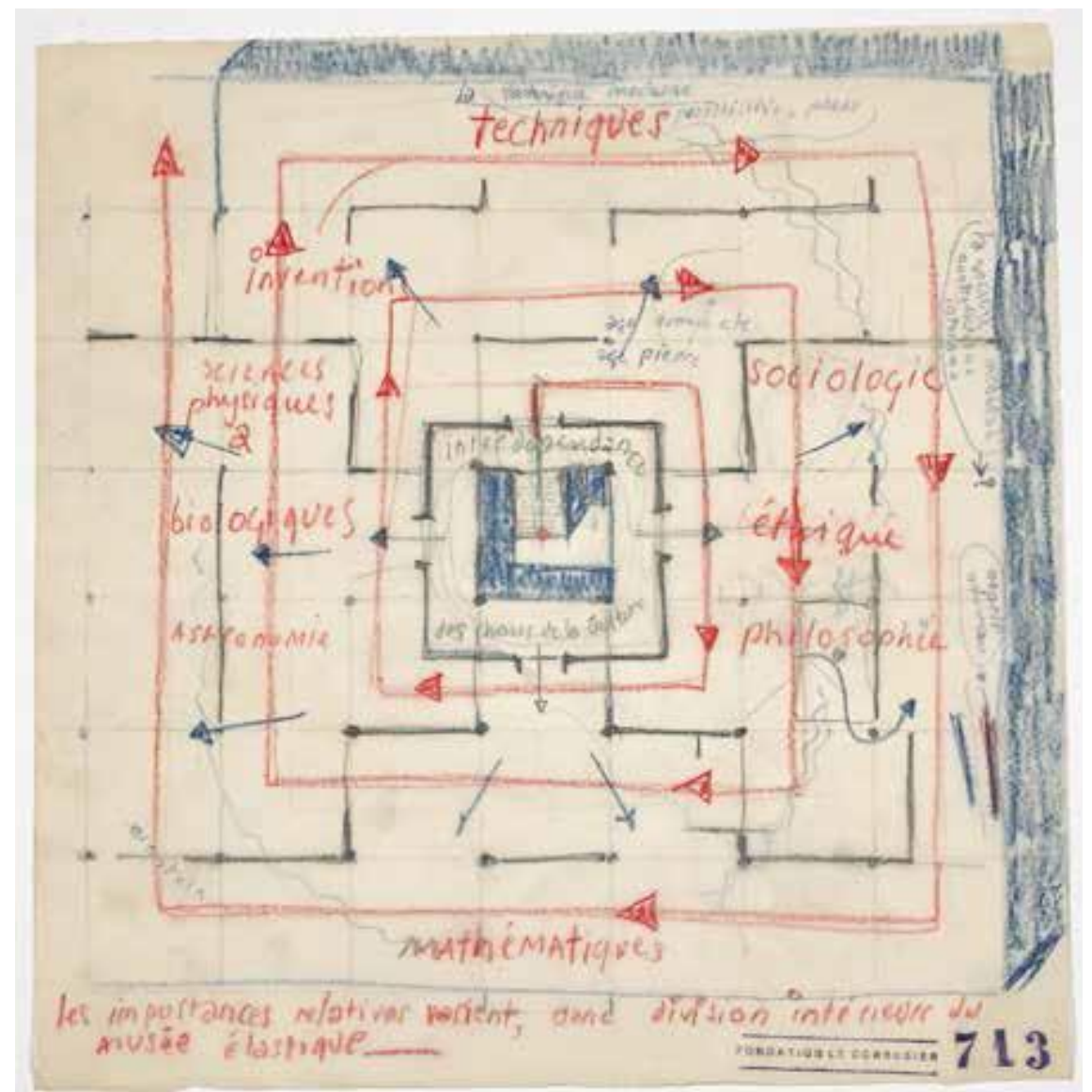

9. Le Corbusier et Pierre Jeanneret, Expo 37, Projet C, schéma de circulation, FLC 713.

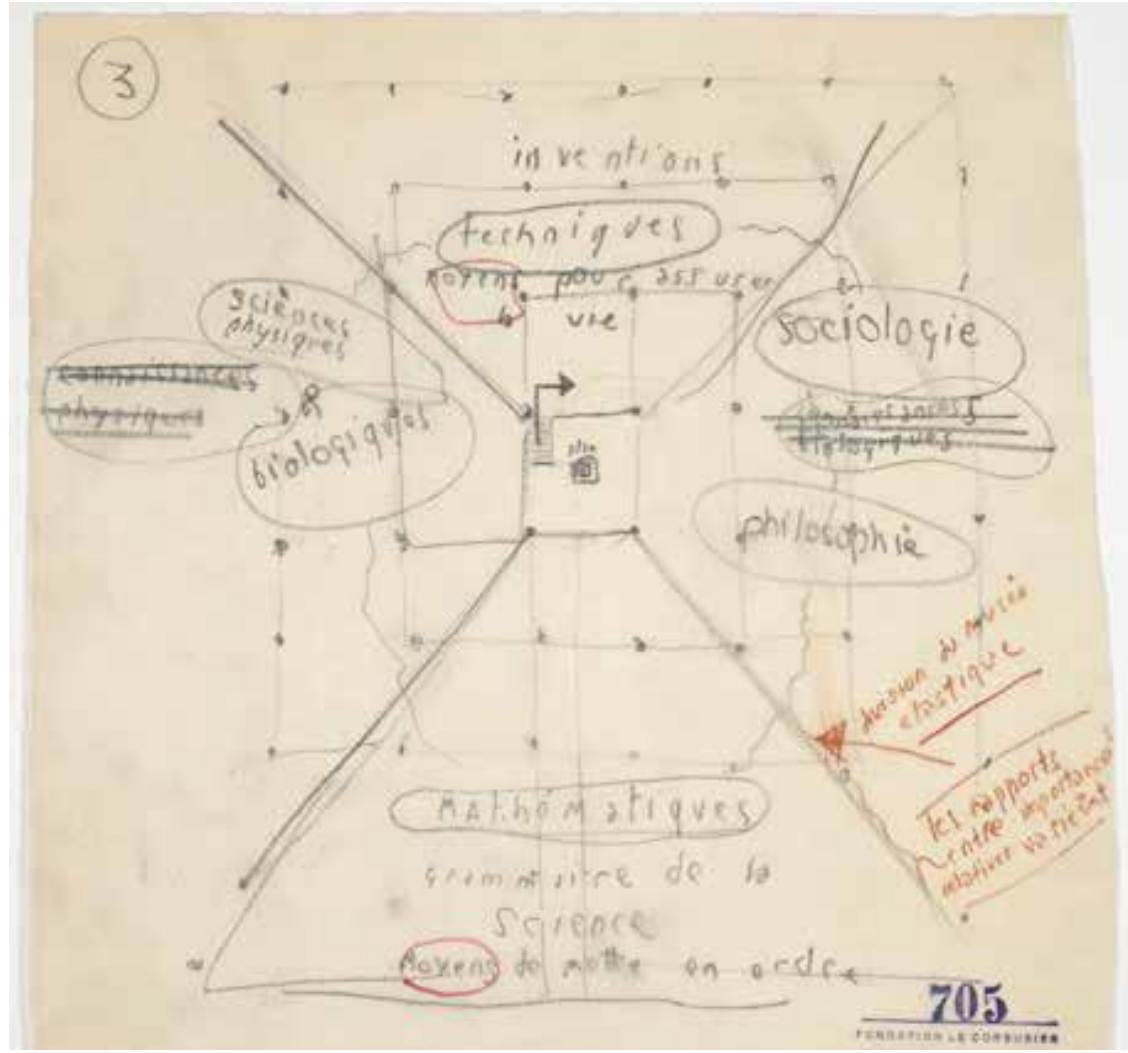

10. Le Corbusier et Pierre Jeanneret, Expo 37, Projet C, schéma d'organisation, FLC 705. 


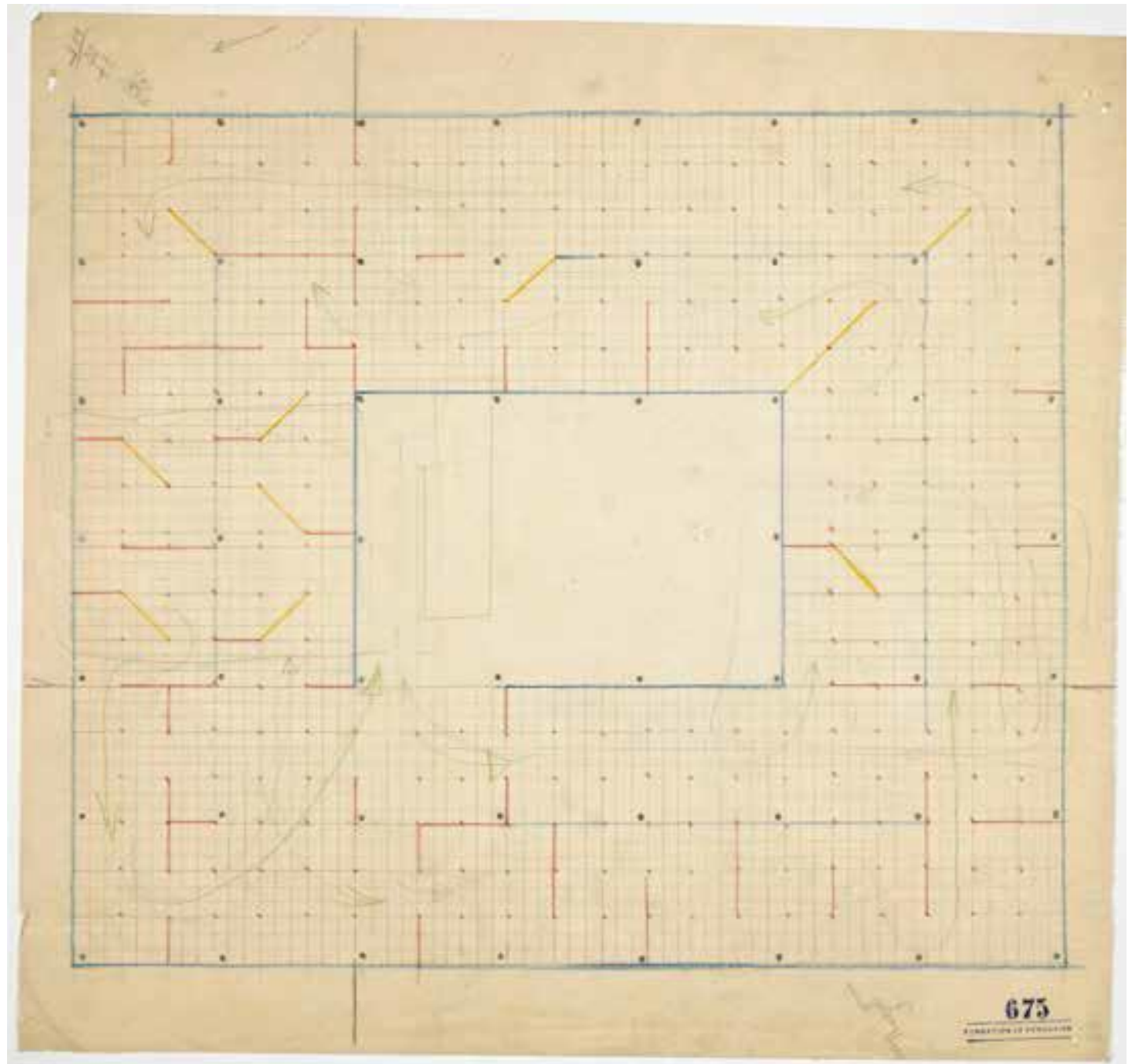

11. Le Corbusier et Pierre Jeanneret, Expo 37, Projet C, schéma d'organisation, FLC 675.

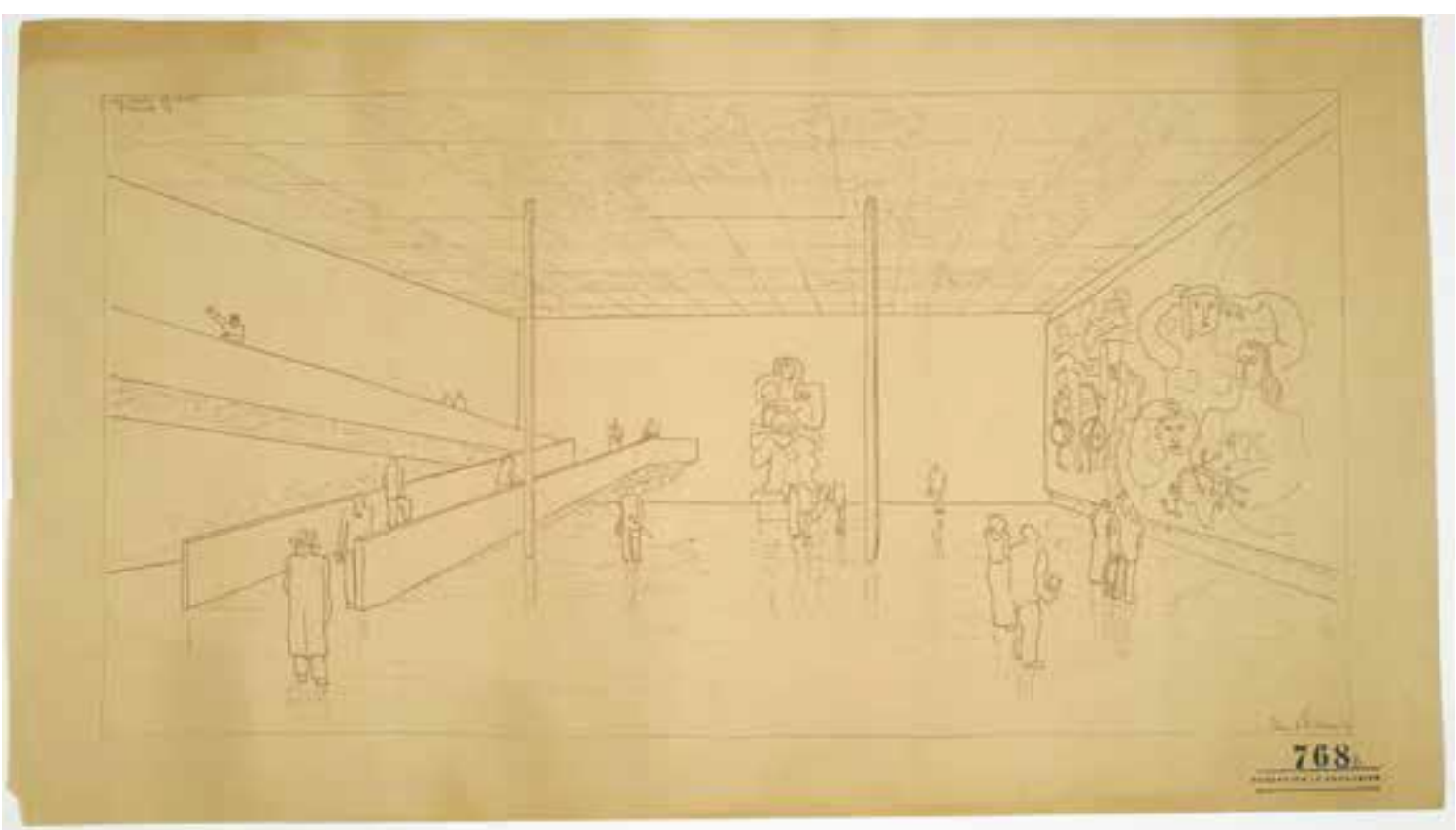

12. Le Corbusier et Pierre Jeanneret, Expo 37, Projet C, perspective, FLC 768 


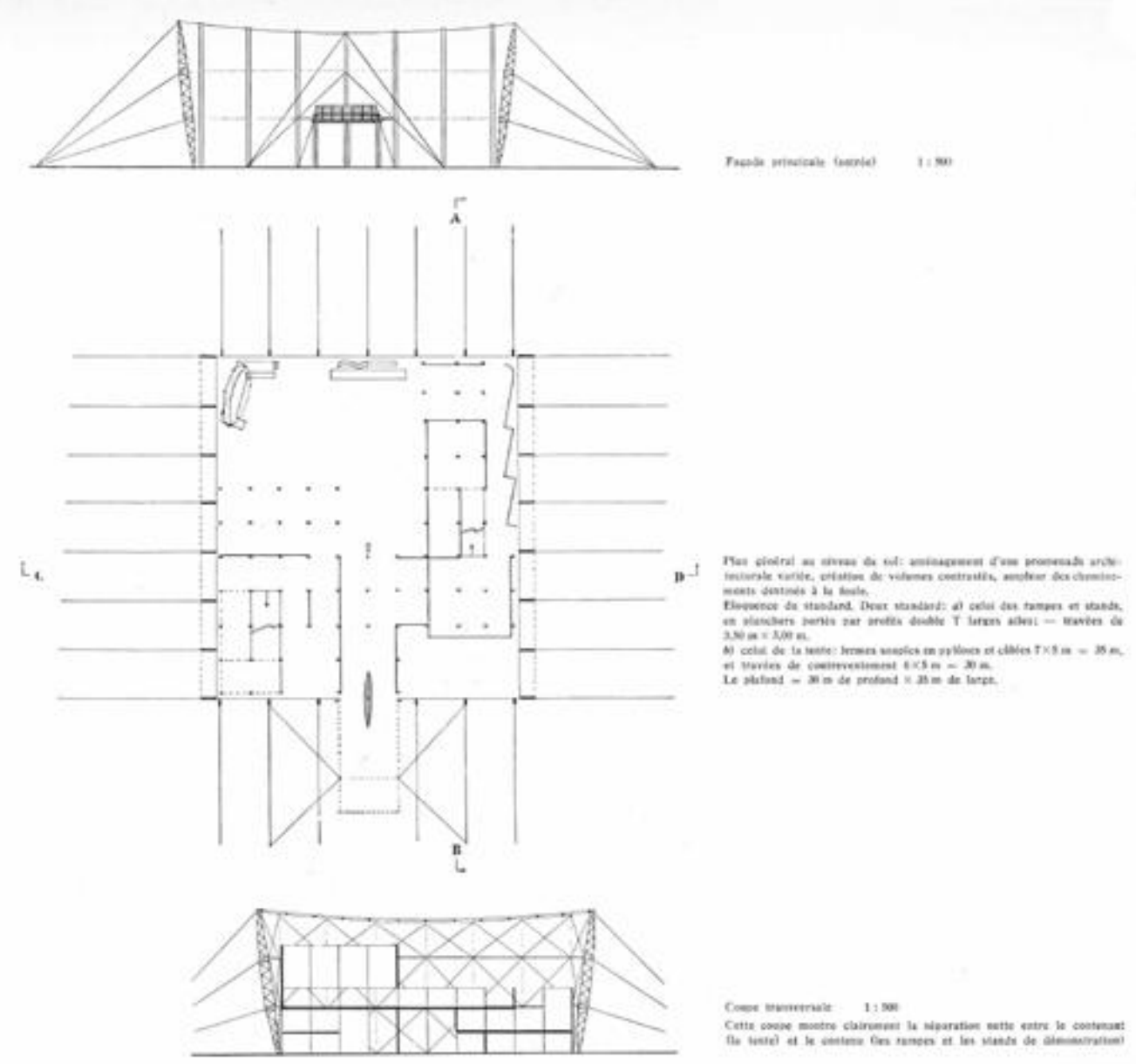

13. Le Corbusier et Pierre Jeanneret, Pavillon des Temps nouveaux, Expo 37, Projet D, élévation, plan et coupe. In Boesiger, Willy (dir.) : Le Corbusier et Pierre Jeanneret, OEuvre complète. 1934-1938. Zurich : Gisberger, 1939. Vol. 3. p. 160.Boesiger, Willy (dir.) : Le Corbusier et Pierre Jeanneret, OEuvre complète. 1934-1938. Zurich : Gisberger, 1939. Vol.

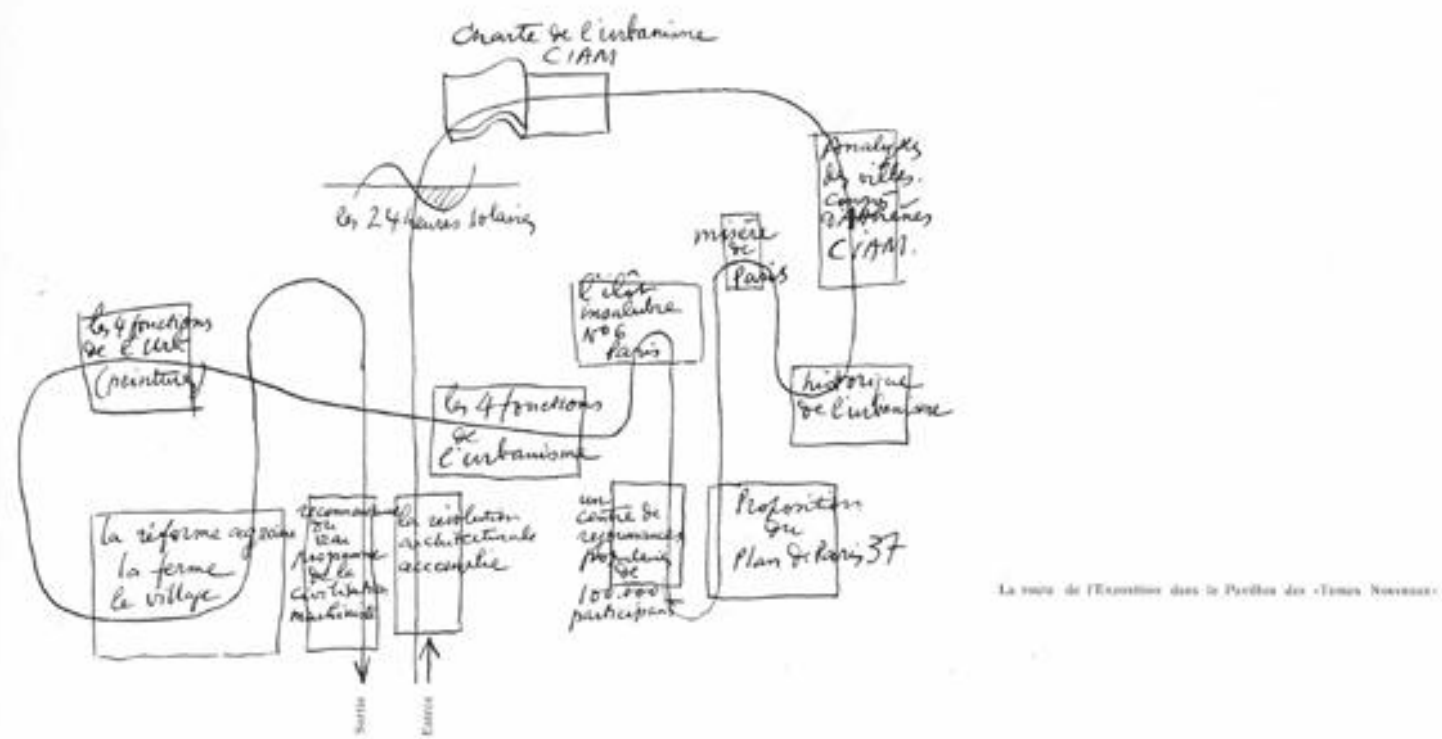

14. Le Corbusier et Pierre Jeanneret, Pavillon des Temps nouveaux, Expo 37, Projet D, la “ route de l'exposition ”. In Boesiger, Willy : Le Corbusier et Pierre Jeanneret, OEuvre complète. 1934-1938. Zurich : Gisberger, 1939. Vol. 3. p. 164. 

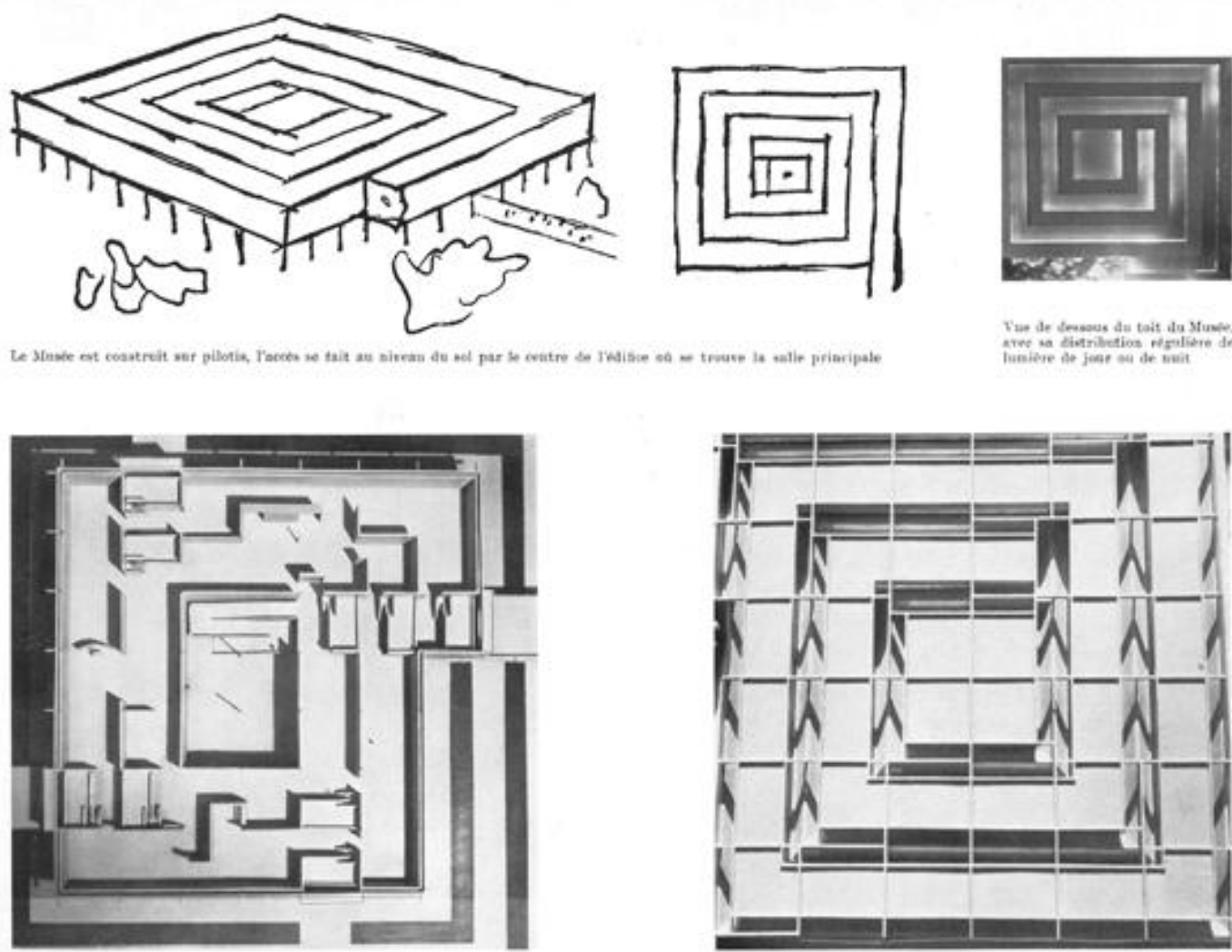

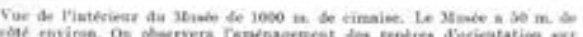

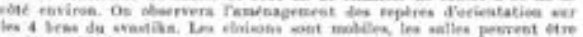

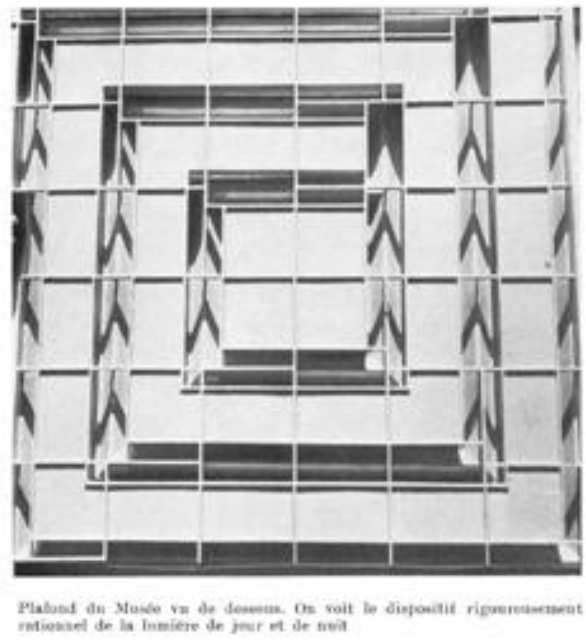

17

15. Le Corbusier et Pierre Jeanneret, Musée à croissance illimitée, 1939. In Boesiger, Willy (dir.) : Le Corbusier et Pierre Jeanneret, OEuvre complète. 1938-1946. Zurich : Gisberger, 1946. Vol. 4. p. 17.

Le projet D, le Pavillon des Temps nouveaux, est une transposition de ces réflexions sous la forme d'une structure éphémère, adaptée à un programme d'éducation populaire et non plus lié à un programme muséal. Les stratégies du parcours à travers les modules constructifs répartis dans l'espace sont semblables.

\section{Le Musée à croissance illimitée, 1939, l'aboutissement d'un modèle}

Le projet du Musée à croissance illimité marque l'incorporation des avancées et des expérimentations effectuées avec les avant-projets pour l'expo 37 dans un bâtiment générique, qui peut être implémenté dans n'importe quel site favorable. Le choix de Philippeville, aujourd'hui Skikda, en Algérie, comme lieu pour le musée dans le volume 4 de l'Euvre complète est une affirmation de la valeur de ready-made du projet, prêt à être construit non seulement en France, mais aussi à être exporté sur d'autres continents. Il porte aussi la marque de la stratégie que Le Corbusier applique pour promouvoir ses projets : Paul Cuttoli, maire radicalsocialiste de la ville et sénateur de Constantine a considérablement contribué au développement de la communauté qu'il gère, faisant construire de nombreuses infrastructures, écoles ou hôpitaux ${ }^{16}$. Marie Cuttoli, sa femme, avait développé une production locale de tapis noués utilisant le savoir-faire traditionnel et initié

\footnotetext{
${ }^{16}$ Sur Paul et Marie Cuttoli voir : http://fse.castanet.free.fr/8_cuttolipaul.html et https://www.facebook.com/media/set/?set=a.477357675671176.1073741848.281519041921708\&type=3.
} 
des collaborations avec des artistes comme Jean Lurçat ou Picasso qui rencontrèrent un véritable succès. Elle collabore régulièrement avec Le Corbusier à partir de 1936 pour l'édition de tapisseries. Les conditions auraient pu être ainsi réunies pour que le projet se concrétise...

Les trois musées construits par l'architecte à partir de 1951 à Tokyo, Ahmedabad et Chandigarh sont des interprétations du modèle adaptées aux contraintes particulières de la commande et des lieux ${ }^{17}$. L'idée de la croissance de la structure dans le temps est mise entre parenthèses.

\section{L'héritage du conflit mondial et la naissance du complexe muséal à la Porte Maillot, 1949- 1951}

Aucun projet concret ne voit le jour entre 1939 et 1945, mais de nombreuses discussions qui dépassent largement le milieu architectural et artistique sont menées sur la question des musées. La politique 'culturelle' de l'occupant allemand, le pillage systématique des collections et leur transfert vers l'Allemagne comme la vente, voire la destruction des œuvres déclarées "dégénérées", qui ont touché aussi bien les collectionneurs privés que les collections des musées nationaux, ont créé une situation d'urgence qui affecte tous les milieux culturels ${ }^{18}$. Avec la perspective de la défaite de l'Allemagne nazie et le retour des auvres spoliées en France, toute l'organisation et la répartition des œuvres dans les musées français doit être repensée. Jean Cassou a été rétabli dans ses fonctions de directeur du Musée national d'Art moderne à partir de 1945. Il avait été nommé directeur du Musée national d'art moderne en 1940, mais n'occupa ce poste que quelques mois avant d'être nommé responsable du dépôt national du château de Compiègne. Son ouvrage sur $L e$ Pillage par les Allemands des auvres d'art [...] en France ${ }^{19}$ et son engagement en tant que conservateur en font une des chevilles ouvrières de la réorganisation des musées français. Il est proche de Le Corbusier et va lui apporter un soutien indéfectible. Il a préfacé Urbanisme en 1925 et fait partie comme lui des auteurs du recueil La Querelle du réalisme, paru en 1936, recueil qui propose un état des lieux sur le rôle de l'artiste et des œuvres d'art dans la société. Il signera également l'avant-propos du catalogue de l'exposition Le Corbusier : Euvres plastiques, du 17 novembre 1953 au 31 janvier 1954 au Musée national d'art moderne, à Paris. En 1964, c'est encore lui qu'André Malraux charge de superviser la rédaction du programme du Musée du $\mathrm{XX}^{\mathrm{e}}$ siècle qui servira de base au projet de l'architecte. Son nom apparaît de manière récurrente dans les organigrammes que Le Corbusier prépare pour son projet pour un Centre expérimental des arts majeurs pour la Porte Maillot en $1949-1950^{20}$.

\footnotetext{
${ }^{17}$ Sur la réalisation des trois musées voir : Mory, Pascal : "Le Corbusier and the Syndrome of the Museum ". Op. cit. [note 1].

${ }^{18}$ Sur la question de la politique culturelle du $\mathrm{III}^{\mathrm{e}}$ Reich, voir l'ouvrage de référence de Bertrand Dorléac, Laurence : L'art de la défaite, 1940-1944. Paris : Seuil, 1993.

${ }^{19}$ Cassou, Jean : Le pillage par les Allemands des xuvres d'art et des bibliothèques appartenant à des Juifs en France. Paris : Éd. du Centre, 1947. L'ouvrage est cité par Schulmann, Didier: "Spoliation des œuvres d'art, France (1940-1944)". In Encyclopedia universalis, http://www.universalis.fr/encyclopedie/spoliation-des-oeuvres-d-art-france/.

${ }^{20}$ Le Corbusier : "Synthèse des Arts majeurs. Projet pour une exposition à installer à la Porte Maillot 1950 ”. In Boesiger, Willy (dir.) : Le Corbusier. Euvre complète. 1946-1952. Zurich: Gisberger, 1953. Vol. 5. pp. 67-71 et Dumont d'Ayot, Catherine ; Benton, Tim : Le Pavillon de Le Corbusier pour Zurich. Zurich : Lars Müller Publishers - IDB, ETH Zürich, 2013.
} 


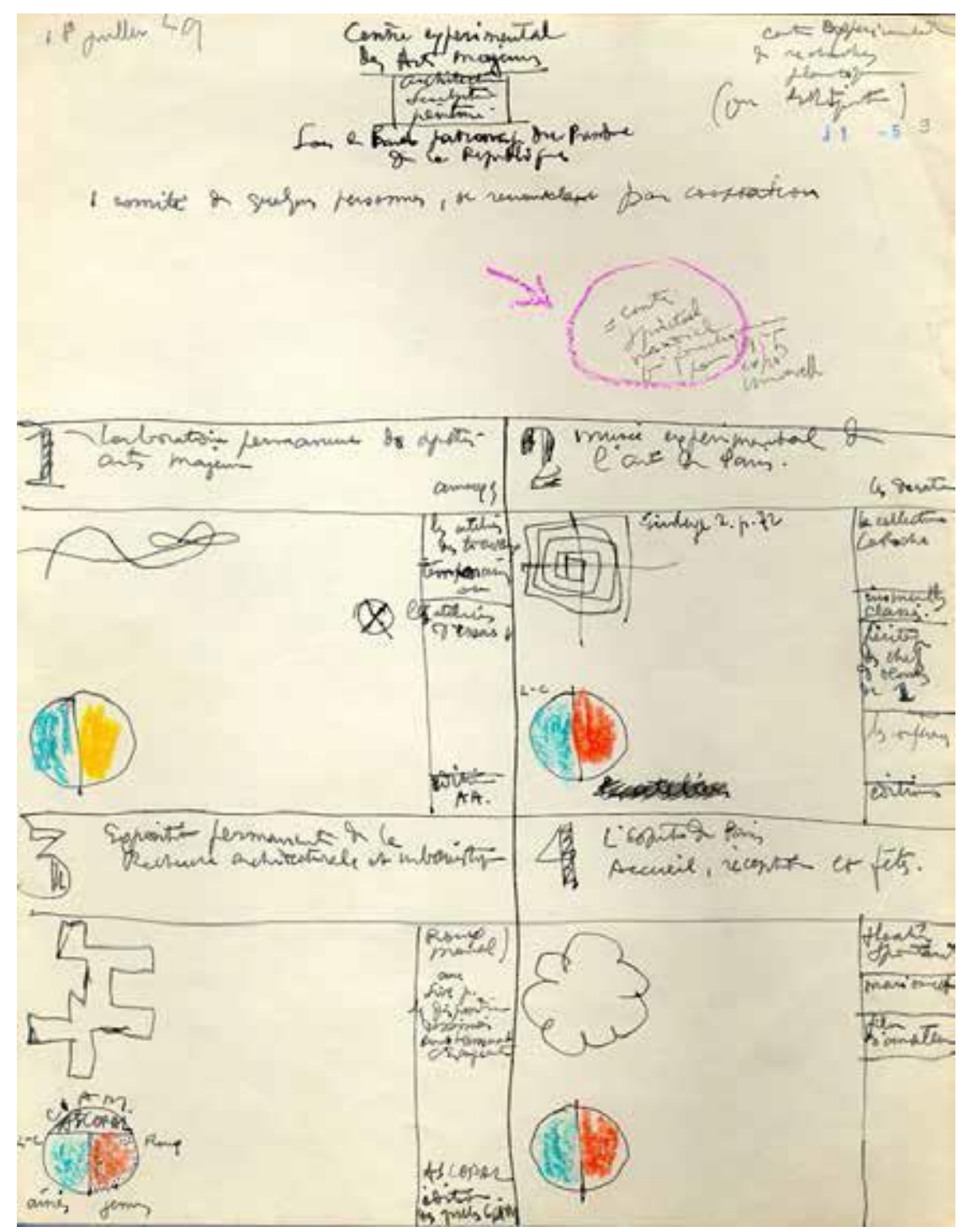

16. Le Corbusier, Centre expérimental des arts majeurs, Porte Maillot, 1949-1950, schéma d'organisation des quatre différentes structures proposées, FLC J1-5-9-001.

Ce projet pour la Porte Maillot est une réponse à l'élargissement de la compréhension du rôle du musée et du statut des œuvres exposées. Ce n'est plus un bâtiment unique qui répond au programme du musée, mais un véritable complexe muséal constitué de parties différenciées : le Laboratoire permanent des arts majeurs, le Musée expérimental de l'art de Paris, une exposition permanente architecturale et urbanistique et l' "Esprit de Paris. Accueil réception et fêtes ". Cette stratégie qui consiste à proposer une sorte de parc d'attraction culturel permet d'élargir le champ d'activité et le public visé, plaçant les ambitions pédagogiques d'une “éducation populaire ” au cœur du projet. Le deuxième point du programme, le Musée expérimental de l'art de Paris vient en réponse au manque de représentation des avant-gardes, notamment françaises, dans les collections publiques. Il s'agit d'une nouvelle occurrence du musée à croissance illimitée, cette fois destiné à un musée dont la collection aurait dû abriter la donation Raoul La Roche.

Sans réels appuis politiques ni financiers, le programme se réduit rapidement au seul "Laboratoire permanent de synthèse des Arts majeurs ", structure légère destinée aux expositions temporaires, qui prend dès 1950 la forme iconique d'une toiture monumentale constituée par un double parapluie-parasol inversé. Le passage du premier projet au second a incité Le Corbusier à abandonner l'idée d'un pavillon temporaire pour 
élaborer un projet "plus construit ", un modèle reproductible dans différents lieux. C'est une forme de readymade qui permet à la fois la reproduction du modèle architectural et l'itinérance des expositions.

\section{Les pavillons d'expositions temporaires pour Zurich et Stockholm}

Le Corbusier a l'opportunité de développer en détail le concept du pavillon d'exposition grâce aux commandes de la galeriste zurichoise Heidi Weber et du collectionneur suédois Theodor Ahrenberg entre 1960 et 1965. Le long parcours en spirale des grands musées est remplacé par une double boucle distendu sur deux niveaux dont la géométrie renvoie au symbole mathématique de l'infini $\infty$. Cette stratégie lui permet de déjouer la petite dimension des structures en offrant un parcours continu rythmé par des changements de direction et d'ouverture sur le paysage. Pour le projet du Zurichhorn, les esquisses des avant-projets montrent le long travail de définition du cheminement intérieur. Les positions respectives de la rampe et de l'escalier font l'objet de nombreuses variantes : la rampe, initialement intégrée à l'intérieur du volume, dans le sens de la longueur, est redéployée à l'extérieur, perpendiculairement au volume principal, ce qui permet un allongement significatif du parcours et un accès beaucoup plus spectaculaire à la terrasse, dans l'axe du panorama du lac. Le projet du Palais Ahrenberg impose une élaboration spécifique : il est prévu pour abriter trois ensembles d'œuvres de trois grands artistes : Picasso, Matisse et Le Corbusier, de même qu'un espace pour des expositions temporaires. Le Corbusier veut trois salles d'importance semblable, chacune avec une double hauteur. La manière de diviser l'espace intérieur du pavillon très fortement déterminé par la géométrie de la toiture double en trois salles est un réel défi qui donne lieu à de nombreuses études - Guillermo Jullian de la Fuente, en particulier, y consacre de nombreuses esquisses. La stratégie de mise en scène du parcours du spectateur à l'intérieur de la structure trouve son aboutissement dans le pavillon de Zurich, cette fois libérée de la contrainte d'une collection permanente et ouverte à des usages multiples. Les modules du 226x226x226 semblent avoir permis à Le Corbusier de réaliser son souhait de la fusion des nécessités du logis et de celles de l'exposition en structure parfaitement flexible et adaptable.

\section{La pratique de l'exposition}

Au début de sa carrière, Le Corbusier s'est intéressé à la manière d'exposer des œuvres dans le cadre des projets d'ateliers d'artistes ou des maisons de collectionneurs. Il s'agit d'un rapport intime et privilégié à l'œuvre d'art, qui n'engage que l'artiste ou un connaisseur averti. Ce rapport est exclusif, pour la villa de Raoul La Roche Le Corbusier propose un meuble central pour ranger les tableaux de la collection et choisir la toile exposée dans un face à face exclusif, modèle qui se révélera insatisfaisant pour le collectionneur. Les accrochages se font toujours dans la petite échelle domestique. L'autre modèle, celui vécu et pratiqué par le créateur lui-même, est celui de l'atelier d'artiste. C'est le programme de l'un de ses premiers projets parisiens en 1922 pour Amédée Ozenfant. Mais c'est surtout le rapport à l'œuvre tel qu'il l'expérimente quotidiennement dans son propre travail de peintre qui influence sa compréhension des nécessités de l'exposition. L'atelier est le lieu de la confrontation productive à un choix d'œuvres déterminé en fonction de l'actualité du travail. Cette forme de l'exposition est au cœur du travail, elle est soumise à des remaniements incessants et ne possède pas de forme fixe, c'est un processus en mouvement. Elle est assujettie à la volonté de l'artiste de s'entourer à chaque moment des œuvres susceptibles d'accompagner son travail, propice au dialogue avec ses propres œuvres, mais aussi des œuvres " amies " qu'il possède, celles de Fernand Léger ou Jacques Lipschitz par exemple, sans oublier les “objets à réaction poétique ", ramassés au gré du hasard et des voyages. 


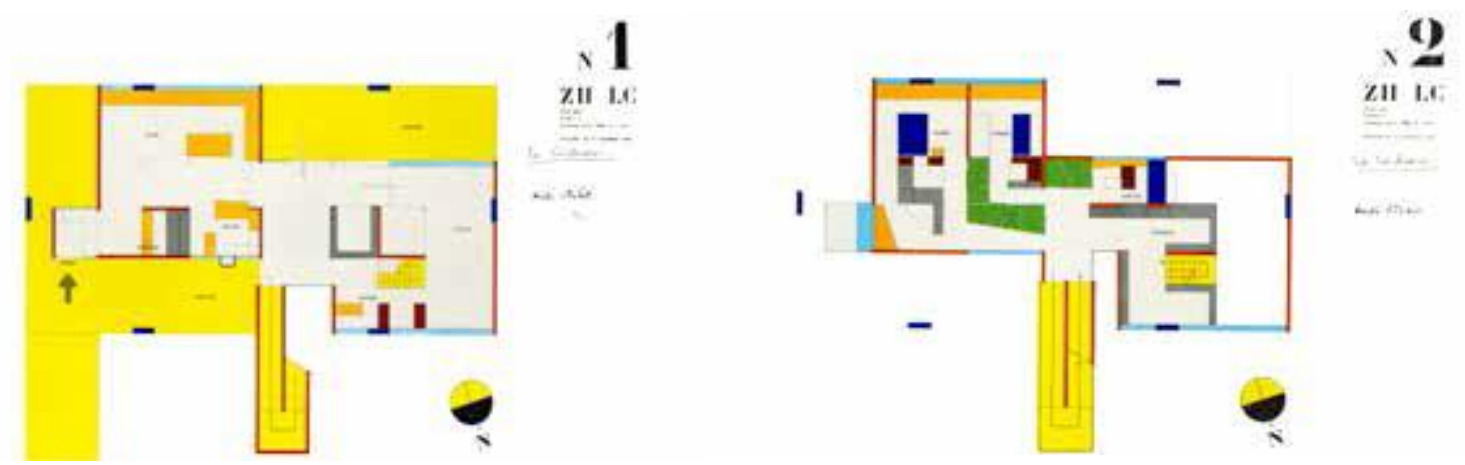

17. Le Corbusier, Pavillon d'exposition pour Heidi Weber, Zurich, décembre 1961, premier permis de construire, premier et second niveaux, à droite, l'atelier, à gauche, le logis. Stadt Zürich, Hochbauamtdepartement, Planauflage / Archiv.

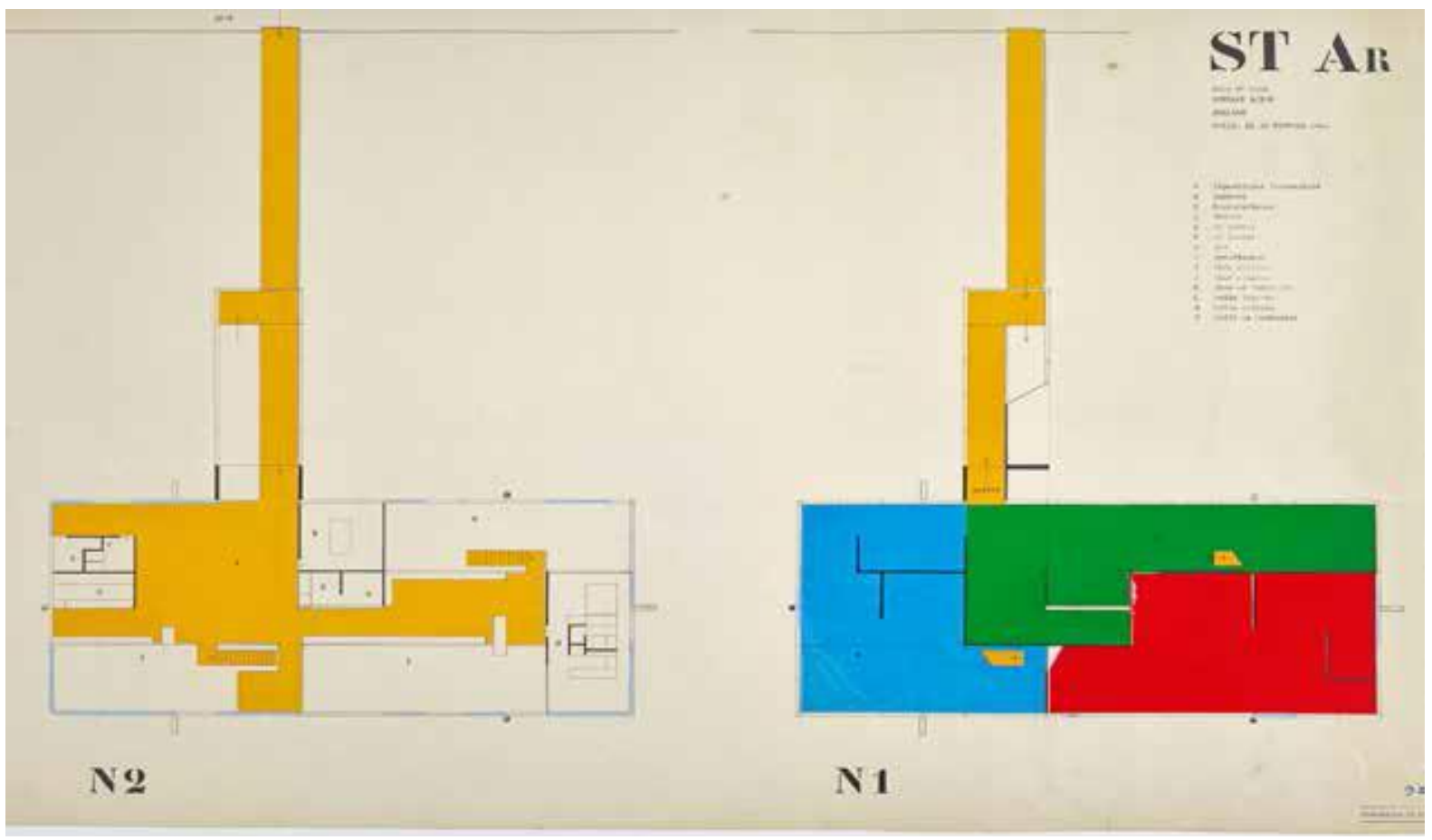

18. Le Corbusier, Palais Ahrenberg, Stockholm, janvier 1962, avant-projet, second et premier niveaux, en jaune, accès et exposition temporaire, en bleu $(\mathrm{J}+\mathrm{M})$ Matisse, en rouge $(\mathrm{I}+\mathrm{L})$ Picasso, en vert $(\mathrm{K}+\mathrm{N})$ Le Corbusier, FLC 25047B.

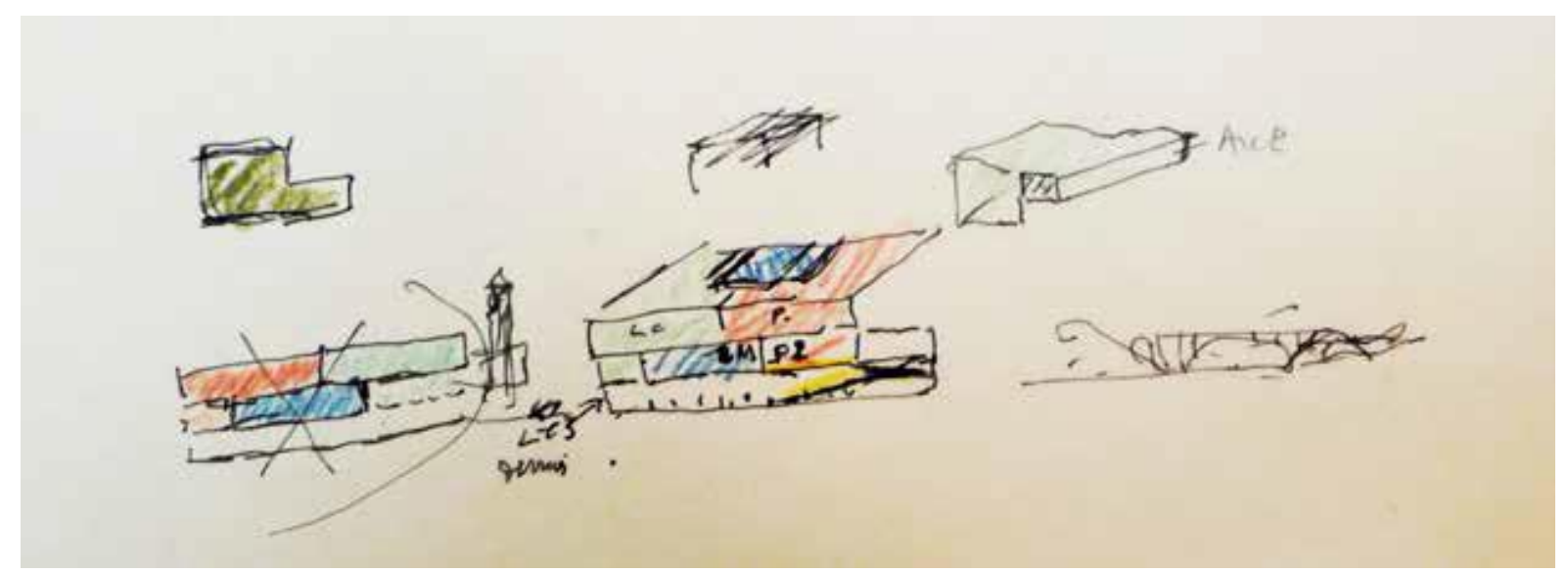

19. Le Corbusier, Palais Ahrenberg, Stockholm, janvier 1962, étude de la disposition des trois salles Matisse, Picasso et Le Corbusier, Centre canadien d'architecture, fonds Guillermo Jullian de la Fuente, DR 1993:0136:0004. 
Très tôt aussi, Le Corbusier expose dans les galeries, en tandem avec Amédée Ozenfant pendant la période puriste, puis seul. Dès 1937, avec l'exposition au Kunsthaus de Zurich ${ }^{21}$, il fait l'expérience de devoir montrer ses propres œuvres dans un musée. Par ses dimensions et par son public beaucoup plus diversifié, le musée rompt avec cette approche intimiste et oblige à concevoir une approche plus pédagogique et une organisation spatiale à même de gérer le rapport simultané à de nombreuses œuvres. En 1940, l'exposition de "La France d'outremer " qui s'est tenue au Grand Palais lui permet de se confronter à la très grande échelle du lieu, mais c'est surtout avec l'exposition de son propre travail au Musée national d'art moderne de la ville de Paris qu'il se heurte à la question de l'échelle des salles d'exposition, expérience qu'il relate dans le Modulor 2 sous le titre "Transformation d'une salle inhumaine 22 ". Il introduit des éléments de partitions de l'espace au format 226×226×226 afin de "rétablir par une initiative efficace un contact entre spectateurs et æuvres (tableaux, sculptures, documents graphiques) ${ }^{23}$ ". C'est ce module qui remplace la trame initiale de $7 \times 7 \mathrm{~m}$ des musées et qui est mis en œuvre dans les scénographies et les aménagements intérieurs de ses expositions successives, puis, finalement, dans le Pavillon de Zurich grâce au système constructif en cornières soudées, matérialisation dans l'espace de cette trame abstraite idéale.

\section{Conclusion}

Le projet du Musée d'Art contemporain de 1931 constitue un changement de paradigme qui se répercute dans l'ensemble de l'œuvre de Le Corbusier. Le statut provisoire de la façade prend à contre-pied non seulement l'architecture académique mais aussi les formes compositives issues de la Modernité. L'architecture moderne supprime tout décor de la façade, Le Corbusier franchit le pas suivant et propose une architecture libérée de la charge du dessin même d'une façade. Le projet est littéralement la transcription d'un concept, d'un parcours construit comme une suite de face-à-face avec les œuvres exposées. L'entrée est disposée au centre de la spirale, la façade n'assume plus l'identité visuelle du musée. Cette logique trouvera un aboutissement dans le Carpenter Art Center à Boston, ou le dedans devient le dehors.

La réduction de l'architecture à une trame, une grille tridimensionnelle dans laquelle le programme viendra s'inscrire relève de la même logique : la recherche d'une abstraction maximale. Les dessins et les esquisses restituent cette intention : de nombreux plans se résument à des grilles de points et de flèches, des schéma d'organisation, tandis que certaines perspectives ne montrent pas directement des espaces, mais se concentrent des mises en situation, des confrontations entre le spectateur et l'œuvre. C'est ce rapport spectateur-œuvre qui détermine le projet, non plus une forme symbolique chargée de la représentation d'une institution. Il reste le face à face avec l'œuvre, le parcours et le discours sur le corpus exposé.

\footnotetext{
${ }^{21}$ Voir Navarro Segura, Maria Isabel (dir.), Le Corbusier expose, catalogue d'exposition. Besançon : Musée des Beaux arts et d'archéologie de Besançon - Milan : Silvana Editoriale, 2011.

${ }^{22}$ Le Corbusier, Modulor 2. Boulogne : éditions de l'Architecture d'aujourd'hui, 1955. pp. 275-279.

${ }^{23}$ Ibid.
} 

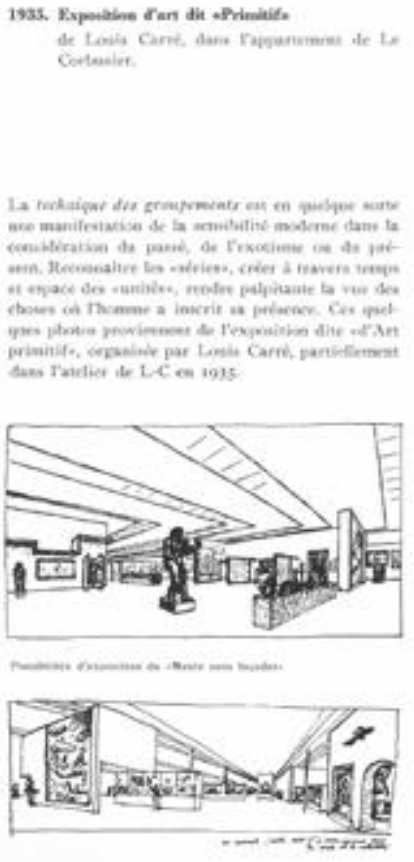
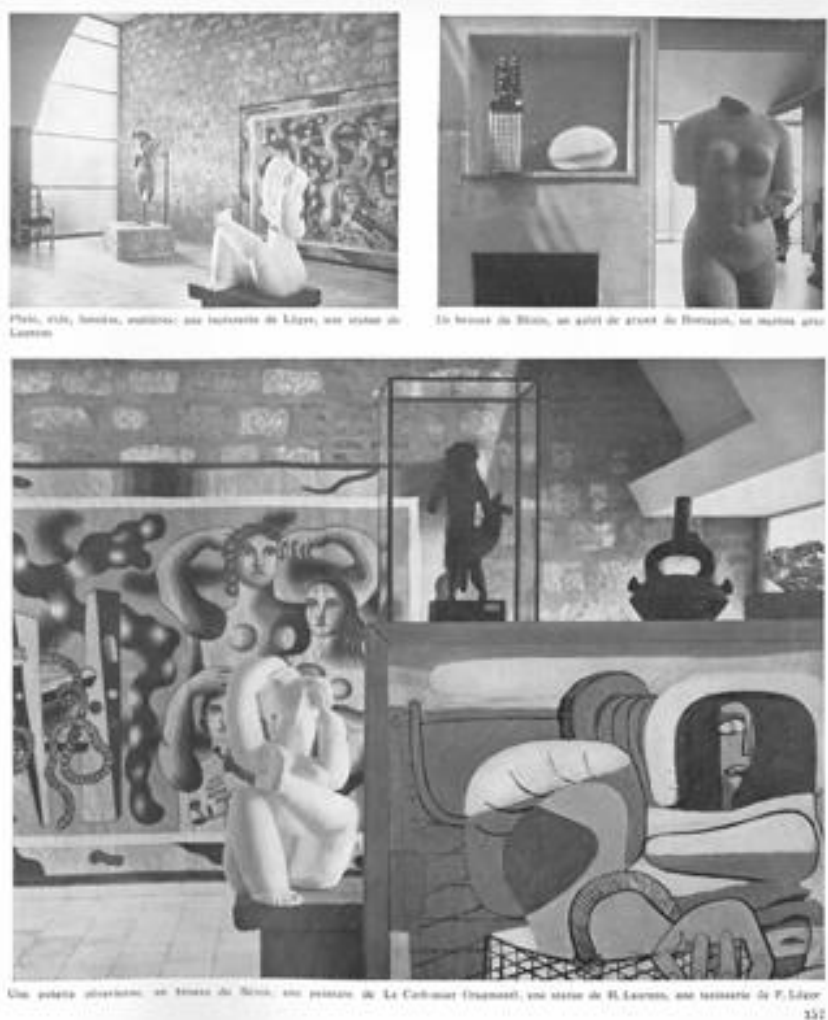

20. Le Corbusier, Exposition des arts dit “primitifs” de Louis Carré dans l'appartement de Le Corbusier. In Boesiger, Willy (dir.) : Le Corbusier et Pierre Jeanneret, OEuvre complète. 1934-1938. Zurich : Gisberger, 1939. Vol. 3. p. 157.
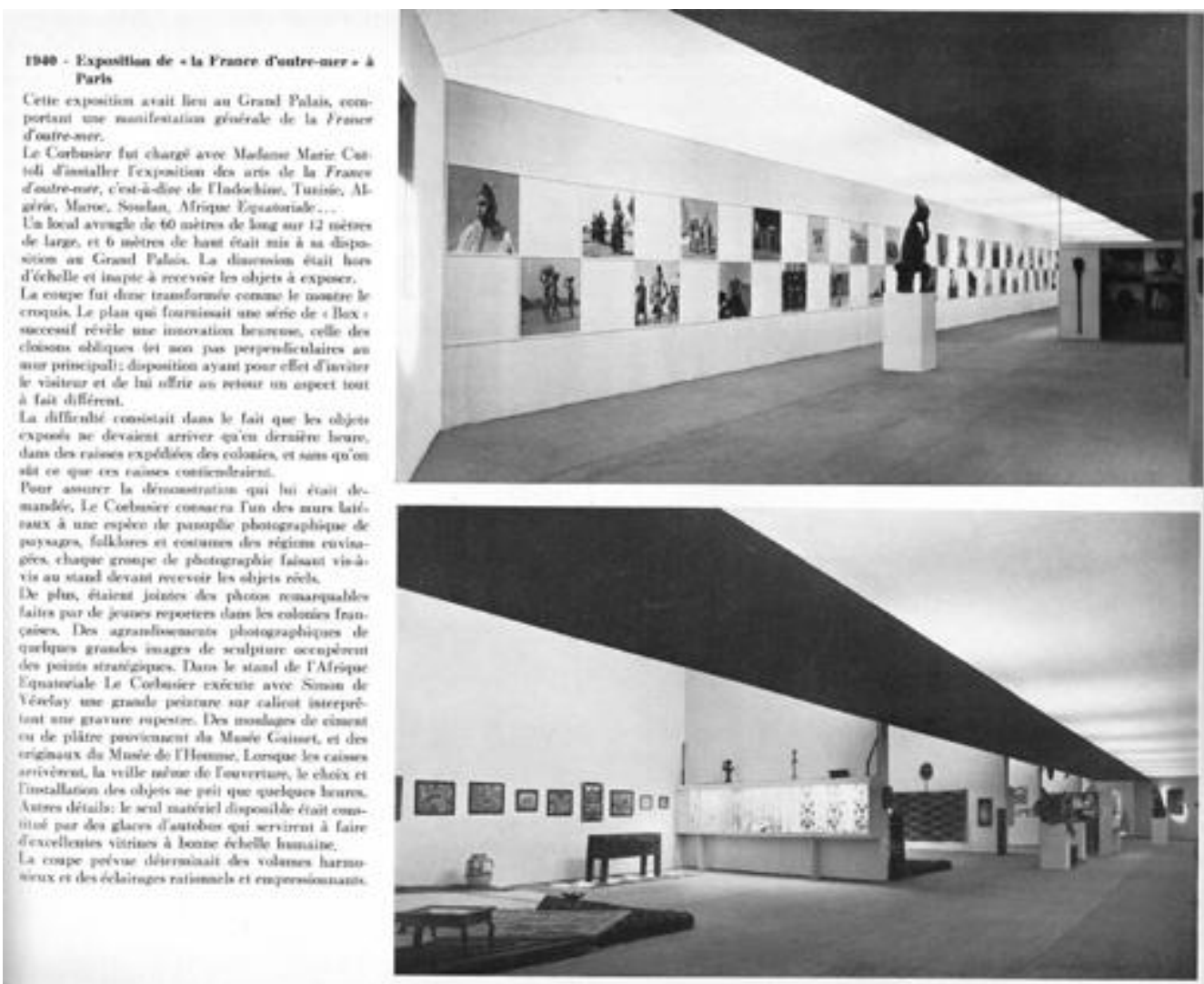

21. Le Corbusier, Exposition de “la France d'Outre-mer” à Paris. In Boesiger, Willy (dir.) : Le Corbusier et Pierre Jeanneret, OEuvre complète. 1938-1946. Zurich : Gisberger, 1946. Vol. 4. p. 91. 


\section{CAPTIONS / Légendes des illustrations}

1. Le Corbusier et Pierre Jeanneret, Mundaneum, perspective de Le Corbusier montrant le panorama vers le lac Léman et le Mont-Blanc, FLC 32114.

2. Le Corbusier et Pierre Jeanneret, Mundaneum, le Musée mondial, schéma montrant le fonctionnement de la circulation en spirale descendante et des trois nefs destinées aux objets (a), lieux (b) et temps (c) et le chemin de fer qui dessert le magasin continu (d), In Boesiger, Willy; Storonov, Oscar (dir.) : Le Corbusier et Pierre Jeanneret, Euvre complète.1910-1929. Zurich : Gisberger, 1937. Vol. 1, p. 193.

3. Le Corbusier et Pierre Jeanneret, Musée d'art contemporain, Paris, 1930, perspective aérienne. In Boesiger, Willy (dir.) : Le Corbusier et Pierre Jeanneret, Euvre complète. 1929-1934. Zurich : Gisberger, 1935. Vol. 2. p. 72 .

4. Le Corbusier et Pierre Jeanneret, Musée d'art contemporain, Paris, 1930, principe de croissance. In Boesiger, Willy (dir.) : Le Corbusier et Pierre Jeanneret, Euvre complète. 1929-1934. Zurich : Gisberger, 1935. Vol. 2. p. 73.

6. Le Corbusier et Pierre Jeanneret, Musée de la ville et de l'état, Paris, 1934, perspective, FLC 28814.

7. Le Corbusier et Pierre Jeanneret, Expo 37, Projet C, plan et élévation. In Boesiger, Willy (dir.) : Le Corbusier et Pierre Jeanneret, Euvre complète. 1934-1938. Zurich : Gisberger, 1938. Vol. 3. p. 155.

8. Le Corbusier et Pierre Jeanneret, Expo 37, Projet C, perspective à vol d'oiseau, FLC 626.

9. Le Corbusier et Pierre Jeanneret, Expo 37, Projet C, schéma de circulation, FLC 713.

10. Le Corbusier et Pierre Jeanneret, Expo 37, Projet C, schéma d'organisation, FLC 705.

11. Le Corbusier et Pierre Jeanneret, Expo 37, Projet C, schéma d'organisation, FLC 675.

12. Le Corbusier et Pierre Jeanneret, Expo 37, Projet C, perspective, FLC 768

13. Le Corbusier et Pierre Jeanneret, Pavillon des Temps nouveaux, Expo 37, Projet D, élévation, plan et coupe. In Boesiger, Willy (dir.) : Le Corbusier et Pierre Jeanneret, Euvre complète. 1934-1938. Zurich : Gisberger, 1939. Vol. 3. p. 160.

14. Le Corbusier et Pierre Jeanneret, Pavillon des Temps nouveaux, Expo 37, Projet D, la "route de l'exposition ”. In Boesiger, Willy : Le Corbusier et Pierre Jeanneret, Euvre complète. 1934-1938. Zurich : Gisberger, 1939. Vol. 3. p. 164.

15. Le Corbusier et Pierre Jeanneret, Musée à croissance illimitée, 1939. In Boesiger, Willy (dir.) : Le Corbusier et Pierre Jeanneret, Euvre complète. 1938-1946. Zurich : Gisberger, 1946. Vol. 4. p. 17.

16. Le Corbusier, Centre expérimental des arts majeurs, Porte Maillot, 1949-1950, schéma d'organisation des quatre différentes structures proposées, FLC J1-5-9-001.

17. Le Corbusier, Pavillon d'exposition pour Heidi Weber, Zurich, décembre 1961, premier permis de construire, premier et second niveaux, à droite, l'atelier, à gauche, le logis. Stadt Zürich, Hochbauamtdepartement, Planauflage / Archiv.

18. Le Corbusier, Palais Ahrenberg, Stockholm, janvier 1962, avant-projet, second et premier niveaux, en jaune, accès et exposition temporaire, en bleu $(\mathrm{J}+\mathrm{M})$ Matisse, en rouge $(\mathrm{I}+\mathrm{L})$ Picasso, en vert $(\mathrm{K}+\mathrm{N}) \mathrm{Le}$ Corbusier, FLC 25047B.

19. Le Corbusier, Palais Ahrenberg, Stockholm, janvier 1962, étude de la disposition des trois salles Matisse, Picasso et Le Corbusier, Centre canadien d'architecture, fonds Guillermo Jullian de la Fuente, DR 1993:0136:0004.

20. Le Corbusier, Exposition des arts dit “primitifs” de Louis Carré dans l'appartement de Le Corbusier. In Boesiger, Willy (dir.) : Le Corbusier et Pierre Jeanneret, Euvre complète. 1934-1938. Zurich : Gisberger, 1939. Vol. 3. p. 157.

21. Le Corbusier, Exposition de “la France d'Outre-mer” à Paris. In Boesiger, Willy (dir.) : Le Corbusier et Pierre Jeanneret, Euvre complète. 1938-1946. Zurich : Gisberger, 1946. Vol. 4. p. 91. 


\section{Bibliographie}

Bertrand Dorléac, Laurence : L'art de la défaite, 1940-1944. Paris : Seuil, 1993.

Boesiger, Willy (dir.) : Le Corbusier et Pierre Jeanneret, Euvre complète. 1938-1946. Zurich : Gisberger, 1946. Vol. 4. pp. 91-92.

Cohen, Jean-Louis : Le Corbusier et la mystique de l'URSS. Bruxelles : Mardaga, 1987.

Courtiau, Catherine : “La Cité internationale”. In Charollais, Isabelle ; Ducret, André (dir.) : Le Corbusier à Genève 1922-1932. Projets et réalisations, catalogue d'exposition. Lausanne : Payot, 1987. pp. 53-69.

Dumont d'Ayot, Catherine ; Benton, Tim : Le Pavillon de Le Corbusier pour Zurich. Zurich: Lars Müller Publishers - IDB, ETH Zürich, 2013.

Gresleri, Giuliano : “Le Mundaneum. Lecture d'un projet”. In Charollais, Isabelle ; Ducret, André (dir.) : Le Corbusier à Genève 1922-1932. Projets et réalisations, catalogue d'exposition. Lausanne : Payot, 1987. pp. 7078.

Gresleri, Giuliano : “Mundaneum ”. In Lucan, Jacques (dir.) : Le Corbusier, une encyclopédie. Paris : Éditions du Centre Pompidou, 1987. pp. 261-293.

Le Corbusier : “ Défense de l'architecture ”. In L'Architecture d'aujourd'hui. 1933. N 10. pp. 38-61.

Le Corbusier: "Mundaneum, 1929”. In Boesiger, Willy; Storonov, Oscar (dir.) : Le Corbusier et Pierre Jeanneret. Euvre complète. 1910-1929. Zurich : Gisberger., 1937. $2^{\mathrm{e}}$ édition. Vol. 1. p. 194.

Le Corbusier: “Musée d'art contemporain”, Paris, 1932. In Boesiger, Willy (dir.) : Le Corbusier et Pierre Jeanneret, Euvre complète. 1929-1934. Zurich : Gisberger, 1935. Vol. 2. pp. 72-73.

Le Corbusier : “Plans pour les musées de la Ville et de l'Etat à Paris ”, Paris, 1932. In Bill, Max (dir.) : Le Corbusier et Pierre Jeanneret, Euvre complète. 1934-1938. Zurich : Gisberger, 1953. Vol. 3. pp. 82-89.

Le Corbusier ; Jeanneret, Pierre : "Exposition de "la France d'Outre-mer" à Paris ". In Boesiger, Willy (dir.) : Le Corbusier et Pierre Jeanneret, Euvre complète. 1938-1946. Zurich : Gisberger, 1946. Vol. 4. pp. 9192.

Le Corbusier ; Jeanneret, Pierre : “Exposition des arts dit primitifs ”. In Boesiger, Willy (dir.) : Le Corbusier et Pierre Jeanneret, Euvre complète. 1934-1938. Zurich : Gisberger, 1939. Vol. 3. pp. 156-157.

Le Corbusier; Jeanneret, Pierre : “Musée à croissance illimitée, 1939 ”. In Boesiger, Willy (dir.) : Le Corbusier et Pierre Jeanneret, Euvre complète. 1938-1946. Zurich : Gisberger, 1946. Vol. 4. pp. 17.

Le Corbusier ; Jeanneret, Pierre : “Pour la création à Paris d'un musée des artistes vivants ”, In Cahiers d'art. 1931. $\mathrm{N}^{\circ} 1$, p. 9.

Mory, Pascal. "Le Corbusier and the Syndrome of the Museum". In Cohen, Jean-Louis ; Ahrenberg, Staffan (dir.) : Le Corbusier's Secret Laboratory. From Painting to Architecture. Ostfildern : Hatje Cantz, 2013.

Perret, Auguste : “Le musée moderne ”. In Mouseion. Décembre 1929. N 9. pp. 225-235.

Reichlin, Bruno: “Solution élégante”. In Lucan, Jacques (dir.) : Le Corbusier, une encyclopédie. Paris : Éditions du Centre Pompidou, 1987. pp. 369-377.

Teige, Karel : “Mundaneum”. In Stavba. Avril 1929. № 10. pp. 145-155. La traduction anglaise est parue dans Opposition. Octobre 1974. $\mathrm{N}^{\circ}$ 4. pp. 80-90. 


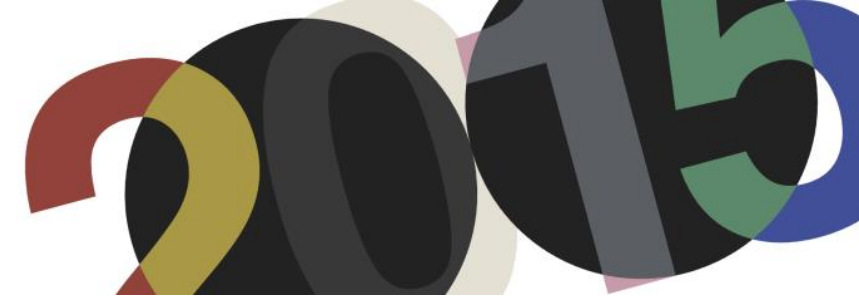

DOI: http://dx.doi.org/10.4995/LC2015.2015.660

\title{
Learning from Le Corbusier
}

\author{
L.J. Duport
}

Ecole Nationale Supérieure d'Architecture de Montpellier

Résumé: Interrogé sur l'enseignement de l'architecture, et bien qu'il ait exposé ses idées sur le sujet principalement dans deux de ses livres : "Précisions» (1930) et «Sur les quatre routes » (1941) Le Corbusier répond : "Je n'ai jamais reçu d'enseignement proprement dit. Je suis autodidacte même dans le sport.». La formidable puissance didactique de Le Corbusier réside en cinq points : sa formation, son positionnement théorique, son invention de typologies, sa diffusion de l'architecture, sa production prolifique. Ainsi, bien au-delà de l'Euvre Complète Le Corbusier offre à qui veut s'en servir un champ pédagogique particulièrement riche à découvrir et à partager. Aucun programme ne lui a échappé que ce soit les villas ou maisons, le logement collectif, les bureaux, les équipements (publics ou privés), les bâtiments institutionnels, les musées, les usines : tout est matière à invention. Cette invention s'accompagne de sa diffusion de l'architecture, de ses idées, à travers publications et conférences à travers le monde. Mais cela n'est rien comparé à sa production aux échelles variées de l'habitat minimum jusqu'à l'édifice monumental. C'est pourquoi avec le regard porté sur le projet des Quartiers Modernes Frugès construits à Pessac en 1926 nous examinerons comment ce "laboratoire 》 constitue une expérience pédagogique qui a valeur d'exemplarité et toujours d'actualité.

Abstract: Asked about the architectural education and although he outlined his ideas on the subject mainly in two of his books: "Précisions" (1930) and "Sur les quatre routes" (1941), Le Corbusier replied: "I have never received proper education. I am self-taught even in sport. ". The amazing power of Le Corbusier's didactic resides in five points: his training, his theoretical positioning, his invention of typologies, his diffusion of architecture, his prolific production. Thus, beyond his "Oeuvres Complètes" Le Corbusier offers to whom wants to use it, a rich educational field to discover and share. No program has eluded him whether it is villas or houses, collective housing, offices, facilities (public or private), institutional buildings, museums, factories : everything is material for invention. This invention is accompanied with his diffusion of architecture, of his ideas in books or lectures all over the world. But this is nothing compare to his production to various scales from the minimum housing to the monumental building. Therefore with the close look on the Modern Quarters Frugès project built in Pessac in 1926 we will examine how this "laboratory" is an educational experience that has of exemplarity value and is still relevant today.

Mots-clés: Enseignement, Habitat, Patrimoine XXe, polychromie, Restauration. Keywords: Education, Housing, Heritage XXe, Polychromie, Restoration. 
Lorsqu'on l'interroge sur l'enseignement de l'architecture, et bien qu'il ait exposé ses idées sur le sujet principalement dans deux de ses livres : «Précisions » (1930) et «Sur les quatre routes » (1941), Le Corbusier répond : «Je n'ai jamais reçu d'enseignement proprement dit. Je suis autodidacte même dans le sport ${ }^{1}{ } »$

La formidable puissance didactique de Le Corbusier réside en cinq points : sa formation, son positionnement théorique, sa diffusion de l'architecture, sa production prolifique, son invention de typologies. Ainsi bien au-delà de l'EEuvre Complète, Le Corbusier offre à qui veut s'en servir un champ pédagogique particulièrement riche à découvrir et à partager.

Sa formation tout d'abord où l'on se rend compte que tout est exploité à dessein : que ce soit par son apprentissage même, par ses croquis et récits de voyages, par ses rencontres ou encore à l'occasion de la lecture de ses premières publications. L'influence de Charles l'Eplattenier (1874-1946) qui dirige l'Ecole d'Art de la Chaux de Fonds sera décisive. C'est lui qui suggère à Charles Edouard Jeanneret de voyager et surtout qui obtiendra la confiance d'un premier client Louis Fallet, pour qui le jeune Jeanneret construira sa première villa à la Chaux-de-Fond (avec l'architecte Chapellaz en 1906).

Cette formation restera fondamentale dans la capacité de Le Corbusier à choisir sa vocation, s'écartant de l'avenir tout tracé qui lui était réservé de graveur de montres. Ses voyages en Italie (1907), en Allemagne (1910) ou encore en Orient (1911) font du jeune Jeanneret un infatigable dessinateur, photographe mais le propulse aussi chez les meilleurs architectes du moment, Joseph Hoffman, Auguste Perret et Peter Behrens. Le Corbusier va ainsi «parcourir le monde à la recherche d'une identité et d'une culture d'architecte ${ }^{2}{ }^{2}$.

Pour lui «Quand on voyage et qu'on est praticien des choses visuelles : architecture, peinture ou sculpture, on regarde avec des yeux et on dessine afin de pousser à l'intérieur, dans sa propre histoire, les choses vues. Une fois les choses entrées par le travail du crayon, elles restent pour la vie ; elles sont écrites, elles sont inscrites (...). Dessiner soi-même, suivre des profils, occuper des surfaces, reconnaitre des volumes, etc. (...) c'est d'abord regarder, c'est être apte peut-être à observer, apte peut-être à découvrir...A ce moment-là le phénomène inventif peut survenir. On invente et même on crée; tout l'être est entrainé dans l'action; cette action c'est le point capital. $»^{3}$

Ses voyages de jeunesse augmentés par sa capacité d'interprétation autorise un positionnement théorique qu'il ne va cesser de publier que ce soit depuis «Vers une architecture » (1923) jusqu'à « Mise au point» (1966) en passant par «Manière de penser l'urbanisme » (1946) ou «Le modulor» (1950). Mais c'est certainement son implication dans "la revue L'Esprit Nouveau qu'il créa en 1920 avec Amédée Ozenfant ${ }^{4}$ et dirigea avec lui et Paul Dermée ${ }^{5}$ jusqu'en 1925, date à laquelle la revue cessa de paraître. Il y écrivit douze articles qu'il rassembla dans un livre, Vers une architecture, ${ }^{6}$ publié en 1923. (...) Bien que ce livre se ressente, dans son style, de la juxtaposition d'articles écrits pour une revue militante il n'en demeure pas moins que Le Corbusier y exposa alors l'essentiel de ses théories, et ne fit, par la suite, que les répéter, les préciser, et les développer dans ses autres écrits ${ }^{7}$

\footnotetext{
${ }^{1}$ Entretien avec les étudiants des écoles d'architecture, Le Corbusier, Denoël, Paris, 1943

${ }^{2}$ Duboy Philippe, Le Corbusier, Croquis de voyages et études, textes choisis, Louis Vuitton, Paris 2009, p.15

${ }^{3}$ Le Corbusier, L'atelier de la recherche patiente, Vincent et Fréal, Paris, 1960, p.37, cité par P.Duboy

${ }^{4}$ Amédée Ozenfant (1886-1966) peintre français, co-fondateur (avec Le Corbusier) de la revue L’Esprit Nouveau et du purisme (en réaction au cubisme)

${ }^{5}$ Paul Dermée (1886-1951), écrivain, poète et critique littéraire, directeur de la revue L'Esprit Nouveau

${ }^{6}$ Le Corbusier, Vers une architecture, Éditions Crès, Collection de "L'Esprit Nouveau", Paris, 1923

${ }^{7}$ Guiton Jacques Le Corbusier, Textes choisis Architecture et urbanisme, Le Moniteur, Paris 1982
} 
Cette invention s'accompagne de sa diffusion de l'architecture et de ses idées à travers des publications comme l'Esprit Nouveau (1920) mais surtout grâce à des conférences à travers le monde, à la fois au sein des CIAM depuis l'origine (1928) ou avec des voyages et des conférences données aux USA, en Russie et en Amérique Latine, en particulier à Buenos Aires en 1929.

Cela n'est rien en comparaison avec sa production prolifique que ce soit de projets non construit à ses nombreuses réalisations aux échelles variées dans le monde entier, de l'habitat minimum, avec le Cabanon à Roquebrune Cap Martin (1952) jusqu'à l'édifice monumental comme le palais de l'Assemblée à Chandigarh (1955). Au-delà de sa propre production elle-même, Le Corbusier était un inventeur de typologies. Aucun programme ne lui a échappé, que ce soit les villas ou maisons, le logement collectif, les bureaux, les équipements (publics ou privés), les bâtiments institutionnels, les musées, les usines. Tout ou presque est matière à invention.

Avec le projet des Quartiers Modernes Frugès construits à Pessac en 1928 nous examinerons pourquoi ce « laboratoire » constitue une expérience pédagogique qui a valeur d'exemplarité et toujours d'actualité.

\section{Les Quartiers Modernes Frugès}

La construction de cette cité entre 1924 et 1926 est le fruit de la rencontre de deux personnalités : un industriel sucrier, Henry Frugès, et un architecte, Le Corbusier. Henry Frugès, curieux de toutes les innovations artistiques et architecturales du moment, souhaitait loger des ouvriers sur "une vaste prairie entourée de bois de pins, en y édifiant une cité-jardin". Le Corbusier, porté par un esprit d'avant-garde, avait déjà abordé les problèmes liés à l'urbanisme. l'habitat et les maisons standardisées.
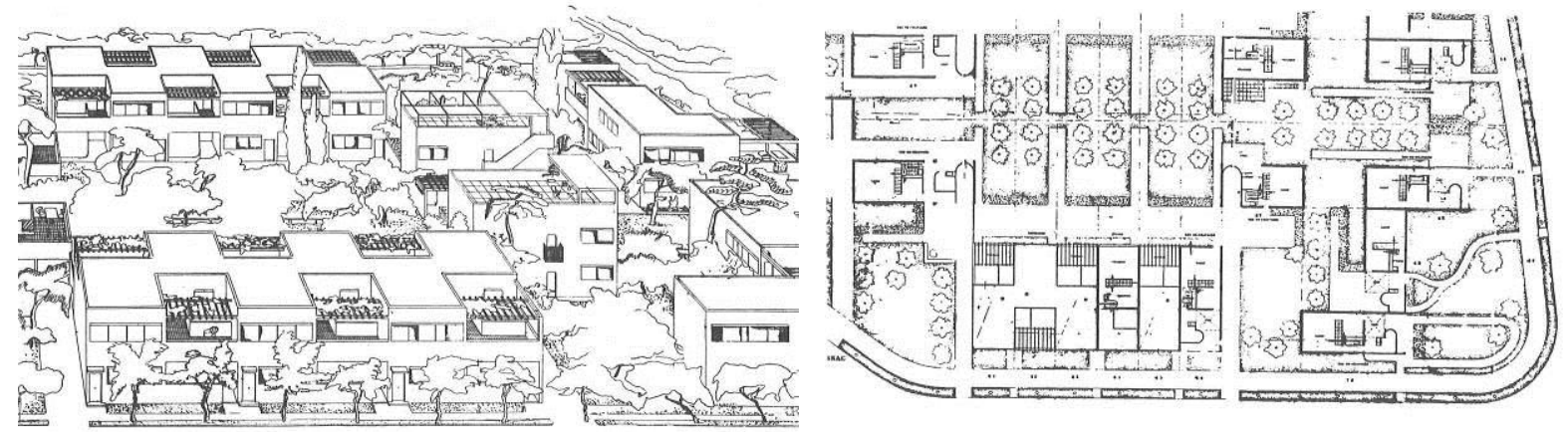

1. - 2. Vers une architecture p.212 et 213 OFLC-ADAGP

La Cité Frugès est née de leurs échanges, et particulièrement de la réflexion de l'architecte, qui adopta des principes strictement fonctionnels et des formes géométriques simples. Avant-gardiste formellement et par sa dimension sociale, la cité est à l'époque une véritable révolution, tant sur le plan de l'habitat social que sur celui de l'architecture C'est en termes de confort et d'esthétique, pour des logements modestes construits à l'époque, que l'architecte se positionna en véritable précurseur. Les modèles d'habitations conçus ici illustrent les cinq points de l'architecture moderne : les pilotis, le toit-terrasse, le plan libre, la fenêtre en longueur, la façade libre.

L'ambition d'origine se trouve diminuée : sur les 150 logements initialement prévus, seulement 51 seront réalisés en 1926 et resteront vides pour leur grande majorité jusqu'en 1929.

De même sa réception se révèle un échec, en raison de l'accueil mitigé que cette expérimentation tournée vers la modernité suscita. Bousculant les esprits, la cité Le Corbusier de Pessac fut accompagnée de nombreuses critiques. 
Parmi les nombreux documents aujourd'hui disponibles et hormis les originaux produits par l'Atelier Le Corbusier trois publications essentielles rendent compte du caractère innovant de la réalisation de la Cité Frugès et de sa fortune critiques.
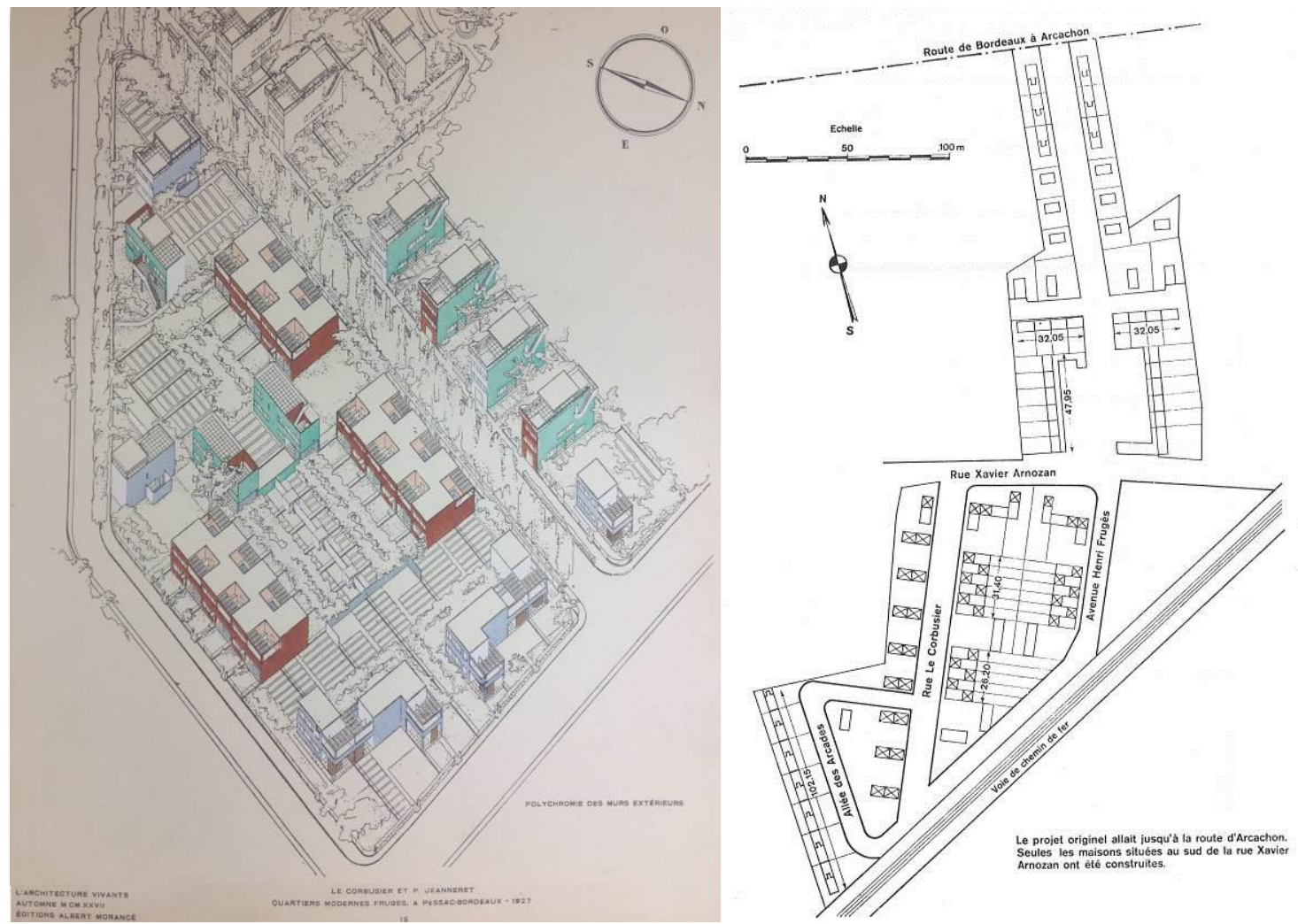

3. Quartiers Modernes Frugès in l'Architecture Vivante @FLC-ADAGP

\section{P.Boudon Pessac de Le Corbusier p.38 @FLC-ADAGP}

La première est le catalogue de l'exposition Le Corbusier at Pessac ${ }^{8}$ à Harvard sous la direction d'Eduard Sekler et de Brian Brace Taylor qui explique la genèse des QMF, la deuxième est le livre de Pessac de Le Corbusier par Philippe Boudon ${ }^{9}$, la troisième est le guide intitulé Le Corbusier: Les Quartiers Modernes Frugès par Marylène Ferrand, Bernard Le Roy et Jean Luc Veyret ${ }^{10}$

Ainsi donc dans Le Corbusier at Pessac Eduard Sekler et Brian Brace Taylor expliquent la genèse du projet d'un point de vue à la fois historique et théorique depuis les analyses effectuées par le jeune Jeanneret à la Bibliothèque Nationale en 1914-1915 de l'«Enquête sur les conditions de l'Habitation en France, Les Maisons Types» par Alfred de Foville de $1894{ }^{11}$ en passant par l'élaboration des plans types de la maison DOM-INO jusqu'à l'intérêt porté aux études de Tony Garnier pour sa Cité Industrielle comme le montre la correspondance entre Jeanneret et Garnier de 1915.

\footnotetext{
${ }^{8}$ Sekler Eduard \& Taylor Brian Brace Le Corbusier at Pessac, The Search for Systems and Standards in the Design of Low Cost Housing, Catalogue de l'exposition éponyme 12 0ctobre 30 Novembre 1972, Carpenter Center for the Visual Arts, Harvard University, en collaboration avec la Fondation Le Corbusier.

${ }^{9}$ Boudon Philippe, Pessac de Le Corbusier, première édition, Bordas, Paris 1969 suivi d'une édition augmentée, Dunod, Paris 1985

${ }^{10}$ Ferrand Marylène, Feugas Jean Pierre, Le Roy Bernard, Veyret Jean Louis, Le Corbusier : Les Quartiers Modernes Frugès, Fondation Le Corbusier, Paris, Birkhäuser, Bâle, Boston, Berlin

${ }^{11}$ De Foville Alfred, Enquête sur les conditions de l'Habitation en France, Les Maisons Types, Paris 1894
} 
Mais l'implication de l'architecte va bien au-delà de la théorie car le jeune Jeanneret va être également architecte consultant pour la S.A.B.A (Société d'Application du Béton Armé) l'entrainant ainsi sur des programmes divers comme le château d'eau de Podensac, un arsenal à Toulouse, une usine hydro électrique ou encore une centrale électrique à Saintes. Ce dernier programme oblige Jeanneret à « résumer ses recherches sur les habitations pour les ouvriers. Sa solution de logements proches de la centrale électrique d'Avril 1917 est la première d'une série de projets de logements ouvriers que Jeanneret entreprit dans la France rurale. Un aspect de ce programme particulier était que les ouvriers et contremaîtres de nuit devaient vivre avec leur famille sur le site à proximité de la machine en fonctionnement constant. Les questions sociales ainsi que la nature pratique soulevée par cette situation dans laquelle la production de la machine et le travail, la famille, la vie et les loisirs de l'hommes sont intimement liés, constituent finalement un thème central des théories de Le Corbusier sur l'architecture et

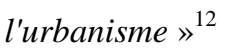

A cela s'ajoute l'idéologie de la Cité Jardin inspirée du modèle anglais des architectes anglais Barry Parker et Raymond Uwin que Jeanneret expérimente dans un projet à la Chaux de Fond et surtout en juin 1917 à Saint Nicolas d'Aliermont avec un projet pour la construction de 25 logements ouvriers. Pour répondre au souhait du commanditaire, l'architecte propose 3 types de maisons avec un traitement différent de la façade afin de différencier les maisons des contremaîtres de celles des ouvriers. Composées de deux niveaux, les habitations sont percées de nombreuses fenêtres pour laisser passer la lumière. Les maisons sont entourées d'un jardin et d'une courette et disposées de part et d'autre d'une voie unique conduisant de la coopérative à une placette en cul-de-sac. La répartition est régulière et aérée, d'une faible densité, laissant une surface large à la verdure.

Une première expérience est menée avec Henry Frugès à Lège constituant l'antichambre des Quartiers Modernes Frugès. Construit en 1923/1924 à Lège-Cap-Ferret le lotissement de six petites maisons, est réalisé pour le compte de l'industriel sucrier afin d'y loger les ouvriers employés à la scierie locale. Le Corbusier propose des maisons minimum selon un type $\mathrm{A}$ et un type $\mathrm{B}$, basées sur des dimensions et une géométrie qui caractérisent «une évolution de ses projets précédents à Saintes et Saint Nicolas d'Aliermont ${ }^{13 .}$

Pour les Quartiers Modernes Frugès à Pessac les premiers plans conçus dès 1924 développent un changement d'échelle ainsi que d'autres expérimentations particulièrement pertinentes comme la polychromie et les assemblages de typologies variées selon les différents secteurs.

«Je vous autorise à réaliser dans la pratique vos théories, jusque dans leurs conséquences les plus extrêmes, je désire atteindre à des résultats vraiment concluants dans la réforme de l'habitation à bon marché : Pessac doit être un laboratoire ${ }^{14} \gg$. Henry Frugès passe commande à l'architecte Le Corbusier en 1924 souhaitant implanter une " cité-jardin " pour loger ses ouvriers.

Ainsi Le Corbusier, dont les préoccupations architecturales du moment sont le logement de masse, va travailler avec Pierre Jeanneret sur le terrain de Pessac Le premier plan comprend 135 maisons, réparties en quatre secteurs. La composition s'inspire des plans des cités jardins anglaises : hiérarchie, diversité et qualité des espaces urbains, les maisons sont composées comme des objets isolés aux formes pures. Les deux architectes définissent un modèle standard, les éléments sont tous identiques sur chaque cellule : ossature, fenêtres (en longueur), escaliers assemblés perpendiculairement à l'intérieur, parallèles à la plus grande façade à l'extérieur. Les maisons se combineront entre elles selon leur type. Mais avant tout, le chantier est un terrain d'application de la méthode d'organisation du travail industriel, standardisé dans ses éléments : la même « cellule » de $5 \mathrm{~m}$ par 5

\footnotetext{
${ }^{12}$ Le Corbusier at Pessac, The Search for Systems and Standards in the Design of Low Cost Housing, p.13

${ }^{13}$ Benton Tim, «Pessac and Lège revisited : standards, dimensions and failures » in Massilia, 2004 p.68

${ }^{14}$ Le Corbusier \& Pierre Jeanneret, Euvres Complètes 1910-1929 volume I p.78
} 
mètres et de 2,50m par 5 mètres, la même fenêtre, le même escalier, le même système de chauffage, les mêmes équipements de cuisine et de salles de bains.

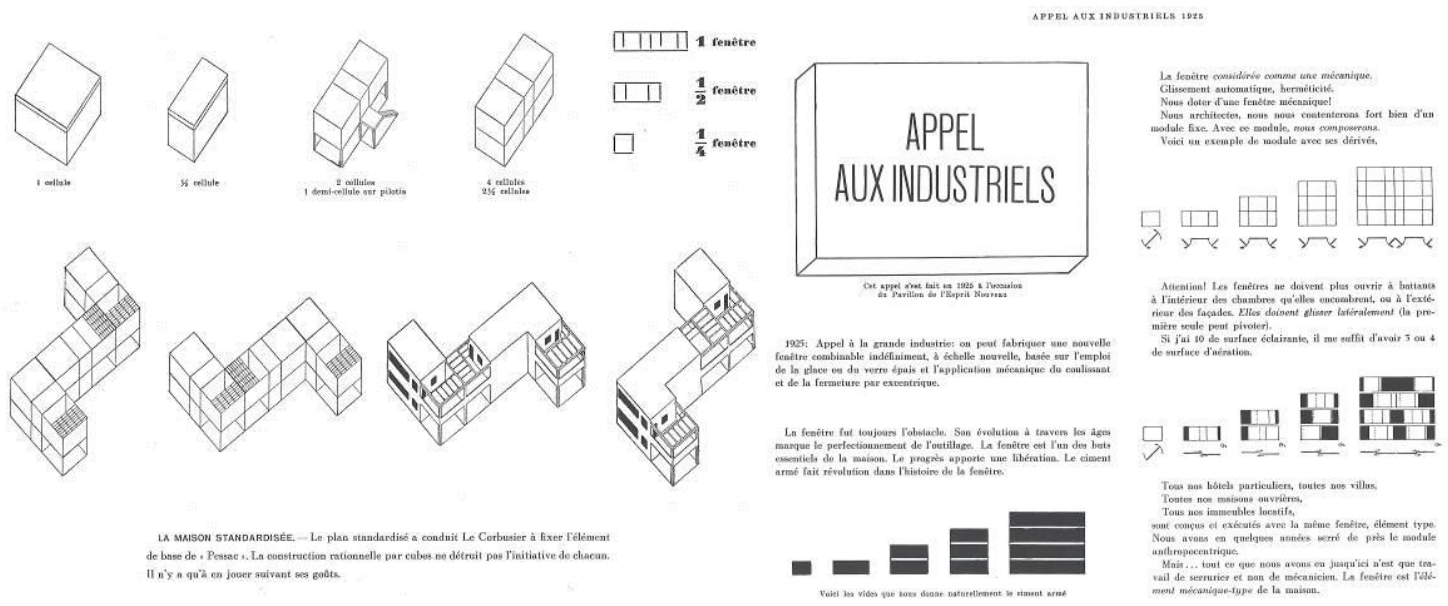

5. Le Corbusier Euvres Complètes 19101929 p.69@FLC-ADAGP

6. Le Corbusier Euvres Complètes 19101929 p.77@FLC-ADAGP

\section{La polychromie}

«Pessac devient une promenade urbanistique bien ordonnée, une sorte de pendant à la promenade architecturale des Villas la Roche Jeanneret dont la polychromie intérieure a été déterminée sensiblement au même moment $»^{15}$

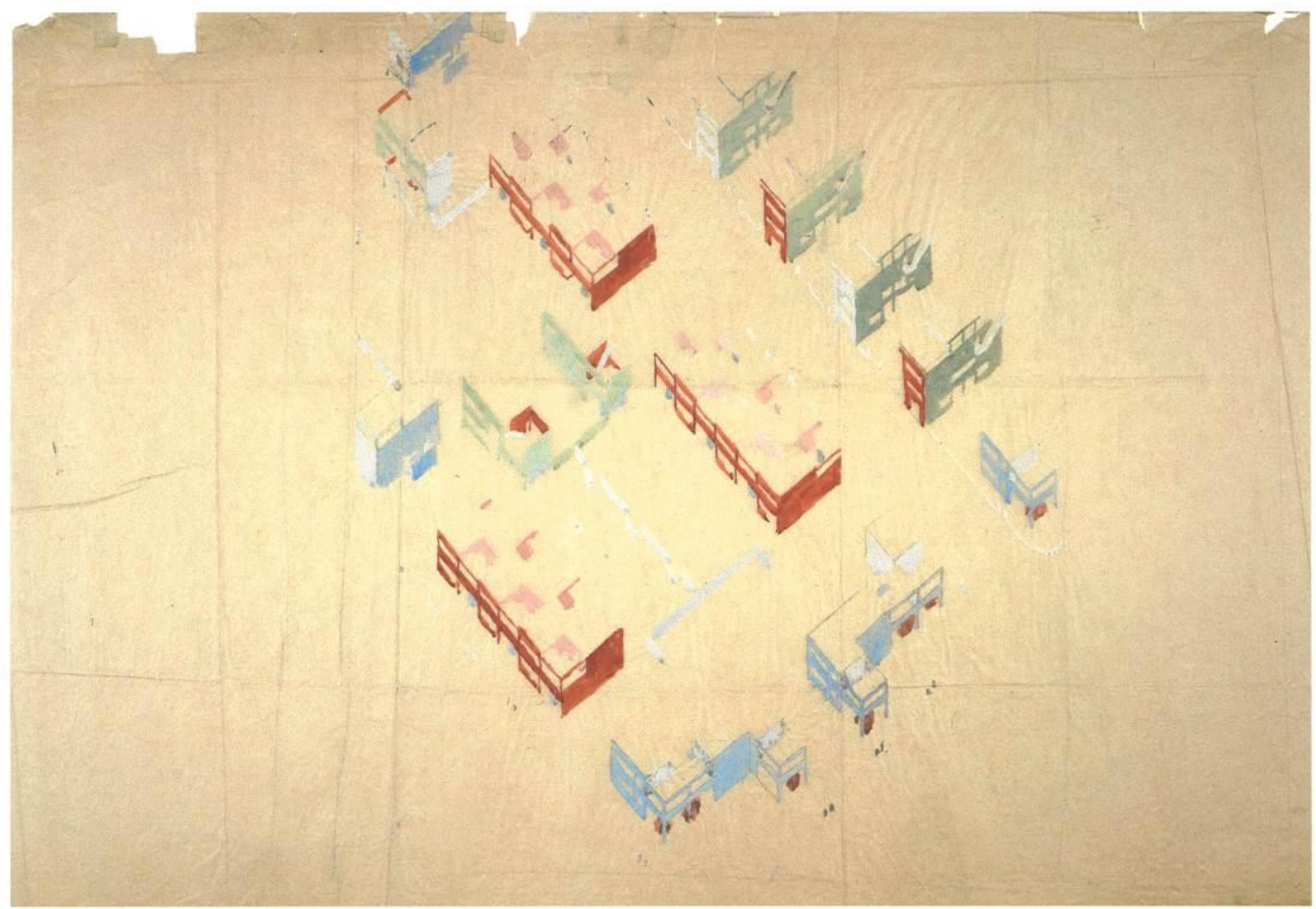

7. Le Corbusier et Pierre Jeanneret, Quartiers Modernes Frugès, Pessac, étude de polychromie, 1924. Gouache sur calque, 78,2 X $110 \mathrm{~cm}$. Fondation Le Corbusier CFLC-ADAGP

${ }^{15}$ Le Corbusier at Pessac, The Search for Systems and Standards in the Design of Low Cost Housing, p.14 

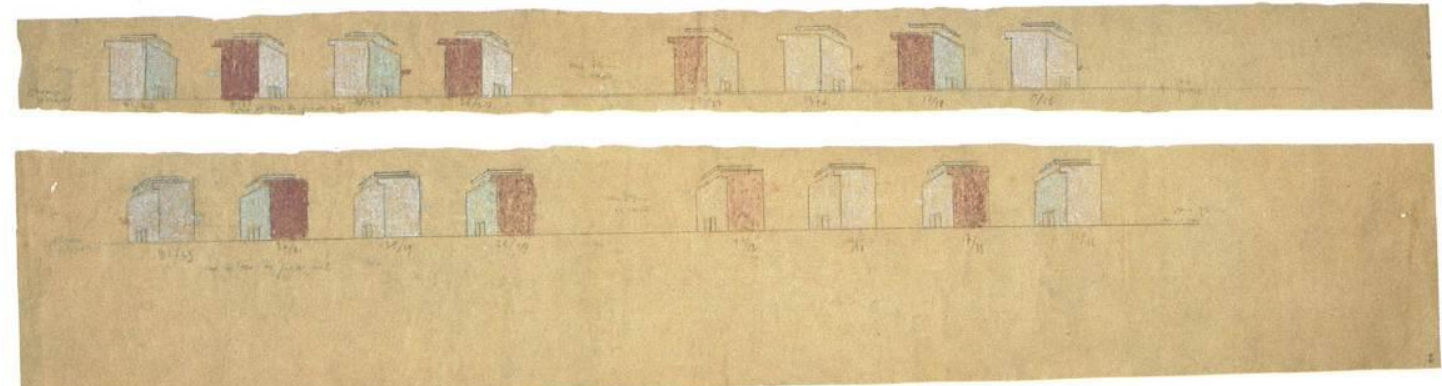

8. Le Corbusier et Pierre Jeanneret, Quartiers Modernes Frugès, Pessac, étude de polychromie, 1924. Gouache sur calque, $41,8 \mathrm{X} 114,2 \mathrm{~cm}$. Fondation Le Corbusier @FLC-ADAGP

C'est ainsi avec les QMF, la première fois que Le Corbusier utilise la polychromie extérieure, justifiant que « la couleur pouvait nous apporter l'espace. Considérer la couleur comme apporteuse d'espace. Voici comment nous avons établi des points fixes : certaines façades peintes en terre de Sienne brûlée pur.

«Nous avons fait fuir au loin des lignées de maisons : bleu outremer clair. Nous avons confondu certains secteurs avec le feuillage des jardins et de la forêt : façades vert pâle ${ }^{16}$.

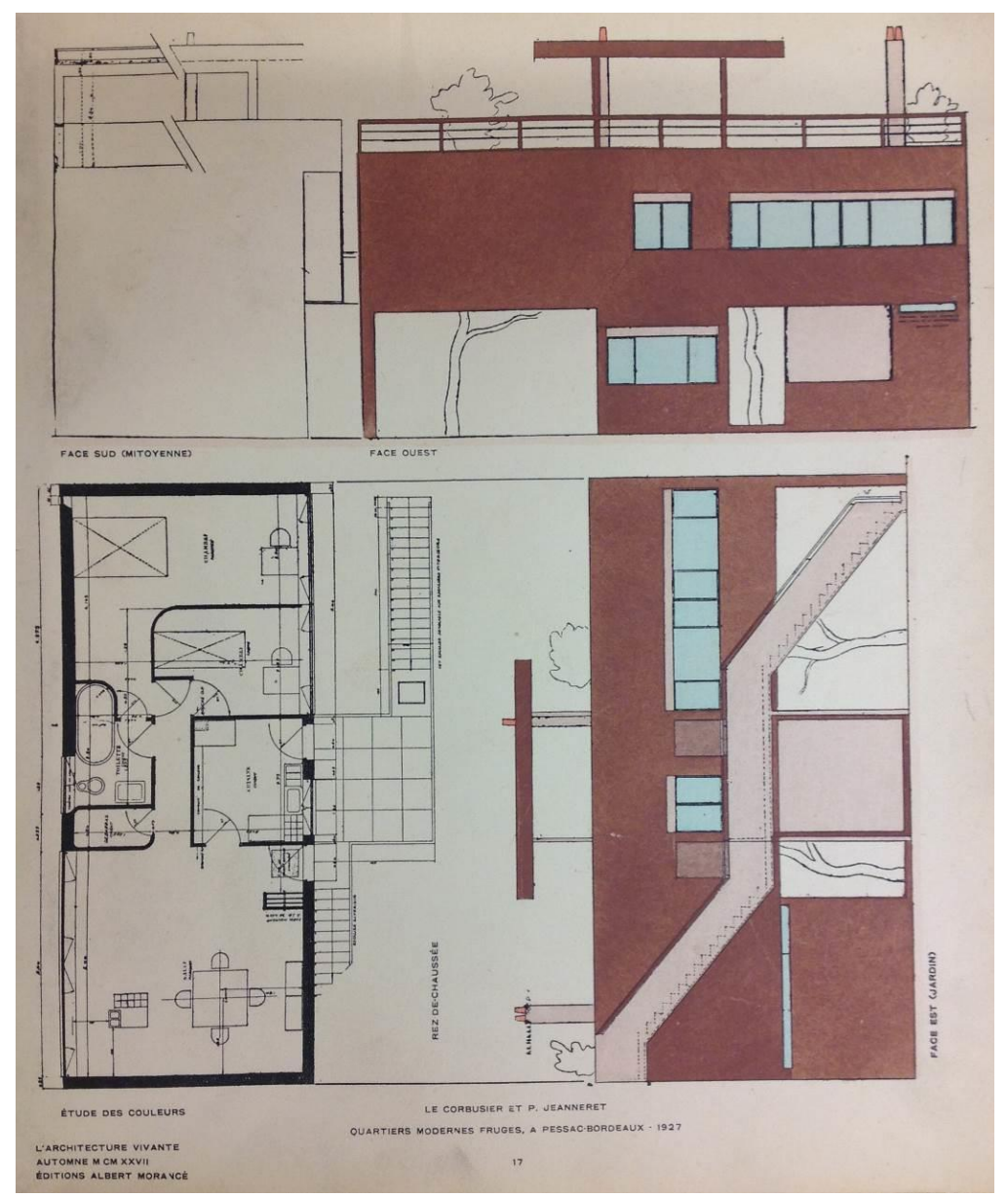

9. Quartiers Modernes Frugès Etude des couleurs in l'Architecture Vivante, 1927 OFLC-ADAGP

\footnotetext{
${ }^{16}$ Le Corbusier \& Pierre Jeanneret, Euvres Complètes 1910-1929 volume I p.86
} 
Enfin et surtout «il se dégage des constructions de Pessac une esthétique inattendue, neuve. Mais cette esthétique est licite, conditionnée par les impératifs de la construction d'une part, et d'autre part, par les bases primordiales de la sensation architecturale, le volume. Les prismes qui se dressent les uns à côté des autres obéissent à des règles de mise en proportion, rapports que nous avons cherché à rendre éloquents et harmonieux. Nous avons aussi appliqué une conception entièrement neuve dans la polychromie, poursuivant un but nettement architectural: modeler l'espace grâce à la physique même de la couleur, affirmer certaines masses du lotissement, en faire fuir certaines autres, en un mot composer avec la couleur comme nous avions fait avec les formes. C'était ainsi conduire l'architecture dans l'urbanisme ${ }^{17}$.
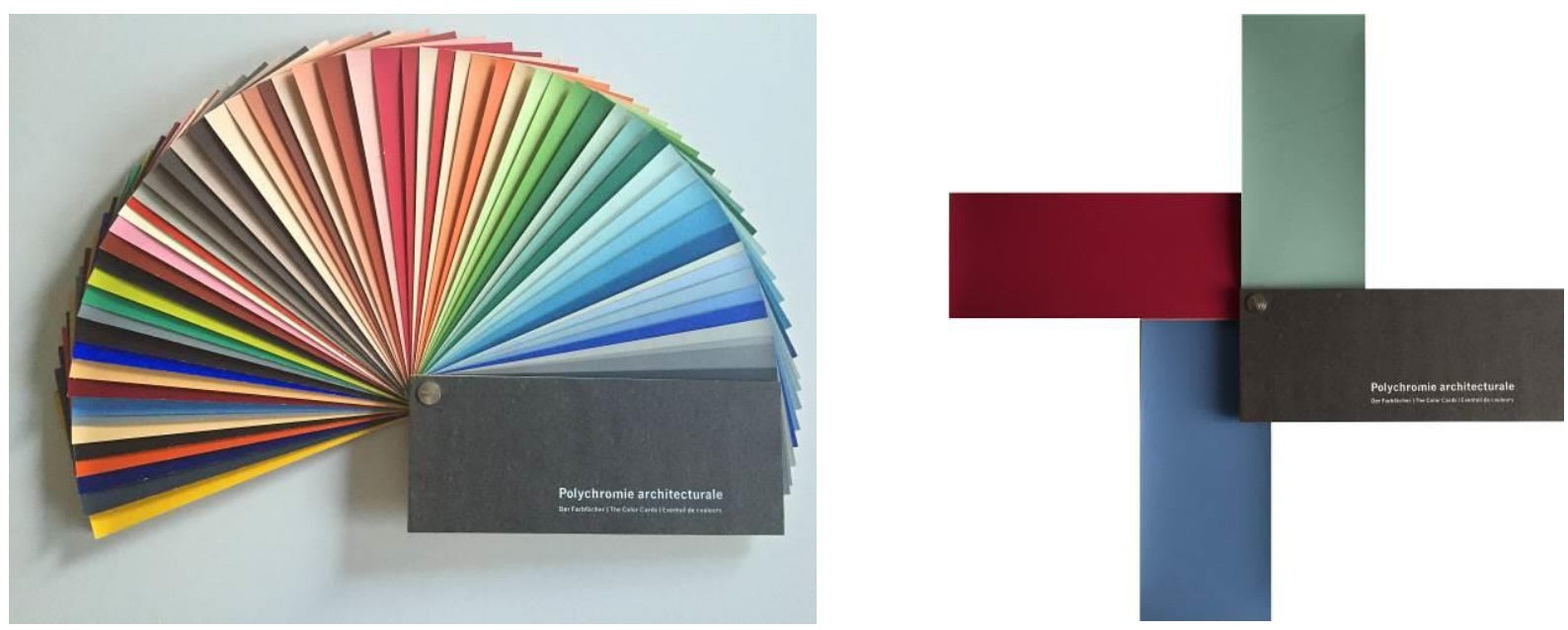

10. Claviers de couleurs Salubra de Le Corbusier @FLC-ADAGP

11. Couleurs des Quartiers Modernes Frugès @FLC-ADAGP

Il faut voir ici les fondements de la polychromie architecturale de Le Corbusier qu'il développera avec le nuancier Salubra en deux étapes, l'une de 43 coloris baptisé «claviers de couleurs » en 1931 puis avec une seconde gamme de 20 couleurs en 1959, cette dernière étant employée dans les projets comme les Maisons Jaoul, ou d'autres projets issus du « brutalisme ».
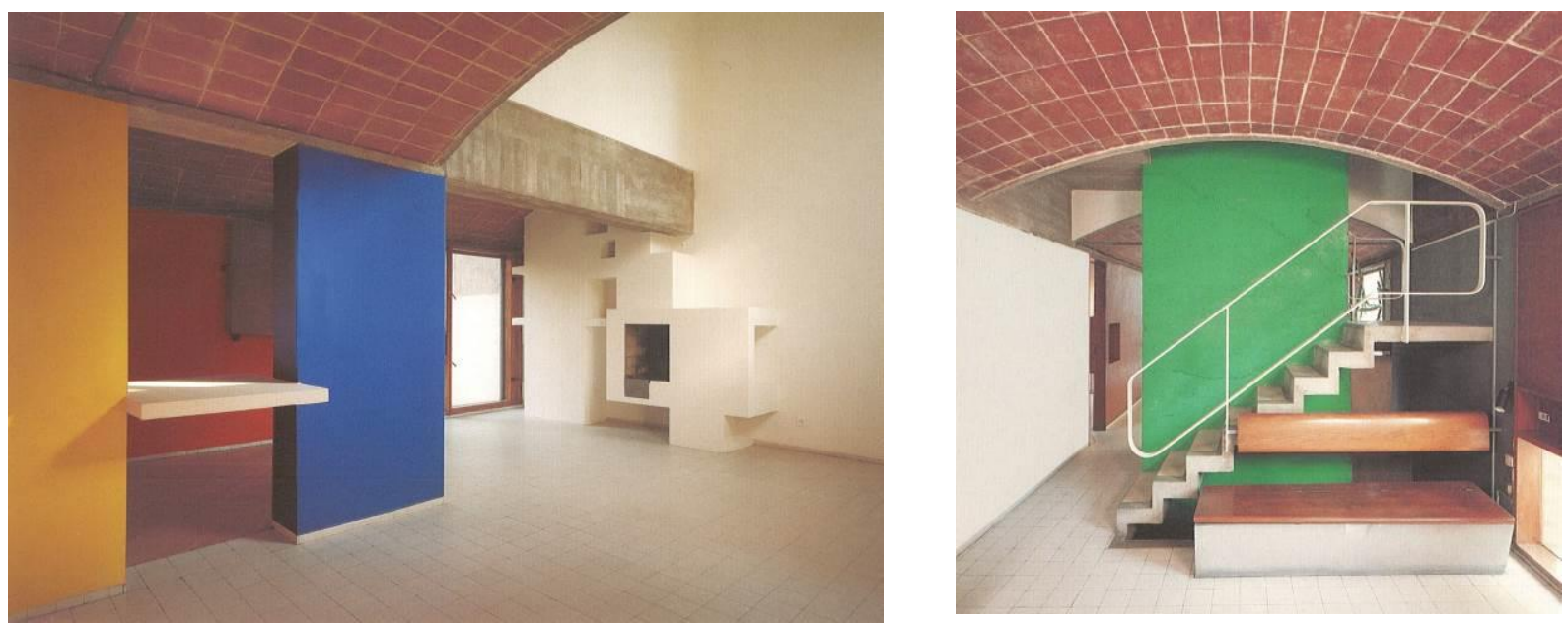

12. Maisons Jaoul, Le Corbusier, Maison A, salon @FLC-ADAGP

13. Maisons Jaoul, Le Corbusier, Maison A, entrée @FLC-ADAGP

\footnotetext{
${ }^{17}$ Le Corbusier, exposé lors de l'inauguration des Quartiers Modernes Frugès, à l'occasion de la visite officielle de M. de Monzie, ministre des Travaux Publics à Pessac le 13 juin 1926, cité par Philippe Boudon, Pessac de Le Corbusier, p.148
} 


\section{Construction}

Le chantier débute en 1925, et permet à Le Corbusier de composer avec les volumes, la lumière et la polychromie: la couleur est choisie en fonction de l'intensité lumineuse et de l'orientation des façades. L'utilisation du canon à ciment projeté sur ossature expérimentée à Lège s'avéra un choix coûteux et erroné. Un mélange extrêmement riche en ciment était exigé, et dans le même temps, il était presque impossible d'arriver à un mur d'épaisseur optimale et uniforme. La construction à Pessac sera finalement réalisée en blocs manufacturés, le ciment projeté servira seulement pour les murs courbes, les chais et murs des jardins. Mais la réalisation de l'opération bute sur de nombreux obstacles : défaillance de l'entreprise locale, difficultés du chantier, techniques de construction inadaptée. Achevées en 1926, les maisons restent vides jusqu'en 1929. Cette occupation tardive, due à l'absence pour des raisons administratives d'adduction d'eau, bloquant la vente des maisons, entrainant la faillite de leur commanditaire. Sur les 135 logements prévus à l'origine, seuls 53 seront finalement réalisés. Cependant les quartiers modernes Frugès sont d'une importance capitale d'un point de vue historique, dans la mesure où ils sont à la fois la première cité de logements sociaux réalisés par le Corbusier et son premier projet d'envergure.

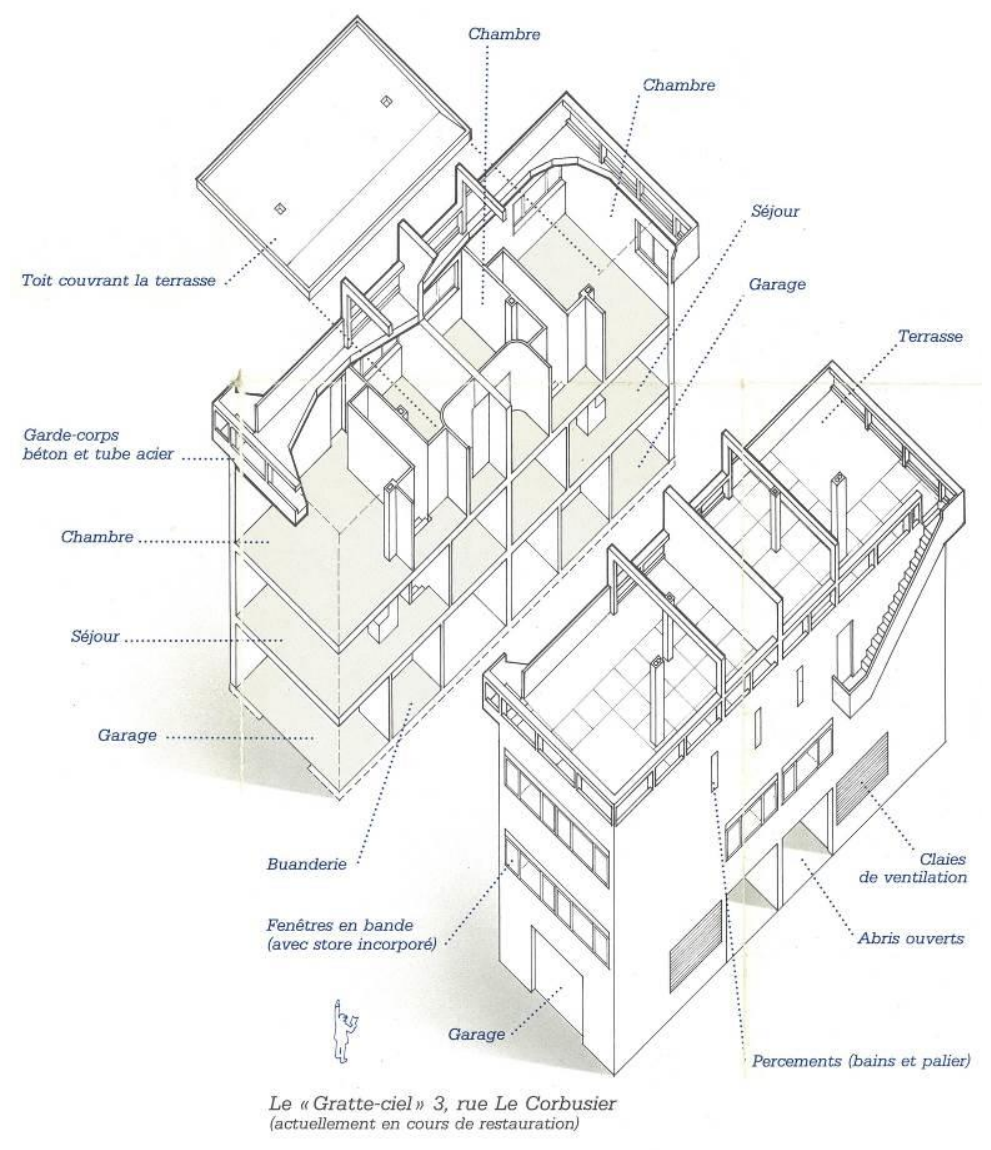

14. Extrait du dépliant présentant l'exposition «L'aventure Le Corbusier », Paris 1987, CFLC-ADAGP

Le parcours dans la cité Frugès permet de découvrir la cinquantaine d'habitations déclinées en 6 typologies différentes : "zigzag", "quinconce", "jumelle", "gratte-ciel", "arcade" et "isolée". 
Gratte-ciel :

Son nom est du à sa hauteur : la plus élevée de toutes les compositions. Cette maison est l'emblème du quartier, les huit bâtiments marquant l'axe principal de l'ensemble de l'opération. Chaque volume comprend deux logements dos à dos sur quatre niveaux, avec une toiture terrasse accessible par un escalier extérieur. Au rez-dechaussée : abri, buanderie et garage, premier étage : entrée, séjour et cuisine, second : deux chambres et sanitaires. Elle possède ainsi la plus grande surface habitable de tous les types de maisons : $110 \mathrm{~m}^{2}$.Côté rue, en alternance les couleurs sont terre de Sienne ou blanche, vert pâle et blanc pour les façades latérales.
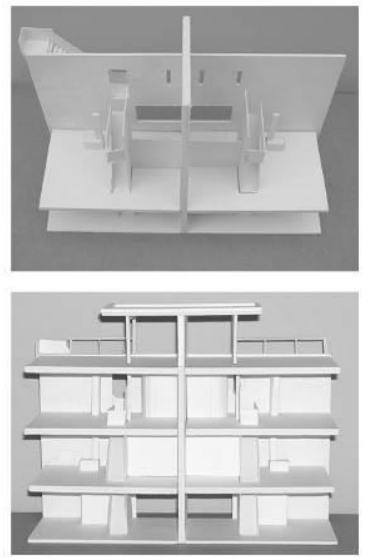

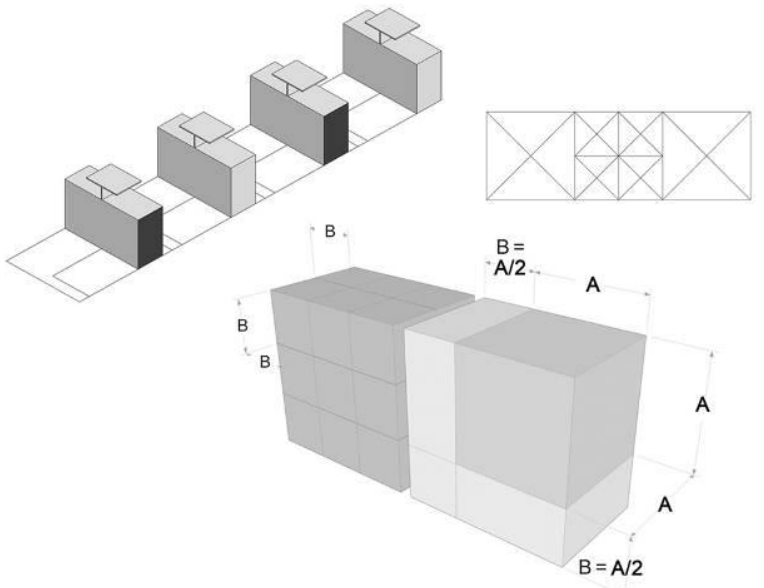

15. Cité Frugès, Les Maisons Gratte Ciel travaux d'étudiants Studio Laurent Duport, ENSAM

Arcades :

L'unité de sept habitations compose la limite ouest de la cité en un long mur percé de grands vides donnant sur le parc voisin La terrasse prend forme au rez-de-chaussée, sous une arcade, comme un patio, dans le prolongement de la maison de $85 \mathrm{~m}^{2}$ de surface habitable. La cuisine, le séjour et l'entrée, le chai, la buanderie sont au rez-dechaussée, les pièces de service sont placées sous voûte. L'étage comporte trois chambres et la salle de bains. La façade côté rue est terre de Sienne, la terrasse ainsi que la voûte sont blanches.
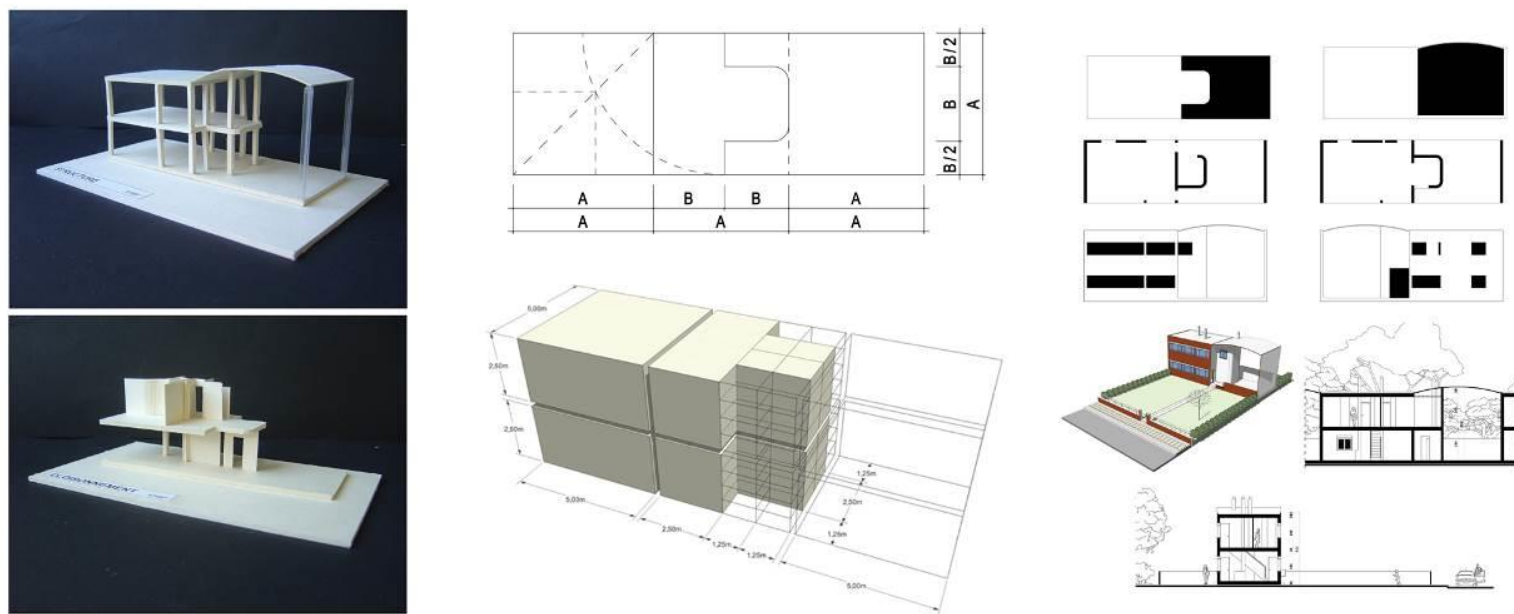

16. Cité Frugès, Les Maisons Arcades travaux d'étudiants Studio Laurent Duport, ENSAM 
Quinconce :

Ce sont des bandes de six logements orientés est-ouest, inversés les uns aux autres ce qui permet une isolation phonique. A l'étage les terrasses en retrait alternent avec la chambre principale. Ici les pièces à vivre se situent au rez-de-chaussée, seule la chambre demeure à l'étage, accompagnée de la salle de bains, et de la terrasse. La surface habitable est de $80 \mathrm{~m}^{2}$. Le chai du rez-de-chaussée est bleu outremer clair, les murs de la terrasse sont couleur terre de Sienne et le reste blanc.
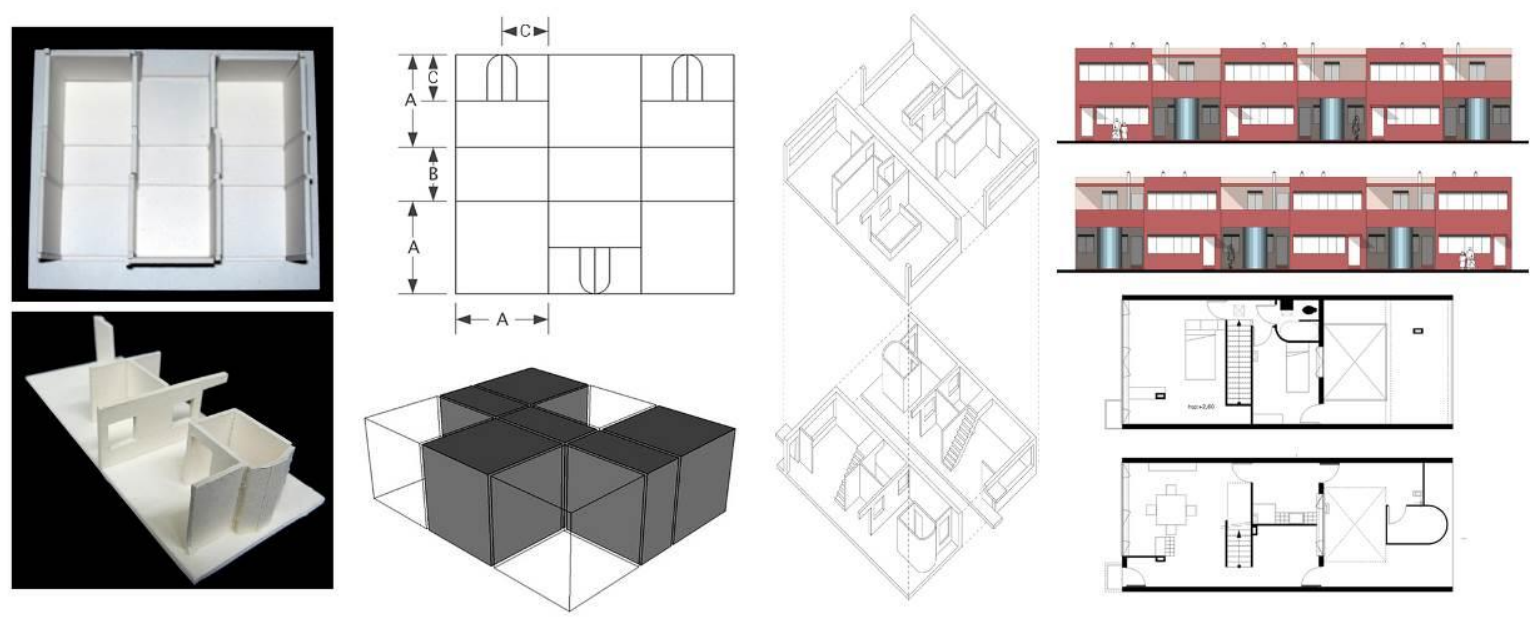

17. Cité Frugès, Les Maisons Quinconces travaux d'étudiants Studio Laurent Duport, ENSAM

Zig Zag :

Semblables au type "Quinconces", deux blocs "zig-zag" sont composés de trois logements accolés mais orientés différemment. Ils sont largement ouverts sur le grand côté de la construction. Les façades sont de couleur bleu outremer clair et blanc. La surface habitable est de $80 \mathrm{~m}^{2}$ répartie sur deux niveaux : au rez-de-chaussée se trouvent le chai, le parloir, la cuisine et la pièce à vivre, et à l'étage deux chambres, les sanitaires et la terrasse.

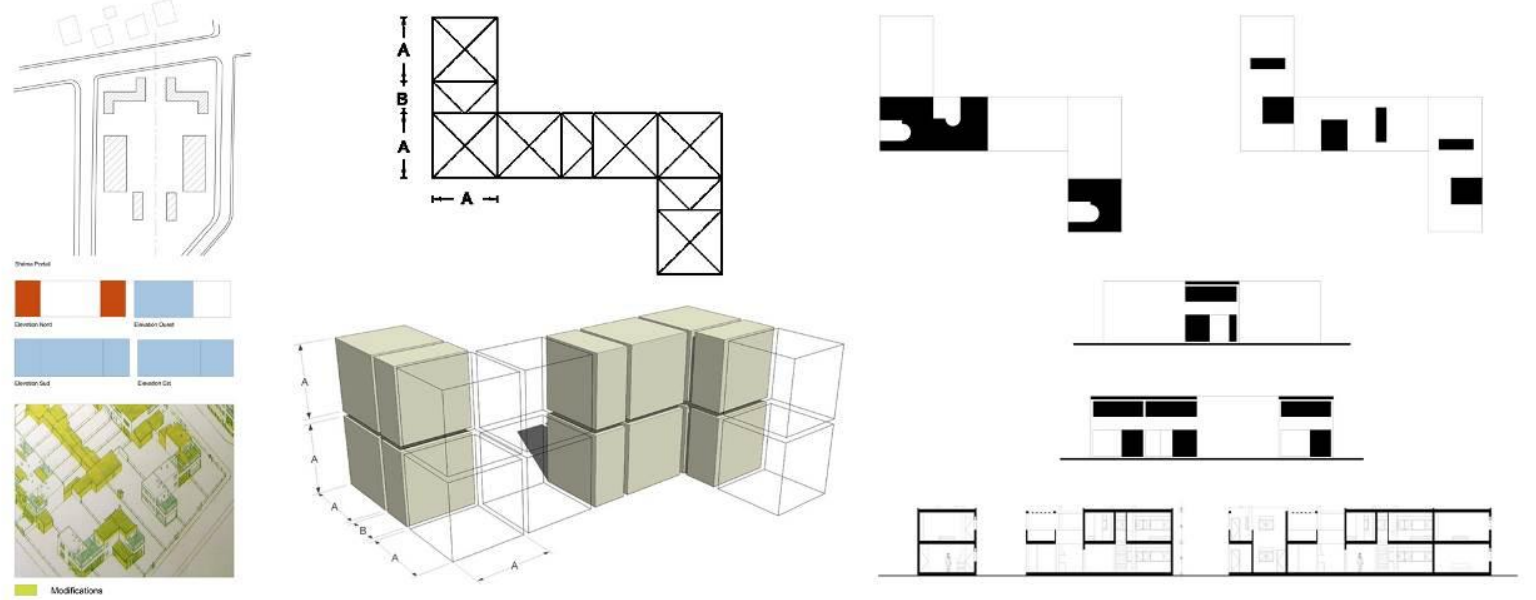

18. Cité Frugès, Les Maisons Zig Zag travaux d'étudiants Studio Laurent Duport, ENSAM 
Vrinat :

Seules deux habitations selon cette typologie étaient prévues dans la cité, une seule a été construite et a bénéficié d'une restauration en 1993. Ce modèle s'organise sur deux niveaux, avec la toiture-terrasse accessible par un escalier extérieur latéral. Le système constructif est celui qui se rapproche le plus des cinq points de Le Corbusier. La surface habitable est de $70 \mathrm{~m}^{2}$. Les pièces habitables sont au 1er étage, au 2ème se situe la terrasse. Les façades sont vert clair et blanches, l'escalier blanc sur sa face extérieure et terre de sienne brulée sur sa face intérieure
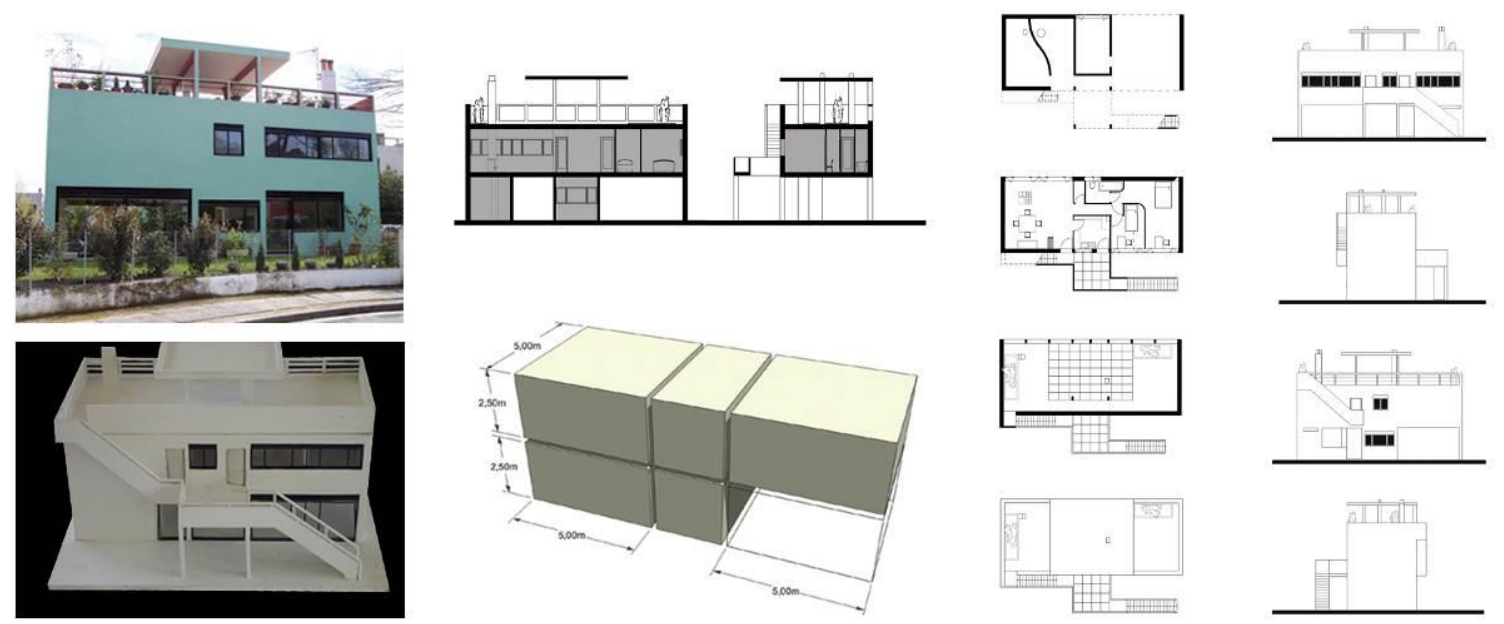

19. Cité Frugès, Les Maisons Vrinat travaux d'étudiants Studio Laurent Duport, ENSAM

Isolée :

L'escalier extérieur court le long de la façade et donne accès aux différentes pièces de vie (deux chambres, cuisine, séjour et salle de bains) situés au premier étage. Au rez-de-chaussée on trouve les pièces de services (garage, et chai). En tout $70 \mathrm{~m}^{2}$ de surface habitable. La façade est verte et blanche, les parois latérales extérieures à l'escalier, et celles intérieures à l'escalier ainsi que la terrasse sont terre de Sienne.

\section{Transformations}

La lecture attentive de l'ouvrage de Philippe Boudon «Pessac de Le Corbusier » dans son édition de 1985 nous offre de précieux éclairages sur la réception des Quartiers Modernes Frugès depuis leur construction. La présentation historique du projet, les réactions de la presse mais surtout l'analyse de la conception de Le Corbusier à Pessac et les interviews des habitants montrent que les modifications effectuées par les occupants « constituent un pas positif et non une conséquence négative de la conception originale de Le Corbusier. Pessac a non seulement permis aux occupants une latitude suffisante pour satisfaire leurs besoins, ce faisant, elle les a aussi aidés à réaliser quels étaient ces besoins ${ }^{18 .}$

\footnotetext{
${ }^{18}$ Huxtable Ada Louise, "Le Corbusier's housing project-flexible enough to endure” in New York Times, 15 Mars 1981
} 


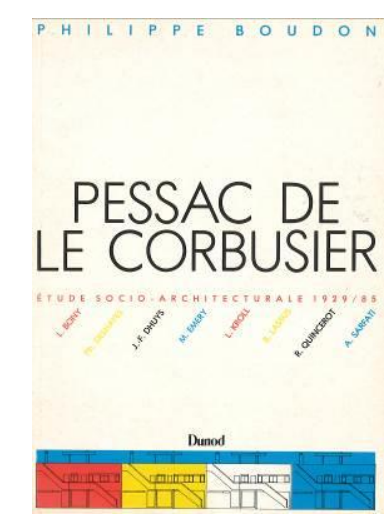

20. Couverture du livre de P.Boudon

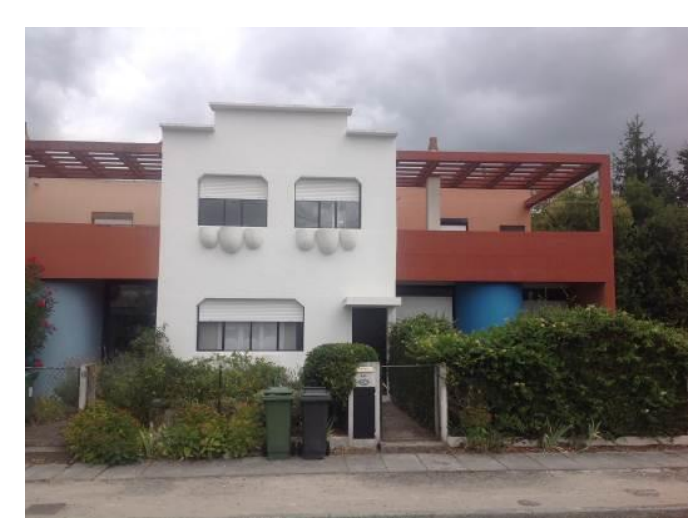

21. Une maison quinconce transformée

Dans la deuxième partie de l'ouvrage, les témoignages d'Alain Sarfati et de Laurent Bony sont particulièrement importants à l'aune du processus de patrimonialisation qui s'annonce à la fin des années 90. Ainsi pour Sarfati Pessac aura été une très grande leçon et «dans le cas de Pessac, toute intervention apparaissait comme une altération de l'œuvre, et pourtant l'histoire nous enseigne que les grandes auvres sont aussi celles qui ont été capable de subir des extensions des transformations. Aujourd'hui au cour du débat sur l'architecture urbaine, sur les morceaux de ville où la politique de quartier, Pessac reste un exemple à explorer. Une des notions clés de l'architecture moderne et celle d'espace une notion qui a alimenté la spécificité du travail des architectes. L'espace, difficile à saisir, à décrire, à qualifier, cet espace de l'architecture est toujours un espace intérieur qui oublie le grand espace qui en résulte, l'espace qu'elle constitue de fait, l'espace public. À Pessac, s'il y a un espace public ce sont les habitants qui l'ont fabriqué tant bien que mal et c'est l'occasion de s'interroger sur les différents couples d'opposition public / privé, intérieur / extérieur, mais aussi sur ce couple d'opposition étonnant architecture / nature. D'une certaine manière, Pessac constitue le lieu idéal pour produire une introduction à l'architecture urbaine et donc un autre regard sur la ville comme espace complexe et non plus simplement fonctionnel ${ }^{19}{ }^{1}$.
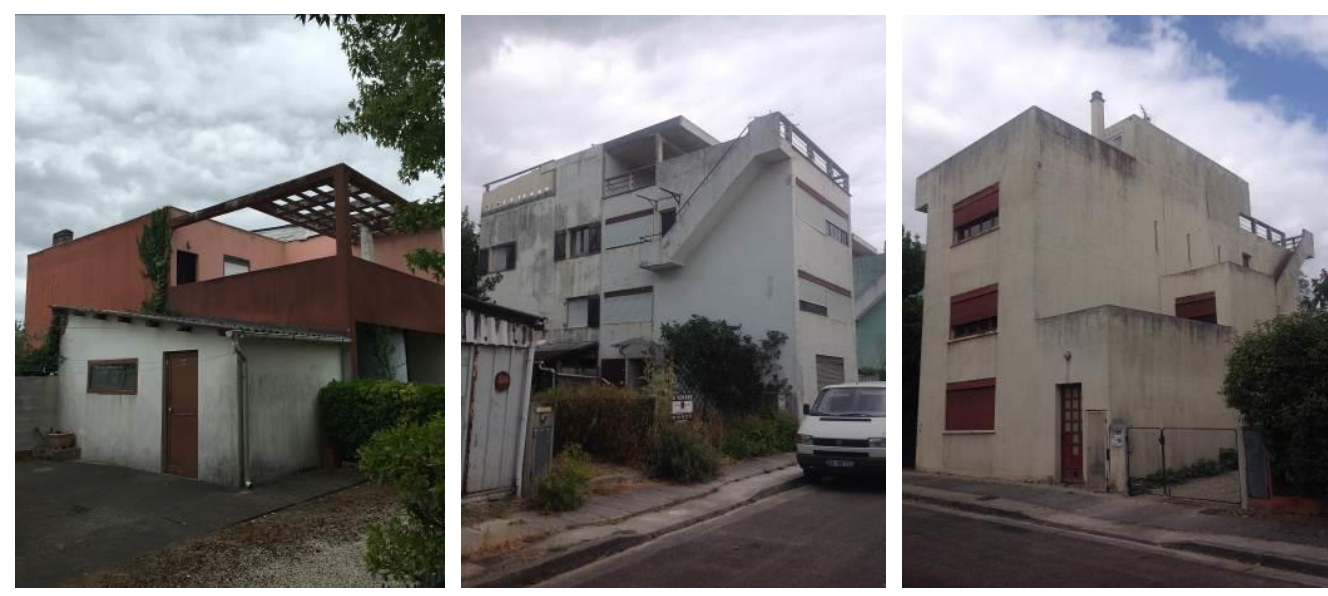

22 - 23 - 24. Quelques maisons transformées.

Pour Laurent Bony la leçon de Pessac est encore plus évidente : "Il faut voir en Pessac, ni un échec ni une réussite incontestable, encore moins incontestée mais simplement un groupe de maisons qui a fait l'objet d'un projet d'architecte, qui a été construit, qui est habité. En cela c'est à la fois ordinaire et exemplaire. Si l'on se rend à Pessac pour y voir ce qui est représenté dans les Euvres Complètes on sera déçu., Si l'on veut y voir un

\footnotetext{
${ }^{19}$ Boudon Philippe, Pessac de Le Corbusier, p.206
} 
quartier vivant construit par le Corbusier et par ses habitants, on constatera que la réalité concrète des maisons a permis, plus ou moins facilement, une appropriation progressive, des transformations liées à l'usage et à la signification de la maison; que les transformations ont le plus souvent utilisé une opportunité construite, une accroche physique, une amorce de marquage existant dans le projet de Le Corbusier. Ces transformations dépassant parfois le projet plutôt qu'elles ne le contredisent.(...) Avec Pessac émerge de toute évidence un conflit entre les recherches de Le Corbusier en 1925 et les préférences architecturales immédiates des habitants; mais il y a surtout des traces concrète de la rencontre entre le travail d'un architecte et la pratique des utilisateurs. L'observation des rajouts et transformation, l'appropriation générale de leur quartier par les habitants intervenant sur chacune de leur maison, nous renseignent sur la signification de la maison, l'ordre domestique, le statut des espaces extérieurs» ${ }^{20}$

\section{Patrimonialisation}

Inoccupées pendant plus de deux ans après leur livraison, aucune maison ne sera vendue car les raccordements aux réseaux de gaz, d'eau et d'électricité ne sont pas terminés. Les maisons achetées par les premiers propriétaires (seulement en 1929/1930 dans le cadre de la loi Loucheur ${ }^{21}$ ), restées vides, ont déjà subi des détériorations. La guerre va accentuer la dégradation de l'aspect d'origine des QMF avec le bombardement de la voie ferrée qui détruit deux maisons et brise la plupart des vitrages. Leur remplacement va entrâner, bien souvent, le changement des menuiseries et le rebouchages de certaines baies, le bois prenant généralement la place des profilés métalliques d'origine. Les réparations, souvent à l'économie des étanchéités des toitures terrasses avec de la tôle ondulée ou d'autres matériaux disparates ainsi que la recherche d'une optimisation/augmentation de surfaces dans ces maisons aux dimensions standardisées, transforment le quartier au fil des années.

Ainsi après une longue période au cours de laquelle les maisons se dégradent et sont l'objet de toutes sortes de transformation avec des démolitions, des extensions, mais surtout des adaptations aux besoins et aux goûts de leurs habitants, il faut attendre 5 mars en 1973 avec la restauration de la maison située au numéro trois de la rue des arcades pour appréhender là une première reconnaissance patrimoniale avec son classement au titre des Monuments Historiques en 1980.

Ce classement induit un rayon de protection de $500 \mathrm{~m}$ autour de ladite maison et donc un contrôle des Monuments Historiques sur toutes les interventions apparentes sur le bâti des maisons de l'ensemble des Quartiers Modernes Frugès.

Parallèlement la municipalité de Pessac amorce la sauvegarde du quartier en réalisant une série de travaux de l'espace public: voirie, réseaux, plantations sont rétablis de la manière la plus conforme possible projet d'origine, et en 1983 achète une maison (un demi «gratte-ciel » au 4, rue Le Corbusier) et la restaure en « Maison Le Corbusier » initiant ainsi un chantier expérimental de Septembre 1987 à mars 1988.

«En 1985, une étude évaluera le niveau de dégradation de la cité par rapport à son état d'origine et recommandera des solutions architecturales techniques à mettre en ceuvre pour la restauration. $»^{22}$

\footnotetext{
${ }^{20}$ Ibid p. 177

${ }^{21}$ Loi du 13 juillet 1928permettant à un particulier d'emprunter à taux réduit afin d'acheter un terrain et d'y faire construire un pavillon ou une maison

${ }^{22}$ Ferrand Marylène, Feugas Jean Pierre, Le Roy Bernard, Veyret Jean Louis, Le Corbusier : Les Quartiers Modernes Frugès p.113
} 
Ainsi: "l'un des problèmes cruciaux de la cité consiste en l'état actuel de son gros ouvre, et tout particulièrement des ouvrages béton : des murs de façade fissurés avec affleurement ou mise à nu des armatures en acier, des gardes corps, des linteaux, des appuis éclatés et boursouflés, des pergolas et des escaliers menaçant de rupture. De gros problèmes sont à noter aussi au niveau de l'étanchéité des terrasses sur la plupart des maisons, ainsi que des problèmes d'imperméabilité au niveau des menuiseries métalliques.

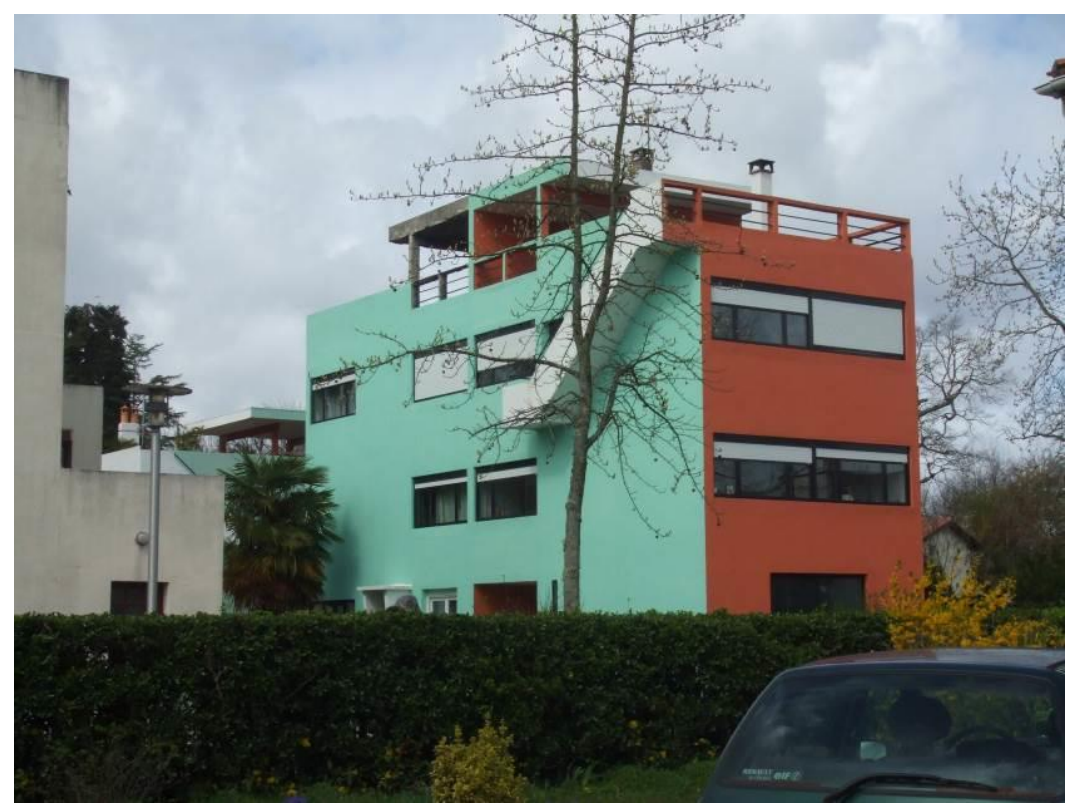

25. Cité Frugès, La maison Gratte-ciel au 4 rue Le Corbusier (Maison Municipale)

Nous pensions que face à cette dégradation et aux transformations tendant à faire disparaître l'ouvre de Le Corbusier, il s'agissait essentiellement de sauver les quartiers modernes Frugès, sans en chasser les habitants. Comment sauvegarder cette ensemble urbain, homogène exemplaire, tout en y associant ses habitants, en les motivant et en les sensibilisant à des actions de restauration, de réhabilitation et de rénovation raisonnées?

La Cité Frugès à Pessac est un monument historique moderne, habitée par une population qui désire y vivre, non pas comme dans un musée, mais comme dans un lieu vivant, en le pratiquant, l'entretenant et l'améliorant.

Il fallait donc élaborer une politique de sauvegarde définie par des recommandations détaillées et des prescriptions particulières. L'alternative n'était pas entre tout conserver ou tout détruire, c'est-à-dire entre la reconstitution fidèle à l'état d'origine ou le renoncement à toute intervention. Il existait une marge de manouvre dans laquelle pouvait s'inscrire des interventions architecturales pertinentes basées sur une armature théorique simple permettant la sauvegarde de cet ensemble historique, tout en conservant le caractère de cité populaire.(...)

Les maisons de Pessac étant, malgré toutes les tentatives d'industrialisation, des constructions composites associant substances et matériaux de longévités variables, le renouvellement cyclique de certaines parties est dans la nature même des choses. Dans tous les cas possibles, on cherchera alors la conservation de la substance ancienne, l'état actuel des techniques permettant de trouver des solutions de réparation et de rajeunissement satisfaisantes. Dans les cas de remplacement intégral des parties manquantes, de matériaux irrécupérables ou d'éléments inefficients, les éléments destinés à les remplacer devront s'intégrer étroitement à la composition de l'ensemble et respecter le plus fidèlement possible la nature et le dessin formel prédominant. Cette clause est en effet parfaitement tenable intellectuellement, techniquement et économiquement, compte tenu, d'une part, de la 
formation très complète et maîtrisée que l'on a sur l'état d'origine, d'autre part, des capacités technologiques de production et de reproduction que l'on possède aujourd'hui et qui concerne des appareils ou ouvrages connus et relativement sophistiqués. Les solutions architecturales projetées, pour améliorer ou adapter des situations techniques défaillantes constituant la cause des dégradations, devront, dans leur composition, rester aussi discrète que possible et toujours garantir la clause de réversibilité de l'intervention. Enfin ces interventions de conservation ne doivent pas faire oublier qu'elles imposent d'abord la permanence de l'entretien de l'œuvre ${ }^{23}$

Par la suite des propriétaires individuels aidés par un système de subventions ainsi que l'OPAC Aquitanis, avec l'acquisition de quatre maisons en 1993 \& 1994 prolongent l'intervention municipale et permettent de préfigurer ce que peut redevenir l'ensemble des quartiers modernes.

Ces initiatives sont confortées par l'élaboration de la Zone de Protection du Patrimoine Architectural, Urbain et Paysager (ZPPAUP) des Quartiers modernes Frugès, créée le 27 octobre 1998 qui énonce les règles constructives à respecter et des conseils pour protéger et mettre en valeur les logements conçus et réalisés par Le Corbusier et Pierre Jeanneret de 1924 à 1927

"Face à la dégradation pathologique et aux transformations tendant à mutiler l'œuvre de Le Corbusier et Pierre Jeanneret, comment sauver les Quartiers modernes Frugès sans en chasser une population qui désire y vivre, non pas comme dans un musée, mais comme dans un lieu vivant en l'entretenant et en l'améliorant". La ZPPAUP des Quartiers modernes Frugès créée permet de répondre à cette problématique. ${ }^{24}$

Ainsi le caractère exemplaire et didactique des Quartiers Modernes Frugès n'est plus à démontrer aussi bien dans son aspect théorique, que sur le caractère de témoignage d'une époque qu'il représente. La valeur ajoutée réside dans le processus de patrimonialisation dont la Cité Frugès a fait l'objet permettant à la fois la reconnaissance d'un ensemble architectural et urbain homogène d'une époque et l'élaboration d'une doctrine contemporaine de restauration qui s'appuie sur trois domaines d'études : le champ architectural, le champ technologique et le champ sociologique.

\section{Aujourd'hui}

Dans le cadre de l'opération de restauration des toitures et façades des maisons des Quartiers Modernes Frugès, la Ville de Pessac accompagne les propriétaires dans leurs projets de réhabilitation par le biais d'un dispositif d'aide administrative, technique et financière et a mis en place en 2011 un dispositif de guichet unique.Il s'agit d'une part de faciliter l'accès aux aides financières pour les propriétaires désireux de réaliser des travaux, mais aussi d'accélérer et d'harmoniser les réhabilitations.

Ce fonds mutualise les aides de la Ville de Pessac et de la Région Aquitaine à parts égales (10 $500 €$ pour chaque partenaire), la DRAC Aquitaine, le Conseil Général de la Gironde et la Fondation du Patrimoine participant également à cette opération selon leurs propres modalités.

D'autre part, la Région et la Ville de Pessac, ont engagé une réflexion commune sur la valorisation des travaux réalisés sur les maisons et sur la cité Frugès, par l'intermédiaire d'une publication dans la collection «Visages du Patrimoine en Aquitaine » dont le partenariat est formalisé jusqu'au 31 décembre 2015.

\footnotetext{
${ }^{23}$ Rencontres de la Fondation Le Corbusier, « La conservation de l'œuvre construite de Le Corbusier », collectif, Fondation Le Corbusier, Paris, 1990, p.74-87

${ }^{24}$ Présentation de la ZPPAUP par la DRAC Aquitaine : http://aquitaine.culture.gouv.fr/dossiers-thematiques/architectureurbanisme/zppaup
} 

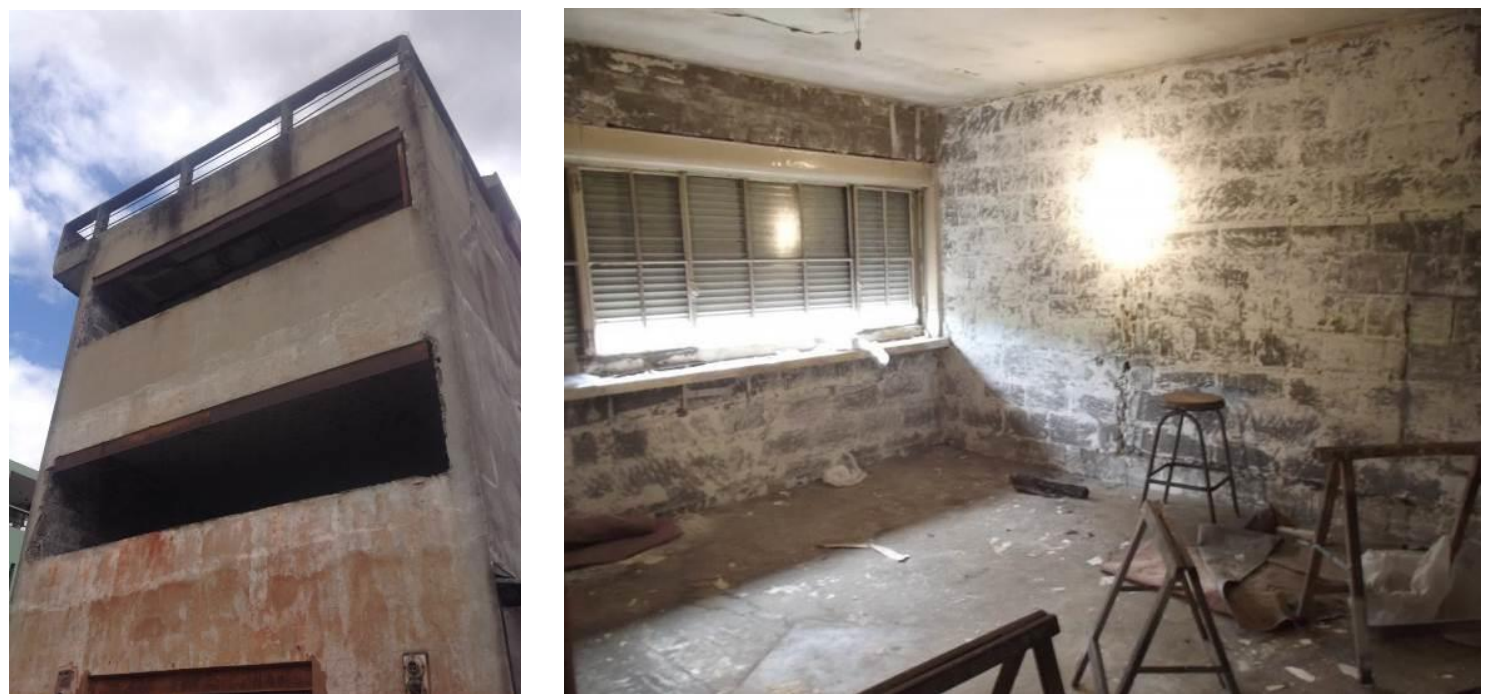

26. Cité Frugès, La maison Gratte-ciel au 12 rue Le Corbusier

27. Cité Frugès, La maison Gratte-ciel au 12 rue Le Corbusier

Du point de vue du marché immobilier, dans son article de Médiapart David Gauthier écrit : «La poussière s'élève à chaque pas. Les deux agents immobiliers viennent de pénétrer dans le rez-de-chaussée de cette maison de type «gratte-ciel ». Elle est en vente, et ils me la font visiter. Ils montent à pas lents le large escalier de béton qui zèbre l'habitation sur ses trois étages. La pièce à vivre est sombre. Impossible de se figurer à quoi ressemblait la vie ici : il ne reste rien des aménagements d'origine. Un des agents parvient à ouvrir de quelques centimètres les volets roulants, laissant filtrer un trait de lumière. Le petit salon apparaît plus nettement. Son état de délabrement est avancé. Le papier peint n'a pas survécu aux affres du temps. Il n'en reste que des lambeaux. "Il faut compter environ 300000 euros pour les travaux, préviennent-ils. En plus des 600000 euros pour acquérir les deux maisons ${ }^{25}{ }$.

En 2015 la Cité Frugès fait l'objet de nombreuses visites par les étudiants, architectes, visiteurs et touristes ou simples curieux, et ce, tout au long de l'année.

La maison " gratte-ciel » acquise en 1983 par la Ville de Pessac a bénéficié d'un chantier de rénovation expérimental exemplaire permettant une cohérence globale du point de vue esthétique et de l'aménagement de l'espace. Classée au titre des Monuments historiques, la Maison Frugès-Le Corbusier accueille «un public toujours plus nombreux, composé tant du grand public que des regards plus avertis répondant, d'une certaine manière, à une tendance de la société, plus intéressée par l'habitat et son évolution.Véritable support d'éducation du regard à l'architecture moderne, elle est aussi source d'inspiration pour de nombreux artistes et se convertit en lieu d'exposition 4 fois par an, déclinant les thématiques en lien avec l'aspect laboratoire de la Cité : l'architecture moderne, l'urbanisme, l'art contemporain, le design... Elle est aussi un lieu ressource pour les chercheurs, étudiants ou les propriétaires de la cité dans le cadre de la restauration de leur maison ${ }^{26}$.

\footnotetext{
${ }^{25}$ Gauthier David, Cité Frugès : « La difficile empreinte de Le Corbusier à Pessac » article in Médiapart, 09 Février 2015

${ }^{26}$ Présentation de la Cité Frugès par la Ville de Pessac (www.pessac.fr)
} 

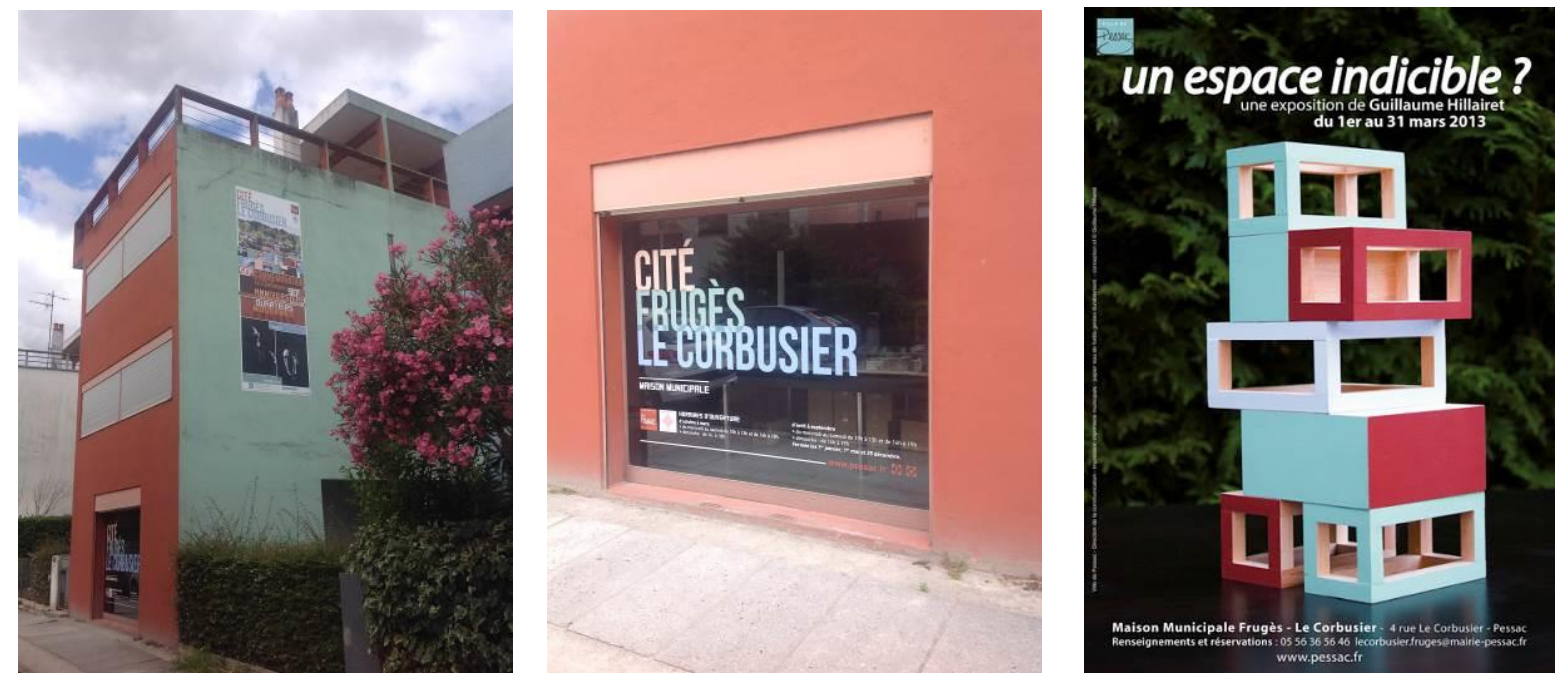

28. - 29. Cité Frugès, La maison Gratte-ciel au 4 rue Le Corbusier (Maison Municipale)

30. Affiche de l'exposition de Guillaume Hillairet à La maison Gratte-ciel du 4 rue Le Corbusier

Pour sa part Cyril Zozor médiateur du patrimoine y travaille depuis 2009 et passe ses journées au contact des visiteurs et des habitants qu'il aide pour valoriser leurs maisons conçues par l'architecte.

"Vous êtes passionné !», entend-il souvent au moment de dire au revoir à ses hôtes. À chaque visite commentée de la cité Frugès-Le Corbusier, c'est un peu la même histoire. Le public boit les paroles du guide, contant mille et une anecdotes sur les maisons bleu et terre de Sienne gratte-ciel, quinconce, arcade ou zigzag, leurs usages et leurs habitants au fil du temps. Son travail consiste à accueillir groupes scolaires et visiteurs, avertis ou non, mais aussi à épauler les habitants de la cité pour protéger, conserver et valoriser leur maison. "C'est un endroit vivant, pas un musée. C'est toute la richesse et la complexité du site. Qu'est-ce qu'on peut faire de manière intelligente pour conserver et continuer à y vivre? Le Corbusier avait du génie, il était en avance sur son temps. Il ne l'est plus. Nos modes de vie ont changé, explique-t-il. Ces habitations étaient conçues pour avoir 300 objets. Nous en avons 3000 aujourd'hui dans nos foyers. Regardez les fenêtres, conçues telles des pellicules cinématographiques. Elles sont magnifiques mais pas pratiques du tout. Comment voulez-vous les laver? ${ }^{27}$

\section{Transmission}

Parmi les nombreux collaborateurs de Le Corbusier, seule une demi-douzaine d'architectes ont été professeurs avec une forte influence sur des générations d'architectes et dans certaines écoles d'architecture. Il s'agit de José Luis Sert (1902-1983) et Jerzy Soltan (1913-2005), de Georges Candilis (1913-1995), de Guillermo Jullian de la Fuente (1931-2008) et de José Oubrerie (né en 1932). Cette implication se traduit selon trois périodes distinctes.

Sert et Soltan ont été les «piliers » de la mise en place de la Graduate School of Design à Harvard. Sert est nommé Dean dès 1953 jusqu'en 1969 et imprimera une forte empreinte sur plusieurs générations d'architectes. Sert sera également associé à Le Corbusier pour la construction du Carpenter Center for Visual Arts, seule réalisation construite par Le Corbusier aux Etats Unis. Soltan, lui est nommé Robinson Professeur of Architecture and Urban Design dès 1959 jusqu'en 1979.

\footnotetext{
${ }^{27}$ Bosdecher Laurie « Le prof devenu médiateur » article in Sud-Ouest, 13 Août 2012
} 
Georges Candilis lui a eu une forte influence sur l'enseignement de l'école des Beaux-Arts en France dès 1965 et sur son évolution avec la création des Unités Pédagogiques d’Architecture, notamment l'UPA nº après Mai 1968. Il va enseigner lui aussi jusqu'à la fin des années 70 .

Jullian et Oubrerie, quant à eux ont plusieurs points communs. «Le premier et qui sont parmi les derniers collaborateurs de l'atelier du 35 rues de Sèvres, donc parmi ceux qui ont quotidiennement côtoyé le Corbusier dans les dernières années de sa vie : dans cette mesure ils sont déjà complices. Le second est qu'après cet épisode qui les a bien sûr marqués, ils ont traversé une période de plus de dix années pendant laquelle ils ont eu diverses activités qui ne les ont pas immédiatement menés à la réalisation d'édifices importants. Ils ont d'abord tenté de faire exister ce dont ils héritaient : des travaux commencés avec le Corbusier et laissés inachevés. Ainsi Guillaume Jullian poursuivit le projet pour le nouvel hôpital de Venise, et José Oubrerie le projet pour l'église de Firminy ${ }^{28}$ qu'il réalisera et achèvera finalement en 2006.

Par la suite dans leurs premiers projets construits, José Oubrerie à Damas et Guillaume Jullian à Rabat, «affichent clairement leurs préoccupations : construire l'espace architectural par le volume et la lumière, et offrir les moyens de la compréhension de cette construction, sans que jamais ceci ne soit donné de façon ostensible : que l'émotion architecturale puisse participer d'une découverte, D'une compréhension, d'une intelligence de l'ouvre ${ }^{29}$.

Après une période d'enseignement en France, Jullian et Oubrerie décident d'émigrer aux Etats Unis et y enseignent à partir du milieu des années 80 en liant des amitiés avec des personnalités comme John Hejduk, Robert Slustky ou Kenneth Frampton. Jullian est professeur invité dans les universités de MIT, Harvard, Cornell, University of Pennsylvania jusqu'en 2003, Oubrerie est lui aussi invité dans les universités de Columbia University, Cooper Union, de Lexington (où il sera Dean et Professeur de 1987 à 1991) puis à Columbus (Head of Architecture and Professeur de 1991 à 2013).

\section{D'autres personnalités}

Tadao Ando est parti de la passion corbuséenne d'un de ses étudiants pour entreprendre avec ses élèves de l’Université de Tokyo la modélisation, à la même échelle (1:200), de toutes les maisons conçues et réalisées (ou non) par Le Corbusier (il en dénombre 106 !). Ce travail a fait l'objet d'une publication ${ }^{30}$ et d'un don à la Fondation Le Corbusier et les maquettes ont été exposées dans différents lieux (Galerie Patrick Seguin, Paris en 2006, Placé le radieux en 2011...)

\footnotetext{
${ }^{28}$ Lucan Jacques, "Deux anciens de chez Corbu" article in AMC n 17 , Octobre 1987 p.52-71

${ }^{29} \mathrm{Ibid}$

${ }^{30}$ Ando Tadao Laboratory « Le Corbusier HOUSES », Toto, Tokyo, 2001
} 

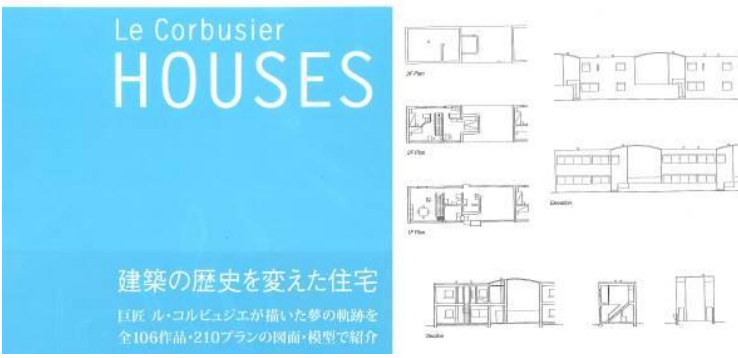

31. Couverture et page 138 du livre de Tadao Ando

Henri Ciriani a enseigné en France de 1969 à 2002 d'abord seul, puis à partir de 1979 au sein d'un collectif, le groupe $\mathrm{UNO}^{31}$. Pour lui la pédagogie c'est "apprendre aux étudiants à courir un cent mètres ». Et cet entrainement se fera dans l'univers formel de "l'espace moderne », entendu comme prolongement de l'œuvre de Le Corbusier ${ }^{32}$. Ainsi sont développés des exercices comme : le logis, une manipulation de la géométrie d'un carré de 10X10 mètres soumis à un programme et «l'espace 30X30 ou l'apprentissage du plan libre: une bibliothèque dont la structure est constituée d'une trame de poteaux de 5 à $6 \mathrm{~m}$ de portée. Il s'agit d'une bibliothèque sur un espace carré de 30X30 mètres où la compacité de la figure oblige, par incapacité de la périphérie à éclairer le centre, à trouver une spatialité particulière pour la lumière de la partie centrale ${ }^{33}$ »
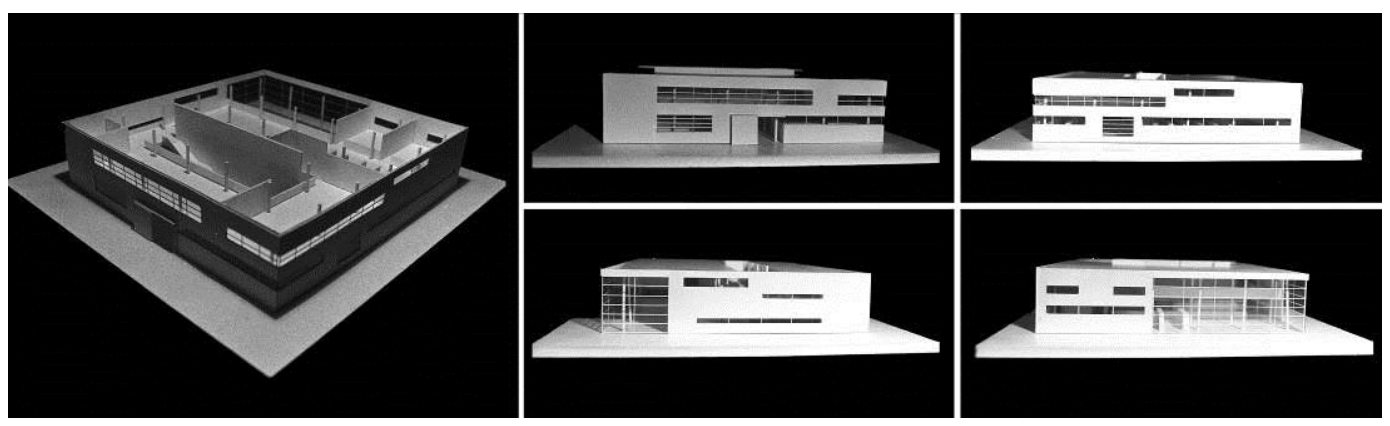

32. L'espace $30 X 30$ une bibliothèque, Laurent Duport ENSAPB 1988

Peter Eisenman travaille depuis de nombreuses années avec ses étudiants de l'université de Yale sur Le Corbusier. En 2014 cela s'est traduit à travers un séminaire qui proposait une discussion très spécifique sur le travail de Le Corbusier sur la base de deux de ses écrits fondamentaux : les cinq points de l'architecture et les quatre compositions. Ces textes sont lus à travers l'analyse et le dessin d'une série de bâtiments spécifiques et leurs évolutions de 1914 à 1965 et sont complétés par des lectures plus générales ainsi que d'autres points de vue de théoriciens comme Stanislaus von Moos, Anthony Vidler, Kurt Forster et Pier Vittorio Aureli.

\footnotetext{
${ }^{31}$ Arnold Françoise et Cling Daniel, «Transmettre en architecture. De l'héritage de Le Corbusier à l'enseignement d'Henri Ciriani », , Le Moniteur, Paris, 2002 p.194-201

${ }^{32}$ L'Architecture d'Aujourd'hui Henri Ciriani Septembre 1992 n $^{\circ} 282$

${ }^{33}$ L'Architecture d'Aujourd'hui, Le Corbusier, Février 1987, p.68-72
} 


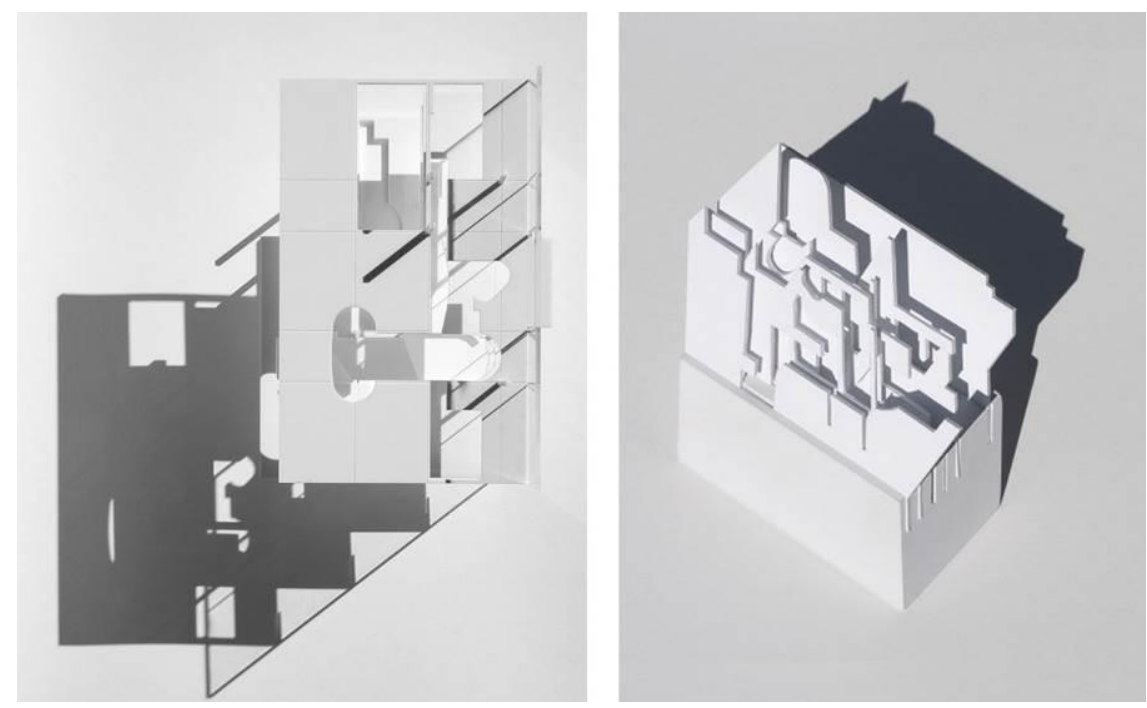

33. Travaux d'étudiants de Peter Eisenman à YSOA, Diagrammatic Modernism

Franz Graf avec ses étudiants de troisième année du Bachelor à l'EPFL, organise chaque année un atelier de techniques et sauvegarde de l'architecture moderne. « Le projet de sauvegarde et le projet dans l'existant font partie d'une discipline culturelle constituée qui élargit le projet d'architecture contemporain avec des questionnements théoriques et pratiques sur l'objet architectural à toutes ses échelles ainsi que le regard rapproché sur la matérialité du bâti qui donnent naissance au projet ${ }^{34}$ Pour l'année 2014 l'atelier a porté sur les Quartiers Modernes Frugès de Le Corbusier à Pessac, sauvegarde et devenir d'une cité d'habitation
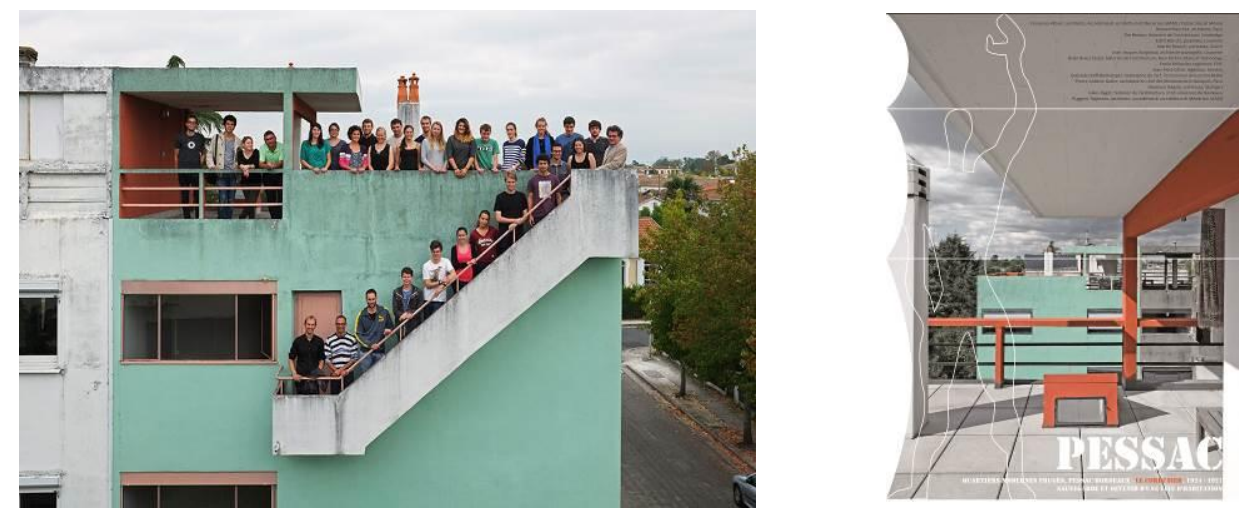

34. Affiche et l'atelier de Franz Graf à l'EPFL

\section{Si je devais enseigner l'architecture ?}

Lors d'une conférence donnée à Buenos Aires en 1929, devant un auditoire de professionnels composé d'architectes, d'ingénieurs et d'étudiants en architecture, Le Corbusier répondit :

«Si je devais enseigner l'architecture? Je commencerais par interdire les « ordres », par faire cesser cette maladie des «ordres», le scandale des «ordres», cette inimaginable défaillance de l'esprit. J'exigerais : respect à l'architecture. Je m'efforcerais à inculquer à mes élèves le sens aigu du contrôle, du libre arbitre, du «comment et du « pourquoi ». Je leur enseignerais le mépris des formules. Je leur dirais : tout est rapports.(...)

\footnotetext{
${ }^{34}$ Présentation de l'atelier Graf à l'EPFL : http://tsam.epfl.ch/
} 
Avant de dessiner il faut toujours savoir « de quoi il s'agit », «à quoi ça sert », "pour quoi c'est faire ». Enfin il faut apprendre à regarder $\gg^{35}$

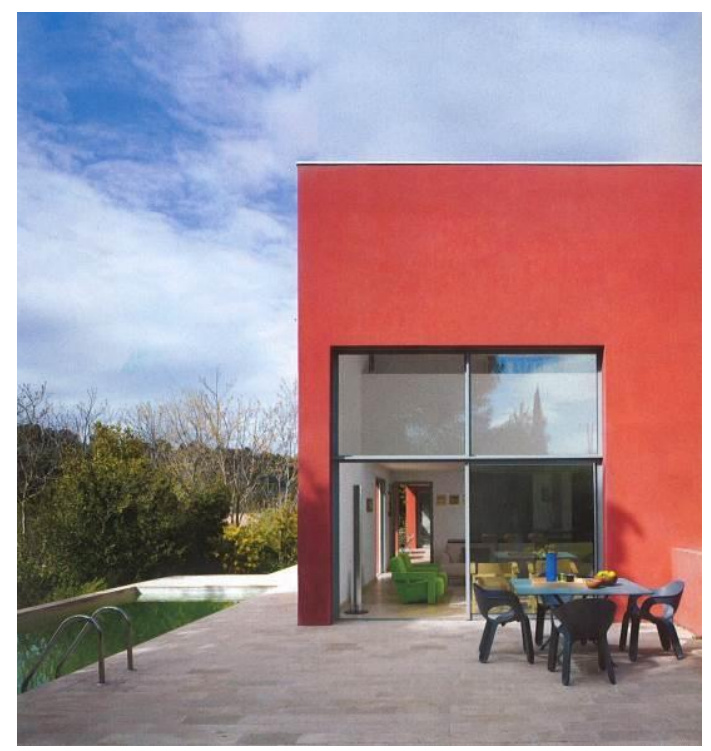

35. Tribute to Le Corbusier, Villa CLMT, Nîmes, Laurent Duport architecte.

\section{Acknowledgements}

Ines Zalduendo, Special Collections, Frances Loeb Library / Harvard University GSD

Shelley Hayreh, Avery Architectural and Fine arts Library, Columbia University

Students of Studio Laurent Duport "Urban Grafts", Ecole Nationale Supérieure d'Architecture de Montpellier, 2006-2015

\section{Sources of Images :}

Image 1 : tirée de «Vers une architecture » p.212

Image 2 : tirée de «Vers une architecture » p.213

Image 3 : Quartiers Modernes Frugès tirée de l'Architecture Vivante, 1927

Image 4 : tirée du livre de Philippe Boudon, Pessac de Le Corbusier, p.38

Image 5 : tirée de Le Corbusier Euvres Complètes 19101929 p.69

Image 6 : tirée de Le Corbusier Euvres Complètes 19101929 p.77

Image 7 : Le Corbusier et Pierre Jeanneret, Quartiers Modernes Frugès, Pessac, étude de polychromie, 1924. Gouache sur calque, 78,2 X $110 \mathrm{~cm}$. Fondation Le Corbusier

Image 8 : Idem, Etude de polychromie, 1924. Gouache sur calque, 41,8X114,2 cm. Fondation Le Corbusier

Image 9 : Quartiers Modernes Frugès Etude des couleurs tirée de l'Architecture Vivante, 1927

Image 10 : Polychromie architecturale Eventail des 63 « couleurs Salubra » de Le Corbusier

Image 11 : Couleurs de la Cité Frugès issues de Eventail des 63 «couleurs Salubra » de Le Corbusier

Image 12 : Maisons Jaoul, Le Corbusier, Maison A, salon, photographie Jean Christophe Pratt

${ }^{35}$ Guiton Jacques Le Corbusier, Textes choisis Architecture et urbanisme, Le Moniteur, Paris 1982 
Image 13 : Maisons Jaoul, Le Corbusier, Maison A, entrée, photographie Jean Christophe Pratt Image 14 : Extrait du dépliant accompagnant l'exposition «L'aventure Le Corbusier », Paris 1987 Image 15 : Cité Frugès, Les Maisons Gratte Ciel travaux d'étudiants Studio Laurent Duport, ENSAM Image 16 : Cité Frugès, Les Maisons Arcades travaux d'étudiants Studio Laurent Duport, ENSAM Image 17 : Cité Frugès, Les Maisons Quinconces travaux d'étudiants Studio Laurent Duport, ENSAM Image 18 : Cité Frugès, Les Maisons Zig Zag travaux d'étudiants Studio Laurent Duport, ENSAM Image 19 : Cité Frugès, Les Maisons Vrinat travaux d'étudiants Studio Laurent Duport, ENSAM Image 20 : couverture du livre de P.Boudon

Image 21 : une maison quinconce transformée, photographie Laurent Duport Image 22 : une maison quinconce transformée, photographie Laurent Duport Image 23 : une maison Gratte Ciel transformée, photographie Laurent Duport Image 24 : une maison Gratte Ciel transformée, photographie Laurent Duport Image 25 : La maison Gratte-ciel au 4 rue Le Corbusier (Maison Municipale) photographie Laurent Duport Image 26 : Cité Frugès, La maison Gratte-ciel au 12 rue Le Corbusier photographie Laurent Duport Image 27 : Cité Frugès, La maison Gratte-ciel au 12 rue Le Corbusier photographie David Gauthier Image 28 : La maison Gratte-ciel au 4 rue Le Corbusier (Maison Municipale) photographie Laurent Duport Image 29: La maison Gratte-ciel au 4 rue Le Corbusier (Maison Municipale) photographie Laurent Duport Image 30 : Affiche de l'exposition de Guillaume Hillairet à La maison Municipale, Ville de Pessac Image 31 : Couverture et page 138 du livre Le Corbusier HOUSES de Tadao Ando Image 32 : L'espace 30X30, Photographies maquette Fond Laurent Duport Image 33 : Travaux d'étudiants de Peter Eisenman à YSOA, Diagrammatic Modernism Image 34 : Affiche et l'atelier de Franz Graf à l'EPFL

Image 35 : Tirée de ARQUITECTURA Y DESIÑO n 91 Casas muy especiales, Manifesto Colorista p.151, photographie Eugeni Pons.

\section{Bibliography / references}

Ando Tadao Laboratory: Le Corbusier HOUSES, Tokyo: Toto, 2001

Arnold Françoise et Cling Daniel: Transmettre en architecture. De l'héritage de Le Corbusier à l'enseignement d'Henri Ciriani , Paris: Le Moniteur, 2002

Benton Tim, Pessac and Lège revisited : standards, dimensions and failures in Massilia, 2004 p.68

Bois Yve-Alain and others: De Stijl et l'architecture en France, Bruxelles: Mardaga, 1985

Bosdecher Laurie Le prof devenu médiateur Sud-Ouest, 13 Août 2012

Boudon Philippe: Pessac de Le Corbusier, première édition, Paris: Bordas, 1969, édition augmentée, Paris: Dunod, 1985

De Foville Alfred: Enquête sur les conditions de l'Habitation en France, Les Maisons Types, Paris 1894 
Duboy Philippe: Le Corbusier, Croquis de voyages et études, textes choisis, Paris: Louis Vuitton, 2009

Ferrand Marylène, Feugas Jean Pierre, Le Roy Bernard, Veyret Jean Louis: Le Corbusier : Les Quartiers Modernes Frugès, Paris: Fondation Le Corbusier, , Bâle, Boston, Berlin: Birkhäuser, 1998

Guiton Jacques: Le Corbusier, Textes choisis Architecture et urbanisme, Paris: Le Moniteur, 1982

Huxtable Ada Louise, Le Corbusier's housing project-flexible enough to endure New York Times, 15 Mars 1981

L’Architecture d'Aujourd'hui Henri Ciriani Septembre 1992 n²82

L’Architecture d'Aujourd'hui, Le Corbusier, Février 1987, p.68-72

Le Corbusier \& Pierre Jeanneret:Euvres Complètes 1910-1929 Zurich: Artemis, 1964

Le Corbusier: Vers une architecture, Éditions Crès, Paris: Collection de "L'Esprit Nouveau", 1923

Lucan Jacques, Deux anciens de chez Corbu AMC n ${ }^{\circ}$, Octobre 1987

Padovan Richard, towards universality, le corbusier mies +destijl, London \& New York: Routledge, 2002

Palazzolo Carlo, Vio Riccardo, In the footsteps of LE CORBUSIER, New York: Rizzoli, 1991

Ragot Gilles:Dion Mathilde: Le Corbusier en France, Paris: Le Moniteur, 1987

Sarkis Hashim: CASE: Le Corbusier's Venice Hospital and the Mat Building Revival, Munich-London-New York: Prestel Verlag, 2001

\section{Documents :}

Special Collections, Frances Loeb Library / Harvard University GSD:

Sekler Eduard \& Taylor Brian Brace Le Corbusier at Pessac, The Search for Systems and Standards in the Design of Low Cost Housing, Catalogue de l'exposition éponyme 12 0ctobre 30 Novembre 1972, Carpenter Center for the Visual Arts, Harvard University, en collaboration avec la Fondation Le Corbusier 


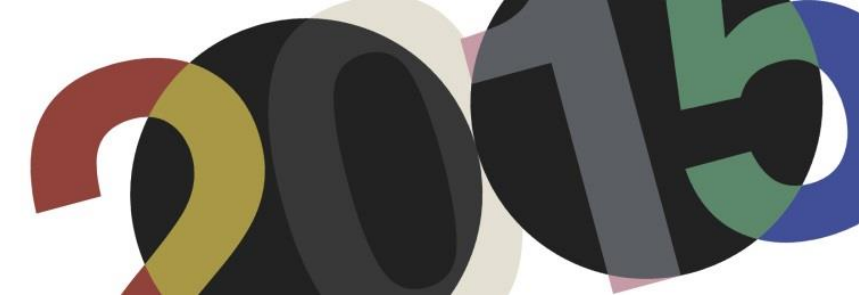

DOI: http://dx.doi.org/10.4995/LC2015.2015.664

\section{Georges Candilis (1913-1995) architecte pour le plus grand nombre}

\section{L.J. Duport}

Ecole Nationale Supérieure d'Architecture de Montpellier

Résumé: Né à Bakou en 1913 Georges Candilis est un architecte d'origine grecque qui étudie à l'Ecole Supérieure Polytechnique d'Athènes où il rencontre Le Corbusier en 1933 lors du 4e congrès des CIAM. Arrivé à Paris en 1945 il intègre l'Atelier de Le Corbusier où il travaille exclusivement sur les études et le chantier de l'Unité d'Habitation de Marseille. Après avoir été chargé de représenter Le Corbusier au 7e CIAM à Bergamo en 1949 Candilis va se rendre au Maroc où il va construire des nombreuses opérations en qualité de directeur de l'ATBAT Afrique et de membre du groupe GAMMA. Il va se révéler un des acteurs du Team X assurant le passage des CIAM au Team X dont il organisera 5 réunions entre 1960 et 1977. De retour en France en 1955 Candilis va s'associer avec les architectes Woods et Josic. L'équipe va remporter le concours Million et construire près de 4000 logements à Bagnols sur Cèze, Toulouse et en région parisienne. D'autres concours vont suivre en France et à l'étranger, l'équipe construira ainsi l'université libre de Berlin. Par la suite Candilis assure seul la mission d'architecte en chef de la station de Leucate Barcares (1962-1976) et entre 1970 et 1978 il est chargé de plusieurs projets au Moyen Orient. Parallèlement Candilis est impliqué dans la diffusion de l'architecture dès 1953 comme membre du comité de rédaction de revues et dans l'enseignement en qualité de professeur à partir de 1963. Il s'éteint à Paris le 10 mai 1995.

Abstract: Born in Baku in 1913 Georges Candilis is an architect of Greek origin who studied at the Polytechnic School of Athens where he met Le Corbusier in 1933 at the 4th Congress of CIAM. Arrived in Paris in 1945 he joined the Atelier of Le Corbusier where he works exclusively on studies and the site of the Unité d'habitation in Marseilles. After being appointed to represent Le Corbusier at the 7th CIAM in Bergamo in 1949 Candilis will travel to Morocco where he will build many operations as Director of ATBAT Africa and a member of the GAMMA group. It will be one of the actors of Team X and ensure the transition from CIAM to Team X for which he will hold 5 meetings between 1960 and 1977. Back in France in 1955 Candilis will partner with architects Alexis Josic and Shadrach Woods. The team will win the Million competition and build nearly 4,000 housing units in Bagnols sur Cèze, Toulouse and around Paris. Other competitions will follow in France and abroad, the team will thus build the Free University in Berlin. Subsequently Candilis assumes alone the chief architect mission of Leucate Barcares station (1962-1976) and between 1970 and 1978 he was responsible for several projects in the Middle East. In parrallel Candilis is involved in the diffusion of architecture since 1953 as an editorial board member of reviews and in architectural education with a grade of Professor since 1963. He died in Paris on May 10, 1995.

Mots-clés: CIAM, Team X, Enseignement, Habitat, Tige, Web.

Keywords: CIAM, Team X, Education, Housing, Stem, Web. 
Parallèlement à la célébration du cinquantenaire de la disparition de Le Corbusier, l'année 2015 est également l'occasion de commémorer le 20e anniversaire de celle de Georges Candilis.

Né à Bakou (capitale de Azerbaïdjan) le 29 mars 1913 (ou le 11 avril 1913 selon les sources) Georges Candilis s'éteint à Paris le 10 mai 1995. Avec ses parents il sillonne la Russie (Bakou, Rostov, Moscou) en étant le témoin de nombreux événements comme «les massacres entre Arméniens et Tartares, la guerre civile entre rouges et blancs et le triomphe des premiers ${ }^{1} \gg$ puis se rend en Turquie avant d'exiler et d'arriver en Grèce à l'âge de 12 ans, obtenant en 1926 la nationalité Grecque.

A la manière d'un choix qui réalise la synthèse entre le monde artistique de sa mère, qui était professeur de piano (comme la mère de Le Corbusier) et celui de son père, commerçant, il intègre en 1931 l'Ecole Supérieure Polytechnique d'Athènes, où il obtient son diplôme d'architecte et ingénieur en 1936. De cet enseignement Candilis garde le souvenir de deux professeurs exceptionnels Dimitri Pikionis ${ }^{2}$ et Anastase Orlandos ${ }^{3}$, «l'un m'a enseigné à comprendre, l'autre à connaître. L'enseignement de l'un sans l'autre n'aurait jamais été la même chose $»^{4}$.

Mais c'est surtout là où il rencontre Le Corbusier à l'occasion d'un événement majeur dont la portée et l'influence vont être déterminants pour lui : le 4e Congrès des CIAM de $1933^{5}$ qui se déroule non seulement à Athènes mais dans l'Ecole Polytechnique même. Au programme : la question des villes et de l'urbanisme comme «prolongement d'attitudes architecturales à l'échelle sociale ${ }^{6}$. Officiellement le Congrès ne commence qu'à Athènes avec l'inauguration d'une exposition de trente-trois plans de villes analysées et augmentés de photographies de réalisations architecturales de membres du Congrès. Mais celui-ci a en fait démarré sur le SS Patris II où la personne de Le Corbusier est omniprésente comme en témoignent certains participants et surtout le film «Architects Congress » de Lazlo Moholy-Nagy ${ }^{7}$.

Georges Candilis assiste à la conférence intitulée « Air-Son-Lumière » donnée par Le Corbusier que tout le monde attend et où ce dernier, arrivé en retard, rend un hommage à l'Acropole en introduction puis présente sa conception de l'immeuble d'habitation équipé de façades-rideaux tempérées. A la fin du congrès, enthousiaste, Candilis avec d'autres architectes et étudiants participe à la création de la section grecque des CIAM. A l'exception du VIe Congrès à Bergame en 1947, il sera désormais impliqué dans la totalité des congrès des CIAM d'après-guerre qui vont se succéder jusqu'en 1959.

De 1936 à 1940 il enseigne à l'École polytechnique d'Athènes puis à l'École nationale Sivitanivios pour la formation des techniciens du bâtiment (1940-1945) il est architecte du ministère des Travaux publics, puis exerce en libéral, construisant de modestes réalisations. Le climat politique qui régnait en Grèce avec la mise en place d'une république dès 1928 et surtout la montée en puissance du général Metaxas ${ }^{8}$, pousse Candilis et quelques autres à une opposition violente, à une prise de conscience et à un engagement politique, puis militaire.

\footnotetext{
${ }^{1}$ Demetriades Dimitri \& Papadaniel Dimitri Entretiens avec Georges Candilis, Article de la revue des Ingénieurs et architectes suisses, 1994.

${ }^{2}$ Dimitri Pikionis (1887-1968) architecte et protagoniste grec des CIAM, développe une conception de l'intégration de l'architecture moderne dans le paysage en parfaite continuité avec la culture méditerranéenne.

${ }^{3}$ Anastase Orlandos (1887-1979) architecte et docteur ès lettres.

${ }^{4}$ Demetriades Dimitri \& Papadaniel Dimitri Entretiens avec Georges Candilis, Article de la revue des Ingénieurs et architectes suisses, 1994

${ }^{5}$ CIAM 4 Athènes 29 juillet-13 août 1933

${ }^{6}$ Candilis Georges: Bâtir la vie, un architecte témoin de son temps, Paris: Stock, 1977 p.82

${ }^{7}$ La copie du film est conservée à l'Institut gta, EPF Zurich.

${ }^{8}$ Ioannis Metaxas (1871-1941) général et homme politique, dictateur de la Grèce de 1936 à 1941
} 


\section{Chez Le Corbusier}

A la fin de la guerre en 1945, grâce à une bourse du gouvernement français Georges Candilis se rend à Paris et après une courte expérience chez André Lurçat, il se présente à l'Atelier du 35 rue de Sèvres où il est reçu par Le Corbusier en personne. Ce dernier l'engage pour s'occuper de l'Unité d'Habitation de Marseille, projet sur lequel il travaillera exclusivement. Dans l'équipe Georges Candilis côtoie Roger Aujame, Fernand Gardien, Jerzy Soltan André Wogensky et surtout Shadrach Woods ${ }^{9}$ avec qui il s'associera plus tard. Il prend conscience de la préoccupation architecturale d'après-guerre : la reconstruction massive de logements avec une administration française qui établit des normes et un cadre réglementaire rigide par la détermination de logements types, de surfaces minimum, l'utilisation de standards rationalisant la construction : portes, fenêtres, placards, planchers.

Mais l'Unité d'Habitation est un projet sur lequel Le Corbusier travaille depuis de longues années et celle de Marseille se révèle un prototype où il met en œuvre une grande partie de ses théories avec l'application du modulor, de la polychromie et la mise en place à l'échelle de trois cent cinquante logements de principes expérimentés auparavant comme les pilotis, la toiture terrasse, les brise-soleil, les pans de verre. Georges Candilis sera chargé des études et de suivre le chantier en relation avec Vladimir Bodiansky ${ }^{10}$ et l'ATBAT ${ }^{11}$. Cette expérience où architecture et ingénierie sont étroitement liées, où la conception du projet est immédiatement suivie de sa réalisation, lui permet de rencontrer à l'atelier de Le Corbusier ou sur le chantier, des personnalités politiques, des artistes, de nombreux architectes et critiques impliqués sur la scène architecturale française et internationale, notamment dans les CIAM. Il sera même chargé de représenter Le Corbusier au 7e CIAM à Bergamo du 23 au 31 juillet $1949^{12}$. Cette participation se traduit par la présentation d'un panneau/dépliant explicatif de l'Unité d'habitation de Marseille réalisé par l'ensemble du groupe Ascoral ${ }^{13}$ des Jeunes dont Candilis est le responsable du comité de rédaction.

Le dépliant qui se veut l'application de la grille CIAM pour la mise en pratique de la Charte d'Athènes explique minutieusement la conception et présente des photos des différentes étapes de la construction de l'unité de grandeur conforme. "J'installe donc le logis au cœur du binôme "individuel + collectif ", et la liberté individuelle étant assurée par le logis, j'organise tout ce que le collectif peut apporter $»^{14}$

\footnotetext{
${ }^{9}$ Schadrach Woods (Yonkers 1923- New York 1973) est un architecte, urbaniste et théoricien américain qui travaille chez Le Corbusier en 1948, puis à partir de 1951 avec Georges Candilis au sein de l'ATBAT Afrique. Ils sont rejoints, de retour à Paris en 1954 par Alexis Josic (1921-2011). En 1970 il s'installe aux Etats Unis où il exerce et enseigne jusqu'en 1973

${ }^{10}$ Vladimir Bodiansky (1894-1966) est un ingénieur français d'origine russe qui crée l'ATBAT en 1945 avec Le Corbusier puis l'ATBAT Afrique en 1951 avec Georges Candilis

${ }^{11}$ A.T.B.A.T Atelier des bâtisseurs sera le bureau d'études techniques en charge de la construction de l'Unité d'Habitation de Marseille sous la direction de Bodiansky voir les articles dans Architectural Design, Janvier 1965

${ }^{12}$ Voir lettre de Le Corbusier à Candilis datée du 24 Mai 1949, archives Famille Candilis

${ }^{13}$ L'Assemblée de Constructeurs pour une Rénovation architecturale fondée à Paris en 1943 par Le Corbusier, visait à établir les modalités pour joindre la reconstruction à l'introduction de préfabrication et industrialisation de la construction

${ }^{14}$ Le Corbusier in dépliant de présentation au $7^{\mathrm{e}}$ congrès CIAM à Bergame, Special Collections, Frances Loeb Library / Harvard University GSD
} 

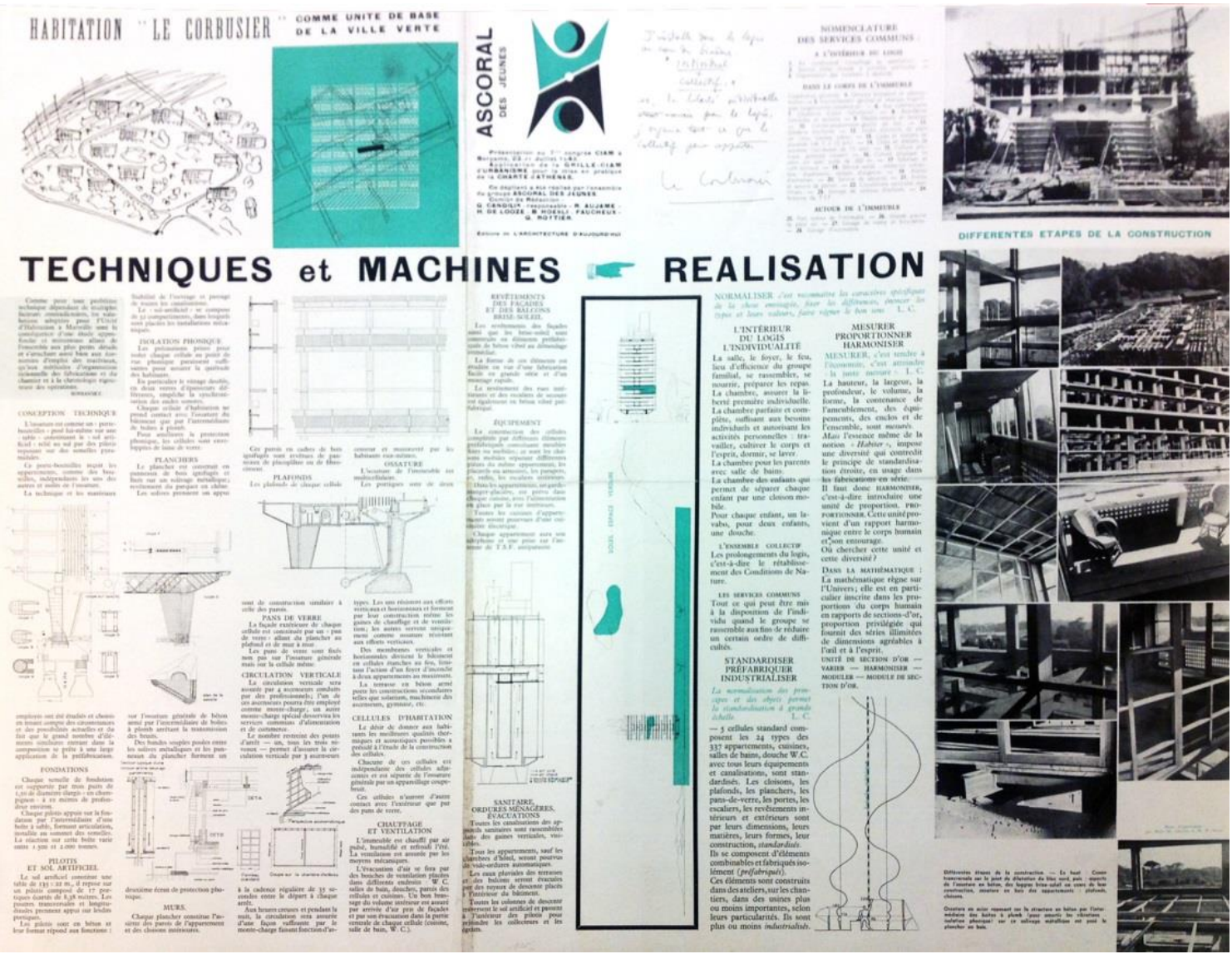

1. Dépliant de présentation pour le 7e congrès CIAM à Bergame. OFLC-ADAGP

A la fin du chantier Georges Candilis considérant que le rôle qu'il avait tenu auprès de Le Corbusier était terminé, décline la proposition qui lui est faîte de suivre le chantier de Chandigarh aux côtés de Pierre Jeanneret mais accepte celle de Bodiansky de devenir le directeur de la filiale de l'ATBAT au Maroc, l'ATBAT-Afrique et choisit de « se tourner vers des régions vierges et de se pencher sur l'architecture du Plus Grand Nombre ${ }^{15}$.A partir de 1951, cet outil de travail permet à Georges Candilis et Shadrach Woods de construire une cité expérimentale de 150 logements pour la population musulmane à Casablanca (Carrières Centrales 1953), puis pour la population européenne à Oran (1954-1955) et à Sidi Bel Abbès (1954).

${ }^{15}$ Bâtir la vie, op. cit. p.182 


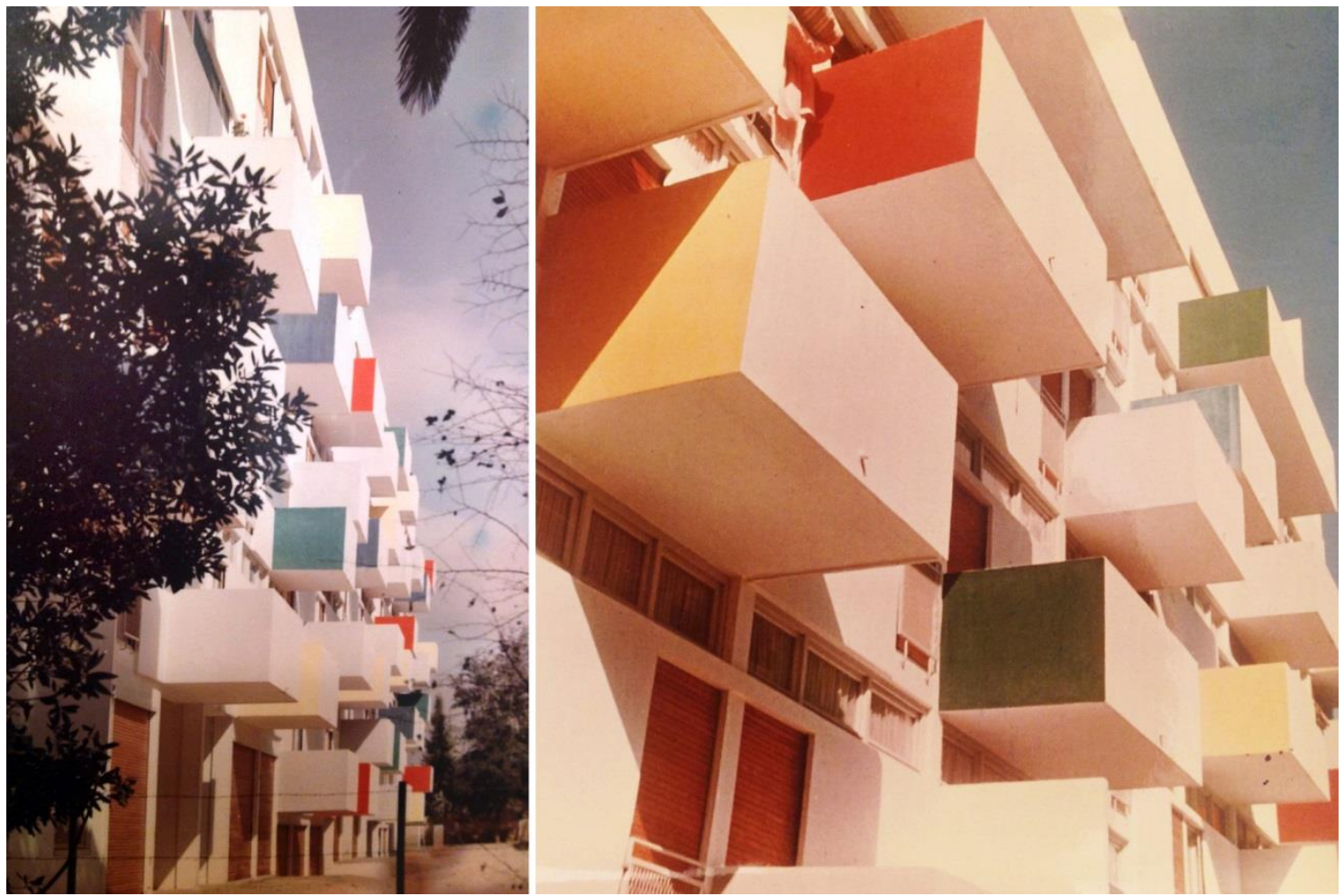

2. Immeuble à Sidi Bel Abbès, Candilis \& Woods architectes, 1954

Pour Candilis et Woods il s'agissait de trouver des formes architecturales, des structures qui tenaient compte des conditions économiques et sociales des plus démunis en leur apportant un élément essentiel dont ils étaient privés : la dignité.

Afin de remplacer les bidonvilles Michel Ecochard ${ }^{16}$ avait conçu des logements simples et économiques, un carré de $8 \mathrm{~m}$ par $8 \mathrm{~m}$ comportant deux chambres, une cour et un petit sanitaire, d'une surface totale de $64 \mathrm{~m}^{2}$. Fondés sur l'analyse des médinas anciennes ces logements étaient assemblés à rez-de-chaussée dans une trame urbaine, constructible en grande série, permettant préfabrication, industrialisation et de loger 350 habitants à l'hectare. Sur ce principe, et avec l'accord d'Ecochard Candilis et Woods proposent, des assemblages sur quatre ou cinq niveaux dans l'idée de réduire par la densité les zones étendues des bidonvilles et de limiter la spéculation foncière en s'appuyant sur une nouvelle interprétation de l'habitation collective marocaine avec des recherches sur trame modulor ${ }^{17}$.

\footnotetext{
${ }^{16}$ Michel Ecochard (1905-1985) architecte et urbaniste français en charge de Casablanca et travaille au Pakistan, au Liban et en Syrie.

${ }^{17}$ Candilis Georges \& Woods Shadrach photographie dessin sur calque Habitation collective marocaine, recherches sur la trame Modulor, Déc.1951, Woods Archives, Avery Architectural and Fine arts Library, Columbia University
} 


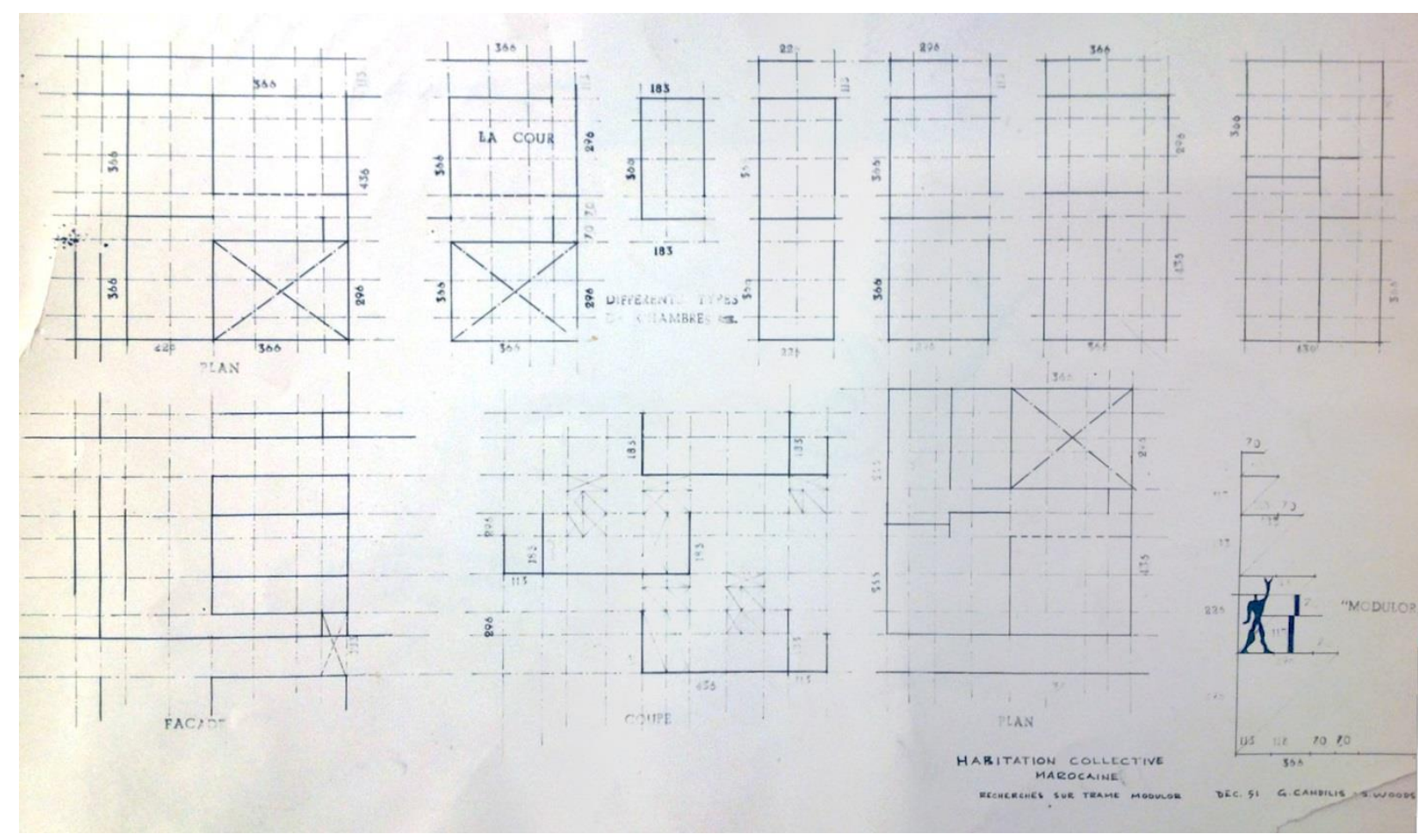

3. Candilis Georges \& Woods Shadrach Habitation collective marocaine, recherches sur la trame Modulor, 1951.

La maison musulmane traditionnelle est ainsi prise comme modèle avec une série de pièces groupées autour d'une cour intérieure à ciel ouvert, cette dernière assurant l'éclairage et la ventilation des pièces et étant utilisée comme espace à fonctions multiple.Avec l'appui d'Ecochard Candilis et Woods réussissent en 1953 avec Bodiansky à construire une cité expérimentale de 150 logements dans les Carrières Centrales de Casablanca, au milieu des maisons à patio en développant trois types d'immeubles selon deux facteurs : l'ensoleillement et le niveau d'évolution des habitants.Ces réalisations réinterprètent les projets des constructivistes russes de la fin des années des années 1920 et notamment les projets de Moisei Ginzbourg ${ }^{18}$ dont Candilis connait les réalisations à travers les publications et notamment la revue de l'association OSA СОВРЕМЕННАЯ АРХИТЕКТУРА, l'Architecture Contemporaine ${ }^{19}$.

\footnotetext{
${ }^{18}$ Moisei Ginzbourg (1892-1946) architecte constructiviste auteur de l'immeuble Narkomfin à Moscou qui aura une grande influence chez de nombreux architectes notamment grâce à la coupe

${ }^{19}$ Revue СОВРЕМЕННАЯ АРХИТЕКТҮРА, l'Architecture contemporaine nº 4 \& 5, Р. 130 à 145 , archives Famille Candilis
} 

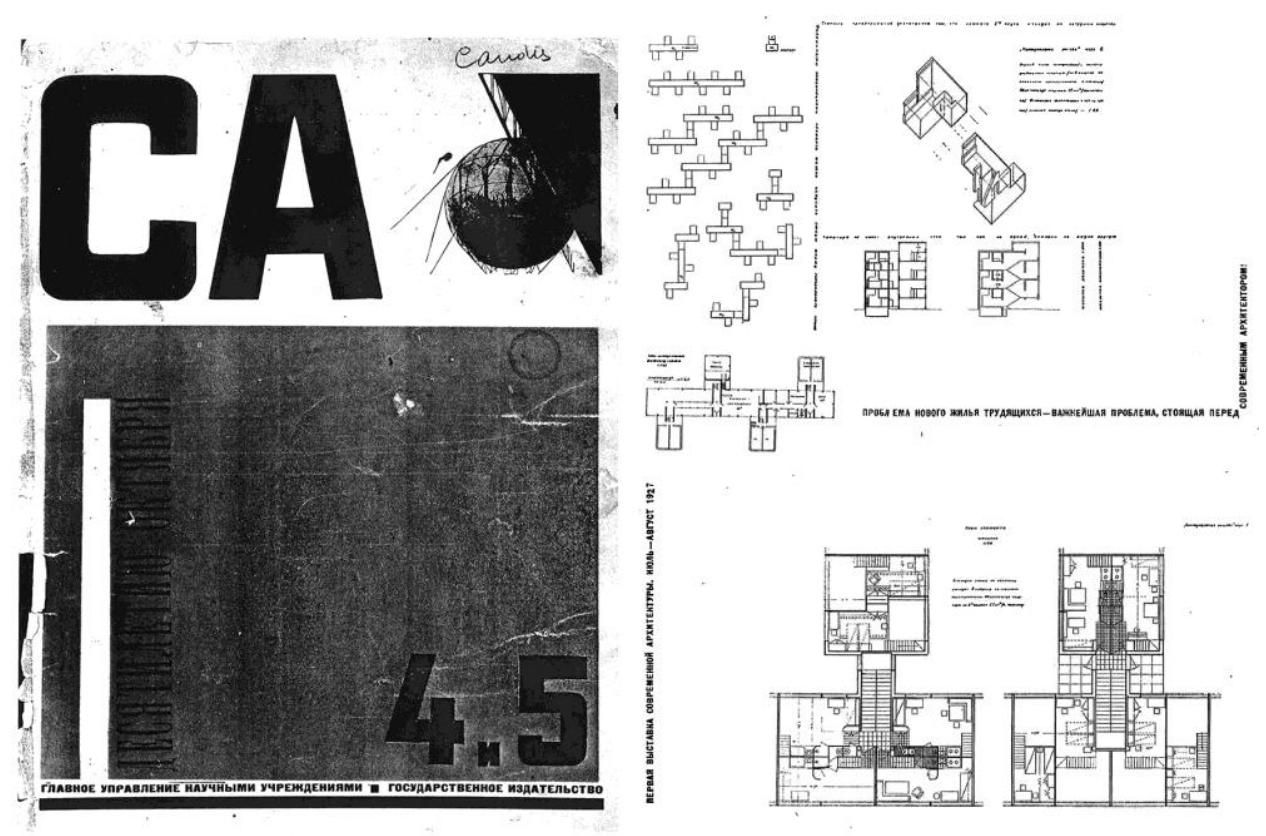

4. Revue СОВРЕМЕННАЯ АРХИТЕКТУРА, l'Architecture contemporaine $n^{\circ} 4 \& 5$

Ainsi sont conçus les immeubles d'habitation « Nid d'Abeilles » aux superpositions simples et idéalement éclairées et l'immeuble « Sémiramis » partagé en deux pour suivre la topographie introduisant ainsi de nouvelles typologies qui seront présentées en 1953 au C.I.A.M.9 d'Aix en Provence par le groupe GAMMA dirigé par Georges Candilis. Ce projet est largement publié et fera notamment la couverture du numéro 57 de décembre 1954 de l'Architecture d'Aujourd'hui dont Candilis est membre du comité de rédaction depuis 1953 et pendant plus de 20 ans. Par la suite ce projet sera à nouveau mis en avant notamment dans un article par Alison \& Peter Smithson qui voient là « l'une des plus grande réalisations depuis l'Unité d'Habitation de Le Corbusier à Marseille $»^{20}$.

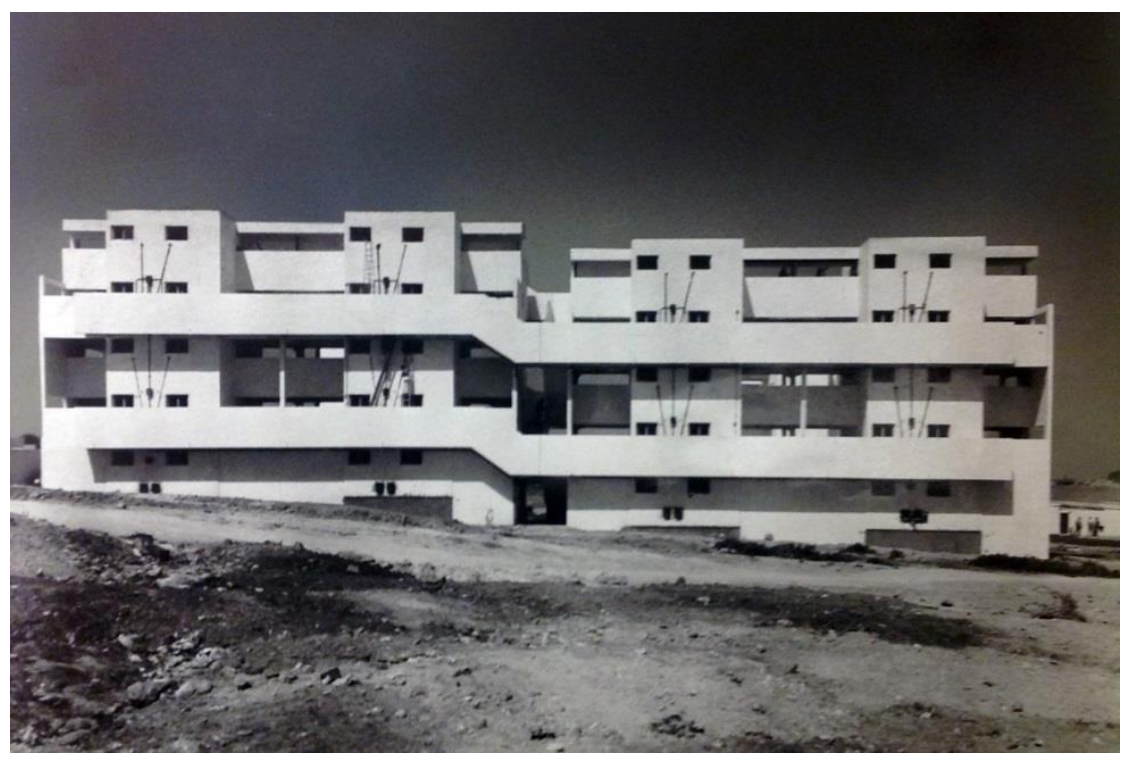

5. Immeuble Sémiramis, Carrières Centrales, Casablanca, Candilis \& Woods architectes.

\footnotetext{
${ }^{20}$ Smithson Alison \& Peter Architectural Design, 1955
} 


\section{Le groupe GAMMA}

La création du groupe GAMMA (Groupe d'Architectes Modernes Marocains) est le résultat d'actions convergentes et successives de Michel Ecochard et de Georges Candilis ${ }^{21}$. Sigfried Giedion ${ }^{22}$ avait demandé à Ecochard en 1947 d'organiser un voyage au Maroc et une contribution au CIAM. L'arrivée de Candilis au Maroc comme directeur de l'Atbat Afrique permet à la fois une réconciliation entre le groupe d'Ecochard et le département de planification urbaine du service de l'urbanisme du Maroc et sa nomination comme animateur du groupe GAMMA auprès des CIAM ${ }^{23}$.

\subsection{Georges Candilis et les CIAM}

Il est nécessaire de revenir sur l'influence de Georges Candilis dans la préparation du CIAM 9 d'Aix en Provence. A l'invitation du groupe suédois des CIAM, une grande réunion a lieu à Sigtuna, près de Stockholm du 25 au 30 juin 1952, quelques temps après une première réunion à Paris chez Le Corbusier.

A Sigtuna, Georges Candilis dirige la 6e et dernière session sur la place de la jeune génération dans les groupes des CIAM. Il commence la discussion avec un manifeste que l'on peut considérer comme la genèse de Team Ten, indiquant qu'il avait noté à Bergame la présence de deux familles : celle qui a fondé l'architecture moderne et celle qui a travaillé sur les bases prévues par les fondateurs.

Le CIAM 9 doit selon lui «marquer une frontière entre deux phases de travaux des CIAM et en même temps entre deux générations ». Il s'appuie en cela sur la conclusion de la réunion de Paris où une lettre co-signée par Le Corbusier, Sigfried Giedion et Jacqueline Tyrwhitt ${ }^{24}$ indique que, concernant le futur des CIAM il serait bon de prévoir une période de transition jusqu'au CIAM 10, que durant cette période une attention particulière pourrait être donnée au CIAM 9 aux travaux de jeunes groupes, et que le thème et l'organisation du CIAM 10 serait placés dans les mains d'une nouvelle génération d'architectes. La circulaire concluant qu'à la lumière du travail montré lors du CIAM 10, le congrès pourrait alors décider si la nouvelle génération a le talent et la vitalité de porter les travaux des CIAM.

Parallèlement à cette discussion sur les anciens et la jeune génération, Candilis insiste pour que le thème du CIAM 9 porte sur l'habitat et non sur le logement, sujet déjà traité lors de plusieurs congrès précédents à Francfort, Bruxelles, Paris, en argumentant qu'une charte de l'habitat serait aussi importante que les résultats du CIAM d'Athènes ${ }^{25}$.

La notion d'habitat est si nouvelle dans le milieu architectural anglo-saxon que les Smithson trouvent nécessaire de le définir avec l'exemple montré par Candilis indiquant que « Habitat est le mot qu'utilisent les français pour décrire non seulement la maison mais aussi son environnement et tout ce qui en relève ${ }^{26}$.

Mais c'est surtout au CIAM 9 que GAMMA présente ses travaux et tente de lier les résultats du « logement pour le plus grand nombre » à la charte de l'habitat proposée. Le projet présenté par Candilis et Woods pour les

\footnotetext{
${ }^{21}$ Cohen Jean-Louis, The Moroccan Group and the Theme of Habitat, Rassegna n52, Décembre 1992, p.58 à 65

${ }^{22}$ Siegfried Giedion (1888-1968), historien et critique de l'architecture, professeur à Harvard et MIT, secrétaire général des CIAM

${ }^{23}$ Cohen Jean-Louis ; Eleb Monique: Casablanca : Mythes et figures d'une aventure urbaine, Paris: Hazan, 1998

${ }^{24}$ Jaquelyne Tyrwhitt (1905-1983), paysagiste et urbaniste, professeur à Harvard et membre des CIAM

${ }^{25}$ Mumford Eric: The CIAM discourse on urbanism 1928-1960, Cambridge: MIT Press, 2000, p.255 et Sarkis Hashim: CASE : Le Corbusier's Venice Hospital and the Mat Building Revival, Munich-London-New York: Prestel Verlag, 2001, p.50 à 53

${ }^{26}$ Alison et Peter Smithson "Collective Housing in Morocco" Architectural Design, janvier 1955, cité par Monique Eleb, à l'universalisme fonctionnaliste, Ecochard, Candilis et l'ATBAT-Afrique, Les Cahiers de la recherche architecturale et urbaine, $\mathrm{n}^{\circ} 2-3,1999$
} 
Carrières Centrales à Casablanca va constituer une étape importante dans la première manifestation « d'une nouvelle manière de penser» ${ }^{27}$.

A la fin du CIAM 9 à Aix en Provence, un petit groupe est formé avec Georges Candilis \& Shadrach Woods pour la France, Jaap Bakema et Aldo Van Eyck pour la Hollande, Rolf Gutmann pour la Suisse, Alison et Peter Smithson, Bill Howell et John Voelker pour l'Angleterre. C'est ce groupe dit des « jeunes » qui sera chargé de l’organisation du CIAM X à Dubrovnik en 1956 et allait devenir le Team pour le Ten ou encore Team X.

\subsection{L'équipe Candilis/Josic/Woods}

De retour à Paris en 1955, Georges Candilis et Shadrach Woods s'associent avec l'architecte Alexis Josic. L'équipe propose une réflexion architecturale nouvelle centrée sur l'habitat. Ainsi pour Georges Candilis, l'habitat est le lieu de l'universel et du contingent. Habiter c'est répondre, d'une part aux besoins universels de se réunir et de s'isoler, et, d'autre part, aux conditions particulières du lieu.

« Inventer des logements simples, véritablement économiques, qui possèdent la qualité du respect, ce n’était pas de la grande architecture, mais cela représentait autant de difficultés, et demandait plus d'imagination et de sensibilité que de construire des palais $»^{28}$.

L'équipe Candilis/Josic/Woods va accompagner ses conceptions de publications : « Depuis toujours, l'homme lutte pour créer son foyer. C'est un des efforts les plus vitaux de son existence. En suivant les différentes phases de cette lutte, nous traçons les grandes lignes de notre conception. 1. recherche d'un lieu 2. Protection contre le froid.3.Équipement vital : eau, lumière, chaleur, évacuation.4. Détermination des fonctions de base : s'isoler, se réunir. Dès sa création, le foyer est constamment évolutif. Le logement doit évoluer également en s'adaptant aux nécessités nouvelles ${ }^{29}$.

L'évolution de cette réflexion va concerner l'organisation urbaine et en particulier l'intégration du logement dans l'espace public : la continuité urbaine va être inventée ou réinventée jusqu'à la constitution de nappes continues. Ce processus va amener l'équipe à contester la charte d'Athènes qui «...avait provoqué l'éclosion de bâtiments, grands et petits, isolés, répétés à l'infini. Au lieu d'aligner des blocs nous avons cherché à les articuler entre eux, à les relayer, à créer des espaces indéfinissables qui rompent avec la monotonie et rendent une échelle agréable. A ce moment déjà c'était lutter contre le gigantisme et humaniser l'habitat ${ }^{30}$

A l'expérience marocaine de l'ATBAT Afrique s'ajoute celle du concours Million dont ils sont lauréats en 1955. L'équipe propose une réflexion architecturale avec l'opération Million, campagne du gouvernement français pour abaisser le coût de construction d'un logement de 3 pièces de $48 \mathrm{~m}^{2}$ pour un budget d'1 million de Francs de l'époque en élaborant des modèles standards applicables immédiatement. Avec l'opération Million on change l'échelle qui transforme les opérations en grands ensembles non plus selon une composition classique de plan de masse mais suivant d'autres dispositions

L'équipe Candilis-Josic-Woods réalisera ainsi de près de 4000 logements en région parisienne : logements collectifs à Ivry, Cité Emmaüs à Blanc-Mesnil (1955-1957), Bobigny (1956-1962) et Gennevilliers (1955-1956). L'équipe est également chargée du projet d'extension de la Ville de Bagnols sur Cèze qui vaudra à cette réalisation le Grand Prix National d'Urbanisme en 1959.

\footnotetext{
${ }^{27}$ Smithson Alison et Peter "Collective Housing in Morocco" Architectural Design, janvier 1955

${ }^{28}$ Candilis Georges: Bâtir la vie, un architecte témoin de son temps, Paris: Stock, 1977 p.185

${ }^{29}$ Candilis G., Josic A., Woods S., « Proposition pour un habitat évolutif » Techniques et Architecture n², 1959 pp.82-85

${ }^{30}$ Candilis Georges: Bâtir la vie, un architecte témoin de son temps, Paris: Stock, 1977 p.38
} 


\section{Bagnols sur Cèze}

La construction en 1954 de la première usine de production d'énergie nucléaire de la rive droite du Rhône à Marcoule (Gard) posait la question de l'habitat de nombreux arrivants amenés à travailler sur le site. Le commissariat à l'Energie Atomique et le Ministère de la Construction décident alors la création d'un « véritable et nouveau centre urbain » sur la commune de Bagnols sur Cèze, à une dizaine de kilomètres de Marcoule qui voit sa population passer de 5000 habitants (en 1956) à plus de 18000 habitants. Bagnols sur Cèze est une ville romaine située sur un carrefour de la route Nîmes-Lyon, c'est une cité médiévale fortifiée, un carrefour routier important et le centre commercial et administratif d'une région agricole. En 1956 Georges Candilis est contacté par Auguste Mionne ${ }^{31}$ le directeur de la Construction Moderne Française, Ce dernier a vu Candilis à l'œuvre quelques années plus tôt, quand il suivait le chantier de l'unité d'habitation de Marseille pour Le Corbusier. Auguste Mionne, mandaté par le Commissariat à l'Energie Atomique pour la construction de logements pour les ouvriers, les cadres et techniciens supérieurs, demande à Candilis de construire quatre-vingt logements en six mois.

\subsection{Le site :}

La topographie et le climat avec les crues de la Cèze et le Mistral au Nord, la route nationale à l'Ouest et la voie ferrée à l'Est imposent l'extension de la ville vers le Sud.

A cela s'ajoutent principes de préservations des traces historiques du paysage : arbres, anciens puits, ancienne muraille, un vallonnement naturel, «la présence des vestiges d'un ancien théâtre romain nous incita à favoriser cette percée nouvelle vers le sud. C'est dans cette direction que nous avons envisagé les prolongements de la cité» $^{32}$

\subsection{La composition :}

Le premier acte a été la création d'un élément de liaison entre la vieille ville et la nouvelle afin d'éviter la ségrégation en positionnant le centre commercial et le centre culturel à la croisée des deux villes. La nouvelle ville a été directement inspirée de l'ancienne, ainsi les rues ne sont pas à angles droits et les unités de logements projetées forment des redents évitant l'alignement en ligne droite. De même trois points dominent Bagnols sur Cèze et servent de repères : une tour romane et deux clochers gothiques. L'extension nouvelle reprend « en contrepoint le thème de ces trois pôles et implante résolument parmi des bâtiments de un ou cinq niveaux, six (deux fois trois) tours de quinze niveaux $»^{33}$.

\footnotetext{
${ }^{31}$ Auguste Mionne (1898-1962) est un entrepreneur créateur en 1936 de la Construction Moderne Française, une Société Coopérative qui sera en charge de l'Unité d'Habitation de Marseille (arch. Le Corbusier), des opérations de logements à Bagnols sur Cèze, Nîmes, Marseille, Béziers (arch. Candilis/Josic/Woods)

${ }^{32}$ Candilis Georges: Bâtir la vie, un architecte témoin de son temps, Paris: Stock, 1977 p.214

${ }^{33}$ Voir la brochure Urbanisme en France du Ministère de la Construction « Bagnols sur Cèze »
} 

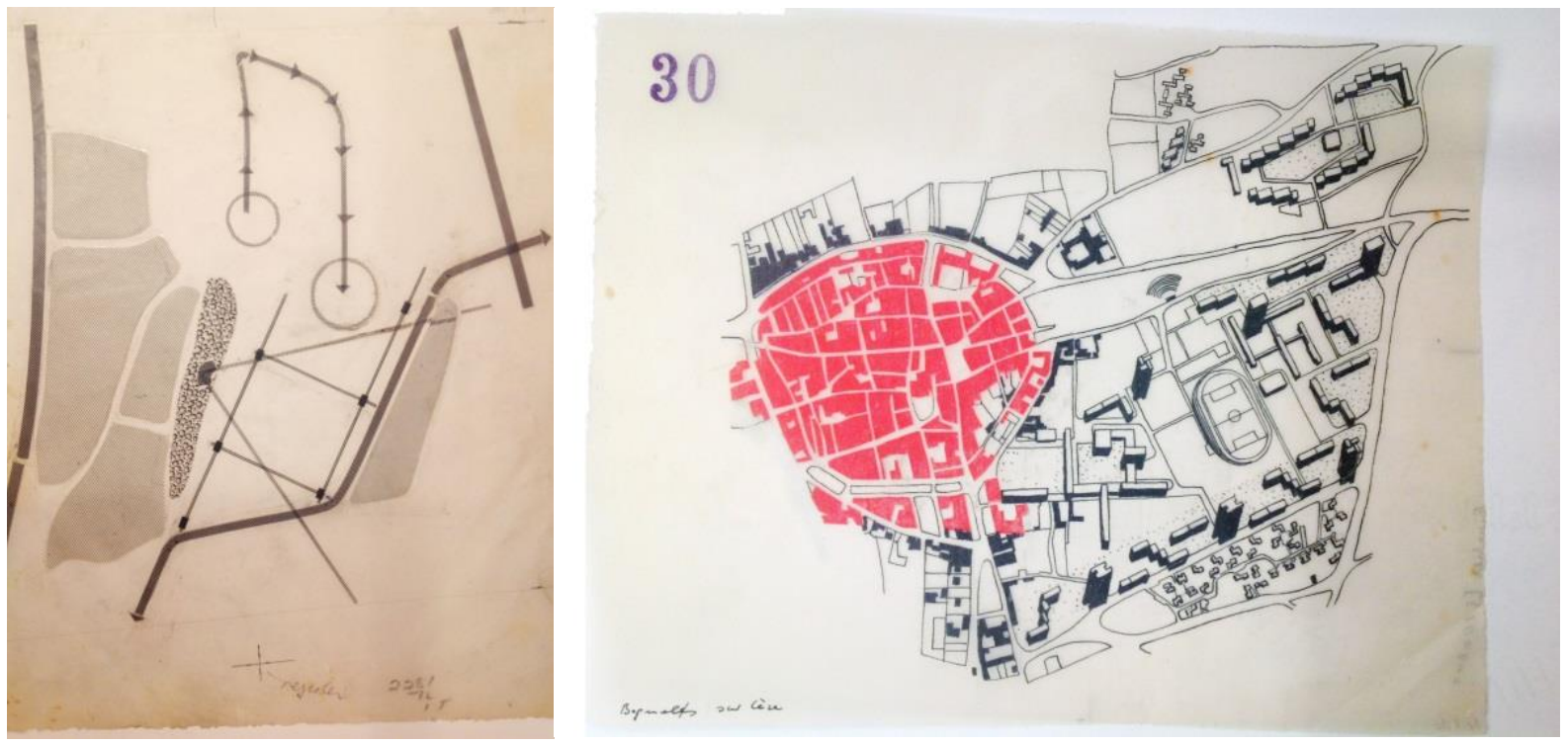

6. Croquis et schémas d'intention, extension de Bagnols sur Cèze, Candilis/Josic/Woods

L'opération distingue quatre entités : le Quartier de la Coronnelle (un premier quartier réalisé dans l'urgence), le Quartier de la Citadelle comprenant 370 logements, un centre commercial et une école de quartier construits en onze mois, période permettant l'étude de l'extension de la ville, le Quartier des Escanaux, qui constitue la principale extension de la ville avec la construction de 1200 logements et enfin la cité-jardin «Le Bosquet », un ensemble de 30 villas réservées aux ingénieurs supérieurs de l’Energie Atomique.

La réalisation la plus emblématique est le quartier des Escanaux où l'équipe Candilis/Josic/Woods propose une composition orthogonale articulant des immeubles bas de cinq niveaux à redents et des tours de quatorze étages. Deux lignes bordent la composition à partir desquelles se développent parallèlement ou perpendiculairement les immeubles bas. Cette disposition avec chaque ligne contenant trois tours, offre une échelle différente des « grands ensembles » rompant l'uniformité et donnant un caractère spécifique à chaque sous-ensemble, le centre étant occupé par le vide constitué par le stade et la piscine. 


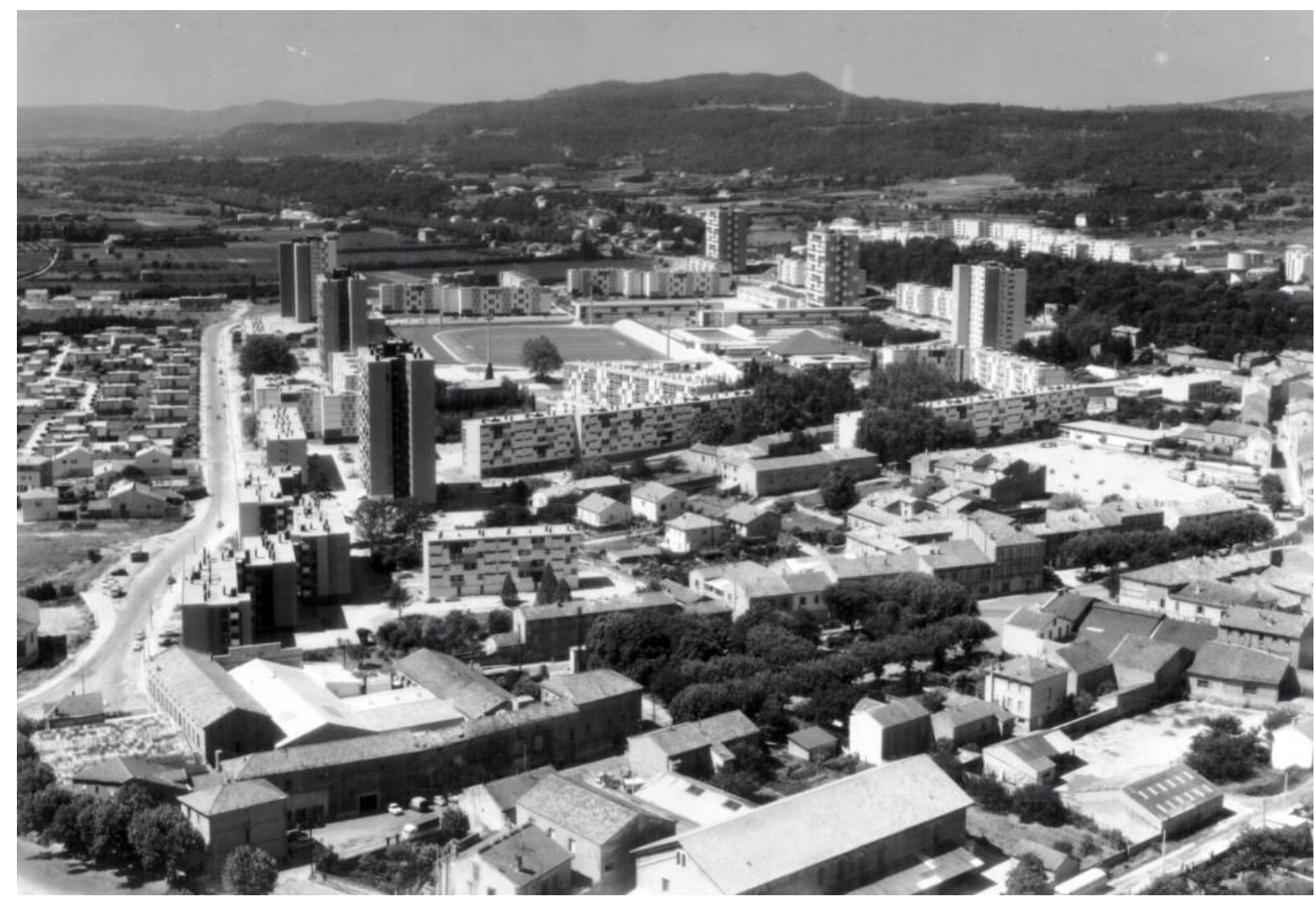

7. Les Escanaux à Bagnols sur Cèze, Candilis/Josic/Woods architectes, vue du ciel

La diversité des logements tente de transcrire dans des typologies modernes les qualités d'un habitat méditerranéen sur lequel Candilis et Woods ont déjà travaillé, notamment au Maroc, à Casablanca avec les immeubles Sémiramis et Nid d'Abeilles où l'espace du logement, principalement traversant, se prolonge à l'extérieur avec loggia, balcon ou terrasse séchoir permettant d'éclairer les salles de bains. Ainsi les immeubles de logements à cinq niveaux sont organisés par assemblage dont l'articulation est l'escalier autour duquel sont répartis symétriquement les logements avec des espaces communs réduits au minimum. Sur les façades de ces immeubles on observe une polychromie sur certains panneaux avec des couleurs primaires : bleu outremer, ocre rouge et ocre jaune.

Cette utilisation par panneaux monochromes rejoint sur certains points les recherches du groupe De Stijl ${ }^{34}$ et les compositions de Piet Mondrian mais aussi la polychromie architecturale de Le Corbusier ${ }^{35}$ expérimentée aux Quartier Modernes Frugès à Pessac.

Cette disposition qui offre de nombreuses variations de perspectives et de typologies de logements bénéficiant principalement d'une double orientation fait de cette opération un exemple qui obtiendra le premier grand prix national d'urbanisme en 1959.

Depuis sa construction le quartier des Escanaux a fait l'objet d'un certain nombre d'attentions. Ainsi des travaux de maintenance et d'entretien vont avoir des conséquences sur l'architecture comme l'isolation par l'extérieur des six tours en 1980. Une vêture est apposée sur les façades entrainant la perte de la force plastique et l'effacement des couleurs initiales, rendant les tours méconnaissables. Dix années plus tard, en 1990, est lancée une campagne de réhabilitation lourde avec changement des menuiseries extérieures en bois pour des

\footnotetext{
${ }^{34}$ Bois Yve-Alain and others: De Stijl et l'architecture en France, Bruxelles: Mardaga, 1985, p.16

${ }^{35}$ Colli Luisa Martina «Vers une polychromie architecturale »,1987 Le Corbusier une encyclopédie p.107
} 
menuiseries PVC accompagné d'un nivellement des façades par la suppression des balcons et séchoirs au profit de l'agrandissement des cuisines. Puis en 1998 des travaux sont engagés sur certains espaces extérieurs. Dans le même temps des aménagements sur les espaces extérieurs sont proposés dans un dessein analogue à celui de l'opération « Banlieues 89 » qui souhaitait consolider le lien entre centre ancien et ville nouvelle par une équipe dirigée par le paysagiste Alain Marguerit, sans résultat.

Le quartier s'inscrit également dans le cadre étatique de la politique de la ville depuis son classement en ZUS (zone urbaine sensible) en 1996. Ce classement s'est accompagné d'un contrat de ville signé en 2000 puis d'un contrat urbain de cohésion sociale (CUCS) en 2007. Plus récemment l'année 2009 a été l'occasion de célébrer par la ville l'anniversaire des 50 ans de sa construction et le quartier fait désormais partie des opérations du Programme National pour la Rénovation Urbaine (PNRU) depuis Décembre 2014.

Dans le même temps que l'extension de Bagnols sur Cèze l'équipe Candilis/Josic/Woods construira deux opérations à Nîmes, le Clos d'Orville et l'ensemble Tour de l'Évêque, (1958-1964), cette dernière définissant les fondements d'une typologie éponyme. Ces réalisations, avec celles du Blanc-Mesnil (1955-1957) et de Bobigny (1957-1962) «témoignent d'un intérêt nouveau pour la notion de continuité » ${ }^{36}$ et constitue une étape importante dans la réflexion de l'équipe Candilis-Josic-Woods sur la forme urbaine et les modes d'assemblages, amorçant les recherches ultérieures dans les réponses aux concours des années qui vont suivre.

\section{Georges Candilis et Team X}

La participation de Georges Candilis à la création de Team X trouve sa légitimité dans sa proximité avec Le Corbusier où dès 1949 il est chargé par ce dernier de le représenter au 7e CIAM. Membre de l'ASCORAL, de l'ATBAT dont il sera directeur de la filiale ATBAT Afrique, co-fondateur du groupe GAMMA, Candilis est en relation avec de nombreux acteurs des CIAM, et surtout présent dans les moments clés qui vont permettre l'élaboration de Team X comme la réunion des CIAM à Sigtuna en 1952 ou le congrès des CIAM d'Aix en Provence en 1953. Mais c'est lors de la réunion des CIAM à Londres en Août 1954 que Candilis s'exprime avec véhémence : «Nous pensons surtout après Aix que le moment est venu de donner de "l'eau de jouvence » au mouvement CIAM, de le réveiller et de l'orienter vers sa tradition et sa destinée - voie tracée par ses fondateurs, Corbu, Gropius, Giedion, Van Esteren, Sert, etc... Nous avons peur que : la sénilité, la fatigue, la médiocrité envahissent CIAM et que les congrès deviennent avec le temps un lieu de rencontres, de fêtes et d'admiration mutuelle, congrès identiques à tous les vétérinaires, des ichtyologues ou des amicales des anciens combattants, ni plus, ni moins. En examinant le congrès d'Aix, au point de vue congrès de travail et au point de vue résultats, il faut avoir le courage de dire la vérité. La façon de travailler par commissions, l'absence totale de préparation ou d'orientation du congrès, les résultats sont à tous points de vue plus que médiocres. Des choses mille fois répétées, des platitudes, des incompréhensions, l'esprit fade, des manques d'imagination et dilettantisme. Il faut rénover et nous voulons tenter notre chance ${ }^{37}$.Ces propos s'accompagnent d'une série de propositions en 8 points qui donnent de précises orientations sur l'organisation des futurs congrès notamment le CIAM X.

En décembre 1954 le désaccord entre les membres anglais (MARS) et hollandais (De 8 et Opbow) de Team X s'estompe notamment grâce à Bakema et une réunion du Team X se tient à l'agence de Candilis le 12 Avril 1955 tentant de redéfinir l'objet même des CIAM et leur futur. Quelques jours auparavant, le 8 Avril 1955 Le Corbusier dans une lettre au destinataire non identifié écrivait : «Les jeunes n'ont pas la force d'embrasser la

\footnotetext{
${ }^{36}$ Abram Joseph: L'architecture moderne en France, Paris: Picard, 2000 p.109

${ }^{37}$ Candilis Georges, Minutes de la réunion des CIAM, Londres 28-29 Août 1954, CIAM Special Collections, Frances Loeb Library / Harvard University GSD
} 
terrible complexité du phénomène moderne La largeur de vue prend peut être ici la forme d'absence de vue, ou alors adopter l'attitude des négations débilitantes et d'un dilettantisme verbal. La charte de l'habitat en tous cas devrait être la conclusion des 25 ans des CIAM et non pas le manifeste de la nouvelle étape. Les CIAM doivent léguer une charte et non pas en élaborer une. C'est très différent $»^{38}$

Etonnamment un mois après Le Corbusier change d'avis lors d'une réunion de préparation du congrès à venir avec Candilis et Bakema. Cette réunion, d'après Candilis, fut décisive pour Le Corbusier dans sa compréhension de l'agenda de Team X. Candilis pense que ce n'était pas avant ce jour-là que Le Corbusier avait saisi le thème du congrès proposé et que sous réserves de quelques confusions entre les nombreuses traductions anglaises et françaises il trouvait cela «très bien ${ }^{39}$ Quelques jours plus tard, fin Mai 1955 Le Corbusier et Candilis rédigent une invitation pour le $10 \mathrm{e}$ congrès qui doit se tenir à Alger $^{40}$. Après de nombreuses vicissitudes sur le lieu du congrès, sa date et son contenu celui-ci se tient finalement à Dubrovnik du 3 au 13 Août 1956. Le Corbusier, qui n’y participera pas, envoie un message adressé au congrès dans lequel il insiste sur les différentes étapes des CIAM et où il précise qu'en 1956 «les CIAM-SECONDS » prennent le relais ${ }^{41}$

A Dubrovnik, Candilis est à la tête de la commission B7 sur l'urbanisme et l'habitat, tandis que la commission B6, « croissance et changement » est dirigée par Bakema et que la commission B4 sur la question du «cluster » est conduite par Peter Smithson. Le trio auquel il faut ajouter Aldo van Eyck, Alison Smithson et John Voelker vont se révéler les véritables artisans du passage des CIAM à Team X et les acteurs principaux des réunions à venir.

Le congrès d'Otterlo du 7 au 15 Septembre 1959 marque la transition entre les deux et c'est l'occasion pour Candilis de présenter le projet d'extension de Bagnols sur Cèze qu'il est en train de réaliser.

L'année d'après, en 1960, la ville de Bagnols sur Cèze sera le lieu de la première réunion de Team Ten programmée par Candilis. Les participants y débattent, s'y prennent en photo, envoient une carte postale à Le Corbusier et continuent les discussions entamées à Otterlo l'année précédente. C'est la première d'une série de 12 réunions dont Candilis en organisera quatre autres, à Paris en 1961, à Royaumont (avec Woods) en 1962, à Toulouse en 1971 puis la dernière à Bonnieux en 1977.

\footnotetext{
${ }^{38}$ Pedret Annie: Team X, an archival history, London - New York: Routledge, 2013 p.166 à 168

${ }^{39}$ Ibid

${ }^{40}$ Lettre du 23 Juillet 1956 de Le Corbusier adressé au Xe congrès des CIAM à Dubrovnik Special Collections, Frances Loeb Library / Harvard University GSD

${ }^{41}$ Pedret Annie: Team X, an archival history, London - New York: Routledge, 2013 p.180
} 


\begin{tabular}{|l}
\hline Jaap Bakema (1914-1981) \\
\hline Aldo van Eyck (1918-1999) \\
\hline Georges Candilis (1913-1995) \\
\hline Giancarlo de Carlo (1919-2005) \\
\hline Peter Smithson (1923-2003) \\
\hline Alison Gill Smithson (1928-1993) \\
\hline Shadrach Woods (1923-1973) \\
\hline Bill Howell (1922-1974) \\
\hline Rolf Gutman (1926-2002) \\
\hline André Wogensky (1916-2004) \\
\hline John Voelker (1927-1972) \\
\hline Blanche Lemco (1923 \\
\hline Sandy Van Ginkel (1920-2009) \\
\hline Geir Grung (1926-1989) \\
\hline Jerzy Soltan (1913-2005) \\
\hline Josep Antoni Coderch (1913-1984) \\
\hline Ralph Erskine (1914-2005) \\
\hline Oskar Hansen (1922-2005) \\
\hline Karoly Polony (1928-2002) \\
\hline Louis Kahn (1901-1974) \\
\hline Kenzo Tange (1913-2005) \\
\hline Amancio Guedes (1925 \\
\hline Stephan Wewerka (1928-2013) \\
\hline Manfried Schiedhelm (1934-2011) \\
\hline Oswald M.Ungers (1926-2007) \\
\hline Guillermo Jullian de la Fuente (1931-2008) \\
\hline
\end{tabular}

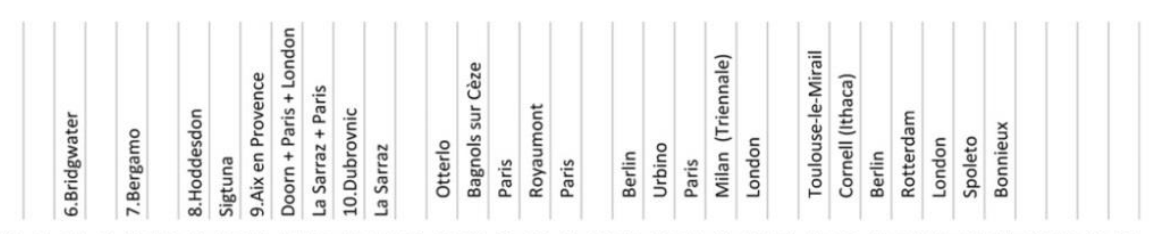

$4546474849505152535455565758596061626364 \quad 6566 \quad 6768697071727374757677 \quad 787980 \quad 81$

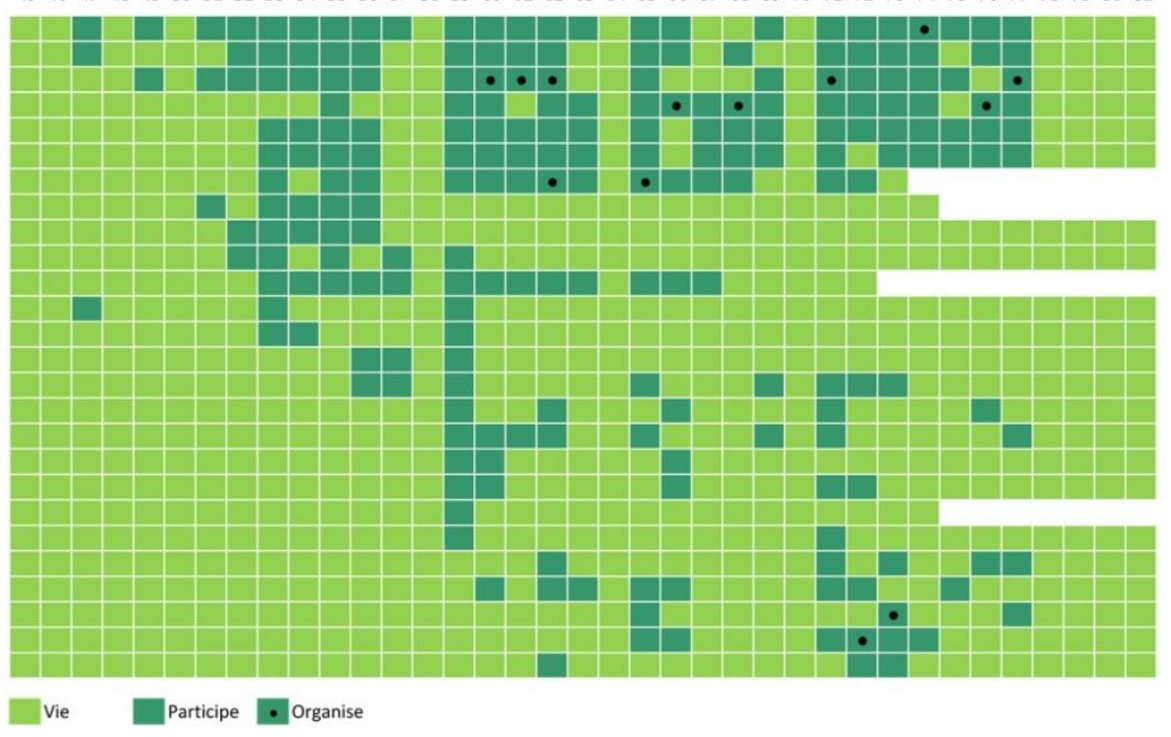

8. Les acteurs des CIAM (après 1945) et de Team X

Toujours en contact avec lui, Candilis informe Le Corbusier du programme de reconversion du Bas Rhône Languedoc ${ }^{42}$. C'est l'occasion pour ce dernier de renouer avec Philippe Lamour, le président de la Compagnie nationale d'aménagement de la région du Bas-Rhône et du Languedoc et d'offrir ses services, sans résultat.

\subsection{Les concours}

Par la suite Georges Candilis et son équipe enchainent les concours : Francfort (1960), Caen-Hérouville puis Hambourg (1961). Ils sont lauréats en 1962 de la ZUP de Toulouse-Le Mirail devant Louis Arretche (2e) et Le Corbusier dont la proposition est classée 10e. Ce projet abandonne définitivement la notion de plan de masse au profit d'une autre manière de penser et de concevoir, s'appuyant sur les notions développées par Woods dans son article sur le «stem $»^{43}$.

La même année le concours pour l'université de Bochum puis celui pour l'université libre de Berlin (1963) sont l'occasion pour l'équipe de penser "l'université pour le plus grand nombre ». Les propositions démontrent encore de nouveaux systèmes d'organisation indépendants de la composition, basé sur le "...pendant et complément du stem, le web...structure horizontale en nappe qui forme une maille capable d'accueillir les activités et de les mettre en relation un réseau qui peut évoluer dans le temps aussi bien par extension externe que par transformation interne $»^{44}$.Ce projet fera l'objet d'un article par Alison Smithson intitulé : «How to

\footnotetext{
${ }^{42}$ Lettre de G.Candilis à Le Corbusier, 31 Octobre 1956 FLC H-3-20 : voir Ragot Gilles ; Dion Mathilde: Le Corbusier en France, Paris: Le Moniteur, 1987 p.374

${ }^{43}$ Shadrach Woods "Stem” Architectural Design n5 1960, p.61

44 Lucan Jacques: Composition, non-composition Architectures et Théories, XIXe-XXe siècles, Lausanne: Presses polytechniques et universitaires romandes, 2009 p.471
} 
recognize and read a mat building ${ }^{45}$ qui fera date dans l'histoire de l'architecture en le comparant au projet de Le Corbusier (+ Jullian) pour l'hôpital de Venise.

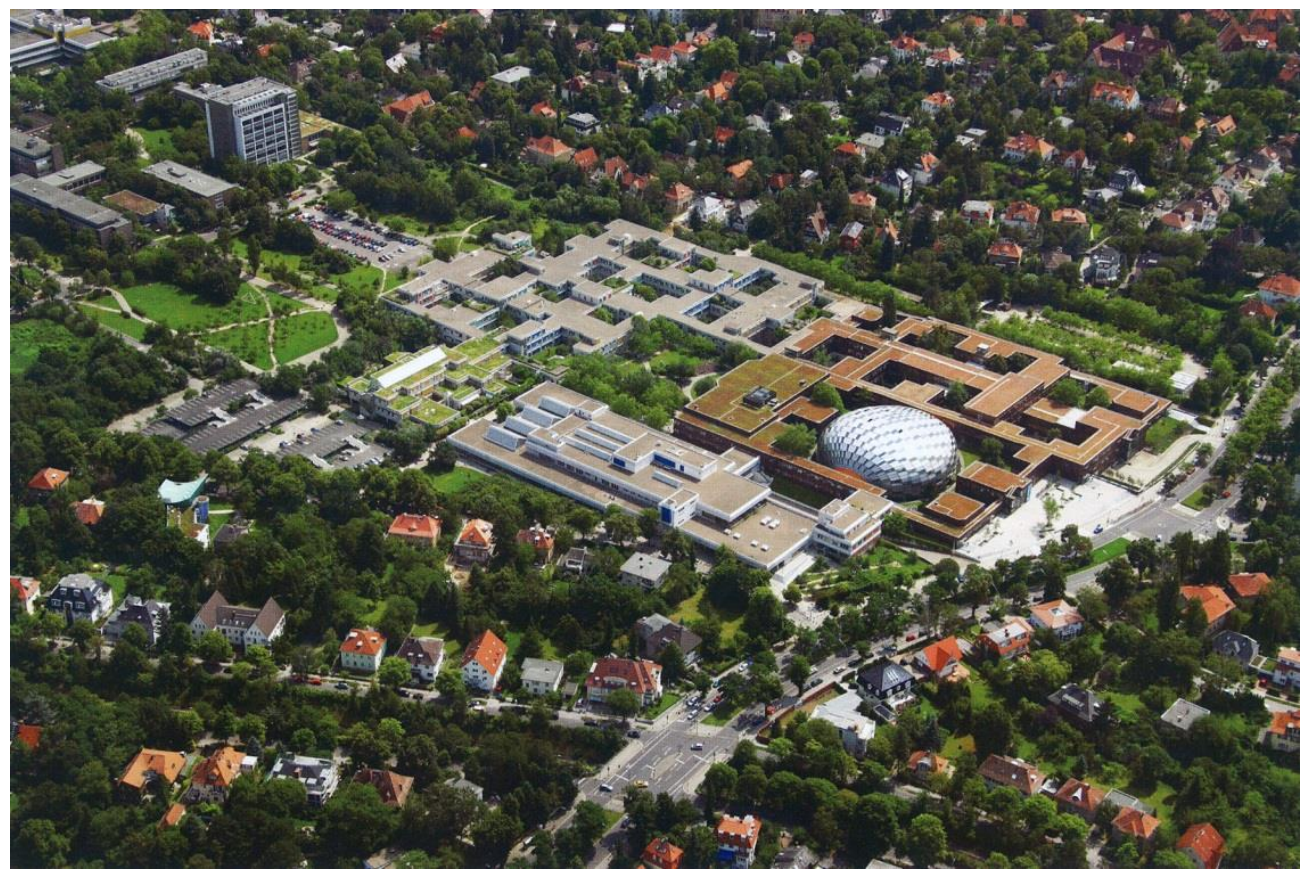

9. Vue aérienne Free University Berlin 2011, crédit photographique : Bavaria Luftbild/Freie Universität Berlin

Candilis réalisera également, pour partie, toute une série de projets d'universités appliquant le même principe typologique du « mat building » comme l'université de Toulouse le Mirail et de nombreuses autres qui ne seront finalement pas réalisées à l'instar de l'université de Zurich (1966), de Madrid (1969), de Larraquie (Syrie, 1973), Yarmouk (Jordanie, 1976) ou encore Hamadan (Iran, 1976).

S'en suivra une période où les projets s'enchaînent, tout comme les échelles. La conquête de nouveaux territoires viennent compléter cette expérimentation ainsi qu'un nouveau mode de vie : celui des loisirs. Ainsi Candilis participe à la mission Racine, mission interministérielle d'aménagement touristique du littoral du LanguedocRoussillon dont il assure la conception comme architecte en chef de la station de Leucate Barcares (1962-1976).

C'est la commande la plus importante que Candilis réalise sur le territoire français. Elle est constituée de plus d'une vingtaine d'opérations. Parmi elles, le village de vacances "Les Carats" est classé Monuments Historiques en 2014. De ce fait sont inscrits les façades, les toitures de tous les bâtiments et la totalité des bungalows de même que les parcelles et les aménagements situés sur la plage. Pour cette résidence, Candilis et Anja Blomsted conçoivent un mobilier en bois comprenant des chaises, tables, tabourets et lit/méridienne avec des équerres d'assemblage en aluminium ${ }^{46}$.

La conception de ce mobilier est sans aucun doute issue de sa passion pour le mobilier en bois courbé initiée par Le Corbusier et son attachement aux meubles Thonet comme le décrit Candilis : «Pendant toute sa vie, Le Corbusier dessine et meuble les intérieurs de ses édifices avec du Thonet. A tel point que certains s'imaginent qu'il en est le créateur! » ${ }^{47}$.

\footnotetext{
${ }^{45}$ Smithson Alison "How to recognize and read a mat building », Architectural Design Septembre 1974

${ }^{46}$ Voir le catalogue de l'exposition « Parallélisme géométrique » par Clément Cividino, Fondation Vasarély, Février 2015

${ }^{47}$ Candilis Georges: Meubles en bois courbé, Stuttgart - Zurich: Krämer Verlag, 1980 p.7
} 

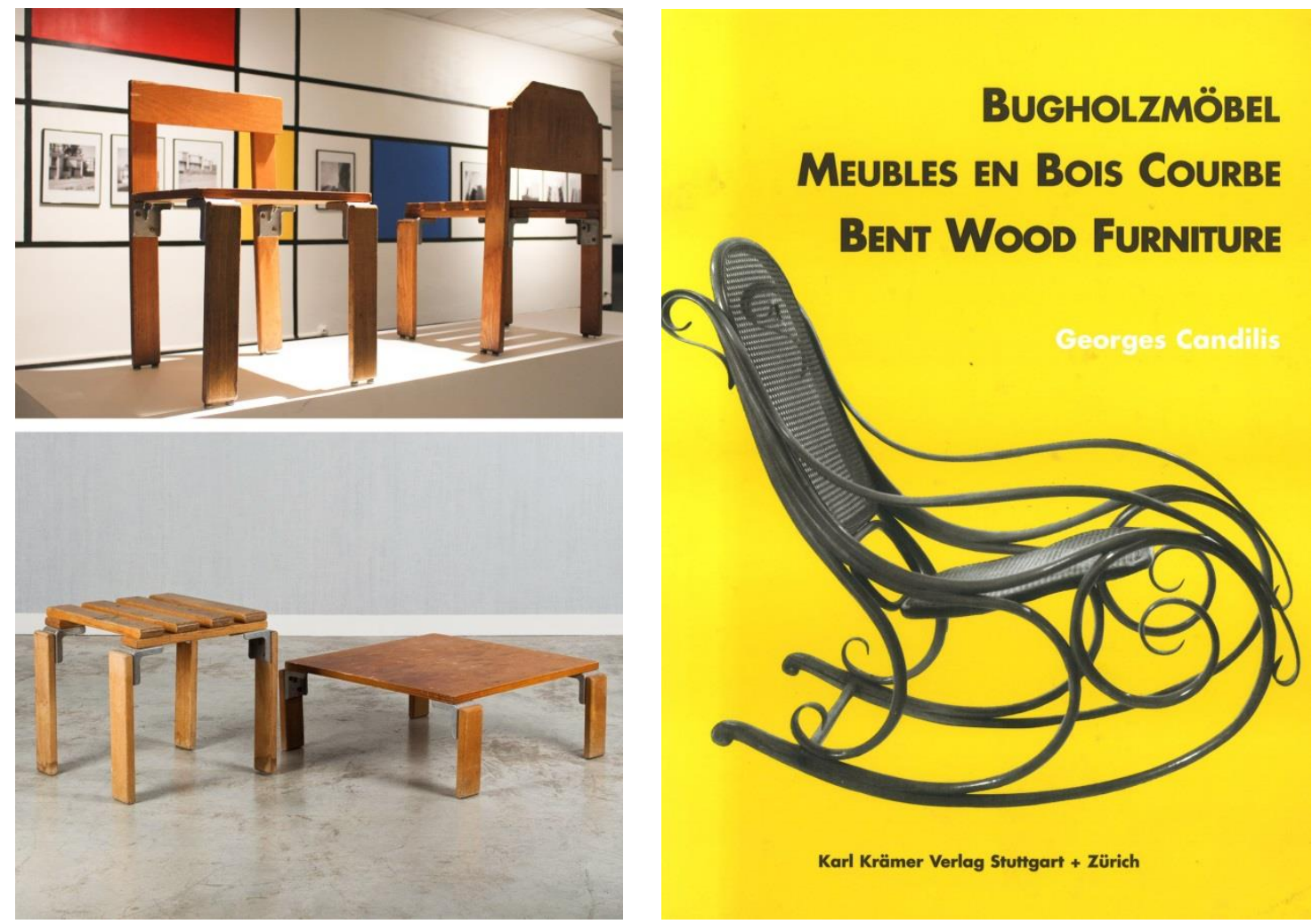

10. Meubles en bois de Georges Candilis et Anja Blomsted,

11. Couverture du livre de Georges Candilis, Meubles en bois courbé

En 1972, dans ce territoire qu'était le Languedoc Roussillon, sorte de laboratoire pour les loisirs, Georges Candilis lance la formule du « camping de l'an 2000 » en implantant à titre expérimental 27 hexacubes sur la commune de Leucate. Conçu par Georges Candilis et Anja Blomsted, l'hexacube ${ }^{48}$ est un nouveau procédé d'habitat modulaire composé de coques en polyester assemblées, constituant des modules habitables de 8 à $12 \mathrm{~m}^{2}$ groupables et permettant de nombreuses combinaisons.

\footnotetext{
${ }^{48}$ Fond Candilis CAP Hexacube / le cubing : tourisme-loisirs-travail CANGE/H/ND/15
} 


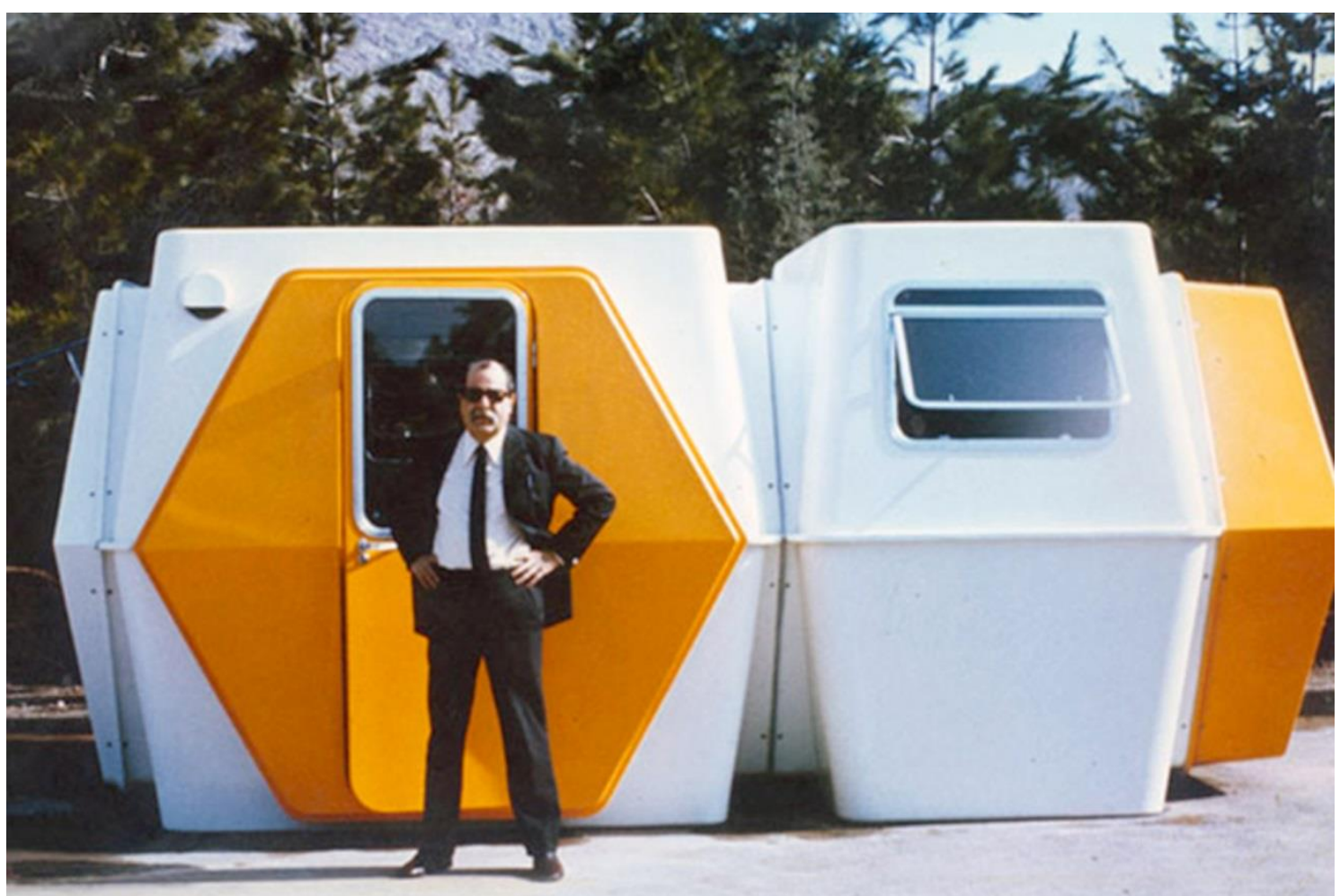

12. Georges Candilis devant l'Hexacube

Entre 1970 et 1978 Candilis est chargé de plusieurs projets au Moyen Orient. De nombreux ensembles résidentiels et d'habitation sont étudiés en Iran, au Koweït, au Qatar et en Arabie Saoudite, certains seront réalisés témoignant ainsi d'une production de Candilis toujours grandissante. Au milieu des années 70, en plus des agences de la rue Dauphine, de Toulouse, de Berlin et d'Athènes, Candilis dirige d'autres structures au Liban et en Arabie Saoudite, l'ensemble totalisant plus de quatre-vingts personnes.

En 1979, de retour en Grèce Georges Candilis « en tant que responsable du développement du Centre Culturel d'Athènes devient président de la délégation grecque à l'Unesco, du Centre International de Delphes et responsable de la candidature Grecque aux Jeux Olympiques de 1996. Juste avant sa mort, en 1995 il livre un très important travail de réflexion sur le futur des J.O. au seuil du XXIe siècle ${ }^{49}$.

\section{Diffusion et transmission}

Candilis, s'il ne se révèle pas comme un grand théoricien, a toujours habilement diffusé ses idées et communiqué sur ses réalisations. Souvent acteur au sein d'un groupe (CIAM, ASCORAL, ATBAT, GAMMA, TEAM X...) il est surtout membre du comité de rédaction de l'Architecture d'Aujourd'hui dès 1953 et ce durant 20 ans. La revue est une véritable tribune pour la publication de ses réalisations dès le numéro 46 daté de 1953. Candilis publie également des articles qui se rapportent à sa pratique ou qui l'explicitent. Les plus importants sont «L'esprit du plan de masse de l'habitat» paru dans l'Architecture d'Aujourd'hui n ${ }^{\circ} 57$ de 1954 mais surtout l'article intitulé «A la recherche d'un sens nouveau du mot architecte» paru en 1975 : «La responsabilité et le rôle de l'architecte parmi les gens qui prennent les décisions pour l'avenir deviennent de plus en plus importantes. Jamais, dans l'évolution de l'humanité, sa présence n'a été aussi nécessaire. Depuis le

\footnotetext{
49 Demetriades Dimitri \& Papadaniel Dimitri, Entretiens avec Georges Candilis, Article de la revue des Ingénieurs et architectes suisses, 1994
} 
commencement de notre siècle, l'apparition de très timide de la notion dite "urbanisme" domine de plus en plus la vie de la société. L'architecture et l'urbanisme se confondent aujourd'hui en une seule discipline, celle de "l'art de bâtir", action étroitement liés à la condition et à la possibilité pour l'homme d'agir, de penser et d'aimer. L'acte de bâtir ne peut plus être pris comme un acte isolé, privilège exclusif d'une profession ou d'un corps constitué. C'est une action collective qui concerne tout le monde, se confond avec la vie même» ${ }^{50}$

Candilis publie également de nombreux articles sur l'architecture en général et sa diffusion mais aussi sur le rôle de l'architecte dans Techniques et Architecture, le Carré bleu, Architectural Design, Architecture Formes Fonctions, Bauwelt, Bauen + Wohnen ce qui lui confère une audience qui dépasse largement les frontières de l'hexagone.

De même concernant l'enseignement de l'architecture Candilis s'y implique fortement jusqu'au début des années 80 où il est alors professeur à l'UP6. Ainsi dès 1963 Candilis et Josic fondent l'atelier extérieur Candilis-Josic, les étudiants se retrouvant régulièrement dans les locaux de l'équipe rue Dauphine. L'année 1965 est l'occasion pour Candilis de commencer à enseigner à la tête de l'un des six ateliers (au sein du groupe C) de l'Ecole Nationale Supérieure des Beaux-Arts qui s'installent au Grand Palais. Sa création est un événement majeur dans l'École des beaux-arts de l'avant Mai 68.

Candilis va rédiger quelques pages où il indique «Aux matières scientifiques complémentaires exigées dans l'enseignement de l'Architecture : les mathématiques, la physique, la chimie, le génie civil, la statique et la mécanique théorique, s'ajoutent aujourd'hui au même titre, et de même importance la sociologie et l'économie politique, la psychologie et la logique, l'histoire et la géographie appliquées, la biologie, le droit et la philosophie... Une cuvre bâtie, une construction, devient "Architecture » quand elle exprime avant tout l'essence de son temps » et de conclure : «A l'enseignement d'hier qui avait pour base : apprendre comment il faut construire, doit s'ajouter un enseignement plus ouvert qui doit aider à concevoir ce qu'il faut construire, car demain il ne suffira plus simplement de connaître mais il faudra comprendre, imaginer et créer un monde nouveau, meilleur que celui d'hier, et pour cela nous devons pouvoir aller jusqu'au cœur de la vérité» ${ }^{51}$ :

\section{Acknowledgements}

Ines Zalduendo, Special Collections, Frances Loeb Library / Harvard University GSD

Shelley Hayreh, Avery Architectural and Fine arts Library, Columbia University

\section{Sources of Images :}

Image 1 : Dépliant de présentation pour le 7e congrès CIAM à Bergame, Special Collections, Frances Loeb Library / Harvard University GSD

Image 2 : Immeuble à Sidi Bel Abbès, Candilis \& Woods architectes, 1954 Woods Archives, Avery Architectural and Fine arts Library, Columbia University

Image 3 : Candilis Georges \& Woods Shadrach photographie dessin sur calque Habitation collective marocaine, recherches sur la trame Modulor, Déc.1951, Woods Archives, Avery Architectural and Fine arts Library, Columbia University

\footnotetext{
${ }^{50}$ Candilis Georges « A la recherche d'un sens nouveau au mot architecte » Architecture Formes Fonctions n ${ }^{\circ} 151969$ p.1321, texte repris et complété dans l'Architecture d'Aujourd'hui n 177 «TEAM $10+20$ », Février 1975 p. 50 \& 51

${ }^{51}$ Candilis Georges «Schéma pour une orientation vers la réforme de l'enseignement de l'architecture » Avril 1965, Texte non publié, Fonds Candilis CAP CANG 318/01
} 
Image 4 : Revue СОВРЕМЕННАЯ АРХИТЕКТУРА, l’Architecture contemporaine $n^{\circ} 4 \& 5$, archives Famille Candilis

Image 5 : Immeuble Sémiramis, Carrières Centrales, Casablanca, Candilis \& Woods architectes, Woods Archives, Avery Library, Columbia University

Image 6 : croquis et schémas d'intention, extension de Bagnols sur Cèze, Candilis/Josic/Woods Woods Archives, Avery Architectural and Fine arts Library, Columbia University

Image 7: Les Escanaux à Bagnols sur Cèze, Candilis/Josic/Woods architectes, vue du ciel, tirée de La Construction Moderne Française, fascicule, 1965, CAP Fonds Candilis

Image 8 : les acteurs des CIAM (après 1945) et de Team X

Image 9 : Vue aérienne Free University Berlin tirée de University Planning and Architecture, The Search for perfection, 2011, crédit photographique : Bavaria Luftbild/Freie Universität Berlin

Image 10 : Meubles en bois de Georges Candilis et Anja Blomsted, exposition «Parallélisme géométrique » par Clément Cividino, Fondation Vasarély, Février 2015

Image 11 : Couverture du livre de Georges Candilis, Meubles en bois courbé, Stuttgart - Zurich: Krämer Verlag, 1980 ,

Image 12 : Georges Candilis devant l'hexacube Fond Candilis CAP CANGE/H/ND/15

\section{Bibliography / references}

Abram Joseph: L'architecture moderne en France, Paris: Picard, 2000

Bois Yve-Alain and others: De Stijl et l'architecture en France, Bruxelles: Mardaga, 1985

Candilis Georges, Josic Alexis, Woods Shadrach: Proposition pour un habitat évolutif, Techniques et Architecture ${ }^{\circ} 2,1959$

Candilis Georges: A la recherche d'un sens nouveau au mot architecte, Architecture Formes Fonctions $\mathrm{n}^{\circ} 15$ 1969

Candilis Georges: A la recherche d'un sens nouveau au mot architecte, l'Architecture d'Aujourd'hui $\mathrm{n}^{\circ} 177$ «TEAM $10+20 »$, Février 1975

Candilis Georges: Bâtir la vie, un architecte témoin de son temps, Paris: Stock, 1977

Candilis Georges: Meubles en bois courbé, Stuttgart - Zurich: Krämer Verlag, 1980

Cohen Jean-Louis ; Eleb Monique: Casablanca : Mythes et figures d'une aventure urbaine, Paris: Hazan, 1998

Coulson Jonathan; Roberts Paul; Taylor Isabelle: University Planning and Architecture, The Search for perfection, London - New York: Routledge, 2011

Demetriades Dimitri \& Papadaniel Dimitri: Entretiens avec Georges Candilis, Revue des Ingénieurs et architectes suisses, 1994

Lucan Jacques: Composition, non-composition Architectures et Théories, XIXe-XXe siècles, Lausanne: Presses polytechniques et universitaires romandes, 2009

Mumford Eric: The CIAM discourse on urbanism 1928-1960, Cambridge: MIT Press, 2000

Pedret Annie: Team X, an archival history, London - New York: Routledge, 2013

Ragot Gilles ; Dion Mathilde: Le Corbusier en France , Paris: Le Moniteur, 1987

Sarkis Hashim: CASE: Le Corbusier's Venice Hospital and the Mat Building Revival, Munich-London-New York: Prestel Verlag, 2001

Smithson Alison \& Peter: Collective Housing in Morocco" Architectural Design, janvier 1955 
Smithson Alison: How to recognize and read a mat building », Architectural Design Septembre 1974

Woods Shadrach: Stem Architectural Design n5 1960

\section{Documents :}

\section{Fonds CAP CANDILIS Georges (1913-1995): CANGE}

Candilis Georges «Schéma pour une orientation vers la réforme de l'enseignement de l'architecture »Avril 1965, Texte non publié, Fonds Candilis CAP CANG 318/01

La Construction Moderne Française, fascicule, 1965

L’Hexacube / le cubing : tourisme-loisirs-travail CANGE/H/ND/15

Woods Archives, Avery Architectural and Fine arts Library, Columbia University

Photographie Immeuble à Sidi Bel Abbès, Candilis \& Woods architectes, 1954

Photographie dessin sur calque Habitation collective marocaine, recherches sur la trame Modulor, Déc.1951

Photographie Immeuble Sémiramis, Carrières Centrales, Casablanca, Candilis \& Woods architectes

Croquis et schémas d'intention, extension de Bagnols sur Cèze, Candilis/Josic/Woods architectes

Special Collections, Frances Loeb Library / Harvard University GSD

Lettre du 23 Juillet 1956 de Le Corbusier adressé au Xe congrès des CIAM à Dubrovnik CIAM Special Collections

Dépliant de présentation de l'Unité d'Habitation de Marseille pour le $7^{\mathrm{e}}$ congrès CIAM à Bergame

Candilis Georges, Minutes de la réunion des CIAM, Londres 28-29 Août 1954, CIAM Special Collections

\section{$\underline{\text { Archives Famille Candilis }}$}

Revue СОВРЕМЕННАЯ АРХИТЕКТУРА, l'Architecture contemporaine $n^{\circ} 4 \& 5$

Lettre de Le Corbusier à Candilis datée du 24 Mai 1949 


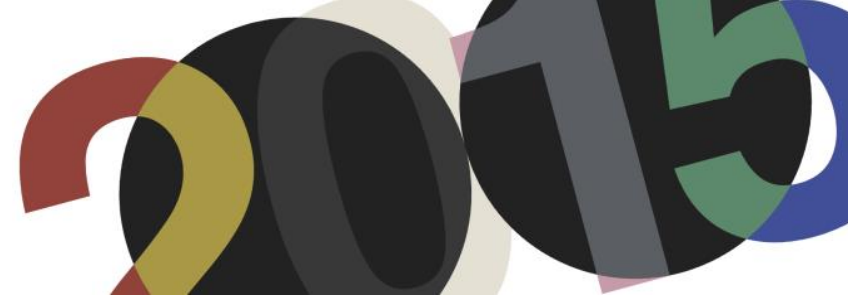

DOI: http://dx.doi.org/10.4995/LC2015.2015.652

\title{
Concevoir aujourd'hui un film sur la villa Savoye
}

\author{
A. Dyephart \\ Ecole Nationale Supérieure d'Architecture de Paris-Belleville
}

Résumé: Si de nombreuses images de la villa Savoye existent, par contre peu de films sont centrés sur elle. Je souhaite présenter ici un projet de film documentaire que je développe depuis 2012. Sur cette villa considérée comme une icône de l'architecture moderne, et déjà tant étudiée, je propose un regard un peu décalé, nourri à la fois par ma formation d'architecte et mon expérience de réalisatrice. J'aborde en particulier la question de l'impact de cette architecture; comment est-elle perçue au XXIème siècle, en quoi peut-elle influer sur notre façon d'envisager l'espace?

Je développerai un aspect de ma démarche qui touche au rapport entre architecture et cinéma: comment montrer la villa par un film? autrement dit comment traduire ce qu'elle représente par des images animées, des sons, mais aussi des 'évènements' qui dévoilent les contrastes de lumière et d'ambiances? De quoi cette architecture est-elle le récit? Ou, comme le proclame une des questions-slogans de Bernard Tschumi : "Et si l'architecture était autant une question de mouvement et d'évènement que d'espace?"1.

Resumen: Si existen numerosas imágenes de la Villa Savoye, escasos son, en cambio, los films que traten de ella. Deseo presentar aquí un proyecto de film documenta, sobre el que estoy trabajando desde el año 2012. Propongo una vision un poco desfasada, nutrida al mismo tiempo por mi formación de arquitecta y mi experiencia de cineasta, sobre esta obra ya tan estudiada, icono de la arquitectura moderna. Abordo especialmente la cuestión del impacto de esta arquitectura; ¿cómo es percibida en el siglo XXI?, ¿qué influencia puede tener en nuestra manera de considerar el espacio?

Desarrollaré un aspecto de mi trabajo que trata de la relación entre la arquitectura y el cine: como mostrar la Villa Savoye en un film? Es decir, como traducir lo que ella representa a través de imágenes animadas, sonido y "acontecimientos" que rebelen los contrastes de luces y de ambientes? ¿ De qué da cuenta esta arquitectura? $O$, como lo proclama una de las preguntas-eslogan de Bernard Tschumi: “¿Y si la arquitectura fuera tanto cuestión de movimiento y de acontecimiento como de espacio?"

Mots-clés: villa Savoye ; film documentaire ; transmission ; création ; recherche formelle.

Palabras clave: villa Savoye, película documental, transmisión, creación, investigación formal.

\section{Questions de points de vue}

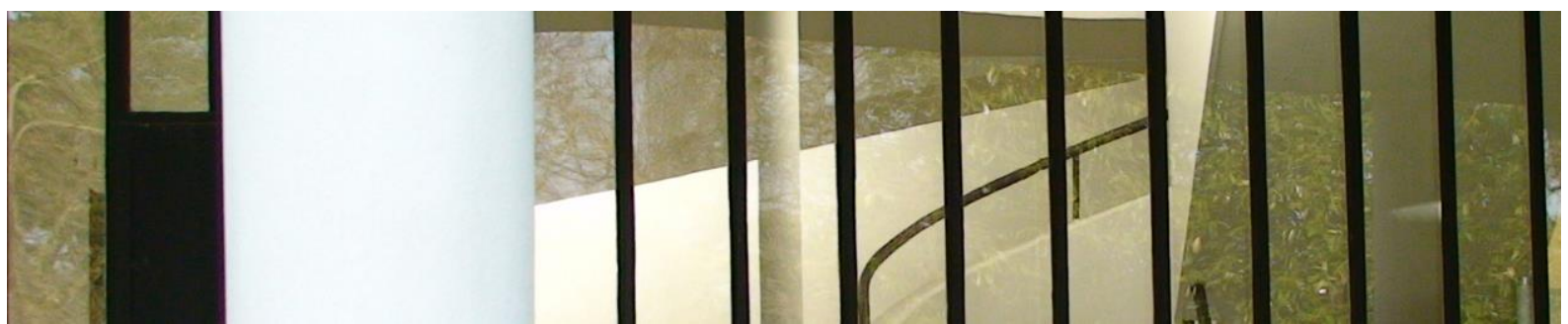

1. Photographie de repérage, hall de la villa Savoye (A.D. 2013). ( F FLC

\footnotetext{
${ }^{1}$ Tschumi, Bernard : Exposition Rétrospective Centre Georges Pompidou 2014.
} 


\subsection{Réception de l'architecture, fenêtre télévisuelle}

Architecte DPLG, je me suis formée à la réalisation de films à la fin des années 90 . Je voulais m'approprier cet outil visuel qui présente l'avantage de concilier des approches plastiques, sonores, textuelles et temporelles, afin de participer à la sensibilisation du public à l'architecture. Le documentaire de création était alors une forme en plein développement, porteuse d'innovation. J'ai également entamé des recherches sur la représentation de l'architecture contemporaine, sur les chaînes publiques françaises de télévision, depuis les années 1960 jusqu'aux années 1990. J'ai mené cette étude dans le cadre d'un DEA puis d'un contrat avec le Ministère de la Culture $^{2}$, motivée par plusieurs constats. Depuis la fin de mes études d'architecture, j’étais frappée par le fossé séparant souvent architectes et habitants, et j'étais convaincue que la discipline architecturale gagnerait à être plus largement connue. J'étais tout aussi intriguée par une présence parcimonieuse et assez formatée de l'architecture sur ce media populaire. Je croyais encore à la mission éducative de la télévision et je savais qu'en France le documentaire était financé principalement par les chaînes publiques. Je voulais donc analyser les films sur l'architecture qui avaient été diffusés, interroger les fréquences de ces diffusions et leurs formes, leur évolution dans le temps, espérant comprendre ce phénomène.

Cette recherche a confirmé le désintérêt des programmateurs de chaînes françaises pour le sujet. Les années 1980 avaient pourtant vu se développer des tentatives pour montrer l'architecture d'une manière vivante, dans une diversité de durées, de formes, en osant des approches originales parfois transdisciplinaires. Mais cette embellie fut de courte durée. Depuis les années 2000, on constate même de plus en plus une sorte de rejet. Les programmateurs de chaîne considèrent l'architecture comme un sujet élitiste, qui ne peut intéresser le public. Aussi, quand ils acceptent de l'aborder, ils préfèrent le portrait de star ou l'actualité médiatique à l'exploration d'une oeuvre ou d'un thème architecturaux. En dehors de la collection de monographies 'Architectures', d'ailleurs très bien faite mais assez fermée, diffusée par la chaîne Arte, point de salut ${ }^{3}$. Cette fermeture est-elle spécifique au monde de la télévision, ou fait-elle partie d'une incompréhension partagée par d'autres acteurs de la société, regardant l'architecture comme 'un monde à part' ne les concernant pas ? La question est à creuser.

Pour revenir à l'image animée j'ai constaté, d'abord comme cinéphile puis dans mes expériences de réalisatrice, les liens intimes existant entre architecture et cinéma. J'ai conçu mon tout premier court-métrage de manière intuitive, en dessinant un story-board, et j'avais l'impression de renouer avec ma pratique du projet architectural. Les relations architecture-cinéma sont d'ailleurs sporadiquement le prétexte de débats ou colloques. Ainsi en 1998, une série de rencontres intitulées 'un architecte, un cinéaste' ont été programmées au Centre Pompidou, présentées par Hubert Damish ${ }^{4}$. Ces dialogues révélaient les nombreux croisements tissés entre ces deux disciplines, architecture et cinéma, des rapports sans doute profonds mais parfois difficiles à cerner. On y sentait aussi l'intérêt réciproque entre architectes et cinéastes. Parmi ces derniers, cependant, plusieurs affirmaient la difficulté à filmer l'architecture.

\footnotetext{
${ }^{2}$ Existe-t-il un espace public télévisuel pour l'architecture contemporaine? DEA Cinéma, Télévision, Audiovisuel, Paris1 Panthéon-Sorbonne, 1999. Complété par une recherche pour la DAPA, Ministère de la Culture, Paris 2001 : Panorama des sources documentaires audiovisuelles sur le thème de l'architecture et la ville diffusées par les chaînes publiques hertziennes. Études signées de mon nom d'état civil : Annick Pancher.

3 "En dehors de la collection, il arrive que nous faisions un projet isolé, mais il faut vraiment qu'il soit particulier (...) La collection Architectures, c'est assez pour parler d'architecture." Thierry Garrel, Responsable de l'Unité de Programmes Documentaires ARTE, 1999, entretien mené dans le cadre du DEA déjà cité Existe-t-il un espace public télévisuel pour l'architecture contemporaine?

${ }^{4}$ Un architecte - un cinéaste: Cycle de débats animés par Hubert Damisch, dont les rencontres entre Alain Fleischer et Bernard Tschumi, Pierre Riboulet et Jean-Louis Comolli, Henri Gaudin et Cédric Klapish, Robert Kramer et Rem Koolhaas, au Centre Georges Pompidou, 1998.
} 
Cette résistance au film explique-t-elle la rareté des documentaires sur l'architecture ? Est-elle liée à la nature de l'architecture, ou à une certaine rigidité dans le regard porté sur elle ? Lors des rencontres évoquées plus tôt, Jean-Louis Comolli dialoguait avec Pierre Riboulet, pour qui il a réalisé le très beau documentaire Naissance d'un hôpital ${ }^{5}$. Il affirmait "Ce qui est gênant dans la relation du cinéma à l'architecture, c'est qu'elle se présente comme quelque chose de visible, c'est le piège, le leurre (...) le cinéma aura peut-être le désir de faire apparaître à l'intérieur de l'architecture ce qui est dissimulé." En me remémorant certains de ces échanges, je suis convaincue qu'une véritable recherche formelle s'impose pour filmer l'architecture.

Pour recentrer mon propos, donc, je pars de ce constat : l'architecture n'a pas 'bonne presse' chez les diffuseurs. Peur d'un sujet mal connu? incompréhension ? Leur attitude pose la question de la réception de l'architecture. Et ce désintérêt décourage les initiatives de réalisateurs et de producteurs dans ce domaine. Il faut donc pour développer ce type de projet une vraie conviction. La mienne est que l'innovation dans l'écriture filmique a un rôle à jouer dans cette transmission de l'architecture. Comment mieux en parler qu'à travers un projet concret ?

\subsection{La villa Savoye, images}

La villa Savoye s'est imposée à moi pour ce projet de film. Peut-être parce que dès mes études, en décryptant ses plans et photos, j'y ai senti une pointe de mystère. Et que ma première visite à la villa est nimbée de cette lumière particulière qui enveloppe une première journée sous la neige, un jour de janvier, alors que jeune architecte diplômée j'entre dans ce parc, je marche au milieu des arbres et découvre une silhouette à la fois frêle et assurée, blanche sur fond blanc, autour de laquelle papillonnent les silhouettes sombres des autres visiteurs. Émotion forte qui s'enrichit au fil de la découverte.

La villa Savoye est aussi un lieu de contradictions. Monumentale dans son allure et pourtant accueillante, à l'échelle de l'homme ; généreuse par la qualité et la variété de ses espaces, et pourtant austère, sobre par ses matériaux ; villa 'blanche' faisant chanter des couleurs. Jalon dans l'oeuvre de Le Corbusier, elle représente une synthèse de ses expérimentations sur l'espace domestique avant de construire à plus grande échelle ; mais elle fut très peu habitée. Enfin la villa saisit par un mélange de rigueur et de poésie, elle exprime une certaine idée de l'architecture, et de la vie. À la fois photogénique et invitant au mouvement, par la promenade architecturale qu'elle incarne, elle donne envie de la filmer. Qu'est-ce qu'un film ? Une capture du réel par l'image animée : la possibilité d'une continuité, un travail de cadrage, une attention à la lumière et au mouvement, une succession de séquences, la recherche d'un rythme. Ceci est un raccourci, bien sûr, mais au-delà des cinq principes d'une architecture moderne, les mêmes termes pourraient être utilisés pour évoquer les villas dites 'blanches' des années 1920, en particulier la villa Savoye. Son caractère emblématique, la singularité de son destin et la pérennité de son empreinte en font un personnage idéal pour un film qui souhaite inviter un public de néophytes à mieux appréhender l'architecture.

Que montrent les videos amateur captées par des visiteurs et proposées sur des sites publics tels 'youtube' ou 'dailymotion'? Le visiteur-filmeur nous embarque dans son parcours, avec ses à-coups, ses surprises, mais aussi ses difficultés à restituer la magie de cette promenade. Pourquoi ? Parce qu'une image embarquée sur un itinéraire figé (presque toujours le même dans toutes les vidéos) réduit le champ du perceptible, laissant à peine au regard le temps de l'adaptation aux différentes échelles et ambiances, la possibilité d'un recul, ne lisant que les évidences. Surtout il manque une structure, un récit, un propos : ce qu'un film construit peut tenter de restituer, mais non une simple captation.

\footnotetext{
${ }^{5}$ Naissance d'un hôpital : documentaire de Jean-Louis Comolli, 1h07, 1992, tiré du livre Naissance d'un hôpital de Pierre Riboulet, Editions Plon, 1988.
} 
Le court métrage Architecture d'aujourd 'hui ${ }^{6}$, réalisé dès 1931 par Pierre Chenal, montre la villa Church, la villa Stein et la villa Savoye à peine terminée. Les images sont émouvantes par le grain et les discontinuités du mouvement, l'allure et les vêtements des personnages, qui suggèrent fortement leur époque. Elles mettent en avant les espaces extérieurs, et transmettent la dynamique si importante pour Le Corbusier. La brève séquence sur la villa Savoye, par exemple, met en scène une femme qui gravit la rampe extérieure.
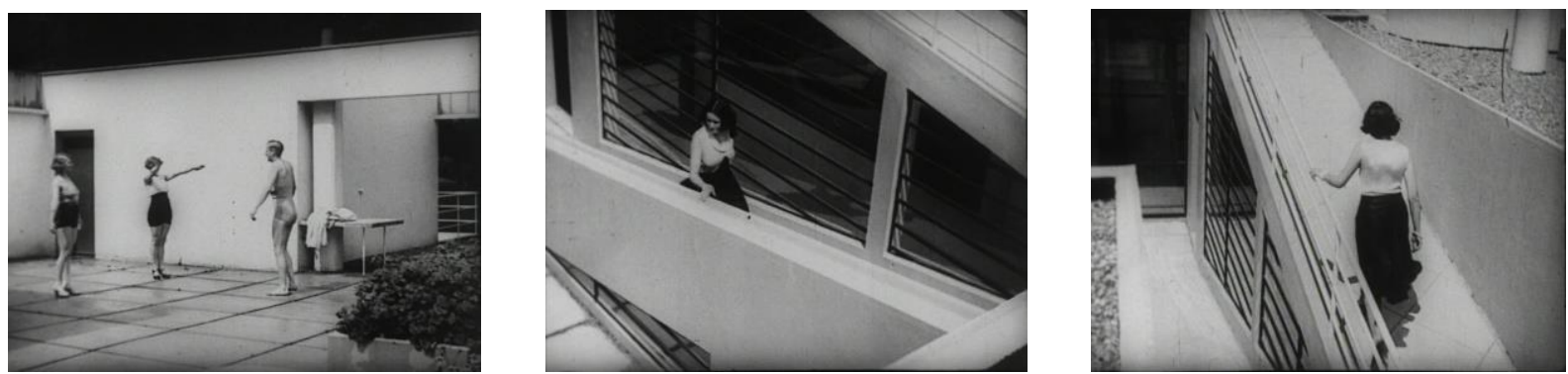

2. - 3. - 4. Photogrammes du film ‘Architectures d'aujourd'hui' de Pierre Chenal, 1931. @ FLC

Le seul film à ce jour entièrement consacré à la villa Savoye, Le Corbusier - villa Savoye ${ }^{7}$, est écrit et présenté par l'historien Tim Benton en 1973. C'est un documentaire didactique, diffusé par la BBC pour l'Open University. Tim Benton y est un guide qui parcourt la villa pour décrypter en quoi elle est une 'machine à habiter', et pointe ses particularités formelles et fonctionnelles.

Mon projet de film propose un éclairage différent, en interrogeant la villa Savoye sur sa vivacité, ce qu'elle nous transmet aujourd'hui, et l'esprit de création.

\subsection{Dialogue entre film et architecture}

Cette communication vise à témoigner de la démarche suivie pour concevoir un tel film. Elle s'appuie sur mes interrogations quant à la manière de transmettre les qualités d'une oeuvre architecturale. Ce travail montre que l'écriture d'un documentaire s'établit sur un réseau de relations avec son sujet, dont découle une forme. Elle peut s'assimiler à un processus de recherche.

Parce qu'il permet de parcourir l'espace, de le découper, de le simuler, d'y inclure des personnes et des actions dans une continuité, le film est un véritable outil de médiation pour l'architecture. Il permet une approche plus synthétique qu'un texte ou une image fixe, il les complète et invite à la visite. Le film, fiction ou documentaire, explore et reconstruit tout à la fois des lieux, dans une certaine durée, par le choix des vues et le rythme du montage.

Un film documentaire se distingue du reportage en ce qu'il est écrit, composé, et porté par des intentions d'auteur. Il ne s'agit pas d'un travail journalistique, se voulant objectif. Un film documentaire apporte des informations sur un sujet, mais il est aussi l'expression d'un regard personnel sur ce dernier, le résultat d'une démarche subjective. C'est pourquoi le documentaire peut prendre des formes très variées, montage d'archives, suite d'interviews, enquête, reconstitutions, immersion dans un milieu, création poétique, etc. L'histoire du documentaire montre aussi qu'il a toujours joué avec les limites de la fiction. Comme l'exprime autrement le réalisateur et essayiste Jean-Louis Comolli "Tout est récit au cinéma et un film documentaire est un récit autant qu'un film de fiction" ${ }^{8}$. Le documentaire, par les images et les situations filmées autant que par des discours, questionne son sujet. Il vise à en approfondir la compréhension, et dans ce but recompose, interprète, met à

\footnotetext{
${ }^{6}$ Architecture d'aujourd 'hui, film 16mm, N\&B, muet, réalisé par Pierre Chenal, 10min, 1931.

${ }^{7}$ Le Corbusier-Villa Savoye, film 16mm réalisé par Tim Benton, couleur, sonore, 24min., 1973.

${ }^{8}$ Rencontre avec Pierre Riboulet, dans le cycle un architecte-un cinéaste, déjà citée.
} 
distance. A condition de mener une véritable recherche de points de vue pertinents, et d'offrir au spectateur cet écart nécessaire pour qu'il trouve sa propre lecture, le documentaire sur l'architecture permet de transformer le regard, le décaler, le préciser, pour déployer notre perception et notre connaissance du sujet. Il devient outil de connaissance.

Je ne résiste pas à la tentation du clin d'oeil. Dès les années 1920 Le Corbusier souhaite que son architecture soit filmée ; il sollicite en particulier Pierre Chenal pour réaliser les films Bâtir (1928) et Architecture d'aujourd'hui (1931) déjà cité, et Jean Epstein pour Les bâtisseurs (1931). Il utilise l'accumulation de photographies dans une conférence de 1924 "censée produire un défilement cinématographique"9 pour montrer la villa La Roche, comme le rapporte Clotilde Simond. Il a enregistré lui-même quelques bobines de film avec une caméra $16 \mathrm{~mm}$, en 1936 et 1937, vues de son voyage en Amérique latine, d'éléments de nature, de quelques intérieurs. "Le brutalisme des cadrages et les fréquentes contre-plongées rapprochent le cinéma de Le Corbusier de celui de deux cinéastes qui ont intéressé le maître : l'un très connu dès les années 1920, Sergueï M.Eisenstein, et l'autre moins célèbre, Maya Deren, dont il fera l'éloge dans les années 1940,10 note Claude Prelorenzo dans un article où il explore ces images animées, alternant avec des photographies prises avec la même caméra. Ces courtes séquences filmées sont restées longtemps confidentielles, mais confirment un véritable intérêt pour une technique qui permet de représenter un regard en mouvement. Ses jugements sur le cinéma évolueront au cours du temps. Il privilégie d'abord le documentaire, comme le souligne Arnaud François dans un article de $1996{ }^{11}$ : "Voilà pourquoi il fit faire tant de films sur ses architectures, pour que le public puisse en saisir la vivacité. Les documentaires qu'il réalisa sur ses constructions avaient deux objectifs : d'une part présenter son oeuvre, et d'autre part mettre en avant le regard subjectif, l'intensification de la vision qui structure son architecture." Recherchant l'efficacité des films pour promouvoir son architecture, il s'ouvre aussi à une utilisation de la mise en scène. Ainsi il incarne son propre rôle dans La vie commence demain ${ }^{12}$, où il dialogue avec l'acteur JeanPierre Aumont qui joue le naïf sur le chantier de la Cité Radieuse de Marseille. Dans les années 1950 il aura le projet d'une véritable fiction au même endroit, avec Camus comme scénariste ${ }^{13}$, projet qui ne semble pas s'être concrétisé.

\section{Filmer la villa Savoye, explorer}

"Suggérer, c'est créer. Décrire, c'est détruire".

Cette phrase de Doisneau m'accompagne depuis longtemps et imprègne ce projet.

\subsection{Le point de vue du film : de l'importance des personnages}

Pour ce projet de film sur la villa Savoye, ma démarche s'appuie dans son intention sur la formule exprimée très tôt par le héros de ce colloque : 'une architecture pour émouvoir' ${ }^{14}$. Jeune étudiante, découvrant en même temps

\footnotetext{
${ }^{9}$ Simond, Clotilde : Cinéma, architecture, arts technologiques : pour quel être ensemble ?, in In situ-de visu-in motu, Infolio éditions, 2014.

${ }^{10}$ Prelorenzo, Claude : Quand Corbu faisait son cinéma, in Le Visiteur $\mathrm{n}^{\circ} 17,2011$.

${ }^{11}$ François, Arnaud: La cinématographie de l'oeuvre de Le Corbusier, in Cinémathèque, printemps 1996.

${ }^{12}$ La vie commence demain : film $35 \mathrm{~mm}$ réalisé par Nicole Védrès et Jean-Pierre Aumont, N\&B, sonore, commentaires écrits par Le Corbusier, 96min, 1949.

${ }^{13}$ François, Arnaud : article cité ci-dessus.

${ }^{14}$ Le Corbusier : "L'ARCHITECTURE est un fait d'art, un phénomène d'émotion, en dehors des questions de construction, au delà. La Construction, C'EST POUR FAIRE TENIR; l'Architecture, C'EST POUR EMOUVOIR." in Vers une architecture, 1923.
} 
les ordres de l'architecture antique et les élans de l'architecture moderne, je me souviens avoir été intriguée par le mélange de liberté et de rigueur que je lisais dans les dessins de Le Corbusier. Les photos, les plans de ses constructions, et surtout ses croquis perspectifs avaient sur moi le pouvoir du rêve, de la suggestion. Ils me donnaient accès à une façon 'autre' d'envisager notre mode de vie.

J'ai retrouvé en visitant la villa Savoye cette impression d'un lieu permettant d'accéder à d'autres possibles, d'agrandir mon quotidien. J'y vois une force mystérieuse, parce qu'elle cristallise un moment fort d'une pensée architecturale, expérimente des principes encore efficaces aujourd'hui. Les infiltrations d'eau, puis bien plus gravement la guerre de 1940 ont causé des dommages qui ont bouleversé l'usage de la villa Savoye, jusqu'à ce qu'elle soit menacée de destruction à la fin des années 50. Vous en connaissez l'histoire. Devenue monument historique et restaurée laborieusement, elle ne contient aucune trace de ses habitants, ce qui provoque chez certains visiteurs une impression de vide, voire de froideur.

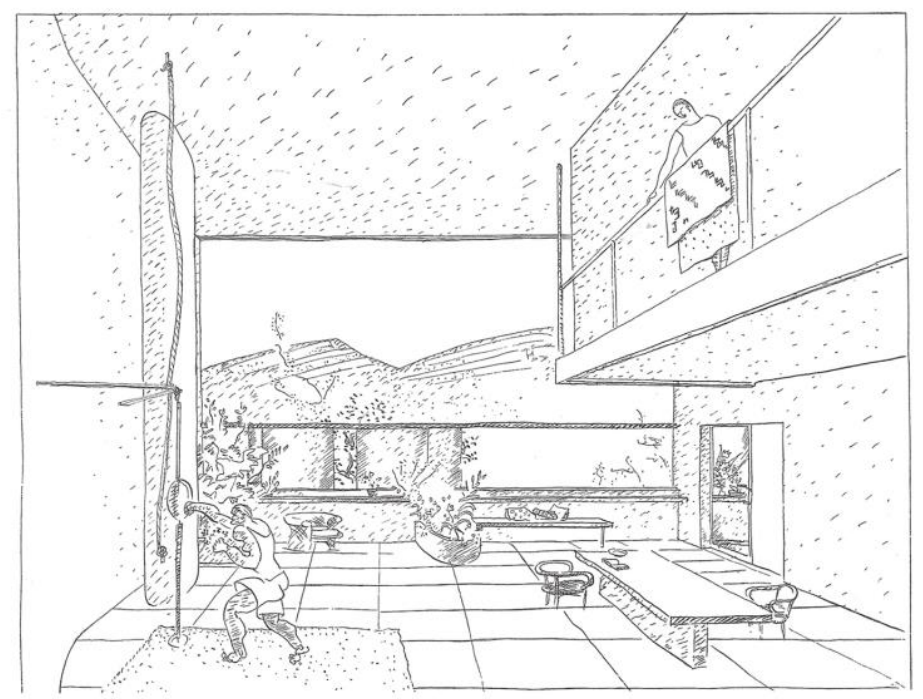

5. Projet Wanner, Genève 1928/29 in Oeuvre complète de Le Corbusier 1910-1929 @ FLC

Les esquisses du Corbu ouvraient et animaient le cadre du logis, en jouant des règles de la perspective pour mieux suggérer la continuité des espaces, en cadrant le paysage et en l'invitant à l'intérieur de l'habitat. L'insertion de petites scènes de vie dans ses croquis amplifiait la sensation de dépaysement et de détente: un boxeur s'entraînant au punching-ball sur une terrasse, un couple prenant un café dans la maison du contremaître, des enfants jouant sur le tapis du salon. L'esquisse est investie par Le Corbusier de plusieurs rôles : note et représentation, mais aussi pensée du projet par "la simulation de différentes solutions" comme l'envisage Gérard Monnier dans son article Esquisse de $1987^{15}$. "Souvent délivrées sous la forme de messages personnels, les esquisses correspondent en fait au moment où l'investissement individuel de l'architecte est à son sommet, avant le développement du travail en agence ". Les personnages et actions qui y sont parfois croqués introduisent également une narration dans l'architecture projetée.

De même, les 'objets à réaction poétique' participent à l'espace, et des objets de la vie quotidienne figurent sur les photos de ses réalisations des années 20, comme les cannes de golf posées dans le vestibule de la villa Savoye. A contrario des dessins 'habités', dans l'espace réel ce sont donc les objets qui suggèrent une présence non directement montrée. Ces artifices introduisent néanmoins la vie dans l'architecture, dès l'étape du projet. Ils participent au travail de communication, d'ailleurs considérable, de Le Corbusier et favorisent une projection du

15 'Esquisse' Gérard Monnier in Le Corbusier, une encyclopédie, Ed du Centre Georges Pompidou/CCI, Paris 1987. 
lecteur ou du visiteur dans ces espaces nouveaux, en écho à "l'investissement individuel de l'architecte " décelé par Gérard Monnier.

La villa Savoye semble conçue pour accueillir et réunir. Nous ignorons presque tout de la manière dont elle a été habitée, beaucoup pensent qu'elle n'est pas vraiment faite pour cela, et pourtant elle attire visiteurs et créateurs. C'est pourquoi la question des personnages est centrale dans mon projet de film. La perception engage les sens, l'esprit et l'imaginaire. Les thèmes induits par la villa se déclineront sur ces trois registres.

\subsection{L'approche documentaire}

Dans ce projet, la forme du film, indissociable du sujet, se doit d'être inventive. Tenter de refléter un regard architectural par une proposition cinématographique, en évitant l'analogie formelle directe. Pour répondre à la fluidité de l'espace, à la diversité des sensations et des perspectives dans la villa, à la transdisciplinarité et la recherche de synthèse artistique de Le Corbusier, le film cherche à incarner ces qualités plutôt que de les décrire.

A partir de mes souvenirs personnels et de mes photographies, j'ai cherché à retrouver mes sensations de découverte de la villa ; j'en ai parlé, j’y suis retournée, j'ai suivi une visite guidée. Assez rapidement j'ai cherché à rencontrer des interlocuteurs institutionnels, l'administrateur, la conservatrice, certains membres de la Fondation Le Corbusier. J'ai replongé dans les livres sur l'architecte, dans ses écrits, puis dans les archives. Je ne développerai pas ici toute cette partie de recherches documentaires, que vous connaissez. Parallèlement s'opère un travail de l'imaginaire, qui se nourrit de toutes ces données, certaines factuelles et d'autres plus psychologiques, afin d'entrevoir une direction pour le film.

En m'interrogeant sur la manière de filmer la villa Savoye, de ma mémoire de cinéphile surgissent quelques images fortes, associées à une ambiance, une couleur. Je revois les personnages hiératiques d'Alain Resnais dans L'année dernière à Marienbad (1961), déambulant dans un château et des jardins désertés, avec une gestuelle et un rythme hypnotisants. D'autres images reviennent, d'Antonioni ou de Tati. Parmi les artistes qui ont proposé des travaux dans la villa, la vidéo intitulée 'Singspiel', où Ulla von Brandenburg réunit en 2009 une 'famille' pour un repas dans le salon, m'avait marquée par sa force mais aussi une certaine familiarité avec mon propre projet, alors très embryonnaire. La sensation d'incommunicabilité et d'infinie répétition transmise par la chanson lancinante et une mise en scène montée en boucle hante l'esprit bien après son visionnage. J'y retrouve ma volonté d'investir vraiment le lieu, sans vouloir jouer sur cette corde de la mélancolie.

Je n'y ai pas pensé pendant tout le temps de l'écriture, mais je songe après coup au film Chronique d'un été réalisé par Edgar Morin et Jean Rouch en 1961. Les auteurs choisissent un panel de personnes de milieux différents, dont certaines parmi leurs amis, pour illustrer une diversité sociologique. Ils les filment dans des situations 'quotidiennes' mais préparées, un repas, une promenade dans la ville, pour tenter de faire émerger une expression sincère, naturelle. Ma démarche peut s'en rapprocher: créer des situations pour faciliter une libération de la parole et du geste, pour traduire une diversité de sensibilités à l'épreuve de la villa Savoye. À ce propos, Aline Caillet, dans son ouvrage sur les dispositifs, parle d' "expérience documentaire " : "le film, conçu comme une situation authentiquement vécue, les invite [les personnages-acteurs] à se produire, à s'inventer eux-mêmes dans le cadre posé." ${ }^{16}$. Pour atteindre à un niveau de profondeur, on doit renoncer à une improbable spontanéité. “Une personne, dès lors qu'elle est filmée, devient un personnage. Jouer son propre rôle, c’est encore -ou déjàen jouer un". 17

\footnotetext{
${ }^{16}$ Caillet, Aline. Chapitre 2 :Renégocier la fiction dans le documentaire'in Dispositifs critiques, Rennes 2014.

${ }^{17}$ Ibid
} 
Comme la conception d'une architecture, celle d'un film s'élabore au fil d'allers et retours entre le premier dessein et les contraintes du réel, les intentions et le possible, les lieux et leur accessibilité, les protagonistes, leur disponibilité et l'histoire qui peut se tisser avec eux et entre eux. Ce que j'expose ici de mon projet aurait pu se comparer à un Avant-Projet Définitif en architecture, assez avancé dans sa définition. Mais l'incertitude de sa production, en particulier celle d'une date de tournage conditionnée par un financement difficile, me pousse à le présenter comme un 'Work in progress'. Pour cette même raison, je ne ferai pas une description précise du traitement du film. J'en présente plutôt quelques caractéristiques en lien avec le sujet.

\subsection{Recherche de personnages}

"Pour donner chair à ses discours L.C. convoque une galerie de portraits, caricatures, êtres de fable. Il en brosse des tableaux simplistes. Il sait à la perfection utiliser à fin de démonstration des petits morceaux d'humanité qualifiés, stylisés par le rôle qu'il entend leur faire tenir" ${ }^{18}$ remarque Marie-Christine Loriers.

'Mes' personnages seront des êtres de chair, invités à jouer leur propre rôle dans des situations tout à fait réalistes au regard de leur activité. La difficulté, et le travail d'auteur de ce point de vue, consiste à favoriser des rencontres, puis de construire un cheminement vivant et humain à travers le film et dans la villa.

Dans ce but je choisis ces 'invités' selon des critères assez inhabituels pour un documentaire. Avant tout ils ont un rapport personnel avec la villa Savoye, au-delà d'un lien avec le lieu ou avec l'architecture par leur activité professionnelle, ce qui favorisera une lecture plurielle, des approches expérimentales, voire émotionelles. Gardien, chorégraphe ou petit-fils des habitants, ils pourront se passer le témoin en croisant des thématiques ou des souvenirs communs. Chacun d'entre eux est donc capable de se relier à un ou plusieurs autres invités. La question centrale du projet étant celle de notre perception actuelle de la villa Savoye, les invités s'exprimeront par le corps, la gestuelle, la parole, un crayon, le rythme, le regard, un texte poétique, un souvenir. Enfin ces choix sont indépendants de la renommée ou de la reconnaissance scientifique.

Ma méthode a donc consisté à définir des rôles possibles, une sorte de casting idéal à partir duquel j'ai recherché des personnes coïncidant avec ces attentes. Cette quête est longue, mais passionnante quand les personnes rencontrées incarnent une des facettes envisagées. Cela devient enthousiasmant quand la personnalité de l'invité appporte bien plus que ce que j'avais imaginé. Contacts, rencontres répétées, si possible dans des contextes de travail, le temps est nécessaire pour les écouter, les connaître. Les paroles entendues, les attitudes, les situations observées vont constituer le matériau avec lequel s'écrira plus précisément le film. Mais avant d'aborder cette étape, je vais présenter deux des rôles choisis pour illustrer mon propos.

\subsubsection{Les passeurs : regard, parole, dessin}

La question de la transmission s'incarne idéalement avec des étudiants en architecture. Par leur situation intermédiaire, à mi-chemin entre un public néophyte et des professionnels de l'architecture, les étudiants peuvent jouer le rôle de passeurs. Comment interrogent-il un de leurs professeurs, quel regard portent-ils? Sont-ils curieux, indifférents ou en opposition à cette architecture qui aura bientôt un siècle ? qu'en font-ils ? Ils représentent à la fois la découverte et l'élaboration d'un futur.

Je dirige rapidement mes recherches vers l'Ecole Nationale Supérieure d'Architecture de Paris-Belleville qui a hébergé pendant des décennies le groupe Uno, fondé par Henri Ciriani, Jean-Patrick Fortin, Edith Girard et Claude Vié. Ces architectes avaient élaboré à la fin des années 1970 une méthode d'enseignement dite 'verticale'

\footnotetext{
${ }^{18}$ Loriers, Marie-Christine : L'icône et le locuteur, p14, in Corbu vu par, ouvrage collectif 1987
} 
car pensée dans la continuité, pour accompagner les étudiants au fil des ans, et s'appuyant sur les apports de l'architecture moderne, particulièrement celle de Corbu. Il reste aujourd'hui peu d'enseignants de ce groupe. L'un d'entre eux, Alain Dervieux, s'est entièrement consacré à l'enseignement. Il communique facilement son énergie et son enthousiasme. Son axe de travail est 'le visible'. Très à l'écoute de ses étudiants, il les fait réfléchir par la pratique sur la perception visuelle qu'aura un habitant ou un visiteur dans les espaces qu'ils conçoivent, les invite en permanence à se mettre à la place de l'usager. Tout en les incitant à l'expérimentation, il leur fournit des outils de conception et d'analyse. Il considère l'architecture moderne, et en particulier la villa Savoye, comme une ressource pédagogique permanente.

Il propose ainsi à ses étudiants un exercice appelé le '30x30' inspiré par le carré de 20 mètres sur 20 de la villa. Sur le thème du plan libre, il leur demande d'aménager l'espace et d'apporter la lumière dans une bibliothèque, structure carrée portée par une trame de poteaux, en respectant certaines règles. Avec un préalable déterminant : le choix d'une 'hypothèse'. Chacun décide d'une notion qu'il veut investir. Il l'exprime par un mot, puis l'analyse afin de la décliner en trois temps qui lui permettront de la traduire spatialement, tout au long de l'exercice. 'Effervescence', 'nébuleuse', 'pluie d'or', 'envie'... les hypothèses sont le support d'une réflexion sensible sur l'espace. Ce choix fait, la première étape porte sur l'entrée: dessiner un poteau, son rapport à la dalle qu'il supporte, son jeu avec la lumière naturelle. Ce travail très élémentaire, qui part de presque rien, soulève déjà beaucoup de questions. Sa méthode progressive me semble idéale pour aider le spectateur à aborder quelques notions fondamentales d'architecture. J'ai suivi le travail du studio depuis deux ans, faisant connaissance avec les étudiants, sondant leurs préoccupations, observant leurs attitudes. Il existe des contrastes forts entre eux, quelques passionnés présentent spontanément leurs dessins et photos de la villa Savoye et d'autres bâtiments visités, certains plus indifférents se contentent de découvrir par le truchement d'Internet, mais je note toujours une dynamique d'ouverture. Je poursuivrai cette observation si possible jusqu'au moment du tournage, afin d'être suffisamment proche d'eux pour pouvoir recueillir une parole encore hésitante. En attente de financement, je dois tenir le projet 'prêt au tournage' et maintenir ces contacts essentiels. Je choisirai pour le film quelques étudiants qui s'expriment assez facilement par le dessin ou la parole. Je capterai les échanges avec leur enseignant avant de les filmer dans la villa, interrogeant, dessinant.
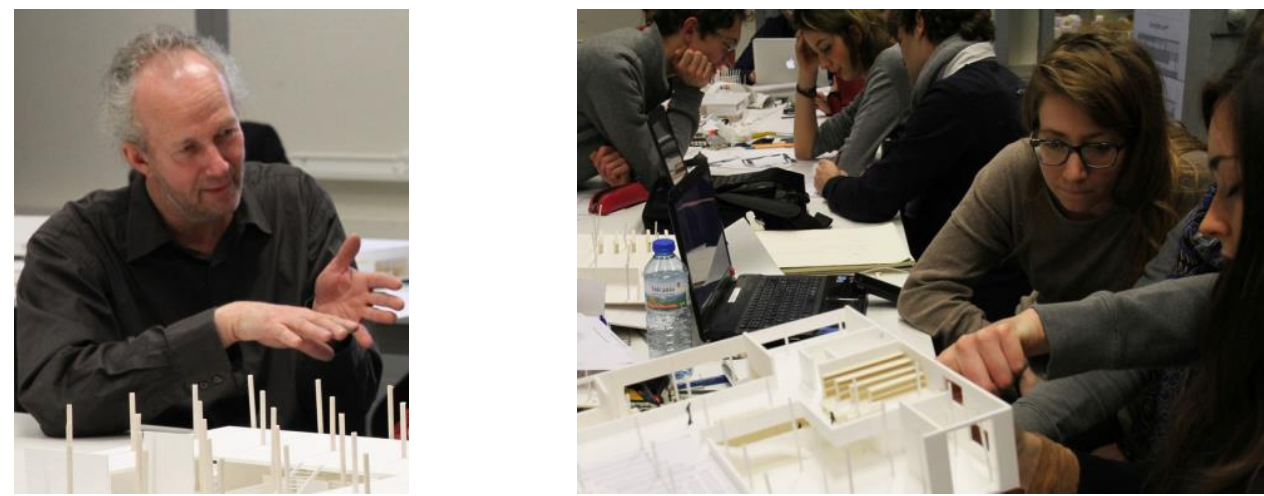

6. - 7. Alain Dervieux et quelques étudiants du studio 30x30, ENSA Paris-Belleville, 2014.

Assez rapidement, j'envisage l'intervention d'Edith Girard, architecte co-fondatrice du groupe Uno qui s'est un peu éloignée d'une certaine primauté de la forme. Parallèlement à son activité d'enseignante, elle a construit des logements collectifs avec beaucoup d'engagement, défendant une qualité des espaces individuels et communs. Dès la première rencontre je suis conquise par cette forte personnalité, volontaire et généreuse. Elle m'explique qu'au début de ses études elle n'était pas très sensible à l'architecture de Le Corbusier, et qu'elle devient de plus en plus 'fan' au fil des ans. Elle évoque la pédagogie du groupe Uno, basée sur le collectif, l'importance de 
notions telles que l'espace ouvert, la continuité, l'expérimentation, la place du dessin et de la maquette, du rapport direct à l'espace en l'arpentant. J'écris quelques situations du film où elle aura toute sa place. En assistant à plusieurs échanges entre elle et Alain Dervieux (qui fut un de ses premiers étudiants), argumentés et vivants, je sais qu'ils pourront proposer des points de vue clairs même pour un spectateur néophyte.

Malheureusement Edith Girard est décédée prématurément, en septembre 2014. Ce projet lui est dédié.

\subsubsection{Les explorateurs : corps et mouvement}

Quand j'ai commencé à travailler sur ce film, des scènes 'rêvées' ont rapidement traversé mon esprit. L'une des premières était une chorégraphie dans la villa Savoye. Comment mieux interroger notre perception sensorielle de la villa que par l'expérimentation du corps?

La présence de la danse est primordiale dans ce documentaire. Parce que le rapport au corps était une des préoccupations majeures de Le Corbusier quand il concevait une architecture. Parce que la promenade architecturale et la plastique de la villa y invitent. Et pour répondre à sa propre proposition dans le film Architecture d'aujourd'hui dont j'ai parlé plus tôt. Edith Girard m'a aidée dans ma recherche en évoquant un atelier proposé à ses étudiants dans la villa Savoye par la chorégraphe Daria Faïn, à la fin des années 80. J'ai retrouvé sa trace et l'ai rencontrée. Son travail porte depuis longtemps sur le rapport corps-architecture. Intéressée par le projet du film, elle est prête à reprendre l'idée de l'atelier. Nous sommes allées ensemble à la villa Savoye, où elle n'était pas retournée depuis presque trente ans. Lui sont revenus des souvenirs de postures des étudiants, à qui elle avait proposé de prendre leur corps comme mesure pour faire un relevé de l'architecture, en s'y collant, et d'en déceler les rythmes pour les reproduire. Depuis nous avons entamé un dialogue à distance, puisqu'elle vit aux Etats-Unis, pour préparer sa participation au film, dont une partie sera chorégraphiée.
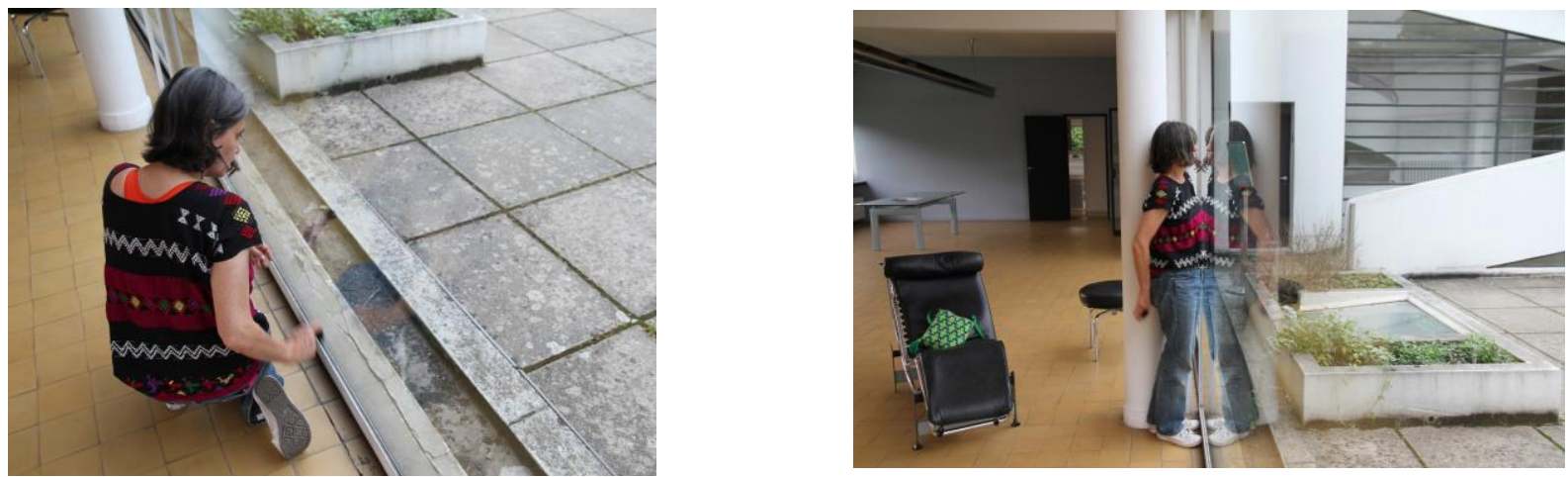

8. - 9. La chorégraphe Daria Faïn revenant dans la villa Savoye, plus de vingt ans après l'atelier qu'elle y a animé auprès d'étudiants en architecture. (C) FLC (C) A.D.

\subsection{Se confronter au lieu}

Chaque invité, par son activité et sa sensibilité, peut participer dans le film à plusieurs actions et propositions thématiques, qui s'articulent en deux ou trois situations. Quel est le lieu le plus à même d'accueillir chacune d'elles, de la faire résonner ? Et réciproquement quelle situation servira telle qualité d'une pièce ? Tout le travail de préparation du film, repérages et recherches, aboutit à une forme de connaissance des lieux comme des invités qui permet de poser une liste d'hypothèses, qu'il faut ensuite affiner par les échanges et l'écriture. Je m'interroge aussi sur les croisements, rencontres susceptibles d'éclairer ces situations, de les relier. Guidée par la nécessité de tracer un parcours filmique, avec ses accidents et ses plages de contemplation, je dresse une sorte de 
cartographie. C'est un exercice de synthèse qui passe par des phases de confusion. Une première écriture du film apparaît, comme une sorte de puzzle dont chaque pièce a plusieurs contours possibles.

Un travail de mise en scène démarre. Sans jamais oublier qu'il s'agit d'un documentaire : écrire une trame assez serrée pour construire un récit, assez lâche pour permettre au réel de s'y développer. En effet, si je peux proposer des configurations aux invités, ce sont eux ensuite qui s'expriment et agissent. Les liens multiples entre eux permettront également une liberté au montage, tenant compte du développement imprévisible de chaque 'scène'. Une recomposition libre, faisant écho à l'idée d'un plan libre. De même la fluidité de l'espace de la villa imprimera celle du film : le passage d'un thème à un autre, d'une situation à une autre se fera dans la suggestion, un glissement, un regard. Si la forme finale du film est forcément unique, linéaire, comme l'un des parcours possibles dans la villa, elle tentera de rendre perceptibles les ouvertures, d'ouvrir des chemins à l'imaginaire.

Pour le tournage, il faut également préciser la manière de filmer. Les cadrages sont importants ; on sait que la villa en propose certains que nous connaissons par de nombreuses photographies. Sans les renier, il serait intéressant d'aller plus loin dans l'observation des formes et de l'espace, tant pour les plans montrant l'architecture 'nue' que pour les plans habités. Si la question de l'usage n'est plus dans la villa celle de l'habiter, il n'en est pas moins important d'observer les corps, de capter leurs contacts avec les éléments, les sons produits, une main qui effleure une surface, un coude qui s'appuie sur une allège, le rythme du pas pour monter la rampe, etc. Les situations sont également proposées avec cette préoccupation.

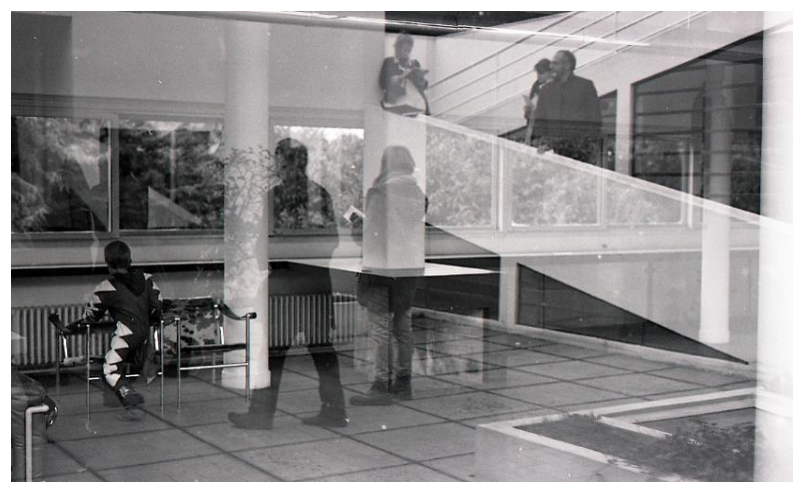

10. Photographie de C.Lefranc, étudiant du studio 30x30, ENSA Paris-Belleville, 2013.

\subsubsection{Un exemple de situation à partir d'un lieu : le hall d'entrée}

Le hall est un espace d'accueil, vaste, où sont disposés librement des éléments hétérogènes; l'escalier, spirale maçonnée qui s'élève verticalement, s'oppose à l'oblique de la rampe, et à l'horizontale dessinée par la courbe vitrée de l'enveloppe. Chaque élément y est distinct, jusqu'au lavabo qui trône derrière l'un des pilotis, et mis en valeur par les rais de lumière arrivant de part et d'autre. Le hall, véritable proposition plastique, semble un lieu idéal pour déclencher la chorégraphie.

Daria Faïn y explore les formes et les proportions, les matières. Elle peut jouer avec les reflets ou se montrer par la transparence de la vitre aux étudiants qui arrivent du parc et découvrent la villa. Elle peut y croiser l'itinéraire d'un autre invité, leurs déplacements exacerbant l'opposition entre l'escalier et la rampe. Elle arpente son plan incliné et souligne le dessin des ouvertures. Elle traverse un petit groupe de visiteurs arrêté sur le palier intermédiaire, écoutant la lecture d'une lettre de Madame Savoye adressée à Le Corbusier et se plaignant des fuites d'eau dans la maison. 


\section{Apports de l'écriture filmique}

La plongée dans l'écriture de ce film documentaire sur la villa Savoye m'a permis de la revisiter d'une manière différente de ma première approche d'architecte, mais cependant connectée à elle. D'abord parce que le documentaire implique un travail de recherche préalable, se nourrit de son sujet pour trouver une forme pertinente en accord avec son propos, ensuite parce que de nombreux thèmes rapprochent les deux disciplines que sont l'architecture et le cinéma. Ma lecture de la villa s'est donc enrichie de ce travail 'sur le terrain', à la rencontre de l'objet et de ceux qui l'observent selon différents points de vue. Le film ouvre à d'autres modes d'expression que le texte et la photo, et les englobe : voix, sons, mouvements, séquences de vie. Ces croisements favorisent un approfondissement de la réflexion formelle en reliant observation et imaginaire, et en s'appuyant en permanence sur la question de la perception.

Pour ce qui est du projet de film, les dossiers de présentation n'ont pas permis d'obtenir des aides financières. La forme choisie, qui n'est ni classique ni dans le style 'télé' dominant aujourd'hui, et le fait que l'architecture fait peur aux diffuseurs, ont rendu ces démarches inefficaces dans un premier temps. J'ai alors décidé de formaliser assez précisément mes intentions pour aboutir à un scénario, forcément virtuel, mais révélant concrètement le dispositif et les choix de réalisation. Ce 'traitement' a séduit un producteur auparavant rétif au sujet. Et plusieurs professionels du documentaire, après l'avoir lu, m'ont dit avoir eu pour la première fois l'impression de comprendre un peu ce qu'est l'architecture. En poursuivant dans cette voie, en cherchant une présentation adaptée et des appuis moins conventionnels, je compte débloquer cet obstacle financier pour commencer le tournage bientôt. Il s'agit donc d'un processus en cours, qui parle de la transmission de l'architecture aujourd'hui, et de ses difficultés.

Comme je l'ai précisé, j'ai été amenée à écrire une sorte de scénario pour convaincre des lecteurs, néophytes en architecture, que ce sujet pouvait être accessible voire intéressant, et que le dispositif choisi était non seulement légitime mais aussi cinématographique. J'ai trouvé deux autres avantages à cette étape inhabituelle et très instructive. D'abord c'était ma première expérience d'écriture aussi proche de la fiction. Au-delà du plaisir que j’y ai trouvé, j'ai pu vérifier la cohérence des choix de personnages et de thématiques, manifeste en particulier quand je devais intervertir deux séquences, privilégier un enchainement plutôt qu'un autre. J'expérimentais alors la fluidité, la variété des parcours possibles dans la construction du film pour provoquer des sensations différentes. Cet exercice était comme une première validation par la maquette de la structure du film mais aussi de son adéquation avec le sujet. Ensuite cela m'amène à reconsidérer la fiction comme un autre mode de médiation de l'architecture. Réflexion et expérimentation à poursuivre.

\section{Conclusion}

J'ai exposé une approche documentaire parmi beaucoup d'autres existantes ou à inventer. Lors de cette courte présentation j'espère avoir montré que l'écriture filmique offre à l'architecture un champ d'exploration. Elle crée un rapport différent au sujet d'étude. Le film embarque son auteur sur le site, et peut montrer des évènements autant que des formes et des discours. Exploration formelle, le film permet de parcourir une architecture, de la voir sous divers aspects, dans la durée, de l'habiter, la confronter à différents visiteurs. Le film pose sans cesse la question du regard, du point de vue, et de la réception. Il permet aussi d'intégrer une dimension poétique à l'apport d'informations, de jouer avec les frontières de la fiction pour mieux révéler et pour toucher le spectateur.

C'est un mode d'investigation autant que de représentation. 
Je ne peux résister au plaisir de citer Le Corbusier parlant de la caméra, dans son texte Esprit de vérité de 1933: "Je dis alors que l'objectif sans nerfs ni âme est un voyeur prodigieux, un découvreur, un révélateur, un proclamateur. Et par lui nous pourrons entrer dans la vérité de la conscience humaine. Le drame humain nous est ouvert. C'est cela qui nous intéresse." ${ }^{\prime 19}$.

J'ai tenté dans cette brève présentation de montrer l'intérêt du documentaire pour l'architecture. Plus largement, je pense qu'une pratique et une réflexion sur le cinéma, documentaire et fiction, fondées sur la réalisation et l'analyse de films, ont une légitimité dans l'enseignement et la recherche en architecture. Mode de médiation, de sensibilisation, le film et les questions qu'il pose peuvent devenir outils de connaissance, et offrent de vraies pistes de réflexion aux architectes.

Je termine par l'exposition du début du film:

\section{Dans un garage - nuit}

nouveau dans la clairière où se dresse la silhouette étrange de la villa, dont il commence à faire le tour...

Un homme dort dans un sac de couchage; à côté de lui, un chien.

Un réveil sonne, l'homme allume une lampe-torche, vérifie l'heure, regarde autour de lui : un espace vide, une sorte de petit hangar.

Il se lève, met une veste et ouvre une porte métallique : "allez Hector, on y va”. Hector bondit dehors.

L'homme, gardien de nuit, éclaire ici et là avec sa lampe torche le bâtiment dont il sort : la villa Savoye. Il s'amuse en créant des jeux d'ombre sur les façades et les pilotis, puis sur les arbres environnants.

Il s'éloigne et entame sa ronde dans le parc. Dans l'obscurité animée par les mouvements de sa main tenant la lampe, on entend ses pas, on devine sa silhouette, les cailloux d'un chemin, feuilles, branches, la silhouette d'un mur de cloture qui se prolonge par une grille. Puis face à lui, à l'entrée du parc, apparaît la loge du jardinier, toute petite maison perchée sur deux pilotis. Il soupire “j’aimais mieux dormir là ! ”.

Le gardien observe, écoute. Il tourne vers sa gauche et s'engage dans un bosquet d'arbres. Il débouche à

\section{Remerciements}

Je tiens à remercier pour leur gentillesse et leur disponibilité les membres de la Fondation Le Corbusier, et en particulier Michel Richard, Directeur de la Fondation, pour son accueil attentif ainsi qu'Arnaud Dercelles, responsable du Centre de documentation et de recherche, pour son aide avisée.

Je remercie également les équipes administrative et enseignante de l'ENSA Paris-Belleville, pour leur accueil chaleureux et leur soutien. Je remercie notamment Alain Dervieux, architecte-enseignant, pour sa générosité et son implication.

\section{Bibliographie}

Caillet, Aline: Dispositifs critiques. Le documentaire, du cinéma aux arts visuels. Rennes: Presses universitaires de Rennes, Collection Arts contemporains, 2014.

François, Arnaud : La cinématographie de l'oeuvre de Le Corbusier, in Revue Cinémathèque, printemps 1996.

Le Corbusier : Esprit de vérité in la revue Mouvement n¹, Paris, juin 1933.

\footnotetext{
${ }^{19}$ Le Corbusier : Esprit de vérité in Mouvement, Paris, 1933.
} 
Le Corbusier : Vers une architecture, Paris 1923.

Loriers, Marie-Christine and others: Corbu vu par, ouvrage collectif. Liège : Pierre Mardaga Editeur, 1987.

Monnier, Gérard : Esquisse in Le Corbusier, une encyclopédie. Paris : Edition Centre Georges Pompidou/CCI, 1987.

Pancher, Annick : Existe-t-il un espace public télévisuel pour l'architecture contemporaine ? Directrice : Hélène Puiseux. D.E.A. Cinéma, Télévision, Audiovisuel. E.P.H.E. et Université Paris1 Panthéon-Sorbonne, UFR Histoire de l'Art et Archéologie, 1999.

Prelorenzo, Claude: Quand Corbu faisait son cinéma in Le Visiteur $\mathrm{N}^{\circ} 17$. Paris : Société française des architectes, 2011.

Simond, Clotilde and others: In situ - de visu - in motu, Architecture, cinéma et arts technologiques. Gollion : Infolio éditions, 2014. 


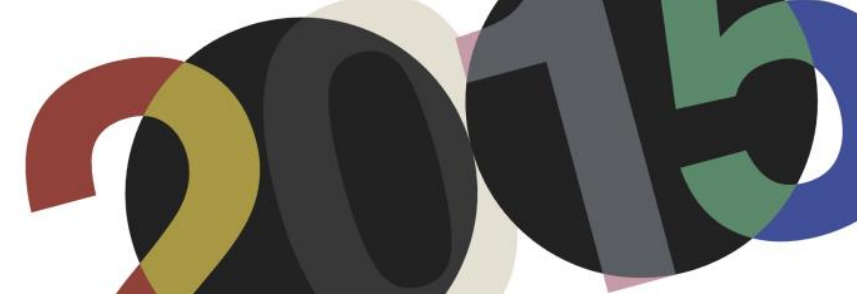

DOI: http://dx.doi.org/10.4995/LC2015.2015.845

\title{
Autour du pyjama de Le Corbusier Le vêtement comme modèle de pensée fondateur
}

\author{
C. Félix-Fromentin \\ Lacth, Ecole Nationale Supérieure d'Architecture et de Paysage de Lille
}

\begin{abstract}
Résumé: Je m'intéresse, depuis le territoire du design, à l'intérêt que Le Corbusier porta pour le vêtement moderne, à partir d'une conférence de 1929 où la réforme du vêtement l'emporte à fonder son concept d' «équipement domestique » pour la «machine à habiter ». La richesse du modèle renvoie vers des écrits préalables, notamment sa théorie des objets-membres artificiels"qui s'est trouvée soutenir une nouvelle définition " prothétique » du design, et par ailleurs des témoignages vécus plus intimes qui amènent un point de vue alternatif et dynamique sur la relation corporelle aux artefacts modernes. Au cœur des débats sur la place et le rôle de la machine industrielle, la position de Le Corbusier révèle sa complexité et sa singularité, qui s'éclaire grâce à des travaux et des concepts propres à l'époque, telle que la Rythmique et la phénoménologie du mouvement, les notions d'œuvre vivante, de sensation et de mesure. Cela emporte à esquisser une conception prothétique corbuséenne, paradoxale, offrant en retour d'enrichir la compréhension de cette idéologie encore très active, et aussi de contribuer à une théorie du vêtement en design, si frêle sur le sujet.
\end{abstract}

Resumen: Me interesa, desde el territorio del diseño, el interés que Le Corbusier trajo a la prenda moderna, desde una conferencia de 1929 en que la reforma de la prenda le lleva a instaurar su concepto de équipo del hogar"por la tháquina para vivir." La riqueza del modelo se refiere a los escritos anteriores, especialmente su teoría de la extremidades objetos artificiales", que se encontró sostener una nueva definición prótesis"del diseño , y por otro lado, testimonios vividos más intimos que conducen a un punto de vista alternativo y dinámico sobre relación cuerpo a los artefactos modernos. En el centro del debate sobre el lugar y el papel de la máquina industrial, la posición de Le Corbusier revela su complejidad y singularidad, que se ilumina gracias a las obras y los conceptos específicos de la época, tal como la Rítmica y la fenomenología de movimiento, las nociones de obras vivas, de sensación y de medida. Esto lleva a esbozar un diseño protésico corbuseano, paradójico, permitiendo a cambio enriquecer la comprensión de esta ideología que aun sigue muy activa, y también para contribuir a una teoría de la vestimenta en diseño, tan frágil sobre este tema.

Abstract: I focus, from the territory of design, on the interest Le Corbusier brought to the modern garment, from a 1929 conference where the dressreform leads him to develop his concept of "quipement domestique"for the thachine à habiter." Richness of the model refers to prior writings, especially his theory of objets-membres artificiels,"which occured supporting a new prosthetic"definition of design, and besides that, intimate testimonies that develop an alternative point of view, more dynamic, about body relationship to modern artefacts. At the heart of debates of the time about the place and role of industrial machinery, the position Le Corbusier holds reveals its complexity and uniqueness, which can be clarify through works and concepts specific of that time such as Eurythmics and the phenomenology of movement, notions of living work of art, sensation and measure. This encourages suggest a Corbusean, paradoxical, prosthetic design, allowing in return enrich the understanding of this ideology still very active, and also to contribute to a theory of dress in design, so slight on this subject.

Mots-clé: Le Corbusier, design, vêtement, prothétique, Rythmique.

Palabras clave: Le Corbusier, diseño, prenda, prótesis, Rítmica.

Keywords: Le Corbusier, design, clothing, prosthetic, Eurythmics. 


\section{Introduction}

«Avec Le Corbusier chez un chemisier où il désire acheter un pyjama.

-Je voudrais un pyjama sombre, uni, de forte couleur, sans revers, sans bordure à filet blanc.

-Nous n'avons pas cela Monsieur. Nous n'avons qu'avec filet blanc.

Le Corbusier proteste :

-Vous, les chemisiers, vous n'avez pas encore inventé un pyjama seyant, pour qu'on n'ait pas toujours l'air d'être dans une chambre à coucher de théâtre!

-Monsieur, on les fait toujours comme cela.

Même réponse avenue de l'Opéra, boulevard Saint Michel, etc... » ${ }^{1}$

Ce souvenir de Jean Petit, relaté dans Le Corbusier parle _non daté, quoique le sujet traité le situe au-delà des années 1940_ semble d'abord une parabole comme celle du cordonnier qui sert à Adolf Loos dans Ornement et Crime $^{2}$ à appeler à un dépassement de l'ornement issu de l'artisanat traditionnel. Si la tonalité s'y apparente en effet, la scène est toutefois possiblement plus authentique, et ceci pour deux raisons. Elle évoque la réalité d'une mutation profonde au début du XXème siècle dans le secteur de l'habillement visant à se débarrasser des codes culturels et sociaux qui imposent aux corps leur tenue ; le pyjama fut un article vestimentaire représentatif, porté en extérieur comme en vêtement d'intérieur informel ${ }^{3}$, par les femmes comme par les hommes, qui suscita beaucoup d'engouement et de créativité.

Par ailleurs, nous reconnaissons à Le Corbusier la qualité et pertinence de ses confessions, témoins de l'intrication de la pensée et de la vie capables de contrebalancer positivement ses textes plus rhétoriques. Comme Paul Valery y invita à l'occasion de son premier cours de Poétique au Collège de France en 1937, sur les questions les plus vastes et complexes, afin de demeurer dans des «proportions humaines », mieux vaut s'en tenir à sa propre expérience vécue et observée scrupuleusement. "Je m'efforce de n'oublier jamais que chacun est la mesure des choses ${ }^{4}$.

Ainsi, ce qui apparaît comme un souvenir trivial n'en est sans doute pas un, et justifie sa citation dans le livre de Petit, d'autant plus que Le Corbusier précise in fine à son sujet : "J'ai écrit quelque part, vers 1929 : tant que le costume n'aura pas été transformé, la révolution ne sera jamais faite. » La transformation du vêtement est annoncée de la sorte comme préalable à la révolution de l'architecture qui allait l'agiter toute sa vie.

Cette assertion suscite la curiosité et invite à fouiller ses textes en quête d'explications. Dans son ouvrage White walls : designer dresses, the fashioning of modern architecture, Mark Wigley s'est en quelque sorte attelé à la tâche quand il s'est interrogé sur le silence historique et théorique qui entourait les murs blancs caractéristiques de l'architecture moderne, dont l'architecte suisse fut le promoteur principal. Son étude, exhaustive et précieuse,

\footnotetext{
${ }^{1}$ Petit, Jean : Le Corbusier parle. Paris : Editions Forces Vives, 1967. p. 53

${ }^{2}$ LOOS Adolf, « Ornement et crime ». In Paroles dans le vide - Malgré tout. Paris : Editions Ivrea, 1994. p.206. Cet essai fut publié par la revue L'Esprit Nouveau.

${ }^{3}$ Le pyjama, en hindi «vêtement de jambe », sorte de large pantalon souvent accompagné d'une kurta (tunique fendue), arrive en France au début du siècle. Réinterprété (notamment par Gabrielle Chanel, Paul Poiret, Sonia Delaunay ou Elsa Schiaparelli) et assorti à une veste-chemise, il est porté dans les années 1920 comme costume idoine aux nouvelles pratiques sportives ou balnéaires. Il ne fut employé comme costume de nuit dans le vestiaire masculin qu'à partir des années 1940, en remplacement de la chemise de nuit ou liquette.

${ }^{4}$ Valéry, Paul : Première Leçon du cours de poétique. In Oeuvres I, Paris : La Pléiade, 1957. p. 1358.
} 
est parvenue à mettre à jour derrière eux un indéniable «principe (moderne) du vêtement $»^{5}$, inhérent à la modernité, quoique effacé voire défendu par l'histoire canonique.

Je m'intéresse pour ma part à Le Corbusier depuis le territoire de ce que l'on appelle aujourd'hui en français très généralement le design, et dans le cadre d'un questionnement sur cet artefact particulier qu'est le vêtement. Car s'il tourmenta le mouvement moderne, l'historiographie du design l'a étonnamment délaissé.

Connexe à l'architecture notamment via le problème des arts décoratifs et la question de l'habitation, l'architecte a côtoyé le milieu du design en émergence, et participé aux actions et débats qui l'agitèrent. Toutefois, sa position est qualifiée d'ambiguë, d'une manière générale par Alexandra Midal dans Design, L'anthologie, plus particulièrement par Reyner Banham dans Théorie et Design à l'ère industrielle (discutant la pertinence de ses « machines » vis-à-vis de l'outil industriel), ou encore par Adrian Forty dans Industrial Design and Prosthesis (où il apparaît comme père malgré lui d'une théorie «prothétique » du design). La visée de cette réflexion peut dès lors s'énoncer ainsi : l'intérêt singulier de Le Corbusier pour le vêtement pourrait-il apporter quelques clartés sur son legs au design?

Dans un premier temps, nous analyserons un texte de 1929 intitulé «L'aventure du mobilier », où le vêtement féminin moderne fonde son concept d' «équipement domestique » pour la « machine à habiter ». Dans un second temps, des écrits préalables sur le sujet, dans L'art décoratif d'aujourd'hui d'une part, dans des écrits plus intimes d'autre part, amèneront à approfondir le modèle lui-même, et à y déceler une problématique constitutive, dont nous explorerons dans un troisième temps les conséquences sur sa conception du design, en nous appuyant sur des témoignages plus tardifs parus dans Quand les cathédrales étaient blanches.

\section{De la réforme du vêtement à la réforme du mobilier - Le vêtement moderne féminin comme machine à s'habiller}

L'appel à la révolution vestimentaire, dont Le Corbusier se remémore avec Petit, se rapporte en réalité à une conférence qu'il a tenue à Buenos Aires le 19 octobre 1929, dont le texte fut publié en 1930 dans Précisions sur un état présent de l'architecture et de l'urbanisme. Il y prédit «L'aventure du mobilier » à partir de celle qu'à vécue le vêtement moderne féminin et ses effets constatés sur la vie quotidienne.

«La femme nous a précédés. Elle a réalisé la réforme de son costume. Elle s'était trouvée dans cette impasse : suivre la mode et renoncer alors à l'apport des techniques modernes, à la vie moderne. (...)

Suivre la mode : elle ne pouvait se mêler d'auto ; elle ne pouvait ni prendre son métro ou son autobus, ni agir avec célérité au bureau ou au magasin. Pour réaliser la construction quotidienne de sa toilette : coiffure, bottes, boutonnage de la robe, elle n'aurait plus eu le temps de dormir.

Alors la femme a coupé ses cheveux, et ses jupes, et ses manches. Elle s'en va tête nue, bras nus, jambes libres. Et en cinq minutes, elle s'habille. Et elle est belle : elle nous séduit du charme de ses grâces dont les couturiers ont admis de tirer parti.

Le courage, l'entrain, l'esprit d'invention avec lesquels la femme a opéré sa révolution vestimentaire sont un miracle des temps modernes. Merci! » ${ }^{6}$

\footnotetext{
${ }^{5}$ Référence au «principe du revêtement » de Gottfried Semper, réactualisé par Adolf Loos.

${ }^{6}$ Le Corbusier, «L'aventure du mobilier». In Précisions sur un état présent de l'architecture et de l'urbanisme. Paris : Edition Altamira, 1994. p. 106-107
} 
Ce constat enthousiaste est opposé sans attendre, dans le registre masculin, aux habits d'apparat encore empesés, empanachés, non adaptés au travail, ne permettant pas de concilier élégance et caractère pratique. Seul le «mécano» se démarque selon l'auteur, qui appelle dès lors à ce que «l'esprit de réforme » ici constaté se répande à tous les actes de la vie. Selon Banham, le jeune architecte est pourtant réputé pour sa panoplie de l'homme moderne, vêtements sombres, chapeau melon, noeud papillon. Le Corbusier est lui-même plus retenu quand il justifie le choix de son costume anglais comme une étape de transition, qui, à défaut d'être moderne, a au moins cet effet important de le «neutraliser », car : «Il est utile d'arborer un aspect neutre en ville ${ }^{7}$.

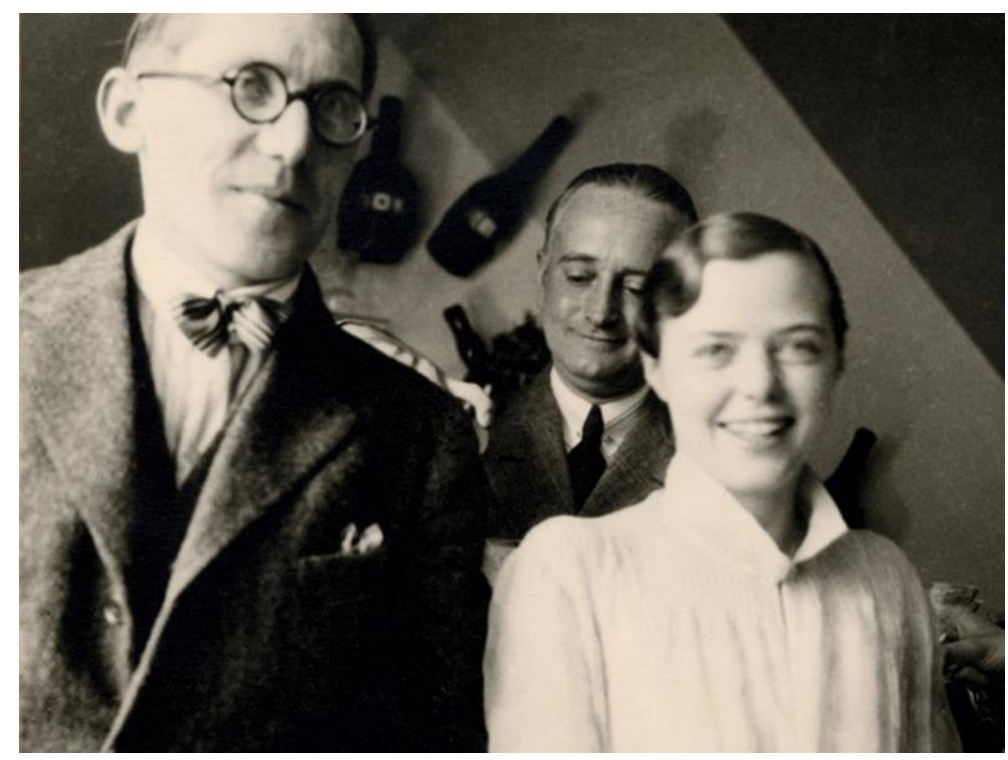

1. Le Corbusier, Pierre Jeanneret, Charlotte Perriand en 1927 CFLC/ADAGP

Pour bien saisir de quoi il est question, il est utile de poser le contexte historique de cette révolution.

Comme cela fut abondamment étudié ${ }^{8}$, les positions corbuséeens prendraient source au cœur de la Lebensreform, vaste contexte de remise en cause esthétique, sociale, politique au tournant du XIXème au XXème siècle. Dans une inspiration nietzschéenne et une méfiance vis à vis du progrès, elle est animée par une quête d'harmonie avec le milieu naturel, intéressée par la compréhension des phénomènes de perception et de cognition, et nourrie diversement des théories psychophysiques, de psychologie expérimentale, ou d'esthétique scientifique en plein développement.

Cette rénovation de la vie fait écho à une réforme du vêtement engagée dans la seconde moitié du siècle précédent visant à affranchir le vêtement de l'arbitraire de la mode, et selon les cas, à lui appliquer les préceptes de l'hygiénisme, à le penser selon des critères de rationalité, honnêteté ou moralité, à servir l'aspiration au Gesammtkunstwerk et l'introduction de l'art dans tous les domaines de la vie. Wigley en relate finement les origines et développements dans les milieux des arts décoratifs et de l'architecture, notons simplement que cette mobilisation fut soutenue activement par Henry van de Velde que l'on sait avoir été lu et apprécié par Le Corbusier. La dynamique qu'il initia fut très suivie, Frank Lloyd Wright ou Peter Behrens par exemple y ont

\footnotetext{
${ }^{7}$ Ibid. p. 107

${ }^{8}$ L'exposition au Centre Pompidou de Paris du 29 avril au 3 août 2015 et son catalogue Le Corbusier - Mesures de l'homme commentent abondamment cet ancrage. On peut y lire par exemple sur le sujet Migayrou, Fréderic : «Les yeux dans les yeux. Architecture \& Mathesis». In Cinqualbre, Olivier; Migayrou, Fréderic (Dir.) : Le Corbusier - Mesures de l'homme, Paris : Editions du Centre Pompidou, 2015. p. 14.
} 
participé en concevant des vêtements dans le cadre de leurs projets. Avant la première guerre mondiale, les avant-gardes artistiques, tant cubistes que futuristes et suprématistes, furent concernés activement à leur tour par cette œuvre portée ou "peinture vivante " comme nouveau champ d'investigation poétique. Paris, en tant que laboratoire de l'avant-garde, par ailleurs capitale de la mode, centralisait les énergies sur le sujet. Alors qu'il y séjournait, celui qui était encore Charles-Edouard Jeanneret fréquenta Paul Poiret et fut introduit dans son cercle. Amédée Ozenfant était pour sa part en affaire dans la mode avec la sœur du couturier. Au sortir de la guerre, en accord avec l'assagissement général et la volonté désormais concrète de construire un monde nouveau à l'ère de la machine devenue omniprésente, les préoccupations autour du vêtement concourent au développement de typologies vestimentaires nouvelles adaptées aux conditions de la vie moderne, dont Le Corbusier se fait le porte-parole dans sa conférence.

Le «mécano » dont il vante l'esprit de réforme fait sans doute référence à la Tuta, conçue par le futuriste Thayaht en 1919. «Tuta d'un pezzo » ${ }^{10}$ (tout d'une seule pièce), il s'agit d'une combinaison intégrale aux contours géométriques en forme de T comme le T-Type Shirt, vêtement universel destiné aux hommes, femmes et enfants pour être porté en toutes occasions. Il serait inspiré du overall américain, à qui Loos prédit la même année une destinée formidable ${ }^{11}$. Equipé de nombreuses poches, agréments pratiques nouvellement attenants au vêtement qui débarrassent des sacoches, il illustre bien cette remarque de l'architecte : «La poche, les poches devraient être la clé de voûte du vêtement moderne $»^{12}$.

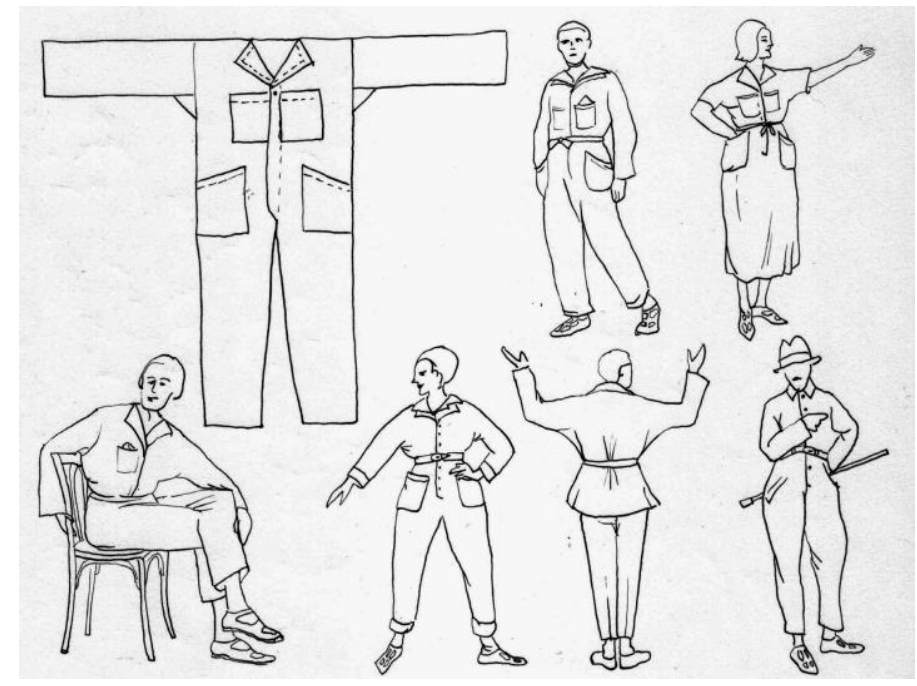

2. La Tuta et ses déclinaisons, 1919, d'après les dessins de Thayaht

Le vestiaire féminin évoqué semble être celui élaboré par Poiret, voire Chanel pour qui «le vêtement doit bouger sur le corps ${ }^{13}$. Pour celle qui s'opposait au luxe des grands couturiers qui confondent costume de théâtre et vêtement pour le quotidien, seul un travail studieux de simplification des formes et de dépouillement, accompagné d'une connaissance pratique du corps vivant, ( ...je m'attaque au mannequin vivant, alors que les

\footnotetext{
${ }^{9}$ La formule est de Robert Delaunay au sujet des vêtements conçus par Sonia. Delaunay, Robert : Du cubisme à l'art abstrait, Paris : Edition SEVPEN, 1958.

${ }^{10}$ Benhamou, Viviana : «Ernesto Thayaht (1893 - 1953), nouvelles perspectives ». In Guillaume, Valérie (Dir) : Europe 1910-1933, Quand l'art habillait le vêtement. Paris : Edition Paris Musées, 1997. p. 44.

${ }^{11}$ Loos, Adolf : «Réponses à des questions du public ». in Paroles dans le vide - Malgré Tout. Op.cit. p.267.

12 «L'aventure du mobilier». Op.cit. p. 107.

${ }^{13}$ Morand, Paul : L'allure de Chanel, Paris : Herman, 1976. p. 52.
} 
autres dessinent, font des poupées ou des maquettes... ${ }^{14}$ ) parvint à atteindre des lignes contemporaines, sans taille, défiant les genres, et agrémentées de poches. Il en résulte une épure de vêtement, qui supporte bien ce commentaire extrait du manifeste du Purisme : «statique, générale, expressive de l'invariant, mais ni accidentelle, ni exceptionnelle, ni impressionniste, ni inorganique, ni protestataire, ni pittoresque ${ }^{15}$. Un objet puriste donc, qu'il s'agit dès lors de transposer au problème du mobilier puis à l'habitation.

Tout d'abord, comme les anciens habits ont opéré leur renouvellement en adoptant une certaine universalité en terme de besoins, fonctions et dimensions, il appelle le mobilier à gagner les qualités du standard. Synonyme de quotidien, régulier, constant, similaire ou de côte moyenne, il peut combler nos «besoins d'hommes » ${ }^{16}$, quand par ailleurs il satisfait à l'esprit de l'époque «ingénié » par la fabrication industrielle vertueuse en terme de «précision, efficacité, pureté des formes et des lignes». Comme Banham le rapporte, on sait que le jeune architecte, alors en mission d'étudier l'avancée des allemands en matière de design, fut initié par Hermann Muthesius notamment à la théorie des types et à la défense du standard ; notions très proches, le type évoque un universel qui s'actualise en le standard dans le contexte technique de la production de masse.

«Fonctions standard,

besoins standard,

objets standard,

dimensions standard. ${ }^{17}$

De là, le vêtement standard, par sa construction générique et géométrale qui peut être rapportée au type poche, va inspirer l'idée de casier. "Je vais affirmer qu'en dehors des sièges et des tables, les meubles ne sont à vrai dire que des casiers. »

«Dispositif moderne » qui permet, à l'instar des poches, de disposer toutes nos choses, elles-mêmes de tailles proportionnées à nos membres et adaptés à nos gestes, observe-t-il, le casier standard satisfait à la situation industrielle. Il autorise l'architecte ou le particulier à élaborer un ensemble cohérent et architectonique en les disposant soit contre les murs, soit indépendamment, faisant office de cloison pleine ou partielle. L'organisation optimisée libère de la place, et fait ainsi gagner de l'espace et du temps.

Dès lors, «il reste à équiper l'intérieur des casiers ${ }^{18}$. Or, si les caissons sont des parallélépipèdes semblables, les solutions pour les aménager au mieux en regard de leur destination sont multiples et variées, qui peuvent aller «du simple apparat» au «raffinement le plus complet» (portes, tiroirs, étagères, tablettes, niches, ...). Le générique accueille d'autant mieux la diversification et la personnalisation.

L'analogie au vêtement moderne est ici encore possible, et riche de problématiques parce que non tranchée. Individualité versus standard : la dualité fait en effet écho à une dispute célèbre opposant en 1914 van de Velde à Muthesius au sein du Deutscher Werkbund. Le Corbusier n'y fait pas explicitement allusion dans sa conférence, mais sa solution pour les casiers indique sa position dans le débat. Alors que le premier soutient la cause d'une certaine expression artistique dans la conception vestimentaire, le second prône une standardisation complète

\footnotetext{
${ }^{14}$ Ibid.

${ }^{15}$ Jeanneret, Charles-Edouard; OZENFANT, Amédée : Après le cubisme. Paris : Éditions des Commentaires, 1918. Fin d'ouvrage non paginé.

${ }^{16}$ «L'aventure du mobilier ». Op.cit. p. 109.

17 «L'aventure du mobilier». Op.cit. p. 110.

${ }^{18}$ Ibid. p. 116.
} 
immédiate $^{19}$. Cette controverse va rapidement concerner toute production industrielle, en reléguant comme mineur le problème du vêtement. Au Bauhaus, Walter Gropius suivit d'abord le point de vue de van de Velde, puis se rallia à celui de son protagoniste. Au sein de l'établissement, à la «Bauhaustracht» (tenue du bauhaus), de coupe simplifiée pouvant être fabriquée dans des textiles variés, succéda la combinaison constructiviste aux nombreuses poches fonctionnelles, portée par Moholy-Nagy notamment, avant que Gropius n'impose le costume-type, le concepteur nouveau devant porter (corporellement) sa nouvelle orientation industrielle.

Le sujet fut toutefois ravivé par Lilly Reich en 1922 en quête d'une voie intermédiaire. Consciente de la nécessité de sortir cet objet utile des domaines de l'art et de l'artisanat, élitistes, et de le relocaliser sur le terrain de l'industrie où le secteur économique de la mode a de toutes façons la mainmise et n'hésite pas à contrefaire la facture manuelle, elle soutient toutefois la particularité de cet artefact qui appelle une « organic unity» ${ }^{20}$ avec la personne qui le porte, pour ce que cela participe à élever «the expression of the soul and his feeling of being alive ». Pour cela, elle propose que soient définis les types, ou patrons génériques, du vestiaire moderne, formes simples que des broderies par exemple viendraient personnaliser. Les artistes ou proto-designers réagirent nombreux à la polémique. La Tuta citée plus haut, modèle d'invariance vestimentaire, est ouverte en réalité à plusieurs variantes, tel que les illustrations diffusées à l'occasion de sa publication y invitent : en plus de décliner l'étoffe, on peut choisir entre manche longue ou courte, version robe, et on est invité à la porter avec une ceinture ou un cordon noué, sur une chemise ou à même la peau. Elle sera imaginée en Bi-tuta (costume en deux pièces) et Tuta termica (version pour l'hiver), révélant la richesse de la typisation initiale.

Une dernière allusion aux possibilités offertes par le vêtement moderne au profit du mobilier, hormis les casiers, concerne les sièges, pour l'attitude ou la «tenue décente $»^{21}$ dans laquelle ils nous posent ou qu'ils autorisent. Selon les heures du jour, les contextes, l'état d'esprit, nous nous asseyons diversement, observe Le Corbusier, poliment pour causer, actif pour pérorer, haut pour énoncer une thèse, béat pour ne rien faire. De la même façon que «le corset n'est plus», que le vêtement nouveau soutient la mobilité individuelle, l'homme moderne a désormais le droit de s'asseoir comme il le souhaite, comme il convient à « sa distinction».

Et cette aventure du mobilier se conclue par cet événement : sa disparition, au profit de l'idée d' «équipement domestique ». Parvenu ainsi au terme de la conférence, résumons : si formellement et constructivement, le vêtement moderne se trouve rapportée à une basique poche, il inspire par ailleurs tant pour sa matérialité, pour ses déclinaisons possibles, ses finitions, que pour le jeu d'accessoirisations et combinaisons, et encore pour la qualité d'élégance qui lui est incontestablement liée. Surtout, il est une référence de mobilité qui suggère à Le Corbusier une idéalité de maison vidée où «l'espace et la lumière abonde », ou l'on agit aisément et promptement. La liberté du corps permise par le nouveau vêtement emporte in fine vers une liberté d'esprit : «Voilà le fond du sac, penser à quelque chose ». Il se fait ainsi le modèle précurseur d'une libération de la vie «quand l'esprit de l'époque est encore recouvert de la défroque insupportable d'une époque mourante ${ }^{22}$.

\footnotetext{
${ }^{19}$ Les enjeux de la dispute sont plus complexes que cela comme Wigley l'explique. In White walls, designer dresses : the fashioning of modern architecture, 2nd ed. Cambridge (Massachusetts): MIT Press, 2001. pp. 147-149.

${ }^{20}$ Reich, Lilly : «Modefragen ». Die Form, N5, 1922. Cité et traduit in Stern, Radu : Against Fashion, Clothing as Art, 1850-1930, 2nd ed. Massachusetts : The MIT Press, 2004. p. 152.

${ }^{21}$ «L'aventure du mobilier». Op.cit. p. 119.

${ }^{22}$ Le Corbusier : Vers une architecture, 1st ed Crès, 1923. Paris : Flammarion, 1995. p.II
} 


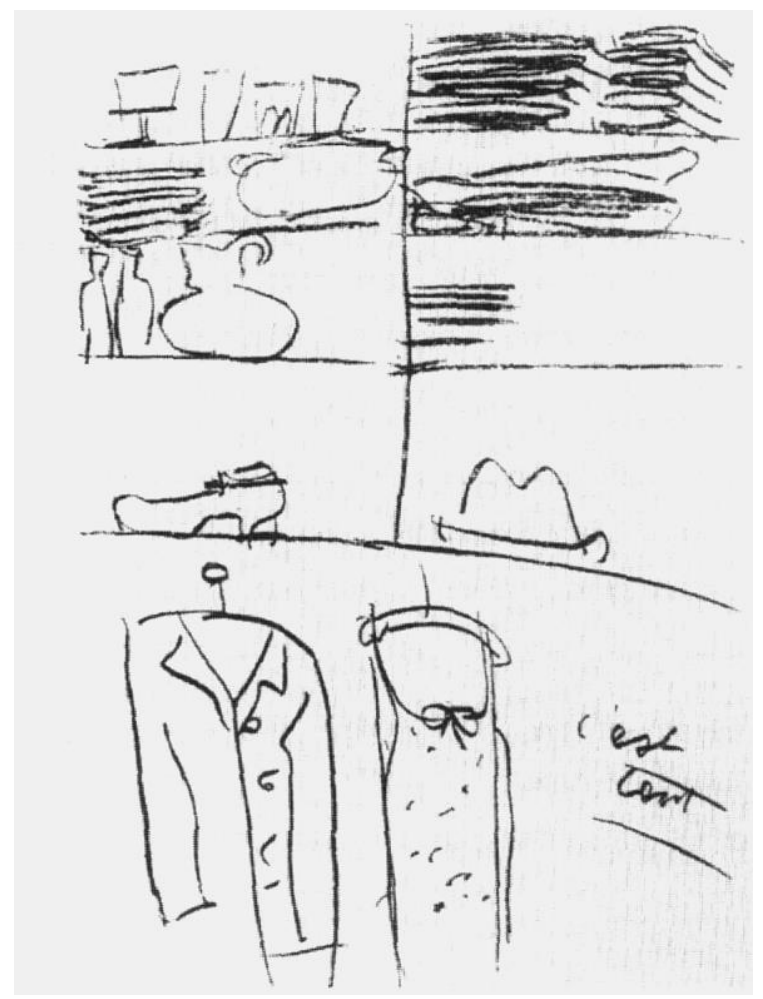

3. Croquis de Le Corbusier, 1929 CFLC/ADAGP

Les principes énoncés avaient en réalité déjà été expérimentés concrètement pour le Pavillon de l'Esprit Nouveau installé en 1925 lors de l'Exposition Internationale des Arts Décoratifs et Industriels Modernes à Paris. Exemple de «machine à habiter », il s'agissait de «montrer qu'un appartement peut être standardisé pour satisfaire aux besoins d'un homme de série »" ${ }^{23}$, et «affirmer que l'architecture s'étend du moindre objet d'usage mobilier à la maison, à la ville et encore au-delà »; principe d'emboîtement, depuis le casier à la cellule d'habitation à son agrégat en colonie urbaine, auquel il convient d'insérer au préalable le vêtement.

\section{Sur le vêtement moderne : objet-membre ou enveloppe rythmique? Le Corbusier, designer de vêtement}

Cherchant dans des écrits préalables ce qui pourrait préciser cette mise en exergue du vêtement moderne, deux pistes retiennent l'attention.

En premier lieu, tel que présenté en 1923 dans Vers une architecture, le costume, ici masculin, apparait, en tête de liste, parmi les «objets-type » que l'époque a crés, formule qui devient en 1925 dans L'art décoratif d'aujourd'hui le leitmotiv de la révolution à mener contre l'expressivité artistique. Le vêtement y est introduit via le métier qui s'y rapporte, hors la mode et le stylisme : «chez un tailleur, un homme devant lui, et lui, un mètre à la main, prenant les mesures sur son homme. Nous revoici sur le plancher des vaches. Sérénité tonifiante des certitudes. $»^{24}$ Cette évocation permet d'insister sur l'échelle et la fonction humaines, garantes selon l'auteur d'une sauvegarde des besoins humains.

\footnotetext{
${ }^{23}$ Le Corbusier : «Pavillon de l'Esprit nouveau, Paris 1925 ». in Oeuvres complètes vol.1 : 1910-1929, Les éditions d'architecture (Artemis), Zurich, 1964, p. 98

${ }^{24}$ Le Corbusier : L'art décoratif d'aujourd'hui. Paris : Flammarion, 1996. p. 70.
} 
L'argumentation s'apparente à celle de la conférence de 1929, mais le type tient la place du standard, et une raison évolutionniste se substitue à la raison industrielle qui emporte à énoncer le fameux concept d' «objetmembre artificiel ». La proposition étudiée ci-avant menant des vêtements, aux casiers, à la maison, se déploie ici dans une perspective de sélection organique dérivée de la théorie de Darwin. Dans un passage qui ferait référence à Samuel Butler, Le Corbusier explique comment les objets ne sont que de simples extensions des membres humains, poussées par l'évolution pour compléter les capacités naturelles et satisfaire de la sorte avec précision les besoins les plus objectifs. «Nous naissons nus et insuffisamment armés. Ainsi le creux de la main de Narcisse nous a conduit à inventer la bouteille; le tonneau de Diogène qui constitue déjà une fameuse amélioration de nos organes de protection (notre peau, et notre cuir chevelu) nous donne la cellule primordiale de la maison ${ }^{25}$, et ainsi de suite, les livres prolongent notre mémoire, et les casiers dérivent d' «étuis », euxmêmes issus de la nécessité d'y ranger des «membres auxiliaires de garantie contre le froid ou le chaud »_sontce des vêtements? ? $^{26}$

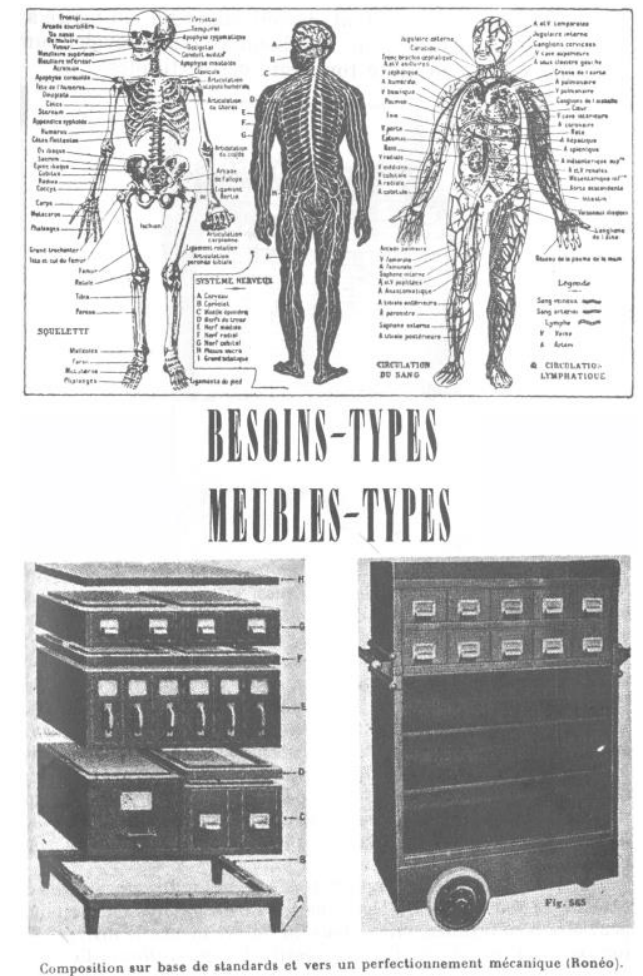

4. Illustrations extraites de L'art décoratif aujourd'hui, 1925 @FLC/ADAGP

Il est à noter que le rejet du décoratif ne signifie pas un rejet du vêtement. Si la toilette féminine est ici exposée comme suspecte pour son exubérance, et les modes comme douteuses, comme Wigler l'a analysé, le vêtementtype montre la voie à tous les objets utilitaires, à toutes les «machines » qu'appelle l'époque. Son origine est la peau, il est une peau supplémentaire ${ }^{27}$, et son horizon l'habitat minimum que le mythe de Diogène exemplarise. Débarrassé de son superflu, rendu objectif et docile, il est un habit qui permet de ne pas être habillé quand on ne peut demeurer nu dans le milieu «extra-humain », une sorte de vêtement de nudité pure qui confère au corps les

\footnotetext{
${ }^{25}$ Ibid. p. 72.

${ }^{26}$ A noter que l'artiste dada Raoul Hausmann, dans un article en 1924 pour le magazine Constructivist G, rapporta le vêtement à un «clothing object», le chapeau à «a head covering ", et la mode à «the function of the body made visible». Cité par Radu Stern, in Against Fashion, Clothing as Art, 1850-1930. Op.cit. p.22.

${ }^{27}$ Métaphore faite par Le Corbusier dans un article pour une revue de psychologie en 1925. Cité par Wigley, op. cit. p.287
} 
prémices de la fonction domestique. Il doit en être ainsi de tout artefact : les artistes décoratifs sont assignés de cette mission orthopédique, activité finalement analogue à celle du tailleur, commente Le Corbusier, mais d'un tailleur moderne quand le client est pour lui un homme-type.

Cette théorie du vêtement-type comme premier objet-membre laisse toutefois dubitatif en regard de la multiplicité des qualités extrapolées du modèle vestimentaire moderne en 1929. Notamment, l'importance accordée au mouvement qu'il autorise est absente. Une autre source toutefois explicite cette préoccupation majeure, et constitue dans notre réflexion une seconde piste, même si le vêtement n'y apparaît qu'indirectement.

En 1908, dans une lettre à sa mère, Charles-Edouard Jeanneret relate sa conception d'une sorte de multi-casier, «meuble fous-y-tout $~^{28}$, pour remédier à la situation ankylosante de sa «tôle d'étudiant » à Paris. Espace réduit de $3 \times 4$ mètres, il décrit comment il est obligé de glisser son corps, de sauter à saute-mouton à pieds joints, d'escalader, de rentrer son ventre, pour louvoyer entre la table, quelques chaises, un fauteuil, la malle qui sert de sofa, le lit, une baignoire-cuvette suspendue, et des habits accrochés à des clous. Las, il se fabriqua un mobilier combiné, pratique, «merveilleux » où tout trouve sa place, qui redonne au corps sa capacité à se mouvoir librement.

Le contexte semble annoncer le futur concept d'équipement domestique, et en effet, lors de la conférence, Le Corbusier rapportait que «l'anomalie du mobilier » l'obsède depuis une vingtaine d'années, qui justifie sa quête d'un casier «de mesure commune» pour contenir efficacement tous les objets, mais aussi « gagner une place considérable », et «circuler à l'aise ».

La relation exprimée ici entre l'aménagement mobilier et la «danse du corps dans l'espace intérieur ${ }^{29}$, peut être approchée et commentée grâce à la Rythmique développée par Emile Jaques-Dalcroze, à laquelle Le Corbusier fut initié par son frère Albert qui s'y exerçait. Anne Boissière relate comment cette théorie ancrée dans une pratique corporelle visant à réformer l'enseignement de la musique, trouve ses commencements expérimentaux au tournant du siècle dans la volonté de Dalcroze de contrer l' «arythmie ${ }^{30}$ de certains de ses élèves_l'anomalie mobilière citée par le Corbusier y fait-elle référence?_, soit le défaut d'équilibre dont un corps peut témoigner dans ses actions. S'il concerne ici l'apprentissage et l'exécution de la musique, ce problème toucha par ailleurs plus largement la problématique des modes de vie à l'ère industrielle accusés de mettre en défaut le rythme vivant par leurs cadences mécaniques. Symétriquement, Dalcroze s'appuie sur la capacité d'un organisme à s'informer de la musique et à la transformer en un rythme vécu qui se manifeste par un mouvement vivant $^{31}$. La dimension synesthésique de la perception peut être exercée, afin d'atteindre une certaine dépersonnalisation subjective qui permet au corps de sentir profondément les combinaisons de rythme. Cet enjeu de la Rythmique la distingue d'autres tendances émancipatrices à cette époque cherchant l'expression passionnelle en phase avec les flux naturels.

Comme la notion de rythme, très débattue à l'époque, le terme mouvement n'est pas à comprendre au sens actuel. Mouvement recouvre une compréhension globale d'une énergie de vie, incluant autant les animations non visibles, comme la joie, changement intime du sentiment que l'on a de l'existence, que les motricités physiques

\footnotetext{
${ }^{28}$ Baudouï, Rémi ; Dercelles, Arnaud : Le Corbusier, Correspondances. Lettres à la famille, t.1 : 1900-1925. Infolio, 2011. Cité par Pitiot, Cloé : «Le Corbusier, Le mobilier corps et âme ». In Le Corbusier - Mesures de l'homme. Op. cit., p. 85.

${ }^{29}$ Ibid. p. 86

${ }^{30}$ Boissière, Anne : Musique Mouvement. Paris : Manucius, 2014. p. 77.

${ }^{31}$ «Si la musique veut ordonner la mobilité du corps, elle doit s'informer, premièrement de ce que le corps attend d'elle. (...) Le corps abandonne donc sa vie propre à la musique pour la recevoir à nouveau de sa main, mais ordonnée et transfigurée ». Ibid. p.97
} 
comme les gestes ou déplacements. De même, la musique ne se résout pas en œuvres artistiques, elle est un phénomène qui fait partie intégrante de l'homme et s'active dans sa présence au monde, comme les travaux de psychologie phénoménologique de Erwin Straus le théorisaient.

Or, la Rythmique nous intéresse ici parce qu'elle se trouva des dispositifs idoines à son plein accomplissement. Les Espaces Rythmiques ${ }^{32}$ projetés par le scénographe Adolphe Appia en 1909-1910 témoignent d'une «complicité de l'espace »: l'existence d'un volume déterminé, de lumières et de conditions matérielles porteuses de «praticabilité ». Nous y reviendrons plus loin, notons pour le moment que l'aire de jeu en trois dimensions profite idéalement de lignes simples et de plots abstraits quoique aux mesures humaines qui sont «la paradoxale condition de la possibilité de la plasticité des corps mobiles et vivants ${ }^{33}$. Réciproquement, l'espace devient vivant pour celui qui le pratique. L'expérience de Le Corbusier dans sa chambre parisienne semble de cette nature.

En 1910, lors de son voyage en Orient, attestant de sa sensibilité pour de tels phénomènes, si ce n'est de son intérêt pour ces travaux, Charles-Edouard écrivait à ses parents au sujet du Parthénon : «Vous êtes pris, vous avez perdu le sens de l'échelle commune. Vous êtes assujetti à un rythme sensoriel (la lumière et le volume) et par des mesures habiles. » ${ }^{34}$

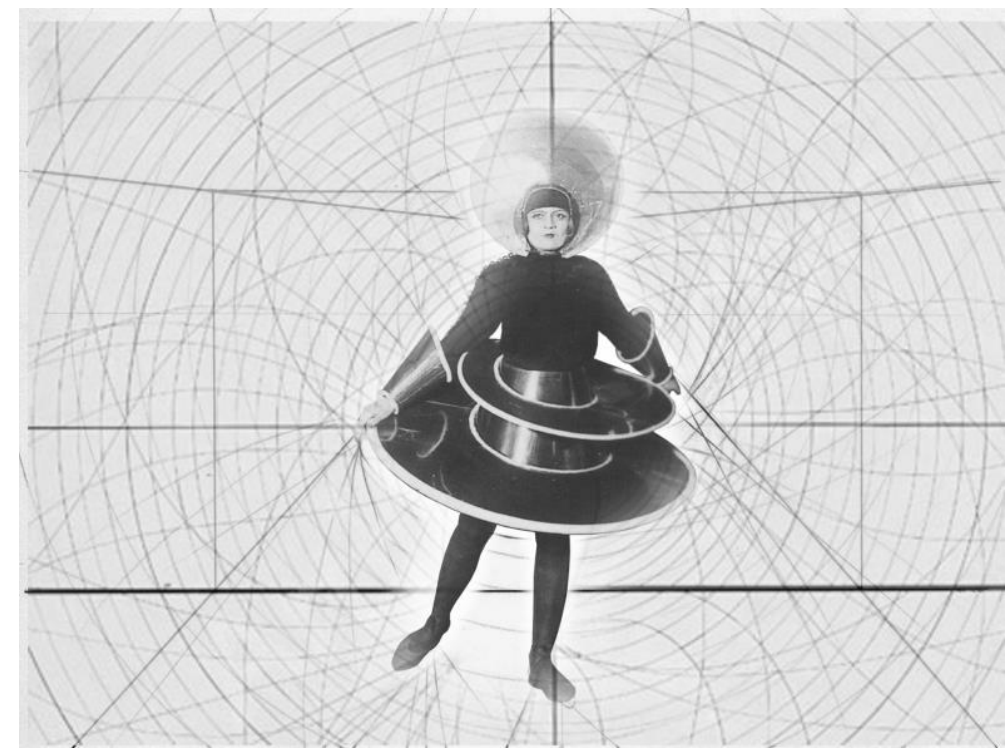

5. Danseuse du Ballet Triadique sur fonds de réseau spatial, d'après les dessins de Oskar Schlemmer

Dès lors, les vêtements modernes présentant ces qualités pourraient-ils recéler d'un potentiel d'enveloppes rythmiques? Cette question fut précisément travaillée au sein du Bauhaus, dans l'atelier de scène d'Oskar Schlemmer qui se fit le miroir des débats en vigueur. Le théâtre est pour lui un art de l'espace, soit «une structure de nombre et de mesures $»^{35}$ apte à simuler toute spatialité. Pour qu'il acquiert pleinement sa fonction, il faut lui conférer un rythme : «Le costume jouera ce rôle, à la fois comme support du mouvement, et pour luimême. L'acteur devient ainsi portion d'espace, portion d'architecture. »

\footnotetext{
${ }^{32}$ Certains dessins sont reproduits dans Appia, Adolphe : L'œuvre d'art vivant, Oeuvres complètes, t.3: 1906-1921. L'âge d'homme, Lausanne, 1988.

${ }^{33}$ Musique Mouvement. Op. cit. p. 93.

${ }^{34}$ Lettre à ses parents du 21 juin 1910, in BAUDOUÏ Rémi, DERCELLES Arnaud : Le Corbusier, Correspondances. Lettres à la famille, t.1 : 1900-1925. Op.cit. p. 311.

${ }^{35}$ Michaud, Eric : Théâtre au Bauhaus. Lausanne : L'âge d'homme-La cité, 1978. p. 128.
} 
Pour Le Ballet Triadique par exemple, il conçut des costumes aux volumétries géométrisées poussés à l'extrême d'une logique de vêtements-machines enveloppant et astreignant les corps organiques des danseurs, figurant de la sorte plastiquement la rencontre de l'homme naturel avec le monde industriel. Tel que Siegfried Giedion a commenté ce spectacle présenté en 1923 lors de la Semaine du Bauhaus _que visita Le Corbusier_, le costume rigide contraint en effet l'acteur à la discipline et aux gestes mécaniques, mais entraîne bientôt ses réactions, ses infléchissements, ses quêtes de nouveaux équilibres, et révèle bientôt une construction hybride spatio-temporelle inédite. Les mouvements s'aiguisent paradoxalement comme aucune machine ne le pourrait, constate l'historien. «De tous les domaines où s'exercent l'activité du Bauhaus, celui-là seul atteint à une parfaite liberté. » ${ }^{36}$ Ces costumes, parfois agrémentés d'accessoires ou éléments scéniques furent pour Schlemmer des «praticables », autrement considérés comme « appareillage » du mouvement par Véronique Fabbri ${ }^{37}$.

Cet exemple atteste d'une certaine influence de dispositifs vestimentaires abstraitisés sur l'émergence d'un rythme ou mouvement vivant, qui va dans le sens de la possibilité de penser une transposition des dispositifs rythmiques de Appia au bénéfice du vêtement moderne. En retour, quand le vêtement moderne apparaît comme enveloppe rythmique, les casiers corbuséens se donnent à comprendre comme des «praticables » contribuant à offrir à l'espace domestique une certaine qualité rythmique.

Objet-membre ou enveloppe rythmique, les deux pistes ont en commun de loger la question du vêtement moderne au cœur des débats de l'époque sur la place de l'homme dans l'ère machiniste, et sur la question de la vie partagée entre approche scientifique et approche philosophique. Dans les années 1920, où la machine s'est immiscée dans toutes les dimensions du quotidien, le corps tend à être considéré comme un objet technique, la cinématographie permet d'en étudier les comportements, le taylorisme de les maîtriser, la psychologie expérimentale d'en mesurer les seuils de perception.

Toutefois, ce qui distingue les deux points de vue se joue autour de la relation des vêtements (et derrière eux des artefacts) avec le corps, qui simule celle de la mécanique à l'organique. La relation est-elle de supplément, qui considère le corps comme incomplet, manquant de défense vis-à-vis des réalités du monde physique, et doit être protégé et complété? Tirant profit des connaissances biologiques, elle motive la maîtrise et la redéfinition de l'organique. Ou bien la relation est-elle d'appareillage, qui ménage un moyen intermédiaire de rencontre, confrontation, idéalement d'harmonie, entre le corps et la nature de plus en plus étrangère du contexte technique? Le vêtement comme enveloppe rythmique constitue « un appareillage extérieur, visible, qui ne fait que souligner l'appareillage ordinaire du corps, d'une manière discrète : ils ne se substituent pas au corps et aux gestes comme des prothèses ou des machines ${ }^{38}$ comme l'écrit Fabbri. Il ne fait qu'accompagner le corps organique dans son fonctionnement vivant.

Le vêtement moderne cristallise derechef une question idéologique majeure pour le design. En bref, doit-il porter? Ou être porté? Elargi du modèle à ses applications, la question devient : les artefacts modernes doivent-il engendrer un homme nouveau ou résulter de l'homme nouveau? Où le modèle du vêtement moderne emporte-t-il notre architecte?

\footnotetext{
${ }^{36}$ Ibid. p. 73.

${ }^{37}$ Fabbri, Véronique : "De la structure au rythme. L'appareillage des corps dans la danse". In Huyghe, Pierre-Damien (Dir.) : L'art au temps des appareils. Paris : L'Harmattan, 2005. pp. 93-121

${ }^{38}$ Ibid.p. 93
} 
Pour tenter de répondre, nous nous tournons vers Le Corbusier, designer de vêtement ${ }^{39}$. En 1952, pour la revue Formes et Vie, il présente un «costume pour la femme d'aujourd'hui », qu'il défend d'être «une création de haute-couture ${ }^{40}$. Il s'agit de vêtements «permanents», aux lignes simples (pièce d'étoffe carré sans coupe spéciale, robe d'une pièce juste plissée sous la taille ), de «dimensions proportionnées », pratique pour les activités de la vie quotidienne. De la sorte taillés pour une femme-type, ils satisfont à la définition d'un objettype par leur absence d'expression artistique. L'auteur précise même que ce costume est fait «pour un être vivant possédant une charpente osseuse, muscles et rondeurs utiles, chair et sveltesse » dont il a pensé, en architecte et peintre, le voilement ou dévoilement. Nous devons comprendre que le corps organique est bien à la base de la proposition_il faut un corps porteur_ mais qu'elle n'entend pas pour autant offrir la condition de la nudité (le textile ne doit jamais serrer mais tomber bien, les jambes et bras nus visent la liberté de mouvement ) ni conférer l'apparence d'un autre corps, non plus suppléer à quelque fonction. Leur géométrie offre de laisser aller le corps ou de le soutenir, il incite une gestualité et permet in fine une attitude libre individuelle (qui peut aller jusque s'inventer de nouvelles manières de s'asseoir). La relation apparaît d'autant plus contrastée que ces vêtements sont de mesure vague par rapport aux contours corporels. A contrario, un vêtement prothèse comme une peau supplémentaire réduirait le jeu à néant.

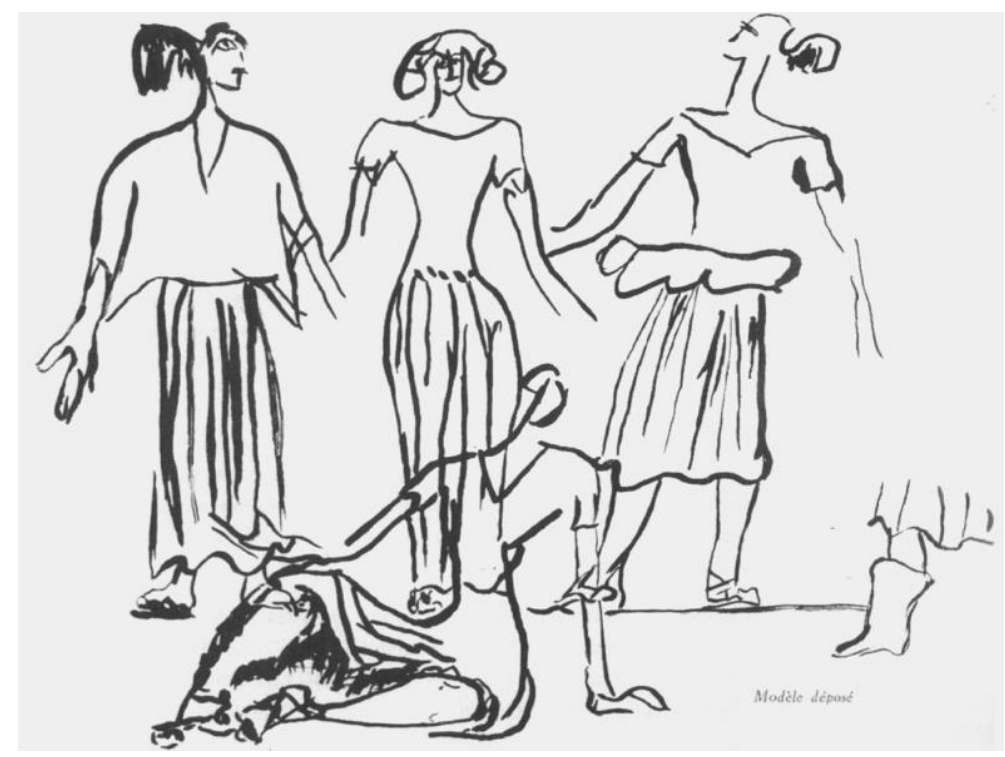

6. Dessin de Le Corbusier, Formes et Vie n², 1952 @FLC/ADAGDP

Le corps est couvert, disparaît majoritairement, mais se manifeste autrement au travers de cet objet, par son mouvement. La tenue se compose et se transforme par ailleurs au gré des envies «éphémères ». C'est dès lors une logique d'appareil qui se manifeste ici. Fabbri explique encore que «l'appareil ne forme pas, mais révèle l'être-forme du matériau (...) il n'a pas pour fonction de soumettre la matière à une forme, ni l'objet à un usage $»^{41}$. Ce costume ne conforme pas, ne porte pas, mais révèle l'être vivant derrière le corps organique.

La position de Le Corbusier n'est ainsi pas évidente, quand ce projet de vêtement témoigne du potentiel du vêtement type à se faire enveloppe rythmique.

\footnotetext{
${ }^{39}$ Le projet s'en tient en l'occurrence à des dessins et commentaires, une indication « Modèle déposé » ne renvoie à aucune information à l'INPI.

${ }^{40}$ Le Corbusier : "Note". Formes et Vie, N², 1952. Paris : Éditions Falaize. p.11.

41 "De la structure au rythme. L'appareillage des corps dans la danse". Op.cit. p. 96.
} 


\section{Sur la conception prothétique corbuséenne du design . Le tailleur-designer}

Selon Forty, quand il analyse les rouages historiques du développement du design industriel, nous avons affaire, avec la théorie des objets-membres, à une conception prothétique du design ${ }^{42}$ que Le Corbusier aurait majoritairement contribué à diffuser.

L'idée d'un parallèle, littéral ou métaphorique, entre le processus d'évolution des objets et celui du monde naturel se développe au XIXème siècle dans le contexte des sciences biologiques naissantes; et profite alors dialectiquement autant à préciser la compréhension du vivant qu'à orienter le déploiement économique du monde artificiel. Une idée de l'organique infiltre à la fin du siècle les discours sur l'art ou l'architecture. Par-delà l'acception théorique que Sullivan ou Wright lui donneront, Muthesius y puisera même en 1902 pour expliquer les variations de la mode ${ }^{43}$. Malgré la diversité et l'imprécision scientifique des extrapolations, malgré le démenti apporté par la génétique quant à la réalité et la pertinence d'un tel schème, la théorie prothétique aura, dans ses diverses versions, une fortune remarquable au XXème siècle et encore actuellement.

Réagissant à la version promue par Le Corbusier, qui laisse imaginer que la conception des objets se situe en dehors des questions poétiques et esthétiques, repliée sur une venue naturelle au monde, Forty remarque que cette thèse ne vaut rien puisqu'elle situe l'acte de design en dehors de la conscience humaine, laissant planer le plus grand mystère. Malgré tout, l'historien pointe que cette idée va faire son chemin dans la discipline et donner prise à un fonctionnalisme radical. Elle invite en effet à considérer le processus créatif d'objet comme la seule traduction de la mécanique corporelle en un produit mécanique artificiel, adossée sur l'étude la plus rigoureuse et exhaustive des dimensionnements et logiques mécaniques de l'être humain. C'est en effet une perspective prise par le design à partir des années 1950 en s'appuyant sur l'ergonomie, comme en témoignent Joe et Josephine, les deux américains modèles que Henry Dreyfuss a conçu comme charte de design ${ }^{44}$. Plus récemment, les modélisations algorythmiques des phénomènes naturels, les biotechniques et biomimétiques, les processus évolutionnaires, etc. actualisent cette conception à l'ère numérique ${ }^{45}$.

Quoique le discours approche «du moins superficiellement $»^{46}$ un tel point de vue, Forty défend Le Corbusier de telles ambitions. Aux côtés des «objets-sentiments» des Beaux-Arts, des «objets à réaction poétique » de la nature, les «objets-membres » illustrent métaphoriquement la quête d'objets-type parfaits fondée davantage sur des questions de pureté esthétique de leur forme, telle que les lois de la nature en génèrent pour les coquillages ou les fleurs, que sur une gestion industrielle de la standardisation des formes des produits en relation aux corps. Par ailleurs, les illustrations de L'art décoratif d'aujourd'hui révèlent assez qu'il n'existe aucune référence formelle, loin s'en faut, au biomorphisme.

Puis l'auteur explique ce qu'il estime des applications prometteuses du concept prothétique. Elles sont de deux natures : d'abord sociale, liée à la nature symbolique de tout objet prothèse du fait de sa présence autour du corps et son influence sur l'habitus ; ensuite sensorielle ou auto-érotique, liée aux contacts corporels et à la

\footnotetext{
${ }^{42}$ Forty, Adrian : «Industrial design and prosthesis ». Ottagono, №16, Septembre 1990. Milano : CO.P.IN.A. pp. 114-129

43 «On peut sans doute expliquer les raisons psychologiques de ce changement dans le fait que certains organes activés en admirant telle forme deviennent las avec le temps et retrouve une activité en s'orientant vers d'autres formes». MUTHESIUS, Hermann : "Die Moderne Umbildung Unserer Äesthetischen Anschauungen (1902). In Kultur und Kunst, Jena : Berlegt Bei Eugen Diederichs, 1909. p.35-75, citation p. 39. Traduction personnelle.

${ }^{44}$ Dreyfuss, Henry : Designing for people (1955), 4th ed. New York : Alworth Press, 2012.

${ }^{45}$ Steadman, Philip : The evolutions of design : biological analogy in architecture and the applied arts, 2nd ed. Abingdon (UK) - New York (USA) : Routledge, 2008.

46 «Industrial design and prosthesis ». Op.cit. . Traduction in Midal, Alexandra : Design, l'anthologie. Saint-Etienne : Cité du design - Genève : HEAD, 2013. p. 398.
} 
participation gestuelle. De tels objets convoquent des qualités esthétiques étendues, capables de suppléer d'une autre façon à des manques du corps que la psychanalyse corrobore. Il faut y voir un nouvel idéal de luxe, suggère l'historien, non plus défini, comme c'est le cas habituellement par des valeurs propres au travail artisanal ou artistique, mais «c'est à cela, à la qualité de l'expérience que l'objet procure aux sens, que la vision prothétique du design attache le plus de valeur ${ }^{47}$. Notons que l'ergonomie tient compte de tels critères esthétiques et psychologiques dans ses « facteurs humains » pourvu qu'on puisse les rapporter à des données (Joe et Joséphine ont des «inhibitions et obsessions $»^{48}$, sont sensibles à un toucher inconfortable, à une couleur agressive ou à une odeur désagréable, etc.).

Bien que Forty ait recours abondamment à des vêtements et accessoires pour étayer sa démonstration, dont un modeste chapeau qui nous rappelle la panoplie-type de notre architecte, Forty ne l'inclue pas dans ces ouvertures du prothétique. Telle que nous l'avons approchée, la position de Le Corbusier ne se retrouve pas en effet dans cette vision du design comme prothèse, quoiqu'elle se définisse bien par un rapport privilégié entre corps et objet. Je voudrais montrer qu'elle ne se résout pas en un formalisme adossé sur des «mesures de l'homme » prises avec le mètre du tailleur, et soutenir a contrario que l'inscription fondatrice du vêtement moderne, (et il faut rappeler qu'il s'agit du vêtement moderne féminin), c'est-à-dire le fait que le vêtement moderne soit la base idéologique de tout objet-membre et maison-cellule, permet d'entrevoir et d'esquisser un point de vue prothétique alternatif aux versions fonctionnaliste, ergonomique et même néo-luxe, riche d'autres mesures et sensations proprement humaines. Cette proposition n'est pas sans conséquence quand on se souvient que le Modulor fut commenté et critiqué comme anthropo-métrique (stricto sensu la caractérisation des «mesures de l'homme ») déshumanisante ${ }^{49}$.

Pour amener cela, nous nous intéressons aux propos que Le Corbusier tient sur la conception à l'âge de la machine lorsqu'il voyage aux USA en 1935, et y découvre une situation avancée sur le plan industriel qui le laisse dubitatif. L'ouvrage qui le relate, Quand les cathédrales étaient blanches, débute ainsi : «Je vais montrer par l'USA, pris comme exemple, que les temps sont neufs mais que la maison est inhabitable ${ }^{50}$. On y trouve un appel réitéré à la réforme du costume masculin, le vêtement moderne acquérant même un statut paradigmatique dans un passage explicite.

«Curieuse fin de civilisation : l'homme qui porta des plumes d'autruche sur la tête, roses, blanches et bleu-roi, une vêture de brocarts ou de soie rutilante, ne sait plus que fourrer ses deux mains dans les poches d'un pantalon noir. (...) Il demeure que la question est à reprendre et que la transformation du costume masculin est nécessaire. » ${ }^{51}$ C'est pour lui une question éthique et institutionnelle. Comme Wigley le révèle, face à l'influence du vêtement et derrière lui au spectre inquiétant de la mode, le mouvement moderne développa un système de défense et traça sa voie sous la surveillance de «Watchdogs » ${ }^{52}$ qui s'assurèrent, à tout le moins, de garder le vêtement féminin à distance. Seul le vêtement standard masculin eut droit de considération officiellement (et les murs blancs comme surfaces-type prothétiques en sont l'écho). Le vestiaire féminin, moderne y compris,

\footnotetext{
${ }^{47}$ Ibid. p.400.

${ }^{48}$ Ibid. p. 194.

49 «Mégalomanie (...) perte de réalité humaine (...) isolement de la nature (...) Dans ce milieu extrêmement conformé, l'homme ne peut être admis qu'anthropologiquement : le Modulor est la fiche anthropométrique. ». Commentaires de Hervé Baley et Dominique Zimbacca parus dans le numéro spécial de Aujourd'hui : art et architecture en 1965 dédié à l'architecte juste décédé

${ }^{50}$ Le Corbusier : Quand les cathédrales étaient blanches. Paris : Plon, 1937. p.7.

${ }^{51}$ Ibid. p. 124.

${ }^{52}$ White walls. Un chapitre est explicitement dédié à la « Fashion Policy ». Op.cit. pp. 35-57.
} 
cristallisant les forces transitoires, changeantes, incontrôlables du monde dont on cherchait à se prémunir ; quand c'est justement ce qui offre à Le Corbusier d'y percevoir « l'esprit de l'âge machiniste », un certain ordre vivant. Il répète d'ailleurs dans son texte l'épanouissement des femmes, comme il le fera de nouveau en 1942 dans son Entretien aux étudiants en architecture, où le vêtement féminin moderne est chargé de ses arguments éthiques sur la modernité.

«Le costume est l'expression d'une civilisation. (...) Le costume décèle les sentiments les plus fondamentaux ; par lui, nous manifestons notre dignité, notre distinction, notre frivolité ou nos ambitions profondes. Bien que standard, le costume masculin ne se dérobe pas à l'intervention individuelle. Mais il ne convient plus. De ce qu'il subsiste, nous avons la preuve que la révolution machiniste n'es pas à maturité. » ${ }^{53}$

Plus loin, dans ce même ouvrage, un passage sur le jazz retient notre attention en ce que Le Corbusier semble y remarquer cette même capacité que le vêtement à traduire le renouveau et à porter la réforme. Le jazz, commente-t-il, est un événement (comme il avait commenté la disparition du mobilier en 1929). Il ne résulte pas d'une conception délibérée. Il représente «les forces présentes » qui se manifestent via les corps accompagnés, «appareillés », de leurs instruments. Nous nous trouvons dans la même situation que le corps appareillé par le vêtement, mais ici la mécanique de l'orchestre (qu'il apparente à une turbine) ancre plus directement le dispositif dans l'ère industrielle. Or, comme l'auteur en témoigne personnellement, il autorise une expérience sensuelle et thymique. «Musique d'époque de construction : novatrice. Elle inonde le corps et le coeur. (...) Elle est si puissante, si irrésistible psycho-physiologiquement, qu'elle nous a arrachsé à la passivité de l'audition, et nous fait danser ou gesticuler, participer. " ${ }^{54}$ Et encore "La musique entre dans la poitrine des hommes et des femmes, s'y rive, y emporte le flux du sang, y met en dynamisme le corps entier, tandis que la pensée s'élève sur l'aile de la mélodie. » ${ }^{55}$

Ce passage illustre le potentiel de la machine, capable de mobiliser profondément les individus, en libérant des énergies originaires. En 1942, il vantera de nouveau les femmes aux vêtements libérés (dont il souligne les couleurs comme signe vital) pour leur démarche vive et saine, leur audace et leur optimisme. Ce sont précisément de tels mouvements (spontanés, animés ou dansés, ou le fait qu'une attitude exprime de la timidité ou de la confiance, de l'insécurité ou, de la stabilité) qui motivèrent les travaux de Straus, en ce qu'ils échappaient (et échappent toujours, signale Boissière) à l'explication scientifique, à la causalité déterministe et aux modélisations objectives. Quand la locomotion et la motricité étaient sujets de tous les intérêts, de tels élans demeurent la seule affaire de celui qui les vit. On peut certes les mesurer, les décomposer et les mimer, (même dans leurs aspects sensoriels), mais on ne sait pas les susciter, on ne parvient pas en reproduire artificiellement la sensation ou «sentiment vivant». Ils se replient en effet sur la catégorie philosophique du « sentir». Et la Rythmique constitue en quelque sorte une méthode pour sentir, (re)trouver et exercer ce qui rejoint le « rythme vécu».

Or, quelque-chose dans le témoignage de Le Corbusier nous y renvoie. Il attire en effet l'attention sur la discordance entre les mouvements libérés, gesticulatoires, et «la mathématique » de la musique jazz. Derrière les corps emportés, sang et âme, il relève avec insistance "l'exactitude implacable », l'orchestre «impeccable, sans trou, régulier, en ascension rythmique $»^{56}$. Un ordre se loge paradoxalement derrière l'expérience de

\footnotetext{
${ }^{53}$ Quand les cathédrales étaient blanches. Op.cit. p. 124-125

${ }^{54}$ Ibid. p. 180

${ }^{55}$ Ibid. p. 181

${ }^{56}$ Ibid. p. 183
} 
saisissement. De même, comme nous l'avions évoqué rapidement, une géométrie épurée est la paradoxale condition de l'activation plastique des corps. Les Espaces Rythmiques sont, comme le commente Boissière, «d'une étonnante immobilité et apparente vacuité » 57.

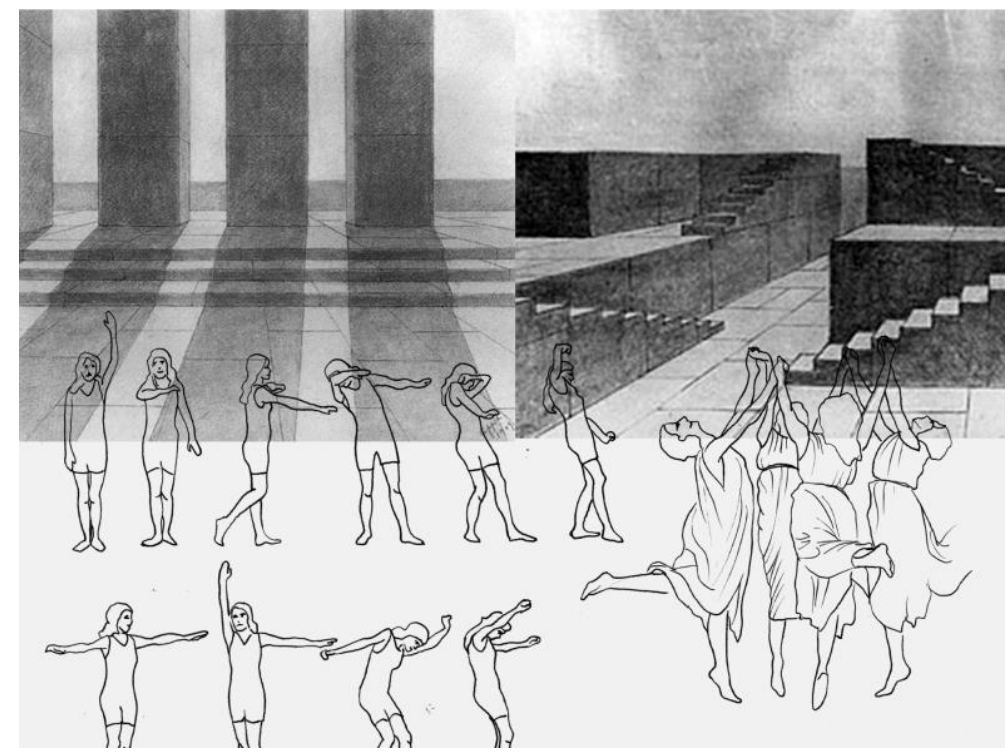

7. Exercices de Rythmique, d'après la Méthode Jacques-Dalcroze,

sur fonds des dessins Espaces rythmiques de Adolphe Appia, 1909-1910

Ils ne sont pas eux-mêmes animés dans leurs dessins. On n'y trouve aucune évocation organique telle que ondulation, serpentine ou entrelac. A contrario, leur composition est régulière, à partir de lignes essentiellement horizontales et verticales, qui se concentrent localement en des escaliers créant une logique ascendante. Elle n'a pas pour fonction de guider le mouvement, mais de fournir tout appui utile pour qu'il s'élance lui-même (comme on s'appuie sur un pilier pour prendre une impulsion). Il n'est pas donné par le dispositif, le corps n'est pas porté. Et ce contexte autorise par contraste l'émergence d'un mouvement ou rythme propre. Le sentiment vivant résulte de cette mobilisation profonde du corps appareillé par un ordre étranger à lui-même.

Un tel dispositif évoque une qualité prothétique dont la condition est la paradoxale dissimilitude avec le corps organique (il n'est pas besoin, au contraire, qu'il soit ergonomique), et dont l'expérience spécifique se situe au niveau de ces sensations d'être vivant. Le vêtement moderne, le costume féminin designed by Le Corbusier, le jazz, et après eux, les objets-type corbuséens, illustrent cette prothétique paradoxale.

De là, comme Straus l'a théorisé, naît une sensation d'espace qui outrepasse l'espace physique, un espace présentiel (ou «espace acoustique »). Celui-ci se définit par une notion subtile de mesure, qui n'a à voir ni avec le mètre mécanique, ni avec le tempo musical, mais qui peut être comprise comme cadre ou envergure au sein duquel on ressent l'espace vivant, et que l'on peut seulement rapporter à des «proportions ${ }^{58}$. C'est bien le corps qui porte, en lui, autour de lui, cette sorte d'espace. Comme Boissière l'analyse, elle peut être comprise dans le cadre de la philosophie de Heidegger, comme un saut qualitatif, de l'ordre du poétique, qui est la condition de l'habiter.

\footnotetext{
${ }^{57}$ Musique Mouvement. Op.cit. p.76

${ }^{58}$ «La mesure serait-elle en nous-même? Serions-nous le créateur de l'espace? Pour qui? Nous sommes seuls. Ce sera donc pour nous seul que nous créerons l'espace, c'est-à-dire des proportions que notre corps pourra mesurer dans l'espace sans limite qui lui échappe. »Ibid. p.115
} 
La prothétique corbuséenne nous apparait dès lors comme un travail de tailleur-designer à qui revient la tâche de concevoir des artefacts comme des enveloppes, de «mesure moyenne » (à l'instar des casiers standards) ou «de dimensions proportionnées » (à l'instar de son projet vestimentaire), fonctionnels au sens de praticables, avec le moyen desquelles le corps pourra transformer les phénomènes complexes ambiants de l'époque (sa «musique ») en un mouvement vivant, et développer son habitation. Comme il en existe des versions extensive ou supplétive, c'est là une prothétique poétique.

\section{Conclusion}

«Pour parler de Le Corbusier, il faut remonter aux années 20. Là, il traça tout son chemin. Quarante ans après, il restait dans ses sillons ${ }^{59}$, commentait Iannis Xenakis en 1965.

Notre rapide parcours autour de la considération de Le Corbusier pour le vêtement moderne ne le dément pas, quand il révèle comment celui-ci se mua à ce moment-là en un modèle fondateur. La conférence de 1929 tient à ce titre un rôle important quand elle synthétise ce qui l'occupait diffusément sur le sujet depuis de nombreuses années, et parvient à en extraire la substance active, la mobilité, au-delà des raisons formelles et fonctionnelles.

Surtout, attestant d'une position hardie au sein du mouvement moderne et du territoire du design en émergence, elle ose focaliser l'attention sur le nouveau vestiaire féminin, ce qui représente une précision par rapport aux écrits théoriques précédents qui avaient posé le costume standard masculin à l'origine d'une idéologie prothétique, nonobstant le scientisme ou l'imprécision qui cerne cette conception. Le féminin se comprend ici, non pas au sens de la féminité et de la mode, mais comme «une forme de l'esthétique qui convient » à «l'esprit de l'âge machiniste », l'idéalité d'une résolution entre ordonnancement et plasticité (comme il le relèvera en 1935 pour le jazz), permanence et éphémère (comme il ne notera en 1952 au sujet de la «femme d'aujourd'hui »), qui précise l'importance accordée au mouvement harmonieux ou gracieux. Il est la musique ou le rythme des temps modernes, au sens que l'on a dit. Tout le propos de la conférence en est insidieusement affecté, et les «objetstype» ou «machines» $\mathrm{y}$ sont vantés nouvellement pour l'espace de jeu qu'ils autorisent, soit comme des praticables ou « appareils».

Toutefois, la richesse du discours tenu ce jour-là et l'inscription de la problématique au cœur des débats ne s'éclairent qu'avec le recours de techniques et théories propres à l'époque, telle que la Rythmique et la phénoménologie du mouvement, les notions d'œuvre vivante, de sensation et de mesure. Il atteste de la sorte de son ancrage vif et pertinent dans une actualité _ il n'est pas banal, il n'est pas universel_et subit consécutivement le risque d'être amoindri le jour suivant. Et en effet, la notion d'équipement domestique à laquelle il aboutit représente aujourd'hui un pont entre objets-membres et maison-cellule, omettant la référence initiale. Sa prothétique par ailleurs se retrouve évaluée en regard d'une technoscientifisation croissante du vivant.

Mais cette conférence constitue également un appel au design à repenser le costume masculin, c'est-à-dire à généraliser la réforme moderne initiée. Et Le Corbusier réitérera cette injonction en 1937 de retour des USA, en 1942 s'adressant aux étudiants ... Appel sans réponse, quoique force est de constater qu'il participe ici-même au réveil d'une pensée du vêtement en design.

\footnotetext{
${ }^{59}$ Aujourd'hui : art et architecture, $\mathrm{N}^{\circ} 51$ spécial, Novembre 1965. Op.cit. p.94.
} 


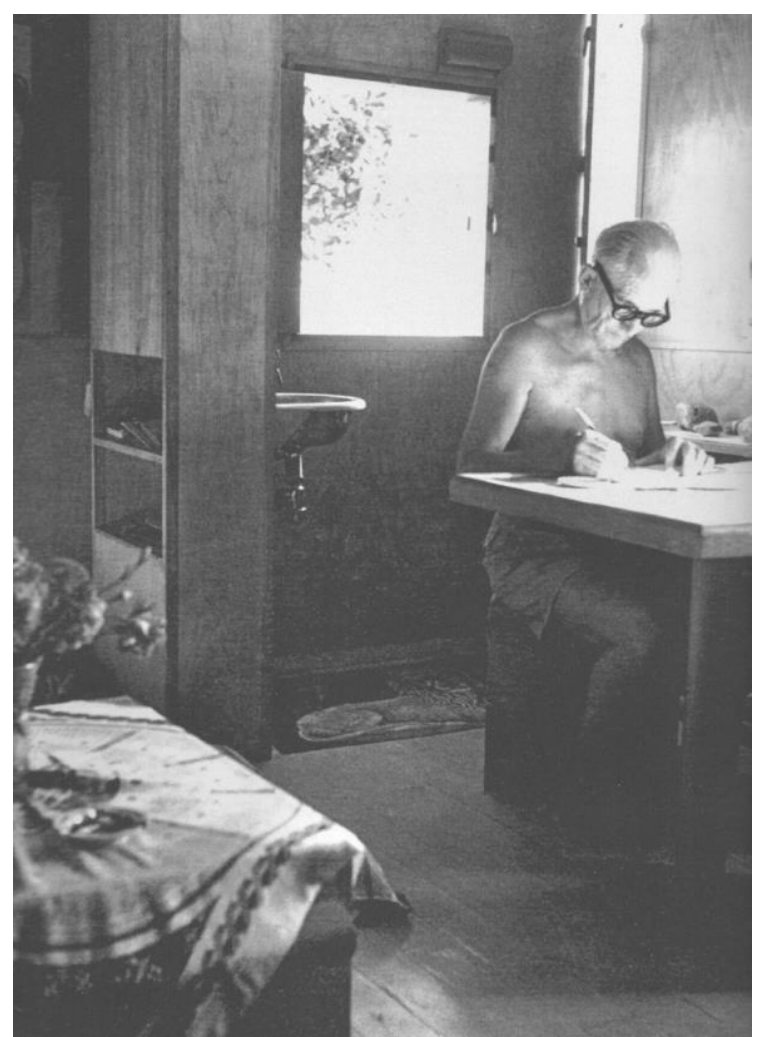

8. Le Corbusier dans le Cabanon, photo Lucien Hervé 1952 @ FLC/ADAGDP

En 1952, Le Corbusier installe son cabanon à Roquebrune-Cap-Martin, conçue selon l'outil de mesure que représente le Modulor. De dimensions très proches de sa chambre d'étudiant de 1908 (3,66m x3,66m x2,66m ), les casiers et le mobilier y sont optimisés, favorisant l'usage et la pratique d'un espace rigoureux, essentiellement vide, animé simplement de quelques lignes et de la lumière naturelle. «Application révélatrice. (...) La mise en service de cette construction a dépassé tous les espoirs. ${ }^{60}$ commente-t-il sommairement. Il y vivra quasiment $\mathrm{nu}$, se plaît-on à répéter. Notre hypothèse est que cette maison, plus petite qu'une cellule d'habitation, plus vague qu'un vêtement-type, constitue pour lui un pyjama architectural ${ }^{61}$, soit, à l'instar du vêtement moderne, une enveloppe rythmique qu'il put exercer corporellement et ressentir comme une architecture vivante.

\section{Références bibliographiques}

Banham, Peter Reyner : Théorie et design à l'ère industrielle. Orléans : édition HYX, 2009.

Boissière, Anne : Musique Mouvement, Paris : Manucius, 2014.

Cinqualbre, Olivier; Migayrou, Fréderic (Dir.) : Le Corbusier - Mesures de l'homme, Paris : Editions du Centre Pompidou, 2015. Catalogue de l'exposition tenue du 29 avril au 3 août 2015 au Centre Pompidou à Paris.

Fabbri, Véronique : "De la structure au rythme. L'appareillage des corps dans la danse". In Huyghe, PierreDamien (Dir.) : L'art au temps des appareils. Paris : L'Harmattan, 2005. pp. 93-121

\footnotetext{
${ }^{60}$ Le Corbusier : Oeuvres complètes, vol.5 : 1946-1952. Zurich : Les Editions d'architecture - Editions Gisberger, 1953. p. $62-63$

${ }^{61}$ Référence à la formule choisie par Gottfried Semper lors de sa dernière conférence tenue à Zurich en 1869 lorsqu'il encourage la jeune génération d'architectes à concevoir enfin le nouvel «habit architectural » digne de prolonger la nouvelle idée de l'histoire telle qu'il leur transmet. in Semper Gottfried : Du style et de l'architecture. Marseille : Parenthèses, Marseille, 2007. p.360
} 
Forty, Adrian : «Industrial design and prosthesis ». Ottagono, $\mathrm{N}^{\circ} 16$, septembre 1990. Milano : CO.P.IN.A. pp. 114-129

Guillaume, Valérie (Dir) : Europe 1910-1933, Quand l'art habillait le vêtement. Paris : Edition Paris Musées, 1997.

Jeanneret, Charles-Edouard; OZENFANT, Amédée : Après le cubisme. Paris : Éditions des Commentaires, 1918.

Le Corbusier : "Note”. Formes et Vie, N², 1952. Paris : Éditions Falaize. p.11.

Le Corbusier : «Entretien avec les étudiants des écoles d'architecture » (1942). in La Charte d'Athènes. Paris : Éditions du Seuil, 1971.

Le Corbusier : L'Art décoratif d'aujourd'hui, $1^{\text {st }}$ ed Crès, 1925. Paris : Flammarion, 1996.

Le Corbusier : Précisions sur un état présent de l'architecture et de l'urbanisme. Paris : Edition Altamira, 1994. Fac-similé de l'éd. de Paris : Crès, 1930.

Le Corbusier : Quand les cathédrales étaient blanches. Paris : Plon, 1937.

Le Corbusier : Vers une architecture, 1st ed Crès, 1923. Paris : Flammarion, 1995,

Loos, Adolf : Paroles dans le vide - Malgré tout. Paris : Editions Ivrea, 1994.

Michaud, Eric : Théâtre au Bauhaus. Lausanne : L'âge d'homme-La cité, 1978.

Midal, Alexandra : Design, l'anthologie. Saint-Etienne : Cité du design - Genève : HEAD, 2013.

Monneyron, Frédéric (Dir.) : Vêtement et littérature. Perpignan : Presses Universitaires de Perpignan, 2001.

Petit, Jean : Le Corbusier parle. Paris : Editions Forces Vives, 1967.

Semper Gottfried : Du style et de l'architecture. Marseille : Parenthèses, Marseille, 2007. Traduction et préface de Jacques Soulillou.

Steadman, Philip : The evolutions of design : biological analogy in architecture and the applied arts, 2nd ed. Abingdon (UK) - New York (USA) : Routledge, 2008.

Stern, Radu : Against Fashion, Clothing as Art, 1850-1930, 2nd ed. Massachusetts : The MIT Press, 2004.

Valéry, Paul : Oeuvres I. Paris : La Pléiade, 1957.

Wigley, Mark : White walls, designer dresses : the fashioning of modern architecture, 2nd ed. Cambridge (Massachusetts) - London (England) : MIT Press, 2001.

Xenakis, Iannis : w/o title. Aujourd'hui : art et architecture, № 51 spécial, Novembre 1965. Boulogne-sur-seine : w/o pub. p.94. 


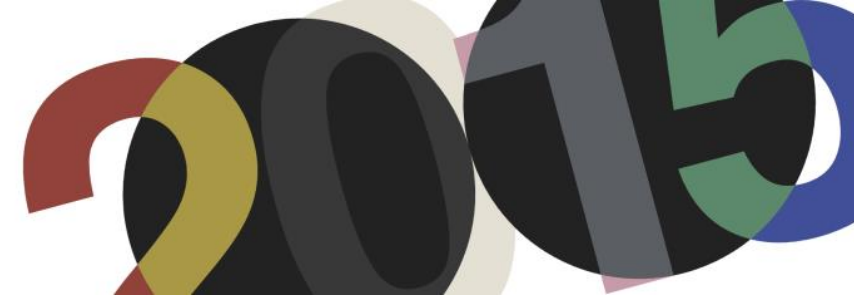

DOI: http://dx.doi.org/10.4995/LC2015.2015.783

\title{
Le Corbusier y Lúcio Costa. Diálogos sobre la síntesis de las artes
}

\section{F. Fernandes da Silva}

Faculdade de Arquitetura e Urbanismo. Universidade de São Paulo

\begin{abstract}
Resumen: En la poética de Le Corbusier, el arte comparece como presencia continua y articulada propuesta en los diálogos entre pintura, escultura y arquitectura, procedimiento que confluye posteriormente en la noción de síntesis de las artes. Es en ese aspecto de su producción que nos detenemos en este trabajo con los textos del arquitecto que se refieren al tema y analizando la interlocución que establece con el teórico brasileño Lúcio Costa. Damos relieve a dos momentos importantes del análisis del tema de los dos arquitectos: primero durante la segunda visita de Le Corbusier a Brasil en 1936, cuando presenta La Arquitectura y las Bellas Artes, texto en el que incorpora a sus ya conocidos postulados arquitectónicos la noción de síntesis de las artes, considerada como forma de ofrecer a la arquitectura recursos expresivos que van más allá del lenguaje abstracto y técnico del funcionalismo. La segunda ocasión de diálogo entre Le Corbusier y Lúcio Costa tiene lugar durante el Congreso Internacional de Artistas, organizado por la UNESCO en Venecia, cuando desenvuelven consideraciones sobre la relación entre arte y arquitectura.
\end{abstract}

Abstract: In the poetics of Le Corbusier, art appears as a continuous and articulate presence, as proposed in the dialogs between painting, sculpture and architecture, a process that converges, later, in the notion of the synthesis of the arts. It is on this aspect of his work that we focus exploring texts written by the architect on the theme. The proposed collaboration between the major arts-architecture, painting and sculpting-is recorded in a paper that the architect presented during his second visit to Brazil, in 1936, when he met Lúcio Costa, the Brazilian architect and theoretician, who was attuned to the poetics of Le Corbusier concerning the relationship between architecture and visual arts. The paper by Le Corbusier A Arquitetura e as Belas Artes [Architecture and Fine Arts], from 1936, emphasizes the idea of modern architecture in dialogue with the machine age, and to this well-known formula, a new topic is added: the collaboration between architecture and the major arts of painting and sculpting. In this way, Le Corbusier in 1952, participates in the International Conference of Artists, organized by Unesco in Venice, this conference was another opportunity for dialog between Lúcio Costa and Le Corbusier, emphasizing the poetic dimension of the architecture.

Palabras clave: síntesis de las artes; Le Corbusier; Lúcio Costa; arquitectura moderna. Keywords: synthesis of the arts; Le Corbusier; Lúcio Costa; modern architecture.

\section{Introducción}

En la poética de Le Corbusier, el arte comparece como presencia continua y articulada propuesta en los diálogos entre pintura, escultura y arquitectura, procedimiento que confluye posteriormente en la noción de síntesis de las artes. Es en ese aspecto de su producción que nos detenemos en este trabajo empleando los textos del arquitecto que se refieren al tema y estableciendo relaciones con sus obras arquitectónicas. En este contexto le conferimos un énfasis especial a los momentos del encuentro entre Le Corbusier y Lúcio Costa, cuando abordan el tema de la síntesis de las artes en un diálogo fructífero con significativos desdoblamientos en la arquitectura moderna brasileña.

La propuesta de colaboración entre las artes mayores -arquitectura, pintura y escultura- está registrada en el texto que el arquitecto presenta durante su segunda visita a Brasil, en 1936, cuando entra en contacto con Lúcio Costa, arquitecto y teórico brasileño, afinado con la poética corbusiana en los aspectos relacionados al diálogo entre arquitectura y artes visuales. En este encuentro surge la concepción del primer ejemplar significativo de la 
arquitectura moderna en Brasil - el Ministerio de Educación y Salud de Rio de Janeiro. El mismo se convierte en paradigma de la arquitectura realizada posteriormente en el país, en la que el tema de la síntesis de las artes será una constante, caracterizada por el trabajo conjunto de arquitectos, pintores, escultores que tienen como mentor a Le Corbusier, el cual encuentra en Lúcio Costa a su principal interlocutor.

El texto que Le Corbusier le confia a Lúcio Costa en 1936, fue publicado casi medio siglo después por el arquitecto brasileño en la Revista do Patrimônio Histórico e Artístico Nacional con el título Le Corbusier: L' Architecture et les Arts Majeurs ${ }^{I}$. Este texto es importante puesto que en él Le Corbusier incorpora la idea de síntesis de las artes, que según el autor, puede ofrecer a la arquitectura recursos expresivos que van más allá del lenguaje abstracto y técnico del funcionalismo.

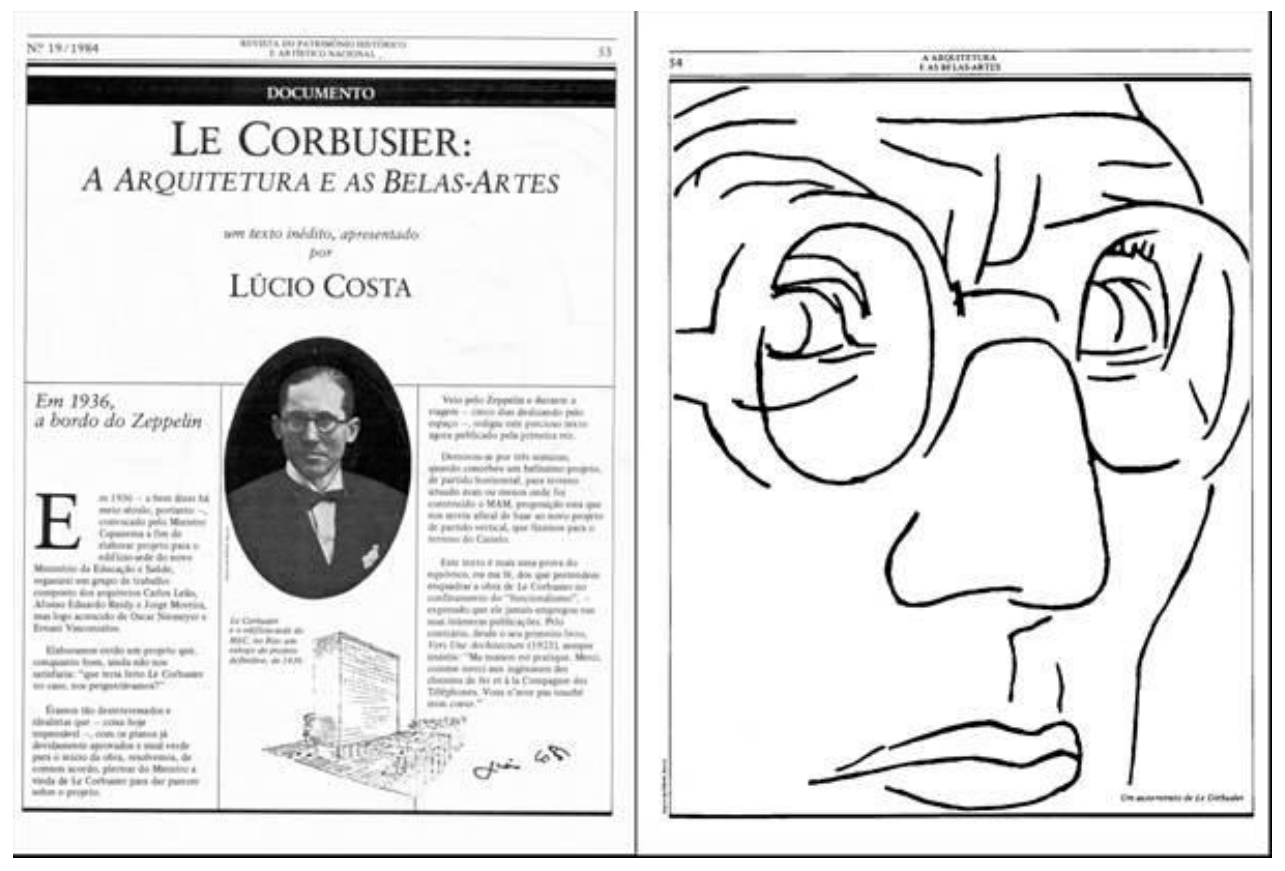

1. Le Corbusier: L’Architecture et les Arts Majeurs (1936), Revista IPHAN, presentación L.Costa.

En octubre del mismo año Le Corbusier participa en Roma del congreso Rapporti dell' architettura con le arti figurative, promovido por la Fondazione Volta. En la ocasión presenta el texto "Les tendances de l'architecture

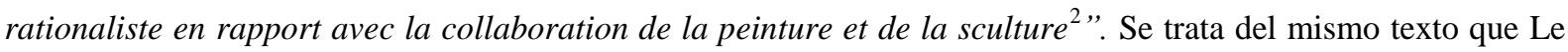
Corbusier le confía a Lúcio Costa durante su estancia en Brasil y que recién en 1980 fue publicado en este país. Es interesante observar que el subtítulo de la publicación brasileña corresponde al título del texto presentado en el congreso italiano y publicado en los Anales do congreso como esclarece Rosa Tamburini, responsable de la organización de los escritos de Le Corbusier en lengua italiana.

\footnotetext{
${ }^{1}$ Le Corbusier: A Arquitetura e as Belas-Artes ( L'Architecture et les Arts Majeurs). In Revista do Patrimônio Histórico e Artístico Nacional n.19, 1984, p.53-68.

${ }^{2}$ Le tendenze dell'architettura razionalista in rapporto alla collaborazione della pittura e della scultura. In Le Corbusier Scritti, org. Rosa Tamburini. Torino: Einaudi Editori, 2003, pp.281-294. De acuerdo com la organizadora de la obra el texto fue originalmente publicado in Reale Accademia d'Italia, Fondazione Alessandro Volta, Convegno di Arti, Rapporto dell'architettura con le arti figurative, Atti del VI Convegno, Roma 25-31 ottobre1936, Roma 1937, pp. 16-26. Hay también una publicación parcial del texto en la Revista Domus 107, novembro 1936, pp.36-38.
} 
La publicación en los Anales del Congreso romano fue ampliamente utilizada por los estudiosos del tema y considerada por Stanislaus von Moos como uno de los primeros textos en que Le Corbusier se dedica al studio de la relacion entre las artes mayores ${ }^{3}$. También Joan Ockam hace referencias a este texto, destacando la idea de colaboración entre las artes propuesta por Le Corbusier y también la importancia que el arquitecto le confiere al uso de colores en la arquitectura, aspecto ya explorado por el pintor Fernand Leger en algunos textos. La historiadora norteamericana revela el trabajo conjunto entre Le Corbusier y Leger en los temas relativos al acercamiento entre arquitectura y artes plásticas y traza un panorama de los debates que tienen lugar en Francia en la segunda posguerra en relación a la síntesis de las artes ${ }^{4}$. Es a partir del traslado de Leger a New York durante la segunda guerra, que Ockman establece la continuidad de la reflexión sobre la síntesis de las artes en territorio americano. De hecho, la propuesta se retoma en el manifiesto Nueve Puntos sobre la Monumentalidad, elaborado en colaboración por F. Leger, por el historiador suizo S. Giedion y por el arquitecto español J.L. Sert, en el que la síntesis de las artes comparece como elemento de representación cívica, calificando los espacios públicos de la ciudad.

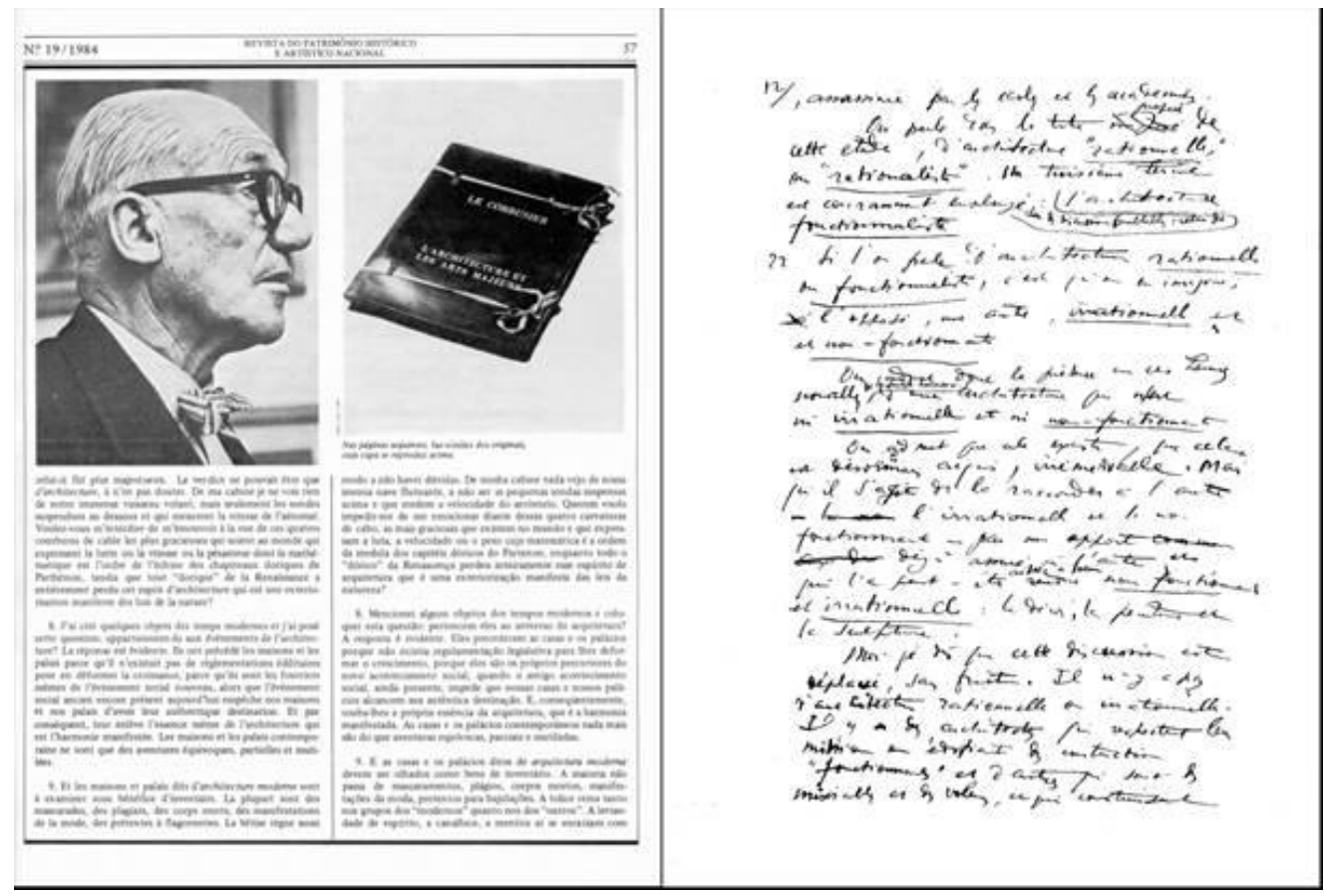

2. Le Corbusier: L’Architecture et les Arts Majeurs (1936). Revista do IPHAN, manuscrito de Le Corbusier.

Como bien observa Juan Calatrava esta nueva historiografía de la arquitectura contemporánea promueve una revisión de la imagen conferida a Le Corbusier como arquitecto funcionalista que aboga por una civilización maquinista. Esta lectura reduccionista queda relativizada en función de nuevos enfoques surgidos en los últimos años, que permiten una visión más compleja y consistente de su obra, que abarca arquitectura, pintura y escultura estableciendo tránsitos y articulaciones entre las distintas esferas expresivas de su producción. En las palabras

3 Stanislaus von Moos. Exhibition Architect? Otra mirada sobre la "síntesis" de Le Corbusier. In Juan Calatrava org. Doblando el Ángulo Recto. Siete ensayos em torno a Le Corbusier. Madrid: Circulo de Bellas Artes, 2009, pp.61-62.

${ }^{4}$ Juan Ockman A Plastic Epic: The Synthesis of the Arts Discourse in France in the Mid-Twentieth Century. In Eeva-Lisa Pelkonen and Esa Laaksonen, ed. Architecture + Art.New Visions, New Strategies. Helsinki: Alvar Aalto Academy, 2007, pp.30-61. 
del historiador y crítico español es posible así distinguir "un autre Le Corbusier", a partir de la idea de síntesis de las artes.

En la estela de estas revisiones es importante lanzar una nueva mirada sobre la arquitectura moderna brasileña deudora de primera hora de la propuesta corbusiana de síntesis de las artes y que en las palabras de S. Giedion se presenta como alternativa a la arquitectura racionalista del entreguerra europeo ${ }^{6}$.

\section{Lúcio Costa y Le Corbusier: interlocuciones con la arquitectura moderna brasileña}

El momento definitorio del diálogo entre Le Corbusier y Lúcio Costa aquí citado tiene lugar en Rio de Janeiro en 1936, cuando Le Corbusier visita Brasil por segunda vez y permanece tres semanas impartiendo conferencias y trabajando como consultor del proyecto del Ministerio de Educación y Salud, proyecto realizado por un equipo de arquitectos liderados por Lúcio Costa ${ }^{7}$. Este encuentro propicia la confluencia de ideas y de experiencias que contribuyen a la concepción del primer ejemplar significativo de la arquitectura moderna realizada en Brasil, caracterizada por el trabajo conjunto de arquitectos, pintores, escultores y por el paisajismo de Burle Marx.

Anteriormente Lúcio Costa ya se había manifestado sobre la relación entre arte y arquitectura en su texto de 1934, Razões da Nova Arquitetura (Razones de la Nueva Arquitectura), señalando la importancia del diálogo entre las artes para una producción arquitectónica significativa y de acuerdo con la época moderna ${ }^{8}$. Del mismo período es el texto de Le Corbusier: L'Architecture et Les Arts Majeurs ${ }^{9}$, 1936, en el que el autor enfatiza la concepción de una arquitectura moderna en diálogo con la era de la máquina y por ende pautada por la economía de medios, pero considera que también es acrecentada de valores de espacio, luz y volumen, cualidades arquitectónicas que van más allá de la pura funcionalidad. A esta formulación, ya divulgada en su libro de 1923 Vers une Architecture, añade un nuevo tema, fruto de sus reflexiones más recientes, que se refiere a la colaboración entre la arquitectura y las artes mayores, la pintura y la escultura, considerándola como factor positivo que merece ser utilizado en casos excepcionales. Además, identifica en la policromía la expresión espontánea de la vida y factor esencial de la manifestación arquitectónica.

De esta manera Le Corbusier incorpora a sus postulados la noción de síntesis de las artes, que tendrá desdoblamientos en las reflexiones del arquitecto en la segunda posguerra y también en el ámbito de los Congresos Internacionales de Arquitectura Moderna (CIAM). Estas concepciones tendrán repercusiones en el proyecto del ministerio, concebido en el momento de la definición de esta propuesta. En este se concreta una arquitectura orientada por las directrices de Le Corbusier, que resulta en la elevación de los volúmenes sobre pilotis, en las terrazas-jardín del ático, en las superficies trabajadas con brise-soleil, en los paños de vidrio y en la planta libre del bloque de la administración. A esta significativa adhesión a los postulados modernos de matriz

\footnotetext{
5 Juan Calatrava. Un autre Le Corbusier: l'idée de la synthèse des arts majeurs. In La lettre du Collège de France. Paris: Collège de France, abril 2010, no. 28, pp.18-28. Consultado en la version grabada hospedada en internet en: http://lettre-cdf.revues.org/1049.

${ }^{6}$ S. Giedion O Brasil e a Arquitetura Contemporânea (Zuric, 1956). In Henrique E. Mindlin Arquitetura Moderna no Brasil. Rio de Janeiro: Aeroplano, 1999. (prefácio)

${ }^{7}$ Forman parte del equipo, dirigido por Lúcio Costa, los arquitectos Affonso Eduardo Reidy, Carlos Leão, Oscar Niemeyer, Jorge Moreira y Hernani Vasconcellos.

${ }^{8}$ Lúcio Costa Razões da Nova Arquitetura (1934), in Lúcio Costa. Registro de uma Vivência . São Paulo: Empresa das Artes, 1995, p.108-16.

${ }^{9}$ Le Corbusier: A Arquitetura e as Belas-Artes (L’Architecture et les Arts Majeurs). Revista do Patrimônio Histórico e Artístico Nacional n.19, 1984, p.53-68. ( publicado en portugués et francés).
} 
corbusiana se incorporan trabajos de artistas plásticos, como las esculturas de Bruno Giorgi, Celso Antonio y Jacques Lipschitz, los murales de Cândido Portinari, además de los jardines del pintor y paisajista Roberto Burle Marx.

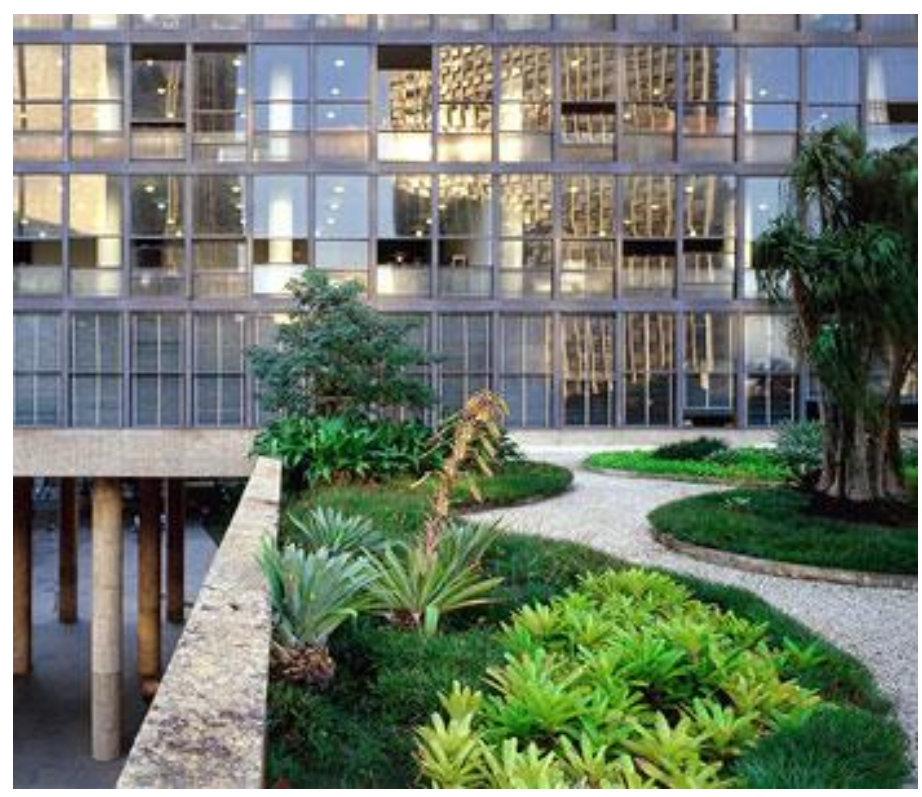

3. Ministerio de Educación y Salud, jardines del paisajista Roberto Burle Marx.

Portinari realiza el dibujo de los azulejos que revisten las superficies de los volúmenes que en la planta baja del edificio conviven con los pilotis. Los azulejos se inspiran en motivos marinos: peces, conchas y caballitos marinos distribuidos en una disposición geométrica que equilibra los elementos figurativos en la concepción del conjunto realizado en blanco y azul, que evocan tanto la ubicación del edificio en una ciudad costera como también la azulejería de los atrios de conventos de la arquitectura tradicional brasileña ${ }^{10}$. Burle Marx concibe los jardines valiéndose de nuevas soluciones formales materializadas en las diversas texturas de la vegetación tropical. Con estas contribuciones la solución arquitectónica de lenguaje moderno aparece mezclada con sugestivas evocaciones locales y se hace matriz de una arquitectura moderna en diálogo con la tradición y con las demás artes.

En un texto de 1987, Carlos Eduardo Comas observa que la posición destacada del edificio en relación al espacio urbano es uno de los aspectos que le confieren dimensión de monumentalidad, convirtiéndose en un marco de referencia y ganando así atributos que lo califican en tanto elemento de rememoración ${ }^{11}$. El autor observa que esos valores están distantes de las propuestas modernas que buscaban en el prototipo la posibilidad de reproducir en serie el edificio o sus partes en producción industrial. Por lo tanto, como señalaba Comas, en principio, las concepciones de monumento y prototipo no dialogan y aparecen como aparente contradicción en el interior de la obra. En este sentido cabe advertir que durante la segunda guerra mundial, cuando se construye el edificio,

\footnotetext{
${ }^{10}$ Los azulejos, por solicitud del propio Portinari fueron realizados en el Atelier de Azulejos Ozirarte, pequeña industria creada y dirigida en la década de 1940 por Paulo Rossi Ozir, volcada a la producción de azulejos artísticos. Rossi Ozir declara que fue realizado un largo proceso de experimentación con los colores hasta alcanzar un tono de azul semejante al utilizado en los azulejos portugueses de la época colonial. Sobre Paulo Rossi Ozir véase Paulo Mendes de Almeida, De Anita ao Museu. São Paulo: Editora Perspectiva, 1976, p.161-13.

${ }^{11}$ Carlos Eduardo Comas, Protótipo e Monumento, um ministerio, o ministerio . En Textos Fundamentais sobre história da arquitetura moderna: vol1, organización Abílio Guerra. São Paulo: Romano Guerra, 2010, p.63-77. (publicado inicialmente in revista Projeto 102, ago 1987, p.136-49)
} 
vamos a presenciar la entrada de la noción de monumento en las discusiones del campo arquitectónico internacional. Analizar este cambio de posición nos ayuda a comprender los distintos factores que confluyen en la propuesta del edificio del Ministerio.

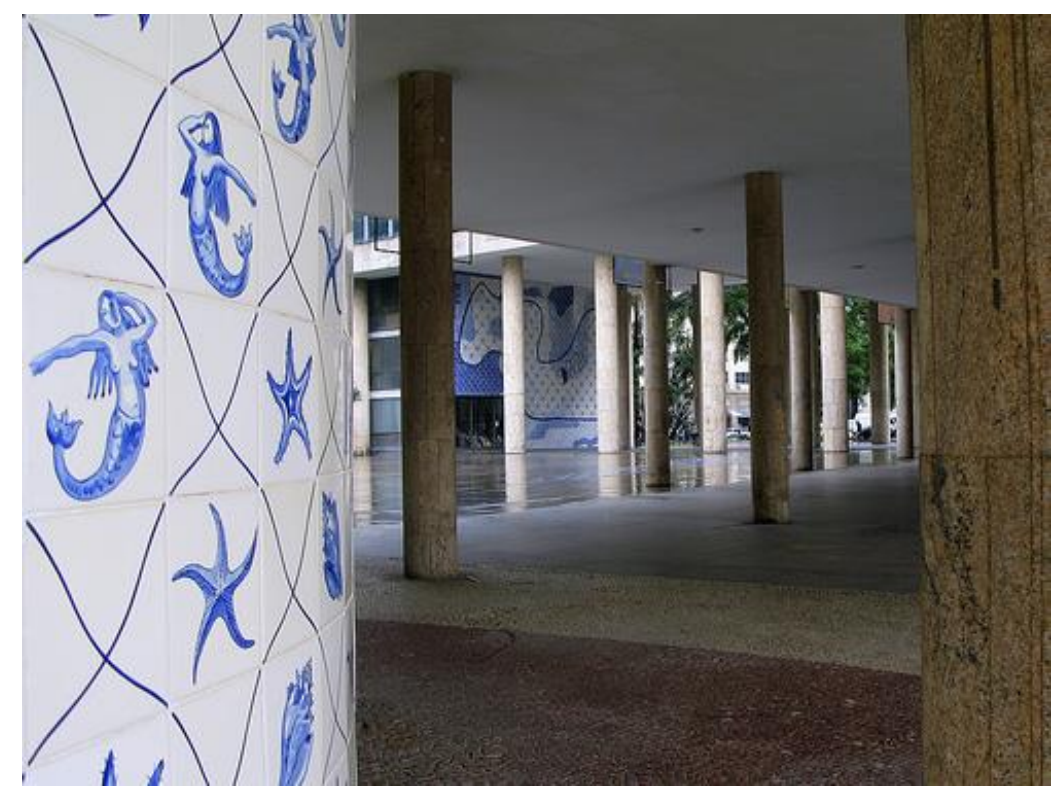

4. Ministerio de Educación y Salud, planta baja - pilots e azulejos.

Le Corbusier ya había introducido el tema de la monumentalidad en clave moderna en su proyecto para la sede de la Sociedad de las Naciones en Ginebra (1927-28) y será por obra de S.Giedion, J.L. Sert y F. Leger, cercanos a Le Corbusier, que se retomará la cuestión como parte del proceso de revisiones de las directrices de la arquitectura moderna durante y después de la segunda guerra mundial. Exiliados en Nueva York, en la diáspora de artistas, arquitectos e intelectuales a América provocada por la II Guerra, Giedion, Sert y Leger, lanzan en 1943 el manifiesto Nueve puntos sobre la Monumentalidad. En el mismo, la noción de monumento se emplea en su concepción etimológica de memoria, de aquello que recuerda, y en tanto memoria, moviliza aspectos subjetivos y emotivos como la pertinencia al lugar y la identidad, cuestiones distantes de una modernidad que hasta entonces se planteaba prioritariamente como propuesta de futuro. Asimismo, el manifiesto sostiene que uno de los elementos que contribuye a la elaboración de una arquitectura-monumento es la participación de otras esferas artísticas, como la pintura y la escultura, en la concepción arquitectural, en la medida en que estas la califican e individualizan.

De este modo, como indica Comas, no es de extrañar que Philip Goodwin en 1943 presente el edificio del Ministerio como solución de una metodología funcionalista pautada por la eficiencia operativa ${ }^{12}$. S.Giedion hará una lectura distinta en su texto Por una Nueva Monumentalidad publicado en la recopilación organizada por Paul Zucker en 1944, en la que se presentan fotos del Ministerio como solución ejemplar de las formulaciones por él defendidas en relación a la monumentalidad. La aparente dicotomía radica en el hecho de que el análisis de Giedion se da en el momento en que el crítico está involucrado con la proposición de monumento que incorpora el aspecto de la relación entre las artes, y así lanza una mirada sobre aspectos de la obra del ministerio que permanecían en un segundo plano frente a los evidentes principios corbusianos allí concretados y sintonizados con la época maquinista. 


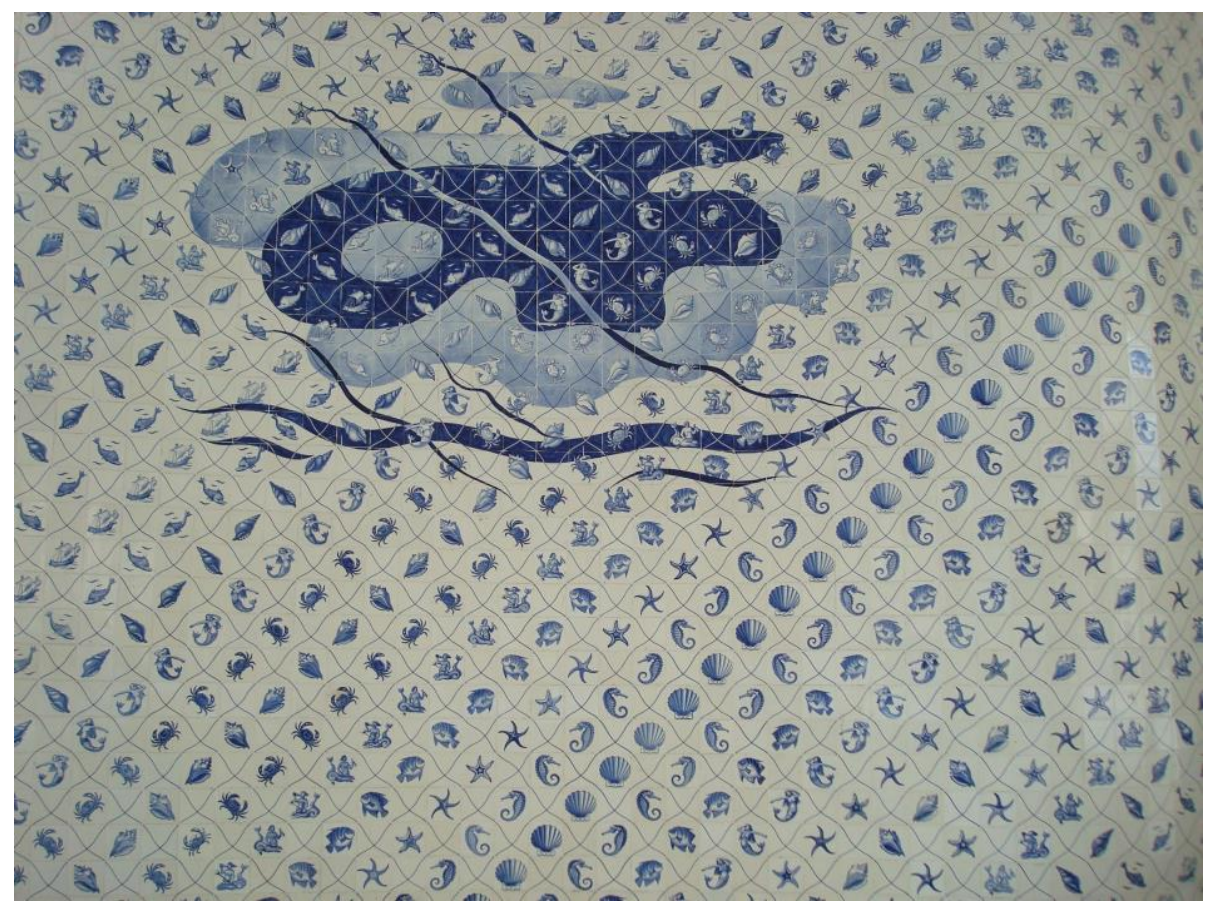

5. Ministerio de Educación y Salud, azulejos en motivos marinos de Candido Portinari

Intencionalmente o no las características de monumento atribuidas al Ministerio condicen con el ambiente cultural que lo produjo, en el que el tema de la brasileñidad gana importancia en la concepción de una arquitectura que se anhelaba expresión del país y representativa de una institución dedicada a la educación y a la cultura. La idea de nación era un factor de cohesión importante en la política del gobierno Vargas, de carácter autoritario y populista. Por otro lado, la presencia de Lúcio Costa como líder del equipo que proyecta el Ministerio reverbera en sus constantes inferencias en lo que atañe a la representatividad del edificio, lo que acrecentaba al proyecto características poco ligadas a la pura racionalidad. Además, tenemos la proximidad de Lúcio Costa con las cuestiones ligadas a la preservación, en las que el término monumento nunca perdió su prestigio en sus aspectos de memoria e identidad.

A partir del proyecto del Ministerio el tema de la síntesis de las artes será una constante en el pensamiento de la arquitectura moderna brasileña. En este contexto se desenvuelven las principales obras del arquitecto brasileño Oscar Niemeyer, desde el proyecto de la Igreja da Pampulha en colaboración con el pintor Cândido Portinari, hasta los palacios de Brasilia. Otros arquitectos como el carioca Afonso Eduardo Reidy, además de otros menos afinados con los principios corbusianos, se alinean a esta tendencia que acaba por caracterizar la arquitectura moderna brasileña. La reflexión sobre el tema de la síntesis de las artes en Brasil ocurre en paralelo a su desarrollo en el campo internacional, y aunque este debate no se desenvuelva de modo constante y articulado, se puede observar que adoptará distintos sentidos a lo largo del tiempo, muchas veces yendo más allá de la especificidad de la interlocución entre arte y arquitectura y definiéndose como propuesta de transformación de la sociedad. 


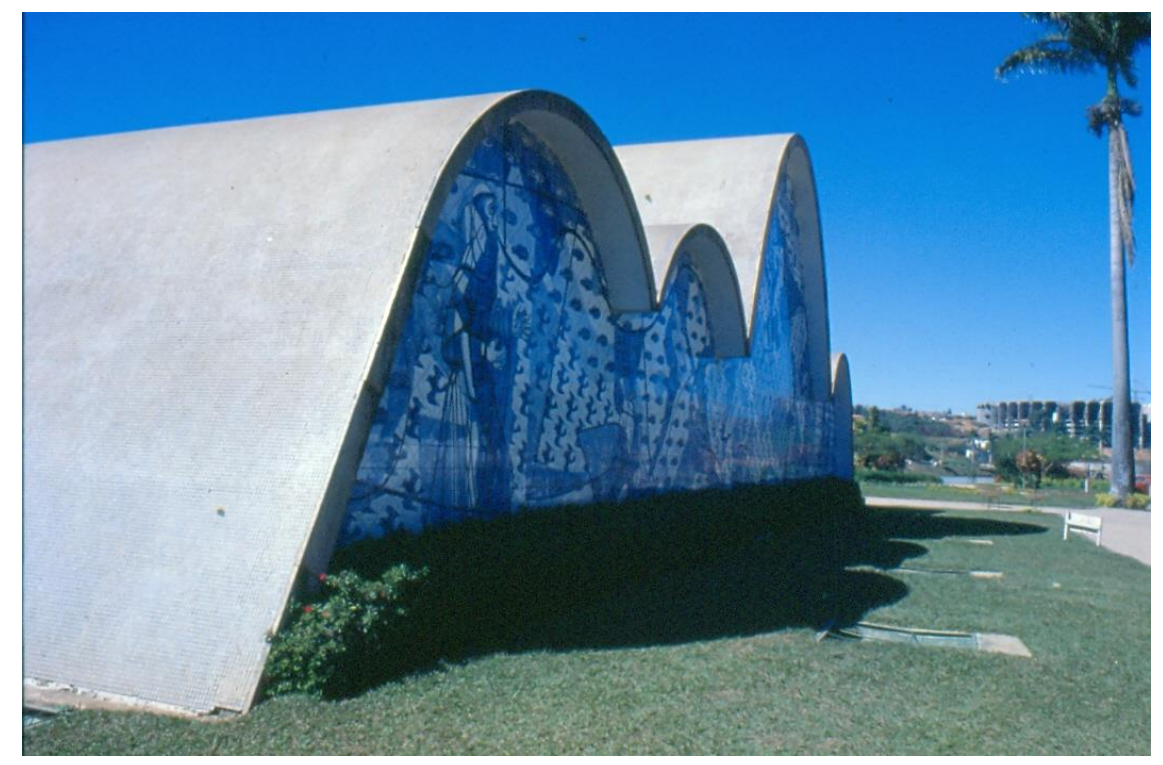

6. Igreja da Pampulha, proyeto Oscar Niemeyer, panel en azulejos Candido Portinari

\section{Le Corbusier y la síntesis de las artes}

Charles- Eduard Jeanneret (Le Corbusier) se establece en París en 1917 donde conoce a Amédée Ozenfant, quien lo vincula a la vanguardia parisiense, en aquel momento volcada a las discusiones sobre el cubismo, y donde tiene la oportunidad de relacionarse con diversos artistas, como Juan Gris, Fernand Leger y Jacques Lipchitz. Al año siguiente, Jeanneret y Ozenfant escriben conjuntamente el manifiesto Aprés le cubisme, que publicado al terminar la primera guerra mundial, se presenta como reflexión estética y social, insertándose en el proceso de reconstrucción en curso en el ambiente cultural francés ${ }^{13}$.

Las elaboraciones formales del purismo propuestas en el manifiesto definen una poética pautada por elementos escogidos entre objetos ya existentes, de los cuales se extraen formas específicas. La elección de estos objetos se define por leyes mecánicas, que establecen que los mismos deben tender hacia un tipo determinado de evolución de las formas, caracterizado por la máxima utilidad y economía de fabricación. Además, también se opta por los más banales, aquellos que se insertan en la vida cotidiana y que mejor representan objetos-tipo, perfectamente legibles y de fácil identificación, con características de generalidad y que tienden a lo estándar.

En 1920 Ozenfant y Le Corbusier fundan con el poeta y publicitario dadaísta Paul Dermée la revista L'Esprit Nouveau, que se torna vehículo de difusión de sus ideas hasta $1925^{14}$. En ella se presentan temas que remiten a experiencias artísticas precedentes, como el impresionismo y el cubismo, y que señalan la conformación de un lenguaje abstracto y lógico, basado en la búsqueda de elementos constantes de la sensibilidad plástica, que aparece en la conformación de los cilindros, de las esferas y de los cubos, y también en los elementos simples y cotidianos, asumidos como nuevos valores y presentes en botellas, vasos y macetas, considerados como parte de la búsqueda de repertorios específicos de la nueva cultura pictórica. ${ }^{15}$

\footnotetext{
${ }^{13}$ Ozenfant e Jeanneret (Le Corbusier) Depois do cubismo (Aprés le Cubisme). Introdução Carlos Alberto Ferreira Martins. São Paulo: Cosac Naify, 2005.

${ }^{14}$ Es en este momento -1925- cuando Charles-Edouard Jeanneret adoptará el pseudónimo Le Corbuisier.

${ }^{15}$ Roberto Gabetti e Carlo Olmo, Le Corbusier e L’Esprit Nouveau. Torino: Einaudi Editori, 1975, p.27.
} 
El acercamiento de Le Corbuisier a Fernand Leger, que en ese momento se dedicaba a la reflexión sobre la pintura y la arquitectura, refuerza su interés por el tema. El trabajo conjunto de ambos se concreta en el Pabellón L'Esprit Nouveau, realizado para la Exposición de Artes Decorativas de París, en 1925. La obra sintetiza los estudios conducidos hasta entonces por el arquitecto en relación a la vivienda. En ella se presenta una célula immeuble-villas derivada de la Casa Citrohan, que a su vez evoca el automóvil en tanto máquina que se basa en la eficiencia y en la simplicidad, características que, según el arquitecto deberían ser parte de la casa moderna. El razonamiento desarrollado por Le Corbuisier, que conducía del módulo hasta la esfera urbana, también está presente en la propuesta del pabellón. Al lado de la célula de vivienda, el arquitecto introduce un ambiente que alberga un diorama donde los proyectos de la Ville Contemporaine y del Plan Voisin se presentan como ejemplos de los posibles desdoblamientos del empleo del prototipo a escala urbana. La espacialidad del pabellón también dialoga con las demás artes, en interacción con la escultura de Lipchitz y la pintura de Leger, además de albergar la propia obra pictórica de Le Corbusier ${ }^{16}$.

La progresión de la obra arquitectónica de Le Corbusier revela su paulatina adhesión a la síntesis de las artes. Su actividad como pintor funciona como campo experimental para la concepción espacial de la arquitectura y en ella se inserta a través de paneles y elementos esculturales, haciendo unitaria la doble acción arquitectónica y plástica. Su trayectoria se centra en la concepción de una arquitectura en sintonía con la sociedad moderna y se desdobla en pinturas, dibujos, collages, murales y tapices. El arquitecto considera estos últimos, por su potencial movilidad, el mural moderno (Muralnomad), que acompaña al hombre urbano cuando cambia de casa. En la poética de Le Corbusier, la emoción plástica y la emoción arquitectural son constantes que remiten a una obra que resuena en diapasón, en sintonía con las leyes, las relaciones y la proporción. En ese universo, es factible invitar a pintores y escultores a alinearse con la arquitectura.

La reflexión sobre la síntesis de las artes también aparece en los sucesivos textos del arquitecto que al mismo tiempo que esclarecen los principios guía de la moderna arquitectura ligada a la civilización de la máquina, eligen la síntesis de las artes mayores como calificadora de esa misma arquitectura. Le Corbusier retoma la problemática de la relación entre las artes en su texto "L’espace indicible"17 Aquí el espacio es considerado como realización de la emoción plástica evocada en la consonancia de tres artes: la pintura, la escultura y la arquitectura. En relación a la síntesis, considera que la aproximación entre esas artes se hace en función del espacio, elemento común a todas ellas. Con todo, las espacialidades se generan a partir de los medios propios de cada una de las artes y confluyen para promover la emoción estética, vista por el autor como esencialmente una función espacial. Así, la acción de la obra se extiende al ambiente, a las paredes de las salas, a las plazas públicas $\mathrm{y}$ al paisaje.

Por lo tanto, se verifica una ampliación de la inserción de las artes, ahora consideradas en el ambiente urbano, a semejanza de lo que había sido propuesto por Giedion, Sert y Leger en relación a la "nueva monumentalidad", con todo, la idea de síntesis se desplaza hacia la concepción espacial preservando así las especificidades de cada medio de expresión. Formulada por el arquitecto en 1946, esta concepción espacial será explotada en sus obras del período, como la Capilla de Ronchamp y el convento de La Turrete, en los que las elaboraciones de luz y la inserción de pinturas del propio arquitecto alimentan la concepción de nuevas espacialidades arquitectónicas, ahora construidas con concreto bruto, que en su rudeza remite a las dificultades enfrentadas por Francia en el proceso de reconstrucción de posguerra.

\footnotetext{
${ }^{16}$ Jean-Louis Cohen. Le Corbusier. La planète comme chantier. Paris: Les Éditions Textuel, 2005.

${ }^{17}$ Le Corbusier. L'Espace Indicible. In L'Architecture d'aujour'hui, (número fora de série). Paris: Éditions de L'Architecture d'aujour'hui, 1946, pp.9-10.
} 


\section{Lúcio Costa y Le Corbusier: interlocuciones entre arte y arquitectura.}

El año de la visita de Le Corbusier a Brasil, el debate sobre la colaboración entre las artes gana un nuevo impulso en París, con la creación de la asociación Unión para el Arte, iniciativa de André Bloc que, desde los años treinta dirige la revista L'architecture d'Aujourd'hui. El periódico se torna uno de los principales vehículos de difusión de los debates y de la producción de la síntesis de las artes. Producto natural de su actuación en favor de esas ideas, en la década de 1950 André Bloc constituye el Groupe Espace, que llevará a cabo constantes investigaciones pictóricas y esculturales de integración con la arquitectura ${ }^{18}$.

Lúcio Costa también continúa trabajando con el tema de la relación entre las artes y en 1948 participa del simposio organizado por la revista inglesa Architectural Review titulado In Search of a New Monumentality ${ }^{19}$, que se inserta en la discusión iniciada en la posguerra como propuesta de revisión de los postulados modernos. El simposio adopta como punto de partida para la reflexión sobre el tema el presupuesto de que la arquitectura funcionalista es insuficiente para enfrentar los problemas del hombre contemporáneo y propone como alternativa la necesidad de una arquitectura que exprese las aspiraciones colectivas. Para tal se retoman las diversas concepciones de la palabra monumentalidad a lo largo del tiempo, buscando circunscribir la que sea más adecuada a las aspiraciones del presente. En el texto escrito para este seminario Lúcio Costa señala la importancia de las contribuciones de la Bauhaus, de Mies van der Rohe y de F.L.Wright para la arquitectura moderna del siglo XX y entre estas destaca el papel de Le Corbusier por su pensamiento que abarca diversos aspectos de la concepción arquitectónica como la técnica y los aspectos funcionales de la construcción, las cuestiones sociológicas y urbanas, además de la dimensión plástica de la arquitectura y sus relaciones con la pintura y la escultura, conformando una totalidad ${ }^{20}$.

Más de una década después del primer encuentro entre Lúcio Costa y le Corbusier surge una nueva oportunidad de diálogo entre los dos arquitectos en relación al tema de la síntesis de las artes. Esta vez ambos participan del Congreso Internacional de Artistas, organizado por la UNESCO en Venecia en $1952^{21}$. En esta ocasión, Lúcio

\footnotetext{
${ }^{18}$ Joan Ockman hace una cuidadosa lectura de los debates sobre la síntesis de las artes en Francia en su texto A Plastic Epic. The Synthesis of the Arts Discourse in France in the Mid-Twentieth Century. In Eeva-Liisa Pelkonen and Esa Laaksonen, (eds) Architecture + art. New Visions, New Strategies. Helsinki: Alvar Aalto Academy, 2007, pp. 30-61.

${ }^{19}$ Los textos del simposio fueron escritos por arquitectos, urbanistas y críticos de arquitectura invitados y están publicados en la revista Architectural Review, n.621, setiembre, 1948, p.117-128, con una introducción, que establece relaciones y divergencias entre los mismos, señalando los principales enfoques. Además de Lúcio Costa, presentado como director del IPHAN y líder del Movimento Moderno en Brasil, participan del simposio: Gregor Paulsson (University of Uppsala), HenryRussell Hitchcock (Wesleyan University), William Holford (University of London), Siegfried Giedion (University of Zurik), Walter Gropius (Harvard University), Alfred Roth (editor de la revista Werk).

${ }^{20}$ Architectural Review, n.621, setiembre, 1948, p. 127. Un estudio profundo sobre Lúcio Costa y la cuestión de la monumentalidad en sus obras, especialmente en relación a Brasilia se encuentra en: Anna Beatriz Ayroza Galvão. A monumentalidade em Lúcio Costa: projeto de arquitetura e cidade moderna (La monumentalidad en Lúcio Costa: Proyecto de arquitectura y ciudad moderna). Tesis de doctorado. São Paulo: FAUUSP, 2005.

${ }^{21}$ Anales del congreso organizado por la UNESCO: El artista en la sociedad contemporánea. Conferência Internacional de Artistas, Venecia, 22-28 de septiembre de 1952. Londres: UNESCO, julio de 1954. La conferencia tiene carácter multidisciplinario con la participación de representantes de las distintas esferas artísticas y su presidencia recayó en Ildebrando Pizzetti; el tema general, el artista en la sociedade contemporánea, es presentado por Giuseppe Ungaretti. Los demás participantes son: Marc Connelly (teatro); Alessandro Blasetti (cine); Arthur Honegger (música); Taha Hussein (literatura); Lúcio Costa (arquitetura); Henry Moore (escultura); Jacques Villon (pintura). Entre los participantes del congreso se encuentran Le Corbuisier, Fernand Leger y José Luis Sert.
} 
Costa escribe el texto El Arquitecto y la Sociedad Contemporánea ${ }^{22}$ para la participación en el congreso. En él aborda dos temas, el primero sobre la unidad habitacional y el segundo sobre el arquitecto y su papel en el mundo contemporáneo. En relación a este segundo tema, Lúcio Costa retoma el pensamiento de Le Corbusier relevando que desde el principio, el arquitecto buscó situar la arquitectura más allá de lo meramente utilitario y que también recomienda la inclusión de expresiones tradicionales que preserven la facción particular de cada pueblo o cultura. Observa asimismo que el carácter eminentemente utilitario de la arquitectura moderna es incapaz de expresar algún sentido monumental. En sintonía con estas concepciones inserta el episodio singular de la arquitectura moderna brasileña, particularmente la obra del Ministerio (1936) que, según Costa, pone el énfasis en la calidad plástica y en el concepto lírico “...aquilo porque há de sobreviver no tempo, quando funcionalmente já não for útil” (“...esto es porque ha de sobrevivir en el tiempo, cuando funcionalmente ya no sea útil”). Tenemos aquí a Lúcio Costa como lector de Le Corbusier e impulsor de una arquitectura moderna atenta a la permanencia y a la innovación.

En el Congreso de Venecia, Lúcio Costa presenta oralmente un resumen del trabajo, en el que retoma el tema de la síntesis de las artes, reformulando la cuestión por él considerada como una postura de integración. Considera como factor esencial pensar la arquitectura en su dimensión plástica, observando que el trabajo conjunto de profesionales que actúan en distintas esferas artísticas debería darse mucho más como interrelación que como síntesis, quedando así preservada la dimensión específica de cada hacer artístico ${ }^{23}$.

En el mismo seminario, en su comunicación Les rapports des artistas entre eux: Synthèse des arts plastiques, Le Corbuisier enfatiza el fenómeno poético como factor esencial en la elaboración arquitectónica colocando la pintura y la escultura como elementos que provocan emoción, propone también que su concepción anterior de síntesis de las artes gane amplitud y se expanda para incluir la colaboración entre las artes aunque manteniendo las especificidades de cada una de ellas que, con sus papeles singulares, permiten establecer diálogos entre las diferencias. Esta propuesta viene asociada a la idea de un obrador, que posibilite el intercambio entre las diversas esferas artísticas, en el que las obras se realicen en condiciones arquitectónicas producidas con los materiales, las dimensiones y las características propias de la realidad. Esta actividad tendría un carácter experimental y de investigación y posibilitaría el intercambio de experiencias no sólo entre la arquitectura, la pintura y la escultura, sino también con otras artes como la música, a danza y el cine. Por lo tanto, lo que se propone es un partenariado entre diversas disciplinas artísticas, articuladas en un proceso que prevé relaciones variadas marcadas por la permanente vitalidad y por la búsqueda de nuevas posibilidades que resulten en fecundas transformaciones ${ }^{24}$. En este momento Le Corbusier ya no considera la relación entre las artes como síntesis, sino como interlocución

\footnotetext{
${ }^{22}$ Lúcio Costa. El Arquitecto y la Sociedad Contemporánea) 1952. In El artista en la sociedad contemporánea. Conferência Internacional de Artistas, Venecia, 22-28 de septiembre de 1952. Londres: UNESCO, julio de 1954, pp.89-100. El texto también está publicado en Lúcio Costa. Registro de uma vivência. São Paulo: Empresa das Artes, 1995, p.268-275.

${ }^{23}$ El texto de la intervención verbal de Lúcio Costa en el Congreso de Venecia de 1952 está publicado en la revista BrasilArquitetura Contemporânea n.1. Rio de Janeiro, ago-set 1953, pp.2,3. Y también en el libro: Lucio Costa. Registro de uma vivência. São Paulo, Empresa das Artes, 1995, pp.266-267 con el título Arte, manifestación normal de la vida. En este libro Lúcio Costa esclarece que cuando viajaba de Francia a Venecia, para participar del Congreso de la UNESCO, encontró en el tren a Le Corbusier que también viajaba a Venecia y que este le dio a ler el texto que presentaría en el congreso.

${ }^{24}$ Le Corbusier Les rapports des artistas entre eux: Synthèse des arts plastiques.. In Cäsar Menz org. Le Corbusier ou la Synthèse des arts. Genève: Skira, 2006, p.259-260.(communication faite a la Conférence internationale des artistas. Venise: Unesco, 1952. (FLC U3-7, 317 a 321). Publicación brasileña con el título: Canteiro de Síntese das Artes Maiores. Comunicación de Le Corbusier en la Conferencia Internacional de Artistas. Venecia, 25 de setiembre de 1952.In Cecília Rodrigues dos Santos et al. Le Corbuisier e o Brasil. São Paulo, Tessela / Projeto Editora, 1987, p.239-241. (FLC$\mathrm{U} 3,10.449 / 450)$
} 
productiva que mantiene las especificidades de cada una de ellas y en este sentido se acerca a la reflexión conducida por Lúcio Costa en el mismo seminario.

Las nuevas concepciones de Le Corbusier sobre la relación entre arte y arquitectura encuentran un espacio favorable para nuevas especulaciones arquitectónicas en su proyecto de pabellón para la Exposición de Bruselas, en 1958. La construcción provisoria representada por los pabellones siempre se mostró campo privilegiado de experimentación arquitectónica y Le Corbuisier no rehúye al desafío. En este caso la obra es concebida por solicitud de la empresa holandesa Philips, que desea un espacio para presentar no sólo sus productos sino fundamentalmente los resultados de sonido y luz posibilitados por la alta tecnología empleada en su producción. La respuesta de Le Corbuisier a esta demanda es la concepción de una envoltura arquitectural destinada a albergar un poema electrónico, obra que sintetizaría todas las potencialidades de las nuevas tecnologías. Para la concreción de la propuesta, será necesario movilizar varios frentes de acción, como la ingeniería, la arquitectura, la música y las artes visuales.

La arquitectura del Pabellón Philips es de superficies curvas que construyen su espacialidad. El cálculo de esas elaboradas superficies fue realizado por el ingeniero de origen griego Iannis Xenakis, que en la ocasión trabajaba en el estudio de Le Corbusier. Con gran interés por la música y por la matemática, Xenakis encuentra en la convivencia con Le Corbusier la posibilidad de construir especulaciones formales alimentadas por los estudios de geometría y composición conducidos por el arquitecto. Su intención era alcanzar la sensibilidad del espectador con efectos de sonido y luz y así evocar la tecnología que los hacía posibles. Para viabilizar sus objetivos, aprovecha la variación de curvas y rectas que define los partes de la superficie del pabellón para regular la variación de densidades sonoras. La movilidad de los cóncavos y convexos relativiza las relaciones topológicas de posición y dialoga con las imágenes y la música que componen el poema electrónico, concebido partiendo de una investigación de Le Corbuisier.

El poema electrónico duraba diez minutos y las paredes del pabellón funcionaban como pantallas de proyecciones que componían una narrativa de música e imágenes. El músico contemporáneo Edgar Varèse fue escogido para componer la melodía que daría ritmo a las imágenes seleccionadas por Le Corbuisier. La escultura O Dia (El día) de Michelangelo inauguraba la serie de imágenes y la seguían imágenes de campos de concentración, de la Anunciación de Giotto, de divinidades negras, de un telescopio, de la cabeza de un toro, de la torre Eiffel, de una galaxia. El poema concluía con el dibujo de una mano abierta, recurrente en el imaginario de Le Corbusier, que en ese momento aparece como símbolo de paz y conciliación, sintetizando la restablecimiento de la cultura europea de posguerra. ${ }^{25}$.

La mano que cierra el poema electrónico se materializa en el proyecto de Le Corbusier para Chandigarh, en India. De hecho, la búsqueda de la variedad de imágenes que componía el poema hecho de luz y sonidos fue conducida por Le Corbusier a la India. En ellas acaece la confrontación de Le Corbusier con otra cultura, que alimentará su imaginario con símbolos y objetos que comparecen en los paneles de colores y densos que pueblan las construcciones propuestas para el centro cívico de la nueva ciudad.

Para Le Corbusier, la síntesis de las artes es una proposición que se modifica a lo largo del tiempo, un mote que promueve la reflexión de la arquitectura en tanto fenómeno poético, señalando su dimensión estética en

\footnotetext{
${ }^{25}$ Las informaciones sobre el Pabellón Philips se basan en el libro de Alessandra Capanna Le Corbuisier Padiglione Philips. Torino: Testo \& Immagine, 2000, que contiene una cuidadosa investigación y documentación sobre esta obra;.y también: Peter Bienz. Il Poème électronique di Le Corbusier e il padiglione Philips all'Esposizione mondiale di Bruxelles del 1958. In Domus 828. Milano: Ed. Domus, luglio-agosto, 2000, pp.16-23.
} 
constante diálogo con el racionalismo de la máquina. A través de ese principio, el arquitecto busca reunir las artes en torno de una misma investigación, volcada a la renovación de la elaboración plástica, en la que colores y formas interactúan en un acuerdo espacial, como manifestación de una nueva época. Mediante las varias inflexiones tomadas por el tema de la síntesis de las artes es posible aprender las contradicciones y las dificultades del proyecto moderno, que no se detiene en la pura racionalidad y en el funcionalismo a que muchas veces se lo reduce y, de esta manera, logra revelar su complejidad interna.

\section{Procedencia de las imágenes}

1. Revista do IPHAN, n.19. Arquivo do IPHAN, Rio de Janeiro

2. Revista do IPHAN, n.19. Arquivo do IPHAN, Rio de Janeiro.

3. Ministério da Educação e Saúde. Rio de Janeiro. Foto da autora.

4. Ministério da Educação e Saúde, Rio de Janeiro. Foto da autora.

5. Ministério da Educação e Saúde, Rio de Janeiro. Foto da autora.

6. Igreja da Pampulha, Belo Horizonte. Foto da autora.

\section{Bibliografía/referencias}

Almeida, Paulo Mendes de. De Anita ao Museu. São Paulo: Editora Perspectiva, 1975.

Anales del Congreso organizado por la UNESCO: El artista en la sociedad contemporánea. Conferência Internacional de Artistas, Venecia, 22-28 de septiembre de 1952. Londres: UNESCO, julio de 1954.

Bienz, Peter. Il Poème électronique di Le Corbusier e il padiglione Philips all'Esposizione mondiale di Bruxelles del 1958. En Domus 828. Milano: Ed. Domus, luglio-agosto, 2000, pp.16-23.

Calatrava, Juan. Un autre Le Corbusier: l'idée de la synthèse des arts majeurs. En La lettre du Collège de France. Paris: Collège de France, abril 2010, no. 28, pp.18-28. Consultado na versão gravada hospedada na internet em: http://lettre-cdf.revues.org/1049.

Capanna, Alessandra. Le Corbusier Padiglione Philips. Torino: Testo \& Immagine, 2000.

Cohen, Jean-Louis. Le Corbusier. La planète comme chantier. Paris: Les Éditions Textuel, 2005.

Comas, Carlos Eduardo. Protótipo e Monumento, um ministério, o ministério. En Textos Fundamentais sobre história da arquitetura moderna: vol.II, organización Abílio Guerra. São Paulo: Romano Guerra, 2010, p.63-77.

Costa, Lúcio. Razões da Nova Arquitetura (1934). En Lúcio Costa. Registro de uma Vivência. São Paulo: Empresa das Artes, 1995, p.108-16.

El Arquitecto y la Sociedad Contemporánea, (1952). En El artista en la sociedad contemporánea. Conferência Internacional de Artistas, Venecia, 22-28 de septiembre de 1952. Londres: UNESCO, julio de 1954, pp.89-100.

Gabetti, Roberto; Olmo, Carlo. Le Corbuisier e L'Esprit Nouveau. Torino: Einaudi Editori, 1975.

Galvão, Anna Beatriz Ayroza. A monumentalidade em Lúcio Costa: projeto de arquitetura e cidade moderna. Tesis de doctorado. São Paulo: FAUUSP, 2005.

Giedion, Sigfried O Brasil e a Arquitetura Contemporânea (Zuric, 1956). En Henrique E. Mindlin Arquitetura Moderna no Brasil. Rio de Janeiro: Aeroplano, 1999. (prefácio)

In Search of a New Monumentality. En Architectural Review, n.621, setiembre, 1948, p.117-128,

Le Corbusier. "A Arquitetura e as Belas-Artes ( L'Architecture et les Arts Majeurs) (1936). En Revista do Patrimônio Histórico e Artístico Nacional n.19. Rio de Janeiro, 1984, p.53-68. 
Le tendenze dell'architettura razionalista in rapporto alla collaborazione della pittura e della scultura (1936). En Le Corbuisier Scritti, org. Rosa Tamburini. Torino: Einaudi Editori, 2003, pp.281-294.

L'Espace Indicible. En L'Architecture d'aujour'hui, (número fora de série). Paris: Éditions de L'Architecture d'aujour'hui, 1946, pp.9-10.

Canteiro de Síntese das Artes Maiores (1952). En Cecília Rodrigues dos Santos et al. Le Corbuisier e o Brasil. São Paulo: Tessela / Projeto Editora, 1987, p.239-241. (FLC- U3.10. 449/450)

Les rapports des artistas entre eux: Synthèse des arts plastiques,.In Cäsar Menz org. Le Corbusier ou la Synthèse des arts. Genève: Skira, 2006, p.259-260.(communication faite a la Conférence internationale des artistas. Venise: Unesco, 1952) FLC U3-7, 317 a 321).

Moos, Stanislaus von. Exhibition Architect? Otra mirada sobre la "síntesis" de Le Corbusier. En Juan Calatrava org. Doblando el Ángulo Recto. Siete ensayos em torno a Le Corbusier. Madrid: Circulo de Bellas Artes, 2009, pp.61-62.

Ockman, Joan. A Plastic Epic. The Synthesis of the Arts Discourse in France in the Mid-Twentieth Century. En Eeva-Liisa Pelkonen and Esa Laaksonen, (eds) Architecture + art. New Visions, New Strategies. Helsinki: Alvar Aalto Academy, 2007, pp. 30-61.

Ozenfant e Jeanneret (Le Corbusier). Depois do cubismo. Introdução Carlos Alberto Ferreira Martins. São Paulo: Cosac Naify, 2005. 


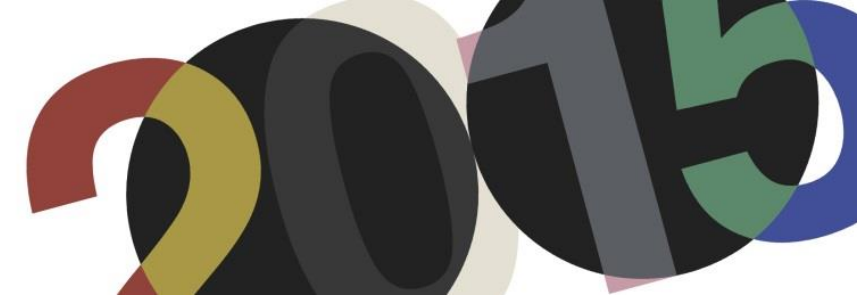

DOI: http://dx.doi.org/10.4995/LC2015.2015.495

\title{
Listening and the League of Nations: Acoustics Are the Argument
}

\author{
S. von Fischer
}

Senior Researcher, Ecole Polytechnique Fédérale de Lausanne (EPFL)

\begin{abstract}
In the debates following the 1926-27 competition for the new headquarters of the League of Nations in Geneva, the acoustic aspect was largely overlooked. The competition coincided with the formation of architectural acoustics as a profession and an academic discipline. Looking at this coincidence sheds new light on the reasoning of Peter Meyer and Sigfried Giedion, who, in support of Le Corbusier and Pierre Jeanneret's scheme, gave remarkable prominence to arguments about acoustics. The transmission of speech in the large Assembly Hall with seating for 2,700 could not be resolved by traditional techniques, and opinions on the modern method of electroacoustic amplification differed greatly. The protagonists who stepped forward in favor of Le Corbusier and Pierre Jeanneret's scheme, for which Gustave Lyon served as acoustic advisor, emphasized the sound quality of their design for the large Assembly Hall. Despite the acoustically infeasible competition brief, they declared literal understanding, based on the intelligibility of speech, to be a fundamental function of the League of Nations headquarters.
\end{abstract}

The questions raised in this paper relate to architecture's aurality and visuality, as well as claims concerning function in debates on Modernism. Diplomatic understanding was evidently at stake in the League of Nations' political program, but, curiously, literal understanding was neglected in the acoustic design for the Assembly Hall by many of the competitors and the jury, and - apart from a short remark by Jacques Gubler in 1985 - was subsequently overlooked by historians.

Keywords: acoustics; function; functionality; League of Nations; Gustave Lyon; Franz Max Osswald.

\section{Introduction: Understanding at the League of Nations}

This paper revisits the arguments following the 1926-27 competition for the headquarters of the League of Nations in Geneva, often referred to as the Palace of the League of Nations. While the architects were concerned with looking at the plans and elevations, at the stage of the competition many of them largely overlooked the projects' acoustical feasibility, which would come to play a prominent role in the assembly hall's technical performance, as well as in the protagonists' rhetoric and Modernism's claims to functionality: "The design they [Le Corbusier and Pierre Jeanneret] had submitted was essentially one for a place to work in, corresponding to contemporary requirements. It incorporated entirely new technical solutions in the Office Wing, an acoustically perfect Assembly Hall,"1 as the authoring architects themselves stated in the first volume of the Euvre Complète.

Le Corbusier and Pierre Jeanneret's scheme was designed using state-of-the-art technologies, both in the acoustical design of the auditorium for the large Assembly Hall, which drew on advice from Gustave Lyon, as I will explain in this paper, and in the communication equipment for the offices, where electroacoustic apparatuses were devised. When investigating the hall's acoustical feasibility more closely, elemental questions relating to the nature of Le Corbusier's approach to architecture's performance as a place "to work in" remain to be

\footnotetext{
${ }^{1}$ Le Corbusier: Le Corbusier et Pierre Jeanneret. Euvre Complète de 1910-1929. Zurich: Girsberger, 1937, p. 161 (original emphasis).
} 
answered. Why did Sigfried Giedion, who was never shy to embrace new technologies, argue in 1927 that loudspeakers were not feasible to amplify the speeches in the Assembly Hall? ${ }^{2}$ In the same year, acoustic scientists successfully enhanced the volume of speech in the Cologne Cathedral by using large loudspeaker systems. $^{3}$

Much has been written about the heated debates in the battle over styles, over historicist and functionalist architectures, 4 over "les académies" and "les autres," 5 and over claims for and against monumentality. It is the hypothesis of this paper that the modern science of architectural acoustics provided a telling argument in the debates following the League of Nations competition results. I will show that expertise in architectural acoustics and arguments advocating a "functional" Palace of Nations entered a mutually empowering coalition. In the debates over the League of Nations competition entries, focusing on acoustics helps us understand the instrumentalization - and at the same time the fundamental importance - of function in architecture. These architectural discourses on function addressed not functionality per se but a performance, projected onto an architectural program and driven by an aesthetic agenda.

\section{A Function Overlooked}

Understanding was at the core of the agenda at the League of Nations. Founded in the aftermath of World War I, the League was created to ensure international security, world peace, and understanding between all nations. The competition launched in March 1926 attracted 377 teams of architects, who delivered a total of more than 10,000 panels in January 1927. After long discussions, the jury awarded 27 projects out of the 377 with nine first prizes, nine first mentions, and nine second mentions. ${ }^{6}$ Before the jury gathered, its members had been alerted to the unrealistic challenge that had been set in terms of the General Assembly's acoustics. ${ }^{7}$ In the unusually large auditorium for 2,675 people, the spoken words would hardly be audible in the rear areas. It was therefore not only political, but also acoustic understanding that was at stake in the designs for the League of Nations' large

\footnotetext{
${ }^{2}$ Giedion, Sigfried: “Wer baut das Völkerbundgebäude?” Bauwelt, 18, № 44 (November 3), 1927, p. 1094. I am indebted to Gregor Harbusch, who in the early years of my dissertation shared his puzzlement over Giedion's remark on loudspeakers.

${ }^{3}$ Electroacoustics pioneer Ferdinand Trendelenburg wrote that such large loudspeakers worked well in free-field conditions, but that many enclosed spaces, especially those with excessive sound reflections ("Überakustik") remained a challenge. Ferdinand Trendelenburg: "Über Bau und Anwendung von Grosslautsprechern" in Elektrotechnische Zeitschrift, 48, 1927, p. 1691. My thanks to Roland Wittje for directing me to this source.

${ }^{4}$ It is important to differentiate the term "Functionalism" as an architectural style, which was not in use until the postwar era and is often regarded as originating in Louis Sullivan's dictum "form follows function," from Behne's 1926 "Zweckbau."

${ }^{5}$ Terminology used by Le Corbusier when comparing his cost estimates of 27/30/40/50 m respectively, for the four projects chosen by the League of Nations' jury, with the calculation of his own project at $12.5 \mathrm{~m}$. Figure 94 in Frampton, Kenneth: "Le Corbusier and 'l'Esprit Nouveau."' Oppositions, No 15/16 (Winter/Spring), 1979, p. 46.

${ }^{6}$ For a detailed account of the competition processes and politics, see Ritter, John: "World Parliament. The League of Nations Competition, 1926." Architectural Review, № 136 (July), 1964. pp. 17-23 (a study motivated by Colin Rowe at the Cambridge School of Architecture); Moos, Stanislaus von: Le Corbusier. Elemente einer Synthese. Frauenfeld: Huber, 1968. pp. 227 ff; Oechslin, Werner; Roth, Alfred: Le Corbusier \& Pierre Jeanneret: Das Wettbewerbsprojekt für den Völkerbundspalast in Genf 1927: à la recherche d'une unité architecturale. Zurich: gta Verlag, 1988 (with a reprint of the Swiss report of experts on behalf of the jury); Pallas, Jean-Claude: Histoire et architecture du Palais des Nations (19242001). L'Art déco au service des relations internationales. Geneva: Nations Unies, 2001 (an illustrated book commissioned by the UN, documenting primarily the history of the building by architects Nenot and Flegenheimer, together with Vago, Boggi, Vacaro, Franzi, and Lefevre).

${ }^{7}$ Letter from Ritter on behalf of the jury, ETH Zürich, gta archive: 33-JGS-1926/27 (provisional numbering code), Nachlass Karl Moser, Hängeregister Völkerbundpalast, Juryberichte.
} 
Assembly Hall. This dimension was, curiously, suppressed both in the competition brief and in many of the competitors' projects, and subsequently overlooked by historians.

In Schweizerische Bauzeitung of July 30, 1927, and in The American Architect of December 20, 1928, the acoustic quality of the architectural projects for the General Assembly's hall was discussed over eight and ten pages respectively. The author of both articles was Switzerland's first expert in architectural acoustics and the founder of the country's first applied acoustics laboratory at an academic institution, E.T.H. in Zurich: Franz Max Osswald. Both his publications prominently featured Le Corbusier and Pierre Jeanneret's scheme as the most feasible, based on the relatively small — though still too large-volume of 40,000 cubic meters and the favorable geometry of the plan, with no parallel walls and a ceiling shaped to reflect sound throughout the large Assembly Hall. These two publications, with a few others, were the basis on which E.T.H. granted Osswald his permission to teach at university level, the venia legendi, in 1929. That was also the year when the Acoustical Society of America held its first meeting and published the first issue of its journal. The year 1929 thus stands for the formation of the academic discipline of acoustics, both in the microhistory of Osswald's career in Switzerland and in the global history of acoustic sciences. ${ }^{8}$

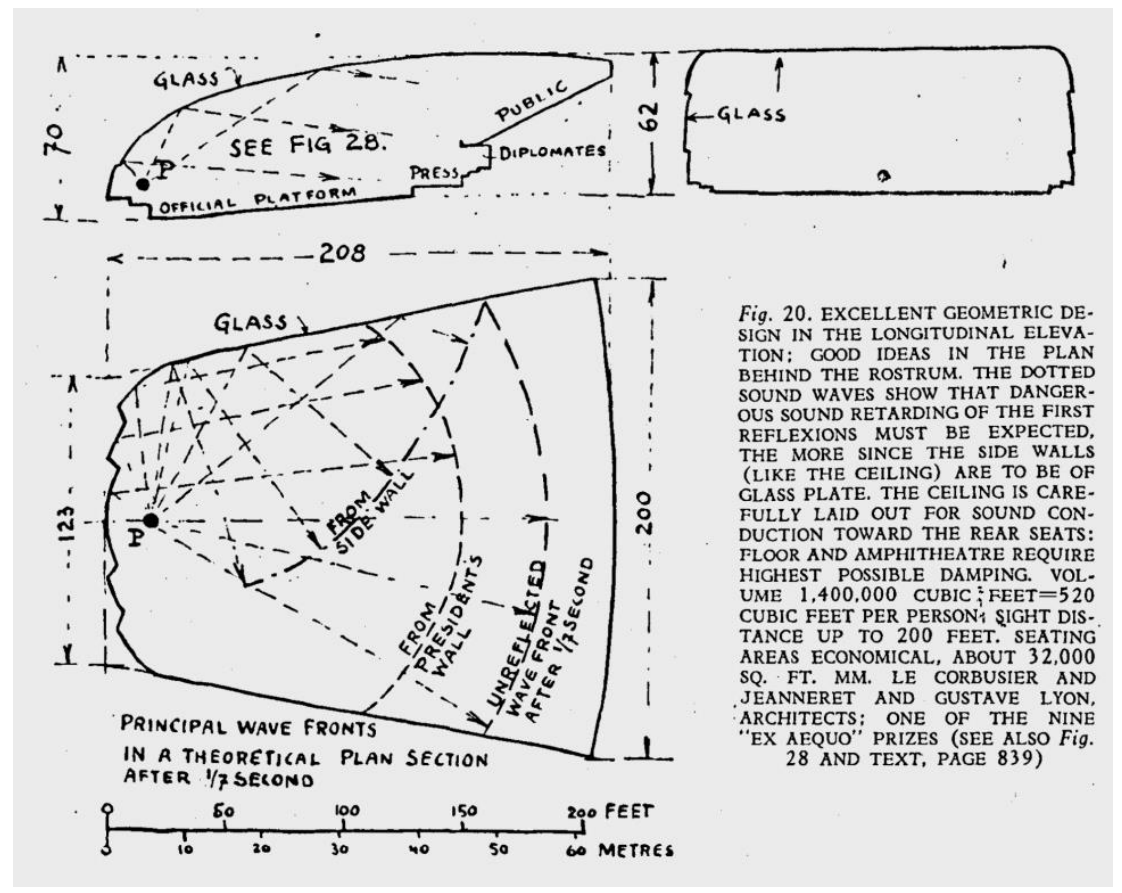

1. Franz Max Osswald's analysis of the acoustic performance of the large Assembly Hall in Le Corbusier and Pierre Jeanneret's proposal to the League of Nations. The American Architect, December 20, 1928.

Osswald's reasoning on the Assembly's acoustics, like most of his methods, took account of reverberation time as established by the Harvard physicist Wallace Clement Sabine ${ }^{9}$ around $1900{ }^{10}$ The reverberation formula

\footnotetext{
${ }^{8}$ Osswald, Franz M.: Schall und Raum. Antrittsrede an der Eidgenössischen Technischen Hochschule in Zürich, 29. Juni 1929. Zurich: E.T.H., 1929. For a longer history of Osswald's career, see Fischer, Sabine von: Das akustische Argument. Zurich: gta Verlag (in preparation).

${ }^{9}$ Sabine, Wallace C.: Collected Papers on Acoustics. Cambridge, MA: Harvard University Press, 1922.

${ }^{10}$ Emily Thompson's benchmark historiography has done a great deal to mark the year 1900 as the founding moment of modern architectural acoustics. Thompson, Emily: The Soundscape of Modernity. Architectural Acoustics and the Culture of Listening in America, 1900-1933. Cambridge, MA: MIT Press, 2002.
} 
calculates the time that a sound signal takes to pass the human ear's hearing threshold at zero decibel. If the duration is too short, the sound is considered "dead" or "dry," but this mostly applies to concert halls and is seldom considered problematic elsewhere. Much more often, and especially in the case of halls for speech, the reverberation time may be too long, and the words spoken cannot be understood. Such long reverberation times, or echo, may be desirable for chants in a Gothic cathedral; in the auditorium for the assembly of the League of Nations delegates, where international understanding lay at the heart of the program, it was not.

According to the reverberation formula " $\mathrm{T}=0.16 \mathrm{~V} / \mathrm{A}$," which is still in use today, the reverberation time is calculated proportional to the volume of the space, and reversely proportional to the absorbing capacity of the materials. As a sketch for the archive shows, Le Corbusier and Pierre Jeanneret calculated the volume per person in the auditorium. The total number of persons required by the competition brief to be seated in the Assembly Hall added up to 2,675; this number resulted from the program requirements, which listed a party of 25 speakers at the center of the podium (including the president, secretary general, and interpreter), 400 delegates, 400 secretaries, 250 diplomats, 600 journalists, and an audience of 1,000.

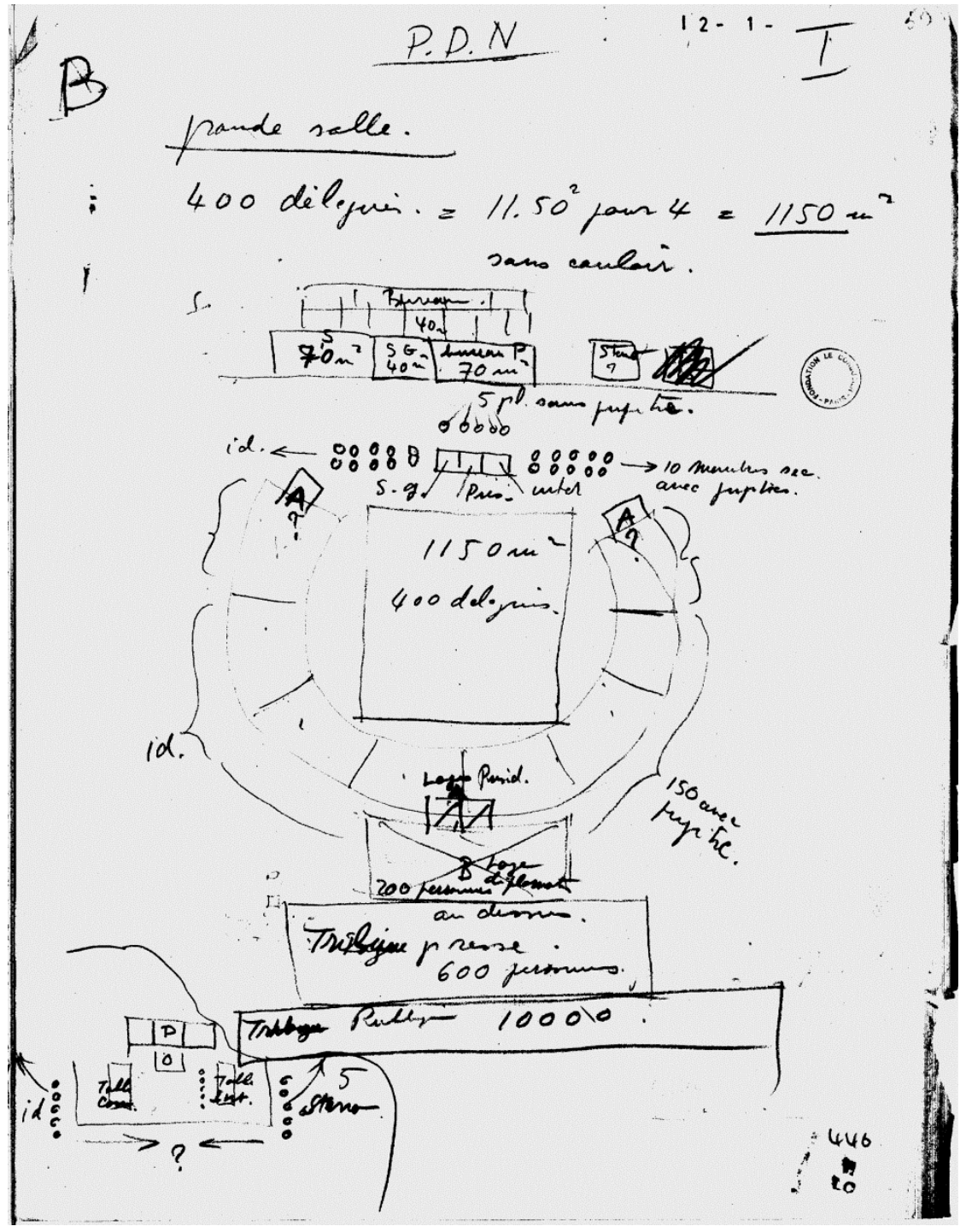

2. Le Corbusier and Pierre Jeanneret's study for the General Assembly's layout for 2,675 people. 

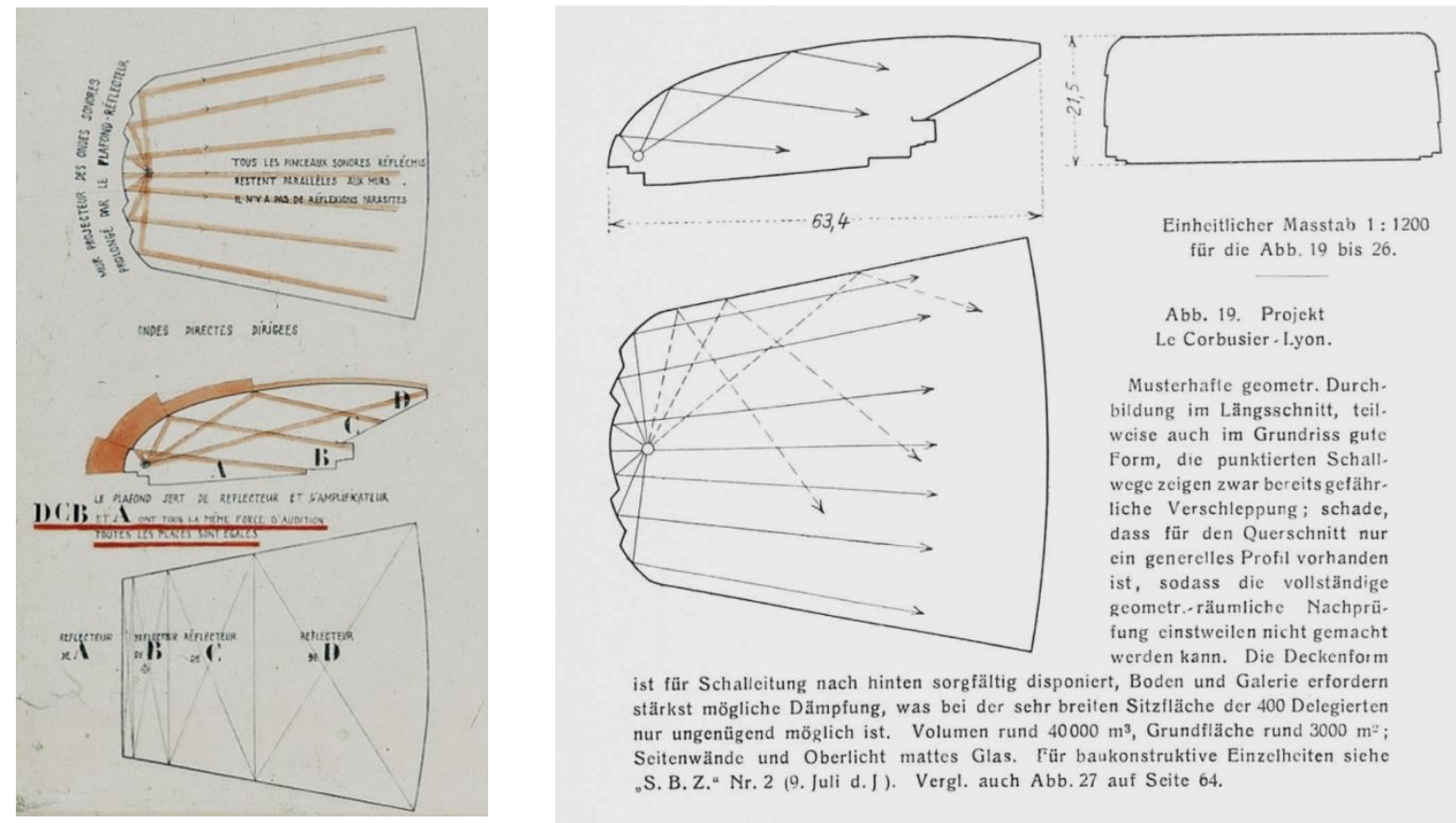

3 - 4. Detail of the acoustic principles on the competition panel and in Schweizerische Bauzeitung.

On panel 10 of Le Corbusier and Pierre Jeanneret's competition entry, showing the plan of the large Assembly Hall in the center, the acoustical design is explained in the lower left-hand corner. Sound is understood as wave fronts which are directed from the speakers into the audience by the architectural elements:

"Ondes directes dirigées:

Mur projecteur des ondes sonores prolongé par le plafond-réflecteur.

Tous les pinceaux sonores réfléchis restent parallèles aux murs. Il n'y a pas de réflexions parasites.

Le plafond sert de réflecteur et d'amplificateur.

D C B et A ont tous la même force d'audition.

Toutes les places sont égales."

The schematic drawing of the sound wave reflections from the ceiling into all areas of the audience equally was copied from the competition panels into Franz Max Osswald's Schweizerische Bauzeitung article of July 30, 1927, which had praised the acoustical design by "Lyon - Le Corbusier." In the issue of July 9, soon after the publication of the jury report on May 5 in which nine projects were awarded a first prize ex aequo (followed by nine first and nine second mentions), editor Peter Meyer had written a fierce commentary. Meyer's attack on the "pompuous gestures of the monumental palaces" 12 was a fiery introduction to the following pages, in which Le Corbusier and Pierre Jeanneret's project was published in extenso, though with only marginal mention of the acoustical aspects. These were discussed on three weeks later, on July 30, when another eight pages dedicated to the controversial competition focused on Le Corbusier and Pierre Jeanneret's project, this time with special attention to the Assembly Hall's acoustics. In this second review, "Zum Problem der Akustik im grossen Versammlungs-Saal des Völkerbund-Gebäudes in Genf" (On the Problem of Acoustics in the Large Assembly Hall of the League of Nations Building in Geneva), Osswald spent ample time inveighing against many projects' large volumes of up to 260,000 cubic meters and dome structures where echos would render any speech

\footnotetext{
${ }^{11}$ ETH Zürich, gta archives: Völkerbundpalast, Le Corbusier, 185-01-10.1.

12 Meyer, Peter; Le Corbusier: "Internationaler Wettbewerb für das Völkerbund-Gebäude in Genf." Schweizerische Bauzeitung, 90, № 2 (July 9), 1927, p. 13.
} 
unintelligible. In the article, function is emphasized to the point of becoming a rhetoric, and we can only assume that, as editor, Peter Meyer was instrumentalizing Franz Max Osswald's scientific expertise in the service of his own Modernist propaganda. In a single sentence, Osswald's text refers to function (in German: "Zweck," “Zweckmässigkeit") three times. ${ }^{13}$ Le Corbusier and Pierre Jeanneret's scheme was the only one to receive any praise for its acoustical design in the article. Nevertheless, Osswald still considered its 40,000 cubic meters to exceed the ideal auditorium volume of 10,000 , or at most 20,000, cubic meters.

Auditorium geometries where sound was reflected and directed primarily by the ceiling were a standard feature of architectural handbooks around 1930, and Osswald himself experimented with architectural geometries, for example in his own hors concours proposition for an Assembly Hall for the League of Nations (see Fig. 17 , lower right). He also experimented with models of an "auditorium with variable volume"14 for which he built both a large presentation model and an acoustic study model. The images produced from these models followed Wallace C. Sabine's examples, which employed a technique adapted from schlieren photography. ${ }^{15}$
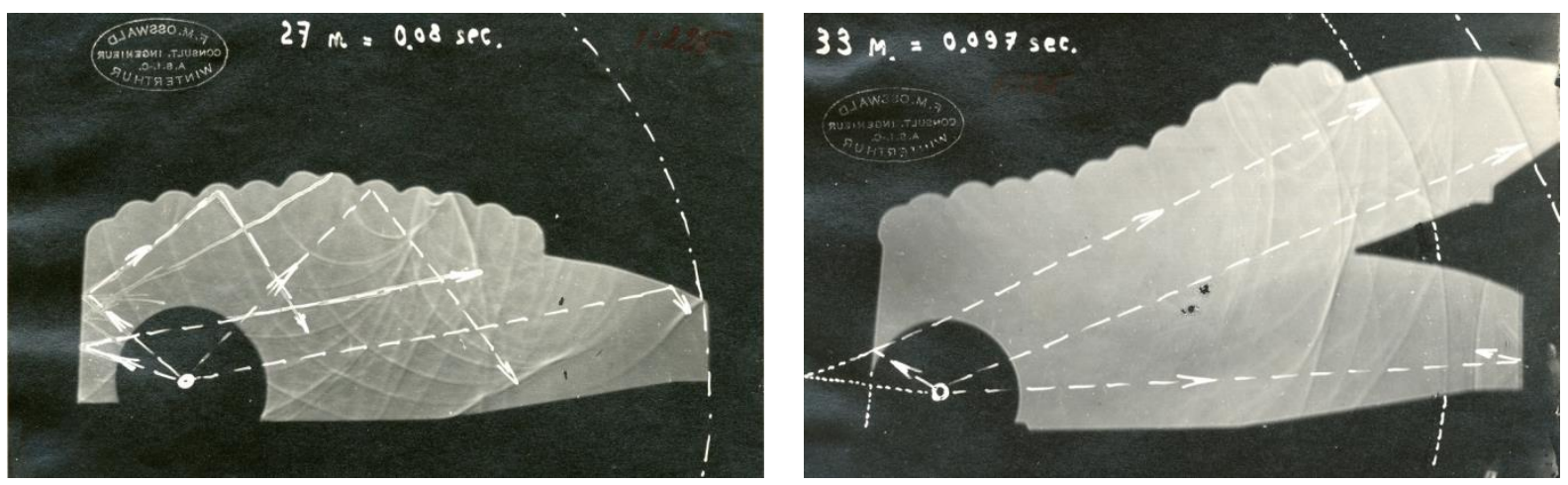

5 - 6. Osswald's photographic experiments for an auditorium of variable size in 1930.

7. Osswald's laboratory for applied acoustics at ETH Zurich.

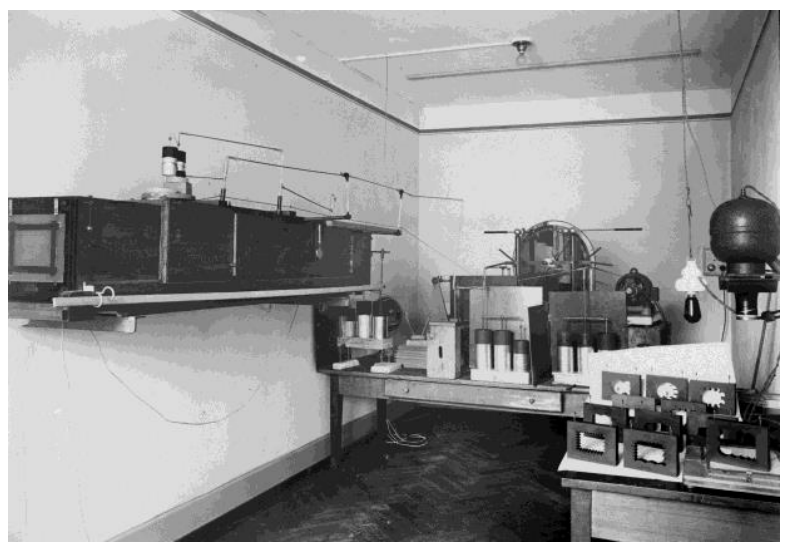

\footnotetext{
13 “der Architekt hat nun die Wände, Decken und Galerien zu einer zweckmässigen und schönen Form aufzubauen, wobei wir bewussterweise die Zweckmässigkeit voranstellen, denn, um nocheinmal daran zu erinnern, Verständigung ist doch der Endzweck!" (emphasis added). Osswald, Franz M.: “Zum Problem der Akustik im grossen Versammlungs-Saal des Völkerbund-Gebäudes in Genf." Schweizerische Bauzeitung, 90, № 5 (July 30), 1927, p. 59.

${ }^{14}$ Osswald, Franz M.: “Akustischer Konzert- und Vortragsaal mit veränderlichem Volumen.” Schweizerische Bauzeitung, 96, $\mathrm{N}^{\circ} 18$ (November 1), 1930, pp. 224-225.

15 Sabine, Wallace C.: “Theatre Acoustics." The American Architect, 104, No 1984, 1913, pp. 256-278. For more on Osswald's architectural sound photography, see von Fischer, Sabine: “A Visual Imprint of Moving Air” (in preparation).
} 


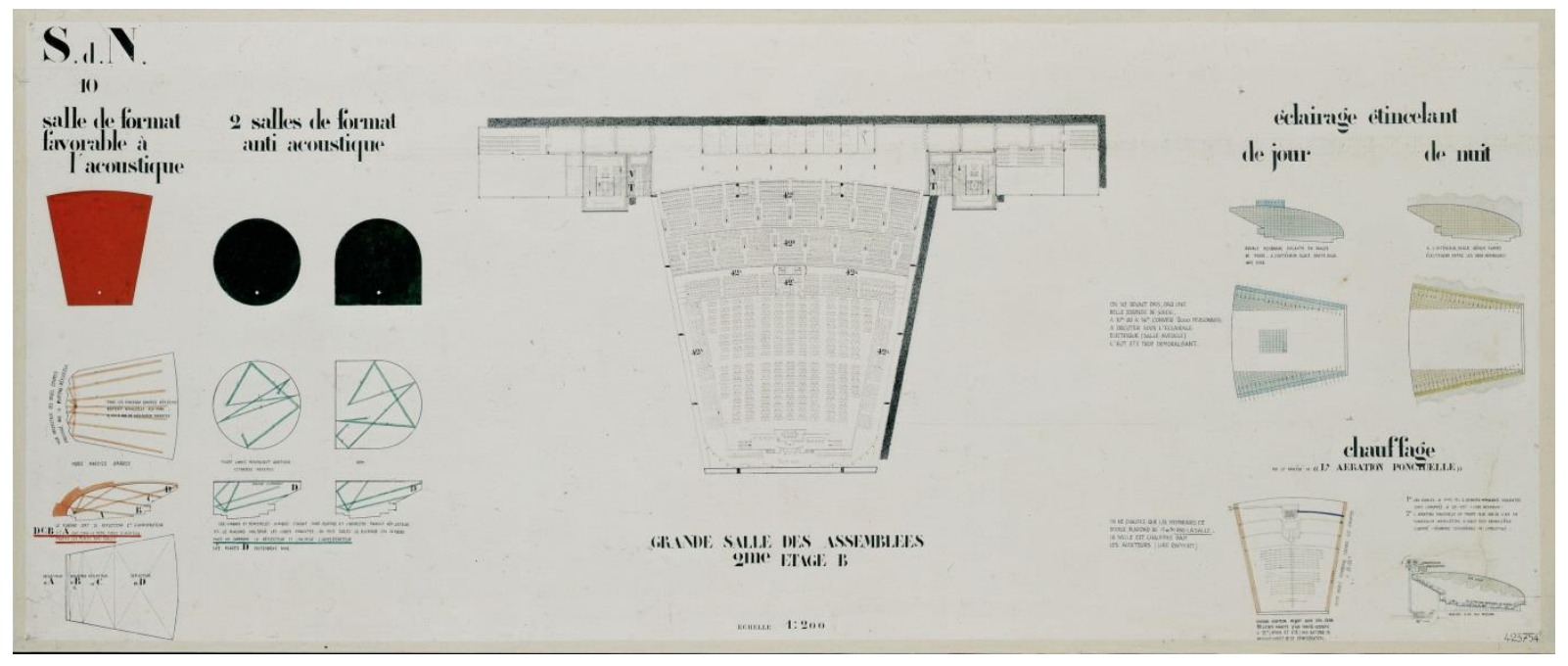

\section{Directing Sound}

Few of the competitors articulated their solutions for the auditorium's acoustics as explicitly as Le Corbusier and Pierre Jeanneret did in their graphic presentations. The panels were clearly didactic, placing their own auditorium plan next to a diagrammatic explanation — in bright and bold red letters—of the "salle de format favorable à l'acoustique." In counterpart, a circular and a semicircular shape were boldly, in black lettering, said to be " 2 salles de format anti acoustique"; ${ }^{16}$ such shapes (and this was not difficult to predict) occurred in many of the competition entries. Symmetrical plans with curved walls were a typical nineteenth-century solution for auditoriums and derived from the auditorium's precursor, the Greek amphitheater. For Le Corbusier, however, amphitheaters belonged to a completely different typology, being open to the sky.

Le Corbusier and Pierre Jeanneret relied on completely different references, those of modern architectural acoustics. They were advised by Gustave Lyon, a French engineer who had made a name for himself as director of the Parisian piano manufacture Maison Pleyel. As the director of Pleyel, Lyon devised a concert hall according to the laws of directed sound, calculating the time it took sound to travel from the orchestra to the audience. The ceiling was parabolically curved and low enough to prevent overly long delays between the direct sound and the reflected sound, which would be desirable neither with regard to the intelligibility of the spoken word nor to the clarity and distinctness of musical sound.

Lyon's internationally acclaimed design for the Maison Pleyel concert hall became a model for parabolic ceiling geometry in auditoriums. However, as the sound traveled not only from the podium to the audience but vice versa, it disturbed both the musicians and the music itself. The rear of Salle Pleyel wall was therefore, after its first remodeling, lined with absorbent Molleton. Photos, plans, and sections of the concert hall were published internationally, in the state with the absorbent rear lining. On July 18, 1928, the highly flammable Molleton caught fire, ${ }^{17}$ and a young American died. In view of this tragedy, Gustave Lyon addressed a personal letter to Le Corbusier on July 21 expressing his regret and saying that the repair would be undertaken "without delay."18

\footnotetext{
${ }^{16}$ ETH Zürich, gta archives, Völkerbundpalast, Le Corbusier, 185-01-10.1.

${ }^{17}$ Osswald, Franz M.: “Akustisch hochwertige Parabelsäle.” Schweizerische Bauzeitung, 95, № 4, 1930, pp. 47-51.

${ }^{18}$ Lyon to Le Corbusier (“Mon cher ami”), July 21, 1928, FLC Correspondences: LYON, GUSTAVE, 64-70: E2-9-65-001.
} 


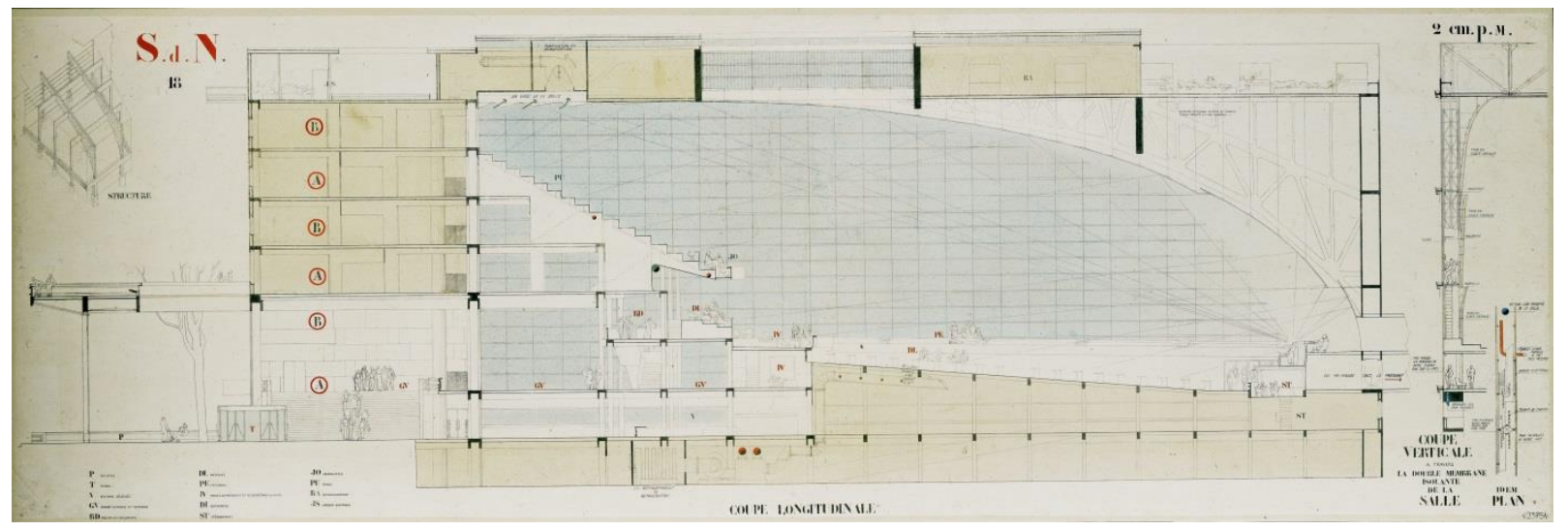

8 - 9. Le Corbusier and Pierre Jeanneret's competition panels 10 and 14.
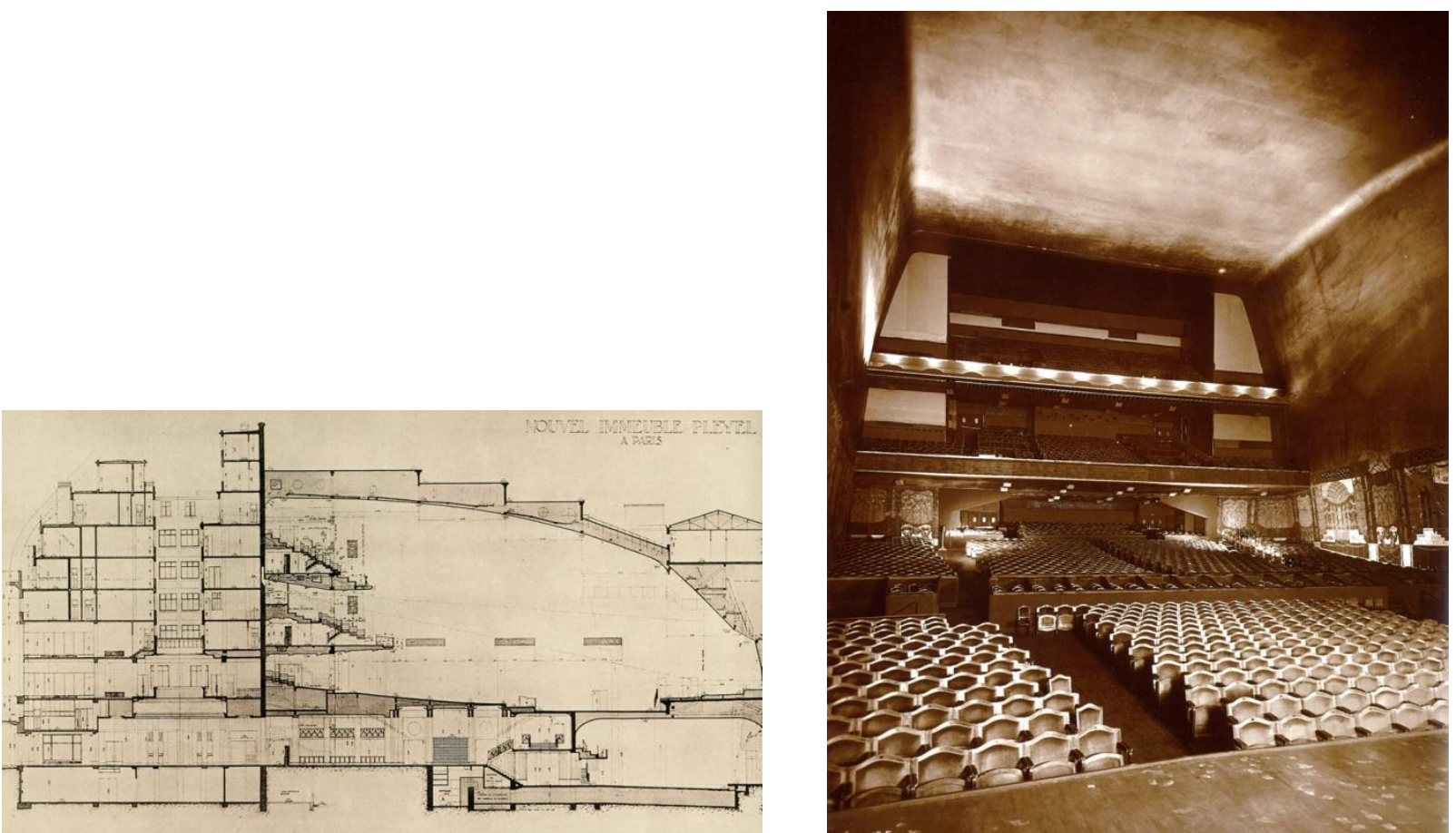

10 - 11. Section of Salle Pleyel by Gustave Lyon; Interior of Salle Pleyel, 1927.

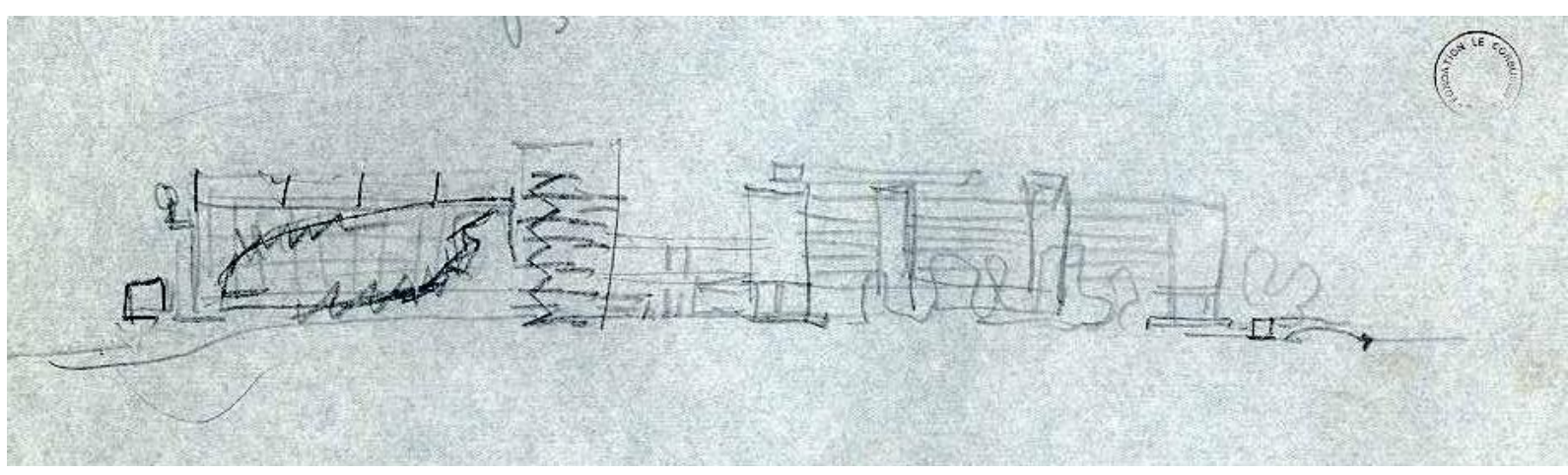

12. Section of Le Corbusier and Jeanneret's large hall for the General Assembly (1927). 


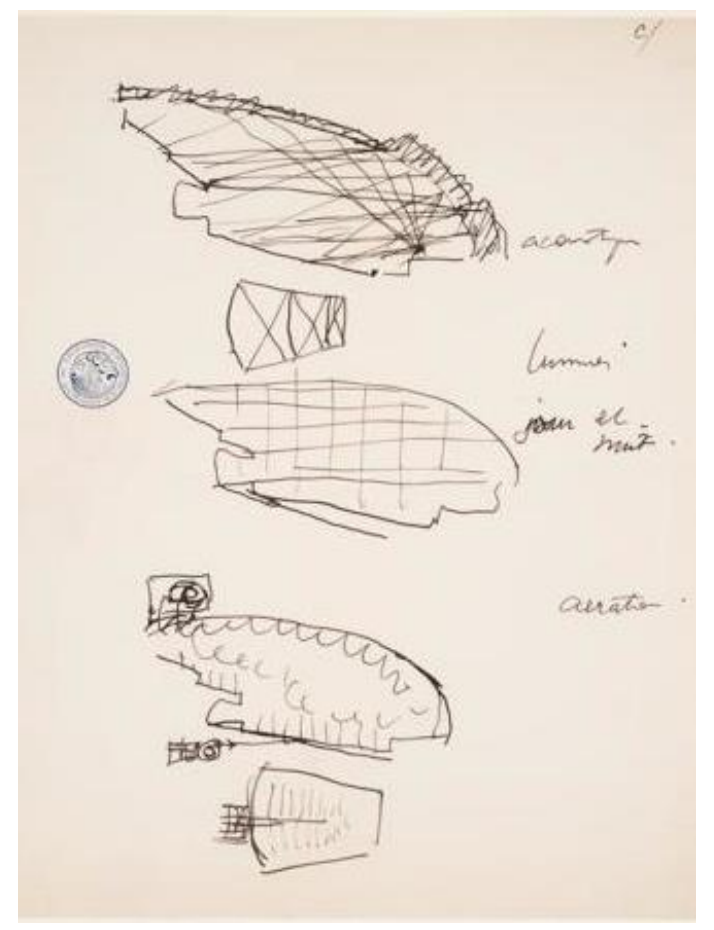

13. Sketch explaining acoustics, lighting, and ventilation of the large hall for the General Assembly (1929).

Correspondence between Gustave Lyon and the atelier of Le Corbusier is documented from 1927 until $1935,{ }^{19}$ the year before Lyon's death. According to Alfred Roth's oral account, as passed on by Gubler und Quincerot, ${ }^{20}$ Lyon visited Rue Sèvres to give his acoustical consultations. Even more telling are the journals, newspaper clippings, and letters in the archive in which Le Corbusier and Gustave Lyon expressed their mutual admiration:

\begin{abstract}
"Mon cher ami Le Corbusier,
je viens de recevoir votre lettre contenant le chèque de $80 \mathrm{f}$ que je vous retourne, car il n'a jamais été fait état de cette recette, puisque vous étiez notre délégué expert. Je profite de vos observations si sérieuses pour vous signaler le rôle puissant que vos idées neuves audacieuses et logiques ont pu avoir de la genèse de la conception de la salle de musique. Vous savez combien et dès la première parution de vos conceptions nouvelles j'y ai pris plaisir et porté intérêt.

C'est vous, pour parti, qui m'avez amené à ne pas m'arrêter en route sous prétexte de vieilles formules à respecter. Et à ne me laisser conduire que par la logique appuyée sur l'éxperience des temps trèspassés. Je vous souhaite de triompher de toutes les difficultés que des jaloux cherchant à semer sur votre route, et vous assurer que j'ai le plus grand désir de vous aider de tout mon faible pouvoir. Croyez, mon cher ami a mes très cordiaux sentiments d'estime et de très sympathique admiration, G. Lyon"
\end{abstract}

\footnotetext{
${ }^{19}$ FLC, Correspondences: LYON, GUSTAVE, 64-70: Correspondance avec L.C. 26/08/1927-09/02/1935.

${ }^{20}$ Gubler, Jacques; Quincerot, Richard: "Da Maratona a Ginevra." Parametro, No 140 (October), 1985, p. 27, footnote 35: "Intervista con Roth. Roth e assolutamente sicuro che Lyon sia andato all'atelier di L. C." Gubler and Quincerot's essay "From Marathon to Geneva" (in six versions in the archive of the CCA in Montréal) was possibly intended for a 1980 publication in Oppositions 15/16 or 19/20. On editorial and publishing practices and policies in New York architecture circles, see Förster, Kim: The Institute for Architecture and Urban Studies (1967-85). Zurich: gta Verlag (in preparation).
} 


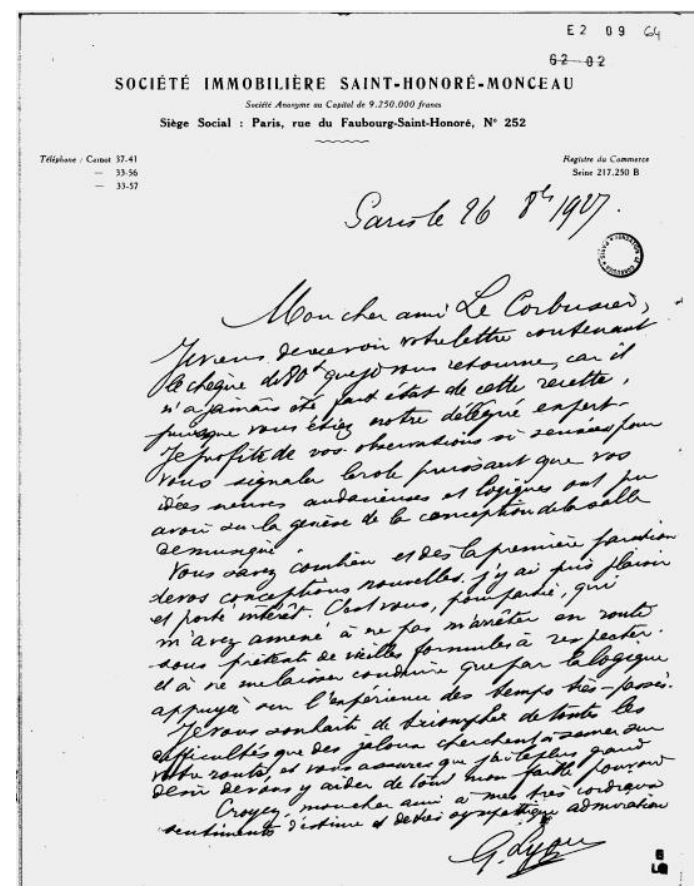

14. Letter from Gustave Lyon to Le Corbusier, August 26, 1927.

Old formulas were to be replaced with new ones, a project on which Le Corbusier and Lyon embarked with enthusiasm. In a letter dated August 26, 1927, ${ }^{21}$ the acoustician called the architect "our expert delegate" and gave him substantial credit for the renewal in architectural acoustics. In return, the architect praised the acoustician on the front page of the evening edition of $L$ 'Intransigeant ${ }^{22}$ of October 15, 1927: “Acoustique: Une conquête de la technique moderne" was a eulogy on Lyon's calculations of the sonic realm by mathematical formula. The laws of statics and dynamics having been recognized a long time ago, it was thanks to Gustave Lyon and his science that acoustics had escaped from the world of mysteries. Now that these acoustic laws had been successfully applied in the Salle Pleyel, wrote Le Corbusier, it would no longer be possible to build a theater as before.

In 1928, Lyon defended Le Corbusier and Pierre Jeanneret's League of Nations competition entry, as part of the vast and vehement public campaign in the course of which the cousins filed a lawsuit against the award of the building commission to a team composed of other prize winners, who, they claimed, had stolen many ideas from their scheme. In a public declaration in the second issue of Cahiers d'Art, Lyon signed the "manifestation des savants, des industriels, des poètes, des financiers en faveur du projet le Corbusier et Pierre Jeanneret" 23 jointly with 83 prominent Parisians and international celebrities, among them composers, directors, and writers.

Lyon was not mentioned in the project description in Cahiers d'Art, but his name was all the more prominent on the two following pages: "La Salle Pleyel. Une preuve de l'évolution architecturale" was the title of Le Corbusier's article honoring "le savant directeur de la Maison Pleyel qui vient de sortir victorieux de ses quarante années de recherches." In it, Le Corbusier argued that the "chimera of acoustics" had been vindicated

\footnotetext{
${ }^{21}$ Lyon to Le Corbusier (“Mon cher ami Le Corbusier”), August 26, 1927, FLC Correspondences: LYON, GUSTAVE, 64 70: E2-9-64-001.

${ }^{22}$ Le Corbusier: “Acoustique: Une conquête de la technique moderne.” L'Intransigeant (October 15, 1927), p. 1.

${ }^{23}$ Amundsen, M.M. and others: "Manifestation des savants, des industriels, des poètes, des financiers en faveur du projet le Corbusier et Pierre Jeanneret." Cahiers d'Art, 3, No 2, 1928, p. 87.
} 
by "calculus" and that this new truth could assure the intelligibility of all speeches: "Mais voici qu'aujourd'hui, la salle Pleyel, c'est la vérité aussi, la vérité de fait, la vérité fonctionnante, s'opposant à la vérité factice de l'Institut; et l'Institut s' incline devant cette nouvelle vérité irréfutable. [...] Comment les responsables de la S.D.N. toléreraient-ils qu 'on leur livrât une salle où l'on n'entendrait pas les discours? Et il est à présumer que dans le monde entier, tout futur tenancier de salle exigera le maximum de sécurité acoustique." ${ }^{24}$

The collaboration lasted. According to Jean-Louis Cohen's study of the Moscow projects, in the 1930 proposal for Moscow Le Corbusier again mentioned Lyon's "science of sound," which promised to "make the housing units completely soundproof." ${ }^{25}$ In 1931, when designing the Palace of the Soviets, Le Corbusier insisted on setting up a contract with Lyon and paying him for his expertise, and even sent him an advance payment. Though, in the final project he combined Lyon's proposal with another Parisian expert's calculations. ${ }^{26}$

Lyon's career, like Osswald's, coincided with the emergence of the discipline of architectural acoustics in the mid-1920s, at the awakening of professionalization and the formation of an academic discipline in 1929. Lyon's own stationery at the beginning of the 1930s presented his expertise elaborately in the letterhead as "ACOUSTIQUE ARCHITECTURALE, ORTHOPHONIE DES SALLES, AERATION DES SALLES, ISOLEMENT PHONIQUES DES SALLES, (SYSTEME GUSTAVE LYON)" and continued in smaller print with applications of soundproofing for offices, apartments, and the outdoors, followed by the description of his professional status as "INGENIÉUR ACOUSTICIEN." ${ }^{27}$ This makes it obvious that, in accordance with the proliferation of architectural acoustics as a professional field and an academic discipline, the director of the Maison Pleyel had expanded and professionalized his acoustic expertise to offices, housing, and urbanism.

\section{Modern Voices and Their Arguments}

Already before Osswald's expert critique of the acoustics in the League of Nations competition was published in Schweizerische Bauzeitung on July 30, 1927, Sigfried Giedion drew on his expertise in a commentary in the Neue Zürcher Zeitung of July 24, 1927. ${ }^{28}$ First and foremost, Giedion quoted Osswald's observation that any auditorium larger than 20,000 cubic meters created acoustic problems. How, Giedion asked, "could the feeble human voice penetrate such massive monumentality?"29 This connection between acoustics as a function and monumentality as an anti-acoustical concept remained Giedion's primary argument in favor of Le Corbusier and

\footnotetext{
${ }^{24}$ Le Corbusier: "La Salle Pleyel. Une preuve de l'évolution architecturale." Cahiers d'Art, 3, No 2, 1928, p. 89. Le Corbusier's draws his praise of calculus nevertheless into synthesis with the arts: "une oeuvre gigantesque manifestant les conquêtes de la peinture moderne et exprimant - libéré de toute tradition, - le lyrisme de l'époque." Ibid., p. 90. It is this synthesis that Christopher Pearson's analysis of the "acoustical trope" foregrounded as "the new 'biological system' of design used by Lyon in his acoustic ceiling for the Salle Pleyel in Paris." Pearson, Christopher: "Le Corbusier and the Acoustical Trope: An Investigation of Its Origins.” The Journal of the Society of Architectural Historians, 56 (June), 1997, p. 182.

25 "Response to Moscow," quoted in Cohen, Jean-Louis: Le Corbusier and the Mystique of the USSR. Theories and Projects for Moscow 1928-1936. Princeton; NJ: Princeton University Press, 1992, p. 146.

${ }^{26}$ Letter of October 31, 1931, quoted in ibid., p. 168, footnote 18; 180.

${ }^{27}$ Lyon to Le Corbusier, letter dated February 9, 1935. FLC Correspondences: LYON, GUSTAVE, 64-70: E2-9-67-001.

${ }^{28}$ Giedion, Sigfried: "Die Architektur am Wendepunkt. Anmerkungen zum Wettbewerb um das Völkerbundgebäude." Neue Zürcher Zeitung, July 24, 1927, p. 4. Giedion's article was not the first to respond to the jury report; Peter Meyer had commented on the competition results ten days earlier in Neue Zürcher Zeitung. The article is in Giedion's files.

29 "Wie soll eine schwache menschliche Stimme so viel Monumentalität durchdringen?” Ibid.
} 
Pierre Jeanneret's project, although he admitted in the Zurich newspaper that these were "precarious matters, especially as the experts of the young science of acoustics do not always agree."30

A few months later, in his extensive article on the competition in Bauwelt of November 3, 1927, Giedion again repeated Osswald's arguments against over-large auditoriums, along with his criticism of inadequate sound quality in contemporary loudspeaker technology and the idea that auditoriums should preferably be designed with variable size. Giedion seems to have completely appropriated Osswald's knowledge as his own, and by this point no longer mentioned his name.

Of the four crucial functions that Giedion lists for the Palace of Nations in his Bauwelt article, the acoustics inside the General Assembly auditorium took the first place, followed by the organization of the offices, the circulation of traffic, and the complex's relationship to the landscape. Regarding the acoustics of the large Assembly hall, Giedion argued that any volume larger than 20,000 cubic meters would cause acoustic problems, pointing out that some architects had devised spaces of 260,000 cubic meters or prided themselves on recreating the Pantheon for the Great Assembly. According to his newly acquired expert knowledge, the 2.4 square meters for each of the 2,600 persons, as laid out in the competition brief, would need to be reduced; otherwise the result would be in a space beyond control, where "the human voice is not expected to be present." 31 He did mention the possibility of loudspeaker amplification, but discarded it immediately: "At the current moment, loudspeakers with their distortion and interference make it hopeless from the outset to believe that any such monumental ambition could be satisfied unconditionally by these means." 32

Giedion gave detailed explanations of the two projects he favored, the one by Le Corbusier and Pierre Jeanneret (awarded one out of nine ex aequo first prizes), and the one by Hannes Meyer and Hans Wittwer (awarded one out of nine second mentions). The presentation of the two was unequal, however. Expanding at length on acoustics for the first scheme, he abandoned the topic when presenting Meyer and Wittwer's project, in which the authors had decided to resolve the sound transmission issue by using loudspeakers. Instead, Giedion emphasized the auditorium design as devised by Gustave Lyon for Le Corbusier and Pierre Jeanneret, providing abundant explanations on "acoustical quality" ("Hörsamkeit") and a comparative section of the Salle Pleyel.

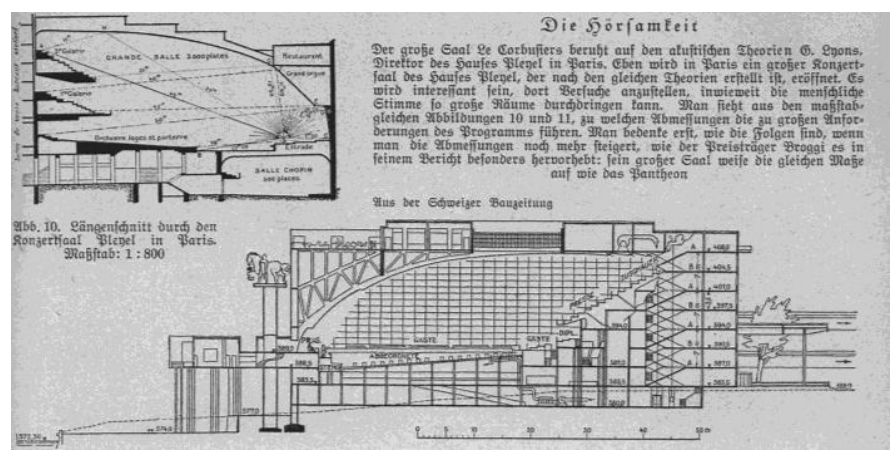

15. “Acoustical Quality” (“Hörsamkeit”) in Giedion’s expert explanation, Bauwelt, 1927.

\footnotetext{
30 "Man spürt, die Sachlage ist prekär, um so mehr als die Vertreter der immerhin noch jungen, akustischen Forschung selbst nicht ganz einer Meinung und Theorie zu sein scheinen.” Ibid.

31 "Eine menschliche Stimme hat hier nichts mehr zu suchen." Giedion, Sigfried: "Wer baut das Völkerbundgebäude?" Bauwelt, 18, No 44 (November 3), 1927, p. 1094.

32 "Bei dem heutigen Stand der Lautsprecher mit ihrer Verzerrung und Interferenz ist es von vornherein hoffnungslos, wenn man glaubt, damit bedingungslos jedem Monumentalanspruch genügen zu können.” Ibid.
} 
On the one hand, the comparison of Le Corbusier and Jeanneret's auditorium with the Salle Pleyel, both reproduced at scale 1:800, elevated the unrealized project to the level of a European cultural monument. On the other, the assembly hall for Geneva was clearly bigger than the concert hall in Paris, prompting Giedion's critical comment that "it will be interesting to test the extent to which the human voice can penetrate such large spaces." ${ }^{, 33}$ Here, he no longer seems certain that the acoustics are truly feasible. The "acoustic security" invoked in Le Corbusier's own texts for the competition seems to falter; however, Giedion soon gets back on course and closes his long explications on acoustics with the remark that others have designed far larger auditoriums.

Why did the propagandists of Modern architecture not argue for loudspeaker transmission? Some of them did, but their arguments were largely ignored, as they did not serve the argument of architecture's functionality in Le Corbusier's scheme. Just two decades later, when the United Nations headquarters ${ }^{34}$ was designed and built between 1946 and 1952 in New York, loudspeakers, simultaneous interpretation booths, and radio transmission had become taken for granted as ways to ensure auditory understanding between the nations. There is no doubt that the quality of sound transmitted by loudspeaker amplification before the end of the 1930s was questionable - yet the criticism that electroacoustics lacks authenticity is still upheld today, in the age of hi-fi and wave field synthesis. In 1927, a few competition entrants were already praising the potential of large loudspeakers as "a modern invention" by which, no matter how long the conduits, the sound could be transmitted without distortion even to the outermost corners, and - something that may have sounded futuristic in the ears of a public used to loud public speaking_- "speaking in a large space will be possible at a normal volume." $" 35$

Now that Osswald's critique has resurfaced from the archives and can be introduced into the historiography of the League of Nations competition, we can better understand Giedion's advocacy of acoustic quality and his reasoning regarding loudspeakers. Giedion's doubts about the acoustic performance of Le Corbusier's "acoustically perfect" scheme are, we may speculate, expressed in a handwritten note on the last page of his own offprint of Osswald's Schweizerische Bauzeitung article: "2,700 persons: this means: the world is watching" ("2700 Personen: das heisst: die Welt ist Zuschauer"). ${ }^{36}$ Whether intended or not, the idea that the world is watching, and not listening, leaves the problem of acoustics unresolved. While the literal "understanding"- that is, hearing - of words in the auditorium of the Great Assembly was the crucial argument for some of the Modernist actors presented here, all of them seemed to have recognized the impossibility of a solution that would deliver what one could fairly call "acoustical quality."

In a long and irritated letter dated October 2, 1927, Richard Neutra, who had submitted unsuccessfully with Rudolph Schindler, ${ }^{37}$ went as far as to conclude that acoustics were not a real concern for the hall for the General Assembly because the "entire representational fall session of the League of Nations is undoubtedly rather

\footnotetext{
33 "Versuche anzustellen, inwieweit die menschliche Stimme so grosse Räume durchdringen kann." Ibid.

${ }^{34}$ See Touloumi, Olga: “Architectures of Global Communication, 1941-1970.” PhD thesis, Harvard University, 2014.

35 "Ein moderner, mit neuen Erfindungen versehener Großlautsprecher bietet den Vorzug, durch verteilte Lautsprecher bei vollkommener Gleichgültigkeit der Leitungslängen, auch die äußersten Stellen, wie Lagen, Ecken u.s.w. ohne Reflexwirkung verzerrungsfrei zu besprechen. Der Redner braucht nur mit normaler Lautstärke zu sprechen und wird bei Verwendung von mehreren Mikrophonen in seiner Bewegungsfreiheit nicht beeinträchtigt.” ETH Zürich, gta archives: Nachlass Karl Moser, Hängeregister Wettbewerb Völkerbundspalast, Projektbeschrieb Distel \& Grubitz. 27.

${ }^{36}$ Osswald, Franz M.: "Zum Problem der Akustik im grossen Versammlungs-Saal des Völkerbund-Gebäudes in Genf." Schweizerische Bauzeitung, 90, No 5 (July 30), 1927. Annotated offprint in the Sigfried Giedion papers. Osswald's publication is held in several library collections, and in the Karl Moser papers, all at ETH Zürich, gta archives.

${ }^{37}$ Neutra and Schindler entered the competition in cooperation with the Austrian Institut für Auslandbeziehungen. See Hines, Thomas: Richard Neutra and the Search for Modern Architecture. New York, Oxford: Oxford University Press, 1982, p. 7.
} 
theatrical and in practice is virtually unnecessary. ${ }^{, 38}$ In defense of his own project, Neutra meticulously corrected Osswald's description and schematic drawings in Schweizerische Bauzeitung.

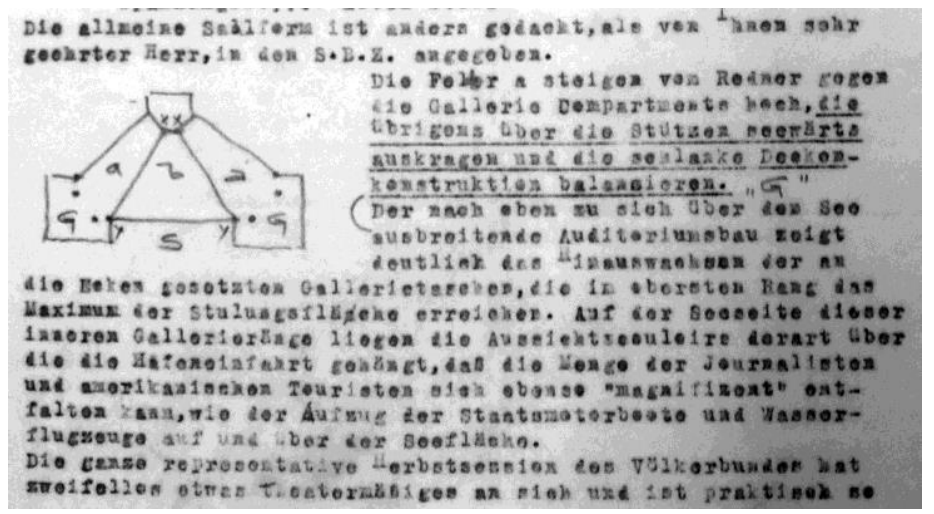

16. Detail from Neutra's letter.

In Osswald's 1928 article in The American Architect, Neutra and Schindler's project was the only one to be named and completely redrawn. Whereas in 1927 he had noted in capital letters that there were no galleries (which he considered essential for reducing the volume of the assembly space), the sketch in the 1928 publication showed Neutra and Schindler's scheme featuring four corner galleries and one rear central gallery. These served as the fourth example of auditorium plans and sections, in the top right-hand corner of the first page of Osswald's analysis of several dozen of the 377 projects, in which he discussed typical solutions and common errors.
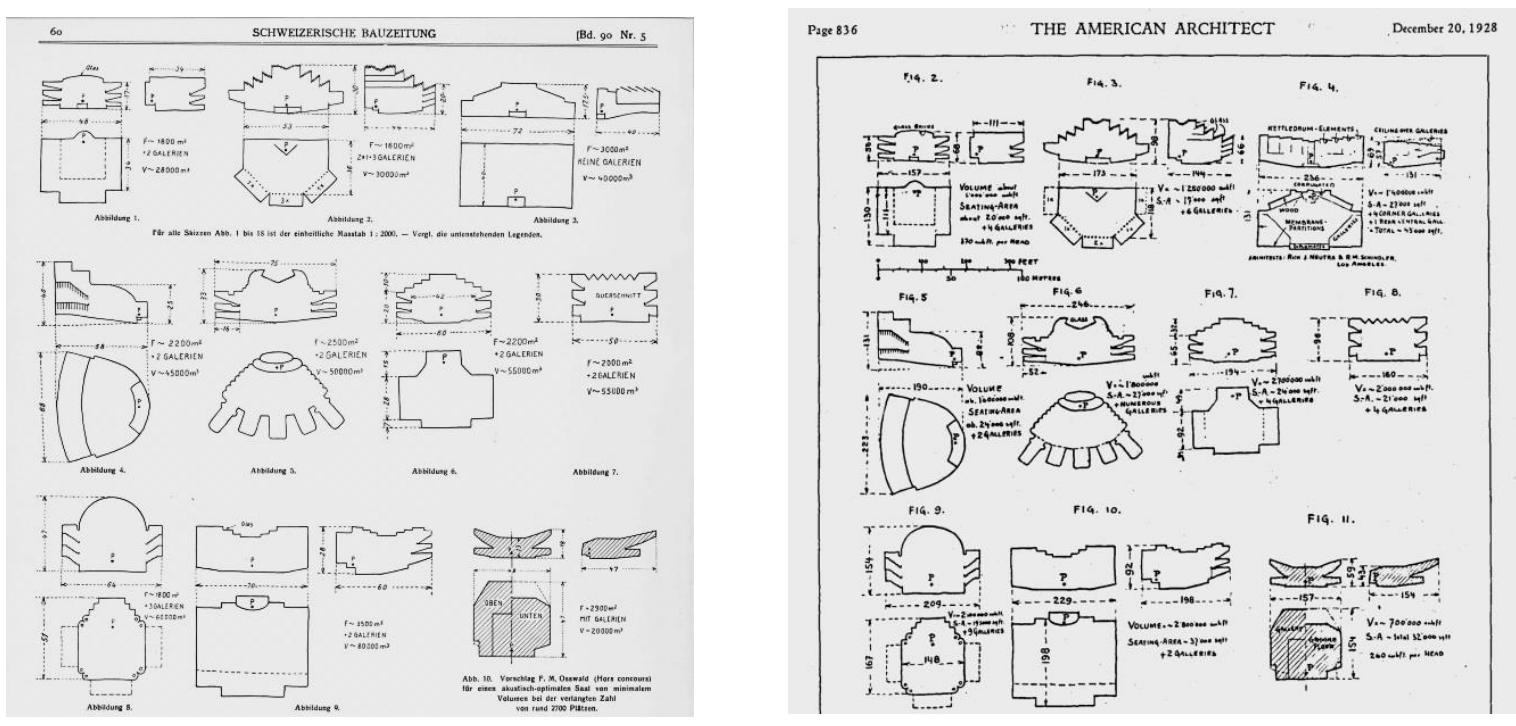

17 - 18. Franz M. Osswald's schematic plans and sections demonstrating acoustically misconceived auditoriums in Schweizerische Bauzeitung (Fig. 17) and The American Architect (Fig. 18), with Richard Neutra's scheme on the top right.

\footnotetext{
38 "Die ganze repräsentative Herbstsession des Völkerbundes hat zweifelsohne etwas Theatermässiges an sich und ist praktisch so gut wie unnötig." ETH Zürich, gta archives: 43-K(DD)-1927-10-02, pp. 2-3.The unsigned letter responds to the author of the wrongful representations of plans and sections of Neutra's scheme in Schweizerische Bauzeitung and is now part of Giedion's archive. My thanks to Daniel Weiss, who pointed out that the typeface indicates Richard Neutra as the probable letter-writer.
} 
The League of Nations assembly hall had to serve the purposes of international understanding in the political sense, and in the literal sense of understanding the words spoken, for nearly 2,700 people. This had no precedent in any tradition of indoor building. "2,700 persons: this means: the world is watching," we can speculate further, anticipated telecommunication networks. And yet Giedion insisted that the large Assembly Hall was a physical space of the analogue, an auditorium according to the principles of the lecture halls with which he was familiar; only under these conditions could Le Corbusier and Pierre Jeanneret's Modern project be presented as more apt, more feasible, and ultimately more functional than other projects - as a Modern solution superior to traditional forms of architectures of representation.

Remarks such as Giedion's on the world watching, or Neutra's remark on theatrical ritual in which acoustics are of no importance, raise questions not only on the visuality and aurality of architecture, but fundamentally on modern argumentation concerning functionality. In 1928, in Une maison - un palais, Le Corbusier elucidated the large Assembly Halls's acoustics, lighting, and ventilation in a 28-page chapter: "Une salle pour 2,600 personnes, organe de visibilité et d'audition." 39 In 1930, in Précisions, the chapter on acoustics ${ }^{40}$ is abbreviated, but illustrated with two pages of drawings, which are shown with the original red highlighting of the sound reflections. Also in red are the words "pas d'onde retardée," the core concept of Gustave Lyon's principle for auditorium acoustics. $^{41}$
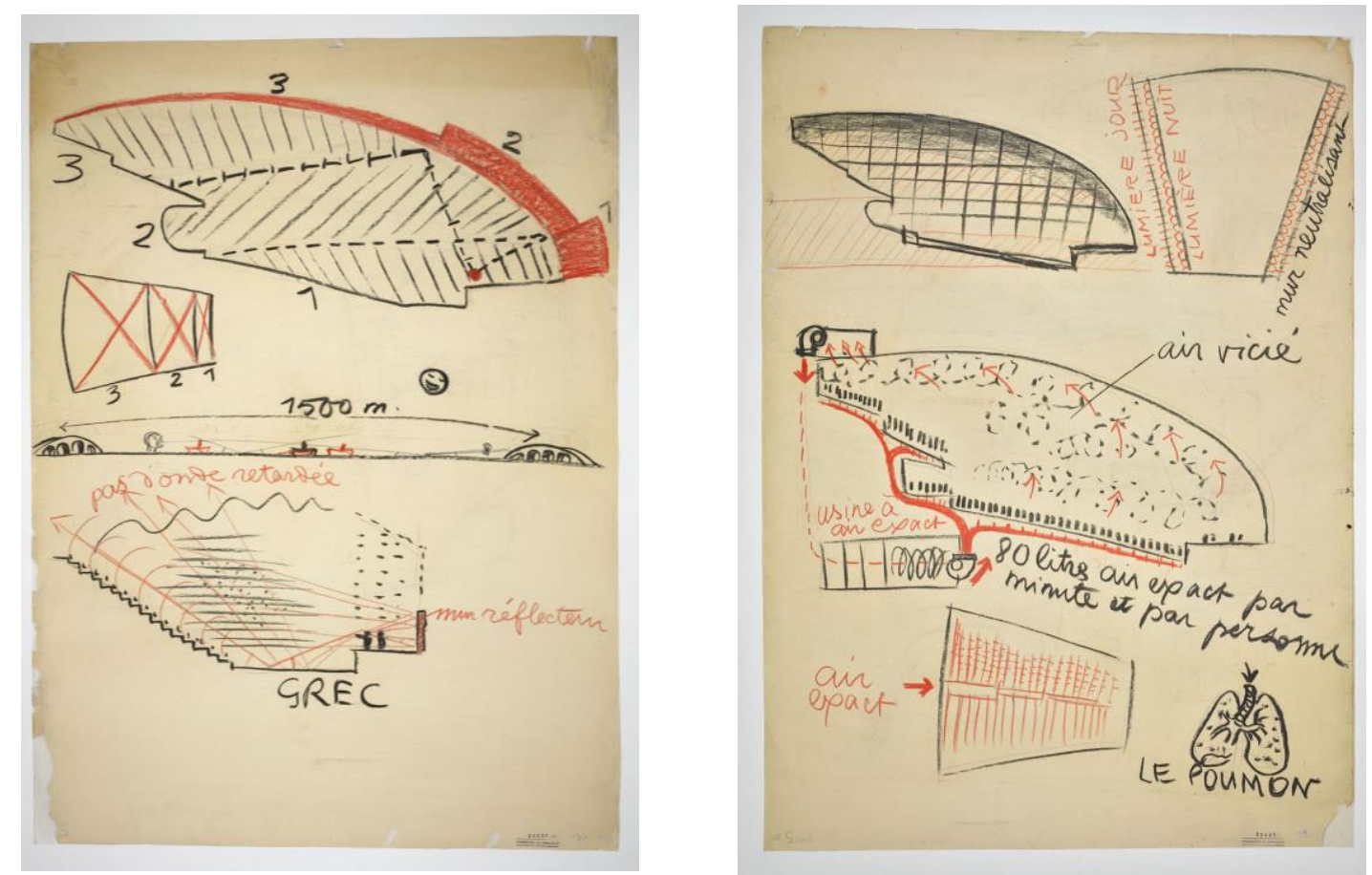

19 - 20. Explications on acoustics, lighting and ventilation for Précisions (archival drawings).

\footnotetext{
${ }^{39}$ Le Corbusier: Une maison - un palais. À la recherche d'une unité architecturale. Crès, Paris: Collection de l'Esprit nouveau, 1928, pp. 106-133.

${ }^{40}$ Le Corbusier: Précisions. Sur un état présent de l'architecture et de l'urbanisme. Crès, Paris: Collection de l'Esprit nouveau, 1930, pp. 158-164.

${ }^{41}$ FLC 33507A; 33495B.
} 
Reproduced in Précisions in black and white with long explanations, ${ }^{42}$ these drawings are based on Lyon's theory. While acousticians in 1927 embraced loudspeaker technology, albeit hesitantly, as a potential, architects in 1930 still enforced the idea that the problem had to be resolved by the architecture itself, by the sound reflections coming from the walls and the ceiling. "Understanding each other by means of the ear" (in other words, without electroacoustic assistance), Le Corbusier wrote, was the only way to a true understanding. The problem was one of the senses: “de l'oeil et de l'oreille: visibilité et acoustique, dans un lien où l'on réunit comme en une véritable Tour de Babel, les gens de tous le pays et de toutes les langues, en des débats dont l'enjeu est la paix du monde. S'entendre des oreilles est le seul chemin que peut prendre le coeur ou la raison."43

Le Corbusier's interest in acoustics was programmatic in that acoustics was a modern science; it was not limited to the technological, but also embraced the psychological and physiological. On the fourteenth of the competition panels, with a bird's-eye rendering of the entire complex and four perspective sketches of the General Assembly's exterior and interior, the lobby, and the roof garden, the words collaged next to the sketches are remarkable: the Great Assembly is described as the "heart" (next to the exterior view) and as the "throat," the "eardrum," and a "vessel of light" 44 (next to the interior view). In the Modernist rhetoric around the League of Nations competition, it was clearly the technological aspect of acoustics that was instrumentalized in the claims that a project was feasible, functional, and forward-looking.

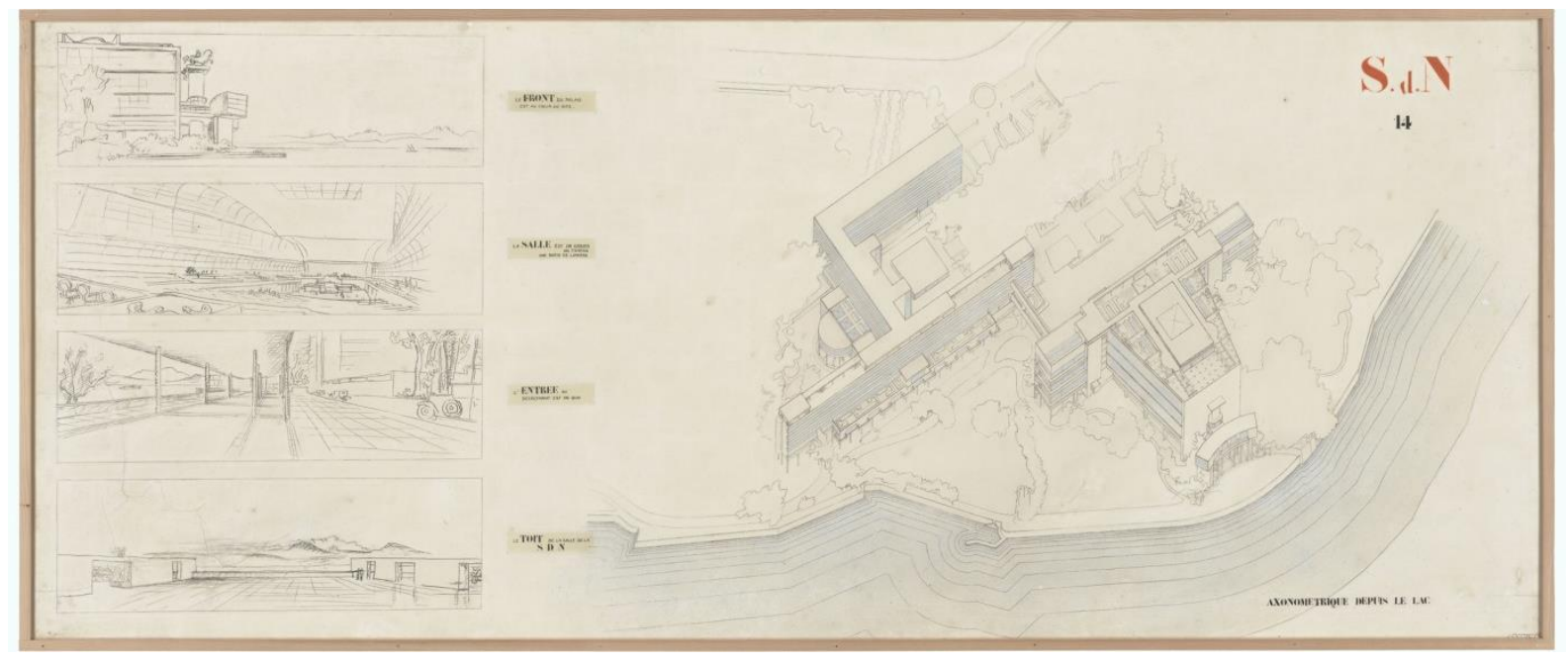

21. "Le front du palais est au coeur du site"; "La Salle est un gosier, un tympan, une boîte de lumière." Le Corbusier and Pierre Jeanneret's competition panel 14.

\section{Conclusion: Acoustics as a Function in Architecture}

The conjunction of the League of Nations competition with the formation of architectural acoustics as a professional and academic discipline set the scene for the prevalence of acoustics in the discourses surrounding Le Corbusier and Pierre Jeanneret's competition entry. When speaking in favor of Le Corbusier and Pierre Jeanneret's scheme, Franz Max Osswald and Gustave Lyon, Peter Meyer and Sigried Giedion all foregrounded the acoustical quality ("Hörsamkeit," as Giedion introduced it to his readers in Bauwelt in 1927). Le Corbusier

\footnotetext{
${ }^{42}$ Le Corbusier: Précisions. Crès, Paris: Collection de l'Esprit nouveau, 1930.

${ }^{43}$ Ibid., pp. 159, 164 (text interrupted by illustrations).

44 "La Salle est un gosier, un tympan, une boîte de lumière.” ETH Zürich, gta archives: Völkerbundpalast, Le Corbusier, 18501-14.1.
} 
himself described the Palace of Nations as a building with an "acoustically perfect Assembly Hall" for not only the administrators, but also the vast number of nearly 2,700 speakers and listeners "to work in." But while they emphasize acoustics as a fundamental function in architecture, the actors in the debates over the competition's outcome pick and choose from modern science. The programmatic exclusion of electroacoustic technologies in Meyer's and Giedion's lines of argument demonstrates that the young science of acoustics was consulted only selectively, and was instrumentalized in claims to be Modern without any further interest in a technological future-which in terms of electroacoustic communication was still decades away. The first fall session in the Palace of the League of Nations was held in September 1937, in an Assembly Hall of approximately 19,000 cubic meters and 1,540 seats, thus considerably smaller than the size given in the competition brief, and initially without loudspeaker equipment. ${ }^{45}$

The episodes of debate over its acoustics in the years from 1927 to 1930, which I have outlined in this paper, suggest that function is a performance projected onto architectural programs. History will resound in a different timbre if we understand function anew: as program, as projection, and as performance. Acoustics, and this is my argument, gives us the opportunity to revisit the history of the League of Nations competition and of 1920s architectural discourses. Without listening, there can be no understanding.

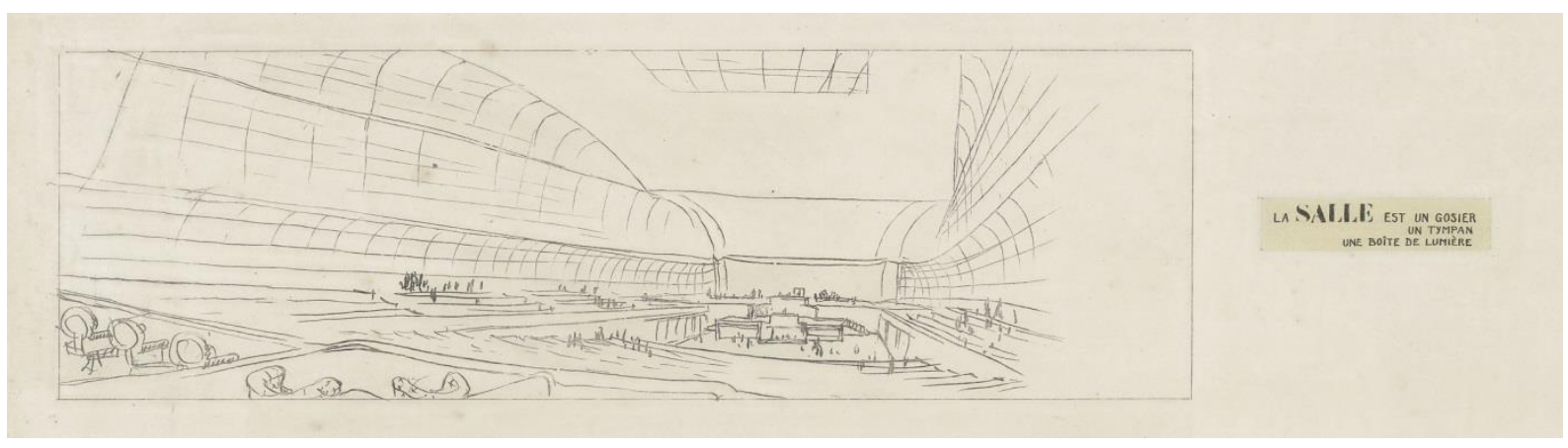

22. Le Corbusier and Pierre Jeanneret's competition panel 14, detail.

\section{Acknowledgments}

This paper was developed from research conducted for my dissertation "Hellhörige Häuser. Akustik als Funktion der Architektur. 1920-1970" ("Proof of Sound. Acoustics as a Function of Architecture, 1920-1970"), an investigation into the conjunction and interdependency of the modern science of applied acoustics and architectural problems in the first half of the twentieth century.

I would like to thank Prof. Laurent Stalder and Prof. David Gugerli of E.T.H. Zurich, as well as Ing. Kurt Eggenschwiler of Empa for their astute advice during the writing of the doctoral thesis on which this paper is based, and Kate Sturge of the Max Planck Institute for the History of Science in Berlin for her help in editing this first English text on the debates on acoustics at the League of Nations.

\section{List of illustrations}

Figs. 1 and 18: Osswald, Franz M.: "The Acoustics of the Large Assembly Hall of the League of Nations, at Geneva, Switzerland.” The American Architect, 84, № 2559 (December 20), 1928. p. 838; p. 836.

\footnotetext{
${ }^{45}$ Chéronet, Louis: Le Palais des la SDN. Paris: L'Illustration, 1938, p. 64 (ETH library copy from the private library of Franz Max Osswald).
} 
Figs. 2, 12, 14, 19, and 20: Archives Fondation Le Corbusier (FLC), Paris: Palais de la Sociéte des Nations, Genève, 1927: I2-1-59-001; I2-I-78-001; Correspondances: Lyon, Gustave (64-70): Correspondances avec L.C. 26/08/1927-09/02/1935: E2-9-64-001; Précisions, 33507A; 33495B. All: CFLC-ADAGP.

Figs. 3, 8, 9, 21, and 22: gta Archiv, Institut für Geschichte und Theorie der Architektur, ETH Zürich: 185-10, Völkerbundpalast, Le Corbusier, 100-01-10; 100-01-14; 100-01-18. All: CFLC-ADAGP.

Figs. 4 and 17: Osswald, Franz M.: "Zum Problem der Akustik im grossen Versammlungs-Saal des VölkerbundGebäudes in Genf." Schweizerische Bauzeitung, 90, № 5 (July 30), 1927. p. 62; p. 60.

Figs. 5, 6, and 7: Database of "Epistemes of Modern Acoustics" project under the direction of Prof. Viktoria Tkaczyk, Max Planck Institute for the History of Science, Berlin (under construction, online 2016).

Figs. 10 and 11: Boyer, Guy: La salle Pleyel. Ed. Alain Metternich. Paris: Connaissance des arts, 2006, p. 14; p. 16.

Fig. 13: Centre Canadien d'Architecture / Canadian Centre for Architecture, Montréal, CCA Collection DR1985:0625: Le Corbusier. Concept diagrams in longitudinal section and plan of the acoustical, lighting, and air circulation systems for the Great Hall of the Palace of the League of Nations, Geneva, Switzerland, December 1929. Pen and ink, 27.0 x $21.1 \mathrm{~cm}$. CFLC-ADAGP.

Fig. 15: Giedion, Sigfried: “Wer baut das Völkerbundgebäude?” Bauwelt, 18, № 44 (November 3), 1927. p. 1097.

Fig. 18: gta Archiv, Institut für Geschichte und Theorie der Architektur, ETH Zürich: 43-K(DD)-1927-10-02, Nachlass Sigfried Giedion, Korrespondenz.

\section{Bibliography}

Amundsen, M.M. and others: "Manifestation des savants, des industriels, des poètes, des financiers en faveur du projet le Corbusier et Pierre Jeanneret." Cahiers d'Art, 3, № 2, 1928. pp. 87-88.

Behne, Adolf: Der moderne Zweckbau. Munich: Drei Masken, 1926.

Chéronet, Louis: Le Palais des la SDN. Paris: L’Illustration, 1938.

Cohen, Jean-Louis: Le Corbusier and the Mystique of the USSR. Theories and Projects for Moscow 1928-1936. Princeton, NJ: Princeton University Press, 1992.

Le Corbusier: “Acoustique: Une conquête de la technique moderne.” L'Intransigeant, October 15, 1927. pp. 1.

Le Corbusier: “La Salle Pleyel. Une preuve de l'évolution architecturale.” Cahiers d'Art, 3, № 2, 1928. pp. 89-90.

Le Corbusier: Une maison-un palais. À la recherche d'une unité architecturale. Crès, Paris: Collection de l'Esprit nouveau, 1928.

Le Corbusier: Précisions. Sur un état présent de l'architecture et de l'urbanisme. Crès, Paris: Collection de l'Esprit nouveau, 1930.

Le Corbusier: Le Corbusier et Pierre Jeanneret. Euvre Complète de 1910-1929. Zurich: Girsberger, 1937.

Le Corbusier: Palais de la Société des Nations, Villa les terrasses, and other buildings and projects, $1926-1927$. New York: Garland; Paris: Fondation Le Corbusier, 1982.

Fischer, Sabine von. Das akustische Argument. Neue Parameter in der Architektur des 20. Jahrhunderts. Zurich: gta Verlag (in preparation).

von Fischer, Sabine: “A Visual Imprint of Moving Air” (in preparation).

Förster, Kim: The Institute for Architecture and Urban Studies (1967-85). Zurich: gta Verlag (in preparation).

Frampton, Kenneth: “Le Corbusier and 'l'Esprit Nouveau."” Oppositions, No 15/16 (Winter/Spring), 1979. pp. $13-58$. 
Giedion, Sigfried: "Die Architektur am Wendepunkt. Anmerkungen zum Wettbewerb um das Völkerbundgebäude.” Neue Zürcher Zeitung, July 24, 1927. p. 4.

Giedion, Sigfried: “Wer baut das Völkerbundgebäude?” Bauwelt, 18, № 44 (November 3), 1927. pp. $1093-1098$.

Gubler, Jacques; Quincerot, Richard: “Da Maratona a Ginevra.” Parametro, No 140 (October), 1985. pp. $24-31$.

Hines, Thomas S.: Richard Neutra and the Search for Modern Architecture. New York, Oxford: Oxford University Press, 1982.

Meyer, Peter; Le Corbusier: “Internationaler Wettbewerb für das Völkerbund-Gebäude in Genf.” Schweizerische Bauzeitung, 90, № 2 (July 9), 1927. pp. 13-20.

Moos, Stanislaus von: Le Corbusier. Elemente einer Synthese. Frauenfeld: Huber, 1968.

Oechslin, Werner; Roth, Alfred: Le Corbusier \& Pierre Jeanneret: Das Wettbewerbsprojekt für den Völkerbundspalast in Genf 1927: à la recherche d'une unité architecturale. Zurich: gta Verlag, 1988.

Osswald, Franz M.: “Zum Problem der Akustik im grossen Versammlungs-Saal des Völkerbund-Gebäudes in Genf." Schweizerische Bauzeitung, 90, № 5 (July 30), 1927. pp. 59-66.

Osswald, Franz M.: "The Acoustics of the Large Assembly Hall of the League of Nations, at Geneva, Switzerland," The American Architect, 84, № 2559 (December 20), 1928. pp. 833-842.

Osswald, Franz M.: Schall und Raum. Antrittsrede an der Eidgenössischen Technischen Hochschule in Zürich, 29. Juni 1929. Zurich: E.T.H., 1929.

Osswald, Franz M.: “Akustisch hochwertige Parabelsäle.” Schweizerische Bauzeitung, 95, No 4, 1930. pp. 47-51.

Osswald, Franz M.: "Akustischer Konzert- und Vortragsaal mit veränderlichem Volumen." Schweizerische Bauzeitung, 96, № 18 (November 1), 1930. pp. 224-225.

Osswald, Franz M.: "Raumakustik in geometrischer Betrachtung." Zeitschrift für technische Physik, 17, No 12, 1936. pp. 561-563.

Osswald, Franz M.: “Zur akustischen Gestaltung von Grossräumen.” In 100 Jahre S.I.A Festausgabe der SBZ zur Jahrhundertfeier. Zurich: Jegher, 1937. pp. 66-70.

Pallas, Jean-Claude: Histoire et architecture du Palais des Nations (1924-2001). L'Art déco au service des relations internationales. Geneva: Nations Unies, 2001.

Pearson, Christopher: "Le Corbusier and the Acoustical Trope: An Investigation of Its Origins." The Journal of the Society of Architectural Historians, 56 (June), 1997. pp. 168-183.

Ritter, John: "World Parliament. The League of Nations Competition, 1926." Architectural Review, No 136 (July), 1964. pp. 17-23.

Sabine, Wallace C.: “Theatre Acoustics.” The American Architect, 104, No 1984, 1913. pp. 256-278.

Sabine, Wallace C.: Collected Papers on Acoustics. Cambridge, MA: Harvard University Press, 1922.

Thompson, Emily: The Soundscape of Modernity. Architectural Acoustics and the Culture of Listening in America, 1900-1933. Cambridge, MA: MIT Press, 2002.

Touloumi, Olga. "Architectures of Global Communication, 1941-1970." PhD thesis, Harvard University, Graduate School of Design, 2014.

Trendelenburg, Ferdinand: "Über Bau und Anwendung von Grosslautsprechern." Elektrotechnische Zeitschrift, 48, 1927, p. 1685-1691. 


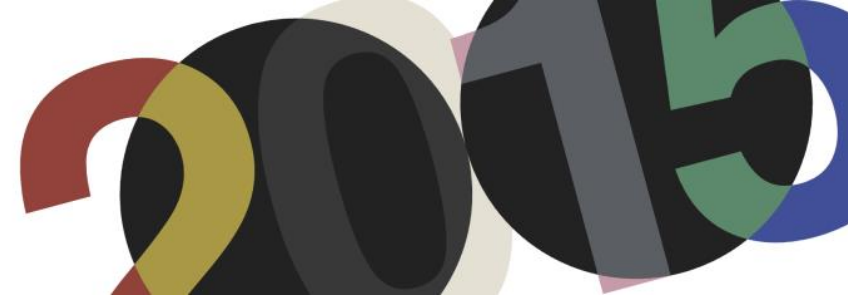

DOI: http://dx.doi.org/10.4995/LC2015.2015.972

\title{
Le Corbusier. Arquitectura urbana: Millowners Association Building y Carpenter Center
}

\author{
M. P. Fontana*, M. Y. Mayorga Cárdenas** \\ * Dra. Arq. Prof. Universidad de Girona UdG \\ ** Dr. Arq. Prof. Universidad Politécnica de Cataluña UPC
}

Resumen: La obra de Le Corbusier es una amplia exploración de soluciones urbanas y arquitectónicas que plantean relaciones de continuidad entre edificio y ciudad, arquitectura y entorno, espacio interior y espacio exterior: rampas, cuerpos bajos, entrantes y salientes, plantas libres y fachadas con espesor, son algunos de los elementos de integración y/o de mediación utilizados por el maestro suizo.

El Millowners Association Building de 1954 ubicado en la ciudad de Almedabad en la India, y el Carpenter Center for Visual Arts de la Graduate School of Design of Harvard de 1961-1964 en la ciudad de Cambridge, en Estados Unidos, son dos edificios que presentan rasgos característicos en común: una volumetría básica, uso del hormigón armado visto, uso de similares elementos de fachada y una rampa que sobresale del edificio y que confiere a ambos un carácter reconocible y peculiar.

Los dos edificios ya han sido puestos en relación por diferentes críticos como Giedion 1967, o Frampton 1975, e incluso se ha considerado uno como antecedente del otro. Sin embargo, un análisis comparativo permite verificar que aunque la rampa es el elemento común más evidente, éste juega un papel muy diferente en la definición de las relaciones urbanas de cada uno de los edificios con su entorno inmediato y con la ciudad. Y además que también, en la relación del edificio con la ciudad entran en juego otros elementos y soluciones arquitectónicas, que de manera solidaria, son determinantes definidores de su relación con el entorno y su carácter urbano.

\begin{abstract}
The work of Le Corbusier is a comprehensive exploration of urban and architectural solutions which show continuity relationships between city and building, architecture and environment, interior and exterior space throughout elements of integration and / or mediation used by the Swiss master like ramps, lower volumes, incoming and outgoing, open floor plans and thick facades.

The Association Millowners Building (1954) located in the city of Almedabad in India, and the Carpenter Center for Visual Arts at the Graduate School of Design of Harvard (1961 to 1964) located in the city of Cambridge, in the United States, are two buildings that have some characteristics in common, like a basic volume, use of reinforced concrete, using similar facade elements and a projected ramp gives a recognizable and distinctive character of both buildings.

Different authors compared the two buildings as Giedion 1967 or 1975 Frampton, and have stated that one has been based on the other. However, a comparative analysis verifies that although the ramp is the most obvious common element, it plays a very different role in the definition of urban relationships of each of the buildings with their immediate environment and the city. Moreover other elements configure crucial aspects in the relationship between the buildings and the urban space creating architectural solutions and interesting relations that are crucial for the definition of the relationship with the environment and the urban character of every building.
\end{abstract}

Palabras clave: Le Corbusier, Millowners Association Building, Carpenter Center for Visual Arts, Urban Architecture. Keywords: Le Corbusier, Millowners Association Building, Carpenter Center for Visual Arts, Arquitectura Urbana.

En la arquitectura, al igual que en el drama, el fin está a la vista, y el espectador no ignora ninguno de los elementos cuya suma constituye esa unidad particular de la que ellos participan.

Martienssen 


\section{Arquitectura y ciudad: Ahmedabad y Cambridge}

La arquitectura es un acto de voluntad consciente. Arquitecturar, "es poner en orden".

¿Poner en orden qué? Unas funciones y unos objetos.

(...) Espacios, distancias y formas, espacios interiores y formas interiores, encauzamiento interior y formas exteriores y espacios exteriores -cantidades, pesos, distancias, atmósfera, es con todo esto con lo que actuamos. Tales son los hechos a considerar.

Desde ese momento, confundo solidariamente, en una sola noción arquitectura y urbanismo.

Arquitectura en todo, urbanismo en todo.

Le Corbusier.

La obra de los últimos años de Le Corbusier es considerada una condensación ${ }^{1}$ o reconsideración de las ideas de su recorrido proyectual precedente. Dentro de los edificios proyectados y construidos por el arquitecto suizo en la última década de su vida, destacan el Millowners Association Building (1954) en Ahmedabad y el Carpenter Center for Visual Arts de la Graduate School (1963) en Cambridge. Entre los dos proyectos se observan a primera vista algunas similitudes formales y en las soluciones arquitectónicas que hacen que inevitablemente sean comparables.

En los dos proyectos se proponen sendas rampas de acceso peatonal, a la vez que se identifican soluciones formales similares, como la existencia de un cuerpo cúbico principal, la presencia de volúmenes bajos secundarios que le complementan, la agregación de elementos exentos de comunicación vertical y el tratamiento de fachada; a la vez también, se utiliza un lenguaje "brutalista" donde el hormigón armado toma protagonismo y da carácter a todo el conjunto edificado. De esta manera volúmenes principales y bajos, brise-soleils, pilotis, rampas y escaleras configuran un todo muy unitario, donde sin embargo las diferentes soluciones adoptadas de inserción urbana, de relación entre interior y exterior, y entre edificio y entorno definen un carácter urbano muy marcado.

Para aproximarnos a la explicación del cómo se establece esta relación y articulación del edificio con su entorno, enfocamos la mirada en ciertos aspectos, partes y elementos de relación del edificio: el lugar y emplazamiento, la configuración del suelo, el acceso y la planta de recibo, la apertura-clausura y la espacialidad de la fachada, el techo practicable, la adición de volúmenes bajos y la disposición de volúmenes verticales, ámbitos del proyecto que en su materialización plantean soluciones arquitectónicas y espaciales que definen la condición del límite ${ }^{2}$ entre el edificio y la ciudad, donde los bordes adquieren espesor y profundidad, donde lo privado se convierte en público o colectivo, donde el paisaje, natural o urbano, se convierte en un interior enmarcado.

\footnotetext{
${ }^{1}$ Agrest, d., Allen, S., Essays. Practice: Architecture, Technique and Representation. Critical voices in art, theory and culture. Psychology Press, 2000. Pág. 120-121

${ }^{2}$ A. Sichenze, Il limite e la cittá, Franco Angeli, 1995
} 


\section{Millowners Association Building}

Geographic coordinates of Ahmedabad, India:

Latitude: $23^{\circ} 01^{\prime} 32^{\prime \prime} \mathrm{N}$

Longitude: $72^{\circ} 35^{\prime} 14^{\prime \prime} \mathrm{E}$

Elevation above sea level: $56 \mathrm{~m}$
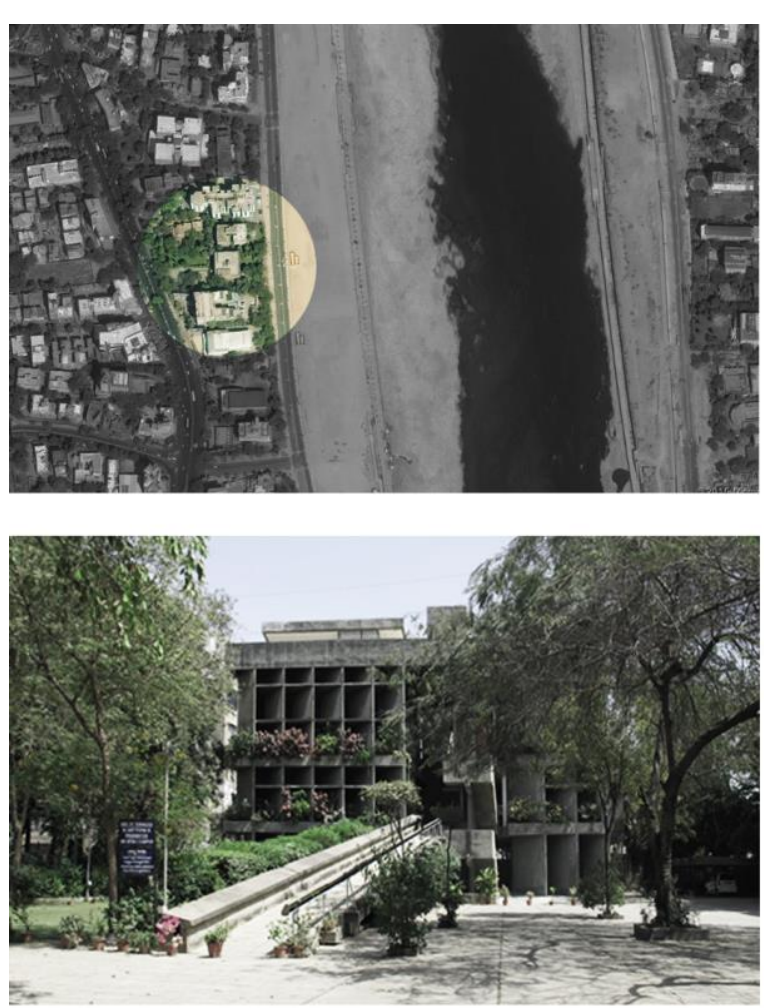

1961-1964 Carpenter Center for Visual Arts

Geographic coordinates of Cambridge MA:

Latitude: $42.37^{\circ} \mathrm{N}$

Longitude: $71.13^{\circ} \mathrm{W}$

Elevation above sea level: $13 \mathrm{~m}$
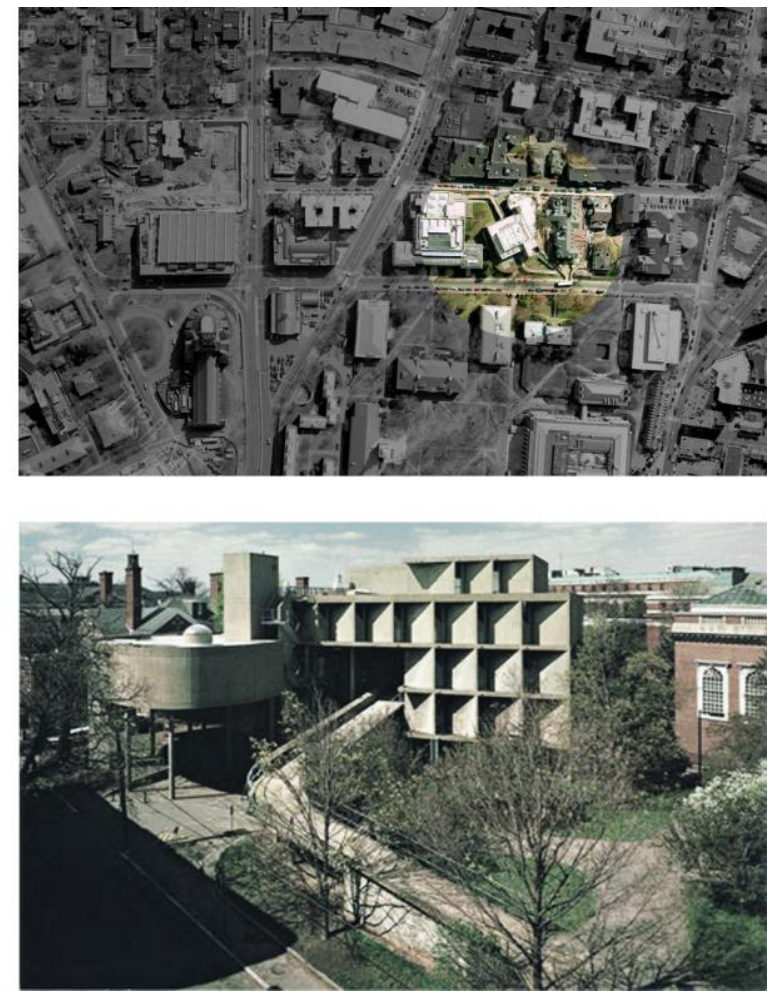

1. Emplazamiento: Los edificios en su respectivo entorno urbano en vistas aéreas y de conjunto

Fuentes:

Imágenes 1a .y 1b. de elaboración propia sobre imágenes aéreas de Anmedabad y Cambridge de Google Maps 2015.

Imagen 1c. recuperada de: http://forum.bulk-online.com/showthread.php?24081-P-amp-BS-India-2012-Photo-Gallery/page9 Imagen 1d. recuperada de:

http://2.bp.blogspot.com/_M2eFv12BZcs/SvxdtD_fN4I/AAAAAAAAAZE/UHR1D_Q9EDk/s1600/027C.jpg

\section{Millowners Association Building (1954)}

El edificio de la Asociación de Hilanderos, emblema de la actividad textil del lugar, se sitúa en la ciudad de Ahmedabad, en la India, en un ámbito con determinantes paisajísticas excepcionales, en una parcela ajardinada de forma alargada perpendicular al río Sabarmati, entre la Asham Road y la senda de la rivera. Estas condiciones hacen que el edificio esté rodeado de verde y que se resuelva de manera categórica con un frente hacia la ciudad y otro hacía el río. El edificio muestra su doble condición: urbana, mediante la solución de fachada hacía la calle con rampa extendida y escalera de acceso exenta y paisajística, hacía el río donde se hace evidente la condición de disfrute desde el interior de las vistas panorámicas. De entrada, observamos que se destacan algunos aspectos clave: una determinada estructura, una orientación en respuesta a los vientos dominantes, la presencia de fachadas en brise-soleil y de un techo jardín utilizado para fiestas nocturnas ${ }^{3}$. La sala

\footnotetext{
${ }^{3}$ LE CORBUSIER 1910-65, A cura di Willy Boesiger, Hans Girsberger, Prima edizione. Bologna. 1987, Traduzione di: De Benedetti Mara Titolo originale dell'opera: Le Corbusier 1910-65. Verlag fur Architektur (Artemis), Zurigo, 1967. Pág. 90
} 
de la asamblea destaca como principal función, por la curvatura de los muros por razones acústicas, la iluminación indirecta y el manejo térmico con cuerpos de agua y jardines colgantes; el mobiliario también destaca por su disposición totalmente integrada al proyecto. En cuanto a la circulación, son muy presentes, la rampa peatonal externa que conecta los estacionamientos con las oficinas y que forma con el cuerpo de escaleras un conjunto plástico en fachada. Los materiales utilizados, son pocos y el resultado final es un conjunto muy unitario: hormigón a la vista para la mayoría del edificio en su estructura y en las fachadas este y oeste, y ladrillo para los muros más cerrados de las fachadas norte y sur, además de piedra y recubrimientos en madera.

\section{Carpenter Center for Visual Arts de la Graduate School (1963)}

El edificio destinado a ser el Centro Universitario para las artes visuales en Harvard (Cambridge), se encuentra situado en una parcela de poca extensión, dentro de una manzana alargada, que se caracteriza por la presencia de edificios históricos de estilo georgiano. El edificio que se inserta en un espacio muy limitado entre el Fogg Museum y el Faculty Club, se abre hacia los dos frentes libres de la manzana, hacia las calles Prescott y Quincy respectivamente. En cuanto al programa de usos, el edificio está pensado como un espacio de encuentro para los universitarios en torno al arte visual en su expresión en dos y tres dimensiones (modelos, esculturas, pinturas, etc.) a partir de la idea base del proyecto de integrar socialmente el arte a toda la comunidad universitaria, mediante un sistema de circulación ${ }^{4}$ continuo que relacionara los distintos espacios de exhibición y de trabajo. Se busca a través de la orientación del edificio y de los cerramientos utilizados la mejor iluminación posible y, a la vez, se plantean soluciones arquitectónicas que ponen en relación interior y exterior, visual y físicamente. La transparencia y elevación lograda a través de los pilotes, la continuidad física de la rampa pasante, el control de la iluminación, y la expresividad de las fachadas, las escaleras y todo el conjunto por los materiales utilizados, en su mayoría hormigón a la vista y vidrio, otorgan unidad formal al conjunto a pesar de la gran complejidad volumétrica del edificio.

\section{Urbanidad y espacios colectivos: el suelo, el piano terra, el piano nobile, el techo, la fachada, los cuerpos anexos.}
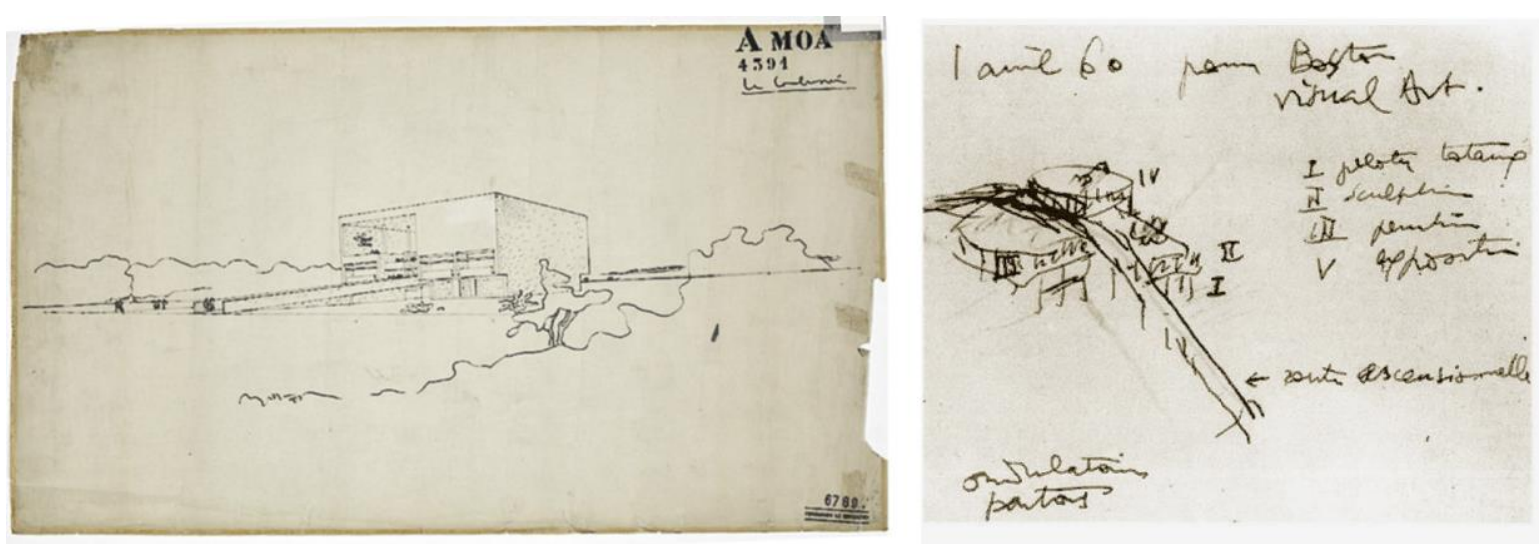

2. Aproximaciones iniciales. Perspectiva y croquis de los edificios y sus extensiones hacia el entorno en el proceso de proyectación.

Fuentes:

Imagen 2a . 06789@FLC-ADAGP.Imagen 2b. Carnet P60 1 april 1960 @FLC-ADAGP.

\footnotetext{
${ }^{4}$ Idem, pág. 164
} 
Establecer una comparación entre los dos edificios, el Millowners Association Building (1954) y el Carpenter Center for Visual Arts de la Gradute School (1963), exige de entrada la priorización en el análisis, de una serie de aspectos para poner el énfasis en aquellos criterios proyectuales y soluciones arquitectónicas adoptadas, que favorecen su "urbanidad." Para los casos que nos ocupan, en el que proponemos indagar sobre su cualidad de "ser urbanas" o de "hacer ciudad", cabe entonces realizar un estudio, desde diversos enfoques y a distintas escalas, en donde se consideran determinantes ambientales, urbanas y arquitectónicas principalmente, a partir de preguntas generales como: ¿Cómo pueden parecerse tanto dos edificios en localizaciones tan diversas?, ¿Cuáles elementos les son comunes?, ¿Qué condiciones de entorno han sido tenidas en cuenta? Sin embargo para llegar a estas respuestas deberemos asumir otros interrogantes más específicos tales como: ¿Qué aspectos y también, qué partes o elementos del conjunto arquitectónico podemos considerar que favorecen la habitabilidad urbana?, ¿Cuáles han sido las respuestas formales y soluciones arquitectónicas específicas? Para concluir finalmente ¿Por qué podemos considerar que estos dos proyectos ejemplarizan la urbanidad de la arquitectura? Y finalmente, ¿Pueden estos criterios proyectuales, soluciones arquitectónicas y urbanas tener vigencia en la materialización de la urbanidad en la arquitectura contemporánea?

Metodológicamente hablando, el análisis entre las dos obras, no pretende ser una comparación directa, en cuanto verificación de diferencias y semejanzas, ni tampoco un constatación contrastada de tipo genealógico dentro del iter proyectual de Le Corbusier, para mostrar el proceso de proyectación de cada obra. Más bien se trata de identificar, mostrar y valorar en las dos obras del maestro suizo construidas, aquellas decisiones proyectuales y soluciones arquitectónicas y urbanas, en las que residen los atributos físicos para una respuesta adecuada al entorno, favoreciendo el confort ambiental, el civismo y la apropiación social de la arquitectura y la ciudad. Para el caso nos interesaremos en algunos espacios de relación de los edificios que contienen en sí mismos, diversas partes y elementos, e identificando por una mayor claridad en la exposición tres ámbitos principales: los planos horizontales y sus conexiones desde el suelo exterior hasta el techo jardín; los espacios de relación vertical como las fachadas, entendidas en su doble condición de marcos para el paisaje y de espacios habitables, y los volúmenes complementarios, o sea aquellos cuerpos anexos que sobresalen del volumen principal y generan una apropiación de los espacios exteriores del edificio.

2.1. Entre el suelo y el cielo: el piano-terra, la rampa, el piano nobile. y el techo jardín

2.2. Entre el interior y el exterior: el espesor de la fachada.

2.3. Entre el edificio y la ciudad: los volúmenes complementarios.

Para cada apartado se propone un reportaje gráfico inicial que muestra las características principales de cada espacio mediante un análisis comparativo en los dos edificios, y donde se destacan algunas de las soluciones utilizadas por Le Corbusier para configurar la condición urbana de los edificios. Es interesante observar que, a pesar del aparente parecido inicial entre los dos edificios, encontramos en cada caso soluciones diversas que responden a condiciones y objetivos específicos, sea del programa que del lugar.

\footnotetext{
${ }^{5}$ La "urbanidad" de lo material, para Manuel de Solà Morales, "resulta de la articulación de cosas urbanas, que no depende de las funciones o la actividad, sino de la materia. Es decir está hecha de tacto y de visión, de sensaciones y de sugerencias. Está presente sobre la "piel" de las ciudades, sus construcciones, texturas, contrastes, calles espacios libres, jardines, muros, perfiles y vacíos. Rampas, escaleras, portales, esquinas, etc., espacios que hacen que sintamos con nuestro peso, las medidas y la forma de la ciudad". "Para una urbanidad material (2005)", en: de Solà Morales, Manuel. De cosas urbanas. Gustavo Gili, Barcelona, 2008. Pág. 147.

6 "Para una urbanidad material (2005)", en: de Solà Morales, Manuel. De cosas urbanas. ed. Gustavo Gili, Barcelona, 2008. Pág. 146.
} 


\subsection{Entre el suelo y el cielo: el piano-terra, la rampa, el piano nobile. y el techo jardín}

Este primer ámbito de exploración de los proyectos de A-MOA (1954) Ahmedabad. y VAC-BOS (1961-64) Cambridge, nos remite a los espacios horizontales y a su superposición e interacción. Dentro de una secuencia de en orden vertical desde abajo hacia arriba, se pueden identificar por lo menos 4 sustratos del edificio: El piano terra, la rampa, el piano nobile y el techo jardín.

\subsubsection{El piano terra: el espacio urbano del edificio}
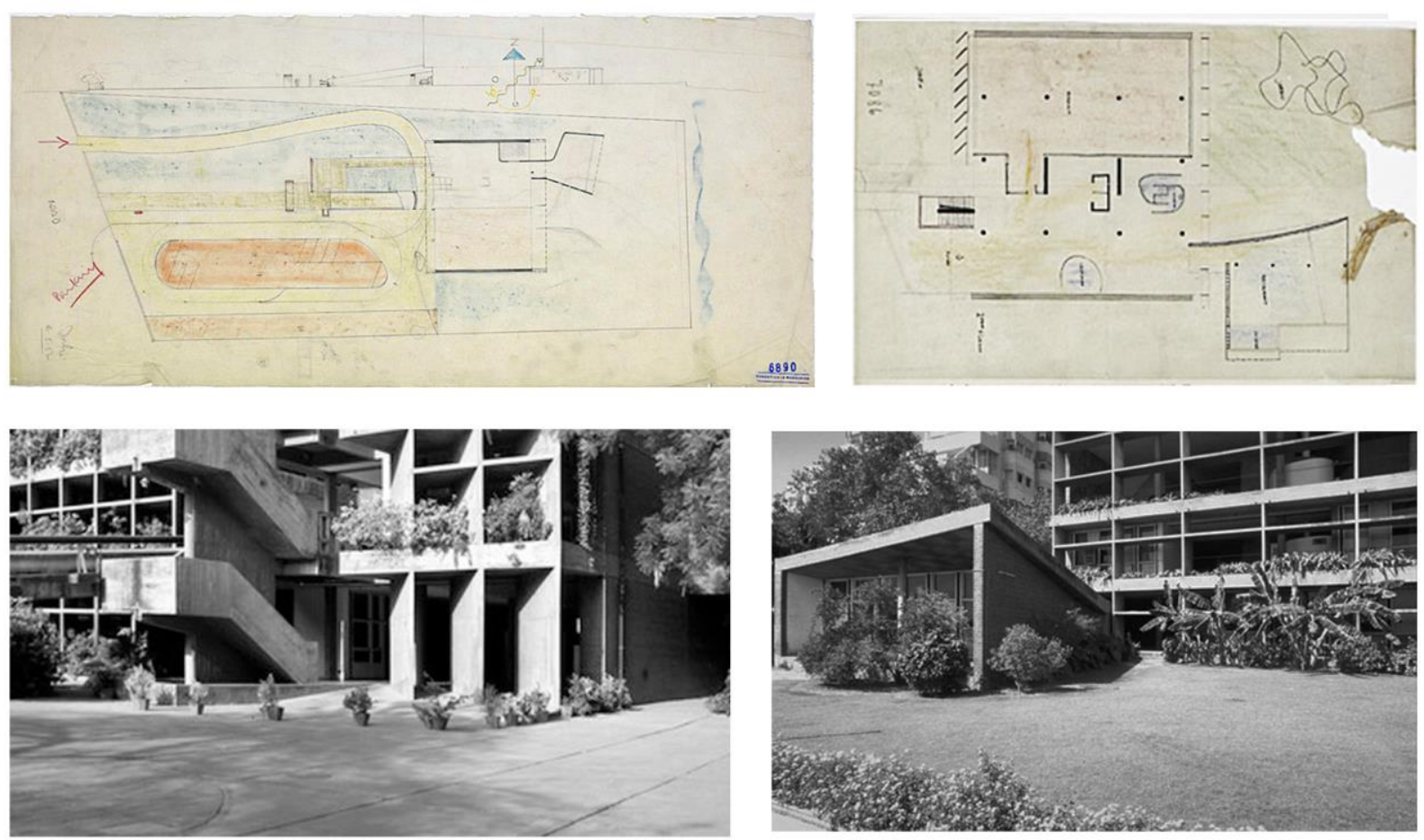

3. El piano terra A-MOA. El edificio y sus relaciones en la planta baja, en planos del proceso proyectual y en vistas exteriores.

Fuentes:

Imagen 3a. 06890 @FLC-ADAGP, Imagen 3b. 07086 @FLC-ADAGP.

Imagen 3c.Recuperada de: http://www.archdaily.com/464142/ad-classics-mill-owners-association-building-le-corbusier/ Imagen 3d. Recuperada de: www.emol.com/especiales/le_corbusier/ 

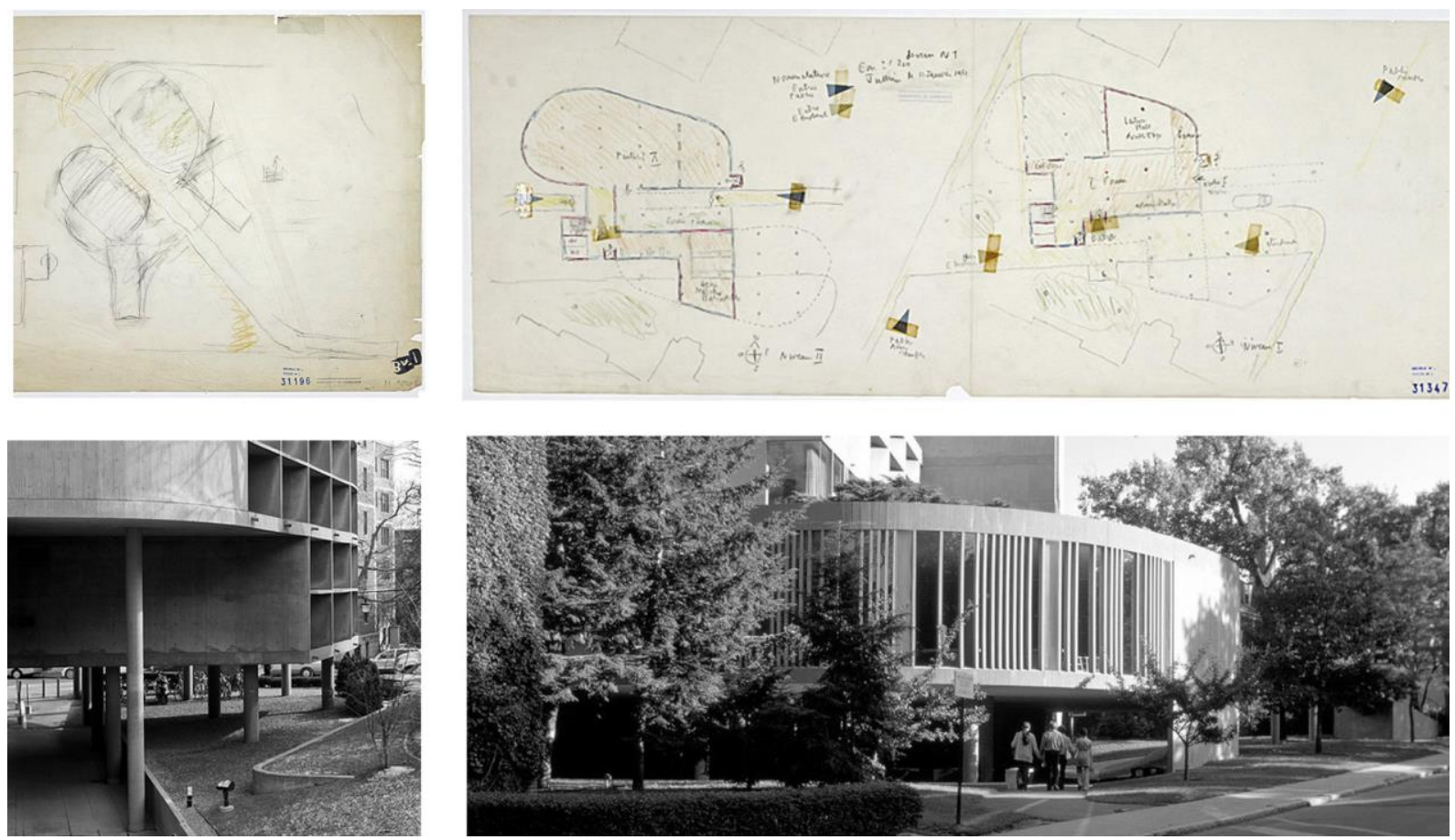

4. El piano terra VAC-BOS. El edificio y sus relaciones en la planta baja, en croquis y planos del proceso proyectual y en vistas exteriores.

Fuentes:

Imagen 4a. 31196 @FLC-ADAGP, Imagen 4b. 31347 @FLC-ADAGP.

Imagen 4d. Recuperada de https://www.flickr.com/photos/scottnorsworthy/3390210497/

Imagen 4e. Recuperada de https://www.flickr.com/photos/scottnorsworthy/3390210495/

La planta baja es uno de los ámbitos en los que se define con mayor incidencia la calidad de las relaciones entre los edificios y el espacio urbano circundante ${ }^{7}$, sin embargo su denominación en español no aporta ningún valor calificativo, ni siquiera orientativo de su trascendencia respecto a la ciudad ${ }^{8}$, por eso se asume la definición del italiano que encierra una acepción que tiene que ver con la relación o vínculo del plano de apoyo del edificio con el terreno. Cuando se habla de piano terra, también nos referimos a un ámbito que posee cambios topográficos, es decir una cota cero que dimensionalmente está contenida en un altura que va desde la cota $+6 \mathrm{~m}$ a $1 \mathrm{la}-6 \mathrm{~m},{ }^{9} \mathrm{y}$ que se extiende desde el interior del edificio hacia su entorno, abarcando espacios públicos y colectivos, aceras, calles, plazas, áreas verdes e incluso accesos a edificios vecinos, públicos, privados o de libre ingreso.

\footnotetext{
${ }^{7}$ En la relación suelo-pared se consigue la exhibición o el énfasis. Atender a los muros como materia del espacio urbano es reconocer el protagonismo de las plantas bajas. Allí donde se produce la disolución del límite privado-público, la diversidad espacial de las circulaciones, los modos en que se interpenetran interior y exterior, en portales, aparcamientos, terrazas, comercios, etc.. "Para una urbanidad material (2005)", en: de Solà Morales, Manuel. De cosas urbanas. ed. Gustavo Gili, Barcelona, 2008. pp 147

${ }^{8}$ Otros idiomas definen mejor que el nuestro, que con calificativo de "baja" trata casi despectivamente el momento aludido, y asi "Piano terra, Ground floor, Rez-de -chaussée o Erdgeschoss" son términos que aluden de manera distinta pero inequívocamente a la trascendente toma de contacto del edificio con su entorno, la calle, la tierra o el suelo. Pere Joan Ravetllat. En: La planta baja: una intersección entre el edificio y la ciudad DPA, pp26

${ }^{9}$ Jane Jacobs con su elogio encendido de la calle anónima frente a la calle especializada y posteriormente engullida por usos particulares, ha sido quien mejor ha explicado y defendido la importancia de ese sustrato en el que se producen las actividades que le dan vida y sentido a la ciudad. En realidad, la ciudad no tiene cota 0 , ya que lo relevante para su confort y uso tiene que ver, entre otras cosas, con el modo en que se resuelva el compás entre las cotas $+6 m$ y la -6m respecto a la calle convencional. .Rubert, M. Espacio público y cota cero, pp. 12
} 
A-MOA (1954). El edificio sede de la asociación de Hilanderos, se dispone sobre un terreno plano, en una parcela de forma alargada e irregular en forma de cuña, el volumen principal en sus cuatro plantas de altura, se localiza a una distancia de tres cuartos de la longitud del solar respecto al frente urbano, y de dos tercios respecto al frente que delimita el terreno hacía el río Barmati. Esta posición permite liberar la mitad de la parcela hacia la ciudad y un cuarto de ésta hacia el río. Así se define de entrada una amplia zona de acceso hacia el oeste y una de dimensión menor hacia el este. En el ámbito de ingreso se localiza en sentido longitudinal la rampa de acceso, que se encuentra flanqueada por los estacionamientos al costado sur y por un área verde y cuatro pequeñas edificaciones alineadas (no construidas) respecto a la rampa. Mientras que en la zona este hacía el río se dispone un cuerpo bajo conectado al volumen principal (que por un tiempo fue ubicado al costado norte y finalmente quedo dispuesto en al costado sur). La ocupación lineal del terreno ha permitido dejar espacios libres de construcción, la composición lineal hacer un uso racional del espacio que no es muy grande y de proporción muy alargada. La existencia de la rampa hace que el acceso peatonal se acerque al acceso a la vez que el edificio se retrocede y posee una amplia antesala. La planta baja del volumen principal actúa a manera de recinto cubierto permeable, delimitado por los pilotes perimetrales de las fachadas este y oeste, que son en realidad brise-soleils verticales, y los muros laterales cerrados y en ladrillo de los lados sur y norte. Parte de los usos de la planta baja son de acceso público y mediante su ordenación y agrupación permiten y sugieren atravesar el volumen hasta un espacio que balconea sobre la orilla del río. (Fig. 5)

VAC-BOS (1961-64). En una parcela reducida y muy limitada en superficie y rodeada de edificios preexistentes de estilo georgiano, se dispone este centro para la cultura y el arte visual, abierto para toda la comunidad del Campus de la Harvard University. El edificio se configura mediante una agrupación de volúmenes en torno a uno cúbico y principal de 4 plantas y sótano. La compleja localización y orientación parece ser una de las causas que hicieron optar por el planteamiento de un edificio girado respecto a los límites de la parcela definida por las calles paralelas Quincy y la Prescott. La decisión de proponer una rampa peatonal en trazado diagonal, pasante a través del edificio y con entrega en las dos calles, fue la idea estructurante del proyecto en su disposición en el solar desde su planteamiento inicial ${ }^{10}$. La multiplicidad de niveles producida por la adición de cuerpos de formas redondeadas, no solo tendrá su repercusión en la configuración volumétrica, sino que también sobre el diseño de la planta baja. En piano terra del edificio en este caso es una superficie de diversos niveles, que sea adapta en planta y alzado a los límites de los edificios existentes y a las calles vecinas, y donde mediante la rampa y un sistema de senderos entre los espacios verdes se proponen una serie de pasos, que permiten que el edificio se pueda atravesar por medio de diversos recorridos peatonales. En la planta baja semienterrada bajo el edificio, se observan volúmenes superpuestos, así como también la rampa sobre pilotes. Las funciones que se disponen en la planta baja son las de hall de entrada, control de acceso, taller y sala de conferencias.

En Ahmedabad, el piano terra es plano, extendido, legible y recorrible libremente; el edificio con sus elementos complementarios se extiende longitudinalmente en la parcela alargada; el volumen cúbico principal se acerca al río y en sentido opuesto propone una gran antesala, y los usos colectivos se sitúan bajo el volumen protegidos por la sombra. Mientras que en Cambridge, se produce una concentración de recorridos, superposiciones y cambios de nivel, que dentro de una lógica de aprovechamiento máximo del limitado solar, hacen que sea un edificio dinámico, que invita a ser cruzado y a ser descubierto donde el piano terra adquiere una tridimensionalidad ligada estrechamente al edificio para luego extenderse hacia las calles vecinas.

\footnotetext{
${ }^{10}$ A partir de los planos y croquis de archivo se deduce que durante el proceso de proyectación, se presentaron variaciones de las entregas de la rampa sobre las calles con diversos desarrollos y también, respecto a la forma de los volúmenes bajos complementarios que fueron establecidos de forma esquemática de forma ortogonal, de forma redondeada y dispuestos también de distinta manera y dimensión. La rampa en su disposición en diagonal vinculada al volumen cúbico dispuesto en escorzo, respecto a la manzana fue una constante.
} 


\subsubsection{La rampa: entre el piano terra y el piano nobile}
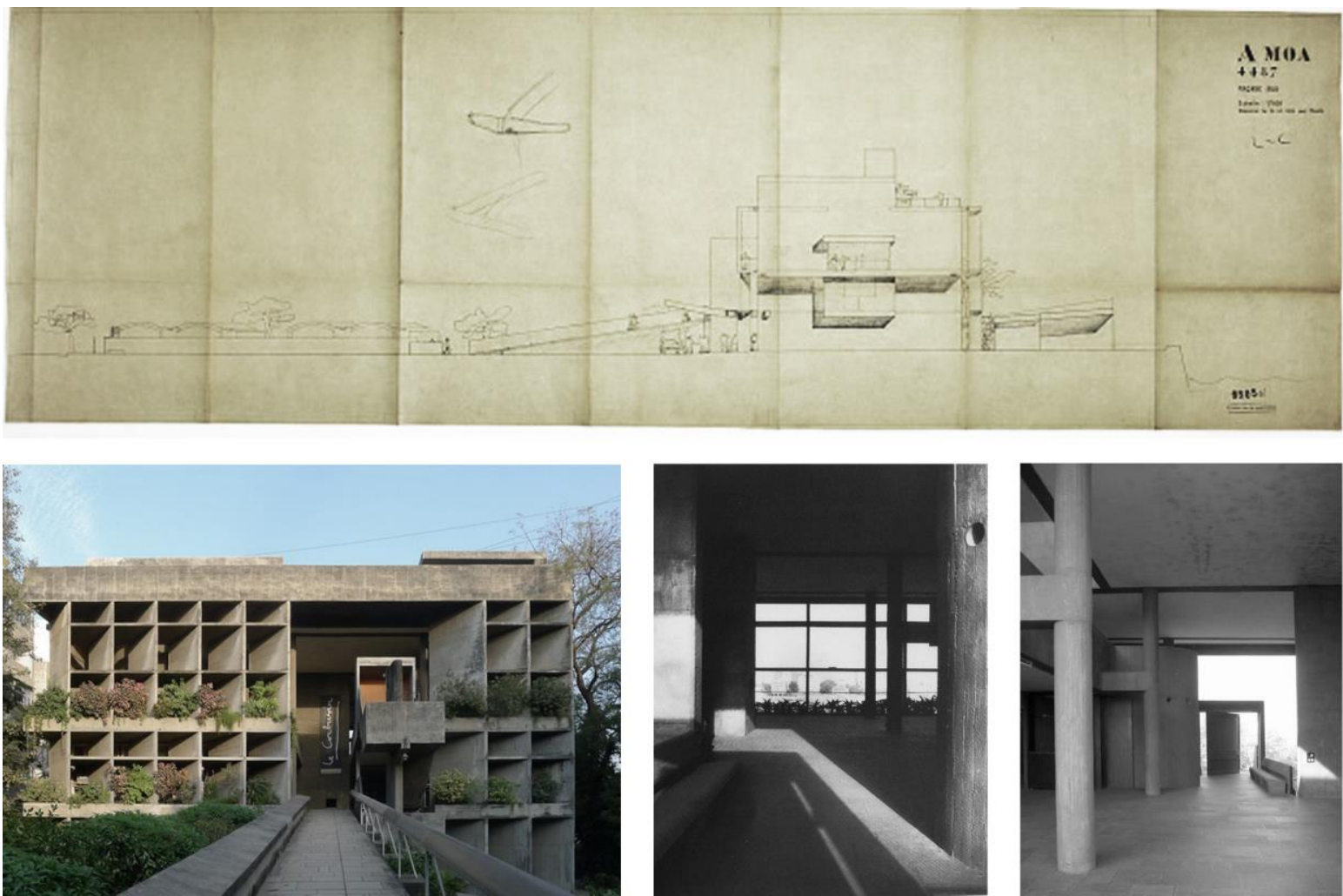

5. La rampa y el acceso al edificio A-MOA. Plano del proceso proyectual y vistas exteriores e interiores.

Fuentes:

Imagen 5a. 06805 OFLC-ADAGP. Imagen 5b. LC_Ahmedabad_Panovscott

Imagen 5c. Curtis, W. Le Corbusier, Ideas and Forms, Imagen 5d. Recuperada de: https://www.travelblog.org/Photos/801308

"Si queremos averiguar la forma de cualquiera de sus arquitecturas - de Le Corbusier-, hemos de identificar el dispositivo puerta-rampa, porque "arquitectura" será cuanto ocurra en ese trayecto". Quetglas ${ }^{11}$. Uno de los aspectos más reconocibles de los dos proyectos es la presencia de una rampa peatonal, elemento común a muchos edificios de Le Corbusier, que en este caso asegura, la experiencia móvil a través de un recorrido de aproximación, iniciático, dislocado y ascensional ${ }^{12}$, en el que nuestra mirada secuencial incorpora nuevos elementos a considerar en la escena. Secuencia a través de la que se produce la unión entre el tiempo y el espacio de la arquitectura $^{13}$.

\footnotetext{
${ }^{11}$ J. Quetglas ha demostrado que la primera vez que utiliza Le Corbusier una rampa, no es en la Ville La Roche (1923-1925), "asociada a la colección de pintura, para permitir una percepción graduada de los cuadros en la pared", sino en un matadero "los proyectos de Jeanneret de diciembre 1917, Matadero Frigorífico en Challuny, y de febrero de 1918, Matadero Frigorífico en Garchivy -éste último fue vuelto a presentar como Matadero Frigorífico de Bordeaux, en noviembre del mismo 1918”. Promenade architecturale. Por J. Quetglas visitado en http://www.arranz.net/web.arch-mag.com/5/homeless/05s.html.

${ }^{12}$ Sólo el trayecto en rampa permite una percepción continuada, manteniendo la mirada fija en el objeto que nos atrae, al tiempo que es función de tres variables simultáneas: la distancia, el ángulo y la altura desde la que consideramos el objeto de nuestra atención. La rampa será, por tanto, el trayecto idóneo para considerar lo plástico. Martienssen, en su ensayo sobre la idea de espacio en la arquitectura griega, sugiere que el efecto del habitual camino en rampa quebrada hacia un templo dórico equivale a hacer girar y acercar el templo hacia el espectador, como considerándolo desde todos los puntos de vista.

${ }^{13}$ GIEDION, Sigfried, Espacio, Tiempo y Arquitectura, Ed. Científico-médica, Barcelona, 1968. El autor sostiene que la arquitectura moderna debía responder a la nueva relación espacio-tiempo.
} 

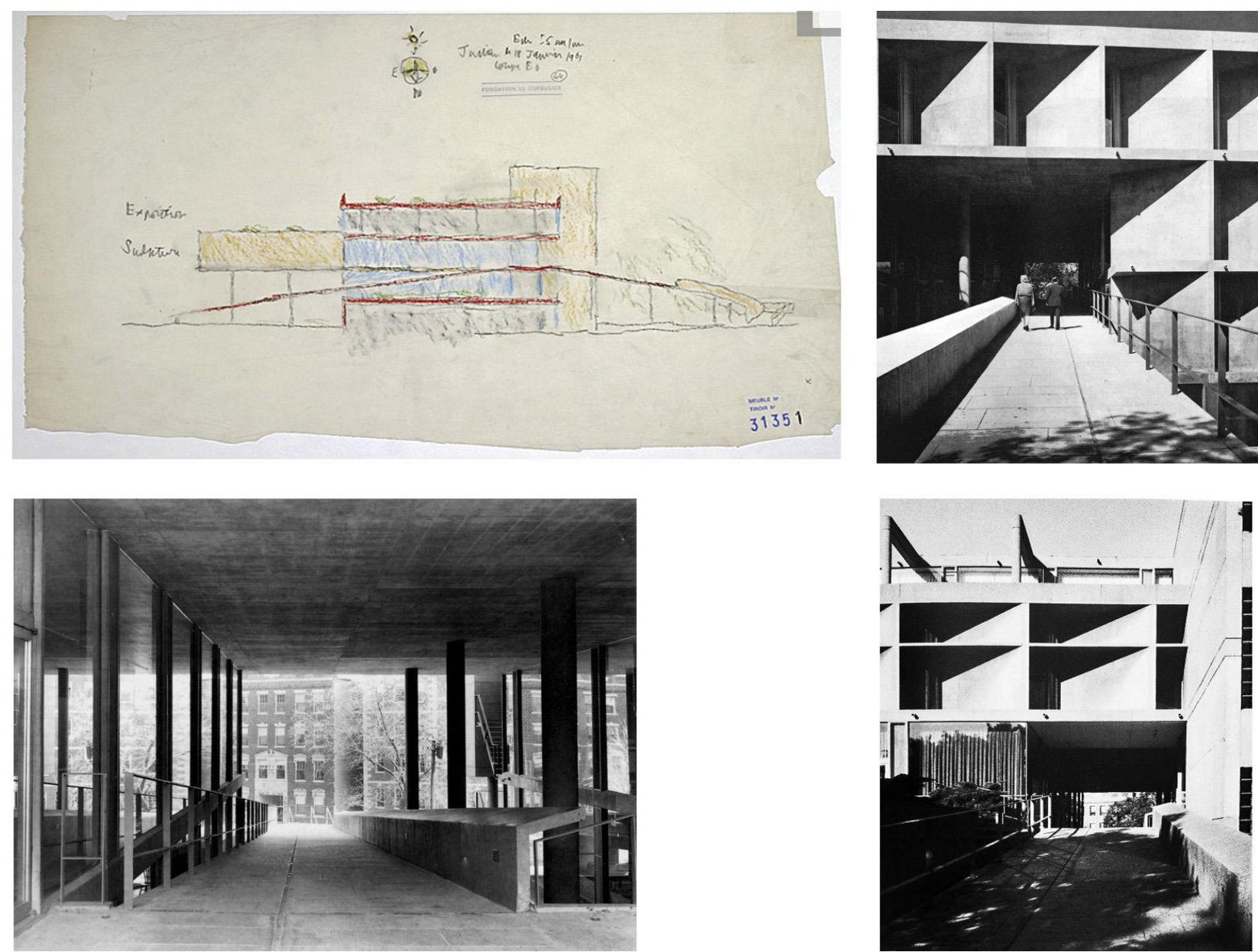

6. La rampa y el acceso al edificio VAC-BOS. Croquis del proceso proyectual y vistas exteriores e interiores.

Fuentes:

Imagen 6a. 31351 @FLC-ADAGP. Imagen 6b. Le Corbusier, Obra Completa 7-P61

Imagen 6c. LC 1961-64, Imagen 6d. Curtis, W. Le Corbusier, Ideas and Forms

Como anotábamos en la configuración del piano terra en Ahmedabad, la rampa cumple un papel definitorio en la ocupación del suelo, por su localización central longitudinal en la parcela alargada. La rampa como extensión del edificio y elemento de conexión entre el área de acceso al solar y vinculo ascensional hasta el acceso del edificio y de relación con el piano nobile, que se asoma al río, revela mediante tres variables simultáneas (la distancia, el ángulo y la altura), la relación de unión y separación del edificio con el lugar. Respecto a la distancia la rampa en su desarrollo también acerca y aleja a la vez, el momento de acceso real al edificio. Cabe preguntarse, ¿En qué momento accedo al edificio? La respuesta que resulta intencionalmente ambigua pasa por resolverse si nos fijamos en el umbral y puerta que marcan la entrada: a través del ángulo de la pendiente, observamos que el ascenso permite enfocar la mirada en la totalidad del edificio y poco a poco, ir descubriendo sus detalles, en la fachada, la elaborada solución adoptada para el acceso y el piano nobile. Precisamente es la relación con el piano nobile la que determina la altura de la rampa y su relación estrecha con la escalera externa, una proporción conveniente que permite que la rampa, como plano artificial e inclinado, no produzca una condición de ruptura en la relación visual con el suelo, ni con el edificio. Se trata de asumir que es igual de importante relacionarse con el suelo natural como con la planta de acceso elevada, así como con la fachada donde entrega la rampa. 
VAC-BOS (1961-64). En el caso de Cambridge, la rampa que tiene su desarrollo en diagonal en la parcela y que termina configurando una "S" con sus entregas en las calles, establece de entrada la organización del edificio, dividiendo y uniendo el programa de usos y los dos ámbitos principales. El hecho de ser una rampa pasante le otorga una condición de calle peatonal elevada y pública a utilizar por todos los transeúntes y vecinos del lugar. La relación de distancia de la rampa con el edificio mismo e incluso vecinos es de mucha proximidad, la rampa en sus tramos curvos y rectos, en su longitud obliga a ampliar el abanico de visión durante el recorrido incorporando elementos del entorno. El ángulo de desarrollo, de la inclinación permite atravesar el edificio con facilidad, aunque esto provoque un punto de contacto real con el edificio reducido. La altura de la rampa hasta llegar al piano nobile es en una segunda planta, aunque esta altura se encuentra realtivizada por la existencia de pisos semienterrados. Los cruces peatonales por debajo de rampa son muy utilizados, así como también los senderos que vinculan el edificio con los jardines del entorno de la planta baja.

En el análisis de los proyectos que nos interesan aquí de A-MOA (1954) Ahmedabad. y VAC-BOS (1961-64), podríamos partir de una semejanza obvia, que es la presencia de la rampa en los dos proyectos, sin embargo son precisamente más las particularidades las que nos permiten reconocer las bondades y matices del uso de la rampa en cada caso: En el primer caso la rampa cumple inicialmente con una función urbana de conexión con la zona de aparcamiento y con los cuerpos anexos (no construidos); la extensión de la misma hacía la calle pone en marcha un recorrido ascensional que fija la mirada en el acceso del edificio, donde se produce una sutil desviación obligada antes de abrir de nuevo la mirada hacía el espacio de la pianta nobile, y de allí hacia el disfrute visual del río. En el segundo caso la rampa cumple inicialmente con la misma función de conexión desde la calle con el acceso, pero la condición urbana del edificio obliga a plantear otra respuesta, dado que está localizado entre dos calles y la rampa es la forma más expedita de conectar estos dos puntos de acceso. A partir de esta decisión todo el proyecto se estructura a partir de esta conexión en diagonal, donde la rampa permite cruzar literalmente el edificio y produce una complejidad en la planta baja a partir de la elevación general sobre pilotes. la rampa de Ahmedabad, es una extensión del edificio hacia la ciudad que cumple con su función de relación hacía la calle y se interrumpe en vestíbulo de acceso, mientras que la rampa de Cambridge, es una calle peatonal que el edificio le ha aportado a la ciudad, que cruza el edificio y que además se integra espacialmente en su interior. 


\subsubsection{El piano nobile: acceder/estar/mirar/cruzar}
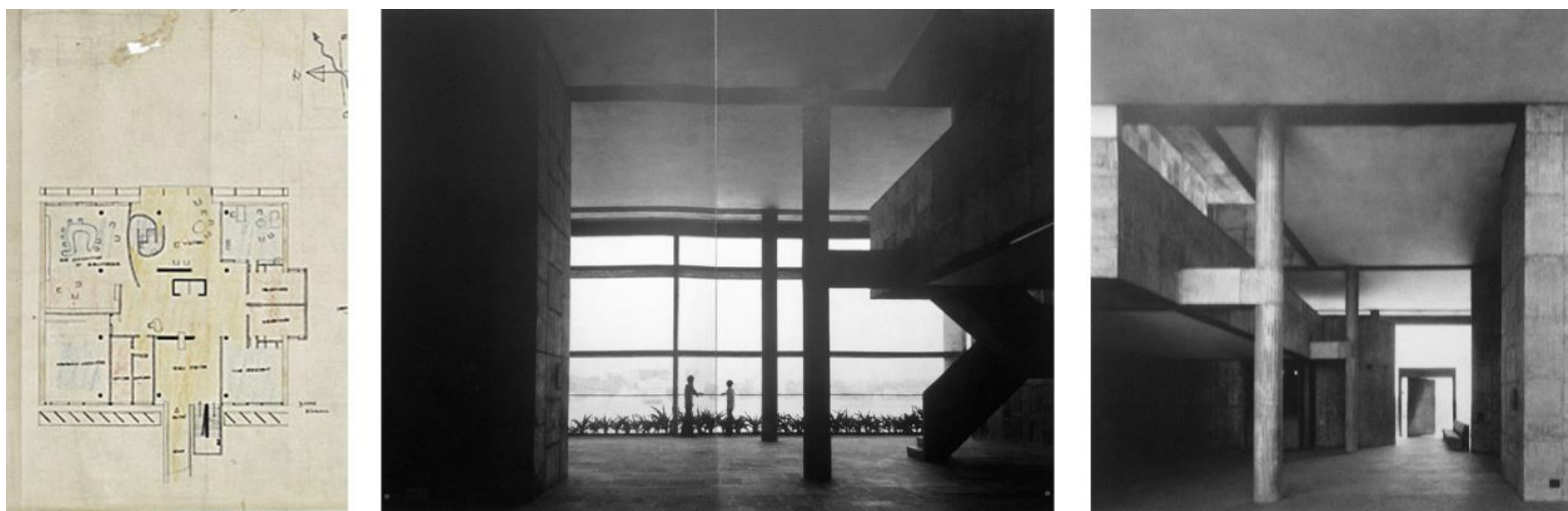

7. El piano nobile y el acceso al edificio A-MOA. Planta y vistas interiores.

Fuentes:

Imagen 7a. 07086 @FLC-ADAGP.

Imagen 7b. Framptom, K. GA No. 37

Imagen 7c. Framptom, K. GA No. 37

La decisión de elevar el acceso al edificio y conectarlo mediante una rampa, tiene su aplicación en varios proyectos de Le Corbusier: el efecto especial logrado gracias a la elevación del espacio de entrada hace que esta planta adquiera una valoración destacada en el ámbito del edificio y logra una relación especial con el paisaje tal como sucede en la arquitectura clásica con la cual tanta deuda tiene Le Corbusier. "Exigid una sala grande en lugar de todos los salones" y "una pared llena de ventanas que, si es posible, den sobre una terraza para baños de sol ${ }^{\prime 14}$, son dos sentencias que se aúnan para definir dos de las características que debería poseer un piano nobile, ser un espacio para recibir $\mathrm{y}$, a su vez, presentar unas condiciones ambientales especiales en cuanto relación del interior con el exterior, efecto parecido a la elevación sobre pilotes, donde se produce una sensación de intimidad abierta, que se aleja y toma distancia de la calle y del exterior, pero a la vez balconea sobre ello: en esto consiste la urbanidad de una planta elevada. En ambos edificios observamos que la planta elevada se encuentra vinculada a la rampa y a la escalera en su condición de acceso al edificio.

\footnotetext{
${ }^{14}$ Le Corbusier. Hacia un arquitectura. Ediciones Apóstrofe, Barcelona, p. 96
} 
En A-MOA (1954) en Ahmedabad, el salón de acceso se delimita, mediante el umbral, la puerta y los muros laterales, y desde él se sugiere una continuidad hacia la zona de ascensores y distribuidor que luego desemboca en el salón de visitantes que se proyecta hacia el paisaje del río Sabarmati, donde se consolida la idea de un piano nobile, compuesto por zonas destinadas a oficinas (de presidencia, vice presidencia, secretaría) y salas de reuniones, y organizado en torno a un secuencia longitudinal de salones de acceso público, desde la entrada hasta la fachada donde encontramos un interior exteriorizado.
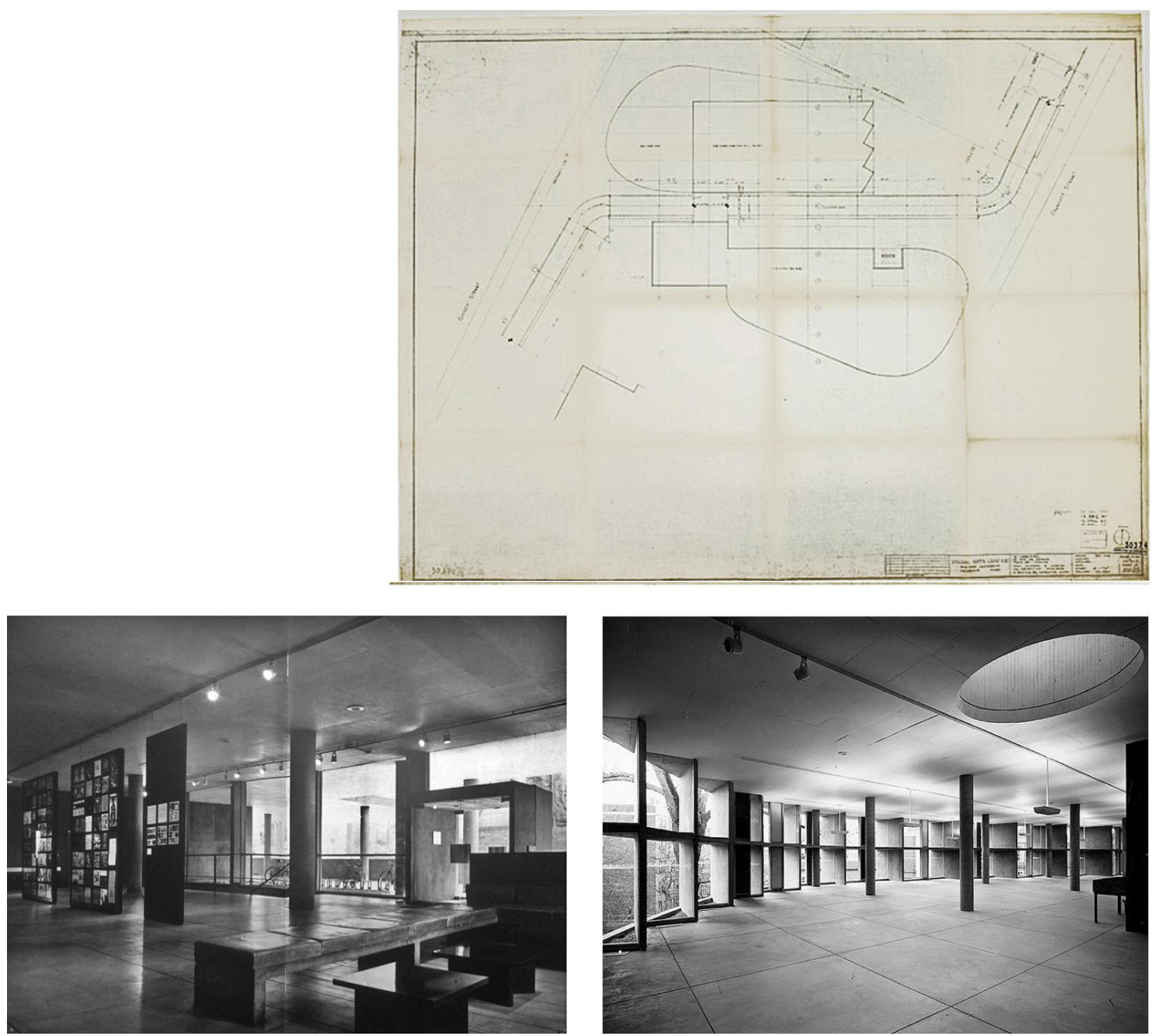

8. El piano nobile y el acceso al edificio VAC-BOS. Planta y vistas interiores.

Fuentes:

Imagen 8a. 30374 @FLC-ADAGP.

Imagen 8b. Framptom, K. GA No. 37

Imagen 8c. Recuperada de: http://www.gsd.harvard.edu/images/content/5/5/v2/556116.jpg

En VAC-BOS (1961-64) Cambridge, se accede al piano nobile, desde una rampa pasante que conecta los dos frentes de las calles Quincy y Prescott. El hall de acceso está apoyado en su función circulatoria en el gran volumen que contiene las escaleras y el ascensor y los baños en proximidad a la calle Quincy. La rampa entrega en la planta en una zona muy limitada y el hall queda definido mediante un puente que hacia un lado comunica con una sala de exposiciones rectangular y hacia el otro hacia una amplia sala de estudio elipsoidal. En el piano 
nobile la forma cúbica principal del edificio se disuelve y expande a través de las salas y la terraza del techo jardín de la sala de exhibiciones.

Mientras que en Ahmedabad las condiciones de relación del piano nobile, se establecen de una manera más clásica y legible respecto a la secuencia lineal configurada mediante los espacios de acceso, estancia y mirador; en el caso de Cambridge, la lógica pasante de la rampa le imprime una complejidad inusitada al piano nobile que se integra a la rampa a su paso por el interior, y produce un espacio interior que se expande física y visualmente sin reducirse simplemente a configurar el espacio de acceso y ampliando, de esta manera, los matices de relación entre edificio y entorno. Es un espacio que articula, integra y conecta otras estancias y que amplifica la complejidad espacial del piano terra, proponiendo un mayor dinamismo espacial y logrando maneras alternativas de atravesar y estar en el edificio.

\subsubsection{El techo jardín: elevarse, mirar y estar.}

La aplicación del techo jardín en la arquitectura de Le Corbusier ha tenido diversas soluciones de acuerdo a cada proyecto y lugar y ha sido un elemento que a lo largo de su iter proyectual fue revisitando y adaptando, a partir de la exploración técnica y formal, asumiendo y estudiando también, los recursos formales de las arquitecturas tradicionales $^{15}$ así como también, las especificidades ambientales y culturales de cada sitio geográfico. La cubierta practicable, como espacio útil que alberga funciones y actividades, y como parte estrechamente ligada al edificio y que lo relaciona con el entorno, es uno de los elementos destacables en los proyectos dos proyectos analizados.
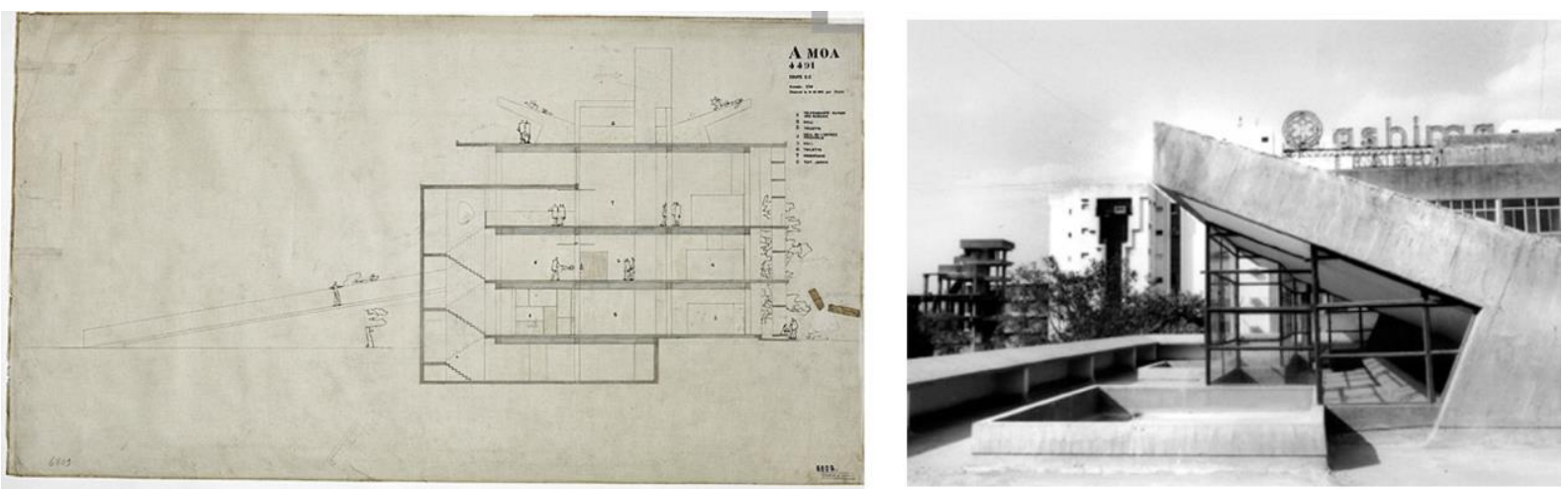

9. El techo jardín A-MOA. Plano de sección y vistas exteriores de terrazas en los dos edificios.

Fuentes:

Imagen 9a. 06809 OFLC-ADAGP.

Imagen 9b. Recuperada en: https://www.flickr.com/photos/doctorcasino/5511177270

En A-MOA (1954) de Ahmedabad, el edificio presenta un techo jardín, compuesto por una cubierta que sirve de terraza jardín, y por una cubierta grávida que recoge el agua y que emerge del volumen en posición desplazada hacia el norte, en la distancia en sección entre las dos se conforma un sistema de iluminación y ventilación natural del espacio del salón de asambleas situado en la planta inferior. A su vez se disponen sobre en el techo un espacio cubierto y el volumen de los ascensores.

\footnotetext{
15 "Les éléments architecturaux préconisés eussent une attitude foncièrement nouvelle par l'agencement, la dimension et le matériau, leur soumission à la loi solaire donnait à nos propositions une parenté indiscutable avec les architectures traditionnelles". Le Corbusier: "L'architecture", apartado 1, Entretien.
} 

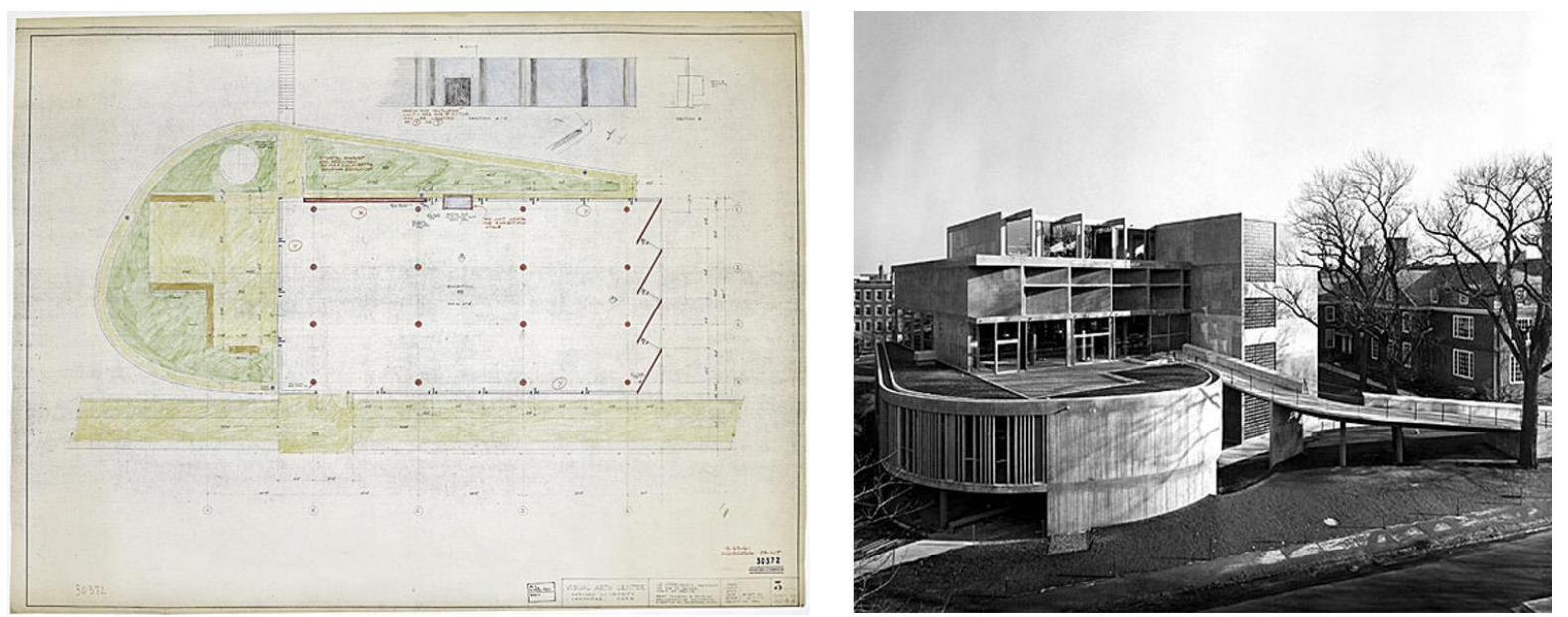

10. El techo jardín A-MOA y VAC-BOS. Planos de sección y planta y vistas exteriores de terrazas en los dos edificios.

Fuentes:

Imagen 10a. 30372 @FLC-ADAGP.

Imagen 710b. Recuperada en: http://media.news.harvard.edu/gazette/wp-content/uploads/2012/08/Carpenter-

Center_Frisbee_500.jpg

Por su parte en el VAC-BOS (1961-64) de Cambridge, el edificio que presenta un desarrollo en distintos niveles debido a la interacción ente el volumen principal y los complementarios. Nos muestra otro tipo de soluciones para el techo jardín, en la segunda planta o nivel de acceso se localiza una zona descubierta sobre el volumen elíptico que corresponde a al auditorio, dicho espacio es una terraza ajardinada que complementa la sala destinada a las exposiciones. Sobre la cubierta del volumen principal se localiza otra terraza ajardinada en relación al volumen de oficinas.

Encontramos que aunque en los dos casos se aplica la solución de techo jardín, es bastante diferente la manera en la que se aprovecha este espacio: en la sede de Hilanderos de Ahmedabad destaca el papel simbólico y ambiental logrado, porque el lugar con sus connotaciones culturales y clima así lo exigían, mientras que en el Carpenter Center se opta por soluciones más convencionales, donde si que juegan un papel determinante en la relación interior-exterior del edificio.

\subsection{Entre el interior y el exterior: el espesor de la fachada}

«Ce qui compte c'est la profondeur de l'ombre» Le Corbusier: Carnet H31, 1954

\subsubsection{La fachada: un marco para el "paisaje"}

En la arquitectura de Le Corbusier se establece un sentido de orden en el que las fachadas presentan una estrecha relación con los planos horizontales, y no son simplemente una solución a la apertura y clausura en la relación interior-exterior, dado que en su conformación se superponen capas, se proponen diversos mecanismos de control de la luz y el clima, se establecen grados de exposición y de intimidad, a la vez que se orienta también la mirada y se enmarcan paisajes. Le Corbusier como pionero de la arquitectura moderna, introdujo a partir de las innovaciones de la técnica constructiva, un nuevo lenguaje arquitectónico a través del cual exploró las posibilidades del concreto armado, el hierro y el vidrio. Esto ha representado un cambio en la arquitectura hacia un control de la transparencia y la apertura, y en una relación más estrecha entre interior y exterior. Los problemas que Le Corbusier fue encontrando en ese camino desde los años 20, son objeto de revisión y evolución, como lo muestran los proyectos de postguerra. 

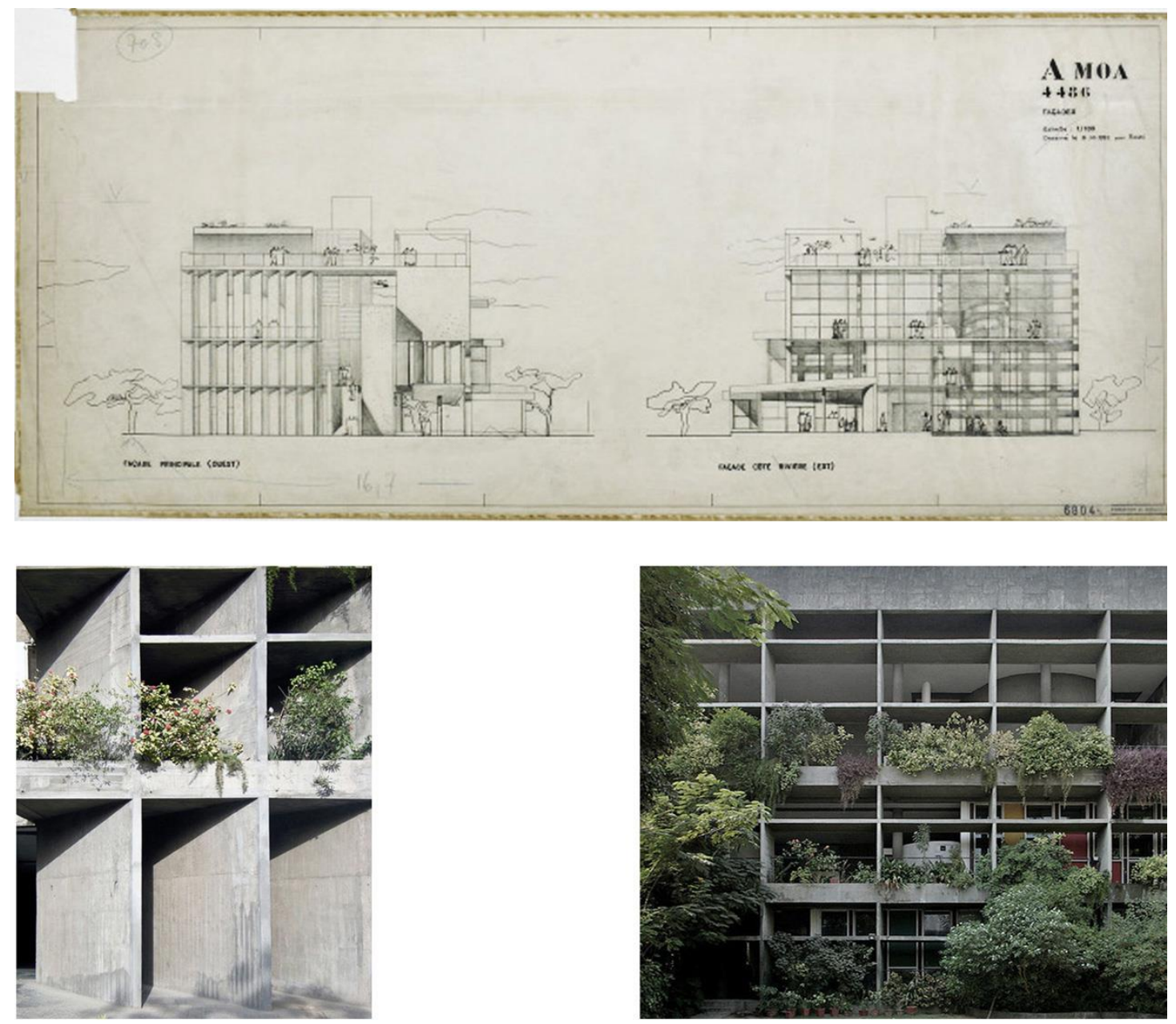

11. Soluciones de fachada con brisesoleils verticales y horizontales ajradinados y pan de verre con aeratours A-MOA. Planos y vistas exteriores.

Fuentes:

Imagen 11a. 06804 @FLC-ADAGP. Imagen 11b. Recuperada en: http://www.archdaily.com/464142/ad-classics-mill-ownersassociation-building-le-corbusier/, Imagen 11c. Recuperada en: https://www.pinterest.com/pin/329185053987465227/

En el caso del A-MOA (1954) Ahmedabad, la respuesta formal y las soluciones adoptadas en la configuración de las fachadas son decisiones que tienen que ver con la orientación, las vistas, el control climático y las costumbres locales $^{16}$. En el edificio que destaca por la nitidez de un volumen principal, se observa que hay un gran esmero en la solución de las fachadas oeste y este respectivamente, hecho que no obvia el interés de Le Corbusier a los planos llenos que son necesarios para la que la luz se limite o refleje. Desde una vista de conjunto destaca el contraste entre la fachada oeste hacia la ciudad y la fachada este hacia hacia al río. Hacia la calle, los brise-soleil verticales asumen el protagonismo, haciendo que el edificio se cierre al ruido y a la luz directa, la mirada desde fuera y desde el interior está limitada y dirigida por una estructura amplia y presente en la cara más pública del edificio. Una malla de grandes pantallas en hormigón con espacios destinados a jardineras procura la protección solar y la privacidad. Mientras que hacia el río otra malla en hormigón pero esta vez con una ordenación más horizontal y con aperturas mayores y con jardineras, enmarca el paisaje.

\footnotetext{
16 "He took cues from India's vernacular architecture, emulating the deep reveals, overhanging ledges, shade screens, and grand, pillared halls". Curtis, William J.R. Le Corbusier: Ideas and Forms. Phaidon Press, 1994. Print.
} 

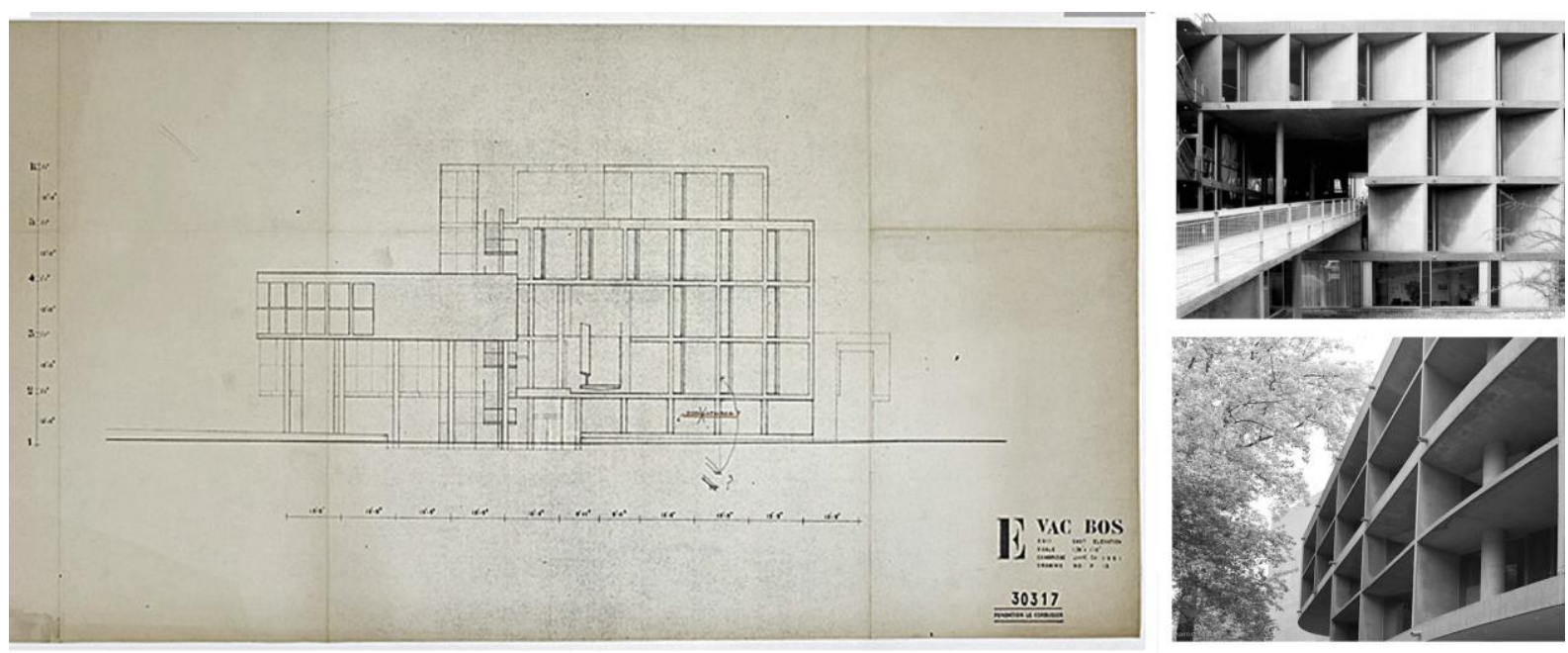

12. Soluciones de fachada con brisesoleils verticales y horizontales y pan de verre con aerateurs. VAC-BOS. Planos de fachada y vistas exteriores.

Fuentes:

Imagen 12a. 30317 OFLC-ADAGP.

Imagen 12b. Recuperada en:

http://www.wiglaf.org/ aaronm/photography/cambridge/tn/Carpenter\%20Center\%20South\%20wall.jpg.html

Imagen 12c. Recuperada en: http://scandinaviancollectors.tumblr.com/post/84258119515/le-corbusier-the-carpenter-centerfor-the-visual

En el VAC-BOS (1961-64) en Cambridge, en cambio, la solución de fachada del volumen principal es la misma para los dos frentes hacia las calles, donde Le Corbusier utiliza una retícula profunda de brise-soleils verticales, que están orientados respecto a la protección solar más conveniente y dirigen la vista hacia los jardines de la propia parcela del edificio. En este centro universitario la volumetría es más compleja del edificio de Ahmedabad, la agregación de volúmenes complementarios se realiza mediante procesos de intersección de formas, dentro de las cuales se hacen reconocibles dos grandes cuerpos elipsoidales a distinto nivel. Estos volúmenes al proyectarse hacia afuera son los que definen los límites del edificio más próximos a la calle, y sus fachadas son el resultado de la utilización de brise-soleils verticales con muros llenos, para la fachada hacia la calle Prescott, y muros llenos con ondulatoires hacia la calle Quincy.

En Ahmedabad Le Corbusier propone un sistema de protección al sol directo, permitiendo la formación de sombras de distinta profundidad en función de la orientación y la penetración de la brisa, según las necesidades que reconoció en la arquitectura tradicional del lugar, mientras en el Carpenter Center, propone una protección del sol filtrada para conseguir una luminosidad difusa con cierto grado de intimidad en los interiores, y favorecer los espacios de estudio y las salas de exposición con condiciones específicas de confort térmico. Dada la gran variedad de recursos utilizados en ambos proyectos (brise-soleil, pan de verre, ondulatoire, aerateurs, loggia profunda y fachada jardín), verificamos que las soluciones de las fachadas ${ }^{17}$ son necesarias para configurar de manera precisa la acción de mirar hacia el exterior, y de matizar la relación con el paisaje urbano o natural, más allá de la simple función de definir el cerramiento del edificio.

\footnotetext{
${ }^{17}$ MOOS, Stanislaus Von, Le Corbusier, Ed. Lumen, Barcelona 1977, p. 352 (capítulo “La vista como un cuadro").
} 


\subsubsection{La fachada: un espacio de dimensión variable}
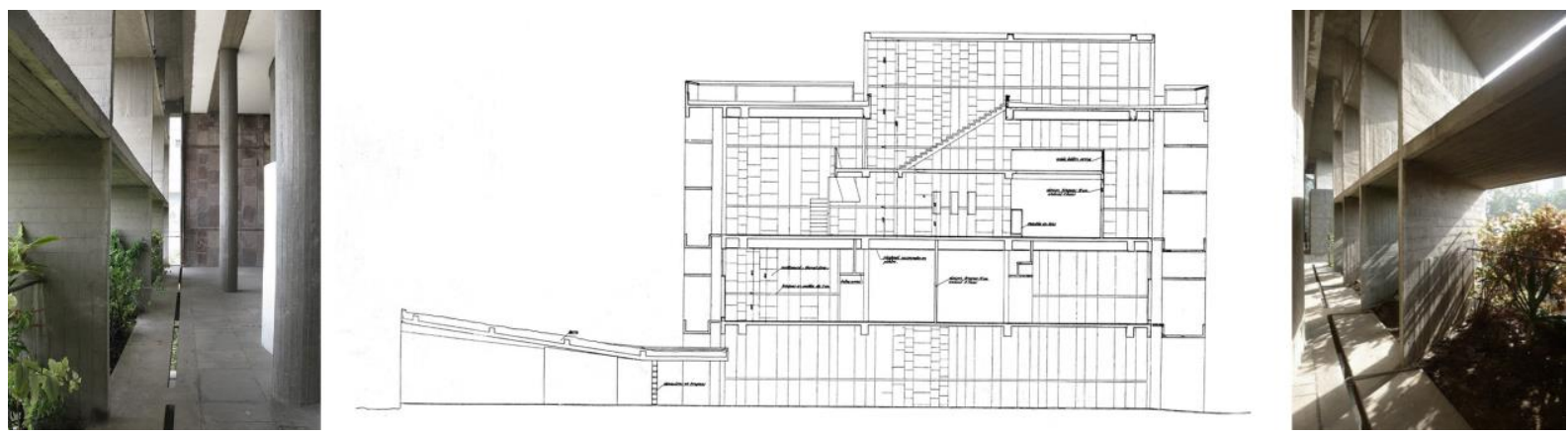

13. Soluciones de fachada con brisesoleils verticales y horizontales ajardinados A-MOA. Plano de sección y vistas.

Fuentes:

Imagen 13a Recuperada en: http://www.archdaily.com/464142/ad-classics-mill-owners-association-building-le-corbusier/ Imagen 13b. Le Corbusier Obra completa 6 P152

Imagen 13c. Recuperada en: http://www.archdaily.com/464142/ad-classics-mill-owners-association-building-le-corbusier/

Uno de los aspectos a destacar en la arquitectura lecorbuseriana, es el entendimiento de la fachada como espacio de transición dotado de un espesor variable y destacar que las soluciones que se materializan en los dos proyectos objeto de estudio, y que fueron aplicadas en varias de sus obras, hacen parte de la propia evolución técnica del maestro suizo, camino que estuvo en su desarrollo acompañado de descubrimientos, redenciones y paradojas. ${ }^{18}$ En cuanto al manejo del clima el recorrido estuvo compartido con sus colaboradores ${ }^{19}$ y marcado por distintos momentos desde un convencimiento sobre la técnica y la creación de sistemas mecánicos de aplicación universal, hasta llegar a propuestas carentes de cualquier determinismo mecanicista ${ }^{20}$. Las fachadas se convierten en un ámbito espacial donde las relaciones entre interior y exterior, se definen según criterios compositivos, formales y funcionales, a la vez que también se atienden las condiciones ambientales y paisajísticas particulares del lugar. En una nota de Le Corbusier, publicada en 1970 por su colaborador Jean Petit luego de su muerte en 1965, titulada "12 petites inventes", el maestro suizo hace una relación descriptiva de algunos de los elementos propuestos por él y aplicables a las fachadas: "Brise-soleil, 1930-1965. Aerateurs, 1945. Pans de verre ondulatoires, $1957^{21} \mathrm{Si}$ bien podemos hacer una relación de los elementos utilizados en las fachadas, también encontramos necesario observar su uso en cada caso en particular, e incluso la combinación de ellos para conseguir diversas soluciones respecto a la relación entre espacio interior y exterior, en términos físicos, visuales y climáticos. Al estudiar los espacios de transición de las fachadas de A-MOA (1954) en Ahmedabad, se hace obligatorio referirse a lo que representó la India y específicamente Ahmedabad para Le Corbusier ${ }^{22}$. En

\footnotetext{
18 Jorge Torres Cueco. Le Corbusier. Views of Technique in Five Movements.

${ }^{19}$ Requena-Ruiz, I. (2012). "Bioclimatismo en la arquitectura de Le Corbusier: El Palacio de los Hilanderos". Informes de la Construcción, 64(528): 549-562 doi: 10.3989/ic.11.121. Pág.

${ }^{20}$ Jorge Torres Cueco. Le Corbusier. Views of Technique in Five Movements.

21 "BRISE-SOLEIL, 1930-1965: Creátion d'un dispositif permettant au soleil de donner plein effet en hiver et d'etre juglé en été aux périodes caniculaires. Trente-cinq années de mise au point. Dispositif actellement très Cornu des architectes du monde entier. (...). AERATEURS, 1945: Fentes verticals dans un mur, fermées d'une toile méttallique moustiquire et munies d' un volet pivotant. Assurent un parfaite ventilation des locaux. (...), PANS DE VERRE ONDULATOIRES, 1957: Solution raisonnable au vitrage moderne. La pellicule vitreé des façades indépendantes de la structure portante est raidie par des membrure fine en béton armé. L'emploi du Modulor permet de grandes variations de densité des mebrures." Petit, 1970, pág. 188.

22 "La India se revela, pues, como un terreno extremadamente fértil para Le Corbusier. En el espacio de catorce años construirá allí una decena de obras que hacen época, grandes o pequeñas, en Chandigarh y en Ahmedabad". Framptom. Kenneth: Le Corbusier, Akal arquitectura. 2000: pág. 157.
} 
cuanto al brise- soleil, son identificables tres rasgos principales ${ }^{23}$ que asociados a otros proyectos, se han materializado en el caso de la sede de la Asociación de Hilanderos: el desarrollo espacial en profundidad del brise-soleil $^{24}$, la integración de este espacio al recorrido del edificio y, su uso para elevar el conjunto y contemplar el paisaje. El brise-soleil en las plantas altas permitirá ampliar la fachada como si de una loggia ajardinada se tratara, en sus distintas versiones hacia oeste y este. Mientras que en el piano-terra serán amplios pilotes que producirán un espacio de penumbra.

En el caso del VAC-BOS (1961-64) en Cambridge, destaca por su parte, el empleo de brise-soleils con aerateurs que controlan la radiación solar y dan privacidad al interior del cuerpo cúbico y a la sala de estudio ${ }^{25}$, y la disposición de otros elementos como el pan de verre curvo conformado por los ondulatoires y los aerateurs intercalados, que en su conjunto hacen que la fachada del auditorio se convierta en una sinuosa vidriera. Para la fachada del volumen que contiene la escalera y los servicios optó por la utilización de muros cerrados con pan de verre, solución de fachada que acentúa la fuerza expresiva del cuerpo prismático.
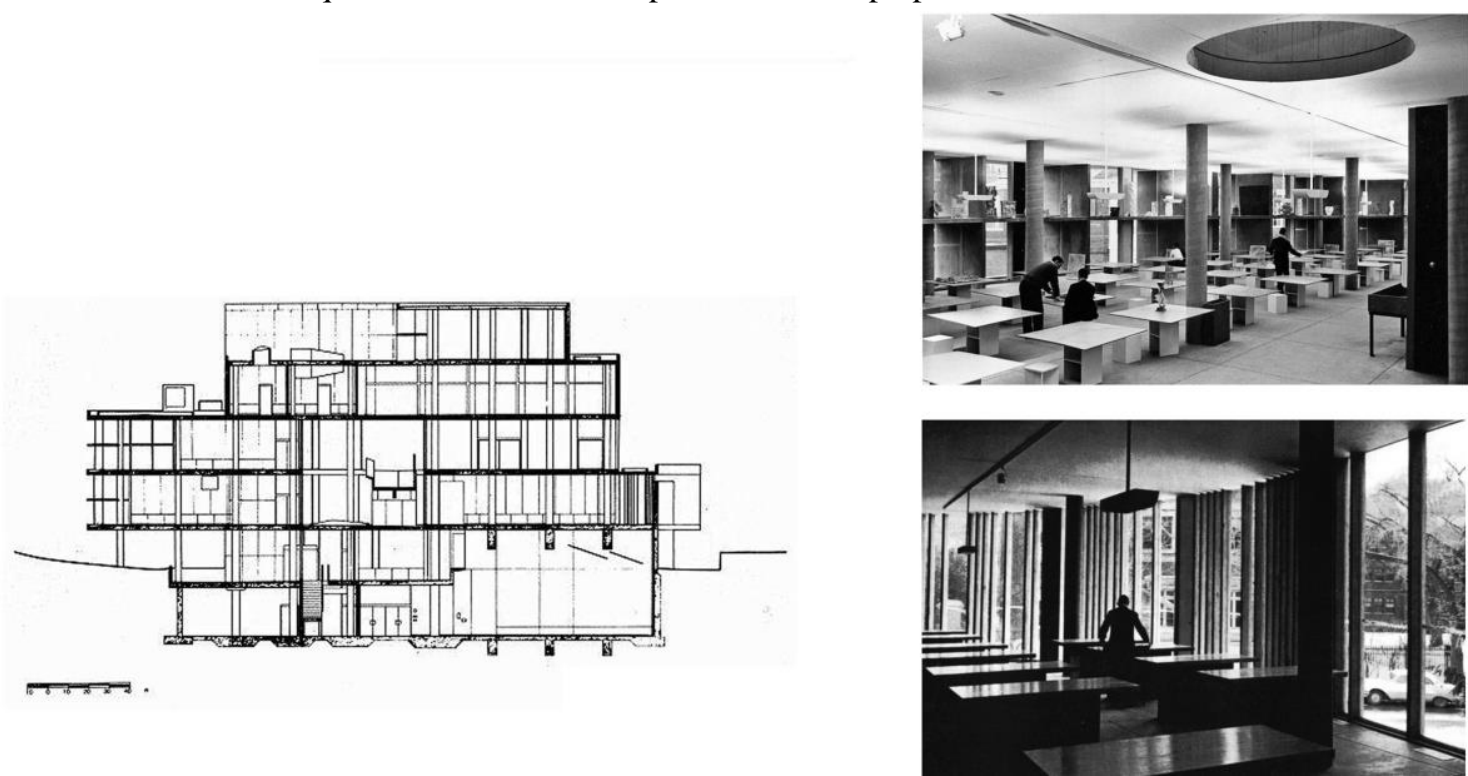

14. Soluciones de fachada con brisesoleils verticales y horizontales y pan de verre con aerateurs VAC-BOS. Plano de sección $\mathrm{y}$ vistas interiores.

Imagen 14a Le Corbusier Obra completa 7-65

Imagen 14b. Recuperada en: http://artnewengland.com/images/2013/02/CCVA-interior.jpg Imagen 14c. Le Corbusier Obra Completa 7-67

\footnotetext{
23 “Ahmedabad permitirá a Le Corbusier explorar el tema del brise-soleil, [...] Tales rasgos son: el desarrollo en profundidad del brise-soleil para hacer de él un espacio en sí mismo, encapsulado en el volumen cúbico de la casa; la integración de este espacio gracias a la idea de "paseo arquitectónico" que atraviesa el volumen; y, por último la elevación del conjunto en una especie de belvedere que encuadra el paisaje”. Frampton. Kenneth: Le Corbusier, Akal arquitectura. 2000: pág. 158

24 “Los brise-soleil se adaptaron al soleamiento y captación de los vientos dominantes, dejando a los cerramientos de cada zona la gestión de iluminación, ventilación y privacidad. Esta segunda parte se realizaba mediante cortinas o contraventanas interiores y aerateur, provocando una participación activa del habitante en el control de las condiciones climáticas para ajustarlas a su confort”. Requena pág. 92

25 “En su obra única en EE.UU., el Carpenter Center for Visual Arts” (Boston, 1961), aplicó el brise-soleil de grandes elementos verticales de hormigón, adaptado a la forma orgánica de la planta buscando orientación sur y protección del soleamiento de poniente, lo cual produjo una relación formal con el "Palacio de Hilanderos"'. Requena pp 94
} 
Para los dos proyectos Le Corbusier propuso diversas soluciones en fachada y aunque aparentemente los edificios compartan un lenguaje formal, tanto los objetivos como los resultados esperados en cuanto a relación interior-exterior son muy distintos, dado que las soluciones en cuanto a relación física y visual, son coherentes con los usos y localización de cada edificio ${ }^{26}$.

\subsection{Entre el edificio y la ciudad: los volúmenes complementarios}
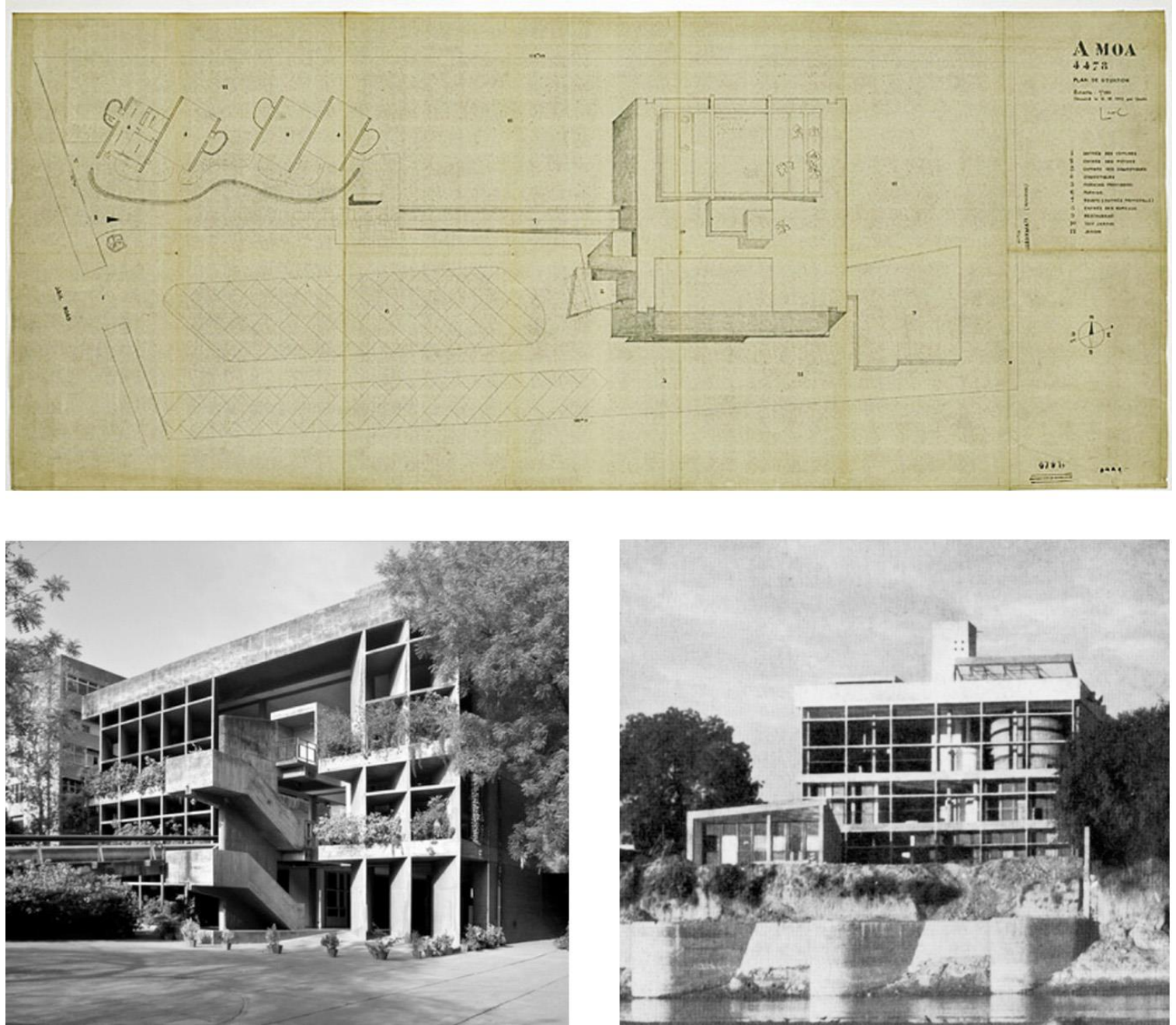

15. Volúmenes complementarios, escaleras y cuerpos bajos A-MOA. Planta de cubiertas del proyecto completo con las viviendas anexas no construidas y vistas exteriores.

Fuentes:

Imagen 15a 006791B CFLC-ADAGP.

Imagen 15b. Recuperada en: http://www.archdaily.com/464142/ad-classics-mill-owners-association-building-le-corbusier/ Imagen 15c. Le Corbusier Obra Completa 6-146

26 "Se trata de entender mediante las técnicas e inquietudes actuales por la sostenibilidad, la manera de relacionar la arquitectura con el clima, para conseguir el confort interior con recursos bioclimáticos pasivos. La investigación se circunscribe a este campo atemporal de la arquitectura, puesto que evaluar aspectos inexistentes en el periodo de estudio produciría lecturas obvias y anacrónicas". Requena-Ruiz, I. (2012). "Bioclimatismo en la arquitectura de Le Corbusier: El Palacio de los Hilanderos”. Informes de la Construcción, 64(528): 549-562 doi: 10.3989/ic.11.121 

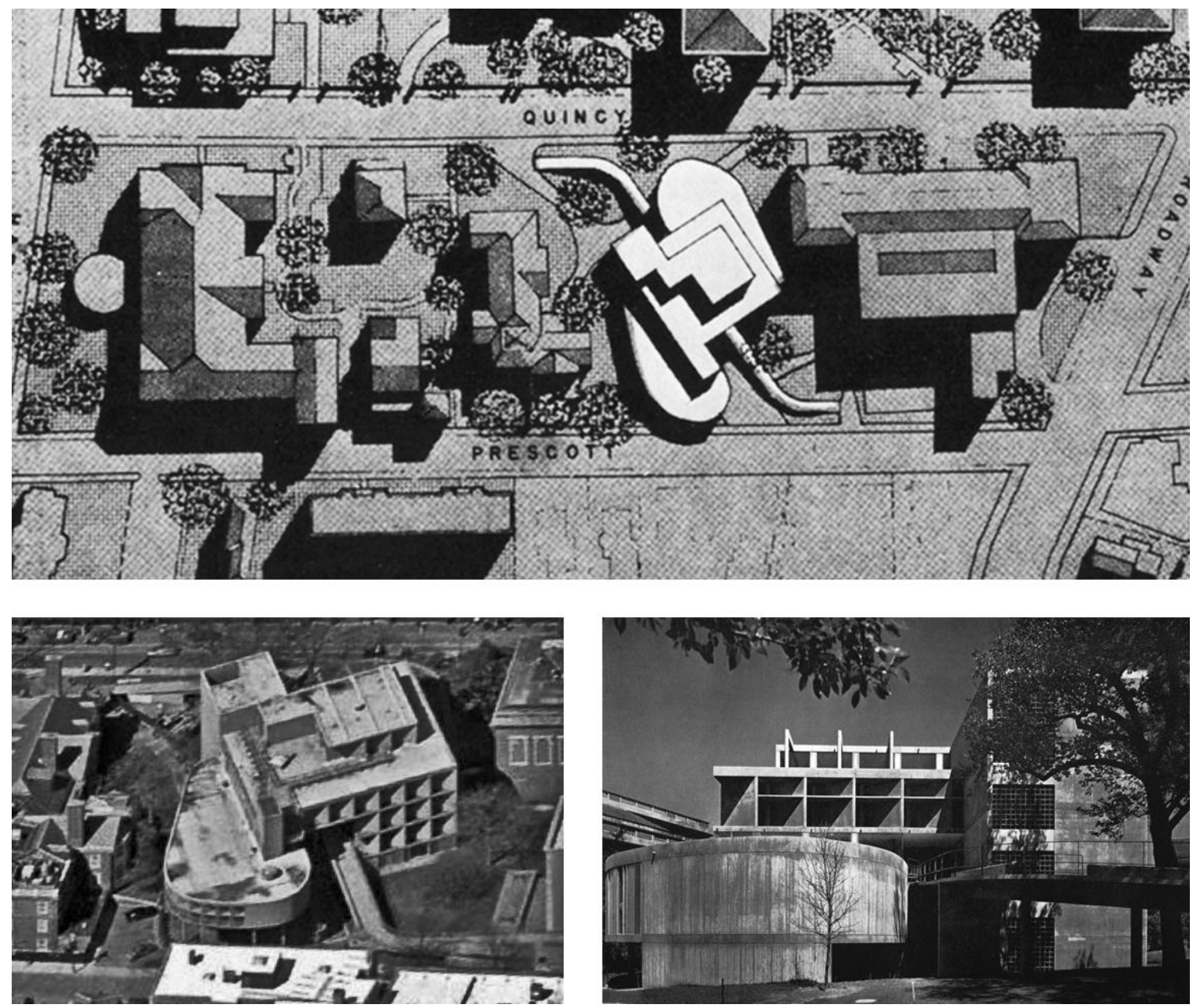

16. Volúmenes complementarios, escaleras y cuerpos bajos VAC-BOS. Planta de localización con el entorno construido y vistas aérea y exterior.

Fuentes:

Imagen 16a Le Corbusier Obra Completa 7-62

Imagen 16b. Recuperada en:

https://www.bing.com/maps/\#Y3A9cjF3MXgxOTI2ZnIyJmx2bD0xOCZkaXI9MTgwJnN0eT1vJnNzPXlwLmNhcnBlbnRlci UyMGNlbnRlcn5wZy4xfnJhZC44MA==

Imagen 16c. Recuperada en:

http://fondationlecorbusier.fr/corbuweb/morpheus.aspx? sysId=13\&IrisObjectId=4676\&sysLanguage=fr-

fr\&itemPos=9\&itemSort=fr-fr_sort_string $1 \% 20 \&$ itemCount=78\&sysParentName=\&sysParentId=64

Le Corbusier utiliza diversas maneras para relacionar el edificio con su entorno, mediante relaciones basadas en la interiorización de elementos externos (el suelo, la calle, el paisaje) y así como mediante extensiones que partiendo desde el edificio lo arraigan al lugar (las escaleras, las rampas, los cuerpos bajos). Se reconocen en los edificios una lógica de conjunto que tiene que ver con el programa, la ocupación del sitio y el sistema de relaciones entre todos los elementos que genera su perceptible unidad, la "medida de un orden"27. Volúmenes principales, volúmenes complementarios, rampa y tratamiento del piano-terra, son elementos que interactúan

27 "El arquitecto mediante la manipulación de las formas, consigue un orden que es una genuina creación del espíritu: con las formas conтueve profundamente nuestros sentidos y despierta nuestra sensibilidad a la creación. Las relaciones que crea provocan una tremenda repercusión en nosotros; él nos muestra la medida del orden que se vivencia en consonancia con el orden del mundo." Le Corbusier. Hacia una Arquitectura. Apóstrofe, Barcelona, 1977 
dentro de la composición para configurar el conjunto. Si nos referimos a los volúmenes complementarios, podemos identificar por lo menos tres tipos, los cuerpos bajos, las escaleras y los edificios anexos.

En A-MOA (1954) de Ahmedabad, encontramos que dentro de la parcela alargada, se localizan desde los límites con la calle y hacia el río, una serie de volúmenes que establecen una secuencia lineal en correspondencia con las condiciones geométricas del solar, las posibilidades de ocupación y la idea de recorrido. La ordenación que se produce desde el acceso peatonal, inicia con las cuatro viviendas de empleados (no construidas), agrupadas en pares, la rampa peatonal, la escalera, el volumen principal y el cuerpo bajo de oficinas.

La agrupación de las cuatro unidades destinadas a viviendas de servicio, de una planta de altura y localizadas cercanas a la calle mediante una ordenación en diagonal, responden en su localización y disposición a la configuración de un borde interno del conjunto, un muro bajo sinuoso les brindaría privacidad y a la vez establecería una línea de fondo que acompañaría el recorrido de acceso hasta el inicio de la rampa en donde se localiza un pequeño espacio de sombra. La rampa que en este punto inicia su ascenso establece un vínculo funcional y formal con la escalera, que por su configuración adquiere un aspecto escultórico, el elemento de conexión vertical en su desarrollo enlaza tres niveles y finalmente remata en el umbral y la puerta de acceso. Bajo el volumen principal, la posibilidad de cruzar la planta nos lleva hacia el último volumen de la composición, un cuerpo bajo que se conecta al cuerpo mayor que por su geometría, parece buscar al ampliarse capturar el paisaje del río.

En el caso de VAC-BOS (1961-64) de Cambridge, el conjunto con todos los volúmenes se encuentra concentrado ocupando el centro de la estrecha parcela, pero a pesar de esto el volumen principal es aún reconocible, porque los grandes volúmenes complementarios elipsoidales, de proporción horizontal se escalonan en sección y liberan el suelo gracias a los pilotes. Se identifican un volumen principal que se encuentra maclado con dos cuerpos bajos de distinto nivel y de forma elipsoidal correspondientes a salas de estudios, dos cuerpos de escaleras adjuntos al volumen principal y la rampa pasante. En este caso todos los volúmenes que participan de la composición, se integran e interpenetran, siendo difícil desvincularlos o aislarlos formal y estructuralmente, pues todos comparten una misma ordenación de la estructura, independientemente de las formas. En un recorrido desde la calle Quincy y atravesando el conjunto, percibimos la posibilidad de ascender por la rampa, que se levanta como un pliegue extendido y elevado de la calle, el volumen de las escaleras principales aparece como un elemento escultórico que destaca por su hermetismo, de la misma manera el volumen de la sala de la primera planta se percibe bastante cerrado, los dos cuerpos conforman el paso por donde discurre la rampa. Al acceder y finalmente al atravesar observamos como el cuerpo de la sala de la segunda planta acompaña, pero más distante, la salida de la rampa hacia la calle Prescott.

La urbanidad de estos dos conjuntos, viene en gran parte definida por la interacción que se produce entre los distintos volúmenes: en Ahmedabad, se produce una relación de secuencia longitudinal, donde todos los cuerpos complementarios acompañan, tensionan y dirigen un recorrido lineal, en cambio en el conjunto de Cambridge, la misma forma de la parcela, la posición central y girada del edificio, la transparencia de las plantas bajas, y la sinuosidad de la rampa establecen un orden complejo donde todos los cuerpos complementarios se disponen para un recorrido impuesto por la rampa en forma de "S". Se produce una resonancia formal, a través de las geometrías redondeadas de los cuerpos complementarios, proporcionando una relación amable con los edificios colindantes -Museo de Arte Fogg y Club universitario- y el entorno inmediato. "Por razones de emoción, los diversos aspectos de la obra, la sinfonía que en realidad se ejecuta, sólo aprehensibles a medida que nuestros pasos nos llevan, nos sitúan y nos desplazan, ofreciendo a nuestra vista el paso de los muros o las perspectivas, lo esperado o lo inesperado de las puertas que descubren el secreto de los nuevos espacios, la sucesión de las sombras, penumbras o luces que irradia el sol penetrando por las ventanas y los vanos, la vista de las lejanías 
edificadas o plantadas, como también la de los primeros planos sabiamente dispuesta...La buena arquitectura se camina y se recorre tanto dentro como fuera. Es la arquitectura viva". ${ }^{28}$

\section{La vigencia de la arquitectura urbana: "Todo está en todo"}

El Millowners Association Building de 1954 ubicado en la ciudad de Almedabad en la India, y el Carpenter Center for Visual Arts de la Graduate School of Design of Harvard de 1961-1964 en la ciudad de Cambridge son dos edificios construidos y actualmente en uso, que han sido abundantemente estudiados y comparados. La comparación/relación entre los proyectos ha sido abordada por varios autores a partir de diferentes enfoques: la más conocida es probablemente la que propone Kenneth Frampton en el número monográfico de la revista GA de 1975, dedicada a los dos edificios, donde propone una genealogía de ambos a partir de una referencia común al palacio y donde destaca el carácter dialectico de "formas binarias" que se combinan en ambos a través de su dicotomía. ${ }^{29}$ Giedion también establece una relación entre ambos con referencia al papel de la rampa "el antecedente inmediato del Carpenter Center es la rampa de un edificio admisnistrativo en Ahmedabad"30; y en la misma línea Curtis refuerza la idea del Carpenter Center como la síntesis de otros proyectos anteriores donde la referencia inmediata respecto a la rampa es el Millowner Association Building ${ }^{31}$ y Guillermo Jullian de la Fuente claramente afirma que el Carpenter Center es "le cousin du Palaisdes Filateurs à Ahmedabad (1951-1956) qui projette pareillement le dedans vers le dehors" ${ }^{32}$. Además de las referencias o similitudes con otros proyectos un aspecto que la mayoría de críticos ha puesto en evidencia es el valor del Carpenter Center y de los últimos trabajos, como "condensación" del pensamiento de Le Corbusier, tal como explica Stan Allen en su texto donde hace referencia a la posición de varios autores como la de Fred Koetter que no ve más que una pieza de museo (contextual grotesque) o la de John Hejduk que en cambio ve una vuelta a las primeras obras. ${ }^{33}$ Finalmente otra mirada es la de Jacques Sbriglio, donde aborda los dos edificios desde el punto de vista del uso común del material $^{34}$.

Aunque los dos edificios han sido comparados en varias ocasiones porqué hacen parte de la última etapa proyectual de Le Corbusier, por las analogías evidentes en ciertas recurrencias formales en las plantas, por el uso de elementos de fachada similares, por la expresividad en el uso del hormigón, una nueva mirada a las obras en sí, tal como podemos percibirlas hoy en día, permite verificar que cada edificio plantea una espacialidad y una respuesta urbana diferente en función del lugar en donde se ubica. Tal como habíamos comentado al principio, no hemos pretendido rastrear en la genealogía de los dos proyectos de Le Corbusier, ni aportar una descripción completa y exhaustiva dado que este objetivo excede el alcance de este escrito, mientras, en cambio, hemos intentado comprobar su "estado de salud" indagando sobre su actualidad y vigencia como arquitecturas urbanas. Como si de dos pacientes se tratara a través de la observación de las dos obras, hemos incidido sobre algunos puntos vitales de la relación entre edificio y entorno. Como hemos visto, la arquitectura de Le Corbusier, y de

\footnotetext{
${ }^{28}$ Le Corbusier. Mensaje a los Estudiantes de Arquitectura. Infinito, Buenos Aires, 2001.

${ }^{29}$ Frampton, K, "Millowners Association Building, Ahmedabad, India, 1954: Carpenter Center for Visual Arts, Harvard University, Cambridge, Massachusetts, U.S.A. 1961-64”. Volumen 37 GA Global architecture, 1975.

${ }^{30}$ Giedion, S, Espacio, tiempo y arquitectura, Dossat, Madrid, 1979 (5a ed.), (1a ed. ingl. 1941). (Reverte, 2009) Espacio, tiempo y arquitectura (Edición definitiva). Pág. 542-547

${ }^{31}$ Curtis, W.J., Le Corbusier. Ideas and Forms, Phaidon, 1996. Pág. 215-222

${ }^{32}$ Jullian de la Fuente, G., "Carpenter Center for the Visual Arts (1960-1962): un memento corbuséen”. En Le Corbusier, une encyclopédie. Centre Georges Pompidou, 1987. Pág. 84-85

${ }^{33}$ Agrest, d., Allen, S., Essays. Practice: Architecture, Technique and Representation. Critical voices in art, theory and culture. Psychology Press, 2000. Pág. 120-121

${ }^{34}$ Sbriglio, J., ed. Le Corbusier et la Question du brutalisme. Editions Parentheses, 2013
} 
estos dos edificios en concreto, sigue siendo de gran interés por la riqueza en la conjunción de las reflexiones y de la variedad de soluciones arquitectónicas en el manejo urbano del edificio.

Los dos casos de estudio, más allá de su parecido formal, que a un análisis más profundo adquiere sus matices sea en términos espaciales, que en términos urbanos, son proyectos ejemplares de una aproximación al proyecto donde la gran variedad de soluciones arquitectónicas genera las condiciones para que el edificio dialogue con la ciudad y, de paso, nos deja muchas enseñanzas, una de ellas, que cada parte del edificio desarrolla además de un papel funcional específico, un papel relacional entre espacios u otros elementos: el piano-terra se prolonga más allá de la planta baja y de sus límites específicos, configurando el espacio urbano del edificio; la rampa prolonga el edificio hacía la ciudad y/o hace que la ciudad penetre en su interior; el piano nobile en su condición de espacio interior se exterioriza, ya sea en términos de relación visual y/o de relación física para acceder, estar, mirar o simplemente cruzar; el techo jardín es un espacio para estar y mirar o es la extensión de una de las actividades interiores; la fachada con espesor, con sus múltiples tratamientos para el control climático (brisesoleil, aerateurs, pan de verre, ondulatoires, etc.) es un marco para el paisaje urbano o natural y es un espacio con dimensión y grosor variable, donde se materializan de manera diversificada la relación entre el interior y el exterior $\mathrm{y}$, finalmente, los volúmenes complementarios son cuerpos anexos a los edificios principales que producen efectos plásticos y escultóricos y ayudan a dinamizar la relación con la ciudad, a extender la espacialidad interior del edificio hacía afuera y a conformar una serie de espacios exteriores casi siempre de acceso público o colectivo.

Sus obras, como los escritos de la última década, son complejas condensaciones, compuestas por muchos elementos y fragmentos, pero con partes y huellas reconocibles que, a pesar de todo, siguen conformando un todo coherente y unitario. Aunque pasan los años y se suceden múltiples interpretaciones por parte la crítica arquitectónica favorables y no tan favorables con la obra de Le Corbusier; el Millowners Association Building de 1954 de Almedabad en la India, y el Carpenter Center for Visual Arts de la Graduate School of Design of Harvard de 1961-1964 de la ciudad de Cambridge gozan de un muy buen "estado de salud" y como obra construida nos ofrecen la posibilidad de comprobar y ejemplarizar que la buena arquitectura allí se queda impasible y ajena tanto a los elogios como a las críticas: "Todo está en todo: coherencia, unidad Arquitectura y urbanismo conjugados: un único problema reclamando una única profesión",35.

\section{Bibliografía}

ALlEN, S., AGREST, D., Essays. Practice: Architecture, Technique and Representation. Critical voices in art, theory and culture. Psychology Press, 2000. ISBN 978-9057010323

BOESIGER, W., GIRSBERGER, H, Le Corbusier 1910-65, Prima edizione. Bologna: 1987, Traduzione di: De Benedetti Mara Titolo originale dell'opera: Le Corbusier 1910-65. Verlag fur Architektur (Artemis), Zurigo, 1967. ISBN 9783764360368

CURTIS, W. Le Corbusier: Ideas and Forms. Phaidon Press, Oxford: 1986, ISBN 0-7148-2387-2, Rizzoli, New York: 1986, ISBN 0-8478-0726-6

DE LA FUENTE, J. “Carpenter Center for the Visual Arts (1960-1962): un memento corbuséen”. En Le Corbusier, une encyclopédie. Paris: Centre Georges Pompidou, 1987. ISBN 9782858503988

DE SOLÀ MORALES, M. De cosas urbanas. Barcelona: Gustavo Gili, 2008. ISBN 9788425222603

FRAMPTOM, K. Le Corbusier, Madrid: Akal arquitectura. 2000. ISBN 978-84-460-1306-8

\footnotetext{
${ }^{35}$ Le Corbusier, Mise au point, 1966 (Fondation Le Corbusier). Versión en castellano traducida por Jorge Torres, Abada Editores, 2014. pág. 22
} 
FRAMPTON, K. "Millowners Association Building, Ahmedabad, India, 1954: Carpenter Center for Visual Arts, Harvard University, Cambridge, Massachusetts, U.S.A. 1961-64”. En: GA Global Architecture, Volumen 37. 1975.

GIEDION, S, Espacio, tiempo y arquitectura, Madrid: Dossat, 1979 (5a ed.), (1a ed. ingl. 1941). (Reverte, 2009) Espacio, tiempo y arquitectura (Edición definitiva). ISBN 9788429121179

LE CORBUSIER PLANS, 1950-1951 (2005) DVD 10 Fondation Le Corbusier. Paris: Echelle -1

LE CORBUSIER PLANS, 1959-1964 (2005) DVD 16 Fondation Le Corbusier. Paris: Echelle -1

LE CORBUSIER. Hacia un arquitectura. Barcelona: Ediciones Apóstrofe, (2006) ISBN 9788445502778.

LE CORBUSIER: Entretien avec les étudiants des écoles d'architecture. Paris: Minuit, 1958. ISBN 9782707304278

LE CORBUSIER. Mensaje a los Estudiantes de Arquitectura. Buenos Aires: Infinito, 2001. ISBN 9789879637036

LE CORBUSIER, Precisiones. Respecto a un estado actual de la arquitectura y el urbanismo. Barcelona: Ediciones Apóstrofe, 1999. ISBN 84-455- 0183-6

LE CORBUSIER, Mise au point, 1966 (Fondation Le Corbusier). Versión en castellano traducida por Jorge Torres, Madrid: Abada Editores, 2014. ISBN 978-84-16160-19,8

MARTIENSSEN, R.D. La idea del espacio en la arquitectura griega: con especial referencia al templo dórico y a su emplazamiento. 5 a ed.. Buenos Aires: Nueva Visión, 1977. ISBN 9789506020217

MOOS, S. Le Corbusier, Barcelona: Ed. Lumen, 1977. ISBN 8426411266

PETIT, J, 1970 Le Corbusier Lui même. Gèneve: Editions Rousseau. ISBN 9781499582758

QUETGLAS, J. "La promenade architecturale", recuperado en: http://www.arranz.net/web.archmag.com/5/homeless/05s.html

RAVETLLAT P. J. “La planta baja: una intersección entre el edificio y la ciudad”. En: DPA 21 Cota Cero, Barcelona: Ediciones UPC, 2005. ISBN 9788460803362

REQUENA-RUIZ, I. (2012). “Bioclimatismo en la arquitectura de Le Corbusier: El Palacio de los Hilanderos”. En: Informes de la Construcción, 64(528): 549-562 doi: 10.3989/ic.11.121. ISSN 0020-0883

RUBERT, M. "Espacio público y cota cero” En: DPA 21 Cota Cero, Barcelona: Ediciones UPC, 2005. ISBN 9788460803362

SICHENZE, A., Il limite e la cittá, Milano: Franco Angeli, 1995. ISBN 9788820492434

SBRIGLIO, J., ed. Le Corbusier et la Question du brutalisme. Marseille: Editions Parentheses, 2013. ISBN $978-$ 2-86364-284-9

TORRES, J. Le Corbusier: Visiones de la técnica en cinco tiempos. Barcelona: Fundación Caja de Arquitectos, 2004. ISBN 9788493370114 


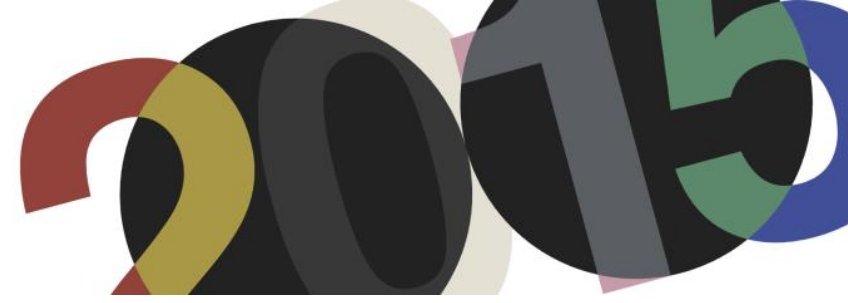

DOI: http://dx.doi.org/10.4995/LC2015.2015.957

\title{
Le Corbusier and Ariadne
}

\section{A. Fonti}

Dipartimento di Architettura Design Urbanistica, Università di Sassari

\begin{abstract}
From a letter dated 1913 to W. Ritter in which he described the "erotic obsession" which had caused him to depict the statue of the Sleeping Ariadne in the gardens of Versailles as a scantily-clad odalisque in the painting entitled La Versailles du Grand Turc, up to his last graphic project of 1964 entitled "Nassaince du Minotaure II", the "private mythology" of Le Corbusier's works was dominated by Minoan-Cretan mythology, to the point that the bull symbol became the unifying principle of his entire pictorial, plastic and architectural work. Dozens of Le Corbusier's architectural projects include the theme of the labyrinth. The "main ouverte" and Ariadne - la Licorne were intended to "join up" from afar Chandigarh with the Bhakra dam. For the dam Le Corbusier designed architectural elements and he planned to install a copy of the "Ariadne" sculpture, similar in size to the "open hand" at Chandigarh. The Chandigarh-Bhakra complex - the planned city and the hydroelectric infrastructure - was the realization of the global post-war reconstruction plan, an approach devised by Le Corbusier together with the UN'S CIAM, based on the model of the TVA, the New-Deal Federal Agency, which had planned the development of the most backward area in the States starting from hydropower generation. The story is encrypted on the back of the tabernacle at Ronchamp.
\end{abstract}

Resumen: De una carta de fecha 1913 a W. Ritter en el que describía la "obsesión erótica", que le había hecho representar la imagen de la Ariadna dormiente en los jardines de Versalles como una odalisca desnuda en el cuadro titulado La Versalles du Grand Turc, hasta su último proyecto gráfico de 1964 titulado "Nassaince du Minotaure II", la "mitología privada" de las obras de Le Corbusier fue dominado por la mitología minoico-cretense, hasta el punto de que el símbolo del toro se convirtió en el principio unificador de toda su obra pictórica, plástica y arquitectónica. Decenas de proyectos de arquitectura de Le Corbusier incluyen el tema del laberinto. La "main ouverte" y Ariadna - la Licorne estaban destinadas a unirse de lejos Chandigarh con la presa de Bhakra. Para la presa Le Corbusier diseñó elementos arquitectónicos y que planeaba instalar una copia de la escultura "Ariadna", similar en tamaño a la "mano abierta" en Chandigarh. El complejo de ChandigarhBhakra - la ciudad planificada y la infraestructura hidroeléctrica - fue la realización del plan mundial de la reconstrucció posguerra, un enfoque ideado por Le Corbusier, junto con el CIAM de la ONU, basado en el modelo de la TVA, el New-Deal Agencia Federal, que había planeado el desarrollo de la zona más atrasada de los Estados Unidos a partir de la generación de energía hidroeléctrica. La historia está cifrada en la parte posterior del tabernáculo en Ronchamp.

Keywords: Minoan-Cretan mythology; Ariadne; Taureaux; hydropower; Chandigarh; Ronchamp.

Palabras clave: Mitología minoico-cretense; Ariadna; Taureaux; energía hidroeléctrica; Chandigarh; Ronchamp. 


\section{Introduction}

From the publication of the Tate Dossier ${ }^{1}$, the project for the 1958 exhibition of the paintings known as 'Bulls' at the Tate Gallery, which confirmed Le Corbusier's intention of unifying his entire pictorial production in the 'sign of the bull', it became evident to what extent Minoan-Cretan mythology was to dominate the 'private mythology' of Le Corbusier and how it marked symbolically his whole 'plastic' production: painting, sculpture and architecture.

Le Corbusier himself recognised an unconscious phase of dominion of the 'sign of the bull' over his imagination, from the 1920s to April 1952, the date of his return from his third trip to Chandigarh and completion of his projects for the Capitol complex and for the main ouverte. Subsequently, in the conscious phase he re-painted 'retroactively' the Purist still-life paintings of the 1920s, bringing out from them the sign of the bull, and renaming them intentionally Taureaux. Thus he started the series of 'bull' paintings, which he would continue to the end of his life (Fig. 1).

An early sign of the powerful influence of the Minoan myth on Le Corbusier's imagination is found in his 1913 letter to William Ritter $^{2}$, in which he confessed his erotic infatuation with the statue of the sleeping Ariadne in the gardens of Versailles ${ }^{3}$ (Fig. 2), according to the myth abandoned in sleep by Theseus on the small island of Naxos during his return trip from Crete to Athens. A strong erotic impulse drew him to depict her in colour in the nude, unclothed and as enticing as a Rubens odalisque in the gouache he entitled Versailles du Grand Turc ${ }^{4}$ (Fig. 3). Fifty years after this 'love at first sight', one year before his death, a large copy of the portrait of Ariadne still hung above the revolving access door to the Le Corbusier Centre in Zurich ${ }^{5}$ (Fig. 4). Le Corbusier's vision of the feminine and eroticism is marked by the Dionysian, coloured and Bacchic elements of his Turkish depiction of the Versailles statue, itself a 1600s copy of a Hellenic marble of the second century AD.

The feminine-Dionysian combination is typical of Le Corbusier's cultural background. He was deeply influenced by Schurè's Le Grands Initiés. Esquisse de l'histoire secrète des religions ${ }^{6}$, which he received as a gift from his teacher L'Eplattenier, who considered him his best pupil and led him on the path of architecture. Schurè's book outlined effectively the mythological world of Ancient Greece on the basis of the oppositions between Solar-Apollonian-male-mountain on the one hand and lunar-Dionysian-female-valley bottom on the other, the place where waters flow, the delta of the river and of Venus.

\footnotetext{
${ }^{1}$ Coll, Jaime: "Le Corbusier. Taureaux: an analysis of the thinking process in the last series of Le Corbusier's plastic work", in Art History, vol. 18, n. 4. December 1995, Oxford and Cambridge (Mass): Blackwell Publisher, pp. 537-567.

2 Jencks, Charles: Le Corbusier and the Continual Revolution in Architecture, New York: Monacelli Press, 2000; italian ed. Le Corbusier e la rivoluzione continua in architettura, Milano: Jaka Book, 2002, p. 84.

${ }^{3}$ Corneille Van Cléve, Ariane endormie, 1684-1688.

${ }^{4}$ Le Corbusier, Un Versailles du Grand Turc, (FLC 4097).

${ }^{5}$ Le Corbusier, Arianne, (FLC 4 November 1963).

${ }^{6}$ Schuré, Edouard: Le Grands Initiés. Esquisse de l'histoire secrète des religions, Paris: Perrin et Cie, 1889, passim.
} 


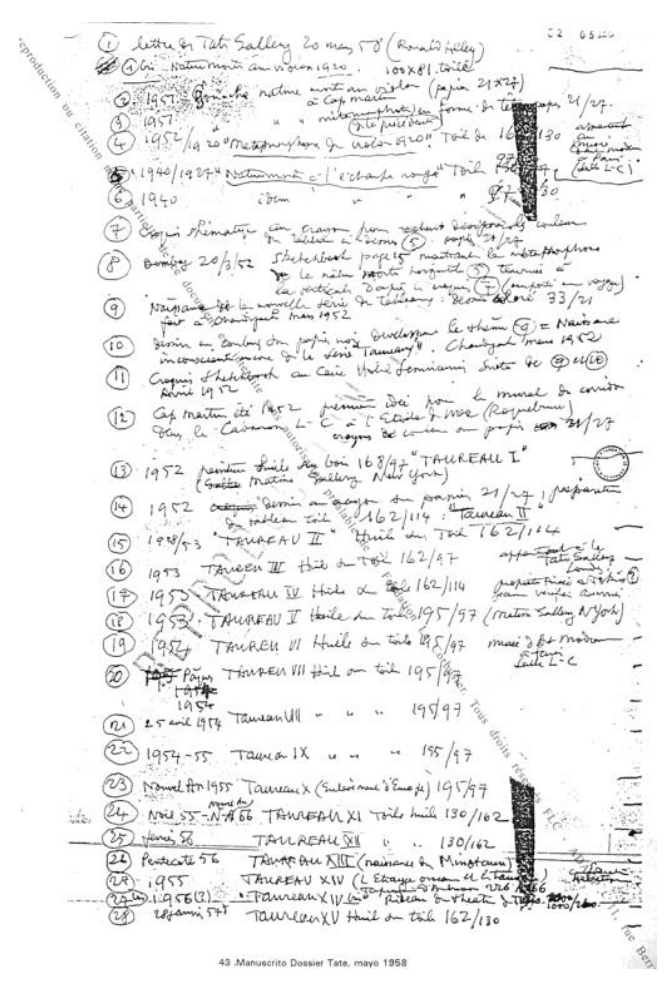

1. Le Corbusier, Dossier Tate, 1958 (FLC C2-05 100, (FLC-ADAGP).

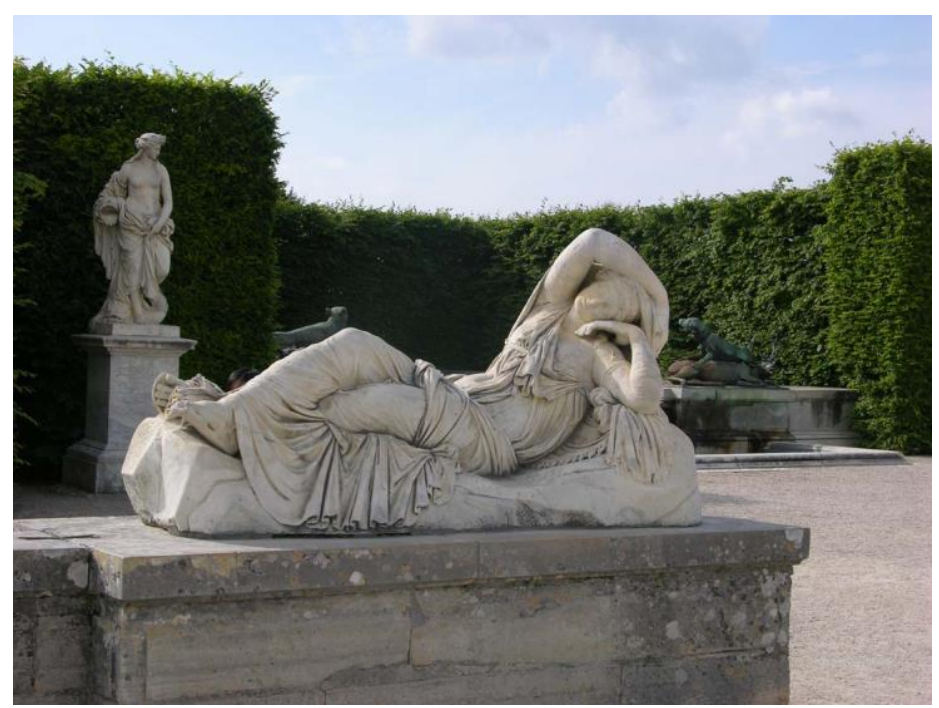

2. Corneille Van Cléve, Ariane endormie, 1684-1688, (AF Archives). 


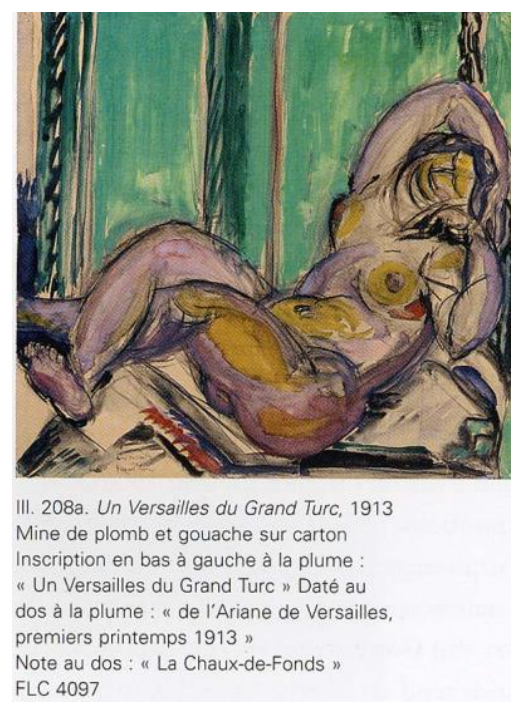

3. Le Corbusier, Un Versailles du grand Turc, 1913 (FLC 4097, @FLC-ADAGP)

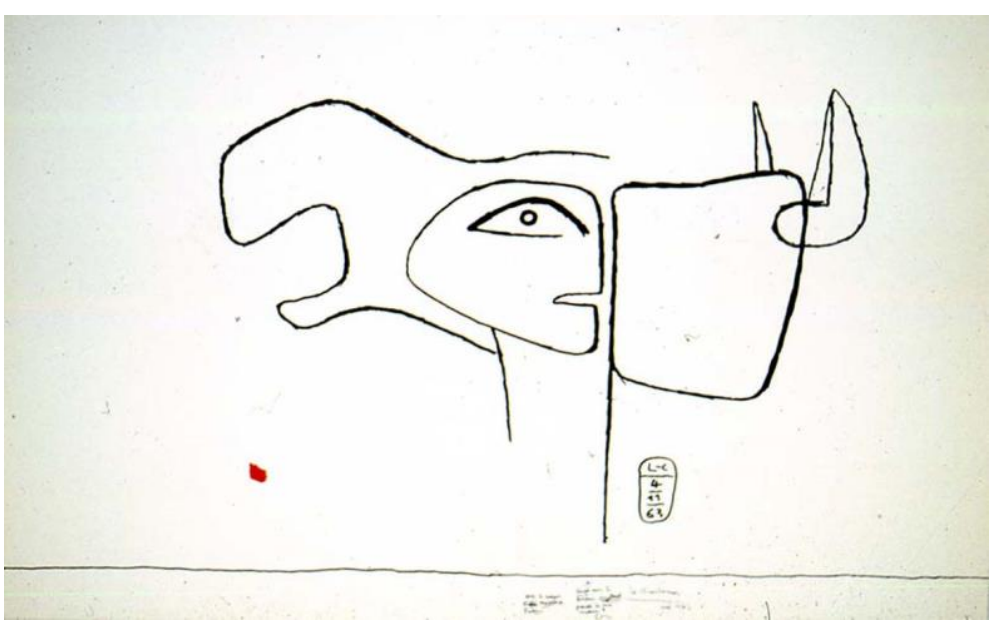

4. Le Corbusier, Arianne, 4 November 1963 (@FLC-ADAGP)

\section{Ariadne, Dionysius and the Labyrinth}

In 1913 the mythological connection between Ariadne and Dionysius (hence the continuity between Cretan Minoan mythology and Greek mythology) was still obscure, as shown in the question posed by Nietzsche: "Who knows, but, me, what Ariadne is!"7.This is an essential question (answer), because if we ignore Ariadne we ignore Dionysus, who met Ariadne deserted at Naxos, and if we ignore Dionysus we ignore the 'origins of tragedy' and hence of classical Greek culture.

The question of Ariadne's identity was later answered by the mythological studies of Kerényi on the Dionysian relationship between Crete and Athens and between Ariadne and Athena. In parallel, it was answered by the archaeological studies in Crete, which shed light on the ruins of the Minoan labyrinths and outlined the whole of Crete's 'Palatial' civilisation. This was marked by the architectural and urban-temple design of the labyrinth, which was centripetal. This design is typical of the island civilisation in the Cyclades and Crete, as opposed to

\footnotetext{
${ }^{7}$ Nietzsche, Friederich: Ecce Homo, Leipzig: Insel Verlag, 1908; italian ed. Ecce Homo, Milano, Adelphi, 16th ed., 2012; Kerényi, Karl: Labyrinth-Studien, Zurich: Rhein-Verlag, 1950; italian ed. Nel labirinto, Torino: Boringhieri, 1983, p. 167.
} 
the mainland Mycenaean temple type, the oriented megaròn which gave rise to the Parthenon. This was finally confirmed by the translation of 'linear b' writing starting from 1952.

In short, Kerényi's interpretation, developed in the 1930s and confirmed by archaeological studies identifies Ariadne as the greatest Cretan divinity, the 'Lady of the Labyrinth'. A double divinity, Arihagne and Aridela, celestial and subterranean, lunar and bull-like, 'the purest' in the night and 'the brightest' in the underworld, double as the labyrinth itself is double, identified with the central courtyard which marked the palace-cities of this 'neo-palatial civilisation' as a space dedicated to the fundamental rite in honour of Ariadne, the ecstatic dance in accordance with the steps guided by the swastika shape of the maze - the symbolic shape of the labyrinth - etched into the flooring.

The proper name of the upper labyrinth is the 'palace of the two axes', etymologically because it was built with the labris, the two-headed axe which was the symbol of the highest priesthood, that of Daedalus, architect of the labyrinth and of the dance which the labyrinth itself is: "Ariadne danced the labyrinth" . Below this is the lower labyrinth, 'the palace of the viscera', illuminated by Aridela and inhabited by the Minotaur, whose name is Asterion, 'the starry one', the monster with the head of a bull but dotted with stars, which prompted Gide's Theseus to say: "le monstre était beau"9 (the monster was beautiful). The other rites of the cults of Ariadne are the taurocatapsia, the 'great leap' of the bull, and the propitiatory offering of honey and wine. The archaeological findings which shed light on religious and mythological practices, above all on the culture of wine and dance, placed the divinities of Ariadne and Dionysius at the centre of Minoan-Cretan civilisation and connected this civilisation directly with Athenian civilisation ${ }^{10}$. Theseus' desertion of Ariadne at Naxos, half way between Crete and Athens, before setting off to found Athenian democracy, represents the need to first remove Dionysian femininity, which by its Bacchic nature could subvert sexual taboos and hence disrupt all social order.

\section{Le Corbusier: Daedalus and La Licorne}

These themes were explored in depth in Le Corbusier's cultural circle: consider his relationship with Christian Zervos, author of books on pre-Cycladian archaeology and editor of the Cahiers $d$ 'art, the art journal of the avant-garde movements in which Le Corbusier published an account of his trip to Athens. Or consider his collaboration with the review Minotaure, which focused the attention of the surrealist movement on primitivism, blending archaeology, ethnology and Jungian psychology in the search for a new unconscious, pre-classic universality.

At the same time as the first issues of the review came out, on his return from Greece, Le Corbusier inaugurated his own Parisian house-atelier with an exhibition entitled 'L'art primitive dans la maison d'aujourd'hui' (primitive art in today's home) where he exhibited among ethnic and Cubist works the gypsum copy of a Greek kriophoros which he coloured with violent brush strokes (Fig. 5). This was his way of linking primitivist ethnic universality to avant-garde/neo-Humanistic art in the sign of a classic yet not Apollonian statute, but rather Dionysian, as the numen protecting the new home of Corbusier and Yvonne ${ }^{11}$

\footnotetext{
${ }^{8}$ Calasso, Roberto: Le nozze di Cadmo e Armonia, Milano: Adelphi, 2005, p. 74.

${ }^{9}$ Gide, André: Theésée, Paris: Gallimard, 1947; italian ed. Thésée, Bari: Palomar, 1996, p. 100.

${ }^{10}$ Kerenyi, Karl: Dionysos. Urbild des unzerstörbaren Lebens, München-Wien: Langen-Müller, 1976; italian ed. Dioniso, Milano: Adelphi, 1992, passim.

${ }^{11}$ Le Corbusier: Les arts dits primitifs dans la maison d'aujourd'hui, exhibition, 3-13 july 1935, Rue Nungesser et Coli 24, $\mathrm{XVI}^{\circ}$ (FLC C1-5 139-144).
} 
Mogens Kustrup has demonstrated that Le Corbusier attributed to Yvonne a Minoan mythological identity. He depicted her as Pasiphae - Ariadne - Icone - the Licorne, figures depicted in the frescoes of the Swiss Pavilion and the petit cabanon, and in the Poème de l'angle droit ${ }^{12}$ and a host of sketches, designs, paintings and sculptures. Yvonne's Cretan mythological identity as the Licorne would appear to be matched by that of Le Corbusier as the Bull - Theseus - 'the Athenian' - Daedalus ${ }^{13}$.

The double and multifaceted character of Ariadne allows her to be identified in more than one woman, firstly in Josephine Baker, a protagonist of the deep cultural impact produced by the primitive dances of the Revue Negre on the whole avant-garde movement of Paris. For her, Le Corbusier designed a music hall ${ }^{14}$ - like Daedalus, the architect of the Ariadne's dance - and he depicted her in pictures and sculptures such as La Danseuse ${ }^{15}$, the primitive dancer, the black manifestation of Ariadne.

The close link between Le Corbusier-Daedalus and Ariadne was repeated in his Indian experience, where Ariadne took the identity of Minnete Da Silva, the cosmopolitan Singhalese grande dame, a London architect, who introduced him to the upper echelons of politics and the enlightened entrepreneurship of India involving him in the foundation and activities of the Marg (Modern architecture research group) an avant-garde group and journal of modern Indian architecture, sponsored by businessmen such as Tata. Le Corbusier celebrated the meeting in a note in his cahier in connection with his re-reading of Gide's Theseus during a flight from Geneva to Delhi in 1958: "J'ai eu le temps de lire Thésée (Gide) Ariane et Dédale + Marg. Et avoir change d'atmosphère. Être // jeune, à nouveau!!" 16.

The previous year Le Corbusier dedicated to Yvonne, as she lay dying, the monologue of the ghost of Icarus in Gide's Theseus together with the Iconostase ${ }^{17}$ (Fig. 6), and his draft plans for Le poème de l'angle droit (Poem of the right angle), which were the icons of his imaginary autobiography but also the greatest homage to Yvonne-Icone: Yvonne as the 'angel droit', the other title of the Poème, sacred as the Madonna in orthodox icons (Fig. 7). The analogy 'angel'/'angle' was not new in the Parisian avant-garde movement, where Jean Cocteau expressed it: "En hébreu le mot ange et le mot angle sont synonymes. La chute des anges symbolise, dans la Bible la chute des angles, c'est-à-dire, la crèation tout humaine d'une sphère conventionnelle "18.

But it is above all the Licorne, a naked, winged female figure with the head of a one-horned goat, depicted in the main ouverte from which it is born and which guards it in accordance with Mallarmè's verse "garder ton aile dans ma main" ", which sums up the complexity of the meanings Le Corbusier attributes to this figure, making it the leading character of the Poème (Fig. 8). Thus an angelic winged figure; with the head of a goat, hence Dionysian, but female and unique, non-reproducible just as the Licorne, the figure which seems to be lacking in the Apollonian Olympus of Athens but which, according to Kerényi's studies, is present in the mythological

\footnotetext{
${ }^{12}$ Le Corbusier, Poème de l'Angle Droit, Paris: Éditions Tériade, 1955.

13 Kustrup, Mogens: "La peinture du silence", in Massilia, Sant Cugat del Vallés (ES): Associaciò d'idees. Centre d'investigacion Estètiques, 2005, pp. 156-169.

${ }^{14}$ Casali, Valerio: "Le Corbusier, Josephine Baker e il Music-Hall”, in Massilia, Sant Cugat del Vallés (ES): Associaciò d'idees. Centre d'investigacion Estètiques, 2004, pp. 136-151.

${ }^{15}$ Le Corbusier, La danseuse, scluptures (FLC 104, 215, 3398, 6379).

16 "I had time to read Theseus (Gide) Ariadne and Daedalus + Marg. And the atmosphere has changed. Being young, once again!!” (author's translation), Kustrup: “La peinture du silence”, p. 160.

${ }^{17}$ Le Corbusier, Carnet Nivola I, (FLC W1-8 113).

18 "Angel and Angle are synonyms in Hebrew. The fall of the angels can thus be translated as a fallo of the angles. The fall of the angles thus means: ideal sphere, disappearance of Divine Force, apparition of the conventional, the human" (author's translation), Cocteau, Jean: "Le secret professionnel”, in Poésie critique, vol. 1, Paris: Gallimard, 1959, p. 24.

${ }^{19}$ Mallarmé, Stéphane: Autre èventail (de Mademoiselle Mallarmé), 1884.
} 
syncretism which links in continuity Ariadne to Athena through the figure of Dionysius, who met Ariadne (of whom he was both spouse and son) when she reawakened after being abandoned in Naxos.

And it is in Phidias' statue of Athena Parthenos - the divinity of the Parthenon - that we can identify the model of the Licorne held in the open hand. This model is found in the right hand of Athena which holds the small winged figure of the Athena Nike, symbol of the victory conferred by Athena Parthenos on the winners of the Games. By 'translating' the small Athena Nike into the Licorne, Le Corbusier moved symbolically beyond the Neo-Classical winckelmanian 'Apollonian' vision of the Greek world, rediscovering its ancient Dionysian and Cretan origin, identified with the figure of Ariadne-La Licorne. And this was the sense of his discovery of Greece as a colourful, sound-filled and 'acoustic' world, lively and vital, during his trip to Athens with the CIAM in $1933^{20}$.

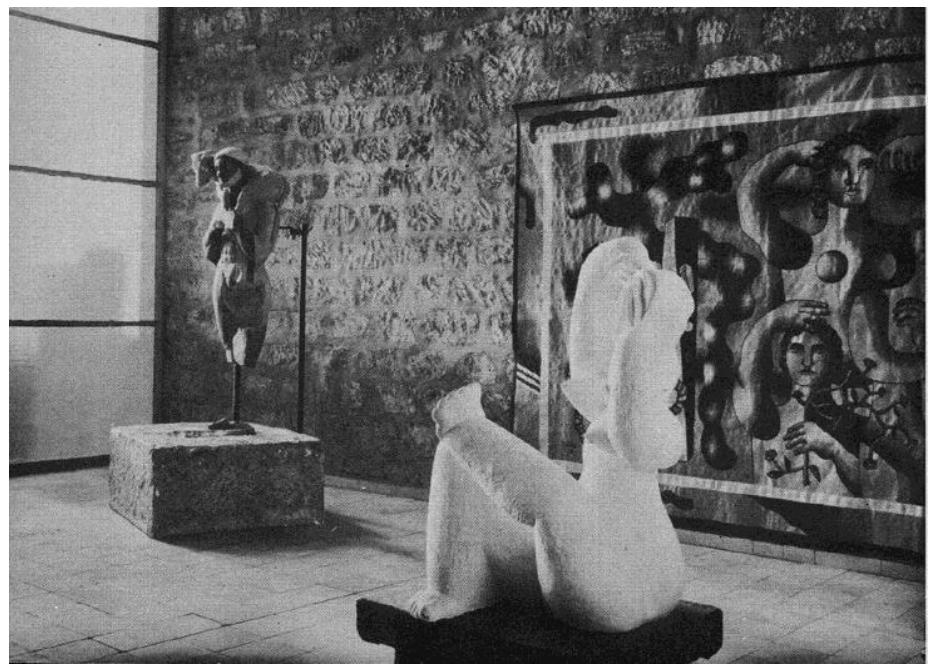

5. Le Corbusier, Les arts dits primitifs dans la maison d'aujourd'hui, exhibition, 3-13 july 1935, 24NC, (FLC C1-5 139-144, (CFLC-ADAGP).

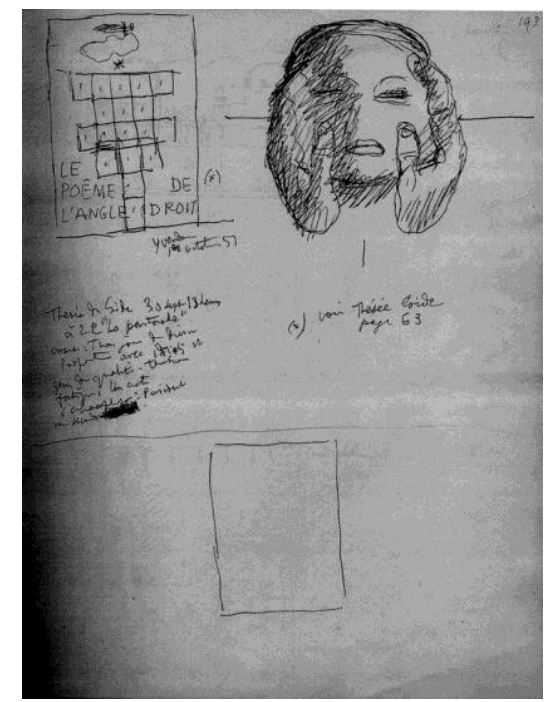

6. Le Corbusier, Yvonne dying, Carnet Nivola I, (FLC W1-8 113, OFLC-ADAGP)

${ }^{20}$ Le Corbusier, "En Grèce, à l'échelle humaine”, in Le voyage en Gréce, Paris: Cahiers périodiques, 1939. 


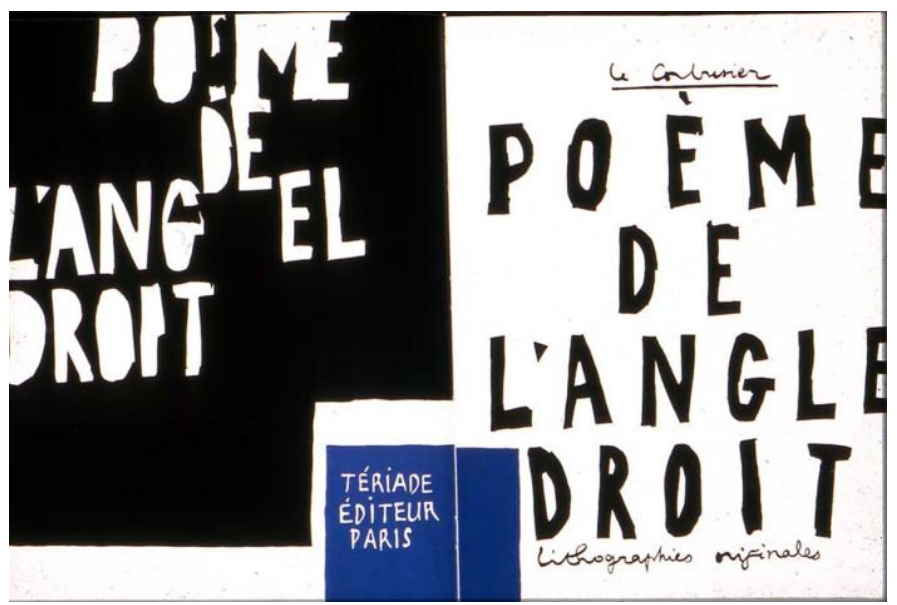

7. Le Corbusier, Poème de l'angle droit, 1955.

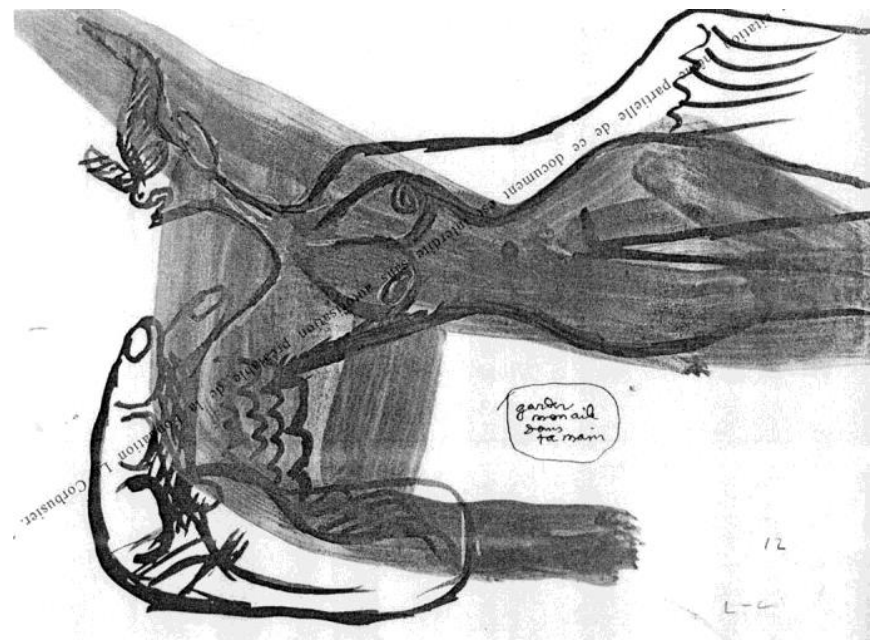

8. Le Corbusier, main ouvert e Licorne (CFLC-ADAGP).

\section{The signe du taureau and architecture: Chandigarh and Ronchamp}

Thus, While the Minoan-Cretan mythological imagination, 'the sign of the bull' marked Le Corbusier's entire 'private mythology' as expressed in his paintings and sculptures, it is only in the 'conscious phase' that this vision also spread to his architecture, as is shown by the enigmatic drawing entitled 'le dénouement du meandre': the hollow between the horns, the sign of the bull, is the principle of the impluvium necessary in flat roofs as opposed to the principle of the displuvium of the pitched roof shown in the sketch of the roof of the Parthenon $^{21}$ (Fig. 9).

In unveiling the meander, the façade of the Parthenon with its pitched roof shows the wrong direction out of the labyrinth and is opposed to the cross section of the projecting roof of Ronchamp and to the plan for the Governor's Palace of Chandigarh with its concave roof with impluvium, being the right direction for 'revealing the meander'. But it is in the façade of the Parliament that the 'sign of the bull' 'translates' the pitched roof of

${ }^{21}$ Le Corbusier, Entre-Deux (FLC 3.1.1957). 
the Parthenon into the pronaos, with eight "columns" like the Parthenon but concave and evidently dominated by the 'sign of the bull' and the function of the impluvium (Fig. 10).

The principle of the architectural impluvium, 'the unveiling of the meander' becomes the analogue of the 'law of meander', natural and universal, which shapes the delta of rivers and the fluvial terrain of the territories which Le Corbusier always noted accurately as he flew over them ${ }^{22}$. The two dimensions came together in the parallel and mutually-influencing events of Chandigarh and of the Bakrha dam (for the dam, Le Corbusier sought and obtained a commission for some architectural features) (Fig. 11).

The interest of Le Corbusier for fluid dynamics in relation to the construction of river dams is documented starting from 1940 by his exchanges with Engineer Coyne, the designer of the French dam of Chastang in accordance with innovative methods which combined the dam itself and the machinery for the production of hydro-electric power (Fig. 12). The drawings of the waterfall produced by the dam's floodgates were to become the model for the 'cascade' produced by the gargouille of the chapel of Ronchamp, whose dynamics regulates all measurements of the chapel's impluvium roof (Fig. 13).

Le Corbusier's interest in dam architecture on the scale of territorial and urban planning became much stronger during his mission to the US in 1946, when he attempted to involve in his plan for post-war reconstruction and territorial and urban planning on a global scale the Tennessee Valley Authority (TVA), the 'new deal' Federal Agency which had planned the exploitation of the natural resources and territorial and urban layout of the whole Tennessee-Mississippi-Missouri basin, starting from the development of hydro-electric resources with the construction of 11 dams and the project for the construction of some twenty new towns. The TVA's refusal of any involvement in the global project contributed to the failure of the project for the UN headquarters building, which Le Corbusier had envisaged as the centre of a world administrative capital from which the UN's CIAMs would have directed global reconstruction and planning, the most ambitious and Utopian of his projects ${ }^{23}$.

After the failure of the global government of the UN and the beginning of the Cold War with the division of the world into two opposing blocs, the project for the complex of Chandigarh, the foundation city and new capital, and for the Bhakra dam applied the TVA's planning model to India - the leading nation of the few non-aligned countries. On the summit of the Bhakra dam ${ }^{24}$, Le Corbusier planned to install a copy of the sculpture entitled Eau, Ciel, Terre ${ }^{25}$ of the same huge size as the main ouverte of Chandigarh. This sculpture will evolve into a new sculpture named $\mathrm{La} \mathrm{mer}^{26}$ which is the plastic translation of the numerous series of drawings that begin with the sketch entitled Naissance des Taureaux ${ }^{27}$, the fundamental graphic theme of most of Taureaux ${ }^{28}$ (Fig. 14). The symbol main ouverte-la licorne which he had placed on the cover of the Poesie sur Algier ${ }^{29}$ (Fig. 15) evolves between Bhakra and Chandigarh in what that union had generated, the naissance of Taureaux.

\footnotetext{
${ }^{22}$ Sanchez-Pombo, Marina: "La arquitectura de los fluidos. Le Corbusier y los rios", in Massilia, Sant Cugat del Vallés (ES): Associaciò d'idees. Centre d'investigacion Estètiques, 2004, pp. 48-69.

${ }^{23}$ CIAM document, (FLC U3-13 84)

${ }^{24}$ Le Corbusier, Carnet L 50, 8.12.1957 (FLC W1-3 1088).

${ }^{25}$ Le Corbusier, Eau, Ciel, Terre, 1954 (FLC 14).

${ }^{26}$ Le Corbusier, La mer, 1963 (FLC 36).

${ }^{27}$ Le Corbusier, Carnet K 43, "10 aout 1952, repeint 1956", (FLC W1-3 652).

${ }^{28}$ Jornod, Naima; Jornod, Jean-Pierre: Le Corbusier. Catalogue raisonné de l'oeuvre peint, vol. II, Milan: Skira, 2005, pp. 874-889.

${ }^{29}$ Le Corbusier, Poésie sur Alger, Paris: Éditions Falaize, 1950.
} 
At the same time, the construction of Ronchamp synthetized in a monument Le Corbusier's private mythology decreeing the 'crisis of Rationalism, ${ }^{30}$. 'The sign of the bull', the architectural principle of the impluvium roof, clearly acquired the character of the 'law of the meander', transforming the roof in the hollow of a river delta which collects the waters and directs them to the gargouille which is shaped according to the 'sign of the bull', but also to the 'law of the meander': the slope of the roof is calculated from lower to upper "comme une onde croissante $^{, 31}$, opposed to the natural gravity of the descending pluvial wave (Fig. 16).

The 'cascade' produced by the gargouille falls into the fountain which contains elementary geometric volumes similar to natural crystals (crystals that for Luca Pacioli testified to the presence of the "Divina Proporzione" in nature) in the point where the wall swells externally, matching the internal confessional, as if in the place of 'confession' the architecture had been fecundated and mysteriously made 'full of grace' (Fig. 17).

On the north side, the two cement canopies frame the entrance, drawing in a plastic form the 'sign of the bull' just as the merlons on the Cretan palace of Knossos, the archaeological site of Ariadne's mythological labyrinth: the entry to the Ronchamp church is made through that sign (Fig. 18).

Mogens Kustrup had noted that the pagan and sexual meaning of those references could jar rather blasphemously with the dedication of the Chapel to the Virgin. Indeed, the figure of Mary, the small wooden statue placed in the recess on the façade, which connects the inside with the outside of the church, appears as a mysterious entity: from the outside it is in full sunlight, but is seen from behind, since she faces inside. From the inside she is backlit and only her contour is visible, set among the glass-concrete elements forming the shiny constellation of the Capricorn ${ }^{32}$.

But it is on the back side of the tabernacle, the hidden side of the 'house of God', that the mystery seems to reveal itself as enriched by other meanings: set opposite the front image of the Agnus dei qui tollis peccata mundi, there is a male figure, with a tree-like design ${ }^{33}$, appearing to behold a water horizon broken into two levels, the section of a watershed ending with the sea, blocked by a dam which stands against tall mountains topped by a sky painted in the fundamental colours which should have been the colours of the main ouverte pointing towards the Himalaya. Above, an explosion of red light: the dawn depicted by Le Corbusier in his carnets during a flight to Chandigarh ${ }^{34}$. Higher still, the blue sky is topped by the shape of the cross which, in the side facing the congregation, shows the crucifix above the agnus Dei (Fig. 19).

\footnotetext{
${ }^{30}$ Stirling, James: "Ronchamp; Le Corbusier's Chapel and the Crisis of Rationalism", in Architectural Review, 119, March 1956, pp.155-161.

31 “as a growing wave”, Le Corbusier, Textes et dessins pour Ronchamp, Paris: Éditions Forces Vives, 1965, p. 39

${ }^{32}$ Kustrup: "La peinture du silence", pp. 164-5.

${ }^{33}$ Le Corbusier, Textes et dessins pour Ronchamp, 1965, p. 8.

${ }^{34}$ Le Corbusier, Carnet J37, (FLC W1-3 361-362).
} 


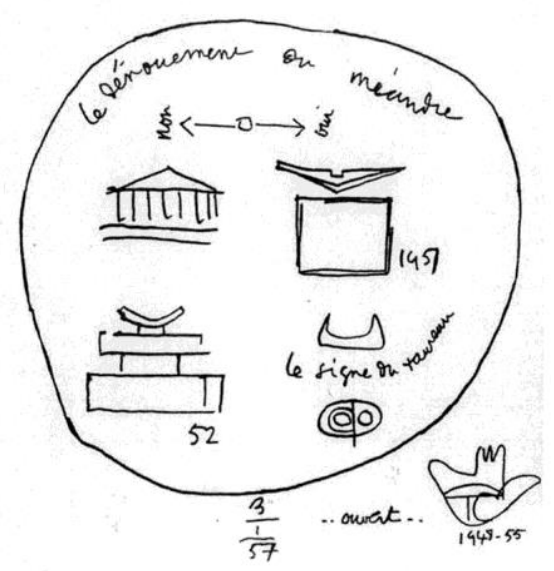

9. Le Corbusier, le dénouement du méandre, 3 January 1957, (OFLC-ADAGP)

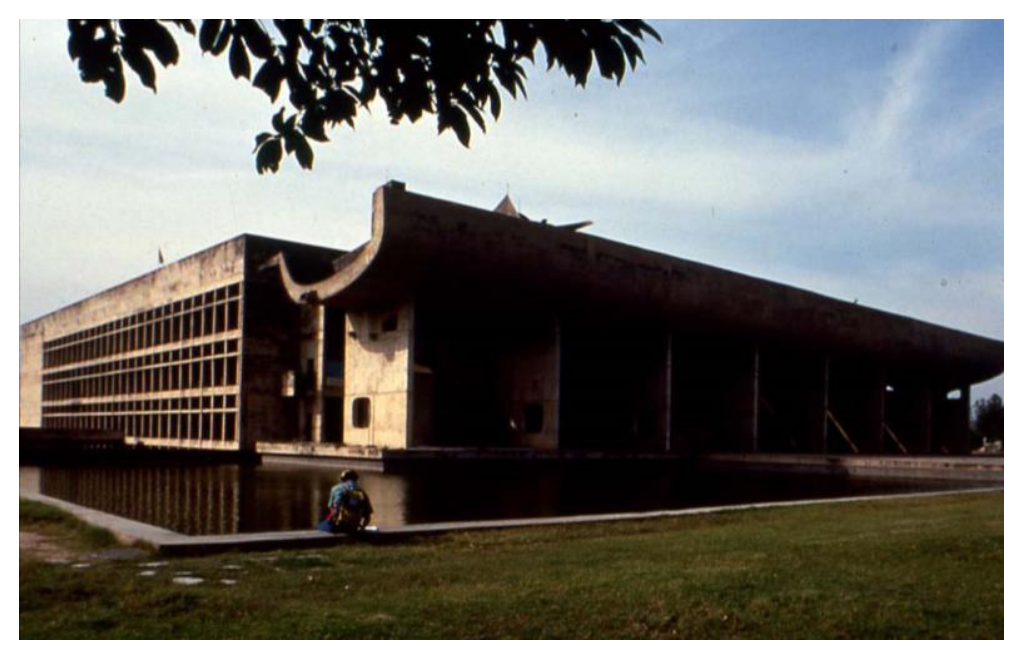

10. Le Corbusier, Parliament of Chandigarh, (AF archives).

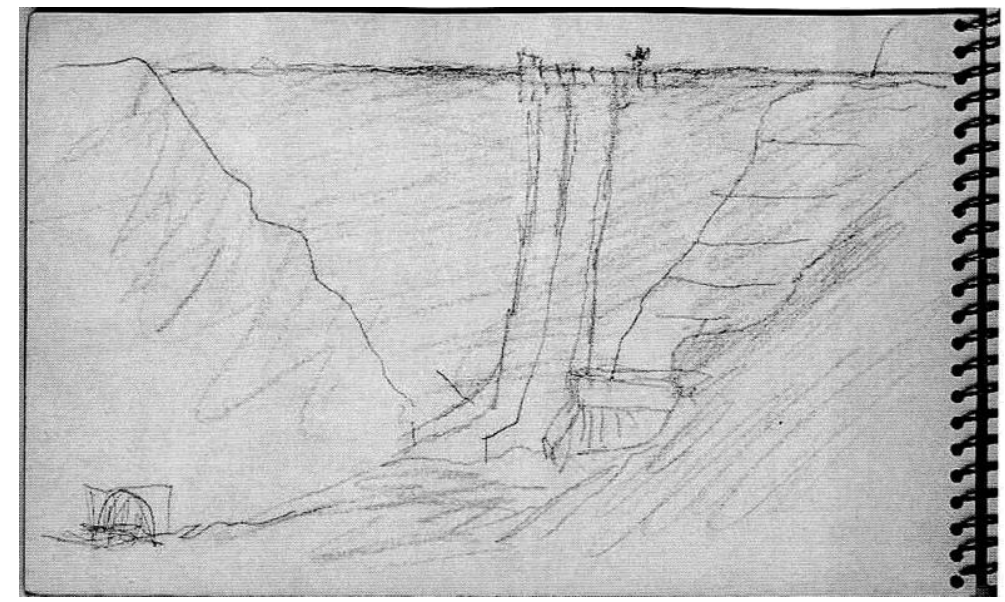

11. Le Corbusier, sketch of Bhakhra Dam, Carnet M52 (OFLC-ADAGP W1-4 086) 


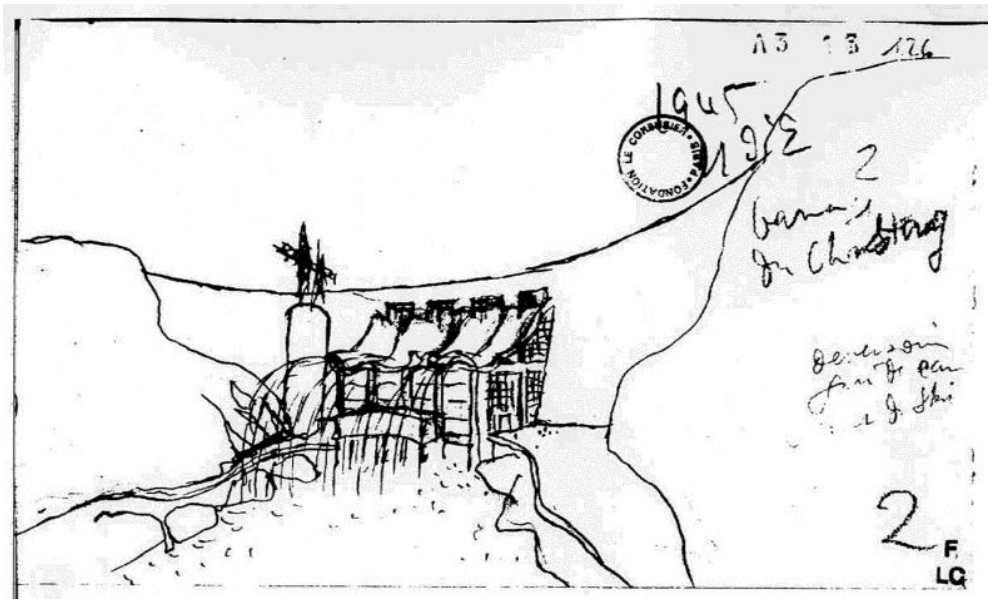

12. Le Corbusier, sketch of Chastang Dam, (@FLC-ADAGP A3-18 126).

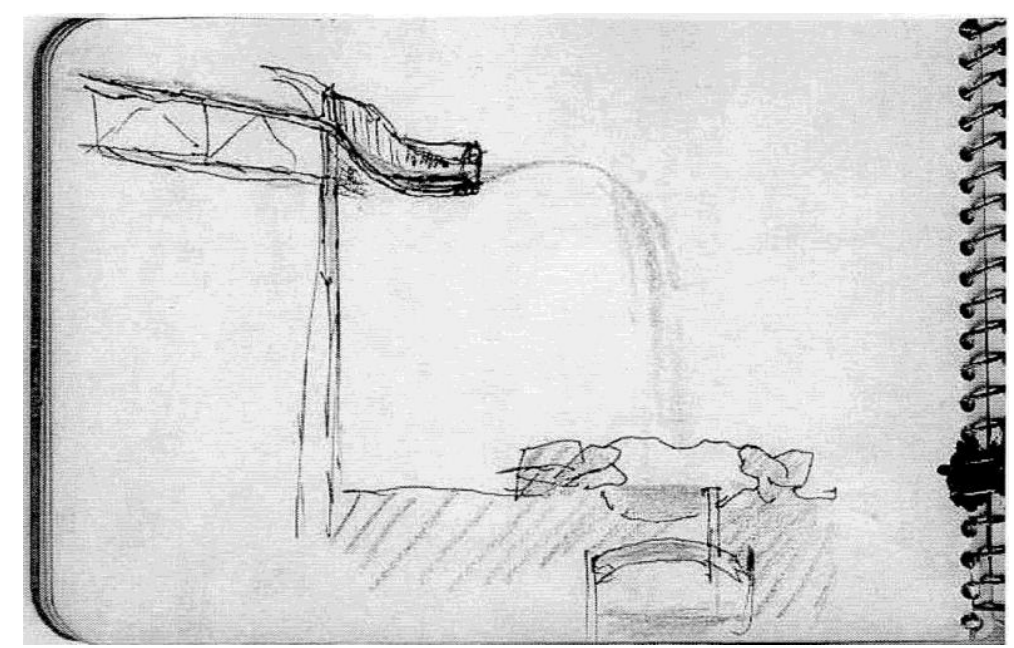

13. Le Corbusier, sketch of the gargoyle of Ronchamp Carnet E18 (CFLC-ADAGP W1-2 327)

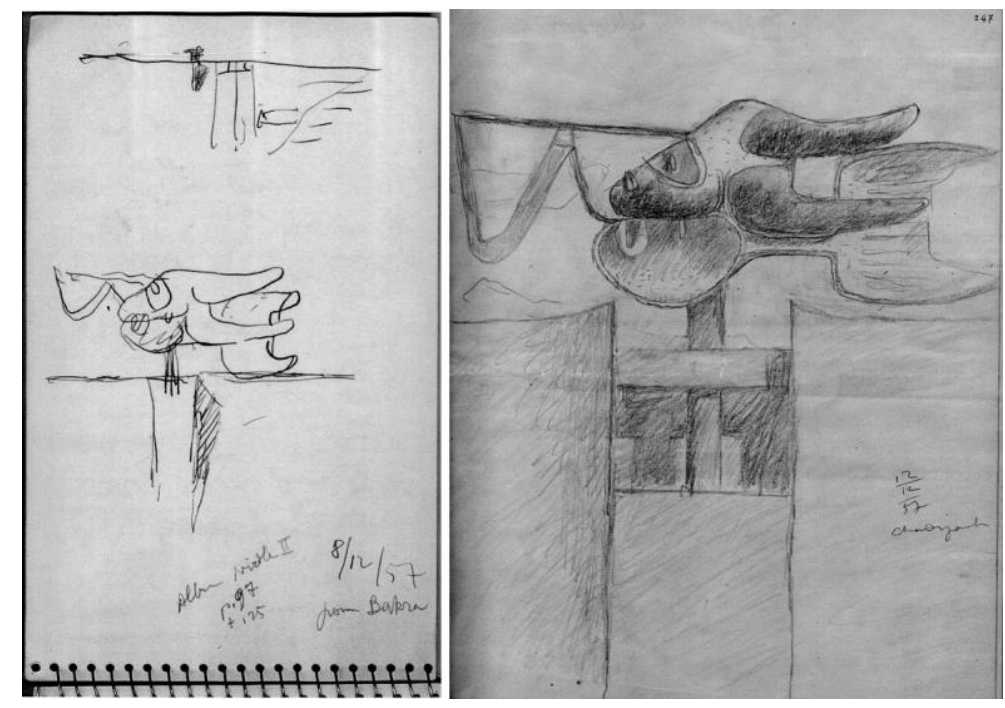

14. Le Corbusier, "naissance du taureaux" on the summit of Bhakhra Dam, 1957, Carnet M52 (CFLC-ADAGP W1-3 1088). 


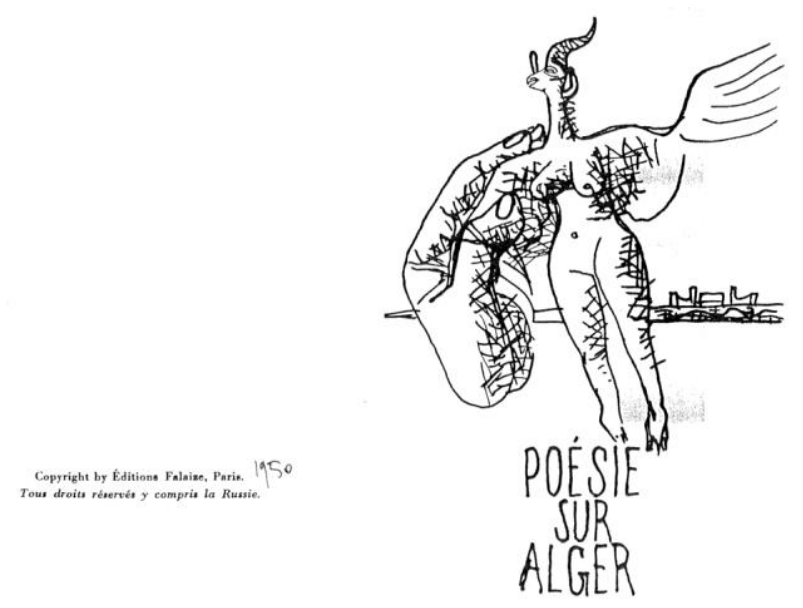

15. Le Corbusier, Poésie sur Alger, 1950.

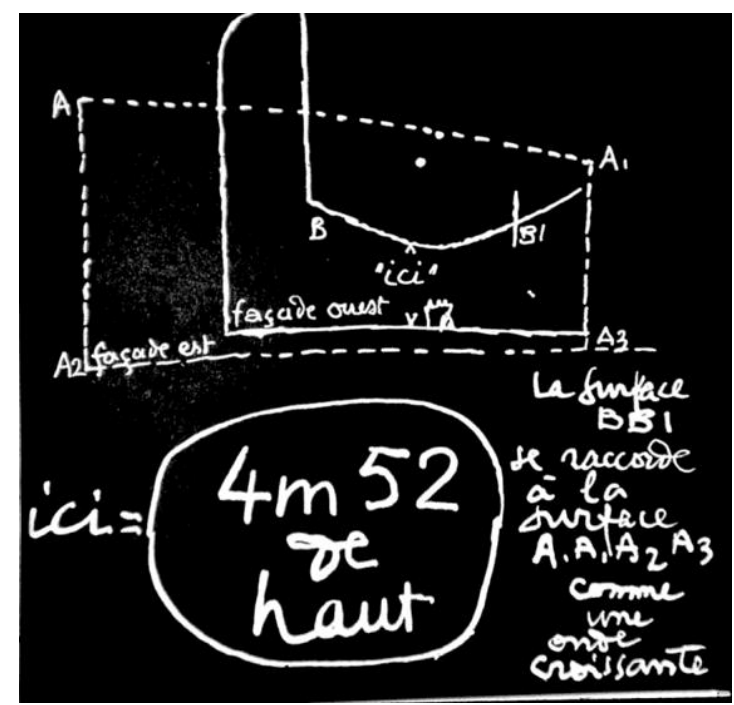

16. Le Corbusier, Textes et dessins pour Ronchamp, 1965, p. 39.

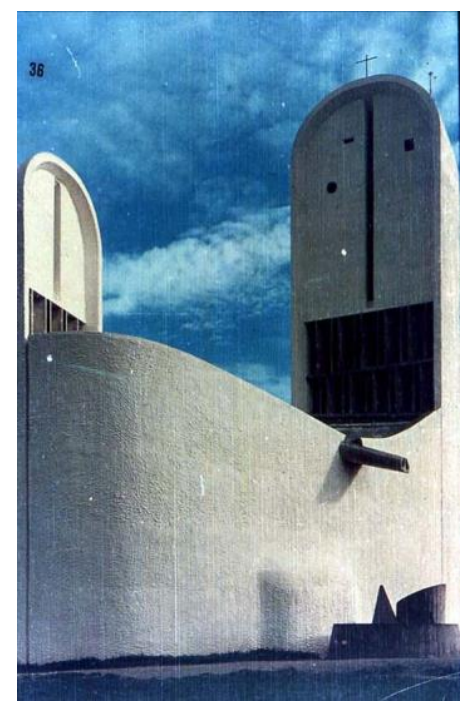

17. Le Corbusier, Ronchamp, (AF Archives). 


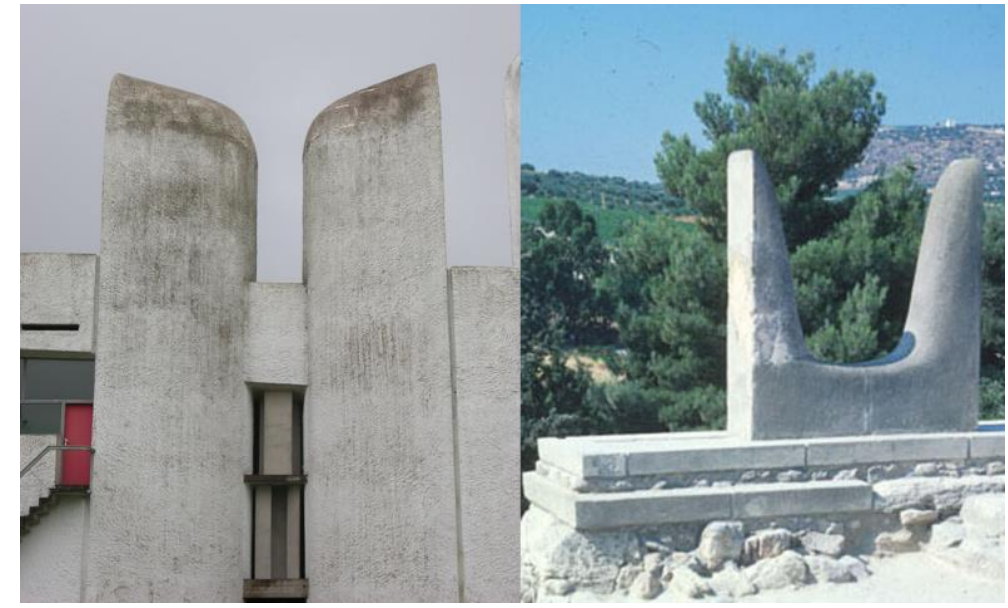

18. Le Corbusier, Ronchamp Northern facade; detail of the palace of Knossos. (AF Archives).

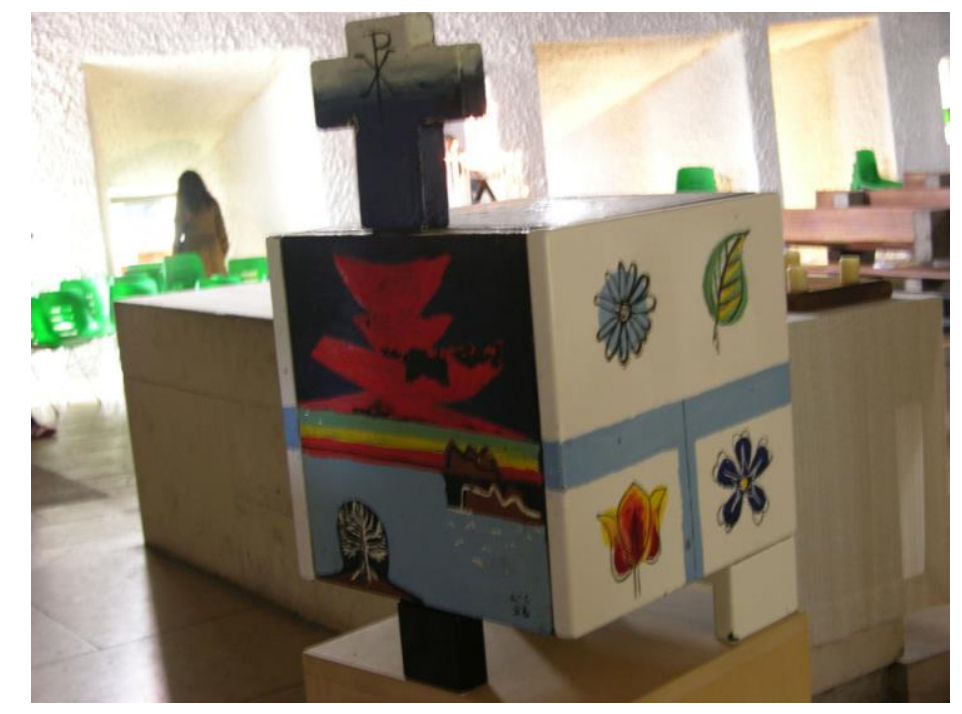

19. Le Corbusier, tabernacle of Ronchamp, 1958, (AF Archives).

\section{Conclusions}

In the essential opposition between nature and architecture, Le Corbusier assigns the male gender to architecture, made up of orthogonal planes, and the female gender to nature, which is curved. Since he assigns a female character to river beds too, the dam acquires symbolic value as the union of nature and architecture, confirmed by the natural tree form, hence female, set within the male outline. But more than this by the project of the great sculpture derived from the "birth of the bulls". This is the strong symbolic value of the Bhakra dam, the first element of the Cyclopean water channelling and power generation project for northern India, from the Bay of Bengal to the Arabian Sea. In the words of President Nehru Bhakra was the new temple of resurgent India, the symbol of India's progress. Nerhu also defined Chandigarh as the 'temple of the new India'.

The civil sacredness of Chandighar and Bhakra and the religious sacredness of Ronchamp come together in the faces of the tabernacle, just as they were joined together in Le Corbusier's original culture, that of the Cathar community of Chaux des Fonds, imbued with the ideal of social engagement as the expression of the humanitarian and social Christian mission which is the hallmark of the Cathar heresy. 
The symbolic relationship between Chandigarh, Ronchamp and its mystery of the Virgin Mary is confirmed by the stained-glass windows where the moon of Chandigarh - that in which for the first time in his life Le Corbusier detected the traits of a human visage - is joined to what can be nothing other than the stylised drawing of a female sexual organ, commented by the words 'Mother of God'. Mary's role as the mother of God is associated with the moon, which physiologically regulates maternity, but also with the sexuality denied by the mystery of immaculate conception of Mary, who is a woman only as a 'virgin and mother' (Fig. 20).

The new bell of Ronchamp, designed by Le Corbusier and made by Jean Prouvé, bears the names of Amelie, Charlotte, Yvonne (grandmother, mother and wife) and Marie. Le Corbusier's entire experience of the feminine resounds in Ronchamp, celebrating - besides the mother of God - the sacred female nature of Mother Earth and of Life. But it would be an omission not to quoting the monologue of Icarus' Ghost in Gide's Theseus, dedicated by Le Corbusier to the dying Yvonne: "Mais la raison de tout cela, Dieu limpide? de tant de peines, de tant d'efforts. Et vers quoi? La raison d'être? Et de chercher à tout des raisons? Vers quoi tendre, sinon vers Dieu? Comment se diriger? Où s'arrêter? Quand pouvoir dire: ainsi soit-il; rien ne va plus? Comment atteindre Dieu?, partant de l'homme? Si je pars de Dieu, comment parvenir jusqu'à moi? Cependant, tout autant que Dieu m'a formé, Dieu, n'est-il pas créé par l'homme? C'est à l'exacte croisée des cheimns, au coeur même de cette croix, que mon esprit veut se tenir",35.

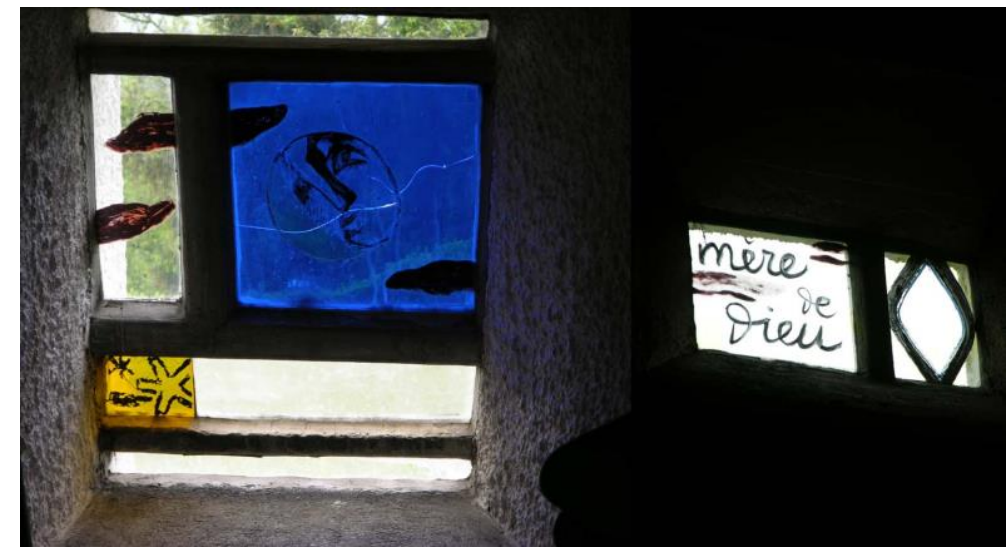

20. Le Corbusier, windows of Ronchamp, (AF Archives).

\section{Bibliography}

Calasso, Roberto: Le nozze di Cadmo e Armonia, Milano: Adelphi, 2005.

Casali, Valerio: “Le Corbusier, Josephine Baker e il Music-Hall”, in Massilia, Sant Cugat del Vallés (ES): Associaciò d'idees. Centre d'investigacion Estètiques, 2004.

Coll, Jaime: "Le Corbusier. Taureaux: an analysis of the thinking process in the last series of Le Corbusier's plastic work", in Art History, vol. 18, n. 4. December 1995, Oxford and Cambridge (Mass): Blackwell Publisher.

Cocteau, Jean: “Le secret professionnel”, in Poésie critique, vol. 1, Paris: Gallimard, 1959.

\footnotetext{
35 "But what is the reason for all that, limpid God? For so many pains, so many efforts. And all for what? What is the reason for being? And for seeking reasons for everything? Where are we to turn if not toward God? How are we to direct our steps? Where are we to stop? When can we say: so be it, nothing more to be done? How can we reach God, after starting from? And if I start from God, how can I reach out to myself? And yet, just as God formed me, isn't God created by man? It is at the exact crossroads, heart of that cross, that my mind wants to linger" (author's translation) Gide, André: Theésée, Paris: Gallimard, 1947; italian ed. Thésée, Bari: Palomar, 1996, p. 85-87.
} 
Gide, André: Theésée, Paris: Gallimard, 1947; italian ed. Thésée, Bari: Palomar, 1996.

Kerényi, Karl: Labyrinth-Studien, Zurich: Rhein-Verlag, 1950; italian ed. Nel labirinto, Torino: Boringhieri, 1983.

Kerenyi, Karl: Dionysos. Urbild des unzerstörbaren Lebens, München-Wien: Langen-Müller, 1976; italian ed. Dioniso, Milano: Adelphi, 1992, passim.

Kustrup, Mogens: "La peinture du silence", in Massilia, Sant Cugat del Vallés (ES): Associaciò d'idees. Centre d'investigacion Estètiques, 2005.

Jencks, Charles: Le Corbusier and the Continual Revolution in Architecture, New York: Monacelli Press, 2000; italian ed. Le Corbusier e la rivoluzione continua in architettura, Milano: Jaka Book, 2002.

Le Corbusier, Poème de l’Angle Droit, Paris: Éditions Tériade, 1955.

Jornod, Naima; Jornod, Jean-Pierre: Le Corbusier. Catalogue raisonné de l'oeuvre peint, vol. II, Milan: Skira, 2005.

Le Corbusier, “En Grèce, à l'échelle humaine”, in Le voyage en Gréce, Paris: Cahiers périodiques, 1939.

Le Corbusier, Poésie sur Alger, Paris: Éditions Falaize, 1950.

Le Corbusier, Textes et dessins pour Ronchamp, Paris: Éditions Forces Vives, 1965.

Nietzsche, Friederich: Ecce Homo, Leipzig: Insel Verlag, 1908; italian ed. Ecce Homo, Milano, Adelphi, 16th ed., 2012.

Sanchez-Pombo, Marina: "La arquitectura de los fluidos. Le Corbusier y los rios", in Massilia, Sant Cugat del Vallés (ES): Associaciò d'idees. Centre d'investigacion Estètiques, 2004.

Schuré, Edouard: Le Grands Initiés. Esquisse de I'histoire secrète des religions, Paris: Perrin et Cie, 1889, passim.

Stirling, James: “Ronchamp; Le Corbusier's Chapel and the Crisis of Rationalism”, in Architectural Review, 119, March 1956. 


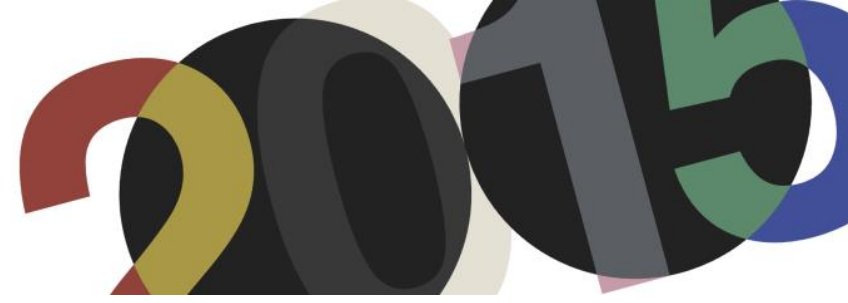

DOI: http://dx.doi.org/10.4995/LC2015.2015.612

\title{
Architecture and Art: La Ronchamp's symbiosis as a 'total work of art'
}

\author{
S. Frances Dias, M. João Durão
}

Faculty of Architecture Technical University of Lisbon, AIC International Colour Association

\begin{abstract}
Le Corbusier developed his own unique poetics of architecture, perceived and understood as an art. In La Ronchamp, due to his complete creative freedom, he found a space to express his most poetic and artistic views. The research paper thus analysis the Chapel as a case study, in order to clarify Corbusier's artistic and architectural vision, ideals and driving principles: drawing firstly from the architectural characteristics that define the space, secondly defining an integrated set of principles that conceptualize the architecture as an art, and lastly, an analysis of the particularities that compose the chapel as a total work of art', analyzing the union of the arts, both in concept, form and meaning, and in the overall context of Corbusier's unqiue theory. Thus, the research paper aims to understand and uncover how the poetics and emotional condition lives through Ronchamp: the meaning it encases, the artistic values is sustains and the timeless ways it recreates. The overall study has both practical and theoretical applications and implications for architects and artists with an interest in the integration of art and architecture, as well as the conceptual connections between the arts; a vital issue in the contemporary world for the definition of a more meaningful and sustainable environment.
\end{abstract}

Keywords: Art, Architecture, Le Corbusier, Principles, Poetry, Emotion.

\section{Introduction}

The paper is an explores La Ronchamp as a 'total work of art', (a manifestation of a unique poetics and an art), as the architectural project where Corbusier most represented his artistic visions and architectural ideals in a unified and free way, a result of his complete creative freedom and desire to create a unique sacred place. Thus, in order to do so, the methodology used for the research includes both textual analysis, and formal analysis of the design; the textual analysis comprises an in depth literature review, cross analyzing various references that clarified Corbusier's purpose, vision, ideal and creative process to achieve it, as well as the experience of the space described and perceived by the various authors, in order to arrive at common grounds and thus further identify a series of articulating principles. The Ronchamp Chapel has been the focus of research through multiple perspectives of various authors, however, in this case study and brief research paper, the approach is to clarify the artistic and architectural aspects, the connections between the arts, the creative, emotional and poetic principles and the work process and ideal that led Le Corbusier's to create this unique sacred and timeless space, in order to clarify the underlying driving principles that sustain it's artistic and architectural characteristics and the connections between the arts that sustain it. The particular study of Corbusier's study synthesis and symbiotic relationship of the arts and architecture, from the Ronchamp case study and as analalysed throughout the work, has both practical and theoretical applications and implications for architects and artists with an interest in the integration of art and architecture, as well as the conceptual connections between the arts; a matter of the essence, in the various fields of artistic creation in the contemporary world for the understanding, comprehension and definition of a more meaningful and sustainable environment. 


\subsection{Le Corbusier: Context, Aims and the Ideal of Architecture - A brief introduction}

Leonardo Benevolo, in 'History of Modern Architecture: Volume 2', (1977) explains the context within which Le Corbusier's work emerges. The economic and cultural situation in France during the years of the First World War, was mainly a concern for qualitative problems, such as improvements of lifestyle and general overall circumstances. While the rest of Europe was being swept by Art Noveau, France tried to create a new academic reformulation in order to refit the needs of modern society and life. In this scenario, Le Corbusier emerges, managing to create a link between both, maintaining the traditional aspects of France aesthetics (and traditional architecture values) and combining them in a new way to better define modernity (both ordinary life and overall existence). In Benevolo (1977) words: "Thus he would act as a mediator between the modern movement and French traditions, and introduce into international culture some of the values inherent in this tradition.", 1

Padovan (2002), in the same way, explains that " Le Corbusier conceives the new spirit, not as a complete break with the past, but as a recovery of architecture's authentic principles, (...)." '2. This new spirit, continues the author, aimed to bring new life, and a new aspect to human 'constants' that in their essence, remain unchanged. His aim, through his writings and his architecture was to reclaim architecture's strengths and power, and in doing so, to "' (...) redirect architecture to its unchanging fundamentals. ,3 (Padovan, 2002, p. 23).

For Le Corbusier, the architecture of his time, had lost sight and understanding of architecture's role and its fundamental principles. In regards to this non-satisfaction and non-signification of the architecture of his time, Le Corbusier, claims: "We are unhappy living in unworthy houses because they ruin our health and our morale. (...) Our houses disgust us; we flee from them (...). We become demoralized. ",4. As such, he sustained a deeper and better Architecture could and should be created: one that was artistic in essence and created an emotional connection with its inhabitants. On this issue, it is of vital importance his statement where he distinguished architecture from mere construction: "'ARCHITECTURE is an artistic fact, an emotional phenomenon that is outside questions of construction, beyond them. Construction: THAT'S FOR MAKING THINGS HOLD TOGETHERE; Architecture: THAT'S FOR STIRRING EMOTION. ",5

To conclude this brief introduction about the place of Architecture and the role of the Architect that sustained all of Le Corbusier's Architectural creations, one last thought and statement is in order, that summarizes both Le Corbusier's views and the underlying research aims, in using La Ronchamp as the case study. The sentence is derived from Le Corbusier's book 'Towards a New Architecture', where he claims: " The architect, through the ordinance of forms, realizes an order that is a pure creation of the mind; through forms, he affects our senses intensely, provoking plastic emotions; through the relationships that he creates, he stirs in us deep resonances, he gives us the measure of an order that we sense to be in accord with that of the world, he determines the diverse movements of our minds and our hearts: it is then that we experience beauty. " 6 .

\footnotetext{
${ }^{1}$ Leonardo Benevolo, History of Modern Architecture. (Cambridge, Massachusetts: MIT Press , 1977), 436

${ }^{2}$ Richard Padovan, Towards Universality: Le Corbusier, Mies, and De Stijl. (Hove, United Kingdom: Psychology Press, 2002), 23

${ }^{3}$ Richard Padovan, Towards Universality: Le Corbusier, Mies, and De Stijl. (Hove, United Kingdom: Psychology Press, 2002), 23

${ }^{4}$ Le Corbusier and Jean-Louis Cohen, Toward an Architecture. (Los Angeles: Getty Publications, 2007), 94

${ }^{5}$ Le Corbusier and Jean-Louis Cohen, Toward an Architecture. (Los Angeles: Getty Publications, 2007), 97

${ }^{6}$ Le Corbusier and Jean-Louis Cohen, Toward an Architecture. (Los Angeles: Getty Publications, 2007), 92
} 


\subsection{La Ronchamp in the architectural world}

La Ronchamp was initially received by a series of mixed reviews and opinions. According to Gans (1987), once the project was complete, the 'architectural world' was in shock: those that knew Corbusier and associated him to the 'machine age' and to 'reason' perceived the chapel as an 'expressionist aberration'; where as others, Gans caims " (...) saw its organic form as a humanistic enrichment of modern architecture and its Modulor proportions as evidence of its underlying rationality." today, it is unquestionable that La Ronchamp most represents 'the total work of art' that so well describes and defines Le Corbusier. Considered a true masterpiece by many, La Ronchamp has grown to be an architectural icon of the contemporary architectural and artistic world. Muller (2004) clarifies that there is an innate inability to categorize La Ronchamp: "Examining critiques about Ronchamp places the project within the context of experiments in New Brutalism and the rejection of modernism. Some have suggested the project is expressionist or that it is the precursor to post- modernism. "8. However, according to Muller (2004) none of these critiques are acceptable or satisfactory, for none describe the real character of Ronchamp. On this same issue, the nature of La Ronchamp, Pauly (1997) claims it is it's poesis that defines it, claiming it to be " (...) a poetic masterpiece that explores various forms of expression." ", that just as the ancient cathedrals, it seeks to be a union of the arts and of life. Muller (2004) on Ronchamp's unique poesis also claims: "It is the appreciation of the poesis particular to Le Corbusier that is responsible for the chapel's success as an architectural set piece. ${ }^{\text {"10 }}$. The Art of Ronchamp does in fact escape labels and categories; as such, that the chapel is a poiesis is unquestionable and is generally understood as an architectural and artistic masterpiece: how that poetics and emotional condition lives through Ronchamp (the meaning it encases, the artistic values is sustains and the timeless ways it recreates) is what the case study (and the present research paper) aims to uncover and understand.

\section{Ronchamp's Background and Context}

\subsection{History and Context of the Site}

The site faces north to the Voges hills, east of the town of Belfort, west to the Langres and South to the Jura mountains, forming a unique condition that encloses what has come to be known as 'the four horizons'; the mountain/hill free standing, in the midst of such a landscape thus possesses ' '(..) an aspect not unlike his much-admired Acropolis. "11, accentuates Muller (2004). Besides these natural special conditions of the landscape, the unique hill of Le Ronchamp is a sacred site of pilgrimage and has a long historical tradition. Gans (1987) explains that the history of this hilltop can be traced back in time through multiple generations all the way back to the Romans. Muller (2004) adds more historical context to the site, such as a connection with military defense a result of the positioning of the site in invasion routes of the Romans, a site of shared landscape between Swiss and German's, as well as being the site of pagan worship, and lastly, the historical context that

\footnotetext{
${ }^{7}$ Deborah Gans, Chapelle Notre-Dame-du-Haut 1954, in: The Le Corbusier Guide. (New York: Princeton University Press, 1987), 74.

${ }^{8}$ Linda Muller, The symbiosis between art and architecture as evidenced in Le Corbusier's Ronchamp. (Vancouver, Canada: University of British Columbia, 2004), 82.

${ }^{9}$ Danièle Pauly, Le Corbusier: La Chapelle de Ronchamp, The Chapel at Ronchamp. (Springer Science \& Business Media, 1997), 123.

${ }^{10}$ Linda Muller, The symbiosis between art and architecture as evidenced in Le Corbusier's Ronchamp. (Vancouver, Canada: University of British Columbia, 2004), 82.

${ }^{11}$ Linda Muller, The symbiosis between art and architecture as evidenced in Le Corbusier's Ronchamp. (Vancouver, Canada: University of British Columbia, 2004), 71.
} 
finds most evidence in today, the site of miracles that functions as a religious gathering for pilgrims. All these historical events have made the site be celebrated throughout the ages as a spiritual place (a sacred site) and, as such, it has possessed religious buildings that honor its unique values since the XIX century. The original chapel, a small space in scale, was renovated and transformed to fit the requirements of the pilgrims, and by the 1930's it was transformed into a larger cathedral, that was completely destroyed by the bombings of the World War II.

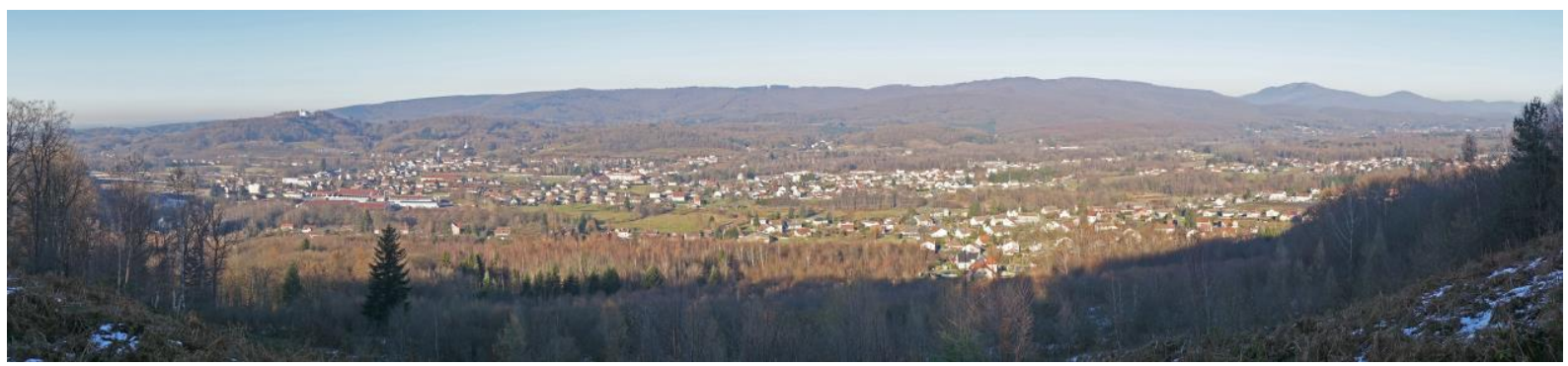

1. Panorama of Ronchamp; Source: https://commons.wikimedia.org/wiki/File:Panorama_Ronchamp-Champagney.JPG

\subsection{The Comission and the Program}

After the bombings and the complete devastation of the existing Church, with their unique sacred space devoid of a religious place for worship, the Notre-Dame-du-Haut property development company, decided to launch a commission for the project of a new chapel; they had initially intended to restore the former chapel, but due to cost, decided on a complete reconstruction instead. Muller (2004) clarifies that after France's difficult post WWII period, there was a climate of redevelopment and a "stimulus for innovation"; as such, 'Ronchamp embraced the spirit of renaissance, as well as the renewal of spirit and faith (...)." ${ }^{12}$. When Le Corbusier was contacted for the commission, he initially refused the offer (a consequence of the Saint-Baume project, where the ecclesiastical entities had rejected his design), however he agreed to further listen to the proposal: a chapel for a pilgrimage site, that was still very much alive in its tradition, and to which Le Corbusier would have complete creative freedom. Corbusier became interested in the project and the program, but it was the site and the landscape that was the determining factor, an interest that grew from the very first visit to the site.

The program for the new chapel was simple: it was to be composed of the main nave, three small chapels (for independent services), an outdoor sanctuary for open-air ceremonies for pilgrims, dedicated to Virgin Mary should house a 'seventeenth century sculpture' of the Virgin and Child in wood, a sacristy and a small office in the upper floor, and lastly, the ability to collect rain water (due to water being rare on the hill). Muller (2004) accentuates that besides the programmatic references, ' (...) the architectural program at Ronchamp embraces premises of sanctuary, pilgrimage and humility. " ${ }^{13}$; and that these specific emotions were integral part of the programmatic requirements. Simultaneously, other restraints conditioned the project: such as the lack of road access to transport building materials to the site, and the clients desire to re-use the old materials in a manner of 'economy' of means but also a way to convey humility and sustainability through the chapel.

\footnotetext{
${ }^{12}$ Linda Muller, The symbiosis between art and architecture as evidenced in Le Corbusier's Ronchamp. (Vancouver, Canada: University of British Columbia, 2004), 71.

${ }^{13}$ Linda Muller, The symbiosis between art and architecture as evidenced in Le Corbusier's Ronchamp. (Vancouver, Canada: University of British Columbia, 2004), 71.
} 


\subsection{Project Development and Design Process}

Corbusier begins the project by visiting the site, in 1950, where he drew inspiration specifically from the hill and the ruins of the old chapel. After this visit, in the very first sketches of the chapel, Corbusier created two strong and curved lines (the south and east walls) ; these responded to what has become known as 'the four horizons', where the concept for the chapel seem to already be clearly outlined. In the series of drawings that followed Corbusier defined the elevations (featuring the outdoor altar and choir gallery), and also the curved sweep of the roof structure. Corbusier's vision kept developing in a kind of 'form search' through drawings and sketches, mostly in his notebooks. After this 'form finding' stage, another visit to the site and a series of perspective studies, Corbusier focuses on the plan, aiming to clarify form, content, site, program and concept simultaneously, within one single gesture or form, creating what he defines as an "organism"; for the architect, the plan had to be a graphic manifestation of the 'initial idea' and the 'dialogue with the landscape' ${ }^{14}$. However, according to Cohen (2004) another major influence on the plan development was the position of the altars ${ }^{15}$. The plan thus results in an asymmetrical, irregular shape: a synthesis of that initial 'impression'. This whole process was not an abstract or logical development, but instead, it responded to a 'visual and sensory experience', an impression and an ideal drawn from the site. After the generation of the form in the sketchbooks, Corbusier proceeded to design in the Atelier the detailed drawings for the project, during which he defined the organic roof structure. After this stage, models were created (of wire and wood), upon which the final design and plan on 1952 was based, followed by a formal presentation to the Archbishop of Besançon in November 1950.

The project was then presented to the clients on January 1951, however, some opposition delayed the construction date (the opposition was mainly from parishioners of Ronchamp, from regional authorities and from the press). The construction of the chapel begun in September 1953 and was finished on June 1955. This second stage of the project, Pauly (1997) clarifies, runs from the presentation date to September 1953 when construction begun; during this second stage is defined by a series of transformations: explorations of the North and West façade, interior perspectives and details, exploring the materials and construction details, clarifying tensions and concepts, etc.

\subsection{Influences}

In a later conversation with students, Corbusier claimed: " (...) the site is the nourishment offered by our eyes to our senses, to our intelligence, to our hearts. The site is the base of the architectural composition.", 16 . In fact, the site was the main propeller for La Ronchamp, at multiple levels. Gans (1987), on this influence, explains that Corbusier was driven by two opposing tendencies throughout all of his life: ' '(...) one toward the generation of universal types applicable to any setting and the other toward site-specific responses to landscape." ${ }^{17}$. In the Ronchamp, too, both forces are found at play within the project development: at the one side the search for

\footnotetext{
${ }^{14}$ Reference to: "As Le Corbusier stated, the plan for the chapel was the product of a graphic transcription of the first impression, of the initial idea that came to the architect as he entered into his first "dialogue" with the landscape. It was a "response", a question of "creating the right organ".," Danièle Pauly, Le Corbusier: La Chapelle de Ronchamp, The Chapel at Ronchamp. (Springer Science \& Business Media, 1997), 70.

15 Reference to: "The chapel's plan, which became increasingly asymmetrical as the planning phase progressed, was governed, inside and out, by the positions of the altars.'. Jean-Louis Cohen, Le Corbusier, 1887-1965: The Lyricism of Architecture in the Machine Age. (Taschen, 2004), 65.

${ }^{16}$ Le Corbusier, Le Corbusier talks with students. ( New York: Princeton Architectural Press , 1999), 40.

${ }^{17}$ Deborah Gans, Chapelle Notre-Dame-du-Haut 1954, in: The Le Corbusier Guide. (New York: Princeton University Press, 1987), 74.
} 
universalities and archetypes that define the artistic, poetical and rational existence on the other side, the desire to the respond uniquely and specifically to the atmosphere of the landscape.

For Corbusier, in La Ronchamp, the landscape imprinted such strong emotions that it was the site and its sacredness that fuelled his creative energies. In Corbusier's words: " "One begins with the acoustics of the landscape, taking as starting point the four horizons.... They are what gave the orders.... To them the chapel addresses itself." " 18 . Le Corbusier, thus, possessed these two main influences for Ronchamp, the landscape and the sacredness of the site: the site's history as a 'sacred place' of pilgrimage, and the landscape's depth and amplitude converted into what he defined as 'the four horizons'. Understanding the 'genius loci' of the environment and the energies of the specific site location led to the unique conceptualization that fed all the stages of the design, acting both locally and universally, and finding a way to bridge the gap between those two apparently opposing principles.

\section{Architectural Elements for a 'Union of the Arts'}
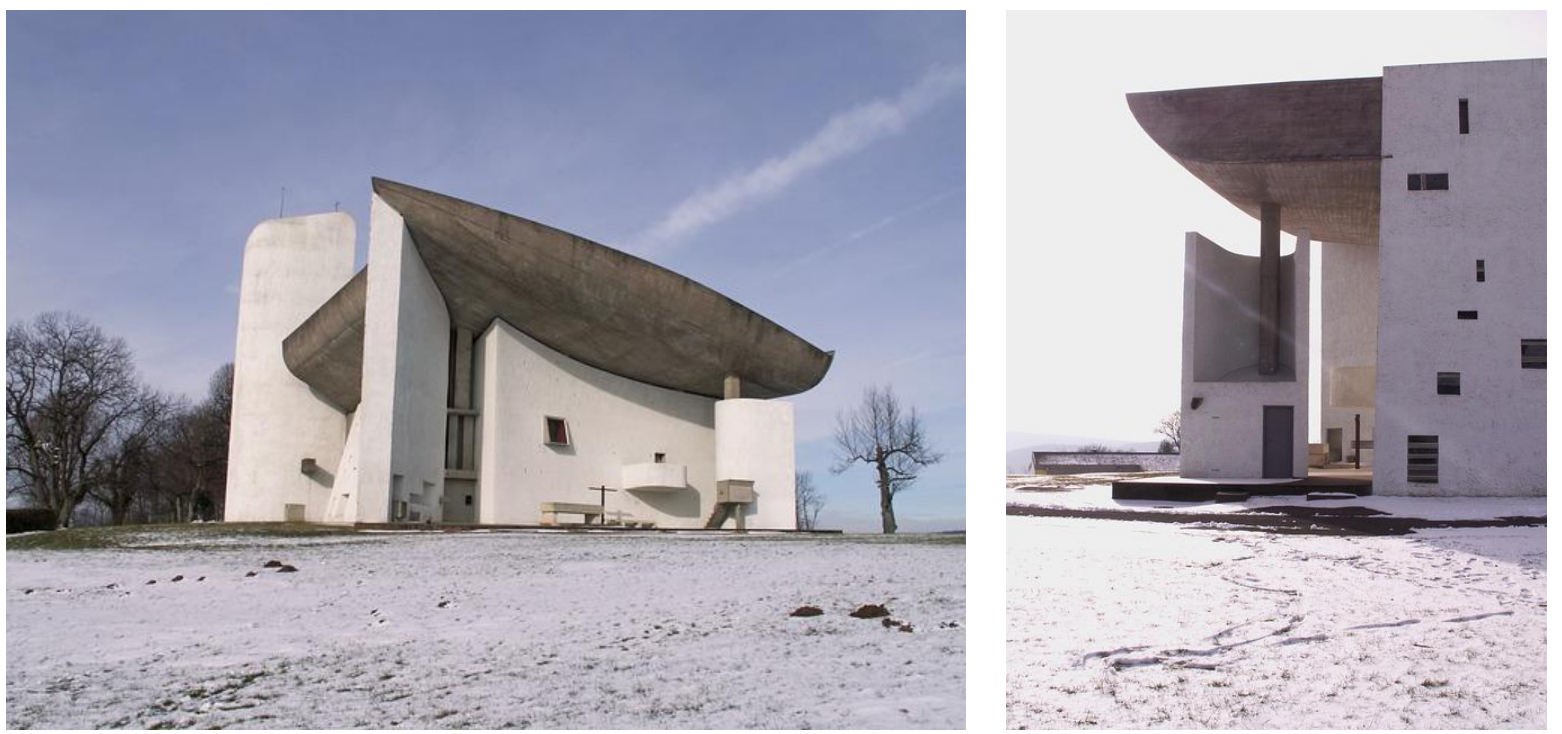

2. La Ronchamp Chapel; Source: http://pixabay.com/en/notre-dame-you-skin-de-ronchamp-372579/; 3. Detail of the East Facade elements from the North side; Source: http://pixabay.com/en/notre-dame-you-skin-de-ronchamp-372581/

\subsection{The Procession: The 'promenade architecturale'}

Gans (1987) explains that Corbusier, influenced by the architecture and sculptural character of the 'acropolis' conceived Ronchamp as a sort of 'acropolis' in itself; the site's landscape, for Le Corbusier, carried great resemblance with the Jura Mountains of his youth and the Acropolis, two defining great influences in the project: " As on the acropolis, the procession is orchestrated by a sequence of axial perspectives defined but not enclosed by the built forms of ziggurat, chapel, and youth hostel." ${ }^{19}$. The procession rests at the arrival at the door, next to the open air altar, the place for the pilgrims. Besides this initial conceptual 'procession' influenced

\footnotetext{
18 As cited by Deborah Gans, Chapelle Notre-Dame-du-Haut 1954, in: The Le Corbusier Guide. (New York: Princeton University Press, 1987), 74.

${ }^{19}$ Deborah Gans, Chapelle Notre-Dame-du-Haut 1954, in: The Le Corbusier Guide. (New York: Princeton University Press, 1987), 75.
} 
by the acropolis, La Ronchamp also is a tribute to the concept developed by Corbusier as 'promenade architectural', that claims architecture should be lived and experienced as a succession of spaces, as a wandering through space. So too, at La Ronchamp, Corbusier applied this principle, that also echoes the 'pilgrimages' journey. The chapel is designed to be discovered successively, where each façade and each space echoes its own meaning. Pauly (1997) on this issue, also emphasizes that in order to fully grasp the outside forms it is necessary to embark in a journey around the volumes, observing each façade at a time, walking through the paths and gazing at each form; however, in the interior, the author explains an opposite situation occurs: the process of understanding the essence of the architecture, " (...) occurs through the visitor experiencing a series of different sensations, generated by the ambience created through the play of light within the spatial composition." 20.

\subsection{The Conceptual Facades}

Thus, the facades, in order to be fully apprehended and experienced need to be observed from the 'walking' experience around the chapel, contemplating and 'living' each façade at its own pace, and understanding the opposing principles, the distinct forms, elements and character that define each one of them. North and West walls are concaved and closed, the South and East bend in to admit light and receive long distant views.

The south and east walls, as a response to the site, are respectively 'receivers' and 'transmitters' : they are open to the landscape and address the people in a welcoming and embracing way; while the south wall 'receives' and welcomes the public and the crowds of people leading them to the indoor spaces (it possesses a beacon tower and an open wall), the east wall 'transmits' and 'communicates' through the small outdoor chapel, a 'sanctuary' designed to 'communicate' open air ceremonies on pilgrimage days . Both facades are defined by the projection of the roof structure that defines a covered area for gatherings, with the floor defined by paving stones that follows the form of the roof and the roof structure tilting down (to the north and west side) that accentuates even more the 'openness' of the chapel. Where as the South façade is defined by a series of openings in a 'vast' white wall, the East façade's outdoor sanctuary is composed of free-standing forms that define the liturgical elements (altar, bench, pulpit and choir gallery); the altar, the primordial element is composed of a block of white stone, placed on orthogonal bases defined by the Modulor proportions. According to the author Danièle Pauly (1997), these elements create 'a human dimension' to the space and " (...) highlight the thickness of the wall, emphasizing its solid appearance." 21 . The south wall is thicker and tapered more intensely than the others, it possesses its own unique character, being the façade from which the interior is accessed.

The North and West facades, the posterior of the chapel, in opposing concepts and forms, are enclosed and confined. Although they represent the more functional aspects of the chapel, both co-operate together in creating a poetical encounter by accentuating a 'play' of mass, form and space; also, they accentuate the plastic elements of the chapel and create a mysterious 'promenade architecturale'. Where these two facades meet, two towers (back to back against each other) create a vertical reference, and a gap is defined between them containing the entrance used on a day-to-day basis by the users of the chapel. Both facades are defined by 'parabolic curves' and complete whiteness of almost 'solid' walls. Where as the north façade contains only some small openings, the west façade, (the only one with no openings), possesses a second tower at the far end (the highest of the three towers) that allows for the chapel to be spotted at a far. This façade also possesses the rain collecting elements,

\footnotetext{
${ }^{20}$ Danièle Pauly, Le Corbusier: La Chapelle de Ronchamp, The Chapel at Ronchamp. (Springer Science \& Business Media, 1997), 45.

${ }^{21}$ Danièle Pauly, Le Corbusier: La Chapelle de Ronchamp, The Chapel at Ronchamp. (Springer Science \& Business Media, 1997), 38.
} 
that were transformed into a poetical and artistic 'form' like sculpture: concrete free forms define the gargoyle (gun like projecting form, in an oblique angle), a 'receptacle' raising from the ground, and 'free forms' such as pyramids and a cylinder within the receptacle.

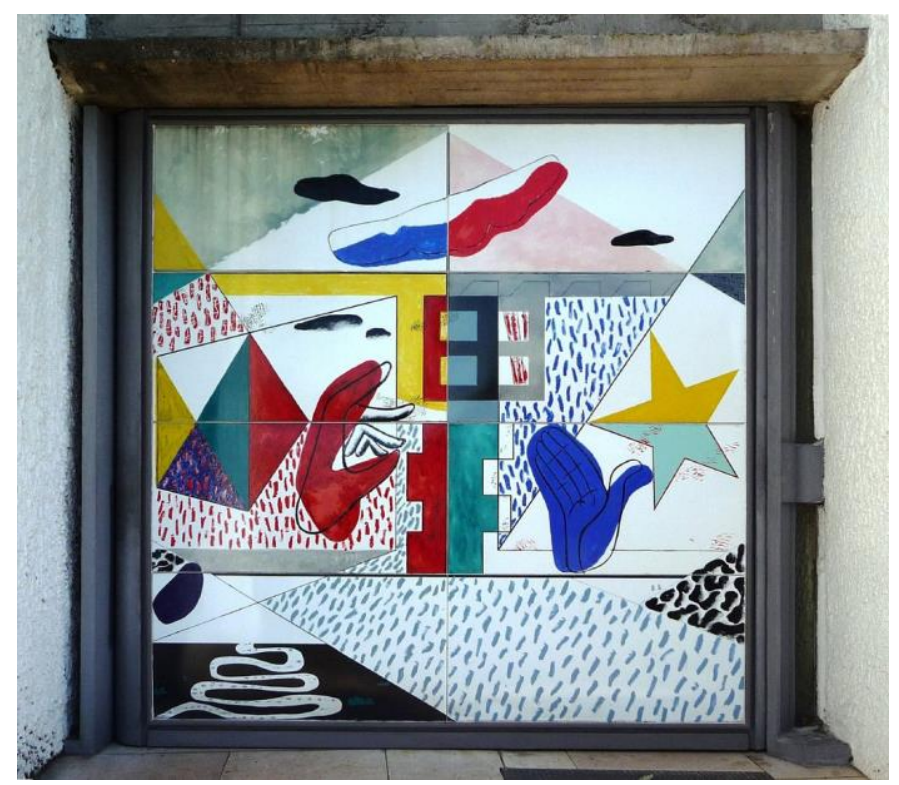

4. La Ronchamp's main entrance doors: Corbusier's painting; Source:

http://public-domain.pictures/view/image/id/3648223450\#!Ronchamp+door

\subsection{The Painted Doors: Symbols and Signs}

The approach route of the chapel is from the Southeast. The south entrance door (the main access to the chapel) is comprised of two revolving doors of two square sized panels (one facing the outside and one facing the inside) painted by Le Corbusier in his studio. The enamel paintings, much like Le Corbusier's work, are intuitive and expressive creations; they use primary colors and their derivatives, in a sort of free-form expression, and possess a visual vocabulary and language that seem to find its origin in nature (organic forms, landscapes, mountains, stars, clouds, and rivers) and in geometry (pyramids, lines, circles, shapes and triangles), echoing the conceptual and poetical references that originated La Ronchamp in the first place; this fact finds more evidence in the representation of the hands that clarify the meaning of the chapel itself: on the outside paintings two hands are represented, open one in welcoming and one offering, where as in the painting facing the inside space are represented hands in prayer and meditation ${ }^{22}$. They are a sort of archetype of Corbusier's poetical vocabulary and artistic values that are echoed throughout the chapel: a balance between geometry and intuition, free forms and order, poetry and symbolism, etc.

\footnotetext{
${ }^{22}$ Firstly identified and clarified by Pauly (1997). On these paintings, Pauly (1997) also claims: 'The enamel-painted signs on the two surfaces of the door are inextricably linked with the symbolic nature of the chapel. As with the forms of the building, these simple signs evoke a dialogue with the landscape." Danièle Pauly, Le Corbusier: La Chapelle de Ronchamp, The Chapel at Ronchamp. (Springer Science \& Business Media, 1997), 52.
} 


\subsection{The Interior Emotional Space}

The interior space is a rich and visually complex atmosphere. It can be accessed in two ways, each providing its own set of emotions: the main doors of the South or the smaller entrance of the north; according to Pauly (1997), the impressions received from both the entries and the emotions generated from both occasions are 'equally intense and sensationally rich'. Echoing these two types of entrances, the interior space is composed of two types of individual sensations, defined by two distinct types of spaces: the main central space of the chapel, corresponding to the south and east facades, and the north and west spaces, that are formed as nuclear systems, containing the individual and smaller chapels. The first, the general main space of the central chapel is perceived as open but yet confined; It is, like the outside form, a balance between reason and emotion: orthogonal lines define a kind of order (the cross and the mass of the altar), where as curved lines of the west wall and the weight of the curved roof define a more emotional kind of sensation; it creates a space for seclusion, introspection and meditation, through its somber, shadowy and mysterious atmosphere. This main space is organized around the stone center altar, located beneath the highest point of the building, placed (traditionally followed) on the East: a central focus and center of the architecture (various joining forces, lines and geometries), the spatial perception and the poetical and spiritual dimensions. Corbusier later described the importance of the altar for the monastery La Tourette, as a masking of a 'gravity' and an establishing of 'hierarchies' both psychological and physical ${ }^{23}$.

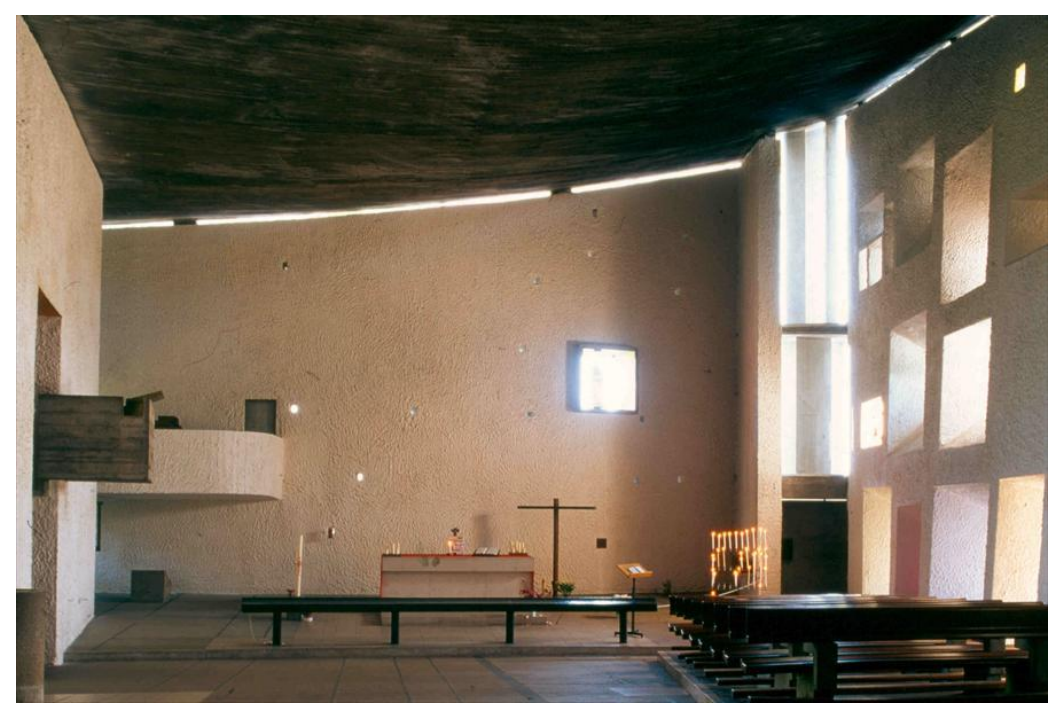

5. The main interior space; Photograph by: Paul Kozlowski; Source:

http://www.fondationlecorbusier.fr/corbuweb/morpheus.aspx?sysId=13\&IrisObjectId=5147\&sysLanguage=enen\&itemPos=13\&itemSort=en-en_sort_string1\%20\&itemCount=78\&sysParentName=\&sysParentId=64; Copywright: (C) ADAGP

The slope of the floor follows the natural slope of the hill, and slopes towards the alter; the floor is made of cement paving; the interior is modest and bare in character, with plain wooden pews down the south side. Above

\footnotetext{
${ }^{23}$ Reference to Corbsuier's words on the matter: "' The altar marks the center of gravity and engenders a value, a hierarchy of things. In music there is a key, a range, a chord; here it is the altar - the most sacred of places that creates this note, and whose role it is to trigger the radiance of the oeuvre. This is facilitated by proportions. Proportion is an ineffable thing. ' As cited by Danièle Pauly, Le Corbusier: La Chapelle de Ronchamp, The Chapel at Ronchamp. (Springer Science \& Business Media, 1997), 48.
} 
the central altar, the east wall is perforated by several pinhole like windows and by a window with the Madonna and Child in silhouette; this window's image also serves the outside altar used during pilgrimages.

The second type that is on the other side of this interior main space is a more darkened area, corresponding the North and West facades; just like it's exterior, it is emphasized by dramatic shadows and the absence of openings; it contains the individual chapels. One of three chapels in the interior is painted red.

Both types of spaces create a visually rich and emotionally and spiritually balanced space. According to Gans (1987) what is most striking, within the interior, is the emotion of stillness and emptiness. Pauly (1997) explains that this interior environment grew out of Corbusier's desire to create both a place for 'silence and meditation' and a place that 'symbolized the dramatics of prayer'.

\subsection{Sculpted Space and Free Forms: A Plastic Artistic Expression}

Corbusier's approach to space was to consider it as a mass, a whole entity and then removing specific parts to create the overall whole of the architecture; in other words, he considered La Ronchamp as a sculpture would. When Corbusier asserts "' (...) 'transfer lyricism to the materials, to flex and bend them to best serve the design',., 24 ; he views form as a sculptor, clarifies on this issue Pauly (1997). Pauly (1997) further explains that the plastic language developed by Ronchamp, is a synthesis of Corbusier's quest in the paintings of the twenties and the sculptures of the forties and fifties. This plasticity of form highlights the sensory aspects of the spatial elements in a kind of visual language that had been being developed by Corbusier. As such, he modeled the materials as a sculptor would, as an organic form, shaping them and carving them, to express the unique concept and the overall driving idea. The volumes of the chapel, as a result, seem to be carved out, as hollows; the overall form, thus, both considered like a sculpture and perceived as a living sculptural space. Besides this specific approach to a create a kind of 'sculpted space', the forms, just like in a sculpture, are conceived of as plastically free, each carved out to its own unique shape with its own poetical and artistic statement that resonates the overall whole. As a result, and as described by Pauly (1997), the shapes communicate amongst themselves and with the landscape ${ }^{25}$, thus, establishing a dialogue: the dynamics of the roof, the curvilinear forms of the volume, the free standing elements of volumes projected, the receding forms, the masses of the towers, etc.; all the elements communicate amongst themselves and echo the overall artistic vision conceived of as a 'sculpted space'. On this issue, Pauly (1997) also clarifies, Corbusier himself, described Ronchamp as an " acoustic sculpture" and aimed to create a "phenomenon of concordance" between the landscape and the space, through sculptural forms ${ }^{26}$. All the free forms, from the micro to the macro, create a poetical language that engages the user visually, emotionally, poetically, metaphorically and spiritually, acting as an artistic object.

\subsection{Secondary Elements}

The secondary elements, the furnishing and all the details are designed by Le Corbusier, and as such, are an extension of his artistic and architectural vision; these echo the values and the emotional qualities of the overall

\footnotetext{
${ }^{24}$ Danièle Pauly, Le Corbusier: La Chapelle de Ronchamp, The Chapel at Ronchamp. (Springer Science \& Business Media, 1997), 110.

${ }^{25}$ Reference to: "These shapes complement and communicate with each other in the same way as they "dialogue" with the surrounding landscape and the four horizons." Danièle Pauly, Le Corbusier: La Chapelle de Ronchamp, The Chapel at Ronchamp. (Springer Science \& Business Media, 1997), 44.

${ }^{26}$ Pauly (1997) further explains that the main inspiration for this was the Acropolis, where he saw the inextricable connection between architecture and landscape, and perceived architecture as a sculptural form.
} 
space and as such form an integral part of the whole design adding aesthetic value to the architectural space. These elements serve various functions, Pauly (1997) clarifies on this issue: they serve a functional purpose, they structure the space (such as ramps, benches, etc.) and inject a sense of equilibrium (altar, pulpit, etc.); they create rhythm of space and of mass and contribute to the 'hollow' like feel of the overall space. The volumes defined by the cubic pulpit in concrete, the stairs leading up to choir gallery, the orthogonal volume of the confessional are designed and perceived as solid spaces and elements; they are each designed with geometrical lines, and introduce the verticality and horizontality element in the space. In Pauly's words: " (...) these elements impart a sensation of stability and, as in a score in music, form dark graphic notes that stand out sharply against the white stippled surfaces." ${ }^{27}$. All these forms possess an inherent sense of plasticity and aesthetic value, and are an extention of the architect's visión contributing to the overall whole and meaning.

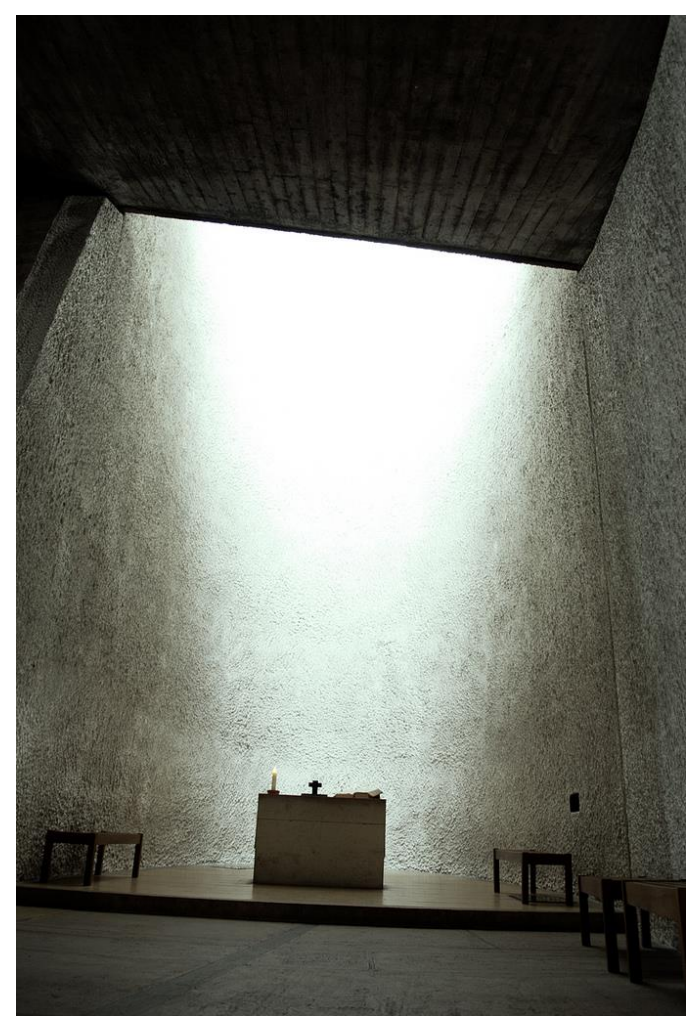

6. The light and the Darkness in one of the secondary chapel spaces; Photograph by: Luis Garcia Quinteiro; Source: http://public-domain.pictures/view/image/id/8080800853\#!\%23ronchamp

\subsection{Volumes and Light}

For Corbusier, it is light that immerses the space, grants it its unique atmosphere and transforms it into a poetical experience. In Ronchamp, light is contained and used controllably, in creating a deep mystical experience: an atmosphere of shadows and midst's highlighted by a poetical and metaphorical contained use of light. Pauly (1997) clarifies this same principle: ' 'Light in fact takes the lead, qualifying the space and lending a spiritual dimension to the edifice.",28. Light, is each space, is treated differently and uniquely: in the main

\footnotetext{
${ }^{27}$ Danièle Pauly, Le Corbusier: La Chapelle de Ronchamp, The Chapel at Ronchamp. (Springer Science \& Business Media, 1997), 50.

${ }^{28}$ Danièle Pauly, Le Corbusier: La Chapelle de Ronchamp, The Chapel at Ronchamp. (Springer Science \& Business Media, 1997), 113.
} 
central chapel it floods the space from above from a little opening left in the joining of the roof with he wall systems, it also frames the altar with little openings that resemble sparkles of stars and finds its way in the shadowy space through the colored and filtered small openings, where the tiny openings on the outside open up to large and deep poetic instances on the inside. Also of reference is the way by which light falls from the 'heavens' in the side chapels: it is captured, reflected and drawn down through the rough surfaces to fall straight into the plane of the alters; each of the towers is lit differently, according to the orientation of the tower and the different times of day. The interior space is flooded with darkness and that darkness is then flooded in specific areas by streaming light; as such, the space is enclosed and mystical, and it is revealed only through light. Each specific way light is conceived creates a mystical experience within those shades of 'darkness' that define the interior spaces. Light reveals from the darkness is not only a physical manifestation within the chapel but also a metaphorical, artistic, poetical and spiritual one. Light is indeed one the fundamental means of expression and of creation of the spatial and special poetical atmosphere defined in Ronchamp. It is this complex and unique treatment of space and light, shadows and darkness that creates an environment for meditation and contemplation.

\subsection{Colour}

The atmosphere of the chapel is white, both outside and inside, however colour finds its way inside the space in little details: such as the windows or the doors. According to Pauly (1997), ' ' (...) colour is present to accentuate the white stippled surfaces, against which the colour stands out sharply." ${ }^{29}$ This is part of Corbusier's theory and understanding, that in order to truly understand and perceive white, colour must be present in a polychrome way. The side windows in the main space and the painting that compose the doors use vibrant colors, mainly primary colors. In these 'little details of bold colour', (colored glass, enamel doors, etc.) colour vitalizes the atmosphere and adds poetical and artistic value; these small openings, the south façade, convert into the interior space as large and expressive ones; each containing a different type of glass, colour and motif (colored or painted glass, inscriptions of praise to the Holy Virgin and motifs inspired by nature such as birds, stars, sun, butterflies, etc.). The colour used in the windows (one for each window) echoes the colours used in the painting of the doors: blue, red, green, yellow and violet. Some of the windows that are left transparent allow for the viewing of the landscape outside. Colour is also applied in more intense ways: at the side chapel painted red and the violet adjacent wall; these spaces are not perceived by the main space but instead they need to be 'walked into' adding an element of surprise and mystery through colour; the dark violet, creates an effect where the wall 'dissolves in the shadows'; it is the colour of Lent, and refers to the notions of Sacrifice. Both ways of applying colour create an emphasis in the architecture and in the poetical and mystical experience of the space. Colour, as such, is an integral part of the architecture itself, rather than a decorative element; it characterizes, defines and accentuates specific points in the space adding another dimension to it: a poetical or mystical experience. The use of colour is not only functional and spatial but also symbolic, emotional and spiritual.

\footnotetext{
${ }^{29}$ Danièle Pauly, Le Corbusier: La Chapelle de Ronchamp, The Chapel at Ronchamp. (Springer Science \& Business Media, 1997), 118.
} 

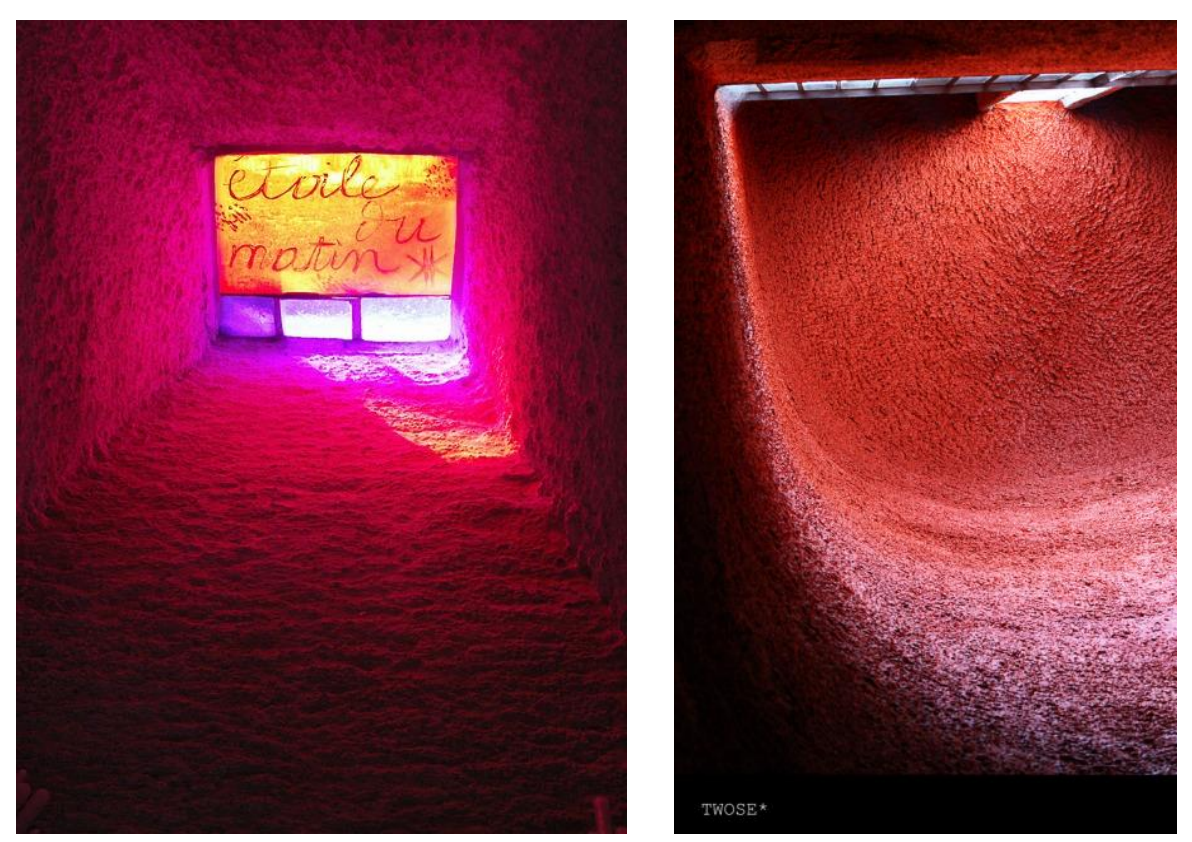

7. Detail of windows: colour, symbolism and poetry; Source: http://pixabay.com/en/notre-dame-you-skin-de-ronchamp372585/; 8. The ceiling of the red chapel; Source: http://public-domain.pictures/view/image/id/1250552392\#!red+light

\subsection{Sound and Touch}

The sound of Ronchamp was important to Corbusier in various levels and possesses a specific value within the poetics of the space. Firstly, as a metaphor, for Corbusier believed Ronchamp to be 'an architectural symphony'; on the Chapel being an 'acoustic' form, Muller (2004) also explains: " Le Corbusier considered the chapel a "land of acoustic sculpture," or an "acoustic plastic work," (...)., ${ }^{30}$ For Corbusier believed the 'acoustic forms' were the result of a true work of architecture or sculpture in the environment. Secondly, as Pauly (1997) and Gans (1987) explain, Corbusier believed there should be music coming from the chapel at specific times, coming from the bell tower; these were intended to play modern music by Edgar Varèse, " (...) so that Ronchamp would have $a$ " limitless voice coming from the most distant ages and reaching the most modern hours of today." 31, the sound was to propel the form beyond the space in which it found itself. Thirdly, the sound within the space functions as a kind of echo space, where silence abides, but every sound is magnified; and lastly, the sound of the water coming from the gargoyle on the outside, a surprise element that acts as a 'meditative' and contemplative element for the users wandering around the chapel.

As for the 'touch' element, although not referred by any of the writers, the tactility of the materials also has a central role in the experience of La Ronchamp; the materials and the textures vary creating a rich experience for the user: either rough and very tactile (the overall skin of the building) or very smooth and soft from the polished alters or the wood of the benches, create an enriching experience that engage all of the senses.

\footnotetext{
${ }^{30}$ Linda Muller, The symbiosis between art and architecture as evidenced in Le Corbusier's Ronchamp. (Vancouver, Canada: University of British Columbia, 2004), 79.

${ }^{31}$ Deborah Gans, Chapelle Notre-Dame-du-Haut 1954, in: The Le Corbusier Guide. (New York: Princeton University Press, 1987), 75 .
} 


\section{Properties and Principles of Ronchamp's Poetry}

In regards to Architecture itself, its qualities and properties, in one brief sentence Corbusier summarizes: "Architecture is a thing of art, a phenomenon of the emotions, lying outside questions of construction and beyond them. The purpose of construction is to make things hold together; of architecture to move us. ",32. From the above statement, as well as the analysis outlined previously, the following principles still deserve further attention: Emotional Values, Poetical Values, Principle of Intensity and the Principle of Harmony.
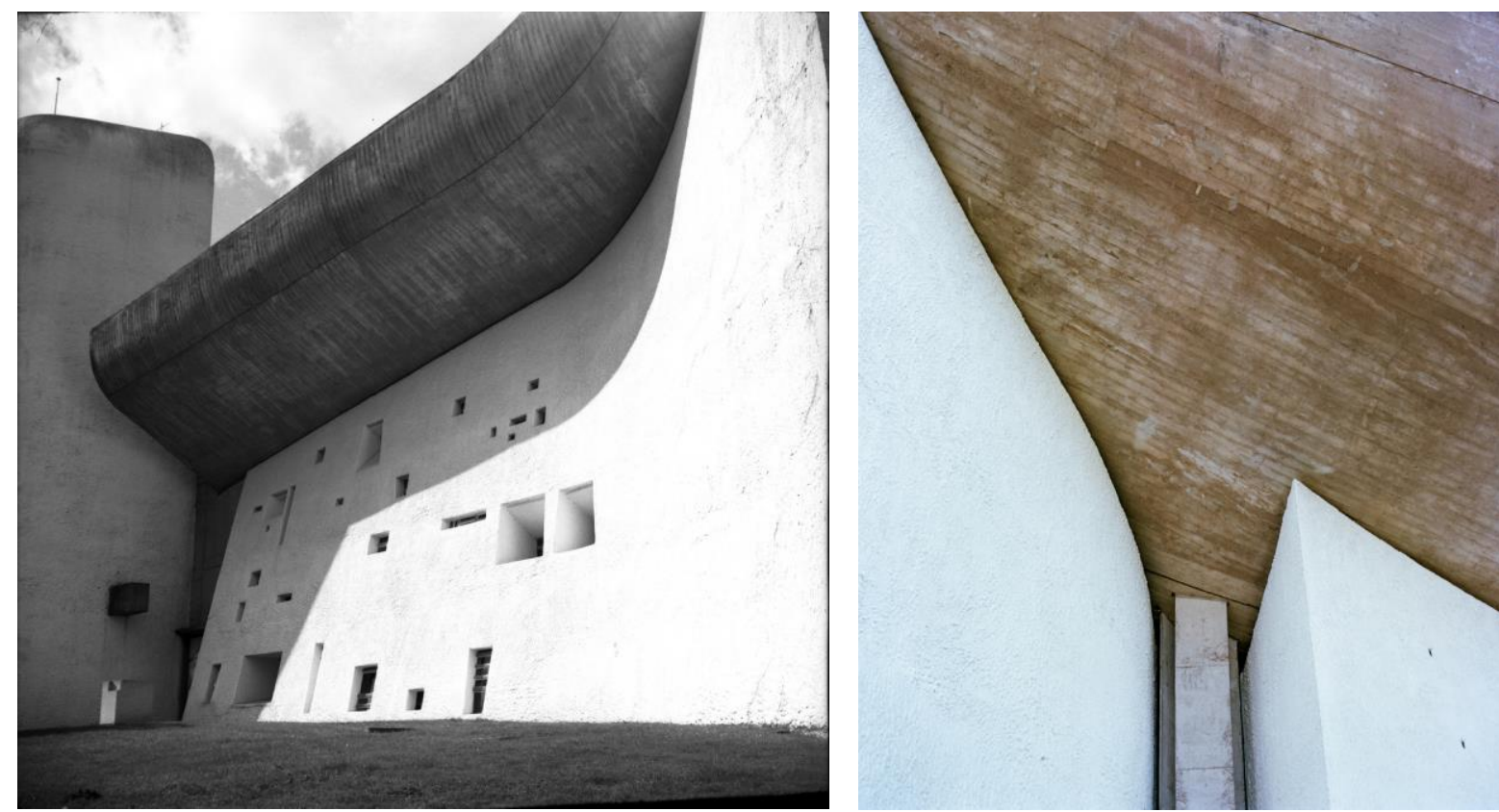

9. The Poetics of the overall Forms; Source: http://public-domain.pictures/v iew/image/id/7960727692\#!Ronchamp;

10. Detail of façade materials, forms and justaposition of contrasting elements; Source: http://public-

domain.pictures/view/image/id/10426275855\#!Chapelle+de+Ronchamp+-+Le+Corbusier

\subsection{The Property of Emotion: Emotional Values}

Corbusier was interested in provoking emotions, in creating sensations; he did so in a very unique and complex way in Ronchamp. Throughout the whole chapel there exists a multiple range of emotions that come forth: group gathering and the emotion of union (outside) contrasting with solitude and meditation in the interior; enclosed and protected element (viewed from the outside) yet disturbing, embracing and mystical experience (when on the inside); where as light, welcoming and intriguing emotions flood from the outside, within the inside, the viewer must sit in darkness and 'find' the light. Emotions range from stillness, solitude, happiness, contentment, contemplative, intrigued, unknown, discovery, mystery, mysticism, awe, and resignation. These complex emotions do not occur on one single instance, but occur as the 'promenade architecturale' unfolds: as the user travels through the space, each space echoes back its own range of emotions.

Besides this complex range of emotions, there is also another type of emotion that characterizes La Ronchamp: and that is the underlying aesthetic emotion that is echoed forth through the space as a union, as a whole, as an artistic unity its own accord. The aesthetic emotion is complex in nature, and therefore, should also be understood and perceived as a unity. Nothing else about it can be said or added. As such, it is also this

${ }^{32}$ Danièle Pauly, Le Corbusier: La Chapelle de Ronchamp, The Chapel at Ronchamp. (Springer Science \& Business Media, 1997), 128 
underlying aesthetic emotion that so well defines La Ronchamp. On this issue, Pauly (1997) claims, citing Le Corbusier: " After all, was this building not intended to be a machine à émouvoir? As Le Corbusier wrote: 'The Chapel? A vessel of silence, of sweetness. A wish: Yes! To achieve, through the language of architecture the feelings evoked here.",33.

\subsection{The Principle of Intensity (of Emotion and Poetry): Joining Opposites}

On the intensity of the poetic value at La Ronchamp, Pauly (1997) explains: " Although the poetic phenomenon, generator of emotion, is always present in Corbusier's work, it would seem to be most intense in this building. " 34 . Throughout Ronchamp, there is an inherent balance of opposites and a desire to represent both aspects of intensities throughout the whole design of the Chapel; in emotions (with emotions of expansion on the outside and contraction in the inside), in light (creating intense dark shadow areas inside contrasting only by small hints of controlled light), in forms (where the geometrical forms act as a kind of geometrical counterpart to the curved forms of the roof and the main structure), in colour (opposing the blaring whiteness of the chapel with elements of controlled color accents) and in (...). As such Corbusier doesn't exclusively represents one side of the polar contrast, but instead represents both sides, contrasting one against the other; like two sides of the same coin, each potentiates and amplifies the depth of emotions and the intensity of the poetical experience. This ideal of 'depth' and of 'intensity' through polar contrasts is found both at a micro scale and at a macro scale: from the very little detail to the overall from. An example of this is the East and the South façade concept that contrasts with the north and west facades, both types represent two opposing polarities: where as the East and South facades are open, inviting and respond to the human scale; the west and north facades are enclosed, concave, and dramatic in scale. Both poetically and emotionally, these opposing concepts amplify and intensify the experience of the space.

\subsection{The Principle of Harmony: Proportions and Wholeness}

The play of proportions is a crucial element that unites the whole of the space, both outside and inside, in the various scales of the building. The dimensions of all of the chapel as well as the secondary elements and details were calculated by the use of Modulor, thus, each element (including furniture) is in harmonic consonance with the proportions of the whole chapel. Le Corbusier himself claimed: "Harmony can only be attained by that which is infinitely precise, exact and consonant; by that which delights the depths of sensation without anybody's knowing; by that which sharpens the cutting edge of emotions." 35 . As such, in order to achieve this type of harmony, all elements must be in accordance in a mysterious and subdued hidden way.

For Corbusier, there was an inextricable link between the emotions a form conveyed and the proportions that guided its inherent existence; as such, the proportions that defined Ronchamp, aimed to create an innate sensation; on this issue, Muller (2004) claims: ' Ronchamp's design presumed that proportion would transport architecture beyond the physical form to a state of innate sensation: Le Corbusier compared proportion to a key

\footnotetext{
${ }^{33}$ Danièle Pauly, Le Corbusier: La Chapelle de Ronchamp, The Chapel at Ronchamp. (Springer Science \& Business Media, 1997), 45.

${ }^{34}$ Danièle Pauly, Le Corbusier: La Chapelle de Ronchamp, The Chapel at Ronchamp. (Springer Science \& Business Media, 1997), 127.

${ }^{35}$ As cited in Danièle Pauly, Le Corbusier: La Chapelle de Ronchamp, The Chapel at Ronchamp. (Springer Science \& Business Media, 1997), 52.
} 
that comprises the unifying force in architectural design. "36. As such, Muller (2004) continues, 'architectural sensations' are indeed the result of specific geometric forms. But harmony is also present in yet another way, one that depends on the harmonies of the proportions but also lives beyond it: it is the sense of harmony of poetry that allows for the spirit to be moved. On this issue, Corbusier claimed: ' Everything is harmony, relationships and presences. (...) There are presences: the eternal aspect of that which is permanent." ${ }^{37}$. It is this sense of harmony as a 'poetic' value and as 'presence' that also finds echo in Ronchamp.

\subsection{The Principle of Perception: Open fields of Meaning and the Phenomenological Experience}

Another principle emerges through the analysis of La Ronchamp, and that in the principle of the Perception. It is through perception that open fields of meaning can emerge.

Maria João Durão (2003) explains that the term perception derives from the latin 'perceptio' (meaning 'harvest' or 'correct knowledge') from 'percipio' (meaning 'understand', 'experiment/feel', and 'capture with intelligence') and from de 'capio' (that means 'capture' or 'apprehend'). She clarifies that the semantics of the word have their roots in touch and movement, thus, " (...) the senses need to be touched (by light, form, sound, odour or taste). "38. Perceptual processes, she clarifies, are no longer exclusively associated with the traditional way 'sensation-perception-cognition' but, by the contrary, they merge sensations with cognition. Also, the sense of perception is beyond the mere registration of an image in the brain, but rather involves a process of filtering where "' (...) the perceptions are inferred in ways that make sense to us. ",39. Lastly, perception, thus, is primarily associated with vision; but it also entails all the other senses.

Roger Scruton (1979) claims that "In all architectural experience the active participation of the observer is required for its completion." 40 . It is throught the observer's perception that the understanding of the space emerges. Thus, the experience of the architecture space is always multiple and open for interpretation. Scruton further explains, that the user perceives with a kind of 'imaginative ordering of experience', beyond 'literal significances' of common 'perceptions'. This 'imaginative experience', as he points out, is derived from all the senses that together contribute to the full experience of architecture.

Also of reference is the words of Pallasma (1996), where he explains that a memorable experience of art and architecture, is when 'space', matter and time, fuse into 'one single dimension', thus permeating, through our perceptions, our consciousness. In the process, he explains: 'We identify ourselves with this space, this place, this moment, and these dimensions become ingredients of our very own existence.", 41.

Another point worth clarifying, in the understanding and the importance of perception in the experience of the meaningful architectural space is Steven Holl's theory. According to Steven Holl, emotions and sensations are

\footnotetext{
${ }^{36}$ Linda Muller, The symbiosis between art and architecture as evidenced in Le Corbusier's Ronchamp. (Vancouver, Canada: University of British Columbia, 2004), 79.

${ }^{37}$ Le Corbusier and Ivan Zaknic, The Final Testament of Perè Corbu: a Translation and Interpretation of Mise au point by Ivan Zaknic. (New Haven and London: Yale University Press, 1997), 83.

${ }^{38}$ Maria João Durão, Funções Peceptuais para o Design de Espaço. (Lisbon: Caleidoscópio - Revista de Comunicação e Cultura, 6, pp. 155-167, 2006), 155.

${ }^{39}$ Maria João Durão, Funções Peceptuais para o Design de Espaço. (Lisbon: Caleidoscópio - Revista de Comunicação e Cultura, 6, pp. 155-167, 2006), 159.

${ }^{40}$ Roger Scruton, The Aesthetics of Architecture. Princeton, (New Jersey: Princeton University Press, 1979), 94

${ }^{41}$ Juhanni Pallasmaa, The embodied image: imagination and imagery in architecture. (Chichester: John Wiley \& Sons, 1997), 50.
} 
triggered by 'exhilarating perceptions', and these are evoked by complex use of materials, light, shadows, textures, colours, details, etc.

All the elements at La Ronchamp act in unison to our human perceptions. It is through their complex play of forms, textures, and all other elements, that the Chapel demands an 'active participation' and allows for an open interpretation to emerge. At La Ronchamp, all the senses act together, communicating to our perceptions in different, unique and deep ways. Through our perceptions, the space becomes a 'memorable and complete experience'.

\subsection{The Principle of Unity:}

Corbusier claimed: " "'Painting, architecture and sculpture are unique phenomena of plastic nature in the service of poetic research in that they are capable of releasing the poetic moment.", ", 42 . So too, with Ronchamp, through the union of the different arts, Corbusier aimed to create this poetic moment: so intense and so vibrant that it allowed for a flow of 'sacred' life to find a space to occur. Thus, there is an inherent union at multiple levels; firstly the union between the architecture elements: the union between the architectural piece and the landscape (nature), the union between the organic forms of Ronchamp at the environment it is set upon, the union between the various artistic fields, the union between the multiple scales of the desing (ranging from the overall design to the smallest detail of individual elements). Secondly, the union in the harmonies of the overall space; and lastly, the union between the distinct emotions, poetry and meaning that act conceptually, metaphorically and spiritually. Whithout this unifying principle of union, La Ronchamp woulnd't be La Ronchamp.

\section{The Principle of Art and Architecture: Symbiosis and Interdependence}

\subsection{The 'Total Work of Art'}

Corbusier has a unique vision in regards to the union of architecture and of art; he elevated architecture to its most noble aspirations, that of being an art (communicating to man's inner worlds), being a 'mother' of the other arts and housing them within architecture as a unique 'poetic and artistic' vision. In La Ronchamp, he found the freedom and the 'sacredness' he needed to create these ideas and make them manifest in a 'total work of art'.

On this issue, Pauly (1997) explains that the complete freedom given to Corbusier allowed him to explore and 'make manifest' an idea that he was exploring since the thirties and that he had made manifest in writings and conferences until the fifties: " (...) the notion of architecture as a forum which allows for a synthesis of various art forms. ${ }^{, 43}$.

As such, Pauly continues, a work of art may be integrated into a building in which it must enter into a 'genuine dialogue' with its architectural context; the many arts are incorporated into the major art, the architectural environment, which Le Corbusier defined as a 'collaboration of the arts'. In Ronchamp, he clarified and explored this purpose of uniting the arts within architecture and that of architecture being also an art, with a unique

\footnotetext{
${ }^{42}$ As cited by Danièle Pauly, Le Corbusier: La Chapelle de Ronchamp, The Chapel at Ronchamp. (Springer Science \& Business Media, 1997), 123.

${ }^{43}$ Danièle Pauly, Le Corbusier: La Chapelle de Ronchamp, The Chapel at Ronchamp. (Springer Science \& Business Media, 1997), 108.
} 
purpose in mind: " (...) to draw forth from a constructed work (architecture) presences engendering emotion, which are essential to the poetic phenomenon. ",44.

According to the author, volumes, light, colors and materials, turn Ronchamp into a total work of art (aspects analyzed in part 3 of the present research paper), but also, the inherent poetics of space and the ability to awaken emotion (aspects analyzed in part 4 of the present research paper). As such, La Ronchamp is a 'total work of art' for multiple reasons that co-exist in unisson: firstly because architecture is perceived and created as an art, created as a sculptural form following an artistic process, secondly because it incorporates within itself multiple art forms that contribute to the overall artistic vision, and lastly because as a work of art, it communicated poetics and provokes specific emotions in the viewer.

\subsection{The 'Relationship' between Architecture and Art}

Another aspect that still needs further clarification is the specific and unique relationship Corbusier developed between Architecture and Art, that found space through Ronchamp and grew from his notion of a 'synthesis between the arts'. This relationship was described by Muller (2004) in her thesis, where she sustains that the connections between architecture and art extend beyond the mere synthesis between the arts, into a degree of symbiosis - an issue of the utmost validaty and pertinence. In regards to the function of art in Le Corbusier's La Ronchamp, Muller (2004) explains that although critics have diverse opinions, they agree that the chapel 'represents a synthesis of art and architecture' on various levels. However, what is of the essence, continues Muller, is that the 'art is an integral part of the architecture' ", (...) and that the piece functions as a consequence of the interdependence of the art and architecture, rather than the art functioning as a constituent of the whole. ,45.

The difference between a synthesis and a symbiosis, explains Muller (2004), as is evident in Ronchamp, is that the art is not merely a 'decorative' element, nor is there an effort in joining art with architecture; instead, it is Ronchamp as a whole, as a union of all the arts it comprehends that allows for an achievement of its Architectural and Artistic character; each element supports the architecture in creating a unique and meditative space and transforming the mere space in a 'presence'. Muller's synthesises, "In the achievement of symbiosis, Le Corbusier contributes to XX century design syntax the appreciation that architecture is a function of emotion. This distinguishes symbiosis from the concept of synthesis, wherein the art is a constituent of the architecture, but not primary to it." ${ }^{46}$. With Ronchamp, Muller (2004) continues, not only is it Le Corbusier's premiere integrative work of art, but also " (...) the art is integral to the architecture to the extent that the architecture is art and the architecture could not respond to the demands of the form without the art. " 47 . This interconnectivity and connection functions at multiple levels: conceptually, symbolically, metaphorically, and in meaning, supporting the overall whole.

\footnotetext{
${ }^{44}$ Danièle Pauly, Le Corbusier: La Chapelle de Ronchamp, The Chapel at Ronchamp. (Springer Science \& Business Media, 1997), 109.

${ }^{45}$ Linda Muller, The symbiosis between art and architecture as evidenced in Le Corbusier's Ronchamp. (Vancouver, Canada: University of British Columbia, 2004), 26.

${ }^{46}$ Linda Muller, The symbiosis between art and architecture as evidenced in Le Corbusier's Ronchamp. (Vancouver, Canada: University of British Columbia, 2004), 89.

${ }^{47}$ Linda Muller, The symbiosis between art and architecture as evidenced in Le Corbusier's Ronchamp. (Vancouver, Canada: University of British Columbia, 2004), 63.
} 


\section{Results/Conclusions}

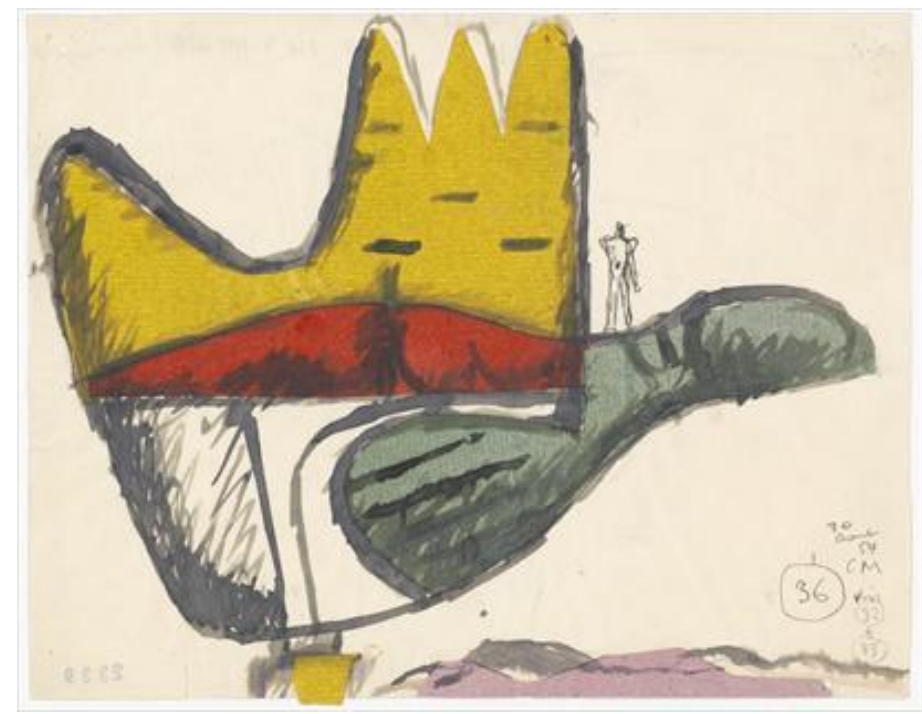

11. Le Corbusier's drawing, "La Main Ouverte", 1954, Watercolour and paper mounted on paper, Dimensions : H : 0,21 m x $\mathrm{L}: 0,27 \mathrm{~m}$; Source:

http://www.fondationlecorbusier.fr/corbuweb/morpheus.aspx?sysId=13\&IrisObjectId=7068\&sysLanguage=enen\&itemPos=1\&itemSort=en-en_sort_string1\%20\&itemCount=107\&sysParentName=\&sysParentId=71; Copywright:

FLC/ADAGP

Corbusier claimed: "Nothing is transmissible but thought. (...) Thought alone, the fruit of labor is transmissible. Days pass, in the stream of days, in the course of a life...." ${ }^{48}$. So too, the work aimed to clarify Corbusier's vision and thought, through the analysis of La Ronchamp, arriving at the point that originated the work in the first place: the unique approach of the 'union of the arts'.

As a first conclusion, it is of reference to clarify the unique way in which the art and architecture are interdependent, functioning in a mutually subordinate relationship. As previsouly seen, not only as a synthesis but as a symbiosis, that establishes Ronchamp as a unique architectural element and summarizes Corbusier's ideals in regards to the union of the arts, it's interdependence and its symbiosis in content, form and meaning. At La Ronchamp, it is created and established new paradigms and ideas about the symbiosis of art and architecture: where not only do they act to support each other, but, in a specific space they enhance each other's meaning and work collaboratively and sustainably towards one 'whole'.

As a second conclusion, in regards to architecture, La Ronchamp emerged through the present research work, as a perfect example that summarizes Le Corbusier's views on what architecture should really be (clarified in point 1.1.). The principles that underly La Ronchamp (the principle of harmony throught form and colour, the principle of the intensity of light and contrast, and others referred above) work together as a whole, creating an architectural masterpiece that embodies it's creator's ideal: a work that transcends mere construction and communicates to the human capacities through emotion, awakening in throught its experience deeper connections. Architecture, in this sense, as it was shown, has little regard to the aspects of function, considering

\footnotetext{
${ }^{48}$ Le Corbusier and Ivan Zaknic, The Final Testament of Perè Corbu: a Translation and Interpretation of Mise au point by Ivan Zaknic. (New Haven and London: Yale University Press, 1997), 83.
} 
them only on a first level or approach. Instead, once function is established, it takes a into consideration all of the other aspects that sustain it as a art, (as analysed in points 4.and 5.).

As a third note, it is important to emphasize the poetics of the space and the principle of poetry. Poetry, as an aspect of vital importance for Le Corbusier, emerges through the combination of multiple elements. It was found, that poetry doesn't result from one single instance, one concept or one overall form, but instead results as a combination of all aspects of the chapel: cooperating as a whole, driven by harmony and intensity, to promote a poetical experience sustained by vision and emotion.

On a fourth note, the richness and meaning of La Ronchamp also exists in its open interpretation (as all works of art) and different possibilities of apprehension and perception. It is through our perceptions that the work becomes alive in content, form and meaning, gaining multiple levels of sensitivity and understanding, as each detail as well as the whole, permits multiple significations to emerge.

As a fifth conclusion, it was understood that through La Ronchamp's architectural emotions, Le Corbusier creates a space that is in tune both with the self and with the universal laws. In Corbusier's words: "' Architectural emotion: that's when the work resounds inside us in tune with the universe whose laws we are subject to, recognize, and admire. " 49 . These laws have become clear throughout the research, but, what has become even clearer is that it is through them, in a space like La Ronchamp, that the self grows and finds its place within the self and within the world.

Lastly, the research concludes, as a summary, that not only is Ronchamp's uniqueness and meaning sustained by a series of properties and architectural elements that create a rich and complex environment, but also (and mainly), by an interaction and cooperation between all fields of artistic and architectural expression that work together in creating one single vision: Corbusier's vision for a space that belonged to the landscape, a union between metaphorical opposing principles such as light and darkness, a place for worship and contemplation that unified people, and lastly, a space that is and acts, as an Art in its most noble sense (communicating through multiple artistic expressions). This vision, within this space thus allows for multiple emotions, meanings and significances to emerge and resonate in the consciousness and in the spirit of man.

\section{Images Sources and References}

Image 1: Panorama of Ronchamp; Source: https://commons.wikimedia.org/wiki/File:Panorama_RonchampChampagney.JPG

Image 2: La Ronchamp Chapel; Source: http://pixabay.com/en/notre-dame-you-skin-de-ronchamp-372579/;

Image 3: Detail of the East Facade elements from the North side; Source: http://pixabay.com/en/notre-dame-youskin-de-ronchamp-372581/

Image 4: La Ronchamp's main entrance doors: Corbusier's painting; Source: http://publicdomain.pictures/view/image/id/3648223450\#!Ronchamp+door

Image 5: The main interior space; Photograph by: Paul Kozlowski; Source:

http://www.fondationlecorbusier.fr/corbuweb/morpheus.aspx?sysId=13\&IrisObjectId=5147\&sysLanguage=enen\&itemPos=13\&itemSort=en-en_sort_string1\%20\&itemCount=78\&sysParentName=\&sysParentId=64; Copywright: (C) ADAGP

Image 6: The light and the Darkness in one of the secondary chapel spaces; Photograph by: Luis Garcia Quinteiro; Source: http://public-domain.pictures/view/image/id/8080800853\#!\%23ronchamp

\footnotetext{
${ }^{49}$ Le Corbusier and Jean-Louis Cohen, Toward an Architecture. (Los Angeles: Getty Publications, 2007), 97
} 
Image 7: Detail of windows: colour, symbolism and poetry; Source: http://pixabay.com/en/notre-dame-youskin-de-ronchamp-372585/;

Image 8: The ceiling of the red chapel; Source: http://public-

domain.pictures/view/image/id/1250552392\#!red+light

Image 9: The Poetics of the overall Forms; Source: http://public-

domain.pictures/view/image/id/7960727692\#!Ronchamp

Image 10: Detail of façade materials, forms and justaposition of contrasting elements; Source: http://publicdomain.pictures/view/image/id/10426275855\#!Chapelle+de+Ronchamp+-+Le+Corbusier

Image 11: Le Corbusier's drawing, "La Main Ouverte", 1954, Watercolour and paper mounted on paper, Dimensions : H : 0,21 m x L : 0,27 m ; Source:

http://www.fondationlecorbusier.fr/corbuweb/morpheus.aspx?sysId=13\&IrisObjectId=7068\&sysLanguage=enen\&itemPos=1\&itemSort=en-en_sort_string 1\%20\&itemCount=107\&sysParentName=\&sysParentId=71;

Copywright: (c) FLC/ADAGP

Some images belong to the public domain, and therefore, are not protected by specific copyright and can be freely used for publications. Other images, Images 5 and 11, belong to the Corbusier Foundation and thus have been authorized for the present publiscation.

\section{Bibliography/references}

Benevolo, L., 1977. History of Modern Architecture. MIT Press.

Cohen, J.-L., 2004. Le Corbusier, 1887-1965: The Lyricism of Architecture in the Machine Age. Taschen.

Corbusier, L., 1999. Le Corbusier Talks with Students. Princeton Architectural Press.

Corbusier, L., 2000. The Modulor: A Harmonious Measure to the Human Scale, Universally Applicable to Architecture and Mechanics. Springer Science \& Business Media.

Corbusier, L., Žaknić, I., 1997. The Final Testament of Perè Corbu: a Translation and Interpretation of Mise au point by Ivan Zaknic., First. ed. Yale University Press, New Haven and London.

Corbusier, L., Cohen, J.-L., 2007. Toward an Architecture. Getty Publications.

Durão, M. J. (2006) Funções Peceptuais para o Design de Espaço. Caleidoscópio - Revista de Comunicação e Cultura, 6, $\quad$ pp. $155-167 \quad$. $\quad$ [online]. $\quad$ Available http://revistas.ulusofona.pt/index.php/caleidoscopio/article/view/2291 (Accessed 10 October 2013).

Gans, D., 1987. Chapelle Notre-Dame-du-Haut 1954, in: The Le Corbusier Guide. Princeton Architectural Press, New York.

Holl, S. et al. (1994) Questions of perception: phenomenology of architecture. a+ u Publishing Company.

Muller, L., 2004. The symbiosis between art and architecture as evidenced in Le Corbusier's Ronchamp. University of British Columbia, Vancouver, Canada.

Scruton, R. (1979) The Aesthetics of Architecture. Princeton, New Jersey: Princeton University Press.

Padovan, R., 2002. Towards Universality: Le Corbusier, Mies, and De Stijl. Psychology Press.

Pallasmaa, J. (2011) The embodied image: imagination and imagery in architecture. Chichester: John Wiley \& Sons.

Pauly, D., 1997. Le Corbusier: La Chapelle de Ronchamp, The Chapel at Ronchamp, 1st edition. ed. Springer Science \& Business Media. 


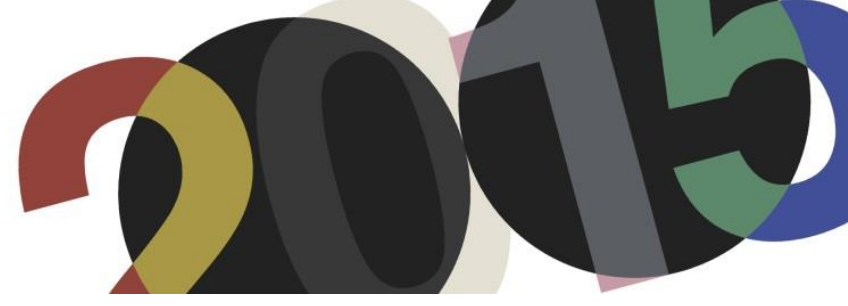

DOI: http://dx.doi.org/10.4995/LC2015.2015.862

\title{
Summer houses in Portugal: the legacy of the Exitenzminimum and the work of Le Corbusier
}

\section{T. Freitas}

Faculdade de Arquitectura da Universidade do Porto

\begin{abstract}
The program of the summer house will mark the acceptance period of modern architecture in Portugal. The modern life is put into practice by a group of architects to an enlightened bourgeoisie clientele, in some summer resorts that will start to be developed in the Portuguese coastline.

The Existenzminimum, will be a German expression used throughout the twentieth century, particularly after the First World War, where the concerns of social nature and housing, for a large number of people will be important issues to be discussed by architects. Petit cabanon was Le Corbusier's summer house in Roquebrune-Cap-Martin. This small pavilion experienced new possibilities of living in minimum area, similar to the theories of the existenzminimum studied by Modern architects in the post-first world war period. New ways to dwell in minimum space are then reinterpreted in the early experiences of holiday houses in Portugal where a simple way of living started to be tested.
\end{abstract}

Resumen: El programa de la casa de verano se cumplirá el plazo de aceptación de la arquitectura moderna en Portugal. La vida moderna se pone en práctica por un grupo de arquitectos a una clientela de burguesía, en algunos centros turísticos de verano que comenzarán a desarrollar en la costa portuguesa.

El Existenzminimum, será una expresión alemana utilizado a lo largo del siglo XX, sobre todo después de la Primera Guerra Mundial, donde las preocupaciones de carácter social y vivienda, para un gran número de personas serán temas importantes a tratar por los arquitectos. Petit Cabanon fue la casa de verano de Le Corbusier en Roquebrune-Cap-Martin. Este pequeño pabellón experimentó nuevas posibilidades de vivir en área mínima, similar a las teorías de la Existenzminimum estudiados por arquitectos modernos en el periodo posterior a la primera guerra mundial. Nuevas formas de habitar el espacio mínimo son entonces reinterpretadas en las primeras experiencias de casas de vacaciones en Portugal, donde una forma moderna de habitar comenzó a ser testada.

Keywords: Petit cabanon; Le Corbusier; Holiday houses; Existenzminimum; Arquitecture; Modern.

Palabras clave: Petit cabanon; Le Corbusier; Casas de Verano; Existenzminimum; Arquitectura; Moderno.

\section{Introduction}

The modern summer house in Portugal will start to be developed in large scale between the decade of 1940 and 1960. This new program will give opportunity to a range of architects to test a new typology in direct relationship with the nature. Existenzminimum, will be the German expression for minimum housing, which began to be used regularly in the post First World War. A "minimum to a maximum" of people was the object. According to Ana Tostões ${ }^{1}$; this concern was felt in postwar Europe, with the aim of responding to the urgent need to create urban spaces from a consequence of centripetal social transformations, which shifted non-urban population in masses to the cities. That's how the architecture of this period becomes a concern of social consciousness. Architects such as Le Corbusier, Bruno Taut, Ernst May will make a research in the way of living

\footnotetext{
${ }^{1}$ Tostões, Ana, A idade maior. Cultura e tecnologia na arquitectura moderna potuguesa, FAUP ed., Porto,2015 [2003], P.302.
} 
in minimum space. Ten years later, in 1930, Le Corbusier will have the opportunity to work in projects for holiday houses around the world. In these houses, Le Corbusier investigates modern architecture, relating it with local materials and techniques. Maison Errazuriz, Maison Mandrot, Maison aux Mathes, Maison de Week-End and Maison Murondins are examples of this approach, " The vernacular materials are not an obstacle for a modern aestetique "2. In the decade of 1950, at Roquebrune-Cap-Martin, Le Corbusier experiments the standardization of space according to the modulor, in the cabanon he builds for Yvone the idyllic primitive hut. In Portugal these new attempts in modern architecture will have a large influence in the construction of the modern summer house. These small holiday pavilions will question the way man can live in modern housing. The primitive hut, the ideal getaway, and the "heterotopia" these houses build in pine forests along the sea create idyllic places in communion with nature where a group of elite bourgeoisie settles. It is here that the bourgeoisie created a core of families who meet year after year in the summer, and witnessed a new way to live, above all, more modern.

\section{Developing}

\subsection{The summer house in Portugal}

The summer residence will appear in Portugal at the end of the nineteenth century. Derived from the Roman villae, they became Palladian buildings in the Renaissance and later chalets. According to Rui Ramos, " This house appears as a synthesis between the farm house, the leisure house, or vacation of the upper classes, initially designated as cottage orné, characterized by the use of rustic materials and asymmetrical compositions" $^{3}$, these chalets give regard to a picturesque countryside and vocabulary in the Romantic period, abandoning the symmetries and looking for an organic relationship with the plot and the landscape.

In Portugal, Sintra becomes the ideal place for these new cottages where the romantic and eclectic taste will be dominant. Cascais or the Granja, and later the Estoril will be the seaside resorts of Portugal between 1865 and the 1930s. Conversely, from the decades 1930/1940, the search for a new architectural model of holiday house derived from the chalet begins. In the Rodizio, architects born in the 1910s where Keil do Amaral stands as a prominent figure, will begin testing new models of the holiday house.

From the late 1950s, and according to Ana Tostões ${ }^{4}$, a widespread acceptance of modern architecture by an elite bourgeoisie begins; one which will eventually be on the forefront of the development of new resorts in Portugal.

Here is where the new model of holiday houses will appear. According to Susana Lobo, these houses will be models "The former appearance, of the new, in several summer resorts along the coast, where the detached

\footnotetext{
2 "la rusticité des materiaux n`est aucunement une entrave à la manifestation d'un plan clair et d’une esthétique modern"translated by author from the french edition ; Le Corbusier; Jeanneret, Pierre, "Maison de M. Errazuriz, Au Chili, 1930", in Boesiger, W (dir.) Le Corbusier oeuvre complète, volume2, Les Editions d`Architecture (Artemis), Zúrich, 1964, P.48.

3 "Esta casa surge como síntese entre a casa agrícola e a casa de recreio ou de férias das classes altas, inicialmente designada como cottage orné, caracterizada pelo uso de materiais rústicos e composição assimétrica", translated by author from the portuguese edition; Ramos, Rui, A casa, Arquitectura e Projecto doméstico na primeira metade do século XX Português, FAUP publicações, Porto, 2010, P.78.

${ }^{4}$ Tostões, Ana, "Casas de Férias modernas, anos 50 e estilo contemporâneo- A utopia de uma doce vida", in Jornal de Arquitectos, $N^{o}$ 196, Ordem dos Arquitectos, Lisboa.2000, P. 45-53.
} 
holiday house is presented as a true laboratory project, on domestic architecture"5 for a new model of modern living.

According to Rui Ramos ${ }^{6}$, the urbanization along the beaches from Ofir in the North to Rodízio in the South, reveals this new way of modern living. These resorts appear as places capable of providing the contact with nature, the despoliation of a number of domestic routines, which are now abandoned in favor of a more uncompromising and "modern" lifestyle. These holiday houses represent a new leisure time outside the main residence, the weekend and holiday in the countryside or at the beach.

The summer house attempts to be like a small pavilion, expirimenting the theories of Existenzminimum where the furniture is designed as an integral part of the architecture, the doors lose their formal value and become curtains, beds and bunk beds can be stacked and the living room becomes the central space of the house. The rooms are like sleeping alcoves, ressembling us ship or train cabins. The connection between the exterior and the interior becomes almost direct, made by large window panels adding to the continuity of the pavements in patios and terraces.

Examples of these formal researches around the holiday house in Portugal, are testimony in houses that are built from north to south of the country.

\subsection{Existenzminimum in the post-world war}

With Germany destroyed by World War I, the theme Existenzminimum, will gain more prominence, both in new housing construction as in the study of new ways of living. At the second meeting of CIAM, in Frankfurt in 1929, the concept of Existenzminimum, presents itself as a Claim. " During the congress participants struggled to formulate a program that reconciled the demands of physical creation of living space, from the material resources of the economy and optimal use of space; of tolerable social cohesion, from the family unit and public hygiene in living mass" 7 . That's how the architecture of this period becomes a concern of social consciousness.

According to Sara Lia Brysch ${ }^{8}$ architects such as Le Corbusier, Walter Gropius, Bruno Taut and Ernst May will research programs around new models of minimal standardized housing. These new neighborhoods gain the name of Sidlungen. Topics such as women's emancipation or inserting these in the labor market will encourage discussion of other debates that lead to optimization of housing space and consequently the kitchen itself. These investigations and debates give rise, at Frankfurt in 1926, to the "Frankfurt Kitchen" created by Margarete Schutte Lihotzky, which becomes the first modern kitchen. These and other problems of this period lead to an

\footnotetext{
5 "O aparecimento ex. nuovo de diversos núcleos de veraneio junto à costa, onde a casa unifamiliar de férias se apresenta como verdadeiro laboratório de experimentação projectual sobre a arquitectura doméstica" translated by author from the portuguese edition; Lobo, Susana, Arquitectura e Turismo: Planos e Projectos, as cenografias do lazer na costa Portuguesa, da $1^{a}$ República à Democracia, volume II, PhD thesis, DAFCTUC, Coimbra, 2012, P.777.

${ }^{6}$ Ramos, Rui Jorge García, A casa: arquitectura e projecto doméstico na primeira metade do século XX português, FAUP publicações, Porto, 2010.

7 "Durante o congresso os participantes procuraram formular um programa que conciliasse as exigências de criação física de espaço habitacional, a partir da economia de recursos materiais e do aproveitamento optimizado do espaço; da coesão social tolerável, a partir da unidade familiar e da higiene pública no convívio de massas" translated by author from the portuguese edition; Brysch, Sara Lia, Existenzminimum, a questão da habitação Mínima entre o Moderno e o Contemporáneo, master thesis, FAUP, Porto, 2011, P.1.

${ }^{8}$ Brysch, Sara Lia, Existenzminimum, a questão da habitação Mínima entre o Moderno e o Contemporâneo, master thesis, FAUP, Porto, 2011.
} 
optimization of the living space of the house, the creation of the family-type and consequently the construction of the model house.

At Weissenhof sidlungen, in Stuttgart, at the year of 1927, architects such as Gropius, Le Corbusier, Scharoun and others, directed by Mies Van der Rohe, create the exemplary residential scheme for the modern urban resident. In his town houses, Le Corbusier experiments the new concepts of what he thinks should be the modern house: the conquest of sun, air and space are his aims. "The view, the plants, the sun : are a conquest of the modern age" " Le Corbusier builds one single family house and two town houses. In the town houses, the rooms are organized in a common space along with the social area and the kitchen; there is an optimization of the storage space and the beds are stacked in cupboards. The area is optimized in one big multi-functional room. The terrace is used as a panoramic garden over the city. The ground floor is organized in different storage and maid rooms. The concepts of Existenzminimum, are put in practice with an exterior purist language.

\subsection{Le Corbusier Houses of the decade of 1930}

At a certain time, there was a crescent need to balance the industrialization and the modern way of life, as well as a growing interest in building modern housing adapted to society and integrated into the local culture.

The study of culture and popular traditions will be the basis for creating a new architecture which is sensitive to the human needs.

In the work of Le Corbusier there are two initial moments: a first moment based in a purist language, revealed in his first works, predominately in the single-family houses built between 1920 and 1930; and a second moment in which the architect will be sensitive to local realities, as well as the physical characteristics of the plot, developed in the construction of small houses built in natural surroundings, after 1930.

In small holiday houses of the decade of 1930, Le Corbusier makes a big relationship with the vernacular architecture. Maison Errazuriz, Maison Mandrot, Maison aux Mathes, Maison de Week-End and Maison Murondins will be a perfect example of this acquaintance, which will be of great importance in the 1940/50 in Portugal.

\subsubsection{Maison Errazuriz, 1930, Chile.}

This house, which was never built, was to be located in a plot with a descending topography towards the shore of the Pacific Ocean. Traditional materials were to be used, not as a claim but as mere result of the impossibility for the use of industrial materials and of specialized construction labor at the site. The house was composed of two interlocking volumes. The interior makes use of pillars and beams in wood and thick granite walls, contrasting with the modern roof that was inverted (butterfly roof), but covered in traditional clay tiles. The ramp which gives access to the main bedroom is built in apparent stone, making evident the concept of "promenade architectural" in a craftwork approach.

\footnotetext{
9 "La vue, des plantes, le soleil : c'est une conquiste architecturale des temps modernes" translated by the author from the french edition ; Corbusier, Le, "Weissenhof à Stuttgart 1927", in Boesiger, W (dir.), Le Corbusier oeuvre complète, volume 1, Les Editions d`Architecture (Artemis), Zurich, 1964, P.152.
} 


\subsubsection{Maison Mandrot, 1930-1, Pradet, France.}

This vacation house is designed for Madame Mandrot, the first CIAM hostess. The house is designed in a remote location in Provence, Pradet, near Toulon. The house, which is organized in an L shape, is built by local entrepreneurs making use of a contrast between modern and traditional construction techniques. Concrete slabs and apparent local stone walls are put in contrast. The plot locates itself in a headland overlooking the landscape, to take part of this panoramic view the house organizes itself around an exterior patio created between house and guest's room. The relationship between nature and tradition is established by the house and the landscape, in its contemplation and the use of its local materials.

\subsubsection{Maison aux Mathes, 1935, France.}

This house located in a small pine forest in front of the Atlantic Ocean, is built on a restricted budget. Le Corbusier, unable to travel to the site, sent a local entrepreneur to supervise the building plans. The house was built in phases with the use of a well-established program and making use of pre-fab construction methods. Organized in a rectangular plan, all the rooms establish direct access to an open balcony. The organization is very similar in the upper and ground floor. The façade towards the ocean is frankly open, organized as a common balcony/corridor. The window panels protected of the sun by this transition space are divided in a metric structure that designs windows and doors constructed in wood, glass and pre-fab cement. This structure is painted in the primary colors of blue and red. The rear façade protects itself from the sun. Small square windows in the ground floor and a large longitudinal opening at the upper floor. The house is built in the dunes, preserving intact all natural elements of the plot "The house is built in the sand of the pine forest, without the creation of no artificial garden" ${ }^{\prime 10}$.

\subsubsection{Maison de Week-end, 1935, France.}

This vacation house is designed for a client who wanted to build a house camouflaged in the natural vegetation of the plot. Corbusier projected a small house built in stone walls combined with a concrete roof made in vaults covered by grass. This project introduces the mixture of different materials and their combination, wooden interiors in plywood, glass brick and clay brick walls and roofing in concrete. Being a small house, it is nonetheless very different in the spaces it creates. In the exterior, the garden is punctuated by different trees, combined with a small pavilion "kiosk" that is subtracted from the main volume of the house, creating a courtyard between the two. The interior space is organized in a big common room, with living, dining and kitchen functions. The bedroom is the only private division of the house. The green coverage camouflages the house in the garden, making the chimney and the lantern the only visible elements. "The petit maison de weekend, invokes the need to combine the principles of modern architecture with local materials and techniques, as well as it proposes to demystify the concept: a material, a use"11.

\footnotetext{
10 "La maison est plantée dans le sable de la forêt; kl n'y aucum jardin artificiel" translated by the author from thefrench edition ; Corbusier, Le, "Maison aux Mathes", in Bill. Max (dir), Le Corbusier oeuvre complète, volume 3, Les Editions d`Architecture (Artemis), Zurich, 1964, P.135.

11 "A petit Maison de week-end invoca por um lado a necessidade de conjugar os princípios da arquitectura moderna com materiais e técnicas locais, e por outro lado propõe a desmistificação do conceito : um material, um uso" translated by author from the portuguese edition; Rocha, Ana Patricia dos Santos, Casa das Marinhas, Arquitectura moderna e tradição portuguesa na obra de Viana de Lima, master thesis, FAUP, Porto, 2009, P.70.
} 


\subsection{The Cabanon}

The Cabanon was constructed in 1952, as a summer retreat for Le Corbusier. His idea was to build a modest summer house, nevertheless it was a great example of architecture "but concentrating on the interior and what he produced was in fact an example of the cultured art of living, of prime architectural merit" $"$ "

The house was built in 1952. Corbusier and his wife Yvone, maintained a solid friendship with Thomas Rebutato, who was owner of a small restaurant in Roquebrune Cap-Martin. Rebutato had retired himself and bought a plot at Cap Martin where he built a bar-restaurant, Etoile de Mer. Thomas Rebutato made an exchange with Corbusier, giving him permission to use a part of his plot and build a small pavilion, the Cabanon. On the other hand, with the aim of valorizing his property, he commissioned Corbusier on the design of five touristic rooms known as Unité de camping, at the other side of the plot built in 1957.

The Cabanon, apparently a banal program, was an essential work in Corbusier`s career as an architect, participating in the contemporary architectural debate. A small house, done as an object that will demonstrate a very particular way of modern living, a model to be repeated.

The Cabanon, projected as an extension of the restaurant, follows its alignments of height and occupies a very small area (no more than 15 square meters). The license for its construction is obtained as an extension of the restaurant "chambre de villegiature", having the cabanon a doorway passage between the two. The plot is very narrow, and has an excellent view towards the bay of Monaco and Cap Martin. Being confronted with these natural restraints, Corbusier has no other solution as of building a small pavilion with the essential means for living in. The interior, is divided in two areas, access (made by a corridor of 70x366m) and a main living area. The living area is divided in sleeping (two individual beds) eating/lounge (organized with a table and two stalls) and bath (organized with a lavatory and an individual toilet). The plan libre, one of the main conceptual points of the cabanon, organizes the entire house by the use of fixed furniture.

The Modulor works as a human figure that designs and dimensions the furniture, an essential part of the organization of the house, which is produced with a level of detail near to arts and crafts.

The hut is camouflaged in the Mediterranean vegetation, covered with rafts of wood, reminding us of the primitive cabin hut. The interior in contrast to the rough exterior, is all lined in plywood and different colored panels. The shutters that enclose all the house show the level of detail that was put in the entire project. They are designed as movable paintings, being mirrors and paintings at the same time "In short, they bring the outdoors in and vice versa, with a play of interior contemplation by which the outside becomes the inside and these are projected out, while the two aspects blend together more and more and make the expansion of the virtual space more effective"13.

This small pavilion represents and condenses the importance of the minimum space for modern living that was being debated from 1929 (CIAM congress) onwards. Corbusier summarizes this debate in his small Cabanon in the decade of 1950, defining the minimum space for two living people and combining it with a plastic and spiritual approach.

\footnotetext{
${ }^{12}$ Alison, Filippo, Le Corbusier, L'Interno del cabanon, Le Corbusier 1952 Cassina 2006, Trienal and Electa, Milano, 2006, P.20.

${ }^{13}$ Alison, Filippo, Le Corbusier, L'Interno del cabanon, Le Corbusier 1952 Cassina 2006, Trienal and Electa, Milano, 2006, P.24.
} 


\subsection{Holiday houses in Portugal between 1940 and 1974}

In an attempt to establish a parallel between the Existenzminimum, the work of Le Corbusier in the decade of 1930, the Cabanon and holiday houses in Portugal of the 1950s, I made an investigation in a number of case studies in Portugal where the principles were the same. I will present two in some detail in this paper.

\subsubsection{Ribeiro da Silva house - Ofir, Fernando Távora, 1957.}

Ribeiro da Silva House in Ofir is one of the most important holiday houses built in Portugal in the decade of 1950. In this house, architect Fernando Távora will establish a dialogue between the Modern Movement and the Portuguese vernacular architecture. Távora makes a reinterpretation of Le Corbusier in this house, visible in some of its main characteristics.

Ofir as a summer resort has its origin in the village of Fão, a fishing village located in the North of Portugal. Ofir will start to be developed in 1945. Its initial development is done around the main street (Avenida António Veiga) that establishes relation between the village of Fão and the sea. Later, the main Pine forest is divided in big plots where detached houses were built.

According to Tiago Bragança Borges ${ }^{14}$, Ofir is constructed from the initiative undertaken by the Sociedade de Engenheiros Reunidos of Oporto headed by Raul de Sousa Martins, which aims to create in Ofir, a touristic resort for the northern elite. "Similar to Rodizio, Ofir has also taken a leading role with respect to the beginning of the proliferation of holiday houses in Portugal"15.

At Ofir, the architect Alfredo Angelo de Magalhães will be the leading architect, in the construction of the first touristic facilities such as the Hotel and Restaurant Ofir, which will launch the summer resort within the bourgeoisie of Oporto. This architect will be the responsible for the first houses built between 1945 and 1947.

The Ribeiro da Silva house is projected in 1955 and the execution takes two years. It is located in a big plot in the main pine forest of Ofir, towards the North of the resort. In this project, Távora feels the need to create a new integrated architecture. For this he will make use of the plot and its natural features, using the topography, the winds, the solar orientation and the best views towards the nearby river.

In order to establish a contrast between modern and vernacular architecture, Távora uses traditional materials and construction techniques, such as pitched roofs covered with clay tiles, wooden joinery in the windows and the roof trusses, natural stone pavements in the floors and granite stone walls painted in white.

On the other hand he uses modern concepts and building techniques, concrete used in the construction of the roof slabs and the chimney, the design of the openings, the organization of the house in different functional zones and the standardized distribution of the sleeping areas.

The different areas of the house are organized in three zones. Social, private and services, these expand towards garden patios, establishing an open relationship between interior and exterior. The living room opens itself towards a natural dune where a water fountain is located. The services with kitchen, maid bedroom, storage and service bathroom open to a rear patio. The sleeping area, with five bedrooms and bathrooms is organized in a

\footnotetext{
${ }^{14}$ Borges, Tiago Bragança, Ofir do Arquitecto Alfredo Ângelo de Magalhães, master thesis, IST-UTL, Lisboa, 2012.

15 "À semelhança do Rodízio, Ofir vem também assumir um papel de destaque no que concerne ao início da proliferação das casas de férias em Portugal" translated by author from the portuguese edition; Dantas, Joana Croft de Moura Drummond, $A$ casa de férias como habitação Mínima em Portugal, master thesis, IST-UTL, Lisboa, 2011, P.111.
} 
standardized way, resembling to the Existenzminum theories. The beds are put against the wall in a longitudinal way, with individual storage cupboards.

Le Corbusier stands closely in the work of Távora, and is easily seen in the architectural signs that are present in the house at Ofir. The cupboard/shelve in concrete in the eating area, is directly related with the storage/shelve in the week-end house near Paris. The openings of the bathrooms façade, designed as an abstract drawing are closely related with Ronchamp or the rear faced of Maison aux Mathes. The main concept of using stone walls in contrast with concrete slabs, can be related to Le Corbusier`s approach at Maison Mandrot. The thick granite walls painted in white at Ofir and in Maison de week-end show direct similarities that can be seen in the images presented. Using modern architecture concepts with traditional materials and techniques are introduced by Távora in Ofir, resembling us of Corbusier experiences in the 1930.
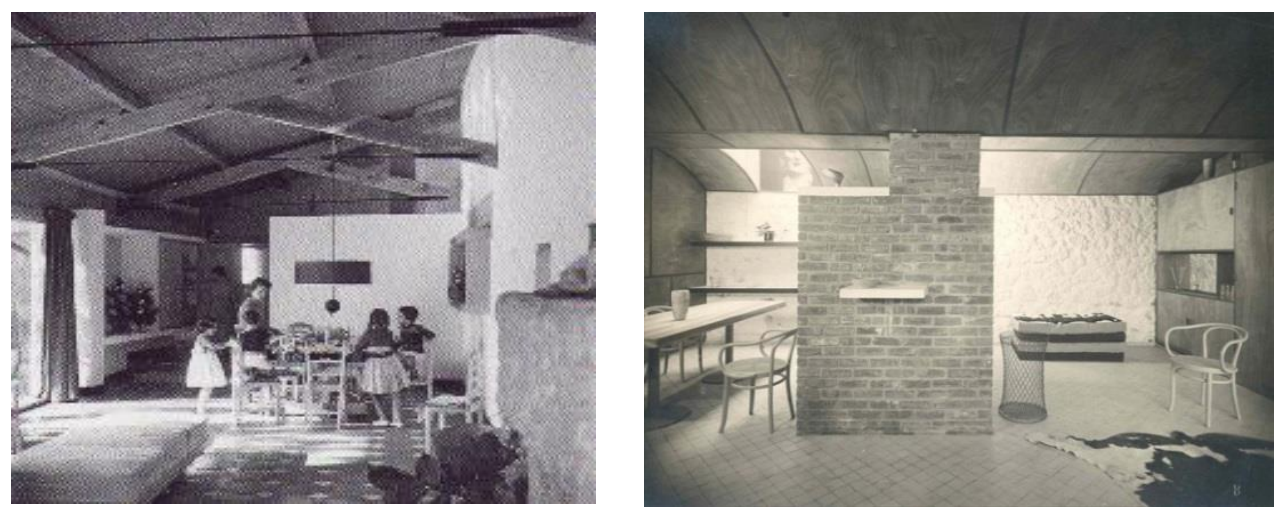

1. Ribeiro da Silva House, Ofir.

2. Maison de week end, Paris.

Fernando Távora will establish in this house a "third way", working as a milestone in the transition of modern architecture in Portugal. It makes a relation between modern and vernacular, questioning the absolute principles of the modern movement and giving them a cultural and local value. Worldwide this issue was being tested by architects of 1950/60, such as Coderch in Spain or Aalto in Finland.

\subsubsection{Pereira da Costa houses - Moledo do Minho, Carlos Carvalho Dias, 1963.}

Moledo Minho was already a holiday resort for the elite since the beginning of the century. The summer chalets of the elite families were located on Avenida de Santana above the railway. According to João Cerqueira ${ }^{16}$ in the 1940s, Moledo has an urban growth result of the urbanization plan created in 1941 by David Moreira da Silva, which amends the general plan of improvements from 1929, designed by Carlos Ramos. According to the author, the plan divides the Camarido pine forest, in plots that are never less than a thousand square meters. By the 1950, there were no buildings on this new core, only warehouses for fishermen and small rental holiday houses. Between the decade of 1950 and 1970, detached holiday houses start to be built in these plots.

The Pereira da Costa houses are built in Moledo do Minho in 1963, by architect Carlos Carvalho Dias and are a result of his CODA project (final course project). The project is a set of evolutionary minimum houses for the pinewood of Camarido. The initial project, was conceived as small settlement of houses, but only two were built.

\footnotetext{
${ }^{16}$ Cerqueira, João Francisco Delgado, A casa de férias do concelho de Caminha: entre a revisão vernacular da Modernidade e a livre expressão de estilos contemporâneos, master thesis, FLUP, Porto, 2003.
} 
The pine forest, its topography and its vegetation are maintained in an attempt to approach the existing natural settings. As in Maison aux Mathes the pine forest and the dune is maintained in all its original aspects. The two buildings are quite far apart and approach two different streets, establishing individualized access.

The South house is organized in a rather functional way and easily understood from the exterior. Two clearly distinct, day and night areas. The daytime area includes kitchen, common living room and toilet, the night area organizes three small rooms and a toilet. From the outside these two areas with pitched roofs appear as very evidently connected by a connection corridor with a flat roof.

The organization of the South house, is clearly modern, the architect establishes the separation between functional zones in the same house, the rooms are like small cells where the openings appear in small dimensions, resembling us of the cabins vessels, the Cabanon, and the theories of the Existenzmnimum.The living space is situated between two patios, one in the East that is the main access to the house and the other to the West in open communion with the pine forest, extending itself in a lounge patio paved in granite.

The North house is designed in a more compact way. It organizes its different areas in a more common approach, but uses the natural topography of the plot to divide the areas in sleeping and living, making use of stairs to adapt to the natural topography.

The exterior architectural design of these two houses, still show some similarities between the modern and the rustic cabin. These contrasts are evident in the use of granite walls in apparent contrast with white plastered walls. Wooden shutters painted red enclosing small windows designed as abstract paintings resembling us the small windows of Maison aux Mathes in contrast with large glass panels of the living rooms using iron frames with a geometric design.
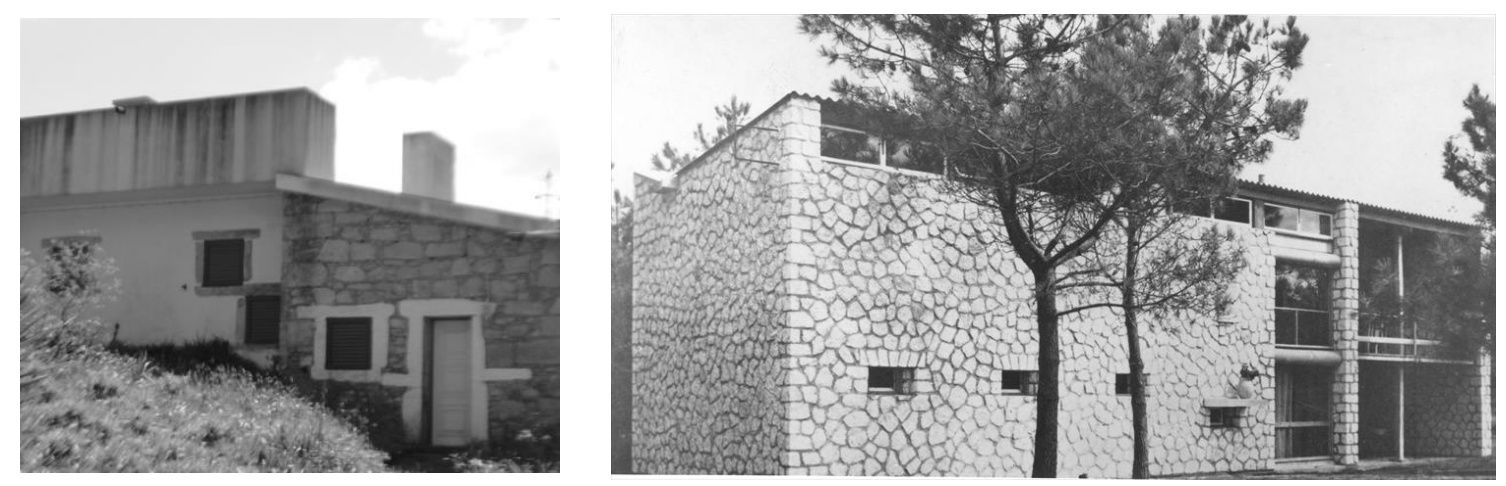

3. Pereira da Costa Houses, (North house), Moledo do Minho

4. Maison aux Mathes, Les Mathes.

The pitched roofs, initially covered in fiber cement in undulated panels are later replaced by clay tiles, establishing a clear contrast with the flat roofs of the connection corridors.

This is a transitional work, where the modern comes into contact with a reinterpretation of vernacular architecture, similar to Le Corbusier`s approach in his summer houses of the 1930s. In the way Távora establishes this connection in Ofir in the decade of 1950, other Portuguese architects started to test these possibilities of transition, questioning the modern movement principles and integrating architecture with a cultural and local approach. 


\section{Conclusions}

Summer houses in Portugal between 1940 and 1974 are assumed as a research laboratory in the production of modern architecture, testing the transition stage between modern and vernacular and creating new models to live a house.

The architects, largely influenced by the work of Le Corbusier, produced modern architecture with local materials and techniques in contrast to the use of modern materials such as concrete. Modern functional distributions and standardized areas, directly relate with the experiences of the Existenzminumum, organize the houses, with large living rooms directly related with the exterior and small sleeping alcoves adapted to the dimensions of the man.

The program of the summer house will imprint a period of acceptance of modern architecture in Portugal, made possible by the acceptance of an uncompromising modern way of life, where the domestic space of the house is transformed.

\section{Acknowledgements}

The author acknowledges the courtesy for the images submitted with permission by LA Fondation Le Corbusier, and BLAU Publisher, and for the books available at the library of Faculdade de Arquitectura da Universidade do Porto.

\section{Source of Images}

Image 1. Sousa, Rui Morais de, Fernando Távora, Blau, Lisboa, 1993.

Image 2. Fondation Le Corbusier/ADAGP

Image 3. Freitas, Tiago, Moledo do Minho, 2015.

Image 4. Fondation Le Corbusier/ADAGP

\section{Bibliography/references}

Alison, Filippo, Le Corbusier, L'Interno del cabanon: Le Corbusier 1952 Cassina 2006, Trienal and Electa, Milano, 2006.

Borges, Tiago Bragança, Ofir do Arquitecto Alfredo Ângelo de Magalhães, master thesis, IST-UTL, Lisboa, 2012.

Brysch, Sara Lia, Existenzminimum, A questão da habitação Mínima entre o Moderno e o Contemporâneo, master thesis, FAUP, Porto, 2011.

Cerqueira, João Francisco Delgado, Casa de férias do concelho de Caminha: entre a revisão vernacular da Modernidade e a livre expressão de estilos contemporâneos, master thesis, FLUP, Porto, 2003.

Boesiger, W; Bill, Max (Dir.) Le Corbusier oeuvre complète, Les Editions d`Architecture (Artemis), Zurich, 1964.

Dantas, Joana Croft de Moura Drummond, A casa de férias como habitação Mínima em Portugal, master thesis, IST-UTL, Lisboa, 2011.

Lobo, Susana, Arquitectura e Turismo: Planos e Projectos, as cenografias do lazer na costa Portuguesa, da $1^{a}$ República à Democracia, volume II, PhD thesis, DAFCTUC, Coimbra, 2012.

Ramos, Rui, A casa, Arquitectura e Projecto doméstico na primeira metade do século XX Português, FAUP publicações, Porto, 2010. 
Rocha, Ana Patrícia dos Santos, Casa das Marinhas, Arquitectura moderna e tradição portuguesa na obra de Viana de Lima, master thesis, FAUP, Porto, 2009.

Tostões, Ana, A idade maior. Cultura e tecnologia na arquitectura moderna potuguesa, Faup ed. , Porto,2015 [2003], pp.302.

Tostões, Ana, "Casas de Férias modernas, anos 50 e estilo contemporâneo- A utopia de uma doce vida", in Jornal de Arquitectos, $N^{o}$ 196, Ordem dos Arquitectos, Lisboa.2000, pp. 45-53. 


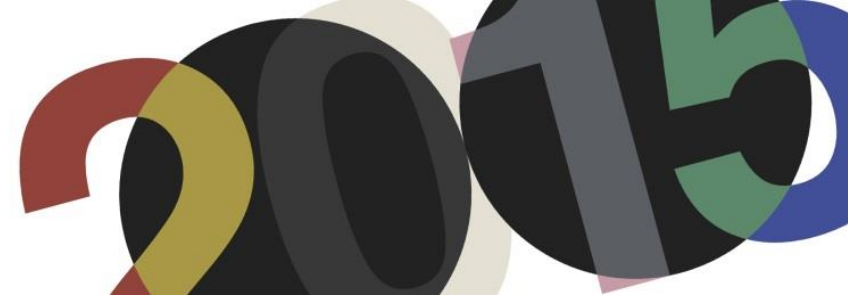

DOI: http://dx.doi.org/10.4995/LC2015.2015.910

\title{
La Villa Sarabhai. La riqueza de lo ambiguo
}

\author{
A. García González, V. Mas Llorens, J. Santatecla Fayos \\ Escuela Superior de Arquitectura de Valencia
}

\begin{abstract}
Resumen: La Villa Sarabhai ha sido considerada en gran parte de las referencias críticas como un paradigma de la "architecture femelle" por absorber el emplazamiento y por sus espacios abovedados, llegando a ser asociada con la arquitectura rústica, folklórica, incluso primitiva. Sin embargo, la evolución del proyecto muestra que no existe ninguna voluntad por parte de Le Corbusier de integrar la villa en su entorno ni de rendir tributo a la arquitectura tradicional. Le Corbusier continúa evolucionando dando un nuevo giro a estrategias arquitectónicas ya consolidadas y resistiéndose a las clasificaciones: genera una planta libre mediante muros; transforma la terraza jardín de una habitación sin techo en una pradera; y en lugar de laminar el espacio en vertical lo lamina en horizontal. No obstante, el objetivo de su arquitectura se mantiene firme desde los años 20, generar una sensación continua de desconcierto. En la Villa Sarabhai el visitante no es capaz de afirmar si se encuentra en un edificio anclado al terreno o que se posa sobre él, en una construcción arquitrabada o abovedada, arriba o abajo, dentro o fuera, ni siquiera si lo que percibe es real o una representación de la realidad. Así, la ambigüedad se convierte en el medio para alcanzar la riqueza arquitectónica.
\end{abstract}

Abstract: Villa Sarabhai is considered by many critics to be a paradigm of "architecture femelle", because it absorbs the setting and has vaulted spaces, which are elements associated with a rustic, folkloric, and even primitive, architecture. However, the evolution of the project shows that Le Corbusier did not intend to integrate the villa into the landscape or pay tribute to traditional architecture. Le Corbusier kept evolving. He added new twists to his consolidated architectonic strategies and defied classification: he generated a free plan by using walls; he transformed the garden terrace from a room without a ceiling into a prairie; and, instead of laminating the space in vertical, he laminated it in horizontal. Nevertheless, the aim of his architecture remained constant since the 1920s, generating a permanent feeling of bewilderment. Inside Villa Sarabhai, visitors are not able to confirm if they are in a building which is anchored to the ground, or in one which is resting on it; in an orthogonal construction or in a vaulted one; up or down; inside or outside; not even sure whether what they perceive is real or a representation of reality. The ambiguity becomes the means for reaching the architectonic richness.

Palabras clave: Le Corbusier; Villa Sarabhai; Ahmedabad; Architecture femelle; Bóveda; Ambigüedad. Keywords: Le Corbusier; Villa Sarabhai; Ahmedabad; Architecture femelle; Vault; Ambiguity.

\section{Un paradigma en la arquitectura de Le Corbusier.}

La importancia atribuida por Le Corbusier a la Villa Sarabhai queda patente en el número de páginas que le dedica en la Euvre Complète 1952-1957, muy superior al de sus coetáneas Villa Shodhan y Maisons Jaoul. Sin embargo, mientras estas últimas despertaron el interés de la crítica incluso antes de su finalización, la Villa Sarabhai fue ignorada hasta finales de los años 60, cuando Von Moos se refiere brevemente a ella en su monografía sobre Le Corbusier, dentro de un capítulo titulado La cubierta ondulada ${ }^{1}$. Von Moos sostiene que la Villa Sarabhai es la culminación de una de las dos corrientes antitéticas que recorren la obra del arquitecto, la architecture femelle, que comienza con las casas Monol (1919), por oposición a la architecture mâle, iniciada con las casas Citrohan (1922) y finalizada en la Villa Shodhan (1951). Compara estas casas con grutas cuyas formas rupestres introducen un vocabulario folklórico que recuerda a la arquitectura antigua de las islas griegas.

\footnotetext{
${ }^{1}$ Von Moos, Stanislaus: Le Corbusier. Barcelona: Editorial Lumen, 1977.pp. 160-165.
} 
La idea de dos genealogías en la obra de Le Corbusier había sido establecida en 1965 por Serenyi en su artículo Le Corbusier's Changing Attitude Toward Form ${ }^{2}$, aunque éste no menciona la Villa Sarabhai, considerando el último ejemplar de esta línea de investigación a las Villas Jaoul (1951). Serenyi sostiene que el tipo Citrohan se caracteriza por ser angular y dominar el emplazamiento, mientras que el tipo Monol es ondulante y absorbe el emplazamiento. Desde entonces hasta la actualidad otros autores entre los que destacan Curtis ${ }^{3}$ o Jencks ${ }^{4}$ han insistido en la existencia de dos tradiciones en la arquitectura doméstica de Le Corbusier y en la adscripción de la Villa Sarabhai a la architecture femelle, que relacionan con un tipo de implantación, un tipo de cubierta y un tipo de construcción que constituye una vuelta a lo primitivo. Sin embargo, la exclusión de la Villa Sarabhai como ejemplo final de la genealogía Monol por parte de Serenyi, resulta sorprendente dada la repercusión de su escrito. Ésta queda explicada en un artículo posterior Timeless but of its Time: Le Corbusier`s Architecture in

India ${ }^{5}$. En él se hace referencia al exterior angular de la villa, obviado en otras críticas, afirmando que la villa es la yuxtaposición de los dos tipos, el masculino y el femenino, aunque reconoce que el interior constituye la raison d'être de la casa. El comentario de Serenyi plantea ciertas dudas sobre la aptitud de la Villa Sarabhai como integrante de la architecture femelle. Además, la mayor parte de las escasas referencias entorno a la villa se centran en su versión construida y constituyen líneas anecdóticas dentro de textos que tratan aspectos más amplios de la obra de Le Corbusier. Así pues, se detecta un vacío crítico relativo al análisis de la evolución de la obra que demuestre la hipótesis establecida. Esta investigación no tiene como objetivo realizar una descripción, siguiendo una línea temporal, de los documentos del proyecto que se conservan en la Fondation Le Corbusier, trabajo realizado exhaustivamente por Suarez ${ }^{6}$. Sino un análisis a lo largo del tiempo de aquellos pasos importantes, relativos tanto a la implantación, como a la forma y espacio generados por el diseño de la cubierta y el sistema constructivo, que permita arrojar luz sobre la idoneidad de la Villa Sarabhai como paradigma de la architecture femelle.

\section{El desarrollo de una idea.}

La Villa Sarabhai debía construirse en el interior de una finca de exuberante naturaleza llamada The Retreat, situada en una zona de Ahmedabad conocida como Shahibagh, al Norte del corazón de la ciudad y próxima a la rivera Este del río Sabarmati. El terreno era propiedad del suegro de Manorama Sarabhai, Seth Ambalal Sarabhai ${ }^{7}$, quien había construido una gran casa colonial para su familia. Con el paso de los años el patriarca había ido favoreciendo la emancipación de sus hijos cediéndole a cada uno de ellos una parte de la finca en la que construirse su propia vivienda. Cuando Manorama Sarabhai enviudó no se hizo excepción y le fue ofrecido un terreno en el que vivir con sus dos hijos, Suhrid y Anand, de diez y trece años respectivamente.

\footnotetext{
${ }^{2}$ Serenyi, Peter: "Le Corbusier`s Changing Attitude Toward Form". En Journal of the Society of Architectural Historians. Marzo 1965, vol XXIV, №2. pp. 15-19.

${ }^{3}$ Curtis, William: Le Corbusier. Ideas and Forms. London: Phaidon Press Limited, 2003. pp. 210-212.

${ }^{4}$ Jencks, Charles: Le Corbusier and the Continual Revolution in Acrchitecture. New York: The Monacelly Press, Inc. and Charles Jencks, 2000. pp. 307-308.

${ }^{5}$ Serenyi, Peter: "Timeless but of its Time: Le Corbusier`s Architecture in India". En Brooks, H.Allen: Le Corbusier. New Jersey: Princeton University Press, 1987. pp. 172-175.

${ }^{6}$ Suárez, Maria Candela: "Villa de Mrs Manorama Sarabhai". En Le Corbusier plans. CD10. París: Echelle-1 - Fondation Le Corbusier, 2005-2010.

${ }^{7}$ Seth Ambalal Sarabhai, era uno de los hombres más influyentes de la ciudad. Había consolidado la gran empresa algodonera de su familia, además de haber sido presidente de la Asociación de Hilanderos y miembro del equipo municipal de Ahmedabad.
} 


\subsection{Dos casas en una. La dualidad Nave-Ala.}

El 26 de noviembre de 1951 el encargo ya había sido formalizado a través de una nota ${ }^{8}$ en la que se detallaban las necesidades funcionales de la villa. El programa debía estar fraccionado en dos edificios, uno ocupado por la villa principal y el otro reservado al servicio. El edificio principal debía estar dividido a su vez en dos zonas, una destinada a la Sra Sarabhai y su hijo menor y la otra dedicada exclusivamente al primogénito. La primera debía constar de: un garaje abierto y cubierto para un solo coche, un salón con un comedor separable, una bibliotecaestudio para la Sra Sarabhai, un baño completo, una cocina independiente con una gran despensa con reservas para seis meses, una pequeña habitación para el servicio, un dormitorio con baño para la Sra Sarabhai y otro para su hijo menor, ambos con terrazas al aire libre y verandas ${ }^{9}$ con camas para dormir al exterior. La segunda debía incluir un dormitorio con baño y un estudio con cocina o kitchenette. Finalmente, la nota hace referencia a la construcción de una piscina que debía estar en contacto con la casa. Junto a las especificaciones de carácter funcional, se incluyen una serie de condicionantes relacionados con la implantación. En primer lugar, el terreno estaba 4 pies por debajo del nivel del agua y la rivera del río Sabarmati podía desbordarse con los monzones, en consecuencia resultaba necesario elevar la casa. En segundo lugar, la casa debía orientarse para captar los vientos frescos del Sud-Oeste y evitar los vientos fríos del Norte en invierno. El escrito añade además, que la ley no permitía construir a menos de 15 pies del linde de la propiedad.

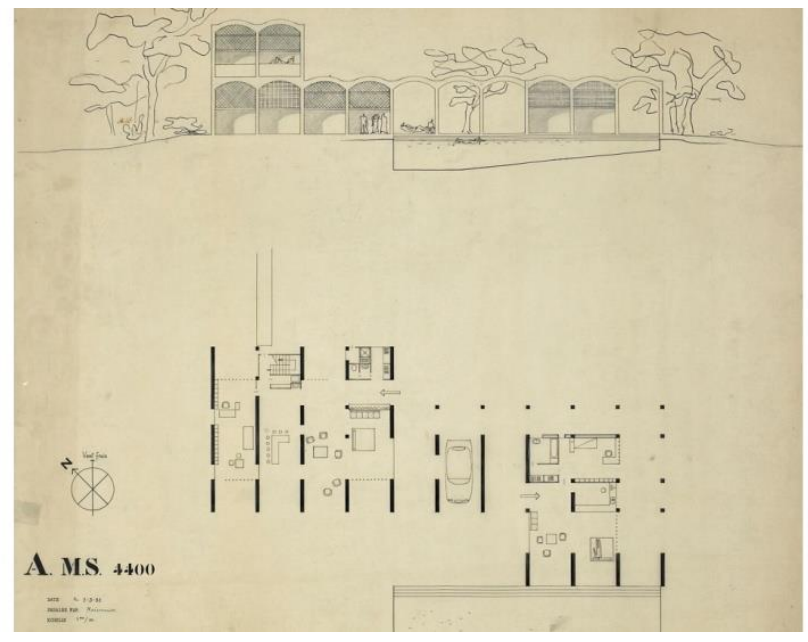

1. Planta baja y alzado Sud-Oeste de la primera entrega de la Villa Sarabhai. Marzo 1952, FLC 6675.

Los primeros documentos fechados que se conservan de la Villa Sarabhai datan del 7 de marzo de 1952 y constituyen la primera entrega de planos preparada por el atelier para el tercer viaje de Le Corbusier a la India. La entrega consta de dos documentos: el documento FLC 6675, que contiene el alzado Sud-Oeste y la planta baja; y el documento FLC 6677, con la implantación y la planta primera. En 1953, Le Corbusier publica parte de estos planos en la Euvre Complète 1946-1952, revelando el objetivo principal de su propuesta:

"Le plan cherche à réaliser les meilleures conditions d'ombre et de ventilation naturelle" 10

\footnotetext{
${ }^{8}$ Nota conservada en la Fondation Le Corbusier detallando el programa de la Villa Sarabhai FLC P3-7-20.

${ }^{9}$ La palabra veranda proviene del término inglés verandah, que a su vez procede del término hindi varandā, empleado en la India para denominar a espacios exteriores cubiertos, asociados a un edificio o a un jardín, que proporcionan cobijo del sol y de la lluvia.

${ }^{10}$ Boesiger, Willy: Le Corbusier. Cuvre complète 1946-1952. $8^{\text {a }}$ ed. Zurich: Les Editions d’Architecture, 1985. p. 160.
} 
En el plano de implantación, se aprecia que la forma irregular de la parcela, la posición Nord-Este del viario principal y la presencia de tres pequeñas construcciones, cuya integridad debía ser preservada, obligan a Le Corbusier a disponer la edificación en la zona Este de la propiedad, próxima a los lindes sin viario. La edificación se sitúa sobre un montículo artificial, señalado en los planos mediante una línea orgánica, con el fin de responder a posibles desbordamientos del río, y se orienta en la dirección Sud-Oeste siguiendo las indicaciones de la nota de noviembre.

El único alzado que se dibuja en esta propuesta, y por tanto el que se erige en principal, es el Sud-Oeste, con vistas al jardín. El edificio se percibe como una adición de módulos tridimensionales, en los que la geometría dominante es la curva, que generan un volumen complejo, evitando la monotonía gracias a la división asimétrica del programa. De este modo, la villa presenta una dualidad entre dos sistemas de generación: la adición de unidades abovedadas y la división del programa en dos alas, tal y como exigía la Sra Sarabhai.

La independencia tanto formal como espacial de cada una de las naves se alcanza mediante dos mecanismos. Desde el exterior, la sombra generada por las verandas, situadas en sendas fachadas principales, pone de manifiesto el carácter elemental de cada una de las naves. En el interior, su cubierta imprime al espacio una marcada direccionalidad. Cabe resaltar que las bóvedas son sustentadas por un sistema mixto de muros y pilares, cuando la estructura podría haber sido íntegramente resuelta mediante un sistema puntual. Sin embargo, los pilares tan sólo se emplean para aumentar la dimensión de ciertos espacios y abrir la casa hacia el Sud-Este. Así pues, la planta presenta una gran rigidez, ya que cada unidad funcional queda restringida a una unidad espacial incluso en aquellos espacios que aúnan varias naves, que quedan divididos en varios ambientes, lo que indica que la introducción de muros en el sistema no es una decisión puramente estructural.

La diferenciación de las dos alas dentro del sistema modular se produce mediante tres estrategias. En primer lugar, de las 10 unidades abovedadas que forman la villa en planta baja, las cuatro situadas al Nord-Oeste sobresalen respecto al plano de la fachada de acceso, mientras las tres situadas al Sud-Este lo hacen respecto a la fachada opuesta, dando lugar a una tensión asimétrica en planta entre ambas. En segundo lugar, las tres bóvedas que quedan entre sendas alas no son ocupadas por espacios interiores, de modo que la oposición lleno-vacío las articula en planta al tiempo que permite su diferenciación en alzado. Por último, el ala Nord-Oeste consta de dos bóvedas en planta primera, mientras que la opuesta tan sólo se desarrolla en planta baja, lo que atiende no sólo a una división funcional, sino también a una significación del ala más representativa. Así, el ala Nord-Oeste contiene en planta baja los espacios públicos de la vivienda y en la planta primera los dormitorios de la Sra Sarabhai y de su hijo menor, mientras el ala Sud-Este queda reservada al primogénito. El espacio de articulación entre ambas alas no se concibe como un espacio de encuentro o como un distribuidor, sino como un filtro o una exclusa que asegura la independencia de cada una de las alas dentro de la superestructura general. El ejemplo más ilustrativo de ello es que la nave central de la articulación es destinada al cobijo del automóvil. Así pues, la villa se concibe como dos casas en una.

\subsection{Unidad espacial versus unidad funcional.}

La discusión de la documentación entregada con la Sra Sarabhai tiene como resultado una serie de comentarios escritos sobre sendas copias de los planos originales, FLC 6676 y 6678. En primer lugar, se debe tratar de invertir la posición de las dos alas de la casa para que el bloque de servicio quede al Este, más próximo a la carretera $^{11}$. En segundo lugar, un sombreado rosa diferenciando el espacio interior del exterior, deja constancia

\footnotetext{
11 "essayer de reverser le plan/ de A en b de façon/ à avoir les domestiques/ à l'est vers la route". FLC 6678.
} 
de la necesidad de solventar la ambigüedad de los planos originales. En tercer lugar, se indica la necesidad de incrementar el salón en una nave, absorbiendo el comedor y sustituyendo el muro que los separa por pilares. A pesar del temprano estadio en el que se encuentra el proyecto, algunos de los croquis y comentarios que les acompañan adelantan cuestiones constructivas. En el documento FLC 6676, junto a los muros se hace referencia a una construcción con ladrillos vistos, enlucidos y coloreados en algunos puntos, así como a la construcción de muros en piedra. En este mismo documento, varios de los croquis exploran el sistema de construcción de las bóvedas. En uno de ellos se explica la formación de la bóveda disponiendo primero una hilada de azulejos de 7"x7" a modo de cimbra sobre la que colocar una hilada de ladrillo; mientras que en otro se aprecia como las bóvedas descansan sobre vigas de canto que a su vez apoyan sobre los muros, lo que permite sustituir los muros por pilares siempre que sea necesario. Un símbolo de interrogación acompaña a los dibujos indicando lagunas en el sistema.

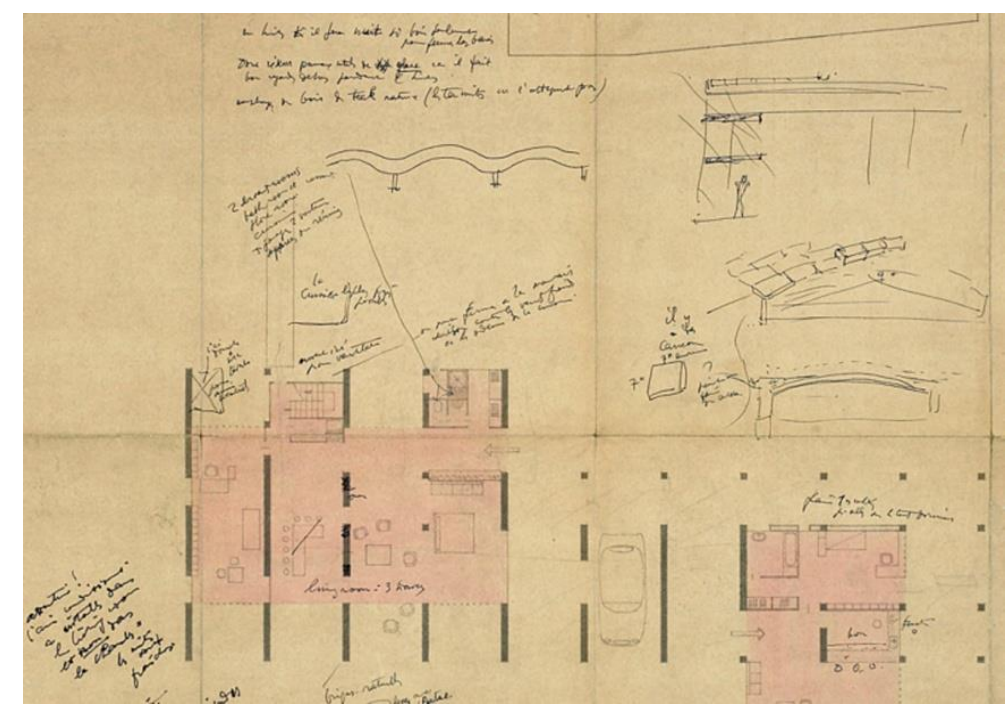

2. Correcciones sobre el proyecto de marzo de 1952 de la Villa Sarabhai. Detalle del documento FLC 6676.

El documento FLC 6772 contiene dos bocetos de implantación que tratan de responder a las peticiones realizadas por Mrs Sarabhai. En el primero de ellos, se trata de acercar el bloque de servicio a la carretera sin tener que intercambiar las posiciones de las dos alas, orientando el eje longitudinal del edificio en la dirección Norte-Sur y situando el edificio de servicio al Norte, alineado con él. En el segundo, la nueva orientación se mantiene, pero además se invierte la posición de las dos alas. La piscina, rectangular en la primera entrega, adquiere un contorno dual, combinando ángulos rectos en las zonas próximas al edificio con curvas en las zonas más próximas al jardín, convirtiéndose en un elemento de transición entre lo artificial y lo natural. 


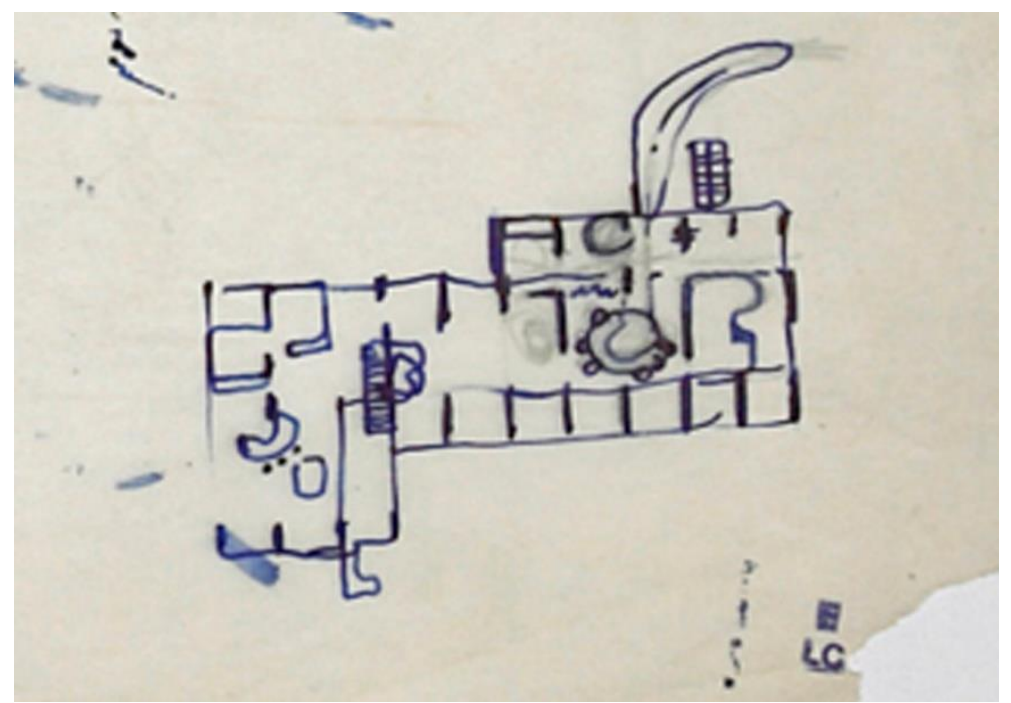

3. Boceto de la planta baja de la Villa Sarabhai. Detalle del documento FLC 31904.

El documento FLC 31904, desarrolla el esquema de la planta baja correspondiente al segundo boceto del documento FLC 6772, aunque el edificio vuelve a su orientación original, es decir, con su fachada principal orientada al Sud-Oeste y no al Oeste. En el interior, tal y como se anunciaba en el documento FLC 6676, salón y comedor pasan a formar un único espacio, aunque se divide en tres ambientes correspondientes a cada una de las tres naves que lo constituyen, manteniendo la rigidez de la propuesta anterior. Sin embargo, en un pequeño boceto situado en el ángulo inferior del documento, el comedor deja de estar adscrito a una única bóveda, ocupando el espacio intermedio entre dos de ellas. Los pilares son sustituidos íntegramente por muros de diferentes longitudes entre los cuales se infiltran formas orgánicas, de modo que el sistema lineal comienza a imponerse al puntual, pero adquiriendo su flexibilidad.

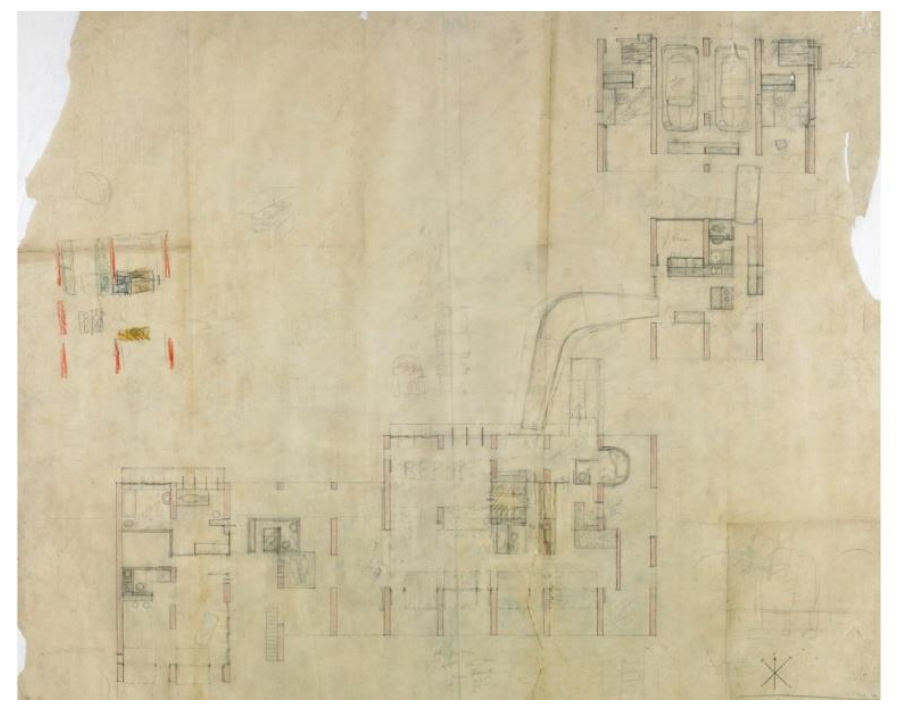

4. Boceto de la planta baja de la Villa Sarabhai de mayo 1952. FLC 31882.

El 21 de mayo de 1952 se continúa el desarrollo del esquema de planta baja en el documento FLC 31882. El volumen principal mantiene las premisas de fluidez espacial e inserción de formas orgánicas del pequeño boceto del documento FLC 31904, pero con mayor mesura. A pesar de que los muros no son continuos, sus alineaciones siguen presentes, incluso en los espacios más diáfanos como el salón-comedor y el acceso. Si en la propuesta de marzo cada unidad funcional quedaba limitada por una unidad espacial; en esta propuesta diversas unidades 
funcionales se disponen a caballo entre dos naves contiguas. Ejemplo de ello son el baño situado entre la veranda del ala del primogénito y la primera nave de la articulación, o el baño y la habitación ubicados entre las dos últimas naves al Sud-Este del ala principal. En el segundo ejemplo expuesto, se observa cómo Le Corbusier encuentra en esta oposición unidad espacial-unidad funcional el acomodo para las formas orgánicas dibujadas en el boceto FLC 31904.

\section{3 ¿Excavado o Construido?}

Los documentos FLC 6768A, B, C y D contienen cuatro perspectivas, que aunque no están datadas, tanto por la forma del edificio principal como por la de la piscina, cabe pensar que fueron desarrolladas entre mayo y junio de 1952. En ellas se estudia tanto el diseño de la cubierta como la relación del edificio con el terreno. Las propuestas A y D se presentan como extremos opuestos dentro del proceso de ideación de la cubierta. En el documento A, el alzado del proyecto de marzo (FLC 6675), sufre una transformación del contorno superior de la cubierta, de modo que éste ya no corresponde con los trasdoses de la bóvedas, sino con una curva que las va uniendo de dos en dos de manera similar a las casas Jaoul, a pesar de que las bóvedas impares mantienen su trasdós intacto. La agrupación de pares de bóvedas, aunque aporta variedad a la unidad, provoca un aumento del canto de la cubierta incrementando la sensación de pesadez, efecto que queda reforzado por el sólido anclaje del edificio al terreno. En la propuesta D, las bóvedas recuperan la uniformidad de la propuesta de marzo y reducen su grosor a la mínima expresión. La palabra Shell (cáscara), manuscrita sobre el dibujo ilustra con claridad la pretensión de Le Corbusier de construir una cubierta lo más ligera posible. La ingravidez de la cubierta obliga a disponer vigas transversales sobre las bóvedas para arriostrarlas, por lo que resulta necesario prolongar los muros que conforman los testeros para ocultar su canto. Las opciones B y C son similares a la perspectiva D pero sin las vigas de arriostramiento. En ellas el montículo que elevaba la villa para evitar inundaciones desaparece, de modo que el forjado de planta baja queda elevado respecto al nivel natural del suelo, apoyado en los muros de carga, debilitando la relación entre construcción y terreno. En los cuatro documentos se observa una distinción material entre los elementos de carga y soporte. Así las bóvedas se representan en un material continuo, mientras que los muros son de ladrillo. El documento FLC 31894, que se corresponde con las propuestas B y C, muestra un detalle de la sección transversal de las bóvedas en el que se confirma la disposición de vigas entre éstas y los muros. A pesar de ser un elemento intermedio, las vigas quedan asociadas a la cubierta tanto por su material como por su esbeltez, así, son más estrechas que el muro con el fin de marcar el límite entre ambos. Las bóvedas, formadas por tres capas, alcanzan su mínimo espesor estructural en la clave, aunque sobre ellas se dispone un sustrato vegetal, a modo de aislamiento térmico, que incrementa el grosor total de la cubierta. Sobre él se establece un sistema de canales de agua y pasarelas, los primeros destinados al riego de la cubierta, mientras que los segundos facilitan el tránsito por ella, ya que el sustrato vegetal reproduce la ondulación de las bóvedas. Además este documento desvela la función del pequeño volumen que aparece en la cubierta de las perspectivas A, B y C. Se trata de un pabellón abierto que permite maximizar el frescor de la brisa resguardándose del sol y la lluvia en los meses de más calor. 


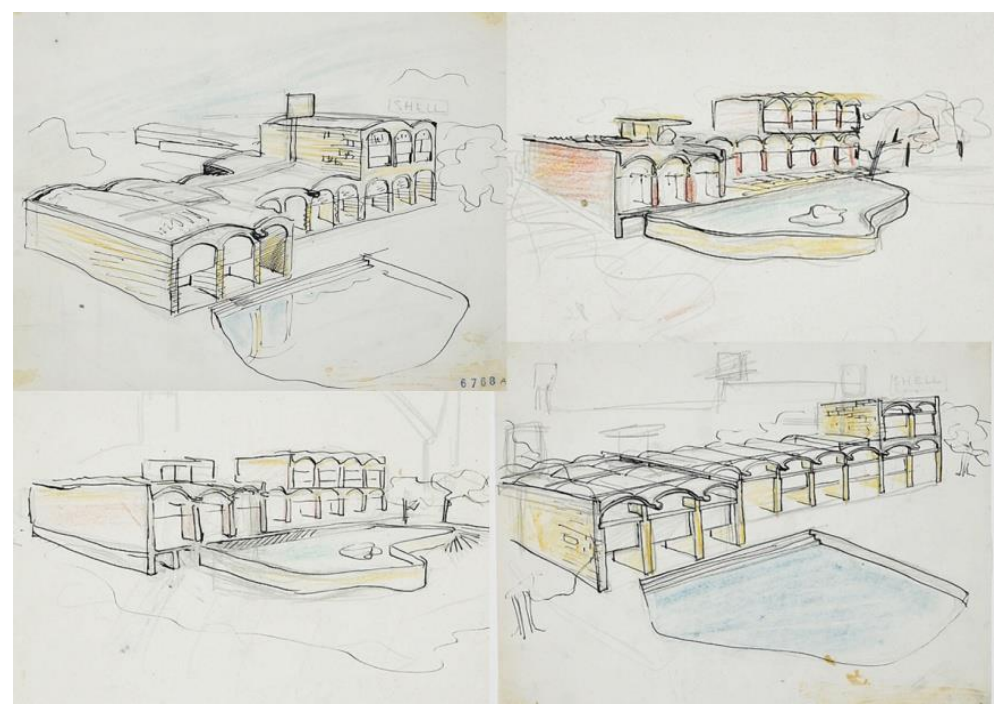

5. Perspectivas exteriores de la Villa Sarabhai desde el Oeste. De arriba a abajo, izquierda a derecha: FLC 6768 A, B, C, D.

En las secciones, FLC 31889 y 31885, dibujadas en junio, se observa que el interés por mostrar con claridad la geometría de las bóvedas en fachada se traslada también al interior. Así pues, todos los espacios situados a caballo entre dos bóvedas tienen su altura limitada a la de la cara inferior de las vigas que las sustentan, impidiendo que la incipiente independencia de la distribución respecto a la estructura altere la percepción de la geometría de la bóveda en el espacio interior. A finales de mes se dibujan nuevos planos de la cubierta, así en el documento FLC 31886, del 20 de junio, se muestra un croquis del ala de Anand en el que además de los sistemas de caminos y canales y de la cabane couverte se muestra un solarium y un trampolín al que se accede por unas escaleras lineales que ya aparecían en las plantas de mayo. El día 21 se delinea el documento FLC 31887, en el que se observa cómo el sistema de croquis se extiende no sólo a toda la cubierta del edificio principal, tanto de planta baja como de planta primera, sino también a la del volumen de servicio, al que se accede mediante una escalera lineal situada en perpendicular a su alzado Nord-Oeste. El diseño de la cubierta como una superficie verde sin barandillas, con caminos y canales, sobre la que se elevan nuevas construcciones remite a una topografía organizada en distintos niveles en lugar de a una cubierta, de modo que desde su superficie todo lo que queda bajo ella se debe considerar producto de una excavación en lugar de una construcción. Si bien es cierto que desde la cubierta de planta baja se divisa el volumen de planta primera, la falta de relaciones visuales entre ellos remite a un muro situado sobre la pradera más que a una parte de la villa.

A diferencia de las terrazas jardín de los años veinte, que se perciben como una habitación sin techo, y del resto de viviendas abovedadas en las que el ajardinamiento es un mero aislante, ya que no ha de ser contemplado por nadie porque la cubierta no es accesible ${ }^{12}$, en la villa Sarabhai el objetivo de Le Corbusier es la búsqueda de la naturalidad:

"Les demi-cylindres des voûtes, une fois l'étanchéité assurée, sont recouverts de terre et le dessus de la maison devient un magnifique jardin de gazons parfaits et de fleurs (...). L'architecte Le Corbusier déclare la guerre en principe, aux jardiniers quels qu'ils soient qui, bien qu'étant envoyés du ciel, donnent un faux visage à la vie en

\footnotetext{
${ }^{12}$ Las cubiertas abovedadas tan sólo tienen un acceso explícito en los estudios de los proyectos de la Saint Baume (1948) y Roq et Rob (1949) cuando por situarse la edificación en un terreno escarpado el acceso se debe realizar por la cubierta. FLC 17773 y 18671 respectivamente.
} 
imposant les plantes précisément exotiques et multipliant exagérément des plantes dénommées «rares», faussant, faussant...sous le couvert de la nature, faussant l'ambiance même" 13

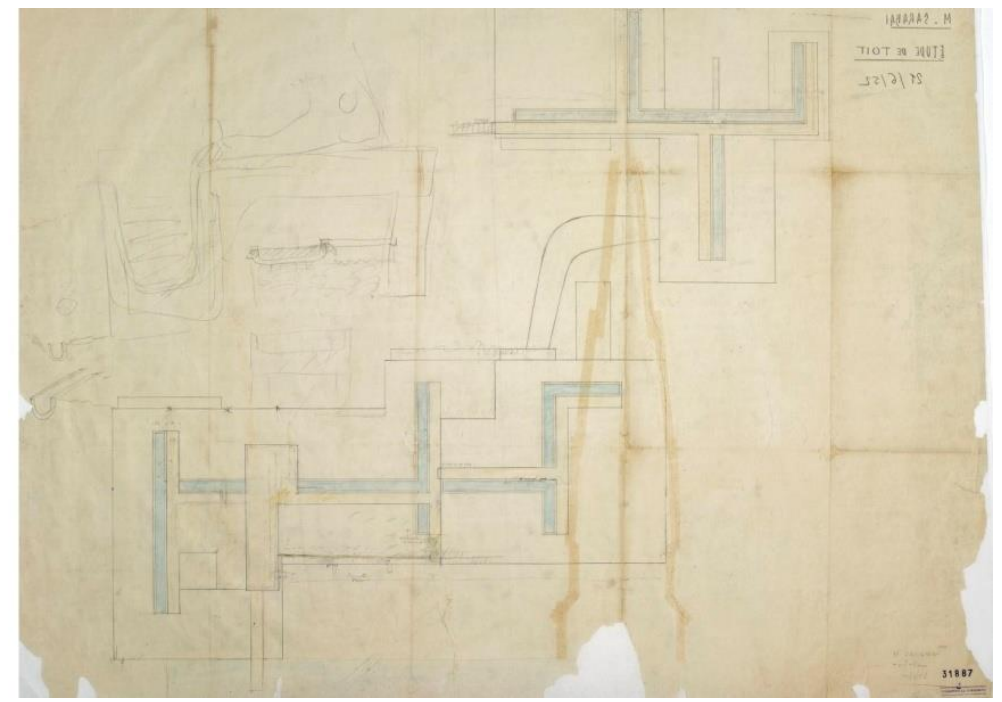

6. Planta de cubiertas de la Villa Sarabhai de junio de 1952. FLC 31887.

\subsection{Un punto discontinuo: la transposición carga soporte}

Entre junio y noviembre se realizan diversos croquis de implantación en los que se estudian los accesos y el contorno de la piscina ${ }^{14}$. En el caso de la piscina, su contorno se va ensanchando y complicando a medida que avanzan las propuestas, alcanzando su punto crítico en el documento FLC 31903, en el que la piscina queda unida a las dos alas del edificio principal haciéndose necesario generar un puente para acceder al otro lado del jardín. En el siguiente documento, FLC 31902, la superficie de la piscina se reduce drásticamente y se aleja del edificio adquiriendo una forma ameboidea, de modo que en lugar de ser un elemento de transición entre la ortogonalidad del edificio y la organicidad del jardín, pasa a formar parte de éste último.

En noviembre se prepara una segunda entrega bajo el nombre de project d'exécution ${ }^{15}$ con motivo del cuarto viaje de Le Corbusier a India. En lo que se refiere a la planta de cubiertas y a la planta baja, las diferencias con la propuesta de junio no son significativas, sin embargo, en el documento FLC 6680 se dibuja por primera vez la planta primera. En ella se refuerza la oposición unidad funcional-unidad espacial de la planta baja, ya que las habitaciones de Mrs Sarabhai y de su hijo menor no se limitan a ocupar cada una su crujía, como en la propuesta de marzo, sino que se maclan en una tercera crujía central, al tiempo que el baño de la Sra Sarabhai se libera de los muros de su nave para ocupar parte de la veranda de la nave contigua. En el diseño de la cubierta se sustituye el trampolín por un tobogán que se desliza desde la cubierta de la cabane couverte hasta la piscina vinculando, mediante el juego, el jardín real con el artificial.

En los alzados principales, dibujados en los documentos FLC 6687 y 6689, se produce una transposición de los conceptos ligero-pesado asociado a los elementos de carga-soporte debido a dos factores. En primer lugar, a la

\footnotetext{
${ }^{13}$ Boesiger, Willy: Le Corbusier et son atelier rue de Sèvres 35. Euvre complète 1952-1957. 10ª ed. Basel-Boston-Berlin: Birkhäuser Publishers, 1999. p. 114.

${ }^{14}$ Documentos FLC 31906, 31905, 31903, 31902.

${ }^{15}$ Documento FLC P3-5-497 del 11 de noviembre de 1952. Planos enviados: FLC 6691, 6679, 6683, 6693, 6694, 6695A, 6696, 6697, 6698, 6699, 6702, 6703.
} 
desvirtuación del concepto de la bóveda como cáscara, debido al aumento del grosor del canto por la contención de la tierra vegetal de acabado. En segundo lugar, debido al aumento de altura del perfil de los muros, que supera el arranque de las bóvedas otorgando mayor esbeltez al primer elemento y generando ambigüedad en la percepción de la transmisión de cargas.

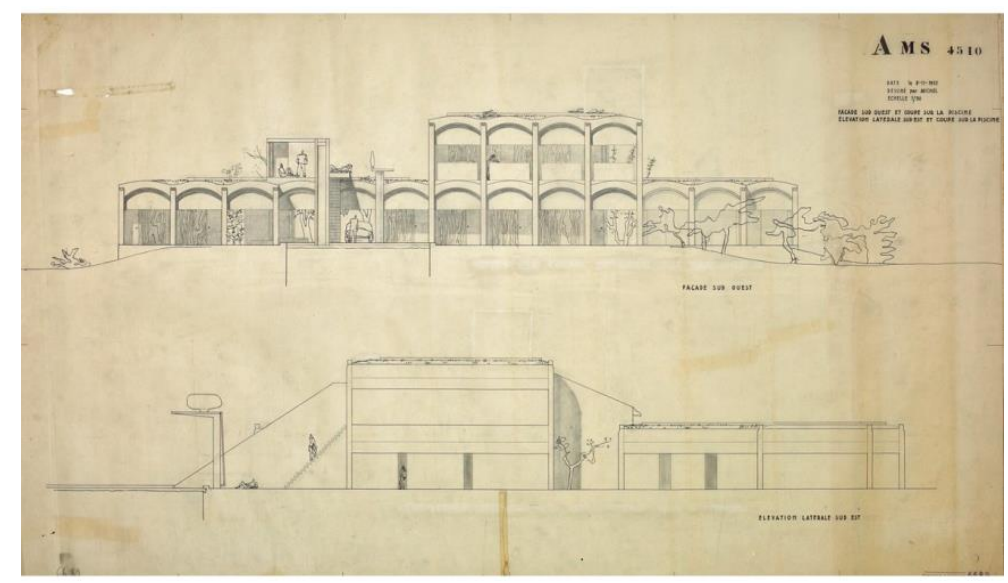

7. Alzados Sud-Oeste y Sud Este de la Villa Sarabhai correspondientes al proyecto de noviembre de 1952. FLC 6687.

\subsection{La oposición forma espacio}

Entre los documentos no fechados del proyecto, se conservan dos perspectivas parciales de la fachada, FLC 6731 y FLC 6769, que indican un estadio intermedio entre los alzados de noviembre de 1952 y los del proyecto definitivo de febrero de 1953. En ellos, la ondulación del extradós de las bóvedas se oculta tras un revestimiento plano de remate horizontal, al tiempo que se maciza su tímpano. Sin embargo, tanto el intradós de las bóvedas como las vigas que las sustentan sobresalen de dicho plano, quedando en vuelo a modo de marquesina. En estos dibujos se observa cómo Le Corbusier intenta modificar el perfil del edificio sin renunciar a la bóveda como elemento compositivo interior-exterior generando una fuerte ambigüedad de sistemas en la fachada.

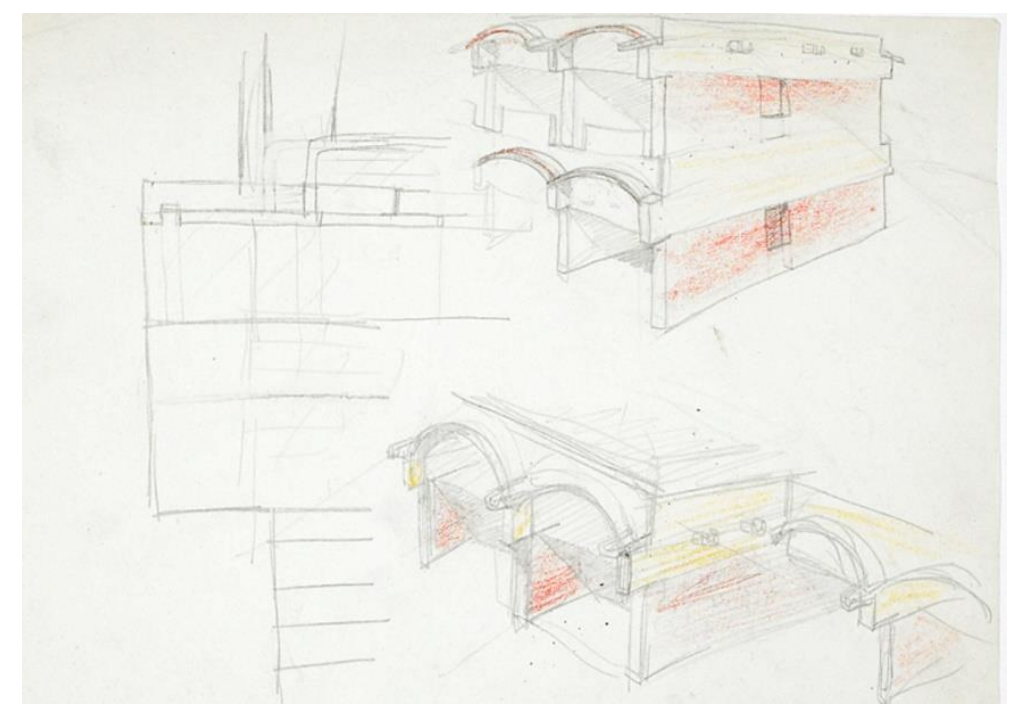

8. Estudio de las fachadas de la Villa Sarabhai realizados entre noviembre de 1952 y febrero de 1953. FLC 6769. 
En febrero de 1953 se prepara un conjunto de planos ${ }^{16}$, entre los que se encuentran planos de ejecución y detalles constructivos que debían ser enviados a la India a final de mes. En el plano de cubierta, FLC 6697, se observa que las pasarelas que acompañaban a los canales de agua desaparecen definitivamente, de modo que toda la cubierta se vuelve una pradera transitable. El documento FLC 6703 muestra como la búsqueda de una estructura de cubierta ligera se lleva hasta sus máximas consecuencias. El espesor de las bóvedas en la clave se reduce a $7 \mathrm{~cm}$, ya que se construyen tan sólo con dos hiladas de ladrillo, de 2 y $5 \mathrm{~cm}$ respectivamente, y sobre ellas se dispone directamente una chapa y una lámina impermeable que quedan protegidas por el sustrato vegetal. El arriostramiento del conjunto se consigue mediante la disposición de tirantes de acero anclados a las vigas de hormigón en las dos bóvedas extremas de cada planta. En las secciones dibujadas en el documento FLC 6696A se observa cómo, mientras en la fachada de acceso la villa surge directamente del terreno, en la fachada del jardín se interpone una losa entre el terreno y la edificación que en algunas zonas queda en vuelo. Sin embargo, de nuevo, los cambios más significativos respecto a la propuesta anterior se encuentran en los alzados, FLC 6693 y 6695. El perfil curvo de las bóvedas de las naves queda oculto en fachada por una ancha franja de hormigón que además limita la altura de los muros tanto en las fachadas principales como en los testeros, restándoles el protagonismo que habían ganado en el proyecto de noviembre. Así, desde el exterior el edificio se percibe como un prisma ortogonal horadado según un patrón modular, mientras que desde el interior el edificio se percibe como una suma de espacios abovedados, de modo que lo recto se opone a lo curvo y la generación de tipo sustractiva a la aditiva.

\subsection{La villa construida. Una máquina de desorientar.}

En la villa construida, cuando se traspasa el umbral de la nave de acceso, situada entre sendas alas, la direccionalidad de la bóveda y la longitud del muro que sustenta el tobogán, invitan a continuar caminando hacia el jardín, resaltado por el marco de penumbra. El espacio, alto y profundo, se percibe con claridad como una unidad de forma simple y límites precisos. Sin embargo, a medida que se avanza, los muros que flanquean el acceso quedan interrumpidos, multiplicándose las visuales. La riqueza espacial de la casa se revela de forma progresiva. Primero se interrumpe el muro de la izquierda, abriéndose una diagonal desde la cual se divisa el acceso al ala principal, aunque lo ajustado de la abertura invita a continuar en la dirección de la bóveda en busca de un camino más amplio. Más adelante se percibe otra interrupción del muro, esta vez a la derecha, abriéndose una nueva diagonal que anuncia el acceso al ala del primogénito. Antes de llegar a ella se localiza el acceso del ala principal, que exige un giro de $90^{\circ}$ consecuencia del cual la percepción del espacio cambia radicalmente. Éste, limitado ahora por la altura de las vigas, se percibe bajo y de límites imprecisos, aunque sigue manteniendo su profundidad.

\footnotetext{
${ }^{16}$ El 27 de febrero de 1953, Le Corbusier envía una carta a Gautam Sarabhai con la lista de planos de la villa Sarabhai que ha enviado a India FLC P3-5-183.
} 


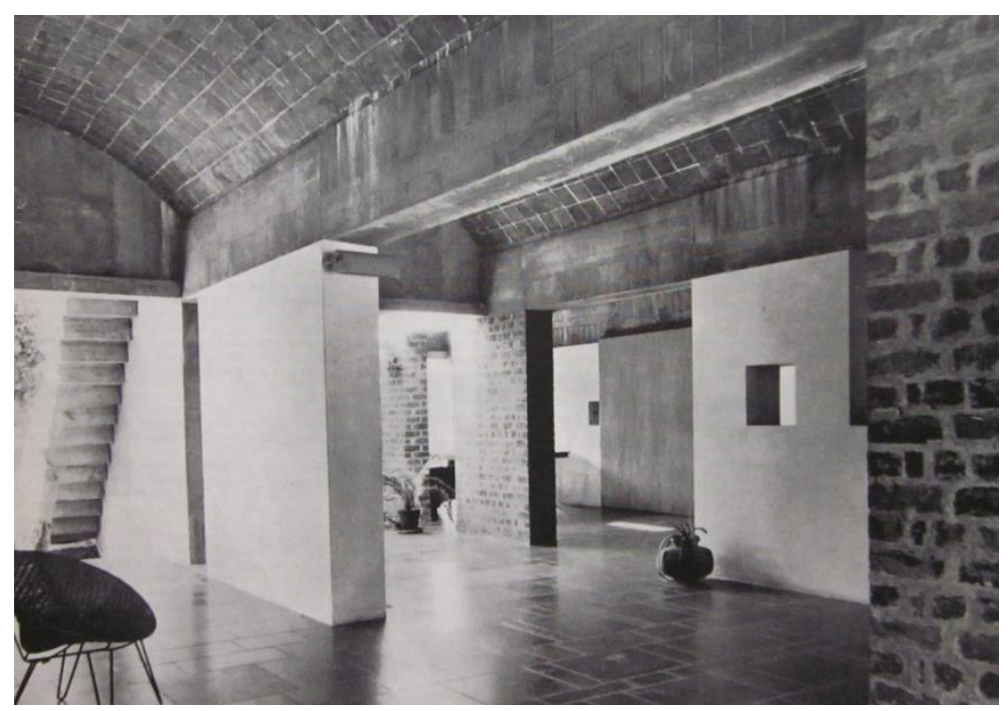

9. Nave de acceso a la Villa Sarabhai dentro del espacio de articulación entre las dos alas del edificio.

Las alineaciones de segmentos de muros con una estudiada alternancia de posiciones, provoca un efecto de laminación del espacio. En palabras del propio Le Corbusier:

"La composition consiste à ouvrir des trous dans ces murs, tout parallèles, en jouant des pleins et des vides. Mais en jouant intensément le jeu architectural" 17

$\operatorname{Doshi}^{18}$, uno de los arquitectos que asistieron a Le Corbusier en el proyecto, añade que los muros dan la sensación de ser deslizables gracias a la libertad que les otorgan las vigas de canto. Además explica que la oposición entre la unidireccionalidad espacial de las bóvedas y los movimientos laterales a los que incitan los muros, provoca que la casa se perciba de forma totalmente distinta, no sólo en función de la posición del espectador, sino también, en función de si las puertas de las verandas están abiertas o cerradas. Así, no se identifica un itinerario a seguir y tampoco una jerarquía en la distribución, el espacio fluye en todas direcciones. De este modo, el espacio es igual y diferente a la vez, provocando la desorientación del espectador.

El modo de disponer los materiales en la villa contribuye a la confusión entre interior y exterior. Le Corbusier comenta a propósito de los materiales de la villa:

"Une autre recherche fut poursuivie: reprendre contact avec les matériaux dignes et fondamentaux de l'architecture: la brique amie de l’homme, le béton brut ami aussi, les enduits blancs amis de l'homme, la présence de couleurs intenses provocatrices de joie, etc... "l9

Le Corbusier sigue empleando los materiales de acuerdo a los principios establecidos en las Maisons Jacquin y Loucheur en 1929. Cada material, bien concreto, como el ladrillo o el hormigón, bien abstracto, como los enlucidos, se emplea para formar todas las caras de un mismo elemento constructivo. De este modo se consigue que cada uno de ellos se perciba como un volumen independiente, especialmente los muros. No obstante, cuando el muro es enlucido, alguna de sus caras se pinta de un color diferente o se le superpone un mural permitiendo la desintegración volumétrica del elemento de manera puntual. Una primera percepción de la villa permite asociar

17 Boesiger, Willy: Cuvre complète 1952-1957. Op.cit. p. 114.

${ }^{18}$ Doshi, Balkrishna.V: "The Unfolding of an Achitect". En Global Architecture. "Le Corbusier. Sarabhai house \& Shodhan house". №32. Tokio: A.D.A. EDITA, 1974.

19 Boesiger, Willy: CEuvre complète 1952-1957. Op.cit. p. 114. 
el material concreto a los segmentos exteriores y el abstracto a los interiores. Sin embargo, cuando el espectador parece haberse orientado, un segundo nivel de percepción revela que en las verandas y en las naves de articulación se emplean tanto enlucidos como materiales vistos, disolviéndose la identificación de un tipo de material con un tipo de espacio, bien interior o bien exterior.

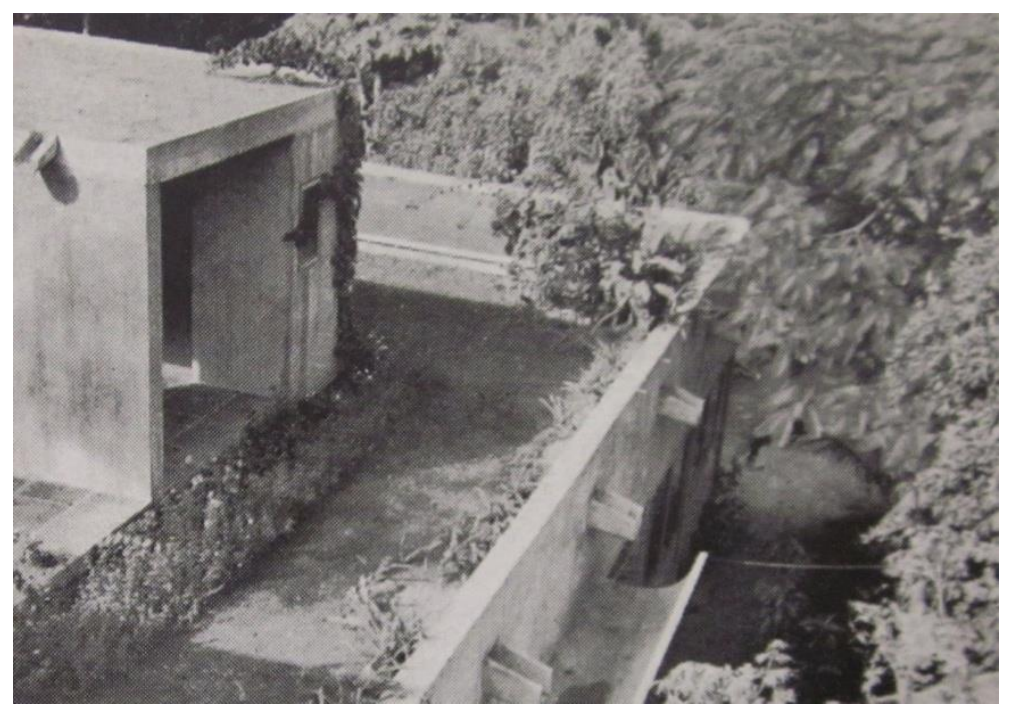

10. Pabellón sobre la cubierta ajardinada de la Villa Sarabhai.

\section{La ambigüedad como herramienta de proyecto}

En el proceso evolutivo de la villa Sarabhai, se observa cómo Le Corbusier intenta despegar el edificio ligeramente del terreno. Primero, sustituyendo el montículo inicial, que impedía las inundaciones, por una elevación de la losa de planta baja sobre los muros; y finalmente, tras recuperar de nuevo el montículo, volando la losa de planta baja respecto a éste en algunas zonas. Le Corbusier había empleado esta estrategia en otras obras consideradas referentes de la architecture femelle como la Villa Henfel (1934), generando ambigüedad entre el peso de los muros, en este último caso de piedra, y la débil relación del edificio con el terreno.

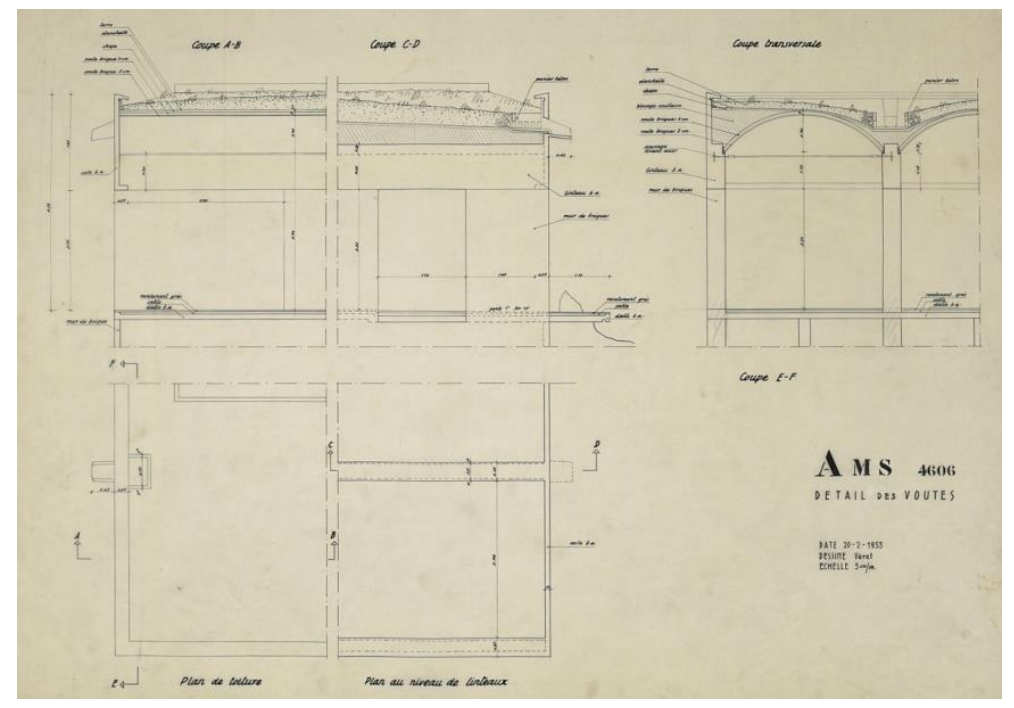

11. Detalle del encuentro del edificio con el terreno de la Villa Sarabhai. FLC 6703

Así pues, no se aprecia la intención de que la villa absorba el emplazamiento a través de su implantación y tampoco su forma contribuye a ello. Como se observa en la evolución formal de la piscina, Le Corbusier emplea 
las envolventes orgánicas para asociar un elemento artificial a un ambiente natural. Sin embargo, la ortogonalidad del edificio, contrasta con las formas orgánicas que lo rodean, y su integración no difiere de la de cualquier villa de Le Corbusier situada en un jardín con arbolado. Si bien es cierto que la mayor parte de la villa se desarrolla en planta baja, los dormitorios de Mrs Sarabhai y su hijo, situados en planta primera, tienen la suficiente entidad como para evitar que la villa pase desapercibida en su entorno. La cubierta jardín no se divisa desde el plano del suelo de modo que no puede considerarse un elemento integrador y tampoco se construye ningún montículo próximo a los testeros, como ocurre en la Villa Henfel (1934), que la oculte parcialmente.

Como apuntaba Serenyi, desde el exterior, la villa tampoco cumple los requisitos del supuesto tipo, ya que, aunque durante la mayor parte del proceso exhibe la ondulación de su cubierta al exterior, en la fase final ésta es ocultada. De este modo se consigue una fuerte sensación de sorpresa cuando se cruza el umbral, ya que ningún rasgo de la envolvente del edificio hace presagiar su interior abovedado. La ambigüedad entre sistema arquitrabado y sistema abovedado para generar desconcierto no es una estrategia surgida por primera vez en este proyecto, Le Corbusier la había empleado en su primer proyecto de villa abovedada, la Villa au bord de la Mer (1916). Cabe resaltar además, que la adscripción del sistema abovedado a un tipo concreto no es tan evidente ya que uno de los ejemplos de architecture mâle más celebrados, la Villa Shodhan, comienza su proceso evolutivo con una cubierta abovedada.

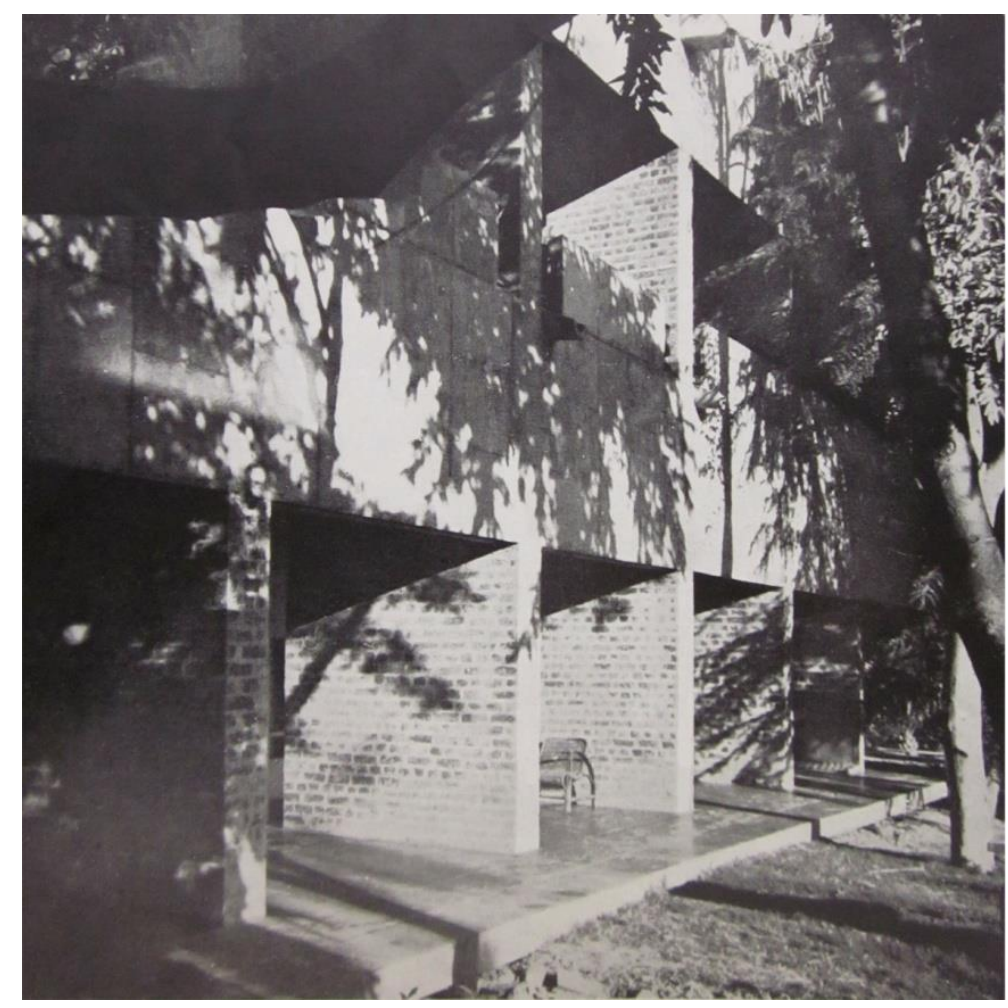

12. Fachada Sud-Oeste de la Villa Sarabhai. 


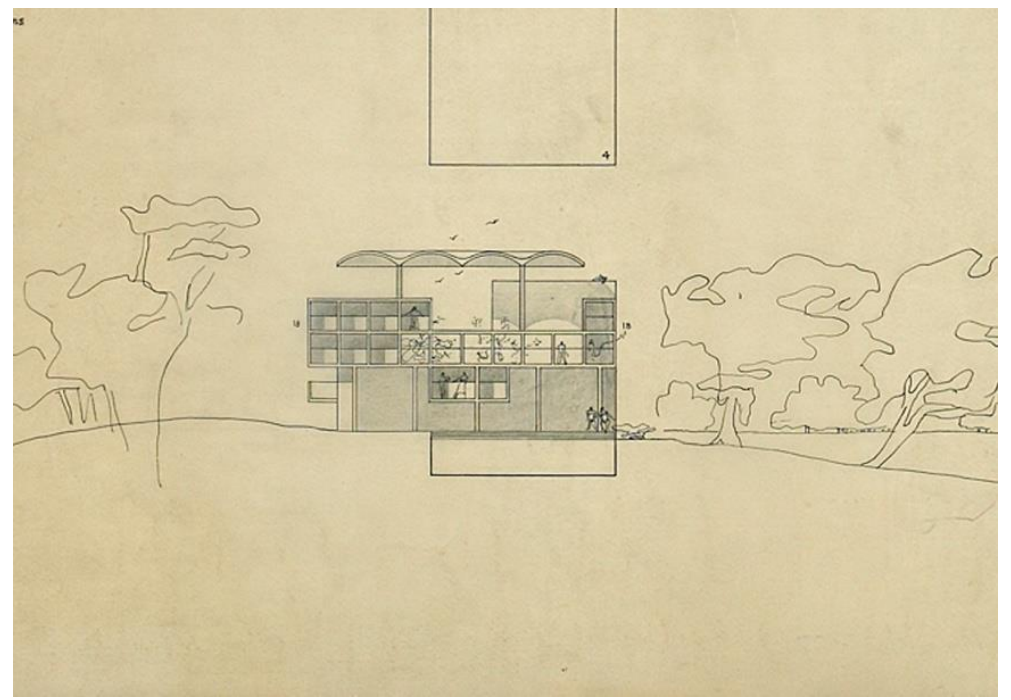

13. Fachada Sud-Oeste de la Villa Shodhan del proyecto de octubre de 1951. FLC 6444A

La asociación del espacio abovedado con una gruta más que con la forma en sí, parece tener que ver con la idea de cubierta pesada y espacios bajos de sombras profundas, ya que el sistema abovedado empleado por Le Corbusier es de tipo modular y por tanto difícil de encontrar como tal en estado natural. Sin embargo, desde las primeras etapas del proyecto, Le Corbusier se esfuerza en reducir al máximo el espesor de la bóveda, teniendo en cuenta la capacidad técnica del país, y si ésta adquiere un canto apreciable es debido a la necesidad de contener el sustrato vegetal que la aísla térmicamente y no atendiendo a una voluntad formal. La asociación del espacio abovedado con un espacio bajo está relacionada con la ausencia de dobles y triples alturas generadas en otros espacios domésticos considerados masculinos, como la Villa Shodhan. La bóveda genera una sensación de compresión-expansión espacial similar a la que generan las dobles alturas, salvo que las primeras lo hacen de forma progresiva y de manera comedida, mientras las segundas lo hacen de forma abrupta. En la primera entrega de la Villa Sarabhai además del espacio abovedado, existe una doble altura asociada al despacho de la Sra Sarabhai, que desaparece en las siguientes propuestas. Sin embargo, en otros proyectos abovedados, como la Cité permanente d'habitation en la Sainte-Baume (1948) o las casas Roq et Rob (1949), si que emplea dobles alturas.

El espacio de la Villa Sarabhai, tampoco parece encajar dentro de referencias primitivas, rupestres o folklóricas. Así cuando Le Corbusier se refiere a las bóvedas de la villa en la Euvre Complète no destaca su rusticidad o pesadez sino virtudes clásicas.

\section{"La beauté des voûtes cylindrées catalanes réclamait le calme, 20}

La configuración inicial de la villa parece partir de un sistema basado en la confluencia unidad espacial-unidad funcional asociado tradicionalmente a los sistemas abovedados. Sin embargo, dicha asociación no era un imperativo para Le Corbusier, ya que ya había combinado la planta libre con el sistema abovedado soportado por pilares en proyectos como la Réorganization agraire, ferme et village radieux (1938). Así pues, la limitación inicial de estancias a crujías es resultado de la influencia del proyecto de viviendas adosadas en la Sainte-Baume (1948) o de las investigaciones sobre las Unités d'habitation iniciadas en 1944, en las que las viviendas estaban formadas tan sólo por una o dos crujías debido a la existencia de medianeras.

\footnotetext{
${ }^{20}$ Boesiger, Willy: Euvre complète 1952-1957. Op.cit. p. 114.
} 


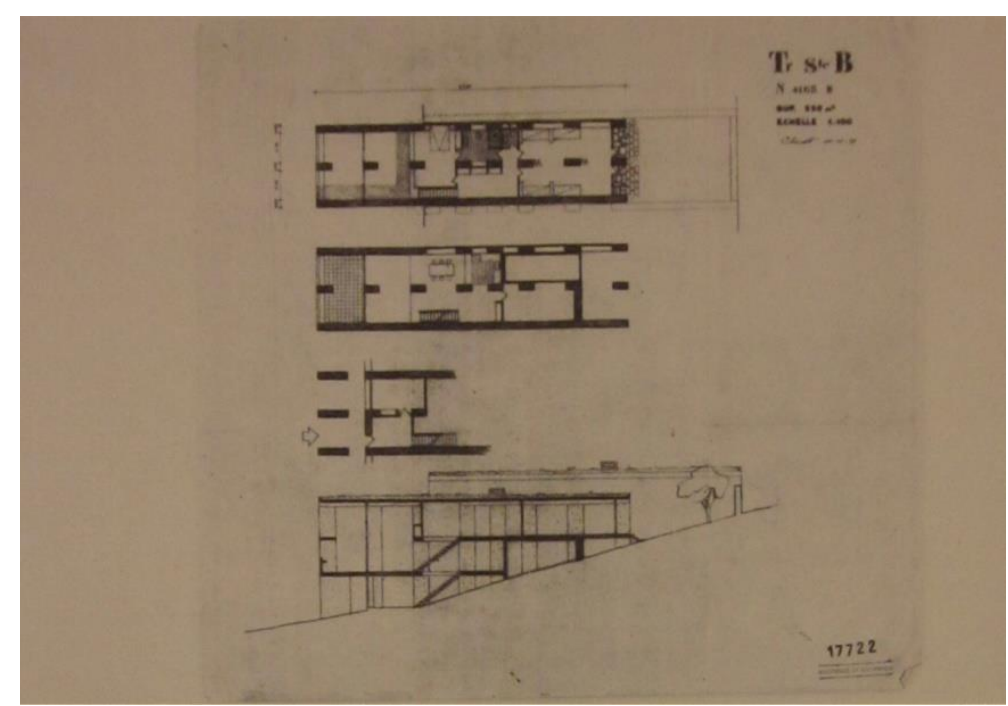

14. Plantas y sección de una de las casas familiares del proyecto de la Basilique en La Saint-Baume de noviembre de 1949. FLC 17722

Cuando Le Corbusier asume que dicha constricción puede ser eliminada debido a la inexistencia de medianeras, comienza a flexibilizar la distribución hasta conseguir una planta tan libre como las de sus proyectos de los años 20, pero en lugar de empleando pilares, mediante el empleo de muros. La elección del sistema de soporte no está vinculada a la tecnología o a la cualificación de la mano de obra del país; ya que la Villa Shodhan, contemporánea y situada en la misma ciudad, sí se construye mediante un entramado de pilares y vigas; ni siquiera a una tradición constructiva, ya que igualmente resulta imprescindible emplear vigas para la distribución de la carga. Así, la elección de un sistema mural atiende a dos razones: una ambiental, facilita el flujo de las brisas a través de la casa evitando su recalentamiento; y otra espacial, laminar horizontalmente el espacio consiguiendo, con una única altura, la misma riqueza espacial de otras de sus obras en las que se combinan espacios de distintas alturas.

En definitiva, la arquitectura de Le Corbusier se resiste a clasificaciones, y la Villa Sarabhai no constituye una excepción, de modo que no se puede considerar un paradigma de la architecture femelle sino del empleo de la ambigüedad como estrategia proyectual. Si se analiza en conjunto el proceso de ideación de la villa, se observa que se trata de un proceso continuo de adición de ambigüedades con el fin de conseguir el mismo efecto anunciado por Le Corbusier en relación a la Villa Savoye:

"Les visiteurs, jusqu'ici, se tournent et se retournent à l'intérieur, se demandant comment tout cela se passe, comprenant difficilement les raisons de ce qu'ils voient et ressentent; (...)Et ...ils ne s'ennuient pas, je crois! ”21

El visitante no es capaz de distinguir si está ante un sistema arquitrabado o abovedado, si está en una casa o en un complejo formado por dos, si está arriba o está abajo, si está dentro o si está fuera. Este proceso alcanza su punto álgido en el primer piso de la villa, cuando Le Corbusier cubre uno de los muros con una fotografía en la que se muestra una de sus esculturas junto a una de sus pinturas apoyada sobre el muro medianero de piedra de su estudio. Así la realidad es sustituida por la representación de otra realidad, resultando difícil la distinción entre ambas.

\footnotetext{
${ }^{21}$ Le Corbusier: Précisions sur un état présent de l'architecture et de l'urbanisme. $6^{\mathrm{a}}$ ed. Paris: Les Éditions G.Crès et $C^{\mathrm{ie}}$. p. 136.
} 


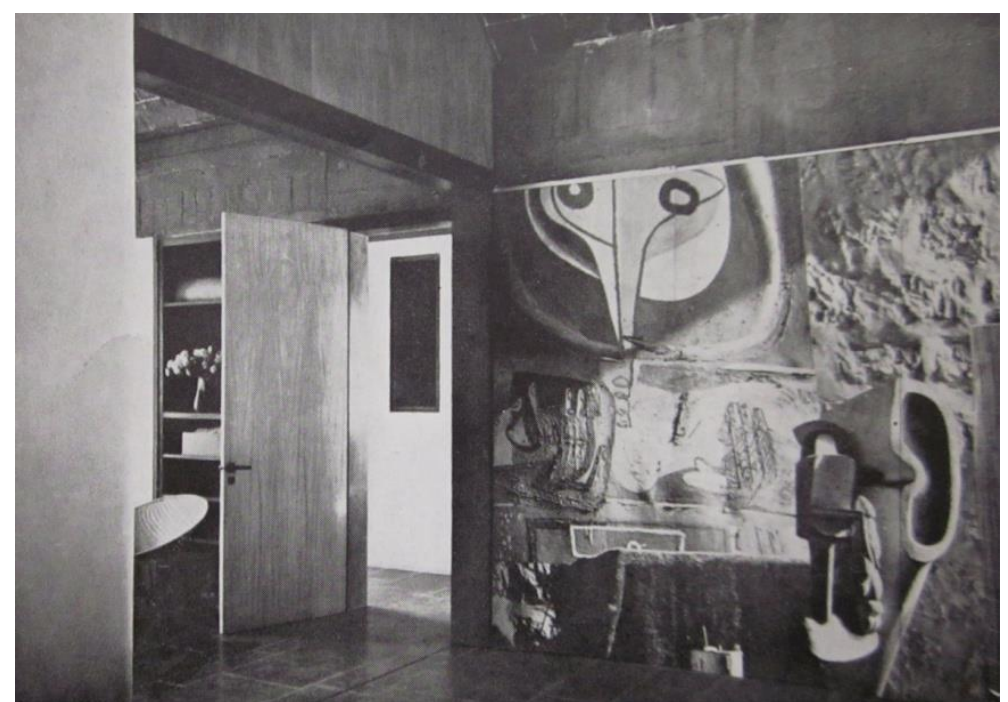

15. Interior de la planta primera de la Villa Sarabhai mostrando un fotomural con dos obras de Le Corbusier dispuesto sobre uno de los muros.

\section{Agradecimientos}

Los autores agradecen a Michel Richard, director de la Fondation Le Corbusier, haber facilitado el acceso al archivo de la Fondation para el desarrollo de esta investigación y la inestimable orientación de Arnau Dercelles, responsable del Centro de Documentación e Investigaciones de la Fondation, en la consulta de los documentos.

\section{Procedencia de las imágenes}

1, 2, 3, 4, 5, 6, 7, 8, 11, 13, 14. Fondation Le Corbusier.

9, 10, 12,15. (C) J. Paul Getty Trust. Fotografías de Lucien Hervé. The Getty Research Institute, Los Ángeles (2002.R.41).

\section{Bibliografía/referencias}

Boesiger, Willy: Le Corbusier. Euvre complète 1946-1952. 8a ed. Zurich: Les Editions d’Architecture, 1985.

Boesiger, Willy: Le Corbusier et son atelier rue de Sèvres 35. Euvre complète 1952-1957. 10ª ed. BaselBoston-Berlin: Birkhäuser Publishers, 1999.

Curtis, William: Le Corbusier. Ideas and Forms. London: Phaidon Press Limited, 2003. pp. 210-212.

Doshi, Balkrishna: "Legacies of Le Corbusier and Louis I. Kahn in Ahmedabad". En Architecture and Urbanism. Mayo 2001, No 368.

Doshi, Balkrishna.V: "The Unfolding of an Achitect". En Global Architecture. "Le Corbusier. Sarabhai house \& Shodhan house". N³2. Tokio: A.D.A. EDITA, 1974.

Jencks, Charles: Le Corbusier and the Continual Revolution in Acrchitecture. New York: The Monacelly Press, Inc. and Charles Jencks, 2000.

Le Corbusier: Précisions sur un état présent de l'architecture et de l'urbanisme. $6^{\mathrm{a}}$ ed. Paris: Les Éditions G.Crès et Cie.

Serenyi, Peter: "Le Corbusier`s Changing Attitude Toward Form". En Journal of the Society of Architectural Historians. Marzo 1965, vol XXIV, No2. 
Serenyi, Peter: "Timeless but of its Time: Le Corbusier`s Architecture in India". En Brooks, H.Allen: Le Corbusier. New Jersey: Princeton University Press, 1987.

Suárez, Maria Candela: "Villa de Mrs Manorama Sarabhai". En Le Corbusier plans. CD10. París: Echelle-1 Fondation Le Corbusier, 2005-2010.

Von Moos, Stanislaus: Le Corbusier. Barcelona: Editorial Lumen, 1977. 


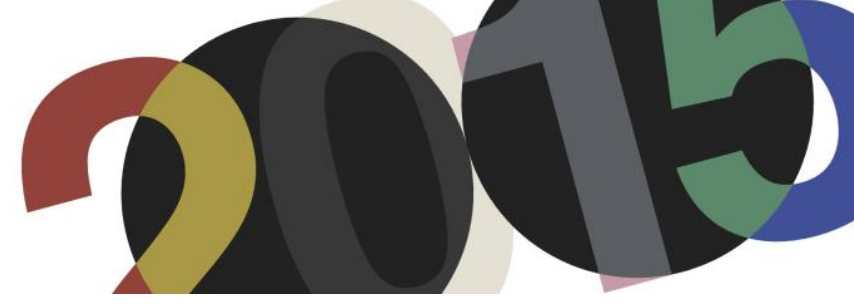

DOI: http://dx.doi.org/10.4995/LC2015.2015.992

\title{
INFLUENCIAS PINTORESCAS DE LE CORBUSIER EN EL PABELLÓN BRASILEÑO DE OSAKA`70
}

\author{
S. García-Gasco Lominchar \\ Escuela Superior de Arquitectura de Valencia, Universitat Politècnica de València, UPV \\ PROARQ. Universidade Federal do Rio de Janeiro, UFRJ
}

Resumen: Iñaki Ábalos, en su libro "Atlas pintoresco" traza una linea de investigación sobre el Movimiento Moderno y su relación con la naturaleza y el paisaje. El autor establece un análisis en el que desenmascara los elementos pintorescos en la obra de Le Corbusier de manera que, aun apareciendo muchos de ellos en estado "latente" desde sus primeros postulados teóricos, paulatinamente y "casi de forma secreta" se irán adueñando de su modo de proyectar hasta conquistar todas las escalas de la arquitectura en su etapa final.

Algunas de las características arquitectónicas de la llamada Escuela Paulista parecen ser a su vez influencia de la obra tardía de Le Corbusier. El pabellón de Paulo Mendes para la Exposición Universal de Osaka'70 nos sirve en este artículo para establecer un análisis de determinados aspectos pintorescos de Le Corbusier que subyacen en la arquitectura brasileña en general y de Paulo Mendes en particular.

Abstract: Iñaki Abalos develop in "Atlas pintoresco" a research about Modern Movement and its relationship with nature and landscape. The author provides an analysis which unmask the picturesque elements in the work of Le Corbusier. These elements, even being l'atent"in its earliest theoretical postulates, gradually and almost secretly"will take over his way of projecting to conquer all scales of architecture in its final stage.

Some of the architectural features of the so-called Paulista School seems to have influences of the later work of Le Corbusier. Paulo Mendes pavilion for the World Expo Osaka'70 can serve to establish an analysis of some of the picturesque aspects of Le Corbusier underlying brazilian architecture in general and Paulo Mendes in particular.

Palabras clave: Pintoresco; Escola Paulista ; Le Corbusier; Paulo Mendes da Rocha; Naturaleza; Paisaje. Keywords: Picturesque; Paulista School; Le Corbusier; Paulo Mendes da Rocha; Nature; Landscape. 


\section{Introducción}

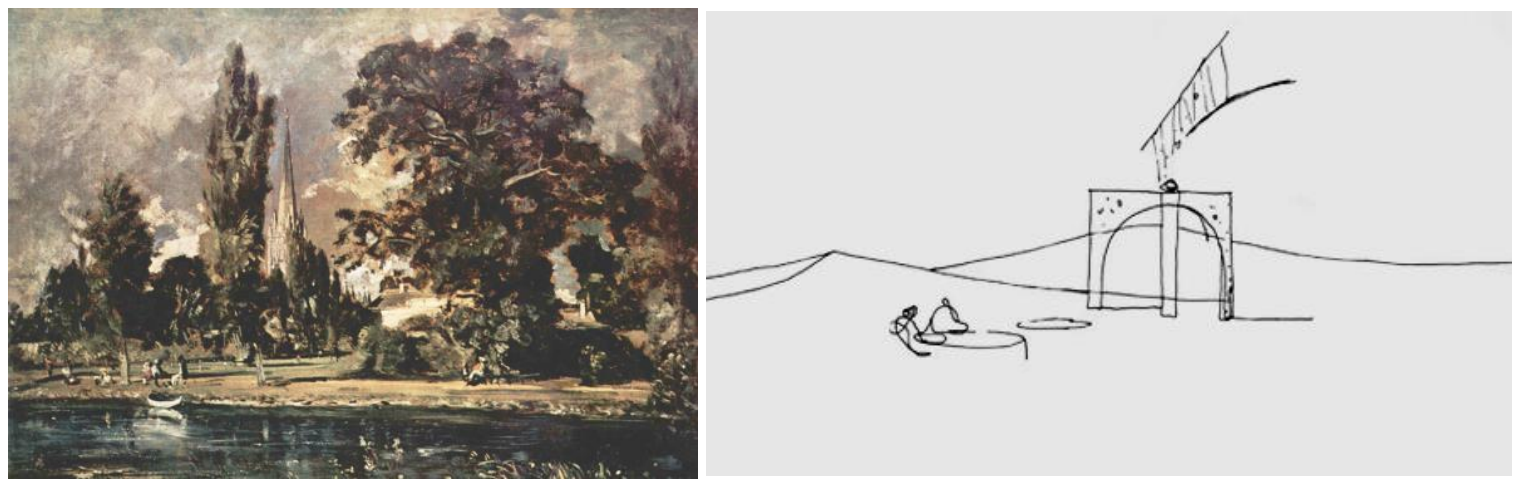

1. La Catedral de Salisbury vista desde el rio. John Constable. 1820

2. Boceto del pabellón de Brasil para Osaka’70. Paulo Mendes da Rocha. 1969

Tenemos, por un lado, el cuadro La Catedral de Salisbury vista desde el rio de John Constable. A su lado se encuentra uno de los esbozos que Paulo Mendes realizó para materializar la idea del proyecto del pabellón nacional de Brasil en Osaka'70.

Si comparamos las dos imágenes podemos observar algunas similitudes obvias: en ambas aparece representado un paisaje. Constable representa una escena típicamente pintoresca ${ }^{1}$ protagonizada por el cauce de un rio de aguas tranquilas rodeado de una vegetación bucólica y amable. De fondo, la Catedral de Salisbury aparece en el centro de la escena, entre las copas de los árboles. Su presencia no es meramente casual: Constable está persiguiendo el contraste entre una naturaleza en estado primigenio y una construcción que representa la presencia del hombre en el lugar. La contraposición entre naturaleza y artificio. A la sombra de los arboles aparecen ciudadanos disfrutando del espacio natural, paseando a la vera del rio o tumbados en la hierba. El cielo tormentoso de fondo contrasta con la luz dorada en primer plano, que transmite tranquilidad y sosiego. Los trazos rápidos y abocetados del pintor indican su interés por la transmisión de ciertas sensaciones y no tanto su representación formal.

Observando el boceto de Paulo Mendes, a pesar de pertenecer a técnicas de representación muy distintas y realizadas en épocas diferentes, se puede encontrar en él la misma alusión a la relación naturaleza-artificio que aparece en el cuadro de Constable: unas suaves colinas y un gran pilar conformado por dos arcos en cruz representan, en palabras de Paulo Mendes, la naturaleza en contraste con la ciudad ${ }^{2}$. El encuadre de la composición responde al mismo esquema: la construcción aparece en la parte central del dibujo, mientras que la línea del horizonte de las colinas desaparece en los límites de la escena. En el tercio izquierdo del diseño, un grupo de personas aparecen tranquilamente sentadas en la pendiente de una de las colinas. Parecen disfrutar del lugar y observar la construcción de fondo. Junto a ellos aparecen dos círculos que no están definidos en el proyecto. Ateniéndose únicamente al análisis del boceto, se puede interpretar en ellos dos pequeños estanques junto a los que están sentadas las personas representadas.

\footnotetext{
${ }^{1}$ Pintoresco, ca. (De pintor).

1. adj. Se dice de los paisajes, escenas, tipos, costumbres y de cuanto puede presentar una imagen peculiar y con cualidades plásticas.

2. adj. Se dice del lenguaje, estilo, etc., con que se pintan viva y animadamente las cosas.

Fuente: R.A.E

3. adj. Estrafalario, chocante.

${ }^{2}$ Macadar, Andrea. Paulo Mendes da Rocha. Entrevista, São Paulo: Vitruvius, ano 07, n. 026.02, abr. 2006 Cap. 3
} 
Ambas imágenes comparten una clara analogía representativa. Las dos reproducen escenas bucólicas de carácter contemplativo.

¿Existe alguna relación entre Paulo Mendes y el pintoresquismo inglés de principios del XIX?

Es difícil establecer un enlace entre dos imágenes tan aparentemente opuestas. Incluso en el caso de existir una influencia real de Constable sobre el dibujo de Paulo Mendes cabría preguntarse si esa influencia no acaba en la expresión y el encuadre gráfico, sin más consecuencias. Sería razonable que la coincidencia, fruto de la asimilación de un bagaje cultural humanista del arquitecto, no tenga una influencia (consciente) sobre el proceso creativo que establece en su arquitectura. Sin embargo, ante esta comparativa que pueda parecer superficial, subyace una evidencia. En las dos imágenes aparece representado lo mismo: el contraste entre la naturaleza y la arquitectura, naturaleza y artificio, y la relación humana ante tal contraste. Paulo Mendes y John Constable dibujaron en esencia la misma imagen con 150 años de diferencia.

A pesar del radicalismo en los postulados del Movimiento Moderno en su relación con el lugar y la abstracción de su arquitectura, existieron formulaciones pintorescas dentro de la modernidad que no pudieron ser enunciadas correctamente por su contradicción con las propias bases del movimiento. Algunos de los arquitectos más representativos, como Le Corbusier, Bruno Taut o Mies Van der Rohe, entre otros, establecieron puentes entre la estética pintoresca y la ideología moderna ${ }^{3}$.

Iñaki Ábalos, en su libro Atlas pintoresco traza una línea de investigación sobre el asunto. El autor establece un análisis en el que desenmascara los elementos pintorescos en la obra de Le Corbusier, de manera que, aun apareciendo muchos de ellos en estado "latente" desde sus primeros postulados teóricos, paulatinamente y "casi de forma secreta" se irán adueñando de su modo de proyectar hasta conquistar todas las escalas de la arquitectura en su etapa final. Entre los elementos más representativos de ese pintoresquismo anunciado por Ábalos se encuentran tres grandes cuestiones que son características de la obra tardía de Le Corbusier: la alusión al lugar, o genius locci, la promenade architecturale y el uso del hormigón visto. Además, Ábalos señala dos etapas diferenciadas en los postulados teóricos del arquitecto: una primera etapa, positivista, con la creencia ciega en que el desarrollo social y tecnológico daría solución a los problemas del mundo: "La naturaleza como portadora de leyes físicas, precisamente las mismas leyes físicas que han permitido alumbrar el maquinismo" "y una etapa tardía, post-II Guerra Mundial, donde la naturaleza se torna paisaje sujeto a la percepción. Esta última concepción de la naturaleza es la que dará origen al Le Corbusier pintoresco que Iñaki Ábalos defiende.

Le Corbusier desarrollará en su segunda etapa algunas de sus obras más importantes: La Unité d’habitation de Marsella (1947), la capilla de Ronchamp (1955), la asamblea de Chandigarh (1951-1965), el convento de la Tourette (1959) o Saint Pierre de Firminy (1966-2007), recientemente acabada. Todas ellas se caracterizan por un alejamiento de las doctrinas maquinistas iniciales hacia un expresionismo más dramático y perceptivo. El ángulo recto pierde su hegemonía y el contraste prevalece sobre la claridad de las formas arquitectónicas. Es la etapa donde el arquitecto desarrolla los brise-soleil como sistemas para el control lumínico, pero también como elementos de composición expresiva. También toman protagonismo los llamados objetos de reacción poética, elementos orgánicos o alusiones a la curva femenina que le servirán de inspiración para la creación de formas

\footnotetext{
3 Ábalos, Iñaki. "Le Corbusier pintoresco: el pintoresquismo en la modernidad". En Atlas Pintoresco.Vol.2: Los viajes. Barcelona: Ed Gustavo Gili. 2005. p 115

${ }^{4}$ Ibídem, p. 121
} 
arquitectónicas. El uso del hormigón visto y la alusión a los volúmenes másicos y pesados frente a la levedad de la etapa anterior caracterizan estas obras, muchas de ellas muy ligadas al entorno donde se construyen.

Según Alan Colquhoun, el conflicto conceptual entre el desarrollo tecnológico y el idealismo estético tendente al clasicismo es lo que caracteriza la teoría de Le Corbusier ${ }^{5}$. La base que sustenta las teorías enunciadas por el arquitecto puede posicionarse entre estos dos puntos aparentemente opuestos. Le Corbusier se ve a sí mismo como arquitecto y artista, siendo estas dos facetas las que determinen su discurso. Colquhoun cita como influencias en su teoría los principios positivistas y constructivos representados por la tradición moderna, por un lado, y los postulados teóricos clasicistas del siglo XVIII, la influencia del libro de Henry Provensal 'L'Art de demain" (1904) y la doctrina artesanal de su maestro Charles L'Epplatenier por otro. Serán las dos cuerdas que Le Corbusier tratará de anudar en el desarrollo de toda su obra.

Se ha escrito extensamente sobre la fuerte influencia que Le Corbusier ejerce en la implantación del Movimiento Moderno en Brasil ${ }^{6}$. Sin embargo, dicha influencia no será ejercida a lo largo de los años ni en el mismo lugar ni de la misma forma. El proceso histórico y la búsqueda de una identidad Brasileña se desarrollará de forma linear y en ciudades diferentes, comenzando en Rio de Janeiro como capital del país, donde un Le Corbusier "purista" ayudará a proyectar el primer gran edificio moderno de Brasil: el Ministerio de Educación y Ciencia (MEC). En el edificio aparecen reflejados los cinco puntos de Le Corbusier para una arquitectura moderna: planta libre, suelo liberado a través de pilotis, independencia estructura-cerramiento, cubierta jardín, fachada libre. A partir del primer contacto de Le Corbusier con Brasil en 1929, se sucederán otros tantos en forma de visitas o cartas personales, dando lugar a múltiples y ricos intercambios que los arquitectos brasileños utilizarán para formalizar su propia modernidad. Al mismo tiempo, Le Corbusier absorberá de Rio un concepto muy importante en su discurso posterior: La presencia de la naturaleza y el paisaje en el proyecto. Décadas más tarde en São Paulo, la arquitectura paulista desarrollada en los años 60 estará fuertemente influenciada por la obra tardía del arquitecto a través de Vilanova de Artigas y la Escuela Paulista ${ }^{7}$. Vilanova combinó el aspecto crítico de aquella revisión de la utopía maquinista hecha por el maestro francosuizo en el contexto amargo de la II Guerra Mundial, con una visión claramente marxista en el que la exhibición de las huellas del encofrado de madera en el hormigón armado aparecerían como señales del trabajo hecho en obra, evitando el refinamiento fetichista de la construcción acabada ${ }^{8}$. Son muchos los matices que podrían ser analizados ante esta afirmación ${ }^{9}$, pero no nos desviaremos y la aceptaremos como una verdad ampliamente reconocida. Lo que parece evidente, como así lo refleja Lucio Costa, es el impacto que produce el cambio de rumbo que emprende Le Corbusier entre los arquitectos brasileños:

\footnotetext{
${ }^{5}$ Colquhoun, Alan. Modernity and the Classical Tradition: Architectural Essays 1980-1987. Cambridge (MA): MIT Press. 1989.

${ }^{6}$ No siendo conveniente en este caso entrar en la demostración de dicho discurso para no desviar nuestra atención.

${ }^{7}$ Tomaremos como referencia los aspectos sobre la "Escuela Paulista" que Ruth Verde Zein establece en su Tesis doctoral: Léase el apartado "2.2. Abecedário das características da arquitetura da Escola Paulista Brutalista" En Zein, Ruth Verde. A arquitetura da escola paulista Brutalista .1953 - 1973. Porto Alegre: UFRGS, 2005. 358 p. Tese (Doutorado) - Programa de Pós-Graduação em Educação, Faculdade de Educação, Universidade Federal do Rio Grande do Sul, Porto Alegre: 2005, p 33

${ }^{8}$ Wisnik, Guilherme. "Urbanizar la vida: una técnica comprometida". En AV monografías 161: Paulo Mendes da Rocha. Madrid: 2013, pp 13

${ }^{9}$ Existen diferentes motivaciones por detrás del uso del hormigón visto en la arquitectura. Uno de ellos puede ser el expuesto por Artigas. Le Corbusier no parece compartir tanto dichas motivaciones socio-políticas como la propia cuestión estética y expresiva de material expuesto.
} 
“(...) me quede sin palabras. (...) de repente comenzaron los pilotis enormes, toda aquella masa. (...) Entonces, después de muchos años, percibi que era una cosa humanística, una concepción" (...) "Fue un cambio inesperado, pues antes era una línea muy estructural, muy industrial y de producto. (...) Sólo un artista plástico podría hacer todas aquellas formas con una seguridad total" Lucio Costa ${ }^{10}$

Siendo una tarea inabarcable para un artículo de este tamaño el establecer las características de toda arquitectura paulista de los 60, podemos conformarnos con centrarnos en una obra que pueda representarla dignamente.

El pabellón de Paulo Mendes para la Exposición Universal de Osaka`70, con el que hemos comenzado el texto, nos puede servir para establecer en él un análisis de los aspectos pintorescos que pueden haber surgido dentro de la concepción de esta obra y poder entenderlos en un contexto más amplio.

\section{Osaka'70. La representación internacional de una arquitectura brasileña.}

El pabellón de Osaka fue construido para representar a Brasil en la Exposición Universal que tuvo lugar en Japón en 1970. Fue convocado a través de un concurso público nacional. Con tan solo 25 días para presentar las ideas, el proyecto ganador resulta de la autoría de Paulo Mendes da Rocha, Jorge Caron, Júlio Katinsky y Ruy Ohtake con la participación de un gran número de colaboradores arquitectos, estudiantes y artistas plásticos. También participa en su concepción el filósofo Flavio Motta.

La propuesta ganadora proponía una idea muy clara: Un gran espacio de convivencia generado por una cubierta de hormigón. Dicha cubierta se apoya sobre una suave topografía creada en forma de tres colinas. En el interior de la parcela se configura el llamado "Largo do café", una plaza protegida por la cubierta y delimitada por las colinas. Desde la avenida del recinto de la Expo, una rampa descendiente y oblicua a la cubierta permite la entrada a los espacios de exposición subterráneos, continuando su recorrido bajo tierra para acabar de nuevo en la superficie, en el centro de la plaza. La estructura se destaca por sus grandes dimensiones (32,5 x $50 \mathrm{~m})$ y sus voladizos. Tres de los cuatro pilares que la soportan se encuentran dentro de las colinas, transmitiendo la sensación de que la cubierta se apoya sobre ellas. El cuarto pilar protagoniza el espacio de la plaza interna. Se trata de un gran pilar en forma de dos arcos cruzados que generan un espacio abovedado. La cubierta está compuesta por un gran número de claraboyas que permiten la entrada de luz pero protegen de la lluvia. Para completar el programa, otro espacio subterráneo destinado a administración cierra el fondo de la parcela. Se accede a él por una rampa tangencial e intencionadamente discreta.

El proyecto se destaca por su homogeneidad constructiva, destacando el hormigón visto de la cubierta y el asfalto para conformar la topografía ondulante.

Según las palabras del propio jurado, el proyecto representa una "poética inconfundible muy ligada a una arquitectura brasileña", con un abordaje "nítidamente brasileño" basado en la liberación del suelo. ${ }^{11}$

En cierto modo, la propia finalidad del proyecto le confiere de antemano un papel representativo de "lo Brasileño" frente al mundo, y su selección como pabellón lo legitima de manera "oficial" como arquitectura de identidad nacional. Entendamos ahora cuales son las características que lo definen como "nítidamente brasileño". Antes de seguir, debemos dejar claro el hecho generalista que supone algo tan complejo como la

\footnotetext{
${ }^{10}$ Costa, Lúcio. "Presença de Le Corbusier, entrevista a J. Czajkowski, M. C. Burlamaqui e R. Brito", Revista Arquitetura. Rio de Janeiro: FAU/UFRJ 1987. Traducción propia.

${ }^{11}$ Acta del jurado, publicada en la revista Acrópole, No 361, 1969, p. 13 En Zein, Ruth Verde, Amaral, Izabel. "A Feira Mundial De Osaka de 1970: O Pavilhão Brasileiro”. Arquitextos $N^{o}$ 16. Porto Alegre: UFRGS. PROPAR. 2011 , pp 4. Traducción propia.
} 
búsqueda de una arquitectura nacional, más si cabe a través de una única obra. Sin embargo, parece razonable que en un determinado contexto geográfico y temporal, junto a unas influencias que puedan ser compartidas, se generen respuestas similares a problemas comunes, lo que puede derivar en la creación de una identidad propia. No en tanto, el tema de una arquitectura brasileña supondría una investigación que se sale del objetivo principal del texto, por lo que podremos asumir como estrategia ciertas afirmaciones que ya han sido escritas para continuar.

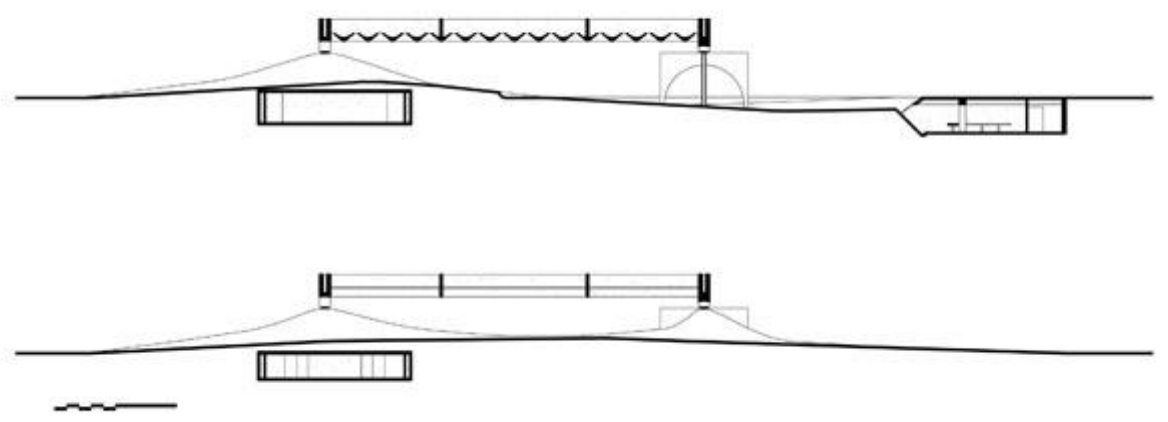

3. Sección transversal de la cubierta del pabellón.

Parece clara la asunción de la planta libre como una característica propia de Brasil por parte del jurado. Otros autores, como Ruth Verde Zein, también le otorgan un carácter representativo “(...) esta obra notable del Brutalismo Paulista, que genera una discusión sobre la identidad brasileña, terminó volviéndose de hecho en una referencia de la identidad arquitectónica nacional ${ }^{, 12}$.

Asumamos entonces estas hipótesis y analicemos cuales serían sus características.

Sin extendernos en las cuestiones políticas y económicas de Brasil en el momento de su construcción, es por lo menos importante remarcar la situación de aislamiento internacional y desaceleración económica que vive Brasil después de una etapa desarrollista que culmina con el golpe militar de 1964. La arquitectura brasileña, años antes elogiada en el mundo y puntera en el desarrollo tecnológico del hormigón, sufre ahora una etapa de aislamiento, al tiempo que las pautas disciplinares del Movimiento Moderno comienzan a agotarse ${ }^{13}$. No se trata de una situación particular de Brasil. Se trata de un momento de transición en el que el Movimiento Moderno está sufriendo desde hace décadas una profunda revisión.

En el mundo, esta revisión está dando paso a otras tipologías y técnicas constructivas experimentales que van a ser expuestas en Osaka. Prevalece en los pabellones el uso de estructuras metálicas tridimensionales y de cerramientos livianos, como los textiles, algunos de ellos resultado de avances tecnológicos en otros campos (para situarnos en el contexto, recordemos que en el pabellón de Estados Unidos el tema principal es la llegada a la Luna). Sin embargo, la hegemonía del hormigón visto en Brasil continúa siendo indiscutible y su desarrollo tecnológico continúa desde el inicio del Movimiento Moderno. En este contexto el jurado del concurso siente que el país no será capaz de destacarse por nuevas técnicas. Puede leerse en el discurso del jurado un cierto sentimiento "derrotista" y conservador:

$\begin{array}{ll}{ }^{12} & \text { Idem } \\ { }^{13} & \text { Ibidem. pp } 6\end{array}$ 
"Muchos concursantes se dejaron llevar por los aspectos técnicos del pabellón. Como Brasil no pretende competir con los países desarrollados (EUA y URSS gastarán cerca de 30 millones de dólares con sus pabellones), este énfasis sobre el lado tecnológico fue descartado "14
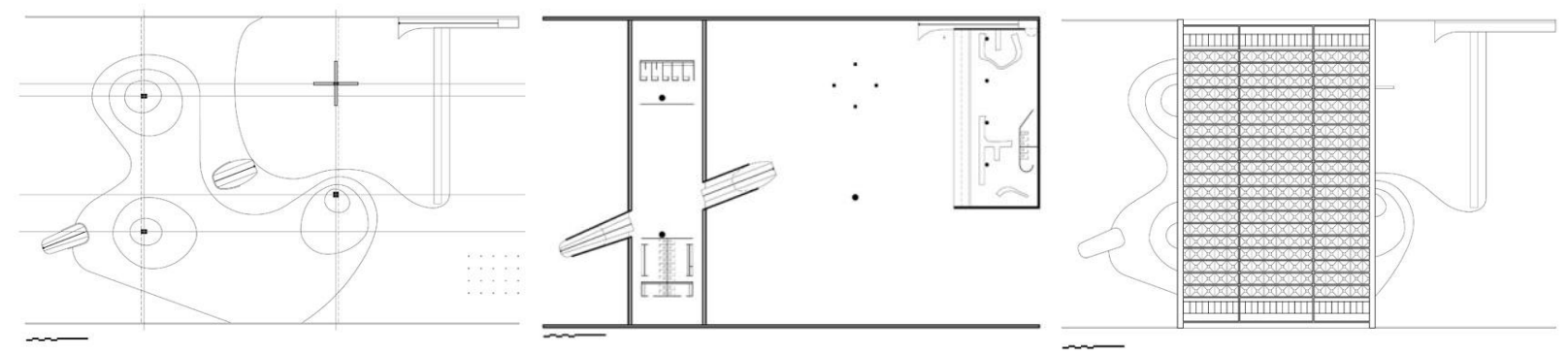

4. cubierta, planta y subsuelo del pabellón de Osaka.

El desarrollo técnico del hormigón en Brasil permite durante las décadas del 30 al 60 el uso de una herramienta de construcción eficaz que, junto con el apoyo de algunos ingenieros con sensibilidad arquitectónica, dará como resultado la Arquitectura Moderna Brasileña internacionalmente reconocida. Es por tanto razonable que, en una etapa donde el país se ha "descolgado" del tren de la tecnología y su arquitectura va a quedar expuesta ante el mundo nuevamente, se opte por hacer lo que mejor se sabe hacer: construir con hormigón.

Quizá en eso estén de acuerdo el jurado y el autor. Para Paulo Mendes, la cuestión de la identidad arquitectónica brasileña está relacionada íntimamente con la tecnología que el jurado quería para representar al país. Lo que Brasil podría ofrecer al mundo no era una nueva y original forma, si no el bagaje tecnológico que permite la construcción de esa forma. Como Paulo Mendes afirma "El pabellón representa un conocimiento, desarrollo tecnológico "15.Su ambición va más allá de lo meramente nacionalista, tiene un espíritu universal.

El tema de la gran cubierta que genera un espacio donde el espacio público se desarrolla es ya recurrente en la arquitectura Brasileña del año 69, una formulación importada por Le Corbusier que tiene sentido en el clima brasileño. Paulo Mendes habrá sido influenciado por la cubierta de la FAUSP (1961), un espacio concebido para el conocimiento y el desarrollo intelectual y social. Incluso antes, otros edificios urbanos como la marquesina del parque de Ibiriapuera de Niemeyer (1951) o el Museo de Arte Moderno de Rio, MAM (1953) habrán ofrecido ejemplos de un gran espacio libre y urbano donde todo acontece. No hace falta buscar en otros arquitectos para encontrar la misma referencia. El propio Paulo Mendes, 11 años antes, habría ganado el concurso para construir el Gimnasio Paulistano (1958) con una estructura que se resume de nuevo en un espacio cubierto y abierto a la ciudad, un edificio polivalente que en palabras de Paulo Mendes era "como hacer un bonito teatro en aquel lugar que sirviera para eventos deportivos, o para cualquier otra cosa" Paulo Mendes da Rocha".

Existe detrás de este concepto un posicionamiento humanístico que debe tenerse en cuenta. En clave social el pabellón pretende, con su configuración abierta, generar un espacio para el ser humano, un lugar de encuentro concebido en un ejercicio de libertad. Postulados propios de Vilanova de Artigas que está presente en este

\footnotetext{
${ }^{14}$ Acta del jurado para el pabellón Brasileño de Osaka 70 . Op. Cit. Traducción propia.

15 Macadar, Andrea. Op. Cit.

${ }^{16}$ Mas, Vicente y otros. "Conversaciones con Paulo Mendes da Rocha". Revista Enblanco 14. Valencia: Ed. Generales de la Construcción. 2014
} 
proyecto de una manera literal: "Simbólicamente era un techo ideal, sería el techo de nuestra FAU colocado sobre el propio paisaje, que sería el paisaje simulado por aquellas colinas" Paulo Mendes da Rocha".

Como veremos más adelante, el binomio técnica y naturaleza es para Paulo Mendes una base generadora de la arquitectura. La técnica es la herramienta con la que el arquitecto dialoga con la naturaleza y manipula sus leyes, la transforma y evidencia el poder del hombre frente a ella. Como él, un grupo de arquitectos brasileños establece en algunas obras de inicio de los 50 a los 70 una relación dialéctica entre arquitectura y gravedad a través de la técnica. En las palabras de Vilanova Artigas "Arquitectura, básicamente, es desafiar a ley de la gravedad. Eliminar apoyos, arrojar vanos..." ${ }^{18}$ pero este compromiso en negar la gravedad también es una forma de diálogo con la naturaleza a través de las condiciones gravitacionales. No se tratará pues de una mera hazaña estructural, sino de un posicionamiento humanístico. Desde el punto de vista de J.M del Monte en $L a$ poética de la gravedad, sin la técnica no existiría tal arquitectura, pero sin la base filosófica por detrás de ella resultaría fútil. ${ }^{19}$

\section{Aspectos pintorescos en el pabellón de Osaka.}

\subsection{Naturaleza y lugar}

La fuerte relación entre la arquitectura brasileña y la naturaleza es una de las características propias que mejor la definen. En palabras de Michel Racine "El movimiento moderno brasileño es un movimiento moderno con jardín "20. Esa relación puede explicarse entendiendo la exuberancia del paisaje de un país enorme y joven que aún está en proceso de exploración. La topografía de Rio de Janeiro es de tal potencia que difícilmente puede doblegarse al hombre. Es el hombre quien se integra en esa naturaleza amable que hipnotiza por su presencia masiva. La monumentalidad y sensualidad del relieve Carioca impactará profundamente en Le Corbusier y afectará a su sistema proyectual. En su propuesta para la ciudad de Rio de Janeiro (1929), propone un edificio superestructural lineal de varios kilómetros que recorre todo el litoral por encima de la ciudad existente, adaptándose a la geografía. Se trata de un proyecto premonitorio donde aparece por primera vez un factor que determina el camino a seguir de Le Corbusier: La adaptación al lugar.

En el pabellón encontramos una topografía creada que también representa a la naturaleza. Evoca la monumentalidad de la geografía original ${ }^{21}$. Ya en la década del 70 la ciudad de Rio es mundialmente conocida por su belleza natural y representa la imagen más conocida de Brasil en el mundo. No es por casualidad entonces que se aluda a esa geografía que todos conocen para representar al país. Paulo Mendes toma así prestado un paisaje para su proyecto, pretendiendo trasportar al visitante al lugar representado. La cubierta también está cargada de simbolismo: representa la delimitación de la ciudad en esa naturaleza, marca simbólicamente el espacio "civilizado" dentro de un espacio natural mayor “(...) lo que aquel pabellón quería expresar, antes de

\footnotetext{
${ }^{17}$ Macadar, Andrea. Op.cit. Traducción propia.

${ }^{18}$ Ferraz, Marcelo Carvalho (Coord. Ed.)."Vilanova Artigas", Fundação Vilanova Artigas, Instituto Lina Bo e P.M. Bardi, São Paulo.1997 p.184

${ }^{19}$ Monte. Jose María Garcia del." Poética de la gravedad". Revista del Colegio Oficial de Arquitectos de Madrid N $N^{o}$ 356, Madrid: COAM, 2009. p. 71-80

${ }^{20}$ Racine, Michael en Leenhardt, Jacques (ed). Nos jardins de Burle Max. São Paulo: Editora Perspectiva,1994, pag 114

21 Habría quizá que especificar: geografía original Carioca. Wisnik, Guilherme. "Urbanizar la vida: una técnica comprometida”. En AV monografías 161. Paulo Mendes da Rocha. Madrid: AV. 2013
} 
nada, era la conciencia de la ocupación de la naturaleza de América con las construcciones „22. La creación de una ciudad sobre el territorio es el concepto base del pabellón.

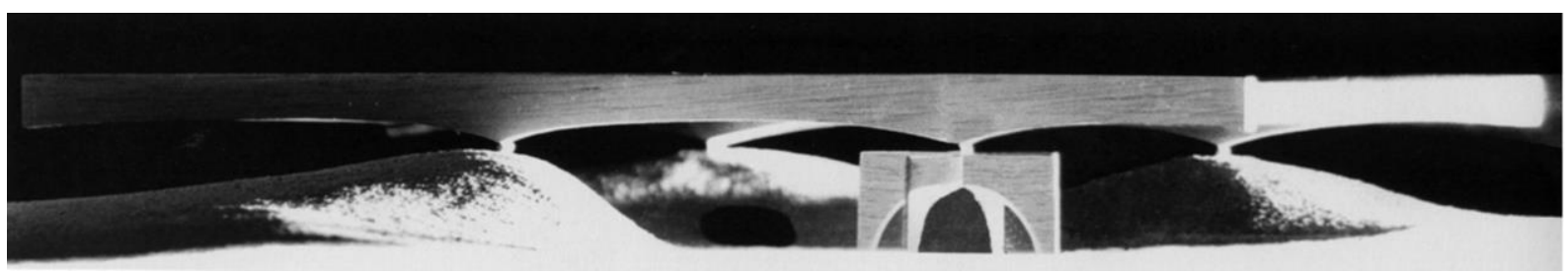

5. Pabellón de Osaka`70. Imagen de maqueta.

Para Paulo Mendes, la manera de actuar sobre el espacio pre-arquitectónico consiste en transformarlo para la creación de un espacio civilizado, la arquitectura precede a una necesidad humana y satisface sus deseos sobre un territorio.

“(...) la transformación del territorio como la parte fundamental da arquitectura, aquello que ampara proyectos que ya existen en nuestras mentes. Y que se hundirían en el pantanal sin esa reconfiguración del territorio - una nueva geografí, necesaria para sustentar los edificios, para caminar sobre lo que antes era manglar" Paulo Mendes da Rocha ${ }^{23}$

La arquitectura es por tanto una acción de elección del lugar primero y su manipulación después. Para Paulo Mendes, la belleza de Rio de Janeiro va más allá que la propia belleza del paisaje. Los espacios creados por la civilización, la abertura de avenidas, los aterros conquistados al mar, la utilización de su propia materia para manipularla es lo que la hace más bella a ojos del hombre y crea en el brasileño una conciencia sobre la posibilidad de modificar su naturaleza.

Difiere aquí del posicionamiento de Le Corbusier en su segunda etapa. En Argel, Ronchamp o la Tourette la relación de la arquitectura con el lugar pretende ser de respeto, dejando la naturaleza primigenia aparentemente "intocada". Paulo Mendes actúa sobre el lugar y lo transforma según sus necesidades. Ambos posicionamientos persiguen el marco de una naturaleza "ideal" entendida de manera diferente. Toda obra construida implica una agresiva manipulación del lugar, la diferencia viene en las intenciones. La pendiente natural sobre la que se asienta el convento de La Tourette se introduce de manera continua por debajo del piloti, restaurando la preexistencia natural. Paulo Mendes manipula la topografía y deja evidencia de esa transformación, sin por ello no aludir a un estado natural. Encontramos una diferencia substancial: el arquitecto brasileño podría fácilmente haber echado mano de la vegetación para cubrir las colinas e imitar un espacio natural, un cliché que todo el mundo identificaría con Brasil. Prefirió sin embargo abstraer el concepto de naturaleza, dejar la evidencia de la manipulación del hombre sobre el paisaje artificialmente creado.

\footnotetext{
${ }^{22}$ Macadar, Andrea. Op. Cit. Traducción del autor.

${ }^{23}$ Mendes da Rocha, Paulo, en "A Natureza é um trambolho". Caros amigos $N^{o} 61$, abril 2002. Traducción del autor
} 


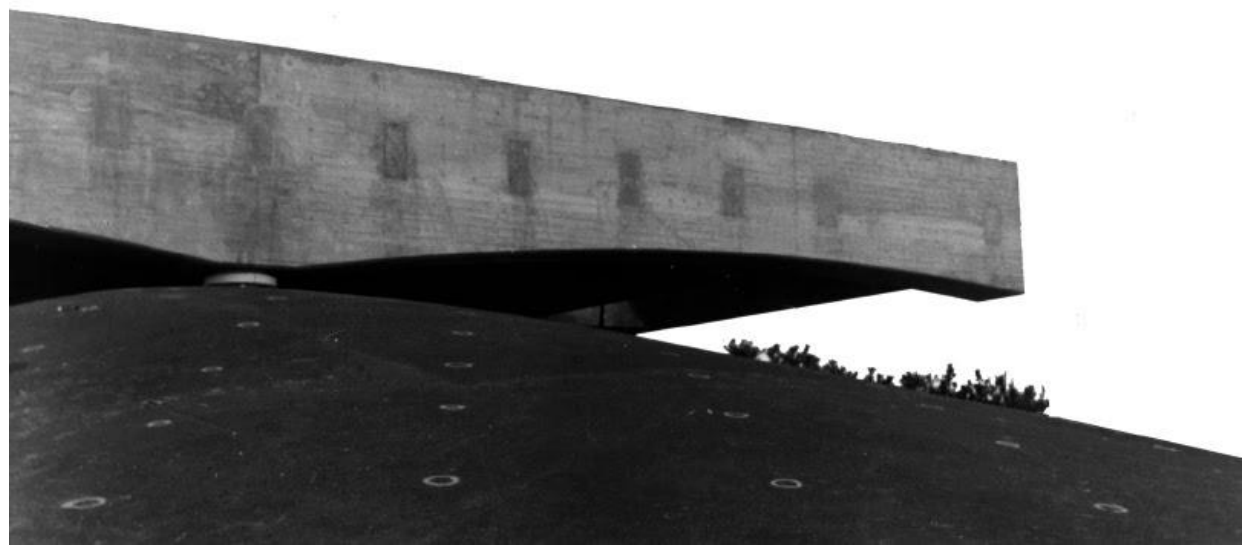

6. Imagen del pabellón construido.

La estructura de la cubierta del pabellón se apoya delicadamente sobre las 3 colinas diseñadas al milímetro para tal efecto. El resultando buscado es un estado de equilibrio armonioso entre la construcción y el espacio creado. Los arcos en los que se transforman las vigas testeras de la cubierta contribuyen a crear un diálogo entre las colinas y la cubierta. Ésta parece aproximarse delicadamente a la topografía en un gesto compartido por ambos elementos, que se tocan tímidamente en un sólo punto a través de un disco de transición. Esa pieza intermedia es la frontera que separa lo construido de la "naturaleza primigenia" creada. Encontramos en la relación de los dos elementos principales del proyecto un paralelismo con el binomio naturaleza-artificio que establecen los preceptos pintorescos. En este juego representaciones del pabellón, Paulo Mendes llama a la construcción, y concretamente al pilar abovedado "la ciudad" mientras que a la topografía la llama naturaleza ${ }^{24}$. Se establece un contraste con la misma intención con la que Constable deja aparecer la catedral entre las copas de los árboles de una forma armoniosa.

\subsection{Promenade Architecturale}

La relación del visitante con la obra también merece nuestra atención. Desde fuera de la parcela, las colinas que componen la llegada proponen al visitante unos recorridos hacia el interior del pabellón. Estos montículos son al mismo tiempo barrera y espacio de continuidad. La intención no es casual: deliberadamente el proyecto no tiene una fachada materializada, sino que podría ser un continuo infinito con múltiples posibilidades de acercamiento. El hecho de que los pilares interiores y exteriores estén dislocados ayuda a potenciar la sensación de un espacio libre y sin corsés geométricos. Ese dislocamiento también ayuda a configurar un fondo visual desde fuera, al aparecer la colina trasera entre las dos delanteras. Con esta operación el Largo do Café queda delimitado y oculto por las tres elevaciones. Se intenta así potenciar el carácter sorpresivo del espacio en el que acaba el recorrido.

A medida que nos aproximamos existen dos formas de llegar hasta el fondo de la parcela: a través de la rampa subterránea o por la superficie rodeando las colinas. La rampa desciende suavemente hasta la sala de exposiciones para después volver a subir hasta aparecer a 40 metros de distancia, ya bajo la cubierta. El proceso de entrada se convierte así en un recorrido espacial lineal donde la relación compresión-descompresión, luz y sombra y espacio enterrado-superficie son los factores que transmiten la experiencia arquitectónica. El visitante que decide caminar por la superficie recorrerá un camino sinuoso e indefinido entre las colinas. A medida que se acerque experimentara el progresivo peso de la cubierta y la escala de sus vanos.

\footnotetext{
${ }^{24}$ Macadar, Andrea. Paulo Mendes da Rocha. Entrevista, Op. Cit.
} 
En ambos recorridos existe un estudiado proceso de entrada donde las sensaciones que provocan forman parte de la experiencia. El objeto arquitectónico como elemento sujeto a la percepción y la contemplación. La promenade architectural aparece claramente definida en ambas circulaciones. Si la rampa alude al dislocamiento y a la relación espacio-tiempo, el camino entre las colinas proporciona un ejemplo de la técnica del paralaje: A medida que el caminante se va acercando a la construcción, la relación del dos primeras colinas con la que queda en el interior y el pilar abovedado irá variando.

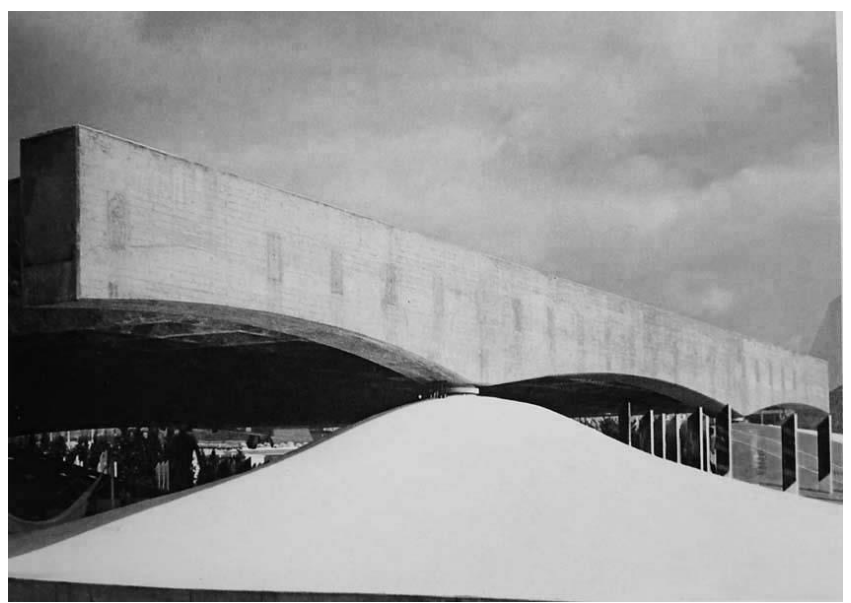

7. Feria de Osaka en funcionamiento.

\subsection{Naturaleza, Técnica y Gravedad}

“Arquitectura es, por encima de todo, el brillo del éxito de la técnica” Paulo Mendes da Rocha

Volvamos a analizar la estructura desde un punto de vista técnico: La cubierta resuelve mediante una estructura pretensada la posibilidad de grandes vanos que generan un espacio libre de pilares. Al igual el piloti, los grandes vanos generados por nuevos sistemas estructurales habrán sido introducidos por Le Corbusier en su propuesta para el auditorio de la Universidad de Brasil (1929), donde proyectará unos arcos externos que sustentan a través de cables tensionados la cubierta del auditorio, liberando el interior de pilares. A partir de ese proyecto se sucederán en Brasil muchos otros sistemas estructurales que perseguirán dar solución a la necesidad de grandes vanos. El sistema nervado del pabellón responde con otro recurso estructural a la misma demanda de un gran espacio totalmente liberado.

La cuadrícula nervada genera una retícula de claraboyas que iluminan el espacio y lo protegen de la lluvia. La forma de los nervios estructurales resuelve a su vez la evacuación del agua de lluvia a través de los pilares. Este concepto, que viene de la cubierta de la FAU, es trasladado a Japón para demostrar el carácter universal de una tecnología creada para hacer frente a la naturaleza.

Sigamos con más detalles: La propia configuración de la cubierta, compuesta por un sistema voladizo-vanovoladizo permite el equilibrio sencillo de la estructura sin necesidad de grandes alardes estructurales. El pilar abovedado absorbe las cargas gravitatorias en un punto para transferirlo a 4 en el terreno. La desaparición del soporte en la parte central, donde naturalmente debería aparecer, ayuda a potenciar la idea de levitación de la cubierta. Tampoco está exento de contenido filosófico. Representa el esfuerzo de la humanidad por vencer a la

\footnotetext{
${ }^{25}$ Mas, Vicente y otros. "Conversaciones con Paulo Mendes da Rocha”. Revista Enblanco 14. Valencia: Ed. Generales de la Construcción. 2014
} 
naturaleza ${ }^{26}$, la lucha contra la opresión de la gravedad. Sin embargo, detrás de las intenciones humanísticas de sus formas también subyace un motivo técnico: al tiempo que vence el peso de la cubierta, soportaría los terremotos mediante su gran resistencia a cortante. La técnica se ha aplicado al lugar y de nuevo se ha utilizado para manipular la naturaleza.

"De la voluntad de entender y transformar la naturaleza nace una arquitectura que la asume, pero para aprovechar su fuerza en su favor. El ensueño de la levedad que tenga a la gravedad como enemigo es escapista, ilusorio y, finalmente, imposible. Por eso, la arquitectura de la levedad ve a la gravedad como servidumbre, mientras que aquélla que la asume tiene las puertas abiertas para hacer de su dificultad e inevitabilidad motivo de su grandeza" Jose María García del Monte ${ }^{27}$

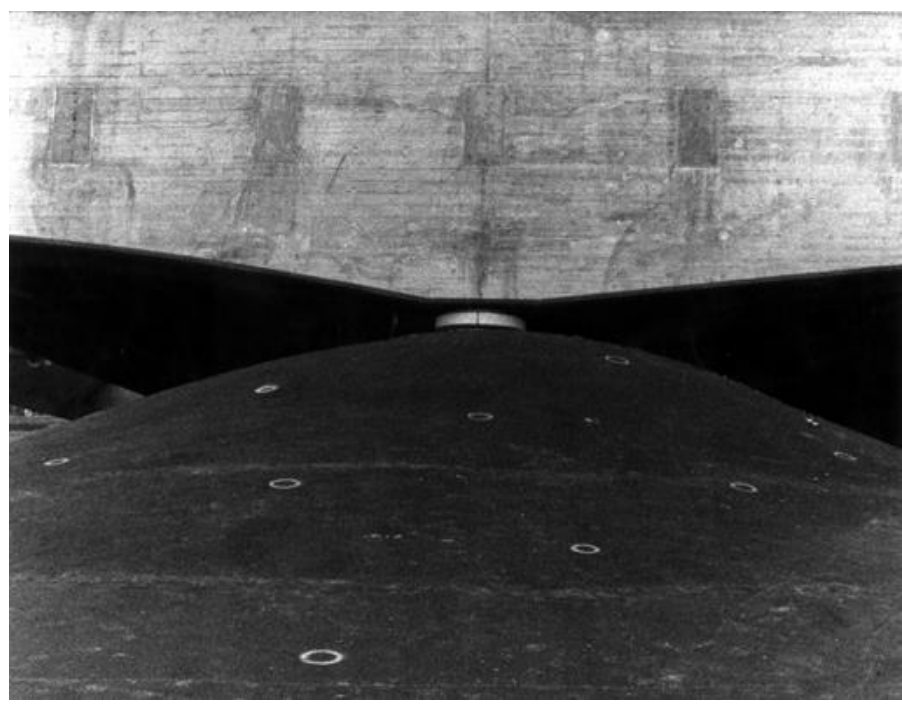

8. Detalle del contacto entre la colina y la cubierta.

\subsection{Acerca del hormigón visto}

“Después de la guerra tuve algunos encargos (...) tuve la ocasión de hacer, de utilizar por fin el hormigón. Por lo limitado de los presupuestos (...) hice hormigón bruto y en Marsella lo hice entre el 47 y el 52 (...) creo una revolución entre la gente e hice nacer un nuevo romanticismo, el romanticismo de "lo jodido" Le Corbusier ${ }^{28}$

La contrucción de la Unité de habitation de Marsella supone la aceptación de la imperfección del hormigón visto como material de expresión estructural y material. Este nuevo punto de vista se aleja de los principios modernos dictados por Le Corbusier décadas antes. Se trata de un acercamiento a posicionamientos estéticos que ya no serán abandonados. Acepta el fallo de ejecución como parte del romanticismo que implica el descubrimiento de las texturas después del desmoldaje, así como la expresividad y las sensaciones que el hormigón es capaz de

\footnotetext{
${ }^{26}$ Sperling, David. "Arquitetura como discurso. O Pavilhão Brasileiro em Osaka de Paulo Mendes da Rocha” En sitio web vitruvius.com.br, periódico “Arquitextos”, no 038.03. 2003

${ }^{27}$ Garcia del Monte, José Maria. Tesis doctoral. De las posibilidades arquitectónicas del pretensado. Madrid: UPM 2010.

${ }^{28}$ Le Corbusier. Entretiens avec George Charensol (1962) et Robert Mallet (1951). Paris : Frémeaux et associés, 2007. Traducción propia.
} 
transmitir a través de sus características. Se trata pues de un posicionamiento personal y por tanto subjetivo: “Aprovecho los recursos (del hormigón), por qué no, me divierte, me interesa” 29

Su maestro, Auguste Perret, del que heredará el conocimiento del material, habrá comenzado a utilizar el hormigón de forma vista mucho antes que él. Afirmaciones como "si la estructura no es digna de quedar vista, el arquitecto no ha hecho bien su misión" ${ }^{30}$ o "el hormigón es un material tan bello y tan mostrable como cualquier otro. Necesita ser trabajado, tratarlo como se trata la piedra" ${ }^{, 31}$ sin duda calaron en el proceso de aprendizaje de Le Corbusier con su maestro, del que adquiere dos características clave que se derivan de esas dos afirmaciones: la valorización de la estructura expuesta y el uso del hormigón armado visto. Justamente dos de las características más representativas del pabellón de Osaka.

\subsection{Naturaleza de lo sublime}

La exaltación de la técnica por parte de Paulo Mendes conlleva un significado implícito acerca del dominio del hombre sobre la naturaleza. Pero esta explicación no sería completa si no se introdujese el factor la percepción y la emoción como otro de los elementos por detrás de la utilización de la técnica. Los grandes vanos y los volúmenes másicos fluctuantes que caracteriza las obras de Paulo Mendes (y también una buena parte de la brasileñas) suponen una demostración de la capacidad de rebelarse contra la gravedad, pero por detrás de esta manipulación subyace la emoción que nos provoca el desajuste del orden escalar establecido en nuestra conciencia, un sentimiento de inquietud, al mismo tiempo que de atracción por el objeto arquitectónico suspendido. Se trata de un sentimiento innato que tiene relación con la escala humana y el orden establecido por la naturaleza. Es el mismo sentimiento que el hombre prehistórico pudo sentir cuando colocó por primera vez una piedra horizontal sobre una vertical para construir el primer dolmen. El uso de hormigón visto y bruto consigue potenciar la idea de peso, de una gran piedra levitando sobre las colinas. Es quizá el efecto perseguido por Le Corbusier con la gran masa levitada de la Tourette sobre la ladera de la montaña, los grandes aleros de la asamblea de Chandigarh o la cubierta redondeada de hormigón visto en Ronchamp, que fluctúa sobre pesados muros estructurales.

En palabras de Kant:

"Rocas audazmente colgadas y, por decirlo así, amenazadoras, nubes de tormenta que se amontonan en el cielo y se adelantan con rayos y con truenos, volcanes en todo su poder devastador, huracanes que van dejando tras de sí desolación, el océano sin límites rugiendo de ira, una cascada profunda en un río poderoso, etc, reducen nuestra facultad de resistir a una insignificante pequeñez, comparada con su fuerza. (...) llamamos gustosos sublimes a esos objetos porque elevan las facultades del alma por encima de su término medio ordinario" Inmanuel Kant ${ }^{32}$

De nuevo, Kant alude a la naturaleza nombrando elementos que al compararlos con nosotros mismos nos transportan a un relación de escalas que nos provoca un sentimiento de inquietud. Para Kant, lo bello es un acto tranquilo de contemplación, lo sublime inquieta al espíritu humano y le causa temor. La línea que separa lo temible de lo sublime está en la experiencia. Para sentir lo sublime es necesario conocimiento.

\footnotetext{
${ }^{29}$ Idem. Traducción propia.

${ }^{30}$ Gargiani, Roberto. Aguste Perret. París: Gallimard/Electa. 1994. Pg 62-63

${ }^{31}$ Perret, Auguste. Anthologie des écrits, conferences et entretiens. Paris, Le Moniteur, 2006. Pg 208.

${ }^{32}$ Kant, Immanuel: Crítica del juicio (1790), Madrid, Espasa Calpe, Colección Austral, 1995. P. 205. Traducción propia.
} 
El sentimiento de lo sublime está intrínsecamente relacionado con la monumentalidad. La gran cubierta de Osaka es la herramienta intelectual con la que Paulo Mendes, además de resolver un problema arquitectónico, está queriendo provocar reacciones sensoriales en el visitante. La escala es el instrumento utilizado para provocarnos esta sensación, generando un efecto de monumentalidad en la estructura.

"Los monumentos arquitectónicos muestran su esfuerzo por alcanzar la perfección estructural que, en gran parte, ha contribuido a la claridad de su forma, la lógica de su escala, y su efecto perdurable” Louis Kahn ${ }^{33}$

Las estructuras nervadas de las catedrales góticas suponen la etapa histórica donde el hombre ha llegó al más alto nivel de desarrollo en relación a la construcción en piedra. Su reproducción no tendría sentido hoy, puesto que las aspiraciones con las que fueron construidas no se corresponden con las actuales. Sin embargo, podemos extraer de esas estructuras monumentales una lección: es el punto final de un camino de dialogo entre hombre y la gravedad a través de la piedra como lenguaje de interlocución. La experiencia acumulada de muchas generaciones conseguirá, a través de nuevos y continuos aportes tecnológicos, comprender la naturaleza de la piedra hasta poder manipular las leyes naturales para construir arcos y pilares de una esbeltez y tamaño nunca antes visto. De la misma manera que los constructores medievales utilizaron la piedra para crear ese diálogo, arquitectos brasileños como Paulo Mendes dialogarán con la gravedad a través del hormigón. En ambos casos el objetivo es el mismo, solo cambia la herramienta con la que se trabaja.

Cuando Paulo Mendes diseñó el pabellón de Osaka quiso, en definitiva, exportar una reflexión arquitectónica al mundo: La manera en que los arquitectos brasileños construyen su arquitectura a través de la técnica aplicada al hormigón armado. La relación dialéctica de estos dos conceptos está ligada con el posicionamiento pintoresco de la obra tardía de Le Corbusier, que se libera de la racionalidad de su primera etapa para plasmar en sus proyectos aspectos sensitivos relacionados con la escala, la monumentalidad, la percepción arquitectónica, la expresividad estructural y material del hormigón o la relación con la naturaleza y el paisaje.

\section{Procedencia de la imágenes}

Figura 1: National Gallery. http://www.nationalgallery.org.uk

Figura 2: Archivo del estudio de Paulo Mendes da Rocha

Figura 3: www.arquiteturabrutalista.com.br. Autor: Eduardo Pompeo Martins (cortesia de Ruth Verde Zein)

Figura 4: www.arquiteturabrutalista.com.br. Autor: Eduardo Pompeo Martins (cortesia de Ruth Verde Zein)

Figura 5: Archivo del estudio de Paulo Mendes da Rocha

Figura 6: Archivo del estudio de Paulo Mendes da Rocha

Figura 7: Archivo del estudio de Paulo Mendes da Rocha

Figura 8: Archivo del estudio de Paulo Mendes da Rocha

\section{Bibliografia}

Ábalos, Iñaki. Atlas Pintoresco. Barcelona: Ed Gustavo Gili. 2005.

Arantes, Carolina y otros. "A natureza é um trambolho. Entrevista a Paulo Mendes”. Caros amigos. N 61. São Paulo: Editora Caros Amigos 2002.

\footnotetext{
${ }^{33}$ Kahn, Louis. "Monumentalidad” (1944). Wrigting lectures. Milán: Ed Rizoli, 1991.
} 
Colquhoun, Alan. Modernidad y tradición clásica: ensayos sobre crítica arquitectónica. Madrid-Gijon: Ediciones Júcar, 1991. Originalmente en Modernity and the Classical Tradition: Architectural Essays 19801987. Mit Pr; 1989.

Costa, Lúcio. "Presença de Le Corbusier, entrevista a J. Czajkowski, M. C. Burlamaqui e R. Brito", Revista Arquitetura. Rio de Janeiro: FAU/UFRJ 1987.

Ferraz, Marcelo Carvalho (Coord. Ed.). "Vilanova Artigas", São Paulo: Fundação Vilanova Artigas, Instituto Lina Bo e P.M. Bardi.1997

Garcia del Monte, José Maria. De las posibilidades arquitectónicas del pretensado. Tesis doctoral. Dept. de Proyectos Arquitectónicos. ETSAM- UPM. Madrid. 2010

Gargiani, Roberto. Aguste Perret. París: Gallimard/Electa. 1994.

Kahn, Louis. “Monumentalidad” (1944). Wrigting lectures. Milán: Ed Rizzoli. 1991.

Kant, Immanuel: Crítica del juicio. Madrid, Espasa Calpe, Colección Austral, 1995

Le Corbusier. Por uma arquitetura. São Paulo: Ed perspectiva. 2013

Leenhardt, Jacques (ed). Nos jardins de Burle Max. São Paulo: Editora Perspectiva,1994

Macadar, Andrea. "Paulo Mendes da Rocha. Entrevista". En Vitruvius 07, n. 026.02, abr. São Paulo:

Vitruvius.2006

Mas,Vicente y otros "Conversaciones con Paulo Mendes da Rocha". Revista Enblanco No14. Valencia: Ed. General de la construcción. 2014

Monte. Jose María Garcia del.” Poética de la gravedad”. En Revista del Colegio Oficial de Arquitectos de Madrid $N^{o}$. 356, Madrid: COAM, 2009.

Perret, Auguste. Anthologie des écrits, conferences et entretiens. Paris : Le Moniteur, 2006

Pisani, Daniele. Paulo Mendes da Rocha. Obra completa. Barcelona: Ed Gustavo Gili. 2013

Sperling, David. "Arquitetura como discurso. O Pavilhão Brasileiro em Osaka de Paulo Mendes da Rocha" En sitio web vitruvius.com.br, periódico "Arquitextos", no 038.03. 2003

Wisnik, Guilherme. "Urbanizar la vida: una técnica comprometida” En AV monografías 161. Paulo Mendes da Rocha. Madrid: Arquitectura Viva. 2013

Zein, Ruth Verde, Aamaral, Izabel. “A Feira Mundial De Osaka de 1970: O Pavilhão Brasileiro” En Arquitextos $N^{o}$ 16. Porto Alegre: UFRGS. PROPAR. 2011

Zein, Ruth Verde. A arquitetura da Escola Paulista Brutalista .1953 - 1973. Tese (Doutorado) UFRGS. Programa de Pós-Graduação em Educação, Faculdade de Educação, Universidade Federal do Rio Grande do Sul, Porto Alegre, 2005

Zein, Ruth Verde. Brutalist connections. São Paulo: Ed. Altamira, 2014 


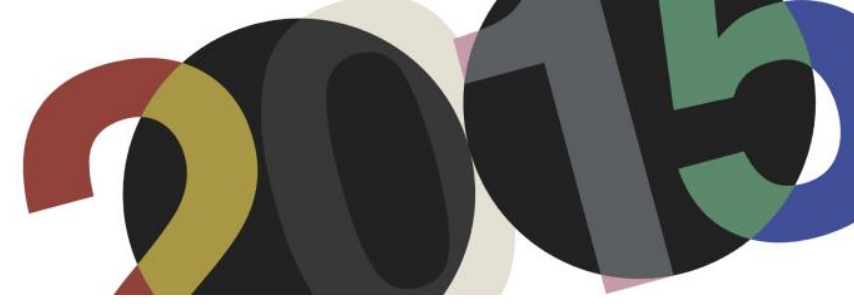

DOI: http://dx.doi.org/10.4995/LC2015.2015.669

\title{
Arquitectura y tapiz de Le Corbusier. La trama y la urdimbre de la casa nómada
}

\section{A. Gelabert Amengual}

Escuela Técnica Superior de Arquitectura de Madrid

\begin{abstract}
Resumen: Durante la primera mitad del siglo XX Le Corbusier tuvo sus primeras experiencias con los tapices de la mano de la galerista Marie Cuttoli y, sobre todo, de Pierre Baudouin, profesor de Aubusson. El arquitecto no dudó en colocar su producción de cartones para tapices a la altura del resto de su creación artística, como ya hicieran antes Leger o Picasso. Comenzó entonces una reflexión sobre las propiedades tanto plásticas como acústicas de los tapices que tuvo oportunidad de experimentar en obras tan importantes como Chandigarh o el Hospital de Venecia. Todas las consideraciones al respecto fueron recogidas después en varios capítulos de sus Obras Completas. Pero fue en la vivienda donde Le Corbusier reconoció el mayor potencial para el tapiz. Fue en el espacio doméstico donde sus experiencias con el tejido adquirieron su máxima trascendencia, llegando a elaborar un discurso que entronca directamente con las disquisiciones de Semper y Loos sobre la potencia espacial del tapiz, al que otorgaba la capacidad de generar la casa para el hombre que la década de los 60 está moldeando.
\end{abstract}

Abstract: During the first half of the twentieth century Le Corbusier had his very first experiences with tapestries thanks to the gallery director Marie Cuttoli and especially the teacher at Aubusson, Pierre Baudouin. The architect had no doubt in putting his production of tapestry cartoons at the same level of the rest of his artistic creations, as Leger or Picasso did before. Then he began a reflection on both plastic and acoustic properties of the tapestries, which he experienced in such important works as Chandigarh or the Venice Hospital. All considerations in this regard were collected in several chapters of his Complete Works. But it is in the home where Le Corbusier recognized the greatest potential for the tapestry. It is in the domestic space where his experiences with tissue acquired their utmost importance. He elaborated a discourse that connects directly with the disquisitions of Semper and Loos on the spatial power of tapestry, and that gives it the ability to generate the home for the man that the 60 s decade is molding.

Palabras clave: Tejido; tapiz; Semper; casa; nómada; contingencia.

Keywords: Tissue; tapestry; Semper ; home; nomad ; contingency.

\section{Le Corbusier en Aubusson}

Le Corbusier mantuvo a lo largo de su vida una estrecha relación con los tapices, que consideraba a la altura de cualquiera de las otras artes plásticas. Su vinculación con el arte textil es explicada con detalle en un artículo que publica en 1960 en la revista Zodiac y que titula Tapisseries Muralnomad.

“Estuve encantado de tener que abordar un dia el problema del tapiz ." Le Corbusier

El texto relata cómo fue Marie Cuttoli quien le encargó el primer cartón ${ }^{2}$ para tapiz. Cuttoli, galerista y coleccionista francesa, ya había encargado obras en esta misma técnica a otros grandes artistas de la época como

\footnotetext{
${ }^{1}$ Le Corbusier, Tapisseries Muralnomad
} 
Picasso, Léger, Miró, Calder. Había sido ella, alrededor de 1935, la que propició el resurgir de esta industria casi abandonada entonces en Francia.

Pero fue un antiguo profesor de dibujo de la fábrica de tapices de Aubusson, Pierre Baudouin quien a través de sus encargos conseguiría que Le Corbusier se dedicara más intensamente a la confección de cartones, confirmando su interés por la relación entre plástica y tejido, entendido tejido como sustantivo y como adjetivo: como trabajo terminado y como proceso de ejecución.

Al final de su vida Le Corbusier había realizado unos treinta cartones para tapices. En su correspondencia quedaron además otros proyectos como los tapices con el león heráldico de San Marcos para el Hospital de Venecia, o las propuestas de Jörn Utzon para que se encargara de otros destinados a la Ópera de Sidney ${ }^{3}$.

El arquitecto francés dedicó además varios capítulos de sus Obras Completas a estos objetos. A través de textos e imágenes, expone de qué forma el tapiz responde al espíritu de su tiempo en la creación artística, y se expresa con una tridimensionalidad plástica cercana a la del propio proyecto de arquitectura. El espacio tejido manifiesta lo tectónico, lo ontológico, lo táctil. La trama y la urdimbre son cruciales en el tejido del espacio, tanto estructuralmente como en su dimensión atmosférica.

En su obra, Le Corbusier no diferencia entre sus trabajos para tapices, pinturas, esculturas, libros, edificios o planeamientos urbanos. Todo es para él una sola misma manifestación artística del espíritu de su época. Sus tapices contienen una arquitectura latente, que puede ser desvelada siguiendo las pistas que para ello nos dejó el arquitecto. Los dibujos en los tapices incluyen las potencialidades de unas plantas (y sus correspondientes secciones) que pueden llegar a ser.

“El trazado regulador es una seguridad contra lo arbitrario ${ }^{4} "$ Le Corbusier.

Las composiciones para tapices se convierten en fuente de inspiración plástica para sus edificios. En la búsqueda de trazados reguladores, la trama y la urdimbre constituyen una referencia eficaz para su trabajo.

Así, resulta que algunas arquitecturas de Le Corbusier se tejen. La trama y la urdimbre se manifiestan de forma más o menos aparente en las plantas de algunas de sus obras, se entrecruzan y conforman un espacio tridimensional complejo que es el espacio propuesto por el arquitecto para la nueva sociedad maquinista que quiere alumbrar a través de su trabajo.

\footnotetext{
${ }^{2}$ Según el diccionario de la Real Academia Española (RAE), 22ª ed., el cartón es el 7. m. Pint Dibujo sobre papel o lienzo, a veces colorido, de una composición o figura, ejecutado en el mismo tamaño que ha de tener la obra de pintura, mosaico, tapices o vidriería para la que servirá de modelo.

${ }^{3}$ Tal y como expone el profesor Juan Calatrava en su texto Le Corbusier, 1955: en los alrededores del El poema del ángulo recto en Juan Calatrava (ed.), Doblando el ángulo recto. 7 ensayos en torno a Le Corbusier. Madrid: Área de Edición del Círculo de Bellas Artes, 2009. 199 p.

4 "Del nacimiento fatal de la arquitectura. La obligación del orden. El trazado regulador es una seguridad contra lo arbitrario. Procura la satisfacción del espíritu. El trazado regulador es un medio; no es una receta. Su elección y sus modalidades de expresión son parte integrante de la creación arquitectónica." Le Corbusier: Vers unes architecture, p. XXIV
} 
A su vez, las descripciones sobre las propiedades atmosféricas, e incluso sociales o económicas, de los tapices muestran cuáles serán las cualidades que se derivarán del uso de esa técnica en la construcción de los edificios, tanto públicos como privados; se atreve incluso a vaticinar quién será el habitante de la casa construida con tapices.

Elabora en este sentido un discurso que entronca directamente con las reflexiones de Gottfried Semper reivindicando el papel de lo textil en los orígenes mismos de la arquitectura, de la estera como el más primitivo divisor del espacio. Semper, como Le Corbusier, atribuye al elemento textil la capacidad de construir por sí mismo el espacio social, más allá del soporte que pudieran darle el resto de elementos.

“Los tapices colgantes eran los verdaderos muros, los límites visibles de espacio. Las paredes sólidas a menudo detrás de ellos eran necesarias por razones que no tenían nada que ver con la creación de espacios; eran necesarias para la seguridad, para soportar una carga, para su permanencia y así sucesivamente. Donde no se planteó la necesidad de estas funciones secundarias, los tapices se mantuvieron como los medios originales de separación del espacio. Incluso cuando se hizo necesaria la construcción de muros sólidos, sólo eran la estructura interna, una estructura invisible escondida detrás de los representantes verdaderos y legítimos del muro, los coloridos tapices tejidos. ${ }^{5}$ " Gottfried Semper

Este posicionamiento es válido en el terreno privilegiado para el uso del tapiz: la vivienda. La misma técnica, en cambio, cumple una función distinta al salir del espacio doméstico. En los edificios públicos ya no es más el encargado casi único de la construcción de los espacios, sino que pasa a jugar un papel mucho más tecnológico, su rol será crucial en cuanto al control de las propiedades acústicas de las grandes construcciones de hormigón armado. Los tapices devienen entonces tapisseries acoustiques. El tapiz sigue, en cualquier caso, ligada a la definición atmosférica del edificio.

\section{Propiedades plásticas, propiedades atmosféricas}

La primera vez que aparecen los tejidos en la Obra Completa es en el Volumen 3: 1934-1938 en la Exposition d'art dit 'Primitif' de Louis Carré en el apartamento de Le Corbusier (1935). En las dos páginas que se le dedican en la publicación, se muestra algún tapiz de Leger de forma recurrente (concretamente, aparece en tres de la cuatro imágenes que ilustran la exposición). El proyecto que sigue inmediatamente es el Pavillon des 'Temps Nouveaux'. La construcción de este pabellón para la Exposición Internacional de París de 1937, con cables y lonas, cierra un espacio cuya dirección estructural (urdimbre) es tejida tridimensionalmente por los recorridos (trama). Los accesos se producen en dirección perpendicular a la de los pilares metálicos, y en la misma se desarrollan las rampas que recorren el pabellón; una arquitectura tejida relatada tras una exposición en la que el tapiz resulta la obra más destacada.

Tras el proyecto de Chandigarh, el tapiz adquiere una nueva dimensión en la obra de Le Corbusier, debido en gran parte a la estrecha relación que mantuvo con los tejedores de Kashmir durante su experiencia en la India. Y es así como en el Volumen 6: 1952-1957 se dedica un capítulo íntegro del índice a las Tapisseries, en el que a lo largo de dos páginas de la Obra Completa se relatan varias de sus experiencias con los tapices: desde su relación con Pierre Baudouin en Aubusson, hasta los tapices para Chandigarh pasando por el cartón para el arquitecto

\footnotetext{
${ }^{5}$ Gottfried Semper: The Four Elements of Architecture, en The Four Elements of Architecture and other Writings, p. 104
} 
japonés Sakakura. Además, y sobre todo, se apunta aquí por primera vez la vinculación del tapiz con el hombre nómada que está surgiendo en esa época, una relación desarrollada en el texto Tapisseries Muralnomad al que se hacía referencia en el arranque del presente texto.

Todas estas explicaciones preceden al proyecto de la Villa Shodan (Ahmedabad, 1951). La casa Shodan no tiene una dirección clara: los vientos soplan en una dirección, la estructura se dispone en la otra; la casa parece mirar en la primera, la circulación principal con la rampa se desarrolla en la otra; el acceso se produce en la primera dirección, el pavimento se ordena en la perpendicular... Los espacios se cruzan constantemente en distintos planos, las direcciones se atan conformando un edificio tejido.
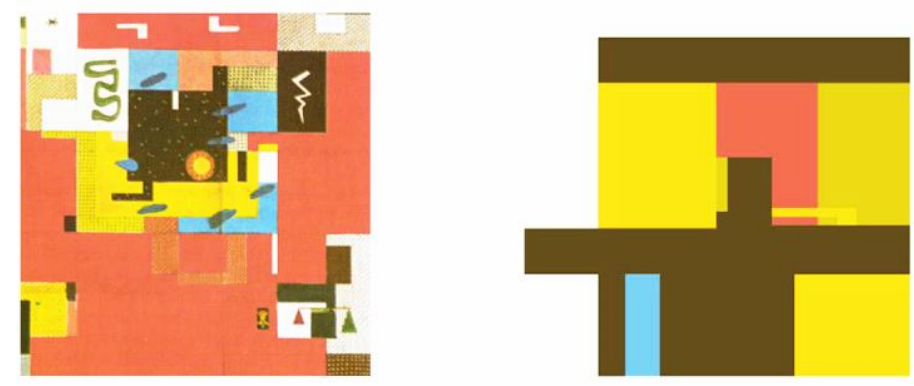

1. Uno de los tapices que preceden el proyecto de la casa Shodan en el Volumen 6 de la Obra Completa (izq.). Plantas superpuestas de la casa Shodan (der.)

Tras haber ofrecido varias pistas con los proyectos descritos hasta ese punto, en las páginas dedicadas al Capitolio de Chandigarh en el Volumen 8: 1965- 1969 les dernieres ouvres de las Obras Completas el enlace entre tapiz y composición arquitectónica se hace ya explícito. Con el último tapiz de la serie dedicada a Chandigarh y diseñados para el Palacio de la Justicia, Le Corbusier desvela abiertamente la relación plástica que existe entre el diseño de sus tapices y algunos de sus edificios. Ese último tapiz aparece ocupando toda una página (par) y al otro lado, ocupando también la página completa (impar) la planta del segundo proyecto para el Hospital de Venecia (1965). Entre uno y otra podemos leer: L'étonnante ressemblance des formes.

Incluso de forma más clara que en la Villa Shodan, en el Hospital de Venecia dos direcciones se cruzan: en los tres niveles del edificio de nuevo encontramos dos direcciones estructurales, dos direcciones de circulación, dos direcciones de iluminación, dos direcciones de compartimentación, dos direcciones de mobiliario... que también en esta ocasión se cruzan tejiendo un edificio-tapiz. El nudo semperiano como manifestación del estado tensional de la arquitectura. 

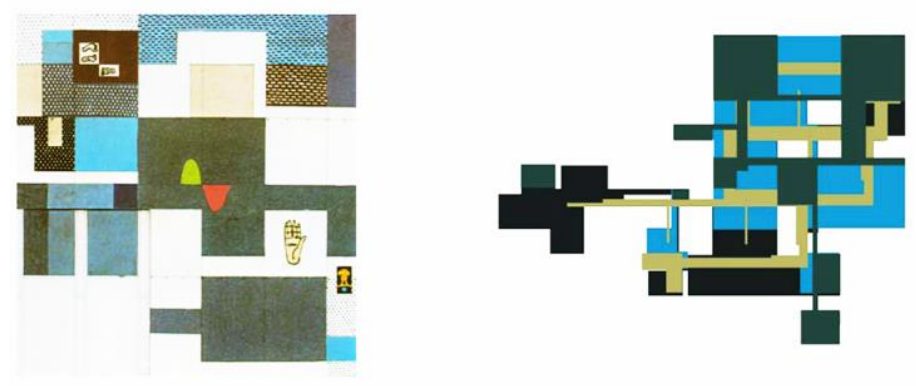

2. Uno de los tapices que preceden al Hospital de Venecia en el Volumen 8 de la Obra Completa (izq.). Plantas superpuestas del Hospital de Venecia (der.)

Existe por lo tanto un camino bidireccional que va desde los proyectos de las dos últimas obras citadas anteriormente (Shodan y Hospital de Venecia) hasta los diseños de los cartones para los tapices de Chandigarh. La superposición de las plantas de esos edificios muestra su doble dirección y el cruce de los espacios en su voluntad de tejerse, la asombrosa similitud de formas no es casual.

Pero es que es posible emprender también un camino complementario: el que parte de los tapices para llegar a las arquitecturas a través de su definición atmosférica.

Como se ha citado, los tapices (y la acústica del Capitolio de Chandigarh) ocupan un espacio muy importante al final de la Obra Completa. Toda esa extensión, que acaba con L'étonnante ressemblance des formes es en realidad dedicada a describir la importancia atmosférica de los elementos textiles en los espacios construidos en hormigón armado. En las 13 páginas completas dedicadas a versar sobre las propiedades de los tapices que cuelgan en el Capitolio, se mencionan cuestiones como la escala, la simbología, la acústica o el cromatismo:

“Los 650m2 de tapices fueron fabricados en los talleres de Kashmir en 1955 y 1956. Los habilidosos tejedores de tapices en India apenas necesitaron cinco meses para completar el trabajo. Ocho tapices de $64 \mathrm{~m} 2$ cada uno y uno de 144m2 cuelgan de las paredes traseras de las salas del Palacio de Justicia.

En el edificio del Parlamento, también, los tapices cumplen una función acústica. Cuando el visitante accede por la entrada baja a oeste del Parlamento, experimenta un espectáculo arquitectónico apabullante. Entra en un hall alto, sombreado, fresco. En el muro norte, tras las columnas y la rampa, hay un tapiz azul-rojizo de 25 metros de largo extendiéndose de suelo a techo y cubierto con motivos simbólicos. Además de su función óptica, también tiene una finalidad acústica. ${ }^{6, "}$ Le Corbusier

Le Corbusier ya había hablado de ese papel fundamental del tapiz en la definición atmosférica de los grandes edificios de hormigón armado en el texto Tapisseries Muralnomad, en el que hace referencia explícita tanto a las salas de tribunal del Palacio de Justicia de Chandigarh como a la gran sala de teatro de Sakakura, para quien realizó un cartón 1956. Este tapiz, de $230 \mathrm{~m}^{2}$, serviría como telón del teatro Bunka Kaikan de Tokyo. El mismo cometido cumplen los tapices para Chandigarh, colgados en las paredes del Palacio de Justicia y que fueron

\footnotetext{
${ }^{6}$ Le Corbusier: Le Corbusier: les dernières oeuvres [1965-1969], p. 118
} 
colocados por razones acústicas, y con la voluntad de situar uno junto al otro el trabajo en hormigón armado del arquitecto (resonante) y el trabajo en lana de los artesanos (absorbente acústico). El tapiz se convierte aquí en un instrumento privilegiado para el encuentro entre plástica y arquitectura.

\section{Mural-nómada}

Pese a haberlos utilizado en varias ocasiones en sus edificios públicos, Le Corbusier siempre consideró que el terreno privilegiado de la recuperación moderna de la actividad textil era la vivienda, la escala doméstica. Desde el momento en que el tapiz constituye un tema con entidad propia en su obra, Le Corbusier determina que éste debe cambiar su uso. Ya no formará nunca más parte del mobiliario de la vivienda, no deberá asemejarse a cualquier otro mueble auxiliar, ni en tamaño ni en posición. Ni siquiera es para él un cuadro, enmarcado y suspendido en el centro de un vano. El tapiz debe ocupar una pared de suelo a techo, y construirse según las dimensiones del Modulor (226-296-366 cm) con la voluntad de ajustarse a la medida del hombre. Dejará de ser entonces un adorno para convertirse en un elemento más en la composición arquitectónica, un elemento capaz de ordenar el espacio interior de la vivienda ${ }^{7}$. El tapiz es el Mural de los tiempos modernos, que han convertido al hombre en nómada.

“(...) jel hombre moderno es un nómada! Nuestro nómada cambia de casa porque su familia ha crecido, o, por el contrario, porque sus hijos se han casado. El tapiz le da la posibilidad de proveerse de un 'mural', es decir, una pintura de grandes dimensiones, de potencial arquitectónico. Desenrolla su tapiz y lo despliega sobre el muro, hasta el suelo. ¿Quiere mudarse? Enrolla su 'mural', lo pone bajo su brazo y baja las escaleras para instalarse en su nueva ubicación. " Le Corbusier

La potencialidad arquitectónica deviene el atributo fundamental del tapiz, que ha dejado de ser un objeto decorativo para se un objeto conformador del espacio. Es aquí donde el vínculo con las propuestas de Semper se hace más evidente, ya que mientras que en los grandes edificios públicos el tapiz trabaja frente al hormigón, matizando sus propiedades, aquí el tapiz sustituye al muro, que deja de ser necesario para levantar la casa El tapiz es el elemento que resuelve el nuevo interés por el arte de una nueva sociedad en constante movimiento. No es posible pintar un mural en las paredes de un apartamento que se abandonará al cabo de unos años, en cuanto la situación familiar cambie. Su función en cualquier caso "no es la de potenciar el muro; por el contrario significa una destrucción violenta del mismo, haciéndole perder sus valores de estabilidad, peso, etc" como dice Le Corbusier en 1932 en una carta a Vladimir Nekrassov. Juega un papel crucial en la apropiación del espacio. El tapiz es el 'mural del nómada' que colma en los hogares un deseo poético de sus habitantes. Introduce una serie de nuevas relaciones, con su textura, su materia, la lectura de su proceso de confección. La impronta manual del elemento constructivo, o la energía viva de la arquitectura repercutiendo sobre el usuario.

\footnotetext{
${ }^{7}$ En el mismo sentido, Adolf Loos afirmará que la tarea del arquitecto es la definición de los elementos textiles que conforman el espacio: "Pongamos que el arquitecto tuviera aquí la misión de hacer un espacio cálido y habitable. Las alfombras son cálidas y habitables. Este espacio podría resolverse poniendo una de ellas en el suelo y colgando cuatro tapices de modo que formaran las cuatro paredes. Pero con alfombras no puede construirse una casa. Tanto la alfombra como el tapiz requieren un armazón constructivo que los mantenga siempre en la posición adecuada. Concebir este armazón es la segunda misión del arquitecto.” Adolf Loos: El principio del revestimiento, p. 151

${ }^{8}$ Le Corbusier: Le Corbusier et son atelier rue de Sèvre 35: oeuvre complète 1952-1957, pp. 132-133
} 


\section{Suspender las presencias contingentes}

Como señala Josep Quetglas en su texto La línea vertical, Le Corbusier define la casa en la introducción a la segunda edición de Vers une architecture como un bastión fuera del alcance de las embestidas de la naturaleza que le es hostil, que nos acosa:

"Una casa que sea ese límite humano, que nos rodee, que nos separe del fenómeno natural antagonista, que nos dé nuestro medio humano, a nosotros, los hombres.". Le Corbusier

Es en ese mismo sentido que la modernidad trató de suspender el tiempo, ineludible manifestación natural, en sus proyectos. Le Corbusier da cuenta de ello en su texto L'espace indecible, publicado en abril de 1946 y en el que se plantea el ejercicio de describir cuál será la forma más elevada de apropiación y gestión del espacio por parte de la arquitectura:

"No es un efecto del tema elegido, sino una victoria de la proporción en todas las cosas, tanto en los aspectos físicos de la obra como en la eficiencia de las intenciones, reguladas o no, aprehendidas o inaprensibles y, no obstante, existentes y deudoras de la intuición, milagro catalizador de saberes adquiridos, asimilados aunque tal vez olvidados. Pues en una obra concluida con éxito hay masas intencionales ocultas, un verdadero mundo que revela su significado a quien tiene derecho, es decir, a quien lo merece.

Se abre entonces una profundidad sin límites que borra los muros, expulsa las presencias contingentes y realiza el milagro del espacio inefable. ${ }^{10, "}$ Le Corbusier

No queda duda al respecto de cuál debe ser el papel de las incertidumbres en la arquitectura: las presencias contingentes serán expulsadas en la búsqueda del éxito pleno de la obra arquitectónica.

La vida del habitante nómada al que Le Corbusier hace depositario de sus tapices está altamente expuesta a la contingencia, a la sucesión de eventos que escapan de su control a priori y que pueden hacer movedizo el espacio que habita. ¿Cómo obviar la presencia de ese tiempo incierto en la casa del habitante nómada, que se ve obligado a construir un nuevo hogar cada vez que su circunstancia le apremia a moverse?

El tapiz se convierte en el dispositivo capaz de permitir que el espacio permanezca inmutable pese a las embestidas de la incertidumbre. El tapiz construye un espacio confortable, equipado. Un lugar que resuelve incluso las aspiraciones poéticas de sus ocupantes. El tapiz suspende el tiempo.

\section{Procedencia de las imágenes}

1. Mayol, Jaume: Arquitectures teixides. No publicado

2. Mayol, Jaume: Arquitectures teixides. No publicado

\section{Bibliografía/referencias}

Le Corbusier: Le Corbusier \& P. Jeanneret: oeuvre complète 1934-1938 / publiee par Max Bill (12th ed.) Zurich: Editions d'Architecture Artemis, 1995

\footnotetext{
${ }^{9}$ Le Corbusier, Vers une architecture. p. XXI

${ }^{10}$ Le Corbusier, El espacio inefable
} 
Le Corbusier: Le Corbusier et son atelier rue de Sèvre 35: oeuvre complète 1952-1957 / publiee par W. Boesiger (9th ed.) Zurich: Editions d'Architecture Artemis, 1995

Le Corbusier: Le Corbusier: les dernières oeuvres [1965-1969] publiee par W. Boesiger (5th ed.). Zurich: Editions d'Architecture Artemis, 1995

Le Corbusier: Vers une architecture. Présentation de Jean-Louis Cohen. París: Flammarion, 2005

Le Corbusier: "El espacio inefable" (Pérez Colina, Marisa trad.). En Minerva. "Dossier Le Corbusier". Marzo 2006, N 2. Madrid: Círculo de Bellas Artes, 2006

Golan, Romy: Muralnomad. The paradox of wall painting, Europe 1927-1957. New Haven, USA: Yale University Press, 2009

Loos, Adolf. "El principio del revestimiento". En Loos, Adolf: Escritos I, 1897-1909. Madrid: Corquis, 1993

Oddo, Maurizio: Le Corbusier: dalla pittura al muralnomad. Palermo: Medina, 1997

Semper, Gottfried: The four elements of architecture and other writings. Cambridge: Cambridge University Press, 1989 


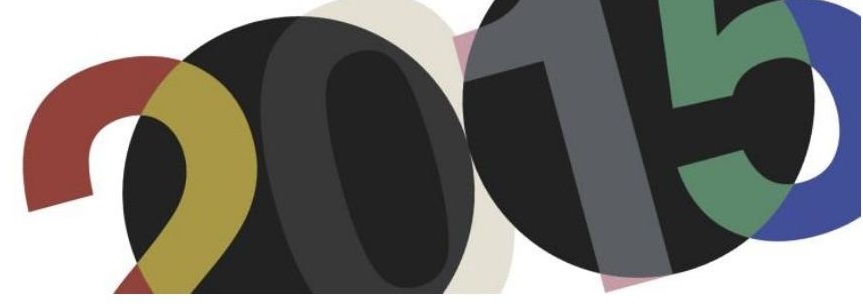

DOI: http://dx.doi.org/10.4995/LC2015.2015.553

\section{Génesis del proyecto de la Cité de Refuge de París}

\section{A. Gómez García}

Escuela Politécnica Superior. Universidad CEU San Pablo

Resumen: Este artículo analiza los croquis de las primeras versiones del proyecto de la Cité de Refuge de Paris desvelando las sucesivas estrategias empleadas en el proceso de proyecto así como la génesis de la propuesta finalmente construida. A partir de la ordenación y análisis de los croquis que se conservan en la Fondation Le Corbusier se exponen los mecanismos perceptivos y compositivos que Le Corbusier empleó, las decisiones puntuales en las primeras fases del proyecto, sus consecuencias formales y organizativas así como las connotaciones simbólicas que otorgaba a cada una de las formas arquitectónicas y a su organización en la época de redacción de este proyecto.

Abstract. This article analyzes the sketches about the project first versions of the Cité de Refuge in Paris, unveiling the successive strategies used in the design process as well as the genesis of the proposal finally built. After arrange and analysis the Fondation Le Corbusier documentation, they are exposed perceptual and compositional mechanisms that Le Corbusier used, the specific decisions in the early stages of the project, its formal and organizational consequences as well as the symbolism of the architectural forms usual for him at the time working in this project.

Palabras claves: Le Corbusier, Cité de Refuge, figura y fondo, secuencia perceptiva.

Keywords: Le Corbusier, Cité de Refuge, figure and background, perceptive sequence. 


\section{Introducción}

El proyecto de la Cité de Refuge de París se desarrolla entre los meses de mayo de 1929 y junio de $1930^{1}$. Entre la primera idea, presentada el 25 de septiembre de 1929, y la versión definitiva con la que se inicia la obra el 24 de junio de 1930, se suceden hasta cinco propuestas diferentes. La razón no es otra que la compra por lotes del terreno, llevada a cabo en tres momentos diferentes, al mismo tiempo que se elabora el proyecto. Le Corbusier dibuja los primeros croquis ese mismo mes de mayo, sobre una parte del solar denominada Lote 2 con acceso desde la rue Cantagrel y con un área de $976 \mathrm{~m} 2$, y de acuerdo con un programa, provisional, redactado por el comisario Albin Peyron ${ }^{2}$. Mientras, la Institución benéfica promotora de la construcción tramita la adquisición de un adyacente Lote 1, de $728 \mathrm{~m} 2$ de superficie y con salida a la rue Chevaleret, cuya compra formaliza en julio de 1929. En marzo de 1930 adquiere a su vez un tercer lote, muy pequeño, que amplía el lindero hacia la primera vía. Esta coincidencia del proceso proyectivo con las variaciones del terreno hará que su evolución no resulte lineal dando lugar a ciertas contradicciones que este artículo propone estudiar.

El análisis en profundidad de las cuatro primeras versiones nos permitirá entender el desarrollo y las vicisitudes del proyecto antes de llegar a la solución definitiva, los mecanismos perceptivos y compositivos que el arquitecto empleó, así como las consecuencias formales y organizativas derivadas, especialmente aquellas que fueron filtradas por la mirada pictórica del arquitecto. También, las connotaciones simbólicas que por aquellos años Le Corbusier otorgaba a cada una de las formas arquitectónicas que empleaba así como el modo en que éstas construían su particular promenade architecturale.

\section{Análisis}

El encargo de la Cité de Réfuge supone todo un reto para un arquitecto que, a pesar de no tener mucha experiencia en este tipo de inmuebles, cuenta con la absoluta confianza de su cliente ${ }^{3}$. No es un proyecto fácil pues el objetivo consiste en insertar, en una gran urbe, una unidad arquitectónica completamente autónoma con un complejo sistema de espacios de alojamiento, comedor y talleres de reinserción social además de servicios de asistencia, cuyo destino debe reflejarse de algún modo en la construcción. El carácter ciertamente singular de los usuarios demanda, en este sentido, dotar al edificio de una especial significación. A grandes rasgos el programa, en el inicio, puede estructurarse en cuatro áreas:

1. Dormitorios separados para hombres y mujeres con un total de 500 o 600 camas.

2. Estancia y comedor colectivos con cocina y dependencias anexas.

3. Talleres de formación ocupacional.

4. Servicios auxiliares, tales como despachos de dirección y administración, sala de actos, ambulatorio médico, dormitorios del personal, vestuarios ó lavandería.

Para estudiar la distribución de tan complejo programa Le Corbusier utiliza, como en otras ocasiones, unos organigramas en base a círculos y cuadrados proporcionales a los espacios reales que, conectados entre sí,

\footnotetext{
${ }^{1}$ Una historia detallada, tanto del proceso de proyecto como de la construcción del inmueble, puede encontrase en Brace Taylor, Brian: La cité de Refuge di Le Corbusier. Officina edizioni. Roma, 1979.

${ }^{2}$ Alvin Louis Octave Peyron, Nimes 1870-París 1944, fue comisario territorial de l'Armée du Salut desde el 5 de mayo de 1917 hasta el 11 de Septiembre de 1934.

${ }^{3}$ El primer contacto de Le Corbusier con l'Armée du Salut fue en 1925 con el encargo de la ampliación del Palais du Peuple, gracias a la amistad de su hermano Albert con Winnaretta Singer, princesa Edmond de Polignac, benefactora tanto de la Cité de Refuge como del Asile Flottant. Brace: Op. Cit, p.29.
} 
garantizan un funcionamiento correcto ${ }^{4}$. Si bien es cierto que estos esquemas no deberían, necesariamente, condicionar una determinada configuración sí que en esta ocasión, como iremos viendo, su síntesis se refleja, de una manera u otra, en todas las versiones.

La primera decisión que toma es utilizar sólo dos piezas, una para los usos más relacionados con el exterior y otra para los más privados, dejando los talleres ocupacionales, junto con la cocina, la lavandería y un pequeño jardín, en un nivel bajo rasante. Las dos piezas principales se conectan entre sí por un puente y, mientras la más pequeña se sitúa junto a la calle, la otra se desplaza hasta el fondo del solar (fig.1). La primera aloja los usos de administración, recepción y salón de actos mientras que la segunda, mucho más grande, alberga el comedor y oficio en planta baja sobre la cocina y hasta cuatro niveles de dormitorios más uno de terraza-azotea. En principio se trata de una propuesta de indudable raigambre urbanística, un trozo de tejido urbano que se define por unas piezas de geometría simple colocadas en un plano horizontal que se extiende sobre la naturaleza, lo que no deja de formar parte de lo que por aquellos años defendía el arquitecto: “... je compose atmosphériquement... le centre de gravité de la composition architecturale s'est élevé: il n'est plus celui des anciennes architectures de Pierre qui entraînaient avec le sol une certaien liaison optique" ${ }^{5}$. No obstante, no debemos descartar que desde el inicio del proyecto tenga ya en mente la futura salida a la rue Chevaleret cuya rasante, en el punto de acceso, se sitúa cinco metros por debajo de la rue Cantagrel.
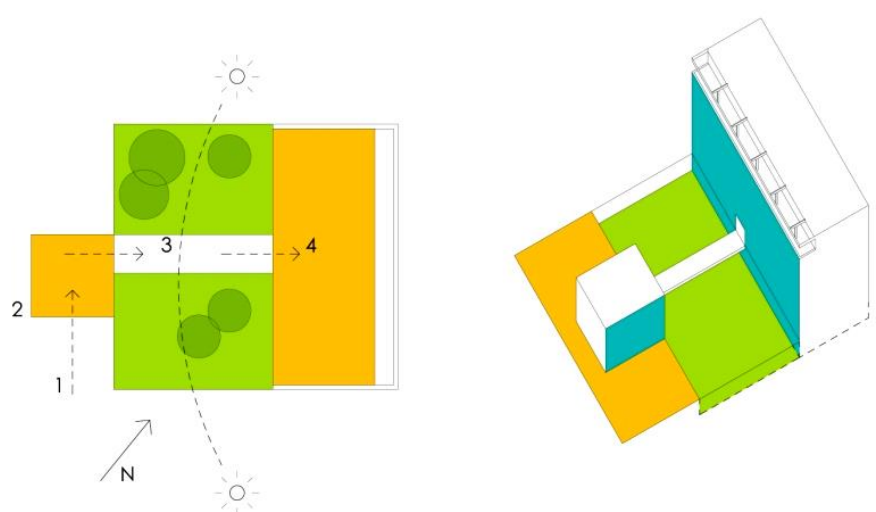

1. Esquemas de idea de la primera versión (dibujos del autor)

Con las primeras decisiones aparecen también los aspectos más singulares que se deben resolver y que, básicamente, podrían resumirse en la adecuada formalización de la pieza de recepción, el modo de cruzar sobre un trozo de naturaleza y la manera de entrar en el nuevo refugio. Con respecto a este último, el acceso se hará, así lo decide Le Corbusier, a través de una fachada completamente acristalada, como gustaba escribir en esa época: “Je ne chauffe plus mes maisons, ni même l'air. Mais un flot abondant d'air pur à 18 degrés circule

\footnotetext{
${ }^{4}$ Croquis FLC-11.201. Otros organigramas pueden encontrarse en el archivo de la Fondation Le Corbusier de París, por ejemplo para el Palais des Soviets (FLC-27.600) o para la Mill Owner's Association de Ahmedabad (FLC-6.880).

5 "El centro de gravedad de la composición arquitectural se ha elevado, ya no es el mismo que el de las antiguas arquitecturas de piedra que componían con el suelo una cierta unión óptica... yo compongo atmosféricamente”. Le Corbusier: Précisions sur un état présent de l'architecture et de l'urbanisme. Collection de "L'Esprit Nouveau". Les Éditions G. Crés et C. Paris, 1930, pp.50 y 58 (edición en castellano: Le Corbusier: Precisiones. Respecto a un estado actual de la arquitectura y el urbanismo. Editorial Apóstrofe. Barcelona, 1999).
} 
régulièrement à raison de 80 litres par minute et par personne... ce sont les murs neutralisants (notre invention) qui vont empêcher cet air à 18 degrés de subir quelqu'influence que ce soit" ${ }^{6}$.

Una vez pensadas, las piezas son colocadas en el solar adaptándose, tanto en forma como en posición, a sus directrices geométricas, momento que recoge el croquis FLC-11.191 (fig.2)7.

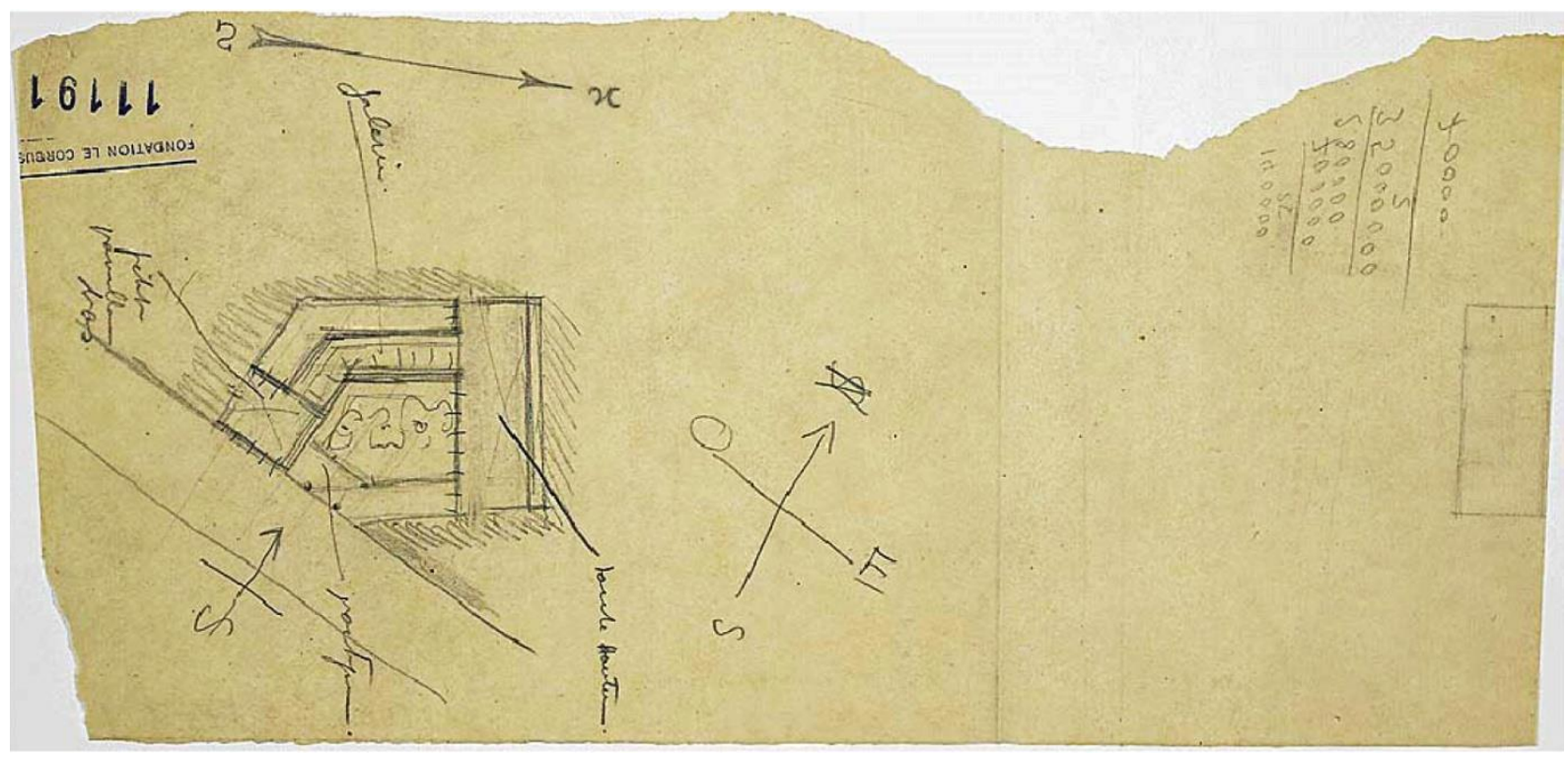

\section{FLC-11.191@}

La primera pieza, así como el primer tramo del puente, siguen la dirección que determina la rue Cantagrel mientras que el segundo tramo y el bloque de dormitorios se orientan según el trazado de las medianeras. Es interesante destacar aquí como, en el tránsito entre ambas direcciones, se produce un cambio del ángulo de visión del bloque de dormitorios que, de oblicuo en la primera, se hace perpendicular en la segunda anticipando uno de los mecanismos que se emplearán en el engarce de las piezas del proyecto final. Este cambio de visión parece apropiada a la mirada de un pintor tal como describe Von Moos: "La ensambladura de formas aisladas, previamente modeladas como unidades plásticas que se ordenan según la percepción de forma y colores, corresponde a la mirada de un pintor" ${ }^{\prime \prime}$.

Después, una vez decidida la ordenación de los volúmenes, el proceso de proyecto se centra en resolver las dos cuestiones más conflictivas: por una parte, la adaptación de la forma y localización de la primera pieza a la doble geometría que definen la calle y el solar y por otra, la articulación de la, podríamos decir, violenta entrada frontal en el bloque de dormitorios así como su trasformación, dentro de él, en un recorrido vertical hasta alcanzar la terraza.

\footnotetext{
6 "Ya no calefacto mis casas, ni tan sólo el aire. Pero una oleada abundante de aire puro a $18^{\circ}$ circula regularmente a razón de 80 litros por minuto y por persona... son los muros neutralizantes que impedirán que este aire de $18^{\circ}$ sufra cualquier influencia”. Le Corbusier: Précisions. Op. cit. p.66.

${ }^{7}$ En la Fondation Le Corbusier de París se conservan más de 1200 dibujos relacionados con la génesis, proyecto y obra de la Cité de Refuge. No están numerados ordenadamente, ni siquiera fechados, por lo que cualquier intento de interpretación cronológica choca, inevitablemente, con una subjetiva hipótesis. Los dibujos analíticos que se presentan en este artículo han sido realizados expresamente por el autor a partir de la copia que guarda la Biblioteca del MNCARS de Madrid y de la publicación digital del archivo realizada por Codex Images International en 2005.

${ }^{8}$ Von Moos, Stanislaus: Le Corbusier. Editorial Lumen. Barcelona, 1977, p.376.
} 

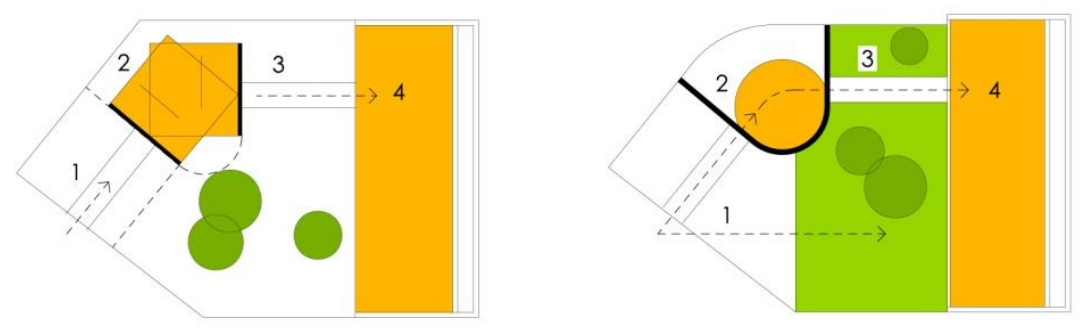

3. Esquemas de configuración del vestíbulo en la primera versión (dibujos del autor)

En cuanto a la primera, cómo resolver el cambio de trayectoria del recorrido, la propuesta consiste en situar el pabellón de entrada precisamente en el punto de giro asumiendo un papel de pieza de charnela. Éste se configura a partir de dos planos, uno de entrada colocado en paralelo con la rue Cantagrel, y otro de salida según la geometría interna del solar. La formalización resulta de dibujar, primero, ambos planos separados para después unirlos formando un volumen de directriz parabólica ${ }^{9}$ (fig.3). Una forma así resulta apropiada, indudablemente, para albergar una sala de actos aunque no tanto para significar el punto de recepción dada su insuficiente concentración espacial. En este sentido, resultaría más acertado recurrir a una configuración cilíndrica pero en ese caso el problema se invertiría ya que posiblemente no funcionara bien como sala de actos. Le Corbusier decide, directamente, utilizar las dos formas, es decir, superponer un volumen parabólico a un cilindro de tal modo que ambas compartan una parte de su directriz curva mientras se pliegan, con distintas velocidades, en el resto. Sea como fuere, la decisión parece clara: situar en el punto de acceso un volumen de revolución que, como objeto ensimismado, se muestre autónomo ante un tenso plano de vidrio. Este plano de fondo, a su vez, forma un diedro junto con el plano horizontal opaco sobre el que se coloca la pequeña pieza y si uno remite, en su transparencia y verticalidad, a la ciudad el otro lo hace a la naturaleza.
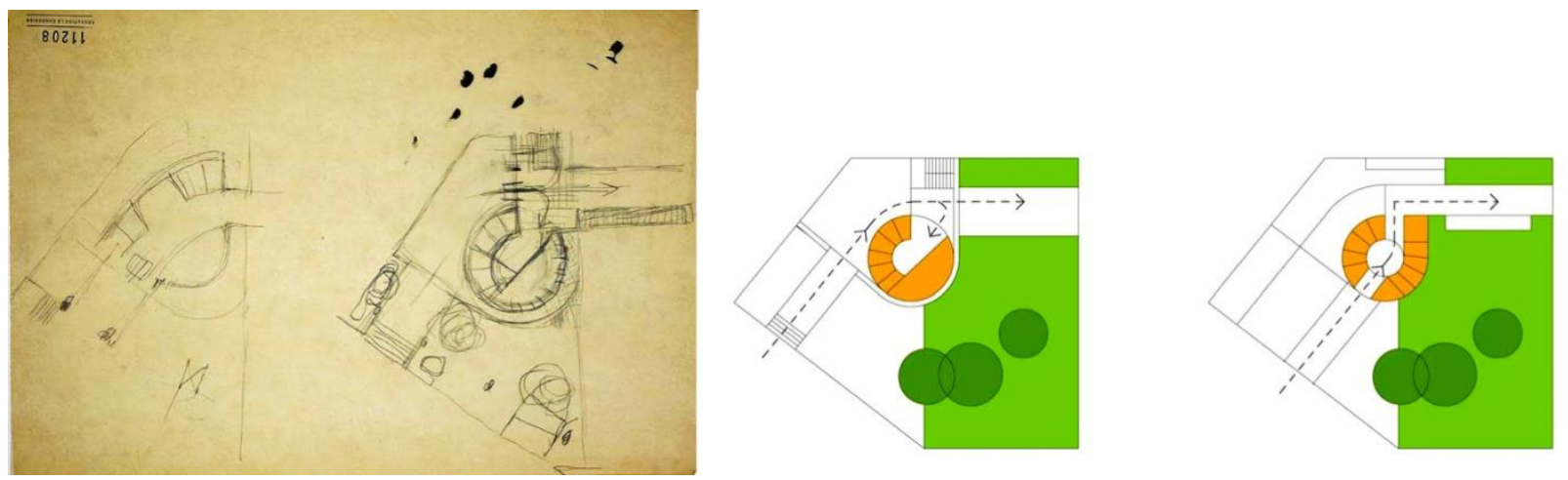

4. FLC-11.208@ y esquemas de los croquis FLC-11.208 y FLC-11.209 (dibujos del autor)

Los croquis FLC-11.208 y FLC-11.209 (figs.4) estudian la relación del recorrido con el cilindro-parábola desde un punto de vista perceptivo. Por una parte se tantea si el volumen debe ser atravesado o rodeado y por otra, su capacidad de respuesta a la doble escala hombre-naturaleza que aquí se genera. Con respecto a lo primero, si se atraviesa interiormente el cilindro, es indudable que se experimentará una decidida concentración espacial en el tránsito lo que puede resultar favorable en el sentido de dotar de significado a la recepción a pesar de la desorientación que genera su geometría al multiplicar las posibles direcciones visuales. Esto sería fácilmente

\footnotetext{
${ }^{9}$ Este mecanismo de formar volúmenes con planos que se doblan o curvan aparece en casi todas las casas blancas de los años veinte. Véase, por ejemplo, la fachada de la maison Ozenfant, el interior de la maison Cook o la azotea de la ville Savoye.
} 
atenuado introduciendo un segundo orden, bien de distribución ó bien de estructura, que indicara adecuadamente el giro de $45^{\circ}$ que es necesario hacer. Si se rodea, el problema anterior se soluciona ya que el propio cilindro actúa de charnela pero la experiencia espacial desaparece por completo siendo sustituida por otra de volumen. La alternativa oscila, por lo tanto, entre una percepción interior y una exterior y, aunque en algún croquis se dibuja la solución de atravesar el cilindro, serán muchos más los que optan por rodearlo.
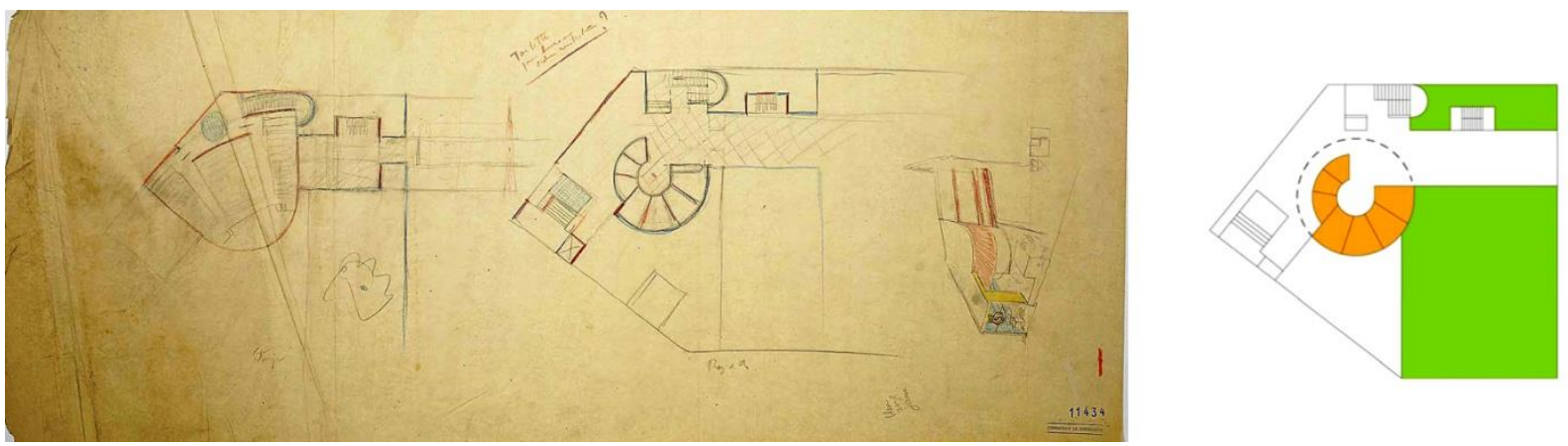

5. FLC-11.434@ y esquema del autor

En cuanto a la segunda cuestión referente a la doble escala, Le Corbusier nos sorprende con una propuesta inesperada, con un recurso más propio de la pintura que de la arquitectura: un cambio de la forma haciendo una mitad del cilindro más pequeña que otra, con dos tamaños distintos a la vez, en cierto modo como aquellas copas y vasos que dibujaba Picasso y ante las que el ojo oscilaba en profundidad como si fuese el objetivo de una cámara fotográfica. De esta manera, una parte del volumen, la más pequeña, queda sobre la plataforma relacionándose así con el hombre que camina mientras que la más grande se asoma al vacío del jardín (fig.5).

Sea como fuere, la idea de utilizar un cilindro como vestíbulo y charnela de giro del recorrido tampoco es muy novedosa. Si bien es cierto que se trata de un volumen difícil de ocupar, su elección responde a su capacidad de expresar una finalidad dotada de significado, de asumir un rol similar al de las cuatro columnas que prescribía Vitruvio en sus Libros o aquellas otras que el propio Le Corbusier había visto en 1911 en las casas pompeyanas ${ }^{10}$. El carácter de "lugar seguro" al que se accede parece aquí una razón suficiente para que el vestíbulo se resuelva con un volumen de tan marcada centralidad. De hecho, así parece haberlo entendido en otras obras anteriores, como en la ville Favre-Jacot de Le Locle, la ville Stein o la ville Savoye, del mismo modo que otros muchos arquitectos (véase por ejemplo el Länderbank que Otto Wagner había construido en la Hohenstaufengasse 3 de Viena entre los años 1882 y 1884).

Después de atravesar esta primera pieza llegamos al puente. Se trata, sorprendentemente, de un puente ocupado y abierto hacia el exterior sólo en una dirección lo que conlleva un modo particular de mirar a la naturaleza, en una dirección oblicua y de arriba hacia abajo, una mirada distanciada como escribe el profesor Rovira: "Sus edificios ignoran voluntariamente su relación con el jardín, prefieren contemplarlo desde la seguridad desdramatizada de la luz sin sombra que les proporcionan sus alargados ventanales y se apartan de cualquier contacto con la tierra" ${ }^{\prime 1}$.

El posible acceso a este jardín, a través de rampas y escaleras, fue analizado con mucho interés en el estudio buscando conciliar el movimiento lineal del recorrido elevado con la libertad formal que demanda el espacio

\footnotetext{
${ }^{10}$ Jeanneret, Ch. E.: Voyage d'Orient. Carnets. Electa, 1987. Carnet 4, pp. 126 y 127.

${ }^{11}$ Rovira, Josep M.: Le Corbusier en el Concurso del Palacio de la S.d.N. 3ZV Revista de arquitectura. ETSAB, octubre de 1993, p.22.
} 
abierto pero al parecer ninguna de las soluciones estudiadas, escaleras de un solo tramo lineal, circulares ó dobles, resultó convincente.

El segundo punto crítico que vimos aparecer ya con las primeras decisiones era la llegada al bloque de dormitorios atravesando un plano de vidrio y la transformación del movimiento horizontal en vertical. En este sentido son varias las soluciones que se estudian (fig.6). En una, Le Corbusier enfrenta un muro curvo, que separa oficio y comedor al final de la gran sala común indicando un cambio de dirección (FLC-11.207) ${ }^{12}$ a la vez que deja las escaleras al otro lado del acceso reforzando así también la composición transversal. En otras, sin embargo, el núcleo de comunicación vertical se sitúa enfrente invadiendo la luz que filtra la banda separadora de la medianera del fondo, luz que resuelve, asimismo, la iluminación natural de ciertas habitaciones de servicio además de mejorar notablemente la de los dormitorios colectivos (FLC 11.189). Aunque todas las opciones estudiadas valoran, de un modo u otro, la ascensión hasta la cubierta, lugar donde culmina el recorrido con una nueva mirada hacia la ciudad, será la primera, por la continuidad que aporta al movimiento, la que se elija.
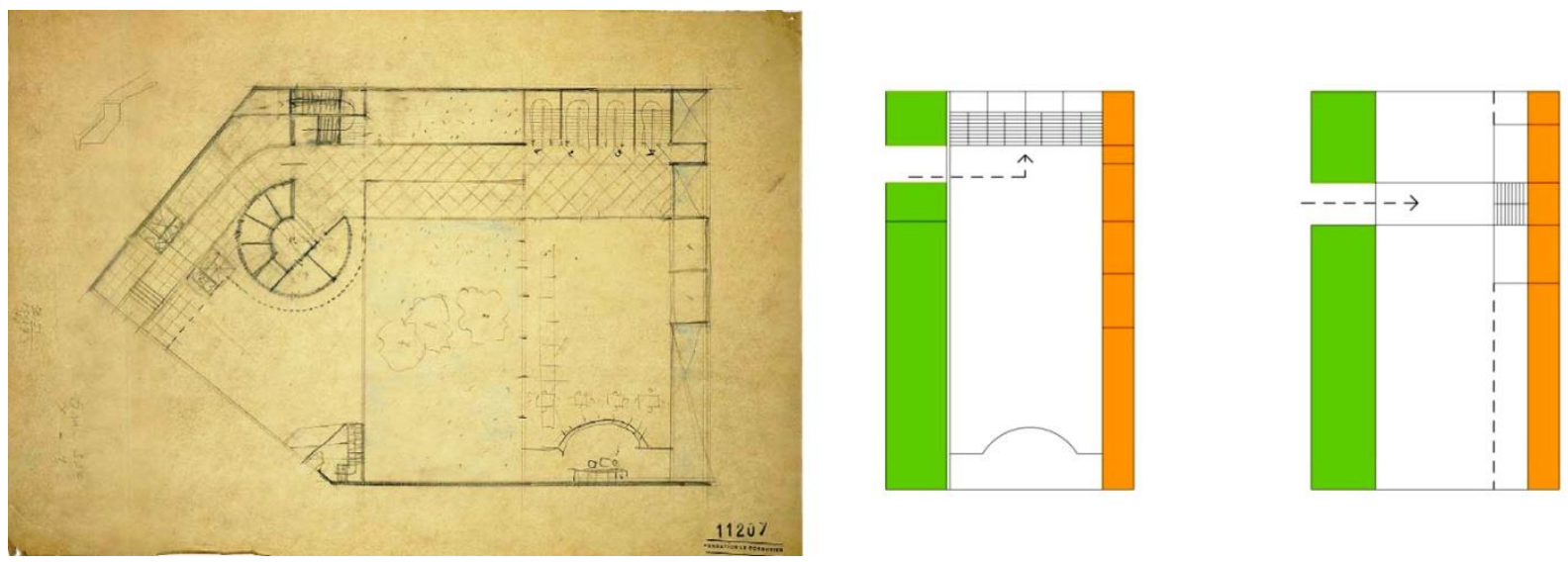

6. FLC-11.207@ y esquemas de los croquis FLC-11.207 y FLC-11.189 (dibujos del autor)

En definitiva, podemos resumir este primer proyecto para la Cité de Refuge como la selección de unas pocas piezas definidas desde argumentos funcionales o simbólicos que, una vez colocadas en el solar, asumen sus directrices geométricas para configurar una secuencia visual que transita por encima de la naturaleza hasta alcanzar un refugio seguro desde el que poder contemplar, en condiciones más dignas, la ciudad. Los momentos claves que, de una manera consciente, construyen esta secuencia son (fig.7):

\footnotetext{
${ }^{12}$ Un plano curvado que se antepone al espectador que llega detiene, por un instante, su avance mientras despliega una
} alternativa de recorridos tal como ensayara anteriormente en los proyectos de la maison Citrohan o de la ville Stein. 


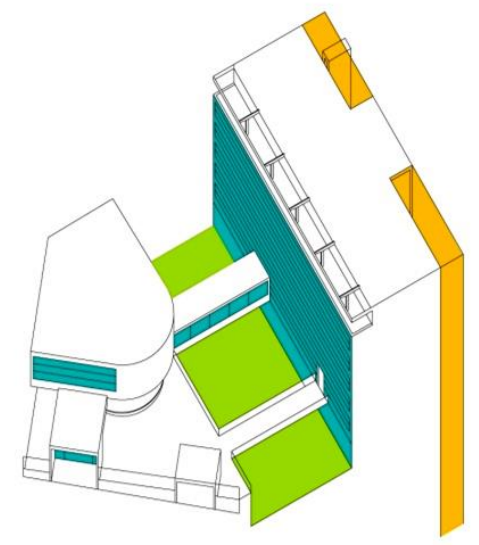

7. Axonometría de la primera versión según el croquis FLC-11.222 (dibujo del autor)

1. El acceso a la plataforma a través de un pórtico cúbico. Entre este pórtico y el vestíbulo media un espacio que se define en profundidad mientras la mirada, en su recorrido, se dirige lateralmente hacia la gran fachada acristalada situada al otro lado del vacío. Delante, un cilindro y tras él, un puente ocupado.

2. La entrada al vestíbulo cilindro-parabólico atravesando un muro que, doblado, se cruza también al salir. Entrar y salir a través de un mismo plano en direcciones diferentes es un recurso genuinamente pictórico, un ejemplo de "oscilación bidimensional" propia del Cubismo. No obstante, en esta ocasión podría entenderse también como un mecanismo de corrección de la mirada similar a aquellos "indicadores de lectura" que el propio Le Corbusier introducía, generalmente en forma de pipas cruzadas, en algunos de sus primeros cuadros (véase por ejemplo, Nature morte au violon rouge de 1919). La penetrabilidad del volumen se muestra mediante el acristalamiento de la parte parabólica. Una vez en su interior, se debe realizar un giro de $45^{\circ}$ hasta situarse en una nueva dirección que no es otra que la interna del solar. En este sentido se entiende la propuesta de una estructura radial para el techo de la sala de actos que aparece en algunos croquis.

3. El tránsito por un puente sobre un trozo de naturaleza situada un nivel por debajo hasta alcanzar el volumen de dormitorios que se aloja tras una gran pantalla de vidrio.

4. La ascensión entre dos muros de vidrio extendidos a lo largo de toda la altura del bloque que atrapan la luz en su espesor convocando la presencia de una terraza-jardín, en la última planta, desde la que se domina el viejo tejido urbano. Aquí concluye el recorrido.

Estos cuatro momentos, enlazados a través de la alternancia de visiones oblicuas y frontales así como la sensación de ascenso confiada a los planos transparentes que marcan los intervalos del recorrido, conforman la experiencia arquitectónica que da sentido a esta primera versión.

A pesar de que en el mes de julio de 1929 se formaliza la compra del Lote 1, ampliando la superficie del solar hasta $1.704 \mathrm{~m} 2$ y duplicando los accesos desde la calle ${ }^{13}$, los planos de la primera versión se entregan, como ya se indicó, en septiembre de 1929; después, ya con las nuevas condiciones del emplazamiento, se modifica el proyecto entre los meses de septiembre y diciembre.

\footnotetext{
${ }^{13}$ Brace Taylor: Cité. Op. cit, pp.47 y ss.
} 
La primera decisión consiste en disponer un segundo bloque de dormitorios en el eje norte-sur, paralelo al primero, y aún un tercero perpendicular a los dos anteriores, configurando así un esquema más propio del París del siglo XIX que del XX (fig.8). La actitud de Le Corbusier sorprende enormemente porque se limita a conquistar la nueva superficie asumiendo que el primer proyecto ya está construido pero será precisamente esta ausencia de una mirada global la que conduzca el proceso a un punto muerto, condición necesaria para generar la propuesta definitiva.
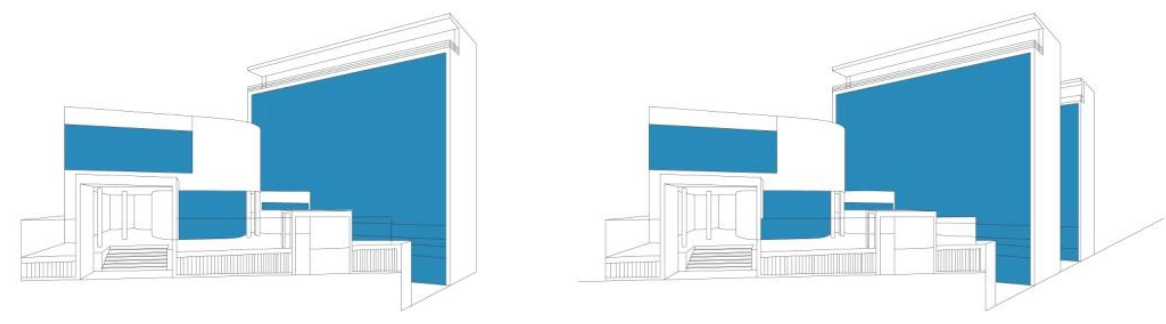

8. Perspectiva desde la rue Cantagrel de la primera y segunda versión (dibujo del autor)

En el segundo proyecto, el recorrido se extiende hasta un segundo bloque dejando el primero como pieza de tránsito. La ocupación se duplica pero no en igualdad de condiciones. Además, la secuencia perceptiva que tanto interesaba a Le Corbusier en la primera idea ya no culmina en la azotea sino dentro de un volumen que, por su configuración en "L", no parece suficientemente cualificado (fig.9). Por otra parte, la dispersión compositiva se acentúa al no existir un fondo acristalado con el que relacionar el objeto-vestíbulo sino dos repetidos aunque, bien es cierto, que transparentar sólo las caras a sur, como hiciera también en el Centrosoyuz o en el Pavillon suisse, enfatiza la profundidad visual del mismo modo que en la propuesta anterior. Por último, desaparece la relación con el jardín en el tránsito por el puente ya que sitúa aquí el ambulatorio médico, optimizado en su funcionamiento.

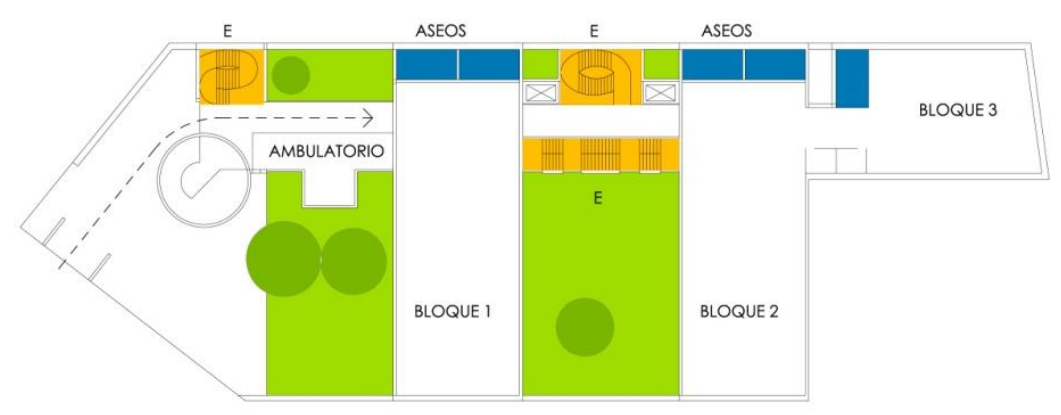

9. Esquema de idea para la segunda versión (dibujo del autor)

A pesar de estos cambios, sin embargo, la estrategia de proyecto sigue siendo la misma que antes, es decir, delinear un recorrido paralelo a los límites del solar en el que se atraviesan, una tras otra, las piezas de geometría simple que conforman los espacios más significativos: un pórtico de entrada, un cilindro de recepción que soporta un volumen parabólico y un puente que, sobre la naturaleza, conduce a los bloques de dormitorio. En el montaje, cada pieza contribuye a la unidad del conjunto definiendo los intervalos de continuidad o pausa con los que se crea la secuencia perceptiva. 
Los aspectos más importantes de esta segunda versión son:

1. Un único recorrido lineal que atraviesa el cilindro, o pasa junto a él, cruza el puente, y alcanza un primer bloque de dormitorios cuya distribución interior permite su continuidad en horizontal. El énfasis, en este sentido, lo introduce el tercer bloque, en su orientación perpendicular a la rue Chevaleret ${ }^{14}$.

2. Una lectura de los volúmenes en dos tiempos dado el paralelismo y la identidad de los primeros bloques.

3. La creación de un espacio de desarrollo, en base a la alternancia de intervalos de tránsito y pausa, condicionado por la estrechez y orientación del solar.

El resultado, en cualquier caso, no resulta muy convincente por dos cuestiones: una, porque se niega, como ya se adelantó, la relación con el jardín y dos, por la mezcla de funciones de distinto nivel de privacidad que se produce desde el puente en adelante. No obstante, debemos destacar algunos puntos que nos parecen especialmente interesantes:

La dinamización que caracteriza el jardín semienterrado por la presencia de pilotis bajo el ambulatorio y los bloques de dormitorio. Su extensión en horizontal recupera así, en parte, la idea urbanística de Le Corbusier: “... c'est que ce quise passe au sol concerne la circulation, la mobilité; et que ce qui se passe dans l'air, dans les bâtiments, c'est le travail, l'immobilité" ${ }^{15}$. Esta continuidad natural bajo la edificación se produce en ambas direcciones, a norte con la transparencia de los talleres y a sur con la elevación del segundo bloque ofreciendo unas condiciones especialmente reconfortantes a los espacios de trabajo.

El acceso principal, desde la rue Cantagrel, se mantiene como en el primer proyecto, es decir, atravesando una puerta que, por su condición volumétrica, enmarca la distancia que media hasta el vestíbulo. De este modo, su profundidad prolonga la expectativa y predispone para lo que será la primera experiencia arquitectónica significativa. Esta caja autónoma, sin edificio asociado, se resuelve con sólo tres planos definiendo, con una clara intención, un prisma rectangular completo cuya materia parece haber sido vaciada. Un elemento similar, aunque despojado de este significado, se utiliza en el Inmmeuble Clarté de Ginebra. En todos los croquis de esta segunda versión, el cilindro del vestíbulo, que aún soporta un volumen parabólico, se sitúa tangente al recorrido apostando decididamente por su función de giro (función plástica) antes que de espacio (función simbólica). Como en la primera, conserva dos escalas diferentes e incluso, en algún momento, se refuerza su intensa concentración volumétrica con la presencia de una escalera encerrada en una caja de lados curvos haciendo que su espacio de muestre más fluido.

La composición resultante combina linealidad, giro y simetría, aportando complejidad al primer proyecto (fig.10). Linealidad en el recorrido continuo según la dirección paralela a las medianeras; giro de la secuencia espacial que nos traslada desde una visión exterior oblicua de las piezas a una visión interior frontal y penetrante a través de la transparencia de tres grandes planos, y simetría central de corte neoclásica ${ }^{16}$. Tanto el primer mecanismo como el segundo expresan movilidad y dinamismo mientras que el tercero implica estaticidad configurándose de este modo el equilibrio entre espacios colectivos, en horizontal, e individuales, en vertical.

\footnotetext{
${ }^{14}$ En el archivo de la Fondation Le Corbusier hay al menos dos croquis donde se intenta subsanar la inadecuación del recorrido que acaba contra el tercer bloque de dormitorios, en los que se propone situar aquí una pequeña sala de actos. Son, en concreto, los dibujos FLC-11.075 y FLC-11.241.

15 "Lo que pasa en el suelo concierne a la circulación, la movilidad; y lo que ocurre en el aire, en los edificios, es el trabajo, la inmovilidad”. Le Corbusier: Précisions. Op. cit, p.50.

${ }^{16}$ Brace Taylor: Cité. Op. cit, p.47.
} 


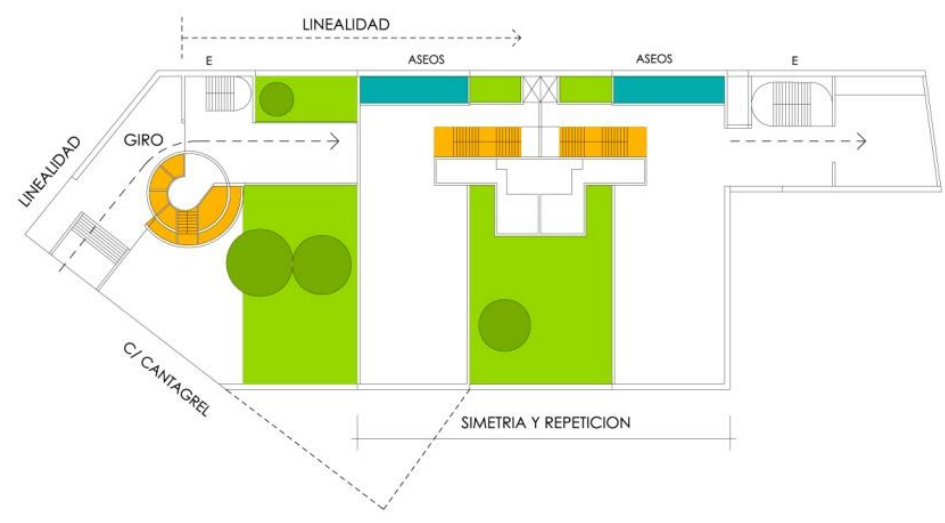

10. Esquema compositivo de la segunda versión (dibujo del autor)

En definitiva, esta segunda versión del proyecto amplía la primera extendiendo sus ideas sin modificaciones sustanciales. Le Corbusier demuestra así que su confianza en una estrategia de montaje, de engranaje de piezas cuya volumetría se dicta por condiciones de función, símbolo y posición en la secuencia visual, resulta suficiente como garantía de la unidad del proyecto. No obstante, esta confianza se ve pronto desmontada. Como ya dijimos, la nueva propuesta no resultó satisfactoria, al menos para el arquitecto y así, a comienzos de abril de 1930 , encontramos al estudio de la rue Sèvres trabajando en cambios importantes que conducirán a una tercera versión de la Cité de Refuge. El replanteo de las ideas coincide con el regreso de Le Corbusier de Moscú tras visitar las obras del Centrosoyuz. Allí, además de los habituales contactos con los arquitectos del grupo OSA, especialmente con Moisej Guinzburg, tiene ocasión de visitar la recién inaugurada Casa comunal del Instituto textil, de Ivan Nikolaev, una construcción que parece haberle impactado significativamente. Su llegada a París coincide también con un aumento de la contribución económica por parte de la princesa Edmond de Polignac lo que permite iniciar de inmediato las obras de la Cité $e^{17}$.

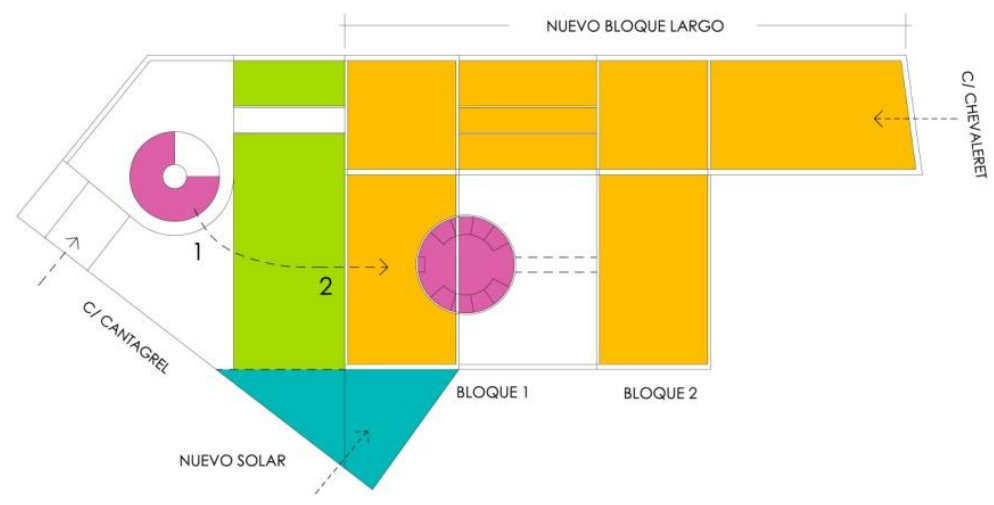

11. Tránsito de la segunda a la tercera versión (dibujo del autor)

\footnotetext{
${ }^{17}$ Brace Taylor: Cité. Op. Cit, p.51.
} 
La decisión principal que conduce a esta nueva versión del proyecto consiste en girar el primer bloque de dormitorios para hacerlo continuo con el tercero (fig.11). Este movimiento, en apariencia sencillo, supone un cambio trascendental pues conduce a una completa redefinición, no sólo del proceso de entrada, sino de la totalidad del esquema compositivo. Ahora el plano de fondo se construye con un extenso bloque que se sitúa a lo largo de la medianera trasera y, ante él, las pequeñas piezas que definen el acceso y contienen los usos colectivos se recortan como si se tratara de un bodegón. En cierto modo se trata de un abandono de la estrategia del segundo proyecto a favor de la del primero aunque la orientación de los dormitorios cambia radicalmente.

El recorrido ya no atraviesa figuras a lo largo de un plano horizontal sino que vuelve a acometer contra uno vertical acristalado. Además, mientras Le Corbusier trabaja en esta nueva versión, l'Armée du salut adquiere un tercer solar, muy pequeño y de forma triangular, que abre el interior del solar, y en consecuencia la visión de conjunto, hacia la rue Cantagrel. Ahora, desde esta vía, se aumenta considerablemente el ángulo de visión invitando con ello a prestar una especial atención a la imagen unitaria del conjunto. Le Corbusier decide ocuparlo directamente prolongando el primer bloque de dormitorios aunque esta lógica decisión supusiera perder la acotación plástica de la composición.

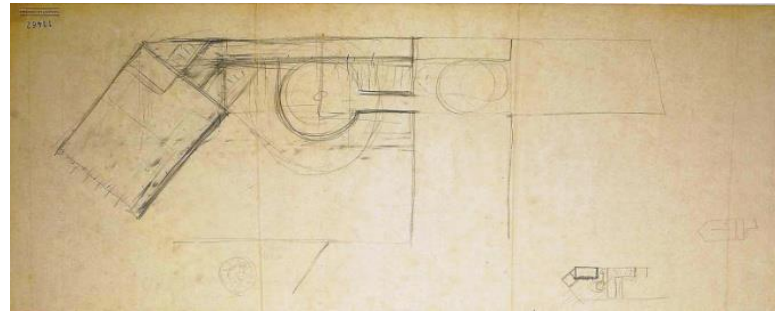

12. FLC-11.462@

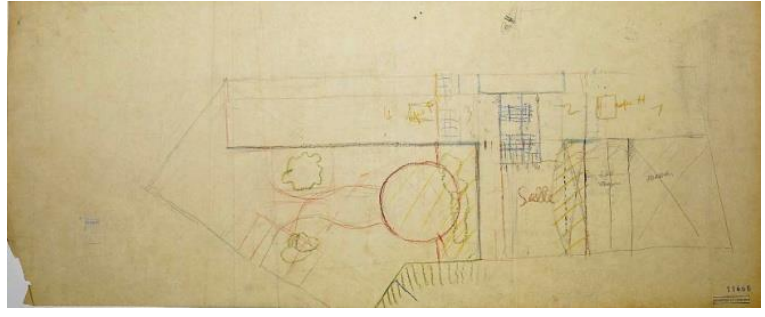

13. FLC-11.466@

Al girar de uno de los bloques norte-sur se forma otra vez un diedro espacial, ahora vertical, que define un nuevo escenario. La primera consecuencia afecta a la posición de la pieza circular-parabólica que debe abandonar su anterior ubicación si quiere seguir asumiendo su papel de indicador de giro. Desde un punto de vista funcional podrá servir mejor a los tres bloques de dormitorio al acercarse a su encuentro pero hay una razón perceptiva que se nos antoja aún más importante y es la posibilidad que ofrece de definir un juego de doble escala acorde con la diferencia entre lo colectivo y lo individual al colocar los volúmenes de acceso en un eje que discurre por delante del bloque. Ya no se trata de encadenar una secuencia plástica como en la versión anterior sino de alcanzar una unidad subordinante completa o, lo que posiblemente interesara más al arquitecto, una verdadera composición pictórica. Con ella, no sólo no se pierde la tan corbuseriana implicación temporal del hombre con la arquitectura sino que, además, su promenade architecturale se refuerza a través de una idea de montaje, y es de esta superposición de tiempo y montaje de la que surgirá el proyecto definitivo ${ }^{18}$. Es ahora cuando entendemos la enorme importancia que tuvo la compra del pequeño solar triangular ya que sin él no podría verse el cilindro en su nuevo papel de centro compositivo. Podemos ver en el croquis FLC-11.462 (fig.12) cómo el antiguo volumen, aún con la parte parabólica encima, abandona su emplazamiento original para situarse en una posición tangente al recorrido, una vez que el primer bloque ya ha sido girado mientras que en el FLC-11.466 (fig.13) define, junto a un muro curvo, un nuevo eje longitudinal. Este plano curvado, como ya vimos en la primera versión, se emplea para transformar una dirección en otra perpendicular, reconduciendo el trayecto hacia los dormitorios. En esta

\footnotetext{
${ }^{18}$ La idea de montaje tiene un inmediato antecedente en la arquitectura que los rusos vienen haciendo desde 1925 y es posiblemente esto lo que Le Corbusier ha visto en su estancia en Moscú (Feo, Vittorio de: La arquitectura en la URSS 1917 1936. Alianza Forma, 1979, pp.58 y ss. Edición original: Editorial Riuniti, 1963.
} 
propuesta, el comedor pasa a alojarse bajo el bloque de fondo cediendo su sitio a una gran sala común cuya relación con la pieza de recepción es estudiada con mucho interés en diversos croquis.

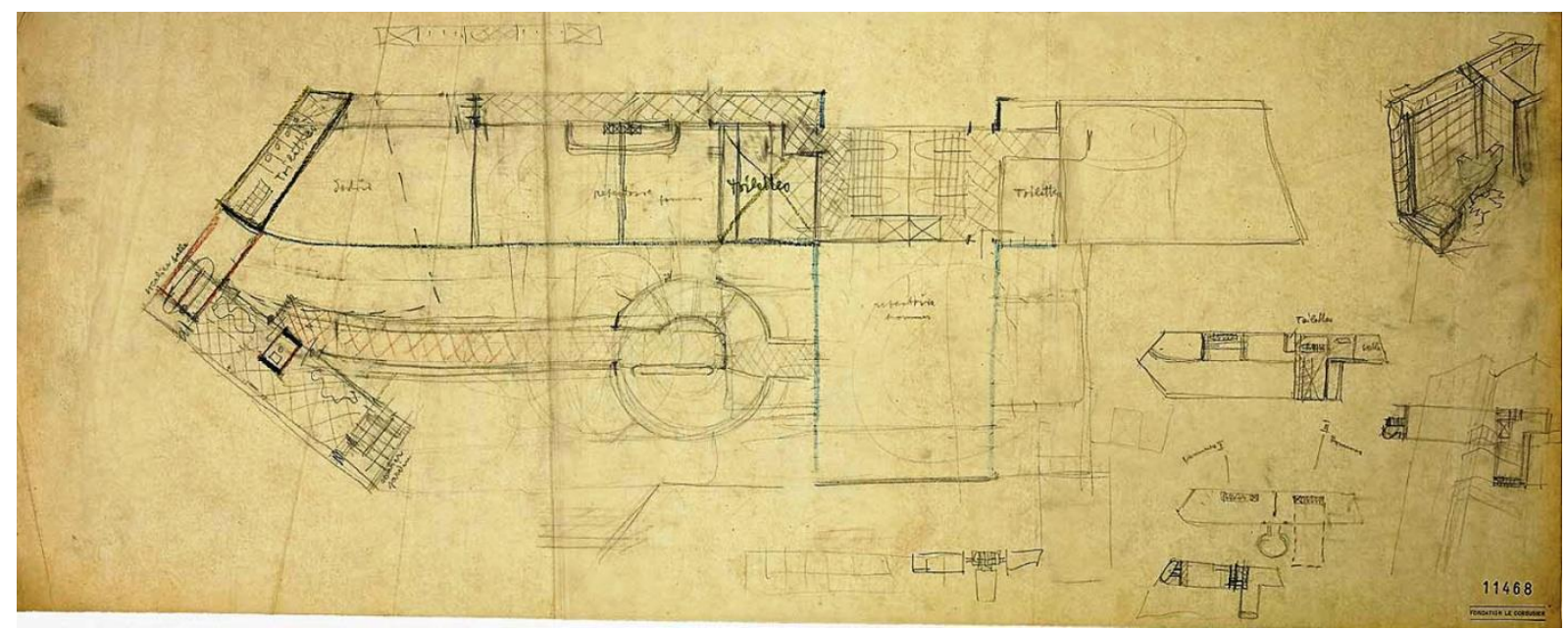

14. FLC-11.468@

Aún queda pendiente el modo de alcanzar el volumen cilíndrico así cómo decidir sobre su distribución interior. En cuanto a lo primero, en los croquis encontramos que la solución se confía, de nuevo, a un puente pero su comprometida situación, entre las tensiones de alrededor, dificulta particularmente su diseño (fig.14). De este modo en un estudio aparece con una inquietante curvatura, ó como vibración oscilante en otro, en un gesto que, más allá de mostrar su condición de elemento de tránsito, recuerda el modo en el que los pintores cubistas solían expresar el sonido ${ }^{19}$. Esta oscilación se mantendrá hasta el final del proceso de proyecto aunque de horizontal termine haciéndose vertical. Por otra parte, la necesaria presencia de una pieza a la que confiar el giro del recorrido que antes asumía el cilindro, ahora desplazado al otro lado del puente, hará necesario un nuevo pórtico de recepción que será, otra vez, un triedro desmaterializado (fig.15).
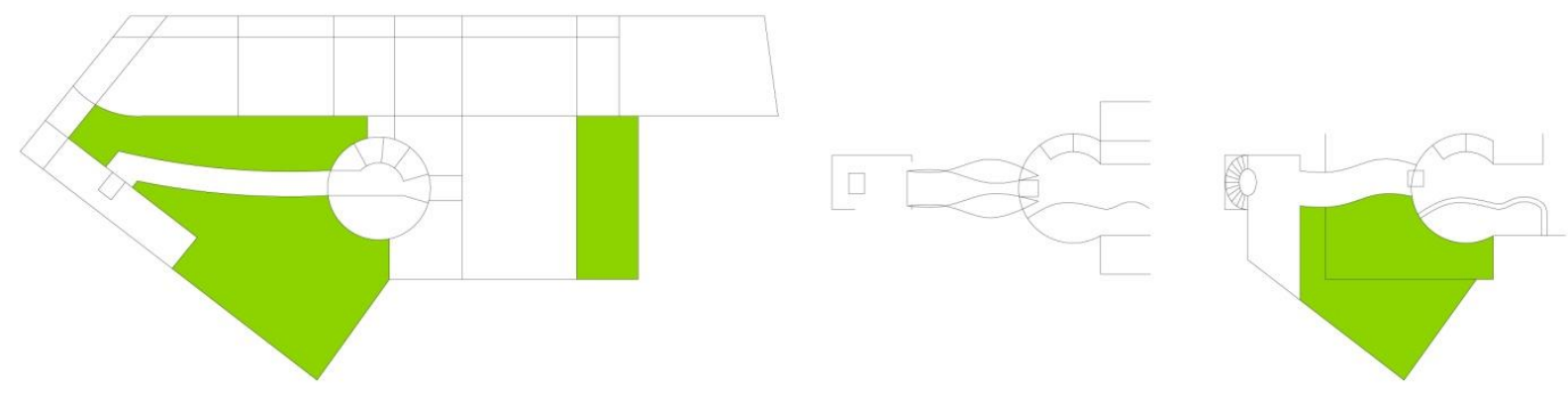

15. Estudios del puente según los croquis FLC-11.468, FLC-195 y FLC-11.192 (dibujos del autor)

En cuanto a la distribución interior del cilindro, la duda supone elegir entre una organización acorde a su envolvente y un orden complementario ó, dicho de otra manera, entre un plano que limite exclusivamente su espacio interior y una superficie profunda que, en su espesor, pueda alojar algunas funciones. Las versiones que encontramos en este sentido son numerosas pero casi todas ellas se deciden por las dos opciones a la vez, situando un mostrador a un lado, como objeto autónomo, y acomodando pequeñas estancias al otro. La forma

\footnotetext{
${ }^{19}$ Palau i Fabre, Josep: Picasso Cubismo 1907-1917. Ediciones Polígrafa, SA. 1990, pp.290 y ss.
} 
ondulada del primero prolonga el camino hasta el siguiente espacio al tiempo que alude tanto a la centralidad y circularidad del cilindro como a la presencia de los despachos de atención al indigente situados enfrente. Éstos, terminarán saliendo del cilindro para dejar el espacio completamente vacío.

El planteamiento del proyecto ha cambiado por completo en esta tercera versión, reconduciéndose ahora hacia una estrategia más unitaria en la que cada volumen se sitúa en un nivel apropiado, tanto de significación como de escala. Cada uno es acentuado o matizado en función de las relaciones plásticas con los demás enriqueciéndose de este modo la secuencia perceptiva que recorre de manera continua el conjunto, transitando de una escala menor a otra mayor. En esta imbricada configuración, lo privado e íntimo actúa de marco de lo representativo y público, sin mediación de un espacio vacío específico, empleando una táctica similar a la de otros proyectos como el Centrosoyuz, el Pavillion Suisse e, incluso, la Asamblea de Chandigarh. Ya no hay una distancia expectante entre lo colectivo y lo individual minusvalorándose ahora el papel que jugaba la naturaleza semienterrada en las dos versiones anteriores.
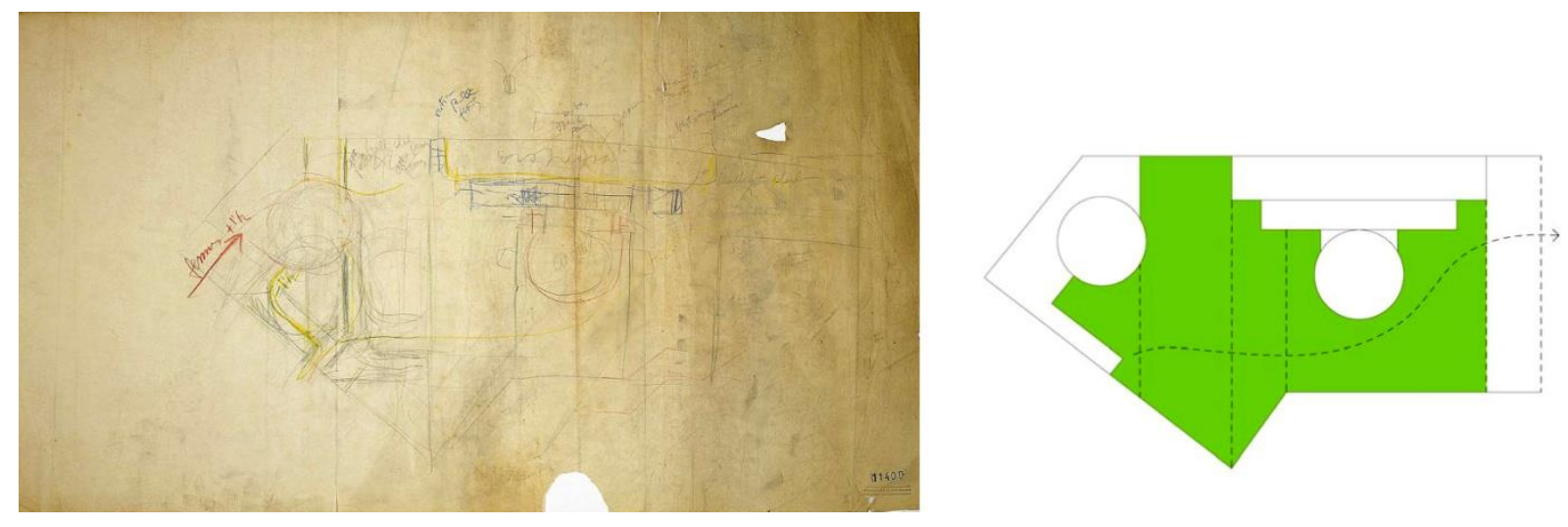

16. FLC-11.400@ y esquema del autor

Siguiendo el curso de las sucesivas versiones observamos, no sin cierta decepción, que aquel espacio verde que actuaba como fondo de la arquitectura, como elemento de contemplación que marcaba el umbral de salvación del indigente, ha sido reemplazado por un patio de servicio, un patio donde pueden acceder vehículos (fig.16). Aquel lugar tan íntimo, tan significativo en la primera versión del proyecto se ha convertido, en esta tercera, en uno más funcional, casi residual. No obstante, se le dedican numerosos estudios, centrados tanto en el encuentro del cilindro con su plano de apoyo como en el expresivo modo en que los volúmenes se repliegan ante el aire que desplazan los vehículos al pasar, algo que ya hiciera en la temprana ville Favre-Jacot en Le Locle.

A finales de abril de 1930, el estudio de Le Corbusier presenta los nuevos planos de una cuarta versión muy cercana ya a la definitiva. Después de las últimas modificaciones, el edificio ha quedado organizado con dos familias de volúmenes relacionados entre sí a través de la jerarquía de una doble escala, como si de una pintura de bodegón se tratase. Los más pequeños, delante, conforman el proceso de entrada y contienen los usos colectivos actuando como figuras, mientras que un amplio plano se extiende por detrás asumiendo el papel de lienzo. El montaje se realiza sobre una geometría de dos direcciones, una para los movimientos de penetración, inicio y final del recorrido, y otro para su desarrollo (fig.17). En un primer eje, se conecta la puerta de acceso al solar, una plataforma y un pórtico de recepción; en un segundo, girado $90^{\circ}$ con el anterior, se sitúan el puente, el cilindro-vestíbulo, ahora ya liberado del volumen parabólico, y una gran sala de estar y de atención al acogido. El salón de actos ha sido desplazado, definitivamente, al nivel inferior, junto con la cocina y un dormitorio de personas mayores, mientras que se añade una segunda planta semienterrada para los talleres y los almacenes. Sobre la sala de estar de la planta de acceso quedan ahora el ambulatorio, la farmacia y el almacén de ropa, además de una terraza orientada a sur. Por encima, el gran bloque en forma de "T" aloja, sobre una planta de 
comedores, los dormitorios, tanto de hombres como de mujeres. En el primer piso, los hombres ocupan un dormitorio común bastante amplio mientras las mujeres disponen en el segundo de habitaciones individuales. Las plantas tercera, cuarta y quinta, se distribuyen en tres grandes espacios de dormitorio, dos de ellos subdivididos en habitaciones menores y otro completamente diáfano, mientras que la sexta, retranqueada con respecto a la planta quinta, sólo acoge individuales. Finalmente se sitúan los apartamentos del personal y del director, en un séptimo nivel cuya fachada retranqueada se diferencia significativamente de las inferiores.
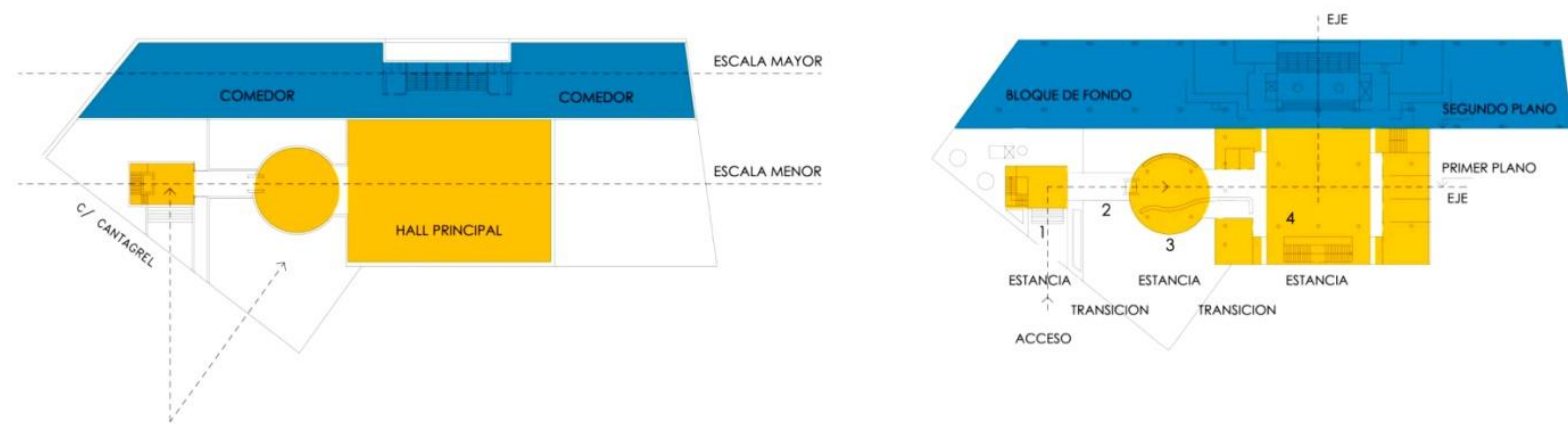

17. Doble escala y secuencia de estancia y transición (dibujos del autor)

Los criterios pictóricos se han impuesto en esta versión a los funcionales aunque aún está pendiente alcanzar la unidad compositiva con la que el edificio finalmente se construyó. No obstante, faltan algunos cambios, fundamentalmente dos: por un lado hacer desaparecer el bloque perpendicular que aún se superpone a los usos colectivos y por otro resolver los condicionantes urbanísticos de las Ordenanzas locales en las plantas sexta, séptima y octava, lo que se hará con una solución de retranqueo ondulante de las fachadas. Otros seguirán produciéndose aunque con menor trascendencia como, por ejemplo, la incidencia del movimiento del coche en las superficies de fachada que delimitan el espacio abierto semienterrado ó los puntos de articulación de los ejes entre las piezas pequeñas y las grandes.
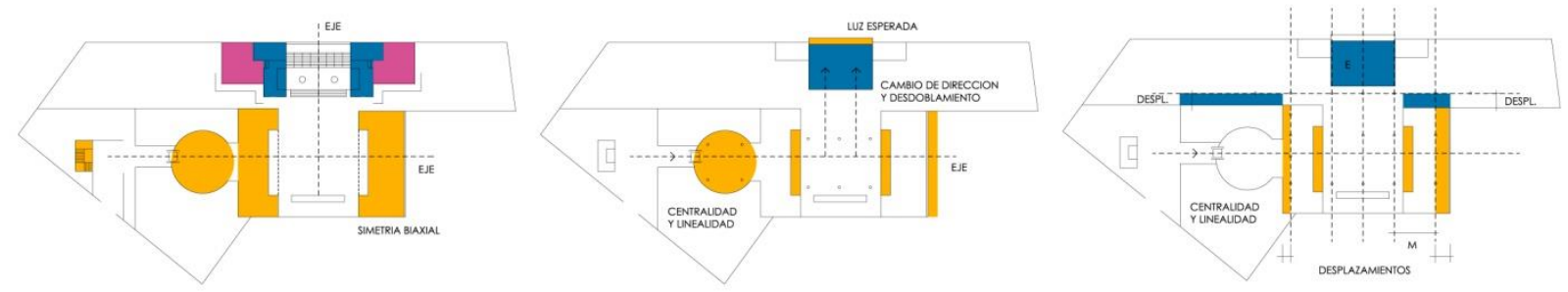

18. Esquemas compositivos de la cuarta versión (dibujos del autor)

La solución final no hubiera sido posible sin el cambio de actitud que se produjo entre las versiones segunda y tercera, en ese momento clave en que Le Corbusier decide cambiar la posición del cilindro de recepción introduciendo un segundo eje que, paralelo al de la primera versión, definía el proyecto entre dos planos verticales, dos láminas virtuales que se recorren atravesando sucesivos planos de luz dispuestos en perpendicular (fig.18). El mecanismo se asemeja al que utilizó el arquitecto en la ville Stein de Monzie o en el Concurso para 
la Sociedad de Naciones, y corresponde a lo que Colin Rowe denomina transparencia fenoménica, en clara referencia al Cubismo ${ }^{20}$.

A lo largo del mes de Junio de 1930 se redacta la quinta y última versión en la que, definitivamente, desaparece el que fue tercer bloque de dormitorios que aún permanecía perpendicular al de fondo, alcanzando la composición unitaria buscada y rompiendo, por otra parte, el único vínculo formal que aún se mantenía con la primera propuesta (fig.19).

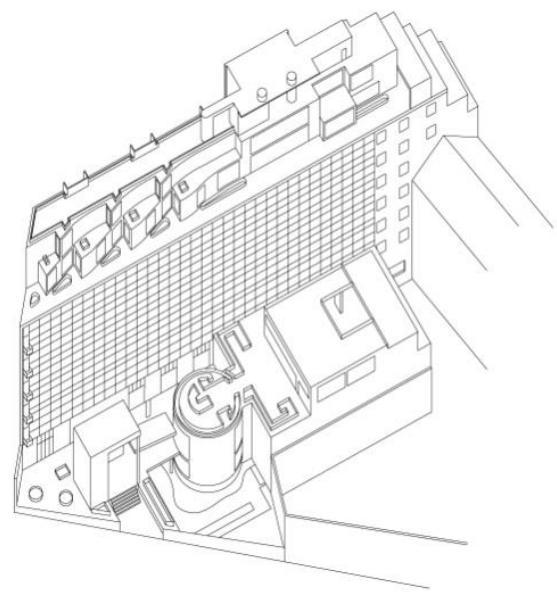

19. Axonometría final (dibujo del autor)

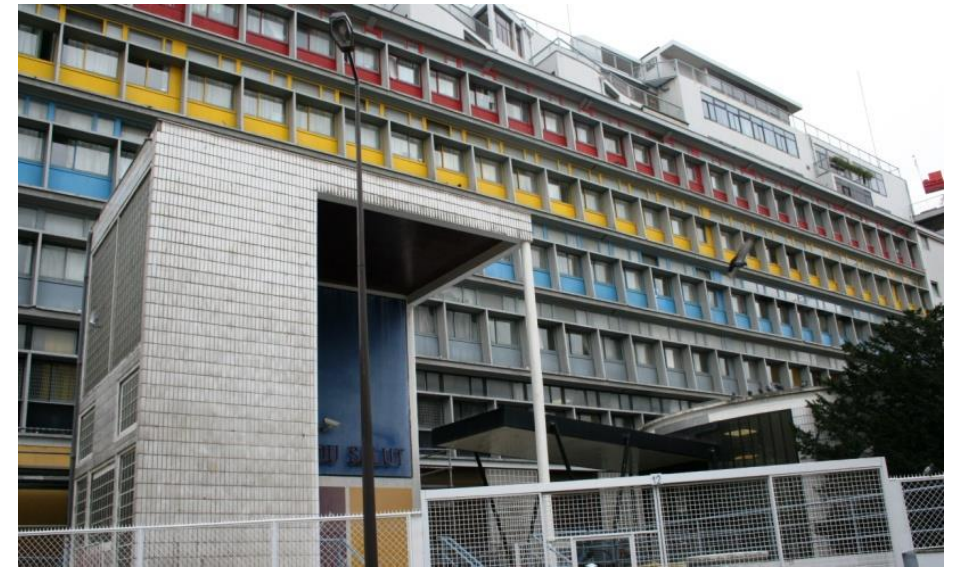

20. Cité de Refuge (fotografía del autor 25.01.2007)

Con ella dan comienzo las obras el 24 de junio de 1930 con la colocación de la primera piedra por parte de M. Désiré Ferry, ministro de Higiene Pública ${ }^{21}$ aunque, como es bien sabido, todavía se sucederán muchos cambios, no sólo durante la obra, sino aún muchos años después de inaugurado el edificio el 7 de diciembre de 1933 (fig.20).

\section{Conclusión}

La compra por lotes del solar que ocuparía la Cité de Refuge al mismo tiempo que se desarrollaba el proyecto dio lugar a que su proceso de ideación pasara por cinco fases sucesivas. Tras una primera versión, desarrollada sobre únicamente una parte del terreno a la vez que se tramitaba la compra de otra, el estudio de Le Corbusier propuso una segunda, sorprendentemente continuista, lo que condujo a una solución poco satisfactoria. Esta inercia, dando a entender que el primer proyecto ya estaba construido y planteando el segundo como su ampliación, fue pronto corregida para volver a enfocar el proyecto ahora desde una mirada global, tanto del solar como del programa. De este modo, se revisaron cada una de las piezas, ya elegidas desde el principio, así como las relaciones entre ellas para poder construir una significativa secuencia perceptiva, y se recondujo la respuesta hacia la unidad compositiva con la que finalmente se ejecutó. El análisis de la abundante documentación que se conserva en el archivo de la Fondation Le Corbusier de Paris, nos ha permitido mostrar este complejo proceso, las permanencias formales en cada versión, los distintos esquemas organizativos que empleó y, en definitiva, la estrategia empleada por Le Corbusier, en esta ocasión, en la que su mirada de pintor se impuso sobre su método racionalista de proyecto.

\footnotetext{
${ }^{20}$ Rowe, Colin: Manierismo y arquitectura moderna y otros ensayos. Editorial G.G. Barcelona, 1978, pp.166 y ss. Edición original M.I.T. 1976.

${ }^{21}$ Brace Taylor: Op. cit, p.68.
} 


\section{Lista de imágenes}

1. Esquemas de idea para la primera versión (dibujo del autor)

2. FLC-11.191@

3. Esquemas de configuración del vestíbulo en la primera versión (dibujos del autor)

4. FLC-11.208@ y esquemas de los croquis FLC-11.208 y FLC-11.209

5. FLC-11.434@ y esquema del autor

6. FLC-11.207@ y esquemas de los croquis FLC-11.207 y FLC-11.189 (dibujos del autor)

7. Axonometría de la primera versión según el croquis FLC-11.222 (dibujo del autor)

8. Perspectivas desde la rue Cantagrel de la primera y segunda versión (dibujo del autor)

9. Esquema de idea para la segunda versión (dibujo del autor)

10. Esquema compositivo de la segunda versión (dibujo del autor)

11. Tránsito de la segunda a la tercera versión (dibujo del autor)

12. FLC-11.462@

13. FLC-11.466@

14. FLC-11.468@

15. Estudios del puente según los croquis FLC-11.468, FLC-195 y FLC-11.192 (dibujos del autor)

16. FLC-11.400@ y esquema del autor

17. Doble escala y secuencia de estancia y transición (dibujos del autor)

18. Esquemas compositivos de la cuarta versión (dibujos del autor)

19. Axonometría final (dibujo del autor)

20. Cité de Refuge (fotografía del autor 25.01.2007)

\section{Bibliografía}

Brace Taylor, Brian: La cité de refuge di Le Corbusier. Officina edizioni, Roma, 1979

Feo, Vittorio de: La arquitectura en la U.R.S.S. 1917-1936. Alianza Forma, 1979 (ed. original Editorial Riuniti, 1963)

Jeanneret, Ch. Edouard: Voyage d'Orient. Carnets. Electa, Barcelona, 1987

Le Corbusier: Précisions sur un état présent de l'architecture et de l'urbanisme. Collection de "L'Esprit Nouveau". Les Éditions G. Crés et C. Paris, 1930 (edición en castellano: Le Corbusier: Precisiones. Respecto a un estado actual de la arquitectura y el urbanismo. Editorial Apóstrofe. Barcelona, 1999).

Palau i Fabre, Josep: Picasso Cubismo 1907-1917. Ediciones Polígrafa, S.A. 1990

Rovira, Josep M.: Le Corbusier en el Concurso del Palacio de la S.d.N. 3zv Revista de arquitectura. E.T.S.A.B. Octubre 1993

Rowe, Colin: Manierismo y arquitectura moderna y otros ensayos. Editorial G.G. Barcelona, 1978 (ed. original M.I.T. 1976)

Von Moos, Stanislaus: Le Corbusier. Editorial Lumen. Barcelona, 1977

VV.AA.: Le Corbusier Plans. Echelle-1. Codex Images International. Paris, 2005 


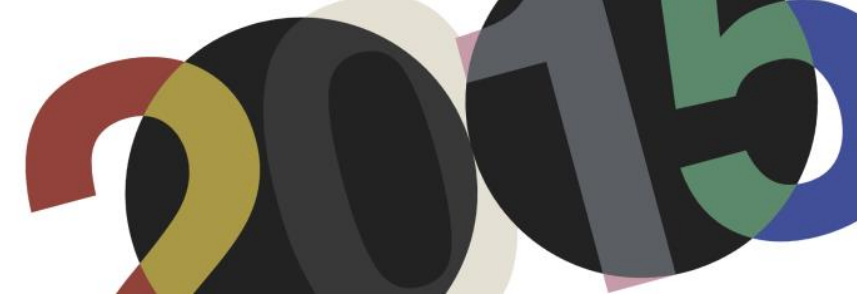

DOI: http://dx.doi.org/10.4995/LC2015.2015.791

\title{
Le Corbusier: architecture, music, mathematics: longing for classicism?
}

\author{
C. G. Gonçalves*, M. J. Soares** \\ * CITAD, Universidade Lusíada de Lisboa / ISMAT \\ ** CITAD, Universidade Lusíada de Lisboa
}

\begin{abstract}
This paper aims to study the role of the relationships between architecture, music and mathematics in Le Corbusier's thought and work and their relevance in his reinterpretation of classical thinking. It seeks to understand to what extent working with this triad - a foundational and, up until the seventeenth century, dogmatic aspect of architecture in general and of its aesthetics in particular - expresses a will not to break with the fundamental and defining aspects of what could be considered as architectural thought rooted in classical tradition: that which is governed by the will to follow the universal order in the work of art; building a microcosmos according to the macrocosmos; linking, in proportion to one another, the universe, man and architecture. The Modulor presents itself as a manifestation of that will, synthesizing these aspects while proposing itself as an instrument for interdisciplinary thought and practice in which the aforementioned aspects of classical thought are present, clearly and pronouncedly. Le Corbusier's thought and work presents itself as a twentieth century memory of an ancient and ever present tradition conscious of its struggle for "humanity".
\end{abstract}

Resumen: Este artículo pretende estudiar el papel de la relación entre arquitectura, música y matemática en el pensamiento y la obra de Le Cobusier y su significado en su reinterpretación del pensamiento clásico. Intenta entender en qué medida con esta triada - aspecto fundacional y hasta el siglo XVII dogmático de la arquitectura, en general, y de su estética, en particular - Le Corbusier expresa su recusa por cortar el vínculo con los aspectos fundamentales y definidores de lo que puede considerarse un pensamiento de tradición clásica en arquitectura: aquel tutelado por la voluntad de seguir el orden universal en la obra de arte - construyendo un microcosmos según un macrocosmos - para así vincular, a través de la proporción, universo, Hombre y arquitectura. El Modulor se presenta como manifestación de esa voluntad, sintetizando estos aspectos y presentándose como un instrumento para un pensamiento y una práctica interdisciplinares en los cuales el pensamiento clásico se encuentra clara y marcadamente presente. El pensamiento de Le Corbusier, través su mirada hacia la relación arquitectura-música-matemática, se presenta, en el siglo $X X$, como una memoria de una antigua y siempre presente tradición, consciente de su busca por "humanidad".

Keywords: Le Corbusier; Architecture, music and mathematics; classical thought; Modulor.

Palabras clave: Le Corbusier; Arquitectura, música y mathematica; pensamiento clásico; Modulor.

\section{Introduction}

One of the most fascinating themes in studying the history of architecture is relating tradition with modernity. One discovers that there is a tradition to being modern and that sometimes these two aspects can, almost unexpectedly, manifest themselves simultaneously within the same person. This seems to be the case with Le Corbusier.

It is well known that twentieth century modernism was a backdrop for passionate debate on tradition. One of modernism's foremost protagonists - Arnold Schoenberg (1874-1951) - very ably defined what was, paradoxically, a lucid position; that from an accepted and beloved, but outdated, tradition one can create a new order that strives to become a new tradition: "I venture to credit myself with having written truly new music 
which, being based on tradition, is destined to become tradition." If the topic were architecture, this could be Le Corbusier's discourse.

Tradition is deeply linked with the idea of the classical or even classicism. This idea of classical refers to a way of thinking - of reading the world and relating it to architecture - and eventually to a method.

It is no coincidence that in Modern Architecture Since 1900 William Curtis begins the chapter "Form and Meaning in the Late Works of Le Corbusier" with this quotation from Henri Focillon: "The principle which gives support to a work of art is not necessarily contemporary with it. It is quite capable of slipping back into the past or forward into the future... The artist inhabits a time which is by no means necessarily the history of his own time." And in The Classical Language of Architecture, John Summerson describes Le Corbusier as "the most inventive mind in the architecture of our time and also, in a curious way, one of the most classical minds"3.

\section{Architecture, music and mathematics}

Founded in Antiquity - with the Pythagorean School, to be precise - the tradition strongly linked with classical thinking in general, and Humanism in particular, that links proportions in architectural to intervals in music through mathematical relations, was also deeply rooted and also further developed during the Middle Ages. In reality, that tradition was only broke in the mid- $17^{\text {th }}$ century. However, despite that chiasm, it does not seem to have totally disappeared from subsequent architectural thought.

In this tradition, along with mathematics, music has always enjoyed a special status, in part precisely because of its correlation to mathematics - both geometry and arithmetic. This aspect fascinated architects and provided them with tools to bring their works into line with the laws of the universe. Whilst it is true that this scenario was seriously challenged in the $17^{\text {th }}$ century, the aura was not gone forever and the spirit within which it was built remained. And, of course, music continued to fascinate architects (as well as many other authors and scholars). It is important to mention that throughout history it is more frequent that architects seek theoretical knowledge or inspiration in music than the opposite. ${ }^{4}$

\subsection{Music and mathematics}

“La musique est évidemment une des joies de la vie." [Fig.1]

Considering himself a "musician at heart", two ideas related to music, as stated in The Modulor ${ }^{6}$, fascinated Le Corbusier: one was the fact that music, with scarce means, was able to generate infinite solutions that were all different from each other; the other was that music was governed by simple, clear and "economic" rules.

Accordingly, for Le Corbusier music had gone further than architecture and was thus an example to be followed: “... how many of us know that in the visual sphere - in the matter of lengths - our civilizations have not yet

\footnotetext{
${ }^{1}$ Schoenberg, Arnold, Style and Idea, p.174.

${ }^{2}$ Curtis, William, Modern Architecture Since 1900, p. 271.

${ }^{3}$ Summerson, John. The Classical Language of Architecture, p. 111.

${ }^{4}$ For a general study on architecture and music see Gonçalves, Clara Germana, Arquitectura: diálogos com a música: concepção, tradição, criação.

${ }^{5}$ Le Corbusier, Modulor 2, 1955 (Let the User Speak Next: Continuation of "The Modulor" 1948), p.330. In the final paragraph of the book.

${ }^{6}$ Le Corbusier, The Modulor: A Harmonious Measure to the Human Scale Universally Applicable to Architecture and Mechanics.
} 
come to the stage they have reached in music? Nothing that is built, constructed, divided into lengths, widths, volumes, has yet enjoyed the advantage of a measure equivalent to that possessed in music, a working tool in the service of musical thought."7

This constant fascination with music throughout history in general, and the history of architecture in particular, is continued today in the works of authors such as Marcos Novak (b.1957) who argues that "music has reinvented itself in far more profound ways than architecture has dared" ${ }^{\prime \prime}$.

However, for Novak to link architecture and music under the Pythagorean-Platonic tradition is to associate the former with the cadaver of a cosmological musical tradition that has been dead for a long time. He is speaking out against a tradition that still exists. And he refers to one of the most important of Le Corbusier's collaborators, Iannis Xenakis (1922-2001): "Xenakis claims that we are all Pythagoreans. Perhaps this is so, since we are obviously still enamored with numbers. Most of our conceptions about the relationship of architecture and music are remnants of Pythagorean belief. The most prevalent conception is concerned with the static balance of fixed, perfect parts, eternal because desiccated, desiccated because imagined to preexist in an ideal, immaterial world." 9 In Musique, Architecture, Xenakis had indeed claimed: "We are all Pythagoreans." ${ }^{10}$ He also focuses on a note citing Bertrand Russel (1872-1970) in 1924: "Perhaps the oddest thing about modern science is its return to Pythagoricism." "It would seem that the paradox was not exclusive to architecture...

Xenakis' mentor, Le Corbusier, was also fascinated by this tradition. And he considered himself not only a musician but also a "mathematician at heart"12. The following shows how passionately and poetically Le Corbusier spoke of mathematics:

"Mathematics is the majestic structure conceived by man to grant him comprehension of the universe. It holds both the absolute and the infinite, the understandable and the forever elusive. It has walls before which one may pace up and down without result; sometimes there is a door: one opens it -enters - one is in another realm, the realm of the gods, the room which holds the key to the great systems. These doors are the doors of the miracles. Having gone through one, man is no longer the operative force, but rather it is his contact with the universe. In front of him unfolds and spreads out the fabulous fabric of numbers without end. He is in the country of numbers. He may be a modest, and yet have entered just the same. Let him remain, entranced by so much dazzling, all-pervading light.",13

But music came at first. Le Corbusier describes arriving at mathematics through music: "More than these thirty years past, the sap of mathematics has flown through the veins of my work, both as an architect and painter; for music is always present within me."14

\footnotetext{
${ }^{7}$ Le Corbusier, The Modulor, pp.16-17.

${ }^{8}$ Novak, Marcos, "Breaking the Cage", p.69. And he continues: "In this century alone, we have witnessed a series of emancipations: in Arnold Schönberg, the emancipation of dissonance; in Edgard Varèse, the emancipation of noise; in Iannis Xenakis, the emancipation of stochastic form; in John Cage, the emancipation of nonintention." Novak, Marcos, "Breaking the Cage", p.70.

${ }^{9}$ Novak, Marcos, "Breaking the Cage", pp. 69-70.

${ }^{10}$ Xenakis, Iannis. Musique, Architecture, p.73.

${ }^{11}$ As cited in Xenakis, Iannis, Musique, Architecture, p.73. Originally published in The Nation, 27-9-1924.

${ }^{12}$ Le Corbusier, “The Final Year: a Transcription and Translation of Le Corbusier's Last Recorded Interview”, p. 119.

${ }^{13}$ Le Corbusier, The Modulor, p.71.

${ }^{14}$ Le Corbusier, The Modulor, p.129.
} 
And he cites Jean-Philippe Rameau (1683-1764), for whom music was the foundational discipline:

“... 'Music is not a part of mathematics; on the contrary, it is the sciences which are a part of music, for they are founded on proportion, and resonance of the body of sound engenders all proportion." 15

And in emphasising that it is music - particularly harmony - that dominates, he goes on to develop Rameau's idea:

"This last audacious statement is by Rameau, and it throws light on our investigation: music rules all things, it dominates; or, more precisely, harmony does that. Harmony, reigning over all things, regulating all the things of our lives, is the spontaneous, indefatigable and tenacious quest of man animated by a single force: the sense of the divine, and pursuing one aim: to make a paradise on earth." 16

But whilst it was music that led him to mathematics, it would also appear to be true that his fascination for music was due, at least in part, to the traditional and close links between music and mathematics. The foreword to The Modulor $^{17}$ already makes reference to Pythagoras and the beginnings of Greek musical systematisation based on mathematics. This is revealed in the quotations Le Corbusier uses of authors who argue that mathematics and music are inseparable:

"... 'Music is a secret mathematical exercise, and he who engages in it is unaware that he is manipulating numbers. ${ }^{18}$ (Leibnitz.)

... 'The man practising on the keyboard is unaware that he is handling logarithms.' (Henri Martin.)"'19

One must also consider that in the 1950s mathematics was a study discipline of choice. And at the time many studies on geometry applied to nature and art were carried out. See, for example, the vast body of work produced by Matila Ghyka (1881-1965) ${ }^{20}$ who was a friend to Le Corbusier. This prominence of mathematics was also manifested in events such as the international conference on De Divina Proportione organised by the Milan Triennale in 1951, in which Le Corbusier took part. According to Rudolf Wittkower ${ }^{21}$, this conference had an impact on the Modulor 2 (although the impact on the younger generation was not quite so substantial).

This was followed, by way of example, by a debate 22 at RIBA on 18 June 1957 on the notion "that systems of proportion make good design more easier and bad design more difficult". Forty eight members of the audience voted for the motion while sixty voted against. Bruno Zevi (1918-2000) welcomed this defeat declaring that "no one really believes any longer in the proportional system" ${ }^{\prime 2}$. What about Le Corbusier? Forty eight against sixty

\footnotetext{
${ }^{15}$ Le Corbusier, The Modulor, p.74.

${ }^{16}$ Le Corbusier, The Modulor, p.74.

${ }^{17}$ Le Corbusier, The Modulor, p.16.

${ }^{18}$ This quotation can be found, not surprisingly, in the article by Matila Ghyka, "Frozen Music", p.187.

${ }^{19}$ Le Corbusier, The Modulor, p.74.

${ }^{20}$ One should mention in particular the works Esthétique des proportions dans la nature et dans les arts (1927), Le nombre d'or: rites et rythmes pythagoriciens dans le développement de la civilisation occidentale (1931) and The Geometry of Art and Life (1946) which would seem to have been decisive both in the creation and written formulation of the The Modulor. According to Jean-Louis Cohen, Le Corbusier had copies of the first two books. "Le Corbusier's Modulor and the Debate on Proportion in France", p.3.

${ }^{21}$ Wittkower, Rudolf, "The Changing Concept of Proportion", p.210.

${ }^{22}$ See Pevsner, Sir Nikolaus, "Report of a Debate on the Motion 'that Systems of Proportion make good design easier and bad design more difficult"'.

${ }^{23}$ As cited in Wittkower, Rudolf, "The Changing Concept of Proportion", p.210. Zevi also writes: "The hecatomb took place in the early fifteenth century. It was the triumph of perspective. Architects stopped working concretely on architecture and limited themselves to designing it." The Modern Language of Architecture, p.23
} 
in the 1950s does not seem radical. And Le Corbusier would have voted in favour given the chance and would no doubt have back up his view, as he does in The Modulor with an unimpeachable and universally accepted opinion: “..., Einstein had the kindness to say this of the 'Modulor': 'It is a scale of proportions which makes the bad difficult and the good easy.",24

Although most architects (and artists) abandoned their classical fascinations, “... Le Corbusier's answer is quite different. He distinctly believes in the older systems of proportion, newly dressed up by him and his team. The elements of his Modulor are traditional and extremely simple: square, double square, and divisions into extreme and mean ratios ${ }^{, 25}$. This position contrasts, in Wittkower's opinion, with that of the majority of artists (and, of course, architects) whose position can be summed up by these words by Eliel Saarinen (1873-1950): “To lean upon theoretical formulas ... is a sign of weakness that produces weak art. ",26

Wittkower explains how "the break of the arts away from mathematics, however, was no easy task. ... the 'relapses' during the nineteenth century were countless." 27 And according to Ghyka, in 1943 - curiously enough five years the publication of Wittkower's Architectural Principles in the Age of Humanism and the formulation of the Modulor -: "The predominantly scientific character of Renaissance and Baroque Architecture, ... caused in the seventeenth century the anti-geometric or intuitionist reaction whose manifesto was formulated in France by Perrault; and since then there has been an alternation of pendulum swings, ... This conflict between planned composition and intuition or inspiration is still going on, not only in the realm of architecture." 28 Concerning poetry, Ghyka refers Paul Valéry (1871-1945) whose Eupalinos ou l'architecte ${ }^{29}$, published in 1921, is a clear manifesto for the believe of the close relationship between architecture and music. And Ghyka on Le Corbusier (in 1943): “... Le Corbusier... rediscovered the eternal value of the proportion, of the interplay of proportions within an organic design. He rediscovered also the usefulness of the golden section as a 'regulating theme', ...”30

One should also bear in mind that, although the Golden Section played an unimportant role in Renaissance and post-Renaissance art, in his treatise published in 1854, Adolf Zeising (1810-1876) declared it the central principle of proportion in the macrocosm and microcosm. ${ }^{31}$ In the mid-19 ${ }^{\text {th }}$ century, the idea of proportion regained its esoteric and Pythagorean sense. ${ }^{32}$

In his discussions with the organising committee of the De Divina Proportione congress Le Corbusier called attention to the fact that the title meant renouncing past ages, abandoning scientific exegesis and was not a contribution to the studies in question, i.e., "of bringing harmony into modern times" 33 arguing that it would "be

\footnotetext{
${ }^{24}$ Le Corbusier, The Modulor, p.58.

${ }^{25}$ Wittkower, Rudolf, "The Changing Concept of Proportion", p.212.

${ }^{26}$ Wittkower, Rudolf, "The Changing Concept of Proportion”, p.211.

${ }^{27}$ Wittkower, Rudolf, "The Changing Concept of Proportion", p.202.

${ }^{28}$ Ghyka, Matila, "Frozen Music", pp.189, 191.

${ }^{29}$ According to Mario Curti, "[t]his text had considerable influence in French intellectual circles during the twenties and thirties of the twentieth century, very likely with respect to proportion and the golden section in particular." "Canons of Proportion and the Laws of Nature", p.5.

${ }^{30}$ Ghyka, Matila, "Frozen Music", p.193.

${ }^{31}$ Wittkower, Rudolf, "The Changing Concept of Proportion", p.205.

${ }^{32}$ See Curti, Mario, "Canons of Proportion and the Laws of Nature: Observations on a Permanent and Unresolved Conflict".

${ }^{33}$ Le Corbusier, Modulor 2, p.154.
} 
linked most particularly with the works of the Renaissance" ${ }^{\text {"34 }}$. He went on to propose changing the name of the Congress to Symmetry for "as it may be adopted today by advance guard of modern thought, pursues a double goal: that of denouncing it's false meaning of equality, maintained by a still vocal academic tradition; and that of putting the concept of symmetry back in its proper place, on the plane of equilibrium: the very essence of proportion" 35 .

Le Corbusier's idea appears to be close to the idea of Symmetry in Antiquity; as it has always been accepted except for the period between mid- $17^{\text {th }}$ and early $20^{\text {th }}$ centuries. In line with Corbusian thought: something akin to commensurability, i.e. the definition of form based on a single measurement unit. Symmetry implies proportion, which is the relationship between elements regardless of the measurement unit. By way of example one could cite Albrecht Dürer's (1471-1528) treatise on proportions, De Symmetria Partium in Rectis Formis Humanorum Corporum (1532). Even for Palladio (1508-1580) ${ }^{36}$, symmetry meant much more than the simple application of a system of commensurable proportions. As he inherited a long tradition, he saw symmetry as a meaningful relationship between numbers in harmony with the cosmic order revealed by Pythagoras and Plato. It appears quite clear that these are Modulor's intentions, too.

One can say that during Renaissance design is a means to achieve harmony - an idea exterior to the object - with academicism it is an end in itself. That is line with Le Corbusier: "The regulating line is a mean to an end; it is not a recipe. Its choice and the modalities of expression given to it are an integral part of architectural creation." 37

And somewhat paradoxically; axial symmetry is, after all, a small part of the history of architecture and HenryRussel Hitchcock (1903-1987) and Philip Johnson's (1906-2005) International Style is not so revolutionary.

\subsection{Architecture and music}

For Le Corbusier ${ }^{38}$ architecture and music were both a question of measure. Sounds can be transmitted via writing only if one heeds two conditions: they are divided into sections and are measured ${ }^{39}$. Or one could say: if they are "geometrized".

Le Corbusier used the term "measure" and it was indeed about measure and not length. The difference between measure and length is fundamental to understanding this point. A metre is nothing more than an abstract number, incapable of describing an interval - a measure in space ${ }^{40}$ [une mesure in the original French edition]. It is, in reality, a dangerous measure in that one runs the risk of it being used in its submultiples, which would not be desirable in architecture. ${ }^{41}$

${ }^{34}$ Le Corbusier, Modulor 2, p.154. Here Le Corbusier would seem to reveal a lack of knowledge, given that in the Renaissance the question of commensurability was a fundamental one and that irrational numbers - or measures - were avoided. See Wittkower, Rudolf, “The Changing Concept of Proportion”, p.202.

${ }^{35}$ Le Corbusier, Modulor 2, p.154.

${ }^{36}$ Wittkower, Rudolf, Architectural Principles in the Age of Humanism, p.97.

${ }^{37}$ Le Corbusier, Towards a New Architecture, p.3.

${ }^{38}$ Le Corbusier, The Modulor, p.29.

${ }^{39}$ Le Corbusier, The Modulor, p.16.

${ }^{40}$ Le Corbusier, The Modulor, p.33. Note that this "correction" in the English-language edition clarifies better the notion that was to be expressed.

${ }^{41}$ Le Corbusier, The Modulor, p.33. 
Another statement, as included in The Modulor, linking architecture and music is that architecture, like music, is space and time. ${ }^{42}$ For Le Corbusier, architecture does not have a synchronic presence but a diachronic presence, as is the case for music: "Architecture is not a synchronic phenomenon but a successive one, made up of pictures adding themselves one to the other, following each other in time and space, like music." 43

This idea was certainly in line with that of the promenade architecturale. Le Corbusier affirmed that he rejected the principles that governed Renaissance architecture because, in his opinion, the visual perception was neither the main principle nor even one of the generating design principles. The human eye (with its restricted field of vision) is unable to encompass the philosopher's polyhedrons ${ }^{44}$ [polyèdres philosophiques in the original French edition]. This is a fundamental point. For Le Corbusier saw and felt the relationship between architecture and music more from the intuitive and perceptive viewpoint than by means of a composition in which the conceptual aspect played the leading role, the latter being the case with Alberti (1404-1472) or Palladio.

\footnotetext{
${ }^{42}$ Le Corbusier, The Modulor, p.29.

${ }^{43}$ Le Corbusier, The Modulor,p.73.

${ }^{44}$ Le Corbusier, The Modulor, p.72.
} 


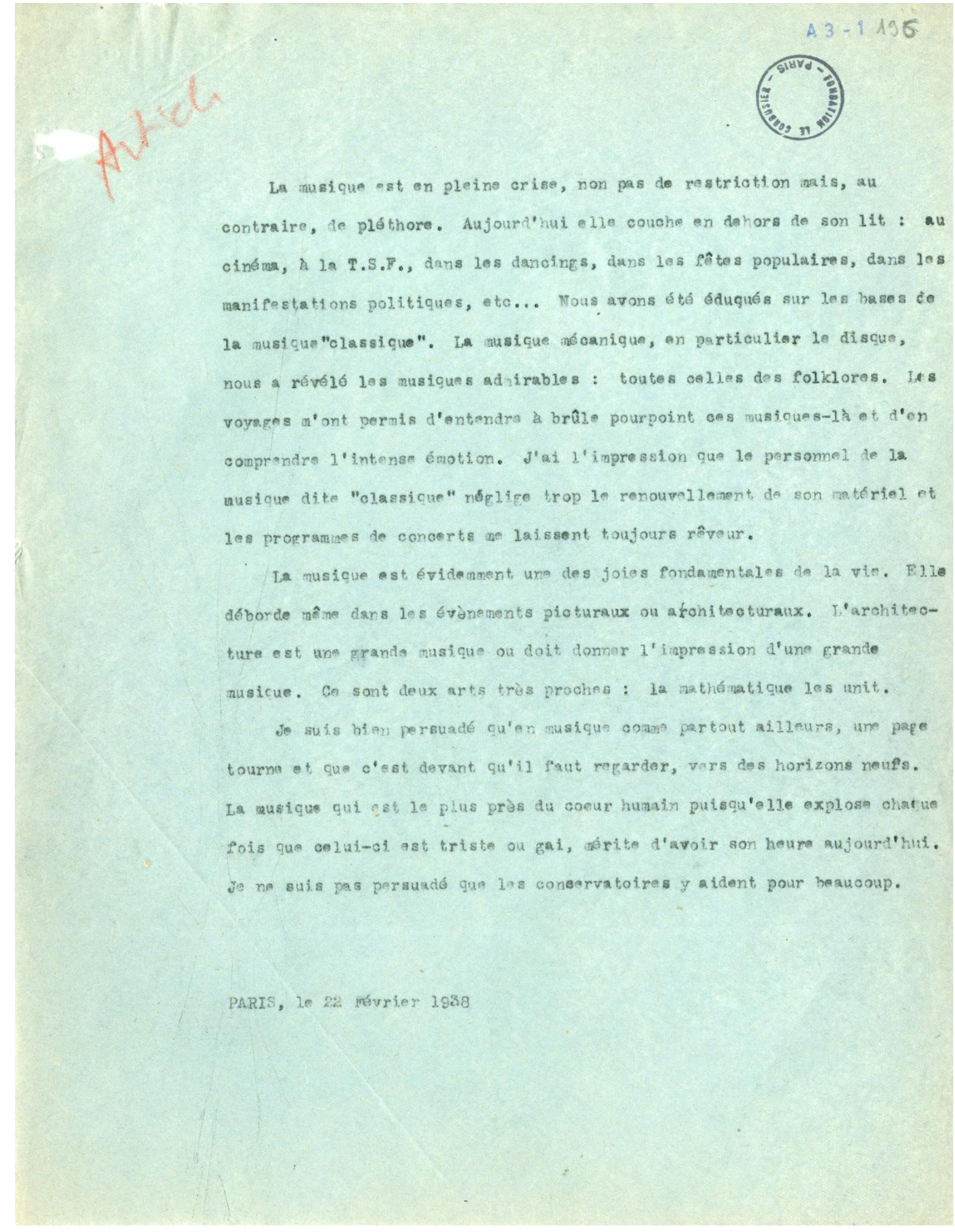

1. Unpublished text on music for La Revue Internationale de Musique. Sent by letter on 22 February 1938 to Charles Leirens of La Maison d'Art. A3(1)195-002@FLC-ADAGP 


\subsection{Working with Xenakis}

A relationship between architecture and music was put into practice in a very fruitful way between 1947 and 1959 - a period in which Le Corbusier and Iannis Xenakis established, through their work relationship, a veritable intellectual partnership in which the musician's and architect's shared interest in, or fascination with, mathematics, and geometry in particular, played a fundamental role. This interest came to manifest itself in a shared course through the development of a theoretical and practical interdisciplinary relationship between architecture and music in which mathematics played an all-important role.

Xenakis was involved in several design projects: the Unité d'Habitation of Marseilles (1947-53), where he was responsible for calculating the concrete structure; the Unité d'Habitation of Rezé-lès-Nantes (1950-55), for which he designed the façades of the crèche located on the terrace, in which one can recognise the neumes of Gregorian musical notation and a "stochastic" 45 distribution of the prefabricated windows calculated on the Modulor ${ }^{46}$; Chandigarh, in particular the Assembly Hall (1951-59) with its enormous hyperboloid; the Convent of Sainte Marie de la Tourette (1953-61); the Maison de la Culture at Firminy (1956-59); and also the Philips Pavilion at the Brussels World Fair of 1958 (1956-58), the design of which he was responsible for and whose experimental attributes were to be of fundamental importance in Xenakis' later trajectory as a composer. ${ }^{47}$ La Tourette is a key work in this collaboration. Here, Xenakis applied to the fenestration a design based on the score for his composition Metastaseis (1953-54), which itself was influenced by the Modulor.

Although Xenakis had been academically trained in engineering and music and had no prior professional experience as an architect, his collaboration in the master's firm was to take on fundamental importance, precisely due to the possibilities for interdisciplinary work it opened up. And it was this interdisciplinarity that Le Corbusier referenced in relation to Xenakis' collaboration in the design project of Convent of Sainte Marie de la Tourette:

"This design of glazed panels for the convent was made by Xenakis, an engineer who became a musician and is now working as an architect at 35 rue de Sèvres: three favourable vocations united in one man. The way in which music and architecture touch upon one another, so often referred to in connection with the Modulor, is now made manifest professionally in a musical score by Xenakis, 'Metastassis' [sic], in which the resources of the Modulor are used as an aid to musical composition. ",48

The alliance between Le Corbusier and Xenakis provided a relationship of not only mutual disciplinary interpretation but also of mutual disciplinary re-interpretation: architectural design and musical composition methods informed each other well beyond the development of mere theoretical supports; Le Corbusier's design system informed Xenakis' compositional system and, in turn, Xenakis applied principles used in musical composition to the architectural object.

\footnotetext{
${ }^{45}$ A type of music developed and created by Xenakis that used statistics - and probability calculation in particular - in music composition.

${ }^{46}$ Sterken, Sven, "Une invitation à jouer l'espace”, p.185.

${ }^{47}$ The attribution of a designer role to Xenakis for the works produced during his time working with Le Corbusier varies depending on the author. Xenakis claims responsibility for a large part of the design of La Tourette, and there is general consensus amongst authors that he designed the Philips Pavilion (with Le Corbusier reluctantly acknowledging him as codesigner). See, for instance, Treib, Marc, Space Calculated in Seconds and Xenakis, Iannis, Musique de l'architecture.

${ }^{48}$ Le Corbusier, Modulor 2, p.326
} 
It was indeed a relationship between architecture, music and mathematics. With the later being the link between the first two. Serving as a guide. Norman Lebrecht ${ }^{49}$ has commented on how the love of the eternal, so often associated with sensibility to mathematics, is evident in Xenakis. Music created through "geometry" was less perishable than works generated by a passing impulse. The structure was fundamental and mathematics should regulate music. This corresponds to the views of Le Corbusier, for whom mathematics would regulate architecture.

\section{The universe, man and architecture}

A link can be established between Corbusian thought and that which corresponds to an idea of a mathematical mathematical-proofed - universe established following traditional principles laid down from Galileo to Newton. Architecture was to be a reflection of that Order:

“..., "nature is ruled by mathematics, and masterpieces of art are in consonance with nature; they express the laws of nature and themselves proceed from those laws. Consequently, they too are governed by mathematics, and the scholar's impeccable reasoning and unerring formulae may be applied to art. The artist, is a medium of infinite, extraordinary sensitivity; he feels and discerns nature and translates it in his own works. ," 50

An observation that also comes extraordinarily close to the idea advanced by Palladio in the Quatro Libbri: "Since architecture, like all the other arts, imitates nature, nothing (in it) can satisfy that is foreign from what is found in nature." 51

Unlike so many of his generation, his discourse is sometimes so close to a classical discourse; a discourse on the objectivity of beauty. In Antiquity, as illustrated by Luc Ferry ${ }^{52}$, the work of art was conceived as a microcosmos. A microcosmos that expressed an idea that is exterior, that belongs to the outer world - to the macrocosmos. The idea of beauty referred to the world's objectivity: the world created by God and ruled by His harmony. In Antiquity, the artist is not a creator ex nihilo, for what was to be revealed was already there, at a deeper level. The artist is the one who has the good fortune to be able to "translate" a divine message. The classic genius is not he who invents; it is he who discovers. Le Corbusier put himself in that position.

Proportion is the main tool for imitation. Proportion is mimesis in practice.

But the demand for a rule clashes with the architect's inherent taste: the architect must judge with his talent. Le Corbusier seems to reflect the constant difficulty reconciling objectivity and subjectivity that has been patent throughout the history of architecture.

"I will fight against any formula and any set of instruments which take away the least particle of my freedom. I want to keep that freedom so intact that at the very moment when golden figures and the diagrams point to a perfectly orthodox solution I may reply: 'That may be so, but it is not beautiful'. And I conclude, once and for all: 'I do not like this, I do not feel it with my taste, my flair, all the intuition of which I have a good enough share to know when I must decide that here is something I do not want.",53 But he continues: "Such a decision

\footnotetext{
${ }^{49}$ Lebrecht, Norman, The Companion to $20^{\text {th }}$ Century Music, p.389.

${ }^{50}$ Le Corbusier, The Modulor, pp.29-30. This observation by Le Corbusier is a reproduction of a conversation with Andreas Speiser, then professor at Zurich University.

${ }^{51}$ As cited in James S. Ackerman, Palladio, p.160.

${ }^{52}$ Ferry, Luc, Homo Aestheticus.

${ }^{53}$ Le Corbusier, The Modulor, p.183.
} 
will certainly not imply any attack on mathematics (which is so near to the divine that it will always be ultimately elusive in its infinite withdrawals), ...,54 This reasoning is, in reality, not a modern one. We find the same perplexity in Palladio, for instance. In Quattro Libri (1570), he writes on rules for the proportion of rooms: "There are still other heights for rooms which fall under no rule, and the architect has to use them according to his judgement and need." And "one cannot give a certain and absolute rule about their [measurements of doors and windows] height and with. ${ }^{, 55}$ On the other side of this discussion, Claude Perrault (1613-88), even declaring the subjectivity of the aesthetic judgement, affirmed the architect's need for a profound knowledge of proportion (essential to architecture).

In closing his essay, "The Changing Concept of Proportion", Wittkower writes: "When all is said and done, it must be agreed that the quest for symmetry, balance, and proportional relationships lies deep in human nature. ... the search for systems of proportion in arts will continue as long as art remains an endeavour of man. ",56

Apropos the use of metrics and the rejection of the Modulor for future large-scale use, Le Corbusier criticised the French Standardization Organisation, AFNOR, arguing as follows: “... 'the AFNOR proposes to standardize all the objects involved in the construction of buildings. The method they are proposing to employ is somewhat over-simplified: simple arithmetic, getting a simpler cross-section of the methods and costumes used by architects, engineers and manufacturers. This method seems to me to be an arbitrary and a poor one. Take trees: if I look at their trunks and brunches, their leaves and veins, I know that the laws of growth and interchangeability can and should be something subtler and richer." 57

Le Corbusier referenced Anglo-Saxon cultures which still today use the inch and the foot as measurement units, thus maintaining a relationship with the human body: "The Anglo-Saxon society uses the foot-and-inch, which knows nothing of the decimal system... The metre reigns over the other part of the world. I am seriously angry with the metre (forty-millionth part of the meridian of the earth) for having desubstantialized itself as it has done, and for having placed itself so perfectly, so dangerously, so unhappily outside the human scale. $" 58$

The relationship between the proportions of the human body and architecture also echoed the classical tradition: Le Corbusier highlighted the fact that the measures used in the various civilizations of Antiquity referenced a single standard, whereby the unit used was almost always related to the human body. He goes further and refers to the primitive $\mathrm{e}^{59}$ : “..., I admired the peasants' house, the house of men, the huts, the modest thing on a human scale. And that's where I invented a part of my Modulor, by rediscovering all the human dimensions in humble things. They are based on the cubit, the foot, the inch, etc.,- used from the very beginning of time, because there was no other way to measure. ${ }^{60}$ All measures are "based on man",61.

The Modern showed nostalgia for permanence and, for this reason, found comfort in the classical tradition. It sought rules for representation of the world - interior and exterior - that were considered lost. It also expressed

\footnotetext{
${ }^{54}$ Le Corbusier, The Modulor, p.183.

${ }^{55}$ Wittkower, Rudolf, Architectural Principles in the Age of Humanism, p.129.

${ }^{56}$ Wittkower, Rudolf, "The Changing Concept of Proportion", p.213.

${ }^{57}$ Le Corbusier, The Modulor, p.36. This is a reproduction of a conversation between Le Corbusier and Hanning, one of his colaborators.

${ }^{58}$ Le Corbusier, The Modulor, pp.114-115.

${ }^{59} \mathrm{He}$ advocates the primitive apropos the regulating lines in the chapter "Regulating Lines" in Towards a New Architecture: "Primitive man has brought his chariot to a stop, ..." p.69.

${ }^{60}$ Le Corbusier, "The Final Year: A Transcription and Translation of Le Corbusier's Last Recorded Interview", p.117.

${ }^{61}$ Le Corbusier, "The Final Year: A Transcription and Translation of Le Corbusier's Last Recorded Interview", p.117.
} 
the idea that the human measurements be present in that relationship. It is also symptomatic that the drawings for the Modulor so clearly mirror the Vitruvian man (as published from Renaissance treatises onwards). [Fig.s 2 and 3]

\section{The Modulor as a synthesis}

Apart from Le Corbusier's personality one should bear in mind that this theme had been present in his mind since his sojourn in Germany in 1910, Matila Ghyka's work on the golden number was fundamental and that, generally, proportions became a central subject of discussion in postwar France. ${ }^{62}$

The title The Modulor: A Harmonious Measure to the Human Scale Universally Applicable to Architecture and Mechanics contains, from the outset, clues to this unequivocal pursuit of order. Measure, harmony, universality, mechanics: four established concepts of order, transversal in history and transversal between themselves.

Unlike the metric system, the "Modulor is a working tool for those who create (those who compose: planners and designers), and not for those who execute (masons, carpenters) "'63. One should note here the traditional one could say, even, classicist - point of view regarding the attribution of different roles and status to those who think and those who execute. This idea had already been strongly rejected in the Bauhaus (for instance) in particular by Walter Gropius (1883-1969) who denounced it in his discourses arguing for the abolishment of the artist-artisan distinction. The connection to classicism - understood as an intellectual attitude reflected in a system of proportions - was also a way of defending the architect's status: "I am not a builder". Just as, during the Renaissance, the architect wasn't also a builder. Leonardo's cosa mentale.

The Modulor presents itself as a manifesto for the cause of a mathematical - arithmetical-geometrical - world. In that world, music affirms its presence as well. The idea of the rule - the ordering instrument - seems to echo music: "The Modulor is a scale. Musicians have a scale; they make music, which may be trite or beautiful." ${ }^{\text {" Le }}$ Corbusier cites Stamo Papadaki (1906-92), who in his investigation of the Modulor's possible applications, attributed a "subtitle" to it: "“A scale of harmonious measurements of space.",65

And if music seems to be absent it is there, deep down. It is the linking element. It's behind. Like, in Renaissance, for Alberti, as Wittkower clarifies, “... harmonic ratios inherent in nature are revealed in music. The architect who relies on those harmonies is not translating musical ratios into architecture, but is making use of an universal harmony apparent in music." 66

The Modulor also illustrates the proximity between different ages in which there is a desire for a world created by, and continuing to exist as, a natural and universal Order. In this sense, Le Corbusier expresses his wish that the Modulor - as a universal system, as a universal rule - could be an instrument to standardise the diverse measurements of length. He was convinced that the Modulor would find practically unlimited application in geographic and temporal terms. Inspired by Rameau, he sought to create the basis for a new and, if possible, everlasting tradition.

\footnotetext{
${ }^{62}$ See Cohen, Jean-Louis, “Le Corbusier's Modulor and the Debate on Proportion in France”. German culture was absolutly decisive from this point of view.

${ }^{63}$ This is part of a Le Corbusier's answer to a letter by John Dale. Le Corbusier, The Modulor, p.178

${ }^{64}$ Le Corbusier, The Modulor, p.5. In the introduction to the second English-language edition.

${ }^{65}$ Le Corbusier, Modulor 2, p.31.

${ }^{66}$ Wittkower, Rudolf, Architectural Principles in the Age of Humanism, p.109.
} 
Considering Le Corbusier as a follower of the Pythagorean-Platonic tradition, even if he did not declare himself as such, the fact is that he tried - in particular with the Modulor - to reconcile within mathematics the geometric with the arithmetical tradition. While the geometry was usual in the Middle Ages, arithmetic was favoured by Renaissance architects. According to Wittkower, "[i]rrational proportions would have presented a dilemma to Renaissance artists, for the Renaissance attitude to proportion was determined by a new organic approach to nature, which aimed at demonstrating that everything was related to everything by integral number. By contrast, the medieval quest for ultimate truth behind appearances was perfectly answered by geometrical configurations of a decisively fundamental nature",67. And "... the medieval artist tends to impose a pre-established geometrical norm upon his imagery, while the Renaissance artist tends to extract a metrical norm from the natural phenomena that surround him." 68 . And "Modulor" as Summerson ${ }^{69}$ so ably explains is a word derived from module and section d'or. It thus couldn't be closer to ancient times... and tradition.

The Modulor is also a synthesis of commensurability and incommensurability. And whilst, on the one hand, Le Corbusier synthesises those two aspects with the Modulor, on the other the Modulor is also meant to be a synthesis of a different nature: i.e. of the present and tradition. "In the light of history [Modulor] appears as a fascinating attempt to coordinate tradition with our non-Euclidian world."70 The Modulor "... is certainly the first consistent synthesis since the break-down of the older systems, reflecting our own civilisation into bargain. At the same time it testifies to the coherence of our cultural tradition." "71 However "Le Corbusier's dual system of irrational magnitudes is still dependent on the conceptions which Pythagorean-Platonic thought opened up for western mankind." $" 72$

We should risk to say that it is also the synthesis of French ever rationalism with German ever metaphysics...

And it embodies the circle, the square, the circle and the square in relation, double square, the first integers...

But Wittkower considers: “... Le Corbusier's is a composite system, and - in spite of its ultimate derivation from Pythagorean-Platonic thought - its vacillating quality seems to reflect the spirit of our non-Euclidian age.",73 And he argues that: “...by taking man in his environment, instead of universals, as his starting point, Le Corbusier has accepted the shift from absolute to relative standards. His Modulor lacks the metaphysical connotations of the old systems." 74 Is this the case?

The Modulor ensures the mutual relations between the parts and between the parts and the whole. Man and building. The Modulor aims to be a new homo bene figuratus. [Fig.s 2 and 3]

\footnotetext{
${ }^{67}$ Wittkower, Rudolf, "The Changing Concept of Proportion”, p.202

${ }^{68}$ Wittkower, Rudolf, "The Changing Concept of Proportion", p.202

${ }^{69}$ Summerson, John, The Classical Language of Architecture, p.113.

${ }^{70}$ Wittkower, Rudolf, "Systems of Proportion”, p.18.

${ }^{71}$ Wittkower, Rudolf, "Systems of Proportion", p.18.

${ }^{72}$ Wittkower, Rudolf, "Systems of Proportion", p.18.

${ }^{73}$ Wittkower, Rudolf, "The Changing Concept of Proportion”, p.212.

${ }^{74}$ Wittkower, Rudolf, "The Changing Concept of Proportion”, p.212.
} 


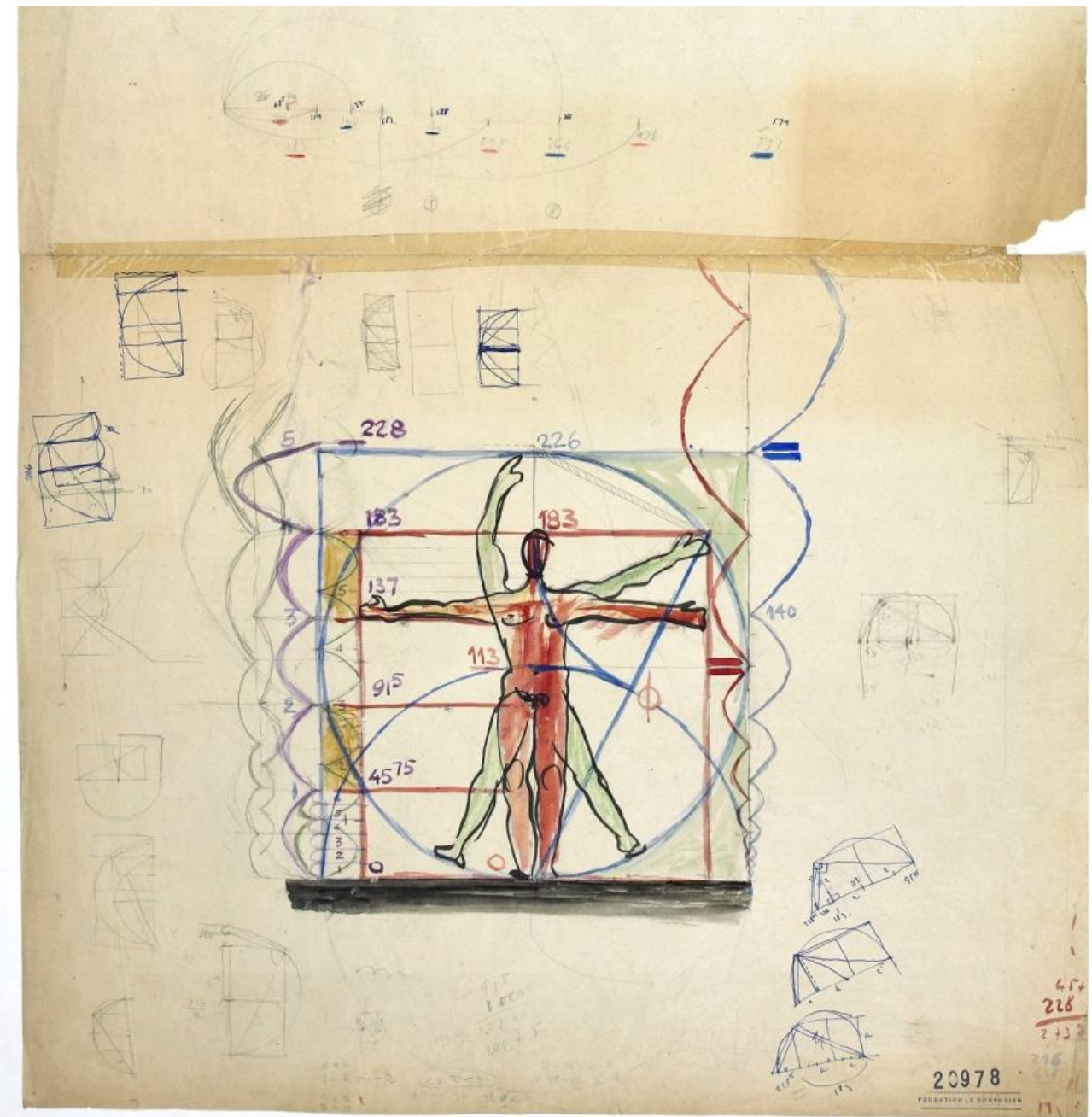

2. Study for the Modulor (undated). Image 32285@FLC-ADAGP 


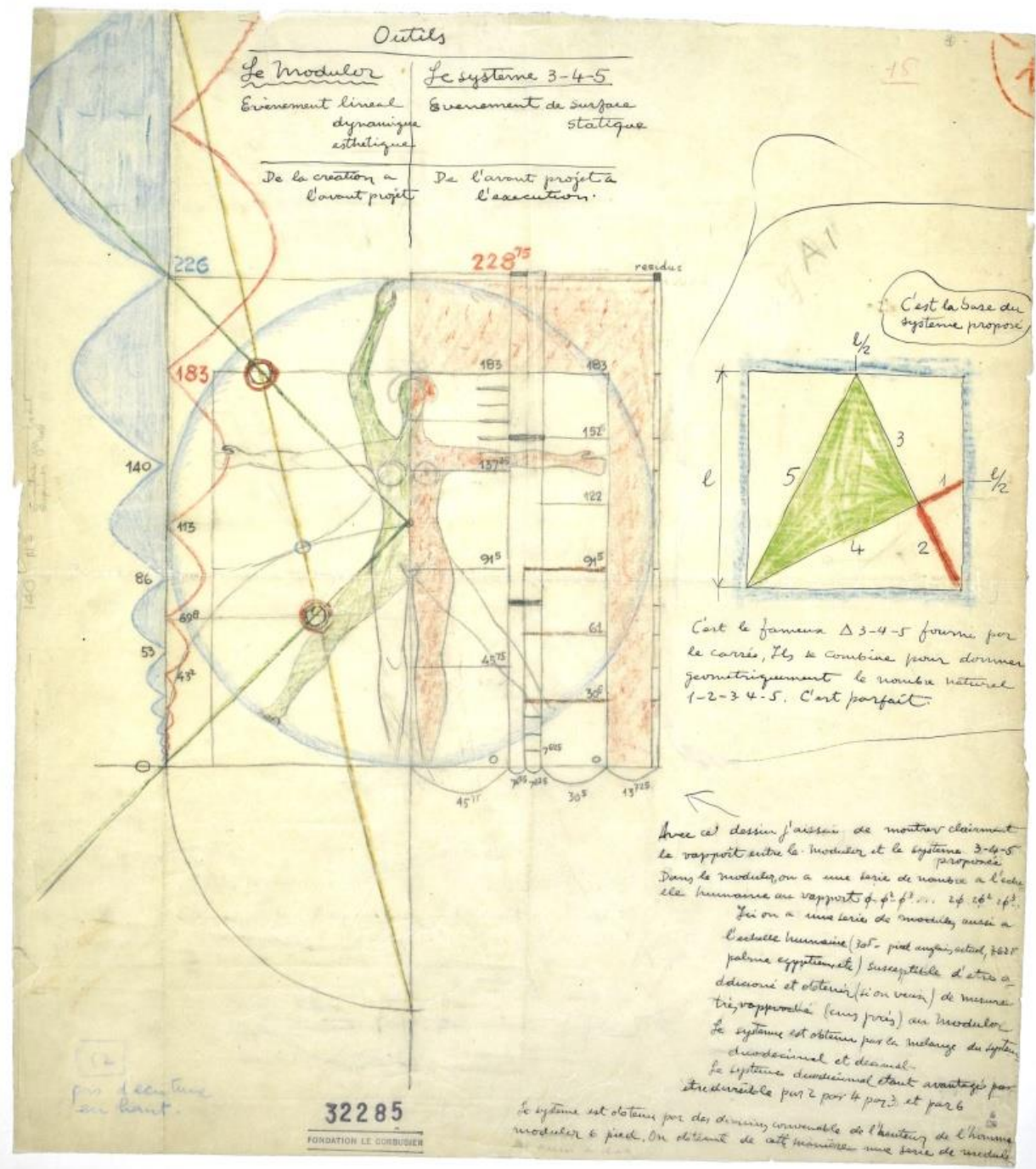

3. Study for the Modulor (undated). Image 20978@FLC-ADAGP

\section{Longing for classicism}

The question arises: is the architecture-mathematics-music relationship - which embodies Pythagorean-Platonic tradition - the result of nostalgia for the past? Is this nostalgia the result of this love? Or are this love and nostalgia simultaneous manifestations of a way of being, a way of creating? This would seem to be the case. This relationship is so fundamental for it is Le Corbusier's main link to Antiquity and the tradition established then and his wish for a timeless classical thought - a timeless way of thinking and building architecture.

And, even though Le Corbusier did not have the erudite knowledge of music that architects such as Alberti and Palladio had, thanks to his more intuitive and perceptive approach he sought to maintain that relationship. He was convinced that, despite his more intuitive and perception-based approach, the ancestral link between the three disciplines was real. As he wrote in his unpublished article [fig.1]: "[L'architecture et la musique] sont deux arts très proches: la mathématique les unit."

Longing for classicism is the desire to continue an ancient tradition - to a certain extent a "primitive" one while wishing to live and act in the present. Le Corbusier seems to have not wanted to lose this tradition, but the truth is that Romanticism also influenced him. The idiosyncrasies introduced by Romanticism came into conflict 
- a creative and stimulating conflict - with the ideals of the new society founded on an idea of functionalism and rationalism that required the neutrality of the object - the artistic object in general and the architectural object in particular - in relation to personal choices. However, he did not want to give up his position.

If it is true that, as Wittkower states, from the $17^{\text {th }}$ century onwards "[w] hat mathematics gained as an abstract discipline from the seventeenth century on, it lost as a guiding principle in the field of aesthetics" "75 and, simultaneously, "[t] he reciprocal notions 'proportion' and 'beauty' were stripped of their metaphysical and universal character" ", it is this metaphysical aspect that Le Corbusier does not seem to have wanted to abandon. Whereas Edmund Burke (1729-1797) in Enquiry into the origin of our ideas of the Sublime and the Beautiful argued that beauty does not have "anything to do with calculation and geometry" countered that it also has to do with them. Le Corbusier did not reject feeling and the subjective, but he did not stop believing in the tradition.

As in the work of Schoenberg, L'Esprit nouveau aspired to becoming a new tradition. Founded on tradition.

And order exists. (And is needed.) As do numbers. And mathematics. They all express the great Order: "Good composition requires the use of a very few elements, but each of those should have a distinct personality, and a strong one at that. It takes only twenty-six letters to write tens of thousands words in fifty languages. [George Sadoul, in a note]. The Universe, at our present state of knowledge, is composed of ninety-two elements. All arithmetic is written with ten figures, and music with seven notes. The year has four seasons, twelve months, and days composed of twenty-four hours. Order is the very key of life." 78

Mathematics - be it geometry or arithmetic - rules human creation. And the universe. Both architecture and music - spatial composition and sound composition - ought to be based on mathematics. Like the universe. And man, the inhabitant of the universe and architecture, through the Modulor, lives and nourishes from that same universe. This is classical thought.

And Le Corbusier's sensibility is very much classical: “... I studied Gothic a lot. I had, for a year - I was in Paris for a whole year - I had the set of keys to Notre-Dame de Paris, given by the ministry to young people who wanted to study it. I wandered around inside, I would go to the top of the towers, into the ambulatories, into every possible corner of Notre-Dame. Notre-Dame is magnificent, it's a very beautiful thing; only my heart is turned toward Greece and not toward the Gothic, which is hard and almost aggressive next to... I'm talking about a Greek feeling and a Gothic feeling. They're two different feelings." 79

An architect, a "musician by heart", a "mathematician by heart" with his heart "turned toward Greece".

Did transcendence exist for Le Corbusier? A transcendent harmony? He refers to "numbers" as "business of the gods". And he states: "Behind the wall, the gods play; they play with numbers, of which the universe is madeup." 80

Le Corbusier: human so human; classical, so classical.

Looking for Harmony.

\footnotetext{
${ }^{75}$ Wittkower, Rudolf, "The Changing Concept of Proportion”, p.202.

${ }^{76}$ Wittkower, Rudolf, "The Changing Concept of Proportion”, p.202.

${ }^{77}$ As cited in Wittkower, Rudolf, "The Changing Concept of Proportion". p.202 See also Wittkower, Rudolf, Architectural Principles in the Age of Humanism.

${ }^{78}$ Le Corbusier, The Modulor, p.75.

${ }^{79}$ Le Corbusier, “The Final Year: a Transcription and Translation of Le Corbusier's Last Recorded Interview”, p.120.

${ }^{80}$ Le Corbusier, Modulor 2, p.17.
} 


\section{Acknowledgments}

This paper is funded by National Funds through FCT - Fundação para a Ciência e a Tecnologia under the Project UID/AUR/04026/2013.

Thanks to Fondation Le Corbusier.

Thanks to Delphine Studer (Fondation Le Corbusier).

\section{Bibliographic references}

Ackerman, James S. Palladio. London: Penguin, 1991. [First pub. 1966.]

Cohen, Jean-Louis, “Le Corbusier's Modulor and the Debate on Proportion in France”. Architectural Histories. 2014, Vol.2, Nº1, pp.1-14. DOI: http://dx.doi.org/10.5334/ah.by

Curti, Mario. "Canons of Proportion and the Laws of Nature: Observations on a Permanent and Unresolved conflict”. Architectural Histories. 2014, Vol. 2, No1, pp.1-7. DOI: http://dx.doi.org/10.5334/ah.bn

Curtis, William J.R. Modern Architecture Since 1900. $2^{\text {nd }}$ ed. London: Phaidon, 1995. [First pub. 1982.]

Ferry, Luc. Homo Aestheticus: l'invention du goût à l'âge démocratique. Paris: Éditions Grasset \& Fasquelle, 1990.

Ghyka, Matila. "Frozen Music". Horizon. 1943, N45, pp.187-194.

Gonçalves, Clara Germana, Arquitectura: diálogos com a música: concepção, tradição, criação. Director: Víctor Pérez Escolano. Ph.D Thesis. Universidad de Sevilla: Sevilla, 2008.

Le Corbusier. The Modulor: A Harmonious Measure to the Human Scale Universally Applicable to Architecture and Mechanics. Basel: Birkauser, 2004. [First published as Le Modulor, essai sur une mesure harmonique à l'échelle humaine applicable universellement à l'architecture et à la mécanique. Boulogne: Éditions de l'Architecture d'Aujourd'hui, 1950.]

Le Corbusier. Modulor 2, 1955 (Let the User Speak Next: Continuation of "The Modulor" 1948. Basel: Birkauser, 2004. [First published as Modulor 2, 1955: la parole est aux usagers: suite de "Le Modulor". 1948. Boulogne: Éditions de l'Architecture d'Aujourd'hui, 1955.]

Le Corbusier. Towards a New Architecture. New York: Dover, 1986. [First published as Vers une architecture. Paris: Éditions Crès, 1923.]

Le Corbusier. "The Final Year: a Transcription and Translation of Le Corbusier's Last Recorded Interview". In Zaknic, Ivan (Ed.). The Final Testament of Pére Corbu: a Translation and Interpretation of Mise au point by Ivan Zaknic. New Haven: Yale University Press, 1997, pp.117-120.

Lebrecht, Norman. The Companion to $20^{\text {th }}$ Century Music. New York: Da Capo Press, 1996.

Novak, Marcos. "Breaking the Cage". In Martin, Elizabeth (Ed.). Pamphlet Architecture. "Architecture as a Translation of Music". 1994, No16, pp.69-71.

Pevsner, Sir Nikolaus. "Report of a Debate on the Motion 'that Systems of Proportion make good design easier and bad design more difficult"'. R.I.B.A. Journal. Sept.1957, pp.456-463.

Schoenberg, Arnold. Style and Idea: Selected Writings of Arnold Schoenberg. Ed. By Leonard Stein. Berkeley: University of California Press, 1984.

Sterken, Sven. "Une invitation à jouer l'espace: l'itinéraire architectural de Iannis Xenakis". In Mache, FrançoisBernard (Ed.). Portrait(s) de Iannis Xenakis. Paris: Bibliothèque Nationale de France, 2002, pp.185-193.

Summerson, John. The Classical Language of Architecture. London: Thames and Hudson, 1995. [First pub. 1963] 
Treib, Marc. Space Calculated in Seconds: The Philips Pavilion, Le Corbusier, Edgard Varèse. Princeton, N.J.: Princeton University Press, 1996.

Wittkower, Rudolf. Architectural Principles in the Age of Humanism. London: Academy Editions, 1998. [First published in 1949.]

Wittkower, Rudolf. "The Changing Concept of Proportion". In Wittkower, Rudolf. Idea and Image: Studies in the Italian Renaissance. New York: Thames and Hudson, 1978, pp.198-215. [First published in Architects'Year Book. Vol. V, 1953.]

Wittkower, Rudolf. “Systems of Proportion”. Architects’ Year Book. Vol. V, 1953, pp.9-18.

Xenakis, Iannis. Musique. Architecture. Tournai: Casterman, 1971.

Xenakis, Iannis. Musique de l'architecture. Sharon Kanach (Ed.). Marseille: Parenhèses, 2006.

Zevi, Bruno. The Modern Language of Architecture. New York: Da Capo, 1994. [Fisrt published as Il linguaggio moderno dell'architettura: arhitettura e storiografia. Turino: Einaudi, 1973.] 


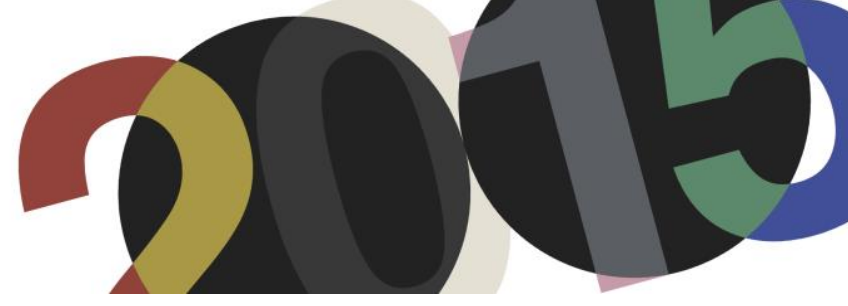

DOI: http://dx.doi.org/10.4995/LC2015.2015.803

\title{
Mirada objetiva y dimensión subjetiva del cine en Le Corbusier
}

\author{
J. González Cubero
}

\author{
Escuela Técnica Superior de Arquitectura de Valladolid
}

\begin{abstract}
Resumen: Los contactos de Le Corbusier con el mundo cinematográfico se dilatan a lo largo de su trayectoria profesional y recorren un amplio espectro. Se concretan en la concepción y construcción de salas dedicadas a la proyección del cine, la participación en proyectos y realización de películas, así como la publicación de un esporádico escrito monográfico titulado "Esprit de vérité" (1933). Este trabajo aborda la singularidad de su pensamiento cinematográfico frente al de otros insignes arquitectos coetáneos y pone de relieve el cambio que experimenta éste entre la película L'Architecture d'Aujourd'hui (1930) y la obra multimedia Le Poème électronique (1958), mostrando un camino que parte de la consideración del cine como un medio donde la imagen se pone al servicio de la arquitectura, y nunca al revés, hasta llegar a utilizar el montaje soviético como mensaje subjetivo del realizador, en este caso también autor de la arquitectura.
\end{abstract}

Abstract: Le Corbusier's contacts with the world of cinematography spanned his entire career and cover a broad spectrum. They materialized in the conception and construction of screening rooms for cinema, the participation in projects and cinema-making, and the publication of sporadic features under the title "Esprit de vérité" (1933). This article covers Le Corbusier's unique cinematographic thought standing apart from those of other distinguished architects of his generation and highlights the change he experienced between the film L'Architecture d'Aujourd'hui (1930) and the multimedia work Le Poème électronique (1958). It traces a path originating with the notion of cinema as a medium where images are at the service of architecture and never the other way around, and winding up with the use of soviet montage as a subjective message of the filmmaker who, in this case was also maker of the architecture.

Palabras clave: Le Corbusier, arquitectura, película, cine, montaje.

Keywords: Le Corbusier, architecture, film, movie, cinema, montage.

\section{Introducción}

Los contactos de Le Corbusier con el mundo cinematográfico se dilatan a lo largo de su trayectoria profesional y recorren un amplio espectro. Van desde la concepción y construcción de salas dedicadas a la proyección del cine, la participación en proyectos y realización de películas, así como la publicación de un esporádico escrito monográfico. Todos revelan cuán diferente es la postura que mantiene respecto a otros artistas y arquitectos coetáneos.

En cuanto a la labor propia de arquitecto, el contacto se produce en apenas dos intervenciones. En 1916 construye la sala de cine La Scala en La Chaux-de-Fonds de su Suiza natal, hoy en día parcialmente desaparecida, y en 1931 proyecta otra en el subsuelo de La Coupole en Paris, proyecto que será pronto abandonado. Son salas que adoptan formas independientes de la herencia teatral, en un periodo de tiempo en que las salas de cine se erigen en fulgurantes templos de la modernidad y remplazan la centralidad de catedrales y palacios en las urbes. Ante tal panorama, la línea editorial defendida por la revista L'Esprit Nouveau, de cuyo equipo forma parte, se suma a la investigación sobre las características que debe tener la sala de cine y promueve en 1921 la realización de una encuesta ${ }^{1}$ dirigida a insignes arquitectos franceses y extranjeros, así como también

\footnotetext{
${ }^{1}$ Sobre el contenido de la encuesta ver Buxtorf, Anne-Élisabeth: "La salle de cinéma à Paris entre les deux guerres. L'utopie à l'épreuve de la modernité". En Leniaud, Jean-Michel (Ed.): Entre nostalgie et utopie: réalités architecturales et artistiques
} 
a personalidades interesadas por el mundo cinematográfico. Al final, debido a la escasa respuesta en contenidos, la encuesta queda sin publicarse.

Va a ser otro arquitecto inmerso en el mundo del cine, Robert Mallet-Stevens, quien más se preocupe por detallar su imagen en los diversos diseños que elabora entre 1917 y 1924, coronándolos con el texto "Architecture. Les cinémas"2 escrito en 1924 en el que describe las características de la sala. En cambio, Le Corbusier tiene un enfoque bien diferente y se despega de la seductora senda arquitectónica de su colega. Sus proyectos urbanos teóricos del periodo de entreguerras acogen las salas en una situación indeterminada en el corazón de la ciudad, según expresa en sus textos, junto con otros lugares para el esparcimiento humano como el teatro, las salas diversas (galería de exposición, sala de conferencias o congresos) o los restaurantes y cafés, comercios y tiendas de lujo. Sin embargo, no dota a la sala de cine de un edificio singular y la camufla entre los lugares de ocio. Se desconoce si este planteamiento de Le Corbusier es debido a que las proyecciones de cine las introduce en el teatro o porque la sala en la que piensa no tiene entidad suficiente.

Otro arquitecto sin veleidades escenográficas como Alvar Aalto, ocupado en encargos de cines a finales de los años veinte, se sobrepone a las contingencias de los mismos para teorizar sobre la sala de proyección en el artículo "Un cine racional" 3 . Avanza la reproductibilidad técnica del cine y, por consiguiente, de las obras de arte que puedan tenerlo como soporte material, característica que las separa de aquellas obras únicas de la historia, tesis que más tarde publicará Walter Benjamin": “[...] una tira de celuloide pertenece a otra familia [de obras de arte], a un tipo objetivo que permite copias ilimitadas. Representa menos una forma que un sistema; y es ejemplo ideal de lo que entendemos por un producto representativo de su tiempo "5.

En cuanto a la sala, Aalto se extiende en detectar el problema luminotécnico y dar una solución para el tratamiento del revestimiento interior. Hace una analogía con el medio cinematográfico para establecer el carácter universal de la propuesta en su condición de sistema estandarizable y adaptable: "[...] la solución, de cara a que su importancia fuera de carácter más general, habría de ser una forma estandarizable, más bien un sistema con capacidad de adaptación" ". A penas se refiere a la forma de la sala en el remate final del artículo y de nuevo se apoya en la analogía cinematográfica: "Y si queremos que las salas de cine encuentren poco a poco su tipo universal, el problema ha de solucionarse con un tipo arquitectónico básico que tenga en cuenta lo variable, lo mutable, lo no monumental, cualidades todas ellas inherentes al cine "7. ¿Y qué tipo básico abstracto puede valer para un espectáculo de luz proveniente de una pantalla bidimensional? Si el tipo arquitectónico es "el concepto que describe una estructura formal"8 según Carlos Martí Arís, el más elemental para ese fin es un contenedor prismático y hermético.

aux XIXe et XXe siècles. Paris-Genève: Champion-Droz, 2005, pp. 117-144, p. 126.

${ }^{2}$ Publicado por primera vez en el Catálogo de la Exposición L'art dans le cinéma français. Paris: Musée Galliera, 1924. Incluido en Mallet-Stevens, Robert: Le décor au Cinéma. Paris: Séguier, 1996, pp. 40-50.

3 Aalto, Alvar: "Un cine racional" ("Rationell biografi"), Kritisk Revy, 1928). En Schildt, Göran (Ed.): Alvar Aalto de palabra y por escrito (Alvar Aalto. In his own words, 1997). Madrid: El Croquis Editorial, 2000, pp. 91-97.

${ }^{4}$ Benjamin, Walter: La obra de arte en la época de su reproductibilidad técnica (1936). México: Ítaca, 2003.

${ }^{5}$ Aalto, Alvar: "Un cine racional" (1928), op. cit., p. 91.

${ }^{6}$ Aalto, Alvar: "Un cine racional" (1928), op. cit., p. 94.

${ }^{7}$ Aalto, Alvar: "Un cine racional" (1928), op. cit., p. 97.

${ }^{8}$ Martí Arís, Carlos: Las variaciones de la identidad. Ensayo sobre el tipo en arquitectura. Barcelona: Ediciones del Serbal, 1993 , p. 16. 
Años más tarde, en un encuentro teatral celebrado en la Sorbona en 1948, Le Corbusier rechaza la sala destinada indistintamente a teatro y cine ${ }^{9}$, aunque hay que tener en cuenta el contexto en el que se produce y el público al

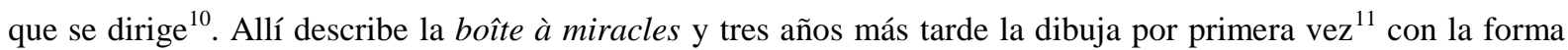
rotunda y desnuda de un prisma rectangular ciego, presidido únicamente por la minúscula puerta que acoge a los espectadores. Es una caja de sueños ambigua que se destina a diversos espectáculos entre los que no se encuentra el cine: "conferencias audiovisuales, música, danza, teatro y juegos electrónicos" 12 . Al margen de que la afirmación se deba bien a la manifiesta desafección de Le Corbusier por la sala de cine o bien porque el cine se incluya entre los juegos electrónicos, la boîte à miracles representa un ideograma del lugar de espectáculo y reunión. Sin embargo, en este tiempo en que las salas ya no son emblema del progreso sino la propia tecnología del cine sigue despojándolas de forma urbana y, además, les quita la centralidad para integrarlas con el resto de equipamientos (cine-clubs) de las Unités residenciales. Se comprueba a lo largo de su obra que los templos del cine, en cuanto contenedores herederos del teatro, no tienen asignado ningún papel identificable en la configuración de la ciudad moderna.

Le Corbusier no se detiene únicamente en sus dos acometidas de la sala de proyección cinematográfica como arquitecto. A lo largo de su carrera extiende sus contactos con el cine imaginando e interviniendo en diversos proyectos cinematográficos y numerosas películas ${ }^{13}$ que dan testimonio, al mismo tiempo, del entusiasmo y recelo profesado hacia este arte. En primer lugar, saca partido de las posibilidades que ofrece el nuevo medio en cuanto instrumento de conocimiento y comunicación de la arquitectura real, antes que como constructor de esa arquitectura inmaterial hecha de luz en la pantalla. A esta concepción del cine, que aprovecha el potencial visual y capacidad promocional de sus ideas, persona y obras, responden dos películas de la trilogía sobre la arquitectura moderna dirigida por el director belga Pierre Chenal. De las tres películas, que nacen para dar más proyección a la revista homónima ${ }^{14}$, la ensombrecida Bâtir (1930) y luego la archiconocida L'Architecture d'Aujourd'hui (1930) cuentan con la colaboración de Le Corbusier. Ambas películas contienen una participación coral de diferentes edificios; en Bâtir comparte cartel con un heterogéneo elenco de arquitectos mientras que en

\footnotetext{
9 Intervención de Le Corbusier en el coloquio posterior a su conferencia "El teatro espontáneo", pronunciada el 11 de diciembre de 1948 en la Sorbona con ocasión de la primera sesión del Centre d'Études Philosophiques et Techniques de Théâtre. En Villiers, André (Pres. por): Architecture et dramaturgie. Paris: Flammarion, 1950, pp. 149-168, p. 167.

${ }^{10}$ Sobre el carácter polemista de Le Corbusier acerca del tema tratado y la condescendencia hacia al público asistente a sus intervenciones ver González Cubero, Josefina: "Hilos de teatro: la puesta en escena del Palacio de los Soviets de Le Corbusier, 1931/ Strands of Theatre: Le Corbusier's Staging of the Palace of the Soviets, 1931”. En Proyecto, progreso y arquitectura $\mathrm{N}^{\mathrm{o}} 7$ (Arquitectura entre concursos), Noviembre 2012. Sevilla: Publicaciones de la Universidad de Sevilla, 2012, pp. 68-89.

${ }^{11}$ Se publica por primera vez con la conferencia "El corazón como punto de reunión de las artes", pronunciada en 1951 en el marco del CIAM VIII celebrado en Hoddesdon, y cuyo contenido coincide prácticamente con el del encuentro teatral. En Tyrwhitt, Jaqueline; Set, José Luis; Rogers, Ernesto N. (Ed.): CIAM 8- The heart of the city. London: Lund Humphries, 1952 , p. 52 .

${ }^{12}$ El dibujo de la boîte à miracles se publica por segunda vez como "prolongements" del Museo de crecimiento ilimitado en la lámina 11 del Museo del Siglo XX, donde se enumeran las actividades contenidas. En Le Corbusier et son atelier rue de Sèvres 35. OEuvre complète 1957-1965 (1965). Zurich: Les Éditions d'Architecture, 1995, p. 170.

13 Arnaud François hace balance e indica su participación en doce realizaciones cinematográficas, total o parcialmente dedicadas a sus proyectos y construcciones. Para una exhaustiva filmografía de Le Corbusier ver François, Arnaud: "La cinématographie de l'oeuvre de Le Corbusier”. En Cinémathèque. № 9. Primavera 1996. Paris: Cinémathèque française, pp. 39-55.

${ }^{14}$ La revista L'Architecture d'aujourd'hui, fundada por André Bloc en 1930, tuvo un papel decisivo en la promoción del discurso y la imagen de la arquitectura moderna. Para promocionarse produce tres documentales (L'Architecture d'aujourd'hui, Bâtir, Trois Chantiers) dirigidos por Pierre Chenal y presentados en París en 1931.
} 
L'Architecture d'Aujourd'hui es reducido a Perret y Mallet-Stevens en la versión larga de la película ${ }^{15}$. La existencia de otra versión corta, en la que se elimina a sus colegas para que la presencia de obras ajenas no perturbe la integridad de su mensaje, deja una película exclusivamente dedicada a su obra, y no sorprende que exista esta versión ni que sea la que utilice en sus conferencias.

Situado en las antípodas ideológicas de Le Corbusier, Robert Mallet-Stevens está de acuerdo en parte con la idea. Para él también el cine es un medio de educación del público y de divulgación de los contenidos de la arquitectura moderna, en cambio, disiente al apoyarse en una arquitectura ficticia hecha para el cine. Con una actitud heterodoxa, no tiene reparos en construir para ser proyectado en la pantalla, como tampoco los tienen otros arquitectos del momento, sea Paul Nelson o Alberto Cavalcanti entre otros. Aunque Mallet-Stevens pronto inicia la actividad de escenógrafo, actividad que marca profundamente su arquitectura de corte ecléctico, y es de los primeros en analizar las relaciones entre arquitectura y cine, defiende conservar la distancia entre lo real y lo imaginario, entre la arquitectura habitada y la cinematográfica, aún cuando aspira a obtener una unidad de concepto entre ellas.

En segundo lugar, Le Corbusier tiene la consideración del cine como un medio donde la imagen se pone al servicio de la arquitectura y nunca al revés. Y sabe que el estatus del arquitecto respecto a la película no es el mismo que respecto al edificio, al ser el cine una actividad subordinada a la idea del director. Quizá la imposibilidad de asumir que la arquitectura sea criada y no señora en el cine sea la razón por la cual se niega a participar en las películas como escenógrafo, pues no concibe que la arquitectura no sea otra que la real, y mejor si es la que sale de su mano. Tampoco que la imagen que se pueda dar de ella contradiga sus postulados. Tan fuerte es su convencimiento que hasta rechaza la atractiva propuesta del productor Alex Korda para realizar los decorados de la ciudad de Eveytown en un futuro 2036, una vez descartados los diseños de F. Léger por H. G. Wells, de la película de ciencia ficción La vida futura (Things to Come, 1936) ${ }^{16}$, dirigida por William Cameron Menzies bajo la dirección artística de Vincent Korda ${ }^{17}$.

\section{Mirada objetiva de la técnica}

La toma de posición a favor del cine narrador de la arquitectura real es la que se atestigua en el contacto más olvidado de Le Corbusier con el cine, aunque sea el más explícito de todos, su pensamiento cinematográfico expresado en el artículo monográfico "Esprit de vérité" (1933) ${ }^{18}$, completamente diferente de las posturas mantenidas por otros insignes arquitectos. Las ideas generales que contiene ${ }^{19}$ revelan una actitud beligerante contra aquel cine capaz de crear el gran engaño del espectáculo de la ficción, el cine de la industria. Considera una mentira el noventa por ciento de su producción y destaca las armas del obligado montaje técnico: "Se

\footnotetext{
${ }^{15}$ Sobre los contenidos de las dos versiones, larga de 18 minutos y corta de 10 minutos, ver Boone, Véronique: "Un tournage comme tournant: l'architecture à l'écran". En AA.VV.: Le Corbusier. Aventures photographiques (XVIII Rencontres de la FLC, La Chaux-de-Fonds, 2012). Paris: Éditions de la Villettte, 2014, pp. 88-101.

${ }^{16}$ Película basada en la novela de H. G. Wells La forma de lo que vendrá (The shape of things to come, the ultimate revolution, 1933), autor igualmente del guión, que anticipa una guerra mundial y los tiempos difíciles de la posguerra.

${ }^{17}$ Finalmente Vincent Korda es asistido por Moholy-Nagy para proyectar la ciudad de Everytown, aunque sus aportaciones se descartaron y los diseños fueron realizados por el propio director artístico. Moholy-Nagy propuso después su propia versión de la ciudad del futuro. En Neumann, Dietrich (Ed.): Film Architecture from Metropolis to Blade Runner. MunichNew York: Prestel, 1996.

${ }^{18}$ El texto se publica originalmente en la revista Mouvement, $\mathrm{N}^{\circ}$ 1, Junio 1933. Incluido en Le Corbusier: "Esprit de vérité". Cinémathèque. № 9. Primavera 1996. Paris: Cinémathèque française, pp. 56-58. Le Corbusier publica previamente otro texto con el mismo título "Esprit de vérité" que, sin tratar del cine, tiene el mismo sustrato conceptual. En Le Corbusier: L'Art décoratif d'aujourd'hui (1925). Paris: Flammarion, 1996, pp. 167-185.

${ }^{19}$ François, Arnaud: “La cinématographie de l'oeuvre de Le Corbusier”. En Cinémathèque, op. cit., pp. 39-55.
} 
beneficia sencillamente de una prestigiosa ventaja técnica: la eliminación de las transiciones, la posible y fácil eliminación de los 'puntos muertos ${ }^{\prime \prime 20}$.

¿Y de dónde provienen los males del cine según Le Corbusier? Si se tiene presente que se trata de un escrito para una revista de cine, por supuesto, el mal lo atribuye al teatro, al teatro filmado de los orígenes del cine: "El Teatro y la gente de teatro que cuentan las historias ponen en peligro al cine. Estas personas llenas de énfasis y frases se interponen entre nosotros y el verdadero voyeur: el objetivo. Como hemos descendido tan abajo, será útil confiar de nuevo, por un tiempo, en la propia técnica, para volver a las cosas esenciales, a los elementos ${ }^{\prime 21}$. Apela a la verdad que puede ofrecer el ojo tecnológico de la cámara que todo lo ve, ojo del demiurgo que capta la imagen de forma diferente al nuestro. Confía, al menos por un tiempo y dejando abiertas otras posibilidades, en la capacidad reveladora del objetivo, "sin nervios ni alma",22 de los fenómenos visuales para entrar en la verdadera conciencia humana.

Ésta es pues la visión científica de la realidad circundante que defiende, la visión objetiva que pasa desapercibida ante nuestros ojos y que, a su juicio, descubre la esencia del drama humano del que apenas percibimos su radiación. Es conocido que la visión dirige su arquitectura, según las múltiples declaraciones de sus escritos, pero además de ser un instrumento para descubrirla es un objetivo en sí misma en la puesta en escena del cine. Lo tiene claro desde los tiempos de la revista L'Esprit Nouveau, al publicar con Ozenfant el artículo "Formation de l'optique moderne" $(1924)^{23}$. Si el realismo de sus documentales tiene como fin presentar su obra, plasmar la mirada subjetiva que estructura su arquitectura ${ }^{24}$ es otra cosa, y ésta tiene que encontrar su estilo dentro del medio cinematográfico para que mane de la pantalla.

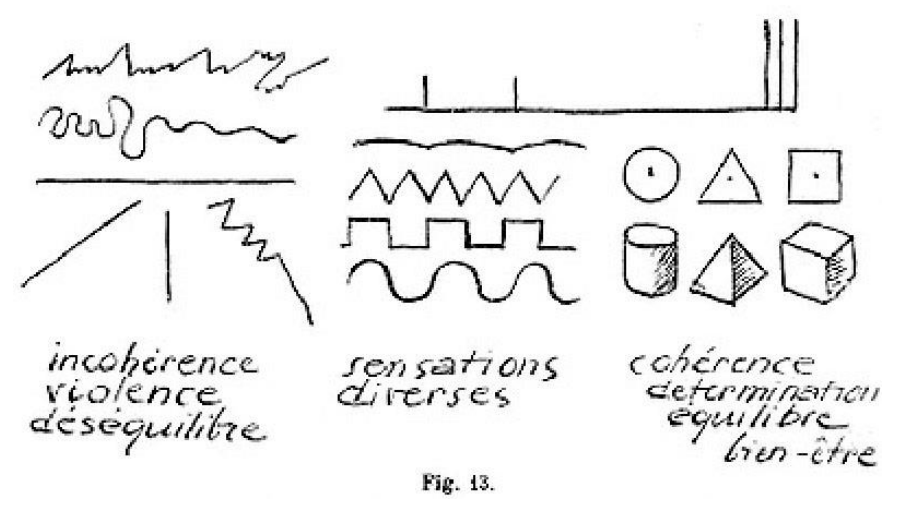

1. Le Corbusier. Diagramas de sensaciones de "Architecture d'époque machiniste". En Journal de psychologie normale et pathologique. № 23, 1926, y Almanach d'architecture moderne. Paris: Crès, 1926. OFLC-ADAGP.

\footnotetext{
20 "Il exploite tout simplement un avantage technique prestigieux: la suppression des transitions, la suppression possible et facile des 'points morts"”. Le Corbusier: "Esprit de vérité" (1933). En Cinémathèque, op. cit., p. 56.

21 "Le Théâtre et les gens de théâtre qui racontent des histories on mis le cinéma en perdition. Ces gens pleins d'emphase et de phrases se sont interposés entre nous et le veritable voyeur: l'objetif. Puisque nous avons glissé si bas, il sera utile de se confier à nouveau, pour un temps, à la technique même, pour revenir aux choses essentielles, aux elements". Le Corbusier: "Esprit de vérité" (1933). En Cinémathèque, op. cit., p. 58.

22 "sans nerfs ni âme”. Le Corbusier: "Esprit de vérité" (1933). En Cinémathèque, op. cit., p. 58.

${ }^{23}$ Ozenfant, Amédée; Jeanneret, Charles-Édouard: "Formation de l'optique moderne”. En L'Esprit Nouveau, № 21. Marzo 1924. Paris, s. p. (Edición española: Ozenfant, Amédée; Jeanneret, Charles-Édouard: "Formación de la óptica moderna". En Acerca del purismo. Escritos 1918-1926. Madrid: El Croquis, 1994, pp. 147-155).

${ }^{24}$ François, Arnaud: "La cinématographie de l'oeuvre de Le Corbusier". En Cinémathèque, op. cit. pp. 39-55.
} 
En este sentido, es pertinente acudir a los diagramas ${ }^{25}$ (1) confeccionados por Le Corbusier, concomitantes con los diagramas afectivos de la "cinemática óptico-estética" del arquitecto de origen serbio Miloutine Borissavliévitch, cuya teoría está centrada en la línea a través de la modelización gráfica de la visión ${ }^{26}$, difundida en Prolégomènes a une esthétique scientifique de l'architecture (1923) y Les théories de l'architecture (1926). Estética científica de la arquitectura que tiene en cuenta la forma visual como instrumento de control de las emociones, derivada de los modelos alemanes de la psicología. Los intereses interdisciplinares de Le Corbusier le conducen indirectamente a vislumbrar la emergente disciplina de la psicología, punto de encuentro con Eisenstein, quien tiene gran conocimiento de la misma en Europa y mantiene una estrecha colaboración con psicólogos rusos durante toda su vida.

"Esprit de vérité" es todo un alegato al cine sin trucos, una llamada a la sinceridad del medio, pero asoma una sombra de duda. Si se tiene en cuenta que cuando lo escribe ha pasado su periplo soviético, se puede confirmar su rastro. Le Corbusier conoce a Eisenstein durante el primer viaje que hace a Moscú en octubre de $1928^{27}$ con motivo de presentar el proyecto del Centrosoyuz; parecen entenderse bien y existe sintonía intelectual entre ellos. El tuerto franco-suizo de vista bidimensional y el soviético-letón de hemisferio cerebral derecho de tamaño prodigioso $^{28}$, responsable del procesamiento de las imágenes visuales y la información espacial, tienen características físicas cruzadas respecto a sus dedicaciones profesionales. Durante el encuentro se interesan por sus respectivos trabajos, lo cual da la posibilidad a Le Corbusier de ver El Acorazado Potemkin (1925) y La línea general (1926-28).

Poco propenso a ello, el entusiasmo embarga a Le Corbusier por sus afinidades, según se deduce de sus declaraciones en la única entrevista publicada durante su estancia: "El cine y la arquitectura son las dos únicas artes de la época contemporánea. Me parece que en mi trabajo pienso de la misma manera que S. Eisenstein, cuando elabora su propio cine. Sus obras están imbuidas con el sentido de la verdad. Al testificar exclusivamente la realidad, están cerca en su pensamiento de lo que me esfuerzo por hacer en mis trabajos" ${ }^{, 29}$. En la entrevista ensalza la forma en que La línea general eleva lo cotidiano a una cota lírica que, de las dos películas, es la que más se ajusta a los postulados del Frente de Izquierda de las Artes (LEF) al que pertenece Eisenstein. En términos generales consisten en la "construcción de la vida" como propósito del arte, aplicados para el cine documental o el de ficción indistintamente. Hablando con propiedad, La línea general es una película de no-ficción sobre la colectivización del campo que enseña un koljós, con diseños ex profeso para la película por Andrei Burov, arquitecto apasionado de Le Corbusier que lo acompaña en el encuentro con Eisenstein reflejado en las fotografías existentes.

Burov sostiene la misma postura que la LEF y quiere participar en el cine en calidad de arquitecto antes que de decorador para construir un edificio real que pueda seguir funcionando después del rodaje y, por consiguiente,

\footnotetext{
${ }^{25}$ Le Corbusier: “Architecture d'époque machiniste”. En Journal de psychologie normale et pathologique. № 23, 1926, p. 325-350. Vuelto a publicar en Le Corbusier: Almanach d'architecture moderne. Paris: Crès, 1926.

${ }^{26}$ Thibault, Estelle: La géométrie des émotions: les esthétiques scientifiques de l'architecture en France, 1860-1950. Wavre: Mardaga, 2010.

${ }^{27}$ Jean-Louis Cohen trata el tema ampliamente. En Cohen, Jean-Louis: Le Corbusier et la mystique de l'URSS. Théories et projets pour Moscou 1928-1936. Bruxelles-Liège: Pierre Mardaga, 1987.

${ }^{28}$ A tenor de la disección realizada al cerebro de Eisenstein por su amigo durante treinta años, el neuropsicólogo Alexander Luria.

29 "Le cinéma et l'architecture sont les deux seuls arts de l'époque contemporaine. Il me semble que dans mon travail, je pense de la même manière que S. Eisenstein, quand il a élabore son propre cinéma. Ses travaux sont pénétrés du sens de la vérité. Témoignant exclusivement de la réalité, ils sont proches par leur pensée de ce que je $m$ 'efforce de faire dans mes travaux". Le Corbusier: Entrevista publicada en Sovetskij Ekran No 46, 13 noviembre de 1928. Citada en Cohen, Jean-Louis: Le Corbusier et la mystique de l'URSS, op. cit., p. 72.
} 
que las necesidades del cine se conviertan en una realidad, algo que al final no pudo realizarse. La secuencia de la lechería racionalista, con su equipo científico de laboratorio para el tratamiento de la leche y las vestimentas blancas del personal, como si de un hospital se tratase, conforman un ejemplo social y arquitectónico del espíritu nuevo que Le Corbusier quiere imprimir impregnado del lirismo de la máquina, no obstante, el Potemkin le deja una huella indeleble.

En la estancia soviética Le Corbusier aprende mucho, y cuando después llega la hora de reflejar sus edificios con la imagen en movimiento reivindica la sinceridad de la forma artística que, al contrario que los soviéticos, no ve en la ficción. Un realismo del contenido que elogiará de Pierre Chenal, al que apenas había conocido poco tiempo antes de dirigir la película L'Architecture d'Aujourd'hui (1930), por su capacidad de capturar la verdad de la nueva arquitectura en el cine, presentándola como tema y actor principal tridimensional que se pone en el plano bidimensional de la imagen, en vez de ser un simple fondo escenográfico.

No parece que a Le Corbusier le sea fácil cambiar de idea y de nuevo reitera esta concepción de lo que debe ser el cine, elogiando aquel que descubre lo que escapa a la visión humana en detrimento del cine de platós, cuando expone su intervención ante los asistentes al Convegno Volta $(1936)^{30}$, dedicado ese año a la relación entre la arquitectura y las artes visuales, un asunto que le preocupa desde hace tiempo: "En la vida, afuera, están las manifestaciones de los nuevos tiempos. El cine, por ejemplo, cuya perfección actual del equipo técnico permitirá a los espíritus inventivos suplantar a los "profesionales" de platós donde se usan, sin duda, demasiados trucos. En el cine, ustedes que tienen el ojo habituado a encontrar cosas donde otros no encuentran nada, ustedes que tienen el espíritu agudizado a los problemas de la elección, la proporción, la armonía, la Gran Naturaleza ya está abierta - en el cine. Los platós de Hollywood palidecerán” "31. En la síntesis de la que habla le Corbusier en el Convegno sólo están pintura, escultura y arquitectura, motivo por el que la referencia al cine es un comentario puramente marginal, no es el objetivo de la síntesis de las artes, y ejemplifica bien lo lejos que coloca al cine, en especial el aborrecido artificio de la ficción. Sin embargo, sigue aferrado a explotar las capacidades del cine como medio de difusión porque a continuación inicia un periodo que se prolonga a lo largo de la década de los años cincuenta en el que su participación en proyectos y películas es abundante. La mayoría giran en torno a la Unité de Masella, que por esas fechas tiene entre manos, aunque alguno que otro trata de la Ville Radieuse.

El proyecto de Vers la Ville Radieuse (1948) de Jacques Gestalder, la docu-ficción de La vie commence demain (1949) de Nicole Védrès, Le Corbusier travaille (1951) de Gabriel Chereau, La Cité Radieuse (1953) de Jean Sacha, Le Corbusier, Marseilles (1954) de Matthew Nathan, proyectos no realizados de Sacha y Wogensky (1955), L'Unité d'Habitation de Marseille (1954) de Paola Mazzetti, Le Corbusier, l'architecte du bonheur (1957) de Pierre Kast, de nuevo la pseudo-ficción del proyecto de Demain (1961) de Michelle Bataille y La maison des hommes (1961) de Jean Marie Drot integran la cinematografía.

\footnotetext{
${ }^{30}$ Convención anual organizada por la Fondazione Alessandro Volta, creada por sociedad Edison de Milán bajo los auspicios de la Real Academia de Italia.

31 "Nella vita, fuori, sono le manifestazioni del tempo nuovo. Il cinema, per esempio, la cui attuale perfezione degli apparecchi tecnici permetterà agli spiriti inventivi di soppiantare i 'professionisti' dei teatri di posa dove si consumano, decisamente, troppi artifici. Nel cinema, voi che avete l'occhio abituato a scoprire cose là dove gli altri non trovano nulla, voi che avete lo spirito affinato ai problemi della scelta, della proporzione, dell'armonia, la Grande Natura è ormai aperta al cinema. I teatri di posa di Hollywood impallidiranno". Le Corbusier: "Les tendances de l'architecture rationaliste en rapport avec la collaboration de la peinture et de la sculpture". Convegno di Arti, 25-31. Octubre 1936. Roma: Reale Accademia d'Italia, 1937, pp. 107-119. Citado en Panzeri, Miriam: “'Occhi che vedono'. Sintesi delle arti e cinema secondo Le Corbusier". En Crepuscoli dottorali. Quaderni di arte, musica e spettacolo, No 1. $1^{\circ}$ semestre 2011, pp. 77-92, p. 89.
} 
Sin entrar en detalles sobre los numerosos contactos cinematográficos, analizados exhaustivamente por Véronique Boone ${ }^{32}$, lo que aparece a lo largo de ese itinerario son indicios de un cambio. Desde la arquitectura como figura y el ser humano como fondo se llega a lo contrario y los habitantes frecuentan las escenas con más protagonismo y asiduidad a medida que se van concluyendo las obras en curso de la Unité de Marsella. También aparecen las dudas sobre qué género, documental o ficción, llega mejor al público para transmitir la arquitectura. Le Corbusier siente debilidad por el documento, como si quisiera defender su arquitectura acompañándola de una forma de vida avanzada ante un público de especialistas, en vez de pensar que puede ser el marco de los eternos sentimientos humanos que la ficción del cine plasma y dirige a cada persona, aunque esa punta del iceberg parece adivinarse.

La carta que envía al arquitecto Ernesto Nathan Rogers en 1952 sintetiza estas inquietudes: "Me gustaría hacer una película sólo dedicada a una gran trama sentimental que se desarrollara en el decorado de la Unidad de habitación de Marsella",33. ¿No es acaso esta confidencia la confirmación de que el cine que defiende ha fracasado en la transmisión de L'espace indicible $(1945)^{34}$, del espacio inefable que perseguía con su arquitectura capaz de provocar lirismo y emoción?

\section{La dimensión subjetiva del montaje}

A partir de 1960 proliferan las solicitudes para filmar en Marsella, sin embargo, sigue aferrado a la idea a rodar su gran película sobre la ciudad que no verá la luz, asido a una imperiosa necesidad de hacer más propaganda que cine. A diferencia de la fotografía, en la que aprecia la formalización de los efectos plásticos producidos, Le Corbusier no piensa de la misma manera respecto al cine para concebir la estética del futuro, porque lo hace antes en términos técnicos que compositivos y de estructura. A pesar de ello, demuestra que también se puede llegar a una forma de expresión de lo real mediante la remodelación de éste con la ayuda de algunos efectos de montaje suave.

Es cierto que el cine no restituye la riqueza de la experiencia real de la arquitectura, tal y como se puede percibir in situ, y que no puede dar mas que informaciones parciales porque desintegra la continuidad espacio-temporal de la realidad frente a lo que se representa en la pantalla, no obstante, proporciona un punto de vista intencionado sobre la misma. No cabe duda que filmar la arquitectura real es cortarla y el trabajo de posproducción es emprender la construcción de una organización espacial específica, por medio del ensamblaje físico del montaje técnico, para ser contemplada por el espectador en la pantalla.

Sólo cuando el montaje técnico se explora en sus capacidades compositivas y se convierte en discurso alcanza formas narrativas que han marcado la historia del cine básicamente con dos tipos de montaje, el de la transparencia y el soviético. El primero, el montaje narrativo por continuidad desarrollado por el cine clásico, es aquel que borra las huellas de su presencia en la transición entre planos para evitar los desajustes visuales que recuerdan el origen fragmentario de la película. Por lo tanto, el montaje transparente contribuye de manera esencial a producir la ilusión de realidad, o lo que es lo mismo, a fabricar un falso real. De las dos películas de

\footnotetext{
${ }^{32}$ Para un análisis de la cinematografía específica sobre la Unité de Marsella ver Boone, Véronique: "La médiatisation cinématographique de l'unité d'habitation de Marseille: de la promotion à la fiction". En Massilia 2004. Annuaire d'études corbuseenes. Sant Cugat del Valles: Associació d'idees, 2004, pp. 192-199.

33 'Je désire faire un film en ne le vouant qu'à une grande intrigue sentimentale qui se développera dans le décor de l'Unité d'habitation de Marseille". Carta de Le Corbusier a Ernesto Nathan Rogers, datada el 25 enero de 1952, AFLC, R3 1103. Citada en Panzeri, Miriam: “'Occhi che vedono'. Sintesi delle arti e cinema secondo Le Corbusier”. Crepuscoli dottorali, op. cit., p. 87.

${ }^{34}$ Le Corbusier: "L'espace indicible". En L'Architecture d'Aujourd'hui (Art). No hors-série. 1946, pp. 9-17.
} 
Pierre Chenal realizadas con la colaboración de Le Corbusier es en L'Architecture d'Aujourd'hui (1930) donde se aprecia más claramente la adscripción al montaje transparente, especialmente visible cuando aparecen personajes en movimiento (2). En el encadenado de planos y secuencias se busca una coherencia visual y temporal de espacio y movimiento que transmita un efecto lo más natural posible; tal es el caso del acercamiento del automóvil a la villa Stein y de la subida a la rampa de la villa Savoye.

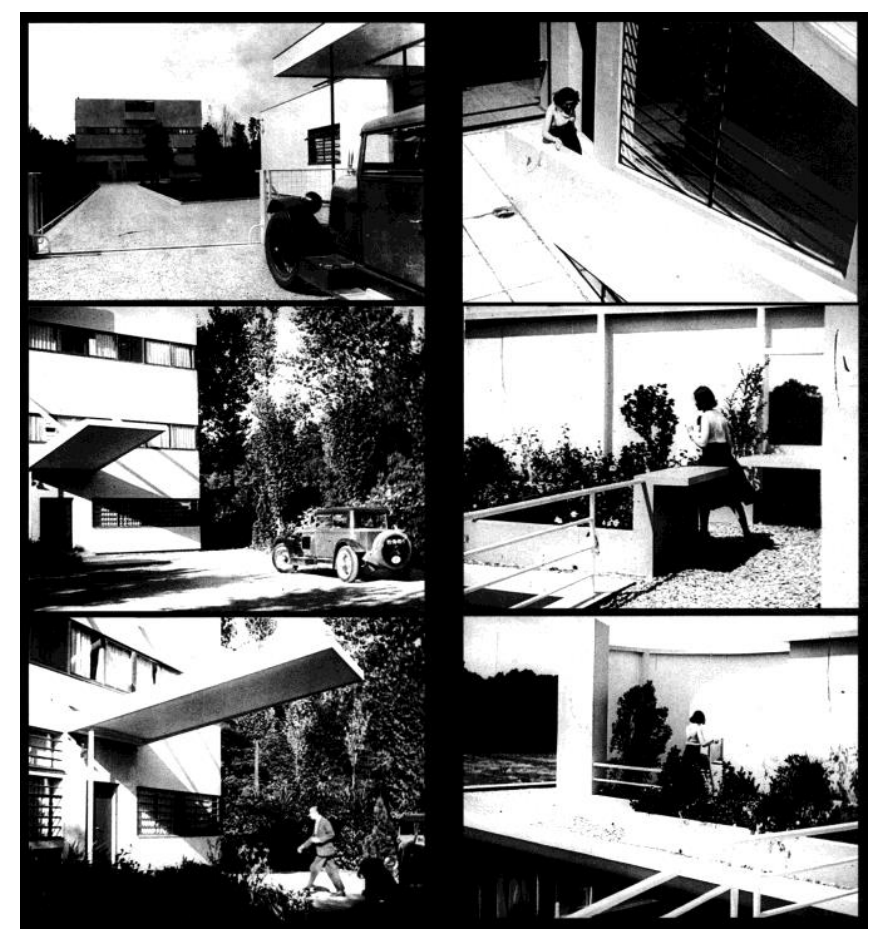

2. Fotogramas de L'Architecture d'Aujourd'hui (1930) de Pierre Chenal con la colaboración de Le Corbusier. OFLCADAGP.

Es muy probable que Le Corbusier quisiera intervenir estrechamente en la edición para controlar el resultado final de la película, y que quizás su insatisfacción le lleve posteriormente a promocionar únicamente la versión corta más de su gusto, del mismo modo que se preocupa de la edición del negativo de la película de R. Vitrac, Un voyage aux Cyclades (1934), una obra ajena que defiende por sus poderes evocadores y cuya música corrió a cargo de su hermano Pierre Jeanneret. También en Les Mains de Paris (1934), de la productora César-film, supervisa el rodaje y el montaje, descartando cualquier otra persona que pudiera aparecer en pantalla apoyando otras tesis. Especialmente interesante es su disconformidad con el montaje, según los datos de la filmografía recopilados por Arnaud François ${ }^{35}$, porque a su juicio los planos son muy largos y las vistas insuficientes, e indica expresamente desde dónde deben tomarse.

A sabiendas de las repercusiones que tiene la organización definitiva de la cinta, Le Corbusier insiste en construir la imagen para que no se altere la visión que tiene de la arquitectura, sin embargo reconoce en "Esprit de vérité" la especificidad del cine: "Creo haber demostrado por tanto que el cine se sitúa en su propio terreno. Que se convierte en una forma de arte en sí mismo, un género, como la pintura, la escultura, el libro, la música

\footnotetext{
${ }^{35}$ François, Arnaud: “La cinématographie de l'oeuvre de Le Corbusier”. En Cinémathèque, op. cit., pp. 39-55.
} 
y el teatro son géneros. Y que todo está abierto a su investigación ${ }^{\prime \prime 36}$. Como se puede llegar a crear una arquitectura inexistente a partir de determinadas relaciones establecidas entre las imágenes según el montaje soviético, Le Corbusier se afana en controlar el producto cinematográfico bajo parámetros arquitectónicos sin conocer los recursos del medio. Ya lo dice con claridad el director Dziga Vertov cuando explica su actividad: "Soy un constructor",37.

A fin de cuentas eso es lo que son Le Corbusier y Eisenstein, cada uno en su campo. Es sintomático que los dos se refieran a la Histoire de l'Architecture (1899) de Auguste Choisy ${ }^{38}$ y utilicen sus dibujos. Choisy expone su interpretación del método compositivo pintoresco en el arte griego ${ }^{39}$ explicándolo con la Acrópolis de la Atenas. Se basa en la primera impresión favorable que se busca despertar en el espectador por medio de la composición y combinación de una serie de cuadros correspondientes a puntos de vista principales.

Le Corbusier tuvo pronto la experiencia directa de la Acrópolis e introduce en Vers une architecture (1923) las impresiones de la visión cercana de la mano de Choisy: "Las falsas escuadras han proporcionado vistas espléndidas y un efecto sutil; las masas asimétricas de los edificios crean un ritmo intenso. El espectáculo es macizo y elástico, nervioso, de una agudeza aplastante, dominador ${ }^{\text {"40 }}$. Ese mismo año Moisei Ginzburg publica el libro Le rythme en architecture (1923) que contiene también los dibujos de la acrópolis de Choisy y, concretamente, alude a los propileos para referirse al equilibrio óptico ${ }^{41}$. Unas páginas más adelante, Le Corbusier hace referencia a la visión del conjunto: "El plan es concebido para una visión lejana: los ejes siguen el valle y las falsas escuadras son las habilidades del gran director de escena"42, y en las dos ocasiones se refiere a las falsas escuadras como si se tratase de las deformaciones de un decorado para producir un determinado efecto.

\footnotetext{
36 “Je crois avoir montré que le cinéma se situe dès lors sur son terrain propre. Qu'il devient une forme d'art en soi, un genre, comme la peinture, la sculpture, le livre, la musique, le théâtre sont des genres. Et que tout est ouvert à son investigation”. Le Corbusier: "Esprit de vérité" (1933). En Cinémathèque, op. cit., p. 58.

37 “Je suis un constructeur". Vertov, Dziga: Articles, journaux, projets. 10/18. Paris: Union Générale d'Éditions, 1972, p. 28-30.

${ }^{38}$ Para la relación Choisy-Le Corbusier-Eisenstein ver Bois, Yve-Alain: "Introduction”. En Assemblage. № 10. (Serguei M. Eisenstein, Montage and Architecture), 1989, pp. 110-131. También González Cubero, Josefina: "Sesión continua: 'Nómadas en el jardín'. Ville contemporaine y Ville radieuse”. Massilia 2004bis (Le Corbusier y el paisaje). Sant Cugat del Valles: Associació d'idees. 2004, pp. 70-95.

${ }^{39}$ Choisy, Auguste: Historia de la arquitectura (Histoire de l'architecture, 1987). Buenos Aires: Victor Leru, 1958.

40 "Les fausses équerres ont fourni des vues riches et mouvementées; les masses asymétriques des édifices créent un rythme intense. Le spectacle est massif, élastique, nerveux, écrasant d'acuité, dominateur”. Le Corbusier: Vers une Architecture (1923). $5^{\text {a }}$ ed. Paris: Crès, 1928, p. 31.

${ }^{41}$ Guinzbourg, Moisséi Ia.: Le rythme en architecture (1923). Gollion: Infolio, 2010, pp. 103 y 115.

42 "Le plan est conçu pour une vision lointaine: les axes suivent la vallée et les fausses équerres sont des habiletés de grand metteur en scène". Le Corbusier: Vers une Architecture (1923), op. cit., p. 39.
} 


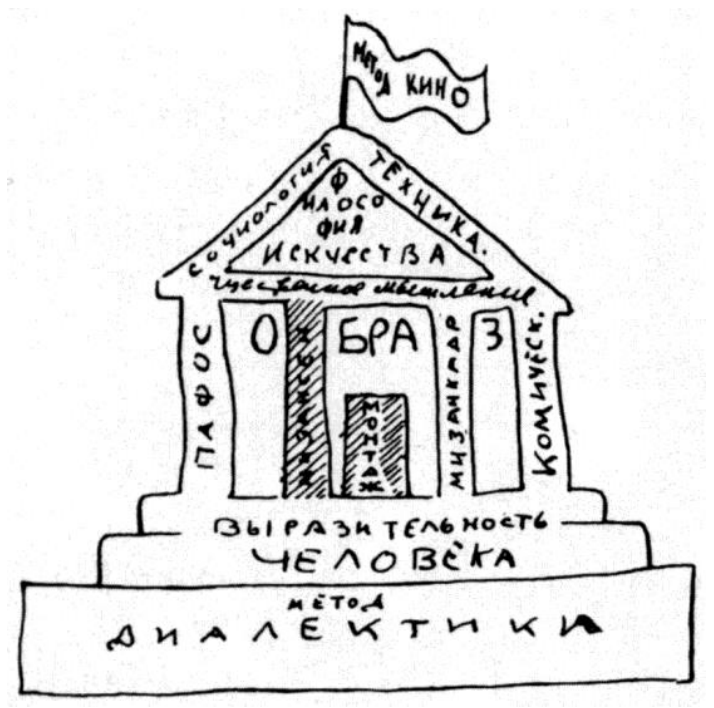

3. Eisenstein. Dibujo de su teoría cinematográfica, fechado en Moscú el 10 de marzo de 1939. En Bulgakova: Oksana: Sergej Eisenstein- drei Utopien. Architekturentwürfe zur Filmtheorie. Berlin: PotemkinPress, 1996.

A su vez la huella de la Acrópolis se nota en el "esqueleto argumental", en palabras de Eisenstein, de la rigurosa arquitectura de El Acorazado Potemkin. El espíritu del conjunto ateniense sobrevuela en la declaración que hace en 1928, poco antes de estrenar La línea general, al periodista español Julio Álvarez del Vayo, al cual conoce durante la producción de La huelga (1925): "Potemkin tiene algo de templo griego" "43. Un clasicismo subyacente existente también en la obra de Le Corbusier que Alan Colquhoun identifica por inversión en la villa Savoye en la estructuración vertical de sus volúmenes ${ }^{44}$. Aunque la Acrópolis para Eisenstein es un ejemplo perfecto de una de las películas más antiguas ${ }^{45}$, y explica el porqué en su texto "Montaje y Arquitectura" de finales de los años treinta con dibujos propios sobre la base de los de Choisy, no pretendo detenerme en esta analogía arquitectónica, sino en otra que el director dibuja para resumir gráficamente su teoría cinematográfica: el boceto de la fachada de un templo pseudo griego ${ }^{46}$ en el que encaja términos explicativos (3).

A la base del podio del templo le asigna el "método dialéctico" y al remate del mismo la "expresividad humana"; al frontón la "filosofía del arte" y a cada faldón de la cubierta las "emociones" y la "técnica", coronándose con la bandera del "método fílmico". En el interior del cuerpo edificado, entre otros elementos, destacan los dos pilares centrales que jalonan la entrada denominados como la "puesta en escena" y el "encuadre"; en el centro, la puerta del "montaje" que nos introduce en la arquitectura del cine y sobre ella la "imagen". No puede haber un dibujo más sintético que resuma visualmente las complejidades de sus ideas acerca de su cine intelectual.

Hay que retrotraerse a los dibujos de la Acrópolis que realiza en su Viaje a Oriente cuando todavía es CharlesÉdouard Jeanneret, los cuales, a excepción de las vistas lejanas, son todos de la puerta del recinto templario, los

\footnotetext{
${ }^{43}$ Álvarez del Vayo, Julio: Rusia a los doce años. Madrid: Espasa Calpe S. A., 1929, p. 114. En la visita que el autor realiza a la casa de Eisenstein para la entrevista confirma su conocimiento de la arquitectura y la existencia en su biblioteca de numerosos libros arquitectura, literatura, mímica, escenografía y libros de viajes por Extremo Oriente. Álvarez del Vayo, además de periodista, era abogado y miembro del PSOE, y más tarde será diplomático y político, siendo designado en dos ocasiones Ministro de Estado durante la II República española.

${ }^{44}$ Colquhoun, Alan: "Desplazamiento de conceptos en Le Corbusier" (1971). En Colquhoun, Alan: Arquitectura moderna y cambio histórico. Ensayos 1962-1976. Gustavo Gili, Barcelona 1978, pp. 113-126.

${ }^{45}$ Eisenstein, S. M.: "Montaje y Arquitectura". En Eisenstein, S. M.: Hacia una teoría del montaje. Vol. 1. Barcelona: Paidós, 2001, pp. 87-109, p. 89.

${ }^{46}$ Dibujo de Eisenstein fechado en Moscú el 10 de marzo de 1939. En Bulgakova: Oksana: Sergej Eisenstein-drei Utopien. Architekturentwürfe zur Filmtheorie. Berlin: PotemkinPress, 1996, p. 172.
} 
propileos, de su fachada anterior y posterior y del tránsito a través de ellos. A la puerta como articulación de la arquitectura es a la que dedica su atención juvenil. A juzgar por el dibujo del citado templo, la puerta para Eisenstein es el paradigma del montaje cinematográfico, hecho de enlace y ruptura por contrapuntos, oposiciones y choque, y de cómo una serie de imágenes se pueden combinar para producir nociones abstractas que no pueden ser representadas directamente. En arquitectura la puerta (y la ventana por extensión) establece el raccord (separación y enlace a la vez) de mirada y movimiento, y su equivalente en el cine corresponde al corte. Así pues, la puerta de Eisenstein nos hace comprender mejor la arquitectura de Le Corbusier. No está de más recordar que un mes antes del viaje por tierras soviéticas Le Corbusier ha concebido la primera versión del proyecto de la villa Savoye y dos meses después presenta los dibujos al cliente ${ }^{47}$.

Por consiguiente, el interés de Le Corbusier no consiste en la coreografía del anodino ojo cinético del recorrido arquitectónico, como comprobó sobradamente Tim Benton ${ }^{48}$, y que se ha convertido en lugar común al hablar de la promenade architecturale. Si se tiene en cuenta que el montaje cinematográfico soviético se caracteriza por el uso artístico, sobre la base del montaje técnico, de la ausencia del continuo espacio-tiempo, se puede establecer el paralelismo con el montaje de Le Corbusier, en el cual el tiempo de su narración arquitectónica difiere del tiempo que introduce el movimiento humano en la percepción de la obra de arquitectura, como frecuentemente se confunde. Una representación del tiempo que encuentran en el Greco, convertido en objetivo ${ }^{49}$ del Viaje a Oriente de Le Corbusier y del extenso escrito dedicado al pintor por parte de Eisenstein a finales de los años treinta $^{50}$.

La promenade architecturale se configura como una serie de acontecimientos visuales percibidos en tiempo real, cuyos momentos de mayor intensidad, aquellos instantes pregnantes que recogen los dibujos y fotografías de sus publicaciones, forman cuadros concebidos en sí mismos y puestos en relación en tiempo ficticio con otros de la sucesión para provocar asociaciones, no necesariamente lineales, en la mente del espectador, que le transmitan emociones y, por tanto, le inoculen las ideas de orden plástico del autor, lo que en definitiva caracteriza el montaje de Eisenstein. Así pues, la arquitectura de Le Corbusier nos hace comprender mejor el cine de Eisenstein y viceversa.

Hay que acudir de nuevo al artículo "Esprit de vérité" para encontrar el denominador común de la arquitectura y el cine: "Es cierto que todo -y aquí también [cine]- es arquitectura, es decir, organización, establecimiento de relaciones $y$, por la elección de relaciones, intensidad" ${ }^{\text {,51 }}$. En su opinión, las grandes superproducciones de los estudios son indecentes y superfluas, lo mismo que afirma de la fastuosa arquitectura Beaux-Arts en Vers une architecture, porque el arte con mayúsculas emplea medios pobres, simplemente son meras relaciones. Y éstas

\footnotetext{
${ }^{47}$ La primera versión del proyecto es de septiembre de 1928, FLC 19583, y la fecha de datación de los dibujos de presentación al cliente del 17 de diciembre de 1928, FLC 19431-32-24-35.

${ }^{48}$ Tim Benton hizo la prueba de recrear la promenade en la Villa Savoye con una cámara que captase las mismas imágenes que el ojo del espectador, para ilustrar el paseo mediante el procedimiento del ojo cinético. Su tentativa fracasa porque se da cuenta que se trata de un recorrido virtual y que es necesario pasar a otros procedimientos que corresponden al campo propio del cine. Benton, Tim: "Le Corbusier y la promenade architecturale". En Arquitectura. № 264-265. Enero-abril 1987, pp. 3847. La película finalmente realizada -Open University, A305 film 13, Ville Savoye, 1972, 25 minutos-, dirigida por Nick Levison, fue premiada con la medalla de plata en el Congreso trienal de la Unión Internacional de Arquitectos celebrado en Madrid en 1975.

${ }^{49}$ Daza, Ricardo: "Le Corbusier visita Bucarest y sus alrededores. Impresiones del viaje de Oriente". En Bitácora Urbano Territorial. Vol. 1. № 10 . 2006, pp. 64-81.

${ }^{50}$ Eisenstein, Serguei: “El Greco". En Eisenstein, Serguei: Cinematismo. Buenos Aires: Domingo Cortizo, 1982, pp. 155206. En varias ediciones francesas figura en español como "El Greco y el cine".

51 "Il est certain que tout -et ici aussi [cine]- est architecture, c'est-à-dire mise en ordre, établissement de rapports et, par le choix des rapports: intensité”. Le Corbusier: "Esprit de vérité" (1933). En Cinémathèque, op. cit., p. 56.
} 
radican en el maridaje de opuestos en Le Corbusier y el principio del conflicto del método dialéctico en Eisenstein. Extraña que Le Corbusier nunca mencione a Eisenstein fuera de su país, ni siquiera en el texto dedicado al cine, pero su silencio es muy elocuente y el ataque lo dirige hacia otras latitudes. A Diógenes, el cínico, le dedica sus últimas palabras: “El cine llama 'a los ojos que ven', a los hombres sensibles a las verdades. Diógenes puede encender su linterna, es innecesario que se embarque para Los Ángeles ",52.

Ambos, Le Corbusier y Eisenstein, con el espacio-tiempo de la arquitectura y el cine respectivamente, logran inculcar sus ideas esculpiendo la visión del visitante; esta es la dimensión subjetiva que imprimen en cada arte a través del montaje. Dicha forma expresiva está presente de manera inconsciente en la génesis de las obras de Le Corbusier, en lo que puede designarse como el espíritu del cine dentro de su arquitectura ${ }^{53}$, no obstante, no parece dispuesto a admitir en el cine un montaje que no sea el más realista posible, aunque, a la postre, también sea un artificio.

Si se tiene en cuenta por un lado el juicio negativo que emite en "Esprit de vérité" sobre el montaje cinematográfico y por otro su coetánea concepción arquitectónica de montaje como puesta en escena de la realidad material, se puede lanzar la hipótesis de que posiblemente tenga un cierto desasosiego por el desconocimiento de los recursos expresivos específicos del cine y la dificultad del manejo de las imágenes en movimiento. Con este propósito Claude Prelorenzo llama la atención sobre las quince bobinas de película sin montar registradas por Le Corbusier con los medios limitados de la cámara en mano durante sus viajes a Francia, Sudamérica, Argelia y Suiza entre 1936 y $1937^{54}$. Por el absoluto silencio de su autor acerca de ellas, la renuncia inmediata de la práctica de rodaje y el hecho de no haberlas destruido le llevan al convencimiento de tratarse de pruebas amateur sobre las posibilidades que ofrece el cine al arquitecto y de cómo puede serle útil. Entre la diversidad de temas, técnicas de rodaje y géneros que se muestran, apunta el rastro del montaje soviético en la brevedad de los planos y el uso del contrapicado, incluso en algunos planos fijos entre los que sobresale el paradigmático el ensayo con la escalera de la favela en Río emulando la escalera de Odessa del Acorazado Potemkin (4).

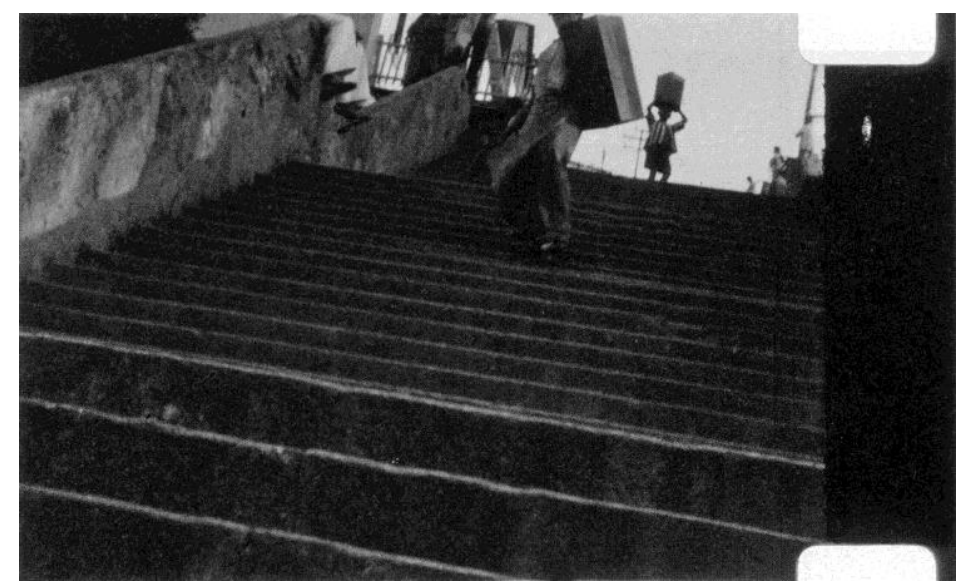

4. Le Corbusier. Escalera de favela en Río emulando la escalera de Odessa del Acorazado Potemkin. FLC, secuencia 100366. (CFLC-ADAGP.

\footnotetext{
52 “Le cinéma fait l'appel 'à des yeux qui voient'. À des hommes sensibles aux vérités. Diogène peut allumer sa lanterne: inutile qu'il s'embarque pour Los Angeles". Le Corbusier: "Esprit de vérité" (1933). En Cinémathèque, op. cit., p. 58.

${ }^{53}$ François, Arnaud: "L'esprit du cinéma et l'oeuvre”. En Le Corbusier. L'oeuvre plastique. Paris: Éditions de la VilleteFundation Le Corbusier, 2005, pp. 77-98.

${ }^{54}$ Prelorenzo, Claude: "Gammes cinématographiques" y Benton, Tim: "Le Corbusier photographe secret". En Le Corbusier. Aventures photographiques, op. cit., pp. 70-87 y pp. 47-69 respectivamente. Las bobinas fueron incorporadas por Jacques Barsac en su documental realizado 1987 para conmemorar el centenario de su nacimiento.
} 
A los argumentos de Prelorenzo hay que añadir otras influencias del rastro soviético que la propia arquitectura de Le Corbusier refrenda. El experto uso que Eisenstein realiza del gran angular $(28 \mathrm{~mm})$ le permite crear imágenes dinámicamente profundas. Una característica apreciable en las villas, que nos emplazan siempre a ver horizontes amplios, a ver toda su extensión de extremo a extremo desde el interior, o entre exterior e interior. Su porosidad horizontal favorece el cruce de vistas, al mismo y a distinto nivel, para la asociación de elementos que se contraponen en la profundidad del espacio. Además Eisenstein introduce apariciones de la luz que concentran puntos de interés, direcciones de mirada y movimiento de los personajes. Su fotógrafo Eduard Tissé utiliza grandes espejos para concentrar la luz del sol y hacer resaltar así bloques de espacio o dotar a los volúmenes de destellos esculturales. Las apariciones sorprendentes de la luz en los interiores domésticos de las villas de Le Corbusier, gracias a luces cenitales naturales, marcan el camino o sencillamente señalan una determinada posición con haces de luz para hacerla explícita.

Si previamente a la II Guerra Mundial tiene la convicción de que el cine que le interesa es el documental, en la posguerra admite sin reparos que "Me gusta mucho el cine. No voy a él casi nunca" "55 al final de su ponencia en la Sorbona sobre el "Le théâtre spontané" (1948). Atrás queda el entusiasmo de los años treinta hacia la cinematografía de Eisenstein, y al cine no parece dedicarle mucho tiempo en sus especulaciones conceptuales desilusionado por la complejidad de manejar el medio. El conflicto que Le Corbusier mantiene a lo largo de su vida ante el cine va ha oscilar del didactismo de lo real hacia la seducción de la ficción como construcción de la imagen, y de tener la ilusión de poder controlar el resultado cinematográfico a confiar en manos expertas sin abandonar una cierta supervisión.

Respecto a la construcción de la imagen en movimiento hay que traer a colación el escrito "A y Pangeometría" (1925) de Lissitzky en el que expone las cuatro concepciones del espacio: Planimétrico, Perspectivo, Irracional e Imaginario. Según Cornelis Van de Ven, es el espacio imaginario de Lissitzky el producido por el cine porque “[...] el mundo real del espacio y del tiempo es evocado por medio de un efecto no material, esto es, por el movimiento "56. Por su lado, Éric Rohmer, en su tesis sobre la organización del espacio en Fausto de Murnau, distingue tres espacios en el cine: La composición plástica de las escenas (espacio pictórico), los decorados o el lugar de rodaje (espacio arquitectónico) y el resultante gracias al montaje de los planos (espacio fílmico ${ }^{57}$. Espacio imaginario y fílmico se dan la mano y alojan escenografías para las necesidades psicológicas del hombre.

Quizá el deseo de Le Corbusier de transmitir verazmente sus principios haya sido el verdadero impedimento para que las películas hubieran llegado a ser otra cosa, en las que pesan tanto el encumbramiento del personaje, él mismo, como la obra. La falta de "funcionalismo emocional" del que habla Juan Antonio Ramírez pudiera ser la causa. En otras palabras, dar imagen veraz de su arquitectura en el cine ha producido exclusivamente documentos audiovisuales no exentos de cierta poética fotográfica.

\footnotetext{
55 “J'aime beaucoup le cinéma. Je n'y vais presque jamais”. Le Corbusier: "Le théâtre spontané”. En Villiers, André (Pres. por): Architecture et dramaturgie, op. cit., p. 167.

${ }^{56}$ Van de Ven, Cornelis: El espacio en arquitectura (Space in Architecture, 1977). Madrid: Cátedra, 1981, p. 285.

${ }^{57}$ Rohmer, Éric: L'Organisation de l'espace dans le Faust de Murnau (1977). Paris: Cahiers du cinéma, 2000.

${ }^{58}$ Ramírez, Juan Antonio: "Introducción. Arquitectura e imagen móvil: el espectáculo debe continuar". En AA. VV., Los espacios de la ficción. La arquitectura en el cine. Valencia: Iseebooks, 2008, pp. 11-25.
} 

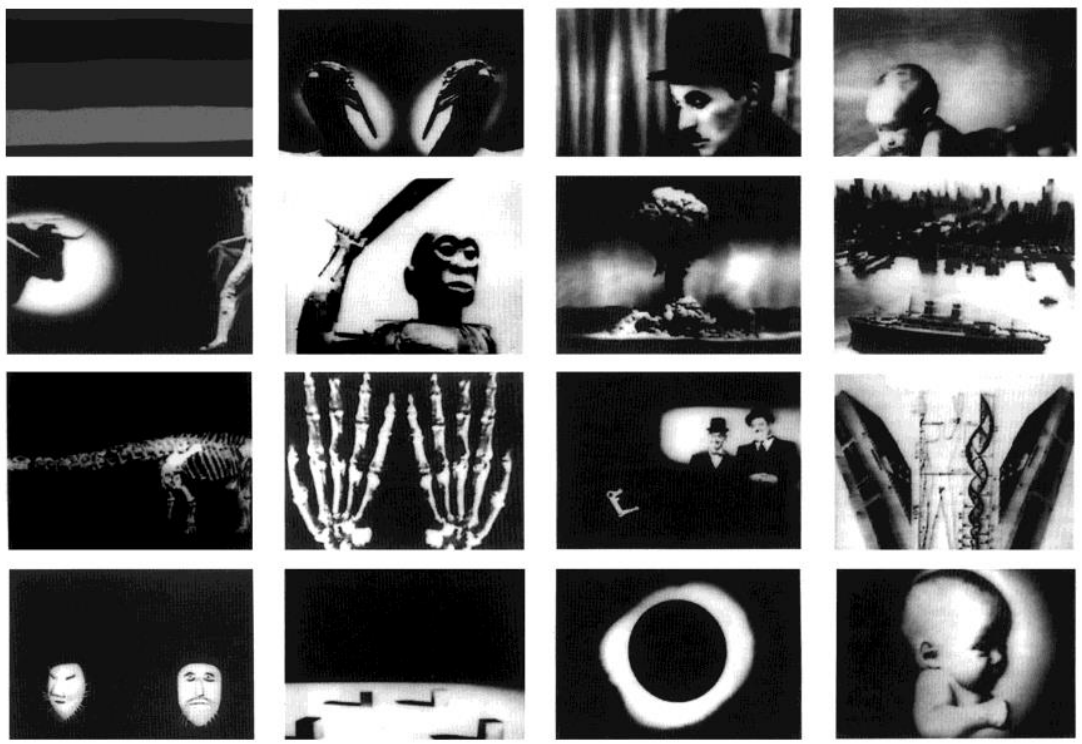

5. Fotogramas de Le Poème électronique (1958) de Le Corbusier, Yannis Xenakis y Edgar Varèse. (C) Philips Company Archives.

Sólo cuando tiene la oportunidad de realizar Le Poème électronique (5), presentado en el Pabellón Philips de la Exposición Universal de Bruselas de 1958 y realizado en colaboración con Yannis Xenakis y Edgar Varèse, la concepción de la obra es bien distinta. Con el advenimiento del cine sonoro en los años treinta y la electrónica de la posguerra, la arquitectura de Le Corbusier desarrolla una plástica acústica que integra la plástica visual del montaje cinematográfico. Le Poème électronique no es propiamente una obra cinematográfica de género sino un cine de arte realizado sin cámara al que Le Corbusier puede llegar a controlar su resultado, puesto que las imágenes en escasos momentos son producto de rodaje y en su mayoría muestran una sucesión de fotografías y dibujos animados por procedimientos ópticos. En lo que respecta a lo visual, es la única obra de su cuño que curiosamente contiene, con matices, formas narrativas características de las técnicas del montaje soviético ${ }^{59}$, aunque es más próximo al montaje productivo de Kuleshov y su discípulo Pudovkin que lo construyen en base a los detalles más significativos.

Planteado con la estética del fragmento, el Poème está integrado por una mixtura de materiales iconográficos a cuyas imágenes se imprime una dinámica temporal que secunda el deslazamiento físico del espectador por el pasaje entre la entrada y salida del pabellón. Con la puesta en escena de la imagen, es decir, de su disposición en el espacio concebido a tal efecto, y en la penumbra del estómago arquitectónico, se cierra el círculo iniciado con la arquitectura en el cine para encaminarse éste al seno de la arquitectura.

La sala de cine que nunca llega a definir explícitamente Le Corbusier es ahora concebida como una caja de los milagros hermética y penetrable, de expresiva liviandad circense y única, para alojar su obra cinematográfica. Los múltiples intentos de que su arquitectura se introduzca en el cine de mirada objetiva quedan desterrados ante la poderosa dimensión subjetiva del Poème électronique. Gracias al espectáculo de materia y luz por partida doble, arquitectura y cine en íntima comunión, cargado de intenciones y dirigido a la emoción, ¿no es acaso esa presencia y desaparición al unísono de los muros la cúspide de su espacio inefable?

"La cuarta dimensión parece ser un momento de evasión ilimitada, producida por una consonancia excepcionalmente justa de los medios plásticos empleados y desencadenada por ellos.

\footnotetext{
59 Boudon, Pierre: "L’architecture comme cosmos". En Actes sémiotiques [En línea]. ํ 112. 2009. Disponible en: $<$ http://epublications.unilim.fr/revues/as/2621>.
} 
No es un efecto del tema elegido, sino una victoria de la proporción en todas las cosas, tanto en los aspectos físicos de la obra como en la eficiencia de las intenciones, reguladas o no, aprehendidas o inaprensibles y, no obstante, existentes y deudoras de la intuición, milagro catalizador de saberes adquiridos, asimilados aunque tal vez olvidados. Pues en una obra concluida con éxito hay masas intencionales ocultas, un verdadero mundo que revela su significado a quien tiene derecho, es decir, a quien lo merece.

Se abre entonces una profundidad sin límites que borra los muros, expulsa las presencias contingentes y realiza el milagro del espacio inefable "60.

\section{Procedencia de las ilustraciones}

1. Le Corbusier. Diagramas de sensaciones de "Architecture d'époque machiniste". En Journal de psychologie normale et pathologique. № 23, 1926, pp. 325-350, y Almanach d'architecture moderne. Paris: Crès, 1926. @FLC-ADAGP.

2. Fotogramas de L'Architecture d'Aujourd'hui (1930) de Pierre Chenal con la colaboración de Le Corbusier. OFLCADAGP.

3. Eisenstein. Dibujo de su teoría cinematográfica, fechado en Moscú el 10 de marzo de 1939. En Bulgakova: Oksana: Sergej Eisenstein- drei Utopien. Architekturentwürfe zur Filmtheorie. Berlin: PotemkinPress, 1996, p. 172.

4. Le Corbusier. Escalera de favela en Río emulando la escalera de Odessa del Acorazado Potemkin. FLC, secuencia 100366. CFLC-ADAGP.

5. Fotogramas de Le Poème électronique (1958) de Le Corbusier, Yannis Xenakis y Edgar Varèse. (C) Philips Company Archives.

\section{Bibliografía/referencias}

AA.VV.: Le Corbusier. Aventures photographiques (XVIII ${ }^{\mathrm{e}}$ Rencontres de la FLC, La Chaux-de-Fonds, 2012). Paris: Éditions de la Villettte, 2014.

- Benton, Tim: "Le Corbusier photographe secret", pp. 47-69.

- Prelorenzo, Claude: “Gammes cinématographiques”, pp. 70-87.

- Boone, Véronique: “Un tournage comme tournant: l'architecture à l'écran”, pp. 88-101.

Aalto, Alvar: "Un cine racional” ("Rationell biografí”), Kritisk Revy, 1928). En Schildt, Göran (Ed.): Alvar Aalto de palabra y por escrito (Alvar Aalto. In his own words, 1997). Madrid: El Croquis Editorial, 2000.

Álvarez del Vayo, Julio: Rusia a los doce años. Madrid: Espasa Calpe S. A., 1929.

Benjamin, Walter: La obra de arte en la época de su reproductibilidad técnica (1936). México: Ítaca, 2003.

Benton, Tim: "Le Corbusier y la promenade architecturale". En Arquitectura. No 264-265. Enero-abril 1987, pp. $38-47$.

Bois, Yve-Alain: "Introduction”. En Assemblage. No 10. (Serguei M. Eisenstein, Montage and Architecture), 1989, pp. 110-131.

\footnotetext{
60 "La quatrième dimension semble être le moment d'évasion illimitée provoquée par une consonance exceptionnelle juste des moyens plastiques mis en œuvre et par eux déclenchée.

Ce n'est pas l'effet du thème choisi mais c'est une victoire de proportionnement en toutes choses - physique de l'ouvrage comme aussi efficience des intentions contrôlées ou non, saisies ou insaisissables, existantes toutefois et redevables à l'intuition, ce miracle catalyseur des sapiences acquises, assimilées, voire oubliées. Car dans une œuvre aboutie et réussie, sont enfouies des masses d'intention, un véritable monde, qui se révèle à qui de droit, ce qui veut dire: à qui le mérite. Alors une profondeur sans bornes s'ouvre, efface les murs, chasse les présences contingentes, accomplit le miracle de l'espace indicible”. Le Corbusier: “L'espace indicible”. En L'Architecture d'Aujourd'hui (Art). No hors-série. 1946, pp. 9-17, p. 10 .
} 
Boone, Véronique: “La médiatisation cinématographique de l'unité d'habitation de Marseille: de la promotion à la fiction”. En Massilia 2004. Annuaire d'études corbuseenes. Sant Cugat del Valles: Associació d'idees, 2004, pp. 192-199.

Boudon, Pierre: "L’architecture comme cosmos". En Actes sémiotiques [En línea]. N 112. 2009. Disponible en: <http://epublications.unilim.fr/revues/as/2621>.

Bulgakova Oksana: Sergej Eisenstein- drei Utopien. Architekturentwürfe zur Filmtheorie. Berlin: PotemkinPress, 1996.

Buxtorf, Anne-Élisabeth: "La salle de cinéma à Paris entre les deux guerres. L'utopie à l'épreuve de la modernité". En Leniaud, Jean-Michel (Ed.): Entre nostalgie et utopie: réalités architecturales et artistiques aux XIXe et XXe siècles. Paris-Genève, Champion-Droz, 2005, pp. 117-144.

Choisy, Auguste: Historia de la arquitectura (Histoire de l'architecture, 1987). Buenos Aires: Victor Leru, 1958.

Cohen, Jean-Louis: Le Corbusier et la mystique de l'URSS. Théories et projets pour Moscou 1928-1936. Bruxelles-Liège: Pierre Mardaga, 1987.

Colquhoun, Alan: "Desplazamiento de conceptos en Le Corbusier" (1971). En Colquhoun, Alan: Arquitectura moderna y cambio histórico. Ensayos 1962-1976. Gustavo Gili, Barcelona 1978, pp. 113-126.

Daza, Ricardo: "Le Corbusier visita Bucarest y sus alrededores. Impresiones del viaje de Oriente". En Bitácora Urbano Territorial. Vol. 1. No 10 . 2006, pp. 64-81.

Eisenstein, Serguei M.:

- “Montaje y Arquitectura”. En Eisenstein, S. M.: Hacia una teoría del montaje. Vol. 1. Barcelona: Paidós, 2001, pp. 87-109.

- "El Greco”. En Eisenstein, Serguei: Cinematismo. Buenos Aires: Domingo Cortizo, 1982, pp. 155-206.

François, Arnaud:

- "La cinématographie de l'oeuvre de Le Corbusier". En Cinémathèque. No 9. Primavera 1996. Paris: Cinémathèque française, pp. 39-55.

- "L'esprit du cinéma et l'oeuvre". En Le Corbusier. L'oeuvre plastique. Paris: Éditions de la Villete- Fundation Le Corbusier, 2005, pp. 77-98.

Guinzbourg, Moisséi Ia.: Le rythme en architecture (1923). Gollion: Infolio, 2010.

González Cubero, Josefina:

- "Sesión continua: 'Nómadas en el jardín'. Ville contemporaine y Ville radieuse". Massilia 2004bis (Le Corbusier y el paisaje). Sant Cugat del Valles: Associació d'idees. 2004, pp. 70-95.

- "Hilos de teatro: la puesta en escena del Palacio de los Soviets de Le Corbusier, 1931/ Strands of Theatre: Le Corbusier's Staging of the Palace of the Soviets, 1931". En Proyecto, progreso y arquitectura $\mathrm{N}^{\mathrm{o}} 7$ (Arquitectura entre concursos), Noviembre 2012. Sevilla: Publicaciones de la Universidad de Sevilla, 2012, pp. 68-89. Publicado también en Massilia. Annuaire d'études corbuséennes, "La boite à miracles-Le Corbusier et le théâtre”, Fondation Le Corbusier, Paris; Éditions Imbernon, Marseille, 2012, pp. 122-143.

Le Corbusier:

- Vers une Architecture (1923). 5ª ed. Paris: Crès, 1928.

- “Architecture d'époque machiniste”. En Journal de psychologie normale et pathologique. № 23, 1926, pp. 325-350.

- Almanach d'architecture moderne. Paris: Crès, 1926.

- "Esprit de vérité". En Mouvement. № 1. Junio 1933. Reimpresión en Cinémathèque. № 9. Primavera 1996. Paris: Cinémathèque française, pp. 56-58. 
- "Les tendances de l'architecture rationaliste en rapport avec la collaboration de la peinture et de la sculpture". Convegno di Arti, 25-31. Octubre 1936. Roma: Reale Accademia d'Italia, 1937, pp. 107-119.

- “L'espace indicible”. En L'Architecture d'Aujourd'hui (Art). No hors-série. 1946, pp. 9-17.

- "El teatro espontáneo" (1948). En Villiers, André (Pres. por): Architecture et dramaturgie. Paris: Flammarion, 1950, pp. 149-168.

- OEuvre complète 1957-1965 (1965). Zurich: Les Éditions d'Architecture, 1995.

Mallet-Stevens, Robert: “Architecture. Les cinémas”. En Mallet-Stevens, Robert: Le décor au Cinéma. Paris: Séguier, 1996, pp. 40-50.

Neumann, Dietrich (Ed.): Film Architecture from Metropolis to Blade Runner. Munich-New York: Prestel, 1996.

Ozenfant, Amédée; Jeanneret, Charles-Édouard: “Formation de l'optique moderne”. En L'Esprit Nouveau, No 21. Marzo 1924. Paris, s. p. (Edición española: Ozenfant, Amédée; Jeanneret, Charles-Édouard: "Formación de la óptica moderna". En Acerca del purismo. Escritos 1918-1926. Madrid: El Croquis, 1994, pp. 147-155).

Panzeri, Miriam: “'Occhi che vedono'. Sintesi delle arti e cinema secondo Le Corbusier”. En Crepuscoli dottorali. Quaderni di arte, musica e spettacolo, № $1.1^{\circ}$ semestre 2011, pp. 77-92.

Rohmer, Éric: L'Organisation de l'espace dans le Faust de Murnau (1977). Paris: Cahiers du Cinéma, 2000.

Thibault, Estelle: La géométrie des émotions: les esthétiques scientifiques de l'architecture en France, 18601950. Wavre: Mardaga, 2010.

Tyrwhitt, Jaqueline; Sert, José Luis; Rogers, Ernesto N. (Eds.): CIAM 8- The heart of the city. London: Lund Humphries, 1952.

Van de Ven, Cornelis: El espacio en arquitectura (Space in Architecture, 1977). Madrid: Cátedra, 1981.

Vertov, Dziga: Articles, journaux, projets. 10/18. Paris: Union Générale d’Éditions, 1972. 


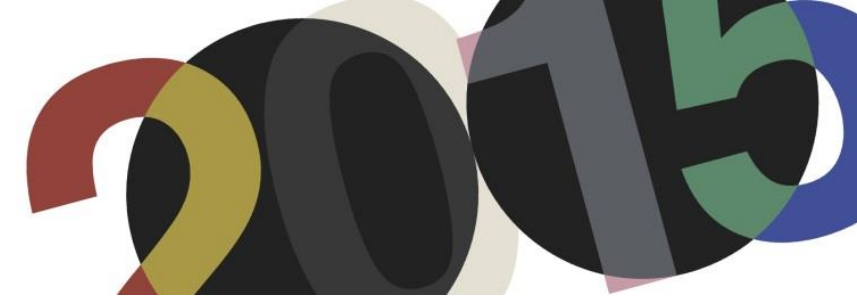

DOI: http://dx.doi.org/10.4995/LC2015.2015.927

\title{
Memory and change through Le Corbusier. Fragments of urban views
}

\author{
F. Gorgeri
}

Department of Architecture - DIDA - University of Florence

\begin{abstract}
In the urban project of Le Corbusier the relationship between new and existing is opportunity of poetic composition. The real traces of the past of one place are transformative tools by which the new project is developed. The projects after World War II, like reconstruction project of Saint-Dié, are occasions to reflect about the new urban developments, rapid and extensive, and the relation of them with the landscape in a new territorial vision. The fragments of past and the new buildings are seen like belonging to a same context of reference and the entire urban composition forming part of a landscape on more large scale. Therefore, the urban project is an ensemble of architectural objects and nature that are held together by calculated visual relation. It is a kind of montage of urban views related to the dimension and measure of the human subject, like visual points or pedestrian paths. Memory and change are linked together by the natural history process and commensurate also to the human measure by a three dimension urbanism where the architecture can anew make the city.
\end{abstract}

Resumen: En el proyecto urbanístico de Le Corbusier la relación entre la nueva y la existente es la oportunidad de la composición poética. Las huellas reales del pasado de un lugar son herramientas de transformación por el que se desarrolla el nuevo proyecto. Los proyectos después de la Segunda Guerra Mundial, como el proyecto de reconstrucción de Saint-Dié, son ocasiones para reflexionar acerca de los nuevos desarrollos urbanos, rápidas y amplias, y la relación de ellos con el paisaje en una nueva visión territorial. Los fragmentos del pasado y los nuevos edificios son vistos como pertenecientes a un mismo contexto de referencia y toda la composición que forma parte urbana de un paisaje de más gran escala. Por lo tanto, el proyecto urbano es un conjunto de objetos arquitectónicos y la naturaleza que se mantienen unidas por la relación visual calculada. Es una especie de montaje de vistas urbanas relacionadas con la dimensión y la medida del ser humano, al igual que los puntos visuales o caminos peatonales. La memoria y el cambio están unidos entre sí por el proceso de la historia natural y acorde también a la medida humana por un tres dimensiones urbanismo donde la arquitectura de nuevo puede hacer de la ciudad.

Keywords: urban project; landscape; memory; Saint-Dié.

Palabras clave: proyecto urbano; paisaje; memoria; Saint-Dié. 


\section{Introduction}

The relationship between new and existing in architectural and urban things is considered by Le Corbusier as opportunity of poetic composition in which the architectural work is the subject and the transformative tool of the dynamic action of the time, whether it understood as a phenomenological and perceptive path both as historical and social aspect.

The remains and relic of the pass are seen as traces of signs and objectual fragments to relocate them in a new urban reality, according to a calculated "acoustic visual"1 that restores a dynamic balance between the parts and pieces in question, able to re-connect the past to the present in a heterogeneous continuity.

The destructive action by the Second World War and the transformative quickness of general relations in the territory have changed approaches and intervention planning. It is an interruption of historical continuity that requires to rethink the relationship with time and the concepts of new and progress, valid until then.

In this irreversible modification of the past, Le Corbusier see a solution of continuity from which can be born new life and new architecture.

Therefore, he adopts a new poetic measure that even more refer to geographical dimension and landscape and in the same time more closely linked to the human scale. In particular, the project for the reconstruction of the city of Saint Dié, generated between April 1945 and February 1946, is an opportunity to reflect on the principles and theories developed until that moment and starting point and reference, an incipit or better a "prototype" and a "drapeau", for future projects, as the pilot plan for Bogotà, where coexist past and present, nature and artifice, reality and imagination, objects and traces of the contest with memories of spatiality already lived elsewhere.

\section{Recostruction plan for Saint Dié like prototype}

"The war sparked the era of the movement, a fracture of crystallization, the start of works so wide that we can include since today the architecture and town planning. [...] Never forget the fundamental need for an overall plan [...] provisional element could serve as a model for future endeavors [...] and become the first social organizations [...]: the barracks of wartime will become the inclined plan that leads to the social achievements; its multifaceted existence will bring generating functions of life ". ${ }^{4}$

The city of Saint Die des Vosges, located in the Lorraine region on the border between France and Germany, was destroyed by retreating German troops between 8 and 14 November 1944.

It is a cityscape enclosed within urban walls, with the limit of the river at south and of the Vosges at north, grown up around a commercial area, dominated by a gothic cathedral and characterized by narrow streets between buildings and a main street, the rue Thiers, to which it is added the twentieth-century development determined by the textile industry in the south of the area and at the side of the railway track.

\footnotetext{
${ }^{1}$ Le Corbusier: "Il cuore della città punto d'incontro delle arti. Acustica visiva", in Rogers, Ernesto Nathan; Sert, Josep Lluis; Tyrwhitt, Jaqueline (edited by): CIAM 8. Il cuore della città: per una vita più umana delle comunità. Milano: Hoepli,1954. p. 46.

${ }^{2}$ Le Corbusier: Euevre Complete. 1938-1946. Zürich: Girsberger, 1946. p. 133.

${ }^{3}$ Ibidem

${ }^{4}$ Le Corbusier: "I problemi della ricostruzione. Quando la pace tornerà sulle strade" in De Carlo, Giancarlo: Le Corbusier. Milano: Rosa e Ballo, 1945. pp. 145-147. Original text in Le Corbusier: Le quatrês route. Terres, air, fer, eau. Paris: Gallimard, 1941.
} 
More than ten thousand people are evacuated and then the part of town north of the river Meurthe, the area between the cathedral and the business district, and a narrow band over the other side of the river, are burned with mines and grenades, saving only the peripheral areas, further south. The textile city of about twenty thousand inhabitants shows extensive damage and more than ten thousand people are homeless.

By the subsequent arrangement of the rubbles in tas de pierres, where were urban blocks, the urban morphological structure emerges clearly in its parts, as a scheme of zoning and paths in the landscape.

In this devastated landscape, only the cathedral at north and the church beyond the river Meurthe, as well as the building of railway station, stand still up, connected visually and physically by the main street.

Destructions and rubbles are signic traces of the formal and social history of the city, to which to give continuity in the opportunity of the needed transformation itself.

They reveal a system of permanent signs and unexpected relationships from which the geographical background, the existing territorial structures and the landscape dominants resurface and to which the social ties that have generated the settlement, were and remain anchored.

“[...] La destruction à peu près complète de l'anciènne ville a eu comme effet de dégager et de remettre en valeur le paysage environnant qui est agréable et charmant. C'est une révélation pour le visiteur et plus encore pur l'habitant. Trésor retrouvé [...]", 5

"La zone déstruite est un rectangle rasé à la granade et par l'incendie, qui était le berceau même de la ville, le lieu où elle nacqui et commença de s'édifier". 6

So, in Saint Dié, the destructive event is subjected to an interpretive and poetic reading of the morphology and of the new spatialities that the inflicted wounds have reopened. The reading of the territorial spatiality, made possible by new visual perspectives, provides the opportunity for a wide-scale project despite the small size of the valley where is located the city. The topographical and settlement structure which constituted the geography of the place in the stratigraphy of the urban past of Saint-Dié is brought back to a new form in the continuity of a substantial adherence to generative connotations.

\footnotetext{
${ }^{5}$ Musée de Saint-Dié: Le Corbusier et Saint-Dié, Musée municipal de Saint-Dié-des-Vosges, 14 octobre-10 novembre 1987. Saint-Dié: Musée municipal de Saint-Dié, 1987. p. 98. Foundation Le Corbusier Paris - bibliothèque (FLC-b). Letter of Le Corbusier to Raoul Dautry like Ministre de la reconstruction et de l'urbanisme, 21 Decembre 1945 (FLC H3-18-146). Also in: Le Corbusier: "A Plan for Saint-Dié” in Architectural Record, N. 100, October 1946, pp. 79-82 (FLC X1-15:20); Le Corbusier: "Un plan pour Saint-Dié" in Homme et l'architecture, N. 5-6, Novembre-Decembre 1945; Le Corbusier: "Ein plan für Saint-Dié in Werk, N. 33, April 1946, pp. 109-112. See also: Le Corbusier: "Plans for the Reconstruction of France" in Architectural Record, n. 99, March 1946, pp. 92-93.

${ }^{6}$ Ibidem. p. 100.
} 


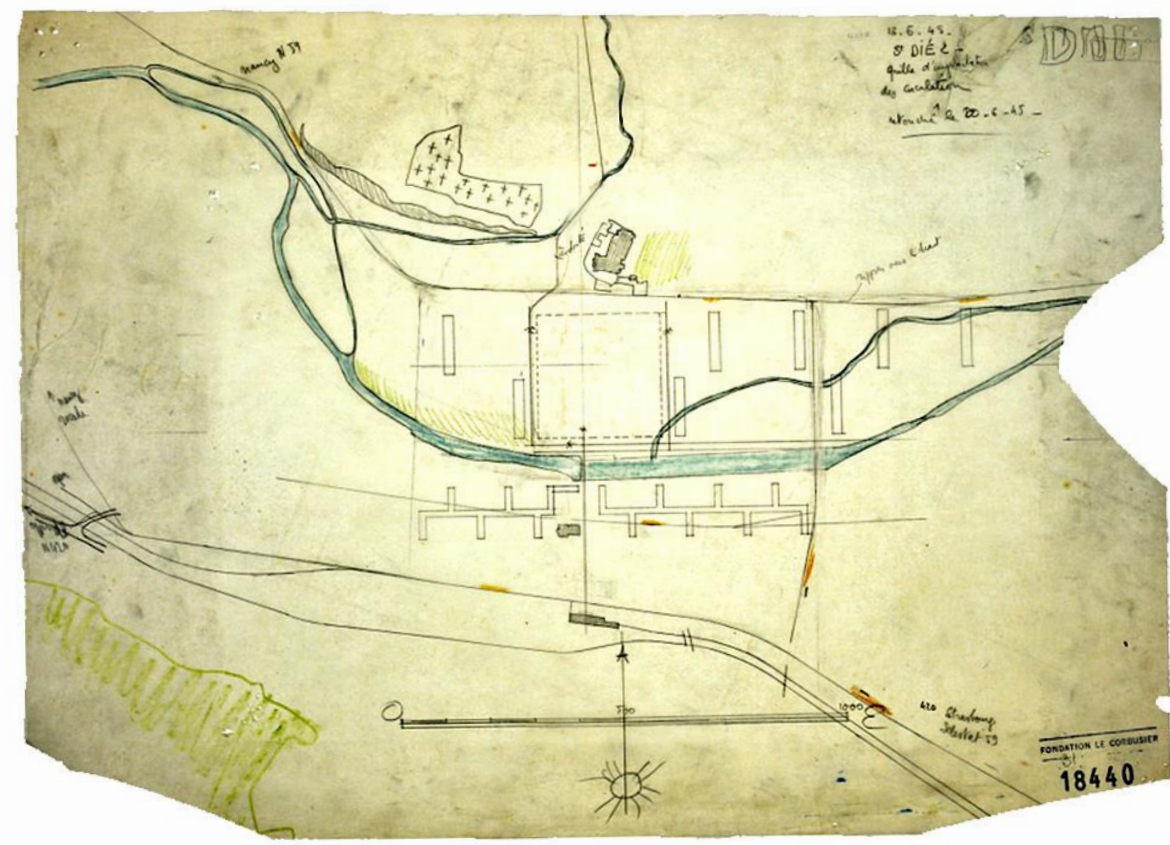

1. Le Corbusier, Sketch for the reconstruction project of Saint-Dié dated 16 June 1945 with the three remaining "fragments" of the destroyed city. 18440 @FLC-ADAGP.

The morphological structure is a kind of urban background track that guides the arrangement of the constituent elements of the project, so that both existing and new things originate by the same basic references.

The first sketches ${ }^{7}$ reveal the reading of the city on a geographical scale, as a compact and figural nucleus present in the landscape and with the elements of it, like river and mountains. Then, the attention is poured on the heart of the city and on what may suggest remained traces of it. The three remaining fragments of the existing city and the trace of the main street, like an ordering axis, are the constituent pieces on which the whole composition is innervated within the territorial context and landscape where it is anchored.

“Après-guerre 1939-1944: la cathédrale et la ville de St-Dié, par exemple. La cathédrale d'abord: la nef romane, privée de ses voûtes, est éclairée violemment, et l'on voit en pleine lumière les chapiteaux dans une splendeur sculpturale glorieuse, que la pénombre seule avait fréquentée jusqu'ici.

Le transept est entier, et l'abside aussi jusqu'au jaillissement des voûtes gothiques dont quelques amorces seulement demeurent encore attachées aux chapiteaux. La messe pourrait être dite dans ce décor extraordinaire, synthétique, symphonique: cette palpitante chose humaine bâtie, et toute déchirée, est installée là comme une épopée au milieu des bêtises quotidiennes. La technique moderne permet de sauver tout cela, permet de l'employer, permet d'y inscrire le souvenir du tragique passé tout récent. Il suffirait d'une dalle de béton portée haut sur de minces potelets extérieurs à la cathédrale, et qui servirait désormais de couverture. La glace de

\footnotetext{
${ }^{7}$ In the spring of 1945, on initiative of his friend Jean-Jacques Duval and the Association Populaire des Sinistrés, Le Corbusier received a request from a town planning study for the city, and on April is named Architecte-Urbaniste-Conseil de la Ville de Saint-Dié. After some sketches, in June Le Corbusier processes the first version of the reconstruction project with a general plan and five detail tables. Cf. Musée de Saint-Dié: Le Corbusier ...cit. See: Sequeira, Marta: Para um espaço público. Le Corbusier e a tradição greco-latina na cidade moderna. Ministério da Ciência, Tecnologia e Ensino Superior. Lisboa: Fundação Calauste Gulbenkian, Fundação para ciência e a tecnologia, 2012. See also: Clericuzio, Peter: "Le Corbusier and the Reconstruction of Saint-Dié. The debate over Modernism in France, 1944-46" in The Chicago Art Journal, N. 20, 2010. pp. 46-71.
} 
Saint-Gobain fournirait en maints endroits les vues sur ces perspectives que j'ai signalées: de nature, de ciel, d'architecture". 8

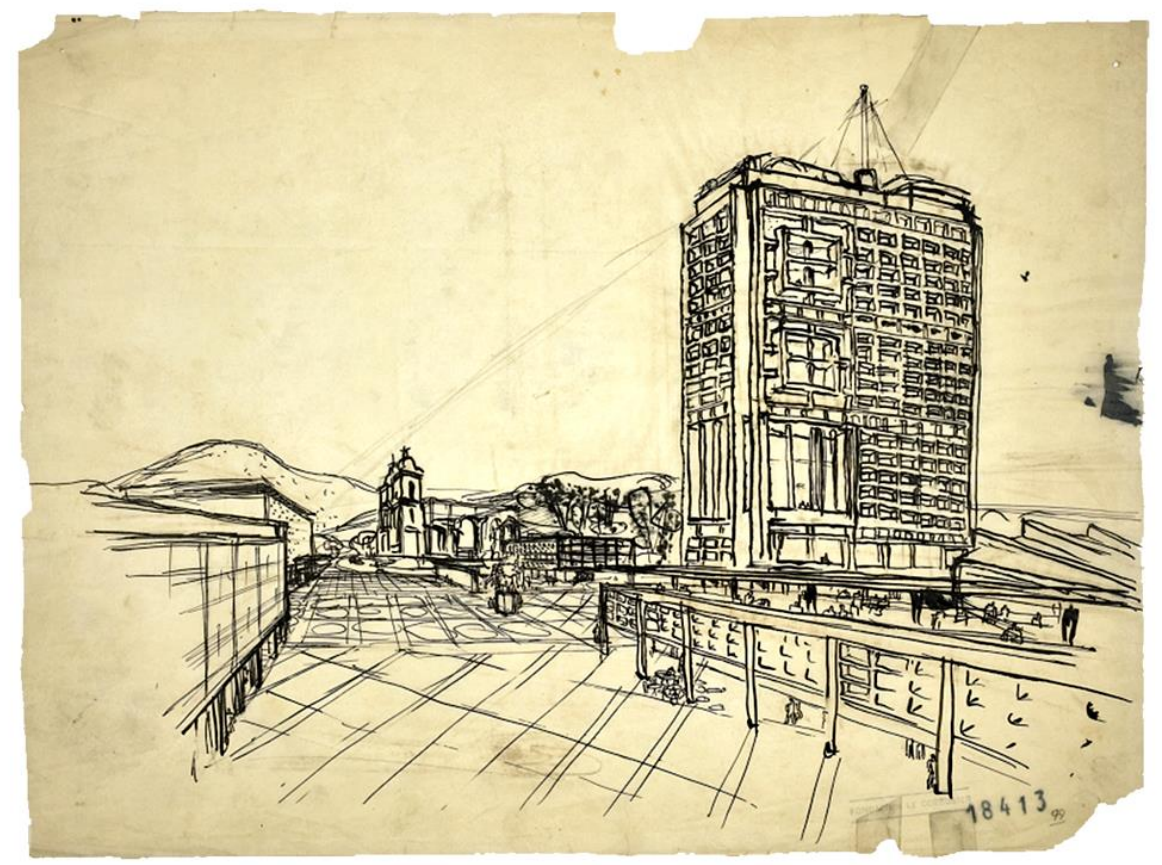

2. Le Corbusier, View through the main axis, old rue Thiers, with the cathedral, the admistrative skyscraper and the mountains on the background, August 1945. 18413 CFLC-ADAGP.

The cathedral is a remained fragment that evokes the whole urbanity and determines a visual pivot in the background of the mountain relief, as well as the civic core is kept as a morphological fragment of socially identity where converges each new settlement part.

The new civic center, the heart of the city, occupies the area of the previous urban centrality with the cathedral which is included among the new functional and formal elements. The cathedral is a connecting link and a space-time hinge: a piece of the common, collective identity and a "message of courage, audacity, temerity".

The first draft of the project in June 1945 provides already for the arrangement of functional areas and new infrastructures, which will be maintained in subsequent drafts and final version, and a kind of preparation for

"layer" of the addressed issues: in particular, the green system and the relationship with the landscape, the road infrastructures and the pedestrian center, the residential area and the production area, the river as a natural limit at the same time of division and connection between the parts, the urban core as the civic and morphological core.

\footnotetext{
${ }^{8}$ Le Corbusier: "A propos d'architecture d'accompagnement et de respect du passé”, aprile 1946 (FLC), published in Le Corbusier: Le passé à réaction poétique. Paris: Caisse Nationale des Monuments et des Sites, 1988, p. 96. (FLC-b).

${ }^{9}$ Le Corbusier: Maniera di pensare l'urbanistica.[1946]. Roma - Bari: Laterza, 1997. p. 52.
} 


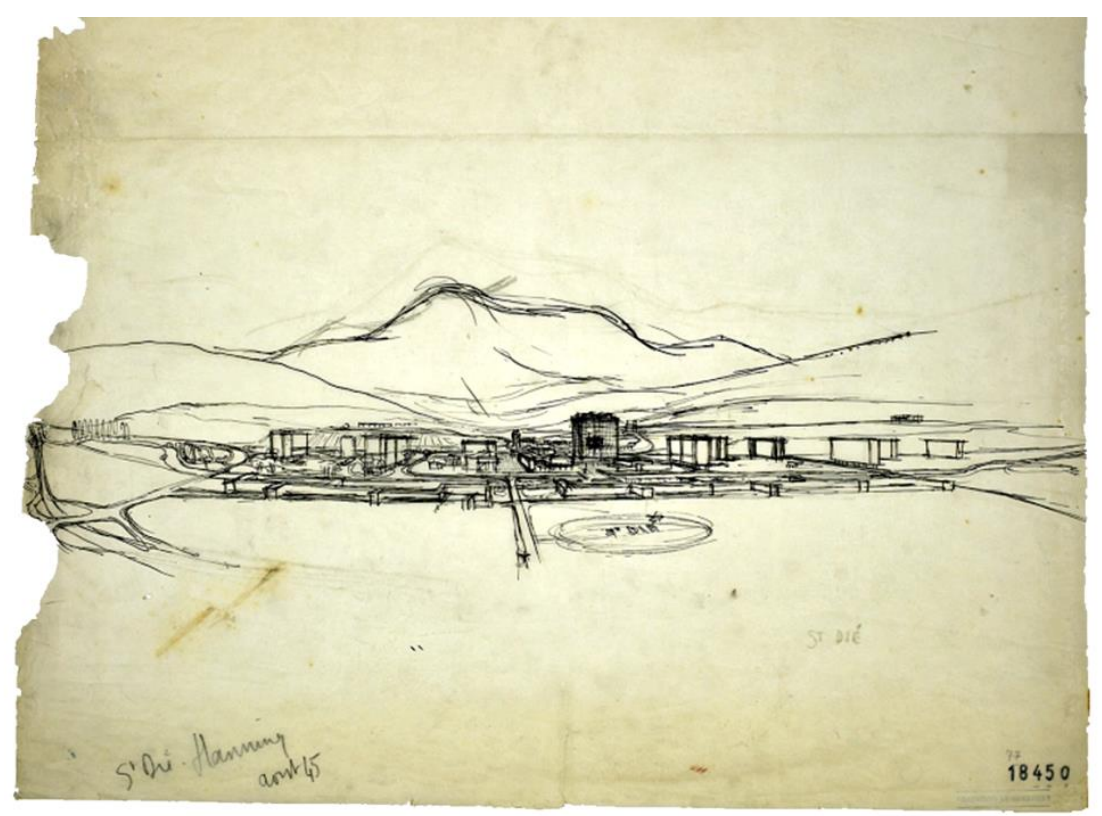

3. Le Corbusier, Overview of the plan for Saint Dié through the main axis and with the mountains on the background. August 1945. 18450 @FLC-ADAGP.

Residences and industrial buildings belong to the landscape and have an extensive nature; the urban core is the civic part, built by and for the community: the public space made up of representative square-agorà as a place of identity, limited and figuratively identified with an ideal quadrangular enclosure of 300 meters on each side.

In this first version of the project are also already included any elements considered "biologically" strictly necessary: residential units (ISAI), administrative offices, coffees, the center of tourism, the Maison Commune, the industrial building.

In the project for Saint Dié the principles set out in the IV CIAM become methodologies tools.The road system is a network connecting to the service of architectural events previously placed in areas with a specific destination: are detected units (housing, working, leisure and circulation) corresponding to areas where the buildings are arranged according to their plastic, volumetric and visual relationship and only later connected by roads. The concept of zone, which corresponds to a part of the city defined by a type of building, breaks the traditional bond between architecture and urbanism and hierarchy connected to the mesh road ${ }^{10}$, but includes a new priority, the landscape: the city is anew characterized by architecture. In this urban composition, the architectural objects look like fragments from different projects and a kind of machines for the vision: they are physical presences linked by perceptive experience and, at the same time, evocative references. The past presences, the landscape and new buildings are the pieces of the new urban composition.

The plan is described as "an arrangement of pure biological elements", able to express clearly the functions to which they are intended, according to their forms plastics thought from within outward.

It is also a reflection about duality between center and periphery, residence and workplace, including "sprawling cities and deserted countryside", which still needs to be remedied, restoring the work mode in the experience of the city and the production sites in the morphology of the same. It is indicates a way to return to architecture its fundamental and transformative value, in parallel with the provisions of urban planning and landscape.

\footnotetext{
${ }^{10}$ Cf. Gerosa, Pier Giorgio: Le Corbusier, Urbanisme et mobilité. Basel - Stuttgart: Birkhäuser, 1978.

${ }^{11}$ Musée de Saint-Dié: Le Corbusier... cit. p. 59.
} 
"The city planner is nothing more than the architect", : architecture and urbanisme contribute together to create a new unit ${ }^{13}$, a "unite of conform dimension". The plan can be divided into horizontal registers that identify some functional areas, which are referred to the central area and dimensioned according walking distances.

The heart of the city and of the whole plan is the civic center occupying the old city center.

It is predicted with spaces reserved exclusively for pedestrians. So, the scale of project is the human walking, the right distance between housing and working and the right dimension of the voids between volumes for the good perception of it.

"Le centre civique est le lieu éminent de la cité, son coeur et son cerveau. C'est là que par des monuments et par des actes se développe la vie urbaine et que s'inscrit son histoire",14.

The medieval morphological structure is taken as an operating fragment of memory for the definition of the project: urban spaces are united with the duality of religious and civic center; the existing main street joins two religious visual fulcrums, two churches, such as testimonial objects and evocative cores and they are also the connecting with the landscape background along with the other new representative buildings.

The heart of Saint Dié, the Chapter, consists of four orthogonal spaces that, as in Mundaneum (1929), representing the action fields of spatial volumes: the tower of the administration center which plays a role of urban landmark, cafeterias and common house like social center, the space of the museum of knowledge like a cultural center and one of the accommodation facilities like a place of tourist reception.

In the design of this civic heart converge also other references that come from the "magic box"15 of the personal memory and spatial experiences, like the square of San Marco in Venice ${ }^{16}$ and the greek agorà. It is a memorial use of the past, also it. With the attitude to considere the process design in continuity and like a kind of anthology of other projects, the civic center recalls the space-volume relationships used in the Palace of the Soviets, the presence of two spatial directions back to the Palais des Nations and the volumes gifted of its own field of visual and proportional action like in Mundaneum. In the same center coexist buildings thought for hypothetical places, like the museum at unlimited growth, together with buildings designed for specific destinations like the halls of the palace of the Soviets or the administrative high-rise for Algier, along with remains of existing buildings like the cathedral.

This heterogeneity and juxtaposition of "pieces" from different architecture allow to design a paratactic composition organized on the basis of a flexible grid, (but geometrical and proportional grid of 25 squares with each side of 60 meters), where the volumes are distribuited according balance weight, of volumes and distance between them. In this composition, the cathedral remains the core of witnesses of the past and focus visual connection with the mountain scenery. The costitutive elements of the city are developed around the axis of the main street to create a series of squares and open spaces according to the principles of pre-existing and duration studied by Lavedan and Poëte.The Grand Rue, rue Thiers, is the traced for the new urban center where there is

\footnotetext{
${ }^{12}$ Le Corbusier: Maniera ... cit. p. 9.

${ }^{13}$ Wogenscky, André; "Le projet pour Saint-Dié. Structure sociale et structure architectural” in Foundation Le Corbusier Paris: Le Corbusier. La Ville, l'urbanisme. Les rencontres de la foundation Le Corbusier. Rencontres des 9 et 10 jun 1995 ". Paris: Fondation Le Corbusier, 1995. pp. 62-72. (FLC-b).

${ }^{14}$ Musée de Saint-Dié: Le Corbusier... cit. p. 102. Also in Le Corbusier: "Un plan pour Saint-Dié" in L'Homme et l'architecture, Nn. 5-6, Novembre-Décembre. 1945, p. 44; in Werk, n.1, Jan. 1946, p. 112.

${ }^{15}$ Le Corbusier: "Il cuore ... cit. p. 52.

${ }^{16}$ Musée de Saint-Dié: Le Corbusier... cit. p. 37.
} 
the community life, and in which are arranged the residences and workplaces. The civic center is a center of gravity that unifies socially and morphologically: it is the city itself.

In drawing up the plan dated June 1945, the administrative tower is decentralized and occupies the north-east quadrant; the axis of connection is unique, underlines the existing main street, rue Thiers, and combines two religious units like two visual focus. In this first version, the civic space revolves around a central more concentrated and with greater hierarchy of empty squares. A second version, after a few months, shows a different orientation of the administrative high-rise, rotated ninety degrees and the hint of the second axis parallel to the main one, now partially intended vehicular crossing of the river and the connection with the road infrastructure bordering the center.

The museum of knowledge and the cultural area have the shape and position of the final version, while the area that will be dedicated to receptive is occupied by the constituent elements of the administrative area.

In the final version of the project there are two axis north-sud and so two visual focus: one axis links the church at south to administrative hide-rise that become the the main visual background, the other one parallel at first, focus on the cathedral through the cultural area and a sequence of differente voids, compressed and dilated. In this second visual axis, the direct link is only of vision and the pedestrian path between the figurative fragments is deviated. In this way, the main walking path remains what connects the elements, while a secon path frames, exalting it, the identity fragment, represented by the cathedral. This biaxial disposition sets up the urban heart by the connection between civic nucleus and religious nucleus, even more like in the medieval city.

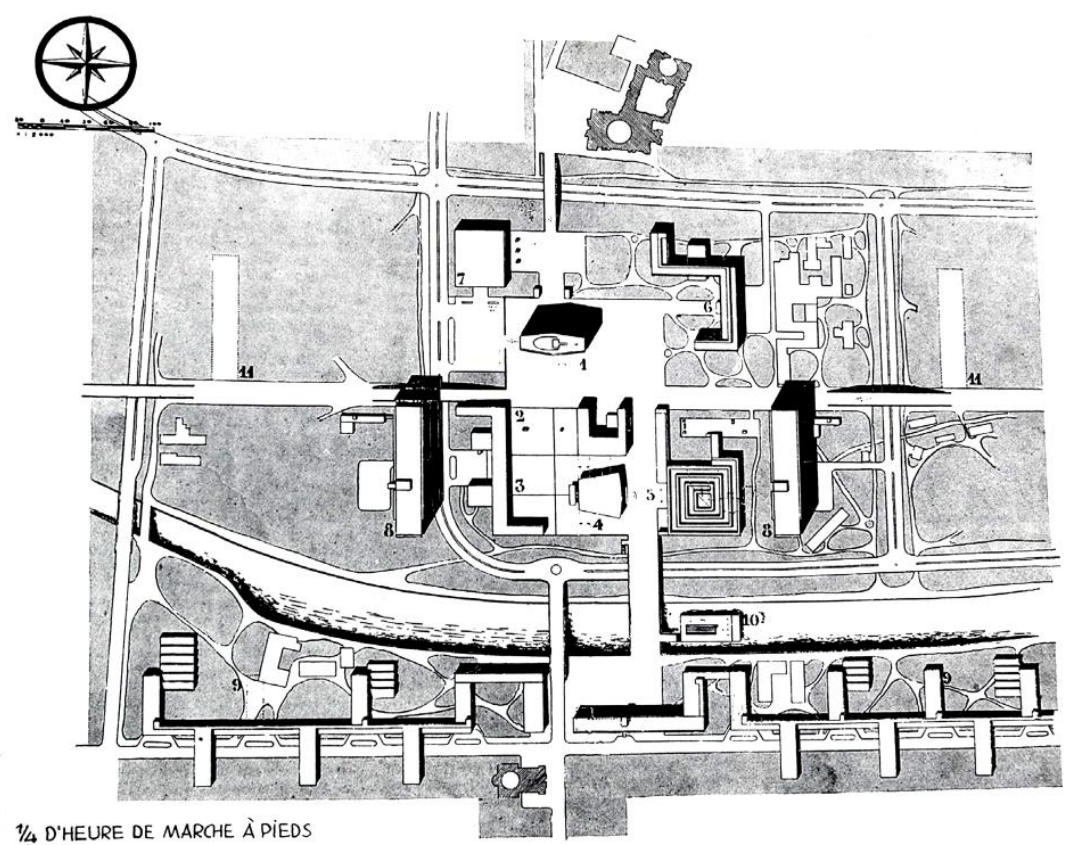

4. Le Corbusier, The civic centre of Sant-Dié, version of 1 January 1946.

Religious fulcrum and civic fulcrum, memorial elements of the past and objects of the present time, have the same urban significance. All the elements of the civic center are freely arranged on the basis of a grid with orthogonal mesh crossed by the nature and delimited a north and south by natural and building elements.

Also the factories, located on the left bank of the River Meurthe, are an essential part, economic and social, as well as a symbol and a necessity for the reconstruction. In the first sketch they are grouped to form a kind of urban wall that recreates a restraining margin between the center and the periphery; the subsequent hypothesis the units of production are a filter maintaining the effect of boundary and interface. 
The dwelling units are located in the north of plan. Here, the vertical garden-city and the horizontal garden-city coexist in the same place.

The continuity between the residence and the civic center is favored by a systematic pattern of roads that includes the total pedestrianization of area between them, thought mainly green.

The mobility system is also an application of theories mentioned in the Ville Contemporaine (1922) with main attention to hierarchy differentiation of roads and complex system connecting the city with the territory and urban parts. Also it is refer to Ville Radieuse (1932), where over the sharp division between the different systems of circulation, there is the mutual independence between buildings and roads, and the ground is an ideal plan of nature. There is also a recall to the concepts and theories about the industrial linear city and the Usine verte, like a new and better settlement.

The horizontal registers where are placed dwelling and working units, at north and south, generate a kind of filtering urban wall: a new urban limit in the territory that draw a new skyline. It is a limit that refer to medieval urban limit but with the peculiarities of the present time: it is curtain opened in and to the landscape.

Geometry and nature are not only compositional elements but also operational tools of cohesion and connection of whole set. Geometry is used as a measure proportional to calibrate weighted distances as well as means of union with the human dimension, as subsequently theorized even with the Modulor. Nature is the "fluid" compositional element able to mix and hold together the composition of autonomous pieces to obtain a new set, according to a defined shape and at the same time open to continuous developments.

The original urban settlement took into account the position suggested by the topography of the place itself, that is the most favorable geography indication for the settlement arrangement. So, selecting and retracing some existing urban signs, made even more apparent by the violent destruction of the war, emphasizing and reconnecting the urban development to specific anthropogeographic values and designing the new settlement starting from the same recognized principles of the existing, while excluding any imitative principles.

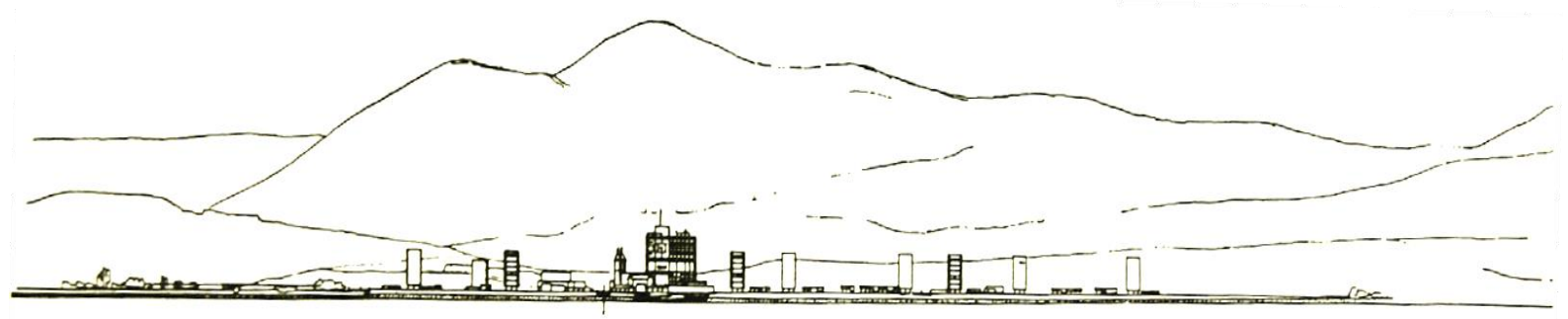

5. Le Corbusier, Skyline of Saint-Dié in the landscape showing the building of the first and second phases.

\section{Urban projects over the reconstruction}

In the same years of the project for Saint-Dié, Le Corbusier develops other reconstruction projects including Saint Gaudens, La Rochelle-Pallice ${ }^{17}$.

\footnotetext{
${ }^{17}$ Petrilli, Amedeo: L'urbanistica di Le Corbusier. Venezia: Marsilio, 2006. pp. 143-149.

See also: Le Corbusier: Euevre...cit. pp. 162-169. Le Corbusier: L'urbanistica dei tre insediamenti umani [1945]. Milano: Etas Kompass, 1961.
} 
Saint Gaudens is a small old Pyrenean town designated like site for the headquarters of the company that extracts natural gas from the Pyrenees. In his project of 1945-46, Le Corbusier suggests a town planning in three dimensions integrated to the landscape and considering primarily an overall territorial vision.

New settlements are arranged as autonomous nucleus around the little old town center. Two industrial plants are located next to the railway track in a bend of the river Garonne, flowing foot of plateau where the town lies.

A residential area for about 5000 inhabitants is planned west of the city, integrated to a large green area and with morphological elements dictated by topographical and environmental conditions and by landscape scenographic criteria. Another urban settlement is expected to the east and it is defined horizontal garden city.

The two housing developments, west and east, are connected to the historical settlement by an existing axis coming ut radially from the latter.

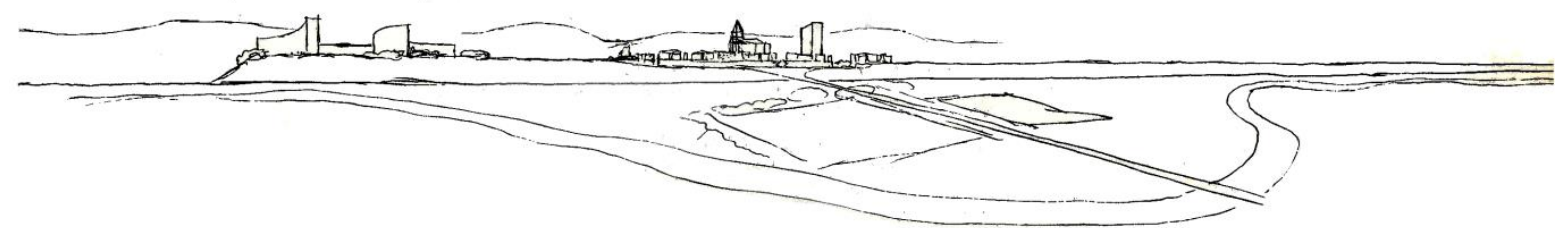

6. Le Corbusier, Skyline of Saint Gaudens in the landscape showing from left the new housing settlement, the civic and civil center and to more south, two new industrial establishments.

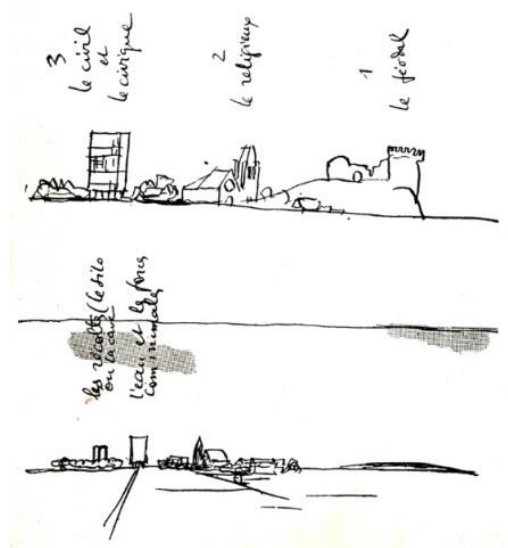

7. Le Corbusier, Sketch for the project of Saint Gaudens with the three compositive elements: the civic center, the religious nucleus and the medieval ruins.

Inside the old nucleus is concentrated any civic activity provided, primarily in a single tower building that is related in balance to mass and height, to the gothic cathedral and the ruins of the medieval castle.

Also in this occasion "the forms of the buildings will be determined by the conditions of the land, the horizons, the views and the orientation". [...] The old small town will see its centre of civic and civil forces rise up, its mass balancing that of the cathedral." ${ }^{18}$ Attention and interest in the historical pre-existence like vision fragments of urban composition characterize also the choices for the reconstruction plan of La Rochelle-Pallice. La Rochelle is a gothic town overlooking the Atlantic port; la Pallice is the neighboring industrial area link to the port and the railway system. Even though they had both been mined during the war, they remained intact. Le Corbusier hypothesizes the preservation of the historical city La Rochelle in its entirety, as a stand-alone

${ }^{18}$ Le Corbusier: Euevre...cit. p. 162. 
fragment of landscape to be linked to new housing and production developments. The old town is surrounded by a large green ring and linked by a circulation system to the new industrial green town and to vertical and horizontal garden city. Here, the green ground and the horizon vision are the connection of different elements in the territorial context.

The small historic towns are considered the nucleus, the renovated civic center and so the heart, of the new urban developments according to a geographical dimension scale. As well as the reconstruction project for Saint Dié, also the projects for Saint Gaudens and for Rochelle-La Pallice, will not be realized.

A few years after, between 1949 and 1953, Le Corbusier designs the pilot plan for Bogotá ${ }^{19}$, in collaboration with Josep Lluis Sert and Paul Lester Wiener. Bogotá is considered political, administrative and cultural core of a territory at geographic scale. This project is a kind of city model that summarizes several methodologies in order to consider simultaneously the main elements at urban, metropolitan and geographic scale, deducted from the analysis of the formal conditions of the existing city.

There are some compositional tools and theoretical applications in it, which are together for the first time. In particular, the civic center is an urban element that represents a new urban function, due to the reinterpretation of the center of power and the most important public space of the city in the Hispano-American urbanism; the urban sectors to divide the area according to regular pattern while taking account of the original morphology and their road hierarchy according to the rule of $7 \mathrm{~V}$, like indispensable framework for the circulation and the composition in intermediate scale.

Some aspects already investigated in the reconstruction project for Saint Dié return here: the presence of an urban center closed to traffic, around which the whole project is oriented and the presence of a pervasive nature that determines the cohesion, even perceptive, of the settlement at the foot of mountains, that form the background of it. Even in Bogotà, the urban project includes a sort of anthology of projects designed for other specific locations or only theorized, as weel as the central theme of housing, now refering also to the just built Unité d'Habitation in Marseille.

The analysis step makes to reference to the history, the topography and the envirement of the city; this step is followed by the superposition of a grid derived from the Carta d'Atene, as well as proposed in 1949 at CIAM 7 in Bergamo. The project step relates to more planning scales, under which four plans are developed: the regional plan, metropolitan plan, the urban plan and the civic center plan, considering the conservation of the historic area and most of the old buildings.

\section{“[...] Souvent, l'Euvre révolutionnaire se manifeste par un caractère hautement tradizionnaliste,20.}

The main civic and representative space is defined from renewing its center itself, around already plaza de Bolívar. From the first sketches, the urbanism in three dimensions is explicit: volumes and spaces overlap and confront directly with geography and history, taking into account new patterns of relationships which add to the

\footnotetext{
${ }^{19}$ Cf. Le Corbusier: Euevre Complete. 1936-1952. Zürich: Girsberger, 1945. pp. 42-45. See also: O'Byrne Orozco, Maria Cecilia (edited by): Le Corbusier en Bogotà 1947-1951. V. 1-2.. Bogotà: Fondation Le Corbusier; Universida de los Andes; Pontificia Universidad Javeriana, 2010. in particular the Fontana, Maria Pia; Mayorga, Miguel: "Arquitectura en todo, urbanismo en todo.Le Corbusier: del Centro Cívico al centro de Bogotá”, pp.82-101. See also: Rogers; Sert; Tyrwhitt: CIAM 8...cit. pp.150-152.

${ }^{20}$ From the technical documents for the project of pilot plan from archive German Samper in O'Byrne Orozco, Maria Cecilia (edited by): Le Corbusier en Bogotà 1947-1951. V.1. Bogotà: Fondation Le Corbusier; Universida de los Andes; Pontificia Universidad Javeriana, 2010. p. 3.
} 
established city order, superimposing a series of formal rules arising from the reinterpretation of pre-existing conditions.

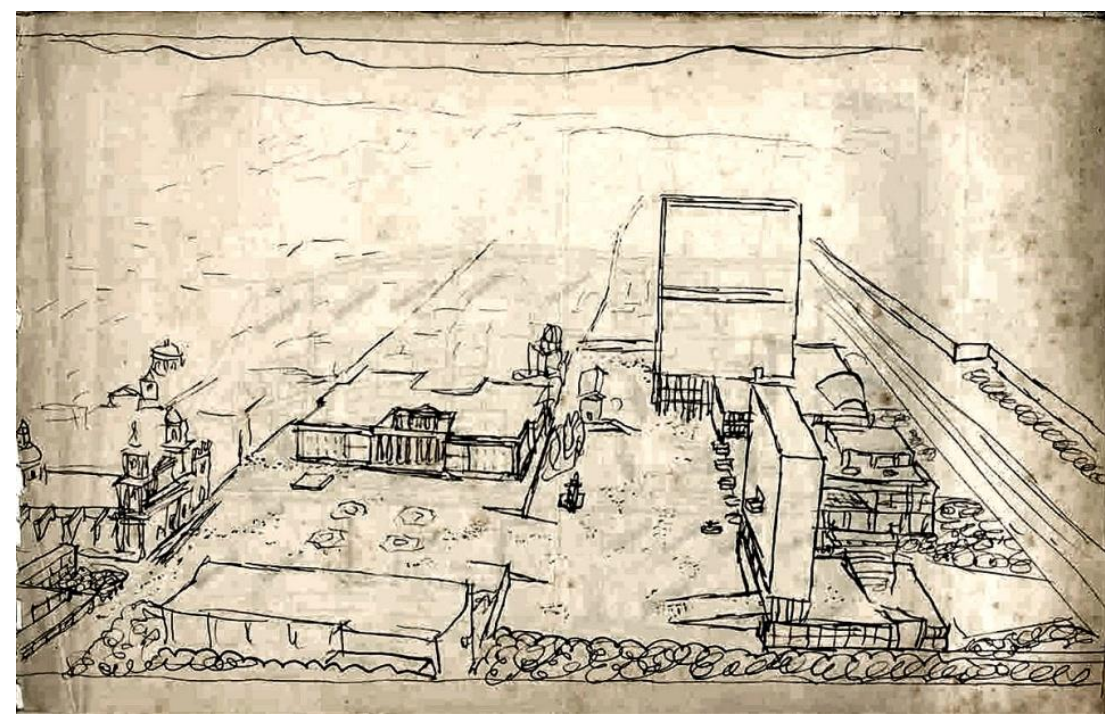

8. Le Corbusier, Sketch of civic center of Bogotá.

New architectural volumes overlap to the checkerboard pattern of the colonial city, emphasizing its relationship with the landscape in order their position and orientation, through a main urban axis, in the longitudinal direction,, that is also an visual axis. In the Civic Center, urban and regional heart, the urban-architectural approach is integrated and becomes more visible: the unit is governed by the mixture of elements from the geographical basis and forms of urban development of the existent historic center. It is verifies the new potentialities of the architecture to make town. The Civic Center is drawn into the mesh of sectors proposed for the city, structured by a linear system of three focal points of tension: Bolivar Square, an area south of the square and another north. Two new high buildings and some others significant preexisting, between them the cathedral and parliament palace, mark the void on different levels around the old colonial square, Plaza de Bolívar, looking for the balance relations also with other lower administrative buildings. The relantionship of new architectures with the landscape context, mainly with the mountains and with the historical and anthropogeographic heritage, is achieved by a calibrated study of position and dimension of all the compositional elements, whether natural or constructed elements, like a different fragments. So, it is also a scenographic project, where the human subject is at the same time actor and spectator: it is the costruction of a landscape in the territory. 


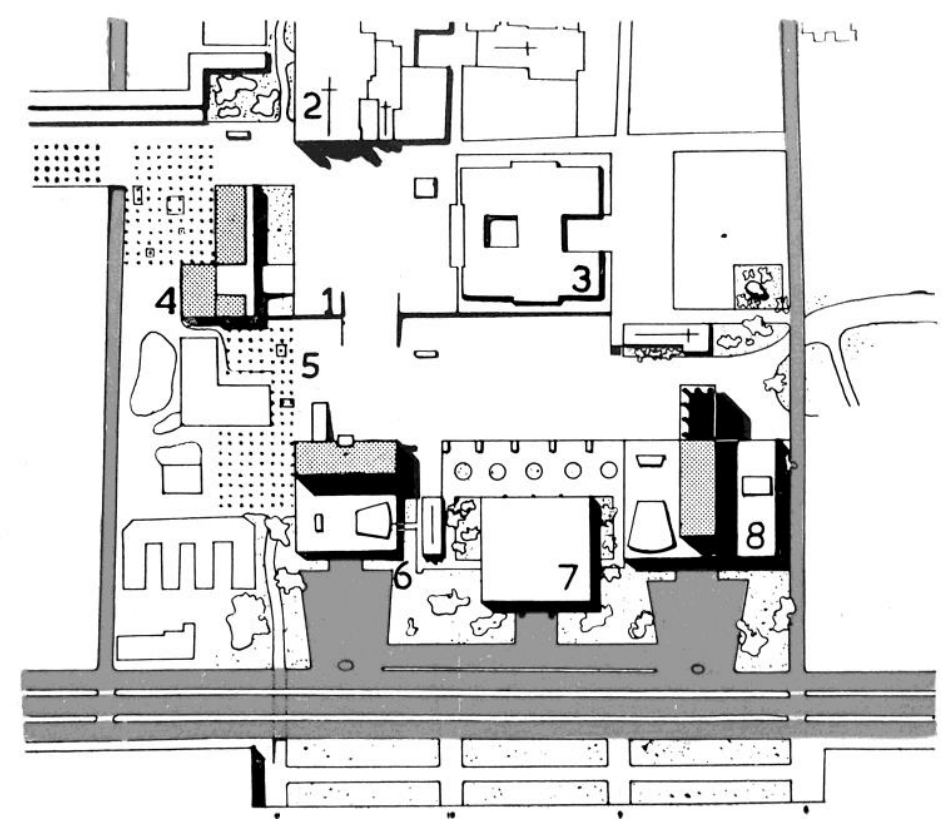

9. Le Corbusier, Plan of civic center of Bogotá.

\section{Conclusions}

"The city for Le Corbusier is not so much a reality as a representation, a collage of images"

In this kind of integrated plan, each building is a sign and a kind of visual pivot in the landscape: the city itself is considered a territorial signal and a civic core reconstituted in the new unit: a composition of calibrated visual resonances.

"There are mathematical points of consonance which might be called acoustic points of visibility, points of agreement where things take a decisive value. Just move a few steps because they do not have more: the relationship is gone, or we are out of range" ${ }^{22}$

The space, the void, rather than the object, is the key element for the place as a whole. These places where the agora coexist with the acropolis, where the voids are prevailing, a city of objects if compared at the traditional solid city as defined by Colin Rowe ${ }^{23}$, are a kind of great machine à voir that allows the synthesis of arts and where is possible the symphony of things.

Natural elements and territory and anthropic elements, such as traces of the historic stratification, are considered in the same way part of a calculated scenic and phenomenological system.

They are fragments and frames at the same time.

The buildings, scattered on a large and not delimited surface, find a new cohesion through optical triangulations, dynamic but controlled, which determines the measure and relationship with the landscape.

\footnotetext{
${ }^{21}$ Colomina, Beatriz: Privacy and publicity: modern architecture as mass media. Cambridge (Massachusetts) - London: The MIT press, 1996. p. 319.

${ }^{22}$ Le Corbusier: Il cuore... cit. p. 46.

${ }^{23}$ Rowe, Colin; Koetter Fred: Collage city. [1978].Cambridge (Massachusetts) - London: The MIT Press, ( $8^{\circ}$ ed.) 1995. pp. 60-63.
} 
This plastic equilibrium is understood like a kind of balanced symmetry ${ }^{24}$. The scale of perception follows the criterion of scenic effect linked to the movement of the subject and the relative position of the architecture: a peripatetic vision, second the declension of greek picturesque described by Auguste Choisy ${ }^{25}$, in a composition of heterogeneous and discontinuous pieces with apparent disorder ${ }^{26}$ held together in unit with a balance generated between mass of volumes and relative intermediate space.

The perceptual relations are equilibrated by ponderal weights that are generated by the volumes and the space between them and the relations of the foreground and background figures established by reference to the moving subject that passes through them in predetermined promenades architecturales.

It is a kind of paratactic narrative that consists of poetic fragments, each of them referring to their whole, and where the landscape is the cohesion and the constitutive and operational device.

"Environment and landscape exist only through the eyes". ${ }^{27}$

In this methodological system, the historical references are sublimated and synthesized in a conceptual background as if they came from a "tools box" of personal memory, where are contained together to other past experiences, memory of different things and places, like organic forms, artistic works and Italian squares or other Mediterranean public spaces: a "box of the mind", in bulk, where they "float and ferment" 28 to emerge through forms and compositions always new and different, as if the design process was always dynamically and tirelessly underway ${ }^{29}$.

In every case, the projects refer the general atmosphere of the context so that they establish a spatial and historic continuity of development. So, for example, also the project for the hospital of Venice is another type of proposal for an urban development in open form, like a mat, and in continuity with the conceptual traces of contiguous existing historical city.

In Saint-Dié, Bogotà, but also Chandigarh and then Firminy, the perceptual scale follows the criterion of scenographic effect linked to movement of the human subject and to the relative position of the architectures. Here, the buildings are scattered in a space not bounded: autonomous objects, monadic, as part of other totality and radiating centrifugal force, are monumental plastic sculptural forming pins of a city as landscape.

These urban landscape are thought of as a espace indicible ${ }^{30}$, a relation of agreement and harmony between nature and architecture, memory and present, in which buildings, objects à réaction poétique, establish an acoustic relation with the place.

The existing buildings and the new ones establish a relationship of dialogue between them and generate a narrative composition starting from memorial fragments. The "change", in this way, creates a new formal continuity. It is a reintegration into the historical process of the fragments of the past, physical traces of the time, according to new interpretations that allow the valorization of the diachronic and identity aspects at the same time purifying the fragments themselves from the feature of simple citational presences. The phenomenological

\footnotetext{
${ }^{24}$ Le Corbusier: Propos d'urbanisme. Paris: Bourrelier et C., 1946. pp. 17-18.

${ }^{25}$ Cf. Choisy, Auguste: Histoire de l'architecture. [1899]. Paris: Baranger, 1929.

${ }^{26}$ Ibidem

${ }^{27}$ Le Corbusier: Maniera...cit. p. 80.

${ }^{28}$ Wogenschy, André: Le mani di Le Corbusier. Roma: Mancosu Editore, 2004. p. 59.

${ }^{29}$ Cf. Rogers, Ernesto Nathan, Le Corbusier tra noi, Milano: All'insegna del pesce d'oro, 1966.

${ }^{30}$ Le Corbusier, "L'espace indicible" in L'Architecture d'Aujourd'hui. No Number, "Art”. Paris, April 1946. pp. 9-17.
} 
aspect and the human movement of the promenade establish a new narrative compositional unity. The equilibrium generated in the spatial dimension by balance weights, volumes like sized masses to which correspond calibrated distances, is also transposed in the temporal dimension like the relationship past - present.

The whole composition creates a dynamic of space-time, complex and not completely stated: an open urban work originated by poetic measure of architecture in landscape.

\section{Acknowledgements}

Thanks to the staff of Fondation Le Corbusier Paris and Inter-Library DIDA University of Florence. Immensely grateful to Claudia Conforti for the advises and to Vittorio Gregotti for the revision of research.

\section{List of images:}

1. Author: Le Corbusier. Fondation Le Corbusier - Paris, FLC 18440.

2. Author: Le Corbusier. Fondation Le Corbusier - Paris, FLC 18413.

3. Author: Le Corbusier. Fondation Le Corbusier - Paris, FLC 18450.

4. Le Corbusier: Euevre Complete. 1938-1946. Zürich: Girsberger, 1946. p. 139.

5. Le Corbusier: Euevre Complete. 1938-1946. Zürich: Girsberger, 1946. p. 134.

6. Le Corbusier: CEuevre Complete. 1938-1946. Zürich: Girsberger, 1946. p. 163.

7. Ibidem and Le Corbusier: L'urbanistica dei tre insediamenti umani. [1945]. Milano: Etas Kompass, 1961. p. 107.

8. Rogers, Ernesto Nathan; Sert, Josep Lluis; Tyrwhitt, Jaqueline (edited by): CIAM 8. Il cuore della città: per una vita più umana delle comunità. Milano: Hoepli, 1954. p. 151.

9. Rogers, Ernesto Nathan; Sert, Josep Lluis; Tyrwhitt, Jaqueline (edited by): CIAM 8. Il cuore della città: per una vita più umana delle comunità. Milano: Hoepli, 1954. p. 152.

\section{Bibliography}

Choisy, Auguste: Histoire de l'architecture. [1899]. Paris: Baranger, 1929

Clericuzio, Peter: "Le Corbusier and the Reconstruction of Saint-Dié. The debate over Modernism in France, 1944-46" in The Chicago Art Journal, N. 20, 2010. pp. 46-71

Colomina, Beatriz: Privacy and publicity: modern architecture as mass media. Cambridge (Massachusetts) London: The MIT press, 1996

De Carlo, Giancarlo: Le Corbusier. Milano: Rosa e Ballo, 1945

Gerosa, Pier Giorgio: Le Corbusier, Urbanisme et mobilité. Basel - Stuttgart: Birkhäuser, 1978.

Le Corbusier: Le quatrês route. Terres, air, fer, eau. Paris: Gallimard, 1941

Le Corbusier: "Un plan pour Saint-Dié" in Homme et l'architecture, Nn. 5 -6, Novembre-Décembre 1945

Le Corbusier: "Plans for the Reconstruction of France" in Architectural Record, N. 99, March 1946, pp. 92-93

Le Corbusier: "L'espace indicible" in L'Architecture d'Aujourd'hui. No Number, "Art". Paris, April 1946. pp. 9-17

Le Corbusier: "Ein Plan für Saint-Dié" in Werk, N. 33, April 1946, pp. 109-112

Le Corbusier: “A Plan for Saint-Dié” in Architectural Record, N. 100, October 1946, pp. 79-82 
Le Corbusier: Propos d'urbanisme. Paris: Bourrelier et C., 1946

Le Corbusier: Euevre Complete. 1938-1946. Zürich: Girsberger, 1946

Le Corbusier: Euevre Complete. 1936-1952. Zürich: Girsberger, 1952

Le Corbusier: L’urbanistica dei tre insediamenti umani [1945]. Milano: Etas Kompass, 1961

Le Corbusier: “A propos d'architecture d'accompagnement et de respect du passé”, [avril 1946], in Le Corbusier: Le passé à réaction poétique. Paris: Caisse Nationale des Monuments et des Sites, 1988

Le Corbusier: Maniera di pensare l'urbanistica. [1946]. Roma - Bari: Laterza, 1997

Musée de Saint-Dié: Le Corbusier et Saint-Dié, Musée municipal de Saint-Dié-des-Vosges, 14 octobre-10 novembre 1987. Saint-Dié: Musée municipal de Saint-Dié, 1987

O'Byrne Orozco, Maria Cecilia (edited by): Le Corbusier en Bogotá 1947-1951. V. 1-2.. Bogotà: Fondation Le Corbusier; Universida de los Andes; Pontificia Universidad Javeriana, 2010

Petrilli, Amedeo: L'urbanistica di Le Corbusier. Venezia: Marsilio, 2006

Rogers, Ernesto Nathan; Sert, Josep Lluis; Tyrwhitt, Jaqueline (edited by): CIAM 8. Il cuore della città: per una vita più umana delle comunità. Milano: Hoepli, 1954

Rogers, Ernesto Nathan, Le Corbusier tra noi, Milano: All'insegna del pesce d'oro, 1966

Rowe, Colin; Koetter Fred: Collage city. Cambridge (Massachusetts) - London: The MIT Press, ( $8^{\circ}$ ed.) 1995

Sequeira, Marta: Para um espaço público. Le Corbusier e a tradição greco-latina na cidade moderna. Ministério da Ciência, Tecnologia e Ensino Superior. Lisboa: Fundação Calauste Gulbenkian, Fundação para ciência e a tecnologia, 2012

Wogenscky, André; "Le projet pour Saint-Dié. Structure sociale et structure architectural” in Foundation Le Corbusier Paris: Le Corbusier. La Ville, l'urbanisme. Les rencontres de la Foundation Le Corbusier. Rencontres des 9 et 10 jun 1995. Paris: Fondation Le Corbusier, 1995

Wogenschy, André: Le mani di Le Corbusier. Roma: Mancosu Editore, 2004 
campos a los que recurre, como la fotografía, la tipografía, el dibujo o el diseño gráfico, y en general el mundo de la imagen.

La evolución de la publicidad va ligada al desarrollo de los sistemas de reproducción masiva y a los medios de difusión. En un primer momento, y gracias a los avances en el campo de la litografía, el cartel fue el primer recurso publicitario que supera la mera finalidad práctica para experimentar con los medios plásticos. Eslabones de este proceso pueden ser las figuras de Jules Chéret (1836-1932), Alphonse Mucha (1860-1930), Henri de Toulouse-Lautrec (1864-1901) y Aubrey Beardsley (1872-1898). Su desarrollo en las primeras décadas del siglo XX viene marcado por el carácter experimental de las vanguardias, especialmente los proyectos propagandísticos promovidos tras la Revolución Rusa, con artistas tan destacados como El Lissitzky (18901941) o Aleksandr Ródchenko (1891-1956); así como, el aspecto más decorativo promovido por el Art Déco, ejemplificado en la figura de Cassandre (1901-1968).

La importancia que adquirió la disciplina se muestra claramente en los programas docentes de la Bauhaus ${ }^{1}$, donde la publicidad era uno de los cinco campos en que se dividía el "segundo nivel" o "enseñanza principal". En 1919 aparecía vinculada al Taller de imprenta, todavía enfocado como un trabajo artesanal, dirigido por Lyonel Feininger (1871-1956), al que sustituyó Herbert Bayer (1900-1985) en 1925, dando una mayor importancia a la tipografía y la propaganda. A partir de 1928, se hizo cargo del mismo Joost Schmidt (18931948), ya bajo el nombre de Sección de tipografía y publicidad.

Como muestra del momento de exaltación de este nuevo medio de comunicación de masas, se pueden citar las palabras del escritor Blaise Cendrars (1887-1961), "La publicidad es la flor de la vida contemporánea; es una afirmación de optimismo y alegría [...].Sin duda, la publicidad es la más bella expresión de nuestra época, la mayor novedad actual, todo un arte. Un arte que recurre al internacionalismo, o poliglotismo, a la psicología de masas, y que revoluciona todas las técnicas estáticas o dinámicas conocidas al utilizar, de forma intensiva, continua y eficaz, materias nuevas y procedimientos inéditos",2.

\section{La arquitectura expositiva como arquitectura publicitaria}

El empleo arquitectónico de los recursos publicitarios tiene su ejemplo más claro en la arquitectura de ferias y muestras internacionales, así como en el desarrollo de la arquitectura corporativa y marcas comerciales. En palabras de Moisés Puente: “Como los puestos de los charlatanes, lo importante es hacerse notar, atraer al espectador hacia aquello que se anuncia. El 'pasen-y-vean' ya no se vocea, es la propia arquitectura la que se encarga de hacerlo. El pabellón de exposiciones se carga de toda la iconografía derivada de la arquitectura publicitaria: colores, luces, neones, grandes rótulos, banderolas, logotipos, marquesinas-anuncio en un ambiente festivo por competir por la atención de los visitantes ${ }^{3,}$.

Analizando la evolución de la arquitectura expositiva desde el punto de vista del uso de los recursos arquitectónicos como medio de propaganda y publicidad, se pueden establecer cuatro etapas bien diferenciadas. En una primera fase, el prototipo elegido fue el recinto expositivo o pabellón vitrina, ejemplificado en el Crystal Palace de Joseph Paxton, levantado con motivo de la Great Exhibition of the Works of Industry of all nations,

\footnotetext{
${ }^{1}$ Wick, Rainer: La pedagogía de la Bauhaus. Madrid: Alianza Editorial, 2007.

2 Cendrars, Blaise: "Publicité = Poésie". En Aujourd'hui. Paris, 26 de febrero 1927.

${ }^{3}$ Puente, Moisés: Pabellones de exposición. 100 años. Barcelona: Editorial Gustavo Gili, 2000. p. 10.
} 
celebrada en Londres (1851). Un gran contenedor acogía en su interior un vasto espacio donde se disponían los distintos artilugios, y donde pequeños stands, a la manera de vitrinas expositivas, se destinaban a inventos de grandes empresas o a productos nacionales. Como si de un gabinete de curiosidades se tratara, los elementos expuestos se yuxtaponen sin solución de continuidad.

Se puede reconocer una segunda fase cuando se empiezan a diversificar los espacios expositivos, generando distintos pabellones $\mathrm{y}$, especialmente, desde el momento en el que se comienzan a levantar espacios representativos de las diferentes nacionalidades. La imagen exterior que cada Estado quiere transmitir en las muestras internacionales se asociará, en muchos casos, con la tradición, los tópicos e, incluso, el exotismo, recurriendo al empleo del historicismo y el eclecticismo, donde los estilos arquitectónicos del pasado se reinterpretan como manifestaciones de esa pretendida identidad sociocultural. Los históricos estilos nacionales, sobre todo los más extravagantes, se convirtieron en reclamo para el público, ávido de novedades.

Un tercer estadio puede ser identificado con la irrupción de la modernidad. La consolidación del Estilo Internacional llevará aparejada, en gran medida, la uniformidad en la imagen exterior de los edificios. Volúmenes prismáticos, formas rotundas, grandes superficies acristaladas, supresión de elementos decorativos y su característico color blanco exterior, definirán esta nueva imagen que rechaza cualquier identidad geográfica o social, como muy bien se puso de manifiesto en la Exposición Internacional de Arquitectura Moderna, celebrada en el MOMA de Nueva York en 1932.

Ante esta nueva arquitectura, despojada de historicismos, se hizo necesario el apoyo de diferentes recursos arquitectónicos, diseño gráfico, publicidad, tipografía, eslóganes, montajes fotográficos, banderolas, piezas artísticas, etc., para llamar la atención del visitante y desplegar todo un discurso propagandístico. Con esto no quiere decirse que anteriormente no habían sido utilizadas banderas, carteles, tipografía u otros recursos publicitarios, si no que es, a partir de este momento, cuando su uso se hace indispensable y especialmente destacable, cuando la arquitectura engloba en su diseño estos elementos, sin quedar constituidos como meros añadidos. En este sentido son significativas las palabras de Moholy-Nagy: "El concepto de 'fachada' ha sido eliminado de la arquitectura. Ya no hay lugar del edificio que no sea aprovechado con un propósito funcional. El aprovechamiento del frente (balcones, carteles publicitarios, eléctricos) se continúa con el de la terraza (jardines, pistas de aterrizaje de aviones) $)^{4, "}$.

Algunos de los ejemplos más destacados de la apropiación arquitectónica de las técnicas publicitarias se produjeron tras la Revolución Rusa, en un enorme despliegue propagandístico e ideológico apoyado por el constructivismo. Resulta paradigmático el Pabellón de la URSS para la Exposition des Arts Décoratifs de 1925, en París, donde Konstantín Mélnikov (1890-1974) despliega una gran pirotecnia publicitaria para el primer pabellón ruso, en una muestra internacional, tras la Revolución de Octubre de $1917^{5}$. Mélnikov saca el máximo partido posible al estrecho solar del que disponía, generando en diagonal una escalera exterior, muy llamativa gracias al juego de paneles de madera que la cubrían, dispuestos alternativamente para generar la sensación de que se desplegaban y se alzaban al paso del visitante. El acceso se remarcaba con un gran emblema de la hoz y el martillo, mientras un poco más abajo, la tipografía repetía esas mismas formas con el nombre de la Unión

\footnotetext{
${ }^{4}$ Moholy-Nagy, László: La nueva visión. Principios básicos del Bauhaus. Buenos Aires: Ediciones Infinito, 2008. p. 97.

${ }^{5}$ Garrido, Ginés: Mélnikov en París, 1925. Barcelona: Fundación Caja de Arquitectos, 2011.
} 
Soviética. El pabellón señalaba su posición dentro de la exposición mediante una torre-hito de estructura metálica y planta triangular, base para el apoyo nuevamente de tipografía.

Durante la década de 1920 se promoverán los proyectos de plataformas para oradores, como por ejemplo la diseñada por Ilya Cháshnik (1902-1929) en 1920, o la Tribuna de Lenin, proyectada por El Lissitzky en 1924; así como las torres de propaganda, como el proyecto de quiosco rotativo para el IV Congreso del Komintern (1922) o el Radio-orador (1922), ambos diseñados por Gustav Klutsis (1895-1942). En estos últimos casos, se trata de estructuras tridimensionales de paneles propagandísticos, donde la tipografía juega un papel destacado.

La reivindicación de la tipografía y los signos gráficos como elementos compositivos autónomos e independientes, se había producido gracias al cubismo, cuando pintores como George Braque (1892-1963) o Pablo Ruiz Picasso (1881-1973) introducen en sus cuadros componentes extrapictóricos, como letras, números o notas musicales, elementos que hasta el momento no formaban parte del lenguaje plástico.

El empleo de la tipografía, no sólo como mero complemento en carteles, rótulos y letreros, sino como parte fundamental de la composición arquitectónica se aprecia claramente en la arquitectura neoplástica. Un ejemplo significativo es el Café De Unie en Róterdam (1924-1925), diseñado por J. J. P. Oud (1890-1963). El uso del color y la tipografía ayudan en la composición de la fachada, y son elementos decisivos en ella tanto como huecos y vanos. Otros proyectos donde la tipografía juega un papel destacado son el Cineac (1933) de Jan Duiker (1890-1935), en Ámsterdam, o la remodelación del cine Vreeburg (1936), de Gerrit Rietveld (18881964), en Utrecht, donde sobresale el monumental rótulo luminoso, principal elemento estructurador de la fachada. Con claras influencias neoplásticas, se puede mencionar, igualmente, el diseño titulado Bildarchitektur II (proyecto de un quiosco), que el húngaro Lajos Kassák (1887-1967) realiza en $1922^{6}$. Se trata de una pieza prismática donde tres muros independientes, y casi autónomos, se individualizan con el tratamiento del color y la tipografía. Esos muros ciegos adquieren el protagonismo del proyecto, convirtiéndose en superficies que pueden acoger todo tipo de propaganda.
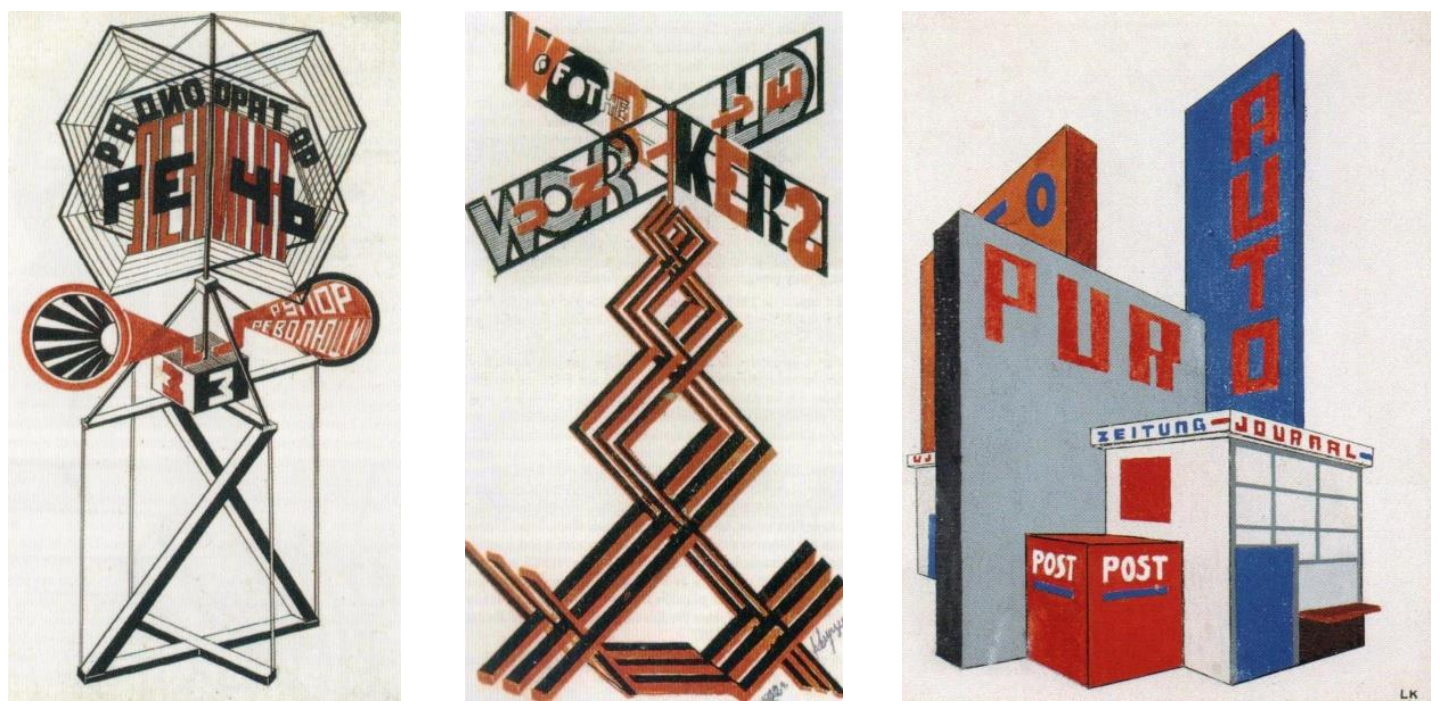

1. Gustav Klutsis: Radio-orador, núm. 3, 1922. 2. Gustav Klutsis: Proyecto del quiosco rotativo de propaganda para el IV Congreso del Komintern, 1922. 3. Lajos Kassák: Bildarchitektur II (proyecto de un quiosco), 1922.

\footnotetext{
${ }^{6}$ VV.AA: Lajos Kassák y la vanguardia húngara. Valencia: IVAM, 1999.
} 
Esta visión panorámica puede ser completada con la Exposición Internacional de Estocolmo, en 1930, donde Erik Gunnar Asplund (1885-1940) mostraba al mundo el triunfo del funcionalismo ${ }^{7}$. La profusión de elementos acristalados aconsejó la instalación de grandes líneas de toldos, que alargaban los voladizos. Sobre estos, grandes letras indicaban la especialización de cada uno de los espacios construidos, guiando a los visitantes en sus recorridos, acompañados, siempre, por banderolas. La magnífica torre-mástil diseñada por Sigurd Lewerentz (1885-1975), ubicada en el pabellón de entrada, puede ser considerada el paradigma de la simbiosis entre arquitectura y publicidad. Un gran número de marcas de patrocinadores se suceden con letras y números de diferente tipografía, acompañadas de un enorme reloj y un par de ojos (que identifican a uno de los anunciantes). La estructura metálica tridimensional que lo sustenta se complementa con una red de cables que arriostran la estructura frente al viento. Su inspiración claramente en el constructivismo ruso, tiene de precedentes ejemplos como el Pabellón de Empresas Cooperativas Dražice (1926-27), de Jiři Kroha (1893-1974); el Pabellón de la U.R.S.S. en la Feria de Comercio de Praga de 1928, de Jaromír Krejcar (1895-1950)후 o el proyecto de un Pabellón de exposiciones para el recinto ferial de Budapest (1930), de Alexander Bodon (1906-1993) ${ }^{9}$, que presenta en el frente de acceso una estructura de cinco soportes en celosía, sobre los que se alza un gran cartel publicitario, a la vez que sujetan la marquesina de entrada.

Por último, y tras la crisis del movimiento moderno, la culminación de todo este proceso se lleva a cabo en el pabellón expositivo como pieza icónica en sí mismo, capaz de atraer la atención por su propia imagen, muchas veces desnuda de cualquier otro reclamo o elemento publicitario.

\section{El reclamo publicitario en la obra expositiva de Le Corbusier}

El interés que la publicidad y los medios de comunicación de masas despertaban en Le Corbusier, ha sido puesto de manifiesto en repetidas ocasiones ${ }^{10}$. Las técnicas expositivas y publicitarias de la arquitectura comercial ya llamaban su atención desde sus primeros viajes iniciáticos, recogiendo en sus cuadernos bocetos de escaparates y vitrinas, como por ejemplo las tiendas de la Grabenstraße vienesa, especialmente los almacenes Wiener Werkstätte, obra de Josef Hoffmann (1870-1956), o la galería Knizé, de la que realiza croquis de su fachada ${ }^{11}$.

En sus textos y publicaciones, emplea las imágenes publicitarias, a la manera de ready mades, de una forma similar a las manipulaciones dadaístas ${ }^{12}$. En las páginas, por ejemplo, de la revista L'Esprit Nouveau, parodia los recursos explotados por la publicidad comercial, apropiándose de técnicas abstractas y recurriendo a la tipografía $^{13}$, dando como resultado imágenes rotundas de una lógica aplastante.

\footnotetext{
${ }^{7}$ López Peláez, José Manuel: Asplund. Exposición Universal de Estocolmo. Madrid: Rueda, 2004.

${ }^{8}$ VV.AA.: El arte de la vanguardia en Checoslovaquia, 1918-1938. Valencia: IVAM Centro Julio González, 1993.

${ }^{9}$ García, Rafael: Arquitectura moderna en los Países Bajos, 1920-1945. Madrid, Akal, 2010.

10 Por ejemplo, entre otros, Colomina, Beatriz: Privacidad y publicidad. La arquitectura moderna como medio de comunicación de masas. Murcia: CENDEAC - Colegio Oficial de Arquitectos de Murcia - Observatorio del Diseño y la Arquitectura de la Región de Murcia, 2010.

11 Daza, Ricardo: Tras el viaje a Oriente. Charles-Édouard Jeanneret-Le Corbusier. Barcelona: Fundación Caja de Arquitectos, 2015.

${ }^{12}$ Colomina, Beatriz: Doble exposición. Arquitectura a través del arte. Madrid: Ediciones Akal, 2006.

${ }^{13}$ Von Moos, Stanislaus: "Exhibition architect? Otra mirada sobre la 'síntesis' de Le Corbusier". En Calatrava, Juan (Ed.):

Doblando el ángulo recto. Siete ensayos en torno a Le Corbusier. Madrid: Círculo de Bellas Artes, 2009. pp. 43-66.
} 
Dentro de la arquitectura expositiva de Le Corbusier, se pueden identificar algunos hitos importantes en relación al empleo de los recursos publicitarios como elementos de la composición arquitectónica, que se analizan, brevemente, a continuación.

\subsection{El pabellón de L'Esprit Nouveau (1925)}

En su primer enfrentamiento con la arquitectura de exposiciones y pabellones para ferias, el Pabellón de L'Esprit Nouveau para la Exposition des Arts Décoratifs de 1925, en París, Le Corbusier recurre al mejor contenedor que, entiende, puede mostrar las nuevas artes industriales y decorativas, el espacio donde se utilizarán los objetos creados por la técnica moderna: la vivienda. Vinculado a sus propuestas teóricas sobre urbanismo, el pabellón se convierte en una reivindicación del nuevo camino que debe tomar la arquitectura residencial. Lo expuesto es la propia vivienda moderna y su equipamiento. El pabellón, por tanto, no corresponde propiamente a un ejemplo de arquitectura expositiva.

En su interior, es interesante destacar el empleo de recursos museográficos que ayudan a la comprensión del espacio que se está visitando. Un ejemplo sería cómo se indican los recorridos de la visita. Evitando el empleo de cartelería, sobre las propias paredes del pabellón se trazan esquemas en planta del edificio que muestran la composición de espacios, o la diferencia entre interior y exterior. Con la utilización del grafismo, pequeños rótulos y flechas, o la sutil colocación de la alfombra en el suelo, se van remarcando los itinerarios expositivos.

Lo que se muestra en el pabellón es, fundamentalmente, la organización de la vida moderna, rodeados de un mobiliario funcional y acompañados por piezas escogidas de arte contemporáneo. Su ubicación en el espacio recrea la vida real, y evita cualquier recurso expositivo vinculado a los tradicionales museos o salas de exposiciones. No hay vitrinas, pedestales o piezas remarcadas. El mobiliario (como por ejemplo las sillas Thonet) se dispone tal y como debería colocarse para su correcto funcionamiento. Es por esto por lo que, en ocasiones, encontramos fotografías en las que determinadas piezas de mobiliario invaden esa alfombra-itinerario. La alfombra delimita, marca el recorrido y acompaña durante la visita.

Al tratarse de una célula aislada, y no un pabellón propiamente dicho, en el exterior tenía que resolver el aspecto de los cerramientos que formarían las medianerías con las unidades adyacentes. El estudio del color, la delineación de los elementos estructurales conformando paños a la manera de paneles, el grafismo empleado o la ubicación de los accesos introducen las variables necesarias para que el pabellón sea atrayente al público que visita la exposición. El aspecto de vivienda queda reservado al frente donde se ubica el patio cubierto, con la línea de antepecho y la gran cristalera cerrando la sala a doble altura.

El elemento más llamativo se lleva a cabo junto al acceso en planta baja, en un muro lateral, prácticamente ciego, donde se reproducen en perspectiva caballera las iniciales de L'Esprit Nouveau (E N), a partir de cuatro compartimentos de la retícula estructural remarcada en las fachadas. A pesar de la sencilla tipografía, las letras destacan por su gran escala, en un recurso publicitario para promocionar la revista a la que representaba, como si se tratara de una gran portada de la publicación ${ }^{14}$. De manera similar, pero de una forma mucho más espectacular, Alvar Aalto (1898-1976) emplea el mismo recurso, reproduciendo los titulares del periódico en la fachada principal del Turun Sanomat Building (1927-1929), en Turku (Finlandia), para captar la atención de los

\footnotetext{
${ }^{14}$ De hecho, una fotografía coloreada de las iniciales fue utilizada como portada para el número 274 de la revista Casabellacontinuità (abril 1963).
} 
viandantes. La idea ya había sido propuesta anteriormente en el proyecto no ejecutado de los hermanos Vesnin para la sede del periódico Pravda (1924), en Moscú.

Por último, cabe señalar el empleo de las obras artísticas para el reclamo del visitante. En el frente del Pabellón de L'Esprit Nouveau, dando la bienvenida a todos los que se acercaban, se dispuso la escultura Bagneuse (19231925), obra de Jacques Lipchitz (1891-1973). La apuesta por nuevos modelos progresistas para la vida moderna tenía su reflejo, no solamente en la arquitectura y el espacio construido, sino también en la decisión de apoyar un arte nuevo, vanguardista, radicalmente diferente de la tradición. En el interior, junto a las piezas de mobiliario, obras de Fernand Léger (1881-1955), Juan Gris (1887-1927), Amédée Ozenfant (1886-1966), Lipchitz o el propio Le Corbusier, decoraban los espacios.
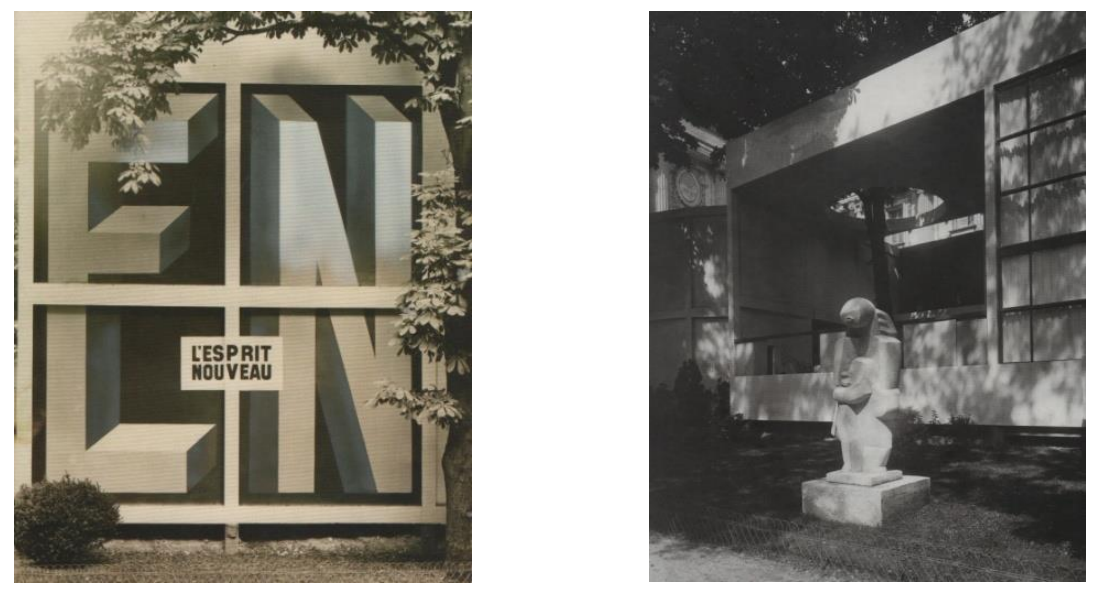

4. Le Corbusier: Pabellón de L’Esprit Nouveau, París, 1925. CFLC-ADAGP. 5. Le Corbusier: Vista del Pabellón de L’Esprit Nouveau, París, 1925. CFLC-ADAGP.

El uso del arte como reclamo tiene su ejemplo más interesante en el Pabellón de la República Española para la Exposición Internacional de París de 1937, obra de Luis Lacasa (1899-1966) y Josep Lluís Sert (1902-1983). Uno de los principales reclamos fueron las obras de arte expuestas no sólo en el interior del pabellón, sino también en su exterior. La apuesta decidida por la modernidad, hizo que se solicitara la colaboración de un grupo magnífico de artistas contemporáneos, muchos vinculados con la escuela de París, y ampliamente reconocidos. La pieza que distinguía el edificio desde lejos, y que se constituía en el hito que daba la bienvenida, era la escultura de Alberto Sánchez (1895-1962) El pueblo español tiene un camino que conduce a una estrella. Junto a ella, obras como Montserrat de Julio González (1876-1942) o Cabeza de mujer de Picasso, recibían al visitante frente a los escalones de acceso. El espacio donde discurría el jardín que separaba el pabellón español del dedicado a Polonia lo ocupaba la Dama oferente, también del pintor malagueño.

Una vez traspasado el umbral, el espacio central bajo el volumen edificado era ocupado por una fuente de mercurio diseñada por Alexander Calder (1898-1976). A la derecha de la entrada, el espacio se cerraba con el Guernica de Picasso, imagen conmovedora que no dejaba indiferente a ninguno de los visitantes, y que se convertiría en el máximo reclamo del pabellón. El ámbito de la rampa era compartido por dos esculturas de Francisco Pérez Mateo (1903-1936): Bañista y Oso. Ya en el interior, la escalera que conducía desde la segunda hasta la primera planta, presentaba el Payés de Joan Miró (1893-1983). El grito desgarrado de Montserrat, las atrocidades reflejadas en el Guernica, la pérdida de la libertad que representaba el Payés, se convertían en mensajes directos y efectivos. Todo un despliegue artístico, de primer orden, que buscaba la legitimación del gobierno republicano y que se ha convertido en un hito de la historia del arte. 
Las obras de arte como piezas de reclamo y captación del interés también son empleadas por Le Corbusier en otra serie de proyectos, aunque con una relevancia mucho menor sobre la composición y estructuración del espacio. Pueden servir de ejemplo, los proyectos del Palais de la Société des Nations (1927), en Ginebra, y el del Centrosoyuz, construido en Moscú entre 1928 y 1936, con la colocación de esculturas de forma clásica sobre grandes columnas, remarcando accesos y puntos significativos; los primeros bocetos para el Ministerio de Educación (1936) de Río de Janeiro, con la presencia significativa de grandes esculturas antropomórficas; y dentro de la arquitectura expositiva, el proyecto de Musées de la Ville et de l'Etat (1935), en París, cuyas fachadas de tratamiento plano contrastan con los grupos escultóricos, que introducen diversos juegos de sombras arrojadas.

En el caso del pabellón para la Exposición Ideal Home (1939), en Arundell Clarke, Londres, los elementos escultóricos aumentan de escala hasta superar el tamaño de la propia pieza expositiva. Una retícula tridimensional, que recuerda estructuras constructivistas, acoge en su interior la representación volumétrica de un gran ojo y una nube, atravesados por los rayos del sol que corona el conjunto. El pabellón, elevado del suelo, parece suspendido del árbol que se dispone detrás. Para acceder hasta él, el visitante tendrá que ascender por una larga rampa. Los ideales del urbanismo moderno se materializan en un juego escultórico de marcado carácter propagandístico, cuyo eslogan (The Radiant City. Sun, space, green) se grafía en el cerramiento de la caja expositiva, reducida al mínimo.

Para su segundo ejemplo de pabellón en una exposición internacional, esta vez para el Pavillon des Temps Nouveaux en París (1937), los mayores recursos expositivos empleados por Le Corbusier se concentraron en el interior. El pabellón en sí no causó el mismo impacto que su precedente de L'Esprit Nouveau, donde contenido y contenedor se confundían en un mismo mensaje. En la nueva propuesta, la arquitectura se había subordinado al contenido. El pabellón era un mero contenedor, de carácter efímero, que protegía la exposición. Todos los esfuerzos de diseño se centraron en los recursos museográficos, el montaje y el contenido. El diseño de un recorrido laberíntico, en forma de bucle, guiaba a los visitantes entre los materiales expuestos. La circulación era continua, creando un espacio fluido a través de rampas, que unían cinco niveles expositivos bajo el contenedor uniforme. Destacaba, principalmente, el empleo de numerosos recursos museográficos. Con la ayuda de paneles, pinturas murales, esquemas, maquetas, dioramas, fotografías y fotomontajes, en el interior se exponían todos los temas que Le Corbusier y los CIAM habían estado desarrollando.
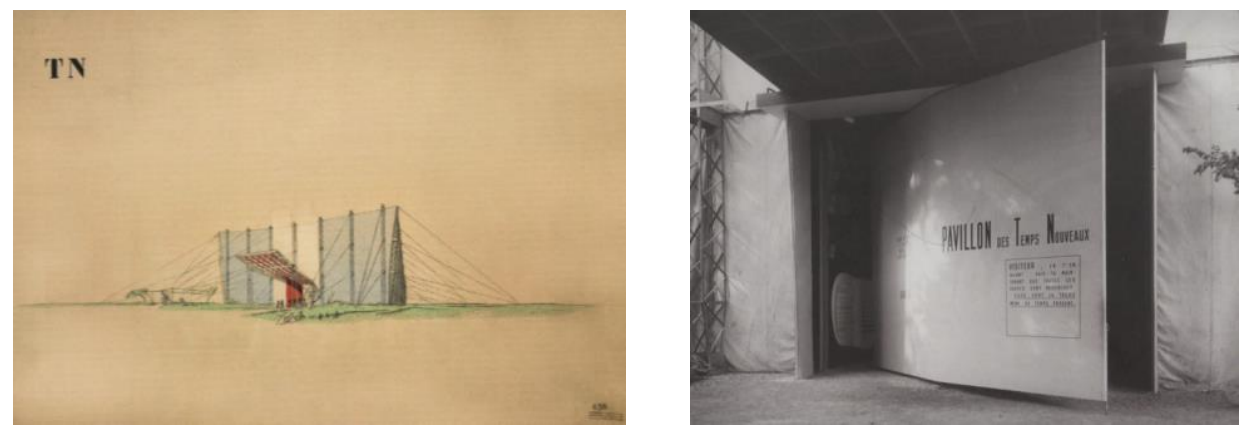

6. Le Corbusier, Pavillon des Temps Nouveaux, perspectiva, 1937. FLC 658 OFLC-ADAGP. 7. Le Corbusier, Pavillon des Temps Nouveaux, puerta pivotante, 1937. OFLC-ADAGP. 
La imagen exterior del pabellón presentaba las características de una tienda. Para su construcción se utilizó un sistema de estructura metálica, tirantes, cables y tensores, recubriendo todo el esqueleto con lonas. En uno de los diseños, se muestra un estudio de color, diferenciando tonos blancos y azulados para la envolvente, mientras que la puerta de entrada, remarcada por una gran marquesina, aparecía pintada en rojo. El tono vivo de este color hacía de reclamo para el visitante, que identificaba fácilmente el lugar de acceso. La puerta pivotante de eje central diferenciaba la entrada y la salida. Esta puerta, con su gran dimensión se convierte a la vez en un recurso expositivo, puesto que se transforma en una superficie más donde exponer o donde grafiar.

\subsection{Pabellón Nestlé (1928)}

Uno de los mejores ejemplos donde puede apreciarse el despliegue publicitario dentro de la arquitectura expositiva de Le Corbusier es el Pabellón Nestlé, un stand promocional de esa gran sociedad comercial. El encargo solicitaba la realización de un pequeño pabellón de exposiciones, que fuera desmontable y fácil de transportar, puesto que la intención era que fuese reutilizado en las ferias de París (1928), Burdeos (1929) y Marsella (1930), aunque, finalmente, sólo se montó en la primera de ellas.

El pabellón se resolvió mediante una estructura metálica recubierta de paneles de vidrio y de madera sobre los que se aplicaba un original diseño gráfico, respetando la imagen de la marca comercial, pero fuertemente influido por la estética desarrollada en la revista L'Esprit Nouveau.

La cubierta inclinada se resolvió a dos aguas, con su recogida hacia el interior y evacuando a través de dos tubos metálicos colocados en ambos extremos, simulando formar parte de la estructura del pabellón. Formalmente, supone el antecedente de las cubiertas tipo paraguas que Le Corbusier desarrollará en versiones de pabellones posteriores como los de la Exposición de Lieja (1939), el Pavillon Synthèse des Arts Majeurs (en Porte Maillot, 1950), o el Palacio de exposiciones de Estocolmo (1962), y que conducirán a la solución definitiva de la Maison de l’Homme o Pabellón de Zúrich (1963-1967).

Exteriormente, Le Corbusier recurrió al empleo de dos banderas, una en cada extremo, como dispositivos para captar la mirada. Los mástiles son elementos verticales que contrastan con el volumen edificado como una pieza longitudinal. Se convierten en ejes que fijan el edificio al lugar, lo señalan y lo identifican en la distancia. La bandera, agitada por el viento, es una forma dinámica, cambiante, que introduce destellos de color en su continuo movimiento. Podemos encontrar otros ejemplos de la utilización de mástiles y banderas en la arquitectura del maestro, como en el Pabellón de la Aviación S.T.A.R. (1930), en Le Bourget, donde la estructura del mástil con la ayuda de unos cables, sujeta la marquesina que remarca el acceso al interior. En otros casos, su uso no se haya necesariamente vinculado a los espacios expositivos, como por ejemplo en el testero de los Immeubles-Villas (1922), o como en el caso del Centrosoyuz, acorde con la imagen del edificio debido a su carácter representativo.

La imagen exterior del Pabellón Nestlé se hizo más llamativa con la inclusión de enormes reproducciones de botes de cacao, logotipos y marcas comerciales, realizados en llamativos colores, que contrastaban con el azul pálido aplicado a los cerramientos exteriores. Esta idea publicitaria sería ampliamente utilizada a partir de los años 50 en todo tipo de ferias, como por ejemplo en el Castello pubblicitario Pirelli, realizado por Luigi Gargantini en $1951^{15}$, donde el pabellón ha desaparecido, para dejar lugar, únicamente, al carácter publicitario de pancartas, paneles, logotipos, cajas y piezas llamativas, llevado hasta un punto extremo, casi de paroxismo.

\footnotetext{
${ }^{15}$ Publicado, por ejemplo en el número 260 de la revista Domus (julio-agosto 1951).
} 

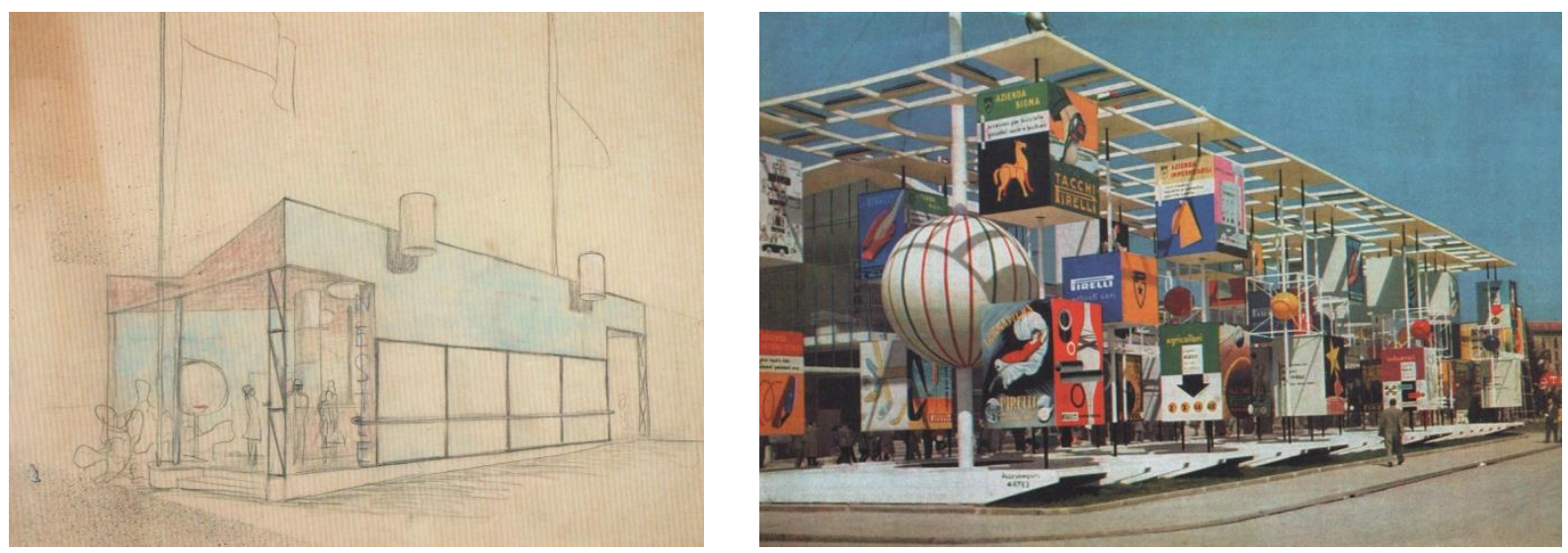

8. Le Corbusier, Pabellón Nestlé, perspectiva, 1928. FLC 18092 OFLC-ADAGP. 9. Luigi Gargantini, Castello pubblicitario Pirelli, 1951.

En el Pabellón Nestlé se diferencian, claramente, dos funciones. La parte frontal del edificio, correspondiente a la fachada principal, se formula como punto de venta de los productos de la marca comercial. La parte inferior del cerramiento se construye en vidrio para mostrar la gama de productos, como si se tratara de expositores. En el lado opuesto un mostrador, a todo lo largo del pabellón, permite su compra.

Un pasamanos continuo recorre el cerramiento, tanto por el interior como por el exterior, dando la sensación de que los productos están expuestos para contemplarlos por ambos lados. Cuando se recorren los escaparates desde fuera, la barandilla te invita a continuar curioseando en el interior. Acompañando el recorrido lineal, de una sola dirección, se encuentra la bancada que conforma el espacio de atención a los compradores. El mostrador repite el mismo tipo de pasamanos, delimitando perfectamente el flujo de visitantes.
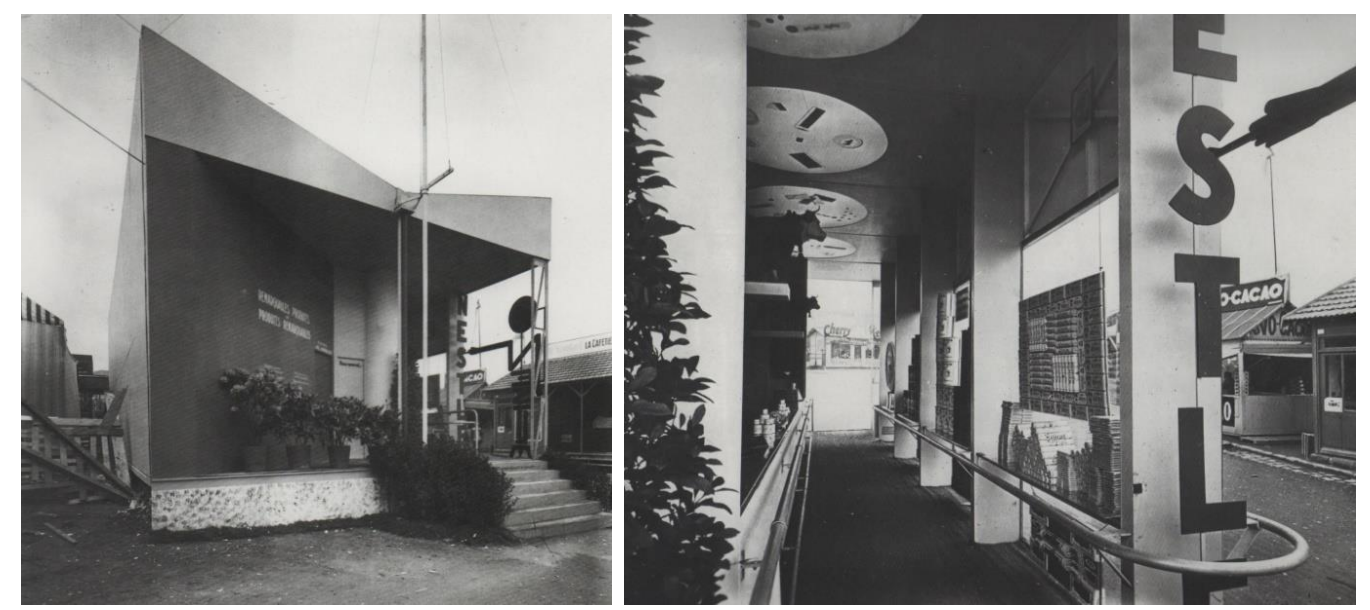

10. Le Corbusier, Pabellón Nestlé, lateral, 1928. OFLC-ADAGP. 11. Le Corbusier, interior del Pabellón Nestlé, detalle del pasamanos, 1928. OFLC-ADAGP.

En la tienda Mortimer Gall Electrical Centre (1936), ubicada en la Cannon Street de Londres, Walter Gropius (1883-1969) y Maxwell Fry (1899-1987), utilizaron un motivo parecido al curvar la esquina de su escaparate, facilitando con ello el movimiento hacia la puerta del establecimiento, situada lateralmente. En un nivel superior, el nombre de la tienda se lee siguiendo ese mismo movimiento que acaba sobre la entrada del local. 
La parte posterior del pabellón Nestlé se dedica a una función puramente expositiva, donde se daba a conocer la marca comercial, su historia y los productos que ofrecía. El espacio monótono que produciría una sala rectangular es fuertemente modificado con la inclusión del cuerpo triangular que conforma la trasera del mostrador de ventas. El lado opuesto, rectilíneo, es ocupado por los expositores. El espacio intermedio es el que acoge a los visitantes. Nuevamente, un esquema lineal en una sola dirección ordena el recorrido.

En ambos extremos del volumen del pabellón se diferencian tres accesos-salidas. El primero corresponde a los compradores del punto de venta, el intermedio al acceso de personal (que conduce al espacio tras el mostrador), y el último es el utilizado por el visitante de la exposición. El desnivel de la calle imposibilitó el acceso a cota cero por ambos extremos, obligando a la colocación de unos escalones para salvar la diferencia entre entrada y salida.

El carácter simétrico de la composición sólo se rompe con la colocación, en vertical, del nombre de la marca comercial. Su posición en el extremo izquierdo del pabellón indica al visitante el punto por donde puede acceder al interior (materializado incluso con un círculo sobre los signos gráficos). Las letras, independizadas de carteles o paneles de apoyo, se muestran como piezas exentas, pintadas en un contrastante tono anaranjado. Sobre ellas, destaca la letra $\mathrm{N}$, de mayor tamaño, cuyo brazo derecho se quiebra para señalar amablemente, como si de un brazo y una mano se tratara, el lugar de acceso al local y el recorrido recomendado.

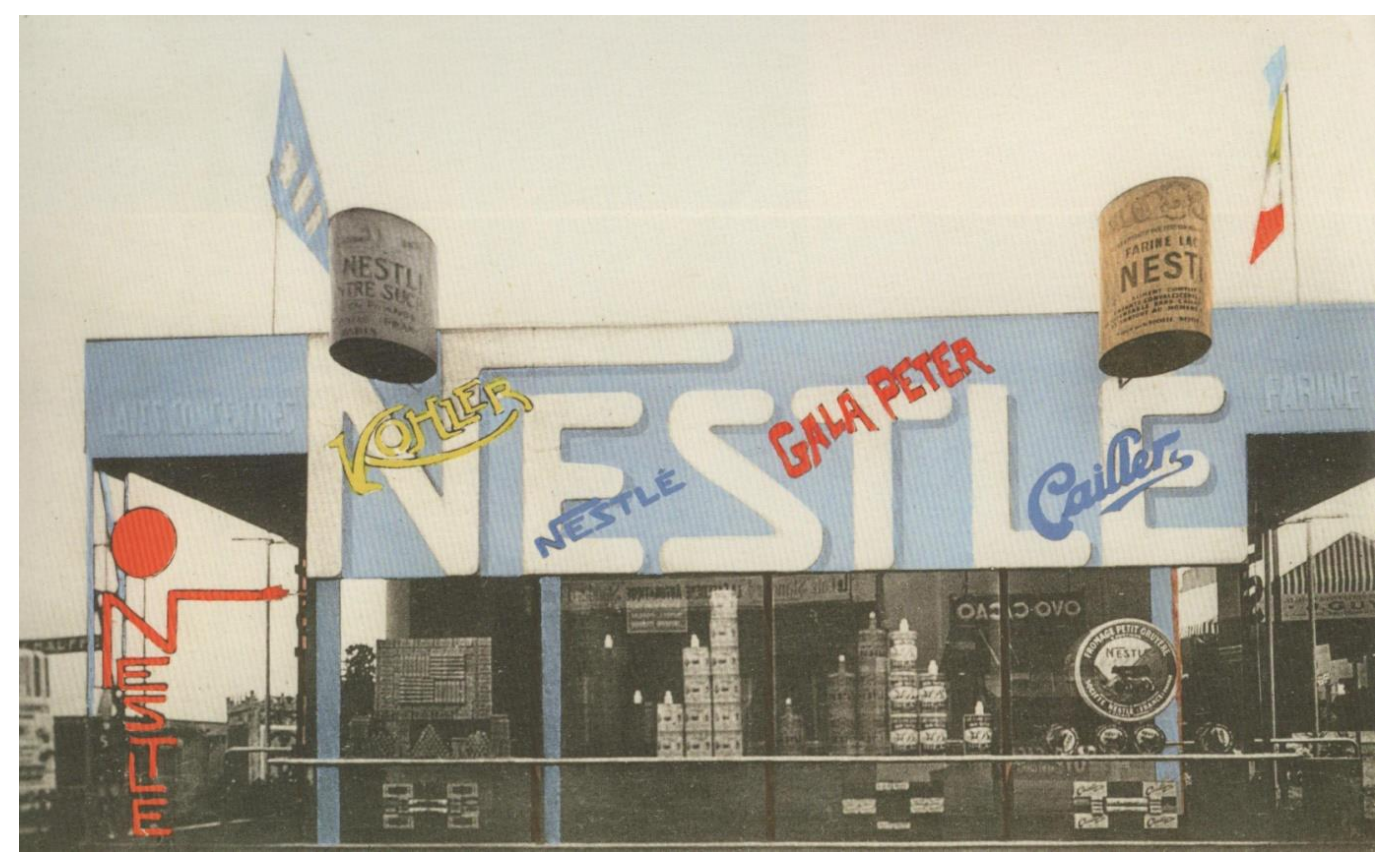

12. Le Corbusier, Pabellón Nestlé, 1928. CFLC-ADAGP.

\subsection{Pabellón Bat'a (1937)}

La empresa, de origen checo, Bat'a se había ganado un gran prestigio internacional por su dinámica, su carácter innovador y sus productos, realizando desde zapatos a aviones. Jean Bat'a, el director de la empresa tenía contactos con Le Corbusier desde 1932, y el arquitecto había preparado un estudio sobre tiendas de la marca en 1936, principalmente zapaterías. 
Los diseños para las Boutiques Bat'a, adaptados a diferentes dimensiones de locales, muestran una composición elegante y sobria en fachadas, generalmente simétricas, donde los elementos publicitarios han sido reducidos al mínimo. Centrado, y sobre la zona de escaparates, se disponía un rótulo identificando la marca comercial. La fachada, resuelta en profundidad, permitía concretar un espacio intermedio entre el tránsito de la calle y el interior cerrado de la boutique. En ese lugar, los clientes podían contemplar con tranquilidad los productos colocados en expositores dispuestos en el perímetro o, en otros casos, exentos en el centro del espacio.

Para la Exposición Internacional de París de 1937, la empresa sólo pudo obtener un solar de $130 \mathrm{~m}^{2}$, donde poder construir un pequeño pabellón, que finalmente no llegó a realizarse. La pieza propuesta por Le Corbusier

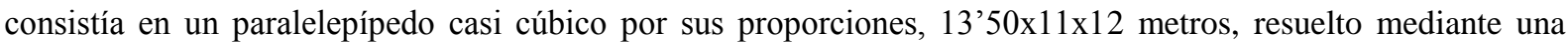
estructura de pilares de acero, compuestos por perfiles en doble $\mathrm{T}$.

Considerando que el lugar no permitía crear grandes alardes arquitectónicos en su exterior, Le Corbusier centró todo su interés en el interior del pabellón. Nuevamente, sólo se recurre al empleo de la tipografía para generar el nombre de la marca, en una composición de fachada, esta vez claramente asimétrica. El espacio interior, por el contrario, se hallaría recubierto de paneles luminosos y tiras fotográficas. Los paneles de vidrio mate se encontrarían decorados, como sucedía, por ejemplo, en el techo donde se representaba el planisferio. Con un ingenioso sistema, sobre parte de estos paneles se proyectarían anuncios publicitarios de la marca.

De los plafones del techo se suspendería un avión modelo ZLIN XII, fabricado por la propia empresa. Este recurso también lo planteó, en la misma exposición para el Pavillon des Temps Nouveaux. En ese caso, la maqueta de un avión introducía la comparación entre el urbanismo moderno (con ejemplos expuestos a lo largo de todo el montaje) y una ciencia de precisión como es la aeronáutica. Le Corbusier nos estaba diciendo que la vivienda debía ser una machine à habiter. En el caso del Pabellón Bat'a, el avión suspendido del techo quería demostrar la diversidad de productos que la firma, originariamente dedicada a la venta de calzado, había llegado a comercializar, en una muestra clara de su apuesta por la modernidad.

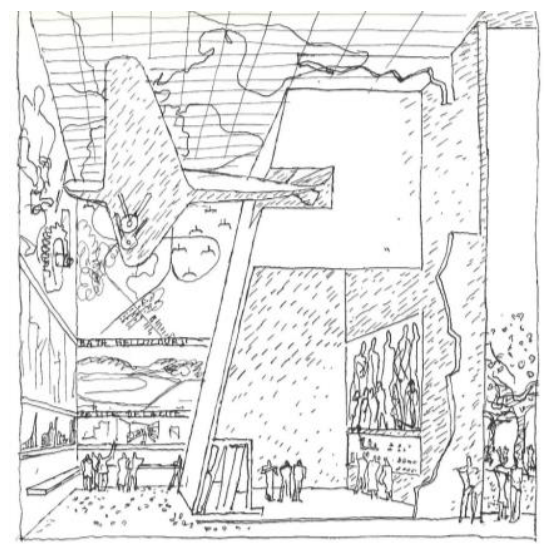

13. Le Corbusier, Pabellón Bat'a, perspectiva del interior, 1937. FLC 17814 CFLC-ADAGP.

El pabellón no llegó a construirse debido a las malas relaciones que surgieron entre Jean Bat'a y Le Corbusier, a causa, principalmente, de un malentendido en cuestión de honorarios. Finalmente, el encargo fue llevado a cabo por otro arquitecto. La propuesta de Le Corbusier resolvía el espacio expositivo en una única planta. El espacio se generaba alrededor de unas cabinas centrales, dedicadas a la pedicura, que ordenaban un recorrido abierto y fluido. El sistema de accesos, no diferenciado, se resolvía con una entrada y una salida, localizadas en distintas fachadas. 
La iluminación natural era, únicamente, cenital, y entraba filtrada a través de los paneles de vidrio que componían el techo. La iluminación artificial se resolvía en tres niveles distintos. Un primer nivel correspondía a la iluminación aportada por las vitrinas y expositores de las zonas bajas del pabellón. La segunda fuente de iluminación artificial era generada por los paneles luminosos colocados en la parte intermedia de las paredes. Por último, en la parte superior del edificio, se habían colocado unas líneas de neones, como iluminación de apoyo.

Como puede apreciarse en las secciones y la perspectiva interior, los recursos expositivos jugaban un papel fundamental en la percepción espacial del interior. El espacio se subdividía en tramos y franjas, por la colocación de paneles de cerramiento que, o no llegaban al suelo, o no llegaban al techo. Sobre todo el espacio, los plafones decorados con el planisferio unificaban el espacio, que era sobrevolado por el modelo de avión suspendido. Sobre casi un cuarto de este techo, y en una especie de cámara oscura, se programaban proyecciones publicitarias.

El cerramiento lateral era completamente ciego, acogiendo en toda su superficie los paneles expositivos. Estos se disponían en bandas horizontales que iban ganando en anchura conforme se iba subiendo en altura. Cuanto más alejada se encontraba la información del visitante, mayor dimensión se daba a los paneles, y por tanto, a lo representado. De manera similar al montaje expositivo planteado en los stands interiores del Pavillon des Temps Nouveaux, todos los cerramientos eran invadidos por lo expuesto, todas las superficies eran ocupadas. Como si de un avión de guerra se tratara, los visitantes eran bombardeados por la publicidad de Bat'a.

\section{Procedencia de las imágenes}

Imagen 1. CC-0427/G. Klutsis/C377-73. State Museum of Contemporary Art. Costakis Collection. Tesalónica. Imagen 2. CC-0386/G. Klutsis/C978-747. State Museum of Contemporary Art. Costakis Collection. Tesalónica. Imagen 3. Kassák Museum. Budapest.

Imagen 4. CFLC-ADAGP.

Imagen 5. CFLC-ADAGP.

Imagen 6. FLC 658 OFLC-ADAGP.

Imagen 7. CFLC-ADAGP.

Imagen 8. FLC 18092 CFLC-ADAGP.

Imagen 9. Domus, julio-agosto 1951, número 260.

Imagen 10. CFLC-ADAGP.

Imagen 11. CFLC-ADAGP.

Imagen 12. CFLC-ADAGP.

Imagen 13.FLC 17814. CFLC-ADAGP.

\section{Bibliografía}

Para obtener una visión panorámica de las principales obras, la evolución en los proyectos e ideas sobre la arquitectura expositiva de Le Corbusier, puede servir de referencia la siguiente bibliografía mínima (prescindiendo de monografías generalistas y estudios de edificios individuales):

Boralevi, Alberto: "The architectural conception of the museum in the work of Le Corbusier". En Museum Management and Curatorship, 1983, vol. 2, 2, pp. 177-189. 
Herschdorfer, Nathalie; Umstätter, Lada (Eds.): Le Corbusier and the power of Photography. Londres: Thames \& Hudson Ltd., 2012.

Mory, Pascal: "Le Corbusier and the syndrome of the museum". En Ahrenberg, Staffan; Cohen, Jean-Louis (Eds.): Le Corbusier's secret laboratory. From Painting to Architecture. Estocolmo: Hatje Cantz, 2013. pp. $257-$ 273.

Moulis, Antony: "Le Corbusier, the museum projects and the spiral figured plan". En Takhar, Jaspreet (Ed.): Celebrating Chandigarh. Ahmedabad: Mapin, 2002. pp. 348-357.

Navarro Segura, María Isabel: Le Corbusier expone. Las Palmas de Gran Canaria: Centro Atlántico de Arte Moderno, 2011.

O'Byrne Orozco, María Cecilia: Espirales, laberintos, molinetes y esvasticas en los museos de Le Corbusier, 1928-1939. Bogota: Universidad de los Andes-Ediciones Uniandes, 2011.

VV.AA.: Le Corbusier expose. Milán: Silvana Editoriale, 2011. 


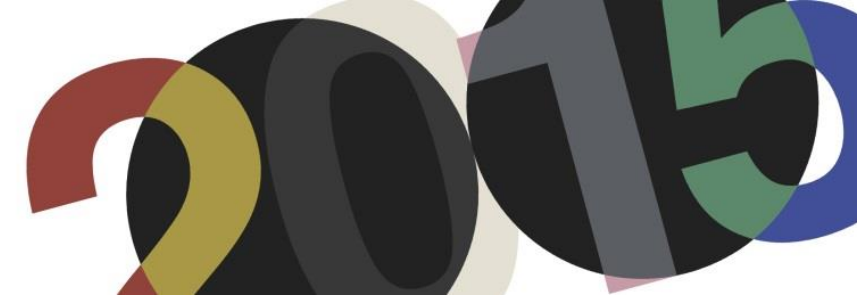

DOI: http://dx.doi.org/10.4995/LC2015.2015.645

The Baghdad Affair.

\title{
How diplomacy supplanted one of the last major projects by Le Corbusier
}

\author{
N. Grande \\ (Departamento de Arquitectura, DARQ/FCTUC; Centro de Estudos Sociais, CES, Universidade de Coimbra)
}

\begin{abstract}
After the Iraqi Republican Revolution of 1958, the resultant government commissioned two parallel projects for two great Stadiums in Baghdad, with similar complementary features: one to the Swiss architect Le Corbusier - who had developed a previous project (1955-1958) for the monarch Faisal II -, continuously designed in his Paris studio until his death in 1965; another to the Calouste Gulbenkian Foundation, in Lisbon, entirely funded and supervised by this institution, and designed by two prominent Portuguese architects at the time: F. Keil do Amaral and Carlos M. Ramos. Facing a progressive administrative and financial chaos in the country, the Iraqi authorities opted for the Gulbenkian Foundation's solution - built between 1962-1965 and inaugurated in 1966, after an intriguing diplomatic process -, postponing Le Corbusier's proposals yet without breaking their contract with him. This essay presents an explanation for this mysterious "affair" based on a recent research conducted at the Presidency Archive of the Calouste Gulbenkian Foundation, but also at the Canadian Centre for Architecture (CCA) where different documents reveal the continuous mismatch between Le Corbusier's will and the Iraqi authorities procedures.
\end{abstract}

Resumen: Después de la Revolución Republicana iraqui de 1958, el gobierno resultante encargó dos proyectos paralelos para dos grandes estadios en Bagdad con características similares: uno a lo arquitecto suizo Le Corbusier - que habia desarrollado un proyecto anterior para el monarca Faisal II (entre 1955 y 1958 ) -, diseñado de forma continua en su estudio de París hasta su muerte en 1965; otro a la Fundación Calouste Gulbenkian, en Lisboa, totalmente financiado y supervisado por esta institución, y diseñado por dos destacados arquitectos portugueses de la época: F. Keil do Amaral y Carlos M. Ramos. Frente a un caos administrativo y financiero progresivo en el país, las autoridades iraquíes optaron por el proyecto presentado por la Fundación Gulbenkian - construido entre 1962-1965 e inaugurado en 1966, después de un intrigante proceso diplomático -, posponiendo las propuestas de Le Corbusier todavia sin romper su contrato con él. Este ensayo presenta una explicación para esta t'rama"misteriosa, basado en una investigación reciente llevada a cabo en el Archivo de la Presidencia de la Fundación Calouste Gulbenkian, sino también en el Centro Canadiense de Arquitectura (CCA) -, en la que los diferentes elementos documentales revelan la falta de correspondencia continua entre la voluntad de Le Corbusier y los procedimientos de las autoridades iraquies.

Keywords: Le Corbusier; Baghdad Stadium complex; Calouste Gulbenkian Foundation.

Palabras clave: Le Corbusier; Estadio de Baghdad; Fundación Calouste Gulbenkian.

\section{Introduction}

The Baghdad Stadium complex, for which the renowned Swiss architect Le Corbusier was first commissioned in 1955 , is one of the most fascinating non-built projects of the last decade of his life, but it has also become one of the most mysterious affairs of his long career. Scholars like Rémi Baudoui ${ }^{1}$, Mina Marefat ${ }^{2}$ or Caecilia Pieri $^{3}$

\footnotetext{
${ }^{1}$ Rémi Baudouï, "Bâtir un stade : Le projet de Le Corbusier pour Bagdad, 1955-1973", in Azara (ed.) Ciudad del Espejismo: Baghdad, de Wright a Ventury. Barcelona: Azara, 2008, pp.91-102.

${ }^{2}$ Mina Marefat, "Mise au Point for Le Corbusier's Baghdad Stadium”, Docomomo Journal 41, September 2009, pp.30-40.

${ }^{3}$ Caecilia Pieri, "The Le Corbusier Gymnasium in Baghdad: Discovery of Construction Archives (1974-1980)", Les Carnets de L'IFPO, May 30, 2012.
} 
who have researched this subject, had wondered how such a major project could have been indefinitely postponed, especially considering the effort dedicated to it in the form of hundreds of drawings produced at Le Corbusier's atelier, at rue de Sèvres, in Paris, from 1957 to 1965.

This essay proposes an explanation to this long-lasting mystery ${ }^{4}$, based on a recent research using the archive of the first Chairman of the Gulbenkian Foundation in Lisbon ${ }^{5}$. The Foundation was initially involved as a sponsor for Le Corbusier's Baghdad Sport City in the early 1960s, but in fact, played a decisive diplomatic role in supplanting the project for another one of similar programme designed by two prominent Portuguese architects of the time - Francisco Keil do Amaral (1910-1975) and Carlos Manuel Ramos (1922-2012).

Another recent research was led by us at the Canadian Centre for Architecture (CCA), where different archive elements (letters, drawings, model photographs) from the personal collection of one of the last Le Corbusier's collaborators on the Baghdad project - Guillaume Jullian de la Fuente (1931-2008) ${ }^{6}$ - reveal the continuous mismatch between the architect's will and the Iraqi authorities procedures.

The most intriguing aspect of this tale is that the Keil and Ramos project was designed and built between 1960 and 1966, while Le Corbusier and his collaborators were still developing their third proposal for the same client - the Iraqi Government -, being one of the proposals most probably designed for the same site of the Portuguese project, as we will try to describe in this essay.

\section{Two main actors, two different roles}

\subsection{The involvement of Le Corbusier: a struggle for the right placement}

"Paris, September, $5^{\text {th }}, 1960$

( ...)

Mr. Director-General, this is the third study you have asked me to make. The first, on the site of the English urban planners, the second on the site of the Greek urbanist, and the third, after the rather dictatorial propositions of the Railway authorities... I have pursued this study with sufficient care so that the present letter can enable you to assume your responsibilities. If disorder should reign in the Stadium [project], this disorder should exist each week in the future.

Please accept the expression of my highest compliments,

Le Corbusier ".

In September 1960, through this firm message addressed to Nouraddin Muhiaddin, Director General of Buildings of the Ministry of Works and Housing, Le Corbusier expressed his clear irritation about the "disordered" development of his project for the new Baghdad Stadium, in face of successive changes of plans and locations suggested by the government authorities, at least since his first proposal dated May 1958. In fact,

\footnotetext{
${ }^{4}$ See Nuno Grande, "Gulbenkian vs. Le Corbusier. Estádio de Bagdade: "Mil e uma noites" de diplomacia política e cultural", Jornal Arquitectos 250, Mai-Ago 2014, pp.414-417.

${ }^{5}$ Fundação Calouste Gulbenkian in Lisbon, Arquivo da Presidência [Presidency Archive], 1956-1966.

${ }^{6}$ Canadian Centre for Architecture (CCA) in Montreal, Guillaume Jullian de la Fuente Collection.

${ }^{7}$ Le Corbusier, letter addressed to the Director-General of Buildings of the Ministry of Works and Housing of Iraq, Baghdad, September, 5, 1960. Montreal: CCA, Guillaume Jullian de la Fuente Collection, DR1993:0127, (author’s translation).
} 
during this period, the Iraqi political status quo had undergone drastic changes which affected the pursuit of several public commissions and investments. Let us see how.

As Mina Marefat describes in her essay, "Baghdad: a Sports City That Might Have Been"8, the commission awarded to the Swiss architect to design an Olympic Stadium had come about in 1955, as a result of the policy for the building of great public works, pursued throughout that decade by the young Iraqi King Faisal II. His aim was to endow the Iraqi Capital with grandiose buildings by renowned western architects, such as Le Corbusier, but also Frank Lloyd Wright, Walter Gropius, Alvar Aalto and Gio Ponti. Respectively, they were commissioned to design the Sports City complex, an Opera House, a State University Campus, a National Museum, and the new Ministry of Development Headquarters.

After his first trip to the Iraqi capital, on November 1957, Le Corbusier elaborated his proposal for the ambitious complex to be built on the right bank of the Tigris River, including: an Olympic size Stadium with a capacity for 50.000 spectators, a sports hall for 3.500 spectators, an exterior volleyball court with seats for 3.000 , and a set of swimming pools with stands for 5.000, as well as tennis courts and a restaurant. These "pieces" were to be placed on a trapezoidal shaped terrain, with a North-South orientation, covered by grass lawns bordered by trees and punctuated with canals fed from the river waters ${ }^{9}$.

The site had been designated in the 1956 Baghdad's Master Plan designed by the firm Minoprio, Spencely \& P.W Macfarlane - the "English urban planners" as mentioned by Le Corbusier in his letter of 1960.

To ensure the success of the enterprise, at a time when he was still intensely involved in the Chandigarh plan in India, Le Corbusier established a strategic partnership with the French engineer Georges-Marc Presenté, based in Paris, who was then developing an industrial compound plan in Bassora, Iraq ${ }^{10}$.

After their agreement, Le Corbusier sent his first project proposal to Baghdad - delivered by Presenté himself in May 1958 -, which was then approved by the Iraqi authorities on July 12, precisely two days before an unexpected Revolutionary Coup that led to the overthrow and brutal assassination of King Faisal II by a unit of pro-republican militaries.

Thereafter, taking into account not only the political and economic instability that had taken root in Iraq, but also the greater animosity of the new governors towards Western countries - specially Anglo-Saxon -, many of the projects that had been launched by the previous monarchy were either abandoned or postponed sine die. That was not the case of the Stadium complex, as the new Iraqi authorities, headed by General Abdul al-Karim Kassen, remained interested in proceeding with the enterprise, while pondering its construction in new locations. Thus describes Mina Marefat:

"In the spring of 1959, Le Corbusier received a telegram inviting him to an urgent visit to Baghdad: the main motive was a change in the choice of the site. The British agency Minoprio, Spencely and MacFarlane had been fired after the revolution of 1958 and the Greek planner Konstantin Doxiadis, already present in Iraq for two years, was the responsible for preparing the new master plan ${ }^{11}$."

\footnotetext{
${ }^{8}$ Mina Marefat, "Baghdad: a Sports City That Might Have Been", in Jean-Louis Cohen (ed.), Le Corbusier, An Atlas of Modern Landscapes. London: Thames \& Hudson, 2013, pp.385-391.

${ }^{9}$ Idem, p.388.

${ }^{10}$ Mina Marefat, “À la recontre du Gymnase de Le Corbusier à Bagdad”, in Le Gymnase de Le Corbusier à Bagdad. Paris: Editions du patrimoine, Centre des Monuments Nationaux, 2014, p.6.

${ }^{11}$ Idem, p. 10 .
} 
The new master plan by Doxiadis, completed in 1958, established an expansion strategy for Baghdad, based on an extensive grid of large rectangular sectors, side-lined by new roads, according to the prevailing direction northwest-southeast. This direction was parallel to the course of the Tigris River which became the central axis of this new "Dynapolis" (dynamic city), as Doxiadis referred to it. The architect Panayota Pyla, who has extensively studied this plan, describes it as follows:

"This rectangular area was not only subdivided by a system of road patterns that incorporated some of the existing major roads but also suggested the opening of new ones that would adopt a rectilinear pattern. The new road system was to provide "an easy connection of the city to the country", to tie the city into a larger regional schema. Residential sectors and subsectors were also arranged according to a rectangular grid system, modified in the middle, to accommodate the commercial district. The commercial district included the existing old city centre and also new commercial centres expected to emerge along the main axis of the Dynapolis ${ }^{12}$."

In his brief visit to Baghdad, between the 3rd and 6th of April 1959, Le Corbusier was confronted with the proposal of new locations for the Olympic Stadium within the "rectilinear pattern" of Doxiadis. Some sites were then considered, either on the left bank of the Tigris, at the expansion grid towards Sadr City, or on the right bank, at Al-Mansour, also under the planned network. None of the locations pleased Le Corbusier who, nevertheless, accepted this new commission based on the constraints pointed by the "Greek urbanist" - as labelled in his letter of 1960 .

Back in Paris, the architect designed a new solution for the complex, based on abstract rectangular shaped areas - first of $900 \times 550 \mathrm{~m}$; latter of $700 \times 550 \mathrm{~m}$ - with a northwest-southeast dominant orientation, as proposed in the master plan. Interestingly, this was also the kind of regular pattern proposed in his plan for Chandigarh, eight years before, with which Le Corbusier distributed the different new city sectors. Somehow, this recent urban experience allowed him to face the Baghdad plan restrictions with a clear pragmatism.

Le Corbusier adopted a final rectangular abstract area - approx. 700 x 550 meters -, as a support for the different venues: stadium, gymnasium, swimming pool and tennis courts. At the atelier, and as in a playful collage game, these ideas were represented by elementary cardboard models, cut at the same scale and cyclically repositioned over the rectangle area, testing the best accesses and insolation exposures. This strategy enabled Le Corbusier and his collaborators to develop and refine the project over the next months, while its definitive location was still being negotiated with the Iraqi authorities.

On June 20, 1960, Le Corbusier wrote to G. M. Presenté confirming his agreement on the type of location implied by the Doxiadis plan, and describing his recent studies:

"Dear Mr. Presenté,

1. Today a decision was taken by both sides for the acceptance of the new location (Greek urbanist) replacing the first location (English urban planner). This new field is now labelled "terrain 700 meters."

2. I have implanted the key elements: a) the stadium; b) the pool; $c$ ) the gym pavilion; d) the tennis courts.

12 Panayota Pyla, "Back to the Future: Doxiadis's Plans for Baghdad", Journal of Planning History, Vol. 7, nº, Sage Publications, 2008, p.9. 
These four main buildings are now oriented north-south and east-west ${ }^{13}$."

Given the abstract outlines of those studies, it is difficult to figure out which of the locations was then chosen to perform the design tests, once the northwest-southeast orientation, indicated in his plans, fit strategically in any of the expansion grids designed by Doxiadis on both banks of the Tigris River.

However, and as described by Mina Marefat ${ }^{14}$, Le Corbusier had the ambition to return to the first project's site, as proposed in 1958, near the centre of Baghdad. In the late summer of 1960, and fulfilling his ambition, that same site was reassessed, as mentioned in the letter sent by Le Corbusier to Nouraddin Muhiaddin, DirectorGeneral of the Ministry of Works and Housing. In that message, the location was then identified as the "third study" for the Stadium complex, on a terrain negotiated with the Railway authorities, close to the actual Baghdad International Station.

In the rectangular schemes that follow the letter, Le Corbusier indicated the minimum length needed for the terrain - $750 \mathrm{~m}$ (being $50 \mathrm{~m}$ for parking as demanded by the Railway authorities) - traced according to the northwest-southeast direction of Doxiadis' plan. Analysing those schemes, we can conclude that Le Corbusier was, in fact, imagining his new Olympic Stadium complex as a hub point of the Baghdad centre, reinforcing its connection to the master plan, but also to the East bank, through Al-Jumariyah Bridge, to the airport area, in the West, and to Mosul in the North.

On March 1st, 1961, Le Corbusier wrote to Igor Platounoff, Director-General of Buildings, at the Ministry of Works \& Housing, in Baghdad, stating:

"My definitive plans are completed. I agree with you to maintain on the site the small parking 50 meters width. The delicate question is to know where it should be located on the site in connection with the axis of the road leading to the [Al-Jumariyah] bridge ${ }^{15,}$.

But the most interesting part of this letter is its conclusion, intentionally underlined by Le Corbusier, which reveals his total impatience with the way the project was being led, also with regard to payment:

"Dear Mr. Platounoff, this is the fourth time the site is changed and your Ministry has not yet effected the payments which are due; this is hardly conceivable!

I take the liberty of asking you to kindly obtain this payment without further delay.

Yours sincerely

LE CORBUSIER ${ }^{16, "}$.

\footnotetext{
${ }^{13}$ Le Corbusier, letter to Georges-Marc Presenté, June 20, 1960. Montreal: CCA, Guillaume Jullian de la Fuente Collection, DR1993:0127, (author's translation).

${ }^{14}$ Mina Marefat, “À la recontre du Gymnase de Le Corbusier à Bagdad”, in Le Gymnase de Le Corbusier à Bagdad. Paris: Editions du patrimoine, Centre des Monuments Nationaux, 2014, p.10.

${ }^{15}$ Le Corbusier, letter to Igor Platounoff, Director-General of Buildings, Ministry of Works \& Housing in Iraq, March 1, 1961. Montreal: CCA, Guillaume Jullian de la Fuente Collection, DR1993:0127, (translation by Le Corbusier's office).

${ }^{16}$ Ibidem.
} 
The project sent to Platounoff in 1961, defined the last options for the Stadium complex, successively detailed up to the most complete version presented in 1964, a year before Le Corbusier's death. In both versions, the main buildings were distributed according to a north-south direction on a rectangular layout sector with a northwestsoutheast orientation, as already mentioned. This "rotation" effect - non-existent in the first project of 1958 made the general proposal become more "organic", especially considering the design of the "in-between" spaces among the buildings, filled by sweeping lawns or "islands" of trees.

This same "organicism" allowed Le Corbusier to return to his longstanding concept of promenade architectural, linking the meandering paths between the green spaces to four elegant curved ramps with which he envisioned the public accesses to the Olympic Stadium. These ramped "promenades", also developed in another project of his at that time - the Carpenter Centre in Massachusetts, USA - smoothly integrated the majestic building in the park, "moulding" it to the overall landscape design. As we shall see further on, this "organic", or sometimes even "animalistic" shapes, so present in various forms designed for the Baghdad project, reveal a matured and uncomplicated facet of Le Corbusier towards the end of his life, which led him to freely play with the relation between "artificial "and "natural ", architecture and landscape.

However, if the project gained progressively new shapes, the relations of Le Corbusier with the Iraqi government worsened from year to year due to constant delays, not only in the payment of his fees but also in the building calendar of the Olympic Stadium complex. The political unrest in Iraq in those early years of the 1960s - that would lead to the removal of General Abdul al-Karim Kassen in 1963 and the replacement of several governmental ministers - intensified the discrepancies between Le Corbusier and the Iraqi authorities, despite the constant letters and drawings sent from his studio to Baghdad.

Curiously, as described by Mina Marefat ${ }^{17}$, one of the few great enthusiasts of Le Corbusier within the government technical staff was the active and talented Iraqi architect Rifat Chadirji, whose training in Europe allowed him to recognise the seminal importance of the Swiss architect on the world stage. Comparing the status of Le Corbusier in the twentieth century with the one Michelangelo had in the Renaissance, Chadirji wrote, in the early 1960's, to the Minister of Works \& Housing, stating that the Baghdad Stadium was "one of those rare ideal constructions of all times ${ }^{18}$." Apparently, the letter did not produce the desired effect.

The death of Le Corbusier in 1965 put an end to his struggle against the bureaucratic and technocratic Iraqi systems. However, and as we will see below, the local bureaucracy and technocracy were also accompanied by foreign diplomacy, in particular that from Portuguese institutions, which, we believe, had the most decisive role in the outcome of this intriguing "affair".

\subsection{The involvement of the Calouste Gulbenkian Foundation: a diplomatic struggle}

"Lisbon, July, 4th, 1958

Dear Ambassador and Friend

(...)

17 Mina Marefat, “À la recontre du Gymnase de Le Corbusier à Bagdad”, in Le Gymnase de Le Corbusier à Bagdad. Paris: Editions du patrimoine, Centre des Monuments Nationaux, 2014, p.17.

${ }^{18}$ Ibidem 
During a talk held with Dr. Jaffar Dhia [the Iraqi Minister of Development], he addressed us the suggestion of building a Stadium in Baghdad, asserting that this is a very well regarded project among the Iraqi monarchy, and that it [the funding of the Calouste Gulbenkian Foundation] would be greatly appreciated.

$$
\text { (...) }
$$

There is no doubt that Le Corbusier is an exceptional architect, but his services will certainly be expensive, since they are greatly sought after by central and local governments all around the world. Furthermore, there is no certainty that he is an expert in the building of stadia.

It occurred to us that the best qualified and most up-to-date technicians for carrying out this work are some of the Portuguese architects to whom we are indebted for the magnificent stadia that we have in Lisbon and Porto.

Whatever however we address the question, my dear Friend, you will certainly agree that there are great advantages that the task of erecting such a building should be trusted to one of our compatriots. Moreover, it would create a current between the two countries that should be improved.

(...)

I would like to know if you could meet with Dr. Dhia Jaffar, before he enters the hospital, formally inviting him to visit Lisbon on behalf of our Foundation; during that visit, we would be most delighted to show him the kind of excellent buildings that we owe to the talented work of our national architects. We might be able to arrange a meeting between them and Dhia Jafar, to exchange views on the project, and I am sure that we would then be able to supplant Mr. Le Corbusier and make progress in gaining acceptance for our bid”.

(...)

Friendly Regards

José de Azeredo Perdigão ${ }^{19}$,".

This letter of July 1958, belonging to the Presidential Archive of the Calouste Gulbenkian Foundation in Lisbon, reveals the debut of a strategic relationship between this institution and the Iraqi Government, related to the funding of the Olympic Stadium in Baghdad, commissioned to Le Corbusier, as we have described. Addressed by the Chairman of the Foundation, José de Azeredo Perdigão, to the Ambassador of Portugal in London, Pedro Theotonio Pereira, the letter suggests the deepening of diplomatic negotiations on the subject with the Iraqi Minister of Development, Dhia Jafar, who was then, coincidently, receiving medical treatment in England.

The negotiations with Minister Jafar had begun some months before, through an exchange of letters with the Delegation in London of the Gulbenkian Foundation, supervisor of the institution's shares in British oil companies based in Iraq. This close liaison with the Middle East resulted from the substantial profits that the mentor of the Foundation - the Armenian millionaire Calouste Sarkis Gulbenkian ${ }^{20}$ - received from his oil business investments, which represented, at the time of his death (1955), about 5\% of the Iraq Petroleum Company revenues. The Foundation, created in 1956 as a result of his testamentary wish, and based in Lisbon -

\footnotetext{
${ }^{19}$ José de Azeredo Perdigão, Chairman of the Calouste Gulbenkian Foundation, letter to the Portuguese Ambassador in London, July 4, 1958. Lisboa: Fundação Calouste Gulbenkian, Arquivo da Presidência, [Presidency Archive], 1956-1966, (author's translation).

${ }^{20}$ For further reading see Calouste Gulbenkian Foundation, Calouste Sarkis Gulbenkian. The Man and His Achievements. Lisbon: Calouste Gulbenkian Foundation, 1999
} 
where he had lived since 1942 -, had the mission of funding the Arts, Sciences, Social Charity and the Armenian Communities around the world, seeking to maintain the best diplomatic relations with all the countries where the founder had left his legacy.

In that sense, Azeredo Perdigão - to whom Calouste Gulbenkian entrusted the presidency of the Foundation before his death - had the will to sponsor the construction of a large public building in Baghdad, like the Olympic Stadium, as a way to repay the monarch Faisal II for the financial dividends of the institution in that country. His letter to the Portuguese Ambassador in London revealed, however, another personal wish: that the building should be erected by Portuguese architects, commissioned directly by the Gulbenkian Foundation, who should also control the whole building process in order to diminish the funding costs. In his words, in its negotiations with the Iraqi authorities the Gulbenkian Foundation should "be able to supplant Mr. Le Corbusier".

Azeredo Perdigão's letter was sent ten days before the Iraqi revolution of July 14, 1958, which led, as we described, to King Faisal's assassination and the establishment of a republican government controlled by the military. As a result of this political change, the Iraq monarchic structure was dismantled, the minister Dhia Jafar exiled himself in London, and the Gulbenkian Foundation proposal seemed to be definitively condemned to failure. Surprisingly, on October 6, 1958, Sayed Fu-ad al-Rikabi, the new Iraqi Minister of Development, addressed a letter to Azeredo Perdigão, expressing the interest of the new Republic of Iraq in maintaining the project for a great stadium in Baghdad, designed by Le Corbusier, relying, for this purpose, on the Gulbenkian Foundation previous financing proposal. Despite his secret wish, the Chairman of the Foundation reiterated his enthusiasm for the initiative, proposing an exchange of missions between Iraqi and Portuguese technicians, to be held in both countries, in order to guarantee a mutual support. Azeredo Perdigão was, in fact, trying to defend the Foundation's interests and shares in the Iraq Petroleum Company, then affected by the threat of a possible nationalisation process by the new revolutionary regime. In this sense, the Foundation's diplomatic charm had to be maintained at all costs.

On December 31, 1958, two technicians of the new Iraqi Government arrived in Lisbon, invited by the Calouste Gulbenkian Foundation, to learn more about the institution and visit some sports venues recently built in Portugal. The Portuguese newspaper Mundo Desportivo (World Sports) highlighted this visit in its daily edition: "Two individuals of great importance in Iraq came to visit the stadiums of Portugal ${ }^{21 " . ~ T h e y ~ w e r e: ~ A . ~ F a h i m i, ~}$ Director-General of Physical Education of the Iraq Government and Rifat Chadirji, architect, managing director of Fifth Technical Section of the Ministry of Development and, as described, one of the great enthusiasts of the Stadium designed by Le Corbusier.

After visiting all the venues, Chadirji confessed to be very pleased with what he saw, especially with the recent Restelo Stadium in Lisbon, designed by Carlos Manuel Ramos and Jorge Viana:

"This stadium impressed me particularly for two reasons: first by the way the problem of the public internal movement was solved; secondly, by its magnificent coverage over the public stands. It is undoubtedly the first major coverage in aluminium I see, among those which I already knew ${ }^{22 " .}$

\footnotetext{
${ }^{21}$ Article at Mundo Desportivo, Lisbon, December 31, 1958 (author's translation).

${ }^{22}$ Small testimony by Rifat Chadirji, Mundo Desportivo, Lisbon, December 31, 1958, p.7 (author's translation).
} 
At the end of their visit, although generally impressed with Portuguese architectural skills, the two Iraqi technicians reaffirmed the will of the Ministry of Development in Iraq in maintaining the project presented by Le Corbusier in that very same year, for which they were counting on the support of the Calouste Gulbenkian Foundation. In a quick response, Azeredo Perdigão wrote to the Iraqi Minister of Development, in January 1959, stating that he would only be able to bear the cost of Le Corbusier's Olympic Stadium (valued at 1 million and 50 thousand pounds) and not the total charge for the Sports complex, which included the gymnasium pavilion, the outdoor sports field, the swimming pool and the tennis courts (estimated at 2 million 400 thousand pounds) ${ }^{23}$.

During the following months, throughout different courteous letters and telegrams, Azeredo Perdigão tried to convince the Iraqi government to suspend Le Corbusier's Sports complex and to commission another less ambitious and less expensive project, totally financed by the Foundation and headed by a group of Portuguese designers, to be gathered under the auspices of his institution ${ }^{24}$. We should remember that the Calouste Gulbenkian Foundation was then launching the building process of its new Headquarters in Lisbon, involving an extensive multidisciplinary team of designers and external consultants.

On November 1959, the Foundation sent two of its best technicians to Baghdad - the architect José Sommer Ribeiro and the engineer João Vaz Raposo - with the purpose, not only to repay the visit of the Iraqis, but also to clarify the institution's role on the financing of the new Sports complex, its possible location and other logistic conditions. In their various meetings with the Iraqi technicians, the Portuguese were confronted with three alternatives: a) the financing of Le Corbusier Stadium complex; b) the financing and construction of three smaller stadiums in Mosul, Baghdad and Kirkuk; c) the financing and construction of a single stadium in Baghdad designed by Portuguese architects and built on the left bank of the Tigris River.

Those different alternatives indicated a lack of clear policies of Iraqi public investments, as noted in the technical report that Sommer Ribeiro and Vaz Raposo wrote after their trip:

"The complete isolation in which the country finds itself since the Revolution, the quality of the Revolution itself, the people's ambitions, and the demagogic process in which they were instructed, has largely contributed to the confusion that exists inside the Iraqi administration, and to the alarming increase on the cost of living.

The "People's Revolution", and the rights that all claim to have won with it, do not easily combine with the immense needs of this Republic which nothing has done, virtually, and which will have to face serious health problems as tuberculosis and misery in a desperate scale.

It is incomprehensible how a city of 1 million inhabitants, where more than 250.000 live miserably, wishes to build two stadiums, especially when the problems of housing, elementary education and hunger are so clear ${ }^{25}$ ".

The several uncertainties created during those technical meetings, would finally be solved by an autocratic decision of the Chief of Government, General Abdul Kassem, as described in the same report:

\footnotetext{
${ }^{23}$ Fundação Calouste Gulbenkian, Lisboa: Arquivo da Presidência, Correspondência de 1959 [Presidency Archive, Mail correspondence of 1959].

${ }^{24}$ Throughot 1959, several massages were exchanged between José de Azeredo Perdigão and the Iraqi Minister of Developmet. Lisboa: Fundação Calouste Gulbenkian Arquivo da Presidência, Correspondência de 1959 [Presidency Archive, Mail correspondence of 1959].

${ }^{25}$ José Sommer Ribeiro and João Vaz Raposo, Missão Técnica a Bagdad, Novembro de 1959 [Technical Mission to Baghdad, November 1959]. Lisboa: Fundação Calouste Gulbenkian, Arquivo da Presidência, 1956-1966 [Presidency Archive, 1956-1966], 1959, p.3 (author's translation).
} 
"The exchange of views in the Office of the Minister of Public Works, our statement that we had come to Iraq to study technical problems related to the Baghdad Stadium, and the insistence of the Iraqi technicians on the construction of three stadiums, led the Minister to ask for an audience with General Kassem, which was held immediately, confirming the Cabinet decision about the construction of a single stadium, and naming the architect [Rifat] Chadirji as the representative of the Government in this endeavour. (...) On the other hand, it was confirmed that the project should be designed by Portuguese architects, with the consultancy of an Iraqi architect, something we accepted with great pleasure. For that task Chadirji suggested the architect Kamil ${ }^{26 "}$

Suddenly, the Portuguese technical mission gained a diplomatic dimension: obtained the guarantee from the Iraqi leadership that a "single stadium" would be built, with a determined location, and that it "should be designed by Portuguese architects" under the logistical and financial control of the Calouste Gulbenkian Foundation, as a kind of turnkey project.

So, just seven months after the visit of Le Corbusier to Baghdad (April 1959), the Iraqi Government took an internal measure that apparently would make it impossible for him to erect his Olympic Stadium in the coming years. After that resolution, and as we described before, the Swiss architect would face constant changes of locations, delays on the payment of his fees, and bureaucratic difficulties imposed on his project, which were not the result of the Iraqi administrative chaos alone. In fact, all these actions appeared to be manoeuvres to conceal a political decision from Le Corbusier that could severely affect his reputation. Even if thwarted by the hard circumstances, the role of the governmental architects thorough this process - especially of the prominent consultant Rifat Chadirji - became obviously ambiguous.

Before their departure from Baghdad, Sommer Ribeiro and Vaz Raposo visited the predicted site for the new Stadium complex to be built under the Gulbenkian Foundation sponsoring and supervision. The terrain was located on the Tigris left bank, between the traditional centre and the new urban expansion towards Sadr City, as planned by Doxiadis. In fact, the site followed the master plan rules, integrating its regular pattern with a northwest-southeast orientation. It is our conviction that this was one of the locations suggested to Le Corbusier in his visit to Baghdad, some months before, which supported his second experimental study but also the design grid for the third and definitive project, on the other bank of the river.

In the early months of 1960, a final plan for the Stadium complex was agreed between the Gulbenkian Foundation and the Iraqi authorities, which included many of the features previously requested from Le Corbusier: an Olympic swimming pool with covered stands (now with 2000 seats), a volleyball court also with coverture (1000 seats), three tennis courts and a new Stadium's capacity (then reduced to 30.000 seats). Only the Gymnasium building project was left out of the plan. This size reduction made it possible to maintain the budget close to the one proposed by the Foundation ( 1 million and 50 thousand pounds) ${ }^{27}$.

In the same year, Azeredo Perdigão put together a cohesive team of design specialists from various fields, including the architects Francisco Keil do Amaral (a long-time adviser to the Foundation) and his colleague Carlos Manuel Ramos, and the engineers Luís Guimarães Lobato, João Vaz Raposo and Alderico Machado, at that time deeply involved in the building of the Foundation's new Headquarters. Keil do Amaral and Carlos

\footnotetext{
${ }^{26}$ Idem, pp.12-13 (author's translation).

${ }^{27}$ Luis Guimarães Lobato, Consultant Engineer, Report on Baghdad Stadium, February, 16, 1960. Fundação Calouste Gulbenkian: Arquivo da Presidência [Presidency Archive], 1956-1966, (translation by the Foundation's services).
} 
Manuel Ramos worked in partnership since 1958 on the project of the monumental "City Palace" for the Arts and Congresses (not built) and on the landscape design of the north front of Park Eduardo VII, both for the Municipality of Lisbon ${ }^{28}$.

Keil had been a municipal architect in Lisbon, between 1943 and 1947, where he developed seminal works, such as the extension of the Portela Airport, the design of the parks Eduardo VII Park and Campo Grande, several facilities at the Monsanto Park, the Park Metro Station, and later, as a liberal architect, the notable building for the Portuguese Industries Fair. Twelve years younger, Carlos Manuel Ramos was mainly known for his impressive project for the Restelo Stadium, one of the buildings most appreciated by the Iraqi technicians in their visit to Lisbon.

In the first months of 1960 , the team worked under pressure to attain a preliminary project and a large scale model of the Stadium complex. During the same period, the Foundation received in Lisbon an Iraqi technical mission - led once again by A. Fahmi, the engineer Mahmoud and the architects Chadirji and Kamil - to oversee the ongoing proposals. In May 1960, General Abdul Kassem approved the preliminary project, and, during the following year, Keil and Ramos worked hard to complete the detailing drawings, essential for the assessing of the final budget and the signing of the building contracts.

The Calouste Gulbenkian Foundation agreed with the Baghdad authorities to choose an Iraqi constructor for that purpose, based on an open competition. The construction was finally attributed to the local company of the entrepreneur Mohamed Makzoumi who started the preliminary works by the end of 1961. After the piles had been laid for the foundations, the "first stone" was symbolically placed on July 14, 1962, evoking the fourth anniversary of the Republican Revolution.

The construction took place over a four-year period, supervised by the Portuguese team with the support of the mentioned Iraqi technicians. By the third visit of Keil and Ramos to the building site, on April 1966, the main features of the Sports complex had been already completed, and the Stadium's east stand emerged above ground $^{29}$. This had a horseshoe shape, a solution that Ramos had already tried out at the Restelo Stadium, while the covered west stand displayed its structural skeleton of elegant curved concrete beams, formally used by Keil in his earlier project for the Lisbon Industrial Fair.

The Baghdad Stadium complex was finally inaugurated on November 6, 1966, at a ceremony attended by the highest Iraqi dignitaries, especially the new republican leader Abdul Rhaman Arif, in power since 1963, after another military coup that led to the arrest, trial and death penalty condemnation of General Abdul Kassem. The despotic "creator" had not survived to see his political "creation".

The key moment of the Stadium opening ceremony was a football match between the Iraqi National Team and Benfica, by then the biggest soccer club in Portugal, whose travel expenses were entirely paid by the Foundation. The Chairman Azeredo Perdigão, accompanied by a large entourage, was particularly delighted to see the immense crowd visiting the new arena, then baptised by the local authorities as "The People's Stadium" (AlShaab). The next day, the Baghdad newspapers announced the result - Iraq 1/Benfica 2 - with another fine performance by Eusébio, the world famous Benfica player. However, the Portuguese victory had not only been

\footnotetext{
${ }^{28}$ For further reading see Keil do Amaral, O Arquitecto e o Humanista, (coord. A. Tostões, F. Amaral, I. Moita). Lisboa: Câmara Municipal de Lisboa, 1999.

${ }^{29}$ Francisco Keil do Amaral e Carlos M. Ramos, Viagem a Bagdad, em Abril de 1966, para assistência às obras do "People's Stadium" [Trip to Baghdad in April 1966 to supervise the works of the "People's Stadium"]. Lisboa: Fundação Calouste Gulbenkian, Arquivo da Presidência, [Presidency Archive], 1956-1966, (author's translation).
} 
accomplished at the sporting level; the Gulbenkian Foundation's artful diplomacy had also attained a winning score.

\section{Two parallel projects: vicinities and variances}

As a result of our research, we now understand that the unusual Iraqi Government that arose from the 1958 Republican Revolution also unusually managed to commission two parallel projects for two great Stadiums in Baghdad with similar complementary features: one to the Swiss architect Le Corbusier - who had developed a previous project (1955-1958) for the monarch Faisal II -, continuously designed in his Paris studio until his death in 1965; another to the Calouste Gulbenkian Foundation, developed in its premises in Lisbon, until 1966, by Portuguese architects Keil do Amaral and Carlos M. Ramos. We have also described how the new Iraqi Republic, then facing a progressive administrative and financial chaos, opted for the funding requirements imposed by the Gulbenkian Foundation for the whole project, delaying or even abandoning Le Corbusier's proposals, yet without breaking their contract with him.

Since both preliminary projects were developed in parallel - in the case of Le Corbusier, from his second version adjusted to the master plan of Konstantin Doxiadis -, it is worth taking the risk to analyse the vicinities and the variances one can find between these two proposals. We do not wish to compare the historical significance of the authors and their works - always undisputed in the exceptional case of Le Corbusier - but only to realise how their professional skills, forged within Modern Internationalism, "adapted" themselves to the peculiar circumstances of the assignment.

The main principles of Le Corbusier's 1964 proposal were already set out in his preliminary project of 1961. As mentioned in chapter 2.1, his integration of the Sports complex in the regular grid imposed by the Doxiadis plan, was based on the rotation and alignment of the different facilities in a North-South direction. Thus, and with the exception of the tennis courts and the training soccer fields, all other precincts were distributed according to the rectangular site's diagonal, headed by the great Stadium at its northwest side.

Curiously enough, the plan by Keil and Ramos - also integrated into the Doxiadis grid - proposed an identical diagonal composition and the same North-South alignment for the different volumes; however using less length to do so, due to the inclusion of an extended car parking areas within the lot. Confined to a smaller area, the Portuguese architects implanted the great Stadium at the southwest front surrounded by all other sports facilities.

The major differences between the two proposals can be found, above all, in the architecture of the Stadium and in its public access systems.

Le Corbusier Stadium - planned for a large capacity (50,000 seats) - was a compact and homogeneous volume. Its oval shape was supported by a modular structure based on massive "beam-walls" rhythmically settled along its elliptical perimeter. These structural "ribs" generated the facade composition exposing the depth of the stands, the layers of internal galleries, but also the main building materiality: le beton brut, the elected material for most of Le Corbusier's post-war works. In this project, the Swiss architect evoked the magnificent Roman circuses, and especially the Rome Coliseum, as suggested in one of the numerous existing sketches in the CCA archive.

The Stadium designed by Keil and Ramos was smaller (30,000 seats), and based on a dual composition, dividing the two main stands: the big "popular stand", with a horseshoe shape sprawled over the terrain; and the "noble stand", with a squared and monumental composition. In both cases, the structural system was also supported by a regular set of concrete "porticos", more internalized at the popular stand, and more externalised at the noble one. This "ribbed" structure supported the curved roof of the noble stand while, under the popular stand, the covered 
foyer was protected by an elegant concrete brise-soleil, suspended on the main façade, probably detailed by Carlos M. Ramos.

In terms of public access to the Stadium, the differences were even clearer. As described before, Le Corbusier integrated his arena within a promenade architectural, through different "artificial" and "natural" meanders. This "organic" design transformed his buildings into a set of "creatures" moving over a green park. Assuming that "animal" condition, his Stadium plan resembled a giant "turtle" with four curved long "legs" - the four public access ramps - leading to the interior of its "shell".

Again, in the design of the roof "shell", Le Corbusier echoed that very same zoomorphic metaphor. In several sketches, the profile of the stands" "beam-walls" assumed the shape of giant "antelopes" whose "heads" supported a crossed structure of steel cables, over which Le Corbusier extended a light shield, made of translucent canopies or, in another solution, of prefabricated metal plates. Several of his non concluded studies on the subject can also be consulted in the CCA archive, revealing some proximity with similar solutions used for the covering of the Maison de la Jeunesse et de la Culture, at Firminy, a project that Le Corbusier was also developing at that time.

In the proposal by Keil and Ramos, the public accesses to the Stadium were designed in a more conventional way. In a probable response to the autocratic wish of the Iraqi leader, the public entries assumed the aforementioned dual character: the prominent access gate to the "noble stand" was located at the end of a monumental alley, set in a west-east direction according to the Stadiums central axis; the access to the "popular stand" was placed at the back and separated in two gates (North and South). As we described before, only the noble stand received coverage, made of curved metal plates, applied to the crossed concrete "ribbed" structure, linking the roof to the main facade. This dual condition became clear in the nicely detailed section drawings of the two stands, which can be consulted at the Calouste Gulbenkian Foundation archives.

Finally, it is important to compare how the remaining areas of these sports complexes were developed within their terrains.

In the layout of Le Corbusier, the swimming pools were implanted according to freely set open spaces and water tanks, with various shapes and sizes, joined in a clear "pictorial" composition. The outdoor pool stand, with its "boomerang" shape, followed this expressionist configuration. More conventional, the volleyball field was located in the middle of a square enclosure, composed of a set of ramps accessing two opposite stands. The gymnasium project - perhaps the most studied plan apart from the Stadium itself - underwent several versions, always dependent on the type of coverage desired by Le Corbusier. Here too, he designed a cable system structure, covered by an inclined "light" ceiling - once more evoking the project for Firminy - which would be finally replaced, in the 1964 version, by a curved rigid roof adapted to the climatic and logistic conditions found in Baghdad. In his various studies, the accesses to the interior of this compact volume were based on an external ramp system, prolonging the "promenade" effect designed for the complex ${ }^{30}$.

In the layout proposed by Keil and Ramos, we find an identical harmonic match between the different volumes around the Stadium, which readapted some of the constructive solutions we have described for the big arena. The 50 meters olympic pool was surrounded by an elegant suspended stand, which seemed to "float" over the ground. The different volumes designed for the pool spas were covered by delicate domed caps, a solution that Keil had

\footnotetext{
${ }^{30}$ For further reading see Mina Marefat, "À la recontre du Gymnase de Le Corbusier à Bagdad", in Le Gymnase de Le Corbusier à Bagdad. Paris: Editions du patrimoine, Centre des Monuments Nationaux, 2014.
} 
rehearsed, a few years earlier, in his project for the Park Metro Station in Lisbon. The volleyball field was also flanked by two opposing stalls, one of which was covered by an extensive portico of stately curved concrete beams, creating another gateway to the precinct.

The Keil and Ramos Stadium complex did not foresee the construction of a gymnasium, because at the time of the agreement with the Iraqi authorities its construction would have caused a significant increase in the Gulbenkian Foundation funding. However, two decades after the inauguration of the complex sponsored by the Foundation, the gymnasium designed by Le Corbusier was built in a park immediately adjacent to it, by a new leader of the Iraqi government: Sadam Hussein. This posthumous work of Le Corbusier, detailed and built by his associate - the engineer Georges-Marc Presenté -, and inaugurated in 1980, became neighbour of the Stadium designed by Keil do Amaral and Carlos Ramos.

So, time has played its last ironic card in this "Baghdad Affair": several years later and for the first time, two parallel "plays", separated by the same political and diplomatic "plot", came to occupy the same "stage".

\section{Conclusion: how diplomacy does not supplant memory}

In the life of all great architects, as in the life of many other creators, "success" alternates with "failure", although few pages have been dedicated to such failures in most of the Architectural History books. Only recently, and based on extensive academic researches, conducted through institutional or personal archives, we have begun to understand the seminal importance of such unrealised projects in the conceptual path of the great architects who have built masterpieces all over the world. This is certainly the case of Le Corbusier, of whom it is possible to say that the quality of his unbuilt projects is comparable to his existing works; and that many of his failures were ultimately significant in changing his way of "thinking" and "making" architecture. This immaterial legacy is what we usually call "memory".

The Baghdad Olympic Stadium is one of these major unrealised projects, as were other stadiums planned by Le Corbusier before, in Paris or Chandigarh. Designed at the end of his life, this "failed" project must have generated insufficient new perspectives in his career, but, on the other hand, allowed that an important page could be written in the career of the Portuguese architects Keil do Amaral and Carlos Manuel Ramos, and therefore, in the history of Portuguese Architecture.

In Baghdad, the shrewd diplomacy of José Azeredo Perdigão, the funds emanating from the Calouste Gulbenkian Foundation, and the climate of political instability in the country, supplanted what could have been the last built masterpiece of Le Corbusier's life. But no diplomacy is able to supplant the latent "memory" that this project has left, as an immaterial legacy, to his disciples and admirers of different generations; who, before and after his death, have learned and still learn today with his brilliance.

In fact, it is even possible to say that the Le Corbusier's Baghdad Stadium, in its physical simplicity, in its structural audacity, in its iconic presence, has somehow resurfaced in other similar works of other key architects.

Let us just highlight three examples designed by major creators, among those recently awarded with the Pritzker Prize: the Olympic Stadium for the Munich Games, by the German architect Otto Frey (built in 1972), the Serra Dourada Stadium in Goiania, by the Brazilian architect Paulo Mendes da Rocha (1975), and the Municipal Stadium in Braga by the Portuguese architect Eduardo Souto de Moura (2004). In the latter case, and safeguarding the differences of site, scale and shape, there are some remarkable crossovers between Souto de Moura's work and the one by Le Corbusier: the way the Stadium is supported by massive concrete "beam-walls" rhythmically settled along its perimeter and perforated by several layers of galleries; the way that its coverage is 
based on steel tensioned cables tied to the "heads" of the stands; and the way the building launches its ramps into its surroundings inviting us to freely enter.

Somehow, Portuguese Architecture will always be indebted to this non-built work of Le Corbusier. Actually, and as an architectural "memory" this failure became a resounding success. 


\section{Images}

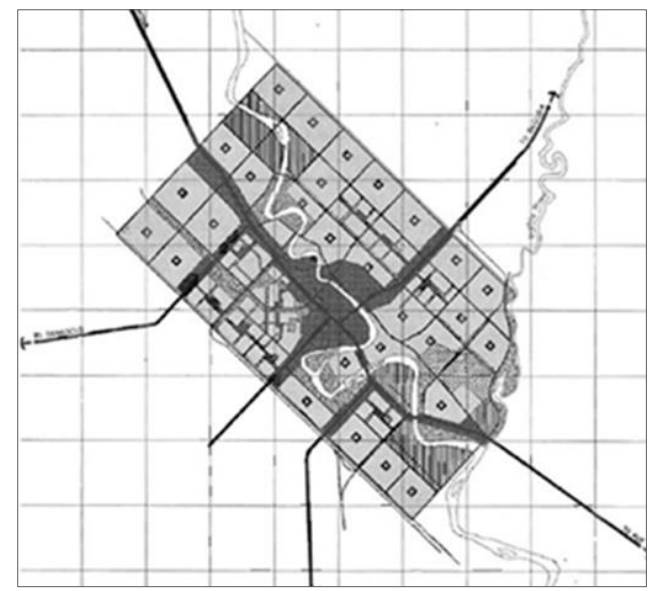

1. Baghdad Master Plan (Dynapolis), by Konstantin Doxiadis, 1958

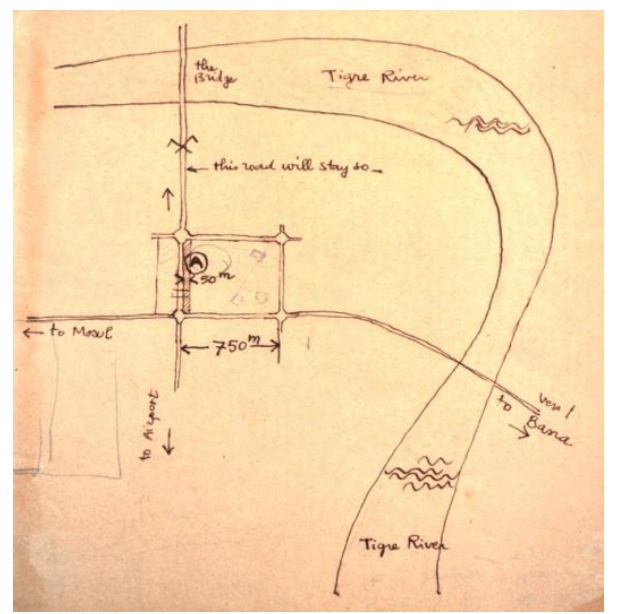

2. Urban scheme by Le Corbusier, integrating the Stadium terrain at Doxiadi's Master Plan grid (detail), 1959

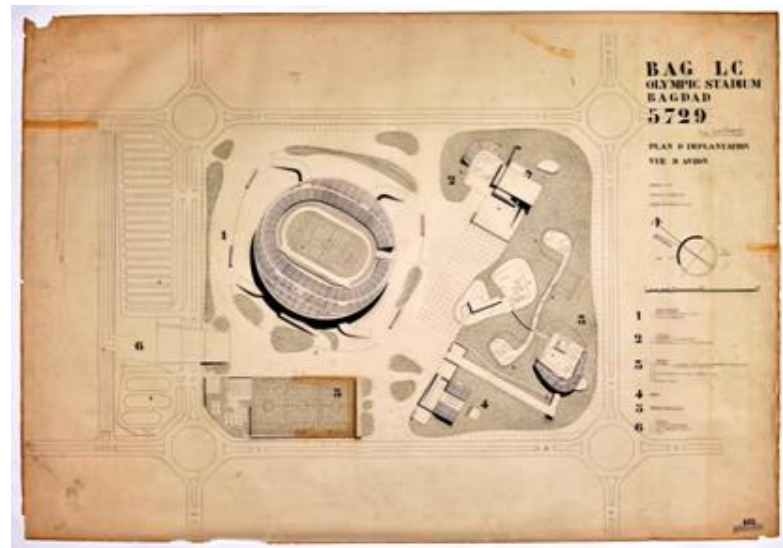

3. Le Corbusier, implantation of the Baghdad's Olympic Stadium complex, 1961 


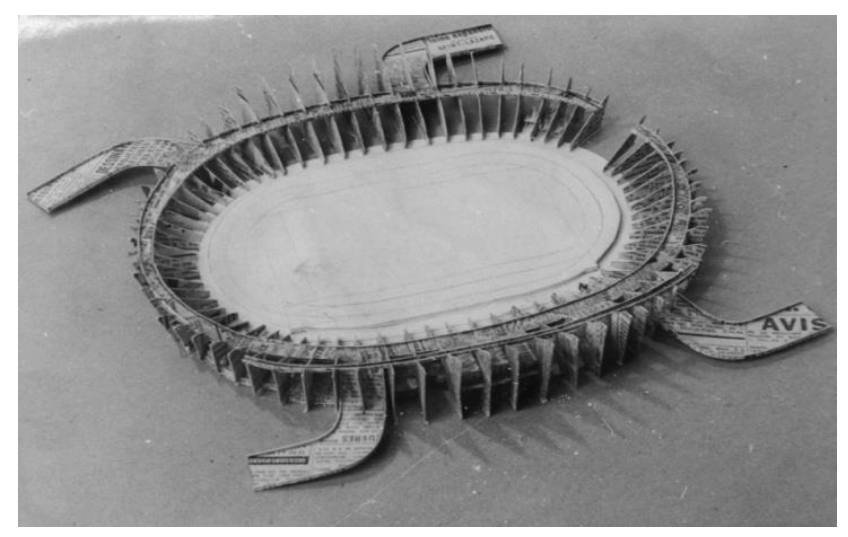

4. Le Corbusier, Model of the Baghdad's Olympic Stadium, with its "turtle" shape. Not dated

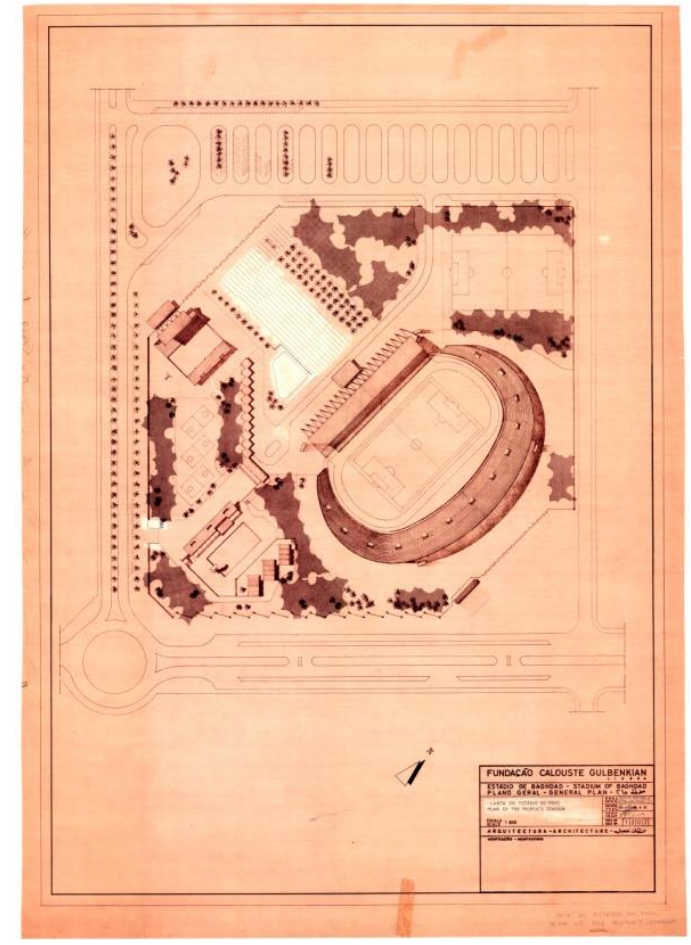

5. F. Keil do Amaral and Carlos M. Ramos, implantation of Baghdad's Stadium complex, 1961

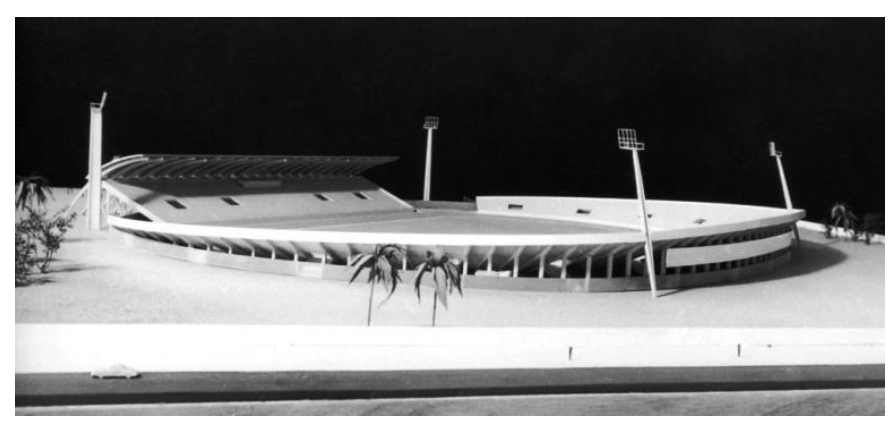

6. F. Keil do Amaral and Carlos M. Ramos, model of Baghdad's Stadium complex, 1961 


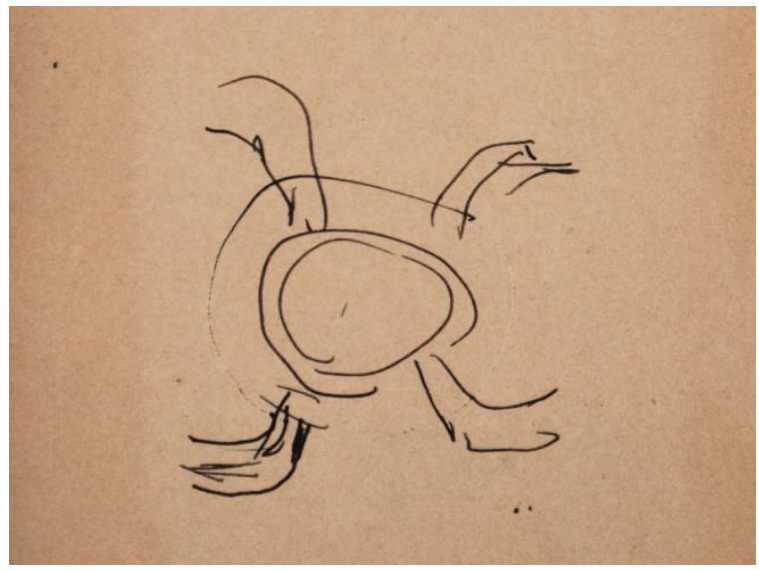

7. Le Corbusier, sketch for the Baghdad Olympic Stadium, with its "turtle" shape (detail), 1959

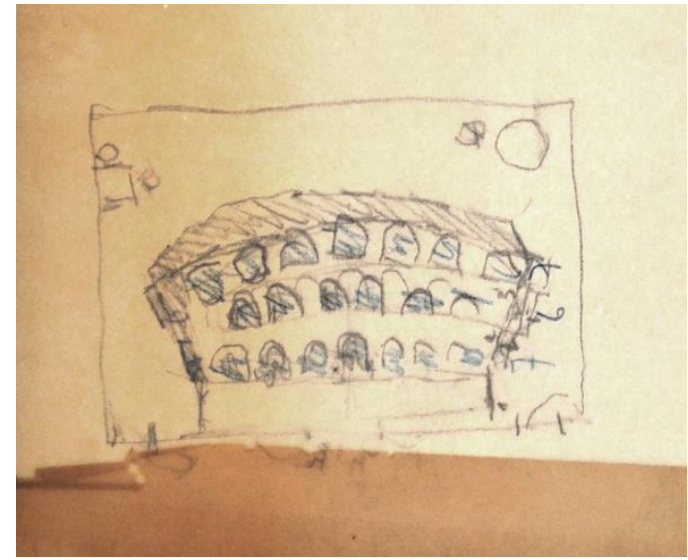

8. Le Corbusier, sketch for the Baghdad Olympic Stadium, evoking the Roman Coliseum (detail). Not dated

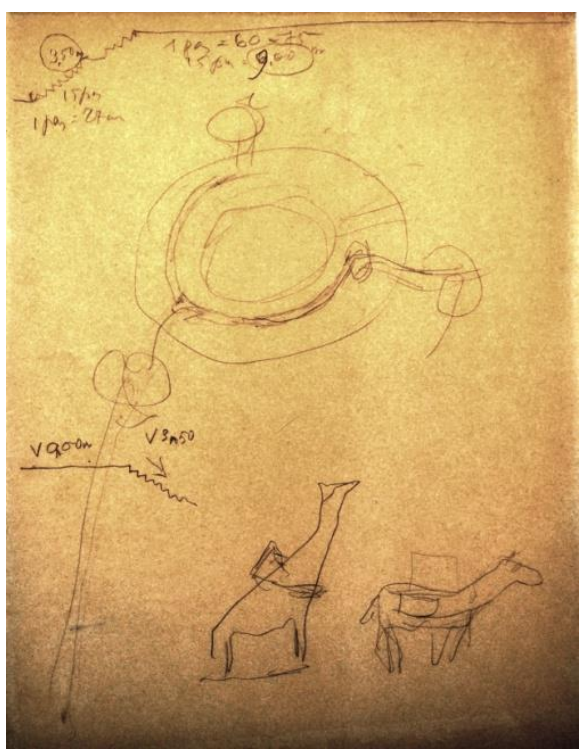

9. Le Corbusier, sketches for the Baghdad Stadium stands, with its "antelopes" shapes (detail). Not dated 


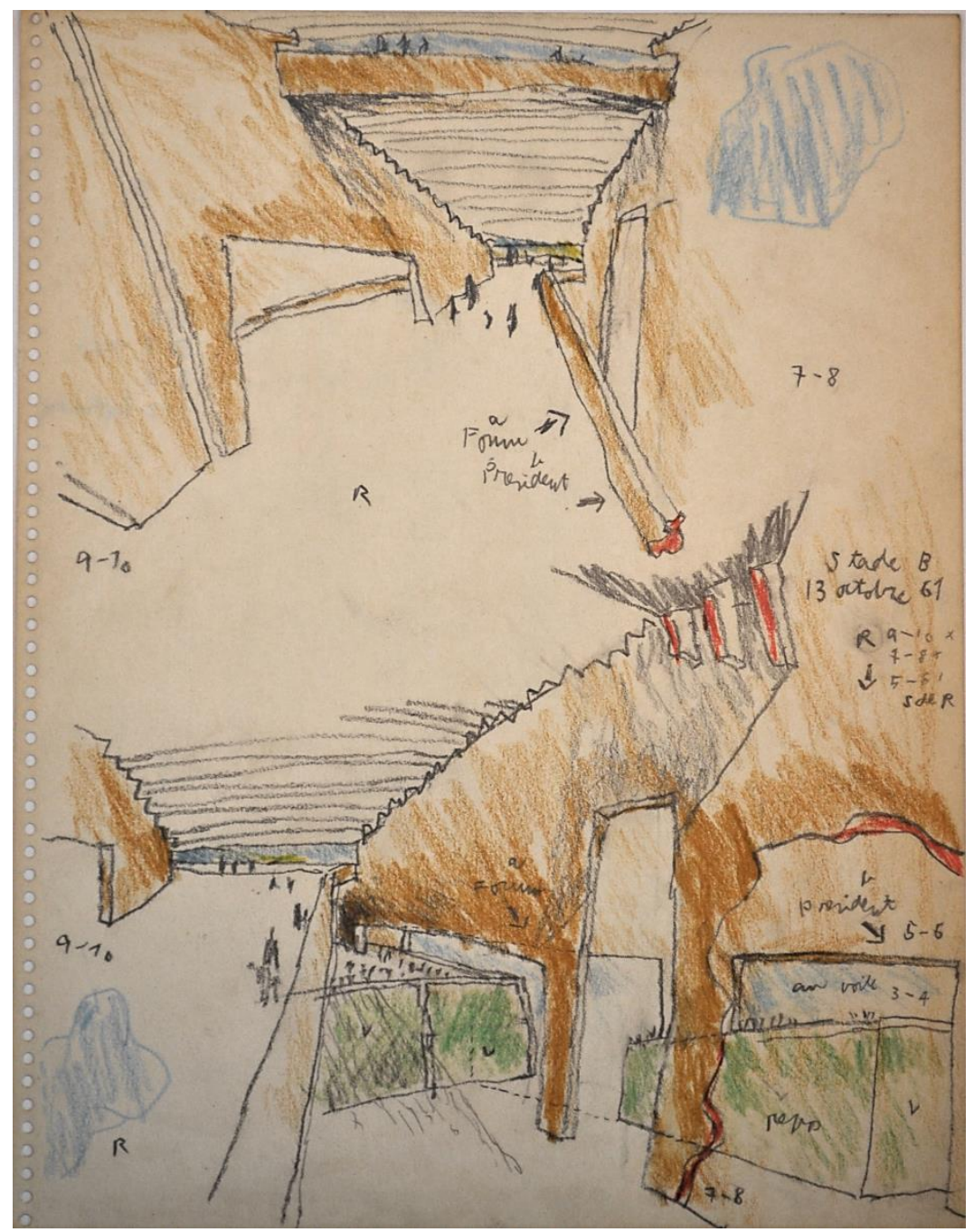

10. Sketch of the Baghdad Stadium interior proposed by Le Corbusier (drawing attributed to G. Jullian de la Fuente), 1961

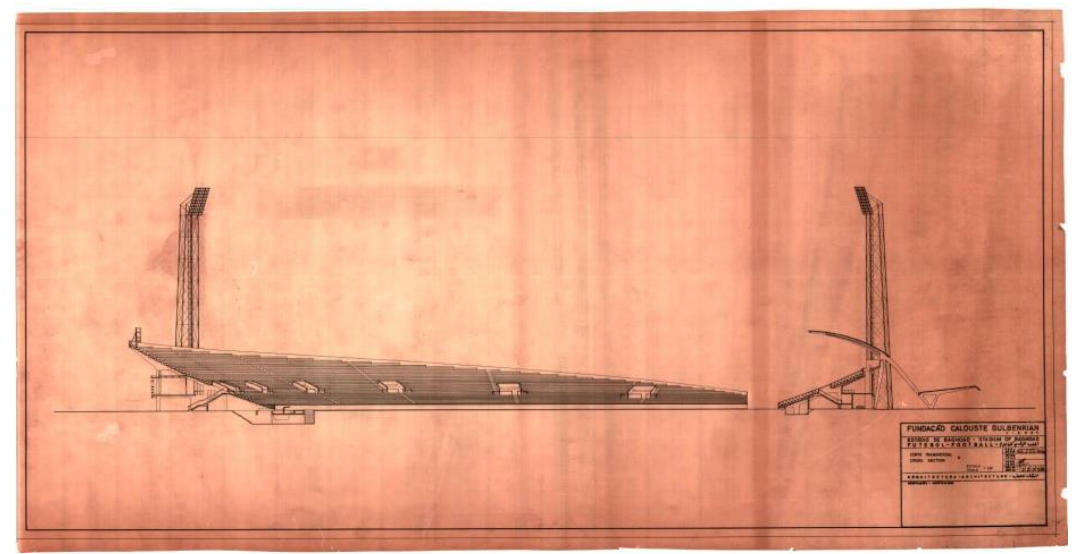

11. Section of the Baghdad Stadium proposed by F. Keil do Amaral and Carlos M. Ramos, 1961 


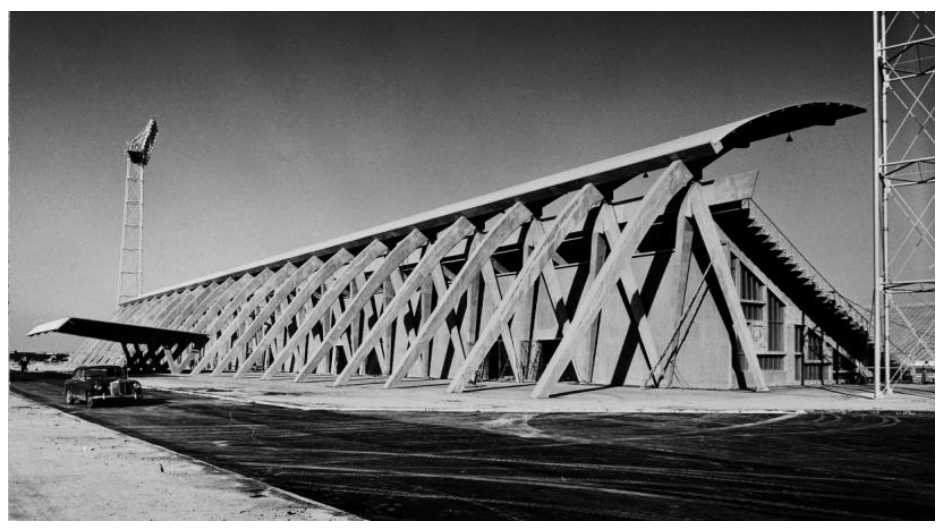

12. Baghdad Stadium by F. Keil do Amaral and Carlos M. Ramos. View of the "noble stand" from the outside, 1966

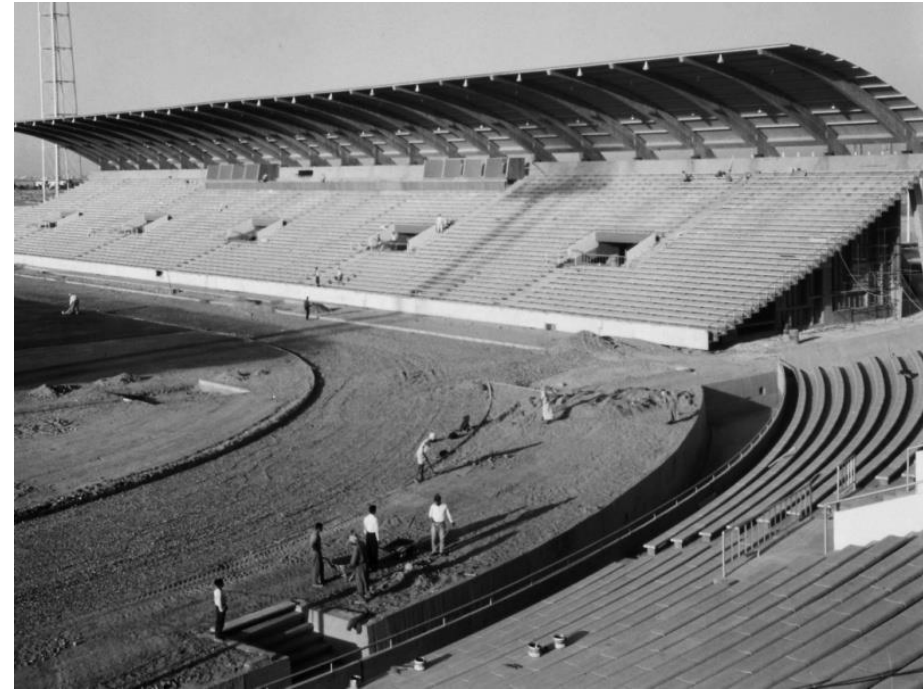

13. Baghdad Stadium by F. Keil do Amaral and Carlos M. Ramos. View of the "noble stand" from the inside, 1966

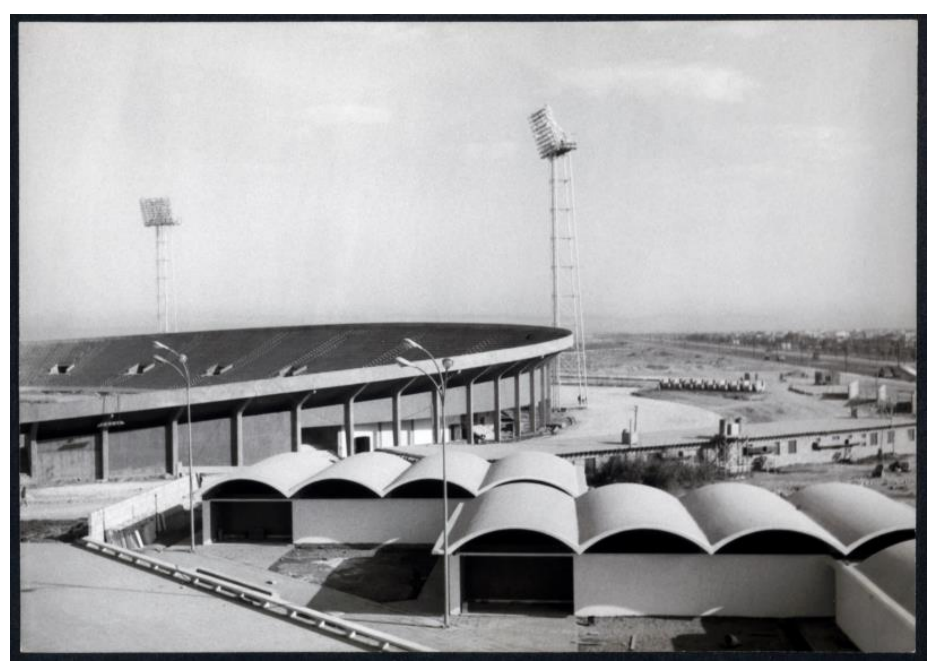

14. Baghdad Stadium by F. Keil do Amaral and Carlos M. Ramos. View of the swimming-pool spa areas, 1966 


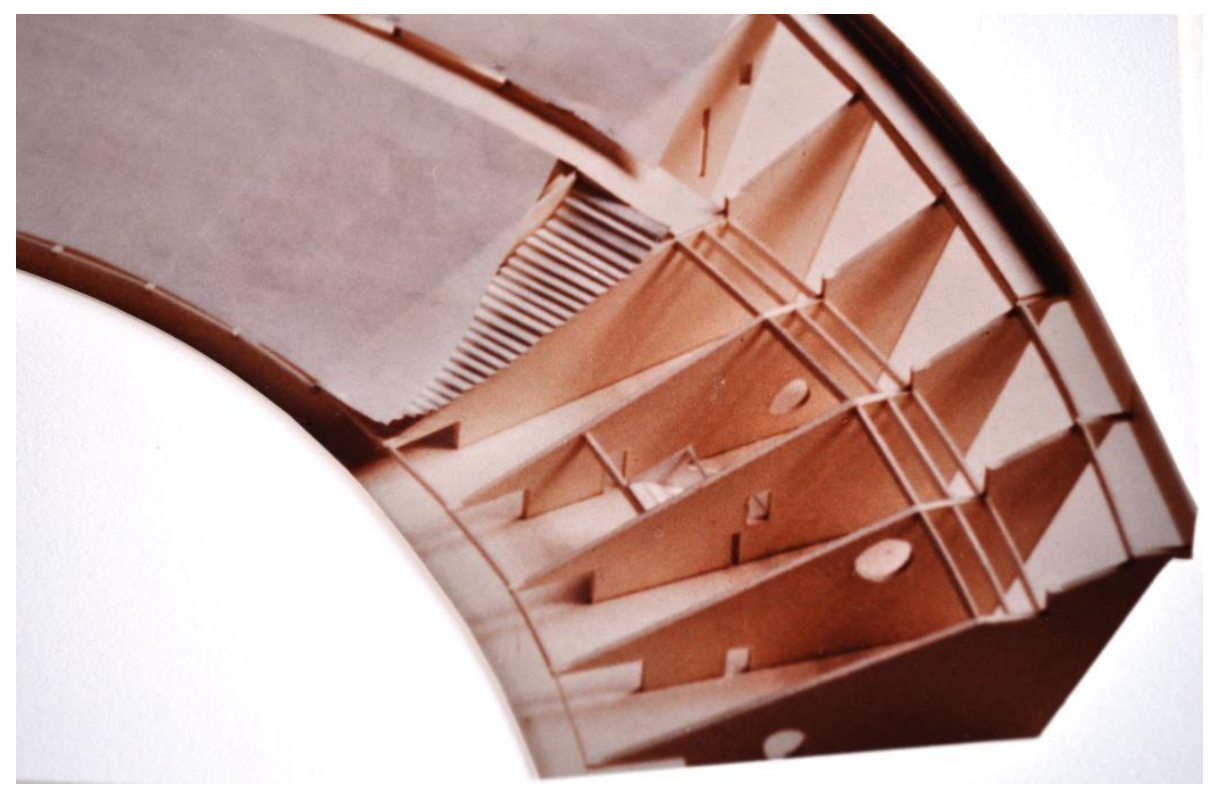

15. Le Corbusier, Study model of the "beam-walls" of the Baghdad's Stadium. Not dated

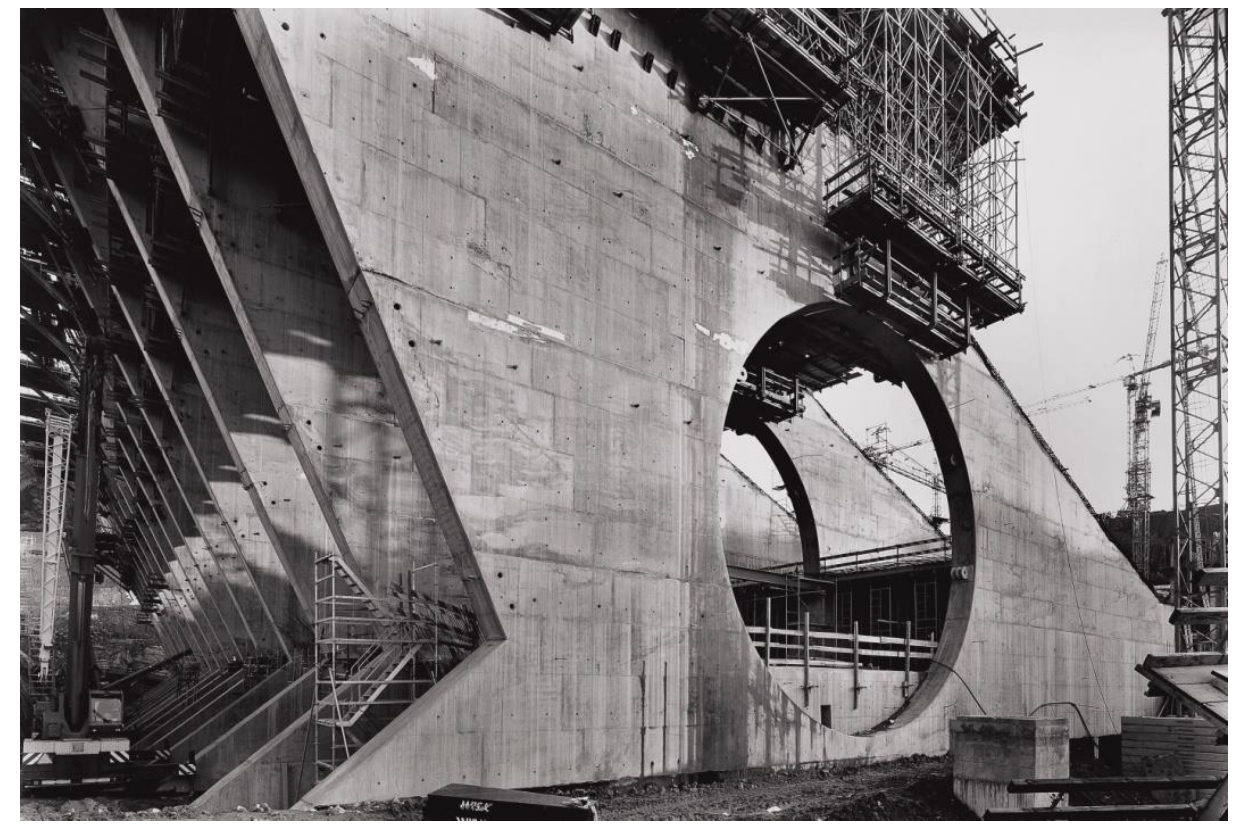

16. Building of the "beam-walls" of the Braga Municipal Stadium, designed by Eduardo Souto de Moura, 2003 


\section{Source of images}

Image 1 - Doxiadis Associates, The Master Plan for Baghdad, Iraq, 1958 [Doxiadis Associates, "Progress of the Housing Problem." (May 1959), cover].

Image 2 - Fonds Guillaume Jullian de la Fuente. Collection Centre Canadien d'Architecture/Canadian Centre for Architecture, Montréal. DR1993:0127:037:001

Image 3 - Fondation Le Corbusier, Paris, FLC 00425.

Image 4 - Fonds Guillaume Jullian de la Fuente. Collection Centre Canadien d'Architecture/Canadian Centre for Architecture, Montréal. DR1993:0127:038:019

Image 5 - Arquivo do Serviço de Obras da Fundação Calouste Gulbenkian, Lisboa.

Image 6 - Arquivo do Serviço de Obras da Fundação Calouste Gulbenkian, Lisboa.

Image 7 - Fonds Guillaume Jullian de la Fuente. Collection Centre Canadien d'Architecture/Canadian Centre for Architecture, Montréal. DR1993:0127:006

Image 8 - Fonds Guillaume Jullian de la Fuente. Collection Centre Canadien d'Architecture/Canadian Centre for Architecture, Montréal. DR1993:0127:013

Image 9 - Fonds Guillaume Jullian de la Fuente. Collection Centre Canadien d'Architecture/Canadian Centre for Architecture, Montréal. DR1993:0127:027

Image 10 - Fonds Guillaume Jullian de la Fuente. Collection Centre Canadien d'Architecture/Canadian Centre for Architecture, Montréal. DR1993:0127:016

Image 11 - Arquivo do Serviço de Obras da Fundação Calouste Gulbenkian, Lisboa.

Image 12 - Arquivo do Serviço de Obras da Fundação Calouste Gulbenkian, Lisboa.

Image 13 - Arquivo do Serviço de Obras da Fundação Calouste Gulbenkian, Lisboa.

Image 14 - Arquivo do Serviço de Obras da Fundação Calouste Gulbenkian, Lisboa.

Image 15 - Fonds Guillaume Jullian de la Fuente. Collection Centre Canadien d'Architecture/Canadian Centre for Architecture, Montréal. DR1993:0127:038:028

Image 16 - Photo by Alessandra Chemollo

\section{Bibliography}

Azeredo Perdigão, José, Letter to the Portuguese Ambassador in London, July 4, 1958. Lisboa: Fundação Calouste Gulbenkian, Arquivo da Presidência, 1956-1966.

Baudouï, Rémi, "Bâtir un stade : Le projet de Le Corbusier pour Bagdad, 1955-1973", in Azara (ed.) Ciudad del Espejismo: Baghdad, de Wright a Ventury. Barcelona: 2008, pp.91-102.

Calouste Gulbenkian Foundation, Calouste Sarkis Gulbenkian. The Man and His Achievements. Lisbon: Calouste Gulbenkian Foundation, 1999.

Câmara Municipal de Lisboa, Keil do Amaral, O Arquitecto e o Humanista, (coord. A. Tostões, F. Amaral, I. Moita). Lisboa: Câmara Municipal de Lisboa, 1999.

Grande, Nuno, "Gulbenkian vs. Le Corbusier. Estádio de Bagdade: "Mil e uma noites" de diplomacia política e cultural", in Jornal Arquitectos 250, Mai-Ago 2014, pp.414-417.

Keil do Amaral, Francisco; Ramos, Carlos M., Viagem a Baghdad, em Abril de 1966, para assistência às obras do "People's Stadium". Lisboa: Fundação Calouste Gulbenkian, Arquivo da Presidência, 1956-1966.

Le Corbusier, letter addressed to the Director-General of Buildings of the Ministry of Works and Housing of Iraq, Baghdad, September, 5, 1960. Montreal: Canadian Centre for Architecture, Guillaume Jullian de la Fuente Collection, DR1993:0127. 
Le Corbusier, letter to Georges-Marc Presenté, June 20, 1960. Montreal: Canadian Centre for Architecture, Guillaume Jullian de la Fuente Collection, DR1993:0127.

Le Corbusier, letter to Igor Platounoff, Director-General of Buildings, Ministry of Works \& Housing in Iraq, March 1, 1961. Montreal: Canadian Centre for Architecture, Guillaume Jullian de la Fuente Collection, DR1993:0127.

Lobato, Luis Guimarães, Report on Baghdad Stadium, February, 16, 1960. Lisboa: Fundação Calouste Gulbenkian, Arquivo da Presidência, 1956-1966.

Marefat, Mina, "À la recontre du Gymnase de Le Corbusier à Bagdad”, in Le Gymnase de Le Corbusier à Bagdad. Paris: Editions du patrimoine, Centre des Monuments Nationaux, 2014, p.6.

Marefat, Mina, "Baghdad: a Sports City That Might Have Been”, in Jean-Louis Cohen (ed.), Le Corbusier, An Atlas of Modern Landscapes. London: Thames \& Hudson, 2013, pp.385-391.

Marefat, Mina, "Mise au Point for Le Corbusier's Baghdad Stadium”, in Docomomo Journal 41, September 2009, pp.30-40.

Pieri, Caecilia “The Le Corbusier Gymnasium in Baghdad: Discovery of Construction Archives (1974-1980)", in Les Carnets de L'IFPO, May 30, 2012.

Pyla, Panayota, "Back to the Future: Doxiadis's Plans for Baghdad”, in Journal of Planning History, Vol. 7, nº1, Sage Publications, 2008, p.9.

Ribeiro, José Sommer; Raposo, João Vaz, Missão Técnica a Bagdad, Novembro de 1959. Lisboa: Fundação Calouste Gulbenkian, Arquivo da Presidência 1956-1966. 


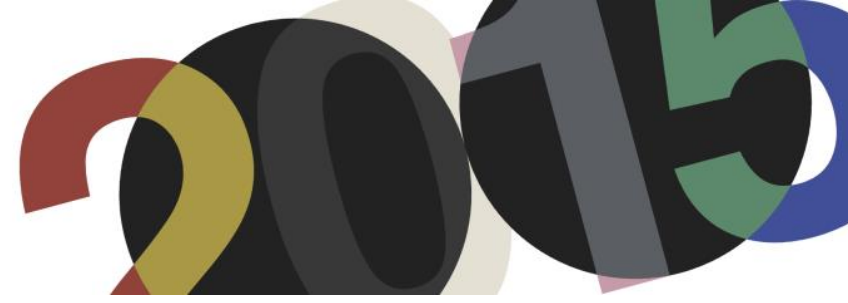

DOI: http://dx.doi.org/10.4995/LC2015.2015.760

\title{
Bruno Zevi on Le Corbusier: another way to an "organic architecture"
}

\author{
L. Guido
}

Independent scholar

\begin{abstract}
Bruno Zevi was an enthusiastic promoter of Frank Lloyd Wright's architecture and theories. However, the critical enquiry and propaganda of the Italian architect and historian about so-called "organic architecture" reveals a major cultural debt to Le Corbusier. In 1945, Zevi published "Verso un'architettura organica" [Towards an organic architecture], the first version of his history of architecture. The title is clearly a polemical reference to Le Corbusier's book "Vers une architecture" (1923). In 1977, together with other architects, Zevi promoted the Machu Picchu Charter, a document to "update" the Athens Charter (1933). The places held significance: Athens was the birthplace of western civilization and architectural rationalism. Machu Picchu symbolised the contribution of an alternative way of viewing the world. Are those merely examples of Zevi's provocations? The relationship between Zevi and Le Corbusier is problematic and ambivalent. Zevi adopts the educational and communicative methods of Le Corbusier and his critical writing style, but his interpretation of the French-Swiss architect also demonstrates an attempt to delineate a new concept of "organic architecture", related to his researches on a historiographic redefinition of the Modern Movement.
\end{abstract}

Resumen: Bruno Zevi fue un entusiasta promotor de la arquitectura y las teorías de Frank Lloyd Wright. Sin embargo, la investigación crítica y la propaganda del arquitecto italiano e historiador sobre la llamada ärquitectura orgánica"revela una importante deuda cultural para Le Corbusier. En 1945, Zevi publicó "Verso un'architettura organica" [Hacia una arquitectura orgánica], la primera versión de su historia de la arquitectura. El título es claramente una referencia polémica al libro de Le Corbusier "Vers une architecture"(1923). En 1977, junto a otros arquitectos, Zevi promovió la Carta Machu Picchu, un documento para "actualizar" la Carta de Atenas (1933). Los lugares celebradas importancia: Atenas fue la cuna de la civilización occidental y el racionalismo arquitectónico. Machu Picchu simbolizaba la contribución de una forma alternativa de ver el mundo. ¿Son esos meros ejemplos de las provocaciones de Zevi? La relación entre Zevi y Le Corbusier es problemática y bivalente. Zevi adopta los métodos educativos y comunicativos de Le Corbusier y su estilo crítico escrito, pero su interpretación del arquitecto franco-suizo también demuestra un intento de delinear un nuevo concepto de "arquitectura orgánica," en relación con sus investigaciones en una redefinición historiográfico de la Movimiento Moderno.

Keywords: Bruno Zevi; Le Corbusier's legacy; modern language invariants; five points; organic architecture.

Palabras clave: Bruno Zevi; El legado de Le Corbusier; invariantes de lenguas modernas; cinco puntos; arquitectura orgánica.

\section{Introduction}

In his autobiography entitled Zevi su Zevi (1993) [Zevi on Zevi], the well-known Italian historian and critic of architecture hastily informs his readers of his "Understanding with Le Corbusier" : "I was at lunch next to Mrs Giedion, when he came in with that absent-minded, bored attitude of his. I didn't know what to do. As a passionate supporter of Wright, they thought I was anti-Le Corbusier; should I greet him? How would he react?

\footnotetext{
${ }^{1}$ Zevi, Bruno, Zevi su Zevi. Architettura come profezia, Venezia: Marsilio, 1993, p. 211 [author's translation from Italian] The edition of this book, from which the extract is taken, is the result of a review and extension of an autobiography Zevi had previously published with a small publisher under the title of Zevi su Bruno Zevi, Milano: Magma, 1977. In the first Milan edition, the short paragraph dedicated to two anecdotes concerning Le Corbusier, quoted here almost in full, was missing, whereas in the revised edition of 1993 it appeared in a section entitled "lost sheets."
} 
It was he who came towards me. He shook my hand: «You're Zevi. They all say you're against me. But I know it's not true» [...] Villa Savoye is a unicum; its rationalism vibrates with poetry. The Chapel in Ronchamp is also a unicum, the only informal architecture in history. Informal lies between expressionist and organic, and culminates in space, light and in the path inside the roof [sic], but above all in the quality of the sound, in the prodigious acoustic function. In his later years, when he came to Venice to design the new hospital, Le Corbusier was irritable to such an extent as was in keeping with an intellectual of high calibre. He could not bear the light, given the state of his eyes; he could not bear long speeches; basically he could not bear students. He saw some written protests in the entrance hall of the University of Architecture [Istituto Universitario di Architettura]. He asked me to translate them and commented: "They're idiots. They know nothing». ${ }^{2}$

In his description of Le Corbusier, Bruno Zevi appears to subconsciously draw himself. In fact, for those who ever met Zevi, the anecdote could easily recall his own rather shameless, provocative attitude.

The idea of handling the relationship with the person, taking him by surprise - both face to face and in writing the ability to ascribe the events to his own historic-critical view and the knowledge of using extremely direct, cutting judgements are, without doubt, some of the traits that Le Corbusier and Zevi had in common. Was this merely a temperamental similarity, or was there something deeper linking the two figures?

As is well-known in the community of scholars of architecture, Zevi's role was to diffuse the ideas and architecture of Frank Lloyd Wright and to modernise the Italian architectural panorama after the Second World War, with the introduction of new figures and themes.

The period in which he had most influence was between 1945 and the early 70s, when Zevi was also unanimously considered a figure whose authority stretched far beyond Italy: that is to say, before his views were gradually put aside when younger historians, such as Manfredo Tafuri or Paolo Portoghesi, appeared on the scene.

Zevi's connection with the masters of the so-called Modern Movement, with some of whom he had a direct relationship, has always been rather complex. On the one hand, Zevi was the spokesperson for the social and moral statements inherent in the modernist project. On the other, he never spared ferocious criticism of Gropius, Mies van der Rohe or Aalto when, in his opinion, their architectural production showed obvious signs of creative decline. However, his relationship with Le Corbusier reveals a position of open criticism, aiming to positively record the changes in direction of the Swiss-French architect and to catch the pedagogic/popular meaning of his books and actions undertaken (especially when Le Corbusier's post war work was also seen as a criticism of the International Style). In other words, when faced with Le Corbusier, Zevi reviews his judgement and exploits in favour of his historic narrative the turning point represented by works which no longer closely adhered to the logic of functionalism, such as the Chapel in Ronchamp (1950-55), the Philips Pavilion (1958) and the

\footnotetext{
${ }^{2}$ Ibid, p. 211. The place where they met, which Zevi mentions in the first part of the anecdote, is not clarified. The meeting certainly took place before the construction of the Chapel of Ronchamp, up to which point in time Zevi regularly refers to architectural events as "anti-Lecorbusierian". In 1949, Zevi reached the peak of his intense criticism of rationalism and Giedion's critical historic view, when he wrote a note addressed to the 1949 CIAM congress in Bergamo, in which both Le Corbusier and Giedion took part (see note 17). With all probability, the episode Zevi remembers must have taken place during the days of the congress De divina Proportione, held during the 9th Triennale in Milan in 1951. Numerous eminent figures took part in the Milan meeting, including Ernesto Nathan Rogers, Pier Luigi Nervi, Max Bill, Lucio Fontana, Georges Vantongerloo, Rudolf Wittkower, Matila Ghyka, James Ackerman, Gillo Dorfless, Bruno Zevi, Sigfried Giedion, and Le Corbusier. The conference proceedings have only recently been published and edited by Fulvio Irace and Anna Chiara Cimoli, (Eds.) La divina proporzione. Triennale 1951, Milano: Electa, 2007
} 
"Mannerist projects"3 for Chandigarh (1951-65), Maisons Jaoul (1954-56) and the Visual Arts Center in Cambridge, Mass. (1961-64). The opportunities to expand on these convictions are scattered not only in numerous articles and essays, but also in the updates of Zevi's history of architecture. Within those pages, Zevi redefined the concept of organic architecture, which changed from being associated primarily with Wright to becoming synonymous with post-rationalism at first and then to almost being replaced by the idea of the "zero degree" of architectural writing.

Interpretational passages supported by devising the theory of the "invariants of the modern language" (1973) and accompanied by demonstrative actions such as the Machu Picchu Charter (1977), which bring to mind the pedagogical and communicative method adopted by Le Corbusier in his Five Points (1926) and in the Athens Charter (1933).

\section{Zevi on Le Corbusier}

Towards the end of the Second World War, at the age of twenty-seven, Zevi published the manuscript prepared in London ${ }^{4}$ between 1943 and 1944, entitled Verso un'architettura organica ${ }^{5}$ (1945) [Towards an organic architecture]. Following a series of amendments and supplements, this book subsequently became his Storia dell'Architettura Moderna (1950) [History of Modern Architecture], regularly updated until the author's death. The reference to Le Corbusier's Vers une architecture (1923) appears a foregone conclusion. However, it is useful to point out that it constitutes a method of choice he repeated throughout later years. Zevi's various headings were borrowed from other books. For example Saper vedere l'architettura (1948) was inspired by Saper vedere (1933) by art critic, Matteo Marangoni, while his Linguaggio Moderno dell'Architettura (1973) was inspired by well-known essayist John Summerson's The Classical Language of Architecture (1964), whereas Zevi su Bruno Zevi (1977) came from Roland Barthe's autobiography titled Barthes par Roland Barthes (1975).

Verso un'architettura organica offers Zevi the opportunity to speak of Le Corbusier for the first time and to compare his work with contemporary American events. The meaning of the book, as he declared in the preface, was to investigate "[...] a type of architecture which has been given the name of organic", a word which had the advantage, according to the author, of not ending "in -istic, showing it was not a programme or a dream of architecture, rather a concrete trend of buildings and architects [...]" 7, proposing, therefore, "[...] an internal discourse, an intimate criticism of modern architecture in the early period." A promise, which Zevi maintained over the following pages, accusing "a genius such as Le Corbusier" of being one of the main people responsible for a widespread "architectural decadence"10 and for the prescriptive dogmatism of architecture in the years prior to the Second World War. He highlights the normative features of modern architecture, its parallel crisis

\footnotetext{
${ }^{3}$ Zevi, Bruno, Storia dell'architettura moderna. Da William Morris ad Alvar Aalto: la ricerca spazio temporale, vol. 1, Torino: Einaudi, 2001, p. 109 (first edition in 1950; main updates and reprints in 1975, 1994, 2001) [author's translation from Italian]

${ }^{4}$ Zevi, Bruno: Zevi su Zevi, p. 44

${ }^{5}$ Zevi, Bruno, Verso un'architettura organica. Saggio sullo sviluppo del pensiero architettonico negli ultimi cinquant'anni, Torino: Giulio Einaudi Editore, 1945. A few year later he also published the English edition: Towards an organic architecture, London: Faber \& Faber, 1950

${ }^{6}$ Zevi, Bruno, Verso un'architettura organica, p. 12 [author's translation from Italian]

${ }^{7}$ Ibid.

${ }^{8}$ Ibid.

${ }^{9}$ Ibid. p. 42

${ }^{10}$ Ibid.
} 
with the birth of European non-democratic regimes, and the inability of the Modern Movement to truly blend functional ideas and form. There are no detailed references to Le Corbusier's works, merely vague hints at the master's alleged approach to architecture.
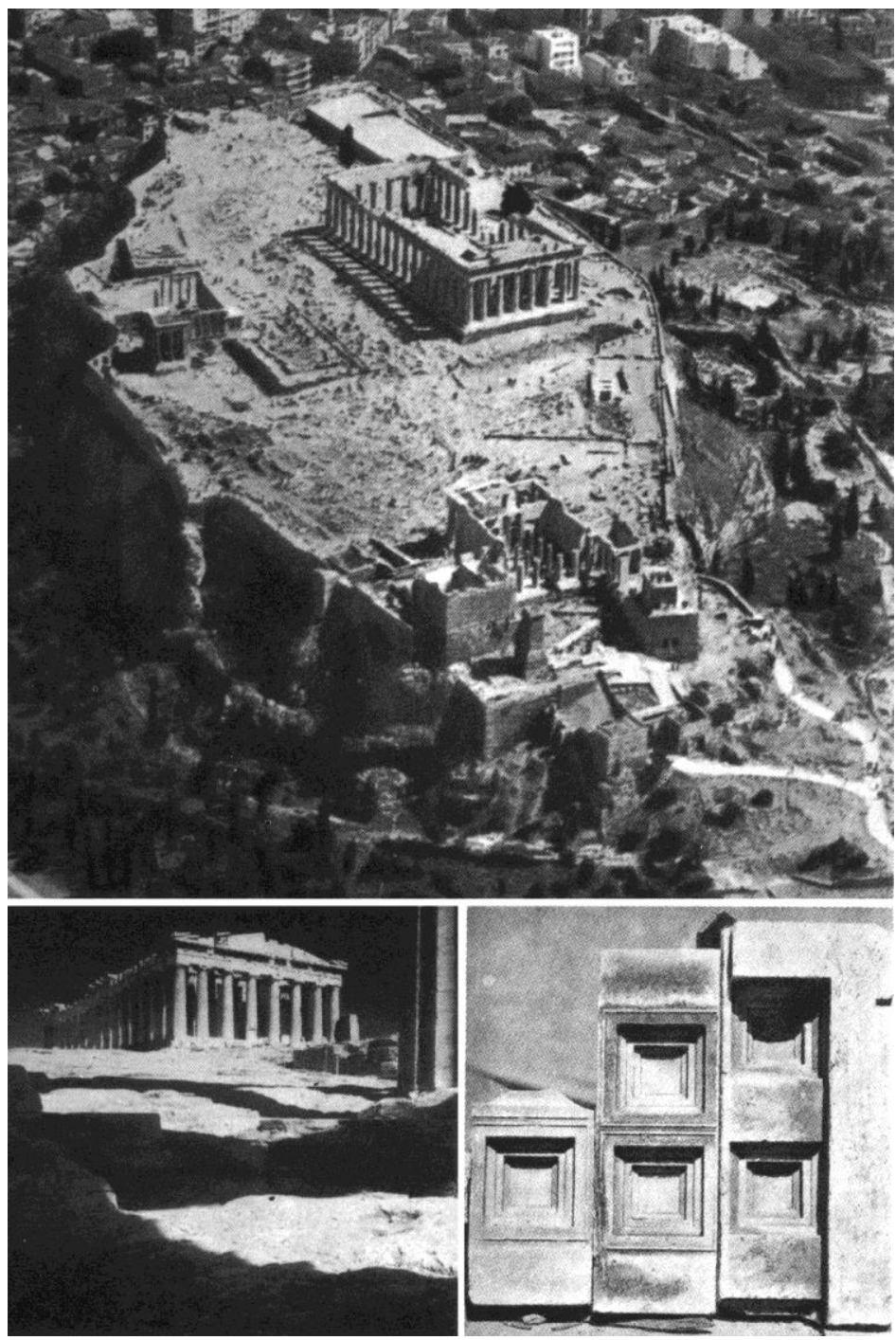

1. Top: Bird's eye view of the Acropolis of Athens; Bottom: The living rock at the base of the Parthenon; The square coffers of the Parthenon (The pictures, their placement and captions are taken from the book by Bruno Zevi, Architettura e storiografia) 

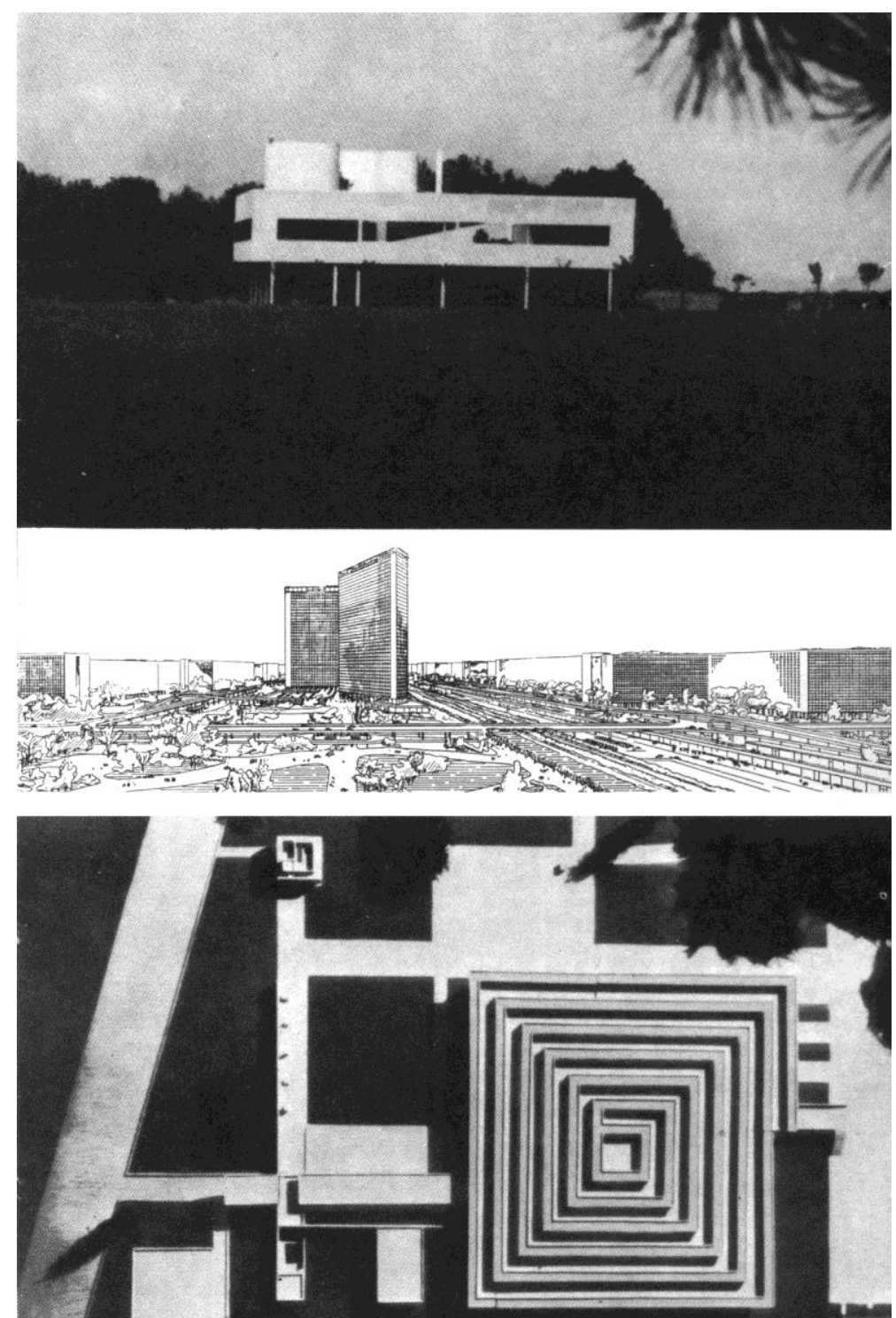

2. Top: The «pure» volume of Villa Savoye in Poissy (1929); Middle: Skycrapers in the Antwerp artificial landscape (1933); Bottom: Le Corbusier's taste for square in the Museum of Unlimited Growth (1939) (The pictures, their placement and captions are taken from the book by Bruno Zevi, Architettura e storiografia) 
Zevi contrasted this interpretation with what he believed to be the positive qualities of organic architecture, which represented "[...] an effort to set free from the theoretical rigidity of the clichés [of Functionalism] and humanisation "11, invoking the thoughts of Aalto. ${ }^{12}$ The key critical passage, however, is his attempt to extend the term organic beyond the pales of Wright's domain and to avoid linguistic misunderstandings. Zevi dedicates an entire chapter of his book to this aspect and indirectly reconnects to Walter Curt Behrendt's theories of modern architecture. ${ }^{13}$

In his direct comparison between Wright and Le Corbusier, Zevi re-dimensioned the skills of the latter, making Le Corbusier's architecture less important, but specified how he did not "[...] aim to make comparisons of value. It was merely an approximate means to clarify the distinctions. Thus, by criticising a part of European work and the attitude of some architects, and in setting out the trends in America, I had fresh in my mind the fact that my readers knew the positive qualities of the former ${ }^{\prime \prime 14}$

Positions and method which also appear to be confirmed in the report L'architettura organica di fronte ai suoi critici (1947) [Organic architecture face to face with its critics] given at the 1st National Congress of the APAO (Associazioni Per l'Architettura Organica) [Associations for Organic Architecture] ${ }^{15}$, in which the term organic is subjected to a definite shift in meaning: "There is an American functionalist architecture, from which Wright's organic architecture descends; it is a functionalist architecture which has generated our movement. If you take into account the vitality of the functionalism of Le Corbusier compared to the message of Sullivan, you will get an idea of the horizons open to European organic architecture, beyond Wright's cultural contribution. "16

However, the true objection of the controversy was not Le Corbusier and his architecture, which Zevi used once again as a pretext. Rather, it was the historiographic construction of the Modern Movement given by Sigfried Giedion in his Space, Time and Architecture (1941). Zevi's intention was made clear only in 1949, when he sent a message to the CIAM (Congrés Internationaux d'Architecture Moderne) in Bergamo, addressed mainly to Giedion. The text -translated both in English and French- was distributed to all participants of the congress in the hope of opening up to organic architecture, by reopening the debate on the different traditions of Modernism: "there is no modern architect living who does not recognize the great versatile ability of Le Corbusier and his followers, but many feel that his approach is only one of the aspects in the present order of things. [...] While it is evident that the members of the CIAM need not all swear by Giedion's theses [...]. In fact, in Giedion we find a somewhat incomplete history of modern architecture from 1859 to 1914, and a very brief history of it after 1933. Or rather this last part is so brief as to be practically non-existent.",17

\footnotetext{
${ }^{11}$ Ibid. p.61

${ }^{12}$ His explicit reference in the preceding page is to Alvar Aalto's article "The Humanising of Architecture", in The Architectural Forum, Dec. 1940, pp. 505-506

${ }^{13}$ See: Amirante, Roberta and Carreri, Emanuele, Introduzione all'edizione italiana, in Behrendt, Walter Curt, Il costruire moderno. Natura, problemi e forme, Bologna: Editrice Compositori, 2007 (1st ed. Modern Building. Its Nature, Problems, and Forms, New York, 1937)

${ }^{14}$ Zevi, Bruno, Verso un'architettura organica, p.141 [author's translation from Italian]

15 The Congress was held in Rome on 7 December 1947, at the Accademia d'Arte Drammatica, whereas the report was published in Zevi, Bruno: Zevi su Zevi, pp. 55-63

${ }^{16}$ Zevi, Bruno: Zevi su Zevi, p. 59 The text of the conference was previously published in the magazine Metron, n. 23-24, 1948 [author's translation from Italian]

${ }^{17}$ Zevi, Bruno, "Messaggio al Congrés Internationaux d'Architecture Moderne", Metron, n. 31-32 (1949). Giedion's reply and Zevi’s subsequent retort were published in Comunità No. 5 (1949) an No. 6 (1950)

See: Zevi, Bruno, Tutto Zevi, Rome: Mancosu Editore, 2001. The publication Tutto Zevi [The complete Zevi], consisting of a book acting as a table of contents and $12 \mathrm{CD}$-ROMs, represented a sort of database containing the main documents and
} 
Zevi's first essay on Le Corbusier appeared in 1959, as part of the catalogue for the exhibition on Le Corbusier and the technological developments of contemporary architecture, held at the National Gallery of Modern Art in Rome. The text aimed at analytically investigate Le Corbusier's poetry and architectural trends after World War II, but was not unrelated to Zevi's critical historic construction.

At first, the title of the brief essay appears critical: "Le Corbusier, poeta senza storia" 18 [Le Corbusier, a poet without history]. Zevi highlighted the attempt by the modernist architects to present their discoveries as axiomatic conquests and permanent truths of the society in which they lived, in contrast with the historicist spirit of traditional academies: "Every human achievement has its price: the rationalist generation was missing the sense of history. ${ }^{19}$ This was the framework within which Zevi presented Le Corbusier's ideas as a sequence of positive contradictions: "Le Corbusier's entire subject matter lies within these opposite poles, ranging from enchantment to mathematics to lyric poetry: the square layout of the Villa in Poissy and at the opposite end of the scale the fluid, undulating plan of Ronchamp; the Cartesian regulatory plans for Paris, the landscape sensitivity of Algiers, the communal dimension of Saint-Dié and the classicist weave of Chandigarh; the atrophy of building material in the two-dimensional bands of glass and plaster of the Swiss Pavilion, and the «béton brut», the rough brutality of concrete walls of the Unité d'habitation in Marseilles; the "purism», the love of primary geometric and stereometric forms and, at the opposite end, the virtuosity of the paraboloid surfaces enclosing the «empty stomach» of the Philips Pavilion at the Universal Exhibition in Brussels. An overwhelming propagandistic vein is at the service of an essentially solitary spirit. ${ }^{, 20}$ In his list of Le Corbusier's bravura in architecture, Zevi also underlined Le Corbusier's departure from the five points he had promulgated during the 20s. And this is where Le Corbusier's pragmatism, with its restlessness and second thoughts, joins up with Zevi's historic project: "les objets à réaction poetique are at first a statement of rigid, suspended prisms, sinuous adjectives of intellectual, programmatic, rationalist texts; in the Ronchamp's Chapel and in the Philips Pavilion they subjugate the entire building in an organic process, in which the distinction between the elements and orders of architecture is wiped out, and the moulding attacks, embraces, possesses and sometimes even destroys the consistency of the architecture in an electronic poem. ,21

According to Zevi, Le Corbusier's poetics finally arrives at the organic. Between the 50s and 60s, during his promotion of the post-rationalist and organic approach, Zevi also reflected on the possibility of redefining the relationship between history and modern architecture. ${ }^{22}$ The clean slate proposed by Purism and Functionalism had, without doubt, put the historic disciplines and traditional historicist teaching of the academies in a difficult position. However, the time had come in which the teaching of architectural history contributed in a

publications from Zevi's archive, selected by Zevi himself before he died. The publication is, however, to be considered as posthumous and spoiled by a series of software and cataloguing restrictions.

${ }^{18}$ Zevi, Bruno, "Le Corbusier, poeta senza storia" in Forme e tecniche nell'architettura contemporanea, preface by Palma Bucarelli, Rome: Editalia, 1959, pp. 13-16 [author's translation from Italian]. This was a catalogue of an exhibition originally set up in Zurich in 1957 and presented in Rome from 20 March to 20 April 1959.

${ }^{19}$ Ibid. p. 13

${ }^{20}$ Ibid. pp. $14-15$

${ }^{21}$ Ibid. p. 16

${ }^{22}$ See: Zevi, Bruno, Architettura e storiografia, Milano: Libreria editrice politecnica Tamburini, 1950. A book republished in 1974 in a new edition, to which he added the subtitle, Le matrici antiche del linguaggio moderno [The ancient matrices of modern language]. 
propositional manner to the «battle of Modernism». Zevi methodically proposed the foundations for a new historic discipline: operative criticism, ${ }^{23}$ or history as an operative methodology of architectural practice. ${ }^{24}$

The architect who remained mostly involved in Zevi's continually redefining of his thoughts was actually Le Corbusier. In fact, in one of his editorials, Zevi decided to turn his previous judgement of the non-historicity of Le Corbusier's language upside down: "Genius [...] summarises and exalts history, it represents it but does not record it, it anticipates it and therefore does not stop it; at a certain point, compared to the events of everyone, it stands as anti-history. Le Corbusier, however, [...] astounds, because he is the only architect in the world who has completely, heroically lowered himself into the lacerations in the world. Take a look at the other masters. Wright's creativity, at least from 1930 onwards, had acquired such a dimension as to make it impossible to relate to history [...] In different ways, Gropius and Mies and Oud refused history [...] Only Le Corbusier has the human grandeur, the vitality and the courage to be available" 25 , whilst considering the collapse of the functionalist society, the psychological traumas of the war conflict and the uncertainties of reconstruction.

At the death of Le Corbusier in 1965, this new interpretation became even more explicit, even though for many years it was never adequately revealed After holding a lecture in remembrance of the Swiss-French maestro at the faculty of architecture in Rome, Zevi prepared an essay, which was to appear in a Latin American journal again with the emblematic title of "El coloquio del Le Corbusier con la historia." resolve any doubts, the more general idea of an architect, capable of holding a dialogue with architectural questions of the past in a non-historic key, came to constitute the essential nucleus of Zevi's theoretical thinking. An investigation into the past then became a working method for the contemporary architect. It was actually possible to capture the unexpressed artistic values and subversive moments from history. However, the operative historian (i.e. the architect turned militant critic) could gain the contemporary expressive code above all from a comparison of personalities and different periods. At this point, Zevi outlined the idea that architectural language could constitute a critical text and, at the same time, an instrument of historical analysis.

\footnotetext{
${ }^{23}$ Amongst the numerous articles written by Zevi we should point out a brief selection: Zevi, Bruno, "La historia como instrumento de sintesis de la enseñanza de la arquitectura" and "La estética moderna y la historiografia arquitectonica" in 2 Conferencias, Universidad de Buenos Aires, 1952; "Il rinnovamento della storiografia architettonica" in Annali della Scuola Normale Superiore di Pisa, vol. XXII, Florence: Vallecchi, 1954; "La storia dell'architettura per gli architetti moderni", L'architettura, cronache e storia, n.23 Sept. 1957; "Un gesto probante: gli architetti scelgono la critica storica", L'architettura, cronache e storia, n.50 Dec. 1959; "La storia dell'architettura: serve a formare gli architetti?" L'architettura, cronache e storia, n.66 Apr. 1961; "History as a Method of Teaching Architecture" in Whiffen, Marcus (ed.) The History, Theory and Criticism of Architecture: Papers from the 1964 AIA-ACSA Teacher Seminar, Cambridge, Mass.: The MIT Press, 1965

${ }^{24}$ See: Zevi, Bruno, "La storia come metodologia del fare architettonico" [History as methodology of architectural practice] inaugural lecture in the auditorium of the University of Rome on 18 December 1963, republished with amendments in Il linguaggio moderno dell'architettura. Guida al codice anticlassico, Torino: Einaudi, 1973, pp. 87-107

${ }^{25}$ Zevi, Bruno, "La registrazione veritiera di Le Corbusier", in L'architettura, cronache e storia, No. 68 Jan. 1961, p.75 [author's translation from Italian]

${ }^{26}$ Zevi, Bruno, "El coloquio de Le Corbusier con la historia", La Torre, Universidad de Puerto Rico, n. 52 , Jan.-Apr. 1966, pp.167-180; republished in Italian with amendments in Zevi, Bruno, Pretesti di critica architettonica, Torino: Einaudi, 1983, $155-163$
} 

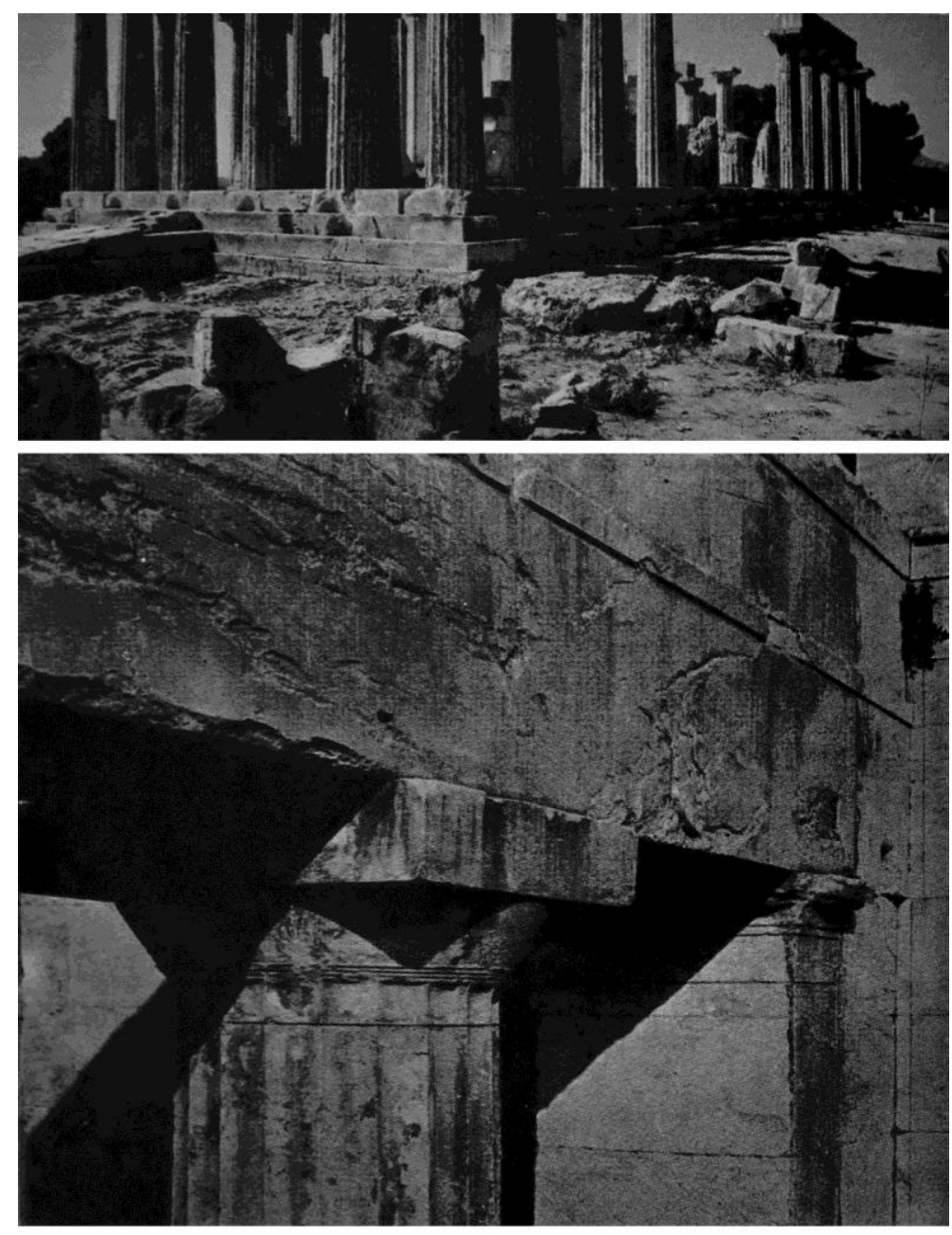

3. Separation of the volumes from the ground and moulding in Greece and Le Corbusier's architecture. The stylobate of the Temple of Aphaia, Aigina ( $5^{\text {th }}$ century BC) and capital of the Propyleia, Athens (The pictures, their placement and captions are taken from the book by Bruno Zevi, Architettura e storiografia) 

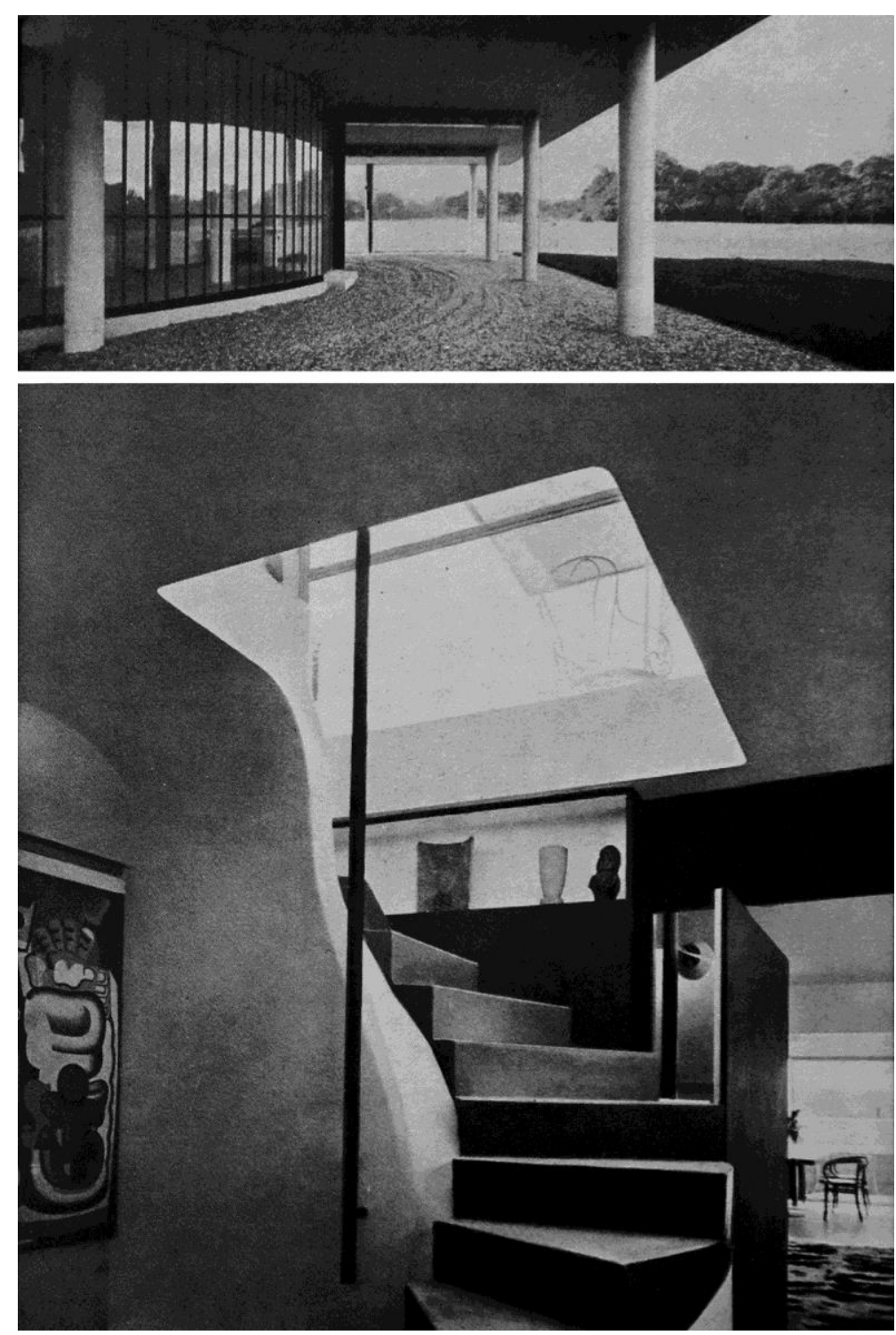

4. Separation of the volumes from the ground and moulding in Greece and Le Corbusier's architecture. Villa Savoye pilotis and furniture in a building near Porte Molitor, Paris (1933) (The pictures, their placement and captions are taken from the book by Bruno Zevi, Architettura e storiografia) 
The fundamental difference between this approach and the post-modern hypotheses developed by Paolo Portoghesi or Charles Jencks was that history in the eyes of Zevi became a laboratory where everything continually came under discussion without any precise reference points, in which only the spatiality of the work counted. On the contrary, the growing theories on post-modernism to which Zevi was as an ardent opposer, tended to offer an idea of history as a supermarket and architecture as an assembly of icons and archetypes: by giving up the typical tension of modernism to radicalise the creative/design moment, the past became the place from which architects ended by drawing their formal and, therefore, stylistic repertory.

In the light of this concept of history according to Zevi "in Le Corbusier cultural and creative pathways blend, there is absolute synchrony between historic conscience and poetic outburst, which is a unique phenomenon in the panorama of the maestri of modern architecture, and therefore assumes a technical and operative value and a linguistic and ethical ensemble. If, despite the difficult years, the nerve-wracking events and alternating fortunes, Le Corbusier unceasingly challenges the system, rejects every conformism, never becomes in any sense of the word an "official of the superstructure» [...] the reason [...] lies in the assiduous, daily, untiring dialogue he has with the past, in the justification he takes from it and which serves to cleanse or enrich, to stimulate or set aside and protect, nevertheless as a point of reference to show enthusiasm, to pause or to recover. "27 Le Corbusier's conversation with history, explained Zevi, was divided into three stages: the first corresponded to his period of training, to the trips during which he came into contact with the architectural and urban reality of the past, to his apprenticeship as artisan first and then as architect and to the transformation from Charles Edouard Jeanneret into Le Corbusier. The second stage stretched from the 20s to the Second World War. Here Zevi highlighted how in Vers une architecture several chapters are dedicated to the past, but how deep down "this period of Le Corbusier's conversation with history is all to be restudied. "28 Furthermore, he added that his unhistoricity could be identified in his rejection of historicism. The third stage was the one in which Le Corbusier took a critical position compared to his previous achievements, aware that "now the hope of redeeming the world by means of rationality has succumbed. "29

Zevi did not merely use historic data to support his argument, but used the provocative approach of the militant critic: "Le Corbusier takes on the stature of Wright's genius, perhaps less powerful, but more in touch with contemporary life, because it is a continual, ever-new conversation with history., 30

The organic is ferried more clearly from the world of Wright to post-rationalism, to end up in the "informal scream of Ronchamp." 31 From a young age, Zevi had specified the non-absolutist character of the organic concept, which envisaged the introduction into architecture of psychological components. Furthermore, organic architecture was the result of an evolutionary idea of architecture, conceived as a growing organism, recording the renewed material and spiritual questions of the designer and of the person living in it. Essentially, Zevi's organic had an ethical question as its foundation, but no figurative repertory.

The concept of history does not merely act as the background for Zevi's interpretation, but becomes an integral part of Zevi's provocative lesson: Le Corbusier's path re-interpreted as another way to an organic architecture.

\footnotetext{
${ }^{27}$ Zevi, Bruno, Pretesti di critica architettonica, p.155 [author's translation from Italian]

${ }^{28}$ Ibid. p. 159

${ }^{29}$ Ibid. p. 161

${ }^{30}$ Ibid. p. 162

${ }^{31}$ Ibid.
} 


\section{Zevi and Le Corbusier: the Five Points and the Invariants of the Modern Language of Architecture}

In the 70s, Zevi systematically perfected his effective communicative approach, insisting on a polemical style of writing, motivated by his work as article writer for the well-known Italian weekly newspaper $L$ 'Espresso. During this period he published Il linguaggio moderno dell'architettura (1973) [The modern language of architecture], a book in which he developed the theory of the "invariants" of modern architecture, i.e. a series of seven points, or principles, by means of which to critically analyse contemporary architectural production. An approach with the ambition of arousing dissent, and the validity of which "should be tested on works and on the drawing boards. ${ }^{, 32}$

These invariants probably constitute Le Corbusier's most vivid heritage in Zevi's interpretation of architecture. The reason lies in Zevi's reflections on Le Corbusier's five points. Naturally, many other theories and examples were also vivid in the mind of the Roman critic and historian. We can quote at least two, widely verifiable by quotations and deductions taken from other texts: $:^{33}$ the six points on organic architecture expressed by Wright in 1908 "In the cause of architecture, ${ }^{, 34}$ and the seventeen points of Theo van Doesburg regarding neoplastic architecture. ${ }^{35}$

However, within the limits imposed by this essay and for questions we feel are important to illustrate, we will pause mainly on the aspects which highlight a bond with Le Corbusier's ideas. A bond which stands out for its analogies and contrasts developing around the typical themes of the $60 \mathrm{~s}$ and $70 \mathrm{~s}$, concerning architecture as language and the semiotics of the work of art.

Like Le Corbusier's five points, Zevi's seven invariants aim to educate and popularise at the same time. Both cases suggest the keys to interpreting architecture. The main difference is that, whereas Le Corbusier provides instructions to apply to the project, Zevi thinks of how, of a procedure which does not contemplate precise rules such as those of Le Corbusier. We can attempt a rapid comparison. Le Corbusier's famous five principles are: 1) the pilotis, or the reinforced concrete structure instead of walls. The pillars "rise directly from the floor to 3, 4, 5, 6, etc. metres and elevate the ground floor. The rooms are thereby removed from the dampness of the soil $[\ldots]^{336} 2$ ) the roof garden. "The flat roof demands in the first place systematic utilization for domestic purposes: roof terrace, roof garden [...] In general, roof gardens mean to a city the recovery of all the built-up area ${ }^{, 37} 3$ ) the free design of the ground-plan, as a result of adopting a structure in reinforced concrete, each floor can be organised according to the principle of functionality: "the result of this is absolute freedom in designing the ground-plan,38 4) the fenêtre en longuer, wide horizontal cuts in the wall, rather than vertical holes. 5) the free design of the façade. "By projecting the floor beyond the supporting pillars, like a balcony all round the building,

\footnotetext{
${ }^{32}$ Zevi, Bruno, Il linguaggio moderno dell'architettura. Guida al codice anticlassico, Turin: Einaudi, 1973, p.11 (The modern language of architecture, Seattle, London: University of Washington Press, 1978, 1st English edition) [author's translation from Italian]

${ }^{33}$ See: Zevi, Bruno, Poetica dell'architettura neoplastica. Il linguaggio della scomposizione quadrimensionale, Torino: Einaudi, 1974, pp.110-117 (1st ed. 1953)

${ }^{34}$ See: Wright, Frank Lloyd, "In the cause of architecture", in The Architectural Record, March, 1908

${ }^{35}$ See: Van Doesburg, Theo, "Tot een beeldende architectuur” [Towards a plastic architecture], in De Stijl, VI, n. 6/7, 1924

${ }^{36}$ Le Corbusier and Jeanneret, Pierre, "Five points towards a new architecture", in Conrads, Ulrich, Programs and manifestoes on 20th-century architecture, Cambridge, Mass.: The MIT Press, 1971, p. 99. The declaration "Les cinq points de l'architecture nouvelle" by Le Corbusier was originally published in Almanach de l'Architecture moderne, Paris, 1926

${ }^{37}$ Ibid., p. $99-100$

${ }^{38}$ Ibid., p. 100
} 
the whole façade is extended beyond the supporting construction. It thereby loses its supportive quality [...] The façade may thus be designed freely. ${ }^{, 39}$

Zevi's seven invariants are: 1) Listing of functional requirements; 2) Asymmetry and Dissonance; 3) Antiperspective Three-dimensionality; 4) Four-dimensional decomposition (fluid space planning); 5) Cantilever, shell and membrane structures; 6) Space-in-time 7) Reintegration of building, city and landscape.

Zevi's principles appear cryptic unless we understand his argumentations. They were also accused of being symptoms of anti-conformism and madness. ${ }^{40}$ However, they can easily be compared to Le Corbusier's five points and other reflections by him. For example, the first invariant is an invitation to commence the project without any kind of a priori: it holds together Le Corbusier's principles of a free floor plan and free façade, it uses similar arguments. However, Zevi specifies, simply out of protest, that it is also an invitation to free oneself from any dogma, commencing with the five points. The principle of the cantilever, that is to say a courageous structural concept of the building, echoes Le Corbusier's reflections on the pilotis and reinforced concrete. The invariant on the decomposition of the spatial box is an explicit reference to the De Stijl movement. It alludes to spatial fluidity and to how this feature is connected to the way of conceiving planes, lights and colours. The breaking up of the box, decomposed into sheets, is none other than the search for a method to measure out light and expand the boundaries of space by eliminating the perimetric walls. The horizontal window is part of this process, according to Le Corbusier's description: "together with the intermediate ceilings the supports form rectangular openings in the façade through which light and air enter copiously." ${ }^{, 41}$ On the other hand, the question of reintegrating building, city and landscape is quickly confirmed by the garden roof and the pilotis, which are principles arising from reflections on town planning, placing reasoning about the city before architecture.

However, how can we not think of the architectural promenade compared to the invariants which contemplate the anti-perspective tri-dimensionality and space in time? Furthermore, Zevi himself stresses that Le Corbusier refers to Greek and Roman architectural culture, in other words to the pre-Renaissance spatial values, as he captures modernism and avoids the blinkers of the traditional Beaux-Arts structure.

The pages of Il Linguaggio moderno dell'architettura are full of invectives against the design cowardice, the Renaissance rules, the schools of architecture, seen as backward structures and places in which inadequate teaching methods prevail. Concepts expressed with the same verve as many fragments in Vers une architecture: "Rome is a bazaar in full swing, and a picturesque one. There you find every sort of horror [...] and the bad taste of the Roman Renaissance. We have to judge this Renaissance by our modern taste, which separates us from it by four great centuries of effort, the 17th, 18th, 19th and 20th [...]. The lesson of Rome is for wise men, for those who know and can appreciate, who can resist and can verify. Rome is the damnation of the halfeducated. To send architectural students to Rome is to cripple them for life. The Grand Prix de Rome and the Villa Medici [The French Academy in Rome is located in the Villa Medici] are the cancer of French architecture. ${ }^{, 42}$

We will not develop this any further to avoid forcing any interpretations. However, it is correct to say there is something else.

\footnotetext{
${ }^{39}$ Ibid.

${ }^{40}$ See review by Jameson, Conrad, "The Modern Language of Architecture by Bruno Zevi", Journal of the Society of Architectural Historians, vol. 40, n. 1 (Mar., 1981) pp. 80-82

${ }^{41}$ Le Corbusier and Jeanneret, Pierre, "Five points towards a new architecture", p. 100

${ }^{42}$ Le Corbusier, Towards a new architecture, New York: Dover Publication, 1986 (1st ed. 1923) pp.172-173
} 
In an issue of L'architettura of 1974, Zevi wrote an editorial entitled "Le invarianti di Le Corbusier" [Le Corbusier's invariants], an impossible tongue-in-cheek interview: "Let us now turn to Le Corbusier: what do you think of the language of the Modern Movement, of the seven invariants? He answers irritated, almost to imply he has no time to lose. He hands us a text and nine sketches: a conference with students of architecture in the thirties. "Les sept invariants? Je m'en fiche!» [The seven invariants? I couldn’t care less]"43 Actually, this was not one of Zevi's publicity stunts to promote his book on the language of the Modern Movement. The fragments of text he included in the editorial were actually by Le Corbusier, despite the ambiguous context in which Zevi places them. They come from the book Précisions sur un état présent de l'architecture et de l'urbanisme ${ }^{44}$ not yet translated into Italian at the time. Zevi quotes the text of the last of the ten conferences held in Buenos Aires in October 1929, entitled "The World City and some perhaps untimely considerations." To be precise, the reference is to the second part of the conference, in which Le Corbusier, after having rapidly run through the main topic, introduced an improvised theme: Si je devais enseigner l'architecture? [If I had to teach you architecture? $]^{45}$

The similarities between Zevi's and Le Corbusier's reasoning and words are extraordinary, to the extent that it makes one think Zevi had Le Corbusier's text at hand when he drafted the first part of his book.

Let us compare a few phrases. Zevi: "The Listing of functions implies the decomposition and critical rejection of the classical rules, that is of the «orders», of the a priori, of the hackneyed expressions, of conventions of any original and kind..." ${ }^{, 46}$ Le Corbusier: "I would begin by forbidding the 'orders', by putting a stop to this dry rot of the orders, this incredible defiance of intelligence. ${ }^{, 47}$

Zevi: "A door? Open it anyway, except in the centre of the room. If the door leads away from the median, the space acquires depth [...] Where to illuminate that same room? In any point that is not in the centre, so as not to divide the room into three parts with a lit area between two dark areas at the sides. Let us re-semanticise the window according to the internal space and re-qualify light." ${ }^{, 48}$ Le Corbusier: "I ask a young student. How do you make a door? How big? Where do you put it? How do you make a window? But, incidentally, what is a window for? [...] In what part of a room do you make a door?... Perhaps you have several solutions. You are right, there are several solutions, and each one gives a separate architectural sensation. "49

Zevi: "To re-educate them [the architects] we would have to abolish the use of T-squares, set-squares, compasses, drafting machines, all the paraphernalia prepared according to classical grammar and syntax." Le Corbusier: "By the way, I forbid you to draw an axis on your plans -axes are merely formulated to dazzle the unwary. ",51

\footnotetext{
${ }^{43}$ Zevi, Bruno, "Le invarianti di Le Corbusier", L'Architettura, cronache e storia, n.227, Sept. 1974, p. 282 [author's translation from Italian]

${ }^{44}$ Le Corbusier, Precisions sur un état present de l'architecture et de l'urbanisme, Paris: Vincent \& C.ie, 1960 (1st ed. 1930)

${ }^{45}$ The text was published in English, with amendments and adaptations, under the title "If I had to teach you architecture", Focus, No. 1, London 1938

${ }^{46}$ Zevi, Bruno, Il linguaggio moderno dell 'architettura, p.11 [author's translation from Italian]

${ }^{47}$ Le Corbusier, "If I had to teach you architecture", in Sharp, Dennis, (ed.) The Rationalists. Theory and design in the modern movement, London: Architectural Press, 1977, pp. 79-80

${ }^{48}$ Zevi, Bruno, Il linguaggio moderno dell'architettura, p.20-25 [author's translation form Italian]

${ }^{49}$ Le Corbusier, "If I had to teach you architecture", p. 80

${ }^{50}$ Zevi, Bruno, Il linguaggio moderno dell'architettura, p.27 [author's translation from Italian]

${ }^{51}$ Le Corbusier, "If I had to teach you architecture", p. 80
} 

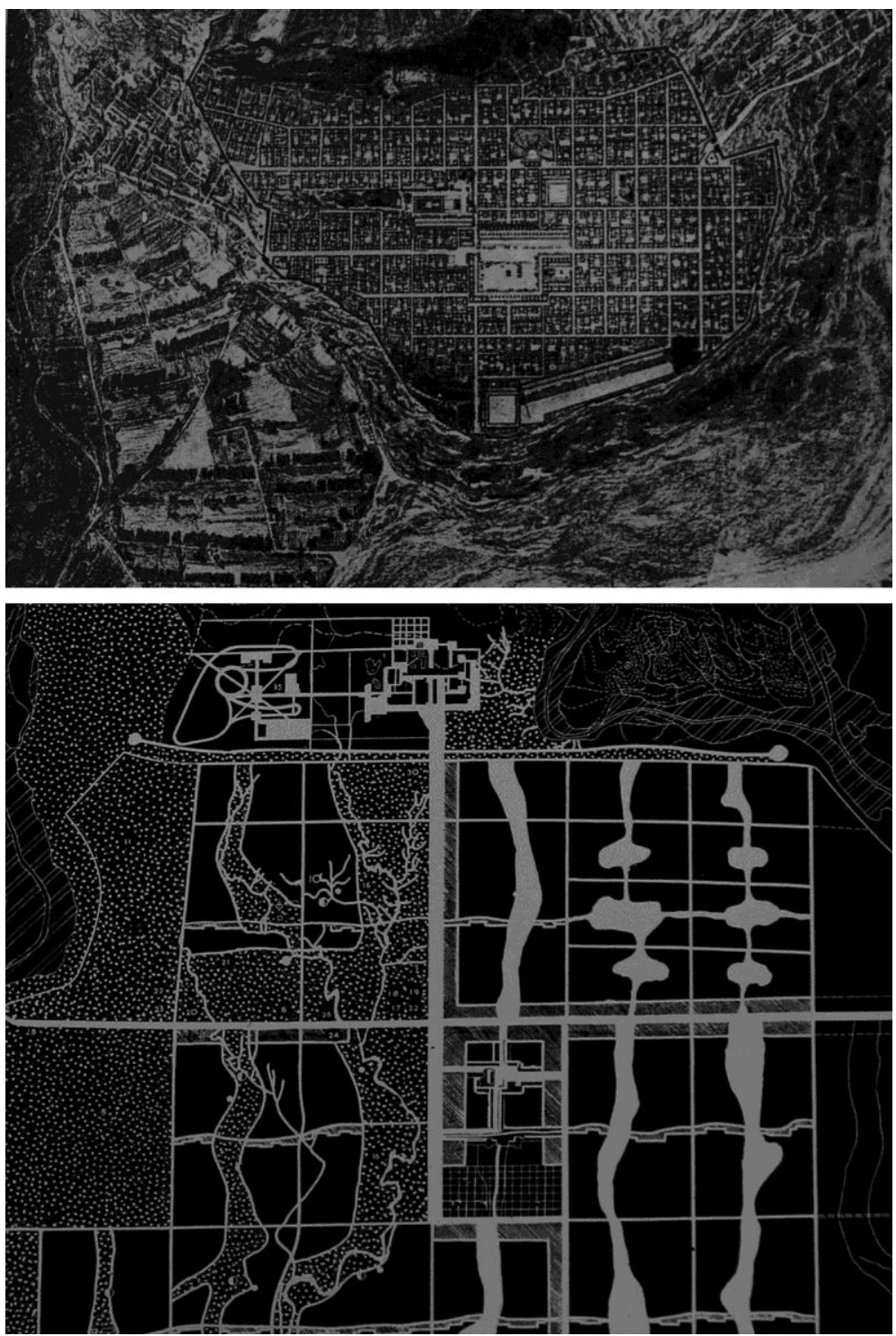

5. Le Corbusier and the Greek city grid. Top: Plan of Priene in a drawing by Patrice Bonnet; in the upper section, near the mountain, the Acropolis (at the end of 4th century BC) Bottom: Le Corbusier's plan of Chandigar, Punjab Capital City, India; in the upper section, near the mountain, the «Capitol» and the Acropolis in the northen area. (The pictures, their placement and captions are taken from the book by Bruno Zevi, Architettura e storiografia) 

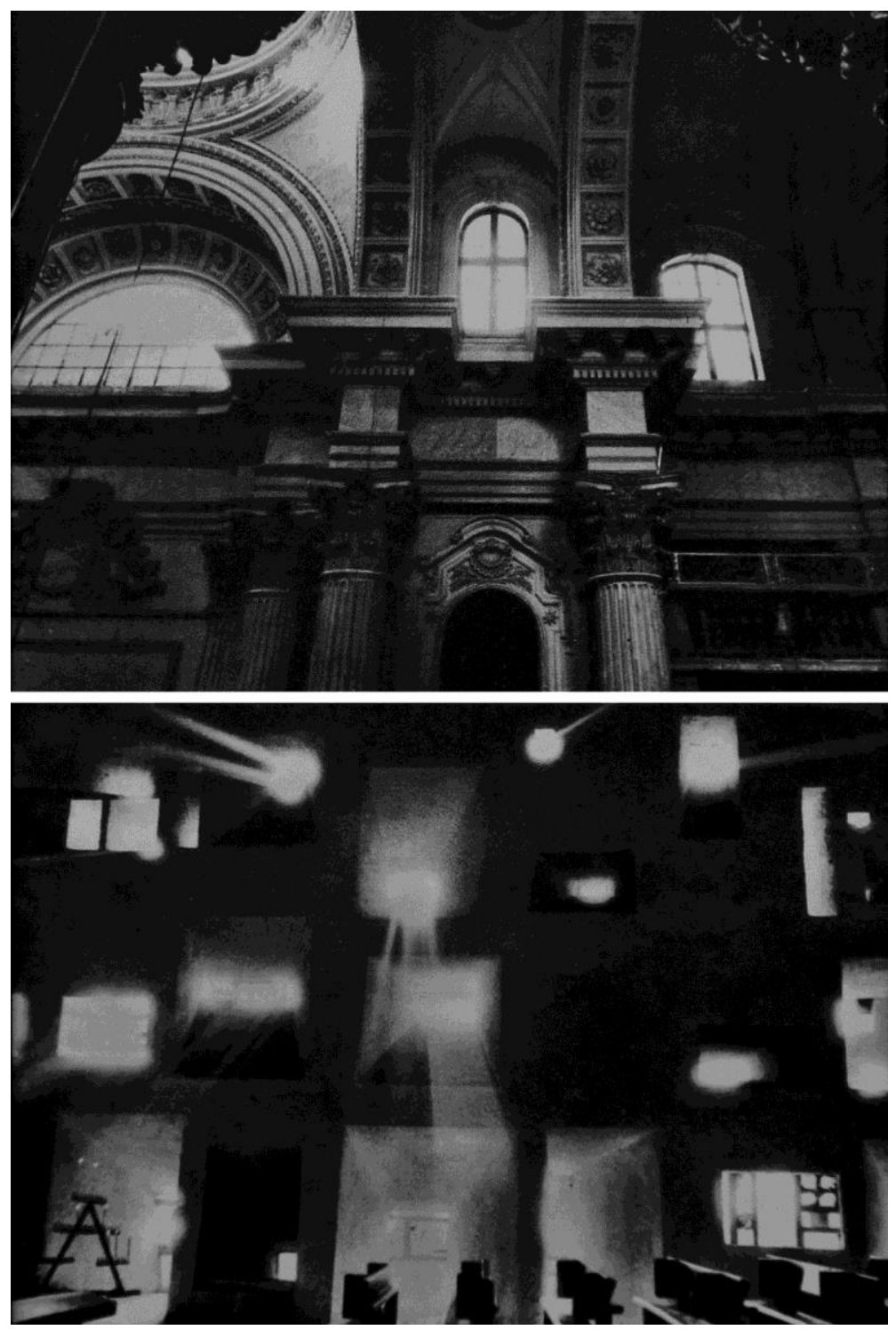

6. Top: Light dissonance comparing the two rooms of the church of Santa Maria in Campitelli by Carlo Rainaldi. On the right, the entrance room, on the left the space flooded by light focused on the altar, under the dome. Bottom: The wall adorned of bright holes in the Le Corbusier's Chapelle of Notre-Dame du Haut, Ronchamp (1950-53). The quantitative and qualitative difference of light is a tool to re-integrate architectural spaces and to achieve a space-time vision. This poetic device is chosen in baroque and post-rationalist architecture. (The pictures, their placement and captions are taken from the book by Bruno Zevi, Architettura e storiografia) 
Zevi: "[...] every distinction between the interior and exterior space, between architecture and town planning crumbles; the fusion of building and town creates urban-architecture." 52 Le Corbusier: "It is no longer possible to separate architecture and town-planning - they are one and the same thing. ",53

Too many similarities to pass unobserved and too many affinities to be able to mention them all. It is sufficient to grasp the sense of psychological investigation and bibliographic excavation carried out in this part of the text. No comparison is mechanical, and perhaps the differences are the same as the analogies. The general picture should be clear and, in addition, we know that it is impossible to make any simplistic transposition of the concepts discussed. What counts is that even the differences in conceiving architecture by antithesis shows the extent to which Zevi was influenced by Le Corbusier. Le Corbusier's message, thanks to Zevi, has widened its horizons further.

\section{The Athens Charter and the Machu Picchu Charter}

"An overwhelming propagandistic vein is at the service of an essentially solitary spirit." 54 Zevi had written about Le Corbusier. An observation which was actually autobiographical, but which fits both personalities perfectly. In fact, it was his pedagogical and, at the same time, propagandist temperament which led Zevi to draw up the Machu Picchu Charter (1977) as an open challenge to the Athens Charter (1933), drawn up by Le Corbusier under the aegis of the CIAM.

The basic idea behind Machu Picchu Charter -arousing from the international congress Reunion de Grandes Maestros de la Arquitectura, organised by the Universidad Nacional Federico Villarreal in the cities of Lima and Cuzco, from 6 to 13 December 1977- was to update the Athens Charter by recording, in a written reflection, the changes which had hit society, towns and architecture during the four decades following the meeting of the CIAM. The purpose of the congress was to present to the public the most advanced research in the field of architecture and town planning compared to the major global changes. The parallel intention was to produce a conclusive declaration to read out and symbolically sign in the ancient city, symbol of the Inca culture. There were numerous participants. To name but a few, they included Felix Candela, Jorge Glusberg, Charles Eames, Josè Luis Sert, Buckminster Fuller, Gordon Bunshaft, Paul Rudolph, Pier Luigi Nervi, Paolo Soleri, Frei Otto, Gottfried Böhm, Ricardo Legorreta, Kenzo Tange, Kunio Mayekawa, Oscar Niemeyer, and Clorindo Testa.

Why did Zevi suggest Mach Picchu? The answer is contained in the document: "Athens 1933, Machu Picchu 1977. The places are significant. Athens stood for the cradle of the western civilization. Machu Picchu symbolizes the independent cultural contribution in the other world. Athens stood for rationality and enlightenment personified by Aristotle and Plato. Machu Picchu stands for everything which escapes the global illuminist mentality and for everything not classifiable by its logic. „,55

The Athens Charter dwelt on the five fundamental points of Dwelling, Recreation, Work, Transportation and Legacy of history. A subdivision which finished by characterising the new regulatory town plans with policies of zoning: the separation of the sectors then created a series of problems for the contemporary town, by undermining and decreasing human relationships. Furthermore, consistent with the situation in the 30s, the town

\footnotetext{
${ }^{52}$ Zevi, Bruno, Il linguaggio moderno dell'architettura, p.59 [author's translation from Italian]

${ }^{53}$ Le Corbusier, "If I had to teach you architecture", p.79

${ }^{54}$ Zevi, Bruno, "Le Corbusier, poeta senza storia" p. 16 [author's translation from Italian]

${ }^{55}$ The text of the Machu Picchu Charter was published in Italian, English, Spanish and French in L'Architettura, cronache e storia, No. 268, February 1978, pp.546-563 (cit. p.547)
} 
was seen as a different entity from the region that influenced it, even though they were interdependent for economic, social and political questions. Moreover, recommendations concerning the historic parts of the town aimed mainly to protect and conserve the historical heritage.

The Machu Picchu Charter updated the problems faced previously, and stressed that the relationship of interdependence between town and region was now overcome by the fact that the towns had spread to the point of becoming unique entities alongside those of large regional areas. The underlying problem had become the reintegration of functions. It had become necessary to promote public transport and multipurpose, as opposed to separate functions. As regards the historic heritage, the need was now stressed to exploit, as well as preserve architectural property, and the idea was accepted to graft the contemporary on to historic town centres. There was also a reflection on architectural design which in the Athens Charter had no reason to exist, dominated as it was by the ideas of Le Corbusier, since it was considered an acquired and shared element. This point corresponded to the promotion of multiple architectural languages, in other words to Zevi's theories on the language of the Modern Movement and to his theory of the invariants. The Charter was then re-discussed and presented the following year, in 1978, at the congress of the UIA (Union Internationale des Architectes) in Mexico City.

Even though the experience was not such a well-publicised event globally, despite Zevi's efforts to broadcast it, it represents a declared attempt to retrace in a different light one of the most important experiences of Le Corbusier in a secular, non-celebratory manner.

\section{Conclusion}

Compared to the official story of the Modern Movement narrated by Giedion, in Zevi's Storia dell'architettura moderna "[...] the final chapter was not dominated by Le Corbusier, Gropius and Mies, but by Wright."

Zevi's History is, without doubt, a vision characterised by the presence of the maestri, but the continual updates still makes it one of today's most complete books due to the thoroughness of its investigation into the Modern Movement - in its numerous aspects - into its epigones and the attempts made to revive it.

This is not a forward-looking history in the strict sense, that is to say a story which presents continual leaps forward. On the contrary, it is an analysis which pauses to look at the moments of rupture, which had not necessarily been reinterpreted as a race towards the future.

What was important for Zevi was not the radicalism of the innovative features present in the architectural creations. On the contrary, he was interested in the ability of the architects to challenge pre-constituted values, as he loved to remember in the final years of his life, quoting the French philosopher, Jean Baudrillard.

Naturally, the books also count for what they did not include, particularly for what concerned his precise historiographic choices. Zevi was intransigent in not admitting the end of the Modernist experience and for this reason the revivalist historicists, typical of post-modernism, find no place, not even in the final editions of his texts. Zevi had learned that "[...] modern architecture is not «a style», but a continual process, a game which continually destroys its own rules and has to be reinvented each day. Thus, when Le Corbusier, in the Chapelle de Ronchamp in 1950, contradicted the free floor plan, the pilotis, the garden roof, the horizontal window, all

\footnotetext{
${ }^{56}$ Zevi, Bruno, "Dal manierismo al linguaggio- Architecture versus Historic Criticism", annual conference of the Royal Institute of British Architects, London 6th December 1983, published in Zevi su Zevi, p. 151 [author's translation from Italian] Zevi astutely and polemically provided a clarification in his message to the CIAM in Bergamo (see note 17)
} 
the «principles» which he had diffused in 1921 [sic], and when, in a certain sense, he resuscitated the spirit and forms of Expressionism, this did not constitute a trauma for my History, as the Expressionist poetics already existed in it as a permanent factor of the language of the Modern Movement. "57

Not by chance did he speak of zero degree language in architectural writing towards the end of the $90 \mathrm{~s}^{58}$

That is the possibility for architects to free themselves from the academies of thought, against which he had dedicated an entire life of battles and research, in exactly the same way as Le Corbusier. This was perhaps the reason why, in June 1997, when Zevi was invited to take part in the Le Corbusier International conference, ${ }^{59}$ organised in Paris by the Le Corbusier Foundation, he wrote an autobiographical speech in the strict sense, dedicated to his role as historian and critic of modern architecture. On that same occasion, Zevi highlighted Le Corbusier's ability in his Ronchamp project to challenge previous architectural research and the extent to which this was significant for subsequent developments in modern architecture.

The studies on the ancient matrices of the language of the Modern Movement did not serve merely to corroborate the theory of the invariants, but also to seek out those moments in history in which pre-established values had been challenged, by actually bearing in mind Le Corbusier's example. Zevi never dwelt on formal similarities. What he wanted to say out loud was that "[...] the historiographic revolution is a component of the architectural revolution which cannot be eliminated." 60

The process Zevi intended to put into practice and which he suggested to his readers was fundamentally to place oneself in a destabilising situation, lacking any precise equilibrium. We should probably refer to the Jewish unrest which agitated the minds of the great intellectuals of the twentieth century and which also characterised the final decades of architecture to find a valid explanation both from a psychological and historical viewpoint. Basically, Zevi had never worried too much about scandalising his listeners in exactly the same way as Le Corbusier, about whom he enjoyed speaking to us. This is his Le Corbusier heritage: "For this heroic availability, his defeats are a perpetual indictment and his bitter «Je m'en fiche!» acquires an ethical value. "61

\section{Source of images}

All pictures, their placement and captions are taken from the book by Zevi, Bruno Architettura e storiografia. Le matrici antiche del linguaggio moderno, Torino: Einaudi, 1974

\section{Bibliographical references}

Aalto, Alvar "The Humanising of Architecture", in The Architectural Forum, dec. 1940

Amirante, Roberta and Carreri, Emanuele, Introduzione all'edizione italiana, in Behrendt, Walter Curt, Il costruire moderno. Natura, problemi e forme, Bologna: Editrice Compositori, 2007

Irace, Fulvio and Cimoli, Anna Chiara, (Eds.) La divina proporzione. Triennale 1951, Milano: Electa, 2007

\footnotetext{
${ }^{57}$ Ibid.

${ }^{58}$ See: Zevi, Bruno, Paesaggistica e linguaggio grado zero dell'architettura. Landscape and zero degree of architectural language, Venice: Canal \& Stamperia, 1999 and the magazine L'architettura, cronache e storia, No. 503-506, 1997

${ }^{59}$ See: Zevi, Bruno, Tutto Zevi, Rome: Mancosu Editore, 2001

${ }^{60}$ Zevi, Bruno, Architettura e storiografia. Le matrici antiche del linguaggio moderno, Turin: Einaudi, 1974, p. 36 [author's translation from Italian]

${ }^{61}$ Zevi, Bruno, Storia dell'architettura moderna, vol I. p. 110 [author's translation from Italian]
} 
Jameson, Conrad, "The Modern Language of Architecture by Bruno Zevi”, in Journal of the Society of Architectural Historians, vol. 40, n. 1 (Mar., 1981) pp. 80-82

Le Corbusier and Jeanneret, Pierre, "Five points towards a new architecture", in Conrads, Ulrich (ed.), Programs and manifestoes on 20th-century architecture, Cambridge, Mass.: The MIT Press, 1971

Le Corbusier, "If I had to teach you architecture", in Sharp, Dennis, (ed.) The Rationalists. Theory and design in the modern movement, London: Architectural Press, 1977

Le Corbusier, Precisions sur un etat present de l'architecture et de l'urbanisme, Paris: Vincent \& C.ie, 1960

Le Corbusier, Towards a new architecture, New York: Dover Publication, 1986 (1st ed. 1923)

Van Doesburg, Theo, "Tot een beeldende architectuur" [Towards a plastic architecture], in De Stijl, VI, n. 6/7, 1924

Wright, Frank Lloyd, "In the cause of architecture”, in The Architectural Record, March, 1908

Zevi, Bruno, "Il rinnovamento della storiografia architettonica", in Annali della Scuola Normale Superiore di Pisa, vol. XXII, Firenze: Vallecchi, 1954

Zevi, Bruno, "Carta del Machu Picchu”, in L'Architettura, cronache e storia, n. 268, febbraio 1978

Zevi, Bruno, "El coloquio de Le Corbusier con la historia", in La Torre, Universidad de Puerto Rico, n. 52 , Jan.Apr. 1966

Zevi, Bruno, "History as a Method of Teaching Architecture", inWhiffen, Marcus (ed.) The History, Theory and Criticism of Architecture: Papers from the 1964 AIA-ACSA Teacher Seminar, Cambridge, Mass.: The MIT Press, 1965

Zevi, Bruno, "Il colloquio di Le Corbusier con la storia", in Pretesti di critica architettonica, Torino: Einaudi, 1983

Zevi, Bruno, "La historia como instrumento de sintesis de la enseñanza de la arquitectura" and "La estética moderna y la historiografia arquitectonica", in 2 Conferencias, Universidad de Buenos Aires, 1952

Zevi, Bruno, "La registrazione veritiera di Le Corbusier", in L'architettura, cronache e storia, n.68 Jan. 1961

Zevi, Bruno, "La storia come metodologia del fare architettonico", in Il linguaggio moderno dell'architettura. Guida al codice anticlassico, Torino: Einaudi, 1973

Zevi, Bruno, "La storia dell'architettura per gli architetti moderni”, in L'architettura, cronache e storia, n.23, Sept. 1957

Zevi, Bruno, "La storia dell'architettura: serve a formare gli architetti?", in L'architettura, cronache e storia, n.66 Apr. 1961

Zevi, Bruno, "Le Corbusier, poeta senza storia", in Forme e tecniche nell'architettura contemporanea, preface by Palma Bucarelli, Roma: Editalia, 1959

Zevi, Bruno, "Le invarianti di Le Corbusier" in L'Architettura, cronache e storia, n.227, sett. 1974

Zevi, Bruno, “Messaggio al Congrés Internationaux d'Architecture Moderne”, in Metron, n. 31-32, 1949

Zevi, Bruno, "Paesaggistica e linguaggio grado zero dell'architettura. Landscape and zero degree of architectural language," in L'architettura, cronache e storia, n.503-506, 1997

Zevi, Bruno, "Un gesto probante: gli architetti scelgono la critica storica", in L'architettura, cronache e storia, n.50, Dec. 1959

Zevi, Bruno, Architettura e storiografia, Milano: Libreria editrice politecnica Tamburini, 1950

Zevi, Bruno, Architettura e storiografia. Le matrici antiche del linguaggio moderno, Torino: Einaudi, 1974 (1st ed. 1950) 
Zevi, Bruno, Il linguaggio moderno dell'architettura. Guida al codice anticlassico, Torino: Einaudi, 1973

Zevi, Bruno, Paesaggistica e linguaggio grado zero dell'architettura. Landscape and zero degree of architectural language, Venezia: Canal \& Stamperia, 1999

Zevi, Bruno, Poetica dell'architettura neoplastica. Il linguaggio della scomposizione quadrimensionale, Torino: Einaudi, 1974 (1st ed. 1953)

Zevi, Bruno, Storia dell'architettura moderna. Da William Morris ad Alvar Aalto: la ricerca spazio temporale, vol. 1, Torino: Einaudi, 2001 (1st ed. 1950)

Zevi, Bruno, The modern language of architecture, Seattle, London: University of Washington Press, 1978

Zevi, Bruno, Towards an organic architecture, London: Faber \& Faber, 1950

Zevi, Bruno, Tutto Zevi, Roma: Mancosu Editore, 2001

Zevi, Bruno, Verso un'architettura organica. Saggio sullo sviluppo del pensiero architettonico negli ultimi cinquant'anni, Torino: Giulio Einaudi Editore, 1945

Zevi, Bruno, Zevi su Bruno Zevi, Milano: Magma, 1977

Zevi, Bruno, Zevi su Zevi. Architettura come profezia, Venezia: Marsilio, 1993 (1st ed. 1977) 


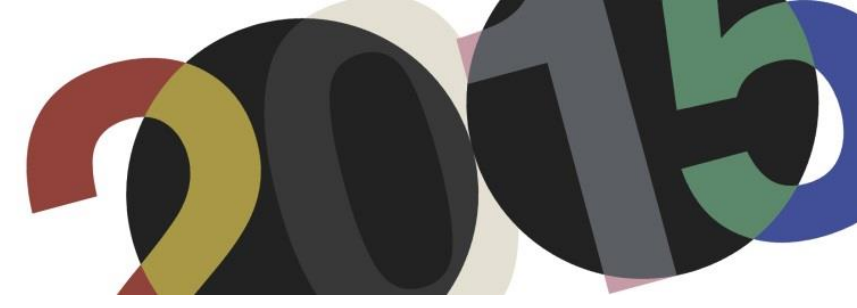

DOI: http://dx.doi.org/10.4995/LC2015.2015.648

\title{
Maestro y discípulos: \\ Japón y el pabellón para la Exposición Internacional de París de 1937
}

\author{
P.J. Gutiérrez Calderón \\ Escuela Técnica Superior de Arquitectura de Madrid - Kyoto Seika University
}

\begin{abstract}
Resumen: En 1937, Japón presentaba para la Exposición Internacional de París un pabellón que rompía con los modelos de arquitectura tradicional y vernácula que había construido en anteriores exposiciones. El descaro de la propuesta generó no poca controversia en el país nipón debido al lenguaje empleado, alejado de las tipologías y sistemas constructivos autóctonos para introducir un nuevo modelo, aplicando nuevos materiales como acero y vidrio. Entre el primer proyecto presentado a concurso, obra de Kunio Mayekawa y el proyecto finalmente construido, obra de Junzo Sakakura, aparecerá un común denominador en la figura del maestro: Le Corbusier. El artículo analiza la influencia que supuso el maestro en la realización de los proyectos. Mientras Mayekawa evolucionaba buscando su propio camino, Sakakura diseñará el pabellón en el estudio de la calle de Sèvres, influenciado por las enseñanzas y sugerencias de Le Corbusier, para conseguir aunar en su arquitectura la profunda tradición japonesa con la modernidad. El pabellón puede considerarse pionero de la arquitectura moderna japonesa que entra a formar parte de la escena internacional, alzándose con uno de los premios de arquitectura otorgados por la organización francesa, junto a los pabellones de Aalto y J. L. Sert.
\end{abstract}

Abstract: In 1937, a Japanese Pavilion was presented to the International Exhibition in Paris. This pavilion broke with the traditional and vernacular architecture that Japan had built in previous exhibitions. The audacity of the proposal generated a lot of controversy in the japanese country, due to its language, away from the native typologies and constructive systems. Indeed, the approach introduced a new model, using new materials such as steel and glass. The first project submitted to the competition, designed by Kunio Mayekawa, and the final built project, designed by Junzo Sakakura, have a common denominator represented by the figure of the Master: Le Corbusier. The article analyzes the influence of the Master in the ejecution of the projects. While Mayekawa progressed looking for its own way, Sakakura designed the pavilion in Sèvres Street Studio, influenced by the training and suggestions of Le Corbusier. Then, he managed to combine in its architecture deep Japanese tradition with modernity. The pavilion can be considered as a pioneering work of modern Japanese architecture that becomes part of the international scene, indeed, it was awarded with one of the architectural prizes granted by the French organization, together with the pavillions designed by Aalto and J.L.Sert.

Palabras clave: Mayekawa; Sakakura; Le Corbusier; Pabellón japonés; Arquitectura moderna. Keywords: Mayekawa; Sakakura; Le Corbusier; Japanese Pavilion; Modern Architecture. 


\section{Introducción, antecedentes y objetivos.}

En 1937, Japón presentaba para la Exposición Internacional de París un pabellón que rompía con los modelos de arquitectura tradicional y vernácula que había construido en anteriores exposiciones. El descaro de la propuesta generó no poca controversia en el país nipón debido al lenguaje empleado, alejado de las tipologías y sistemas constructivos autóctonos para introducir un nuevo modelo, aplicando nuevas tecnologías como acero y vidrio.

Para entender la disgresión estilística que supone este pabellón y la evolución que supuso para la arquitectura japonesa en los inicios del siglo XX hay que volver la mirada a dos arquitectos protagonistas del proyecto, que introducían de manera decidida el lenguaje moderno en un país cuyo peso de la tradición hacía muy difícil conseguir esa evolución. El primero, Kunio Maekawa, ganaba el concurso convocado al efecto pero que no llegará a construirse por ser considerado demasiado avanzado y poco japonés. El segundo, Junzo Sakakura, rediseñará y materializará el proyecto con un lenguaje moderno, gracias -en parte- a la intervención del gobierno francés. Ambos, unos años antes, habían sido colaboradores en la rue de Sèvres, París. Ambos vivirán la arquitectura como protagonistas en la introducción del movimiento moderno en Japón, poniendo en práctica las enseñanzas que recibieron de su maestro Le Corbusier.

El objetivo que plantea este artículo "Maestro y discípulos: Japón y el pabellón para la Exposición Internacional de París de 1937” es analizar el pabellón que representó a Japón en la exposición "Artes y Técnicas de la Vida Moderna", estableciendo analogías con la obra del maestro Le Corbusier para discernir los puntos de contacto e influencias que hicieron emerger la arquitectura moderna en Japón, a partir del estudio del proyecto ganador del concurso, obra de Maekawa, y el proyecto finalmente ejecutado en la colina de Trocadero, obra de Sakakura, frente a la Torre Eiffel.

\section{Japón en la Exposición de París: un pabellón en tiempos convulsos.}

"Una gran época ha comenzado. Existe un espíritu nuevo. Existe una multitud de obras concebidas en este espíritu nuevo que se encuentran, particularmente, en la producción industrial. La arquitectura se ahoga con las costumbres. Los "estilos" son una mentira. El estilo es una unidad de principio que anima todas las obras de una época, el resultado de un estado de ánimo que tiene su propio carácter especial. Nuestra propia época determina, día a día, su propio estilo. Nuestro ojos, desgraciadamente, no son capaces de discernirlo".

\section{Le Corbusier ${ }^{1}$}

Durante la década de los años treinta, Europa se enfrentaba a un período de gran agitación, marcado por la inestabilidad social, política y económica. Las secuelas de la Primera Guerra Mundial habían derivado en una grave crisis económica, y un auge preocupante del nacionalismo, exacerbado en Alemania y Rusia que mostraban su autoritarismo político mermando la ferviente actividad artística de los años veinte, persiguiendo y cerrando escuelas de diseño innovadoras o transgresoras como el caso de la Bauhaus. Es en este contexto internacional cuando se decidió convocar en París en 1934 una Exposición Internacional programada para 1937 bajo el título de "Arte y Tecnología en la Vida Moderna" cuyos objetivos eran por un lado mostrar los nuevos avances de la tecnología y su convivencia con el mundo del arte, como dos realidades no distantes sino complementarias y necesarias, unidas por la nueva vida moderna, y por otro intentar -en el contexto de la grave crisis económica y la inestabilidad política que precedería a la segunda Guerra Mundial-promover la paz con el acercamiento de los distintos países. A pesar de que en 1936 - un año antes de su inicio- la situación se agravaría

\footnotetext{
${ }^{1}$ Le Corbusier: Hacia una arquitectura. Barcelona: Ediciones Apóstrofe, S.L. 1998. pp. 68-69.
} 
con la ocupación alemana de la zona de Renania y con el estallido de la Guerra Civil española, Leon Blum, jefe del gabinete del Frente Popular francés dio un nuevo impulso para su definitiva ejecución e inauguración en mayo de 1937, invitando a cuarenta países entre los que se encontraba Japón, que aceptó la invitación.

En 1936, el país nipón creó una comisión técnica para el desarrollo del futuro pabellón, que pretendía enseñar al mundo la imagen de un país civilizado, moderno, ensalzando sus tradiciones y difundiendo la sutileza de la cultura japonesa, mostrándose como un país atractivo para el turismo, a la vez que procuraba evitar cualquier gesto de tipo político o belicista, a pesar de haber comenzado las hostilidades contra China, que acabarán con la invasión en 1937, o de haber firmado el "Pacto Antikomitern" con la Alemania nacionalsocialista debido a la amenaza comunista rusa. Con la idea de mostrar de manera aséptica la cultura y la tecnología, y con el espíritu de desarrollar futuras relaciones comerciales, la comisión para la Exhibición de París fue formada por el Ministerio de Comercio, la Cámara de Comercio, la Asociación del Comercio de Japón y la Asociación para la Promoción Internacional de la Cultura. Fue ésta última la que se encargaría de la gestión del diseño del pabellón, delegando su comisariado a Hideto Kishida, profesor de la Tokyo University, que convocaría un concurso de arquitectura restringido para definir el pabellón que representaría a Japón en la Exposición Internacional de París. Maeda, Mayekawa, Ichiura, Yoshida y Taniguchi fueron los arquitectos invitados que presentarían sus propuestas, defendiendo una arquitectura para los nuevos tiempos, ante un clima conservador y ultranacionalista, muy apegado a la arquitectura tradicional y enfrentado a la novedosa arquitectura moderna ${ }^{2}$.

\subsection{El proyecto ganador del concurso: Kunio Mayekawa.}

Los pabellones presentados a anteriores exposiciones internacionales habían sido extremadamente tradicionales tanto en la tipología como en el sistema constructivo empleado. La imagen de la casa tradicional japonesa, de un templo budista o un santuario sintoísta eran temas recurrentes para asociar la arquitectura del país nipón a los pabellones expositivos, como el "Ho-o-den" - reinterpretación del Pabellón del Fénix en Uji- presentado a la "World's Columbian Exposition" de Chicago de 1893.

Era de esperar que los pabellones se asemejaran al modelo historicista que Japón había presentado en ocasiones anteriores, buscando una imagen reconocible que la asociara a los templos a partir del trabajo con la madera usada para la estructura y cerramiento - y la ejecución de la cubierta al modo tradicional, que establecía una mímesis con el lenguaje de la arquitectura vernácula japonesa. Sin embargo, la propuesta ganadora del concurso, la de Mayekawa, establecía una ruptura con el modelo tradicional para introducir en su arquitectura los nuevos paradigmas que había aprendido de su maestro Le Corbusier con el que había estado trabajando durante los años 1928 a 1930.

Mayekawa, atendiendo a los requerimientos del país organizador y al título de la exposición, diseñó un pabellón construido en acero y vidrio, con un lenguaje propio alejado de la imagen tradicional japonesa. Partiendo del lugar y la topografía de la zona habilitada para su construcción, con unas vistas excepcionales hacia el Sena y la Torre Eiffel, Kunio Mayekawa quería explorar la configuración de los diferentes niveles del pabellón para adecuarse a la pendiente y ofrecer una solución arquitectónica apropiada al lugar. Para ello, había escrito a su maestro Le Corbusier ${ }^{3}$ con la intención de que le informase desde París de las características de la parcela asignada a Japón, solicitándole que le enviara alguna fotografía de la colina de Trocadero.

\footnotetext{
${ }^{2}$ Noboru, Kawazoe: Contemporary Japanese Architecture. Tokyo: Kokusai Bunka Shinkokai, 1968.

${ }^{3}$ Correspondencia entre Mayekawa y Le Corbusier. Fundación Le Corbusier. París. Cartas E2-15, 174-182.
} 
Con esta información, Mayekawa presentó al concurso una propuesta que se adaptaba a los nuevos tiempos, influenciado por las lecturas de "Vers une architecture" y "L'art décoratif d'aujourd" hui" "libro que traducirá a su lengua materna tras regresar a Japón, después de completar su formación en el estudio de la calle Sèvres-.

El proyecto presentado, que evolucionaba un modelo estudiado en su trabajo de graduación, se adaptaba a la topografía, fragmentándose en dos volúmenes paralelepipédicos, perpendiculares entre sí que finalizaban en un tercer volumen curvo a modo de mirador sobre la colina.

El acceso se desarrollaba en la cota superior, con una fachada lineal, retranqueada tras una marquesina modulada por pilotis y un cuerpo vertical a modo de torre donde se disponía la entrada, coronando el alzado con grandes letras que anunciaban el país.

El modelo, determinado por los materiales a emplear de acero y vidrio -y por tanto limitado a un sistema constructivo sencillo de montar-, presentaba un programa determinado por el acceso, la posición en la ladera, y las relaciones que surgían entre las diferentes cotas del terreno y los jardines diseñados al efecto.

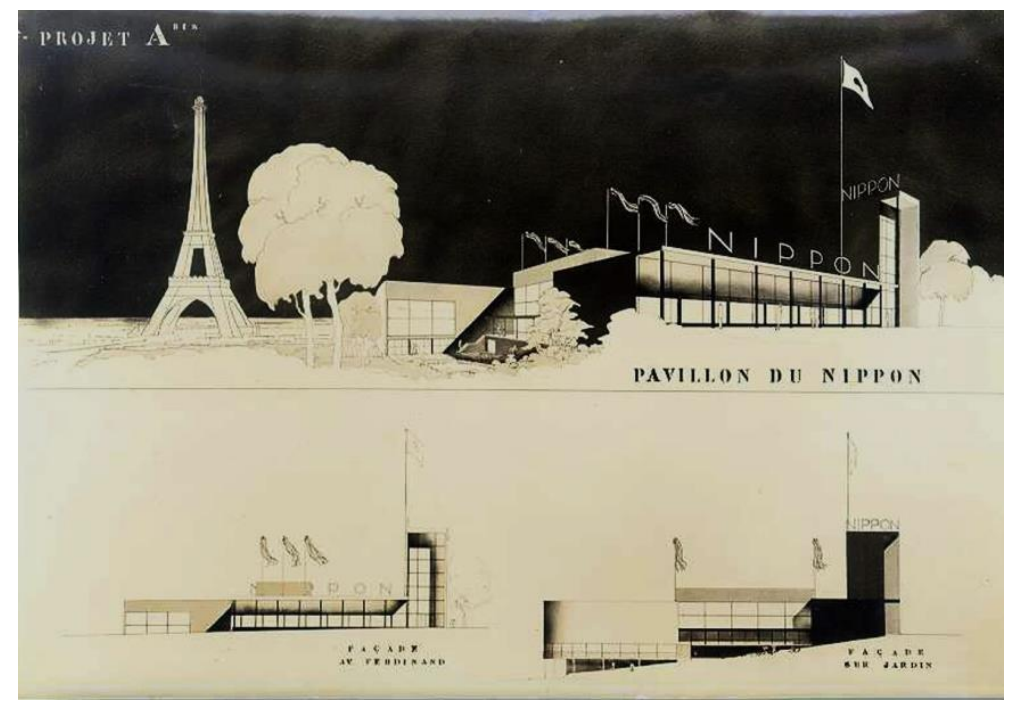

1. Pavillon du Nippon. 1937. Fotografía de la propuesta presentada a concurso enviada por Mayekawa a Le Corbusier.

De este modo, entrando a través del pórtico, Mayekawa disponía un espacio diáfano, abierto totalmente a la fachada mediante grandes planos de vidrio, acotando dos espacios para un tocador y un salón, y una gran zona destinada a la sección comercial. A una cota más deprimida, pero dentro de un volumen de mayor altura que el anterior, se disponía la sección científica que ocupaba todo el espacio con una proporción significativamente diferenciada. Éste se abría al exterior mediante una marquesina sobre pilotis, que permitía un porche sobre el jardín en la cara noreste, y que mediante un recorrido exterior, bajando unas escaleras, llegaba al plano de suelo donde se disponía la terraza restaurante. En este nivel, se establecía la continuidad del jardín con la zona de descanso, estudiando muy bien la relación entre exterior e interior, que servía además de antesala para el gran espacio representativo del proyecto. En este punto el terreno natural continuaba deprimiéndose en el exterior, y tomaba protagonismo la última pieza diseñada en curva que se alzaba sobre el terreno mediante pilotis exentos.

\footnotetext{
${ }^{4}$ Hiroshi, Yamaguchi: "Kunio Mayekawa and Japanese Modern Architecture". The Exhibition Organizing Committee for Kunio Maekawa Retrospective (ed): The Work of Kunio Maekawa: A Pioneer of Japanese Modern Architecture. Tokyo: Bijutsu Shuppan-Sha, 2006. pp 201-203
} 


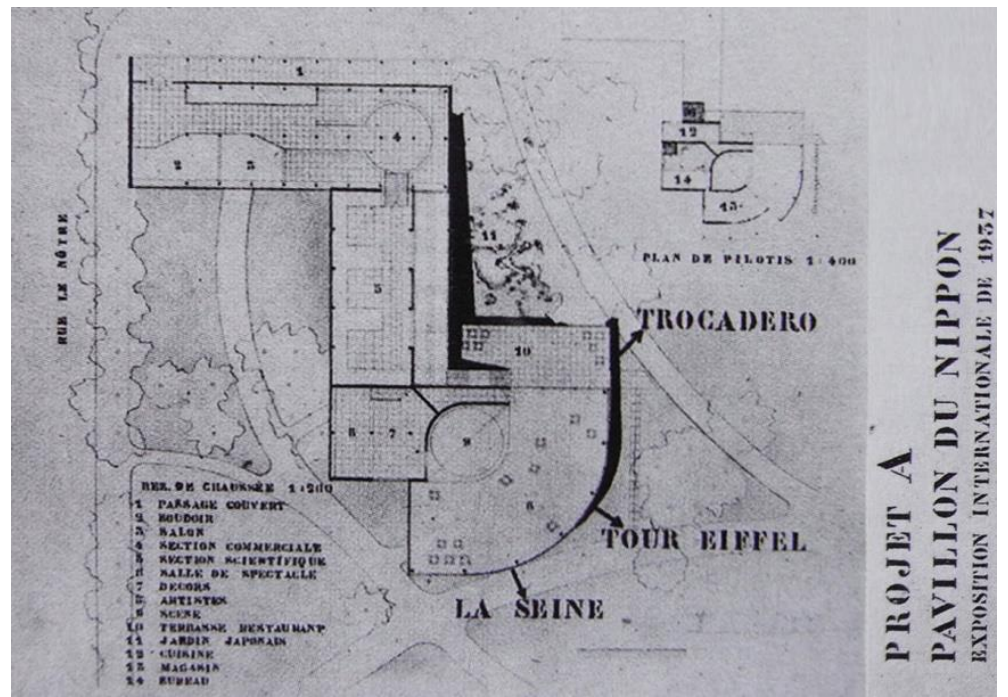

2. Japanese Pavilion, 1937. Paris International Exposition. Planta de la propuesta para el pabellón de Japón presentada al concurso. Kunio Mayekawa. Montaje del autor.

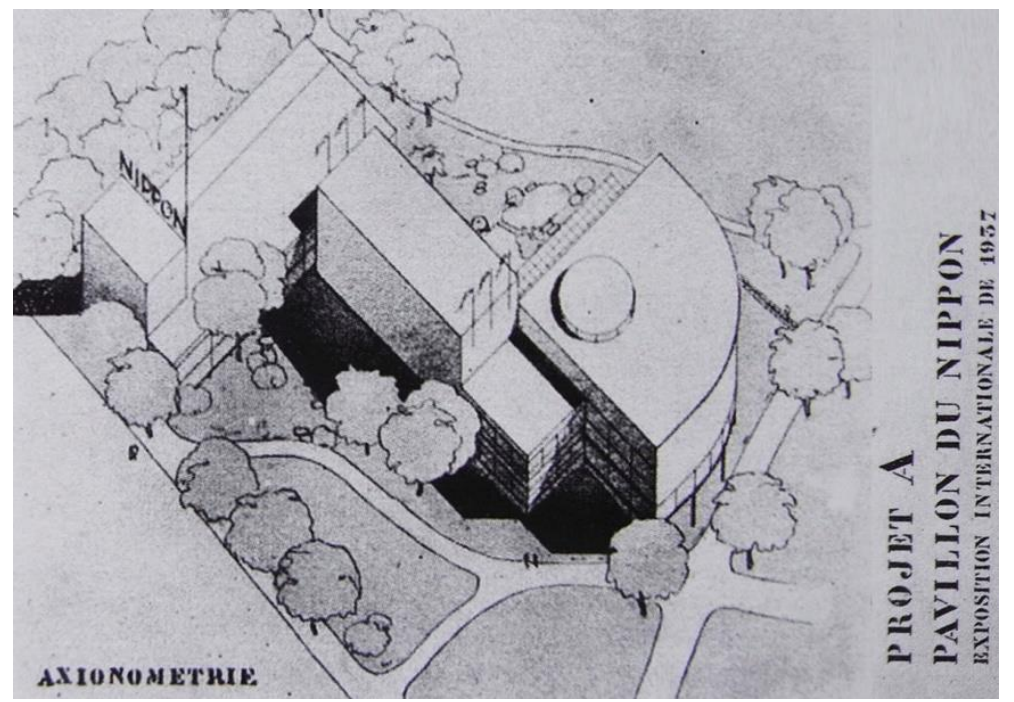

3. Japanese Pavilion, 1937. Paris International Exposition. Axonometría de la propuesta para el pabellón de Japón presentada al concurso. Kunio Mayekawa. Montaje del autor.

La sala de espectáculo era la protagonista del proyecto, el epicentro desde donde se divisaba, debido a su posición privilegiada en alto, la colina de Trocadero, la Torre Eiffel y el río Sena. Aprovechando esa posición introducía la forma curva para divisar todo el entorno, sin discontinuidad, con una doble altura donde comparar frente a la vista parisina, las vistas de Japón montadas a lo largo de este "panorama”. Así el visitante contrastaba la visión que le brindaba el lugar parisino frente a la visión de Japón ofrecida por la arquitectura de Mayekawa, que con vistas a atraer el turismo, mostraba unos paneles con fotomontajes del Gran Buda de Kamakura, el torii del santuario sintoísta de Itsuikushima en Mijayima, el castillo de Himeji, los cerezos en flor, y el monte Fuji. 


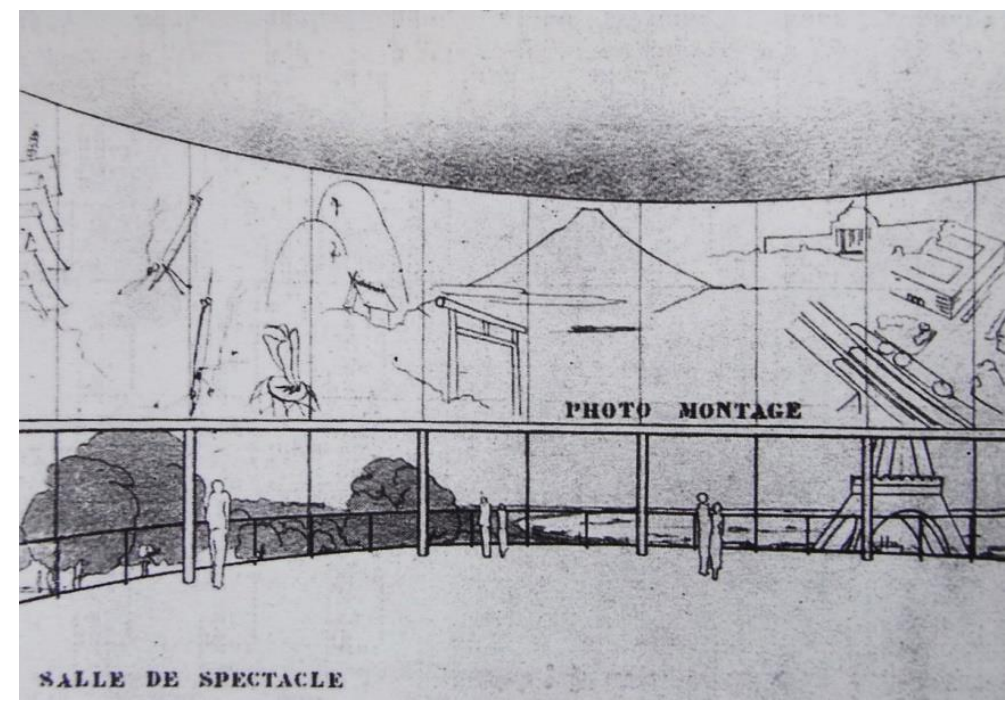

4. Japanese Pavilion, 1937. Paris International Exposition. Vista interior de la sala de espectáculos de la propuesta para el pabellón de Japón presentada al concurso. Kunio Mayekawa.

El gobierno japonés quería mostrarse al mundo como una nación democrática, industrial y económicamente avanzada, con un rico patrimonio cultural y natural. Sin embargo, a nivel interno no parecía que las decisiones fueran muy democráticas, tal y como se desarrolló el encargo del pabellón. El peso de la tradición era tan marcado, que el Comité para la Exposición de París aplazó la decisión de construir el proyecto ganador porque el diseño "no era típico japonés", manifestando que debería capturar el espíritu de la arquitectura japonesa, construyéndose con técnicas y materiales locales a pesar de ir en contra de las condiciones de participación de la exposición impuestas por Francia -que requerían el uso de materiales modernos-, incluso amenazando con abandonar la exposición si no se le permitía trabajar con los materiales y técnicas constructivas tradicionales.

Kishida, el comisario encargado de la selección, concluyó que la propuesta de Mayekawa confrontaba las dos corrientes arquitectónicas que habían surgido en Japón con los arquitectos modernos, -unos inspirados en el estilo occidental, frente a aquellos que estaban convencidos de que no sería posible adoptar ese nuevo lenguaje arquitectónico, manteniéndose en una corriente historicista ${ }^{6}$-. En esta tesitura se planteaba el dilema de "qué era lo típico japonés", marchándose a Berlín para inspeccionar las instalaciones olímpicas de 1936 sin esperar a tomar una decisión final. El Comité para la Exposición de París eligió el diseño de Kenjiro Maeda por ser un diseño más tradicional. Sin embargo, para complicar más la decisión, el gobierno francés requería en sus bases que todos los edificios de la exposición fueran construidos con materiales modernos -acero y vidrio- y ejecutados por trabajadores franceses. Estos requerimientos obligaron a los representantes japoneses a replantearse nuevamente el fallo, teniendo en cuenta que el diseñador debería estar familiarizado con las técnicas y condiciones laborales francesas, hablar el idioma y estar preparado para supervisar el trabajo desde París. Desechando a los arquitectos que habían sido elegidos por Kishida, seleccionaron a un joven arquitecto que acababa de regresar de París tras una estancia de siete años trabajando en el estudio de Le Corbusier: Junzo Sakakura.

\footnotetext{
5 Tadayoshi, Fujiki: “Tokyo-Paris 1936-1937”. En Process: Architecture. "Sakakura Associates” May 1993, n¹10. Tokyo: Process Architecture CO. Ldt. 1993. pp.33-38.

${ }^{6}$ Reynolds, Jonathan M.: Maekawa Kunio and the Emergence of Japanese Modernist Architecture. Berkeley: University of California Press, 2001. pp. 36-37.
} 


\subsection{El proyecto realizado: Junzo Sakakura.}

Tras su retorno a Japón en la primavera de 1936, Junzo Sakakura volvía a París en septiembre de ese mismo año con un encargo envenenado: ser capaz de responder a las expectativas creadas por el Comité para la Exposición de París de crear un pabellón con un marcado estilo japonés pero adaptado a las demandas de modernidad exigidas por la organización francesa. A su llegada a París, y habiendo realizado un estudio pormenorizado del emplazamiento del pabellón, Junzo Sakakura comenzó a desarrollar el nuevo proyecto en una esquina de la oficina de Le Corbusier en la rue Sèvre. Tras siete años trabajando allí, contó con la ayuda de un antiguo discípulo de Le Corbusier que en esos momentos trabaja por su cuenta -Pollack-, un miembro del estudio de Le Corbusier -Bosch-, y el estudiante Seichi Inoue.

Con un profundo respeto por la naturaleza donde se asentaba, el proyecto de Sakakura se adaptaba tanto a la topografía existente como a la vegetación y árboles de la parcela atendiendo a un estudio detallado del espacio, las alturas y la relación interior-exterior con el paisaje en el que se insertaba. El diseño partía de un volumen principal, que se fragmentaba en distintas alturas, y al que se anexionaban dos cuerpos: uno situado en la cota más alta de la parcela, al oeste, y otro cuerpo formado por una rampa adosada al este, que separándose del volumen principal, se constituía como un elemento autónomo, abrazando la vegetación, para conectar la cota superior del edificio principal, la cota inferior, y prolongar el recorrido marcando la salida en el punto más deprimido del terreno.

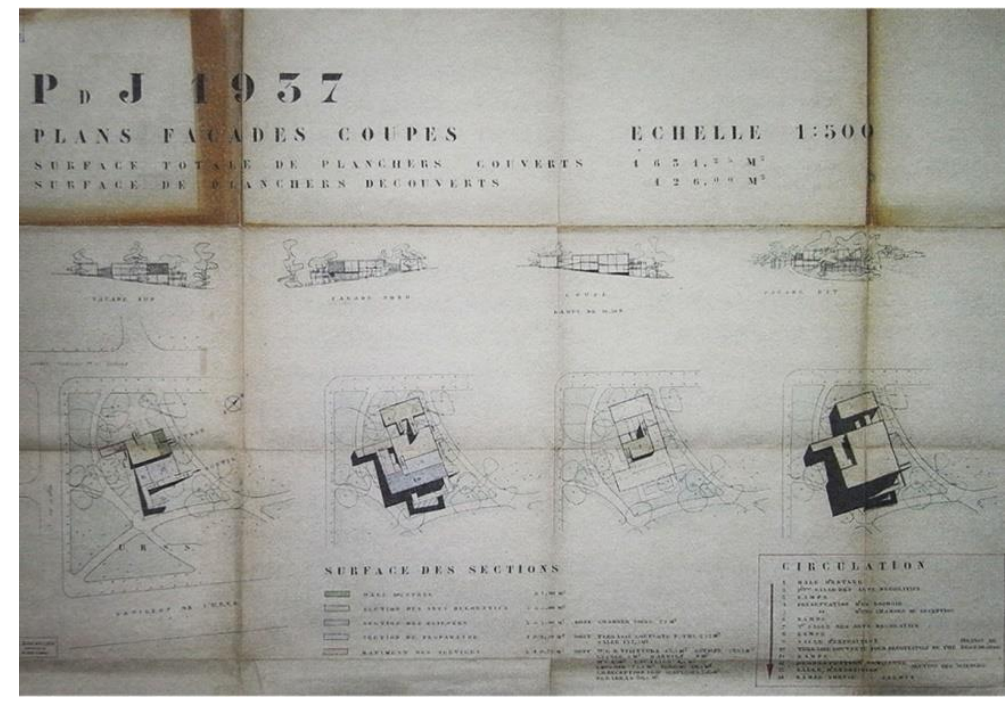

5. Pavillon du Japon, 1937. Exposition Internationale des Arts et des Techniques Appliques a la Vie Moderne. Paris. Plano Original de plantas y alzados a escala 1:500.

El proyecto entendía perfectamente la topografía y se desarrollaba insertándose en ella. La entrada se realizaba por la zona central, a una cota intermedia, a través de un pórtico que marcaba de manera escultórica la entrada. El hall de acceso era un espacio abierto y fluido, perfectamente integrado en la naturaleza diseñada al exterior, gracias al uso de los pilotis de acero y su cerramiento en vidrio. Similar a la técnica tradicional en madera, Sakakura trabajaba la estructura metálica de pórticos perfectamente ordenados en una malla de orden que otorgaba serenidad al espacio. Abierto visualmente al exterior gracias a los grandes paños de vidrio que cerraban el conjunto, conectaba los diferentes espacios situados a cotas distintas a partir de una rampa que articulaba todo el conjunto. 

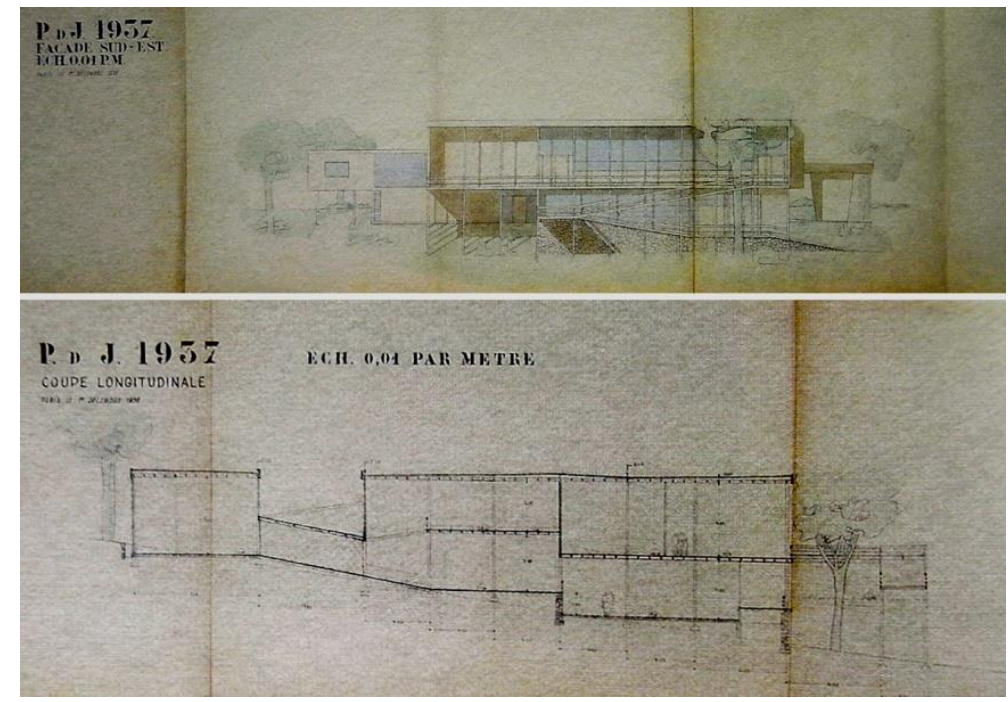

6. .Pavillon du Japon, 1937. Exposition Internationale des Arts et des Techniques Appliques a la Vie Moderne. Paris. Plano Original de alzado y sección. Montaje del autor.

Desde el hall de entrada, la rampa conectaba de manera autónoma con el volumen situado en la cota más elevada de la parcela, destinado a la exposición de las artes decorativas. Desde ahí, la rampa se desdoblaba para volver a ingresar en el edificio principal leyéndose, al estar cubierta, como un objeto independiente. El recorrido planteado por Sakaura que permitía salir al exterior para conectar un volumen diferente y luego volvía a entrar en el edificio principal, presentaba una celosía inspirada en el diseño del muro tradicional japonés denominado "namako kabe", aunque reinterpretado para conseguir un efecto de filtro muy permeable que permitiese el paso de luz, evocando los recorridos exteriores que conectaban los distintos pabellones de los templos tradicionales japoneses.

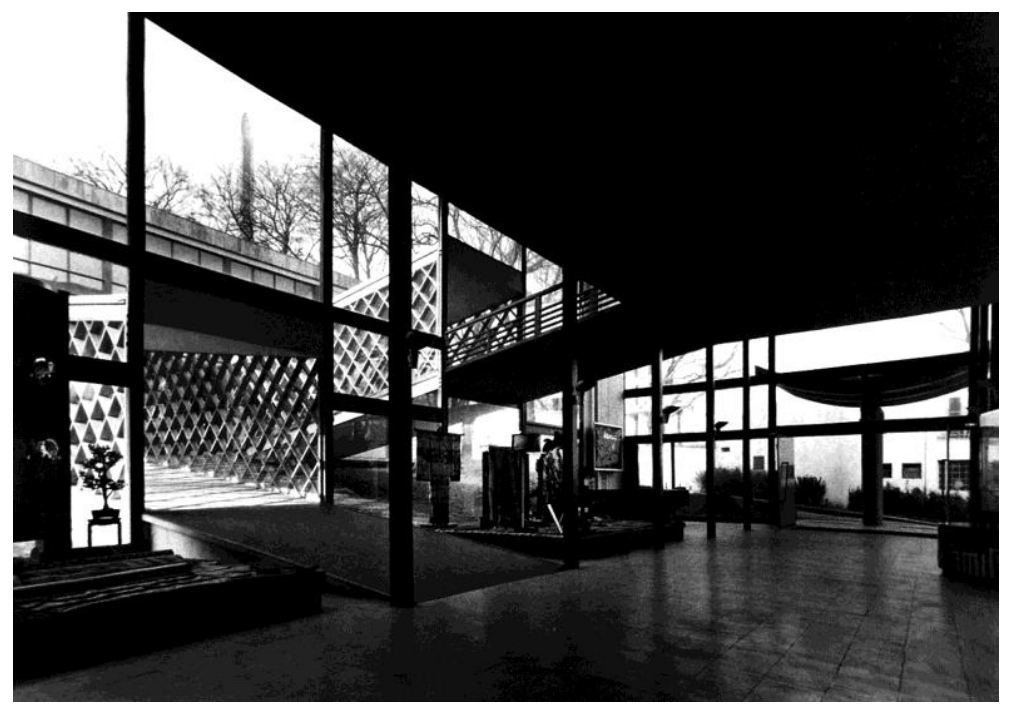

7. Japanese Pavilion, 1937. Paris International Exposition. Vista del interior del pabellón, con la rampa de acceso a la segunda planta.

Esa ida y vuelta de la rampa permitía capturar el espacio de los diferentes niveles de manera sucesiva, descubriendo cada estancia y sorprendiendo al espectador que recorría el pabellón para situarlo en el forjado superior, a cuyos lados se abría la planta baja, situándose a modo de pasarela sobre el hall. La planta alta guiaba al espectador por distintos niveles, conectados entre sí mediante la rampa, dentro de un espacio abierto y diáfano, 
cualificando cada estancia por la diferencia de cota. El empleo de estructura metálica, paneles de asbestocemento en zonas opacas y cerramiento de vidrio, hacía de esta arquitectura una construcción en seco liviana, etérea, que permitía un espacio fluido y continuo entre el interior y el exterior, ejemplificado en el diseño de la terraza mirador cubierta, a modo de porche, a la que se llegaba tras salir de la sala de propaganda. En una continuidad del recorrido que revelaba los espacios intersticiales tan interesantes en la arquitectura tradicional japonesa, y que enfatizaban el carácter tradicional al tamizar la luz mediante el empleo de unos toldos que emulaban el papel de arroz, este espacio disfrutaba de las vistas hacia el Sena y la Torre Eiffel, como fondo contemplativo reinterpretando el jardín japonés.

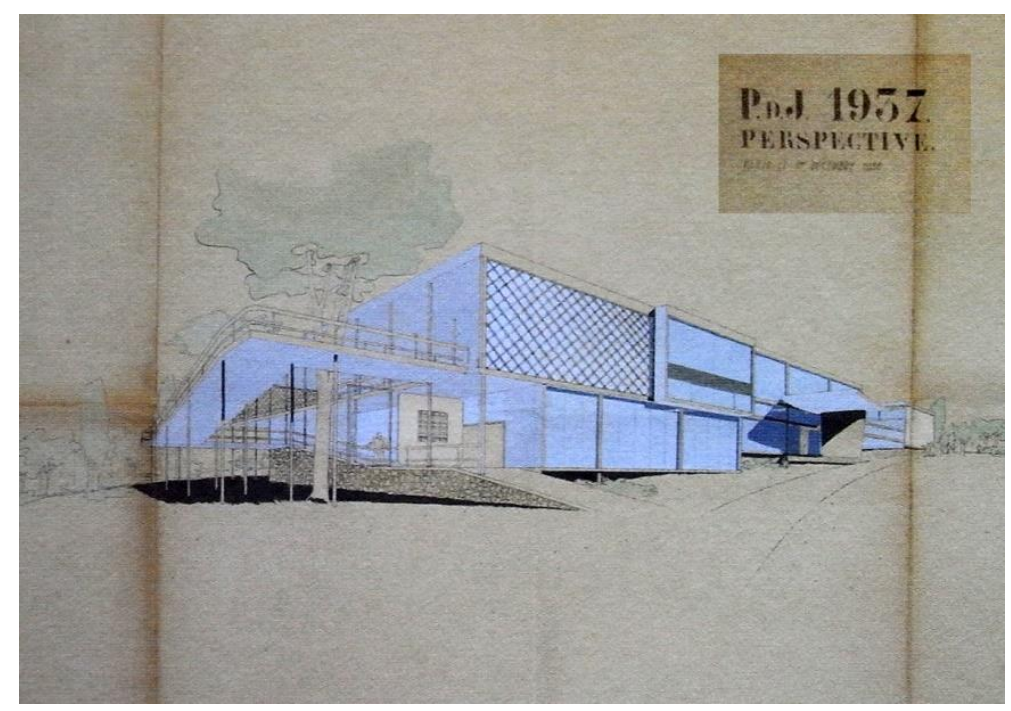

8. Pavillon du Japon, 1937. Exposition Internationale des Arts et des Techniques Appliques a la Vie Moderne. Paris. Plano Original de vista exterior en perspectiva. Montaje del autor.

El recorrido desde la terraza, situada en una cota privilegiada sobre la ladera de Trocadero, continuaba gracias a la rampa que articulaba el remate del proyecto en la fachada sureste. Separándose de la fachada cinco metros, y abrazando un árbol preexistente, descendía por el exterior hasta entrar nuevamente bajo la zona de terraza, a cubierto pero al exterior, para continuar el descenso hasta la cota de la sala de ciencias. El punto más deprimido de la actuación permitía solo a nivel espacial una visión global del conjunto del edificio para salir nuevamente a la rampa que nos acompañaba hasta el exterior del pabellón.

La memoria de proyecto de Sakakura justificaba la reinterpretación de la arquitectura tradicional japonesa en el edificio proyectado. La nueva arquitectura partía de la esencia del espacio y del estudio de las zonas de recorrido y zonas estanciales, asimilándolas a la articulación y composición de los elementos que conformaban el Palacio de Katsura.

Los recorridos y la interrelación con el paisaje aquí se diseñaban a partir de la rampa y la relación de las estancias con el jardín, tratando de captar la esencia de la tradición con un lenguaje arquitectónico adaptado a los nuevos tiempos.

\footnotetext{
${ }^{7}$ Sakakura, Junzo: “Japanese Pavilion for the International Exhibition, Paris 1937”. En Gendai Kenchiku, Junio 1939, №1. Tokyo, 1939. Reeditado y traducido al inglés en Process: Architecture. "Sakakura Associates" May 1993, nº110. Tokyo: Process Architecture CO. Ldt. 1993. pp.32-34.
} 


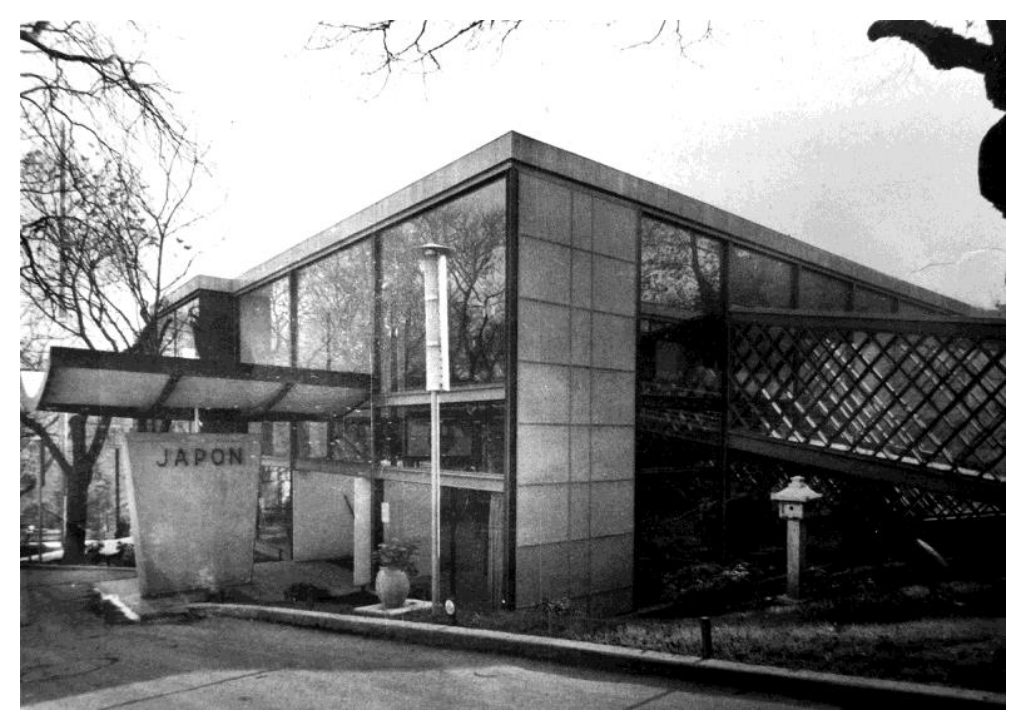

9. Japanese Pavilion, 1937. Paris International Exposition. Vista del exterior del pabellón, con la rampa de acceso a la segunda planta.

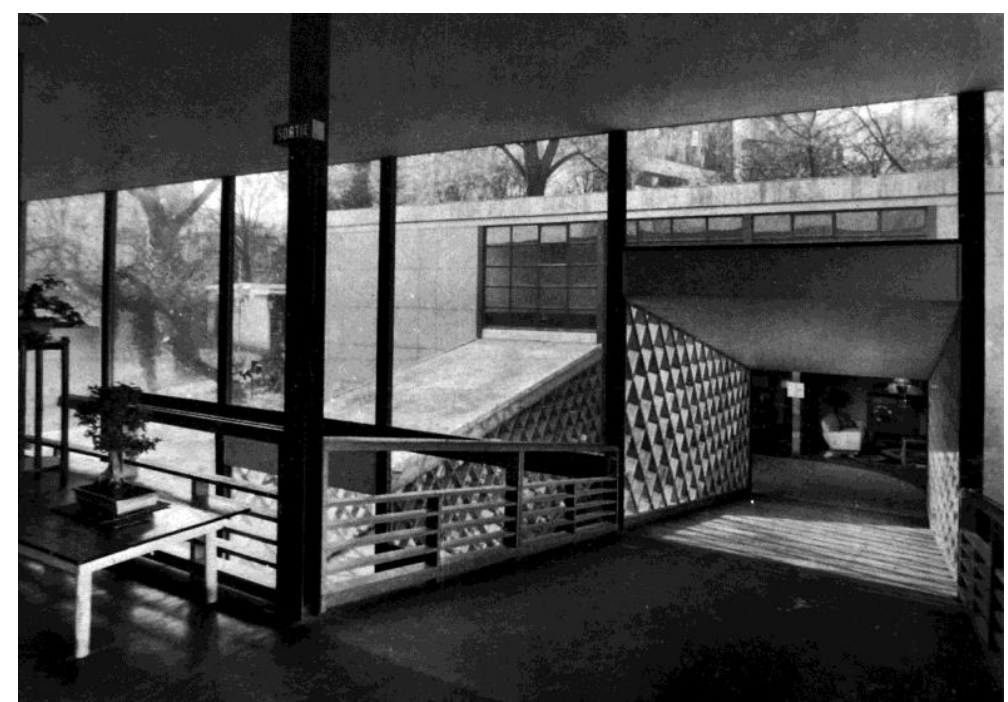

10. Japanese Pavilion, 1937. Paris International Exposition. Vista del interior del pabellón, desde el desembarco de la rampa en la segunda planta.

“La relación creada entre los espacios interiores y exteriores en el pabellón japonés para la Exposición de París de 1937 fue similar al sentimiento que produce cuando te sientas en el espacio conocido como "Koshoin" en el palacio de Katsura, mirando hacia el exterior, al lago, con los paneles shoji abiertos. En el pabellón japonés, sin embargo, los espacios estaban conectados por la pendiente exterior ${ }^{8,}$.

\footnotetext{
${ }^{8}$ Sakakura, Junzo: "Kamakura Museum of Modern Art”. En Kenchiku Bunka, Junio 1963, №6. Tokyo, 1963. Reeditado y traducido al inglés en Process: Architecture. "Sakakura Associates" May 1993, n¹10. Tokyo: Process Architecture CO. Ldt. 1993. pp.46.
} 


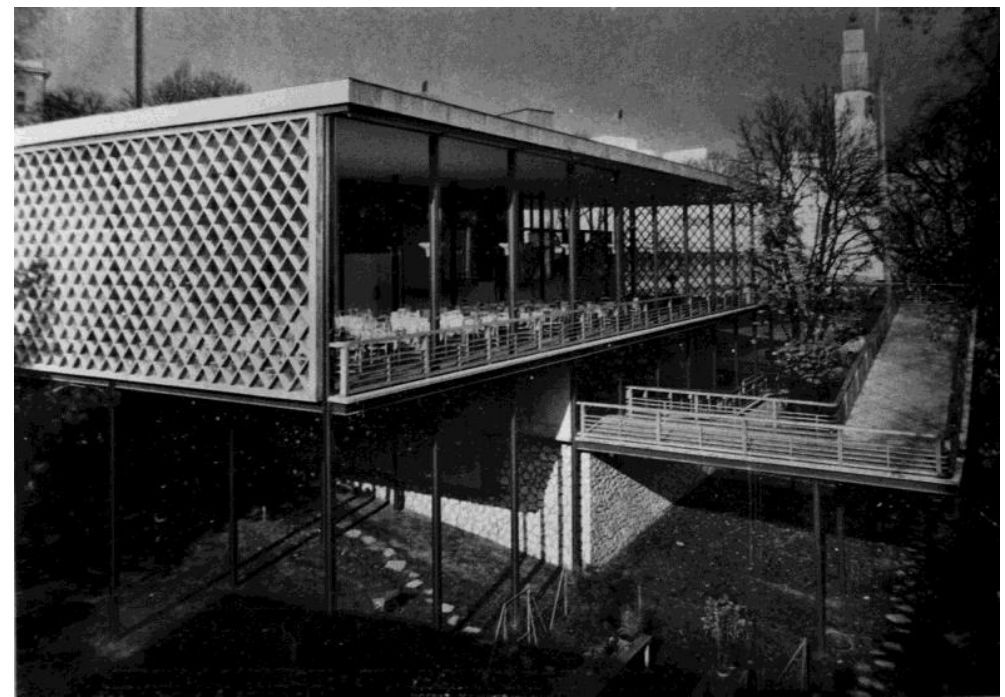

11. Japanese Pavilion, 1937. Paris International Exposition. Vista desde la terraza restaurante, con la rampa exterior de salida.

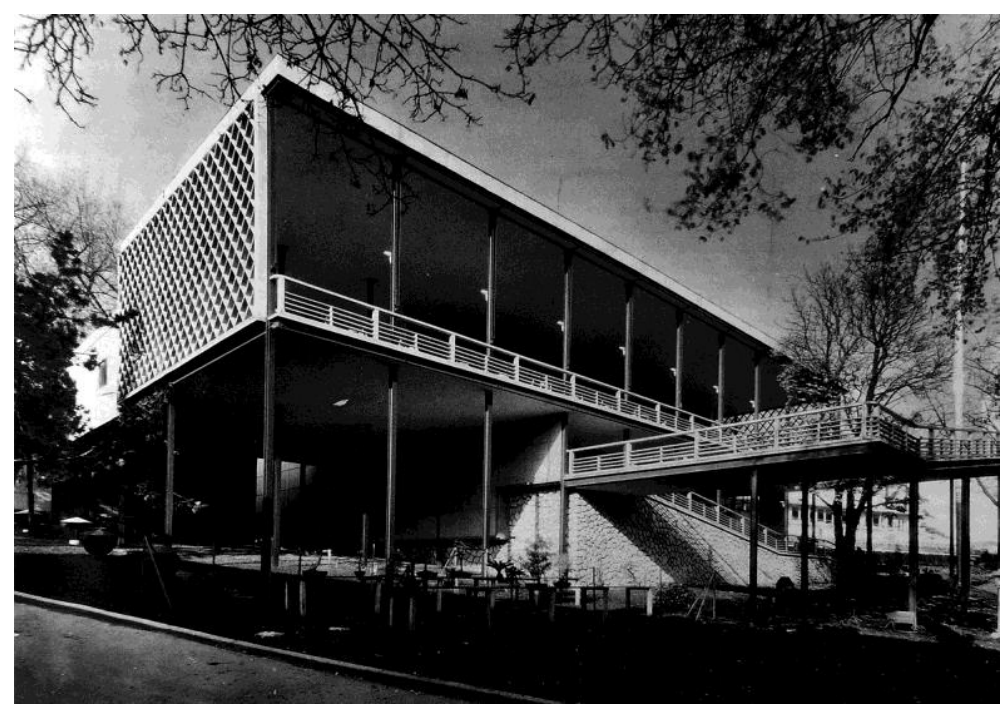

12. Japanese Pavilion, 1937. Paris International Exposition. Vista exterior del pabellón.

Esta visión del autor era compartida y reafirmada por la crítica que había captado la esencia de esta nueva arquitectura. Los comentarios de Giedion mostraban la importancia del recorrido para una clara definición de los espacios interiores y exteriores protagonizados por la rampa, entendiendo el logro que supuso la obra de Sakakura por su capacidad para armonizar modernidad y tradición a través de un nuevo lenguaje en arquitectura.

"A pesar de que todos los pabellones en la exhibición de París fueron construidos con un sentimiento de apertura, el pabellón de Japón es, probablemente, el más maravilloso. Las rampas que varían su pendiente pasan a través del centro del edificio, conectando cada parte y dirigiendo tanto al exterior como al interior. A pesar de tener habitaciones pequeñas, el hecho de que se encuentren unidas visualmente al jardín hacen que éste se pueda sentir más que cualquier otra cosa. Aunque el pabellón es occidental en estilo, logra 
completamente el sentido del espíritu japonés. El nombre del arquitecto que está en la treintena, Sakakura, debería ciertamente grabarse en nuestras mentes." S. Giedion ${ }^{9}$.

A pesar de los intentos por aunar a la modernidad la esencia de la arquitectura tradicional japonesa, el exceso de conservadurismo de los miembros del Comité, acostumbrados a una versión historicista de la arquitectura, produjo en ellos una reacción de descalificación al ver casi terminado el nuevo proyecto. Cuando la estructura fue tomando cuerpo y los volúmenes ya se adivinaban, los delegados japoneses se indignaron y criticaron nuevamente que el diseño no era típicamente japonés, apartando a Sakakura de las reuniones para definir el contenido expositivo del pabellón. La selección del diseño del interior del pabellón y su exhibición corrió a cabo de los representantes del Ministerio de Comercio y del Comité para la Exposición de París, que expusieron la versión más rancia y tradicional de la cultura japonesa que poco tenía que ver con el verdadero objetivo de la exposición “Arte y Tecnología en la Vida Moderna”.

Cuando Sakakura vio la exhibición que habían montado, deploró la forma en que halagaban a Europa occidental mientras le prohibían formar parte de las reuniones para determinar qué objetos formarían parte de la exposición. El resultado, lógicamente, mostraba un exagerado contraste entre el continente -un pabellón moderno y avanzado- y el contenido, - de marcado carácter tradicional- dando un resultado incoherente que entendió muy bien Giedion, cuando en su crítica para el semanario Die Weltwoche comentaba que los japoneses tenían que estar muy agradecidos a Sakakura, "por evitar que Japón fuera el hazmerreír de la exposición, al llenar el interior del pabellón con un torpe simulacro de muebles, basura para las tiendas europeas, y por la inconsistencia mostrada por el conjunto de inventos exagerados y poco armoniosos que no podían igualar la calidad del propio edificio" ${ }^{\text {, }}$, coincidiendo con los comentarios de H.R. Hitchcock para Architectural Forum a propósito del desastre de la exposición presentada por Japón a pesar del excelente resultado formal de su pabellón ${ }^{11}$.

El pabellón japonés fue terminado a principios de Junio, en medio de un clima de crispación interna, pero una vez abierto al público el edificio fue objeto de las mejores críticas y elogios de gran parte de los arquitectos venidos de todas las partes del mundo.

\section{Dos proyectos, un maestro.}

“El sentimiento moderno es un espíritu de geometría, un espíritu de construcción y de síntesis”.

Le Corbusier ${ }^{12}$.

\subsection{Un discípulo a distancia.}

Kunio Mayekawa había trabajado en el estudio de Le Corbusier desde 1928 a 1930. Durante esa época, además de trabajar en proyectos como la Ville d'Avray, el Centrosoyus de Moscú, el Salon d'Automne ${ }^{13}$, los estudios

\footnotetext{
${ }^{9}$ Giedion, Sigfried: “Paris Exhibition, 1937”. En Die Weltwoche, 1937. Recogido en Gendai Kenchiku, Junio 1939, N$^{\circ}$. Tokyo, 1939. pp. 12.

${ }^{10}$ Giedion, Sigfried: "Paris Exhibition, 1937”. En Die Weltwoche, 1937. Recogido en Gendai Kenchiku, June $1939, \mathrm{~N}^{\circ} 1$. Tokyo, 1939. pp. 12.

${ }^{11}$ Hitchcock, Henry Rusell: "Paris Exposition, 1937”. En Architectural Forum, September 1937, Vol.67 No3. New York: Ed. Time Inc. 1937. pp. 173.

${ }^{12}$ Le Corbusier; Jeanneret, Pierre: Le Corbusier et Pierre Jeanneret. Oeuvre Complète 1910-1929. Zurich: Publiée par Willy Boesiger, 1964. pp. 97.

${ }^{13}$ Donde colaboró en el diseño y fabricación del mobiliario creado por Le Corbusier, Jeanneret y Charlotte Perriand.
} 
iniciales para el concurso del Palacio de los Soviets de Moscú, y sobre todo la construcción de la Villa Saboye, participaría en el II CIAM de 1929 acompañando a Le Corbusier, y visitaría junto al maestro la WeissenhofSiedlung de Stuttgart, analizado los fundamentos de la vivienda mínima ${ }^{14}$ que le servirán en los años posteriores a la Segunda Guerra Mundial como base para iniciar el camino de la reconstrucción de Japón. En paralelo a su trabajo en el despacho, Mayekawa se presentaba a concursos convocados en su país a título personal. No es de extrañar que algunos de estos proyectos tuvieran reminiscencias de los proyectos realizados por Le Corbusier, como el Nagoya City Hall, del que tomará como referencia el Centrosoyus de Moscú. El desarrollo del concurso para el pabellón de Japón fue realizado en 1936 en su propio despacho, tras haber regresado de París y haber trabajado para A. Raymond hasta 1935. Para su diseño, Mayekawa tomó como referencia un antiguo proyecto que le sirvió para obtener su titulación, trabajándolo y adaptándolo a las nuevas necesidades requeridas por el concurso.

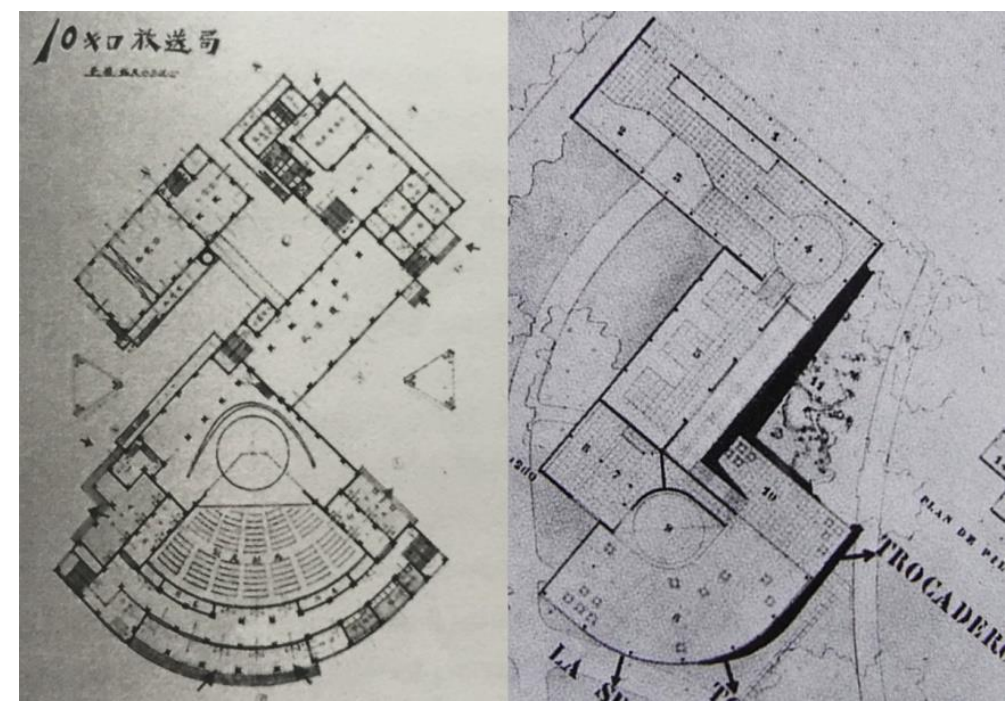

13. Comparativa entre el proyecto de graduación y el proyecto del pabellón. Montaje del autor.

Este proyecto había tenido como inspiración inicial algunos de los proyectos publicados en la revista $L^{\prime}$ Architecture Vivante ${ }^{15}$, como el Palacio del Trabajo de los hermanos Vesnín -con una forma curva muy particular que Mayekawa reinterpretaba para culminar su intervención-, o el Palacio para la Liga de las Naciones de Le Corbusier, cuyos volúmenes se articulaban e independizaban de acuerdo a su función, generando unos espacios interiores y exteriores a través de la propia geometría. Volumétricamente, el edificio para la graduación y el edificio del concurso presentaban numerosas similitudes, como la articulación de los cuerpos de acceso situados en perpendicular, y el anexo de sector circular que completaba el conjunto de manera idéntica al planteamiento de la sala de espectáculo. Además su circulación interior se desarrollaba de la misma manera, con la diferencia de que al asentarse sobre un terreno con topografía accidentada necesitaba conectar los distintos volúmenes mediante escaleras para generar la transición entre los distintos espacios. Sorprende que habiendo estado trabajando en la Villa Saboya, donde las circulaciones y el recorrido se organizaban en torno a una rampa que podría conectar todos los espacios expositivos de manera continua, Mayekawa planteara una jerarquía de

\footnotetext{
${ }^{14}$ Hiroshi, Matsukuma: "The Pursuits of Kunio Mayekawa. The Revitalization of Modern Architecture". The Exhibition Organizing Committee for Kunio Maekawa Retrospective (ed): The Work of Kunio Maekawa: A Pioneer of Japanese Modern Architecture. Tokyo: Bijutsu shuppansha, 2006. pp 303-305

${ }^{15}$ Reynolds, Jonathan M.: Maekawa Kunio and the Emergence of Japanese Modernist Architecture. Berkeley: University of California Press, 2001. pp. 52-54.
} 
niveles, adaptados a la topografía pero conectados mediante escaleras. En el proyecto de concurso buscaba una relación con el exterior, creando los porches, que modificaban sustancialmente la imagen de los huecos retranqueados de la fachada de pilotis que cerraba el conjunto. La ausencia de detalles historicistas, la aparición de una planta libre sobre pilotis, ventanas corridas y fachadas libres acercaban la propuesta a las ideas de Le Corbusier.

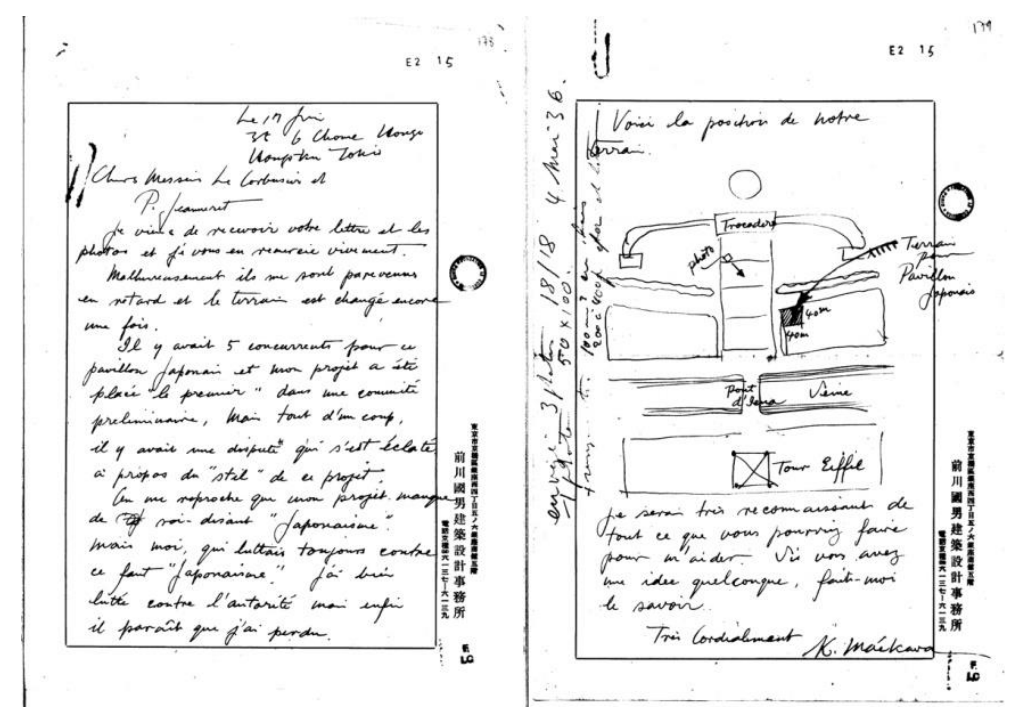

14. Carta enviada por Mayekawa a Le Corbusier, donde le comenta los problemas de "estilo poco japonés" de la propuesta. Se detalla aquí la primera ubicación propuesta para el pabellón.

El volumen curvo sobre pilotis mostraba una imagen conceptualmente similar a la Villa Saboye, separándose del suelo para conseguir un plano de estancia elevado, desde el que dominar el paisaje. Las ideas materializadas en el Pabellón de L'Esprit Nouveau eran conocidas por Mayekawa, acentuadas por el interés en el capítulo "Confesiones" del libro L'Art Décoratif d'aujourd'hui, que había cambiado su percepción de la arquitectura, motivándole a trabajar con Le Corbusier ${ }^{16}$. Sin embargo, para el diseño de este concurso Mayekawa prefería continuar con sus propias investigaciones en arquitectura, partiendo del conocimiento adquirido en París, pero evolucionando y adaptando las ideas aprendidas de su maestro a su propia cultura. El pabellón de Japón para la Exposición de París en 1937, ejemplificaba a la perfeccción la actitud de Mayekawa, que buscaba su propio camino a través de la arquitectura, pero mostrando un profundo respeto a su maestro y compartiendo con él mediante correspondencia las dudas, inquietudes, y las fotografías de la propuesta presentada al concurso para conocer su opinión ${ }^{17}$.

\footnotetext{
16 Según palabras de Mayekawa en su edición del libro L'Art Decoratif d’Aujourd'hui en japonés. En Yuzuru, Tominaga: "Exploring the Ethical Spirit of Modern Architecture". The Exhibition Organizing Committee for Kunio Maekawa Retrospective (ed): The Work of Kunio Maekawa: A Pioneer of Japanese Modern Architecture. Tokyo: Bijutsu shuppansha, 2006. pp 305.

${ }^{17}$ Correspondencia entre Mayekawa y Le Corbusier: Fundación Le Corbusier, E2-15 (174), 1936. Envío de fotografías tomadas de la propuesta presentada al concurso.
} 


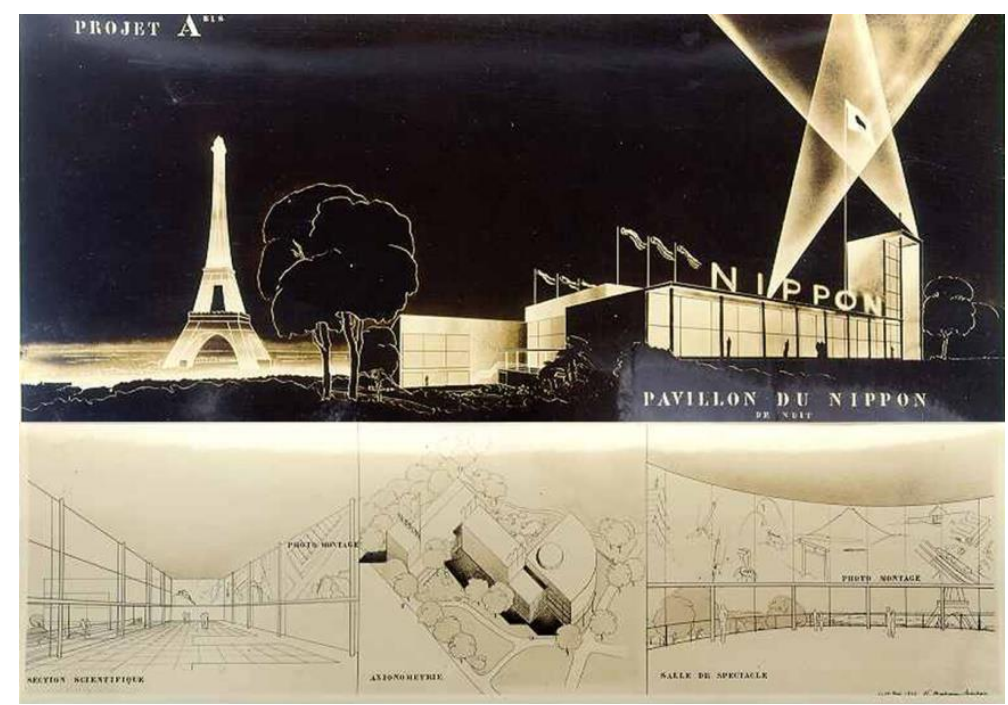

15. Pavillon du Nippon. 1937. Fotografías de la propuesta presentada a concurso enviada por Mayekawa a Le Corbusier. Montaje del autor.

Él mismo comentaba en una entrevista publicada en 1937: "la gente me pregunta: tú fuiste discípulo de Le Corbusier, ¿verdad?. Entonces, ¿por qué no construyes casas que parezcan las de Le Corbusier?. Me sentí honrado de tales comentarios. Sin embargo, durante los dos años que estuve en el estudio de Le Corbusier, él me enseñó, precisamente, a no cometer sus mismos errores" ${ }^{\prime 18}$. Y es que, como muy bien comenta Hiroshi Yamaguchi, "Mayekawa nos descubrió la posición de un arquitecto que, desafiando la verdadera esencia de la arquitectura moderna de Le Corbusier, supo encontrar su propio camino como arquitecto" 19 en el contexto de la compleja cultura japonesa, con la referencia clara de un maestro del cual aprender, para crecer, evolucionar y desarrollarse.

\subsection{Un discípulo al lado del maestro.}

El proyecto de Sakakura, a diferencia del anterior, se desarrolló no a 10.000 kilómetros de distancia, sino en el mismo estudio de la calle Sèvres. La proximidad y cercanía se aprecia durante toda la fase de diseño del proyecto y sobre todo durante la fase de ejecución, ya que Le Corbusier construye para la Exposición Internacional el Pabellón de los Nuevos Tiempos y era habitual la visita de obra a ambos pabellones junto a su pupilo Sakakura.

El paralelismo que se puede observar entre los dos pabellones es sustancial atendiendo al concepto de circulación y organización espacial de los recorridos mediante la rampa. Ésta ya había sido estudiada para este tipo de espacios expositivos en la Villa La Roche ${ }^{20}$, donde Le Corbusier permite una percepción graduada de la colección de pintura que cuelga de la pared. Para una exposición, organizar los distintos espacios a partir del

\footnotetext{
18 Mayekawa, Kunio: “Comentarios”. En Mokuyokai Zasshi, December 1937. Tokyo: Tokyo University. 1937. pp. 14. Recogido al inglés en Yuzuru, Tominaga: "Exploring the Ethical Spirit of Modern Architecture".". The Exhibition Organizing Committee for Kunio Maekawa Retrospective (ed): The Work of Kunio Maekawa: A Pioneer of Japanese Modern Architecture. Tokyo: Bijutsu shuppansha, 2006. pp 302.

${ }^{19}$ Hiroshi, Yamaguchi: "Kunio Mayekawa and Japanese Modern Architecture". The Exhibition Organizing Committee for Kunio Maekawa Retrospective (ed): The Work of Kunio Maekawa: A Pioneer of Japanese Modern Architecture. Tokyo: Bijutsu shuppansha, 2006. pp 302.

${ }^{20}$ Quetglas, Josep: “Promenade Architecturale”. En Web Architecture Magazine. №5 Ediciones Actar. Internet Editor: Yes.
} 
recorrido continuo que ofrece un rampa sería una buena solución. También la experimentación de los recorridos en la Villa Saboye supone un punto de influencia en Sakakura, al interpretar la secuencia de espacios a partir de los puntos de arranque y desembarco de la rampa, la organización de los sentidos de ascenso en ida y vuelta para leer por completo el edificio en una "promenade architecturale", y sobre todo a partir del empleo de la rampa para conectar espacios interiores, exteriores y de transición, abiertos al jardín.

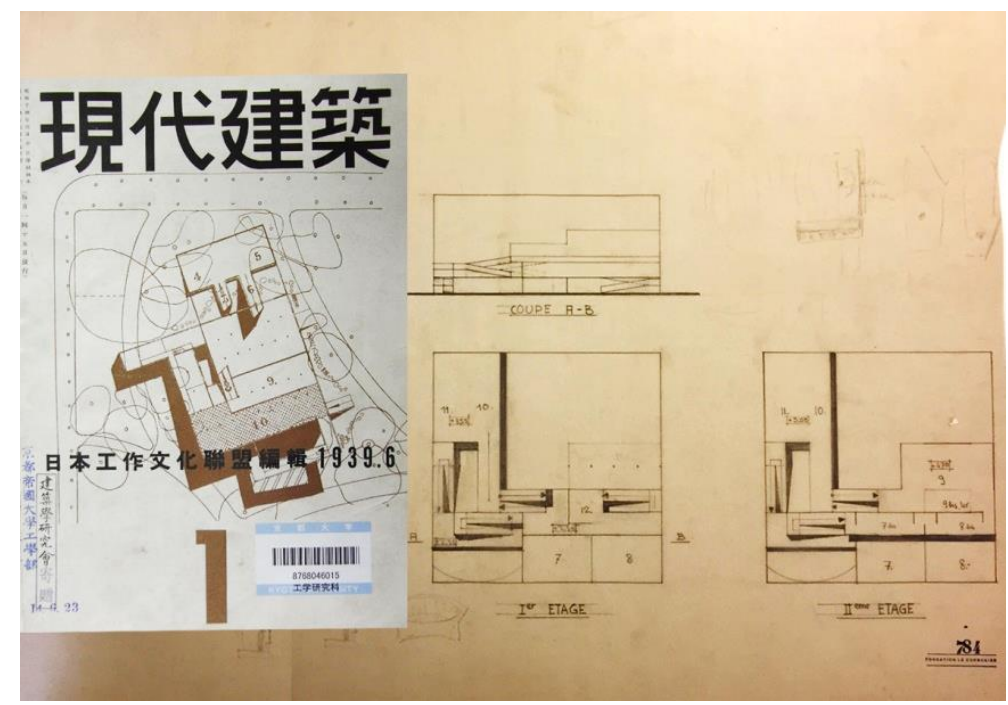

16. Esquema de circulaciones en los pabellones de Japón y de los Nuevos Tiempos. Montaje del autor.

Éste es el planteamiento que utiliza Sakakura sacando el máximo partido a la pendiente del solar para establecer las conexiones de su pabellón, utilizando la rampa no solo como medio de comunicación, sino como elemento escultórico en sí mismo, que permite desde la terraza de la planta superior aparecer como un objeto autónomo que sale al exterior, abraza la vegetación, gira y desciende para cobijarse bajo el forjado mientras se recorre el jardín, nos introduce nuevamente en el pabellón para mostrar la zona de ciencia, llevándonos -a través de este paseo continuo- por todos los espacios expositivos hasta la salida del pabellón.

El criterio estaba en sintonía al utilizado por Le Corbusier para el Pabellón de los Nuevos Tiempos, que necesitaba de la rampa para establecer un recorrido continuo a través de las diversas zonas expositivas variando su cota, introduciendo al espectador en un montaje ensimismado desde el que mostrar sus ideas urbanísticas a partir de la "promenade architecturale".

La lectura de las circulaciones es entendida muy bien por la crítica, con los comentarios de Giedion y H.R. Hitchcock que se estudiaban con anterioridad, y por la crónica de Chermayeff para la revista Architectural Review, donde establecía el paralelismo de las actuaciones de Sakakura y Le Corbusier en base a la circulación que proponían en ambos pabellones. Con el título "Circulación: diseñar: exhibir. El arquitecto en la Exposición", Chermayeff hacía una especial mención al pabellón japonés comentando que "las características nacionales prevalecen, a pesar de que surgieran de una curiosa influencia Japón- vía Europa- vía Japón. La elegancia japonesa de la construcción en madera aqui se expresa a través del acero”. Afinando su análisis, más adelante relacionaba al discípulo con el maestro al afirmar que "ambos, Le Corbusier y su último pupilo Sakakura, han actuado bajo el dictado de Le Corbusier de que "las escaleras son enemigas de lo público" y han empleado exclusivamente rampas. [...] Mientras Le Corbusier usa rampas como parte de la exhibición del espacio, Sakakura, francamente, las trata sólo como un medio de comunicación entre elementos claramente separados 
por la estructura, finalizando con una rampa de salida desde el restaurante situada lógica y simplemente fuera de su edificio pero integrada deliciosamente en el diseño del jardín. "21

El espacio de exhibición del pabellón de Japón era rico en cuanto a la disposición de dobles alturas, pasarelas y continuidades visuales, con un patrón de flujo de circulación, que estaba en armonía con el entorno y los jardines diseñados al exterior. En contra del análisis efectuado por Chermayeff, la rampa no parece que fuera sólo un "medio de comunicación entre elementos", sino el medio para crear una "promenade" necesaria para entender la configuración espacial de la actuación, justificando la disposición sobre la ladera de la colina, jerarquizando los espacios para ofrecer al espectador un recorrido expositivo en una fruición espacial.

La selección de un método constructivo novedoso con estructura metálica y el empleo de nuevos materiales como acero, vidrio y los paneles de asbesto-cemento eran conocidos por Sakakura, que ya los había trabajado en los proyectos del estudio de Le Corbusier. El único problema que le causaba alguna ansiedad era el detalle. Consciente de la importancia, redibujó una y otra vez las barandillas y la rampa, así como la marquesina de la entrada, que le estaba dando numerosos problemas en su composición.

La anécdota de la influencia de Le Corbusier en el diseño del pabellón la comentaba el propio Sakakura, cuando su maestro, al verle en dificultades para diseñar la entrada, se acercó y le preguntó “¿en Japón no tenéis también líneas curvas como los torii sintoístas?"22 y dibujándole un croquis contribuyó a dar ese toque de genialidad a la entrada sintetizando la esencia japonesa, tal y como haría años después en India al captar el espíritu de lo sagrado para reinterpretarlo en su arquitectura.

Las visitas de obra junto a Le Corbusier también contribuyeron a matizar la imagen del edificio. Queda constancia del comentario que hizo a Sakakura cuando el muro trasero del pabellón fue pintado con los colores pasteles de las cortinas de teatro kabuki, que a ojos del maestro "no eran ni de un sitio ni de otro" 23 animándolo a usar colores brillantes, que fue la decisión que primó al final.

\footnotetext{
${ }^{21}$ Chermayeff, Serge: "Circulation: design: display. The architect at the exhibition”. En Architectura Review. Vol. 82, №488. July. 1937. pp. 91-104.

${ }^{22}$ Tadayoshi, Fujiki: “Tokyo-Paris 1936-1937”. En Process: Architecture. "Sakakura Associates” May 1993, n¹10. Tokyo: Process Architecture CO. Ldt. 1993. pp.36.

${ }^{23}$ Tadayoshi, Fujiki: "Tokyo-Paris 1936-1937”. En Process: Architecture. "Sakakura Associates” May 1993, n¹10. Tokyo: Process Architecture CO. Ldt. 1993. pp.37.
} 


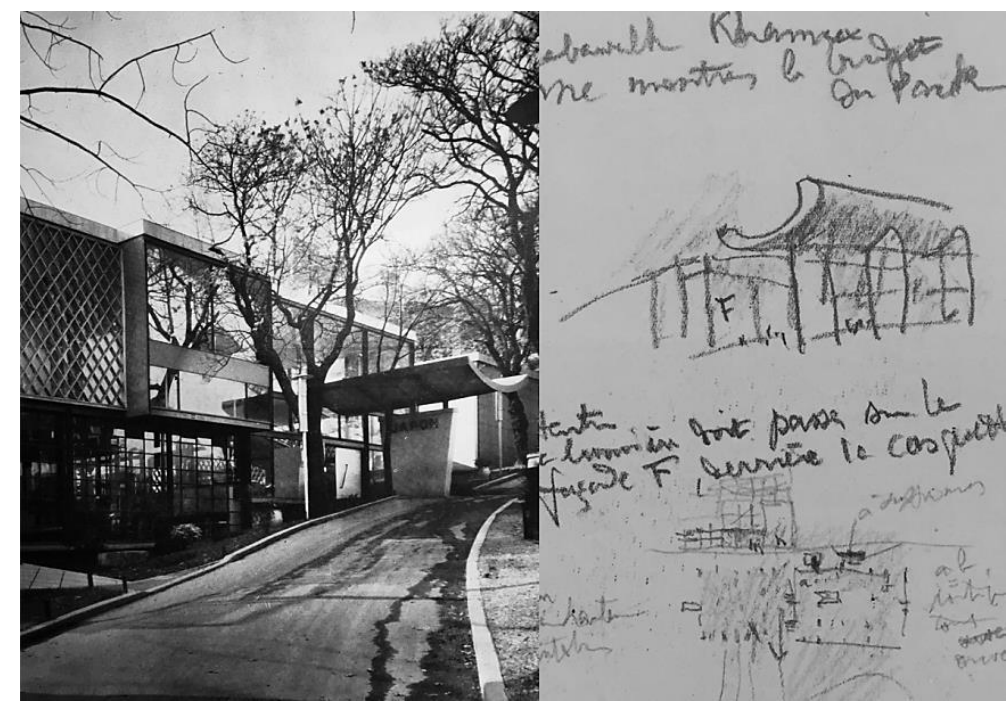

17. Comparativa entre la pérgola de entrada al pabellón y dibujo de Le Corbusier para India. Montaje del autor.

En un artículo escrito para la revista Gendai Kenchiku ${ }^{24}$ que acompañaba a la publicación del Pabellón de Japón en París unos años después, Junzo Sakakura exponía las nuevas ideas sobre arquitectura que habían influenciado en la construcción del pabellón, justificando su actuación en base a los criterios de la exposición, que trataban sobre el "Arte y la Tecnología en la Vida Moderna". Entre sus comentarios, explicaba cómo la máxima corbuseriana de "la casa es una máquina de habitar" no había sido bien interpretada en Japón, porque la palabra "máquina" se refería al diseño, a los logros de la ciencia moderna y de la tecnología; y "habitar" al hecho de ser vivida. La casa era diseñada según los logros tecnológicos de una época con el propósito de vivirla. Este sentido de vivir el espacio es lo que Le Corbusier le había transmitido y lo que Sakakura pretendía mostrar con su pabellón: una construcción capaz de mostrar los avances tecnológicos de una época que pudiese ser vivida, donde el visitante se sintiera inmerso en un recorrido a través de la cultura japonesa, no solo por los materiales expuestos, sino por la propia arquitectura - capaz de aunar la modernidad con la esencia de la tradición de los palacios imperiales o los jardines-. En sus propias palabras el Pabellón de Japón para la exposición de París de 1937 fue "la manera de expresar mediante la obra construida lo que entendía que debía ser la nueva arquitectura en Japón, y cómo debía desarrollarse en un futuro." 25

\section{Conclusiones}

Hoy, estudiando este proyecto desde la distancia, podemos hacer dos lecturas diferentes a partir de las dos propuestas presentadas - la ganadora del concurso y la ejecutada- teniendo en cuenta la influencia y puntos de contacto de sus autores con el maestro. Esta relación, que se refleja en la arquitectura del pabellón, nos muestra los caminos de dos discípulos de Le Corbusier, que partiendo de un mismo origen -el estudio de la calle Sèvresofrecen dos soluciones distintas, derivadas de dos respuestas personales distintas.

Por un lado Mayekawa, que nos descubrió la posición de un arquitecto que, desafiando la verdadera esencia de la arquitectura moderna de Le Corbusier, supo encontrar su propio camino en el contexto de la cultura japonesa.

\footnotetext{
${ }^{24}$ Sakakura, Junzo: “Japanese Pavilion for the International Exhibition, Paris 1937”. En Gendai Kenchiku, Junio $1939, \mathrm{~N}^{\circ} 1$. Tokyo, 1939. pp. 10-11.

${ }^{25}$ Sakakura, Junzo: “Japanese Pavilion for the International Exhibition, Paris 1937”. En Gendai Kenchiku, Junio 1939, № $^{\circ}$. Tokyo, 1939. pp. 10.
} 
Por otro lado Sakakura, que de la mano del maestro, aprendió a armonizar la tradición y la modernidad, interiorizando un profundo conocimiento del espacio y de los recorridos que recordaban la disposición del Palacio de Katsura frente a las propuestas para la Villa Saboya o el Pabellón de los Nuevos Tiempos de Le Corbusier.

Las dos propuestas, a pesar de sus diferencias, son extremadamente coherentes con la temática propuesta para la exposición “Arte y Técnica de la Vida Moderna”, y con los planteamientos teóricos desarrollados siguiendo las enseñanzas de Le Corbusier. Aunque siempre quedará la obra construida, el Pabellón Japonés para la Exposición de París de 1937, que alzándose con uno de los premios de arquitectura otorgados por la federación francesa junto con el pabellón de Finlandia de Aalto y con el pabellón de España de Jose Luis Sert-, fue capaz de colocar por primera vez a Japón en la escena internacional, a la vanguardia de la arquitectura moderna.

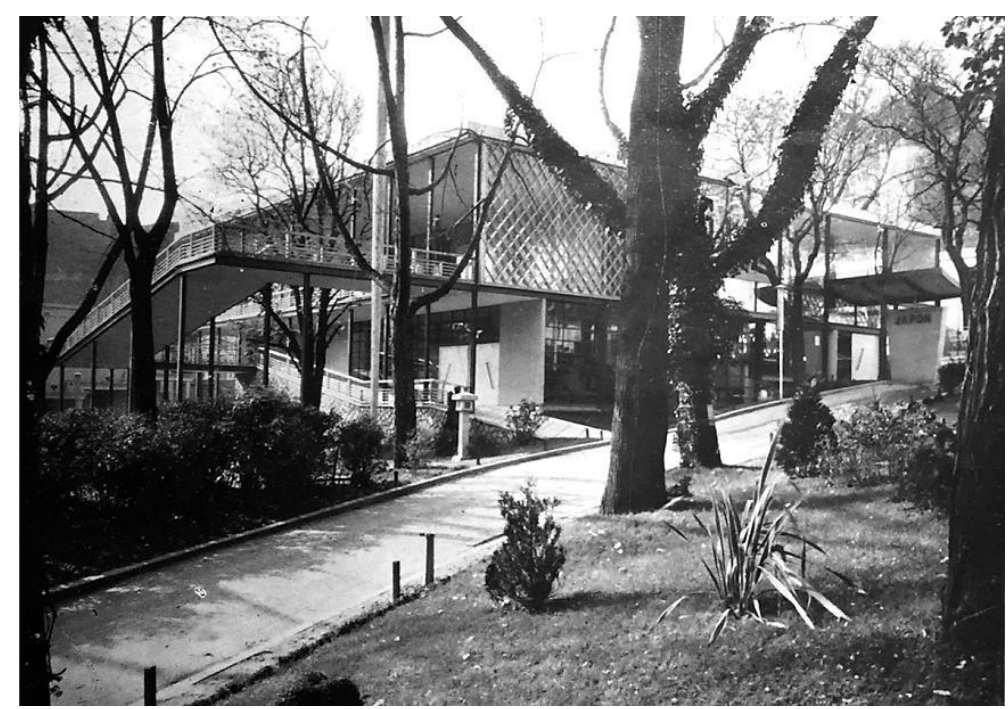

18. Pabellón de Japón, 1937. Vista desde el sur, con el acceso, la terraza restaurante y la rampa exterior de salida.

\section{Agradecimientos}

Departamento Proyectos Arquitectónicos. Cátedra Blanca CEMEX - Grupo Investigación Cultura del Hábitat. ETSAM. Universidad Politécnica de Madrid. (España).

Architecture and Design Department. Arai Lab. Kyoto Seika University. Kyoto (Japón).

\section{Procedencia de las imágenes}

Imagen 1. Pavillon du Nippon. 1937. Fondation Le Corbusier, Paris. E2-15. 182-004. CFLC-ADAGP

Imagen 2. Kokusai Kenchiku 12, nº9. Septiembre 1936. Tokyo.

Imagen 3. Kokusai Kenchiku 12, nº9. Septiembre 1936. Tokyo.

Imagen 4. Kokusai Kenchiku 12, nº. Septiembre 1936. Tokyo.

Imagen 5. Junzo Sakakura Architect. Kamakura:Kenchiku Shiryo Kenkyusya, 2010.

Imagen 6. Junzo Sakakura Architect. Kamakura:Kenchiku Shiryo Kenkyusya, 2010.

Imagen 7. Gendai Kenchiku, №1. Junio 1939. Tokyo, 1939.

Imagen 8. Junzo Sakakura Architect. Kamakura:Kenchiku Shiryo Kenkyusya, 2010.

Imagen 9. Gendai Kenchiku, № 1. Junio 1939. Tokyo, 1939. 
Imagen 10. Gendai Kenchiku, Nº1. Junio 1939. Tokyo, 1939.

Imagen 11. Gendai Kenchiku, Nº1. Junio 1939. Tokyo, 1939.

Imagen 12. Process: Architecture. Nº110. May 1993. Tokyo: Process Architecture CO. Ldt. 1993.

Imagen 13. The Work of Kunio Mayekawa, a Pioneer of Japanese Modern Architecture, Tokyo: BSS, 2006.

Imagen 14. Fondation Le Corbusier, Paris. E2-15. 178-179.

Imagen 15. Fondation Le Corbusier, Paris. E2-15. 182-005 y 182-006.

Imagen 16. Gendai Kenchiku, №1. June 1939. Tokyo. Fondation Le Corbusier, Paris. 784 @FLC-ADAGP

Imagen 17. Gendai Kenchiku, Nº1. June 1939. Tokyo. Fondation Le Corbusier, Paris. K-41, 571 CFLC-ADAGP

Imagen 18. Gendai Kenchiku, Nº1. Junio 1939. Tokyo, 1939.

\section{Bibliografía}

Architectural Forum. Vol.67, N³. September 1937,. New York: Ed. Time Inc. 1937.

Architectural Review. Vol. 82, Nº488. July 1937.

Chermayeff, Serge: "Circulation: design: display. The architect at the exhibition". En Architectural Review. Vol. 82, No488. July. 1937. pp. 91-104.

Gendai Kenchiku, №1. Junio 1939. Tokyo, 1939.

Giedion, Sigfried: “Paris Exhibition, 1937”. En Die Weltwoche, 1937. Recogido en Gendai Kenchiku, №1. Junio 1939,. Tokyo, 1939. pp. 12.

Hitchcock, Henry Rusell: "Paris Exposition, 1937”. En Architectural Forum, Vol.67. №3. September 1937,. New York: Ed. Time Inc. 1937. pp. 173.

Hiroshi, Matsukuma: "The Pursuits of Kunio Mayekawa. The Revitalization of Modern Architecture". The Exhibition Organizing Committee for Kunio Maekawa Retrospective (ed): The Work of Kunio Maekawa: A Pioneer of Japanese Modern Architecture. Tokyo: Bijutsu shuppansha, 2006. pp 303-305

Hiroshi, Yamaguchi: "Kunio Mayekawa and Japanese Modern Architecture". The Exhibition Organizing Committee for Kunio Maekawa Retrospective (ed): The Work of Kunio Maekawa: A Pioneer of Japanese Modern Architecture. Tokyo: Bijutsu shuppansha, 2006. pp 302.

Kamakura \& Hayama The Museum of Modern Art (ed.): Junzo Sakakura architect. Kamakura:Kenchiku Shiryo Kenkyusya, 2010.

Kokusai Kenchiku 12, No9. Septiembre 1936. Tokyo, 1936.

Le Corbusier; Jeanneret, Pierre: Le Corbusier et Pierre Jeanneret. Oeuvre Complète 1910-1929. Zurich: Publiée par Willy Boesiger, 1964.

Le Corbusier: Hacia una arquitectura. Barcelona: Ediciones Apóstrofe, S.L. 1998.

Mayekawa, Kunio: “Comentarios”. En Mokuyokai Zasshi, December 1937. Tokyo: Tokyo University. 1937. pp. 14. Recogido al inglés en Yuzuru, Tominaga: "Exploring the Ethical Spirit of Modern Architecture". ". The Exhibition Organizing Committee for Kunio Maekawa Retrospective (ed): The Work of Kunio Maekawa: A Pioneer of Japanese Modern Architecture. Tokyo: Bijutsu shuppansha, 2006. pp 302.

Noboru, Kawazoe: Contemporary Japanese Architecture. Tokyo: Kokusai Bunka Shinkokai, 1968.

Quetglas, Josep: "Promenade Architecturale". En Web Architecture Magazine. No5 Ediciones Actar. Internet Editor: Yes.

Reynolds, Jonathan M.: Maekawa Kunio and the Emergence of Japanese Modernist Architecture. Berkeley: University of California Press, 2001. 
Sakakura Associates. Process: Architecture. N¹10. May 1993. Tokyo: Process Architecture CO. Ldt. 1993.

Sakakura, Junzo: “Japanese Pavilion for the International Exhibition, Paris 1937”. En Gendai Kenchiku, Junio 1939, No1. Tokyo, 1939. pp. 10-11.

Sakakura, Junzo: “Japanese Pavilion for the International Exhibition, Paris 1937”. En Gendai Kenchiku, Junio 1939, No1. Tokyo, 1939. Reeditado y traducido al inglés en Process: Architecture. "Sakakura Associates" May 1993, n¹10. Tokyo: Process Architecture CO. Ldt. 1993. pp.32-34.

Sakakura, Junzo: “Kamakura Museum of Modern Art”. En Kenchiku Bunka, Junio 1963, Nº. Tokyo, 1963. Reeditado y traducido al inglés en Process: Architecture. "Sakakura Associates" May 1993, n¹10. Tokyo: Process Architecture CO. Ldt. 1993. pp.46.

Tadayoshi, Fujiki: “Tokyo-Paris 1936-1937”. En Process: Architecture. "Sakakura Associates" May 1993, n¹10. Tokyo: Process Architecture CO. Ldt. 1993. pp.36-38.

The Exhibition Organizing Committee for Kunio Maekawa Retrospective (ed): The Work of Kunio Maekawa: A Pioneer of Japanese Modern Architecture. Tokyo: Bijutsu shuppansha, 2006.

Yuzuru, Tominaga: "Exploring the Ethical Spirit of Modern Architecture". The Exhibition Organizing Committee for Kunio Maekawa Retrospective (ed): The Work of Kunio Maekawa: A Pioneer of Japanese Modern Architecture. Tokyo: Bijutsu shuppansha, 2006. pp 305. 


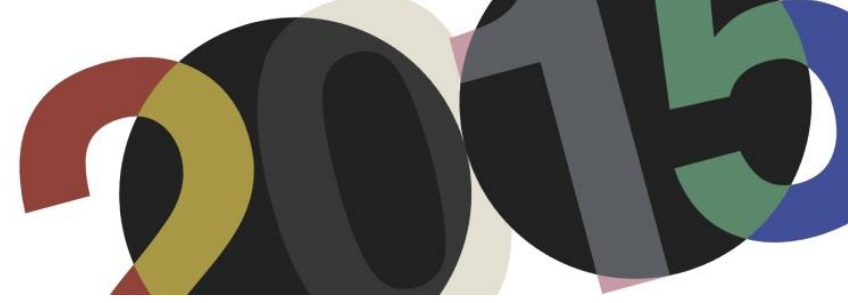

DOI: http://dx.doi.org/10.4995/LC2015.2015.911

\title{
Le Corbusier between sketches. A graphic analysis of the Acropolis sketches
}

\section{S. Harris}

Escuela Superior de Arquitectura de Barcelona, UPC

\begin{abstract}
In contrast to Le Corbusier's later written accounts and the opinions critics have formed from these texts, this article concentrates on the ideas and opinions Le Corbusier developed in-situ during his first visit to the Acropolis in 1911. Using a detailed method of graphic analysis, this research deconstructs a set of Le Corbusier's original sketches of the Acropolis made in Carnet 3 during his Voyage d'Orient in 1911. Comparing them in chronological sequence reveals how the ideas of the architect evolved whilst he was immersed in the physical experience of the Acropolis.

The article focuses on two themes prevalent in the sketches and also in his later work: The various relationships between architecture and ground; and the representation of dynamic spatial experience across time and space. It finds that Le Corbusier used in-situ sketching as an intentional and rigorous method to analyse the Acropolis, actively forming his opinions through experimentation and refinement rather than merely illustrating pre-established ideas.

This analysis reveals how Le Corbusier made use of his prior knowledge of the Acropolis but also, how he used his sketches to gradually transform this into a personal and original interpretation of the site and its buildings. It also shows that a number of his most celebrated ideas are not present in these sketches and may have developed in retrospect under the influence of other authors.
\end{abstract}

Resumen: Este artículo se centra en las ideas y opiniones de Le Corbusier desarrolladas in-situ durante su primera visita a la Acrópolis en 1911 y contrasta con escritos posteriores del propio Le Corbusier e historiadores de estos textos. Este artículo deconstruye una serie croquis originales dibujados por Le Corbusier en el Carnet 3 de su Viaje al Oriente a través de un análisis gráfico detallado. Comparando sus croquis originales en secuencia cronológica revela como las ideas del arquitecto evolucionaron mientras que estaba inmerso en la experiencia física de la Acrópolis.

El artículo se enfoca en dos temas predominantes que son presentes tanto en los croquis como en su obra posterior: Las relaciones entre la arquitectura y el terreno; y la representación de la experiencia espacio-temporal del conjunto arquitectónico. El artículo argumenta que Le Corbusier utilizaba sus croquis in-situ como método intencional y riguroso para analizar la arquitectura formando sus opiniones por experimentación y refinamiento más que para ilustrar conceptos preestablecidos.

Este análisis muestra como Le Corbusier aprovechaba sus conocimientos previos de la Acrópolis, además de transformarlos gradualmente por medio de sus croquis en una interpretación personal y original del lugar y de la arquitectura. También explica que varias de sus ideas más celebradas no están presentes en estos croquis y que las desarrolló retrospectivamente bajo la influencia de otros autores.

Keywords: Le Corbusier; Sketch; Acropolis; Graphic analysis; Voyage to the Orient.

Palabras clave: Le Corbusier; Croquis; Acropolis; Análisis gráfico; Viaje al Oriente.

\section{Introduction}

From the start of his career up to his final projects, his sketches provide an extremely direct and personal window onto his thought process, both when reflecting on his own ideas and when reacting to those he observed around him. Le Corbusier's sketches are not only records of his thoughts and opinions, but in fact formed his ways of thinking. These were often minimal, fast and emotive sketches with which he perfected both his analytical and design ideas. His sketches allow an incomparable insight into his developing opinions and his method of research. This article investigates a turning point in Le Corbusier's formation as an architect, through analysing a set of the sketches he made on his first visit to the Acropolis in 1911 which are recorded in their 
original order in the Carnet 3 of the Voyage d'Orient ${ }^{1}$. This differs from the copious literature ${ }^{2}$ on this particular visit both in its approach and results. It treats his sketches as the evolving record of a learning process rather than as clear statements of definitive opinions. By applying a novel and detailed method of graphic analysis, the sequence of exploratory sketches reveals the growth of Le Corbusier's ideas and how he went about "designing" his interpretations of the Acropolis, its setting and its temples. This method allows a new appraisal of Le Corbusier's visit based exclusively on concurrent and in-situ sources, in contrast to the many accounts in the literature which focus instead primarily on his largely retrospective writings. The article also presents a range of ways in which Le Corbusier manipulated his sketches in order to develop and radicalise his opinions. This uncovers Le Corbusier's graphic techniques underlying his analysis and design, revealing his highly intentional but also flexible and experimental method.

Of all the buildings Le Corbusier studied during his Voyage to the East, it appears that his visit to the Acropolis was a revelation to the young architect and fundamentally altered his way of thinking about architecture from then on. The dramatic change in Le Corbusier's architectural thinking at this moment is described by Jacques Lucan $^{3}$ and referred to as a step change by Geoffrey Baker ${ }^{4}$. Le Corbusier himself referred back to his experience of the Acropolis so often that J-L Cohen refers to it as a kind of "Acropolis syndrome". Given the significance of the ideas which emerged during his visit on his later work, both theoretical and built, it is interesting to consider how his thoughts emerged and developed during his time in contact with the monument. This may shed light on his process of learning about precedents and appropriating architectural ideas.

Most scholars have based their research primarily on Le Corbusier's own writings about his visit, however most of these were in fact written in retrospect ${ }^{6}$ and influenced to varying degrees by his later reflections and the theories of others. Apart from a few brief written notes and letters, the only concurrent record of his analysis in situ are photographs and a group of sketches. The set of sketches in Carnet 3 in particular give a glimpse of his direct and immediate reaction to architecture and sense of place, however, until now, these have not been thoroughly studied in detail from a graphic perspective.

This article contributes to the existing literature through charting the intellectual metamorphosis which took place during his intense study of the Acropolis in 1911 and questions what sequence of reasoning his ideas went through $^{7}$ and how the sketches in fact determined the direction of his thoughts.

\footnotetext{
${ }^{1}$ Corbusier, L.: Voyage d'Orient : Carnets. Milano : Mondadori. 2002. Facsimile reproduction of the original carnets.

${ }^{2}$ Amongst the main authors are Allen Brooks, Kenneth Frampton, Geoffrey Baker, J Lucan, J-L Cohen and Ricardo Daza. See the Bibliography for further references.

${ }^{3}$ Lucan, J. : Le Corbusier : une encyclopédie. Paris : Centre de Création Industrielle. 1987. pp.20-22

${ }^{4}$ Baker, Geoffrey: Le Corbusier - the creative search - the formative years of Charles-Edouard Jeanneret. New York: Van Nostrand Reinhold, 1996. pp174-187

${ }^{5}$ Cohen, J.-L.: "Vers Une Acropole: d'Athènes a Ronchamp". In Le Corbusier - L'Invention d'un architecte Paris : Fondation Le Corbusier. 2014. p388

${ }^{6}$ Ibid. pp377-384. Brooks, Allen: Le Corbusier's Formative Years: Charles-Edouard Jeanneret at La Chaux-de-Fonds. Chicago: University of Chicago Press. 1999. pp279-285. Moos, S. von. Le Corbusier : elements of a synthesis. Rotterdam: 010 Publishers. 2009 pp30-34.

${ }^{7}$ Daza Caicedo, R., \& Quetglas, J.: Tras el viaje de Oriente: Charles-Édouard Jeanneret-Le Corbusier. Barcelona: Fundación Caja de Arquitectos. 2015. Ricardo Daza provides a comprehensive account of Le Corbusier's Voyage to the Orient, accompanying an explanation of his typical daily visits to the Acropolis with Le Corbusier's texts, and other sources from the time.
} 
The importance of this research lies first in the method of graphic analysis used to deconstruct the original sketches revealing their underlying logic and second, in the insights into his method of reasoning which this analysis of the sketches reveals.

The hypothesis is that the sketches focus on different themes to those often discussed from Le Corbusier's later texts, and which reflect his immediate preoccupations whilst in direct contact with the Acropolis. This research shows that he used sketching to actively investigate and learn rather than just to memorise what he saw. In fact various themes crucial to his later work are not only illustrated, but were actively developed in-situ through using his sketches to experiment with and refine his analysis ${ }^{8}$. Combining his prior knowledge with direct observation, the process of sketching on location helped to transform his thoughts into original interpretations of the essence of classical architecture and discover its new relevance to twentieth century architecture. This leads to a number of conclusions regarding the focus of Le Corbusier's thoughts when on location which extend, and in certain respects contrast with, the prevailing views about the influence of the Acropolis on his later work.

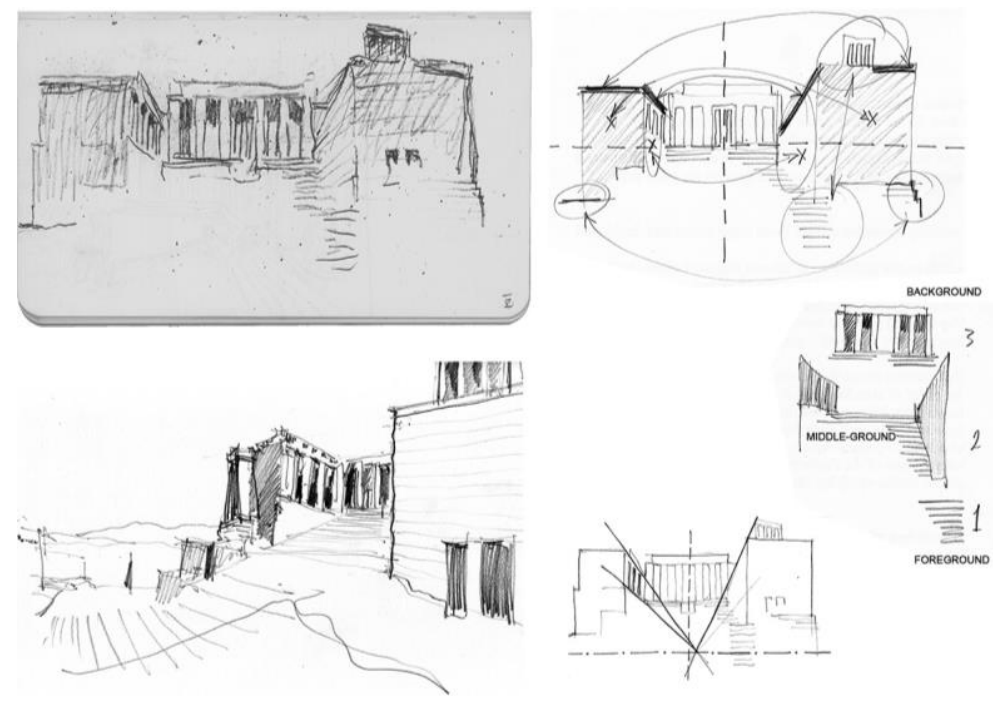

1. Examples of graphic analysis of sketch 107, Carnet 3, Voyage d'Orient. Clockwise from top left: Le Corbusier, Sketch 107, Carnet 3, Voyage d'Orient, 1911.; Propylaea, author's in-situ sketch 2014 for comparison with 107; Composition analysis of original sketch $107(\mathrm{SH})$; Depth of field analysis (SH); Perspectival analysis $(\mathrm{SH})$.

This analysis compares the set of original sketches of the Acropolis in the Carnet 3 of the Voyage d'Orient, following a method of graphic analysis based on that used by Josep Quetglas in his organisation of the Villa Savoye drawings ${ }^{9}$. Due to the fact that they are preserved in chronological order, and share equivalent formats and similar content, the set may be compared and contrasted with an unusual degree of precision. Two particular architectural themes have been selected for the following analysis: the relationship between architecture and the ground, and the dynamic experience of architectural space through movement. These have been selected for two reasons: First, for the importance Le Corbusier attributed to them in both the Acropolis and his own work ${ }^{10}$; and

\footnotetext{
${ }^{8}$ Due to their order in the Carnets, these have been preserved in their most likely original order. The sequence of sketches chart the evolution of his interpretations of the architecture and show that in contrast to Baker's opinion (Baker. Op.Cit.p182) that Le Corbusier used drawing to imprint images on the mind (after the manner of his teacher l'Eplattenier), Le Corbusier's method of drawing on the Acropolis in particular, fast, excited, exploratory sketches served to actively propel his reasoning forward more than merely recording and memorising fixed conclusions.

${ }^{9}$ Quetglas, J : Les Heures Claires. Barcelona : Massilia. 2008

${ }^{10}$ Corbusier, L.: Ed. Boesiger, W.: Oeuvre Complète. Paris : Éditions d'architecture. 1965
} 
second because their influence on each one of these carnet sketches can be clearly seen to evolve throughout the sequence. In order to compare like with like and minimise the number of variables between drawings ${ }^{11}$, the original sketches have been redrawn by myself in the form of diagrams to enable clear and direct comparison across the range of sketches and viewpoints. Each set of diagrams focuses on specific graphic characteristics of the sketches and reduces the information in each sketch to its essential minimum. These analyse the graphic construction of the sketches, focusing on changes in composition, scale, proportion, perspective and view point, context, spatial continuity and depths of field (foreground, middle-ground and background), as well as the various drawing techniques Le Corbusier used, including different qualities of line and shading. Comparing the resulting diagrams in chronological sequence shows the direction in which his thoughts moved and the degree to which they changed.

In outline, this research finds that variations in the way Le Corbusier represented important relationships between architectural elements and their surroundings reflect a continuous process of experimentation through which he refined his conceptions of the Acropolis and its temples. Whilst these were sometimes inspired by his prior knowledge, the ideas underlying the sketches always took a course of their own developing along unexpected conceptual paths through trial and error and continual revision. Although Le Corbusier's ideas about the Acropolis continued to evolve significantly during the years after his visit, several patterns emerge in the carnet sketches showing his ideas at the time were converging towards certain clear architectural concepts regarding the relationship of architecture and ground, and the representation of movement and spatial sequence. But it finds that a number of Le Corbusier's later theories were absent from his thoughts. This suggests that many of the ideas stated in his later texts were either not at all clear to him whilst on location, or were simply not present amongst his concerns at the time when confronted by the physical presence of the Acropolis. Significant themes in Le Corbusier's later work that are notably absent include mathematical precision, number and measure, historical imagination, precise plastic form and natural light ${ }^{12}$. The promenade architecturale (the observer's pathway through the built space) does not follow as directly from Choisy as Le Corbusier's later writings may suggest ${ }^{13}$. It shows an appreciation of distinct, immersive spatial environments arranged in order, but not a stipulated path connecting a set of fulcrum viewpoints in the manner of Choisy ${ }^{14}$. This article separates his actual discoveries in-situ from his prior knowledge and ideas he appropriated from others, from later influences and from his retrospective thoughts, and traces the course of his original in-situ analysis of the Acropolis.

The article is organised in the following way. First, the relationship between architecture and ground, and the role of various types of platform and plinth is discussed. The second section considers the role of movement in Le Corbusier's representation of the Acropolis. The final section draws conclusions about Le Corbusier's use of sketching from the results of the detailed analysis of his in-situ sketches.

\footnotetext{
${ }^{11}$ Thompson, D. Wentworth: On Growth and Form. Cambridge: Cambridge University Press. 1961 (abridged edition) pp.268-276

${ }^{12}$ Frampton, K.: Le Corbusier. London: Thames and Hudson. 2001. p14. Frampton cites "L'Art de Demain" by Henri Provensal (1904), which was later paraphrased by Le Corbusier in Vers Une Architecture, (1922)

${ }^{13}$ Corbusier, L.: Vers Une Architecture. Paris. 1923. Reprinted as Towards a new architecture. London : Architectural Press. Translation by Etchells, F. 1987

${ }^{14}$ Choisy, A: Histoire de l'architecture. Paris. 1899
} 
Original sketches by Le Corbusier are referred to by the page number in the Carnet 3 from the Voyage $d^{\prime}$ 'Orient ${ }^{15}$. All other sketches and diagrams are by the author ( $\mathrm{SH}$, the author's initials, is written in the captions).

\section{Architecture, base and ground.}

From the first to the last sketches of the Acropolis in Carnet 3, the relationship between natural ground, built architecture and the various man-made levels in between, is of central importance. Of the few elements consistently portrayed, the parts which either separate or join the ground with the principle buildings are repeatedly given great visual significance and considerable variety in their graphic treatment. Le Corbusier experimented with a series of alternative combinations of temple and ground before reaching a definitive conclusion in his final sketches. His writings also confirm this interest in the connection between temple and ground, especially in the degree of separation or integration between the two and what effect this may have on the perception of the temple in its context ${ }^{16}$.
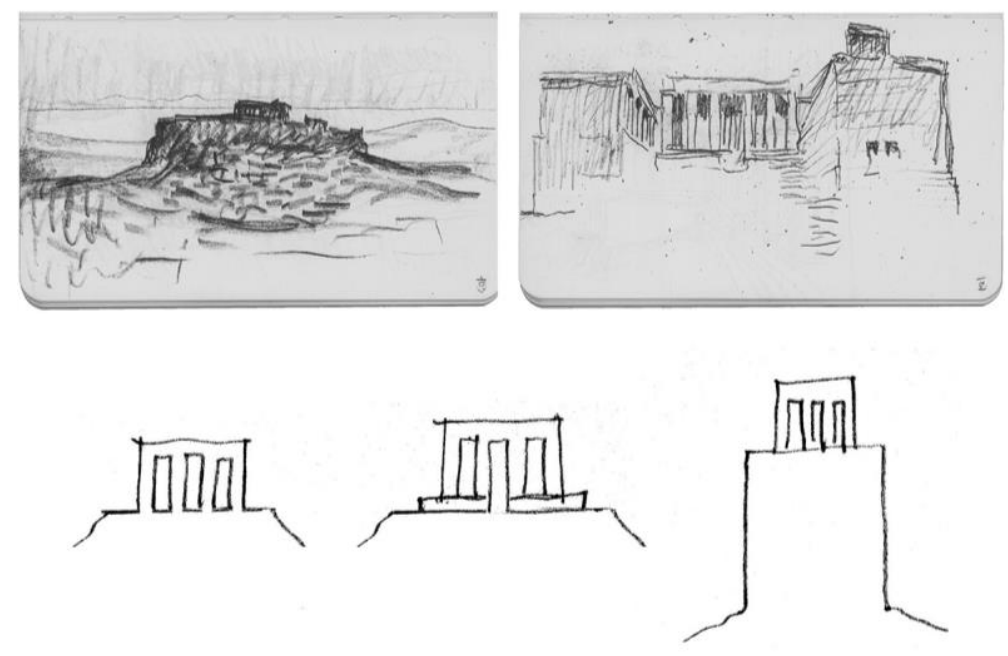

2. Clockwise from top left: Le Corbusier, Sketches 103 and 107, Carnet 3, Voyage d'Orient, 1911.; Schematic diagrams (SH) showing developing variations in relationship of temples and ground in sketches 103 and 107.

Through reducing the sketches to diagrams of ground, building and the intermediate layer, it may be seen that Le Corbusier's reasoning was influenced by several factors.

First, in the degree of connection or separation between temple and ground. In the sketches seen from the distance, temple, base and ground are all fused together as one single element. Although 98 shows a tonal emphasis on the central Parthenon, 103 and 104 show the Parthenon, Acropolis and the hill itself as a single mass. This idea is repeated in his written notes about the visit published in $1966^{17}$. From sketch 109 onwards, the horizontal steps become an extremely important part of the sketches separating the temple from the ground and

\footnotetext{
${ }^{15}$ Corbusier, L.: Voyage d'Orient : Carnets. Milano : Mondadori. 2002. Facsimile reproduction of the original carnets.

${ }^{16}$ Corbusier, L.: 1923. Op.cit.: p.208

${ }^{17}$ Corbusier, L.: Le voyage d'Orient. Paris : Ed. Parenthèses. 1966. p.166-7. However, the poetic description was written later and appears to describe the in-situ sketches so precisely as to suggest that it was written later using the sketches as an aide memoire and hence simply recapitulating the conclusions drawn in the carnets.
} 
its context. These repeated sets of horizontal lines focus attention on the temple above by literally underling it. Sketches 111 and 113 show the temple of Athena Nike presented as if it were a sculpture on a pedestal, emphasising the separation of temple from ground in the same way that the sculptures drawn in 117 and 119 are elevated and isolated by their plinths (figure 3). This is confirmed in the following pages by notes about sculptures on pedestals.
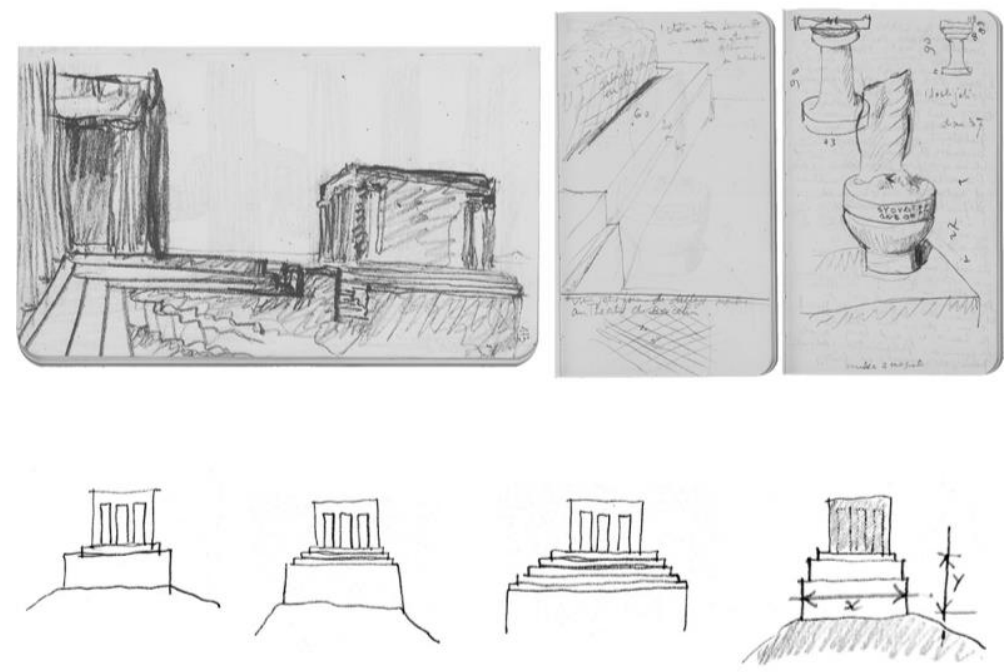

3. Clockwise from top left: Le Corbusier, Sketches 113, 117 and 119, Carnet 3, Voyage d'Orient, 1911.; Schematic diagrams (SH) showing developing variations in relationship of temples and ground from sketches 109 to 119.

Second, the use of steps to change the level of the observer's viewpoint. Le Corbusier was certainly interested in the complexity of the ground-levels on the Acropolis, and had already studied how the Erechtheion made use of different levels to create different temples out of a single building. Rather than repeat what he already knew (as shown by the ink section through the Propylaea copied from Choisy's drawing the previous year ${ }^{18}$ ), in sketches 106-113, Le Corbusier chose not to draw the ramp through the Propylaea threshold, but showed the changes in level through the repetition of steps and shading on plan. These steps were drawn approximately, but with increasing emphasis as the sketches continue (fig 6, sketch 111). Their precision was less important than the fact that they demonstrated the change of level which mattered to Le Corbusier for the effect this had on the visitor's perception of the building and landscape ${ }^{19}$. This may be seen in the upward facing viewpoint of 107 and the drawing's position at the top of the page emphasising the height of the entrance and its effect on the spatial sequence (figure 1).

Third, this set of horizontal lines creates a relationship with the distant horizon, in effect creating a foreground horizon line. See for example the very slight difference in height between 111 and 113 which gives 113 a closer relationship between the horizon line and the horizontal lines of steps, without quite touching so as to remain visible (figure 6). In Sur l'Acropole ${ }^{20}$, Le Corbusier states how the steps connect on to the horizon. The stylobate steps also emphasise the contrast between the horizontal lines of the steps and the architrave and the vertical

\footnotetext{
${ }^{18}$ See the section in ink of the Propylaea (FLC1784) and plan of the Erechtheion (FLC 1785). Daza (Op.Cit. 2015).

${ }^{19}$ Baker quotes Le Corbusier's description of the oversize steps of the Parthenon. Baker (Op.Cit. 1996) p175

${ }^{20}$ Corbusier, L. Sur L'Acropole. 1926 in Corbusier, L., \& Duboy, P.: Croquis de voyages et études. Paris: Quinzaine littéraire - Louis Vuitton. 2009
} 
columns sandwiched in between, whose verticality is optically emphasised by the fluting as well as by the entasis of their sides, as seen most clearly in 113 .

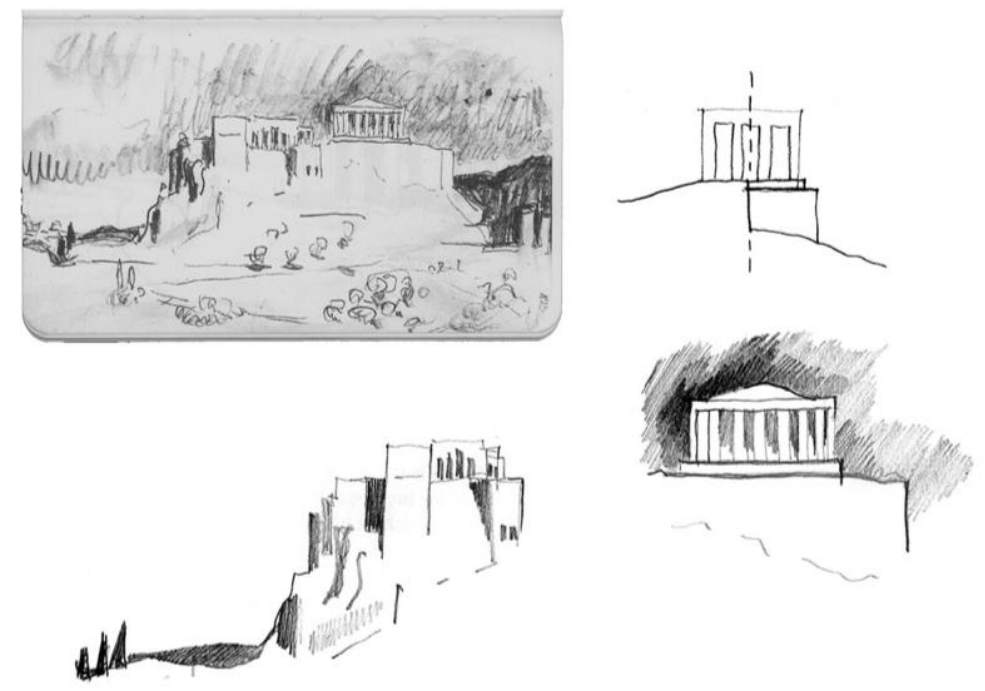

4. Clockwise from top left: Le Corbusier, Sketch 123, Carnet 3, Voyage d'Orient, 1911.; Schematic diagrams of 123 (SH) showing integration of cliff and buildings to the left and the Parthenon separated from the ground by its plinth on the right.

However various important themes in Le Corbusier's later work (in his writings and projects) which are often traced back to his first visit to the Acropolis, do not appear in his carnet sketches. Frampton states that Le Corbusier's sketches are full of measurement and annotations, whilst these specific sketches are not, and in places they even contain significant artistic license over number and proportion such as in the colonnade of $113^{21}$. According to Baker, Le Corbusier believed perfection in the Acropolis came down to mathematics and measure, not just the interaction of geometric shapes ${ }^{22}$. But whilst Le Corbusier does mention the mathematical precision of the stone-cutting in Sur L'Acropole, he made no attempt to convey this in his sketches. Although plinths and pedestals from elsewhere in Athens have been measured precisely and noted (as in 117 and 119), the steps in the carnet sketches are drawn emphatically, but often so hastily that mistakes with vanishing points often occur and the proportions and number of steps is usually approximate (Figure 6 sketch 111). However, this approach differs from Le Corbusier's written descriptions of precise measurements, proportions and optical adjustments, smoothness, and fineness of jointing ${ }^{23}$. Instead, architectural proportion is sketched only very approximately, and is in some cases deliberately modified in order to better illustrate other issues of greater interest to him whilst in situ (figure 6, sketch 113). The nature of the small, fast, soft pencil sketches does not lend itself to exact renderings of the precision of the stone masonry, nevertheless, he drew mouldings, fluting and occasionally entablatures in a deliberately impressionistic manner (see the carefully conceived and repeated watercolours of the Parthenon columns ${ }^{24}$ ).

Furthermore, although some authors trace the inspiration behind Modulor man back to the Parthenon, there is no direct evidence of this in the carnet sketches, and no specific reference made to human scale, and so this idea might seem to have been developed later and been related back to the Parthenon in retrospect. Rather than

\footnotetext{
${ }^{21}$ Email from K. Frampton to the author, 29/6/2011 "Le Corbusier's sketches invariably carry data and dimensions."

${ }^{22}$ Baker, G. Op.cit.; p181

${ }^{23}$ Corbusier, L. Op. cit. Vers Une Architecture and Sur l'Acropole.

${ }^{24}$ Daza, R. Op. Cit. : p. 273
} 
technical execution, Le Corbusier appears to have been interested most of all in the effect the plinth had on the relationship between temples and place - at first with the ground immediately beneath and later with the far horizon. Although he was specifically conscious of all these matters, as his earlier drawing of the corner columns of the Parthenon shows ${ }^{25}$, they were not of prime interest to him when on location.

The set of sketches trace the development of these ideas through a series of graphic experiments and variations. They show Le Corbusier's vision of architecture and ground diverging towards two conclusions: on the one hand fusing them both together, and on the other, emphasising steps and plinths in order to separate them clearly. Both versions are combined in different parts of sketch 123 connecting the Propylaea and its buildings to the cliff top (figure 4 left), whilst separating the Parthenon high up on its own plinth (figure 4 right).

\section{Movement}

The carnet sketches show how Le Corbusier developed his ideas of space experienced in motion and across time. This was one of the first times where he took particular interest in architecture organised according to the observation of a viewer moving progressively through a sequence of spaces. Whilst the initial sketches form picturesque compositions of the Acropolis seen from the distance in a relatively traditional arrangement, reminiscent of landscape painting from the previous century, the later sketches increasingly imply movement and spatial progression. This is a gradual but important change in how space is represented, which may have sprung initially from his prior knowledge of the theories of Choisy, but then developed through a process of trial and refinement as the sketches progressed. Given the importance of the promenade architecturale in Le Corbusier's later work, and his direct quote of Choisy's explanation of the Acropolis in Vers Une Architecture ${ }^{26}$, it is interesting to question to what degree these ideas were influenced by his prior knowledge of the theories of others, and to what degree he transformed them into his own interpretations by means of his investigative sketches whilst he was physically present on the Acropolis.

Although the ideas develop gradually through experimentation from one sketch to the next within each group, this process can be seen to evolve in three main stages. The first of these groups $(98,103,104)$ demonstrates a comparatively "picturesque" stage. The second (106-115) starts with a close interpretation of Choisy's theory of picturesque sequence but gradually transforms this into an individual and original interpretation of space. The third group $(123,125)$ shows a mature stage where each sketch implies spatial progression through the "dynamic" composition of the image.

\subsection{Sketches 98-104}

The first group, sketches 98, 103 and 104, concentrate on describing the Acropolis in its context which is reduced to a minimal selection of surrounding elements. The three sketches show distant views of the Acropolis from Mount Lycabettus to the North. The principle variation is the scale of the Acropolis in relation to the page and its position within the frame. This has the effect of changing the relationship of the Acropolis to its context. Although all three follow the same picturesque structure, they develop increasingly complex depths of field, progressively shifting the focus of the sketches towards the relationship between the Acropolis and its setting in the landscape.

\footnotetext{
${ }^{25}$ Brooks, A. Op. cit; p284

${ }^{26}$ Corbusier, L.: Vers Une Architecture. Paris. 1923. Reprinted as Towards a new architecture. London : Architectural Press. Translation by Etchells, F. 1987. p52
} 

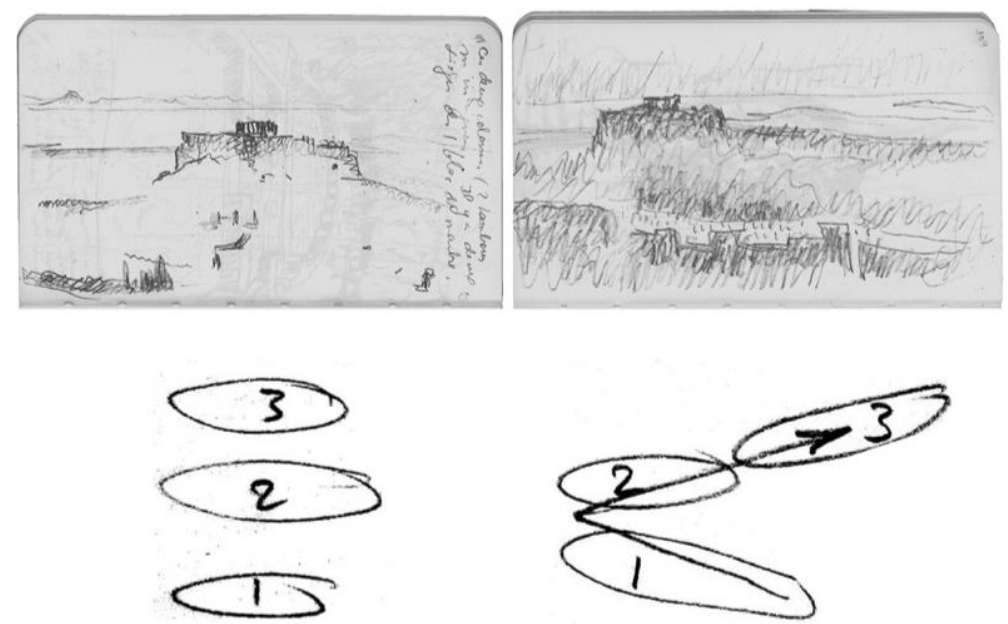

5. Clockwise from top left: Le Corbusier, Sketches 98 and 104, Carnet 3, Voyage d'Orient, 1911.; Schematic diagrams (SH) showing developing variations in depths of field in the above sketches.

Each view is comprised of three receding planes (depths of field), foreground ("1"), middle-ground ("2") and background (" 3 "), each of which may be either continuous, joined on to one of its neighbours, or discontinuous from other fields within the drawing. Different arrangements of these regions dramatically juxtapose the architecture with other selected elements of the landscape or context. The relatively picturesque structure of 98 places the Acropolis in the middle ground between abstract foreground shapes and the distant horizon (figure 5). The three regions are isolated vertically up the page ${ }^{27}$. This structure evolves in the third sketch (104) which arranges the three regions diagonally and begins to suggest movement across the page. As opposed to the comparatively flat and simultaneous perception of the three depths in 98, the diagonal spatial structure of 104 begins to lead the viewer's eye through the drawing past the Acropolis and into the background. The sense of movement through space which this implies is developed further in the following sketches and is echoed by Le Corbusier's written description of the view ${ }^{28}$.

\subsection{Sketches 106-115}

The second group, sketches 106, 107, 109, 111, 113 and 115, focus on the entrance to the Acropolis through the main gateway, the Propylaea. The first of these demonstrate the influence of Le Corbusier's prior knowledge on his understanding of the Acropolis. In the Histoire de L'Architecture ${ }^{29}$, published some twelve years before Le Corbusier's visit, Auguste Choisy had explained the irregular arrangement of the architecture on the Acropolis in terms of the experience of the viewer approaching, entering and moving between the buildings. It seems that Le Corbusier visited the Acropolis with these ideas already firmly established and it is often considered that they became strong personal convictions on account of his research in-situ. However, a detailed look at the sketches

\footnotetext{
${ }^{27}$ Many 19th century watercolours of the Acropolis by artists such as E. Lear, L.Lange, and W. Turner show equivalent picturesque structures where by the Acropolis fades into the background providing an idyllic classical backdrop for the foreground scene.

${ }^{28}$ Le Corbusier describes the scene at dusk with the daylight fading over the Peloponnese and the lights beginning to brighten the city below. The Acropolis reminds him of an ocean liner heading out across the "sea" of the Athenian plane. This impression of virtual movement corresponds with the new dynamic arrangement of the landscape in 104. Corbusier, L.: Le voyage d'Orient. Paris : Ed. Parenthèses. 1966. p166-7.

${ }^{29}$ Choisy, A. Op. cit.
} 
in chronological order suggests that although Le Corbusier started off with these ideas, he rapidly transformed them into original interpretations of his own.
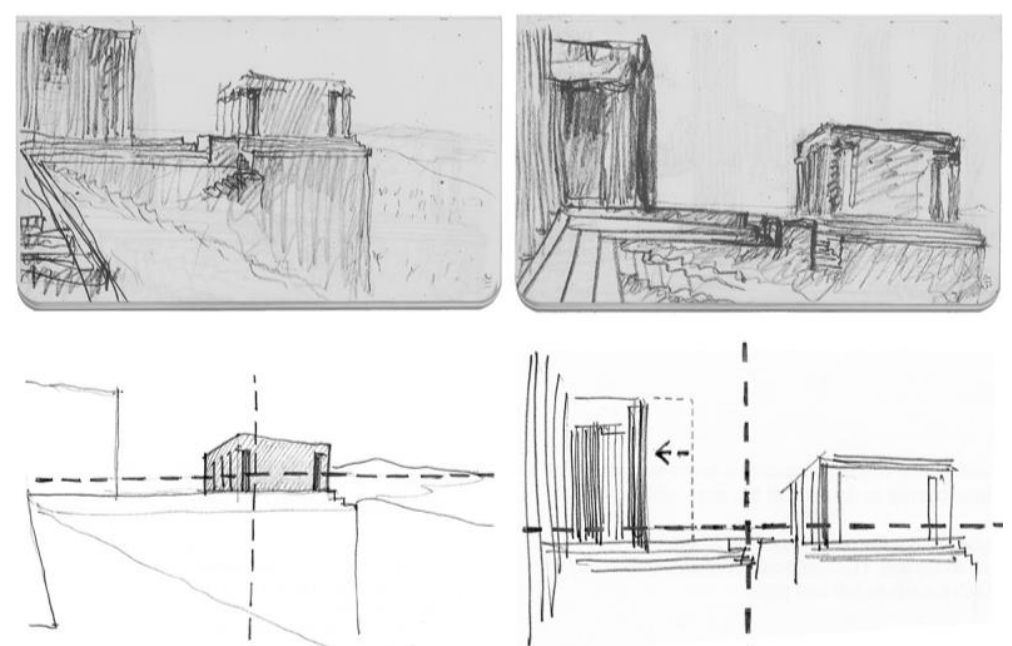

6. Clockwise from top left: Le Corbusier, Sketches 111 and 113, Carnet 3, Voyage d'Orient, 1911.; Diagrams (SH) showing differences in composition and central focus of the image. Diagram 113 (bottom right) also shows the removal of one bay in the original sketch.

According to Choisy, the viewer's perception of the Parthenon is built up through a carefully choreographed sequence of views along the approach route, each of which leads on to the next building up the drama of the spatial experience. Choisy explains this through a set of images (his own reconstructed illustrations) in the manner of stills from a cinematic storyboard. These images are static in the sense of being still frames within a sequence, but a sense of movement is generated by seeing each image one after another. In Vers Une Architecture, Le Corbusier refers to this architectural arrangement on the Acropolis as excellent "stagemanagement" and illustrates his text with Choisy's own drawings ${ }^{30}$. In the late 1930s, the filmmaker Sergei Eisenstein also saw parallels between Choisy's explanation of the arrangement of buildings on the Acropolis with his own experience of film making through splicing together sections of footage ${ }^{31}$. In his essay "Towards a Theory of Montage", he explains how a set of images seen one after another create meaning depending on the order in which they are seen. Motion is implied by the sequential order of the images. In terms of Choisy's illustrations, movement occurs between the drawings and not within them. As Eisenstein describes in terms of cinema, Choisy had also described a storyboard made up of a sequence of framed views each of which was complete in its own right, but when seen together formed a highly choreographed route through the complex.

Le Corbusier starts his own analysis in sketches 106 and 107 from the same point of departure as Choisy, facing up towards the entrance steps of the Propylaea (figure 1). Sketch 107 echoes Choisy's first view extremely closely implying that Choisy's illustration and theory of movement in the arrangement of the Acropolis spaces were initially at the front of his mind. However the following sketches do not copy Choisy's other critical viewpoints so closely, but instead depict a different interpretation of the spatial sequence. J-L Cohen mentions

\footnotetext{
${ }^{30}$ Corbusier, L.: Vers Une Architecture. Paris. 1923. Reprinted as Towards a new architecture. London : Architectural Press. Translation by Etchells, F. 1987. p52

${ }^{31}$ Interestingly, Eisenstein also illustrates his explanation with very simple sketch diagrams showing the sequence of views on the Acropolis as if they were the frames of a film. See Eisenstein, S.: Towards a Theory of Montage. London : British Film Institute. 1994. Original essay 1937-40 published posthumously.
} 
the cinematographic arrangement of the sketches relating to the entrance Propylaea ${ }^{32}$ (sketches 107-115) panning around from the north to south-west to south. Although 109-113 do resemble sections of a panoramic view, the repetition and distortion of 113 (figure 6) show that Le Corbusier was also trying to explain the different attributes of the spatial ensemble. The sketches describe the overall spatial environment through which the visitor passes, incorporating the impressions of volume, mass, distance and material on all sides rather than just the sequence of masses appearing consecutively in front. Rather than follow the direction of movement, as in a film, using visual cues to lead from one frame to the next, Le Corbusier instead drew a set of views facing outwards, sideways and backwards when he reached the threshold of the Propylaea. The impression of the visual sequence is lost if a backwards facing view (in other words, of the exit) is spliced into the entrance progression. The following sketch 115 moves still further away from Choisy's perspectives and shows that Le Corbusier was by then no longer intending his set of sketches to repeat the same storyboard of sequential views. Instead, he drew a view facing out of the Propylaea directly towards the Western front of the Parthenon, ignoring the rest of Choisy's illustrations leading towards the Caryatids and around the Parthenon. This decision demonstrates that by sketch 115, Le Corbusier was now using his sketches to explore what he found and to rationalise the impressions which this evoked in him, rather than continuing to base his impressions on the ideas of others.

This change from the mere visual depiction of spaces to a more immersive exploration of space is also apparent in the difference between the two plans on page 106 (figure 7). The upper plan, most likely drawn first due to the improved proportions of the lower plan, concentrates on the number and rhythm of columns marking the threshold. The lower plan however concentrates far more on describing the volumes and masses on either side of the entrance. Whilst the first plan shows a quick sketch of the principle architectural elements in approximately correct relation, number and proportion, the second seems to be determined by Le Corbusier's direct physical experience of volume and mass and the spatial relationships between them. Tone is used to show the depth of the porticoed spaces and mark the edge of the fortifications and the drop of the cliff edge. The abstract depiction of sequence in the upper plan is replaced by direct understanding of volume and mass determined by direct physical immersive experience.

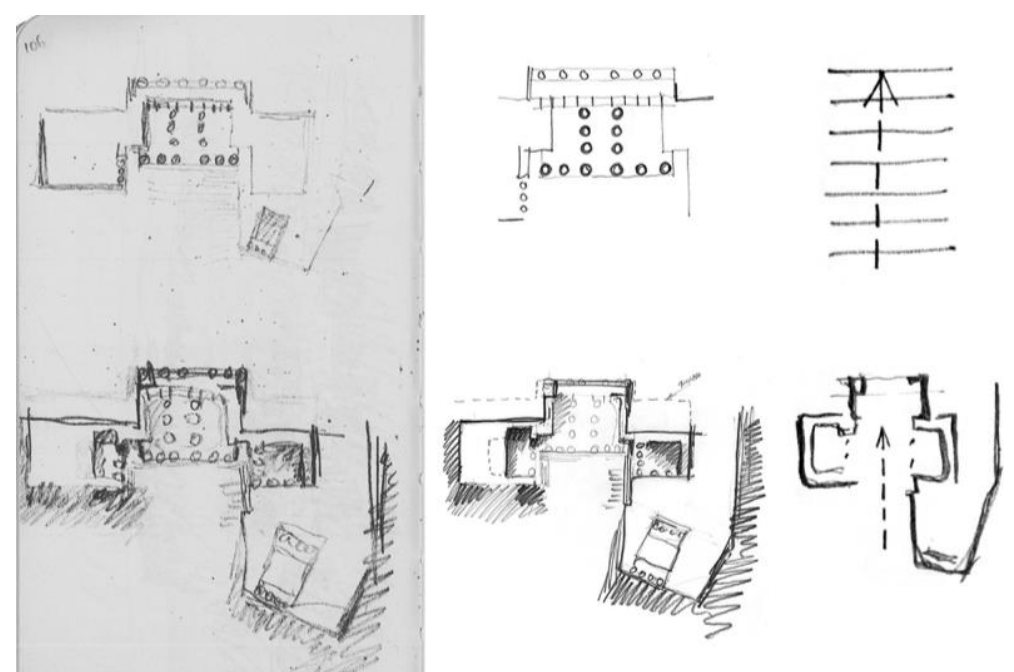

7. Clockwise from left to right: Le Corbusier, Sketches 106, Carnet 3, Voyage d'Orient, 1911.; Schematic diagrams (SH) showing different representations of number and rhythm along the central entrance axis (above), and of volume and space (below).

${ }^{32}$ Cohen, J.-L.: "Vers Une Acropole: d'Athènes a Ronchamp". In Le Corbusier - L'Invention d'un architecte Paris : Fondation Le Corbusier. 2014. p381 
The change in Le Corbusier's understanding of spatial depth can also be seen in the increasingly complex way in which the various depths of field are combined. Up until 111, depths of field had been arranged alongside one another, either vertically (98), horizontally (109) or diagonally (104) (figure 5). Sketch 113, however, makes a significant jump in the organisation of depth with critical consequences for the portrayal of architecture and landscape, moving from adjacent relationships to the juxtaposition of extreme differences in depth (figure 6). By leaving the centre of the drawing empty, the foreground architecture frames either side of the distant horizon, creating a dramatic counterpoint between horizontal steps and the horizon line itself $^{33}$.

However, whilst this contrast between near and far depths of field may serve to emphasise the contrast between elements such as columns and horizon, by itself it does not create a narrative sequence. Incorporating a third depth of field can generate a directional sequence of spaces, in effect, a beginning, middle and end. In the following sketch, 115 (figure 8), the foreground now not only frames the background, but is overlaid across the entire picture-plane. Background and minimal middle ground are shown through a transparent screen of the foreground portico overlaid onto the main view of the Parthenon in the distance.
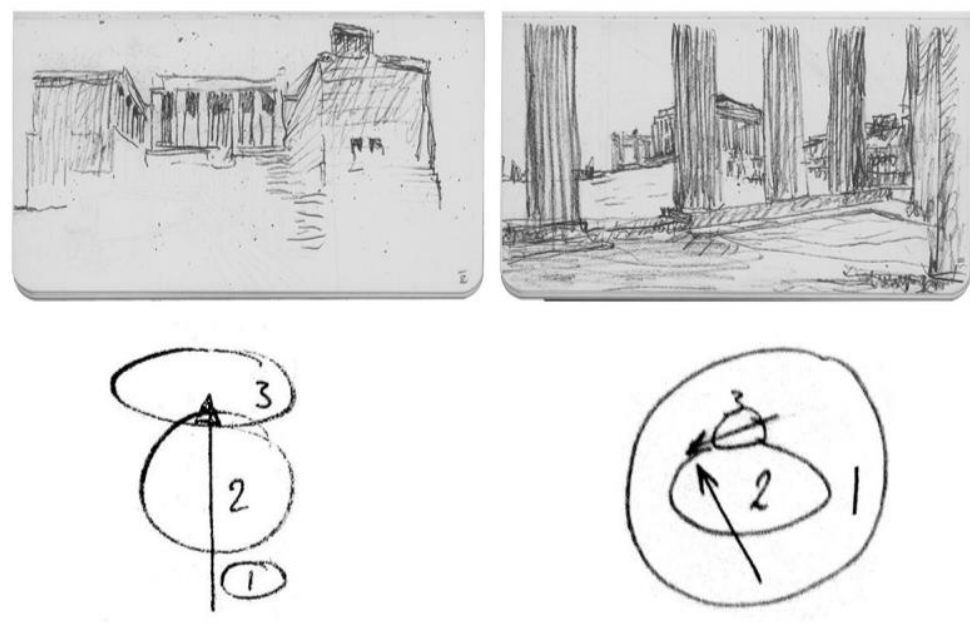

8. Clockwise from top left: Le Corbusier, Sketches 107 and 115, Carnet 3, Voyage d'Orient, 1911.; Schematic diagrams $\mathrm{SH})$ showing developing variations in depths of field in the above sketches.

\subsection{Sketches 123 and 125}

Le Corbusier saw that the apparent symmetry of the buildings was in fact made to appear that way through a great variety of asymmetrical contrivances. This way of opposing unequal parts to create an overall sense of order and balance caught Le Corbusier's interest. As the sketches progressed, he looked for new ways to express the asymmetry of the Acropolis which he appreciated was so vital to its effect on the viewer. Referring to these sketches, Allan Brooks highlights the spatial juxtaposition between masses of different size, height and transparency, and how overall this achieved a balanced asymmetry ${ }^{34}$. The compositions became increasingly

\footnotetext{
${ }^{33}$ The Propylaea portico is artificially pulled into the left of the page (by eliminating one column from the portico in front) bringing the set of buildings all into one single space.

${ }^{34}$ Brooks, A.:1999. Op.cit.: p.283 "Details were not recorded, only the relationship of part-to-part. Irregularity, not regularity, caught his eye."
} 
sophisticated in the later sketches managing to maintain a sense of order in the sketch despite the irregular arrangement of the architecture, through balancing contrasting tones, textures and qualities of line.

In contrast to the rapidity of the carnet sketches and the impressionistic quality of their lines, the compositions themselves are structured with considerable care and intention. They are composed according to a careful arrangement of regulating lines, proportion and scale, making subtle use of graphic techniques to balance dramatically asymmetric compositions. Perhaps in order to compensate for the repeated asymmetry of the spaces of the Acropolis, the graphic compositions often make use of primary geometric arrangements such as dividing pages according to the golden proportion, or balancing elements of the composition across vertical axes in the centre of the drawing (figures 9 and 10).

In the later sketches, the space of the foreground becomes increasingly important and serves to connect the viewer directly with the space within the image. Sketch 113 artificially compresses the Propylaea's southern wing by removing one of the two bays shown in 111 (figure 6).

This brings into the foreground the Propylaea portico and steps at the left of the picture frame. A variety of elements occupy the foreground in the following three sketches, creating continuous spatial regions leading from the picture plane (the apparent position of the observer) right up to the architectural focus of the sketch in the middle ground.

On the other hand, the contrast between the focal space occupied by the architecture and the distant landscape is heightened in the later sketches. This emphasises the relationship between the architecture and horizon whilst making the composition more striking and dramatic. Opposites are contrasted across a central compositional axis which not only accentuate their differences, but creates a sense of order through balancing architecture/nature, solid/void, near/far. Regions of opposite tones or contrasting textures mirror one another across the centre-line of certain drawings, giving an impression of order to an otherwise highly asymmetric composition. Such use of balanced asymmetrical compositions and drawing techniques graphically compensates for the apparent irregularity of the architectural composition.

Le Corbusier also made careful use of the graphic composition of the images to explain the architectural composition, through selecting, emphasising or minimising the different spatial relationships between various parts of the architecture, context and observer. The way the image is composed - symmetry, contrast, balance, scale, perspective, viewpoint etc - allowed him to highlight those aspects of the architecture he considered most significant. In various cases, the views have been redrawn several times in succession varying the graphic composition in order to switch the focus of the drawing onto different aspects of the same building. 


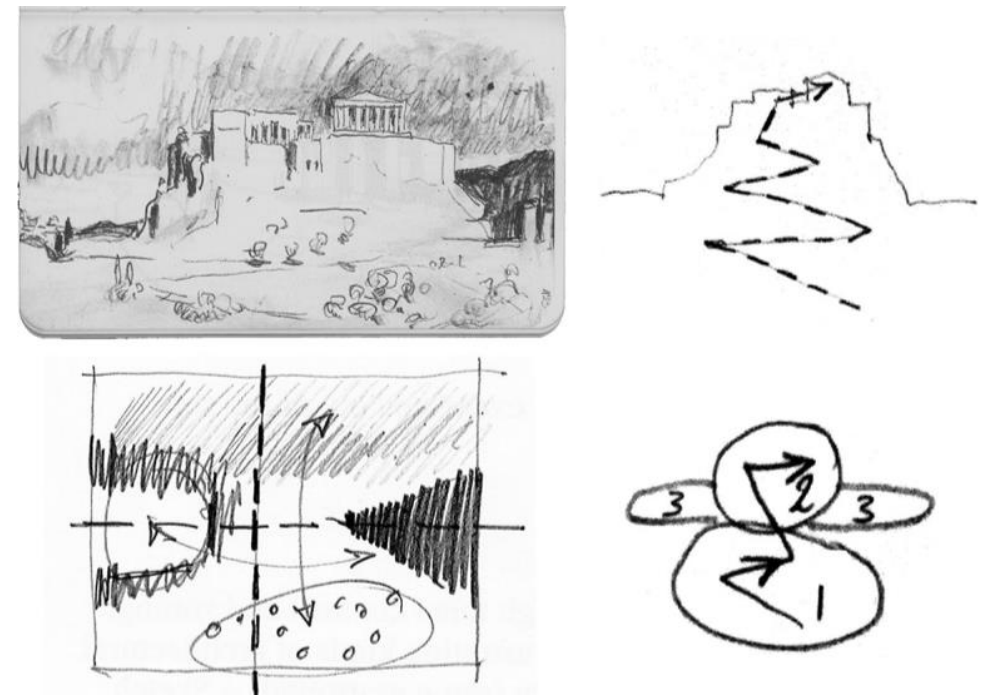

9. Clockwise from top left: Le Corbusier, Sketches 123, Carnet 3, Voyage d'Orient, 1911.; Schematic diagrams (SH) showing the visible pathway between viewer and the Parthenon; depths of field; balanced asymmetry of contrasting graphic techniques.

The complexity of the composition reaches its culmination in the final two in-situ Carnet sketches which emphasise the monumentality of the Acropolis (Sketch 123, figure 9) and the dynamic spatial arrangement of its individual buildings (Sketch 125, figure 10). Sketch 123 portrays the SW facade of the Acropolis and is in some respects similar to a zoomed out version of the Propylaea steps in 107 (figure 7). However, the treatment of the three depths of field transform it into a narrative journey describing the route towards the Parthenon. This distils Choisy's sequence of views into one single image and explains the logic behind the irregular arrangement of the buildings on the Acropolis.

The image shows a realistic spatial progression through continuous spatial regions, placing the viewpoint of the observer within the foreground on the path leading up and into the Acropolis. It also marks the progression through various architectural conditions from landscape to architecture integrated into the landscape at the Propylaea to the Parthenon totally separated from the ground by its plinth. The conceptual hierarchy of architectural elements emphasised graphically through the contrast of tone, texture and depth of field, culminating in the architectural and graphic climax of the Parthenon, raised and separated from the ground and dramatically silhouetted against the dark sky behind. This spatial continuity between viewpoint and building engages the viewer far more closely with the space of the picture than in the more abstract foreground spaces of the initial sketches ${ }^{35}$.

In sketch 125, The arrangement of three depths of field generates a directional sequence of spaces, rather than merely a contrast between different depths. As well as the continuous foreground, the asymmetrical composition balanced across a central axis and the contrasting depths of field dramatically overlapping one another, the sketch also uses an oblique viewpoint with the principle vanishing point positioned at the right of the picture. Apart from strengthening the contrast between architecture and horizon, the angled view of the building creates a diagonal axis across the page and through the Propylaea leading towards the distance ${ }^{36}$. This creates a visually

\footnotetext{
35 Alvaro Siza takes this idea further by drawing himself as the observer within the picture plane.

${ }^{36}$ Edmund Bacon calls this line a "shaft of space" referring to the area alined with the facade of the Temple of Hephaistos in the Agora below. Bacon, E.: Design of Cities. London: Thames and Hudson. 1967. pp.70-71.
} 
continuous path across the composition leading the eye into and through the spaces of the drawing and results in a far more dynamic image than a central axial viewpoint would allow, and helps to immerse the viewer in the space giving a clear direction of movement and spatial sequence.

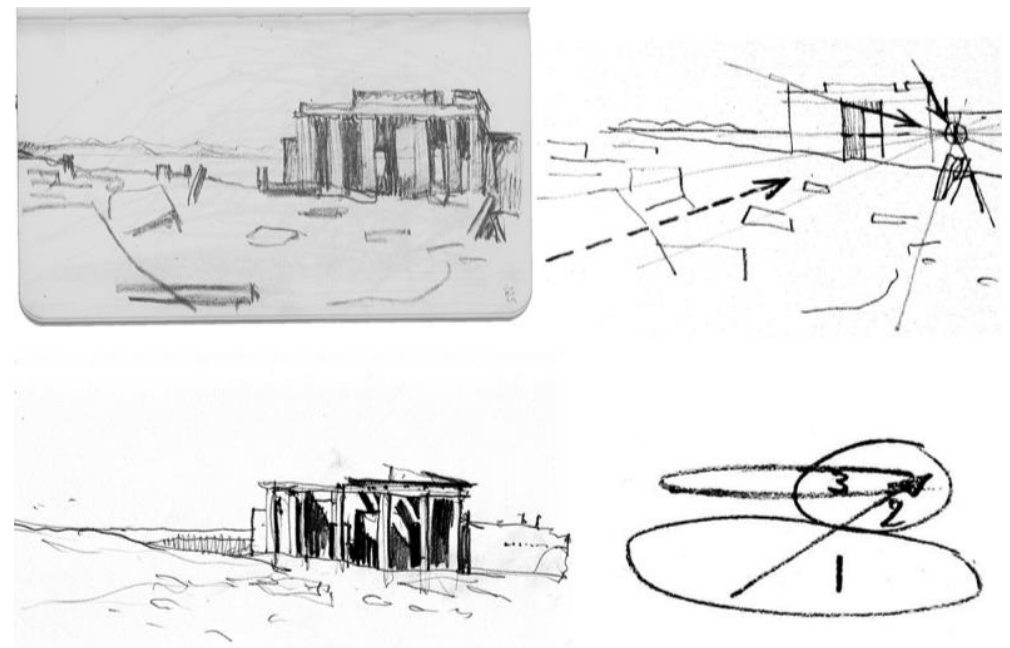

10. Clockwise from top left: Le Corbusier, Sketch 125, Carnet 3, Voyage d'Orient, 1911.; Schematic diagrams (SH) showing diagonal spatial composition; overlapping depths of field; and author's in situ sketch (2014) showing the city and Piraeus shaded to the left of the Propylaea (not drawn in Le Corbusier's sketch although it did exist as may be seen in photographs of the time ${ }^{37}$ ).

During the course of the sketches, Le Corbusier's own direct experience of the Propylaea came to change his initial understanding of it based on his prior knowledge. His sketches trace this change from initially depicting volumes and their relative positions to later exploring more emotive spatial qualities, using levels, light, depth and viewpoints to create a sense of movement through space within each picture.

\section{Conclusions}

This article demonstrates that Le Corbusier used his sketches as a structured method for his own personal investigation of the Acropolis and not just to illustrate pre-formed or borrowed concepts. I show that the Carnet sketches not only trace the path of discovery, but show how Le Corbusier was consciously using them to pathfind his conceptual way by means of trial and refinement. The sequential and systematic evolution of Le Corbusier's ideas shows that the sketches propelled and directed his train of thought. I find that the carnet sketches show a propositional approach to analysis focused on uncovering the principle questions underlying major features of the architecture, rather than purely recording the architectural solutions already stated by others. This method followed an intentional order but allowed him sufficient freedom to develop original interpretations of the Acropolis. This assisted him in transforming his prior knowledge of the Acropolis based on the theories of others into his own original interpretation of the architecture. More than just a record of what he discovered, these sketches reveal how he attempted to go about looking for it.

\footnotetext{
${ }^{37}$ See photographs and maps from Baedeker's guide to Athens, 1910, reproduced in Daza Caicedo, R., \& Quetglas, J.: Tras el viaje de Oriente : Charles-Édouard Jeanneret-Le Corbusier. Barcelona : Fundación Caja de Arquitectos. 2015
} 
In-situ, Le Corbusier's attention focused on the interface between ground architecture and horizon. This developed significantly during the course of the sketches and diverged into two alternative ideas, one of using steps and level changes to integrate architecture into the surface of the ground and another of using platforms and steps to separate and distinguish the architecture from the ground. The Carnet 3 shows that his appreciation of these relationships became broader and more complex during the course of the sketches rather than converging on one single concept.

The sequence shows that Le Corbusier's compositions developed from static picturesque depictions of the Acropolis to carefully constructed images which emphasised the dynamic experience of the viewer's movement through the architecture. As they proceed, the drawings convey an increasingly concentrated sense of movement through space. Diagonal viewpoints, asymmetric compositions and continuous spatial regions are all used to imply a variety of spaces related one to another and consequently implying the possibility of passage between them. The order of the views drawn in sketches 98 to 125 shows he was less interested in portraying a sequential fly-through or storyboard of the Acropolis, than in using the drawings as a means to analytically investigate the Acropolis.

In contrast to many texts about Le Corbusier's visit to the Acropolis, the sketches he made on location however make little mention of a number of issues which are considered by many authors to have been of central importance during Le Corbusier's revelatory first visit. This suggests that during his visit in 1911, Le Corbusier gave less importance to a number of his most celebrated ideas than is often assumed. Some of these, such as mathematical systems of proportion, material precision and "the plastic system brought together in light" developed only after his visit, with significant influence from other sources ${ }^{38}$ but were not immediately inspired by his in-situ experience of the Acropolis in person. Nevertheless, other ideas, such as the promenade architecturale, were formulated in-situ through gradual trial and revision in his sketches.

Le Corbusier used fast but expressive drawing techniques to represent fundamental architectural relationships and to most clearly reveal the primary effects that these produced on the observer. He used the compositions of the sketches and a variety of graphic techniques to emphasise his particular interests whilst minimising, or eliminating altogether, other aspects which were of only secondary importance to him at the time. The insistence on certain specific issues throughout the sketches, as well as the avoidance of others and the frequent poetic license in the representation of many views, show that these sketches were highly intentional interpretations of the Acropolis. The article finds that these interpretations became increasingly sophisticated as the sketches progressed and shows that he deliberately used his sketching as an active method to learn about the Acropolis.

Although inspired to great degree by the Acropolis, each sketch is in fact an individual and highly personal design project generated through the same propositional thought process Le Corbusier used in the design of his own built projects. The graphic analysis of these sketches reveals exactly how he went about finding and developing original interpretations of the most classic of architectural references. Le Corbusier's method of investigative sketching achieved particularly original results in the new interpretations which he extracted from such a well-known subject. It is also interesting to note the importance of these sketches in his later opinions, which he contrasted so directly and robustly with the dominant views of the time about the Acropolis ${ }^{39}$. In order to learn from this method, and understand how it may be replicated in other circumstances and used to maximum

\footnotetext{
${ }^{38}$ Frampton, K.: 2001. Op.cit.

${ }^{39}$ Corbusier, L.: Vers Une Architecture. Op.Cit. and Corbusier, L.: Precisiones respecto a un estado actual de la arquitectura y del urbanismo. Barcelona : Poseidón. 1978
} 
advantage today, this research has sought to explain in precise terms how Le Corbusier used the method, where he started from, what steps he took and how he reached his decisions.

The sketches are themselves evidence of a propositional mind with prior knowledge but without fixed preconceptions. Le Corbusier worked out his opinions and ways of seeing through using exploratory sketching to actively engage with his surroundings. This set of drawings demonstrates the initial phases of ideas which were later to become some of the determining characteristics of his work. As Jacques Lucan writes, on the Acropolis, “toute a commencé là..." ${ }^{40}$. The Acropolis sketches are the record of Le Corbusier's painstaking discovery of his most celebrated principles.

\section{Image Sources:}

Original 1911 sketches from Corbusier, Le.: Voyage d'Orient : Carnets. Milano : Mondadori. 2002 p98, p103, p104, p106, p107, p109, p111, p113, p115, p117, p119, p123, p125.

All other images and diagrams are by the author.

\section{Bibliographical References}

Baker, G: Le Corbusier - the creative search - the formative years of Charles-Edouard Jeanneret. New York: Van Nostrand Reinhold, 1996

Benton, T: The Rhetoric of modernism : Le Corbusier as a lecturer. Basel [etc.] : Birkhaüser. 2009

Brooks, A: Le Corbusier's Formative Years: Charles-Edouard Jeanneret at La Chaux-de-Fonds. Chicago: University of Chicago Press. 1999

Choisy, A: Histoire de l'architecture. Paris. 1899

Cohen, J.-L., Bergdoll, B., \& Pare, R.: Le Corbusier : an atlas of modern landscapes. London : Thames. 2013

Cohen, J.-L.: "Vers Une Acropole: d'Athènes a Ronchamp”. In Le Corbusier - L'Invention d'un architecte Paris : Fondation Le Corbusier. 2014

Corbusier, L.: Precisiones respecto a un estado actual de la arquitectura y del urbanismo. Barcelona : Poseidón. 1978

Corbusier, L.: Voyage d'Orient : Carnets. Milano : Mondadori. 2002

Corbusier, L.: Le voyage d'Orient. Paris : Ed. Parenthèses. 1966

Corbusier, L.: Ed. Boesiger, W.: Oeuvre Complète. Paris : Éditions d'architecture. 1965

Corbusier, L.: Cohen, J.-L., \& Benton, T.: Le Corbusier le grand. London : Phaidon. 2008

Corbusier, L., \& Duboy, P.: Croquis de voyages et études. Paris : Quinzaine littéraire - Louis Vuitton. 2009

Corbusier, L.: Vers Une Architecture. Paris. 1923. Reprinted as Towards a new architecture. London : Architectural Press. Translation by Etchells, F. 1987

Corbusier, L., Moos, S. von, \& Rüegg, A.: Le Corbusier before Le Corbusier : applied arts, architecture, painting, photography, 1907-1922. New Haven [etc.]: Yale University Press. 2002

Daza Caicedo, R., \& Quetglas, J.: Tras el viaje de Oriente : Charles-Édouard Jeanneret-Le Corbusier. Barcelona : Fundación Caja de Arquitectos. 2015

\footnotetext{
${ }^{40}$ Lucan, J.: Op.cit
} 
Fondation Le Corbusier. Rencontres, Amirante, R., \& Corbusier, L.: L'Invention d'un architecte : le voyage en Orient de Le Corbusier. Paris : Éditions de la Villette. 2013

Frampton, K.: Le Corbusier. London : Thames and Hudson. 2001

Lucan, J. : Le Corbusier : une encyclopédie. Paris : Centre de Création Industrielle. 1987

Moos, S. von. Le Corbusier : elements of a synthesis. Rotterdam : 010 Publishers. 2009

Quetglas, J : Les Heures Claires. Barcelona : Massilia. 2008

Thompson, D. Wentworth: On Growth and Form. Cambridge : Cambridge University Press. 1961 (abridged edition) 
While presenting himself as a prophet in the field of architecture, he concurrently produced works which incorporated new perceptions of nature, cosmos and balance. His shifting conceptualization was particularly evident in the final ensemble of paintings he produced beginning in 1952, the Taureau series, featuring a mythologically-inspired vocabulary of totemic figures and animals, wherein he developed a private cosmology of sun and moon, male and female, the machine and Mediterraneità. The sources for these new works were varied, and just as he sought inspiration in the architecture and landscapes of Brazil and Northern Africa from the late 20s onward, he would find new stimulations during in his Postwar travels as well, in India and beyond. Moreover, the porosity of the Corbusian palimpsest created the conditions wherein over the course of his career he himself would find fresh inspiration when he happened to come across his own works from an earlier stage of production viewed flipped or upside-down. Thus, in the early 1950s when the he saw the painting Le Grand verre à côtes et l'écharpe rouge (a painting which he had revised and reworked between 1927-40) turned on its side, he drew inspiration for the first of this last major series of canvases, the Taureau I of 1952 (Figures 1,2). ${ }^{3}$ This painting demonstrates a certain reflexivity as the "marriage of contours" that he espoused since the 20s was reconfigured in new, and at times completely abstract, ways. The horizontal lines dividing the Taureau canvas between head and body speak to the interplay that he saw between land and sky, human and animal. Indeed, the connection to the animal world was referenced explicitly in a series of sketches that he executed in India, dated March 16, 1952, where he noted "intuitively over the past 20 years I have evolved by figures in the direction of animal forms, vehicles of character, force of the sign, algebraic capacity for entering into a relationship between themselves and thereby producing 1 poetic phenomenon." On a sketch a few pages later, he indicates, "The idea (notion) of a human bestiary perhaps came to me unconsciously through such frequent contact throughout the world and throughout all social classes with men and women, in business circles committees, intimate moments/ The characters appear, qualifying people and keeping or //proposing // their typology." ${ }^{\text {It was through }}$ his travels and lived experiences that he was able to conceptualize these mythical tropes. These developments thus speak to larger conceptions of condensation and replacement in his œuvre, and reveal organizing principles, networks, and cross-fertilizations that extend across the range of Le Corbusier's production. The small always contains the large, the inside is always an outside, the female contains elements of the male, and vice versa.

Additional premonitions for this series can be found in the 1952 canvas, Metamorphose du Violon wherein the essentials of the composition of the Taureau paintings are present: round orbs, an emphasis on the outline of forms, and an overlapping compositional effect (Figure 3). The ropelike braiding of lines is reminiscent of the thick ropes included in paintings of the 30s while the title itself is indicative of his post-painterly drive towards transformation and metamorphosis. By dating the work 20/52 he reveals a perceived link between earlier works and this later phase of production. He would articulate this more clearly in a letter to the British Curator Ronald Allen, when he explained, "From one thing to another, thirty years later, the mind busy with something else and particularly with the usefulness for human figures to possess their own 'bestiary' arose successive deformations. And one fine day the discovery of a bull on my canvases came to light quite out of my control. Then, development of the thing itself, its flourishing (Taureau VIII to XIII approximately) and finally a change of sensibility with respect to the theme and a new arrangement of elements of the painting." 6 The menu of forms and the processes that Le Corbusier mobilized in his painting and in his architecture reveal the ongoing dialogue aimed to achieve a "new world of space." It is this feedback loop of reciprocity which makes the relationship

\footnotetext{
${ }^{3}$ Le Corbusier describes this connection in Creation is a Patient Search, New York: Praeger, 1960, p. 32.

${ }^{4}$ Le Corbusier, Sketchbooks, Volume 2, 1950-54, MIT Press, 1981. Notebook F24, 700.

${ }^{5}$ Ibid, 707.

${ }^{6}$ Le Corbusier, letter to Ronald Allen, June 25, 1958, translated by Jaime Coll, FLC C2-11-22.
} 
between Le Corbusier's paintings and architecture so rich, consisting of an evolving constellation of elements which alternately inflect and reflect one another.

The paintings in this final series also exhibit anthropomorphic qualities which link them to his lifelong studies of women as well. This can be seen in Taureau II of 1953 where the prominent central placement of twinned orbs metaphorically alludes to breasts (Figure 4). In his notebooks he would identify these creatures with the spirit of his wife Yvonne, and the conjunction between male beast and female figure reveals again the myriad range of references which characterize his work. Indeed, he had described Yvonne as representing a humanity that was both earthy and anti-intellectual, full of common sense, a sort of archetypal primitive presence that he had celebrated in the pages of L'Esprit nouveau but also an ideal inspiration of femininity, which was very productive for the artist and enabled him to create - a type of modern muse. ${ }^{7}$ This interplay between male and female sources of inspiration can also be found in some of his earliest works, including a mythologicallyinspired series of watercolors featuring Zeus as Bull spiriting away Europa, from whose out-stretched hand rises a brilliantly colored bird (Figure 5). We see him navigating oppositions between masculine and feminine, light and the dark, the wild and the civilized, as he explores the typologies of animal nature.

These canvases were also connected to a contemporary series of drawings focused on the birth of the Minotaur, in which Le Corbusier deployed a mythologically-inspired vocabulary of totemic humans and animals. The mythical Minotaur - part man, part bull — had served as a potent symbol for many $20^{\text {th }}$ century artists, including Salvador Dali, Andre Masson, and in particular, Pablo Picasso. It appeared as Picasso's alter ego in the Vollard Suite of the 1930s as part of a broader exploration of Classicism in his work, inspired in part by the group of 30 etchings he completed to illustrate Ovid's Metamorphoses in 1931. Le Corbusier's own lifelong interest in Greek mythology can be traced to his youthful travels, in particular his Voyage d'Orient, as well as studies based on black-figure Greek vases found in Parisian museums. It again found expression in the 50s and 60s as evidenced by the drawings Le Corbusier executed in the 1954 edition of Homer's Iliad, sketching over and reworking the original illustrations by John Flaxman. Moreover, the Minotaur had also been emblematic for Surrealists, and provided not only the name of the Surrealist-oriented magazine published from 1933 to 1939 (and to which Le Corbusier contributed a 1936 article on Louis Soutter) but also served as a potent symbol and personification of forbidden desires, lasciviousness, violence, guilt, and despair. The connection to mythical beasts in the Taureau paintings was commented on by the British art historian Herbert Read, who hailed Le Corbusier as a "universal artist" and applauded his achievements in these late paintings as "The theme of this work of grand design - Les Taureaux - is one that has haunted European civilization since its beginnings: the Minotaur, archetype of our ambiguous human destiny, of our terror and our deliverance." 8

Indeed, in Le Corbusier's creations, he blended both dark and light aspects of his psyche. The scholar Jaime Coll has examined the ways in which the Taureau paintings served to reveal the use of the "unconscious, the irrational, chance, automatism and eroticism in a personal, innovative and complex synthesis." ${ }^{9}$ Yet, they also reveal a certain levity, as a contemporary reviewer of his work at the Pierre Matisse Gallery in New York in 1956 observed:

\footnotetext{
${ }^{7}$ For an insightful discussion of the relation between Le Corbusier and Yvonne see Guillemette Morel Journel, "En somme j'ai travaillé comme un zèbre à Vézelay," in Moments Biographiques, Paris: Fondation Le Corbusier, 2008. p. 122.

${ }^{8}$ Herbert Read, Le Corbusier, Les "Taureaux" Recent Paintings 1952-1955, Pierre Matisse Gallery, New York 1958. n.p.

9 Jaime Coll, "Le Corbusier. Taureaux: an Analysis of the Thinking Process in the Last Series of Le Corbusier's plastic work," in Art History, Volume 18, Issue 4, pages 537-567, December 1995. P. 537.
} 
"[Le Corbusier] enjoys and controls the counterpoint of irregular against regular shapes, linear networks against patterns of colored planes and right angles against curves, but he never loses an overall structural lucidity which one is tempted to call architectonic. The pictorial mastery, however, is only part of the pleasure, for these canvases sparkle with a delicious humor and verve. None of the fearful drama of the bull ring is here, but rather a mood of carnival gaiety and pageantry which has the contagious cheer of exposition murals." 10

This was especially true of the sketches he was completing at this time, such as FLC 6353, a drawing executed in Bogota showing a female nude strolling along a sunny expanse accompanied by a bull's head, or FLC 6237, which pairs an outstretched nude with an ambling bull. In both his paintings and his sketches he explored symbols and signs: hands, footprints, snakes, lightning, sun, moon, clouds, trees, the course of the sun, all of which harken at a cosmological nostalgia, while retaining a "gaiety" that distinguishes his work from that of many of his contemporaries.

One sees a compilation of these themes and motifs in one of the final canvases that he executed in this series, Taureau XVII (Figure 8). In this work, abstraction and fragmentation align to produce a combinatory effect through the reduction of the Taureau figure to ciphers, revealing an interplay with symbolic forms. Both recuperative and regenerative, it reveals his continuous experimentation even in these later works. The bright and vibrant colors, as well as the inclusion of abstracted references to the symbolic bulls that had populated his earlier canvases along with more figurative allusions to leg and hoof in the lower portion of the canvas show his continued formal experimentation. The rotation and flipping of forms also allude to his earlier experimentations with flipping his own canvases in order to fund new wellsprings of inspiration for his graphic work.

Thus the conjunction of dualities in his late canvases represent his most abstract production, and when considered in light of the translations and changes in perspective, size, and shape witnessed in his explorations of the forms over the course of his career, one perceives the negotiations, assimilations, and hybridizations evident in Le Corbusier's production. Such processes speak to the poetics of his modes of conceptualization, as figures are combined and reworked. These figures provided a fertile field of projection for Le Corbusier's myriad conceptions of form and space, nature and culture, inner and outer. Throughout, ambiguous signs of looking and disclosing, desire and its satisfaction, play together. Moreover, in his late paintings Le Corbusier strove to achieve a "synthesis of the arts," and his repositioning was indicative of larger shifts reflecting a new humanism through a fusion of the poetic expression of technology, the vernacular, and regional influences, as well as a responsiveness to social needs. Yet he would always insist that synthesis should not be mistaken as a mere subordination of painting and sculpture to architecture or vice-versa. Rather it was defined as the problem of how to arrive at a unity without compromising the autonomous status of either. Each of the three media is said to have its own poetic function, which, under the correct circumstances, can be brought into play and create new visions and energies. He thus continued the reworking which characterizes all stages of his artistic production, from the Purist period onward, and yet, at the same time enacted the continuation of experimentation in the drive toward abstraction, the invention of new form, which is not just a reworking, but a reinvention. He developed a pictorial language which explored the "fantastic possibilities, [and] unexpected relations which reveal a latent poetry...there is a world in a painting. . . there are illuminations and scenes . . radiant or menacing skies, houses and mountains, seas and lagoons, suns and moons. And there are besides all the cries of the subconscious, sensual or chaste, and everything that you can imagine."11

\footnotetext{
${ }^{10}$ Art Digest, February 1956. FLC C1-1-217

${ }^{11}$ Le Corbusier, "Biographical Notes," in New World of Space. New York: Reynal and Hitchcock, 1948. p. 11.
} 


\section{Bibliography}

Coll, Jaime. "Le Corbusier. Taureaux: an Analysis of the Thinking Process in the Last Series of Le Corbusier's plastic work," in Art History, Volume 18, Issue 4, pages 537-567, December 1995.

Le Corbusier, New World of Space, Raynal \& Hitchcock, New York, 1948.

“Tapisseries Muralnomad," Zodiac no. 7 (1960) pp. 57-63.

Creation is a Patient Search, New York: Praeger, 1960, p. 32.

Sketchbooks, Volume 2, 1950-54, MIT Press, 1981.

Morel Journel, Guillemette. "En somme j’ai travaillé comme un zèbre à Vézelay," in Moments Biographiques, Paris: Fondation Le Corbusier, 2008.

Read, Herbert. Le Corbusier. Les "Taureaux" Recent Paintings 1952-1955, Pierre Matisse Gallery, New York 1958. 


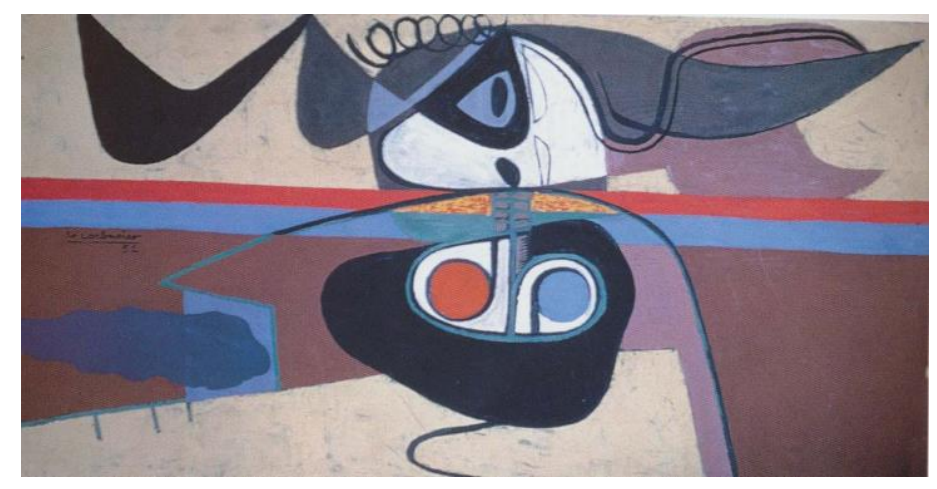

1. Taureau I, 1952, FLC 158.

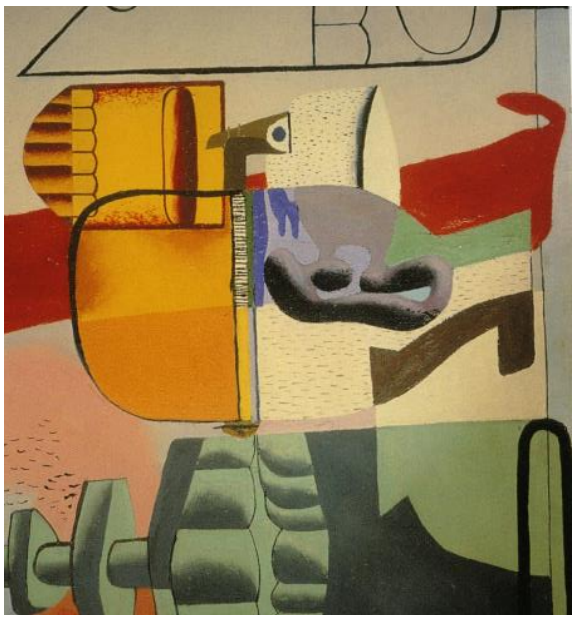

2. Le Grand verre à côtes et l'écharpe, 1927-1940 (rotated clockwise), FLC 226.

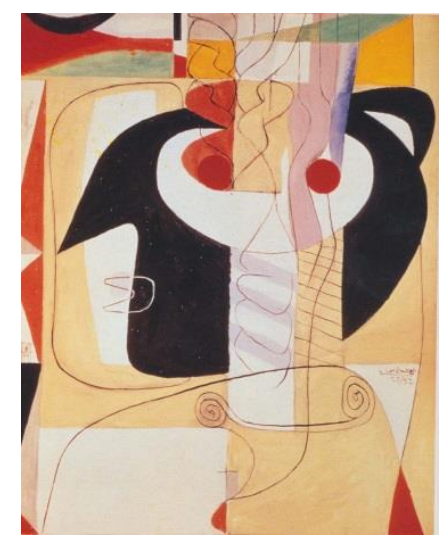

3. Metamorphose du Violon, 1952, FLC 432. 


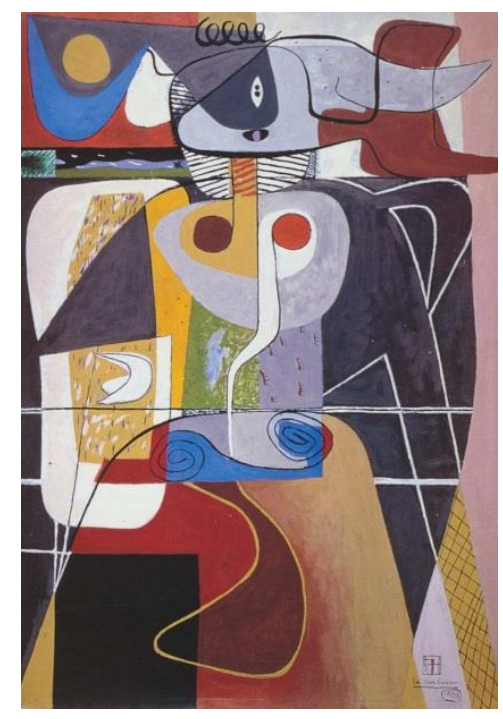

4. Taureau II, 1953, FLC 159.

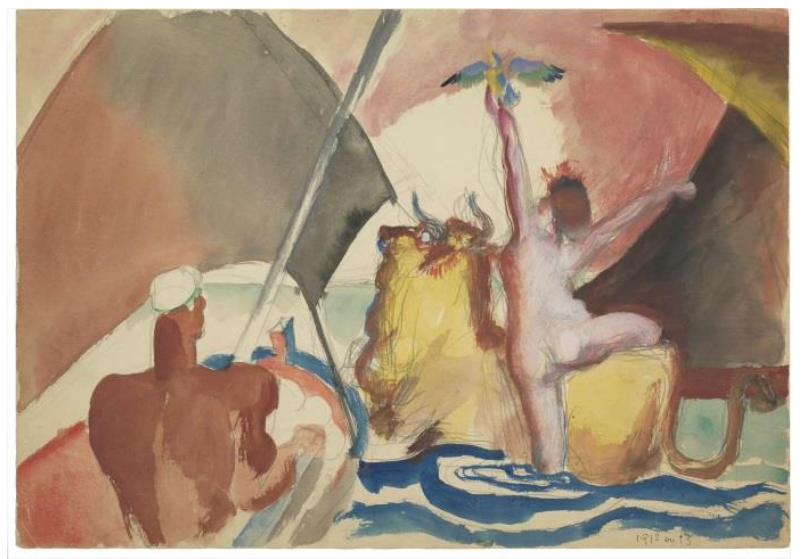

5. Zeus and Europa, FLC 4494.

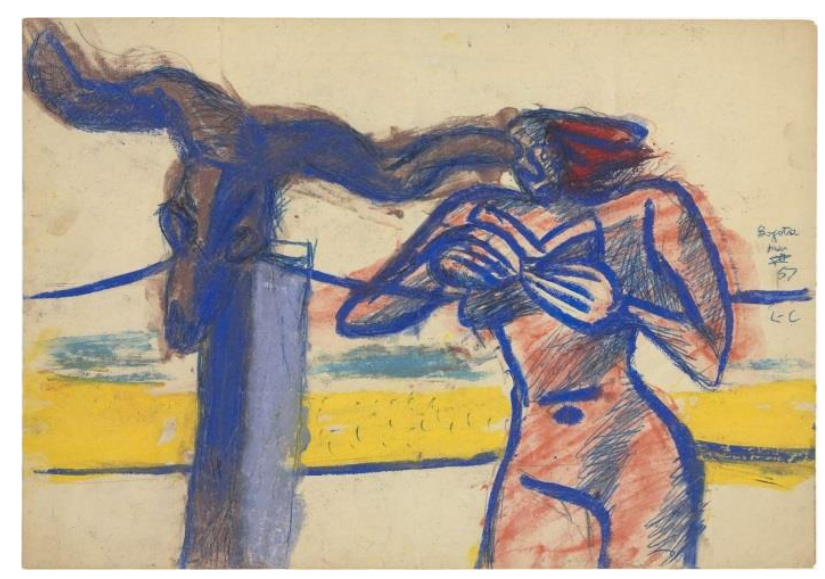

6. FLC 6353. 


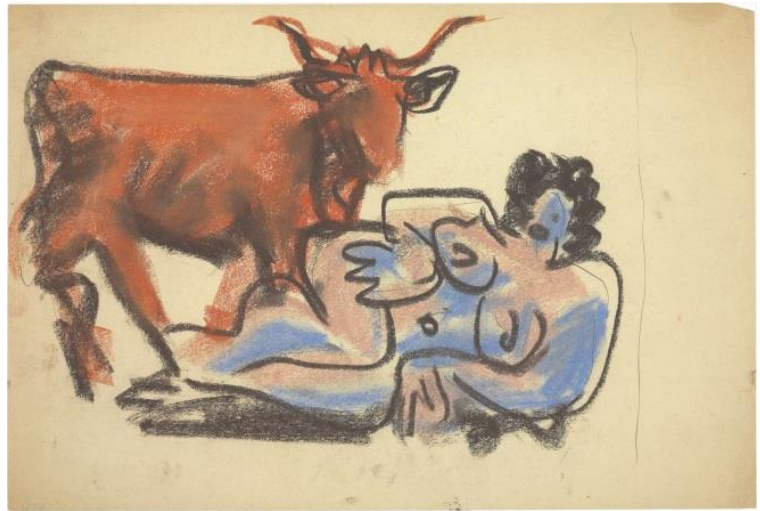

7. FLC 6237.

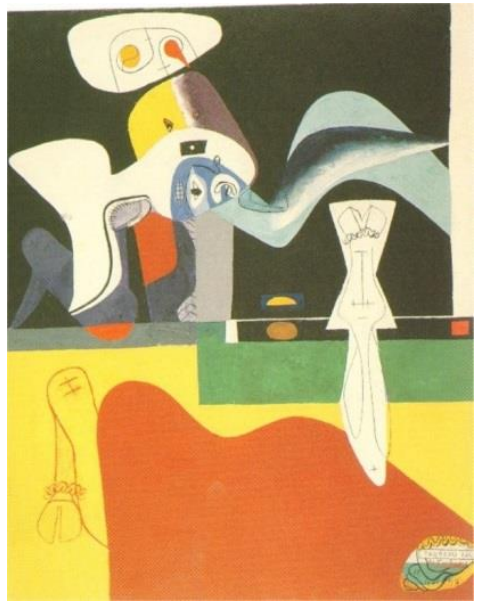

8. Taureau XVII, FLC 441. 


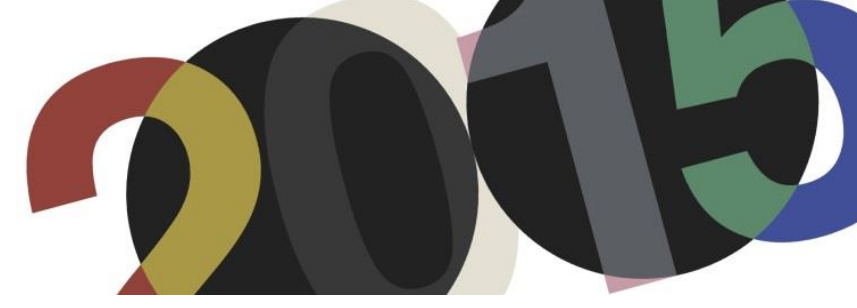

DOI: http://dx.doi.org/10.4995/LC2015.2015.554

\title{
El dibujo y la noción de horizonte en Le Corbusier
}

\author{
G. Hidalgo Hermosilla
}

\author{
Pontificia Universidad Católica de Chile
}

\begin{abstract}
Resumen: Este trabajo indaga en la particular forma de dibujar la arquitectura de Le Corbusier: una sintesis de distintas tradiciones gráficas que adquirió en su juventud y que fue capaz de integrar coherentemente en un estilo muy personal. Intentándola definir, William J. R. Curtis lo asimiló a un sistema de apuntes taquigráficos y la consideró dotada de un poder alquímico. Es un hecho que esta forma de dibujar abrió una vía fecunda de aproximación a la arquitectura, tanto para estudiarla como para generarla. En este trabajo intentamos precisar una de sus cualidades: la capacidad de situar, que se verifica a partir de la noción de horizonte. Como se sabe, el concepto de horizonte tomó una forma precisa con el surgimiento de la perspectiva renacentista, pero que en el caso de Le Corbusier es reformulada a partir de sus primeras experiencias con las visiones amplias, paisajísticas, elevándolo a referencia fundamental del hombre en el mundo, remitiéndolo por tanto a dimensiones históricas, culturales, existenciales.
\end{abstract}

Abstract: This paper explores the particular way of drawing the architecture Le Corbusier: a synthesis of different graphic traditions acquired in his youth and which he was able to integrate coherently in a very personal style. Trying to define his way of drawing, William JR Curtis assimilated it to a system of shorthand notes and considered it equipped with an alchemical power. It is a fact that this way of drawing opened a fruitful approach to studying and generating architecture. This paper attempts to clarify one of his qualities: the ability to situate, putting into play the notion of horizon. As it is known, the concept took its precise form with the emergence of Renaissance perspective, but in the case of Le Corbusier it was reformulated from his first experiences with the panoramic views, raising it to the fundamental reference of the relationship of man and world, and thus returning it to historical, cultural and existential dimensions.

Palabras clave: Le Corbusier; Dibujo; Horizonte.

Keywords: Le Corbusier; Drawing; Horizon.

\section{Introducción}

La particular forma en que Le Cobusier llegó a dibujar la arquitectura se puede rastrear, paso a paso, gracias a la extraordinaria cantidad de documentación que dejó, ya sean estos escritos, cartas, y por supuesto los mismos dibujos. Después de que todo este material fue convenientemente catalogado, se dispuso de una vía expedita para estudiar y analizar sus dibujos, particularmente aquellos de su juventud ${ }^{1}$. No son pocos los antecedentes que dan cuenta del origen de esta manera de dibujar. En la base de todo está su formación en la Escuela de Arte de La Chaux-de-Fonds y la innegable influencia de su maestro Charles L’Eplattenier y, a través de éste, del crítico inglés John Ruskin ${ }^{2}$. Posteriormente, se suma a este proceso su propia autoformación que abarcó una amplitud

\footnotetext{
${ }^{1}$ Uno de los primeros trabajos exhaustivos de catalogación de los dibujos juveniles de Le Corbusier fue el realizado por: Seckler, Mary Patricia May. The Early Drawing of Charles-Édouard Jeanneret (Le Corbusier) 1902-1908. New York and London: Garland Publishing, 1977.

${ }^{2}$ Hidalgo, Germán. "La constatación de un aprendizaje. El viaje a Italia de 1907 de Ch-É. Jeanneret”. Massilia, Annuaire d'Etudes Corbuseennes. Sant Cugat del Vallés: Associacio d'Idees, Centre d'Investigacions Estètiques, 2008, pp. 04-30.
} 
de ámbitos, y un vivo interés por los temas y problemas propios de su época. Todo ello fue decantando en una forma particular de dibujar, en la que es posible detectar estos componentes originales ${ }^{3}$.

Tanto la observación atenta como la disciplina misma del dibujo, no pueden comprenderse al margen de los preceptos ruskinianos que dominaron completamente su primera formación en el seno de su ciudad natal ${ }^{4}$. Del mismo modo que la síntesis lograda en los dibujos de su viaje a Oriente no puede entenderse sin el trasfondo del postimpresionismo de Paul Signac, por mencionar a uno de los artistas que en aquella época seguía con real interés y admiración ${ }^{5}$. Las implicancias de este complejo proceso de formación quedan a la vista con nitidez si se comparan los dibujos que realizó en los dos viajes más importantes de aquella época: el de Italia de 1907 y el de Oriente de 1911, en los que podemos identificar dos momentos claramente diferenciados.
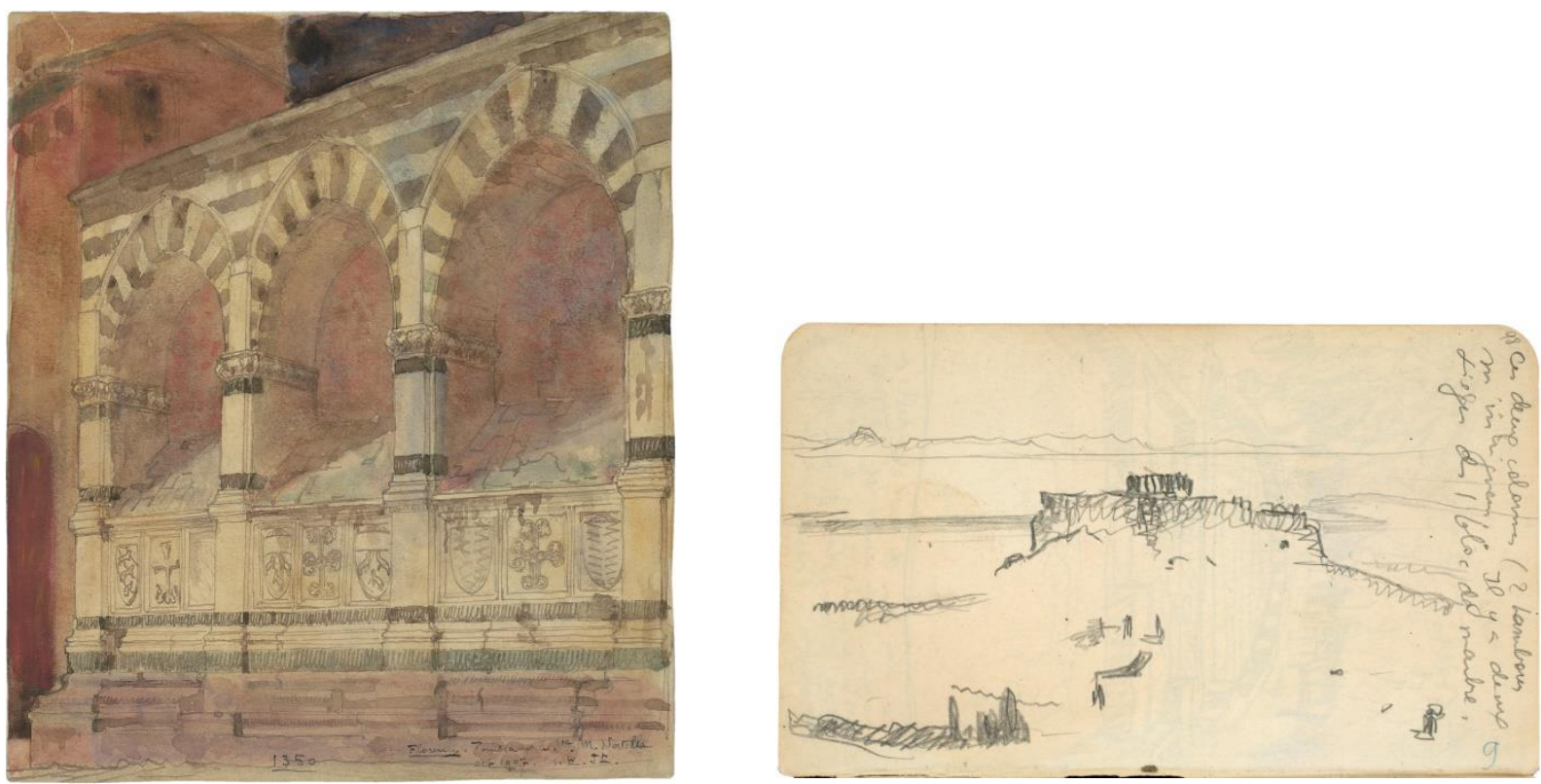

1. Izquierda. Ch-É. Jeanneret. Santa Maria Novella, sarcófagos del muro del patio de ingreso, Florencia, 8 de octubre de 1907. Derecha. Ch-É. Jeanneret. La Acrópolis vista desde el Monte Licabeto. 1911.

En relación a estos antecedentes cabe preguntarse: cómo se puede explicar que Ch-É. Jeanneret, Le Corbusier, dibujara así en el viaje de 1907 (Figura 1. Izquierda), y cuatro años después, en el viaje a Oriente, dibujara de esta otra manera (Figura 1. Derecha). ¿Qué pasó en esos cuatro años?

\footnotetext{
${ }^{3}$ Hidalgo, Germán. La Arquitectura del Croquis. Dibujos de Ch-E. Jeanneret en Italia 1907 y en Oriente 1911. Un estudio de sus antecedentes. Universidad Politécnica de Cataluña, Escuela Técnica Superior de Arquitectura de Barcelona, Departamento de Composición, 2000. Tesis doctoral inédita.

${ }^{4}$ La visión de Ruskin sobre el dibujo la encontramos sintetizada en: Ruskin, John. The Elements of Drawing. London: George Allen, 1856. Traducción Española: Técnicas de dibujo. Barcelona: Editorial Leartes, 1999.

${ }^{5}$ Hidalgo, Germán. La Arquitectura del Croquis. Op. cit., pp. 371-380.
} 


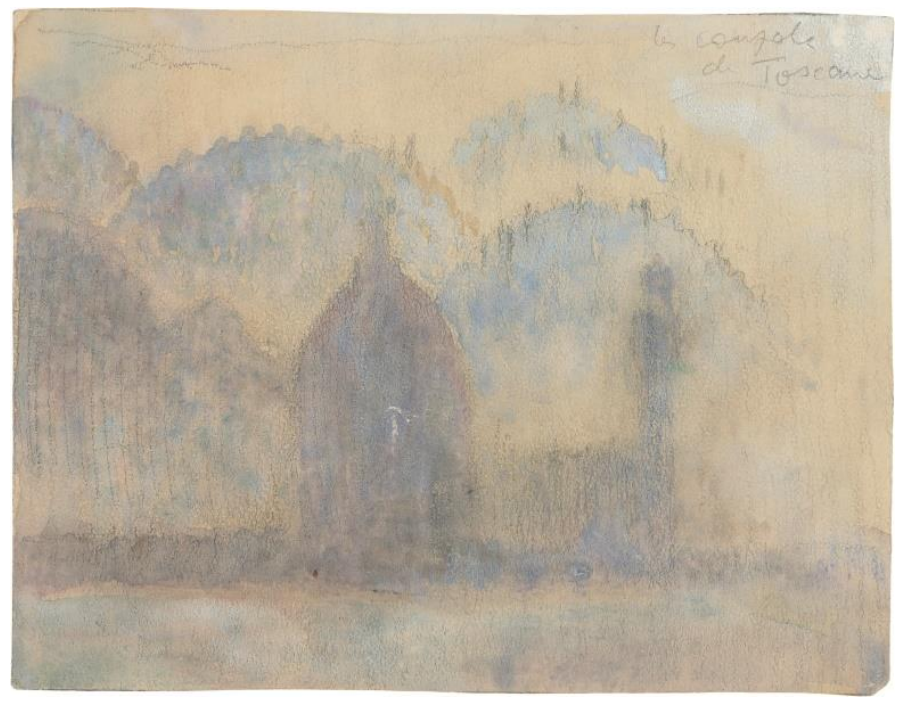

2. Ch-E. Jeanneret. Santa Maria de las Flores, Florencia, 1907.

Un tercer dibujo suyo nos puede ayudar a entender qué ocurrió en este proceso (Figura 2). Este tercer dibujo, es al igual que el primero una acuarela, y también fue realizada en 1907, en la misma ciudad de Florencia. Sin embargo, fue hecha cuando su autor concluye la visita y deja la ciudad, es decir, cuando se va. E irse, como todos sabemos, no es lo mismo que llegar. En efecto, cuando Jeanneret dejó Florencia, él mismo lo escribe en una sus cartas a L’Eplattenier, ya había aprendido ${ }^{6}$. ¿Qué aprendió Jeanneret en ese viaje, y qué relación tiene este aprendizaje con esta acuarela y con el problema que nos ocupa?

A juzgar por el talante de la primera acuarela, aprendió que una representación no tiene por qué ser tan detallada. Es más, fue la urgencia de realizarla la que lo llevó a tomar de lo visto sólo lo esencial: la acuarela fue hecha desde el tren, cuando Jeanneret se iba. Segundo, y como un modo de asegurarse, aprendió que lo visto como esencial, había que enfatizarlo en el dibujo, de modo de no dejar lugar a dudas con respecto a lo observado. Tercero, que la distancia es buena consejera: era bueno ver de nuevo, otra vez, desde lejos, aquello que desde cerca no le había revelado sus secretos. Cuarto, y esto quizás sin que él mismo lo supiera en ese instante: que para comprender algo debemos encontrar la posición correcta; aquella posición desde donde las mismas cosas que ya hemos visto toman un nuevo sentido. Así, desde esta posición, el tren en donde él mismo viajaba, la cúpula de la catedral, el campanil de Giotto y las colinas cercanas y lejanas, coinciden, se alinean en el dibujo.

Esta observación, que en el viaje de 1907 se le revela por primera vez, cuatro años más tarde madurará y tendrá su confirmación. En efecto, en el dibujo de la Acrópolis de Atenas de 1911 ya es plenamente consciente. Y para demostrar su real trascendencia, Le Corbusier siguió escribiendo sobre ella, no una sino muchas veces.

Por ejemplo, en "Tres advertencias a los señores arquitectos III. El Plan”, la describirá con mucha precisión y claridad. Justamente, a los pies de una imagen de la planta de la Acrópolis de Atenas anotó: "El desorden aparente del plan sólo engaña al profano. El equilibrio no es mezquino. Está determinado por el famoso paisaje

\footnotetext{
${ }^{6}$ Carta de Ch-É. Jeanneret a su maestro Charles L'Eplattenier, 1 de noviembre de 1907. Le Corbusier. Il Viaggio in Toscana (1907). Venecia: Cataloghi Marsilio, 1987, pp. 136-137. "He aprendido por qué los florentinos han deseado tener en su catedral la cosa más noble y más grande que se puede hacer y que ha sido hecha. Así la he visto desde el tren, a lo largo de cuatro distintas oportunidades y cada vez en la neblina matutina, y icaray, debí ser verdaderamente torpe para no comprender". Identificamos en esta declaración un símil de lo que muestra la acuarela de la catedral de Florencia, vista desde la distancia. Se debe destacar su carácter único, sin igual entre las que realizó en aquel viaje.
} 
que se extiende desde el Pireo al Monte Pentélico. El plan está concebido para una visión lejana: los ejes siguen el valle y las falsas escuadras son habilidades del gran director de escena. La Acrópolis sobre su roca y sus muros de sostén, se ve desde lejos, en forma total. Sus edificios se amontonan en la sucesión de sus múltiples planos"'.

En su libro El Viaje de Oriente, dice algo similar: "Un día. Alguna tarde, desde la falda del Licabete que domina la Acrópolis, he visto más allá de la ciudad moderna encendiendo sus luces, la colina desamparada, y su vigía de mármol el Partenón, dominándola para conducirla, parecía, hacia el Pireo, al mar que fue esa vía vibrante a través de la cual tantos tesoros conquistados vinieron a alinearse bajo los pórticos de los templos"».

Y cuando habla directamente sobre el "eje", lo confirma en forma elocuente: "El eje de la Acrópolis va del Pireo al Pentélico. Del mar a la montaña, de los Propileos, perpendiculares al eje, a la lejanía del horizonte, al mar. Horizontal perpendicular a la dirección que os ha impuesto la arquitectura en el lugar donde estáis, percepción ortogonal que hay que tener en cuenta. Alta arquitectura: la Acrópolis extiende sus efectos hasta el horizonte. Los propileos en el otro sentido, la estatua colosal de Atenea en el eje, y el Pentélico al fondo. Eso importa"."

Estos breves textos contienen y dan forma a una de las observaciones más potentes de Le Corbusier, podría decirse capital para lo que llegó a ser el grueso de su obra arquitectónica. Ella se organiza en torno a un elemento bien específico: el eje que va desde el Pireo al Monte Pentélico, pasando por la Acrópolis y por el mismo Monte Licabete desde el cual había dibujado los templos, oportunidad cuando había encontrado, otra vez, un punto preciso para dibujar y hacer "coincidir" naturaleza y arquitectura.

La primera conclusión que dejan estos dibujos es que para producir este encaje entre naturaleza y arquitectura era necesario establecer un distanciamiento. La segunda, que la arquitectura no se puede ver, ni apreciar, desde una corta distancia, por lo cual la mirada amplia se impone como requisito ${ }^{10}$. Josep Quetglas demostró cómo Le Corbusier armó algunas vistas interiores de la Villa Savoye, a partir de la adición de sucesivas perspectivas cónicas convencionales, de $60^{\circ}$ de apertura, ampliando el cono visual y la capacidad de ver del ojo, al extremar su horizontalidad. Según Quetglas, se trataba de "algo que sólo puede provenir de la mirada y de la agudeza escenográfica de Le Corbusier: me refiero a la ampliación del encuadre hacia la izquierda, que incluye el parque en la escena y que cambia la dirección y calidad de la mirada [...] Esta heterogeneidad del espacio percibido, que corta en dos el ángulo de visión, es una de las características más íntimas y constantes de la mirada de Le Corbusier" ". Por último, los dibujos introducen claramente la noción de horizonte como un factor decisivo en la comprensión del hecho observado.

\section{La noción de horizonte en Le Corbusier}

Una primera cuestión que se debe abordar, es saber si la idea de horizonte estaba presente efectivamente en el pensamiento de Le Corbusier y de qué manera, para luego tratar de explicar qué entendía por ésta.

\footnotetext{
${ }^{7}$ Le Corbusier. Hacia una arquitectura. Barcelona: Editorial Apóstrofe, 1998, p. 39.

${ }^{8}$ Jeanneret, Charles-Édouard (Le Corbusier). El Viaje de Oriente. Murcia: Colegio Oficial de Aparejadores y Arquitectos Técnicos. Librería Yerba, 1993, p. 183.

${ }^{9}$ Jeanneret, Charles-Edouard (Le Corbusier). Op. cit., p. 151.

${ }^{10}$ Monsteys, Xavier. "El hombre que veía amplios horizontes: Le Corbusier el paisaje y la tierra”. En Massilia, Annuaire d'Etudes Corbuseennes. Sant Cugat del Vallés: Associacio d'Idees, Centre d'Investigacions Estètiques, 2004 (bis). pp. 06-21.

${ }^{11}$ Quetglas, Josep. Les Heures Claires. Proyecto y arquitectura en la Villa Savoye de Le Corbusier y Pierre Jeanneret. Sant Cugat del Vallés: Massilia, 2008, pp. 141 y 142.
} 
Entenderemos aquí horizonte en un sentido práctico, como aquella "horizontal que pasa por el punto de vista [del observador]"12, definiendo así una superficie horizontal perpendicular al plano del cuadro. A pesar de ello, no podemos dejar de considerar la idea de horizonte planteada por Gadamer, por ser el más pertinente a nuestros propósitos, al situarla en un ámbito cultural más amplio: "Todo presente finito tiene sus límites. El concepto de la situación se determina justamente en que representa una posición que limita las posibilidades de ver. Al concepto de la situación le pertenece esencialmente el concepto de horizonte. Horizonte es el ámbito de visión que abarca y encierra todo lo que es visible desde un determinado punto" ${ }^{\text {". }}$. Ambas nociones son atingentes a nuestro argumento, ya que como veremos más adelante, inevitablemente terminaran por encontrarse en el modo en que los comprendía Le Corbusier.

Una conocida frase tomada de Hacía una arquitectura nos puede ayudar a avanzar hacia la comprensión que Le Corbusier tenía de la noción de horizonte: "El hombre ve las cosas de la arquitectura con ojos que están a un metro setenta del suelo. Sólo se puede contar con objetivos accesibles al ojo, con intenciones que utilizan los elementos de la arquitectura" ${ }^{\prime 14}$.

En El Modulor, refiriéndose a la arquitectura del Renacimiento, la cual a su juicio se alejaba de los datos del problema -"la visión del ojo"- señalaba que: "Su sistema se instalaba fuera de la interpretación de la percepción visual y quienes hoy contemplan la obra no pueden tener contacto [con ella] porque le falta dicha interpretación visual con las intenciones subjetivas que se pretende haber cumplido. Cuando cierra los ojos y se absorbe en la consideración de todas las posibilidades, el hombre abstrae. Si construye es con los ojos abiertos; mira con sus ojos -que son dos y no diez, o ciento o mil- y están colocados delante de la cabeza, en la frente, la de él, mirando hacia adelante y no pudiendo ver, por tanto, ni de costado ni de espaldas, ni apreciar la esfera que le rodea, deslumbrante de las combinaciones que brotan de los poliedros filosóficos. La arquitectura se juzga con los ojos que ven, con la cabeza que gira, con las piernas que andan. [...] El ojo humano no es el de una mosca, situado en el corazón de un poliedro, sino en el cuerpo de un hombre, a uno y otro lado de la nariz y a una altura media de 1,60 m el suelo. Tal es el aparato que disponemos para apreciar la sensación arquitectónica. El cono visual está adelante, concentrado en un campo material, limitado en la realidad, y limitado también en el espíritu que tras el aparato físico, ni interpreta, ni aprecia, ni mide lo que no tiene tiempo de captar ${ }^{15}$.

La cita lo deja bastante más claro: la arquitectura, y lo que interesa a la arquitectura, se aprecia desde una altura en que se encuentran los ojos, un metro y sesenta centímetros del suelo, cuando el hombre se encuentra de pie y camina. Pero no sólo eso, allí también se reconoce que el cono visual, propio de la forma de ver del ser humano, se encuentra limitado en la realidad material, y que la mirada y el espíritu sólo pueden concentrarse en aquello que efectivamente pueden captar. Cabe preguntarse, entonces, por ese límite que define lo visible y lo separa de aquello que no se puede captar, que no se puede medir ni apreciar. ¿Dónde encontrar ese límite, sino en el horizonte que dibuja para nosotros el 'campo material' del mundo real? El horizonte entendido pues, aunque en la cita Le Corbusier no lo dice textualmente, como ese límite perceptual, inherente a quien sólo tiene dos ojos dispuestos a uno y otro lado de la nariz, montados en una cabeza que gira, además de dos piernas que le permiten desplazarse: el hombre. Hasta aquí, hay un completo acuerdo entre esta comprensión de horizonte y la planteada por Gadamer.

\footnotetext{
${ }^{12}$ Panofsky, Erwin. La perspectiva como forma simbólica. Barcelona: Fabula Tusquets Editores, 1999, p. 12.

${ }^{13}$ Gadamer, Hans-Georg. Verdad y Método. Salamanca: Ediciones Sígueme, 1999, p. 372. El destacado no es nuestro.

${ }^{14}$ Le Corbusier. Hacia una arquitectura. Op. cit, p. 143.

${ }^{15}$ Le Corbusier. El Modulor. Barcelona: Editorial Poseidón, 1976, p. 70.
} 
Pero para confirmar esta dimensión del problema, se puede consultar un pasaje del Poema del Ángulo Recto, donde Le Corbusier lo plantea en forma lírica: "El universo de nuestros ojos descansa sobre una meseta orillada de horizonte. El rostro vuelto hacia el cielo. Consideramos el espacio inconcebible hasta aquí inalcanzado. Reposar tenderse dormir - morir. La espalda al suelo... iPero me puse de pie! Puesto que eres recto hete allí listo para los actos. Recto sobre la meseta terrestre de las cosas incomprensibles tú contraes con la naturaleza un pacto de solidaridad: ese es el ángulo recto. De pie frente al mar vertical hete allí de pie ${ }^{, 16}$.
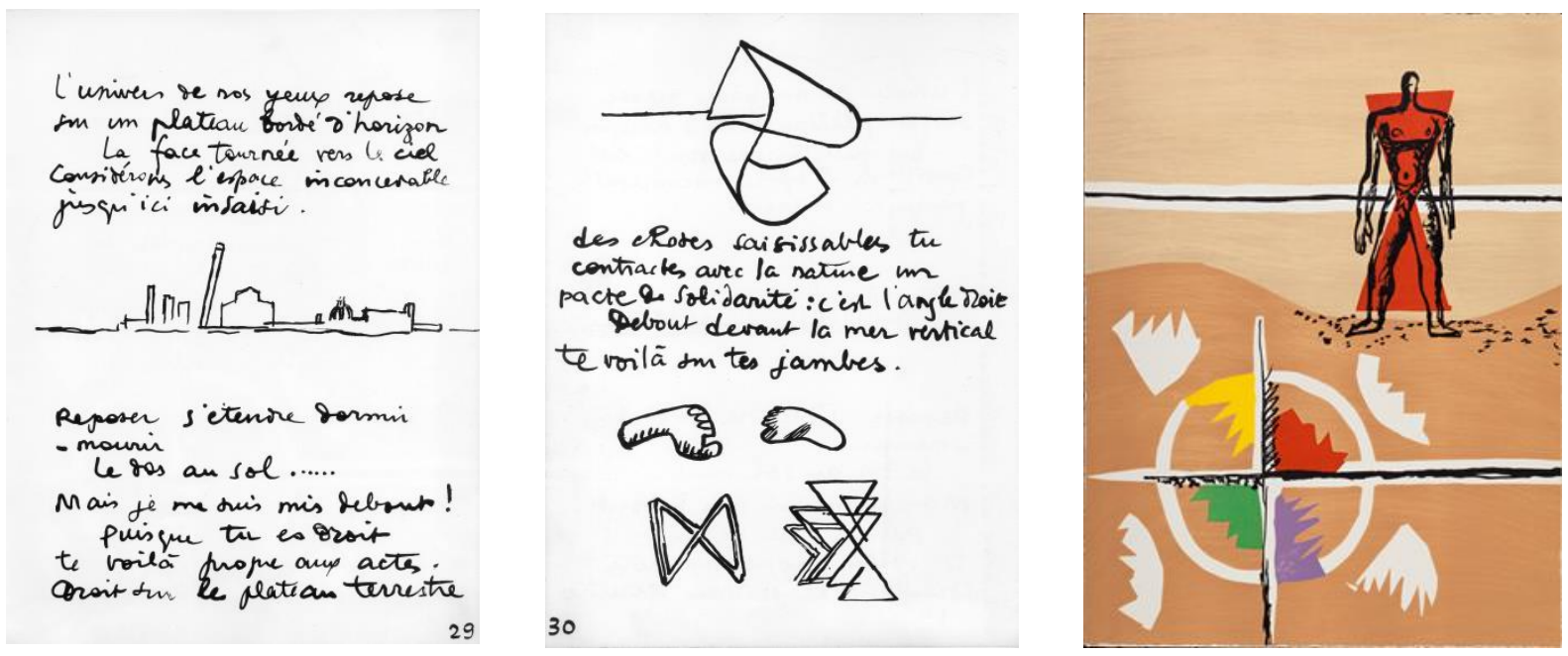

3. Le Corbusier. Poema del Ángulo Recto. A3 Milieu. Izquierda a derecha, páginas 29, 30, y 31.

El texto, para más señas, va acompañado de tres imágenes bien distintas entre sí, en su naturaleza y sentido (Figura 3). La primera, muestra la silueta de un conjunto de edificios de variada morfología, dispuestos sobre una línea horizontal, vistos de frente y desde la lejanía (Figura 3. Izquierda). Se trata precisamente de una agrupación de edificios que nos hace recordar sus dibujos juveniles, de vistas amplias y trazadas como pura silueta $^{17}$, es "una meseta orillada de horizonte". La segunda imagen (Figura 3. Centro), muy diferente a la anterior, es un diagrama compuesto por varios dibujos; el primero y más grande, que se sobrepone a una línea horizontal, es una suerte de cinta de Moebius representada tridimensionalmente; más abajo, hay dibujadas dos plantas de pies enfrentadas y dos esquemas con variaciones del símbolo del infinito. La última (Figura 3. Derecha), es una composición más compleja y acabada, claramente ilustrativa de la temática del poema. En ella vemos a un hombre de frente y de pie, parado sobre un suelo sinuoso que parece ser la orilla de una playa. Tras el hombre, y a la altura de su pelvis, cruza una línea horizontal que coincide con la altura de los ojos de quien observa la imagen. El hombre tiene inscrito sobre su cuerpo el símbolo del infinito, representado a través de dos triangulo rojos unidos por sus vértices. Sin duda, es el hombre que protagoniza el poema, aquel que se ha puesto de pie y ha hecho el pacto de solidaridad con la naturaleza, formalizado en el ángulo recto, el cual por su parte yace a sus pies trazado sobre el suelo. Ya no pueden quedar dudas sobre la noción de horizonte en Le Corbusier.

\footnotetext{
${ }^{16}$ Le Corbusier. El Poema del Ángulo Recto. Santiago de Chile: Universidad Finis Terrae, 2006, pp. 29-30. Traducción de Hernán Marchant. El poema en el francés original es el siguiente: A.3 Milieu. "L'univers de nos yeux repose sur un plateau bordé d'horizon. La face tournée vers le ciel. Considérons l'espace inconcevable jusqu'ici in saisi. Reposer s'étendre dormir -mourir. Le dos au sol... Mais je me suis mis debout! Puisque tu es droit te voilà propre aux actes. Droit sur le plateau terrestre des choses saisissables tu contractes avec la nature un pacte de solidarité: c'est l'angle droit. Debout devant la mer vertical te voilà sur tes jambes".

${ }^{17}$ La vinculación de este tipo de vistas, dibujadas por Le Corbusier en sus viajes de juventud, y sus posteriores pinturas puristas la encontramos en Silver, Kenneth E. Esprit de Corps. The Art of the Parisian Avant-Garde and the Frist World War, 1914-1925. London: Thames and Hudson, 1989.
} 
Aun así, en uno de sus artículos, Robin Evans aporta un antecedente más a este argumento. Refiriéndose al desinterés de Mies van der Rohe por el problema del horizonte, señalaba: "sin embargo, resulta significativo que Le Corbusier, quien proclamaba la línea horizontal de visión como un rasgo esencial de hombre, desestimó el doble de la altura del Modulor (366 centímetros) en interiores, explicando que quería evitar la equiparación del suelo y el techo" ${ }^{, 18}$.

A pesar de ser ésta una referencia indirecta, ya que el crítico la recibió de un antiguo colaborador de Le Corbusier, nos permite confirmar dos cuestiones de las que ya hemos hablado y además señalar una nueva. En relación a lo primero, el valor que Le Corbusier le confería al horizonte es algo real; segundo, que comprendía la noción de horizonte como una dimensión primordial del hombre; y por último, que Le Corbusier evitaba la organización visual preconcebida y única, desestimando la introducción de variables abstractas.

Diferenciar con claridad entre las áreas correspondientes a cielo y suelo en una imagen y en la arquitectura, no es más que la intención de establecer con radicalidad un sentido de orientación particular, precisa, circunstancial. Todo lo contrario de lo que Robin Evans observa en el Pabellón de Barcelona, donde además "es casi imposible escapar del plano de simetría [horizontal]"19, siendo la única manera de evitarlo, cambiar de posición, agachándose, sentándose, etc.

De los antecedentes aportados por Evans, es posible deducir que en el Pabellón de Barcelona el horizonte es un dato previo, dado, implícito en la simetría horizontal que lo ordena como producto de su altura $(312 \mathrm{~cm})$ y de las cantarías que acusan la altura media $(156 \mathrm{~cm})$. En Le Corbusier en cambio, al evitar esta equivalencia, el horizonte será siempre consecuencia de las múltiples posiciones que puede adoptar el hombre en relación al paisaje. Tal como lo sugiere el Poema del Ángulo Recto, el horizonte para Le Corbusier es el primer componente que permite al hombre sellar el 'pacto de solidaridad' con la naturaleza. El Horizonte, por tanto, se construye, se conquista, articulando el horizonte visual, propio de la forma de percibir del ser humano y el horizonte real, dado, propio de la naturaleza y del entorno construido; es decir, el que se nos presenta en el primer dibujo que acompaña al poema A3, y que identificamos como una meseta orillada de horizonte.

En este sentido, el mismo Modulor, como sistema dimensional, podría ser entendido como un estudio de plataformas que permiten definir horizontes precisos. En términos prácticos, se trata de definir alturas desde donde captar la realidad visual intencionalmente. En términos de Gadamer, se trataría de planos que sitúan y permiten definir posiciones desde donde comprender el mundo.

\footnotetext{
${ }^{18}$ Evans, Robin. "Las simetrías paradójicas de Mies van der Rohe”, en su Traducciones, Girona: Editorial Pre-Textos, 2005, p. 277. Allí se indica como fuente Jerzy Soltan, un antiguo colaborador de Le Corbusier.

${ }^{19}$ Evans, Robin. Op. cit., p. 275.
} 

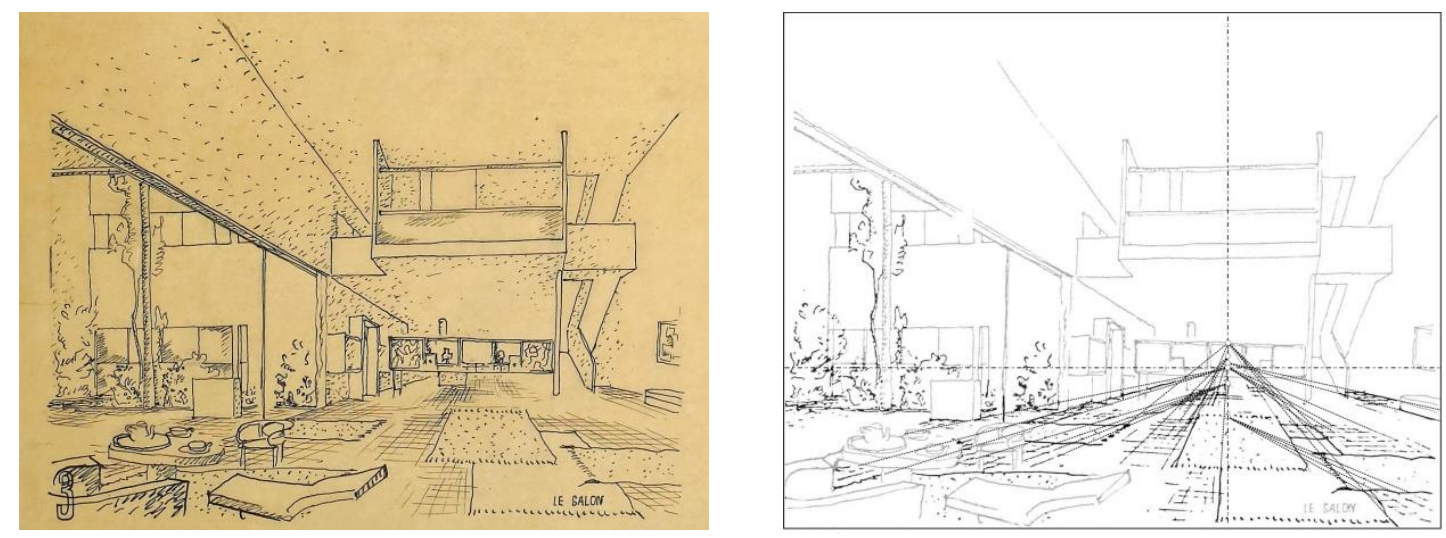

4. Izquierda. Le Corbusier. Dibujo del salón de la Villa Meyer. Derecha. Víctor Velázquez. Trazado del horizonte y puntos de fuga sobre el dibujo de Le Corbusier de la Villa Meyer.

Finalmente, hay un último antecedente que permite comprender con mayor precisión la noción de Horizonte en Le Corbusier, tanto en un sentido práctico como cultural. De acuerdo a lo señalado por Víctor Velásquez, la técnica que Le Corbusier probablemente utilizaba para dibujar algunas vistas de sus proyectos consistía en calcar o copiar una perspectiva cónica previamente ejecutada con instrumentos ${ }^{20}$. Realizando un riguroso análisis de un dibujo del interior de Villa Meyer (Figura 4. Izquierda), Víctor Velásquez demuestra los calces y descalces entre la perspectiva cónica que sirvió como base y el dibujo que finalmente trazó encima Le Corbusier. Una de sus conclusiones, desde mi punto de vista quizás la más significativa, es que el dibujo trazado a mano respetó casi todas las referencias definidas por la perspectiva, con excepción del punto de fuga único, ya que se trata de una perspectiva centralizada. Como consecuencia, algunos elementos, particularmente los muebles más cercanos al observador, se proyectan a puntos de fuga diversos, distintos de aquel que organiza la imagen. Lo curioso de estos descalces es que la disposición de estos nuevos puntos no es arbitraria. Casi todos confluyen en la línea vertical que, en el plano geometral, define la posición del observador. Más curioso aún es que estos puntos no se alejan demasiado de la línea del horizonte, situándose sobre o bajo ella (Figura 4. Derecha).

Lo importante, para nosotros, es que estos sucesivos puntos de fuga, dispuesto en vertical, generan una dilatación del horizonte en esa misma dirección, produciendo una suerte de ventana: un área que permite el acomodo de los distintos elementos que buscan su referente en 'otros' horizontes. Se podría decir que se trata de un horizonte que vibra, en su intento de introducir en "un espacio totalmente racional, es decir, infinito, constante, y homogéneo "21 , propio de la perspectiva renacentista, una dimensión propia de la percepción humana.

\footnotetext{
${ }^{20}$ Velásquez, Víctor: “Un Dibujo de la Villa Meyer”. En Massilia. Annuaire d'Etudes Corbuseennes. Sant Cugat del Vallés: Associacio d'Idees, Centre d'Investigacions Estètiques, p. 71.

${ }^{21}$ Panosfky, Erwin. Op. cit., p. 12 y ss.
} 


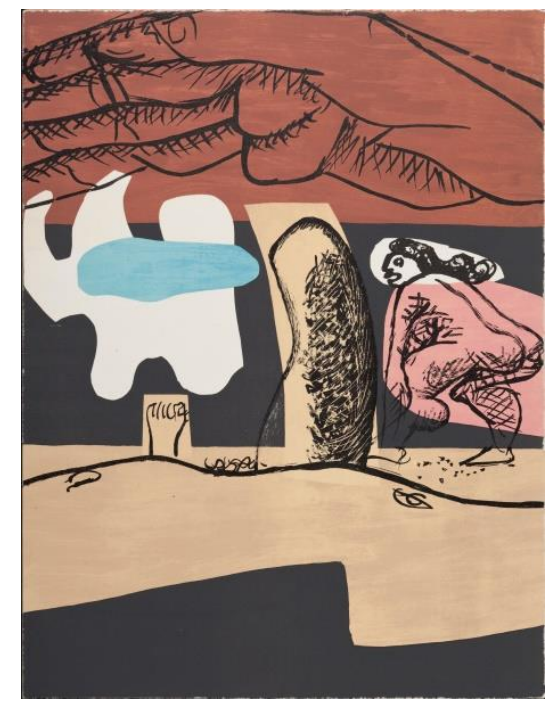

5. Le Corbusier. Poema del Ángulo Recto. C2 Chair, página 85.

En el caso de Le Corbusier, no hablamos pues del horizonte como una línea, como lo establece canónicamente la perspectiva renacentista, sino como un área que recuerda el esquema en espina de pez con que Panofsky explica la perspectiva angular de la antigüedad ${ }^{22}$. Esta comprensión del horizonte, como un 'línea' expandida, se ve confirmada en otra imagen del Poema del Ángulo Recto ${ }^{23}$ (Figura 5). En ella, un hombre aparentemente recostado en la playa mira hacia la costa por sobre su propio cuerpo, defiendo un área rectangular de contemplación que queda contenida entre su vientre y la mano derecha que utiliza como visera ${ }^{24}$. El área en cuestión es enfatizada por un fondo negro, sobre el cual se recortan: el muslo derecho y parte del pie izquierdo del hombre que está tendido, el cuerpo de una mujer, probablemente la que motiva el poema. Es decir, se concentran en esta área los elementos que constituyen el límite visual próximo, humano, que se contrapone al límite más extremo, pero aun así posible de percibir de la naturaleza. Esta situación representada en la imagen es descrita elocuentemente en la parte final del poema, C2 Chair: "Pasa la mujer. ¡Oh, yo dormía, perdóneme! Con la esperanza de capturar la suerte tendí la mano... El amor es una palabra sin frontera. Es también una creación humana un ensayo un intento" ${ }^{25}$. Tanto la imagen como el poema son, pues, un llamado de atención sobre aquello que se ha identificado como "la superación de los sentidos a ras de tierra -el olfato y el oído-, desplazados por la hegemonía del sentido de la distancia: la mirada; y cerrando el círculo, la combinación entre ojo y mano",26.

\footnotetext{
${ }^{22}$ Panofsky, Erwin. Op. cit., pp. 22-23.

${ }^{23}$ Le Corbusier. El Poema del Ángulo Recto. Op. cit., p. 85.

${ }^{24}$ Robin Evans, asertivamente refiere un gesto similar, a propósito de un autorretrato de Joshua Reynolds. En el cuadro, vemos al pintor sosteniendo sus instrumentos de trabajo con la mano derecha, mientras que la otra la utiliza como visera para protegerse de los potentes rayos del sol, en su afán de otear la lejanía. ¿Qué hace esa mano sino replicar el horizonte por medios humanos? Evans, Robin. Op. cit., pp. 266-267.

${ }^{25}$ Le Corbusier. El Poema del Ángulo Recto. Op. cit., p. 84. En el original: "!Passe la femme. Oh je dormais excusez-moi; Avec l'espoir de saisir la chance j'ai tendu la main... L'amour est un mot sans frontière. C'est aussi c'est encore une création humaine un essai une entreprise.

${ }^{26}$ Quetglas, Josep. "La línea vertical". En AA.VV: Le Corbusier y la síntesis de la artes. El Poema del Ángulo Recto. Madrid: Círculo de Bellas Artes, 2006, p. 54.
} 


\section{La noción de horizonte en la generación de la arquitectura}

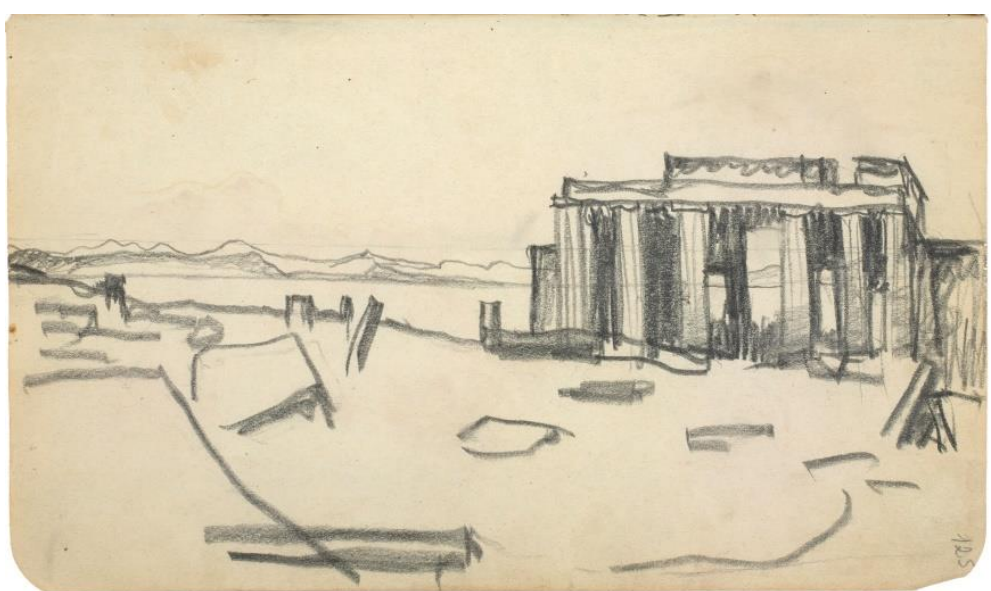

6. Ch-É. Jeanneret. Acrópolis de Atenas. Los Propileos vistos desde el Erecteion, 1911.

Un dibujo de las ruinas de los Propileos, realizado por Le Corbusier en 1911 es revelador de cuando hasta ahora hemos expuesto (Figura 6). Los elementos que lo componen se ordenan a partir de la coordinación del horizonte "visual", propio de la mirada del observador, con el horizonte "real", límite que delinea el encuentro de la tierra con el mar en la lejanía. Como ya se ha dicho, el horizonte en Le Corbusier es una entidad que representa la coordinación visual entre observador y mundo, que además estructura el dibujo en términos formales, constituyendo su fundamento. En ello radica su importancia.

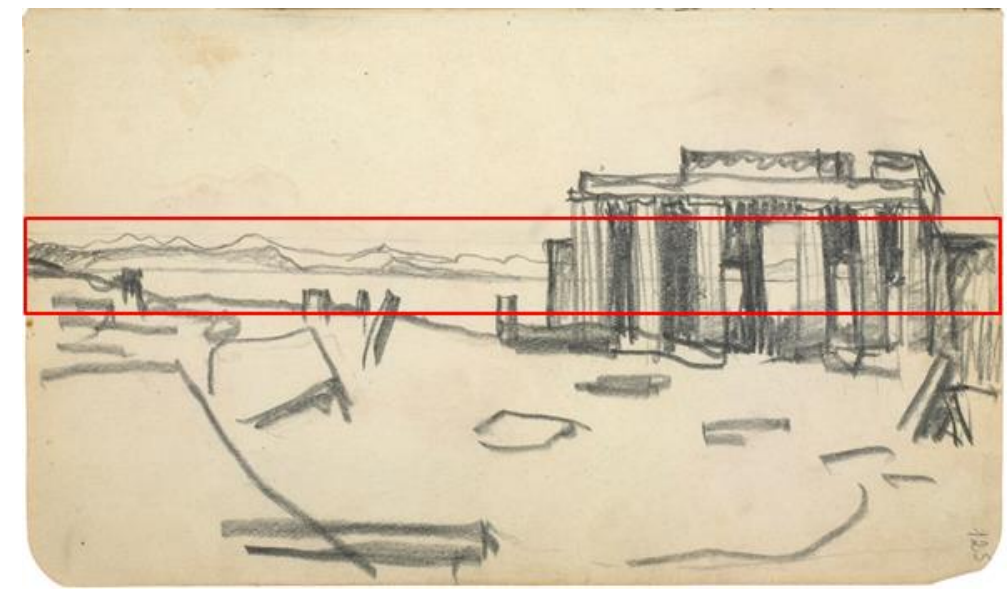

7. Horizonte "real" expandido verticalmente.

Si esa línea horizontal, como ya hemos sugerido a propósito de las imágenes anteriores, fuese expandida verticalmente, configuraría un área rectangular que corresponde a esa porción de mundo que se ve con mayor nitidez y precisión, y que en consecuencia acapara el principal interés del observador (Figura 7). Dicho así, el área en cuestión se puede entender como el lugar donde la mirada se detiene, atrapada por una figura que la modela, pero que sin embargo puede traspasar: una gran ventana de forma horizontal. 


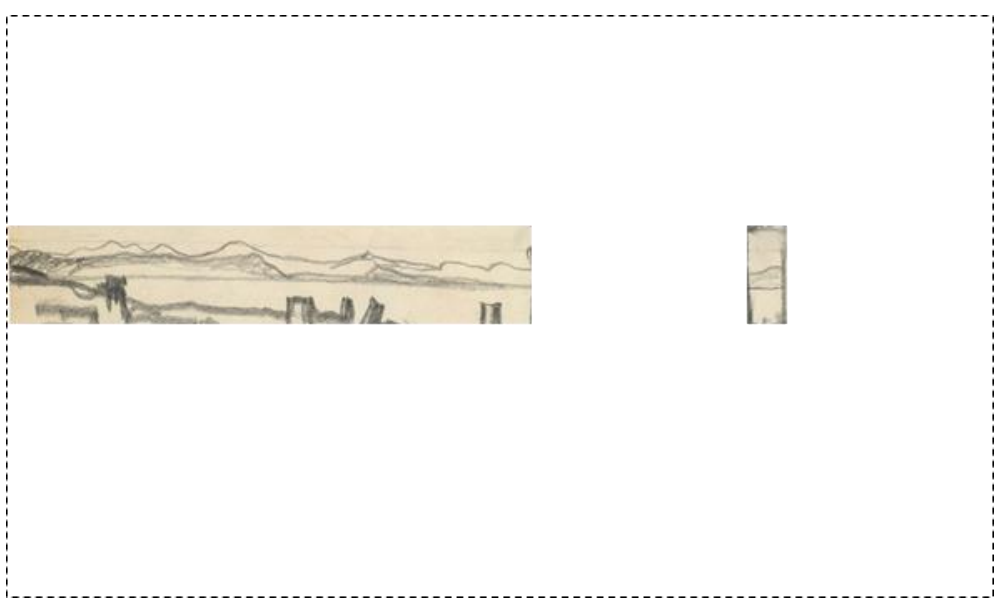

8. Recorte de ventanas en el horizonte expandido.

Pero si la miramos con mayor detención, esta área se puede reducir a dos ventanas (Figura 8): una menor, conformada por el umbral central que definen las ruinas de los propileos, que atrae la mirada puntualmente y a través de la cual ésta avanza dimensionando la profundidad del paisaje; y una mayor, mucho más amplia, situada a la izquierda de las ruinas, donde la mirada en principio reposa, para después desplazarse, siguiendo la silueta de las colinas lejanas.

En esta observación, la arquitectura o sus restos son utilizados como un dispositivo para aproximarse visualmente al paisaje. A través de ella se mide el paisaje, y la lejanía cobra un nuevo sentido al ser contrastada con los elementos construidos, más próximos al observador. Lejanía, elementos construidos y observador, llegan a ser uno en el dibujo. El observador, y dibujante, queda así, situado en relación al mundo que lo envuelve.

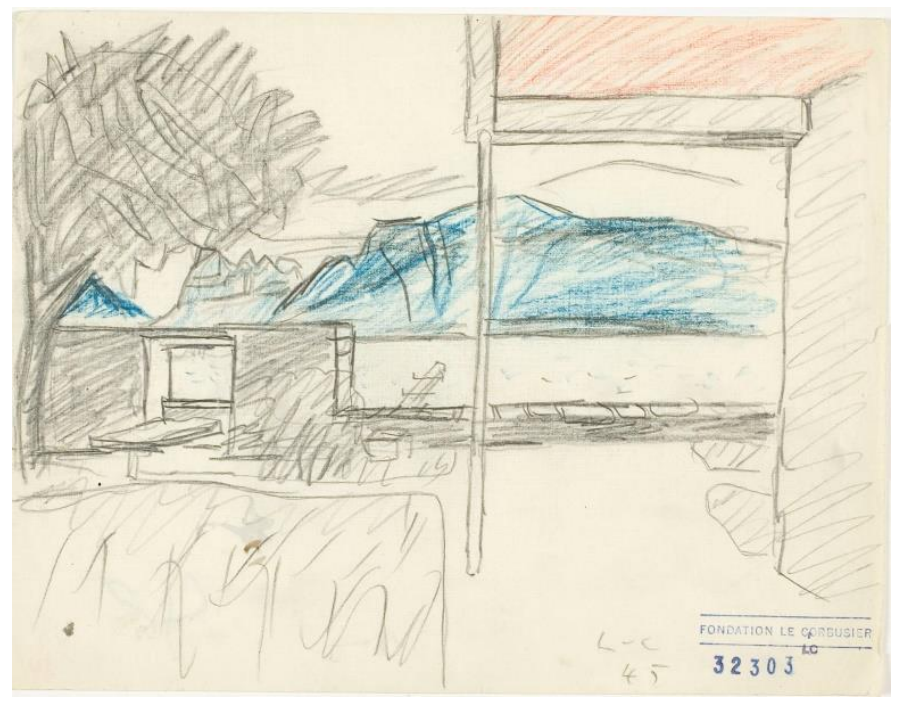

9. Le Corbusier. Patio de la Petit Maison, 1945.

Le Corbusier desarrolló literalmente esta observación una década más tarde, en la pequeña casa que proyectó para sus padres en la orilla del Lago Leman. Lo confirma una serie de dibujos que realizó muchos años después de haberse construido la casa y que publicó en 1954, en el libro Une Petite Maison ${ }^{27}$. Uno de los dibujos (Figura 9) hace patente este problema al mostrar el encuadre del paisaje a través del muro que se abre extensamente

${ }^{27}$ Le Corbusier. Une Petite Maison. Zurich: Editions Girsberger, 1954. Traducción española, Una Pequeña Casa. Buenos Aires: Ediciones Infinito, 2008, pp. 72-73. 
hacia la derecha y puntualmente en la ventana junto al árbol, tal como las ruinas encuadraban el paisaje, en el dibujo que había hecho en Atenas en 1911.

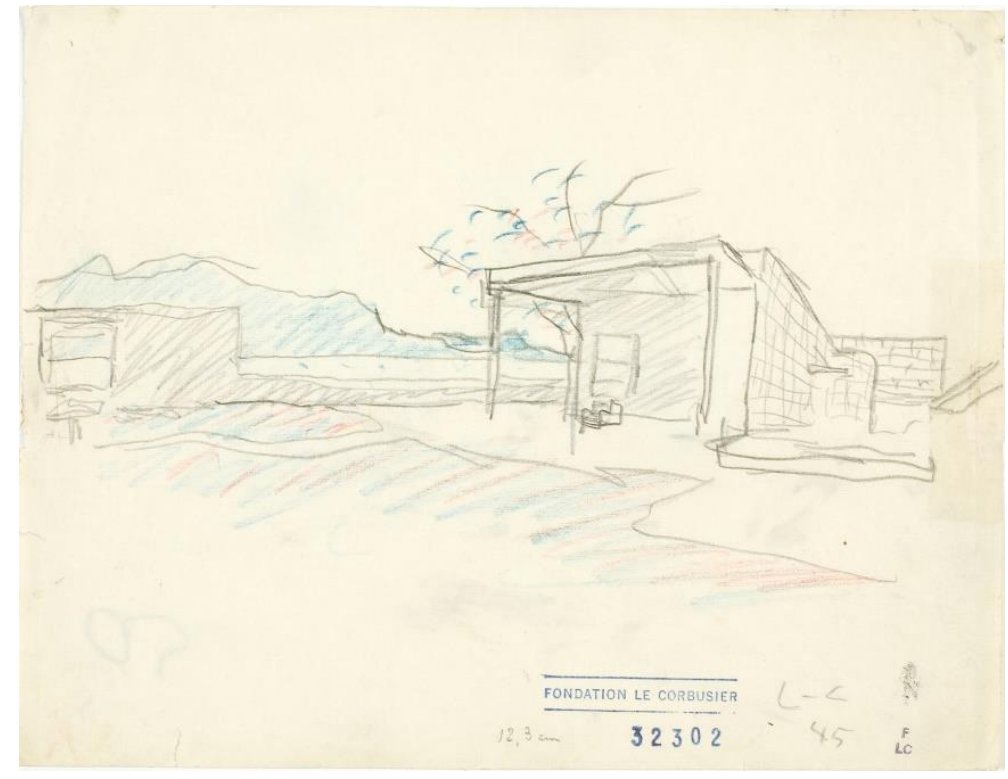

10. Le Corbusier. Patio de la Petit Maison visto en escorzo desde la izquierda, 1945.

Un segundo dibujo (Figura 10), muestra la misma escena pero vista en escorzo desde la izquierda, extremando completamente el ángulo de visión, para evidenciar el modo en que el lago y la montaña pasan por detrás del muro, y cómo una porción de ellos queda atrapado en la ventana cuadrada. En este segundo dibujo, a diferencia del anterior, el horizonte visual del observador coincide con el horizonte real, que en este caso tiene correspondencia con la línea donde se encuentran el lago y la montaña. De acuerdo a estas referencias, el dibujo permite visualizar la situación de la casa y el muro que la envuelve, en relación al paisaje lejano y a la posición del observador.

Por último, un diagrama (Figura 11) hace explícita la presencia del horizonte y del ángulo recto como fundamento de la situación de la casa frente al paisaje. En esta imagen, aparentemente, la vertical es asumida por el delgado pilar que sostiene el alero que cubre la terraza, tal como se muestra en los dos dibujos de la casa que hemos comentado.

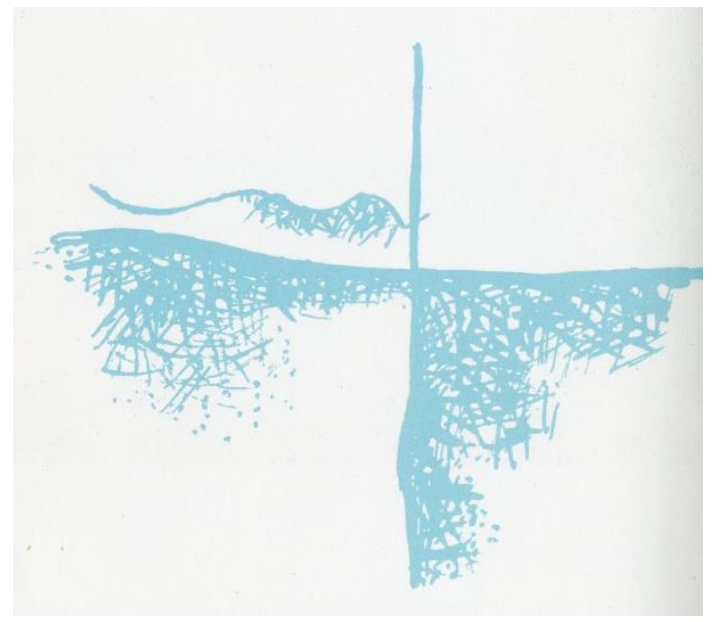

11. Le Corbusier. Diagrama del “Ángulo Recto” aplicado a la Petit Maison, 1945. 


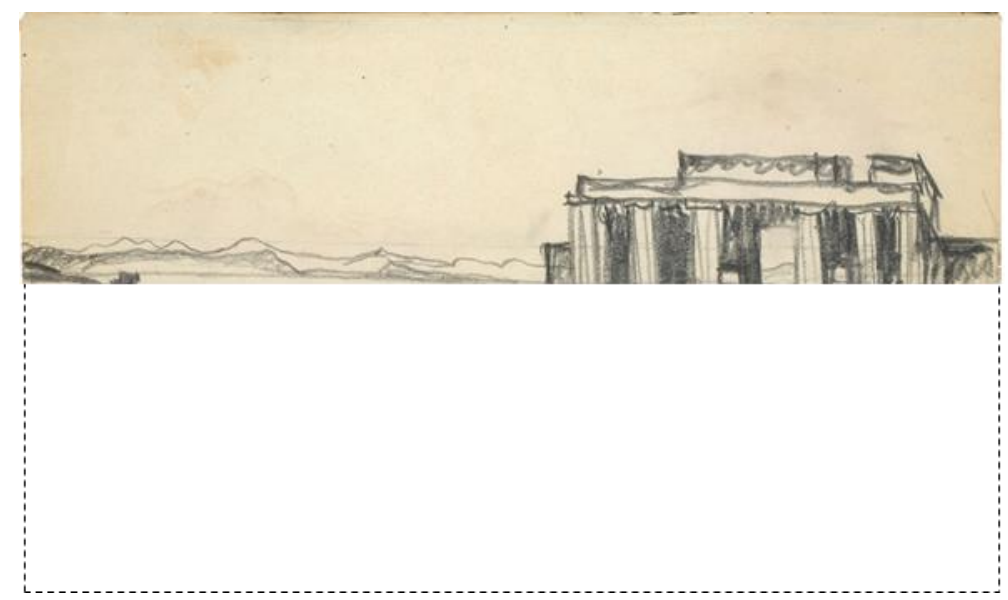

12. Área visible sobre la línea del horizonte.

Por otro lado, si volvemos a mirar el mismo dibujo (Figura 12) y consideramos ahora el horizonte "real" no como una ventana, sino como una línea que determina un arriba y un abajo, el cielo y la tierra o cielo y el mar, encontraremos una segunda observación, que está claramente vinculada con el primer dibujo que hemos comentado del poema A3 del Poema del Ángulo Recto. Esta observación trata del tema del "coronamiento" y se construye por medio del ocultamiento del suelo próximo y lejano, impidiendo ver de dónde emerge lo visible y, por tanto, dimensionar el distanciamiento entre lo lejano, lo cercano, y el observador. De este modo, vemos que la parte superior del dibujo descansa ahora sobre una tensa línea horizontal, sobre la cual se dibujan simultáneamente, como si de un ejercicio de comparaciones se tratara, lo que corona la corteza terrestre y lo que corona la arquitectura.

Como es sabido, en torno a este tema, en esencia de comparaciones de atributos y de contrastes, entre elementos naturales y construidos que intercambian posiciones, Le Corbusier realizó una serie de ejercicios proyectuales y de obras concretas en los que los materializó. Quizás entre las más evidentes está el ático De Beistegui, de 1930, y la cubierta de la Unidad Habitacional de Marsella, entre otros ${ }^{28}$. El medio para ponerlo en práctica es siempre el mismo: un muro que encierra parcialmente un espacio, el cual, de acuerdo a su altura o sus perforaciones, oculta o deja ver el paisaje circundante. Es decir, la arquitectura, al igual que los dibujos, es la que permite situar a los usuarios en su entorno, revelando y construyendo -a la vez- la situación de estar en ese lugar en particular.

\section{Conclusión}

Podemos concluir subrayando tres aspectos sobre lo ya dicho:

Primero, que en Le Corbusier el dibujo es un instrumento que le permitió situarse con precisión frente al mundo dado; y luego nos ha permitido a nosotros, simples espectadores, situarnos del mismo modo ante la realidad que observó y dibujó.

Segundo: que en este reconocerse frente al mundo dado, la noción de horizonte fue fundamental ya desde sus experiencias de juventud, incluyendo incluso su viaje a Italia de 1907. Y que, más tarde, la noción horizonte

\footnotetext{
${ }^{28}$ Ricardo Daza, propuso una observación similar al comparar la cubierta de la Unidad de Habitación de Marsella con un dibujo realizado en Delfos, durante el viaje a Oriente. Daza, Ricardo. "Paisaje Homérico. La Unidad de Habitación de Marsella". En Cuadernos de Extensión. Semana de Le Corbusier 17-20 mayo 2011. Santiago de Chile: Escuela de Arquitectura UC, 2011, pp. 89-92.
} 
también fue fundamental en su comprensión de la arquitectura, siendo parte fundamental de sus proyectos, obras teóricas y construidas.

Por último, y a pesar de que sus dibujos se estructuran a partir de la línea del horizonte, ellos se distancian de la comprensión canónica, abstracta, propia de la perspectiva renacentista, al llevar esta línea más allá de su condición abstracta, geométrica, y reemplazarla por un área que da cabida a distintos puntos de fuga que se distribuyen en la vertical, aquella que define la posición del observador. Esta área, así concebida, le permitió poner en acuerdo lo cercano y lo lejano, los límites propios de la percepción humana y los límites del mundo dado; limites en tanto que, aún, pueden ser percibidos.

\section{Figuras}

Figura 1. Izquierda. Ch-É. Jeanneret. Santa Maria Novella, sarcófagos del muro del patio de ingreso, Florencia, 8 de octubre de 1907. Acuarela y tempera sobre papel. 19 x 26,6 cm. Fuente: Le Corbusier. Il Viaggio in Toscana (1907). Venecia: Cataloghi Marsilio, 1987, figura 23. Derecha. Ch-É. Jeanneret. La Acrópolis vista desde el Monte Licabeto. Lápiz grafito. 10 x $17.8 \mathrm{~cm}$. Ch-E. Jeanneret / Le Corbusier. Voyage d'Orient. Carnets. Milano: Electa; Paris: Fundation Le Corbusier, 2002, Carnet 3, p. 98.

Figura 2. Ch-É. Jeanneret. Vista de la Cúpula de Santa María de las Flores y del Palacio Viejo. Florencia, primeros días de octubre de 1907. Acuarela sobre papel. 17,5 x 13,6 cm. Fuente: Le Corbusier. Il Viaggio in Toscana (1907). Venecia: Cataloghi Marsilio, 1987, figura 44.

Figura 3. Le Corbusier. El Poema del Ángulo Recto. Poema A3 Milieu. Izquierda a derecha, páginas 29, 30, 31.Fuente: Le Corbusier. El Poema del Ángulo Recto. Santiago de Chile: Universidad Finis Terrae, 2006.

Figura 4. Izquierda. Le Corbusier. Dibujo del salón de la Villa Meyer. Derecha. Víctor Velázquez. Trazado del horizonte y puntos de fuga sobre el dibujo de Le Corbusier de la Villa Meyer. Fuente: Velásquez, Víctor: "Un Dibujo de la Villa Meyer". En Massilia. Annuaire d'Etudes Corbuseennes. Sant Cugat del Vallés: Associacio d'Idees, Centre d'Investigacions Estètiques. 2002, pp. 71-87.

Figura 5. Le Corbusier. Poema del Ángulo Recto. C2 Chair. Fuente: Le Corbusier. El Poema del Ángulo Recto. Santiago de Chile: Universidad Finis Terrae, 2006, p. 85.

Figura 6. Ch-É. Jeanneret. Acrópolis de Atenas. Los Propileos vistos desde el Erecteion. Lápiz grafito. 10 x 17.8 cm. Fuente: Ch-E. Jeanneret / Le Corbusier. Voyage d'Orient. Carnets. Milano: Electa; Paris: Fundación Le Corbusier, 2002, Carnet 3, p. 125.

Figura 7. Horizonte expandido verticalmente. Elaboración del autor (Figura 6 intervenida).

Figura 8. Recorte de ventanas en el horizonte expandido. Elaboración del autor (Figura 6 intervenida).

Figura 9. Le Corbusier. Patio de la Petit Maison, 1945. Fuente: Le Corbusier. Une Petite Maison. Zurich: Editions Girsberger, 1954. Traducción española: Una Pequeña Casa. Buenos Aires: Ediciones Infinito, 2008, pp. 72-73.

Figura 10. Le Corbusier. Patio de la Petit Maison visto en escorzo desde la izquierda, 1945. Fuente: Le Corbusier. Une Petite Maison. Zurich: Editions Girsberger, 1954. Traducción española: Una Pequeña Casa. Buenos Aires: Ediciones Infinito, 2008, p. 71.

Figura 11. Le Corbusier. Diagrama del “Ángulo Recto” aplicado a la Petit Maison, 1945. Fuente: Le Corbusier. Une Petite Maison. Zurich: Editions Girsberger, 1954. Traducción española: Una Pequeña Casa. Buenos Aires: Ediciones Infinito, 2008, p. 58.

Figura 12. Área visible sobre la línea del horizonte. Elaboración del autor (Figura 6 intervenida).

\section{Bibliografía}

Daza, Ricardo. "Paisaje Homérico. La Unidad de Habitación de Marsella". En Cuadernos de Extensión. Semana de Le Corbusier 17-20 mayo 2011. Santiago de Chile: Escuela de Arquitectura UC, 2011, pp. 77-93. 
Evans, Robin. "Las simetrías paradójicas de Mies van der Rohe", en su Traducciones. Girona: Editorial PreTextos, 2005, pp. 246-289.

Gadamer, Hans-Georg. Verdad y Método. Salamanca: Ediciones Sígueme, 1999.

Hidalgo, Germán. La Arquitectura del Croquis. Dibujos de Ch-E. Jeanneret en Italia 1907 y en Oriente 1911. Un estudio de sus antecedentes. Universidad Politécnica de Cataluña, Escuela Técnica Superior de Arquitectura de Barcelona, Departamento de Composición, 2000. Tesis doctoral inédita.

Hidalgo, Germán. "La constatación de un aprendizaje. El viaje a Italia de 1907 de Ch-É. Jeanneret”. Massilia, Annuaire d'Etudes Corbuseennes. Sant Cugat del Vallés: Associacio d'Idees, Centre d'Investigacions Estètiques, 2008, pp. 04-30.

Jeanneret, Charles-Édouard (Le Corbusier) El Viaje de Oriente. Murcia: Colegio Oficial de Aparejadores y Arquitectos Técnicos. Librería Yerba, 1993.

Le Corbusier. Hacia una arquitectura. Barcelona: Editorial Apóstrofe, 1998.

Le Corbusier. El Modulor. Barcelona: Editorial Poseidón, 1976

Le Corbusier. El Poema del Ángulo Recto. Santiago de Chile: Universidad Finis Terrae, 2006. Traducción Hernán Marchant.

Le Corbusier. Une Petite Maison. Zurich: Editions Girsberger, 1954. Traducción española: Una Pequeña Casa. Buenos Aires: Ediciones Infinito, 2008.

Le Corbusier. Il Viaggio in Toscana (1907). Venecia: Cataloghi Marsilio, 1987.

Monsteys, Xavier. "El hombre que veía amplios horizontes: Le Corbusier el paisaje y la tierra". En Massilia. Annuaire d'Etudes Corbuseennes. Sant Cugat del Vallés: Associacio d'Idees, Centre d'Investigacions Estètiques, 2004 (bis). pp. 6-21.

Panofsky, Erwin. La perspectiva como forma simbólica. Barcelona: Fabula Tusquets Editores, 1999.

Quetglas, Josep. "La línea vertical”. En AA.VV: Le Corbusier y la síntesis de la artes. El Poema del Ángulo Recto. Madrid: Círculo de Bellas Artes, 2006, pp. 51-57.

Quetglas, Josep. Les Heures Claires. Proyecto y arquitectura en la Villa Savoye de le Corbusier y Pierre Jeanneret. Sant Cugat del Vallés: Massilia, 2008.

Ruskin, John. The Elements of Drawing. London: George Allen, 1856. Traducción Española: Técnicas de dibujo. Barcelona: Editorial Leartes, 1999.

Seckler, Mary Patricia May. The Early Drawing of Charles-Édouard Jeanneret (Le Corbusier) 1902-1908. New York and London: Garland Publishing, 1977.

Silver, Kenneth E. Esprit de Corps. The Art of the Parisian Avant-Garde and the Frist World War, 1914-1925. London: Thames and Hudson, 1989.

Velásquez, Víctor: “Un Dibujo de la Villa Meyer”. En Massilia. Annuaire d'Etudes Corbuseennes. Sant Cugat del Vallés: Associacio d'Idees, Centre d'Investigacions Estètiques. 2002, pp. 71-87. 


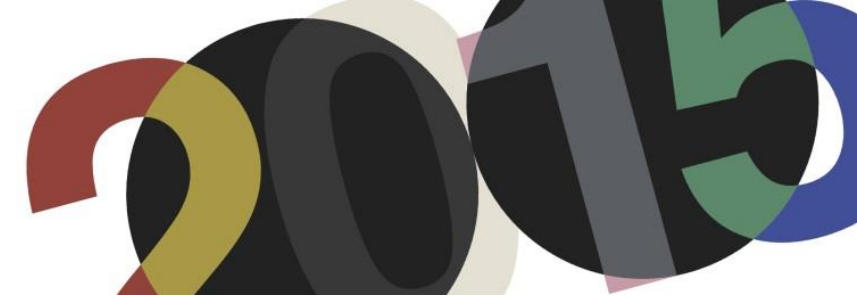

DOI: http://dx.doi.org/10.4995/LC2015.2015.799

\title{
Mapping the Stylistic Affiliations of Le Corbusier's Work
}

\author{
P. Ilias Panigyrakis
}

TU Delft, School of Architecture and the Built Environment

\begin{abstract}
The paper deals with Le Corbusier's connection to the term "style". A classification of his work in specific architectural styles is discussed, followed by a description of the procedure through which the style of the man Le Corbusier was constructed; in an attempt to search meaning in his continual stylistic shifts and the rationale that kept his lifetime's work and identity strongly compact when we consider him retrospectively.
\end{abstract}

Resumen: El artículo trata la conexión de Le Corbusier con el término éstilo." Se discute una clasificación de su obra en estilos arquitectónicos específicos, seguido de una descripción de los procedimientos a través del cual el hombre fue construido al estilo de Le Corbusier; un intento de búsqueda de sentido en sus cambios estilísticos continuas y las razones que mantuvo el trabajo y la identidad de su vida fuertemente compacta, cuando lo consideramos retrospectivamente

Keywords: Le Corbusier; Style; Stylistic Shifts.

Palabras clave: Le Corbusier; Estilo; Cambios Estilísticos.

\subsection{Prologue}

It is said that Le Corbusier used to keep a picture of his 1914 Maison Dom-ino scheme side by side with a picture of the Parthenon from his 1911 visit in Athens. It is also known that he viciously fought against the talk of styles in the architectural discourse. How should we interpret then the above mentioned coupling of Dom-ino, the epitome of technique of the 20th century architecture, along with the Parthenon, the most imitated object of any iconographic style prior to Modernism? This research will argue for the stylistic affiliations of Le Corbusier's work in an attempt to map the trajectory of architectural forms applied in the extensive work of the legendary architect.

In his 1936 Oeuvre Complete, Le Corbusier writes:

"In a hundred years we could speak of a "style". We should not do so today, but only of STYLE, which is, the moral tendency of any work created, truly created ."

It is here clearly stated that although Le Corbusier's name was strictly affiliated with Modernism's moralistic arguments against 19th century's affluence of styles and formalistic expressions, he strongly sustained an artistic approach towards the architectural form, not unlike his painting aspirations, thus in stylistic terms. Several styles have been clearly used by Le Corbusier in his career of sixty years: from the regional styles of La Chaux-deFonds and the Villa Savoye's strict Modernism until Ronchamp chapel's formalistic excess and 1950's brutalistic experiments. Even on one of his final schemes, the 1965 Venice hospital, Le Corbusier showcased his

\footnotetext{
1 “Dans cent ans, nous pourrons parler d'un 'style'. Il n' en faut pas aujourd' hui, mais seulement DU STYLE, c'est-à-dire de la tenue morale dans toute oeuvre créée, veritablement créée."

Le Corbusier, Le Corbusier et Pierre Jeanneret, Oeuvre Complète: 1910-1929, Paris: Les Editions d' Architecture, 1936, pp.2.
} 
flexible formalistic capability, borrowing from the structuralist style of his 30-years younger, Candilys' compositions. Style, as a term aims for the systematic approach towards the artistic creation2. However, although the 19th century architectural theoreticians went through great pains to define a methodological approach towards architectural styles, since the dawn of Modernism it has been abolished from architecture's critical analysis3. This however does not mean that it was not continuously used in terms of the architectural practice. The correspondence between architectural form and extrinsic factors is that which posits it as an "undiscussed, self-evident" analytical tool upon which our historical consciousness is based ${ }^{4}$. It is this basic role of style for the ordering of historiography that establishes its use essential for the relevance of produced innovative works. And although modernist rhetoric denounced style as an operative motive, the production of style has provided the organizing factor and orienting framework for the social production of the architectural discipline $^{5}$ that is currently re-emerging, in relation to the social changes of the second half of the 20th century characterizing architecture's development with its immediacy ${ }^{6}$.

\subsection{Objectives}

The objectives of this research would be to point out, in architectural terms, the "STYLE" or "styles" used by Le Corbusier.

- What defined his stylistic periods?

- What were the reasons for his recurring stylistic shifts?

- How did he structured his personal image, and to what extent this affected his stylistic engagements?

- What role did his careful post-production played in the formation of his work's image?

\subsection{Methodology}

The research will be organized in two parts, dealing with two aspects of style a) towards his work and b) Le Corbusier himself.

○ Le Corbusier: The Architectural Styles: The first part will deal with the classification of his architectural work in specific stylistic groups as well as his linkage to wider stylistic movements. The built architectural projects will be chronologically presented, noting his projects that proved to be pivotal to his stylistic shifts. Moreover, a short comments will be made on Le Corbusier's main design or constructional inventions in order to observe to what degree these innovations shaped his stylistic endorsements throughout his architectural career.

○ Le Corbusier: The Style of the Man: The second part will deal, more generally, with Le Corbusier's personal style of appearance, tracing an overview of his wide spectrum of coinciding interests that structured his persona as a sophisticated artist. His unceasing passing through multiple design and knowledge fields will be put in perspective with the structuring of his image, along with other factors that shaped his figure such as: his careful post-production of his work, his participation and direction of exhibitions and associations as well as his numerous publications.

\footnotetext{
${ }^{2}$ Schapiro, Meyer, Theory and Philosophy of art: Style, Artist and Society, George Braziller, Inc., New York, 1994.

${ }^{3}$ Bakel, Anton Paulus Maria von, Styles of Architectural Designing: Empirical Research on Working Styles and Personality Dispositions, Ph.D. submitted at the Technische Universiteit Eindhoven, 2009.

${ }^{4}$ Makkreel, Dilthey, Philosopher of the Human Studies, Princeton, Princeton University Press, 1992.

${ }^{5}$ Brain, David, "Discipline and Style: The Beaux Arts and the Social Reproduction of an American Architecture". In Theory and Society vol.18. Berlin: Springer,1989. pp. 807.

${ }^{6}$ Hvattum, Mari, "Crisis and Correspondence: Style in the Nineteenth Century".In Architectural Histories, vol 1, EAHN, Zurich, 2013. pp. 1-8.
} 
○ Style by Le Corbusier: In conclusion, a short note will be made on Le Corbusier's personal attitude towards the notion of style.

LE CORBUSIER /CHARLES EDOUARD JEANNERET

ARCHITECTURAL STYLES

$1887-7965$
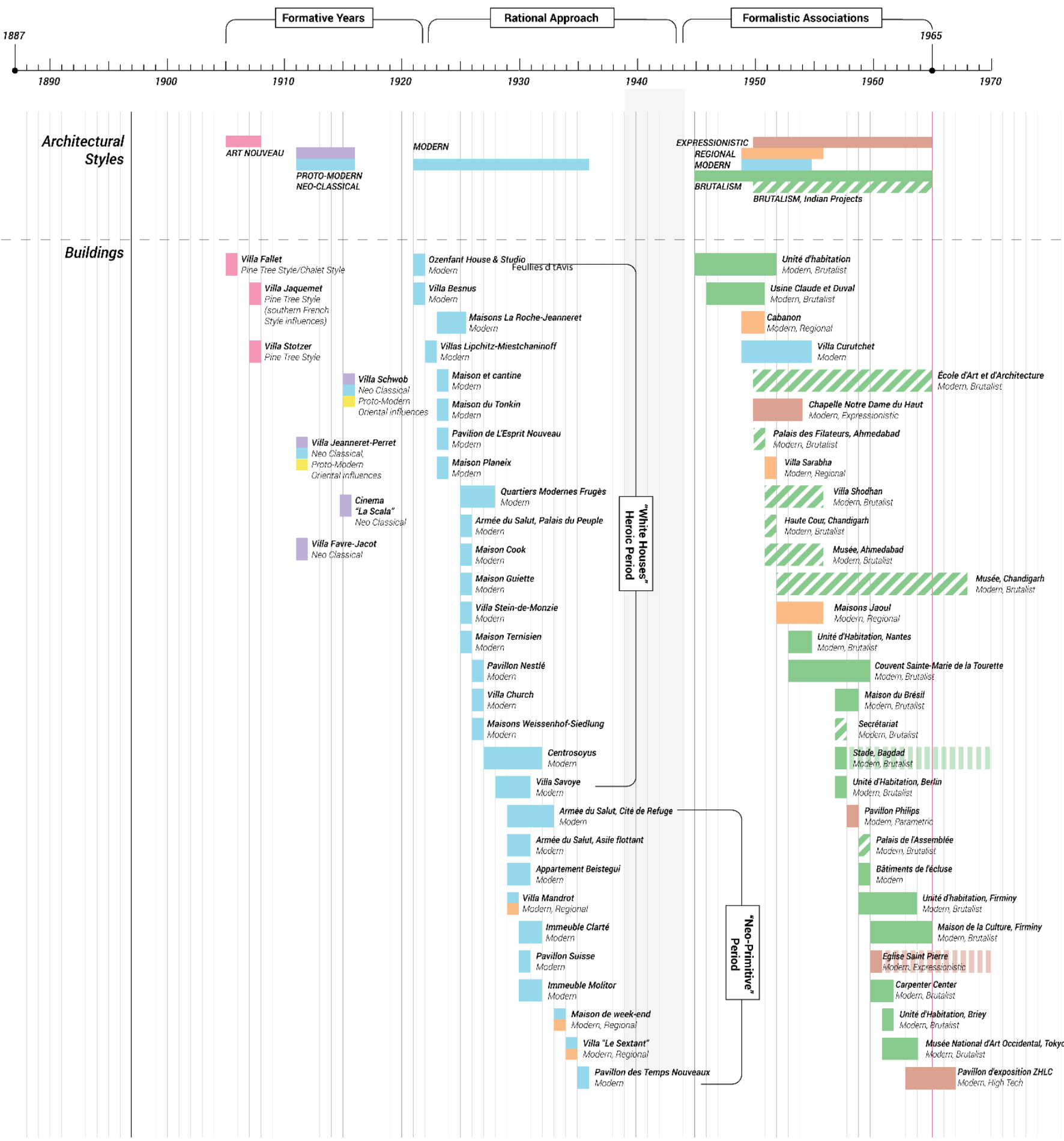

1. Classification of Le Corbusier's buildings during his lifetime corresponding to architectural styles and periods. 


\section{Part 1. Le Corbusier: The Architectural Styles}

Le Corbusier's total work is usually summed up in 3 periods that subsequently typify his early, mature and late work, throughout the years: A) 1887-1922, B) 1922-1944 and C) 1944-1965 ${ }^{7}$. This study will attempt to address these periods through an analysis of the principles that Le Corbusier posed as his basic starting points for his architecture and the different formal characteristics of his styles.

\subsection{The Formative Years (1887-1922)}

This first period could be characterized as Proto-Modern. The elements of the architectural vernacular that Le Corbusier deemed dominant were gradually simplified towards a new direction that allowed modernism to emerge. Regional, Art Nouveau and Neo-classical were mutated stylistically losing their cohesion with the motives that generated them: local elements wore off, contradiction between art nouveau and industry climaxed and neo-classical doctrines seemed all too distanced.

Le Corbusier's early years were marked by his largely influential roots in his upbringing at La Chaux-de-Fonds. The regional styles of the area, as well as the popular Art Nouveaux styles of the epoch do appear in Charles Jeanneret's first works. His very first contribution to designing a building at the early age of 17, was the Villa Fallet, in the "pine tree style" (style sapin) a regional art nouveau ramification that was popularized by the La Chaux-de-Fonds Art School, founded by Jeanneret's mentor and teacher, L'Eplattenier. The style bared heavy influences from the chalet style of the alpine vernacular architecture that was also applied in his 1917 Villa Jaquemet and Villa Stotzer ${ }^{8}$.

Jeanneret's subsequent travels in Vienna and Budapest introduced him to the styles of the Jugendstil and the Viennese Secession. His short employment under Auguste Perret in Paris and under Peter Behrens in Berlin also sparked new influences in subsequent villas Jeanneret built in his hometown, now in a much more innovative approach. The Villa built for his parents does merge the regional Art Nouveau tendencies with early protomodernist forms such as the ones deployed by Perret or Behrens merged with neo-classical experiments. On the contrary the subsequent Villa Schwobb, or Villa Turque, carries clear oriental characteristics, probably inspired by his 1911 journey to the east; proving that Le Corbusier was already expanding his vocabulary beyond his patrons' teachings, in search now of a style of his own ${ }^{9}$. While the regional styles of Chaux-de-Fonds provided young Jeanneret with the basis for his artistic and constructional beginnings it was the early modernist styles of his mentors that affected his departure for a search of a modern aesthetic. The journey to the East had limited influence on his work, with Villa Schwobb being the only clearly "oriental" project of this period. It was more in a cultural level that we can trace the effect of the oriental vernacular styles in the architect's new strongly held beliefs of the need for human society to reconnect with the natural world, and the importance of finding a new form of sacred or spiritual experience for the skeptical world of the $20^{\text {th }}$ century, industrialized West ${ }^{10}$. Although his later involvement with the technological advances of the machine age is well acknowledged it is important to note his equally strong interest from his early years in the low-tech and the vernacular styles that would later reappear with a leading role in his more mature period.

\footnotetext{
${ }^{7}$ This periodization is taken from: Curtis, Wiliam, Le Corbusier: Ideas and Forms, Phaidon, 1980.

${ }^{8}$ Lowman, Joyce, Le Corbusier 1900-1925: The Years of Transition, Ph.D. submitted at the University College of London, 1981, pp 60.

9 ibid, pp 54

${ }^{10}$ Dummet, Emma, Vernacular Architecture, nature and the sacred: Le Corbusier and the influence of the 'journey to the east. In eSharp Issue 4. Glasgow: University of Glasgow Publications, Spring 2005.
} 
The year 1917, marks for Le Corbusier a new beginning, ending the confusing styles of the "La Chaux-de-Fonds years of 1900-1917" and leading to more precise stylistic endorsements. With the exemption of the "Maison Dom-ino" of 1914 conceived with Max Dubois, it was mainly his Paris years of 1917-1922 that laid the foundation for the architectural style that brought him in mainstream acknowledgement: the original Modern Style of the 1920's.

Throughout these years (1917-22), the Dom-ino house of the years 1914/15 evolved to a series of residential projects centered on the concept of a repeatable unit formed by a prefabricated skeleton without strict standardized program. This scheme produced several variants such as: the "Troyes", 1919 (houses of grosbeton), the "Monol" houses, 1920 and the "Citrohan" houses that spanned almost a decade of variations (19191927) until the realization of one of them, in the Weissenhofsiedlung in Stuttgart. Although this series of projects could not be argued to consist a style of their own, in retrospect it is evident that this line of projects led to the 5points of his new architecture that provided the promoting rhetoric of the structural prototype of the Dom-ino and led to its culmination in the characteristic style of his 1920's white houses. It is also debatable that the 1919 perspective of the Dom-ino house provided not only the concept but also formal features to his modern style, such us:

- the fascination with the voluminous space that concrete and metal could generate

- the emphasis on transparency

- the sanctioning of movement

- and the exhibition of technology and structure as artistic elements

The year when Le Corbusier would put his projects into test and start structuring his style, was 1922 when his first commissions in Paris finally resulted in built projects.

\subsection{The Rational Approach (1922-1944)}

The Heroic Era of the 1920's marked Le Corbusier as the principle instigator of the modern architectural movement. To quote Philip Johnson, "Le Corbusier was the man who first made the world that a new style was being born" $"$. Although the importance of the role of other architects in establishing the "International Style" was recognized, Le Corbusier held by himself an adequate collection of projects that portrayed the whole spectrum of this new style's implementations in his work alone. A) His series of "white houses" tested the former experiments of the Dom-ino archetype in specificities of building materials, constructional techniques, clients' preferences, different budgets and topographic particularities. B) In addition, a different approach to the Modern Style was inspected through a series of social housing projects that featured more subtle forms and provided the urbanistic vision, the context for this style's formalistic endeavors as well as its moralistic basis. C) A third category of this period could be discerned in three pavilions that were built for exhibitions such as the Neslté Pavilion exhibiting another aspect of the modern style: the flexibility that it could acquire adapting to time limitations, social events and the use of demountable structures. In all these three categories underline the A) sophisticated, B) simplified and C) light versions of the modern style.

\footnotetext{
${ }^{11}$ Hitchcock, H.R.; Johnson P. The International Style: Architecture since 1922. , New York: 1932.
} 


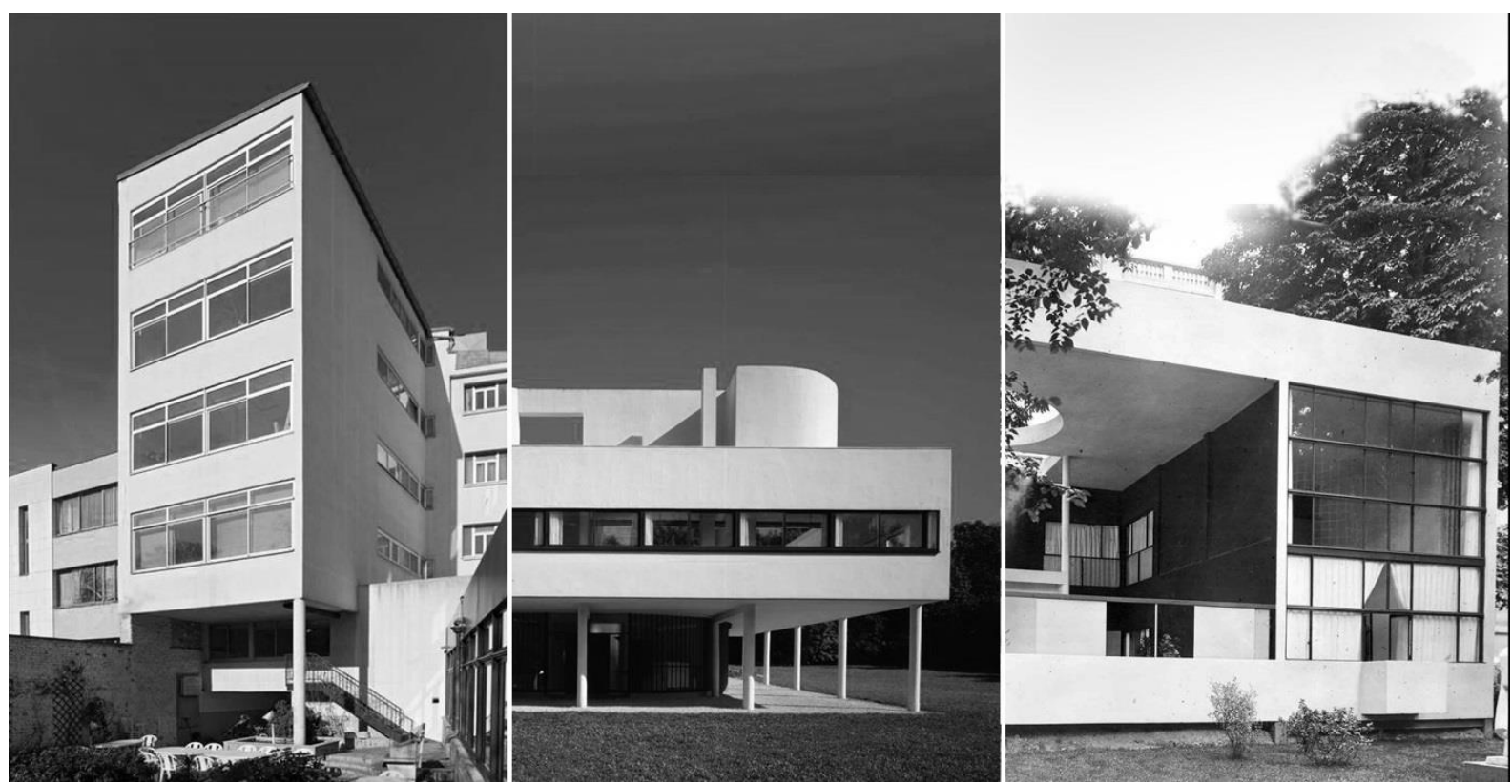

2. Three types of buildings compose the Modern Style of the "Heroic Period" of Le Corbusier in the 1920's: Residential Blocks, Villas and Pavilions.

The "white houses" of the years 1922-1927 that crystalized the Modern Style were no more than a handful. Starting with the 1922 Ozenfant House \& Studio and ending with the realization of the Villa Savoye in 1931, the undisputable peak of these experimentations. The houses gradually composed a very specific style that nevertheless, allowed wide variations. Some specific characteristics that demonstrate the rigorous formal vocabulary of these buildings were:

- the white plastered surfaces

- the ribboned-windows

- the smooth, perfect finishes

- the pilotis and more specifically, the circular slender concrete columns

- the use of windows and volumes for a composition of the façade with an elementaristic effect, not unlike the De Stijl exponents of the epoch.

The houses also popularized the use of the golden number. This however was not considered as a reference to neo-classicism, but as an embrace of the mathematical nature of beauty that the modern style aimed for, through the use of proportionality and ergonomy. It is also key for understanding that from its beginning, the original modern style of Le Corbusier was prospectively determined to have a formal aspect. In contrast to the contemporary Bauhaus initiative that claimed a modern style that derived from functional uses, in Le Corbusier we can recognize his architecture works artistically destined in the same way as he has a priory defined the equivalent style of purism in his paintings.

The second series of buildings, the social housing projects are linked less through formal elements and more in matters of design methods in combination with their social mission. The 1922 project for the city of three million habitants opened the way to a wider understanding of the Dom-ino archetype in new a social context. Its formal vocabulary was much harsher than his contemporary villas but in a way more simple and disciplined. Such urbanistic projects that Le Corbusier subsequently produced gave notoriety to his practice while also justified the formation of a modern architectural style since it could impose a modern "lifestyle" as an instrument of authority 
in the "machine age". These projects made clear that Le Corbusier's modern style was not limited to the scale of the villas but could even be applied to the size of a whole city. The housing project in Pessac from 1925 was representative of his efforts and displays paradigmatically the problems that the implementation of modern style in a massive scale would have.

There are several points that should be discerned regarding the formal aspect of this series of buildings. Firstly, despite the economic limitations and the high degree of standardization, Le Corbusier managed to feature in these buildings his 5 points of architecture. This meant that a stylistic cohesion could be maintained in a totally different scale of size and budget and in a different intensity as well. Standardization and homogeneity were also exhibited as stylistic features, something that could not be argued for his villas. A sort of customization offered to the inhabitants also had a formal impact that characterized these projects, as for example was the case in Pessac. Most of these housing projects are rarely perceived from an artistic viewpoint but it could be said that they were the first to test the adaptation of the middle class in modern aesthetic standards perceiving the modern style as the materialization of a communal feeling of progress rather than an artistic novelty.

If the Villa Savoye could be noted as the peak of Le Corbusier's villas, an equivalent pivotal project for his mass housing projects would be the Cité de Refuge of the Armée du Salut built between 1929 and 1933. With a strategically subtle composition of elements the Cité pinpoints the social aspect of the new style, with the innovative building functioning perfectly in terms of space, temperature and light; paired with an intense artistic presence. This project was the first to signal the institutional implementation of Le Corbusier's ideas. From this moment on he had already departed his visionary projects beyond housing, towards "Public palaces" instead, in projects such as the League of Nations (1927), the Mundaneum (1929) or the Palace of the Soviets (1931). Although these projects ended in fiascos, the Cité provided a valid prototype for a new set of communal buildings in the 1930's, such as the Pavilion Suisse. These projects were mainly variations on the theme of the glass slab with attached communal elements at ground level ${ }^{12}$. All of them, affirming undisputedly the service of the machine-house and concluding the evolution of the Dom-ino and Citrohan schemes in clearly dictated forms and methods of construction.

The third category of buildings that completes Le Corbusier's "Heroic Era" were the three ephemeral pavilions: the pavilion for L'Esprit Nouveau (1923), the Nestle pavilion (1927) and the Pavilion de Temps Nouveaux (1936). This category is not matched with the importance and influence the villas or the housing projects had. It does however emerge as an exemption. These three projects innovate in a small scale laying the foundation for a flexible directive of the Modern Style. At the Exposition Internationale des Arts Décoratifs of 1927, the Pavilion de L' Esprit Nouveau popularized the concrete cell and manifested the image of the new architecture delivered of the applied arts. The Nestle Pavilion did the same for metal and glass structure. Demountable and functional, paired with the use of graphic design, these structures operated in a totally different context of appearance than Le Corbusier's other works. In the pavilions we can trace not a style, with the sense of set of architectural forms, but more of a strategy of promotion and display of modernism as an experiential process and cultural event integrated in a degree zero of means or time limitations, but nonetheless distinct. Throughout the 1920's it could be said that the three typologies of villas, housing projects and pavilions illustrate the complete assurance of Le Corbusier's formal system in maturity and their evolution in the dawn of the 1930's even hints at reasons for changes in style that were imminent.

The 1930's and more precisely, since the completion of the Villa Savoye, a neo-primitive period for Le Corbusier's work commenced; still in the context of modernism. Projects such as the Villa Mandrot and the Villa

${ }^{12}$ Curtis, Wiliam, Le Corbusier: Ideas and Forms, London: Phaidon Press, 1980. 
"Sextant" introduced the use of vernacular masonry with the trademark white coating missing. Housing projects such as the Immeuble Molitor and the Pavilion Suisse, portray a new materiality for bigger projects as well, with the use of glass brick, masonry and brick walls, wooden and stone cladding. Novel forms were introduced as well, such as the arced interiors, the sculptural supports and the sophisticated furniture pieces. Not quite as distanced to his earlier forms, Le Corbusier's realized projects from 1933 to 1944 display a break with the pure forms of his 1920's architecture and reflect the disturbing years before and during wartime.

\subsection{Formalistic Associations (1944-1965)}

It is ironic that the Unite d' habitation designed in 1945, inaugurates Le Corbusier's formalistic period. This project brings together all the conceptual features that a "social engineer" would sought to solve. But artistically the post-war period meant for the modern movement and consequently for Le Corbusier (or was it vice-versa?) a turn for the notion of style as "total design"- controlling, structuring and solving new needs- to a return to style's understanding as the "synthesis of the arts". Le Corbusier's response was a creative tour de force in structuring a much more personal and experiential set of forms that resulted in his expressionistic attempts. The most distinctive and meticulous set of forms was the modern style of brutalism. The first Unite in Marseille (19451952) along with the factory "Claude et Duval" (1946) propelled the new style that instantly became a trend for public buildings and since $1953^{13}$ was promoted as a distinctive, counterbalancing style to modernism itself. The forms were typically reminiscent of infrastructures and thus, familiar for public use. This is also the factor that rendered them presumably socialistic. Of course, for Le Corbusier brutalism was more an artistic endeavor than a moralistic argumentation. With the Convent of La Tourette (1960) being his most representative of his brutalistic buildings in France he moved on in several other series of buildings still in the context of this style. The brick houses, such as the Maison Jaoul (1951-1956) or the Villa Sarabhai (1951), are the most distinguishable of such a variation on brutalism. While the three museums in Ahmedabad, Chandigarh and Tokyo are almost identical and conceptual descendants of the Mundaneum project. All of the brutalistic buildings share in common the brutal appearance of their materials (naturally), they feature the use of proportions dictated by the Modulor and bear applied decorations by Le Corbusier himself or his collaborators.

A special category of Le Corbusier's brutalistic style would be the projects he produced in India. And that is because, the forms that he produced there sparked a widely distinctive style of post-colonial civic architecture. Whether it is debatable or not if Le Corbusier structured this style specifically for Chandigarh and the country of India, retrospectively is irrelevant, since it is now a trademark of the city's governmental facilities. A couple of formal characteristics, separate this category from the rest of Le Corbusier's brutalistic work. The most apparent is the remarkable symbolisms while more recognizable is the extensive use of the brise soleil not as an element applied on the surface of the building, but as the façade itself. Another one is the playful complexity derived from problems of sun exposure and air circulation.

Apart from the brutalistic buildings, Le Corbusier's late plastic period generated a great number of ambiguous and non-classifiable projects in terms of architectural style. The Notre Dame du Haut Chapel at Ronchamp (1950-1954), probably Le Corbusier's best-known building, is proof of his ability to lay a complete total work of art, separately from his main stylistic engagement with brutalism. Ronchamp, along with the Philips Pavilion (1958), the Saint Pierre Chapel (1960-2006) and the Heidi Weber Museum (1960) portray a technological expressionism, totally a rebellious towards the International Style. During the decade 1955-1965 instead of a

\footnotetext{
13 The term "new brutalism was used by Alison Smithson in 1953, while the book "New Brutalism: Ethic or Aesthetic?" (1966) brought together a group of architects that whose work was characteristic of the style.
} 
rigorous stylistic commitment, Le Corbusier's Atelier “de la recherché patiente" was evidently striving for a constant succession of forms. And it did so in a spectacular way. It could be noted that Ronchamp provided a model for a 1960's neo-plasticism as well as a harbinger to post-modernism, the Philips Pavilion seems like a predecessor of 1990's and early 2000's fascination with parametric design and blobitecture while the Heide Weber Museum seems like a mixture of the contemporary high-tech style and the light modernism of the Eames. Lastly, the St. Pierre chapel is yet to be comprehended as to the decisions that led to its development, though it strikingly precedes the fascination of monolithic structures in recent years, in comparison for example with Koolhaas's Casa da Musica (2006).

If we were to speak over Le Corbusier's regionalistic influences we should place them in context of his expressionistic attitude since the local elements seem to have been used more in order to break with pure modernism's homogeny and less as an attempt to apprehend the regional culture as the later movement of critical regionalism did. If his first period the regional influences where placed under consideration, questioning and dismissal, in his third period they are summoned to enrich the expressionistic characteristics of his projects through the hand-mafe, the textures, the colours etc.

In contrary to his 1920 machine aesthetic, by the end of his life he had adopted practically the opposite approach: a steady, organic, artisanal approach to building, and a healthy respect for history and tradition. Of all his late stylistic experiments notwithstanding, there is no "Modern Architecture" to which he was faithful-only the basic principle of being critical and creative. It is a matter of contention, whether Le Corbusier's emotional defense of architecture' s status as an art was the weakness or the strength of his theoretical system. It was a system that entangled him in contradictions in its attempts to find architectural and technical solutions to the problems of industrialization, aesthetics and mass-culture. These contradictions are bound to be expressed in terms of style, being modern, brutalist or post-modern, they are the architectonic metaphors of industrial reality.

\section{Part 2. Style in Le Corbusier's Life}

Although Le Corbusier's architectural styles shifted, mutated and unfolded in every direction, the expression "in Corbusian style" is only comparable to "Paladian style", as the only architectural styles to be attributed to one sole creator. This is only representative of Le Corbusier's influence not only through his actual work but through his presence as an artistic persona and the man that personified $20^{\text {th }}$ century architectural anxieties.

It is known that Le Corbusier went through great pains in order to structure his profile but the question of what constitutes the brand "Le Corbusier", has come to pass in the realm of mythology even for the 21 'st century, where Le Corbusier's mystical figure continues to dazzle us. And this was part of the plan, for although Le Corbusier was determined to be well known, he was also determined not to be known well. He never added an autobiographical memoir to his extensive writings, and he disclosed so few personal details that he seemed to have no private life at all. However, one thing everyone knew about him was his relentless Protestant work ethic, befitting the son of a Calvinist watchmaker ${ }^{\mathbf{1 4}}$.

Le Corbusier was documented to be shy, but nonetheless a cunning self-promoter imposing himself as a trademark from as early as 1917, when he started living in Paris and entered Perret's "Thursday luncheon meetings of artists" and Max Dubois's "Sunday outings" "15. His public image was his biggest achievement: the

\footnotetext{
${ }^{14}$ Filler, Martin Moos, Makers of Modern Architecture, New York Review of Books, New York: 2007.

${ }^{15}$ Lawman, Joyce, Le Corbusier 1900-1925: The Years of Transition, Ph.D. submitted at the University College of London, 1981, pp 229.
} 
Le Corbusier project that was incomparably designed and executed. A short description of his professional titles and endeavors does shed a light on his ascension to his hard earned status.

LE CORBUSIER /CHARLES EDOUARD JEANNERET $1887-1965$
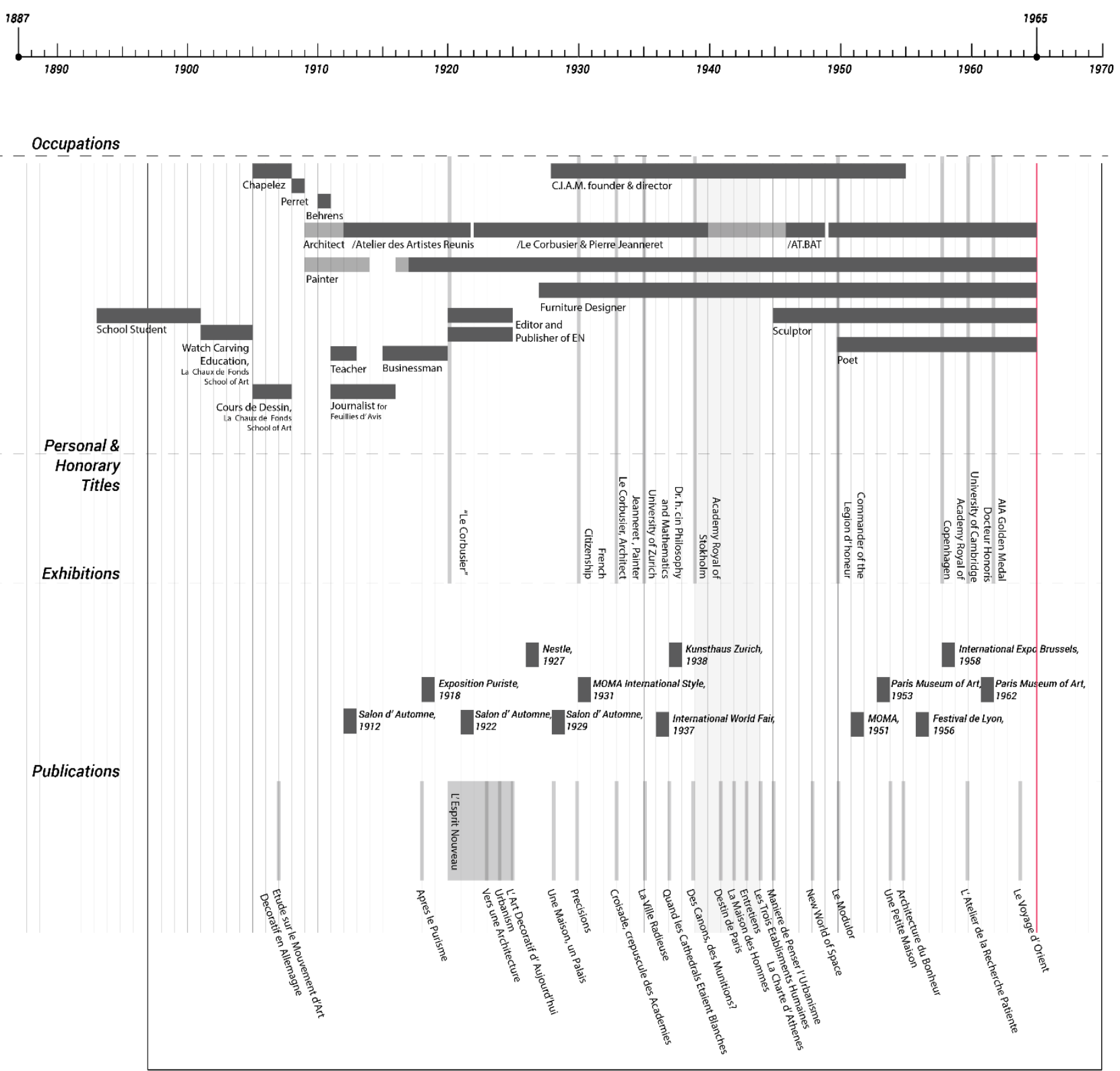

3. Classification of Le Corbusier's titles of occupation or of honorary achievements in parallel with his major publications and exhibitions.

His early years at La Chaux-de-Fonds and Paris seem quite extraordinary considering the change of his occupations. At first destined to become a watch carver, young Jeanneret was closely mentored by a couple of important artists through his passing from interior design, architecture, painting, teaching, journalism, entrepreneurship and then back to architecture again. His hiding his descent and later portrayal of himself as selfinstructed and exquisitely talented sheds the fact that by the time he was almost thirty, he himself did not had a clear image of what he wanted to present himself as. Most compelling was his dilemma between architecture and 
painting. And it was probably this dualism that led to his adoption of the pseudonym, "Le Corbusier", in 1920 and the distinguishing of the uses of his name according to his featured profession by 1930: Jeanneret for painting and Le Corbusier for architecture.

His swift rising among the artistic and architectural circles of Paris proves his intelligent dealing and expanding his contacts as well as a high production of work being architecture, urban design, writing or painting. It is also clear that he claimed ideas produced by others as his own but we have no image as to what extent he acted deliberately this way. Several people have posthumously expressed their resent over Le Corbusier's neglect of honoring them. They did however administered several aspects of Le Corbusier's versatile identity. Max Du Bois and Auguste Perret introduced him to concrete technology, Ozenfant brought out the painter in him, Perriand the furniture designer, Savina the sculptor while lastly, Pierre Jeanneret's mysterious figure conceals us the extent to which he fueled the architectural vigor of his cousin ${ }^{16}$. During the years 1949-1965 at Le Corbusier's atelier at rue des Sevres, a large team of young and talented people assembled beside him providing him with formal as well as conceptual contributions over his projects. The designs of Ronchamp (Maisonnier), la Tourette (Xenakis), the Carpenter Center (J. de la Fuente) or the Venice Hospital project (Julian) bear witness to the importance of his disciples and collaborators. Nonetheless, the image of the black clothed crow-like figure, with the owl-like glass and the beret or pipe occasionally placed him at the center of attention.

Le Corbusier's keen eye for acquaintances as well as his international appeal that led to the grand scale of his post-war commissions reveal Le Corbusier's keen eye for political acquaintances. It is an achievement how he managed to have commissions for the League of Nations, Soviet Russia, Vargas' dictatorial Brazil, the UN in New York, and in the midst of the cold war constructing Punjab's capital in India. It also of great wonder how he managed to hide his affiliations with the Vichy government that became known only recently. Le Corbusier's style seems to be more disciplined in matters of his seducing his clientele and befitting of his following. What is nowadays being studied under the label of personal brand or brand-image and is often misused instead of the term "style"-for they are both about specialization-was spearheaded by Le Corbusier. And it was his personal relationships that kept his office running and alternate forms and construction methods with patient clients who could overlook the impracticalities of Le Corbuisier's capricious designs and temperament.

Despite his careful positioning, one think that served foremost his self-projection and that we can apprehend as largely internal and personal was his ceaseless production of writings. Whether books, pamphlets, journals, articles or his extensive mailing correspondences, writing was for Le Corbusier the main instrument of identification. It is the link that connects his diverse forms of his architectural projects under the roof of -isms: "modernism", "purism', “functionalism" or "brutalism". The spirited literature is the context upon his styles were grouped keeping his audience hooked on each of his ventures and still considering them part of a compact rationale. Largely inspired by Ruskin, Le Corbusier considered the architect foremost, an intellectual, an artisthero with deep knowledge of philosophy and literature. It is a fact that Le Corbusier's identity card stated himself as an "homme des lettres". With no more than 57 actually executed projects, the more than 50 books he produced were his most immediate way of achieving a status of a prudent, well-advised and innovative architect. His book The Athens Charter is an exemplary occasion when he capitalized on the momentum of the CIAM when acting alone he published the material that was produced by the organization as a whole. In his early years, books were also his way of leaving his provincial hometown, being funded to travel in order to write reports (trip to Germany) or contributing to journals (voyage d' orient), while later as an editor and publisher, through the

\footnotetext{
${ }^{16}$ Le Corbusier et son atelier, rue de Sevres 35, Oeuvres Completes vol. 7: 1957-1965, Zurich: Les Editions d' Architecture, 1977.
} 
publication of L'Esprit Nouveau Le Corbusier's was able to criticize, promote and censor others and more effectively his own profile. Presenting himself as the prophet of the modern movement.

Le Corbusier's Euvre Complètes displays a stunning work done in post-production. It also features extensive photographical documentations of himself in social meetings, such as his encounter with Einstein. Photography, being precise, calculated, rational and expressive was from the start the ideal collaborator for an architect vacillating between an engineer and an artist, adopting "seeing" as his central narrative. Though he abandoned the perspective of being a professional photographer himself, during his lifetime Le Corbusier hired his personal photographers placing often himself as the object to be photographed. To name just a few of them, Le Corbusier's most famous photographers were: Gravot, Burri, Boissonas, Steiner and Herve with whom he either extolled or denounced for the way they portrayed him or his work, while he demanded personal control of the photographer's material.

Finally, Le Corbusier's orchestral manipulation of his all-embracing identity was assisted by his manifold artistic interests and mainly his easiness with painting. In the 1920's there was a strong dependence of much early modern architecture on painting. Cubism, Constructivism, De Stijl and Purism were all instrumental in the creation of the various ${ }^{17}$ currents of modern architecture. His experience in structuring with Ozenfant the painting style of purism, through exhibitions, publications and public relations, definitely predisposed him for his leading the waves of the modern movement. And while his 1920's and 1930's years where marked by his dramatic separation of architecture and painting occupancies, his post-war period revealed his dexterity in orchestrating his multi-faceted talents in complete works of art (gesamtkunstwerk), therefore expanding swiftly his stylistic vocabulary. After the 1940's whence the opposition of architecture to be unified with the visual arts had started to shift, architects turned to painters and artist for collaboration. But Le Corbusier needed not such a thing. He supplied his buildings with murals, decorations, sculptures, furnishings and interior designs, even composing the "modulor" and the "claviers des couleurs" as his stylistic guides. In contrary to his earlier manifestos, this attitude reveals a much more form-oriented effort. In combination with his work experience this all-inclusive artist was led to his most personal undertakings in Ronchamp and Chandigarh. Perhaps one of the reasons that Le Corbusier is not as publicly recognizable nor has he ever been comprehensibly classified as he should be: he simply did too much. Rather than sticking to a single, easily identifiable style, his work continually evolved $^{18}$.

\section{Conclusion}

Mainly, Le Corbusier used the word "fait" (effect, event) instead of the word "style", such as in his expression "le fait brutal". And most famously he attacked the notion of style in his frontispiece of the chapter "Eyes that do not see", from his Vers Une Architecture (1923): “Architecture is stifled by custom. The styles are a lie. Style is a unity of principle animating all the work of an epoch, the result of a state of mind which has its own special character. Our own epoch is determining, day by day its own style. Our eyes, unhappily, are unable yet to discern it."

Le Corbusier did not consciously set off to structure a style. He did however pioneer several ones. What he was determined to do from the start was to establish a doctrine that would affect all of modern life. By 1910 in a letter to his friend and mentor W. Ritter, he writes: "General culture today, when no single style reigns, seems to

\footnotetext{
17 “The Paintings and Sculptures of Le Corbusier”, Guedes A.. In Architecture SA / Argitektuur SA Johannesburg: JannuaryFebruary 1988.

${ }^{18}$ Rose, Steve, The many Contradictions of Le Corbusier, theguardian.com, 2008.
} 
me to be the basis for everything". Therefore, it was the absence of a style that was motivating him. Even though he represented modern era's disapproval of the $19^{\text {th }}$ century styles, the question "in what style he should built" was laid before him: a modern style could emerge, he wrote, but not from copying styles of the past, although at the same time being aware that he himself was at a loss to produce such a style $(1914)^{19}$. Would not he be surprised that fifty years later, neither we can grasp the full meaning his "Corbusian style"? For we are still under its spell. In our affluence of styles, one think we know for sure is that they are "Corbusian" ${ }^{20}$ children.

${ }^{19}$ Le Renouveau dans l'Architecture, Jeanneret, Charles-Edouard. In L'Oeuvre, vol 2, La Chaux-de-Fonds : 1914.

${ }^{20}$ Habraken, John, Palladio's Children, London:Taylor \& Francis, 2005. 


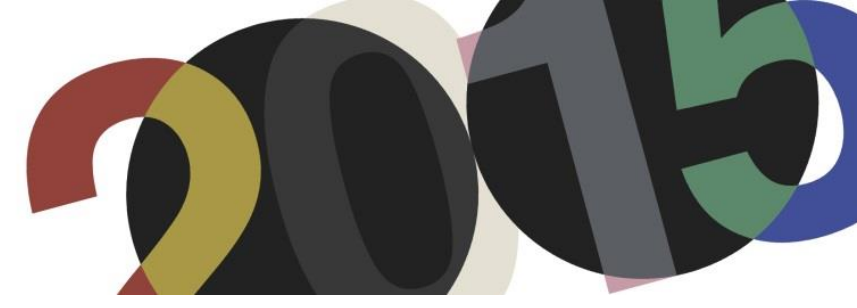

DOI: http://dx.doi.org/10.4995/LC2015.2015.895

\title{
THE INEVITABLE ORDER: Revisiting the Calibrated Biomimetics of Le Corbusier's Modulor
}

\author{
R. Itham Mahajan \\ Senior Architect, M/s. VBT Consortium, Bengaluru, India
}

\begin{abstract}
Biomimetics is a philosophy in Architecture that addresses issues not through mimicry but by understanding the rules governing natural forms. Biomimetics has gained popularity in the past few decades but it would be more apposite to state that this philosophy may have had its origins many years previously in the conceptualization of the Modulor, as Le Corbusier strived to unite Mathematics, Physiology \& Design. Common knowledge shows that disturbed by application of generic Imperial and Standard systems of measurements, the Modulor was ideated to help perceive the built environment as a physical extension of the human body. Le Corbusier's attempt to develop a harmonious scale towards the measurement of the absolute has been criticized for adopting industrial efficiency; though alienating human emotion was farthest from Corbusier's thought. What then is the architectural paradox in comprehending The Modulor as the universal proportioning system- racial differences in anthropometry, mechanizing architectural built forms within and without or simply an apprehension of losing mannerisms in architecture? Trying to unravel the mysteries of nature through analytics of the numbering system, Corbusier was consumed by the all-pervasive need to find answers to eternal questions in scientific spirituality. This paper explores the inevitable order of Le Corbusier's universe, revisiting the conceptualization of the Modulor, its relevance to architectural philosophies in general and Biomimetics in particular and the universal application of the same as a governing factor in Design methodologies.
\end{abstract}

Keywords: Le Corbusier, Biomimetic, Modulor, Universal Application, Design.

\section{Introduction}

Architectural design process necessitates the unified perception of synthesis, interpretation and analysis. Perennial debates revolve around the justification of theoretical exploration regulating creative processes. Departing from classical codes and established styles at the turn of the century, Design thought in general and Architectural contemplation in particular has been at the crossroads, attempting to arbitrate between pragmatic logic and transcendental deliberation. Design philosophers and visionaries passionately pursued this line of research, investigating assessment criteria for appreciating the intellectual aesthetic of human environments. One such Architect and Design philosopher set out to explore and expound the syntax of the architecture of the new era. Not convinced enough to affirm by the appropriateness of the Imperial and Metric system, this architect embarked on the quest for the eternal solution to decode the nature of spaces that influence physical comfort and sensory delight. He dedicated a life time in the pursuit of that universal key that integrates Human anthropometry and numbers applicable to generation of Biomimetic spaces, which relate at physical and metaphysical levels. Thus was born, Le Corbusier's Harmonious Scale of Measure, the MODULOR, to guide anthropocentric architectural thought, the world over. This radical proposal as regards Theory of Architectural proportions relevant to human habitation, credited to Le Corbusier may be considered the early years of inception of Biomimetic Architecture. 


\section{Inspiration}

The preoccupation of Le Corbusier with proportions could be traced back to his journeys throughout Europe during the formative years of his architectural training and his detailed study of ancient buildings. Leonardo da Vinci's depiction of the "Vitruvian Man" and Alberti's understanding of harmonic proportions were perhaps early inspirations, but gradually Le Corbusier's enthusiasm for ergonomics pertinent to spatial requirements for functionality culminated in a proportioning system that he called "the Modulor". During the early stages of conception of the Modulor, Le Corbusier favoured measurements, analogical to the Harmonic scales in his familiar field of music.

One of the pivotal chapters of Vers une architecture also dealt with 'regulating lines', a proportional grid used in designing buildings. This point was further illustrated with an elevation of Villa Schwob superimposed with a proportional grid.

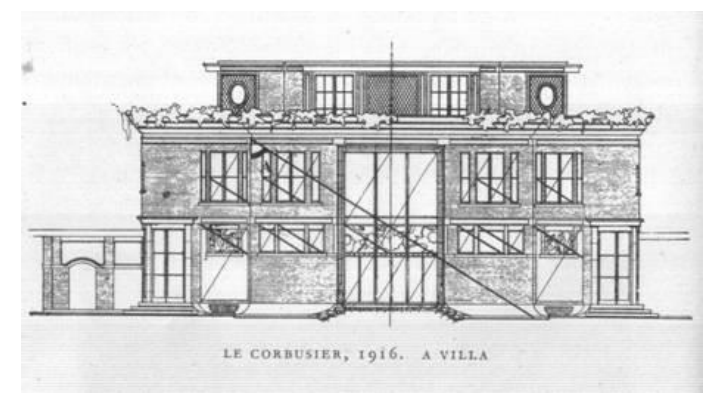

1. Le Corbusier, 'Regulating Lines', in Vers une architecture, 1924

The study of application of Regulating Lines in design and layout in the works of the Renaissance masters had no doubt inspired Corbusier also to develop similar principles. These may have set the preliminary stage for developing a harmonious proportional grid, having been inspired by Rudolf Wittkower's research into proportional systems in Renaissance architecture ${ }^{2}$, who himself was deeply affected by Panofsky's 1921 seminal essay on the 'History of the Theory of Human Proportions' ${ }^{3}$. Starting with geometric principles, universal to all fields of science and art, where relevant, Le Corbusier's inclination seems to have steered to the formulation of a specific code.

\section{Conception of the Modulor}

Many factors have influenced the conceptual evolution of the MODULOR. Modulor emerged as a reflective process through the confluence of the Golden Rectangle, Human anatomy and Mathematics. Corbusier's study of Ancient civilizations led him to believe that Architectural monuments belonging to bygone years also employed the mathematics of the Human body for design. He felt these buildings owed their grace to dimensioning system which employs the elbow (cubit), the finger (digit), the thumb (an inch), foot, pace and so on for measurement.

\footnotetext{
${ }^{1}$ Le Corbusier discusses how a villa of small dimensions designed with Regulating Lines gives the effect of being monumental amidst bigger buildings built without rule.

${ }^{2}$ Rudolph Wittkower's Architectural Principles in the Age of Humanism discusses proportions of The Palladian Villa.

${ }^{3}$ Franceso Benelli elaborates on Matter of Proportion.
} 

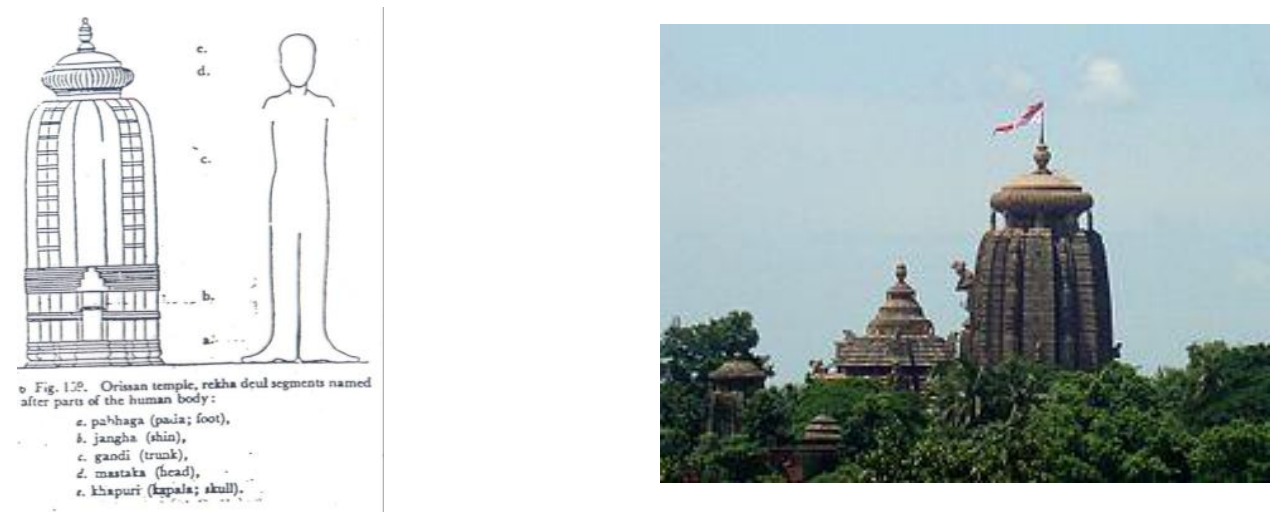

2. Parts of the human body in relation to Indian Temple Architecture ${ }^{4}$ (Source: https://en.wikipedia.org/wiki/Lingaraja_Temple)

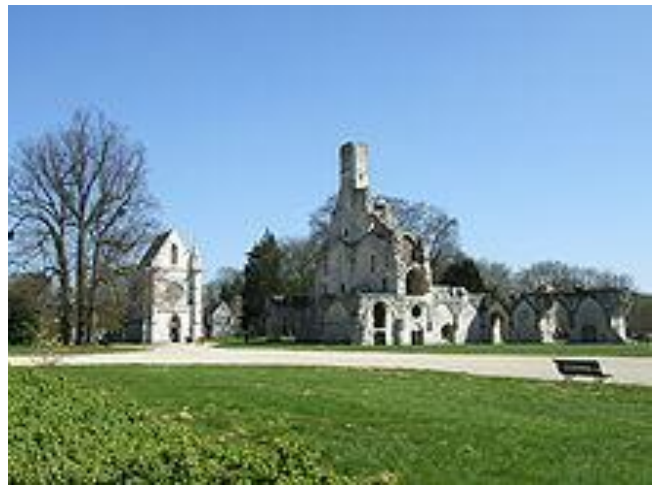

3. Moduloric proportions in The Abbaye de Chalis (Source: https://en.wikipedia.org/wiki/Chaalis_Abbey)

Detailed study of Egyptian, Greek and Indian Architecture showing specific relation to the human body and Corbusier's own on site experiments with The Abbaye de Chalis in the summer of 1948, whose measurements correspond to human proportions further encouraged him to work on a system of proportion based on Human Anatomy.

\subsection{INSPIRATION FROM THE DIVINE PROPORTION}

Le Corbusier was passionate about configuring a system of proportional measurement that would correspond to the subconscious requirements of the human body while incorporating the inherent aesthetics of the Golden Section. Universal standards corresponding to the integration of the human height based on divine proportion could form an ideal system of measurement. Spaces designed on this basis would be, he reasoned more functional and designers would be unable to produce impractical forms. Einstein himself has known to famously summarise the intent as being to create a "scale of proportions which makes the bad difficult and the good easy"

Though initially sceptical about the application of the Golden ratio to art, Corbusier's views did change dramatically following the publication of Matila Ghyka's influential book "Aesthetics of Proportions in Nature and in the Arts".

\footnotetext{
${ }^{4}$ Percy Brown's Indian Architecture (Buddhist and Hindu Period) discusses Temple Architecture in detail.

${ }^{5}$ Albert Einstein quoted in Modulor: 58
} 

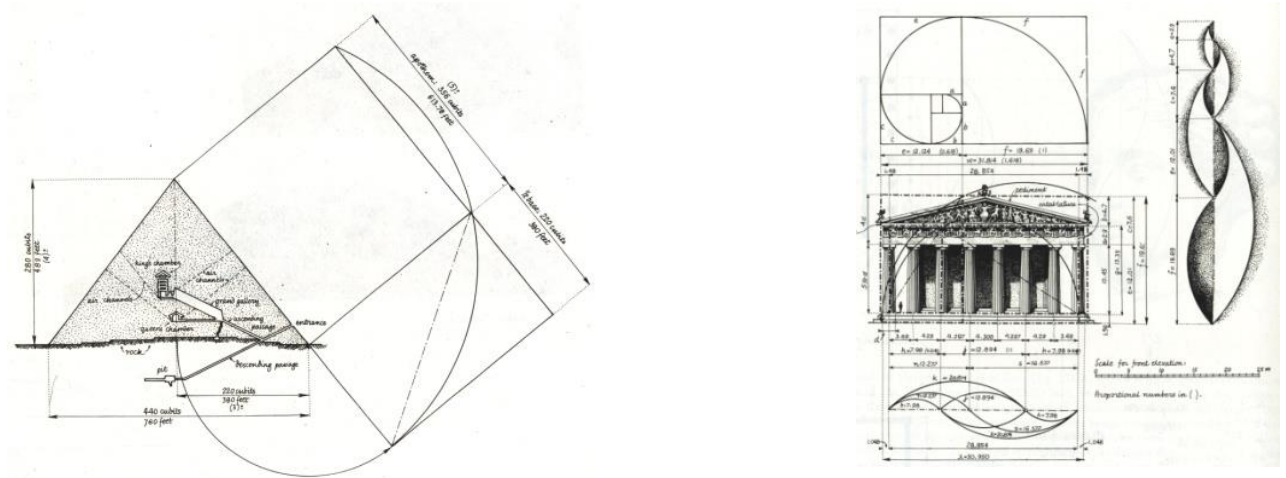

4. The Golden proportions in the Great Pyramid and the Parthenon ${ }^{6}$

Le Corbusier's absorption with the appreciation of aesthetics associated with the Golden Ratio could be linked collectively to his interest in phenomenology of basic forms and structures and his lineage that encouraged musical education, justifying his craving for a harmony achieved through numerical patterns. He is known to have felt that mathematics is the essence of his work due to his passion for architecture and music combined.

H.E. Huntley, author of the The Divine Proportion, explains that "the reason that we prefer visual aspects of a Golden Rectangle over a perfect square is measured in the amount of time it takes for the human eye to travel within its borders. This period of time is in same proportion (Phi) to the beats that exist in specific musical intervals. "7

\subsection{Pertinence to Human Anatomy}

The Modulor is a univocal attempt to overlay the proportions of the human body with geometry, similar to earlier attempts by Vitruvius. Comparable to the Vitruvian depiction of superimposed Euclidean geometry as an allegorical connection between humanity and architecture, Corbusier's Modulor also uses a Euclidean geometric overlay on the body for similar purposes. After much experimentation and through a process of selective elimination of the shorter French male and the curvaceous Female body, Le Corbusier settled on a six-foot-tall $(1.828 \mathrm{~m})$ English male body with one arm upraised. This was also adapted to ensure practical relevance to the feet and inches system of measurement ${ }^{8}$.

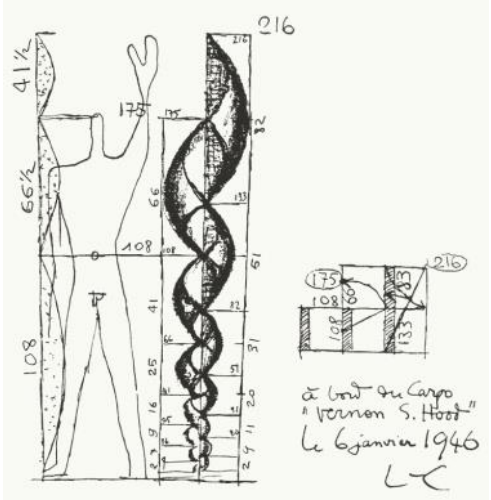

5. Corbusier's sketch of the Modulor integrating human anatomy with the Golden proportions.

\footnotetext{
${ }^{6}$ Gyorgy Doczi discusses Proportional Harmonies in Nature, Art and Architecture in The Power of Limits.

${ }^{7}$ H.E. Huntley elaborates on the aesthetics of Simple Mathematics.

${ }^{8}$ The Modulor strip as interpreted in The Modulor: 50
} 


\subsection{Integration of Mathematics}

The initial inspiration for the Modulor came from a vision of a hypothetical man inscribed with three overlapping but contiguous squares. In response to Corbusier's conundrum of 'this hypothetical man-with-armupraised, $2.20 \mathrm{~m}$. in height; put him inside two squares 1.10 by $1.10 \mathrm{~m}$. each, superimposed on each other; put a third square astride these first two squares', his assistant Hanning was to discern 'The place of the right angle'9.

To solve Le Corbusier's puzzle, Hanning started with the central square and then generated a golden section arc from a diagonal of half the square in one direction and another arc from the diagonal of the full square in the opposite direction. These arcs then generate two new contiguous squares which are also defined by a rightangled triangle with its right angle passing through the common boundary between the two newly-formed squares. Mlle Elisa Maillard's alternative solution for Le Corbusier's problem initially produces a golden section from the starting square to generate the second square and then uses the diagonal of the newly-produced golden rectangle to form one edge of the right angle triangle. The remainder of the triangle generates the second square. Le Corbusier rapidly simplified Maillard's geometric solution to the three square problem and placed the human figure at its centre. He then used the vertical dimensions of these three squares which overlap to form golden rectangles, to produce measures that integrate human proportions and the Golden Section.
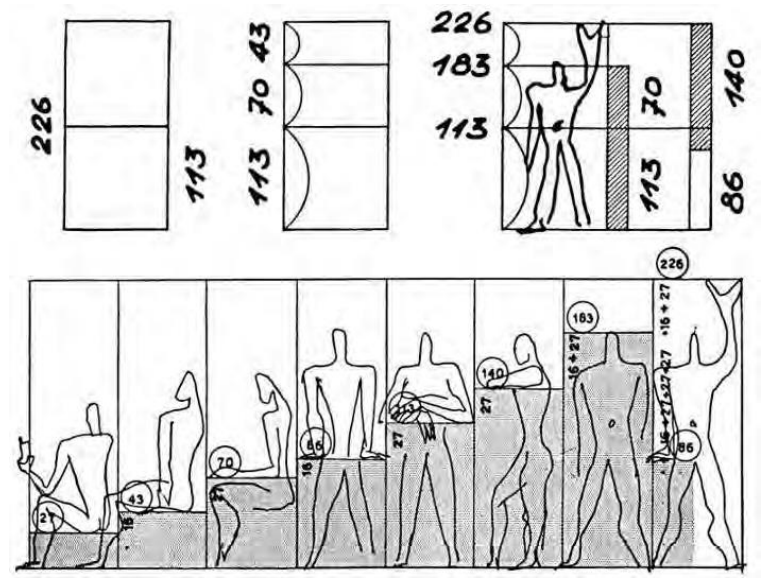

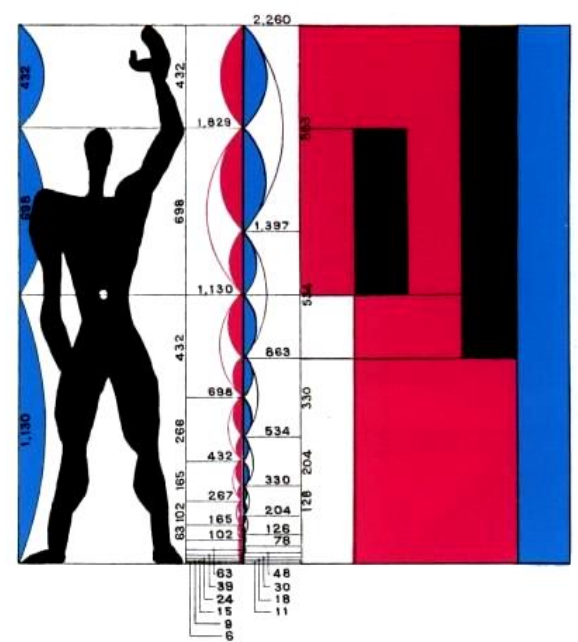

6. Corbusier's sketch showing basic Modulor dimensions and the Red and Blue series. (Source: The Modulor)

To accommodate varied dimensions and add versatility to the Modulor, Le Corbusier introduced the red series based on the unit 108, and the blue series based on the double unit 216. The Modulor strip now included the graphic of a man of height $1.75 \mathrm{~m}$ with arm outstretched engaged at four points, $0,108,175$ and 216 , the red series on the left and the blue strip on the right, the series going progressively from zero to infinity.

\section{Biomimetics and the Modulor}

Biomimetics as a philosophy in Architecture proposes to resolve issues and enhance performance in built spaces through an intensive research in Living systems. Corbusier could easily be credited with the Architectural application of functioning of one such living system - The Human Body. Corbusier's study was inclusive of not only ergonomic comfort as a design solution, but tended to transcend physical boundaries to relate to sensory perception and the Metaphysical.

\footnotetext{
${ }^{9}$ The Modulor : 37
} 


\subsection{The Modulor and Ergonomic Comfort}

Le Corbusier worked towards application of the Modulor in the volumetric spatial unit in the Unite d' Habitation in plan, interiors and facade detail. Le Corbusier considered the Pavillon de l'Esprit Nouveau a "minimum living unit" in which he also designed some Prefabricated Sectional Furniture based on the Modulor. Similarly, the design for the Unité d'Habitation has been acknowledged for having created a living-cell for a family with several children that enjoyed the visual and spatial expanse of a double-height living room, despite severe economic restraints. It was an accomplishment in the up gradation of social housing in post war France.

\subsubsection{The Modulor in Spatial Function}

The Modulor conceived to be applicable to Built environments may have been substantiated by Corbusier's study of "Objects meant to contain men, made to the measure of men". His graphic dimensional research of Railway carriages and cargo boats apart from the study of the intimacy and comfort of les petits apartments seemed to further validate the proposed dimensions of the Modulor.
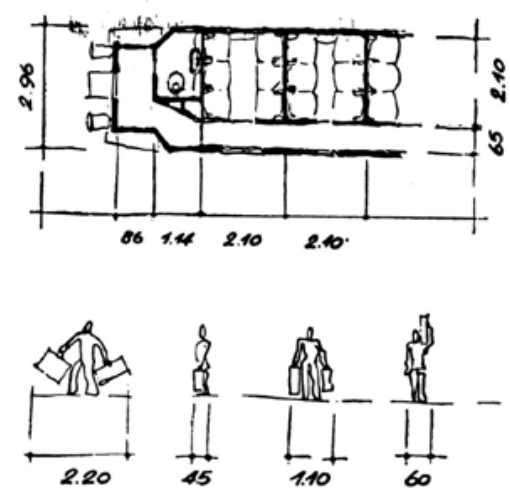

7. Corbusier's sketch of dimensional sketch of cargo boats and train carriage. (Source: The Modulor)

\subsubsection{The Modulor in Built Environment}

The façade of Unite d'Habitation is formed by a pattern of single and double height balconies generated from 15 different types of dimensions determined by the Modulor system. The rooms are $3.66 \mathrm{~m}$ wide and $2.26 \mathrm{~m}$ high or $4.84 \mathrm{~m}$ in double height. The framework is a module of $4.19 \mathrm{sqm}^{10}$.
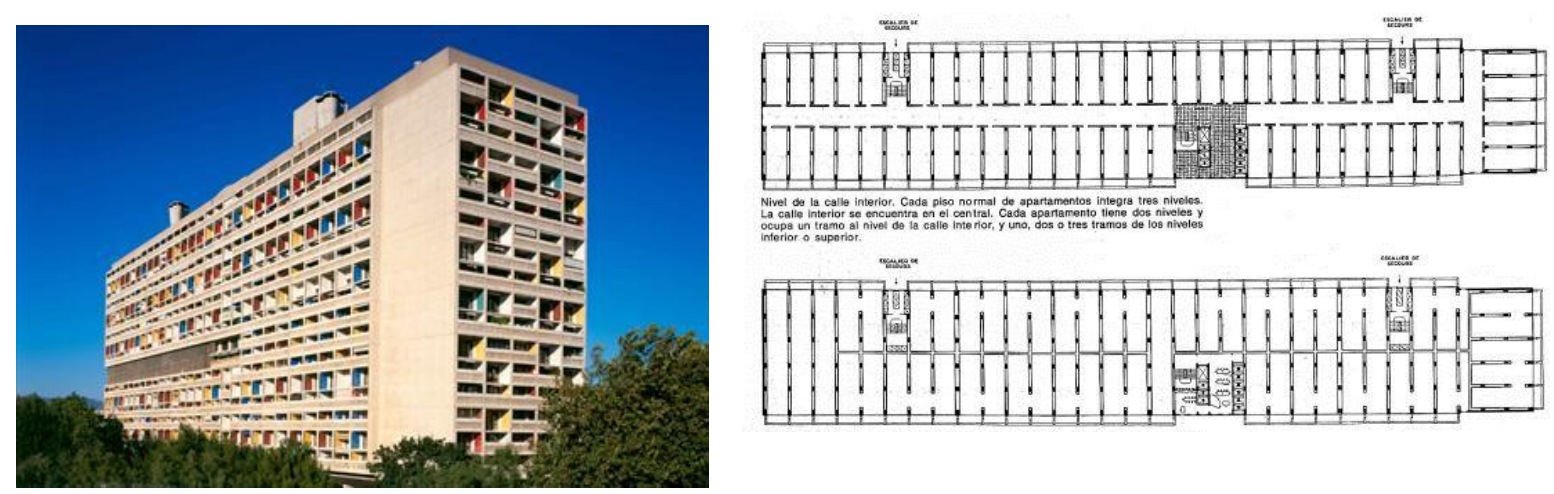

${ }^{10}$ Jean Jenger discusses Corbusier's work in the Architecture of a New Age :77 
8. The Modulor at Unite d'Habitation.

(Source: Unite d' Habitation, Marseille, Photo: Paul Kozlowski 1997- 1/1

(FLC-ADAGP)

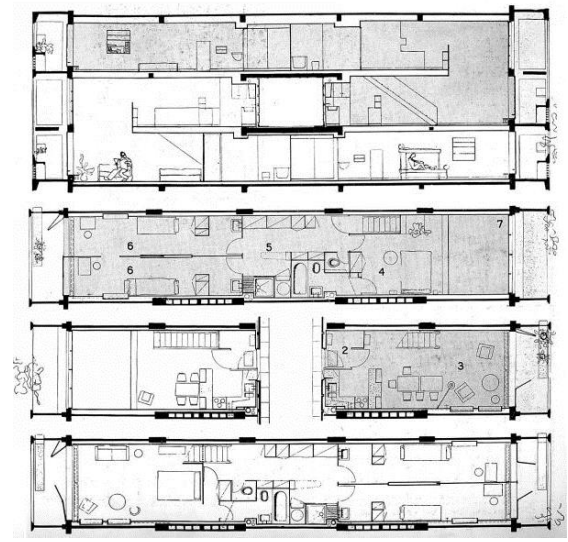

The design of the Jaoul houses built in Neuilly for two families with identical plans with all proportions based on Modulor was another experience to understand human centric dimensions to enhance order in Architectural design $^{11}$. Le Corbusier's cabin at Cap martin Square also incorporates a square plan of Modulor measurements 3.66 by 3.66 with a height of $2.66 \mathrm{~m}$.
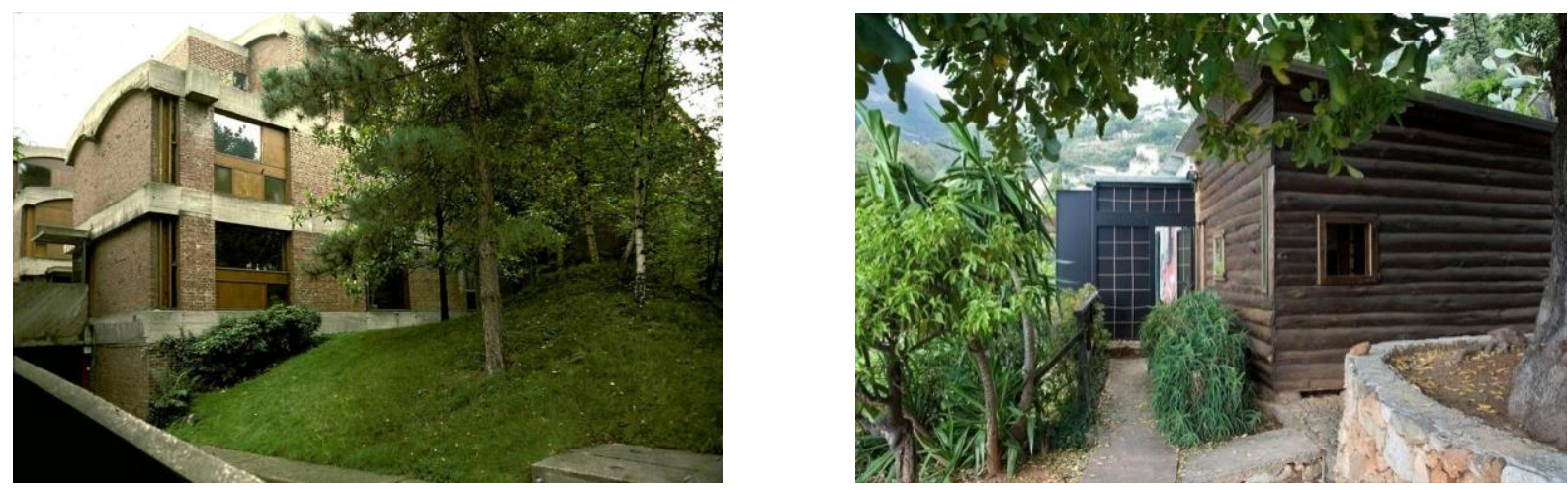

9. The Jaoul House (Source: Maisons Jaoul, Neuilly -sur- Seine 5/12 @FLC-ADAGP)and Le Corbusier's Cabin at Cap Martin square (Source: Cabanon de Le Corbusier, Roquebrune- Cap Martin, Olivier Martin - Gambier 2006 1/16 @FLCADAGP)

\subsubsection{The Modulor in Climate Control}

Le Corbusier's work in tropical climates helped ideate the invention of the brise-soleil . Clive Entwistle, the British architect, who translated several of Le Corbusier's books, wrote to him in August 1946: 'I take this opportunity on behalf of young people here to thank you for your latest gift to architecture: the brise-soleil, a splendid element, the key to infinite combinations. Now architecture is ready to take its place in life. You have given it a skeleton (independent structure), its vital organs (the communal services of a building), a fresh shining skin (the piloti). And now you have given it magnificent clothes, adaptable to all climates! You must be a little proud!' (Oeuvre Complete. Vol.IV. p113) ${ }^{12}$.

At the Secretariat, Chandigarh, Corbusier designed a linear layout to maximize natural lighting and crossventilation. In order to visually harmonise the scale, the immense façade of the Secretariat was designed using the Modulor to section it into visually decipherable elements through the brise-soleils to mitigate solar heat gain.

\footnotetext{
${ }^{11}$ Jean Jenger discusses Corbusier's work in the Architecture of a New Age :86

12 Christopher Mackenzie questioned the Corbusier's assumptions on a visit to India under Le Corbusier in the Sun in Architectural Review Archives.
} 


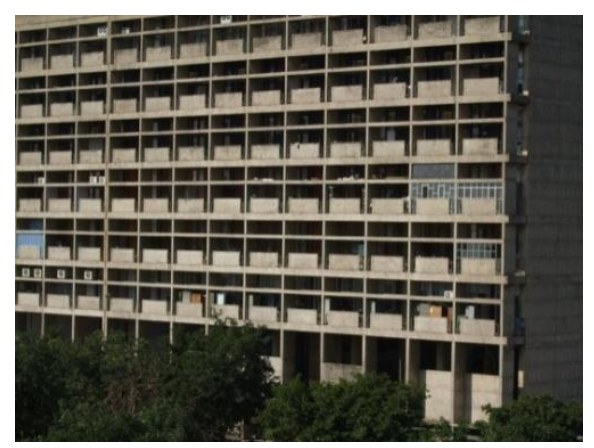

10. The Brise Soleil in The Secretariat, Chandigarh.

\subsubsection{The Modulor and Furniture Design}
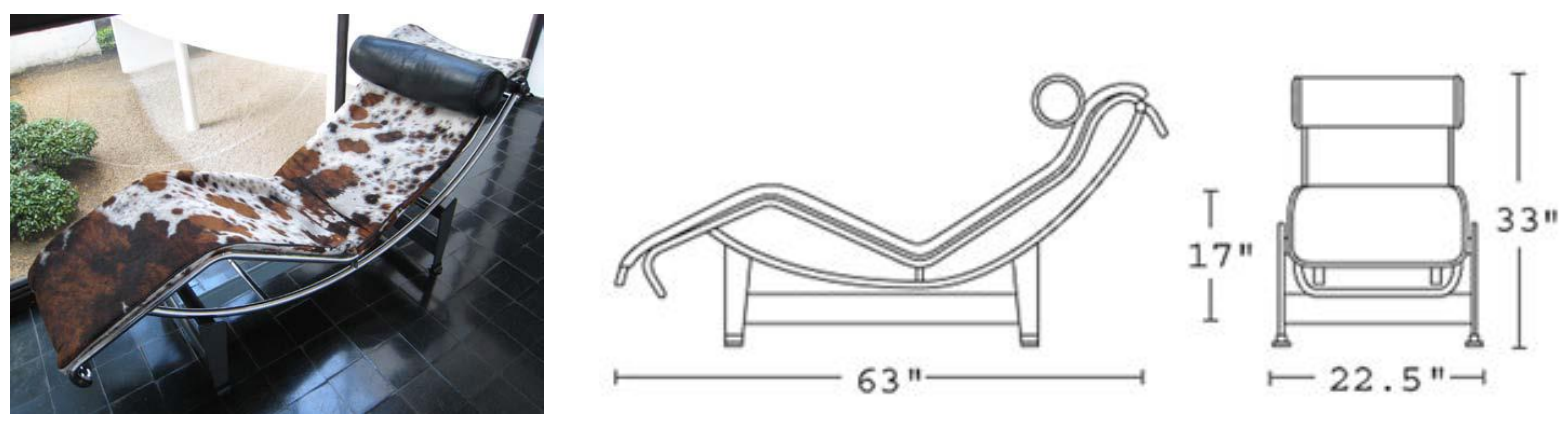

11. The Modulor finds Application in the Lounge Chair

The Modulor also finds application in furniture design. Le Corbusier Chaise Lounge Chair LC4 also corresponds to the spinal curve catering to ergonomic comfort. The height of the seating is $430 \mathrm{~mm}$, the dimension corresponding to the sitting posture of the Modulor man ${ }^{13}$.

\subsection{The Modulor and The Sensory}

Referring to the Modulor, Le Corbusier also propagates "the full-scale application of mathematics in building: three-dimensional urbanism (on the ground and in space)", adding that "measures enter into everything: pilotis, highways and roads, swimming pools, buildings, from top to bottom and in every object of the interior, car parks ..." ${ }^{14}$. The purpose of the Modulor was not limited to generation of anthropocentric dimensions for human habitation, but also needed to be inclusive of sensory perception related to psychological delight and comfort.

\subsubsection{The Modulor and Visual perception}

The visual perception of architectural form and appreciation of visual connect to the exterior surrounds must have been one of the foremost concerns in Corbusier's mind, so much so that an entire Section is dedicated to "The eyes that do not see" in his Towards a New Architecture.

\footnotetext{
${ }^{13}$ Tris Chris discusses the Modulor in a presentation on Proportion in Architecture, University of Hongkong.

14 The Modulor 1954: 168
} 


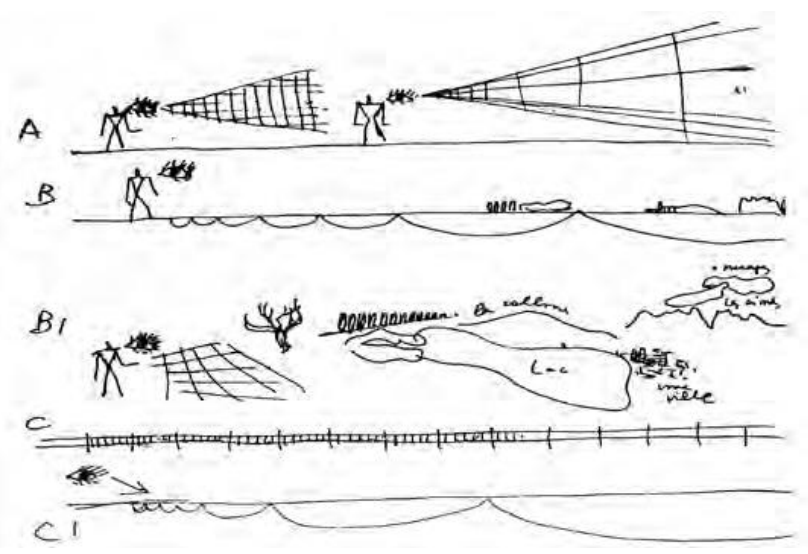

12. Visual Perception based on eye levels. (Source: The Modulor)

Fig.12 indicates the progression of harmonious scale $\mathrm{C} 1$ as against the simple arithmetic scale $\mathrm{C}$, which can be used to visualize the vista B1 inclusive of various elements of landscape, appropriate to cone of vision A1.

This is further collaborated by a letter from Le Lionnais, Mathematician ${ }^{15}$ who discusses the eye level of $1.6 \mathrm{~m}$ at which man 'establishes contact with the universe. His eyes look forward.....His life, then, is made up of a continuous sequence, succession, accumulation of visions'. M. Gabriel Dessus also writes: ' I believe as you do, that it is essential to have a scale.....This scale must be a geometrical series, because the eye appreciates relationships'.

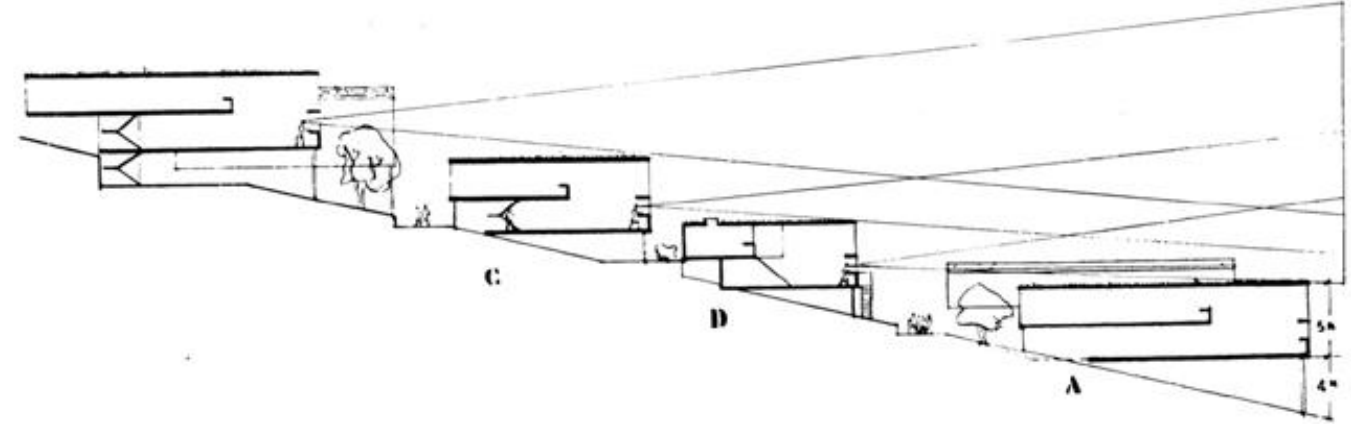

13. Roq et Rob at Cap Martin. Site section (Oeuvre complete, volume 5: 56).

\subsubsection{The Modulor and Psychological Comfort}

Le Corbusier also believed that the proportional system of the Modulor encourages psychological association owing to space related to the dimensional requirements for a said activity aligning physically with the human body. In support of this, Corbusier also claimed architecture "as a part of the mechanical system that surrounds us and functions as an extension of our limbs...its elements, in fact, artificial limbs".

\footnotetext{
${ }^{15}$ Modulor 2: 18
} 


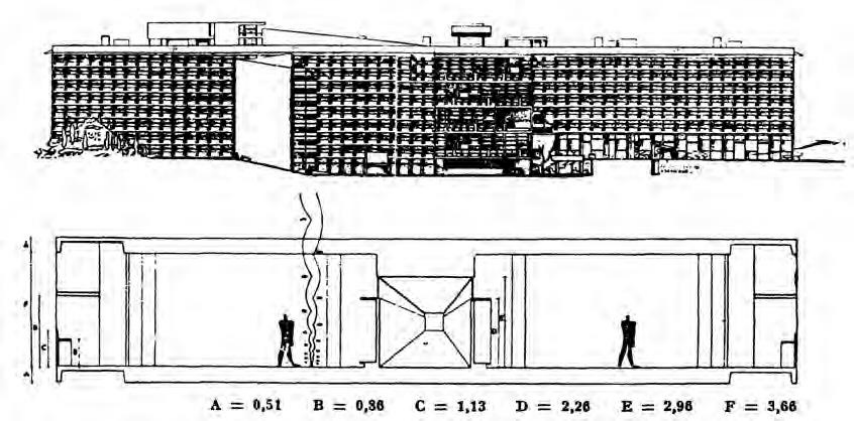

14. Spatial volumes configured to Moduloric Dimensions (Source: The Modulor)

The inner dimensions of the Secretariat at Chandigarh adopted Moduloric proportions to generate spatial volumes relating to the activity zone concomitant with human comfort.

Tapestries in the Court of Justice in Chandigarh are another example of visual relief through appreciation of certain proportions. These tapestry designs referred to the architectural plan with special emphasis on Le Corbusier's adulation of the right angle as fundamental element of order and the Modulor.

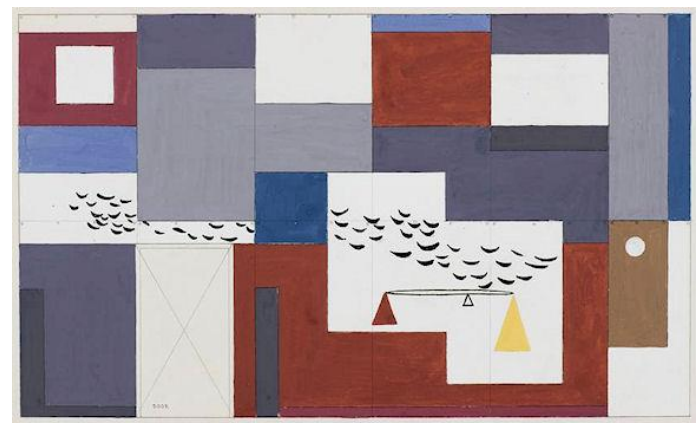

15. Tapestries in Court of Justice in Chandigarh based on Modulor proportions.

Though the tapestries were created for acoustical purposes, they would also serve as a psycho-physiological stimulant. Further, each of the tapestries was a structured composition of several rectangular units with a standard width of 4'-7", corresponding to that of the loom.

In one of his later projects, Le Corbusier's proposed design for a hospital in Venice in 1964 assigned to each patient, a 'unite lit', a spatial module of $3 \times 3 \mathrm{~m}$ with a glassed opening of $3 \times 1 \mathrm{~m}$, placed above a ceiling of $2.26 \mathrm{~m}$ height. The glass opening will project light on a curved wall $3.66 \mathrm{~m}$ high. The light thus projected and diffused into the spatial enclosure of Modulor proportions was meant to enhance the therapeutic environment.

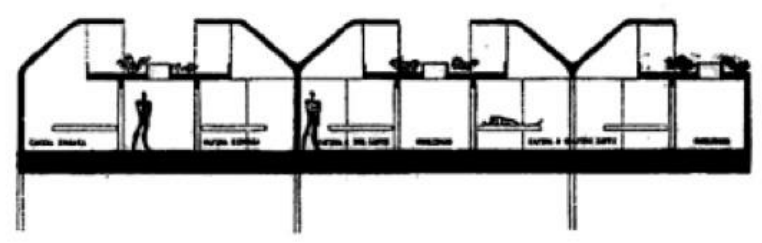

16. The Unite Lit in Venice Hospital

\subsection{The Modulor and The Metaphysical}

It is not difficult to comprehend that the Modulor was not meant to be just a scheme of numbers to apply or a set of rules to abide by. Corbusier wanted the Modulor to relate at sub conscious and super conscious levels. As the 
pages of the Modulor turn and the volume nears the end, the intellectual fervour which engulfed Le Corbusier to personify his design deliberations becomes relatable.

\subsubsection{The Modulor and Music}

Xenakis discusses the rhythmic articulation of the pans de verre ondulatories through modulor dimensions which was generated through a combinatorial number system used for syncopation of these elements similar to the system for orchestrating his composition "metastasis". This is also evident in the glissandi form in Philips pavillion, Brussels world fair $1958^{16}$.

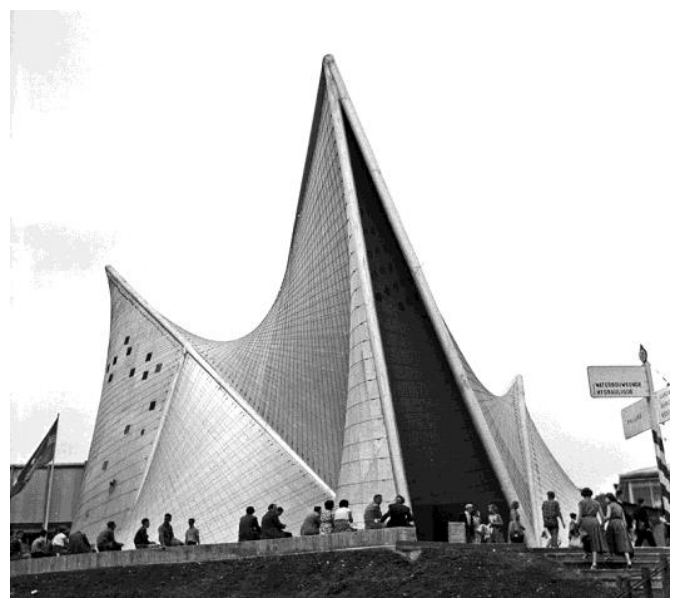

17. Glissandi form in Philips Pavilion, Brussels World fair (Source: "Expo58 building Philips" by Wouter Hagens - Own work. Licensed under CC BY-SA 3.0 via Commons -

https://commons.wikimedia.org/wiki/File:Expo58_building_Philips.jpg\#/media/File:Expo58_building_Philips.jpg)

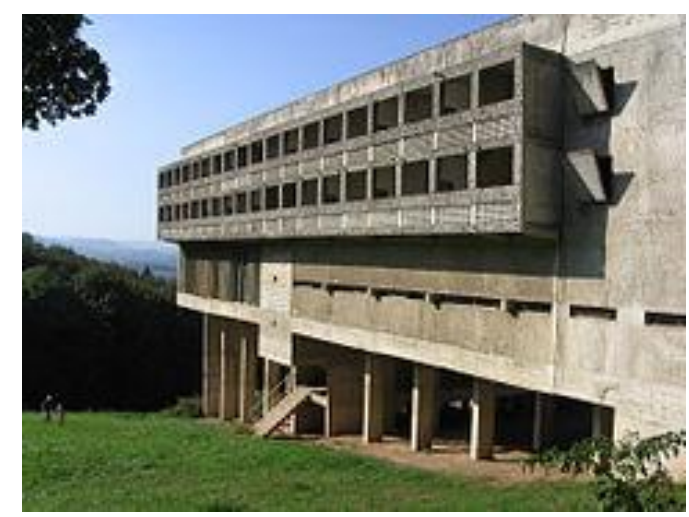

18. Pans de verre Ondulatories through Modulor dimensions (Source: "Sainte Marie de La Tourette 2007" by Alexandre Norman - French Wikipedia. Licensed under CC BY-SA 3.0 via Wikipedia -

https://en.wikipedia.org/wiki/File:Sainte_Marie_de_La_Tourette_2007.jpg\#/media/File:Sainte_Marie_de_La_Tourette_2007. jpg

\subsubsection{The Modulor and Esoteric}

Eminent architect \& critic Kenneth Frampton also discusses the similarity between the most important dichotomous figure in the alchemical cosmos, Mercury and the abstract scale of interlocking blue and red

\footnotetext{
${ }^{16}$ Kenneth Frampton elaborates on the application of the Modulor through Xenakis' works in Le Corbusier:181
} 
proportions of the Modulor. Similar references to the mythical ascension of pagan Mercury from earth to sky and descending again as part of the continuous cycle is also evident in Corbusier's moving account of cloud formations while flying over Pampas.

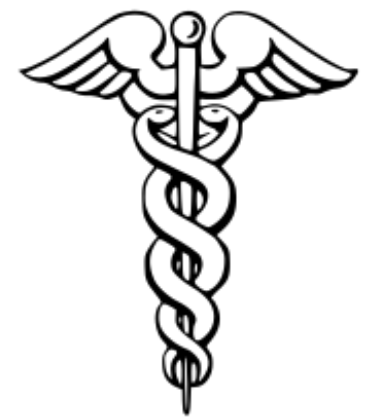

19. Mercury's Caduceus bears a strange resemblance to the Modulor strip (Source: https://en.wikipedia.org/wiki/Caduceus)

\subsubsection{The Modulor and Higher level of meaning}

The higher level of meaning associated with the Modulor further intensifies as we approach 'The Poem of the Right Angle'. The panel A3 depicting the upright Modulor as the procreator with reference to the earth and the cardinal symbols, the alchemical rota or wheel representing the 4 seasons.
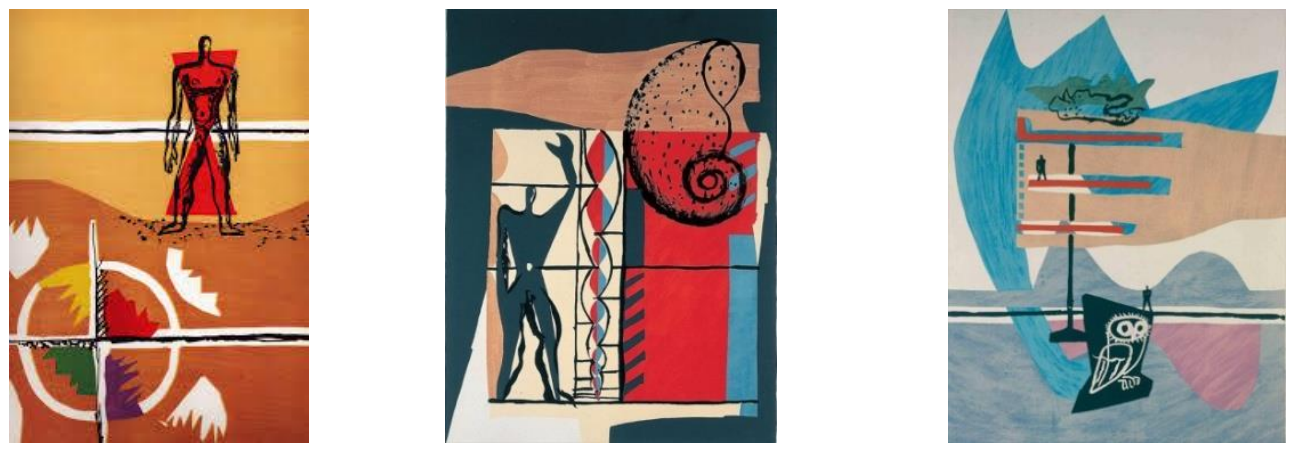

20. The Modulor in A3, B2 and B3 panels of The Poem of the Right Angle.

The Modulor further appears in panel B2 juxtaposed with a shell symbolic of golden proportions. In panel B3 in an architectural frame comprising of floor plates and foundation placed atop an irregular field surrounding the white line image of the wise owl, emerges a Modulor man cleared of obstacles.

The poem of the right angle is a window to the philosophical significance of the Modulor man in Corbusier's thought. The Modulor to Le Corbusier was not just a proportion. Famously referred to as his Alter Ego, Corbusier's Modulor seems to be an extension of his spiritual self.

\section{Possibilities and Limitations}

Panel exercises ${ }^{17}$ proving the versatility of the Modulor as a design tool have been chronicled. The sometimes overly perceived cubist application of the Modulor has also been addressed in the configuration of 'light-funnels' in the south wall of the Ronchamp, irregularly arranged but forming a unified composition by the 'Modulor' system as an expression of the human values depicted in the wall.

\footnotetext{
${ }^{17}$ Modulor 2: 92
} 
Corbusier says "It is a working tool for those who create and not for those who execute"18.

The Modulor has been criticized however for rendering very impractical values to smaller dimensions and not favouring ease of construction. This explains the selective use of this scale in architecture and its brief yet impactful brush with popularity.

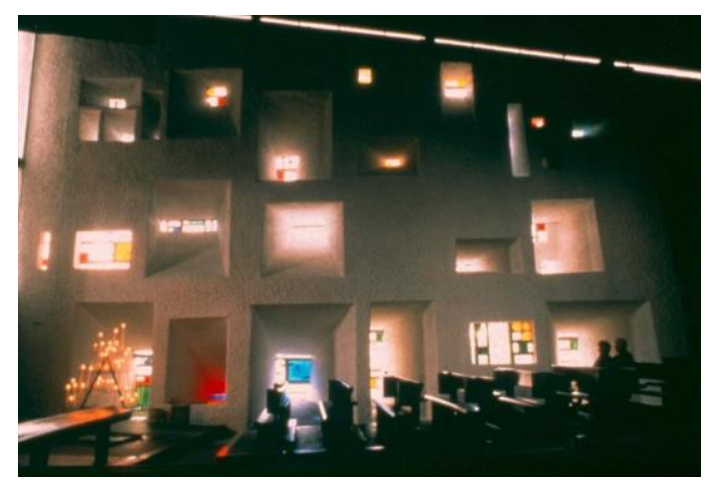

21. Light Funnels in Ronchamp (Source: Chapelle Notre Dame du Haut, Ronchamp, Photo: Paul Kozlowski 8/15 @FLCADAGP )

Corbusier does argue that all references at the Unite d' Habitation are based on just fifteen different measures based on the Modulor reducing complexity in dimension. Further, he adds that work inside the building can be completed without scaffolding even in the double height spaces with a maximum height of $4.85 \mathrm{~m}^{19}$. Corbusier's Cubist and Brutalist style of Architecture did find many protégés but however even his most ardent followers could not find full application of the Modulor in their works.

\section{Reflections}

As a parallel to publishing scientific findings, the following queries do arise in researched thought elaborating on the significance of the Modulor, the inspiration, the conceptualization and the application.

- What would be the impact or relevance of the adaptive or approximated Modulor in the current Market regulated Architectural scenario where urban real estate economics is governed by escalating unit rates and land prices? Can commerce driven Architectural practices with tight deadlines and stringent budgets accommodate the Modulor in their Design methodology or Construction practices? Every square inch needs to be accounted for in the built up areas as per regulatory bodies and priced for commercial gains.

- As a sensory perception of space, will using the Progressive scale of measure help produce a harmonious unified composition as opposed to the Linear scale which is manipulated as a number rather than a relationship, limited by the dimensions of the drawing interface? The metre or the Kilometre can both be represented by 1 Centimetre, it all depends on the size of the drawing sheet.

- Enfin, validated by various mathematical studies, lauded by philosophers and approved by commercially successful establishments, is it not surprising that the Modulor was not awarded the status of a unit by itself like the Kelvin or Ampere, honouring the inventor, instead of necessitating the reconversion to the metric or imperial system?

\footnotetext{
${ }^{18}$ Modulor 2: 178 ( In reply to John Dale)

${ }^{19}$ Modulor 2: 124
} 


\section{Conclusion}

Corbusier's faith in the mathematical order of the universe, his tryst with the divine proportion and his obsession with anthropocentric measurements did result in the harmonious scale of the Modulor. Its application has received bouquets and brickbats alike. But with an intent so pristine, a scientific approach so well researched, an intensity so fervent and a path breaking ideology so intellectual, it is not difficult to comprehend that Le Corbusier's innovation can elevate any design idea into a work of art. With the Modulor guiding the design process, it is impossible to not tune into the inevitable order of the universe with the human spirit at the epicentre. As Corbusier says "The Modulor is a tuned piano. Play it well"20.

\section{Bibliography/References}

Benelli, Francesco, Rudolf Wittkower versus Le Corbusier: A Matter of Proportion journal.eahn.org/articles/10.5334/ah.ck/2013

Brown, Percy, Indian Architecture (Buddhist and Hindu Period), 2nded, w/o.pl. : Tobey Press, 2013, ISBN 1446510212 (ISBN13: 9781446510216 )

Corbusier Le, Towards a New Architecture, New York: Dover Publications Inc, 1986, ISBN: 0486250237 (ISBN13: 9780486250236)

Corbusier Le, The Modulor, 2nded, Basel: Birkhauser GmbH, 2011, ISBN: 3764361883 (ISBN13: 9783764361884)

Corbusier Le, Modulor 2, 2nded, Basel: Birkhauser GmbH, 2011, ISBN: 3764361883 (ISBN13: 9783764361884)

Corbusier Le, Le Poeme de L'angle Droit, w/o.pl :Hatje Cantz Publishers, 2012, ISBN: 3775734708 (ISBN13: 9783775734707)

Chris Tris, Proportion in Architecture-University of Hongkong, Faculty of Architecture.

Doczi, Gyorgy, The Power of Limits: Proportional Harmonies in Nature, Art, and Architecture, w/o.pl. : Shambhala Publications, 2005. ISBN: 1590302591 (ISBN13: 9781590302590)

Frampton Kenneth, Le Corbusier: Architect of the Twentieth Century, New York: Thames \& Hudson, 2001, ISBN: 0500203415 (ISBN13: 9780500203415)

Jenger, Jean, Le Corbusier - Architecture of a new age (New Horizons), w/o.pl. : Thames \& Hudson, 1996, ISBN: 0500300674 (ISBN13: 9780500300671)

Joshi, Kiran Prof., Urban and architectural work of Le Corbusier in Chandigarh, Department of tourism, Chandigarh administration, Chandigarh, India, Oct 2006

Mackenzie Christopher, Le Corbusier in the Sun, Architectural Review Archives.

Payne, Alina A., Rudolf Wittkower and Architectural Principles in the Age of Modernism, Journal of the Society of Architectural Historians, Vol. 53, No. 3 (Sep., 1994), pp. 322-342: University of California Press on behalf of the Society of Architectural Historians.

${ }^{20}$ Modulor 2: 130 


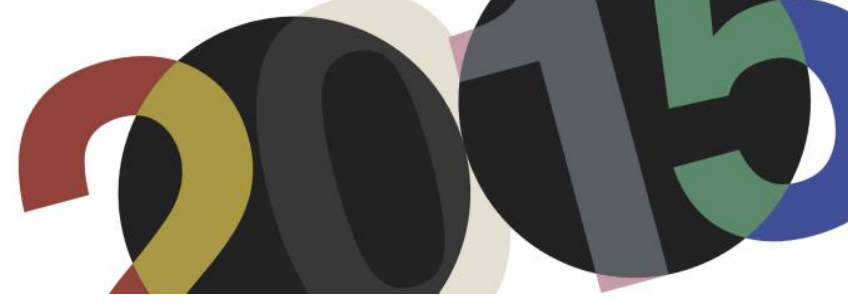

DOI: http://dx.doi.org/10.4995/LC2015.2015.647

\title{
On Diagonal Time in Le Corbusier's Visual Arts Center
}

\author{
M. Jasper \\ University of Canberra
}

\begin{abstract}
This paper introduces the concept of diagonal time as an interpretive category for understanding composition strategies and spatial effects in certain projects of Le Corbusier. It is organized around two propositions: first, there is a largely untheorised temporality created in certain works of modernist architecture and those of Le Corbusier in particular; second, this temporality can be characterized as one not bound to a vision in motion nor does it require a body's movement to gain presence. In order to test these propositions the paper undertakes a formal analysis of Le Corbusier's Visual Arts Center, Cambridge, Massachusetts (1960-1964). The Visual Arts Center's apparent reliance on movement for its coming into being is interrogated by focusing on other devices and strategies. Four such strategies are explored: oblique and transverse form relationships, expressive volumes, figure/ground ambiguities, and voided centres. Building on the archival and criticalhistorical work of Curtis and Sekler, the paper advances a line of inquiry into modernist architecture's trajectory only alluded to in secondary scholarship, contributes to understanding key formal elements in an important building from Le Corbusier's late period, and addresses a major conference theme, that of the transversal.
\end{abstract}

Keywords: architecture; composition; Le Corbusier; space; temporality; Visual Arts Center.

\section{Introduction}

“time ... increasingly appears for itself," Gilles Deleuze ${ }^{1}$

\subsection{Propositions}

In his 1965 essay on Le Corbusier's just opened Visual Arts Center, published as an homage following Le Corbusier's death in August of the same year, John Hejduk (1929-2000) conjectures that the building generates a cut in time. Different from a temporality conceived as linear and progressive, and as implied in the title of the essay, for Hejduk the building creates architectural conditions that are "out of time". This insistence on the building's capacity to engender a time out of joint, one liberated from movement and structure according to Hejduk, implies a specific kind of architectural temporality. It also highlights a too little explored aspect of modernist architecture more commonly discussed in terms of formal and spatial characteristics.

Taking Hejduk at his word, a number of general questions are raised. How are buildings and projects composed such that time is confronted? Is there a specifically modernist concept of time, a modernist mode for the creation and expression of time? Just as there are different space concepts, are there different architectural concepts of time and if so how do they work and what are their distinguishing characteristics?

\footnotetext{
1 Deleuze, Gilles: Cinema 2 The Time-Image. Translated from the French by Hugh Tomlinson and Robert Galeta Minneapolis: University of Minnesota Press, 1989. p. xi.

${ }^{2}$ Hejduk's essay is first published as "Hors du temps dans l'espace" in L'Architecture d'aujourd'hui, $\mathrm{N}^{\mathrm{o}} 122$, SeptemberNovember 1965. pp. xi, xxiii. An expanded version referenced in this paper is contained in John Hejduk, Mask of Medusa: Works 1947-1983. Edited by K Shkapich. New York: Rizzoli International, 1985.
} 
Another way to formulate the question: is Hejduk finding evidence of a liberation of time from movement? Is it a liberation similar to that which Gilles Deleuze (1925-1995) discerns in certain post-1945 works of art and cinema such that a pure time is made palpable and architectural-plastic qualities released independent of movement?

Two propositions - simultaneously thematic, methodological and conceptual - provide a preliminary framework for responding to these questions. The first proposition is that there is a largely untheorised temporality created in certain modernist works of architecture and those of Le Corbusier in particular. The second proposition: this temporality can be characterized as one not bound to a vision in motion nor does it require a body's movement to gain presence. In certain modernist works of architecture, rather, there is a condition of vibration and energy already contained or produced by the building independent of movement. Time, to take Deleuze's implied formula, has "gone creative", and this condition perhaps resembles or renders physical a concept of direct time in the realm of architecture.

To begin to investigate these propositions I examine a building that engages overtly movement and thus by implication imbeds or releases a concept of time. The Visual Arts Center, Cambridge, Massachusetts (19601964, hereafter VAC) also known as the Carpenter Center for the Visual Arts, is an important project in Le Corbusier's late period and provides material for the analysis ${ }^{4}$. VAC's apparent reliance on circulation for its coming into being is tested by focusing on other devices, strategies, and formal effects. Both on the surface and perhaps in reality it treats the spiral, the diagonal, and the torqued perceptions produced as generators of singular effects, ones perhaps bound to, rendering, or recording a concept of time.

In the Visual Arts Center I suggest we are confronted with forms of simultaneity and conditions of time as overlapping durations. The temporality rendered in VAC, that is, is an always already compressed time, one different from that which is composed by a line of images or vignettes and thus is reliant neither on futures nor pasts. This state is the consequence in part of compressions and releases which work to create folds in, or give thickness to, a kind of temporality potential in modernist architecture and which is labelled for the purposes of this paper diagonal time. This condition is named diagonal time to differentiate it from a linear past-present-future time and a purely empirical succession of things.

\subsection{Approach}

To begin to frame an approach to the concept of a temporality specific to certain works of modernist architecture, I borrow the notion of direct time as theorised by Deleuze and deployed most fully in his Cinema 2. The Time Image. In Cinema 2, Deleuze proposes that in some mid-twentieth-century films and works of fine art a new relationship of movement and time is made visible. Time is no longer subordinate to movement, he writes, and a reversal occurs such that "time ceases to be the measurement of normal movement, it increasingly appears for itself ${ }^{, 5}$.

\footnotetext{
${ }^{3}$ Deleuze does not specifically propose this effect, but it's appropriateness is suggested when he writes in relation to the cinema image: "What is specific to the [time-] image, as soon as it is creative, is to make perceptible, to make visible, relationships of time which cannot be seen in the represented object and do not allow themselves to be reduced to the present..” Deleuze, 1989, p.xii.

${ }^{4}$ Standard references include W. E. Boesiger (Ed.): Le Corbusier et son atelier rue de Sèvres 35. Oeuvre complète, volume 7 , 1957-1965. Zurich: Les Editions d'Architecture, 1965, pp. 54-67. Sekler, Eduard F. and Curtis, William: Le Corbusier at Work. The Genesis of the Carpenter Center for the Visual Arts, Cambridge, Harvard University Press, 1978.

${ }^{5}$ Deleuze, 1989, p.xi.
} 
Requiring further elaboration in subsequent studies, I believe a phenomenon similar to that which Deleuze discerns in the realm of philosophy, cinema and certain works of painting and sculpture can be claimed for architecture. An examination of projects that release or make concrete a deleuzian direct time, one not bound to a promenade architecturale from the point of view of time may, in turn, reveal a range of formal moves and composition devices at work along with their resultant formal-spatial effects. A preliminary analysis of VAC will be used to explore this idea.

The Visual Arts Center freeze stops a moment in time and thus illustrates an architectural concept of direct time by means of a number of devices and strategies. (Fig 1) Four such aspects are briefly explored: oblique and transverse form relationships; ambiguity in figure/ground relationships; expressive volumes; and voided centres that create intensity independent of animating factors.

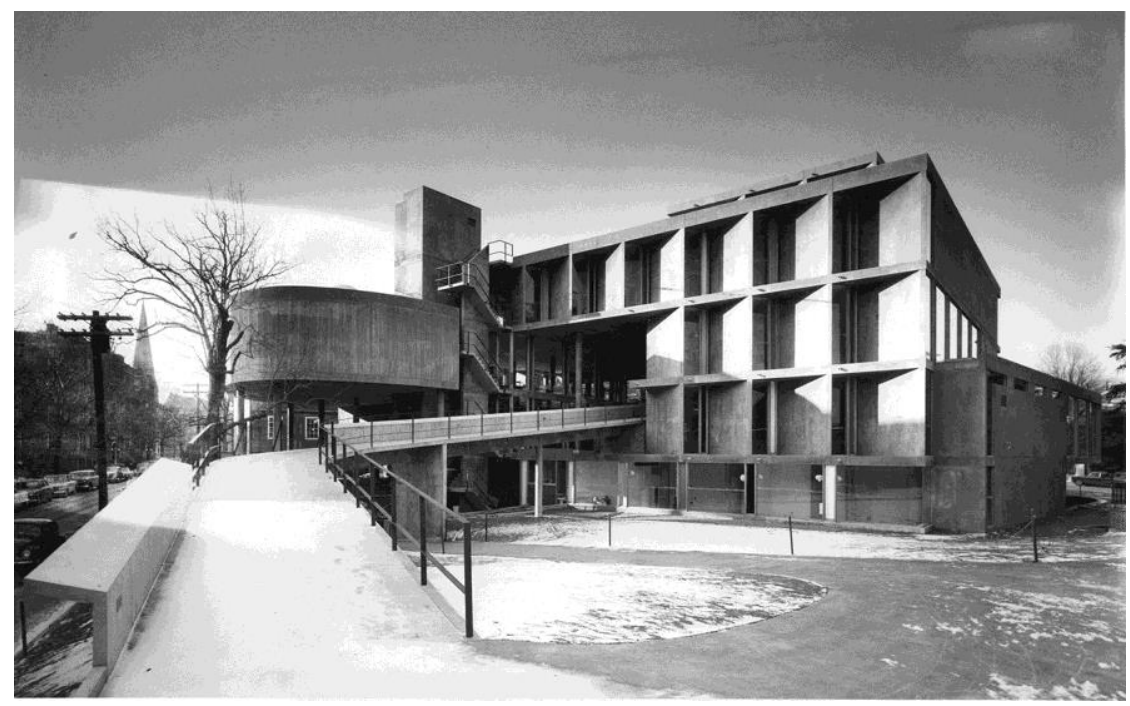

1. Le Corbusier, Visual Arts Centre, view from Prescott Street. (C) Fondation Le Corbusier-ADAGP, 2015.

\subsection{Scholarly context and structure}

In the Oeuvre complète presentation of the project, Le Corbusier highlights the autobiographical role of the VAC, a "demonstration of Le Corbusier's theories". He emphasises five such theories or devices: the interpenetration of internal and external space, the use of rough concrete (béton brut), the ramp as organising device, the free plan, and the use of brise-soleil. Different from Le Corbusier's focus on these formal and spatial devices, I believe VAC can be read to display a turn in his thinking and a specific notion of time, one whose potential for practice and theory has yet to be examined or exploited.

Taking primarily visual material as the object of study, I start with observations on approximate configurations aligned with four aspects and then move to identify their specificity in order to test how certain motives and effects might be generalized into architectural strategies that work directly on time. In so doing I hope to begin to identify the formal logics and morphologies underlying the building and their potential extension as an interpretive and creative category. In this way I endeavour to follow what Colin Rowe (1920-1999) characterized as a Wölflinian style of "intensive critical workout" .

\footnotetext{
${ }^{6}$ Le Corbusier, Oeuvre complete 1957-1965, p.54.

${ }^{7}$ Colin Rowe: The Mathematics of the Ideal Villa and Other Essays, Cambridge, The MIT Press, 1976. p.16.
} 
I work from published drawings, photographs both recent and dating from the time of the building's completion, writings of Le Corbusier, and secondary writings. I have benefited, as do all scholars working on this building, from the archival and critical-historical efforts of William Curtis as well as that of Colquhoun, Sekler, Serenyi, and von Moos in particular. These scholars provide important interpretations of the building's design history, speculate on Le Corbusier's intentions, and interpret the role of the building in Le Corbusier's life-work.

Von Moos discusses aspects of the project to highlight Le Corbusier's typological design method and the metaphoric nature of certain forms ${ }^{8}$. Sekler's analysis focuses on the provenance of forms and spatial ideals and the relation of Le Corbusier's painting to this architectural practice. Curtis highlights in his important survey, recently published in an expanded second edition, formal inventions, transformations of established elements and the condensation of spatial ideas but he does not specifically discuss temporality ${ }^{9}$. In terms of method, and though he does not directly discuss VAC, Alan Colquhoun provides an exemplary and elegantly spare approach to Le Corbusier's late period work and I have benefited from his comparative approach ${ }^{10}$. Similarly, Peter Eisenman's Ten Canonical Buildings provides a methodological framework for the present essay, one whose depth and breath of interrogation a longer study of VAC will attempt to approach ${ }^{11}$.

Far from attempting to establish the origins of forms or ideas - either within the work individually or within the context of a trajectory of Le Corbusier's work - I focus on the relatively modest aim of conjecturing on how the project works on time, attempting a preliminary description of the devices and formal moves used and the consequent architectural effects from the point of view of time.

Drawings published in Le Corbusier at Work of the building in design development phase and as built constitute primary analytic materials. They compliment the drawings published in the Oeuvre complète 1957-1965 which record an interim phase in the design process. The latter for example show an internal horseshoe ramp connecting Levels 2 and 3 that was abandoned. Secondary writings from the period and more recent scholarship on Le Corbusier provide historical and critical context. Floor plans are named according to the convention of the Oeuvre complète, thus the ground floor is Ground Level, the next floor up is Level 1, and so on.

Throughout I use the name of the building as it is given in the Oeuvre complète and as referenced by Le Corbusier in project correspondence published in Le Corbusier at Work, that is, Visual Arts Center, abbreviated as VAC. Drawings from Le Corbusier's office carry the office's characteristic three-character project name shorthand, in this case VAC-BOS for Visual Arts Center, Boston, and thus the shorthand naming convention used here is consistent with the practice of the 35 rue de Sèvres office.

The paper is organized in three sections, the first setting out the generating propositions, materials of study, and the approach. Section two proffers a formal analysis of Le Corbusier's Visual Arts Center according to four themes: diagonals, expressive volume, ambiguities, and voided centre. Section three returns to the proposition of an architectural concept of time, responds to the opening questions, and outlines future areas of research as a form of conclusion.

\footnotetext{
${ }^{8}$ von Moos, Stanislaus: Le Corbusier. Elements of a Synthesis. Cambridge, Mass.: The MIT Press, 1979. pp. 85, 87.

${ }^{9}$ Curtis, William J. R.: Le Corbusier. Ideas and Forms, 2nd ed. London: Phaidon Publishing, Inc., 2015.

${ }^{10}$ Colquhoun, Alan: "Formal and Functional Interactions: A Study of Two Late Buildings by Le Corbusier". In Essays in Architectural Criticism: Modern Architecture and Historical Change. Cambridge, Mass.: The MIT Press, 1981. pp. 31-41.

${ }^{11}$ Eisenman, Peter: Ten Canonical Buildings 1950-2000. New York: Rizzoli, 2008.
} 


\section{Analysis}

“ACTION OF THE WORK (architecture, statue or picture) on its surroundings... REACTION OF THE SETTING: ... the whole environment brings its weight to bear on the place where there is a work of art, the sign of man's will, and imposes on it its deep spaces or projections, its hard or soft densities, it violences or its softnesses... In a complete and successful work there are hidden masses of implications, a veritable world which reveals itself to those whom it may concern, which means: to those who deserve it. Then a boundless depth opens up, effaces the walls, drives away contingent presences, accomplishes the miracle of ineffable space." Le Corbusier ${ }^{12}$

An examination of the project reveals at least four formal devices or composition strategies in play. These are diagonal and transverse planning, volumes treated as expressive space, ambiguities in figure-ground relationships, and an absent or voided centre. Each in some manner is rendered in VAC and goes beyond or differs from other formal-spatial conditions and motifs in Le Corbusier's work. Diagonal and transverse planning moves away from Le Corbusier's emphatic bias to frontality and cross-axial planning. Expressive volumes realised in lung-like figures disrupt a purely Domino reading. Ambiguities abound in the project and there is a blurring of figure-ground relations in favour of a mannered manipulation of contour and surface resulting in figure-figure readings. The centre, finally, is absent and calls for perhaps most emphatically to explain its potential an interpretation of the project's impact as engendering a specific kind of temporality.

\subsection{Diagonals, or going beyond frontality}

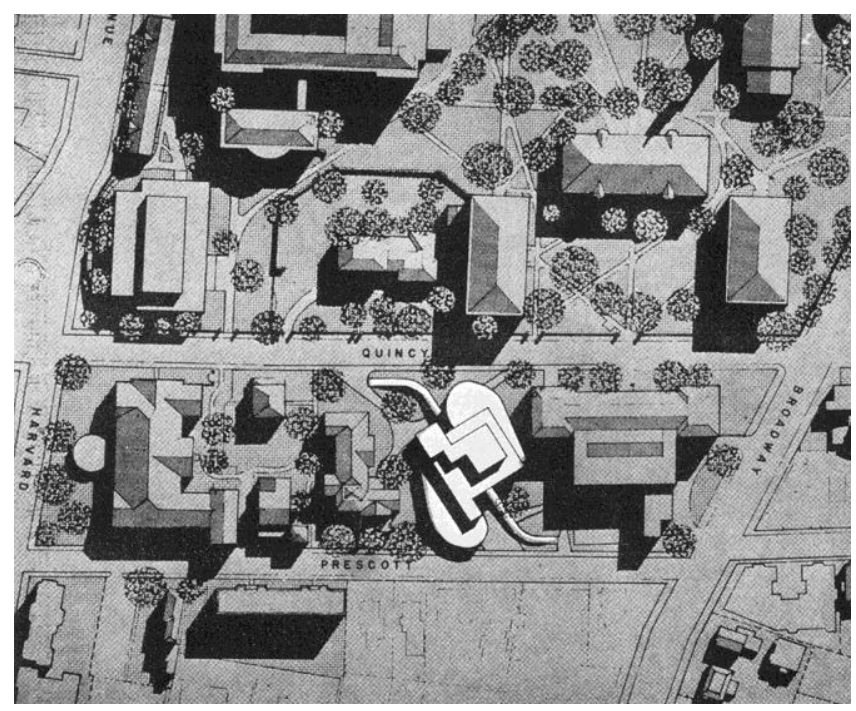

2. Le Corbusier, Visual Arts Center, Site Plan, with Prescott Street at the bottom and Quincy Street at the top of the frame, north is to the right of frame. (W. E. Boesiger (Ed.), Le Corbusier et son atelier rue de Sèvres 35. Oeuvre complète, volume 7, 1957-1965. Zurich: Les Editions d'Architecture, 1965. p.55 @ Fondation Le Corbusier-ADAGP, 2015).

The first thing that is striking when examining drawings or photographs of the project is the rotation of the building relative to the bounding orthogonal field of streets and buildings. (Fig. 2) There are at least two major

\footnotetext{
${ }^{12}$ Le Corbusier: New World of Space. New York and Boston: Reynal \& Hitchcock and The Institute of Contemporary Art, 1948. p. 8.
} 
consequences resulting from this rotation: peripheric tensions of the edge are created, and field extensions beyond the building volume engender an expanding space.

Rotation also creates conditions which challenge potential bay readings and disrupt frontal and cross-axial factors as everything in one sense is or has become diagonally engaged in a perimeter condition. In VAC oblique and transverse moves are at work throughout. Diagonal motions off the parallel streets of Prescott and Quincy initiate this condition. The Level 1 and 2 studios continue this non frontal logic with a spiralling and echeloned cascade along the outer edge of the lung-shaped spaces. The plans as published in the Oeuvre complète show a U-shaped ramp connecting Levels 2 and 3 in a clock-wise spiral moving up the building, which if built would have continued and intensified the external ramp's momentum upward, or alternately have contributed to a corkscrew motion downward from the roof-top apartment and garden.

Frontal views are difficult to achieve and are deemed static; three-quarter views are favoured. Peripheral composition is sought over centralized, and interpenetration favoured over separation. Thus VAC can be seen to be centrifugally ordered though not purely: it is in part channelled and vertically stacked at the same time that it is self-bifurcating and horizontally distributed. This bifurcation might be characterised as creating a diptych condition, as an examination of sketches and the Quincy Street elevation reveal. (Fig. 3, 4, 12)

Out of these relations, a general, fairly constant diagonal condition is shown to exist. A review of the plans reveals a disposition different from the enfilade (room to room) plan and the poché (served and servant) plan. It is a case in certain floors of an open plan (Levels 1 and 2 for example) and in others a free plan (Level 3). The building favours transverse over cross-axial or longitudinal arrangements though as with other readings there is an ambiguity at work in relation to the larger site and campus setting. One enters on the oblique, and continually slides in either a counter clock wise or clock wise motion up the building. This was already announced in the 1 April 1960 sketch and the building as movement reinforced as desirable by President Pusey according to Le Corbusier's sketchbook notes of mid June $1960^{13}$. (Fig. 3, 4) The movement continues back down again, sliding always on the edge and compressed by the looming, bulbous volume of either the painting or the sculpture studio to one's side. The building is layered by open Ls (els) cut by the flattened Z-shaped circulation ramp slipping along the edges in a sideling manner. Studio spaces thrust forward in part in a burst of centrifugal energy and there is the implied promise of future vertical extension. With some imagination, the building can be read as folding over itself in an almost boolian movement, as if the ramp were holding down a vertically moving force, the ramp preventing the building from elevating further off the ground.

This can be considered another aspect of Le Corbusier going beyond frontality, and Kenneth Frampton (1930) provides a clue as to what is at stake. To further unpack the formal moves and motivations of this aspect, consider Frampton's description of modern architecturte during these years as trapped by frontality, unable to adopt the "multi-directional spatiality of the De Stijl or Suprematist movements", and "unable to abandon ... [an] emphasis on frontality" ${ }^{\text {"14 }}$. There is evidence of this bias in VAC's reliance on the free plan, column-slab or wall-slab model, horizontally layered within a central regular volume and thus indebted to or relying on a Domino space concept.

\footnotetext{
${ }^{13}$ Le Corbusier Sketchbooks Volume 4, 1957-1964. New York, Cambridge, Mass.: The Architectural History Foundation, The MIT Press in collaboration with the Fondation Le Corbusier, Paris, 1982. Sketchbook P61, figure 566.

${ }^{14}$ Frampton, Kenneth: "John Hejduk and the Cult of Humanism". In A+U (Architecture and Urbanism or Kenchiku to Toshi), $\mathrm{N}^{\mathrm{0}} 53$, May 1975. pp. 141-142. p. 142.
} 


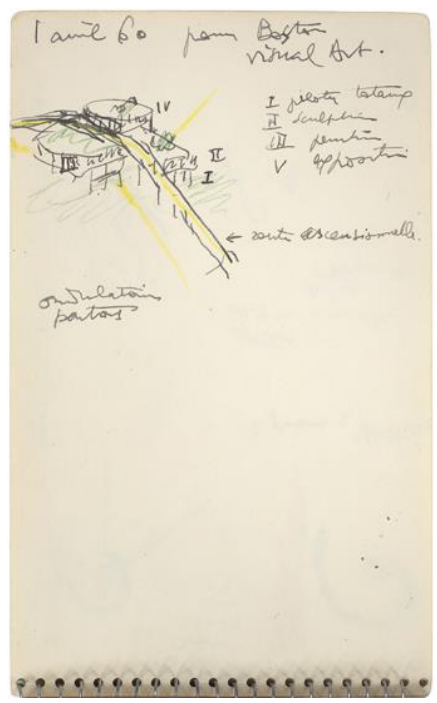

3, Le Corbusier, Sketch of 1 April 1960. (Le Corbusier Sketchbooks Volume 4, 1957-1964. New York, Cambridge, Mass.: The Architectural History Foundation, The MIT Press, 1982. Sketchbook P60, figure 522. (C) Fondation Le CorbusierADAGP, 2015).

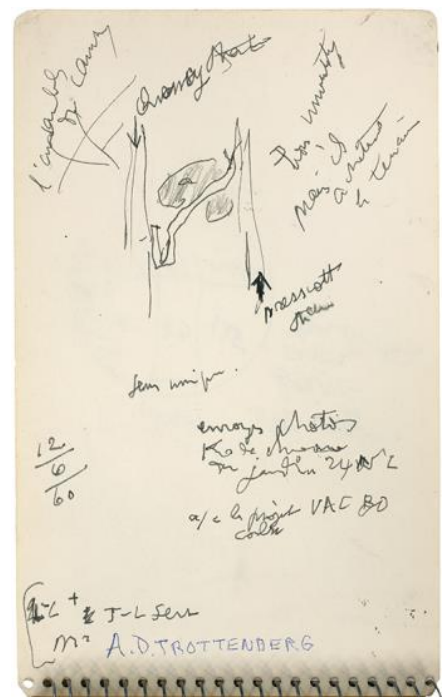

4, Le Corbusier, Sketch dated 12 June 1960 with an emphatic initial forty-five degree rotation and a bias to a larger studio volume on the north. (Le Corbusier Sketchbooks Volume 4, 1957-1964. New York, Cambridge, Mass.: The Architectural History Foundation, The MIT Press, 1982. Sketchbook P61, figure 566. ( Fondation Le Corbusier-ADAGP, 2015). 


\subsection{Free volumes, or expressive space}

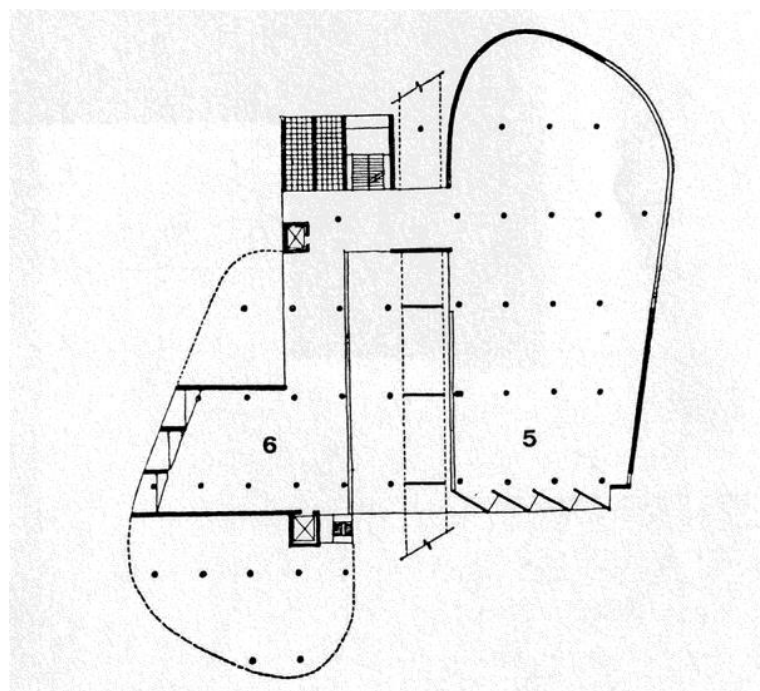

5. Le Corbusier, Visual Arts Center, Level 1 plan. Note the reading of the central square volume has disappeared. (W. E. Boesiger (Ed.), Le Corbusier et son atelier rue de Sèvres 35. Oeuvre complète, volume 7, 1957-1965. Zurich: Les Editions d'Architecture, 1965. p. 54 (C) Fondation Le Corbusier-ADAGP, 2015).

The central rotated square volume of VAC, whose sensation disappears at points, can be claimed to contain two states: horizontal space formed by floor and ceiling planes when extruded (an illustration that is of the Domino diagram) and a line in motion formed by the ramp. (Fig. 5) If one extends the description and abstracts the reading, then one can generalize the differences of these two: planes enclose horizontal space, the line of the ramp elaborates space in it's pull and push and torsion; planes bring into focus providing emphasis, lines dissipate, leading the eye away from a static, single field focus the effect of which is to remove firm boundaries so that a new reality can be created.

We can perhaps say that the building disposes the two studio volumes so as to engender a dynamic space beyond Domino limits to produce what can be characterised as expressive space. This reading is supported by a previously unpublished elevation study of the Prospect Street elevation in a January 1961 development phase, clearly showing the role of the two studio volumes relative to the central one ${ }^{15}$. The demands of expressive space can be considered an evolution of Le Corbusier's free plan into a free section, one animated by organ events and object types, one which might only later be rationalized in terms of site, structure, desired compositional effect or operational need if at all. This sensitivity might extend to a divergence on the one hand toward continuity and on the other toward separation or toward different kinds of continuity where continuity is understood as a unity of space and structure. Separation of supporting point columns and functional partitions: structure does not define space but punctuates it as photographs of the studio spaces in particular demonstrate. Look again at the site planning as providing additional evidence. VAC occupies a relatively flat, urban site and to a certain extent creates its own topography. A consequence of the volume disposition is the use of overlap and strategies of central compression and peripheral dispersion in pursuit of an architectural idea. (Fig. 3, 5, 6, 7)

This line of analysis might suggest that VAC is about movement of volumes and despite appearances is not primarily an illustration of the promenade architecturale. Thus would imply a time concept which differs from

${ }^{15}$ Curtis, 2015, pp. 372-373. 
one aligned with a primarily empirical (chronological) idea of time, one subordinate to movement, a this then that, a past then present, a before and after. In VAC we are never satiated by a space triggered by movement as the ramp's role is constantly denied or deferred: frustrated, it is never allowed to arrive fully; there is no culmination.

We observe then in VAC an intensification of local spatial conditions horizontally and vertically in that junction split between Levels 1 and 2. Those mandolin or lung-shaped organs of the two studios vertically staggered put in motion a spiralling disposition that edges along their Georgian neighbours. Site elements are organised such that a force, or multiple forces, are shaped and temporarily focused only to be quickly dispersed outward so that even in the absence of a peripatetic eye there is still a vibration produced thus recording perhaps a pure time independent of any reliance on motion or movement to bring it forth. If perhaps it is too early to state a preliminary finding, one might thus far be justified in claiming that VAC works equally on concepts of space and on problems of time, though which form of time is unclear at this stage. Another way to characterise this state might be as a mannerist use of shapes and devices that have accompanied Le Corbusier and which differ from other late buildings. At the Millowners' Association Building (Ahmedabad, 1954) ${ }^{16}$, a precedent for VAC on certain elements, the ramp runs straight on, landing frontally at the entry and the lung-like main hall and meeting rooms remain inboard. In the Congress Hall in Strasbourg (unbuilt, 1964) ${ }^{17}$, the organs are also contained whereas at VAC they burst out gripping vice-like the squared volume though not in a centrifugal manner, resulting in ambiguous free organs, perceived as partial figures.

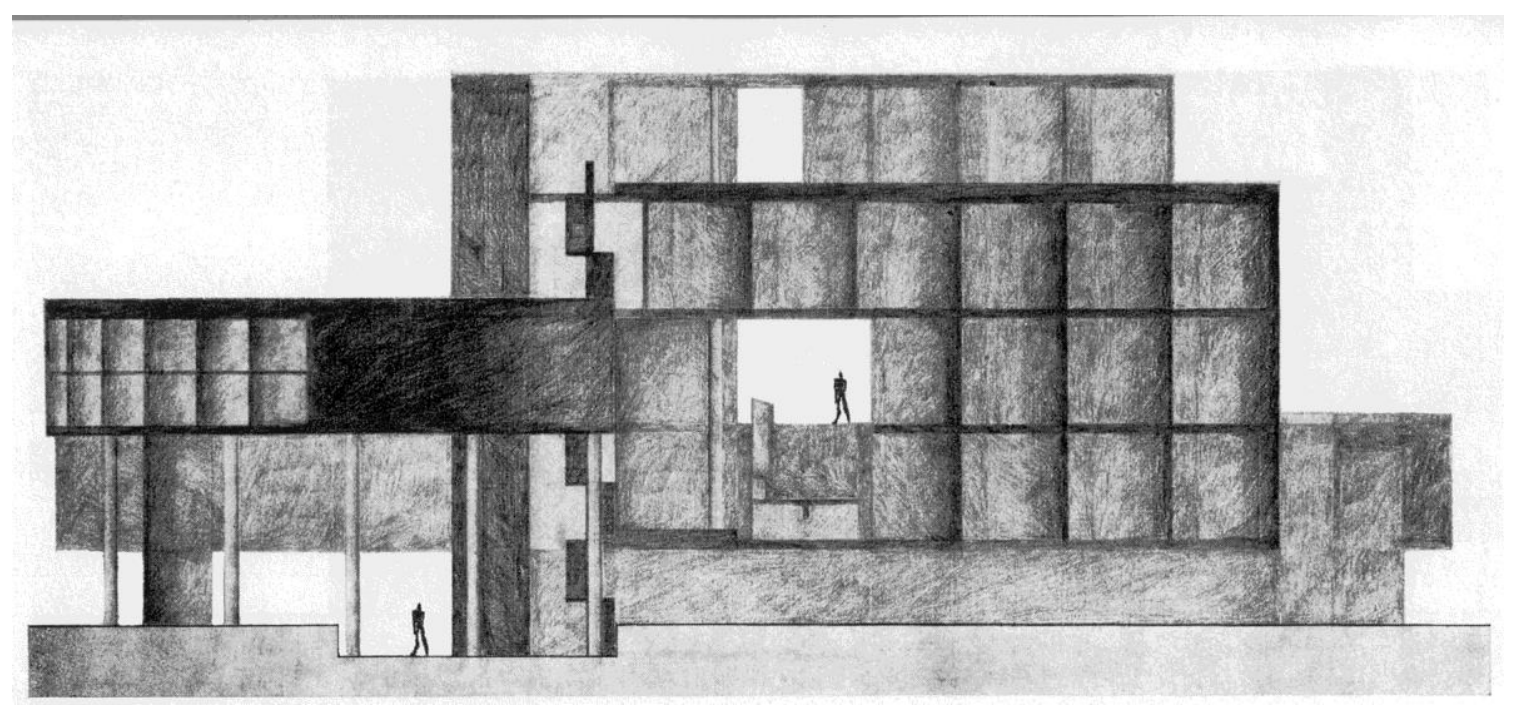

6. Le Corbusier, Visual Arts Center, East façade with ramp. (W. E. Boesiger (Ed.), Le Corbusier et son atelier rue de Sèvres 35. Oeuvre complète, volume 7, 1957-1965. Zurich: Les Editions d'Architecture, 1965. p. 60 () Fondation Le CorbusierADAGP, 2015).

\footnotetext{
${ }^{16}$ W. E. Boesiger (Ed.), Le Corbusier et son atelier 35 rue de Sèvres. Oeuvre complète, volume 6, 1952-1957. Zurich: Les Editions d'Architecture, 1965. pp. 144-157.

${ }^{17}$ Oeuvre complète, volume 7, 1957-1965, pp. 152-163.
} 


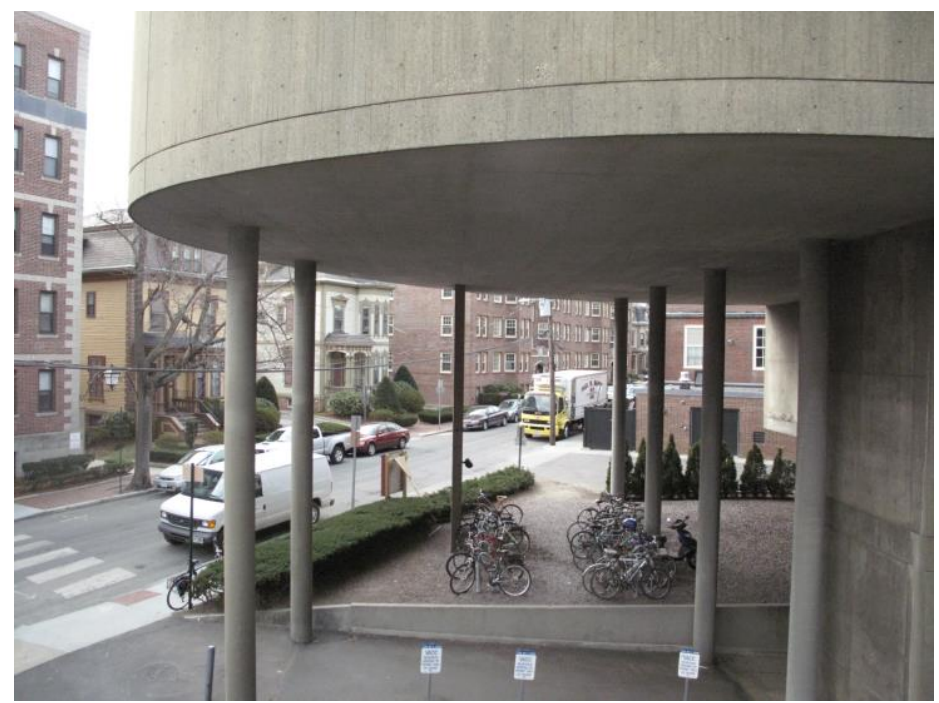

7. Le Corbusier, Visual Arts Center, View under studio space along Prescott Street (@ Fondation Le Corbusier-ADAGP, 2015; Camille Tokerud Photography Inc, 2015).

\subsection{Ambiguities}

“A plan is a section...” John Hejduk ${ }^{18}$

Thus far, a formal analysis of VAC from the point of view of an architectural notion of time has explored two aspects, that of diagonal and transverse relationships engendered by site rotation, and that of external and internal volumes rendered expressive, the consequences in part of free-plan and free-section ideas. In general, as has been suggested, the overall architectural condition is one of complex ambiguities. The building as read is conceived around diagonal movements with functional spaces disposed either as coincident with circulation or as appendages to lines of circulation which bifurcate a volume in rotation creating what might be characterised as a diptych state. This move disrupts or goes beyond an interpretation of frontality.

These traits are neither mutually exclusive nor interdependent but are offered as terms in provisional suspension to allow their reintegration in a future proposition about architectural time.

The third theme to be developed concerns ambiguities in object/field and figure/ground conditions. VAC cannot be fully absorbed from without. Values of wholeness, the ideal of being able to stand at some point and receive a palpable impression of the whole, is specifically not an aim. Even that bird's-eye view sketch from April 1961 only partially outlines some elements but does not yield the complexity of resultant conditions. (Fig. 1, 3, 12) Development of focus is somewhat of an arbitrary and for Le Corbusier intentionally ambiguous proceeding, A potential single, central focus is consistently broken up, concentration in one point is never sought nor gained. Consider the external views which struggle to find a stable viewpoint.

So while this is perhaps too easy a parallel and things are evidently more subtle, can we say that when read at the scale of the site VAC is all figure and no ground and when read internally at the scale of the building all field and no object. In other words, we here confronted with a constant architectural state of middles or of background intensities.

\footnotetext{
${ }^{18}$ Hejduk, 1985, p.73.
} 
This is surely one response, in part, to the fact that in VAC the site and project brief required intensive development as elaborate external deployments were not fully possible within the more or less set and limiting boundaries. Inversion or intensification in the place of extension: more fluid at studio Levels 1 and 2, no less concentrated at the ground and upper floors being bound by those floor and ceiling plates and directed horizontally. Especially if you study the sliding or staggered distribution of main spaces and the dense centre, doubled or echoed by perimeter incidents. Views under and through the studios across the ramp's cut demonstrate this overall field reading. (Figs. 7, 8)

No simple dispersal of focus but more of a constant rebound, waves bounding back to confront initial ripples. In mounting or descending the ramp, the walls of the studios channel the effect. When inside, potential release is denied or multiplied, energy bounced back from or ricocheted off all those perimeter incidents: curving wall, ondulatories, brise-soleils, smooth columns engendering centrifugal forces, aérateurs (vertical narrow pivoting doors with fly screens) channelling space. Peripheral interest in horizontal expansion in the studios; contained concentration of a rather constant nature, sliding and swung along vertically when up and over the ramp.

Look at the plans: the field is a constant condition in the studio spaces ${ }^{19}$. (Fig. 9) A sense of clear volumes is not the main thing: it does not conclude or ever solidify. It is an end but only in a tentative way, an effect of space sliding away along diagonal lines sprung out through brise-soleil, the oblique cut of the end wall in plan and vertical plane. In VAC, the effect of deferred arrival is similar though the means different. Certainly the artist's apartment perched on the final floor might want to satisfy a desire for a conclusion or pyramidal cap. If the internal ramp had been built between the second and third floors, then perhaps in Cambridge the third floor would have gained some hierarchical role but it was not.

If the plan is a section in the work of Le Corbusier as claimed by Hedjuk in his 1965 essay, it is equally valid to claim the section is a plan, one recording ambiguous conditions of overlapping matrices. The square volume is never perceived and is constantly broken up and dissolved. Even in the purest state at Level 3 the stair and lift forever blur the edges from the saw-tooth brise-soleil and create an effect of curious irresolution.

These ambiguities reveal a lingering tendency that might be described as Cubist and Post-Cubist. There is a direction as well as an eccentricity introduced by placement and delineation of walls establishing a dominant direction in organizing spatial flow. These contribute to that constantly shifted centre further, the fourth aspect discussed below. Differing elevation treatments further complicate the readings with brise-soleil, full height fixed glass sheets, and narrow vertical aérateurs providing different kinds of animation.

This could be interpreted as introducing a Cubistic gesture (directional) in a Post-Cubist or Neo-Plasticist (nondirection, square grid) realm. Plan tensions are introduced between a bias to the vertical against uniform extensive or explosive forces, not at the points but out to the edges of the Level 3 diamond plan, precariously balanced on the splitting ramp, all reinforcing the ambiguities and fluctuations in figure and field, matrix and object readings.

\footnotetext{
${ }^{19}$ The as built plans published in Sekler and Curtis, 1978, better demonstrate this condition.
} 


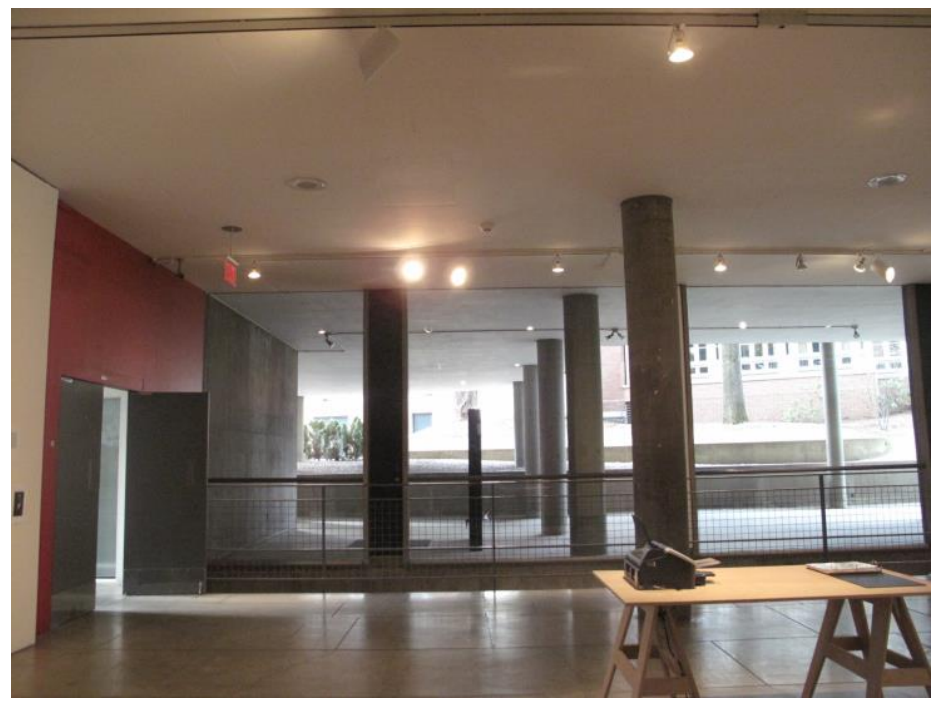

8. Le Corbusier, Visual Arts Center, View through studio space at Ground Floor (@ Fondation Le Corbusier-ADAGP, 2015, Camille Tokerud Photography Inc, 2015).

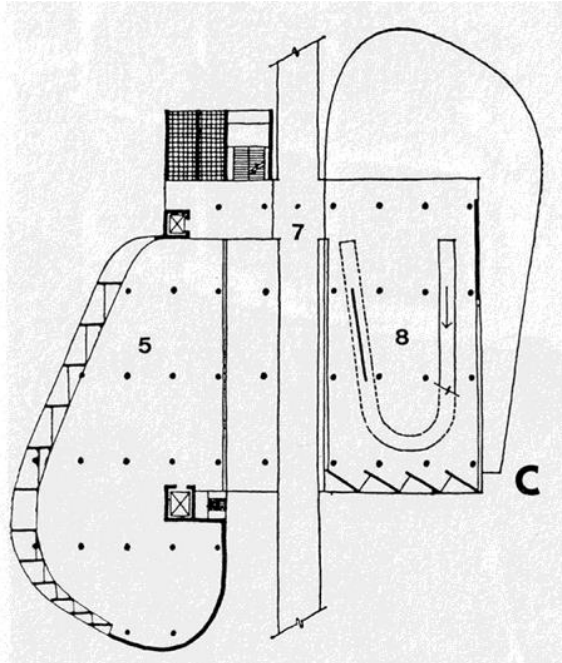

9. Le Corbusier, Visual Arts Center, Level 2 plan, noting the proposed horseshoe ramp linking levels 2 and 3 was not built. (W. E. Boesiger (Ed.), Le Corbusier et son atelier rue de Sèvres 35. Oeuvre complète, volume 7, 1957-1965. Zurich: Les Editions d'Architecture, 1965. p. 55 () Fondation Le Corbusier-ADAGP, 2015).

\subsection{Voided centres}

Form relations, concepts of space, and perhaps as I am proposing notions of time are all being worked on here. At first blush, and as suggested above, two composition devices are constantly explored in VAC. The first, an expansion "or exfoliation toward the periphery and beyond"20. A second composition strategy is that of a condensation of space and mass towards an always-voided centre.

This idea of the voided centre confirms a move away from a trabeated logic of post and beam frames, of singular columnar surfaces, and of articulated roofs toward a ground-less architecture of round columns, freestanding partitions, and flat-slab floors and ceilings.

\footnotetext{
${ }^{20}$ The term exfoliation is Kenneth Frampton's, used to characterize tensions in the periphery of Hejduk's contemporary diamond projects and with useful application here. Frampton, 1975, p. 14.
} 
In other words, a critical work on the Domino world of column-slab construction, engaging full on the implications and effects of two kinds of architectural freedoms, those of "liberated space [and] liberated structure" as Hejduk writes in an undated manuscript sheet from the period but which can be approximately dated to 1965-66, thus around the time he was writing his homage for L'Architecture d'aujourd'hui ${ }^{21}$.

To begin, we notice that columns appear to play a fundamental role at VAC. Other conditions on closer inspection, however equally dominate, setting up differences between the (Domino) flat slab and point column, the brise-soleil window walls, and etched floors. A peripheral dispersion of incident in the case of VAC's middle floors and a peripheral, shifting look, an animated vision - largely frontal even if following a switchback or Zshaped pattern - in the case of the central volumes and ramp element. (Fig. 2) In all readings, the geometric centre is a void, a void occupied by a ramp and outdoor slices of space both oblique and diagonal with elevator cores, stairs, slots co-penetrating, attracting attention to the edges. In VAC any assumption of a central focus is relegated to dismembered spaces in a sort of serial installation of interest (organs, events, ribbon-galleries) round the extremities of the plan.

Contradictions and complexity with two different compositional strategies yielding in one regard, however, similar effects. There is no one centre, it being replaced by a kind of indefinite though not neutral space. Never uniform, in fact it is always potentially fully animated such that hierarchy (of figure over ground or object over matrix) is shown specifically not to be the intent as discussed in the previous section. The absence of one dominant centre, produces this other kind of condition, of being always already in an ambiguous kind of middle condition. (Fig. 10, 11, 12)

So while there is perhaps the idea or promise of a denouement, it is endlessly deferred. I believe this is further evidence of a concept of time at work. You never fully arrive, suggesting time itself has always already passed you by, or perhaps the building surpasses time. There is no interior; everything is in a liminal state. This is a shift in emphasis from previous form studies that focus and make manifest a phenomenon of all-over kinetic equilibrium. In the same pendulum arc used to realize the condition for a neutral container, the two together mimic what Hejduk described as a Michelangelo effect, writing: "The effect is like in Michelangelo's architecture. At first there's a sense of a perfectly neutral condition. Then when you begin to penetrate, it becomes kinetic and dynamic ${ }^{, 22}$.

Look again at the structural system as further demonstration of this state. VAC is set out in a rectangular bay grid rotated relative to the bounding streets, generally employing round section columns with local incidents. In terms of consequent volumetrics, there are the narrow horizontal volumes folding back on itself. (Fig 13) VAC is a hybrid of the Domino flat plate point column grid and an assembly of independent organs. A stable interior is of secondary importance with ascendancy given emphasis, especially in the early schemes where certain of the key uses were located at the Level 2 ramp's arrival ${ }^{23}$. As already noted there is a promise of arrival and culmination that is never satisfied.

The voided centre, finally, is revealed in the reading of the horizontal planes of floor and ceiling as dominant in the one reading, the enclosing walls channelling movement and reinforced by a highly articulated and in parts

\footnotetext{
${ }^{21}$ Hejduk, annotations on a sheet of unpublished sketches for Diamond House B, Canadian Center for Architecture, John Hejduk Archive/Fonds 145, Series 2: Professional Work, File 15: Diamond Houses, Sub-file 4: Miscellaneous Diamond House Sketches, drawing DR1998_0063_005.

${ }^{22}$ Hejduk, in interview with Wall, 1985, p.90. On the idea of kinetic equilibrium, see also Hejduk, 1985, p. 52.

${ }^{23}$ As Curtis relates, in the final scheme as built the administration offices were relocated from level two to the ground floor thus removing the programmatic imperative to take the ramp. In Sekler and Curtis, 1978, 139ff.
} 
transparent ceiling and floor in the experience of the ramp in the other. Horizontal extensions are reinforced by the shear, taut, unencumbered ceiling plane matched by a vertical pull of the studio organs, themselves staggered diagonally. In VAC the centre is occupied by a cut, that of the ramp, marking a spring-point of pin-wheeling elements. But contrary to possible assumptions, there is no tension; rather there is a state of ambiguous equilibrium, all the architectural energies moved to the perimeter.

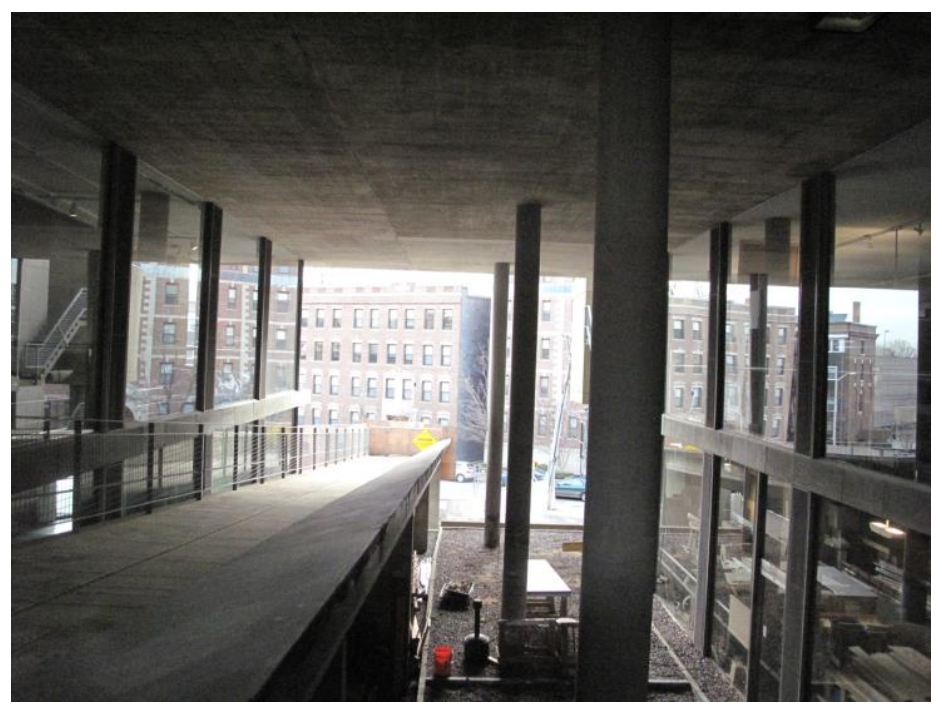

10. Le Corbusier, Visual Arts Center, Ramp between Levels 1 and 2 (@ Fondation Le Corbusier-ADAGP, 2015, Camille Tokerud Photography Inc, 2015).

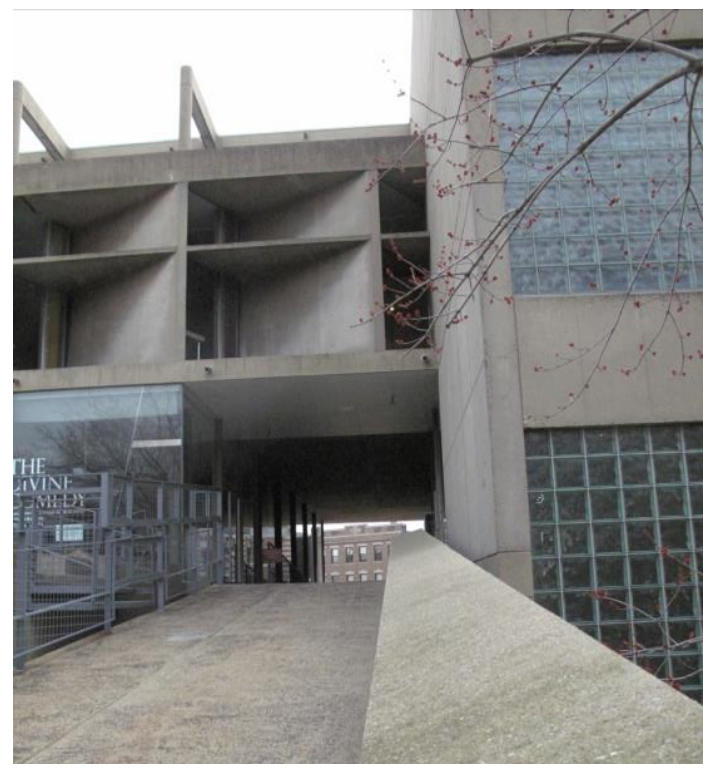

11. Le Corbusier, Visual Arts Center, Ramp from Quincy Street (ㅇ Fondation Le Corbusier-ADAGP, 2015, Camille Tokerud Photography Inc, 2015). 


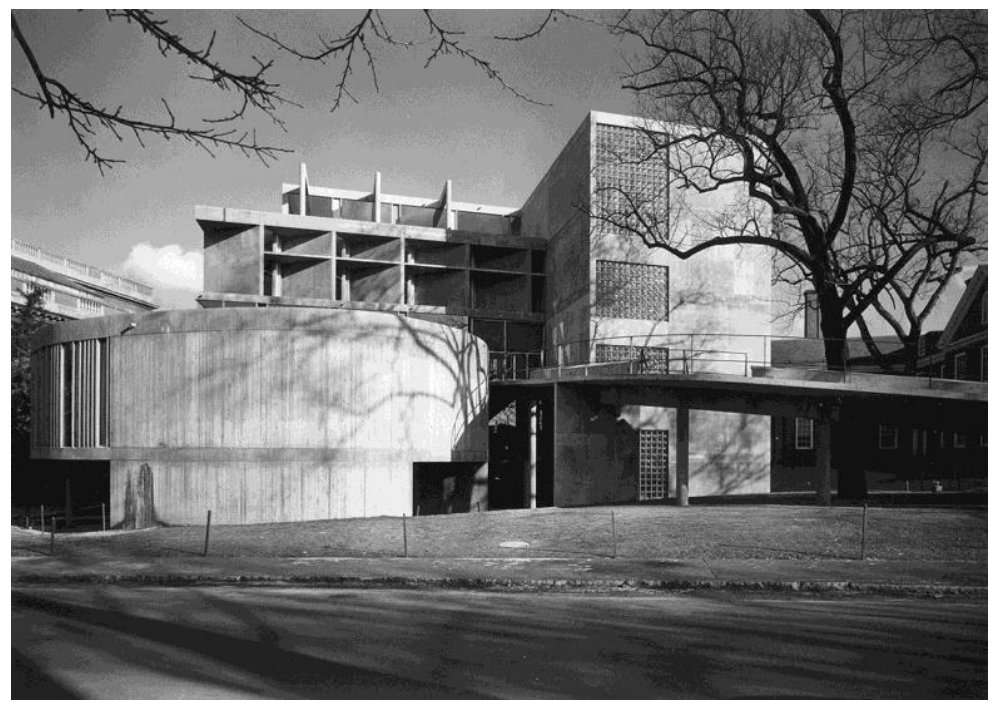

12. Le Corbusier, Visual Arts Center, View from Quincy Street @ Fondation Le Corbusier-ADAGP, 2015).

\section{Conclusion}

“... we are plunged into time, " Gilles Deleuze ${ }^{24}$

\subsection{Findings}

The four spatial-formal effects now surveyed, we return to the germinal questions and opening propositions around time. Is there a concept of time rendered in VAC, of a time concept specific to a work of architecture? What kind of temporal structures are at work and do they share aspects of being plunged into a direct time? In the too brief proceeding analysis explicit has been the question of a pure time, both as an effect created or made manifest in the building and as an interpretive category. In other words, can we claim some evidence of what I've proposed to call a diagonal time in the Visual Arts Center?

In terms of frontality, which we started with, here is Le Corbusier clearly working to get over or to abandon the limits he sees in a reliance on frontality by at least two moves, that of charging the perimeter and voiding the centre. Linked to all these, and perhaps a first move, there is the rotation of the building relative to to site conditions which allows him to move away from cross axial planning which characterises so much of the layered site planning in his early carer from the Villa at Garches to the League of Nations. For when confronted with the receding or encompassing walls as one approaches up the ramp always on the oblique the observer is always in a transverse state, even without moving. And in the rotation appears a curious, ambiguous notion of time, characterized by Hejduk as a "moment of the present"25. It is not just an entry or threshold condition of walls, but the entire project that is working on and intensely occupies the present.

\footnotetext{
${ }^{24}$ Deleuze, 1989, p. xii.

${ }^{25}$ These terms come out during Hejduk interviews in the 1980s: "The place where a perspective or diamond configuration on the horizontal plane flattens out and the focus moves to the lateral peripheral edges.... This is the moment of the hypotenuse of the diamond: it is here that you get the extreme condition, what I call the moment of the present. ... It's here that you are confronted with the flattest condition. It's also the quickest condition, the fastest time wise in the sense that it's the most extended, the most heightened; at the same time, it's the most neutral, the most at repose." (Hejduk, 1985, p. 90)
} 
From the above analysis we can perhaps say that VAC renders manifest an idea of time out of joint, one that does not rely on movement to gain presence. Different from Le Corbusier's early period emphasis on an Acropolian sequence, and the motor and visual aspects that implies and the parallax effects so immediate and palpable in that whirl of columns and tilting planes proceeding up and through the building; and despite the combination of oblique movement and peripheral incident dispersed over and across several floors, and the free organs staggered vertically; despite or in addition to all this, time perhaps appears directly.

The four aspects when reviewed together provide a provisional description of its main characteristics: diagonal and transverse relationships, and a voided centre that creates intensity independent of any other animating presence. In addition, there is a specific idea of structure: the flat slab and point structure in VAC overlapping with dense perimeter conditions and the cantilever, lung-like shapes in an open-ended plan. Perhaps supporting or enabling it all, field and ground ambiguities. To varying degrees, and with all the qualifications called for, there is a suggestion of an architectural concept of time. It is one that shares aspects with those post-1945 phenomena described by Deleuze.

Thus we are confronted with forms of simultaneity, with a concept of time as over-lapping durations, the consequence of compressions and release, all working to create folds in, or give thickness to, time. And these seem to be valid and real findings, if only tentative conclusions which nonetheless call for further research with other concrete examples to be sought and terms of reference refined and amended.

Providing a kind of open unity to the form relations and spatial orders at issue - voided centre, peripheral tension, exploded field, volume become plane and thus creating the conditions for flat space to appear - the specific notion of time revealed in VAC is I believe that dimension which ensures a single whole is never completely given. And in this instance, direct or diagonal time would be that function or operation that holds it all together. As suggested in this brief analysis, diagonal time has the strange power to affirm parts that do not make a whole in space, nor form a succession in time. Time is exactly the diagonal of all possible spaces, those made possible as a result of the freedoms Hejduk found in Le Corbusier, that of liberated space and liberated structure. In place of frontality and cross-axial planning, VAC proposes transverse relationships. The ramp's cut displaces a Domino ideal by expressive volumes and partial figures.

The following comparative table lists some characteristics of diagonal time as developed above.

\begin{tabular}{|c|c|}
\hline Linear time & Diagonal time \\
\hline $\begin{array}{ll}\text { - } & \text { Frontality } \\
\text { - } & \text { Cross-axial planning } \\
\text { - } & \text { Domino } \\
\text { - } & \text { Free plan } \\
\text { - } & \text { Contour and simple mass } \\
\text { - } & \text { Hierarchy }\end{array}$ & $\begin{array}{ll}\text { - } & \text { Diagonality } \\
\text { - } & \text { Transverse planning } \\
\text { - } & \text { Expressive volumes } \\
\text { - } & \text { Free section } \\
\text { - } & \text { Ambiguities in figure-ground } \\
& \text { relations } \\
\text { - } & \text { Voided centre }\end{array}$ \\
\hline
\end{tabular}

Table 1. Aspects of diagonal time versus linear time

\subsection{Further lines of research}

A number of lines of further research should be followed, with two already alluded to.

The study of the diagonal in plan and conditions of diagonality as a general condition in mid-twentieth century architecture should be pursued. Efforts might include tracking parallel manifestations of the diagonal in a series 
of architectural projects and a limited number of theoretical-historical texts. On the side of project, the research might start with an interrogation of Hejduk's Diamond Projects series (1962-1967), Eisenman's House projects (1965-1969), and Louis Kahn's (1901-1974) project for the Philadelphia College of Art (1960-1966) each rendering different aspects of the diagonal. In parallel to the formal analyses, the research might examine the diagonal and its various manifestations in period writing and teachings of key architectural historians. Colin Rowe, Vincent Scully (1920) and Rudolph Wittkower (1901-1971) might provide a start. Each theorises to different degrees the modernist project and alludes to the diagonal and related concepts of ambiguity, folding, the oblique, and torqueing.

A second line of expanded research should examine more emphatically whether and by what means Deleuze's notion of direct time provides a way to think about and test different architectural concepts of time, only touched on above. According to Deleuze, a reversal in the relation of movement and time can be discerned in the realms of philosophy and cinema. For philosophy, the reversal has slowly occurred, and only in some thinkers, over hundreds of years whereas in cinema it has occurred since 1945 and thus at a much more accelerated pace with the movement-image of classical cinema being supplanted by a time-image. Deleuze describes certain devices which render time manifest in itself, prior to or proceeding movement and he finds evidence of this condition in certain films of Renoir, Fellini, and Welles among others.

To conclude, and as a final promise to future research, I return to the concept of pure time in Cinema 2. Deleuze succinctly characterises it: there are certain conditions rendered in works of cinema - and by extension I would claim in certain architectural projects - such that one is taken directly into an experience of time irrespective of any reliance on movement. There are certain kinds of aesthetic works so conceived and constructed, he writes, that "... we are plunged into time rather than crossing space" 26.

The above is an initial suggestion of the interpretive and creative potential a concept of diagonal time may hold for architecture. An analysis of Le Corbusier's Visual Arts Center has provided an initial case study and further research on other modernist architects would I believe reveal others.

\section{Acknowledgements}

Research on and writing of this paper was in part undertaken while at Columbia University as a Visiting Scholar in 2015 and I'm thankful to Professor Mary McLeod of Columbia's Graduate School of Architecture, Planning and Preservation for her early encouragement. The project benefitted from a period of leave from teaching with the support of Professor Lyndon Anderson, Dean of the Faculty of Arts and Design, University of Canberra, and Professor Dharmendra Sharma, Chair of the Outside Studies Program. Financial support to attend the Le Corbusier 50 years later International Congress was provided by the University of Canberra Faculty of Arts and Design Conference Fund 2015. I thank Dean Anderson, Associate Dean of Research Professor Angelina Russo and Head of Discipline Dr Andrew MacKenzie for their on-going encouragement. Certain themes were explored in a 2014 seminar in advanced architectural analysis and I thank my postgraduate students for their engagement. This paper is dedicated to Camille Tokerud who undertook the photographic analysis. Camille was a true collaborator and the project benefitted from her positive energy and critical eye.

\footnotetext{
${ }^{26}$ Deleuze 1989, p. xii.
} 


\section{Source of images and tables}

Figures 1-6, 9, 12 (C) Fondation Le Corbusier-ADAGP

Figures 7, 8, 10, 11 Camille Tokerud Photography Inc

Table 1 (C) the Author

\section{Bibliography}

Besset, Maurice: Le Corbusier. Translated from the French by Robin Kemball. London: Academy Editions, 1976.

Boesiger, W. E. (Ed.): Le Corbusier et son atelier rue de Sèvres 35. Oeuvre complète, volume 6, 1952-1957. Zurich: Les Editions d'Architecture, 1965.

Boesiger, W. E. (Ed.): Le Corbusier et son atelier rue de Sèvres 35. Oeuvre complète, Volume 7, 1957-1965. Zurich: Les Editions d'Architecture, 1965.

Colquhoun, Alan: "Formal and Functional Interactions: A Study of Two Late Buildings by Le Corbusier". In Essays in Architectural Criticism: Modern Architecture and Historical Change. Cambridge, Mass.: The MIT Press, 1981.pp. 31-41.

Colquhoun, Alan: "Die Fassade in ihren modernen Varianten". In Werk, Bauen + Wohnen, $\mathrm{N}^{\mathrm{0}} 12$, December 2005. pp. 12-19.

Curtis, William J. R.: Le Corbusier. Ideas and Forms, 2nd ed. London: Phaidon Publishing, Inc., 2015.

Deleuze, Gilles: Cinema 2 The Time-Image. Translated from the French by Hugh Tomlinson and Robert Galeta. Minneapolis: University of Minnesota Press, 1989.

Eisenman, Peter: Inside Out Selected Writings 1963-1988. New Haven: Yale University Press, 2004.

Eisenman, Peter: Ten Canonical Buildings 1950-2000. New York: Rizzoli, 2008.

Frampton, Kenneth: "John Hejduk and the Cult of Humanism". In A+U (Architecture and Urbanism or Kenchiku to Toshi), №53, May 1975. pp. 141-142.

Hejduk, John: “Hors du temps dans l'espace”. In L'Architecture d'aujourd'hui. N¹22, September-November 1965. pp. xxi, xxiii.

Hejduk, John: “Out of Time and Into Space”. In John Hejduk. Mask of Medusa: Works 1947-1983. Edited by K. Shkapich. New York: Rizzoli International, 1985. pp. 71-75.

Le Corbusier: New World of Space. New York and Boston: Reynal \& Hitchcock and The Institute of Contemporary Art, 1948.

Le Corbusier Sketchbooks Volume 4 1957-1964. New York, Cambridge, Mass.: The Architectural History Foundation, The MIT Press, 1982.

Rowe, Colin: The Mathematics of the Ideal Villa and Other Essays, Cambridge, The MIT Press, 1976.

Rowe, Colin and Slutzky, Robert: “Transparency: Literal and Phenomenal”. In Perspecta, No.8, 1963. pp. 4554.

Sekler, Eduard F. and Curtis, William: Le Corbusier at Work. The Genesis of the Carpenter Centre for the Visual Arts. Cambridge, Mass.: Harvard University Press, 1978.

Serenyi, Peter (Ed.): Le Corbusier in Perspective. Englewood Cliffs, New Jersey: Prentice-Hall, Inc., 1975. von Moos, Stanislaus: Le Corbusier. Elements of a Synthesis. Cambridge, Mass.: The MIT Press, 1979. 


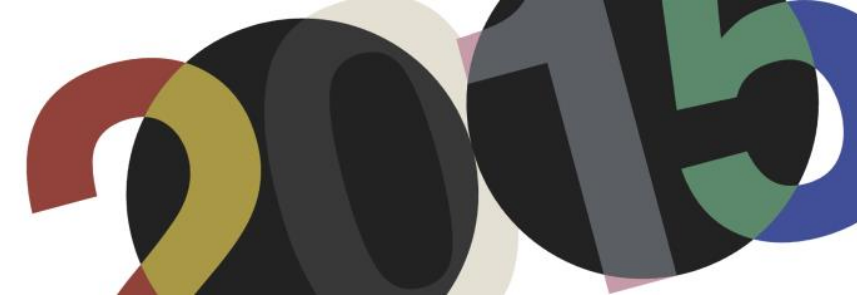

DOI: http://dx.doi.org/10.4995/LC2015.2015.634

\title{
Charles-Edouard Jeanneret miembro de l'OEUVRE
}

\section{Jimenez Caballero}

Escuela Técnica Superior de Arquitectura Universidad de Navarra

\begin{abstract}
Resumen: Esta investigacióvn presenta la influencia en Charles-Edouard Jeanneret de su maestro Charles L'Eplattenier a través de dos instituciones: l'École d'Art de La Chaux-de-Fonds donde ambas figuras se encontraron y la asociación de la Suiza francófona l'OEUVRE, en la que los dos coincidieron también un breve espacio de tiempo en la misma época. La actividad en ambas instituciones representa la doble vertiente de un único proyecto para reformar los procesos artísticos ligados a los oficios artesanales; el propósito era incorporar al producto industrial producido en serie el valor añadido de su calidad artística, siguiendo el ejemplo de la Werkbund alemana. Para tal fin era necesario llevar a cabo una profunda reforma en el programa de enseñanza de dibujo en l'École d'Art, y desarrollar a la vez, una serie de acciones que permitieran visualizar los logros alcanzados. Su estrategia estaba apoyada en dos pilares: formación y propaganda. La presente investigación detalla de que manera Jeanneret participó en este proyecto a través de su intervención tanto en l'École d'Art y las nuevas estructuras para renovar la enseñanza del dibujo, como en la asociación l"OEUVRE y sus distintos proyectos, A través de estas iniciativas encontramos el origen de algunos temas a los que Le Corbusier dedicará su atención; identificamos personajes que jugarán un papel importante en distintos momentos de su vida o proyectos y artículos que anunciarán propuestas teóricas y prácticas de sus trabajos posteriores.
\end{abstract}

Abstract: This research presents the influence in Charles-Edouard Jeanneret of his master Charles L'Eplattenier in the context of two institutions. On one hand 'École d'Art de La Chaux-de-Fonds, where both figures met and where they established a first line of common work; and on the other hand, the association from the french-speaking Switzerland called l'Oeuvre, in which both briefly met. The activity in both institutions had the same goal and was in reality a single project: the reform of artistic processes bounded to the craft trades to provide the mass-produced industrial goods with the added value of artistic quality, following the example of the Deutscher Werkbund. In order to do this, it was necessary to carry out a profound reform of the drawing education program of l'Ecole d'Art and develop a series of propaganda actions allowing to visualize its achievements. Thus, the strategy was based on two pillars: education and propaganda. This research details how Jeanneret contributed to this project through his involvement in both, l'École d'Art's renovation of drawing education and the Association l'Oeuvre's various projects. Through them we discover the origin of some of the subjects that Le Corbusier will devote its attention to, characters that will play an important role in different moments of his life, or projects and articles that announce theoretical proposals or practices of his subsequent work.

Palabras clave: Cours Supérieur; Nouvelle Section; Ateliers d'Art Réunis; L'OEUVRE.

Keywords: Cours Supérieur; Nouvelle Section; Ateliers d'Art Réunis; L'OEUVRE.

\section{Introducción}

Le Corbusier pasó sus primeros años de vida en un entorno bastante aislado de las corrientes renovadoras de comienzo de siglo; instruido en un sistema educativo tradicional y educado en una familia en la que madre y padre tenían dos personalidades muy diferentes: fuertemente vinculado a la región y al trabajo local el padre, y de mentalidad muy abierta y avanzada la madre quien había influido sobre todo en la formación de su hijo mayor Albert, prestando menor atención a las inquietudes y anhelos profesionales del menor para el que se esperaba una formación a la manera tradicional y su incorporación al taller de fabricación de relojes de su padre, como la mayoría de los jóvenes de la región. La manera en que en este contexto se desarrolló el embrión de una de las 
personalidades más influyentes del siglo XX es el punto de partida de la investigación que conduce a identificar una serie de elementos justificativos.

De la influencia de l'École d'Art en la que Jeanneret comienza su preparación artística y de la influencia de su maestro Charles L'Eplattenier tenemos testimonios recogidos en las cartas y en el diario del propio protagonista ${ }^{1}$. Menos conocida es la pertenencia del joven Jeanneret a la asociación francosuiza l'OEUVRE y algunas circunstancias de su fundación y de sus actividades en los primeros años de existencia ${ }^{2}$.

Los inicios del siglo XX en Suiza contemplan el enfrentamiento que tanto en los medios escritos como en las distintas exposiciones organizadas, libraron las corporaciones gremiales de los oficios artísticos contra las industrias y el público más conservador en el propósito de identificar un estilo que representara el carácter nacional ${ }^{3}$.

En ese contexto en el año 1913 se fundan en Suiza dos asociaciones artísticas: la Schwezerischer Werkbund -la Werkbund suiza- en la parte alemana y l'OEUVRE en la zona francófona. Con ellas, Suiza pretende sumarse al movimiento con el que numerosos artistas de Inglaterra y Alemania pretenden subsanar la ruptura que se ha producido entre el oficio artesano y el producto manufacturado a raíz de la revolución industrial. La sintonía entre ambas asociaciones queda manifestada en el hecho de que Alphonse Laverrière, presidente del Consejo fundador de la Werkbund suiza, es también presidente de l'OEUVRE desde su fundación hasta el año 1935; a su vez Schlosser, en su condición de secretario del consejo de la Werkbund suiza, es también miembro del Consejo de dirección de l"OEUVRE. Es natural por tanto, que esta asociación se presente y se refiera a ella misma, como la hermana gemela de aquella, que a su vez es la ramificación en el país helvético de la Werkbund fundada en Alemania por Hermann Muthesius con el propósito de demostrar la importancia de incorporar un buen diseño a la producción en serie y su repercusión en la economía nacional. Laverrière junto con Charles L’Eplattenier, pintor, escultor y profesor en l'École d'Art de La Chaux-de-Fonds fueron los promotores e impulsores de la asociación l'OEUVRE que fijó su sede en Lausanne.

\section{La renovación en la escuela de arte}

Unos años antes, en 1897, Charles L'Eplattenier se había incorporado a l'École d'Art de La Chaux-de-Fonds como profesor. En su selección habría influido seguramente, el que además de ser un artista de cierta relevancia formado en las Escuelas de Arte de Budapest y Paris, mantenía precisamente por ello numerosas relaciones con gentes del mundo de las artes de otros países. En 1903 el Consejo Académico le encomendó la dirección del centro y dos años más tarde, en 1905, ponía en marcha el Cours Superieur de Décoration. Con este nuevo curso, L’Eplattenier comenzaba a desarrollar su programa para introducir en los oficios locales las nuevas ideas para

\footnotetext{
${ }^{1}$ Sobre los comienzos de la formación de Le Corbusier, Cfr. Turner Paul, The beginnings of Le Corbusier's Education 19021907, The Art Bulletin Vol. 53, No. 2 (Jun., 1971), College Art Association, pp. 214-224

${ }^{2}$ Allen Brooks, en Le Corbusier, the formative years, pp. 354 y 355, menciona la concurrencia de Jeanneret en la creación de esta asociación y su artículo en el número 2 de la revista de l'Oeuvre; también se refiere a su presencia como miembro del jurado en el concurso de dibujo de Étrennes Helvetiques; no trata de su participación en otras actividades y programas que demuestran su colaboración con l'Oeuvre.

${ }^{3}$ Mauderli L., Positioning Suiss Design: The Sweizerischer Werkbund and l'Oeuvre as the beginning of the Twentieth Century, pp. 25-37.
} 
unir el estudio del arte con la práctica, y conseguir a través de esta confluencia, el propósito de renovación de los oficios artísticos ${ }^{4}$.

Es natural que para este propósito estimulara a los alumnos más destacados e inquietos a participar en el proyecto y que se apoyara en ellos para desarrollarlo. Dentro de su plan de formación incorporaba los viajes de estudio a los países precursores en la incorporación del diseño a los procesos industriales; servirían para conocer sus experiencias y para adquirir algunos objetos que pudieran ser la demostración evidente de esa feliz incorporación. Es en ese contexto en el que el maestro anima a su alumno Charles-Edouard Jeanneret a viajar a Alemania, donde va a permanecer desde abril de 1910 hasta mayo de 1911 con el encargo de realizar un informe sobre el estado de la práctica y la formación de las artes decorativas en aquel país. El informe se publicó en 1912. Se editaron 500 ejemplares y Jeanneret se sintió decepcionado porque no tuvo el eco que él esperaba ${ }^{5}$.

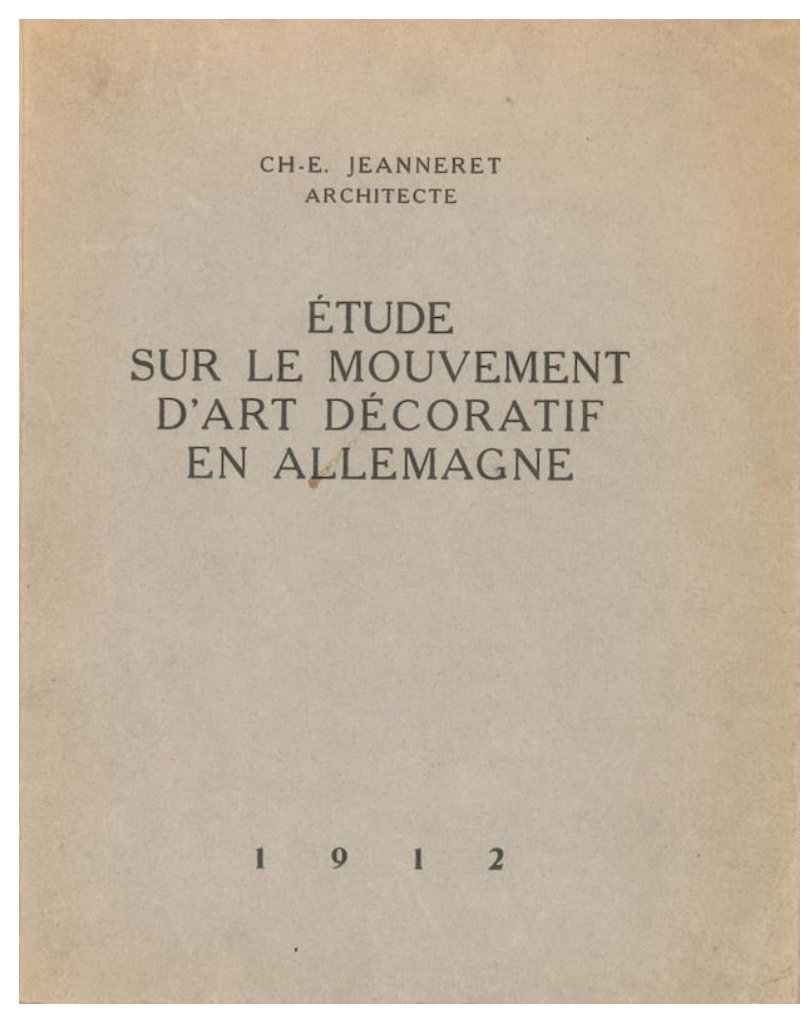

1. Portada de la publicación del trabajo original de Jeanneret para l'École d'Art de La Chaux-de-Fonds. Bibliothèque de la ville de La Chaux-de-Fonds, Fonds Le Corbusier LC/513/14287 @FLC-ADAGP.

A su regreso de Alemania en 1911, L'Eplattenier junto con Jeanneret y el reducido grupo de alumnos de su confianza en l'École d'Art, da un paso más en su propósito y crea la denominada Nouvelle Section. Se trata no ya de un curso, sino de un nuevo programa de estudios alternativo al programa oficial y que se propone ser la

\footnotetext{
${ }^{4}$ L'Eplattenier sintonizaba con los estilos propios del Art Déco, y trataba de aplicar procesos de racionalización a los modelos de la naturaleza creando un estilo local propio de la región que se denominó el estilo sapin por el empleo recurrente de la simplificación de la forma del abeto en los trabajos que realizaba con sus alumnos. Cfr. Dictionnaire historique de la Suisse
}

${ }^{5}$ Fox Weber N., Le Corbusier: A life, Alfred A. Knoph, p. 108; tambien en Petit J., Le Corbusier: lui-même p. 44 
aplicación práctica de las conclusiones obtenidas del informe de Jeanneret ${ }^{6}$. Este programa se puso en marcha después de haber sido presentado al Consejo de Dirección de la escuela y una vez obtenida su aprobación.

PROSPECTUS era el título del cuidado folleto en el que se presenta la Nouvelle Section, o la nueva línea de formación de la escuela, y explica claramente en sus páginas, que su propósito es "establecer en nuestro país una colaboración eficaz entre el arte y la industria" ${ }^{7}$.
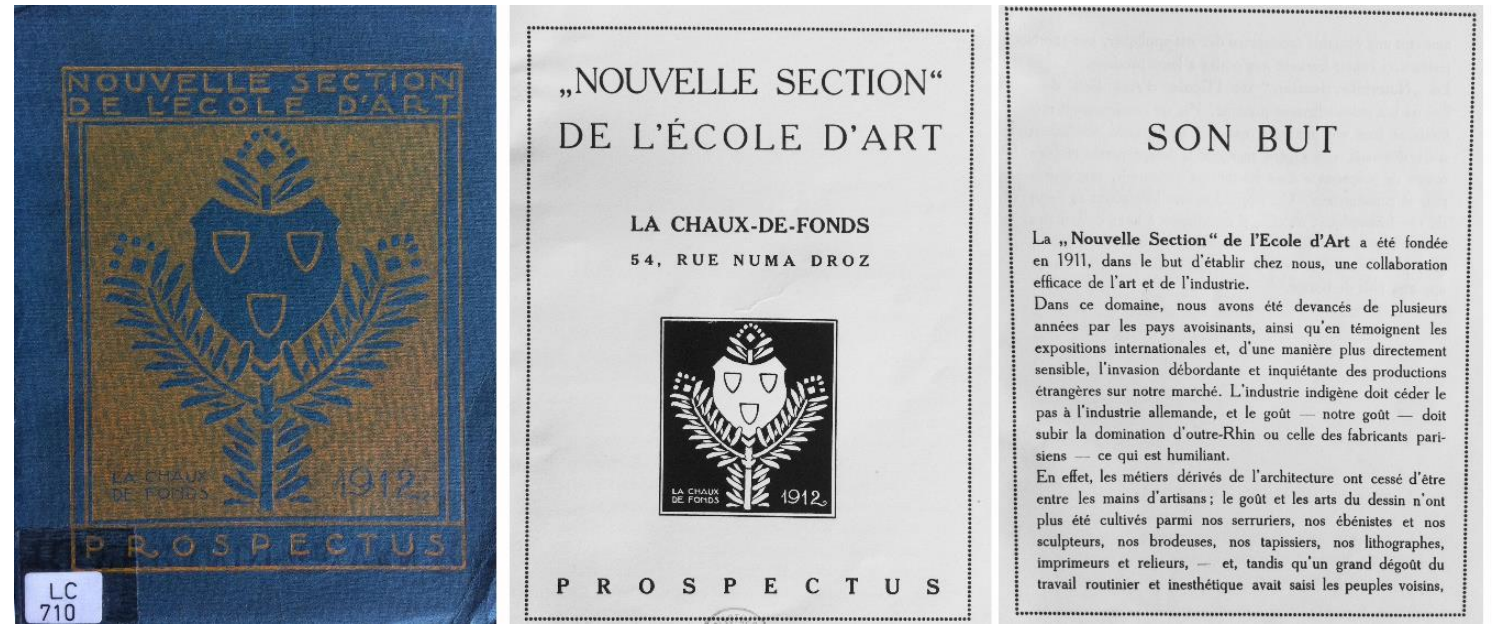

2. PROSPECTUS. Ejemplar original presentando la Nouvelle Section de la Escuela de Arte. Bibliothèque de la ville de La Chaux-de-Fonds, Fonds Le Corbusier LC/101/864

Este nuevo programa docente constaba de dos cursos con un examen previo de admisión. Superado el primer grado, se obtenía el título oficial o brevet para poder impartir enseñanzas de dibujo y decoración. El segundo grado se impartía con clases prácticas de oficios donde se recibían y se realizaban encargos profesionales, haciendo de la escuela una entidad con sus puertas siempre abiertas y preparada para el trabajo en régimen de taller. Incorporaba la gran novedad que era el completar la formación teórica con la práctica.

L’Eplattenier se hizo cargo de la docencia en el primer grado; en el segundo había tres grupos distintos según los diferentes oficios. Los responsables de cada uno de ellos eran: Georges Aubert para los talleres de diseño, modelado y escultura; Léon Perrin para el de composición ornamental y Charles-Edouard Jeanneret para geometría, arquitectura, decoración interior y objetos ${ }^{8}$. Los temas que impartía éste último según el programa de la propia escuela eran: a) estudios teóricos: elementos geométricos, características, valores relativos, decorativos

\footnotetext{
${ }^{6}$ En el documento publicación del informe de Jeanneret sobre las Artes Decorativas en Alemania, se recoge textualmente: "La Comisión de la Escuela de Arte en su sesión de 22 de febrero de 1912 ha decidido la publicación del informe sobre el Arte Decorativo en Alemania que le ha sido presentado por M. Ch.-Ed. Jeanneret, persuadida como está de que las indicaciones que contiene deben ser divulgadas en el interés del desarrollo del Arte Decorativo en nuestro país". Está firmado por el secretario G. Moser y el Presidente H. Bopp-Boillot-. Traducción de la autora.

${ }^{7}$ Traducción de la autora. "La Nouvelle Section de l'École d'Art a été fondée en 1911, dans le but d'établir chez nous, une collaboration efficace de l'art et de l'industrie" en PROSPECTUS de la Nouvelle Section. L'École d'Art de La Chaux de Fonds había sido fundada en 1870 con el único propósito de proporcionar a la industria relojera los artesanos de los diferentes oficios que intervenían en la fabricación de relojes.

${ }^{8}$ Esta organización de los temas y su distribución está contenida en la publicación PROSPECTUS Nouvelle Section de l'École d'Art. L’Eplattenier impartía 18 horas de clase semanales, Perrin 6, Aubert 10, y Jeanneret impartía 12. Los tres habían sido alumnos del Cours Supérieur de Décoration y los tres habían regresado de estancias prospectivas en el extranjero o habían sido llamados a los países en los que se encontraban para invitarles a participar en este nuevo propósito.
} 
y monumentales; b) estudios prácticos: arquitectura, mobiliario, proyectos conjuntos, objetos varios, dibujos de proceso, planos, secciones, perspectivas; c) ejecución de obras de arquitectura, de decoración, de interior y de objetos varios ${ }^{9}$.

La nueva sección de docencia, la Nouvelle Section, fue aprobada por unanimidad el 12 de junio en la Comisión de l'Ecole d'Art presidida por Mr. Bopp-Boillot y ratificada posteriormente por el Consejo Comunal. Los alumnos que estaban en esta sección ya tenían una cierta experiencia profesional pues habían hecho algunos trabajos mientras cursaban el Cours Supérieur de donde todos procedían y cuyo programa, que había incorporado al aprendizaje del dibujo las prácticas profesionales, había dado lugar a algunos trabajos ${ }^{10}$. Para darle más relevancia a esta práctica profesional y dentro del mismo propósito renovador, se había fundado también en 1910 la Association Indépendante des "Ateliers d'Art Réunis" ${ }^{\prime 1}$. Se trataba de una entidad creada con antiguos alumnos de la Escuela y a la vez que el Cours Superieur. Su objetivo era el de atraer trabajos profesionales que realizar de acuerdo a las nuevas tendencias estéticas. Los posibles clientes serían atraídos por la solvencia que proporcionaba a sus componentes el ser titulados de l'École d'Art. En esta organización también participaba Jeanneret, que debía integrarse tan pronto regresara de Alemania ${ }^{12}$. A partir de su puesta en marcha, los encargos artísticos que llegaban a la escuela de arte comenzaron a desviarse de manera casi natural hacia esta nueva aspcoación ${ }^{13}$.

Aunque el proyecto de L'Eplattenier era ambicioso, la Nouvelle Section tuvo una corta vida. Comenzó a funcionar en agosto de 1912 con casi una veintena de alumnos y en la sesión del 9 de abril de 1914 el Consejo de Dirección de la Escuela de Arte la condujo a su clausura. Sus alumnos se integraron en el programa tradicional de la Escuela, que había seguido funcionando y en el que estaban el resto de alumnos junto y los que no habían superado la prueba de selección de aquella.

Los tres fieles alumnos colaboradores de L'Eplattenier, responsables de las enseñanzas en el segundo grado de la Nouvelle Section, prepararon un encendido informe para la sesión del Consejo en la que se iba a tomar el acuerdo de la desaparición y lo remitieron al Consejo de Dirección cuatro días antes; el documento terminaba con la dimisión de todos ellos intentando disuadir al órgano directivo de su decisión. Los profesores más conservadores nunca habían asumido las ideas que estos jóvenes traían de otras regiones europeas; tampoco estaban dispuestos a ceder la autoridad en las materias que impartían, para conseguir una total homogeneidad de la enseñanza en $l$ 'École d'Art que los renovadores consideraban imprescindible ${ }^{14}$.

\footnotetext{
${ }^{9}$ Traducción de la autora de PROSPECTUS: "Cours de Monsieur CH:-E. JEANNERET: Eléments géometriques, leurs caractères, leurs valeurs relatives, décoratives et monumentales. Applications diverses à l'architecture, au mobilers, à divers objets (dessins d'exécution, plans, coupes, perspectives etc.). Exécution pratique d'oeuvres d'architecture, de décoration d'intérieur et d'objets divers". Jeanneret impartía 12 horas de clase semanales y cobraba por ello 1.320 francos. Cfr. también Extrait des procès-verbaux de la commission de l’Ecole d'Art, Fonds Le Corbusier LC/101/864 p.6

${ }^{10}$ Algunos de los trabajos realizados antes de 1910 fueron: Sala de música en La Chaux de Fonds y casa para Mr. L Fallet en 1906; restauración de la capilla de Cernier-Fontainemelon y casa en Tavannes en 1907; una villa en La Chaux de Fonds en 1908; sala de música en La Chaux de Fonds en 1909 y la decoración del Crematorio en 1910.

${ }^{11}$ Hellmann A., "Les Ateliers d'art réunis de La Chaux-de-Fonds (1910-1916)" en Art+Architecture en Suisse 2002/3

${ }^{12}$ Seguían estos talleres el modelo iniciado en Glasgow, Munich, Darmstadt o Viena con la aspiración de alcanzar en las grandes obras el propósito de la obra de arte total. A la organización de estos talleres se refiere también Dumont M.-J. en $L e$ Corbusier Lettres à Charles L'Eplattenier, pp. 50-54

${ }^{13}$ En PROSPECTUS: "A cette époque, quelque anciens élèves ayant fondé l'Association Indépendante des "Ateliers d'Art Réunis" (1910), l'exécution des grande-travaux passa tout naturellement à cette Société" Traducción de la autora

${ }^{14}$ L'Eplattenier tenía la idea de una escuela de arte semejante a la de Nancy de Victor Prouvé y el conflicto surgido entre los distintos sectores mereció la publicación de un pequeño libreto de encendida redacción reivindicativa titulado Un
} 
Las rivalidades entre la escuela tradicional y los seguidores de L’Eplattenier habían comenzado desde el primer momento. El Diplôme d'Honneur obtenido por los alumnos de la Nouvelle Section en la Exposición Internacional de Milán de 1906 con un diseño de reloj criticado en su estética por los profesores más conservadores unido al incremento constante de alumnos que solicitaban su admisión en la Nouvelle Section, no hacían sino agrandar la rivalidad entre las dos secciones. Los enfrentamientos se habían llevado a la vida pública donde formaban parte de las discusiones entre rivales políticos ${ }^{15}$. Para empeorar las cosas, el desencuentro en la Escuela de Arte se utilizaba como argumento en un ambiente social muy agitado que iba a conducir al cambio en el poder local muy poco después, sin olvidar el ambiente prebélico en gran parte de Europa del que participaba Suiza a pesar de su neutralidad.

El desvío de trabajos hacia los Ateliers d'Art Réunis, el cuestionamiento artístico de l'Eplattenier y la injerencia en el gobierno de la Escuela de los informes, que a solicitud de los interesados, habían remitido figuras relevantes en la educación artística de otros países opinando sobre la forma de enseñanza, no hicieron sino aumentar el malestar ${ }^{16}$.

El enfrentamiento entre las dos secciones de la Escuela se hizo insostenible y en la sesión del 12 de marzo de 1914, los representantes de la antigua escuela se hicieron con todo el programa académico disolviendo la Nouvelle Section, prescindiendo de todos sus profesores y manteniendo solo a L'Eplatennier como profesor de dibujo con una dedicación de 6 horas de dibujo técnico y 7 horas de dibujo de composición ${ }^{17}$.

Cuando los profesores despedidos presentaron su informe en el que se referían a los años de funcionamiento de este programa con los nombres de los alumnos que lo habían seguido y sus profesores, al mencionar a Jeanneret incluían: " Ch.-E. JEANNERET, architecte, La Chaux-de-Fonds, professeur (breveté) á la Nouvelle Section de l'École d'Art, membre fondateur de l'OEUVRE, ex-premier dessinateur -1908-1909- chez Perret frères,

Mouvement d'Art à La Chaux-de-Fonds à propos de la Nouvelle Section de l'Ecole d'Art firmado por Ch. Ed. Jeanneret, Léon Perrin, y Gustave Aubert, que se puso a la venta al precio de 30 céntimos. Esta publicación recopila la secuencia histórica de estos años en l'École d'Art y los enfrentamientos entre la Ancienne y la Nouvelle Section. Un ejemplar de esta publicación tiene una dedicatoria manuscrita del propio Jeanneret para su amigo Auguste Klipstein que dice así: "à toi Auguste ce tableau de nos misères!!.......... . Mais, Dieux merci, ceci nous valut de comprendre que l'art dans une bourgade est un leurre " Para ti Auguste este tablero de nuestras miserias! ..... Pero gracias a Dios, ello nos sirvió para entender que el arte en una aldea no es más que una ilusión. Traducción de la autora.

${ }^{15}$ En la prensa local, La Feuille D'Avis y el National Suisse entre otros encontramos numerosos artículos que tratan de estas desavenencias y de los enfrentamientos entre las diferentes secciones de la escuela. Como prueba del tono de la discusión pública librada Cfr. National Suisse 26 août 1911 o La Sentinelle 25 avril 1914. También en Baudoui R., Dercelles A. Le Corbusier Correspondance Lettres à sa famille 1900-1925, carta de su padre a Ch.-E. Jeanneret de 14 de septoembre de 1911

${ }^{16}$ Fueron remitidas cartas a personas de reconocida solvencia en la enseñanza de arte, en las que se les solicitaba un informe sobre el planteamiento y resultados de esta sección de la escuela de La Chaux-de-Fonds. Se escribió a: Eugêne Grasset, Paris; Rupert Carabin, Paris; K. Ernst Osthaus, Hagen; Peter Behrens, Berlin; Theodor Fischer, Munich; Alf Rollee, Viena. Los tres últimos eran miembros del comité ejecutivo de la Werkbund y Behrens además era miembro de honor. Estas cartas se remitieron el 6 de marzo de 1914. También envió una carta de adhesión Hector Guimard. Cfr. Un Moucement d'Art à La Chaux-de-Fonds, Bobliothèque de la ville de La Chaux-de-Fomds, LC/101/1379

${ }^{17}$ Una intervención muy dura de Mr. Jeanneret se produjo tras la votación, provocando la absurda situación de que el presidente Mr Hirschy y el secretario Mr. Graber, votada y aceptada la supresión de la Nouvelle Section, pidieron que se estudiara la implantación de un curso similar al que se acababa de suprimir a la vez que se lamentaban del poco eco que en la escuela tenían las corrientes más innovadoras. L’Eplattenier presentó también su dimisión el 18 de marzo. Cfr. Un Mouvement d'Art à La Chaux-de-Fonds. 
architectes, Paris (architectes du Théâtre des Champs Elyssées); en 1910 l'un des six premiers dessinateurs (sur vingt-quatre) chez Peter Behrens, architecte, conseiller artistique de AEG à Berlin"18.

Entre los méritos de Léon Perrin y Georges Aubert también figuraba el ser miembros fundadores de $l^{\prime} O E U V R E$.

Todo este movimiento renovador en la escuela de arte de Charles L'Eplattenier a través del Cours Supérieur y la Nouvelle Section, no era sino la cara de una moneda cuyo envés era l'OEUVRE la asociación nacida para reunir con una atadura más íntima el arte y la industria en la sociedad civil. Se definía a sí misma como un hogar acogedor de las ideas progresistas. Agrupaba en su seno a artistas, industriales, comerciantes, hombres competentes en esos ámbitos y de buena voluntad decididos a hacer penetrar el arte en la vida, a elevar el gusto del público y a desarrollar las industrias artísticas. Sus medios de acción serían fundamentalmente dos: la educación y la propaganda. A ello se unía la determinación de conseguir encargos y realizar trabajos artísticos, aunque la asociación como tal no aspirara a tener actividad industrial o explotación comercial alguna ${ }^{19}$.

\section{La fundación de $L^{\prime} O E U V R E$}

$L^{\prime} O E U V R E$ fue fundada el 9 de Noviembre de 1913 en Yverdon por el arquitecto Alphonse Laverrière ${ }^{20}$ y el artista Charles L'Eplattenier. Laverrière fue su primer presidente y L'Eplattenier su primer vicepresidente. Su intención era imitar a la Werkbund alemana aspirando a establecer un modelo similar de cooperación como el de la Werkbund y las industrias AEG en aquel país ${ }^{21}$. Además de ser vicepresidente L'Eplattenier estaba también a cargo de las Artes Decorativas, siendo particularmente activo en ese campo.

El nombre de Jeanneret figuraba desde el primer momento entre el reducido grupo de delegados de Lausanne que convocaban a la asamblea constituyente de la asociación con un tono idealista, apelando a la vitalidad y alegría de un proyecto conjunto en el que se establecerían los lazos de amistad duraderos con los que trabajar en el ideal común de alcanzar la obra soñada. La sesión constituyente sería el domingo 9 de noviembre a las dos de la tarde en la sala principal del Ayuntamiento de Yverdon, y estaría precedida de un encuentro en el Hotel du Paon. Una idea de la relevancia de Jeanneret en el proyecto la da el que su nombre como convocante para la sesión constituyente aparezca junto con los del presidente y vicepresidente de la nueva asociación.

\footnotetext{
${ }^{18}$ : Traducción de la autora: Ch.-E. Jeanneret; arquitecto, La Chaux de Fonds, profesor (diplomado) en la Nouvelle Section de la Escuela de Arte, miembro fundador de l'OEUVRE, ex primer dibujante -1908-1909- en hermanos Perret arquitectos, Paris (arquitectos del teatro des Champs Elysées); en 1910 uno de los seis primeros dibujantes (sobre veinticuatro) en Peter Behrens, arquitecto y consejero artístico de AEG en Berlin. En Un Mouvement d'Art.., pg. 20

${ }^{19}$ Estatutos de 1'OEUVRE Cfr. PROGRAMME DE L“OEUVRE ASSOCIATION SUISSE ROMANDE DE L“ART ET DE L“INDUSTRIE. Bibliothèque de la Ville, La Chaux-de-Fond, Fonds Le Corbusier LC/104/881

${ }^{20}$ Alphonse Laverrière estudió en ENSBA como Carles L'Epplatennier. El contacto entre antiguos alumnos era grande y puede estar en los orígenes de la relación que condujo a la creación de l'Oeuvre. Cfr. "Architecture et arts appliqués :sur l'OEuvre, ses ambitions et sur quelques-uns de ses protagonistes" en: Neuenschwander Joëlle: Les Held de Montreux, une menuiserie modèle

${ }^{21}$ Cfr. P. Frey, Architecture et arts appliqués : sur l'Oeuvre, ses ambitions et sur quelques-uns de ses protagonistes $\mathrm{pp} .51-$ 57. Figuras directivas de varias industrias se unieron a l'Oeuvre y promocionaron sus ideas y formas de trabajo en sus empresas como Favre-Jacquot, propietario de industrias Zenith, que se convirtió en gran patrón de la asociación a partir de 1918. La intención de l'Oeuvre era emular los procesos creativos de la haute-couture de Francia en la cual la producción de piezas artesanales se convertían en objetos de lujo. De este modo, los diseños se creaban en ateliers y estudios de diseño, luego se manufacturaban en fábrica y, finalmente, artesanos con educación artística y gran habilidad, estaban a cargo de los acabados y ornamentación.
} 


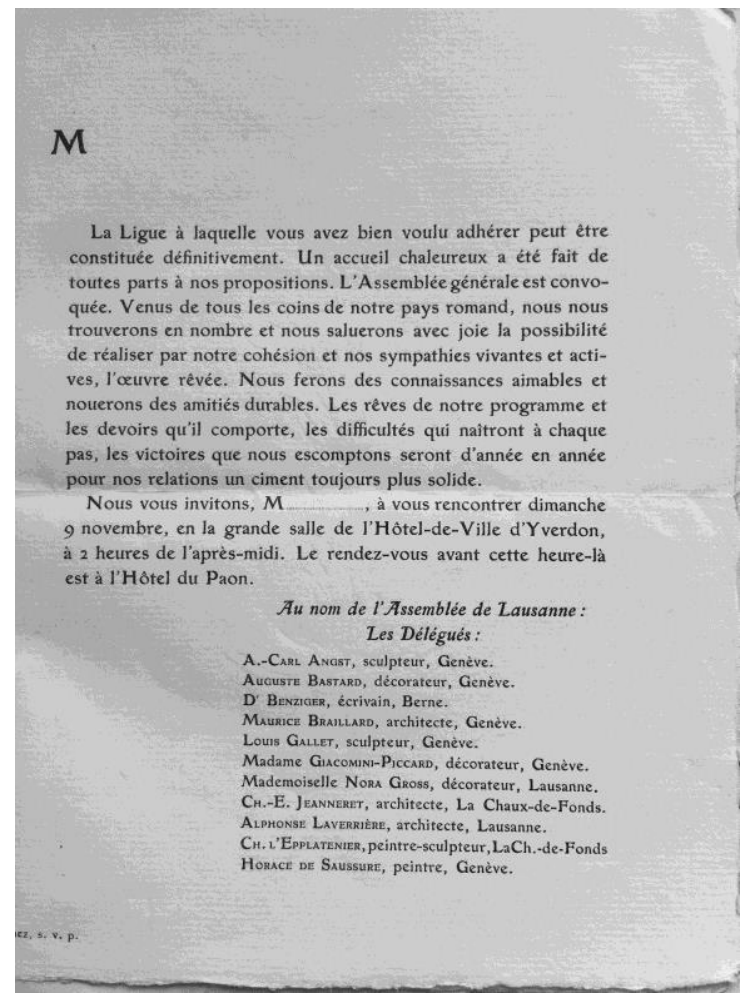

3. Modelo de la carta en la que se convocaba a la asamblea constituyente de $L^{\prime} O E U V R E$. Bibliothèque de la ville de La Chaux-de-Fonds, Fonds Le Corbusier LC/104/882

El compromiso social de $l^{\prime} O E U V R E$ consistía en integrar la cultura en todos sus niveles, con el diseño y el arte suizo. La consecuencia de ese propósito sería el reformar los diseños tradicionales y conseguir con ello unas repercusiones económicas mediante la competencia de las producciones industriales con las de otros países del entorno. Era natural que prestaran atención y siguieran las pautas de lo que se hacía en los centros del diseño de aquellos lugares en los que se estaban llevando a cabo las reformas más importantes, como Gran Bretaña, Alemania, Austria, Bélgica u Holanda.

Su programa enunciado brevemente consistía en:

- Propaganda: exposiciones, artículos en prensa, publicaciones propias y conferencias.

- Desarrollo de las artes aplicadas: apoyo a los artistas, decoradores e industrias de artísticas; concursos; archivo de modelos, dibujos y documentación para el estudio de las industrias nacionales.

- Mejora en la enseñanza del dibujo: reforma de los programas escolares y de la educación del gusto en la escuela $^{22}$.

- Defensa de los intereses artísticos: mejora de las condiciones de trabajo de los artistas, protección de los derechos de autor y creación de un órgano de intermediación entre artistas e industriales.

Como herramientas para su penetración entre el gran público la asociación iba a editar una revista y un boletín periódicos ${ }^{23}$, además de organizar unas exposiciones de arte aplicado y de crear un museo comparativo de lo

\footnotetext{
${ }^{22}$ Es en este punto del programa donde se advierte la relación que había entre toda la renovación que L’Eplattenier quería llevar a cabo en l'École d'Art y un proyecto de alcance social mucho más amplio y ambiciosos que era el que se proponía I'OEUVRE.
} 
bello y lo feo; esta iniciativa sería el complemento educativo para proporcionar al público no instruido una mejor comprensión de la belleza de las formas y para combatir de ese modo las formas más vulgares.

La asociación estaba formada por tres tipos de miembros: activos, auxiliares y colaboradores y la Asamblea General elegía entre sus miembros al Consejo de Dirección; al menos tres quintas partes de ellos debían ser artistas y la cuota de ingreso eran 200 francos. Además de la Asamblea y el Consejo, la asociación contaba con un tercer órgano de gestión que eran los Comités Especiales ${ }^{24}$.

El Consejo de Dirección estaba formado por quince miembros, seis debían ser artistas y otros seis comerciantes o industriales; cinco de los miembros se renovaban anualmente. Estaba compuesto de presidente, vicepresidente, secretario, vicesecretario y tesorero. La duración en el tiempo de la asociación sería ilimitada y para su disolución serían necesarios los dos tercios de la asamblea general; esto ocurrió; en 2003 tras noventa años de existencia.

Las autoridades federales y cantonales dieron una calurosa bienvenida a la asociación y en los medios ilustrados de la suiza francófona se saludaba con placer y esperanza su llegada.

Para la labor práctica que l'OEUVRE pretendía llevar a cabo, su tercer órgano de gestión estaba formado por los siguientes Comités:

- Comité de Propaganda. Se ocupaba de los artículos para revistas y periódicos; de la elaboración de la revista y el boletín; de la organización de conferencias, tertulias y exposiciones o de la creación del museo de lo bello y lo feo entre otras cosas.

- Comité para el estimulo y desarrollo de las artes aplicadas. Se ocupaba de la organización de concursos entre los artistas y los fabricantes para mejorar los productos industriales; del apoyo de diferente tipo a las industrias y del apoyo publicitario de las fabricas cuyos propietarios formaban parte del Consejo de l'OEUVRE.

- Comité para la mejora y unificación de la enseñanza del dibujo y de las artes aplicadas. Su ambicioso programa pretendía reorganizar los programas de enseñanza en las escuelas primarias, secundarias, superiores y profesionales; mejorar el aprendizaje teórico y práctico; mejorar las pruebas para los diplomas de enseñanza y perfeccionar las normativas para la concesión de becas de estudios.

- Comité para la defensa de los intereses artísticos. Trataba de conseguir una relación fluida con las sociedades que contribuían al desarrollo del arte industrial; establecer una oficina de contactos que facilitara las relaciones entre artistas, industriales, comerciantes y público en general y la defensa de los Derechos de Autor.

\section{Jeanneret y sus actividades en l'OEUVRE}

Es razonable que siendo L'Eplattenier una figura con marcado protagonismo tanto en l'École d'Art como en l'OEUVRE, el equipo de personas de confianza en ambos escenarios fuera también el mismo pues en realidad todo era parte de un mismo proyecto liderado por una misma persona y, que como se definía en el manifiesto de

\footnotetext{
${ }^{23}$ El diseño y el contenido de la revista eran en todo semejantes a la revista DAS WERK que publicaba la Werkbund suiza. Hasta tal punto eran semejantes que se repetían los artículos en una y otra. Como por ejemplo el del nuevo edificioo de la Universidad de Zurich publicado en el n ${ }^{\circ} 2$ de $L^{\prime} O E U V R E$ en francés y en DAS WERK en alemán.

${ }^{24} \mathrm{La}$ estructura participativa y organizativa de $l$ OOEUVRE, los distintos comités y sus funciones se recogen PROGRAMME DE L“OEUVRE ASSOCIATION SUISSE ROMANDE DE L“ART ET DE L“INDUSTRIE. y STATUTS DE L“OEUVRE ASSOCIATION SUISSE ROMANDE DE L“ART ET DE L"INDUSTRIE, Op. cit.
} 
presentación de $L^{\prime} O E U V R E$, tenía un claro objetivo ${ }^{25}$. En el manifiesto fundacional exponía que su propósito era: "... desarrollar en el país la actividad en el campo del arte aplicado y trabajar en el perfeccionamiento de las industrias artísticas consideradas un valioso medio de cultura popular y un importante factor de prosperidad económica. Su propósito es agrupar a los artistas, industriales, comerciantes, artesanos y a todas aquellas personas competentes y de buena voluntad que quieren incorporar el arte a la vida, permitiéndoles contener la competencia de los productos extranjeros ${ }^{26 "}$.

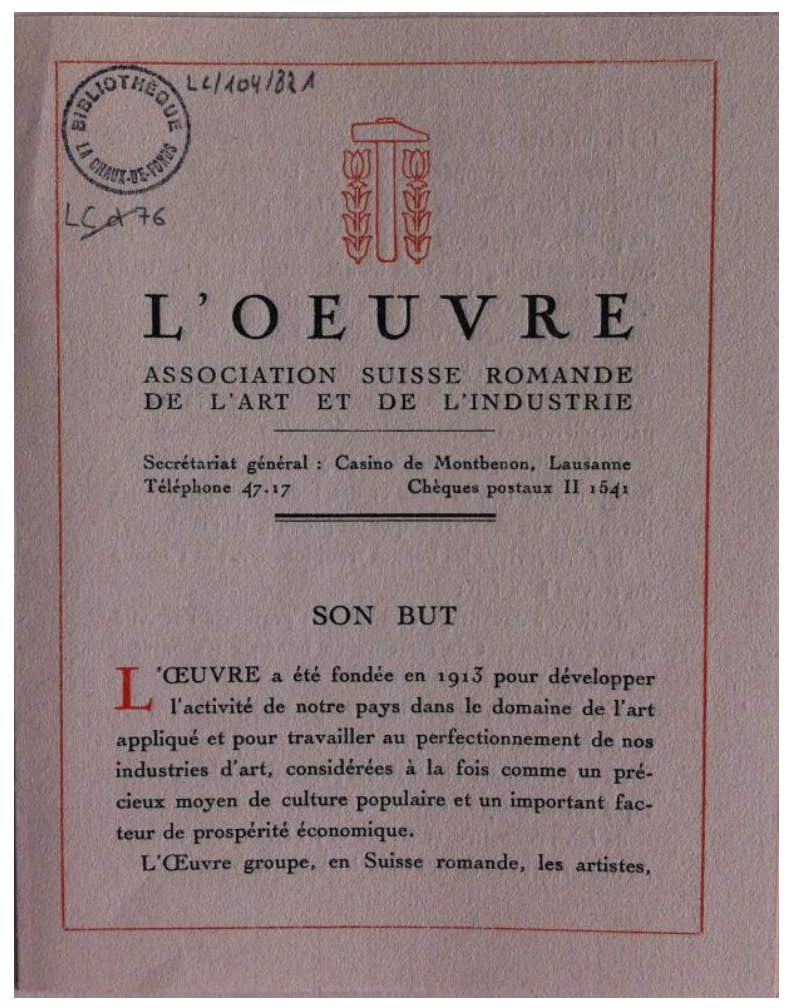

4. Portada de uno de los folletos divulgativos de L'OEUVRE. Bibliothèque de la ville de La Chaux-de-Fonds, Fonds Le Corbusier LC/104/881

Es natural que dado el papel que Jeanneret desempeñaba en la reforma de l'École d'Art, el Comité en el que se implicara desde el primer momento fuera el de la mejora y unificación de la enseñanza del dibujo; pero aunque esta coincidencia abunde en la idea de un mismo proyecto, la actividad de Jeanneret en l'OEUVRE quedaría reflejada también en otras iniciativas.

$L^{\prime} O E U V R E$ se iba a ocupar de la enseñanza del dibujo desde las clases de primaria, con una especial atención a su uso como herramienta del arte aplicado, apoyando en sus dificultades y esfuerzos a aquellos maestros cuyo propósito fuera acomodar más estrechamente arte e industria, aunque sin pretender en ningún modo sustituir a las autoridades escolares ${ }^{27}$.

\footnotetext{
${ }^{25}$ L'OEUVRE Association Suisse Romande de l'Art et de l'Industrie. LC/104/82 A. Bibliothéque de la Ville de La Chaux de Fonds

${ }^{26}$ Traducción de la autora. Literalmente del folleto publicado para dar a conocer y presentar el nuevo movimiento en el que bajo el epígrafe SON BUT se enuncia el propósito de la asociación.

${ }^{27}$ Archives Biblithèque de la ville de La Chaux-de-Fonds (8382-2) LCd 76
} 
La presencia tanto de L'Eplattenier como de su alumno Jeanneret en el Comité mencionado y en sus iniciativas queda documentado al aparecer como miembros del jurado de algunos concursos de dibujo que l'OEUVRE organizaba. En el boletín n 5 de 19 de junio de 1914, se recoge la decisión del jurado sobre el concurso de dibujo infantil patrocinado por L'OEUVRE y organizado por Etrennes helvetiques. Como miembros del jurado figuran Ch.-Ed. Jeanneret y Ch. L'Eplattenier de La Chaux-de-Fonds y varios de los premios corresponden a alumnos de la Nouvelle Section de la Escuela de Arte de esa localidad. En el boletín nº se completan las valoraciones del jurado sobre el citado concurso aprovechando la ocasión para efectuar una crítica sobre los procedimientos tradicionales de enseñanza que $l^{\prime} O E U V R E$ quiere combatir. Afirman entre otras cosas que "los aprendices arquitectos, siguen practicando las aguadas impecables, en los dibujos de fachadas copiadas de Vignola o de otros modelos de sus cuadernos. El sentido constructivo está ausente y el diseño de imaginación no aporta nada original ${ }^{\prime 28}$. Afirman que entre los veinticinco concursantes arquitectos hay una gran proporción de futuros "afeadores" y concluyen que l'OEUVRE desde su fundación cuenta con documentación recopilada que permitirá afrontar la cuestión de la enseñanza del dibujo, ya que el concurso ha demostrado ..."la penosa situación en la que se encuentran los oficios artísticos basados en esa disciplina y sus métodos de enseñanza, tan estrechos y neutralizantes que provocan nefastas consecuencias desde los primeros años de la escuela primaria". ${ }^{29}$

Al igual que Jeanneret preparó en 1912 su informe sobre Artes Decorativas en Alemania para la Escuela de Arte, en el contexto de l'OEUVRE también preparó un informe paralelo sobre la Escuela de Artes y Oficios de Zurich. Este documento nunca vio la luz en Suiza, pero sí que lo hizo en un momento dado en Francia ${ }^{30}$.

De la presencia de Jeanneret en otras iniciativas de l'OEUVRE podemos señalar la publicación de un artículo en el $\mathrm{n}^{\circ} 2$ de la revista correspondiente a febrero de $1914^{31}$ que puede ser su primer artículo de opinión, más allá de las crónicas e impresiones de sus viajes en La Feuille d'Avis, titulado Le Renouveau de l'architecture y cuyo ejemplar reclamaba por no conservar ya ninguno ${ }^{32}$.

\footnotetext{
${ }^{28}$ Traducción de la autira en Boletín L'OEUVRE $\mathrm{n}^{\circ} 6$ de 10 de julio de 1914

${ }^{29}$ Traducción de la autora Firmado por los miembros del jurado, el 29 de abril de 1914 Boitel, Jeanneret. L’Eplattenier, Perregaux y Musper y publicado en los Boletines 5 y 6 de 19 de junio y 10 de julio de 1914.

${ }^{30}$ Bibliothèque de la Ville de La Chaux-de-Fonds, LC/109/893 Articles parlant du rapport de la sous-commission de l'enseignement de la société "L'OEuvre, Association suisse romande de l'art et de l'industrie", sur l'enseignement des arts en Suisse, présenté à la commission de l'enseignement du comité central technique des Arts appliqués. extraits de: Les Arts français, $n^{\circ} 24,1918$. Les Arts français, $n^{\circ} 25,1919$. Les Arts français, $n^{\circ} 26,1919$. Les Arts français, $n^{\circ} 27,1919$.

31 L'OEUVRE publica una revista y un Boletín bimensual. La revista llevaba por título: L'OEUVRE Revue Suisse d'Architecture, d'Art et d'Art Appliqué. La suscripción anual era de 18 frs en Francia, 20 frs en el extranjero y 12 frs para los miembros asociados. La dirección editorial estaba en Bümpliz-Berna

${ }^{32}$ El título, como Allen Brooks apunta, recuerda a Le Renouveau dans l'art que L'Epplatennier publicó en el suplemento L'Abeille National Suisse, el 20 de Febrero de 1910
} 


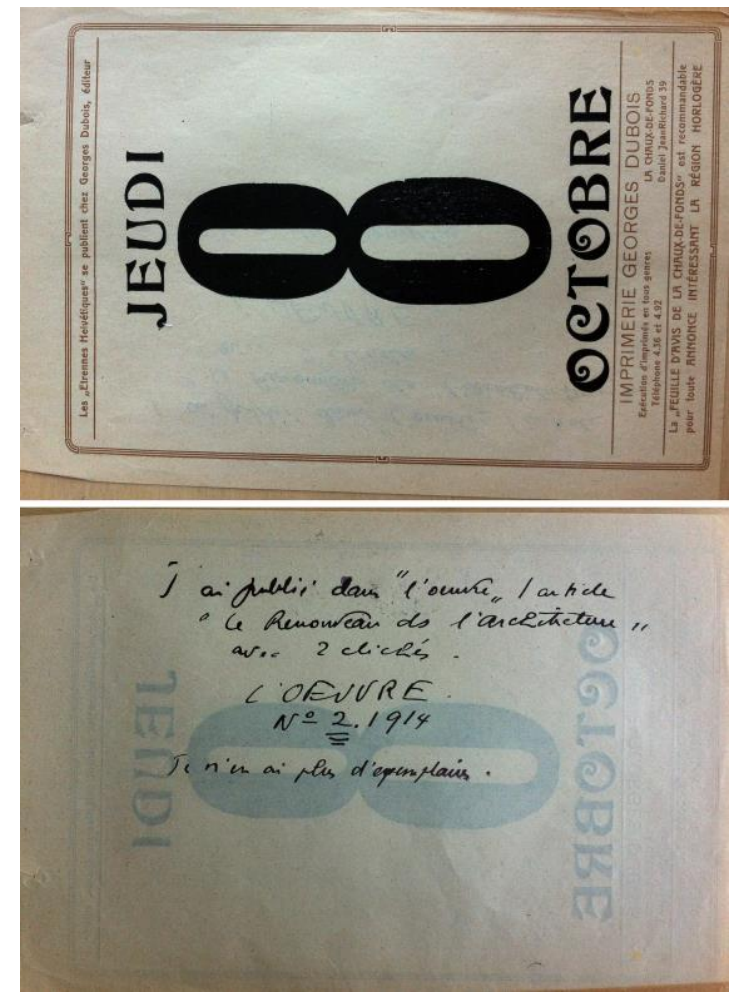

5. Anverso y reverso de hoja de calendario manuscrita de Ch.-Ed. Jeanneret en que dice que no le quedan ejemplares de la revista, Bibliothèque de la ville de La Chaux-de-Fonds, Fonds Le Corbusier LC/104/881
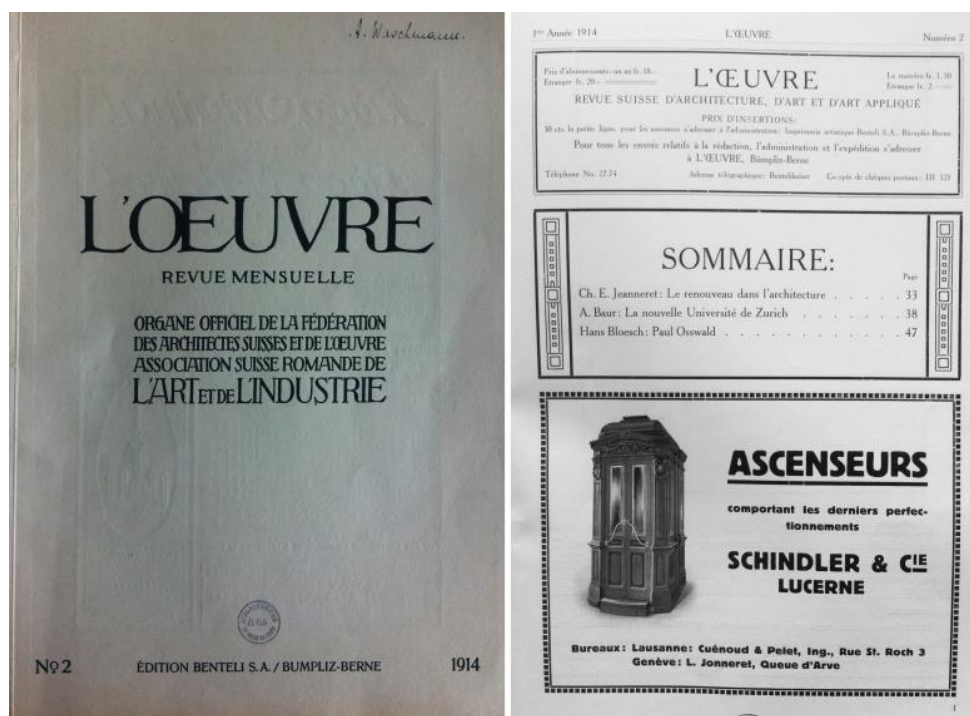

6. Portada y sumario de contenido de la revista L’OEUVRE $n^{\circ} 2$ con el artículo de Ch.-E. Jeanneret. Bibliothèque de la ville. de La Chaux-de-Fonds. Fonds Le Corbusier LC126 

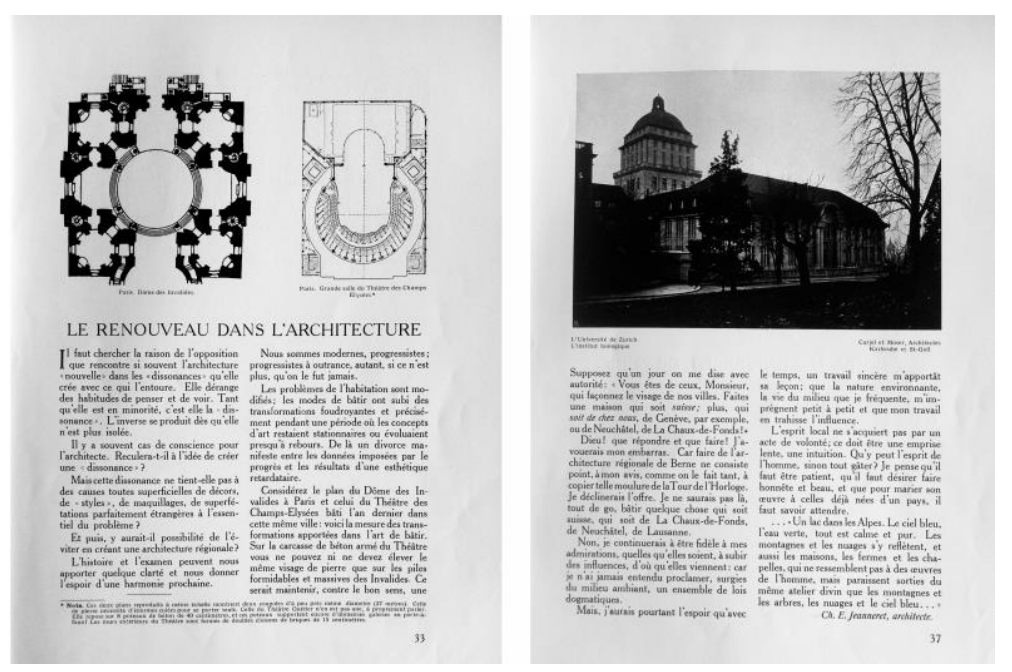

7. Páginas 33 y 37, inicial y final del artículo de Charles-Edouard Jeanneret. Bibliothèque de la ville. La Chaux-de-Fonds. Fonds Le Corbusier LC/126

Sólo se publicaron seis ejemplares de la revista debido a los problemas económicos de la guerra pero se siguió publicando el Boletín cuyo título era L'OEUVRE Organne Officiel de la Fédération des Architectes Suisses et de l'Association Suisse Romande de l'Art et de l'Industrie ${ }^{33}$. En la portada del Boletín $\mathrm{n}^{\mathrm{o}} 3$ correspondiente al mes de abril de 1914 se publicaba el comienzo del artículo de Jeanneret ya aparecido en la revista con un à suivre para ser continuado en boletines sucesivos.

${ }^{33}$ L'OEUVRE Órgano Oficial de la Federación de Arquitectos Suizos y de la Asociación Suiza Romance del Arte y la Industria. Traducción de la autora. Su suscripción anual era de 4 frs. lo editaba DAS WERK Bumpliz-Berne y su dirección como la de la Asociación era la de su presidente: rue des Terreaux, 10 Berne. 


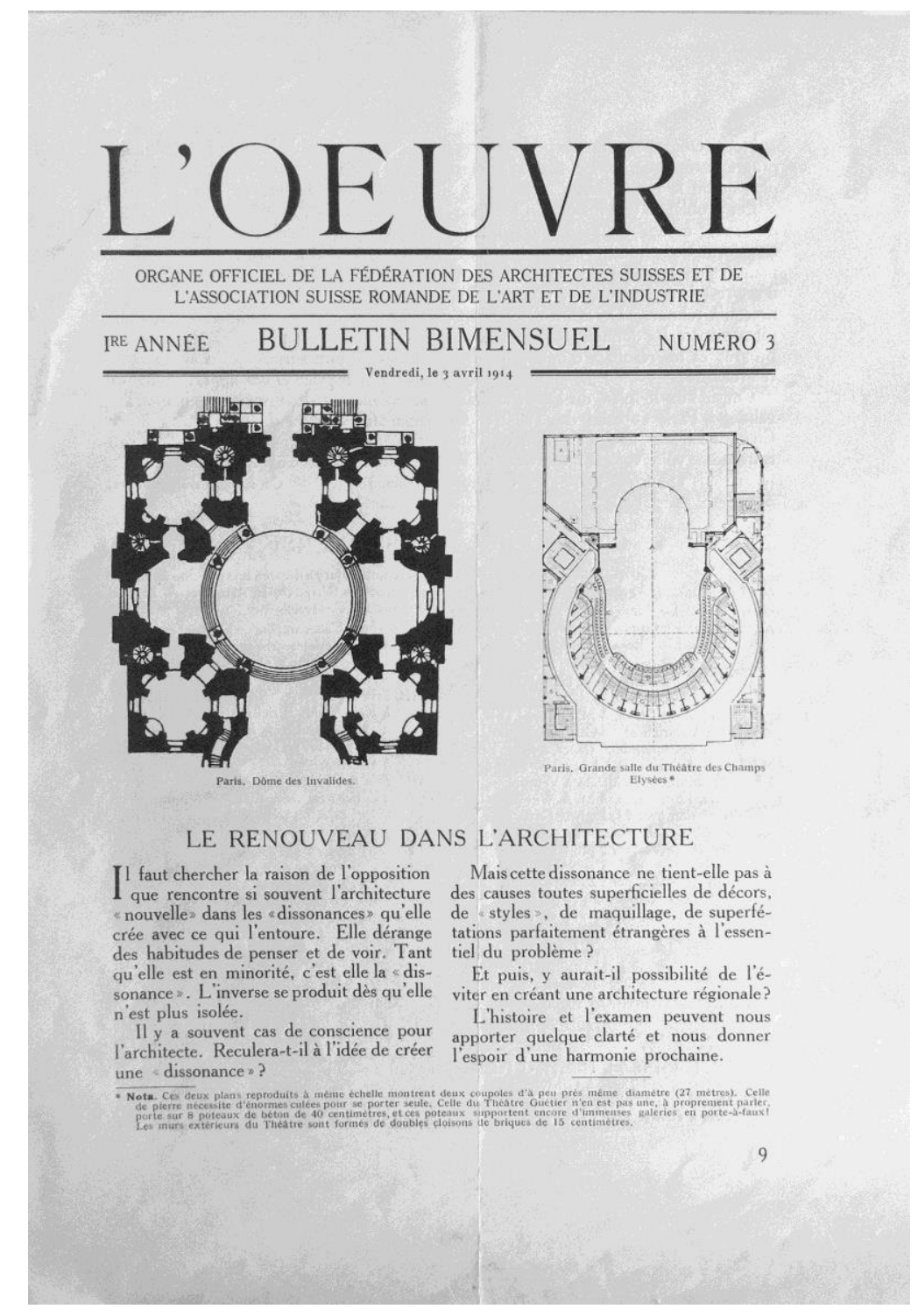

8. Portada del Boletín $L^{\prime} O E U V R E \mathrm{n}^{\circ} 3$. Bibliothèque de la ville de La Chaux-de-Fonds, Fonds Le Corbusier LC/127

Tanto con la revista como con el Boletín, Jeanneret tuvo la ocasión de conocer y participar en una publicación que seguía una línea compositiva y editorial similar a la de otras publicaciones comprometidas con la renovación estética tanto en su formas como en sus temas; su diseño, variedad temática o selección de imágenes resuenan en las publicaciones de Le Corbusier de unos años más tarde. Temas que van desde la tecnología a las artes y desde la arqueología al diseño de objetos varios, como sucede en l'Art Décoratif d'aujourd'hui donde la semejanza y el uso de formatos similares a la revista $D A S W E R K$ deja rastros por ejemplo en el uso de imágenes, como la de la bailarina del pájaro de fuego perteneciente a los diseños de Léon Bakst para los ballets rusos. ${ }^{34}$

Mucho otros temas de los tratados en las publicaciones de 1'OEUVRE van a anticipar las cuestiones sobre las que Le Corbusier teorizará años más tarde permitiendo pensar que fue en los breves años de pertenencia a la asociación cuando se despertó al menos, su interés hacia ellas. Cuestiones como la tipología de la vivienda

\footnotetext{
${ }^{34}$ La misma imagen publicada en DAS WERK y que pertenece al libro L'Art Décoratif de Léon Baskt de Jean Cocteau y Arsène Alexandre de 1913, es utilizada en el capítulo Témoins de L'Art Décoratif D'Aujourd hui de Le Corbusier en 1925
} 
obrera $^{35}$; la importancia del arte aplicado a los objetos ${ }^{36}$; la formación de los espíritus para discernir entre el objeto halagador repleto de quincalla del lleno de armonía $^{37}$ o el papel que deben jugar los museos y sus colecciones de piezas. Intervino también en la preparación de exposiciones como Les Arts du Feu en 1916, Intérieurs ouvriers en Lausanne en 1918 o la Exposition nationale d'Art appliqué en Lausanne en 1922 pero en la que se venía trabajando desde antes de 1919 y que serviría de preludio a la Exposición de las Artes Decorativas de Paris de 1925, en la que l'OEUVRE intervino en el diseño y montaje del Pabellón de Suiza.

Me gustaría referirme finalmente a dos datos más de la relación entre Jeanneret y l’OEUVRE.

En el boletín n 17 el mes de noviembre de 1915 encontramos la referencia a la reunión de la Asamblea General celebrada el día 17 de octubre anterior. En el apartado de los comités especiales L'Eplattenier como vicepresidente, informa a la asamblea sobre la actividad del grupo de Neuchâtel que ha tenido varias reuniones y ha constituido un comité de enseñanza presidido por Mr. Ch.-E. Jeanneret arquitecto en la Chaux de Fonds confirmando su pertenencia a la asociación en esta fecha; también recoge una relación de miembros a 31 de diciembre de 1915, en la que además del propio Jeanneret figura Mme. Helène de Mandrot cuya dirección en Chateau de la Sarraz nos permite establecer cuál fue el vínculo que unió a estos dos personajes y que dio lugar a fijar el emplazamiento en el que se celebraría el primer CIAM $^{38}$.
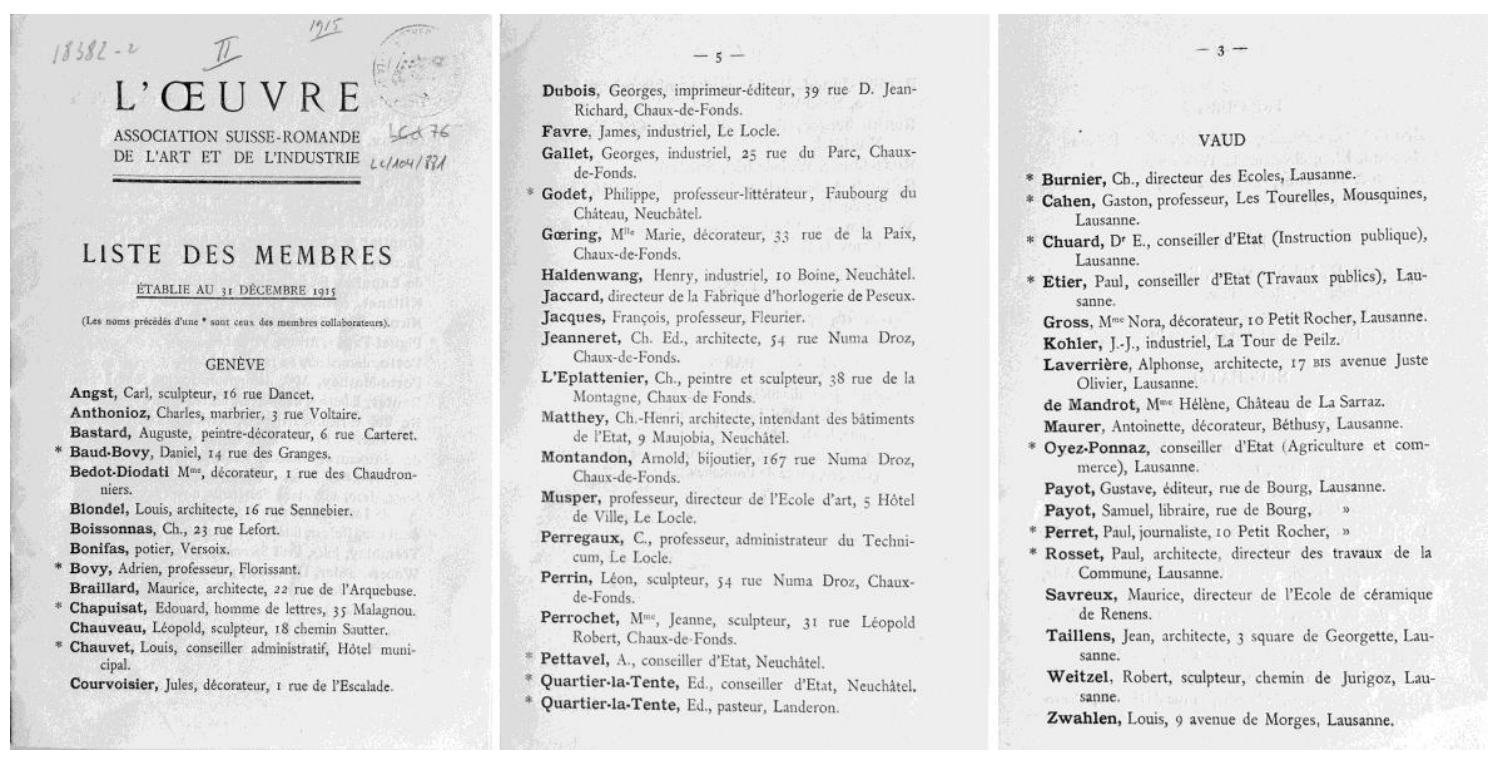

9. Listado de miembros activos de L'OEUVRE a 31 de diciembre de 1915. Bibliothèque de la ville de La Chaux-de-Fonds, Fonds Le Corbusier LC/104/881

${ }^{35}$ Boletín $L^{\prime}$ OEUVRE $\mathrm{n}^{\circ} 3$ de 1914 recoge el concurso internacional sobre la vivienda obrera en la región hullera de la Campine en Bélgica patrocinado por el rey de Bélgica y otras iniciativas que l'OEUVRE va a emprender sobre este mismo tema de la vivienda obrera.

${ }^{36}$ Boletín L“OEUVRE n ${ }^{\circ} 9$ de 1915. L'OEUVRE presenta su intención de organizar una exposición de Arte aplicado, en interiores, amueblamiento, decoraciones etc.... para la que pide la colaboración de todos los miembros de la organización, ya que este asunto representa un tema de interés capital.

37 Boletín L'OEUVRE n ${ }^{\circ} 1$ de 1916, artículo de M.L. Jouhaud tomado de Petit Messager des arts de título El Arte Regional de Mañana.

${ }^{38}$ Mme. Helène de Mindrot aparece vinculada a otras iniciativas de esta asociación como por ejemplo, en el año 1918 aparece como directora de la escuela de bordado de La Sarraz en el alojamiento I del catálogo de la exposición que l'OEUVRE organiza sobre interiores obreros del 22 de novuembre al 22 de diciembre en Lausanne 
Por otra parte, en 1916 1'OEUVRE organiza una primera exposición sobre los oficios artísticos con fuego en Neuchâtel que es trasladada posteriormente a La Chaux-de-Fonds ${ }^{39}$. De la participación de Jeanneret en esta exposición tenemos algunas evidencias documentadas.

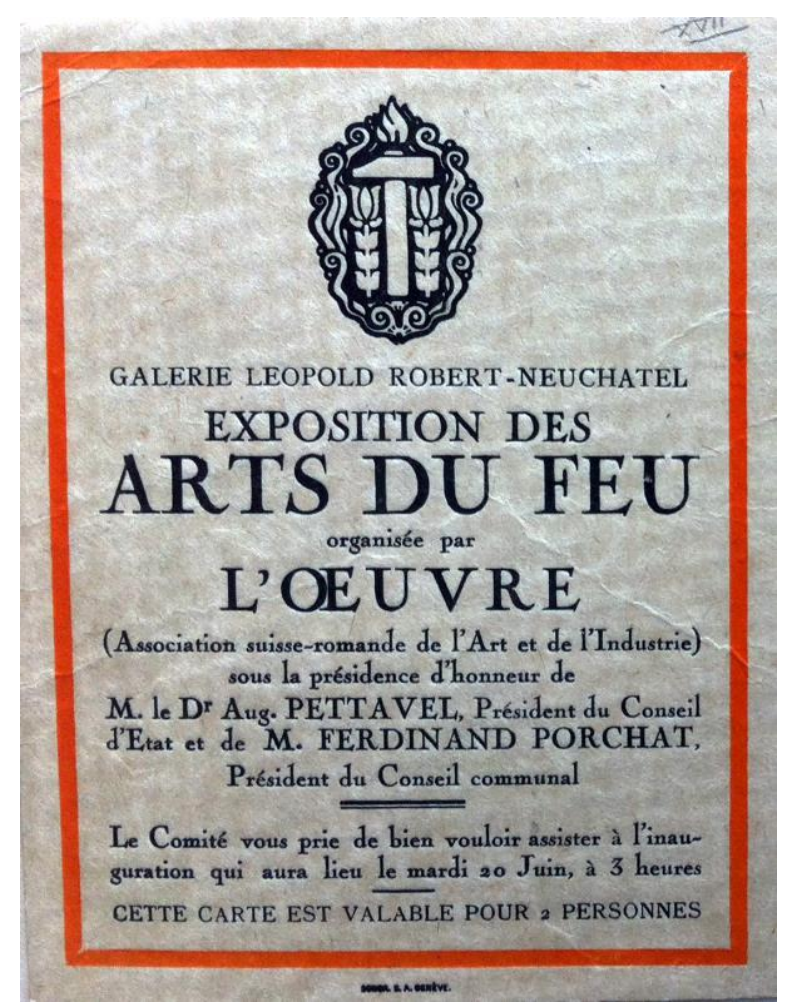

10. Invitación para la inauguración de la Exposición sobre Les Arts du Feu en Neuchâtel. Bibliothèque de la ville de La Chaux-de-Fonds, Fonds Le Corbusier LC/104/882

En primer lugar el diseño que realizó para la instalación de la exposición y del que quedan los bocetos de Jeanneret recogidos en sus cuaderno de apuntes ${ }^{40}$. También la noticia publicada en La Feuille d'Avis de 16 de agosto en la que con motivo de la inauguración en el vestíbulo del edificio de correos de la localidad se dejaba constancia de lo bien presentada que estaba la exposición en la que se reconocía el buen gusto y el saber hacer de M. Ch-Ed. Jeanneret. ${ }^{41}$

\footnotetext{
${ }^{39}$ La exposición se habúa programado para que desde el 1 de mayo al 30 de noviembre fuera expuesta en las siguientes ciudades: Ginebra, Neuchâtel, La Chaux-de-Fonds, Zurich y Lausanne.

${ }^{40}$ Besset M., Franclieu de F., Wogensky A., Le Corbusier sketchbooks volume I 1914-1918, pp, 30 y 31, Thames \& Hudson, London

41 "... L'exposition elle-même est très bien présentée:on reconnaît dans son arrangement le gô̂t sûr et très avisé de M. Ch.Ed. Jeanneret, architecte..." La exposición en sí misma esta muy bien peresentada: se reconoce en su distribución el gusto certero y muy cultivado de M. Ch.-Ed. Jeanneret. arquitecto. Traducción de la autora.
} 


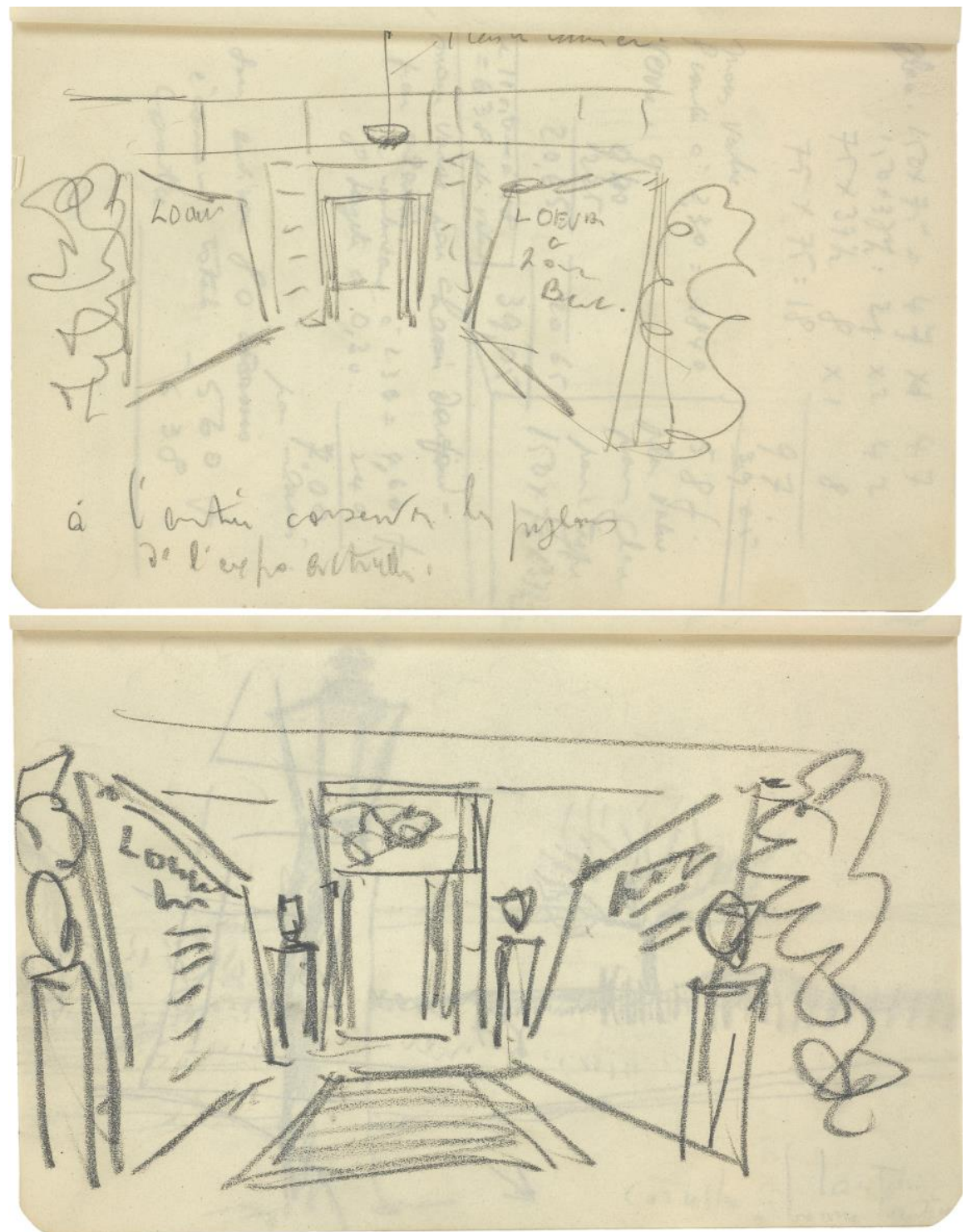

11. Cuaderno de Apuntes de Le Corbusier 1914-1918 pp. 30 y 31 con bocetos para la entrada e la exposición Les Arts du Feu en los que se lee $L^{\prime} O E U V R E$ a pour But.... FLC Carnet A1-30 y A1-33. (FLC-ADAGP.

Jeanneret se ofreció también a realizar el diseño para las vitrinas que iban a contener los objetos de esta exposición y el consejo lo aceptó a la vez que agradecía la oferta; estas vitrinas no llegaron a emplearse porque el nivel de exigencia que el arquitecto solicitaba para su ejecución impidió que estuvieran terminadas a tiempo. 

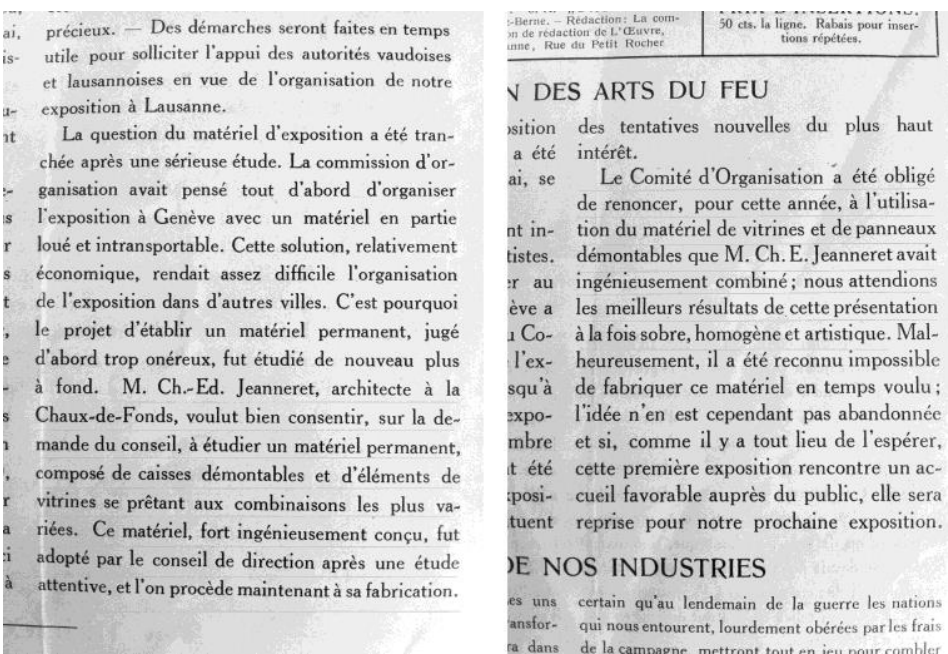

12. Fragmentos del Boletín $L^{\prime} O E U V R E$ en que se recoge la participación de Jeanneret en el diseño de vitrinas. Bibliothèque de la ville de La chaux-de-Fonds, Fonds Le Corbusier LC/127

Las actividades de L’Eplattenier en las que vinculó a sus más apreciados pupilos, especialmente Jeanneret, definieron los intereses y preocupaciones de esas jóvenes personalidades, induciéndoles el deseo y compromiso de cambiar la sociedad a través del arte.

Los enfrentamientos personales unidos a la situación política hicieron fracasar el nuevo programa de $l^{\prime} E c o l e$ d'Art; otros problemas más complejos y variados, sin olvidar desde luego la primera gran guerra en Europa limitaron el desarrollo de 1'OEUVRE. Jeanneret, profundamente decepcionado, decidió continuar su misión lejos de su maestro y de aquella pequeña ciudad, pero la huella del hombre que le condujo a su vocación de arquitecto y le hizo creer en su capacidad para adecuar el mundo nacido de la sociedad industrial a una nueva estética, había comenzado a conformar la personalidad de Le Corbusier ${ }^{42}$.

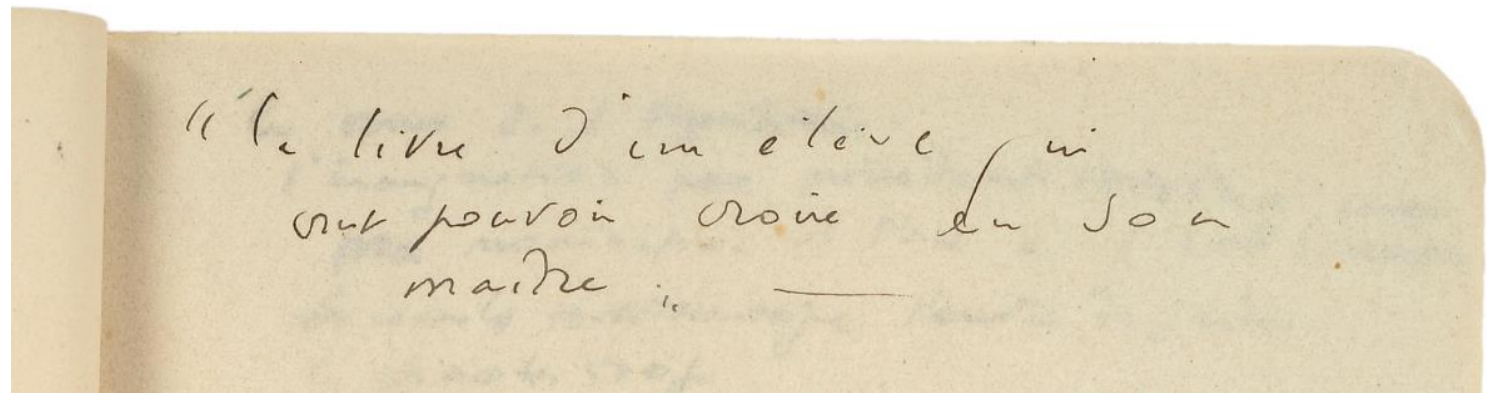

13- Anotación en el reverso de la página 30 del cuaderno de dibujo Le livre d'un élève qui crut pouvoir croire en son maître. FLC Carnet A1-51. OFLC-ADAGP.

\footnotetext{
${ }^{42}$ Los sentimientos de admiración y de decepción que sintió Jeanneret hacia su maestro se recogen en algunas de sus cartas donde él mismo se refiere a ellos, como por ejemplo en la carta escrita a su padre el 18 de junio de 1918 en que fcontaba el nuevo rumbo que había dado a su vida. Cfr. Baudoui R., Dercelles A. Op. Cit.
} 


\section{Conclusión}

En esta investigación he pretendido aportar nuevas evidencias sobre las iniciativas, inquietudes, intereses y también desencantos que contribuyeron a la formación de Le Corbusier y que influyeron en sus ambiciones y en algunas de sus decisiones posteriores.

\section{Agradecimientos}

Quiero agradecer al personal de la Bibliothèque de la Ville de La Chaux-de-Fonds su ayuda y amabilidad facilitándome el acceso a los documentos solicitados y su disponibilidad para orientarme en las dudas que se me podían presentar. Especialmente a Carlos Lopez y Sandrine Zaslawsky. Igualmente quiero agradecer a la Fondation Le Corbusier la cesión de los derechos de propiedad de las imágenes que aparecen en esta comunicación.

\section{Bibliografía/Referencias}

Allen Brooks, H: Le Corbusier, the formative years, Chicago: The University of Chicago Press, 1997

Assemblée Générale de l'OEUVRE, Extrait du Procès Verbal, L’OEUVRE Bulletin, № 17, Novembre. Lausanne: S. A. DAS WER, 1915.

Aubert, G; Perrin, L; Jeanneret, Ch.-E: Un Mouvement d'Art à La Chaux-de-Fonds, La Chaux-de-Fonds: s.e. 1914

Bodoni, Réné; Dercelles, Arnaud: Le Corbusier Correspondance Lettres à sa famille 1900-1925, Gallion (CH): Infolio éditions, 2011

"Ca va mieux-Des erreurs", La Sentinelle Journal D'information et D'annonces Organne Des Socialistes Du Jura, 25 avril, La Chaux-de-Fonds: 1914

Cocteau, Jean; Alexandre, Arsène: L'Art Décoratif de Léon Baskt, Paris: Maurice de Brunoff, 1913

Dumont, Marie-Jeanne: Le Corbusier Lettres à Charles L'Eplattenier, Paris: Editions du Linteau, 2006

Exposition des Arts du Feu, L’OEUVRE, Bulletin, No 17, Lausanne: S. A. DAS WER, 1915

Fox Weber, Nicholas: Le Corbusier: A Life, New York: Alfred A. Knoph, 2008

Frey, Pierre: "Architecture et arts appliqués : sur l'OEuvre, ses ambitions et sur quelques-uns de ses protagonistes" en Alphonse Laverrière : parcours dans les archives d'un architecte, Lausanne: PPUR 1999

Hellmann, Anouk: "Les Ateliers d'art réunis de La Chaux-de-Fonds (1910-1916)", en Art+Architecture en Suisse. Berne: Société d’histoire de l’Art en Suisse, 2002/3

Jeanneret, Ch.-E.: "Le Renouveau Dans L'architecture", en L'OEUVRE № 2, Bumpliz-Berne: Edition Bentelli S.A., 1914

Jeanneret, Ch.-E.: "Le Renouveau Dans L'Architecture", en L'OEUVRE Bulletin, $\mathrm{N}^{\circ}$ 3, Bumpliz-Berne: Imprimerie Bentelli S.A., 1914

L’Eplattenier, Charles: "Renouveau d'Art" en L'ABEILLE Suplement du National Suisse, $\mathrm{N}^{\circ} 2$ dimanche 20 février, La Chaux-de-Fonds: s.e. 1910

Les Arts du Feu, La Feuille d’Avis, 16 août, La Chaux-de-Fonds: s.e., 1916

Mauderli, Laurence: "Positioning Suiss Design: The Sweizerischer Werkbund and l'Oeuvre as the beginning of the Twentieth Century", en The journal of the Decorative Arts Society 1850 - the Present, $\mathrm{N}^{\circ}$ 25. s.1: "Decorative Arts: Exhibitions and Presentations", Decorative Art Society 1850 to the Present 2001 pp. 25-37, http://www.jstor.org/stable/41809311 
Neuenschwander, Joëlle: Les Held de Montreux, une menuiserie modèle. Lausanne: Cabédita, 1992

Petit, Jean: Le Corbusier: lui-même, Genève: Editions Rousseau, 1970.

PROSPECTUS "Nouvelle Section" de L'École d'Art, La Chaux-de-Fonds: s.e., 1912

Turner, Paul: "The beginnings of Le Corbusier's Education 1902-1907" , The Art Bulletin Vol. 53, No. 2. s.1. College Art Association, Jun.1971, http://www.jstor.org/stable/3048831

Un Concours de Dessins, L’OEUVRE, Bulletin, № 5, Bumpliz-Berne: Imprimerie Bentelli S.A., Juin 1914

Un Concours de Dessins, L’OEUVRE, Bulletin, Nº 6, Bumpliz-Berne: Imprimerie Bentelli S.A., Juillet 1914 


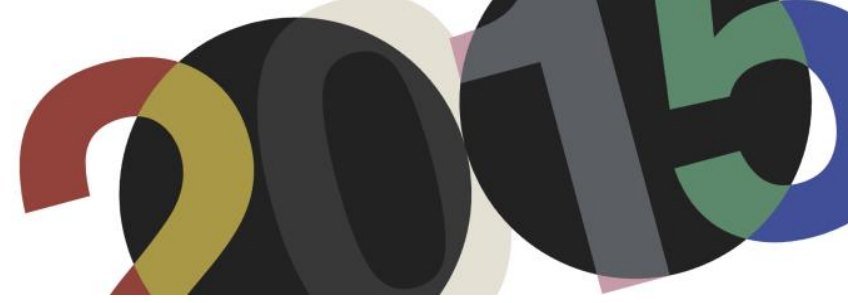

DOI: http://dx.doi.org/10.4995/LC2015.2015.743

\title{
Ratio and the Divine Proportions: Le Corbusier and Rudolf Wittkower
}

\author{
J. Kirk Irwin \\ MPhil/PhD student at Birkbeck, University of London
}

\begin{abstract}
This paper will evaluate Le Corbusier's notion of ratio as expressed in his Modulor and Modulor 2. Particular emphasis will be placed on the dialogue (or polemical exchange) between Rudolf Wittkower and Le Corbusier contained within Modulor 2 concerning the nature of the Divine Proporzione. The historiography of this area of art and architecture includes a vigorous debate from the mid-twentieth century among Modernist architects and art historians over the nature of the Divine Proportions. It is in this context that the dialogue between Le Corbusier and Wittkower occurs. Le Corbusier describes human form with a Fibonacci-based number system expressed through a universally applied system of measure, Le Modulor. Wittkower describes a set of harmonic proportions, conceptually universal, that describe the essence of Renaissance Architecture. Both influenced the course of Modern Architecture in the late twentieth-century.
\end{abstract}

Keywords: Le Modulor, Wittkower.

"Past decisions - customs - habits - all these stay with us through the most overwhelming events, disturbing, constricting, wantonly interfering with the free play of the mind." I

Even with the abundance of material written on the subject, Le Corbusier's Le Modulor continues to present several opportunities for research. Perhaps because it was through this text that Le Corbusier's method of measure received international attention, or perhaps because he proposed the Modulor as a tool applicable for all scales of design from that of a person to an entire city, or perhaps because of the oddly anthropomorphic qualities of the Modulor Man, Le Modulor continues to fascinate even those with a casual interest in twentieth-century Modernism. Le Modulor, with its descriptive subtitle, "a Harmonious Measure to the Human Scale Universally applicable to Architecture and Mechanics," is fundamentally anthropomorphic and it is Le Corbusier's image of a human figure with an enlarged hand raised above its head that has become a familiar icon of Modernism. What may be less familiar is the mid twentieth-century dialogue in which Le Modulor existed, and in particular, the dynamic between Le Corbusier and Rudolf Wittkower. Le Corbusier quotes Wittkower liberally in the sequel to Le Modulor, Modulor 2. Wittkower on the other hand does not mention Le Corbusier in his Architectural Principles in the Age of Humanism, published one year after Le Modulor in 1949. The outlook of the two men could not me more different; Wittkower the academic, who escaped Nazi Germany to live in England then in New York, and Le Corbusier the French-speaking artist turned architect from Switzerland. Yet, both presented polemics that shaped the outcome of late twentiethcentury architecture and design pedagogy.

\footnotetext{
${ }^{1}$ Le Corbusier (Charles Edouard Jeanneret), The Modulor: A Harmonious Measure to the Human Scale Universally Applicable to Architecture and Mechanics and Modulor 2 (Let the User Speak Next). 2 volumes. Birkhäuser, Basel, 2000. [Facsimile of the 1954 Faber and Faber 1st English Language Edition, 15.
} 
This paper will evaluate Le Corbusier's notion of ratio as expressed in his Modulor and Modulor 2. Particular emphasis will be placed on the dialogue between Wittkower and Le Corbusier contained within Modulor 2 concerning the nature of the Divine Proporzione. The historiography of this area of art and architecture includes a vigorous debate from the mid-twentieth century among Modernist architects and art historians over the nature of the Divine Proportions. It is in this context that the dialogue between Le Corbusier and Wittkower, written primarily from the point of view of Le Corbusier, attempts to describe human form with a Fibonacci-based number system expressed through the Modulor.

Significantly, the Divine Proportions are not the same as the Golden Section. Proportions used by the Renaissance masters are either harmonic relationships of whole numbers or their square root, such as the square root of 2 (1.414) and the square root of 3 (1.732) rather than the Golden Section, or Fibonacci number of 1.618. These are sometimes equated as a result of a misreading of Rowe's Mathematics of the Ideal Villa; a misinterpretation embedded in current design pedagogy and design criticism. Further, the ratio which provides the basis of the Modulor differs profoundly from the Vitruvian anthropomorphic proportions of 1:10, 1:8, and 1:6. Vitruvius describes a set of several related proportions which when synthesized become the basis of a rich visual vocabulary. Le Corbusier uses one ratio with many numbers and presents these in relation to the human figure and the anthropomorphic qualities of architecture. Wittkower describes several ratios in proportion to one another.

Le Corbusier and Wittkower came together within a cultural and academic context that embraced both historians and architects allowing for an exchange that would most likely not be possible in the present day. The dialogue between Le Corbusier and Wittkower studied as an historical event raises several questions. What was the relationship between art, architecture, and history in the mid twentiethcentury? Why did Le Corbusier and Wittkower bother with one another? Did Wittkower not see that the Modulor was a ratio rather than a set of proportions? Why did Le Corbusier need to place this dialogue in his book in the first place?

The relationship between Le Corbusier and Rudolf Wittkower has been addressed in Bellini's Rudolf Wittkower vs. Lecorbuser. ${ }^{2}$ Much of the source material for Bellini's article is found in the Wittkower archive at Columbia University. Included in this collection are notes, letters, and précis pertaining to the 1951 conference on proportion held in Milan, La Divina Proporzione, the procedings of which are well documented by Cimoli and Irace. One note in the Wittkower archive, typed onto scrap paper, dismisses Le Corbusier's participation as propaganda and calls into question his speaking skills. A hand written letter from James Ackerman to Wittkower refers to Le Corbusier as a part of the old guard in a summary of the conference, saying, "I think the thing worked very well, and that the best ideas were the new ones. The old guard - Corbusier et al don't really belong, perhaps, because the sense of cooperation and feel for tradition is coming in with the second generation. " Then he says, "I wish I had spoken about the Golden Section versus formulated theories."3

These correspondences are revealing in that they show that there was not a unity of purpose beyond coming

together to present research and theories on proportion in architecture. Le Corbusier is consistent with

\footnotetext{
${ }^{2}$ F. Benelli. Rudolf Wittkower versus Le Corbusier: A Matter of Proportion. Architectural Histories, 3(1): 8, pp. 1-11

${ }^{3}$ Columbia University. Rudolf Wittkower Archive, Box

39.
} 
Wittkower and Ackerman in this regard. In the second part of Modulor 2 in a chapter called "Far from The Taboos," Le Corbusier describes his experience of the Milan conference. After saying that he attended reluctantly at the persuasion of the president of the conference, he summarizes Wittkower's contribution, then Giedion's, followed by Matila Ghyka and Hans Kayser. In what could be taken as a bitterly sarcastic remark, he says, "Milan Triennale of 1951, "De Divina Proporzione", eulogies not the Golden Section, the ancient part of humanity - Pythagoras-

\section{Le Lionnais wrote to me:}

"On the technical plane, I believe that the Golden Number does not represent a particularly exceptional or privileged concept' (see page 18) [Le Corbusier's parentheses]. He adds: “... As often happens, the adoption of a convention - however arbitrary it may be -can lead to substantial progress, provided on remains faithful to it, because it becomes a principle of selection and order. "4

Lionnais is consistent with Arnheim in his critique of the Modulor. In "A review of Proportion," Arnheim addresses the notion of standardization in relation to the human body. He says, "Of course, in an informal way, houses, furniture, tools have always been adapted to the human body, but Le Corbusier hopes to standardize these relations be deriving his scales from the main proportions and dimensions of the day. Unfortunately, however, the human figure cannot be standardized, and since the stature of any population is distributed statistically in a bell-shaped curve, it seems ludicrous to specify the relation between man and his objects to the fraction of an inch."5

The relationship between ratio and proportion, the idea of anthropomorphic measure, and anthropomorphic proportion itself remain central to the mid century dialogue. Several of the participants in the 1951 conference differentiate between ratio and proportions. Wittkower refers to Palladio's ratios in his discussion of architectural and musical harmonics reminding his audience that a ratio is a correlation of two quantities, and that a proportion is an equation of two ratios. He makes the case in his Principles that Palladio and Alberti employed several ratios in proportional relationships in their buildings. He emphasizes the whole number relationships 1:2, 2:4, 1:4 and so on. His lecture in Milan, consistent with what he wrote in Principles, says that the Renaissance had no concern for the Golden Ratio because of the Renaissance concern for commensurability of proportion, or its capacity to be quantified measured and built.

The précis to his lecture at the Milan conference on proportion in 1951 exists in both the Wittkower archive and the Le Corbusier archive at the Fondation Le Corbusier. Wittkower's lecture was about the use of proportion in the Middle Ages compared to the Renaissance distinguishing between the geometric use of proportion and the arithmetic use of proportion. He emphasizes that the reason for this distinction is the overwhelming concern during the Renaissance for the measurability of proportions. In opposition to Le Corbusier, he says that the Golden Section would not have been much of a concern for the Renaissance because of its being an irrational number. ${ }^{6}$

\footnotetext{
${ }^{4}$ Modulor2,145

${ }^{5}$ Rudolf Arnheim. “A Review of Proportion.”The Journal of Aesthetics and Art Criticism, Vol. 14, No. 1 (Sep., 1955) 48.

${ }^{6}$ Columbia University. Rudolf Wittkower Archive, Box39.
} 
Giedion took a different view. Gideion's lecture included a reference to the universality of the Golden Number. This would have been favorably received by Le Corbusier who quotes Giedion as saying “... Attitude of the 19 th Century:" 'The part becomes master of the whole' (Nietzsche, 1884). [Le Corbusier's parentheses] "The Golden Section seems to maintain itself throughout human history (prehistoric cave paintings). The Golden Section was applied at the most widely differing periods and always in accordance with specific methods."7

Wittkower's studies of proportion refer to Vitruvian anthropomorphic proportions, but these do not factor prominently in his Principles or in the 1951 Milan lecture. While he shows conclusively the use of harmonic proportions, the proportions employing the Vitruvian anthropomorphic proportions of 1:6, 1:8, and 1:10 are not correlated to the spatial constructs of Renaissance architecture.

Le Corbusier on the other hand, using one ratio to which he attributes anthropomorphic qualities the Golden Number 1.618, shows how a ratio can be applied at multiple scales; the person, the room, the building, and the city. Why are Vitruvian anthropomorphic proportions not a significant part of the dialogue from Wittkower's point of view? Why did Wittkower not respond to Le Corbusier by showing that the anthropomorphic proportions of Vitruvius already exist in Renaissance architecture and already achieve what Le Corbusier was attempting to achieve through the Modulor. At least two reasons are plausible, first is that Wittkower may have been following.

Panofsky's lead, and second that Wittkower's historiographical position simply did not facilitate a study of the Vitruvian anthropomorphic proportions. In Meaning in the Visual Arts Panofsky says,

... "And new attempts were made in connection with a remark by Vitruvius to identify human

proportions with those of buildings and parts of buildings, in order to demonstrate both the architectonic 'symmetry' of the human body and the anthropomorphic vitality of architecture. This high evaluation of the theory of proportions was, however, not always matched by a readiness to perfect its methods. The more enthusiastic the Renaissance authors wax about the metaphysical significance of human proportions, the less disposed they seem, as a rule, to empirical study and verification. What they actually produced was generally little more than a recapitulation (at most, an emendation) of Vitruvius or, even more often, a reproduction of the nine-units system already known to Cennini. Only occasionally did they

attempt to specify the measurements of the head by a new method or, to keep up with the conquest of the third dimension, sought to supplement the statements about length and width with statements about depth..."

Alina Payne in her article "Rudolf Wittkower and Architectural Principles in the Age of Modernism" presents an historiography suggestive on another reason. Payne describes Wittkower's analysis in contrast to that of Geoffrey Scott's, The Architecture of Humanism. She describes Wittkower's focus on the structural and geometric basis of architectural form and its "symphonic quality." She later quotes from Scott whose anthropomorphic understanding of architecture is evident in his description of architectural ornament; "Thus, for example, the curves of the volutes are recognized as bold or weak, tense

\footnotetext{
${ }^{7}$ Modulor 2, 142.

${ }^{8}$ Rudolf Arnheim. “A Review of Proportion.”The Journal of Aesthetics and Art Criticism, Vol. 14, No. 1 (Sep., 1955) 42.
} 
or lax, powerful, flowing, and so forth. But we must recognize them as having these qualities by unconscious analogy with our own movements, since it is only in our own bodies that we know the relation of the line-or movement-to the feeling it denotes.... The cornices and the other devices tie elements together to force a single impression of mass upon the eye; the orders, the use of rusticated bases and battered plinths speak to our sense of powerfully adjusted weight." 9

Payne makes the point that Wittkower's Humanism differs from that of Scott and that Wittkower understood his historiographical position as a polemic differing from that of Scott. Wittkower's study was about the architectural expression of Pythagorean proportions and their relationship to musical harmonies, not about the expression of Vitruvian anthropomorphic proportions in architecture. This intentional historiographical position allowed Wittkower to frame his work as a history of form and structure rather than as a history of the anthropomorphic qualities of architecture and how human beings coincide with buildings and places. Wittkower did not ask if the Vitruvian proportions exist alongside the harmonic proportions that he identifies as the principles of architecture in the age of Humanism. He does not respond to Le Corbusier by citing Vitruvius, but rather presents his position citing the harmonic proportions that he identifies in Alberti and Palladio.

The Vitruvian Man drawn by Leonardo (Figure 1) includes the 1:10 and 1:8 proportional relationships simultaneously. The overlay superimposed upon the original shows how this can be. If one divides the right line of Leonardo's square into ten segments, these correspond precisely with the measure from the top of the forehead to the chin. If one divides the left line of the square into eight segments these correspond precisely with the measure from the top of the head to the chin. Circles struck from the $6 / 10$ point, and the $5 / 8$ point result in circles intersecting the upper left and right corners of the square, and the outer extent of the figure's hand.

With this as background, the question of whether the Vitruvian proportions exist in Palladio's and Alberti's architecture is worth exploring. Two examples show that they do, first Palladio's Villa Rotonda, and second, Alberti's San Sebastiano.

Palladio's plan from the Quattro Libri is shown in Figure 2. To the right of the image is a line divided into ten segments representing the Vitruvian proportion of 1:10. To the left is a line divided into eight segments representing the Vitruvian proportion of 1:8. To its left is a line divided into six segments representing the Vitruvian proportion of 1:6.

If one creates a circle with its center at the intersection of the module 8 line and the centerline with a radius equal to $5 / 8$ of the length the circle will coincide with the corners of a square formed by each of the four porticos.

If one creates a circle with its center at the intersection of the module 10 line and the centerline with a radius equal to $6 / 10$ of the length the circle with coincide with the interior face of the columns at each porticus. A circle measured with a center at the 2/6 node on the module six line will equal the diameter of the dome. If an equilateral triangle is struck based on the length of the square, the apex coincides with each of the four portals.

A similar geometric relationship exists at San Sebastiano shown in Figure 3. If one creates a circle with its center at the intersection of the module eight line and the centerline with a radius equal to $5 / 8$ of the

\footnotetext{
${ }^{9}$ Alina Payne. "Rudolf Wittkower and Architectural Principles in the Age of Modernism." Journal of the Society of Architectural Historians, Vol. 53, No. 3 (Sep., 1994) 333.
} 
length the circle will coincide with the corners of a square formed by each of the four porticos. If one creates a circle with its center at the intersection of the module ten line and the centerline with a radius equal to $6 / 10$ of the length the circle with coincide with the interior face of the columns at each porticus. A circle measured with a center at the $2 / 6$ node on the module six line will equal the diameter of the dome. If an equilateral triangle is struck based on the length of the square, the apex coincides with the location of the high altar.

These relationships exist in other Renaissance art and architecture. In Masaccio's Trinity (Figure 4) the 1:10. 1:8 and 1:6 ratios exist in proportional relationships which define the spatial construct of the fresco and which relate precisely with the proportions of the Christ figures. In Brunelleschi's placement of his trinity of buildings, San Lorenzo, Santo Spirito, and the Pazzi Chapel the placement of these structures define the 1:10 and 1:8 proportions at an urban scale (Figure 5). Neither Wittkower nor Le Corbusier knew of these relationships because they had not been discovered yet. More research should be undertaken to fully examine the Vitruvian proportions in the context of Wittkower's research on harmonic proportions and the examples shown above are not intended to be exhaustive.

But what of Le Corbusier? Why did he reject the Vitruvian notion of proportion? Perhaps he would have seen these as an absolute system in opposition to L'espirit Nouveau, favoring instead his open system of measure based on the multiples of irrational numbers with their basis in a single ratio with open-ended numerical expressions applied anthropomorphically.

There are several main points to reiterate:

| The Modulor is one ratio applied to many conditions.

| The Divine Proporzione were many ratios applied in proportion to one another to many conditions.

| Le Corbusier's system expressed in Le Modulor was fundamentally anthropomorphic.

| Wittkower's study focused on harmonic proportions not anthropomorphic proportions.

I Wittkower's analysis of harmonic proportions mentions Vitruvian anthropomorphic proportions but does not include an analysis of these as expressed in Alberti and Palladio.

| Current technologies facilitate an analysis showing that the Vitruvian 1:10. 1:8, and 1:6 ratios exist in proportion to one another in Renaissance art and architecture.

Summarizing this essay is challenging. The topic is vast, and the historiographical questions are complex. The theme of Le Corbusier's use of ratio and Wittkower's understanding of proportion span two disciplines, architectural history and architectural practice. The dialogue between the historian and the artist architect was more of a polemical exchange, certainly not a collaboration, cordial but not friendly, and represents a significant historical intersection that defined much of the architectural dialogue for years to come. 


\section{Works Cited}

Arnheim, Rudolf.“A Review of Proportion.”The Journal of Aesthetics and Art Criticism, Vol. 14, No. 1 (Sep., 1955), pp. 44-57.

Benelli, F. Rudolf Wittkower versus Le Corbusier: A Matter of Proportion. Architectural Histories, 3(1): 8, pp. 1-11.

Le Corbusier (Charles Edouard Jeanneret), The Modulor: A Harmonious Measure to the Human Scale Universally Applicable to Architecture and Mechanics and Modulor 2 (Let the User Speak Next). 2 volumes. Birkhäuser, Basel, 2000. [Facsimile of the 1954 Faber and Faber 1st English Language Edition

Panofsky, Erwin. Meaning in the Visual Arts, Garden City NY: Doubleday, 1955.

Payne, Alina. "Rudolf Wittkower and Architectural Principles in the Age of Modernism." Journal of the Society of Architectural Historians, Vol. 53, No. 3 (Sep., 1994), pp. 322- 342.

Wittkower, Rudolf. Architectural Principles in the Age of Humanism. New York: Norton. 1971 


\section{Illustrations}

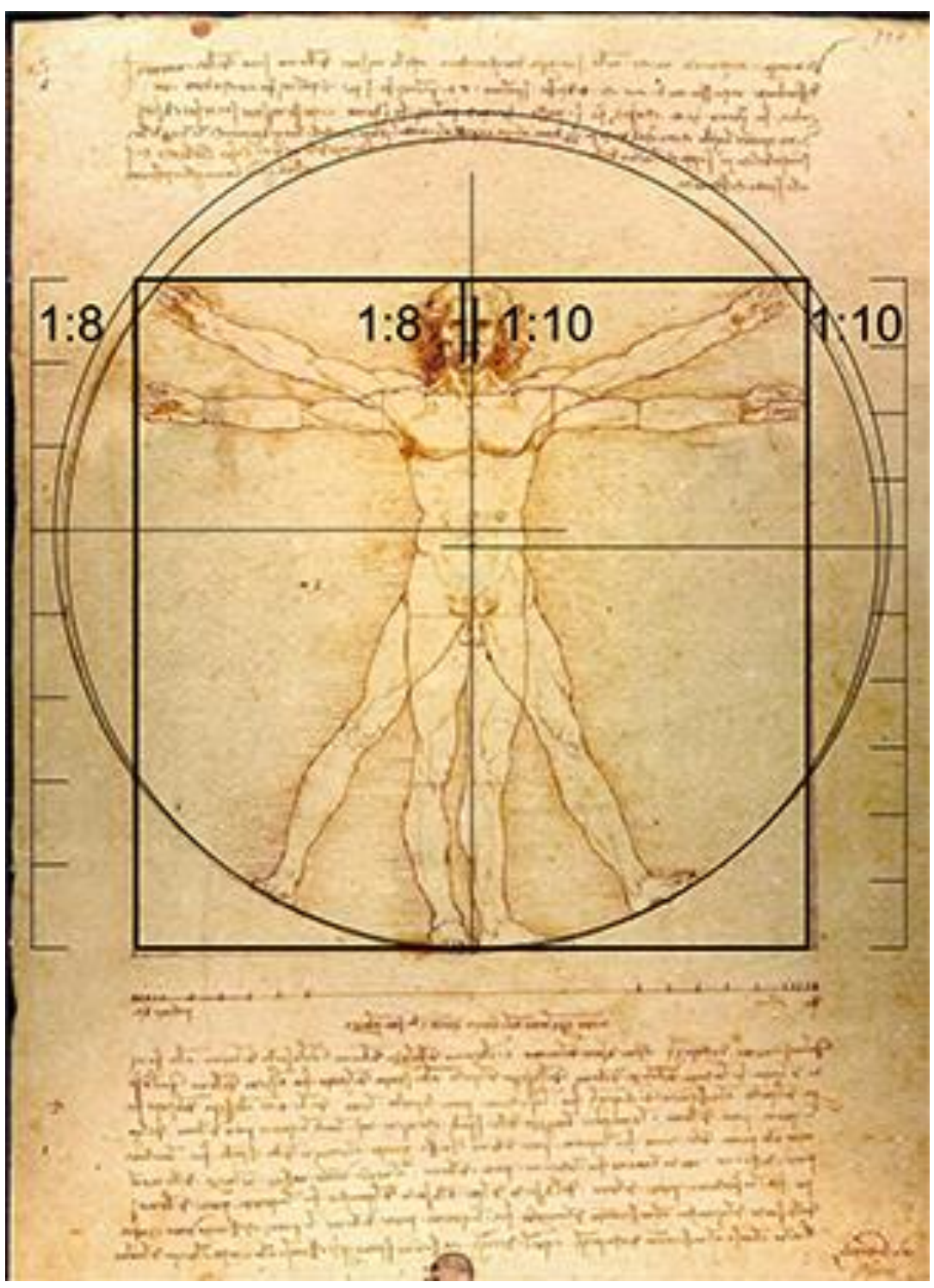

1. Leonardo Da Vinci, Vitruvian Man, Overlay by the author 


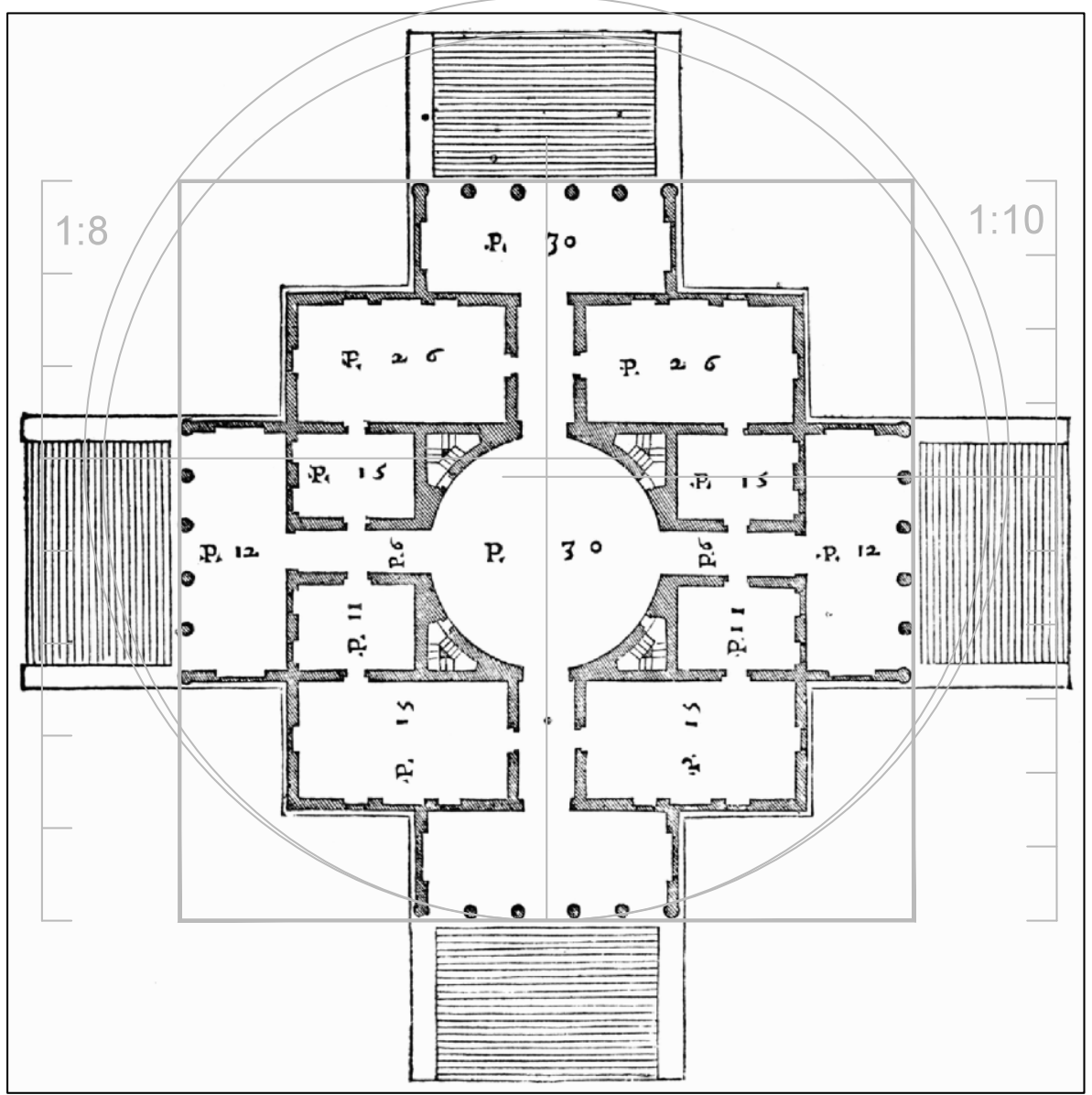

2. Palladio, Villa Rotonda, Quattro Libri, Overlay by the author 


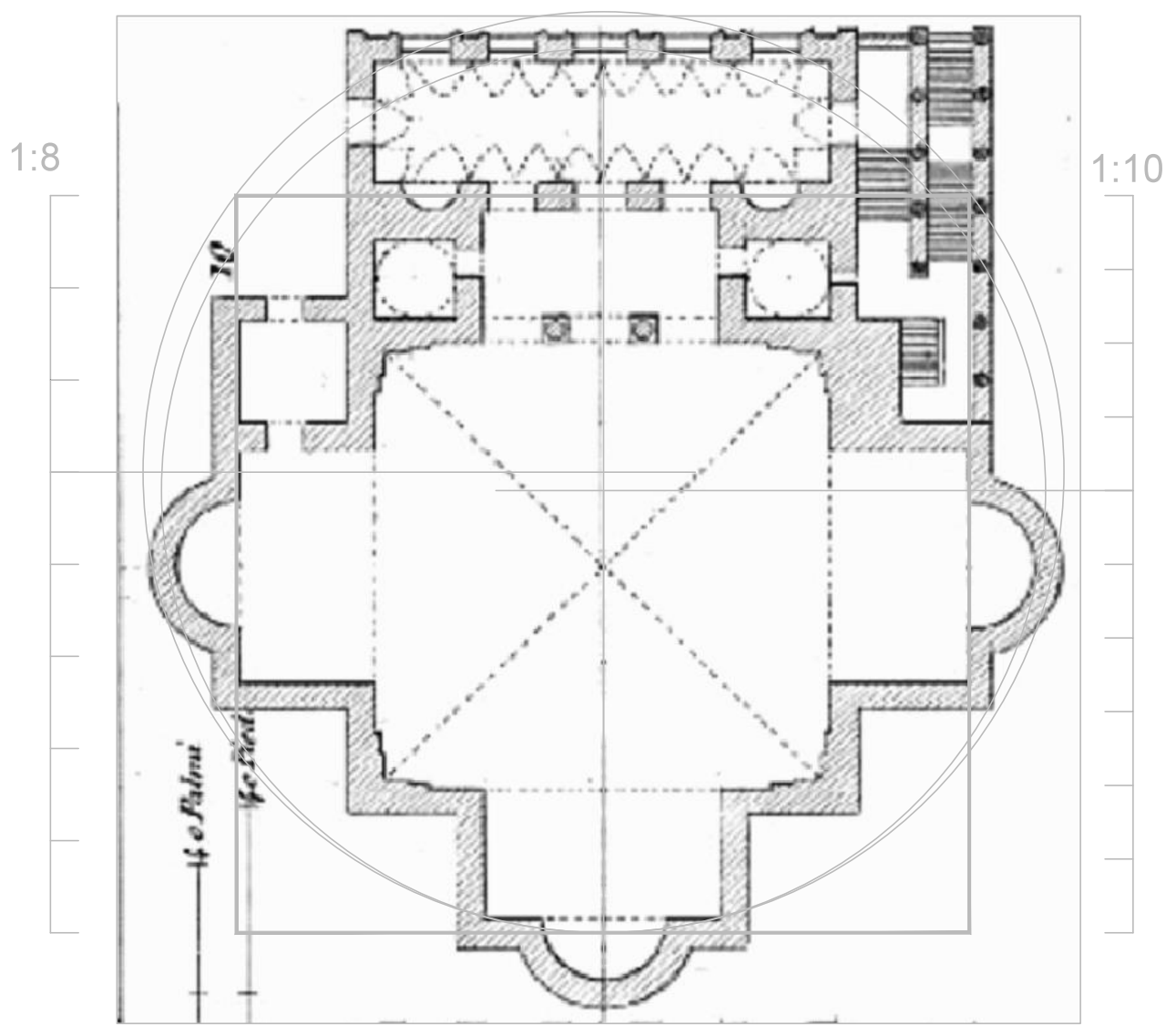

3. Alberti, San Sebastiano, Overlay by the author 


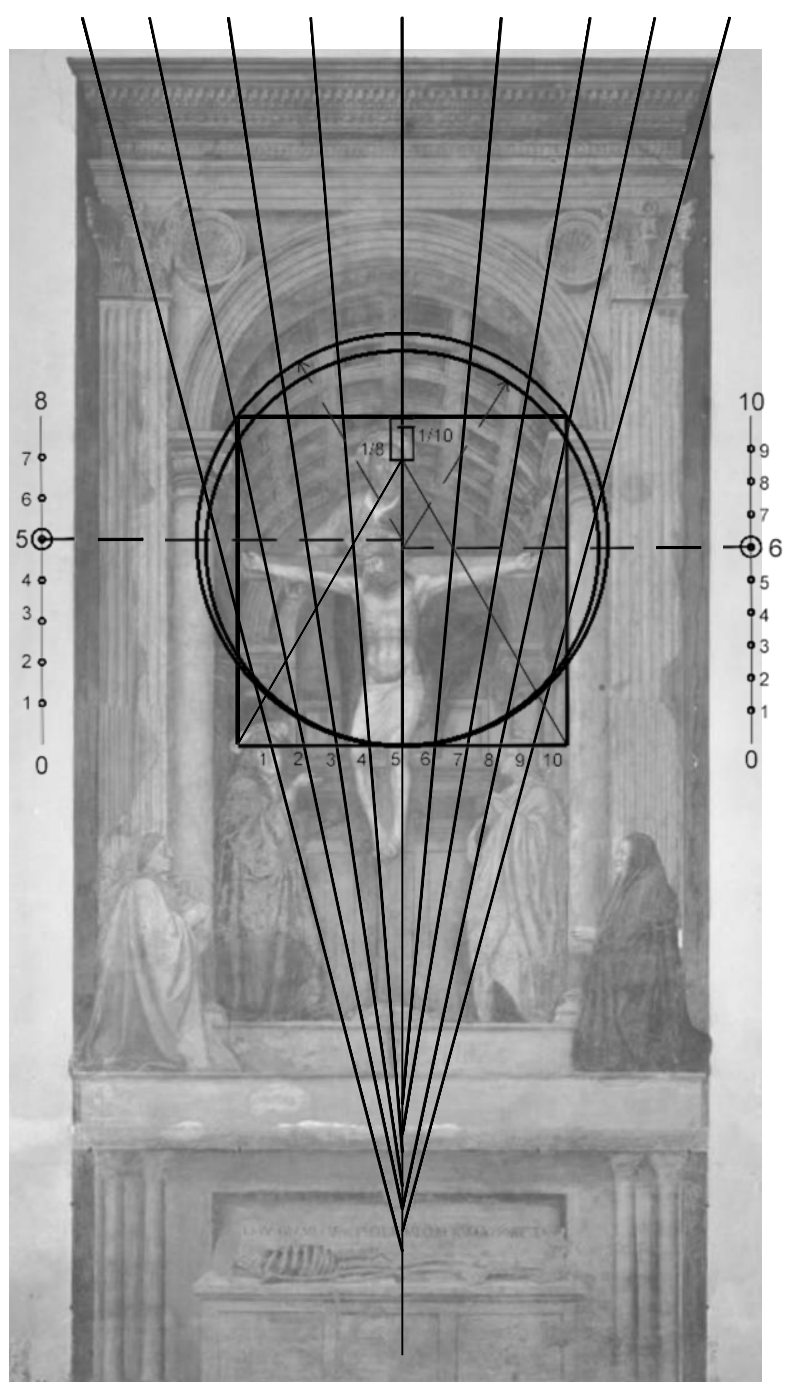

4. Overlay image by the Author. Masaccio Trinity, 1427. 


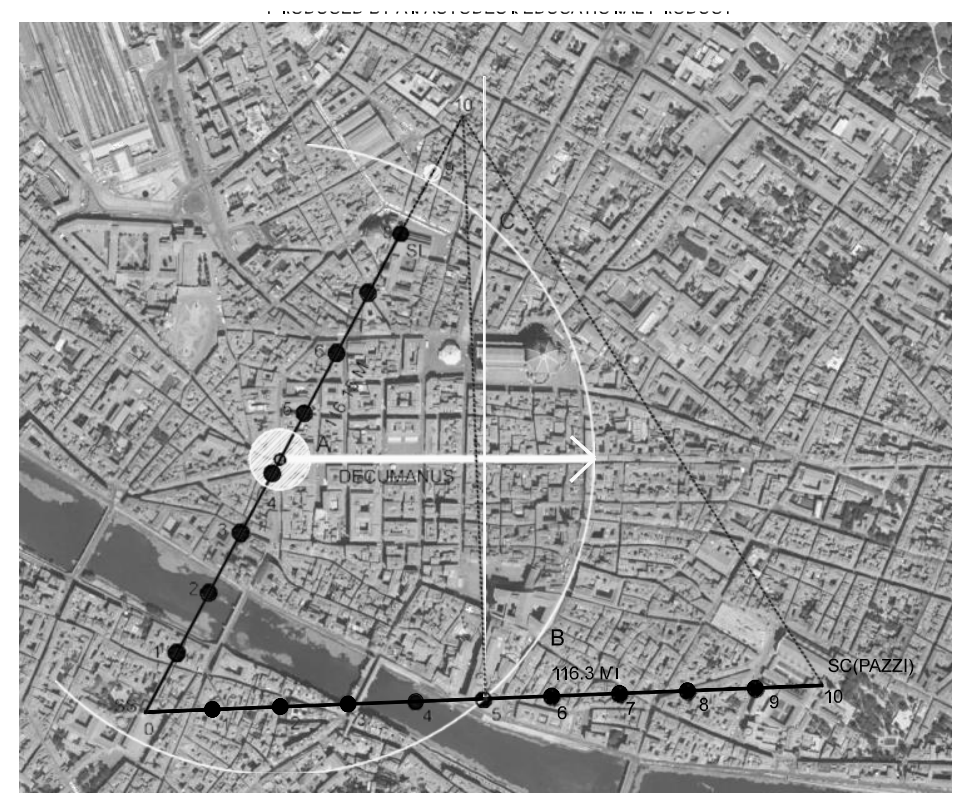

5. Florence, Overlay by the author, image from Google Earth 


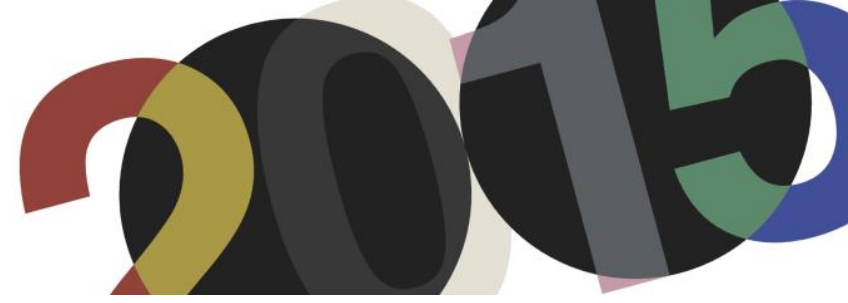

DOI: http://dx.doi.org/10.4995/LC2015.2015.470

\title{
« L'espace indicible »: conceptions et textualités
}

\author{
M. Labbé \\ Faculté de Philosophie de l'Université de Strasbourg
}

Résumé: La notion d'" espace indicible » occupe sans conteste une position centrale dans la théorie architecturale de Le Corbusier après 1945. Loin d'être un simple mot-valise ou un signifiant vide de sens, le concept d'espace indicible vise à penser le sommet de l'expérience esthétique et spirituelle dont est passible l'architecture, cela tant pour rendre compte de l'émotion plastique ressentie face aux chefs-d'œuvre du passé que pour décrire la qualité de l'expérience que l'architecte cherche à produire par ses propres æuvres. Ainsi, dans l'ouvre de Le Corbusier, l'expression "l'espace indicible » désigne non seulement un concept, mais également un ensemble textuel dans lequel la notion est thématisée et au travers duquel elle se constitue progressivement. L'objectif de cet article est double : d'une part, proposer une description des déterminations principales du contenu donné par Le Corbusier à la notion d'" espace indicible »; d'autre part, à partir de l'examen des archives, faire le point sur les textes dans lesquels ce concept se formule.

Abstract: The concept of "ineffable space" unquestionably occupies a central place in Le Corbusier's architectural theory after 1945. Far from being a portmanteau or a signifier devoid of meaning, the concept of ineffable space is aimed at conceiving the height of aesthetic and spiritual experience rendered possible by architecture. This is as much to realise plastic emotion felt in front of masterpiece from the past as to describe the experiential quality that the architect seeks to produce in his/her own work. Thus, in Le Corbusier's oeuvre, the expression "ineffable space" not only denotes a concept but also a textual whole in which the concept is thematised and through which it is progressively constituted. The aim of this article is two-fold. On the one hand, I propose a description of the principle determinants of the content that Le Corbusier assigns to the concept of "ineffable space", and on the other hand, analysing the archives, I wish to take stock of the texts in which this concept is formulated.

Mots-clés: Le Corbusier; espace indicible; théorie architecturale. Keywords: Le Corbusier; ineffable space; architectural theory.

\section{Introduction}

La notion d'« espace indicible» occupe sans conteste une position centrale dans l'univers théorique de Le Corbusier après 1945. Loin d'être un simple mot-valise ou un signifiant vide de sens, le concept d'espace indicible vise à penser le sommet de l'expérience esthétique et spirituelle dont est passible l'architecture, cela tant pour rendre compte de l'émotion plastique ressentie face aux chefs-d'œuvre du passé que pour décrire la qualité de l'expérience que l'architecte cherche à produire par ses propres œuvres.

Or, dans toute la profondeur de son contenu et dans l'usage qui en est fait par Le Corbusier, tout dans cette notion apparaît comme hautement paradoxal. Non seulement l'expression elle-même désigne d'emblée une tentative de description linguistique de ce qui par définition semble échapper au langage (et donc ne se laisserait pas dire), mais les déterminations qu'en donne Le Corbusier sont hautement problématiques et à de nombreux points de vue énigmatiques.

Ainsi, dans l'œuvre de Le Corbusier, l'expression «l'espace indicible » désigne non seulement un concept, mais également un ensemble textuel dans lequel la notion est thématisée et au travers duquel elle se constitue progressivement. L'extrême hétérogénéité de ces sources et les ambiguïtés qu'elles révèlent méritent que nous 
nous y arrêtions avec attention. Comme nous le verrons dans ce qui suit, l'objectif de notre article est double : d'une part, proposer une description des déterminations principales du contenu donné par Le Corbusier à la notion d'«espace indicible»; d'autre part, à partir de l'examen des archives, faire le point sur les textes dans lesquels ce concept se formule. Ces deux dimensions sont en réalité profondément reliées en ce que toute pensée est aussi écriture de la pensée et que tout mouvement spirituel se donne dans et par les traces matérielles dans lesquelles il se recueille. Nous commencerons par faire un état des lieux des contextes textuels dans lesquels apparaît la notion d'espace indicible et, à partir de l'analyse d'un certain nombre de difficultés révélées par l'examen des archives, nous nous proposerons de reconstituer la genèse et les différents états de l'article connu sous le nom «L'Espace indicible». Dans un second temps, à partir de ce travail textuel, nous chercherons à indiquer un certain nombre de pistes de réflexion relatives à l'élucidation du contenu de la notion d'espace indicible.

\section{Textualités}

\subsection{Contextes d'élaboration et d'utilisation du texte}

Il est manifeste que Le Corbusier a porté un intérêt durable et extrêmement minutieux à l'article "L'Espace indicible». Il s'agit d'un texte extrêmement construit, qui semble avoir fait l'objet d'une attention toute particulière, qui a été constamment retravaillé et utilisé dans des contextes tout à fait variés. Tout se passe comme si Le Corbusier cherchait là à rédiger un texte court et percutant, exprimant de manière synthétique l'essence même de certaines de ses intuitions théoriques les plus personnelles ${ }^{1}$, cela en un ensemble de formules mobilisables dans des circonstances multiples et à des époques distinctes. En ce sens, ce texte, condensé de l'expérience esthétique corbuséenne, semble jouer un rôle opératoire extrêmement important aux yeux de l'architecte. Dans ce processus d'élaboration progressive, on voit ainsi la pensée de l'architecte à l'œuvre, sans cesse à la recherche d'une plus grande précision conceptuelle et d'une plus grande intensité dans la beauté poétique des formulations, cela afin de rendre justice à la puissance de l'expérience qu'il s'agit de décrire, alors même que celle-ci, en son caractère indicible, semble par définition échapper à toute volonté de saisie intellectuelle. Et c'est peut-être précisément parce que cette expérience de l'espace est si difficile à mettre en mots que ce texte fait l'objet d'un travail de réécriture incessant.

La diversité de contextes d'élaboration de la réflexion autour de l'espace indicible est l'une des premières difficultés rencontrées par celui qui cherche à mettre en ordre les différents états de ce texte. En effet, le texte de «L'Espace indicible » a été mobilisé au moins dans cinq ensembles textuels distincts et parfois confondus : 1) en vue de la préparation d'un article destiné au numéro hors-série «Art » de la revue L'Architecture d'Aujourd'hui publié en avril 1946 ; 2) dans le cadre de la rédaction de l'article "L'Architecture et l'esprit mathématique » commandé à Le Corbusier par François Le Lyonnais pour le compte d'un numéro des Cahiers $d u$ Sud paru en 1948 ; 3) en vue de la publication de New World of Space chez Raynal \& Hitchcock en 1948 ; 4) dans le cadre de deux projets d'ouvrages avortés aux alentours de 1953, à savoir Trente années de silence, puis l'ouvrage supposé être précisément intitulé L'Espace indicible ; 5) enfin, le texte est également repris dans les deux volumes du Modulor.

Outre cette diversité des contextes et des périodes d'élaboration du texte (parfois concomitantes), une difficulté supplémentaire provient du fait que certains projets pourtant distincts semblent pouvoir être aisément confondus.

\footnotetext{
${ }^{1}$ Le Corbusier : Le Modulor 2. Bâle : Birkhäuser, 2000, p. 25 : «Cette citation étant faite [il parle du texte «L'Espace indicible »], je mesure, avec le recul des ans, que toute mon activité s'est portée vers la manifestation de l'espace. Je suis un homme d'espace, non seulement mentalement mais physiquement ».
} 
En effet, du fait de l'existence d'ambiguïtés dans les dénominations parfois utilisées par Le Corbusier pour qualifier ses propres projets éditoriaux, la consultation des archives fait état d'une certaine confusion dans le classement d'un ensemble d'éléments documentaires relatifs au projet d'ouvrage avorté datant de 1953 et qui devait porter le titre L'Espace indicible. La principale difficulté est la suivante : de nombreux documents supposés concerner cet ouvrage particulier s'avèrent en réalité devoir être rapportés à la préparation de New World of Space (dont la publication date de 1948). En réalité, cette « erreur » d'archivage est révélatrice d'une ambiguité plus profonde et elle n'est évidemment pas le simple fruit d'une négligence. La difficulté trouve son origine dans le fait que Le Corbusier a pu lui-même qualifier ou baptiser ces deux projets distincts d'un même titre. S'il n'y a aucune difficulté dans le fait de reconnaître que le projet d'ouvrage Trente années de silence ${ }^{2}$ a été abandonné au profit d'un autre projet nommé L'Espace indicible, il est parfois plus malaisé de discerner le fait que le nom donné par Le Corbusier au projet américain qui sera finalement publié sous le titre de New World of Space était précisément également L'Espace indicible, ce qui permet d'expliquer pourquoi certains documents de 1948 se trouvent archivés dans des dossiers relatifs à la préparation d'un ouvrage de 1953.

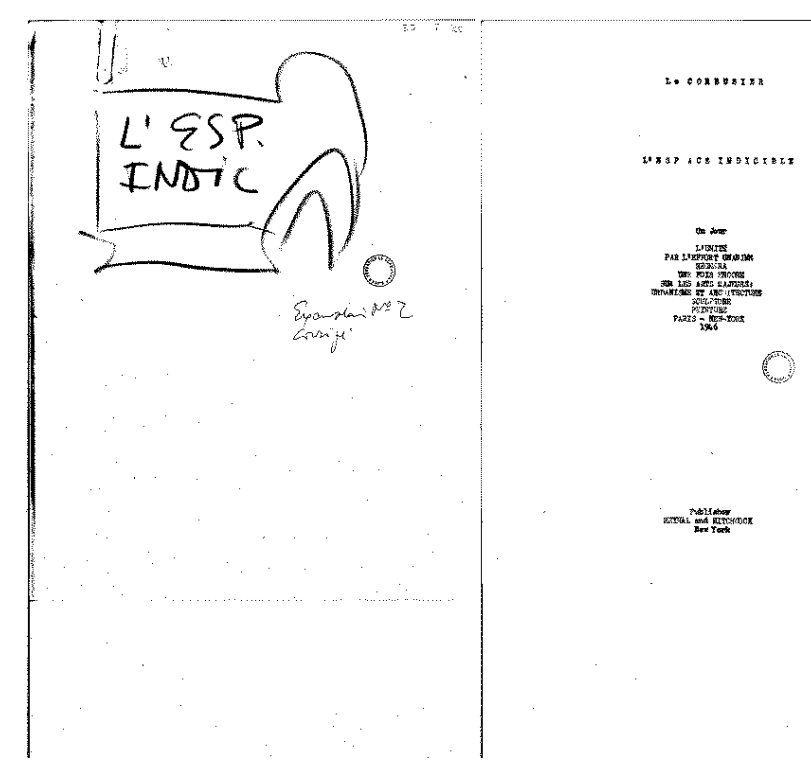

1. Exemple typique de confusion possible entre New World of Space et L'Espace indicible [B3-7-255-001] et [B3-7-255-002] (CFLC-ADAGP.

Le Corbusier fait lui-même état de cette ambivalence de nomination dans une lettre à sa mère du 11 janvier 1948:

"De New York je reçois avis que s'imprime (en terminaison) mon grand livre fait < en > l'an $46:$ L'Espace indicible que les Américains baptisent après douze mois de tâtonnement : New World of Space, car en effet, de

\footnotetext{
${ }^{2}$ L'ouvrage avorté Trente années de silence devait servir de catalogue à l'exposition de 1953 consacrée à l'œuvre plastique de Le Corbusier, mais ne sera pas prêt à temps. Le Corbusier publiera l'article «Déclaration » en lieu et place dans ce catalogue. Ce projet sera abandonné, puis repris sous le titre L'Espace indicible vers décembre 1953 [B3-7-1], originellement en vue d'une exposition de Le Corbusier au MoMa. Ce projet d'ouvrage ne prendra une forme finale qu'en 1958 et devait constituer une sorte de regard rétrospectif sur l'ensemble de la production corbuséenne (alors qu'il ne devait s'agir là aussi au départ que d'un catalogue sur l'œuvre plastique) dans le cadre d'une réflexion théorique ambitieuse [F2-20-298] centrée sur l'idée de «synthèse des arts majeurs », mais ne sera pas publié comme tel et sous ce titre. Il apparaît nettement que les recherches menées par Le Corbusier dans ce cadre seront plus tard absorbées dans L'Atelier de la recherche patiente.

Des renseignements détaillés sur ces projets éditoriaux sont fournis par Catherine de Smet dans son ouvrage Vers une architecture du livre.
} 
l'ensemble de mon ouvre apparaît, tant en urbanisme, qu'en architecture, qu'en peinture et en sculpture, une notion nouvelle d'espace, où règne le calme, la limpidité, la clarté, faisant un contraste certain avec les hérissements du fauvisme et du cubisme, et les décompositions du surréalisme et de l'expressionnisme d'aprèsguerre $^{\prime{ }^{3}}$

De nombreux autres éléments viennent confirmer un certain flottement dans l'expression avant l'adoption d'un titre d'ouvrage définitif pour le projet publié chez Raynal \& Hitchcock ${ }^{4}$. Le contrat signé le 27 mai 1946 porte sur un ouvrage devant s'intituler Space beyond Words. Le Corbusier quant à lui dénomme ce projet L'Espace indicible durant son élaboration et l'ouvrage publié en 1948 s'intitulera finalement New World of Space. Il est à cet égard tout à fait important de remarquer à quel point ces difficultés ne sont pas simplement contingentes ou accidentelles et ne sont pas uniquement le fruit d'un certain flottement dans l'expression ou d'un manque de rigueur. En réalité, ce que révèlent ces dénominations divergentes réside à la fois dans l'ambiguïté du phénomène décrit par le terme d'« espace indicible » (c'est parce qu'elle est précisément «indicible » que cette expérience de l'espace est si difficile à dire de manière adéquate), ainsi que dans les difficultés qu'il y a à lui trouver un équivalent satisfaisant dans la langue anglaise. Difficultés conceptuelles et difficultés linguistiques se rejoignent ici d'une manière absolument non superficielle. On sait que Le Corbusier était très mécontent des traductions possibles de ce vocable et notamment par le choix de traduire «indicible» par le terme anglais "ineffable », comme cela fut le cas dans la version anglaise de l'article de 46 figurant dans New World of Space sous le titre précisément d' "Ineffable Space ». Sans en être pleinement satisfait non plus, Le Corbusier semblait préférer à «ineffable » une traduction d'«indicible» par l'expression «space beyond words ». Comme le souligne l'architecte lui-même dans une série de notes sur l'espace indicible datant du 30 août 1954 :

"indicible [...] un événement possible à occasions favorables. La chose est parfois accessible mais n'est parfois pas même concevable pour certains, puisque les anglo-saxons n'ont pas le mot lui-même" ${ }^{\prime 5}$

Les erreurs d'archivage ne sont ainsi pas uniquement à rapporter à des accidents de classement, mais elles sont révélatrices de deux faits: la confusion potentielle entre deux projets éditoriaux distincts possédant une dénomination commune ; des considérations liées au concept même d'espace indicible, dans la difficulté qu'il y a à la fois à le penser, à le dire et à le traduire. Nous aurons à revenir sur ces aspects plus proprement conceptuels dans la suite de notre propos.

\subsection{Les différentes versions du texte de « L'Espace indicible » et leur mise en ordre}

Après avoir attiré l'attention sur les différents contextes dans lesquels le texte de «L'Espace indicible » pouvait être susceptible d'apparaître, l'analyse des archives nous permet de dénombrer treize états distincts du texte. Cherchant à suivre les différentes étapes de l'écriture et de la réécriture constante de ce texte, notre travail de reconstruction nous amène à proposer de restituer leur succession dans l'ordre suivant :

1/ Le premier état du texte, rédigé en vue de la publication de l'article dans le hors-série «Art» de L'Architecture d'Aujourd'hui paru en 1946, est un manuscrit daté du 13 septembre 1945 [B3-7-209]. Le Corbusier opère déjà de nombreuses corrections sur cette première version et l'on peut voir à quel point la pensée s'élabore ici dans le geste même de l'écriture. Il est à noter que l'article semble avoir eu pour titre initial «Prendre possession de l'espace » (première phrase de ce qui est ici la première partie de l'article), raturé

\footnotetext{
${ }^{3}$ [R2(4)118]

${ }^{4}$ Voir à ce propos par exemple les éléments suivants, dans lesquels Le Corbusier désigne bien le projet de 1948 sous le titre L'Espace indicible : [B3-7-295], [B3-7-485], [B3-7-487], [B3-7-481], [B3-7-180].

${ }^{5}[\mathrm{~B} 3-7-541 \mathrm{~T}]$
} 
ensuite en «L'Espace indicible». Comme cela sera le cas dans la version publiée dans L'Architecture d'Aujourd'hui, l'article se compose de trois parties distinctes : un «chapeau » en guise d'introduction; une première partie qui correspond globalement à ce que nous avons coutume de désigner par le texte "L'Espace indicible »; une deuxième partie dans laquelle Le Corbusier revient sur différentes étapes de son parcours créatif, qu'il s'agisse d'architecture, de peinture ou de sculpture. Celle-ci comporte déjà un ensemble d'indications relatives aux illustrations devant accompagner le texte.

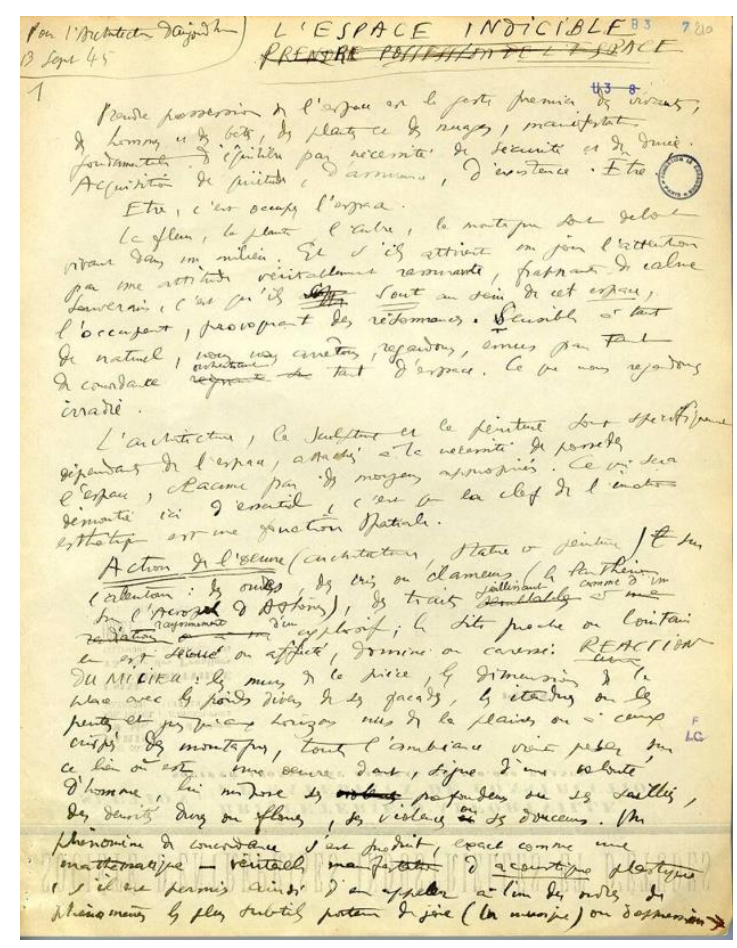

2. Premier manuscrit de «L'Espace indicible » [B3-7-209-002] @FLC-ADAGP.

2/ À partir de cette première version manuscrite et des corrections qui y sont apportées de la main même de Le Corbusier, l'architecte semble avoir fait établir deux versions dactylographiées (ce qui paraît être un procédé constant chez lui). Le premier exemplaire [B3-7-239] est toujours composé des trois mêmes parties que dans le manuscrit et Le Corbusier opère un certain nombre de corrections manuscrites supplémentaires pour corriger le style et affiner l'expression en direction d'une plus grande précision de la pensée.

3/ Le deuxième exemplaire dactylographié [B3-7-247], identique en tous points à l'autre, comporte moins de corrections que le précédent (avec des corrections similaires et certaines nouveautés), mais il paraît indéniable qu'il a été l'objet d'une correction chronologiquement postérieure au premier exemplaire. 


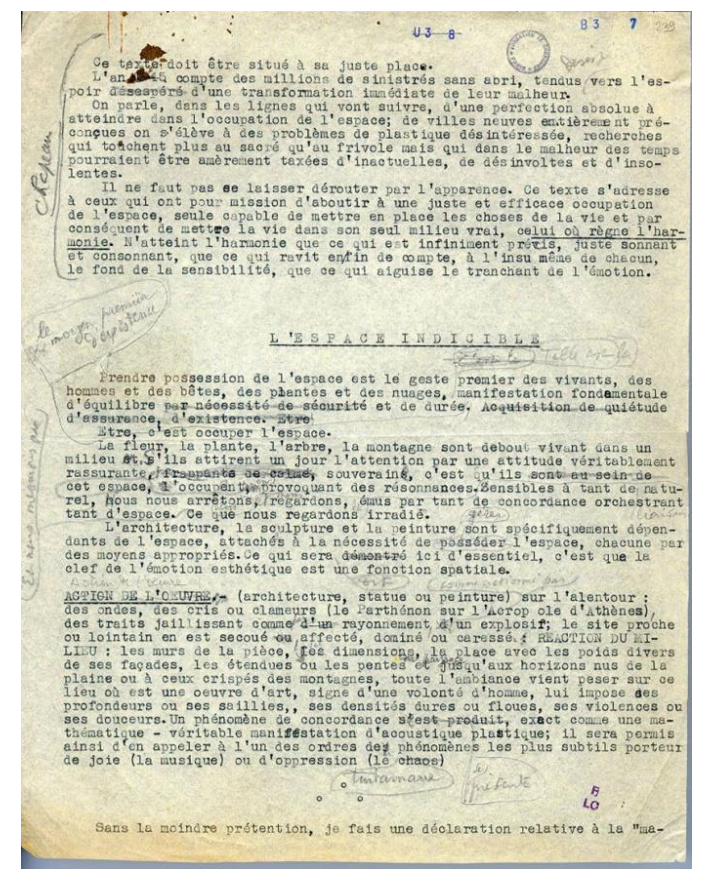

3. Premier exemplaire dactylographié avec corrections manuscrites [B3-7-239-001] @FLC-ADAGP.

4/ Les corrections apportées à la main sur ces deux exemplaires aboutissent à la constitution de deux nouvelles versions dactylographiées identiques. Il s'agit toujours de phases préparatoires à l'article de 1946. La première version [B3-7-507] est à nouveau truffée de corrections manuscrites apportées par Le Corbusier.

5/ La seconde [B3-7-512] comporte elle aussi de nombreuses modifications, à la fois redondantes avec les corrections de l'autre exemplaire et comportant également quelques nouveautés. Le chapeau présent dans les versions précédentes disparaît dans celles-ci (alors qu'il sera repris dans l'article publié en 1946).

6/ Selon toute vraisemblance, il semblerait qu'il faille introduire ici une autre variable pour identifier le sixième état du texte. En effet, bien que les versions précédentes aient clairement été destinées à la publication de l'article de L'Architecture d'Aujourd'hui, Le Corbusier travaillait très souvent sur plusieurs articles à la fois. Il semblerait qu'il ait fait usage de certains éléments de l'article en préparation pour le hors-série «Art » dans le cadre d'une autre commande d'article, à savoir le texte «L'Architecture et l'esprit mathématique » [E2-8-160], paru en 1948 dans les Cahiers $d u$ Sud. La genèse de cet article, dans lequel on retrouve une longue citation de ce que nous avons appelé précédemment la première partie du texte original de «L'Espace indicible », est tumultueuse et parfois difficile à suivre ${ }^{6}$, du fait notamment que le principal responsable du numéro de la revue, François Le Lyonnais, avait été fait prisonnier par les Allemands et que nombre de collaborateurs pressentis de la revue ont eu à subir les aléas de la guerre. L'article, commandé à La Corbusier dès 1942, a été travaillé et rédigé début 1946 (il date l'article du 4 janvier) à bord du Vernon S. Hood. La publication n'aboutira finalement qu'en 1948, mais Le Corbusier a envoyé son article en 1946, dès avant la parution de «L'Espace indicible »

\footnotetext{
${ }^{6}$ Pour une lecture de cet article relativement méconnu de Le Corbusier, ainsi que pour des informations historiques sur sa rédaction et des analyses de son contenu, nous nous permettons de renvoyer le lecteur au numéro des Cahiers philosophiques de Strasbourg (références dans la bibliographie) édités sous notre responsabilité, et plus particulièrement au travail de reconstitution et d'analyse de ce texte mené par Frédéric de Buzon dans ce même numéro.
} 
dans L'Architecture d'Aujourd'hui ${ }^{7}$. Cet article, tout comme la version définitive de 1946, a sans aucun doute été constitué à partir des deux versions dactylographiées immédiatement antérieures. En pleine relecture de celles-ci, travaillant parallèlement à la rédaction de deux articles, il existe des variations entre le texte des Cahiers $d u$ Sud et celui de L'Architecture d'Aujourd'hui, mais l'antériorité du premier sur le second semble évidente (notamment du fait de l'existence d'une variante entre «par leur contour» dans les Cahiers / «par leur contenu » dans les corrections manuscrites de [B3-7-512] qui se retrouveront dans l'article du hors-série). Ainsi, la rédaction de «L'Architecture et l'esprit mathématique » représente un jalon essentiel tant en ce qui concerne la constitution de l'article connu comme «L'Espace indicible » qu'en regard de l'élaboration de la réflexion corbuséenne sur ce thème.

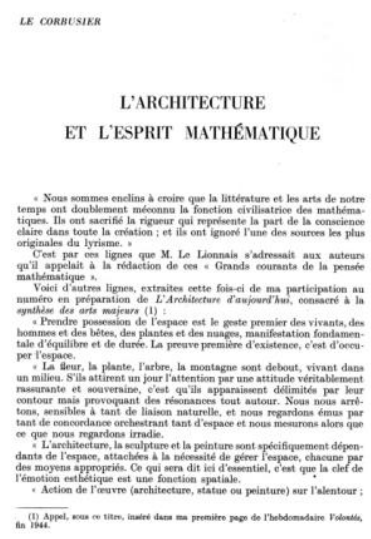

4. «L'Architecture et l'esprit mathématique » OFLC-ADAGP.

7/ De manière tout à fait logique, c'est l'article paru dans L'Architecture d'Aujourd'hui ${ }^{8}$ qui constitue l'état suivant du texte. Par le biais des multiples phases de réécriture suivies par le texte, l'article finalement publié correspond assez globalement au plan tracé dans le manuscrit original de 1945 (avec les trois parties prévues au départ et une série d'illustrations).

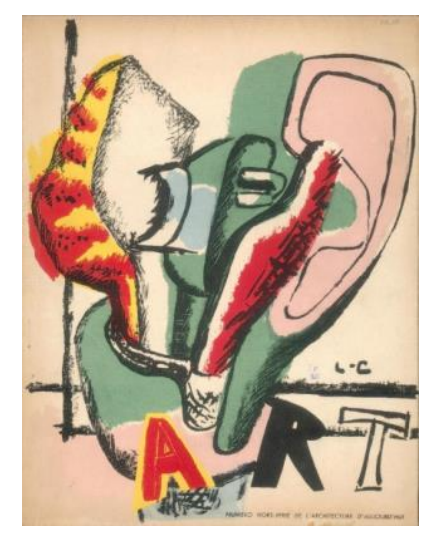

5. Couverture du hors-série « Art » de 1946 [X1-15-298-002] @FLC-ADAGP.

\footnotetext{
${ }^{7}$ Dans «L'Architecture et l'esprit mathématique », Le Corbusier annonce que les réflexions autour de l'espace indicible seront à paraitre dans le hors-série «Art» de 1946, ce qui constitue l'un des indices de l'antériorité temporelle de cette version du texte.

${ }^{8}$ Le Corbusier : «L'espace indicible ». In L'Architecture d'Aujourd'hui, numéro hors-série spécial « Art », Avril 1946, p. 917.
} 
8/ Avec les deux versions suivantes, nous basculons dans un univers textuel différent des précédents. L'horizon dernier n'est plus maintenant la rédaction de l'article de L'Architecture d'Aujourd'hui, mais celui-ci deviendra la base devant servir à la conception du premier chapitre de l'ouvrage New World of Space de 1948. Le Corbusier a à nouveau fait établir deux versions dactylographiées qu'il envoie à New York, très certainement pour que l'on puisse effectuer une traduction du texte. Les deux exemplaires connus (qui étaient probablement au moins trois) portent la mention «corrigé par Mlle Laurence » et semblent avoir été corrigés le même jour, à savoir le 30 septembre 1946. Il s'agit ici sans aucun doute possible de Mercédès Laurence, secrétaire de Le Corbusier au siège des Nations Unies, avec qui il est resté longtemps en contact. De manière surprenante, mais compréhensible dès lors que l'on tient compte des remarques faites dans la section précédente, ces deux versions semblent porter sur un projet d'ouvrage intitulé « L'Espace indicible ${ }^{9}$, mais qui ne saurait être autre que New World of Space (en regard par ailleurs des dates, des éléments de correction mentionnés sur le document et de l'éditeur auquel ils sont destinés).

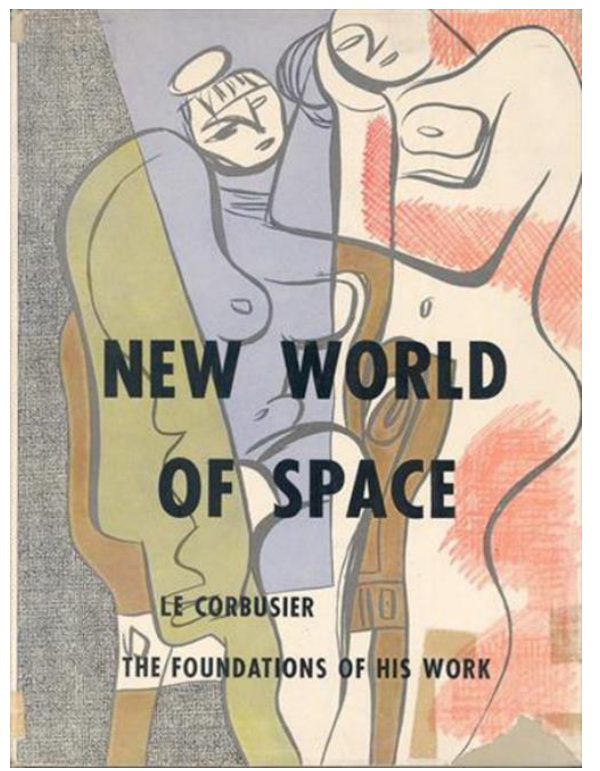

6. Première de couverture de New World of Space OFLC-ADAGP.

Le premier exemplaire dont nous disposions [B3-7-255] («Exemplaire corrigé par Mlle Laurence ») fait état de corrections orthographiques et stylistiques, sans intervention sur le fond. D'une manière tout à fait conforme à ce qui se passera dans New World of Space, le texte «L'Espace indicible » (dans sa version « courte » sans chapeau ni la deuxième partie de l'article de 46) devient ici le premier chapitre de l'ouvrage et sera suivi d'un extrait de Sur les quatre routes ( «L'art de construire ») et d'un chapitre intitulé «Informations », retraçant certaines étapes marquantes de l'itinéraire corbuséen.

9/ L’exemplaire dactylographié suivant, identique au précédent, porte la mention « Exemplaire $\mathrm{n}^{\circ} 3$ Corrigé par Mlle Laurence » et comporte des corrections orthographiques et stylistiques analogues au précédent. Il est clairement indiqué en note manuscrite que : «les lignes sur «L'Espace Indicible » sont parues pour la première fois dans «ART », numéro hors-série de L'Architecture d'Aujourd'hui à Paris, mai 1946 ».

10/ De manière là encore non surprenante, la version suivante est incontestablement la version anglaise «Ineffable Space », publiée en 48 dans New World of Space à partir des versions corrigées par Mlle Laurence des tapuscrits tirés de l'article de 46.

\footnotetext{
${ }^{9}$ Voir par exemple la présence du signe adopté traditionnellement par Le Corbusier pour indiquer ses projets d'ouvrages en [B3-7-295].
} 
11/ La version suivante du texte est une citation de la version courte de l'article de 46 dans le premier volume du Modulor publié en $1948^{10}$. Il est intéressant de noter que Le Corbusier situe ici sa découverte de l'espace indicible dans le contexte de ses réflexions sur les mathématiques.

12/ Cette même version courte sera reprise et publiée sur une page dans le numéro 7 de la revue belge Architecture 53, augmentée de trois paragraphes inédits et accompagnée cette fois d'une photographie de Lucien Hervé.

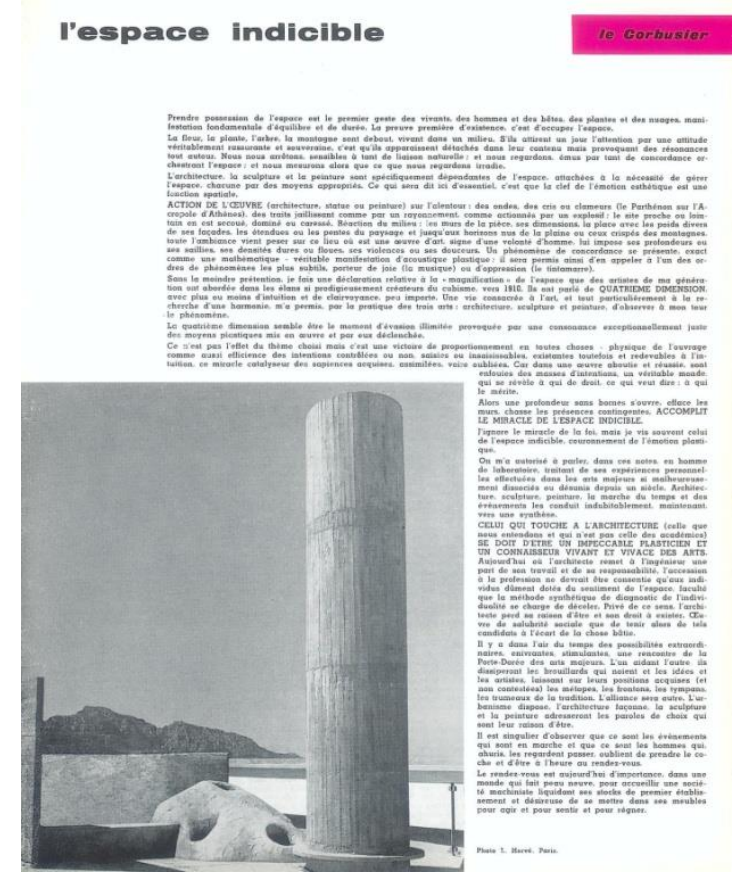

7. Publication dans Architecture 53 [X1-17-138-001] @FLC-ADAGP.

13/ Enfin, le dernier état du texte peut être situé dans le cadre de la publication du Modulor $2^{11}$. Cette fois-ci, la découverte de l'espace indicible est rapportée à des réflexions liant l'architecture et le sacré.

\section{Conceptions}

\subsection{Sens général du concept d'« espace indicible » dans la théorie corbuséenne}

Il ne saurait évidemment être question, dans les limites de cet article, de prétendre épuiser la richesse de sens contenue dans la notion en apparence si énigmatique d'« espace indicible ». Cela d'autant plus que nous avons cherché à montrer que l'article du même nom, ainsi que les textes périphériques dans lesquels ce concept était mis en jeu, sont l'objet d'un intérêt profond et d'une réécriture constante de la part de Le Corbusier. En nous

\footnotetext{
${ }^{10}$ Le Corbusier : Le Modulor. Bâle : Birkhäuser, 2000, p. 31-32. Le texte, cité dans le chapitre 2 «Chronologie », débute ici à «Prendre possession de l'espace» et se termine à «j'ignore le miracle de la foi, mais je vis souvent celui de l'espace indicible, couronnement de l'émotion plastique ». On peut ici se référer au manuscrit original du Modulor [B3-7-15] (page 7), ainsi qu'à la version dactylographiée du texte [B3-19-1] (page 18).

${ }^{11}$ Le Modulor 2, p. 23-25. Le texte débute à «Prendre possession de l'espace », mais la citation de l'article de 1946 est plus courte et se termine à "Alors une profondeur sans bornes s'ouvre, efface les murs, chasse les présences contingentes, accomplit le miracle de l'espace indicible ». Voir également [F1-20-1] (p. 12 à 14), [F1-20-162] (pages 11 à 14) et [F2-1-9] (page 17).
} 
appuyant sur certaines des formulations majeures dans la version «courte » de l'article dont nous avons cherché à établir la genèse dans ce qui précède, nous allons tout de même tenter d'extraire certaines des principales déterminations conceptuelles de «l'espace indicible ».

Il semble tout d'abord manifeste que depuis la rencontre avec le Parthénon, Le Corbusier a toujours été à la recherche de l'expression la plus juste afin de rendre compte des expériences esthétiques et spirituelles les plus hautes. La dimension introspective ou « expérientielle » de l'espace indicible est en effet indéniable : le concept ne vise pas tant à décrire les propriétés d'un objet que la qualité de l'effet produit par cet objet sur un sujet, qualité vécue sur le mode de l'expérience individuelle. Il s'agit bien par ce terme de « saisir l'essence de l'espace indicible, sa raison d'être phénoménologique qui est la transcription d'émotions dans la matière ${ }^{12}$. De ce dernier point de vue qui est celui des concepts permettant de dire le « hors-norme », il est à noter que la pensée de Le Corbusier est marquée par une évolution importante. Avant 1945, c'est avant tout le terme de « beauté » et toutes les déterminations permettant de le traduire dans le langage de l'expérience (tant en ce qui concerne l'expérience du beau par le récepteur de l'ouvrage architectural qu'en regard de l'effort de production de la beauté par l'architecte créateur) qui semblent dominer la terminologie corbuséenne. Après 1945, c'est l'invention du concept d' «espace indicible » qui marquera un tournant terminologique dans l'expression de l'architecte. Car si le terme de «beauté », en tant que concept générique et terme d'une très grande généralité, permet de désigner un ensemble d'expériences s'appliquant d'abord indifféremment à des champs d'objets extrêmement divers (la beauté d'une réalité naturelle comme un coucher de soleil ou une chaîne de montagnes, la beauté d'une œuvre d'art quel que soit le champ artistique pris en compte, la beauté des formes humaines, etc.), le terme d' «espace indicible » pourrait désigner une expérience spécifiquement architecturale entendue dans son sens élargi dans le cadre d'une réflexion sur la « synthèse des arts majeurs ${ }^{13}$.

L'espace indicible, c'est le terme le plus propre à désigner et à dire l'émotion spécifiquement architecturale ressentie face à un édifice parfaitement achevé à tous points de vue. Lorsque le jeu architectural est non seulement «savant» et «correct» (pré-conditions absolument nécessaires), mais également «magnifique », alors peut se produire un phénomène d'espace indicible. Ce phénomène est en même temps toujours une expérience du «hors-norme» et une manière d'essayer de rendre compte de manière rationnelle de cette expérience, c'est-à-dire de tenter de la normaliser, de la caractériser au moyen du langage commun, cela tout en marquant son caractère exceptionnel et insigne (c'est-à-dire en la distinguant dans et par le langage). Si la pensée corbuséenne se constitue ainsi dans une dialectique incessante entre la recherche des normes et la nécessaire reconnaissance de ce qui les excède, la réflexion autour de l'espace indicible marque une étape décisive dans l'approfondissement de cette relation constitutive, ainsi que dans l'exploration du domaine du « hors-norme ». En ce sens, nous sommes tout à fait en accord avec les propos de Roberto Gargiani :

"Il n'est pas étonnant que dans le formulation de l'espace indicible, Le Corbusier chemine vers un objet aux frontières théoriques imprécises, rendant impossible la recherche même de fondements d'une nouvelle vision, alors que c'est de façon méthodique qu'il avait ramené l'architecture à quelques notions essentielles - «les cinq points d'une architecture nouvelle »-, toutes dépendantes du système de structure du béton brut (...) Mais si Le

\footnotetext{
${ }^{12}$ Roberto Gargiani, « Genèse et représentation de l'espace indicible ». In Migayrou, Frédéric ; Cinqualbre, Olivier (dir.) : Le Corbusier, Mesures de l'homme. Paris : Centre Pompidou, 2015 p. 171.

${ }^{13}$ Nous ne reviendrons pas ici sur certains aspects de la notion d'espace indicible déjà bien étudiés par ailleurs (rôle du modèle de la «Fernbild», des illusions d'optique, de la psychophysiologie de la perception, influence du surréalisme), notamment dans les travaux de Roberto Gargiani. Ce dernier remarque par ailleurs que la synthèse des arts majeurs constitue « un préalable essentiel à la définition d'un nouveau concept de l'espace qui va bien au-delà de tout système d'organes fonctionnels ou structurels ».
} 
Corbusier n'avait auparavant défini, avec une autorité presque scientifique, les principes d'une nouvelle architecture et tenté d'établir les lois de la perception, il est certain que cet indicible n'aurait pas même pu être esquissé. Ce qui se déploie au-delà des cinq points et des lois en question est le paysage qu'il entend maintenant explorer $^{\text {"14 }}$

\subsection{Principales caractérisations}

Essayons maintenant d'entrer d'une manière plus précise dans le contenu des descriptions données par l'architecte de cette notion d'« espace indicible». Comment la caractérise-t-il ? Citons ici un premier extrait important :

"La proportion est chose ineffable. Je suis l'inventeur de l'expression : "l'espace indicible » qui est une réalité que j'ai découverte en route. Lorsqu'une ouvre est à son maximum d'intensité, de proportion, de qualité d'exécution, de perfection, il se produit un phénomène d'espace indicible: les lieux se mettent à rayonner, physiquement ils rayonnent. Ils déterminent ce que j'appelle "l'espace indicible », c'est-à-dire un choc qui ne dépend pas des dimensions mais de la qualité de perfection. C'est du domaine de l'ineffable"15

Face à cette « réalité [...] découverte en route ", c'est encore une fois comme si Le Corbusier tentait de forcer le langage à dire ce qu'il ne pourrait par nature exprimer, puisqu'il nous dit que cette expérience particulière de l'espace qu'est «l'espace indicible » est «chose ineffable», «indicible ». Il est clair que le choix de l'expression «l'espace indicible» trahit lui-même une sorte de malaise ou exprime une sorte de paradoxe proche de la contradiction performative, puisqu'il s'agit précisément de chercher à dire par l'acte linguistique de formulation d'un concept (d'énoncer, de mettre en mots, de porter à l'expression) ce qui précisément, par le témoignage même de l'expression choisie, ne se laisse pas dire ou constitue aux yeux de l'architecte un phénomène radicalement indicible. Le choix de l'expression semble bien attester ou dire toute la difficulté qu'il y a à mettre en mots la qualité singulière de l'expérience de l'espace qui est désignée par le terme lui-même. Par ailleurs, le fait de parler d'un espace «indicible » indique très clairement par la négative que le phénomène que l'on tente ainsi de décrire relève avant tout d'un ordre de réalité qui d'abord et avant tout se vit, se sent, s'expérimente et s'éprouve. Si cette expérience de l'espace est indicible, elle n'en demeure pas moins une expérience perceptive et sensible, de l'ordre de la dimension du vécu subjectif.

Ainsi, selon Le Corbusier, le langage ne peut pas dire ce qui «se produit» lorsque «les lieux se mettent à rayonner » et pourtant il faut parler, dire, tenter de mettre en mots cette expérience, qui est la plus haute expérience architecturale vécue par Le Corbusier. Il insiste fortement sur le fait que l'élément essentiel dans ce phénomène d'espace indicible réside dans «la qualité de perfection» de l'ouvrage, c'est-à-dire dans la perfection avec laquelle les éléments architecturaux et plastiques ont été mis en rapport, proportionnés les uns aux autres, de telle sorte qu'ils résonnent ensemble, qu'ils forment un ensemble symphonique de couleurs et de formes. L'espace indicible est le sommet de l'art architectural comme poésie des rapports, dont on fait l'expérience au long d'un parcours. C'est la qualité des rapports qui compte ici, un agencement d'une telle perfection qu'il donne une véritable intensité à l'œuvre. L'espace indicible est le sentiment ressenti face à un ensemble de rapports symphoniques.

De plus, il faut encore remarquer dans cette citation la mention de ce qui n'est pas la cause du phénomène d'espace indicible : «un choc qui ne dépend pas des dimensions mais de la qualité de perfection ». L'émotion

\footnotetext{
${ }^{14}$ Robert Gargiani, « Genèse et représentation de l'espace indicible », p. 164.

${ }^{15}$ Le Corbusier : Un couvent de Le Corbusier. Paris : Éditions de Minuit, 1990, p. 31.
} 
ressentie face à un bâtiment qui rayonne physiquement est bien de l'ordre du «choc », c'est-à-dire de l'événement, de ce qui vous prend par surprise, tout d'un coup, sans prévenir, mais ce « choc » ne dépend pas « des dimensions » de l'objet architectural, il n'est pas comparable (pour utiliser la terminologie kantienne) au choc ressenti face au sublime mathématique qui, de par ses dimensions, me donne à vivre l'expérience d'un écrasement, qui me terrasse en me renvoyant à ma petitesse et à la finitude de mes moyens d'appréhension de ce qui relève de l'«absolument grand» (mon entendement n'arrivant pas à synthétiser, à unifier ou à « comprendre » ce que l'imagination appréhende mais ne peut pas totaliser). Je n'ai pas besoin d'être au pied des Pyramides d'Égypte pour ressentir l'espace indicible, une simple masure peut me faire la même impression ${ }^{16}$. C'est uniquement la qualité symphonique de rapports concertés qui détermine cette expérience, qui illumine le spectateur autant qu'elle sublime le site où se trouve l'ouvrage. Le Corbusier donne une autre description de ce phénomène dans un autre texte :

"La quatrième dimension semble être le moment d'évasion illimitée provoquée par une consonance exceptionnellement juste des moyens plastiques mis en ouvre et par eux déclenchés. Ce n'est pas l'effet du thème choisi mais c'est une victoire du proportionnement en toutes choses - physique de l'ouvrage comme aussi efficience des intentions contrôlées ou non, saisies ou insaisissables, existantes toutefois et redevables à l'intuition, ce miracle catalyseur des sapiences acquises, assimilées, voire oubliées. Car dans une ouvre aboutie et réussie, sont enfouies des masses d'intentions, un véritable monde, qui se révèle à qui de droit, ce qui veut dire : à qui le mérite.

Alors une profondeur sans bornes s'ouvre, efface les murs, chasse les présences contingentes, ACCOMPLIT LE MIRACLE DE L'ESPACE INDICIBLE.

J'ignore le miracle de la foi, mais je vis souvent celui de l'espace indicible, couronnement de l'émotion plastique ${ }^{\prime 17}$

Dans ce texte difficile, Le Corbusier commence par réaffirmer, de manière plus précise, ce qu'il avait déjà indiqué dans le texte précédent, cela avec quelques nouveautés. Le phénomène d'espace indicible est provoqué «par une consonance exceptionnellement juste des moyens plastiques mis en œuvre » et il ajoute que ce «n'est pas l'effet du thème choisi ». Tout comme ce n'était pas les dimensions monumentales de l'ouvrage qui provoquaient l'ouverture de cette «profondeur sans bornes » qu'est l'espace indicible, ce n'est pas non plus le thème, c'est-à-dire le sujet ou plus précisément la nature programmatique de l'édifice qui est impliquée ici. Car on aurait très bien pu être tenté de restreindre la notion d' « espace indicible » à l'architecture religieuse et sacrée uniquement (ou à l'architecture monumentale), à savoir à une architecture prenant explicitement pour thème des sujets eux-mêmes sublimes, ineffables, transcendants (le rapport de l'homme à Dieu, aux forces de la nature, etc.). L'espace indicible est le fruit d'une «victoire du proportionnement en toutes choses ». Nous avions déjà pressenti que ceci renvoyait à la qualité de perfection des rapports unissant les différentes composantes du

\footnotetext{
${ }^{16}$ Pensons ici par exemple aux commentaires donnés en note par Le Corbusier lorsqu'il commente sa découverte de l'espace indicible dans Le Modulor 2, p. 25 : «Ces propos sont nés d'une expérience. J'ai chez moi un vestibule de deux mètres de côté. Un mur fait face à un grand vitrage nord ouvrant sur le toit-jardin. Ce mur est donc dans un éclairage constant, théorique presque. C'est le seul éclairé dans de telles conditions, mon appartement étant orienté est-ouest. J'avais pris l'habitude d'employer ce mur comme banc d'essai pour mes tableaux pendant leur fabrication : petits tableaux ou très grands tableaux. Un jour (à une occasion bien précise), j'ai vu se réaliser sous mes yeux l'espace indicible : ce mur, avec son tableau, s'épanouissait sans limite. J'ai soumis à l'épreuve des amis, des visiteurs. Le tableau étant accroché, d'un coup je l'enlevais. Ce n'était plus, alors, qu'un petit mur de deux mètres, un mur misérable. Ce fait prêtait à réflexion ». Ce fait devrait être mis en relation aussi bien avec l'idée de synthèse des arts qu'avec la citation précédemment donnée selon laquelle l'indicible est « un événement possible à occasions favorables ».

17 «L'espace indicible », p. 10.
} 
bâtiment, c'est uniquement la «physique de l'ouvrage » qui entre en ligne de compte. Plusieurs éléments interviennent ici : si l'espace indicible est le résultat de la pure et simple «physique de l'ouvrage », c'est-à-dire de la qualité de l'organisation matérielle des rapports entre les éléments architecturaux au sein de l'ouvrage, l'édifice achevé dont nous faisons l'expérience est le fruit de l'œuvre de pensée du créateur (« la grandeur est dans l'intention et non dans les dimensions », dit Le Corbusier dans un autre texte), du «génie inventif» pour reprendre une expression de Le Corbusier. L'architecture est bien aussi «chose de l'esprit». Les rapports inscrits dans la matérialité du bâtiment sont le fruit des « masses d'intentions » qui étaient à l'œuvre dans l'esprit en acte du constructeur. En effet, le plus petit élément d'une architecture (emplacement d'une fenêtre, forme d'une poignée de porte, nuance de luminosité sur un volume selon l'orientation du bâtiment et les moments de la journée ou le rythme des saisons) est le fruit d'une intention, c'est-à-dire d'une décision consciente (il est vrai plus ou moins réfléchie et délibérée comme le rappelle Le Corbusier dans le texte). Un édifice est le résultat de la somme de toutes ces micro-décisions, il est l'objectivation matérielle de cette conception des choses par l'activité de pensée d'un esprit. L' « œuvre aboutie et réussie » est la matérialisation, la concrétisation dans le sensible de ce «monde » d'intentions peuplant la pensée de l'architecte. La référence au génie est elle aussi explicite ici, de par le recours au terme d' «intuition ». Seul un être naturellement doué de cette faculté de sentir avec une infinie justesse semble pouvoir faire en sorte que même la part la plus inconsciente de son travail (c'est-à-dire à proprement parler ce qu'il y a en lui de nature) aboutisse à une réussite.

Autre aspect important, l'espace indicible ouvre selon Le Corbusier la «quatrième dimension »: une «profondeur sans bornes s'ouvre, efface les murs, chasse les présences contingentes, ACCOMPLIT LE MIRACLE DE L'ESPACE INDICIBLE ». Dans un autre texte, Le Corbusier affirme que « la clef de l'émotion esthétique est une fonction spatiale ${ }^{18}$. L'émotion esthétique relève d'une juste mise en rapport des éléments dans l'espace architectural, de telle sorte qu'apparaisse cette autre dimension, qui est celle de la profondeur. Cette dernière notion est d'interprétation difficile. Il paraît tout à fait clair que Le Corbusier ne semble manifestement pas se référer ici à la profondeur au sens physique et matériel du terme. Dans le texte de «L'Espace indicible », c'est bien plutôt à une détermination à la fois mentale et spirituelle qu'il faut chercher à ramener la thématique de la profondeur. En effet, il est indéniable que le terme «profondeur » renvoie ici pour une part à la qualité spirituelle de l'expérience atteinte par le sentiment de l'espace indicible, qui est le « couronnement de l'émotion plastique ». De plus, le fait que Le Corbusier compare l'expérience esthétique au sentiment religieux («J'ignore le miracle de la foi, mais je vis souvent celui de l'espace indicible ») donne une dimension spirituelle, quasi-mystique à l'émotion artistique, cela dans une veine tout à fait typique des propos de Le Corbusier. L'espace indicible serait l'équivalent profane pour l'initié de l'art de ce qu'est l'expérience mystique et sacrée pour celui qui vit dans le rapport à Dieu ${ }^{19}$. Il renvoie à la dimension du « miracle », c'est-àdire à une sorte de grâce, de présent quasiment divin parce qu'exceptionnellement rare, contraire au cours ordinaire des choses (un miracle est une violation des lois de la nature). Un tel vocabulaire dénote bien à la fois le prix accordé par Le Corbusier à l'expérience de l'espace indicible, en même temps qu'il fait signe vers notre incapacité de lui assigner des causes déterminantes véritables. Le miracle est ici le nom que nous donnons à notre ignorance.

Enfin, nous voudrions évoquer un dernier point d'importance, qui nous montrera à quel point le concept d' « espace indicible » permet à Le Corbusier d'approfondir certaines de ses obsessions les plus constantes. Tout

\footnotetext{
18 «L'espace indicible», p. 10.

${ }^{19}$ Le Modulor 2, p. 23 : «Par conséquent, voué à la recherche « du meilleur de tout », du plus pur que tout, pour être le plus intense de tous. Un type la tête pleine de proportions, possédé du désir d'harmonie, appelé à s'occuper d'espace, de volume, de rapports, toutes choses qui, forcément, impliquent une mathématique. Le scintillement, l'éclat, la lumière, nés de l'exactitude, conduisent à l'espace indicible, de la nature du sacré et non pas du magique ».
} 
comme le rapport à la musique, Le Corbusier est en effet absolument fasciné par les rapports entre l'architecture et le site, entre la réalité bâtie et son environnement naturel. L'une des constantes marquant avec la plus grande intensité l'architecture de Le Corbusier est sans conteste son amour inconditionnel de la nature et du paysage. Son œuvre représente l'un des dialogues les plus émouvants et les plus profonds entre l'architecture et la nature et il n'est que de visiter les bâtiments de Le Corbusier pour se rendre compte de la beauté des sites dans lesquels les édifices prennent place avec une justesse toujours impeccable. Plus que tout autre architecte, Le Corbusier n'aura eu de cesse de concilier la métaphorique naturelle / organique et la métaphore mécanique. Si l'architecture est autant « machine à habiter » que «machine à émouvoir », la référence à la machine ne se situe jamais en opposition avec la place centrale accordée à la nature. Or, le phénomène de l'espace indicible, possède selon lui une caractéristique reliant spécifiquement l'architecture à son site. L'architecture ne s'oppose ni ne se distingue de son site, au contraire, l'environnement naturel semble en quelque sorte faire partie de l'architecture et participer de l'émotion ressentie face aux euvres d'une perfection ineffable. Citons ici un autre extrait concernant la notion d'espace indicible :

"ACTION DE L'CEUVRE (architecture, statue ou peinture) sur l'alentour : des ondes, des cris ou clameurs, des traits jaillissant comme par un rayonnement comme actionnés par un explosif ; le site proche ou lointain en est secoué, dominé ou caressé. Réaction du milieu : les murs de la pièce, ses dimensions, la place avec les poids divers de ses façades, les étendues ou les pentes du paysage et jusqu'aux horizons nus de la plaine ou ceux crispés des montagnes, toute l'ambiance vient peser sur ce lieu où est une ouvre d'art, signe d'une volonté d'homme, lui impose ses profondeurs ou ses saillies, ses densités dures ou floues, ses violences ou ses douceurs. Un phénomène de concordance se présente, exact comme une mathématique - véritable manifestation d'acoustique plastique: il sera permis d'en appeler ainsi à l'un des ordres de phénomènes les plus subtils, porteur de joie (musique) ou d'oppression (tintamarre) ${ }^{\prime 20}$

On peut voir ici à quel point l'architecture ne se cantonne pas aux limites matérielles de l'édifice pris pour luimême. La grande ouvre architecturale, celle capable de nous faire ressentir le phénomène de l'espace indicible, déborde de toutes parts ses propres limites (ouvrant ainsi «une profondeur sans bornes»). Non pas physiquement bien sûr, mais en ce que la perception de l'œuvre parfaite ouvre cette dimension mentale de la profondeur dont il était question auparavant, permettant l'expérience d'un élargissement de l'horizon spatial (« un moment d'évasion illimitée », disait Le Corbusier dans l'un des textes précédents), s'exprimant de manière privilégiée dans les rapports entre l'architecture et son site. L'espace indicible est ainsi toujours une expérience mentale sur le fondement d'une émotion corporelle (dans les termes de Le Corbusier une expérience relevant du domaine «plastique »).

Les liens entre la dimension «religieuse » ou sacrée de la notion d'espace indicible et la question de l'environnement naturel sont ainsi absolument décisifs pour comprendre les références à une forme de mystique de l'espace lorsque Le Corbusier évoque l'espace indicible. Et il apparait clairement qu'aux yeux de Le Corbusier, la notion d'espace indicible, dans tout ce que sa formulation a de mystérieux, lui permet également de rassembler en une locution unique l'ensemble des déterminations attachées à la dimension spirituelle qu'il n'a cessée de reconnaître à l'architecture : dignité de l'acte humain de construire, musique, mathématiques, insertion dans la totalité naturelle d'une œuvre devant véhiculer par les jeu de ses formes une émotion dont la qualité spirituelle semble similaire au sentiment religieux :

${ }^{20}$ «L'espace indicible », p. 9. 
"Le sentiment du sacré a animé notre effort. Des choses sont sacrées, d'autres ne le sont pas, qu'elles soient religieuses ou non (...) L'art abstrait qui alimente bien justement avec tant de ferveur en cette époque est la raison d'être de Ronchamp: langage d'architecture, équations plastiques, symphonie, musique ou nombres (mais dépourvus de métaphysique) détecteur, dans une rigueur valable, de l'espace indicible" ${ }^{\prime 21}$

\section{Conclusions}

Les réflexions autour de la notion d'espace indicible sont un domaine encore largement à explorer dans le cadre des recherches corbuséennes. Tant en ce qui concerne le contenu de la notion qu'en regard des sources textuelles dans lesquelles celle-ci se constitue, les éléments présentés dans cet article représentent une première étape en direction d'une réflexion plus approfondie et de plus grande ampleur. En tous les cas, il apparaît de manière tout à fait claire que la question de l'espace indicible joue un rôle absolument central dans le dispositif théorique corbuséen, cela en ce que ce concept peut en quelque sorte synthétiser de manière rétroactive l'ensemble des aspirations spirituelles de Le Corbusier en architecture, ainsi qu'il permet un éclairage rétroactif sur de nombreuses dimensions de ses productions et de ses réflexions. Le soin apporté à la rédaction du texte de «L'Espace indicible », sa réécriture constante et la multiplicité des contextes dans lesquels la notion apparaît en attestent de manière incontestable.

\section{Bibliographie}

Bouvier, Yves ; Cousin, Christophe : Ronchamp, une chapelle de lumière. Besançon : CRDP de Franche-Comté - Néo éditions, 2012.

De Smet, Catherine : Vers une architecture du livre : Le Corbusier : édition et mise en pages. Baden : Lars Müller Publishers, 2007.

Gargiani, Roberto : "Genèse et représentation de l'espace indicible". In Migayrou, Frédéric ; Cinqualbre, Olivier (dir.) : Le Corbusier, Mesures de l'homme. Paris : Centre Pompidou, 2015, pp. 163-171.

Gargiani, Roberto ; Rossellini, Anna : Le Corbusier : Béton Brut and Ineffable Space (1940 - 1965) : Surface Materials and Psychophysiology of Vision. Lausanne : EPFL Press, 2011.

Labbé, Mickaël (éd.) : Le Corbusier : penser en architecture, Cahiers philosophiques de Strasbourg, n³4. Strasbourg - Paris : Fondation PUS - Librairie J. Vrin, 2013.

Le Corbusier: "L'Espace indicible". L'Architecture d'Aujourd'hui, numéro hors-série spécial «Art », Avril 1946, pp. 9-17.

Le Corbusier : Le Modulor 2. Bâle Birkhäuser, 2000.

Le Corbusier : Le Modulor. Bâle : Birkhäuser, 2000.

Le Corbusier : Un couvent de Le Corbusier. Paris : Éditions de Minuit, 1990.

\footnotetext{
${ }^{21}$ Bouvier, Yves ; Cousin, Christophe : Ronchamp, une chapelle de lumière. Besançon : CRDP de Franche-Comté - Néo éditions, 2012, p. 29.
} 


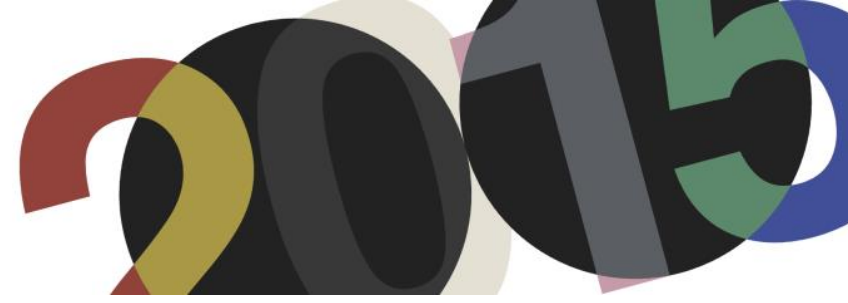

DOI: http://dx.doi.org/10.4995/LC2015.2015.758

\title{
Le Corbusier y Lilette Ripert. Les Maternelles vous parlent, hacia una pedagogía más humana
}

\author{
P. Lacomba Montes
}

Escuela Técnica Superior de Arquitectura de Valencia

\begin{abstract}
Resumen: La escuela de l'Unité d'habitation de Marseille se desarrolló a lo largo de más de una década. Los primeros dibujos realizados por Le Corbusier datan de 1944 y surgen varias evoluciones del proyecto hasta alcanzar la propuesta que finalmente se ejecuta en 1953. Durante este periodo surge la voluntad de atender a los principios pedagógicos de Céléstin Freinet de l'Ecole Moderne que estudiará y aplicará en la arquitectura que propone. Las técnicas planteadas por Freinet se desarrollaron en el centro de l'Unité por Lilette Ripert, una ferviente admiradora de Le Corbusier y colaboradora de Freinet, que reflejará en sus escritos, cartas, poemas y dibujos la capacidad de entender la escuela desde su uso. Se trata de una arquitectura que se desarrolla en paralelo a un sistema educativo y tiene la gran capacidad de adaptarse a los cambios que se proponen y seguir teniendo unos espacios docentes de calidad. Es una arquitectura hecha para sus usuarios y que permanece viva a pesar del paso del tiempo.
\end{abstract}

Abstract: The school of l'Unité d'habitation de Marseille developed over more than a decade. The first drawings date back to 1944 and emerge several project proposals until the final one is reached by 1953. During this process Le Corbusier came across with Céléstin Freinet's pedagogical principles and decided to study and apply them in his architecture. These techniques promoted by Freinet were lately developed in the school by Lilette Ripert, a fervent admirer of Le Corbusier and contributor of Freinet. She was able to understand the school from its use, and showed it in her writings, drawings, letters and poems. The project finally built develops in parallel to the educational system and has the ability to adapt to all changes without losing its spatial qualities. It is indeed a piece of work done with and for its users. Despite the passage of time, it is still alive.

Palabras clave: Les Maternelles; Lilette Ripert; Céléstin Freinet; pedagogy; childhood; Le Corbusier. Keywords: Les Maternelles; Lilette Ripert; Céléstin Freinet; pedagogía; infancia; Le Corbusier.

\section{Introducción}

La construcción de la escuela "Les Maternelles Marseille-Michelet” en la década de los 50 y el éxito de su funcionamiento durante varias décadas se debió a la implicación y dedicación de personajes procedentes de varias disciplinas. Fueron estas relaciones interdisciplinares las que enriquecieron tanto el proceso de elaboración del proyecto como el uso que se hizo de la escuela durante los años posteriores. La correspondencia mantenida entre Le Corbusier y el pedagogo francés Céléstin Freinet (1896-1966) durante el año 1950 refleja ese primer intercambio de intenciones, tratando de introducir los principios de una educación renovadora conocida como l'École Moderne. Posteriormente, la investigación se centra en la correspondencia entre Lilette Ougier (Ripert, N.D.E) (1918-2000) primera institutriz de la escuela, y Le Corbusier y en el legado de Lilette Ripert. A partir de ahí se explica la escuela que Le Corbusier propuso, atendiendo a los principios educativos planteados por Freinet y a través de la correspondencia y los documentos generados en la escuela como muestras de la relación mantenida entre el arquitecto y la primera institutriz. Son ellos los que manifiestan el mayor logro de la escuela: el florecimiento compartido de una pedagogía más humana. El objetivo del trabajo es hacer una reflexión exhaustiva de la escuela sobre la cubierta del edificio de l'Unité d'habitation de Marseille desde el 
punto de vista de su funcionamiento. Cómo lo construido, el espacio proyectado por Le Corbusier, es un reflejo de los principios pedagógicos de Freinet.

Le Corbusier, como arquitecto responsable de la construcción de un lugar de aprendizaje, establece un primer contacto con Céléstin Freinet poco tiempo antes de la ejecución de la escuela. Este primer intercambio de ideas entre ambos personajes deja constancia de la necesidad de atender a unas bases teóricas ideadas por el pedagogo $\mathrm{y}$, por tanto, de unas necesidades programáticas a las que el arquitecto otorga una respuesta. Lilette Ripert, directora que dirigirá la escuela desde 1953 hasta aproximadamente finales de los años 60, había colaborado con Céléstin Freinet ${ }^{1}$, cuya línea educativa es la base de todas sus actividades de innovación didáctica. Demuestra a través de sus escritos el exitoso desarrollo de su profesión dentro de la escuela y por consiguiente el progreso de los niños. Como muestra de su admiración, Le Corbusier apelaría más tarde a Lilette Ripert para los proyectos de Les Maternelles de otras unités d'habitation.

Entre las fuentes de información utilizadas para desarrollar la investigación se encuentran: las teorías pedagógicas de Freinet (Témoignages), el intercambio inicial de ideas entre Le Corbusier y Céléstin Freinet en 1950 (disponible en la Fondation Le Corbusier), la correspondencia mantenida entre Le Corbusier y Lilette Ripert entre 1953 y 1965 (disponible en la Fondation Le Corbusier), el legado de ambos reflejado en el libro póstumo de Le Corbusier, Les Maternelles vous parlent en 1969, las imágenes tomadas durante aquellos años por Louis Sciarli y Lucien Hervé y los planos y documentación gráfica de la escuela.

\section{Intercambio de ideas entre Le Corbusier y Céléstin Freinet. 1950}

Céléstin Freinet (1896-1966) plasmó en la Escuela Moderna los principios de una educación nueva. Sustentada en una pedagogía activa, popular, abierta, centrada en el trabajo, cooperativista, democrática, participativa y metodológica; persigue un lugar en el que los alumnos unan pensamiento y acción. El libro pretendía potenciar el trabajo de los alumnos en el aula, el cuidado de la huerta y de los animales. Se preocupaba por la renovación del ambiente escolar y de la actitud de los maestros y no sólo por el método o las teorías de su sistema. Maestro y niños debían nutrirse mutuamente, como así escribió en Témoinages: "Ces formes majeures son montées dans un cheminement à peine perceptible, en une continuité de tous les jours, dans ceta atmosphére idéale d'une

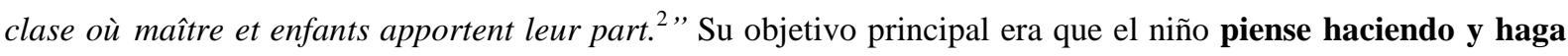
pensando.

Las técnicas de Freinet constituyen un abanico de actividades que estimulan el tanteo experimental, la libre expresión infantil, la cooperación y la investigación del entorno. Están pensadas sobre la base funcional de la comunicación. Entre ellas destacan: texto libre, la revista escolar, los planes de trabajo, las conferencias, la biblioteca de trabajo, la asamblea de clase y la correspondencia escolar.

Freinet entendía que sus planteamientos necesitaban un medio adecuado dónde pudieran aplicarse todas sus teorías. Así, en la carta dirigida por Freinet a Le Corbusier el 14 de febrero de 1950, en plena construcción de 1'Unité, escribe: "Il y a trois ans j'avais, par l'intermédiaire de notar Revue L'EDUCATEUR organisé un concours destiné aux architectes pour la réalisation de locaux scolaires répondant aux besoins de notre

\footnotetext{
${ }^{1}$ Cf. Giorgio De Ferrari, "Bambini fanno - a Marsiglia, a Monaco, a Vancouver", in: Domus, n"565, décembre 1976, p. 2627/IV(article certainement autorisé par Lilette Ripert) ; cf. également : Noél Jouenne, Le Corbusier comme compétence. Pratiques sociales dans I'Unité d'Habitation Le Corbusier de Firminy, p.112.

${ }^{2}$ Manifiesto. Témoignages. Elise y Céléstin Freinet. (FLC U1-17 135)
} 
pédagogie. ${ }^{3 \text { " }}$ Freinet, interesado en establecer ese primer contacto antes de la construcción de Les Maternelles sobre la cubierta de l'Unité d'habitation de Marseille, le transmite esas inquietudes por construir una escuela que responda rigurosamente a sus objetivos: "Nous avons montré pratiquement, experimentalement la nécessité d'une modernisation de notre enseignement, par l'introduction notamment d'outils nouveaux et de techniques aujourd'hui officiellement recommandés: Imprimerie à l'Ecole, Limographe, Journaux Scolaires, Travail libre, Fichiers, Dessin, jardinage, etc..." ",

Atendiendo a las diversas técnicas planteadas por Freinet, en las que propugna un método natural donde sea posible la expresión libre y el intercambio y contraste de ideas, el pedagogo propone a Le Corbusier la introducción de talleres dedicados al trabajo manual: "L'emploi scolaire de ces outils nouveaux necessite une

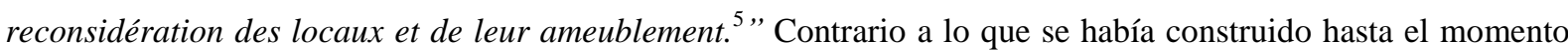
en las escuelas, él propone un concepto de aulas más innovador, rompiendo con la idea de aula tradicional con pupitres individuales. ${ }^{6}$ Según palabras del pedagogo este modo de construir se estaba expandiendo cada vez más, sus técnicas de trabajo habían superado su fase de experimentación y ya estaban puestas en acción. Freinet, en la carta insiste en la construcción de una escuela que responda a los usos y actividades que en ella van a desarrollarse. $^{7}$

En paralelo a estas palabras, entendidas como el inicio de una conversación que forma parte de la evolución de la escuela, Freinet le adjunta unos documentos y un libro ( " $L$ ' Ecole Moderne Français” Fig 1) en los que quedan patentes los intereses de su trabajo. Freinet queda íntegramente a su disposición para cualquier información de utilidad sobre sus técnicas.

C. FREINET

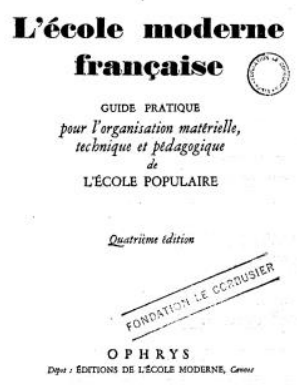

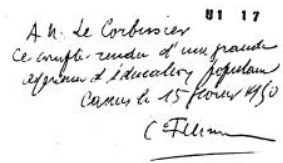

L'ECOLE MODERNE FRANÇAISE

1. Portada de la revista de la documentación sobre l’École Moderne de Céléstin Freinet. OFLC-ADAGP

\footnotetext{
${ }^{3}$ Carta de Céléstin Freinet a Le Corbusier del 14.02.1950 (FLC U1-17 147)

${ }^{4}$ Carta de Céléstin Freinet a Le Corbusier del 14/02/1950 (FLC U1-17 147)

${ }^{5}$ Carta de Céléstin Freinet a Le Corbusier del 14/02/1950 (FLC U1-17 147)

6 “J'ai personnellement mostré la necessité d'une conception nouvelle de L'École-Atelier, comportant une salle commune débouchant sur des ateliers de travail annexes pour les activités essentielles de nos classes. Cette formule se répand de plus en plus comme se répand le principe de la table horizontale qui détrône immanquablement les bancs-pupitres centenaires." Carta de Céléstin Freinet a Le Corbusier del 14/02/1950 (FLC U1-17 147)

7 "Il ne fait pas de doute que les écoles doivent être construites et áménagées en fonction des usagers: élèves et maîtres, et en fonction du travail qu'ils seront amenés à y faire. Vous parlez de réaliser une école-type. Nous serions très heureux que vous puissiez vous interesser à nos techniques de travail qui ont aujourd'hui dépassé le stade de l'experimentation pour s'inégrer à la vie de plusieurs dizaines de milliers d'écoles". Carta de Céléstin Freinet a Le Corbusier del 14/02/1950 (FLC U1-17 147)
} 
Le Corbusier responde a su carta el 24 de marzo de 1950 durante su estancia en Sudamérica, aproximadamente un mes más tarde. Explica a Freinet que el Ministerio de Reconstrución y de Urbanismo le está reclamando "les plans relatifs aux classes d'écoles modernes. Le Ministère ajoute, toujours que sa Commission des prototypes va se réunir, etc... ${ }^{\prime 8}$ Sin embargo Le Corbusier afirma que no le importaría ejecutar una clase tipo, como describía anteriormente Freinet, pero es un trabajo extremadamente lento en lo que concierne a la normalización e industrialización. No quiere someterse a la voluntad de los funcionarios del ministerio que después de unos meses le harán saber que no les interesa. ${ }^{9}$

Está de acuerdo con las propuestas de Freinet y cree también en una relación mucho más integral entre educación y espacio. Por otra parte, Le Corbusier está dispuesto a seguir en su atelier con sus inquietudes personales los estudios emprendidos por L’ASCORAL (Asamblea de Constructores para una Renovación Arquitectónica) ${ }^{10}$

Je serai très heureux de tenir compte de vos suggestions. Soyez assez aimable pour m'en faire part. Je citerai les sources, bien entendu. J'ai lu avec plus grand intérêt vos documents imprimés de l'Ecole Moderne Français. Il est regrettable de voir que la société moderne s'abrutit progresivement à partir de la naissance de ses enfants et cela proportionnellement à l'âge de ses ressortissants. "II

Le Corbusier

\section{La evolución de la escuela}

Durante el proceso de gestación del proyecto se pueden apreciar variaciones entre los primeros croquis de la escuela en 1944 y los últimos dibujos en 1953. En la Ville Radieuse Le Corbusier ya propone, en la planta penúltima de los bloques, zonas de "culture physique et jeux", "centre familial et santé", y una cubierta con solarium, zona de "enfants", pistas, etc. También en el Immeuble del Bastion Kellerman (1937). Era algo que Le Corbusier consideraba como inherente a un inmueble colectivo, donde se debían dar todas las necesidades. La cubierta de la Cité Radieuse también estaba pensada como un espacio común y a lo largo del proceso de gestación algunos elementos serán permanentes (tas de sable, enfants: hélio et hydrothérapie, plage de sable, piste d'entrainement, vide du gymnase, execrases de plein air, piste de 100m..).

En ese período de idas y vueltas, el programa docente proyectado en la planta 17 de la Cité Radiuese se irá modificando atendiendo a diversas particularidades. En la propuesta de marzo de 1944 se limita a ocupar 6 crujías de 8,38m, como 6 aulas (fig 2) o espacios únicamente abiertos a la terraza hacia el oeste. Estos espacios son independientes y no existe ninguna intención de conectarlos espacialmente. Dentro de cada uno se definen unas necesidades para su correcto funcionamiento como son las zonas de servicios, o la zona de reposo. Se propone una rampa para subir a la cubierta que arranca desde un espacio interior de la escuela situado en el extremo sur.

\footnotetext{
${ }^{8}$ Carta de Le Corbusier a Céléstin Freinet. 24/03/1950 (FLC U1-17 148)

${ }^{9}$ Carta de Le Corbusier a Céléstin Freinet. 24/03/1950 (FLC U1-17 148)

10 "Par ailleurs, je sus prêt à poursuivre, dans mon propre atelier, pour ma délectation personnelle, les études entreprises par L'ASCORAL dans la section "SAVOIR HABITER" à l'école primaire. Carta de Le Corbusier a Céléstin Freinet. 24/03/1950 (FLC U1-17 148)

${ }^{11}$ Carta de Le Corbusier a Céléstin Freinet. 24/03/1950 (FLC U1-17 148)
} 


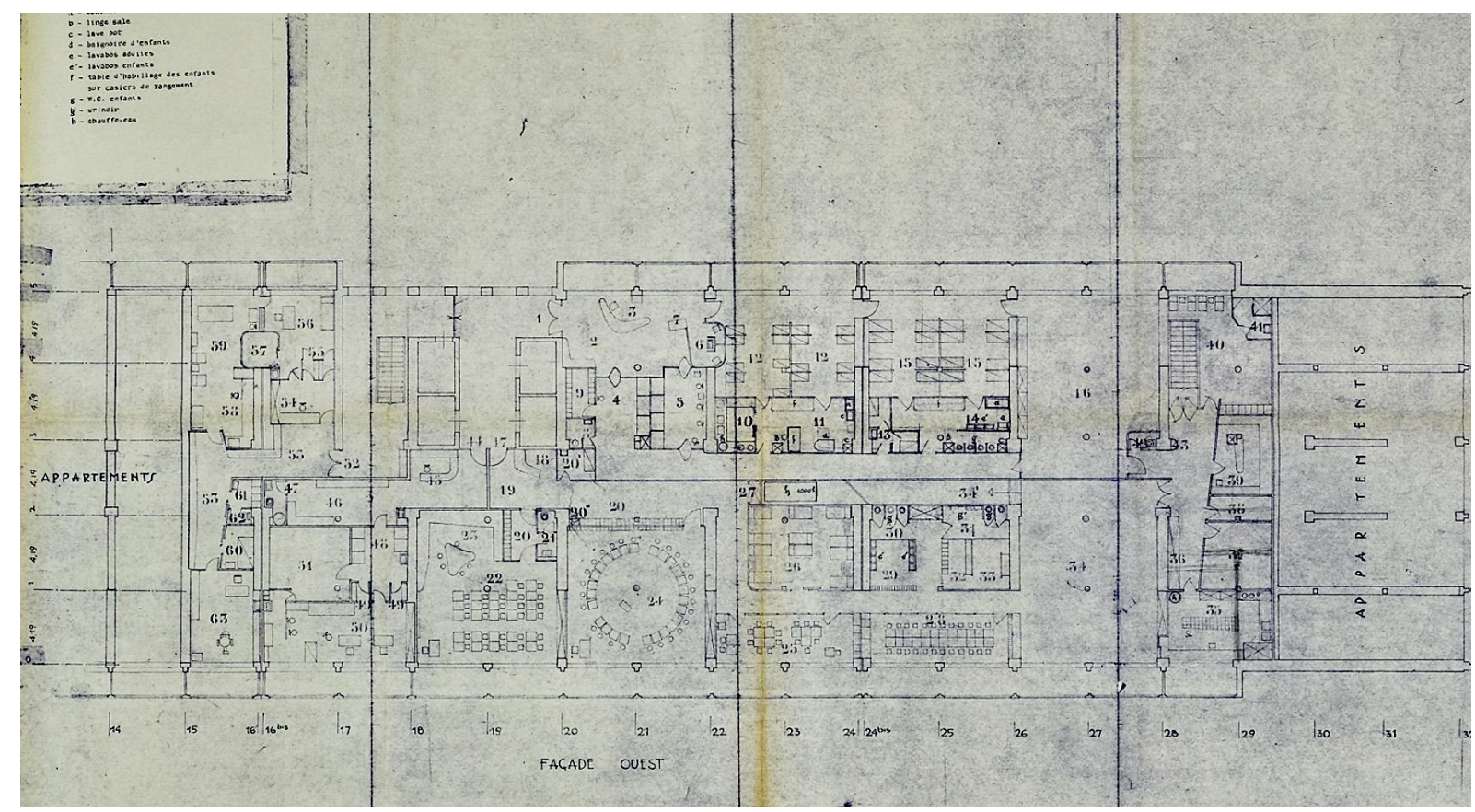

2. Niveau 17. Le Corbusier, Bodiansky. 27/03/1944 (FLC 25360B) OFLC-ADAGP

Dos años más tarde, en la propuesta del 10 de mayo de 1946 (fig 3, 4 y 5), se invierte la posición de "le jardin d'enfants y le service médical" y aparece el gimnasio y los vestuarios en la misma planta. La comunicación vertical es común para estos tres usos, por lo que la escuela pierde esa relación directa que se planteaba en la propuesta anterior a través de la rampa. Ubicada en el lado este, en "le jardin" desaparece esa condición de "aulas" tan definida y quedan espacios más relacionados y abiertos entre sí. En esta propuesta "le jardin d'enfants" se define por los usos y por las actividades que se prevén ("foyer, ping-pong, atelier, musée, bibliothèque.."), como superación de la idea tradicional de aula.

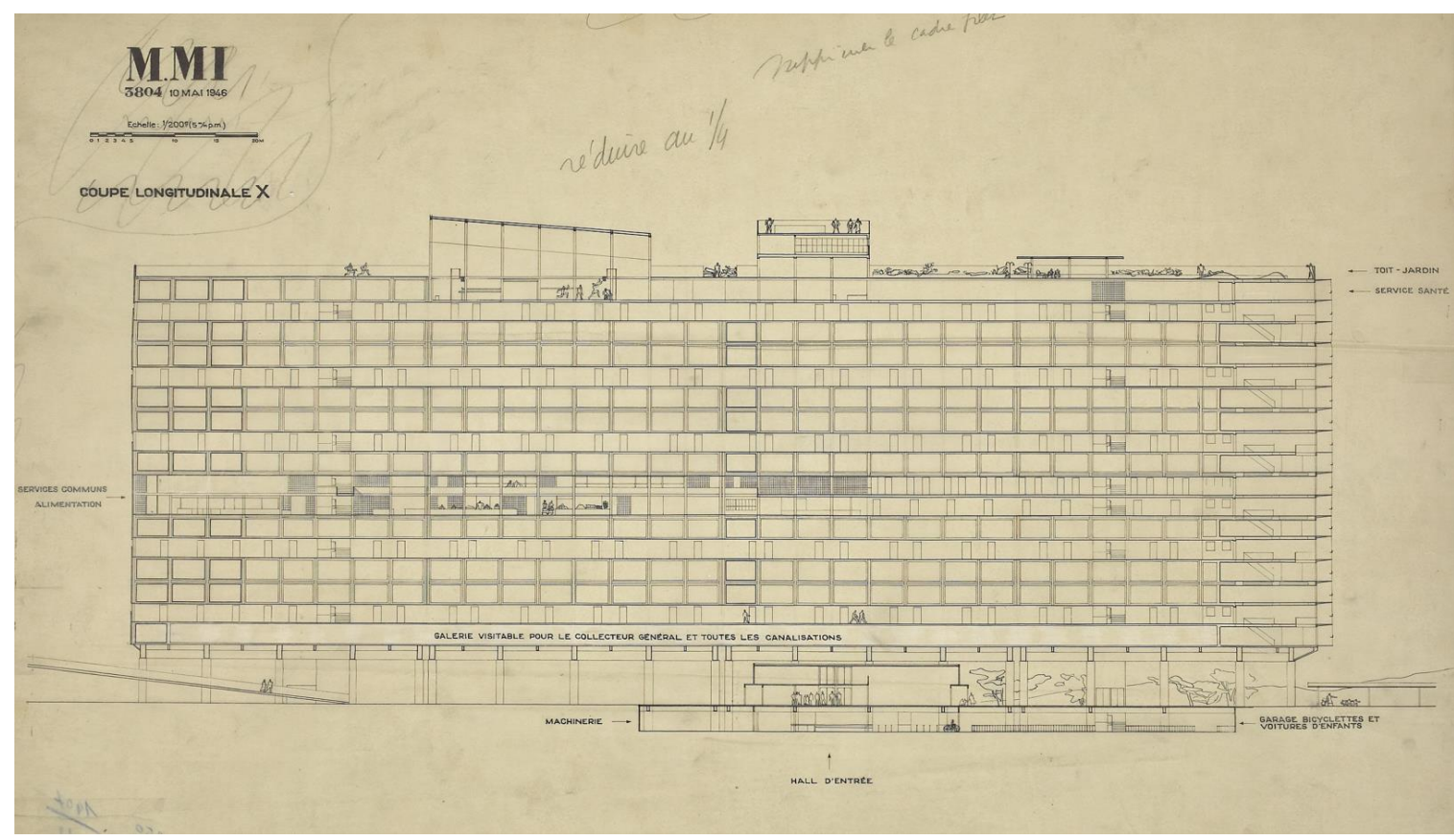

3. Coupé longitudinal. 10/05/1946 (FLC 26314A) @FLC-ADAGP 

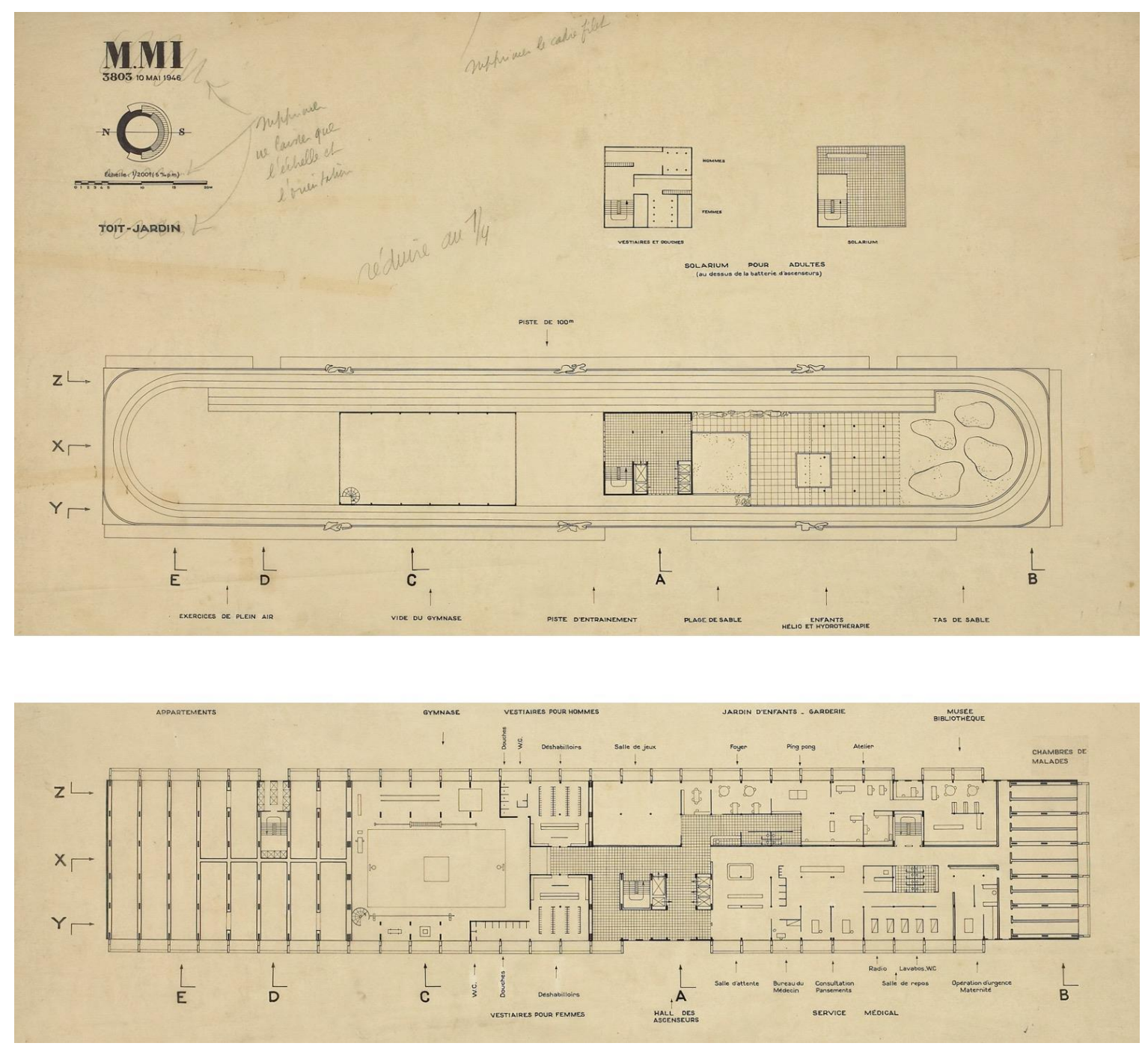

4. Toit-jardin. 10/05/1946 (FLC 26313A) OFLC-ADAGP

5. Services communs sport et santé. 10/05/1946 (FLC 26312A) @FLC-ADAGP

Esta intencionada decisión de clasificar los espacios en función de la actividad prevista únicamente quedará reflejada en esta y en la propuesta de 1947 (fig 8 y 9). Existe otra variación del mismo año (1946), un poco más tardía (fig 6 y 7 ) donde la escuela recupera esa posición en planta volcada hacia el oeste, mirando hacia el mar. En este caso, la escuela amplía su superficie, el área común se configura como un espacio más generoso desde el cual se intuye la previsión de una escalera de doble tramo para subir a la terraza directamente desde la escuela. Los lugares de aprendizaje quedan comprendidos en un gran espacio y la salle de jeux duplica la superficie que se planteaba en la propuesta anterior. Se podría intuir en la manera en la que se propone el aprendizaje alguna influencia de los principios de la escuela moderna descrita por Freinet; el espacio está pensado para el niño, que es el principal protagonista. 

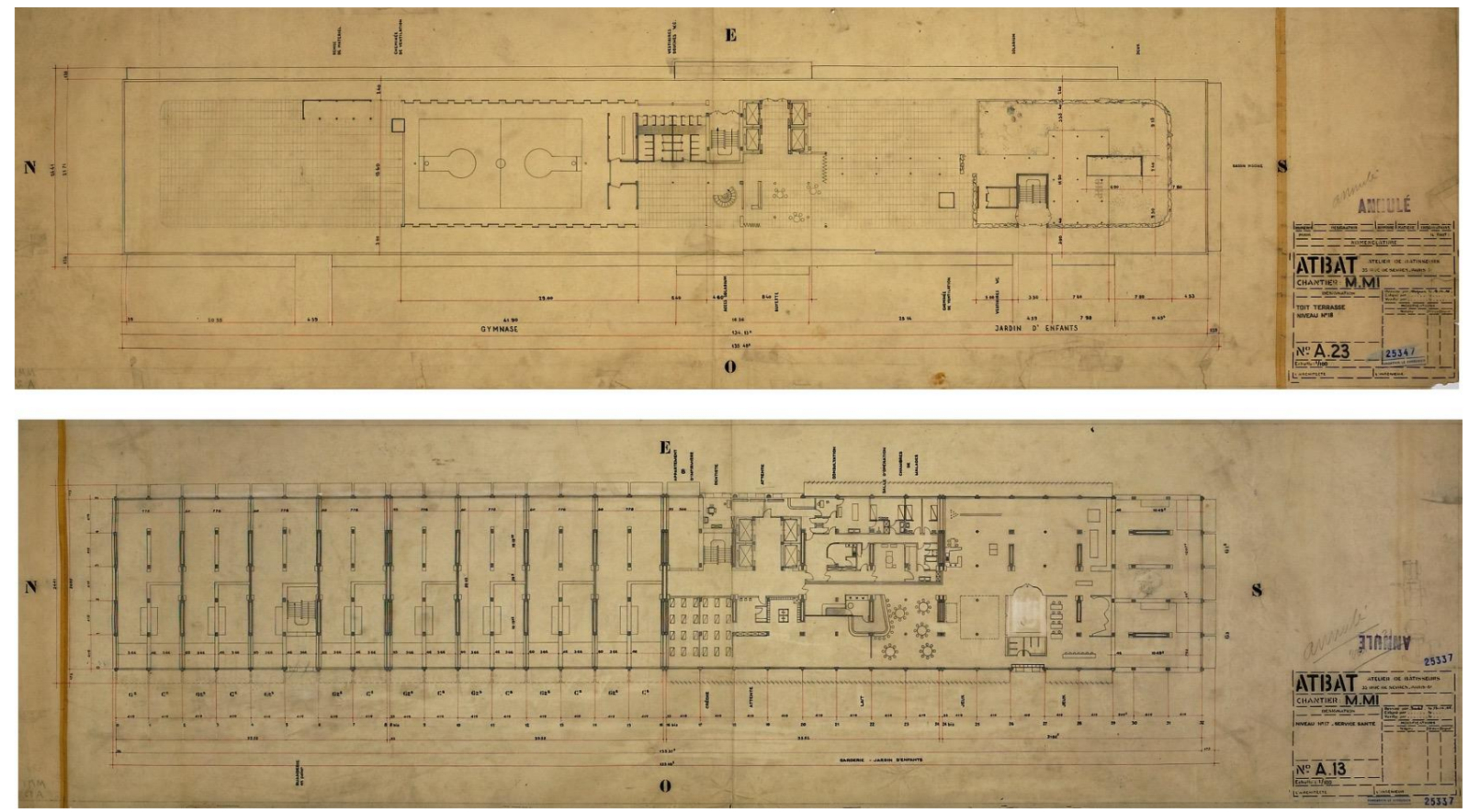

6. Toit-terrasse niveau $n^{\circ} 18.13 / 12 / 1946$ (FLC 25347) CFLC-ADAGP

\section{Niveau no 17 service santé. Badel. 12/12/1946 (FLC 25337) OFLC-ADAGP}

Las variaciones realizadas en la propuesta de febrero de 1947 (fig 8 y 9) mejoran la escuela desde el punto de vista espacial y funcional. Se recupera la rampa, que en este caso de podría entender como un elemento de juego que forma parte del espacio docente. El hecho de establecer una conexión entre las dos plantas significa que la escuela se apropia de la cubierta, que en la propuesta final acabará siendo la parte del programa más abierta. El primer tramo invade la sala de juegos dando pié a que la superficie inclinada sea susceptible de ser utilizada desde la escuela. Se intuye que la rampa está abierta a los espacios docentes y forma parte de una promenade architectural que explica el funcionamiento de la escuela. Es en definitiva una propuesta en la que se definen los espacios en función de su uso, acondicionándolos a través de elementos ligeros, con soportes capaces de facilitar la tarea a desarrollar y con piezas de mobiliario adaptados a la escala del niño. Esos espacios bañados de luz, comunicados entre sí, presentan esa condición de generar una comunidad en la que todos aprenden de todos.

En la propuesta de 1947 Le Corbusier apuesta por no jerarquizar los espacios, construyendo un lugar común en el que no son tan importantes los elementos fijos o la división en estancias sino los usos que se van a desarrollar y que por sí mismos ordenarán el espacio. Esos usos aparecen nombrados en la planta, que solo se entiende cuando se dibujan también los muebles (testigos del uso del espacio) que además se colocan en los lugares intermedios (en los intersticios), cosiendo unos espacios con otros y construyendo un gran salón de aprendizaje. Es además una propuesta muy generosa en superficie y que evita segregar a los niños por su edad en aulas con pupitres. Es una idea por tanto muy cercana a los planteamientos de Freinet, y se puede suponer que el Ministerio fue el causante de los cambios a partir de este momento, pues desde esta propuesta las demás versiones irán alejándose de esos planteamientos. 

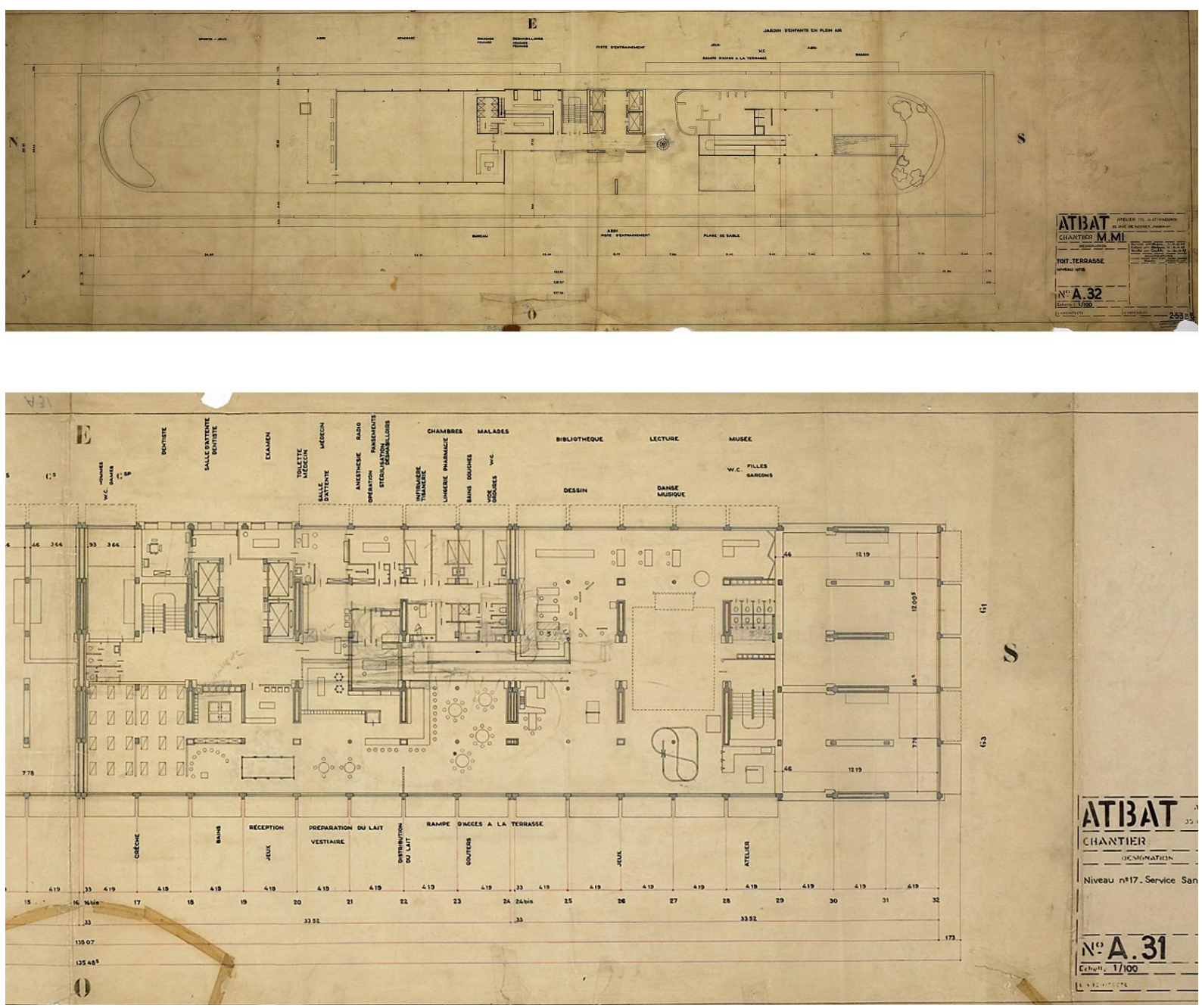

\section{Toit-terrasse niveau $n^{\circ} 18.11 / 02 / 1947$ (FLC 25356A) OFLC-ADAGP}

9. Niveau $n^{\circ} 17$ Service Santé. Badel. 05/02/1947 (FLC 25355) CFLC-ADAGP

Hasta este momento, la escuela se entendía como parte del programa de servicios comunes que Le Corbusier proponía dentro de l'Unité d'habitation. En las diversas propuestas (hasta 1949) descritas hasta ahora, el propio Le Corbusier había proyectado la escuela atendiendo a sus propios criterios e intenciones sin atender al reglamento vigente.

En 1951, André Wogenscky escribe una carta a Le Corbusier, "Le ministère me demande s'il est possible de prévoir une école sur le terrain de l'Unité." ${ }^{\prime 2}$ Un año antes de la finalización de las obras, el tipo de escuela no está definido, y meses después de la inauguración del edificio, gracias a la complicidad feliz y determinada entre Le Corbusier y su futura directora, Lilette Ripert (Mme Ougier), el centro encontraría su lugar.

Los dibujos posteriores a 1949, que son los que finalmente se ejecutan, recuperan un concepto de "aulas" más convencional, en el que se clasifican los espacios según las edades y se rechaza la idea de asumir la escuela como un gran espacio acondicionado para unas actividades concretas. Tras el encargo de 1951 se podría sospechar que en la reconversión de la escuela en "aulas", similar a la propuesta de 1944 y alejada de la propuesta más ambiciosa de 1947, Le Corbusier está condicionado por las normativas vigentes en ese momento.

\footnotetext{
${ }^{12}$ Sbriglio, Jacques. Le Corbusier, L'Unité d'habitation de Marseille. Carta de André Wogenscky a Le Corbusier, 12/09/1951. (FLC R3-8-3)
} 
A partir de 1950, año de la correspondencia entre Le Corbusier y Céléstin Freinet, se comienzan a realizar los planos finales para la ejecución de la escuela. Tal como refleja Le Corbusier en la carta para Freinet del 24 de marzo de 1950, se muestra desilusionado por los plazos y la mala organización que el ministerio presenta ante cualquier propuesta...

"Or, je veux bien exécuter avec le plus entier dévouement une classe type à mettre dans n'importe quel village, travail extrêmement lent de normalisation et d'industrialisation,mais je n'ai aucun désir de soumettre à des fonctionnaires du Ministère qui ne feront savoir quelques mois plus tard que cela ne les intéresse pas de tout et, s îls daignent me répondre...",13

Para explicar la propuesta que finalmente se ejecuta se atenderá en orden cronológico a la correspondencia mantenida entre Lilette Ripert y Le Corbusier a lo largo de la vida útil de la escuela para recorrer desde los rincones más recónditos hasta la pista al aire libre pasando por la rampa y subiendo a la crèche. Lilette Ripert dará pistas de cómo se usaron aquellos lugares pensados y proyectados para el niño. La correspondencia, los dibujos, los planos y las fotografías serán las claves para comprender e imaginar el edificio construido desde su uso, y que Lilette Ripert y los niños fueron capaz de exprimir hasta sus últimos días.

\section{Hacia una pedagogía más humana}

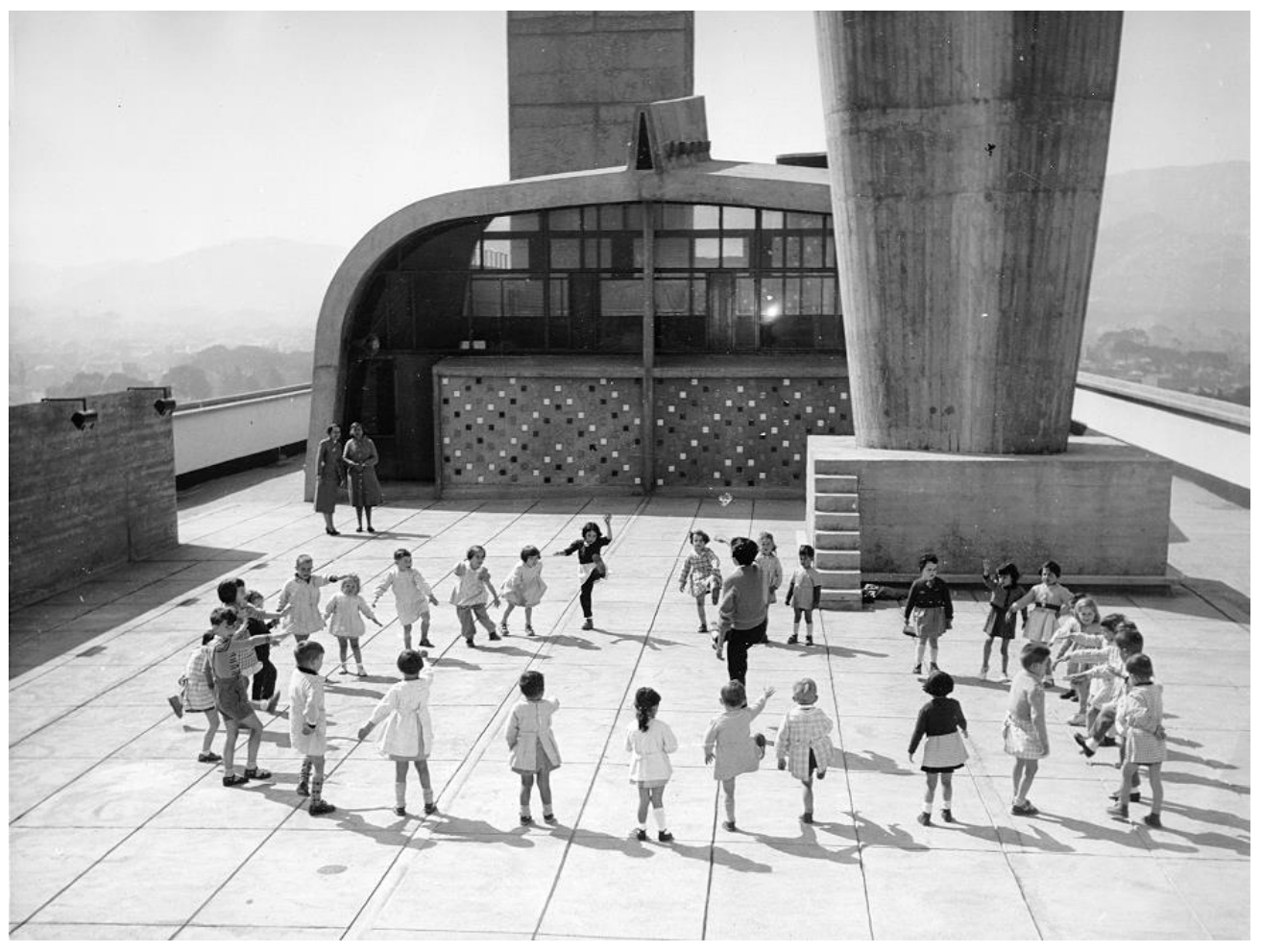

10. Toit-terrasse. Les Maternelles Michelet-Marseille. (FLC L1-11 1) @FLC-ADAGP

\footnotetext{
${ }^{13}$ Carta de Le Corbusier a Céléstin Freinet. 24/03/1950 (FLC U1-17 148)
} 
"Le jour de l'ouverture de la Maternelle, les mamans, leurs gosses à la main, sont montées sur le toit. Elles ont été éblouies par la splendeur du spectacle: ciel, monts, mer, îles...et architecture.,"14

Lilette Ripert, ferviente admiradora de Le Corbusier, colaboradora de Freinet, y apasionada por su trabajo, entendió la escuela utilizándola ${ }^{15}$, siendo capaz de aplicar el método educativo utilizando los espacios proyectados por Le Corbusier (fig 10).

El programa educativo que implanta Lilette Ripert en la escuela abarca numerosas actividades que incitan a un esfuerzo por parte del niño. Freinet defendía que el trabajo escolar debía tener un sentido, una utilidad y una función. Dentro del marco de actividades desarrolladas reinaba la educación artística sobre el resto, pero además, el programa contemplaba juegos sensoriales, la iniciación a la escritura, al cálculo, a la lectura, al canto y a la educación física. ${ }^{16}$ Para aplicar el principio de cooperación defendido por Céléstin Freinet se exigía la creación de un ambiente en el aula en el que existieran elementos mediadores en la relación maestro-alumno. Era necesaria la cooperación entre alumnos, alumnos-maestros y entre maestros, con la finalidad de compartir experiencias y dialogar, poniendo en común los problemas y las posibles soluciones. La organización del aula debía contemplar la participación de los alumnos en la construcción de sus conocimientos, potenciando el trabajo de clase sobre la base de la libre expresión de los niños en un marco de cooperación. ${ }^{17}$ El término de escuela no se limita únicamente al espacio clasificado como tal, sino a todo espacio o elemento capaz de generar una situación en la que niño pueda imaginar, jugar y por lo tanto, aprender. "L'école" se desarrolla en dos niveles superpuestos, físicamente relacionados. Ambos lugares, a pesar de tener unas condiciones físicas muy alejadas, son lugares flexibles que permiten al niño sentirse libre, poder recorrerlo con libertad, experimentar y conocer.

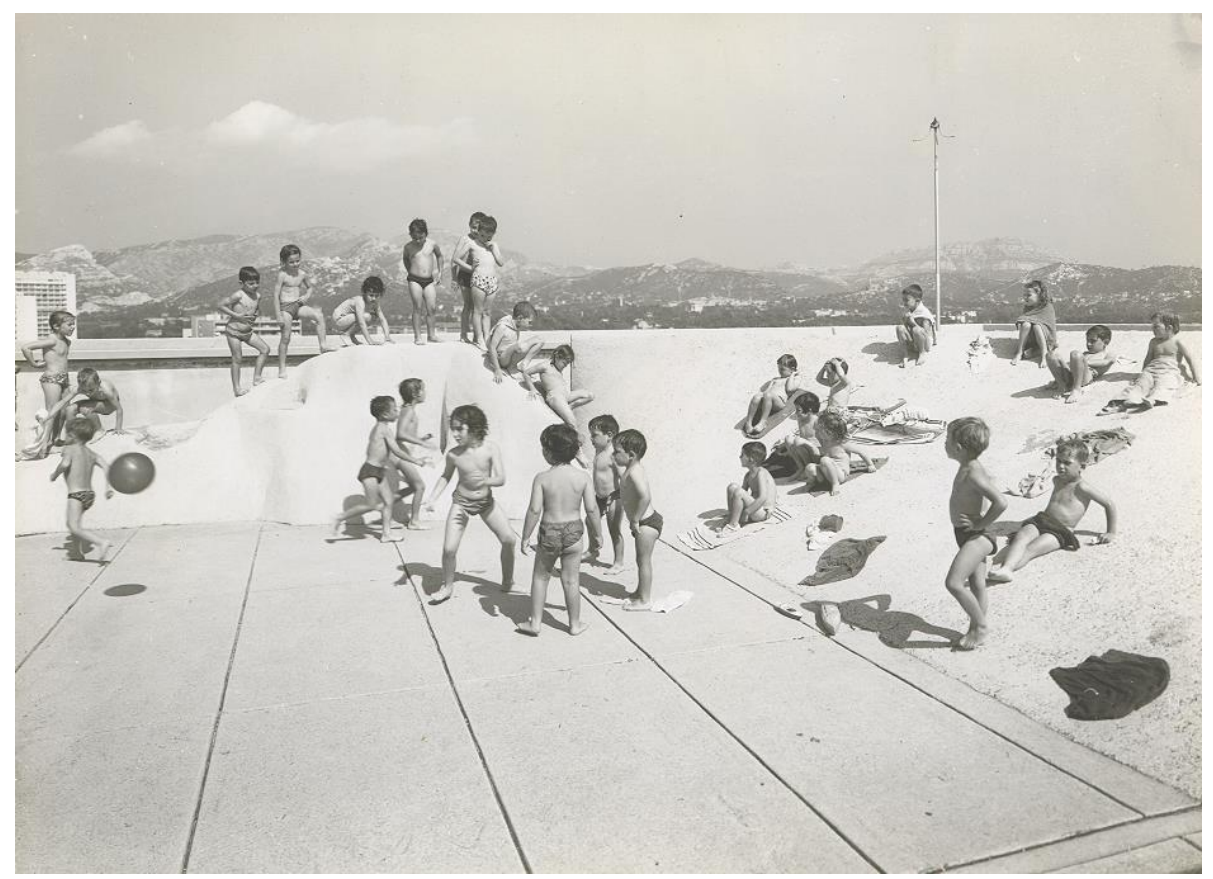

11. Toit-terrasse Les Maternelle Michelet-Marseille. (FLC L1-11-42) @FLC-ADAGP

\footnotetext{
${ }^{14}$ Le Corbusier, Les Maternelles vous parlent. p. 57.

15 "An architecture called total arquitecture as a further step to the expression of full life; life which is substituting the work 'to possess' by the word 'to use' J. Bakema (FLC D3-19 81-83)

${ }^{16}$ Le Corbusier, Op. cit., p.59.

${ }^{17}$ Freinet, Céléstin. L'éducation du travail, París, Editions Ophrys, 1949.
} 
Según el análisis de Le Corbusier, la función principal de la cubierta era reemplazar la vegetación parcialmente demolida para la construcción del edificio. Mientras que las bóvedas del techo de la Maisons Raoul (1951-55) en Neuilly-sur-Seine y en la cubierta de la Petite Maison de fin de semana en La Celle-Saint-Cloud brotaba hierva en abundancia, en la cubierta de L'Unité d'habitation de Marseille la vegetación no adquiere esa importancia. La ausencia de la naturaleza se manifestó con claridad, y en su lugar nos encontramos con una serie de sustitutos con formas orgánicas. ${ }^{18}$ Los niños viven la naturaleza pero con formas abstractas que pueden asemejar las de la naturaleza de su alrededor que ven desde lo alto del edifico (fig 11). La pequeña piscina para los niños mantiene una relación con el océano (fig 12), mientras que los montículos de hormigón proporcionan una analogía metonímica de la cordillera trasera. "The Sardinian mason Salvatore Bertocchi was given a free hand to design these two fantasies as a playground for children in the infants's school." 19 Tim Benton señala que el análisis de Stanislaus Von $\operatorname{Moos}^{20}$ termina con una especulación sobre la manera en la que el edificio, y concretamente la cubierta, se podría considerar "orgánica”, centrándose en particular en las asociaciones espirituales y metafóricas de la naturaleza, derivadas del crítico inglés, John Ruskin. "Von Moos remarks that the high balaustrada of the roof terrace concludes most of the surrounding landscape, allowing a view only of the hills framing the caray silhouette of the Calanques behind. "21 La superficie vertical de 1,60 del antepecho construye, desde la mirada de un niño, el marco de un lienzo que encierra el paisaje circundante: la silueta de las montañas, el sol y el cielo.

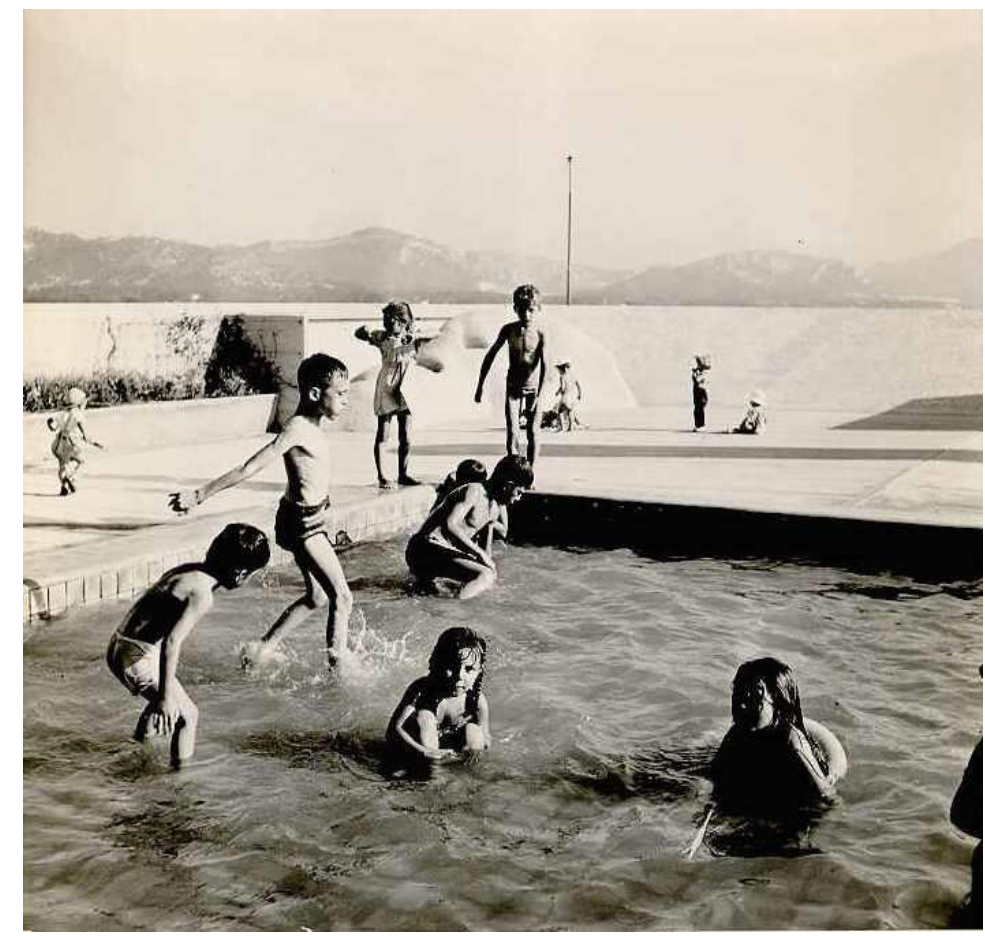

12. Toit-terrasse Les Maternelle Michelet-Marseille. (FLC L1-11 12) @FLC-ADAGP

\footnotetext{
${ }^{18}$ Benton, Tim. Marseille: Unité d'habitation or “The company of clouds, he sky, os the stars.” In: Cohen, Jean-Louis ed. Le Corbusier: an Atlas of Modern Landscapes, 2013, New York: Museum of Modern Art, pp. 201-211.

${ }^{19}$ Ibid.

${ }^{20}$ Stanislaus, Von Moos. Machine and nature: Notes a propos de l'Unité d'habitation de Marseille," in Claude Prelorenzo, ed., Le Corbusier: La Nature (1991: Paris Éditions de La Villette, 2004), p.48.

${ }^{21}$ Ibid.
} 
La cubierta elevada 56m sobre rasante, orientada en el sentido longitudinal norte-sur al aire libre con vistas lejanas hacia el entorno, constituye un escenario suspendido para el niño (fig 13). Una sensación de estar permanentemente volando (fig 11). Von Moos apunta que el rechazo de mirar hacia algunas zonas del entorno tiene ese efecto de dirigir el mirada hacia adentro, sobre el grupo de formas y funciones montadas sobre la cubierta: dos grandes chimeneas de ventilación, una torre de ascensores y de reserva de agua, una sala de educación física, una guardería, un teatro al aire libre, una pista, una piscina, un espacio cubierto, unas colinas artificiales, unos planos inclinados..."The strong vertical elements-the elevator tower and the ventilation stackplay off against the more intimate lower structures (fig 14)." 22 Frente a lo construido, el sol, el mar, las montañas, el viento y el cielo son los fenómenos naturales que estaban allí antes y que todavía permanecen.

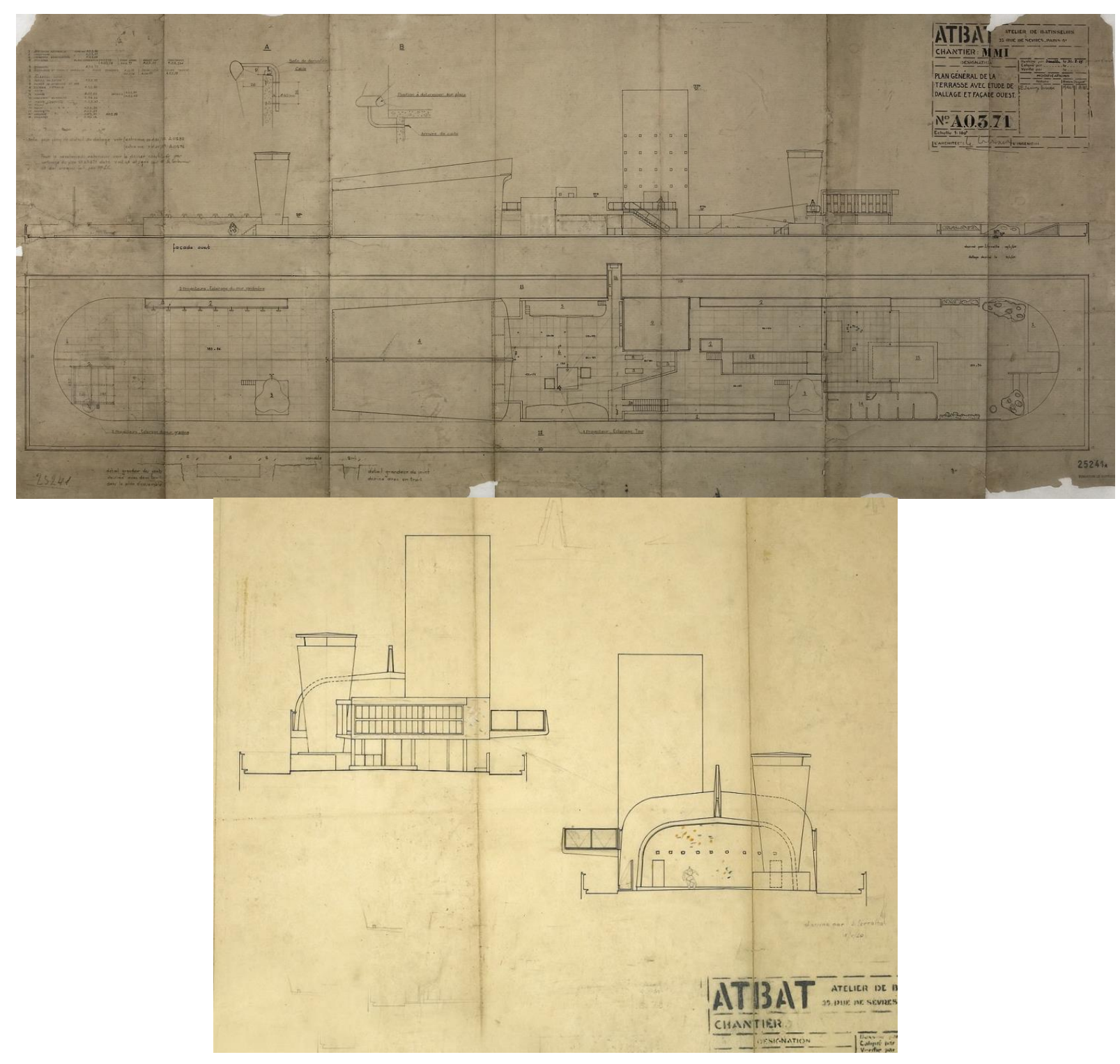

13. Toit-terrasse Les Maternelle Michelet-Marseille. (FLC 25241A) @FLC-ADAGP

14. Facade North-South. Le Corbusier. 18.1949. (FLC 25243) @FLC-ADAGP

\footnotetext{
${ }^{22}$ Benton, Op.cit., p. 201-211.
} 
Tal como revela la correspondencia, Le Corbusier, desde los inicios, toma parte junto con Lilette Ripert en el desarrollo de las actividades que tuvieron lugar en la escuela. Será el propio arquitecto quien dé órdenes y consejos sobre la manera en que deben realizarse ciertas tareas. Uno de los primeros proyectos desarrollados fue pintar el antepecho perimetral de hormigón (fig 15). ${ }^{23}$ Le Corbusier, le aconseja utilizar los muros ocultos por los planos inclinados para realizar las primeras pruebas, "et si cela va bien, essayer sur les murs à gauche et a droite des Dromadaires "24 y que haría falta encontrar un truco con el andamio para que los niños puedan pintar más alto y que el dibujo ocupe toda la superficie llegando hasta lo más alto. "Je vous donne un croquis.... Les gosses sont généralement graphiques, ils dessinent avec les pinceaux. N’hesitez pas à les pousser à faire des surfaces, de grands emplâtres. ${ }^{25}$ Entre varios de los propósitos de Le Corbusier en relación a las actividades realizadas por los niños en la escuela, "Je voudrais que, pour le mois de juillet, quelques peintures soient faites déjà (pour le Congrès du 25ème anniversaire des CIAM). "26

Lilette Ripert seguirá todas las indicaciones y así comenzaron a realizar los primeros ensayos sobre el lavabo y sobre la pista, detrás del plano inclinado. Los niños estaban emocionados de pintar sobre el muro y de trabajar sobre la cubierta. ${ }^{27}$ Es una muestra de cómo el arquitecto tiene también la responsabilidad de educar en el proceso de la arquitectura misma, enseñando a usar, a comprender el espacio y transmitiendo la manera en la que ha creído que va a utilizarse; bajo la idea de que un edificio no se termina cuando se entrega al habitante.

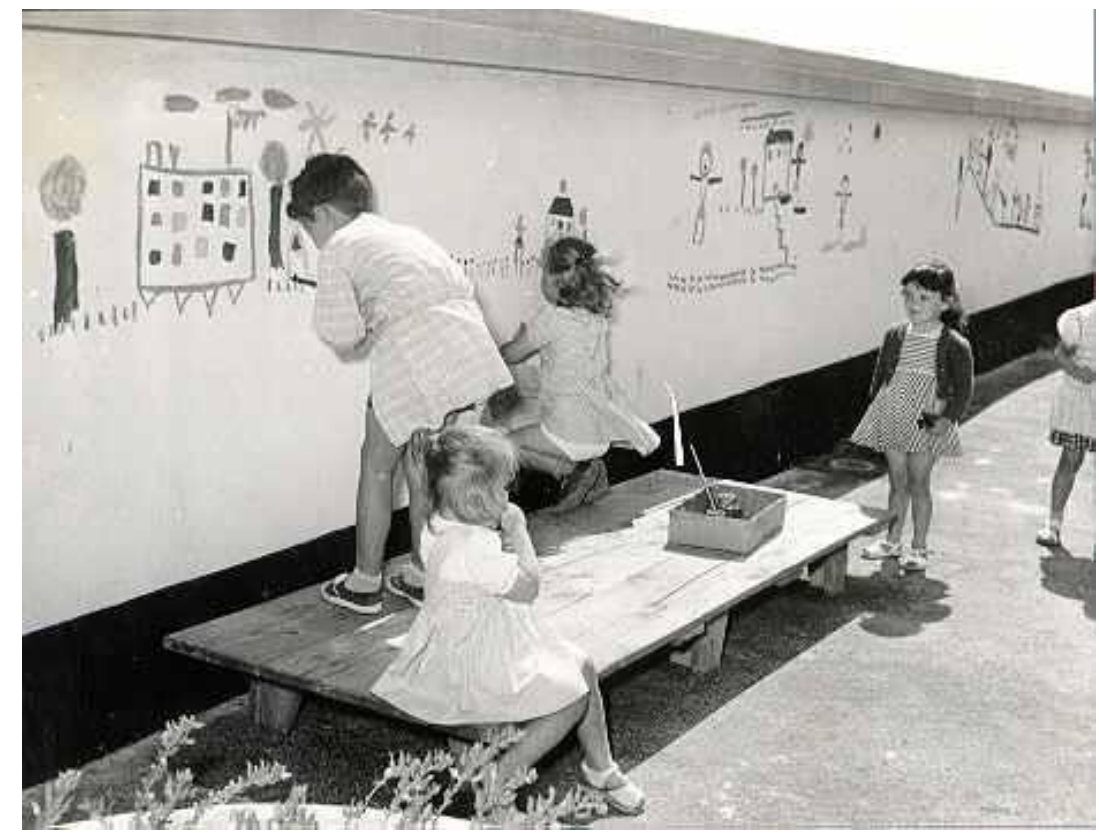

15. Decoración del antepecho que construye el límite de la cubierta. Sciarli. (FLC L1-11 77) OFLC-ADAGP

\footnotetext{
23 "Concernant la frise à faire exécuter par les gamins, il faudrait procéder ainsi: on vous fera un échafaudage de contreplaqué de $2 \mathrm{~m} 26$ de long qui permettra aux enfants de faire un motif de même étendue" y prosigue, "Les motifs de $2 \mathrm{~m} .26$ de long environ, seraient espacés les uns des autres par un intervalle de $1 \mathrm{~m}$, de $50 \mathrm{~cm}$, de $1 \mathrm{~m} 50$, selon les cas". Carta de Le Corbusier a Lilette Ougier (Ripert, N.D.E) del 21/04/1953 (FLC O2-4-4)

${ }^{24}$ Carta de Le Corbusier a Lilette Ougier (Ripert, N.D.E) del 21/04/1953 (FLC O2-4-4)

${ }^{25}$ Carta de Le Corbusier a Lilette Ougier (Ripert, N.D.E) del 21/04/1953 (FLC O2-4-4)

${ }^{26}$ Carta de Le Corbusier a Lilette Ougier (Ripert, N.D.E) del 21/04/1953 (FLC O2-4-4)

${ }^{27}$ Carta de Lilette Ougier (Ripert, N.D.E) a Le Corbusier del 8/05/1953 (FLC
} 
En el nivel 17, junto al núcleo de comunicación, se accede a la escuela. Un tabique curvo que encierra una sala de espera, el gabinete médico del centro escolar y el despacho de la directora, conduce al visitante hacia el interior de l'école. Se circula por un corredor delimitado por el muro que construye el primer tramo de la rampa y una pared con los casilleros, desde donde se accede al aula de los niños entre 4 y 6 años en el lado este. El final de perspectiva del recorrido es la sala de juegos, el espacio común más amplio en esta planta. La salle d'accueil et des jeux es pasante y tiene una fila de pilares circulares en el centro (en sentido transversal), pero que no divide el espacio, ya que las crujías de 4,19m son suficientemente anchas para desarrollar las actividades de teatro, danza, cine... Es además el lugar donde asciende la rampa para subir a la cubierta, y está directamente vinculado al rincón de cocina y una sala común a la escala de los niños.

El techo del perímetro de la planta está ligeramente elevado (sección fig.16) con respecto a los espacios interiores, consiguiendo más altura en las fachadas. Este perímetro más alto coincide con el ámbito del aula que queda abierta al espacio contiguo, y por tanto construye el recorrido espacial que une todos los lugares de la escuela.

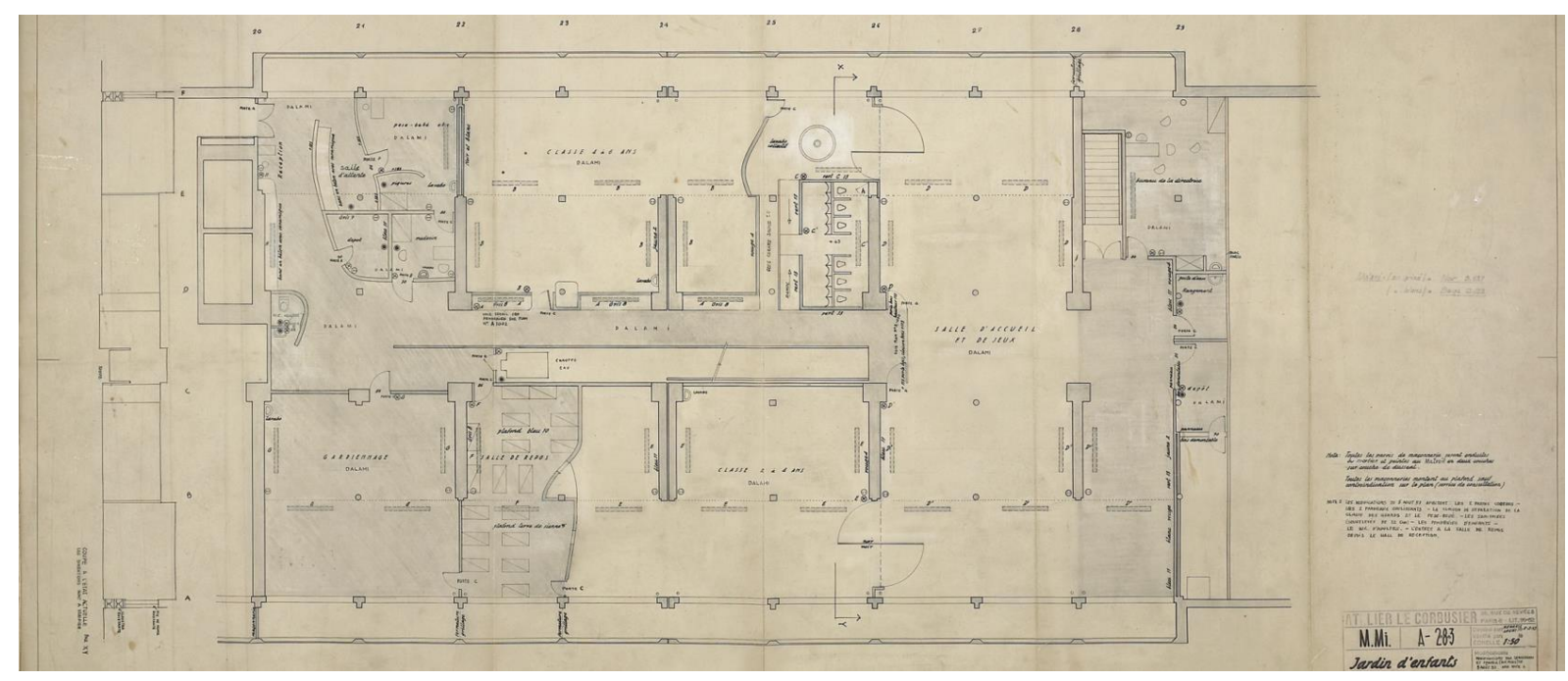

16. Jardin d'enfants niveau 17. Le Corbusier, Xénakis, Sachi. 02/02/1953 (FLC 25668A) OFLC-ADAGP

Los cerramientos que compartimentan los espacios coinciden con los ejes de estructura de hormigón. Las unidades, de proporciones iguales, prácticamente cuadradas, están abiertas hacia el paisaje en uno de sus lados. Tal y como se muestra en la sección transversal el espacio está sutilmente fragmentado de manera que la zona más alejada del exterior queda más comprimida. La línea de estructura marca el límite entre el exterior y el interior. Este paramento transparente, desde el cual se sale a la terraza que recorre longitudinalmente el edificio, tiene la base construida de 80 centímetros (altura de un niño) como elemento de almacenaje (fig 19). A través de ella los niños miran, igual que lo hacen a través del antepecho de la terraza que está construido como una celosía, parcialmente abierta (fig 17). La sala de gardiennage, junto a la salle de repos, la de los niños entre 2 y 4 años y la de los de 4 a 6 (fig 16) son los espacios principales y como muestran las fotografías, pronto quedaron colonizados por sus usuarios. Entre estos espacios se encuentra la zona de servicios, la salle de jeux y la zona administrativa. Estas zonas secundarias se delimitan por paredes onduladas de albañilería y pintadas con pintura Matroil. El bloque sanitario, según indicaciones en los planos, debía colocarse junto a la sala de recepción para que la persona que supervisaba pudiera controlar a la vez. Disponía de elementos colectivos, como la fuente circular (fig 18), donde los niños se lavaban la manos conjuntamente y que, como si de una escultura se tratase, 
se disponía fuera de los inodoros, junto a la sala de juegos, en el espacio intermedio y con un uso mixto que invitaba a entender la higiene como entretenimiento y aprendizaje.
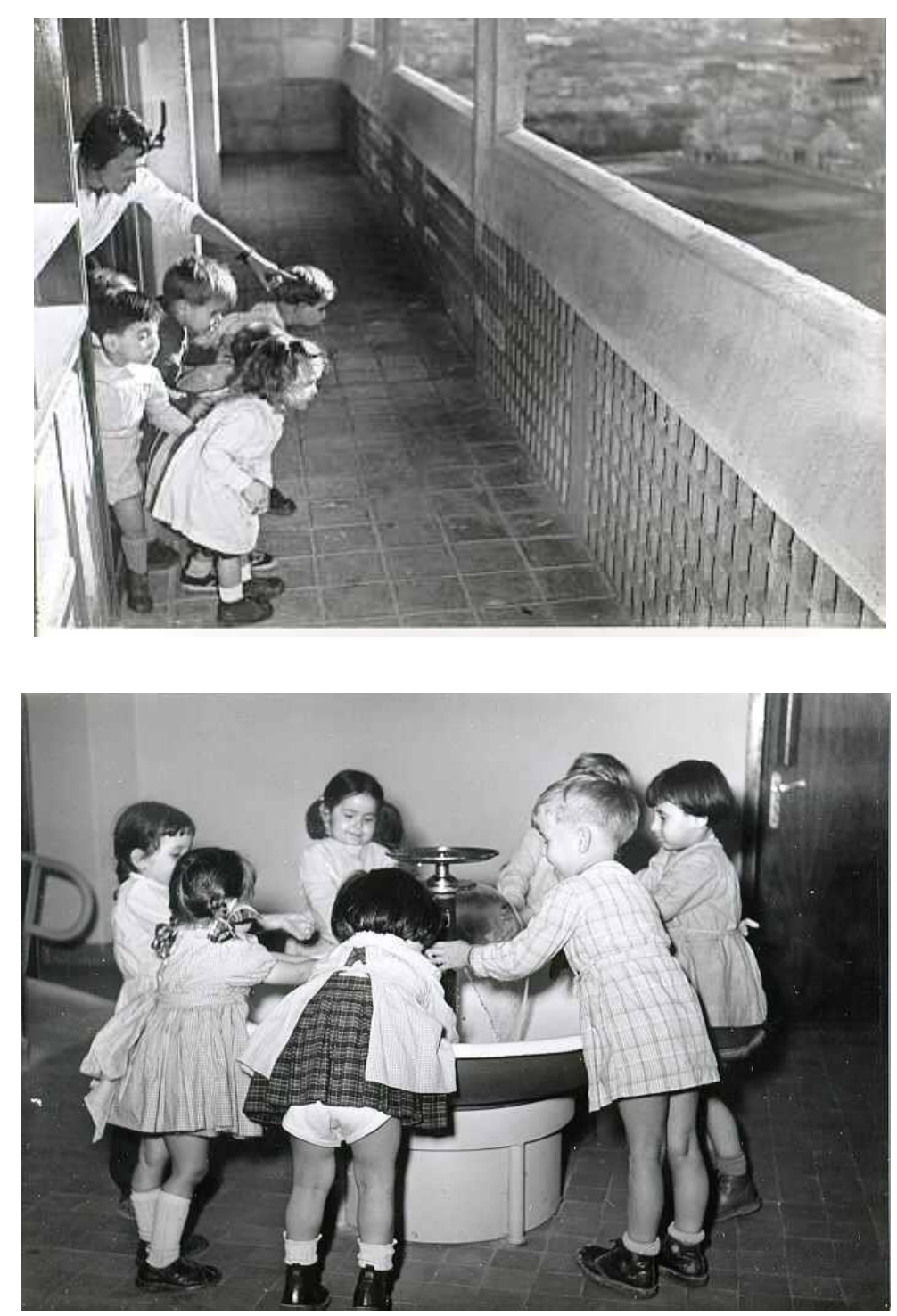

17. Los niños miran desde la terraza. Jardin d'enfants niveau 17. (FLC L1-11 104) OFLC-ADAGP

18. Los niños lavándose las manos. Jardin d'enfants niveau 17. (FLC L1-11 98) OFLC-ADAGP

Utilizando el plan libre, incorpora una serie de espacios que aseguran a la vez la flexibilidad y la intimidad necesarias para el funcionamiento de este tipo de equipamientos. Los puntos de apoyo, los casilleros, los muebles de almacenamiento, los juegos de curvas, la rampa, la policromía aplicada directamente sobre el hormigón en bruto, acompañará a las instalaciones en esta escuela que reflejan una gran atención a la escala del niño. 

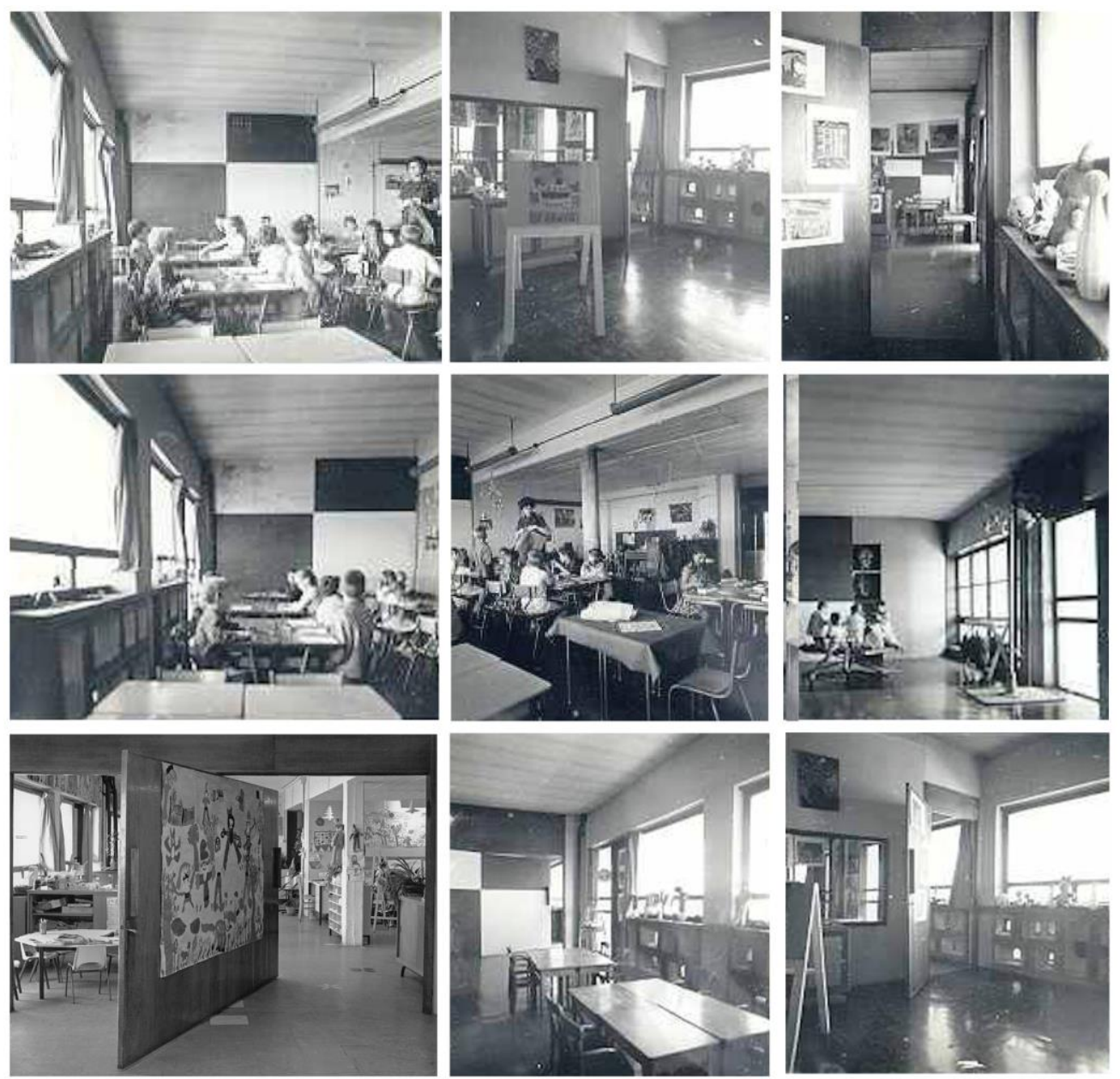

19. El interior. Jardin d'enfants niveau 17. (FLC L1-11-116-117) @FLC-ADAGP

Las superficies planas, onduladas, las pizarras, las puertas pivotantes (fig 19) son elementos que delimitan espacios, que construyen barreras, pero en la mayoría de los casos se aprovechan como superficies susceptibles de utilizarse como tableros sobre los que pintar y dibujar. Lilette Ripert consultaba a Le Corbusier sobre cómo pintar estos tableros. ${ }^{28}$ Son elementos que aúnan varios usos, como los montículos sobre los que los niños escalan, pero que también utilizan como jardineras artificiales que mantenían diariamente (fig 20). ${ }^{29}$ Siempre con esa intención de utilizar todo para varias cosas, de aprovechar cualquier resquicio y rincón para convertirlo en un lugar que los niños pueden usar de otras maneras, que es capaz de activar su creatividad como proponía Freinet, y al fin y al cabo de motivar su aprendizaje.

\footnotetext{
28 “ $1^{\circ}$. Elle vous attendait impatiemment pour vous demander comment peindre les tableaux au mur de la troisième classe mise en service. Je lui ai conseillé de la faire elle-même en s'inspirant des deux autres classes. $2^{\circ}$. Elle réclame impatiemment les indications de couleurs pour ses meubles d'école. $3^{\circ}$. Elle m'a demandé d'ecrire à Calder pour qu'il offre un "mobile” à l'école. Qu'en pensez-vous?.” Nota a la intención de Le Corbusier de A. Wogenscky el 1/10/1954 (FLC) 29 "Il faudrait faire photographier les enfants au moment où les uns peindront autour de la piste et ou d'autres jardineront dans les caisses à fleurs, plantant quelque chose ou arrosant, et ainsi de suite." Carta de Le Corbusier a Lilette Ougier (Ripert, N.D.E) del 13/05/1953 (FLC E2-17 361)
} 


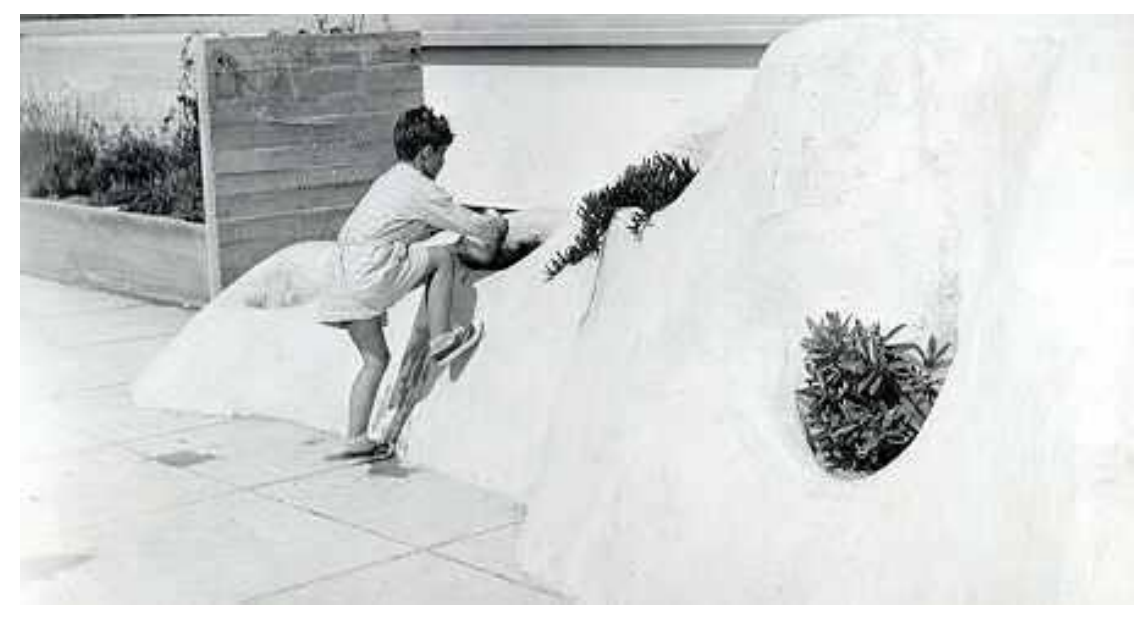

20. Jardinería. Toit-terrasse 17. (FLC L1-11 49) OFLC-ADAGP

Desde la apertura de l'école en 1953 se comienza con la elaboración de fotografías, documentos, dibujos (fig 21), cartas, escritos que hablan de ese proceso tan activo y enriquecedor que la escuela desarrolló durante más de una década. ${ }^{30}$ Lilette Ripert pronto descubrirá la necesidad de construir un documento capaz de contener los trabajos realizados por los niños. Freinet, entre sus propuestas, hablaba de la revista escolar que se origina con las producciones infantiles y se realiza a partir de la propia organización del trabajo. "Quand tout sera un peu rodé j'essayerai de portés enfin le petit cahier d'experiences pédagogiques réalisées dans la joie dans notre école de plein ciel-cahier auquel j’ai beaucoup réflechi depuis un an. ${ }^{31}$

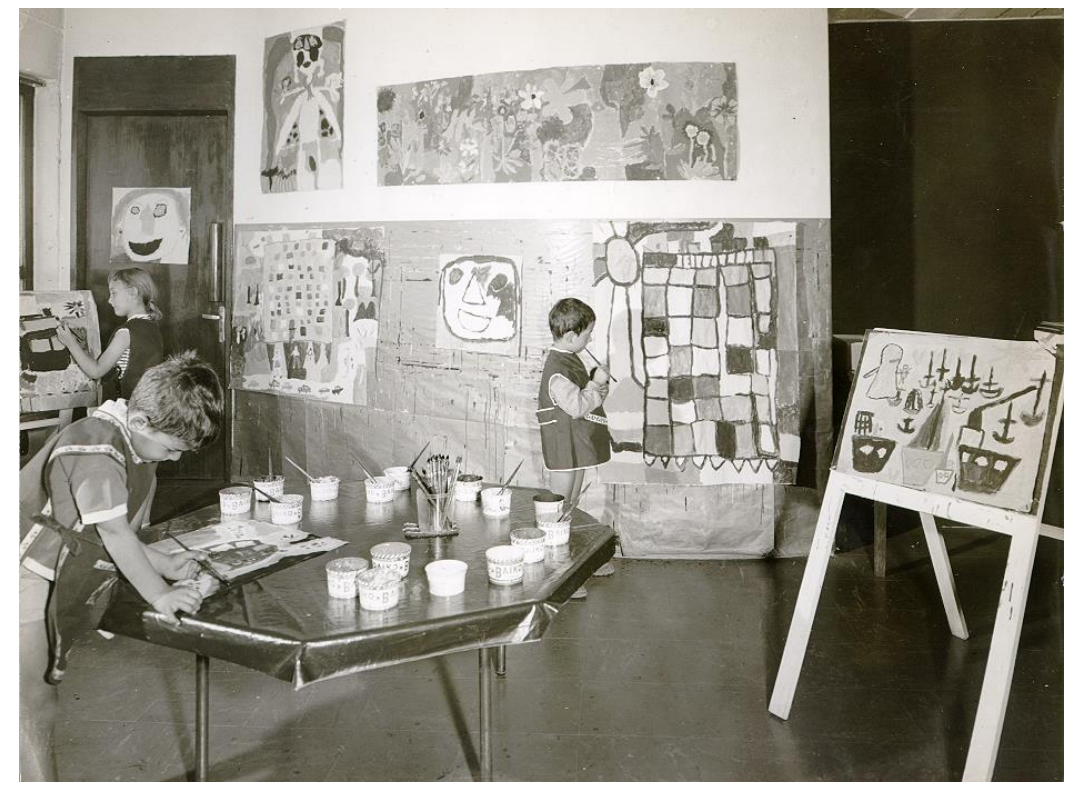

21. Dibujos sobre la pared ondulada del nivel 17. Toit-terrasse 17. (FLC L1-11 75) CFLC-ADAGP

\footnotetext{
30 “Je trouve à mon retour de voyage une série de photographies montrant les enfants sur la toiture de l’Unité Michelet.... La joie inscrite sur la visage des enfants est précisément la meilleure réponse que nous puissions donner aux critiques imbéciles." Carta de Le Corbusier a Lilette Ougier (Ripert, N.D.E) del 17/04/1953 FLC.

${ }^{31}$ Carta de Lilette Ougier (Ripert, N.D.E) a Le Corbusier del 27/10/1954 (FLC O2-4-21).
} 
Entre sus tareas diarias los niños pintan y modelan. El niño piensa haciendo y hace pensando, tal como afirmaba Freinet; Modelando al aire libre, en la terraza cuando el tiempo lo permite, sobre los bancos de hormigón y piedra. Las puertas pivotantes (fig 22) son elementos de entretenimiento para el niño y además permiten configurar los espacios de la escuela; "les petits peignent beaucoup, souvent avec des broches, des grandes papiers, et de la peinture Matroil. Ils vivent dans cette école colorée, dans leur appartement coloré, ils vivent dans le soleil sur le toit, sur la loggia, ce soleil que entre à flots pour les grands ports fénétres, par tous les plans de verre." 32

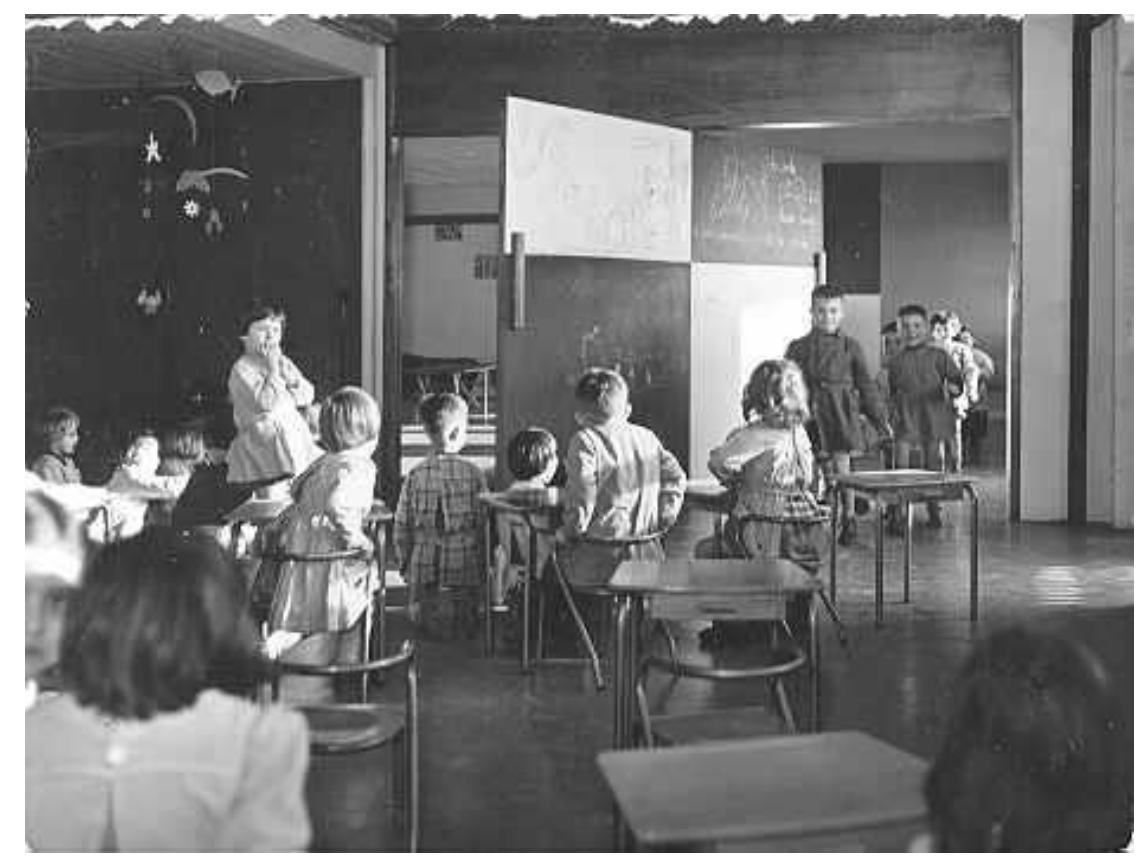

22. Puerta pivotante. Niveau 17. (FLC L1-11 71) OFLC-ADAGP

La rampa de hormigón (fig 23) que comunica la planta inferior con la cubierta se convierte en otro elemento lúdico para los niños. El plano inclinado emerge de la sala de juegos en la planta 17 y es una brecha que atraviesa el suelo hacia el cielo, las nubes, el sol y las montañas. Esta misma rampa sigue ascendiendo hacia la crèche (fig 24) construida sobre la balsa de agua en la cubierta. Ascienden por ella para realizar ejercicio físico en la terraza, juegan en el túnel, escalan sobre las rocas artificiales y se dejan deslizar sobre el plano inclinado. Se bañan en la piscina, bajan al parque, descienden sobre la hierba, recogen flores y construyen cabañas. ${ }^{33}$ Tal como describe Lilette Ripert, la escuela está, ante todo, adaptada al niño. 34 "Il faut faire l'expérience de monter sur la terrasse pour comprendre la vie d'un gosse, et là c'est l'ancien instituteur qui parle. Comprendre la vie d'un gosse quand il est dans la cour de récréation sur le toit-terrasse; en pensant que ce gosse mesure 75 à 80 centimètres et qu'il y a des murs en béton à un mètre vingt. Quelle est sa vision? Il n'y a que le ciel, il ne voit même pas la nature autour. "35

\footnotetext{
${ }^{32}$ Lilette Ripert, "La peinture", manuscrito, s.d (FLC B1-2 53)

${ }^{33}$ Le Corbusier, Les Maternelles vous parlent, op. cit., p. 59

${ }^{34}$ Le Corbusier, Op. cit., p. 60

${ }^{35}$ Entrevista del 22 noviembre 2002. Noél Jouenne, Le Corbusier comme compétence. Pratiques sociales dans I'Unité d'Habitation Le Corbusier de Firminy, p.112.
} 

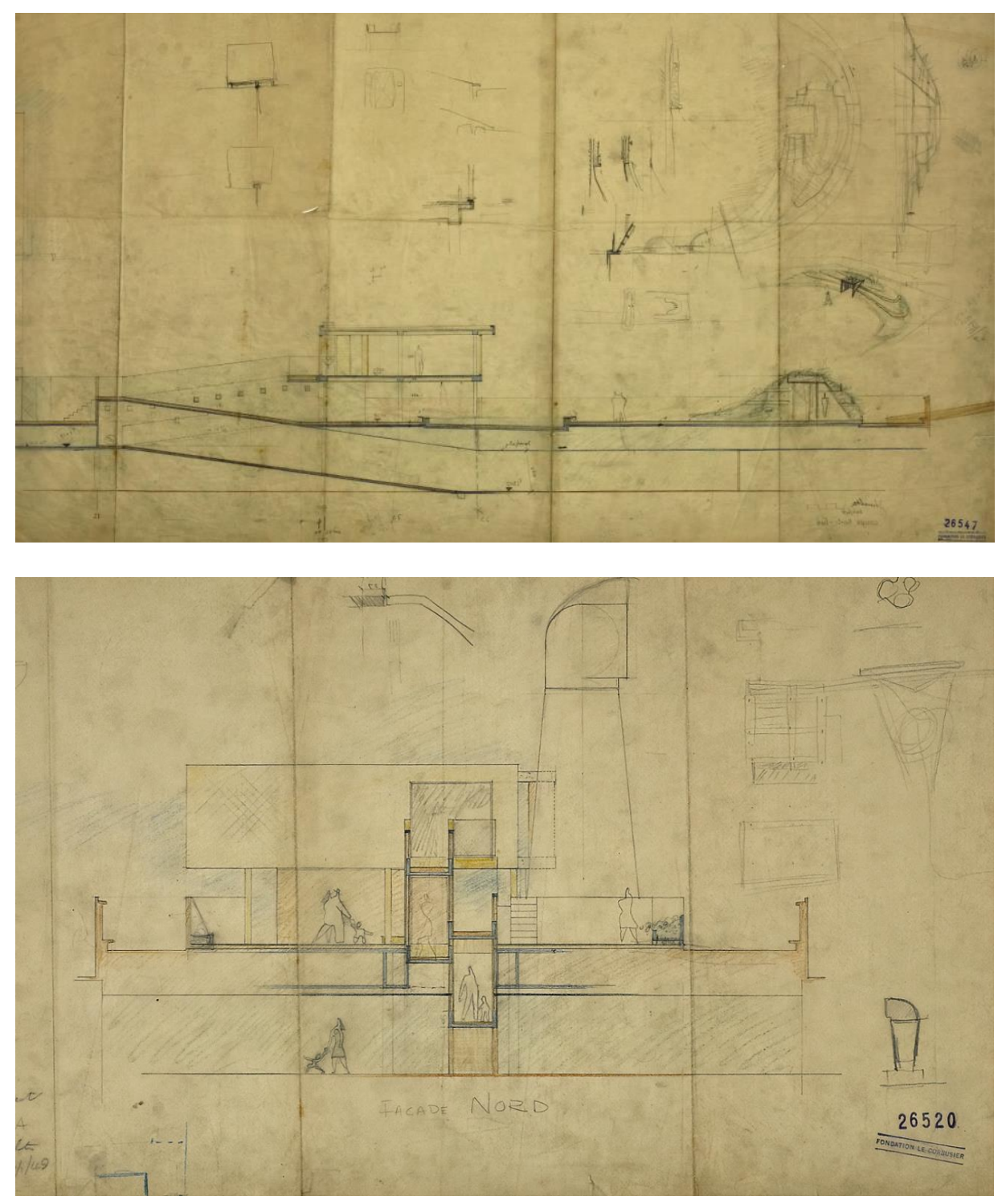

23. Coupe Nord-Sud. Serralta. 20/11/1949 (FLC 26547) OFLC-ADAGP

24. Coupe du rampe. Niveau 18. Serralta. 25/01/1949 (FLC 26520) @FLC-ADAGP

La gran capacidad de imaginación que tienen los niños les permite interpretar lo que la escuela les ofrece para adaptarlo a sus necesidades. Los techos, de $2.26 \mathrm{~m}$ de altura crean esa intimidad cálida que reina en la escuela. Situada en pleno cielo, reúne todas las condiciones para tener una vida feliz. ${ }^{36}$ Muchos visitantes criticaban la "desnudez de la escuela”, a lo que Lilette Ripert responde: “ Elle est nue, mais le soleil, le mistral, la mer, les couleurs, les dessins des gosses, la joie des gosses, parent sa nudité." ${ }^{37}$ La creación de "clubs d'enfant" incrementó la cantidad de actividades en la escuela, "nous avons tout de même commencé et avons déjà un club de théâtre spontané-une talle avec tables de ping-pong électrophone. Je vais essayer de toucher " l'Inspection des sports" pour avoir matériel et subvention-nous allons avoir aussi séance de cinéma et de télévision le jeudi. "38

\footnotetext{
${ }^{36}$ Le Corbusier, Les Maternelles vous parlent, op. cit., p. 60

${ }^{37}$ Le Corbusier, Op. cit., p. 60

${ }^{38}$ Carta de Lilette Ougier (Ripert, N.D.E) a Le Corbusier del 31/12/1954 (FLC B1-2 54)
} 


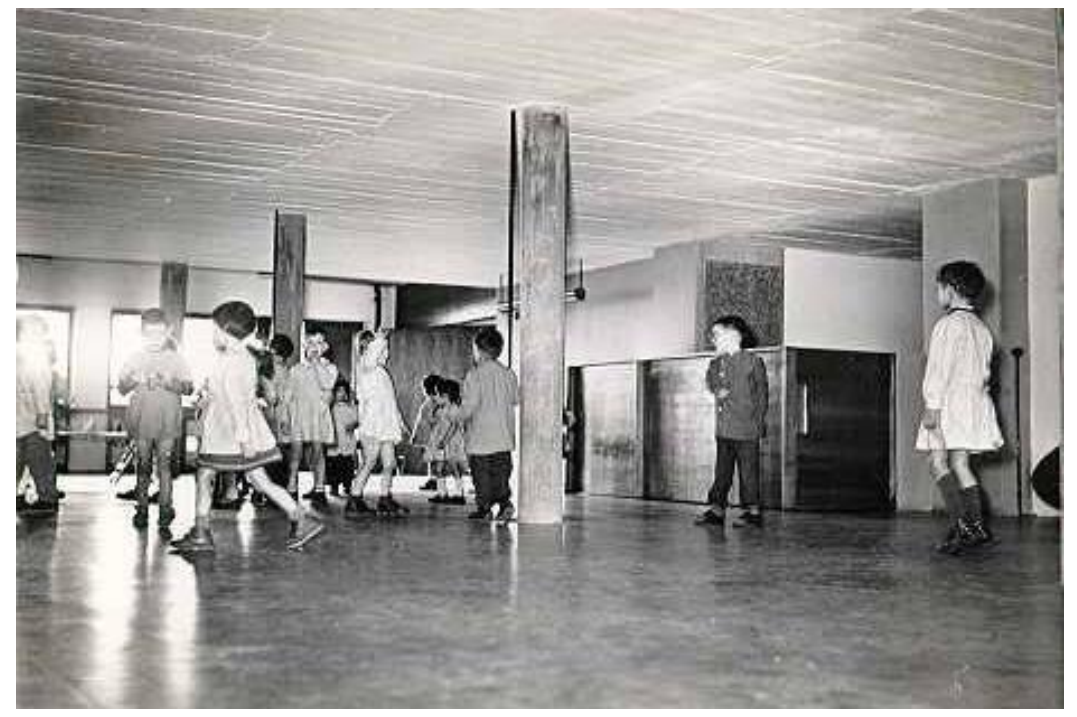

25. La salle de jeux. (FLC L1-11 65) CFLC-ADAGP

El suelo de Dalami, la salle de jeux (fig 25), su luz y su organización abierta permiten una relación estrecha y comunicativa entre todos los lugares de la escuela. Los niños se desplazan de un lugar a otro y se apropian del espacio, lo hacen suyo. El mobiliario es ligero y los niños tienen la libertad de desplazarlo. Sobre las mesas cuadradas hacían el modelado y pintaban las cerámicas, e incluso durante un tiempo se estuvo decidiendo cómo se pintaban los muebles, y Le Corbusier le aconsejaría que solo pintara las patas y dejara los tableros y las sillas blancas (como un niño más, siempre jugando).

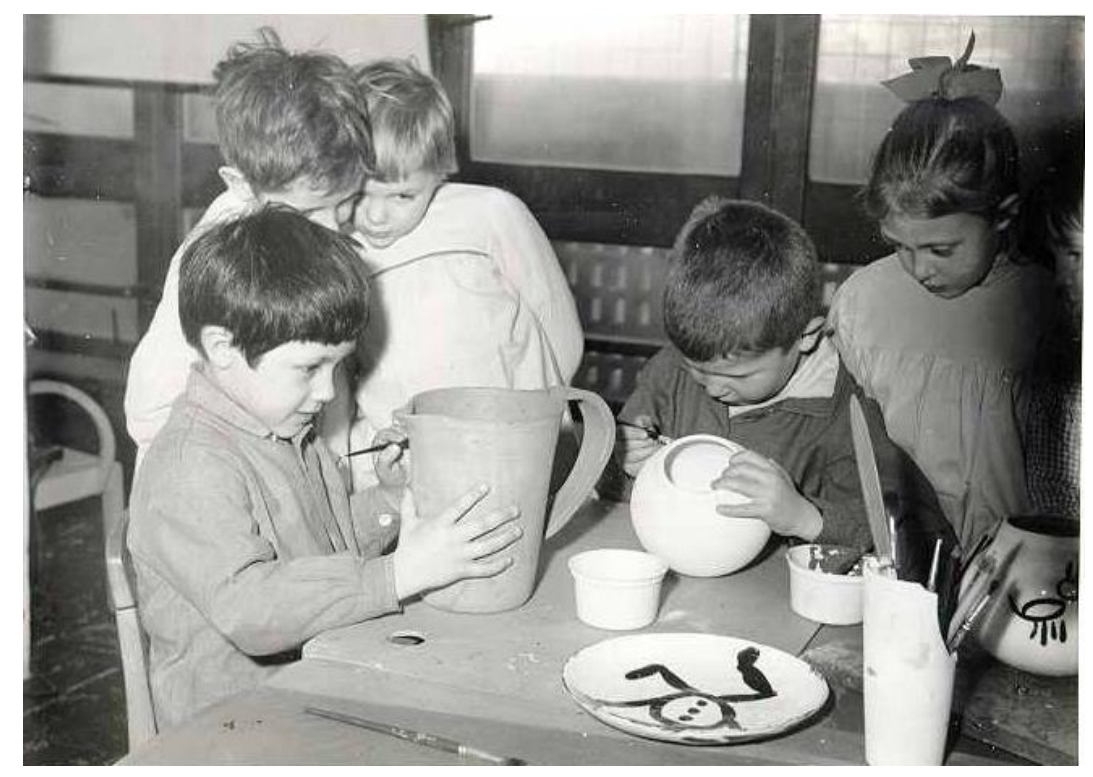

26. Los niños pintando. (FLC L1-11 85) @FLC-ADAGP 
"Voici la dernière utilisation du plan incliné. Je ne sais si vous avez prène qu'il servirait un jour de piste de luge! Les enfants et moi nous sommes bien régalés. Les collines artificielles du Parc ont aussi magnifiquement servi comme piste de ski. Il y a aussi des photos sensationnelles. ${ }^{, 39}$ De nuevo, se demuestra la utilización de estos elementos artificiales como elementos de juego.

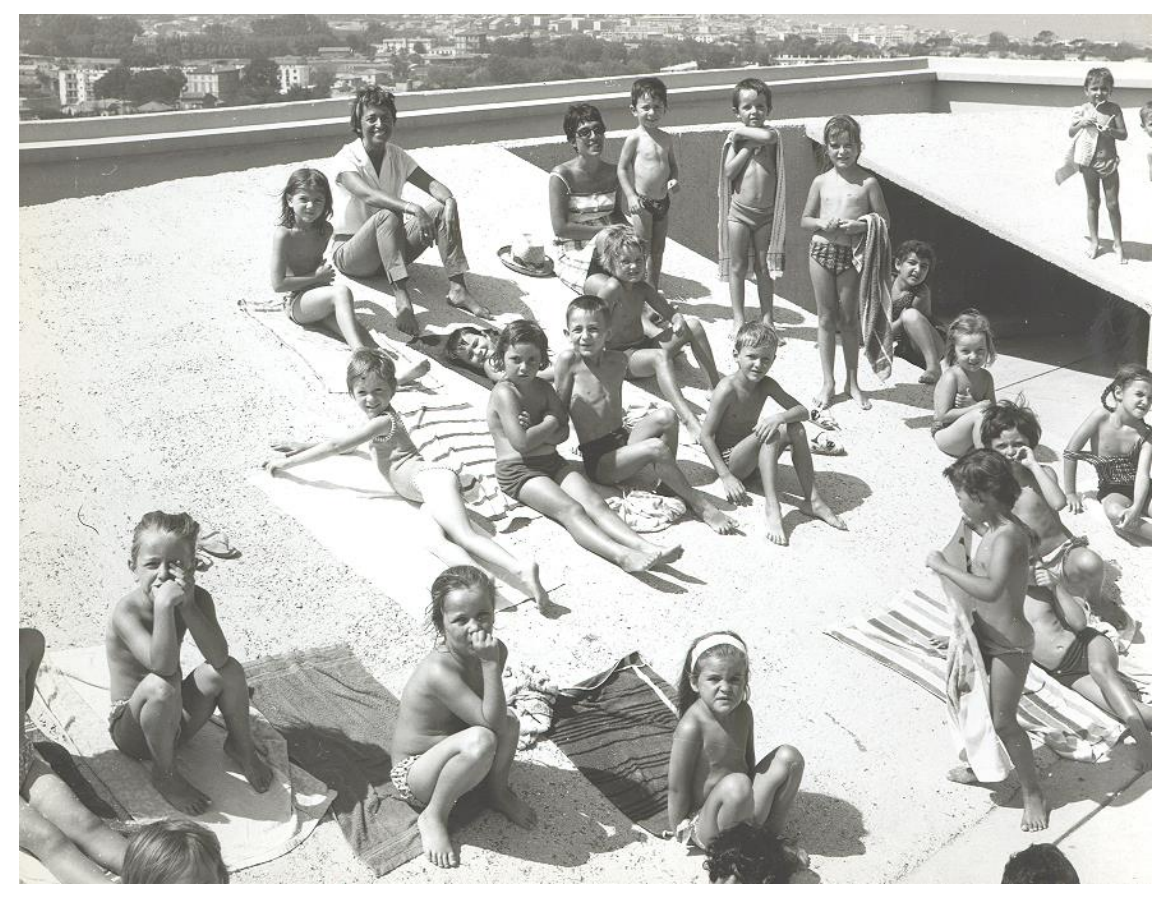

27. El plano inclinado. (FLC L1-11 38) CFLC-ADAGP

\section{Les Maternelles vous parlent}

Le Corbusier reclama continuamente fotografías, escritos y documentación sobre lo que ocurría en la escuela. En 1955 redacta el índice para los cuadernos que recoge el trabajo recopilado por Lilette Ripert y realizado por los niños, documentos, anotaciones escritas por la directora, por los niños y por los visitantes...; "LES CARNETS DE LA RECHERCHE PATIENTE No2. MATERNELLE MICHELET. La Maternelle de Marseille Michelet vous parlent".

"Pour les documents graphiques il me manque des vues qui donnent une notion claire des nouvelles classes dans leur ensemble et avec la foule des gosses et les vues sur la mer ou sur la montagne. Il faut que ces sacrés photographes comprennent un peu qu'ils doivent exprimer la vie." 40

\footnotetext{
${ }^{39}$ Carta de Lilette Ougier (Ripert, N.D.E) a Le Corbusier del 19/01/1960 (FLC O2-4 91)

${ }^{40}$ Carta de Le Corbusier a Lilette Ougier (Ripert, N.D.E) del 07/10/1955 (FLC E2-17 368)
} 


\section{Les Maternelles. Michelet-Marseille, la escuela pionera}

En 1956 Lilette Ripert comienza sus relaciones con directoras o los responsables del resto de Maternelles. Será ella quien aconsejará sobre algunos aspectos a sus responsables. ${ }^{41} \mathrm{Al}$ mismo tiempo Le Corbusier anima a Lilette Ripert a continuar con sus trabajo de redacción para el "Carnet de la Recherche Patiente". "Ne vous croyez pas abandonée; loin da là. Donnez donc un peu de vos nouvelles. "42 El 29 de mayo de 1956 le informa de que van a comenzar la impresión del libro de las dos Maternelles: Marseille y Rezé, y le pide que le envíe "des photographies charmantes et instructives avec les fêtes-kermesses sur le toit et complétez avec vos textes." Lilette Ripert le recuerda que ya tiene todo un álbum completo de fotos, "ainsi que des grandissements de Kermesse (que j'avais confis a Masson) j'envoie tout ce que je peux, tout qui me reste choisiez, ainsi que les textes." ${ }^{44}$ Heilbuth, la secretaria de Le Corbusier, "Il m'a chargée de vous dire sans tarder davantage que votre envoi du 31 mai 56 l'a vivement intéressé. Tout est très bien. „45

La directora no cesa en comunicar a Le Corbusier lo felices que son en el escuela, tanto ella como los niños. "Nous pensons souvent a vous dans notre école. Les enfants toujours nombreux, toujours heureux, continuent à peindre, à danser, à faire du théâtre spontané, à s'épanouir à l'école es sur le toir ."46

Para la escuela de Briey, André Maissonier escribe a Madame Ougier con algunas particularidades; "L'école ne pourra pas occuper toute la surface de la terrasse, il y aura une piste sur le pourtour et une grande esplanade du côté Nord pour récréations, ou fêtes. Elle aurait deux niveaux si tout le programme ne pouvait tenir sur un seul... Nous aurons toujours: petite piscine, jeux en béton et jardinets."47

Será el 9 junio de 1961 cuando el alcalde de Firminy, Claude Petit, se dirija a Lilette Ripert solicitando información para realizar una visita ya que tienen la intención de construir una escuela dentro de la línea de la de Michelet-Marseille. ${ }^{48}$ Una década después de la inauguración del centro, en 1963 Lilette Ripert sigue agradeciéndole a Le Corbusier la satisfacción por haber enseñado en Michelet-Marseille. "Voici dux fotos prises sur le toit il y a quelques jours. Neige ou beau temps vous voyez que nous sommes toujours heureux sur votre toit. "49 Le Corbusier ha sido durante todo este tiempo consciente de la evolución de "su escuela" igual que Lilette Ripert ha sido capaz de aprovecharla como un lugar puramente educativo. La felicita en la carta que le escribe el 3 de febrero de 1964 por los resultados de sus niños. "Je vous félicite de savoir ouvrir les yeux aux gosses que vous envoyez sur le toit de L'Unité de Marseille, - ce toit qui est unique au monde: mer et montagne, architecture ahurissante,- le tout formant un cadre digne de l'intérêt des gens intelligents dont vous êtes un modèle excellent. ",50

En 1965 l'Unité d'habitation de Marseille se declara monumento histórico, y por consiguiente queda prohibido intervenir para realizar cualquier modificación sin la autorización del ministerio y la de Le Corbusier.

\footnotetext{
41 “Je crois savoir que vous avez pris des contacts avec Rezé et que vous entendez bien." Carta de Le Corbusier a Lilette Ougier (Ripert, N.D.E) del 22/02/1956 (FLC E2-17-369)

${ }^{42}$ Carta de Le Corbusier a Lilette Ougier (Ripert, N.D.E) del 22/02/1956 (FLC E2-17-369)

${ }^{43}$ Carta de Le Corbusier a Lilette Ougier (Ripert, N.D.E) del 29/05/1956 (FLC G2-20 447)

${ }^{44}$ Carta de Lilette Ougier (Ripert, N.D.E) a Le Corbusier del 30/05/1956 (FLC O2-4-43)

${ }^{45}$ Carta de Heilbuth a Lilette Ougier (Ripert, N.D.E) del 5/06/1956 (FLC G2-20 486)

${ }^{46}$ Carta de Lilette Ougier (Ripert, N.D.E) a Le Corbusier del 1/02/1958 (FLC O2-4 61)

${ }^{47}$ Carta de A. Maisonnier a Lilette Ougier (Ripert, N.D.E) del 9/07/1959 (FLC M2-14 259)

${ }^{48}$ Carta de F.Gardien a Lilette Ougier (Ripert, N.D.E) del 9/06/1961 (FLC O2-4 104)

${ }^{49}$ Carta de Lilette Ougier (Ripert, N.D.E) a Heilbuth del 18/02/1963 (FLC O2-4 121)

${ }^{50}$ Carta de Le Corbusier a Lilette Ougier (Ripert, N.D.E) del 3/02/1964 (FLC E2-17 381)
} 
Un mes antes de su muerte, el 5 de julio 1965, Le Corbusier se dirige a Lilette Ripert;

"Il y a de quoi crever de dépit, de rage ou de désespérance quand on voit cette toiture occupée par vos gosses, et vous même, avec son bassin, ses collines artificielles, ses rampes, son "mur de la mort" et les montagnes et la mer."

"La photo montrant les gosses nus, les jambes pendantes sur les crête de ce fameux "mur de la mort", celle du bassin avec les gosses faisant trempette à cinquante mètres au dessus du rez-de-chaussés de la maison, sont des arguments étonnants, bouleversants.... "5l

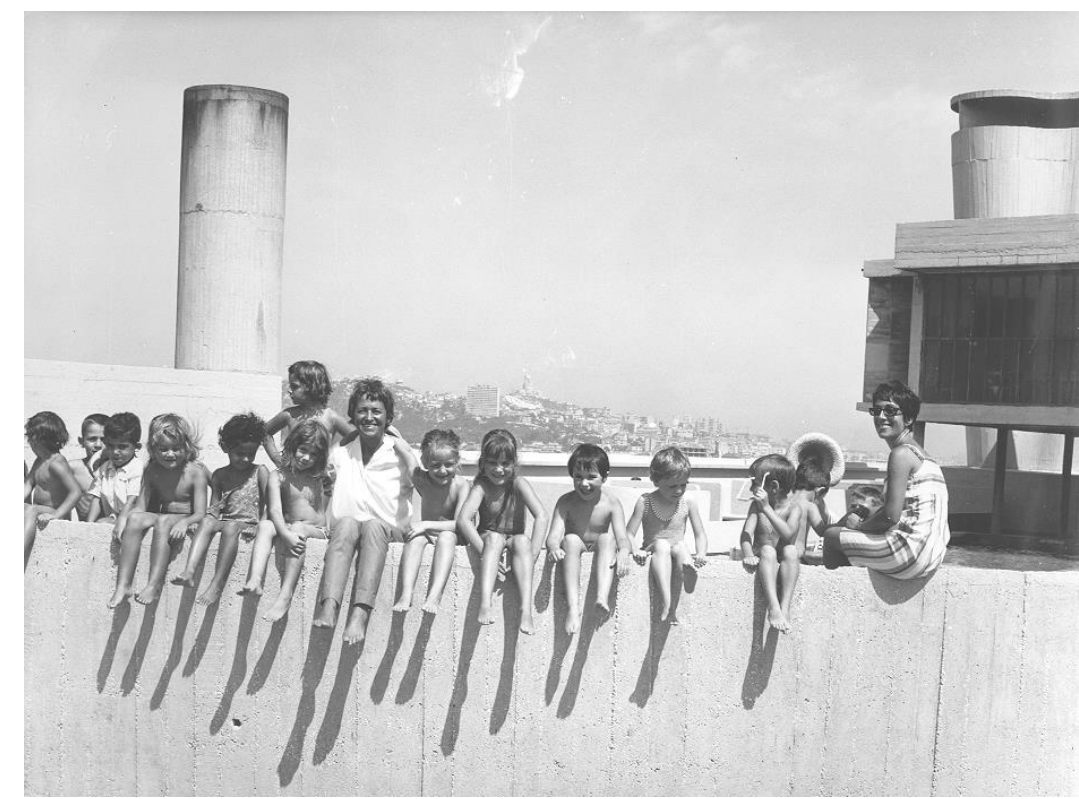

28. "Le mur de la mort". (FLC L1-11-33-001) OFLC-ADAGP

\section{El florecimiento compartido de una pedagogía más humana}

Este recorrido en el tiempo a través de unos escritos, unos dibujos y unas fotografías son el reflejo de una arquitectura construida para sus usuarios. La escuela infantil en las últimas plantas de l'Unité surge como extensión de la vivienda, como parte del recorrido diario del niño y se convierte en un lugar de encuentro abierto a infinitas posibilidades. La propuesta arquitectónica de Le Corbusier constituye el escenario sobre el cual Lilette Ripert aplica el sistema educativo basado en las teorías pedagógicas de Célestin Freinet. El funcionamiento admirable de la escuela ha sido fruto de la complicidad de Le Corbusier y Lilette Ripert meses antes de su ejecución y a lo largo de los primeros años de enseñanza.

Su funcionamiento, bajo la dirección de Lilette Ripert, supuso un periodo muy exitoso en el aprendizaje de los niños, habiendo entendido y aprovechando las instalaciones proyectadas para el desarrollo de las actividades. Su disposición de plan abierto, parcialmente al aire libre, favorece la aplicación de los principios pedagógicos de Freinet: el trabajo en equipo, el de prueba y error experimental y en especial el "método natural" o de aprendizaje auténtico utilizando las experiencias de los niños.

\footnotetext{
${ }^{51}$ Carta de Le Corbusier a Lilette Ougier (Ripert, N.D.E) del 5/07/1965 (FLC E2-17 385)
} 
Aunque la intervención de Freinet fue tardía, en las primeras propuestas de Le Corbusier es evidente su intención de construir una escuela muy abierta alejada de los planteamientos tradicionales, y que potencie la creatividad de los niños que la habitan. El enorme interés mostrado por Le Corbusier en los años de funcionamiento de l'école es una lección que demuestra que la arquitectura no es únicamente la ideación solitaria de un lugar y su entrega una vez construido, sino que lo enriquecedor es el proceso mismo y las interacciones que inevitablemente se producen entre todos los actores (constructores, directora, niños, compañeros, instituciones...); pues tienen también una gran capacidad educadora para la sociedad como conjunto y para los arquitectos mismos.

En definitiva, este viaje al interior del tiempo, hacía un pasado no muy lejano, demuestra sin duda la gran capacidad de l'école de dar una respuesta a un sistema educativo concreto. Después de varias propuestas y tras la relación con Lilette Ripert, el proyecto se desarrolló en paralelo a las teorías pedagógicas que la directora quería implantar. Las diversas actividades que se desarrollaron en la escuela han reflejado la flexibilidad de los espacios y su capacidad de adaptarse y ampliarse. Este trabajo en equipo, las conversaciones y el intercambio de ideas entre disciplinas ha sido el motor de este largo proceso. Los recursos espaciales empleados por Le Corbusier son vitales, pero es la correspondencia, los documentos y las fotografías que hablan de la relación mantenida entre Le Corbusier y Lilette Ripert los que manifiestan el mayor logro de la escuela: el florecimiento compartido de una pedagogía más humana.

\section{Procedencia de las imágenes}

Fondation Le Corbusier.

\section{Bibliografía}

Benton, Tim. Marseille: Unité d'habitation or The company of clouds, he sky, os the stars. In: Cohen, JeanLouis ed. Le Corbusier: an Atlas of Modern Landscapes, 2013, New York: Museum of Modern Art.

Freinet, Céléstin. L'éducation du travail. París: Editions Ophrys, 1949.

Le Corbusier. Les Maternelles vous parlent. Paris: Ed. Gonthier, 1968.

Sbriglio, Jacques. Le Corbusier: L'Unité d'habitation de Marseille. Ed. Birkhauser Verlag AG, 2004.

Stanislaus, Von Moos. Machine and nature: Notes a propos de l'Unité d'habitation de Marseille," in Claude Prelorenzo, ed., Le Corbusier: La Nature 1991: Paris Éditions de La Villette, 2004.

Archivo: Fondation Le Corbusier. 


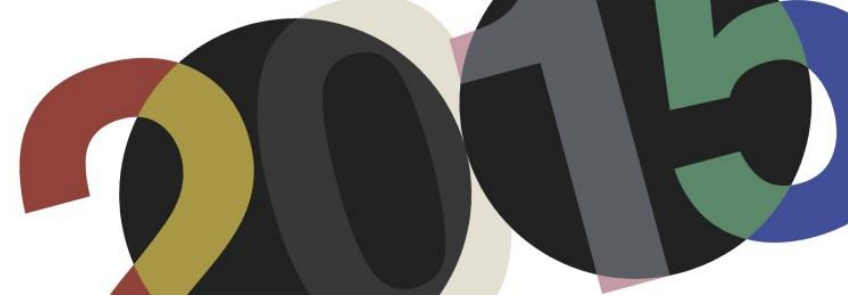

DOI: http://dx.doi.org/10.4995/LC2015.2015.985

\title{
Crónica de un desencuentro: Le Corbusier en las Américas
}

\author{
A. Lapunzina \\ Illinois School of Architecture, University of Illinois at Urbana-Champaign
}

\begin{abstract}
Resumen: La relación de Le Corbusier con el continente americano abarca virtualmente toda su vida activa. Plasmada en una veintena de viajes trasatlánticos y en un conjunto heterogéneo de propuestas, proyectos y obras, esta relación estuvo marcada por frecuentes malentendidos y desencuentros que condicionaron la concreción de algunos de sus proyectos. No obstante, el valor de su obra americana, representada por dos obras extraordinarias -la Casa Curutchet en Argentina y el Carpenter Center en Estados Unidos-y por una serie de proyectos notables que no llegaron a materializarse, merece un tratamiento específico. Este artículo está dedicado a presentar una síntesis de la relación y recíproco desencuentro entre Le Corbusier y el continente americano.
\end{abstract}

\begin{abstract}
The relationship between Le Corbusier and the American continent virtually encompasses his entire professional life. Embodied by about twenty transatlantic trips and a series of heterogeneous projects and buildings, this relationship was marked by frequent misunderstandings that conditioned the materialization of some of his projects. However, the significance of Le Corbusier's work for the Americas, represented by two extraordinary buildings -the Curutchet House in Argentina and the Carpenter Center in the United States - and by a series of noteworthy projects that remained unbuilt, deserves special consideration. This article is dedicated to present an outline of the relationship and reciprocal misunderstanding between Le Corbusier and the American continent.
\end{abstract}

Palabras clave: Américas; Planes urbanos; Casa Curutchet; Carpenter Center; Viajes y Proyectos. Keywords: Americas; Urban Plans; Curutchet House; Carpenter Center; Travels and Projects.

\section{Introducción}

A lo largo de su extendida trayectoria profesional Le Corbusier mantuvo una intensa relación con las Américas. Compleja y ambigua, esta relación fue generada y nutrida por él mismo y por numerosos interlocutores con los que el arquitecto trabó relación, primero en París y más tarde a través de sus viajes al continente americano. Entre sus primeros interlocutores destacaron miembros de las élites sociales y culturales americanas pero más tarde, a medida que su fama y prestigio internacional crecían, se fueron sumando personalidades de otros ámbitos - políticos, intelectuales, artistas, profesionales - y jóvenes colegas, algunos de los cuales colaboraron con él en diversos proyectos o instancias de su actividad profesional. Sustentada en dichas relaciones personales y en una veintena de viajes trasatlánticos, la relación entre Le Corbusier y las Américas fue ciertamente rica y quedó plasmada en un conjunto heterogéneo de proyectos, desde pequeños encargos privados hasta ambiciosos planes urbanos. ${ }^{1}$ Solo dos llegaron a concretarse: la Casa Curutchet en La Plata, Argentina (1949-1952) y el Carpenter Center for the Visual Arts en Harvard University, Cambridge, Estados Unidos (1959-1963). El resto, encargos directos o propuestas desarrolladas por iniciativa propia, no llegaron a materializarse por diversos

\footnotetext{
${ }^{1}$ La bibliografía dedicada a la relación de Le Corbusier con el continente americano es abundante y variada, desde obras monográficas, hasta artículos y tesis doctorales. Desde un punto de vista metodológico hubiera sido necesario referirse a las fuentes bibliográficas a medida que transcurre el texto, pero esto excede la extensión fijada para el mismo. Por lo tanto he optado por proveer en la bibliografía incluida al final del artículo una lista (incompleta) de publicaciones dedicadas a la relación, viajes, proyectos y obras de Le Corbusier en el continente americano.
} 
motivos. Este trabajo plantea que entre las razones que limitaron la concreción de algunas obras, una de las principales fue el desencuentro entre Le Corbusier y las Américas, consecuencia directa de frecuentes conflictos y malentendidos que surgieron en la gestación y/o desarrollo de los proyectos. ${ }^{2}$ Las razones de dichos malentendidos tuvieron origen en su personalidad y en su peculiar y poco objetiva interpretación de la realidad americana, así como también en la pugna entre las expectativas en torno al rol que él creyó tener en cada contexto específico y el que sus interlocutores americanos efectivamente le asignaron, o creyeron asignarle. Las excepciones de la Casa Curutchet y el Carpenter Center constituyen casos aislados en los que las situaciones conflictivas fueron superadas en parte gracias a la gestión de terceros actores que llevaron a cabo los respectivos procesos de concreción de estas dos obras extraordinarias, legado americano de la arquitectura universal y atemporal de Le Corbusier.

\section{Breve Cronología de los viajes, obras y proyectos de Le Corbusier en las Américas}

Al igual que a sus colegas europeos, el continente americano atrajo el interés de Le Corbusier desde el principio de su carrera. El crecimiento vertiginoso de los Estados Unidos, los procesos de mecanización e industrialización puestos allí en práctica, y la extensión de un territorio con ciudades jóvenes y en franco desarrollo aparecían como un terreno fértil para los pioneros de la arquitectura y el urbanismo modernos. Naturalmente, Le Corbusier no fue ajeno a esta tendencia y con frecuencia se refería al continente americano para ilustrar sus ideas y postulados. A mediados de los años veinte, su amigo Blaise Cendrars le presentó en París al poeta y escritor brasileño Paulo da Silva Prado, miembro de una familia influyente de São Paulo; ambos instigaban a Le Corbusier a emprender un viaje a Brasil donde la perspectiva de verse involucrado en el proyecto de Planaltina (germen de lo que años más tarde sería Brasilia) eran más que un aliciente para el joven arquitecto cuyas ideas, postulados y obras construidas ya trascendían las fronteras de Europa. También en París y por aquellos mismos años, Le Corbusier entabló relación con miembros de las élites pudientes de las Américas que residían o visitaban frecuentemente la capital francesa. Con el estímulo de estos contactos, llevar sus ideas al continente americano atrajo a Le Corbusier desde el primer momento, pero aún pasarían unos años para que se concretaran sus primeros viajes trasatlánticos.

Le Corbusier viajó a las Américas numerosas veces - en barco, avión y dirigible - ya sea para dar conferencias o en relación a proyectos de arquitectura y/o urbanismo. Siempre ávido de propagar sus ideas y obtener encargos, aprovechaba estos viajes para establecer contactos que pudieran abrirle las puertas a oportunidades y proyectos interesantes. El primer viaje fue en 1929 para dar un ciclo de conferencias en Buenos Aires; más tarde se sumaron al periplo sudamericano conferencias en Montevideo, São Paulo y Río de Janeiro. Seis años más tarde, en 1935, realizó el primer viaje a Estados Unidos, también para ofrecer conferencias en ciudades de la costa este y del medio-oeste. Invitado por el gobierno brasileño, en 1936 regresó a Río de Janeiro, nuevamente para dictar conferencias y como consultor de dos proyectos públicos de envergadura. Apenas terminada la segunda

\footnotetext{
${ }^{2}$ La figura del "malentendido" es recurrente en la bibliografía sobre la relación de Le Corbusier con el continente americano. William Curtis observó que "Le Corbusier y América [NdA: se refiere a los Estados Unidos] no consiguieron establecer un contacto duradero por haber malinterpretado señales a un lado y al otro." Curtis, William J. R. Le Corbusier Ideas and Forms; New York: Rizzoli, 1987 (126); por su parte Fernando Pérez Oyarzun notó que "la carrera de Le Corbusier en América del Sur fue un catálogo de fracasos y malentendidos." Pérez Oyarzún, Fernando. Le Corbusier in South America: Reinventing the South American city. Publicado en Mostafavi, Mohsen (ed.) Le Corbusier and the Architecture of Reinvention; London: Architectural Association, 2003 (140-153). Estos son sólo dos ejemplos entre muchos, incluyendo artículos que llevan "el malentendido" como tema principal.
} 
guerra mundial, Le Corbusier hizo numerosas idas-y-vueltas a Estados Unidos en relación al proyecto de las Naciones Unidas, y entre 1947 y 1951 viajó cinco veces a Colombia, primero para dar conferencias y luego en relación al Plan de Bogotá que le fuera encomendado. En 1959 y 1960 viajó a Estados Unidos en conexión con el encargo de proyectar el Carpenter Center, y en 1961 regresó por última vez al país del norte para recibir prestigiosas distinciones, entre ellas la Gold Medal del American Institute of Architects. El último viaje al continente americano fue a fines de 1962 para visitar en Brasilia el solar de la Embajada de Francia que le había sido encomendada anteriormente.

La documentación existente en los archivos de la Fondation Le Corbusier revela la existencia de una docena de proyectos de arquitectura y/o urbanismo en las Américas. A pesar que desde mediados de los años veinte habían existido tímidos intentos de obtener sus servicios desde distintos puntos del continente, el primer encargo concreto fue en 1928: una casa en Buenos Aires para la joven escritora e intelectual argentina Victoria Ocampo. A fines de 1929, durante su periplo por Sudamérica, obtuvo tres encargos: una casa de vacaciones en Chile para el diplomático chileno Matías Errázuriz, un pabellón residencial para Julián Martínez en Buenos Aires, y una biblioteca privada en los jardines de la casa de Paulo Prado en São Paulo. A principios de los años treinta hizo esquemáticos bocetos para un atelier de pintura en Santiago de Chile a pedido del pintor chileno Roberto Dávila. En 1935, durante su largo viaje por los Estados Unidos la cosecha de encargos no fue tan rica como lo había sido en el sur seis años antes; no obtuvo ningún encargo concreto pero aun así hizo un proyecto esquemático para la residencia del Presidente del Olivet College, en Michigan. En aquellos periplos por el sur y el norte del continente produjo, generalmente como parte de sus conferencias sobre urbanismo, provocadoras propuestas urbanas para Buenos Aires, Montevideo, São Paulo (1929), Río de Janeiro (1929 y 1936) y Manhattan (1935) que -por su importancia teórico-conceptual—deben ser consideradas como gérmenes de ideas urbanísticas.

En su segunda estadía en Brasil, en 1936, participó como consultor en los proyectos de la Ciudad Universitaria de Río de Janeiro y del nuevo edifico para el Ministerio de Educación y Salud que estaban siendo proyectados por dos equipos de jóvenes arquitectos brasileños dirigidos por Lucio Costa. Hacia fines de los años treinta el inminente estallido de la segunda guerra mundial virtualmente paralizó la actividad profesional en Europa. En este contexto, fiel a su incansable afán de concebir propuestas que pudieran generar algún tipo de actividad, Le Corbusier aprovechó circunstancias fortuitas para producir un no-solicitado pero ambicioso Plan Regulador para Buenos Aires (1938-1939). El fin de la guerra inauguró uno de los períodos de mayor intensidad no sólo en la obra de Le Corbusier en general sino también en su relación con el continente americano. Representando a Francia, Le Corbusier integró el equipo de expertos internacionales encargado de proyectar la sede central de las Naciones Unidas. A fines de los años cuarenta, el gobierno de Colombia le encargó un Plan Piloto para Bogotá, proyecto realizado en colaboración con Josep Lluis Sert y Paul Lester Wiener. Coincidiendo en el tiempo, la publicación del Plan Regulador para Buenos Aires de 1938-39 reavivó sus expectativas en la capital argentina, y paralelamente, en 1948 recibió y aceptó el encargo directo de proyectar una vivienda y consultorio médico para el Dr. Pedro Curutchet en La Plata (Argentina) que fue su primera obra construida en el continente americano. Este intenso lustro de "actividad americana" (1946-1951) culminó con el encargo de proyectar en Caracas un Monumento Funerario para Carlos Delgado-Chalbaud, presidente venezolano asesinado en noviembre de 1950 en confusas circunstancias.

Los últimos dos proyectos realizados por Le Corbusier para el continente americano son el Carpenter Center for the Visual Arts en Harvard University (1959-1963), encargo gestionado por Josep Lluis Sert, y la Embajada de Francia (1962-1965) en la entonces recientemente inaugurada nueva capital de Brasil. El primero de ellos se convirtió en el segundo y último edificio construido, mientras que el proyecto para la Embajada de Francia, que 
quedó pendiente a la muerte del arquitecto, cierra la lista de propuestas, proyectos y obras de Le Corbusier en las Américas.

\section{Un mutuo interés; un persistente desencuentro}

El interés de Le Corbusier por las Américas y el de los americanos por sus ideas fue recíproco; por un lado, el corpus teórico de Le Corbusier atrajo desde muy temprano a las élites intelectuales y a las generaciones emergentes de arquitectos y urbanistas americanos, y por el lado de Le Corbusier, el continente americano se presentaba como un territorio fértil para concretar sus ideas. La previsible convergencia de ambos era ciertamente promisoria, pero aunque se buscaron y convergieron una y otra vez, la relación entre Le Corbusier y las Américas estuvo signada por un persistente desencuentro. Una de las razones que explican este desencuentro fue la personalidad de Le Corbusier y su constante puesta en escena de una ambigua estrategia de relación que Margdes Bacon caracterizó como orientada a provocar en forma simultánea "antipatía y atracción;"3 otra de las razones puede atribuirse a su crónico rechazo a aceptar realidades que no se correspondían con la idea que él mismo se había forjado sobre esas mismas situaciones. Pero tampoco debe ignorarse la respuesta o actitud de sus interlocutores americanos que a menudo recurrieron al talento, prestigio y autoridad intelectual de Le Corbusier como aval de sus propios intereses y proyectos pero a veces fueron recelosos de su participación directa en procesos que pudieran desembocar en obras concretas. Sea por una razón u otras, lo cierto es que salvo las dos excepciones ya mencionadas, uno tras otro los proyectos de Le Corbusier para las Américas no llegaron a consumarse.

Aunque estuvo y/o realizó proyectos para otros países (Chile, Uruguay, Venezuela), la relación profesional de Le Corbusier con las Américas estuvo limitada a cuatro países: Argentina, Brasil, Colombia y Estados Unidos. Con diferentes matices -sobre todo entre los países de América del Sur y los Estados Unidos— afrontó su relación de forma semejante con una mezcla de interés personal y profesional y un cierto paternalismo franco-europeo. Objetivamente, la relación con los Estados Unidos fue la más conflictiva, con recíprocas resistencias a aceptarse mutuamente que quedaron plasmadas en una multitud de situaciones entre las que destacan ácidos intercambios al final de su tour de conferencias en 1935 y su controvertida participación en el proyecto de las Naciones Unidas. Indudablemente, ni en los Estados Unidos estaban dispuestos a "negociar" su propia visión de la modernidad, demostrado progreso, proyección cultural y rol de liderazgo que, basados en su creciente poderío económico y político, aspiraban a consolidar, ni Le Corbusier dispuesto a aceptarlo pasivamente sin exponer -e intentar imponer - sus fuertes convicciones y postulados. Por su lado, en Sudamérica, las élites eran más propensas a mirar hacia Europa y por ende más proclives a aceptar el liderazgo de Le Corbusier como portavoz de las ideas modernas. No obstante, la relación de Le Corbusier con los países del sur tampoco fue fácil y tuvo desenlaces mayormente negativos tanto en Argentina como en Colombia. Aunque lejos de perfecta e ideal, quizás tuvo mejor relación con Brasil, posiblemente gracias a su amistad con Lucio Costa y Oscar Niemeyer (mas allá de diferencias notables con ambos), relación que quedó plasmada con el encargo y construcción de la Maison du Brésil en la Cité Universitaire de París.

Sin embargo, a pesar de los matices y de ser plenamente consciente de las marcadas diferencias entre los Estados Unidos y Sudamérica, en su peculiar visión de las cosas Le Corbusier consideraba al continente y a su gente como una totalidad. Una nota interna del atelier es particularmente reveladora en este sentido: en 1955, enterado de la decisión de Brasil de poner en marcha el proceso de diseño de una nueva y moderna capital en el Planalto,

\footnotetext{
${ }^{3}$ Bacon, Margdes. Le Corbusier in America. Travels in the Land of the Timid; Cambridge (MA)-London: The MIT Press, 2001 (136).
} 
movilizó sus contactos para verse involucrado en la planificación de la nueva ciudad. Luego de muchas frustraciones, algunas muy recientes, su esperanza de construir algo importante en aquel continente fértil y pujante renacía. En una nota pidiendo a sus colaboradores Ducret y Wogenscky que prepararan materiales para el proyecto de la nueva capital de Brasil también advertía que "no hay que olvidar que he sido segado en: a) Río de Janeiro, Ministerio de Educación; b) Río de Janeiro, Ciudad Universitaria; c) Buenos Aires: Plan; d) New York: UN." Aquella nota reflejaba, en pocas palabras, su frustración con todo el continente, pero aun así no iba a dejar pasar la oportunidad de proyectar la nueva capital de Brasil; pero la nota también demostraba su particular interpretación de los hechos precedentes ya que, curiosamente, en ninguno de esos casos había sido contratado para hacerse cargo del proyecto.

Con el tiempo, su fascinación inicial con el continente americano fue cediendo paso a un sentimiento de frustración que, sin embargo, no impidió que volviera una y otra vez cuando un proyecto le entusiasmaba. En 1928, aun antes del primer viaje al continente americano, Victoria Ocampo le encargó por vía indirecta el proyecto de una casa en Buenos Aires. La historia es conocida: quizás por las semejanzas del programa y el terreno, Le Corbusier rescató su frustrado proyecto para la Villa Meyer (Neuilly-sur-Seine, 1925) y con muy ligeras modificaciones se lo envió a su cliente argentina. Curiosamente Victoria Ocampo había encargado un proyecto similar pero en otro solar al reconocido arquitecto argentino Alejandro Bustillo y fue este último el que decidió construir. Cuando tan solo un año más tarde Le Corbusier visitó Buenos Aires, la escritora -una de sus principales anfitrionas - lo recibió en esa flamante casa que había construido en desmedro de su proyecto. Sin embargo, elegante y perspicaz, Le Corbusier elogió la "casa moderna" y la determinación de Victoria Ocampo por construir una obra de esa naturaleza; había indudablemente percibido su posición social y poder económico, que aunados a esa determinación, podían ser llaves que abrieran puertas a interesantes emprendimientos. Muy pronto propuso a su anfitriona una variedad de iniciativas: un rascacielito cerca del Río de la Plata y un complejo de viviendas tipo Villa Savoye en el Tigre, pero ninguno de ellos prosperó.

La Casa Errázuriz en Zapallar (Chile, 1930) sufrió un destino similar. Errázuriz le había encargado el proyecto a Le Corbusier durante su estadía en Buenos Aires. Le Corbusier abordó el proyecto a principios de 1930 y lo envió a su cliente en abril de ese año. Sin embargo, a pesar de su satisfacción con el proyecto de Le Corbusier, Errázuriz decidió construir otro, proyectado por Carlos Landa, arquitecto mexicano establecido en Chile. Le Corbusier no llegó a enterarse y años más tarde seguía ignorando qué había pasado con su proyecto al mismo tiempo que veía con indignación como Antonin Raymond plagiaba su proyecto en Japón. ${ }^{5}$ Los otros proyectos para clientes americanos que Le Corbusier produjo en la primera mitad de los años treinta tampoco llegaron a materializarse. De todos ellos, el pabellón para Julián Martínez es el único que tuvo una base contractual sólida y al que Le Corbusier respondió con un proyecto acabado. Se ignoran las causas del frustrado desenlace del proyecto y es muy probable que sean debidas a cuestiones personales del cliente. De la biblioteca para Paulo Prado en São Paulo solo existen unos pocos dibujos que revelan las intenciones e ideas de Le Corbusier, pero este proyecto fue abortado mucho antes que el proceso de diseño concluyera. La Casa para el Presidente del Olivet College en Michigan fue el único encargo que Le Corbusier creyó haber obtenido en su periplo por los Estados Unidos en 1935. No fue un encargo firme, pero surgió como una oportunidad en conversaciones con Henry Russell Hitchcock y Joseph Brewer (Presidente del Olivet College) durante el breve pasaje de Le Corbusier por Michigan. Le Corbusier no dejó pasar la oportunidad y respondió de inmediato con dibujos

\footnotetext{
${ }^{4}$ Nota interna del atelier de Le Corbusier dirigida a Wogenscky y Ducret; Junio 6, 1955. Archivos FLC, D1-03 (356).

${ }^{5}$ Carta de Le Corbusier al hijo de Errázuriz; Febrero 27, 1948; Archivos FLC G2-10, (84).
} 
esquemáticos pero sin duda interesantes, pero a pesar del entusiasmo de Brewer por las ideas de Le Corbusier el encargo no se materializó.

Los episodios y malentendidos más resonantes y complejos tuvieron lugar entre 1936 y 1952 con los planes para Buenos Aires y Bogotá (tratados separadamente), y con la actuación de Le Corbusier en Brasil (1936) y en el proceso de diseño de las Naciones Unidas (1945-1948). Esa década y media estuvo profundamente marcada por el estallido de la segunda guerra mundial y ante la inminencia de la guerra y la consecuente falta de obras y encargos, Le Corbusier consideró la posibilidad de emigrar temporalmente a América del Sur; intentó tender algunos lazos con Chile, Argentina y Brasil pero además de hospitalidad, muy poco o nada se le ofreció en concreto, y esa posibilidad -aunque débil — se apagó rápidamente. Le Corbusier optó entonces por quedarse en Francia, pero quizás otra hubiera sido la historia si de alguno de aquellos países hubiera llegado un contrato firme para alguna obra importante.

En 1936, Le Corbusier aceptó dar un ciclo de conferencias en Río de Janeiro con la condición de que incluyera algún tipo de actividad profesional; eventualmente se llegó a un acuerdo involucrándolo como consultor en los proyectos de la Ciudad Universitaria de Río de Janeiro y del Ministerio de Educación y Salud en los que trabajaban equipos dirigidos por Lucio Costa. Oficialmente, su rol estaba limitado a comentar los proyectos en curso pero Le Corbusier aspiraba a tener un protagonismo mayor y pronto asumió un rol más importante. Intuyendo su importancia se interesó particularmente en el proyecto para el Ministerio. Luego de elogiar la labor del equipo dirigido por Costa, pasó a la ofensiva cuestionando el emplazamiento elegido y proponiendo otro que juzgaba más apropiado. La proposición no fue inocente: este respondía mejor a sus ideas para Río de Janeiro esbozadas en 1929 y aunque esquemáticos, sus dibujos pueden ser interpretados como un fragmento de aquella visionaria propuesta. Además, de esta forma los roles quedaban implícitamente trastocados y él asumía de facto la dirección de Costa y su equipo. Poco antes del fin de su estadía el cambio de sitio fue descartado, y en vez de dejar que el proyecto original de Costa y sus colaboradores siguiera su curso, invirtió el poco tiempo que disponía en esbozar rápidamente una adaptación al terreno original de su esquema para el sitio alternativo. Luego de la partida de Le Corbusier, Costa y su equipo retomaron el proceso de diseño incorporando algunos aspectos sugeridos en los últimos bocetos que Le Corbusier había presentado, pero el proyecto definitivo, que una vez construido se convirtió en ejemplo paradigmático de la arquitectura moderna, fue enteramente desarrollado por el equipo dirigido por Costa. Grande fue la sorpresa y la desilusión de estos últimos al advertir que Le Corbusier se adjudicaba la coautoría del edificio cuando su participación en el proyecto definitivo fue prácticamente inexistente. Por su parte, el proyecto de la Ciudad Universitaria, que por iniciativa de Costa se desarrollaba como alternativa moderna al proyecto que Marcello Piacentini había presentado el año anterior, quedó plasmado en una serie de dibujos que ponen en evidencia la influencia de Le Corbusier y algunas de sus propuestas anteriores como, por ejemplo, el Mundaneum (1929) y el Palais des Soviets (Moscú, 1931). Sin embargo, el proyecto de Costa y Le Corbusier, y otros, fueron archivados y uno distinto se erigió recién a partir de fines de los años cuarenta.

El caso de las Naciones Unidas es una muestra más de la conflictiva relación entre Le Corbusier y las Américas y constituye uno de los episodios más polémicos, controvertidos y complejos en la carrera del arquitecto y de la arquitectura del siglo veinte. Le Corbusier estaba persuadido que "el mundo" le debía el encargo de las Naciones Unidas en compensación por la injusticia que había sufrido veinte años antes con la descalificación de su proyecto para la Sociedad de las Naciones en Ginebra; en su autoproclamado rol de líder mundial de la arquitectura moderna (que muchos, pero no todos, le reconocían), consideraba que él debía estar a cargo del proyecto independientemente del prestigio y rol de iguales de los otros miembros del equipo internacional de proyectistas. El conflicto por el liderazgo del proceso no tardó en explotar y manifestarse en un enfrentamiento 
personal con Wallace Harrison, representante de los Estados Unidos designado como coordinador del equipo internacional. En un clásico ejemplo del crónico rechazo a aceptar una realidad que no se correspondía con su interpretación de la misma, Le Corbusier convirtió el proceso de diseño de las Naciones Unidas y su enfrentamiento directo con Harrison en una cruzada personal y una sobredimensionada polémica por las decisiones del proyecto y la autoría del edificio. Para ser justos, Le Corbusier no fue el único responsable del enfrentamiento; Harrison hizo todo lo posible para mantener a Le Corbusier a distancia prudencial evitando perder el control del proceso. La explosiva e irreconciliable relación entre ellos, inseparable de su histórica conflictiva relación con los Estados Unidos, contaminó el proceso de diseño y condicionó la colaboración de los miembros del equipo internacional. Frustrado por lo que él percibía como un constante rechazo a su persona y a sus ideas por parte de los Estados Unidos decidió auto-marginarse del resto del proceso y aprovechó cuanta oportunidad tuvo para fustigar las decisiones de Harrison a quien hizo responsable por su frustrada participación en el proceso y acusó de haberse apropiado de sus ideas sin reconocérselas. Efectivamente, Le Corbusier tuvo un rol importante en las etapas preliminares del proceso de diseño, pero aunque reclamó la autoría de la idea, la impronta de su participación en la versión final solo abarca aspectos formales del complejo edilicio.

En los años cincuenta y sesenta Le Corbusier recibió frecuentes contactos para encargarse de proyectos desde diversos puntos de las Américas, pero los rechazaba casi sistemáticamente; tantas frustraciones y oportunidades perdidas habían minado su confianza y su entusiasmo por el continente americano había sido reemplazado por la segura concreción de obras en India. Sin embargo, cuando un proyecto atraía su atención, no dudaba en dejar atrás amarguras y frustraciones. En 1951 aceptó un encargo sui-generis formulado por Lucie DelgadoChalbaud: un Monumento Funerario en Caracas en memoria de su esposo asesinado meses antes mientras ejercía la presidencia de Venezuela. La historia de este proyecto está rodeada de situaciones confusas, desde la decisión de Le Corbusier de hacerse cargo del mismo y la forma en la que lo desarrolló, hasta la misteriosa desaparición de casi toda la documentación gráfica del proyecto. Interpretando con excesivo optimismo información que había recibido de su cliente, Le Corbusier pensó que la concreción de este proyecto estaba garantizada, pero seguramente desconocía la compleja trama política que había detrás y las pocas posibilidades de concreción que su proyecto realísticamente tenía ya que el gobierno venezolano lo rechazó y en su lugar construyó un proyecto de Luis Malaussena.

El último proyecto para el continente americano en el que trabajó Le Corbusier fue la Embajada de Francia en Brasilia. La idea de proyectar la nueva capital de Brasil en el desértico Planalto le entusiasmaba desde los años veinte pero el concurso de anteproyectos no admitió la participación de profesionales extranjeros. Una ilusión incubada por largos años quedaba abortada rápidamente, pero restaba la posibilidad de construir obras importantes en la ciudad proyectada por sus viejos amigos Lucio Costa y Oscar Niemeyer. A ellos recurrió buscando apoyo para obtener el encargo de la Embajada de Francia aún antes que Brasilia fuera inaugurada. Además de esta, se contemplaban otros encargos - La Maison de la France y un Centro Cultural- en los que Le Corbusier demostró mayor interés que en la embajada propiamente dicha. En diciembre de 1962, aun antes de firmar el contrato, Le Corbusier visitó en Brasilia el sitio designado para la embajada. Proyectada en París en 1963, hacia mediados de 1964 Le Corbusier consideró que el proyecto estaba concluido y listo para ser ejecutado bajo la supervisión de Oscar Niemeyer. Pero un golpe de estado militar obligó a Niemeyer a emigrar y el proceso entró en un impasse. Años más tarde, luego del deceso de Le Corbusier, la Cancillería francesa pidió cambios al proyecto original pero los herederos del atelier de la rue de Sèvres rechazaron hacer cambios al proyecto de Le Corbusier y un nuevo proyecto fue encargado a Guillermo Jullian de la Fuente, colaborador de Le Corbusier en el proyecto original. El último proyecto de Le Corbusier en las Américas se sumó así, póstumamente, a la larga lista de procesos inconclusos. 


\section{Malentendidos transatlánticos: dos planes fallidos}

Si muchos de los proyectos de Le Corbusier para el continente americano estuvieron marcados por algún tipo de malentendido o desencuentro esto llegó a niveles mayúsculos con los planes urbanos que hizo para Buenos Aires y Bogotá, dos planes con historias muy disímiles pero un destino semejante. El primero de ellos fue fruto de su inagotable capacidad para producir propuestas e intentar convertirlas en algo concreto; el segundo fue el único verdadero encargo de urbanismo para una ciudad americana y es un hito del urbanismo lecorbusierano.

En una de las conferencias de 1929, Le Corbusier había formulado una propuesta de transformación de Buenos Aires que, basada en los principios de la Ville Contemporaire y el Plan Voisin, tenía como signo distintivo la creación de una Cité des Affaires sobre una plataforma en el Río de la Plata. En los años siguientes, su audaz propuesta se convirtió en una obsesión e intentó convencer a sus amigos argentinos de la necesidad de desarrollar un plan para Buenos Aires basado, precisamente, en aquellos bocetos de 1929. Pero las respuestas que él esperaba nunca llegaron y con los años dejó de insistir. Pero en 1937, la fortuita llegada de dos jóvenes arquitectos argentinos -Jorge Ferrari Hardoy y Juan Kurchan-buscando trabajo en su atelier parisino reavivó su interés. Sin encargos viables, Le Corbusier vislumbró la llegada de Ferrari Hardoy y Kurchan como una oportunidad para desarrollar un plan para Buenos Aires. Les encomendó obtener información (mapas, estadísticas, datos históricos, etc...) para llevar a cabo un ambicioso plan basado en datos sólidos y luego de varios meses de trabajo, el equipo produjo una propuesta documentada a través de una memoria descriptiva y una serie de instrumentos gráficos entre los que sobresalía un gigantesco fotomontaje de la propuesta de transformación de la ciudad superpuesta a la foto aérea de la condición existente. Hábil en el manejo propagandístico y a pesar que nadie se lo había encomendado, Le Corbusier organizó en su atelier una presentación del Plan a un grupo de invitados de la comunidad y embajada argentinas en París. Indudablemente aspiraba a obtener algún resultado concreto, pero todos sus esfuerzos, como el de sus colaboradores al regresar a Buenos Aires, fueron infructuosos. La publicación de un libro dedicado al Plan pasó a ser el objetivo principal de aquellos años, pero tampoco fue posible hasta 1947 cuando - con la oposición de Le Corbusier- Ferrari Hardoy logró publicar parcialmente el Plan en un número especial de La Arquitectura de Hoy, versión castellana de L'Architecture d'Aujourd'hui.

La decisión de Ferrari Hardoy rindió frutos: la publicación llamó la atención del Secretario de Obras Públicas de Buenos Aires y meses más tarde se creaba la Oficina del Estudio del Plan de Buenos Aires (EPBA) bajo la dirección de Ferrari Hardoy. Exultante por el logro, Ferrari Hardoy comunicó a Le Corbusier la buena noticia, pero no era el Plan que habían hecho en París sino un nuevo estudio que respondería a la nueva realidad política y social que gobernaba al país desde hacía unos pocos años. Ignorando la diferencia, Le Corbusier celebró haber logrado el objetivo y fiel a su costumbre requirió un contrato de consultor en Argentina y, "entretanto," el encargo de un edificio importante en Buenos Aires. Su pobre lectura de la situación le había generado exageradas e irrealistas expectativas de obtener encargos en Buenos Aires. Ferrari Hardoy contemplaba la participación de Le Corbusier como consultor de la EPBA, pero eso estaba sujeto a muchos factores que no controlaba y a pesar de su buena voluntad no logró obtener la contratación de Le Corbusier en Buenos Aires. Tardíamente enterado de esa situación Le Corbusier envió una carta particularmente despectiva hacia Ferrari Hardoy y Kurchan en el que manifestaba su enorme frustración con lo sucedido y daba por definitivamente cerrado el capítulo de su relación con Buenos Aires con una lapidaria declaración: "Argentina habrá hecho, en lo que a mí concierne, uno de los gestos más decepcionantes del que haya sido objeto en mi carrera." " El fastidio de Le Corbusier fue premonitorio ya que un mes más tarde, por razones políticas internas, la Oficina del Plan era

\footnotetext{
${ }^{6}$ Carta de Le Corbusier a Jorge Ferrari Hardoy, 10 de Octubre, 1949; Archivos FLC, T2-13 (110).
} 
desmantelada y la labor de Ferrari Hardoy y sus colaboradores pasaba a engrosar la lista de esfuerzos inútiles y oportunidades perdidas.

En New York, mientras trabajaba en el proyecto de las Naciones Unidas, Le Corbusier forjó una sólida relación con el embajador de Colombia, Eduardo Zuleta Ángel, quien con el incentivo de un posible contrato de urbanismo en Colombia lo convenció de aceptar una invitación a dar conferencias en Bogotá que eventualmente tuvieron lugar en junio de 1947. Siempre polémico y fiel a su provocador estilo, en su conferencia sobre urbanismo sorprendió a la audiencia de con una "amable declaración de guerra" al alcalde de Bogotá: criticó la expansión de la ciudad y expresó la necesidad de un enfoque más territorial, acorde con la geografía del país. ${ }^{7}$ Días más tarde el alcalde Mazuera Villegas cumplió con lo informalmente pactado con Zuleta Ángel y propuso a Le Corbusier desarrollar un plan de urbanismo para Bogotá. Para Le Corbusier, todo había salido según lo esperado, y quizás aún mejor: había sido recibido con honores, sus conferencias habían sido seguidas por una multitud, emprendía el regreso con la promesa de un encargo y, lo más importante, esa promesa provenía directamente de "la autoridad," esa figura que desde siempre le había fascinado y consideraba clave para materializar sus ideas.

Aquellos eran años de auge para la planificación urbana en Latinoamérica ya que el Banco Mundial ofrecía créditos para desarrollo urbano a ciudades que contaran con un Plan Regulador. Pero la inestabilidad política colombiana, frecuentes cambios en el Ayuntamiento y una compleja trama de intereses personales y profesionales presentaron obstáculos de todo tipo a la puesta en marcha del Plan. Uno de los problemas era la contratación directa de Le Corbusier, resistida por algunos sectores del ayuntamiento. Mazuera Villegas consideró entonces contratar a Town Planning Associates (TPA), firma consultora dirigida por Josep Lluis Sert y Paul Lester Wiener que ya trabajaba en planes para otras ciudades sudamericanas y gozaba de prestigio y reconocimiento en Bogotá, pero Sert rechazó la propuesta porque sabía que Mazuera ya se lo había ofrecido anteriormente a Le Corbusier. La situación fue eventualmente desbloqueada en marzo de 1949 con la firma de un contrato que estableció la colaboración entre Le Corbusier y TPA; paralelamente se creó en Bogotá la Oficina del Plan Regulador de Bogotá (OPRB), ente municipal encargado de preparar la información necesaria para el desarrollo del Plan y eventualmente encargarse de su implementación.

A ojos de Le Corbusier, la situación estaba re-encaminada y el desarrollo del Plan asegurado y esto redundaría en nuevos encargos de arquitectura. La realidad, no obstante, era muy distinta; el contrato había claramente delimitado su rol poniéndolo a cargo de la segunda de cuatro etapas - el desarrollo del Plan Piloto- con Sert y Wiener actuando como consultores asociados; luego, en la tercera etapa se invertían los roles: TPA estaba a cargo del Plan Regulador basado en el Plan Piloto y Le Corbusier pasaba al rol de consultor. Pero Le Corbusier tenía su propia interpretación y pensaba que por encima de aspectos contractuales lograría mantenerse involucrado en el proceso y obtener encargos importantes. Algunos episodios preanunciaron fricciones y situaciones conflictivas, pero en 1949 el proceso siguió el curso previsto y en agosto Le Corbusier, Sert, Wiener y Herbert Ritter (Director de la OPRB) se reunieron en Cap Martin para delinear las bases del plan. El proceso continuó más tarde en París donde Le Corbusier y su equipo desarrollaron el Plan Piloto guiados, como sugiriera Fernando Arias Lemos, por el piloto automático de los principios urbanísticos del CIAM. ${ }^{8}$ En franco contraste con el optimismo de Le Corbusier - que ignoraba (por ignorancia o por conveniencia) la frágil estructura de

\footnotetext{
${ }^{7}$ Conferencia de Le Corbusier "L'urbanisme comme ordonnateur social," dictada en Bogotá el 18 de Junio de 1947. Para una transcripción virtualmente completa de la misma ver: O’Byrne, Mariia Cecilia (ed.). Le Corbusier en Bogotá 19471951. Tomo 2: Precisiones en torno al plan director. Bogotá: Ediciones Uniandes, 2010 (22-33).

${ }^{8}$ Arias Lemos, Fernando. Le Corbusier en Bogotá, El proyecto del "grand immeuble" 1950-1951; Bogotá: Universidad Nacional de Colombia-Facultad de Artes, 2008 (20).
} 
apoyos en los que se sustentaba todo el proceso - en Colombia había mucha oposición al desarrollo del Plan. Además, la persistente inestabilidad política había provocado la partida de Mazuera Villegas y Herbert Ritter. El reemplazante de Ritter, Carlos Arbeláez, era adepto a las ideas de Le Corbusier pero el apoyo del nuevo alcalde, Santiago Trujillo, estaba lejos de ser incondicional.

En Septiembre de 1950 Le Corbusier presentó el Plan Piloto en Bogotá. Antes de regresar a París recibió el reconocimiento y agradecimiento del Ayuntamiento y del alcalde Trujillo. Inmutable, Le Corbusier interpretó la presentación del Plan como ampliamente exitosa, pero en realidad el Plan fue mucho más cuestionado que lo esperado. No obstante, su interpretación del contrato era que habiendo presentado el Plan Piloto se le debía inmediatamente encargar el diseño de edificios importantes, por ejemplo el Centro Cívico (parte importante de su propuesta). Su obstinación con este tema lo llevó a desoír las advertencias que Sert y Wiener, mejores intérpretes de la realidad política y social latinoamericana, le enviaban con frecuencia. Exasperado por la falta de respuestas el tono de sus cartas subió poco a poco y llegó a un punto álgido cuando fue obligado a celebrar una última reunión de trabajo en Bogotá que estaba originalmente prevista en New York. Indudablemente, el clima de colaboración profesional y mutua confianza que había reinado en Cap Martin en agosto de 1949 se había enrarecido y condicionaba la continuación del proceso. Aun así, Le Corbusier volvió a Bogotá en Mayo de 1951 para presentar la versión final del Plan Piloto. El Ayuntamiento se esforzó en difundirlo a través de una exposición y conferencias, pero las críticas y oposición al Plan continuaron ganando adeptos.

Con la entrega y presentación definitiva del Plan Piloto concluía la segunda etapa del proceso y comenzaba la tercera en la que Le Corbusier pasaba a tener el rol de consultor de Sert y Wiener, pero una vez más volvió al ataque reclamando encargos importantes, en este caso, el Palacio Presidencial. No se percataba que su insistencia solo lograba erosionar la relación con sus socios y generaba rechazos y resistencia en Colombia. Entretanto, Sert y Wiener tomaron las riendas del proceso; era obvio que circunstancias ajenas a la arquitectura y el urbanismo hacían inviable el Plan de Le Corbusier tomado como una totalidad. Sert y Wiener pronto introdujeron cambios en el Plan Piloto que pusieron de manifiesto las diferencias conceptuales entre Sert y Le Corbusier aunque, quizás para no exacerbar más a Le Corbusier, mantuvieron el Centro Cívico virtualmente intacto. Sert y Wiener continuaron su tarea según contrato a lo largo de 1952 y 1953 en condiciones francamente adversas ya que la culminación exitosa del proceso no estaba garantizada. En Agosto de 1953 hicieron la entrega final del Plan Regulador; previamente, en junio, un golpe de estado militar había interrumpido la continuidad democrática y un gobierno de corte populista y dictatorial asumió el poder del país. Una vez más, Le Corbusier entrevió que con el cambio de autoridades surgía una nueva oportunidad para obtener el encargo de "su" Centro Cívico. Trujillo había sido nombrado Ministro de Obras Públicas de Colombia y a él volvió a dirigirse reclamándole el contrato del Centro Cívico que, según él, le había sido prometido; como si nada hubiera pasado intentó restablecer la colaboración. Sin embargo, si bien el Plan había sido sancionado como normativa urbana para la capital colombiana, el poder de turno decidió que un nuevo complejo edilicio para sede del gobierno nacional debía emplazarse fuera de los límites de la ciudad definidos en el Plan Piloto y no en el Centro Cívico como lo había propuesto Le Corbusier, sellando de esta forma su sueño de darle forma a una ciudad capital. Efectivamente, en Mise au point, Le Corbusier recordaba que en Bogotá, en 1950, había sentido que "había pasado una página,"9 pero la realidad sobrepasó sus expectativas; los malentendidos, propios y ajenos, nuevamente causaban el naufragio de uno de sus proyectos en las Américas y

\footnotetext{
9 Žaknić, Ivan. The Final Testament of Pere Corbu: a translation and interpretation of Mise au point. New Haven and London: Yale University Press, 1997 (87).
} 
así el Plan de Bogotá y con él el complejo de edificios que había imaginado para el Centro Cívico se incorporó a la larga lista de frustraciones.

\section{Dos obras concretadas}

La lista de proyectos frustrados es efectivamente larga y no hay duda que numerosos malentendidos contaminaron muchos procesos condicionando su concreción. Pero sería incorrecto afirmar que los malentendidos sean causa única de las pocas concreciones; es plausible también pensar lo opuesto: que el malentendido sea dar por sentado que todos los proyectos estaban llamados a concretarse. Por eso quizás sea más adecuado pensar en un desencuentro: dos corrientes que por mutuo interés están llamadas a converger pero que por una o múltiples razones el encuentro entre ambas no se consuma. De la larga lista de procesos interrumpidos hay dos excepciones: la Casa Curutchet y el Carpenter Center; en ambas Le Corbusier desplegó todo el arsenal de sus ideas y lenguaje arquitectónico como si quisiera dejar firmemente establecido el legado de su obra en suelo americano. Pero estas dos obras podrían haber fácilmente pasado a engrosar la lista de frustraciones si no hubiera sido por la determinación de dos paladines de la arquitectura moderna -Amancio Williams y Josep Lluis Sert-y su incondicional lealtad a Le Corbusier. Ambos condujeron los respectivos procesos de concreción con paciencia y profesionalismo, aun cuando se vieron forzados a hacer algunos ajustes en las obras que alteraron el proyecto original. Sin embargo, a pesar de estos cambios, la autenticidad corbusierana de estos dos edificios es incuestionable. Los dos casos son distintos; en el caso de la Casa Curutchet, Le Corbusier virtualmente se desentendió del proyecto una vez que lo envió a su cliente y delegó toda la responsabilidad en Amancio Williams, fiel intérprete de las ideas del que consideraba su maestro. En el caso del Carpenter Center, Le Corbusier tuvo activa participación en todas las etapas del proceso y gracias a ello se evitaron erróneas interpretaciones de su proyecto que seguramente hubieran tenido consecuencias negativas en el resultado final, pero fue gracias a la mediación permanente de Sert - a su habilidad diplomática para consensuar posiciones y a su determinación para evitar que el proceso descarrilara- que la obra fue concluida con éxito.

La Casa Curutchet es una verdadera joya arquitectónica, un ejemplo extraordinario de la arquitectura de Le Corbusier en los años que siguieron al fin de la segunda guerra mundial, período en el cual el arquitecto llevó a cabo un replanteo de sus ideas, postulados y lenguaje arquitectónicos de las dos décadas precedentes. En esta obra reaparecen con nuevo ímpetu los cinco puntos para una nueva arquitectura enunciados a mediados de los años veinte pero aggiornados y enriquecidos con elementos desarrollados en los años treinta y cuarenta como el pan-de-verre, el brise-soleil y la implementación del Modulor como sistema que gobierna las dimensiones de todos los elementos del edificio. Pero el valor arquitectónico de esta obra no está determinado por la incorporación de dichos elementos sino por la inteligencia conceptual para resolver la complejidad del programa en un terreno exiguo y la inserción del edificio en el heterogéneo contexto de la calle, y por la brillante interacción de los elementos arquitectónicos que generan una maravillosa secuencia espacial que exalta la relación de la casa con el parque que enfrenta.

Distinto por escala, magnitud y trascendencia, el Carpenter Center es también un ejemplo notable de la arquitectura de Le Corbusier, quizás la más importante de las obras construidas en los últimos años de su vida. En el Carpenter Center Le Corbusier se propuso intencionalmente hacer una "demonstración americana" de sus ideas y postulados, y del lenguaje arquitectónico que exploró y desarrolló a largo de más de cuarenta años de actividad profesional. Todos los elementos distintivos de su arquitectura están presentes, desde los emblemáticos pilotis y la consecuente planta libre, hasta los más recientes aereateurs y ondulatoires, pasando por los brise-soleil y pan-de-verre, la materialidad y expresividad del béton brut y el protagonismo de la rampa y 
su implícita promenade architecturale. Una verdadera demonstración de arquitectura corbusierana en el corazón intelectual de los Estados Unidos, un país que identificaba como hostil a sus ideas y donde, como escribiera H. R. Hitchcock, seguramente hubiera podido tener una relación más productiva si hubiera hecho esfuerzos por entender mejor su cultura, ${ }^{10}$ afirmación seguramente extensible al resto de las Américas.

En síntesis, el balance de la relación de Le Corbusier con el continente americano puede parecer magro, pero objetivamente no lo es si se considera que dicho promedio seguramente no difiere mucho de lo que arroja la totalidad de la obra de Le Corbusier y, sobre todo, si se tiene en cuenta el valor de su obra americana. Más allá de todos los malentendidos y recíprocos desencuentros, el legado americano de Le Corbusier quedó plasmado en un puñado de proyectos indudablemente interesantes -Ocampo, Delgado Chalbaud, Plan de Buenos Aires- dos hitos en el conjunto de su obra -la Casa Errázuriz y el Plan de Bogotá- y dos auténticas obras maestras, una en cada hemisferio, que son el testimonio vivo y concreto de su recherche patiente y de la fibra poética de su arquitectura.

${ }^{10}$ Hitchcock, Henry Russell. “Le Corbusier in the United States.” Zodiac \#16 (16) 


\section{Imágenes}

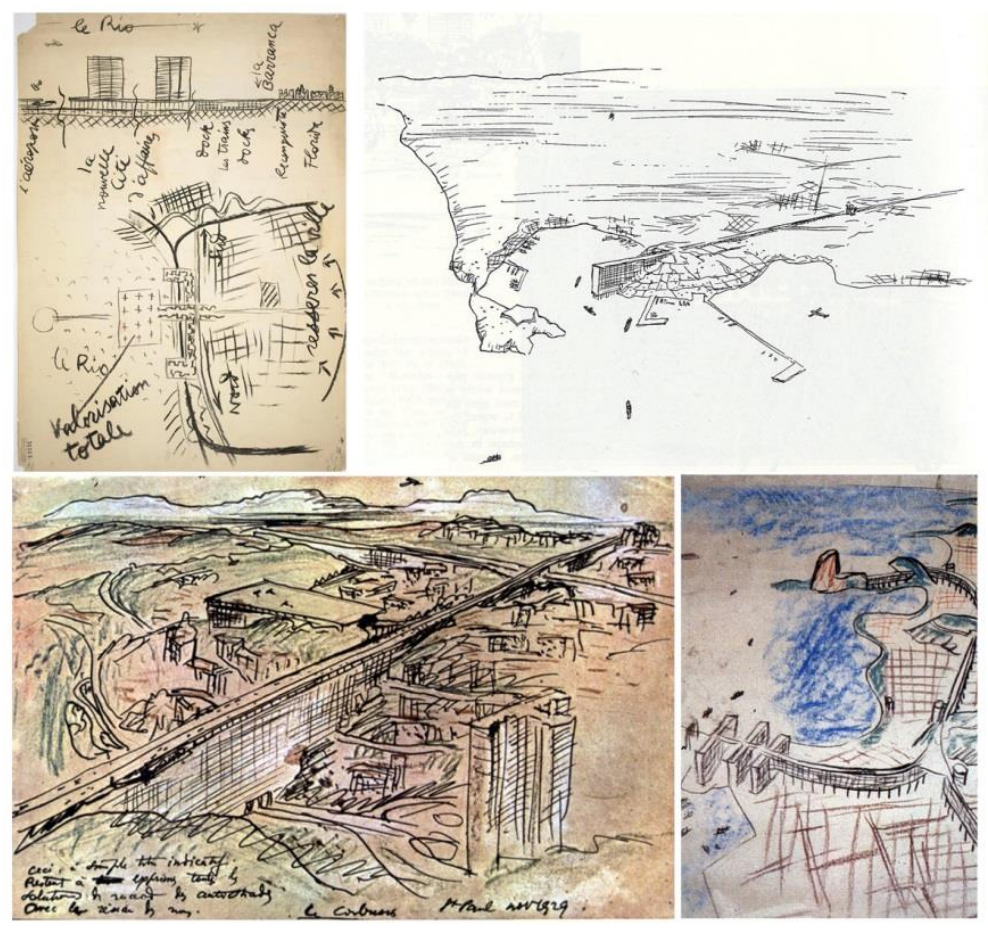

1. Bocetos de propuestas urbanas para Buenos Aires, Montevideo, São Paulo y Río de Janeiro producidas durante sus conferencias de 1929.

[Fuente: FLC Archives OFLC-ADAGP]
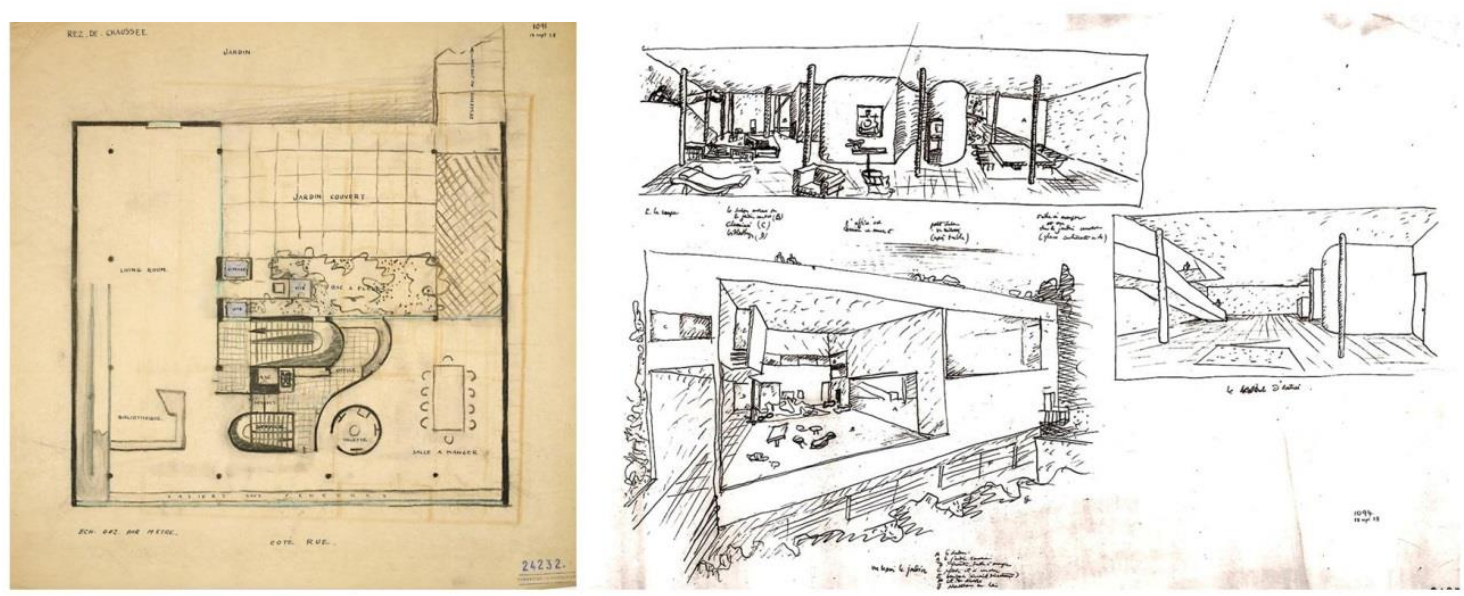

2. Villa Ocampo, Buenos Aires, Argentina; proyecto, 1928; planta del piso principal y perspectivas interiores y exterior. [Fuente: FLC Archives OFLC-ADAGP]
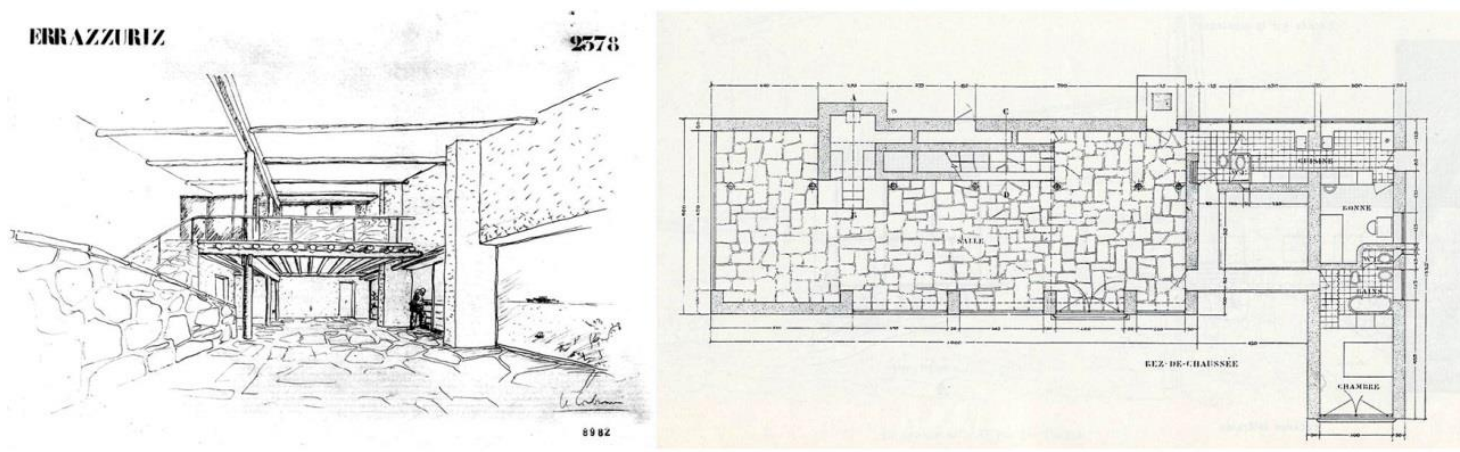

3. Casa Errázuriz, Zapallar, Chile; proyecto, 1930; perspectiva interior y planta principal.

[Fuente: FLC Archives OFLC-ADAGP] 


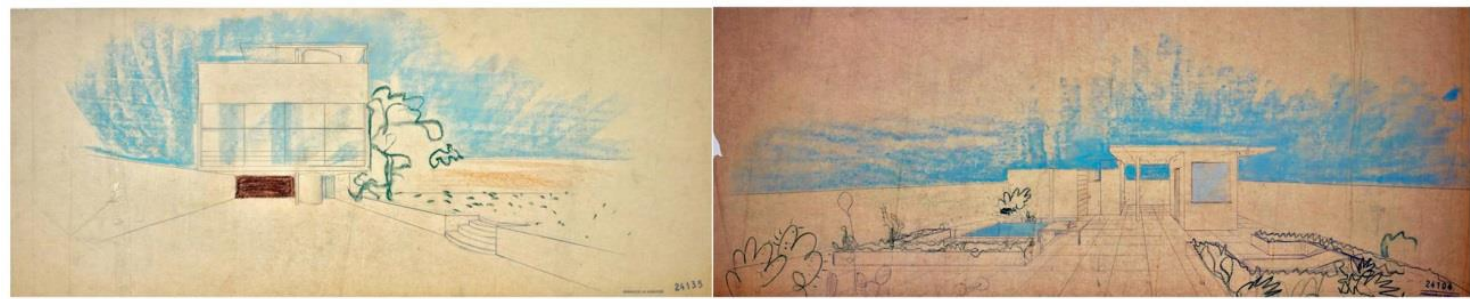

4. Villa Martínez, Buenos Aires, Argentina; proyecto, 1930; perspectiva exterior y de la terraza jardín. [Fuente: FLC Archives OFLC-ADAGP]
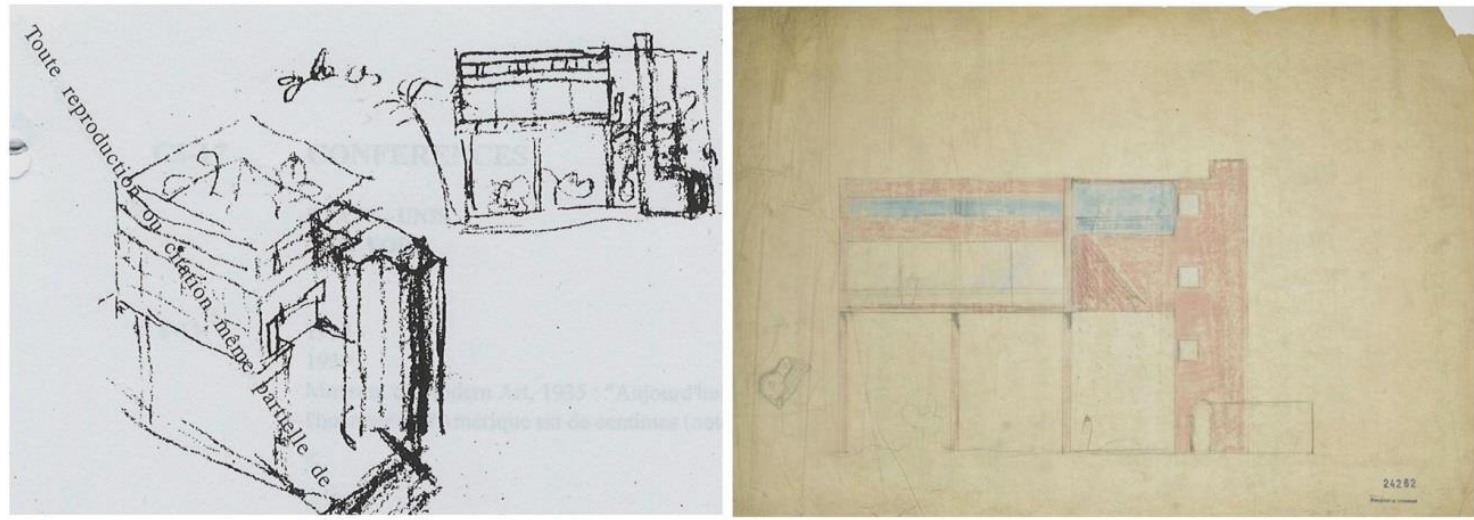

5. Biblioteca para Paulo Prado, São Paulo, Brasil; proyecto, 1930; estudios esquemáticos y fachada principal. [Fuente: FLC Archives @FLC-ADAGP]
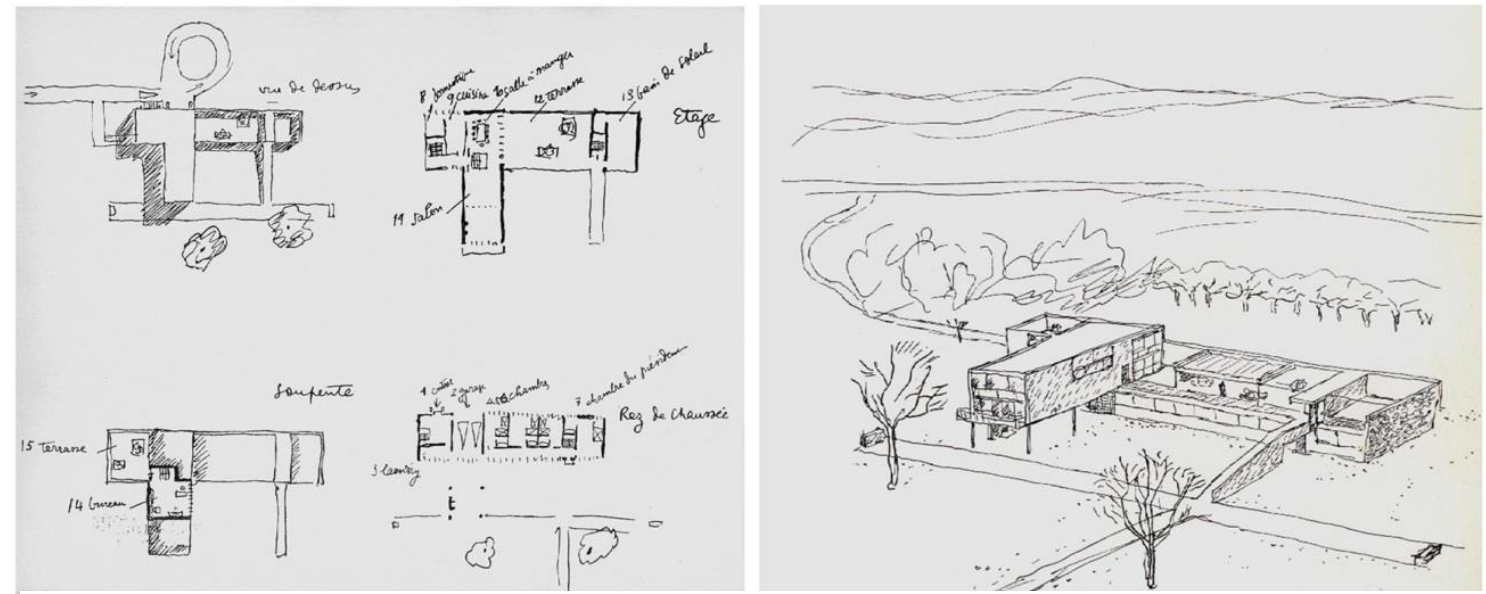

6. Casa para el Presidente del Olivet College, Michigan, Estados Unidos; proyecto, 1935; plantas y axonometría. [Fuente: FLC Archives OFLC-ADAGP]
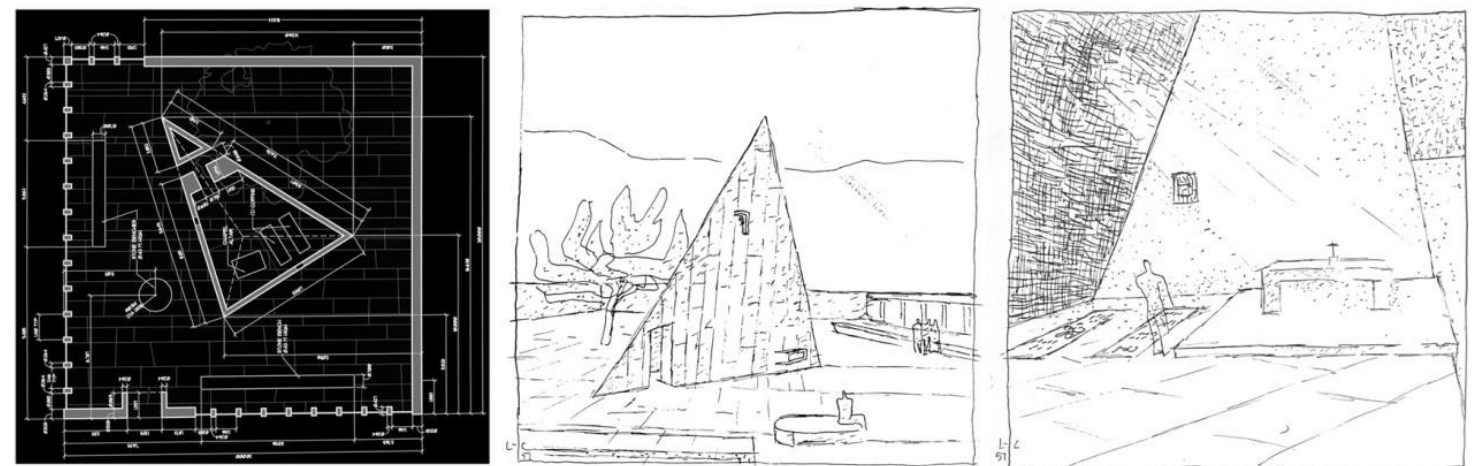

7. Monumento Funerario Delgado-Chalbaud, Caracas, Venezuela; proyecto, 1951; planta [reconstrucción], y perspectivas exterior e interior [Fuente de las dos imágenes de la derecha: FLC Archives @FLC-ADAGP] 

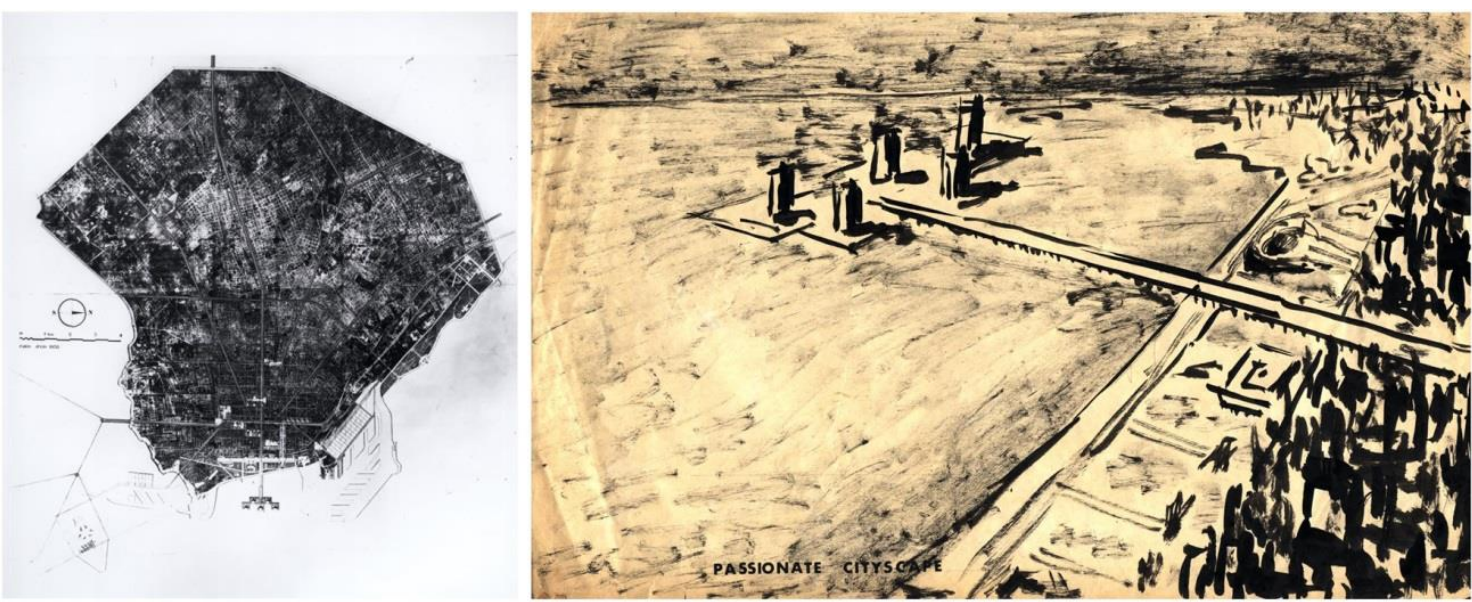

8. Plan Regulador de Buenos Aires, Argentina, propuesta, 1938; fotomontaje de la propuesta sobre la fotografía aérea de la ciudad y perspectiva de la Ciudad de Negocios (Cité des Affaires) sobre el Río de la Plata.

[Fuente: cortesía de la Francis Loeb Library, Harvard University Graduate School of Design OFLC-ADAGP]

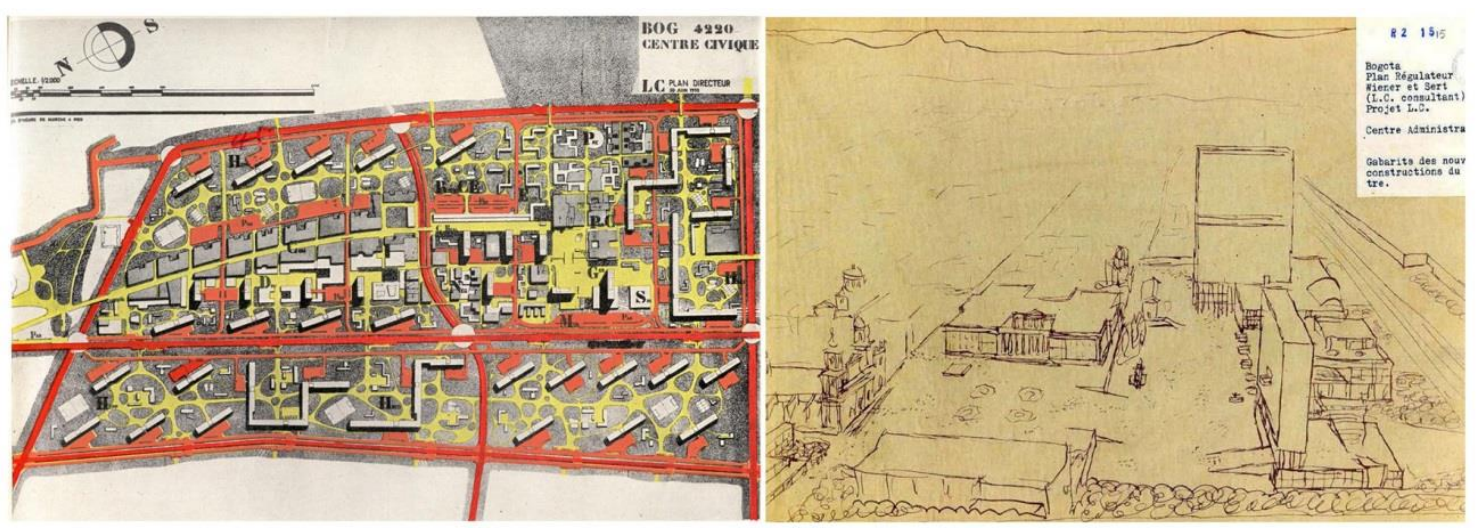

9. Plan de Bogotá, Colombia, 1951-1952, plano de detalle y perspectiva esquemática del Centro Cívico. [Fuente: FLC Archives CFLC-ADAGP]

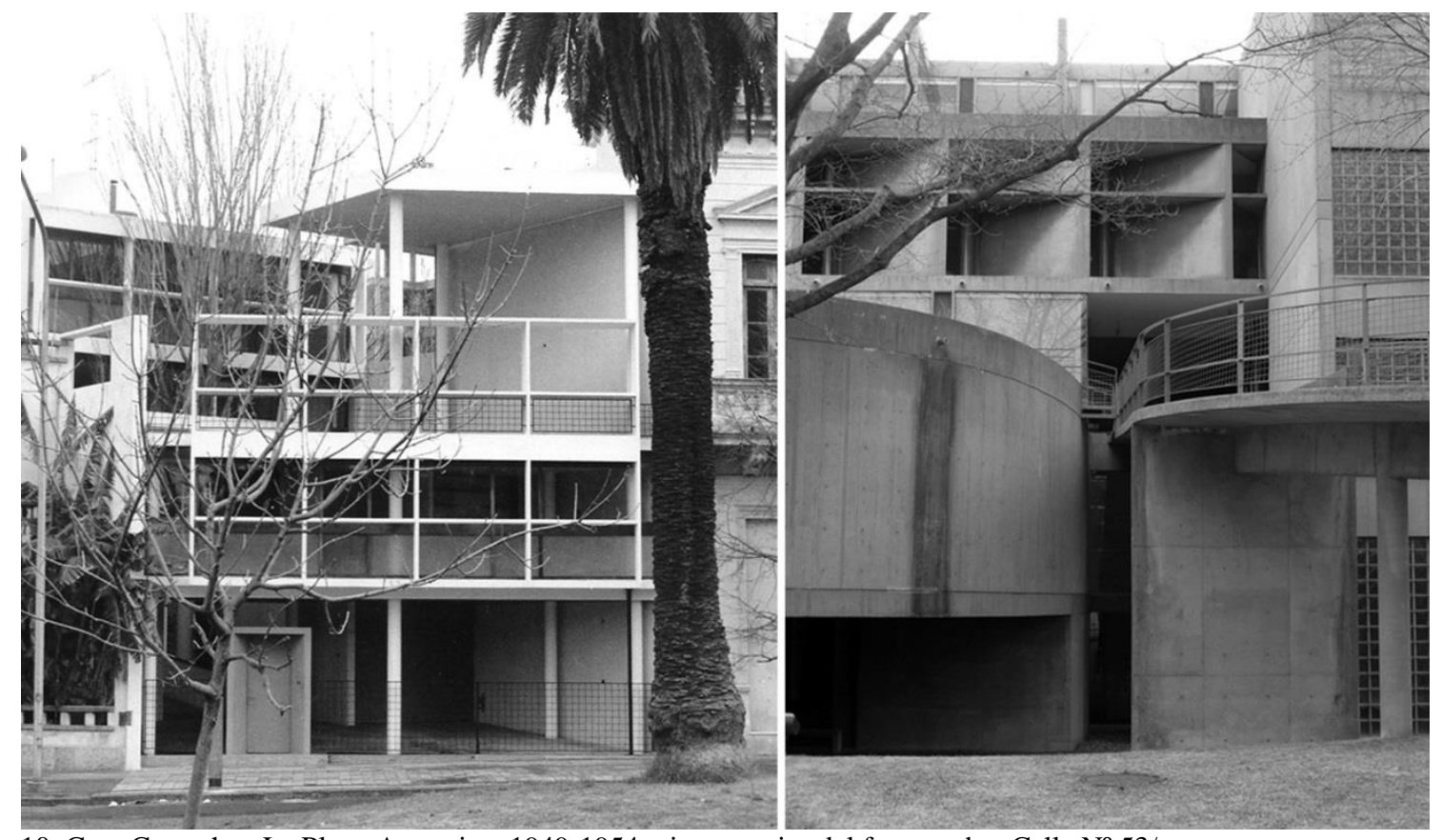

10. Casa Curutchet, La Plata, Argentina, 1949-1954; vista exterior del frente sobre Calle $\mathrm{N}^{\circ} 53 /$

Carpenter Center for the Visual Arts, Cambridge, Massachusetts, 1960-1963; fragmento de la fachada sobre Prescott Street. [Fuente: colección personal del autor] 


\section{Bibliografía/referencias}

Arias Lemos, Fernando, Le Corbusier en Bogotá: el proyecto del "grand immeuble," 1950-1951; Bogotá: Universidad Nacional de Colombia-Facultad de Artes, 2008.

Bacon, Mardges, Le Corbusier in America. Travels in the Land of the Timid; Cambridge (MA) -London: The MIT Press, 2001

Curtis, William J. R. Le Corbusier Ideas and Forms; New York: Rizzoli, 1987

Dudley, George A. A workshop for peace: designing the United Nations headquarters, New York: Architectural History Foundation, 1994.

Hernández Rodriguez, Carlos Eduardo. Las ideas modernas del Plan para Bogotá en 1950; Bogotá: Alcaldía Mayor de Bogotá, 2004.

Lapunzina, Alejandro, Le Corbusier's Maison Curutchet; New York: Princeton Architectural Press, 1997.

Liernur, Jorge F.; Pschepieurca, Pablo. La Red Austral. Obras y proyectos de Le Corbusier y sus discípulos en la Argentina (1924-1965); Bernal (Argentina)-Buenos Aires: Universidad de Quilmes and Prometeo Libros, 2008.

Lissovsky, Mauricio; Moraes de Sá, Paulo Sergio. Colunas da Educação: a construção do Ministérioo da Educação e Saúde; Río de Janeiro: NINC/IPHAN-Fundação Getúlio Vargas, 1996.

Mostafavi, Mohsen (ed.) Le Corbusier and the Architecture of Reinvention; London: Architectural Association, 2003

O’Byrne, María Cecilia (ed.). Le Corbusier en Bogotá 1947-1951. Tomo 1. Elaboracion del Plan Regulador de Bogotál Tomo 2: Precisiones en torno al plan director; Bogotá: Ediciones Uniandes, 2010.

Pérez Oyarzun, Fernando (ed.). Le Corbusier y Sudamérica: Viajes y Proyectos; Santiago de Chile: Ediciones ARQ, 1991.

Rodrigues dos Santos, Cecília; Campos da Silva Pereira, Margareth; Veriano da Silva Pereira, Romão; Caldeira da Silva, Vasco; Le Corbusier e o Brasil; São Paulo: Tessela \& Projeto Editora, 1987.

Sekler, Eduard F.; Curtis, William J. R., Le Corbusier at Work. The Genesis of the Carpenter Center for the Visual Arts. Cambridge (MA)-London: Harvard University Press, 1978.

Žaknić, Ivan. The Final Testament of Pere Corbu: a translation and interpretation of Mise au point. New Haven and London: Yale University Press, 1997 (87). 


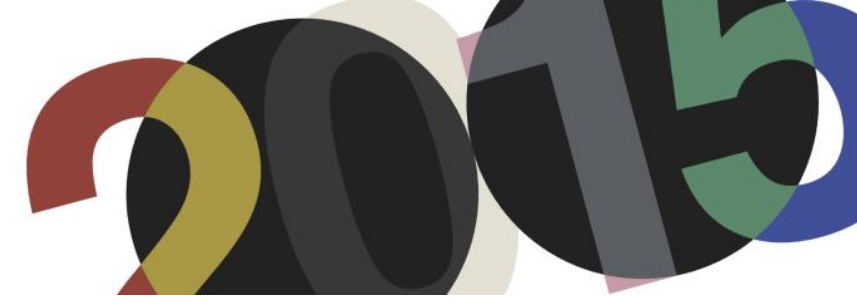

DOI: http://dx.doi.org/10.4995/LC2015.2015.787

\title{
Estrategias geométrico-matemáticas en la obra de Le Corbusier (1923-1933)
}

\author{
T. Larumbe Machín
}

\author{
Escuela Superior de Arquitectura de la Universidad de Navarra
}

\begin{abstract}
Resumen: En la búsqueda de un nuevo orden ideal y universal, Le Corbusier alude constantemente al empleo de los trazados reguladores como instrumentos matemáticos que controlan el impulso creador e introducen la armonía en el trabajo creado, causa de la belleza y el placer estético. La confianza puesta en los trazados como garantía del orden en arquitectura, se manifiesta en el artículo que les dedicará en la revista L'Espirit Nouveau (1921), y que, en 1923, incorpora como un capitulo más en "Vers une architecture". El objetivo de este trabajo es analizar la aplicación práctica de los trazados reguladores y otras estrategias geométricas y matemáticas en los proyectos del arquitecto suizo a lo largo de los años veinte, a partir de la aparición del famoso manifiesto. Los proyectos estudiados son los que han fijado las pautas del análisis, desvelando su evolución histórica y el alcance de su aplicación real en el transcurso de diez años.
\end{abstract}

\begin{abstract}
Along his personal search for an ideal and universal order, Le Corbusier constantly refers to the use of the tracés regulateurs, as a mathematical tool with which the architect can manage his creative impulse and as a way to introduce the harmony in architecture, what is considered the main cause of the beauty and the aesthetic pleasure. Le Corbusier reveals his faith in the tracés as guaranty of architectural order not only in the magazine L'Espirit Nouveau (1921) but also in his celebrated book "Vers une architecture" (1923). The aim of this paper is to analyze the use of the tracés regulateurs during the architect's projects throughout a decade, starting with the publication of the well know manifiesto. All the projects that had been studied have established the guidelines of the analysis, its historical evolution and the relevance of the tracès regulateurs in Le Corbusier's early works.
\end{abstract}

Palabras clave: Trazados reguladores; Geometría; Le Corbusier. Keywords: Tracés Regulateurs; Geometry; Le Corbusier.

\section{Introducción}

“El arquitecto, por el ordenamiento de las formas, obtiene un orden que es una pura creación de su espíritu; por las formas, afecta intensamente a nuestros sentidos provocando emociones plásticas, por las relaciones que crea, despierta en nosotros profundas resonancias, nos da la medida de un orden que se siente de acuerdo con el del mundo, determina reacciones diversas de nuestro espíritu y de nuestro corazón; y entonces percibimos la belleza.",

Partiendo de esta afirmación, es posible deducir dos operaciones que Le Corbusier considera fundamentales a la hora de formular un proyecto arquitectónico. En primer lugar, la selección de una serie de formas elementales "primarias o sutiles, flexibles o brutales", que constituyen la materia prima de la arquitectura. En segundo lugar, la ordenación de los distintos ingredientes plásticos con el fin de alcanzar un todo global, armónico y cohesionado, atendiendo tanto a las relaciones que las distintas figuras establecen entre sí, como a las relaciones que cada una de ellas establece con el conjunto del que forman parte; la arquitectura es un juego sabio, correcto y magnífico de volúmenes reunidos, y en este juego compositivo se encuentra el quid de su belleza. La disposición

\footnotetext{
${ }^{1}$ Le Corbusier, Hacia una arquitectura, $2^{\circ}$ Ed. Barcelona: Editorial Apóstrofe, 2006, p. XXIX

${ }^{2}$ Ibid., p. 8
} 
de los distintos elementos en el espacio debe realizarse a través de una serie de acciones sencillas: enlazar, conectar, yuxtaponer, equilibrar, mesurar, proporcionar o unificar; acciones regidas, a su vez, a través de un conjunto de principios racionales, o reglas matemáticas, que Le Corbusier eleva a la categoría de verdades absolutas.

Este código de reglas matemáticas son los trazados reguladores, que pueden definirse como un sistema de referencia sencillo que sirve para ordenar y clarificar una forma más compleja. Con el empleo de los trazados reguladores, Le Corbusier introduce un mecanismo racional de control sobre el proyecto que ya antes había prevalecido en el Renacimiento, siendo un factor determinante en las obras de Alberti y Palladio ${ }^{3}$. El interés del maestro suizo por el empleo de los trazados reguladores se manifiesta en el artículo que les dedicará en la revista L'Espirit Nouveau (1921), y que, en 1923, se vuelve a publicar en forma de capítulo en su famoso manifiesto Vers une architecture ${ }^{4}$. En él, Le Corbusier se refiere a los trazados reguladores como un medio para canalizar el impulso creador, sometiéndolo a unas reglas matemáticas; se trata de "un seguro contra la arbitrariedad" que "viene a rectificar, a corregir, a depurar, a hacer consonar todas las partes sobre el mismo principio unitario", Además, la aplicación de los trazados reguladores se erige como "la operación de verificación que aprueba el trabajo creado en el entusiasmo, la prueba del nueve escolar", , es decir, los trazados reguladores se convertirán en el instrumento que justifique la belleza, la armonía y el orden del objeto creado.

Sin embargo, más allá de un estudio en torno a las implicaciones teóricas de los trazados reguladores, el objetivo de este trabajo consiste en analizar la aplicación de estrategias geométrico-matemáticas en los distintos proyectos de Le Corbusier, con la intención de extraer las estructuras de las que se sirve para introducir orden en el proyecto y, de esta manera, poder valorar su alcance en la práctica real. Para ello, se ha rastreado de manera minuciosa los proyectos elaborados por el arquitecto suizo a lo largo de una década, siguiendo un estricto orden cronológico, que toma como punto de partida el año 1923 (fecha en que se publicaba la primera edición de Vers une architecture), y como obra de referencia el archivo de planos de Le Corbusier, publicado por Garland Publishers y la Fondation Le Corbusier ${ }^{8}$ en los años 80. Como ya han señalado diversos autores, en los proyectos realizados durante esta primera etapa se fueron definiendo las bases fundamentales sobre las que el maestro suizo desarrollará el conjunto de su producción arquitectónica. Los proyectos estudiados son los que han fijado las pautas del análisis, desvelando su estructura, su propia historia y el uso que Le Corbusier hizo de los trazados reguladores en el transcurso de diez años.

\footnotetext{
${ }^{3} \mathrm{Cfr}$. Summerson, John, El lenguaje clásico de la arquitectura, 11 a Ed. Barcelona: Editorial Gustavo Gili, 1998

${ }^{4} \mathrm{Cfr}$. Le Corbusier, Vers une arquitecture, Paris: Ediciones Crès, 1923

${ }^{5}$ Le Corbusier, Hacia una arquitectura, $2^{\circ}$ Ed. Barcelona: Editorial Apóstrofe, 2006, p. 57

${ }^{6}$ Ibid.

${ }^{7}$ Ibid.

${ }^{8}$ Le Corbusier, Le Corbusier Archive, New York: Garland Publishing, 1984
} 


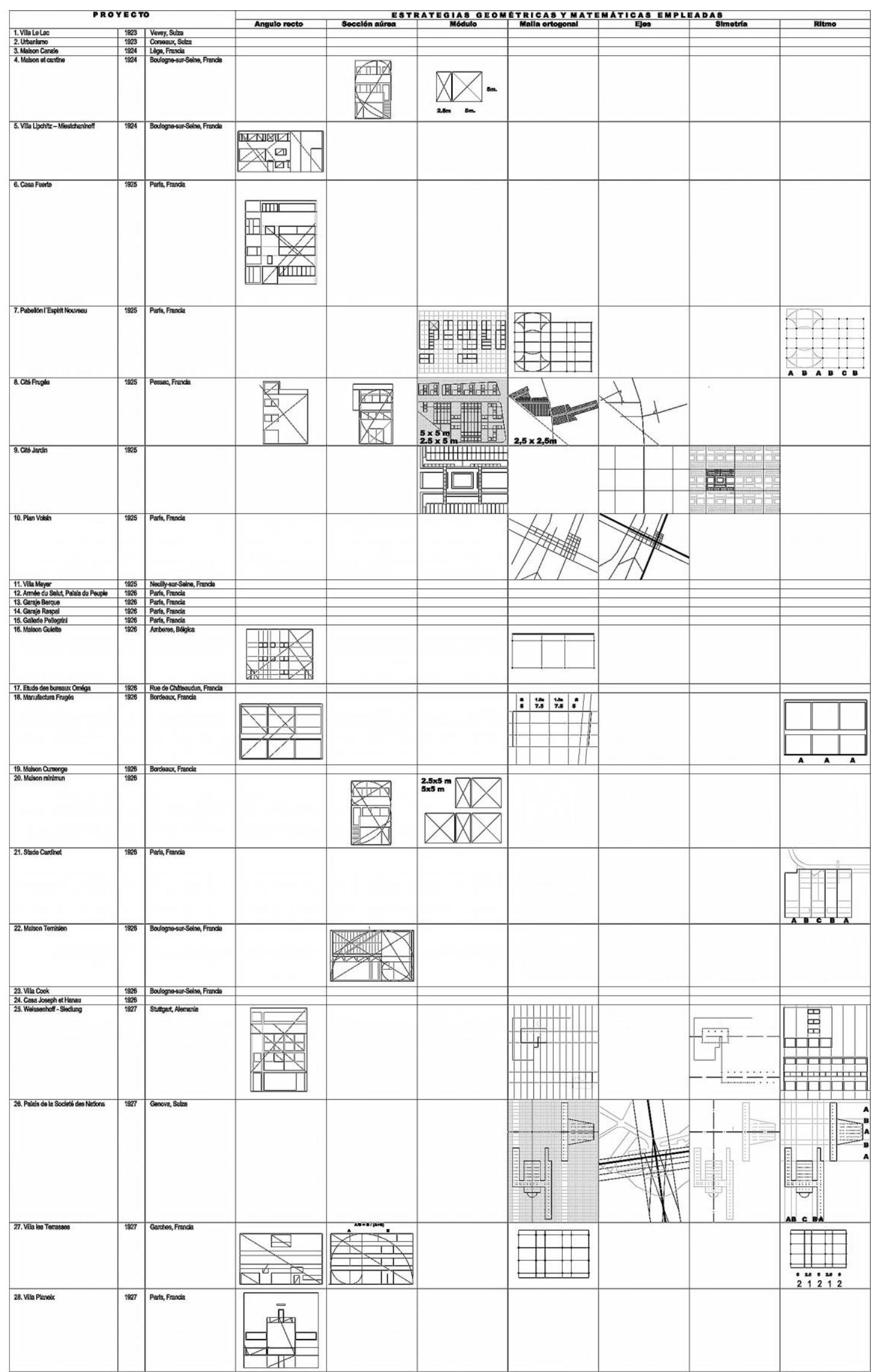

Tabla 1. Estudio de las obras de Le Corbusier realizados a partir de 1923, hasta el proyecto para la Ville Planeix, en 1927. 


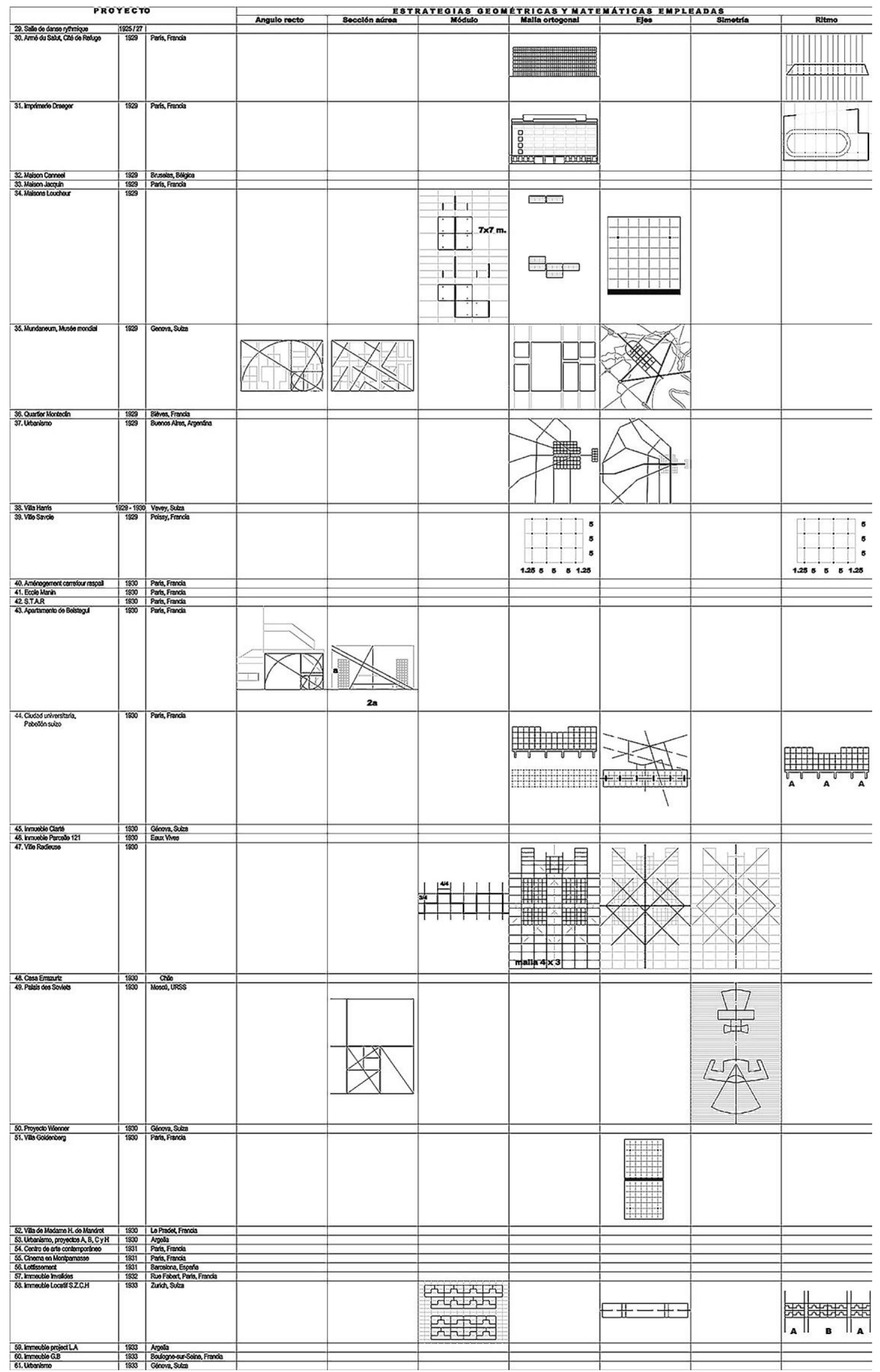

Tabla 2. Estudio de las obras de Le Corbusier, desde el proyecto para la Salle de Danse Rytmique, hasta 1933. 


\section{Estrategias geométrico-matemáticas en la obra de Le Corbusier (1923 - 1933).}

Le Corbusier emplea recursos de composición geométrico-matemáticos en 31 casos de los 61 proyectos analizados, es decir, un 50,8\% del total. Es posible distinguir seis tipos de estrategias diferentes, que son referidas por Le Corbusier en sus textos teóricos: el ángulo recto (se emplea en 17 casos, un 54.8\% de los 31 proyectos en los que se ha observado la impronta de los trazados reguladores); la proporción aurea (8 proyectos, $25.8 \%$ ); el módulo ( 8 proyectos, $25.8 \%$ ); la malla ortogonal (17 proyectos, $54.8 \%$ ); los ejes (12 proyectos, $38,7 \%$ ); el ritmo (12 proyectos, $38,7 \%$ ); y las relaciones de simetría bilateral (4 proyectos, un $12.9 \%$ del total). A su vez, es posible agrupar las distintas estrategias empleadas en dos categorías diferentes, atendiendo a su naturaleza matemática; estrategias aritméticas y reglas geométricas (aunque cabe señalar que la frontera entre ellas, en algunas ocasiones, es difusa). Por un lado, el ritmo vertical que compone las fachadas o la proporción numérica existente entre los dos ejes de las retículas ortogonales son reglas compositivas basadas en las relaciones aritméticas entre sus componentes. Por otro lado, el ángulo recto, el número aureo, la disposición de los ejes y las relaciones de simetría son trazados de naturaleza geométrica. Del módulo se derivan una serie de relaciones tanto numéricas (cuando el módulo es una unidad métrica -como, por ejemplo, las distancias entre pilotis-), como geométricas (cuando la unidad básica de referencia es una figura geométrica, por ejemplo, los módulos cuadrados empleados en las viviendas seriadas).

Además, es posible realizar una nueva clasificación de las distintas estrategias compositivas atendiendo a la escala del proyecto sobre el cual se aplican dichas reglas: desde el diseño de pequeños objetos, hasta la elaboración de planes urbanos, pasando por el diseño de edificios singulares. En el diseño de elementos de pequeña escala (esto es, mobiliario y detalles constructivos), Le Corbusier recurre al empleo del ángulo recto y el sistema modular. En los proyectos de planeamiento urbano, podemos observar el uso de retículas ortogonales, ejes y módulos. Finalmente, dentro de los proyectos de edificación realizados por el maestro suizo, es posible distinguir dos ámbitos distintos donde se aplican las reglas geométrico-matemáticas, que se corresponden con dos de las tres advertencias citadas por Le Corbusier'; la composición de la superficie o el alzado y la ordenación de la planta o el plan generador. En todos los ejemplos analizados, los trazados reguladores se emplean como herramienta de control sobre superficies planas, en ningún caso sirve para moldear el volumen.

\section{Descripción de las distintas estrategias geométrico-matemáticas empleadas.}

\section{1. Ángulo Recto.}

Diversos autores se han referido con frecuencia a Le Corbusier como autor del Poema del ángulo recto, pero en numerosas ocasiones esta imagen es restrictiva y limitada, ya que se asocia exclusivamente con su gusto por la pureza formal, o con el empleo de volúmenes prismáticos y retículas ortogonales en sus obras. Sin embargo, en sus textos, Le Corbusier alude frecuentemente al uso del ángulo recto como elemento que sirve para definir un sistema de proporciones ( “... iHe ahí la proporción!/la proporción que pone /orden en nuestras / relaciones con / lo circundante ${ }^{10}$ ), y como herramienta de composición que sitúa los objetos dentro del espacio del plano ${ }^{11}$. La aplicación del ángulo recto en los proyectos que se han analizado viene a corroborar estas afirmaciones. Le Corbusier hará uso del ángulo recto a la hora de componer, no las plantas, sino los alzados de la mayor parte de los proyectos realizados en su primera etapa, así como los alzados de todas sus célebres viviendas: el proyecto

\footnotetext{
${ }^{9} \mathrm{Cfr}$. Le Corbusier, Hacia una arquitectura, $2^{\circ}$ Ed. Barcelona: Editorial Apóstrofe, 2006, p. 31

${ }^{10}$ Le Corbusier, Poema del ángulo recto, Madrid: Círculo de Bellas Artes, 2006

${ }^{11} \mathrm{Cfr}$. Le Corbusier, Hacia una arquitectura, $2^{\circ}$ Ed. Barcelona: Editorial Apóstrofe, 2006, p. 59
} 
para la Ville Lipchitz-Miestchaninoff (1924); la casa Fuerte, en París (1925); las viviendas de la Cité Frugés, en Pessac (1925); la Maison Guiette, en Amberes (1926); la manufactura Frugés (1926); los edificios de la Wiessenhoff, en Stuttgart (1927); la Ville en Garches (1927); la Ville Planeix, en Burdeos (1927); y el apartamento Beistegui, en París (1930).

El lugar del ángulo recto es un punto presente en el plano de la fachada que queda definido por dos diagonales que se cruzan entre sí, formando un ángulo de $90^{\circ}$. Por este punto pasará una línea virtual (tanto horizontal como vertical), que servirá de referencia para situar los distintos objetos contenidos dentro de la superficie de los paramentos verticales. Al mismo tiempo, el juego de diagonales ortogonales define la relación proporcional entre los lados de la fachada, y su uso se reitera con el objetivo de dimensionar todos los huecos que aparecen en el alzado, obteniendo como resultado una composición a base de rectángulos semejantes entre sí. El juego de proporciones generadas a partir del ángulo recto se aplicará sobre las superficies verticales (planos de fachada, paramentos interiores y despiece de ventanas), y podemos relacionar su empleo con el principio formal de la fachada libre, uno de los cinco puntos enunciados por el maestro suizo para la nueva arquitectura. Tras haber alcanzado una absoluta autonomía en las fachadas, siendo éstas independientes de cualquier condicionante estructural, y libres también de cualquier imperativo constructivo que pudiera encorsetar la composición del alzado, le Corbusier recurrirá al ángulo recto y se servirá de él para establecer unas reglas de juego con las que dibujar sus composiciones sobre el "papel en blanco".
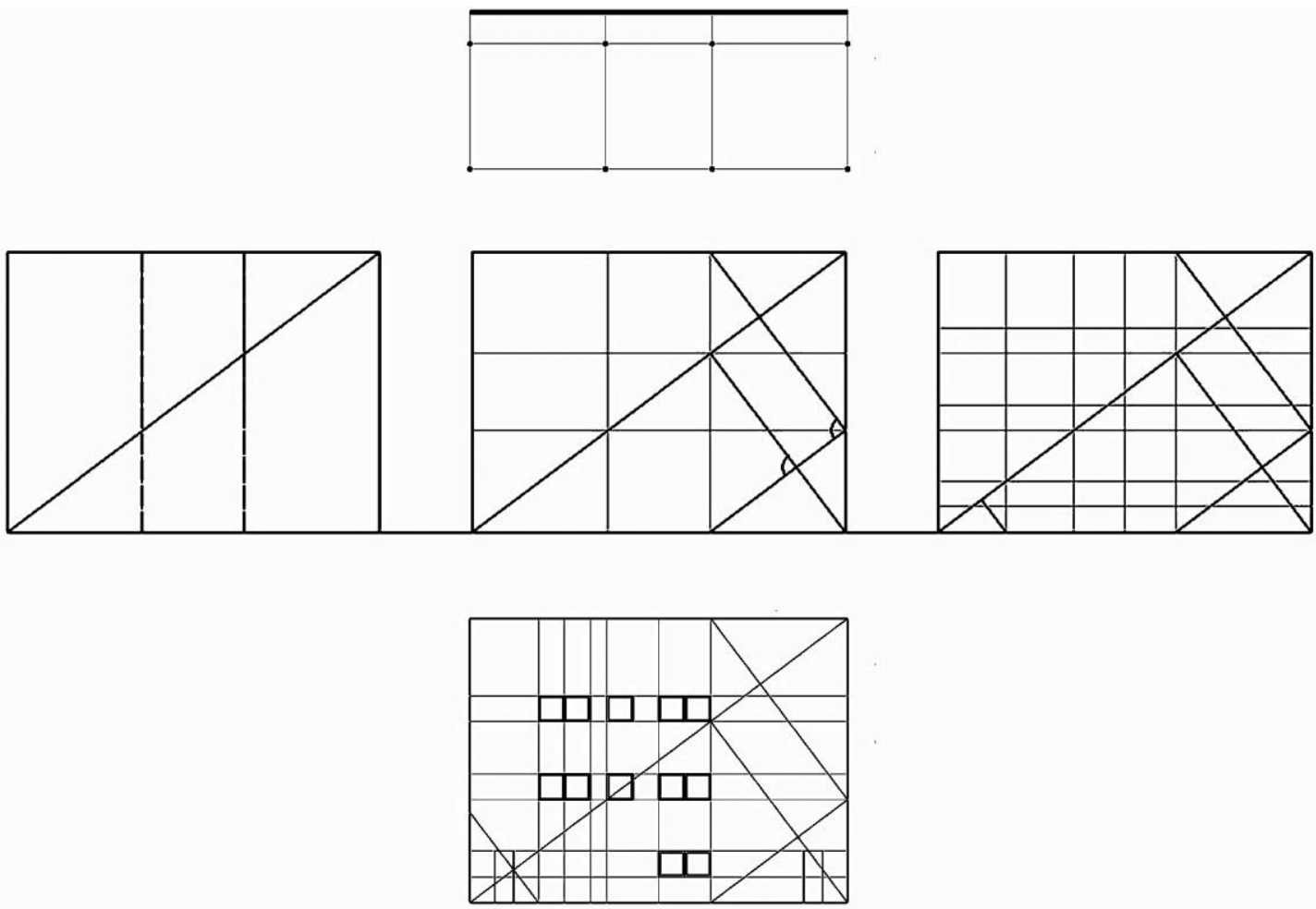

1. Maison Guiette. Amberes, 1926. El trazado regulador del proyecto, de 6 metros de crujía, se desarrolla a partir de su esquema estructural. El ángulo recto, este caso, generará una serie de líneas virtuales que guíen el dibujo del alzado. La composición de los alzados vendrán determinados por los ejes de los pilares, ocultos tras el paramento de fachada, que dibujan unas líneas auxiliares verticales sobre el "papel en blanco". La aplicación del ángulo recto se empleará, a su vez, para determinar la posición exacta donde deban situarse las directrices horizontales, que vendrán a sumarse a las guías verticales para formar un damero virtual en el que se irán situando los huecos de la vivienda. El ángulo recto, por otra parte, no sólo regula la proporción del plano de fachada, sino que también dicta la proporción a la que han de ajustarse cada uno de sus huecos. 


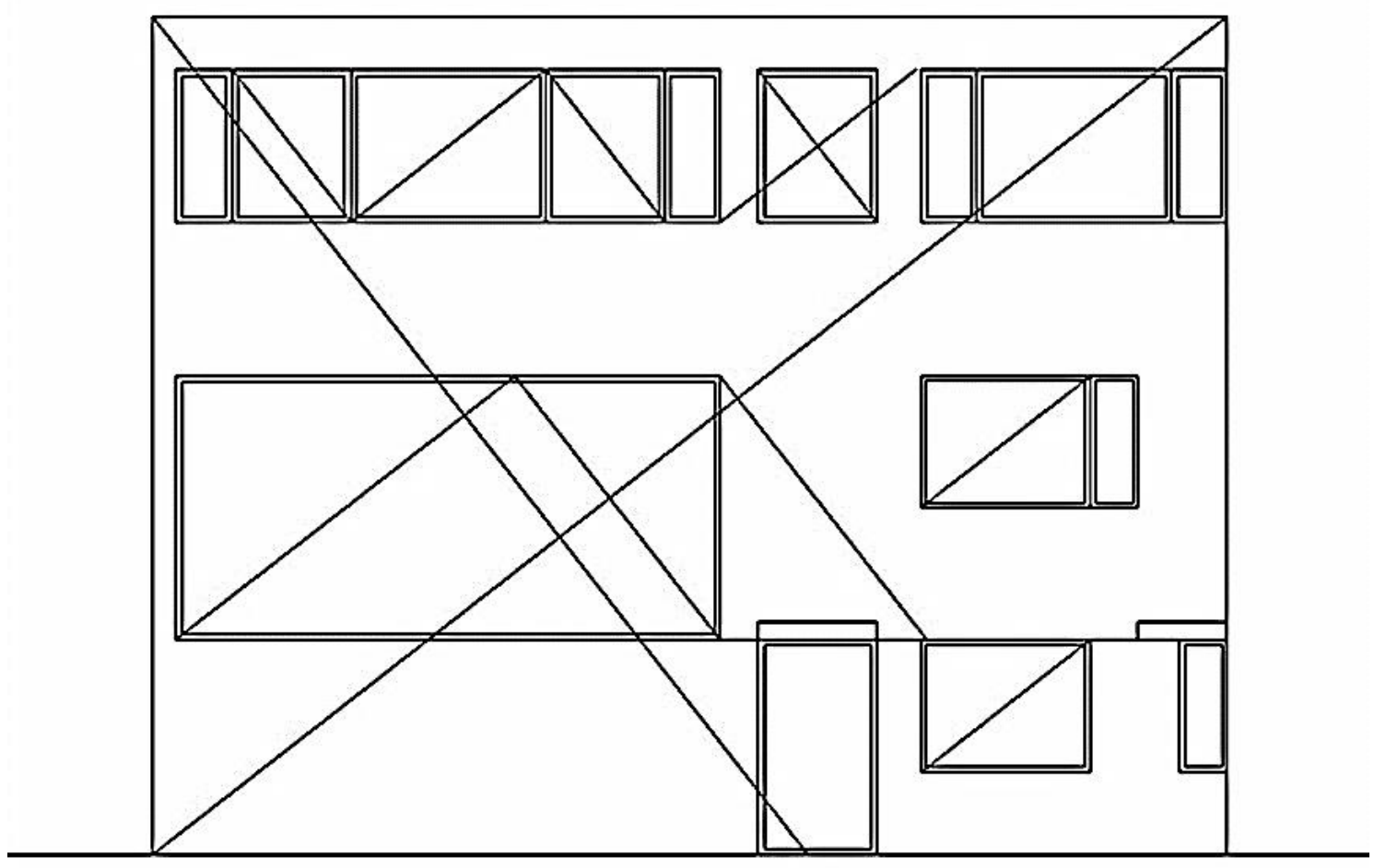

2. Maison Lipchizt Miestchaninoff. París, 1925. La complejidad del solar en el que se sitúa la intervención (un polígono irregular) impondrá su propio orden a la planta de la vivienda y a las dimensiones del volumen. Sin embargo, libre de restricciones estructurales que puedan condicionar el diseño de los alzados, Le Corbusier recurre al ángulo recto para establecer un sistema objetivo de proporciones semejantes entre el paño de fachada y los huecos que en él se sitúan, a través de juegos diagonales, paralelas y perpendiculares. Los alzados son elaborados como si de composiciones pictóricas puristas se tratase.

\section{La sección aurea.}

Dentro del empleo del ángulo recto como trazado regulador y de las relaciones proporcionales que derivan de su uso, hay un caso especialmente significativo: el rectángulo aureo, esto es, aquel en el que la razón proporcional entre sus lados es el número dorado. A pesar de la propaganda que el autor hace de la proporción aurea en la obra El Modulor ${ }^{12}$, sólo encontramos esta proporción en un 25,8\% de los proyectos realizados entre 1923 y 1933, en los que aparece la impronta de los trazados reguladores. Al igual que sucedía con los trazados basados en el empleo del ángulo recto, Le Corbusier recurre a la sección aurea para establecer relaciones proporcionales entre los huecos que componen las fachadas de los distintos proyectos, y para relacionar cada uno de estos elementos con el todo del que forman parte. Este recurso, además de justificar la belleza de la solución empleada, será la respuesta científica con la que trazar unas líneas virtuales significativas en el plano en blanco que sirvan para regular el diseño del alzado. Por tanto, el diseño de los alzados y el modelado de los volúmenes se erige como el ámbito de aplicación por excelencia de la proporción aurea. Encontramos huellas de su uso en el proyecto para la Maison Cantine, en Boulogne-sur-Seine (1924) que, años más tarde, servirá de modelo de referencia para los estándares de vivienda mínima; las viviendas de Pessac (1925) y la Maison Minimun (1926). Además, la proporción aurea servirá para modelar los volúmenes que componen la Maison Ternisien, en

${ }^{12}$ Cfr. Le Corbusier, El Modulor, Barcelona: Editorial Poseidón, 1976 
Boulogne-sur-Seine (1926) y también para diseñar el despiece de las carpinterías del apartamento Beistegui, al que aludíamos en el apartado anterior, y los bastidores que construyen los huecos del proyecto para el Palacio de los Soviets (1930).

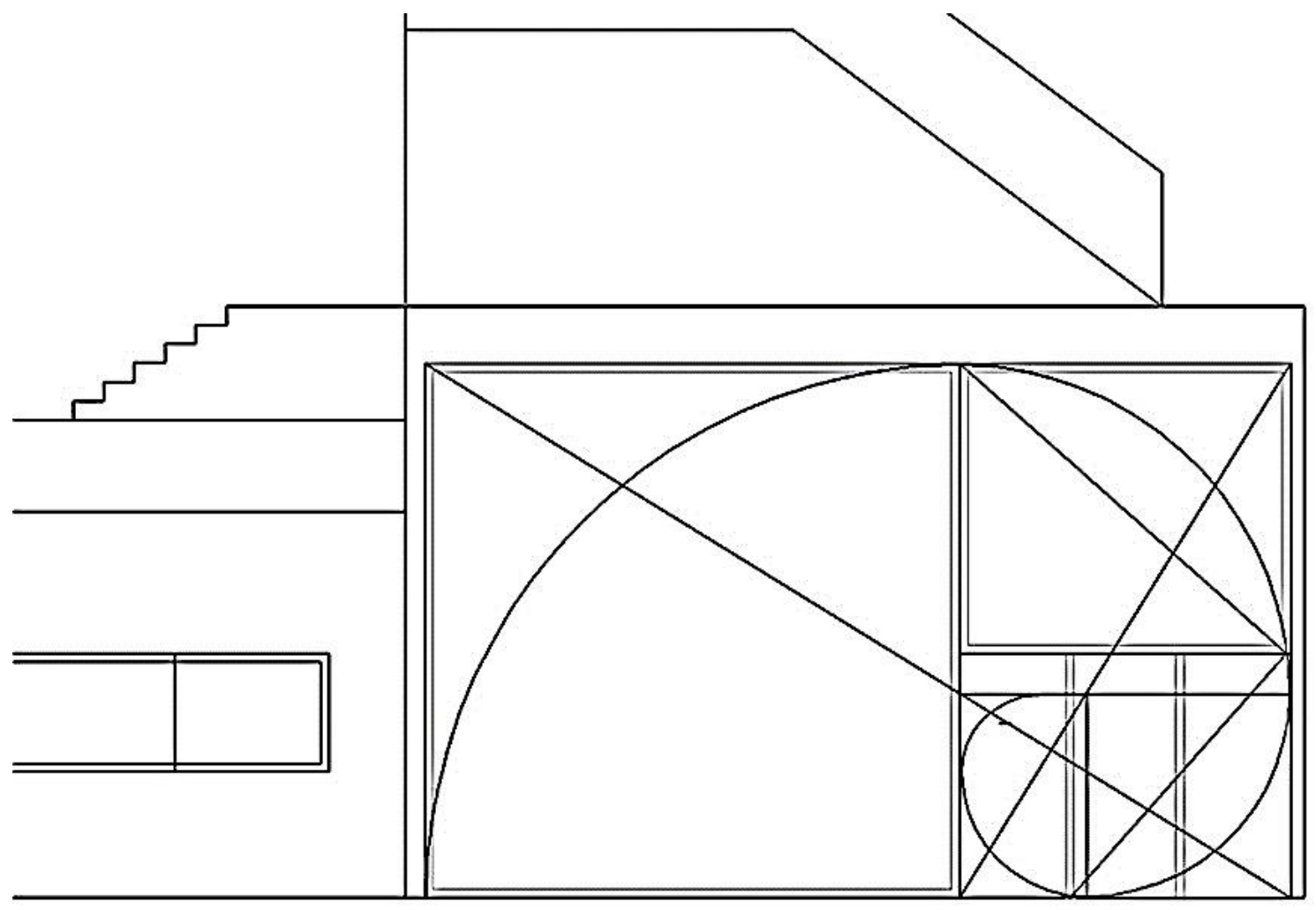

3. Apartamento de Beistegui. París, 1930. Le Corbusier hará uso del ángulo recto y la proporción aurea en el diseño de los distintos detalle constructivos, como el despiece de las carpinterías del gran ventanal que vierte a la terraza del ático, o la composición de los paramentos interiores de la casa.

En los proyectos de la célebre Ville les Terrasses y el inmueble Les Invalides, el número de oro no sólo servirá para proporcionar y componer los alzados longitudinales del volumen, sino también para configurar su estructura, condicionando la distancia entre pilares y estableciendo, con ello, un ritmo basado en la serie Fibonacci. Además, en la Ville Les Terrasses, la composición de los pilotis guardará una relación rítmica simétrica, ABABA, legado de la composición académica. Para acentuar el carácter significativo de la obra, Le Corbusier recurrirá a las medidas de 5 metros, $5 / 2$ y 5/4, empleados también en proyectos anteriores, en su búsqueda de dimensiones ideales. La aplicación de la razón aurea se limitará generalmente a regir la composición de las superficies verticales en los distintos proyectos, ya sean fachadas, particiones interiores, o despieces de los ventanales. De manera significativa, la sección aurea también aparece como trazado para ordenar la planta en dos proyectos particulares; el proyecto para el Museo Mundial y el centro de arte contemporáneo de París (en ambos casos, le Corbusier emplea una tipología en espiral para el diseño del edificio destinado a museo, que se convertirá en un arquetipo personal). En todos estos proyectos, la proporción armónica dotará al proyecto de un fuerte contenido simbólico. 


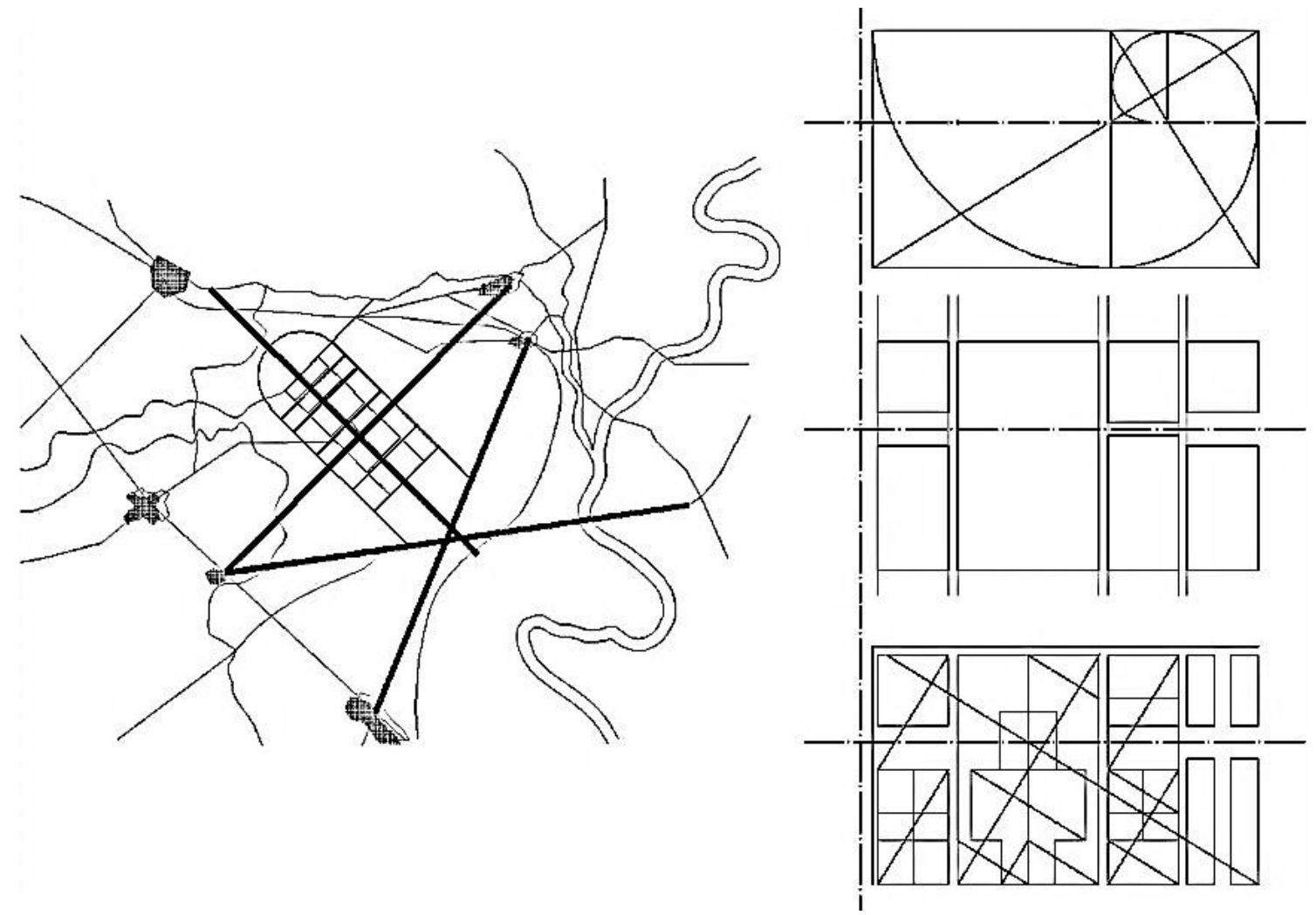

4. Mundaneum. 1929. En este proyecto, Le Corbusier recurre a un sistema de ejes para situar el plan del nuevo complejo cultural en relación al contexto en el que se inserta y para determinar el eje axial del que se servirá para conectar todos los volúmenes del conjunto entre sí. Se trata de uno de los pocos proyectos en el que Le Corbusier aplica un trazado regulador geométrico basado en la proporción aurea y el ángulo recto para definir el plan. Este hecho demuestra la importancia significativa que el arquitecto atribuye al proyecto. La pieza principal del museo se desarrolla a partir de un esquema en espiral, cuyo crecimiento se basa en la serie de Fibonacci.

\section{El Módulo.}

"Un módulo mide y unifica; un trazado regulador construye y satisface." El módulo es una figura empleada como unidad de referencia que sirve para establecer relaciones métricas a partir de combinaciones numéricas sencillas; múltiplos y derivados. Pero al mismo tiempo, Le Corbusier lo emplea como un trazado regulador, puesto que de su propia naturaleza derivan una serie de reglas de composición que confieren un orden unitario al conjunto. Las combinaciones modulares aparecen asociadas desde un primer momento a los sistemas de construcción estandarizados, como se puede observar en su diseño de muebles para el pabellón de l'Espirit Nouveau (1925). Se tratan tanto de unidades volumétricas, como de unidades superficiales. Le Corbusier recurre con frecuencia a la célula-tipo cúbica de $5 \times 5 \times 5$ metros, que aplicará en los proyectos para sus viviendas experimentales; la Maison et Cantine, la Maison Minimun, las viviendas de la Cité Frugés, o la Maison Loucheur, y las distintas combinaciones que del módulo cuadrado de la planta que de ella derivan; $1 / 2$ ( 5 x 2.5 m.), 1/4, ( 5 x 1,25 m.), 3/2 ( $5 \times 7.5$ metros), etc. Pero el módulo también puede tener naturaleza lineal, como unidad que sirve para dividir un eje y generar un desarrollo rítmico. Le Corbusier confiará de nuevo en el número 5 como unidad lineal con la que medir y unificar su proyecto piloto de viviendas colectivas (la Weissenhoff de Stuttgart), que se corresponde con la distancia que guardan sus pilares entre sí. Por último, en los croquis iniciales de su célebre villa, la Ville Savoie de París (1929), de nuevo aparece la retícula ideal de 5 x 5 metros como base sobre la que se distribuye la planta. 
$5 \mathrm{~m}$.
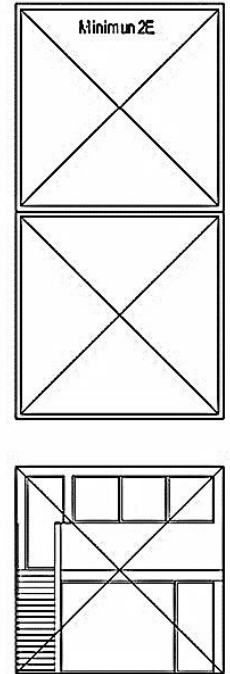

$2,5 \mathrm{~m}$.
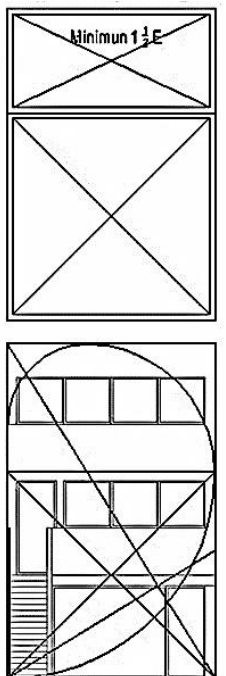
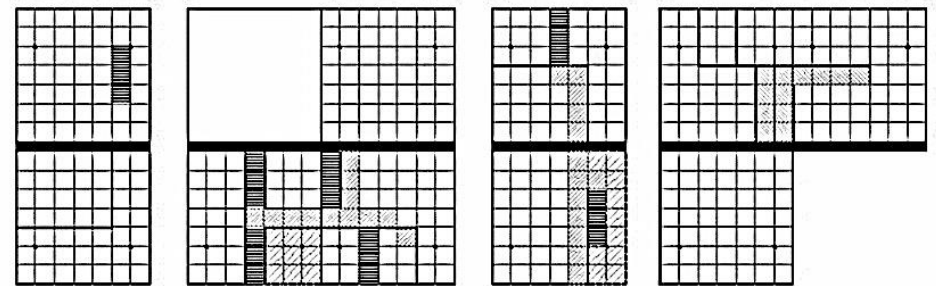

$+H+H$

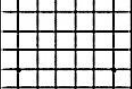

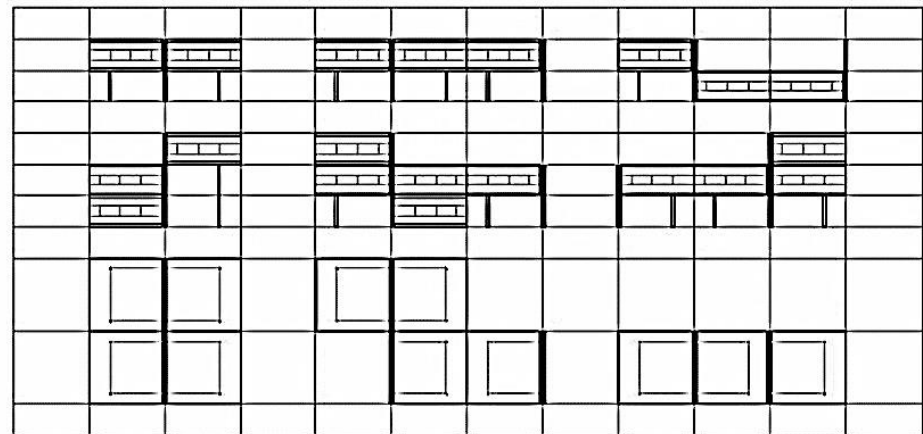

5. Maison Minimum, 1926 (arriba) y Maison Loucheur, 1929 (abajo). En el proyecto para la Maison Minimum, Le Corbusier recurre al módulo estándar que había empleado en numerosas ocasiones anteriormente (entre otras, el proyecto para la Maison Cantine, en Boulogne-sur-Seine, de 1924, y en la Cité Frugés, en Pessac, en 1925); el cubo de 5 x 5 x 5 metros. De esta célula básica se deducen una serie de combinaciones en planta (mitad del cuadrado, doble cuadrado, tres cuadrados, cuadrado y medio...), generando con ello nuevos modelos estándar de vivienda mínima. Por otra parte, los distintos alzados posibles parten también de la unidad 5 x 5, y sus variaciones geométricas; el cuadrado y su rectángulo aureo. Del uso del módulo cuadrado se derivan unas reglas geométricas y aritméticas muy sencillas con las que se pueden aplicar en la configuración de barrios enteros (Pessac), de modo que esa unidad mínima se convierte, en sí misma, en un elemento geométrico regulador. La misma estrategia encontramos en los experimentos derivados de la Maison Loucheur. En este caso, la unidad básica de medida consistirá en un cuadrado de 7 × 7 metros, dividida, a su vez, en una cuadrícula, para facilitar su distribución. 


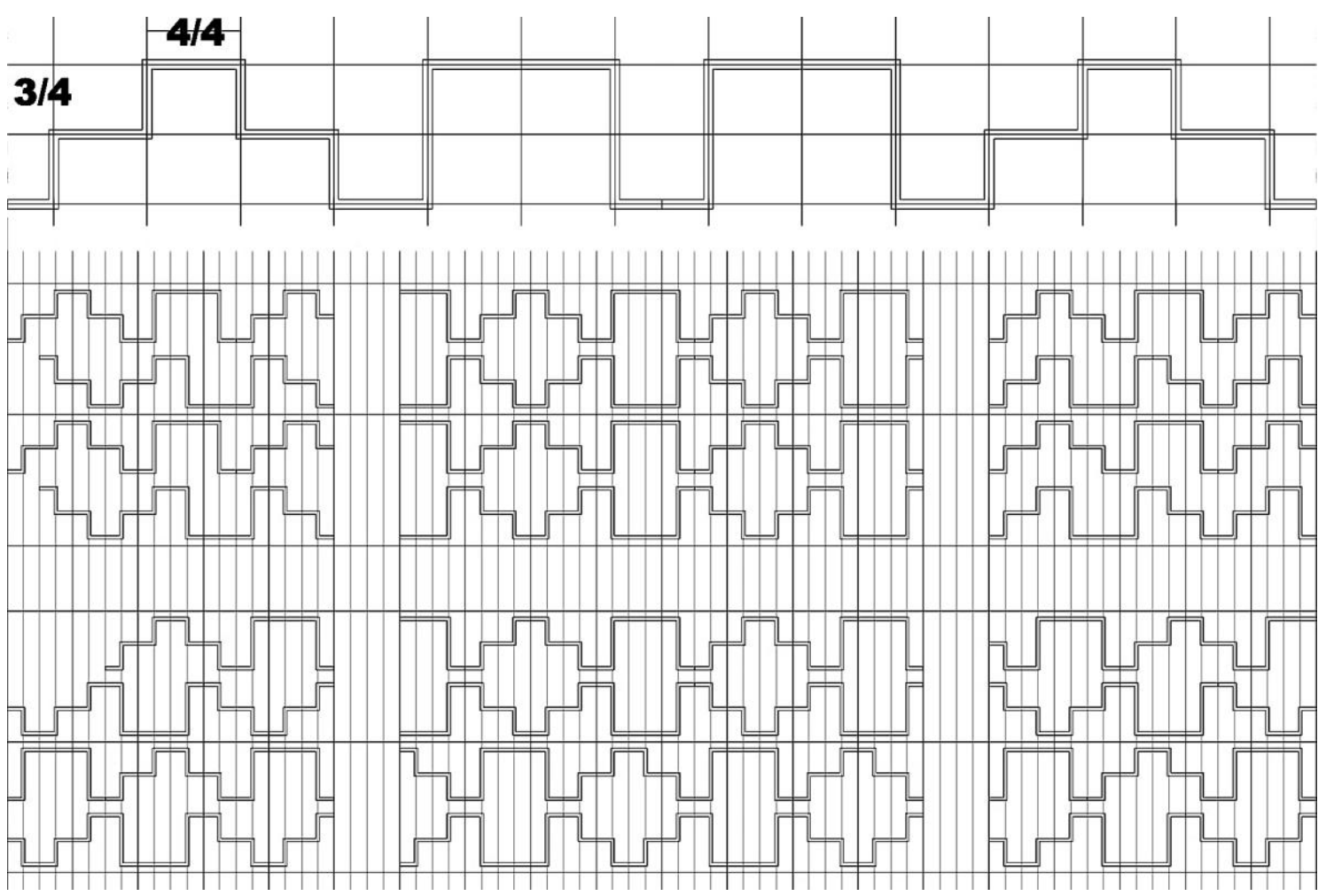

6. Ville Radieuse, 1930 (detalle). Detalle de las posibles supermanzanas que podrían generarse a partir de la combinación de un modelo de bloque residencial dispuesto en redant.

\section{Las mallas ortogonales.}

Mientras que en gran parte de sus textos Le Corbusier cita continuamente diversos trazados reguladores como el lugar del ángulo recto, el eje o los juegos proporciones basados en la razón aurea, no aparecen alusiones explícitas al uso de las mallas ortogonales como esquema compositivo. En su manifiesto hacia una nueva arquitectura, el maestro suizo sólo se referirá al empleo de la malla de manera indirecta al hablar del orden ortogonal que necesariamente ha de regular los nuevos barrios de viviendas en serie ${ }^{13}$, y también mencionará la belleza de la geometría cuadriculada presente en las fachadas de las construcciones fabriles norteamericanas, que deriva de la estricta aplicación de los principios funcionales y constructivos:

"Problema de la época y de la estética contemporánea: todo conduce a la reinstauración de los volúmenes simples (...) La superficie, agujereada por las necesidades del destino, debe tomar las generatrices acusatrices de esas formas simples. Esas acusatrices son prácticamente el tablero de damas o la cuadrícula: Fábricas norteamericanas. ¡Pero esta geometría de miedo! Sin seguir una idea arquitectónica, sino simplemente guiados por las necesidades de un programa imperativo, los ingenieros de nuestros días recurren a las generatrices acusatrices de los volúmenes: muestran el camino y crean realidades plásticas, claras y límpidas, brindando paz. a los ojos y los goces de la geometría al espíritu" "14.

Sin duda, a finales de los años treinta, Le Corbusier seguirá el ejemplo de las construcciones fabriles norteamericanas en las fachadas sus numerosos proyectos de inspiración industrial, como, por ejemplo, la manufactura Frugés de Burdeos (1926); el edificio para la Armé du Salut, en la Cité du Refuge de París (1929);

\footnotetext{
${ }^{13} \mathrm{Cfr}$. Le Corbusier, Hacia una arquitectura, $2^{\circ}$ Ed. Barcelona: Editorial Apóstrofe, 2006, p. 193

${ }^{14}$ Le Corbusier, Hacia una arquitectura, $2^{\circ}$ Ed. Barcelona: Editorial Apóstrofe, 2006, p. 28
} 
la Imprimerie Draeger, también en París (1929); o el pabellón suizo de la Ciudad Universitaria (1930). Sin embargo, años atrás, ya se había servido de las de las mallas ortogonales para regular la composición y la distribución de las plantas en sus grandes proyectos iniciales, como, por ejemplo, el pabellón de l'Espirit Nouveau (1925); el proyecto para el palacio de la Sociedad de Naciones, en Génova (1927); la villa Les Terrasses en Garches (1927); o la Ville Savoie (1929). El uso de las mallas ortogonales como estrategia geométrica de diseño, siempre estará relacionada con el empleo de una estructura porticada a base de pilares. También encontramos una fuerte presencia de la malla ortogonal en la estructura subyacente de sus proyectos urbanos, tanto reales como utópicos, como el complejo residencial de Pessac; el proyecto de Ciudad Jardín (1925); el Plan Voisin (1925); o la Ville Radieuse (1930).
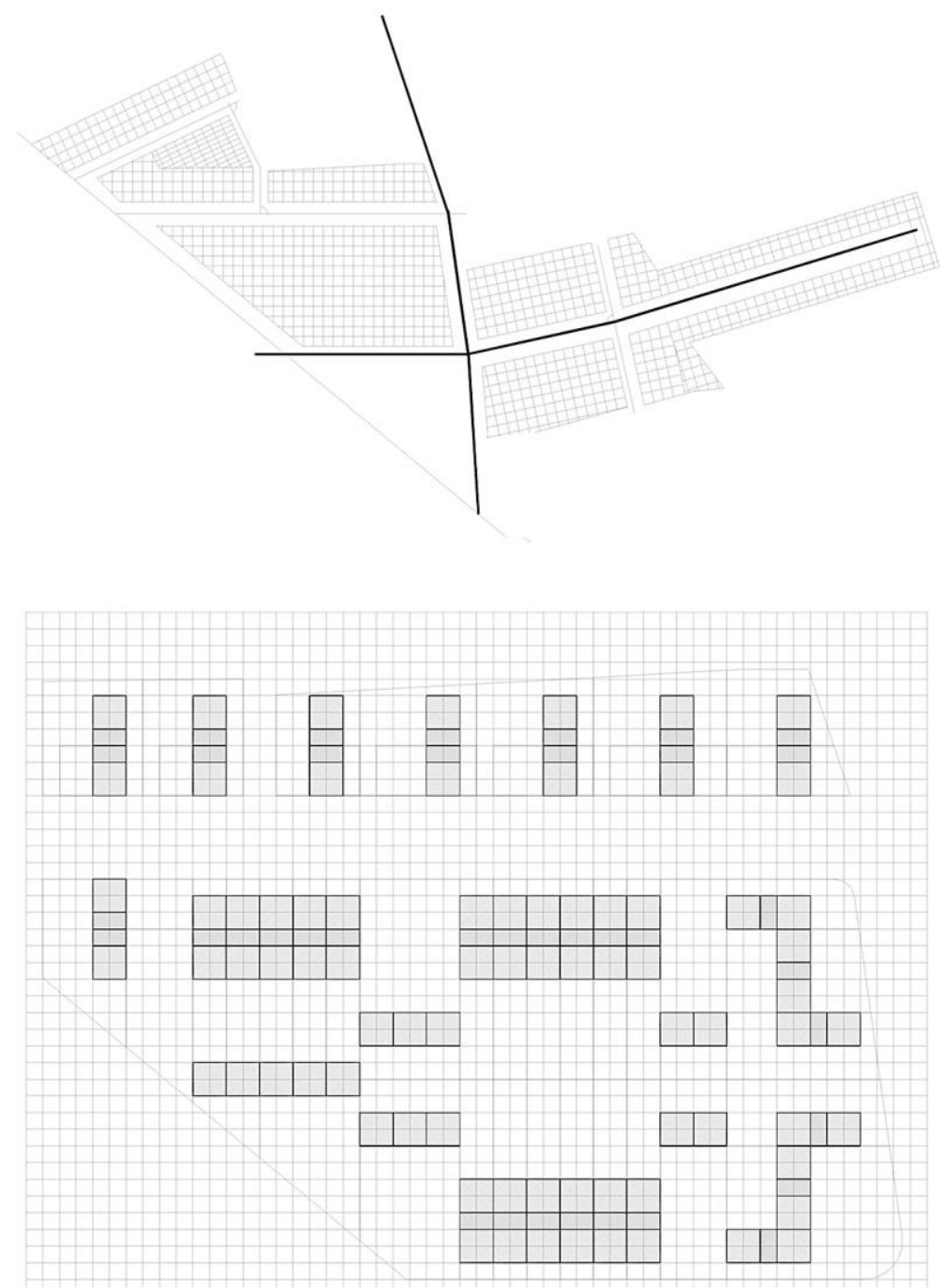

7. Cité Frugés, Pessac, 1926. Complejo urbano (arriba) y detalle de manzana (abajo). En Pessac, unos ejes trazan las directrices generales del proyecto, poniendo en relación la intervención con el resto del territorio y establecen, a su vez, una jerarquía en las calles. Le Corbusier empleará su modelo estándar para la vivienda mínima, que colocará sobre una malla ortogonal de 5x5 metros, que sirve para regular y unificar el conjunto, sobre la que dibujará las divisiones catastrales. 

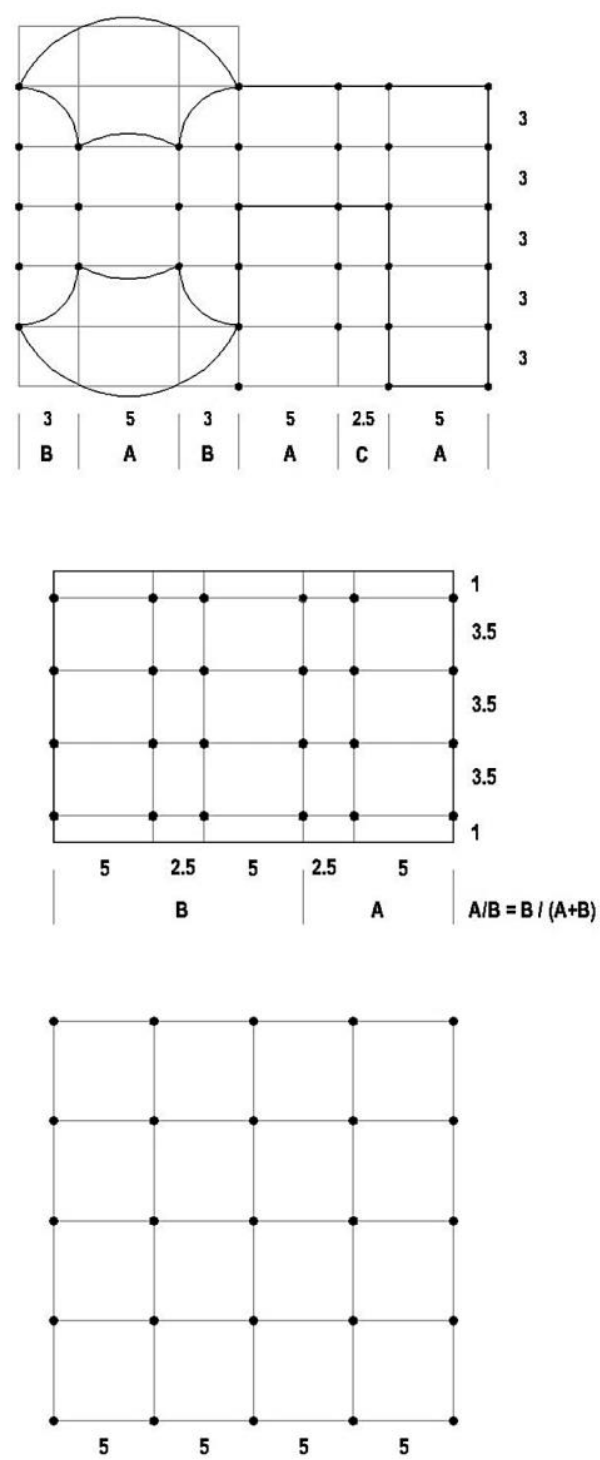

8. Retículas estructurales correspondientes al Pabellón L'Espirit Nouveau, París, 1925 (Arriba); Ville Les Terrasses, Garches, 1927 (en medio); y Ville Savoie, París, 1929 (debajo). En los tres casos, el sistema estructural empleado, a base de pilotis, es un sistema normalizado que contiene en sí mismo un orden, sobre el que se producirá el ritmo y la variación. En los tres proyectos, se revela el interés de Le Corbusier por el número 5, en su objetivo de imprimir dimensiones ideales en sus proyectos.

\section{Ejes, ritmo y simetrías.}

Los ejes son un recurso compositivo lineal que encontramos en un $25,8 \%$ de los proyectos analizados, está directamente relacionado con otro tipo de instrumentos de medida y ordenación, como el ritmo o la simetría, y su empleo pone en evidencia el legado del clasicismo académico francés en la obra de Le Corbusier. Los ejes son utilizados por el arquitecto suizo como trazado que regula tanto las plantas de los edificios, como los planes urbanos de gran escala. Aparecen en los diversos croquis de proyecto desde el momento de la concepción de las obras y en ellos se expresan intenciones distintas en función de las necesidades a resolver, tal y como el autor explica en sus textos: "El eje es el que pone orden en la arquitectura. Poner orden, es comenzar una obra (...) 
En arquitectura, es preciso que un eje tenga un objetivo". ${ }^{15}$ Los proyectos analizados vienen a confirmar esta afirmación, y en ellos se distinguen tres usos distintos del eje: en primer lugar, los ejes sirven para relacionar la intervención arquitectónica con el territorio en el que se inserta; en segundo lugar, se emplean para conectar distintas partes del programa en aquellos proyectos de gran envergadura y complejidad, estableciendo una relación jerárquica entre ellas; por último, el eje aparece como instrumento de medida reglado, a lo largo del cual se desarrollará un esquema rítmico.

El eje, como instrumento que conecta el nuevo tejido urbano con su contexto, está presente en todos los proyectos de planificación urbana elaborados por el maestro suizo. Su empleo es fundamental en aquellos proyectos adscritos a un contexto determinado, como el Plan Voisin, el plan para Buenos Aires o proyecto para el Mundaneum, y no tanto en otros esquemas urbanos ideales y desarraigados, como la Ciudad Jardín (1925) o la Ville Radieuse (1930), en los que el eje es utilizado como un elemento puramente compositivo. Para Le Corbusier, "las ciudades deberán ser concebidas y trazadas en toda su extensión, como fueron trazados los templos de Oriente y como fueron ordenados los Inválidos o el Versalles de Luis XIV",16. Con este objetivo, el arquitecto empleará los mismos principios geométricos que regulan los modelos urbanos barrocos, cuyos trazados, en forma de tridente, se extienden a lo largo de todo el territorio, colonizando el lugar e instaurando en él un nuevo orden. También se servirá de los ejes ortogonales, cardus y decumanus, empleados como referencia en el trazado de las ciudades clásicas.
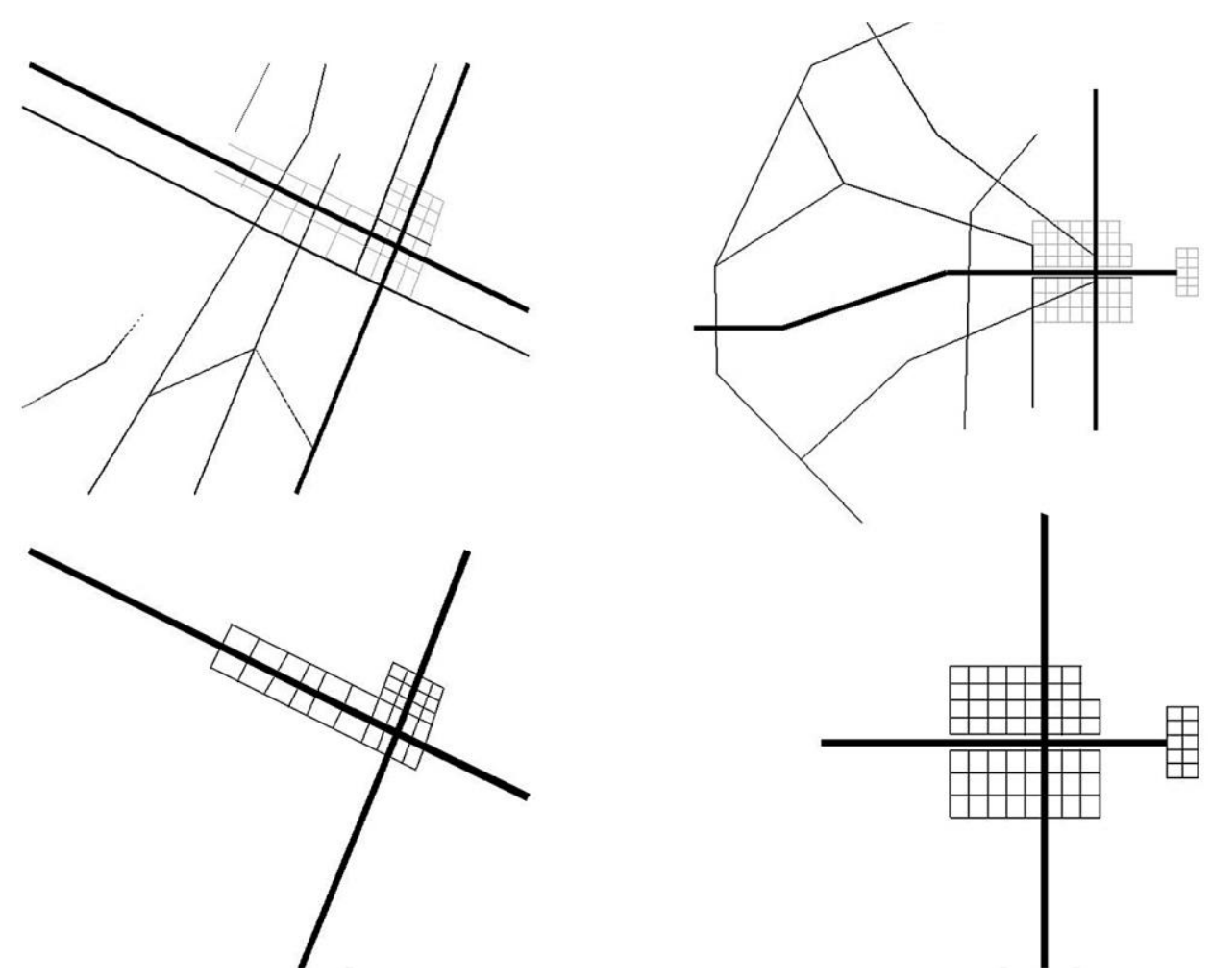

9. Plan Voisin, París, 1925 (izquierda); Plan para Buenos Aires, Argentina, 1929 (derecha). En los planes urbanos aparece el eje como trazado que sirve para relacionar el nuevo entramado con el territorio en el que se inserta. En estos proyectos Le Corbusier recurre al empleo de un sistema de ejes barrocos en forma de tridente, y unos ejes ortogonales (vestigios del esquema romano formado por las vías cardus y decumanos) que se convierten en las directrices principales del nuevo plan y determinan la dirección del entramado urbano, que adoptará la forma de damero.

\footnotetext{
${ }^{15}$ Le Corbusier, Hacia una arquitectura, $2^{\circ}$ Ed. Barcelona: Editorial Apóstrofe, 2006, p. 151

${ }^{16}$ Ibid.
} 
En segundo lugar, Le Corbusier recurre al esquema axial en aquellos proyectos de gran envergadura y complejidad programática con la intención de ordenar los volúmenes que componen el conjunto; "el eje no es aquí una aridez teórica, sino que une los volúmenes capitales y netamente escritos y diferenciados los unos de los otros" "17. Su empleo se manifiesta en los grandes complejos edificatorios como el Palais de la Societé des Nations, en Génova (1927); la Siedlung de Stuttgart (1927); el pabellón Suizo de la Ciudad Universitaria (1930); el proyecto para el Palacio de los Soviets de Moscú (1930). En este sentido, el eje es también empleado para referir un programa muy complejo a unas relaciones muy sencillas entre sus partes, estableciendo una jerarquía, como se observa en el proyecto para el Palacio de las Naciones, donde el eje, además, determina una línea virtual de simetría que imprime al proyecto un carácter monumental; "La ordenación es la jerarquía de los ejes, por lo tanto, la jerarquía de los fines, la clasificación de las intenciones ${ }^{\prime 18}$. En estos casos, el eje se convierte en el elemento generador en el que se expresan las intenciones del proyecto.

Por último, Le Corbusier recurre al eje como un instrumento de medición, dividido en una serie de unidades de longitud, que pueden ser agrupadas en conjuntos armónicos para introducir, de este modo, un ritmo en la composición del alzado. Por tanto, el ritmo también se convierte un esquema regulador, un conjunto de reglas que rigen las relaciones entre los distintos elementos de composición arquitectónica, en este caso, a lo largo de un eje lineal. El autor defiende que el ritmo "es un estado de equilibrio que procede de simetrías simples o complejas o de compensaciones sabias. El ritmo es una ecuación",19, y, como toda ecuación, exige repartir cantidades iguales entre sus miembros. Por tanto, Le Corbusier recurre en numerosos casos a la simetría bilateral, especialmente en sus primeras obras, repitiendo esquemas como: ABA, en la Ville Planeix de Burdeos (1927), el Pabellón Suizo de la Ciudad Universitaria (1930) o el Inmeuble Locatif, de Zurich (1933); AAA, en la fachada de la manufactura Frugés, (1926); ABCBA, en el estadio Cadinet, de París (1926); ABABA en el Palacio de la Sociedad de Naciones (1927) o la Ville Les Terrasses, de Garches (1927). Con el paso del tiempo, Le Corbusier se irá liberando de los esquemas simétricos y recurrirá a sistemas rítmicos basados en la repetición modular uniforme.

\footnotetext{
${ }^{17}$ Le Corbusier, Hacia una arquitectura, $2^{\circ}$ Ed. Barcelona: Editorial Apóstrofe, 2006

${ }^{18}$ Ibid., p. 154

${ }^{19}$ Ibid.
} 

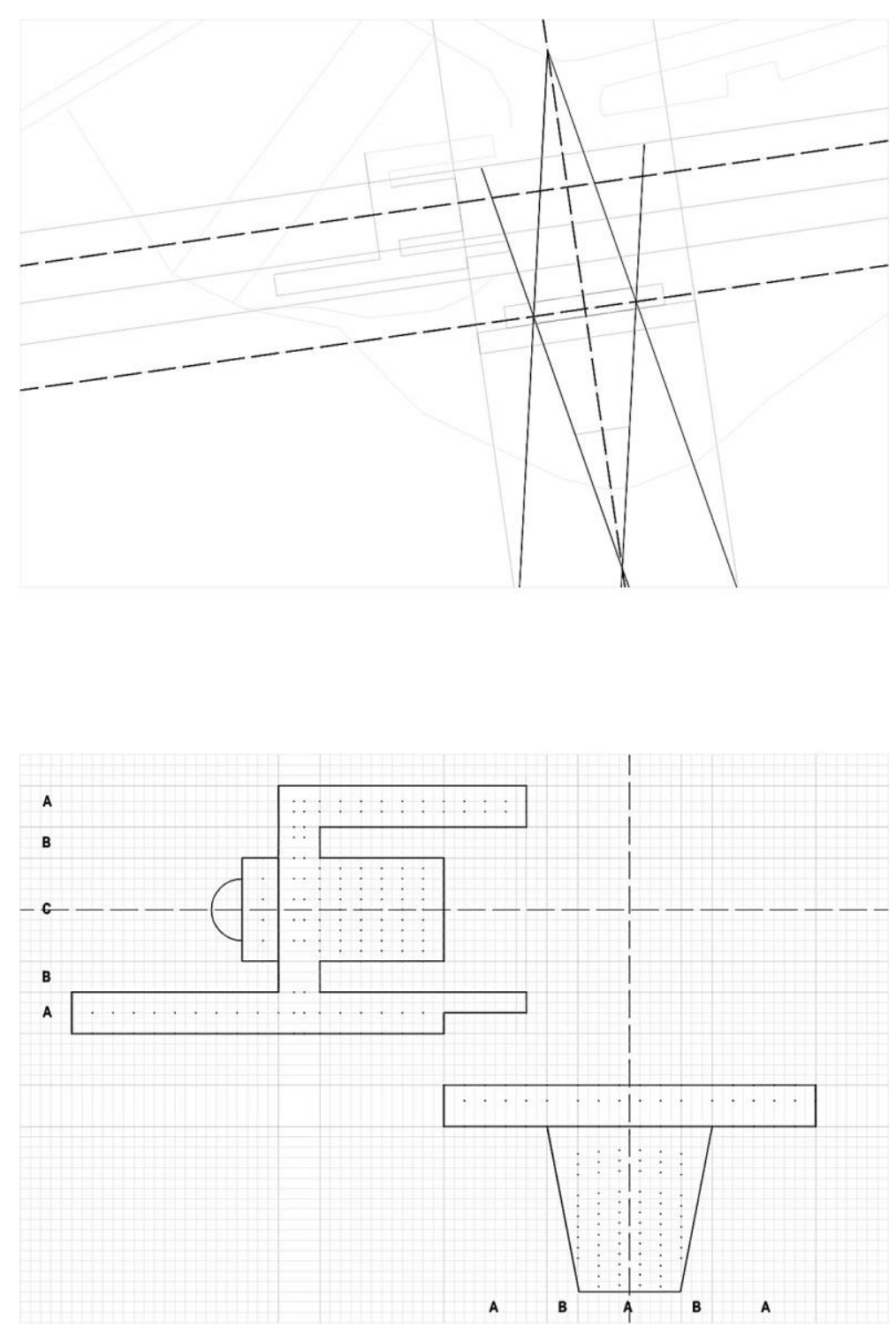

10. Palais de la Societé des Nations, Génova, 1927. Los ejes se emplean en este proyecto desde un primer momento para establecer conexiones entre la intervención y su contexto, para relacionar los volúmenes entre sí y para imprimir en el conjunto un orden jerárquico. Estos ejes a su vez determinan la dirección de la retícula, que introduce una unidad estructural en todo el complejo institucional. Esta retícula es cuadrada pero varía al coincidir con los ejes longitudinales de cada volumen, acentuando la significación de esa dirección concreta. En este proyecto, las reglas académicas de composición, como los ejes, la simetría bilateral y el ritmo ABCBA y ABABA, están muy presentes. 


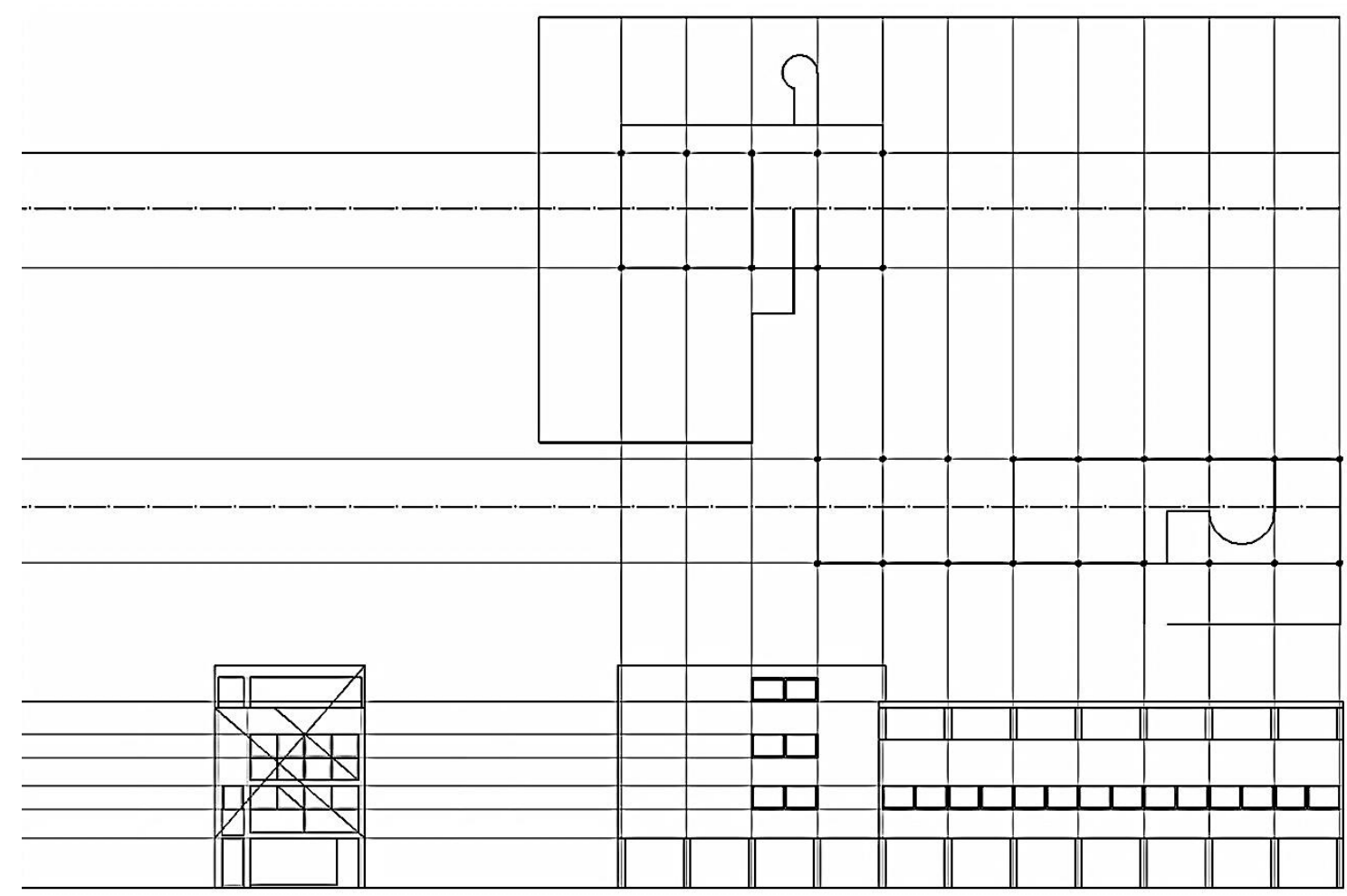

11. Weissenhof-Siedlung. Stuttgart, 1927. Una disposición rítmica de los pilares sobre un eje se empleará como estrategia que ordene el conjunto residencial y como instrumento para relacionar ambos volúmenes entre sí, dando lugar a un todo cohesionado. De nuevo, la distancia entre pilares a lo largo del eje longitudinal es de 5 metros. Los trazados reguladores empleados en la composición del alzado longitudinal combinan líneas horizontales, situadas en el "lugar del ángulo recto", y un ritmo vertical uniforme impuesto por la retícula de pilotis.

\section{Desarrollo y evolución en el empleo de las estrategias geométrico-matemáticas entre 1923 y 1933: La progresiva transparencia de las estructuras geométricas.}

Una vez clasificadas y analizadas las distintas estrategias de composición, resulta necesario dirigir una mirada global al conjunto de obras estudiadas. De este modo, al recorrer de manera transversal los distintos proyectos elaborados a lo largo de los años veinte, es posible apreciar una evolución en el empleo de las distintas estructuras geométrico matemáticas de las que se sirve Le Corbusier para componer sus proyectos. Este desarrollo coincide con la consolidación del registro formal del arquitecto -desde las obras puristas de sus primeros años, hasta el lenguaje brutalista de los años cincuenta-, por lo que su análisis puede alumbrar el estudio de la trayectoria del gran maestro del siglo XX.

En las primeras "obras blancas" de los años veinte, podemos observar que Le Corbusier, en general, se sirve de las mallas reticulares para la composición de la planta, y se apoya en el ángulo recto, el ritmo, la simetría o el número de oro para diseñar los alzados. Es decir, a diferencia de la arquitectura academicista, los planos verticales y los planos horizontales se ordenan según sus propios reglas de composición, que son distintas entre sí. El uso de la retícula ortogonal para ordenar las plantas (como en la Maison Guiette, el pabellón de L'Espirit Nouveau, la Ville Savoie, etc), vendrá determinado por las exigencias del esquema estructural porticado a base de pilotis. Mientras tanto, la fachada permanecerá indiferente al ritmo impuesto por la estructura, y se servirá de trazados de naturaleza geométrica y juegos de proporciones para ordenar los distintos huecos que en ella se dibujan, como si de una composición purista se tratase. En otros casos, el orden de la planta vendrá impuesto, no tanto por la malla estructural, sino por la forma del solar, como en las viviendas entre medianeras, la casa Fuerte 
(1925), la maison Ternisien (1926), la Ville Planeix (1927), o el ático de Beistegui (1930). En estos casos, la fachada continuará siendo objeto de una composición libre basada en el empleo del ángulo recto, el ritmo, la simetría, o el número de oro. Sólo en unos pocos proyectos, como la manufactura Frugés (1926), la Ville en Garches (1927) o los alzados longitudinales para la Weissenhoff-Siedlung (1927) la composición del alzado revela el ritmo de la planta (es decir, la distancia entre los pilotis que componen la planta coincide con el ritmo presente en los alzados). La independencia entre la composición de las plantas y los alzados, será posible gracias a la libertad que ofrecerán los nuevos materiales de construcción y el sistema estructural porticado que de ellos deriva. Pero además, el arquitecto disocia la composición de la planta del diseño del alzado al considerarlos elementos autónomos, absolutamente independientes entre sí. De este modo, el uso de distintos instrumentos de composición para las plantas y los alzados viene a subrayar dos de los cinco puntos que establece Le Corbusier para una nueva arquitectura: el plan libre y la fachada libre.
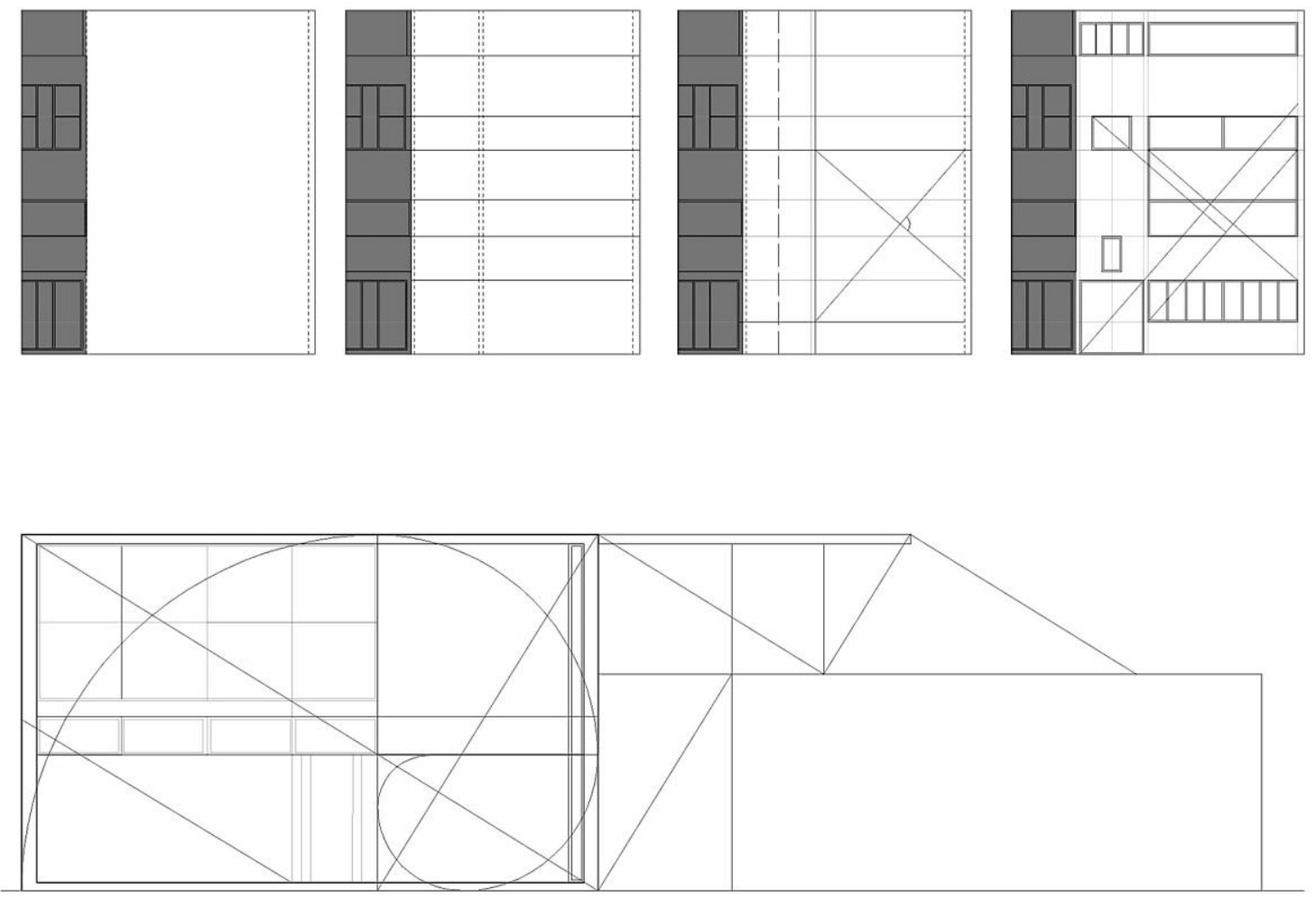

12. Casa Fuerte, París, 1925 (arriba); Maison Ternisien, Boulogne-sur-Seine, 1926 (abajo). El proyecto para la casa Fuerte se sitúa en una parcela entre medianeras de 7.60 metros de crujía con un sistema estructural de muros de carga. Fuertemente condicionada por el contexto en el que se inscribe, la solución trata de establecer una continuidad con la fachada adyacente sirviéndose, para ello, de las mismas líneas horizontales que rigen su composición. Le Corbusier divide el alzado del proyecto en dos zonas, aprovechando la colocación de un pilar estructural para salvar la luz. La parte derecha, la más próxima a la vivienda contigua, servirá para articular el cambio de escala que introduce con los grandes huecos de su composición respecto a las ventanas convencionales de la fachada preexistente. Esta parte consta de tres huecos pequeños dispuestos sobre un eje de simetría, cuya altura viene delimitada por las líneas horizontales toma como punto de partida inicial. En el resto de la fachada, Le Corbusier se sirve de unas líneas diagonales y sus perpendiculares para fijar una serie de relaciones y proporciones que determinan la anchura de los huecos y fijan composición definitiva. Por otra parte, la Maison Ternisien se sitúa en un solar complejo, y su estructura se compone de una serie de muros de carga perimetrales. No hay pilotis, por tanto, la fachada queda libre de cualquier eje estructural que respetar. La sección aurea se aplica para dimensionar los huecos de las fachadas, pero no se limita a un tratamiento superficial de las mismas, sino también da proporción a los distintos volúmenes que componen la vivienda, estableciendo una armonía de proporciones. El proyecto se convierte en un juego sabio y magnífico de volúmenes basado en el número de oro. En ambos casos, mientras el diseño de la planta se encuentra fuertemente condicionado por el solar en el que se inserta, el alzado sigue su propia lógica interna, y goza de gran libertad compositiva. 
Sin embargo, a partir de 1929, y de manera progresiva, el uso de la retícula como instrumento de composición aparece, no sólo en las plantas, sino también en las fachadas, esto es; Le Corbusier recurre a la retícula para dibujar sus alzados. En ellos, los trazados reguladores ya no serán líneas virtuales, es decir, no se tratarán de líneas invisibles que aparecen en los primeros croquis pero se borran en el objeto resultante (como sucedía en las obras puristas de sus primeros años), sino que se revelan en la misma fachada, de modo que el diagrama que rige la composición se imprime en el alzado. El primer ejemplo lo encontramos en l'Armée su Salut. En este edificio, el ritmo vertical de la retícula que compone el alzado coincide con la distancia entre pilotis de la planta, pero, sin embargo, entre el despiece del alzado y el ritmo de pilotis hay un ligero desfase sobre el eje longitudinal, de tal modo que no llegan a coincidir sobre el mismo eje. El paño acristalado de inspiración fabril se coloca como una doble piel sobre la estructura del edificio y es independiente de esta, es decir, la fachada continúa siendo una fachada de composición libre.

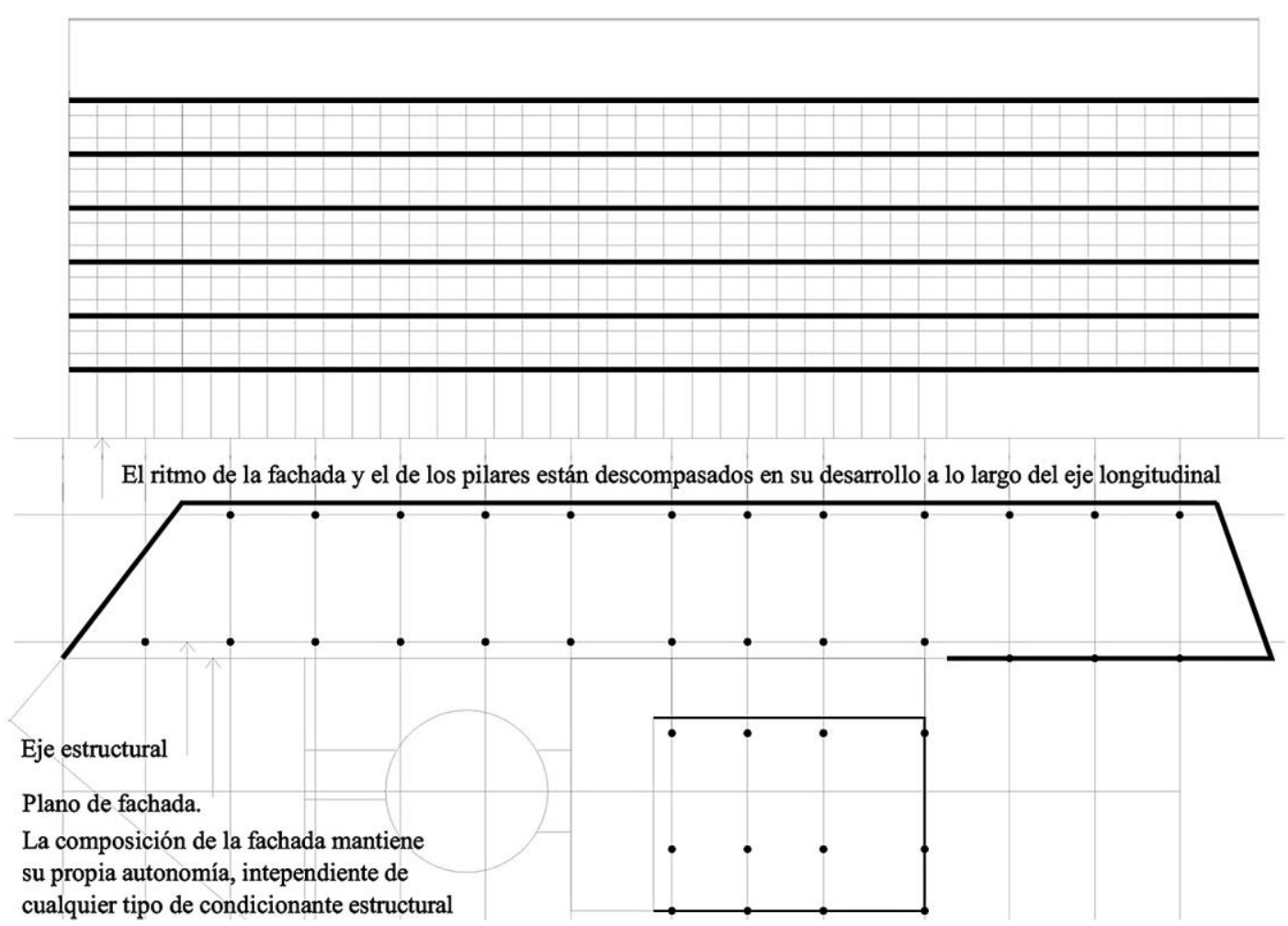

13. Armé du Salut. Cité de Refuge, París, 1929. La fachada se presenta subdividida según un módulo cuya longitud es igual a un tercio de la distancia entre pilares. El alzado principal consta de una piel de vidrio que envuelve el volumen, y que se encuentra separada de la estructura, por tanto, está exenta de cualquier condicionante impuesto por el ritmo de la estructura que pudiera condicionar su composición. Este hecho se acentúa por el hecho de que es posible apreciar una discordancia a lo largo del eje longitudinal entre el ritmo de los pilares, por una parte, y el correspondiente al plano de la fachada, por otra. En l'Armé du Salut, la composición de la fachada se rige según su propia lógica, al igual que sucedía con las obras blancas de los primeros años: sigue siendo una fachada libre. Por otra parte, este ejemplo resulta significativo porque se trata del primer proyecto en el que Le Corbusier aplica la retícula cuadriculada para regular sus alzados, y porque, por primera vez, la línea de forjados se revela en el alzado, siendo empleada como directriz horizontal que determina la composición.

Poco a poco, la estructura irá adquiriendo mayor presencia en fachada, dando cohesión y confiriendo unidad al conjunto. En la Imprimerie Draeger, la planta y el alzado ya no serán dos entidades separadas y ajenas entre sí, sino que el ritmo que ordena la planta, servirá a su vez para componer y ordenar los alzados, de modo que la retícula presente en el alzado revela el sistema porticado a base de vigas y pilares. Finalmente, en el Pabellón Suizo de la Ciudad Universitaria de París, el entramado estructural se convierte en instrumento de composición 
en sí mismo. Los planos horizontales y verticales del proyecto se regirán por las mismas leyes compositivas, que ya no son líneas virtuales de composición, ni diagramas esquemáticos, sino que adquieren corporeidad y se construyen, introduciendo un cambio de registro formal en la trayectoria de gran maestro del siglo XX.

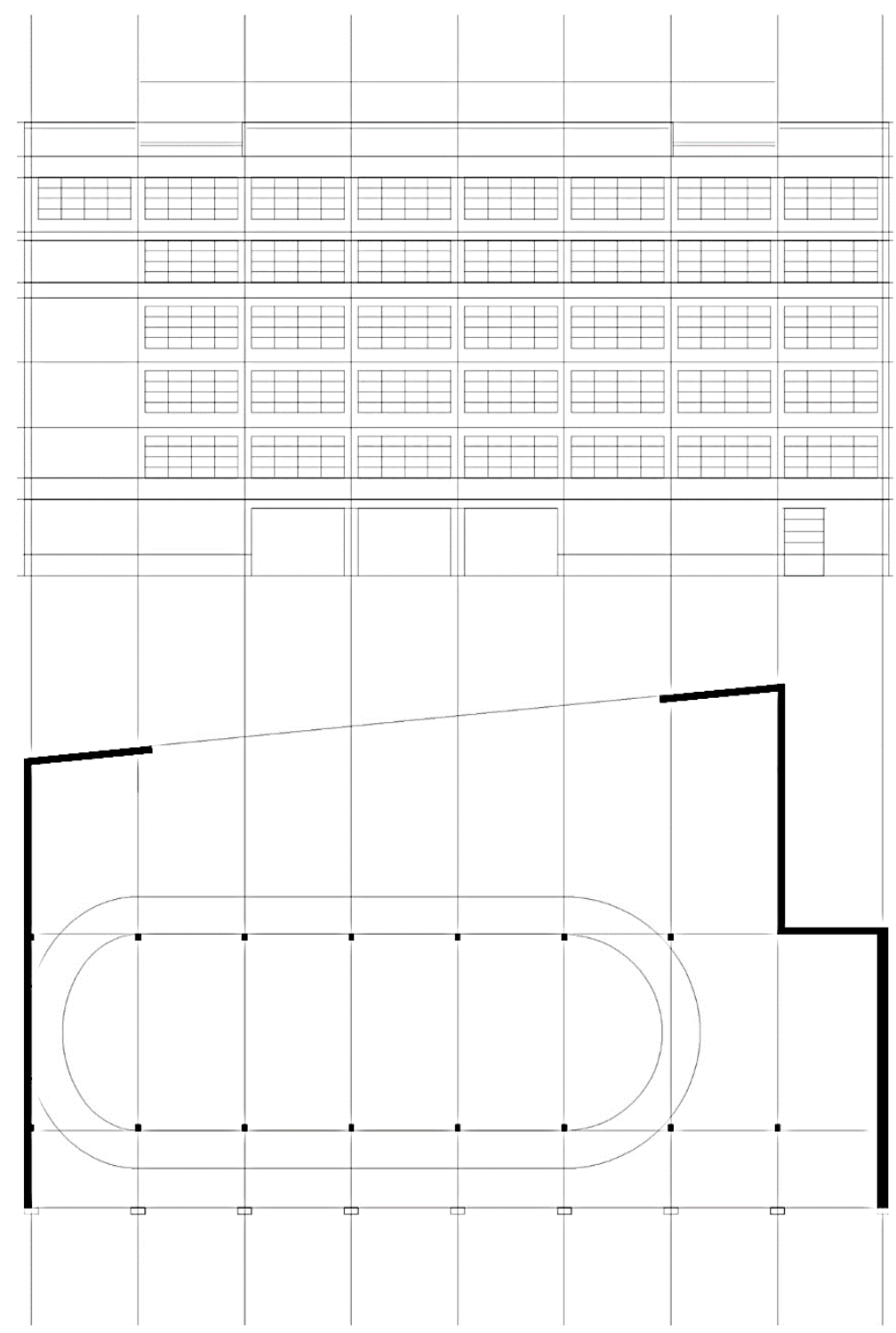

14. Imprimerie Draeger. París, 1929. En este proyecto, por primera, vez Le Corbusier revela en fachada la estructura de pilares y forjados del interior del proyecto. El ritmo de los pilares, y la distancia horizontal entre forjados se traduce en una malla ortogonal con la que el maestro suizo compone los alzados de la Imprimerie. La estructura imprime un ritmo modular vertical (determinado por las directrices de los pilares) y una división horizontal (condicionada por las distancias entre forjados). Se trata del primer proyecto donde la composición de la fachada no es independiente al orden interno del proyecto, sino que depende de la estructura, la fachada deja de ser una máscara. 

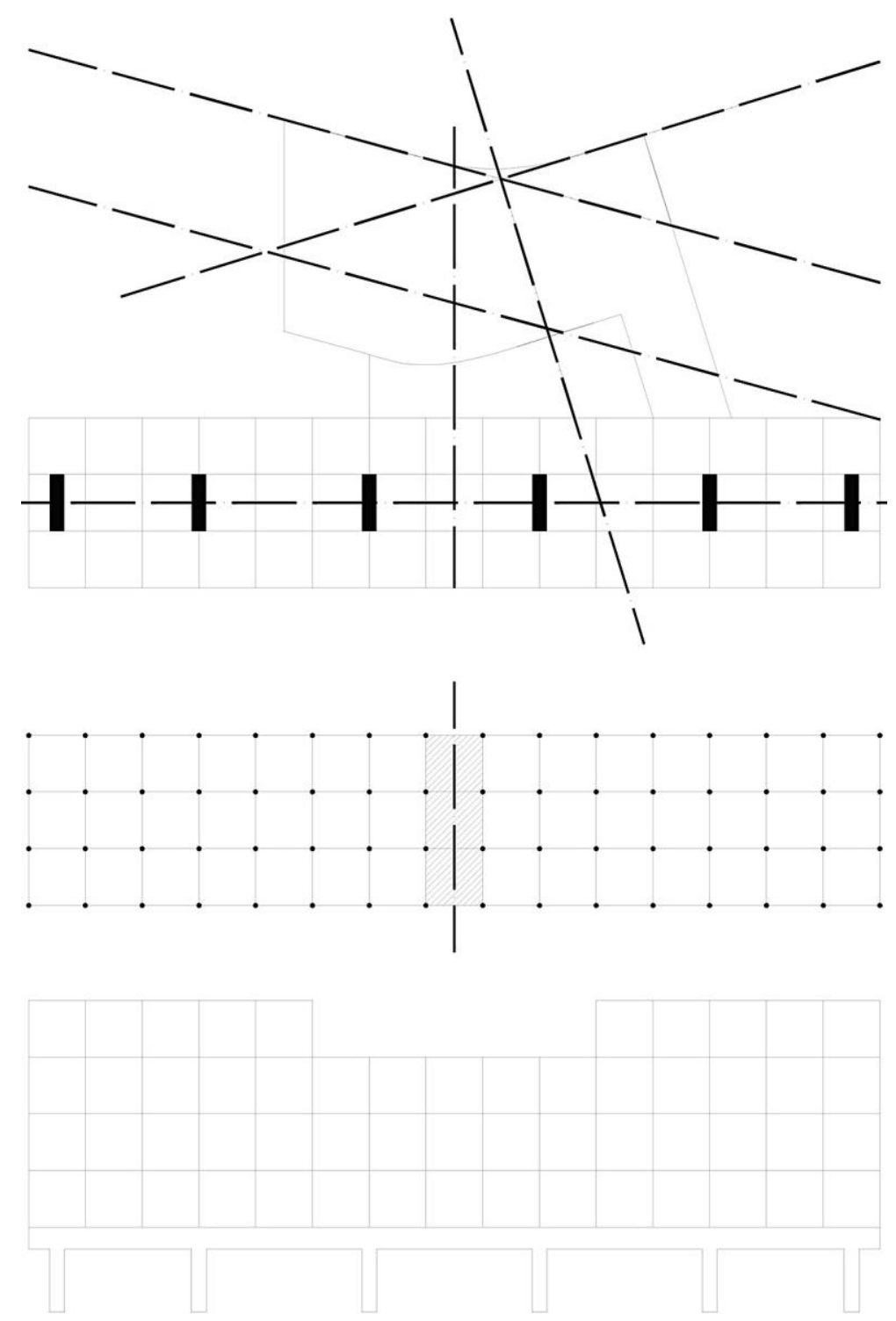

15. Pabellón Suizo, Ciudad Universitaria. París, 1930. El sistema estructural empleado (un entramado ortogonal formado por elementos longitudinales, iguales entre sí) deriva en un trazado regulador. Se trata de un sistema geométrico tridimensional que imprime su orden a todo el proyecto, determinando las reglas de composición que deben regir la composición de la fachada, la distribución de la planta, y la proporción de sus secciones internas; los trazados reguladores ya no más se aplican sobre superficies planas, ya no se trata de una composición pictórica cubista; la propia construcción dibuja la imagen del proyecto, inaugurando, con ello, una nueva etapa en la producción arquitectónica de Le Corbusier.

\section{Bibliografía.}

Baker, Geoffrey H. Le Corbusier, Análisis de la forma, Barcelona: Gustavo Gili, 1985

Le Corbusier, Le Corbusier Archive, New York: Garland Publishing, 1984

Le Corbusier, Une maison, un palais: “a la recherche d'une unité architecturale”, París: G.Cres, 1928

Le Corbusier, El Modulor, Barcelona: Editorial Poseidón, 1976

Le Corbusier, Hacia una arquitectura, $2^{\circ}$ Ed. Barcelona: Editorial Apóstrofe, 2006

Summerson, John, El lenguaje clásico de la arquitectura, 11 ${ }^{\text {a }}$ Ed. Barcelona: Editorial Gustavo Gili, 1998 


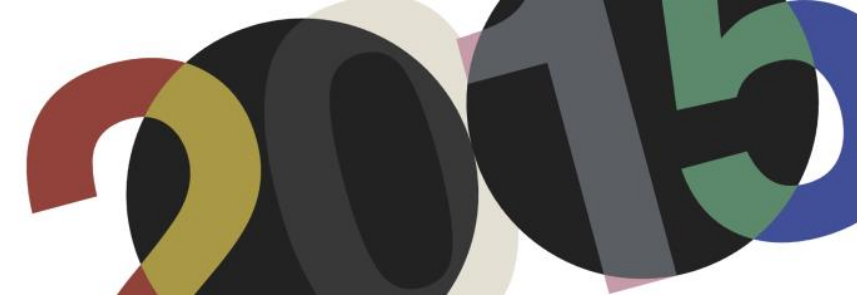

DOI: http://dx.doi.org/10.4995/LC2015.2015.712

\title{
From Impact to Legacy: Interpreting Critical Writing on Le Corbusier from the 1920s to the Present
}

\author{
G. Livesey*, A. Moulis ** \\ * Faculty of Environmental Design, University of Calgary \\ ** School of Architecture, The University of Queensland
}

\begin{abstract}
As a major figure of international modernism, Le Corbusier's work has been subject to extensive critique and review both during his lifetime and since, to the extent that he has become the world's most studied 20th century architect. While numerous attempts have been made to assess Le Corbusier's works and ideas in their meaning and influence, little attention has been given to understanding the phenomena of critical writing and research that continues to surround the architect. Drawing upon research by the authors in preparing a 4-volume anthology of writings on Le Corbusier's work for a major British publisher in 2016, the paper will trace critical reaction to the architect's practice through a survey investigation of research and writing produced mainly in English from the 1920s to the present. The paper will give a chronological account of the issues, ideas and approaches that have emerged in critical writings on Le Corbusier and his architecture, reporting on the historiographic questions that have presented themselves in undertaking such a large-scale survey work. Reviewing the work of well-known critics the survey has also sought out lesser-known voices whose presence reflects Le Corbusier's impact around the world, providing new interpretations through fresh perspectives on his work.
\end{abstract}

Keywords: Architectural criticism; Architectural historiography; 20th century architecture, Le Corbusier.

\section{Introduction}

As a major figure of international modernism, Le Corbusier's work has been subject to extensive critique and review both during his lifetime and since, to the extent that he has become the world's most studied $20^{\text {th }}$ century architect. From early discussion of his seminal treatise Towards a New Architecture in Architectural Review, to large-scale exhibitions, such as Le Corbusier: An Atlas of Modern Landscapes held at the Museum of Modern Art, New York, in 2013, the architect's work has continued to assume a relevance and interest well beyond that accorded to the work of his contemporaries, confirming his considerable influence. While numerous attempts have been made to assess Le Corbusier works and ideas in their meaning and influence, little attention has been given to understanding the phenomena of critical writing and research that continues to surround the architect.

Drawing upon research by the authors in preparing a 4-volume anthology of writings on Le Corbusier's work for a major British publisher in 2016, the paper will briefly trace critical reaction to the architect's practice through a survey investigation of research and writing produced from the 1920s to the present. The survey, which will be presented roughly chronologically, has involved examining a large bibliography of material in English as well as the consideration of material in other languages made available in translation. In the paper the issue of how Le Corbusier's self-creation of an oeuvre through his writings and projects intersected with the responses of his critics will be discussed. Also described is the role key critics played in enhancing the architect's oeuvre, setting out its received interpretation in accord with Le Corbusier's self-construction as an avant-garde architect - a construction that those critics who opposed his work would also be drawn into. From the architect's death in 
1965, Le Corbusier's work continued to have an impact as its precedents and lessons became the subject of history.

In conclusion, the paper reports on the historiographic questions that have emerged from the large-scale survey work that spans from the 1920s to the present. Reviewing the work of well-known critics the survey has also sought out lesser-known voices whose presence reflects Le Corbusier's impact around the world, providing new interpretations through fresh perspectives on his work. Despite a wealth of intensive research on the architect's life and work there are aspects of the his practice that the survey of writings reveals as little researched, suggesting that new avenues for interpretation of Le Corbusier's work remain.

\section{1920-1940}

Every direct Le Corbusier first emerged as a significant figure in the world of architecture in the 1920s with the publication of his early books and projects. Crucial to his reception in the English speaking world was the publication of two of Le Corbusier's early texts translated into English by Frederick Etchells (Towards a New Architecture published in 1927 and The City of To-morrow in 1929). Throughout his career most of Le Corbusier's many publications would be translated into English, often many years after their original publication in French, these would form an essential aspect to the dissemination, reception, and interpretation of his ideas.

The initial reception to his work in the British architectural press was often sceptical and even hostile. ${ }^{1}$ The history of Le Corbusier's reception in Britain has been well documented by Adrian Forty, who argues that it was not until after the Second Word War that his reputation became more secure, only to be challenged by the strong critique of post-war urban renewal that emerged in the 1960s. ${ }^{2}$ Further, the recent publication of Le Corbusier and Britain: An Anthology, edited by Irena Murray and Julian Osley provides a well-considered over-view of Le Corbusier's impact in Britain. ${ }^{3}$ However, there were those British critics who wrote sympathetically and knowingly of Le Corbusier's work in the 1920s and 1930s, including Gordon H.G. Holt, ${ }^{4}$ Harold Tomlinson, ${ }^{5}$ Howard Robertson and F.R. Yerbury, ${ }^{6}$ Frederick Etchells, ${ }^{7}$ and Herbert Read. ${ }^{8}$

Also vitally important to Le Corbusier's burgeoning international reputation was the 1932 exhibition "The International Style" exhibition curated by Henry-Russell Hitchcock and Philip Johnson at the Museum of Modern Art in New York where his work was prominently featured. This was followed up by a small solo travelling exhibition (and catalogue) prepared in 1935 and first shown at MoMA and organized by Philip

\footnotetext{
${ }^{1}$ See Alan Powers, "Introduction," in Irena Murray and Julian Osley, eds., Le Corbusier and Britain: An Anthology (Abingdon: Routledge, 2009), pp. 1-11.

${ }^{2}$ See Adrian Forty, "Le Corbusier's British Reputation," in Michael Raeburn and Victoria Wilson, eds., Le Corbusier: Architect of the Century (London: Arts Council of Great Britain, 1987), pp. 35-41.

${ }^{3}$ See Murray and Osley, eds., Le Corbusier and Britain.

${ }^{4}$ See Gordon H.G. Holt, "The Merit of Le Corbusier," Architectural Review (Vol. 63,1928), p. 56.

${ }^{5}$ See Harold Tomlinson, “Towards a New Architecture,” Architects' Journal, 127, (Sept. 21, 1927), pp. 378-379.

${ }^{6}$ See Howard Robertson and F.R. Yerbury, Examples of French Architecture (New York: Charles Scribner's Sons, 1928).

${ }^{7}$ See Frederick Etchells, "Le Corbusier: A Pioneer of Modern European Architecture," The Studio, 96, (Sept. 1928), pp. 156163.

${ }^{8}$ See Herbert Read, “The City of To-morrow,” The Listener, (Feb. 18, 1931), pp. 272-273.
} 
Goodwin, Henry-Russell Hitchcock, Philip Johnson, Alfred H. Barr, Jr., George Howe, and Joseph Hudnut. ${ }^{9}$ Marges Bacon has extensively examined Le Corbusier's impact on America following his first visit in $1935{ }^{10}$ As Bacon notes in her "Introduction" the relationship between Le Corbusier and America could be characterised as a "transatlantic exchange" in the way it functioned. ${ }^{11}$ She also provides a list of American critics who responded to Le Corbusier's emerging reputation, including Hitchcock, Johnson, Hudnut, Howe, Lewis Mumford, Catherine Bauer, and others. ${ }^{12}$ Le Corbusier's complex approach to America resulted in his book When the Cathedrals Were White: A Journey to the Country of Timid People published in English in 1947 (originally published in French in 1937).

\section{3. $1940-1960$}

The British journal Architectural Review has, since the 1920s, been a consistently important vehicle for Le Corbusier criticism and historical scholarship, publishing many articles by authors such as John Summerson, Colin Rowe, Reyner Banham, James Stirling, and Kenneth Frampton. This would include essays such as Rowe's "The Mathematics of the Ideal Villa"13 published in 1947 which has stood up as one of the most referred to early interpretations of Le Corbusier's work. In the same year and journal Lionel Brett's essay “The Space Machine: an Evaluation of the Recent Work of Le Corbusier" was also published, in which he noted that Le Corbusier's descriptions of his own work leaves the critic "more or less bludgeoned into silence.".

An early attempt to provide a more general critical assessment of Le Corbusier's architecture during the period 1918-1947 is found in Stamo Papadaki’s edited book entitled Le Corbusier, Architect, Painter, Writer published in $1948,{ }^{15}$ including contributions by Fernand Leger, José Luis Sert, and Sigfried Gideon. Reviewing it in The Art Bulletin Henry-Russell Hitchcock notes that the essays are very short, and writes that, "Doubtless the time has not yet come for a really authoritative and objective study of Le Corbusier's work." 16

John Summerson's "Architecture, Painting and Le Corbusier" ${ }^{\prime 17}$ published in 1949 was the culmination of Summerson's early efforts to interpret Le Corbusier, being mainly concerned to explain the architect's formal and aesthetic language spanning his art and architectural practice in relation to the revolution in visual understanding brought about by modern painting.

In the 1950s emerged the British architectural theorist Reyner Banham, who began writing architectural criticism for the Architectural Review. Banham used Le Corbusier's Unité d'Habitation, Marseilles, to announce

\footnotetext{
${ }^{9}$ See Marges Bacon, Le Corbusier in America: Travels in the Land of the Timid (Cambridge, Mass.: MIT Press, 2001), pp. 40-47.

${ }^{10}$ Ibid., pp. 237-311.

${ }^{11}$ Ibid., pp. xiii-xvii.

${ }^{12}$ Ibid., p. xvii.

${ }^{13}$ Colin Rowe, "The Mathematics of the Ideal Villa," Architectural Review, 101, (March 1947), pp. 101-104. See also Daniel Sherer, "Le Corbusier's Discovery of Palladio in 1922 and the Modernist Transformation of the Classical Code," Perspecta, Vol. 35, (2004), pp. 20-39; and, Jeffrey Hildner,"Remembering the Mathematics of the Ideal Villa," Journal Of Architectural Education, Vol. 53, No. 3, (Feb. 1999), pp. 143-162.

${ }^{14}$ See Lionel Brett, "The Space Machine: an Evaluation of the Recent Work of Le Corbusier," Architectural Review, (November 1947), pp. 147-150.

${ }^{15}$ Stamo Papadaki, ed., Le Corbusier, Architect, Painter, Writer (New York: Macmillan, 1948).

${ }^{16}$ Henry-Russell Hitchcock, The Art Bulletin, Vol. 32, Issue 1, (1950), p. 87.

17 See John Summerson, "Architecture, Painting and Le Corbusier," in Heavenly Mansions and Other Essays on Architecture, (London: Cresset Press, 1949), pp. 177-194.
} 
Brutalism, a post-war 'movement' signalling a significant break with pre-war modernism, mainly through the critical re-evaluation of concrete as an aesthetic and expressive material. Following Summerson, Banham also entered the debate on the role of art in Le Corbusier's work in his review of an exhibition at the Institute of Contemporary Art, London, of 1953, seeing the architect's painting and sculpture as central to developments in his formal architectural language. ${ }^{18}$

The architect James Stirling's nuanced view of Le Corbusier's late works perhaps best epitomised that of fellow post-war architects - a sense of shock and puzzlement at the architect's turn to rough sculptural forms (dramatically illustrated in Le Corbusier's Chapel at Ronchamp) followed later by qualified admiration for this newfound expressive language. In his article, "Garches to Jaoul: Le Corbusier as Domestic Architect in 1927 and 1953" (1955), Stirling comments on the roughness of the building of the Maisons Jaoul, its contrast to the fineness of Paris, while Garches stands for his pre-war machine aesthetic representing for Stirling "a continuous reminder of the quality to which all architecture must aspire if modern architecture is to retain its vitality." Stirling's 1956 review of Le Corbusier's Chapel at Ronchamp for Architectural Review,${ }^{20}$ highlighted "the crisis of rationalism" noting a move in Europe towards a humanist modernism (aligned to concepts in art and culture) which was opposed to the technologically driven modernism taking hold in the United States. However, what appeared as a critical rejection by Stirling of Le Corbusier's post-war move to an expressive humanist architecture would, subsequently, turn into a more appreciative reading of this work, particularly Ronchamp. In a 1960 article for the Yale journal Perspecta, entitled “"The Functional Tradition' and Expression”, Stirling describes an unselfconscious or "vernacular" method of architectural designing embodying a "common sense" approach to architecture, which he appreciates as a valuable lesson of the so-called humanist approach that Le Corbusier took to his post-war work. ${ }^{21}$ Stirling's observation of Le Corbusier's turn in the 1930s to a concept of vernacular thinking was not made in isolation. This idea has featured heavily in the critical accounts of the architect's work from the 1960s and up to more recent scholarship by Francesco Passanti. ${ }^{22}$

Meanwhile in the United States the American magazine Architectural Forum (1941-1974) regularly published news and reviews of Le Corbusier's work. Other US journals including Architectural Record, Pencil Points/Progressive Architecture, and American Institute of Architects Journal would also consistently publish critical reviews of Le Corbusier's projects. Of note is John Entenza's magazine Arts \& Architecture which, during its history (1938-1967), participated actively in the Le Corbusier discourse. Also of interest is the phenomenon of important American art journals engaging in critical Le Corbusier scholarship, these included Art Digest, Art News, Art in America, Arts Magazine, Art Bulletin, and Art Forum which published texts by authors such as Ada Louis Huxtable, ${ }^{23}$ Sibyl Moholy-Nagy, ${ }^{24}$ and Rosalind Kraus. ${ }^{25}$

In the 1950s there emerged a strong movement to attack Le Corbusier's concepts, particularly those dealing with the city. This manifested itself in the Team 10 movement, but also with proponents of the Garden City, such as

\footnotetext{
${ }^{18}$ Reyner Banham, “The New Brutalism,” Architectural review, 118 (Dec 1955), pp. 354-361.

${ }^{19}$ See James Stirling, "Garches and Jaoul: Le Corbusier as Domestic Architect in 1927 and 1953," Architectural Review (September 1955), pp. 145-151.

${ }^{20}$ See James Stirling, "Ronchamp and the Crisis of Rationalism,” Architectural Review, (March 1956), pp. 155-61.

${ }^{21}$ See James Stirling, “"The Functional Tradition’ and Expression,” Perspecta, 6, (1960), pp. 88-97.

${ }^{22}$ See Francesco Passanti, "The Vernacular, Modernism, and Le Corbusier," Journal of the Society of Architectural Historians, 56.4, (Dec 1997), pp. 438-451.

${ }^{23}$ Ada Louis Huxtable, "French Architecture Today," Art Digest, 28, (April 15, 1954), p. 18.

${ }^{24}$ Sibyl Moholy-Nagy, "The Achievement of Le Corbusier," Arts Magazine, 40, (November 1965), pp. 40-45.

${ }^{25}$ Rosalind Kraus, "Léger, Le Corbusier and Purism," Art Forum, 10, (April 1972), pp. 50-53.
} 
F.J. Osborn and Lewis Mumford. ${ }^{26}$ This was further augmented by the writings of Jane Jacobs, notably with the publication of her influential book The Death and Life of Great American Cities in 1961 in which she deliberately conflates the urban approach of Le Corbusier's La Ville Radieuse plan with that of the American Garden City planners, fashioning the term 'Radiant Garden City Beautiful' as a means to identify and criticize then current planning practices and the social alienation she held their work responsible for. ${ }^{27}$

During the 1940s and 1950s a number of key texts by Le Corbusier were translated into English including The Four Routes, ${ }^{28}$ The Home of Man, ${ }^{29}$ The New World of Space, ${ }^{30}$ and The Modulor. ${ }^{31}$

\section{1960-1980}

A set of symposia at Columbia University in New York (held between March-May 1961) brought together important critics and architects to examine the works of Le Corbusier alongside fellow modern masters Walter Gropius, Mies van der Rohe, and Frank Lloyd Wright (with a publication released in the same year ${ }^{32}$ ). Presentations on Le Corbusier by friend and collaborator, José Luis Sert, and the Italian architect and critic, Ernesto Rogers, reflected their personal admiration of the architect. The Museum of Modern Art would continue to champion Le Corbusier during Arthur Drexler's term as the director and curator of the Department of Architecture and Design (1956-1985). The exhibition "Le Corbusier: Buildings in Europe and India" was held in 1963, and a subsequent exhibition "Le Corbusier: Architecture Drawings” was shown in 1978.

A 1963 essay by the historian and urban thinker Lewis Mumford on the Unité d'Habitation, Marseilles, revealed quite a different position on the architect, criticising his building as no more innovative, in social terms, than others of its time. ${ }^{33}$ This dichotomy of views was testament to Le Corbusier's skill as a rhetorician that, in turn, played into his critical reception. As Alan Colquhoun was later to observe of this period, "whether the commentators on his work were sympathetic or antagonistic they tended to measure themselves against the myth that [Le Corbusier] himself had created. ${ }^{34}$ At the same time Le Corbusier's work was being appropriated towards agendas not necessarily of the architect's own making - for example, Reyner Banham's books Theory and Design in the First Machine Age (1960), The New Brutalism (1966) and The Architecture of the WellTempered Environment (1969) set Le Corbusier's work in particular directions - made to serve arguments tangential to the architect's personal polemics.

\footnotetext{
${ }^{26}$ See F.J. Osborn, “Concerning Le Corbusier,” Town and Country Planning, 20, (July 1952), pp. 311-316; (August 1952), pp. 359-363. See Lewis Mumford, "Yesterday's City of Tomorrow," Architectural Record, 132, (November 1962), pp. 139144.

${ }^{27}$ Jacobs, Jane. The Death and Life of Great American Cities: The Failure of Town Planning (New York: Random House, 1961), pp. 21-25.

${ }^{28}$ Le Corbusier, The Four Routes (London: Dennis Dobson, 1947).

${ }^{29}$ Le Corbusier and François de Pierrefeu, The Home of Man (London: Architectural Press, 1948).

${ }^{30}$ Le Corbusier, New World of Space (New York: Reynal and Hitchcock, 1948).

${ }^{31}$ Le Corbusier, The Modulor (London: Faber and Faber, 1954).

${ }^{32}$ Four Great Makers of Modern Architecture: Gropius, Le Corbusier, Mies van der Rohe, Wright (New York: Columbia University, 1961).

${ }^{33}$ Lewis Mumford, "The Marseille 'Folly," in Highway and the City (New York: Harcourt, Brace and World, 1963), pp. $53-$ 66.

${ }^{34}$ Alan Colquhoun, "The Le Corbusier Centenary," Journal of the Society of Architectural Historians, Vol. 49, No. 1 (Mar., 1990), pp. 96-105.
} 
Monographs on Le Corbusier in English began appearing in the early 1960s including Peter Blake's Le Corbusier: Architecture and Form (1960) and Françoise Choay's Le Corbusier (1960). Blake's remains the first major effort to interpret Le Corbusier's work in English, and was part of a three volume series that also examined Mies van der Rohe and Frank Lloyd Wright; Blake's text is both thoughtful and highly appreciative. Maurice Besset's Who was Le Corbusier? appeared simultaneously in French and English in 1968 as a thematically organized book with a strong visual quality. ${ }^{35}$ In the 1970s less consequential books such as Martin Pawley's Le Corbusier (1970), Robert Furneaux Jordan's Le Corbusier (1972), Charles Jenck's Le Corbusier and the Tragic View of Architecture (1973), and Stephen Gardiner's Le Corbusier (1974) were produced.

Le Corbusier's death in 1965 triggered a host of tributes by distinguished architects and critics in all major architectural journals internationally. These include Richard Neutra's in the September 1965 issue of Canadian Architect, Philip Powell and Jane Drew's personal reflections in the Architects' Journal (published the same month), Henry-Russell Hitchcock's in Progressive Architecture (October 1965), Jørn Utzon's brief eulogy in the simple publication of drawings by Le Corbusier in Architecture in Australia in December 1965, and Reyner Banham's dramatically titled "The Last Formgiver" in The Architectural Review of August 1966, in which he wryly observed that the kind of unqualified admiration enjoyed by Le Corbusier from his fellow architects meant that he continued to dominate his critics, even in death. ${ }^{36}$

In 1970 the final volume of Le Corbusier's Oeuvre Complète was published. The series of eight volumes, the first of which appeared in 1929, featured projects by the architect alongside his artworks recounted through drawing, text and image. ${ }^{37}$ Edited by Willy Besieger the tri-lingual volumes (in French, German and English) have provided a key source for architects and as well as scholars internationally, despite the fact that the first volume did not include many of the works he executed before 1920 .

Le Corbusier's work was by now routinely published across the globe. The Indian architecture journal Marg published regularly on Le Corbusier's work in India from the late 1950s and into the early 1960s. Other journals with regular contributions on the architect include the South African Architectural Record, Architecture in Australia, Canadian Architect, and the Royal Architectural Institute of Canada Journal.

In Britain the journal Architectural Design (under editorship of Monica Pigeon, 1946-1975) included articles on Le Corbusier by Kenneth Frampton, Alan Colquhoun and Rem Koolhaas. In turn, Architectural Association Quarterly and AA Files have regularly featured articles on Le Corbusier since the 1960s. A 1972 account in AAQ of the architect's influence on modern architecture in South Africa was indicative of impact and worldwide reach of Le Corbusier's ideas. ${ }^{38}$ US based journals such as the Journal of Architectural Education and Perspecta have

\footnotetext{
${ }^{35}$ See Peter Serenyi's review in the Journal of the Society of Architectural Historians, Vol. 30, No. 3 (1971), pp. $255-256$.

${ }^{36}$ Richard Neutra, "Le Corbusier," Canadian Architect, 10, (September 1965), pp. 23-26; Philip Powell and Jane Drew, "Le Corbusier: Appreciations," Architects' Journal, 142, (Sept. 15, 1965), pp. 1592-1593; Henry Russell Hitchcock Jr., "Le Corbusier: A Preliminary Assessment, Estimates of the Man and His Work by Architects, Critics, and Historians Who Knew Him," Progressive Architecture, 46, (October 1965), pp. 232-237; Jørn Utzon, "Le Corbusier," Architecture in Australia, 54.4, (December 1965), pp. 100-101; Reyner Banham, "Le Corbusier: The Last Formgiver," Architectural Review, 140, (August 1966), pp. 86, 97-108.

${ }^{37}$ Le Corbusier, Oeuvre Complète Vols 1-8, London: Thames \& Hudson, 1970.

${ }^{38}$ See Gilbert Herbert, "Le Corbusier and the Origins of Modern Architecture in South Africa," AAQ : Architectural Association Quarterly, 4, no. 1, (01, 1972), pp. 16- 30.
} 
also contributed regularly to the Le Corbusier debates; the $J S A H$, in particular, continues to be a vital vehicle for Le Corbusier scholarship.

One of the earliest scholarly dissertations on Le Corbusier was by the Hungarian-born American, Peter Serenyi. His essays entitled "Le Corbusier's Changing Attitude Toward Form" (1965) published in the Journal of the Society of Architectural Historians and "Le Corbusier, Fourier, and the Monastery of Ema" (1967) published in The Art Bulletin were important early works of scholarship. ${ }^{39}$ His edited collection Le Corbusier in Perspective (1975) brought together essays that encapsulated Le Corbusier studies until that time.

Norma Evenson, who taught at UC Berkeley from 1963 to 1993, produced other significant early scholarship, publishing a seminal account of Le Corbusier's urban project at Chandigarh in 1966, based on several personal visits she had taken to the city. ${ }^{40}$ Urban planner Philippe Boudon's sociological perspective on Le Corbusier's housing complex at Pessac (first published in French in 1969) remains a classic critique of the architect's work. ${ }^{41}$ The establishment of the Fondation Le Corbusier in 1968 and the publication in the same year of Stanislaus von Moos' Le Corbusier: Elemente einer Synthese (English edition 1979) contributed to a significant new context for constructing Le Corbusier's legacy. As Tim Benton has noted, an important aspect of von Moos' first attempt to overview the architect's career was to find a place for his art, providing a means to situate it in an art historical context as never before. ${ }^{42}$ Reviewing the text in 1971, Serenyi writes, "Mr. von Moos' book is the first attempt to grasp the entire work of Le Corbusier in a more comprehensive way....this book will remain an indispensable tool for the specialist and nonspecialist alike." ${ }^{, 43}$

By the early 1970s a host of new Le Corbusier scholars began to establish themselves, using the archives available through the Fondation. In accessing previously unseen materials interest turned to Le Corbusier's early years and his architectural formation. Scholarly research by Paul Turner and Mary Sekler, both undertaking dissertations through the Department of Fine Arts at Harvard University, dealt respectively with the architect's early education and drawings, becoming the first of a wave of studies attempting objective assessments of Le Corbusier situated in a broader social and historical context. ${ }^{44}$ Other early scholars included: Joyce Lowman on the formative influence of engineer Max DuBois on Le Corbusier; Brian Brace Taylor on the Cité de Refuge project; William J.R. Curtis and Eduard F. Sekler on the Carpenter Center; and the work of New Zealand historian and architect, Russell Walden, who edited The Open Hand: Essays on Le Corbusier for MIT Press in 1977 which included essays by several key Le Corbusier scholars who emerged during this period. ${ }^{45}$

\footnotetext{
${ }^{39}$ Peter Serenyi, "Le Corbusier's Changing Attitude Toward Form," Journal of the Society of Architectural Historians, 24, no. 1, (March 1965), pp. 15-23, and "Le Corbusier, Fourier and the Monastery of Ema," The Art Bulletin, 49.4, (December 1967), pp. 277-286.

${ }^{40}$ Norma Evenson, Chandigarh (Berkeley, University of California Press, 1966).

${ }^{41}$ Philippe Boudon, Lived in Architecture: Le Corbusier's Pessac Revisited (Cambridge, Mass.: MIT Press, 1972).

${ }^{42}$ Tim Benton, "New Interpretations, New Evidence," in The Villas of Le Corbusier and Pierre Jeanneret, 1920-1930 (Basel: Birkhäuser, 2007), p. 213

${ }^{43}$ See Peter Serenyi's review in the Journal of the Society of Architectural Historians, Vol. 30, No. 3 (1971), pp. 256-258.

${ }^{44}$ Paul Turner, The Education of Le Corbusier (New York: Garland Publishing, 1977) and Mary P. M. Sekler, The Early Drawings of Charles-Eduard Jeanneret (Le Corbusier) (New York: Garland Publishing, 1977).

45 Joyce Lowman, "Corb as Structural Rationalist," The Architectural Review, (October 1976), pp. 229-293; Brian Brace Taylor, Le Corbusier: La Cité de Refuge 1929/33 (Paris: Equerre, 1980); Eduard F. Sekler and William J.R, Curtis, Le Corbusier at Work: The Genesis of the Carpenter Center for the Visual Arts (MIT Press: Cambridge, Mass., 1978) and Russell Walden (ed), The Open Hand: Essays on Le Corbusier (MIT Press: Cambridge, Mass., 1977).
} 
Two important issues of Oppositions (no. 15/16 in 1979 and no. 19/20 in 1980) focussing on Le Corbusier and edited by Kenneth Frampton represented the centrality of Le Corbusier's work to the architectural theory agendas of the period. For example, Peter Eisenman's essay on the semiotics of the Domino frame, and Barry Maitland's on "The Grid" indicated the way in which Le Corbusier's work, interpreted as a formal language by both critics and architects, was instrumentalised by the new avant-gardes. Mary McLeod's critique of the work in Algiers, Jean-Louis Cohen's study of Le Corbusier's travels to the Soviet Union, and Kenneth Frampton's on the magazine Espirit Nouveau pointed forward to pre-occupations with broader social, political and cultural issues that would dominate the critical reception of the architect's work in the following decades.

During the 1960s and 1970s further publications by Le Corbusier appeared in English including Creation is a Patient Search, ${ }^{46}$ Le Corbusier Talks with Students from School of Architecture, ${ }^{47}$ The Radiant City, ${ }^{48}$ and The Athens Charter. ${ }^{49}$

\section{5. $1980-2000$}

In 1981-1982 the Architectural History Foundation and MIT Press published Le Corbusier's sketchbooks in four volumes. Almost in parallel, between 1982 and 1985, the 32 volumes of Le Corbusier's architectural drawings were published by Garland and edited by H. Allen Brooks (with the related publication of essays accompanying each volume). The essay topics ranged from scholarly analysis of projects or periods in the architect's career, biographical accounts by collaborators and broad surveys of his output. Tim Benton argues that prior to 1984 most material on Le Corbusier "were works of architectural analysis and appreciation," and that after this a period of "genetic" scholarship commenced. ${ }^{50}$

Closer art historical research into the Purist painting phase of Le Corbusier's career begins in 1970s and continued into the 1980s with scholarship undertaken by Kenneth E. Silver, Susan L. Ball, and Christopher Green. ${ }^{51}$ These studies looked beyond a pure examination of the formal connections between Le Corbusier's art and architecture that had dominated earlier critical accounts, seeking to contextualise his art practice within a broader cultural setting and in his working relationship with friend and collaborator Amédée Ozenfant.

Earlier work dealing with Le Corbusier's use of symbols in his art and architecture as well as drawings and poetry appears in the criticism of Richard Allen Moore (1980), which examined esoteric themes in the "Poem of

\footnotetext{
${ }^{46}$ Le Corbusier, Creation is a Patient Search (New York: Praeger, 1960).

${ }^{47}$ Le Corbusier, Le Corbusier Talks with Students form the Schools of Architecture (New York: Orion Press, 1961).

${ }^{48}$ Le Corbusier, The Radiant City: Elements of a Doctrine of Urbanism to be Used as the Basis of Our Machine-Age Civilization (New York: Orion Press, 1967).

${ }^{49}$ Le Corbusier, The Athens Charter (New York: Grossman, 1973).

${ }^{50}$ Benton, "New Interpretations, New Evidence," pp. 213-215.

${ }^{51}$ Kenneth E. Silver, Espirit de Corps: The Art of the Parisian Avant-garde and the First World War, 1914-1925 (Princeton: Princeton University Press, 1989); Susan L. Ball, Ozanfant and Purism: The Evolution of a Style, 1915-30 (UMI Research Press, 1982); and, Christopher Green "The Architect as Artist," in Michael Raeburn and Victoria Wilson, eds., Le Corbusier: Architect of the Century (London: Arts Council of Great Britain, 1987), pp. 110-130.
} 
the Right Angle" (based on his prior research and PhD dissertation at Ann Arbor) ${ }^{52}$ and Stuart Cohen and Steven Hurtt's assessment of primitive archetypes in relation to the Chapel at Ronchamp. ${ }^{53}$

William J.R. Curtis's book Le Corbusier: Ideas and Forms, published in 1986, presented a broad and readable synopsis of the architect's career highlighting the historian's search for precedents and symbolic themes in his work. Intended to synthesize scholarship undertaken in the 1970s and 1980s, Curtis draws from secondary sources including particularly the work of von Moos, Serenyi, Banham, Rowe, and Colquhoun. ${ }^{54}$

In the 1980s key Le Corbusier scholars, Colquhoun, Frampton and Jean-Louis Cohen produced important critical work. Colquhoun's writings on Le Corbusier appearing in his Essays in Architectural Criticism (1981) and Modernity and the Classical Tradition (1989) largely undertook the task of squaring Le Corbusier's modernist approach with the architectural historicism that preceded it, seeing hidden continuities, mainly in the form of inversions of past practices, in the architect's design methods. Both Frampton and Cohen, who had critical work featured in the journal Oppositions, would go on to write major synoptic accounts of Le Corbusier in the 2000s.

Celebration of the centennial of Le Corbusier's birth in 1887, include major retrospective exhibitions at the Hayward Gallery in London organized by Tim Benton, Neave Brown, Christopher Green, and Richard Francis (along with the publication of it catalogue Le Corbusier: Architect of the Century) and the Pompidou Centre in Paris, which staged Le Corbusier, 1887-1965: une encyclopedie with a catalogue edited by Jacques Lucan. Both were important events generating a host of new critical and historical research on the architect. The centennial year also saw the publication of special issues of journals devoted to Le Corbusier, which included The Architectural Review, Architecture d'aujourd'hui, Casabella, Bauwelt, Assemblage, Arch+ and the South American journal Projeto. Published for the first time in English in 1987 were two major works of scholarship by Tim Benton and Brian Brace Taylor. Benton's study of the villas of the 1920s, based on his detailed examination of the Le Corbusier Archives, had been originally published in French in 1984, and was later revised in 2007. ${ }^{55}$ Benton, along with the ground-breaking study of the villas and his significant contribution to the Architect of the Century exhibition and catalogue emerged as an important Le Corbusier scholar during this period. Brian Brace Taylor's landmark study of the Cité de Refuge project in Paris, first published in French in 1980, finally appeared in English during the centennial year. ${ }^{56}$

The year also featured the first English translations of two major texts by Le Corbusier, The Decorative Art of Today (translated by James Dunnett, and originally published in 1925) and Journey to the East translated by Ivan Zaknic (first published in French in 1966). The latter publication established a new wave of interest in this period of Le Corbusier's life and several scholars in the 1980s and 1990s examined Le Corbusier's early travels including Giuliano Greseli, Sibel Bozdogan, Zeynep Çelik, and Stanislaus von Moos. Subsequently, in 1991, a translation by Edith Schreiber Aujame of Le Corbusier's Precisions appeared which would complete the English

\footnotetext{
${ }^{52}$ Richard Allen Moore, Le Corbusier: Myth and Meta Architecture: The Late Period (1947-1965), (Atlanta: Georgia State University, 1977), Le Corbusier and mécanique spirtuelle, (Ann Arbor, UMI, 1979) and 'Alchemical and mythical themes in the poem of the Right Angle, 1945-65', Oppositions, no. 19/20, (Winter-Spring 1980), pp. 111-139.

${ }^{53}$ Stuart Cohen and Steven Hurtt, "The Pilgrimage Chapel at Ronchamp," Oppositions, no. 19/20, (Winter/Spring 1980), pp.142-159.

${ }^{54}$ William J.R. Curtis, Le Corbusier: Ideas and Forms (Oxford: Phaidon, 1986), pp. 8-9.

${ }^{55}$ Tim Benton, The Villas of Le Corbusier and Pierre Jeanneret, 1920-1930 (Basel: Birkhäuser, 2007).

${ }^{56}$ Brian Brace Taylor, Le Corbusier, the City of Refuge, Paris 1929/33 (Chicago: University of Chicago Press, 1987).
} 
translations of Le Corbusier's major texts; reviewing the book, Mary McLeod underscores how difficult translating Le Corbusier can be and laments the lack of a scholarly introduction to the work translated so many years after its original publication in $1930 .{ }^{57}$

Communities of scholars were now forming, creating debates around Le Corbusier's work through new perspectives. For example the Berlin-based architecture journal Daidalos (1981-2001) publishing in both German and English, featured several important essays by critic/historians such as Bruno Reichlin, Werner Oeschlin, Giuliano Gresleri, Peter Carl, and Jürgen Joedicke in which discussion of the architect's ideas and projects produced an opportunity to play out contemporary concerns of the discipline in a way that gave Le Corbusier's work renewed relevance.

Into the 1990s more specialist scholarship emerged bringing interdisciplinary concepts and questions to Le Corbusier's work. For example in her celebrated book Privacy and Publicity: Modern Architecture as Mass Media of 1994, Beatriz Colomina brought a distinctive agenda to the discussion of Le Corbusier's work. ${ }^{58}$ In referring to the architect's extensive archives, she examined photographs, drawings and advertising laid out in his publications as a means to foreground practices of representation that emerged with the rise of mass media in the twentieth century, arguing that media was actively displacing architecture from its traditional expression through built works.

The publication in 1997 of H. Allen Brooks' monumental work on Le Corbusier's early career entitled Le Corbusier's Formative Years: Charles-Edouard Jeanneret at La Chaux-de-Fonds, ${ }^{59}$ built on his detailed research begun in the 1970s, and established new understandings of Le Corbusier's early ideas and influences, while continuing to stand as essential scholarship.

Alan Colquhoun in his review of Le Corbusier 1987 centennial publications in the $J S A H$ notes how the critical reception of the architect now had a more objective tone, proving that "Le Corbusier studies had evolved from the mythologies and demonologies of the 1950s. ${ }^{, 60}$ While this was certainly true it is also the case that, by the 1990s, Le Corbusier's work was being contextualised in a much broader cultural field - beyond the specifics of earlier disciplinary debates.

\section{2000-Present}

In the introduction to his 2001 book simply titled Le Corbusier Kenneth Frampton ponders the redundancy of rewriting the history of the architect's oeuvre - so amply described by historians (including himself) in the previous five decades. Yet, not surprisingly, Frampton's answer comes in acknowledging the continued emergence of finely detailed scholarship that throws ever more light on its subject - highlighting the broad scope of his production across architecture, urbanism, painting, graphic design and publishing. Reviewing Frampton's book William J.R. Curtis complains that the number of works providing a full overview of Le Corbusier's career

\footnotetext{
${ }^{57}$ Mary McLeod, "Le Corbusier: Precisions," Journal of the Society of Architectural Historians, Vol. 55, No. 1 (March 1996), p. 92.

${ }^{58}$ Beatriz Colomina, Privacy and Publicity: Modern Architecture as Mass Media (Cambridge, Mass: MIT Press, 1994).

59 H. Allen Brooks, Le Corbusier's Formative Years: Charles-Edouard Jeanneret at La Chaux-de-Fonds (Chicago: University of Chicago Press, 1997).

${ }^{60}$ See Colquhoun, “The Le Corbusier Centenary," pp. 96-105.
} 
are few, and that Frampton's work follows his typical themes, is "extremely compressed," and often lacks a sympathetic description of the projects. ${ }^{61}$ Also acknowledging the range and diversity of Le Corbusier's output was a 2001 conference Le Corbusier \& the Architecture of Reinvention held at the Architectural Association, London. Convened by Mohsen Mostafavi and Charles Jencks in response to the latter's publication Le Corbusier and the Continual Revolution in Architecture (2000), the event highlighted new work of established critics alongside the work of then emerging scholars such as Hilde Heynen and Daniel Naegele.

Detailed scholarship continued to be produced and a host of books on Le Corbusier exposing very specific aspects of his career, and new interpretations, appeared. Books on photography, travels, automobiles and the machine aesthetic, including: Marges Bacon's book Le Corbusier in America: Travels in the Land of the Timid (2001); Simon Richards' Le Corbusier and the Concept of Self (2001); Alexander Tzonis's Le Corbusier: the poetics of machine and metaphor (2001); Catherine de Smet's Le Corbusier: Architect of Books (2005); Antonio Amado's Voiture Minimum: Le Corbusier and the Automobile (2011); Christine Boyer's Le Corbusier: home de lettres (2011); Arthur Rüegg's Le Corbusier: Furniture and Interiors (2012); and, Tim Benton's LC foto: Le Corbusier, Secret Photographer (2013). Large-scale synoptic works also emerged including Jean-Louis Cohen's documentary opus Le Corbusier: Le Grand (2008) and a populist biography of Le Corbusier's life by Nicholas Fox Weber also published in $2008 .{ }^{62}$

Le Corbusier's range of material output - from architectural models and drawings to paintings and sculpture became the subject of major exhibitions including L'Esprit Nouveau: Purism in Paris, 1918-1925 (Le Corbusier, Ozenfant and Leger) held at the Los Angeles County Museum of Art in 2001, ${ }^{63}$ and Le Corbusier ou la Sythése des Arts at the Musée Rath, Geneva, in 2006, the latter attempting to highlight Le Corbusier's artistic output in its own right - separately of his architectural work. Following were large-scale touring exhibitions combining original materials with newly commissioned models and photographs: Le Corbusier: The Art of Architecture, organized by the Vitra Design Museum in collaboration with the Netherlands Architecture Institute, the Royal Institute of British Architects and the Fondation Le Corbusier in 2007, and Le Corbusier: An Atlas of Modern Landscapes curated by Jean-Louis Cohen for the Museum of Modern Art, New York, in 2013. The catalogue edited by Cohen provides a range of geographically organized short essays by mainly established scholars that also indicate possible directions for new scholarship. ${ }^{64}$

In 2007 a new English translation by John Goodman of Le Corbusier's most important text is published, with the corrected title Toward an Architecture. Featuring a lengthy introduction by Jean-Louis Cohen, the text attempts to correct the many faults found in Frederick Etchells' translation of 1927. Tim Benton praises the scholarly effort, but suggests that a certain spirit found in the Etchells version has been lost. ${ }^{65}$

Recent research of Le Corbusier has tended to seek out what might be seen as hidden aspects of the architect's career, constructing arguments about his motivations and architectural precedents that cannot be understood as a

\footnotetext{
${ }^{61}$ William J.R. Curtis, “The ever-elusive Le Corbusier - even today writers can't quite figure him out," Architectural Record, Vol. 190, No. 2, (February 2002).

${ }^{62}$ Simon Richards' and Nicholas Fox Weber's books, along with several other recent publications, have been reviewed in Tim Benton, "New Books on Le Corbusier," Journal of Design History, Vol. 22, No. 3, (2009), pp. 271-284.

${ }^{63}$ See Carol S. Eliel, L'Esprit Nouveau: Purism in Paris, 1918-1925 (Los Angeles: Los Angeles County Museum of Art, 2001).

${ }^{64}$ Jean-Louis Cohen, ed., Le Corbusier: An Atlas of Modern Landscapes (London: Thames and Hudson, 2013).

${ }^{65}$ See Tim Benton, "Le Corbusier: Toward an Architecture (1924)," Journal of Architectural Education, Vol. 62, No. 1, (September 2008), pp. 74-75.
} 
straightforward deepening of the paths of preexisting scholarship. For example, new sources of Le Corbusier's 'modernity' are discovered in unlikely places; the particular vernacular architectures of the Balkan and the Bosphorus regions as described by Adolf Max Vogt in Le Corbusier: The Noble Savage ${ }^{66}$ or the copying of precedents out of the work of $18^{\text {th }}$ century architect François Joseph Belanger as proposed by Jan Birkstead. ${ }^{67}$ Birkstead's research is also notable for looking beyond the vast resources of the Fondation to access materials from Le Corbusier's Swiss hometown La Chaux-de-Fonds in an attempt to construct new and previously undisclosed perspectives on the work. The journal Massilia operating between 2002 and 2013 looked at Le Corbusier's impact in South American and outside Europe, giving further definition to communities of researchers that have built around the architect's work, undertaking historical studies by which we can continue to deepen our understanding of the architect in his times. Significant work presented in Massilia included Maria Cecilia O'Byrne's essay on Le Corbusier's Mundaneum museum and the 2007 edition devoted to discussion of the Chilean architect Guillermo Jullian de la Fuente - between 1959 and 1965 one of Le Corbusier's chief collaborators and credited as co-author of the Venice Hospital project. ${ }^{68}$

Though the 1991 publication in English of Le Corbusier's Precisions stands as the last major text to be made available in translation, recent scholarship has continued to reveal significant unpublished material by the architect. For example, Le Corbusier's early manuscript "La Construction de Villes" (The construction of cities) - compiled by Christoph Schnoor and published for the first time in German in 2008 - evidences the young Le Corbusier's encounter with principles of city design during his travels in Berlin and Munich in 1910-11 and is yet to appear in English. ${ }^{69}$

\section{The historiography of criticism}

A decade-by-decade analysis of the Avery Index of Architectural Periodicals shows ever-increasing growth in the number of articles specifically addressed to Le Corbusier and his work. The only exception is the decade of the 1970s, following Le Corbusier's death in 1965, in which the number of commentaries diminished to the level they had been in the 1940s. This relative hiatus in writing on Le Corbusier marked a period of transition from direct dealing with the architect and his works to reflections on his ideas and approaches - their origins, meaning and continued relevance. However, from the 1980s to the present, growth in critical scholarship and writing on Le Corbusier became exponential once again - taking up at almost double the level it had been in the 1960s. Since 2000 there has been nearly 900 articles on Le Corbusier in architectural periodicals. This is comparable to discussion of contemporary star-architects, such as Rem Koolhaas and Zaha Hadid, who each have up to 950 articles addressed to them and their work over the same period. Beyond this comparison, if we add the large exhibitions and major book publications previously mentioned that have been produced on Le Corbusier since 2000 , it is evident that critical reflections on his work play a significant role in the disciplinary context as well as in broader public discourse of architecture.

\footnotetext{
${ }^{66}$ Adolf Max Vogt, Le Corbusier, The Noble Savage: Towards an Archeology of Modernism (Cambridge, Mass.: MIT Press, 2000).

${ }^{67}$ Jan Kenneth Birksted, "The Politics of Copying: Le Corbusier's Immaculate Conception," Oxford Art Journal, 30, 2 , (2007), pp. 305-326.

${ }^{68}$ See Maria Cecilia O’Byrne, “El museo del Mundaneum : génesis de un prototipo, “ Massilia (2004), pp.112-135 and the special issue on Guillermo Jullian de la Fuente, Massilia (2007).

${ }^{69}$ Christoph Schnoor, (ed.) La Construction des Villes: Le Corbusiers erstes stadtebauliches Traktat von 1910/11 (Berlin: Verlag, 2008).
} 
The historiography of criticism of Le Corbusier also reveals the way in which well-known historian/critics made their reputations out of their commentaries on the architect, and continued to deepen their investigation of his work - sometimes re-visiting their own earlier interpretations - Colin Rowe, Reyner Banham, Alan Colquhoun, Timothy Benton, Stanislaus von Moos, Jean-Louis Cohen, William Curtis, Mary McLeod, and Beatriz Colomina for example. Of particular note is the 2013 revised edition of Moos' Elements of a Synthesis (1968) that provides an additional survey addressed to a host of recent scholarship on Le Corbusier, reengaging themes and materials laid out by Moos in his original critical account.

By the early 1990s critics began to frame Le Corbusier's output through a range of interdisciplinary perspectives - media and gender studies, psychoanalysis and post-colonialism - situating the work in diverse contexts that answered to debates of contemporary interest in the redress of history. Concern moved away from an examination of the built work to other forms of his production - texts, drawings, photographs, notes and letters that offered new sites of investigation. Le Corbusier's work seen in relation to the social and cultural attitudes of the times provided fertile ground for commentary and discussion. Yet even though the work of his contemporaries may well have raised the very same issues and attitudes, seen in such close examination, for scholarship, it was Le Corbusier and his work that became emblematic of the means by which to negotiate and understand them - much the same as the architect's work had stood in for the modernist project up to half a century earlier.

Looking closely at material written by established historians who have examined Le Corbusier's work over several decades, it is also possible to observe how views of the architect change. While the early versions of their research capture a vitality and strength of perspective - writing that is, in most cases, well known - their later works are inevitably more nuanced and complex incorporating new research material and greater reflection. The resulting understanding of Le Corbusier as an architect and historical figure is myriad rather than singular, as Jean-Louis Cohen's attempt to capture the various personas of the architect in his 2008 Introduction to $L e$ Corbusier: Le Grand vividly illustrates. ${ }^{70}$

Le Corbusier's archives held by the Fondation Le Corbusier in Paris are indeed extensive comprising 400,000 documents and the forms of access to them has shaped possibilities of research. From its inception in 1968, the Fondation inevitably provided impetus to historical study. In the 1970s initial investigations focussed on the architect's early years, while later into the 1980s attention moved to individual projects or sets of works within a period. Since 1990 the Fondation has taken a more active role in fostering research, holding annual meetings of researchers and publishing Le Corbusier's works and writings. With the digitisation of the archive in the 1990s improved access to research materials fed growth in scholarship - making new and diverse kinds of study possible.

Compiling the history of Le Corbusier has been a worldwide endeavour. The architects many travels have produced an array of critical accounts focussed on the places he visited, lectured, worked and staged exhibitions. Despite the 'universality' of Le Corbusier's modernism it is clear that the architect's encounters with national and regional contexts constitute unique circumstances of investigation. As Alan Power notes Le Corbusier's work has often acted as a mirror to the societies with which he engaged ${ }^{71}$ and a similar kind of reception of the

\footnotetext{
${ }^{70}$ Jean-Louis Cohen, "The Man with a Hundred Faces," in his Le Corbusier Le Grand (New York: Phaidon, 2008), pp. 6-17.

${ }^{71}$ Powers, "Introduction," in Murray and Osley, eds., Le Corbusier and Britain, p.1.
} 
architect's work can be found in scholarship. The work of Indian scholars on Le Corbusier's work at Chandigarh, for example, evidences the rehearsal of issues of nationhood and identity that speak strongly to an internal audience as much as to audiences interested in the impact of the architect's work globally. Documenting contributions to this national debate are a set of publications marking various anniversaries since the conception of Chandigarh - Chandigarh: Forty Years After Le Corbusier, Celebrating Chandigarh: 50 years of the idea, Le Corbusier: Chandigarh and the Modern City - Insights into the Iconic City Sixty Years Later, and Vikramaditya Prakash's 2002 book Chandigarh's Le Corbusier: The Struggle for Modernity in Postcolonial India - indicating the way Le Corbusier's legacy continues to be shaped by renewed interpretations of his cultural encounters. ${ }^{72}$

\section{Conclusions}

The selecting of material, currently available in English, for a large anthology of writings on Le Corbusier presents many challenges. Firstly, we determined that it is important to capture a chronology of his life including important periods, developments, projects, and themes. Secondly, it is vital to include material from across the many decades of writing on his work and by key Le Corbusier scholars. Thirdly, it is also crucial to include less well-known writings that contribute to the larger discourses. Fourthly, the availability of material in translation is also a key consideration to capture the tone of distinctive of national debates around Le Corbusier's work, although we recognize that much important scholarship has not been translated into English. Fifthly, that we include at most 2-3 contributions by a single author, and limit the number of articles from a particular collection in order to produce a balanced yet diverse coverage of sources.

What also emerges from a survey as extensive as the one we are undertaking is the vastness of scholarly materials on Le Corbusier and yet the presence of gaps in the research. For example, more attention might be paid to Le Corbusier's design of individual urban projects beyond the obvious interest in Chandigarh, which continues to be object of new criticism. The role and impact of Le Corbusier's architectural collaborators might be better interpreted beyond the personal commentaries and recollections of those individuals - for example, studies of the likes of André Wogenscky, Iannis Xenakis, Maxwell Fry, Jane Drew, the art agent Heidi Weber, and others. While work has certainly begun on his collaboration with figures such as Charlotte Perriand, Guillermo Jullian de la Fuente and his cousin Pierre Jeanneret, there is certainly more research that could emerge. Le Corbusier's unbuilt projects undertaken in the last years of his career have also received limited attention, as has his work with Jean Prouvé on the post-war project for prefabricated steel housing. Finally, is it time for a new book that examines the entire career, or has that task become too monumental? ${ }^{73}$ For the fact that these omissions (and no doubt others) still exist in our understanding of one of the key architects of the $20^{\text {th }}$ century, who is also the more studied of his time, is to admit to the strong and seemingly inexhaustible fascination that remains around the figure of Le Corbusier now 50 years after his death.

\footnotetext{
${ }^{72}$ C. Gordon and K. Kilian, eds., Chandigarh: Forty Years After Le Corbusier, (Amsterdam: Architectura \& Natura, 1991); Jaspreet Takhar, ed., Celebrating Chandigarh, (Chandigarh: Chandigarh Perspective, 2001); Hasan-Uddin Kahn, ed., Le Corbusier: Chandigarh and the Modern City: Insights into the Iconic City Sixty Years Later, (Ahmedabad: Mapin Publishing, 2009); Vikramaditya Prakash, Chandigarh's Le Corbusier: The Struggle for Modernity in Postcolonial India, (Seattle: University of Washington Press, 2002).

${ }^{73}$ Beyond recent detailed scholarly accounts, Le Corbusier has also become the subject of popular biography. See Anthony Flint, Modern Man: The Life of Le Corbusier, Architect of Tomorrow (New York: New Harvest, 2014)
} 


\section{Bibliography}

Bacon, Marges. Le Corbusier in America: Travels in the Land of the Timid, Cambridge, Mass.: MIT Press, 2001.

Ball, Susan L. Ozanfant and Purism: The Evolution of a Style, 1915-30, UMI Research Press, 1982.

Banham, Reyner. “The New Brutalism,” Architectural review, Vol. 118, 1955, pp. 354-361.

Benton, Tim. The Villas of Le Corbusier and Pierre Jeanneret, 1920-1930, Basel: Birkhäuser, 2007.

Birksted, Jan Kenneth. "The Politics of Copying: Le Corbusier's Immaculate Conception," Oxford Art Journal, 30, 2007, pp. 305-326.

Boudon, Philippe. Lived in Architecture: Le Corbusier's Pessac Revisited, Cambridge, Mass.: MIT Press, 1972.

Brett, Lionel. “The Space Machine: an Evaluation of the Recent Work of Le Corbusier," Architectural Review, Vol. 102, 1947, pp. 147-150.

Brooks, H. Allen. Le Corbusier's Formative Years: Charles-Edouard Jeanneret at La Chaux-de-Fonds, Chicago: University of Chicago Press, 1997.

Cohen, Jean-Louis, ed., Le Corbusier: An Atlas of Modern Landscapes, London: Thames and Hudson, 2013.

Cohen, Jean-Louis; Benton, Tim. Le Corbusier Le Grand, New York: Phaidon, 2008.

Colomina, Beatriz. Privacy and Publicity: Modern Architecture as Mass Media, Cambridge, Mass: MIT Press, 1994.

Colquhoun, Alan. "The Le Corbusier Centenary," Journal of the Society of Architectural Historians, Vol. 49, No. 1, 1990, pp. 96-105.

Curtis, William. Le Corbusier: Ideas and Forms, Oxford: Phaidon, 1986.

Etchells, Frederick. "Le Corbusier: A Pioneer of Modern European Architecture," The Studio, No. 96, 1928, pp. 156-163.

Evenson, Norma. Chandigarh, Berkeley, University of California Press, 1966.

Gordon, C.; Kilian, K. eds., Chandigarh: Forty Years After Le Corbusier, Amsterdam: Architectura \& Natura, 1991.

Herbert, Gilbert. "Le Corbusier and the Origins of Modern Architecture in South Africa," AAQ : Architectural Association Quarterly, 4, no. 1, 1972, pp. 16- 30.

Hildner, Jeffrey. "Remembering the Mathematics of the Ideal Villa," Journal Of Architectural Education, Vol. 53, No. 3, 1999, pp. 143-162.

Holt, Gordon H.G. “The Merit of Le Corbusier,” Architectural Review, Vol. 63, 1928, p. 56.

Huxtable, Ada Louis. "French Architecture Today,” Art Digest, 28, 1954, p. 18.

Jacobs, Jane. The Death and Life of Great American Cities: The Failure of Town Planning, New York: Random House, 1961.

Kahn, Hasan-Uddin. ed., Le Corbusier: Chandigarh and the Modern City: Insights into the Iconic City Sixty Years Later, Ahmedabad: Mapin Publishing, 2009.

Kraus, Rosalind. "Léger, Le Corbusier and Purism," Art Forum, 10, 1972, pp. 50-53.

Le Corbusier, The Four Routes, London: Dennis Dobson, 1947.

Le Corbusier; de Pierrefeu, François. The Home of Man, London: Architectural Press, 1948.

Le Corbusier, New World of Space, New York: Reynal and Hitchcock, 1948.

Le Corbusier, The Modulor, London: Faber and Faber, 1954. 
Le Corbusier, Creation is a Patient Search, New York: Praeger, 1960.

Le Corbusier, Le Corbusier Talks with Students form the Schools of Architecture, New York: Orion Press, 1961.

Le Corbusier, Oeuvre Complète Vols 1-8, London: Thames \& Hudson, 1964.

Le Corbusier, The Radiant City: Elements of a Doctrine of Urbanism to be Used as the Basis of Our MachineAge Civilization, New York: Orion Press, 1967.

Le Corbusier, The Athens Charter, New York: Grossman, 1973.

Moholy-Nagy, Sibyl. “The Achievement of Le Corbusier,” Arts Magazine, 40, 1965, pp. 40-45.

Mumford, Lewis. “Yesterday's City of Tomorrow," Architectural Record, 132, 1962, pp. 139-144.

Mumford, Lewis. Highway and the City, New York: Harcourt, Brace and World, 1963.

Murray, Irena; Osley, Julian, eds. Le Corbusier and Britain: An Anthology, Abingdon: Routledge, 2009.

O’Byrne, Maria Cecilia. "El museo del Mundaneum : génesis de un prototipo, “ Massilia, 2004, pp.112-135.

Osborn, F.J. “Concerning Le Corbusier,” Town and Country Planning, 20, 1952, pp. 311-316.

Papadaki, Stamo, ed., Le Corbusier, Architect, Painter, Writer, New York: Macmillan, 1948.

Prakash, Vikramaditya. Chandigarh's Le Corbusier: The Struggle for Modernity in Postcolonial India, Seattle: University of Washington Press, 2002.

Passanti, Francesco. "The Vernacular, Modernism, and Le Corbusier," Journal of the Society of Architectural Historians, 56.4, 1997, pp. 438-451.

Raeburn, Michael; Wilson, Victoria eds. Le Corbusier: Architect of the Century, London: Arts Council of Great Britain, 1987.

Read, Herbert. "The City of To-morrow," The Listener, No. 18, 1931, pp. 272-273.

Robertson, Howard and Yerbury, F.R. Examples of French Architecture, New York: Charles Scribner's Sons, 1928.

Rowe, Colin. "The Mathematics of the Ideal Villa," Architectural Review, Vol. 101, 1947, pp. 101-104.

Schnoor, Christoph. (ed.) Le Corbusier: La construction des villes , Zurich, Verlag, 2008.

Sekler, Eduard; Curtis, William. Le Corbusier at Work: The Genesis of the Carpenter Center for the Visual Arts MIT Press: Cambridge, Mass., 1978.

Sekler, Mary P. M. The Early Drawings of Charles-Eduard Jeanneret (Le Corbusier), New York: Garland Publishing, 1977.

Sherer, Daniel. "Le Corbusier's Discovery of Palladio in 1922 and the Modernist Transformation of the Classical Code," Perspecta, Vol. 35, 2004, pp. 20-39.

Silver, Kenneth E. Espirit de Corps: The Art of the Parisian Avant-garde and the First World War, 1914-1925, Princeton: Princeton University Press, 1989.

Stirling, James. "Garches and Jaoul: Le Corbusier as Domestic Architect in 1927 and 1953," Architectural Review Vol. 118, 1955, pp. 145-151.

Stirling, James. "Ronchamp and the Crisis of Rationalism,” Architectural Review, March, 1956, pp. 155-61.

Stirling, James. “'The Functional Tradition' and Expression,” Perspecta, 6, 1960, pp. 88-97.

Summerson, John. Heavenly Mansions and Other Essays on Architecture, London: Cresset Press, 1949.

Takhar, Jaspreet. ed., Celebrating Chandigarh, Chandigarh: Chandigarh Perspective, 2001. 
Taylor, Brian Brace. Le Corbusier: La Cité de Refuge 1929/33, Paris: Equerre, 1980.

Tomlinson, Harold. “Towards a New Architecture,” Architects’ Journal, No.127, 1927, pp. 378-379.

Turner, Paul. The Education of Le Corbusier, New York: Garland Publishing, 1977.

Vogt, Adolf Max. Le Corbusier, The Noble Savage: Towards an Archeology of Modernism, Cambridge, Mass.: MIT Press, 2000.

Walden, Russell. (ed), The Open Hand: Essays on Le Corbusier, MIT Press: Cambridge, Mass., 1977

The authors would like to acknowledge the thoughtful suggestions provided by Mary McLeod, and the support of the staff of the Canadian Centre for Architecture in Montreal during a visit in November 2014. 


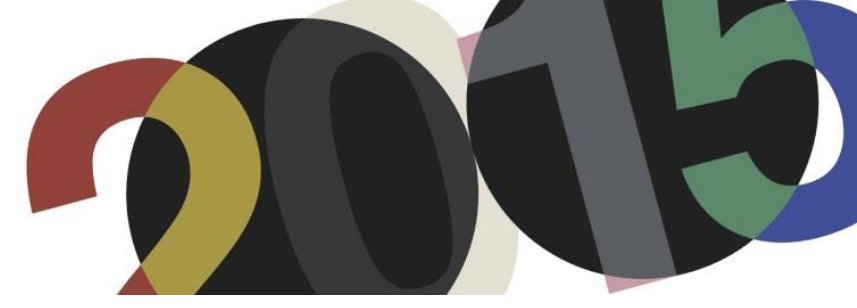

DOI: http://dx.doi.org/10.4995/LC2015.2015.732

\title{
La mirada de Pedro Vieira de Almeida a Le Corbusier: una visión desde Portugal en la segunda mitad del siglo $\mathrm{XX}$
}

\author{
T. Lopes Dias \\ Universitat Politècnica de Catalunya / Centro de Estudos de Arquitectura e Urbanismo, Universidade do Porto
}

\begin{abstract}
Resumen: Pedro Vieira de Almeida (Lisboa, 1933 - Matosinhos, 2011) es uno de los más importantes críticos y teóricos de la arquitectura en la segunda mitad del siglo XX en Portugal. En 1963, presenta en la Escuela de Bellas Artes de Oporto una tesis titulada "Ensayo sobre el espacio de la arquitectura", influida por el pensamiento de Bruno Zevi. Hasta la Revolución de los Claveles (1974), va a compaginar su práctica profesional como arquitecto con una intensa actividad crítica ejercida sobre todo en periódicos y revistas culturales. Desde sus primeros trabajos se evidencia una notable capacidad de utilizar conceptos críticos innovadores en el análisis de obras de arquitectura, lo que será fundamental en sus estudios historicos desarrollados a lo largo de su vida, dados a conocer en publicaciones y exposiciones retrospectivas sobre arquitectos clave. Este ensayo propone una reflexión sobre el legado de Le Corbusier poniendo el aciento en algunos artículos de Vieira de Almeida escritos entre 1965 y 1970, así como en la investigación que ha llevado a cabo en los últimos años de su vida. Esta lectura diacrónica pone de relieve el papel central del maestro franco-suizo en la lectura crítica de Vieira de Almeida del racionalismo, a través de las nociones por él manejadas: "estructura crítica como condición base de la creación", las vertientes poético-simbólica y mítica de la arquitectura o el concepto de carácter más instrumental de la "espesura”.
\end{abstract}

\begin{abstract}
Pedro Vieira de Almeida (Lisbon, 1933 - Matosinhos, 2011) is one of the most prominent critics and theorists of architecture in the second half of the 20th century in Portugal. In 1963, he presented at the Oporto School of Fine Arts a thesis entitled "Essay on architectural space", clearly influenced by the thoughts of Bruno Zevi. Until the Carnation Revolution (1974), he will combine his professional practice as an architect with an intense critical activity, developed mainly in newspapers and cultural magazines. Since his early work, a remarkable ability to use innovative concepts in the critical analysis of buildings have been put forth, with major consequences in his historiographical studies, developed throughout his life through publications or retrospective exhibitions on key architects. The following paper proposes a reflection on the legacy of Le Corbusier based on Vieira de Almeida's theoretical work, linking some texts written between 1965 and 1970 with his research carried out in his last years of life. This diachronic study highlights the central role of Le Corbusier in Vieira de Almeida's critical approach to rationalism, by means of notions as: "criticism as a basic condition of creation", poetic-symbolic and mythical aspects of architecture, or the more instrumental concept of "thickness".
\end{abstract}

Palabras clave: Crítica; Teoría; Pedagogía; Poética; Espesura; Ronchamp.

Keywords: Critique; Theory; Pedagogy; Poetics; Thickness; Ronchamp.

\section{Los fundamentos de una nueva mirada}

Dos meses después de la muerte de Le Corbusier, en Agosto de 1965, Pedro Vieira de Almeida publica dos pequeños artículos en revistas de arte y cultura, en los cuales subraya la necesidad de enmarcar la obra y la trayectoria profesional del maestro franco-suizo con conceptos críticos actuales. En ambos artículos destaca la "intervención lúcida" y la "coherencia operativa” de Le Corbusier y, con deseo polémico, ilustra el texto con imágenes de la capilla de Ronchamp.

En el texto publicado en Seara Nova, revista de una élite intelectual comprometida con la lucha ideológica contra la dictadura de Oliveira Salazar, relaciona las dificultades de interpretar la obra de Le Corbusier con el 
espíritu abierto y generoso del maestro, que apreciaba obras tan diversas a la suya como la de Gaudí. La fuerza expresiva y el dinamismo propagandista de su intervención habían llevado además a que esta fuera comprendida a un nivel superficial o anecdótico, sobre todo por los seguidores corbusianos más ortodoxos. "Sin embargo", añadía Vieira de Almeida, "su renovación más audaz y sus propuestas más revolucionarias siempre estuvieran sustentadas por un raciocinio crítico ejercido libremente y combativamente sobre los problemas contemporáneos. Justo ahí estaba la fuerza comunicante y catalizadora de su acción”.

Prácticamente al mismo tiempo, en la Revista de Artes e Letras de la prestigiosa Fundación Calouste Gulbenkian, reflexiona sobre el papel de Le Corbusier en la consolidación del Movimiento Moderno: "nadie le niega la autenticidad de su genio creativo o la vasta extensión de su ámbito de influencia, pero sí se le niega, casi sistemáticamente, la coherencia operativa y la posibilidad de dejar un legado, a nivel metodológico y ético, capaz de permanecer actual”. Tal como el título del artículo nos sugiere, es exactamente lo que él va a defender: "Le Corbusier, un arquitecto coherente"2.

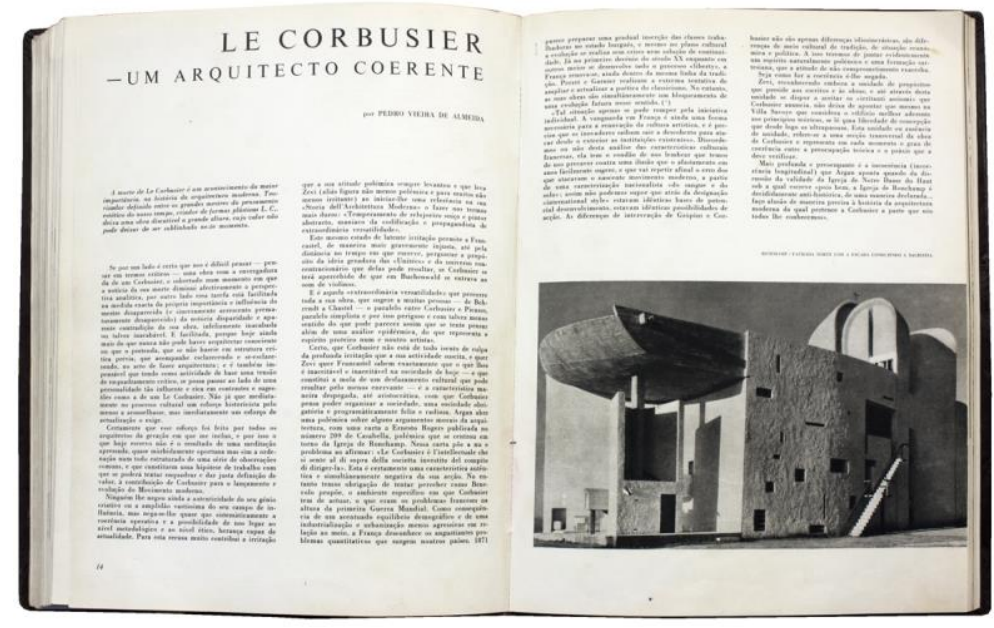

1. Artículo de Pedro Vieira de Almeida publicado en Octubre de 1965 (Colóquio: Revista de Artes e Letras, №35, pp.14-15)

Su idea de coherencia es distinta de la que está en la base de la discusión entre Ernesto N. Rogers y Giulio Carlo Argan a propósito de Ronchamp. Argan señala una contradicción no sólo entre las formas curvas, casi biomórficas, de la capilla y el muro sur de cariz neoplástico, sino también de la propia obra dentro de la historia de la arquitectura moderna ${ }^{3}$. Vieira de Almeida, por su parte, exige otros métodos de observación crítica: "La coherencia de Le Corbusier es una coherencia de intervención. Asumiendo una actitud pedagógica mucho más ambiciosa que la de Gropius, y con los riesgos que ella misma implica, Le Corbusier propone intervenir en la evolución de la arquitectura moderna con sucesivas contribuciones que pueden ser dispares entre sí-y lo son ciertamente -, pero cuya validez es llamar la atención de los arquitectos para sucesivos problemas que la evolución de las circunstancias va descubriendo (...). La coherencia de Le Corbusier es una lucha permanente contra la pérdida y la degradación semántica de los lenguajes",4.

\footnotetext{
${ }^{1}$ Almeida, Pedro Vieira de: "Le Corbusier". En Seara Nova. Octubre 1965, № 1440. Lisboa. p.304.

2 Almeida, Pedro Vieira de: "Le Corbusier - um arquitecto coerente". En Colóquio: Revista de Artes e Letras. Octubre de 1965, Nº 35. Lisboa: Fundação Calouste Gulbenkian, pp.14-18.

${ }^{3}$ Rogers, Ernesto N.: "Il metodo di Le Corbusier e la forma della 'Chapelle de Ronchamp'”. En Casabella-Continuitá. Septiembre/ Octubre de 1955, № 207. Milano: Mondadori. Argan, Giulio Carlo: "La chiesa di Ronchamp (Lettera a Ernesto Rogers)". En Casabella-Continuitá, Enero/ Febrero de 1956, № 209. Milano: Mondadori.

${ }^{4}$ Almeida, Pedro Vieira de: "Le Corbusier - um arquitecto coerente". Op. cit. p.14.
} 
Esta propuesta de relectura crítica debe ser analizada tanto en el contexto portugués como en el contexto internacional, donde las críticas de Argan van a encontrar eco en otros historiadores como Nikolaus Pevsner, Bruno Zevi o Sigfried Giedion.

\section{Ronchamp: ¿una traición?}

Para aclarar el carácter polémico de los dos artículos de Vieira de Almeida hay que tener en cuenta que desde 1957 un activo grupo de su generación llevaba a cabo, en la revista Arquitectura de Lisboa, una intensa crítica a los principios del urbanismo y a los cánones formales de la arquitectura de entreguerras. Lejos parecía estar el momento de unanimidad vivido en el Congreso Nacional de Arquitectura (Lisboa, 1948) donde los arquitectos más jóvenes defendían al unísono la vivienda colectiva en altura, con soluciones tipo unidades verticales dispuestas según los principios de la Carta de Atenas y utilizando el lenguage de los "cinco puntos". Diez años después, y cuando las experiencias del "nuevo urbanismo" formaban ya parte del perfil urbano de Lisboa - véase el barrio de Alvalade - Nuno Portas presenta la unidad habitacional horizontal como alternativa tanto a las concepciones de la vivienda unifamiliar (tan al gusto del régimen de Salazar) como a la singular Unité vertical ${ }^{5}$. Como ha sugerido el historiador José-Augusto França, la influencia de Le Corbusier fue, en una primera fase de la arquitectura moderna en Portugal, casi mítica. Podemos considerar igualmente que en el período en que se empieza la revisión de la modernidad (alrededor de 1956-57, con la encuesta a la arquitectura popular, la participación en el CIAM de Dubrovnik y con la renovada Arquitectura) hay un rechazo de sus propuestas igualmente mítico. En efecto, ahora como antes, las obras de Le Corbusier llegan a Portugal filtradas por otras experiencias, sobre todo brasileñas ${ }^{6}$.

El acento de Vieira de Almeida, puesto en la fuerza pedagógica de la acción llevada a cabo por Le Corbusier a lo largo de su vida (lo que él denomina infra o supra-coherencia) e ilustrado con imágenes de Ronchamp (una obra que demostraba cuán flexibles podían llegar a ser las matemáticas del Modulor), no podía sino desconcertar a sus compañeros, fuesen los jóvenes revisionistas, fuesen los maduros y convictos modernistas. Hemos mencionado ya como Vieira de Almeida hacía coincidir los proyectos más innovadores de Le Corbusier con una crítica reflexiva sin la cual no era posible el desarrollo de la arquitectura moderna. Esta es justamente la idea que va a presentar en la "página de arquitectura" del Jornal de Letras e Artes, de la que será responsable a partir de 1965 con un espacio de divulgación de problemas, de dudas y de métodos de trabajo, más que de divulgación de soluciones ${ }^{7}$. En el artículo-clave "Estructura crítica: condición base de la creación", Vieira de Almeida reescribe y profundiza lo que ya había señalado en los dos textos citados: "La conciencia de la necesidad de una base crítica y el esfuerzo por obtenerla dentro del marco de la propia actividad profesional son sin duda las más importantes marcas de una modernidad auténtica, de una definitiva madurez en la evolución de lo que se ha llamado en arquitectura el movimiento moderno" ${ }^{\text {. }}$.

\footnotetext{
${ }^{5}$ Portas, Nuno: "Conceito de casa em pátio como célula social”. En Arquitectura. Enero/Febrero de 1959, No 64. Lisboa. Además de la propuesta de Adalberto Libera para el barrio de Tuscolano - unitá d'abitazione orizzontale -, presenta casaspatio del atelier ATBAT en Marruecos, de Chamberlain, Powell \& Bon en Londres y de Jorn Utzon en Dinamarca.

${ }^{6}$ Las revistas especializadas publican artículos cortos, con poca información gráfica y sin textos críticos. De los trabajos de Le Corbusier de la posguerra, serían publicados en la revista Arquitectura el plan de Chandigardh y la Unité de Marsella $\left(\mathrm{N}^{\circ}\right.$ 49 y No $50-51,1953)$ y en la revista Binário la Unité de Marsella y La Tourette ( $\mathrm{N}^{\circ} 37,1961$ y ํo 56, 1963).

${ }^{7}$ Almeida: "Arquitectura como disciplina interdisciplinar". En Jornal de Letras e Artes, 27-10-1965. Lisboa: Ed. Lux. p.5.

${ }^{8}$ Almeida, Pedro Vieira de: "Estrutura crítica - condição base de criação". En Jornal de Letras e Artes, 12-1-1966. Lisboa: Editora Lux. p.5.
} 
El nombre de Le Corbusier surge después de estas líneas: su arquitectura, tal como la pintura de Paul Klee, demostraba en su opinión una conciencia crítica reflexiva, racional, técnica, que no conllevaba a la limitación de la creatividad ni a la esterilización de los medios expresivos. Por otra parte, esa misma conciencia, con toda la responsabilidad e idoneidad que acarrea, es exactamente lo que permite criticar la gratuidad de algunas experiencias de vanguardia, e incluso ultrapasar las vanguardias autosuficientes o ensimismadas, finalmente académicas. Sin ese ejercicio crítico, señalaba Vieira de Almeida, la arquitectura se podría volver abstracta, alienada o incluso reaccionaria. Un esfuerzo crítico que se debe desarrollar en todos los planos, obligando a que la teoría informe la práctica pero también a que sea informada por ésta, en continua interrelación. Aunque el nombre de Le Corbusier no sea mencionado ninguna vez más, podemos intuir que era el ejemplo que tenía en la mente: ¿Quién más, entre los maestros de la primera mitad del siglo XX, había reformulado su cuerpo teórico anterior? ¿Qué obras de la posguerra habían superado mejor esos principios de la nueva arquitectura que Ronchamp, La Tourette, o el Carpenter Center?

En un ambiente como el portugués, marcado hasta finales de los años cincuenta por la ausencia de producción teórica, por la intermitencia de publicaciones periódicas de arquitectura y por el equívoco de tomar la crítica como una crónica de costumbres o de gusto, la página que Vieira de Almeida idealizaba como un espacio de debate y discusión tendría naturalmente un impacto reducido. Así como su interpretación de la coherencia corbusiana - vinculada como hemos visto a una progresiva y dinámica relación entre teoría y práctica, a una dialéctica crítica indispensable cuando la disciplina rompe con el mundo cerrado y autosuficiente de la tratadística o de la manualística. En aquellos años, en Portugal, seguirían aplicándose las texturas rugosas (el béton brut o la pared encalada tipo papier-mâché) que marcaran la obra de Le Corbusier en la posguerra, pero esta - y sobre todo Ronchamp - permanecería interpretada como un duro golpe a los parámetros racionales y puristas que habían orientado las mejores propuestas de entreguerras y que con tanto coste habían llegado a Portugal $^{9}$.

Una interpretación sin duda deudora de lo que los grandes historiadores del movimiento moderno habían escrito en los años sesenta y setenta. En el prólogo a la segunda edición en castellano de Pioneros del Diseño Moderno (1962), Nikolaus Pevsner señalaba que mientras escribía este libro en los años treinta, "la arquitectura de la razón y el funcionalismo estaba en pleno movimiento en muchos países, mientras en otros iniciaba su curso promisor”, y se consideraban “fantásticos desvarios” las propuestas de Gaudí o Sant'Elia. Pero a la sazón, se veía rodeado "nuevamente por fantasías y extravagancias, y una vez más se cuestiona[ba] la validez del estilo a cuya prehistoria se dedica [ba] este libro”. Sin embargo, en las páginas finales, Pevsner asegura la actualidad de su investigación poniendo de relieve el siguiente argumento: "El Expresionismo fue un breve intervalo continuador del Gropius temprano precediendo al Gropius maduro de los edificios de la Bauhaus en Dessau (...). Ahora estamos en medio de un segundo intervalo semejante, del cual son responsables Le Corbusier (con recientes obras como la capilla de Ronchamp) y los brasileños " ${ }^{\text {"10 }}$. De este modo, auguraba un nuevo período de plenitud que surgiría naturalmente del ciclo lógico de períodos "románticos" seguido de otros racionales. En una de las ultimas ediciones de su célebre manual Esquema de la Arquitectura Europea, la vigencia del estilo maduro de Gropius seguirá siendo defendido frente a Ronchamp, "el más famoso y el más discutido manifiesto del nuevo irracionalismo" ${ }^{\text {11. }}$.

\footnotetext{
${ }^{9}$ Cf. Tavares, Domingos: Da rua Formosa à Firmeza. Porto: Edições ESBAP, 1980.

${ }^{10}$ Pevsner, Nikolaus: Pioneros del Diseño Moderno, de William Morris a Walter Gropius, $4^{\mathrm{a}}$ ed. Buenos Aires: Ediciones Infinito, 2003 [1936, 1962]. pp.14 y 85.

${ }^{11}$ Pevsner, Nikolaus: Storia dell'architettura europea. Bari: Editori Laterza, 1966 [1943]. p.298.
} 
Por otro lado, Bruno Zevi defendía el movimiento orgánico como única posibilidad de humanizar las ecuaciones desnudas del primer Le Corbusier y de la Bauhaus. En la edición revisada y ampliada de su Historia de la Arquitectura Moderna, en 1975, añade el capítulo "La tercera época: itinerarios de los años cincuenta-setenta", donde denuncia una crisis "encarnada por los protagonistas, en especial por la prestigiosa figura de Le Corbusier”, quien había abdicado del “compromiso doctrinario y didáctico” de los cinco puntos y había inaugurado, con la capilla de Ronchamp, "un período tan rabiosamente imaginativo como incomunicable"12. En realidad, esta idea ya estaba presente en el libro de Zevi de 1960, Architectura in Nuce: la exuberancia creadora de la última etapa de Le Corbusier anula los cinco puntos, que son traicionados y casi tomados en broma en Ronchamp. Curiosamente, Zevi lo escribe en la misma página donde alerta del peligro de que "el movimiento moderno, nacido como antítesis de la academia y los estilos, caiga él mismo en la academia estilística” "13. En ambos libros, la capilla de Ronchamp es presentada como una obra inexplicable. Un grito, un terremoto, una destrucción: así se refiere a ella Zevi en el primero, a lo largo de los apartados que va revisando. Es el caso del capítulo dedicado al arquitecto franco-suizo en la sección "los maestros del período racionalista", donde escribe: "Tan sólo entre los maestros del período, Le Corbusier tiene el valor de registrar el derrumbamiento de toda esperanza de rescatar el mundo mediante la razón" "14. Ni prosa ni poesía, dirá en el segundo libro, observando que en la capilla "no se encuentra una sola fachada plausible, escolásticamente aceptable, en cuanto proporciones, ritmo, equilibrio y contraste entre huecos y macizos: estas fachadas son sinceramente feas, incompletas, aparentemente accidentales ${ }^{\prime \prime 15}$.

Finalmente, Sigfried Giedion, en el ensayo introductorio a la nueva edición de Espacio, Tiempo y Arquitectura (1962) observa que el enfoque escultórico de la última etapa del maestro no puede ser tenido en cuenta como un ejemplo: "Con bastante razón, desde muchos sitios han llegado advertencias de que un edificio como Ronchamp podría ser un desastre en manos de arquitectos mediocres. El secreto de la obra de Le Corbusier está en que él es arquitecto, pintor y escultor" ${ }^{\prime \prime}$.

\section{El "tronco" de la arquitectura}

Todas estas posiciones reflejan el debate que ha irrumpido en revistas como Casabella, L'Architettura o Architectural Review y son fundamentales para enmarcar los estudios de Vieira de Almeida, que tienen un avance significativo cuando se le encarga el volumen sobre arquitectura moderna (siglo XX) en una vasta colección de Historia del Arte en Portugal. En esta obra de 1986, presenta una lectura de la producción nacional a partir de los dos modelos avanzados por Françoise Choay: el modelo progresista y el modelo culturalista. Esto le permite establecer una primera malla de entendimiento crítico que conocerá algunos ajustes, como veremos, pero que en sus líneas fundamentales se mantendrá. En esta malla, Vieira de Almeida sitúa los dos elementos de polarización que representan el conflicto latente en la evolución de la arquitectura portuguesa: Ventura Terra (1866-1919) y Raul Lino (1879-1974) ${ }^{17}$. Al mismo tiempo, es capaz de reconocer que a algunos arquitectos habrá que situarlos en una posición intermedia, pues en su obra se produce una convergencia de los dos modelos:

\footnotetext{
${ }^{12}$ Zevi, Bruno: Historia de la Arquitectura Moderna. Barcelona: Editorial Poseidon, 1980 [1950, 1975]. p.372.

${ }^{13}$ Zevi, Bruno: Architectura in Nuce: una Definición de Arquitectura. Madrid: Aguilar, 1969 [1960]. p.200.

${ }^{14}$ Zevi, Bruno: Historia de la Arquitectura Moderna. p.106.

${ }^{15}$ Zevi, Bruno: Architectura in Nuce. p.96.

${ }^{16}$ Giedion, Sigfried: "La arquitectura en los años 1960: esperanzas y temores". En Espacio, Tiempo y Arquitectura, $9^{\mathrm{a}}$ ed. Barcelona: Editorial Científico-Médica, 2009 [1941, 1962].

${ }^{17}$ Almeida, Pedro Vieira de; Fernandes, José Manuel; Maia, Maria Helena: Arquitectura Moderna. Lisboa: Edições Alfa, 1986. pp.73-90.
} 
Le Corbusier es para él un ejemplo claro. Al contrario de Choay, que lo sitúa siempre en el modelo progresista, Vieira de Almeida defiende que los vectores culturalistas siempre han estado presentes a lo largo de su trabajo, acentuándose particularmente en obras como Ronchamp.

Esta idea estaría formulada posiblemente años antes, en 1970, cuando en las líneas finales de un texto crítico incluido en el catálogo de la exposición dedicada a Raul Lino - el jefe de fila del modelo culturalista entre los arquitectos portugueses -, cita a Le Corbusier. Puede parecer insólito juntar los nombres de Raul Lino y de Le Corbusier; lo será, ciertamente, si tenemos en cuenta un análisis sintáctico. Sin embargo, el denominador común era aquí otro: la matriz poética de la arquitectura. De este modo, y no sin una irónica petición de disculpas a sus “amigos racionalistas más extremos”, Vieira de Almeida termina el texto con la transcripción de lo que considera el pequeño testamento del maestro franco-suizo: “J'ai 72 ans. J'ai bâti ma première maison à 17 ans et demi et j'ai continué mes travaux parmi les aventures, les dificultés, les catastrophes et de temps a l'autre du succes. Ma recherche tout comme mes sentiments est dirigée vers ce qui est la principale valeur de la vie: la poésie. La poésie est dans le coeur de l'homme et c'est pour cela qu'il peut s'ouvrir aux richesses de la nature ${ }^{, 18}$.

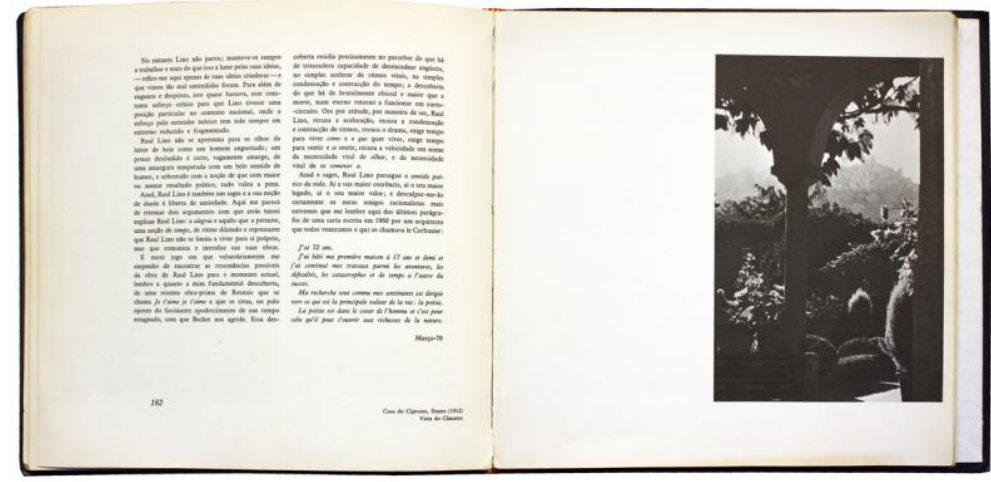

2. Catálogo de la exposición retrospectiva de Raul Lino (1970): texto de Pedro Vieira de Almeida con cita de Le Corbusier.

Se anticipa aquí un tema que sería fundamental en los estudios críticos de Vieira de Almeida: la matriz poética de la arquitectura, que consideraba adquirir un valor estructural en la obra de Le Corbusier y que funcionaría como un prisma a través del cual la historia de la arquitectura moderna podía ser cuestionada. La primacía de la interpretación del racionalismo como punto de llegada ya había sido criticada por Bruno Zevi: Pevsner, Giedion y Walter Curt Behrendt terminaran sus estudios en el racionalismo, pero sólo el último había informado de su crisis. Además señalaba el claro error en Giedion de presentar a Frank Lloyd Wright antes de Le Corbusier, y cambió ese orden en su Historia, exponiendo el organicismo wrightiano como una salida para la crisis del periodo racionalista. Pero una vez más, prevalecía el modelo dualista: la tradición del esto-o-lo-otro que Robert Venturi señaló como una limitación de la arquitectura moderna ortodoxa, y que Hugh de Cronin Hastings había trazado como una división inherente al propio Movimiento Moderno, entre una facción más clásica, racional o cristalina (de la tradición del pensamiento francés) y otra más romántica o orgánica (de la tradición del pensamiento alemán) ${ }^{19}$. Es la dualidad y la inevitabilidad del esto-o-lo-otro lo que Pedro Vieira de Almeida pretende superar cuando profundiza a lo largo de los años el concepto de espacio de la arquitectura, tema de su

\footnotetext{
${ }^{18}$ Le Corbusier, apud Almeida, Pedro Vieira de: "Raul Lino, arquitecto moderno". En Almeida, Pedro Vieira de; Carvalho, Manuel Rio; França, José-Augusto; Pimentel, Diogo: Raul Lino. Exposição retrospectiva da sua obra. Lisboa: Fundação Calouste Gulbenkian, 1970. p.182. (en francés en el original)

${ }^{19}$ Hastings, Hugh de Cronin: "Townscape: A Plea for an English Visual Philosophy". En Ockman, Joan: Architectural Culture: 1943-68. New York: Columbia Books of Architecture, Rizzoli, 1993.
} 
tesis del 1963, con obras de otros campos del conocimiento como la antropología, la etnología, la filosofía o la psicología. Su biblioteca personal nos da cuenta de estos intereses: Claude Lévi-Strauss, Jean Pierre Vernant, Gaston Bachelard, Otto F. Bollnow, Abraham Moles y Elisabeth Romer, o incluso el concepto japonés de "Ma". Son autores u obras que rellenan sus estanterías y nos ayudan a situar su particular lectura de la historia de la arquitectura, centrada sin embargo en la especificidad disciplinar del concepto de espacio: el espacio empírico de la experiencia, donde sujeto(s) y objeto(s) se interfluencian en un mismo sistema en el cual el espacio es también parte activa, y no el abstracto espacio-tiempo de la ciencia.

El esquema interpretativo que Vieira de Almeida propone resulta de la delimitación de un conjunto de tres vectores considerados en su simultaneidad: 1) una vertiente mítico-religiosa; 2) una vertiente poético-simbólica; 3) y una vertiente práctico-sociológica. El diagrama que dibuja indica que, hasta determinado momento, estos tres vectores habían llegado a formar parte inextricable de un único modelo común, de un mismo tronco de la arquitectura, y que a partir de los siglos XVII-XVIII, pero sobre todo a partir de la Revolución Industrial, uno de ellos va a ganar protagonismo absoluto: el práctico-sociológico, que con la guerra de 1914-18 y los postulados del racionalismo se convierte en una "burbuja" 20 . A estos tres vectores podemos asociar algunas características de los modelos de Françoise Choay: a los dos primeros, la ideología espiritual o estética, el peso del pasado y de la tradición, el predominio de la cultura, de la belleza (al cual correspondería un espacio bien circunscrito y diferenciado, con un acentuado sentido táctil) del modelo culturalista; y al último, la ideología productivista y higienista, el avance impetuoso del tiempo (al cual correspondería un espacio abierto e ilimitado, de sentido visual) del modelo progresista.

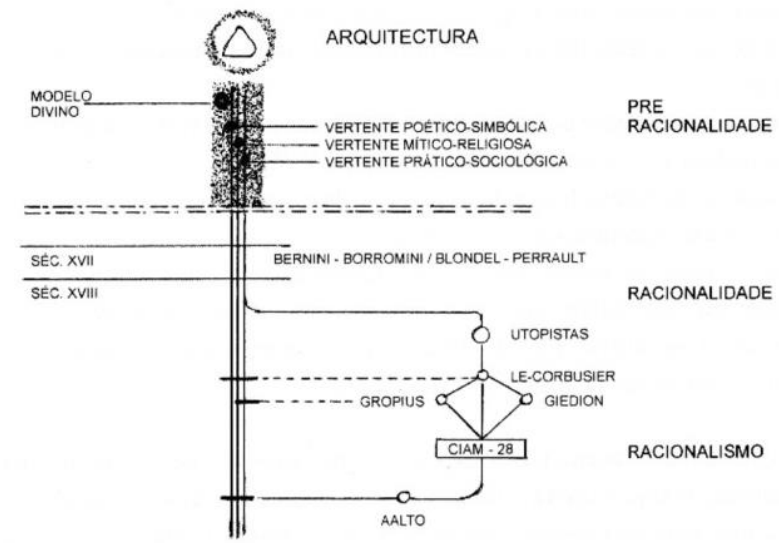

3. Diagrama de Pedro Vieira de Almeida: los tres vectores como "tronco" común, la ruptura de los siglos XVII-XVIII y la vertiente práctico-sociológica "inflada" con el racionalismo.

La complejidad de esta propuesta interpretativa, que hace hincapié en la simultaneidad de los tres vectores para una posible comprensión de la arquitectura a lo largo de la historia, no nos permite desarrollar todas sus consecuencias en este artículo. Esta breve y parcial lectura diacrónica de los estudios históricos de Vieira de Almeida debe, por otro lado, poner en relieve el papel central de Le Corbusier en la revalorización del tronco de la arquitectura, lo que proponemos hacer tomando únicamente como caso de estudio la capilla de Ronchamp.

\footnotetext{
${ }^{20}$ El término "burbuja" (borbulha) se refiere a una sobrevaloración casi obsesiva de los parámetros práctico-sociológicos. Cf. Almeida, Pedro Vieira de: O Tronco da Arquitectura. Do racionalismo como borbulha. Porto: CEAA, 2002.
} 


\section{Ronchamp: la capilla-anta y la noción de espesura}

En 2010, una relectura crítica del material compilado para la encuesta a la arquitectura popular en Portugal (1955-61) es la excusa de Pedro Vieira de Almeida para poner en práctica un vastísimo utillaje conceptual que recupera sus tempranas concepciones espacialistas y las amplía con los vectores míticos o poético-simbólicos del tronco de la arquitectura ${ }^{21}$. Esta investigación encuentra un precedente en un texto anterior donde propone aislar, como instrumento crítico, la noción de espesura en el lenguaje arquitectónico. Allí retoma la llamada de atención del historiador y arquitecto holandés Cornelis van de Ven sobre el nexo entre una arquitectura de masa y una determinada concepción de espacio interior, y reflexiona sobre la diferencia entre las aberturas en la pared espesa y las aberturas en la pared delgada: estas, observa, se limitan a dejar entrar la luz necesaria para la aprehensión del espacio, pero las primeras "controlan la luz en intensidad, tonalidad y temperatura", modelándola; y la luz modelada, concluye, resulta fundamental en el tratamiento expresivo del espacio ${ }^{22}$. La espesura es, por lo tanto, una propiedad que Vieira de Almeida asocia directamente a una noción de espacio expresivo, y "sólo el espacio expresivo permite hablar de espacio arquitectónico”, lo que le permite defender, en contra de algunos prejuicios que habían permanecido desde el International Style, que "el espacio de la arquitectura no se opone a la noción de masa - por el contrario, depende de ella",23. Naturalmente, en estos últimos trabajos suyos, Ronchamp es valorada como la obra que integra, en una magnífica dialéctica, una poética de paredes delgadas y una poética de paredes espesas.

Además va a ser frecuente su mención a esta obra de Le Corbusier como la iglesia o capilla-anta, y como es de esperar, la referencia a la raíz ancestral de la arquitectura no es gratuita. Años antes, Vieira de Almeida señalaba el dolmen (o anta) y el menhir como los dos gestos-arquetipo instauradores de toda la arquitectura. Asimismo, asociaba esta oposición a otra que Jean Pierre Vernant había señalado en su análisis del espacio en la Grecia Clásica: el espacio cerrado, protegido, de connotación femenina, asociado a la Diosa Hestia, y el espacio abierto, dinámico, de connotación masculina, asociado al Dios Hermes. De su libro Mito y Pensamiento en la Grecia Antigua, citaba: "Puede decirse que la pareja Hestia-Hermes exprime, en su polaridad, la tensión que define la representación arcaica del espacio "24. Es esta tensión mítica que considera resuelta de manera magistral en Ronchamp. La utilización simultánea de una poética de paredes espesas y de una poética de paredes delgadas en el muro sur con sus "huecos habitables" y en el muro este con sus "perforaciones estrelladas" - contribuye de forma decisiva para esta tensión. Podíamos incluso arriesgar, llevando al límite la sugerencia de Vieira de Almeida, ver a Hestia y a Hermes en la sucesión de concavidades y convexidades que, en su punto de máxima tensión - cuando la cubierta convexa sobrepasa al muro naciente cóncavo - producen un espacio-transición

\footnotetext{
${ }^{21}$ Investigación coordinada por Vieira de Almeida en el Centro de Estudos Arnaldo Araújo (CEAA) de la Escola Superior Artística do Porto (ESAP), donde ejerce la docencia universitaria desde los años ochenta.

${ }^{22}$ Almeida, Pedro Vieira de: A noção de espessura na linguagem arquitectónica. Porto: CEAA, 2011 [2005].

${ }^{23}$ Almeida: Dois parâmetros de arquitectura postos em surdina. Leitura crítica do Inquérito à arquitectura regional caderno 2. Porto: CEAA, 2013 [2011]. p.26. Vieira de Almeida refiere el texto de Alfred Barr Jr. en el catálogo de la exposición del 1932 en el MOMA, en particular el siguinte pasaje: "modern architecture thinks in terms of volume of space enclosed by planes or surfaces, as opposed to mass and solidity".

${ }^{24}$ Sobre esta cuestión, ver los siguientes textos de Pedro Vieira de Almeida: "O Dólmen e o Menhir"; "Quadro de referência das estruturas espaciais"; "Hermes - Héstia" (En Almeida: Apontamentos para uma teoria da arquitectura. Lisboa: Livros Horizonte, 2008) y "A poética de Le Corbusier - A poesia de Valéry - Uma pedagogia impossível” (En Almeida, Pedro Vieira de; Cubero, Josefina González; Trevisan, Alexandra (eds.): Ler Le Corbusier. Porto: CEAA, 2009).
} 
poéticamente ambiguo $^{25}$, ni interior ni exterior, ni cerrado ni abierto, donde se posiciona, delante de la explanada natural, un segundo altar.

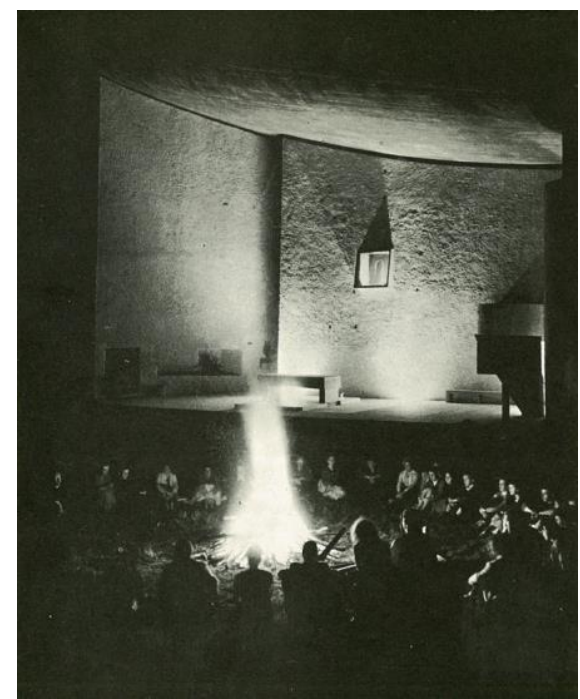

4. Fotografía nocturna de Ronchamp, con el espacio ambiguo del segundo altar al fondo (Le livre de Ronchamp. Cahiers Forces Vives/Editec, 1961)

Es importante subrayar que la metáfora visual se revela para Vieira de Almeida un valor añadido en el momento de construir una interpretación exigente y rigurosa. Con todo, ni su utilización, ni la imagen elegida, eran novedad: las metáforas fueron abundantemente utilizadas, desde el propio autor - la coquille de crabe -, hasta sus detractores - Zevi hablaba de la rudeza medievalizante de sus murallas de fortificación -, y la anta ya había sido evocada por James Stirling en su artículo del 1956, posiblemente el más influyente en apuntar el agotamiento de la base esquemática de la arquitectura moderna ${ }^{26}$. Pero en Vieira de Almeida el peso de los valores culturales e incluso míticos gana otra relevancia, pues consideraba que la tensión polarizadora de Hermes-Hestia impregnaba no solamente una representación arcaica del espacio, sino también las categorías primarias de una forma occidental del habitar, heredera aún de esos valores. De ahí su defensa de una noción de habitar hecha de intimidad y recato que cobraba la máxima importancia a la hora de equilibrar el movimiento, la velocidad, o la transparencia hermesianas de la vida moderna.

La importancia de Ronchamp es por eso doble: además de su coherencia interna, defendida como hemos visto por la articulación de dos poéticas constructivo-espaciales - una poética de paredes espesas y una poética de paredes delgadas -, es su coherencia con la propia historia de la arquitectura lo que Vieira de Almeida señalará como hallazgo fundamental. La capilla representa un cambio en la forma de Le Corbusier pensar la arquitectura - del beauxartiano sistema combinatorio de elementos a una arquitectura de instauración de valores espaciales -, y en este sentido es interpretada como un retorno al "tronco común" de la arquitectura y como un "ajuste de cuentas" con la burbuja del racionalismo de la primera mitad del siglo XX. En Ronchamp, el sistema estructural que el autor venía estudiando y aplicando desde 1914 - el sistema Domino - sigue presente, pero ahora una cal texturada uniformiza toda la superficie, como una piel arrugada que envuelve el esqueleto y los órganos. " $L a$ arquitectura no es asunto de columnas, sino de acontecimientos plásticos”, escribía Le Corbusier en ocasión de

\footnotetext{
${ }^{25}$ El espacio-transición es teorizado en su tesis del 1963, Ensaio sobre o espaço da arquitectura, y va a formar, juntamente con la espesura, los dos parámetros para una relectura crítica a la encuesta a la arquitectura popular en Portugal.

${ }^{26}$ Stirling, James: "Ronchamp: Le Corbusier's chapel and the crisis of rationalism". En Architectural Review. Marzo 1956, No 119. Londres. pp.155-161.
} 
la inauguración de Ronchamp, y "los acontecimientos plásticos no se regulan mediante fórmulas escolares o académicas; son libres e innumerables "27. Teniendo en cuenta esta arquitectura de instauración espacial y de acontecimientos plásticos, las palabras de Zevi con respecto al "furor expresionista" de Ronchamp tal vez pudieran obtener otro sentido, una vez que la arquitectura expresionista - arquitectura de masa - divulgaba precisamente estos valores. Más difícil sería encontrarle sentido a la predicción de Giedion de que "la casa maciza tradicional se disgrega en el significado de la concepción espacio-temporal", pues Ronchamp de eso daba pruebas contrarias.

En el pensamiento de Vieira de Almeida, la arquitectura de instauración de valores espaciales, la arquitectura de base culturalista y el tronco de la arquitectura estaban fuertemente vinculados. Recordemos como resumía de forma escueta esas dos formas opuestas de hacer arquitectura que marcarían los dos polos de la arquitectura portuguesa: Ventura Terra, formado en París, desarrolla una arquitectura de composición, en la mejor tradición Beaux-Arts, donde los materiales se organizan segundo un sistema lógico; Raul Lino, formado en Alemania, desarrolla una arquitectura de instauración de valores espaciales, donde los materiales se estructuran según un sistema expresivo. En las casas macizas tradicionales de Raul Lino, los valores ancestrales del habitar se traducían arquitectónicamente en las paredes espesas, en los materiales “calientes”, en los espacios-núcleo y en los espacios-transición.

\section{Conclusión}

Para Vieira de Almeida, Ronchamp, fenómeno poético, es la materialización de la más vital y superior forma de crítica: parafraseando a T. S. Eliot, "la crítica utilizada por un experimentado y talentoso [arquitecto] en su propia obra ${ }^{, 28}$. La coherencia pedagógico-didáctica de Le Corbusier estriba en el volte-face que representa esta obra con respecto a su primera etapa, en el reequilibrio de valores que propone y en su posicionamiento en el tronco de la arquitectura. La concepción espacial que rige esta obra - basada en un tratamiento expresivo de la luz, en la sugestión de espacios-núcleo sin interrupción de la continuidad espacial y en una compleja dialéctica interior/exterior, abierto/cerrado, cóncavo/convexo -, es para el teórico portugués una evolución necesaria del manifiesto de los "cinco puntos", grado cero de la arquitectura del siglo XX. Por otra parte, la antihistoricidad de Ronchamp, tal como la planteaba Argan, la considera como su gran fuerza pedagógica, una vez que "toda orientación pedagógica tendrá que ser antihistórica y dinámica" ${ }^{, 29}$. Solo así se podían evitar la academia, los estilos, las convenciones.

En las últimas líneas del artículo de 1965, “Le Corbusier - un arquitecto coherente”, Vieira de Almeida defendía que la influencia del purismo en el maestro franco-suizo había condicionado su concepción de la arquitectura, donde la visión de los objetos predominaba sobre la visión del espacio. Chandigarh, escribe, es el ejemplo de un urbanismo "donde la distancia entre edificios, no obstante se presenten como objetos de extrema calidad, no permite la existencia de zonas de influencia que, en su interpenetración, puedan definir nuevos núcleos de espacio vital”. Esto explicará, en parte, la ausencia de Le Corbusier en su tesis del 1963 sobre el espacio de la arquitectura. Pero si la muerte de Le Corbusier había imposibilitado, a escala urbana, un "ajuste de cuentas" similar al que representó Ronchamp a pequeña escala, también es verdad que en Chandigarh ya había señales que podrían contrariar ese urbanismo de objetos dispersos. Esto mismo lo reconocería Vieira de Almeida años más tarde, cuando reflexionaba sobre el monumento de La Mano Abierta, cuya concepción coincide con la

\footnotetext{
${ }^{27}$ Le Corbusier: Modulor 2. Los usuarios tienen la palabra. Madrid: Ediciones Apóstrofe, 2005 [1955]. p.265.

${ }^{28}$ Eliot, apud Venturi, Robert: Complejidad y Contradicción en la Arquitectura. Barcelona: Gustavo Gili, 1972 [1966]. p.19.

${ }^{29}$ Almeida. "A poética de Le Corbusier - A poesia de Valéry - Uma pedagogia impossível”. Op.cit.
} 
construcción de Ronchamp: La Mano Abierta, en la dialéctica establecida entre un contenido monumental de significado universal y un acercamiento al perfil de las montañas envolventes, funcionaba como un referencial de profundidad y a través de ella se volvía presente la distancia, lo que predecía otro camino que ya no pudo ser explotado $^{30}$.

Es significativo que en el momento de arriesgar y avanzar con una definición de arquitectura, Vieira de Almeida, y a pesar de su interpretación espacialista que le impide de hablar de volúmenes reunidos bajo la luz, asuma su deuda con Le Corbusier, y en particular con lo que el maestro refería en su "testamento" como el valor principal de la vida: la poesía. Escribía Vieira de Almeida: "La arquitectura es el revelar o el instaurar poéticamente los lugares del hombre, haciendo significar la luz en una matriz espacial, jugando con el color, la materia y la forma "31. Sin entrar a fondo en la pertinencia de esta definición, podríamos preguntar, ¿no funcionaría también como una magnífica interpretación de Ronchamp?

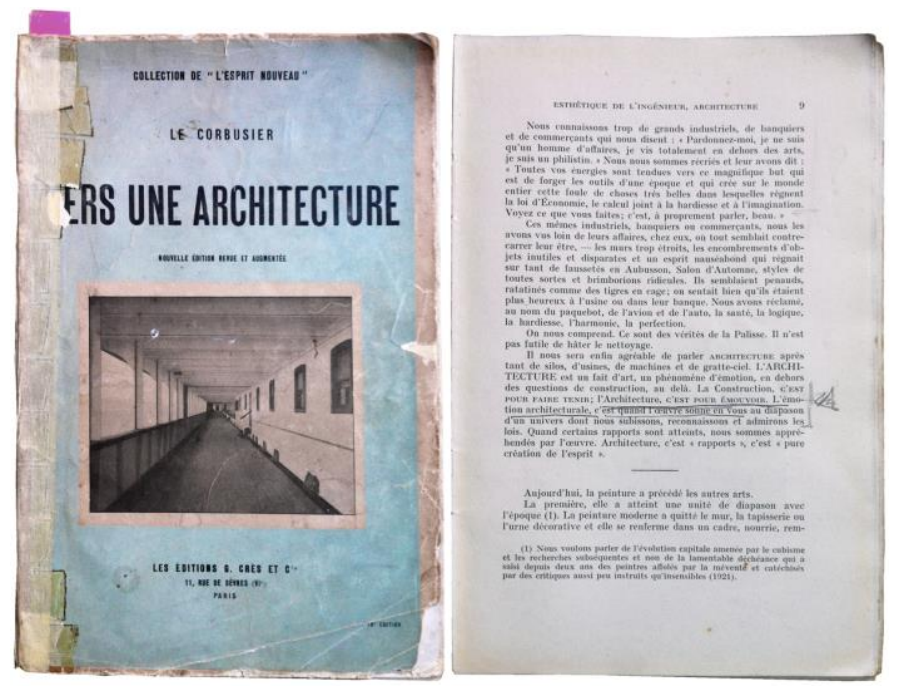

5. Ejemplar de Vers une Architecture de Pedro Vieira de Almeida: en la pagina 9, la frase de Le Corbusier "l'Architecture, c'est pour émouvoir", está subrayada.

\section{Agradecimientos}

A la Fundação para a Ciência e a Tecnologia de Portugal, por la beca FCT - DFRH - Bolsa SFRH/ BD/ 84258/ 2012, financiada por subvenciones del Ministerio de Educación y Ciencia y del Fondo Social Europeo - QREN Portugal 2007-2013. A José Àngel Sanz, Rui Jorge Garcia Ramos e Maria Helena Maia por las revisiones del texto y las sugerencias para mejorarlo.

\section{Procedencia de las imágenes}

Imagen 1: Colóquio: Revista de Artes e Letras. Octubre de 1965, № 35. Lisboa: Fundação Calouste Gulbenkian. pp.14-15. Fotografia del autor.

\footnotetext{
${ }^{30}$ Ibidem. Véase la referencia al libro de Adolf von Hildebrand, El problema de la forma en la obra de arte (1893), en el seguimiento de esta idea: “...que a través de ella se vuelva presente la distancia, en el sentido del análisis hildebrandiana de las cualidades expresivas del espacio" (p.266).

${ }^{31}$ Almeida, Pedro Vieira de: "Uma definição de arquitectura". En Almeida: Apontamentos para uma teoria da arquitectura. Op. cit. pp.33-35.
} 
Imagen 2: Almeida, Pedro Vieira de; Carvalho, Manuel Rio; França, José-Augusto; Pimentel, Diogo: Raul Lino. Exposição retrospectiva da sua obra. Lisboa: Fundação Calouste Gulbenkian, 1970. pp.182-183. Fotografía del autor.

Imagen 3: Almeida, Pedro Vieira de: O Tronco da Arquitectura. Do racionalismo como borbulha. Porto: CEAA, 2002. p.38.

Imagen 4: Le Corbusier; Petit, Jean: Le livre de Ronchamp. Cahiers Forces Vives/Editec, 1961.

Imagen 5: Archivo de Pedro Vieira de Almeida. Fotografía del autor.

\section{Bibliografía}

Almeida, Pedro Vieira de: “Le Corbusier”. En Seara Nova. Octubre 1965, No 1440. Lisboa. pp.304-305.

Almeida, Pedro Vieira de: "Le Corbusier - um arquitecto coerente". En Colóquio: Revista de Artes e Letras. Octubre de 1965, No 35. Lisboa: Fundação Calouste Gulbenkian. pp.14-18.

Almeida, Pedro Vieira de: “Arquitectura como disciplina interdisciplinar". En Jornal de Letras e Artes, 27-101965. Lisboa: Editora Lux. p.5.

Almeida, Pedro Vieira de: "Estrutura crítica - condição base de criação". En Jornal de Letras e Artes, 12-1-1966. Lisboa: Editora Lux, p.5.

Almeida, Pedro Vieira de; França, José-Augusto; Pimentel, Diogo: Raul Lino. Exposição retrospectiva da sua obra. Lisboa: Fundação Calouste Gulbenkian, 1970.

Almeida, Pedro Vieira de; Fernandes, José Manuel; Maia, Maria Helena: Arquitectura Moderna. Lisboa: Edições Alfa, 1986.

Almeida, Pedro Vieira de: O Tronco da Arquitectura. Do racionalismo como borbulha. Porto, CEAA, 2002.

Almeida, Pedro Vieira de: Apontamentos para uma teoria da arquitectura. Lisboa: Livros Horizonte, 2008.

Almeida, Pedro Vieira de; Cubero, Josefina González; Trevisan, Alexandra (eds.): Ler Le Corbusier. Porto: CEAA, 2009.

Almeida, Pedro Vieira de: A noção de espessura na linguagem arquitectónica. Porto: CEAA, 2011.

Almeida, Pedro Vieira de: Dois parâmetros de arquitectura postos em surdina. Leitura crítica do Inquérito à arquitectura regional - caderno 2. Porto: CEAA, 2013 [2011].

Argan, Giulio Carlo: "La chiesa di Ronchamp (Lettera a Ernesto Rogers)". En Casabella-Continuitá, Enero/ Febrero de 1956, N 209. Milano: Mondadori.

Giedion, Sigfried. Espacio, Tiempo y Arquitectura, 9a ed. Barcelona: Editorial Científico-Médica, 2009.

Pevsner, Nikolaus: Pioneros del Diseño Moderno, de William Morris a Walter Gropius, $4^{\mathrm{a}}$ ed. Buenos Aires: Ediciones Infinito, 2003.

Pevsner, Nikolaus: Storia dell'architettura europea. Bari: Editori Laterza, 1966.

Rogers, Ernesto Nathan: "Il metodo di Le Corbusier e la forma della 'Chapelle de Ronchamp"”. En CasabellaContinuitá. Septiembre/ Octubre de 1955, N 207. Milano: Mondadori. pp.2-6.

Stirling, James. "Ronchamp: Le Corbusier's chapel and the crisis of rationalism". En Architectural Review. Marzo 1956, № 119. Londres. pp.155-161.

Zevi, Bruno: Historia de la Arquitectura Moderna. Barcelona: Editorial Poseidon, 1980.

Zevi, Bruno: Architectura in Nuce: una Definición de Arquitectura. Madrid: Aguilar, 1969. 


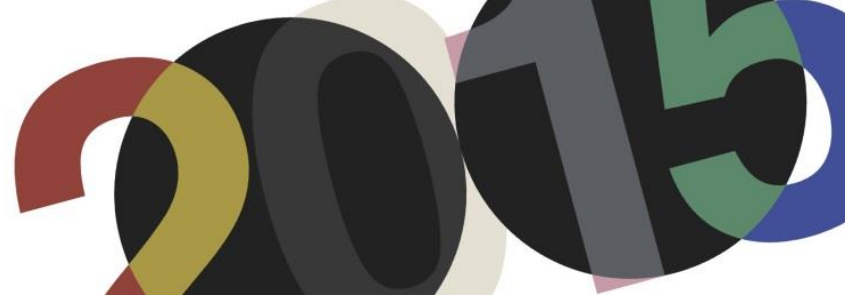

DOI: http://dx.doi.org/10.4995/LC2015.2015.793

\title{
El epígono de El Modulor: La serie amarilla en las investigaciones de Rafael Leoz
}

\author{
J. López Díaz*, J.A. Ruiz Suaña** \\ * Universidad de Murcia \\ ** Universitat Politècnica de València
}

Resumen: El arquitecto español Rafael Leoz de la Fuente (1921-1976) antes de terminar sus estudios en 1955, comenzó a colaborar con otros compañeros en la realización de proyectos de vivienda social. Su experiencia en la obra del Poblado Dirigido de Orcasitas, le llevó a iniciar un proceso investigador al que dedicó gran parte de su trabajo.

Los trabajos teóricos del arquitecto tuvieron una importante difusión y repercusión internacional, en gran parte, fruto de su amistad con Jean Prouvé y Le Corbusier. La sintonía personal y coincidencia de intereses entre ellos llevaron a éste último a proponer a Rafael Leoz como miembro del Cercle d'Études Architecturales de París en 1962.

Dentro de su ambicioso proyecto de investigación teórica Rafael Leoz estableció dos objetivos consecutivos, por una parte la ordenación abstracta del espacio, para posteriormente organizar y construir el espacio concreto en que habitan las personas.

A partir de las publicaciones de Rafael Leoz y documentación original de su archivo, se intentará precisar las relaciones personales y profesionales entre Le Corbusier y Rafael Leoz. Así mismo se mostrarán los vínculos entre El Modulor de Le Corbusier y las investigaciones de Rafael Leoz, sus propuestas modulares y dimensionales a partir de la Serie Amarilla como complemento y consecuencia de las series Roja y Azul del Modulor, llegando hasta el desarrollo de organizaciones de vivienda social.

Abstract: The Spanish architect Rafael Leoz de la Fuente (1921-1976) before finishing his studies in 1955, began to collaborate with other partners in the realization of social housing projects. His experience in the work of the Poblado Dirigido de Orcasitas, led him to initiate a research process to which he dedicated much of his work.

The theoretical works of the architect had an important dissemination and international impact, to a large extent, due to his friendship with Le Corbusier and Jean Prouvé. Personal tuning and coincidence of interests between them, led Le Corbusier to propose to Rafael Leoz as a member of the Cercle d'Études Architecturales in Paris in 1962.

Within this ambitious project of theoretical research Rafael Leoz established two consecutive goals, on one hand, the abstract spatial planning, to later organize and build a specific space in which people dwell.

From publications of Rafael Leoz and original documentation of his files, this paper tries to clarify personal and professional relationships between Le Corbusier and Rafael Leoz. Also pretends to establish some links between the Modulor of Le Corbusier and Rafael Leoz investigations. Moreover it will show Leoz's modular and dimensional proposals from the Yellow Series both as a complement and a result of the Red and Blue series of the Modulor, reaching the development of organizations of social housing.

Palabras clave: Rafael Leoz; Le Corbusier; Modulor; construcción modular; prefabricación; vivienda social. Keywords: Rafael Leoz; Le Corbusier; Modulor; modular construction; prefabrication; social housing. 


\section{Introducción}

En este trabajo se propone mostrar la relación entre Le Corbusier (1887-1965) y el arquitecto español Rafael Leoz de la Fuente (1921-1976). El pensamiento y la obra del maestro suizo ejerció —y lo sigue haciendo - una extraordinaria influencia en otros autores, y Rafael Leoz no quedó al margen de ésta. La vinculación entre los dos arquitectos es doble, por una parte la sintonía personal entre ellos y la coincidencia en sus intereses hizo que Le Corbusier fuera una referencia profesional y personal para el arquitecto madrileño con mutuo reconocimiento; y por otra parte el trabajo de Le Corbusier — tanto teórico como sus obras - resulta fundamental para entender la labor investigadora a la que Rafael Leoz dedica la mayor parte de su carrera profesional.

A partir de algunas obras publicadas de ambos arquitectos y de documentación de sus archivos, se intentará poner de manifiesto los encuentros e influencias biográficas y profesionales entre ambos. Del mismo modo se intentará precisar el empleo que hace Rafael Leoz del Modulor de Le Corbusier en sus investigaciones teóricas para la prefabricación de viviendas. Para ello se relacionarán algunos capítulos de su libro Redes y ritmos espaciales con documentación de la Fundación Rafael Leoz, estableciendo vínculos entre ambas fuentes y una breve revisión crítica sobre el desarrollo y el alcance de su propuesta para el dimensionado de viviendas.

Un recorrido por los encuentros, acontecimientos y relaciones personales compartidas servirá para situar la relevancia que el maestro Le Corbusier ocupó en la vida y trabajo de Rafael Leoz. A continuación, centrando la mirada en su labor teórica; se presentarán, en primer lugar, los objetivos generales de la investigación de Rafael Leoz, seguido de una breve exposición de su primera parte relativa al espacio abstracto. En una segunda instancia se propondrá una visión de la influencia del Modulor a la hora de definir las medidas materiales del espacio vivido. Por último se mostrará —en un caso concreto- el recorrido y los posibles límites del procedimiento que propone Rafael Leoz para el dimensionado de viviendas.

\section{La afinidad intelectual con Le Corbusier}

Le Corbusier y Rafael Leoz coincidieron en algunas ocasiones desde que Jean Prouvé interviniera en favor del arquitecto español para que el franco-suizo escuchara de viva voz sus teorías sobre la división y ordenación del espacio arquitectónico. Aquella relación fue uno de los factores que marcó el desarrollo de la carrera profesional de Leoz, pues la continua repetición de los elogios de Le Corbusier por la administración franquista, por la prensa general y algunas revistas especializadas, pudo ser un distorsionante en la recepción del trabajo de Rafael Leoz.

Existen numerosos puntos de contacto entre ambos arquitectos en el plano teórico y en su concepción de la arquitectura. A ambos les unía su preocupación por la vivienda social, su afán por la investigación y especialmente por los hallazgos en el terreno de la modulación, y una concepción de la arquitectura integrada en las Bellas Artes, en la línea de lo expuesto desde principios de siglo por la Deutsche Werkbund y la Bauhaus.

En octubre de 1960 tuvo lugar una reunión de arquitectos en la ciudad de San Sebastián, en la que Rafael Leoz mostró a José Antonio Coderch sus trabajos sobre coordinación modular y las distintas formas de entender el espacio arquitectónico mostrándole además algunas fotografías de sus maquetas e investigaciones. Coderch le recomendó que expusiera esos trabajos a Jean Prouvé, a quien él había conocido en una de las Bienales de Milán. El viaje de Leoz a París se produjo poco después, entre los meses de noviembre y diciembre de 1960, y de su entrevista con Prouvé existe documentación en los archivos de la Fundación Rafael Leoz. En la carta escrita por el constructor francés, éste da cuenta del interés en él despertado por la entrevista con Leoz a la vista 
de sus teorías. Es en esas misivas enviadas en las Navidades de 1961 entre Leoz y Prouvé, donde el francés afirma: “Les heures pendant lesquelles j'ai écouté l'exposé de vos idées m'ont réjoui car de telles recherches menées avec tellement de science et de foi sont rares. En effet, si le souci de l'industrialisation du bâtiment est dans toutes les bouches, il y a généralement carence de propositions car il est plus facile de parler que d'étudier et de réaliser. Votre nouveau module ouvre des horizons" (Imagen 1). Además Prouvé aseveraba que este nuevo horizonte abierto por Leoz podría llevar a la desaparecida armonización entre arquitectura y tecnología, y le deseaba que una adecuada colaboración industrial le permitiera mostrar pronto resultados. Como Leoz exponía en Redes y ritmos espaciales, "conocí a Prouvé y desde entonces es la persona que mejor me ha ayudado, haciéndose cargo de las ideas y de las circunstancias".1.

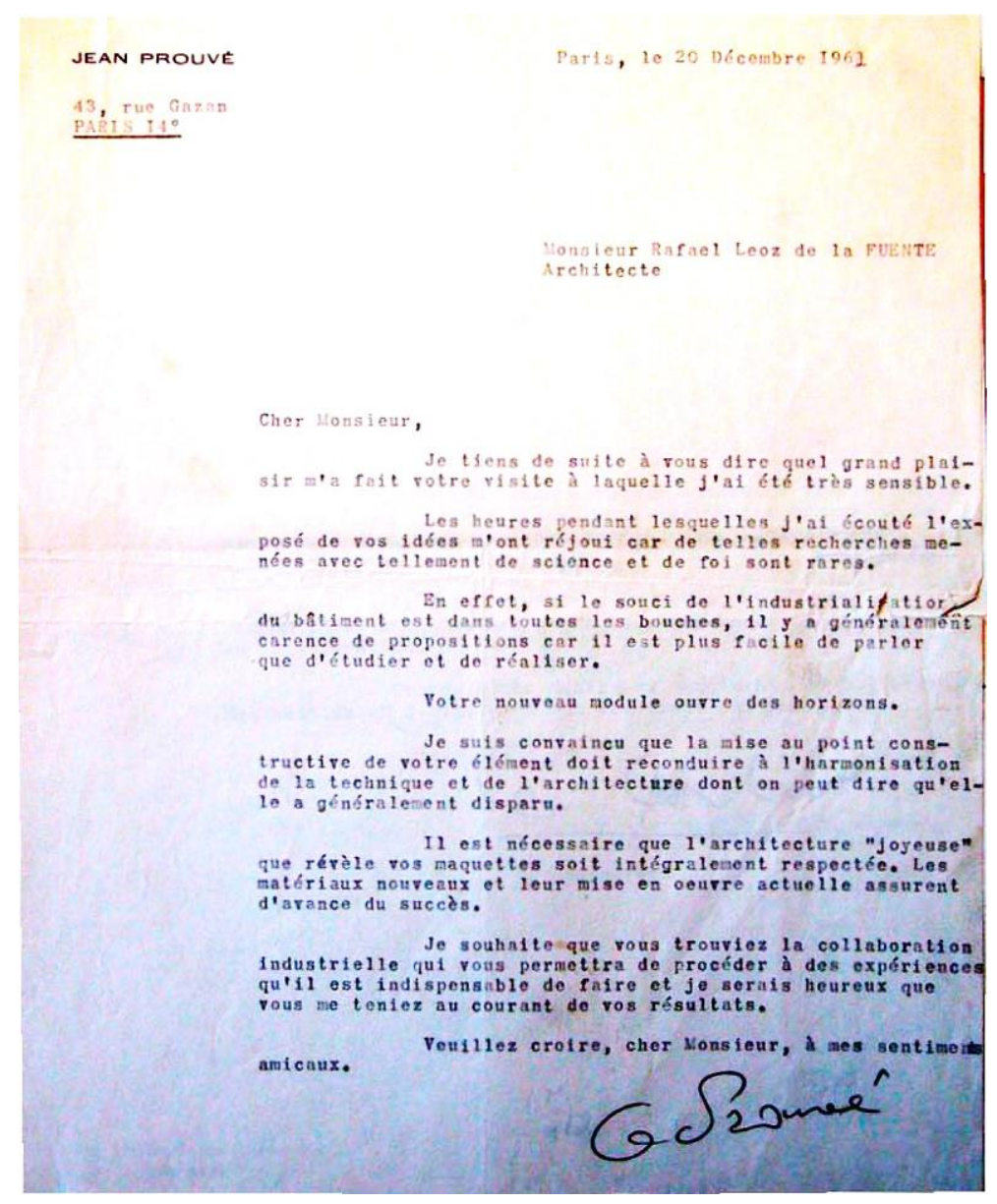

1. Carta de Jean Prouvé a Rafael Leoz.

A partir de esta entrevista se inició una amistad entre ambos que perduró en el tiempo y que llevó a Leoz a elegir a Prouvé como prologuista de su libro Redes y ritmos espaciales, originalmente había sido Le Corbusier el elegido por Leoz, aunque su fallecimiento en Cap Martin en 1965 truncó esta posibilidad. De hecho, después del éxito internacional de Leoz en Brasil, con su premio en la Bienal de Sao Paulo de 1961, fue Jean Prouvé quien gestionó el encuentro con Le Corbusier en 1962.

\footnotetext{
${ }^{1}$ Leoz de la Fuente, Rafael: Redes y ritmos espaciales. p.23.
} 
Rafael Leoz fue recibido por Le Corbusier el 10 de febrero ${ }^{2}$, antes de que el español marchara a Alemania a dictar una conferencia el día 12 con motivo de la exposición sobre arquitectura española contemporánea celebrada en Munich y promovida por el Instituto de Cultura Hispánica y la DGA, en la que se mostraba el trabajo del español. Rafael Leoz siempre contó de este encuentro que, lo que debía haber sido una pequeña entrevista de media hora, se convirtió — al escuchar y quedar bastante interesado Le Corbusier — en una extensa conversación y en el inicio de una buena relación amistosa. En aquel encuentro, y según explicaba la prensa que difundía la noticia, Le Corbusier mostró a Leoz el Museo de Bellas Artes de Estocolmo para que comprobara en cuánto se acercaban sus principios teóricos sobre la modulación. La teoría de la división y organización del espacio arquitectónico mostrada por Rafael Leoz debió sorprender positivamente a Le Corbusier (Imagen 2), quien rápidamente, junto a Prouvé, promovieron y organizaron un acto de presentación de estas teorías en una conferencia el 28 de febrero de 1962 ante un grupo de arquitectos franceses, con una perspectiva similar, llamado el Cercle d'Études Architecturales (CEA), presidido en aquel momento por Jean Dubuisson, hasta ese momento el único español invitado al CEA había sido Eduardo Torroja.

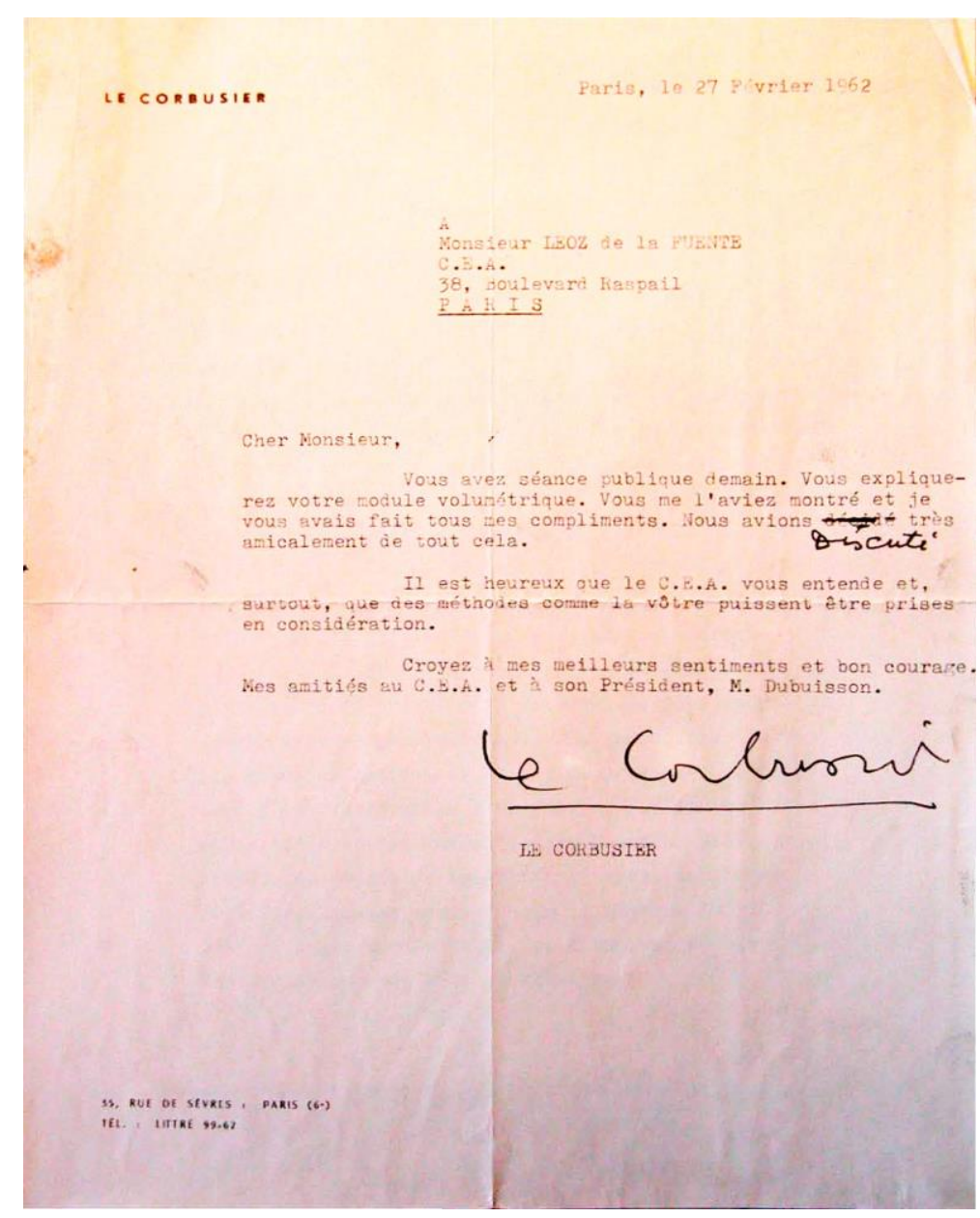

2. Carta de Le Corbusier a Rafael Leoz.

\footnotetext{
${ }^{2}$ Así consta en una nota interna, escrita seguramente por la secretaria de Le Corbusier en 1962: “M. Jean Prouvé a téléphoné le 7 février 1962 recommandant M. Leoz de la Fuente, architecte espagnol de talent qui désire voir absolument L-C. M. de la Fuente est jusqu'au lundi 12 février [...]. Il part ensuite faire des conférences en Allemagne. L-C a reçu M. de la Fuente le samedi 10 février à midi. Il a trouvé ce jeune architecte sympathique et ne manquant pas le capacités architecturales". Nota manuscrita, Archivo Fundación Le Corbusier (FLC), París.
} 
La cuestión, un tanto negativa, fue que el propio encuentro y los elogios de Le Corbusier se convirtieron por momentos en el todo, especialmente para el Régimen y su prensa propagandística, tan necesitados de formas que mostraran a la sociedad española la imposible normalidad y el anhelado y constante "éxito" español en el extranjero.

Tres años después, en 1965, Rafael Leoz volvió a intervenir en el CEA de París, y nuevamente la prensa española —en este momento Leoz era ya una personalidad pública que había recibido el reconocimiento oficial en 1964 con la imposición de la Cruz de Caballero de la Orden de Isabel la Católica a iniciativa del Ministerio de Asuntos Exteriores - se hizo amplio eco de la noticia y, también, de los elogios de los grandes arquitectos franceses. Además, en aquella ocasión Leoz intervino en el Congreso Mundial de la Unión Internacional de Arquitectos (UIA), otro organismo con el que le uniría una positiva relación desde ese momento, pues en las dos ediciones siguientes (Praga, 1967; Buenos Aires, 1969) recibiría nuevos reconocimientos a su trabajo en forma de galardones internacionales.

La Embajada española en París, como era habitual en este tipo de acontecimientos, mantuvo la visita de Leoz junto con los corresponsales españoles de la agencia EFE y de los principales medios, en un tono de notoria relevancia. Lo que la prensa española recogió sobremanera fueron las palabras elogiosas de Le Corbusier a Leoz, comentarios que no dejan lugar a dudas del aprecio del arquitecto franco-suizo hacia el español y hacia su trabajo:

"Existe actualmente un genio de la arquitectura, el hombre que más profundamente ha penetrado en la pura esencia de la composición arquitectónica. Estaría por decir que ha encontrado las leyes contemporáneas del ritmo y de la armonía basándose en las matemáticas. Con él desaparece la incertidumbre. Como siempre, este hombre habla humildemente, casi avergonzado de lo que ha hecho. Después de sus teorías todo lo demás viene como consecuencia: la industrialización, estética y economía de la arquitectura, las leyes permanentes de la composición en el plano y en el espacio... Hay otras muchas consecuencias imposibles de adivinar actualmente. En sus vidrieras se manifiesta toda una teoría del color, en sus mosaicos toda una teoría del ritmo y de las formas. Lo que ha hecho Leoz es sorprendente. Durante cuarenta años he pensado y laborado en la misma dirección que Leoz. Me satisface el pensar que, quizás mi labor pasada influyera en su trabajos”.

Por su parte, Jean Prouvé, con su mentalidad más práctica de constructor, dejaba caer un mensaje: “Lástima que Leoz no haya encontrado todavía el apoyo industrial y financiero para llevar a la práctica sus teorías. Aquí, ya lo hubiera encontrado" — subrayaba Prouvé—. De hecho, según comentaba la nota de EFE, Leoz junto a Prouvé y el propio Le Corbusier, viajarían esa misma tarde a Nancy (donde se encontraba la fábrica de Prouvé), para visitar "diversas industrias metalúrgicas" interesadas en la fabricación del Módulo HELE. El mensaje de Prouvé iba sin duda destinado a las autoridades españolas para impulsar definitivamente la creación del Instituto de investigación que perseguía Leoz, y que se mencionaba en todos los artículos de la prensa, pero que no acababa de ver la luz de manera definitiva.

También George Candilis elogiaba la propuesta de Leoz, “con las teorías de nuestro colega español, cualquier buena arquitectura contemporánea es susceptible de ser reproducida e industrializada económicamente”. Y Jean Dubuisson, Presidente del CEA, añadía: "Los trabajos de Leoz de la Fuente marcarán un hito en la Historia de la Arquitectura. Sus teorías son tan universales que, en el primer momento, son difíciles de comprender en todo su alcance. Después, casi inmediatamente, se encuentra asombrado por su profundidad. 
Todo es perfecto y armónico y obedece a una ley suprema. Nos sentimos orgullosos de ser sus amigos y de haberle abierto las puertas del CEA hace ya más de tres años",

Parece imposible sustraerse a los elocuentes elogios, por lo que afirman, pero también por quiénes lo expresan. La noticia del éxito de Leoz en la conferencia del CEA, y el velado mensaje de Prouvé, no cayeron en saco roto. El día siguiente de recibir en Madrid la información de la Embajada y de leer las noticias de agencias y corresponsales, la Dirección General de Relaciones Culturales inició el trámite de urgencia, a propuesta del propio Ministro de Asuntos Exteriores, para la concesión a Leoz de la Gran Cruz de la Orden del Mérito Civil, en la entonces muy próxima celebración del "18 de julio", condecoración impuesta por el propio Franco 4.

El broche a esta relación de afecto y admiración lo iba a constituir el prólogo del libro de Leoz, que en estos artículos de prensa se afirmaba iba a ser editado y publicado en París, escrito por Le Corbusier. Sin embargo, unas pocas semanas después del encuentro con Leoz en el CEA, Le Corbusier moría en un baño veraniego en la Costa Azul.

El periódico ABC le encargó a Rafael Leoz un texto para completar un extenso reportaje a cuatro páginas sobre la figura de Le Corbusier aparecido el 5 de septiembre. Leoz redactó un sentido artículo homenaje que no escondía la desazón de perder al mejor defensor de sus ideas:

"Le Corbusier ha muerto;El mundo aún no se ha enterado de lo que ha ocurrido!. Para la Arquitectura es una tragedia, sin enmienda ni arreglo posible. Era el único hombre que quedaba capaz de hacernos vibrar a todos con sus ideas puramente arquitectónicas de tan gran fondo social. [...] La última vez que lo vi, no hace más de cuarenta días, estaba más joven de espíritu que nunca. Era estupendo ver a un hombre de su edad tan

\footnotetext{
${ }^{3}$ Las citas están tomadas del cable de la Agencia EFE, de 3 de julio de 1965 Archivo de la Fundación Rafael Leoz -AFRL. Los periódicos madrileños y nacionales se hicieron amplio eco de la noticia: "Don Rafael Leoz: «Es el genio de la arquitectura actual», ha dicho Le Corbusier", Diario Madrid, 9 de julio de 1965; "Éxito en París del arquitecto Leoz. El célebre urbanista Le Corbusier lo califica de genio" Ya, 6 de julio de 1965; "Éxito de los arquitectos españoles en París", Arriba, 6 de julio de 1965; "Las teorías del español Leoz de la Fuente, elogiadas por Le Corbusier”, ABC, 6 de julio de 1965. A todas estas informaciones que reproducían por lo general lo recogido por la agencia EFE, hay que sumar las entrevistas realizadas a Leoz por la periodista Josefina Carabias, destacada en París como corresponsal del diario Ya: "Se pueden obtener reproducciones arquitectónicas artísticas en serie. Prefiero trabajar en casa y para mi país, dice Leoz", Ya, 9 de julio de 1965; y por el periodista catalán Juan Bellveser, corresponsal de los diarios Madrid e Informaciones: "Rafael Leoz de la Fuente ¿Qué es el Módulo L? Elemento de construcción integrado por cuatro poliedros”, 9 de julio de 1965. De esta última entrevista sorprende alguna respuesta de Leoz, difícil de contrastar, como cuando afirma que ya existe un juguete basado en el Módulo L comercializado en Japón, Alemania Occidental y Estados Unidos, o la respuesta al tamaño ideal y si se han llevado a cabo ensayos reales: "En cuanto al tamaño, he previsto hasta ahora tres medidas, de 3,60, 4,20 y 4,80 metros respectivamente. Por lo que atañe a los materiales, todos pueden servir para el módulo: el hormigón, el cristal, las estructuras metálicas, etc. [...] Se han hecho ensayos reales hasta ahora, en Caracas. Pero en otros países como Brasil, Méjico, Alemania y Estados Unidos, hay arquitectos dispuestos a emplearlo, y en España han hecho proyectos en el mismo sentido mis colegas don Miguel Durán Loriga y don Roberto Puig. Por otra parte en el Comité para la Construcción que se reunirá del 20 al 30 de agosto en Copenhague, mi sistema es objeto de una de las principales ponencias,..."

4 "Orden del Mérito Civil. Expediente de concesión de la Gran Cruz a Don Rafael Leoz de la Fuente, arquitecto" (1965). Leg. R.9962, exp.10, Archivo del Ministerio de Asuntos Exteriores. El Archivo de la Fundación Rafael Leoz cuenta también con la felicitación del General Fernando Fuertes de Villavicencio, entonces Segundo y posteriormente y hasta la muerte del Dictador, Primer Jefe de la Casa Civil de Franco. Fuertes de Villavicencio le enviaba a Leoz una serie de recortes sobre los éxitos en París y le comunicaba que había enviado copia de ellos a García Lomas, Director General de Arquitectura, lo que refleja que se habían ido produciendo conversaciones entre varios miembros del Régimen para la creación del Instituto de Investigación Rafael Leoz. Carta de Fernando Fuertes de Villavicencio a Rafael Leoz, Palacio de Oriente, 12 de julio de 1965. Archivo de la Fundación Rafael Leoz.
} 
permeable a las nuevas ideas, y a jugarse el todo por el todo por los nuevos valores, que él creía encontrarían nuevos caminos hacia el futuro".

Rafael Leoz también dejaba un hueco para criticar el resquemor generado por Le Corbusier tanto en nuestro país - siempre fue "sospechoso" de colaborar con la República y especialmente con la Generalitat catalana- como en la arquitectura en general, para acabar resumiendo bastante acertadamente la labor de Le Corbusier como padre de la arquitectura moderna:

“¡Pobre gente! Sin saberlo, quizá, se lo debían casi todo a él. Los nuevos tratamientos de los materiales, las nuevas concepciones de las estructuras y del espacio arquitectónico en general, como sus originales disposiciones urbanísticas admirables, planteadas por él hace más de cuarenta años y que nadie ha sabido ni podido todavía superar. [...] Las figuras como Le Corbusier molestarán siempre y acomplejarán a los hombres de su misma profesión, que habiéndoles copiado siempre en lo básico, no querrán nunca hablar de ellos ni reconocer su valor [...] Sus fieles, los que agradecemos su herencia, no tenemos ya nada que hacer después de su muerte, salvo recordarle e intentar seguir su evolución, con su mismo espíritu, la gran senda que él ya nos trazó ${ }^{\prime 5}$.

En otro obituario de Rafael Leoz a Le Corbusier, en la Editorial del número 77 de Temas de Arquitectura, regresaba a lo expuesto en $\mathrm{ABC}$, haciendo hincapié en lo criticado y "ultrajado" del personaje. Nuevamente se vinculaba en lo personal y profesional a Le Corbusier y se ponía el primero de la fila entre sus seguidores y defensores, pareciendo por momentos hablar en primera persona. En esta ocasión Leoz incluía algunos de los detalles más humanos de su primer encuentro con el gran arquitecto:

"Hablé con él por primera vez hace unos años. Como era natural iba muy impresionado, porque, además, Prouvé me había advertido que no podría dedicarme más de cinco minutos. Aquellos cinco premiosos minutos se convirtieron en más de seis horas ininterrumpidas de densa conversación, incluyendo el almuerzo, que hicimos juntos con la máxima sencillez en un pequeño bistrot cerca de su estudio. Desde aquel momento no tuve mejor amigo profesional ni consejero más preciso",6.

Las referencias a Le Corbusier continuaron en la prensa cada vez que Leoz era entrevistado, y en algunas de ellas lo identificaba como un maestro, ciertamente en España no tenía ningún arquitecto como referencia ${ }^{7}$. A

\footnotetext{
${ }^{5}$ LEOZ, R.: "Le Corbusier no estaba en el programa", $A B C, 5$ de septiembre de 1965, págs. 30-33 [Existe una copia del artículo en los fondos de la Fundación Le Corbusier]. El texto fue muy del agrado de Luis $\mathrm{M}^{\mathrm{a}}$ Ansón, que le remitió una carta de felicitación a Leoz, en la que mencionaba haber estado presente en París durante el acto de homenaje en el Louvre a Le Corbusier: "En Francia, he leído una buena parte de lo que se ha publicado en la Prensa estos días. Puedo asegurarle que no he leído un artículo tan conciso, tan exacto, tan justo, tan sentido como el suyo. Hacía mucha falta que en España se dijera todo lo que usted ha dicho. Aquí las grandes empresas tantas veces con su falta de visión y el poder público con su favoritismo amenazan con prostituir nuestra joven arquitectura, creando valores falsos e impresentables. Su artículo de hoy era algo más que un homenaje a la figura gigante de Le Corbusier. Era un programa de honestidad y exigencia para la arquitectura española. Mi enhorabuena por él”. Carta de Luis Ma Ansón a Rafael Leoz, en Madrid a 5 de septiembre de 1965. Archivo de la Fundación Rafael Leoz.

${ }^{6}$ LEOZ, R.: Editorial, TA, 77, (1965).p.1.

${ }^{7}$ También la prensa francesa identificaba a Rafael Leoz como un discípulo de Le Corbusier, y así aparecía calificado en un artículo de La revue française. Esta publicación mensual dedicaba un número a un tema monográfico o al conocimiento profundo de algún país. El número de junio de 1967 estaba dedicado a España. Junto a artículos sobre temas de cultura que trataban cuestiones más o menos tópicas o reconocibles (Salzillo o los castillos españoles), aparecían los que explicaban los avances de nuestro país, en pleno desarrollismo, redactados por algunos Ministros de Franco (como López Bravo de Industria y López Rodó de Desarrollo), y entre medias Leoz y sus módulos. "Un disciple espagnol de Le Corbusier, Rafael Leoz", La revue française, 200, (1967), págs. 61-62.
} 
finales de 1965 Leoz destacaba como texto más influyente en su juventud el libro Cuando las catedrales eran blancas, y confesaba que su obra más admirada era la iglesia de los dominicos en Tourette (Lyon), la obra de un hombre que definía como "padre de una arquitectura de la luz, propia de un poeta"8.

La relación con la Fundación Le Corbusier continuó tanto a la muerte de Le Corbusier como a la de Leoz, al menos hasta 1978, con la presencia de A. Wogensky, Director de la Fundación Le Corbusier, en el programa de la exposición homenaje a Leoz inaugurada por los Reyes de España aquel año. En el programa de conferencias aparecían el nombre de Prouvé, junto al de Wogensky y Coderch, como Consejeros de Honor de la Fundación Rafael Leoz. En realidad, lo que luego se convirtió en el Patronato de Honor de la Fundación Rafael Leoz, fue en un primer momento el "Consejo Técnico" del Instituto Rafael Leoz. En septiembre de 1967 en una carta a Prouvé se recordaba su última conversación sobre el tema mantenida por ambos en el Instituto Politécnico de Zurich, que este Consejo Técnico pensaba ser reunido en Madrid por primera vez a finales de ese mismo año, y que junto a Prouvé, se invitaría a José Luis Sert — todavía Decano de Harvard y con quien Leoz mantuvo cierta relación tras haber coincidido en Estados Unidos-, el arquitecto venezolano Raúl Villanueva, André Wogensky (entonces Director de la Fundación Le Corbusier de París), Ramón Torres (Director de la Escuela de Arquitectura de la Universidad de México), Fernando Belaúnde Terry (arquitecto, y entonces Presidente del Perú, gran admirador de Leoz, a quien agasajó de manera notable en cada una de sus estancias en el país andino); el discípulo de Le Corbusier, George Candilis, y el arquitecto brasileño Enrique Midlin, quien apoyó desde un primer momento a Rafael Leoz.

\section{La investigación de Rafael Leoz}

Rafael Leoz describe su dedicación profesional como una trayectoria de varias etapas. En una primera etapa, tras terminar sus estudios de Arquitectura, se dedicó a proyectar y construir junto a otros compañeros ${ }^{9}$.

"Durante aquel período adquirí el convencimiento de que algo no marchaba bien ni en la Arquitectura ni en la técnica de la construcción que entonces tuvimos que emplear nosotros. Estaba seguro de que tenían que existir otros caminos y otras soluciones distintas y más eficaces. Y con esa íntima y gran preocupación seguí trabajando en mi vida profesional, ya completamente solo" ${ }^{\prime \prime}$.

Tras su experiencia junto a Joaquín Ruiz Hervás en la construcción del Poblado Dirigido de Orcasitas ${ }^{11}$, Rafael Leoz considera la vivienda uno de los puntos de apoyo de la justicia social y colectiva ${ }^{12}$, por ello inicia una etapa de investigación teórica dirigida a la industrialización de la construcción de viviendas.

\footnotetext{
8 "Rafael Leoz de la Fuente, autor de una industrialización estética y económica de la construcción", Ya, 10 de octubre de 1965 Archivo de la Fundación Rafael Leoz.

${ }^{9}$ Realizaron proyectos y concursos, algunos premiados, como Grupo 122, formado por Jose Luis Iñiguez de Onzoño, Antonio Vázquez de Castro, Joaquín Ruiz Hervás y Rafael Leoz de la Fuente.

${ }^{10}$ Leoz de la Fuente, Rafael: Redes y ritmos espaciales. p. 21.

${ }^{11}$ López Díaz, Jesús. La obra del arquitecto Rafael Leoz de la Fuente (1921-1976) pp.101-125.

${ }^{12}$ Leoz: Redes y ritmos espaciales. p. 49.
} 


\subsection{Redes y ritmos espaciales}

La tarea de investigación se inicia con la búsqueda de elementos básicos, a modo de "átomos", que puedan dividir el espacio de manera regular y adimensional de forma que, agregados entres sí, generen redes tridimensionales que llenen el espacio. Tras una rigurosa investigación, Rafael Leoz concluye que existen cuatro poliedros con simetría central que macizan el espacio tridimensional cartesiano, sin dejar huecos entre ellos: el cubo o hexaedro regular, el prisma recto de base rectangular, el rombododecaedro y el heptaedro o poliedro de Lord Kelvin ${ }^{13}$.

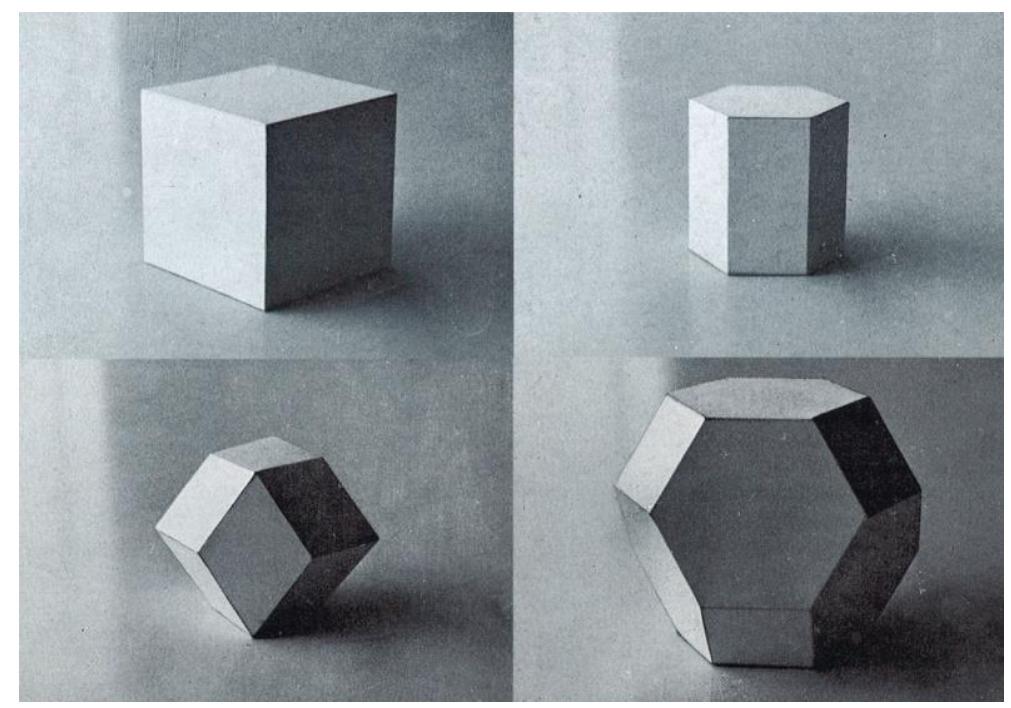

3. Los cuatro poliedros: el cubo o hexaedro regular, el prisma recto de base rectangular, el rombododecaedro y el heptaedro o poliedro de Lord Kelvin.

A partir de las redes espaciales formadas por los cuatro poliedros, se deducen redes planas que sirven de herramienta para el arquitecto, como soporte donde organizar la representación espacial en planos. Las redes se obtienen seccionando los cuatro poliedros que llenan el espacio. Estas redes son tres y están formadas por tres triángulos: Escuadra (triángulo rectángulo de catetos iguales, dos de ellos forman un cuadrado), Cartabón (triángulo rectángulo con ángulos de $30^{\circ}$ y $60^{\circ}$, mitad de triángulo equilátero) y Triángulo Hemipitagórico (tiángulo rectángulo, uno de sus catetos es el doble del otro, dos de ellos forman un rectángulo doble-cuadrado). De esta forma se obtienen tres redes planas: la cuadrícula, la red hexagonal regular y la red de doble cuadrado ${ }^{14}$.

\footnotetext{
${ }^{13}$ Íbidem. p.62.

${ }^{14}$ Moya Blanco, Luis: Rafael Leoz. Artistas españoles contemporáneos. pp.36-37.
} 


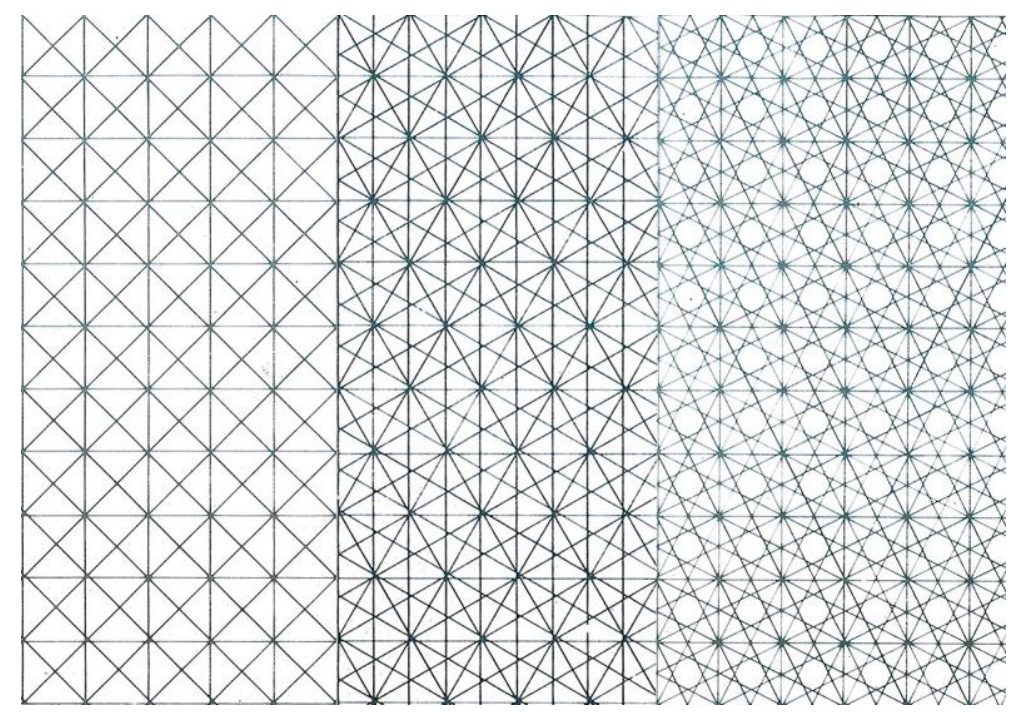

4. Redes planas: Escuadra, Cartabón y Triángulo Hemipitagórico.

El desarrollo de la investigación sobre ritmos espaciales a partir de las tramas propuestas se realiza inicialmente sobre una red espacial de hexaedros regulares o cubos, limitándose a una red plana de cuadrados. A partir de esto Rafael Leoz propone una unidad "molecular" que denomina módulo HELE ${ }^{15}$, que es el resultado de la agregación geométrica del menor número de cuadrados capaz de generar el mayor número de combinaciones entre dos de ellas ${ }^{16}$. En apartados siguientes del presente trabajo se indicará el empleo que Rafael Leoz hace del módulo HELE en el desarrollo de sus propuestas sobre proporción y dimensionado.

Estos ritmos y redes planas todavía sin dimensiones representan una ordenación ideal del espacio abstracto y suponen el soporte para ordenar y organizar los elementos que la industria fabricará una vez aplicadas a estas redes las dimensiones adecuadas.

\subsection{Proporciones y dimensiones}

Como señala Luis Moya, en la investigación de Rafael Leoz quedan separados el problema de la coordinación dimensional y el de la fijación material de las medidas. La coordinación dimensional se resuelve mediante las redes espaciales y redes planas propuestas por Rafael Leoz, y las medidas serán resultado de experiencias de tanteo de módulos básicos ${ }^{17}$.

"Una vez fijadas estas redes espaciales, se puede pasar a representar cada una de ellas con unas funciones matemáticas que enlazarán la forma y el volumen del cuerpo, pasando más tarde al estudio posterior de los intervalos de validez de las variables: tamaño, dimensión o volumen, para hacerlos funcionales a cada problema. Una vez fijados estos intervalos, en cada caso particular, es cuando tenemos que determinar concretamente los materiales, la forma de articularlos, etc. ",18

\footnotetext{
${ }^{15}$ Leoz de la Fuente, Rafael: Redes y ritmos espaciales. pp.67-79.

${ }^{16}$ Rafael Leoz describe varias propiedades geométricas y proporcionales del módulo HELE además de sus posibilidades combinatorias. Aunque no es objeto de este trabajo, el módulo HELE supuso un propuesta de Rafael Leoz con gran reconocimiento en el entorno arquitectónico.

${ }^{17}$ Moya Blanco, Luis: Rafael Leoz. Artistas españoles contemporáneos. pp.47-48.

${ }^{18}$ Opinión acerca de los ensayos realizados sobre coordinación dimensional atribuidos a Rafael Leoz por Luis Moya. Íbidem. p.49.
} 
Esta propuesta se puede ver concretamente en "Tablas numéricas de proporciones" que Rafael Leoz incluye en Redes y ritmos espaciales. En este capítulo, se hace cargo de las funciones matemáticas que relacionan las redes espaciales Escuadra, Cartabón y Triángulo Hemipitagórico, aplicándolas a varias sucesiones numéricas (aritméticas y geométricas) elaborando diversas tablas que presentan los resultados de estas relaciones. Para la realización de estas tablas de proporciones y relaciones numéricas, Rafael Leoz declara utilizar tres puntos de partida: El Modulor de Le Corbusier, el libro L'humanisation de l'espace. Le système $\phi$ de Alfred Neumann e Industrialización de la construcción de Neufert. Así mismo, explica que considera muy útiles las sucesiones aritméticas de razón 12 y 10 centímetros y las sucesiones de Fibonacci partiendo de 10 y de 12; y 24, 30 y 60 centímetros. Las serie azul y serie roja de El Modulor también están incluidas en las tablas de Rafael Leoz ${ }^{19}$.

\section{El Modulor}

En la tarea investigadora de Rafael Leoz sobre la modulación y relaciones dimensionales, resulta fundamental el interés por el Modulor.

"Es evidente la importancia que dentro de este campo de la Arquitectura tiene «el Modulor» de Le Corbusier, verdadero hito que marca una etapa en la historia de la Arquitectura. ${ }^{, 20}$

No sólo se hace explícito en el texto del propio autor, sino también en documentos existentes en el Archivo de la Fundación Rafael Leoz; exponemos algunos que manifiestan la dedicación al estudio e investigación sobre el Modulor.

En una lámina (Imagen 5) con el título "Serie dimensional del Modulor" un dibujo de Rafael Leoz reproduce el Modulor de Le Corbusier y sus relaciones dimensionales. Conviene recordar que el Modulor es el resultado del trabajo de Le Corbusier para proponer una "medida organizada sobre la matemática y la escala humana, constituida por una doble serie: la roja y la azul"21 que además unifica, en medidas tangibles, los sistemas métrico y anglosajón. En el dibujo de Rafael Leoz aparece representado el gráfico con las tres medidas de el Modulor: 113, 70, 43 (centímetros) relacionados por la razón $\phi$ (sección áurea) y serie de Fibonacci. Las tres medidas representadas 113; 182 y 226 son los tres valores esenciales del Modulor, correspondiendo respectivamente al plexo solar, el vértice de la cabeza (razón $\phi$ de 113) y la extremidad de los dedos con el brazo levantado ${ }^{22}$. La serie roja se genera como sucesión de Fibonacci a partir de 113 centímetros, relacionando cada valor a través de la razón $\phi$; la serie azul se forma como una sucesión de Fibonacci desde 226 centímetros (el doble de 113) aplicando la misma relación $\phi$.

\footnotetext{
${ }^{19}$ Estas tablas numéricas aparecen en Leoz, R: Redes y ritmos espaciales. pp.213-235.

${ }^{20}$ Íbidem. p.237.

${ }^{21}$ Le Corbusier: El Modulor. p.56.

22 Íbidem. p.63.
} 


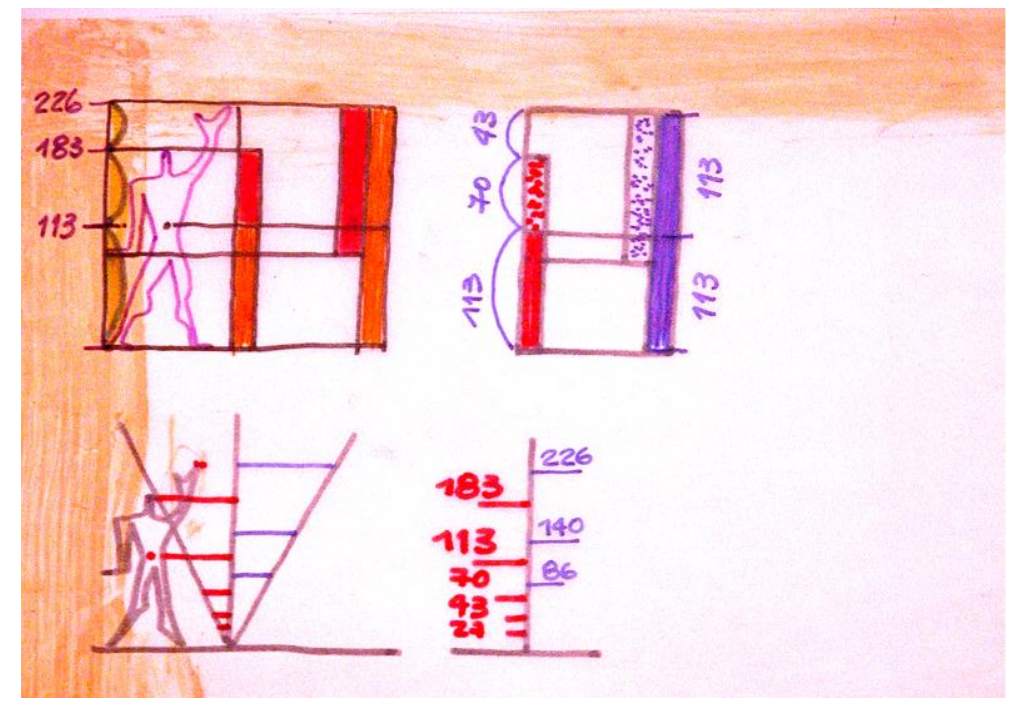

5. Serie dimensional del Modulor. Dibujo de Rafael Leoz.

Este dibujo va acompañado del texto: "NOTA: Consideramos esta serie para el dimensionamiento de los planos verticales, aplicando la interrelación dimensional en el plano horizontal. MÓDULO (0.12) - IMPORTANTE: Profundizar en las posibilidades combinatorias de ambos sistemas ${ }^{, 23}$. Esto manifiesta que el interés de Rafael Leoz por las medidas de las series del Modulor está en la posibilidad de relacionar las dimensiones en el plano horizontal con los planos verticales, algo que posteriormente veremos cómo desarrolla.

En otra lámina (Imagen 6) Rafael Leoz descompone gráficamente la serie roja del Modulor buscando relaciones entre los valores de ambas series.

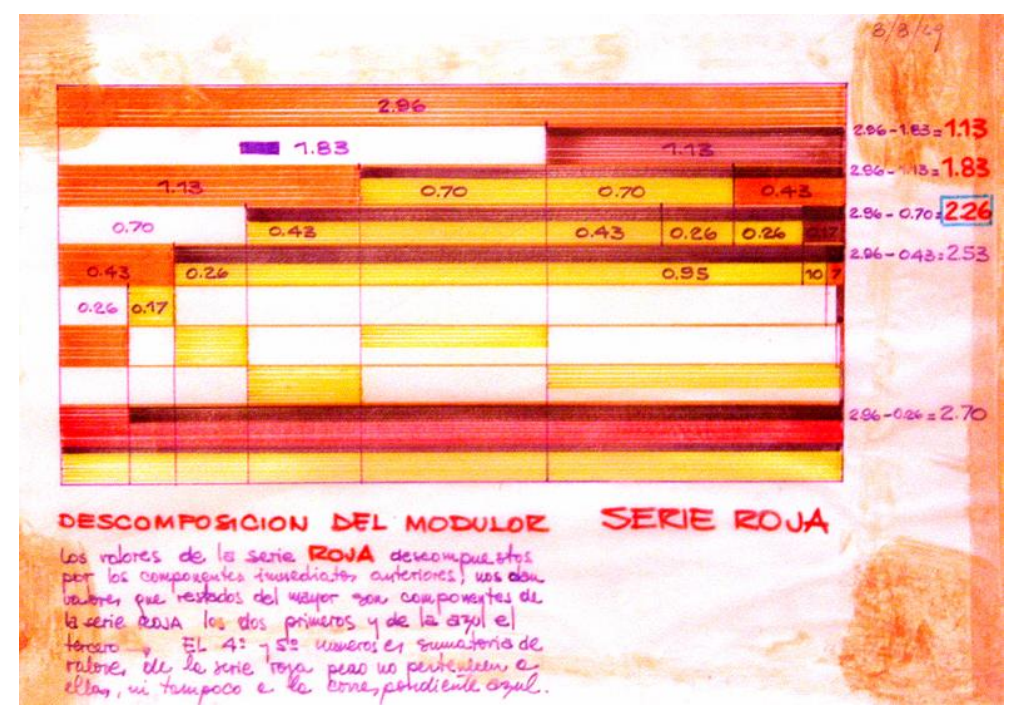

6. Descomposición del Modulor. Dibujo de Rafael Leoz.

\footnotetext{
${ }^{23}$ Nota manuscrita debajo del dibujo montado en una lámina junto a otras tablas y gráficas bajo el título Estudio y tanteos sobre: coordinación dimensional. Documento localizado en el Archivo de la Fundación Rafael Leoz, fechado el 9/7/1969.
} 


\subsection{La serie amarilla}

Como ya se ha indicado, las sucesiones aritméticas de razón 12 y las sucesiones de Fibonacci partiendo de 12 son especialmente relevantes en la investigación de relaciones dimensionales porque para Rafael Leoz el módulo 0,12 metros es una medida importante para la construcción ${ }^{24}$. Como puede verse en la tabla de la Imagen 7, a partir del módulo 0,12 se organiza una serie de vínculos entre la serie modular con la sucesión de Fibonacci a partir de 12 y la superficie de unidades moduladas cuadradas. Es destacable cómo se incluye una columna "Superf. base X 4" donde se indica la superficie de cuatro elementos modulares correspondientes a un módulo HELE.

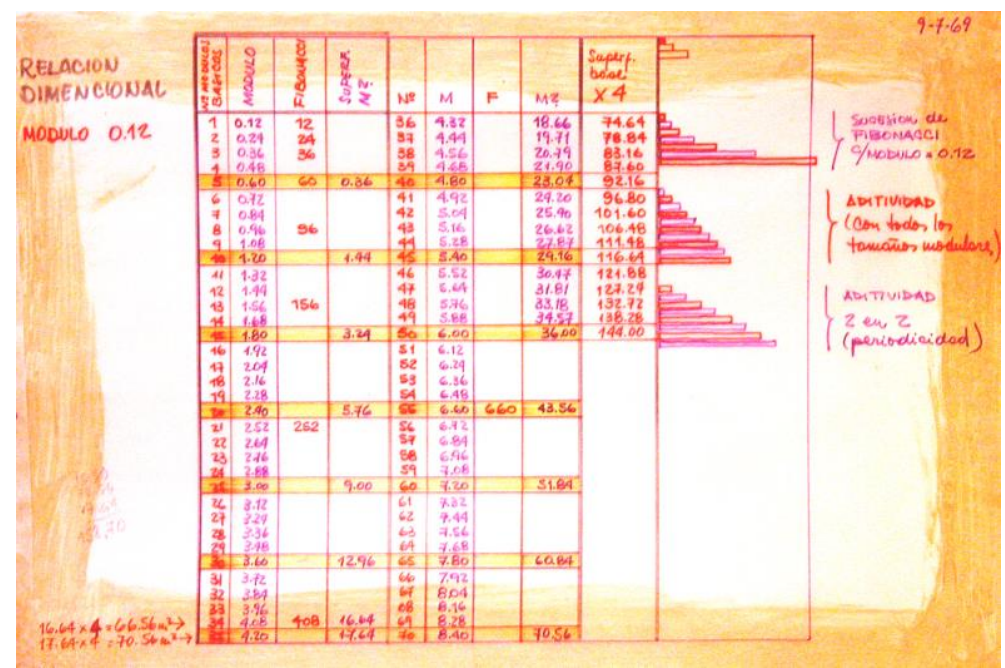

7. Relación dimensional. Módulo 0,12. Dibujo de Rafael Leoz.

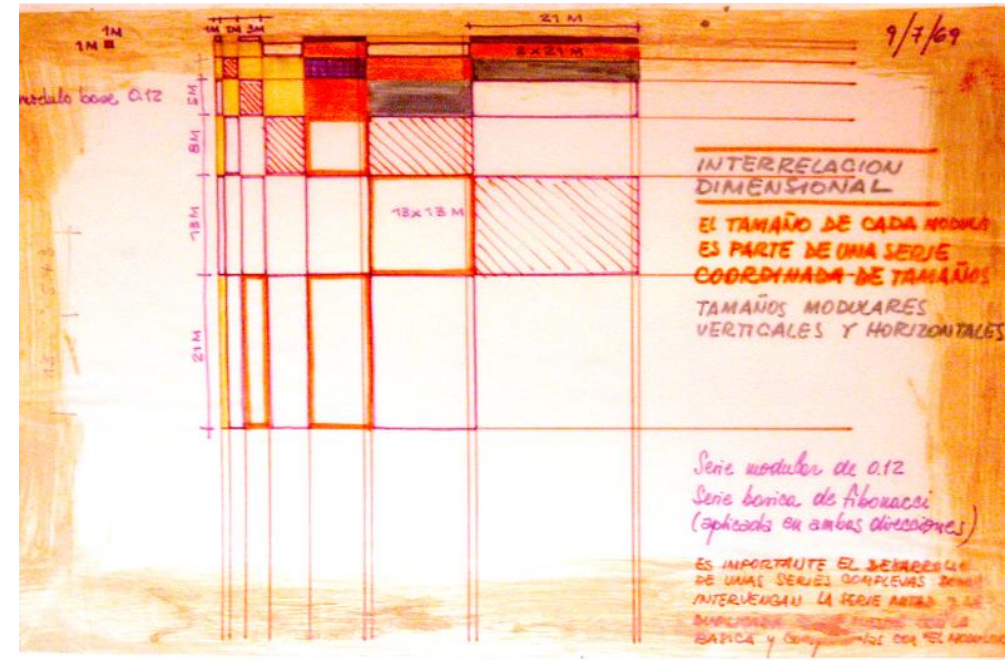

8. Interrelación dimensional. Dibujo de Rafael Leoz.

\footnotetext{
${ }^{24}$ Leoz, R: Redes y ritmos espaciales. p.237.
} 
Rafael Leoz, de manera análoga a Le Corbusier en el Modulor ${ }^{25}$, realiza un estudio gráfico en una malla de relaciones longitudinales y superficiales a partir de una serie de Fibonacci modular de 0,12 metros, aplicada a dos direcciones ortogonales. (Imagen 8)

En la lámina se indica que "es importante el desarrollo de unas series complejas donde intervengan la serie mitad y la duplicada básica nuestra con la básica y compuestas con "El Modulor”.

Inicialmente se plantea el módulo de 0,12 metros como adecuado para la construcción pero no ofrecía relación con las dimensiones humanas, algo que el Modulor sí resuelve. Por este motivo, Rafael Leoz se propone relacionar el módulo 0,12 metros con las series Roja y Azul. Esto lo hace aplicando la razón $\phi$ a una progresión a partir de 0,012 metros; a esta sucesión la denominará Serie Amarilla. La relación entre las tres series de Fibonacci queda establecida de manera que un valor de la Serie Amarilla se corresponde con la mitad del correspondiente de la Serie Azul del Modulor y con un cuarto de la Serie Roja.

La vinculación ente la sucesión aritmética de 0,12 metros como módulo de utilidad técnica constructiva y las dos series del Modulor, se establece mediante el denominador común (0,003 metros) de la interrelación de las sucesiones de las series Roja, Azul y Amarilla. A partir de 0,003 Rafael Leoz desarrolla una sucesión aritmética relacionada con las tres sucesiones de Fibonacci. ${ }^{26}$ De esta manera Rafael Leoz atribuye relaciones dimensionales humanas, presentes en el Modulor, al módulo 0,12 metros empleado para dimensionar las redes espaciales.

\subsection{Tabla numérica básica}

Recapitulando lo dicho hasta ahora sobre la investigación de Rafael Leoz; por una parte se han propuesto unos poliedros fundamentales que agregados tienen la capacidad de llenar el espacio cartesiano tridimensional sin dejar huecos entre sí; de estas agregaciones se deduce tres redes espaciales y sus correspondientes proyecciones en redes planas: Escuadra, Cartabón y Triángulo Hemipitagórico. Estas redes sirven de soporte para los ritmos espaciales que pueden utilizarse para la tarea de proyecto del arquitecto. Hasta aquí la investigación se ha ocupado de la organización del espacio abstracto, adimensional.

Tras esta primera parte, se acomete la investigación para dotar de dimensiones a estas redes. Rafael Leoz desarrolla unas tablas que incluyen las relaciones geométricas entre las tres redes y las aplica a varias sucesiones matemáticas que considera relevantes: las progresiones aritméticas de 10 y 12 centímetros, y las sucesiones de Fibonacci partiendo de 10, 12, 24, 36 y 60 centímetros; como también la Serie Azul y Serie Roja del Modulor.

Teniendo en cuenta que el objetivo de toda esta tarea es la construcción prefabricada de viviendas, en esta parte de la investigación se busca relacionar la dimensión 0,12 centímetros — que Rafael Leoz considera muy importante por sus enormes posibilidades de resolver cuestiones constructivas y técnicas - con las dimensiones humanas. Para ello propone, por una parte, la Serie Amarilla que relaciona el módulo 0,012 metros con la Serie Azul —en relación 1/2 - y la Serie Roja —en relación 1/4 —, y por otra parte, también incluye la sucesión aritmética de 0,003 metros que contiene los valores de las otras tres sucesiones.

Dentro de la exposición que se hace en Redes y ritmos espaciales sobre las relaciones dimensionales, es especialmente relevante la "Tabla numérica básica"27. En esta tabla se integra todos los elementos propuestos

\footnotetext{
${ }^{25}$ Le Corbusier: El Modulor. p.86.

${ }^{26}$ Leoz, R: Redes y ritmos espaciales. pp.237-238.

${ }^{27}$ Íbidem. p.236.
} 
como resultado de la investigación para el dimensionado de las redes espaciales, y se justifica como una "tabla de trabajo" 28 con un repertorio más reducido de series numéricas más dominables y limitadas para facilitar su utilización a la hora de acometer el proyecto arquitectónico.

Además de la versión de esta tabla que aparece en Redes y ritmos espaciales, en el Archivo de la Fundación Rafael Leoz se encuentra una versión — probablemente anterior y preparatoria de la publicación — que incluye una gráfica de relaciones dimensionales entre las Series Roja y Azul del Modulor y la Serie Amarilla de Rafael Leoz, esta gráfica no se encuentra en la publicación. (Imagen 9)

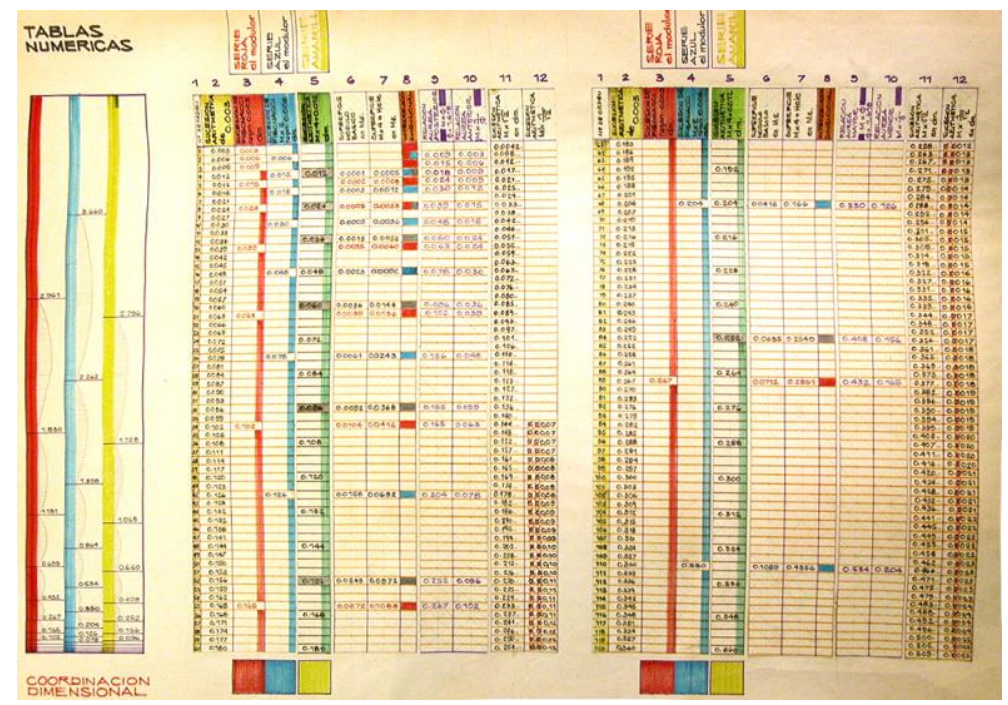

9. A la izquierda gráfico de coordinación dimensional entre las series Roja, Azul y Amarilla; tablas preparatorias de la "Tabla numérica básica" publicada en la página 236 de Redes y ritmos espaciales. Dibujo de Rafael Leoz.

La tabla está formada por doce columnas que describimos a continuación: La primera contiene el número de orden de las filas, la segunda es la sucesión aritmética de 0,003 metros; la tercera contiene la sucesión de Fibonacci a partir de 0,003 metros y la Serie Roja del Modulor; la cuarta es una sucesión de Fibonacci desde 0,006 metros y por tanto está formada por la Serie Azul del Modulor; la quinta columna es la Serie Amarilla y está compuesta por la sucesión de Fibonacci desde 0,012 metros cuyos múltiplos son el módulo constructivo que propone Rafael Leoz. Las columnas sexta y séptima contienen superficies, una columna el área de un módulo cuadrado y la otra la de cuatro módulos que se corresponde a la superficie de un módulo HELE. La columna octava indica las interrelaciones dimensionales marcando en color las vinculaciones de las tres series de Fibonacci. Las columnas novena y décima se ocupan de multiplicar por $\phi$ y por $1 / \phi$ respectivamente, para proporcionar relaciones áureas entre componentes de las columnas 3, 4 y 5. Y las dos últimas columnas operan relacionando los módulos cuadrados con el sistema de la escuadra ${ }^{29}$.

Esta tabla es un intento de condensar los resultados de la investigación sobre dimensionado de las redes espaciales, para Rafael Leoz tiene una finalidad práctica y por ello propone un procedimiento para utilizarla sistemáticamente $^{30}$. Lo resumiremos diciendo que según el programa de la vivienda se determina la dimensión

\footnotetext{
${ }^{28}$ Íbidem. p.239.

29 Íbidem. p.239-241.

${ }^{30}$ Íbidem. p.242.
} 
de un lado del módulo cuadrado a partir de las disponibles en las tres series de Fibonacci, a la vez se vincula con la superficie de un módulo cuadrado y el cuádruple módulo HELE; de esta manera se "definiría" la planta. A partir de estos datos se obtiene la altura ${ }^{31}$ mediante la correspondencia con la columna 10 — que es la que opera el factor $1 / \phi$ - teniendo "definida una célula con su volumen dimensionado armónicamente „32.

Ante esta propuesta procedimental sistemática cabe preguntarse qué recorrido y aplicación real tiene a la hora de enfrentarse a la tarea del proyecto arquitectónico.

\section{Sugerencias para casos concretos}

El capítulo sexto de Redes y ritmos espaciales se titula "Sugerencias para casos concretos", y se ocupa de exponer una serie de láminas ${ }^{33}$ reproducidas en pequeñas dimensiones en las que aparecen algunos dibujos de prototipos de viviendas que, según el texto, se desarrollaron durante el verano de $1969^{34}$. Los dibujos originales de la mayoría de estas láminas se encuentran en el Archivo de la Fundación Rafael Leoz; algunas tienen especial interés para deducir el nivel de desarrollo y aplicación que alcanza el procedimiento propuesto sobre dimensionado a través de la "Tabla numérica básica".

En uno de los dibujos (Imagen 10) aparecen algunas herramientas gráficas que representan la metodología de dimensionado en planta según los criterios de la "Tabla numérica básica". Sobre un papel milimetrado se organiza la vinculación entre módulos de 12 centímetros y su relación en longitudes y superficies en metros; utilizando como referencia una tabla de series modulares, de Fibonacci a partir de 12 y de superficies correspondientes. En el mismo dibujo se encuentra un esquema en planta de una "célula" modular acotada tanto en módulos M de 12 centímetros como en metros. Se anota también la relación entre la superficie de un módulo cuadrado y la de cuatro módulos agregados, correspondiente a un módulo HELE.

\footnotetext{
${ }^{31}$ Respecto a esta cuestión queremos recordar la nota que aparece en el dibujo Rafael Leoz de El Modulor (Imagen 3): "NOTA: Consideramos esta serie para el dimensionamiento de los planos verticales, aplicando la Interrelación dimensional en el plano horizontal. MÓDULO (0.12)”.

${ }^{32}$ Leoz, R: Redes y ritmos espaciales. p. 242.

33 Íbidem. pp.247-260.

${ }^{34}$ Íbidem. p.245.
} 


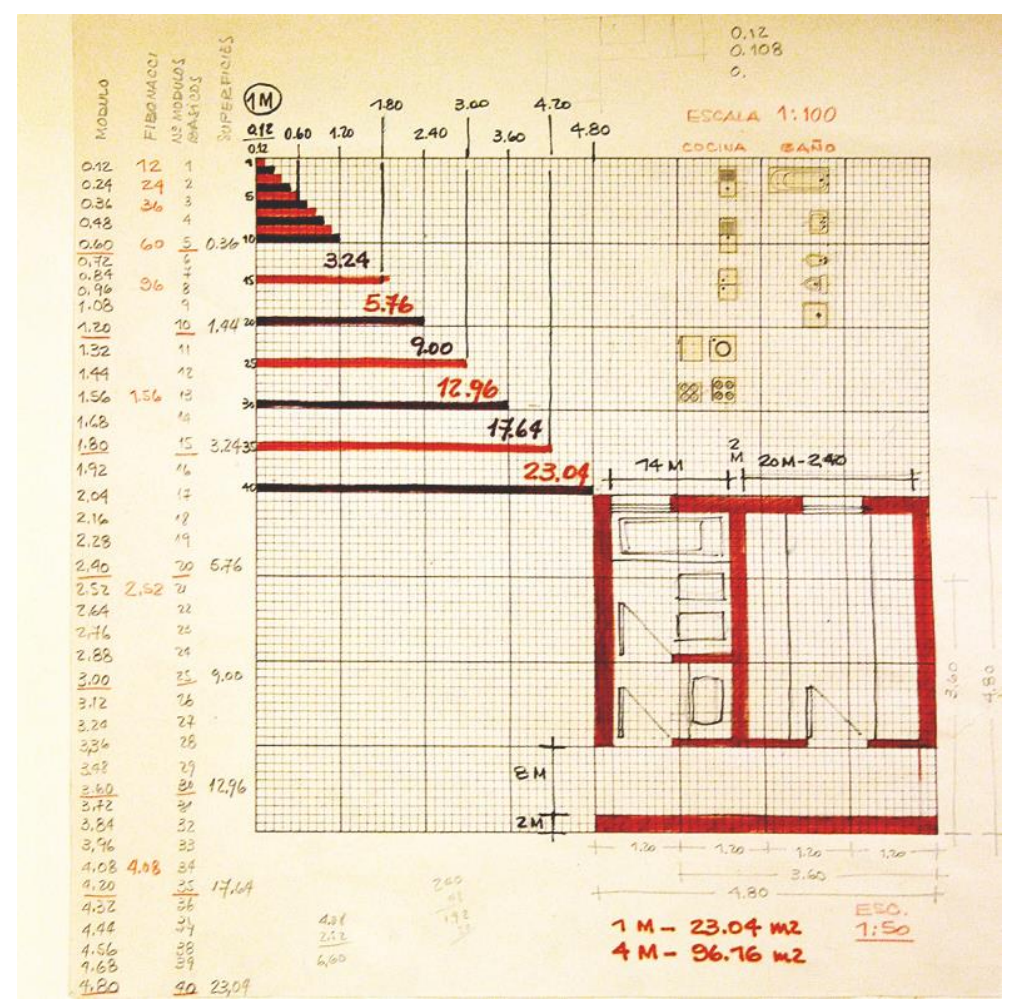

10. Tabla y gráfica de relaciones dimensionales entre metros, serie Amarilla, módulos y superficies. Esquema de dimensiones de planta de un módulo. Dibujo de Rafael Leoz.

Este esquema parece responder a la intención de utilizar módulos de 12 centímetros para organizar "células" cuadradas a partir de una superficie de módulo HELE elegida. En este caso se trata de una aproximación al resultado que se obtiene utilizando el procedimiento sistemático de la "Tabla numérica básica": partiendo del elemento 4,791 de la Serie Roja de la columna 3 de la tabla se vincula con la superficie 22,95 de un módulo y 91,80 de cuatro módulos. Pero debemos destacar que la relación dimensional se realiza únicamente en planta, en esta lámina todavía no se muestra el mecanismo de relación dimensional volumétrico —entre planta y secciónque según la "Tabla numérica básica” se desarrolla a partir del Modulor. Más adelante se tratará sobre esta cuestión.

\subsection{Caso concreto}

Una vez visto un modo de seleccionar las dimensiones de un módulo cuadrado en relación con la superficie de una vivienda con una agrupación HELE, observemos cómo este sistema se aplica a un caso concreto (Imagen 11). Se trata de una vivienda en una única planta organizada por cuatro módulos cuadrados formando un módulo HELE. 


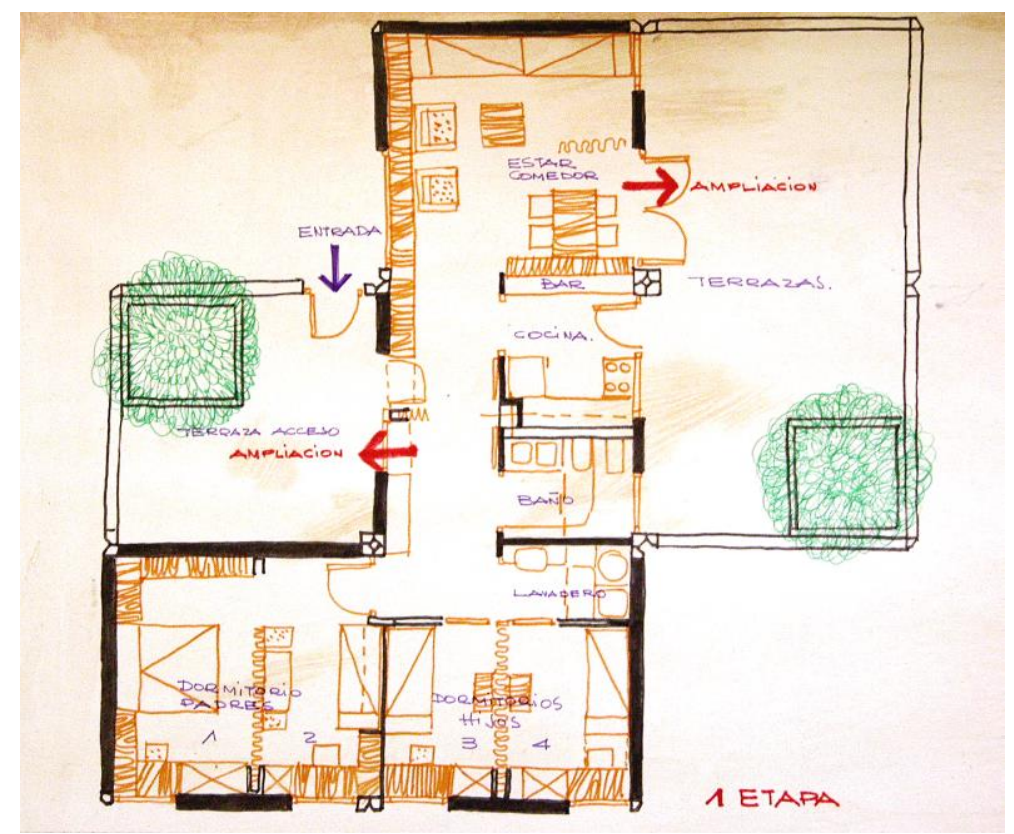

11. Esquema de planta de vivienda formada por cuatro módulos cuadrados organizados en módulo HELE. Dibujo de Rafael Leoz.

La planta está formada por cuatro módulos cuadrados de 4,80 metros de lado y 23,04 metros cuadrados de superficie cada uno; los cuatro se disponen según módulo HELE sumando una superficie total de 92,16 metros cuadrados en una vivienda para cuatro personas organizada en torno a un "módulo central" que contiene el acceso, baño y cocina (Imagen 12); en esta planta se asocia dos espacios de terraza para posibles ampliaciones de la vivienda. Todos los espacios y elementos constructivos están dimensionados con módulos que son múltiplo de 12 centímetros.

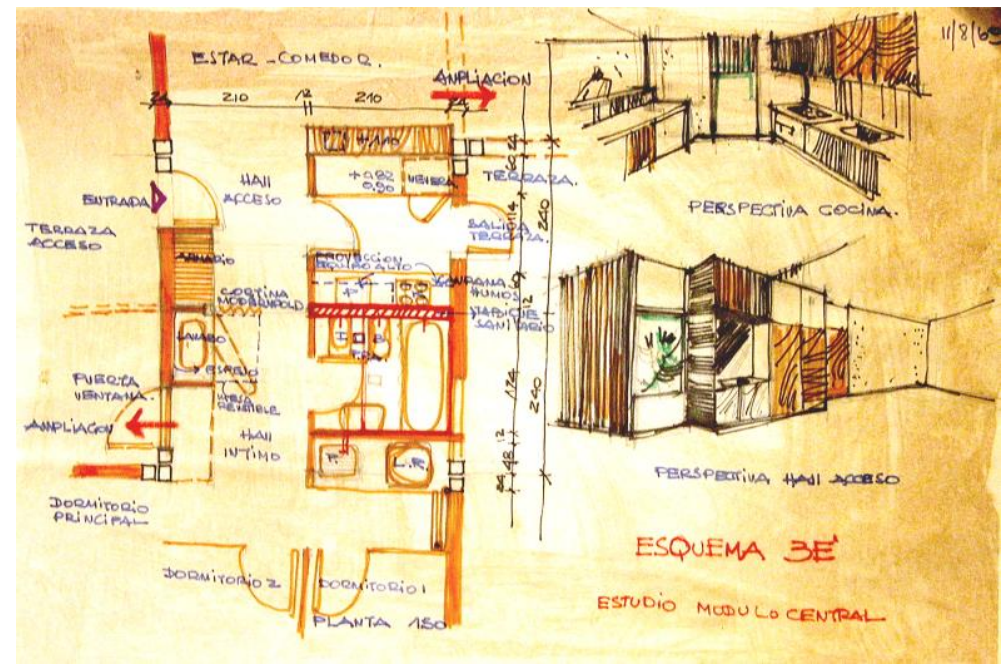

12. Estudio módulo central, planta acotada y perspectivas. Dibujo de Rafael Leoz.

El resultado es una vivienda organizada en planta a partir del módulo 12 centímetros. Este rigor dimensional queda plasmado al ser dibujada sobre una retícula cuadrada de módulos iguales (Imagen 13) 


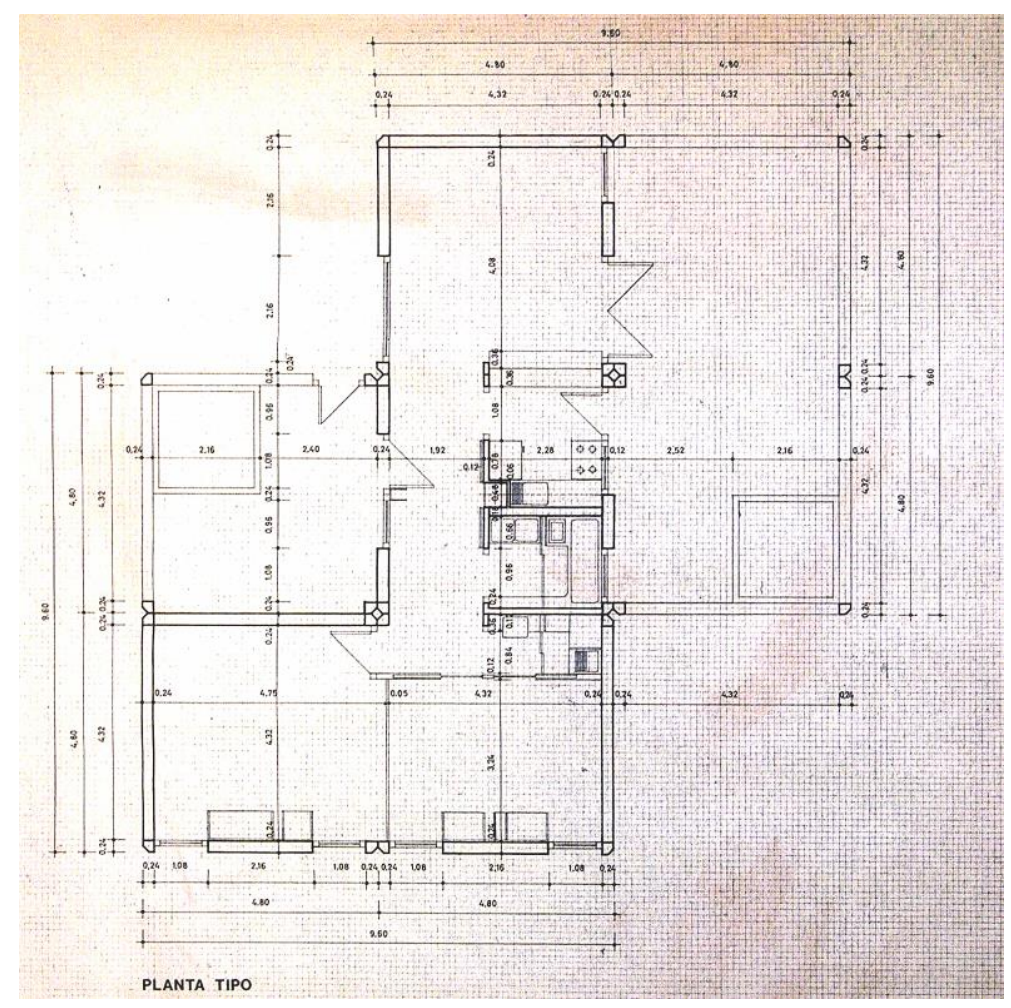

13. Plano planta tipo acotada.

Según lo visto en el caso que nos ocupa, la organización dimensional en planta se deduce del procedimiento sistemático de la "Tabla numérica básica". Detengámonos ahora en la interrelación dimensional espacial, esto es, qué medidas aplica Rafael Leoz a la sección, a la correspondencia entre planta y planos verticales de la vivienda. Observando el alzado de un panel de cerramiento se observa que está organizado con módulos de 12 centímetros (Imagen 14), pero se producen desajustes en altura ya que algunas dimensiones no son múltiplos de 12 centímetros, lo que supone fragmentar el módulo; aunque debemos indicar que todas ellas estarían incluidas en la columna segunda de la "Tabla numérica básica": sucesión aritmética de 3 centímetros. 


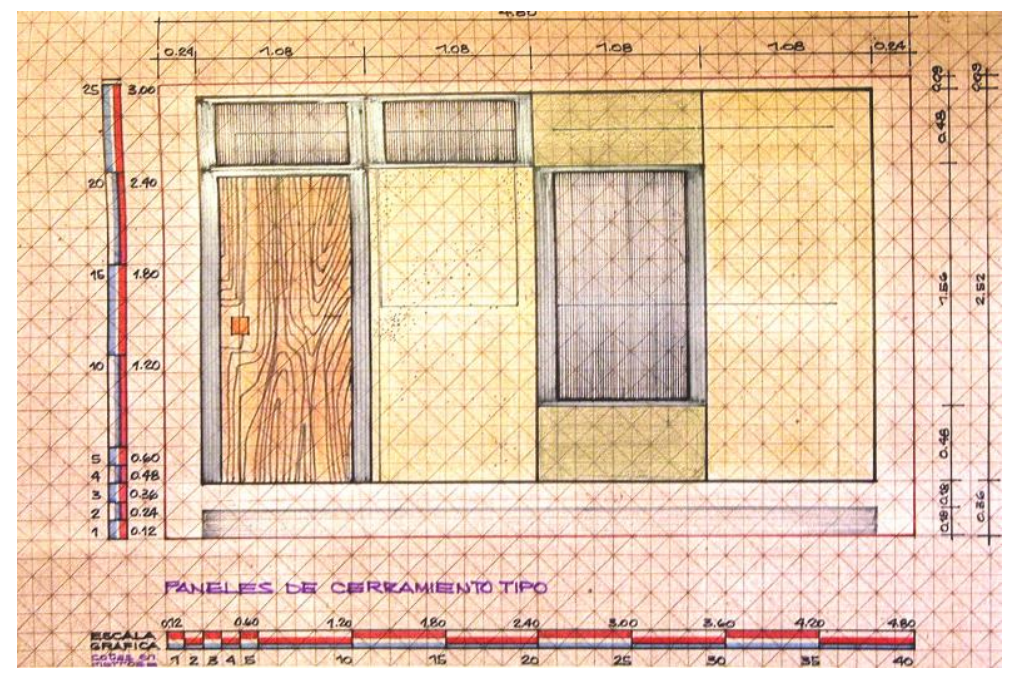

14. Alzado/sección de panel de cerramiento acotado en módulos y centímetros. Dibujo de Rafael Leoz.

Pero además, exigiendo el rigor que podría derivarse de la aplicación sistemática de la "Tabla numérica básica" - conjugando las relaciones dimensionales entre planta y planos verticales - vemos que la altura correspondiente a 22,95 metros cuadrados sería 2,96 metros. A la vista del dibujo esta dimensión se aproximaría muy bien - considerando tolerancias dimensionales y juntas - a 2,97 metros, correspondiente a la distancia entre los límites superior e inferior del panel, incluyendo los elementos estructurales. La altura libre 2,52 metros corresponde a 21 módulos de 12 centímetros, pero no coincide con ninguna dimensión de la "Tabla numérica básica". Con este criterio se proporciona medida a los planos verticales de la vivienda, desarrollando todo un inventario de paneles cuyas dimensiones se expresan en módulos. (Imagen 15)

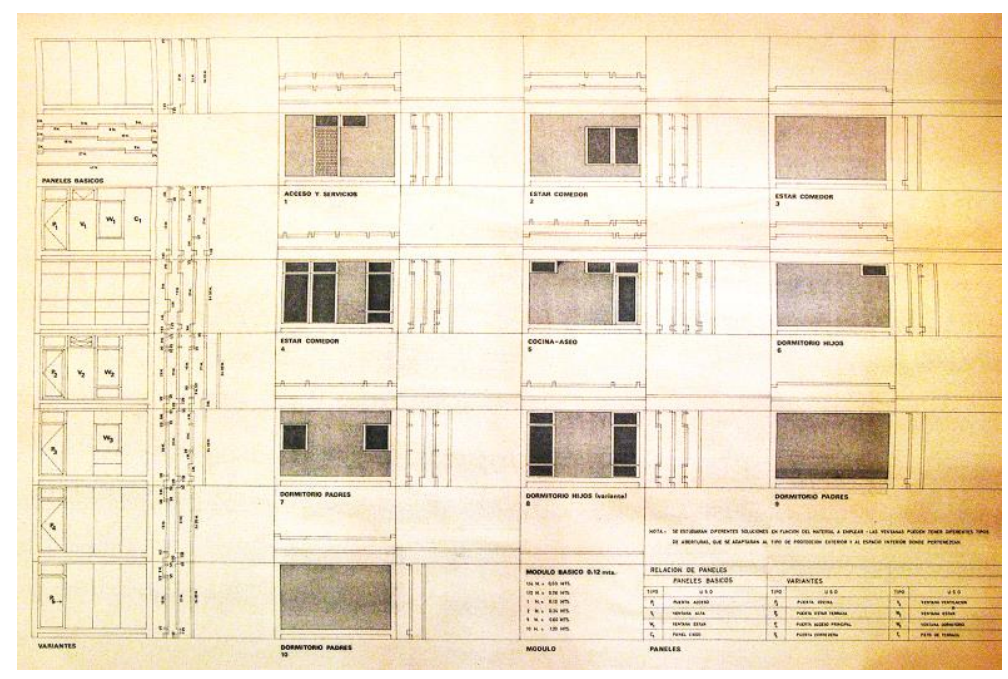

15. Relación de paneles acotados en módulos básicos 0,12 $\mathrm{m}$.

Este caso concreto que hemos analizado responde de manera suficientemente satisfactoria al procedimiento que Rafael Leoz indica para utilizar la "Tabla numérica básica" para dimensionar los diversos elementos de las viviendas. Aún así, en una primera aproximación y teniendo en cuenta los datos de la tabla, resulta dudoso que la aplicación sistemática de la tabla sea eficaz para desarrollar otras obras con características distintas al caso desarrollado. 
Si aplicamos el procedimiento utilizado a dos ejemplos correspondientes a las dimensiones inmediatamente inferior y superior de las columnas 4 y 5 de la tabla; se deduce que se trata de viviendas formadas por cuatro módulos cuadrados de 4,524 y 5,922 metros de lado, formando módulo HELE de 81,84 y 140,28 metros cuadrados de superficie. Y recordemos que "una vez definida la planta, con su dimensión correspondiente, aplicamos la relación áurea menor núm. 10 para obtener la altura, y así tenemos definida una célula con su volumen dimensionado armónicamente ${ }^{, 35}$; siguiendo esta instrucción las alturas de los ejemplos serían 2,796 y 3,66 metros. Si como en el caso concreto estudiado esta distancia incluye los elementos estructurales podemos considerar que la altura libre del espacio habitable es admisible en ambos casos, pero su funcionalidad se verá comprometida cuando se emplee un módulo menor al del ejemplo.

\section{Conclusiones}

En cierta medida, la particular carrera profesional de Rafael Leoz puede explicarse a partir de dos circunstancias que aparecen en su biografía. Sus primeros trabajos en algunos concursos y proyectos de vivienda social le llevaron, con Joaquín Ruiz Hervás, a la realización del proyecto del Poblado Dirigido de Orcasitas. La experiencia profesional - y sobre todo personal - de compartir con los futuros propietarios la construcción material de sus propias viviendas resultó decisiva en los intereses profesionales de Rafael Leoz, especialmente cuando los edificios de este barrio empiezan a presentar daños estructurales que llevarían a su demolición. Esta circunstancia y la situación de calidad habitacional en España y Latinoamérica llevan a que dedique su trabajo a investigar sobre la posibilidad de la prefabricación industrial de elementos que permitan generalizar la construcción de viviendas. Otro componente que orientó su tarea profesional fue la influencia de la obra de Le Corbusier, con quien entablaría una buena relación personal a través de Jean Prouvé.

La investigación teórica de Rafael Leoz aborda en primer lugar el estudio de redes espaciales abstractas que organicen racionalmente el espacio tridimensional cartesiano, para a partir de ello atribuir dimensiones y tamaños adecuados para la prefabricación de elementos con que se construirá la arquitectura. En esta segunda tarea se pretende aunar el rigor en las medidas que exige la industria con la "humanización" de las dimensiones. Esto se convierte en la conjugación de dos factores: la dimensión modular 12 centímetros —que servirá "en materia de construcción para resolver problemas técnicos",36 - y del Modulor "pues dio la pauta para todas las fabulosas aplicaciones que Le Corbusier supo realizar aplicándolo ${ }^{\circledR 37}$. Rafael Leoz ofrece la Serie Amarilla como instrumento de acuerdo entre ambos factores; la serie propuesta es una sucesión de Fibonacci - como también los son las series Roja y Azul del Modulor - a partir de 0,012 metros.

En coherencia con el rigor investigador y el empeño sistematizador que informa su trabajo, Rafael Leoz confecciona la "Tabla numérica básica" donde establece un procedimiento para determinar las dimensiones de la Arquitectura — especialmente de la vivienda — a partir de las necesidades de programa.

Conviene tener en cuenta que la investigación de Rafael Leoz se dirige a ser aplicada al dimensionado de ritmos organizados sobre las tres redes espaciales; la investigación sobre la aplicación de los resultados de su trabajo a módulos de las diferentes redes es una tarea pendiente que no se ha abordado en este trabajo. En este caso el estudio se ha limitado al módulo cuadrado de la red Escuadra.

\footnotetext{
${ }^{35}$ Íbidem. p.242.

${ }^{36}$ Leoz, R: Redes y ritmos espaciales. p.237.

${ }^{37}$ Íbidem. p.239.
} 
Después de aplicar a un caso concreto el procedimiento que Rafael Leoz sistematiza en la"Tabla numérica básica”, se puede considerar que aunque resulte adecuado en el ejemplo analizado, los resultados que se obtendría en otros casos no serían tan buenos y llevaría a poner en cuestión la aplicación sistemática del procedimiento; especialmente para la obtención de la altura de la célula de planta cuadrada que constituye la vivienda.

Si se considera que el objetivo de la investigación de Rafael Leoz es la prefabricación industrial de elementos para la construcción de viviendas, puede resultar discutible el empleo de distintas alturas de vivienda en relación a las dimensiones modulares en planta porque, si bien puede lograrse relaciones volumétricas armónicas, quizá sea un sistema que genere una variedad dimensional de elementos constructivos que complique y perjudique la prefabricación, más todavía si se consideran factores económicos. Como dice Luis Moya: "En el fondo está la realidad creadora del arquitecto, que se valdrá de los elementos fabricados como antes se valía de ladrillos de medidas fijas, y también está la libertad de elección y de modificación que ejercerá quien ha de usar el edificio ${ }^{, 38}$

Además de estas cuestiones, salvo para pocos casos concretos, este sistema parece olvidar la escala humana en favor de las relaciones proporcionales de los espacios. El rigor del procedimiento de aplicación de la "Tabla numérica básica" podría responder a la exigencia modular constructiva, pero iría en detrimento de la aproximación a factores relacionados con la percepción y sensibilidad de los que habiten. Tal vez la propuesta de Rafael Leoz liberada de rigidez pueda abrir nuevas posibilidades para dimensionar las viviendas y otras obras, dejando — como también era el propósito de Rafael $\mathrm{Leoz}^{39}$ - al arquitecto el control del proyecto; como indica el propio Le Corbusier refiriéndose al Modulor: "Les ofrece la facilidad que puede resultar del empleo de medidas seguras; pero son ustedes quieres tienen que elegir en el ilimitado depósito de las combinaciones del Modulor ${ }^{, 40}$.

\footnotetext{
${ }^{38}$ Moya, Luis: Rafael Leoz. Artistas españoles contemporáneos. p.47.

39 "La Arquitectura corre el peligro de ser aplastada por la técnica constructiva sin sensibilidad y deshumanizada. Será la Arquitectura la que deba tomar las riendas del asunto”. Íbidem. p.30.

${ }^{40}$ Le Corbusier: El Modulor. p.122.
} 


\section{Procedencia de las imágenes}

Imagen 1: Carta de Jean Prouvé a Rafael Leoz. Archivo de la Fundación Rafael Leoz. 20 de diciembre de 1961. Imagen 2: Carta de Le Corbusier a Rafael Leoz. Archivo de la Fundación Rafael Leoz. 27 de febrero de 1962.

Imagen 3: Leoz de la Fuente, Rafael: Redes y ritmos espaciales. [imagen realizada a partir del contenido de página]. Madrid: Editorial Blume, 1969. p. 63

Imagen 4: Leoz de la Fuente, Rafael: Redes y ritmos espaciales. [imagen realizada a partir del contenido de páginas]. Madrid: Editorial Blume, 1969. pP. 108, 118, 128.

Imagen 5: Leoz de la Fuente, Rafael: Serie dimensional del Modulor. [rotulador sobre papel]. Archivo de la Fundación Rafael Leoz. 9 de julio de 1969.

Imagen 6: Leoz de la Fuente, Rafael: Descomposición del Modulor. [rotulador sobre papel]. Archivo de la Fundación Rafael Leoz. 8 de agosto de 1969.

Imagen 7: Leoz de la Fuente, Rafael: Relación dimensional. Módulo 0,12. [rotulador sobre papel]. Archivo de la Fundación Rafael Leoz. 9 de julio de 1969.

Imagen 8: Leoz de la Fuente, Rafael: Interrelación dimensional. [rotulador sobre papel]. Archivo de la Fundación Rafael Leoz. 9 de julio de 1969.

Imagen 9: Leoz de la Fuente, Rafael: Tablas numéricas. Coordinación dimensional. [rotulador sobre papel]. Archivo de la Fundación Rafael Leoz. 1969.

Imagen 10: Leoz de la Fuente, Rafael: Relaciones módulos y superficies. [rotulador sobre papel]. Archivo de la Fundación Rafael Leoz. 1969.

Imagen 11: Leoz de la Fuente, Rafael: 1 Etapa. [rotulador sobre papel]. Archivo de la Fundación Rafael Leoz. 1969.

Imagen 12: Leoz de la Fuente, Rafael: Esquema 3E'.Estudio módulo central. [rotulador sobre papel]. Archivo de la Fundación Rafael Leoz. 11 de agosto de 1969.

Imagen 13: Leoz de la Fuente, Rafael: Planta tipo. [copia reprográfica de plano sobre papel]. Archivo de la Fundación Rafael Leoz. 1969.

Imagen 14: Leoz de la Fuente, Rafael: Paneles de cerramiento. [rotulador sobre papel]. Archivo de la Fundación Rafael Leoz. Septiembre de 1969.

Imagen 15: Leoz de la Fuente, Rafael: Relación de paneles. [copia reprográfica de plano sobre papel]. Archivo de la Fundación Rafael Leoz. Septiembre de 1969.

\section{Bibliografía/referencias}

Le Corbusier: El Modulor. Trad. Rosario Vera. $3^{\text {a }}$ ed. Barcelona: Editorial Poseidon, 1980.

Leoz de la Fuente, Rafael: Redes y ritmos espaciales. Madrid: Editorial Blume, 1969.

López Díaz, Jesús. La obra del arquitecto Rafael Leoz de la Fuente (1921-1976): Teorías e investigaciones sobre la vivienda social. Director: José Enrique García Melero. Universidad Nacional de Educación a Distancia, Departamento de Historia del Arte, 2011.

Moya Blanco, Luis: Rafael Leoz. Artistas españoles contemporáneos. Madrid: Servicio de Publicaciones del Ministerio de Educación y Ciencia, 1978. 


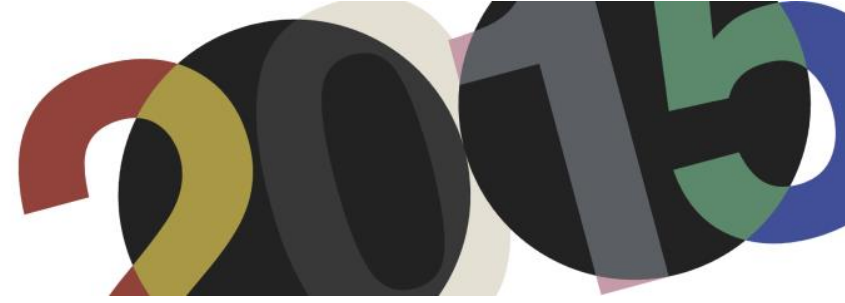

DOI: http://dx.doi.org/10.4995/LC2015.2015.527

\title{
La mediterraneidad en la obra de Le Corbusier. La bóveda catalana lecorbuseriana: Influencias y evolución
}

\author{
E. López García \\ Seconda Università degli Studi di Napoli. Dipartimento di architettura e disegno industriale Luigi Vanvitelli
}

\begin{abstract}
Resumen: Le Corbusier durante gran parte de su vida busca volver la vista hacia las tradiciones mediterráneas. Con el fin de desvelar la arquitectura y el paisaje españoles, realiza un gran número de viajes en tren y coche a lo largo de su territorio y será durante su visita a Barcelona en 1928 cuando nace su interés por la técnica de la bóveda catalana. Es una época de su carrera en la que empieza a interesarse por métodos de construcción y materiales tradicionales. Para el arquitecto la bóveda catalana es un sistema con grandes posibilidades formales y una gran flexibilidad frente a su sencillez de medios. Le Corbusier muestra la influencia de sus viajes por el Mediterráneo, en especial de su viaje a Barcelona, y de su relación con varios arquitectos españoles en una gran cantidad de obras residenciales realizadas entre los años 20 y 50. Consiguió definir la expresividad del proyecto a través de la repetición de un único elemento arquitectónico, el sistema abovedado sobre una retícula, y de la utilización de diversos materiales como el ladrillo, vidrio y hormigón. Tras años de estudios de estos elementos el arquitecto adapta la bóveda catalana a las innovaciones estructurales del hormigón armado, demostrando una gran autonomía formal y temporal respecto al resto de sus proyectos y consiguiendo aunar tradición y modernidad en una única obra.
\end{abstract}

Abstract: Throughout his life Le Corbusier was inspired by Mediterranean traditions. In order to discover Spanish architecture and landscape, he went on numerous of car and train trips throughout its territory. During his visit to Barcelona in 1928 he discovered the craftsmanship of thin-tile Catalan vaults. This was a period in his career in which he began to be interested in traditional building methods and materials. Le Corbusier looked at Catalan vaults as a very flexible formal system versus its simplicity of means. He showed the influence of his travels around the Mediterranean, particularly when he travelled to Barcelona and his relationship with many Spanish architects, in a large number of residential projects built between the 20s and the 50s. He managed to define the project expressivity through the repetition of an unique architectural element, the vault on a grid system, and the use of different materials such as brick, glass and concrete. After several years studying these elements he was able to adapt the Catalan vault system to innovative reinforced concrete structural solutions, showing a great formal and temporary autonomy compared to the rest of his projects while combining tradition and modernity in a unique work..

Palabras clave: Mediterráneo; viajes; bóveda catalana; tradición; modernida.

Keywords: Mediterranean; trips; Catalan vault; tradition; modernity.

\section{Viajes de le Corbusier por españa}

“A lo largo de estos años me convertí en un hombre de todas partes, viajé a través de los continentes. No tengo más que una atadura profunda: el Mediterráneo. Soy fuertemente mediterráneo...Mediterráneo, reino de las formas en la luz. La luz en el espacio....En todo me siento mediterráneo. Mi resorte, mis fuentes, hay que encontrarlas en el mar que nunca dejé de amar. " Le Corbusier ${ }^{1}$

\footnotetext{
${ }^{1}$ Le Corbusier. Discurso "Air, son, lumière”. Pronunciado en Atenas el 3 de agosto de 1933 con motivo del IV CIAM. Atenas, 1933.
} 
Le Corbusier se definía constantemente como un amante de los paisajes y de la cultura mediterránea. Se encontraba en una constante búsqueda de la perspectiva de la mediterraneidad y quizás fue este interés lo que le llevó a visitar España en numerosas ocasiones. Definió España como un país ardiente y místico y dedicó varios de sus viajes en tren y coche a analizar gran parte de sus lugares, desde las principales ciudades hasta los pueblos más remotos de Castilla. A través de sus viajes asimilaba los secretos de la intervención humana en el territorio y los plasmaba en sus cuadernos. Así confirmó que ninguna forma de representación gráfica podría sustituir una experiencia espacial. Inició su experiencia en España en 1928 recorriendo Castilla en tren de camino a Madrid, visitó también Segovia, Toledo y El Escorial. En las entrevistas llevadas a cabo en España insistió en las raíces mediterráneas de su obra y en la superioridad del mundo latino frente a los pueblos del norte. Le Corbusier siempre exaltó la claridad y precisión plástica del sur².

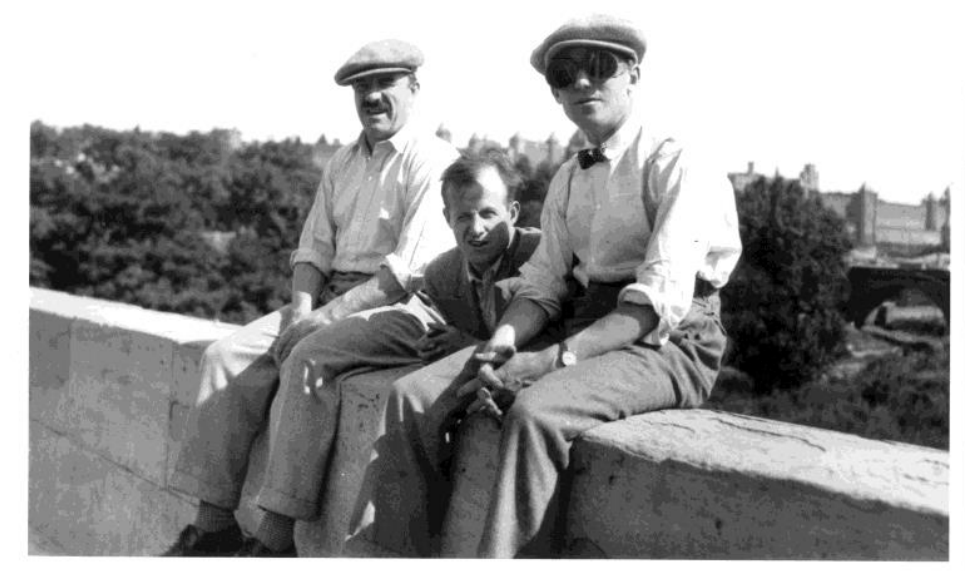

1. Fernand Léger, Pierre Jeanneret et Le Corbusier en España, 1930. FLC-ADAGP.

Posteriormente, en 1930 realiza otro viaje por España, esta vez en coche, acompañado por Fernand Leger, Pierre Jeanneret y Albert Jeanneret. Recorrieron la costa del Mediterráneo y el sur de España, volviendo a Madrid y regresando a Francia a través de San Sebastián. A diferencia de su anterior viaje, en este último quedó impresionado por los paisajes y las infraestructuras de la Península. Las arquitecturas vernáculas españolas que observaba a gran velocidad desde las carreteras recorridas le servirían como inspiración para futuros proyectos. Impresionado por la vasta y tranquila naturaleza del lugar Le Corbusier comentó: "Los españoles, son un pueblo que tienen la fortuna hoy de ser el único en el mundo de vivir en un estado de serenidad sublime" Como podemos observar el Mediterráneo siempre estuvo muy presente en su obra y gracias a ello según autores como Josep Farran i Mayoral Le Corbusier ha conseguido encaminar a la arquitectura por el buen camino de las grandes tradiciones mediterráneas.

\section{Aproximación a la técnica de la bóveda catalana durante su viaje a Barcelona}

Serán sus viajes a Barcelona los que harán despertar en Le Corbusier el interés por la técnica constructiva de la bóveda catalana. Durante su estancia en Madrid en 1928 fue invitado por su gran discípulo Josep Lluís Sert para acudir a Barcelona. Lo curioso es que el recibimiento en ambas ciudades fue radicalmente distinto, explica

\footnotetext{
${ }^{2}$ Lahuerta, Juan José. Le Corbusier e la Spagna, con la riproduzione dei carnets Barcelone e C10 di Le Corbusier. Milano: Mondadori Electa, 2006.
} 
Salvador Guerrero, comisario del ciclo de la Residencia de estudiantes de Madrid: "En Madrid, los intelectuales, como Ortega y Gasset, le reciben con gran interés; sin embargo, los arquitectos lo hicieron con cierta tibieza, en especial Luis Lacasa, que criticaba su racionalismo formalista y del que decía que era un periodista y charlatán. En cambio, en Barcelona contaba con un peso indiscutible”3.

Durante esta visita a Barcelona, invitado para pronunciar una conferencia, conoce las obras de Gaudí y da importancia a algunas soluciones constructivas de origen popular, las Escuelas para los hijos de los trabajadores de la Sagrada Familia. Este interés lo demuestra en su Carnet C11 al dibujar las cubiertas onduladas de las escuelas junto a la bóveda catalana acompañados de una gran cantidad de anotaciones técnicas entre ellas medidas y características del sistema constructivo. Le sorprende el ingenio constructivo de la cubierta pues resuelve la forma y estructura del edificio con una lámina fina y delgada ${ }^{4}$. Para él se trata de un sistema con grandes posibilidades formales y una gran flexibilidad, frente a la gran sencillez de medios. Lo que le atrae de Gaudí es que es un hombre de oficio, un constructor con una gran habilidad técnica. Sin embargo, no se interesa tanto por la obra de Gaudí en particular sino por la construcción y formalización de la bóveda catalana. Después de este viaje a Barcelona Le Corbusier recurrirá constantemente a arquitectos catalanes para comprender la técnica de este sistema.

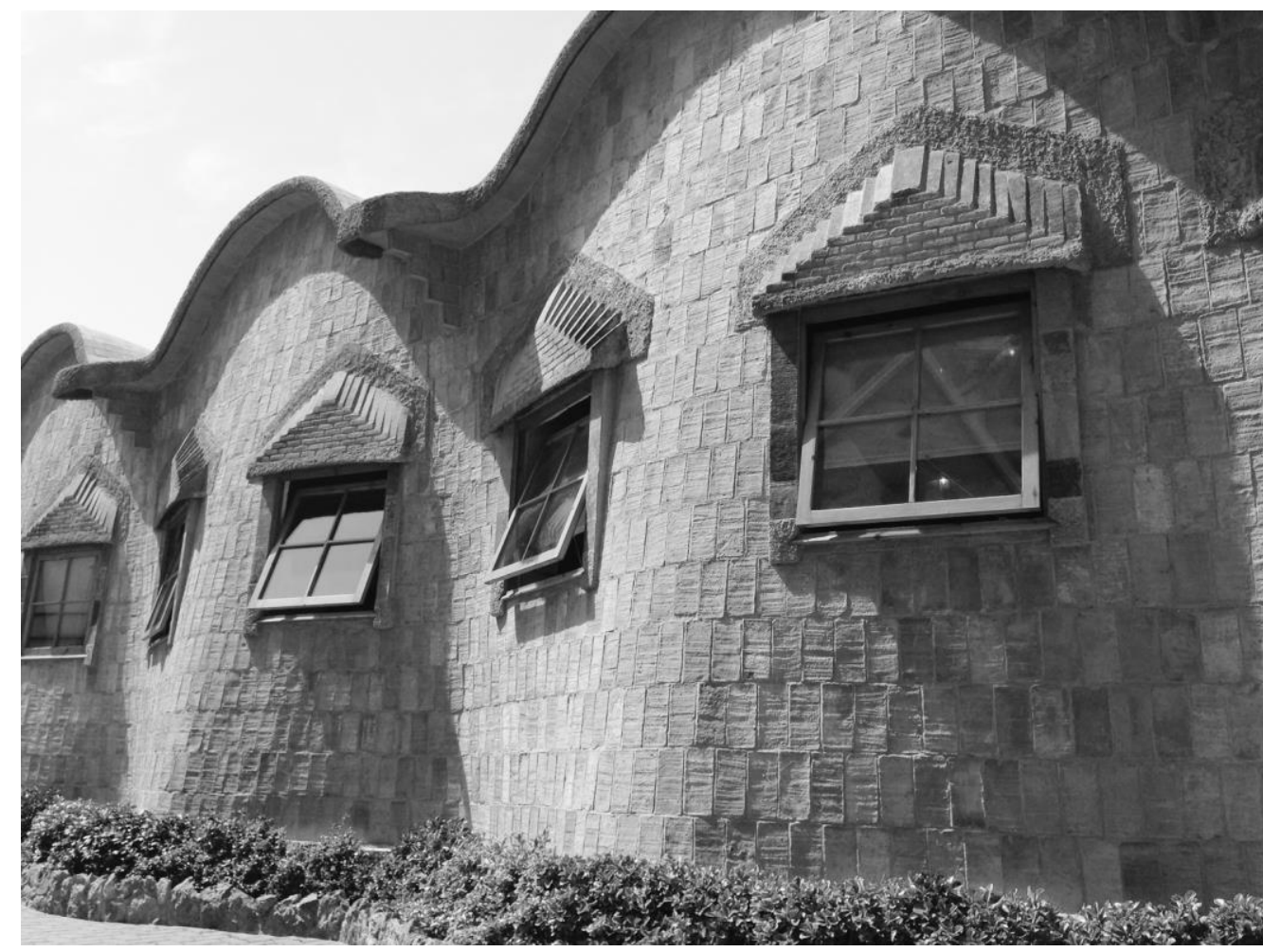

2. Fotografía exterior de las escuelas de la Sagrada Familia. Fuente: Producción propia (Esmeralda López García)

\footnotetext{
${ }^{3}$ Diaz de Tuesta, M.José. Aquel Madrid de Le Corbusier. La Residencia de estudiantes recuerda la estancia de los genios de la arquitectura. Madrid: El País, 2009.

${ }^{4}$ Huerta, Santiago. Las bóvedas de Guastavino en América: libro publicado con ocasión de la exposición: Guastavino Co. (1885-1962) Madrid: Instituto Juan Herrera, 2001.
} 
En los años 20 y 30 se empieza a abismar en el arquitecto un pequeño alejamiento de las posiciones dogmáticas del purismo. Se trata del inicio de una fase de transición en su carrera en la que las técnicas constructivas tradicionales toman cada vez más fuerza en su obra, situándose su viaje a Barcelona en el momento central de esta transición. Le Corbusier poco a poco se aleja de las vanguardias de los años veinte ajenas a la tradición, dirigiendo su obra hacia soluciones basadas en las culturas locales e invitando a los profesionales catalanes a observar la obra de Gaudí y de su entorno más tradicional. Nos encontramos ante una época de su carrera caracterizada por una cierta incertidumbre en la búsqueda de una nueva línea de diseño, en la que combina la estética moderna con la utilización de materiales tradicionales.

\section{Presencia de la bóveda catalana en el movimiento moderno español y relación con Le Corbusier}

La bóveda tabicada tuvo una gran importancia en el movimiento moderno español tanto en Madrid como en Barcelona siendo este elemento el punto de partida de una búsqueda hacia una arquitectura verdadera. Este sistema constructivo convive con las nuevas técnicas empleadas en los años 20 y 30 y se convierte en un elemento capaz de aunar sencillez, tradición y economía de medios. Gracias a estas características el movimiento moderno asume su uso como propio, siendo muy utilizada en viviendas y pequeñas escuelas e irá siempre ligada al concepto de repetición. Además, tuvo mucho auge durante la posguerra española debido a la escasez de materiales del momento histórico y a la situación política del país que desconfiaba de la arquitectura moderna representada por los grupos GATEPAC y GATCPAC. Aun así y a diferencia de las circunstancias de uso iniciales, la bóveda catalana tuvo más transcendencia en los planteamientos radicales del movimiento moderno que en otros arquitectos opuestos a esta postura.

Fue quizás esta aproximación de los arquitectos de la Península a la tradición constructiva lo que generó que Le Corbusier estuviera en continuo contacto con miembros del grupo GATCPAC, Grup d'Arquitectes $i$ Tècnics Catalans per al Progrés de l'Arquitectura Contemporània, sobre todo con Josep Lluís Sert, Josep Torres Clavé y Antoni Bonet i Castellana. Estos arquitectos edificaron proyectos que utilizaban la bóveda catalana en los años treinta. Los dos primeros, aunque autoproclamados modernos y revolucionarios, utilizaron este método en las casas de vacaciones en Garraf (Barcelona, 1934-1935), y Sert lo volverá a emplear en el plan de Chimbote presentado en Bérgamo en $1949^{5}$.

"La buena arquitectura no se ha hecho nunca por fórmula ni siguiendo al pie de la letra una doctrina: sería demasiado sencillo... Podemos, para obtener esto, aprovechar todos los medios que tenemos a mano, desde los más tradicionales a los más modernos; desde la piedra al ladrillo, el hormigón armado, el acero y el cristal, siempre que estén controlados por un espíritu de orden, claridad y respeto a las construcciones milenarias, osatura espiritual de todas las grandes creaciones arquitectónicas” Josep Lluís Sert ${ }^{6}$

\footnotetext{
${ }^{5}$ Grijalba bengoetxea, Alberto. Cabrero. La arquitectura de Francisco cabrero. Valladolid: Universidad de Valladolid, 2000.

${ }^{6}$ Sert, Josep Luis. ¿Qué orientación debe darse a la arquitectura contemporánea en Cataluña? En revista del GATEPAC. Barcelona 1934, $\mathrm{AC} \mathrm{n}{ }^{\circ} 16$ pp. 43-44.
} 
Le Corbusier mantiene una estrecha relación con Sert, con quien reflexiona sobre el sistema de la bóveda tabicada. Éste le habla del maestro catalán especializado en este sistema Doménech Escorsa y a partir de ese momento se convertirá en un punto de referencia constante para Le Corbusier. Con él mantendrá un contacto frecuente para obtener información sobre cómo utilizar este elemento constructivo.

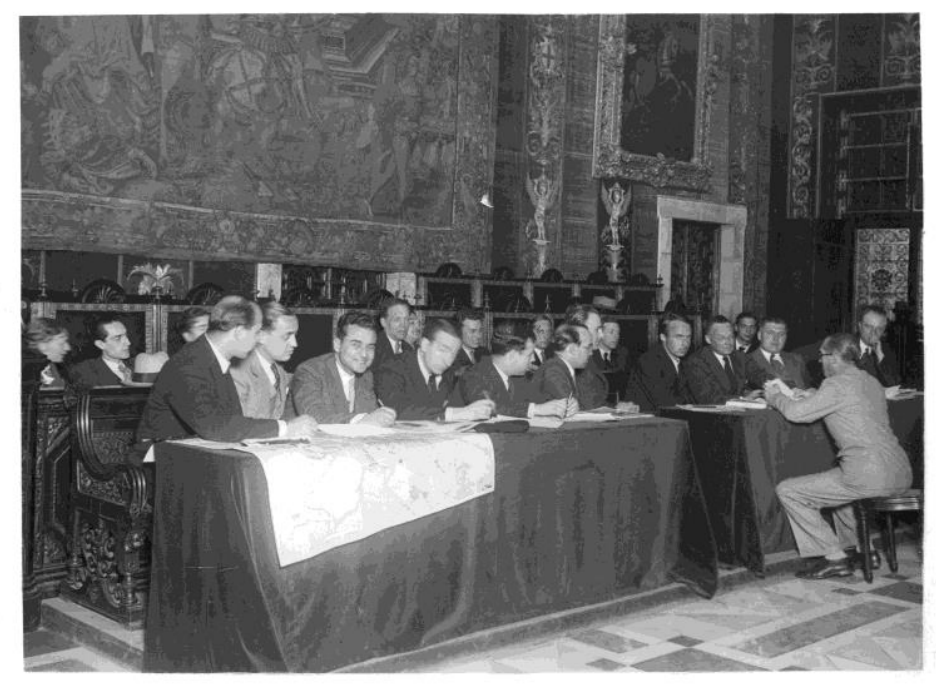

3. Le Corbusier en la reunión del CIRPAC (Comité Internacional para la Resolución de los Problemas de la Arquitectura Contemporánea), Barcelona 1932. Fotógrafo: Sagarra y Torrents. ( FLC-ADAGP.

Otra de las figuras claves en el uso y estudio de la bóveda catalana en España fue Antoni Bonet, colaborador de Sert y de Le Corbusier. Realizará varios proyectos con este sistema como la casa La Ricarda (El Prat de Llobregat, Barcelona, 1963), la casa Martínez (Buenos Aires, 1942) y la Casa Belingheri (Punta Ballena, 1945) Precisamente Bonet colaboró con Le Corbusier en los años 50 durante la evolución del proyecto para la casa Jaoul, realizando algunos croquis de soluciones abovedadas onduladas. Las trayectorias profesionales de Le Corbusier y Bonet, tras abandonar éste último el estudio, estuvieron unidas por dos obras: la Maison de weekend Jaoul y La Ricarda. Además ambos desarrollaron una línea de investigación paralela en torno al tratamiento de los materiales tradicionales y al estudio de la técnica constructiva de la bóveda catalana.

\section{Adaptación del sistema tradicional: Tradición y modernidad}

El interés de Le Corbusier por el método de construir tradicional fue una constante de estudio en su actividad profesional. En particular, ve grandes posibilidades formales en la bóveda catalana. Una de sus líneas de uso en la obra del arquitecto es su aplicación como elemento generador del edificio, pues repitiéndola en secuencia es capaz de definir la forma del complejo y a su vez resolver estructuralmente el proyecto. Recurrirá a esta técnica constructiva de manera recurrente desde su viaje a Barcelona en 1928 hasta inicios de los años 60 ${ }^{7}$. Las principales preocupaciones de Le Corbusier en este periodo eran por un lado la búsqueda de un contraste en los materiales utilizados, desvinculándose de esta manera de las vanguardias del momento, y por otro, encontrar un único elemento formal que fuera capaz de generar el proyecto.

\footnotetext{
${ }^{7}$ Huerta, Santiago. Las bóvedas de Guastavino en América: libro publicado con ocasión de la exposición: Guastavino Co. (1885-1962) Madrid: Instituto Juan Herrera, 2001.
} 
Después de su interés inicial por los sistemas tradicionales será tras su viaje a la India en febrero de 1951 cuando se reaviva en Le Corbusier el interés por la utilización de sistemas constructivos tradicionales. En ese mismo año, durante el congreso internacional de arquitectura moderna CIAM VIII en Hoddesdon, realizó un croquis de una bóveda catalana que incluía información constructiva, de ejecución, dimensiones y materiales aportada por Josep Lluís Sert y Domènec Escorsa. Este croquis lo realiza el 9 de julio de 1951, poco antes de dibujar la sección para la casa Jaoul.

El interés de Le Corbusier por la utilización de la bóveda catalana evoluciona a lo largo de su carrera. Inicialmente era una respuesta formal-tipológica que respondía además a un elemento usado en el Mediterráneo, pero después se convertirá en una solución alternativa a la técnica del hormigón armado. El arquitecto hace numerosas referencias en su obra a la arquitectura vernácula mediterránea y manifiesta una gran preocupación por la bóveda, el muro y los materiales tradicionales.

\section{Uso de la bóveda catalana en la obra de Le Corbusier}

Le Corbusier estudia dos soluciones para reinterpretar el sistema de la bóveda catalana: el tradicional de tres estratos superpuestos y el de dos estratos, realizados con materiales diferentes. Es esta diferencia el principal condicionante que dará como resultado la cubierta tabicada propuesta por Le Corbusier. Se trata de una solución intermedia entre el sistema en hormigón utilizado por los constructores romanos y el sistema tradicional.

En las bóvedas de las obras de Le Corbusier la primera hilada no puede ser considerada completamente colaboradora con la segunda, pues no se lleva a cabo la regla del desfase relativo entre las juntas de ambas capas. El relleno de hormigón aligerado en el trasdós modifica el funcionamiento estructural de la bóveda y es la sección resistente la que comprende la zona del refuerzo. En los años 50 ya integra el sistema tradicional artesanal con las posibilidades estructurales del hormigón armado $^{8}$. El esquema estático de esta solución abovedada equivale al de un arco de hormigón con un tirante que contrarresta el empuje horizontal. De esta manera el arquitecto elimina el valor constructivo de esta técnica conservando únicamente su expresión formal y reelaborando así el sistema. Posteriormente se ha confirmado con las propias notas de Le Corbusier que él consideraba la estructura de ladrillo como encofrado perdido, reduciendo así su capacidad resistente.

\section{La bóveda catalana en los proyectos de Le Corbusier}

\subsection{Proyectos iniciales}

Le Corbusier propone los primeros modelos abovedados en el proyecto no construido de la casa Monol (1919) y la villa Paul Poiret en Sans Lieu (1916) En estas obras sigue el ejemplo de los almacenes Wallut, realizados por Auguste Perret en Casablanca entre 1914 y 1916, y a los cuales hace referencia en su libro 'Une maison-Un palais', en el que trabajaba durante su viaje a España. En la casa Monol se produce una transición desde una forma unitaria de los primeros bocetos hasta un conjunto de unidades volumétricas individuales resueltas mediante la combinación de varios prismas coronados por bóvedas tabicadas. En este caso la cubierta abovedada es de chapa ondulada y los muros son de relleno de tapial.

\footnotetext{
${ }^{8}$ Huerta, Santiago. Las bóvedas de Guastavino en América: libro publicado con ocasión de la exposición: Guastavino Co. (1885-1962) Madrid: Instituto Juan Herrera, 2001.
} 


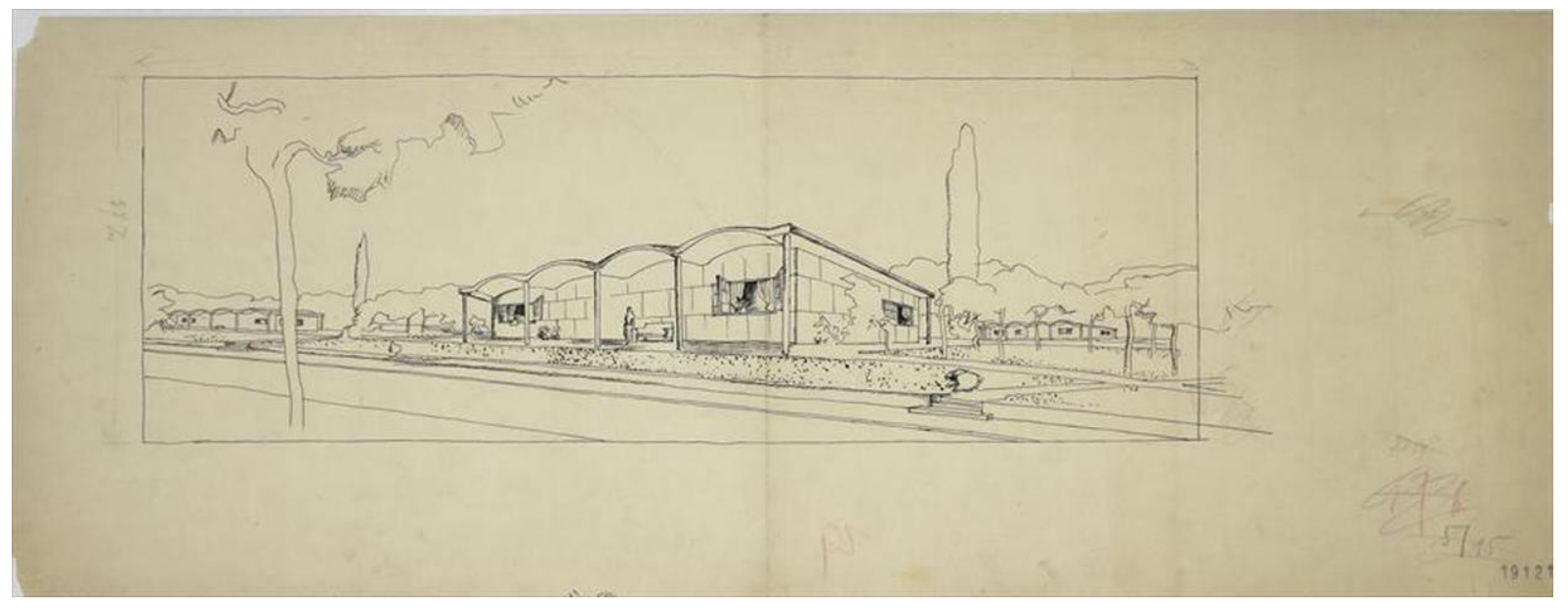

4. Le Corbusier, Dibujo de estudio para las casas Monol. FLC 19121 @ FLC-ADAGP.

Más delante Le Corbusier realizó el proyecto para una pequeña casa de fin de semana en las afueras de París, la casa Henfel (1935), continuando su línea de investigación de este sistema constructivo. En los primeros croquis se puede observar la duda formal en cuanto a la continuidad de la cubierta entre los módulos ${ }^{9}$. En el proyecto preliminar del proyecto de la casa de fin de semana la Celle-Saint-Cloud repite los dibujos de las bóvedas de la escuela parroquial de la Sagrada familia de Gaudí, realizados durante su visita a Barcelona en el Carnet C11. En ambos dibuja respectivamente: a la izquierda las bóvedas catalanas o la casa con tales bóvedas y a la derecha las escuelas de Gaudí o la casa con muros y bóvedas ligeramente onduladas sin ninguna regla geométrica.

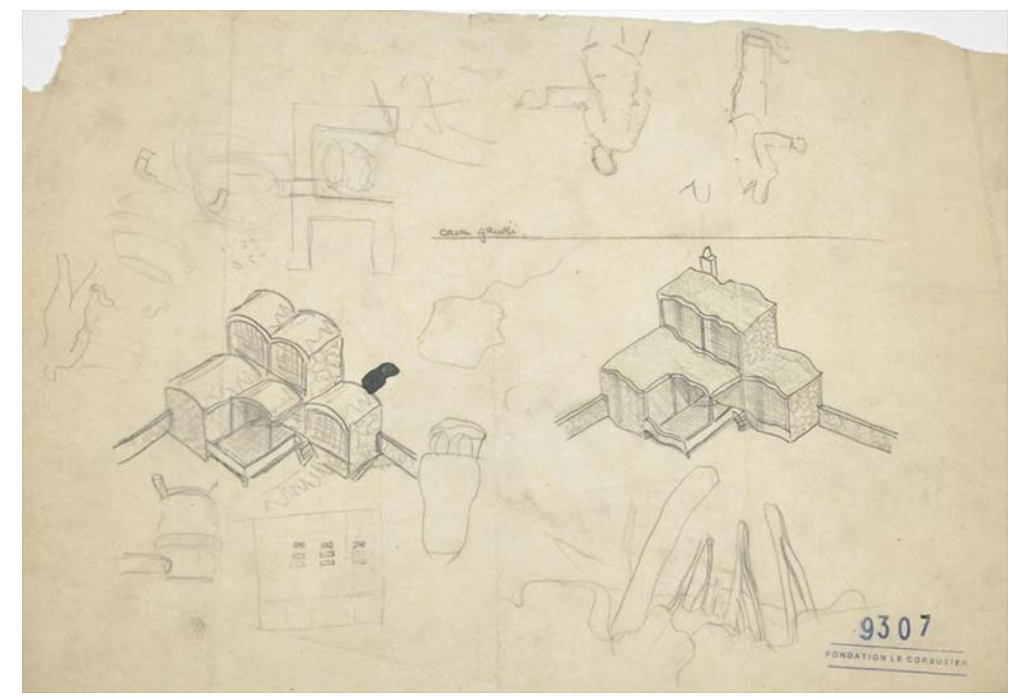

5. Le Corbusier. Croquis preliminares casa de fin de semana, La Celle-saint-Cloud. FLC 09307 () FLC-ADAGP

En este momento de su carrera está todavía presente la búsqueda formal-tipológica y la carga expresiva de un único elemento arquitectónico. La duda entre las dos propuestas, que muestran sus croquis preliminares, responde a la búsqueda de una expresividad conseguida a partir de la repetición en serie o no del sistema abovedado sobre una retícula. Además de esta solución formal, el empleo articulado de diferentes materiales como el ladrillo, vidrio y hormigón aportan al proyecto una cierta autonomía respecto a las vanguardias del

\footnotetext{
${ }^{9}$ Le Corbusier. Le Corbusier \& P.Jeanneret: Ouvre complète 1934-1938. Zurich: d'Architecture Artemis, 1995.
} 
momento. El principal elemento generador del edificio es el elemento abovedado y es la solución que no cambia durante el desarrollo de las diversas hipótesis. Las soluciones características de la propuesta serán la combinación de las paredes de GRC con el muro de piedra y la cubierta abovedada.

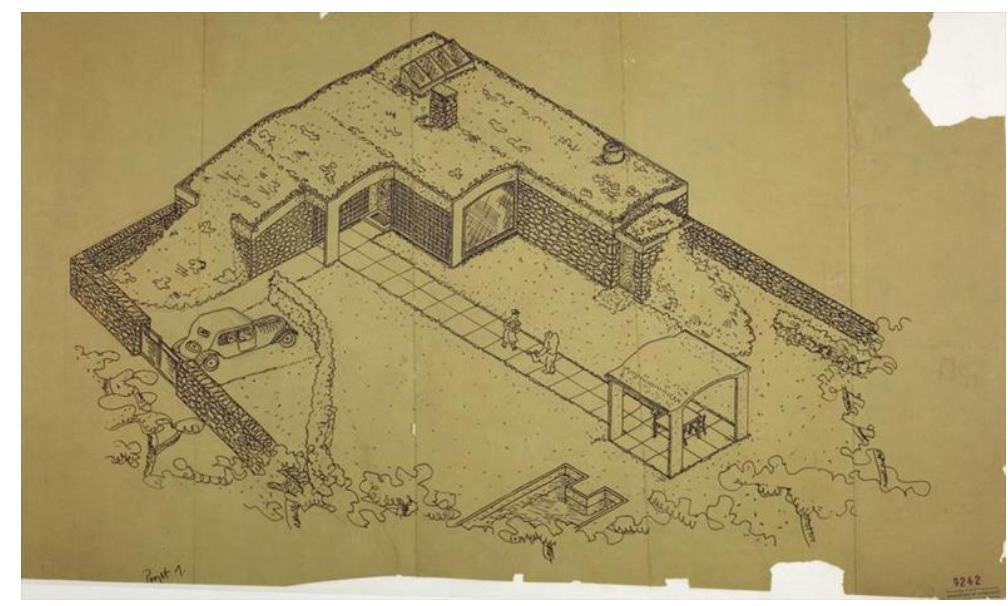

6. Le Corbusier. Croquis preliminares casa de fin de semana, La Celle-saint-Cloud. Se muestra la carga formal del sistema abovedado. FLC 09242 @ FLC-ADAGP

\subsection{Madurez en el uso del sistema abovedado}

Posteriormente realizará uno de sus proyectos abovedados más conocidos, la casa Jaoul en Neuilly-sur-Seine. Ya en la primera sección transversal de este proyecto realizada a mano alzada el 25-7-1951 aparece la bóveda rebajada para cubrir las crujías. Por tanto, los elementos generadores de las casas adosadas son las bóvedas catalanas y la crujía mural, que dan lugar a una tipología espacial y constructiva diferente. La intención espacial de Le Corbusier estaba muy clara en esta casa como podemos observar en varios de sus croquis iniciales con la combinación de bóveda y muro. Las vigas de descarga de las bóvedas se resuelven con vigas metálicas en los muros divisorios, mientras en aquellos de fachada con vigas de hormigón conformado. En la segunda etapa de trabajo en el proyecto, de noviembre a diciembre de 1951, resuelve el perfil de la cubierta con un remate ondulado que cubre toda la sección transversal del edificio generado por la presencia de las bóvedas interiores. Las crujías de ambas casas son distintas, 3,66 y 2,26 metros y la bóveda catalana parte del dintel de las vigas a una altura de 2,26 metros, generando de esta forma un rectángulo áureo ${ }^{10}$.

Los muros longitudinales de ladrillo incorporan jácenas vistas de hormigón que constituyen el apoyo de las bóvedas y cuyos empujes horizontales son absorbidos cada 4,5 metros por tirantes de acero. Al tratamiento exterior de estas vigas de hormigón le proporciona una textura rugosa conferida por el encofrado de tablilla y crea así una alternancia entre el aspecto rugoso del hormigón y el ladrillo caravista del aparejo inglés de los muros de carga ${ }^{11}$.En esta obra tienen una gran presencia la sinceridad constructiva de vigas, bóvedas y muros en contraposición con otras de sus obras.

\footnotetext{
${ }^{10}$ Maniaque Benton, Caroline. Le Corbusier and the Maisons Jaoul. New York: Princeton Archietecture press, 2009.

${ }^{11}$ González Cubero, Josefina. "La arquitectura del suelo. Las casas Jaoul en Neuilly-sur-Seine”. En Massilia: Anuario de estudios lecorbusierianos. Barcelona: Fundación Caja de arquitectos, 2003.pp. 162-177.
} 


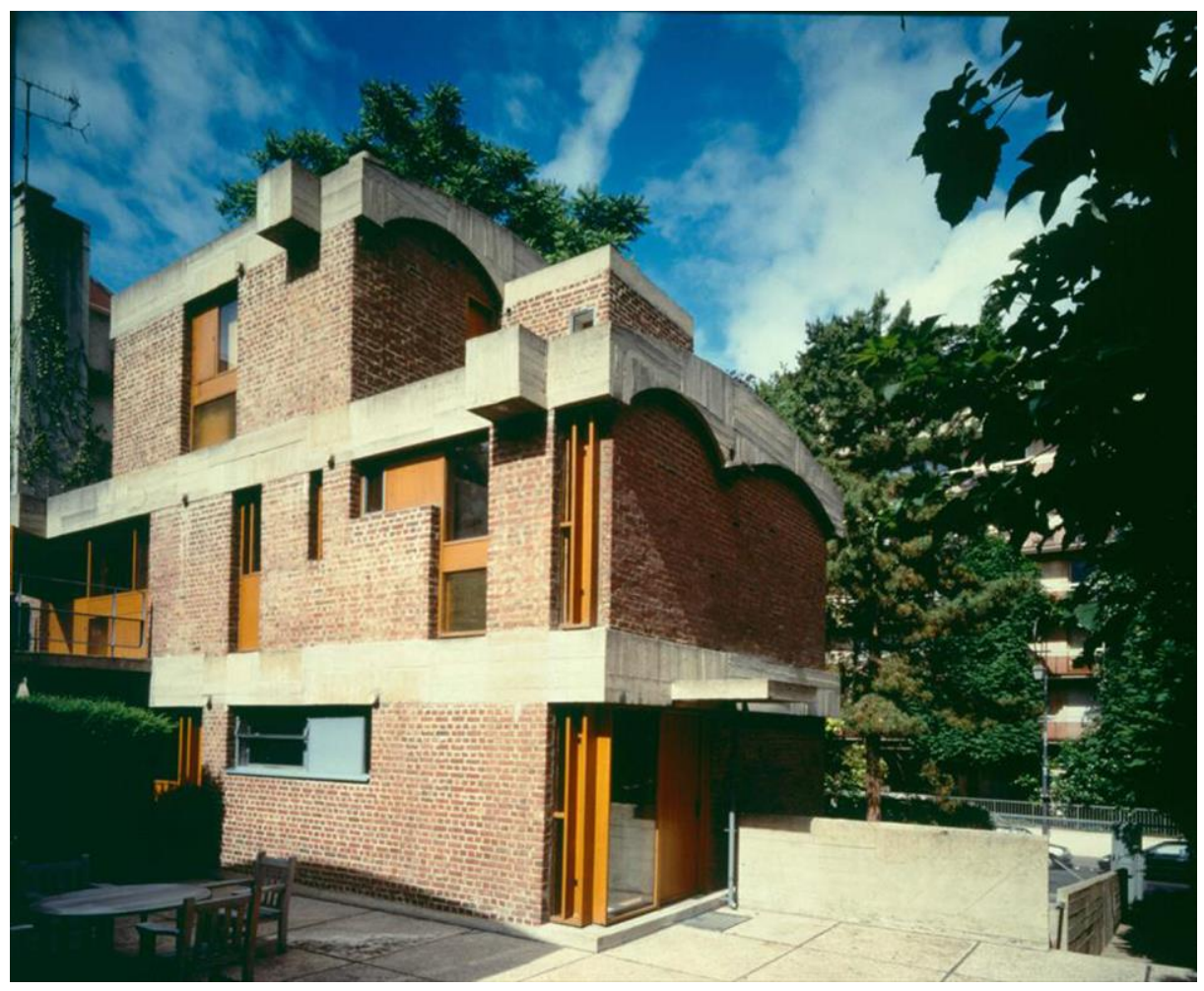

7. Le Corbusier. Vista externa de la casa Jaoul. Alternancia de hormigón y ladrillo. ㄷ FLC-ADAGP

En cuanto a las notas referentes al predimensionamiento estructural de las impostas de las bóvedas de este proyecto se pone de manifiesto una fragmentación entre su intención formal frente a la estructural al utilizar este sistema. Estos cálculos se llevan a cabo mediante la aplicación de fórmulas sencillas como resultado de la teoría elástica de las estructuras de hormigón armado. En tales apuntes no se considera la colaboración de la resistencia del ladrillo. Por tanto el esquema estructural de la bóveda sería el equivalente al de un arco de hormigón con un tirante que contrarresta el empuje horizontal ${ }^{12}$. Este análisis de las notas de Le Corbusier nos confirma el interés del arquitecto por la expresión formal de esta técnica tradicional, dejando a un lado su uso constructivo.

${ }^{12}$ Huerta, Santiago. Las bóvedas de Guastavino en América: libro publicado con ocasión de la exposición: Guastavino Co. (1885-1962) Madrid: Instituto Juan Herrera, 2001. 


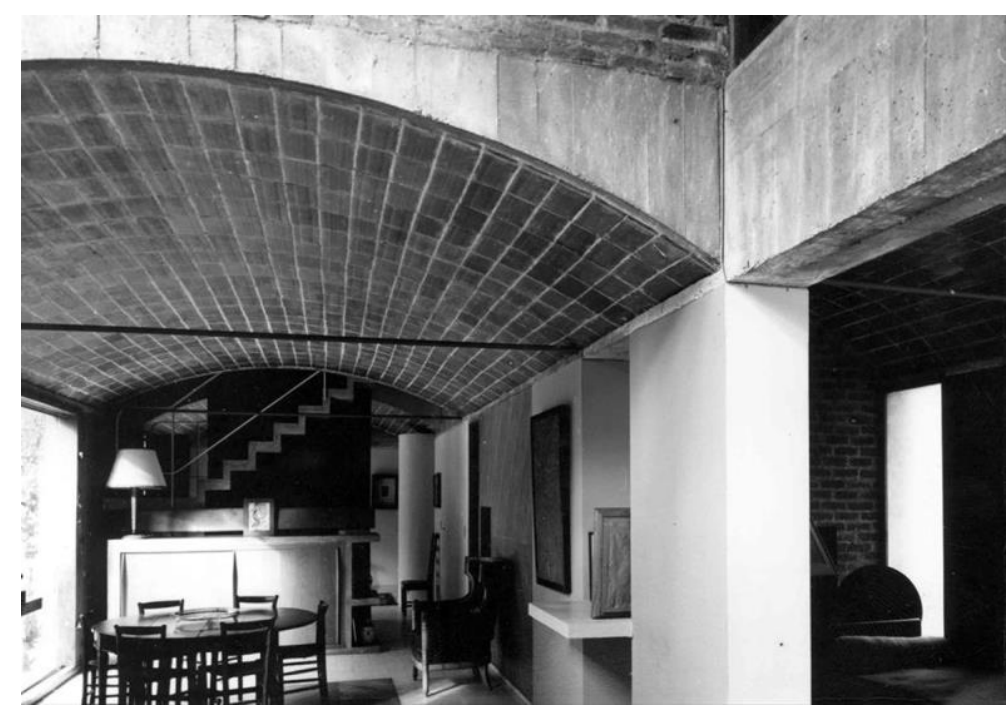

8. Vista interna de la casa Jaoul. Fotógrafo: Lucien Hervé ㄷ FLC-ADAGP

\subsection{Proyectos de bóveda catalana fuera de Europa: Solución ante la carencia de medios técnicos.}

Gracias a que Le Corbusier tuvo la oportunidad de construir en India podrá exportar allí su sistema abovedado. Uno de esos proyectos será la casa Sarabhai (1955) en Gujarat State usando al igual que en las casas Jaoul la bóveda catalana rematada con cubierta ajardinada. La solución tanto tipológica como constructiva de las bóvedas es la misma que la de ésta última casa: dos estratos, uno con ladrillos cuadrados de espesor $2 \mathrm{~cm}$ y otro con bloques perforados de hormigón aligerado de $5 \mathrm{~cm}$, apoyados sobre vigas de hormigón armado ${ }^{13}$ Este sistema constructivo de bóvedas apoyadas en vigas de hormigón armado a vista permite abrir libremente huecos en los muros, dispuestos en paralelo y proporciona un efecto arquitectónico tremendamente vivo.

Asimismo, en el proyecto de las maisons des peons de Chandigarh en 1952 utiliza este procedimiento formal. Esta obra y la casa Jaoul constituyen el inicio y el fin de la incorporación real de las bóvedas catalanas en su obra. Le Corbusier plantea el uso de la construcción tabicada en este proyecto ya que se trata de una técnica rápida, eficaz y económica. Por ello merecía la pena su aprendizaje y empleo en la India, debido al amplio número a realizar y los problemas de escasez de medios técnicos en el lugar. Este planteamiento ya había estado presente en el proyecto para M.Peyrissac en Cherchell (Norte de África, 1942), en el que propone unas bóvedas tabicadas construidas por los indígenas. También en este proyecto está condicionado por el lugar y el momento, pues no existía mano de obra especializada y los materiales eran difíciles de encontrar ${ }^{14}$.

\footnotetext{
${ }^{13}$ Huerta, Santiago. Las bóvedas de Guastavino en América: libro publicado con ocasión de la exposición: Guastavino Co. (1885-1962) Madrid: Instituto Juan Herrera, 2001.

${ }^{14}$ Willy Boesiger. Le Corbusier 1910-1965. Barcelona: Editorial Gustavo Gili S.A., 1994
} 


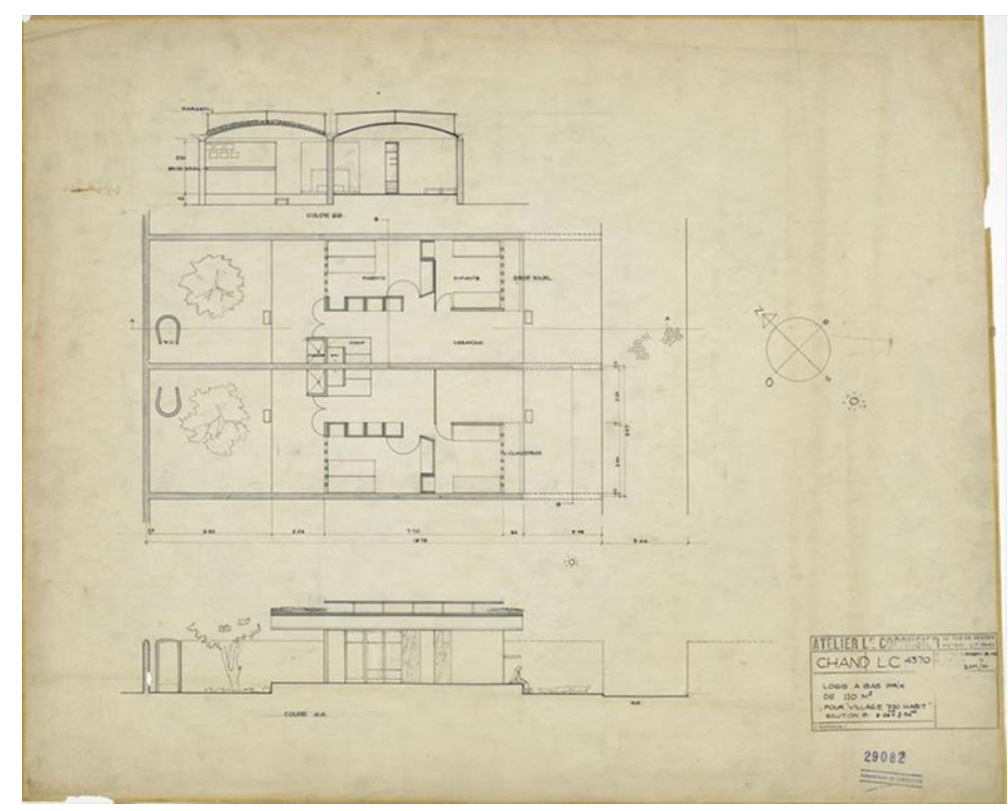

9. Le Corbusier. Planta y secciones de la Maison des Péons, Chandigarh. FLC 29082 @ FLC-ADAGP

\section{Conclusiones}

Le Corbusier a través de todas estas obras y de su búsqueda por entender e interpretar el sistema de la bóveda catalana pretende definir un modelo arquitectónico basado en los sistemas tradicionales que pudiera ser fácilmente adaptable a cualquier espacio, situación o contexto. No se trata simplemente de utilizar una solución constructiva ya definida, sino de reinterpretarla y adaptarla a la realidad y a las facilidades del momento. Los principales puntos de su investigación examinaban un sistema constructivo capaz de abaratar los costes de producción mediante la utilización de bloques de hormigón normalizados pero manteniendo presente la forma de la técnica tradicional.

Se puede observar una evolución en su carrera desde el interés inicial por las técnicas industrializadas hasta la posterior utilización de materiales naturales y técnicas tradicionales. Se trata por tanto de un proceso y no de un cambio en su manera de construir, ya que la búsqueda de la modernidad madurada durante el primer periodo será un legado presente durante toda su carrera. La bóveda catalana es el sistema constructivo que le permite experimentar este cambio y su viaje a Barcelona en 1928, con la visita a la escuela de la Sagrada familia, su fuente de inspiración. Esta construcción está presente en su memoria durante toda su carrera y será un recuerdo formal que recordará en numerosas ocasiones.

\section{Procedencia de imágenes}

Todas las imágenes utilizadas en el artículo proceden de la Fundación Le Corbusier, salvo la segunda imagen que es propiedad de la autora del artículo.

\section{Referencias bibliográficas}

Boesiger, Willy. Le Corbusier 1910-1965. Barcelona: Editorial Gustavo Gili S.A., 1994

Díaz de Tuesta, M.José. Aquel Madrid de Le Corbusier. La Residencia de estudiantes recuerda la estancia de los genios de la arquitectura. Madrid: El País, 2009. 
González Cubero, Josefina. "La arquitectura del suelo. Las casas Jaoul en Neuilly-sur-Seine”. En Massilia: Anuario de estudios lecorbusierianos. Barcelona: Fundación Caja de arquitectos, 2003.pp. 162-177.

Grijalba Bengoetxea, Alberto. Cabrero. La arquitectura de Francisco cabrero. Valladolid: Universidad de Valladolid, 2000.

Huerta, Santiago. Las bóvedas de Guastavino en América: libro publicado con ocasión de la exposición: Guastavino Co. (1885-1962) Madrid: Instituto Juan Herrera, 2001.

Lahuerta, Juan José. Le Corbusier e la Spagna, con la riproduzione dei carnets Barcelone e C10 di Le Corbusier. Milano: Mondadori Electa, 2006.

Le Corbusier. Discurso "Air, son lumière”. Pronunciado en Atenas el 3 de agosto de 1933 con motivo del IV CIAM. Atenas, 1933.

Le Corbusier. Le Corbusier \& P.Jeanneret: Ouvre complète 1934-1938. Zurich: d'Architecture Artemis, 1995.

Maniaque Benton, Caroline. Le Corbusier and the Maisons Jaoul. New York: Princeton Archietecture press, 2009.

Sert, Josep Luis. ¿Qué orientación debe darse a la arquitectura contemporánea en Cataluña? En revista del GATEPAC. Barcelona 1934, AC nº16 pp. 43-44. 
works that encoded many of the parameters and mechanisms which would later define the medium, progressively becoming an immensely popular form all over Europe.

In fact, Töpffer's strips, as well as his other works, attracted the attention of fellow cartoonists and intellectuals alike, including both the illustrious scientist Auguste de la Rive and the romantics, such as Balzac, or Victor Hugo $^{3}$. They would even reach Johann Wolfgang von Goethe, who was particularly fond of them, and ultimately played a major part in Töpffer's decision to publish them ${ }^{4}$. Goethe was not the only major name of modern literature who appreciated some aspect of the Swiss teacher's oeuvre: Almost a century later, Leo Tolstoy cited La Bibliothèque de mon oncle [My Uncle's Library], one of Töpffer's most popular works in prose, as an early inspiration ${ }^{5}$. Outside the literary scene, Töpffer's influence can be tracked as far as Henri de Toulouse-Lautrec, whose sketchbook Cahier de Zigzags makes a direct reference to Voyages en Zigzag (1844), one of Töpffer's most popular books. He would not be the only one in his appreciation, since, as we will see, this book would have a crucial role in the shaping of Le Corbusier's obsessions during young Jeanneret's formative years ${ }^{6}$.
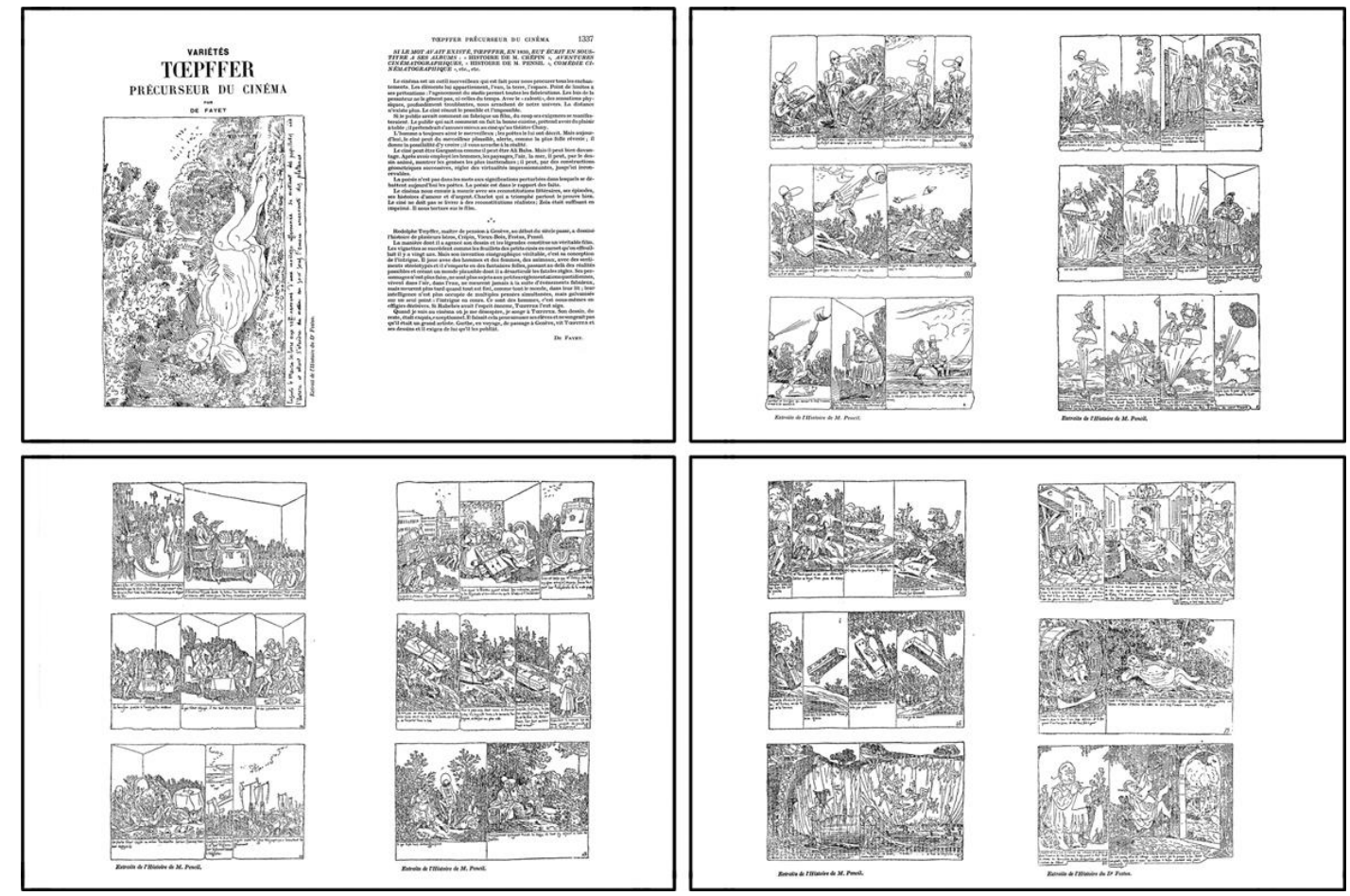

1. Le Corbusier on Töpffer: [1-4]. Le Corbusier: The eight plates of "Toepffer, précurseur du cinema”, in L'Esprit Nouveau 11-12, November 1921. OFLC-ADAGP

Of course, the publication of "Toepffer, précurseur.." can be explained by purely contextual reasons: In 1921, Töpffer's strips had been adapted into an animation film, Histoire de Monsieur Vieux-Bois (Lortac and Cavé, $1921)^{7}$, which prompted filmmaker Jean Choux to write three articles on the topic in the magazine La Suisse ${ }^{8}$.

\footnotetext{
${ }^{3}$ See Kunzle. Op. cit. p. 6.

${ }^{4}$ See cf. Von Goethe, Johan Wolfgang: Conversations of Goethe with Eckermann and Soret. London: George Bell \& Sons, 1874. An account of Goethe's impressions on Töepffer can be found in Kunzle. Op. cit.. pp. 49-56.

5 "Tolstoy confessed he was 'strongly influenced by... Töpffer (his Bibliothèque de Mon Oncle)' when he wrote Childhood, Boyhood, and Youth." Quoted in Aylmer, Maude: The Life of Tolstoy: First Fifty Years. New York: Dodd, Mead, 1910. pp. I, 160.

${ }^{6}$ See Kunzle. Op. cit. p. 151

${ }^{7}$ The film was a faithful adaptation of l'Histoire véritable des amours de Mr Vieux-Bois (title of the 1839 edition).
} 
Also, the publication of articles on items located somewhere in the periphery of official culture, be it architecture or Fine Arts, was not alien to the history of L'Esprit Nouveau, and, in fact, was very much in line with its very philosophy. The magazine where we can find pages devoted to architecture, painting, or poetry, also featured frequently images of machinery and vehicles, advertisements and digressions on the new cultural movements and the avant-garde, Apollinaire's calligrams, and even cartoons, be those drawn by Pablo Picasso, George Grosz, or by popular press cartoonists such as Léon Kern, Marcel Arnac, Barboni, Abel Faivre, Marcel Capy, or even Frans Masereel.

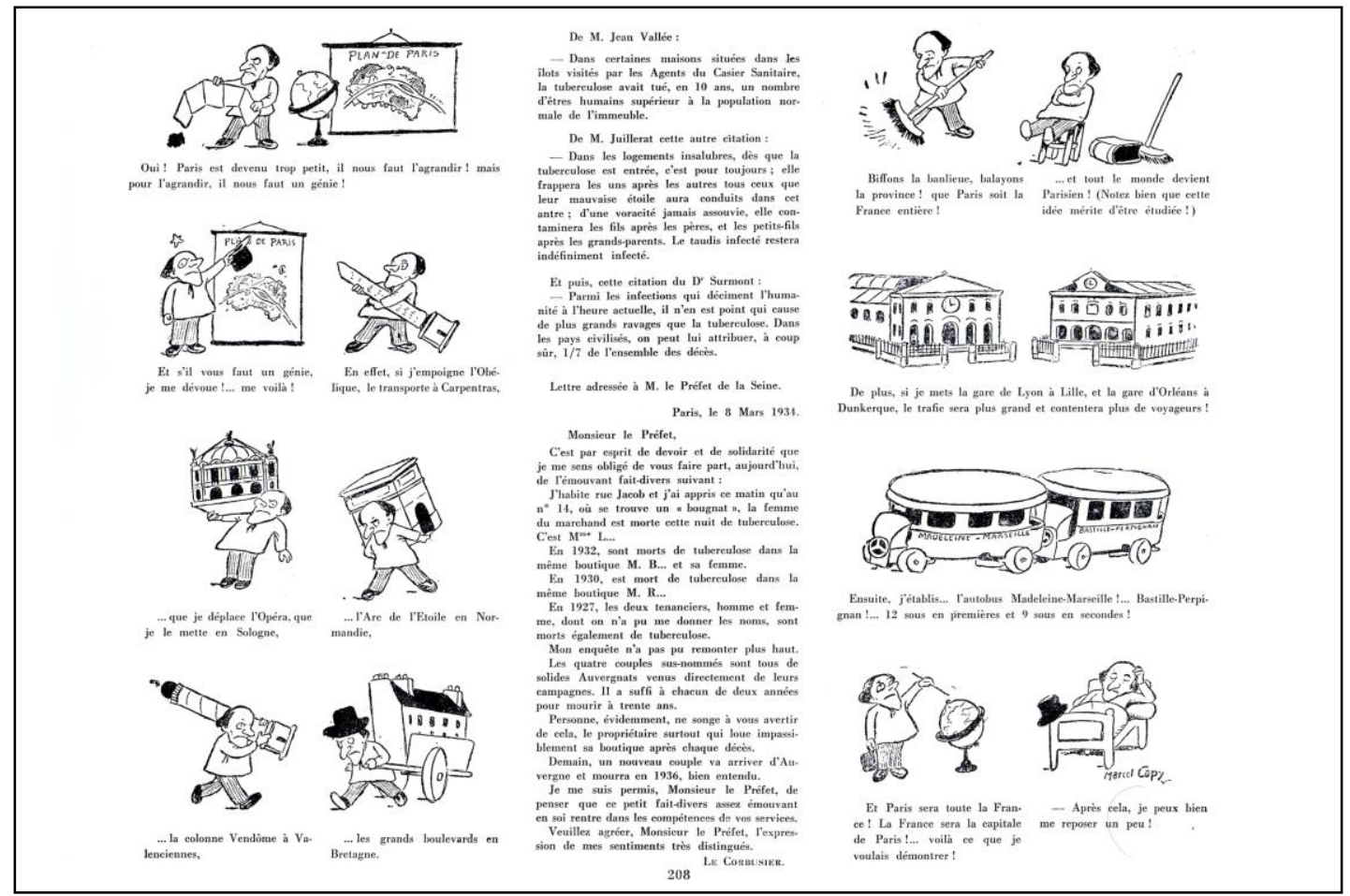

2. Des Cartoons, des Munitions: [5] Page 208 of Le Corbusier's La Ville Radieuse (1935) featuring the proto-comic "Paris trop petit", by Marcel Capy. OFLC-ADAGP. Originally published in Le Journal No 12068 (Paris, November 1, 1925).

Le Corbusier frequently peppered his early manifestoes with cartoons clipped from contemporary newspapers, which fitted well his inflammatory prose, helping him underline his points. An assorted collection of cartoons, usually lifted from the Parisian conservative daily Le Journal, can be found in "Coupures de Journaux" (LEN n 25), and in its revised and expanded version published in Urbanisme (1924; 119-33), as well as in L'Almanach d'Architecture Moderne (1925), Une Maison, un Palais (1928), which reprinted some of the drawings from "Toepffer, précurseur..." , and even La Ville Radieuse (1935). Among those, the most outstanding case might be perhaps La Ville Radieuse, both because the cartoons are scattered throughout the book, interspersed in between the text, sketches, and plans, and because of the prominent presence of Marcel Capy, a prolific author and a favourite of Le Corbusier, who also included a note of gratitude to the cartoonist ("Merci, Capy!"; 120). Le Corbusier's relationship with caricature and cartoonists would grant him one of the infamous diplomas awarded by the architect-cartoonist by excellence, Saul Steinberg. The document, part of a series awarded to personalities

\footnotetext{
${ }^{8}$ The first of those articles was published on August 23, 1920. All three can be found in Edera, Bruno: Histoire du cinéma suisse d'animation. Lausanne: Cinémathèque suisse, 1978.

${ }^{9}$ Four panels from pages 23 and 24 of 'Histoire de Mr. Pencil' misquoted as 'Histoire de M. Pensil', by 'F. Töpper' (Genevois) appear in pages 188 and 189. See: Le Corbusier: Une maison - un palais. "A la recherche d'une unité architecturale.". Paris: Éditions Crès, "Collection de l'Esprit Nouveau", 1928.
} 
such as Igor Stravinsky, Charles Eames, Billy Wilder, Josef Albers, or Alberto Giacometti, amusingly entitled him to practice architecture, and was published in the fifth Volume of the Oeuvre Complète (1946-1952). In return, Le Corbusier would reportedly tell Steinberg: "You draw like a king".

All these diversions just underline Le Corbusier's polyhedral personality, along with the omnivore nature of his approach to design, which claimed for the need of a transversal understanding of the architectural fact. Le Corbusier's architecture was at its very core, part of a transdisciplinar exploration that had its origin in a fundamental interest in all the aspects of modernity, a complex, multi-faceted era that demanded a new spirit, a 'spirit of construction and synthesis ${ }^{\text {'10 }}$ that could gather all those parts together. Architecture became, in Le Corbusier's work, the discipline called upon to produce a true synthesis of the arts -including among those all forms of communication and technology. Along with this new understanding of the integration of the different disciplines, the modern era required the development of a new glance, a new eye capable of apprehending the rapid and multiple reality of the emerging urban world. It is in this context that we can frame Le Corbusier's interest in cinema, an urban medium whose mechanical eye, the eye of the camera, was capable of a glance that integrated time and space, thus becoming the perfect means to record and reproduce the experience of modern space epitomized by the modern city. As Georg Simmel put it, the city of the new century created in the observer a dramatic "intensification of nervous stimulation ${ }^{11 "}$. The modern flanêur, we should add, was one that became overwhelmed by an increasingly vertical space whose complexities could only be perceived through the lapse of time. This is the scenario where the pictorial avant-garde arose, where the multiple vision of collage and cubism bred, and where Le Corbusier's own experiments with Purism evolved in the 1920s. His interest on cinema, which resulted in fruitful relationships with artists such as Eisenstein -a man with an early fascination with cartoons as well- seems to explain sufficiently, in this sense Töpffer's presence in L'Esprit Nouveau. In fact, in his article, Le Corbusier based his argumentation on Töpffer's relevance in his alleged role as a forefather of cinema:

"Si le mot avait existé, Toepffer, en 1830, eut écrit en sous-titre à ses albums: "Histoire de Monsieur Crépin", aventures cinématographiques, "Histoire de M. Pensil"[sic], comédie cinématographique, etc., etc. [...] Rodolphe Toepffer, maître de pension à Genève, au début du siècle passé, a dessiné l'histoire de plusieurs héros (...) La manière dont il a agencé son dessin et les légendes constitue un véritable film. Les vignettes se succèdent comme les feuillets des petits cinés en carnet qu'on effeuillait il y a vingt ans. (...) Quand je suis à cinéma où je me désespère, je songe à TOEPFFER. Son dessin, du reste, était exquis, exceptionnel. Il faisait cela pour amuser ses élèves et ne songeait pas qu'il était un grand artiste."

These few references to Töpffer were scattered in a much longer reflection on cinema, which seemed to justify well enough the inclusion of the cartoonist. Once Le Corbusier's attraction towards the new medium of film has been established, it seems only logical that Töpffer's Muybridge-like sequential stories attracted his attention, even if out of sheer archaeological curiosity. However, his infatuation with the Swiss pedagogue was more than a circumstantial, or passing one: In a letter to August Klipstein from 1911, Le Corbusier asked him to "please send [him] the following book: the adventures of Monsieur Vieux-Bois", adding that in it, he would "find a French or Latin Busch, obviously a precursor as a draftsman", and concluding that he "should be delighted to

10 "Il y a un esprit nouveau cést un esprit de construction et de synthèse guidé par une conception claire." "L'Esprit Nouveau", in L'Esprit Nouveau $\mathrm{n}^{\circ} 1,1918$.

${ }^{11}$ See Simmel, Georg: "The Metropolis and Mental Life". Adapted by D. Weinstein from Kurt Wolff (Trans.): The Sociology of Georg Simmel. New York: Free Press, 1950. pp.409-424. 
write a doctoral thesis on Töpffer" ${ }^{12}$ With this last sentence, Le Corbusier also showed a more than casual knowledge of graphic narrative: The 'Busch' he mentions is Wilhelm Busch (1832 - 1908), a German cartoonist, painter and poet, famous because of his illustrated poems and for creating the characters Max und Moritz. Actually, Jeanneret's knowledge of Töpffer's work was older and deeper, and I would argue that it would evolve into a life-long relationship, in the sense that it seems to have helped shape some of Le Corbusier's later obsessions: From the fascination with travel, and an ascetic sense of design that paired his synthetic approach to drawing, to his penchant for the overlaps between narrative and architecture, and the introduction of time in the perception of architectural space.

\section{Photography and Drawing. Towards Le Corbusier's Ligne Claire.}

As Stanislaus von Moos explains in his eponymous Voyages in Zigzag, Le Corbusier's relationship with Töpffer dates back to his childhood, and to Voyages en zigzag, ou excursions d'un pensionnat en vacances dans les cantons suisses et sur le revers italien des Alpes. The book, written by Töpffer and published for the first time in Paris in 1844, was one of several volumes, targeted to a young audience, where the Swiss schoolmaster recounted, as the subtitle states, the "excursions of a boarding school on vacation In the Swiss cantons as well as on the Italian slopes of the Alps". Richly illustrated both by Töpffer and Alexandre Calame, who provided fifteen drawings of Alpine landscapes, the book offered "a Romantic celebration of the Alps, mixed with genre scenes" that made it a perfect reading for youngsters. As von Moos notes, "[t]he book's many charming illustrations of the Alps, its humor and edifying morals, had earned it a place of honor on bookshelves of many middle-class households in French-speaking Switzerland by $1900^{\prime \prime 13}$ Young Charles-Edouard Jeanneret's family was one of those, and von Moos rightfully finds in Töpffer's "Petit Tour" through Switzerland the origin of Le Corbusier's passion for travelling, for creating carnets de voyage, and -I would add- of his infatuation with the figure of Töpffer, and the latter's influence on the development of yet another passion: drawing.

Through his brother Albert ${ }^{14}$, we know that young Charles-Edouard's earliest drawings were done as copies after the images of the Alps published in Voyages en Zigzag. In the light of this, and with the advantage of knowing the development of Le Corbusier's subsequent career, as well as his vindication of Töpffer's figure, it is not difficult to see shades of Töpffer's nervous line in the evolution of Le Corbusier's trademark linear style. As Beatriz Colomina explains in "Le Corbusier and Photography", his alleged despise of photography, sustained by statements such as "[t]he camera is a tool for idlers, who use a machine to do their seeing for them" or "[d]on't take photographs, draw; photography interferes with seeing, drawing etches into the mind", cannot

\footnotetext{
12 “A propos, faites venir ce livre-ci: les aventures de Monsieur Vieux-Bois (édité à Genève). Vous póuvrez voir là un Busch francais, latin, et surtout un précurseur comme dessinateur. Je ferias volontiers une these de doctorat sur Töpffer". CharlesEdouard Jeanneret to August Klipstein, n.d. (1911); FLC E 26-145. Quoted in Rüegg. Op. Cit., note 13, p. 283. Le Corbusier refers to Histoire de M. Vieux Bois (1827/ 1837), also known as Les amours de Mr. Vieux Bois or simply Monsieur Vieuxbois. In his "Catalogue de la bibliotheque Le Corbusier avant 1930" (Paris, February 1970), Paul V. Turner lists two books by Töpffer: Le Docteur Festus (Paris, s.d.) and Voyage à la Grande Chartreuse (Genève, 1920).

${ }^{13}$ All previous quotations: Rüegg. Op. Cit., p. 23

${ }^{14}$ From a personal communication by Albert Jeanneret. Le Lac, Corseaux, c1968. See VON MOOS (1968); 13. This reference does not appear in the English edition of the book.

${ }^{15}$ Corbusier, Le: Creation is a patient search. New York: Frederick Praeger, 1960, p. 37. Quoted in Colomina, Beatriz: Le Corbusier and Photography. In Assemblage. October 1987, № 4. p. 8.

${ }^{16}$ In Wogensky, André: Le Corbusier Sketchbooks. Cambridge: MIT Press and New York: Architectural History Foundation, 1981- 82. The quotation appears in Vogt, Adolf Max: "Remarks on the 'Reversed' Grand Tour of Le Corbusier and Auguste Klipstein”. In Assemblage. October 1987, № 4. p. 41
} 
be taken at face value: As a medium of the Temps Nouveaux, the mechanical eye of the camera forcefully had been reserved a prominent role in the recording of the emergent, mechanical, and a (newly?) objective reality. In fact, Le Corbusier made extensive use of photographs in his travels in the East, and photographic image played a fundamental part in the communication of the message of his first books, from Vers une architecture (1923) to L'Art Decoratif d'ajourd'hui (1925). However, it is also clear that while photography was an undeniably useful tool, drawing was a far superior one, because "[b]y working with our hands, by drawing," he wrote, "we enter the house of a stranger, we are enriched by the experience, we learn." 17 Thus, when reviewing the materials in Viaggio in Oriente, or the archives of L'Esprit Nouveau, we find many instances where Le Corbusier obsessively draws "after" photographs (both his own and those found in newspapers or catalogues, as well as postcards), as in an attempt to remove anything superfluous, and capture their essence. We know that Le Corbusier used to sketch his buildings repeatedly, and even when dealing with photographs, he could not resist to endlessly edit them, whiting out with an airbrush anything that obstructed the understanding of the idea(l) in them.
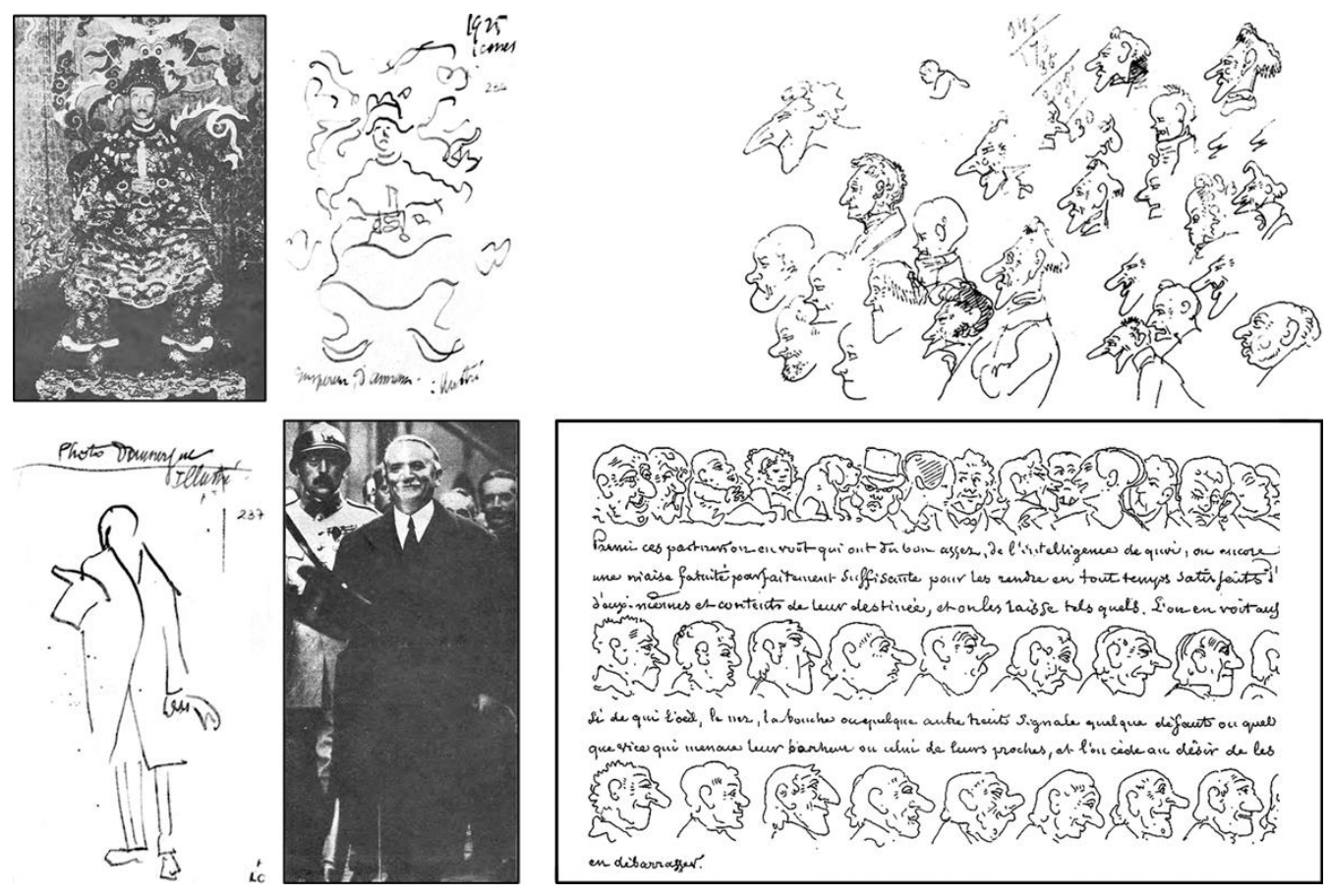

3. [6-9] Photographs from L'1llustre of Emperor Khai Dinh and President Gaston Doumerge and drawings done after them, as layouts for L'Art decoratif d'aujourd'hui, 1925. OFLC-ADAGP [10] Caricature studies by Rodolphe Töpffer, date unknown. [11] Excerpt from Töpffer's Essai de physiognomonie.

"Les perspectives qui accompagnent ses projets (...) sont exécutées au trait. Le dessin est épuré à l'extrême: seuls les contours (...) sont tracés. Si ces dessins appartenaient au genre de la bande dessinée, on les rapprocherait de l'école belge de la 'ligne claire'." 18

Again, it is difficult not to think of Töpffer when picturing Le Corbusier obsessively reducing complex photographs into drawings made with a few lines -a process not unlike the method used by Hergé, who famously

\footnotetext{
${ }^{17}$ Corbusier, Le, Op. cit. Quoted in Colomina, Op. cit., p. 8.

${ }^{18}$ Migayrou, Frédéric; Cinqualbre, Olivier: Le Corbusier: Mesures de l'homme. Catalogue of the Exhibition. Paris: Editions du Centre Pompidou, 2015.
} 
traced his own sketches over and over, until only the lines that were 'the clearest and simplest' remained on the page. In this sense, illustrations that appeared in L'Esprit Nouveau, such as "Boudoir" (LEN no 27), or "Cabinet de Travail" ( $L E N \mathrm{n}^{\circ}$ 28), both belonging to the Atelier Primavera des Magasins du Printemps, would not seem out of place in a comic book by masters of the Franco-Belgian 'ligne claire' such as Hergé, Joost Swarte or Yves Chaland. The overlaps with Töpffer are particularly vivid in Le Corbusier's sketches of human figures after photographs, where organic, curving lines instilled the figures with a dynamism and liveliness that the inevitably static photographs lacked. As opposed to the staleness of photography, or traditional architectural rendering, Le Corbusier's trademark ligne claire style allowed his architectural representations to convey a meaning, transmit a message, or even tell a story. Colomina pictures Le Corbusier 'reworking... his fetishized drawings'. However, it seems worth adding that there was a particular type of drawing that Le Corbusier had a fetish for: drawings that progressively left L'Eplatenier's naturalistic approach behind and searched for a certain iconic stylization that rendered his buildings, and reality itself, in their ideal state ${ }^{19}$-or perhaps it just rendered them as Le Corbusier saw them. If we design with the images we have in our mind, one wonders to what point Jeanneret's mind might had been shaped by Töpffer's calligraphic imagery, and whether to what point the latter's synthetic approach to drawing appeared as a perfect way to convey graphically the spirit of synthesis the former was looking for ${ }^{20}$. In the suspended reality of a kindly drawing style, standing somewhere between the architectural rendering and the sketch, Le Corbusier's machine-houses overcame their previous artificiality and blended with their surroundings. Töpffer's 'ligne claire' presented itself as a tool to represent the utopian dimension of modern architecture.

\footnotetext{
${ }^{19}$ Compare, for instance, the extensive use of (heavily edited) architectural and vehicle photographs in "Trois rappels a messieurs les architectes" (LEN n $\left.{ }^{\circ} 1\right)$, or "Des yeux qui ne voient pas... Les Paquebots" (LEN nº 8) with the ubiquity of handmade drawings in the articles of later issues, such as "Maisons en Série" (LEN n $\left.{ }^{\circ} 13\right)$.

${ }^{20}$ Obviously, this 'ligne claire' style is not alien to the tradition of architectural representation. Even in the same period we can find examples which bear even a closer resemblance to Hergé's Tintin. Victor Bourgeois's renderings for La Cité Moderne in Berchem-Sainte-Agathe from 1922-25 are very explicit in this sense. What makes Le Corbusier's case especially relevant is his refusal to give an accurate definition of the architectural object, which rather stays in an intermediate stage of evanescence, constructed by imprecise lines and dots. Le Corbusier's drawings seem to want to retain the narrative options of the cartoon, turning the buildings into characters which, subject to multiple readings by the viewer, evolve and interweave with their environments, blending with them.
} 

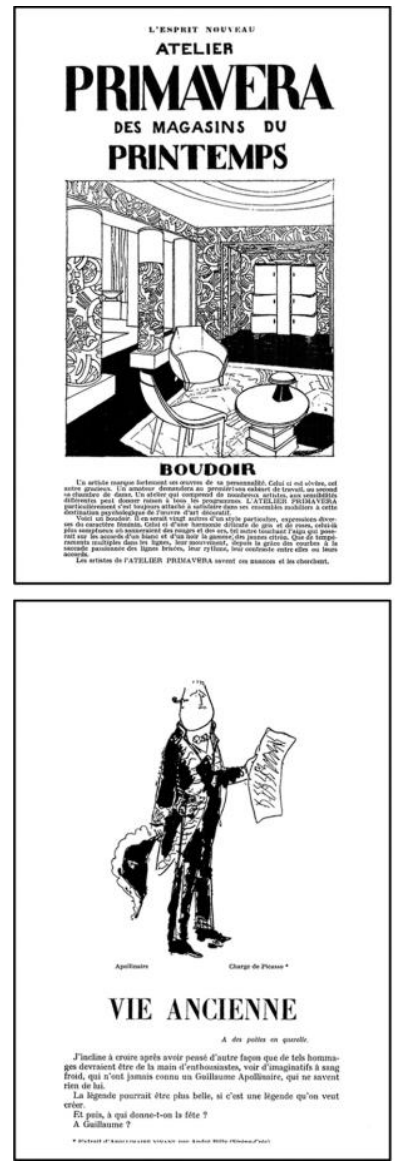
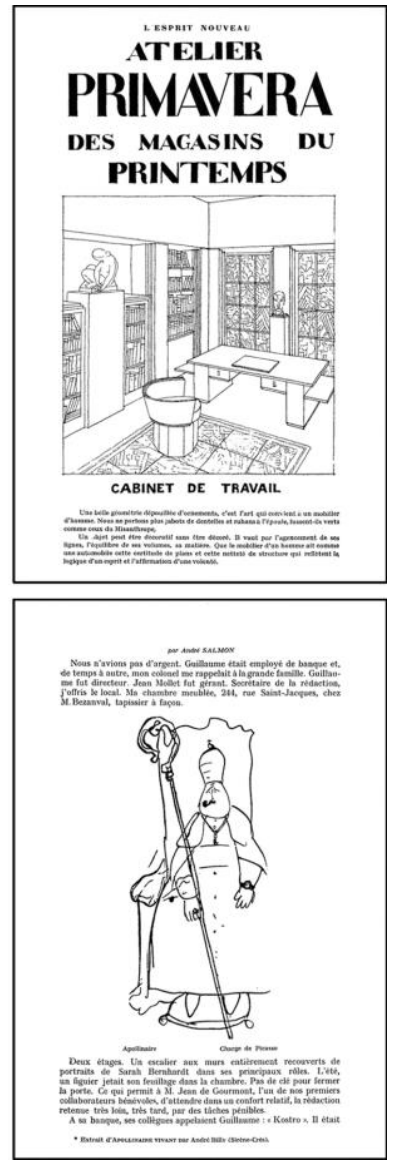
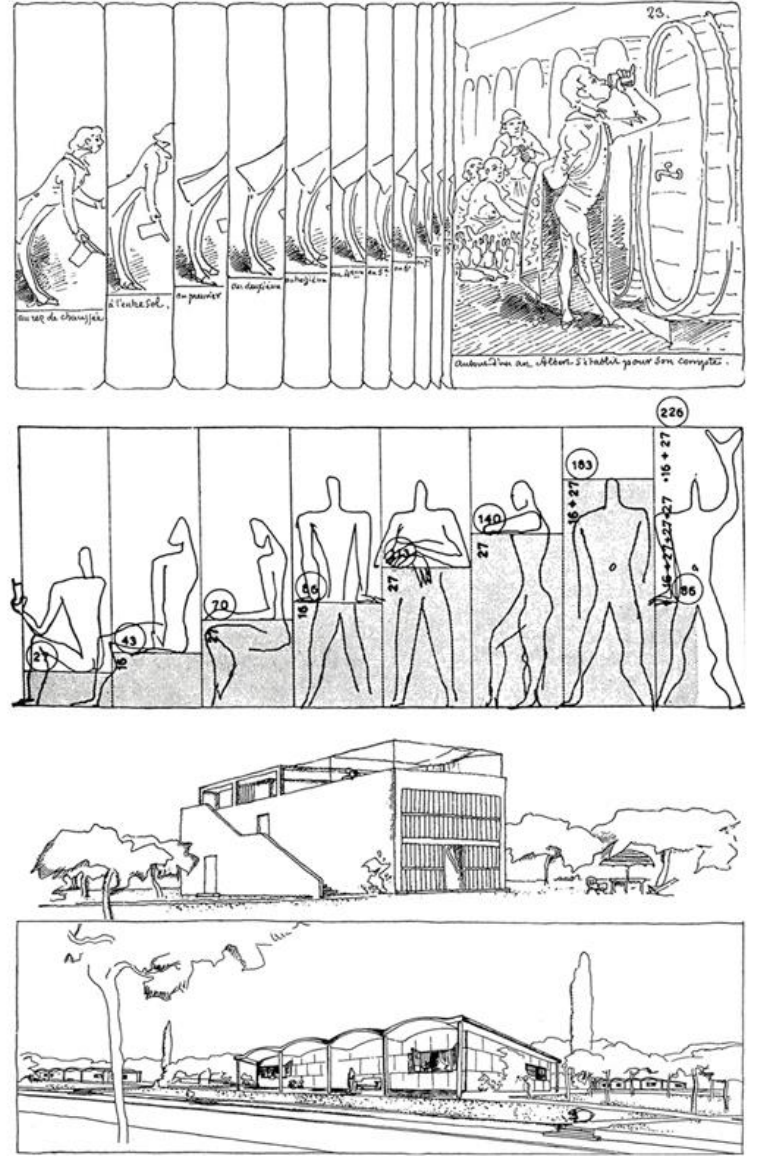

4. L'Esprit Nouveau and drawing: [12], [13] Atelier Primavera des Magasins du Printemps: "Boudoir" (LEN n $\left.{ }^{\circ} 27\right)$, and "Cabinet de Travail" ( $\left.L E N n^{\circ} 28\right)$. [14, 15] Cartoons by Picasso in André Salmon's "Vie Anciene" (LEN no 26).

5. Töpffer / Le Corbusier: Sequential drawing and Platonic utopias: [16] Rodolphe Töpffer: Plate from Histoire d'Albert,, 1845. [17] Le Corbusier: Le Modulor., sequence of proportions in relation to height, 1954. [18-19] Le Corbusier-Saugnier: Renderings of the Maison Citrohan (1921) and the Maison Monol (1919) published in "Maisons en Série" (LEN n 13). CFLC-ADAGP.

But also, Töpffer's works had an additional quality also reflected on Le Corbusier: Töpffer's simplified, pervasively linear style spawned both from the requirements of the printing technique he used, and from their nature as a vehicle for the narrative. And this narrative aspect is a key element when analyzing Le Corbusier's graphic production. As Colomina points out, in relation with Corbusier's use of advertising techniques, he frequently used 'the association of ideas that can be produced through the juxtaposition of images and of images with writing.' In Le Corbusier, '[i]mages are not used to "illustrate" the text; rather they construct the text ${ }^{, 21}$. Certainly, the juxtaposition of images and words was frequent in Le Corbusier, who found in the different forms graphic narrative a useful communication tool.

\footnotetext{
${ }^{21}$ Publicity brochure for Vers une architecture, 1923 (?). See Colomina, Op. cit., p. 15.
} 


\section{Linear narratives and Narratives en Zigzag.}

"Los dibujos que ilustran diversos proyectos de Le Corbusier hacen uso de un heterodoxo orden narrativo... los textos incluidos (la voz en off del arquitecto) evolucionan a la par de las imágenes, configuran una narración próxima al lenguaje fílmico o al del cómic e introducen el tiempo en el espacio, que sería difícilmente perceptible desde un estático punto de visión. "122

One of the first instances where Le Corbusier used some sort of graphic narrative might be his plate for the article Classement et Choix ${ }^{23}$ ('Ordering and Choice') in L'Esprit Nouveau $\mathrm{n}^{\mathrm{o}} 21$ (1921). Here, after a succinct recount of his intermittent Grand Tour of 1907-11, he concluded with a 'menu' of sorts (the term is used by von $\operatorname{Moos}^{24}$ ) where he presented four 'tasty bits' of his trip: Pera (Istanbul), Istanbul as seen from the Bosporus, a third panel containing isolated domes, arched windows and superimpositions of geometrical shapes, and finally, a drawing of Siena's skyline. All images were framed in four consecutive panels with captions on their right, making the whole work like one of Töpffer's comic strips lying on its side. As von Moos notes, "[t]he focus of interest lies not so much in the urban configurations as such, but in the mechanism of their perception. As with "Mr. Pencil" in Topffer's "strip," it is the drawing that matters, not the landscape it represents... the emotion a place generates, not the nature of that place as such. ${ }^{25 "}$ Indeed, the whole tableau seems to work mainly as a linguistic exercise where Le Corbusier tests the possibilities of the comic strip as a communication device, playing with the alliterations between the urban landscapes he represents in order to articulate a visual narrative in the mind of the reader in a more effective way than an illustrated text would. In that sense, the mechanism works, for the adjacency between the cityscapes, all represented in a similar style, conveys a certain cinematographic illusion: In the eye of the reader -the contemporary reader, at least- the changes of size, scale, and point of view read as a camera zooming in an out on an urban landscape.

This and other examples of panel grids used to frame images, or sequences of images and texts arranged on the page in order to build a discourse, are frequent and varied in Le Corbusier's production, and L'Esprit Nouveau featured several of them: The essay "Sur la Plastique", published in the first issue (LEN no 1, 1920; 38-48) and signed by Le Corbusier and Ozenfant, contains several pages with figures made of different arrangements of square panels housing repeated objects, lines, drawings of buildings, or photographs with varying degrees of similarity with the language of comics: A four-panel strip on top of page 44, which features four vistas of different buildings, conveys a similar narrative feeling as Classement et Choix, albeit without the use of words. The arrangement of squares at the bottom of the same page works mostly as an abstract diagram that explains the geometrical patterns behind drawings, facades and buildings. The drawings on page 43, with its variations on the surface of a cylinder, and on page 45, which encases artworks by Monnet, Rodin, Juan Gris, Seurat, and archaic sculptures, classifying them as 'mauvais' or 'bon', are closer to a true 'menu' of images, and to the sensibility of Magritte's subsequent Les Mots et Les Images (La Révolution Surréaliste $\mathrm{n}^{\circ}$ 12, December 15, 1929), even if devoid of the latter's narrative quality.

\footnotetext{
${ }^{22}$ Baltanás, José: Le Corbusier, promenades. Barcelona: Editorial Gustavo Gili, 2005

${ }^{23}$ Le Corbusier: "Classement et Choix". In L'Esprit Nouveau n ${ }^{\circ} 21,1925$.

${ }^{24}$ Rüegg. Op. Cit., note 13, p. 26

${ }^{25}$ Ibid, p. 27
} 
A different take on the use of the grid can be found in Le Corbusier's 'iconostatic' layout for Le Poeme de l'Angle Droit, where the different plates were thematically arranged in a series of horizontal strips. Theoretically, this arrangement was supposed to suggest a conventional left-to-right, top-to-bottom reading order; however, the juxtaposition of the strips blurred them into a bigger, encompassing grid that opened the possibilities to establishing other reading orders, or even non-sequential narratives, as some experimental comics do nowadays. The publication in book format constructed a more conventional narrative; however, the graphic proximity of the rendering style and the calligraphy provides an integration between text and image that prevents it from becoming neither an illustrated text nor a commented picture book. Here, too, words and pictures work as a whole.
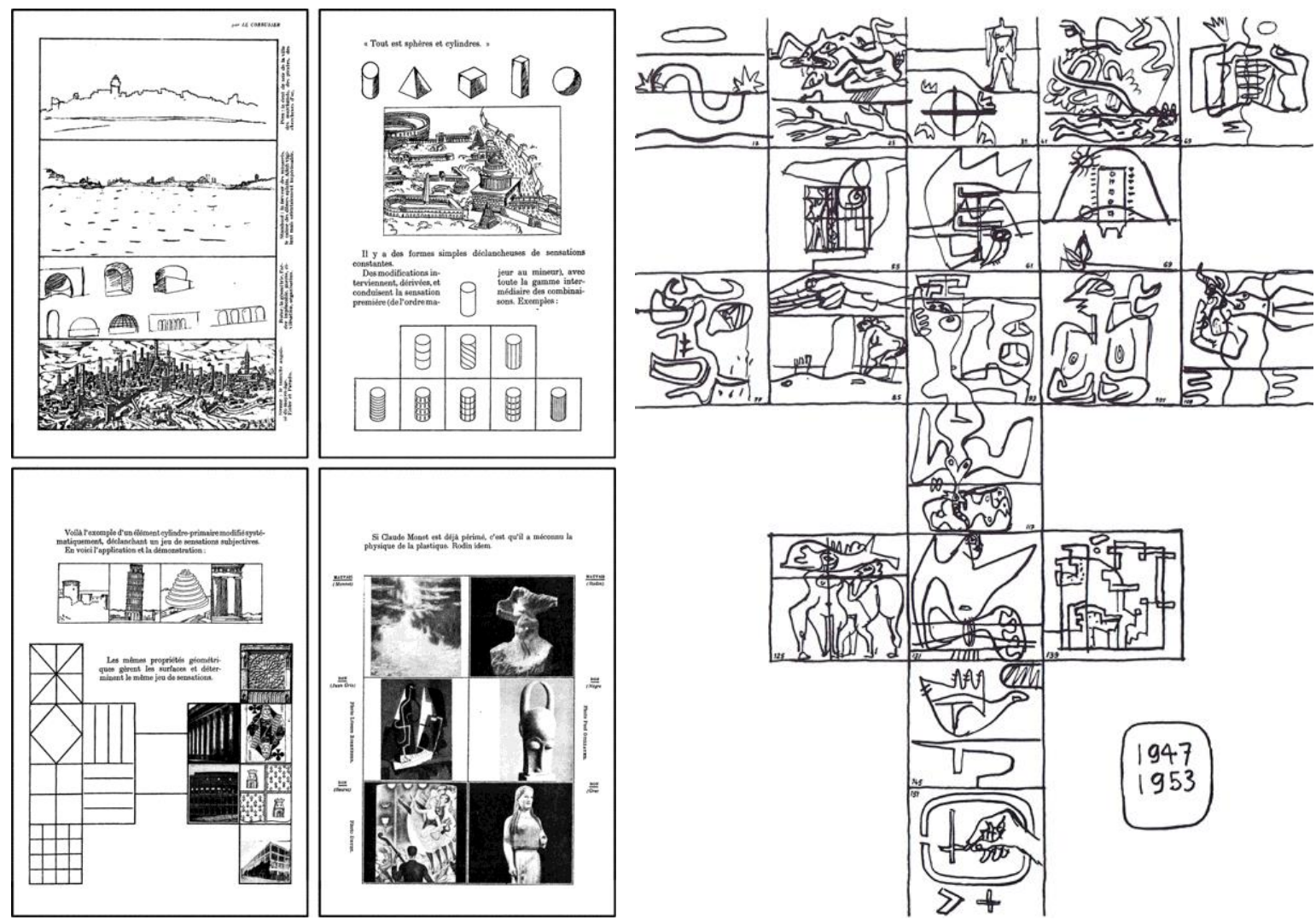

6. Ordering and panels: [20] Le Corbusier: Classement et Choix, $\left(L E N \mathrm{n}^{\circ} 21,1924\right)$. [21-23] Le Corbusier and Ozenfant: Sur la Plastique, (LEN n $\left.{ }^{\circ} 1,1920\right)$. OFLC-ADAGP.

7. Ordering and panels: [24] Le Poème de l'Angle Droit: Layout of the plates. OFLC-ADAGP.

This is hardly surprising. After all, the year 1918, which marked Le Corbusier's breakthrough into purism, also marked the first publication, among others, of Guillaume Apollinaire's Calligrammes. These hybrid forms indubitably helped define the imaginary of a still young Charles-Edouard Jeanneret, as Apollinaire's presence in $L^{\prime}$ Esprit Nouveau seems to confirm ${ }^{26}$. Adding to the use of panels, the combination of words and pictures, generally organized in a sequence of drawings in cascade, was another favourite of Le Corbusier that can be found at every point of his career: very obviously in cinq points d'une Architecture Nouvelle, most notably in les quatre compositions, and all throughout his multiple explicative -and narrative- sketches drawn in and around his conferences.

\footnotetext{
${ }^{26}$ See "Calligrammes" (LEN n 21 , March 1924; 103-7), and the entire $L E N \mathrm{n}^{\circ} 26$ (October 1924), a special issue dedicated to Apollinaire.
} 


\subsection{A matter of context}

Strange as they may seem from today's perspective, when Le Corbusier's figure is undetachably linked to the realm of high art, these excursions into the popular, the lowcult, the lesser forms of expression, were just a natural response to the zeitgeist of the time, and help illustrate the unprejudiced interest that the new forms of visual narrative arose in the artistic world. If Goethe had enjoyed Tópffer's early proto-comics (or proto-comic strips), the avant-garde certainly did not disregard the power of the newly-born form. Working in a moment where comics, heir to the tradition of the satirical press, were not firmly encoded as a medium for children yet, artists such as Pablo Picasso, George Grosz, or the surrealists ${ }^{27}$, were great admirers of 'the funnies', while others, such as Sergei Eisenstein where passionate admirers of the cartoonists (Honoré Daumier, in Eisenstein's $\operatorname{case}^{28}$ ). Through Gertrude Stein, we know that Picasso was a dedicated reader of Rudolph Dirks's Katzenjammer Kids, a strip made in the image of Max und Moritz, the series created by 'that' Busch mentioned by Le Corbusier ${ }^{29}$. Wilhelm Busch, on the other hand, was a very real influence in George Grosz's work, who admitted that he 'very much liked to flip through Wilhelm Busch' (as did Sigmund Freud, or Albert Einstein), even considering him a precursor to surrealism ${ }^{30}$. Paul Klee, on the other hand, regarded Busch as the 'First Futurist' and found in him "an intellectual kin". George Herriman's Krazy Kat was greatly admired both by 'popular entertainers such as Disney and Frank Capra', and by the intellectuality of the time, which included writers such as H. L. Mencken, Ernest Hemingway, T.S. Eliot, E.E. Cummings and Umberto Eco, or painters such as, again, Picasso, Joan Miró and Willem de Kooning ${ }^{31}$.

The aesthetics and, less surprisingly, the conventions and mechanics of sequential narrative presented an obvious appeal to an avant-garde scene whose work dealt with the search for a new vision, often related to the introduction of time lapse within perception. This fondness of comics' language was particularly patent among the surrealists: In the 1940s, the catalogue for the New York exhibition First Papers of Surrealism (1942), coorganised by André Breton and Marcel Duchamp included a panel from Superman next to a portrait of Friedrich Nietzsche; and Breton, who decades later would declare himself an admirer of Jean-Claude Forest's Barbarella $^{32}$, used speech balloons in his 1943 illustration Tragic, in the Manner of Comics. Much earlier, roughly at the same time that Le Corbusier was writing about Töpffer, the first issue of the New York Dada Magazine (1921) included a panel by mythical cartoonist Rube Goldberg, whose clumsy, ridiculously complex machineries have been noted by many authors as a precedent for the very similar machines that Duchamp (The Large Glass, 1915-23; Coffee Mill, 1911), and Francis Picabia (Ici, c'est ici Stieglitz, foi et amour, 1915) were producing at that point. This affinity was only natural, since many painters of this generation started as

\footnotetext{
${ }^{27}$ Sculptor David Hare, editor of the surrealist magazine $V V V$ (New York, 1942-44) championed comics in his essay "Comics", published in Les Temps Modernes $\mathrm{n}^{\circ}$ 1, 1946. Hare claimed for the legitimacy not only of comic strips, but even of the 'vulgar' comic books of the 1940s. See Hadler, Mona: "David Hare, Surrealism, and the Comics." In The Space Between: Literature and Culture, 1914-1945. December 2011, Vol. VII, No 1. pp. 93-108.

${ }^{28}$ See Ackerman, Ada: Regards de Serguë Eisenstein sur l'oeuvre d'Honoré Daumier: une réception méconnue. Advisor(s): Porterfield, Todd; Le Men, Ségolène. PhD Dissertation. Paris: Université Paris-Ouest-Nanterre-La Défense Montréal: Université de Montréal, 2010

${ }^{29}$ See Stein, Gertrude: The Autobiography of Alice B. Toklas. New York: Harcourt, Brace and Company, 1933, pp. 13-15.

${ }^{30}$ A thorough overview of Wilhelm Busch's influence on culture and art during his time and after can be found in Angelika Morris's excellent Manifestations of Wilhelm Busch's Aestheticsin Eduards Traum. Supervisory Committee: Dr. Angelika Arend, Dr. Helga Thorson, Dr. Lisa Surridge. Masters Dissertation. University of Victoria, Victoria (BC), 2010.

${ }^{31}$ See Heer, Jeet: "Krazy Kat reprinted by Fantagraphics". In National Post. Toronto: Postmedia Network, April 2002, and O'Connell, Karen et al: Krazy Kat: The Comic Art of George Herriman. New York: Harry N. Abrams, 1986.

${ }^{32}$ See Forest, Jean Claude: "Ma vie, mon oeuvre, en douze pages, pour en finir avec cet episode et passer a autre chose". In $A$ Suivre. January 1984, № 73. pp. 45-56.
} 
commercial humorists; Duchamp himself wanted to launch a career as a humorous cartoonist before turning to the higher plateau of Fine Arts $^{33}$.

Many avant-garde artists experimented with comics at one point or another: both Dalí and Eisenstein -who was a consummated caricaturist-, drew comic strips in their youth ${ }^{34}$, and even Picasso produced a series of 5 consecutive drawings with captions made on occasion of a trip to Barcelona in 1904. But most interestingly, many of those incorporated sequential narratives in their work too: René Magritte used multi-panel compositions in several occasions, such as The Interpretation of Dreams (1935) -a variation on Les Mots et les Images-, l'arc en ciel (1948), and l'homme au journal (1928), a four-panel composition where the disappearance of the main character after the first frame suggests the lapse of time. Speech balloons were also frequent in his works, such as l'usage de la parole (1928) or Drat! (1948). Dalí, on the other hand, created several works that showed a clear affinity with comics while he was living in New York: "Crazy Movie Scenario", one of the illustrations he produced for The American Weekly, and two beautiful pages of preparatory designs for the ill-fated film Les Mystères surréalistes de New York (1935) that stood somewhere in between a storyboard and a comic strip ${ }^{35}$. Even Picasso, whose work has often been qualified as narrative -even if sometimes in a derisive way ${ }^{36}$ - used the narrative possibilities of the panel sequence in Songe et Mensonge de Franco (1937), two plates of "etchings in comic-strip form" where he depicted Franco's "calamitous effect on civilization and on the lives of ordinary citizens $^{\prime \prime 37}$.
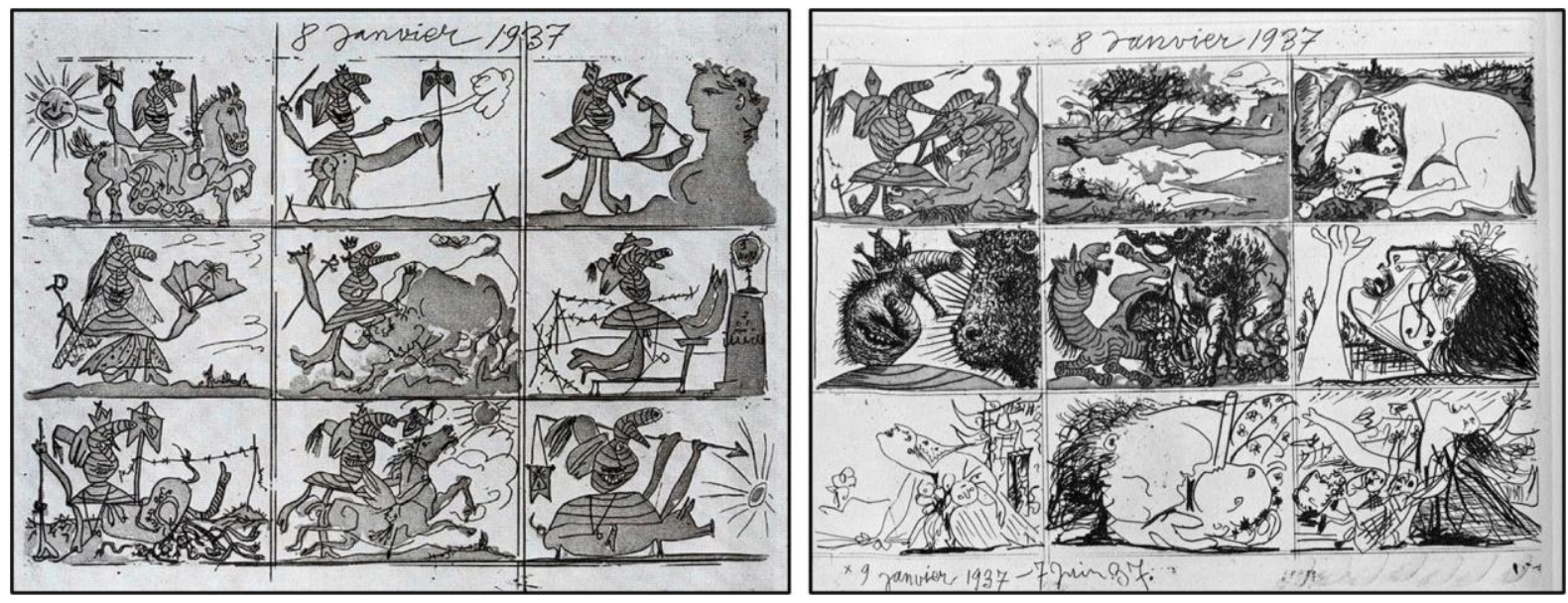

8. Surrealism and bande dessinée. [25] Pablo Picasso: Songe et Mensonge de Franco (1937).

\footnotetext{
${ }^{33}$ For a survey on the connections between the Surrealists and Rube Goldberg, see North, Michael: "Goldberg Variations". In Machine-Age Comedy. New York: Oxford University Press, 2008.

${ }^{34}$ In 1916, a 12-years-old Salvador Dalí drew a series of one-page strips -possibly copied from magazines- as well as singlepanel cartoons for his younger sister Ana María [see Raeburn, Michael (dir.): Salvador Dalí: the early years. London: Thames \& Hudson, 1994].

${ }^{35}$ A survey on Dalí's excursions into comics and cartooning can be found in Roig, Sebastià: "Els ninots de Dalí". In Diari de Girona, Sunday Supplement, August 72011.

${ }^{36}$ I am referring to Georges Boudaille's review of the Salon de Mai in 1968. See Holloway, Memory Jockisch: Making Time: Picasso's Suite 347. New York: Peter Lang Publishing, 2006, p. 33.

${ }^{37}$ Utley, Gertje: Picasso: The Communist Years. New Haven: Yale University Press, c2000, p. 18. One of the earliest and most vocal proponents of the relationship between Songe et Mensonge de Franco and comics was Gerald Gassiot-Talabot, who made this connection for the first time in the exhibition La Figuration narrative Dans l'art contemporain' (Galerie Europe / Galerie Creuze, October 1965). See also: Couperie, Pierre; Gassiot-Talabot, Gerald: Bande Dessinée et Figuration Narrative, Paris: Musée des Art Decoratifs, 1967. Some authors even argue that Roy Lichtenstein's variations on Picasso's Woman in an Armchair are a comment on the Spanish painter's fondness of comics.
} 
The avant-garde's relationship with comic books was old and deep, and can be tracked back almost to the origins of the medium, as pointed out by Lyonel Feininger, whose etching Kathedrale (1919) was used by Walter Gropius in the Programm des Staatlichen Bauhauses in Weimar to illustrate the 'synthesis of the arts'. Long before breaking out as a renowned painter and member of the Berliner Sezession and the German expressionist groups (Die Brüke, Der Blaue Reiter, the Novembergruppe et al), Lyonel Feininger had been a successful cartoonist and one of the pioneers of American comics, creating two comic strips, "The Kin-der-Kids" and "Wee Willie Winkie's World" 1906-7 for the Chicago Tribune that stand as landmarks in the history of the medium.

Le Corbusier was certainly aware of all the agitation that was taking place in an avant-garde scene he himself belonged to, glimpsing the potentialities of this transmediatic hybridization between mass media and art, between fine arts and popular culture. One can only imagine Le Corbusier's joy when he was given back Louis Soutter's 'illustrated' version of Une Maison, un Palais (1928), with its pages turned into beautiful pictograms. However, Le Corbusier's interest in graphic narrative seems to spawn less from its abilities for artistic agitation than from a search for clarity. Töpffer's strips were so valuable because of their inherent economy: they were ideal because they were the perfect vehicle to transmit a clear, distinct message; because their simple, abstract outlines could be completed in the reader's mind with all the details they lacked, not letting the latter obstruct the flux if the narrative. All these aspects are very vividly illustrated by Le Corbusier's presentation of his Ville Contemporaine (1922) in the last issue of L'Esprit Nouveau (January 1925), where the overlap with Töpffer makes itself more evident, depicting the project was depicted in a cinematographic sequence of four panoramic panels with captions that fit in the tradition of the XIX Century 'broadsheets' where Busch's drawn stories had been gestated.
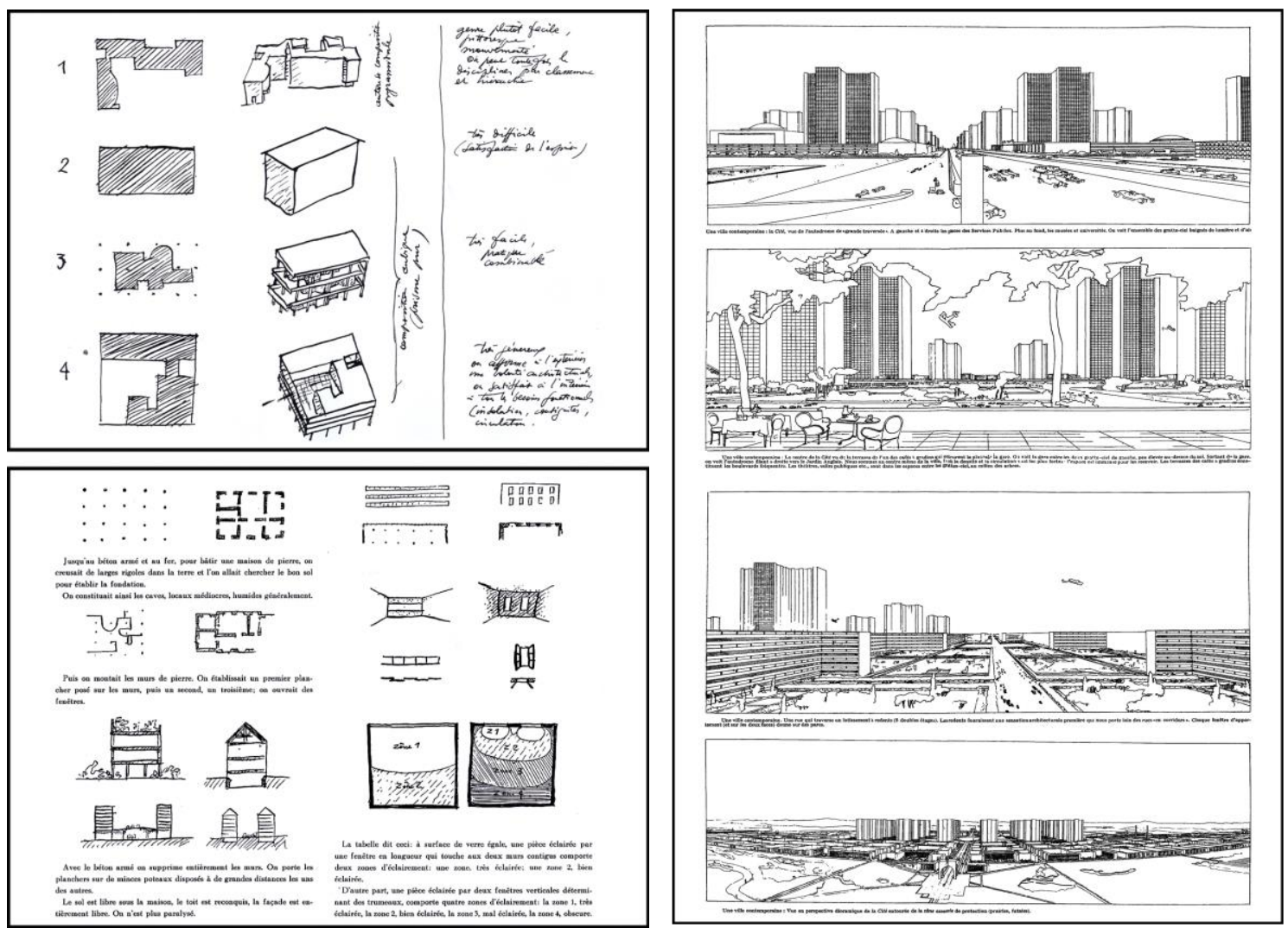

9. On Storytelling. [26] Les quatre compositions, 1929. [27] Cinq points d'une architecture nouvelle, c1927. OFLC-ADAGP.

10. [28] Presentation of Une Ville Contemporaine (1922) in L'Esprit Nouveau $\mathrm{n}^{\circ} 28$, January 1925. OFLC-ADAGP. 


\section{Beyond the panel: The Letter to Madame Meyer. From Sequence to multi-sequentiality, from Promenade to Enjambment}

This kind of sequential panoramas, which literalize the cinematographic suggestions of "Claissement et choix" are frequent throughout Le Corbusier's published works. His Oeuvre Complète shows many instances of this, such as the series of drawings of New York from the ferry accompanying "Méditation sur Ford" (OC 1934-38, pp. 16-7), the vignettes on the environment of Fort-l'Empereur, or his trip through a simplified Paris in La Ville Radieuse. Digging through his working documents, we can also find many occasions where he used narrative, sequences of drawings, vignettes, or storyboard-like compositions for multiple purposes. In the aforementioned "Le Corbusier and Photography", Beatriz Colomina shows some of those: a series of vignettes with instructions to modify some photographs of S. Maria di Cosmedin for their publication in Vers une architecture; a page of sketches from the draft manuscript of Vers une... which could easily be mistaken for a preliminary for Magritte's Les Mots et les Images; or a drawing by Le Corbusier with the word "Roneo" on top illustrating sequentially his controversy with Auguste Perret over the fenêtre en longueur.

However, from an architectural point of view, the most interesting documents are those where graphic narrative appears as a tool used to represent a specific conception of architectural space. In Le Corbusier's career, this moment is unquestionably represented by his Lettre a Madame Meyer (1925), wherein the Swiss architect introduced the client to his design concepts for the never-built Ville Meyer at Neuilly-sur-Seine through a series of footnoted sequential vistas of the house. Anecdotic as it might seem, this letter -actually an annotated storyboard- marks a key moment in the evolution of Le Corbusier's conceptualization of space, both by recording it (the change), and by providing the architect with a tool to represent and explore his new conception. As Bruno Reichlin explains in his seminal "Jeanneret - Le Corbusier, Painter/ Architect" ${ }^{38}$, in the lapse from the 1900 s to the 1930s, Le Corbusier's conceptualization of space evolved from the fragmented compartmentation of Beaux Arts architecture, to the sequentiality of the prómenade architecturale and, finally, to the simultaneity of architectural enjambment. In his discussion, Reichlin argues that this evolution from a sequential to a simultaneous conception of space, where architectural spaces interpenetrate each other, is related to Jeanneret's experiments in purism: Therefore, paintings such as The Red Bowl (1919) or Still Life with Stack of Plates and a Book (1920) display a space that unfolds under the glance of the spectator, revealing, behind their apparent flatness, the coexistence of different spaces that overlap in silent collision.

\footnotetext{
${ }^{38}$ Reichlin, Bruno: "Jeanneret/Le Corbusier, Painter-Architect". In Blau, Eve; Troy, Nancy J. (eds.): Architecture and Cubism. Montreal: Canadian Centre for Architecture; Cambridge, Mass: MIT Press, 1997. pp. 195-218.
} 

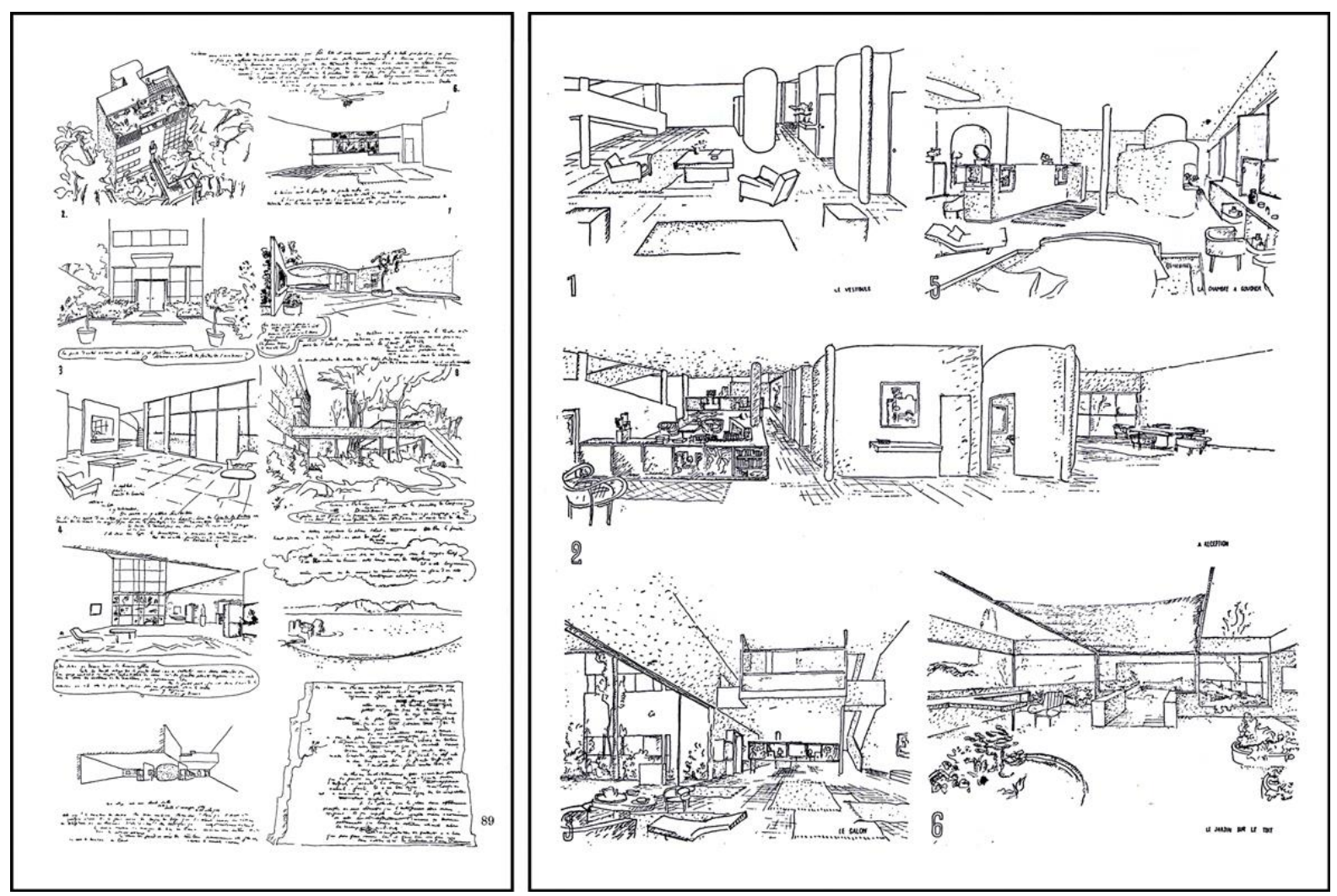

11. The Letter to Madame Meyer. Le Corbusier: Lettre a Madame Meyer, October 1925. Original document [29] and an excerpt of a sheet with sketches for the second project [30]. OFLC-ADAGP.

In this context, Reichlin argues that the letter, in which the architect exploited 'all the cinematic possibilities of the cartoon', rendered a space where "... perspectives extended to the point of taking in an entire itinerary. They presuppose movable points of view, cavalier perspectives, and rapid zoom shots, from panoramic view to closeup of plan. Explanatory cartoonlike 'bubbles' are inserted to avoid breaking the optical continuity that the drawings suggest, and to prevent the reader from mistaking these drawings -these graphic annotations- for illusionistic renderings of the building to be built." Certainly, they were not supposed to be built, because they were, rather than the representation of an architectural space, the representation of the perception of that space. Previously we noted how cinema, a discipline located in the intersection between technology and art and capable of gathering together image and narration, was inevitably chosen as the medium to capture and reproduce the fast experience of space that the new urban world brought about. However, the reality of the modern perception of space entailed a multiplication of the points of view which, alchemically fused in the flâneur's retina throughout time, generated a simultaneous experience of space: both the one in front of the viewer, but also those spaces perceived with the corner of the eye, and even those he just walked through, retained by retinal persistence. This is the type of perception that the avant-garde, be it via collage or cubist painting, tried to represent, introducing kaleidoscopic visions bred in the post-humanist refusal of a privileged point of view.

These are also the two modes of vision that can be identified in Le Corbusier, exemplified by his cinematic perception of the Acropolis in Athens (Vers une Architecture, 1923), and the simultaneous perception of space depicted by the Lettre a Madame Meyer. It is in this context where the letter, a marginal document that stands somehow out -tangent at most- of the general line of Reichlin's discourse, bears, however, a pivotal role in the full understanding of the influence of purism on Le Corbusier's move towards enjambment, and shows that his disparate interests in the different media are in fact parts of a single exploration. To a certain extent, it works as a 
mediator between cinema and purism, and between the latter and architecture. On the one hand, with its introduction of a space-time sequence within the encompassing space of the page, the graphic narrative of the letter mediates between the substitutive sequentiality of cinema, where each moment is automatically replaced by the next one, and the simultaneity that we find in purist painting. As opposed to the temporal sequence, the letter builds a physical sequence in praesentia ${ }^{39}$ where each individual space can be inspected in isolation, while still perceiving its connection with the rest. Thus, the concomitances between La Lettre and purism unveil a further presence in the latter's spatial juxtaposition/superimposition: Along with the multispatiality pointed out by Reichlin, we can argue that purist paintings enclosed -in a less rhetorical way than cubist painting ${ }^{40}$ a multitemporal experience, becoming, like the cartoon, a still mechanism that gets activated under the effect/action of the glance of the reader. In this context, La lettre becomes especially significant because it clarifies this journey from painting to architecture by showing the encounter of Jeanneret and Le Corbusier in a medium that offered a meeting point between painting and architectural design, and between the abstraction of purism and the concretion of architectural rendering.

The spatiotemporal qualities of la Lettre a Madame Meyer become even clearer when comparing it with the pages of the comics available at the time, which had already evolved from single strips to full-tabloid pages. In this sense, the most vivid example might be the well-known plates of September 22 and 29, 1907, of Little Nemo in Slumberland, where Winsor McCay took his characters on a dreamlike journey through a hyperbolic Manhattan. Free from the constraints of reality, McCay built a much more complex version of the letter's multispace, but the mechanics are essentially the same. In this case, the espace encadré (framed space) of each single panel is merged, with the mediation of the immaterial ether that fills the space between frames, into a supraspace conformed by the joint perception of the espace multicadre (multi-panel space) of the page. In McCay's case, this supraspace appeared in the form of a non-Euclidean, hyperurban scenario that underlined the urban origin of the kaleidoscopic/panoptic vision cultivated by the Cubists. However, it is notable how Reichlin's remarks ('the cinematic possibilities of the cartoon', 'perspectives extended to the point of taking in an entire itinerary', 'movable points of view', 'optical continuity') could equally be used to describe these plates. Curiously enough, the same kaleidoscopic vision can also be found in a sketch drawn by Le Corbusier that same year: an annotated study of Santa Croce in Florence, done during his first trip to Italy, where the viewing eye became progressively fragmented and the watercolours gave way to a more synthetic, linear style.

\footnotetext{
${ }^{39}$ For some insight on the concept of sequence in praesentia, see Groensteen, Thierry: "Töpffer: the Originator of the Modern Comic Strip". In Lefèvre, Pascal; Dierick, Charles (eds.): Forging a New Medium: The Comic Strip in the Nineteenth Century. Brussels: VUB University Press, 1998, p. 108.

${ }^{40}$ As Reichlin notes, "[i]n theoretical writing on cubism, the theme of duration, the time required to read a work, to read a representation that in fact has the notion of time implicit in it, constantly recurs... But the theme of duration was in the air at the time." To support this comment, Reichlin quotes Jean Metzinger in "Cubisme et la tradition" (Paris-Journal, August 16, 1911): "([he cubists] have allowed themselves to move around the object... Formerly a picture took possession of space, now it reigns also in time." See Reichlin, op. cit., note 28, p. 216.
} 

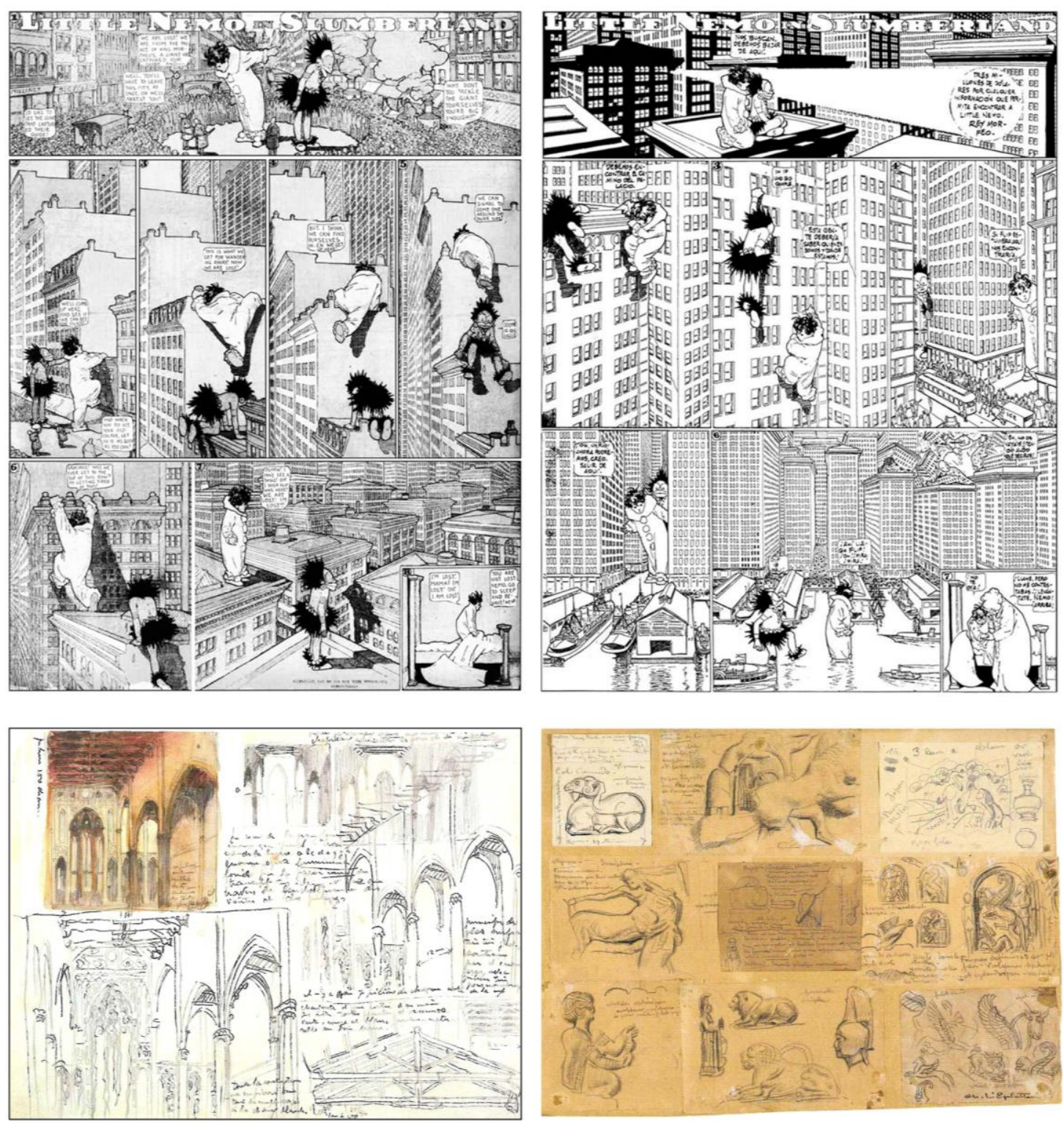

12. 13. Kaleidoscopia. [31, 32] Winsor McCay: Little Nemo in Slumberland, Sunday pages from September 22 and $29,1907$. [33] Charles-Edouard jeanneret, Interior Study of S. Croce, Florence, 1907. pencil and watercolor on ivory paper, FLC (149). CFLC-ADAGP [34] Charles L:Eplattenier, Monumental sculptures from various museums (including the Louvre?), pencil and ink on 9 sheets of notepaper, pasted on wrapping paper.

Thus presented, the evolution of Le Corbusier's conception of architectural space (compartmentation / promenade / enjambment) mirrored the development of the mechanics of graphic narrative (broadsheet /comic strip / comic page): The broadsheets, an ancestor of comics that had gained an increasing popularity by the eighteenth century had consisted generally of a static succession of commented scenes usually arranged within a grid. Töpffer's revolution in the 1830 s was to imbue the medium with a cinematic impulse, by making them actual bandes dessinées (literally drawn strips) that captured movement and depicted spatially the lapse of time. Thus, Töpffer precluded, more than half a century before the advent of cinema, the form of the filmstrip and the very logic of the unidirectional montage of cinematography. By the 1910s, this cinematic impulse had already been expanded from the unidirectionality of the strip into the two-directional space of the page. 


\section{Beyond Purism (A Conclusion).}

Beyond their interest as isolated elements of study, all these concomitances, only help underline the role that apparently minor disciplines may have in the understanding of the architectural fact. This is even more necessary when studying Le Corbusier, whose omnivorous appetite for anything related to visual culture, paired with his transversal, promiscuous understanding of architecture, makes the examination of the periphery of the discipline -of culture, even- almost obligatory. In this sense, the exploration of Le Corbusier's relationship with Töpffer, with cartoons, and, in an ampler spectrum, with the medium of comics -whose development overlapped with Jeanneret's own life-, helps complete the understanding of his relationship with the media, but even more interestingly sheds some new light on crucial aspects of his figure: his search of a certain approach to drawing, his aesthetic preferences, his use of communicational tools, and even the evolution of his conception of space. From its location within popular culture, the presence of the bande dessinée suggests a new direction that helps build the grounds where Le Corbusier's aesthetic imaginary was forged, opening up new aspects of his complex personality, and bringing in a new angle about the multi-faceted context in which modern architecture was gestated.

\section{Source of images}

[1-4] Le Corbusier (De Fayet): “Toepffer, précurseur du cinema”. Printed in L'Esprit Nouveau No 11-12, November 1921, pp. 1336-1346. [5] Le Corbusier: La ville radieuse, éléments d'une doctrine d'urbanisme pour l'équipement de la civilisation machiniste. Boulogne (Seine): Éditions de l'architecture d'aujourd'hui, 1935, p. 208. [6-9] Le Corbusier: L'Art decoratif d'aujourd'hui, 1925. Printed in Colomina, (1987), p.9. [10] Rodolphe Töpffer: sketches. Source unknown. [11] Rodolphe Töpffer: Essai de physiognomonie. Genève: par autographié chez Schmidt, 1845, p. 25. [12] Printed in L'Esprit Nouveau no 27, November 1924. [13] Printed in L'Esprit Nouveau no 25, July 1924. [14, 15] Pablo Picasso: Cartoon for André Salmon's article "Vie Anciene". Printed in L'Esprit Nouveau $\mathrm{n}^{\circ}$ 26, 1924. [16] Rodolphe Töpffer: Histoire d'Albert, Geneva: Self-published, 1845, p. 23. [17] Le Corbusier: Le Modulor, sequence of proportions in relation to height, and to harmonic furniture dimensions, c1946. FLC 7125. [18, 19] Le Corbusier-Saugnier: Maison Citrohan (1921); Maison Monol (1919) in "Maisons en Série". L'Esprit Nouveau $\mathrm{n}^{\circ}$ 13, December 1921. [20] Le Corbusier: Illustration for "Classement et Choix", L'Esprit Nouveau no 21, March 1924, pp. 1539, 1540-1. [21-23] Le Corbusier and Ozenfant: Illustrations for "Sur la Plastique", L'Esprit Nouveau n ${ }^{\circ}$ 1, October 1920, pp. 43-5. [24] Le Corbusier: Le Poème de l'Angle Droit: Lithographies Originales. Paris: Tériade, 1955. [25] Pablo Picasso: Songe et Mensonge de Franco (1937). National Gallery of Canada, ${ }^{\circ} 18726.1$ and 18726.2. [26] Le Corbusier: Les quatre compositions, 1929. Printed in Oeuvre complète1910-1929. Zurich: Erlenbach, Éditions d'architecture, 1946, p. 189. [27] Le Corbusier: Cinq points d'une architecture nouvelle, ibid, p. 129. [28] Le Corbusier: Une Ville Contemporaine (1922). Printed in L'Esprit Nouveau no 28, January 1925. [29] Le Corbusier: Lettre a Madame Meyer, October 1925. Printed in Oeuvre complète1910-1929. Zurich: Erlenbach, Éditions d'architecture, 1946, p. 88. [30] Le Corbusier: Villa Meyer, Neuilly-sur-Seine. Second Project, c1925. Ibid, p 90. [25] Idem. Property of FLC. [27], [28] Winsor McCay: Little Nemo in Slumberland. New York Herald, 1907. [29] Charles-Edouard Jeanneret, Interior Study of S. Croce, Florence, 1907. FLC (149). Printed in Von Moos (2002), p. 30. [30] Charles L'Eplattenier: sketches. Bibliothèque de la Ville de La Chauxde-Fonds - Fonds Le Corbusier (277). Printed in Von Moos (2002), p. 160.

\section{Bibliographical References}

Ackerman, Ada: Regards de Sergueï Eisenstein sur l'oeuvre d'Honoré Daumier: une réception méconnue. Advisor(s): Porterfield, Todd; Le Men, Ségolène. PhD Dissertation. Paris: Université Paris-Ouest-Nanterre-La Défense - Montréal: Université de Montréal, 2010.

Aylmer, Maude: The Life of Tolstoy: First Fifty Years. New York: Dodd, Mead, 1910.

Baltanás, José: Le Corbusier, promenades. Barcelona: Editorial Gustavo Gili, 2005. 
Colomina, Beatriz: "Le Corbusier and Photography". In Assemblage. October 1987, № 4. pp. 6-23.

Corbusier, Le; Ozenfant, Amédée: L'Esprit Nouveau. 28 issues, Paris, 1920-5.

Corbusier, Le: Almanach d'architecture moderne. Paris: Éditions Crès, "Collection de l'Esprit Nouveau", 1925.

Corbusier, Le: Une maison - un palais. "A la recherche d'une unité architecturale.". Paris: Éditions Crès, "Collection de l'Esprit Nouveau", 1928.

Corbusier, Le: Creation is a patient search. New York: Frederick Praeger, 1960. English translation of L'Atelier de la recherche patiente, Paris: Vincent \& Fréal, 1960.

Couperie, Pierre; Gassiot-Talabot, Gerald: Bande Dessinée et Figuration Narrative, Paris: Musée des Art Decoratifs, 1967.

Edera, Bruno: Histoire du cinéma suisse d'animation. Lausanne: Cinémathèque suisse, 1978.

Forest, Jean Claude: "Ma vie, mon oeuvre, en douze pages, pour en finir avec cet episode et passer a autre chose”. In A Suivre. January 1984, N 73. pp. 45-56.

Groensteen, Thierry; Peeters, Benoît: Töpffer: L’invention de la Bande Dessinée. Paris: Hermann, 1994.

Groensteen, Thierry: "Töpffer: the Originator of the Modern Comic Strip". In Lefèvre, Pascal; Dierick, Charles (eds.): Forging a New Medium: The Comic Strip in the Nineteenth Century. Brussels: VUB University Press, 1998. pp. 105-14.

Hadler, Mona: "David Hare, Surrealism, and the Comics." In The Space Between: Literature and Culture, 1914 1945. December 2011, Vol. VII, No 1. pp. 93-108.

Heer, Jeet: “Krazy Kat reprinted by Fantagraphics”. In National Post. Toronto: Postmedia Network, April 2002.

Holloway, Memory Jockisch: Making Time: Picasso's Suite 347. New York: Peter Lang Publishing, 2006.

Kunzle, David: Father of the comic strip: Rodolphe Töpffer. Great Comics Artists Series. Jackson: University Press of Mississippi, 2007.

Metzinger, Jean: “Cubisme et la tradition”. In Paris-Journal, August 16, 1911.

Migayrou, Frédéric; Cinqualbre, Olivier: Le Corbusier: Mesures de l'homme. Catalogue of the Exhibition. Paris: Editions du Centre Pompidou, 2015.

Morris, Angelika: Manifestations of Wilhelm Busch's Aesthetics in Eduards Traum. Supervisory Committee: Dr. Angelika Arend, Dr. Helga Thorson, Dr. Lisa Surridge. Masters Dissertation. University of Victoria, Victoria (BC), 2010

North, Michael: “Goldberg Variations”. In Machine-Age Comedy. New York: Oxford University Press, 2008.

O'Connell, Karen et al: Krazy Kat: The Comic Art of George Herriman. New York: Harry N. Abrams, 1986.

Raeburn, Michael (dir.): Salvador Dalí: the early years. London: Thames \& Hudson, 1994.

Reichlin, Bruno: "Jeanneret/Le Corbusier, Painter-Architect". In Blau, Eve; Troy, Nancy J. (eds.): Architecture and Cubism. Montreal: Canadian Centre for Architecture; Cambridge, Mass: MIT Press, 1997 pp. 195-218.

Roig, Sebastià: "Els ninots de Dalí". In Diari de Girona, Sunday Supplement, August 72011.

Simmel, Georg: "The Metropolis and Mental Life". Adapted by D. Weinstein from Kurt Wolff (Trans.): The Sociology of Georg Simmel. New York: Free Press, 1950

Stein, Gertrude: The Autobiography of Alice B. Toklas. New York: Harcourt, Brace and Company, 1933

Utley, Gertje: Picasso: The Communist Years. New Haven: Yale University Press, c2000

Vogt, Adolf Max: "Remarks on the 'Reversed' Grand Tour of Le Corbusier and Auguste Klipstein". In Assemblage. October 1987, № 4. pp. 38-51. 
Von Goethe, Johan Wolfgang: Conversations of Goethe with Eckermann and Soret. London: George Bell \& Sons, 1874.

Von Moos, Stanislaus: Le Corbusier, Elemente einer Synthese. Frauenfeld, Stuttgart: Huber, 1968. English translation: Le Corbusier: Elements of a synthesis. Cambridge, Mass.: MIT Press, c1979.

Von Moos, Stanislaus: "Voyages en Zigzag". In Rüegg, Arthur; Von Moos, Stanislaus (eds.): Le Corbusier before Le Corbusier: Applied Arts, Architecture, Painting, Photography, 1907-1922. New Haven: Yale University Press, c2002. pp. 22-43.

Wogensky, André: Le Corbusier Sketchbooks. Cambridge: MIT Press and New York: Architectural History Foundation, 1981- 82. 


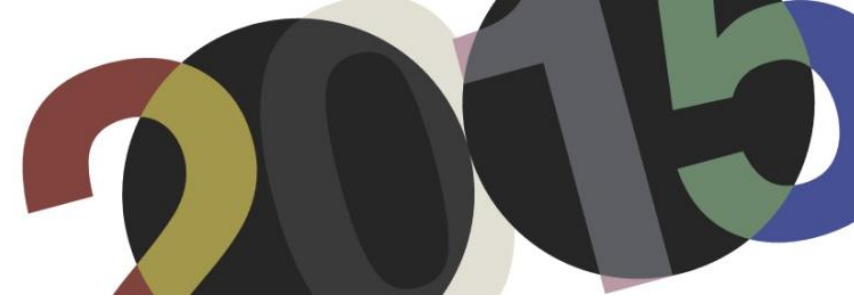

DOI: http://dx.doi.org/10.4995/LC2015.2015.978

\title{
Le Corbusier's legacy in the tropics: modern architecture in Angola and Mozambique
} (1950-70)

\author{
A. Magalhães \\ CITAD/ Centro de Investigação - Território, Arquitectura e Design / Universidade Lusíada
}

\begin{abstract}
Le Corbusier's work and thought are a predominant influence over the Modern Movement, and their worldwide spreading acquired a significant dimension during the Second Post-War period. Such predominance of the architectural models conveyed by Le Corbusier may have originated in the rationale enunciated in his written work, which clearly explains a set of doctrinaire parameters, or in his active determinant role in international organisations such as the CIAM, but particularly in his ability to become a global architect, which led to a large international publication of his work. This paper intends to analyse the significance of the Corbusian legacy in architectural production in Angola and Mozambique during the 1950 s and 1960s. These two former Portuguese colonies, far away from the centre of power dominated by the dictatorship of the so-called Estado Novo, were tantamount to a land of freedom and were, for a significant range of young architects working and building there, a laboratory for testing new languages of the Modern Movement, particularly on the basis of the Corbusian vocabulary. Two of those young architects Vasco Vieira da Costa (1911-1982) and Fernão Simões de Carvalho (1929-), who worked in Angola from the beginning of the 50s, were trainees in Le Corbusier's Paris ateliers. In addition to the work developed by those two architects, the specificity of the architectural production in Angola and Mozambique, particularly private order work, is clearly referenced to the Corbusian lexicon, whether in a more orthodox or a more hybrid way.
\end{abstract}

Keywords: Le Corbusier; Le Corbusier's legacy; Architecture in Lusophone Africa; Colonial; Tropical.

\section{Introduction}

“Le Corbusier, vous que j'ai vu ému par l'hommage filial du Brésil, voici l'hommage du monde...

(...) Voici les architectes de la Grèce, et ceux de l'Inde.

Voici le message d'Aalto, qui a transformé la Finlande, celui de l'Angleterre, qui dit: "Il n'est pas un architecte de moins de soixante ans qui n'ait été influencé par lui." Voici celui des Soviétiques: "L'architecture moderne a perdu son plus grand maître". Voici celui de Neutra, celui des architectes américains qui regrettent ce que vous pouviez faire encore.

Voici la voix du président des Etats-Unis: "Son influence était universelle, et ses travaux sont chargés d'une pérennité qu'ont atteinte peu d'artistes de notre histoire...". (...)

Voici l'hommage des villes épiques, les fleurs funèbres de New-York et de Brasilia.

Voici l'eau sacrée du Gange, et la terre de l'Acropole" André Malraux ${ }^{1}$

\footnotetext{
${ }^{1}$ Présence d'André Malraux sur la toile (2008-2013) André Malraux [Em linha]. [S.1. : s.n.]. [Consult. 12 Jul. 2014]. WWW:<URL:http://www.malraux.org/>.
} 
In his eulogy dedicated to Le Corbusier (1897-1965), André Malraux (1901-1976) stressed the universal nature of Le Corbusier's work and figure. It is a universal nature pointing to two ways: his knowledge of the world and the influence of his theoretical and built work on twentieth century architects. Le Corbusier's work and thought are a predominant influence over the Modern Movement, and their worldwide spreading acquired a significant dimension during the Second Post-War period. Such predominance of the architectural models conveyed by Le Corbusier may have originated in the rationale enunciated in his written work, which clearly explains a set of doctrinaire parameters, or in his active determinant role in international organisations such as the CIAM (Congrès Internationaux d'Architecture Moderne), but particularly in his ability to become a global architect, which led to a large international publication of his work.

This article's intention is to analyse the significance of the Corbusian legacy in architectural production in Angola and Mozambique during the 1950s and 1960s. These two former Portuguese colonies, far away from the centre of power dominated by the dictatorship of the so-called Estado Novo, were tantamount to a land of freedom and were, for a significant range of young architects working and building there, a laboratory for testing new languages of the Modern Movement, particularly on the basis of the Corbusian vocabulary ${ }^{2}$.

\section{Dissemination and legacy of Le Corbusier's work}

Within the framework of the Modern Movement, it is essential to understand which factors determined the dissemination of Le Corbusier's work and thought and the significance of his legacy. Firstly, we must consider the transnational dimension of his work, since, between non-implemented designs and built works, Le Corbusier designed all along his life projects for twenty-two countries in four continents, in lands as different as Russia or Brazil, Algeria or Japan. As Jean Louis Cohen expressed so well, Le Corbusier had "the planet as his building site".3. Such trans-nationality may be understood as well in the way he valued travelling, not only as a way of learning but also as le voyage utile, as he called it himself ${ }^{4}$, as a permanent element of reciprocity between the idea of knowing and the idea of disseminating. Le Corbusier's travels aimed at disseminating his work or spreading the modern doctrine (his own or the CIAM's) or procuring new projects have been often studied. Yannis Tsiomis, for instance, speaks about a "traveller's strategy" where we may find three constants: his contacts with the political or technical "authorities", the conferences he held for a more or less initiated audience, and his urban planning or architectural proposals for the places he visited, always procuring new orders ${ }^{5}$. The significance of international relations in his profession, both in the dissemination of his work and in the construction of a doctrinaire thought of a dominant nature, may also be seen in his decisive action in international organisations such as the CIAM. Additionally, we need to stress the extensive dissemination of his work in large circulation periodicals, notably through L'Architecture d'Aujourd'hui magazine with which he was always connected, and also the significance of the edition of an autobiographical narrative through his Oeuvres Complètes, which were published in eight volumes as from 1929.

In addition to his built work, Le Corbusier's vast written work, which cannot be dissociated from his creative process, was an essential means for the construction of a Modern doctrine. Within the framework of the Modern

\footnotetext{
${ }^{2}$ This theme was developed in the Phd thesis: Magalhães, Ana: Migrações do Moderno: Arquitectura na diáspora- Angola e Moçambique (1948-1975), directorship Ana Tostões; Fernando Hipólito, Universidade Lusíada de Lisboa, 2015.

${ }^{3}$ Cohen, Jean-Louis: La Planète comme Chantier. Paris : Textuel, 2005.

${ }^{4}$ Giedion, Sigfried: Space, Time and Architecture - The Growth of a New Tradition. $5^{\mathrm{a}}$ ed. Cambridge : Harvard University Press, 1997, p. 520.

${ }^{5}$ Tsiomis, Yannis (org.): Le Corbusier-Conférences de Rio: Le Cobusier au Brésil. 1936. Paris : Flammarion, 2006, p. 8.
} 
Movement, as Alan Colquhoun explained, "it was Le Corbusier who built its most elaborate theoretical grounds. His theory is significantly different from the theory of other architects not only its type but also in its degree. While for Walter Gropius the theory was instrumental and the drawing its direct product, for Le Corbusier the theory was justification. Le Corbusier tried to justify architecture as an autonomous normative discipline (...)". 6

His communication capacity allowed him to make his written work not only an essential means to disseminate his work and his way of thinking the world and architecture but also a form of consolidating his own knowledge. In 1920, he wrote: "To write a little puts ideas clearly, engages, compromises, constraints us to follow the strength of its theory. It is necessary to reflect constantly, all the time, at each pretext to be sensible. To be sensible, is to be conscious, the contrary to that which one attributes to sensibility. To write and to make the step of a giant and to cross clearly the underforces of his instints and sensations. ",

Another essential feature of Le Corbusier's written work (and also, in a way, his drawn and built work) consists in a constant return to the same themes; not only as a way of highlighting and disseminating his way of thinking and his work but also as a way of reflecting his own route: "Il n'est pas inutile, je le répète, de lire constamment dans son propre ouvrage. La conscience des évènements est le tremplin du progrès."8

Among his vast written work, we should highlight, first and foremost, the texts of "L'Esprit Nouveau" collection, particularly "Vers une Architecture", a book published in 1923. "Vers une Architecture" was surely one of the most read, discussed and interpreted books on architecture all along the twentieth century. Originally published in instalments in the Esprit Nouveau magazine, and written in a pamphleteer manner, "Vers une Architecture" is a great manifesto that translates as a poetic vision of architecture for a new age and a new spirit. Two main themes rule the speech of the work: the assertion of a way of architectural production in tune in the Age of the Machine and a critical disruption in History.

Although "Vers une Architecture" and the set of books in L'Esprit Nouveau were widely spread, "Cinq Points pour une Architecture Nouvelle" (1927), the statement written in the context of the presentation of the Weissenhofsiedlung projects, will actually be the work that will universally disseminate and reproduce the Corbusian premises. This is perhaps the text that, due to its simplicity and objectivity, will more effectively be the basis for an architectural lexicon. To comply with the "Cinq Points" meant to comply with the mathematical formula that allowed for designing Modern Architecture in a new construction and synthesis spirit within an international framework ${ }^{10}$. An exhaustive and categorical application of the "Five Points", and subsequently the Charte d'Athènes (1938-1941), was surely the way that was most identifiable with the globalized imagery of Modern Movement architecture, mainly in its production after the Second World War, both in the reconstruction of the European cities and in the construction in new lands.

During the post-war period, we should highlight the publication of Modulor (1950) followed by Modulor II (1955). The systematisation of a grid in proportions that try to establish a harmonic measurement in architecture based on the human body and mathematics that was presented in Modulor was widely used by architects and

\footnotetext{
${ }^{6}$ Colquhoun, Alan: Modernidade e Tradição Clássica, Ensaios sobre Arquitectura. São Paulo : Cosac e Naify, 2004, p. 99

${ }^{7}$ Boyer, M. Christine: Le Corbusier, Homme de Lettres. New York : Princeton Architectural Press, 2011, p. 298

${ }^{8}$ Le Corbusier: Précisions - Sur un État Présent de l'Architecture et de l'Urbanisme. Paris : Éditions Vincent Freal, 1960, p. 136

${ }^{9}$ Under the Collections de l'Ésprit Nouveau, Le Corbusier published seven books, all in the pamphleteer and propaganda tone of "Vers une Architecture" (1923): "Urbanisme" (1924), “Almanach d'Architecture Moderne" (1925), "L'Art Décoratif d'Aujourd'hui" (1925), "Peinture Moderne" (1925) com Amadée Ozenfant, "Une Maison, un Palais" (1928), "Précisions sur un État Présent de l'Architecture et de l'Urbanisme" (1930) and "Croisades ou le Crépuscle des Académies" (1933).

${ }^{10}$ Curtis, William J. R.: Le Corbusier Ideas e Formas. Madrid : Hermann Blume, 1987, p. 70.
} 
architecture students in Europe and the Americas as from the beginning of the 1950s, mainly upon the dissemination of the construction of the Unité d'habitation de Marseille. And it should be stressed that the Unité de Marseille was perhaps one of the most published and visited $20^{\text {th }}$ century architectural works. And that is why it became a universal, tested, repeated, copied model ${ }^{11}$.

Just like he did in Modulor, Le Corbusier published, in 1959, the second series of "Salubra, Claviers de Couleur" colour catalogue, in which he fulfils his need for systematising the architectural language and creating work instruments, and which results from the experiments he carried out all along his life, both in his architectural works and in his paintings. This second Salubra series acquires an expressive chromatic power that was tested in his second post-war works, such as the Unité de Marseille.

The significance of the extensive written work of Le Corbusier exceeds his doctrinaire assertion and its resulting dissemination within the framework of the Modern Movement. Beyond being a testimony of the times and History, the poetic dimension of Le Corbusier's texts underlines the complexity and wealth of the Corbusian legacy.

\section{The Corbusian heritage in the tropics: the case of architectural production in Angola and Mozambique during the 50s and 60s.}

After World War II, when Portugal was still living under a dictatorship, anachronistically valuing its empire and its colonies, a number of young architects went to Africa and affirmed a modernity that was far from the Statesanctioned architectural models. Such modernity was translated into freedom in a firmer appropriation of the modern movement codes in an international meaning.

It is permissible to establish that the first sign of flexibility and openness of Portuguese architecture to the forms and principles of international modern architecture was ensured at the $1^{\text {st }}$ National Architecture Congress, in 1948. In Portugal, upon the end of World War II and the democratization of the European States, the strife against the Salazar regime became manifest, leading to the organization of the various oppositions, who believed in a swift fall of the so-called Estado Novo. The political crisis within the regime forced it to use efficient measures that led to a tougher, more consolidated government, and at the same time to a growing agitation among the various opposing sectors in the Portuguese society, branding it politically, socially, economically and culturally. A new generation of architects, trained in the Arts Schools of Lisbon and Porto, laid claim to a new social, ethical and political consciousness. If, on the one hand, they claimed a new vision of reality, on the other hand, they tried to theorize and reinforce an idea of architecture, international and orthodox, according to the premises of the Modern Movement. These young people were the ones who gave life to the Congress. At the outcome of the Congress, this "African generation" 12 went to Angola or Mozambique, surely motivated by different reasons: ideological or political, or simply looking for new work opportunities. In a less restrictive society away from the center of power, these architects had in common the possibility of building with a modern vocabulary.

\footnotetext{
${ }^{11}$ Curtis, William J. R.: Le Corbusier Ideas e Formas. Madrid : Hermann Blume, 1987, p. 174.

${ }^{12}$ Fernandes, José Manuel: Geração Africana-Arquitecturas e Cidades em Angola e Moçambique, Lisboa: Livros do Horizonte, 2002.
} 


\subsection{Two Le Corbusier disciples}

Two of those young architects, who worked in Angola from the beginning of the 50s, were trainees in Le Corbusier's Paris ateliers. Vasco Vieira da Costa (1911 - 1982) worked at the Rue de Sèvres atelier between 1946 and 1948, and later Fernão Lopes Simões de Carvalho (1929) worked at the Boulevard Flandrin atelier, incorporated in the team coordinated by André Wosgenscky that was developing large projects, between 1956 and 1959. This ten-year difference corresponds, however, to a period of intense work at Le Corbusier's ateliers. The post-war period was, as everybody knows, a particularly productive period in Le Corbusier's work: from the order of the first Unité d'Habitation, in Marseille (1946/1952), to large projects such as Firminy (1960) or Chandigarh (1950-1965) and also the Ronchamps Church (1950-1955) and the La Tourette Convent (1953).

Vasco Vieira da Costa finished his Architecture degree in Porto Beaux Arts School in 1945, and in that same year he was admitted to the Urban Planning Institute of the Paris Sciences College. Between 1946 and 1948, he worked with Le Corbusier. This direct experience with the master's postulates, in a period marked by large postwar urban reconstruction plans in application of the principle of the Athens Charter, shaped in a decisive manner his way of thinking and designing. Also an essential feature during his stay in Paris is the completion of the project of the Building of the Ministry for Education and Health, in Rio de Janeiro (1936/1945), by a team of Brazilian architects led by Lúcio Costa and having Le Corbusier as a consultant, in which the fitting of the dogmas of the Modern Movement to the conditions of a tropical climate is paradigmatic and ground-breaking.

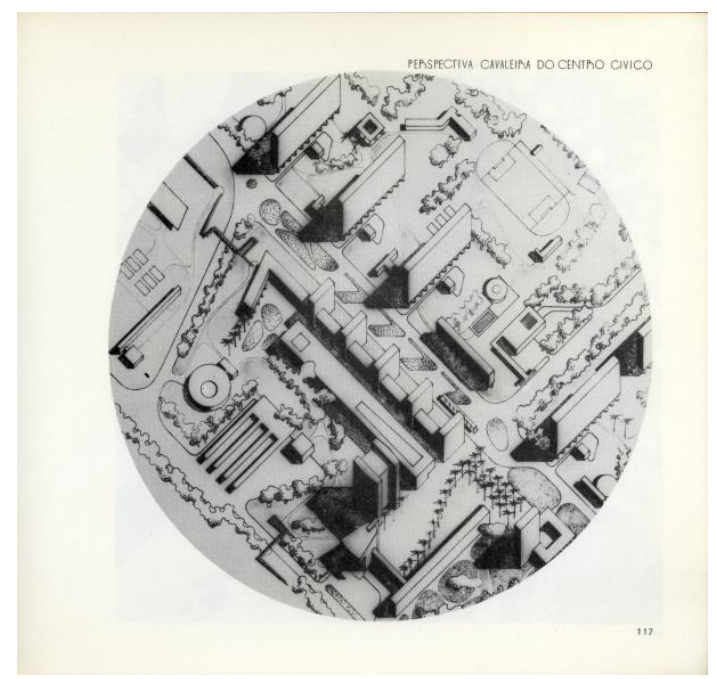

1. Vasco Vieira da Costa - "Luanda Sathelite Plan no 3". 1948. Civic Center Center detail and housing units. (Costa, 1984, p. 117)

His CODA, submitted after his permanence at Rue de Sèvres, "Design of a Satellite City for Luanda" (1949), applying the modern dogmas to the erection of a colonial town, is surely paradoxical: "It is therefore incumbent on the European man to create in the native the need for comfort and a higher life, thus inciting him to the work that will lead him to settle down, and this will facilitate a more stable workmanship. The positioning of the houses and the location of native boroughs are the two main constituents that should govern the composition of the plan of a colonial town (...). In this way, we would rather place native boroughs around the central hub, taking due care to locate it, at all times, toward the lee of European housing areas, which must nevertheless be, at all times, isolated by means of a green screen wide enough to prevent the mosquito from passing over it. As it seems of necessity, under a health and social point of view, native populations should form various scattered groups that will embrace as small satellites the European hub, and so each sector of this hub will be served by a 
native group. In this way, we will shorten the distance to be covered between work place and residence." ${ }^{\prime 13}$ It should be noted, however, that this hierarchical social organization model is based perhaps more on Le Corbusier's 1922 "Ville Contemporaine" project than on the Athens Charter postulates, in which the city was already thought for a "classless" society. In 1949, he returned to Luanda, where he had lived since his childhood, and was incorporated in the Technical Services of the Municipality, developed a set of remarkable projects of which we highlight the Kinaxixe Market (1950-1952), the building of the current Ministry for Public Works in Largo da Mutamba, the Karl Marx Student Hostel, the housing building for Public Servants, the Anangola building or the Pius XII Institute.

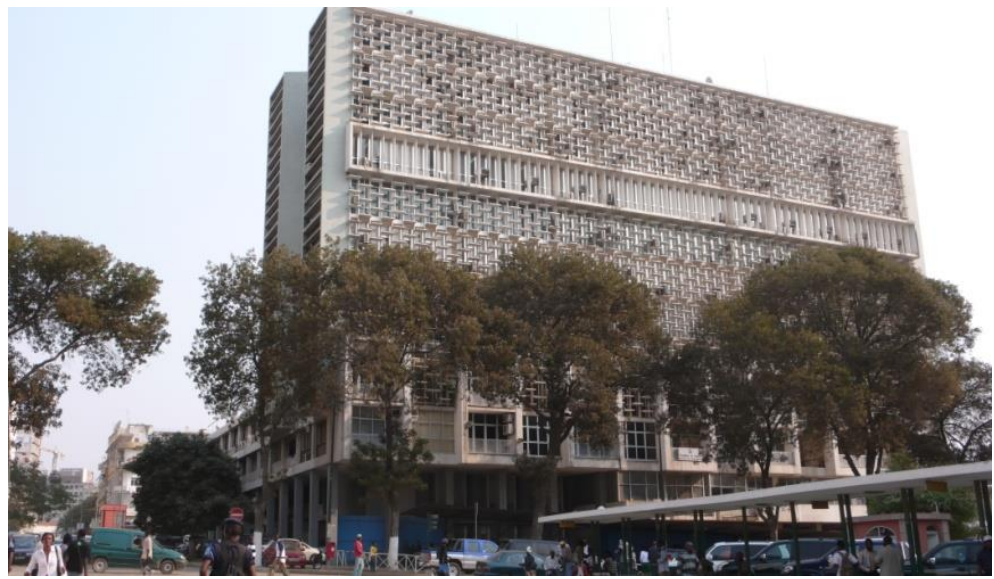

2. Mutamba building - Ministry for Public Works, Luanda (1968) - Vasco Vieira da Costa. (Ana Magalhães, 2008)

The work of Vieira da Costa brands Luanda's built-up landscape and its Corbusian grammar has surely contaminated the city's common and anonymous architecture. It is an architectural language expressed through multiple plastic features, such as grids and "brise-soleil", protruding "boxes", shadowing shelves, buildings on "pilotis", circulations through long open air galleries, textures of glazed warm- and strong-colored tiles.

Fernão Fernão Simões de Carvalho, born in Luanda, completed his Architecture degree at Lisbon Beaux Arts School, in 1955, where he submitted, in 1957, his final paper on a Television Center project. After training at Gabinete de Urbanização do Ultramar (Overseas Urban Planning Office), he took an interest in urban issues, and in 1956 he decided to go to Paris, with a scholarship by the French Government, where he will incorporate Le Corbusier's atelier until December 1959. At the Boulevard Flandrin atelier, under guidance by André Woscenscky, he worked on the detail project of the Unité d' Habitation in Berlin, and subsequently the Briey-enForêt Housing Unit. He further participated in the La Tourette Convent project and followed up, as "architecte de chantier", the works of the Brazilian Pavilion in the Paris Campus. At the same time, he studies at the Institut d' Urbanisme at Sorbonne with Robert Auzelle. These two vectors will be the basis of the consolidation of Simões de Carvalho's training and will be a determining factor in the work he will develop in Angola. On the one hand, the stark imprint of the large projects developed at Le Corbusier's ateliers during that period, not only those in which he takes part but also Chandigarh or Firminy, the building and "béton brut" plasticity experiences, applying the "Modulor" system; on the other hand, the teachings by Auzelle, a critic of the Athens Charter, who “(...) proposes that several social and economic factors be put into context in a more integrated and technical vision." 14 His Urban Planning degree was completed in 1965 upon submission of a Master Plan for the

\footnotetext{
${ }^{13}$ Revista de Arquitectura. Fernando Távora (dir.) No 0. 1987. Porto : Faculdade de Arquitectura da Universidade do Porto. p. 24.

${ }^{14}$ Milheiro, Ana Vaz: Luanda no Futuro: o Bairro do Prenda. In SARDO, Delfim (org.): Falemos de Casas: Entre o Norte e o Sul. Lisboa : Athena, 2010, pp. 308-317.
} 
Fishermen Borough in Luanda Island. While such project is based, on the one hand, on the study of a wider urban structure within the zoning principles of the Charte d'Athenes, on the other hand it reveals a sensitive understanding of pre-existences and an attentive study of popular housing of that site.

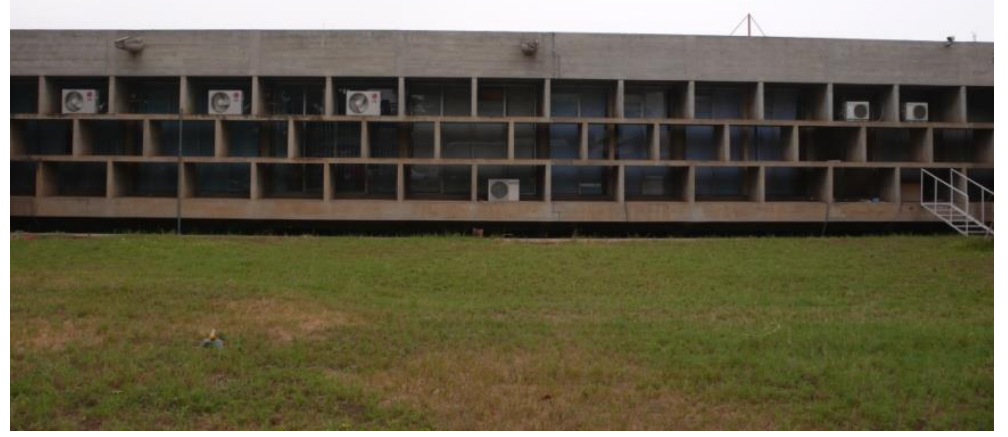

3. Rádio Nacional de Angola, Luanda (1963-1967) - Fernão Simões de Carvalho -. (Ana Magalhães, 2008)

One of his most remarkable works is the radiobroadcast centre, Centro de Radiodifusão de Angola (1963-1967), currently Rádio Nacional de Angola, an essential facility that is located in downtown Luanda. This is a large rectangular-located building at the center of the plot, away from the plot limits to create surrounding landscaping places. Upon location of the volume, the topography of the land is shaped in such a way as to make the building have a main floor at access street level and a semi-underground floor for technical and storage areas. In this way, the main volume is a large box within a concrete grid that rests on a base floor. The Northwest façade, where the main entrance is located in a central volume-bridge, ensures an asymmetric treatment of this large concrete shell: on the one side, a series of vertical concrete elements serve as "brise-soleil" extending the grid of the side façades, and on the other side, a large opaque surface covered with glazed brick tiles. Such volume-bridge would have been the connection to the central administrative building over the main street, but it was never built up. On the side façades, a long grid wraps up the rising volume and leans over the garden. This reticulate grid in concrete, away from the glass façade, allows simultaneously for inside shading and ventilation. 


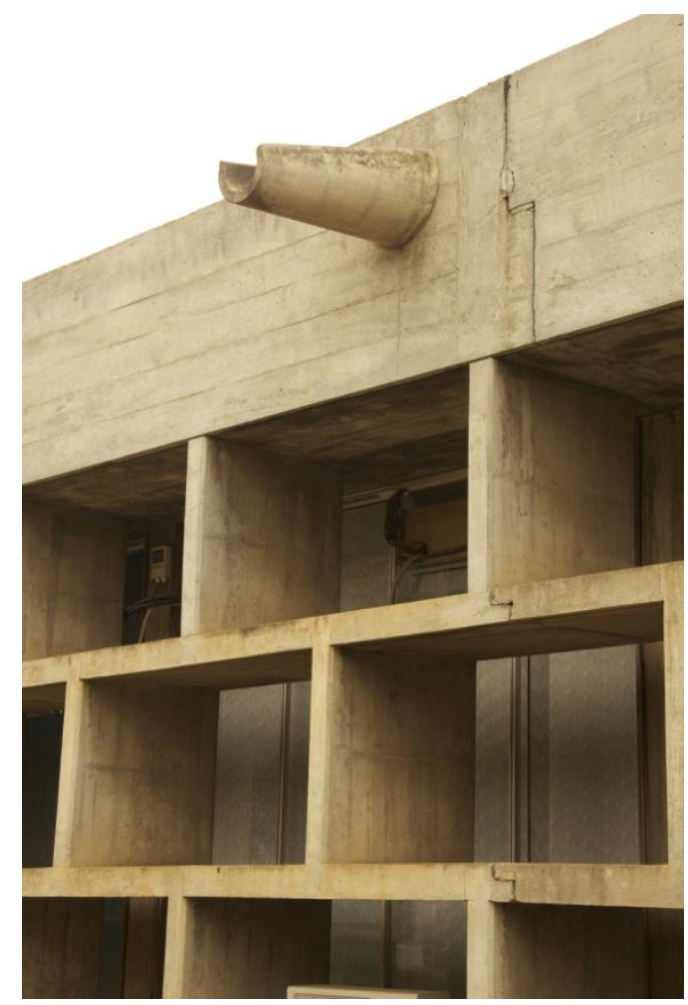

4. Rádio Nacional de Angola, Luanda (1963-1967)- Fernão Simões de Carvalho. Detail Brise-soleil. (Inês Gonçalves, 2008 in Magalhães, 2008, p. 156)

The building scheme is based on the Modulor harmonic measurements system. In this way, the rectangular plan is organised in $3.66 \mathrm{~m}$ modules (corresponding to the base modules of Modulor blue series ${ }^{15}$ - the module used for the width of the Unité's apartments, for instance), and its overall sizes are $101.35 \mathrm{~m} \times 64.75 \mathrm{~m}$ (corresponding to $27 \times 173.66$ modules added by a peripheral brise-soleil grid $1.265 \mathrm{~m}$ wide). The 3.66 module is therefore applied to the dimension of the corridors or the open-air patio areas. Similarly, the most frequent net height of the building corresponds to $2.96 \mathrm{~m}^{16}$ (a measurement that, if you add the technical areas under suspended ceiling and the slab thickness results in the 3.66 size once again), a measurement that is also the base measurement of the composition of the external grid.

Other than applying the Modulor, references to Le Corbusier are a strong presence in this work. The design of the Centro de Radiodifusão is a clear reference to the research on the expression of the béton brut in the master's late work, particularly in Chandigarh, in Ahmedabad or in the plasticity of the La Tourette Convent. In addition to the alternating square-lined geometry, Simões de Carvalho is at ease using the Corbusian lexicon in his expressive concrete gargoyles or in crossing materials: dominant concrete together with brick tiles and glazed surfaces.

\footnotetext{
${ }^{15}$ Le Corbusier: Le Modulor | Modulor 2. Tradução, Prefácio e Notas Marta Sequeira. Lisboa : Orfeu Negro, 2010, p. 105.

${ }^{16}$ Red series of Modulor. Le Corbusier: Le Modulor | Modulor 2. Tradução, Prefácio e Notas Marta Sequeira. Lisboa : Orfeu Negro, 2010, p. 105.
} 


\subsection{Formal vocabulary}

However, in addition to the work carried out by those architects who worked directly at the master's ateliers, the specificity of the architectural production in Angola and Mozambique, particularly private order works, is referred to Modern Movement works generally, and to the Corbusian grammar in particular. Although they knew some of Le Corbusier's written work (particularly Vers une Architecture and Le Modulor), it would be mainly through publications or periodicals that architects became aware of international projects and works. We highlight L'Architecture d'Aujourd'hui magazine, the most read international periodical among Portuguese architects (most of whom knew French as their first foreign language). The Portuguese magazine Arquitectura also played an essential role in disseminating the Modern Movement architecture, from the works of the founding Masters to a few fundamental texts. The Corbusian lineage and the influence of the principles of the CIAM are, however, the dominant, and the publication of the complete Charte d'Athènes, which started in 1948, the year of the Congress, merely stressed such dominance. Le Corbusier's Unité d'Habitation building in Marseille (1945), inaugurated in October 1952, would be published on the magazine immediately the next year.

This Corbusian vocabulary as applied, whether in a more orthodox or a more hybrid way, translates into an assertion of the "Cinq Points", a thorough exploitation of the "brise-soleil" vocabulary, the control of the technical capabilities and expressive qualities of the "béton brut". The search for the plastic expression and spatial qualification, the employment of colour, exhaustively studied in the Salubra and employed in Le Corbusier's post-war projects, as well as the search for the total work of art in the sense of integration or contamination between art and architecture, coming close to the Corbusian concept of "espace indicible", all these are elements that cross over such African works.

\subsection{The Unité as an unavoidable model}

The Marseille Housing Unit project, which was designed between 1945 and 1952, contributed in a significant and universal way to the definition of collective housing typologies after World War II. The "Unite d'habitation de grandeur conforme" developed as a prototype re-equating the functionalist dimension through the expressionmanifesto of the house as a living machine will allow for a wide experimentation in the study of housing for the masses, by researching new forms of conjugation and internal organisation of the dwellings, circulation schemes or space hierarchy.

The Housing Unit model, a mixed repeatable block, will be thoroughly exploited, not only in the European reconstruction after the war, but also in other lands and geographies, seeking its adaptation to different climates, cultures and social contexts. But if "(...) as a prototype the Unité was unavoidable, the problem was to transform its fundamental lessons into a more flexible terminology attuned to particular cities, societies and climates." ${ }^{17}$

\footnotetext{
${ }^{17}$ Curtis, William: Modern Architecture since 1900. $3^{\mathrm{a}}$ ed. London : Phaidon, 1999, p. 443.
} 


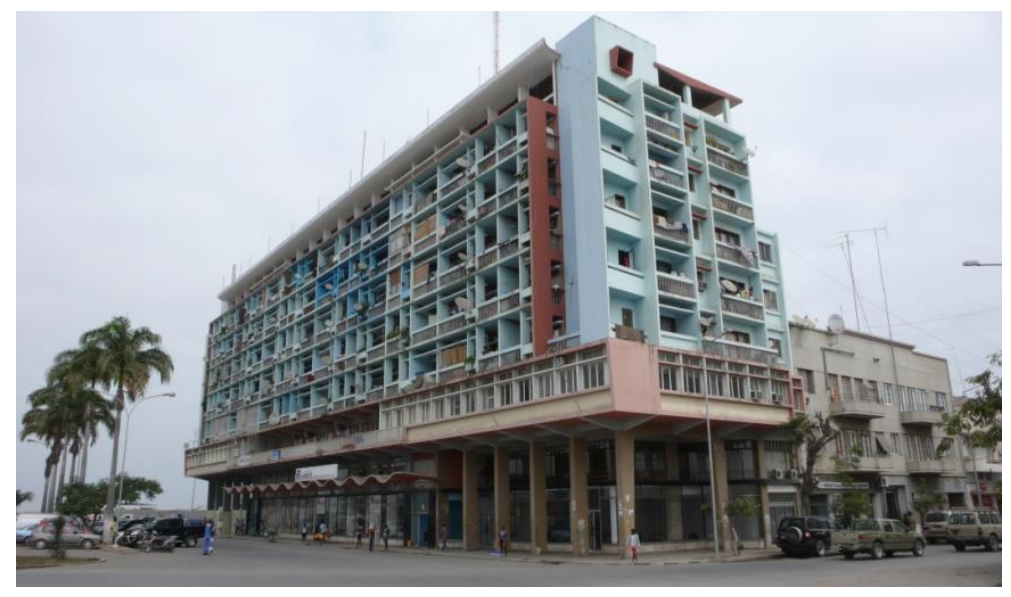

5. Universal building, Lobito (1957-1961) - Francisco Castro Rodrigues. (Ana Magalhães, 2008)

The Angolan and Mozambican cities, which predominant model was characterized by the sectorial city having a design inspired by the Garden City, based on a radial and axial composition, with wide avenues and extensive low-density residential areas, favour the single house. However, here and there, particularly in Luanda or Maputo, one can find a few detail plans that fall within the conceptual and formal framework of the urban models based on the Charte d'Athènes and foster the construction of collective housing units.

Such housing buildings addressed to an urban colonial middle class started to be designed at the end of the 50s and are a significant mark of the largest Angolan and Mozambican cities of the 60s. Although in a much lesser size than the Marseille Housing Unit, such buildings are mixed housing, service and shop blocks, which are based on the premises of the reference model and test new housing typologies as appropriate for the tropical climate.

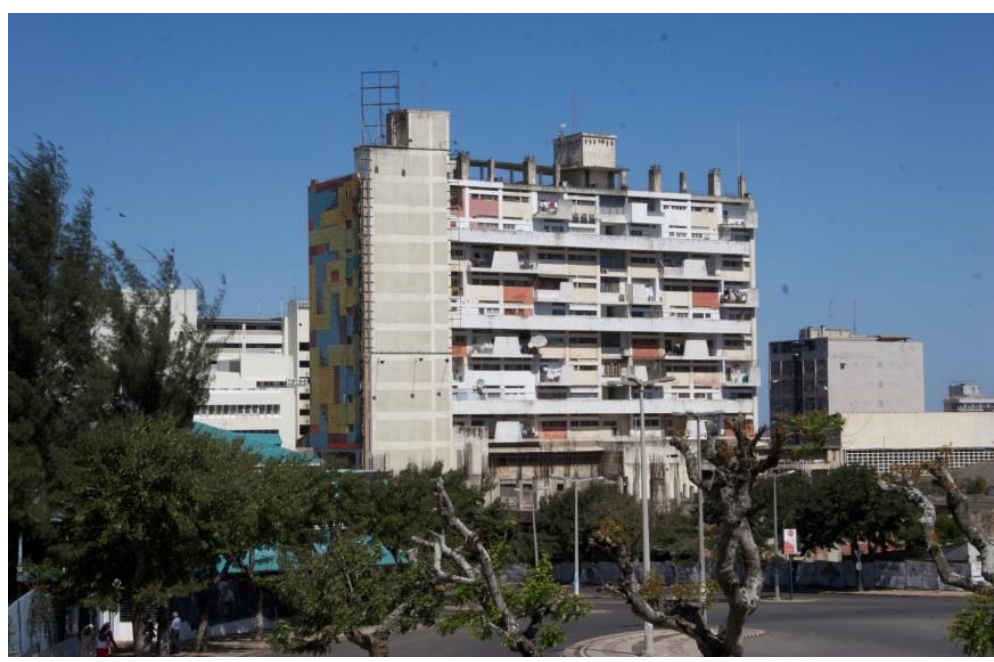

6. Montepio de Moçambique building, Maputo (1955-1960) - Alberto Soeiro. ((Inês Gonçalves, 2008 in Magalhães, 2008, p. 226)

In Maputo, the Tonelli building (1954-1958), designed by Pancho Miranda Guedes (1925-), the Montepio de Moçambique building (1955-1960), by Alberto Soeiro (1917-?), or in Lobito, the Universal building (19571961), designed by Francisco Castro Rodrigues (1920-2015), are exemplary cases of interpretation of the Corbusian prototype. A circulation through an external peripheral gallery, a skilful composition of the housing cell conjugation structure and a rational sense of the internal organisation of the dwellings are common 
denominators of all three projects and reflect not only an appropriate response to the characteristics of the climate but also the colonial society's desire for modernisation.

Such works, which are the heirs of the Unité and the modern premises, are, however, late examples, developed between the end of the 50s and all along the 60s, at a time when, in Europe, architects were acquiring a critical conscience over the dogmas of the Modern Movement.

\section{Conclusion}

The Corbusian legacy understood in the meaning of absorption of his vocabulary, fulfilment of his postulates or comprehension of his doctrine exceeds the geographies and the territories of his own work. The huge impact of such work created by the Master's communication and dissemination ability has permitted new readings and interpretations, and respond to different social cultural or geographical contexts. The architectural production in Angola and Mozambique during the 1950s and 1960s is basically marked by the acceptance of the Corbusian models, in addition to a direct contact with Le Corbusier's ateliers that was experienced by the Angolan architects Vieira da Costa and Simões de Carvalho. As a general rule, the interpretations of architecture as implemented followed a line between orthodox and hybrid models, but the fascination (love or hatred) with Le Corbusier's figure also permitted more eclectic and ironical readings, such as the rewriting of a sentence in "Vers une Architecture" proposed by Pancho Mranda Guedes (1925-): "I claim for architects the right and liberties that painters have held for so long. Architecture is not apprehended as intellectual experience but as sensation". ${ }^{18}$

In the celebration of the work and figure of Le Corbusier fifty years after his death, knowing the extension of his legacy in geographies and cultures as different and faraway as, in this case, Angola and Mozambique means to understand better his dimension as a global architect.

\section{Acknowledgements}

This work is financed by national funds by FCT - Foundation for Science and Technology under the UID Project / AUR / 04026/2013 and also to CITAD - Research Centre for Territory, Architecture and Design.

\section{Bibliography/references}

Boyer, M. Christine: Le Corbusier, Homme de Lettres. New York : Princeton Architectural Press, 2011.

Cohen, Jean-Louis: La Planète comme Chantier. Paris : Textuel, 2005.

Colquhoun, Alan: Modernidade e Tradição Clássica, Ensaios sobre Arquitectura. São Paulo : Cosac e Naify, 2004.

Costa, Vasco Vieira: Luanda - Cidade Satélite $n^{o}$ 3. Concurso para a Obtenção do Diploma de Arquitecto (1948). Porto: Escola Superior de Belas Artes do Porto - Curso de Arquitectura, Departamento de Arquitectura da Faculdade de Engenharia de Luanda, 1984.

Curtis, William J. R.: Le Corbusier Ideas e Formas. Madrid : Hermann Blume, 1987.

Curtis, William: Modern Architecture since 1900. $3^{\mathrm{a}}$ ed. London : Phaidon, 1999.

\footnotetext{
${ }^{18}$ Santiago, Miguel: Pancho Guedes, Metamorfoses Espaciais. Casal de Cambra : Caleidoscópio, 2007, p. 130-131.
} 
Fernandes, José Manuel: Geração Africana-Arquitecturas e Cidades em Angola e Moçambique, Lisboa: Livros do Horizonte, 2002.

Giedion, Sigfried: Space, Time and Architecture - The Growth of a New Tradition. $5^{\mathrm{a}}$ ed. Cambridge : Harvard University Press, 1997.

Le Corbusier: Le Modulor| Modulor 2. Tradução, Prefácio e Notas Marta Sequeira. Lisboa : Orfeu Negro, 2010.

Le Corbusier: Précisions - Sur un État Présent de l'Architecture et de l'Urbanisme. Paris : Éditions Vincent Freal, 1960.

Magalhães, Ana; Gonçalves, Inês: Moderno Tropical, Arquitectura em Angola e Moçambique- 1948-1975. Lisboa: Edições Tinta da China, 2009.

Magalhães, Ana: Migrações do Moderno: Arquitectura na diáspora- Angola e Moçambique (1948-1975), directorship: Ana Tostões; Fernando Hipólito. Universidade Lusíada de Lisboa, 2015.

Milheiro, Ana Vaz: Luanda no Futuro: o Bairro do Prenda. In SARDO, Delfim (org.): Falemos de Casas: Entre o Norte e o Sul. Lisboa : Athena, 2010.

Présence d'André Malraux sur la toile (2008-2013) André Malraux [Em linha]. [S.1. : s.n.]. [Consult. 12 Jul. 2014]. WWW:<URL:http://www.malraux.org/>.

Revista de Arquitectura. Fernando Távora (dir.) No 0. 1987. Porto : Faculdade de Arquitectura da Universidade do Porto.

Santiago, Miguel: Pancho Guedes, Metamorfoses Espaciais. Casal de Cambra : Caleidoscópio, 2007.

Tsiomis, Yannis (org.): Le Corbusier-Conférences de Rio: Le Cobusier au Brésil. 1936. Paris : Flammarion, 2006. 


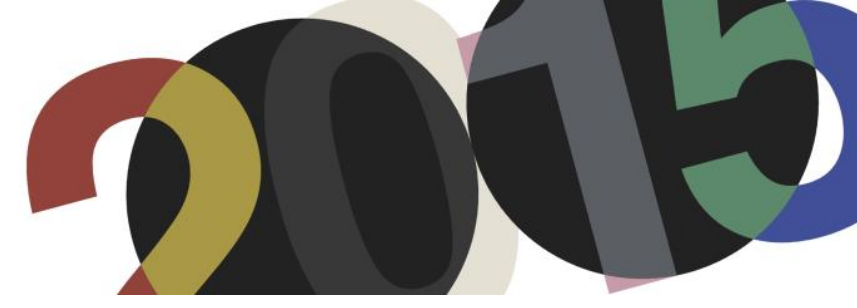

DOI: http://dx.doi.org/10.4995/LC2015.2015.631

\title{
Le Corbusier, el punto de partida de Juan Borchers
}

\author{
S. Maino Ansaldo
}

Universidad Técnica Federico Santa María

\begin{abstract}
Resumen: La figura de Le Corbusier ejerció una influencia sin contrapeso en la arquitectura moderna chilena, caracterizada salvo excepciones, por una adopción superficial y figurativa de sus ideas y formas. Entre estas excepciones está el singular caso del arquitecto Juan Borchers Fernández (1910-75) quien mediante sus agudas observaciones y lúcida crítica expone su adhesión mientras al mismo tiempo desmonta las contradicciones, los errores de interpretación y las falencias de las tesis lecorbuserianas. Para el análisis se utilizaron dos libros fundamentales (Vers une Architecture, 1923; Le Modulor, 1950) y dos artículos (L'angle droit, 1923; L'espace indicible, 1946) de Le Corbusier y las referencias a ellos en los libros, artículos, manuscritos, correspondencia y libretas de viajes de Borchers.
\end{abstract}

Abstract: Corbusier's influence in Chilean modern architecture is unique and it is characterized, with few exceptions, by superficial and figurative adoptions of his ideas and forms. Among these exceptions is the singular case of the architect Juan Borchers Fernández (1910-1975), whose acute observations and lucid review expose his adherence while at the same time they reveal the contradictions, misinterpretations and shortcomings about corbuserian's thesis. This analysis is based on two fundamental original books (Vers une Architecture, 1923; Le Modulor, 1950) and two articles (L'angle droit, 1923; L'espace indicible, 1946) by Le Corbusier and references to them in Borchers' books, articles, manuscripts, correspondence and travel journals.

Palabras clave: Chile, teoría de la arquitectura, plástica, escala.

Keywords: Chile, Architectural theory, plastic, scale.

\section{Introducción}

Juan Borchers Fernández (1910-1975) es uno de los pocos teóricos de la arquitectura moderna chilena con una línea de pensamiento original, condensando en un heterodoxo corpus teórico su adhesión a los planteamientos de la arquitectura moderna junto a una reinterpretación de la arquitectura clásica. Si bien, intelectualmente las raíces del pensamiento borchiano están en la cultura alemana, sus referentes de la disciplina son franceses e italianos, particularmente la figura sin contrapeso de Le Corbusier.

Al igual que Le Corbusier los viajes, la observación, la medición y la vivencia directa de las piezas fundamentales de la cultura arquitectónica occidental, fueron acciones centrales en la construcción de su teoría ${ }^{1}$. Borchers comienza a leer las obras de Le Corbusier una vez iniciados sus estudios de arquitectura en 1929, conociéndolo en su primer viaje a Europa en 1938, hecho que lo marca indeleblemente a lo largo de toda su trayectoria.

\footnotetext{
${ }^{1}$ Cf. MAINO, S. 2014. Pensar la distancia, pensar a distancia. Juan Borchers, viaje y obra (1947-1950). Doctor,
} Universidad Politécnica de Cataluña. 
“Conocí a Le Corbusier el año 38 en Paris a 27 años de su "Voyage Utile”. Tenía entonces 51 años. Hablamos en varias ocasiones, bis a bis en la mesa de su taller. "2

Este es un momento particular para Le Corbusier; en la esquina del taller de rue Sevres están las maquetas del fallido proyecto para el concurso del Palacio del Soviets y el polémico del Palacio de las Naciones en Ginebra. Ese período marca para Borchers el Jugendwanderung ${ }^{3}$ de Le Corbusier, edad juvenil según la gradación de la evolución del espíritu humano expuesta por Leo Frobenius en su Paideuma ${ }^{4}$, momento caracterizado por una concepción del mundo casualmente ordenada, predominando lo intuitivo frente a la rigidez de la causalidad intelectiva. Época de los ideales en la cual el individuo es capaz de transformar la realidad en una unidad orgánica, mediante un acto creativo.

Entre los años '30 y '40 mientras se veían en la arquitectura chilena las primeras expresiones de un racionalismo epidérmico, Borchers proyecta una serie de viviendas y edificios teñidos por el influjo de las formas y los postulados lecorbuserianos. Posteriormente, en los 60' proyecta y construye junto a los dos miembros del Taller, Isidro Suarez y Jesús Bermejo, sus dos obras más conocidas, la Cooperativa Eléctrica de Chillán, 1960-1966 (fig.1) y La Casa Meneses, 1960-1970 (fig. 2), cuyas similitudes formales con la obra de Le Corbusier no dan lugar a dudas, cercanía corroborada en su correspondencia con Bermejo de la época: "el punto de partida es "VERS UNE ARCHITECTURE”,". Esta cercanía al pensamiento lecorbuseriano no tiene que verse como una ciega militancia, sino un inicio sobre el cual, con el paso de los años, se fue consolidando un punto de vista propio e independiente de la arquitectura. Es así como podemos descubrir una serie de proximidades y distanciamiento con Le Corbusier y su aparato intelectual, de las cuales trataremos seis íntimamente ligadas entre ellas.

\footnotetext{
2 Borchers, Juan. "Prólogo". En Peñafiel, José Domingo: Le Corbusier y su Modulor. Director: Juan Borchers. Pontificia Universidad Católica de Chile, 1974. pp. 1-11.

${ }^{3}$ Caminar juvenil, espíritu juvenil.

${ }^{4}$ Frobenius, Leo. La Cultura Como Ser Viviente. Contornos De Una Doctrina Cultural Y Psicológica. Madrid: Espasa-Calpe, 1934.

${ }^{5}$ Borchers, Juan: Lo Plástico, Plástica, cosa General. Santiago: Ediciones Universidad Central, 2014. Publicación de: Carpeta Plástica, 1962/1966, FJB-D0539.
} 

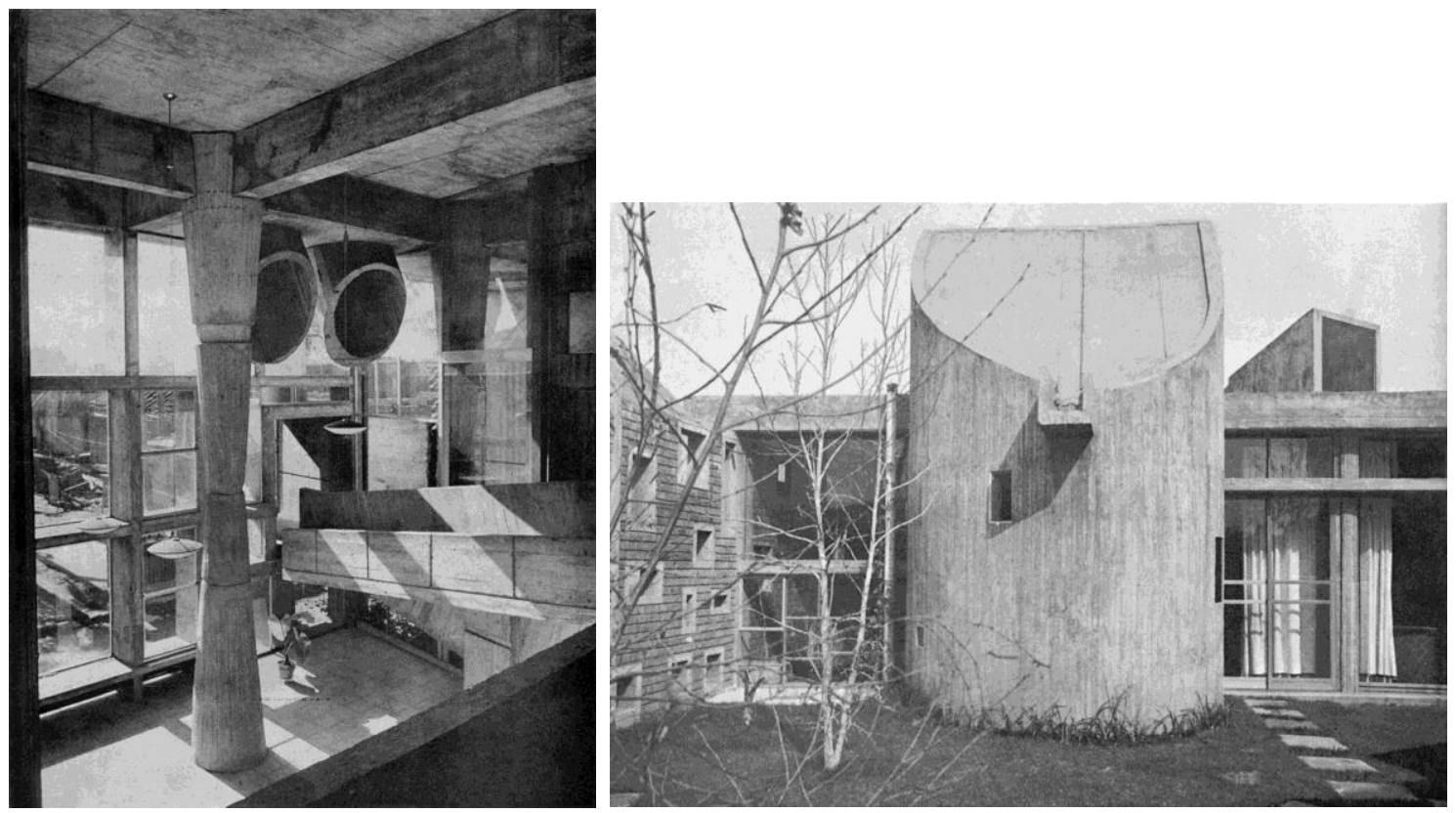

1. Interior del edificio Copelec. De fondo el brise soleil, separador entre el espacio interior y el patio posterior, a la derecha la rampa y al centro una de las columnas doble cónicas.

2. Exterior de la Casa Meneses.

\section{El hieratismo y las leyes del arte}

El período Purista de Le Corbusier está marcado por un fuerte ahistoricismo, desprendiendo las formas de su significado espacio-temporal, centrando su atención en la fisiología de las sensaciones y la especulación matemática. Uno de los conceptos estudiados por Le Corbusier y aplicado por Borchers es el hieratismo, cuya definición encontramos en el artículo L'Angle droit de Amedee Ozenfant y Le Corbusier en L'Esprit Nouveau' . Ozenfant y Le Corbusier manifestan la existencia de las leyes axiales de la obra de arte, las cuales se pueden encontrar en el pasado; leyes que dan cuenta de una persistencia en nuestros organismos en la manera de percibir las obras de arte, una inmutabilidad fundamentada en la invariabilidad de nuestros órganos de los sentidos. El sistema postulado plantea que una obra de arte emociona y desencadena en nosotros un juego de recuerdos adquiridos y heredados mediante asociaciones automáticas. Dentro de este sistema, el hombre es un animal ordenador, al necesitar del orden para moverse dentro de la naturaleza, la cual en principio, tiene una apariencia caótica. Para esto el hombre ha elaborado sistemas de orden, en el entendido que estos sistemas le permiten explicar aquello que le rodea, con diferentes grados de distanciamiento de la realidad. La geometría es uno de esos sistemas, un sistema perfecto, sin contacto material con lo real, símbolo de perfección, irrealizable prácticamente 7 . "El espíritu de orden ha creado signos, símbolos convencionales de ideas bien definidas que permiten construir la geometría y el lenguaje, hacer inteligibles las cosas, a uno mismo y a los demás, mediante abreviaciones eficaces" $"$. Los signos originados de esta manera son precisos, actuando según los autores, sobre

\footnotetext{
${ }^{6}$ Le Corbusier; Ozenfant, Amédée. "El Ángulo Recto". En Levene, Richard; Márquez Fernando (eds.): Acerca Del Purismo. Escritos 1918/1926. Madrid: El Croquis Editorial, 1993. p. 103-114.

${ }^{7}$ Ibíd., pp. 105.

${ }^{8}$ Ibíd., pp. 106.
} 
nuestros sentidos fisiológicamente, es decir, los procesos y las funciones producidas en los órganos por su interacción con el entorno son comprensibles mediante los principios de las ciencias exactas. De esta forma, como complemento a la componente de significado de un signo, se incorporan las leyes fisiológicas en su proceso de ideación y construcción. Los autores hacen la salvedad de que estos signos no son abstractos, ni convenciones de la escritura o las matemáticas, realizando de paso una crítica a la excesiva simplificación y depuración del neoplasticismo. Declarados los fundamentos de la relación entre hombre y arte, los autores inician la explicación del hieratismo:

"A falta de una palabra mejor, entendemos por hieratismo el estado del espiritu en que desemboca una civilización cuando, saliendo del período empírico, se vuelve consciente de algo que antes solamente sentía. Despojamos este término del sentido sagrado que la etimología le confiere, e incluso, si se lo dejáramos, tendríamos derecho a utilizarlo aquí, que la ciencia, antaño patrimonio de sacerdotes que la utilizaban religiosamente, ha cambiado de manos. Para evitar cualquier equívoco, hacemos laico el término hieratismo"."

Definido el hieratismo, el paso siguiente es identificar sus medios o las formas de expresión:

"El espiritu hierático se expresa, pues, mediante equivalentes plásticos que proceden de una elección reflexionada de elementos cuyas propiedades fisiológicas y espirituales conoce exactamente.

Esos elementos están constituidos por objetos que tienen propiedades sensibles particulares y están dispuestos siguiendo ordenaciones que tienen efectos particulares específicos" 10 .

Para Ozenfant y Le Corbusier la fisiología tiene directa relación con comprender cómo vemos y qué figuras son legibles y reconocibles sin esfuerzo. El texto del artículo está acompañado por una serie de reproducciones de bajorrelieves egipcios, pudiéndose considerar el aporte de Borchers al estudio del hieratismo la incorporación de elementos tridimensionales: "Hay dos formas hieráticas: el cono y la pirámide, ahora bien pueden, reduciendo la zona de movimiento a ciertas directrices, conservarse inmóviles otras figuras. La esfera es inmóvil" ${ }^{\prime 1}$. Todas estas son formas cuya percepción no cambia con el desplazamiento del sujeto.

\section{El cilindro, la esfera y el cono, la herencia de Cezanne}

Conocido es el aforismo de Le Corbusier, "La arquitectura es el juego sabio, correcto y magnífico de los volúmenes bajo la luz" ${ }^{\prime 2}$ heredera para Borchers de la enigmática definición de los fundamentos de la pintura acuñada por Cézanne, expuesta en una carta a su amigo Emile Bernard ${ }^{13}$ :

"Trate la naturaleza a través del cilindro, de la esfera, del cono, todo ello situado en perspectiva, o sea que cada lado de un objeto, de un plano, se dirija hacia el punto central ",14.

\footnotetext{
${ }^{9}$ Ibíd., pp. 108-109.

${ }^{10}$ Ibíd., pp. 109.

${ }^{11}$ Borchers, Juan. Cuaderno de Egipto. 1948 (FJB-L22-044).

${ }^{12}$ Le Corbusier. Hacia Una Arquitectura. Barcelona: Ediciones Apóstrofe, 1998.

${ }^{13}$ La carpeta trabajo FJB-D1125 (1943-1947) de Borchers contiene las cartas enviadas por Cézanne a Emile Bernard, transcritas de L'Esprit Nouveau: Revue internationale d' esthétique (1920).

${ }^{14}$ Carta de Cézanne a Emile Bernard, Aix-en-Provence, 15 de abril de 1904. En Doran, Michael (ed.): Sobre Cézanne.

Conversaciones y testimonios. Barcelona: Gustavo Gili, 1980. pp. 51-52.
} 
Para Borchers los cubistas actuaron bajo la sugestión de los planteamientos de Cézanne considerándolo el fundador de la pintura moderna, a diferencia de Apollinaire que ve las últimas pinturas de Cézanne un resultado del cubismo, asignándole el título de padre del cubismo a Gustave Courbet ${ }^{15}$. Aunque hay variadas interpretaciones de la frase de Cézanne, según el historiador del arte Michael Doran el principio apunta a una "aprehensión de volúmenes por el estudio de sólidos simples" "16, tal como la entiende Le Corbusier, interpretación errada según Borchers. El error radica en que la atención de Cézanne no está puesta en los tres sólidos simples, sino en la superficie y la relación de colores entre ellas, nadie verá claramente estas tres figuras estereométricas en una tela de Cézanne ${ }^{17}$.

La profunda influencia que ejercen estas cartas de Cézanne sobre Borchers se reconocen en el principio gnoseológico de aproximación directa a la naturaleza, desconfiando de lo que ya se ha dicho sobre ella. Una mediación en esta aproximación ocultaría el sentido del original de dicha naturaleza proponiéndose Borchers como salida, practicar su estudio concreto y concienzudo, dibujar lo que veía y no lo que sabía.

La manera de abordar la descripción de un objeto, según Borchers, es una tríada jerarquizada, “objeto ideal”, "objeto geométrico" y "objeto sensible". Cada uno define en un plano diferente un mismo objeto real. El objeto sensible es capturado a través de los sentidos con todas las particularidades que definen su apariencia individual. El objeto geométrico surge de realizar una serie de generalizaciones del objeto sensible, con las cuales se logra comprender y reducir la variedad del objeto sensible a un número manejable de variables y elementos, mediante el número y la figura geométrica. El objeto ideal es una categoría que agrupa una serie de objetos sensibles bajo un modelo en el cual se explica la esencia del conjunto de objetos. Entre el objeto sensible y el objeto geométrico median los sentidos y entre el objeto geométrico y el objeto ideal media la mente. El objeto geométrico se capta siempre siendo "el intermediario entre la sensación y la idea" 18 . Borchers desea trabajar con ese margen abierto entre el objeto intelectualizado y el objeto real, buscando abordar mediante reglas las variaciones como algo constitutivo del ser del objeto.

La posición de Borchers se puede ver como una crítica al excesivo privilegio otorgado a la geometría en el proyecto y análisis de las obras por los arquitectos modernos, asignándole atribuciones que van más allá de ser un instrumento de composición y orden, transformando en una operación automática el reemplazo del objeto sensible (obra construida) por el objeto geométrico (trazado, dibujo). La simple construcción material del objeto geométrico reduce las posibilidades de expresión del objeto sensible. Si retomamos la primera definición en que ubicábamos al objeto geométrico como intermediario entre el ideal y el sensible, podremos entender que si aceptamos el remplazo del objeto geométrico por el objeto sensible, se transformaría un medio, es decir, la geometría, en un fin.

\footnotetext{
15 Apollinaire, Guillaume. Meditaciones Estéticas. Los Pintores Cubistas. Sobre La Pintura. Pintores Nuevos. Madrid: Antonio Machado Libros, 2001.

${ }^{16}$ Doran, op. cit., p. 247.

${ }^{17}$ Borchers, Juan. La Medición Como Substrato Del Fenómeno Arquitectural. Con Cantidades Crear Cualidades. Hogar y Arquitectura, Revista Bimestral de la Obra Sindical del Hogar, 1970, p. 26-39.

${ }^{18}$ Borchers, Juan. s/t, block. 1948 (FJB-D0590).
} 


\section{La arquitectura gótica y la Naturaleza. La Plástica}

"La arquitectura gótica no es, en su fundamento, una arquitectura en base a esferas, conos y cilindros. Sólo la nave expresa una forma simple, pero de una geometría compleja de segundo orden (cruceros de ojivas). Por esta razón, una catedral no es muy hermosa y buscamos en ella compensaciones de orden subjetivo, fuera de la plástica. Una catedral nos interesa como solución ingeniosa de un problema difícil, pero cuyos datos han sido mal colocados porque no proceden de las grandes formas primarias. La catedral no es una obra plástica; es un drama: la lucha contra la fuerza de gravedad, sensación de orden sentimental ${ }^{\prime \prime 19}$.

La crítica a la arquitectura gótica es evidente, su categorización como solución ingeniosa silencia su valor estético. Las catedrales góticas tanto francesas como españolas fueron objeto de intenso análisis e interpretación de Borchers, al principio en perfecta sintonía con el aserto de Le Corbusier, la estructura resistente fue el aspecto en el cual puso su atención, para luego dar paso al contexto próximo y las asociaciones con la naturaleza, el crecimiento y la transformación de las plantas, con el objetivo de extraer leyes universales de sus configuraciones. Si bien Le Corbusier y Borchers creen en las leyes de la naturaleza como proveedoras de un orden susceptible de ser aplicado en la arquitectura, el imaginario no es el mismo.

"Desde el punto de vista de la arquitectura, me coloco en el estado de espíritu del inventor de aviones. La lección del avión no está tanto en las formas creadas y, ante todo, hay que aprender a no ver al avión como un pájaro o una libélula, sino una máquina de volar; la lección del avión está en la lógica que ha presidido el enunciado del problema y ha conducido al triunfo de su realización "20.

Más adelante Le Corbusier escribe "desear volar como un pájaro, era plantear mal el problema",21 . Al igual que Le Corbusier, Borchers busca las leyes y no las figuras de la naturaleza, pero en vez de utilizar un paradigma de la modernidad como el avión, objeto construido por el hombre, basado en las leyes de la aerodinámica, Borchers se aboca a la observación de la flora y la fauna, determinando las leyes matemáticas y geométricas que contienen esas formas.

"La arquitectura es la primera manifestación del hombre que crea su universo, que lo crea a imagen de la naturaleza, sometiéndose a las leyes de la naturaleza, a las leyes que rigen nuestra naturaleza, nuestro universo. Las leyes de la gravedad, de la estática, de la dinámica, se imponen por la reducción al absurdo: sostener o derrumbarse ${ }^{, 22}$.

El imaginario maquinista no tuvo ecos en Borchers, lo cual no significaba que no hubiera experimentado los avances de la tecnología. Había cruzado el Atlántico en barco, había volado en avión desde Punta Arenas a Santiago y había disfrutado de la velocidad del automóvil en los terrenos abiertos de la pampa ${ }^{23}$. Podríamos suponer que ese imaginario maquinista abierto por Le Corbusier tal vez no tuvo eco en Borchers por provenir de un país poco industrializado, pero las razones para obviarlo son más profundas, tal como lo expone en Meta Arquitectura.

\footnotetext{
${ }^{19}$ Le Corbusier, op. cit., 1998. pp. 180.

${ }^{20}$ Le Corbusier, op. cit., 1998. pp. 85.

${ }^{21}$ Ibíd., pp. 89.

${ }^{22}$ Ibíd., pp. 56.

${ }^{23}$ Borchers, Juan. Meta Arquitectura. Santiago de Chile: Mathesis Ediciones, 1975. pp. 286.
} 
"Ese siglo, cuyo impulso fue dirigido a la construcción de máquinas, en el cual todo fue organizado: las organizaciones sofocaron el organismo. La era del mecanismo alcanzó sus ápices mundiales; cubrió todo el planeta. La cultura se identificó y significó lo mismo que orden y realización mecánica. Fue igualmente su fuerza como su ilusión: la mecanización y la uniformización del mundo' como finalidad, el último fin de la felicidad humana, olvidando que el mundo no es una organización sino un organismo "24.

La oposición entre la comprensión mecánica y orgánica ${ }^{25}$ del mundo fue tratada por Goethe y expuesta sucesivamente por Spengler ${ }^{26}$ y Frobenius. La concepción filosófica del mundo que nos rodea como un ser vivo, cambiante, alejó a Borchers del manifiesto pro ingenieril de Le Corbusier. La naturaleza se alza como el campo de búsqueda de las verdades trascendentes y de construcción de un imaginario de formas. Especial interés y resonancia tuvo la figura de Goethe y sus estudios de la naturaleza ${ }^{27}$ en Borchers, dadas las similitudes encontradas en sus métodos, fines y referencias. Goethe utiliza como método de observación de la naturaleza el registro de las características aparentes de las plantas, para luego mediante una inducción plantear conclusiones que tienen como fin alcanzar una relevancia universal, pese a lo limitado del campo de investigación. El concepto de metamorfosis propuesto por Goethe consiste en la transformación de diferentes partes de una totalidad, siendo cada una de ellas una derivación, es decir, una transición gradual de un elemento en otro. Bajo estos supuestos, Borchers ve cada una de las catedrales góticas como la concreción de las múltiples posibilidades de una idea que da lugar a un trazado, una manifestación sensible de un conjunto interno de variables limitadas. Cada una de las catedrales es una exteriorización de un orden, del mismo modo que una hoja lo es de una planta. $\mathrm{Al}$ igual que Le Corbusier, Borchers aplica los trazados regidos por proporciones, tanto a objetos naturales como a construidos, pero como una herramienta representativa de la diferenciación entre el objeto geométrico y el sensible (fig. 3). El estudio geométrico de los objetos naturales de configuración simple, tales como el huevo o la hoja, le permite reconocer las sutiles irregularidades de lo que aparenta ser similar, "dando lugar dentro de lo regular a la eterna variación”. Borchers lleva esta diferenciación al ámbito de la arquitectura, homologando el objeto sensible a la obra de arquitectura construida y el objeto geométrico al esquema de dicha obra, aclarando que el esquema no es la obra, sino que una generalización o reducción de un objeto concreto. El significado asignado a las irregularidades en las medidas aparentemente similares en templos y catedrales es una variable fundamental de la plasticidad en la arquitectura, contraponiéndose a los deseos de exactitud de la arquitectura moderna. Si para Le Corbusier "la plástica, es aquello que se ve y se mide con los ojos" reconociéndose lo plástico a través de la proporción o las "cantidades dispuestas en relaciones precisas" 28 , Borchers abre las puertas a una valoración de las diferencias.

\footnotetext{
${ }^{24}$ Ibíd., pp. 161.

${ }^{25}$ Acerca de la tradición mecanicista y organicista en arquitectura, cf. Rowe, Colin. The Architecture of Good Intentions : Towards a Possible Retrospect. London: Academy Editions, 1995.

${ }^{26}$ Spengler, Oswald. La Decadencia De Occidente. Bosquejo De Una Morfología De La Historia Universal. Madrid: Editorial Espasa Calpe, 1958.

${ }^{27}$ Cf. Goethe, Johann Wolfgang von. Teoría De La Naturaleza. Madrid: Editorial Tecnos, 1997.

${ }^{28}$ Ibíd.
} 


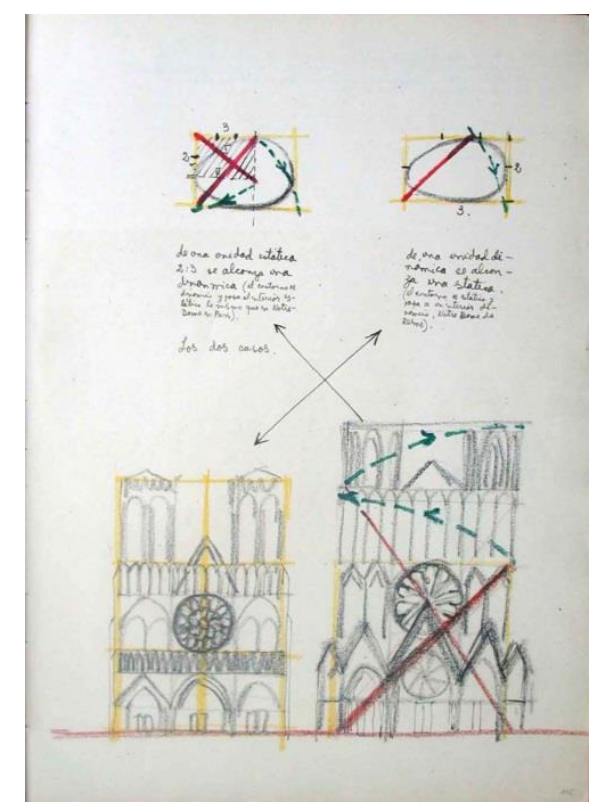

3. Trazado de las fachadas de las catedrales de Notre Dame de Reims y Notre Dame de París y su comparación con el trazado de un huevo. Cuaderno de Egipto, 1948. FJB-L22-004.

\section{El Partenón y su tiempo: sincronía o anacronía}

“Después de dos mil años, los que han visto el Partenón han sentido que había en él un momento decisivo de la arquitectura, 29 .

Las páginas dedicadas al Partenón en Hacia una Arquitectura, acompañadas por la fotografías de Frederic Boisonnas, describen y analizan al monumento paradigmático de la arquitectura moderna, valorándolo como un emblema de austeridad, pureza y decantación hacia lo más económico. Ese objeto celebre por las "sabias compensaciones", símbolo de la eliminación completa de las impurezas fruto de un proceso finalizado en el momento en que ya no era preciso quitar nada, es para Borchers la expresión de la muerte de una civilización.

Para Borchers, la arquitectura es sincronía, es decir, hay una coincidencia entre el objeto proyectado y la época en la cual es pensado. Por el contrario, la geometría que soporta a ese objeto proyectado es anacrónica, ya que no cobra sentido en la época, porque está fuera de su tiempo. Pero no toda obra por ser construida en su tiempo, es de su tiempo; una afirmación que se puede inducir de la observación realizada por Borchers acerca de la falta de armonía respecto de su tiempo del Partenón: "El primer templo griego era más armónico en el sentido viviente que el Partenón, tenía un poder de sincronismo superior al del Partenón, con el Partenón comienza el anacronismo" 30 . Una pregunta que surge de esta afirmación es: ¿Con que argumentos una obra valorada como una referencia irremplazable de orden y simetría, y paradigma de la arquitectura griega puede ser considerada "anacrónica"? Una primera pista surge del término "viviente", un eco del concepto acuñado por Goethe de "naturaleza viviente", aplicado por Spengler y Frobenius a sus interpretación de la cultura como si de un ser vivo se tratara. Dicho esto, no tan extraño resultará este juicio si utilizamos como elemento de contrastación el cuadro sinóptico de Spengler en el cual clasifica con personajes y hechos, cada una de las cinco etapas del ciclo de vida

\footnotetext{
${ }^{29}$ Le Corbusier, op. cit., 1998. pp. 180.

${ }^{30}$ Carta de J. Borchers a I. Suarez, 16/5/1949 (FJB-C0063).
} 
de las cuatro culturas relevantes de la Historia Universal (cultura egipcia, antigua, árabe y occidental), ubicando a la Acrópolis de Atenas y a su Partenón en la cuarta etapa de la Cultura Antigua, un período de "suma perfección de un lenguaje "perespiritualizado" de las formas", alejado del nacimiento y el perfeccionamiento de las formas de una cultura y previo al fin de un estilo. Spengler con el participio "perespiritualizado" hace alusión a un lenguaje en el cual el pasado se ha desvanecido al punto de tener una impresión inmóvil, intemporal, inmutable en su interior, una característica propia del estilo dórico, según él. Al igual que la geometría fruto de sucesivos procesos de abstracción, simplificación y decantación pasó a ser anacrónica, el Partenón como expresión representativa del pensamiento plástico griego, es el producto de un proceso similar de abstracción, simplificación y decantación en el cual, desde la posición del Partenón, los templos construidos con anterioridad pueden ser considerados ensayos. Así interpretado podemos concluir que en la medida que el producto de una cultura se depura, resolviendo sus problemas y dudas, pierde su condición viviente, orgánica y cambiante, transformándose en formula, una obra que no deja espacio al titubeo, a la vacilación, a la ambigüedad. Bajo este punto de vista la anacronía o sincronía no es interna a la obra, en el sentido de una cierta perfección en la aplicación de un sistema plástico, sino que tiene relación con el estado de desarrollo de una cultura.

\section{La escala en arquitectura (o la crítica al Modulor)}

Borchers conocía el sistema proporcional del Modulor en el año $1948^{31}$, posiblemente a través de la breve mención aparecida en las Oeuvre Complete 1938-1946 o en el artículo publicado por Matila Ghyka en la revista británica Architectural Review, en febrero de $1948^{32}$. El Modulor fue expuesto por primera vez el 25 de abril de 1947, en una conferencia dictada por Le Corbusier en el Congreso anual del American Designers Institute, conferencia publicada en la revista “Design” el mismo año ${ }^{33}$. En 1950 por fin verá la luz el libro bajo el título, Le Modulor ${ }^{34}$, cuyo objetivo primordial es la normalización de la construcción a nivel mundial, sin diferenciar economías o culturas. El sistema de medidas está fundado en la escala humana y la matemática, restringiendo el sistema proporcional a las medidas del cuerpo humano y un sistema de crecimiento reglado por la serie de Fibonacci. Al igual que en el principio de Protágoras, "el hombre es la medida de todas las cosas", el Modulor es la síntesis de un antropocentrismo y la simple constatación de que el hombre mide todos los objetos consigo mismo.

Le Corbusier, fuertemente impactado por la obra de Matyla Ghyka, construyó geométricamente el Modulor a partir de la altura estandarizada de un hombre (1,83 m.) y su división mediante la sección áurea. Borchers veía con escepticismo la validez universal que se le daba a la sección áurea como invariable estética sin un fundamento ni matemático, ni fisiológico ${ }^{35}$. El matemático norteamericano George Birkhoff también lo afirma en su libro La Media Estética ${ }^{36}$, estudiado por Borchers: "la sección aurea no es diferente a otras proporciones respecto de poseer propiedades geométricas simples." Con ello Borchers se desliga del tradicional tratamiento

\footnotetext{
${ }^{31}$ Borchers menciona el Modulor en su Cuaderno de Egipto. 1948 (FJB-L22-044). El libro lo compró en el mes de octubre de 1950 (FJB-C0170)

${ }^{32}$ Cf. Ghyka, Matila 1948, "Le Corbusier's Modular and the Concept of the Golden Mean", The Architectural Review n ${ }^{\circ} 103$, p. 39-42.

${ }^{33}$ Cf. Matteoni, Dario. La Ricerca Di Una Idea Di Proporzione: Il Modulor. Parametro n ${ }^{\circ}$ 85. Faenza: Faenza Editrice. 1980.

${ }^{34}$ Le Corbusier. Le Modulor : Essai Sur Une Mesure Harmonique a L'echelle Humaine Applicable Universellement a L'architecture Et a La Mécanique. Boulogne: Editions de l'architecture D'aujourd'hui, 1950.

${ }^{35}$ Borchers también estudio la obra del psicólogo alemán Gustav Fechner.

${ }^{36}$ Birkhoff, George David. Medida Estética. Rosario: Imprenta de la Universidad Nacional del Llitoral, 1945.
} 
estético de las proporciones y de las facultades simbólicas concedidas a la proporción aurea. Para él "las relaciones proporcionales no son bellas ni no bellas ${ }^{\text {"37 }}$.

Según Borchers, otra de las influencias que gesta el Modulor es la música serialista ${ }^{38}$, aunque dudando si Le Corbusier tenía una noción clara y definida del fenómeno musical o solo utilizaba las expresiones musicales de manera metafórica ${ }^{39}$. Esta duda se funda en la falta de especificación en la manera de relacionar las unidades de la serie como en la música serialista, en la cual la secuencia de notas no es aleatoria sino definida por reglas.

Por último, una debilidades del Modulor para Borchers es no declarar sus fuentes de información, alejándose de la tendencia de la investigación de indicar el origen, haciendo difícil ubicar su "invención" en el contexto de su tiempo y en la historia, catalogándola de "elucubración” validada por su talento y experiencia dimensional.

El punto de partida de Borchers para la determinación del concepto de escala en la arquitectura fueron los objetos que forman parte del medio natural, tales como animales, árboles y hombres; todos ellos unidades reconocibles cuyas medidas son referencias para nuestros sentidos: tacto o visión. A estos objetos los llamó portadores de escala, dada su capacidad de contener y transportar medidas estandarizadas. La correlación entre las medidas de este conjunto de objetos y el hombre, da pie a Borchers para adjetivar la escala de la cual son portadores, como escala humana ${ }^{40}$, un concepto que lo considera un suceso contemporáneo, de la mano de su principal divulgador, Le Corbusier.

La experiencia sensible de la escala es mediada por el órgano de la visión y su capacidad para percibir la lejanía, la cercanía y la progresión de la profundidad, junto a los mecanismos de corrección óptica que dan lugar a los fenómenos perspectivos. El concepto de fenómeno perspectivo hace alusión a la experiencia de la profundidad y como ella se hace presente a la conciencia del observador a través de los sentidos.

Descritos estos dos campos, los objetos portadores de escala humana y el de los fenómenos perspectivos, Borchers emplaza el fenómeno arquitectónico en la zona de mediación entre estos dos, denominándolo mundo intermediario (fig. 4). Con este gesto, aunó de manera expresa dos campos de difícil integración, argumentando además, la carencia de este nexo en las teorías contemporáneas de la arquitectura ${ }^{41}$, no así en el pasado. A diferencia de su propuesta, el sistema de proporciones de Le Corbusier es lineal, "más allá de 2 m. 26 (última medida que dice del cuerpo humano), las medidas que aparecen en el Modulor son sólo extensión ilimitada donde ciertamente caben métricamente y análogas las iniciales. Realmente pudieron ser otras cualquiera" ${ }^{42}$.

Todo el largo proceso de experimentación y reflexión acerca de la escala en arquitectura se decanta en la obra póstuma de Juan Borchers Meta Arquitectura (1975), madurada junto a Jesús Bermejo, donde expone la serie

\footnotetext{
${ }^{37}$ de la Cruz, Rodrigo. Introducción. Revista ARS n 8 / 9. Número dedicado al Centenario del nacimiento de Le Corbusier, 1987. pp. 57-58.

${ }^{38}$ El arquitecto y músico Xenakis trabajó con Le Corbusier desde 1948 en adelante.

${ }^{39}$ Borchers, Juan. "Conclusión". En Peñafiel, José Domingo: Le Corbusier y su Modulor. Director: Juan Borchers. Pontificia Universidad Católica de Chile, 1974. pp. 46-58.

${ }^{40}$ No se debe confundir medir con el cuerpo con la escala humana.

${ }^{41}$ Cf. Padovan, Richard. Proportion: science, philosophy, architecture. 1999; Irace, Cimoli. La Divina Proporzione. Atti del convegno (Milano, 27-29 settembre 1951). 2007.

${ }^{42}$ Borchers, op. cit., 1974.
} 
cúbica, el papel del número y la acción de medir en arquitectura desde el punto de vista perceptual, aritmético, geométrico, histórico, filosófico y musical. La serie cúbica es un sistema de control métrico y rítmico de la obra de arquitectura, compuesto por 22 valores divididos en 3 sistemas representativos de cambios en el fenómeno de la percepción (fig. 5). Aunque no profundizaremos aquí en esta similitud, Borchers evidencia en el Prefacio su deuda hacia la obra de Dom Hans van der $\operatorname{Laan}^{43}$, señalando que utiliza el sistema del monje holandés ampliándolo en ciertos ámbitos. La obra de van der Laan era y es absolutamente desconocida en Latinoamérica salvo contadas excepciones, siendo El Modulor (1950) de Le Corbusier el referente casi único en el ideario moderno acerca de las proporciones en arquitectura. Si la comparamos con el Modulor ${ }^{44}$, podremos ver que la serie cúbica ${ }^{45}$ está constituida por una sucesión de magnitudes de crecimiento más lento y el sistema de medidas aborda tanto la escala humana como aquella del objeto, quedando esta última bajo el control de la percepción.
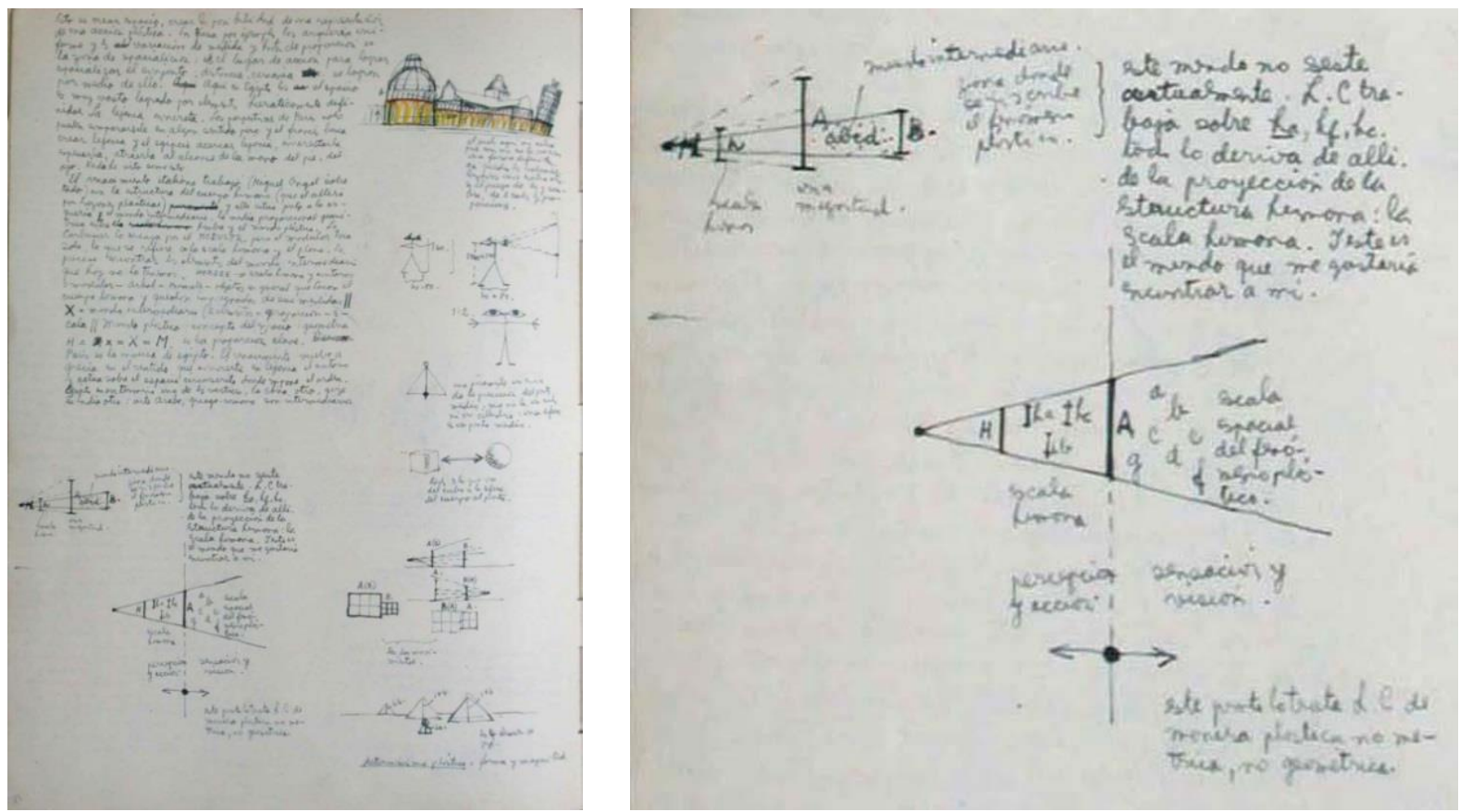

4.-4a. Cuaderno Egipto, noviembre de 1948. FJB-L22-044. "mundo intermedio / zona donde / se inscribe / el fenómeno / plástico / este mundo no existe / actualmente L. C: tra- / baja sobre ha, $h b, h c /$ todo lo deriva de allí / todo esto que va / de la proyección de la / estructura humana: la / escala humana. Y este / es el mundo que me / gustaría encontrar a mi."

\footnotetext{
${ }^{43}$ Laan, Hans van der. Le Nombre Plastique; Quinze Leçons Sur L'ordonnance Architectonique. Leiden: E.J. Brill, 1960.

${ }^{44}$ Le Corbusier planteó dos series a partir de la subdivisión mediante sección aurea de la altura de un hombre $(1,83 \mathrm{~m}$.) y la altura de un hombre con el brazo estirado (2,26 m.). La serie roja: 6, 9, 15, 24, 39, 63, 102, 165, 267, 432, 698, 1.130, (1.829), 2.959, 4.788, 7.747, 12.535, ... ; la serie azul: 11, 18, 30, 48, 78, 126, 204, 330, 534, 863, 1.397, (2.260), 3,658, $5.918,9.576,15.494,25.069, \ldots$ Entre paréntesis se marcan las dos alturas antes descritas.

${ }^{45}$ Los valores de la serie cúbica de Juan Borchers son: 4, 5, 7, 9, 12, 16, 21, (28), 37, 49, 65, 86, 114, 151, (200), 265, 351, 465, 616, 816, 1081, 1432. Entre paréntesis se marcan los dos cambios entre los tres campos. A diferencia del Modulor no son medidas sino que números.
} 


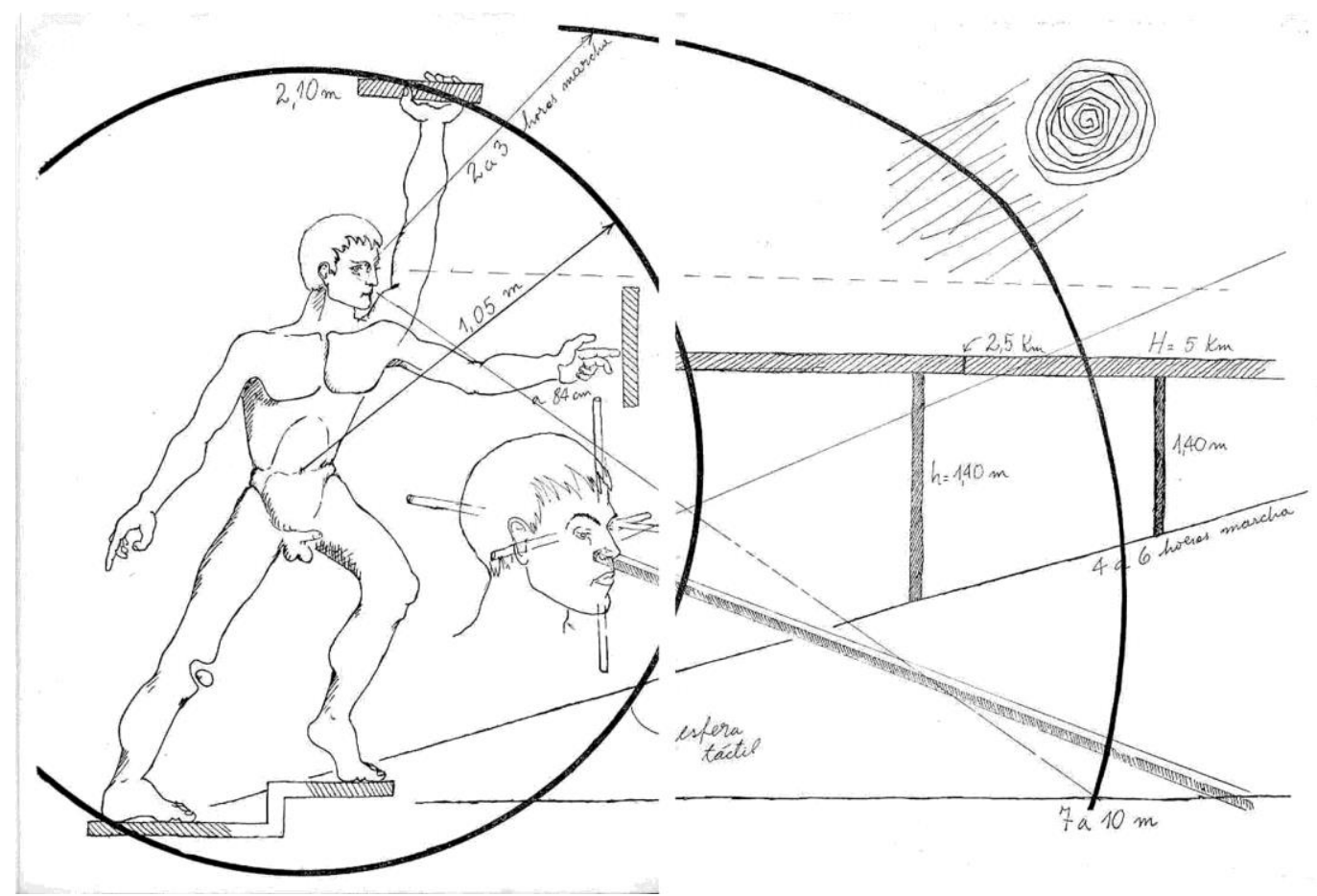

5. Los tres campos definidos por los cambios en la percepción: táctil, el visual o pictórico y el musical.

\section{7. "L'espace indicible"}

“"Estremecerse es lo más grande que puede hacer la humanidad.»Y aquel a quien el sino le haya negado este estremecimiento debe intentar descubrir los misterios; debe lanzarse sobre las cosas que imponen respeto, para despedazarlas, destruirlas y sacar de las ruinas su botín de ciencia. El afán de sistema es afán de matar lo viviente. En el sistema, las cosas vivas quedan fijadas, anquilosadas, atadas a la cadena de la lógica. El espíritu ha vencido cuando ha logrado llevar a buen término su empresa de petrificación ",46.

El Campo de los Milagros es una pieza fundamental en los estudios de Borchers, al igual que para Le Corbusier. En la descripción del proyecto para el Palacio del Soviets (1931) de Le Corbusier en las Oeuvre Complete 19291934, presentó una comparación entre el Campo de Pisa y sus componentes: el Duomo, el Baptisterio y la Torre, registrado a su paso por Pisa en tren el 4 de junio de 1934. Los dibujos del alzado del Palacio del Soviet y del Conjunto de Pisa aparecen en paralelo y ligados por el modo común en que se manifiestan sus reglas arquitectónicas desde la unidad al detalle, todo ello comprimido en una dimensión temporal y perceptiva, "tout a coup".

Pese a la instantaneidad de la percepción de Le Corbusier no debemos olvidar que la de 1934 fue su tercera visita a Pisa, habiendo sido cada una de las anteriores, una aproximación en diferentes escalas y una insistencia en lo mismo. Los dibujos de Le Corbusier son una cristalización y un testimonio de esas aproximaciones e insistencias. En su primera visita (1907), Jeanneret levantó minuciosamente los elementos arquitectónicos y precisó el rol de ellos en el ensamblaje de cada uno de los edificios. En su segunda visita (1911) se refirió esencialmente a las relaciones entre los edificios del conjunto entendiendo el Campo como un total, resaltando

\footnotetext{
${ }^{46}$ Spengler, op. cit., pp. 25
} 
las cualidades volumétricas. En el tercero (1934) dibujó el perfil del ensamble entre los edificios, una vista lejana que rememora una experiencia anterior, siendo utilizada como aclaración de su proyecto para el Palacio de los Soviets, el ensamblaje de edificios individuales y la autonomía relativa de cada una de las partes. Ese tiempo de decantación que cubre unos veintitrés años es comprimido en su frase tout a coup, momento en que la apariencia velada se transforma en una aparición.

Doce años después de la tercera visita a Pisa, Le Corbusier publicó $L$ ' espace indicible ${ }^{47}$ en la revista $L$ ' Architectured' Aujourd' hui ${ }^{48}$, articulo que a fines de la década del '50 transformó en un proyecto de libro que no se llegó a editar ${ }^{49}$. El artículo, compuesto paralelamente por textos e imágenes, navega entre sus proyectos de arquitectura y urbanismo no construidos, las pinturas y las esculturas. Amparándose en su extensa práctica en las artes mayores -arquitectura, escultura y pintura- aboga por su encuentro, esclareciendo la misión de cada una de ellas: "El urbanismo dispondrá, la arquitectura dará forma, la escultura y la pintura dirigirán las palabras selectas que son su razón de ser" ${ }^{\text {} 50}$. Los proyectos utilizados son un acicate para la crítica y la reflexión, delimitando a través de lo ya realizado su búsqueda en el presente; búsqueda no libre de contradicciones y ambigüedades. En lo medular, para Le Corbusier toda obra de arte posee una parte intencionadamente oculta, un mundo verdadero que revela su significado solo a quien lo merece o a quien está dotado de la capacidad de síntesis necesaria para poder sentir y comprender el fenómeno. El espacio indecible se manifiesta en el momento de la anulación de los muros, los elementos concretos, pasando de lo contingente a lo trascendente. Los objetos ya no son vistos a través de un recorrido de un ojo atento, sino mediante su manifestación simultánea ${ }^{51}$. El espacio indecible es la cúspide de la emoción plástica. Podremos ver más adelante como esta caracterización coincide con la visión de golpe.

Entre su primer viaje a Europa en 1938 y 1950, Borchers dedica el trabajo más intenso y extenso al Campo de los Milagros la tercera de las cinco veces que lo visitó. El registro en las libretas ${ }^{52}$ de esta estancia se presenta dentro de un horizonte común de análisis de los elementos de un conjunto desde diferentes posiciones del observador, cuadro a cuadro, constatando las diferencias perceptuales que ellas implicaban. Borchers refleja en el objeto observado sus movimientos por el Campo; contrasta la perspectiva desde cada punto, con el fragmento de planta que le corresponde, destacando las superficies visibles, su perfil, sus zonas de sombra y las iluminadas (fig. 6). Los dibujos, expresión de la relación entre sujeto y objeto guardan similitudes con el dibujo de la portada del capítulo dedicado al plan en Vers une architecture (fig. 7), representando la Acrópolis de Atenas con una sección de la planta y la visión en perspectiva. El conjunto planta-perspectiva reproducido por Le Corbusier en estas páginas y otras posteriores, pertenecen a la Histoire de l'Architecture ${ }^{53}$ de Auguste Choisy ${ }^{54}$, quien

\footnotetext{
${ }^{47}$ Le Corbusier. El Espacio Inefable. Minerva. Revista del Círculo de Bellas Artes. IV época, n 2. 2006. pp. 6-11.

${ }^{48}$ Sabemos que Borchers leyó el articulo L' espace indicible de Le Corbusier, por su referencia en Meta Arquitectura: "Hacia 1945, fecha muy próxima al "Saggio" de Zevi, Le Corbusier había publicado su artículo, emotivo y espiritual, $L$ ' espace indicible." (Borchers, op. cit. 1975, p. 54).

49 Cf. Smet, Catherine, Construcción suspendida: la obra editorial inacabada. En AAVV. Le Corbusier et le livre. Barcelona: COAC. 2005. pp. 164-199.

${ }^{50}$ Le Corbusier, op. cit., p. 11.

${ }^{51}$ Álvarez, Fernando. No dejar solas a las sombras. Algunos comentarios sobre "l' espace indicible" de Le Corbusier, DC PAPERS, Revista de Crítica y Teoría de la Arquitectura, $\mathrm{n}^{\circ}$ 1. 1998. pp. 57-77.

${ }^{52}$ Pisa queda registrada en dos libretas y un cuaderno: las libretas $n^{\circ} 7$ (FJB-L02-0007) y $\mathrm{n}^{\circ} 8$ (FJB-L02_0008) y el Cuaderno para Isidro (FJB-L21-0043).

${ }^{53}$ Choisy, Auguste. Histoire De L'architecture. Paris: Gauthier-Villars, 1899.
} 
dedica cuatro conjuntos planta-perspectiva ${ }^{55}$, las únicas de un libro profusamente ilustrado, para mostrar como en la Acrópolis de Atenas se produce el equilibrio de masas, seleccionando y privilegiando ciertos puntos de visión, desde donde los ángulos en los que se inscribe cada uno de los perfiles en planta de los diferentes cuerpos que componen el conjunto son simétricos. A diferencia de Choisy, Borchers fija aquellos momentos en que se establecen relaciones de continuidad entre los edificios. En su afán por comprender la realidad en la cual está inmerso, no toma el objeto arquitectónico como un cadáver el cual es objeto de disección, sino que lo aprecia como un cuerpo vivo del cual es necesario experimentar todas sus posibilidades. La obra de arquitectura no es únicamente una sumatoria de apariencias, sino también un fenómeno continuo posible de ser sentido y expresado unitariamente. Veinticinco años después saldrá a la luz como una imagen que rememora su experiencia:

"En el lapso, que debió de ser breve, pero que en mi imaginación me parece inmenso, apareció súbitamente el conjunto del Duomo de Pisa. Lo que duró esa percepción fugaz puedo pensarla como unos pocos minutos, si es que no más breve, un inmenso esqueleto desnudo hecho en mármol; una gran osamenta con el color de hueso" ${ }^{, 56}$.

La imagen que percibe Borchers de Pisa es sublime: la gran osamenta. Una asociación antropomórfica en la que subyace una estructura ligada a lo figurativo y un entramado denso de relaciones abstractas. Las posibilidades de lectura de esta imagen son varias. Primero está la asociación con el cuerpo humano, constituido por carne y huesos. La segunda, parafraseando a Goethe "en el esqueleto se ha conservado de manera segura y para la eternidad, el carácter exacto de toda forma "57. La tercera, el esqueleto se puede considerar como un complejo dimensional en el cual las partes están reguladas por reglas de proporción que constituyen un total. Y por último, parafraseando a Le Corbusier y su caracterización del proyecto para el Palacio del Soviets como un ser vivo compuestos por... "los tendones y los huesos de soporte y articulación, las capas musculares y las vísceras que contienen a las multitudes $" 58$.

La apariencia se transmuta en aparición justo en el momento en que toda la racionalidad acumulada es suspendida y reemplazada por una expresión, dejando de lado el pensamiento rigidizado por la normativa, abriéndolo al nombre poético, vital. La forma aparente o, como le dice Spengler, forma intuitiva, es la manera de estudiar la realidad en la antigüedad. Un paso más allá de esa forma intuitiva es su comprensión mediante las leyes invisibles que lo constituyen, aquello que no es aparente y que se plantea mediante la hipótesis metódica: "Pero la mirada profunda, que penetra en lo esencial, extrae de esa contingencia formas puras que, ocultas en lo más hondo, no se dejan descubrir fácilmente. Estas formas constituyen la base de todo el devenir humano"59.

\footnotetext{
${ }^{54}$ Cf. Banham, Reyner. Teoría Y Diseño En La Primera Era De La Máquina. Barcelona: Ediciones Paidos. 1985; Hidalgo, Germán. Los ecos de la planta: Organización lógica de las sensaciones espaciales, ARQ n 58. 2004. p.68-71.

${ }^{55}$ Esta secuencia descrita por Choisy es reproducida por Sergei Eisenstein en su artículo Montaje y Arquitectura (1938) en el que trata, precisamente acerca de la representación de un fenómeno y su multidimensionalidad. Le Corbusier conoció a Eisenstein en Moscú en 1928, declarando en una entrevista a un periodista moscovita: "Arquitectura y cine son las únicas artes de nuestro tiempo. En mi propio trabajo yo he pensado como Eisenstein lo hace en sus películas." (WEBER, N. F. 2008. Le Corbusier : a life, New York, Alfred A. Knopf). Contemporáneamente, Borchers comparó algunas de las películas de Eisenstein con obras de arquitectura por sus características geométricas.

${ }^{56}$ Borchers, op. cit., 1975, p. 245

${ }^{57}$ Goethe, Johann Wolfgang von. Teoría De La Naturaleza. Madrid: Editorial Tecnos, 1997.

${ }^{58}$ Le Corbusier, op. cit., 2006. pp. 8.

${ }^{59}$ Spengler, op. cit., 1958, pp. 150.
} 
Podría resultar contradictorio que en ambos casos esta visión de golpe -Borchers lo denomina lapso breve y percepción fugaz- tuviera un tiempo tan largo para salir a la luz, pero resulta evidente que la primera intuición, indeleble e indecible en un principio, es develada tras las diversas aproximaciones al objeto arquitectónico, logrando en definitiva que esa aparición inicial sea comprendida, cercada, por intermedio de la apariencia, por la representación intencionada de la realidad.

"Esa primera sensación perduraría siempre, como la base soterrada que los trabajos, más analíticos y prolijos posteriores, no sólo no la borra, sino que además, la sostiene como si fuera su esencia fundamental "60.

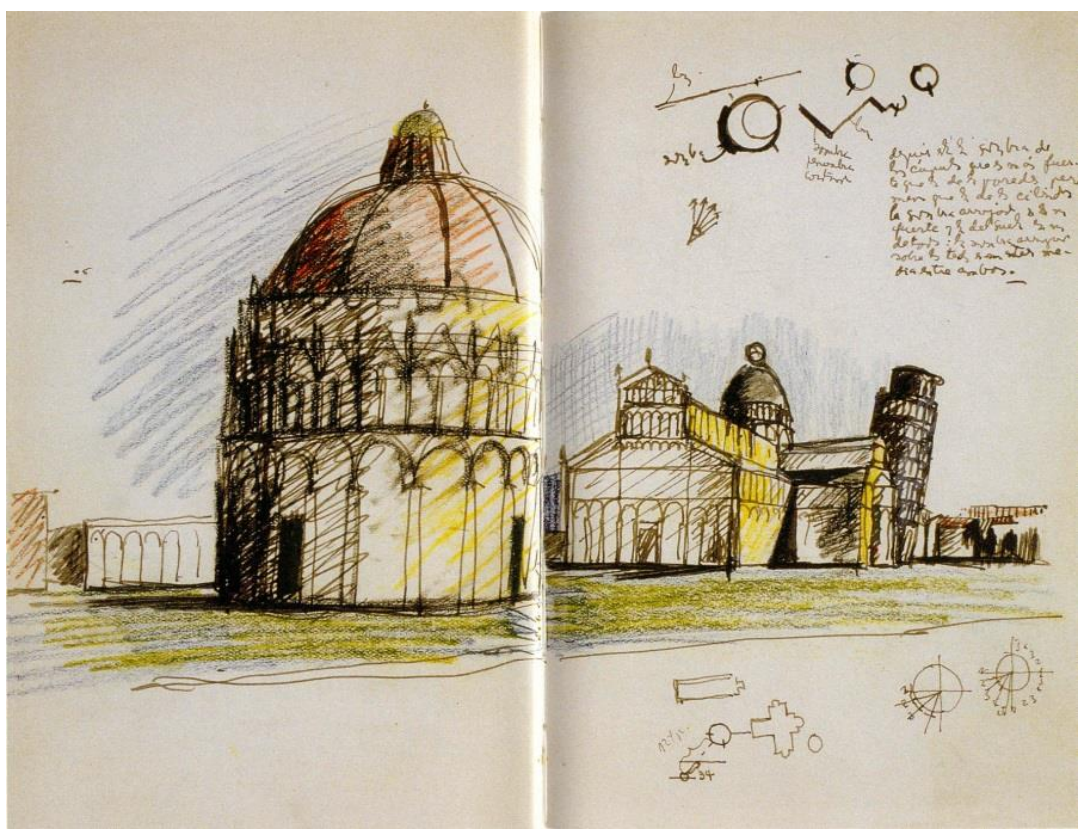

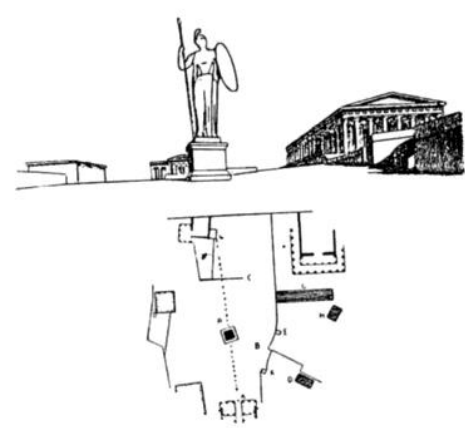

TRES ADVERTENCIAS A LOS SEÑORES ARQUITECTOS III EL PLAN

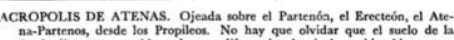

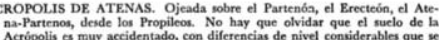

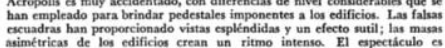

6. Dibujos del Campo de los Milagros, Pisa, Libreta 7, entre el 1 y el 4 de Octubre de 1948 (FJB-L02-0007).

7. Portada de la tercera advertencia dirigida a los arquitectos, incluida en Hacia una arquitectura, Le Corbusier (Le Corbusier, 1998, p. 31)

\section{Conclusión}

Le Corbusier se alza como el referente intelectual de la arquitectura contemporánea de Borchers, punto de partida para iniciar la construcción de su propia teoría, tejida con asociaciones del campo de la filosofía, la matemática, las ciencias naturales, la historia, la poesía, la música y la antropología.

Las leyes fisiológicas del arte son un campo de estudio común, ampliado por Borchers con las investigaciones de la psicología experimental y las certidumbres obtenidas por el conocimiento de las relaciones matemáticas entre estímulo y sensación, dotando la construcción de la serie cúbica de un rigor científico del cual adolecía el Modulor.

\footnotetext{
${ }^{60}$ Borchers, op. cit., 1975, pp. 245.
} 
Si bien, ambos buscan fundamentar su obra en leyes de validez universal, el imaginario asociado se enmarca en dos tradiciones opuestas de la arquitectura: la mecánica y la orgánica. Le Corbusier elogia la exactitud moderna de las máquinas y las leyes que las gobiernan, en cambio Borchers, seducido por la naturaleza viviente, por los organismos, centraliza su atención en las diferencias y transformaciones de las configuraciones de un mismo tipo, en cuanto a ser expresión de vida. Si para Le Corbusier la Naturaleza es una analogía discursiva en sus planteamientos arquitectónicos, para Borchers es la fuente de las reglas de control de la obra de arquitectura.

Todas estas diferencias y similitudes expresan la relevancia del maestro para Borchers, sin duda el mayor de sus contemporáneos, sin perder de vista la necesaria reformulación de sus principios.

En 1965 Borchers, durante el ciclo de diecisiete conferencias (escritos-lecturas) parcialmente publicados en Institución Arquitectónica en 1968, relata el silencio que siguió a la muerte del maestro:

“Acababa de leer el decimotercero escrito-lectura; poco después, horas, moría Le Corbusier, y esto fue causa por lo que dejé pasar dos meses antes de reiniciar las lecturas. "61

\section{Agradecimientos}

Agradecimientos al Archivo de Originales Sergio Larraín García-Moreno de la Facultad de Arquitectura, Diseño y Estudios Urbanos de la Pontificia Universidad Católica de Chile, por su colaboración en la elaboración de este artículo.

\section{Procedencia de las imágenes}

Imagen 1 y 2 Borchers, J. 1970; Imagen 3, 4 y 6 Fondo Documental Juan Borchers F., Archivo de Originales SLGM. FADEU. Pontificia Universidad Católica de Chile; Imagen 5 Borchers, J. 1975; Imagen. 7 Le Corbusier 1998.

\section{Referencias bibliográficas}

Álvarez, Fernando. No dejar solas a las sombras. Algunos comentarios sobre "l' espace indicible" de Le Corbusier, DC PAPERS, Revista de Crítica y Teoría de la Arquitectura, n ${ }^{\circ}$. 1998. pp. 57-77.

Apollinaire, Guillaume. Meditaciones Estéticas. Los Pintores Cubistas. Sobre La Pintura. Pintores Nuevos. Madrid: Antonio Machado Libros, 2001. Traducción de: Les Peintres Cubistes :(Méditations Esthétiques). Paris: Eugène Figuière et Cie, 1913.

Borchers, Juan. Institución Arquitectónica. Santiago de Chile: Editorial Andrés Bello, 1968.

Borchers, Juan. La Medición Como Substrato Del Fenómeno Arquitectural. Con Cantidades Crear Cualidades. Hogar y Arquitectura, Revista Bimestral de la Obra Sindical del Hogar, 1970, p. 26-39.

Borchers, Juan. "Prólogo"; "Conclusión”. En Peñafiel, José Domingo: Le Corbusier y su Modulor. Director: Juan Borchers. Pontificia Universidad Católica de Chile, 1974. pp. 1-11; pp. 46-58.

Borchers, Juan. Meta Arquitectura. Santiago de Chile: Mathesis Ediciones, 1975.

\footnotetext{
${ }^{61}$ Borchers, Juan. Institución Arquitectónica. Santiago de Chile: Editorial Andrés Bello, 1968.
} 
Borchers, Juan: Lo Plástico, Plástica, cosa General. Santiago: Ediciones Universidad Central, 2014. Publicación de: Carpeta Plástica, 1962/1966, FJB-D0539.

Choisy, Auguste. Histoire De L'architecture. Paris: Gauthier-Villars, 1899.

de la Cruz, Rodrigo. Introducción. Revista ARS n 8 / 9. Número dedicado al Centenario del nacimiento de Le Corbusier, 1987. pp. 57-58.

Doran, Michael (ed.): Sobre Cézanne. Conversaciones y testimonios. Barcelona: Gustavo Gili, 1980. pp. 51-52.

Frobenius, Leo. La Cultura Como Ser Viviente. Contornos de una Doctrina Cultural y Psicológica. Madrid: Espasa-Calpe, 1934. Traducido del alemán: Paideuma : Umrisse Einer Kultur- Und Seelenlehre. München: C.H. Beck'sche Verl, 1921.

Goethe, Johann Wolfgang von. Teoría De La Naturaleza. Madrid: Editorial Tecnos, 1997.

Le Corbusier. Hacia Una Arquitectura. Barcelona: Ediciones Apóstrofe, 1998. Traducción al castellano de: 1923. Vers une architecture, Paris, Saugnier.

Le Corbusier; Ozenfant, Amédée. "El Ángulo Recto". En Levene, Richard; Márquez Fernando (eds.): Acerca Del Purismo. Escritos 1918/1926. Madrid: El Croquis Editorial, 1993. p. 103-114. Publicación del artículo: L'angle droit, L’Esprit Nouveau n¹8, 1923.

Le Corbusier. El Espacio Inefable. Minerva. Revista del Círculo de Bellas Artes. IV época, n 2. 2006. pp. 6-11. Traducción al castellano de: L'espace indicible. L'Architecture d'Aujord'hui. 1946. pp. 10.

Le Corbusier. Le Modulor : Essai Sur Une Mesure Harmonique a L'echelle Humaine Applicable Universellement a L'architecture Et a La Mécanique. Boulogne: Editions de l'architecture D'aujourd'hui, 1950.

Spengler, Oswald. La Decadencia de Occidente. Bosquejo de una Morfología de la Historia Universal. Madrid: Editorial Espasa Calpe, 1958. Traducción al castellano de Der Untergang Des Abendlandes Umrisse Einer Morphologie Der Weltgeschichte. Viena - Leipzig: Wilhelm Braumüller, 1918-22.

\section{Fuentes documentales}

Borchers, Juan. s/t, block. 1948 (FJB-D0590).

Carta de J. Borchers a I. Suarez, 16/5/1949 (FJB-C0063).

Borchers, Juan. Cuaderno de Egipto. 1948 (FJB-L22-044). 


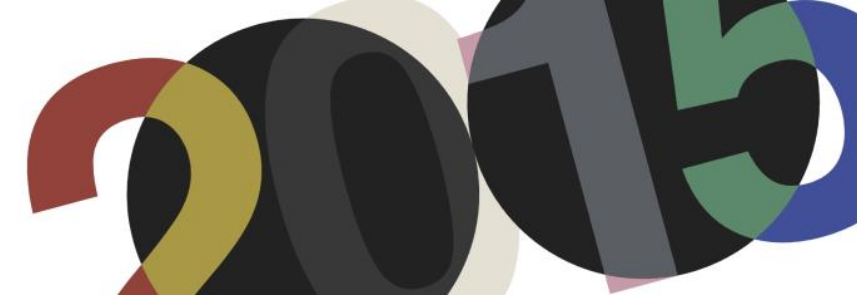

DOI: http://dx.doi.org/10.4995/LC2015.2015.984

\title{
Le Corbusier and the American Modulor
}

\author{
M. Mameli \\ Dipartimento di Ingegneria Civile Ambientale Architettura, Università di Cagliari
}

\begin{abstract}
The definition of the Modulor as a set of measurements obtained through "universal" rules for composition of the new architecture has a long and complex development, stemming from a combination of studies in architecture, geometry and mathematics, but also from approximation and intuition. The process began in Paris in 1920, was completed in 1946 in New York and its results were published in an autobiographical vein in 1950 in the book entitled Le Modulor completed in 1955 by the book Le Modulor II. In his trip to New York in 1946 as French delegate for the project of the United Nations' headquarters, his urgency to define the Modulor responded to an immediate need: to create a simple tool and a compositional principle to be applied to the United States' building programme and to UN reconstruction and recovery programs. Unfortunately Le Corbusier did not manage to find a patron in America. He was unable to apply the Modulor in the USA. Not so in Europe, where work started on building the Unités d'habitation in Marseilles.
\end{abstract}

Resumen: La definición del Modulor como un conjunto de medidas obtenidas a través de reglas "universales" para la composición de la nueva arquitectura tiene un largo y complejo desarrollo, derivada de una combinación de estudios de arquitectura, geometría y matemáticas, sino también de aproximación y intuición. El proceso comenzó en París en 1920, se completó en 1946 en Nueva York y sus resultados se publicaron en el libro titulado Le Modulor completado en 1955 por el libro Le Modulor II. En su viaje a Nueva York en 1946 como delegado francés para el proyecto de la sede para las Naciones Unidas, la urgencia de definir el Modulor respondió a una necesidad inmediata: para crear una instrumento fàcil y un principio compositivo que se aplicará al programa de construcción de los Estados Unidos y para los programas de reconstrucción de la ONU. Desafortunadamente Le Corbusier no encontró un patrón en América. No fue capaz de aplicar el Modulor en los EE.UU.. No es así en Europa, donde comenzó a trabajar en la construcción de la Unités d'habitation de Marsella.

Keywords: New York; UN Headquarter; Modulor; USA.

Palabras clave: New York; Naciones Unidas; Modulor; USA.

\section{Introduction: definitions}

Modulor is the term devised in 1946 by Le Corbusier and his assistants at Rue de Sèvres to indicate a new system of measurements for residential buildings and architecture, which came to be formalised at its highest degree of definition by the graded ribbon with the red and blue series (Fig. 1). The word Modulor joins together the words "module" and "or" (gold). A module is a repeatable unit which can be arranged with other units in different ways; the golden module (Modulor) is the specific module whose arrangement rule is based on the "golden number" or "golden section" or "Phidias' constant" or also "divine proportion". According to Le Corbusier, the Modulor is an "Harmonious Measure on the Human Scale Universally Applicable to Architecture and Mechanics"1. In detail:

\footnotetext{
${ }^{1}$ Le Corbusier: Le Modulor, Éditions l'Architecture d'Aujourd'hui, Boulogne-sur-Seine: Collection ASCORAL, 1950, p. 5. Le Corbusier: Le Modulor II, Éditions de l'Architecture d'Aujourd'hui, Boulogne-sur-Seine: Collection ASCORAL, 1955.
} 
- "measure": these are two mathematical series of measures (the red series and the blue series) providing all the dimensions and points of occupation of space, the measurements of dwellings.

- "harmonious": the numbers of the series are regulated by a "golden" ratio, generated by the particular Pythagorean geometric proportions yielding a single irrational number $\varphi=0,6180339887498948$, the Phidias's constant. These are two Fibonacci series where, based on three measurements a, b and c the ratio of the smaller number (a) to the medium number (b) is equal to the ratio of the medium to the whole number (c) (a:b=b:c where $a+b=c)$. Introduced by Pythagoras and the Pythagoreans and formalised geometrically by Euclid, the golden ratio is Plato's reference for his "theory of the cosmos" in the Timaeus. For Pythagoras and the Pythagoreans the number is the arché of all things, because in the world of phenomena quantitative relations remain unchanged and numerical relations express the order of the universe. The myth of Apollo playing the music of the celestial spheres on the lyre is the quintessential expression of the concept of harmony. In the Italian Renaissance, according to Neo-Platonic humanistic concepts, the golden section became a "divine proportion" because it was the only one among the rules on proportion which held together the mystery of the Holy Trinity (the integer and the two parts comprising it) and the irrationality of faith. In the pages of De divina Proportione by Luca Pacioli, inspired by the treatises of Piero della Francesca, the golden ratio is held to be the standard of beauty for every artistic and architectural composition ${ }^{2}$;

- "on the human scale": these are measures based on the proportions of the human body, based on the height of a man of $1.83 \mathrm{~m}$, equivalent to 6 feet, and used as the reference unit to establish the measures of buildings;

- "applicable universally to architecture and mechanics": in the ideal of Le Corbusier, these principles may be used indifferently in Paris, Marseilles, Algiers, New York and Chandigarh, and in the same way in cities damaged by war, in the most advanced metropolises and in developing countries.

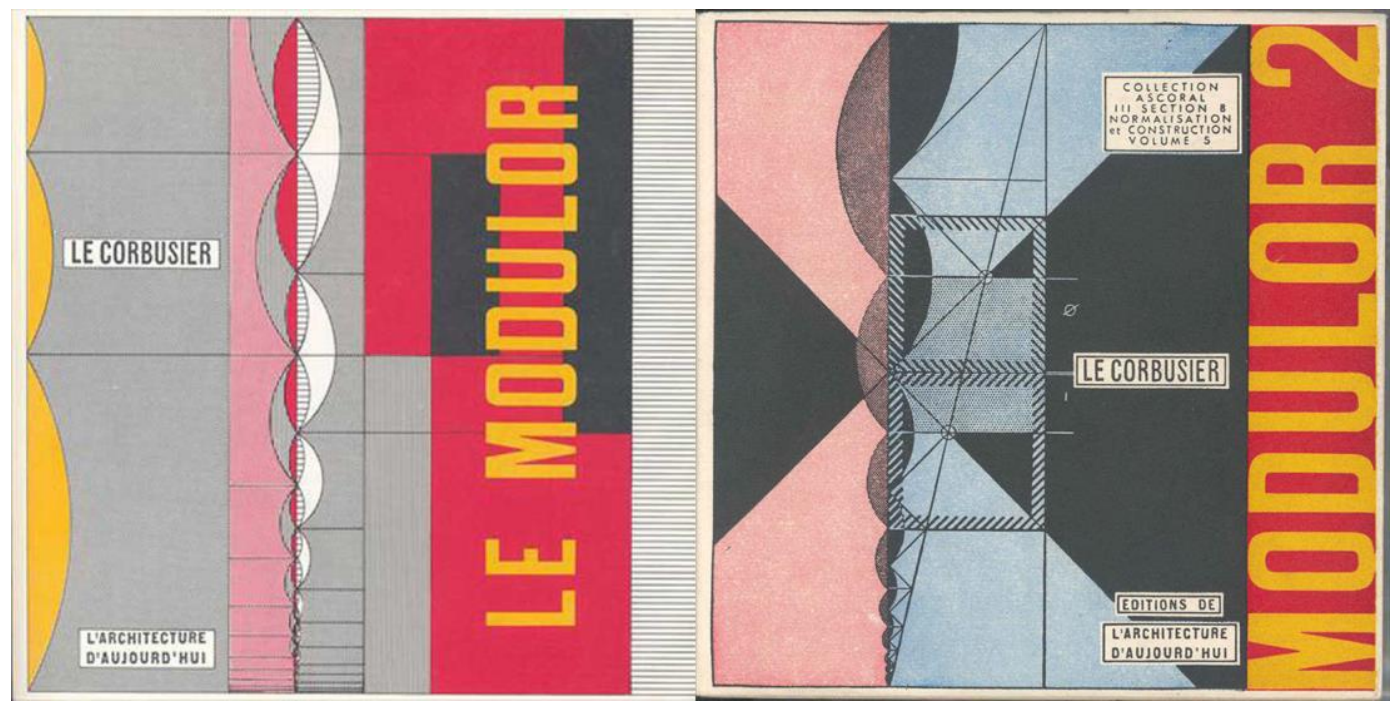

1. Le Corbusier, covers of the books on the Modulor. Le Corbusier: Le Modulor; Le Corbusier: Le Modulor II.

\footnotetext{
${ }^{2}$ Fra' Luca Bartolomeo de Pacioli (1445-1514), Italian mathematician and Franciscan religious. In 1509 he public in Venice De Divina Proportione, conceived in 1497 at the Milanese court of Ludovico il Moro, with the famous engravings attributed to Jacopo de Barbari depicting the Platonic solids. Livio, Mario: La sezione aurea, Milano: Rizzoli, 2003.
} 


\section{The "rule of the right angle" and the "grid of proportions"}

The first definition was developed in 1920: the "rule of the right angle" draws inspiration from the studies on the history of architecture of Auguste Choisy, engineer and teacher of the History of Architecture at the Ecole de Ponts et Chaussée. Le Corbusier had in his personal library a copy of the Choisy's Histoire de l'architecture, in the 1903 edition $^{3}$.

From Choisy's texts, Le Corbusier learnt the method of studying Renaissance architecture through the use of "regulating lines", geometrical constructions and schemes which define the order of the composition of floor plans and façades, also used by Peter Behrens ${ }^{4}$. The analytical principle of the "regulating lines" which made it possible to interpret and understand the main historical buildings, soon became a compositional and design principle: the "loi de l'angle droit". This experience developed in the climate of lively enthusiasm of the Esprit Nouveau, opened by the article Après le Cubisme, and formed part of the broader process of moving beyond Cubism and embarking in aesthetic and cultural renewal pursued by Charles Edouard Jeanneret with his friend, the painter Amedée Ozenfant, on the Revue Internationale d'Esthetique between 1920 and 1925.

The "rule of the right angle" became the geometrical rule and architectural principle of the Purism who partook in the call for a "retour à l'ordre" which was launched after World War One by European artists and was later codified by Jean Cocteau in his "rappel à l'ordre" of $1926^{5}$. The "rule of the right angle" is theorised in the pages of the Esprit Nouveau in the Article "Tracés régulateurs" of 1921 later republished in Vers une architecture $^{6}$ in 1923 and adapted in the chapter "L'angle droit" of the book La Peinture Moderne of 19257. It was also applied to post-cubist pictorial studies presented in the art galleries of Paris from 1921 (Fig. 2). Lastly, it was applied to architecture, in the façades (the "public" side of the home) of the "purist" villas designed like avant-garde paintings: the maison atelier of Amedée Ozenfant, the Stein de Monzie villa and the maison galerie for Swiss banker Raoul La Roche, the greatest supporter and funder of the review (Fig. 3).

In June 1940 the German Army entered Paris: France was to endure Nazi occupation until August 1944. Over this period, the studio of Rue de Sèvres was closed. After his attempts at collaborating with the Vichy government failed, Le Corbusier returned to Paris and focused on study and research to prepare for the reconstruction effort and the need to provide low-cost housing. Thus he studied standardised architectural systems to industrialise building activity.

In 1926, France had established a standard-setting body for the building sector, AFNOR, the French Normalisation Association, under the control of the Ministry of Industry ${ }^{8}$. Le Corbusier was a vehement critic of AFNOR and in 1944 he opposed to it the studies of ASCORAL, the Assembly of builders for architectural renewal, produced by its Section III "Housing Science", Sector b "Standard-setting and construction", aimed at

\footnotetext{
${ }^{3}$ Choisy, Auguste: Histoire de l'Architecture, Parigi: Baranger, 1903 (FLC Z 077).

${ }^{4}$ Cohen, Jean-Louis: "Le Corbusier's Modulor and the Debate on Proportion in France", in Architectural Histories, EHAN, 23, 2014, p. 3. DOI: http://dx.doi.org/10.5334/ah.by.

${ }^{5}$ Cocteau, Jean: Le rappel à l'ordre, Paris: Stock, 1926.

${ }^{6}$ Le Corbusier: Vers une architecture, Paris: Éditions Crès, Collection de "L'Esprit Nouveau", 1923

${ }^{7}$ Le Corbusier: La peinture moderne, Paris: Éditions Crès, Collection de "L'Esprit Nouveau", 1925

8 AFNOR: Association française de normalisation, the official French member of the International Organization for Standardization (ISO), created in 1926 for the standardization of all sectors of construction, under the tutelage of the Ministry industry.
} 
establishing standards and industrial processes in the building sector for reconstruction programmes in France ${ }^{9}$. Following the guidelines given by Le Corbusier, ASCORAL experts Hanning and Maillard formalised a grid using the geometric construction of the golden ratio, the "rule of the right angle", and using as a reference the man with the raised arm (the maximum vertical space occupied by the human body). He told them: "Prenez l'homme-lebras-levé, $2 \mathrm{~m} 20$ de haut; instellez-le dans deux carrés superposés de $1 \mathrm{~m}$ 10; faites jouer à cheval sur les deux carrés qui doit vous fournir une solution. Le lieux de l'angle droit doit pouvoir vous aider à situer ce troisième carré" ${ }^{\prime 10}$. The geometric construction provided the following measures: the unit $(108 \mathrm{~cm})$ corresponding to the solar plexus; the double $(216 \mathrm{~cm})$ corresponding to the man with raised arm; the $\Phi$ ratio of the unit $(175 \mathrm{~cm})$ corresponding to the top of the head; the $\Phi$ ratio of the double $(133 \mathrm{~cm})$ which is $83 \mathrm{~cm}$ corresponding to the resting hand (Fig. 4).

The "grid of proportions", approved and appreciated by academia and based on the height of a $1.75 \mathrm{~m}$-tall man, was patented in 1945. But since it was a single, linear one-dimensional rule applicable to several dimensions, it was called the "rule of proportions".
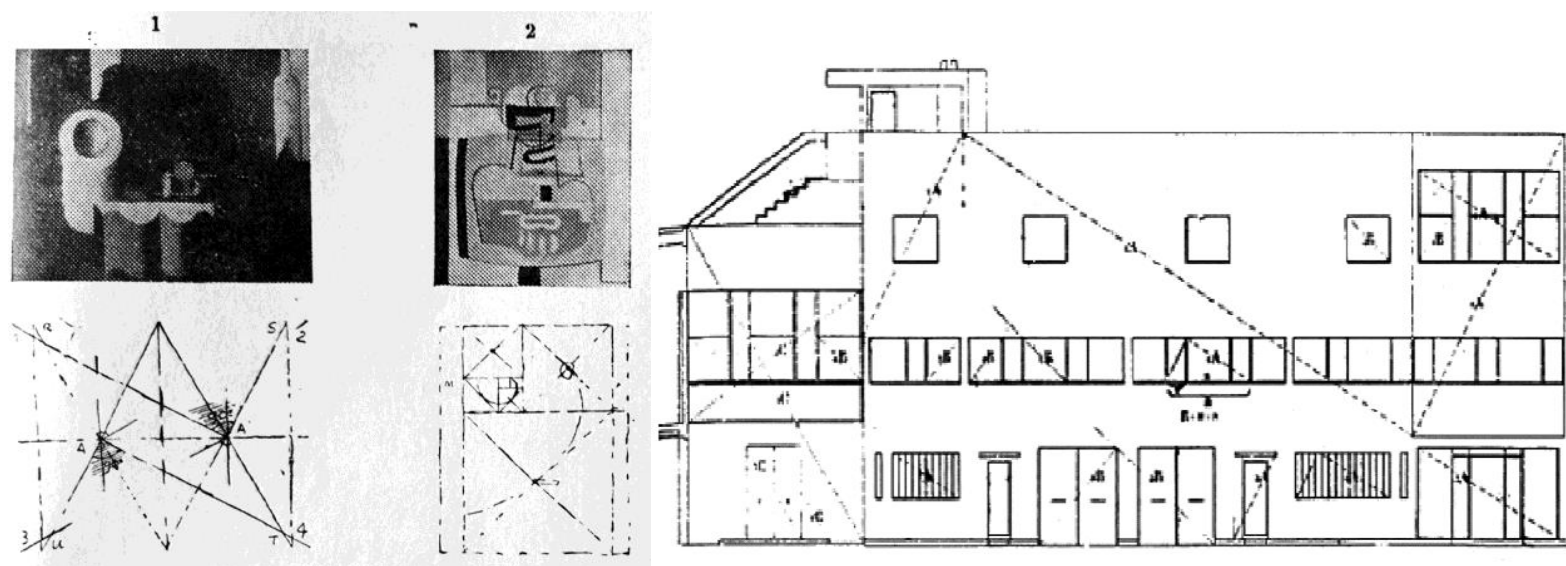

17

2. Le Corbusier, regulating lines used on paintings. Le Corbusier: Le Modulor, p. 213.

3. Le Corbusier, regulating lines on the facade of Maison La Roche. Le Corbusier: Vers une architecture, p. 64.

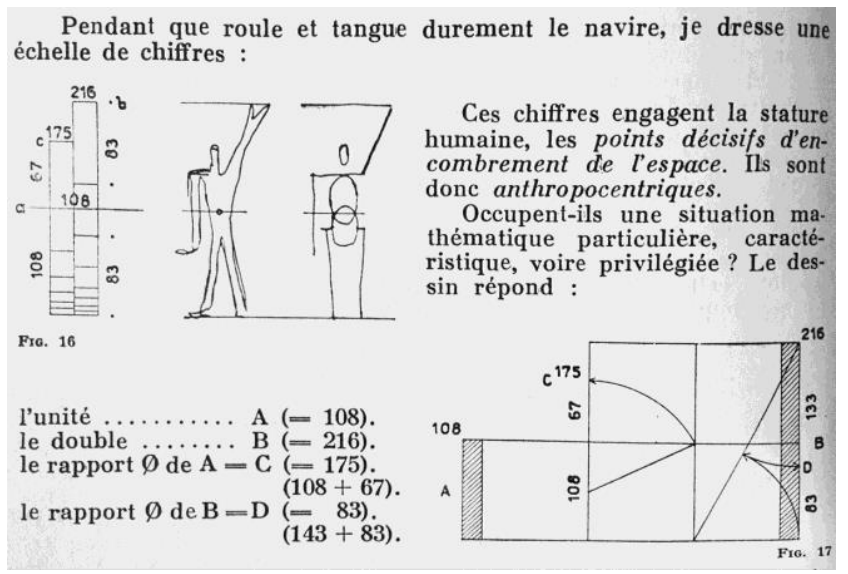

4. Le Corbusier, Modulor and geometric diagrams. Le Corbusier: Le Modulor, p. 50.

\footnotetext{
${ }^{9}$ ASCORAL: Assemblée de Constructeurs pour une Rénovation Architecturale, founded in 1942, it consists of 11 sections, including Section III studies the "Science of housing" into three sub-sections a) housing construction; b) standardization and construction; c) industrialization.

${ }^{10}$ Le Corbusier: Le Modulor, 1950, p. 37.
} 


\section{Modulor and Vitruvian Man}

The last definition of the Modulor was made in Neo-humanist terms, confirmed by Le Corbusier's knowledge of the Renaissance treatises of Luca Pacioli ${ }^{11}$. In a drawing of 1948 entitled Le chemin ${ }^{12}$ (Fig. 5), Le Corbusier reconstructed ideally the cultural origins of the Modulor, which coincide with the path traced along the centuries by the "golden number" as a protagonist of the main civilisations and cultures. The Modulor is set in a definitively universal and meta-historical dimension, imagined by Le Corbusier in a path which goes from India, through Babylon and Ptolemaic Egypt, Pythagorean Greece and the Italian Renaissance, becoming universal in Paris: the Pythagoreans formalised it, Plato made philosophical use of it, for his theory of the cosmos, the Humanists and Neoplatonists recovered it and took it as the unit of reference for artistic and architectural beauty. Le Corbusier studied these notions from the texts: Esthétique des proportions dans la nature et dans les Arts and Le nombre d'or. Rites et Rythmes Pythagoriciens dans le développement de la civilisation occidentale of mathematician Matila Ghyka, a subscriber to the review l'Esprit Nouveau ${ }^{13}$. With that drawing, Le Corbusier claimed direct descent of his Modulor from the mathematical and, above all from the cultural principles of those civilisations: the magnificence and sciences of the ancient Near East and Egypt, the classic era of democratic Athens, with the architectures of Pericles' Acropolis and Phidias, and the Humanism of the architectural principles of Alberti and Palladio ${ }^{14}$. Similarly to Leonardo's universal man during the Renaissance (Fig. 6), after World War Two the Modulor became the Neo-humanist matrix of postwar reconstruction and peace, hence a universally applicable principle ${ }^{15}$ (Fig. 7).

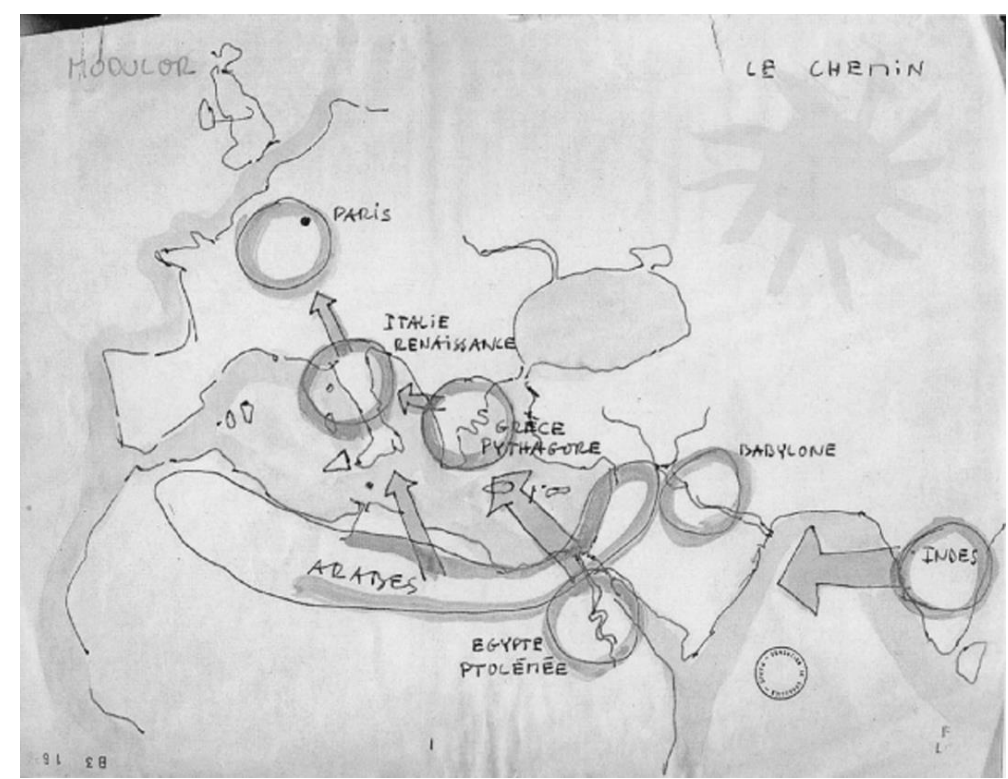

5. Le Corbusier, Modulor Le chemin (FLC B3-16 36, (FLC-ADAGP).

\footnotetext{
${ }^{11}$ Fonti, Alessandro: Lessons of History of Architecture, School of Architecture, University of Sassari, 2006, unpublished. Mameli, Maddalena: Le Corbusier e Costantino Nivola. New York 1946-1953, Milano: FrancoAngeli, 2012, pp. 117-121.

${ }^{12}$ Le Corbusier, Le Chemin, (FLC B3-16 36).

${ }^{13}$ Ghyka, Matila: Esthétique des proportions dans la nature et dans les Arts, Paris: Gallimard, 1927 (FLC Z 010) e Ghyka, Matila: Le nombre d'or. Rites et Rythmes Pythagoriciens dans le développement de la civilisation occidentale, Paris: Gallimard, 1931 (FLC Z 047). Cohen: "Le Corbusier's Modulor and the Debate on Proportion in France", pp. 3-5.

${ }^{14}$ Wittkower, Rudolf: Architectural Principles in the Age of Humanism, London, 1949.

${ }^{15}$ Fonti: Lessons of History of Architecture, 2006.
} 

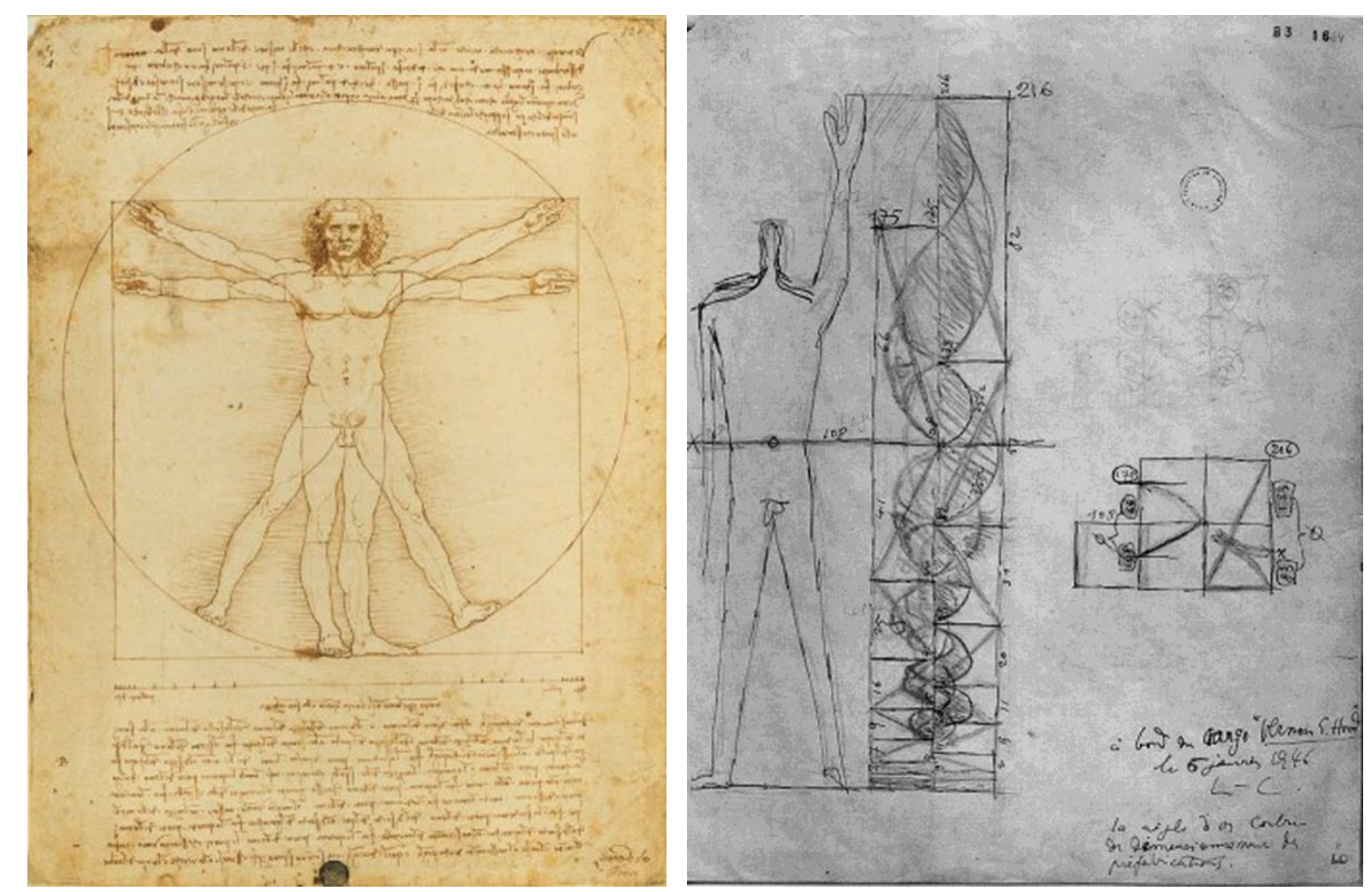

6. Leonardo da Vinci, Vitruvian Man.

7. Le Corbusier, Modulor and geometric diagrams (FLC B3-16 84, OFLC-ADAGP).

\section{Modulor in NY}

In the summer of 1945, definition of the Modulor gained strong momentum when the Ministry of Reconstruction tasked Le Corbusier with studying with total freedom, free from the constraints of building rules, an exemplary housing model for the middle class, the project for a Unité d'habitation de grandeur conforme for 1600 people "the first manifestation of a modern habitat" 16 in Marseilles on Boulevard Jules-Michelet, between 1946 and 1952. Then the Modulor system was experimented personally in the 'petit atelier' he built inside his Parisian office at 35 Rue de Sèvres as a cube using the 2.26 meter measurement; and in the Petit Cabanon in Cap-Martin on the French Riviera: “Application révélatrice. Il s'agit d'une chambre de 366 x $366 \mathrm{~cm}$ e di $226 \mathrm{~cm}$ de haut. Préfabriqué à Ajaccio (Corse) et monté à sec"17.

January 1946, during his 19-day trip to New York, on the 'Liberty' cargo ship Vernon S. Hood of the US Army, which had sailed from Le Havre on 22 December: “Vernon S.-Hood Liberty Ship janvier 1946. C'est dans cette cabine de Cargo via New York que j'ai inventé le signe Modulor",18 (Fig. 8). As reported by Le Corbusier: "je dis à Claudius Petit qui m'accompagnait: "Je ne sortirais pas de ce sacré bateau sans avoir trouvé l'explication de ma règle d'or". Un passager amaible parlementa avec les officiers: la cabine de l'un d'eux fut mise à sa disposition chaque matin, de 8 à 12 heures et le soir, de 20 heures à minuit. C'est là que je m'absorbai dans le tumulte des houles, à coudre quelques idées les unes à la siute des autres. J'avais dans ma poche le ruban

\footnotetext{
${ }^{16}$ Boesiger, Willy: Le Corbusier, Euvre Compléte, vol. 5, 1946-1952, Zurich: Edition d'architecture, 1953, p. 189.

${ }^{17}$ Boesiger: Le Corbusier, Euvre Compléte, vol. 5, 1946-1952, p. 62.

${ }^{18}$ Le Corbusier: Carnet D13 Vernon S.-Hood Liberty Ship janvier 1946 (FLC W1-1 804); Jornod, Naima; Jean-Paul Jornod: Le Corbusier. Catalogue raisonné de l'œuvre peint. I, Milan: Skira, 2005, p. 171; Le Corbusier: Carnets, vol. I, 1914-48, Paris: Herscher, Dessain \& Tolra, 1981, $n^{\circ} 792, n^{\circ} 804$.
} 
gradué par Soltan, enroulé dans une petite boîte en aluminum de film Kodak; cette boîte n'a pas quitté ma poche depuis (...) Au retour à Paris, en février, à latelier de la rue de Sèvres, je confiais à Préveral le soin de le mettre en ordre les meditation di "Veron S. Hood". Les nécessités du langage réclamaient un nom pour désigner la règle d'or. Entre plusieurs vocables, celui de MODULOR fut choisi",19 (Fig. 9).

In December 1945 Le Corbusier had been appointed Head of the Mission for Urban Planning, Architecture and Cultural Relations and had been sent by the French Government to the United States together with Eugène Claudius-Petit, to study the US institutions and promote French culture and technique ${ }^{20}$. The United States was the ideal environment for promoting architectural and urban development theories and implement projects "Les Etats-Unis, à l'avant-garde du progès industriel, sont à meme de donner l'impulsion necessaire au depart de l'action constructive (...) la qualité des techniciens amèricains et la pouissance de leur outillage les rendent aptes à provoquer cette initiative, ${ }^{, 1}$.

A few months later, in February 1946, Le Corbusier was appointed by the French Minister of Foreign Affairs and by the Minister of Reconstruction and Urban Planning representing France to the International Committee made up of architects of Member Countries for the design and construction of the United Nations' Headquarters $^{22}$. For 12 months, between 1946 and 1947, he was in New York "to defend modern architecture on an occasion of global importance $" 23$. He was a member of the International Committee for the Design of the UN Headquarters, but most importantly he wanted to propose a universal program of global urban planning and architectural reconstruction through the American section of CIAM (American Chapter for Relief and Post War Planning Inc.) as the official UN body ${ }^{24}$ (Fig. 10). The aim of the American Chapter was to coordinate the activities of the national CIAM groups by disseminating the Charter of Reconstruction Principles thanks to its know-how in advanced technology sectors with the support of major US agencies and institutions ${ }^{25}$.

Given the global scope of Le Corbusier's project, we can appreciate the significance of the trip to the United States in the process of defining the Modulor. The need to translate the proposed measures into feet and inches led him to change the reference measures. Transferring the French Modulor to the US measurement system was not easy, because the translation into US units of measurements yielded a complex decimal number $(1.75 \mathrm{~m}=$ 5.7414509794 feet). Le Corbusier reported: "Necessité était donc de rechercher des valeurs entières en piedpouce (...) Nous essayons d'appliquer cet étalon: six pieds $=6 \times 30,48=182,88$ centimètres. A notre enchantement, les graduations d'un nouveau "Modulor" sur base d'un homme de six piedsse traduisent sous nos yeux, pour les pieds pouces, en chiffres pleins à tous les échelons!", 26.

\footnotetext{
${ }^{19}$ Le Corbusier: Le Modulor, 1950, p. 55.

${ }^{20}$ CIAM: Urbanisme des CIAM, ASCORAL, Programme d'enquete en USA relative au domaine bati, 7 January 1945; CIAM: Mission d'Architectes et d'Urbanistes françaises aux Etats-Unis organisée par la Direction Générale des Relations Culturelles au service du Ministère des Affaires Etrangeres, Paris, 1945 (FLC D1-13 1).

${ }^{21}$ CIAM Document (FLC U3-19 2).

${ }^{22}$ Le Corbusier: UN Headquarter, New York: Reinhold, 1947; Dudley, George: A workshop for peace: Designing the United Nations Headquarter, New York: The Architectural History Foundation, Cambridge, MA: The MIT Press, 1994; Bacon, Mardges: Le Corbusier in America. Travels in the Land of Timid, Cambridge: The MIT Press, 2001.

${ }^{23}$ Le Corbusier: Memorandum de Le Corbusier relative à la creation des plans du Siege des Nations Unies à New York à l'attention de MM les Delegues de l'U.N. à l'Assemblée Generale de 1948 (FLC I3-11 1-8).

${ }^{24}$ Giedion, Sigfried: letter to Le Corbusier and report of CIAM in US, 4 January 1945 (FLC D2-15 41); Mumford, Eric: The CIAM Discourse on Urbanism, 1928-1960, Cambridge Mass: The MIT Press, 2000, pp. 142-152; Mameli: Le Corbusier e Costantino Nivola. New York 1946-1953, 2012, pp. 15-28.

${ }^{25}$ CIAM: Document New York, 13 March 1946 (FLC U3-19 82-85).

${ }^{26}$ Le Corbusier: Le Modulor, 1950, p. 56.
} 
The European decimal metric system, "universal unit of measurement" the child of the French revolution had its match in the US foot-inch system - anthropometric by definition and derived from the ancient measurement systems - with the unit of 6 feet, with satisfactory approximation and a very small error. Le Corbusier ascribed to one of his assistants the definition of the new universal measure, which suggested to chang the French unit of $1.75 \mathrm{~m}$ just as “dans les romas policiers anglais ou les "beaux hommes" - un policier par example - ont toujours SIX PIEDS de haut?",27.

Consequently, the reference measure of the Modulor becomes $1.83 \mathrm{~m}$, ensuring definitively universal applicability of the system. The new geometric construction provides the measures characterising the occupation of space: the unit $(113 \mathrm{~cm})$ corresponding to the height of the solar plexus; double this length $(226 \mathrm{~cm})$ corresponding to the man with raised arm; the $\Phi$ ratio of the unit $(183 \mathrm{~cm})$ corresponding to the top of the head; the $\Phi$ ratio of the double measure $(140 \mathrm{~cm})$ which is $86 \mathrm{~cm}$ corresponding to the resting hand.

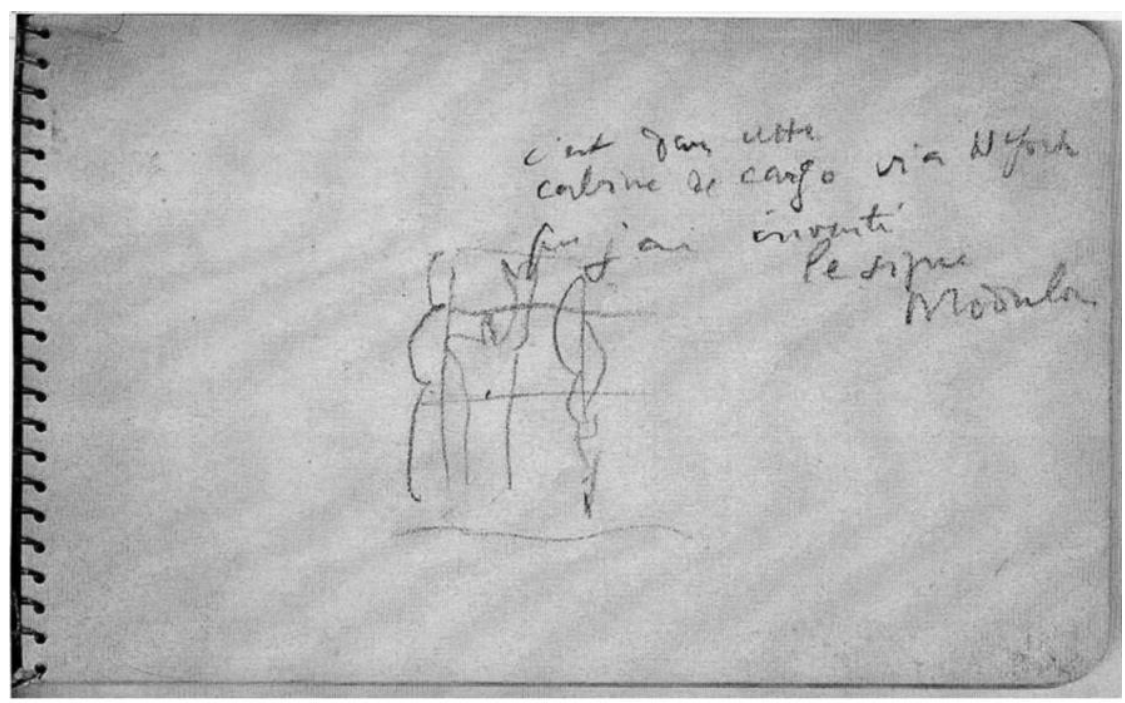

8. Le Corbusier, sketches on Modulor (FLC W1-1 804, CFLC-ADAGP).

${ }^{27}$ Le Corbusier: Le Modulor, 1950, p. 56. 


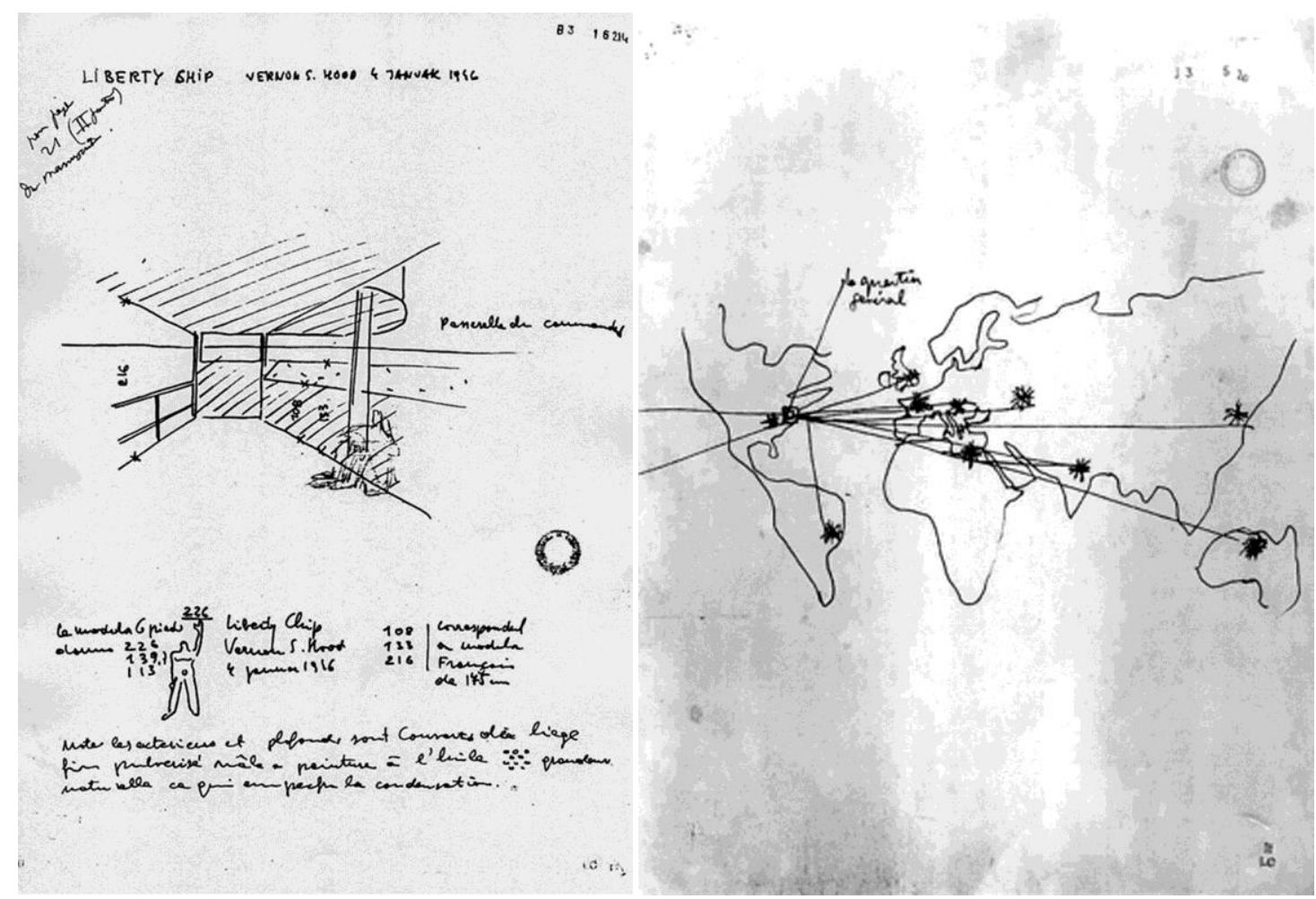

9. Le Corbusier, Liberty ship Vernon S. Hood, French and American Modulor (FLC B3-16 214, OFLC-ADAGP). 10. Le Corbusier, The UN International Program (FLC J3-5 20, OFLC-ADAGP).

\section{Standardisation and Industrialisation}

Thus, the urgency of defining the Modulor stemmed from essentially practical reasons: to formalise a simple tool and compositional principle to be applied to the extensive building programme of the US and UN, with the aim of transforming the whole traditional construction process, joining the Fordist logic of large-scale capitalism with the activities of large builders.

John Dale, Chair of Charles Hardy, Inc. in New York, introduced to Le Corbusier by André Jaoul, wished to produce and promote the MODULOR as a tool for architects, which they could keep at their drawing table together with the compass, in the form of a kit comprising a metal or plastic tape (Fig. 11) measuring $2.26 \mathrm{~m}$ in length, a numerical table and a booklet with instructions and combinations. He also endeavoured to find possible investors for an industrialised building programme.

At the same time, Henry John Kaiser too, the enlightened builder of the Liberty ships (the cargo ships produced in series for the American fleet and for the military supply programme to the UK) was planning to convert war production into the industrial construction of single-family houses in mass-production mode ${ }^{28}$. Le Corbusier wrote: "Sortant de mon cargo le 10 janvier 1946 à New York, j'avais une entrevue avec M. Kaiser, le constructeur célébre des Liberty-ships pendat la guerre. Son nouveau programme est de construire 10.000 maisons par jour aux Etats-Unis ${ }^{29}$. Le Corbusier also contacted the great American public agencies: he

\footnotetext{
${ }^{28}$ Between 1941 and 1945 the US built 2751 Liberty ships, according to a single design. Mitchell, William Harry: The Liberty Ships, Cambridge, Md: Cornell Maritime Press, 1970.

${ }^{29}$ Le Corbusier:Le Modulor, 1950, p. 52.
} 
attempted to establish contacts with the politicians in Washington and with the administrators of the Tennessee Valley Authority, who had planned the whole economy of the Tennessee valley, building dams and new cities.

Le Corbusier had already addressed the problem of standardisation in his Esprit Nouveau. In his Vers une architecture, he quoted Frederick Engels' motto "Architecture or Revolution" and referred to the socialist utopia of creating cities where scientific and technical progress coincides with civil and social advancement, through the development of social and affordable housing on the basis of a low-cost standardised and industrialised design, applying advanced technologies. The issues of techniques and standards are key: airplanes, steamships and cars but especially the Parthenon were referenced as symbols of the need to set standards to produce the best architecture (Fig. 12). In the following years, the advances in the use of reinforced concrete and the projects for the Maison Domino, Maison Citrohan ad Immeubles Villas would make it possible to dream of the Ville Radieuse. The Modulor, the anthropometric human system by definition, was considered the "golden rule" 30 for the sizing of new, prefabricated buildings in the new urban quarters, as it met the need to join the industrialised and standardised production process with the "human" dimension.

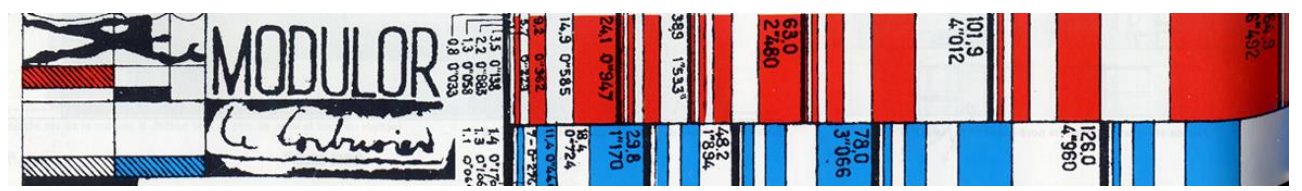

11. The maesuring tape of the Modulor. Maddalena Mameli Archives.
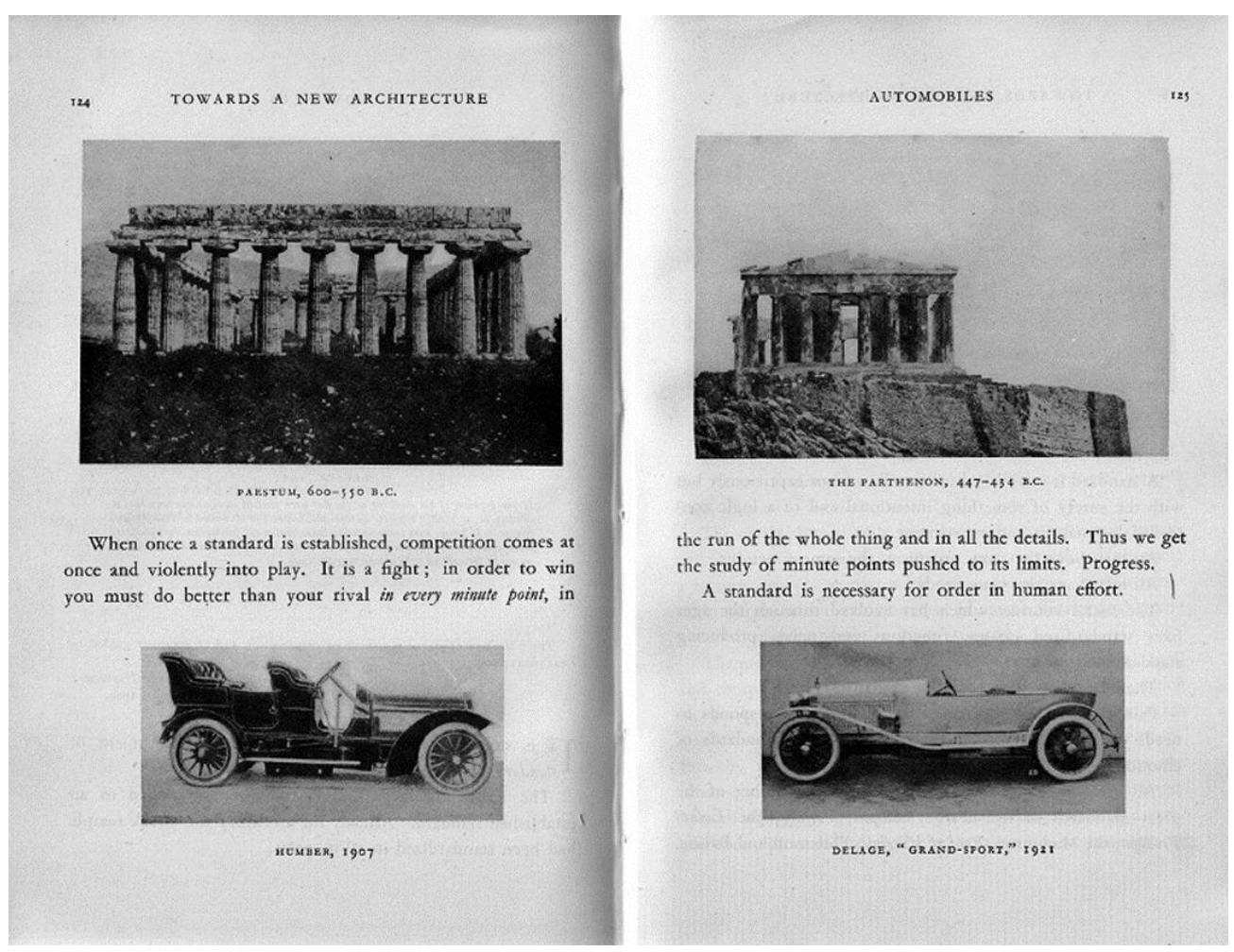

12. Le Corbusier, the concept of standard from greek temple to cars. Le Corbusier: Vers une architecture, pp. 106-7.

\footnotetext{
${ }^{30}$ Le Corbusier: Carnet, "La règle d'or Corbu de dimensionnement de préfabrications" (FLC B3-16 64).
} 


\section{Disappointments and conclusions}

Unfortunately John Kaiser changed its investment programmes and decided to focus on car manufacturing, TVA was not interested in the Modulor and new developments but especially the UN and Rockefeller chose Wallace Harrison as designer of the UN's Headquarters. At the same time, the CIAM's American Chapter failed to win approval of their "global plan" for reconstruction and planning on a world scale.

Le Corbusier did not, in the end, find an American sponsor. The Modulor and its standardised system for the industrialisation of the building sector and its universal principles of harmony found no application in the USA and in the UN's programmes, even though the design of the UN's Headquarters uses the measures of the red and blue harmonic series (Figg. 13-14).

Le Corbusier expressed the depth of his disappointment: "En pays d'U.S.A. voué à la série, j'aurais aimé apporter la sécurité de l'illimitée variété, telle que semble l'assurer notre règle harmonique"3l. His disappointment was also witnessed by his friend and pupil Costantino Nivola, who hosted him during his stay: "The truth is that Le Corbusier came to New York prompted by the same spirit that compelled Renaissance masters to go to Rome or Milan, to offer their artistic services to the era's princes. But the great modern master of architecture, painting and sculpture did not find the Sforza family, the Medicis or the pope in New York. His disappointment compelled him to reconsider many of his previous premises, but not without beneficial conclusions" ${ }^{32}$ and "The United Nations became known as 'the United Nations of America,",33.

In Europe, building works started on the Unite d'habitation in Marseilles: the cement modelled by the architectural order of the Modulor, by the timber formwork and by the trowel of Salvatore Bertocchi, acquired the noble quality of stone in its most material and primitive expressiveness. With the rules of the Modulor, Le Corbusier's modernity revealed its Neoclassical imprint, just as the aesthetics of béton brut, which becomes part and parcel of reinforced concrete architecture, becomes primitive and poetic ${ }^{34}$ (Fig. 15).

A great opportunity Le Corbusier had to present the rules and possibilities of the Modulor in detail to a wide audience, was the conference for the Milan Triennial of 1951 during the International Congress on Proportions in the Arts focused on the Divine Proportion ${ }^{35}$, attended, among others, by Matila Ghyka - who was still publishing works on proportions, rhythm and the golden ratio - and Rudolf Wittkower - who two years earlier had published his Architectural Principles in the Age of Humanism. But two years later in 1953 at Aix en Provence, the group, which would later call itself Team X, was formed and thus started the end of CIAM ${ }^{36}$. The history of the Modulor, which had begun with the "rule of the right angle" after journeys and decades would end in the ineffability of the Poeme de l'Angle Droit ${ }^{37}$ (Fig. 16).

\footnotetext{
${ }^{31}$ Le Corbusier: Le Modulor, 1950, p. 54.

${ }^{32}$ Nivola, Costantino: Ho bussato alle porte di questa città meravigliosa, Cagliari: Arte Duchamp, 1993, p. 76.

${ }^{33}$ Nivola, Costantino: "Le Corbusier in New York. A memoir by Costantino Nivola", in Ingersoll, Richard: Le Corbusier: A Marriage of Contours, New York: Princeton Architectural Press, 1990, p. 6.

${ }^{34}$ Mameli, Maddalena: "Le Corbusier et la pratique du sand-casting", in Sbriglio, Jacques: Le Corbusier et la question du brutalisme, Marseille: Parenthèse, 2013.

35. Caronia, Salvatore: "Impressioni sul primo Congresso Internazionale sulle Proporzioni nelle Arti", in L'ingegnere, Milano: Edizione Istituto propaganda Internazionale, Dicembre 1951 (FLC F1-18 195).

${ }^{36}$ Mumford: The CIAM Discourse on Urbanism, 1928-1960, pp. 225-240.

${ }^{37}$ Le Corbusier: Poeme de l'Angle Droit, Paris: Éditions Tériade, 1955.
} 


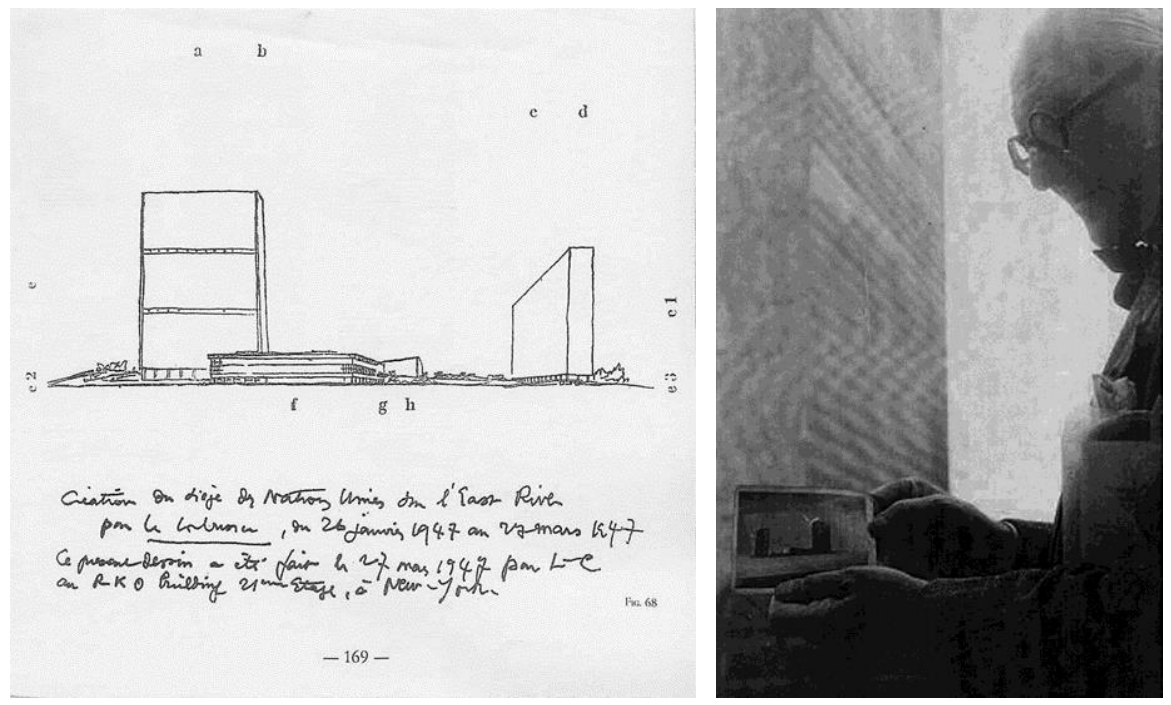

13. Le Corbusier, scketch of UN headquarter project. Le Corbusier: Le Modulor, p. 169.

14. Le Corbusier and the UN Headquarter, (FLC L4-4 37, OFLC-ADAGP)
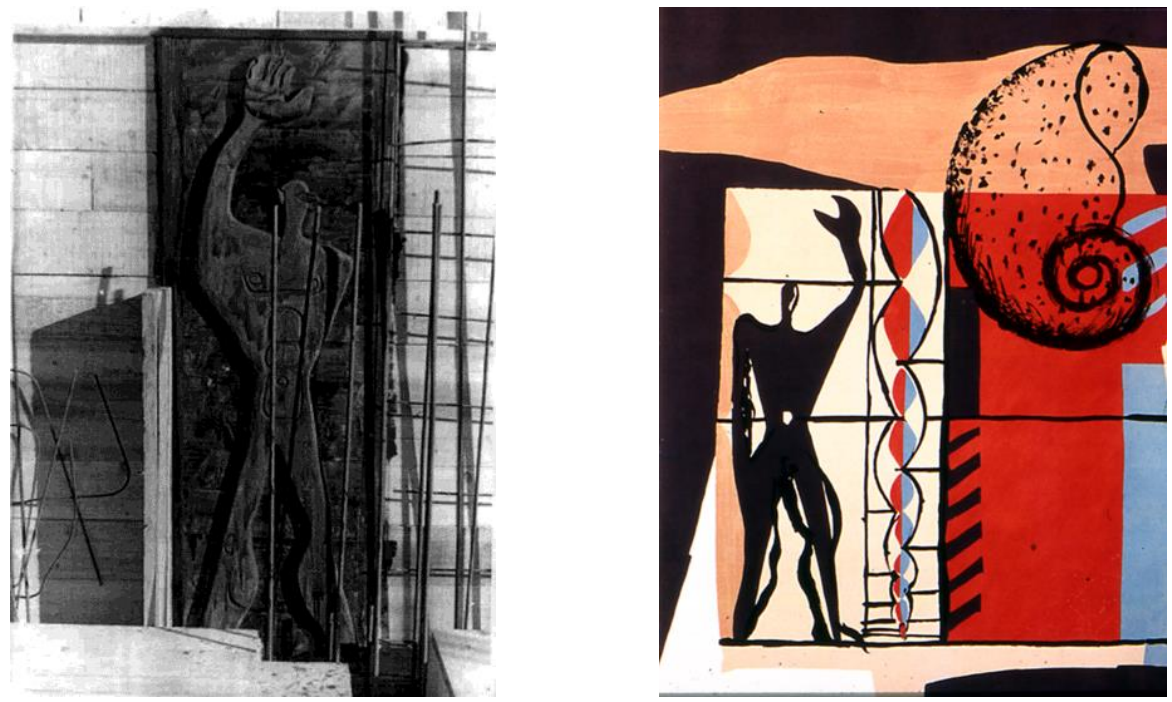

15. The formwork of the entrance wall of the Unité d'habitation in Marseille (FLC L1-14 152, OFLC-ADAGP)

16. Le Corbusier, Modulor in the Poème de l'angle droit. Le Corbusier: Le Poème de l'angle droit, p. 28.

\section{Bibliography}

Bacon, Mardges: Le Corbusier in America. Travels in the Land of Timid, Cambridge (Mass): The MIT Press, 2001.

Boesiger, Willy: Le Corbusier, Cuvre Compléte, vol. 5, 1946-1952, Zurich: Edition d'architecture, 1953.

Cocteau, Jean: Le rappel à l'ordre, Paris: Stock, 1926.

Choisy, Auguste: Histoire de l'Architecture, Parigi: Baranger, 1903.

Cohen, Jean-Louis: "Le Corbusier's Modulor and the Debate on Proportion in France", in Architectural Histories, EHAN, 23, 2014. DOI: http://dx.doi.org/10.5334/ah.by

Dudley, George: A workshop for peace: Designing the United Nations Headquarter, New York: The Architectural History Foundation, Cambridge (Mass): The MIT Press, 1994. 
Fonti, Alessandro: Lessons of History of Architecture, School of Architecture, University of Sassari, 2006, unpublished.

Ghyka, Matila: Esthétique des proportions dans la nature et dans les Arts, Paris: Gallimard, 1927.

Ghyka, Matila: Le nombre d'or. Rites et Rythmes Pythagoriciens dans le développement de la civilisation occidentale, Paris: Gallimard, 1931.

Ingersoll, Richard: Le Corbusier: A Marriage of Contours, New York: Princeton Architectural Press, 1990.

Jornod, Naima; Jean-Paul Jornod: Le Corbusier. Catalogue raisonné de l'œuvre peint. I, Milan: Skira, 2005.

Le Corbusier: Vers une architecture, Paris: Éditions Crès, Collection de "L'Esprit Nouveau", 1923.

Le Corbusier: La peinture moderne, Paris: Éditions Crès, Collection de "L'Esprit Nouveau", 1925.

Le Corbusier: Un Headquarter, New York: Reinhold, 1947.

Le Corbusier: Le Modulor, Éditions de l'Architecture d'Aujourd'hui, Boulogne-sur-Seine: Collection ASCORAL, 1950.

Le Corbusier: Le Modulor II, Éditions de l'Architecture d'Aujourd'hui, Boulogne-sur-Seine: Collection ASCORAL, 1955.

Le Corbusier: Carnets, vol. I, 1914-48, Paris: Herscher, Dessain \& Tolra, 1981.

Livio, Mario: La sezione aurea, Milano: Rizzoli, 2003.

Mameli, Maddalena: Le Corbusier e Costantino Nivola. New York 1946-1953, Milano: FrancoAngeli, 2012.

Mameli, Maddalena: "Le Corbusier et la pratique du sand-casting", in Sbriglio, Jacques: Le Corbusier et la question du brutalisme, Marseille: Parenthèse, 2013.

Mitchell, William Harry: The Liberty Ships, Cambridge, Md: Cornell Maritime Press, 1970.

Mumford, Eric: The CIAM Discourse on Urbanism, 1928-1960, Cambridge Mass: The MIT Press, 2000.

Nivola, Costantino: Ho bussato alle porte di questa città meravigliosa, Cagliari: Arte Duchamp, 1993.

Nivola, Costantino: "Le Corbusier in New York. A memoir by Costantino Nivola", in Ingersoll, Richard: Le Corbusier: A Marriage of Contours, New York: Princeton Architectural Press, 1990.

Sbriglio, Jacques (Ed.): Le Corbusier et la question du brutalisme, Marseille: Parenthèse, 2013.

Wittkower, Rudolf: Architectural Principles in the Age of Humanism, London, 1949. 


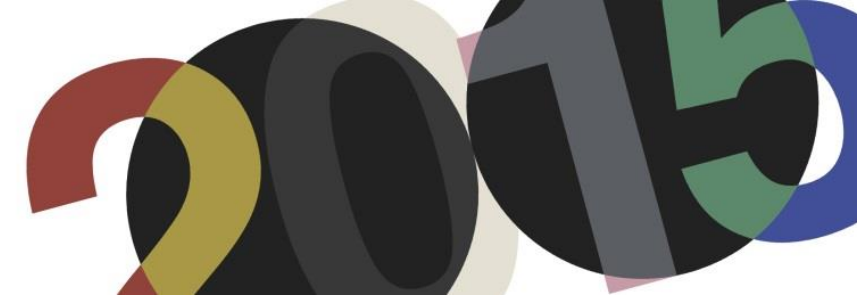

DOI: http://dx.doi.org/10.4995/LC2015.2015.1005

\title{
Maisons Jaoul, confort higrotérmico y su percepción en la arquitectura de tipología unifamiliar de Le Corbusier
}

\author{
D.V. Martín Fuentes \\ Escuela Superior de Arquitectura de Valencia
}

\begin{abstract}
Resumen: Se realiza un estudio completo, teórico, empírico, numérico y perceptual, de las Maisons Jaoul de Le Corbusier intentando esclarecer su comportamiento higrotérmico y climático. Con ello se pretende conocer en detalle la realidad de esta obra emblemática de la arquitectura doméstica del siglo XX. De la contraposición de los datos obtenidos en las dos viviendas de volumetría y compacidad prácticamente iguales, pero con una orientación ortogonal se extraen conclusiones reveladoras que no hacen más que afianzar la condición excepcional de las Maisons Jaoul dentro de la obra del arquitecto. Todo ello, tamizado por la percepción de los actuales habitantes de las viviendas.
\end{abstract}

Abstract: Trying to achieve a better understanding of the higrothermic performance of The Maisons Jaoul of Le Corbusier, they are studied from different approaches: theoretical, empiric, numeric and perceptual. The aim is to understand profoundly this emblematic building of the domestic architecture of the XX century. For that, the study analyses the project, but also compares and contrasts a series of data coming from the two houses which have a very similar volume and compactness but orthogonal orientation to finally take account of the perception of the actual inhabitants. Conclusions are revealing and strengthen the idea of how exceptional the Maisons Jaoul are in the architect's production.

Palabras calve: Le Corbusier; Maisons Jaoul; Confort higrotérmico; bioclimatismo, sostenibilidad. Keywords: Le Corbusier; Maisons Jaoul; Hygrothermal comfort; bioclimatic, sustainability.

\section{Introducción}

Los términos bioclimatismo, eco-eficiencia, sostenibilidad están actualmente muy en boga, más aún cuando la normativa al respecto del comportamiento energético es una realidad que un comportamiento responsable con nuestro entorno no puede obviar.

No podemos olvidarnos aun así que la arquitectura moderna y la arquitectura tradicional de todas las épocas ya han tratado y resuelto ampliamente esta temática. Para no incurrir en los errores cometidos en el pasado hacemos un repaso de las herramientas bioclimáticas de la arquitectura de uno de los maestros del s. XX, Le Corbusier, concretando el análisis en dos de las viviendas de su época madura, las Maisons Jaoul.

\section{Metodología}

En el estudio se plantea el análisis de las Maisons Jaoul desde tres puntos de vista que se suplementan y permiten obtener conclusiones globales: el teórico, el empírico y el perceptual.

Inicialmente se realiza un análisis teórico que se aborda desde dos vertientes completamente distintas. Primero el desarrollo contextual e histórico donde se analizan las herramientas bioclimáticas de Le Corbusier y su aplicación específica en las viviendas. Segundo el numérico realizando un modelizado en base al que se obtienen parámetros de comportamiento térmico, lumínico y de confort higrotérmico. 
Posteriormente el análisis es numérico también, pero empírico. Se realiza un comparativo con los datos obtenidos en una monitorización in situ en Enero de 2015.

Finalmente estos datos se modulan con la opinión de los habitantes actuales de las viviendas y su percepción de la adecuación térmica, lumínica y de confort general. Con todo ello se emiten las conclusiones globales que no hacen más que afianzar la condición excepcional de las Maisons Jaoul dentro de la obra de Le Corbusier.

\section{Le Corbusier bioclimático. Machine à habiter vs Coquille de l'escargot}

Desde el inicio de su carrera, Le Corbusier afronta la adaptación climática del edificio, entendida esta como el confort higrotérmico de sus ocupantes, como un requerimiento programático más. En coherencia con su actitud investigadora, pionera y sistemática, veremos cómo adopta diferentes soluciones a lo largo de su obra, no siempre con la efectividad deseada, pero siempre conceptualmente reveladoras.

Como gran maestro, aprende en cada situación y es capaz de evolucionar. Desde las viviendas que se diseñan como machine à habiter -en las décadas de 1920 y 1930 - hasta las viviendas que concibe para la India o las Maisons Jaoul, con un concepto mucho más íntimo; hay un gran salto que se recorre paso a paso. Aun así no podemos olvidar que Le Corbusier ya decía en 1926: "For mi the house is more tan a machine à habiter; it is also la coquille de l'escargot." ${ }^{1}$ No se puede negar que era consciente de la necesidad de protección y confort que una vivienda debe satisfacer a sus usuarios pero es posible que tal y como indica Caroline Maniaque:

"Witold Rybczynski ha estudiado la historia del confort desde la edad media hasta nuestros días. [...] Para él los arquitectos estaban demasiado centrados en responder visualmente a la estética de la era industrial en vez de al bien estar de los ocupantes." 2

Respecto a los proyectos de la era maquinista, lo más significativo, en términos de control higrotérmico, es su confianza en la utilización de ciertos sistemas muy novedosos. Se concentra en inventar el mur neutralisant y utilizar sistemas que permitan una respiration exacte. Más que una respuesta estructural, propone soluciones mecánicas, intentando crear edificios isothermiques eficaces contra el frío y el calor.

"propongo técnicas científicas internacionales: una sola casa para todos los países, todos los climas: la vivienda con respiración exacta"3.

El mur neutralisant es un sistema de atemperamiento del interior del edificio consistente en la impulsión de aire seco en el interior de la cámara estanca del doble acristalamiento de los paños de vidrio -aunque también en el resto de cerramientos. Este aire se climatizaría: frío, en verano, y caliente, en invierno; mediante intercambiadores de calor. Para la ventilación mecánica, idea L'aireation ponctuelle, que consistía en la impulsión de aire puro a $18^{\mathrm{a}} \mathrm{C}$ con recuperación dentro de circuito cerrado.

\footnotetext{
${ }^{1}$ Le Corbusier, L'Almanach d'Architecture moderne (Paris: Crès, 1926; Paris: Connivence, 1975), 5

${ }^{2}$ Maniaque Benton, Caroline: Le Corbusier and the Maisons Jaoul. New York: Princeton Architectural Press, 2009. p. 109.

${ }^{3}$ Boesiger, Willy (Ed.) ; Le Corbusier ; Stonorov, O: Le Corbusier et Pierre Jeanneret. Oeuvre complète 1910-29. Zurich: Les Éditions d'Architecture, 1973. p. 210.
} 
El mismo Le Corbusier afirmaba que "los primeros efectos de la revolución industrial en la construcción se manifiestan mediante esta etapa primordial: el reemplazo de los materiales naturales por los materiales artificiales, de los materiales heterogéneos y dudosos por los materiales homogéneos y probados con ensayos de laboratorio y producidos con elementos fijos. El material fijo debe reemplazar el material natural, variable hasta el infinito" ". Expresaba su confianza en las tecnologías ya que "en todos los dominios de la industria, se han planteado problemas nuevos, y se han creado las herramientas capaces de resolverlos."

Pero es en ciertos proyectos de vivienda donde debido a los condicionantes climáticos, de presupuesto, de lejanía o por el propio cliente, en los que aparece de una manera más evidente un cierto cambio de actitud. "Los problemas de sobrecalentamiento conducen a Le Corbusier a buscar métodos de naturaleza completamente arquitectónica para controlar las sombras sobre el paño de vidrio; es así que nace el dispositivo de brise-soleil."

Tim Benton analiza y desarrolla en su artículo "La Villa Baizeau et le brise-soleil” cómo para Le Corbusier "este proyecto debe demostrar la capacidad de su arquitectura para resolver todos los problemas naturalmente."7

En el invierno de 1927-28, Lucien Baizeau, un industrial tunecino, le encarga a Le Corbusier el diseño de una pequeña casa en Sainte-Monique, Túnez. Hasta el momento el arquitecto no tiene ninguna experiencia en construcciones adaptadas a climas calurosos. En este caso, es el cliente el que insiste en la necesidad de que la vivienda necesita una protección directa del sol y de los vientos calientes de Sur y Suroeste; así mismo indica que la ventilación interior debe ser "perfecta".

Lejos de limitar los resultados, Le Corbusier propone nuevas soluciones. En este proyecto aparecen los característicos plan libre y façade libre, una sugerente sección en doble U entrelazada que establece una coupe libre (sección libre), también se plantea el "techo-parasol"8 que asegura una protección solar.

Finalmente, algunos de estos elementos desaparecen del proyecto y el sistema utilizado -fuertemente entroncado con el sistema domino- representará posteriormente un arquetipo en el diseño de viviendas y "se convertirá en una fuente de inspiración para el brise-soleil no sin haber influenciado fuertemente el primer proyecto de la Ville Savoye (Octubre 1928)."9

Dos años después, en 1930, es en el proyecto de la casa Errazuris en Chile donde se hace indiscutible la aparición de un nuevo universo material en su arquitectura. El cambio de imagen es explicado en la Oeuvre Complète por la inexistencia de una mano de obra técnica suficiente, la utilización de materiales del lugar y una colocación en obra fácil.

Los muros de piedra que hasta entonces no había utilizado atestiguan que "la confrontación entre la tecnología moderna y la materia desnuda y ruda realizada con técnicas ancestrales constituye entonces un descubrimiento plástico de primer orden. Además, también parece simbolizar que no es posible encontrar una arquitectura

\footnotetext{
${ }^{4}$ Le Corbusier: Vers une architecture. Paris: Vincent, Freal and Cie., 1958. p. 192. (Libro editado por primera vez en 1923)

${ }^{5}$ Ibidem. p. 228.

${ }^{6}$ Siret, Daniel ; Harzallah, Amina: Architecture et côntrole de l'ensoleillment. Conferencia, manuscrito publicado en "Congrès IBPSA France", Ecole national Supérieure d'Architecture de Nantes, France 2006.

${ }^{7}$ Benton, Tim: "La Villa Baizeau et le brise-soleil", A.A.V.V. Le Corbusier et la Mediterranée. Marseille: Editions Parenthèses, 1987. pp. 125-129.

${ }^{8}$ Este hecho es importante puesto que en Marzo de 1951, justo cuando recibe el encargo de la Villa Shodhan (India), Le Corbusier hace explícita referencia al "techo para Baizeau, Túnez" en uno de sus Carnets, 25 años después.

${ }^{9}$ Ibidem. p. 127
} 
francamente moderna si no existe una verdadera conciencia de la cultura y la tradición." ${ }^{10}$ En la siguiente década construye y proyecta diferentes viviendas de estas características.

La Villa de Mme. Mandrot (1931) en Le Pradet, Francia, ilustra el uso de paredes de piedra sin revestir dentro de una sintaxis siempre moderna. La planta es libre y esto permite la existencia de grandes paños de vidrio, que en bastantes casos se sustituyen por láminas opacas o paneles contrachapados para atenuar el calor y la intensidad lumínica. Estos entrepaños presentan un diseño de cuidada geometría que recuerda a las composiciones pictóricas neoplasticistas.

Las mismas características presenta la Villa en los Mathes (1935). El cliente, Albyn Meyron, escribe a Le Corbusier indicando que no desea "una construcción ligera, industrial, perecedera y que exija gastos de mantenimiento. Confiesa su desconfianza en los prototipos industriales y su aspecto exterior de bains parisiens" $"$. La casa resulta entrar en armonía con el entorno, se cierra bien en inverno, resiste el salitre del ambiente y las lluvias de otoño, pero no necesita mimetizar imágenes, ni lenguajes, ni siquiera materiales, únicamente sistemas y disposiciones. La distancia con el regionalismo típico de otras arquitecturas del momento es patente, de hecho no existe reminiscencia alguna de una determinada tradición estilística.

En la Villa Henfel (1934-35) denominada maison de week-end y construida en las afueras de París, el diseño está encaminado a satisfacer un "principio impuesto": la casa debe ser lo menos visible posible, tal y como se recoge en la Oeuvre Complète. Para ello se implementan recursos que en otros casos se habían justificado por la lejanía e imposibilidad de controlar la obra, pero que en realidad parecen responder a una sensibilidad con el entorno: “...techo de hierba sobre bóvedas rebajadas, elección de un material tradicional, la sillería con aparejo en seco." 12 Destaca el orden de descripción del techo, parece ser más importante la hierba que la propia cubrición.

Presentan continuidad con la nueva actitud la casa Locheur (1929), prototipo de vivienda estandarizada y taylorizada pero con los nuevos materiales; la casa del Dr. Rameaux (1936), las "Maison pour ingénieurs et contremâitres Lannemezan” (1940) y las casas Murondins (1940).

Según varios autores, el proyecto para las casas Locheur en Francia y la casa para Errazuris, suponen en la práctica el fin del sueño de crear la casa taylorizada. Si en las casas Loucheur Le Corbusier asume que la mitad del mercado inmobiliario francés está formado por "innumerables pequeños propietarios [...] y las circunstancias actuales hacen absolutamente imposible de realizar la construcción de una casa en las condiciones técnicas suficientes y en buen precio"13, en la casa de Chile adapta sus ambiciones tecnológicas a la disponibilidad del lugar. El fracaso de este proyecto de taylorización, así lo califica Kenneth Frampton, conduce a una apuesta por "las tecnologías intermedias que combinan técnicas primitivas y punteras según las necesidades y los medios"14.

El viaje que realizó en 1931 a Marruecos y Argelia, le permitió certificar la estrecha relación entre arquitectura, cultura, paisaje y hombre. No hay duda de que quedó influenciado por la intrínseca racionalidad que la arquitectura popular presenta cuando se trata de integrarse en la naturaleza y protegerse de ella.

\footnotetext{
${ }^{10}$ Torres Cueco, Jorge: Le Corbusier: Visiones de la técnica en 5 tiempo. Barcelona: Colección Arquithemas, 2004. p. 151

${ }^{11}$ Carta mecanografiada del 12 de Diciembre de 1934. FLC H-2-9, piezas 161-163. Extraída de Torres Cueco, Jorge: Le Corbusier: Visiones de la técnica en 5 tiempo. Barcelona: Colección Arquithemas, 2004.

${ }^{12}$ Bill, Max (Pub.); Le Corbusier: Le Corbusier. Oeuvre complète 1934-38. Zurich: Les Éditions d'Architecture, 1973. p. 125.

${ }^{13}$ Boesiger, Willy (Ed.) ; Le Corbusier ; Stonorov, O: Le Corbusier et Pierre Jeanneret. Oeuvre complète 1910-29. Zurich: Les Éditions d'Architecture, 1973. p. 78.

${ }^{14}$ Frampton, Keneth: Le Corbusier. Turín, Ediciones Hazan, 1997
} 
Paradójicamente en estos mismos años está desarrollando parte de sus "grandes construcciones" donde aborda, como ya hemos visto, el confort desde una perspectiva muy distinta. En definitiva, las circunstancias en unos proyectos y otros son difícilmente asemejables, pero se puede comprobar que lo ocurrido en estos años abre para Le Corbusier una nueva vía de investigación, encabezada por el brise-soleil, que generará múltiples herramientas [bio]climáticas que se aplicarán en todos sus proyectos -independientemente de la escala- a partir de la década de los años 30 y significativamente después de la guerra.

La máquina como modelo de precisión y progreso universal es desplazada por una relación más cercana con la naturaleza, el lugar, el clima, y una valoración cercana de las culturas vernáculas, que tan bien han funcionado.

"He has an attitude to technology. There is a sense of passion for nature that motivated a very deep desire to find functional solutions that would allow, for instance, the free passage of light, air and control of the sun's energy." 15

\subsection{Herramientas bioclimáticas}

Los problemas de sobrecalentamiento conducen a Le Corbusier a buscar métodos de naturaleza completamente arquitectónica para controlar las sombras sobre el paño de vidrio, es así que nace el dispositivo de brise-soleil, pero no es el único. A lo largo de su obra va desarrollando, en unas ocasiones de manera intuitiva, en otras tras un proceso de profundo análisis otras herramientas enteramente proyectuales que le permiten mejorar el confort higrotérmico de sus edificios.

A las protecciones solares y la orientación, añade otros parámetros indispensables para entender sus construcciones de la década de los 50. En la época en la que diseña las Maisons Jaoul, los materiales que utiliza aportan mayores inercias térmicas, los muros y las ventanas adquieren profundidad (espesor); las cubiertas se ajardinan o doblan y las corrientes de aire se tienen en cuenta.

Se puede de manera sintética enunciar las herramientas que conducen la arquitectura de Le Corbusier hacia un mayor control climático, lo que se traduce en mayor sostenibilidad, y en base a ellas analizaremos las Maisons Jaoul: Orientación, Brise-soleil, Cubierta ajardinada o doble, Materialidad, Cerramientos practicables (ventanas) y Circulación de Aire.

\section{Estudio Teórico. Maisons Jaoul: Brutalismo domesticado}

En Le Corbusier and The Maisons Jaoul, Caroline Maniaque describe de manera extensa y detallada la relación de amistad existente entre el arquitecto y la familia Jaoul. Por fases se analiza el proceso de diseño que concluyó en la solución definitiva de las viviendas.

En 1946, los Jaoul -Michel y su hijo André-compraron un solar en Neully-sur-Seine población cercana a París en la que pretendían instalarse ese mismo año. Dado el poco tiempo del que disponían y que necesitaban resolver el problema de alojamiento inmediatamente incluso estaban dispuestos a vivir en un chalet de madera tipo

\footnotetext{
${ }^{15}$ Menin, Sarah; Samuel, Flora: Nature and Space, Aalto and Le Corbusier. Londres, Ed. Route Ledge, 2003, p. 2.
} 
australiano. Como en esa época Le Corbusier estaba inmerso en muchos de sus grandes proyectos ${ }^{16}$ les puso en contacto con un arquitecto inglés, Clive Entwistle ${ }^{17}$, para que diseñara y construyera su vivienda.

En Junio de 1951, Entwistle dibujo una propuesta que constaba de un bloque de PB+III con las viviendas superpuestas. Su propuesta mezclaba motivos formales de imagen corbuseriana y una estructura modular muy racional, típica de las propuestas de arquitectos ingleses en aquella época. Ese mismo año, en un encuentro durante uno de sus viajes a Nueva York, Michel Jaoul pidió a Le Corbusier que echara un vistazo a los planos y este los criticó, especialmente la superposición de las viviendas. Utilizaba como argumento principal que los materiales bastos y sin necesidad de acabados especiales, además de ser más acordes con la estética que propugnaba por ese entonces permitían un ahorro del $20 \%$.

En definitiva acabó aceptando el encargo del diseño y le dedicó, entre la vorágine de las grandes construcciones una atención y cuidado acordes con la relación amistosa e intelectual que le unía con la familia.

Centrando el análisis en las herramientas bioclimáticas anteriormente reseñadas podemos entender muchas de las decisiones proyectuales que se tomaron. Obviamente las Maison Jaoul son mucho más que lo que aquí se analiza pero merece la pena centrar la atención en estos parámetros para entender el nivel de madurez alcanzado por Le Corbusier en las cuestiones que nos incumben. ${ }^{18}$

\subsection{Orientación}

En 1951, se establece el plan de ordenación de Neully-sur-Seine bajo el que se rigen todas las nuevas construcciones del distrito. La calle de Longchamp, en la que se sitúa el solar adquirido por la familia Jaoul, estaba afectada por un número de plantas de PB+3 y una altura de cornisa de $12 \mathrm{~m}$. Con un coeficiente de edificabilidad de 1.30, la ocupación en planta tenía que ser como máximo de 32\% y adicionalmente se establecía un retranqueo obligatorio del vial de al menos $4 \mathrm{~m}$.

Todos estos condicionantes, junto con el edificio que existía adosado al linde suroeste, hacen que la labor de buscar una buena orientación para las viviendas quede prácticamente relegada a un segundo plano, dando prioridad a un posicionamiento de los volúmenes construidos con criterios principalmente programáticos. A pesar de ello, en la primera visita al lugar Le Corbusier tomó ciertas notas en su cuaderno sobre los ángulos de incidencia solar que dictarían la configuración. Analizó el espacio, su exposición, orientación y las posibilidades de control de la luz antes de desarrollar cualquier idea preliminar. ${ }^{19}$

El obstáculo principal consistía en un edificio de ladrillo de cuatro alturas que está - sigue construido — separado $7.5 \mathrm{~m}$ de la calle. Le Corbusier dibuja el perfil de la medianera desnuda y el sol de la mañana y la tarde asomando a los lados. La utilización de la trayectoria solar como estrategia de diseño sigue siendo a pesar de las dificultades presentes como un acto de fe en el sol.

En otra hoja de ese mismo cuaderno también dibuja el resto de perfiles de cada lado del solar y apunta los inconvenientes "sombra (agujero bastante oscuro) y ruido proveniente de la calle. [...] El esfuerzo destacable

\footnotetext{
${ }^{16}$ La Unité d’Habitation de Marsella (1945-52), todo el diseño de grandes edificios de la India en Ahmedabad y Chadigarh, los proyectos de urbanismo de ese país, el diseño de Bogotá; son proyectos que desarrollaba entonces. Incluso durante 1951 diseñó y pintó las ilustraciones de su manuscrito Le Poème de l'angle droit, que fue publicado finalmente en 1955.

${ }^{17}$ Le Corbusier lo conocía porque se había puesto en contacto con él para traducir el libro Propos d'urbanisme.

${ }^{18}$ No se realiza análisis de la herramienta brise-soleil puesto que no se utilizó como tal en las Maisons Jaoul.

${ }^{19}$ Maniaque Benton, Caroline: Le Corbusier and the Maisons Jaoul. New York: Princeton Architectural Press, 2009. p. 45.
} 
que puso en la elaboración de estos bocetos iniciales claramente muestra su atención a los factores solares para conseguir maximizar su influencia en el diseño inicial." 20

Finalmente, las viviendas se dispusieron en dos lados ortogonales del patio privado, haciendo que tengan orientaciones distintas. En muchas de las versiones que se realizaron, las viviendas tienen un posicionamiento paralelo, pero finalmente tal y como comentábamos tuvo mayor peso una correcta ocupación del espacio existente.

\subsection{Cubierta ajardinada}

La cubierta ajardinada se da en gran cantidad de proyectos de Le Corbusier. Fue formulada muy pronto y respondía más a ideas proyectuales abstractas que a una búsqueda específica de soluciones bioclimáticas. Tan importante era este concepto que lo incluyó en los "cinco puntos" de la arquitectura.

En principio se justificaba como devolución a la "naturaleza" del terreno ocupado por la casa, favoreciendo el disfrute de un jardín privado, pero el mismo Le Corbusier era consciente del papel que jugaba para alcanzar el confort interior. Su capacidad aislante protegía las nuevas cubiertas de hormigón armado plano de los cambios de temperatura exterior. También los planteó como solución para reducir las necesidades de calefacción en los espacios interiores. Adicionalmente la cubierta plana - que facilita el ajardinamiento- posibilita la colocación de las bajantes en el interior de la vivienda y al estar el interior calefactado se evitaba que estas se congelaran con los problemas que esto conlleva.

En 1927 Le Corbusier publicó en la revista L'Architecture Vivante "La teoría de la cubierta Jardín" un documento que trata de la planeación y el uso de la terraza. En él defiende su uso extensivo para todo tipo de climatologías. "Se puede admitir que igualmente es aplicable a los casos medios (climas templados, suaves, o incluso cálidos). El hormigón armado es el nuevo medio que permite la realización de una cubierta homogénea [...]. En Conclusión: razones de orden técnico, económico, de confort e incluso sentimentales nos lleva a adoptar como solución la cubierta terraza". ${ }^{21}$

Obras en localizaciones tan distintas como la villa Le Lac que hizo para su madre frente al lago Le Mans, la villa Henfel (casa para fin de semana) o la villa Sarabhai son testimonio de aquello en lo que Le Corbusier tanto insistió años más tarde: la conjunción entre el soporte de hormigón armado, la impermeabilización flexible y el remate mediante una capa vegetal es una de las soluciones constructivas más acertadas y duraderas que se pueden realizar.

Lo cierto es que la utilización de cubiertas ajardinadas ha tenido gran proyección histórica de manera destacable en la época actual, habiendo generado un curioso concepto comercial, las cubiertas ecológicas, en el marco de la denominada "naturación urbana". Las cubiertas vegetales suponen una herramienta bioclimática de primer orden por la cantidad de ventajas que tienen. No sólo a nivel higrotérmico sino acústico, de contaminación y de absorción de $\mathrm{CO}^{2}$.

En las Maisons Jaoul se incluyeron desde los primeros bocetos, y a pesar de tener un espesor variable debido a la estructura horizontal de bóveda catalana, funcionan como un buen aislante.

\footnotetext{
${ }^{20}$ Ibidem. P.46

${ }^{21}$ Le Corbusier: "Théorie du toit-jardin", en L’Architecture vivante, Otoño-Invierno, 1927. Paris: Jean Badovici. pp. 13-18.
} 


\subsection{Materialidad}

“En la década siguiente (1950-60)... El mundo de la arquitectura anhelaba su trabajo, temblaba y obedecía. [...] De las casas Jaoul, Stirling y Gowan inteligentemente aprendieron un nuevo camino en la arquitectura doméstica (y el resto del mundo aprendió de ellos)" 22

Las Jaoul son una de las obras que mejor representa esa utilización de materiales más elementales que hemos comentado. Las viviendas están construidas con ladrillo, hormigón, rasillas planas, bóvedas "a la catalana”, cubiertas revestidas de hierba.

Cabe destacar que, aunque realmente no es una obra rompedora sino que se encuadra en una línea evolutiva lógica que comenzó en la década de 1930, sí que tuvo mucha repercusión en los arquitectos coetáneos, muchos de los cuales evolucionaron hacia una corriente postmoderna. Probablemente esto ocurrió así porque su dimensión es superior a otras viviendas anteriores, por la complejidad del programa fantásticamente resuelto y por su localización muy cercana a les Champs Elysées en Paris, en Nuilly-sur-Seine.

"No hay referencia alguna a ningún aspecto mecánico en Jaoul, ni en construcción ni en estética. Estas casas que en total costaron 30.000 libras esterlinas, fueron construidas por obreros argelinos equipados con escaleras, martillos y clavos, y, a excepción del vidrio, no se utilizó ningún material sintético; tecnológicamente no suponen ningún avance con respecto a la construcción medieval." ${ }^{, 23}$ Pero destilan modernidad en todos los aspectos.

El nuevo repertorio de materiales: hormigón, ladrillo, madera, tierra y pétreos es sostenible económica, térmica y naturalmente hablando. Son baratos por su abundancia, facilidad de obtención y en general cercanía entre el lugar de producción y de colocación (se reducen los transportes). Además debido a su buen comportamiento térmico reducen el consumo en acondicionamiento interior. Al menos en ese momento eran aislantes con mejor comportamiento que los industrializados y con una inercia térmica muy superior. Al ser productos naturales o con un reducido proceso de fabricación suponen una menor emisión de $\mathrm{CO}^{2}$ a la atmósfera (han sido generados de manera natural por el propio planeta), en muchos casos su reutilización es factible, su mantenimiento y reciclaje es sencillo y en cualquier caso, debido a su composición, son biodegradables.

Aunque es cierto que de este grupo de materiales de construcción se tiende a excluir al hormigón y a los cerámicos (ladrillo), las nuevas técnicas de trituración y molido para generar áridos para nuevos hormigones y rellenos los acercan al grupo de materiales con un reducido impacto negativo sobre el medioambiente por su capacidad de reciclaje.

En estas viviendas, fundamentalmente cuando la composición en planta responde a un sistema de naves concatenadas, los muros son portantes y por tanto su espesor es mayor de lo que había sido en los cerramientos de las viviendas puristas. Los límites de mayor espesor y mayor inercia mejoran el comportamiento térmico y acústico de los paramentos que están "revestidos por el interior (enyesados) para evitar las condensaciones." 24

\footnotetext{
${ }^{22}$ Banham, Reyner: Le Corbusier: "A critique of his work", The Architectural Review. Octubre 1966, no 834. pp. 97-108.

${ }^{23}$ Stirling, James: "De Garches a Jaoul. Le Corbusier como arquitecto doméstico en 1927 y 1953". Anales de Arquitectura. 1993, n ${ }^{\circ}$ 5. Valladolid: Universidad de Valladolid. pp. 209-213. Artículo recogido y traducido, original: "From Garches to Jaoul: Le Corbusier as Domestic Architect in 1927 and 1953". The Architectural Review. Agosto 1955, n 118.

${ }^{24}$ W. Boesiguer y G. Girsberger: Le Corbusier 1910-1965, Barcelona, Editorial Gustavo Gili, 1971.
} 
Y a la vez que los cerramientos opacos adquieren espesor, los entrepaños o cerramientos semitransparentes ganan profundidad y se concreta "La "cuarta pared" -la incorporación de estantes y materiales opacos dentro de las ventanas- (que) es sintomática de la reciente actitud de Le Corbusier ante la profundidad de la superficie. Las ventanas no existen ya para mirar a través de ellas, sino para ser contempladas.. ${ }^{25}$

\subsection{Cerramientos practicables (ventanas)}

Conjuntamente con la nueva materialidad, y a pesar de que esta pueda ser relacionada con una vuelta a los orígenes, la concepción moderna de la ventana como un desencuentro entre dos muros, en el proyecto de las Jaoul se potencia. Los entrepaños que cierran el espacio de muro a muro se construyen en madera -material de altas prestaciones- y se componen de entramados o mallas de cuidada composición que disocian "huecos" de diferente función. Unos son transparentes -aunque no necesariamente practicables- para la iluminación; otros son practicables -aunque no necesariamente transparentes- para la ventilación; otros albergan estantes, incluso muebles cerrados y otros son simplemente opacos.

La madera es un material con muy reducida huella ecológica (si su producción es en bosques responsables) y es un magnifico aislante térmico. Construyendo los huecos a la manera de la "cuarta pared" se minimizan los puentes térmicos en el punto más delicado de la envolvente térmica.

Son ejemplos de esta magistral aplicación de la "ventana" las viviendas trabajadas en la misma línea que la casa Errazuriz posteriormente a 1930. Y a pesar de que al principio es menos obvio, a partir de los tipos de casas S.P.A. Lannemezan para "contremâitre" et ingenieur", 1940, la "cuarta pared" se utiliza explotando al completo sus posibilidades, ya que contiene (en este proyecto en concreto) todos los muebles de las habitaciones a excepción de la cama (mesitas, estantes y pupitres).

El término "cuarta pared" aparece en "Problemes de l'ensoleillement" 26 por primera vez, pero su concepción se inicia con los estudios teóricos para el rascacielos del Barrio de la Marina en Alger (1938-42) y se basa en la aplicación de la "fachada libre". En la Oeuvre complète Le Corbusier señala las ventajas del brise-soleil para el interior de las oficinas cuando éste se agranda y convierte en loggia. Añade además de las bondades de la protección solar, la posibilidad de limpiar el vidrio desde el exterior porque está al alcance de la mano y resalta sobre este cerramiento que su "diseño presenta la posibilidad de una diversidad considerable."27

En el mismo texto el arquitecto explica "...[al brise-soleil] se le añadirá el "brise-vent" con la posibilidad de constituir paredes herméticas acristaladas traslúcidas, transparentes, opacas si queremos. Se alcanza una conquista arquitectónica: la explotación de la cuarta pared de la habitación."28,

Y tal y como se observa en el esquema que acompaña al escrito en la Oeuvre Complete, al igual que en función de la altura se desplaza la posición del paño -para corregir la escala de la protección solar- se puede ajustar su diseño y equipamiento al uso de la estancia que sirve. El entramado admite contener paneles fijos o abatibles, traslúcidos o trasparentes, de vidrio normal o helado, pavés. Incluso se le pueden añadir muebles, cajoneras,

\footnotetext{
${ }^{25}$ Ibidem. Stirling, James.

${ }^{26}$ Boesiger, Willy; Le Corbusier: Le Corbusier. Oeuvre complète 1938-46. Zurich: Les Éditions d'Architecture, 1973. pp. 103-115.

${ }^{27}$ Ibidem, p. 106.

${ }^{28}$ Ibidem, p. 107.
} 
baldas o paneles decorados. El sistema también permite controlar la entrada de luz en la estancia deslizando pantallas correderas unas sobre otras para tamizar al 30\%, 60\% o 100\% las superficies acristaladas.

\subsection{Circulación de Aire}

La introducción en el proyecto arquitectónico de las correcciones climáticas a través del viento y la brisa no resulta sencilla, existiendo una elevada imprecisión en su diseño. "La norma general debe consistir en prever sistemas flexibles y confiar en que los usuarios sepan utilizarlos con la máxima eficacia". ${ }^{29}$ Existen muchas posibilidades como chimeneas solares, aspiradores estáticos, torres solares pero el más sencillo y eficaz es la ventilación cruzada. Ésta se mejora si se produce a través de un patio, por la capacidad que tiene de crear un microclima específico y de actuar como filtro entre las condiciones exteriores y las interiores.

Tal vez el binomio de ventilación cruzada-doble orientación es uno de los que menor desarrollo alcanza en los procesos teóricos de Le Corbusier en un modo perceptible, pero desde luego marca todo su trabajo profundamente desde el inicio y en realidad es generador de preceptos básicos en su lenguaje estilístico y compositivo, especialmente en la década de los 50. Todos sus edificios de esta década, a partir de la experiencia en la India están dotados de aerateurs y las Maisons Jaoul no son una excepción.

Una de las primeras viviendas en las que experimenta con este efecto es la casa Curruchet (1949), vivienda unifamiliar entre medianeras en la ciudad de La Plata, que contiene un patio central encerrado entre dos grandes volúmenes y "situado hacia el medio del lote que actuaría como una suerte de 'chimenea' natural de extracción del aire caliente proveniente de las estancias inferiores" ${ }^{30}$.

Las viviendas de Neuilly-sur-Seine tienen, tal como indicábamos en el apartado anterior, un diseño de huecos que disocia las funciones de manera que existen huecos que son específicos para ventilar. En la figura 1 podemos ver un esquema teórico de las ventilaciones cruzadas que se generarían con la apertura de estos huecos.

\footnotetext{
${ }^{29}$ Serra, Rafael Serra: Arquitectura y Climas. Barcelona, Gustavo Gili, 1999. p. 57.

${ }^{30}$ Gómez Sierra, Carlos M.: "Le Corbusier y la casa Curruchet. Una aproximación teórica desde la problemática del clima", Área digital. "Área historia. Utopía y ciudad". Febrero 2002 nº 2. Chaco, Argentina. Facultad de Arquitectura y Urbanismo.
} 

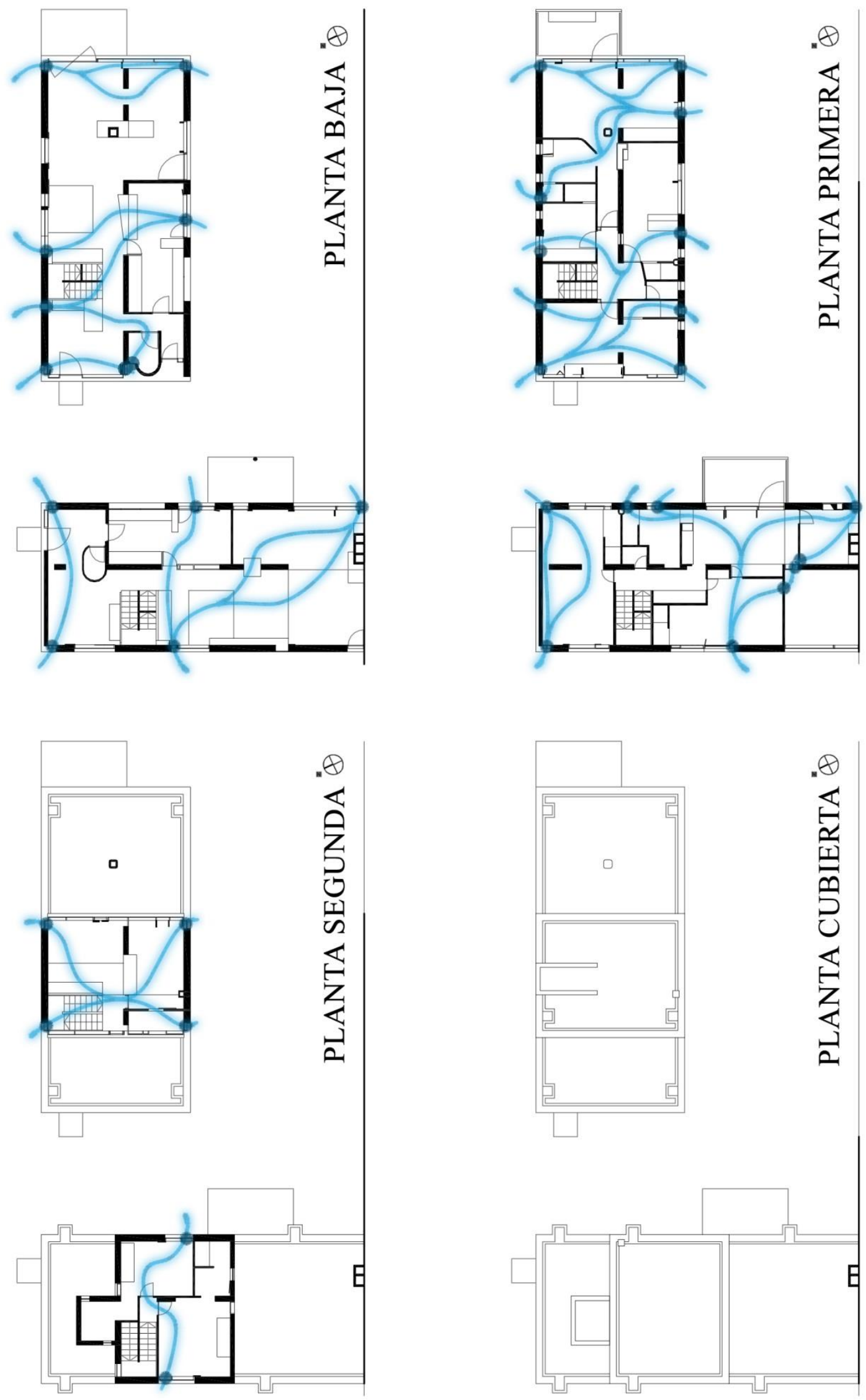

1. Esquema de ventilaciones cruzadas establecidas exclusivamente mediante aerateurs. 
Las estancias que recaen en las fachadas de menor longitud son espacios únicos, así se facilita una buena ventilación cruzada de manera directa. Por el contrario, el resto de estancias dependen de tener las puertas abiertas para que la ventilación se produzca efectivamente. Este hecho que puede resultar incómodo en un edificio público, en una vivienda es bastante factible, al menos durante gran parte de la jornada. Si bien es cierto, algunos trazados de corrientes son muy intrincados y es difícil que se produzcan en momentos en los que no haya viento simplemente por gradiente de temperaturas entre fachadas.

\section{Estudio teórico.}

Los parámetros que influyen en el comportamiento higrotérmico de un edificio son múltiples. Las instalaciones adquieren relevancia en el comportamiento global puesto que pueden corregir en cierta medida los resultados de un diseño poco cuidado - a costa de consumo energético-, pero por el contrario, pueden generar humedades o acrecentar problemas de confort interior. A pesar de todo ello, el comportamiento global depende en mayor medida sobre el diseño arquitectónico y especialmente de la envolvente frente a las condiciones de contorno.

\subsection{Modelizado}

A través de Ecotec Analysis 2011 de Autodesk se han estudiado las viviendas. El modelizado ha permitido obtener datos de la incidencia solar sobre las viviendas y de las sombras que generan pero también el entorno construido y vegetal.

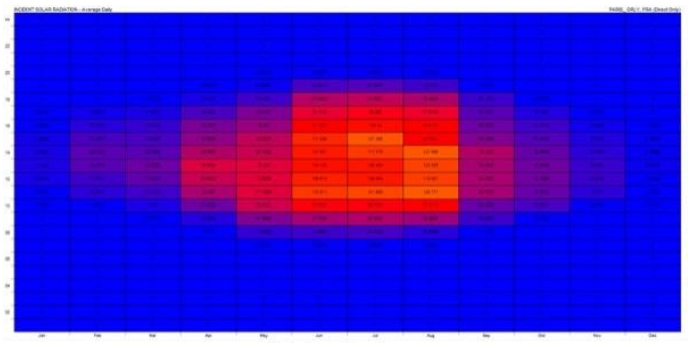

Vivienda A

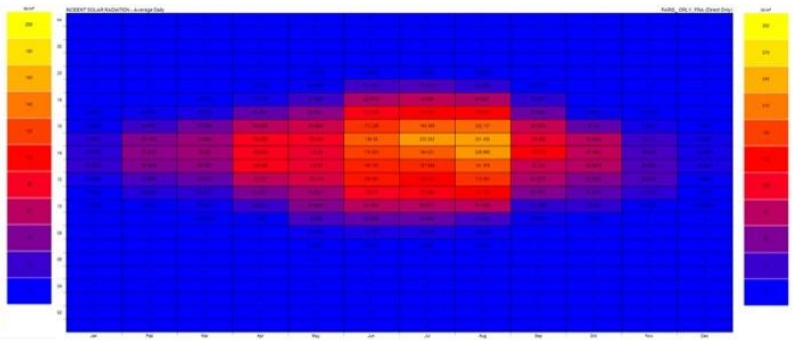

Vivienda B

2. Gráfico comparativo. Radiación Solar Directa y Difusa en las dos viviendas.
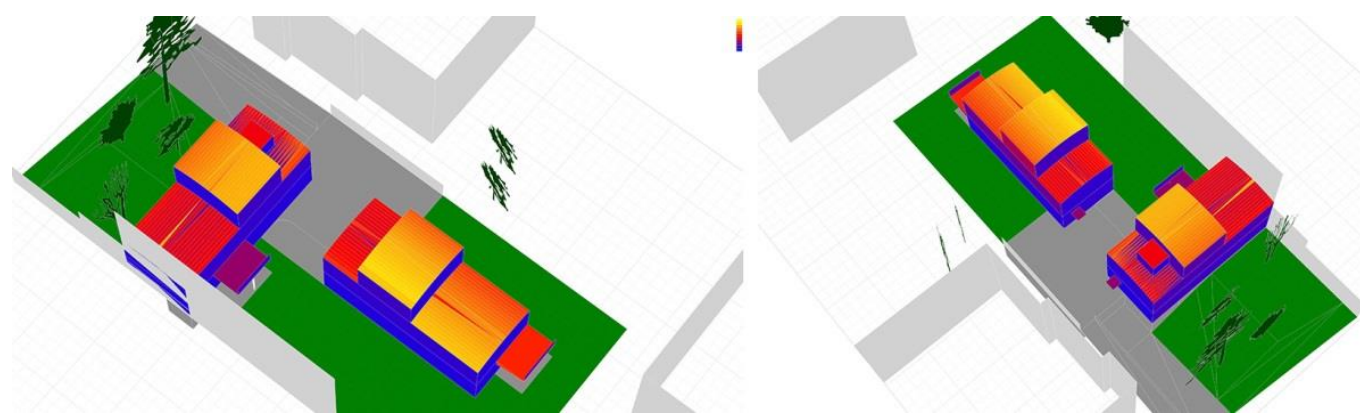

3. Nivel de radiación recibido por cada una de las superficies que componen la envolvente de las viviendas.

Debido a los edificios y árboles que se sitúan en el entorno de la parcela, especialmente al edificio colindante, las viviendas reciben un nivel de radiación bajo. Especialmente la vivienda A, paralela a la rue de Longchamp.

Del estudio se desprende que las dos viviendas deberían tener un comportamiento higrotérmico muy parecido ya que aunque tienen orientaciones opuestas, las condiciones del entorno y su volumetría hacen que la radiación recibida a lo largo del año sea muy parecida. En todo caso la vivienda B, recibe un poco más de asoleamiento 
por lo que podría alcanzar mayores grados de confort, aunque al tener mayor superficie en contacto con el exterior $^{31}$ las pérdidas también son mayores.

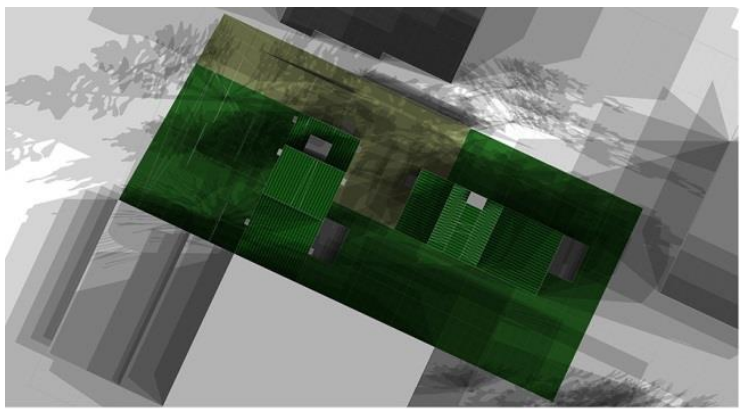

21 de Junio

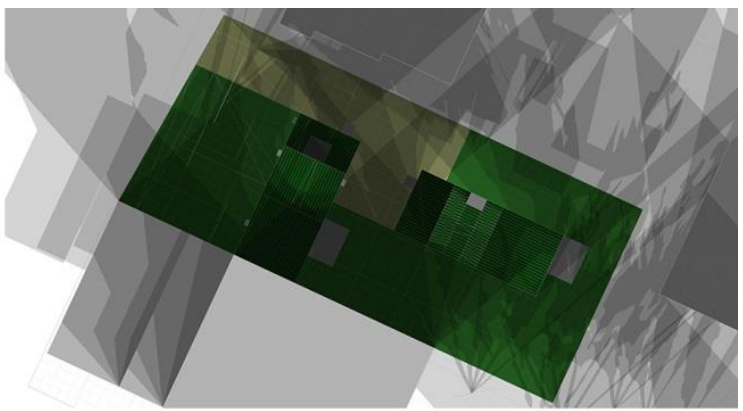

21 de Septiembre

4. Estudio de rango de sombras para los solsticios. 21 de Junio - 21 de Septiembre. Planta.
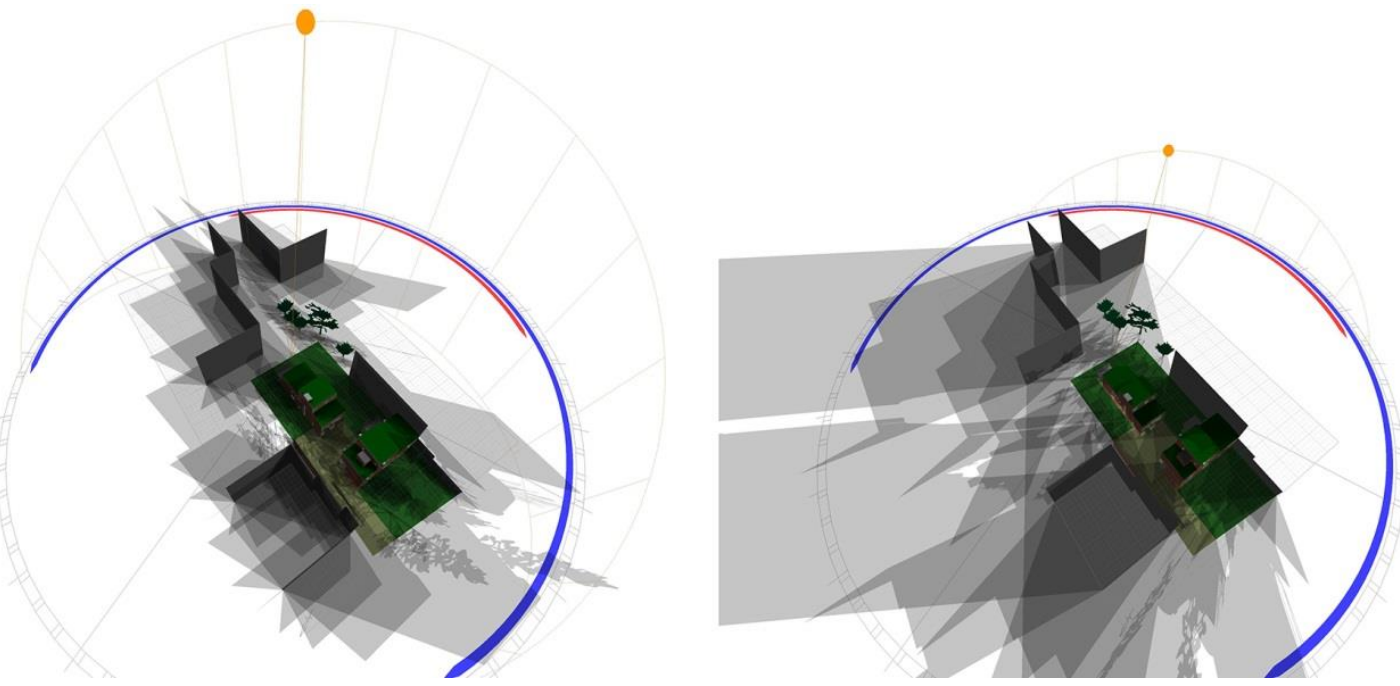

5. Estudio de rango de sombras para los solsticios. 21 de Junio - 21 de Diciembre. Vista aérea.
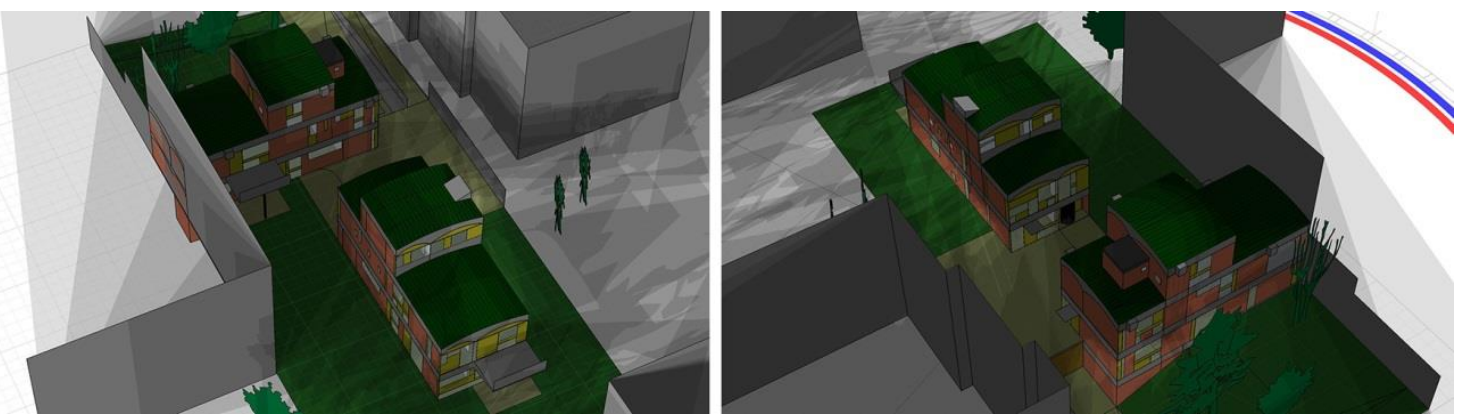

6. Estudio rango de sombras. 21 de Diciembre. Solsticio de invierno.

\footnotetext{
${ }^{31}$ La vivienda A tiene un testero en contacto con el edificio contiguo en el que ni si quiera se dobló el cerramiento. El espacio interior de la vivienda está directamente en contacto con la medianera sobre la que se aplicó el revestimiento interior.
} 

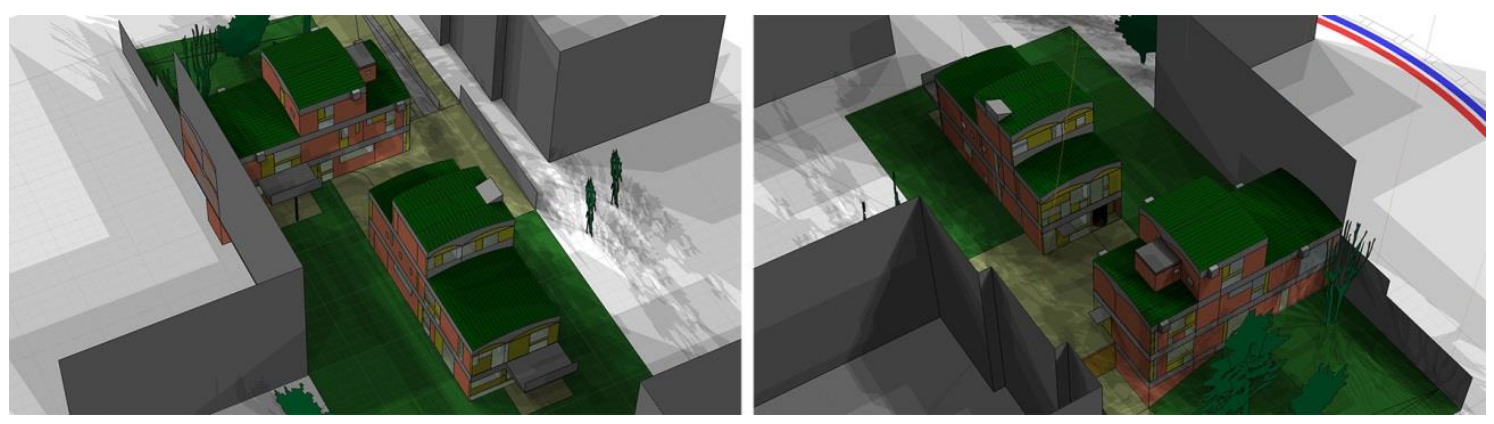

7. Estudio rango de sombras. 21 de Junio. Solsticio de verano.

\subsection{Envolvente}

Durante el periodo en el que se hicieron las mediciones higrotérmicas, adicionalmente se realizó un estudio fotográfico de las fachadas y del interior de las viviendas, así como toma de medidas, que ha permitido realizar un levantamiento planimétrico del estado actual de las mismas.

VIVENDA A

\begin{tabular}{|c|c|c|c|c|c|c|c|c|c|c|c|c|c|c|}
\hline \multirow[b]{3}{*}{$\frac{\dot{\mathrm{z}}}{\overline{\mathrm{z}}}$} & \multicolumn{3}{|c|}{ CERRAM. MACIZO } & \multicolumn{4}{|c|}{ CUATRIÈME MUR } & & & & & & & \\
\hline & \multirow[b]{2}{*}{ 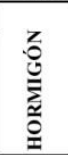 } & \multirow[b]{2}{*}{ 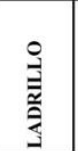 } & \multirow[b]{2}{*}{ 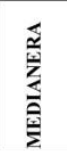 } & \multicolumn{2}{|c|}{ MADERA } & \multirow{2}{*}{ 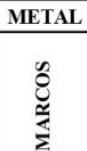 } & \multirow[b]{2}{*}{$\frac{\vec{z}}{\frac{1}{2}}$} & \multirow[b]{2}{*}{ 氙 } & \multirow[b]{2}{*}{$\begin{array}{l}\vdots \\
\vdots \\
0 \\
\vdots \\
\vdots \\
0\end{array}$} & \multirow[b]{2}{*}{ 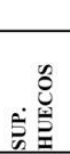 } & \multirow[b]{2}{*}{ 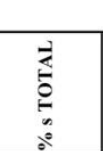 } & \multirow[b]{2}{*}{ 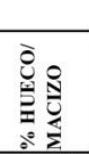 } & \multirow[b]{2}{*}{ 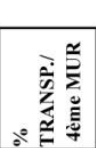 } & \multirow[b]{2}{*}{ 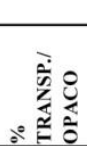 } \\
\hline & & & & $\begin{array}{l}8 \\
\mathscr{z} \\
\Sigma \\
\Sigma\end{array}$ & 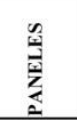 & & & & & & & & & \\
\hline SUR & 4,50 & 13,90 & 43,45 & 0,17 & 0,80 & 0,04 & 0,16 & 63,02 & $18,51 \%$ & 1,17 & $1,60 \%$ & $1,86 \%$ & $13,68 \%$ & $0,25 \%$ \\
\hline ESTE & 27,60 & 48,04 & 0,00 & 4,49 & 10,97 & 1,34 & 16,72 & 109,16 & $32,07 \%$ & 33,52 & $45,84 \%$ & $30,71 \%$ & $49,88 \%$ & $18,09 \%$ \\
\hline & & & & & & & TOTALES & 340,42 & $100,00 \%$ & 73,12 & $100,00 \%$ & & & \\
\hline
\end{tabular}
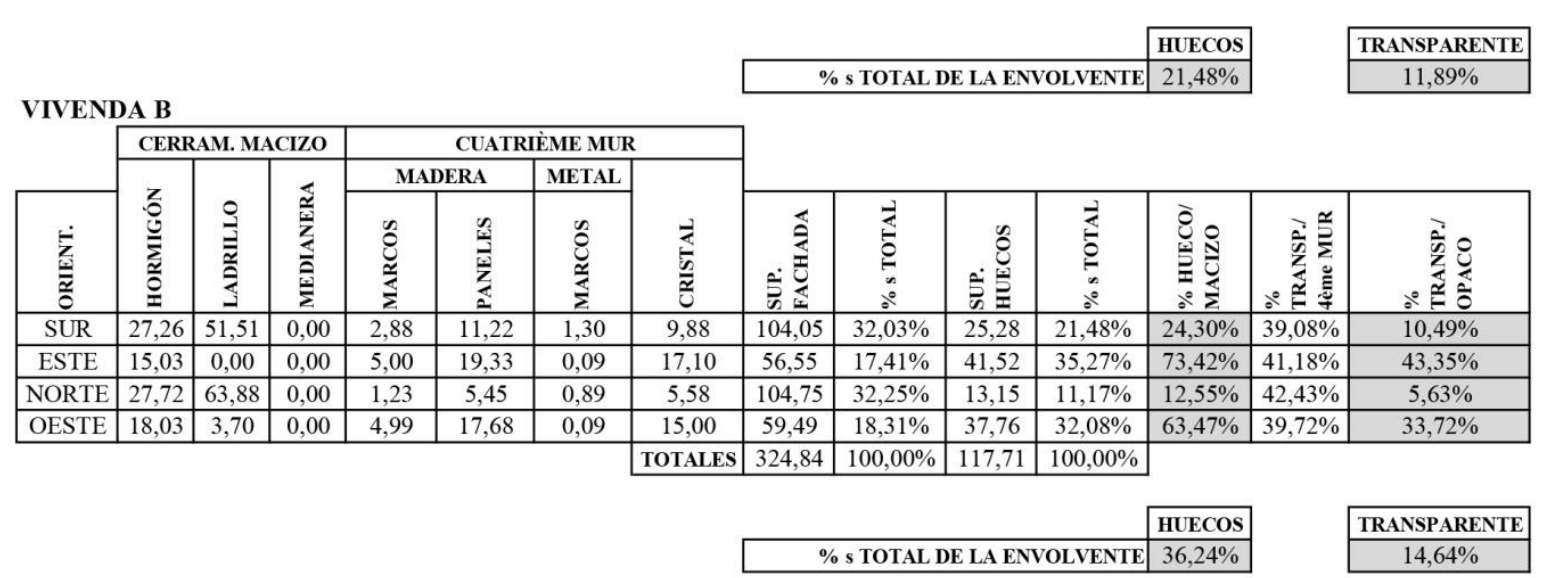

Todos los datos en $\mathrm{m}^{2} \mathrm{y}$ porcentajes

8. Tabla estudio comparativo de la envolvente.

En base a esta información se realiza un estudio comparativo de la envolvente que nos permite observar que la vivienda A tiene un porcentaje global de huecos de 21,48\% y de zona transparente de $11,89 \%$ que son menores que los de la vivienda B, 36,24\% y 14,64\%, respectivamente. Por tanto dentro de la envolvente el porcentaje que ocupa el muro de ladrillo de doble hoja -mucho más aislante que los huecos-es mayor y por tanto el coeficiente global de la vivienda también. Este hecho es contraproducente para la adquisición de ganancias solares pero, como ya hemos visto, la incidencia solar en las viviendas es baja y por tanto prevalece el hecho de mantener las ganacias internas. 
La fachada Sur, que es la orientación más favorable para la latitud de París, en la vivienda A tiene una incidencia mínima puesto que gran parte de ella está en contacto con un espacio interior y en la vivienda B recibe muy poca radiación solar debido a la obstrucción del edificio colindante. Además el porcentaje de trasparencia ${ }^{32}$, de $10,49 \%$, es bastante bajo y tampoco permite un gran acceso de rayos solares.

Con respecto a las fachadas Este y Oeste, que tienen más acceso solar por la mañana y la tarde; en la vivienda B están resueltas prácticamente como un gran hueco que se cierra con el cuatrième mur, pero al ser las fachadas estrechas, su incidencia sobre el global de la envolvente es pequeña, alrededor del $18 \%$ cada una de ellas. Además la fachada Oeste de esta vivienda queda bloqueda completamente por la otra para la incidencia solar de invierno. En la vivienda A estas dos fachadas suponen el 32\% cada una de ellas y aunque también se produce una obstrucción parcial, el porcentaje de transparencia es mayor, estando resuelta la parte maciza con muro de ladrillo de doble hoja y cámara.

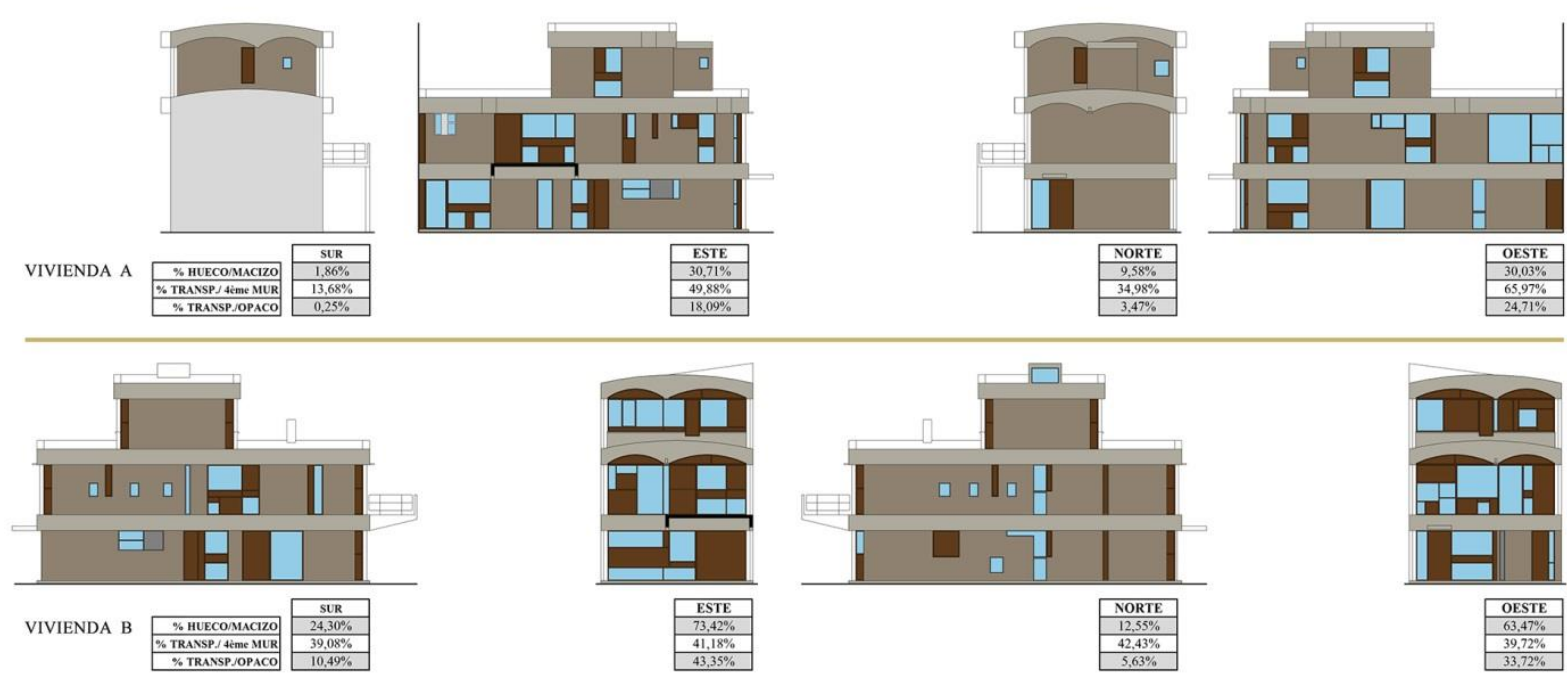

9. Estudio comparativo de la envolvente. Alzados.

En conclusión queda patente que a pesar de que la vivienda B tiene una orientación más favorable, las condiciones de controno y el diseño de huecos de las envolventes hacen que la balanza se incline hacia un mejor diseño de la vivienda A. Con el estudio in situ comporbaremos si este hecho se produce en la realidad.

\section{Estudio empírico}

Durante los días 15, 16,17 y 18 de Enero de 2015, se realizó una campaña de toma de datos en las Maisons Jaoul. Para ello se utilizaron dos medidores Whöler 210 que registran y almacenan medidas de temperatura, humedad relativa y concentración de $\mathrm{CO}_{2}$ según intervalos indicados en su configuración.

Las herramientas se colocaron en las estancias principales de las viviendas en la planta baja, cerca de cerramientos opacos que dan al patio que se genera entre las dos viviendas. Debido al efecto de estabilización de los aparatos de medición se descartan las primeras 3 horas, de manera que en los gráficos que se recogen a continuación se representan las mediciones a partir de las 20:00 h del día 15 de Enero hasta las 20:00 h del día

\footnotetext{
${ }^{32}$ Para el cálculo de este valor se ha tomado el $100 \%$ de las contraventanas que existen abiertas permitiendo la mayor incidencia solar.
} 
18 de Enero. Los datos de temperatura y humedad exteriores se han obtenido de la web http://www.meteofrance.com/ descargando la información pública de los días en los que se realizó la medición.

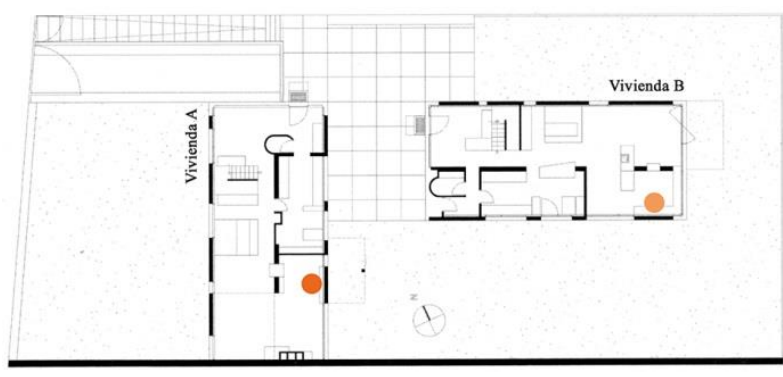

10. Plano de las viviendas con la situación de las herramientas de medición.

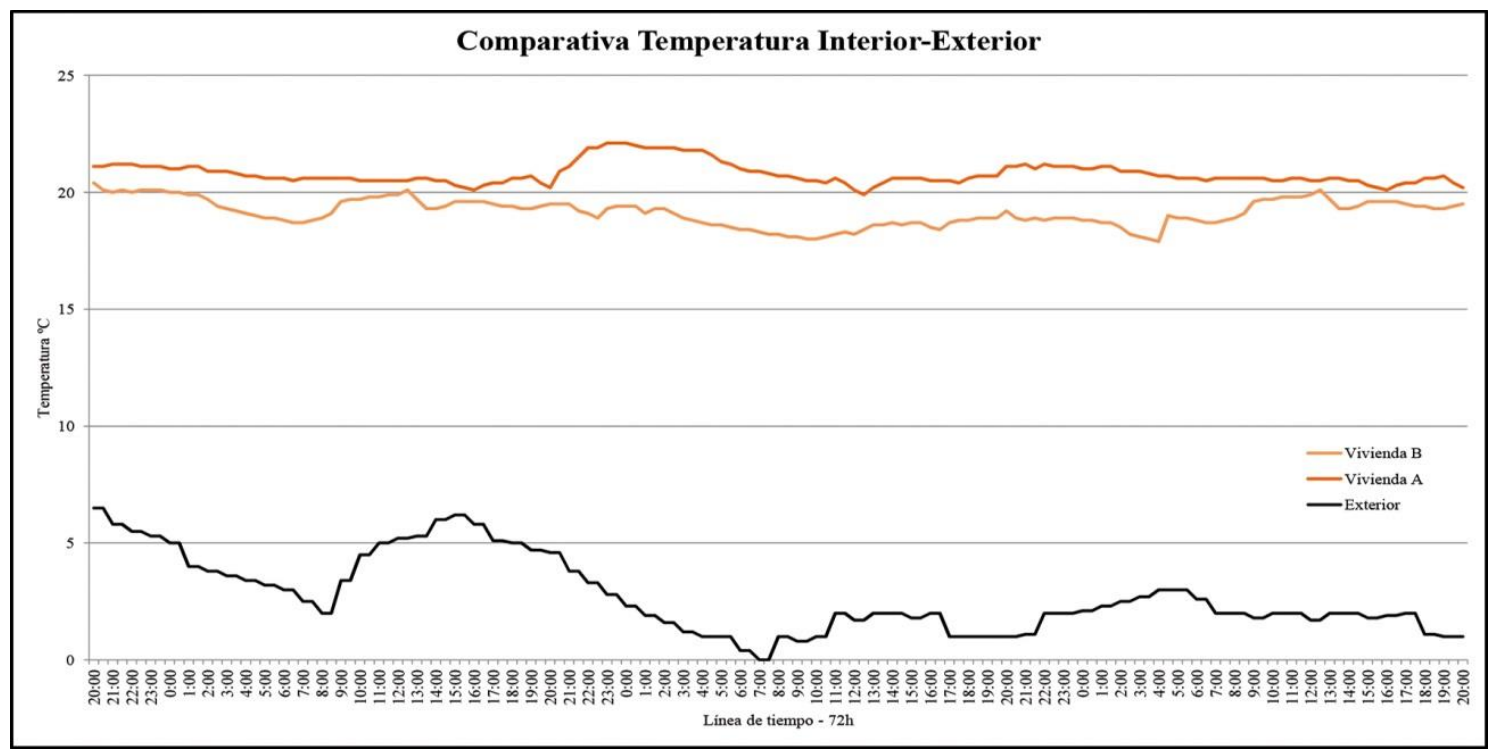

11. Gráfico comparativo. Temperatura interior de las viviendas y Temperatura exterior.

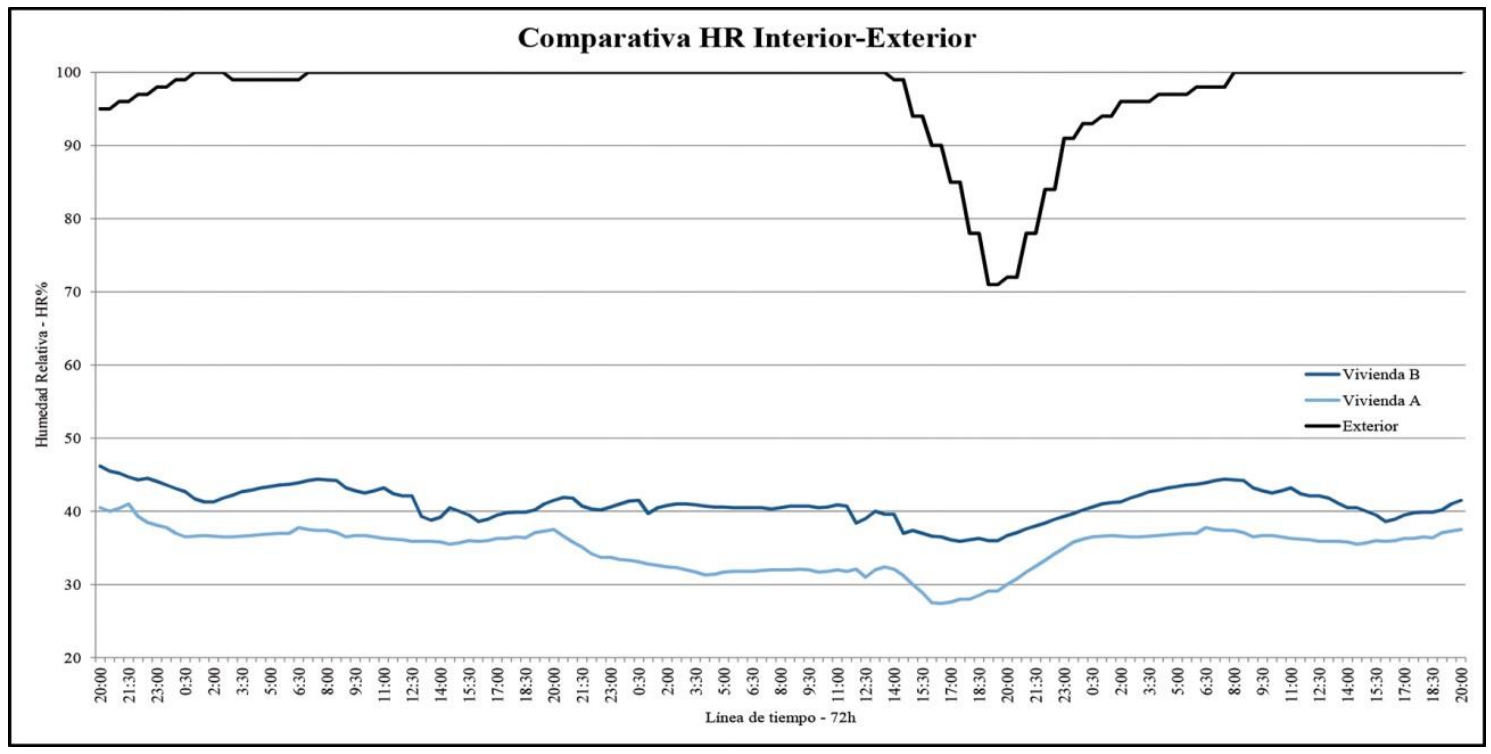

12. Gráfico comparativo. Humedad Relativa interior de las viviendas y Humedad Relativa exterior. 


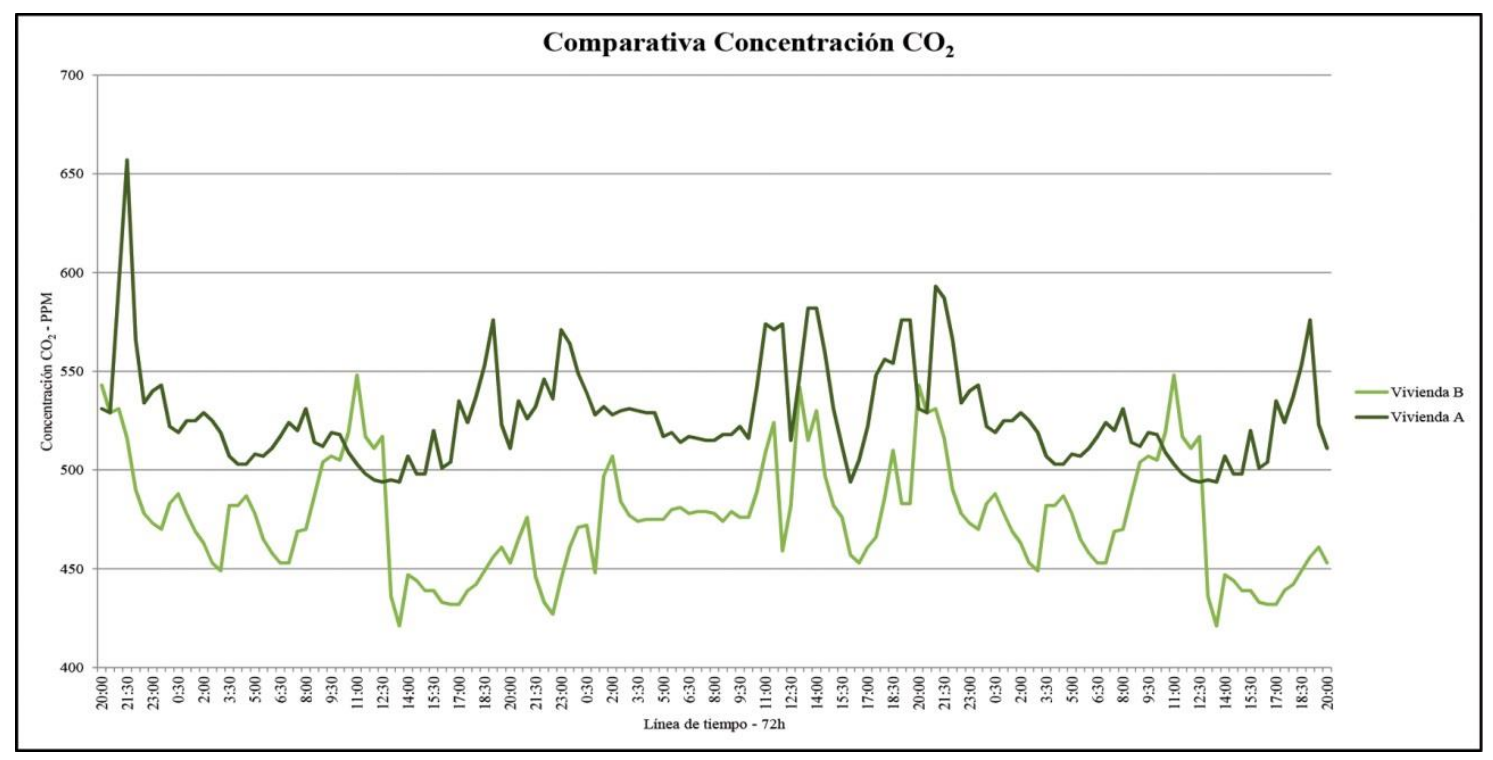

13. Gráfico comparativo. Concentración de $\mathrm{CO} 2$ en el interior de las viviendas.

De los datos extraídos, se pueden extraer varias conclusiones sobre el comportamiento higrotérmico de las viviendas, pero lo más destacable en realidad es comprobar que se produce una diferencia de temperatura y humedad entre la vivienda $\mathrm{A}$ y la B. Esta última es en todo el periodo estudiado más fría y húmeda. En los siguientes gráficos analizamos en detalle esa diferencia.
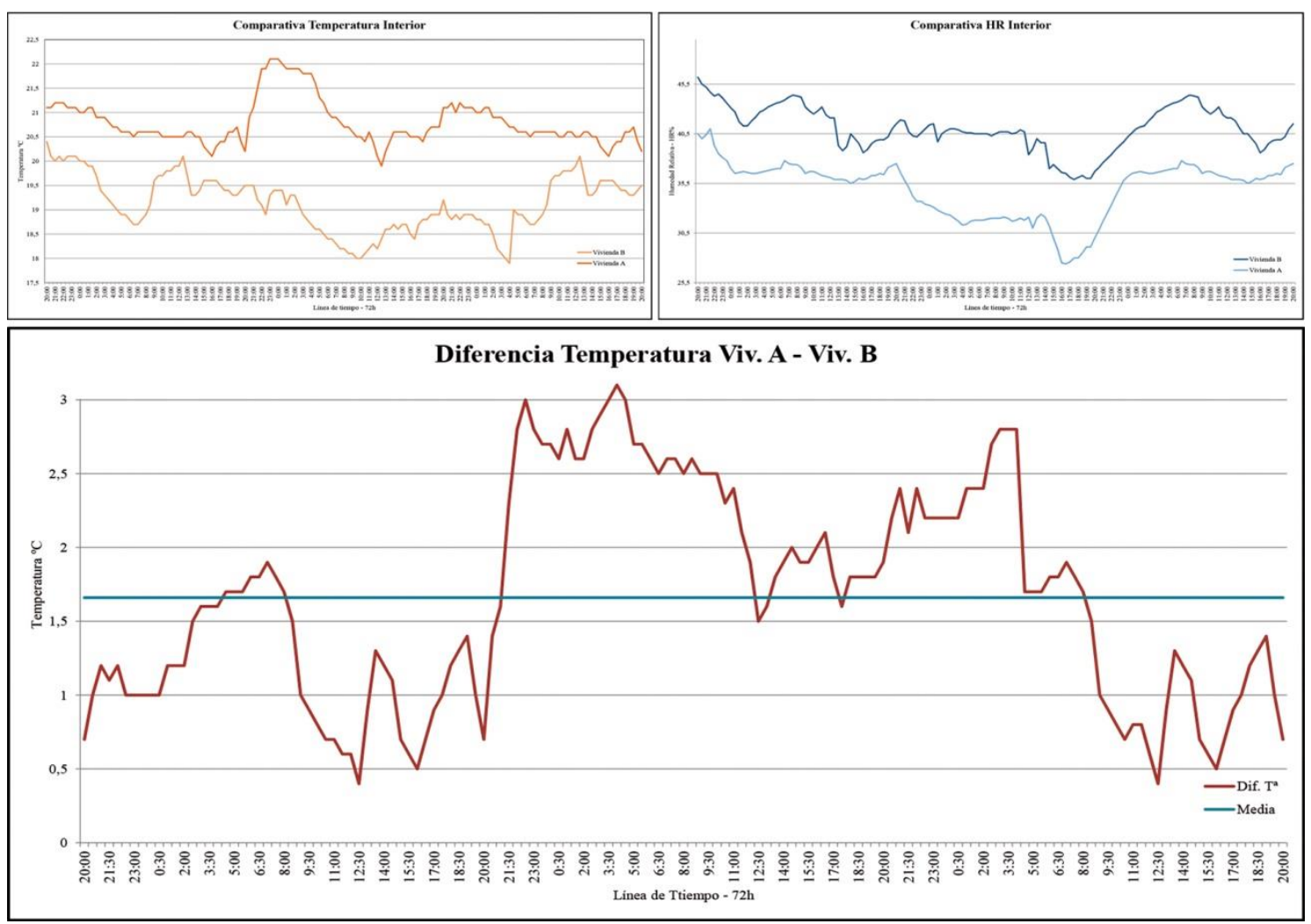

14. Gráfico comparativo. Diferencia de Temperatura y Humedad Relativa. Variación de la diferencia de Temperatura y Media 
La diferencia de Temperatura oscila entre $0^{\prime} 4{ }^{\circ} \mathrm{C}$ y $3{ }^{\prime} 1{ }^{\circ} \mathrm{C}$. Por un lado, las diferencias son menores cuando la incidencia solar es mayor, entre las 12:30 h y las 17:00 h. Este hecho se repite los tres días a pesar de las diferencias térmicas existentes entre ellos. Por el contrario, por las noches y las horas en las que no hay incidencia solar, la diferencia se acentúa hasta llegar al máximo justo antes del amanecer, aproximadamente sobre las 5:00 h.

La diferencia media de Temperaturas es de 1 ' $66^{\circ} \mathrm{C}$ tal y como se indica en el gráfico anterior ${ }^{33}$, y parece que habitualmente es así, puesto que los días en los que se han realizado las mediciones los datos climatológicos han estado muy cerca de la media habitual para la época en París.

Respecto a la Humedad Relativa, la vivienda B tiene registros de humedad entre un 2'7 \% y 9'4 \% superiores a la vivienda A. No son diferencias muy altas, ya que la media se coloca en 6'1\%, pero tal y como veremos más adelante es suficiente como para ser percibido por los ocupantes.

\section{Estudio subjetivo}

Las Maisons Jaoul fueron adquiridas en 2010 por dos hermanas que querían vivir en la zona, que siempre habían vivido juntas y que querían seguir haciéndolo. De este modo estas viviendas unifamiliares, independientes pero que comparten solar, situación completamente característica, cumplían con sus necesidades.

Ambas familias, tanto las hermanas como sus respectivos maridos, nunca han tenido un conocimiento muy profundo de la Historia de la Arquitectura, ni tienen una sensación especial de habitar lo que muchos arquitectos denominaríamos como un tesoro de la Arquitectura del s. XX. Paradójicamente, esta situación hace que su opinión sobre las viviendas no esté mediatizada ni sesgada por una componente podríamos decir ideológica y por tanto se muestra como altamente reveladora.

Tras una larga conversación con Philippe Chevalier - propietario de la vivienda A- y habiendo realizado preguntas a los hijos de las dos familias, se extrae las siguientes conclusiones: Todos ellos perciben que la vivienda A es la más confortable de las dos tanto en inverno como en verano. En general encuentran las casas un poco frías, algo por otro lado lógico debido a las obstrucciones solares existentes, pero especialmente la vivienda $\mathrm{B}$, destacando que es además mucho más húmeda. En general están contentos con las viviendas, especialmente con la posibilidad de pasar de una a otra por el sótano y encuentran los espacios confortables y agradables aunque poco luminosos en algunas épocas del año.

\section{Conclusiones}

Tal y como reflejan los datos del estudio empírico y con el refuerzo de la percepción de los habitantes, el comportamiento higrotérmico de las Maisons Jaoul funciona tal como se podría esperar.

El estudio numérico nos permite deducir que son casas en general algo frías y en las que es difícil la obtención de ganancias solares debido a las condiciones de contorno. Por otro lado la inercia de sus muros permite que los aportes de calor del sistema de calefacción se aprovechen de manera adecuada, especialmente en la vivienda A.

\footnotetext{
${ }^{33}$ La moda en este caso es de valor $1^{\circ} \mathrm{C}$, es decir es la situación que más se repite. Pero debido a que la variación entre unos momentos y otros no es exagerada, la media representa bien la sensación térmica entre las dos viviendas.
} 
Cabía esperar que la vivienda B tuviera un comportamiento algo peor y finalmente ha resultado ser así. En cualquier caso, sería necesario hacer un estudio completo de las viviendas en el periodo estival también y de las instalaciones de calefacción para comprender la diferencia de temperatura y humedad que se han constatado en este estudio.

A pesar de todo ello, las dos familias que actualmente habitan las viviendas han hecho de sus espacios sus coquilles de l'escargot en las que disfrutan de confort, intimidad y protección. Revelando que las Maisons Jaoul siguen siendo unas viviendas con una condición excepcional de la obra de Le Corbusier.

\section{Imágenes}

1. Esquema de ventilaciones cruzadas establecidas exclusivamente mediante aerateurs

2. Gráfico comparativo. Radiación Solar Directa y Difusa en las dos viviendas.

3. Nivel de radiación recibido por cada una de las superficies que componen la envolvente de las viviendas.

4. Estudio de rango de sombras para los solsticios. 21 de Junio - 21 de Septiembre. Planta.

5. Estudio de rango de sombras para los solsticios. 21 de Junio - 21 de Diciembre. Vista aérea.

6. Estudio rango de sombras. 21 de Diciembre. Solsticio de invierno.

7. Estudio rango de sombras. 21 de Junio. Solsticio de verano.

8. Tabla estudio comparativo de la envolvente.

9. Estudio comparativo de la envolvente. Alzados

10. Plano de las viviendas con la situación de las herramientas de medición.

11. Gráfico comparativo. Temperatura interior de las viviendas y Temperatura exterior.

12. Gráfico comparativo. Humedad Relativa interior de las viviendas y Humedad Relativa exterior.

13. Gráfico comparativo. Concentración de $\mathrm{CO} 2$ en el interior de las viviendas

14. Gráfico comparativo. Diferencia de Temperatura y Humedad Relativa. Variación de la diferencia de Temperatura y Media

NOTA: Todas las imágenes elaboradas por el autor.

\section{Bibliografía}

Banham, Reyner: Le Corbusier: "A critique of his work", The Architectural Review. Octubre 1966, n 834. pp. $97-108$.

Benton, Tim: "La Villa Baizeau et le brise-soleil", A.A.V.V. Le Corbusier et la Mediterranée. Marseille : Editions Parenthèses, 1987.

Bill, Max (Pub.); Le Corbusier: Le Corbusier. Oeuvre complète 1934-38. Zurich: Les Éditions d'Architecture, 1973.

Boesiger, Willy (Ed.) ; Le Corbusier ; Stonorov, O: Le Corbusier et Pierre Jeanneret. Oeuvre complète 1910-29. Zurich: Les Éditions d'Architecture, 1973.

Boesiger, Willy; Le Corbusier: Le Corbusier. Oeuvre complète 1938-46. Zurich: Les Éditions d'Architecture, 1973.

Boesiguer, Willy; Girsberger, G.: Le Corbusier 1910-1965, Barcelona, Editorial Gustavo Gili, 1971.

Frampton, Keneth: Le Corbusier. Turín, Ediciones Hazan, 1997 
Gómez Sierra, Carlos M.: "Le Corbusier y la casa Curruchet. Una aproximación teórica desde la problemática del clima", Área digital. "Área historia. Utopía y ciudad". Febrero 2002 nº 2. Chaco, Argentina. Facultad de Arquitectura y Urbanismo.

Le Corbusier, L’Almanach d'Architecture moderne (Paris: Crès, 1926; Paris: Connivence, 1975)

Le Corbusier: "Théorie du toit-jardin", en L’Architecture vivante, Otoño-Invierno, 1927. Paris: Jean Badovici.

Le Corbusier: Vers une architecture. Paris: Vincent, Freal and Cie., 1958.

Maniaque Benton, Caroline: Le Corbusier and the Maisons Jaoul. New York: Princeton Architectural Press, 2009.

Menin, Sarah; Samuel, Flora: Nature and Space, Aalto and Le Corbusier. Londres, Ed. Route Ledge, 2003.

Serra, Rafael Serra: Arquitectura y Climas. Barcelona, Gustavo Gili, 1999.

Siret, Daniel ; Harzallah, Amina: Architecture et côntrole de l'ensoleillment. Conferencia, manuscrito publicado en "Congrès IBPSA France", Ecole national Supérieure d'Architecture de Nantes, France 2006.

Stirling, James: "De Garches a Jaoul. Le Corbusier como arquitecto doméstico en 1927 y 1953". Anales de Arquitectura. 1993, $\mathrm{n}^{\circ}$ 5. Valladolid: Universidad de Valladolid. pp. 209-213. Artículo recogido y traducido, original: "From Garches to Jaoul: Le Corbusier as Domestic Architect in 1927 and 1953". The Architectural Review. Agosto $1955, \mathrm{n}^{\circ} 118$.

Torres Cueco, Jorge: Le Corbusier: Visiones de la técnica en 5 tiempo. Barcelona: Colección Arquithemas, 2004. 


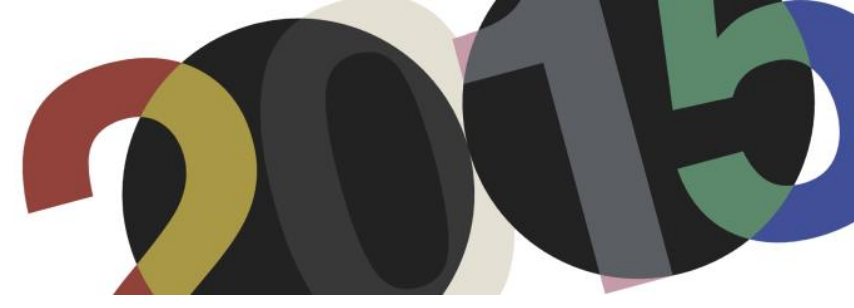

DOI: http://dx.doi.org/10.4995/LC2015.2015.628

\title{
La casa y el recinto. Un proceso abierto a través del proyecto para la Residencia Peyrissac en una explotación agrícola en Argelia
}

\author{
C. Martínez Arroyo*, R. Pemjean Muñoz*, J.P. Sanz Alarcón** \\ * Escuela Técnica Superior de Arquitectura de Madrid \\ ** Escuela Técnica Superior de Arquitectura y Edificación de Cartagena
}

\begin{abstract}
Resumen: El objeto de estudio de esta investigación es el proyecto residencial no construido que realiza Le Corbusier en 1942 para una explotación agricola cerca de Cherchell, Argelia. A partir del conjunto de dibujos que constituye la documentación gráfica existente sobre esta propuesta, el estudio aqui desarrollado basa su interés en describir el proyecto como proceso abierto de reflexión arquitectónica sobre la idea de la casa dentro de un recinto acotado. Se realiza un análisis pormenorizado de los distintos mecanismos y temas de proyecto empleados por el arquitecto mediante el desarrollo de nuevos planos interpretativos de la documentación original. De este modo se encuentran tanto los invariantes como las distintas versiones que construyen el desarrollo de la propuesta. Finalmente se concluye mediante una sintesis critica en la que se relacionan los ámbitos arquitectónicos estudiados con soluciones análogas dentro tanto dentro del conjunto de la obra de Le Corbusier como con ejemplos paradigmáticos del panorama arquitectónico.
\end{abstract}

Abstract: The object of study of this research is the not built residential project designed by Le Corbusier in 1942 for a farm near Cherchell, Algeria. From the drawings that constitute the existing graphic documentation of this proposal, this study based its interest in describing the project as an open process of architectural reflection on the idea of the house within a bounded enclosure. A detailed analysis of the different mechanisms and project themes used by the architect through the developing of new interpretive drawings of the original documentation. In this way the invariants and different versions that built the development of the proposal are present. Finally we conclude with a critical synthesis where we relate the architectural areas studied with similar solutions from Le Corbusier works and paradigmatic examples of the architectural scene.

Palabras clave: Le Corbusier; Argelia; Peyrissac; casa; recinto; patio.

Keywords: Le Corbusier; Argelia; Peyrissac; house; enclosure; court.

\section{Introducción}

El objeto de estudio de esta investigación es el proyecto residencial no construido que realiza Le Corbusier en 1942 para una explotación agrícola cerca de Cherchell, Argelia. Se trata de un proyecto basado en la relectura de la arquitectura tradicional mediterránea desde la óptica y el léxico moderno ${ }^{1}$. La propuesta reflexiona sobre cómo realizar un alojamiento adecuado al clima, en función del sol y los vientos, las condiciones y medios locales. El ejercicio práctico desarrollado por Le Corbusier plantea un hábitat defensivo e interior en relación con la soledad del lugar junto a una arquitectura abierta y vinculada con la amplitud del horizonte que le rodea. A

\footnotetext{
${ }^{1}$ Junto a los croquis del proyecto, se trascriben las palabras de Le Corbusier: En la construcción moderna, encontramos la relación entre el paisaje, el clima y la tradición. Véase Le Corbusier: Oeuvre complète Volume 4 1938-46, 11th edition. Basel: Birkhäuser-Publishers for Architecture, 1999, p. 123.
} 
partir del conjunto de dibujos que constituye la documentación gráfica existente sobre esta propuesta, el estudio aquí desarrollado se basa en el interés del desarrollo del proyecto como proceso abierto de reflexión.

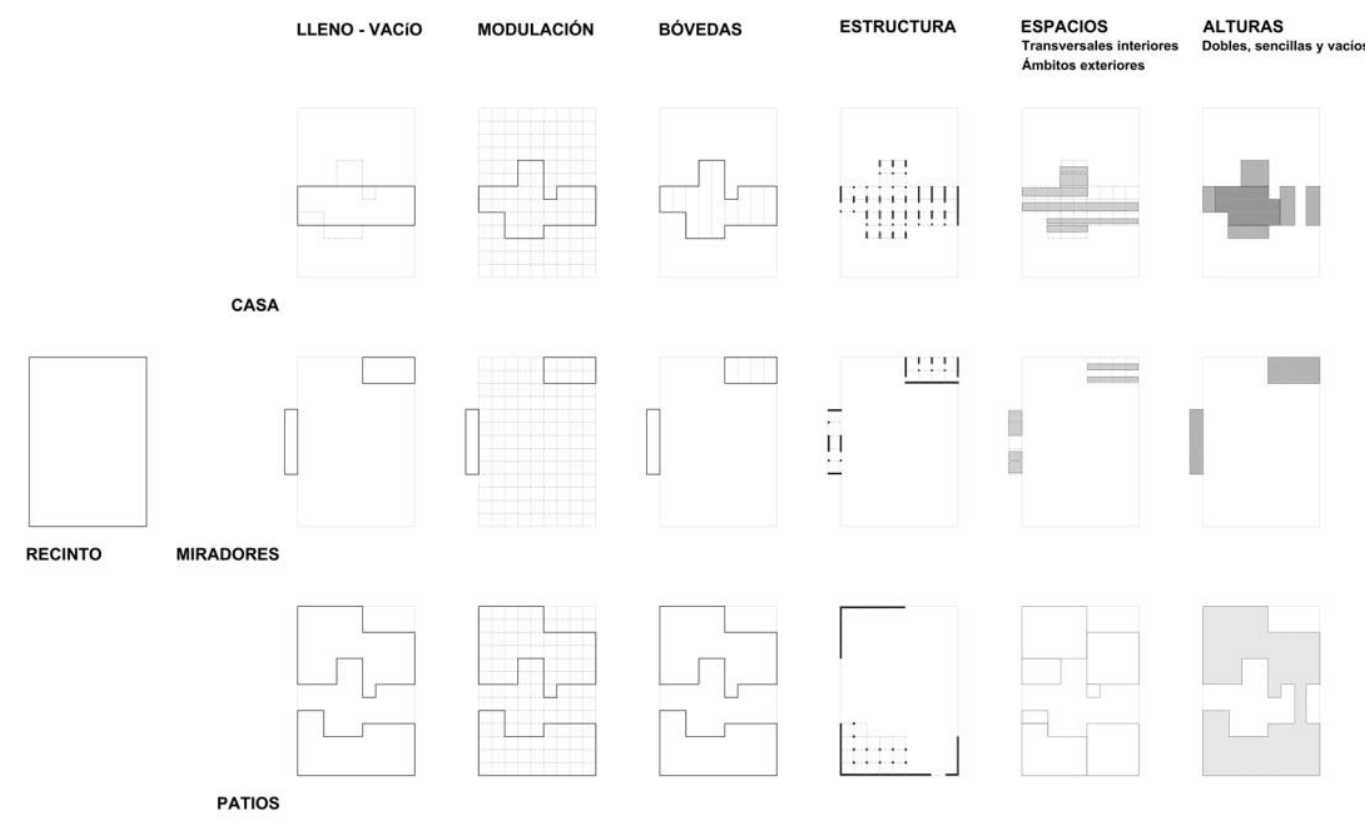

1. Tabla comparativa de los distintos mecanismos arquitectónicos empleados en el proyecto.

Este procedimiento se configura mediante la continua transformación y definición de diversos mecanismos de proyecto a través del dibujo como medio de pensamiento. Estos temas de proyecto que aparecen en los croquis suponen un invariante a lo largo de todo el proceso, adquiriendo distintas versiones que dan lugar a un proyecto abierto e inconcluso.

El objetivo del trabajo es definir el grado de variación e intensidad con el que aparecen los mecanismos utilizados por Le Corbusier y de este modo demostrar mediante el análisis del proyecto los parámetros arquitectónicos empleados. Esta hipótesis de trabajo se traduce, y por tanto aparece reflejada, en la estructura de la investigación. De este modo, la comunicación queda organizada en dos partes diferenciadas.

Una primera de carácter analítico organizada sobre los cuatro elementos fundamentales que estructuran y configuran el proyecto: el recinto, la casa, los miradores y los patios. Esta parte del trabajo se desarrolla a partir de la documentación original existente (28 croquis en planta, sección, axonometría o perspectiva) ${ }^{2}$. Estos planos construyen el guión en torno a la idea de casa dispuesta en el interior de un recinto acotado. Se estudia en profundidad el contenido de cada uno de ellos, extrayendo los datos que ponen de manifiesto los sistemas y mecanismos espaciales, constructivos y materiales que organizan la propuesta. Para ello se realiza una reconstrucción del proyecto mediante la elaboración de una nueva planimetría analítica.

\footnotetext{
${ }^{2}$ Cabe destacar la importancia que adquiere la publicación de este proyecto en la obra completa de Le Corbusier ya que se presenta a lo largo de 8 páginas mediante una selección de dibujos. En este estudio se ha tenido en cuenta el contenido completo de los planos y dibujos originales del proyecto, lo cual ha posibilitado acceder a distintas versiones anteriores respecto a las conocidas por las publicaciones.
} 

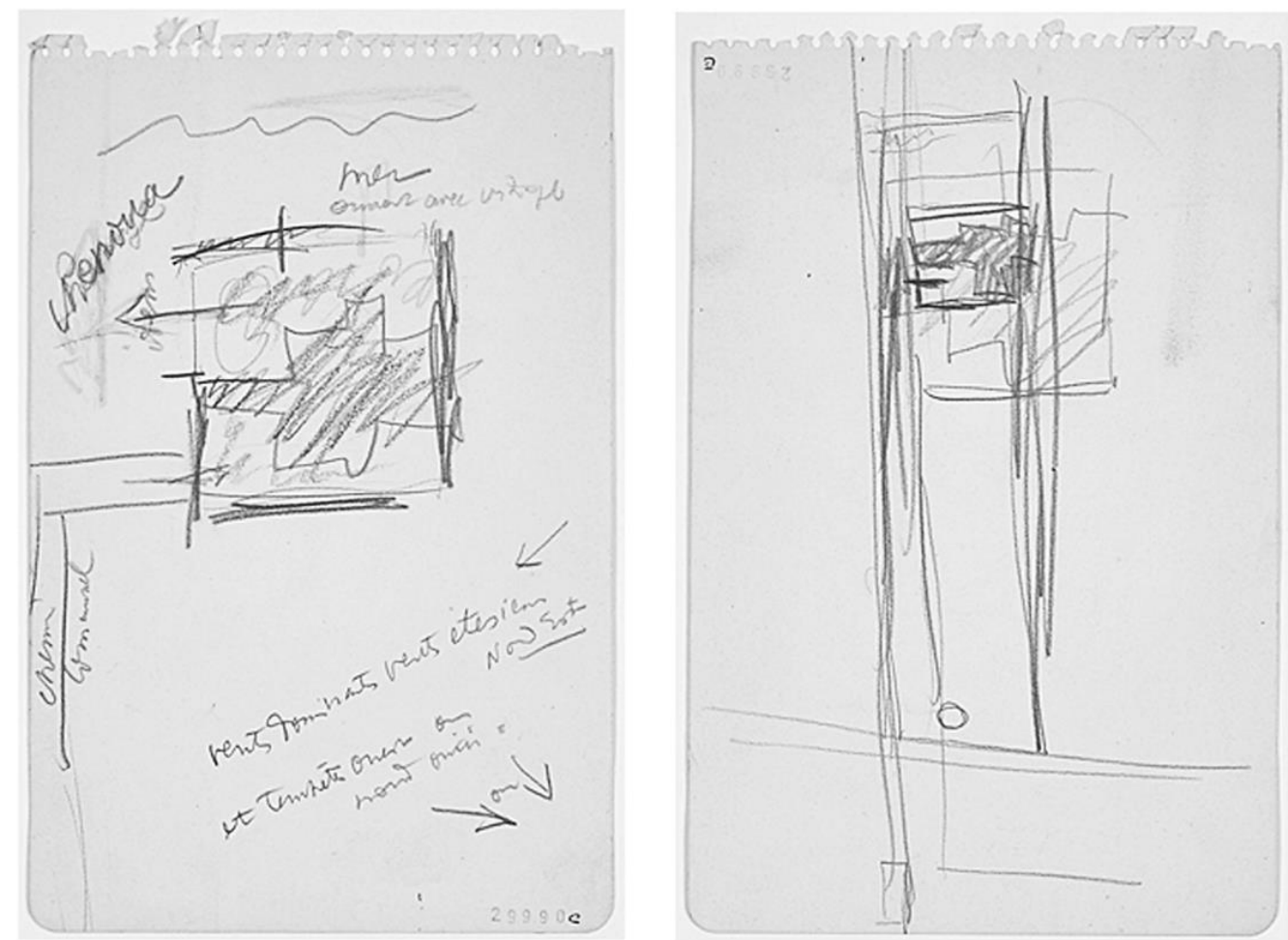

2. Dibujos originales FLC 29990C-CFLC-ADAGP y FLC 29990E-CFLC-ADAGP que muestran la relación del recinto con el paisaje próximo.

La segunda parte, a modo de síntesis crítica, se estructura sobre los diferentes temas de proyecto encontrados y contextualizados dentro de la obra de Le Corbusier: la configuración de transiciones espaciales desde el exterior hasta el interior a través de espacios intermedios haciendo de la casa un umbral, el recinto como muro grueso convertido en espacio destinado a la mirada extrovertida en relación con el horizonte, la ruptura del espacio lineal y unitario bajo las bóvedas de cañón consiguiendo visiones diagonales en los ámbitos de la vivienda; o la combinación gradual de llenos y vacíos bajo la idea de patio y pabellón.

\section{Análisis}

Tal y como se ha señalado anteriormente, los cuatros ámbitos de reflexión permanente y fundamentales que encontramos en los dibujos de Le Corbusier en el proyecto, y que son objeto de análisis pormenorizado en esta investigación, son: la materialización del recinto a través de una tapia recortada, la definición de una masa edificada que forma la casa o espacios interiores, la especialización de los vacíos a modo de patios que se delimitan dentro del recinto y la construcción de espacios de control sobre la mirada lejana hacia el horizonte.

\subsection{El recinto}

La primera idea que se incorpora al desarrollo del proyecto y que nunca desaparece es la de crear un recinto cerrado y materializar un habitar introvertido en el interior entre jardines. En los dibujos se hace incidencia sobre la configuración del recinto como lugar acotado y finito ${ }^{3}$. La casa se propone en apariencia defensiva y cerrada pero a la vez abierta mediante, tanto con un torreón para vigilar a los merodeadores como con miradores hacia el paisaje. La tapia aparece como elemento terso e infranqueable en primer plano mientras que las bóvedas de la

\footnotetext{
${ }^{3}$ Plano original FLC 29990C.
} 
cubierta de los elementos miradores aparecen como elementos que flotan sobre la tapia en un segundo estrato de altura $^{4}$. Esta imagen de prisma regular con elementos curvos configurando la cubierta resulta análoga a la de la villa Savoye.

Los croquis hacen hincapié en el valor del emplazamiento en relación con la inclusión del recinto habitado en el paisaje dando lugar a un diálogo explícito entre lo natural y lo artificial. Así, por ejemplo, cuando el recinto de la casa aparece dibujado de forma prolongada hacia el paisaje circundante por la longitud de los muros que lo delimitan, se estable una clara ligazón entre la pieza arquitectónica y su lugar de inserción ${ }^{5}$.

La construcción de un límite dentro del cual se inserta la casa hace que en el proyecto se maneje constantemente la dialéctica entre la escala doméstica interior y la gran escala exterior en relación con el medio natural. Esta dualidad se ve representada por aquellos dibujos que muestran la imagen exterior de la casa frente a los croquis que inciden en la visión desde el interior de la casa hacia el paisaje ${ }^{6}$. Por tanto el recinto adquiere una doble versión contrapuesta: la de ocultar el interior desde el exterior; y la de abrir los espacios de la casa hacia las vistas.

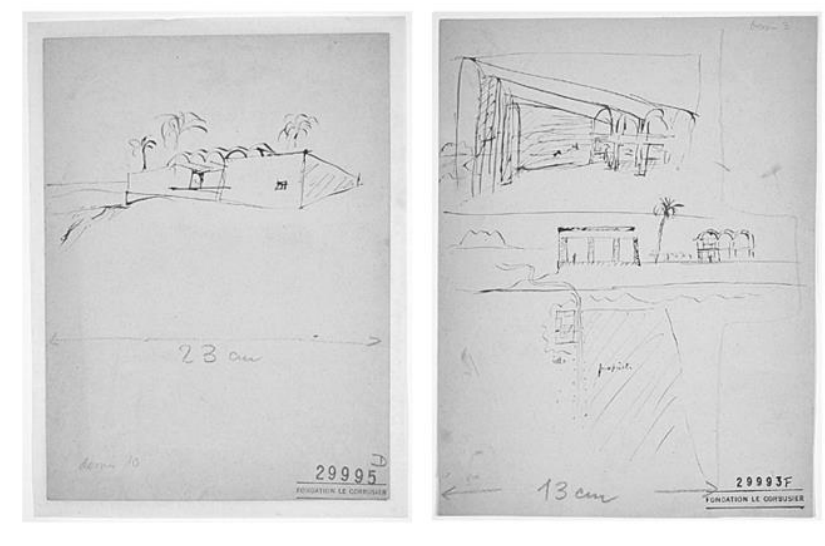

3. Dibujos originales FLC 29995D-@FLC-ADAGP y FLC 29993F-CFLC-ADAGP.

La configuración geométrica del recinto se realiza por la determinación de un límite o perímetro construido a partir de una matriz modulada. Dentro de esta trama regular de 4 metros de lado se van definiendo las distintas versiones que adopta. El recinto aparece siempre como una forma rectangular ortodoxa sobre la que se delimitan zonas ciegas y otras permeables. A lo largo del proceso se muestra como el recinto se va reconfigurando, abriendo y cerrando, en función de las relaciones con el exterior ${ }^{7}$.

\footnotetext{
${ }^{4}$ Plano original FLC 29993H.

${ }^{5}$ Plano original FLC 29990E.

${ }^{6}$ Como por ejemplo sucede en las perspectivas exteriores del plano original FLC 29995D frente a la visión desde el interior de la casa que se dibuja en el FLC 29993F.

${ }^{7}$ En el exterior del recinto queda una gran plantación de naranjos y de tomates sobre una plataforma limitada por un acantilado sobre el borde del mar. También aparece una piscina que hará las veces de aljibe de agua para regar la vegetación circundante. La tapia del recinto se desmaterializa para conectar el interior de los patios con estos elementos del exterior.
} 


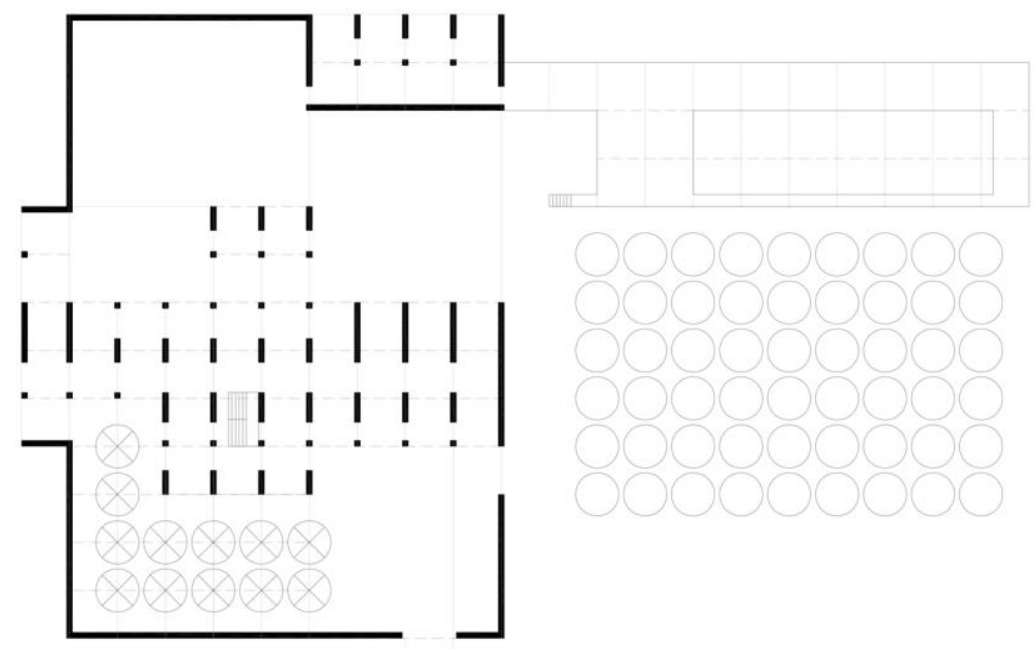

4. Planta baja de la vivienda y los patios realizada a partir de la documentación original sobre la propuesta más desarrollada.

Una vez construida la idea de recinto, otra de las preocupaciones asociadas al mismo es la forma de acceso. El camino de entrada aparece de forma recurrente en los dibujos quedando siempre latente la reflexión sobre este aspecto. Existen dos principales versiones sobre la manera de acceder al recinto. Por un lado aquellos dibujos que muestran una disposición lateral del recorte de entrada en la tapia ${ }^{8}$; y por otra parte, como sucede en la versión más desarrollada, la determinación de un acceso frontal a la dirección de llegada al recinto por el camino de aproximación. La indecisión sobre este aspecto se ve reflejada permanentemente en toda la documentación gráfica existente del proyecto. Ambas formas de acceder influyen directamente en la configuración de los espacios vacíos interiores al recinto que aparecen inmediatamente a continuación de la entrada a través de la tapia. En los accesos laterales se produce el desarrollo de la circulación tangente a la tapia por el exterior creándose un recinto o explanada de acceso previo a modo de vestíbulo. Sin embargo, en las versiones en las que se produce el acceso frontal se crea un patio de entrada pero esta vez en el interior del recinto. Esto hace que se fragmente y se especialice el uso o programa de los patios interiores. Así, estos ámbitos rompen su unidad y se separan según su utilización. La circulación en este caso queda siempre en el interior de la tapia, en un caso tangente a ella y en otro, en la propuesta más desarrollada, separada del borde creándose una perspectiva lineal a través de una secuencia conformada por un doble patio de acceso, uno previo de coches y otro posterior que da servicio a los ámbitos de la vivienda ${ }^{9}$.

\subsection{La casa}

La casa se configura como la suma de módulos construidos dentro de la trama regular. Su forma queda determinada por la relación intrínseca entre los llenos y vacíos mediante mecanismo de adición de piezas. Dentro

\footnotetext{
${ }^{8}$ Tal y como se refleja en el croquis FLC 29992D.

${ }^{9}$ En la planta baja del plano FLC 29995A se puede apreciar la disposición de dichos patios.
} 
del proceso de trabajo se muestra como un sistema dinámico, reconfigurable y no definitivo. La posición de la casa dentro del recinto si que aparece como un invariante en todos los dibujos del proceso del proyecto, quedando establecida en un punto intermedio del mismo, determinando así en todos los casos un vacío delantero frente a uno trasero. La casa queda definida entre dos patios. El lleno divide y fragmenta en dos partes al vacío ${ }^{10}$.

La estructura que materializa los distintos espacios de la casa queda asociada a la idea de matriz modular. De este modo aparece un orden longitudinal del espacio asociado a un tipo de sección estructural en forma de bóveda de cañón ${ }^{11}$. Uno de los proceso más interesantes del proyecto es la permanente indefinición sobre la direccionalidad de las bóvedas, ya que dependiendo del dibujo que analicemos, éstas aparecen según el eje esteoeste, y en otras ocasiones colocadas norte-sur ${ }^{12}$. Esta doble direccionalidad permite reconocer dos tipos de proyectos dentro del proceso. En ambos casos se trata siempre de espacios lineales, paralelos y homogéneos en dimensión. En la versión publicada en la obra completa, la orientación de las bóvedas aparece de forma nítida en sentido norte-sur construyendo la casa por yuxtaposición de elementos estructurales. La direccionalidad de las bóvedas queda ligada así a las vistas y la ventilación ${ }^{13}$.
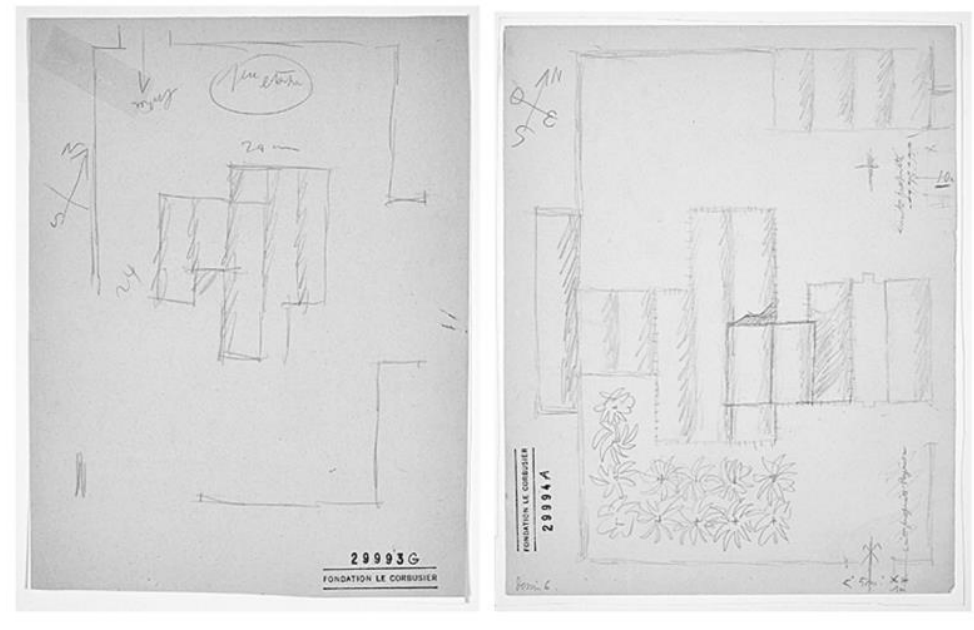

5. Dibujos originales FLC 29993G-CFLC-ADAGP y FLC 29994A-@FLC-ADAGP.

A pesar del carácter marcadamente longitudinal de todas las propuestas, se observa cómo dentro de ese orden paralelo aparece otro en sentido trasversal que define nuevos espacios. De este modo la casa puede entenderse como una sucesión de bandas, de nuevo paralelas, pero perpendiculares a la dirección de las bóvedas. En ellas encontramos dos categorías de espacios: por una parte aquellos definidos entre muros, como estancias acotadas (a veces equipadas alojando mobiliario); y por otro lado unos ámbitos continuos, diáfanos y pasantes que atraviesan toda la longitud de la casa conectando los espacios definidos bajo las bóvedas. Con ello se pone de manifiesto que el aparente carácter longitudinal de la casa es ficticio puesto que la organización de la misma responde a una trama regular en dos direcciones.

\footnotetext{
${ }^{10}$ FLC 29993B.

${ }^{11}$ FLC 29990D.

${ }^{12}$ Según se aprecia en la comparación entre las propuestas de cubierta en las axonometrías analíticas.

${ }^{13}$ FLC 29993 G y FLC 29994A.
} 
La definición constructiva de la estructura portante determina la materialización de los espacios. Se estandariza y homogeniza mediante tres tipos de muros que sujetan las bóvedas: pilar cuadrado, muro de medio módulo y muro completo, lo que da lugar a un juego versátil de combinaciones. Aunque es escasa la documentación existente en este aspecto si se hace referencia a que el módulo del proyecto queda en relación con la construcción de las bóvedas catalanas realizadas mediante ladrillo. Se produce una ambientación de los interiores mediante la combinación de tres materiales: la mampostería vista, las bóvedas encaladas de blanco y los cerramientos de madera. El suelo también queda planteado en madera. La independencia entre estructura y plementería como mecanismo arquitectónico aparece reflejado en este proceso de proyecto. De este modo, frente a la estructura portante masiva de muros y bóvedas, el cerramiento se proyecta mediante una carpintería en entramado asegurando la compartimentación y especialización de los huecos ${ }^{14}$. Éstos quedan materializados mediante paneles opacos, transparentes o translucidos, según las necesidades.

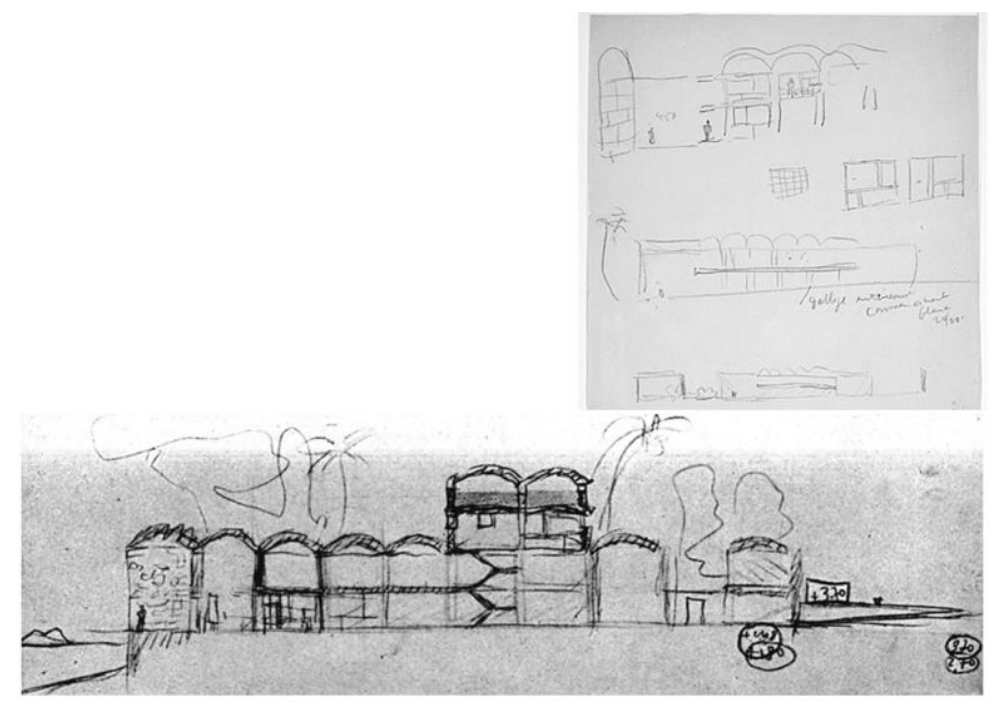

6. Fragmentos de los dibujos originales FLC 29993H-@FLC-ADAGP y FLC 29994D-@FLC-ADAGP de secciones en las que aparecen las alturas de los espacios.

La altura libre de los espacios es otro de los parámetros esenciales en la configuración de los mismos. Se maneja la utilización tanto de espacios de altura sencilla como de ámbitos de doble dimensión. De este modo la casa se convierte en una secuencia de espacios comprimidos y dilatados concatenados. La doble escala aparece en los extremos de la sección aumentando la presencia de la casa en relación con el paisaje mientras que los espacios interiores se configuran mediante una única altura ${ }^{15}$.

Respecto a la definición funcional de la casa, los dibujos aportan algunas anotaciones escritas sobre el posible uso de los espacios e incluso llega a dibujarse algún mobiliario que determina un programa doméstico configurado por partes ${ }^{16}$.

\footnotetext{
${ }^{14}$ FLC $29993 \mathrm{H}$.

${ }^{15}$ FLC $29993 \mathrm{H}$.

${ }^{16}$ FLC 29994B y FLC 29995A.
} 


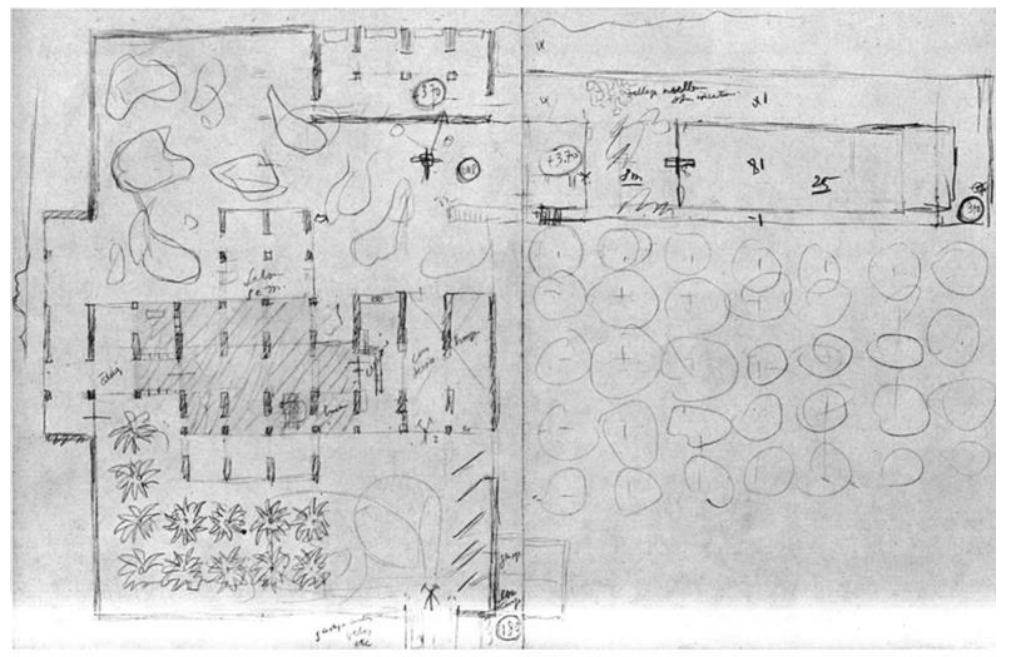

7. Fragmento del dibujo original FLC 29995A-CFLC-ADAGP de planta baja de la propuesta.

\subsection{Los miradores}

El proyecto muestra constantemente la contradicción entre una casa introvertida dentro de un recinto frente a un espacio extrovertido que vierte al paisaje exterior lejano. A partir de esta dualidad, la propuesta incorpora una reflexión permanente sobre la definición de espacios destinados a la apertura de la mirada al horizonte y las vistas, debido a la situación privilegiada de la casa sobre un acantilado. Se trabaja con dos direcciones y visiones principales: al norte hacia el mar y al oeste a la bahía de Cherchell y la montaña de Chenoua. Se produce la abstracción de las condiciones que le interesan del paisaje a través de la capacidad de síntesis sobre la conformación del mismo ${ }^{17}$. La mirada precisa y determinada queda asociada a los dibujos en planta ${ }^{18}$ y el paisaje aparece como recorte, enmarcado por la arquitectura.

Se proyectan estancias configuradas para mirar solamente hacia dos puntos concretos ${ }^{19}$. Aparece por vez primera la idea de conformación de espacios específicos contemplativos, destinados a observar el horizonte mediante zonas donde la tapia se dilata y adquiere espesor ${ }^{20}$. El proceso de proyecto sobre la configuración de estos espacios arroja una profunda reflexión que da lugar a distintas versiones dentro de un proceso secuencial en el que se define la organización de los mismos. Desde un primer momento, casi todos los esquemas dibujados separan los recortes en la tapia del recinto para poder mirar de forma independiente a las dos vistas definidas (norte y oeste) menos en el plano "FLC 29990D" donde la esquina del recinto relacionada con las vistas queda completamente abierta. Estos dos planos de visión separados no quedan vinculados a la casa en la mayoría de los croquis adquiriendo una formalización parecida en la serie de planos "FLC 29990A", "FLC 29990C" y "FLC 29992B". En estos casos siempre existe un muro ciego que separa los recortes de la tapia para la mirada.

\footnotetext{
${ }^{17}$ FLC 29990B.

${ }^{18}$ FLC 29990C.

${ }^{19}$ Así por ejemplo incluso hay algún dibujo, como es el caso del plano FLC 29992A donde la casa aparece desplazada el vértice superior izquierdo de la parcela con una posición totalmente polarizada hacia las vistas.

${ }^{20}$ FLC 29993A.
} 

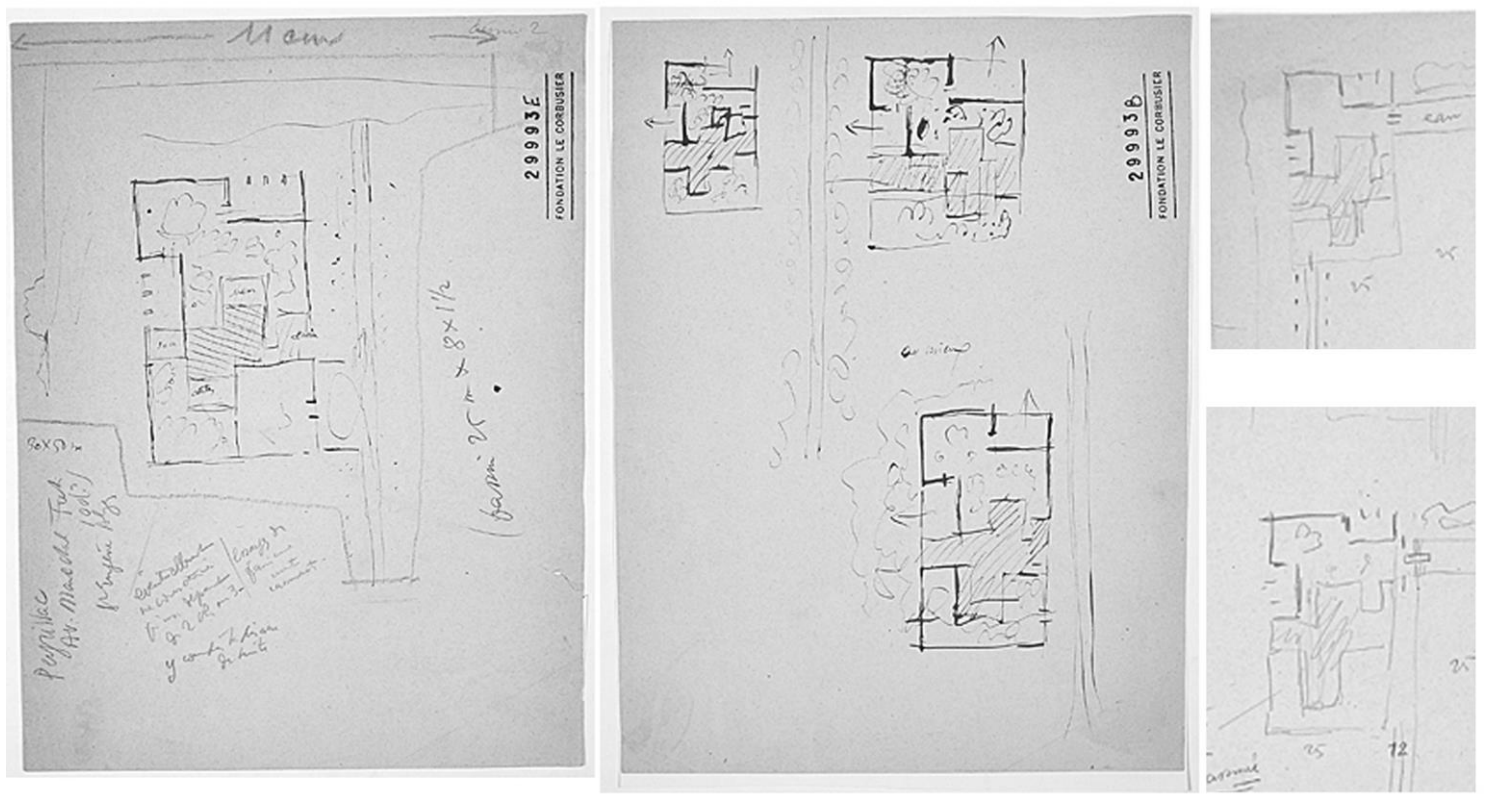

8. Dibujos originales FLC 29993E-@FLC-ADAGP, FLC 29993B-CFLC-ADAGP y fragmentos del dibujo FLC 29993CCFLC-ADAGP.

Éstos quedan ortogonales entre sí y orientados directamente al norte y al oeste. Una versión más avanzada se produce en el plano FLC 29993E cuando el diedro noroeste del recinto se plantea como elemento ciego de forma que la zona abierta a la bahía se desplaza de su posición anterior y se acerca a la casa. Una vez especializados los espacios para mirar, uno vinculado a la casa y otro independiente a ella, se produce un nuevo catálogo de soluciones donde todos ellos se sitúan todavía en el interior del recinto. En esta nueva serie ${ }^{21}$ se van definiendo y acotando los espacios a través de muros convirtiéndolos paulatinamente en espacios cada vez más cualificados y autónomos. Los muros se van plegando hasta encerrar las zonas abiertas al horizonte que aparecen como final perspectivo de la secuencia de recorridos a través de los espacios de la casa. Se realiza la construcción de entradas angostas y laterales a los miradores acentuando la sensación de descompresión espacial en la transición que va lo de introvertido de la vivienda a lo extrovertido de la mirada al paisaje lejano ${ }^{22}$. Un hito dentro del proceso del proyecto aparece cuando se produce la intersección entre la casa y los espacios mirador. De este modo es la propia casa la que se proyecta al exterior ${ }^{23}$. En la versión más desarrollada esta ligazón entre la vivienda y el mirador ocasiona que, como novedad, aparezca éste último en una posición definitivamente exterior al recinto. Así queda completada la reflexión sobre la configuración de los miradores.

\footnotetext{
${ }^{21}$ Representada por los dibujos del plano FLC 29993B.

${ }^{22}$ FLC 29993C.

${ }^{23}$ FLC 29993E.
} 

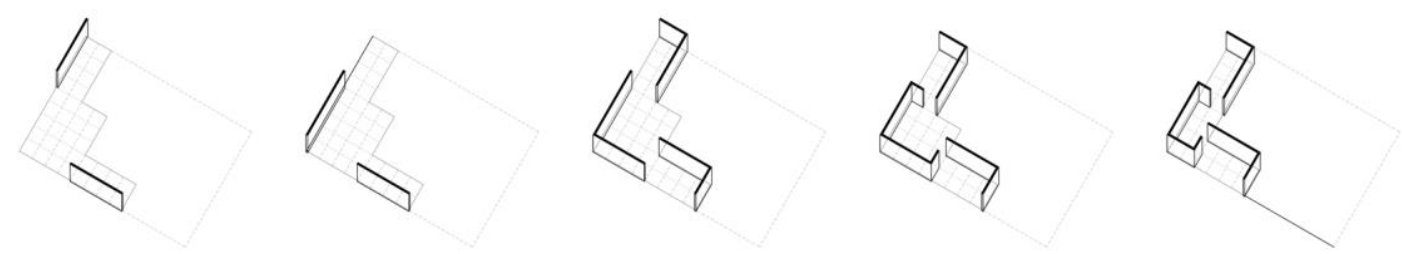

9. Versiones sobre la configuración del diedro noroeste del recinto con los espacios destinados a la mirada del paisaje.

\subsection{Los patios}

La construcción del interior del recinto como un sistema de llenos y vacíos determina una serie de espacios exteriores, a modo de patios, que adquieren autonomía tanto espacial como programática. Se emplea una estructura basada en la suma de elementos equivalentes a partir de la adición de módulos creando un sistema celular, a priori flexible, donde las partes pueden ser intercambiables sin que aparezca una forma definitiva ni predeterminada. Se produce una interacción entre las partes construidas y las exteriores ya que ambas pertenecen a una estructura jerárquicamente superior que las organiza: la trama regular y modulada que define su geometría.

La organización de los patios siempre queda vinculada y determinada por la posición fija que adquiere la casa dentro del recinto. En todos los dibujos la vivienda fracciona en dos partes diferenciadas a los vacíos. De este modo aparece un patio hacia el sur y otro hacia el norte. El primero de ellos sirve tanto de acceso como para la colocación de la vegetación mediante palmeras que tamicen el soleamiento y generen sombra arrojada sobre la casa; y el segundo de ellos, de carácter más artificial, organiza los accesos a los miradores. Así los patios quedan diferenciados en dos vacíos contrapuestos: un vacío artificial al norte y uno colmatado de vegetación natural en el $\operatorname{sur}^{24}$. Se crea la construcción de paisajes domésticos especializados en los patios, por una parte la sala hipóstila de palmeras, y por otra la multiplicidad de colinas artificiales. Estas diferencias aparecen por ejemplo en el plano "FLC 29990C" donde el color categoriza los patios y por tanto muestra las diferencias existentes entre ellos y la especialización de los usos asociados. Se realizan también estudios del orden de plantación de la vegetación asociado a la trama modulada ${ }^{25}$. Es interesante destacar cómo las distintas configuraciones en los acceso a los miradores genera la fragmentación de las diferentes zonas del patio norte. Así es cómo en los planos "FLC 29993B" y "FLC 29993C" aparece la reflexión sobre el uso específico del segmento de patio que queda determinado por el diedro ciego en el vértice noroeste del recinto. La colocación mas cercana de los muros de los dos miradores provocan que este espacio libre gane independencia espacial e incluso se grafíe de forma distinta al resto de ámbitos del patio norte.

\footnotetext{
${ }^{24}$ FLC 29994A.

${ }^{25}$ FLC 29993D.
} 


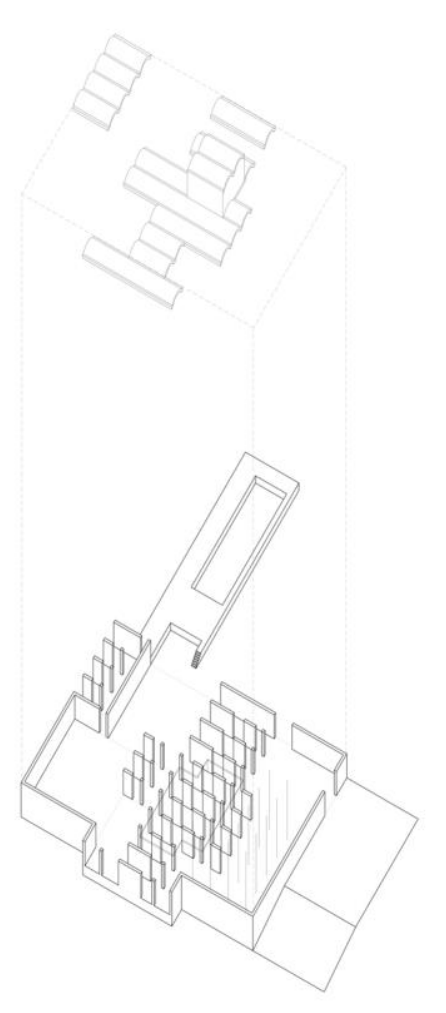

10. Axonometría de conjunto.

\section{Síntesis}

A modo de conclusiones de la investigación se realiza un apartado resumen en el que se hace referencia, de forma sintética, a los temas de proyecto tratados por Le Corbusier a lo largo del proceso.

\subsection{El espacio umbral}

La planta de la Residencia en Argel habla de dialéctica. Por un lado propone el lleno frente al vacío: el lleno de lo construido y el vacío de los patios. En los propios patios se produce un juego doble: el patio sur se conforma como una sala hipóstila llena de palmeras; el patio norte es un espacio topográfico que incluye una serie de pequeñas elevaciones de terreno configuradas como colinas artificiales. La organización de la posición de la casa dentro del recinto responde a un esquema muy similar al de la villa Savoye determinando un patio delantero orientado a sur para la iluminación y otro a norte para las vistas ${ }^{26}$. Cuando se excava un terreno para construir la cimentación se trasladan las tierras a la periferia de la ciudad. Le Corbusier reconoce la mala utilización de estas tierras y su valor por lo que decide aprovechar este material natural junto a lo edificado, generando nuevas topografías que ayudarán a integrar la pieza en su entorno y construir así nuevos paisajes artificiales asociados a los patios.

${ }^{26}$ FLC 29992 C. 


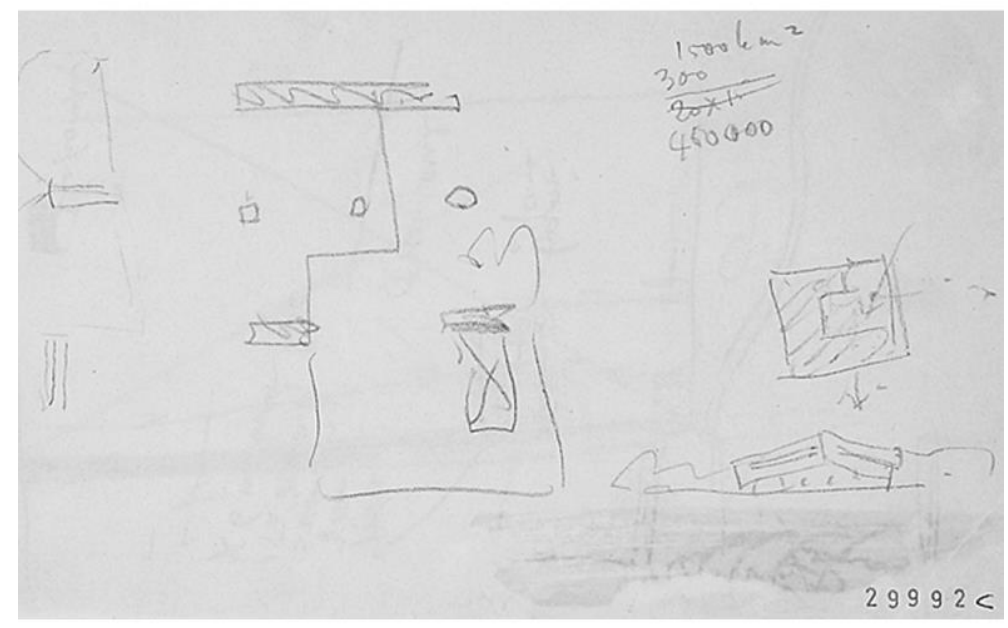

11. Dibujo original FLC 29992C-CFLC-ADAGP en el que se recoge un croquis de la villa Savoye.

Se plantean fachadas a cuatro orientaciones distintas y cuatro paisajes diferentes: al norte el mar; al oeste la montaña; al sur el acceso desde la carretera; al este la zona cultivada y la alberca que servirá para regar los cultivos de tomates. Lo natural frente a lo artificial. Y el sol frente a la sombra. La vivienda es un espacio umbral abierto en el que se busca la sombra y la ventilación cruzada entre la combinación de espacios abiertos, cerrados e intermedios exteriores pero cubiertos.

\subsection{El muro grueso y el ojo que mira}
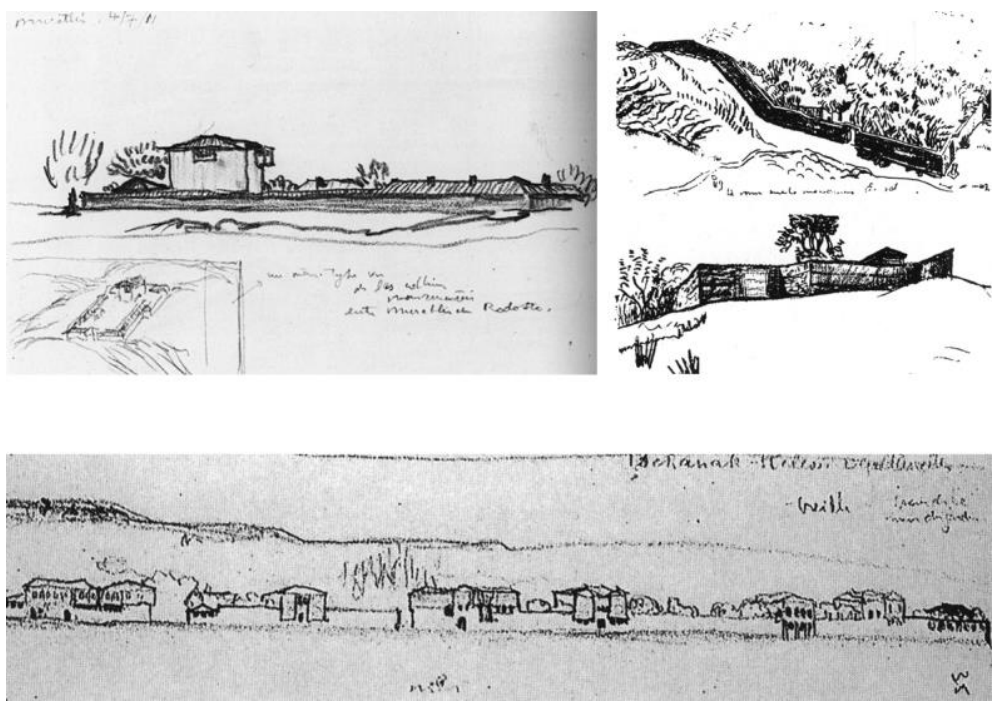

12. Dibujos originales de casas tradicionales de Turquía realizados por Le Corbusier durante su viaje a Oriente en 1911.

En las secciones del proyecto se descubre el grosor del recinto envolvente. ¿Qué significa un muro grueso? Por un lado, supone llevar al extremo la separación entre interior y exterior, señalar estos ámbitos como mundos distintos. Es también un gesto defensivo, la protección frente un entorno hostil ${ }^{27}$. Además, el grosor del muro

\footnotetext{
${ }^{27}$ El propio Le Corbusier señala en la memoria del proyecto publicado "Primera idea: un recinto cerrado con un perro malo..." Véase Le Corbusier: Oeuvre complète Volume 4 1938-46, 11th edition. Basel: Birkhäuser-Publishers for Architecture, 1999. p. 116.
} 
genera sombra. Y lo más importante para Le Corbusier: un muro grueso posibilita el enmarcado, pues la naturaleza es más interesante para el maestro a través de la arquitectura ${ }^{28}$. En los croquis realizados, Le Corbusier da una especial importancia al paisaje circundante: el mar y el horizonte son protagonistas a través de los huecos que se abren al exterior ${ }^{29}$. Para conseguir las visiones lejanas, Le Corbusier vincula la construcción al recinto y abre un único hueco de gran tamaño, ${ }^{30}$ semejante al ojo del cíclope. El ojo que mira es un eco del gran hueco que domina el paisaje urbano en las propuestas de los años 20 para los Inmuebles Villa. Y es también la transposición a la arquitectura moderna de la idea subyacente en los miradores de Estambul dibujados por Le Corbusier en su viaje a Oriente: un recinto que en determinados puntos se hace más grueso y eleva para formar el mirador ${ }^{31}$.

\subsection{El espacio diagonal}

La casa se estructura mediante muros de carga paralelos y bóvedas catalanas apoyadas en éstos. Este sistema, es utilizado por Le Corbusier por primera vez en el Chalet Poiret de 1916 y en el proyecto de las Casas Monol de 1919 y es una constante en otros proyectos. En proyectos posteriores al desarrollo del objeto de estudio de esta investigación que data del año 1942, Le Corbusier también emplea este sistema en el proyecto para SainteBaume de 1948, en las Casas Jaoul en París de 1952 o la Casa Sarabhai en Ahmedabad de 1955) ${ }^{32}$. Existe también una clara vinculación entre este tipo de espacios generados bajo bóvedas de cañón paralelas y los que aparecen en la Porticus Aemilia de Roma ${ }^{33}$. La aparición de las bóvedas sobre el muro perimetral conforma un nuevo skyline en el proyecto. Los muros de carga permiten la división de los planos estructurales en partes más pequeñas y gracias a ello, la aparición de diagonales visuales en planta a través de una trama ortogonal pero fragmentada. Se rompe el concepto de espacio lineal apareciendo una nueva complejidad vinculada con la diagonal.

\subsection{Patio y pabellón}

Le Corbusier propone, en el proyecto de Argel aquí estudiado, un recinto en cuyo interior se dispondrá la residencia. Toda la combinación arquitectónica queda basada sobre el principio que conduce a un juego sutil de llenos y vacíos en relación con las formas fundamentales de la tradición mediterránea. Casa y envolvente forman una simbiosis y los muros de carga paralelos que estructuran la vivienda se ligan, en determinados puntos, al muro perimetral que conforma el recinto. La vivienda es pabellón y casa patio a la vez. Es pabellón entre el bosque de palmeras y la topografía artificial.

\footnotetext{
${ }^{28}$ En el proyecto del Ministerio de Educación en Río de Janeiro (1936-1945) Le Corbusier explica gráficamente el valor de la naturaleza enmarcada por la arquitectura. Véase Le Corbusier: Oeuvre complète Volume 4 1938-46, 11th edition. Basel: Birkhäuser-Publishers for Architecture, 1999. pp. 80-81.

${ }^{29}$ En la publicación de este proyecto en la obra completa se definen los elementos arquitectónicos: el horizonte, el mar, la terraza, los pilares de obra, las bóvedas. Véase Le Corbusier: Oeuvre complète Volume 4 1938-46, 11th edition. Basel: Birkhäuser-Publishers for Architecture, 1999. p. 119.

${ }^{30} \mathrm{El}$ hueco que se abre al paisaje se dispone en zonas de doble altura.

${ }^{31}$ Véase Gresleri, Giuliano: Le Corbusier Viaggio in Oriente, Venecia: Marsilio Editori, 1984. pp. 223, 246-247.

${ }^{32}$ La semejanza con las Casas Jaoul y la Casa Sarabhai se extiende también a la inserción de paneles de madera en los alzados cortos.

${ }^{33}$ Tal y como destaca S.von Moos en su libro "Le Corbusier. Elements of a Synthesis".
} 


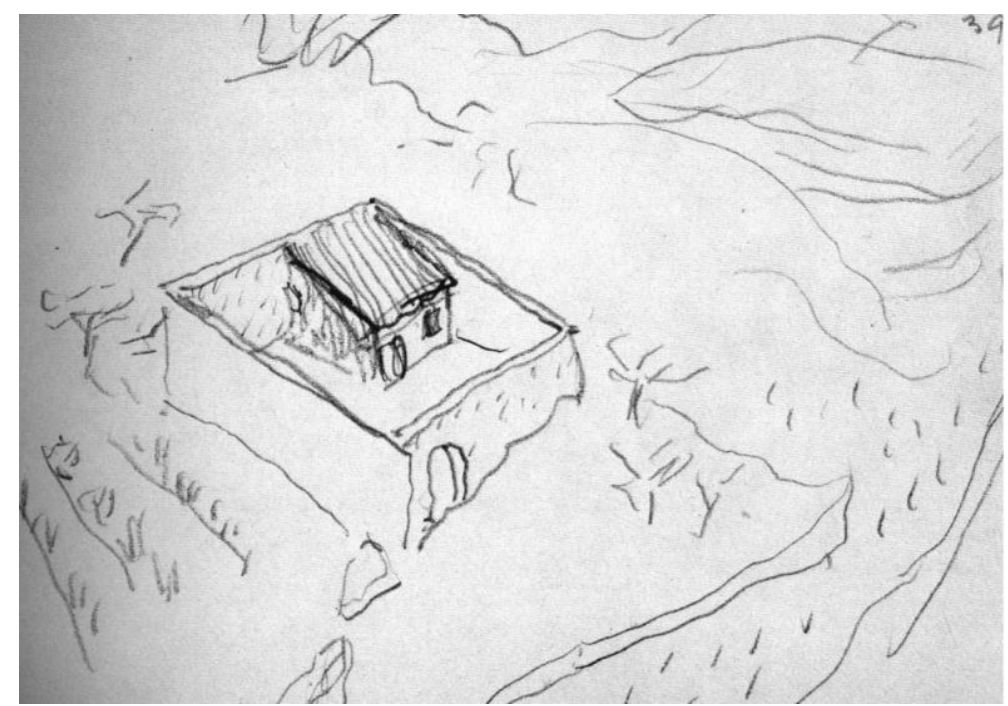

13. Dibujo de Le Corbusier sobre una casa con patio tradicional.

Esto conduce a una doble lectura de la casa a través de su condición introvertida y extrovertida simultáneamente. La construcción como lugar acotado y protegido aparece ligada a la secuencia compleja de espacios interiores, intermedios y exteriores. Estos sistemas se implementan con la versión de la casa como mirador. Al igual que sucedía en los croquis iniciales de la "Maison de week-end" en La Celle-Saint-Cloud de 1934, se realizan estancias en plantas altas que se elevan sobre las tapias, permitiendo que la mirada escape del recinto y se dirija hacia el horizonte.

\section{Procedencia de las imágenes}

(1). Dibujo realizado por los autores de la comunicación: arrroyopemjean+sanz@

(2). Brooks, H. Allen: The Le Corbusier Archive. New York-London: Garland Publishing, Inc., Fondation Le Corbusier, 1982-1984.

(3). Brooks, H. Allen: The Le Corbusier Archive. New York-London: Garland Publishing, Inc., Fondation Le Corbusier, 1982-1984.

(4). Dibujo realizado por los autores de la comunicación: arrroyopemjean+sanz@

(5). Brooks, H. Allen: The Le Corbusier Archive. New York-London: Garland Publishing, Inc., Fondation Le Corbusier, 1982-1984.

(6). Brooks, H. Allen: The Le Corbusier Archive. New York-London: Garland Publishing, Inc., Fondation Le Corbusier, 1982-1984.

(7). Brooks, H. Allen: The Le Corbusier Archive. New York-London: Garland Publishing, Inc., Fondation Le Corbusier, 1982-1984.

(8). Brooks, H. Allen: The Le Corbusier Archive. New York-London: Garland Publishing, Inc., Fondation Le Corbusier, 1982-1984.

(9). Dibujo realizado por los autores de la comunicación: arrroyopemjean+sanz@

(10). Dibujo realizado por los autores de la comunicación: arrroyopemjean+sanz@

(11). Brooks, H. Allen: The Le Corbusier Archive. New York-London: Garland Publishing, Inc., Fondation Le Corbusier, 1982-1984.

(12). Gresleri, Giuliano: Le Corbusier Viaggio in Oriente. Venecia: Marsilio Editori, 1984.

(13) Le Corbusier: Sketchbooks Volume 1, 1914-1948. London: Thames and Hudson, 1981. 


\section{Bibliografía}

Boesiger, Willy: Le Corbusier. Barcelona: Editorial Gustavo Gili, 1985.

Brooks, H. Allen: The Le Corbusier Archive. New York-London: Garland Publishing, Inc., Fondation Le Corbusier, 1982-1984.

Gresleri, Giuliano: Le Corbusier Viaggio in Oriente. Venecia: Marsilio Editori, 1984.

Le Corbusier: Oeuvre complète Volume 4 1938-46, $11^{\text {th }}$ ed. Basel: Birkhäuser-Publishers for Architecture, 1999.

Le Corbusier: Precisiones respecto a un estado actual de la arquitectura y el urbanismo. Barcelona: Ediciones Apóstrofe, 1999.

Le Corbusier: Sketchbooks Volume 1, 1914-1948. London: Thames and Hudson, 1981.

Moos, Stanislaus von: Le Corbusier: elements of a synthesis. Cambridge, Masasachusetts: The Mit Press, 1979.

Regidor, Mabel: "Visita a una casa de Alejandro de la Sota". En Periferia. Junio 1991, N.10. pp. 93-95.

Vidotto, Marco: Alison + Peter Smithson, Obras y Proyectos. Barcelona: Editorial Gustavo Gili, 1997. 


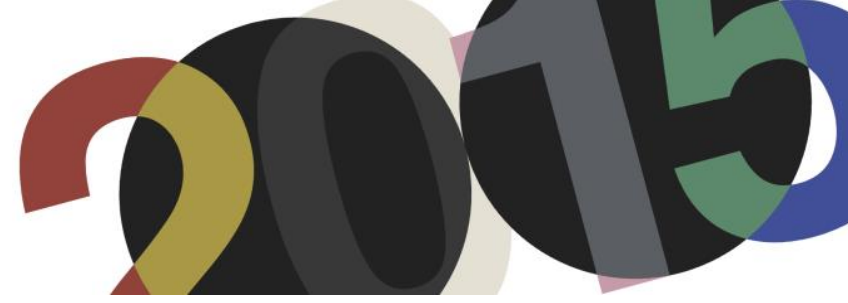

DOI: http://dx.doi.org/10.4995/LC2015.2015.915

\title{
Letter from the Basses-Pyrénnées: An Unintended Trigger for a Site Exchange
}

\author{
L. Martínez de Guereñu Elorza
}

IE University

\begin{abstract}
The contents of an unpublished letter (FLC I1-17-5), sent to Le Corbusier from the Basses-Pyrénées during the development of the Villa Ocampo project (1928), is the key to understanding the Swiss-French master's particular response to the site at the end of the 1920s. Countess Adela Cuevas de Vera, who negotiated the project from Anglet, revealed the Côte Basque as an attractive new market and claimed Le Corbusier's presence there. Furthermore, she reminded him of the prevailing regionalism and the strong cultural identity of the place, as well as the fact that Robert Mallet-Stevens, a great competitor of his, had already embarked there. Whatever the content of this letter awakened in Le Corbusier, led him to submit a very similar version of the third Villa Meyer project (1925) (designed for Paris) to be built in Buenos Aires. This paper re-evaluates the reasons behind a site exchange between two Southern cities on different sides of the Atlantic, studying the role of the negotiation site in the design process; and reassesses Le Corbusier's critical attitude towards regionalism, mapping out his relationship with a French region in which he never intervened. Through primary source research, this paper also recognizes that in architecture, rivalry, pride and ambition can quite often be authentic triggers for action.
\end{abstract}

Resumen: El contenido de una carta inédita (FLC I1-17-5), enviada a Le Corbusier desde los Bajos Pirineos durante el desarrollo del proyecto de la Villa Ocampo (1928), es la clave para entender la muy particular respuesta al lugar del maestro suizo-francés a finales de los años 20. La Condesa Adela Cuevas de Vera, que negoció el proyecto desde Anglet, presentó a Le Corbusier la Côte Basque como un atractivo mercado, al tiempo que reclamó allí su presencia. Le habló del regionalismo imperante y de la fuerte identidad cultural del lugar, recordándole que Robert Mallet-Stevens, un gran competidor suyo, habia desembarcado ya alli. La reacción a esta carta llevó a Le Corbusier a entregar un proyecto muy similar a la tercera versión del proyecto de la Villa Meyer (1925) (proyectado para París) para ser construido en Buenos Aires. Este artículo reevalúa las razones que pueden existir tras el intercambio de lugar entre dos ciudades del Sur situadas a los dos lados del Atlántico, estudiando para ello el papel que el lugar de negociación juega en el desarrollo de un proyecto; y reexamina la actitud crítica de Le Corbusier hacia el regionalismo, mapeando su relación con una región francesa en la que nunca intervino. A través de la investigación de fuentes primarias, este artículo muestra también cómo la rivalidad, el orgullo y la ambición pueden asimismo ser auténticos desencadenantes para la acción durante el desarrollo de un proyecto.

Keywords: Site; negotiation; pragmatism; universalism; regionalism; dwelling.

Palabras clave: Lugar; negociación; pragmatismo; universalidad; regionalismo; habitar.

\section{Introduction}

It is already common knowledge that Le Corbusier and Pierre Jeanneret literally retraced the third version of the Parisian project of Villa Meyer (1925) and submitted it as a project for a house meant to be built in Buenos Aires. The Villa Ocampo (1928) was commissioned under quite unusual circumstances. It had to be designed in little over a month for a site on the other side of the Atlantic. The client, Victoria Ocampo, did not lead directly with the architects, but through Countess Adela Cuevas de Vera, who negotiated the project from Anglet.

Several attempts have been made to justify the pragmatic attitude Le Corbusier and Pierre Jeanneret displayed when deciding to re-use a project that had been specifically designed for another place. None of them seem to be 
convincing enough, especially in the context of the most recent reassessment of Le Corbusier's work. ${ }^{1}$ However, the contents of a forgotten letter, left out of the reconstruction project documents of Villa Ocampo, ${ }^{2}$ may now be the key to understanding Le Corbusier's particular response to the site. It is the third letter Adela Cuevas de Vera sent on September 6, 1928, asking Le Corbusier to submit the "first idea" of the house.

Adela Cuevas de Vera was able to reveal the Basses-Pyrénées ${ }^{3}$ as an attractive new market and to claim the presence of Le Corbusier there: "When will you come here? They are building tremendously, and above all, they are dividing up plots, they are constructing a new cliff road between St. Jean de Luz and Hendaye on uninhabited land...how wonderful if you could line this route with beautiful houses!" " Furthermore, Adela Cuevas de Vera reminded Le Corbusier of the prevailing regionalism and the strong cultural identity of the Basses-Pyrénées, as well as the fact that a great competitor of his had already embarked there. "Mallet Stevens has made a Casino in the bay of St. Jean de Luz. It does not have a pretty outline, but at least it is better than the Basque style, and it offers an idea of what could be done." 5 That was an effective letter: by September 18, Le Corbusier had already finished the plans for Victoria Ocampo.

The fact that Robert Mallet-Stevens was already working at the Côte Basque might have been a stimulus for Le Corbusier, since at that time he was seen as a quite successful architect. In 1924, Adolf Loos had described him as "the most modern architect in France;" had received great critical acclaim and he had even managed to build an entire cul-de-sac in Auteil, named after him; Rue Mallet-Stevens (1925-27). Moreover, Le Corbusier, who had explicitly ridiculed regionalism in Vers une architecture, probably viewed the Basses-Pyrénées as a challenging region in which to test his architectural principles.

The aim of this paper is to re-evaluate the reasons behind a site exchange between Paris and Buenos Aires, studying the role of the negotiation site in a design process; to reassess Le Corbusier's critical attitude towards

\footnotetext{
${ }^{1}$ Cohen, Jean-Louis (Ed.), Le Corbusier: An Atlas of Modern Landscapes, New York: Museum of Modern Art, 2013.

${ }^{2}$ In the reconstruction of the Villa Ocampo documents, Hernán Marchant mentions the first letter, from August 9, 1928, the second letter, from August 27, 1928, and a final letter from September 29, 1928, but ceases to acknowledge the key letter, the third one from September 6, 1928. See Marchant, Hernán, "Villa Ocampo. 1928" (Project 25, DVD 2), in Le Corbusier Plans, Paris: Codex Images International/ Fondation Le Corbusier, 2005. Tim Benton recognizes the existence of the letter from September 6, 1928, and he even comments that Countess de Vera asked "for a first study," so that she could "radio [Victoria Ocampo] with her opinion," but he does not mention the contents that is considered of primary relevance for the hypothesis of this paper. See Benton, Tim, The Villas of Le Corbusier and Pierre Jeanneret 1920-1930, Basel-Boston-Berlin : Birkhäuser, 2007, p. 146. Josep Quetglas does not explicitly talk about the exchange of correspondence between Countess de Vera and Le Corbusier, but he suggests how Le Corbusier must have seen "something other than the construction of another villa” in Victoria Ocampo's commission. See Quetglas, Josep, Les Heures Claires, Sant Cugat del Vallés: Massilia, 2008, p. 30. It is this suspicion of him that led me to search through the exchange of correspondence between Le Corbusier, Countess de Vera and Victoria Ocampo, and to formulate the hypothesis of this paper.

${ }^{3}$ The Basses-Pyrenées is one of the original French departments created during the French revolution on March 4, 1790, out of the Béarn province (including Basse-Navarre), the lands of Labourd and Soule, and some parts belonging to the former greater province of Guyenne and Gascony. Labour, Basse-Navarre, and Soule form the three provinces of the French Basque Country. The Basses-Pyrenées were renamed Pyrenées-Atlantiques on October 10, 1969.

4 "Quand viendrez vous par ici? On bâtit énormément, et surtout on lotît, on construit une nouvelle corniche entre St. Jean de Luz et Hendaye dans des terrains inhabités... quelles merveille si vous pourriez border cette route de jolies maisons!," dossier Vera, FLC I1-17-5-002, FLC I1-17-5-003, September 6, 1928.

5 "Mallet Stevens à fait un Casino sur la baie de St. J. de Luz, il n'est pas joli de ligne, mais tout-de même c'est mieux que le style basque, et il donne une idée de ce que l'on pourrait faire," dossier Vera, FLC I1-17-5-003, September 6, 1928.

6 Adolf Loos, “'L'inhumaine.' Histoire féerique,” in Adolf Loos. Escritos II 1910/1932, El Croquis, El Escorial, Madrid, 1993, pp. 198-201. Originally published in Neue Freie Presse, Vienna, July 29, 1924.
} 
regionalism; and to map out the relationship Le Corbusier had with the Basses-Pyrénées, a French region in which he never intervened.

\section{Negotiation Site}

On August 9, 1928, and from 62, Rue de Varenne in Paris, Countess Adela Cuevas de Vera sent an off-the-cuff letter to Le Corbusier to say that she was in charge of consulting him about the construction of a modern house and also to request seeing the houses he had built in Auteil. ${ }^{7}$ Le Corbusier and Countess Cuevas de Vera had probably met the previous month of May in Madrid, when the Swiss-French master lectured at the Residencia de Estudiantes. ${ }^{8}$ However, the first trace of creative exchange between them goes back to September 1927, when she had already asked him to send "photographs, plans or prints of his houses.",

On August 27, 1928, and from Villa Delphine in Anglet, Countess Cuevas de Vera sent a much more thorough letter asking whether he could design a project for Madame Ocampo, ${ }^{10}$ who wanted to build a house in Buenos Aires "in the style that [they liked], especially in regards to the functional interior." everyday activities, the house would need to include, among other requirements, a layout for a kitchen and an office similar to the one at the Villa in Garches, a series of well-placed cupboards in all serving rooms, and an elevator. As for the interior-exterior relationship, the house would need to have a façade without terraces on the Salguero Street side, a terrace opening onto the garden side, and a roof garden. Le Corbusier was even asked to create something of a similar nature for the interior terrace of the Villa in Garches, which would be "ideal for the light and the sky in Argentina, especially in polychromy." 12

Victoria Ocampo already had another project, from another architect, which she did not like, and which she would need to start constructing if she did not find an alternate solution before October $1^{\text {st }}$. Countess de Vera

\footnotetext{
7 There is no reference to the client or to the construction site on this first letter. "Monsieur. Je suis chargée de vous consulter pour l'édification d'une maison moderne d'out on voudrais que plus tard vous fassiez les plans. Je suis à Paris jusque à Lundi pro claim et voudrais parle avec vous et surtout voir les maisons que vous avec bâties à Auteil," dossier Vera, FLC I1-17-11001, FLC I1-17-11-002, August 9, 1928.

8 "Je reçois votre aimable lettre du 12 décembre me demandant d'aller à Madrid y faire quelques conférences...J'aurai je le souhaite, l'honneur et le plaisir de vous rencontrer à Madrid au printemps," dossier Vera, FLC C3-5-287-001, January 4, 1928.

9 "Je vieux vous demander s'il vous serait possible de ni envoyer quelques photographies, dessins or gravure de vos maisons," dossier Vera, FLC I1-17-9-001, September 2, 1927. During that time, Adela Cuevas de Vera was trying to negotiate the project of a house for herself, which they left for the near future. "Je suis décidée d'après ce que vous me dites, à attendre que les chantiers soient organisés ici pour construire la maison que je souhaite avoir, et pur laquelle je voudrais tout ce que vous pouvez rêver de plus nouveau," dossier Vera, FLC I1-17-1-003, August 27, 1928.

${ }^{10}$ Countess Cuevas de Vera was a rich Argentinian woman who gained access to the circles of European aristocracy by marrying Carlos Caro y Potestad, Count Cuevas de Vera, in Biarritz in 1915. She lived in Madrid as a maid of honor to the Queen until the fall of the Spanish monarchy. Victoria Ocampo, an influential Argentinian who would launch the journal Sur in 1931, had a long and ambivalent friendship with Countess Cuevas de Vera; she respected her opinion, but very often drove her out of her mind. See Juan José Sebreli, Cuadernos, Sudamericana, 2011.

11 "Mon amie, madame Ocampo dont je vous ai parlé veut construire une maison a Buenos Aires dans le style que vous aimons, surtout pour la partie pratique intérieure," dossier Vera, FLC I1-17-1-002, August 27, 1928. One of the lectures Le Corbusier gave in Madrid (and that Countess Cuevas de Vera must have attended) was precisely related to the activities of the modern house, "Architecture, furniture, and works of art." See in relation to the contents of the lecture Fernando García Mercadal, "Le Corbusier en Madrid," in La Gaceta Literaria 34, May 15, 1928 and Le Corbusier : Madrid 1928 : una casaun palacio [exposición], Residencia de Estudiantes, mayo-julio 2010, Residencia de Estudiantes, Madrid, 2010.

12 "Croyez vous possible de faire sur la coté jardin quelque chaise dans le genre daba térrasse intérieure de la Maisons de Garches...? Cela serait idéal, sur tour polychromie pour notre lumière et ciel," dossier Vera, FLC I1-17-1-007, August 27, 1928.
} 
attached the four plans Victoria Ocampo had drawn herself and that showed the programmatic requirements [Fig. 1] as well as a photograph of another house she had built on the edge of the sea in Argentina, so that Le Corbusier could imagine the type of openings that could be made in Buenos Aires [Fig. 2]. ${ }^{13}$ Countess de Vera explicitly clarified that he would not be able to introduce the type of windows he usually made, and also that the house would naturally be built by Madame Ocampo's architect "with the elements of the country." 14 The question mark Le Corbusier added to the letter beside this sentence shows his perplexity towards the proposal, and may even be an index of how stunned he must have been by all these unconventional requirements. Given the amount of work he and Pierre Jeanneret had at their office during the summer of 1928 (Centrosoyuz in Moscú, Mundaneum in Genéve, Villa Savoye in Poissy, etc), and the fact that he did not know Buenos Aires, Le Corbusier initially ignored this strange commission.
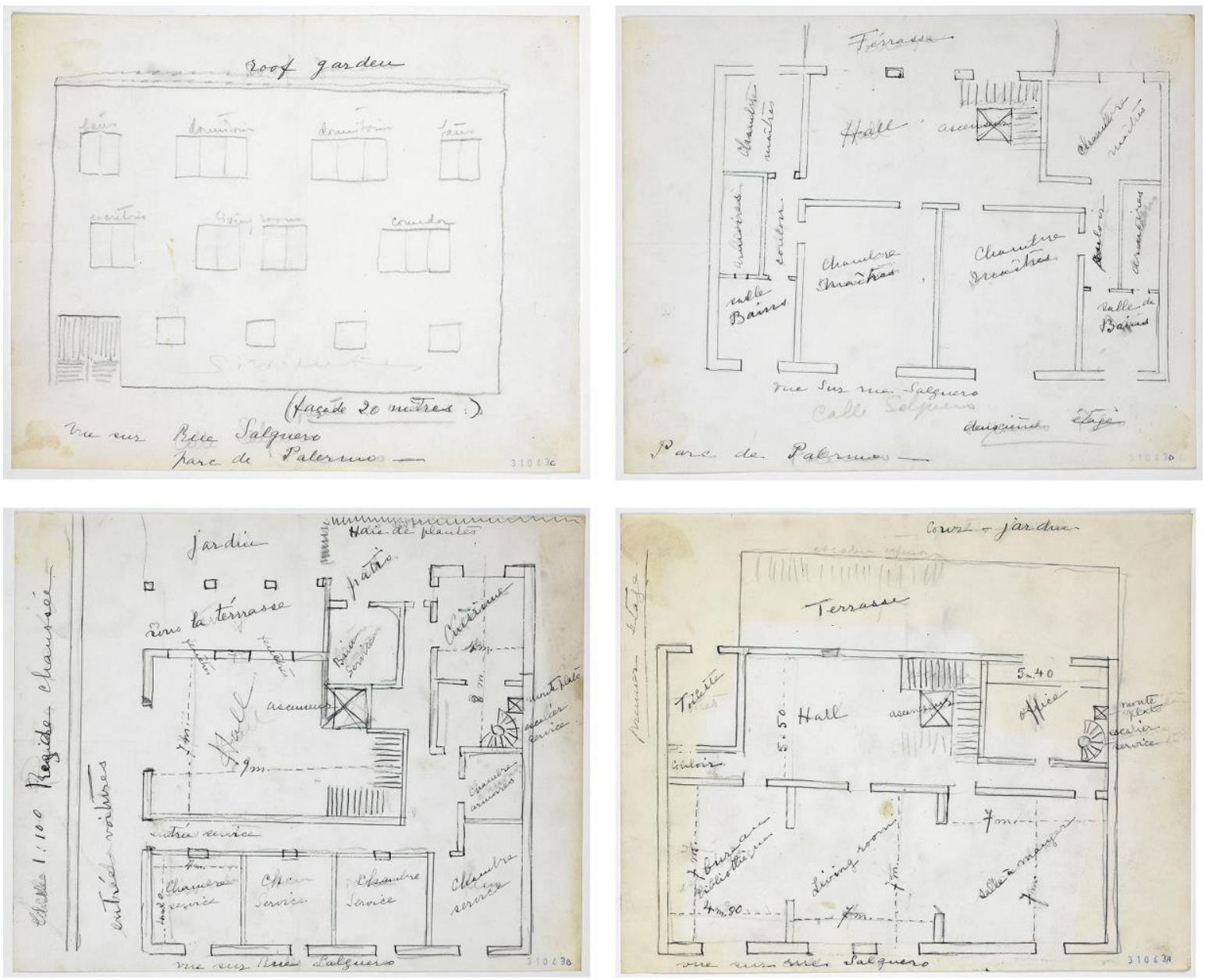

1. From left to right, top to bottom, façade towards Salguero Street, Palermo Park, Buenos Aires (FLC 31043C), second floor plan (FLC 31043D), ground floor plan (FLC 31043B), first floor plan (FLC 31043A).

\footnotetext{
${ }^{13}$ Countess Cuevas de Vera was very explicit with the specific type of openings that would be required for the house: "Pourriez vous d'après les plans, et en vous tenant à set autre genre de fenêtre, lui faire un projet de maison?," dossier Vera, FLC I1-17-1-005, August 27, 1928.

14 “...qui serait naturellement construit par son architecte avec les éléments du pays [?],” dossier Vera, FLC I1-17-1-1, August 27, 1928.
} 


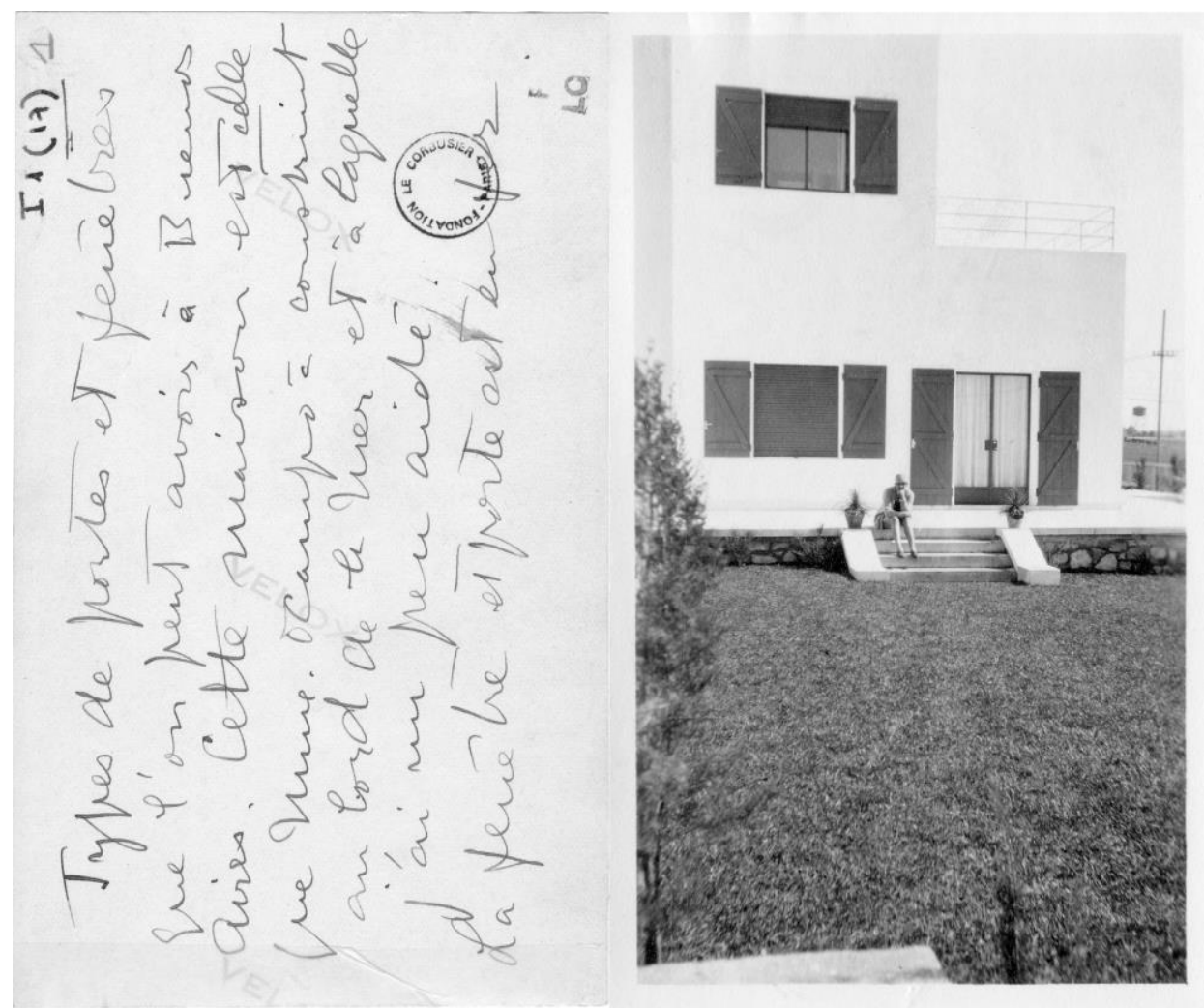

2. "Types de portes et fenêtres que l'on peut avoirs à Buenos Aires. Cette maison este elle que Mme. Ocampo a construit au bord de la Mer et a laquelle J'ai un peu aidé. La fenêtre et port est en fer," dossier Vera, FLC I1-17-1-001; FLC I1-17-1-002, August 27, 1928.

The situation changed radically upon receiving the third letter from September 6, 1928 in which Countess de Vera explained the work opportunities at the Côte Basque, a place she knew well and from which she was negotiating the project. This was not the first time Le Corbusier had been tempted to travel to the Côte Basque. Two years earlier, in March 1926, Le Corbusier had arranged a meeting in Guéthary, 10 kms. towards the south of Anglet [Fig. 3]. ${ }^{15}$ The meeting was to discuss the project of the Villa Meyer he was going to build in Paris. However, in the end, the encounter at the Meyer's summerhouse never took place, similarly to how he never received the expected written responses from the subsequent design versions he submitted in August 1925, October 1925, April 1926 and June 1926. A split existing between Madame Meyer, the client commissioning, negotiating - and potentially inhabiting- the villa, and Madame Hirtz, the rich mother who would pay for it, ${ }^{16}$ pervaded and tightened the entire relationship with the architect during the development of this earlier project. Le Corbusier, in his own words, suffered quite a bit while designing this villa, comparing himself to an "expectant father," since, according to him, "a house which remains on paper [was] a stillbirth." 17 One even may say that it was the split between the promoter-mother and the commissioning-and-inhabiting-daughter, which impeded the project to succeed.

\footnotetext{
${ }^{15}$ FLC F3-4-3-018, Carnet de Notes. 3 02/1926 - 06/1926. At least there are notes regarding the Meyers on seven spreads : FLC F3-4-3-003, F3-4-3-017, F3-4-3-018, F3-4-3-020, F3-4-3-026, F3-4-3-030, F3-4-3-048.

${ }^{16}$ Tim Benton explains this fact in "Villa Meyer (and Ocampo Project)," in Benton, The Villas of Le Corbusier and Pierre Jeanneret 1920-1930, Birkhäuser, Basel-Boston-Berlin, 2007, pp. 139-147. The diary entries, from Carnet de Notes. 3 02/1926 - 06/1926, show the name of the Hirtz at least three times: FLC F3-4-3-003, F3-4-3-030, F3-4-3-048.

17 "Une maison qui reste sur le papier est une fausse couche. Quand je vous dis que véritablement mes fibres de père souffrent.” (H3-01-17), quoted in Tim Benton, “1925. Villa Meyer. Neuilly-sur-Seine, France,” in Le Corbusier Plans, 2005.
} 


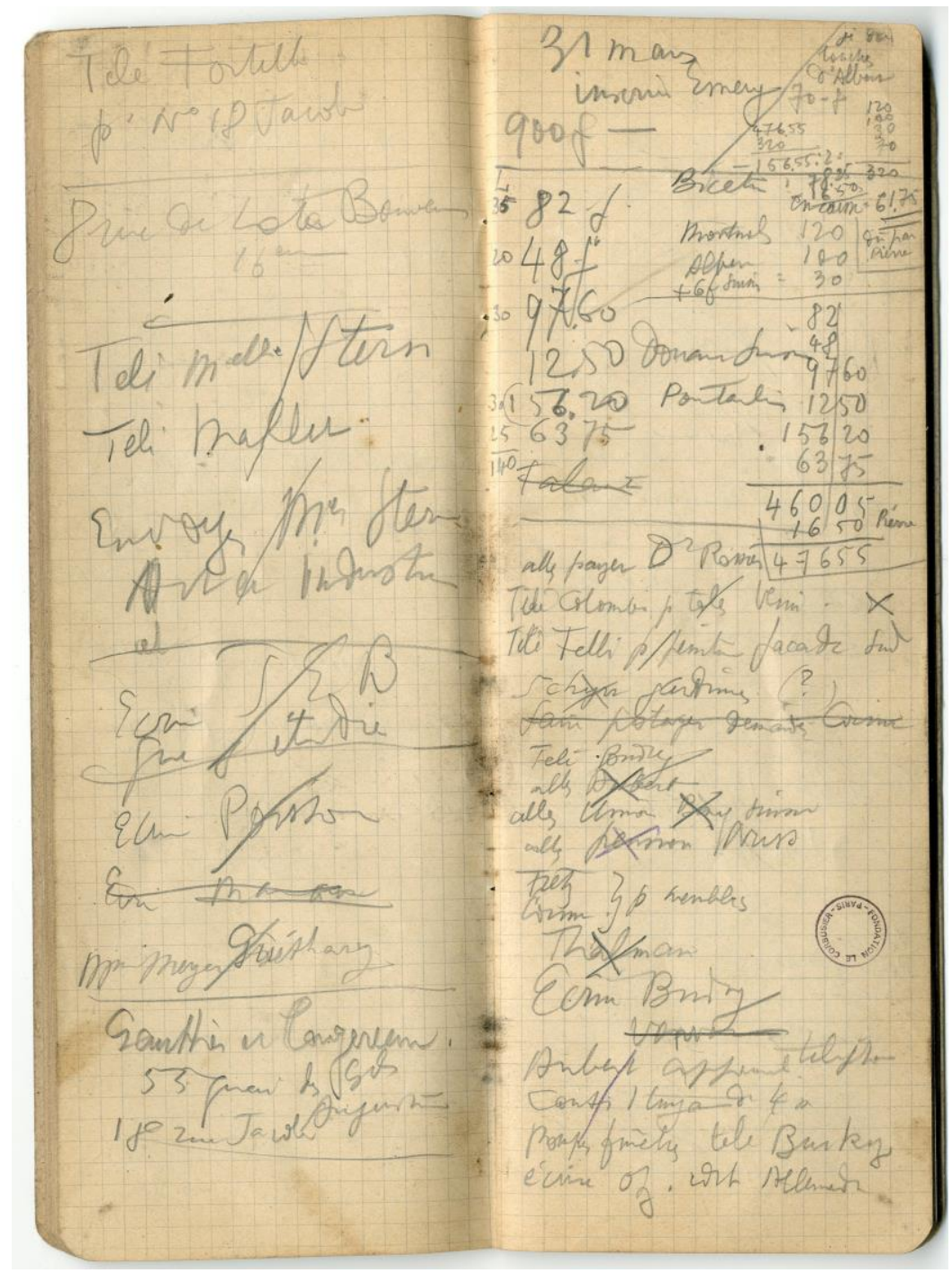

3. Inscription on the left page "Mme. Meyer, Guéthary." FLC F3-4-3-018, Carnet de Notes 3 02/1926-06/1926.

A comparable split existed in the Villa Ocampo project from the outset. While Madame Ocampo, the promoter of the project, would also be the inhabitant of the house in Buenos Aires, the project was negotiated by another person, and most importantly, from another place. Writing from Anglet, at the Côte Basque, and foregrounding the opportunities of an unspoilt area where to build anew, Countess de Vera must have awakened Le Corbusier's interest and eagerness to build outside Paris. It may be worth remembering that beyond the works he built in his hometown in Switzerland and a few exceptions such as the Villa "Le Lac" in Corseaux (1923), the Quartiers Modernes Frugés in Pessac (1924), the Maison Guiette in Antwerp (1926), and the two Maisons du Weissenhof in Stuttgart (1927), all of Le Corbusier's built work was located in Paris and its environs at that time.

Nevertheless, the existing split under the very conditions of the commission must have also awakened the memory of a recently failed project, or in other words, must have set off an alarm as to the insecure nature of this project. It is easy to understand then that with the idea in mind of trying to conquer a new market, Le Corbusier decided to send a project; but not a project designed ad-hoc. The assessment of the risks involved in this extraordinary commission likely led him to try to capitalize on a previous project he considered to be of a similar nature. This might be one of the reasons why Le Corbusier and Pierre Jeanneret submitted an updated project to the third they had prepared, two years before, for the Villa Meyer [Fig. 4, 5] 


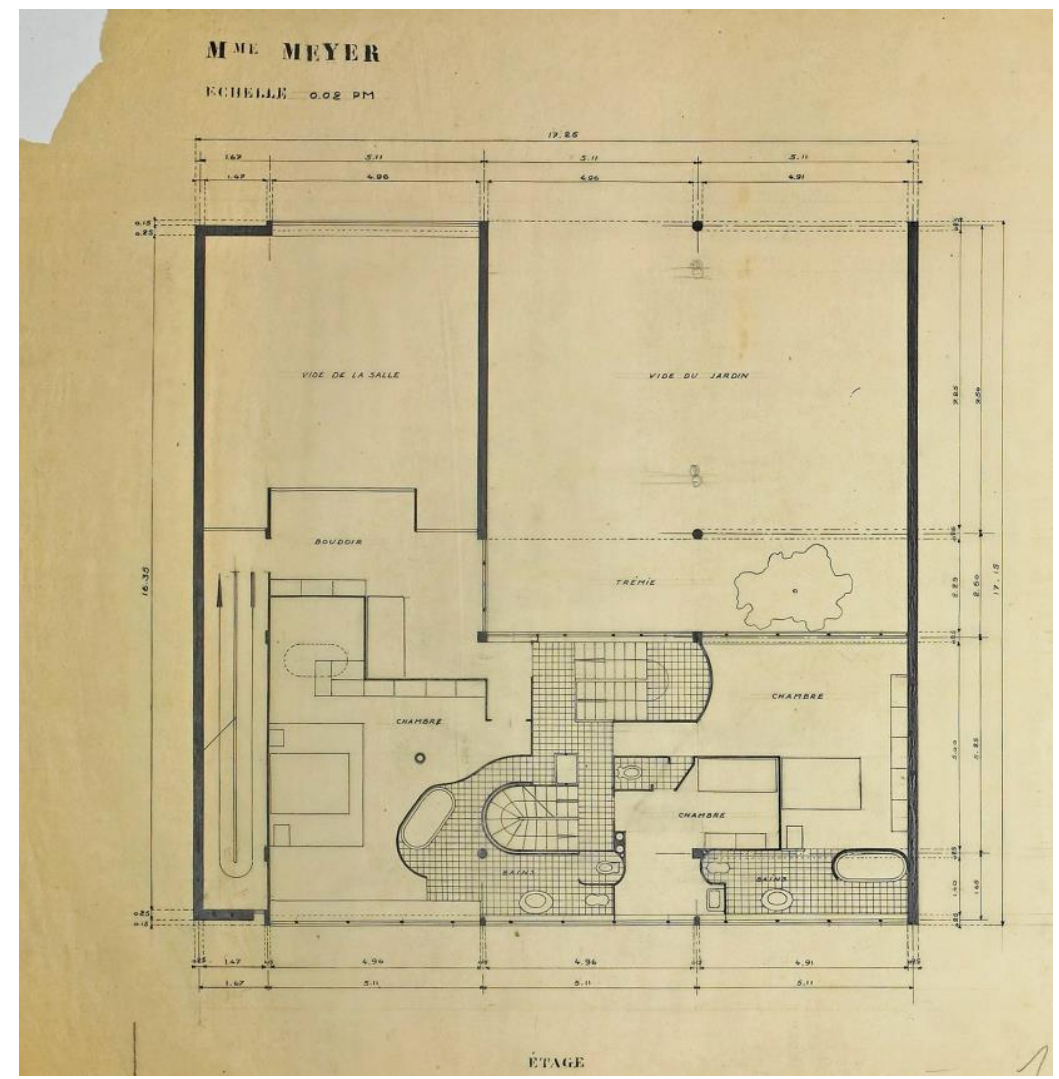

4. Villa Meyer, third project, April 1926, first floor. FLC 10370.

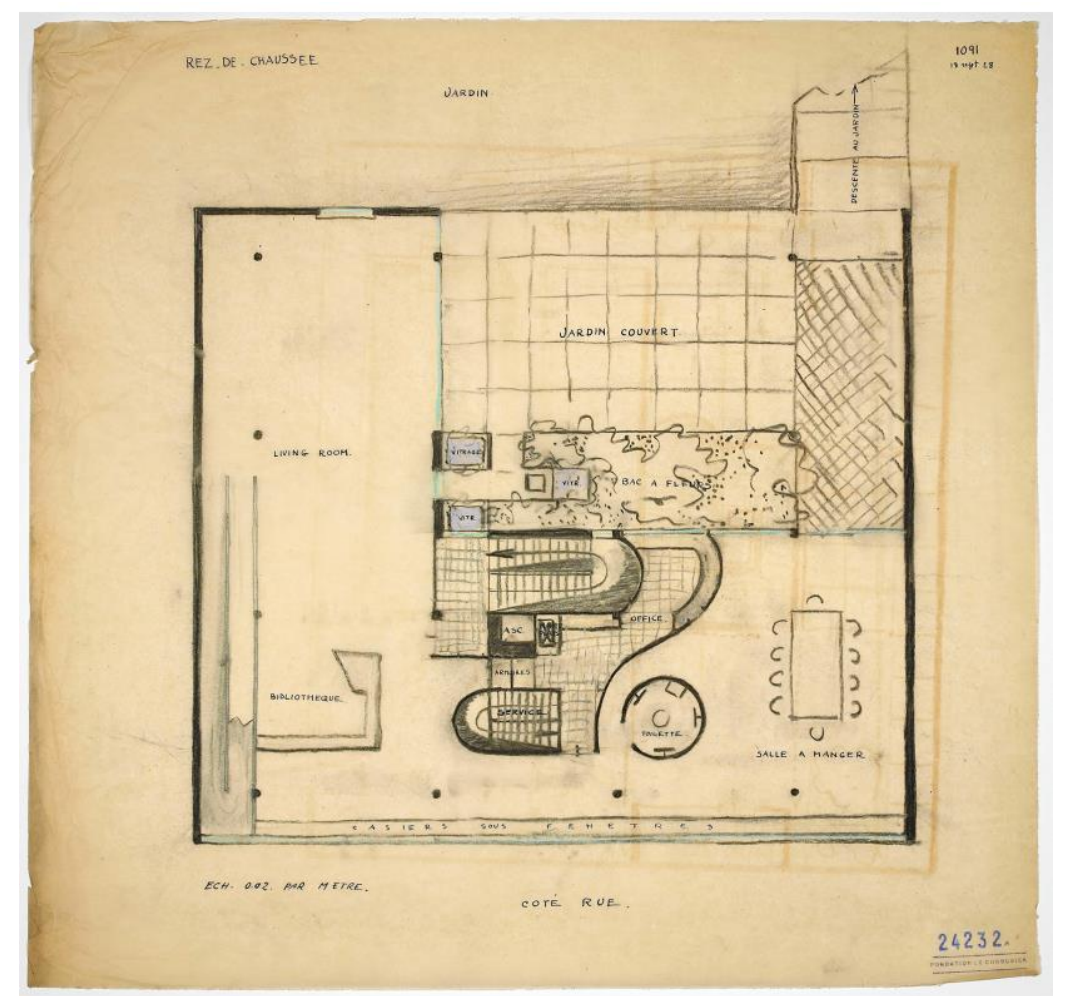

5. Villa Ocampo, September 1928. FLC 24232A. 


\section{3. "R-e-g-i-o-n-a-l-i-s-m!" and the outsiders}

In the letter from September 6, 1928, sent from Villa Delphine in Anglet, Countess de Vera warned Le Corbusier about the pervading Basque style of the region. Le Corbusier had already shown his rejection to regionalism in 1923, since for him it showed quite an opposite state of mind to the one needed for building, living, and conceiving mass-production. Le Corbusier lamented seeing that "the mass-production state of mind was still hateful for both architects and inhabitants," and claimed that "[they had] just gotten as far, all breathless, as $r$ e-g-i-o-n-a-l-i-s-m! Phew!," and that "the funniest thing [was] the devastation of the invaded lands along the way. "18

A few years later, in 1936, Le Corbusier lamented seeing that the regionalism of the Basses-Pyrénées, which only responded to linguistic codes, had been spread towards the north, up to the Bay of Arcachon in the Gironde, an area he very much loved and in which he had vacationed for years. "I like wooden houses because they are honest: both spiritually and in construction. Le Piquey is ruined! I knew it before the roads and the builders. The lagoon, governed by the thirteen-hour rhythm of the tides - a truly cosmic rhythm-breeds constant diversity and infinite combinations. Now the houses have become "Basques" with false beams in painted cement and fake wood!...I do believe that if the land had been in the hands of savages, the other half-the lagoon-would have been saved. Where the hell to find something true...? "19

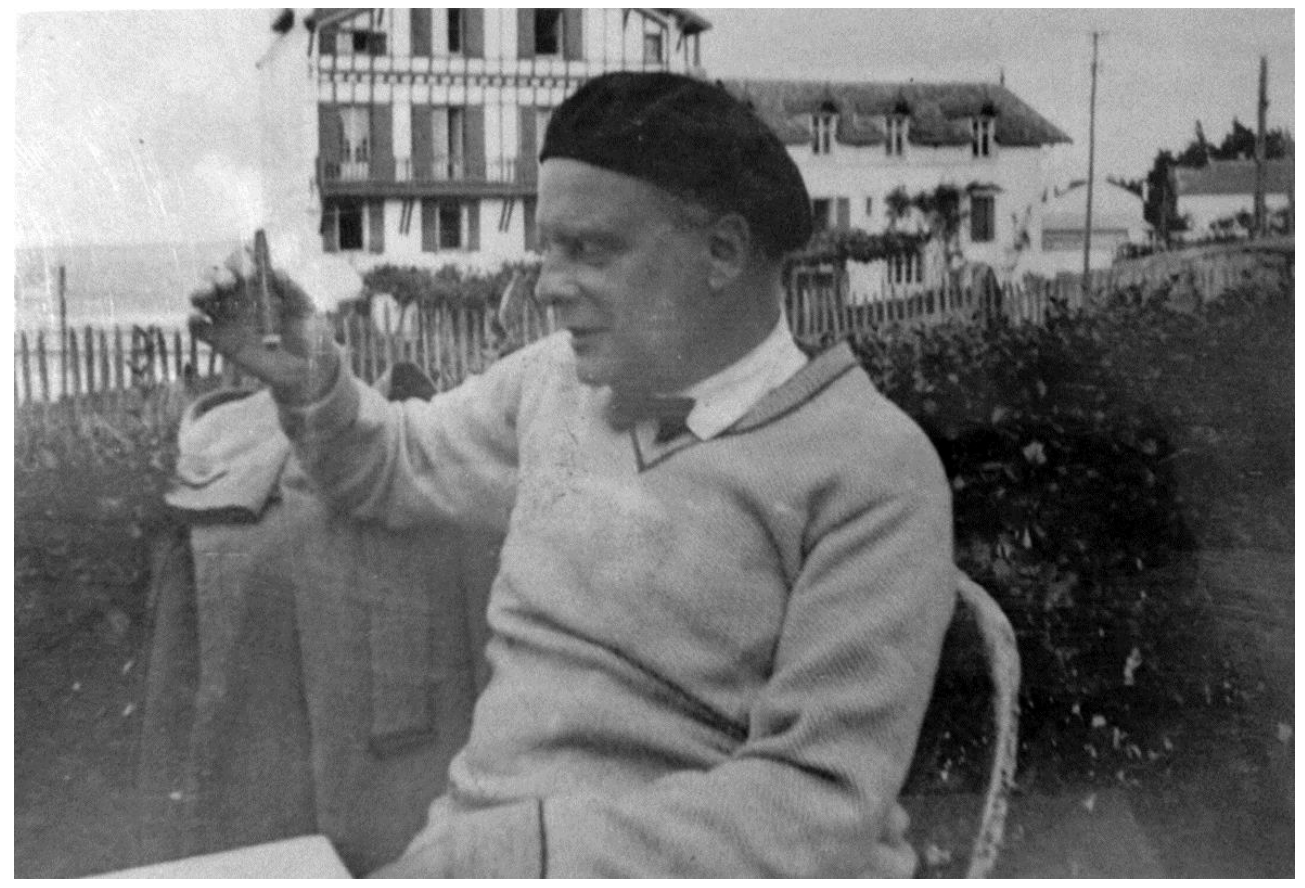

6. Typical Basque houses in Guéthary. Paul Klee at the Côte Basque, August 1929.

\footnotetext{
18 "L'état d'esprit de la série est haïssable aux architects et aux habitants...on en arrive justement, et tout essoufflé, au r-é-gi-o-n-a-1-i-s-m-e! Ouf! Et le plus comique, c'est la devastation des pays envahis qui nous y conduit," in Le Corbusier, Vers une architecture, Paris: Flammarion, 2005, p. 189 (1923). Translated as "Mass-Production Housing," in Towards an Architecture, Los Angeles: Getty Research Institute, 2008, p. 255.

19 This is a note that Le Corbusier wrote in September 1936 in the visitor's book of the Grand Hôtel Chantecler, FLC E2-8109, quoted in Tim Benton, "Atlantic Coast: Nature as Inspiration," in Cohen (ed.), Le Corbusier. An Atlas of Modern Landscapes, pp. 165-166.
} 
The area of the Basses-Pyrénées, right on the Spanish border, which Countess de Vera was presenting as a new area of opportunities to Le Corbusier, was particularly difficult to intervene [Fig. 6]. The local architects did not succeed in stepping back from regionalism, as was the case of Henri Godbarge, who extoled the Basque style and was the main theorist of the neo-Basque regionalist movement after WWI, publishing Arts Basques Anciens et Modernes. Origine, Evolution in 1931. Joseph Hiriart, a quite popular architect who had designed La Maitrise Pavilion (the pavilion of Galeries Lafayette), at the Exposition des Arts Décoratifs (1925), built in 1926 both a house in a very traditional Basque style and another one that would become a gem of Art Deco. Both houses, constructed precisely on Bordegain, Ciboure, the same mountain between St. Jean de Luz and Hendaye that Countess de Vera was referring to, adopted Basque names with eloquent meanings, as is typical in the region: "Villa Lehen-Tokia" (which means "first place") and "Villa Leïhorra," (which means "refuge in land"). ${ }^{20}$ In 1928, Hiriart built the Hôtel-Casino la "Roseraie" in Ilbarritz, Bidart, moving towards modern spatial arrangements, but still keeping a substantial amount of regionalist features on the roof.

Another extreme case was that of William Marcel, a regionalist architect from Bayonne, who in 1923 received the commission to build a hotel-casino on the terrace of the old bathhouse of Saint-Jean-de-Luz by Juste Lisch. The project needed to make a strong statement in order to convince the visitors of the Côte Basque arriving from Paris, to travel a few more kilometers towards Spain (from Biarritz to Saint-Jean-de-Luz). Marcel proposed a hotel of 140 rooms with a casino, a swimming-pool, a garage, and a series of covered galleries, forming a square towards its center, in an ostentatious neo-Basque style that was quite controversial at the time and finally was not built [Fig. 7].

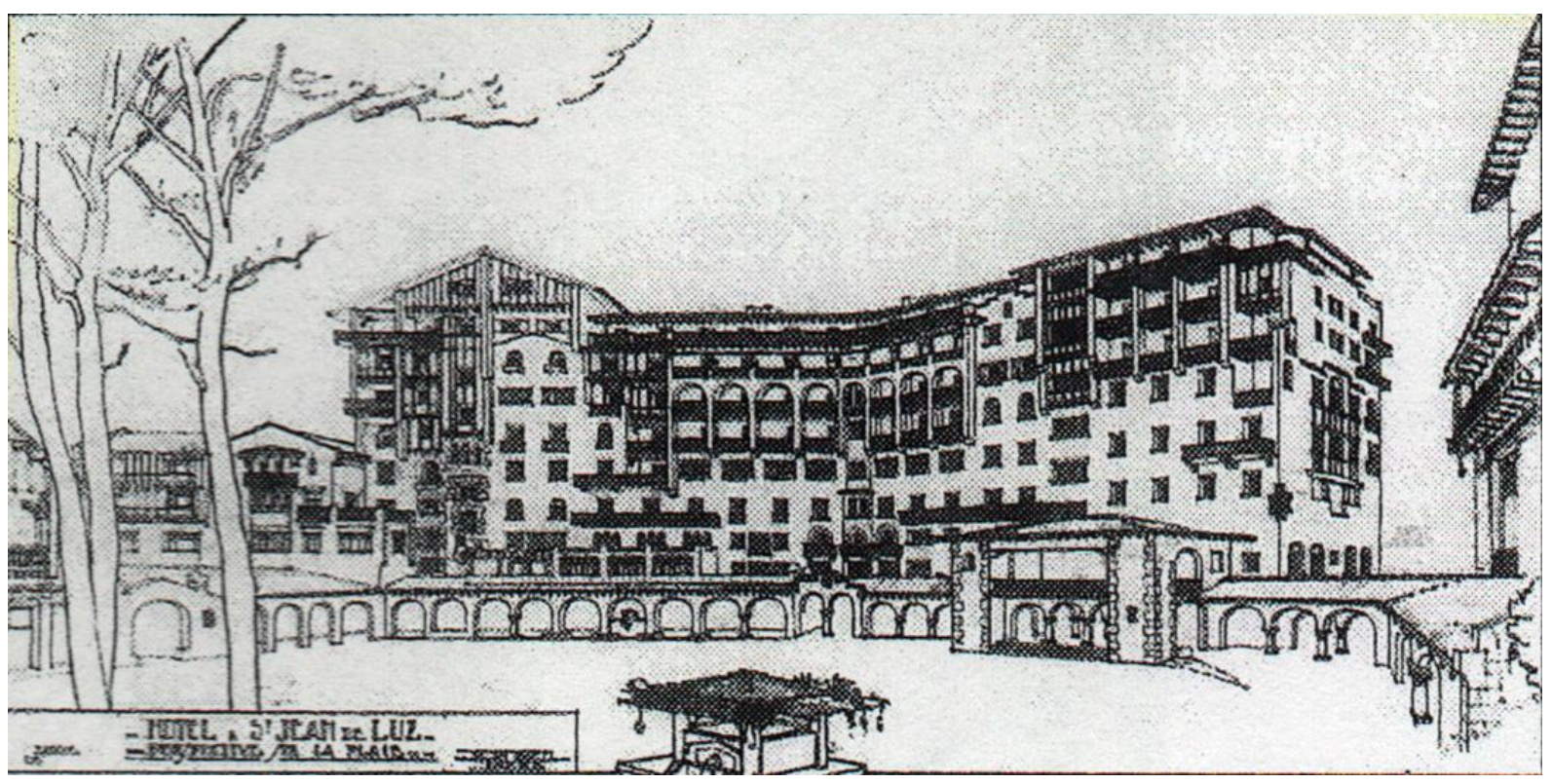

7. Hôtel-Casino La Pergola, Saint-Jean-de-Luz. Project by William Marcel, c1924.

The outsiders however, who visited and were impacted by the built environment of the area, were able to surpass the linguistic features of Basque regionalism, as is attested by many of the works they created during or right after their stays. The many artists of the French and German avant-gardes that spent their holidays in the area were not trapped by the colored timber, the protruding eaves and the inclined roofs, and produced instead artistic works of modern compositional order.

\footnotetext{
${ }^{20}$ I would like to thank here Michel Sarlangue who directed my attention to the development of Bordegain and to these houses.
} 
In 1926, Man Ray had been captivated by a classical villa on the top a cliff in Bidart, which had been built by a Rumanian aristocrat in 1912 and had been given the Basque name "Emak Bakia" ("leave me alone"). Ray was so fascinated by this place that he would convert the Basque expression into one of his artistic mottos and would even shoot a experimental film under the same name in order to claim the artistic freedom of film [Fig. 8]. ${ }^{21}$ In 1929, Paul Klee spent a long vacation with his wife Lilly and his son, Felix, in "Villa Louisiana," another single family house in the Basque style, less than 50 meters away from "Emak Bakia." "Garden House" [Fig. 9], the oil-painting Klee created shortly after, blended the color of the timber and the windows-and-shutters with

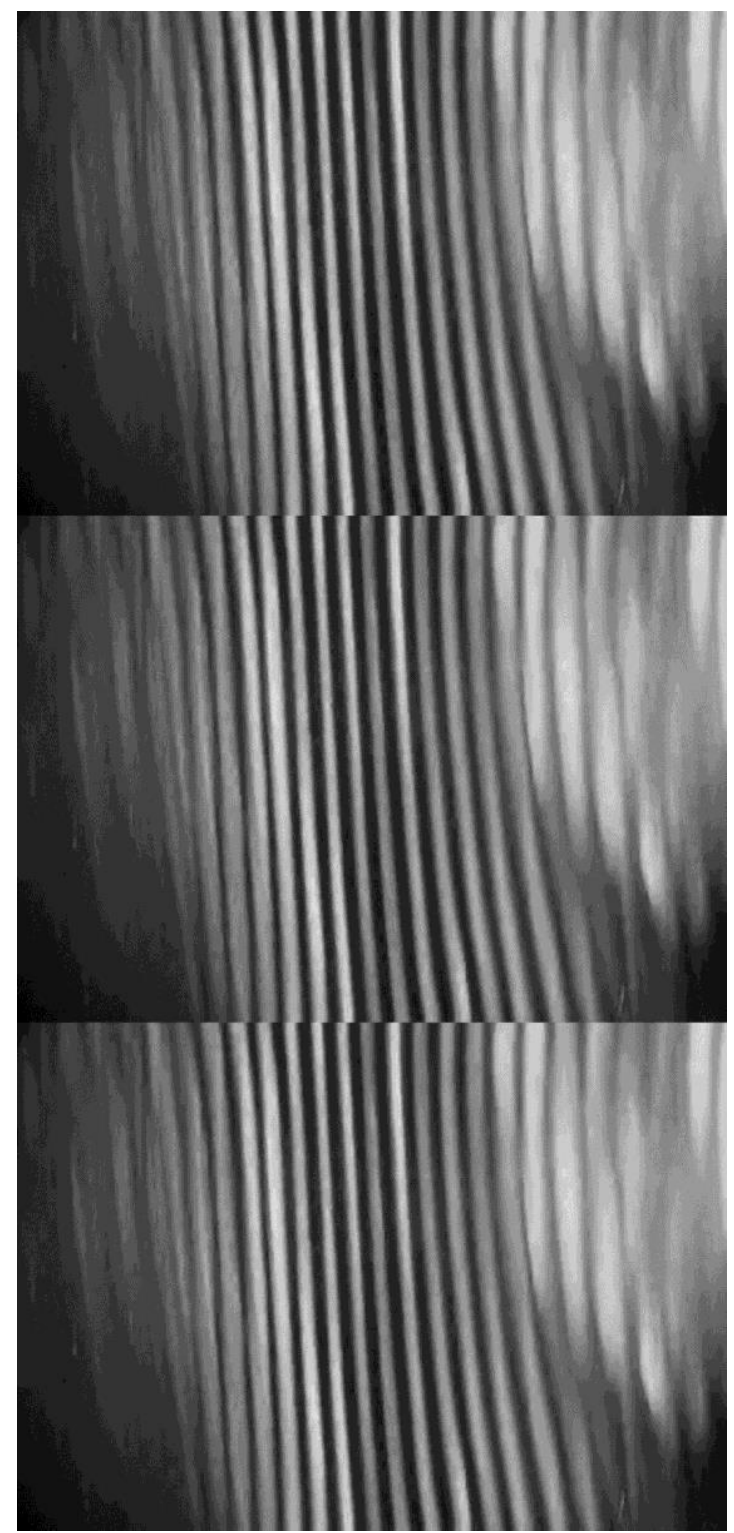

8. Still from Man Ray, Emak Bakia [Leave me alone] 1926, 3'21'’.

\footnotetext{
${ }^{21}$ Only three shots of the Villa in Guéthary and its settings exist in Man Ray's documentary film: a close-up of its front door, two columns of a wall-opening towards the sea, and a view of the nearby coast. Following these hints and the assistance of other informers, Oskar Alegría decided to undertake a quest on foot to find it, which lead to the film "Emak Bakia Baita!," the house of Emak Bakia. See: http://emakbakiafilms.com/en/
} 


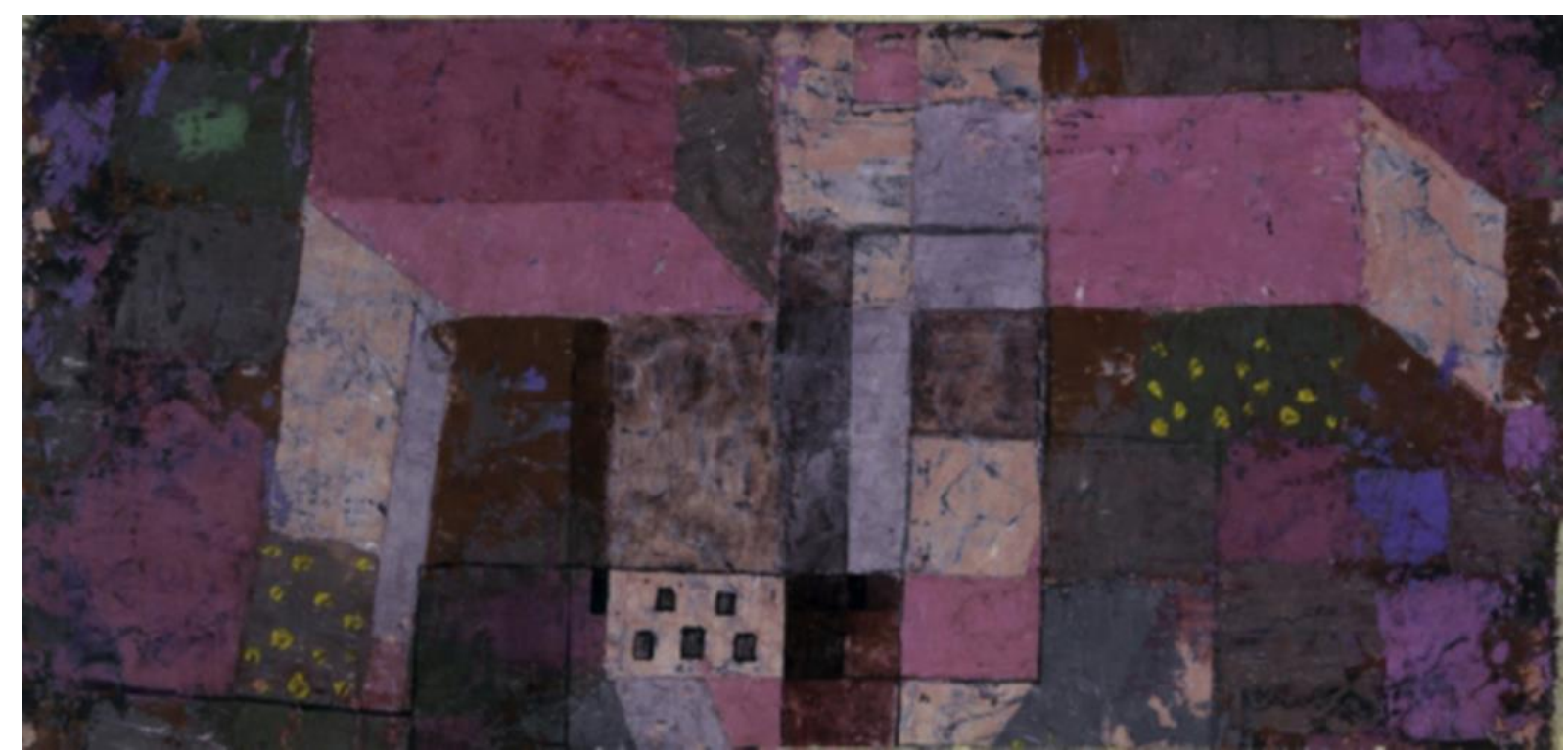

9. Paul Klee, Garden House [Gartenhaus], 1929, 347. Oil-colour and watercolour on muslin on card (21 x $42 \mathrm{~cm})$.

that of the garden, creating an abstract reddish-purple landscape in which five openings are organized in the form of a herringbone. ${ }^{22}$ During the same summer of 1929, the everyday environment for Vasily Kandinsky's vacation was the classical portico of composed columns surrounding the Hotel Euskalduna (1912), a monumental complex of regional inspiration by Henry Martinet that stands on the main avenue of HendayePlage [Fig. 10]. However, Kandinsky did not bring any of the regionalist features of those porticos to the oilpaintings he created in the autumn of 1929, but created many structural porticos of modern spatial composition such as "Scarcely Colored Structure," "Jocular Sounds" or "Horizontal Blue". 23

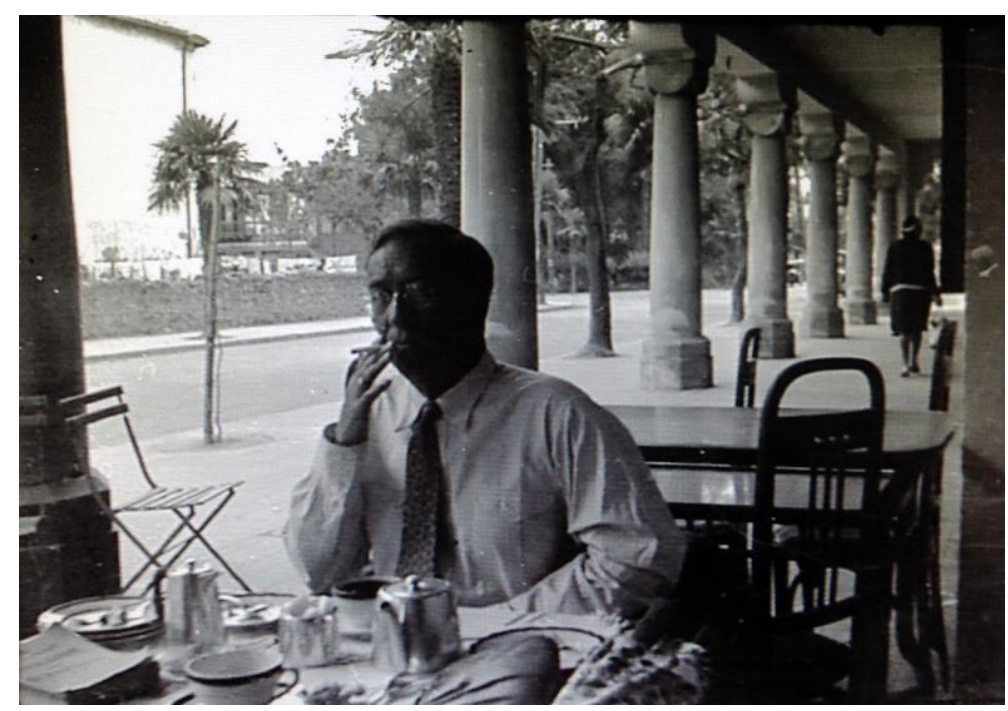

10. Arcades of the Hotel Euskalduna in Hendaye-Plage. Vasily Kandinsky during breakfast, summer 1929 (n. 947 ).

\footnotetext{
22 "In the Garden of Villa Louisiana" $(1929,246)$, another drawing created during the vacation of the Klees in the BassesPyrénées confirms the name of the house where they spent the summer of 1929. Zentrum Paul Klee, Bern.

${ }^{23}$ There are more than twenty photographs showing the everyday life of Kandinsky in Hendaye-Plage during the summer of 1929. The elements of Basque regionalism are pretty apparent in the background of those photographs. Archives at Fonds Kandinsky, MNAM-CCI, Centre Pompidou.
} 
During his long holiday on the Còte Basque, Kandinsky even visited and bought several postcards of the Casino La Pergola by Mallet-Stevens, the real battle winner, among the outsiders, able to surpass regionalism [Fig. 11]. In fact, Mallet-Stevens managed to develop the project and to build the Hôtel-Casino starting from the original and unsuccessful six-floor structure previously constructed by Marcel. ${ }^{24}$ With materials that were new for the region, such as the steel and concrete that were otherwise very attached to the French ferro-concrete tradition, and relying on colors that went beyond the typical red and green of the Espelette pepper, Mallet-Stevens managed to create a quite balanced modern work of architecture. The building was immense, a size Le Corbusier was still dreaming of developing at that time. It was a small city in itself, with a multifunctional program that included a hotel, a casino, restaurants, boutiques, and many different other entertainments, all organized compactly in the form of a strange ocean liner that seemed to have just landed on the beach. However, despite its huge volume, a series of thinner, more slender elements and shapes placed asymmetrically were able to endow the building with an image of lightness that entered into a dialogue with the ephemeral fabric huts of the beach [Fig. 12].

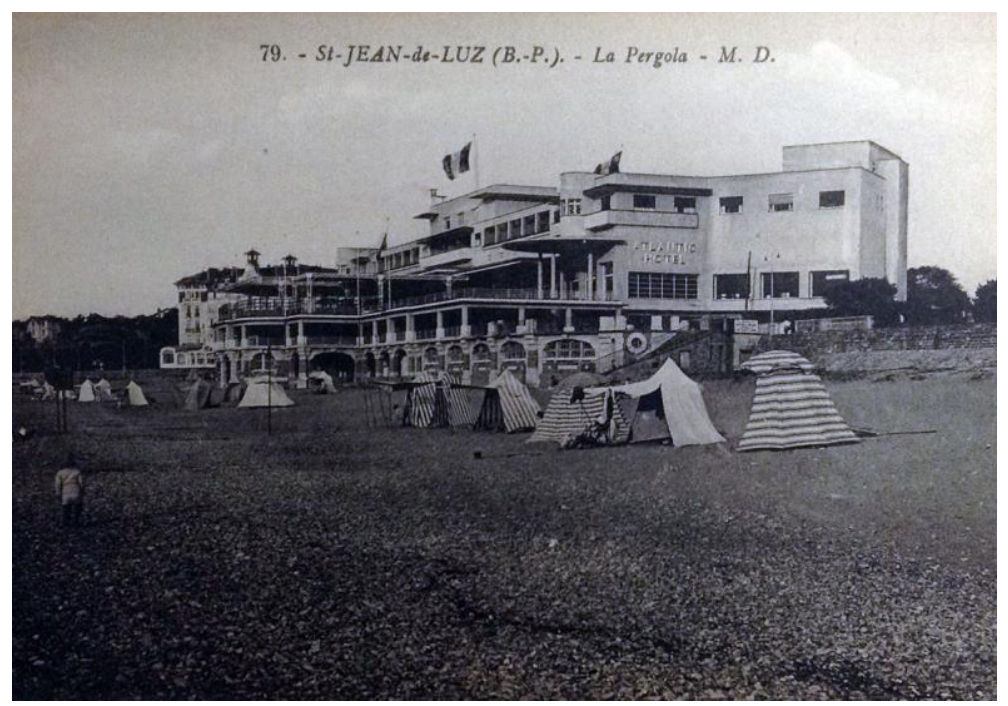

11. Postcard of Casino La Pergola in Saint-Jean-de-Luz, bought by Vasily Kandinsky, summer 1929.

Mallet-Stevens had been much more successful at the Paris Exhibition of 1925 than Le Corbusier and his L'Esprit Nouveau Pavilion, with the bold concrete trees of its garden and the daring hall of his transportation pavilion suspended on only two supports. But the project that truly led Mallet-Stevens to fame was the opening of the Rue Mallet-Stevens he built in Auteil, Paris, in 1927, barely 150 meters away from the houses Le Corbusier had built in the same Parisian neighborhood, and which, coincidentally, Countess de Vera had requested to see in her first letter. The impact the work of Mallet-Stevens caused across France was precisely the reason why the developers of the Casino La Pergola in Saint-Jean-de-Luz called him in the autumn of 1927, so that he would engage with a commission they had been unsuccessfully trying to develop for four years. ${ }^{25}$ MalletStevens succeeded to finish the building in only one year.

\footnotetext{
${ }^{24}$ Lyonnet, Jean Pierre (Ed.), "L'Affaire du Casino de Saint-Jean-de-Luz," in Robert Mallet-Stevens Architecte, Paris: Éditions 15, square de Vergennes, 2005, pp. 188-198.

25 “Casino de Saint-Jean-de-Luz. 1927-1928," in Robert Mallet-Stevens: l'oeuvre complète [Ouvrage publié à l'occasion de l'exposition présentée au centre Pompidou, galerie 2, du 27 avril au 29 août 2005], Paris: Centre Pompidou, 2005, pp. 142145.
} 


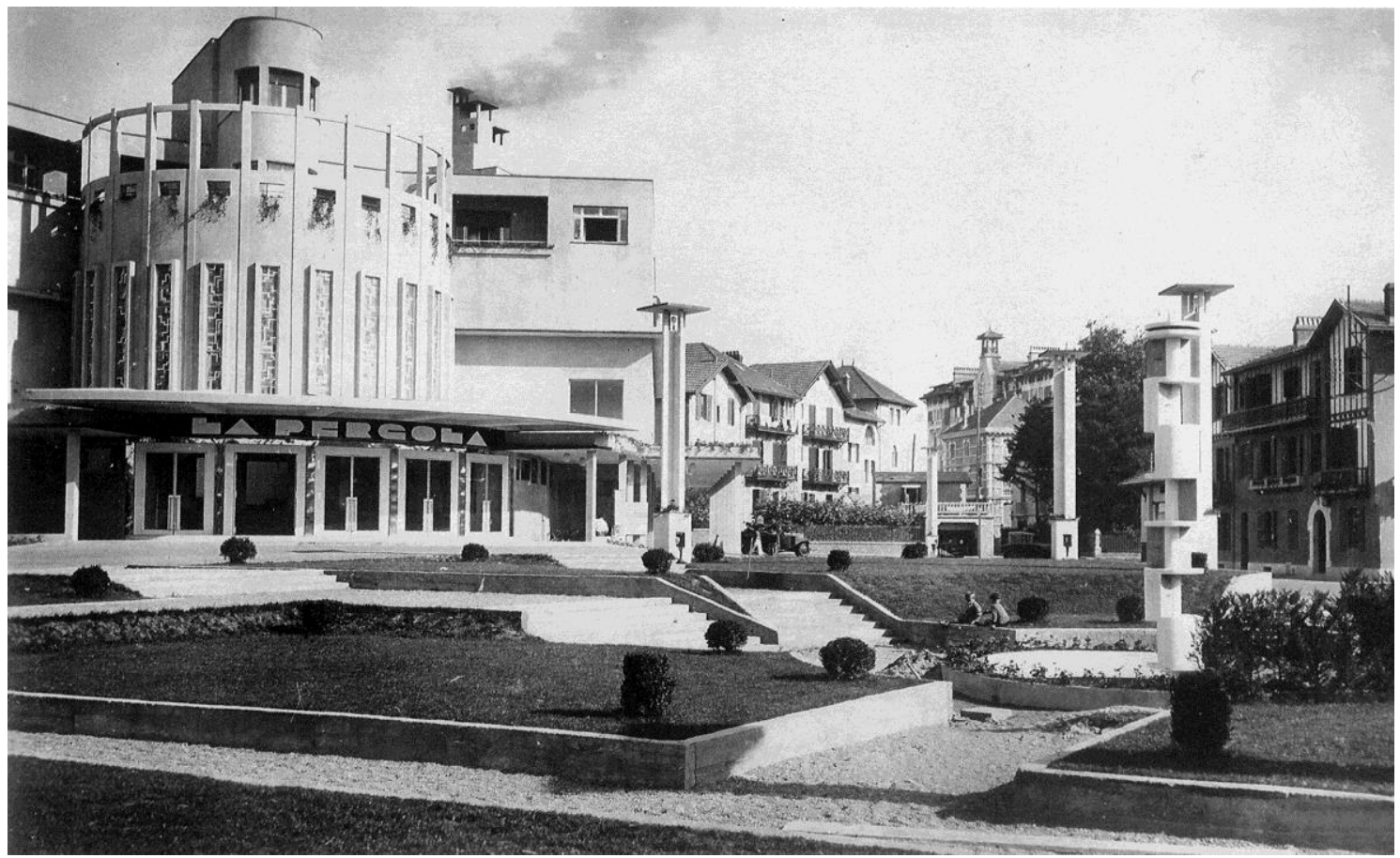

12. Robert Mallet-Stevens. View of Casino La Pergola from the street entrance, 1928.

In terms of professional accomplishment we may say that Mallet-Stevens was far beyond Le Corbusier at that time. Moreover, Le Corbusier was conscious of the challenge implied by interventions on areas of such strong cultural and linguistic identity, as is the Côte Basque. Therefore, it must have been painful for him to realize that his most direct competitor in France had not only carried out this ambitious endeavor successfully, but the realization of this work had also allowed him to monopolize the market of a rising clientele of luxury single family houses in the southwest of France. This might be another motivation behind Le Corbusier's desire to get in on this market, causing him to send a project to Biarritz.

\section{4. "I exist in life only if I can see"}

Le Corbusier sent off the set of drawings he prepared for the Villa Ocampo on September 18, 1928, but the project arrived too late and never took hold. ${ }^{26}$ However, through the debt he created on the part of Victoria Ocampo, Le Corbusier achieved something probably more important than a commission. Since, as it is wellknown, Victoria Ocampo would play a key role in the organization of his lectures in Argentina in October 1929.

"The plan is pure, made exactly in accordance with needs," said Le Corbusier in the lecture entitled "The Plan of the Modern House" referring to the Villa Savoye, and foregrounding the importance of the accommodation of function over the response to site. "[The plan] is in its right place in the rural landscape of Poissy," he continued [Fig. 13]. "But in Biarritz, it would be magnificent. If the view is elsewhere, on another side, if the orientation is different, the hanging garden would simply be turned around. This same house, I should set [sic] down in a corner of the beautiful Argentine countryside. "27

\footnotetext{
26 "Je regrette infiniment que votre projet se sot pas réalisables pur cette tois ici...[Madame Ocampo] va donc faire construire le plan que je vous ai envoyé et elle en est désolée, car elle n'en est pas satisfaite," dossier Vera, FLC I1-17-12, September 29, 1928.

27 "Le plan est pur, fait au plus exact des besoins. Il este à sa juste place dans l'agreste paysage de Poissy. Mais à Biarritz, il serait magnifique. Si la vue est ailleurs, d'un autre côté, ou si l'orientation est différente, le jardin suspend sera tout
} 


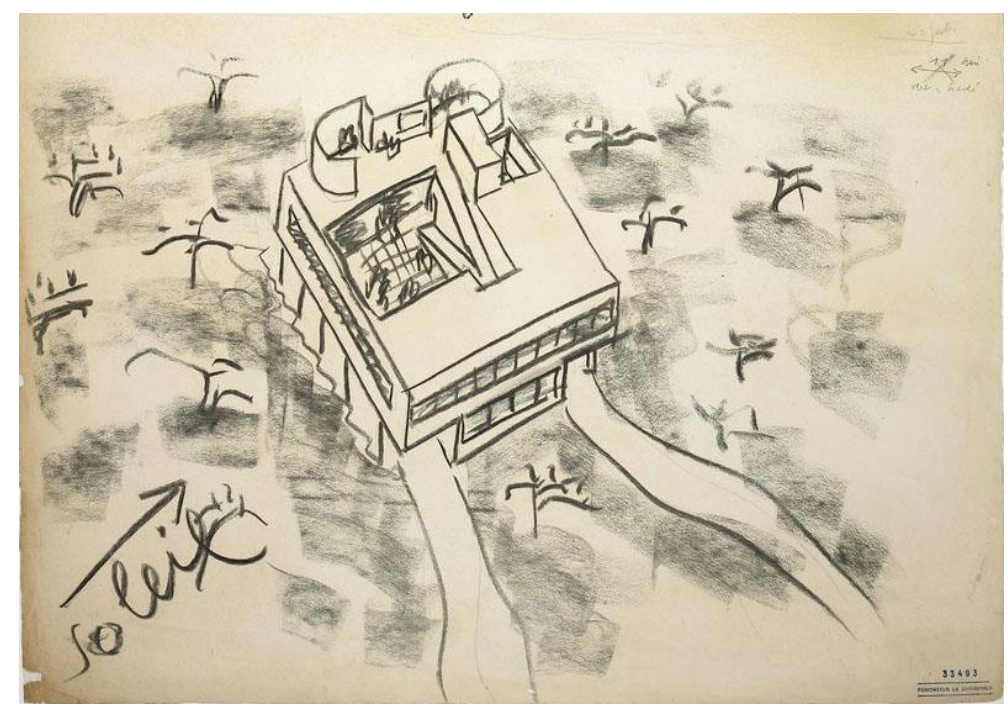

13. Drawing by Le Corbusier during the lecture "The Plan of the Modern House," October 11, 1929. FLC 33493.

This indifference for the siting of a project Le Corbusier seemed to show when he recognized that a house designed for Paris could equally fit in Biarritz or Argentina, is the same he had revealed one year earlier, in September 1928, when he submitted an updated version of the Villa Meyer for a project meant to be built in Buenos Aires. However, this apparent lack of engagement with place should not be seen as a stance toward nonspecificity. As Barry Bergdoll has proposed, Le Corbusier's buildings were "types of viewing devices" for the landscape beyond it. ${ }^{28}$ Thus, we can understand that Le Corbusier was offering a different kind of relationship with site, which did not have to do with the creation of an interviewing interior-exterior relationship; rather, with the connection between the projects and the distant surroundings they overlooked. The importance Le Corbusier gave to these "viewing devices," and his conviction that modern dwelling was about seeing, is confirmed by his famous aphorism, "I exist in life only if I can see," ${ }^{29}$ included in the "American Prologue" he wrote to accompany the ten lectures of Argentina from October 1929.

The fact that Le Corbusier had conceived the Villa Meyer as a viewing device for Saint James Park in Paris, and probably had not been very concerned by achieving a particular engagement with Avenue de Madrid, is clearly revealed in the perspectives he created for the third version of the project. The last perspective of the seven views he put together shows clearly how he arranged his architecture as a frame through which to look [Fig. 14]. ${ }^{30}$ This creative approach produced a constant play between the small scale of the everyday life objects in the

simplement modifié. Cette même maison, je vais l'implanter dans un coin de belle champagne argentine; nous aurons vingt maisons surgissant des hautes herbes d'un verger où continueront de paître les vaches." Le Corbusier, "Le Plan de la Maison Moderne," in Précisions sur un état présent de l'architecture et de l'urbanisme, Paris: Crès, 1930, p. 138.

${ }^{28}$ Berdgdoll, Barry, "From International to Territory: The Project of an Atlas," in Cohen, Jean-Louis, An Atlas of Modern Landscapes, pp. 18-21.

29 “Je n'existe dans la vie qu'à condition de voir," in Précisions sur un état présent de l'architecture et de l'urbanisme, Paris: Crès, 1930, p. 8.

${ }^{30}$ Another coincidence is that Le Corbusier met Mallet-Stevens in April 1926, the same week in which he was drawing the perspectives of the third version of the Villa Meyer. Le Corbusier's diary on Monday April 12, 1926, writes a reminder about some drawings of the Villa Meyer, "Dessins perspec. Meyer," and a few lines below mark a meeting at 7 o'clock with Mallet-Stevens on Tuesday April 13, 1926. These drawings must have been those from the third version of the Villa Meyer, since this third project was sent off on April 24. See FLC F3-4-4-020. 
foreground and the larger scale of the geographical features in the background. In such a spatial relationship, the opening was the main architectural element that made his buildings site-specific. ${ }^{31}$

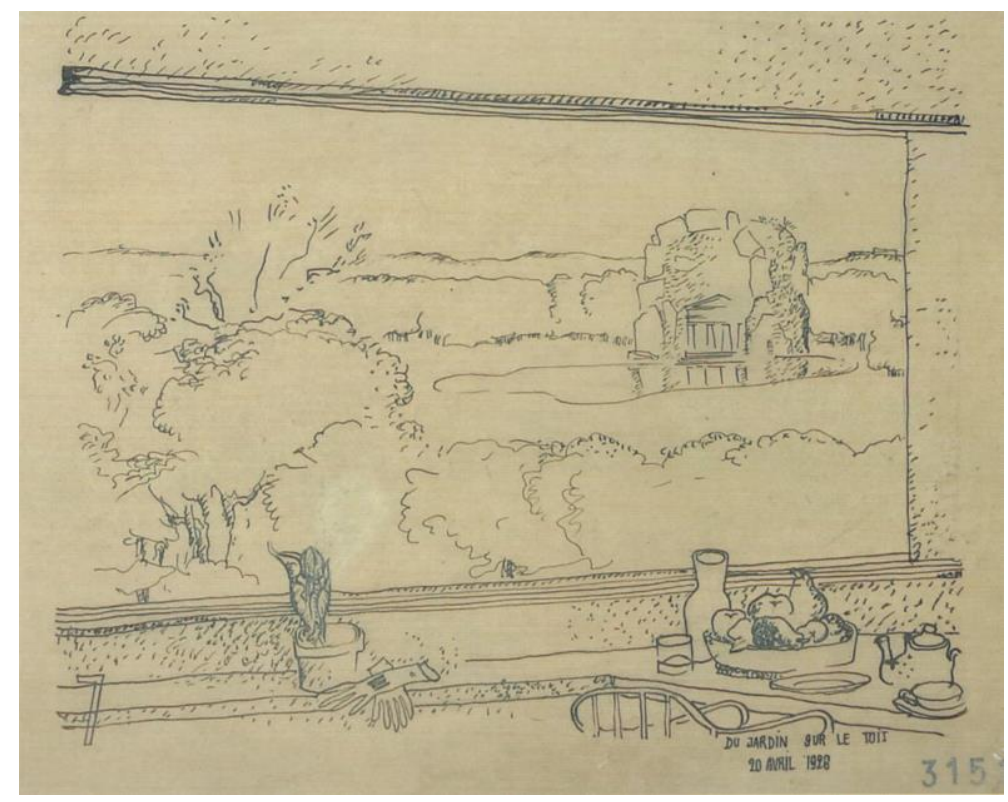

14. Villa Meyer, seventh perspective of the third project, April 1926. FLC 31514.

In a similar way, it is very probable that Le Corbusier conceived the Villa Ocampo as a viewing device for the area around Park of Palermo in Buenos Aires. However, as he did not know the site, the opening he proposed was a more abstract cube of air and which could offer Victoria Ocampo through spatial experience a different kind of modern awareness. It should not be forgotten that Countess de Vera had explicitly asked Le Corbusier whether it would be possible to do something of a similar nature to the Villa in Garches, towards the side of the garden. Le Corbusier drew this cube of air, which included a mezzanine along the side of a double-height terrace, in the last perspective of the three he put together for the project [Fig. 15].

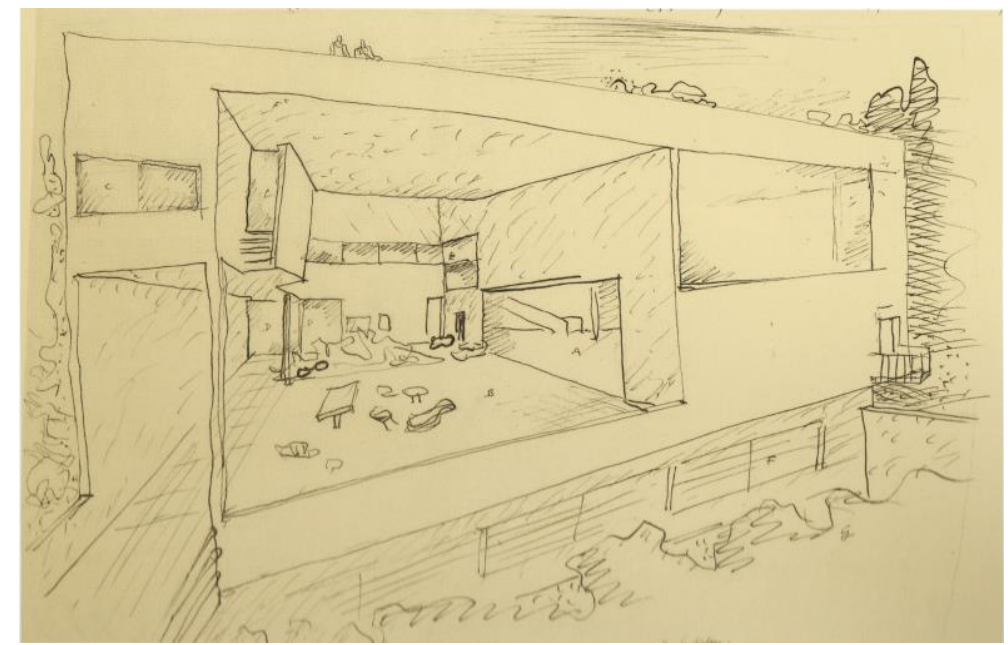

15. Villa Ocampo, perspective of garden front, final project, September 18, 1928. FLC 24235.

\footnotetext{
${ }^{31}$ See also Martínez de Guereñu, Laura, "Zeharka begiratzeko markoak: 'Ikustearen baldintza bakarrarekin existitzen naiz bizitza honetan," in Aldiri, Arkitektura eta abar, nº 9 (Ttipi), Bilbao, 2012, pp. 14-19.
} 
As Jean-Louis Cohen has stated, the more generic projects of Le Corbusier, capable of being inserted into multiple locations, were designed as "camera lucidae" to enable distant observation. ${ }^{32}$ Hence, the hanging gardens, window openings with sills or abstract cubes of air of these projects call all be considered "viewing" architectural elements that allowed Le Corbusier to engage with the landscape no matter the specific site in which they were inserted.

In July 1930, almost one year after his trip to South America, Le Corbusier would finally visit Biarritz en route from Spain to Paris [Fig. 16]. ${ }^{33}$

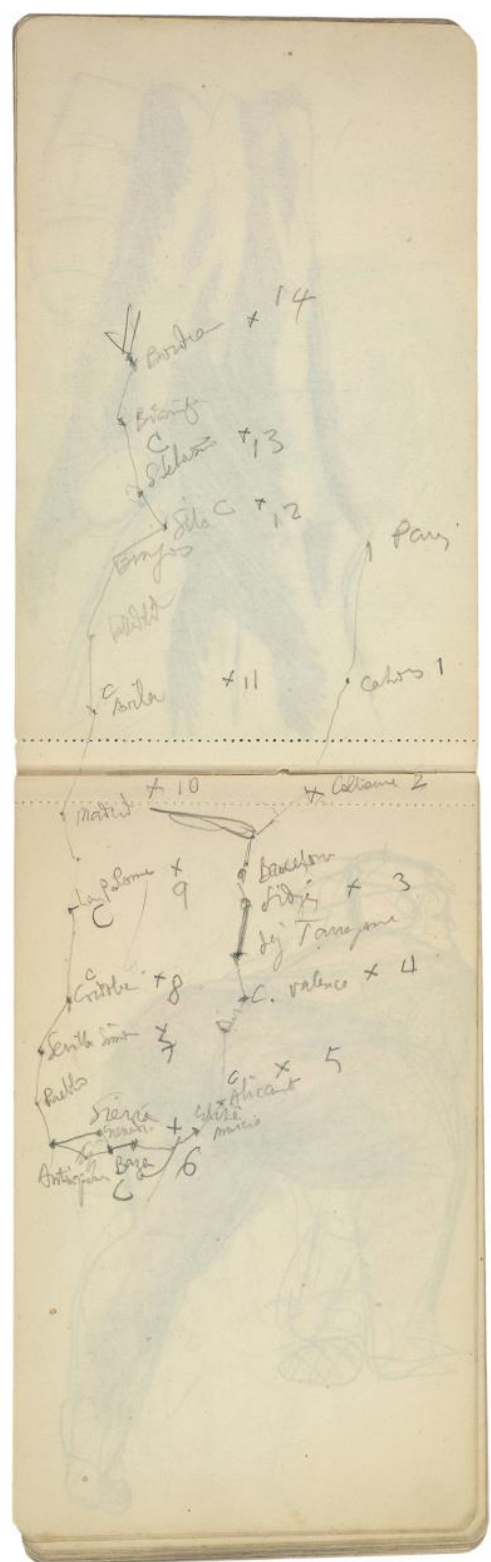

16. Scheme of the trip through Spain in July 1930, realized in Le Piquey. FLC Carnet B8-481, FLC Carnet B8-482.

\footnotetext{
${ }^{32}$ Cohen, Jean-Louis, "In the Cause of Landscape," in Cohen, Jean-Louis, An Atlas of Modern Landscapes, pp. 23-47.

${ }^{33}$ The stop in Biarritz happened on the way back to Paris, after having traveled more than $2.800 \mathrm{kms}$ in 12 days across Spain, in Raoul La Roche's Voisin, with Fernand Léger, his brother Albers, and his cousin and partner Pierre Jeanneret. In Le Corbusier's carnets of the summer of 1930, there is a drawing of a dry tree that has a hand-written route on its back : Madrid, Ávila, Valladolid, Burgos, Silos, San Sebastián, Biarritz, Bordeux. Le Corbusier, Carnet B8. Scheme of the trip to Spain of July 1930, drawn in Le Piquey. See, Lahuerta, Juan José (Ed.), “Espagne”: carnets, Milano: Electa, 2001, p. 36.
} 
One month after the trip, on a letter to Victoria Ocampo on August 30,1930, Le Corbusier would share his impressions of this Southern European country. The terms as well as the tone Le Corbusier employed might now serve to summarize the significance of the Villa Ocampo commission in Buenos Aires in his work and the many opportunities that were brought along with it, after his trip to South America: "Prestigious! Grandiose, distanced, human and gentile. Great souvenir."${ }^{34}$

\section{Acknowledgements}

I would like to thank Arnaud Dercelles and Delphine Studer for kindly sending digitalized material for this research from Fondation Le Corbusier, Michel Sarlangue for sharing with me different local research resources, Bárbara Pons for her help with the transcription and translation of the correspondence, and Josep Quetglas for encouraging me to write this paper. Research on Paul Klee's Papers at Zentrum Paul Klee, Bern, and on Vasily Kandinsky's Papers at the Centre Pompidou Paris, were benefited by travel subsidies from the Fritz Thyssen Foundation.

\section{Source of images}

Fig. 1. Fondation Le Corbusier. () FLC-ADAGP.

Fig. 2. Fondation Le Corbusier. @ FLC-ADAGP.

Fig. 3. Fondation Le Corbusier. @ FLC-ADAGP.

Fig. 4. Fondation Le Corbusier. ( ) FLC-ADAGP.

Fig. 5. Fondation Le Corbusier. @ FLC-ADAGP.

Fig. 6. The Norton Simon Museum Archives, Pasadena, California.

Fig. 7. Robert Mallet-Stevens Architecte, Paris: Éditions 15, 2005.

Fig. 8. MNAM-CCI, Centre Pompidou. Fonds Man Ray.

Fig. 9. Albertina, Vienna - On permanent loan from the Forberg Collection. Photo: Fotoatelier Peter Schälchli, Zürich.

Fig. 10. MNAM-CCI. Fonds Kandinsky.

Fig. 11. MNAM-CCI, Centre Pompidou. Fonds Kandinsky. VK (série 1), blank postcards.

Fig. 12. Jean-Pierre Lyonnet personal archive.

Fig. 13. Fondation Le Corbusier. @ FLC-ADAGP.

Fig. 14. Fondation Le Corbusier. () FLC-ADAGP.

Fig. 15. Fondation Le Corbusier. ๑ FLC-ADAGP.

Fig. 16. Fondation Le Corbusier. ๑ FLC-ADAGP.

\section{Bibliography/ references}

Alegría, Oskar, Emak Bakia baita (The Search for Emak Bakia), 2012. (86 min.)

Benton, Tim, “1925. Villa Meyer. Neuilly-sur-Seine, France,” (Project 61, DVD 1), in Le Corbusier Plans, Paris: Codex Images International/ Fondation Le Corbusier, 2005.

Benton, Tim, The Villas of Le Corbusier and Pierre Jeanneret 1920-1930, Basel-Boston-Berlin : Birkhäuser, 2007.

\footnotetext{
34 "Fait le tour de l'Espagne en auto. Prestigieux! Grandiose, Lointain, humain et gentil. Grand souvenir." Dossier Victoria Ocampo, FLC E2-17-183-003. August 30, 1930.
} 
Benton, Tim "Atlantic Coast: Nature as Inspiration," in Cohen, Jean-Louis (Ed.), Le Corbusier. An Atlas of Modern Landscapes, New York: Museum of Modern Art, 2013, pp. 165-166.

Berdgdoll, Barry, "From International to Territory: The Project of an Atlas," in Cohen, Jean-Louis (Ed.), Corbusier. An Atlas of Modern Landscapes, New York: Museum of Modern Art, 2013, pp. 18-21.

Cohen, Jean-Louis, "In the Cause of Landscape," in Cohen, Jean-Louis (Ed.), An Atlas of Modern Landscapes, New York: Museum of Modern Art, 2013, pp. 23-47.

García Mercadal, Fernando, “Le Corbusier en Madrid,” in La Gaceta Literaria 34, May 15, 1928.

Lahuerta, Juan José (Ed.), “Espagne”: carnets, Milano: Electa, 2001.

Le Corbusier, Precisions. On the Present State of Architecture and City Planning, Cambridge, MA: MIT Press, 1991 (Translated from Précisions sur un état présent de l'architecture et de l'urbanisme, Paris: Crès, 1930).

Le Corbusier, Towards an Architecture, Los Ángeles: Getty Research Institute, 2008. (Translated from Vers une architecture, Paris: G. Crès, 1923).

Marchant, Hernán, "Villa Ocampo. 1928" (Project 25, DVD 2), in Le Corbusier Plans, Paris: Codex Images International/ Fondation Le Corbusier, Paris, 2005.

Martínez de Guereñu, Laura, "Zeharka begiratzeko markoak: 'Ikustearen baldintza bakarrarekin existitzen naiz bizitza honetan," in Aldiri, Arkitektura eta abar, n 9 (Ttipi), Bilbao, 2012, pp. 14-19.

Ray, Man, Emak Bakia (Basque for Leave me Alone), 1926. (19 min.)

Quetglas, Josep, Les Heures Claires, Sant Cugat del Vallés: Massilia, 2008.

Sebreli, Juan José, Cuadernos, Sudamericana, 2011.

VV. AA., Le Corbusier : Madrid 1928 : una casa - un palacio [exposición], Residencia de Estudiantes, mayo-julio 2010, Residencia de Estudiantes, Madrid, 2010.

VV. AA., Le Pays Basque en 101 sites et monuments, Bordeaux : Le Festin, 2013.

VV. AA., Robert Mallet-Stevens Architecte, Paris: Éditions 15, square de Vergennes, 2005.

VV. AA., Robert Mallet-Stevens: l'oeuvre complète [Ouvrage publié à l'occasion de l'exposition présentée au centre Pompidou, galerie 2, du 27 avril au 29 août 2005], Paris: Centre Pompidou, 2005.

\section{Archives}

Archives Départementales des Pyrénées-Atlantiques, Pôle d'archives de Bayonne et du Pays Basque, Bayonne.

Archives Municipales, Anglet.

Fondation Le Corbusier, Paris.

Fonds Kandinsky, MNAM-CCI, Centre Pompidou, Paris.

Zentrum Paul Klee, Bern. 


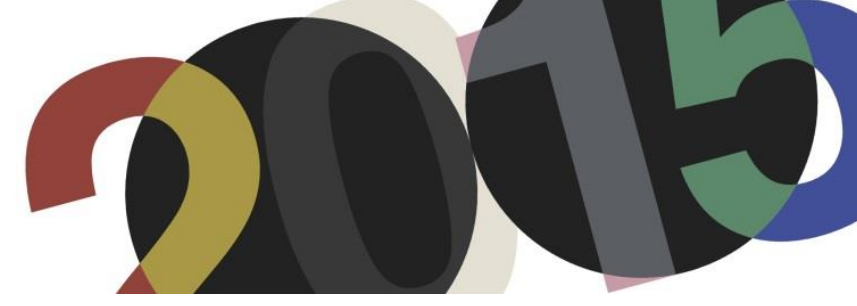

DOI: http://dx.doi.org/10.4995/LC2015.2015.778

\title{
El "hameau" vertical de Le Corbusier. Una alternativa residencial al bloque lineal
}

\author{
Y. Martínez Domingo, J. González Cubero
}

Escuela Técnica Superior de Arquitectura de Valladolid

\begin{abstract}
Resumen: El " hameau" vertical de Le Corbusier es un prototipo de alojamiento colectivo, desarrollado como alternativa plástica a la "Unité d'habitation de grandeur conforme," quizás su obra más sintética. La torre residencial se concreta a partir de las teorías urbanas de la regla de las 7V, a través de la impronta de una de las formas elementales: el volumen cilíndrico, manteniendo prácticamente inalteradas capacidad, forma y dimensiones en cualquiera de los entornos urbanos donde se inserta, los proyectos no construidos de su última etapa para Europa. Lejos de ser un modelo genuino es deudor de otras construcciones previas, los albergues para las colonias infantiles italianas, promovidas por la fábrica FIAT en los años 30, y algunos experimentos residenciales del arquitecto francés Auguste Bossu, erigidos también por esos años en la ciudad de Saint-Étienne. El artículo traza las relaciones entre estas construcciones y las aldeas cilíndricas para solteros, analizando las particularidades de su estructura formal y la dinámica de su organización interna, para comprobar cómo son adoptadas por Le Corbusier en la constitución de la identidad de un nuevo tipo de vivienda colectiva que permanece todavía a la sombra de sus proyectos más reconocidos.
\end{abstract}

\begin{abstract}
The vertical "hameau" of Le Corbusier is a prototype of collective housing, developed as a plastic alternative to "Unite d'habitation de grandeur conforme," perhaps his most synthetic work. The residential tower is generated from urban doctrine of $7 V$ theory through the shape of one of the elementary forms: the cylindrical volume. The towers keep capacity, shape and dimensions unchanged in any urban environments where they are inserted: the unbuilt urban projects in his last stage in Europe. Far from being a genuine type, is based in other previous constructions; the children's summer camps sponsored by the Fiat factory in the 30s, and some residential experiments by French architect Auguste Bossu erected by those years in the city of Saint-Etienne. The article describes the relationship between these structures and the cylindrical villages for singles and analyzes the peculiarities of their formal structure and the dynamic of their internal organization in order to check how those constructions were adapted by Le Corbusier for the constitution of a new collective type dwelling which still remains in the shadow of his most famous projects.
\end{abstract}

Palabras clave: Le Corbusier; hameaux verticaux; comuna cilindrica; torre residencial. Keywords: Le Corbusier; hameaux verticaux; cylindrical commune; residential tower.

\section{Introducción}

Las gigantescas torres, que perfilaron el perímetro celeste de las ciudades teóricas de Le Corbusier, estuvieron siempre dedicadas a la función terciaria, al lugar de los despachos y de la administración. Los edificios para el trabajo primero habían tomado la forma de una gran cruz griega, para luego adaptarse a una planta en Y o en patte de poule, hasta llegar al contorno lenticular, algunos de ellos servirán como contenedores de un programa mixto, residencial y de oficinas para ciertos planes urbanísticos ${ }^{1}$; pero cuando en el volumen $\mathrm{n}^{\mathrm{o}} 4$ de la Oeuvre

\footnotetext{
${ }^{1}$ En el viaje a Nueva York en 1935 reconsidera el rascacielos cartesiano de oficinas en patte de poule, propuesto para los planes de Barcelona (1932), Amberes (1933), Ginebra (1933) y Buenos aires (1938), como contenedor mixto de viviendas y oficinas, así como algunas pastillas lenticulares que se retomaran luego para el barrio de la marina de Argel. González Cubero, Josefina: Le Corbusier. El proyecto de la ciudad moderna. Valladolid, 1996, p. 261.
} 
complète (1938-46) ${ }^{2}$ clasifica los volúmenes para la habitación y los negocios los tipos residenciales son en redents, Y, frontal, en espinas y gradas, ninguno de ellos tiene la proporción formal de una torre. Todos los objetos independientes y aislados, fabricados para ese fin, tienen una componente horizontal, derivada del espesor continuo de una línea directriz, recta o quebrada. La Unité como elemento autónomo por excelencia, no es más que un intervalo desgajado de ella, que utiliza la misma tipología de vivienda y puede entenderse como un gran rascacielos tumbado ${ }^{3}$. Como contrapunto plástico a estos prismas rectangulares surgirán otros prototipos en forma de torres cilíndricas, de los que se tiene constancia solo por algunos proyectos urbanos de su última etapa, para la reforma y expansión de ciertas ciudades en Europa, que como otras tantas propuestas no llegaron a construirse.

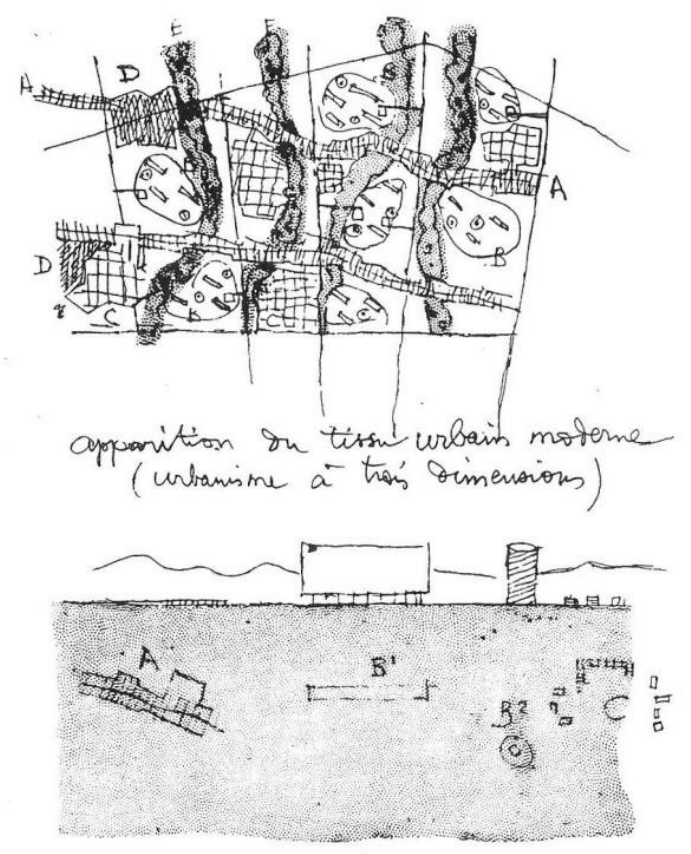

1. LC. Urbanismo de tres dimensiones. (C) FLC-ADAGP

La concepción de la ciudad en sus últimas propuestas estaba regulada por el empleo de sectores urbanos y la teoría de la Regla de las 7 Vías, surgida en 1948 para enunciar una doctrina sobre los transportes, que permitiera adaptar la geometría de los trazados a las condiciones particulares de cada lugar. En este modelo, el control del territorio se establece a partir de la irrigación de 7 tipos de vías de circulación que dibujan una malla irregular con porciones de suelo definidas por el cruce de estas arterias. Cada una de ellas corresponde a un tipo de tránsito, desde las carreteras nacionales, municipales o de circunvalación, reservadas exclusivamente al tráfico rodado, pasando por las calles comerciales y de aproximación a viviendas y parques, donde convive el peatón y el automóvil.

Entre esta segunda clase, que engloba las vías 4, 5, 6, y 7, aparece un tejido urbano moderno, un urbanisme a trois dimensions ${ }^{4}$ (fig. 1), explica gráficamente Le Corbusier, compuesto por cinco categorías: (A) un tipo de agrupamiento urbano que toma la forma de una ciudad lineal, en la que a lo largo de un eje se desarrollan

\footnotetext{
${ }^{2}$ Le Corbusier; Jeanneret, Pierre: Le Corbusier: Oeuvre complete 4, 1938-46, Zurich: Les Editionsd'Architecture, 1970.p.166

${ }^{3}$ González Cubero, Josefina: Le Corbusier. El proyecto de la ciudad moderna. Valladolid: 1996, p.262.

${ }^{4}$ Le Corbusier: OEuvre complète 5, 1946-52. Zurich: Les Editions d'Architecture, 1970, p. 92.
} 
construcciones a ras de suelo de una o dos alturas, donde se localizan tiendas, cafés, cines, etc., articulando la vida cotidiana en el desarrollo de la vía 4; (B) las Unités d'habitation de grandeur conforme o grandes unidades residenciales, concentraciones verticales de vivienda a las que se llega desde las vías 5; (C) las viviendas de baja altura, fundamentalmente la residencia unifamiliar, adosada en cadena o independiente y dispersa; por último, (D) y (E) edificios inmersos en zonas verdes destinadas al esparcimiento, con una función específica para realizar distintas actividades. A, B y C, "constituyen el entorno construido moderno dedicado a la vivienda, envuelta en una naturaleza seductora y llena de recursos tecnológicos, (...) emergiendo desde el suelo con una armonía comparable a un fenómeno natural "5. Para estas categorías se establecen unas densidades de ocupación que tratan de otorgar escala y dimensión a estos tipos constructivos descritos en número de habitantes por hectárea, 50 habitantes por hectárea para el tipo A, 500 y 400 para el tipo B, y 250 para el tipo C, aglutinando el total de la población prevista.

Así la primera de las cuatro funciones del urbanismo, habiter, declaradas en la carta de Atenas, se distribuye al margen de sus prolongaciones al exterior, en unos contenedores de los que resalta el tipo denominado B, caracterizado por la concentración y la altura del mismo $(50 \mathrm{~m})$ y para el único que se establecen dos tipos diferentes. El tipo $\mathrm{B}_{1}$ o comuna vertical, es la famosa Unité d'habitation, una colectividad de 2000 individuos, que reúne las viviendas de las familias con hijos, acumuladas en una secuencia en altura de células adosadas y distribuidas desde una calle interior (vía 6), que busca la socialización de la ayuda mutua, la defensa, la seguridad y la economía ${ }^{6}$. La alternativa formal a estos bloques laminares son unas torres cilíndricas, los hameaux verticaux o caseríos verticales, previstos para solteros o recién casados y clasificados como $\mathrm{B}_{2}$, de la misma altura que las anteriores. A estos cilindros, compuestos en planta por estrechos gajos, se les asocia una densidad de 400 habitantes por hectárea. Una línea helicoidal trama el contorno exterior, parece indicar que la vía de circulación interior, la V6, que reparte las viviendas en el bloque $\mathrm{B}_{1}$, aquí es una rampa en espiral que conduce desde la planta baja hasta la coronación del edificio. Al contrario que las "comunas verticales" la edificación $\mathrm{B}_{2}$ no se levanta del suelo sobre pilotis, surge del suelo desde un recorrido en espiral que determina en parte la textura de este volumen.

\section{Los hameaux verticaux}

La relevancia que adquirió el modelo $\mathrm{B}_{1}$ en su trabajo posterior a estas reglas relegó a los cilindros a un cierto ostracismo; así el tipo $\mathrm{B}_{2}$ se asoció a un paradigma familiar muy específico, en principio transitorio, un estadio vital previo al desarrollo personal pleno, que encontraría después acomodo en el inmueble laminar, provisto de otros servicios comunitarios para los que el tubo cilíndrico no tiene capacidad. La presencia de estos hameaux verticaux siempre estuvo vinculada al entorno de bloques laminares en el desarrollo de urbanizaciones extensas, pero nunca se llegaron a ejecutar, y los encargos que fructificaron siguieron la estela del modelo de la Unité de Marsella, un prototipo para una única edificación. Las torres circulares aparecen en las propuestas urbanas de Marsella-Sur (1946), el barrio Rotterdam en Estrasburgo (1951), en Meaux (1957) y por último en Berlín (1958). La cantidad de ellas depende de la extensión del territorio implicado en el proyecto, desde una sola en Estrasburgo acompañando a dos bloques laminares, hasta las opciones de Berlín en la que llegan a aparecer hasta 22. Sin embargo, no están presentes en los primeros planteamientos de Sant Dié, el primero de los desarrollos urbanos para la reconstrucción de Francia que empleó la regla de las $7 \mathrm{~V}$, como tampoco se utilizó en los

\footnotetext{
${ }^{5}$ Le Corbusier: OEuvre complète 5, 1946-52. Zurich: Les Editions d'Architecture, 1970, p. 93.

${ }^{6}$ Le Corbusier: El urbanismo de los tres establecimientos humanos (1945). Barcelona: Poseidón, 1981, P. 114.
} 
proyectos urbanos latinoamericanos desarrollados en esos años, ni en el único encargo llevado a cabo: Chandigarh. En todos los casos, las piezas cilíndricas mantienen la proporción del volumen mientras que los bloques laminares varían, espesor, longitud e incluso trazado. La independencia del viario respecto de la edificación es total, favoreciendo la estandarización de los prototipos edificados de una forma u otra, y el edificio residencial se inserta en un espacio cada vez más rural, más rodeado de naturaleza atravesada por vías de circulación que canalizan la aproximación de usuarios y vehículos.

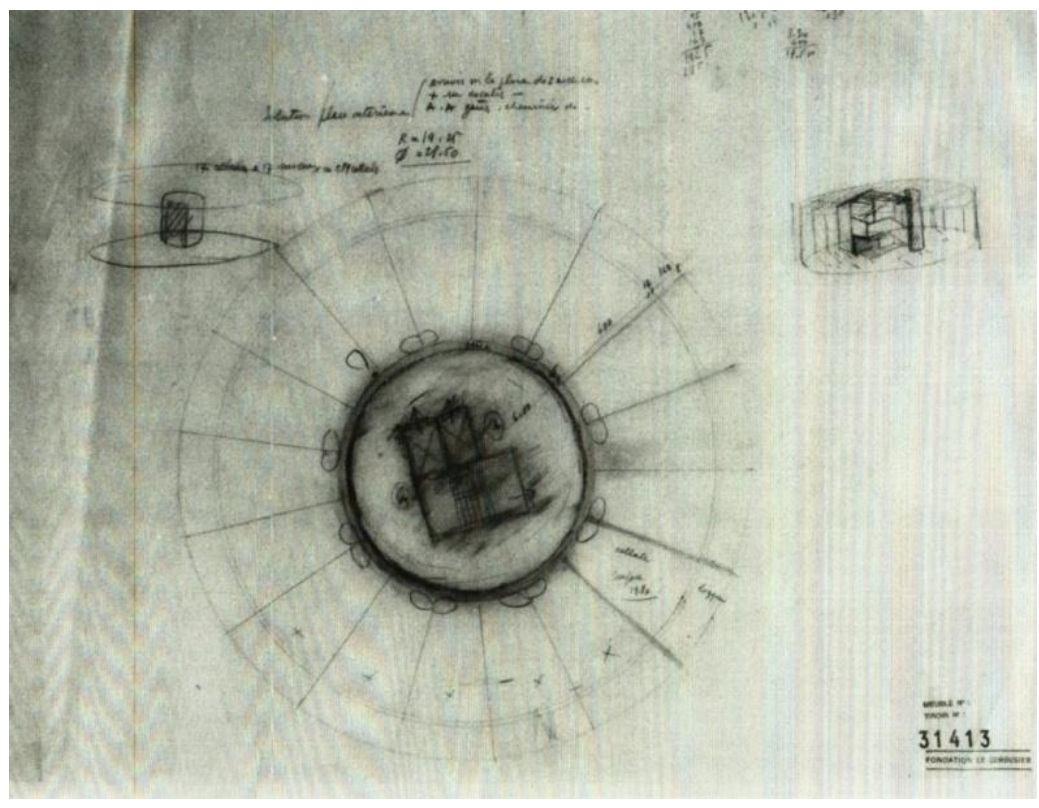

2. LC. "Esquisse pour l'étude d'un immeuble tour cylindrique", 1938. @ FLC-ADAGP.

Los tubos cilíndricos aparecieron definidos en planta y volumen como esquemas gráficos ilustrando los textos sobre el pensamiento urbano posterior a la Ville Radieuse, que explica la idea de ciudad que permanecerá hasta su muerte, un "urbanismo ambiguo y fragmentario, descrito en libros con retazos de los anteriores, que a veces parecen versiones de un mismo original"7. Estas concentraciones verticales, solo en escaso número circulares, defendían con igual ímpetu las ventajas de la concentración y elevación de la vivienda frente a la colonización extensiva de la casita unifamiliar con jardín sobre el territorio, y como ellas están destinadas a liberar suelo para el esparcimiento, son en todo una alternativa formal a las Unités para una sociedad de individuos específica.

En el volumen 14 de la publicación The Le Corbusier Archive, que recoge su obra entre 1937 y 1942, aparece con fecha de 1938 el croquis de un proyecto para una torre cilíndrica que anticipa la distribución interna de los apartamentos dentro de un perímetro circular, descrito como "esquisse pour l'étude d'un immeuble tour cylindrique, vue en plan d'un etage, croquis en perspective d'element interieurs" ${ }^{8}$ (fig. 2). Junto con la planta se representa una vista del interior de uno de los niveles de la torre, sin que se aprecien rampas o desniveles en el piso. La distribución hacia los segmentos en que se encuentra dividida la superficie horizontal, se realiza desde una corona interior, bordeando un núcleo de comunicaciones central. Con la misma fecha aparecen otros croquis

\footnotetext{
${ }^{7}$ González Cubero, Josefina: Le Corbusier. El proyecto de la ciudad moderna. Valladolid: 1996, p. 373. Los textos de esta última etapa se distribuyen entre los libros El urbanismo de los tres establecimientos humanos, Cómo concebir el urbanismo y A propósito del urbanismo.

${ }^{8}$ Le Corbusier: Buildings and Projects, 1937-1942 (The Le Corbusier archive; 14). New York: Garland Publishing; Paris: Fundation Le Corbusier, 1983, p. 524.
} 
que corresponden al plan de un garaje en espiral que forma parte de las dotaciones para un complejo deportivo de montaña en Vars ${ }^{9}$, en los Alpes franceses, situado en las inmediaciones del hotel al final de la carretera de acceso; en el garaje sí se contempla la espiral como forma de recorrido para la disposición de vehículos en un contendor cilíndrico. Una combinación entre ambos esquemas será el dispositivo que organiza los hameaux verticaux, una rampa helicoidal que va repartiendo apartamentos mínimos sobre la corona exterior de un cilindro.

\section{Las torres italianas}

Le Corbusier tiene la oportunidad de practicar la sensación de la conducción y la velocidad en la cubierta de pruebas del edificio Lingotto, que visita en $1925^{10}$, y probablemente recuerda el recorrido del automóvil a través de la rampa que conduce a la pista superior. En un viaje posterior a Turín en 1934, invitado a dar una conferencia en algunas ciudades italianas, ilustra la disertación con unas tablas acompañadas con bocetos de la fábrica de coches y un volumen circular al que se refiere como la "tour Agnelli près Livorno" ${ }^{11}$. Esta torre circular, conocida como la Torre Fiat o Torre Balilla ${ }^{12}$, había sido financiada por el senador y empresario Giovanni Agnelli y construida en 1933 en uno de los emplazamientos de la costa tirrena, en Marina de Massa, como albergue vacacional para los hijos de los trabajadores de la empresa. El ingeniero autor de la obra es Vittorio Bonadé Bottino, colaborador con Giacomo Mattè Trucco en los cálculos y diseño de la fábrica Fiat-Lingotto. La torre-albergue en la costa era quizás la más conocida y, junto con otras tres, forman un conjunto curioso en la tipología de las colonias infantiles promovidas en Italia durante el régimen fascista y construidas bajo proyectos y dirección del ingeniero Bottino. El sistema constructivo y estructural que utilizan, al sustituir los forjados interiores por una rampa helicoidal, es una estructura de la que le Corbusier tomará buena nota.

De todas ellas, la primera en construirse es el Albergo La Torre situada en una localidad montañosa de los Alpes italianos: Sestrières. El complejo turístico que es hoy la ciudad alpina, surgió por iniciativa de Giovanni Agnelli en los años 30. A la par que se le dota de instalaciones deportivas de esquí, se construye esta residencia para esquiadores, una alternativa económica al lujoso Gran Hotel Príncipe de Piamonte que ya existía en las inmediaciones. El conjunto se resuelve con una torre cilíndrica de $38 \mathrm{~m}$ de altura y $18 \mathrm{~m}$ de diámetro, donde se disponen las habitaciones y un cuerpo bajo anexo que acoge distintos servicios y dependencias comunes para completar el programa. Para la elección de una torre el autor aduce desde razones constructivas, como minorar la excavación en terrenos rocosos, hasta económicas, reduciendo los costes de la construcción con la concentración de las instalaciones necesarias ${ }^{13}$. Las habitaciones son camarotes de apenas $7 \mathrm{~m}^{2}$, austeros dormitorios individuales distribuidos a lo largo de un único pasillo inclinado y enroscado en torno a un hueco central. La rampa helicoidal, que parte desde el primer piso para llegar a la parte superior del edificio, es una propuesta

\footnotetext{
${ }^{9}$ Le Corbusier: Buildings and Projects, 1937-1942 (The Le Corbusier archive; 14). New York: Garland Publishing; Paris: Fundation Le Corbusier, 1983, p. 523.

10 Le Corbusier visita por primera vez la Fiat-Lingotto en 1925. Como afirma Ramos Carranza, Le Corbusier dejó abierta la posibilidad de reconocer a estos edificios una crucial aportación a la organización de una nueva ciudad Ramos Carranza, Amadeo: Dibujos y Arquitectura: La Fiat-Lingotto (1916-1927). Sevilla: 2005, p. 375.

${ }^{11}$ Archivio Bottoni: Le Corbusier: Urbanismo, Milano 1934. Milano: Gabriele Mazzotta, 1983, p. 43.

12 "Balilla" es como se conoce a Giovanni Battista Perasso, un muchacho, que según la tradición, animó al alzamiento contra las tropas austríacas durante el Resorgimento. Después sirvió para referirse a cualquier adolescente que perteneciese a las organizaciones juveniles del régimen fascista italiano. También fue el término popular utilizado para definir el vehículo utilitario familiar de los años 30 en Italia.

13 “Albergo turístico la Torre di Sestrières”. En L'Architettura Italiana, XXVIII, 1933, III, p. 45.
} 
sugerida por el senador ${ }^{14}$ que imprimió carácter al resto de las torres de Bottino. Dos anillos de carga concéntricos sujetan el mecanismo; el exterior dibuja el contorno del edificio y el interior delimita el vacio interno, al que asoman en vuelo las 10 espirales de que consta el pasillo que recorre todo el espacio vertical iluminado cenitalmente.

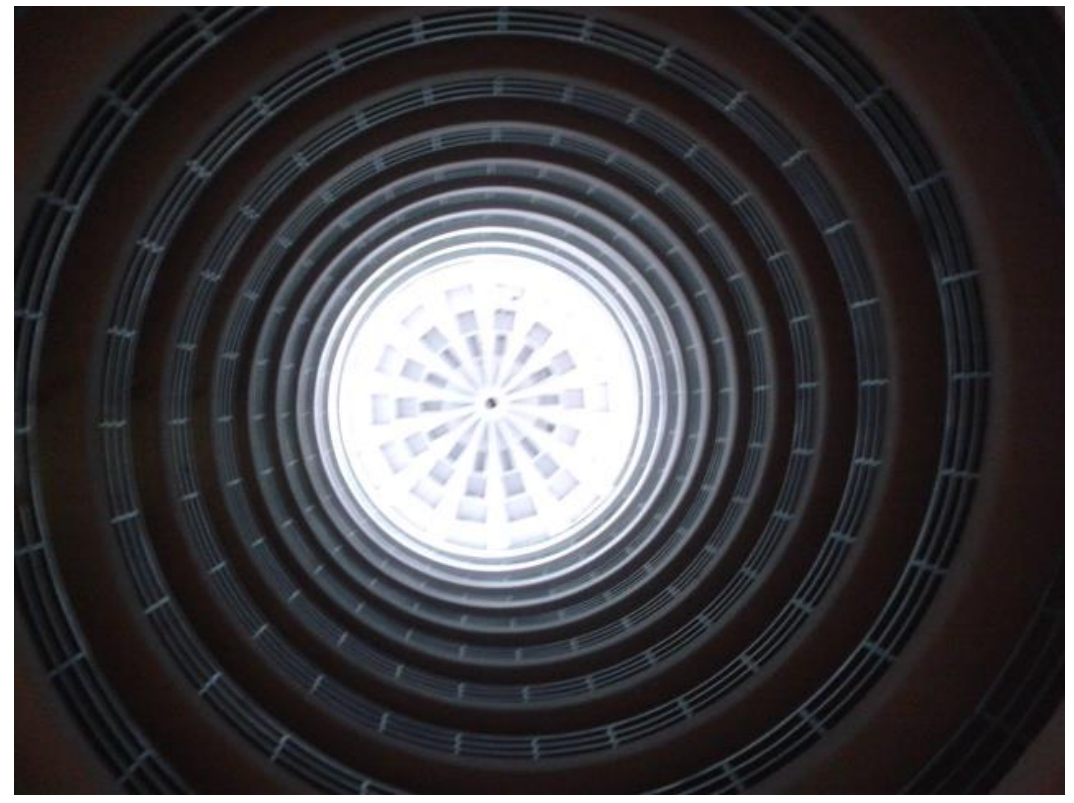

3. Torre Fiat, Marina di Massa, 1938. Interior. (C) Creative Commons.

Un año más tarde se construirá la segunda Torre Fiat, pero esta vez en la costa, en Marina de Massa ${ }^{15}$ una pequeña localidad cerca de Livorno, como expresó Le Corbusier en sus apuntes, sede veraniega de colonias infantiles y juveniles para los hijos de los empleados de la fábrica de automóviles de Turín. A pesar del distinto emplazamiento, se utiliza el mismo esquema para ubicar la zona de dormitorios en una torre cilíndrica, complementando el programa con otros anexos que se extienden en horizontal, a ambos lados de forma simétrica. Aquí el cilindro es de $25 \mathrm{~m}$ de diámetro y la altura crece hasta los $52 \mathrm{~m}$, con una capacidad para 780 camas. La originalidad del planteamiento radica en el desarrollo de los dormitorios a lo largo de una cinta helicoidal corrida de $8 \mathrm{~m}$ de anchura y $420 \mathrm{~m}$ de largo, la rampa gira alrededor de un espacio central protegido por una barandilla que lo recorre de arriba a abajo en una espiral continua (fig. 3). El espacio utilizable fluye sin interrupciones, manteniéndose la inclinación de la pendiente en el interior de las habitaciones. Sin embargo, en la primera construcción en Sestrières, solo el pasillo distribuidor es una rampa ya que la partición vertical de habitaciones había permitido establecer un solado horizontal para cada habitación, regulado por las nervaduras radiales que sujetan la pendiente y que son coincidentes con las paredes divisorias entre habitáculos. En la Colonia de la Fiat en Marina de Massa, el corredor de acceso, separado de los dormitorios por una pared curva de aproximadamente un metro de altura, establece un único plano inclinado, unificando el espacio pero

\footnotetext{
${ }^{14}$ Vivaldi, Gaia: L'ex colonia Fiat Edoardo Agnelli' a Marina di Massa. Firenze: 2007, p. 79.

${ }^{15}$ Massa, antigua ciudad ducal con un pasado glorioso, había formado parte del primer gobierno de la Italia fascista y fue objeto de numerosas intervenciones urbanas por parte del régimen que, a través de la obra pública, trató de conquistar un territorio de valor estratégico.
} 
complicando los detalles constructivos en la adecuación del mobiliario ${ }^{16}$. La mayor amplitud de radio que su predecesora en los Alpes permite disminuir la pendiente y hacer más cómoda la estancia y el tránsito en el plano de apoyo, desde el que puede percibirse a la vez el ambiente de habitaciones y el vacío central del que todos participan ${ }^{17}$. En ambas construcciones este espacio se superpone sobre otros destinados a ámbitos de recreo, administración y distintos servicios, situados en niveles inferiores y ocupando todo el área circular de la planta. El tambor exterior se ve estriado por pilastras semicilíndricas en toda la altura y distribuidas uniformemente, expresión estilística que se repite en el resto de los anexos que forman el conjunto (fig. 4). La tercera torre, el Albergo Duchi D'Aosta, construida de nuevo en Sestrières y muy cerca de la primera, reutilizará también este mecanismo. Se repite así el diámetro de $25 \mathrm{~m}$ y se vuelve a distribuir el espacio interior en habitaciones independientes, esta vez separadas, que combinan alternativamente dormitorios para una o dos personas con aseos incorporados, también repartidos radialmente sobre la corona exterior. El juego distributivo es más heterogéneo y la planta pierde interés, aunque conserva la estructura del pozo central recorrido por la hélice del pasillo.

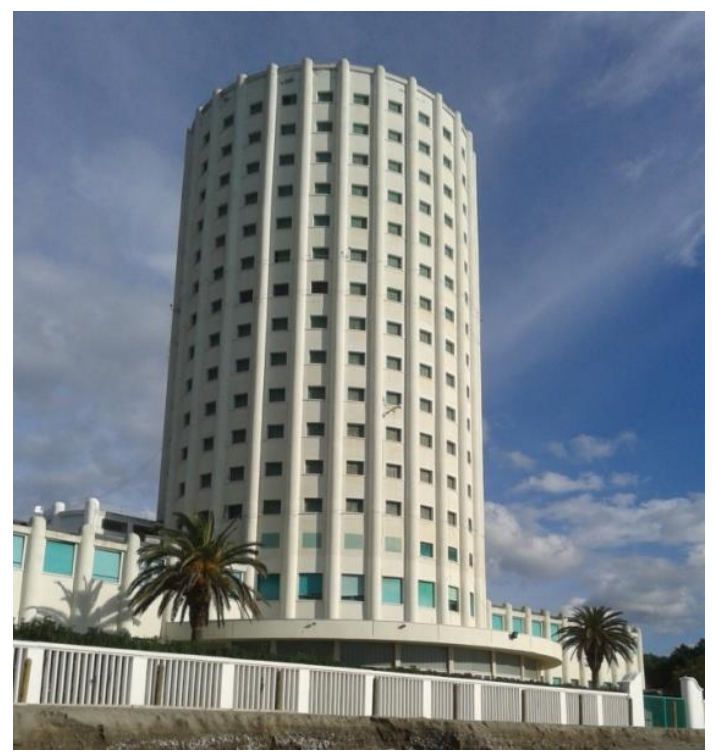

4. Torre Fiat, Marina di Massa, 1938. Exterior. (C) Creative Commons.

En 1937 se inauguró otra colonia juvenil sobre un entorno montañoso, en Sauze d'Oulx, llamada Tina Nasi Agnelli ${ }^{18}$, un edificio de menor desarrollo vertical que las otras torres, de $35 \mathrm{~m}$ de altura y $30 \mathrm{~m}$ de diámetro, que constituye la última realización de este tipo. El organigrama interno es similar a la Torre Fiat en Marina de Massa, aunque el dormitorio corrido y abierto es esta vez más amplio gracias a la anchura de $8 \mathrm{~m}$ de la helicoide, por tanto, el suelo está en pendiente y plantea los mismos problemas con los muebles. Sin embargo, el aspecto exterior nos recuerda el Albergo La Torre de Sestrières. Como en ella, un lienzo continuo y liso de ladrillo visto

\footnotetext{
${ }^{16}$ Las camas pareadas tuvieron que recortar las patas al igual que las sillas para acomodarse a la inclinación de la rampa lo que impidió que el mobiliario pudiera utilizarse en otro inmueble. De Martino, Stefano: "Arquitectura contemporánea en las colonias infantiles italianas". En ARQ 56, 2004, p. 66.

17 "Colonia di Marina di Massa della F.I.A.T." En L'Architettura Italiana, XXVIII, XII, pp. 253-54. La normativa establecida por la Dirección General de Salud para guarderías, internados y colonias determinaba una ratio de volumen de 25 $\mathrm{cm}^{3}$ por cama; en el edificio de Marina de Massa se obtenía esa capacidad al incorporar el espacio del vacío central al ambiente de las camas como el propio autor explica.

${ }^{18}$ Es el nombre de la segunda hija del senador Agnelli.
} 
delimita el contorno, perforado únicamente por ventanas cuadradas desprovistas de elementos decorativos, similares en todo a las del albergue de la costa tirrena.

Esta torre es la que intentara representar Le Corbusier en sus apuntes de camino a Roma, la más conocida y divulgada de todas. Los bocetos sobre los carnets reflejan el punteo de los huecos de forma muy escueta, ni rastro de las líneas verticales y, sin embargo, algunos trazos discontinuos, ¿horizontales?, traducen el tránsito interior en un gesto gráfico que en sus posteriores bosquejos de torres cilíndricas estará siempre presente. El desarrollo de las rampas en torno a un eje vertical derivó en un potente espacio interior característico de las torres de Bottino y fue explotado en las colonias promovidas por la Fiat a través de la traslación del movimiento propio del automóvil al entorno infantil: "Las torres aparecen como formas puras aparentemente destacadas del paisaje pero absorbiéndolo desde dentro, en un movimiento circular.[...]. Lejos de establecer simplemente una analogía mecánica, el edificio compromete a los niños en una divertida complicidad"19.

En las torres de Marina de Massa y Sauze d'Oulx un único espacio continuo descansa sobre la inclinación del plano del suelo y consigue el recorrido ininterrumpido entre las habitaciones, al margen del tradicional paso entre niveles con escaleras a las que parece sustituir. La expectativa de recreo se suma al paseo arquitectónico como alternativa a las escaleras y anima al constante cambio de posiciones del espectador que percibe la estructura del edificio desde múltiples puntos de vista. Las perspectivas son siempre inesperadas y sorprendentes y el movimiento ayuda a una comprensión más acertada de la edificación. En estos edificios tubulares adquieren un protagonismo central siendo la idea constructiva de la estructura, de la habitación y de la forma exterior ${ }^{20}$.

La rampa se incorporó a la disposición formal de las colonias de vacaciones y se identificaron con ella en esa imagen atractiva del espacio curvo e inclinado a la vez. Se erige en un instrumento capaz de servir a un programa completo y va mucho más allá de la simple traducción del tránsito de los automóviles sobre un plano en pendiente. Las torres tomaron la representación de un estilo de vida del que daban testimonio los anuncios de automóviles FIAT en los años 30, una estrategia de promoción en general que influyó directamente en la estética de la arquitectura y, por supuesto, en el maestro suizo. En esos momentos el coche representa la vida urbana y moderna y, por ende, al usuario, un hombre audaz y aventurero que identifica esos conceptos con el producto; esta es parte de la estrategia de seducción para atraer a los potenciales compradores a los que se les vende dosis de deportividad y modernidad a partes iguales. Las colonias de vacaciones se construyeron como torres con una rampa interior helicoidal, de modo que este gesto se convirtió en una especie de sello arquitectónico ${ }^{21}$. La Torre Fiat supuso un orgullo comparable a la fama de la fábrica Lingotto y como tal fue exhibida a los visitantes como una especie de marca patrimonial arquitectónica, entre ellos a Le Corbusier, cuando visita Italia en los años 30. Él mantuvo en la retina ese espacio-dormitorio continuo, identificado con el espacio rampa de tránsito, para después de casi dos décadas reinterpretarlo en un prototipo residencial aparentemente genuino.

\footnotetext{
${ }^{19}$ De Martino, Stefano: "Arquitectura contemporánea en las colonias infantiles italianas". En ARQ 56, 2004 p. 65.

${ }^{20}$ Torkler, Katharina: Ferienkolonien von Industrieunternehmen zur Zeit des Faschismus in Italien. Berlin, 2001, p. 77.

${ }^{21}$ Torkler, Katharina: Ferienkolonien von Industrieunternehmen zur Zeit des Faschismus in Italien. Berlin, 2001, p. 78.
} 


\section{La maison sans escalier}

La rampa, como alternativa a las escaleras es el argumento de otro curioso proyecto también de los años 30, esta vez en territorio francés. La así llamada "maison sans escaliers"22 (fig. 5) se ubica en el centro de Saint-Étienne y es obra del arquitecto Auguste Bossu, que ejerce su profesión con exclusividad en esa villa francesa del departamento del Loira. El conjunto alberga 36 apartamentos, repartidos en 6 niveles a partir de una rampa curvada en torno a un patio interior.

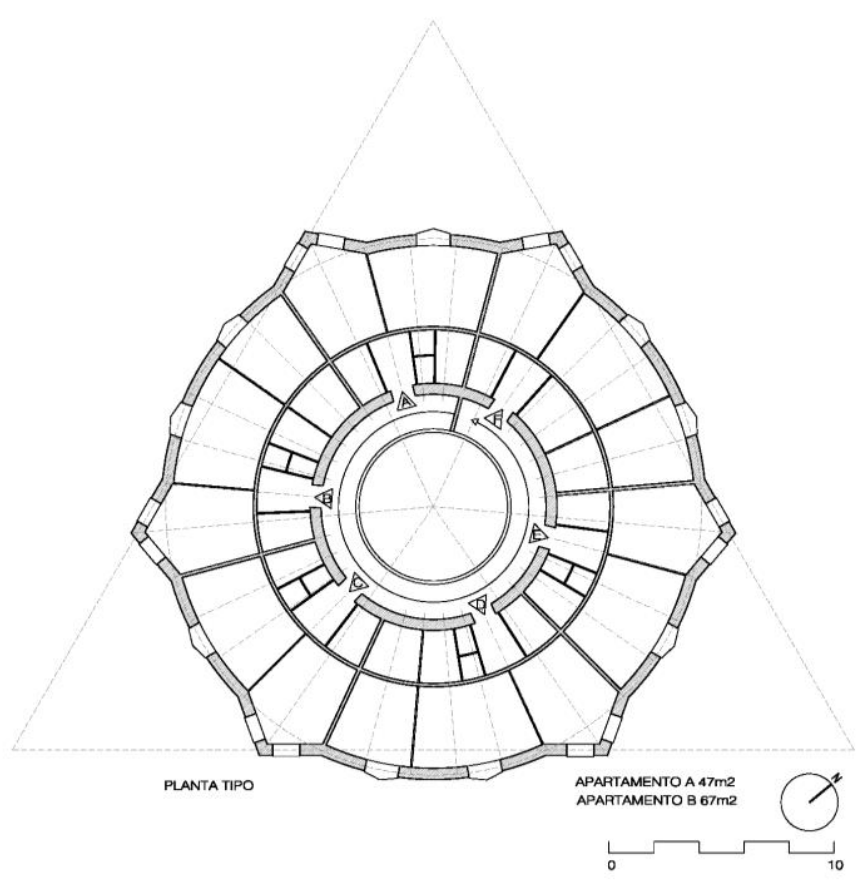

5. Auguste Bossu. Maison sans escalier. Planta. (Dibujo Y. Martínez Domingo)

El pozo comunitario es muy parecido al interior de las torres de Bonadé Bottino, en especial a las torres-hotel de Sestrières de las que es prácticamente coetánea ${ }^{23}$. El vacío es un espacio vertical que se puede contemplar desde la rampa que lo recorre de arriba abajo, mientras sirve de única pieza distributiva de las viviendas que forman el conjunto. El diámetro del tambor exterior es muy semejante a la Torre Fiat en Marina de Massa y la Torre Duchi D’Aosta, aproximadamente $26 \mathrm{~m}$, aunque el diámetro del vacío central es menor. Al igual que ellas, tras la pared interior que delimita este espacio vacío la corona exterior se fragmenta en gajos, que asociados configuran unidades de vivienda de dos tamaños alternos. La diferencia entre ellas, de apenas $20 \mathrm{~m}^{2}$, radica en el número de piezas que vierten hacia fuera: dos o tres estancias. Dos muros de carga concéntricos delimitan la anchura de 7 $\mathrm{m}$, donde se distinguen dos anillos, uno interior con aseos, cocinas y alcobas, y otro exterior de $4 \mathrm{~m}$ de profundidad, donde se ubican las habitaciones exteriores. La corona interior se prolonga hacia la cubierta y sirve de soporte de una tendida cúpula de hormigón con perforaciones que ilumina el vacío interno, mientras que la

\footnotetext{
${ }^{22}$ También conocido como Challet Bizillón, nombre de un antiguo cabaret que se encontraba en el solar donde se edificó la actual vivienda. Bonilla, M.; Vallat, D.: Les Immeubles d'Appartements Modernes: Saint-Etienne, 1923-1939. Saint-Etienne: Ecole d'architecture: Centre d'études foréziennes, 1987, p. 42.

${ }^{23}$ La maison sans escalier se edifica en 1933 aunque los bocetos son de 1932; el Albergo La Torre se ejecuta en Sestrières, también en ese año.
} 
corona exterior altera el contorno cilíndrico por 6 salientes en punta que amplían ligeramente los espacios interiores con los que coinciden. Estas protuberancias contribuyen, junto con la composición vertical de los huecos, a enmascarar la estructura interna del inmueble, es decir, el escalonamiento de los forjados de cada vivienda que están a diferentes niveles al depender del acceso a través de la rampa. La volumetría exterior no traduce el dibujo regular del patio comunitario interior, un diseño geométricamente perfecto determinado por la helicoide de esta pequeña copropiedad en la que el único elemento compartido es el espacio de reparto.

\section{El cilindro como prototipo residencial}

Fuera ésta o las torres italianas de Bonadé Bottino los precedentes del modelo de Le Corbusier, éste recuperó el contenedor tubular exento y condicionado por la estructura de reparto interior de una rampa como organigrama alternativo al bloque residencial laminar. Es una opción formal, del mismo modo que el baptisterio y el campanille componen un fabuloso conjunto frente al camposanto y la catedral en la Piazza dei Miracoli de Pisa. El cilindro exento es la forma elegida como contrapunto al bloque recto, compartiendo como él la altura de desarrollo de $50 \mathrm{~m}$ y conteniendo una densidad de habitantes inferior, dada su capacidad.

La imagen de los potentes silos de grano, ejemplos admirados y referencias de una arquitectura nueva, no se habían concebido para albergar la residencia, pues ésta había tenido en los prismas rectos su forma recurrente, solo una imagen había precedido el comportamiento central y centrífugo de las torres cilindro, sus bocetos para las Villes tours de $1910^{24}$, que luego se abandonarían por los esquemas en cruz. En este caso no puede hablarse de estructura radial, pero sí de concentración al existir un núcleo poligonal en torno al que se reúnen periféricamente unidades hexagonales. En los bocetos empleados en Vers une architecture para describir las formas elementales, el cilindro es el primer objeto representado; también en sus composiciones fotográficas para animar las ideas defendidas en la revista de L'Esprit nouveaux había empleado con frecuencia esta figura, incluso revestida de distintas texturas sobre el lienzo externo. A diferencia de las otras formas elementales, los cilindros no los había manejado en "esa arquitectura de complejos conjuntos de funciones enfundadas en membranas platónicas ${ }^{, 25}$.

Igual que la Unité lineal había surgido como agrupamiento de un modelo de viviendas en duplex con espacio de doble altura, el cilindro utilizará como célula germen otra unidad de tamaño menor y de un solo nivel, que reunida en torno al centro de la figura cilíndrica formará una unidad de habitación de tamaño igualmente eficaz como su alter ego. Esta unidad social, en este caso el hogar llevado al límite mínimo, donde la familia encuentra abrigo, es el núcleo originario de la planificación urbana, como afirma Gerosa: "Le noyau initial de l'urbanisme est une cellule d'habitation (un logis) et son insertion dans un groupe formant une unité d'habitation de grandeur efficace ${ }^{\prime 26}$. Apartamentos diminutos con el espacio imprescindible para alojar a un solo individuo o pareja que incluyen un diminuto aseo y una cama, como si de una habitación de hotel se tratase. Son el resultado de la decimoctava partición de la superficie del anillo de planta con algo más de $20 \mathrm{~m}^{2}$ y superan con creces la unidad biológica celular de $14 \mathrm{~m}^{2}$ que había estimado por habitante en los años 30 . Además, del mismo modo que en la Ville Radieuse se ha previsto la posibilidad de ampliar la unidad familiar, aquí cuando se trata de una pareja simplemente se añade otro sector de circunferencia.

\footnotetext{
${ }^{24}$ Le Corbusier: Carnets 1, 1914-1948. Paris-New York: The architectural History Fondation y Herscher/Dessainet Tolra, 1981, p. 89.

${ }^{25}$ Colquhoun, Alan: La arquitectura Moderna. Una historia desapasionada. Barcelona: Gustavo Gili, 2005, p. 146.

${ }^{26}$ Gerosa, Pier Giorgio: Le Corbusier: Urbanisme et Mobilité. Basel: Birkhäuser, 1978, p. 189.
} 


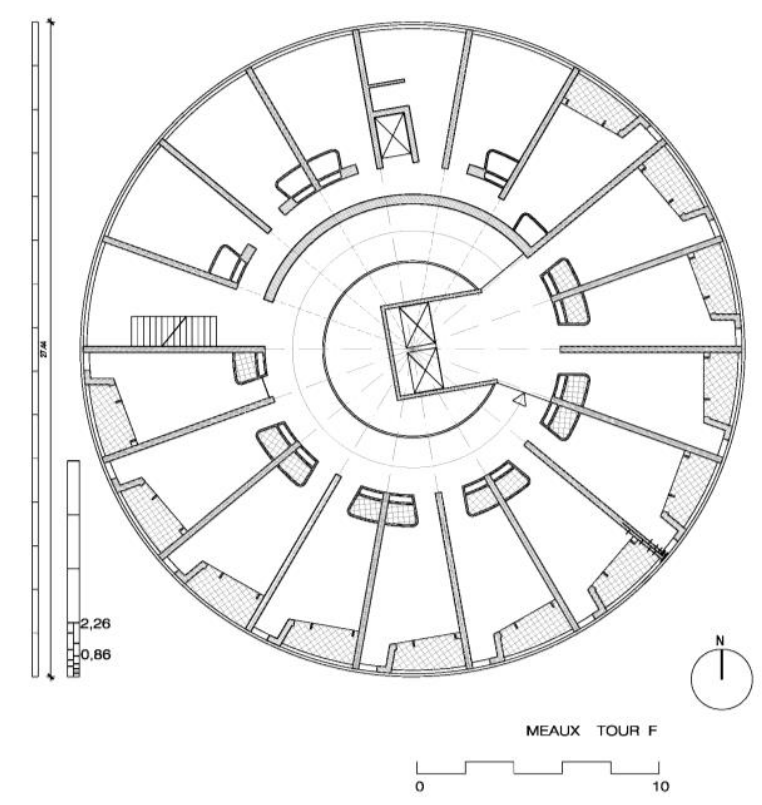

6. LC. Tour F, Meaux. Planta. (Dibujo Y. Martínez Domingo)

El germen de la agrupación es pues este gajo que, al igual que en sus predecesoras, se va adosando lateralmente manteniendo un único frente iluminado, el opuesto al acceso. En ese punto se colocan los minúsculos recintos destinados al aseo, encerrados tras muros curvos, y una pequeña cocina incorporada al único ambiente de que dispone el habitáculo. Según las variaciones existe la posibilidad de disponer de una terraza al exterior que queda incorporada dentro del volumen del edificio, como en las Unités de directriz recta, o bien sin ella completando la superficie en planta al hacer coincidir el frente de la habitación con la envolvente del volumen. La profundidad de la crujía utilizada para la vivienda es muy parecida a la "maison sans escalier", 7,5 m aproximadamente, aunque llega a los $27 \mathrm{~m}$ de diámetro, ligeramente superior a aquella. Lo que sí cambia es el sistema estructural de soporte de los forjados, que también se escalonan. En este caso los muros de carga son radiales, dejando libre de compromisos de soporte a las coronas concéntricas, tanto exterior como interior. Una cámara de servicio separa los habitáculos de la rampa de distribución y la fachada que, al no asumir cargas, puede abrirse en terrazas o simplemente componerse con más libertad entre las líneas verticales de los muros que asoman hacia el exterior (fig. 6).

El alzado se fragmenta a partir de estas líneas verticales, punto de quiebro de la dislocación de los alzados, haciendo patente el escalonamiento entre unidades. El vacio central se ve ocupado por un núcleo de ascensores que se prolonga en cubierta por encima de los 20 niveles de altura, al igual que la cubierta de la circunferencia interior convertida en terraza transitable y con menos expectativas de uso que las cubiertas jardín de las Unités rectas. Una diferencia con respecto al prototipo horizontal, soportado por potentes pilares independientes de la estructura vertical del inmueble, es el contacto con el terreno, el cilindro interior se hunde en el subsuelo y toda la corona circundante descansa sobre la horizontal, el volumen completo llega a la cota 0 , no se despega de ella dejando que el suelo la atraviese. Otra cuestión a tener en cuenta es la orientación de las viviendas dentro de un 
sistema geométrico que no permite discriminar posiciones indeseables. Como ha señalado Xavier Monteys ${ }^{27}$, el cuadrante norte, casi un tercio del conjunto, se utiliza para disponer otros usos administrados, como por ejemplo hotel; son piezas menores que dependen de una circulación interna, paralela a la rampa, y que disponen tanto de un elevador mecánico propio como de un acceso independiente, sin que por ello estén separadas del resto de los habitáculos con los que comparten el núcleo de escaleras, situado en una de las particiones. Se habría resuelto así el incómodo destino de la fachada norte, por otra parte difícil de identificar en el continuo curvo de la piel exterior. El cilindro, como tipo formal contenedor de viviendas, mantiene estas características geométricas y de capacidad en todas las propuestas urbanas donde se utiliza, sin embargo, dentro de la Oeuvre complète, no se hace alusión a la torre cilíndrica residencial cuando se refiere a la Unité d'habitation de grandeur conforme. El bloque laminar recto se configura como un modelo que al adaptarse a las ciudades donde se propone y construye varía ciertos aspectos concretos (profundidad de crujía, anclaje al suelo, servicios internos) mientras que el prototipo circular, al mantenerse inédito, parece no alterar sus aspectos visuales, limitándose Le Corbusier a especular la cantidad y posición respecto de sus compañeras de viaje ${ }^{28}$.

\section{Las propuestas urbanas}

La primera propuesta urbana donde aparecen las torres cilíndricas residenciales es en el desarrollo urbano de Marsella Sur, encargo que llega después de que la primera Unité de grandeur conforme esté en marcha. El plan incorpora un par de ellas al juego de los sólidos laminares que forman el conjunto, réplicas de la ya construida en cuanto a tamaño y orientación. El juego entre elementos parece responder a un equilibrio impuesto, una torre circular por cada dos bloques rectos, paralelos pero no alineados y en un punto intermedio no equidistante la torre. El conjunto formado por cuatro barras y dos cilindros se encuentra dentro de un sector bordeado de vías de circulación rápida, conforme a los principios enunciados por la Regla de las $7 \mathrm{~V}$, conjunto que se establece como modelo para futuras ampliaciones de la estructura urbana. La introducción del edificio tipo ha ayudado a remarcar el carácter cada vez menos jerárquico de este sistema de referencias ${ }^{29}$, son pequeñas aglomeraciones organizadas como una ciudad-jardín a la inglesa que no se ajusta a un entramado ortogonal por la propia variedad de edificios de viviendas que aparecen ${ }^{30}$.

En 1951 cuando Le Corbusier presenta su propuesta para el concurso de Estrasburgo, organizado por el Ministerio de la reconstrucción para una zona de 10 hectáreas, el paquete 2-1 formado por bloques y torre circular respectivamente vuelve a utilizarse (fig. 7). Dos Unitès d'habitation con 400 viviendas cada una se reparten el total de apartamentos previstos, mantienen paralelismo y distancia semejantes a las de Marseille Sud y entre ellas se vuelve a situar una torre circular que completa el programa habitacional con 100 apartamentos más ${ }^{31}$ que sobrepasan la capacidad prevista por las bases de la convocatoria. La composición entre los sólidos habitados y el paisaje circundante, donde pueden ubicarse las prolongaciones de la residencia, recuerda a un fragmento de la propuesta para Marsella Sur.

\footnotetext{
${ }^{27}$ Monteys, Xavier: La gran máquina La ciudad en Le Corbusier. Barcelona: Colegio Oficial de Arquitectos de Cataluña, Demarcación de Barcelona, 1996, p. 140.

${ }^{28}$ Es con respecto a la Urbanización de Meaux sobre la que se ha realizado el análisis de las características constructivas y formales del modelo residencial cilíndrico estudiado.

${ }^{29}$ Gerosa, Pier Giorgio: Le Corbusier: Urbanisme et Mobilité. Basel: Birkhäuser, 1978, pp. 123-124.

${ }^{30}$ González Cubero, Josefina: Le Corbusier. El proyecto de la ciudad moderna, Valladolid, 1996, p. 394.

${ }^{31}$ LC: Oeuvre complète 5, 1946-52. Zurich: Les Editions d'Architecture, 1970, pp. 109-111.
} 


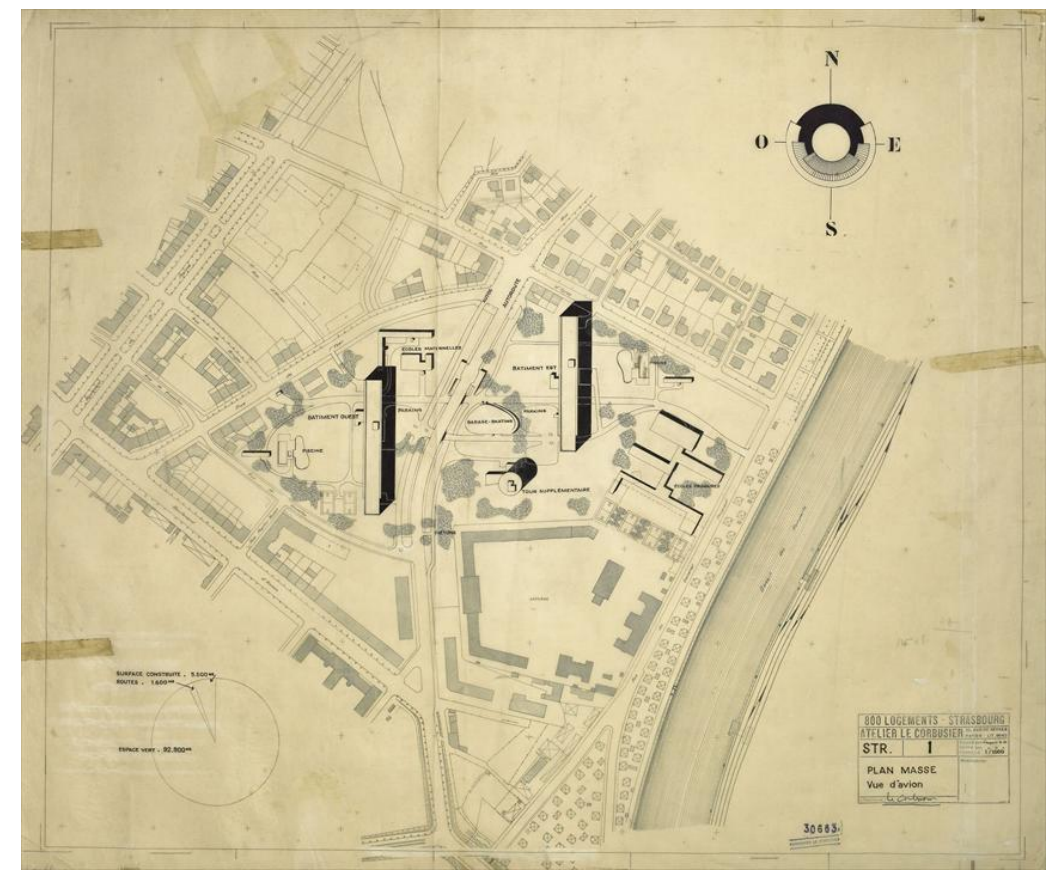

7. LC. Quartier Rotterdam, Estrasburgo, 1951. @ FLC-ADAGP.

Entre 1955 y 1960 se planifica y desarrolla el proyecto para Meaux, tiempo suficiente para la producción de abundante documentación, que permite un estudio profundo del tipo torre, aunque finalmente no se lleve a cabo. Sobre los terrenos sugeridos por el municipio, entre 25 y 30 hectáreas, se propone una distribución de contenedores habitacionales alternando los bloques rectos, paralelos entre sí, con los tubos cilíndrico , siempre en menor número para estos últimos y sin establecer una relación proporcional fija. Los elementos aparecen como resultado de una combinación fortuita, dispuestos en una dispersión deliberadamente no simétrica, en la que la torre es un elemento más del juego casual de la posición de sólidos, como los bloques rectos y los otros edificios. La perpendicularidad de sus posiciones norte-sur contrasta con el cruce irregular de las vías de circulación rodada y los caminos curvos peatonales, dos mallas que se cruzan sin determinar la situación de la edificación. La calle y el edificio han roto por completo su ligazón y la torre circular es un ejemplo de esa autonomía geométrica y posicional. El trabajo para Meaux implicó también una investigación a fondo sobre la prefabricación de algunos de los componentes que en Marsella se ejecutaron in situ y que ahora le Corbusier plantea reconvertir en ensamblajes "en seco" para facilitar el proceso constructivo y aligerar tiempos y coste, algo que implica no solo a los bloques rectos sino a las torres tubulares. A pesar de los esfuerzos por la estandarización y la reelaboración del tipo, tampoco en esta ocasión el proyecto llegó a ejecutarse.

La misma suerte corre la propuesta del Concurso para la reconstrucción de Berlín, organizado por el Senado de la Ciudad de Berlín Occidental con el apoyo del gobierno central de la Alemania Federal, al que Le Corbusier fue "especialmente invitado" 32 a participar junto con otros cinco grupos de arquitectos. Derrotado una vez más, el proyecto fue publicado en el volumen 7 de sus Obras Completas de una manera muy lacónica. No hay detalles, no hay identificación de los diferentes edificios, tan solo unos dibujos recogidos en apenas ocho páginas $^{33}$. En esta ocasión, y dada la dimensión de la zona a reconstruir, Le Corbusier plantea aquí una autentica ciudad verde tipo Ville Radieuse regida por el organigrama de la Regla de las 7V, acomodada a la antigua trama

\footnotetext{
32 Teneiro, Oscar: "The Berlin Comedy. Le Corbusier and the 1958 Competition for the Reconstruction of Central Berlin". En Massilia 2006, p. 76.

${ }^{33}$ LC: Oeuvre complète 7, 1957-65. Zurich: Les Editions d'Architecture, 1970, pp. 230-237.
} 
urbana de la capital alemana y sirviendo de excusa para incorporar todo el bagaje construido y proyectado durante su larga carrera. (fig. 8)

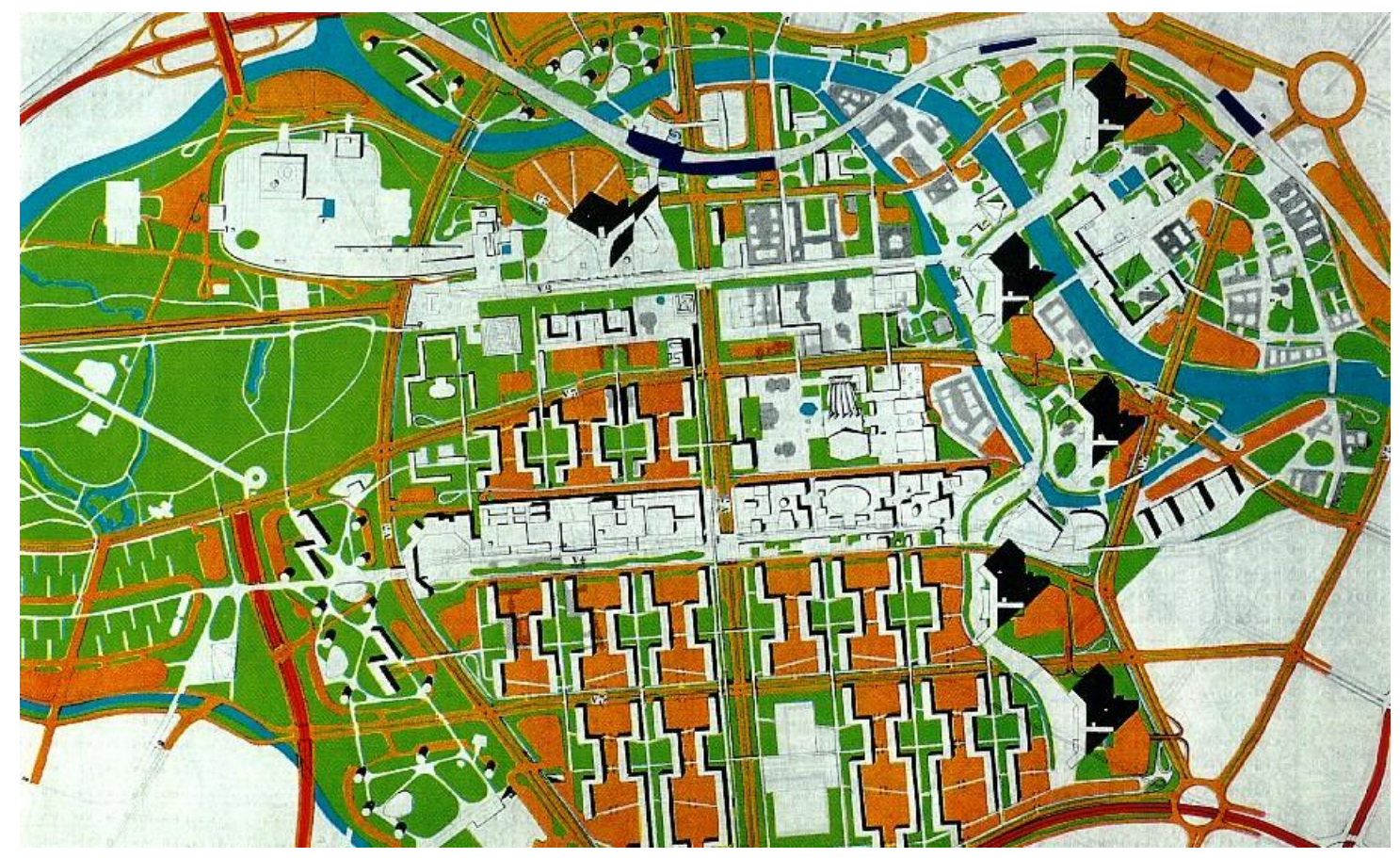

\section{LC. Propuesta para Berlín, 1957. @ FLC-ADAGP}

Junto con la colección de edificios singulares que aparecen en el proyecto para Berlín se reincorporan al catálogo de edificaciones todos los tipos de construcciones en altura que había desarrollado: sus rascacielos de oficinas y administrativos, para la zona residencial ubicada en el área sur, y se rescata el bloque a redent, con una jerarquía un tanto rígida y sin rastro de Unités d'habitation de grandeur conforme. Fuera casi de los límites de la intervención, al suroeste y en el norte, por encima del Spree, aparecen las torres tubulares en número variado y al tresbolillo, compartiendo el espacio ajardinado que discurre a sus pies con edificios en zigzag de ocho pisos de altura. Los hameaux verticaux, nunca ejecutados, no se resisten a desaparecer entre los papeles olvidados de los encargos infructuosos; hasta una veintena de ellos pueden contarse, siendo el prototipo elegido destinado para dos zonas aparentemente sin conexión. La altura y proporción del contenedor cilíndrico, estudiado en los anteriores proyectos urbanos, se mantiene. Desaparecida la Unité como tejido residencial, interventor de una capacidad eficaz, las torres cilíndricas, surgidas como una segunda variante de ellas, se resisten a desaparecer y vuelven a mostrarse como piezas clave en "la vitalidad plástica de la composición (...) justificando las variaciones morfológicas por el hecho de tratarse de torres de apartamentos para una población nómada especifica de solteros y parejas sin hijos ${ }^{\prime \prime 34}$.

Como advierte Gerosa ${ }^{35}$, el planteamiento para Berlín es un resumen de las teorías de sus proyectos urbanos precedentes, donde la ruptura del binomio casa-calle da pie a la proyección de nuevos edificios-tipo que utilizan el plano de la ciudad como un mero marco teórico donde surgir. Esta versión alimentada por la Ville Radieuse recrea un ambiente favorable para la inserción de objetos libremente diseminados entre las superficies verdes, zonas de silencio propicias para la dignidad de la vida y privadas de los inconvenientes del tráfico, de su ruido,

\footnotetext{
${ }^{34}$ Frampton, Kenneth: Le Corbusier. Madrid: Akal, 2001, p. 124.

${ }^{35}$ Gerosa, Pier Giorgio: Le Corbusier: Urbanisme et Mobilité. Basel: Birkhäuser, 1978, p.135.
} 
de la peligrosa velocidad del transporte mecánico, donde las únicas vías de circulación aceptables son las peatonales que conducen al habitante por un serpenteante paseo, primero al aire libre y después al corazón de la edificación que le sirve de abrigo. Rutas de desplazamiento que en el interior de esta comuna vertical se transforman en un continuo recorrido arquitectónico curvo, determinando la composición de las partes y la organización del conjunto para cumplir con la máxima enunciada en Precisiones: "la arquitectura es circulación ${ }^{136}$ (fig. 9).

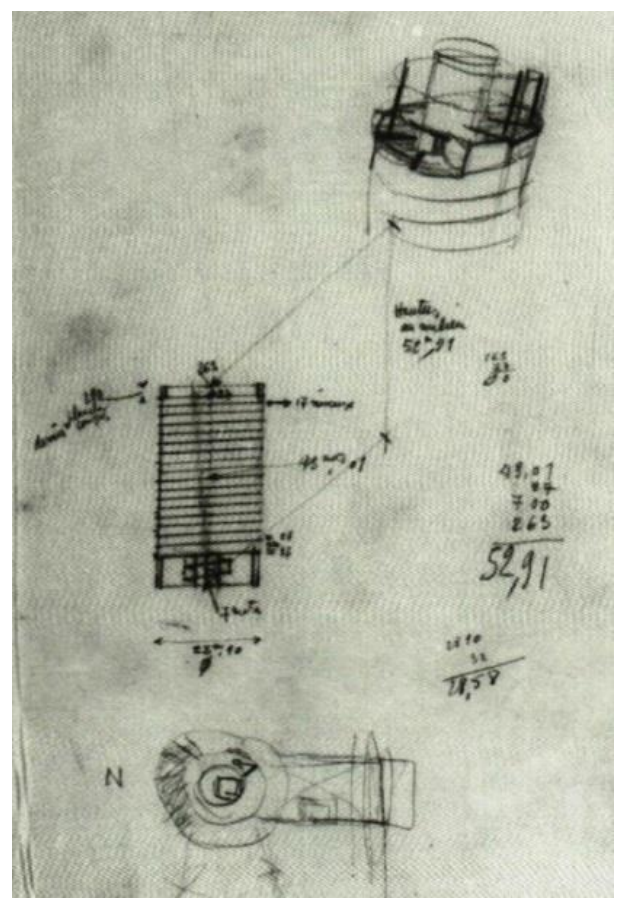

9. LC. Boceto de estudio para las torres cilíndricas de Meaux, 1958. CFLC-ADAGP

\section{Procedencia de las imágenes}

1. Le Corbusier: Oeuvre complète 5, 1946-52. Zurich: Les Editions d'Architecture, 1970, p. 92.

2. Le Corbusier: Buildings and Projects, 1937-1942. (The Le Corbusier archive; 14). New York: Garland Publishing; Paris: Fondation Le Corbusier, 1983, p. 524.

3. https://upload.wikimedia.org/wikipedia/commons/thumb/7/7f/Torre_Fiat_Massa7.jpg/90pxTorre_Fiat_Massa7.jpg.

4. http://upload.wikimedia.org/wikipedia/commons/e/e7/20131124_phoenix_agnelli.jpg.

5. Dibujo Y. Martínez Domingo

6. Dibujo Y. Martínez Domingo

7. http://www.fondationlecorbusier.fr/CorbuCache/900x720_2049_1786.jpg?r=0

8. Le Corbusier: Oeuvre complète 5, 1946-52. Zurich: Les Editions d'Architecture, 1970, p. 283.

9. Le Corbusier; Buildings and Projects, 1937-1942. (The Le Corbusier archive; 14). New York: Garland Publishing; Paris: Fondation Le Corbusier, 1983, p. 283.

\footnotetext{
${ }^{36}$ Le Corbusier: Precisiones (1930). Barcelona: Apóstrofe, 1999, p. 64. Su preocupación por la circulación no se supedita a una determinada escala, está presente en todo tipo de edificios.
} 


\section{Bibliografía/referencias}

“Albergo turístico la torre di Sestrières”. En L’Architettura Italiana , Año XXVIII, Fascicolo III, Marzo 1933. Torino: Societé Italiana di Edizioni Artistiche, Crudo \& Lattuada, 1933, pp. 45-56.

Archivio Bottoni: Le Corbusier: Urbanismo, Milano 1934. Milano: Gabriele Mazzotta, 1983.

Bonilla, Mario; Vallat, Daniel: Les Immeubles d'Appartements Modernes: Saint-Etienne, 1923-1939. SaintEtienne: École d'Architecture: Centre d'études foréziennes, 1987.

“Colonia di Marina di Massa della F.I.A.T.”. En L'Architettura Italiana, Año XXVIII, Fascicolo XII, Diciembre 1933. Torino: Societé Italiana di Edizioni Artistiche, Crudo \& Lattuada, 1933, pp. 253-255.

Colquhoun, Alan: La arquitectura Moderna. Una historia desapasionada. Barcelona: Gustavo Gili, 2005.

De Martino, Stefano: "Arquitectura Contemporánea En Las Colonias Infantiles Italianas". En $A R Q$, NN $^{\circ} 5$. Santiago de Chile: Pontificia Universidad Católica de Chile, 2004, pp. 62-66.

Frampton, Kenneth: Le Corbusier. Madrid: Akal, 2000.

Gerosa, Pier Giorgio: Le Corbusier: Urbanisme et Mobilité. Basel: Birkhäuser, 1978.

González Cubero, M. Josefina: Le Corbusier: El Proyecto De La Ciudad Moderna. Director: Antón Capitel, Tesis doctoral, Universidad de Valladolid, Departamento de Teoría de la Arquitectura y Proyectos Arquitectónicos, 1996.

Le Corbusier: Oeuvre complete 4, 1938-46, Zurich: Les Editions d'Architecture, 1970.

Le Corbusier: Le Corbusier: Oeuvre complète 5, 1946-52. Zurich: Les Editions d'Architecture, 1970.

Le Corbusier: Le Corbusier: Oeuvre complète 6, 1952-57. Zurich: Les Editions d'Architecture, 1970.

Le Corbusier: Le Corbusier: Oeuvre complète 7, 1957-65. Zurich: Les Editions d'Architecture, 1970.

Le Corbusier: Precisiones (Précisions sur un état présent de l'architecture et de l'urbanisme, 1930). Barcelona: Apóstrofe, 1999.

Le Corbusier: El urbanismo de los Tres Establecimientos Humanos (Les Trois Établissements Humains, 1945). Barcelona: Poseidón, 1981.

Le Corbusier: Buildings and Projects, 1937-1942 (The Le Corbusier archive; 14). New York: Garland Publishing; Paris: Fondation Le Corbusier, 1983.

Le Corbusier: Carnets 1, 1914-1948. Paris-New York: The architectural History Fondation, Herscher/Dessainet Tolra, 1981.

Monteys, Xavier. La Gran Máquina: La Ciudad en Le Corbusier. Barcelona: Colegio Oficial de Arquitectos de Cataluña, Demarcación de Barcelona, 1996.

Ramos Carranza, Amadeo: Dibujos y Arquitectura: La Fiat-Lingotto (1916-1927). Directores: Manuel y Juan Luis Trillo de Leyva. Tesis doctoral. Universidad de Sevilla, Departamento de Proyectos Arquitectónicos, 2005.

Teneiro, Oscar: "The Berlin Comedy. Le Corbusier and the 1958 Competition for the Reconstruction of Central Berlin". En Massilia: Anuario De Estudios Lecorbusierianos, No 2006, 2006, pp. 70-133.

Torkler, Katharina: Ferienkolonien von Industrieunternehmen zur Zeit des Faschismus in Italien. Dissertation, Director: Harold Hammer-Schenk, FB Geschichts- und Kulturwissenschaften, Freie Universität, Berlin, 2001.

Vivaldi, Gaia: L'ex Colonia Fiat 'Edoardo Agnelli' a Marina di Massa. Director: Gianluca Belli. Tesi di Laurea. Università degli Studi di Firenze, Dipartimento di Storia dell'Architettura e della Città, 2007. 


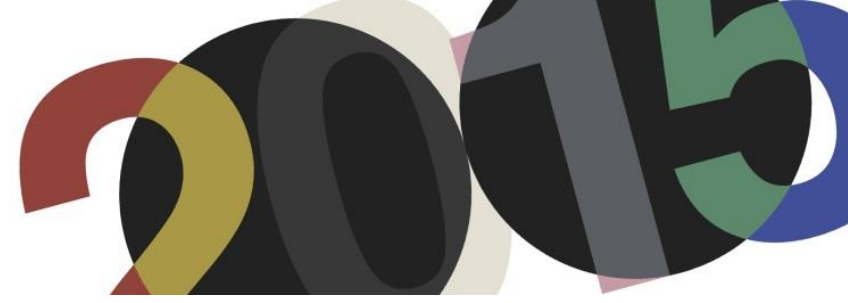

DOI: http://dx.doi.org/10.4995/LC2015.2015.746

\title{
Le Corbusier -hombre y arquitecto- en Cap Martin
}

\author{
A. Martínez Duran
}

Escuela Arquitectura La Salle, Universidad Ramon Llull

\begin{abstract}
Resumen: El escrito recoge la experiencia vital de Le Corbusier en su humilde barraca del Cap Martin, el lugar donde el arquitecto establece su particular pacto con la naturaleza, y finalmente con la vida. La cabaña se construye en 1952 como habitación anexa al chiringuito que regenta Robert Rebutato, fontanero en Niza, pescador, al que Le Corbusier conoce de sus anteriores estancias en la E 1027. En los años siguientes el arquitecto va apropiándose del lugar: L'Étoile de Mer, su terraza, el algarrobo, la barraca de obra. Es el Mediterráneo, pero también la amistad con el pescador, lo que le ligarán a este lugar hasta el día de su fallecimiento en las rocas. De esta relación son muestra varias pinturas murales, entre ellas la que retrata a los dos amigos "À l'Étoile de Mer règne l'amitiè". Este paraje es también objeto de proyectos edificatorios del arquitecto, entre ellos la serie Roq et Rob o las Unités de Vacances. En estas viviendas-taller pensaba establecerse Le Corbusier en sus estancias en esta costa, sin embargo tras la muerte de Yvonne en 1957, Le Corbusier opta por no llevar a cabo sus proyectos, y seguir alojándose en Le Cabanon, esa célula mínima de habitación, parasitada a L'Étoile de Mer. Decide no ocupar el territorio, dejarlo virgen, construir lo mínimo para mantener el máximo espacio libre. Varios planos dan fe de la permuta de propiedades entre Le Corbusier y Rebutato. A cambio de una gran cuña de terreno que incluye la cabaña del arquitecto, éste entrega las Unités de Camping a Robert. Se convierte en propietario de una extensión de rocas para no construir nada, mantener el paisaje intacto y así proteger su soledad.
\end{abstract}

Abstract: The text reflects the life experience of Le Corbusier in his humble hut of Cap Martin, where he establishes its particular pact with the nature, that finally becomes a pact with his life. The cottage was built in 1952 as an attached room to the snack bar that runs Robert Rebutato, plumber in Nice, fisherman, who met Le Corbusier during his stays in the E 1027. In the following years the architect endorses the site: L'Étoile Mer, its terrace, the carob tree and the work shed. It is the Mediterranean, but also the friendship with the fisherman, which will bind him to this place, until the day of his death on the rocks. This relationship is shown in several murals, including the portraying of the two friends "À l'Étoile de Mer règne l'amitié". The architect works too on some projects in this place: Roq et Rob and Unités de Vacances series. In these last ones Le Corbusier found to stay during his visits to the coast, but after the death of Yvonne in 1957, he chooses not to carry out their projects, and keep staying at Le Cabanon, the minimal cell room, parasitized to L'Étoile de Mer. He decides not to occupy the territory, keeping virgin it, building the minimum to maintain the maximum empty. Some drawings attest to the exchange of properties between Le Corbusier and Rebutato. In exchange to a large wedge of land that includes the cabin, the architect deliveries the Unités de Camping to Robert. So he becomes owner of an extension of rocks where isn't possible to build anything, in the way to keep the landscape intact and protect its loneliness.

Palabras clave: Le Corbusier, Le Cabanon, Cap Martin, Mediterráneo. Keywords: Le Corbusier, Le Cabanon, Cap Martin, Mediterranean.

\section{Le Corbusier en el Cap Martin}

"Le Corbusier escribe en un dibujo de agosto de 1950, que forma parte de la serie de proyectos Roq et Rob en la Costa Azul: “atención! conservar este tesoro de escala”. Situado en una de las terrazas de cultivo del lugar, bajo un árbol de grandes ramas, la figura del Modulor contempla la bahía de Cabé, el horizonte. Este paisaje mediterráneo se convertirá en el lugar más querido por Le Corbusier a partir de los años cincuenta. Aquí establecerá el arquitecto su particular pacto con la naturaleza, que también será un pacto de amistad con un personaje sencillo, un homme poli, Thomas Rebutato, antiguo fontanero, dueño y señor de L'Étoile de Mer. Este 
es el chiringuito de playa donde se refugia Le Corbusier en los últimos años de vida, en sus vacaciones y ratos de descanso. Finalmente acabará siendo un trato con la vida, generoso, de renuncia, del que lo da todo para al final no tener nada".

Así empezaba el capítulo sobre Le Cabanon en la tesis doctoral que la autora redacta con el título "La casa del arquitecto", y que trata del habitar en ocho arquitectos de la modernidad, a través del proceso de proyecto y del transcurrir de la vida en la propia vivienda. En el caso de Le Corbusier se recogía la experiencia en su cabaña de vacaciones en el Cap Martin. En esta comunicación se precisan y desarrollan algunos de los aspectos enunciados en aquel texto, en lo que se refiere a la experiencia vital y plástica del arquitecto en este lugar. Puntualmente se introducen referencias al texto original inédito para no volver a incidir en los temas ya tratados.

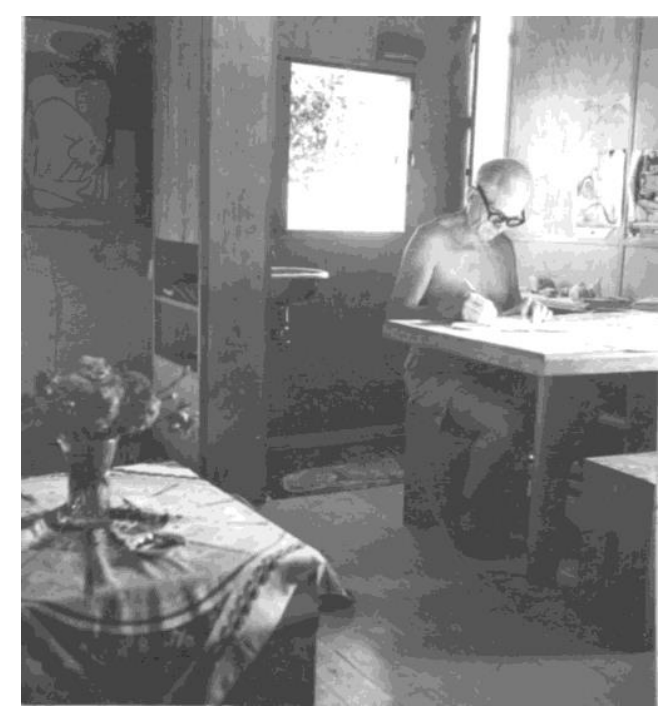

1. Le Corbusier en el interior de su cabaña en el Cap Martin. L4(11)19-239@FLC-ADAGP (Fotógrafo Lucien Hervé)

Le Corbusier construye Le Cabanon en 1952, a los 65 años de edad, en el Cap Martin, una zona de acantilados entre Mónaco y Menton, casi en la frontera con Italia. Desde finales de los años treinta solía acudir a la casa que Eileen Gray y Jean Badovici², la E 1027, tenían en este mismo lugar y en julio de 1949, procedente del CIAM de Bérgamo se instala ahí, junto con J. Ll. Sert, P. L. Wiener y otros, para trabajar en el Plan de Bogotá. Ante la dificultad de aprovisionarse en el pueblo -el camino es empinado y hay que hacerlo a pie- deciden probar suerte en un chiringuito vecino. El trato se cierra rápidamente y de esta forma el dueño del bar, Thomas Rebutato, se encargará durante todo el mes de la manutención de los huéspedes de la Casa Blanca ${ }^{3}$.

Éste, fontanero en Niza, pescador entusiasta, acudía a la zona desde hacía unos años en compañía de su familia y amigos, en vacaciones y los fines de semana, para pescar. Llegaban en tren, y por el camino de ronda descendían a las rocas, donde ponían las bebidas a refrescar en un manantial de agua dulce, bajo un pino. Pasaban el día en

\footnotetext{
1 Martínez Duran, Anna. La casa del arquitecto. Director: Helio Piñón Pallarés. Universidad Politécnica Catalunya, Departamento de Proyectos Arquitectónicos, 2008. http://www.tdx.cat/handle/10803/53596.

${ }^{2}$ Este último era editor de la revista l'Architecture Vivante. Le Corbusier pasaba largas temporadas en el pueblo de Vezelay, donde residía Badovici. En su casa pinta el primer mural. Ver Morel-Journel, Guillemette: "En somme, j'ai travaillé comme un zèbre à Vézelay". En Le Corbusier. Moments biographiques. Paris: Fondation La Corbusier, 2008. pp. 108-125.

${ }^{3}$ La historia es relativamente conocida desde que se publicara el libro de Chiambretto, Bruno: Le Corbusier à Cap Martin. Marsella: Parenthèses, 1988.
} 
la playa de Buse, y terminaban la jornada con una sopa bullabesa en las rocas. En 1948 decide comprar un terreno, a unos $300 \mathrm{~m}$ de la playa, en el que construir una cabaña para guardar los utensilios de pesca y otros bártulos. Debajo de la maleza del solar descubre unos muros de piedra seca, y en las terrazas, olivos, vides y cítricos.

La idea de Rebutato (Robert para los amigos) consistía en construir seis unidades para alquilar o vender, con los que amortizar la compra del solar. Sin embargo, al poco tiempo debe cerrar su negocio de fontanería en Niza y entonces, siguiendo la tradición familiar, decide abrir un pequeño restaurante que bautiza con el nombre L’Étoile de Mer. Espera contar como clientes con los paseantes, pescadores, ferroviarios, campistas, etc a los que ofrece, además de sombra y refrescos, un plato del día.

Llegado el mes de agosto, la estancia de trabajo de los arquitectos en la E 1027 concluye. Le Corbusier e Yvonne $^{4}$ manifiestan su deseo de quedarse más tiempo al propietario del merendero, quien les cede una habitación de alquiler en una de las terrazas inferiores, bajo los olivos. Durante el resto del verano el matrimonio acudirá a desayunar, comer y cenar a la terraza de L'Étoile de Mer. Regresará los veranos siguientes e incluso a partir de entonces varias veces al año. Efectivamente, ambos apreciaban el clima cordial y hogareño que reinaba en el restaurante de la familia Rebutato, y ello fue, junto al paisaje virgen de estas costas, lo que les ató definitivamente a este lugar.

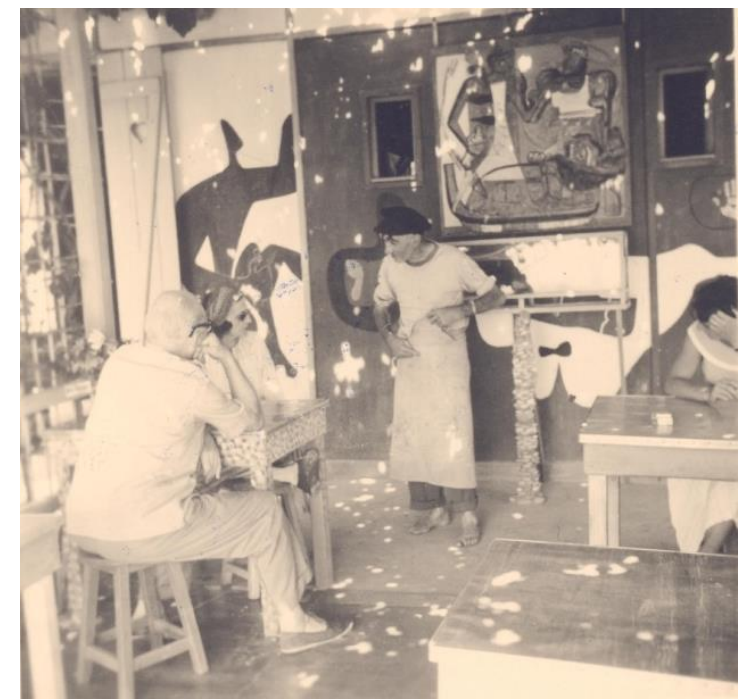

2. Le Corbusier, Yvonne y Robert Rebutato en la terraza del chiringuito. Al fondo el cuadro "À l'Étoile de Mer règne l'amitié". L4(10)69 @FLC-ADAGP (Fotógrafo desconocido)

El siguiente verano el arquitecto encarga a Robert que le prepare un lienzo cuadrado, de 1 x 1 m, con engrudo sobre una tabla de madera. Allí pinta el cuadro "A l'Etoile de Mer règne l'amitié”, con las figuras abrazadas de Robert pescador y Saint André des Oursins, en una barca. Robert, delantal blanco, gorra de visera, descalzo, manos y rostro afilado, expresión despierta, sostiene una botella. De su lado, el perfil de un pescado enorme. En la otra mitad del cuadro, la figura del apóstol, brazos y manos musculados, camiseta imperio blanca y sandalias de pescador, sostiene una cesta negra cargada de erizos de mar. El rostro, oscuro, de trazos indefinidos, del que

\footnotetext{
${ }^{4}$ Varios escritos relatan la relación del arquitecto suizo con la que ha sido una de las casas pioneras de la modernidad, y no es éste el momento de valorarlas, aunque parece cierto que los murales que en los años 1938 y 1939 pintó en diferentes partes de la casa no fueron del agrado de Eileen Gray, y acabaron por deteriorar la relación con Badovici.
} 
se perfila sólo la nariz, se cubre con un tocado o corona. En el borde, la figura vertical de un remo y al fondo, formando parte de la composición geométrica de base del cuadro, un círculo oscuro, el de un erizo de mar.

El matrimonio Jeanneret era aficionado a este manjar, y en cuanto sabían de su llegada, los chicos del pueblo acudían a la cabaña con cestas llenas de erizos, siendo recompensados con una propina doble, en primer lugar por Le Corbusier, y más tarde por Yvonne, quien les gratificaba con una suma aún más generosa que la de su marido. Este trato, entre otras cosas, fue motivo del afectuoso aprecio que les tenían las gentes del lugar.

La pintura se cuelga en la terraza de L'Étoile de Mer, y allí permanecerá hasta hace unos años, en que desaparece. El arquitecto adecúa la pared de soporte con un gran mural: Una figura femenina, las pisadas y las manos de ambos amigos en blanco sobre rojo. En el extradós, negro sobre blanco, un canto rodado, una estrella de mar y una gran figura acostada. Un pequeño espejo inclinado, debajo del cuadro, a la altura de una barandilla, refleja el cielo, quizás incluso el horizonte.

\section{El lugar, un puerto de paz en el Mediterráneo}

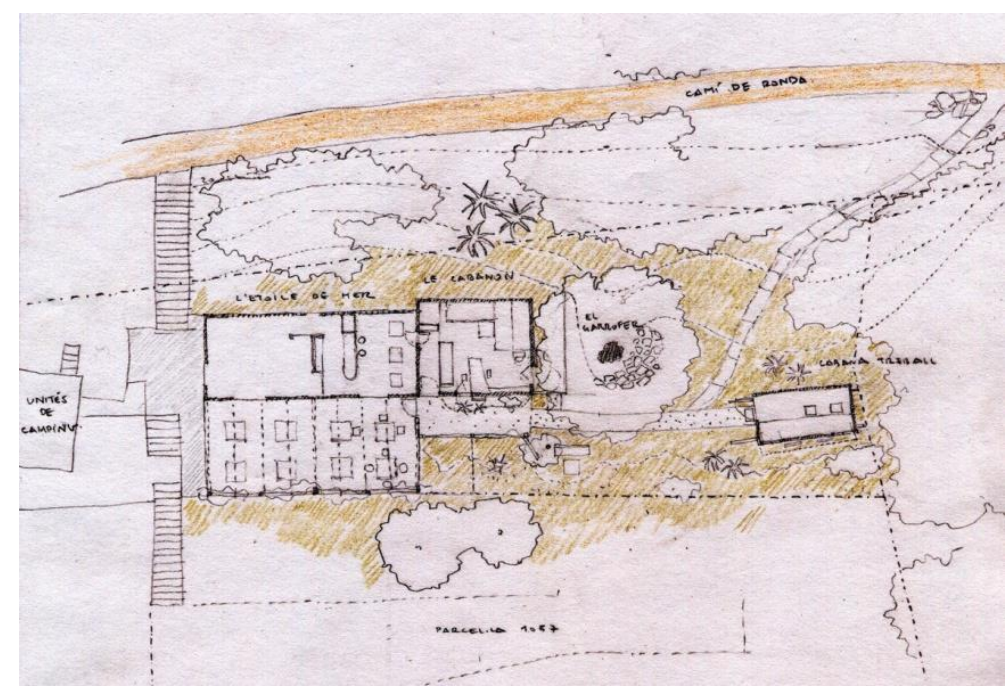

3. Plano de situación: la terraza con las Unités de Camping, L’Étoile de Mer, Le Cabanon, el algarrobo y la barraca de obra (Dibujo Anna Martínez Duran)

Con motivo de la visita del editor Willy Boesiger a Cap Martin, Le Corbusier esboza un croquis de situación. Las instrucciones son precisas: "dejar el coche en M (estación de ferrocarril) y andar a lo largo de la vía del tren hasta $N$ (escaleras de acceso a l'Etoile de Mer) isin bajar a la playa!" ${ }^{5}$ Otros puntos de referencia son: el camino de ronda que, pasando por detrás de Le Cabanon sigue adelante rodeando el Cap Martin, el atajo a pie al pueblo de Roquebrune, la vía del tren, la casa de Badovici, Montecarlo, Menton, el mar, y la pequeña playa. El arquitecto añade en la targeta: "Estaré allí a partir del 5 de agosto, os esperaré con placer- venid por la mañana y comeréis con nosotros a mediodía". El sitio, "un puerto de paz" según Le Corbusier es, sin estas indicaciones, realmente difícil de descubrir. Desde el camino de ronda, pegado a la vía del tren, sólo podemos adivinar, entre los árboles, las cubiertas de fibrocemento del restaurante y la cabaña. Desde el mar sin embargo, sí que es

\footnotetext{
${ }^{5}$ Cita traducida por la autora y transcrita en: Martínez Duran, Anna. La casa del arquitecto. Director: Helio Piñón Pallarés. Universidad Politécnica Catalunya, Departamento de Proyectos Arquitectónicos, 2008. http://www.tdx.cat/handle/10803/53596.

${ }^{6}$ Ibid.5
} 
posible esta visión de todo el conjunto. En la estrecha franja de terreno entre la vía del tren y el acantilado se encuentran, apoyados en las diferentes terrazas de cultivo, la casa E 1027 en primera línea y ligeramente escorzada; un poco más atrás, L'Étoile de Mer con su cañizo, entre las cinco Unités de Camping levantadas sobre pilotis, y la barraca de obra de Le Corbusier. Le Cabanon apenas se distingue, escondido debajo del algarrobo.

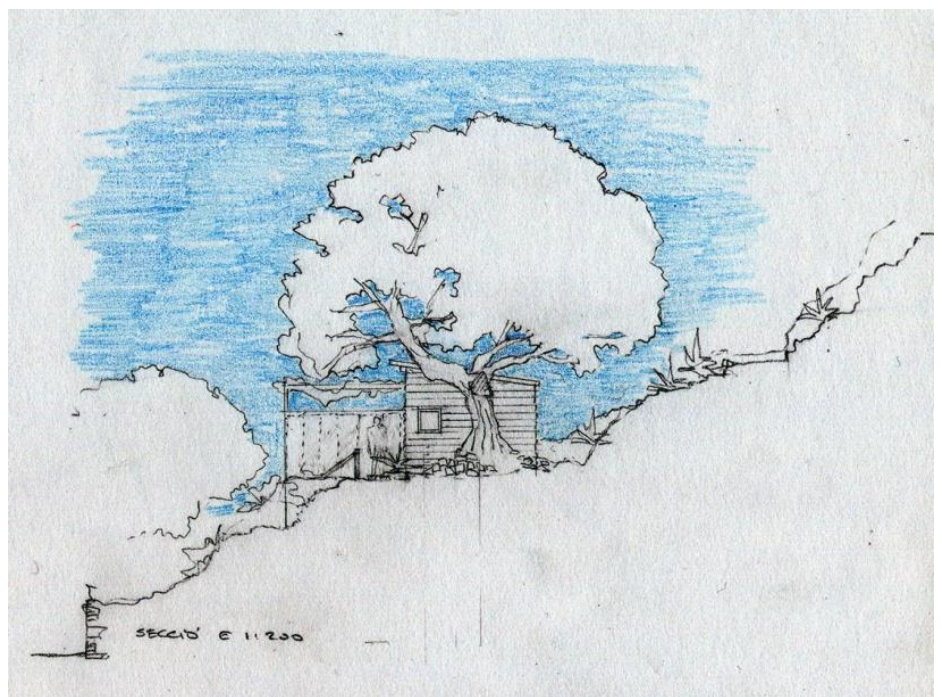

4. Sección del lugar: el camino, las terrazas y Le Cabanon debajo del algarrobo. (Dibujo Anna Martínez Duran)

Efectivamente, la cabaña, adosada y enrasada por delante con el volumen del bar-restaurante, se sitúa entre el terraplén posterior y el viejo algarrobo. En este espacio limitado, ganado a la montaña ${ }^{7}$, se define ciñéndose a la geometría y a las medidas del Modulor: un cuadrado interior de 366 x $366 \mathrm{~cm}$ y $226 \mathrm{~cm}$ de alto, al que se añade un pasillo de entrada, en la medianera, de $70 \mathrm{~cm}$ de ancho. La cubierta es una prolongación de la del chiringuito: a un agua y con caída hacia atrás. La presencia del algarrobo, árbol ligado a la cultura popular del mediterráneo, de aspecto primitivo, sombra profunda y perfume azucarado ${ }^{8}$, es sin duda un contrapunto importante en la elección de la ubicación de la cabaña.

A partir de aquí toda la atención del proyecto se centra en el espacio interior, y si acaso, en su relación con el exterior a través de puntos concretos. El programa se reduce a un sitio donde poder descansar y asearse un poco, un cobijo donde refugiarse en las horas calurosas del verano o en las tardes lluviosas de otoño. El trabajo consiste en articular en esta única habitación $(13.4+2.6 \mathrm{~m} 2)$ las distintas actividades con comodidad, sencillez y precisión, sin estorbos de maletas ni cañas de pescar, y a ser posible, con vistas sobre la bahía de Mónaco, la playa de Cabé, y el Cap Martin. Como explica el propio Le Corbusier en su obra completa "el exterior es independiente del problema que aquí se plantea",.

\footnotetext{
${ }^{7}$ Robert hijo explica cómo tuvieron que excavar el terraplén y nivelar el terreno para asentar el Cabanon. Rebutato, Robert: “Après midi tranquille au cabanon". En Le Corbusier. Moments biographiques. Paris: Fondation La Corbusier, 2008. pp. 1625.

${ }^{8} \mathrm{El}$ algarrobo es un árbol ancestral ligado, como el olivo o el almendro, a la agricultura tradicional mediterránea. Sus semillas se utilizaron por ejemplo como monedas en la antigüedad por la exactitud de su tamaño y peso. También se halla vinculado a la construcción de casas importantes de arquitectura moderna en el litoral mediterráneo.

${ }^{9}$ Boesiger, Willy (Ed.): Le Corbusier. Oeuvre Complète 1946-1952. $7^{\text {a }}$ ed. Zurich: Girsberger, 1976. Traducción de la autora.
} 


\section{Una casa a medida o el Modulor se adecúa}

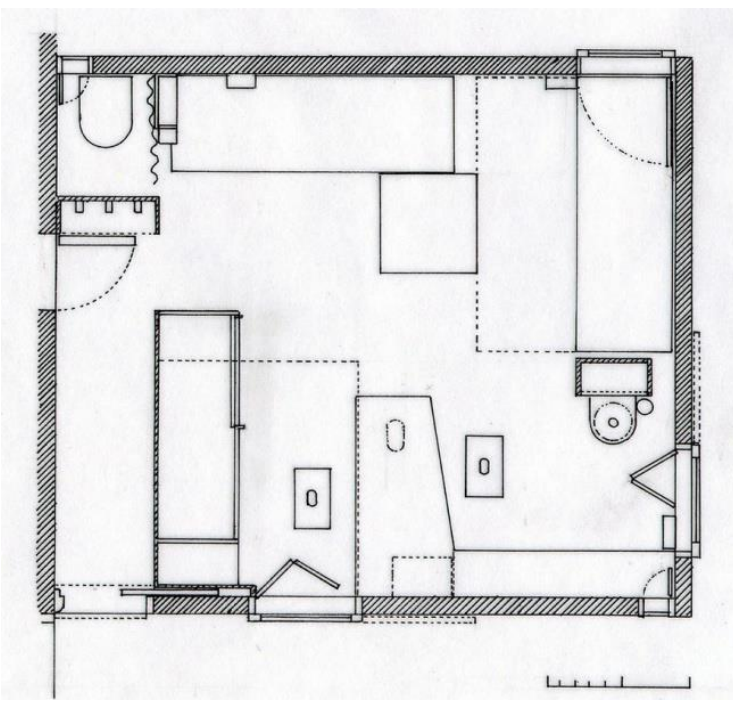

5. Planta de Le Cabanon con la posición definitiva de muebles y ventanas. (Dibujo Anna Martínez Duran)

Los conocidos bocetos que Le Corbusier dibuja "en la esquina de una mesa de un pequeño merendero en la Costa Azul, para regalárselos a mi mujer con motivo de su cumpleaños" $" 10$ son de diciembre de 1951 y en ellos ya aparece la colocación de los muebles, unos rectángulos con sus medidas y nombres. La fachada es una simple envolvente, en la que se regruesa el espacio que ocupa la ventana. Las camas, los estantes y el armario se apoyan en las cuatro paredes del cuadrado, dejando siempre las esquinas libres, donde se sitúan puertas y ventanas. A través de estos vacíos la atención se escapa hacia el exterior. El espacio es dinámico y ninguna directriz prevalece sobre las demás. En sección los muebles se convierten en planos que se superponen a las diferentes alturas. Se advierte el desdoblamiento en la altura del falso techo, dos planos horizontales que se adaptan a la pendiente de la cubierta exterior. Este espacio se utilizará para guardar las maletas, y con ello se justificará una ordenanza de habitabilidad, que no permitía construir todo el volumen interior a $226 \mathrm{~cm}$, tal como refiere el mismo autor: "con la excepción de un hundimiento localizado, para satisfacer los reglamentos"11.

En estos dibujos se observa una preocupación por las relaciones del usuario con los diferentes planos de actividad: el hombre y la mujer, sentados, acostados, o mirando por la ventana. Se comprueban las posiciones posibles y sobre todo las relaciones entre ellos: distancias, visuales, movimientos. Estos esbozos son una aplicación directa de las medidas del Modulor, que aparecen escritas en cada uno de los niveles: 70, 113, 140, $226 \mathrm{~cm}$. La medida aparece pues en el primer paso del proyecto, como algo que lo determina, tanto o más que la forma o posición de las cosas.

A pesar de que Le Corbusier insiste en que estos primeros dibujos "fueron hechos en tres cuartos de hora"12 se trata de unos bocetos completamente seguros, sin indecisiones, hechos por alguien que conoce bien las medidas mínimas de estos espacios habitables y que tiene una preocupación constante por precisar. Entre los muchos croquis que Le Corbusier fue dibujando y acotando a lo largo de su vida, se encuentran los de las cabinas de

\footnotetext{
${ }^{10}$ Le Corbusier, El Modulor y Modulor 2. $3^{\text {a }}$ ed. Barcelona: Poseidón, 1980, en cuyo Epílogo se lee "El imprímase fue dado el 14 de abril de 1955, en Cap Martin".

${ }^{11}$ Boesiger, Willy (Ed.): Le Corbusier. Oeuvre Complète 1946-1952. $7^{\mathrm{a}}$ ed. Zurich: Girsberger, 1976. Traducción de la autora.

${ }^{12}$ Le Corbusier, El Modulor y Modulor 2. $3^{\mathrm{a}}$ ed. Barcelona: Poseidón, 1980.
} 
trenes y barcos de larga distancia, donde el arquitecto se sorprende del espacio tan reducido en el que es posible vivir y en el que están resueltas todas las necesidades. Aplicando las medidas armónicas del Modulor convierte su cabaña de vacaciones en uno de estos pequeños habitáculos, un artefacto que funciona con unas medidas exactas y adecuadas a su fin y en el que las diferentes piezas encajan con precisión como en un reloj.

Una de las características de las casas propias de arquitecto es su capacidad para comprobar en el día a día, la adecuación del proyecto, incluso de la teoría, a la vida, al uso y a los cambios que aparecen con el paso del tiempo. Esto ocurrirá también en este caso, pero aquí algunas de las medidas de proyecto, se adecúan ya en el mismo proceso de obra, transgrediendo la propia norma. Como ejemplo, en estos bocetos la altura del alféizar de la ventana cuadrada en la fachada sur, la que tiene las vistas sobre la bahía y en la cual se observa con mayor frecuencia al arquitecto, se plantea a 113 de altura. Finalmente éstas se disponen más bajas, seguramente para permitir las vistas sobre la bahía mientras el arquitecto trabajaba en la mesa o para asomarse a ella con comodidad $^{13}$.

Entre estos primeros bocetos y los definitivos hay todo un proceso de puesta en solfa, de adecuación, realizado por los colaboradores de Le Corbusier en París, en el que se redibujan cada uno de los elementos del mobiliario o instalaciones, en relación a su funcionamiento, medida y construcción ${ }^{14}$. Ya en el mes de junio de 1952, Le Corbusier se encuentra en el Cap Martin, donde acaba de definir los últimos detalles. Se trata por un lado de unificar y simplificar el diseño de los muebles y por otro de dar un tratamiento más plástico a algunos de estos elementos: lámparas, camas, percheros, falso techo, etc... Los dibujos de estos días son, como todos los de este arquitecto, rápidos, esquemáticos y poco limpios, pero muy intencionados.

También es el momento de solicitar el permiso de obras y de estudiar la acometida de las diferentes instalaciones: agua, electricidad y saneamiento, de lo que se encargará personalmente Robert Rebutato. Para facilitar los trámites administrativos, la obra se presenta como una habitación de veraneo ${ }^{15}$, una ampliación de la edificación existente. Así figura en el plano con el que se solicita permiso, un dibujo gris y muy poco expresivo en el que si se precisan la ubicación, forma, medida y aspecto exterior de la cabaña.

A finales de julio Le Cabanon será trasladado por mar, desde el taller de Charles Barberis en Ajaccio -donde había acudido el arquitecto a supervisar la construcción- hasta Niza, y de allí en tren hasta la estación de Roquebrune-Cap Martin. Es el mismo Rebutato quien se encargará de asentarlo en su emplazamiento definitivo, encima de una base de hormigón. Y en el mes de agosto, Le Corbusier pasará sus primeras vacaciones en su humilde barraca del Cap Martin. La imagen del arquitecto asomado a la ventana Este es de este momento, el de la cabaña en proceso de montaje.

\footnotetext{
${ }^{13}$ Ver tesis de la autora, donde se realiza un análisis de los diferentes documentos y una restitución perspectiva para comprobar estas medidas, y el libro: Alison, Filippo, Le Corbusier. L'interno del Cabanon. Verona: Electa, 2006, en el que se publican algunos detalles de carpintería del proceso de construcción, que así lo confirman.

${ }^{14}$ En la tesis de la autora se hace un seguimiento del proceso de proyecto, a través de los diferentes croquis del arquitecto y de sus colaboradores, motivo por el cual este episodio no se contempla en este artículo.

${ }^{15}$ La expresión original, según figura en el plano es "une chambre de villégiature", es decir una habitación de temporada, incluso de alquiler. La traducción es de la autora.
} 


\section{La vida en el Cap Martin o en L'Étoile de Mer reina la amistad}

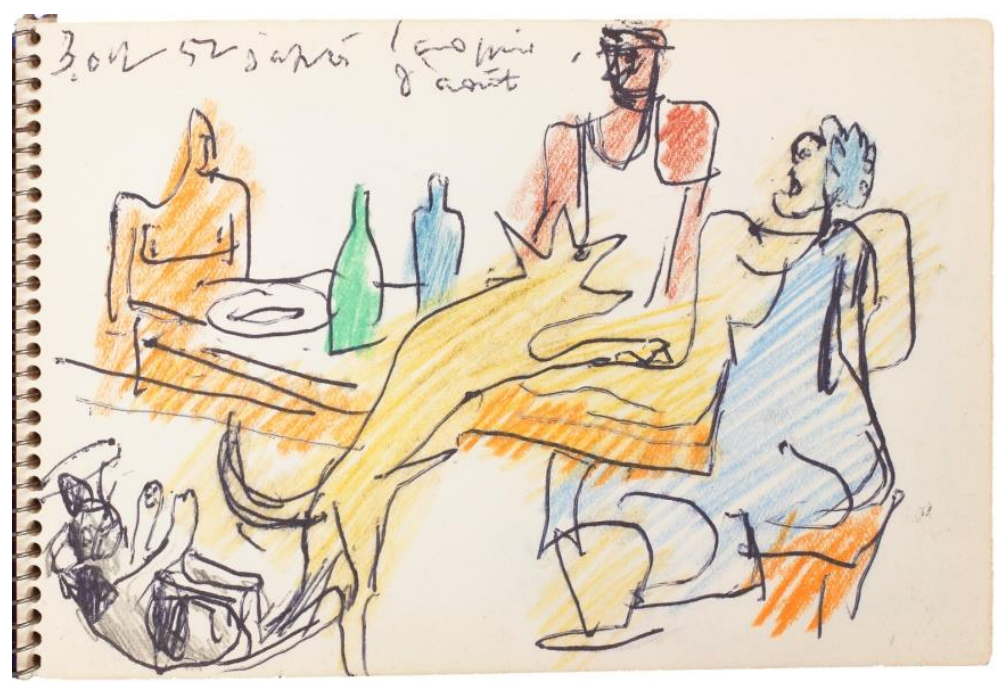

6. El matrimonio, Robert y el perro Youki en la terraza. FLC Carnet F26-838@FLC-ADAGP (Dibujo Le Corbusier)

Le Cabanon es el habitáculo mínimo, que en este caso se acopla a una vivienda ya existente, a un organismo con vida propia. L'Étoile de Mer aporta la terraza de cañizo, el bar y por encima de todo, la cocina. Como en sus grandes proyectos de residencia, también en este caso hay lugar para la vida individual y para la vida en comunidad. Y de la misma forma como se contempla el espacio interior del habitar, también se fomenta la vida al aire libre.

Diferentes fotografías explican el quehacer del arquitecto en ese lugar: una vida distendida la de este maestro de la modernidad, más bien propia de un campista, de un hombre libre, en este lugar frente al mar, su mar, el Mediterráneo "movimiento, horizonte sin fin" $"$. Porque la casa propia es en esencia refugio, territorio protegido, espacio de libertad.

Una puerta en el cierre de hojas de palmera (en la que Brassaï fotografía al arquitecto en taparrabos) separa la terraza de L'Étoile de Mer del espacio exterior que rodea la cabaña. Poco a poco, el arquitecto se fue apropiando, colonizando, este entorno. Primero montó debajo del algarrobo un surtidor para la ducha matinal, y una mesita donde dibujar al fresco al otro lado del paso, en el borde de la terraza. Un par de años más tarde, la barraca de obra, en el extremo opuesto. Allí se retiraba a trabajar solo, lejos del bullicio del bar. Era el lugar idóneo para escribir y acabar de resolver algunos proyectos: dibujos en las paredes, una tabla corrida en la fachada sur, dos ventanas convencionales en sus extremos. En alguna foto de este interior aparece un estante con algas, raíces, cantos rodados, moluscos, caracoles. Son sus objetos de reacción poética ${ }^{17}$, que el arquitecto gustaba de recoger, medir, y dibujar "hablando el lenguaje de la naturaleza, acariciados por tus manos, examinados por tus ojos, compañeros evocadores ${ }^{\prime \prime 18}$. Durante un tiempo éstos fueron tema repetido en pinturas y murales, como el enorme canto rodado negro con marcas blancas que pintó en los bajos de la E 1027, junto a figuras humanas entrelazadas, líneas negras sobre el hormigón.

\footnotetext{
${ }^{16}$ Petit, Jean: Le Corbusier parle. Lugano: Fidia, 1996. Traducción de la autora

${ }^{17}$ La expresión original es "objets à reaction poétique”. La traducción literal es de la autora

${ }^{18}$ Petit, Jean: Le Corbusier. Lui même. Ginebra: Rousseau, 1970. La cita original es : "parlant langue de nature, caressés de vos mains, scrutés de votre oeil, compagnons évocateurs". La traducción es de la autora
} 
Una de las actividades diarias del arquitecto consistía en el baño matinal en las rocas, solo o con Mimi (apodo de Robert hijo) y Youki, el perro que les acompañaba y vigilaba. De regreso a L'Étoile, una ducha, un pastis para el arquitecto, una menta para el chico, y un rato de conversación con el que en el futuro sería aprendiz de arquitecto, charla que muchas veces seguía hasta después de comer ${ }^{19}$.

Grandes amigos de Le Corbusier y de su esposa Yvonne pasarán por L’Étoile de Mer. Además de su hermano Albert Jeanneret, también Sert, Candilis, Picasso, Léger, Brassaï, y otros. El arquitecto y su mujer estimaban el ambiente familiar y alegre del bar, al que acudían las gentes del lugar a jugar a cartas o a la petanca, los jóvenes que acampaban en las terrazas inferiores y se reunían en conciertos improvisados por las noches, los ferroviarios, los carabineros que con su perro patrullaban cada noche el camino, vigilando el contrabando de tabaco, o el aldeano acordeonista que dedicaba sus baladas a Yvonne. Ésta, originaria de un pueblo cercano en el interior de Mónaco, aficionada a contar chistes e historias, se reencontró con el paisaje y las gentes de su juventud. A veces incluso, en los largos viajes del arquitecto, acudía sola al Cap Martin con indicaciones del arquitecto a la familia: “Os mandaré a mi esposa, para que usted y su señora le devuelvan la alegría”.20.

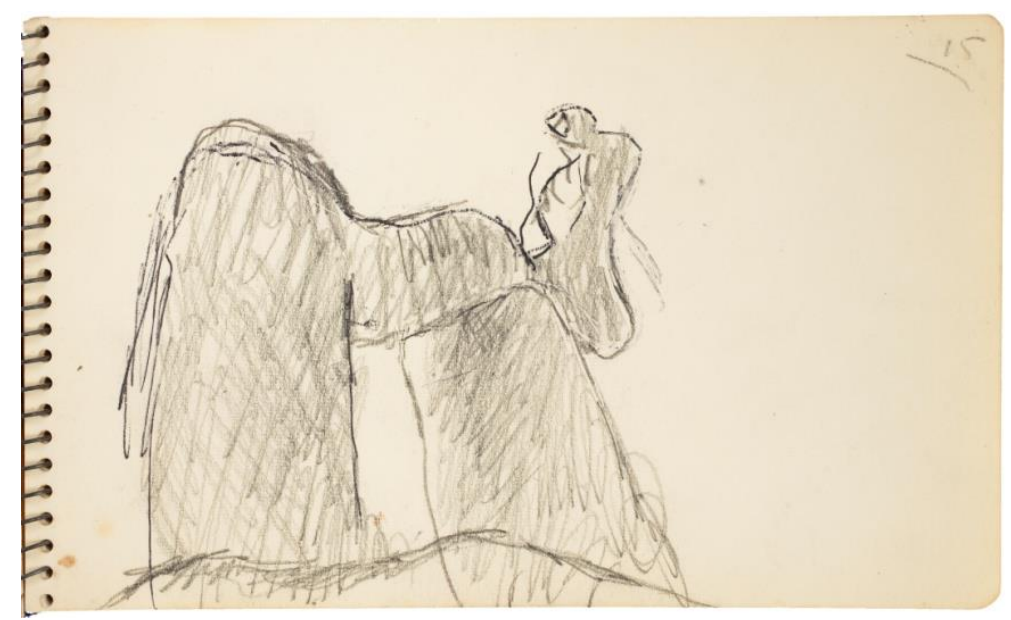

7. Uno de los bocetos de la serie "Je revâis". FLC Carnet G29-982@FLC-ADAGP.

Le Corbusier se refiere a su esposa como "el ángel de la guarda del hogar, querida por todos, pobres, inocentes y ricos, sólo ricos de corazón. Ella medía la gente y las cosas solamente por esta escala. Reina de un pequeño mundo apasionado. Ejemplo de mucho y exenta de cualquier apariencia",21 y a Le Cabanon como "la cabaña de mi mujer". Se confirma con este testimonio el enorme valor del regalo con el que empieza esta historia en el Cap Martin.

\footnotetext{
${ }^{19}$ Rebutato, Robert: “Après midi tranquille au cabanon”. En Le Corbusier. Moments biographiques. Paris: Fondation La Corbusier, 2008. pp. 16-25.

${ }^{20}$ Lamanda, Laura: Testimonianze di Le Corbusier a Cap Martin. En Alison, Filippo: Le Corbusier. L'interno del Cabanon. Verona: Electa, 2006. La traducción es de la autora

${ }^{21}$ Recuerdo de Le Corbusier con motivo del fallecimiento de Yvonne en 1957, en Petit, Jean: Le Corbusier. Lui même. Ginebra: Rousseau, 1970. La traducción de la cita es de la autora. Para apreciar algunos juegos de palabras se transcribe la original: « l'ange gardien du foyer, aimée de tous, des simples et des riches, des riches du coeur seulement. Elle ne mesurait les gens et les choses qu'à cette échelle. Reine d'un petit monde fervent. Exemple pour beaucoup et exempte de tout simulacre".
} 
Por otro lado, son sorprendentes los dibujos de estos días de vacaciones. Sueltos, rápidos, sin prejuicios, relatan el tipo de vida, las vestimentas, las actividades del arquitecto y su mujer: la vida alegre en el bar o las horas de tedio y calor en el interior de la cabaña. Algunos dibujos como los de la serie "Je rêvais", las piernas del arquitecto tumbado en la cama, servirán de base a pinturas posteriores. Otros son simples ejercicios de divertimento, realizados cuando el tiempo se dilata.

\section{El interior, espejos y pinturas}

El interior de la cabaña es sobrio y uniforme, el tono de la madera invade la sala. Los colores se dejan para algunos elementos puntuales como el falso techo o el perchero, para las pinturas del arquitecto, o para los objetos de uso cotidiano: los cubrecamas, los libros, incluso el tapete encima de la mesa y el jarrón con flores. Pocos muebles, pocas ventanas y un único material, es la máxima economía en la arquitectura, reflejo de alguien que busca vivir y disfrutar con lo mínimo, con lo preciso, parafraseando a Sócrates: “¡Cuánto es lo que no necesito!",22.

El acabado exterior es el de la cabaña primitiva, recubierto con secciones de troncos desbastados. En los huecos un marco rectangular único de $14 \mathrm{~cm}$ recoge las diferentes capas del cerramiento. Las dos ventanas de 70 x 70 $\mathrm{cm}$ abren hacia afuera: desde el exterior, el cristal refleja el paisaje, desde el interior, el cuadrado se recorta perfecto, limpio. Unos postigos de madera, enrasados con el tablero interior, oscurecen la estancia. Se pliegan verticalmente: mitad espejo, mitad dibujo. Los espejos, en distintas posiciones, ofrecen multitud de reflejos y vistas engañosas del paisaje, que no corresponden a las que enmarca la propia ventana. De esta forma, sentado en su mesa de trabajo Le Corbusier podía tener vistas casi en $180^{\circ}$, a la vez sobre la bahía de Cabé al Este, y sobre el Cap Martin, al Oeste. Afeitándose por la mañana, veía el algarrobo por la ventana y Mónaco en el reflejo. Seguramente además, colocando los espejos en una posición estratégica, conseguiría reflejar un rayo de luz matutino e introducirlo hasta su cama, en el fondo de la cabaña. Los espejos enriquecen este espacio interior mínimo y austero, que crece y se dilata con visuales lejanas.

En el lateral de una de las camas, frente a la entrada, Le Corbusier coloca una serie de cinco pinturas sobre madera, de formato vertical, aproximadamente $35 \times 70 \mathrm{~cm}$ cada una. Otra vez las figuras del hombre y la mujer se repiten, abrazándose en el dibujo final. En la pared medianera el tema del gran mural es el toro. Éste tiene su origen en su estancia en Ozon, en los Pirineos, y aparece también, como el tema de la mujer, en su "Poema del Ángulo Recto",23, libro escrito y dibujado en estos años.

En este mural se esconde la puerta de yate que separa el interior de Le Cabanon del de L'Étoile de Mer. Con cerradura desde ambos lados, posibilitaba el silencio en la cabaña, el aislamiento, pero abierta con secreto incorporaba la habitación al chiringuito. En la otra cara de la medianera, en la habitación de la familia Rebutato, el arquitecto pinta otro mural, en el que retrata a los cuatro habitantes de la casa: Robert, Marguerite, los dos hijos, y el perro.

\footnotetext{
${ }^{22}$ En las conclusiones de la tesis, la autora insiste en actitudes de este tipo, que se contemplan en los diferentes casos estudiados, y que dan pie a capítulos como "Cultura y diversidad", "Libertad y renuncia", o "Sacrificio y beneficio".

${ }^{23}$ Le Corbusier: Le poème de l'angle droit. Madrid: Círculo de Bellas Artes, 2006.
} 


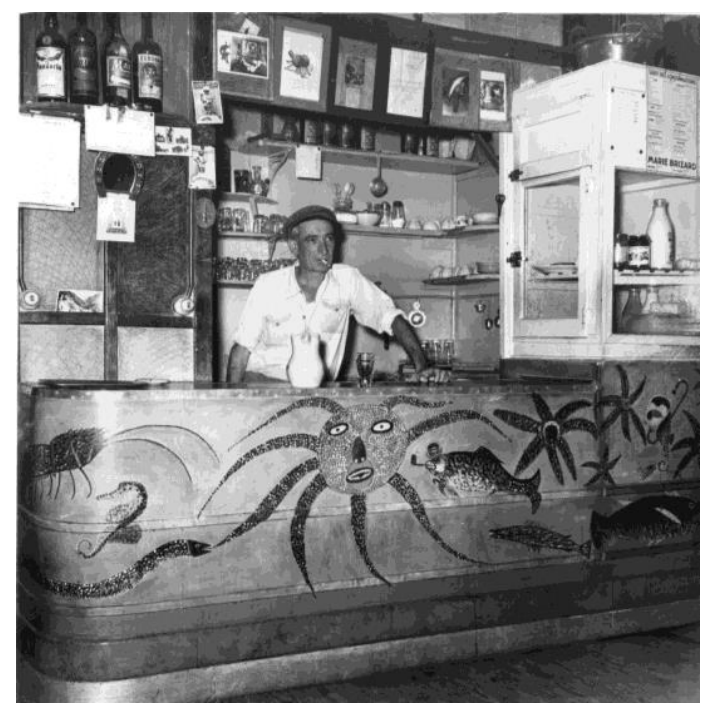

8. Robert Rebutato en la barra de L’Étoile de Mer. L3(5)31@FLC-ADAGP (Fotógrafo René Maestri)

Y sin embargo en la barra del bar no es el Jeanneret pintor, sino Robert quien pinta un paisaje marino con una gran estrella de mar en el centro, rodeada de otros personajes como el caballito, la morena o el pez con sombrero de hongo, pipa, y paraguas, quizás Le Corbusier ${ }^{24}$. Es el mismo arquitecto el que anima a su amigo a decorar con este tipo de pinturas los interiores del local. De quien dice que es "en el fondo, un artista y un sabio. Vivo, emprendiendo, convencido de sus ideas, siempre mejorando, proporcionando" 25 . Seguramente Le Corbusier recordaba a su amigo André Bauchant, el pintor naïf cuya vida bohemia y retirada le maravillara de joven, y del cual un gran cuadro de la Virgen María presidía el cabezal de cama del matrimonio Jeanneret en Nungesser et Coli.

\section{Otros proyectos en el Cap Martin: Roq et Rob y Unités.}

Durante el mes de septiembre de 1949 Le Corbusier trabaja en los proyectos Roq et Rob. Se trata de dos proyectos en Roquebrune-Cap Martin, que contemplaban la construcción de residencias y equipamientos en este paisaje pintoresco, cuya sabiduría popular reconoce el arquitecto en su obra completa: "El paraje arquitectónico está formado por casas pegadas unas a las otras, cuyos ojos (las ventanas) se abren al horizonte infinito. El paisaje contiguo se ha mantenido libre, y se destina a la agricultura o simplemente como reserva natural"26.

El proyecto Roq es un complejo hotelero en un terreno de gran pendiente que Mme.Mélin -cliente del restaurante- poseía debajo de las murallas del pueblo, Roquebrune. Le Corbusier mantiene las terrazas de cultivo del lugar y ordena los apartamentos a partir de la escalera central existente. El proyecto propone la aplicación de su "Brevet 226x226x226", para el que utilizaba un único elemento estructural metálico, viga o pilar. De este

\footnotetext{
${ }^{24}$ Esto supone una rectificación sobre la hipótesis planteada en la tesis (2008), en la que se atribuía la autoría de estas pinturas a Le Corbusier. Esta tiene lugar a partir de la reciente publicación del artículo: Rebutato, Robert: "L’Étoile de Mer, un restaurant au bord de l'eau et ses peintures murales”. En Lorenzo, Claude. (Dir.): Eileen Gray. L'Étoile de Mer. Le Corbusier. Trois aventures en Mediterranée. Paris: Archibooks+Sautereau, 2013. pp. 76-91.

${ }^{25}$ Petit, Jean: Le Corbusier parle. Lugano: Fidia, 1996. Le Corbusier se refiere con frecuencia a Robert como "un homme poli", un hombre culto, educado, cortés. La cita ha sido traducida por la autora, la original es : « au fond de lui, un artiste et un sage. Vif, entreprenant, suivant ses idées, améliorant, proportionnant ».

${ }^{26}$ Boesiger, Willy (Ed.): Le Corbusier. Oeuvre Complète 1946-1952. $7^{\mathrm{a}}$ ed. Zurich: Girsberger, 1976. La traducción es de la autora
} 
proyecto son los atractivos dibujos del complejo de apartamentos cubiertos con bóveda, o de sus interiores en doble espacio longitudinal.

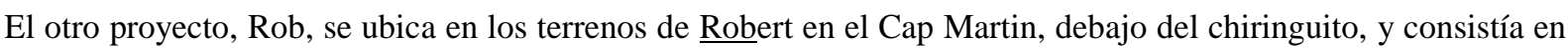
doce cabañas de volumen alveolar $(226 \times 226 \times 226 \mathrm{~cm})$ para gente de paso, y seis apartamentos sobre pilotis, cuya planta baja se destinaba a talleres para artistas. Posiblemente uno de los incentivos del proyecto, además de la voluntad de Robert de sacar partido a su propiedad, era disponer de un lugar en el que acomodar a Le Corbusier, mujer y amigos, en sus estancias en el Cap Martin, dado que éste ansiaba recuperar las condiciones de soledad y aislamiento, propicias para el descanso y la actividad creativa, que había encontrado en la E 1027. Finalmente el proyecto se descarta con la construcción y acomodo del matrimonio en la pequeña cabaña, de la que el arquitecto afirma "me encuentro tan bien aquî".

Le Corbusier dedica los tres años siguientes al proyecto y la tramitación de permisos para la construcción de cinco Unités de Vacances en las terrazas inferiores de L'Étoile de Mer. La obra se propone con bloques prefabricados para las habitaciones, la cocina y los sanitarios, dentro de una estructura de muros y forjados de hormigón, planta baja libre y cubierta ajardinada. Le Cabanon aparece en estos proyectos como un prototipo de habitación: se inserta dentro del edificio, manteniéndose intacto en planta y sección, como quien coloca un mueble en una gran estancia ${ }^{27}$.

En febrero de 1955 un enorme cansancio conduce durante quince días al arquitecto a Le Cabanon. Una gran tormenta azota el Cap Martin durante toda la semana. Le Corbusier contempla asombrado el fenómeno desde su cabaña. Las olas de hasta ocho metros de altura rompen lateralmente sobre el acantilado. Cuando finalmente regresa la calma, Le Corbusier y Robert descienden al borde de las rocas. El terreno donde pensaban construir las Unités de Vacances ha quedado completamente barrido por el temporal.

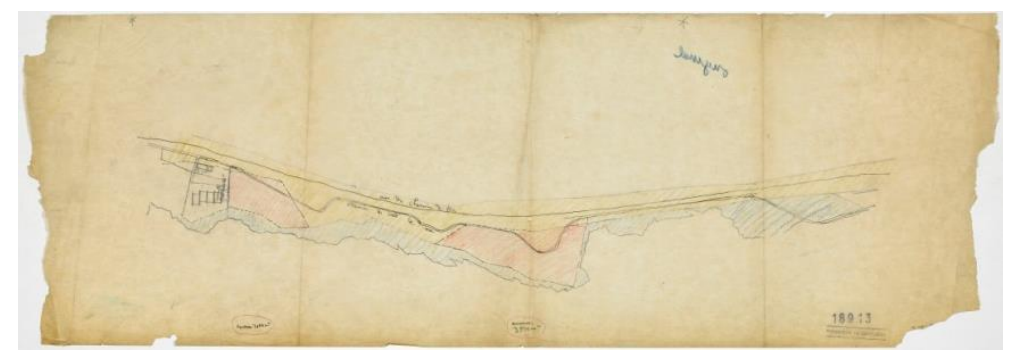

9. Uno de los plano para el proyecto de las Unités de Vacances en el Cap Martin.

Plan FLC 18913@FLC-ADAGP

De vuelta a París el arquitecto decide abandonar el último de los proyectos en el Cap Martin "Seguir siendo dueño y señor en mi cabaña. ¡Tranquilo, sereno! y mi esposa, reina de L'Étoile de Mer”. Pero ya había dado la palabra de compra de este terreno a Rebutato, y de esta forma se ve finalmente propietario de todo este terreno, una gran franja rocosa, inutilizable: "Ese rincón exterior, el único terreno existente en Roquebrune entre la pasarela y el Cap Martin, es sólo mío, yo soy su dueño. Y no puedo hacer nada con él, nada más que amarlo"28.

\footnotetext{
${ }^{27}$ Estos proyectos se hallan ampliamente documentados en el volumen : Le Corbusier, Projet et Rob, Roquebrune-Cap Martin, and other buildings and projects, 1948-1950. Nueva York: Garland, Paris: Fond. Le Corbusier, 1983. Asimismo en la tesis de la autora se hace un seguimiento de los diferentes proyectos.

${ }^{28}$ Petit, Jean: Le Corbusier parle. Lugano: Fidia, 1996. La traducción es de la autora, las citas originales son : «Je demeure maître dans mon cabanon. Tranquille, serein! et ma femme reine de l'Etoile de Mer » $y$ « Ce coin extérieur, le seul terrain existant à Roquebrune jusqu'à la passerelle et Cap Martin, est ainsi mien: je'n suis maître. On n'en peut faire rien, que
} 
Emplea su dinero en un terreno enorme para mantenerlo intacto y seguir viviendo en un espacio mínimo, con sólo lo necesario.

Yvonne fallece en 1957 y él se convierte a sus setenta años en propietario de la nada, del vacío. Pero a cambio de ello podrá seguir disfrutando de este paisaje virgen y de la confianza de la familia Rebutato, en soledad, "porque siempre es mucho más rica y fecunda la renuncia, el dejar que el coger" ${ }^{29}$. Como pago por parte del terreno ofrece a éstos las cinco Unités de Camping que se construyen al otro lado del bar, totalmente prefabricadas en el taller de Barberis, y que siguió alquilando Marguerite hasta $1987^{30}$. Son lo único construido de toda esta serie interminable de proyectos.

\section{Un pacto con la naturaleza, un pacto con la vida}

El arquitecto reconoce en el libro de Jean Petit, que el espacio mínimo de su cabaña no es nada sin el sol, sin el aire, sin el paisaje en el que está situado, y concluye "éste es un tema de urbanismo"31.

La cabaña que Le Corbusier construye en Cap Martin como habitación de veraneo es ejemplo de un episodio mínimo de la historia de la arquitectura y sin embargo en él se muestra con claridad la actitud de respeto a la naturaleza a través de la escala de la construcción. El tamaño del edificio es la herramienta que el arquitecto debe utilizar con mayor precisión, y es algo que en esta obra toma importancia desde los primeros bocetos, los de los $3 / 4$ de hora, pero cuyo mayor acierto reside en la proporción entre lo construido y el entorno, entre el artificio y la naturaleza. Este es el valor real de Le Cabanon y el significado preciso de la afirmación “atención! conservar este tesoro de escala" con el que se iniciaba la comunicación. No es otro que la necesidad de conservar la proporción entre lo pequeño -la obra del hombre- y lo grande -el paisaje, el mar, el aire-. Es necesario que lo pequeño siga siendo pequeño, para que lo grande pueda seguir siendo grande.

Este es el particular pacto con la naturaleza de Le Corbusier, hombre-arquitecto, que acaba siendo también, un pacto con la vida. Porque el arquitecto que construye su propio habitáculo establece, a través de su propia obra, una relación de libertad y de renuncia con la vida. En 1965 Le Corbusier pasa sus últimas vacaciones en el Cap Martin, donde acude ya muy débil y cansado, con recomendaciones expresas de su hermano Albert a la familia Rebutato respecto al régimen alimenticio y las necesidades de reposo que precisaba: "Así se podrá recuperar de su enorme cansancio" ${ }^{, 32}$. Efectivamente, el arquitecto fallece aquel mismo verano, mientras tomaba su baño diario en las rocas, y desde entonces descansa, junto a su esposa Yvonne, en el pequeño cementerio de Roquebrune, frente al mar.

l'aimer». Asimismo, en la tesis de la autora se presentan algunos planos de este proyecto en el que se especifican las diferentes propiedades.

${ }^{29}$ Martínez Duran, Anna. La casa del arquitecto. Director: Helio Piñón Pallarés. Universidad Politécnica Catalunya, Departamento de Proyectos Arquitectónicos, 2008. En http://www.tdx.cat/handle/10803/53596.

${ }^{30}$ El año 2000 Robert y Monique Rebutato, conscientes del valor patrimonial del lugar, ceden la propiedad de l'Etoile de Mer, después de haber conseguido que diferentes administraciones comprasen y restaurasen la E1027.

${ }^{31}$ La cita original es: "Ah! oui, il y a la mer ou le paysage ou le soleil, ciel et espace. Ah, ah, ces 8 m2 ne valent qu'à cette condition.”, en : Petit, Jean: Le Corbusier parle. Lugano: Fidia, 1996. Los 8 m2 no se refieren a Le Cabanon, sino a la cabaña de trabajo.

${ }^{32}$ Petit, Jean: Le Corbusier. Lui même. Ginebra: Rousseau, 1970. La traducción es de la autora 


\section{Agradecimientos}

La autora agradece a la Fondation Le Corbusier la cesión desinteresada de las imágenes y a las bibliotecarias del COAC, delegación de Barcelona, su atención y paciencia a lo largo de tantos años. También a la dirección de la Escuela de Arquitectura La Salle su apoyo en fomentar la investigación a través del grupo "Investigaciones de Arquitectura Mediterránea", IAM.

\section{Procedencia de las imágenes}

1. La Capanna di Le Corbusier al Cap Martin. Domus No 284, julio 1953. pp 1-4. L4(11)19-239@FLC-ADAGP (Fotógrafo Lucien Hervé)

2. Rebutato, Robert: “Après midi tranquille au cabanon”. En Le Corbusier. Moments biographiques. Paris: Fondation La Corbusier, 2008. pp. 16-25. L4(10)69 CFLC-ADAGP (Fotógrafo desconocido)

3.4.5. Martínez Duran, Anna. La casa del arquitecto. Director: Helio Piñón Pallarés. Universidad Politécnica Catalunya, Departamento de Proyectos Arquitectónicos, 2008. En http://www.tdx.cat/handle/10803/53596. (Dibujo Anna Martínez Duran)

6. Le Corbusier, Carnets 1950-1954. Milán: Electa, 1981. FLC Carnet F26-838@FLC-ADAGP

7. Le Corbusier, Carnets 1950-1954. Milán: Electa, 1981. FLC Carnet G29-982@FLC-ADAGP

8. Rebutato, Robert: L'Étoile de Mer, un restaurant au bord de l'eau et ses peintures murales. En Lorenzo, Claude. (Dir.): Eileen Gray. L’Étoile de Mer. Le Corbusier. Trois aventures en Mediterranée. Paris:

Archibooks+Sautereau, 2013. pp. 76-91. L3(5)31@FLC-ADAGP (Fotógrafo René Maestri).

9. Le Corbusier, Projet et Rob, Roquebrune-Cap Martin, and other buildings and projects, 1948-1950. Nueva

York: Garland, Paris: Fond. Le Corbusier, 1983. Plan FLC 18913@FLC-ADAGP

\section{Bibliografía/referencias}

Alison, Filippo, Le Corbusier. L'interno del Cabanon. Verona: Electa, 2006.

Boesiger, Willy (Ed.): Le Corbusier. Oeuvre Complète 1946-1952. 7ª ed. Zurich: Girsberger, 1976.

Chiambretto, Bruno: Le Corbusier à Cap Martin. Marsella: Parenthèses, 1988.

Le Corbusier, El Modulor y Modulor 2. $3^{\mathrm{a}}$ ed. Barcelona: Poseidón, 1980.

Le Corbusier: Le poème de l'angle droit. Madrid: Círculo de Bellas Artes, 2006.

Martínez Duran, Anna. La casa del arquitecto. Director: Helio Piñón Pallarés. Universidad Politécnica Catalunya, Departamento de Proyectos Arquitectónicos, 2008. En http://www.tdx.cat/handle/10803/53596.

Morel-Journel, Guillemette: "En Somme, j'ai travaillé comme un zèbre à Vézelay”. En Le Corbusier. Moments biographiques. Paris: Fondation La Corbusier, 2008. pp. 108-125.

Petit, Jean: Le Corbusier parle. Lugano: Fidia, 1996.

Petit, Jean: Le Corbusier. Lui même. Ginebra: Rousseau, 1970.

Rebutato, Robert: “Après midi tranquille au cabanon”. En Le Corbusier. Moments biographiques. Paris: Fondation La Corbusier, 2008. pp. 16-25.

Rebutato, Robert: L'Étoile de Mer, un restaurant au bord de l'eau et ses peintures murales. En Lorenzo, Claude. (Dir.): Eileen Gray. L'Étoile de Mer. Le Corbusier. Trois aventures en Mediterranée. Paris: Archibooks+Sautereau, 2013. pp. 76-91. 


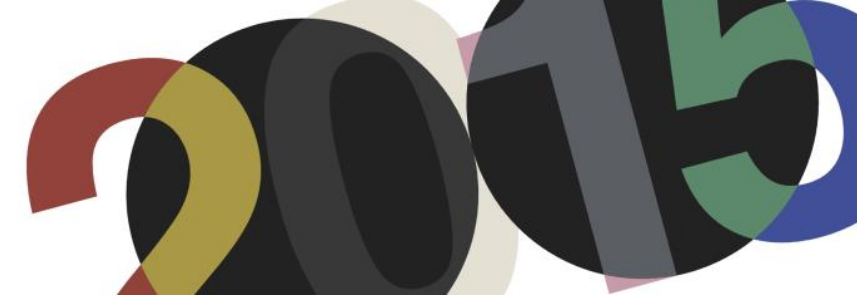

DOI: http://dx.doi.org/10.4995/LC2015.2015.837

\title{
Elogio del cuadrado: cuadrícula, cuadro, cuatro, cubo
}

\author{
A. Martínez-Medina \\ Área de Composición Arquitectónica. Dpto. de Expresión Gráfica y Cartografía. Universidad de Alicante
}

\begin{abstract}
Resumen: Un recorrido por la producción de Le Corbusier evidencia la insistente presencia del cuadrado como base de las composiciones en diversos campos (urbanismo, arquitectura, pintura, mobiliario...) y en diferentes formatos (en planta, alzado y sección, o como marco, módulo y cuadrícula). La presente comunicación realiza un análisis formal (gráfico y simbólico) de sus proyectos y obras, rastreando los modos en que se utiliza el cuadrado permaneciendo en el tiempo como una constante recurrente. Para ello se recorren cuatro áreas temáticas que descienden en escala y en dimensiones: 1) capitolios, 2) museos, 3) pabellones y 4) casas, estudiando una serie de ejemplos en cada área a partir de los planos de la Fundación Le Corbusier, generando discursos que reconstruyen un hilo del tiempo en la evolución de los procesos compositivos. De este modo, se desgrana el empleo del cuadrado, en correspondencia con las áreas de estudio, como: $1^{\circ}$ ) perímetro de la plaza pública donde insertar las arquitecturas representativas, $2^{\circ}$ ) marco o caja-fuerte donde encerrar los tesoros artísticos (o sagrados), $3^{\circ}$ ) volumen cúbico abierto y desmontable y $4^{\circ}$ ) caja definida por la retícula de la estructura. El cuadrado es siempre un medio y no un fin. Persiste un intento de sugerir algunos de los orígenes en su formación clasicista, sus viajes y sus pinturas.
\end{abstract}

\begin{abstract}
A tour through the production of Le Corbusier shows the insistent presence of the square as a basis of compositions in various fields (urban planning, architecture, painting, furniture...) and in different formats (in floor, elevation and profile, or as a theme, module and grid). This communication makes a formal analysis (graphic and symbolic) of its projects and works tracing the different ways to use the square that remains as a recurring constant. We can do it through four thematic areas descending in scale and dimensions: 1) capitols, 2) museums, 3) pavilions and 4) houses, studying a series of examples in each area based on the drawings of the Foundation Le Corbusier, generating speeches that reconstruct a thread of the time in the evolution of the compositional process. In correspondence with the four themes of study, we can discovery the employment of the square as different instruments. First: the square as the perimeter of the public space where to insert the representative architectures. Second: as a frame or safety deposit box where to enclose treasures artistic (or Holy). Third: as a cubic volume open and detachable. Fourth: as box defined by the grid of the structure. The square is always a means and not an end. In addition, there is an attempt to suggest some of the origins in his classic formation, his travels and his paintings.
\end{abstract}

Palabras clave: Le Corbusier, composición, cuadrícula, cuadrado, cuadro, cubo.

Keywords: Le Corbusier, composition, reticle, square, frame, cube.

\section{El cuadrado como composición (introducción)}

Un rápido repaso visual a toda la producción arquitectónica de Le Corbusier (en un principio: Charles-Édouard Jeanneret, 1887-1965) manifiesta la constante presencia de cuadrados que persisten a lo largo del tiempo en muy diversos formatos; la nitidez y rotundidad de esta geometría se vuelve más evidente en los planos y en los volúmenes de su última década. La permanencia de este tema formal en los distintos frentes de trabajo del maestro suizo revela, cuando menos, su apego y confianza en esta forma elemental, al margen de la escala del proyecto o de la materialidad de la obra, la cual sí presenta dos etapas, antes y después de la II Guerra Mundial (IIGM): la estética pulcra del objeto industrial (hecho a máquina) frente a la estética basta del objeto artesanal (hecho a mano). 
A los volúmenes ligeros, pero frágiles, que responden a los cinco principios para una Nueva Arquitectura (1926), le suceden sólidos graves que, en su masa de hormigón visto, se aproximan a los resistentes búnkeres que Paul Virilio veía como arqueología (1958), ruinas de la primera arquitectura moderna del siglo XX. Aunque pudiera especularse con que se trata de dos concepciones distantes de arquitectura, en realidad, ambas etapas responden a una única trayectoria de pensamiento que se sustenta sobre una misma base geométrica que sirve de entramado a casi todas sus obras. De hecho, el cuadrado (el medio y el doble) está presente en todas sus creaciones, sean estas de urbanismo, arquitectura, pintura, exposiciones, diseño de mobiliario o edición de libros, presentándose en diferentes formatos: en planta, alzado y sección o como marco límite, módulo ordenador y cuadrícula base. El propio Le Corbusier, antes de la IIGM, afirmó y evidenció en varias ocasiones su apoyo en los trazados reguladores de ascendencia clasicista (razón y sección áureas) así como, tras la IIGM, razonó la conveniencia del empleo de 'el modulor' elaborado por él mismo; el primero es un sistema de proporciones y el segundo es un sistema de medidas adaptado a la escala humana: ambos son herramientas que derivan de un cuadrado inicial ¿Qué tienen en común la capilla para el Hospital de Venecia, la fachada del Secretariado, la Unité de FirminyVert, el museo de Chandigarh, la sede de los Hiladores, la estructura de las manufacturas de Sant-Dié, los estudios en Cap Martin, el plan de Buenos Aires, las viviendas en Pessac o la casa Citrohan? Entre otras cuestiones, suponen un elogio del cuadrado, bien como inicio en la génesis del proyecto, bien como medio en el diseño, nunca como un fin en sí.

Para descubrir las recurrentes manifestaciones del cuadrado se ha optado por un análisis formal y gráfico de una amplia cantidad de proyectos cuyos planos se recogen en una publicación de 16 volúmenes de la Fundación Le Corbusier $^{1}$. Se ha procedido a escalarlos y medirlos, a cuantificar pórticos, distancias, módulos, proporciones, ejes y diagonales, detectando la presencia y el uso de la figura protagonista. Los resultados de este análisis se han agrupado en cuatro áreas que descienden en escala y en dimensiones: capitolios, museos, pabellones y casas. Dentro de cada línea investigada se genera un discurso que reconstruye un hilo del tiempo en la evolución de los mecanismos compositivos aportando, en algunos casos, ciertas interpretaciones simbólicas. En correspondencia con estos cuatro campos, se desgrana el empleo del cuadrado en sus diferentes capacidades, en tanto que instrumento de orden y de significado. El discurrir cronológico también lo es hacia atrás en un intento de sugerir sus inicios en su formación clasicista, en sus viajes y en sus pinturas ${ }^{2}$. Puede que, para el maestro, todo partiese de un cuadrado patrón — sin escala — como motor de percepción y como garantía de orden, armonía y belleza. Con todo, nos interesa más el proceso evolutivo y cómo los temas (forma y metáfora) pasan de un lugar a otro urdiendo un tapiz de relaciones, aunque la realidad sea siempre más compleja que la aparente sencillez que aquí se expone.

\section{Temas de exploración: capitolios, museos, pabellones y casas (metodología y desarrollo)}

Intentaremos ser sintéticos al ofrecer una visión de la vasta y panorámica obra de Le Corbusier incidiendo en cuatro temas: capitolios (plazas encuadradas), museos de arte (boîte à miracles), pabellones de exposición (cubos desmontables) y casas (cuadradas y cúbicas), que se ordenan por escalas: de la mayor extensión (ciudad, ámbito público) a la menor dimensión (viviendas, ámbito privado).

\footnotetext{
${ }^{1}$ Para la cronología de los proyectos del presente texto, se toman las fechas de: Fondation Le Corbusier. Le Corbusier Plans, 1905-1965. (16 vols.). Paris: Echelle-1, 2005; la mayoría de planos que acompañan al presente proceden de esta fuente. El tratamiento digital de los planos y la composición de las imágenes ha sido realizada por David Gil Delgado.

${ }^{2}$ Calatrava, J. "Una visión del mundo. Le Corbusier: The Art of Postcards". Madrid: Arquitectura Viva, No170, 2015; pp: 4851. Esta exposición insiste en la estrecha relación figurativa entre las obras de LC, sus viajes y las postales.
} 


\subsection{Capitolios encuadrados: marcos llenos y vacíos}

Le Corbusier tuvo la oportunidad de hacer una ciudad de nueva planta con el encargo de Chandigarh (1951-55). Aunque ya había planos, decide, en medio de sus viajes, sustituir el inicial viario orgánico por otro de matriz reticular ordenado según un eje que se dirigía a las montañas y que, emulando su Ville Radieuse (1930), se remata con un área capitolina (fig. 1). En esta cabeza dirigente sitúa los edificios de los tres poderes (ejecutivo, legislativo y judicial) sobre una inmensa plaza: el capitolio se concibe como una gran explanada de "forma rectangular (...) compuesta de dos cuadrados iguales, cada uno dividido en cuatro sectores del mismo tamaño (...). Los cuadrados se encontraban cortados por (...) un canal de agua, un elemento simbólico de purificación"”3. Surge así el cuadrado en la base de los elementos clave en "un lugar que tiene una especie de magia en relación con las montañas y el cielo"4. Los croquis a color hechos en su primera visita así lo atestiguan.

Aunque los diseños preliminares sufren diversos cambios hasta la versión definitiva del capitolio, en todos ellos se mantiene la posición enfrentada entre las sedes parlamentaria y judicial bajo la mirada del ejecutivo (no construido), la disposición de las piezas sobre grandes superficies cuadradas, la presencia de un jardín de inspiración mogol (cuadrícula) en su linde superior y de un juego de relaciones geométricas entre los edificios que conjugan proporciones, formas, medidas y carga simbólica. Como señala Monteys: "En Chandigarh, la explanada, elemento clave de esta composición, se pone en valor a través de distintas operaciones, entre las que destacan las grandes superficies de agua reflejando en ocasiones las fachadas de los edificios"5. Veamos algunas de estas constantes que remiten al cuadrado como base de la composición, sea como vacío y plaza o como lleno y edificio.

Este gran foro se divide en dos cuadrados y, en el extremo norte del lado de unión entre ambos, se dispone la 'pirámide escalonada' del palacio del Gobernador (1951). El eje que une ambos cuadrados guía el conjunto: en el cuadrado este se dispone una plaza cuadrada - vacío - delante del palacio de Justicia (1952), mientras que, en respuesta especular, al oeste, este espacio está ocupado por la planta cuadrada del palacio de la Asamblea (1955) - lleno-; ambos edificios se multiplican con sus imágenes sobre el agua de los estanques cuadrados ${ }^{6}$ : láminas creadoras de un microclima que suaviza las temperaturas extremas. Un juego de alternancia de llenos y vacíos para los poderes legislativo y judicial mediante la simetría, y de jerarquía para el ejecutivo por su posición en cabeza.

El palacio de la Asamblea se emplaza en el centro del cuadrado de poniente y sus medidas (100x100m) reafirman su peso como centro de gravedad ${ }^{7}$. Este edificio se sirve de una retícula de pilares que, por adecuación al programa, presenta diversos módulos: el de la escala urbana (pórtico exterior), el de la escala doméstica (zona de oficinas) y el de la escala pública (el vacío interior que aglutina las dos cámaras: cuadrada y circular). Con este último módulo (de $8,15 \mathrm{~m}$ ) se despeja un espacio dentro del palacio legislativo donde se inscribe la sala circular de representantes, haciendo coincidir las diagonales de ambos cuadrados: del vacío interior y del lleno exterior (fig. 6).

Fuera de la plaza, el palacio del Gobernador también presenta planta cuadrada, el cual cabe con exactitud dentro del volumen casi cúbico que contiene la sala circular de diputados. Es más, no solo coinciden las medidas totales (41x41m), sino también las parciales del módulo único de la estructura $(8,15 \mathrm{~m})$, cuya cifra acusa la escala

\footnotetext{
${ }^{3}$ Casciato, M. [2013]. "Chandigarh: el paisaje de una nueva capital” en: AA.VV. Le Corbusier. An Atlas of Landscapes. Madrid: rev. Monografías, No 176, 2015; pp: 26-33.

${ }^{4}$ Curtis, W.J.R. [1986]. Le Corbusier: ideas y formas. Madrid: Hermann Blume, 1987; p: 201.

${ }^{5}$ Monteys, X. [2005]. Le Corbusier. Obras y proyectos. Barcelona: Gustavo Gili, 2008; p: 162.

${ }^{6}$ Parra, J. "Imágenes y metáforas del agua en el pensamiento de LC". Valencia: ViA-arquitectura, № 10, 2001; pp: 8-15.

${ }^{7}$ Para las connotaciones simbólicas de la Asamblea véase: Curtis, W.J.R. [1986]. Ob. cit; pp: 188-201.
} 
pública de la 'casa' del Gobernador en lugar de referenciar una supuesta escala doméstica, vinculando más estrechamente ambos proyectos. Así pues, el palacio del Gobernador parece estar extraído del interior de la Asamblea (como si hubiese sido 'determinado' democráticamente desde dentro - alegoría-), constituido por un espacio modulado de $5 \times 5$ cuadrados. Superpuesto sobre este esquema compositivo emerge la estructura principal del palacio conformada por un cuadrado de dieciséis pilares que define una sala-tipo de nueve cuadrados (con múltiples posibilidades espaciales ${ }^{8}$ ) que hace coincidir 'topológicamente' la planta del palacio del Gobernador con la sala de lectura de la Biblioteca Nacional en París ${ }^{9}$, de Henri Labrouste, donde Le Corbusier se empapaba de textos e imágenes sobre arquitectura clásica y académica por recomendación de Auguste Perret ${ }^{10}$.

En esta continua alternancia de presencias y ausencias (donde el palacio del Gobernador se extrae del volumen de la cámara de representantes — cuadrado y círculo-, que se engloba en un cuadrado sobre la diagonal del palacio de la Asamblea, cuyo cuerpo se opone a la plaza y a los estanques del palacio de Justicia), la figura del cuadrado adquiere un protagonismo indiscutible (extendido a otros elementos del foro de los poderes, como la Mano Abierta y la Torre de las Sombras) en un juego compositivo que se desvanece, en parte, por la escala y por la inconclusión de las obras. Los cuadrados aquí son explanada y jardín, plazas y estanques abiertos —el vacíoy, también, son perímetro de planta y retícula de estructura, volúmenes y espacios cerrados —el lleno— con sus desplazamientos y compensaciones. El cuadrado marca y enmarca, cuadra y recuadra todos los elementos.

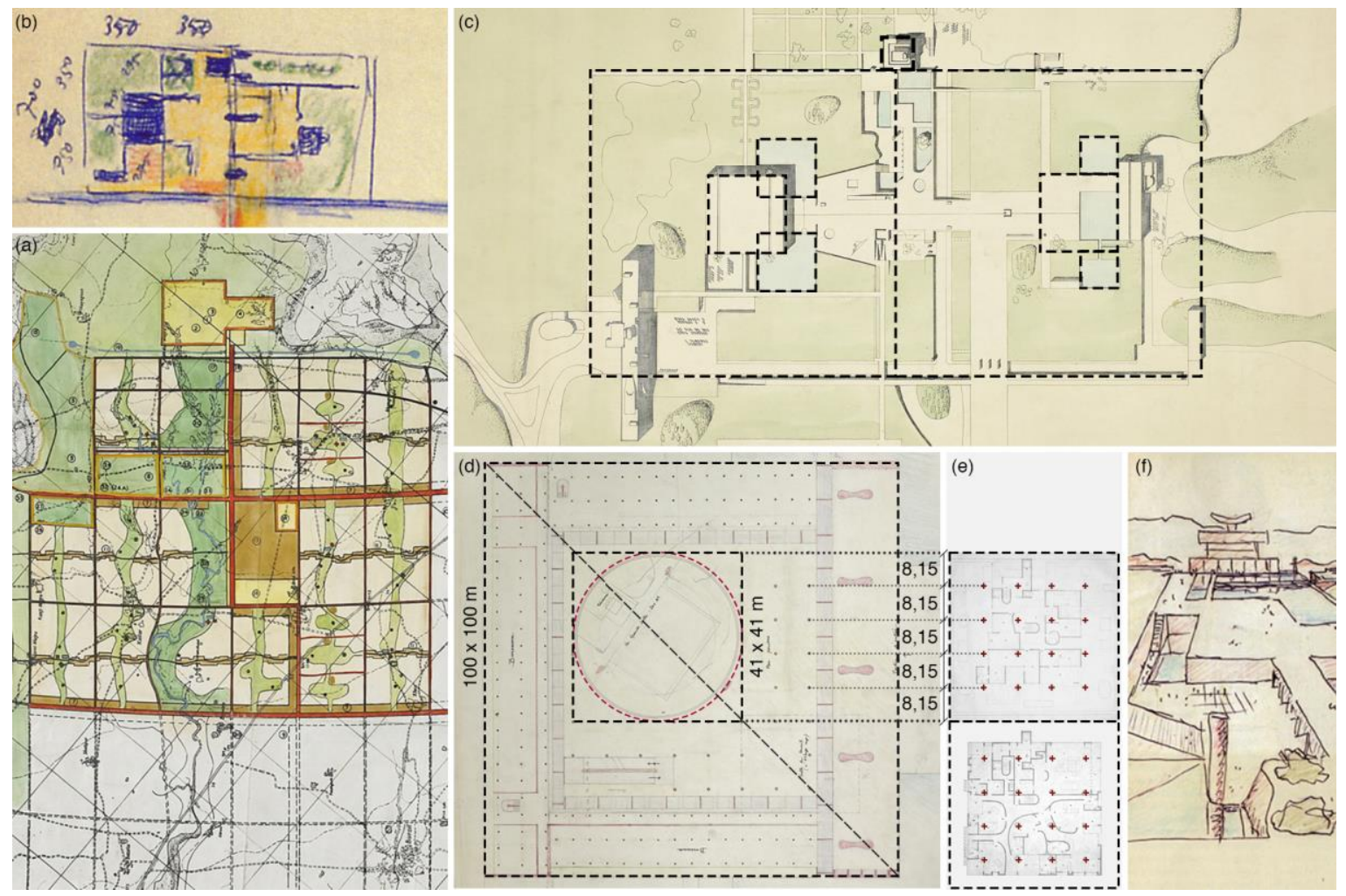

1. Capitolio de Chandigarh: (a) ordenación urbana (5.104@FLC-ADAGP); (b) boceto del capitolio (Casciato 2015); (c) planta de la explanada (5.151 $\mathrm{OFLC}-\mathrm{ADAGP})$; (d) planta del palacio de la Asamblea (2.957@FLC-ADAGP); (e) plantas del palacio del Gobernador (3.792 y 3.794@FLC-ADAGP); (f) croquis palacio del Gobernador (Casciato 2015).

\footnotetext{
${ }^{8}$ Véase el palacio del Gobernador en: Monteys, X. La habitación. Más allá de la sala de estar. Barcelona: Gustavo Gili, 2014.

${ }^{9}$ Este espacio presenta sus doce columnas del perímetro separadas del cerramiento de la sala de lectura iluminada cenitalmente con nueve lucernarios circulares; su concepción bien pudo influir en Le Corbusier. Puede consultarse: Frampton, K. Estudios sobre cultura tectónica. Barcelona: Akal, 1999; pp: 39-66.

${ }^{10}$ Cohen, J.L. [2013]. "Roma: una lección de paisaje urbano" en: AA.VV. Le Corbusier. An Atlas of Landscapes. Madrid: rev. Monografías, nº 176, 2015; pp: 26-33.
} 


\subsection{Museos de arte: boîte à miracles}

De todas las arquitecturas del capitolio punjabí impresiona el palacio de la Asamblea, tanto por su volumen exterior como por su esqueleto interior, todo uno. La rotunda planta del edificio no es un hito extraordinario en la trayectoria del maestro: la usa de modo insistente, una y otra vez, en los museos proyectados y construidos en su vida. Esta serie arquitectónica comenzaría en la trilogía del Mundaneum (1928) y los museos de arte contemporáneo y de crecimiento ilimitado (1931), se construiría en Ahmenabad (1951), Tokyo (1955), Cambridge-USA (1961) y Chandigarh (1964), y culminaría con el proyecto del centro internacional de arte de Erlenbach (1961); todos ellos albergaban colecciones de arte. Resulta casi inevitable relacionar estos museos con las mezquitas selyúcidas de Edirne y Bursa visitadas por Le Corbusier en 1911 que le causan una "Impresión inmensa y definitiva gracias al cuadrado perfecto" ${ }^{" 11}$ que las envuelve y contiene la cuadrícula isótropa de columnas (que eleva cúpulas idénticas).

Un análisis geométrico y métrico de los planos de seis de los museos citados revela proximidades entre ellos y una cierta evolución (fig. 2). Mientras el Mundaneum se concibe en volumen como un zigurat que se recorre por su interior, anunciando su reminiscencias sacras ${ }^{12}$, los demás museos comprimen este ascenso y lo sustituyen por un camino de suaves rampas que acompaña a las salas dispuestas en espiral respecto del centro (movimiento que se traslada hasta el exterior) configurando un cuerpo cúbico hermético, salvo en la planta a cota cero, que exige la iluminación cenital de las salas. Repetidamente, la solución de la estructura es una cuadrícula de columnas cuya distancia entre ejes deviene doméstica (rango 3,75-5,60m) y cuyas mallas de pórticos están seriadas $\left(\mathrm{n}^{\circ}\right.$ par de vanos); solo en dos casos estos espacios isótropos se vacían de columnas en el eje central para señalar el acceso, hecho que no deviene norma. Por último, mientras los museos no ejecutados presentan medidas diversas del recinto exterior (41x41-56x56m), los construidos acusan cifras cercanas (ca. 30m).

En síntesis, las características formales del tipo del museo serían: cuadrado exterior, cuadrícula de pilares interior, desarrollo de las salas de exposición en espiral desde el espacio central y volumen cúbico de hasta cuatro alturas: planta baja como "maraña de pilotes" (diáfana y abierta) y plantas superiores en desarrollo de las estancias (densas y cerradas). La luz llega al interior mediante claraboyas dispuestas en función de la propia orientación del edificio respecto de los cuatro puntos cardinales. Como señala J.L. Cohen "Le Corbusier ha reflexionado durante 30 años de manera incansable sobre el museo antes de darle una forma definitiva [...por lo que....] se puede ver en esta hipótesis, siempre mejorada, una especie de hipertrofia de Ville Savoye" ${ }^{13}$. Quizás esta idea se podría formular a la inversa y entender aquella villa como un museo - más que como una casadesde su origen, y todo museo es para recorrerlo y contemplar las obras expuestas, aunque en Poissy también se mire hacia afuera.

Estas arquitecturas encerradas entre los límites de una planta cuadrada con envoltura maciza no son objetos aislados: su programa se extiende más allá de la caja opaca en otros volúmenes menores (para teatros, salas de muestras, talleres, almacenes...) que se sitúan exentos respecto del perímetro cuadrado, salpicando las explanadas que rodean a los museos. Estas piezas, con sus posiciones desplazadas respecto de los planos de simetría del cuerpo cúbico, establecen una relación dinámica con los ejes de la retícula interior y del cuadrado marco exterior, adaptándose al movimiento de una espiral; ahora bien: las estructuras de estos volúmenes concuerdan con las de sus museos matrices, siendo parte de su expansión. Con esta visión, el museo puede interpretarse como una caja fuerte, blindada, que encierra tesoros artísticos, mientras que los elementos que

\footnotetext{
${ }^{11}$ Le Corbusier en: Daza, R. Tras el Viaje de Oriente. Charles-Édouard Jeanneret. Barcelona: Arquia, 2015; pp: 85 y 126.

${ }^{12}$ Eliade, M. [1956]. Lo sagrado y lo profano. Barcelona: Phaidós, 2015; p: 35, el ziggurat era "una montaña cósmica".

${ }^{13}$ Cohen, J.L. Le Corbusier, 1887-1965. El lirismo de la arquitectura en la era mecánica. Köln: Taschen, 2004; p: 97.
} 
aparentemente custodian su alrededor serían los contenedores que amplían el programa con otras actividades culturales y basculan en torno al museo; estos guardianes suelen ser de menor dimensión con el fin de no competir ante la supremacía del centro.

Con estos antecedentes se puede aventurar que, para Le Corbusier, el arte se integra en el territorio de lo sagrado: "Ver la Acrópolis es un sueño (...); y he aceptado desde hace mucho tiempo que aquí esté como el depósito del calibre sagrado, base de toda medida de arte" ${ }^{\prime 14}$. Museo de arte y templo sacro se aproximan en Le Corbusier ${ }^{15}$. Y para proteger lo sagrado, el hombre traza y construye un muro perimetral que precinta el lugar y lo aísla del exterior, salvo por una puerta, según Mircea Eliade: así han sido los espacios sacros de la mayoría de las diversas religiones a lo largo de la historia. También Ronchamp tiene ese muro casi ciego y protector. Ejemplos de arquitectura religiosa (de lo sagrado, lo inconmensurable o lo inexplicable) que abundan en esta dirección serían las iglesias de Le Tremblay (1929) y de Saint-Pierre en Firminy-Vert (1961), la capilla del hospital de Venecia (1965) o los túmulos funerarios de Delgado-Chalbaud ${ }^{16}$ (1951) y de su propia esposa (1959); todos estos casos -en proyecto u obra - quedan definidos por un perímetro cuadrado, como límite o frontera de separación entre dos mundos. Y todo elemento que defiende algo ha de ser fuerte y resistente, de aquí que estos ejemplos se levantasen o previesen en hormigón, ladrillo o mampostería. Para terminar, conviene recordar que "si toda obra de arte vuelve al origen de su género (...), toda obra de arte guarda un gesto de familiaridad con el origen" ${ }^{n 17} \mathrm{y}$, dado que los museos en Le Corbusier representan un lugar sagrado y sus recintos son cuadrados, quizás el cuadrado sea cofre de tesoros, centro de gravedad y boîte à miracles ${ }^{18}$; quizás esté en la génesis de toda su arquitectura.

\footnotetext{
${ }^{14}$ Jeanneret, Ch.E. [1911; 1965]. El viaje de Oriente. Valencia: COAATA y MOPU, 1984; p: 174.

15 Significativamente "Museos-Arquitectura sacra" es un capítulo en: Boesiger, W.; Girsberger, H. [1971]. Le Corbusier1910-1965. Barcelona: Gustavo Gili, 1987; pp: 233-285.

${ }^{16}$ Estas cuatro obras pueden verse en: Burriel, L.; Fernández-Cobián. Le Corbusier. Proyectos para la iglesia católica. Buenos Aires: Diseño Editorial, 2015.

${ }^{17}$ Quetglas, J. "Hacia Ronchamp" en: AA.VV. Le Corbusier, mensaje en una botella. Alicante: CTAA, 2011; pp: 147-157.

${ }^{18}$ Término usado por Le Corbusier para designar la Kaaba de La Meca y sus propios museos prototípicos; ver: Frampton, K. [1997]. Le Corbusier. Madrid: Akal, 2000; p: 139.
} 


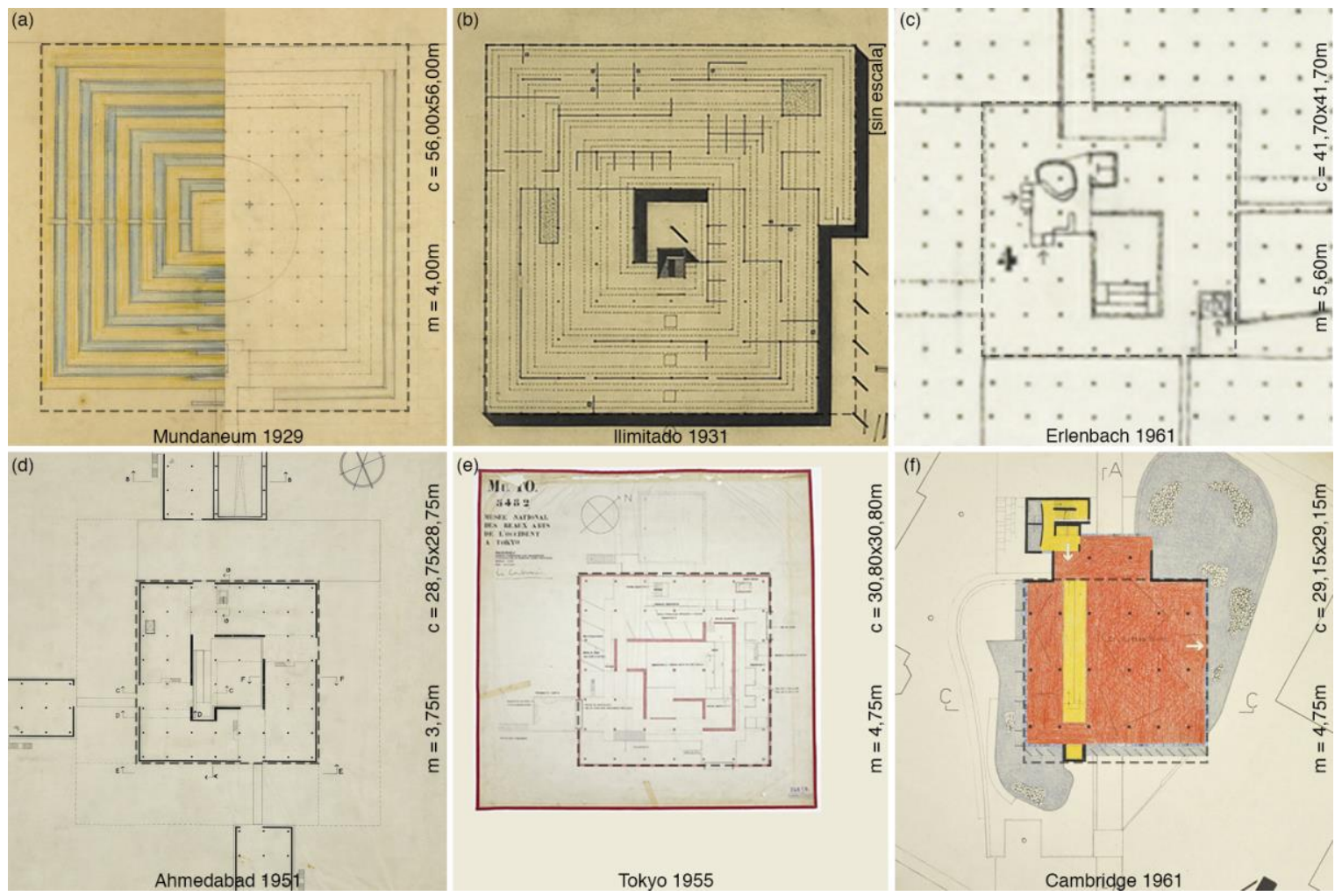

2. Museos: (a) Mundaneum 1928 (24.583@FLC-ADAGP); (b) Museo de Crecimiento Ilimitado 1931 (30.884@FLCADAGP); (c) Centro Internacional de Arte en Erlembah 1961 (23.421@FLC-ADAGP); (d) Museo en Ahmedabad 1951 (6.954 OFLC-ADAGP); (e) Museo en Tokyo 1955 (24.619@FLC-ADAGP); (f) Museo en Cambridge 1961 (31.268@FLCADAGP).

\subsection{Pabellones de exposición: cubos desmontables}

¿Y el origen de los templos que custodian lo sagrado? ¿Cuál sería según el maestro? En su libro Vers un Architecture (1923) propone como templo para las tribus nómadas "un lugar de espacio bien ordenado"19 que es una enorme choza. Este "templo primitivo" presenta una geometría regular, modulada y precisa, que adopta en planta la forma de dos cuadrados (10x20 módulos) en su recinto de verja exterior y de un rectángulo de casi dos cuadrados (4x9 módulos) en el perímetro de lona que encierra el propio templo. En el dibujo de la sección de esta tienda de campaña se regruesa el cuadrado inscrito en su espacio interior. Quizás sea casual la asociación de ideas, pero Le Corbusier, en casi todos los pabellones para exposiciones eventuales que diseña, dado su carácter de evento transitorio y efímero, adopta el tipo de 'cabaña desmontable' y, en lógica consecuencia, los materiales son más ligeros: perfiles, chapas y cables metálicos, superficies y cuerdas textiles. La mayoría de estos pabellones feriales acogía en su interior muestras impactantes en lo visual (imágenes, luces, sonidos) y novedosas en lo artístico (dioramas, urbanismo, fotografía, cine). Contenido (arte de vanguardia) y contenedor (pabellón temporal) entran en resonancia y su geometría, como en los museos, comienza en el cuadrado. Y como corresponde a todo museo, se requiere de un recorrido para observar las piezas o los objetos allí depositados, de aquí que la geometría esvástica sea la base de muchas de sus distribuciones. La serie de estos pabellones incluiría, al menos, seis obras (fig. 3): Les Temps Nouveaux (1937, París), los pabellones de Francia (1937 Lieja y 1939 París), el proyecto para la Exposition Synthèse des Arts Majeurs (1949, Porte Maillot, París), el 'palacio' de exposiciones Ahrenberg (1962, Estocolmo) y la Casa del Hombre (1961-67, Zurich). En esta lista se

${ }^{19}$ Le Corbusier [1923]. Hacia una arquitectura. (1 ${ }^{\text {a }}$ reimp). Barcelona: Apóstrofe, 1998; p: 53. 
establecen dos grupos: con la planta distribuida sobre un cuadrado (pabellones anteriores a la IIGM) y con la planta organizada a partir de dos cuadrados adosados por un lado (posteriores a la IIGM). Todos se erigen con estructuras de acero: pueden ser trasladables.

En el primer grupo, las cubiertas de los pabellones evolucionan desde un andamiaje de tensores que fijan los puntales de sostén atirantados a tierra (y que evocan la imagen del templo primitivo) hasta una estructura de pilares y celosías curvas en vuelo. A su vez, la planta del cuadrado se multiplica hasta los dos o los cuatro cuadrados y la cuadrícula inicial de cables a tracción se sustituye por pilares en los puntos medios de los cuadrados (sean uno o cuatro). El interior de estos espacios expositivos cúbicos se secuencia mediante una promenade que transcurre sobre un juego de rampas en espiral: rampas que en Les Temps Nouveaux se adosan al perímetro vaciando el centro y que en los otros dos pabellones generan una plataforma central elevada desde donde contemplar la muestra. En el segundo grupo, la planta tipo presenta un perímetro exacto de dos cuadrados, con seis pilares situados en sus puntos medios exteriores y con una cubierta unitaria en "forma de caparazón con apoyo a medio vuelo y esquinas en voladizo" ${ }^{\text {20 }}$. Muchos de estos pabellones fueron resueltos por Le Corbusier como si de un tipo genérico de validez universal se tratara: sistematizado para construirse en cualquier parte y acoger cualesquiera objetos. Sin embargo, en estos pabellones, las rampas establecen recorridos que entran y salen del cuerpo de la cubierta conduciendo a los visitantes a través de los dos niveles, y describen un travelling al exterior que recuerda el del interior en sus primeras casas y villas en las que basó los cinco puntos de la "Nueva Arquitectura"; no en vano, el pabellón de Zurich, que estaba pensado como un prototipo de espacio para exposiciones $^{21}$, desarrollaba un programa de vivienda en dúplex. Llama la atención esta doble conexión de los pabellones: con los museos, como contenedor y antecedente, y con el hábitat humano, como contenido y destino en este último caso.

Es interesante este circuito que se retroalimenta: templos primigenios que son tiendas de campaña; tiendas que inspiran pabellones y se adecúan como casas que, en su origen, lo eran a imagen y semejanza de las moradas de los dioses, por lo que lo sagrado vuelve a estar omnipresente, y la Casa del Hombre es un museo de arte que se vuelve cabaña desmontable ${ }^{22}$. Templo, tienda, pabellón, cabaña, templo: todo va y vuelve — ¿lo pensaría así Le Corbusier?) - . De hecho, el pabellón de Zurich se compone de dos cubos dentro del volumen generado por la cubierta sobre la planta de dos cuadrados adosados; estos hexaedros están separados por la rampa y se dimensionan ya con el modulor (module+section d'or), en cuya sistematización de medidas a escala humana había trabajado el maestro en plena IIGM y que dio a conocer en los libros El Modulor (1948) y El Modulor II (1953); libros de formato cuadrado. A lo largo de sus páginas se explica cómo a partir de un cuadrado inicial se genera su sección áurea y su diagonal abatida dando lugar a la figura de un doble cuadrado $(2 \times 1,13=2,26 \mathrm{~m}$ donde se inserta un hombre con la mano alzada) y cuyo desarrollo geométrico se relaciona con la razón de la serie de Fibonacci ${ }^{23}$, proporcionando las medidas humanas para la arquitectura.

Sin embargo, el pabellón por excelencia sería el refugio para las vacaciones que Le Corbusier se construye para sí mismo en Cap Martin (1951): Le Cabanon, una de las primeras obras donde puso en práctica el modulor. El diminuto volumen, casi cúbico y con pendiente a una sola agua, cuenta con dos pequeñas ventanas cuadradas $y$, en su austeridad, recuerda a una celda monacal donde se concentra un programa de existenzminimum individual distribuido en espiral. Está ejecutado en su totalidad en madera que, en las fachadas, muestra la corteza de sus troncos primigenios. Salvo por la cubierta de fibrocemento, esta arquitectura seca (sin agua, sin cemento) y

\footnotetext{
${ }^{20}$ Frampton, K. [1997]. Ob. cit.; p: 133.

${ }^{21}$ Dumont, C.; Benton, T. Le Pavillon de Le Corbusier pour Zurich.... Zurich: Lars Müller Publishers, 2013.

${ }^{22}$ Frampton, 2000, ob. cit.; pp: 131-146. Sitúa el pabellón Philips (1958) como "cima y punto final" del "Arte Sacro" de LC.

${ }^{23}$ Le Corbusier [1948 y 1953]. El Modulor y Modulor 2. (3ª ed.). Barcelona: Poseidón, 1980; pp: 31-64.
} 
desmontable, bien podría ser una 'cabaña para el hombre' en medio del bosque, de no ser porque esta construcción se adosa a la civilización en el testero sudeste del restaurante L'Etoile de Mer, sobre el acantilado y frente al mar. Este cuarto para el retiro del maestro (cuyas experiencias de soledad y silencio Le Corbusier repite a lo largo de su existencia) puede entenderse como un ejercicio de síntesis por el que el frío pabellón se transmuta en una cálida cabaña como hogar del artista — la casa -, y toda ella condensada en un solo cuadrado (de $3,66 \times 3,66 \mathrm{~m})$.

(a)

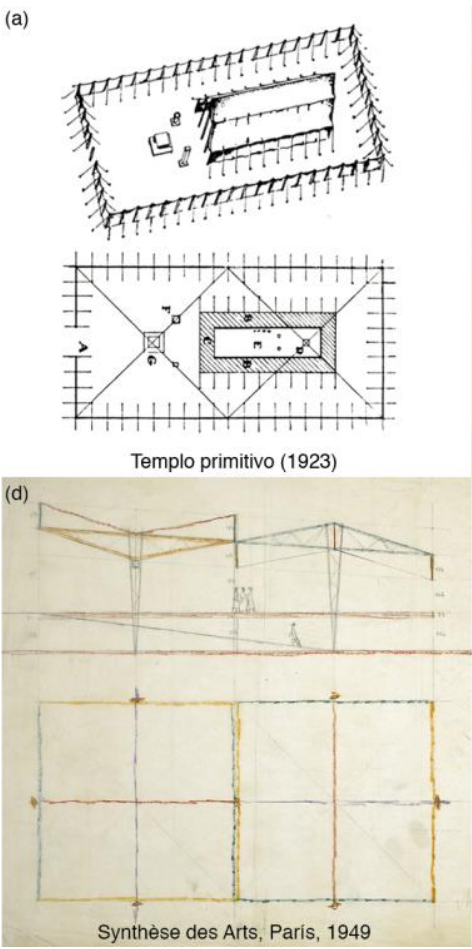

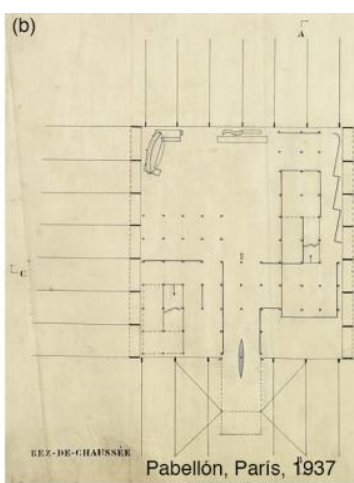

(e)

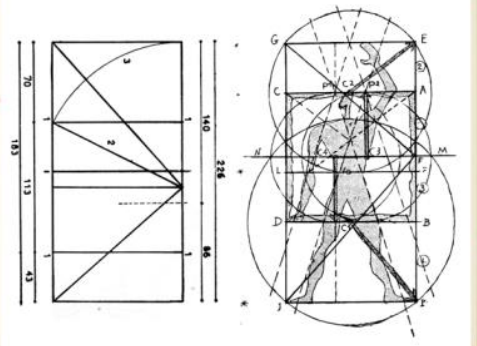

El Modulor, 1942-46

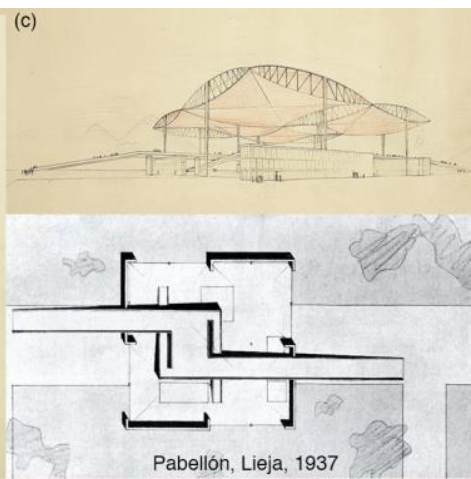

(f)

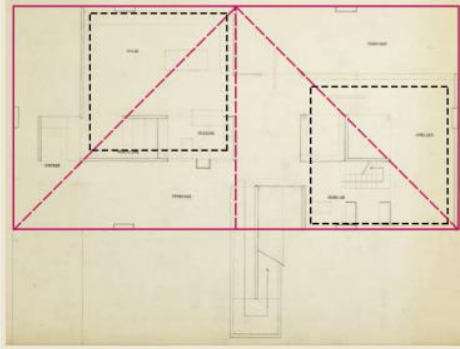

Pabellón, Zúrich, 1961

3. Pabellones: (a) templo primitivo según LC en 1923 (LC 1998); (b) pabellón Les Temps Nouveaux 1937 (783 OFLCADAGP, Monteys 2005); (c) pabellón del Agua Lieja 1939 (24.290@FLC-ADAGP); (d) pabellón Synthèse des Arts 1949 (18.185@FLC-ADAGP); (e) el Modulor 1942-46 (LC 1980); (e) pabellón Casa del Hombre 1961 (21.078@FLC-ADAGP).

\subsection{Casas cuadradas, cajas cúbicas}

Si hay alguna 'casa' en la que se resuma la trayectoria de Le Corbusier, esta es la villa Savoye (1928-29), cuyas cualidades visuales platónicas ${ }^{24}$ la han convertido en un icono de la modernidad. Se trata de una 'casa' concebida como un pallazo exento (con habitación para el servicio doméstico): en los bajos están los útiles (máquinas), en el piano nobile la residencia (familiar) alrededor del cortile, y en la planta alta el belvedere lúdico (terraza-jardín con vistas). Además, esta villa de reminiscencias clasicistas anticipa recursos formales y distributivos propios de sus museos: en ella "Le Corbusier reafirma, con la imposición del cuadrado, las cualidades espirales de la asimetría, la rotación y la dispersión periférica" ${ }^{25}$. Aunque su perímetro no es un cuadrado exacto, su retícula base (20x20m) definida por los pilares exentos (5m) sí lo es, como también lo es el patio tangente a su fachada oeste (10x10m). Quizás se pueda afirmar que tanto Le Cabanon como la villa Savoye son casas cuadradas con vocación cúbica.

\footnotetext{
${ }^{24}$ Rowe, C. [1947]. Manierismo y arquitectura moderna y otros ensayos. Barcelona: Gustavo Gili, 1980.

${ }^{25}$ Frampton, K. [1980]. Historia crítica de la arquitectura moderna (9 ${ }^{\mathrm{a}}$ ed.). Barcelona: Gustavo Gili, 1998; p: 159.
} 
El antecedente de la villa Savoye es la casa Meyer (1925), donde comienza la promenade architectural en el ámbito humano. El programa definitivo se despliega en cuatro plantas con la rampa pegada al linde; el contorno de todas ellas es un cuadrado que se vacía en una esquina por un espacio cuadrado, con la diagonal de ambos coincidiendo (como después en Chandigarh o Zurich). La distancia a la que se sitúa la fachada posterior dentro de la parcela ha sido elegida por Le Corbusier para hacer de la planta un cuadrado. Esta preferencia del maestro por la más elemental de las figuras planas es una práctica que le sirve para encuadrar muchas de sus residencias, sean casas (entre medieras o en fila) o villas (pareadas o aisladas). De la primera tipología sería representativa la casa Cook (1925) en la que el cuadrado se inserta entre la fachada posterior y el pilar exento de la parte delantera, usando el soporte central para dividir la superficie en cuatro cuadrantes. Y de la segunda tipología sería ilustrativo el conjunto de pareadas Loucher (1929), donde los programas mínimo y máximo se resuelven en uno o dos niveles y, recípocamente, las distribuciones se inscriben dentro de uno o de dos cuadrados (resultado este último de adosarse dos por uno de sus lados convertido en un grueso muro intermedio); en estas viviendas destaca que algunos aseos presenten su perímetro cuadrado exento (de esquinas curvas), acusando dentro la forma de fuera.

La larga lista de ejemplos de casas y villas resueltas a partir del cuadrado (como contorno o como geometría de la malla de estructura) expresa bien el calificativo de 'sintético' otorgado al maestro por su proceso de proyecto, ya que el programa se 'cuadra' en formas previas elegidas por él (fig. 4). Evidencia de esta práctica es la solución dada a la casa Curutchet (1949) que se resuelve, desde los primeros bocetos, en un cuadrado encajado al fondo del solar; planteamiento que se mantiene hasta el proyecto definitivo (reforzado por la cuadrícula de pilares), solo que, para entonces, de la residencia privada se ha desgajado la consulta médica volcada sobre una calle de La Plata. Sugerente resulta la sección de esta casa que, en la parte de la vivienda, se inscribe en un cuadrado y define una caja cúbica; este cubo, que se intuye, queda visto en las villas que construye en Ahmedabad en la década siguiente.

Para alcanzar el volumen compacto del hexaedro se requieren plantas, fachadas y secciones también cuadradas, no necesariamente como límites o marcos, basta con que esta forma regular se perciba visual o espacialmente. En este sentido conviene comprobar cómo la sección por la diagonal de la planta de las casas en serie para Artesanos (1925), que parte de una planta cuadrada (7x7m), acusa un perfil de dos cuadrados. Cómo las fachadas de los bloques de viviendas del barrio de Pessac constituyen una composición en damero (de 5x5m). O cómo el alzado y la sección de la villa Baizeau (1928) acusan su perímetro cuadrado. Si se analiza con detenimiento los planos de esta villa —alzado y sección, que responden a la misma proyección ortogonal—, se comprueba que el borde exterior que rodea los forjados está conformado por la sucesión de cuatro cuadrados que deslizan unos junto a otros sobre un eje vertical situado en la mitad de ambas superficies. En este caso, además, se materializa una novedad espacial: si las retículas neutras de pilares exentos revelan la fluidez horizontal del espacio de la planta libre, esta sección sugiere la expansión de esta cualidad también en sentido vertical.

Demostrada la persistencia del cuadrado, tanto como generador de plantas, alzados y secciones como del espacio cúbico, surge otro aspecto que abordar relativo a la presencia del cuadrado como origen de las distribuciones y de las tramas reticulares de pilares de la estructura, el cual revela la serie de relaciones básicas proporcionales en planta en la que basa Le Corbusier sus diseños. Veamos estos mecanismos en las dos viviendas para el barrio experimental de la Weissenhofsiedlung de Stuttgart (1927): las variantes 'Citrohan' y 'Dom-Ino'. En la casa Citrohan (casa, porque estaba pensada para adosarse), las cuatro plantas de la misma quedan definidas por una estructura de 4 pórticos paralelos (entre ejes $=5 \mathrm{~m}$ ) que definen dos cuadrados adosados, siendo las proporciones que vinculan la geometría de la estructura y la de la planta la serie 1:1 y 1:2, la cual se completa con 1:4 al sumar la escalera. En la casa Dom-Ino (casa porque, a pesar de las ventanas de los testeros, son dos las viviendas 
construidas con intención de crear una fila) se emplea un pórtico similar (girado $90^{\circ}$ respecto de fachada), pero, para completar la figura ordenadora del cuadrado, se recurre al cerramiento de fachada de manera que el perímetro de cada vivienda queda definido por 2 y 2,5 cuadrados, repitiéndose modulaciones y proporciones. Al margen de los múltiples ejemplos que ilustran estos engranajes que vinculan la estructura con los perímetros de los cerramientos a través del cuadrado (y con ellos la definición de volúmenes cúbicos), interesa destacar cómo el sistema de proporciones que maneja Le Corbusier es de raíz clásica y se anticipa en las propias viviendas al empleo de los trazados reguladores que, a veces, se aplican al exterior. Y, también, cómo este sistema de razones simples $(1: 1,1: 2,1: 4)$ ha estado presente siempre como instrumento de composición en los diversos temas abordados (incluso en urbanismo), tanto en las cuadrículas base como en los nuevos tipos arquitectónicos generados.

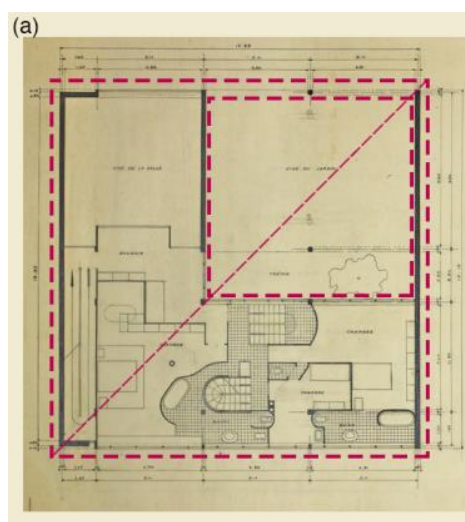

(e)
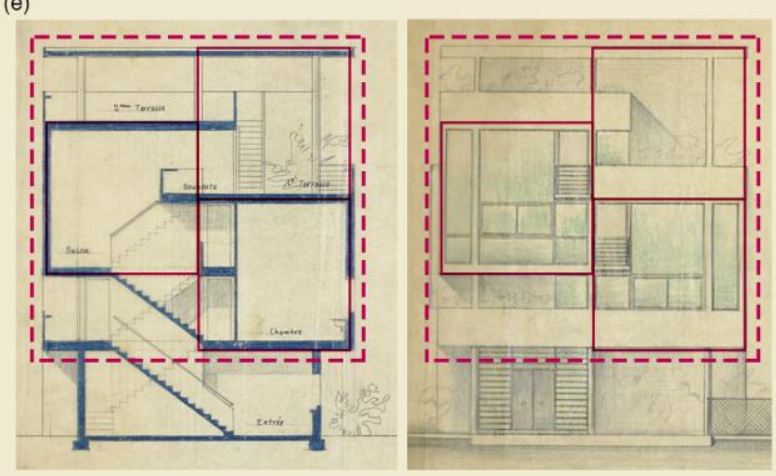

Villa Baizeau, 1928 (c)

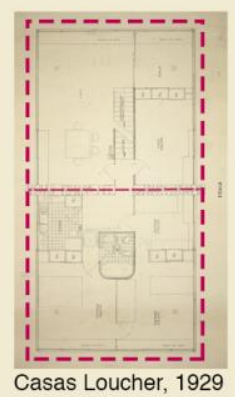

Villa Savoye, 1928

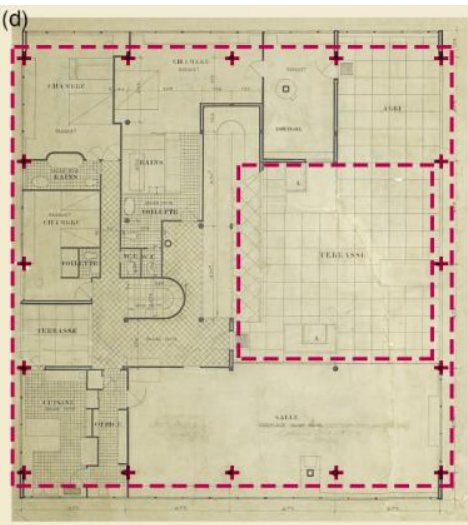

(f)

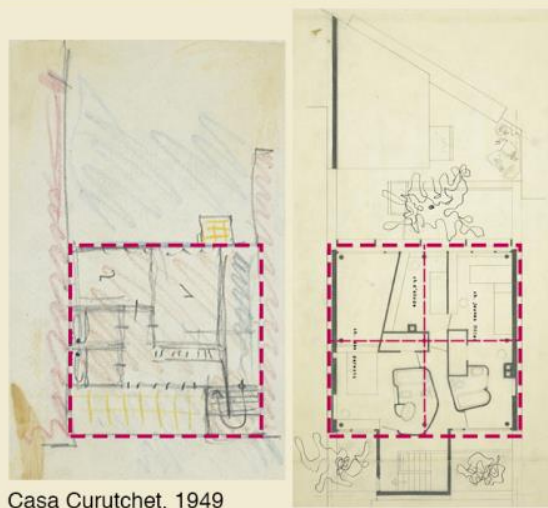

3. Casas y villas: (a) Casa Meyer 1925 (10.370@FLC-ADAGP); (b) Casa Cook 1925 (8.294@FLC-ADAGP); (c) Casas Loucher 1925: vivienda en dos plantas (18.236@FLC-ADAGP); (d) Villa Savoye 1928 (19.440@FLC-ADAGP); (e) Villa Baizeau: sección y alzado 1928 (8.511 y 8.475@FLC-ADAGP); (f) Casa Curutchet: boceto y planta del segundo nivel 1949 (30.542 y 12.101 OFLC-ADAGP).

\section{De regreso al origen (conclusiones)}

Alcanzado este punto procede volver sobre nuestros cuatro temas: capitolios, museos, pabellones y casas, algo que Le Corbusier hacía a menudo. En relación al capitolio de Chandigarh, el recurso al cuadrado (doble) sirve tanto para definir la plaza pública como para subrayar la misma mediante la adopción de esta forma para sus edificios representativos: los palacios de la Asamblea y del Gobernador; muy singular resulta la igualdad de medidas del módulo de la estructura y la coincidencia de ciertos perímetros entre ambos, constatando que el volumen de la residencia del ejecutivo se ha extraído del interior de la cámara de representantes en un juego de llenos y vacíos complementarios. En cuanto a los museos, se ha evidenciado la persistencia de la forma 
cuadrada, ahora como generadora de un volumen estanco y hermético, demostrando la afinidad que para el maestro se establece entre los territorios del arte y de lo sagrado, trazando un muro ciego a su alrededor; estas cajas de seguridad se sostienen gracias a una cuadrícula neutra de soportes. Bastante diferente de cuanto sucede en sus pabellones para exposiciones temporales, donde la estructura es la protagonista al dejar las trazas vistas del cuadrado definiendo el volumen exterior y el espacio interior. Pabellones-cubo que rememoran el arquetipo de arquitectura desmontable y transportable: tienda y cabaña, templo y casa de los pueblos nómadas. Este periplo concluye (o se inicia) en el interior del hábitat humano, en sus residencias, sean casas o villas (todas 'palacios'), donde el cuadrado se presenta tanto en planta, alzado y sección, como en sus retículas base de estructura definiendo estancias, contornos, espacios y volúmenes. Este análisis puede calificarse de 'Elogio del Cuadrado' por la permanencia del mismo a lo largo del tiempo, cuya poética (en sus mecanismos de composición, que anteceden a los trazados reguladores y al propio modulor) ya estaba avanzada en los años 20 , incluso antes (fig. 5).

Le Corbusier, que siempre quiso ser pintor, que siempre viajaba con cuadernos y que siempre dibujaba, pintó en 1918 en París, con 31 años, un óleo sobre lienzo (de 0,70x0,68m) titulado La Cheminée ("La Chimenea"), en cuyo reverso se puede leer "Ceci est mon premier tableau” ("Esta es mi primera tabla”, de madera); está firmado por 'Jeanneret' que, por entonces, aún no había adoptado el nombre de Le Corbusier. El cuadro recrea un cubo blanco que queda mucho más cerca del Cubismo que de su expresión ante la Acrópolis de Atenas: "El Partenón, (...) entroniza su cubo, frente al mar" ${ }^{26}$. En ambos casos confiesa su seducción por la geometría elemental que contienen estos hexaedros brillantes. Un par de años antes, en 1916, había proyectado la villa Schowb en su Chaux-de-Fonds natal. Esta villa, de planta cuadrada en su perímetro principal, define un volumen cúbico al exterior que configura su estructura con una cuadrícula de pilares (3x3 módulos, 16 soportes) que parte de un cuadrado central (con luz coincidente con la villa Savoye) ${ }^{27}$, cuya concatenación de espacios acusa influencias desde los croquis reflejados en sus cuadernos del viaje a Oriente ${ }^{28}$.

Quizás sea más significativo que un par de años antes, en 1914, proyectase la célula del sistema Dom-Ino ('Casa e Innovación'), como un juego de piezas combinables, definiendo con precisión las plantas tipo de las viviendas dúplex y la estructura de sostén. Cada pieza de este ‘juego' era una casa (de sección cuadrada y que se podía adosar por sus testeros) cuyo armazón de hormigón armado estaba conformado por una retícula de 8 pilares dispuestos según 2,5 cuadrados: la relación 1:1 era para las estancias mientras que la de 1:2 albergaba la escalera interior; remataba este manifiesto de independencia de la piel envolvente respecto del esqueleto sustentante la separación de los dos planos de las fachadas a una distancia de 1:4 del módulo. Aquí quedaba ya fijada esa serie de relaciones simples y clásicas de 1:1, 1:2 y 1:4. Por otro lado, en la esquina derecha del plano de la cónica donde se recrea una agrupación de casas Dom-Ino, puede distinguirse que el espacio público alrededor del cual se reúnen, sea una plaza o un jardín en lo alto de una loma, tiene planta de cuadrado doble. Este pintoresquista dibujo sería retocado por Le Corbusier para la publicación de este sistema y de sus revolucionarias ideas: se suprimieron los arcos y los típicos cipreses que evocaban su fuente directa, la cartuja de Ema, en Florencia, encaramada en una colina. Allí había permanecido por un mes en 1907, cuando tenía 20 años, para ejercitar la

\footnotetext{
${ }^{26}$ Jeanneret, Ch.-E. [1911; 1965]. Ob. cit.; p: 170.

${ }^{27}$ En la villa Schowb (como en la casa Citrohan), la distancia de $5 \mathrm{~m}$ lo es entre las caras de los pilares, mientras que, en la villa Savoye, la distancia de $5 \mathrm{~m}$ lo es entre ejes (ee) en una versión intermedia y de 4,75m en la versión final. A lo largo del presente artículo, cuando hablamos de módulo o intereje (ee) referimos, en general, la distancia entre ejes de pilares.

${ }^{28}$ Jeanneret, Ch.-E. [1911]. Voyage d'Orient. Carnets. Milano: Mondadori, 2002 (1987). Este es un camino interesante: los aprendizajes que subyacen en Le Corbusier procedentes de las iglesias ortodoxas y de mezquitas 'turcas'; estas últimas se sintetizan en dos tipos: reticulares (cuadrícula de pilares y cúpulas circulares) y de espacio central (de influencias bizantinas).
} 
vida en soledad ${ }^{29}$ y de allí surgirían muchas ideas arquitectónicas porque los monjes no vivían en celdas, sino en casas individuales (básicamente cuadradas en planta y cúbicas en el volumen) dispuestas junto al corredor del claustro y cada una con su jardín privado e independiente; las lecciones de este lugar serían otro capítulo ${ }^{30}$.
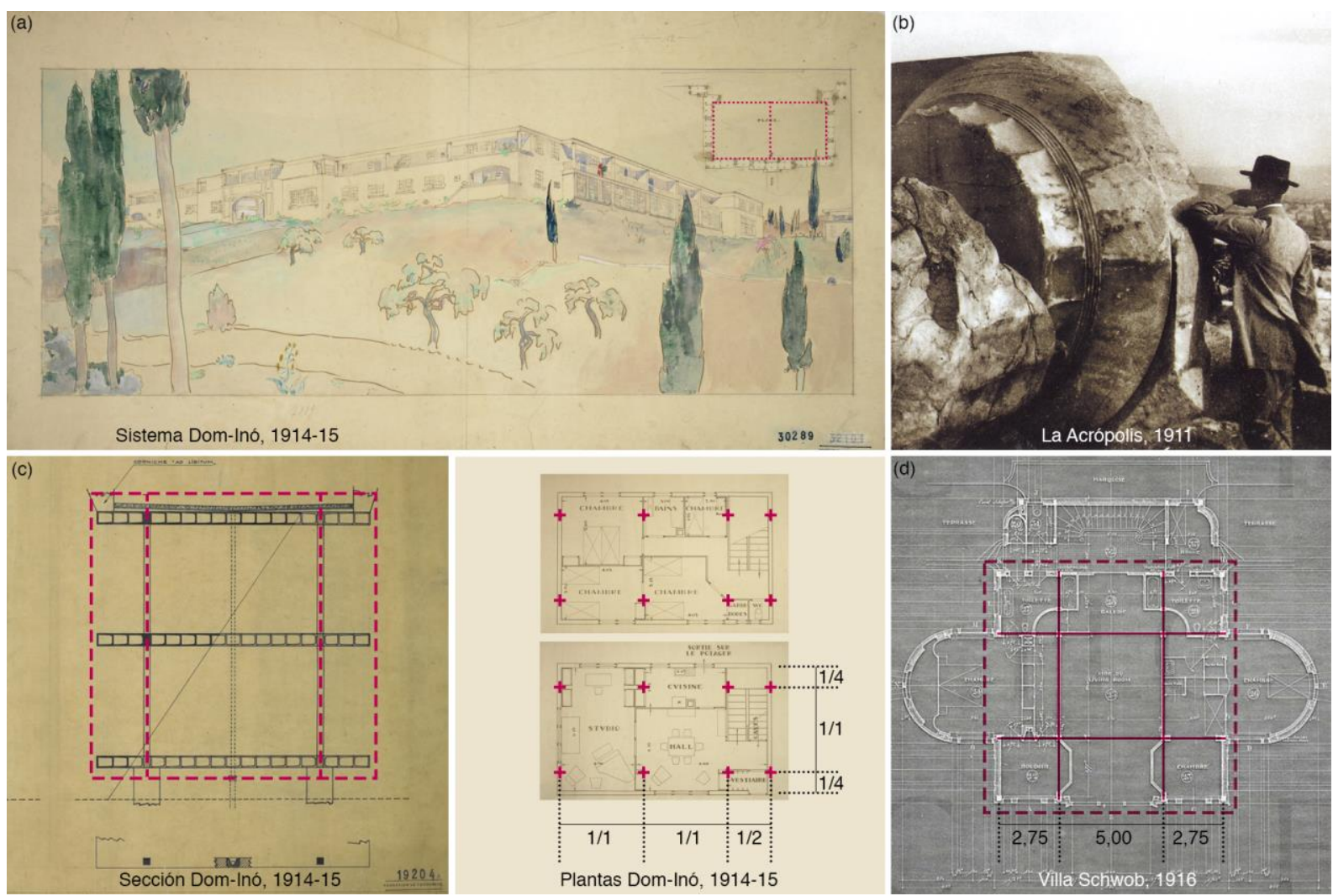

5. Orígenes: (a) perspectiva conjunto de viviendas Dom-Inó 1914-15 (30.289@FlC-ADAGP), (b) Le Corbusier en la Acrópolis de Atenas 1911 (Cohen, 2015), (c) sección cédula Dom-Inó (19.201@FLC-ADAGP), (d) plantas célula-vivienda Dom-Inó (19.172 y 19.211@FLC-ADAGP), (e) planta segundo nivel de la villa Schowb 1916 (33.172@FLC-ADAGP).

La fascinación de Le Corbusier por las construcciones coronando la cima de montañas —acrópolis- queda patente en sus cuadernos de viajes, muy especialmente en los Carnets de su Viaje a Oriente en 1911 que le llevaría por Turquía, Grecia e Italia, el cual, además de ser su primer gran viaje de estudios (y diversión), con 23 años, se revelaría iniciático, ya que el propio Le Corbusier revisita sus blocs el mismo año de su muerte y los prepara para su publicación (1966). De entre todas las ciudades y arquitecturas que le esperaban en el trayecto, son Atenas y el Partenón las que más expectación levantan en su ánimo: “¿Pero por qué (...) debo designarlo como el Maestro incontestable el Partenón (...)?”31. La geometría, la técnica y la perfección modular y de proporciones le sobrecogen: “A la izquierda del Partenón columnas enteras están caídas, echadas abajo (...). Su diámetro sobrepasa la altura de un hombre...”32; impresión que recoge en una fotografía en la que él mismo, de cuerpo entero, está apoyado sobre un capitel, oponiendo su silueta humana al círculo del equino que atraca contra el ábaco cuadrado: imagen que anticipa en tres décadas su modulor. Parte del secreto de las piedras del

${ }^{29}$ Gargiani, R. [1987]. "Vita di Charles-Édouard Jeaneret-Gris, Le Corbusier" en Brooks, A.H. (ed). Le Corbusier. (5 $5^{\mathrm{a}}$ ed.). Milano: Electa, 2001; pp: 292-325.

${ }^{30}$ Benton, T.; Cohen, J.L. (eds.). [2008]. Le Corbusier Le Grand. London: Phaidon Press Limited, 2014; pp: 19-84.

${ }^{31}$ Jeanneret, Ch.-E. [1911; 1965]. Ob. cit.; p: 175.

${ }^{32}$ Ibídem; p: 181. Estas expresiones y la foto de LC apoyado sobre el capitel dórico pueden evocar la planta de la Asamblea de Chandigarh: el cuadrado que contiene la sala circular presenta 20 columnas, número igual a las estrías del dórico del Partenón. 
Partenón es posible intuirlo si se visita y se mide su recinto interior, sagrado. Cuando uno se asoma al borde del estilóbato de un templo griego descubre que modulación y construcción son una misma cosa, y lo que se extiende ante la mirada es la cuadrícula de las losas cuadradas de las bases de los pilares circulares exentos situados en su perímetro, con su volumen, su materia y su pulcra ejecución. Le Corbusier entró al Partenón por en medio del cuarto y el quinto fuste, justo a eje del templo. Años después, en 1923, escribiría: "Porque los ejes, los círculos, los ángulos rectos, son las verdades de la geometría, son los efectos que nuestros ojos miden y reconocen" 33 .

Si tomamos como cierta la metáfora que sobre la vida traza F. Scott Fitzgerald en un breve relato que publica 1921, donde describe la historia vital del protagonista al revés del ciclo natural, se podría considerar que la vida resulta casi simétrica respecto del eje que pasa por el punto en que se alcanza la mitad de la edad que se vive. Bajo esta perspectiva, la anterior afirmación del maestro la realiza cuando tiene 36 años, en el ecuador de su existencia, en plena madurez, por lo que va a gobernar su amplia producción a partir de entonces: un sustrato compositivo académico que verifica en la historia y en diversas culturas. Charles-Édouard Jeanneret se está convirtiendo en Le Corbusier — arquitecto y pintor-, en quien se funden conocimientos de viajes, influencias clasicistas y experiencias cubistas. Aunque muchas claves de su arquitectura, según él mismo, residen en su pintura, el léxico básico al que recurre remite a la geometría del cuadrado de principio a fin, de la villa Fallet a la Casa del Hombre. La persistencia del cuadrado como tema de composición a lo largo de su trayectoria no supone un fin, sino que el cuadrado — en tanto que módulo ordenador, marco límite o cuadrícula base- se configura como el medio en sus procesos de diseño, porque le ofrece la seguridad de controlar las formas (derivadas mediante proporciones de ascendencia clásica) combinadas con los principios de libertad explorados por las vanguardias artísticas. El propio cuadrado acusa simbolismos arcaicos en una síntesis evolutiva entre arquitectura y arte en la que trabajaría el resto de su vida ${ }^{34}$ tejiendo un inmenso tapiz de fils du Temps.

\section{Bibliografía}

AA.VV. Le Corbusier. An Atlas of Landscapes. Madrid: rev. Monografías, № 176, 2015.

Benton, T.; Cohen, J.L. (eds.). Le Corbusier Le Grand. London: Phaidon Press Limited, 2014.

Boesiger, W.; Girsberger, H. Le Corbusier1910-1965. Barcelona: Gustavo Gili, 1987.

Brooks, A.H. (ed.). Le Corbusier. (5 ${ }^{\text {a }}$ ed.). Milano: Electa, 2001.

Burriel, L.; Fernández-Cobián. Le Corbusier. Proyectos para la iglesia católica. Buenos Aires: Diseño Editorial, 2015.

Calatrava, J. (ed.). Doblando el Ángulo Recto: 7 ensayos en torno a Le Corbusier. Madrid: Círculo Bellas Artes, 2009.

Calatrava, J. "Una visión del mundo. Le Corbusier: The Art of Postcards". Madrid: Arquitectura Viva, №170, 2015.

Cohen, J.L. Le Corbusier, 1887-1965. El lirismo de la arquitectura en la era mecánica. Köln: Taschen, 2004.

Curtis, W.J.R. Le Corbusier: ideas y formas. Madrid: Hermann Blume, 1987.

Daza, R. Tras el Viaje de Oriente. Charles-Édouard Jeanneret-Le Corbusier. Barcelona: Fundación Arquia, 2015.

\footnotetext{
${ }^{33}$ Le Corbusier [1923]. Ob. cit.; p: 54.

${ }^{34}$ Calatrava, J. "Le Corbusier, 1955: en los alrededores de El poema del Ángulo Recto" en: Calatrava, J. (ed.). Doblando el Ángulo Recto: 7 ensayos en torno a Le Corbusier. Madrid: Círculo Bellas Artes, 2009; pp: 9-39.
} 
Dumont, C.; Benton, T. Le Pavillon de Le Corbusier pour Zurich. Modèle et prototype d'un espace d'exposition idéal. Zurich: Lars Müller Publishers, 2013.

Eliade, M. Lo sagrado y lo profano. Barcelona: Phaidós, 2015 (trad. L. Gil Fernández y R.A. Díez Aragón).

Fondation Le Corbusier. Le Corbusier Plans, 1905-1965. (16 vols.). Paris: Echelle-1, 2005.

Frampton, K. Historia crítica de la arquitectura moderna (9ª ed.). Barcelona: Gustavo Gili, 1998.

Frampton, K. Le Corbusier. Madrid: Akal, 2000 (trad. J. Calatrava).

Frampton, K. Estudios sobre cultura tectónica. Barcelona: Akal, 1999 (trad. A. Bozal)

Jeanneret, Ch.E. El viaje de Oriente. Valencia: COAATA y MOPU, 1984.

Jeanneret, Ch.-E. Voyage d'Orient. Carnets. Milano: Mondadori, 2002.

Le Corbusier. Hacia una arquitectura. (1 $1^{\text {a }}$ reimp). Barcelona: Apóstrofe, 1998.

Le Corbusier. El Modulor y Modulor 2. ( $3^{\mathrm{a}}$ ed.). Barcelona: Poseidón, 1980.

Monteys, X. Le Corbusier. Obras y proyectos. Barcelona: Gustavo Gili, 2008.

Monteys, X. La habitación. Más allá de la sala de estar. Barcelona: G. Gili, 2014.

Parra, J. "Imágenes y metáforas del agua en el pensamiento de Le Corbusier". Valencia: ViA-arquitectura, $\mathrm{N}^{\circ}$ 10, 2001.

Quetglas, J. "Hacia Ronchamp” en: AA.VV. Le Corbusier, mensaje en una botella. Alicante: CTAA, 2011.

Rowe, C. Manierismo y arquitectura moderna y otros ensayos. Barcelona: Gustavo Gili, 1980.

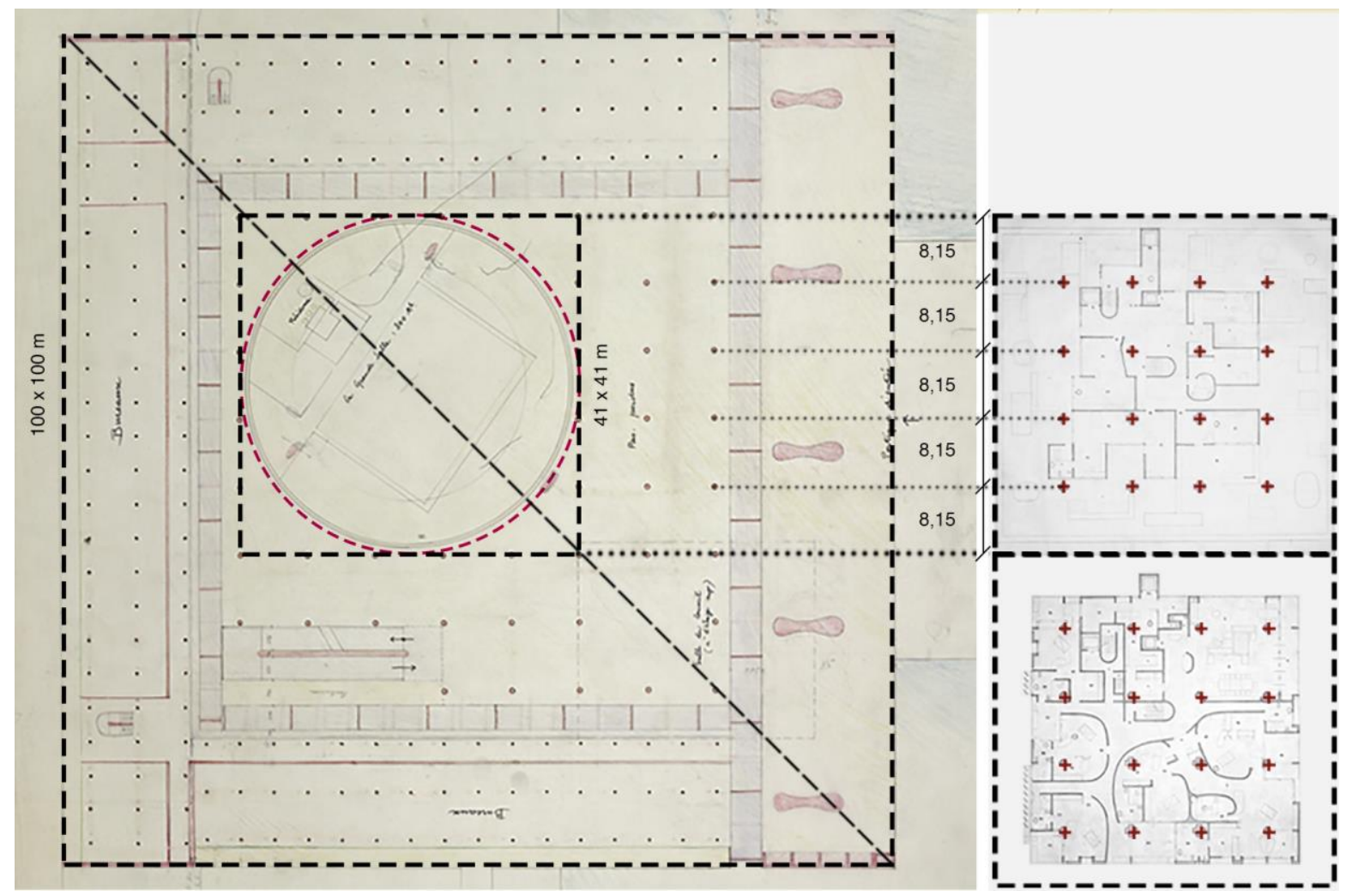

6. Capitolio de Chandigarh: planta baja del palacio de la Asamblea y dos plantas altas del palacio del Gobernador. 


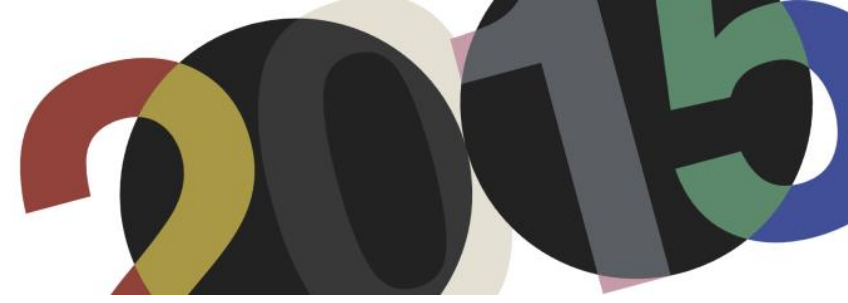

DOI: http://dx.doi.org/10.4995/LC2015.2015.824

\title{
Le Corbusier versus Sergei Eisenstein. La construcción de un sueño
}

\author{
E. Martínez Millana
}

\author{
Escuela Superior de Arquitectura de Madrid
}

\begin{abstract}
Resumen: Este artículo plantea la revisión de la relación entre el arquitecto Le Corbusier y el cineasta Sergei Eisenstein. Se lanza como hipótesis la posible influencia del cineasta en Le Corbusier. Le Corbusier versus Eisenstein en el sentido más profundo de 'avanzar en dirección a': Le Corbusier hacia la cinematografia, no como contraposición. Se esboza el papel de cada figura y su encuentro en el período de 1928-1936, tiempo en que Le Corbusier se aproximó a la Unión Soviética, un contexto que configura un marco complejo a partir del cual es posible entrever aquello que los vincula y que refuerza la hipótesis planteada. Por otro lado, se realiza un análisis de Poème électronique - filme de 480" que Le Corbusier hace en 1958 con motivo de la Exposición Universal en Bruselas - con la intención de visibilizar que Le Corbusier recurre a la técnica del montaje dialéctico de la que Eisenstein era maestro y por tanto la consustancial influencia. Le Corbusier reconoce el potencial de esta técnica de montaje y se sirve de ella como la estrategia clave en su aproximación al ámbito de la cinematografía. El mecanismo del montaje dialéctico forma parte de su propio pensamiento y lo materializa en su arquitectura y también en el caso de estudio que nos ocupa, en la disciplina de la imagen en movimiento, tan próxima a ésta. Pero hay más, en el Pabellón Philips la técnica del montaje oculto - sobre la que Eisenstein había teorizado en aquél periodo - está presente, pues mediante éste mecanismo construye la puesta en escena del espectáculo total. Como veremos, Poème électronique representa la construcción de un sueño.
\end{abstract}

Abstract: This article reviews the relationship between the architect Le Corbusier and the filmmaker Sergei Eisenstein. When launched, it was seen to hypothesise the possible influence of the filmmaker in the work of Le Corbusier. Le Corbusier versus Eisenstein, in the deepest sense of the expression, is portrayed as "towards to": Le Corbusier towards the film, not in opposition to it. It outlines the role of each figure and their interactions during the period between 1928 and 1936, the time when Le Corbusier got closer to the Soviet Union. This context forms a complex framework from which it is possible to glimpse what it is that links them, reinforcing the hypothesis-raised. On the other hand, this work presents an analysis of the Poème électronique - 480" film Le Corbusier made in 1958 for the Universal Exhibition in Brussels - in order to exemplify that Le Corbusier uses the technique of dialectical montage, in which Eisenstein was the undisputed master, thereby highlighting an inherent influence. Le Corbusier recognises the potential of this montage technique and uses it as a key strategy in his approach to the field of cinema. The mechanism of dialectical montage is a part of Le Corbusier's own thought and this materialises both in his architecture as well as in the subsequent case study regarding the discipline of the moving image, which is closely aligned to it. There is, however, more to it. In the Philips Pavilion, the hidden montage technique theorised by Eisenstein in that period - is present, the use of which was the mechanism to construct the stage for the spectacle as a whole. As we will see, Poème électronique represents the construction of a dream.

Palabras clave: Eisenstein; Le Corbusier; Le Poème électronique; montaje dialéctico; montaje oculto; cinematografía. Keywords: Eisenstein; Le Corbusier; Le Poème électronique; dialectical montage; hidden montage; cinematography.

\section{Introducción}

¿Por qué La construcción de un sueño? porque construcción implica técnica, y en este caso se trata del montaje; le sigue sueño, pues implica utopía. Le Corbusier y Sergei Eisenstein comparten esta manera de trabajar, ambos con el firme objetivo de comunicar experiencia. 
El presente trabajo tiene por objetivo la revisión de la relación entre el arquitecto y el cineasta. La investigación, sobre los vínculos que existen entre ambas figuras, ya ha sido emprendida anteriormente por otros autores ${ }^{1}$ desde el punto de vista trans*disciplinar, asociando las disciplinas propias de cada personaje. Se retoman las publicaciones al respecto con la intención de avanzar en la indagación de estas conexiones, y se lanza como hipótesis la posible influencia del cineasta en Le Corbusier. Le Corbusier versus Sergei Eisenstein en el sentido más profundo de 'avanzar en dirección a': Le Corbusier hacia la cinematografía. No como contraposición.

Con esta investigación se visibiliza que las teorías de Eisenstein están presentes en el filme Poème électronique, que Le Corbusier elabora con motivo de la Exposición Universal en Bruselas, en 1958. Reconoce el poder de este mecanismo de representación de la realidad, y la fuerza con que un mensaje puede transmitirse, precisamente por la capacidad que tiene de activar al espectador, e involucrarlo en la construcción de su significado. Por otro lado, no se obvia que el filme forma parte de la boîte à miracles del Pabellón Philips, un contenedor-substancia en el que están presentes también las teorías sobre el montaje que desarrolló el cineasta.

\section{Metodología}

Tras la hipótesis expuesta, la investigación se estructura fundamentalmente en dos bloques: el marco teórico y el caso de estudio.

En el primer bloque, se esboza el papel de cada figura y su encuentro en el período de 1928-1936. En el segundo bloque, se toma como caso de estudio el filme Poème électronique, y se incorporan los aspectos que permiten una más profunda comprensión del espectáculo del que forma parte, el lugar en el que se proyectó. El Pabellón Philips pudo suponer una respuesta a los presupuestos que Le Corbusier aprendió de Eisenstein. Este trabajo indaga sobre las teorías del cineasta en el periodo en que se conocieron, en concreto, sobre un par clave que visibiliza la posible influencia de Eisenstein en Le Corbusier: montaje dialéctico y montaje oculto.

\section{Resultados. Cuerpo del trabajo}

\subsection{Arquitectura y cinematografía desde el montaje}

En este primer bloque se indaga sobre el papel de Le Corbusier y Sergei Eisenstein, acotado en el período de tiempo entre 1928-1936, tiempo en que ambos propusieron teorías y proyectos que, desde sus disciplinas, trataban de construir una Unión Soviética tras la Revolución de 1917.

\subsubsection{Le Corbusier y Sergei Eisenstein}

El período en que Le Corbusier tendió puentes con la URSS se inicia con su visita a Moscú en Octubre de 1928; tiempo en que pudo conocer de primera mano la deriva de la Revolución de 1917. En aquel viaje conoció a Sergei Eisenstein, vio El acorazado Potemkin (1925) y cuatro rollos de Lo viejo y lo nuevo (1929). Le Corbusier concedió una entrevista en la que expresaba su admiración por el cineasta:

"La arquitectura y el cine son las dos únicas artes de nuestro tiempo. Creo pensar en mi propio trabajo como lo hace Eisenstein en sus películas. Sus trabajos penetran únicamente en la verdad. Sólo dan prueba de la realidad. Sus ideas, sus películas se parecen mucho a lo que me estoy esforzando por hacer en mi propio

\footnotetext{
1 Martínez de Guereñu, Laura: Montage: “Le Corbusier y Eisenstein”. En: Massilia 2008. Anuario de estudios Lecorbusierianos. Granada: Colegio de Arquitectos de Granada, 2008.pp.242-255
} 
trabajo. Su insistencia en lo esencial no sólo realza su trabajo por encima de la mera narrativa, sino que eleva los acontecimientos cotidianos que escapan de nuestra atención superficial al nivel de imágenes monumentales $" 2$.

Los textos de Le Corbusier pueden estudiarse de forma paralela a los de Eisenstein. El mismo año en que Le Corbusier publicó Vers une Architecture (1923), Eisenstein escribió Montage of Attractions ${ }^{3}$. Le Corbusier hacía referencia al "gran director de escena" de los edificios de la Acrópolis de Atenas:

"El desorden aparente del plan sólo engaña al profano. El equilibrio no es mezquino. Está determinado por el famoso paisaje que se extiende desde el Pireo al Monte Pentélico. El plan está concebido para su visión lejana: los ejes que siguen el valle y las falsas escuadras son habilidades del gran director de escena. La Acrópolis sobre su roca y sus muros de sostén, se ve desde lejos, en forma total. Sus edificios se amontonan en la sucesión de sus múltiples planos",

Fue en Hacia una Teoría del Montaje (1937), en el capítulo "Montaje y arquitectura", en donde Eisenstein empleó el mismo ejemplo que utilizó Le Corbusier en Hacia una arquitectura: la Acrópolis de Atenas; con este ejemplo, el cineasta vinculaba las teorías de montaje que él desarrollaba en el cine con la arquitectura,

"Sólo la cámara cinematográfica ha resuelto el problema de hacerlo (representar la multidimensionalidad visual) en una superficie plana, pero su antecesor ineludible con esta capacidad es la arquitectura. Los griegos nos han dejado los ejemplos más perfectos de diseño del plano, cambio de plano y duración del plano"

Eisenstein incluyó, en este capítulo, numerosas perspectivas y plantas que Auguste Choisy publicó en Histoire de l'Architecture 6 , y escribió "es difícil imaginar una secuencia de montaje de un conjunto arquitectónico con una composición más sutil, plano a plano, que la que crean nuestras piernas paseando entre los edificios de la Acrópolis ", . Le Corbusier también las utilizó en Hacia una Arquitectura.

Le Corbusier y Eisenstein, desarrollaban, de forma consciente y en paralelo, los mismos presupuestos; y, en este caso, se valieron del mismo ejemplo e ilustraciones para, desde la teoría expuesta en sus publicaciones, comunicar sus ideas.

\subsubsection{Montaje, cinematografía y revolución. Sergei Eisenstein.}

Resulta interesante detenerse en la dimensión de las teorías de Sergei Eisenstein, sobre el montaje en la cinematografía, en el período en que Le Corbusier visitó Moscú. Las claves de éstas ya estaban en las clases que

\footnotetext{
2 "Architecture and the cinema are the only two arts of our time. In my work I seem to think as Eisenstein does in his films. His work is shot through with the sense of truth, and bears witness to the truth alone. In their ideas, his films resemble closely what I am striving to do in my work. This insistence on essentials not only raises his work above mere narrative, bus also raises the everyday events that escape our superficial attention to the level of monumental images" Cohen, Jean-Louis: Le Corbusier and the mystique of the URSS: Theories and projects for Moscow 1928-1936. Princeton, New Jersey: Pinceton University Press, 1992.pp.48-49

${ }^{3}$ Apareció publicado, por primera vez, en la revista LEF: Levy Front Iskusstv (Frente de Izquierda de las Artes), en 1923.

${ }^{4}$ Le Corbusier: Hacia una arquitectura. Barcelona: Apóstrof, 1998.p.39

${ }^{5}$ Eisenstein, Sergei: Hacia una teoria del montaje. Vol.1. Barcelona: Paidós Ibérica, 2001.pp.87-109

${ }^{6}$ Choisy, Auguste: Histoire de l'Architecture. París: Baranger, 1899.p.330

${ }^{7}$ Eisenstein, Sergei: Hacia una teoria del montaje. Vol.1. Barcelona: Paidós Ibérica, 2001.p.89
} 
impartía en la Facultad de Dirección Cinematográfica (VGIK) en Moscú; en 1928-1929, impartió un curso, a modo de laboratorio, sobre dirección, y empezó como profesor oficial en 1932.

Las dos publicaciones que hizo sobre sus clases, El Granito de la ciencia cinematográfica (1933), más tarde reemplazado por Programa de Enseñanza (1936), reflejan "su firme determinación de comunicar todo lo que sabia", En palabras de Eisenstein, "el aspecto más importante no es exponer la solución, sino el método". Durante estos años de enseñanza, entre 1932-1935, el trabajo de Eisenstein "se caracterizaba por la exploración de nuevas posibilidades docentes y sus lecciones constituían una especie de revisión creadora del programa proyectado $^{, 10}$.

Resulta significativo que construyera el desarrollo de la clase como un coloquio, concediendo a los alumnos un papel activo en este proceso, en el que él "utilizaba la discusión de un nuevo problema como preparación para su propia solución, obtenida antes trabajosamente" ". Eisenstein, desempeña el papel del autor productor, "La mejor opinión de nada sirve si no induce a quienes la albergan a hacer algo útil",12; y, como señala Shklovski, "el artista tiene derecho a un cierto número de libertades en su relación con el material de la vida, libertad de escoger, de cambiar, de rechazar. Eisenstein sabe servirse de las cosas "13. Desde la teoría, la docencia y su obra: enseña el mecanismo, utilizándolo.

En la recopilación de sus Lecciones, el primer bloque agrupa la puesta en escena y la división de planos, pues "La puesta en escena contiene en si misma todos los elementos relacionados con la división y el montaje de planos",; $\mathrm{y}$, el segundo, la organización en el plano. Eisenstein los denomina así: "Si mise-en-scène significa puesta en escena, la ordenación de la escena; llamemos a la organización del plano mise-en-plan" "I5. Este par de mecanismos de montaje: la división de la acción en planos, y proyecto y planteamiento de la acción en un plano, es clave en la relación que se establece aquí entre Le Corbusier y Eisenstein.

\section{*La puesta en escena y la división de planos. El montaje dialéctico [ Mise-en-scène ]}

Para Eisenstein, el montaje abarca todos los aspectos de la producción del filme, y contiene operaciones como el planteamiento de la puesta en escena. Ésta ocupaba un lugar esencial en sus ideas, es “la determinación de los detalles de la acción para fines de representación, incluyendo, principalmente, la posición de los actores en los diferentes lugares, su movimiento en el espacio determinado por el decorado, la determinación del decorado para adecuarse a la acción "16.

Hasta aquí, propone una construcción de la puesta de escena que es común en el teatro y la cinematografía: la acción se divide en escenas, y las escenas en puestas de escena; el aspecto clave lo plantea cuando trasciende los

\footnotetext{
${ }^{8}$ Esta segunda versión está incluida en la recopilación que hizo un discípulo suyo, Vladimir Nizhny, a partir de los estenogramas de las clases del curso y las notas separadas que Nizhny tomó, especialmente de todos los dibujos hechos por Eisenstein que se conservan en el Archivo Eisenstein y en los archivos en el Instituto Cinematográfico (VGIK). Nizhny, Vladimir: Lecciones de cine de Eisenstein. Barcelona: Seix Barral, 1963.p.238

${ }^{9}$ Ibíd.p. 163

${ }^{10}$ Ibíd.p. 165

${ }^{11}$ Ibíd.p. 236

${ }^{12}$ Benjamin, Walter: El autor como productor. Madrid: Casimiro, 2015.p.28. Este texto se publica póstumamente a partir del manuscrito que preparó para una ponencia que no llegó a dar en París, 1934.

${ }^{13}$ Shklovski, Viktor: Eisenstein. Barcelona: Anagrama, 1973.

${ }^{14}$ Nizhny, Vladimir: Lecciones de cine de Eisenstein. Barcelona: Seix Barral, 1963.p.233

${ }^{15}$ Ibíd.p. 233

${ }^{16}$ Ibíd.p. 276
} 
límites del teatro, pues allí comienza el cine, "en el cine la división va más allá, cada puesta la escena se divide aún en unidades de montaje y la unidades de montaje en planos" "17. Eisenstein emplea el montaje desde el planteamiento y a lo largo de todo el desarrollo del proyecto.

Resulta interesante que Tafuri y Deleuze escribieran, al tiempo, sobre esta cuestión. Ambos destacaron la idea del plano del montaje como célula.

Tafuri, en La esfera y el laberinto (1980), recogió esta cita de Eisenstein: "El encuadre es una célula de montaje. Exactamente igual que las células nacen por división, originando un fenómeno de otro orden, el organismo o embrión, así, en otro extremo del salto dialéctico del encuadre, nos encontramos con el montaje. ¿Pero qué es lo que caracteriza al montaje y por tanto su célula o encuadre? El choque. El conflicto de dos fragmentos opuestos uno al otro" ${ }^{\text {"18. }}$.

Deleuze, en La imagen movimiento (1983), describió el montaje como un organismo destacando la analogía del plano como célula; y recogió el reproche que Eisenstein hizo a Griffith por no considerar la fuerza motriz por la cual la unidad dividida vuelve a formar una unidad nueva, "como unidad de producción, célula que produce sus propias partes por división, por diferenciación" $" 19$.

Tafuri lo describe como estallido, explosión del encuadre, y explica que "Eisenstein extrae el fotograma estático, fuerza el fotograma ideal a participar en la continuidad dinámica y temática, transfiguración extática provocada por la explosión, tiene por ello este primer significado, multiplica los significados potenciales”; y también subraya como precipita la imaginación del espectador , "es precisamente la fragmentación de los medios expresivos, el enfrentamiento con las leyes relativas a la estructura del organismo, y la desintegración de los elementos formales, lo que él hace precipitar con su imaginaria explosión "20.

Eisenstein, sobre el papel del espectador, describe en el artículo "Montaje de atracciones", publicado en la revisa soviética LEF (1923),

"Este método determina radicalmente las posibilidades de desarrollar una puesta en escena "activa"(el espectáculo es su conjunto): en lugar de ofrecer una "reproducción” estática del acontecimiento dado, exigido por el tema (...) se propone un nuevo procedimiento: el libre montaje de acciones (atracciones) ${ }^{\text {,21. }}$.

Lo describió con mayor precisión, en "Montaje”(1938), más tarde denominado "Palabra e imagen”,

"Su eficacia reside en que incluye en el proceso creador las emociones e inteligencia del espectador. Quien es obligado a marchar por el mismo camino creador recorrido por el autor al crear la imagen. El espectador ve no sólo los elementos representativos de la obra ya terminada, sino que vive también el proceso dinámico de la aparición y composición justamente como fue vivido por el autor (...) el espectador es arrastrado hacia un acto

\footnotetext{
${ }^{17}$ Ibíd.p. 142

${ }^{18}$ Eisenstein, Sergei: "Il principio cinematográfico e l'ideogramma". En: Forma e técnica, 1929.p.36, citado en Tafuri, Manfredo: La esfera y el laberinto. Vanguardias y arquitectura. De Piranesi a los años setenta. Barcelona: Gustavo Gili, 1984.p.93

${ }^{19}$ Deleuze, Gilles: La imagen movimiento. Barcelona: Paidós, 2014.p.56

${ }^{20}$ Tafuri, Manfredo: La esfera y el laberinto. Vanguardias y arquitectura. De Piranesi a los años setenta. Barcelona: Gustavo Gili, 1984.p.90

${ }^{21}$ Eisenstein, Sergei: Reflexiones de un cineasta. Barcelona: Lumen, 1970.p.314
} 
creador en el cual su individualidad no está subordinada a la del autor, sino que se descubre a través del proceso de fusión con la intención de aquél ${ }^{, 22}$.

El objetivo fundamental de Eisenstein es la comunicación con las masas a través de este arte, útil. Empleó el cine como medio y el montaje como técnica principal. Le Corbusier reconoce el potencial de las teorías de montaje del cineasta, precisamente por la capacidad que tiene de activar al espectador e involucrarlo en la construcción de su significado. Estos mecanismos los incorporó en su propio pensamiento y los materializó en su arquitectura, así como en su aproximación al ámbito de la cinematografía.

\section{*La organización dentro del plano. El montaje oculto [ Mise-en-plan ]}

La otra técnica de montaje que enseñaba en sus clases, consistía en la puesta en escena dentro de los límites de un plano: con una única posición y un solo ángulo de la cámara, y sin dividir la escena en planos. A este mecanismo lo denominó “montaje oculto",23.

En ambos mecanismos de montaje: mise-en-plan y mise-en-scène, Eisenstein explica que "el montaje interviene cuando el plano estalla, cuando la pantalla estalla. Cuando la tensión dentro de un plano alcanza sus límites y no puede crecer más el espacio del plano, entonces estalla, dividiéndose en trozos, unidades de montaje” ${ }^{24}$.

Eisenstein defendió la analogía entre la historia del desarrollo del espacio escénico en una representación teatral y la transición del plano al montaje. Sobre la cuestión de la unidad del espacio escénico, en el período barroco, aunque las decoraciones, por lo general, no variaban, explicaba que "trataron de desarrollar un espacio de representación escénica unificado de tal forma que, dentro de la decoración única, pareciera que una serie de construcciones se sucedian unas a otras ${ }^{, 25}$.

Para Eisenstein, el mise-en-plan radica en que "el plano y el montaje no pueden contraponerse uno a otro como esferas diferentes, sino como fases de una sola y única operación, como un salto dialéctico de la cantidad a la calidad. Hay casos en que se puede presentar la acción dentro de un plano con la misma saturación dinámica que por medio del montaje” ${ }^{26}$. En las clases, y de forma extensa en un artículo ${ }^{27}$, se refirió a los grabados de Piranesi para ejemplificar esta cuestión. El montaje oculto opera en un plano que no tiene límites.

Esta técnica de montaje oculto, Eisenstein, la teorizaba y materializaba en sus películas en el período en que conoció a Le Corbusier. Resulta significativa la analogía de este mecanismo en ambas disciplinas, Le Corbusier se pudo servir de ésta para el Pabellón Philips.

\subsubsection{Montaje, arquitectura y revolución. Le Corbusier en la URSS}

Le Corbusier, desde su visita a Moscú en octubre de 1928, quiso vincularse con la URSS. Utilizando como medio la arquitectura, desarrollaba los mismos presupuestos que Eisenstein esbozaba y experimentaba en el cine.

\footnotetext{
${ }^{22}$ Eisenstein, Sergei: El sentido del cine. Buenos Aires: Lautaro, 1941.p.35

${ }^{23}$ Nizhny, Vladimir: Lecciones de cine de Eisenstein. Barcelona: Seix Barral, 1963.p.232

${ }^{24}$ Ibíd.p. 213

${ }^{25}$ Ibíd.p. 212

${ }^{26}$ Ibíd.p. 213

${ }^{27}$ En "Piranesi, Or The Fluidity Of Forms" en Tafuri, Manfredo: La esfera y el laberinto. Vanguardias y arquitectura.De Piranesi a los años setenta. Barcelona: Gustavo Gili, 1984.pp.99-102. También en Oppostions. A journal for Ideas and Criticism in Architecture. №11. Winter 1977. Cambrigde, MA: The MIT Press, 1977.
} 
Sin embargo, como escribe Jean-Luis Cohen, "las afinidades entre la teoría de Le Corbusier, el élan lyrique de la máquina, y Eisenstein, y el pathos de la máquina, permanecieron menos explícitas que latentes",28.

\section{*Defensa del Centrosoyus}

Uno de los dos puntos clave en el período en que Le Corbusier trató de vincularse a la URSS, fue la construcción del Centrosoyus (1928-35). En 1933 publicó Défense de l'Architecture ${ }^{29}$ en el número monográfico que la revista francesa L'Architecture d'aujourd'hui dedicó a su obra conjunta con Pierre Jeanneret. Entre los proyectos que aparecían estaba el Centrosoyus. La imagen de la maqueta para el edificio de las cooperativas rusas, que se mostraba en la revista, era una vista cenital que se asemejaba irónicamente a la figura de un obrero trabajando con la maquinaria. El título que la acompañaba era el de "une maison sans escaliers".

Con esta publicación Le Corbusier se defendía de los ataques de los constructivistas hacia su élan lyrique: éstos alegaban que la arquitectura debía ceñirse a la función y las verdaderas necesidades. "Le Corbusier en lugar de atender únicamente a la función, basaba su trabajo en una serie de estrategias para dotar a su arquitectura de un "valor adicional", un componente estético que podía ofrecer a los habitantes de sus edificios, un papel activo en la creación de su significado". ${ }^{30}$

\section{*La relación truncada con la URSS}

El otro punto clave para comprender el período de Le Corbusier y la URSS, es el del concurso para el palacio de los Soviets, explica Cohen, en su monografía Le Corbusier et la mysthique de l'URSS, "el fracaso del proyecto que presenta al concurso del Palacio de los Soviets, supuso el final de la identificación entre arquitectura moderna y Unión Soviética, ${ }^{\prime 31}$.

Entre las hipótesis planteadas para comprender el proyecto que se presentó, Quetglas establece una muy sustanciosa, basándose en el dibujo que realiza Le Corbusier recién llegado a Moscú en el andén de la estación, lo compara con la perspectiva que presentó al concurso, y detecta que la coincidencia más significativa entre los dos dibujos es el arco, "el collar del caballo, en el dibujo junto a un arco del triunfo, se parece sorprendentemente a lo que será el arco de hormigón del palacio de los Soviets". El arco parabólico de cuero y madera, tomado del modo local de enganchar a los caballos en Rusia, "no un arco del triunfo, una escenografía pasiva y declamatoria, sino un instrumento de trabajo y acción, una máquina de transformar el mundo"32. No parece casual que la imagen que muestra para ilustrar el collar del caballo pertenezca al filme Lo viejo y lo nuevo (1929) de Eisenstein.

\footnotetext{
28 "Still, the affinities between Le Corbusier's theory of "lyricism" of the machine and Eisenstein "pathos of the machine" remained less explicit than latent". Cohen, Jean-Louis: Le Corbusier and the mystique of the URSS. Princeton, New Jersey: Pinceton University Press, 1992.pp.48-50

${ }^{29}$ Le Corbusier: "Defense de 1'Architecture". En L'Architecture d'aujourd'hui, No10. 1933.p.105 y en Le Corbusier: El espíritu nuevo en arquitectura. En defensa de la Arquitectura. Murcia: Colegio Oficial de Aparejadores y Arquitectos Técnicos de Murcia, 1983.

30 Martínez de Guereñu, Laura: Montage: "Le Corbusier y Eisenstein”. En: Massilia 2008. Anuario de estudios Lecorbusierianos. Granada: Colegio de Arquitectos de Granada, 2008.p.242-255. La autora visibiliza en éste artículo las estrategias empleadas por Le Corbusier en relación con los mecanismos montaje, en concreto el dialéctico que estudiamos aquí, y que interesa destacar por ejemplificar su materialización en la arquitectura.

${ }^{31}$ Quetglas, Josep: “Ojos que no ven. 4: los caballos”. En: Massilia 2008. Anuario de estudios Lecorbuserianos. Granada: Colegio de Arquitectos de Granda.p.280

${ }^{32}$ Ibíd.p. 285
} 
Shklovski, crítico y escritor con una gran proximidad a la mentalidad del realizador y coetáneo a él, escribe: "Los films y los libros dedicados a la nueva realidad han necesitado, para nacer, enteras décadas, pero el film de Sergei Mijailovich conseguía comunicar la fe orgullosa en el nuevo orden, en el sueño y en la posibilidad de realizarlo, ${ }^{, 33}$.

Aquello que sobre todo debió calar en Le Corbusier, es esta fuerza con la que el autor se podía comunicar con las masas a través del montaje y de la cinematografía. Este impulso se presenta en su arquitectura, y en el caso que aquí se estudia, por partida doble, a través del Pabellón Philips y el filme Poème électronique que en su interior se proyectó; ambos podrían suponer una respuesta a los presupuestos que aprendió de Eisenstein.

\subsection{Caso de estudio. Poème électronique}

Se aborda el estudio del filme Poème électronique y el contendor-substancia en el que se proyectó.

\subsubsection{El montaje oculto en el Pabellón Phillips}

El Pabellón Philips se construyó con motivo de la celebración de la Exposición Universal de Bruselas en 1958. El equipo que se formó para llevar a cabo el proyecto estaba constituido por Le Corbusier y el músico-ingeniero Iannis Xenakis, que se encargaron de su redacción y construcción; Edgar Varèse compuso la música, el editor Jean Petit se ocupó de localizar las imágenes que Le Corbusier le iba anotando en sus Carnets, y el cineasta Philippe Agostini las rodaba en 16 milímetros.

Jean Petit, en el libro Poème électronique (1958), recogió las primeras ideas que Le Corbusier tuvo sobre este proyecto: "No haré una fachada para Philips, haré un poema. Todo transcurrirá en el interior: la luz, el color, el ritmo. Puede que la única apariencia que tenga el pabellón sea la de un andamio"34; "este es el material fundamental y frágil de la exposición temporal: una botella suspendida en un andamiaje tubular,"35.

\footnotetext{
${ }^{33}$ Shklovski, Viktor: Eisenstein. Barcelona: Anagrama, 1973.

34 “Je ne ferai pas de façade Philips, je vous ferai un Poème électronique. Tout se passera à l'intérieur: son, lumière, couleur, rythme. Peut-être un échafaudage sera-t-il le seul aspect extérieur du pavillon”. Petit, Jean: Poème électronique. Paris: Editions de Minuit, 1958.p.23

35 "Le matériel fondamental et fragile de l'exposition temporaire- une bouteille suspendue à une cage d'échafaudage tubulaire”. Ibíd.p.24
} 

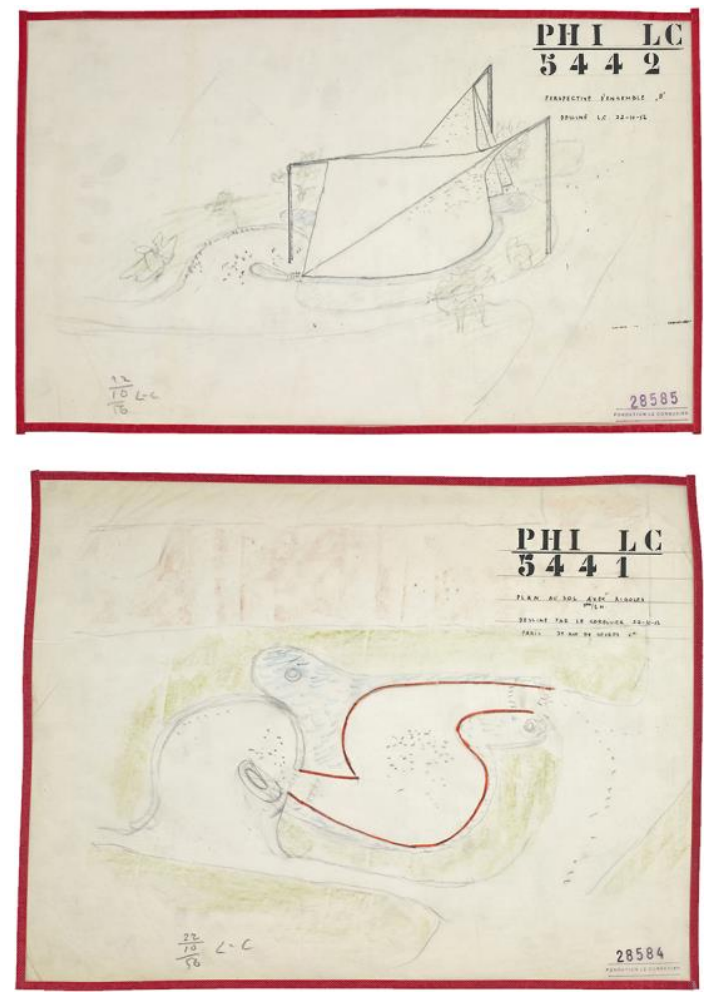

1. Planos del Pabellón Philips dibujados por Le Corbusier 22-10-1956. FLC.28584-85

Esta botella, como recipiente contenedor del espectáculo que en su interior iba a transcurrir, la describió así: "el contenedor será una especie de estómago con una entrada y una salida diferentes, para quinientas personas", un espacio en el que "el público está en pie y observa delante suyo dos paredes cóncavas prácticamente verticales que permiten a los espectadores ver por encima de las cabezas de sus vecinos" ${ }^{\prime 36}$.

Le Corbusier concibió el pabellón como una boîte à miracles, síntesis de las artes. Quesada desarrolla con profundidad esta cuestión y recoge la definición que dio de ésta en la conferencia del Théâtre Spontané en París (1948), en ella "los diversos escenarios y actores materializan el momento en que la caja mágica aparece [...] contiene todo lo que es necesario, iluminación y todos los aparatos necesarios para hacer milagros, levitación, manipulación de sonido, etc. ${ }^{, 37}$.

A partir de su primera intuición del Pabellón Philips, como una botella suspendida en un andamiaje metamorfoseada en estómago, Iannis Xenakis desarrolló la geometría del edificio al detalle, y se convirtió en un "caparazón matemático",38. Levantó un volumen compuesto por superficies regladas "cuya geometría inicial respondía a las leyes de la música escolástica que ya había aplicado para componer su pieza Metástasis $(1953)^{m, 39}$.

\footnotetext{
36 "Le contenant sera une sorte d'estomac, avec une entrée et une sortie différents pour cinq cents personnes", "le public étant debout et regardant devant lui, disposer de deux parois concaves presque verticales, qui permettent aux spectateurs de voir au-dessus de la tête des voisins". Ibíd.p.24

${ }^{37}$ Quesada, Fernando: "Cajas mágicas: Le Corbusier y el Pabellón Philips". En: Massilia 2002. Anuario de estudios Lecorbuserianos. Barcelona: Caja de Arquitectos.p. 181

${ }^{38}$ Xenakis, Iannis: "The Architectural Design of Le Corbsuier and Iannis Xenakis". En: Philips Technical Review. №20. pp.2-3

${ }_{39}$ Quesada, Fernando: “Cajas mágicas: Le Corbusier y el Pabellón Philips". En: Massilia 2002. Anuario de estudios Lecorbuserianos. Barcelona: Caja de Arquitectos.p.187
} 
El edificio se revistió de pintura metalizada, unificando y ocultando su construcción. La carcasa conformada por una serie de superficies regladas, paraboloides hiperbólicos, se construyó con "placas de hormigón de $5 \mathrm{~cm}$ de espesor vertidas en taller, que trabajaban a compresión gracias a una serie de cables metálicos traccionados desde unos grandes puntales de hormigón in situ que actúan como estructura primaria" ${ }^{, 40}$.

La cuestión clave que determina éstas decisiones formales y constructivas era la búsqueda de la eliminación de los límites físicos del pabellón, de sus paredes, haciendo del conjunto un interior puro sin exterior material alguno, es decir "diluyendo su materia constitutiva y constructiva en impresiones sensoriales tal y como reza el texto sobre L'espace indicible, redactado por Le Corbusier en $1945^{, 41}$.

En el posible guión de este proyecto los protagonistas son los visitantes constructores de un sueño que representa el Poème, proyectado en el contenedor-substancia ${ }^{42}$ que es el Pabellón Philips. La puesta en escena se desarrolla en un único emplazamiento, un espacio unitario, en el que la cámara-ojo del visitante activo que lo recorre está ante unos planos cuyos límites aparecen desdibujados, y cobra protagonismo la profundidad. El mecanismo de montaje latente en este proyecto permanece, como lo denominó Eisenstein treinta años atrás, oculto.

En palabras de Adorno, "El principio de montaje pasó al principio de construcción con una coherencia cuyos pasos tendría que escribir esa historiografía estética que todavía no existe ${ }^{, 43}$.

\subsubsection{El montaje dialéctico en el filme Poème électronique}

El Poème électronique consistía en la proyección simultánea de un documento cinematográfico sobre el interior de las paredes, esas pantallas de proyección deformada en la que las imágenes proyectadas fugaban desde la base ancha hacia el cuello de la botella, junto con la emisión de la música electrónica compuesta por Edgar Varèse a través de multitud de altavoces.

La idea inicial era "realizar una biblioteca mundial visual y sonora dentro de la botella que muestra la historia del mundo desde sus orígenes hasta la reconstrucción de la Segunda Guerra Mundial"44. Poème électronique, además de la intención enciclopedista que ilustra el curso de la civilización humana, operaba como herramienta pedagógica y redentora. La naturaleza y la cultura, lo tranquilo y lo tormentoso, el apocalipsis y la salvación.

Sobre la relación del filme y la música, el compositor explicó que "de vez en cuando se coordinarán para un efecto dramático y crear una sensación de unidad", pero la mayor parte del tiempo trabajaron en oposición y contraste buscado "a través de la sincronización de elementos simultáneos sin relación entre ellos se producirá una disociación de ideas que excitará la imaginación y estimulara las emociones" ${ }^{45}$.

\footnotetext{
${ }^{40}$ Ibíd.p. 171

${ }^{41}$ Ibíd.p. 184

${ }^{42}$ Se denomina contenedor-sustancia en el sentido de la filosofía del quiasmo de Merleau-Ponty que defiende que la espacialidad es ontológica, y la profundidad no es puro espacio, es tiempo.

${ }^{43}$ Escrito entre 1961-1969, se publicó póstumamente en 1970. Adorno, Theodor: Teoría estética. Madrid: Akal, 2005.p.107

${ }^{44}$ Quesada, Fernando: “Cajas mágicas: Le Corbusier y el Pabellón Philips”. En: Massilia 2002. Anuario de estudios Lecorbuserianos. Barcelona: Caja de Arquitectos.p.187

${ }^{45}$ Maderuelo, Javier: Edgar Varèse. Madrid: Círculo del Bellas Artes, 1985.p.180
} 


\section{*Elementos visuales > Collage multimedia}

Los elementos visuales que constituyen el Poème son:

-Écrans: Muros cóncavos/pantallas donde se proyecta el filme.

-Ambiances: Proyecciones de luces de colores.

-Tri-trous: Filtros con agujeros colocados delante de los proyectores de cine para definir aéreas perfiladas de color (o ausencia de color) en los écrans y ambiances, así como para proyectar imágenes de contorno acotado.

-Volumes: Dos sólidos tridimensionales suspendidos de dos de los vértices del pabellón. Uno era una escultura de tubos, figura geométrica matemática, y el otro un maniquí industrial, figura femenina, que iluminados con luz ultravioleta brillaban en tono verdoso y rojo respectivamente.

\section{*Elementos visuales > El filme}

El mecanismo principal que Le Corbusier empleó para construir el filme Poème électronique fue el montaje dialéctico. Le Corbusier lo aprendió a través de sus contactos con Eisenstein, treinta años atrás. En la monografía de Marc Treib sobre el Pabellón Philips, el autor cree en esta posible relación y afirma que "Le Corbusier, para su secuencia cinética de fotografías, se basó en las lecciones que Eisenstein le había enseñado"46.

La técnica del montaje dialéctico, de la que Eisenstein es el indiscutible maestro, se manifiesta evidente como herramienta clave del filme. El cineasta, en "Montaje" (1938), describió su funcionamiento así: "la representación $A$ y la representación $B$ deben buscarse de tal naturaleza que su yuxtaposición suscite en la percepción y la afectividad del espectador la imagen más completamente exhaustiva del tema",47.

Le Corbusier, ante la elección de los fotogramas que conformarían el filme, explicó “Allí, las posibilidades son casi infinitas. Pero ¿Cómo elegir? Pensé: Museo del Hombre, Palacio del Descubrimiento, Museo de Historia Natural, Museo de las Tradicionales populares. Dos meses, un año buscando "48. La gran parte serían fotografías estáticas, y muchas de ellas de los libros de esculturas de André Malraux.

Poème está estructurado en siete secuencias, cada una, de un minuto de duración aproximadamente. El cambio de una secuencia a otra no se percibe con facilidad, se diferencian mediante un breve momento de oscuridad.

^Datos técnicos:

Duración: 480"

Fotogramas por segundo: 24

Rodada en $16 \mathrm{~mm}$

\footnotetext{
46 "Le Corbusier, for his kinetic play of photographs in Brussels, he relied on the lessons that Eisenstein had taught". Treib, Marc. Space calculated in Seconds. Princeton, New Jersey: Princeton University Press, 1996.p.147

${ }^{47}$ Eisenstein, Sergei: Reflexiones de un cineasta. Barcelona: Lumen, 1970.p.128

48 “Là, les possibilités sont presque infinies. Mais comment choisir? J'ai pensé: Musée de l'Homme, Palais de la Découverte, Muséum d'Histoire Naturelle, Musée des Traditions Populaires. Des mois, une année à chercher". Petit, Jean: Poème électronique. Paris: Forces Vives, 1958.p.25
} 


\section{+Secuencia \#01: Génesis [0”-60"]}

Los fotogramas aparecen con un ritmo regular, cambian cada 5 segundos.

El primer fotograma A presenta la cabeza de un toro a la izquierda, y en el siguiente fotograma B la figura de un matador a la derecha; en el tercer fotograma $\mathrm{C}$ las dos figuras aparecen a la vez y se hace explicita la idea de combate. Se repiten los fotogramas A y B, y los siguientes muestran detalles de éstos: los cuernos del toro y el matador empuñando el capote, y de nuevo aparece el fotograma $\mathrm{C}$ en el que ambas figuras están enfrentadas.

Le Corbusier contrapone los fotogramas y hace que el visitante participe y construya en su mente la imagen que quiere transmitir, tal y como él la ha concebido. También recurre a la estrategia de la repetición y la del cambio de escala, dando una dimensión mayor a los detalles. La cuestión de los opuestos, que establece el propio tema del combate entre toro y matador, estará presente a lo largo de todo el filme.

La siguiente escena se rodó expresamente para Poème, en ella aparece el cuerpo de una mujer acostada y gira la cabeza, mira a la cámara, sonríe, y de repente le cambia la expresión y se aterroriza. Como señala Treib, esta escena nos remite al cine clásico surrealista, en particular de Luis Buñuel y La Edad de Oro (1930 $)^{49}$. La yuxtaposición de estos fotogramas tiene múltiples interpretaciones y precipita la imaginación del observador.
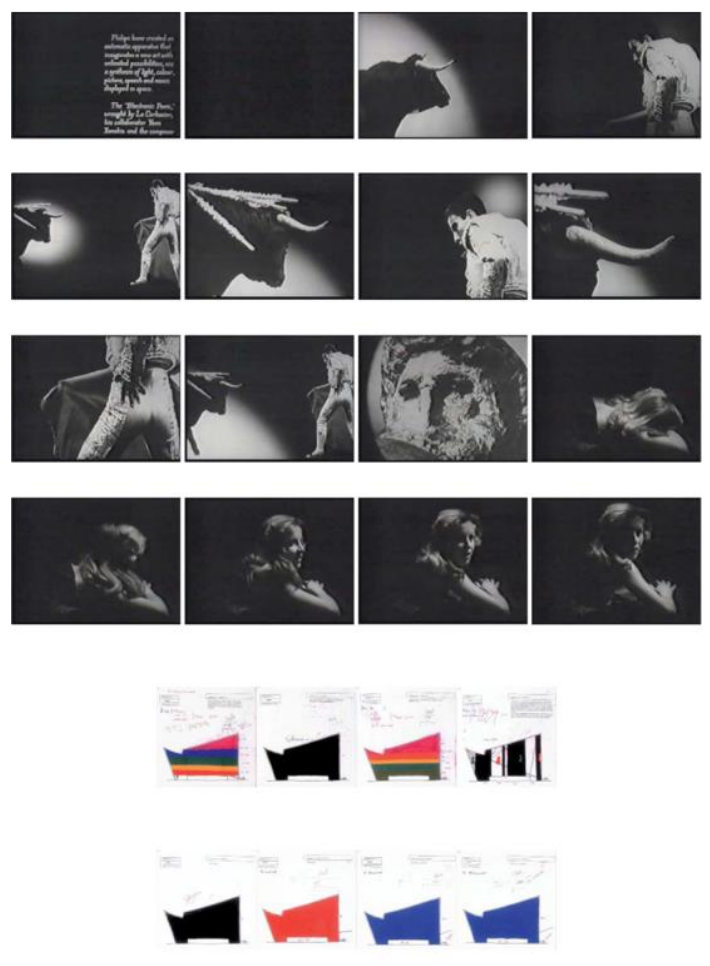

2. [Sequence I] Fotogramas extraídos de Poème électronique por la autora + Ambiances. Philips Company Archives.

\footnotetext{
${ }^{49}$ Treib, Marc. Space calculated in Seconds. Princeton, New Jersey: Princeton University Press, 1996.p.120
} 


\section{+Secuencia \#02: De la Materia y el Espíritu [61"-120”]}

Los fotogramas se muestran a un ritmo más rápido, cambian cada segundo.

La posición que ocupaba la cabeza de la mujer en la última escena de la Secuencia\#01, tras oscurecerse completamente para dar paso a esta Secuencia\#02, la va a ocupar un cráneo, y éste desaparece y reaparece de nuevo en una posición central y enfrentada al espectador; a estos fotogramas, $\mathrm{A}$ [en el lado izquierdo] y A* [enfrentado al observador], le sigue el fotograma B que muestra una concha situada donde antes estaba el cráneo, y reaparece en el fotograma $\mathrm{B}^{*}$ en posición horizontal. La muerte y la naturaleza.

En el siguiente fotograma $\mathrm{C}$ aparece un cráneo diminuto, y en el siguiente fotograma $\mathrm{D}$ vemos a 4 científicos que observan un objeto. El modo en que se muestra el fotograma D merece ser comentado, la imagen completa sólo se revela al final y se ha ido iluminando a cada uno de los personajes como si fueran fotogramas independientes: $\mathrm{D} * 1 / \mathrm{D} * 2 / \mathrm{D} * 3 / \mathrm{D} * 4 / \mathrm{D} * 5$. La muerte, la naturaleza, y la ciencia.

En el fotograma $\mathrm{E}$ una mujer africana aparece en el centro del plano; el fotograma $\mathrm{F}$ muestra un rostro en la parte superior derecha, y le sigue el fotograma $\mathrm{F}^{*}$ que descubre aquello que el rostro observa: el cuerpo de una mujer acostada que pertenece al cuadro de Courbet. En los siguientes fotogramas G diversos rostros de esculturas aparecen ocupando distintas zonas del plano.

En los fotogramas $\mathrm{H}$ se ilumina por partes el esqueleto de un dinosaurio. En los fotogramas I, aparecen unos monos, primero uno, luego varios, y multitud de ellos. Finaliza con los fotogramas J que muestran máscaras diversas mediante la misma estrategia: una, varias, y ocupando distintas zonas del plano.

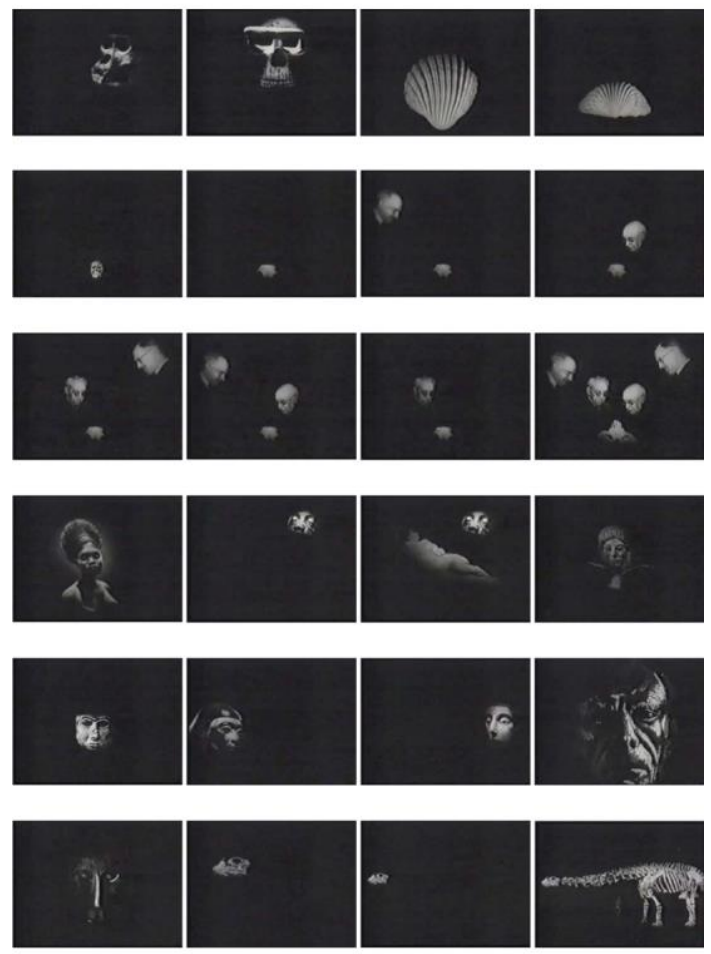

3. [Sequence II-p.1] Ibíd. 


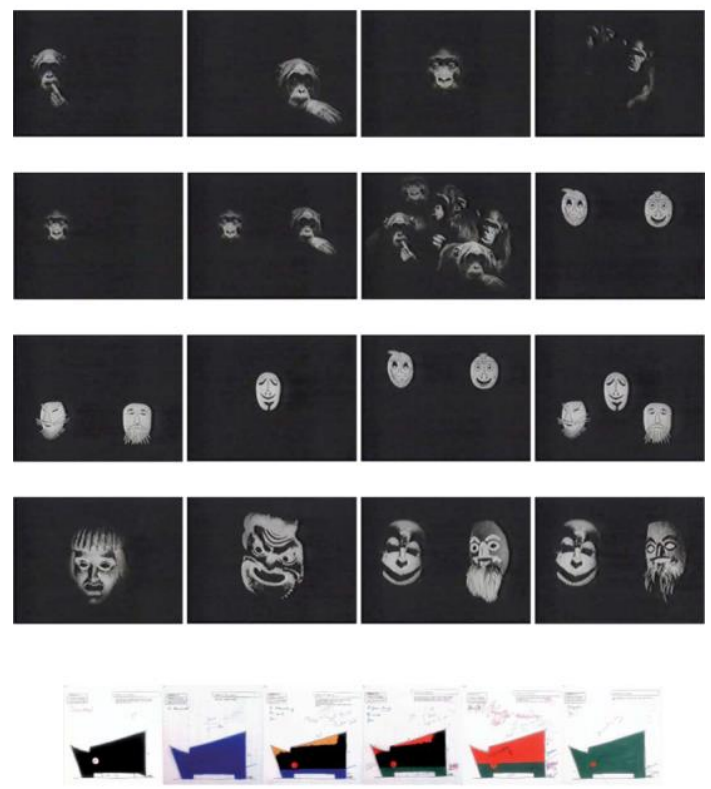

4. [Sequence II-p.2] Ibíd.

\section{+Secuencia \#03 De las Profundidades del Alba [121”-204”]}

Esta secuencia continúa con el ritmo acelerado de la anterior, apenas transcurre un segundo por cada fotograma.

Le Corbusier emplea una nueva estrategia en la primera parte, en los fotogramas $\mathrm{A} / \mathrm{B} / \mathrm{C} / \mathrm{D} / \mathrm{E}$ [con sus respectivas variaciones], consiste en la repetición del objeto representado mediante simetría en eje vertical y horizontal dramatizando así lo que se muestra, en este caso son miradas y cabezas.

Tras oscurecerse la pantalla comienza la segunda parte; el primer fotograma F se muestra por partes: primero un primer plano de las cabezas de las esculturas, dándoles una dimensión monumental, y luego un plano general que muestra las tres; juega con el cambio de escala y transmite la relatividad con que se percibe su dimensión. En los fotogramas $\mathrm{G}$ el esqueleto de la mano humana se muestra de diferentes modos.

Se vuelve a oscurecer la pantalla y comienza la tercera parte. Se repite el [f.F] de la escultura y el [f.G] del esqueleto. A continuación los fotogramas $\mathrm{H}$ muestran las zanjas abiertas de un campo de concentración y con ello la destrucción; y en el fotograma I se ven unos soldados de juguete que podría sugerir la guerra como artificio, en la que las mentes de los soldados están dominadas.

Los siguientes fotogramas muestran: la zanja de un campo de concentración [f.J], tanques de juguete [f.K], un campo de concentración [f.L], los soldados de juguete [f.I], una nueva fotografía de un campo de concentración [f.M], de nuevo los soldados de juguete [f.I], otra fotografía de un campo de concentración [f.N], unos indios y vaqueros de juguete [f.O], armas de juguete [f.P], y un primer plano de un hombre en un campo de concentración [f.L*].

Finaliza con: el Descendimiento de Giotto [f.Q], Cristo [f.R], la Natividad en Chartres [f.S], la Virgen y Niño [f.T], el Ángel [f.U], la Anunciación [f.W], Dios [f.X], la gran compasiva [f.Y], y la Virgen de los Dolores [f.Z].

Esta secuencia sugiere la confrontación entre la dimensión religiosa y la ruina de los efectos de la guerra. 

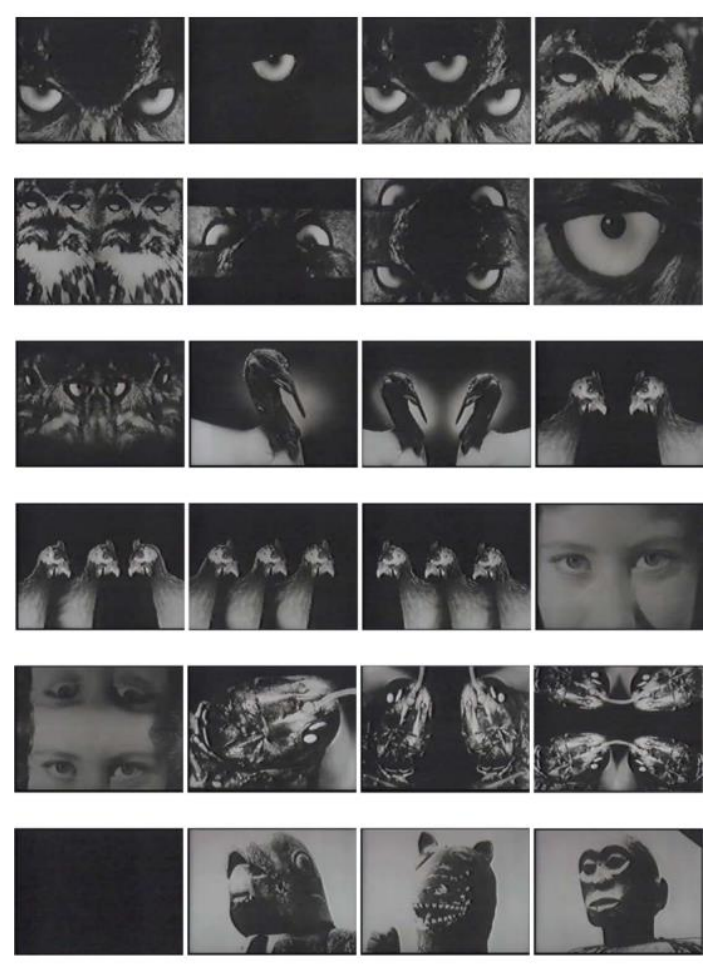

5. [Sequence III-p.1] Ibíd.
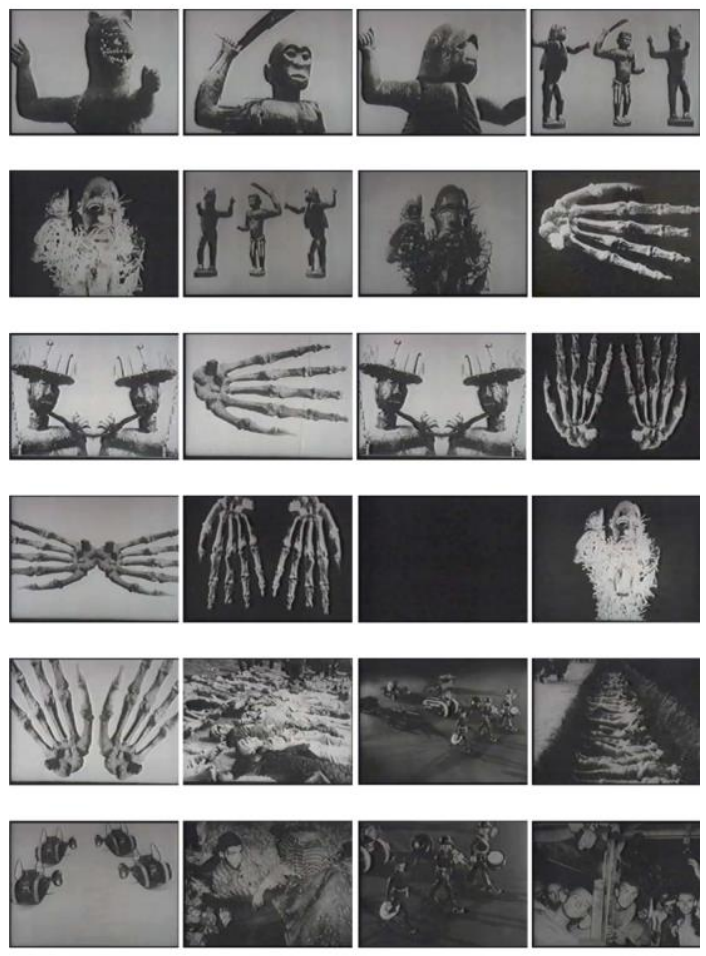

6. [Sequence III-p.2] Ibíd. 

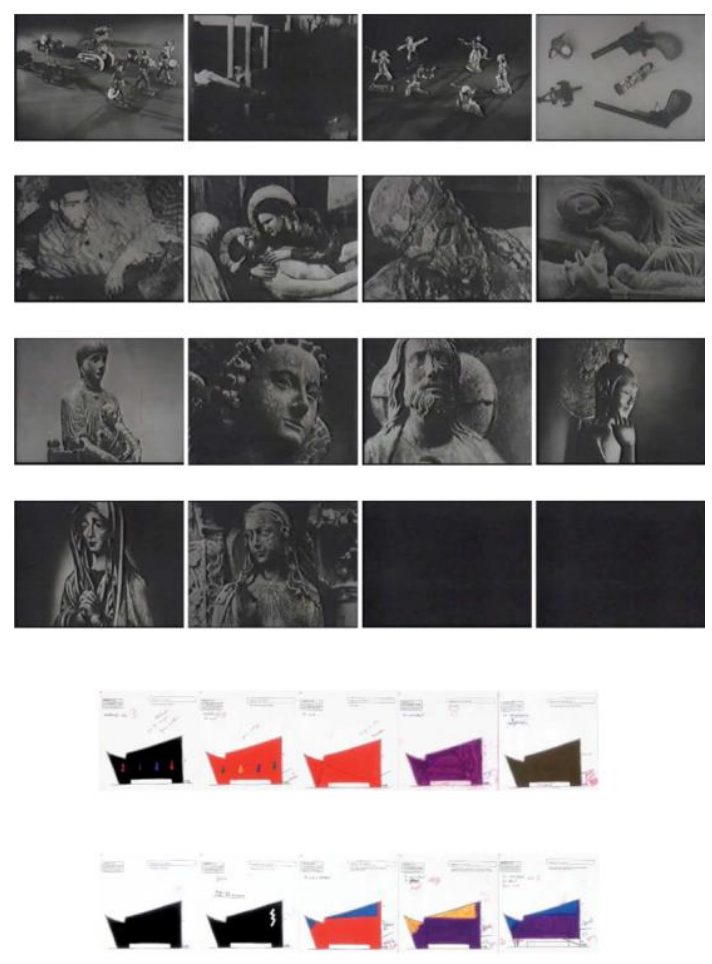

7. [Sequence III-p.3] Ibíd

\section{+Secuencia \#04: Los Dioses hechos por los Hombres [205"-240”]}

Esta es la secuencia más breve del filme; transcurren 2 segundos por cada fotograma.

Aparece en el fotograma A la Isla de Pascua, en [f.A*] sólo una de las piedras iluminada y después se repite el [f.A]. A continuación en el fotograma B se muestra la cabeza Angkor en un primer plano. En el fotograma C aparecen cuatro cubos espaciados en una superficie. Esta contraposición entre los fotogramas [f.A] y [f.C] podría sugerir el trabajo de los hombres en el planeta frente a la geometría como primacía del orden, explica Treib ${ }^{50}$.

En el fotograma D se muestra a Buda, y en el fotograma E el rostro de una Virgen. Se repite el fotograma [f.C]. En el fotograma $\mathrm{F}$ aparece una escultura tribal duplicada que coincide con la forma de los vegetales que muestra el siguiente fotograma G, y más elementos orgánicos en [f.H]. Le siguen los fotogramas [f.D*] que muestran un detalle de [f.D], y para terminar un primer plano de una piedra de la Isla de Pascua duplicada [f.I].

\footnotetext{
${ }^{50}$ Ibíd.p. 126
} 

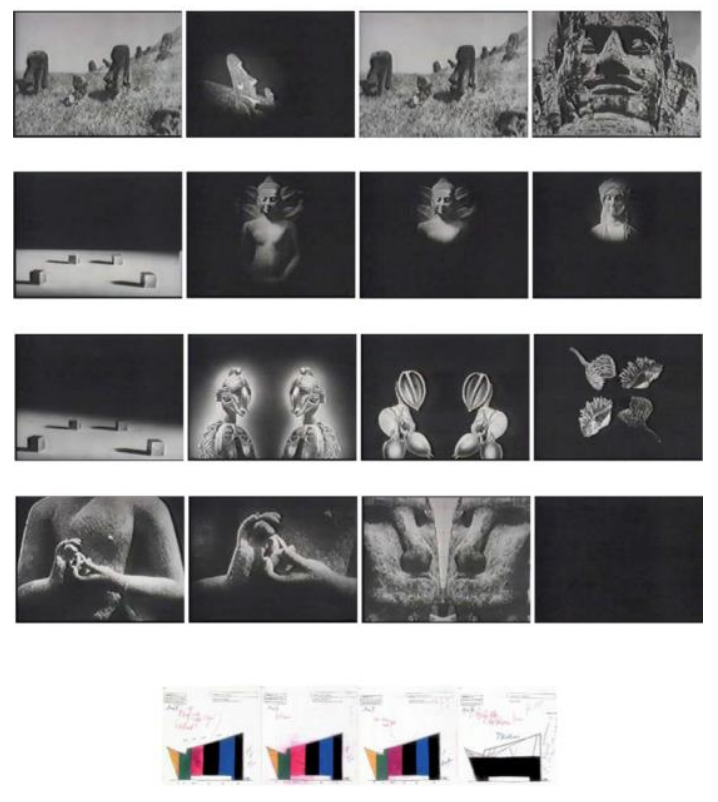

8. [Sequence IV] Ibíd.

\section{+Secuencia \#05 Así florece la Civilización [241”-300”]}

Los fotogramas cambian cada segundo y medio.

Tras 5 segundos de oscuridad aparece el fotograma A que muestra a un ingeniero atómico que está manejando la maquinaria, la estrategia que Le Corbusier emplea para revelar este fotograma es, como en ocasiones anteriores, iluminar primero sólo la cara y luego sólo la maquinaria; el movimiento de la luz consigue animar la fotografía.

En el fotograma B aparece multitud de gente. En el fotograma $\mathrm{C}$ hay un trabajador con el telescopio que observa la dimensión inmensa del cielo. El fotograma D muestra la fundición del acero, y sucesivamente: multitud de gente [f.B], la estratosfera [f.E], multitud de gente [f.B], trabajadores [f.F], cirujanos [f.G], mineros [f.H], otros trabajadores [f.I] y un labrador [f.J].

A continuación: un caballo de granja [f.K], el cómico Charlot [f.L], un avión [f.M], cohete [f.N], antenas [f.O], cohete [f.N], antenas [f.O], avión [f.M], dos niños inquietos mirando [f.P], dos cohetes [f.N*], tres niños inquietos mirando [f.Q], la antenas duplicadas [f.O*], explosiones nucleares diversas [f.R], más niños inquietos mirando [f.S], y finalmente una madeja enmarañada [f.T].

Esta secuencia muestra aquello que la humanidad también ha forjado: la industria y el poder. 

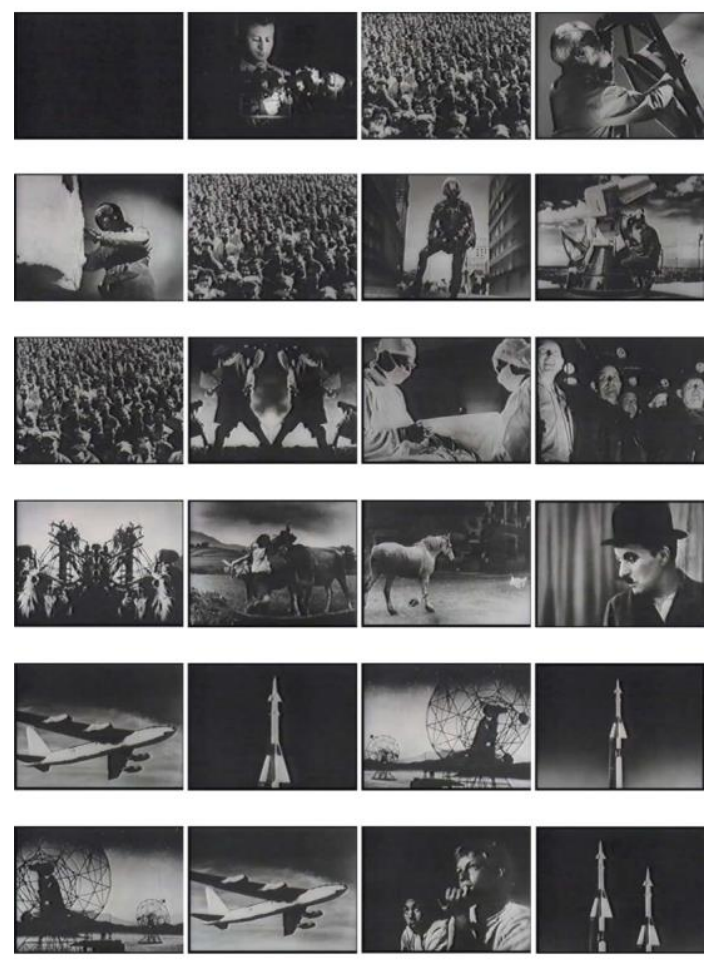

9. [Sequence V-p.1] Ibíd.
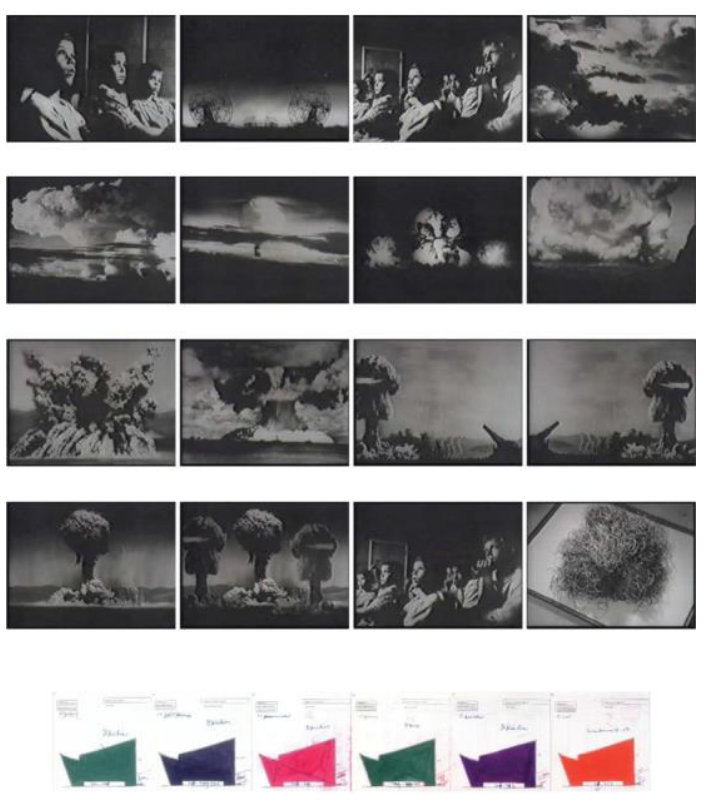

10. [Sequence V-p.2] Ibíd. 


\section{+Secuencia \#06 Armonía [301"-360"]}

Los fotogramas cambian cada segundo y medio.

En los primeros fotogramas A aparece el entramado de la Torre Eiffel y alterna su positivo y negativo. En los fotogramas B se muestran piezas mecánicas en blanco sobre un fondo negro, parece crear su propio baile mecánico, Treib ${ }^{51}$ relaciona estos fotogramas con las primeras películas de Man Ray y con el Ballet mécanique de Fernand Léger

En el fotograma $\mathrm{C}$ aparece la mirada de un búho, en el fotograma $\mathrm{D}$ la de un toro, y en el fotograma $\mathrm{E}$ una pieza mecánica. A continuación reaparecen fotogramas alternados con otros nuevos, en ellos se muestra: el primer plano del rostro del ingeniero atómico [f.F], varias piezas mecánicas [f.G], mineros [f.H], y de nuevo piezas mecánicas duplicadas [f.G*].

De nuevo aparece el trabajador con el telescopio [f.I], piezas mecánicas [f.G*], el trabajador [f.I] y diversos fotogramas de piezas mecánicas [f.E*/G*]. Laurel y Hardy y piezas mecánicas [f.J]. La presencia los cómicos podría sugerir la comedia como alivio, o lo absurdo del juego de la humanidad con la tecnología.

La escala cambia y los siguientes fotogramas muestran: la galaxia [f.J], eclipses solares [f.K], llamas solares [f.L]; y tras la oscuridad: dos enamorados en un banco [f.M] y abrazándose [f.N], y finaliza con bebés [f.O/P/O*/Q/O*].
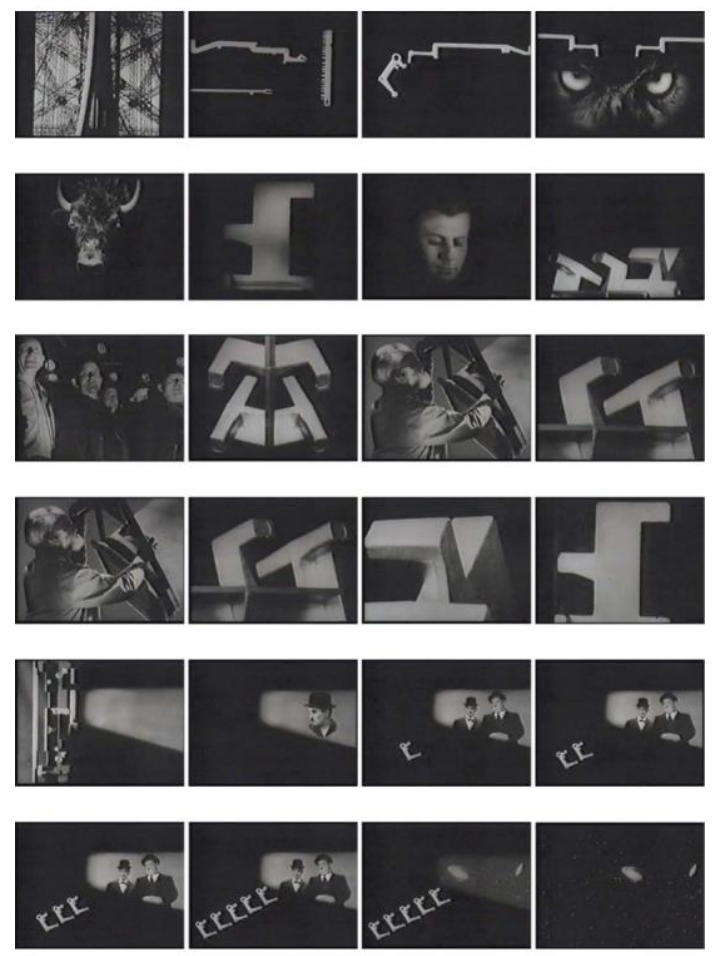

11. [Sequence VI-p.1] Ibíd.

\footnotetext{
${ }^{51}$ Ibíd.p.134
} 

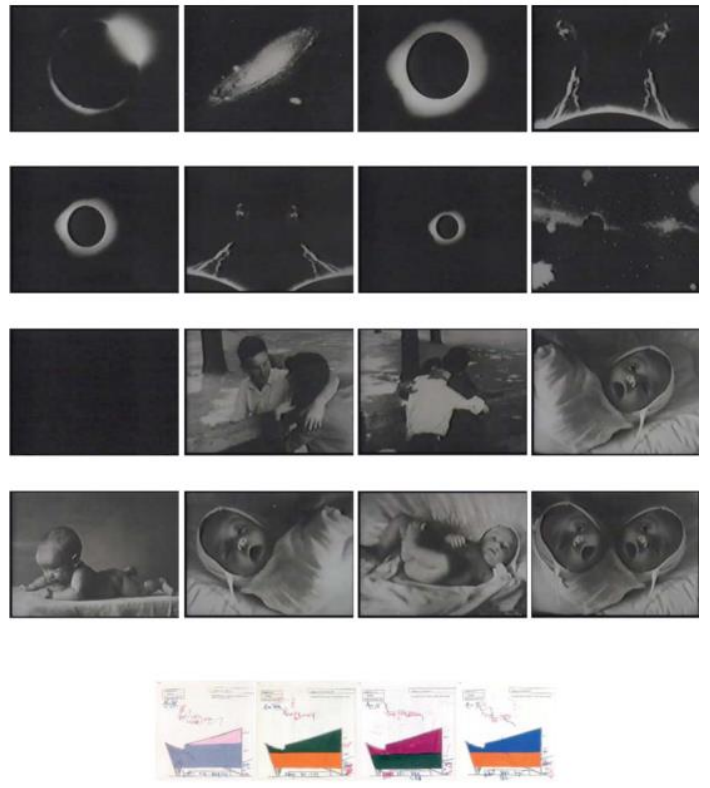

12. [Sequence VI-p.2] Ibíd.

\section{+Secuencia \#07 Para Todo el Mundo [361"-480”]}

Esta es, con diferencia, la secuencia más larga del filme; transcurre un tiempo variable según el fotograma.

Estos muestran: Los cuatro rascacielos de París [f.A], la ciudad de Nueva York [f.B], se repiten [f.A] y [f.B], diversos fotogramas de la ciudad radiante de Marsella y Nantes [f.C/D/E/F], el capitolio de Chandigarh [f.F/G/H], el modulor [f.I/J], un muro aparejado de piedra [f.K], la ciudad de Nueva York [f.L], se repiten con velocidad varias veces [f.K] y [f.L], otro aparejo [f.M], plano de París [f.N], urbanismo de Argel [f.O], las rutas de Europa [f.P].

Para terminar recupera la presencia humana: dos niños [f.Q], la mano abierta de Le Corbusier [f.R], una mujer [f.S/T/U], un niño [f.V], un vagabundo [f.W], un comedor [f.X], un camino en el barro [f.Y], los bebés [f.Z].

La relación de la música y el filme, en esta secuencia parece coincidir con la intención de enfatizar la grandiosidad de sus proyectos en contraposición con el caos de la ciudad de Nueva York.

Esta secuencia responde al objetivo de Le Corbusier de publicitar su propia obra. Si en la anterior retrata una época de caos, pobreza y reconstrucción tras la Segunda Guerra Mundial, aquí muestra su arquitectura como un motivo de esperanza para la humanidad. 

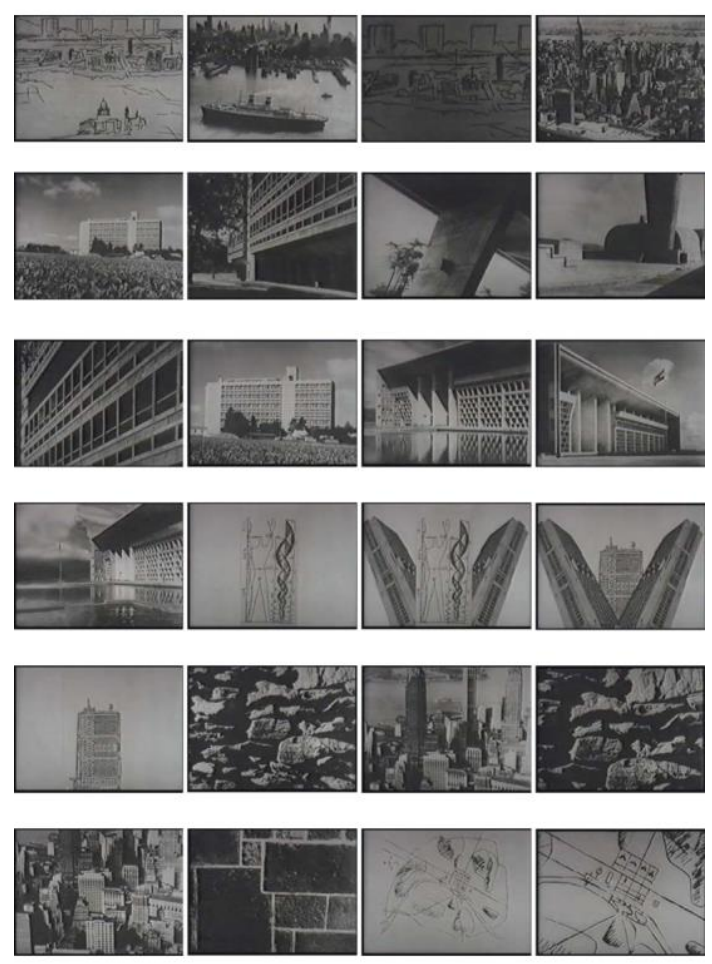

13. [Sequence VII-p.1] Ibíd.
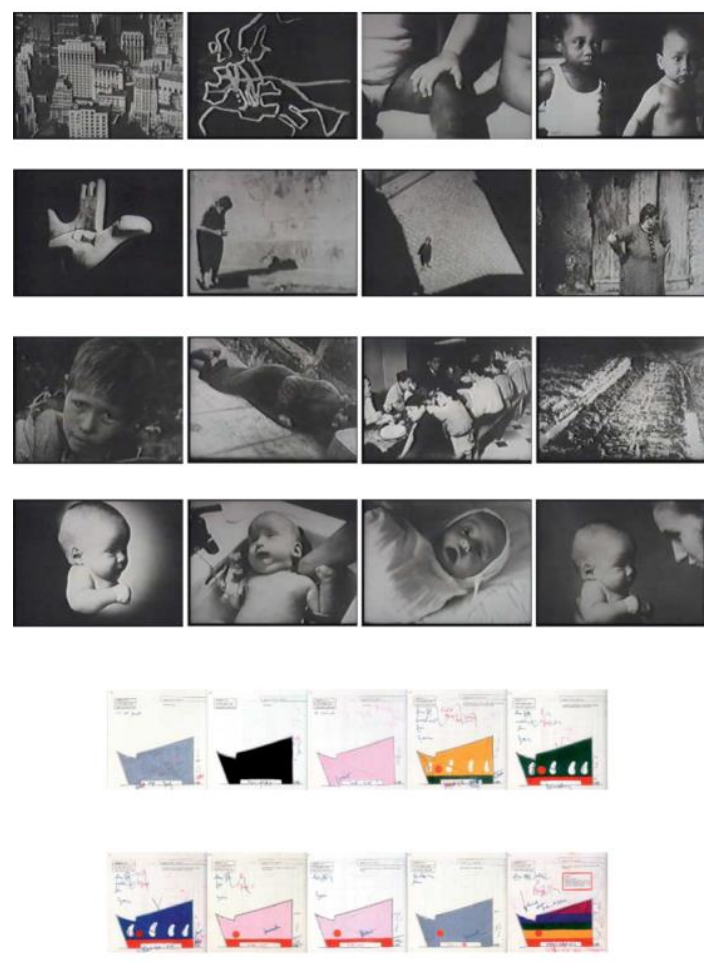

14. [Sequence VII-p.1] Ibíd. 


\section{Conclusiones}

La investigación sobre los vínculos existentes entre Eisenstein y Le Corbusier ha sido emprendido anteriormente por otros autores, sus aportaciones se incorporan al desarrollo del presente artículo y refuerzan la hipótesis planteada: el Poème électronique y el Pabellón pueden suponer una respuesta a los presupuestos que Le Corbusier aprendiera de Eisenstein.

Como describió Cohen, las afinidades entre ellos permanecieron latentes. Para visibilizarlas se estudia el estado de las teorías sobre el montaje de Eisenstein en el período en que Le Corbusier visitó Moscú y se conocieron.

En su retrato de la Historia de la humanidad, Le Corbusier transmite la fe y el sueño por un nuevo orden y la posibilidad de alcanzarlo tras la situación de crisis, pobreza y miseria fruto de la Segunda Guerra Mundial, tal y como Eisenstein consiguió con sus películas, treinta años antes, transmitiendo el éxito de las transformaciones por el cambio político fruto de la Revolución de 1917, Le Corbusier anuncia su propia arquitectura como aquella que traía orden y salvación frente a la crisis del momento.

A través de éste espectáculo da una dimensión monumental a lo esencial de lo común y dirige al visitante a través del cine y la arquitectura, mediante los mecanismos del montaje dialéctico y el montaje oculto. Es posible que el poder de comunicación de su arquitectura se base en la utilización de estos mecanismos.

Con Poème électronique y su contendor-substancia, Le Corbusier trata de representar la construcción de un sueño, y lo consigue. La técnica empleada es el montaje y el sueño la utopía del revolucionario. Le Corbusier reconoció el potencial de las teorías de montaje del cineasta, precisamente por la capacidad que tiene de activar al espectador e involucrarlo en la construcción de su significado. Las incorporó en su propio pensamiento y las materializó en su arquitectura, así como en su aproximación al ámbito de la cinematografía.

\section{Referencias bibliográficas}

Adorno, Theodor: Teoría estética. Madrid: Akal,2005.

Benjamin, Walter: El autor como productor. Madrid: Casimiro,2015.

Cohen, Jean-Louis: Le Corbusier and the mystique of the URSS. Princeton, New Jersey: Princeton University Press, 1992.

Deleuze, Gilles: La imagen movimiento. Barcelona: Paidós,2014.

Eisenstein, Sergei: El sentido del cine. Buenos Aires: Lautaro,1944.

Eisenstein, Sergei: Hacia una teoría del montaje. Vol.1. Barcelona: Paidós Ibérica,2001.

Eisenstein, Sergei: Reflexiones de un cineasta. Barcelona: Lumen,1970.

Le Corbusier: Hacia una arquitectura. Barcelona: Apóstrof,1998.

Le Corbusier: El espíritu nuevo en arquitectura. En defensa de la Arquitectura. Murcia: Colegio Oficial de Aparejadores y Arquitectos Técnicos de Murcia,1983.

Maderuelo, Javier: Edgar Varèse. Madrid: Círculo de Bellas Artes,1985.

Martínez de Guereñu, Laura: “Montage: Le Corbusier y Eisenstein”. En: Massilia 2008. Anuario de estudios Lecorbusierianos. Granada: Colegio de Arquitectos de Granada,2008.

Nizhny, Vladimir: Lecciones de cine de Eisenstein. Barcelona: Seix Barral,1963.

Petit, Jean: Poème électronique. Paris: Editions de Minuit,1958. 
Quetglas, Josep: “Ojos que no ven. 4: los caballos”. En: Massilia 2008. Anuario de estudios Lecorbuserianos. Granada: Colegio de Arquitectos de Granda,2008.

Quesada, Fernando: “Cajas mágicas: Le Corbusier y el Pabellón Philips”. En: Massilia 2002. Anuario de estudios Lecorbuserianos. Barcelona: Caja de Arquitectos,2002.

Shklovski, Viktor: Eisenstein. Barcelona: Anagrama,1973.

Tafuri, Manfredo: La esfera y el laberinto. Vanguardias y arquitectura. De Piranesi a los años setenta. Barcelona: Gustavo Gili,1984.

Treib, Marc. Space calculated in Seconds. Princeton, New Jersey: Princeton University Press, 1996.

Xenakis, Iannis: “The Architectural Design of Le Corbusier and Iannis Xenakis”. En: Philips Technical Review. No20. 


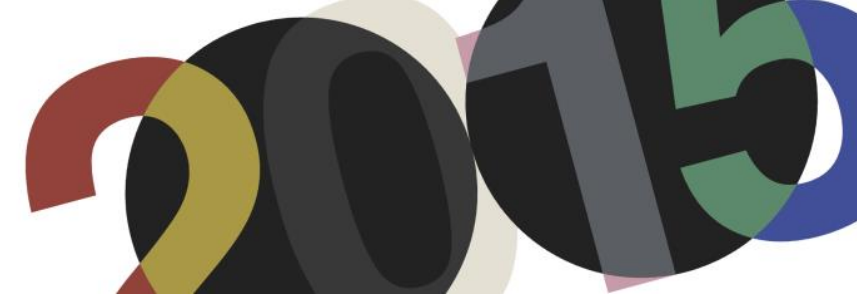

DOI: http://dx.doi.org/10.4995/LC2015.2015.586

\title{
Búsquedas para el establecimiento de una relación armónica con el paisaje. Dos exploraciones paralelas
}

\author{
C.E. Mejía Vallejo, J. Deltell Pastor \\ Escuela Técnica Superior de Arquitectura de Valencia
}

\begin{abstract}
Resumen: Los proyectos para la Sainte-Baume y para Cap Martin retoman el hilo de varias de las investigaciones realizadas previamente por Le Corbusier en torno a la vivienda de densidad media construidas a partir de muros de carga, como son las Maisons Loucheur (1929), las Maisons Murodins (1940), las Maisons pour Maîtres et Contremaîtres de la S.P.A (1940) y las Unités Transitoires (1944). No obstante, es posible afirmar que en ellos se opera una búsqueda nueva que tiene que ver con la asociación de estos módulos residenciales en pro de formar un conjunto coherente y unitario, analizando las implicaciones que ello tiene con respecto al paisaje. A la par que Le Corbusier reflexiona sobre la métrica y optimiza la distribución de estos espacios residenciales, continúa trabajando de manera intensa con la sección para intentar encontrar la manera adecuada de llegar al suelo y de relacionarse tanto con el entorno natural sobre el que el edificio se apoya, como con el paisaje lejano con el que se pretende dialogar. A esta búsqueda se suma otra que ahonda en la necesidad de una definición material acorde. A partir de estas premisas se orquesta un diálogo a varias bandas que recoge reflexiones sobre forma y proporción, sobre materialidad y sintaxis constructiva, así como sobre el entendimiento de una relación deseada entre el hombre y la naturaleza.
\end{abstract}

Abstract: The projects for the Sainte-Baume and Cap Martin take up the thread of several previous investigations by Le Corbusier about the medium density housing built from load-bearing walls, as they are the Maisons Loucheur (1929), the Maisons Murodins (1940), the Maisons pour Maîtres et Contremaittres of the SPA (1940) and the Unites Transitoires (1944). However, one can say that in them lies a new search that has to do with the association of these residential units in favour of forming a coherent and unified whole, analysing the implications that those create with the landscape. At the same time that Le Corbusier makes a reflexion on metrics and optimize the distribution of these premises, he continues to work intensively with section in order to try to find the appropriate way to reach the ground and to relate both to the natural environment on which the building rests, as well as with the distant landscape. In parallel to this work appears a search that delves into the need for a consistent material definition according to it. From these premises he establishes a dialogue that gathers several bands reflections on form and proportion, about materiality and constructive syntax, as well as the understanding of a desired relationship between man and nature.

Palabras clave: Le Corbusier; paisaje; búsqueda; Cap Martin; Roq et Rob; Sainte-Baume. Keywords: Le Corbusier; landscape; search; Cap Martin; Roq et Rob; Sainte-Baume.

\section{Búsquedas en torno a la vivienda colectiva: 35 rue de Sèvres 1948- 1955}

En la Fondation Le Corbusier existen planos de los proyectos Roq et Rob fechados desde octubre de 1949 hasta septiembre de 1955 con algunas interrupciones. Durante este tiempo Le Corbusier fue aportando modificaciones, ensayando nuevos caminos y realizando múltiples variaciones sobre diversos temas. La extensión en el tiempo que ocupan estos proyectos no construidos y la manera discontinua cómo se trabajaron hacen suponer que para Le Corbusier se trataba probablemente de un "laboratorio" de investigaciones, antes que de una apuesta concreta por construir un edificio. De hecho el encargo fue básicamente auto promovido por el propio Le Corbusier, aunque con la complicidad con su amigo Robert Rebutato -propietario de l'Étoile de Mer y de los terrenos adyacentes en los que estaba previsto ubicar Rob- . 
En el momento en el que inicia esta nueva reflexión en Cap Martin Le Corbusier estaba llevando simultáneamente varios proyectos que recorrían caminos casi antagónicos. Entre 1944 y 1958 las reflexiones de Le Corbusier sobre la residencia gravitaron en torno a tres polos: los edificios del tipo Unité d'Habitation, las viviendas unifamiliares singulares (por lo general de planta cuadrada) y los conjuntos residenciales de densidad media. En cada uno de estos "tipos" de proyectos Le Corbusier abordaba cuestiones diferentes, independientemente de la particularidad del programa.

Al hilo de una recherche patiente, organizada y sistemática, Le Corbusier utilizaba los distintos proyectos que se le encargaban -o que él mismo promovía- para indagar cuestiones que trascendían lo inmediato que se estaba proyectando. Las búsquedas apuntaban a aspectos diversos que muchas veces no eran explorables en un mismo proyecto.

El presente artículo se centrará en dos proyectos residenciales de densidad media -Le Village de Pèlerinage de la Sainte-Baume y Roq et Rob-proyectados entre 1948 y 1956 en el 35 rue de Sèvres, ya que se entiende que será en ellos en los que Le Corbusier realice una apuesta clara por definir otra manera de relacionarse con el paisaje.

Para llevar adelante esta búsqueda se podría decir que básicamente se movilizaron cinco parámetros, que cuidadosamente se fueron recombinando:

1.1 La configuración de la planta mediante la repetición de crujías paralelas manifiestas.

1.2 La definición de la estructura -en particular en lo que atañe al encuentro con el suelo y a la transición entre éste y la parte aérea-.

1.3 La sintaxis material.

1.4 La configuración volumétrica.

1.5 Formas de relación con el paisaje.

\subsection{La configuración de la planta}

Quizás sea una simplificación excesiva aventurarse a afirmar que existe una relación entre el "tipo" de edificio a desarrollar y la configuración básica de la planta mediante la cuál éste se aborda. No obstante, durante esta época, resulta posible identificar la utilización recurrente de dos configuraciones básicas para abordar el tema de la vivienda colectiva: bloques lineales, para resolver vivienda de alta densidad y edificios compuestos a partir de crujías paralelas manifiestas, para las viviendas de densidad media. En estos últimos se apuesta claramente por una configuración lineal, en la que a pesar de constituir un único cuerpo construido no obstante se independizan visualmente las diferentes unidades.

Dichas organizaciones de la planta van acompañadas de investigaciones en torno a los sistemas de circulación tanto horizontal como vertical, a las soluciones estructurales y a los mecanismos de configuración volumétrica de los alzados.

\subsection{La definición de la estructura}

Aunque existen diversas combinaciones entre la organización de la planta y el sistema estructural propuesto, por lo general, cada configuración de la planta lleva asociado un tipo de sustentación que de alguna manera le es consustancial. 
No obstante, resulta interesante anotar que así como en los bloques lineales Le Corbusier tiene muy claro el carácter diferencial de la estructura aérea y de aquella que resuelve el contacto con el terreno (a pesar de que en cada uno de ellos se opere un búsqueda concreta), en los proyectos de crujías paralelas aparentemente existen dudas sobre cuál debe ser la forma de la estructura que opera la transición con el terreno y sobre cómo debe ser el diálogo establecido entre ésta y la parte aérea. Es por ello que, en los distintos proyectos realizados en esta época bajo estas premisas, se prueban diferentes tipos de soluciones apareciendo siempre un conflicto entre la voluntad de definir el límite entre las células mediante un elemento constructivo contundente, asimilable al muro, y el deseo de posarse sobre el territorio con el menor impacto, lo que remite a la utilización de elementos puntuales.

Le Corbusier irá alternando la utilización de los dos sistemas, llegando incluso a combinarlos en una misma solución. También está presente el deseo de independizar volumétrica y visualmente las células, que lo lleva a tantear estructuras duales que permitan el deslizamiento relativo de los cuerpos.

\subsection{La sintaxis material}

La manipulación de la percepción de los edificios y de los espacios interiores en función de su construcción incluye tanto la elección de los materiales como la forma de relacionarlos entre ellos.

Al mismo tiempo que en estos proyectos residenciales de densidad media se fuerza una lectura fragmentada de las partes que componen el volumen, también se apuesta por una forma de construcción en la que se hacen explícitos los diferentes materiales utilizados potenciando una lectura diferenciada de los mismos, en cuanto éstos vienen asociados de manera indefectible a su función portante y constructiva. Es difícil afirmarlo con certeza, al tratarse de proyectos no construidos, pero muy probablemente en ellos Le Corbusier habría de renunciar poco a poco a la utilización de la policromía optando por una expresión de las cualidades sensibles de los distintos materiales.

Esta postura tiene una doble repercusión que incide en la construcción del volumen en sí, ya que fuerza una sintaxis material entre partes diversas, y en la relación de éste con el entorno circundante. La utilización de materiales "brutos", que asume claramente su diversidad, sin duda remite a la manera como se construye el paisaje como suma e integración de factores diversos.

No obstante las investigaciones en este sentido van de la mano de las búsquedas en torno a la estructura, por lo que al igual que sucede con ésta se irán alternando soluciones diversas e incluso al parecer contradictorias.

\subsection{La configuración volumétrica}

Los elementos responsables de la configuración volumétrica, y de la consecuente imagen del alzado, también parecen ser susceptibles de ser leídos desde una cierta sistematización. Fundamentalmente, a lo largo de estos años Le Corbusier explora dos mecanismos en el desarrollo de sus proyectos residenciales: el trabajo con planos sucesivos en aras a conseguir una mayor abstracción en la lectura del volumen como un todo (Unités $d$ ' Habitation) y la expresión e individualización del entrepaño definido conjuntamente por la estructura y la forma de la cubierta (Unités Transitoires, Roq et Rob, La Citadelle, etc) -como herramienta para singularizar la lectura de las distintas unidades. 
Vemos pues cómo para un mismo programa, dependiendo del carácter que se le pretendía imprimir al volumen, se optaba por un tipo u otro de solución. Las condiciones específicas de la localización geográfica, si bien influían en la particularización de las soluciones adoptadas, no parecían ser determinantes a la hora de decidir el carácter general de los edificios. Soluciones empleadas en Francia eran susceptibles de ser llevadas a la India, o viceversa.

No obstante sorprende particularmente el trabajo simultáneo en torno a dos formas casi opuestas de manipulación de los aspectos formales y constructivos, en aras a potenciar distintas lecturas escalares y visuales: el recurso a la composición por planos sucesivos (brise soleil) y la individualización de la célula (trabajo con crujías paralelas). Parece claro que Le Corbusier utilizó estas cuestiones como un verdadero laboratorio de expresión lingüística, extrayendo de cada una de ellas soluciones y situaciones espaciales adecuadas para cada proyecto.

La utilización sistemática del brise soleil abunda en la búsqueda de una determinada abstracción en la aprehensión de los edificios. Este recurso posibilita una lectura dual del límite exterior del edificio, mediante la interposición de un espacio de aire que permite establecer una diferenciación entre el alzado que manifiesta las particularidades del uso y el alzado que se muestra al exterior, trabajando la globalidad de sus proporciones. Se trata de un trabajo mediante planos sucesivos en el que el brise soleil es el responsable de la relación con el exterior, mientras que el pan de verre hace las veces de filtro con el interior.

Aunque el brise soleil a buen seguro cumple una determinada función en el control del soleamiento, está claro que su papel excede con creces de este cometido. Se trata también de un recurso eminentemente compositivo, o si se prefiere pictórico, que junto con la proporción general del paño que organiza, constituye la pauta para la lectura del alzado. También permite a Le Corbusier conferir un espesor ficticio a la materia, potenciando así la aparición de efectos claramente vinculados al manejo plástico de la misma como son el relieve, el contraste y el claroscuro, entre otras.

Como contrapunto y necesario complemento del brise soleil aparece el pan de verre ${ }^{l}$. Del diálogo entre ambos surge la posibilidad de incorporar escalas múltiples dentro de una lectura unitaria del conjunto. El pan de verre trabaja con la escala del usuario, con un nivel de proximidad en el que le resulta posible reconocer un sistema pensado a su medida para ventilar, para mirar y para -en ciertos casos- apoyarse.

Mediante la combinación de estos dos mecanismos Le Corbusier establece una doble lectura de las fachadas del edificio: una se concibe para ser vista en su totalidad y desde el exterior, mientras que la otra lo hace para ser vista en su particularidad y desde el interior. Se trata de un sistema extremadamente especializado y refinado en su dualidad.

En los edificios en los que se emplea este mecanismo dual, la relación tanto con el suelo como con el cielo se formaliza de una manera particular, cosa por otro lado obvia atendiendo al voluntario trabajo del lienzo de

\footnotetext{
${ }^{1}$ Es importante anotar que la investigación en torno al pan de verre se extiende a los paños ligeros de fachada utilizados tanto en los proyectos que utilizan brise soleil como en los que no, especialmente en las construcciones que apuntan a un cierto grado de industrialización.
} 
fachada como una unidad en sí. En este sentido, el adoptar soluciones particulares y diferenciadas en los extremos del edificio no hace más que reforzar el carácter "terminado" de la obra, reforzando el hecho de que el lienzo principal responda de manera precisa a una determinada proporción.

Otra búsqueda bien diferente es la que Le Corbusier lleva a cabo en los proyectos en los que opta por la utilización de crujías paralelas explícitas. En ellos el sistema que se utiliza apunta hacia el deseo de promover una cierta manipulación escalar recurriendo a la fragmentación del volumen -mediante la expresión e individualización del entrepaño definido conjuntamente por la estructura y la forma de la cubierta- y de dotar a los edificios de un determinado carácter gracias a la expresión de su construcción. Si bien en el caso anterior veíamos como existía la voluntad de apostar por una lectura de la totalidad del edificio, en este caso pareciera como si el objetivo residiera en la lectura de las partes que componen la obra, bien sean viviendas independientes (por ejemplo Roq et Rob), o espacios de un interior intencionadamente pautado (Villa Manorama Sarabhai).

\subsection{La relación con el paisaje}

La diferencia entre estas dos formas de proceder anteriormente enunciadas con respecto a la definición del carácter de las fachadas difícilmente es atribuible a particularidades del programa, ya que vemos cómo edificios de vivienda colectiva se resuelven tanto con uno u otro mecanismo. No obstante, ambas establecen maneras muy distintas de relación del observador externo con el edificio, y del habitante con el exterior.

En el caso de la utilización del brise-soleil se fuerza a una lectura distante y del todo, mientras que la individualización de las células promueve un aproximación y una relación de interacción con lo construido: la contemplación contrapuesta a la experiencia.

Estas consideraciones llevan implícitas maneras diferentes de entender la relación entre lo edificado y el paisaje. En los casos en los que se recurre al brise soleil por lo general se trata de edificios que se asientan sobre el paisaje y que establecen con él un diálogo mediante la abstracción. La utilización del brise soleil da pie a la lectura del edificio como un todo, tanto por la percepción escalar que éste conlleva, como por le hecho de ser edificios que se levantan del plano del suelo. Estas dos cuestiones surgen quizás como respuesta a una necesidad de establecer un contrapunto con el paisaje, entendido como panorama.

Por el contrario cuando Le Corbusier recurre a muros de carga perpendiculares al plano de fachada como responsables últimos de la imagen del edificio, la relación con el paisaje se invierte. Los edificios pasan de colocarse sobre el paisaje a enraizarse en él. Vistos desde fuera parecen surgir del paisaje. En estos caso se apuesta por una percepción más fragmentada, potenciada por la definición material de los edificios, que establece un diálogo con los elementos que construyen el paisaje y no con la totalidad del mismo, aunque éste siempre siga estando como fondo.

En el texto de presentación de la Villa Mandrot en l' Euvre Complète se puede leer "La composition est ordonnée sur le paysage $»^{2}$. En este proyecto de 1929 ya aparece la voluntad de definir la forma y la materialidad de lo construido en sintonía y estrecho diálogo con el entorno que lo rodea.

La consecuencia última de las distintas formas de combinación de los factores anteriormente mencionados es el establecimiento de diferentes formas de relación entre la pieza construida y el paisaje en el que se asienta. Las

\footnotetext{
${ }^{2}$ LE CORBUSIER (1957). Cuvre complète, Verlag für Architektur, Artemis, Zurich; octava edición 1991. Vol. 2. Pag. 59
} 
primeras a las que se alude son hitos en el paisaje, que se posicionan sobre él pero que no interactúan, mientras que las segundas construyen el paisaje estableciendo un diálogo próximo con los elementos que lo rodean.

A continuación se intentará realizar una aproximación a las búsquedas llevadas a cabo por Le Corbusier en este sentido entre 1948 y 1954 analizando dos ejemplos.

\section{Reflexiones en torno a dos proyectos}

Quizás el proyecto en el que Le Corbusier incide e investiga de forma más exhaustiva estas cuestiones son los conjuntos residenciales $R o q$ et Rob, en Cap Martin. No obstante, es importante señalar que este proyecto presenta muchas similitudes con las propuestas realizadas para el Village de Pèlerinage de la Sainte-Baume, realizado en paralelo e iniciado unos años antes, por lo que se considera oportuno presentarlos a la par.

Refiriéndose al fracaso del proyecto para la Basilique de la Paix et du Pardon Le Corbusier escribió las siguientes palabras:

"Mais ceux qui cherchent à lier les choses de l'homme et les choses de la nature en une harmonie subitement valable, se font aigrement rejeter et rien ne se fait! (...) La surface de l'eau... n'est plus troublée, tout va bien; chacun dormira tranquille! (...)”3.

"Lier les choses de l'homme et la nature en une harmonie subitement valable”; con estas palabras Le Corbusier hace explícita su voluntad de promover una armonía entre lo construido y el entorno natural. Esta vía de investigación lo ocupó a lo largo de muchos años y quizás nunca pudo llegar a ver sus frutos, pues ninguno de los proyectos en los que exploró esta cuestión de una forma más consistente llegaron a ser construidos.

\subsection{Primeras búsquedas}

En torno a estas propuestas se operan varias búsquedas que están relacionadas con la métrica de la crujía básica búsqueda de una modulación que permita optimizar las distribuciones interiores-; con la relación con el plano del suelo -resolución de la dicotomía entre la voluntad de levantar las construcciones del terreno y la utilización de un sistema estructural que llega a él de forma contundente- y con la voluntad de diferenciar y cualificar los espacios mediante una especialización de la sección -búsqueda en torno a posibles maneras de rematar los espacios y en general los volúmenes, lo que conlleva a su vez exploraciones en torno a la forma de la cubierta-

Hay decisiones que presentan una gran estabilidad, y que a lo largo de las distintas propuestas se van perfilando como definitivas como son: el recurso a la planta desarrollada en profundidad compuesta por dos crujías paralelas -de una dimensión en torno a los 2.26 metros de ancho-; la voluntad de manifestar de forma explícita cada unidad mediante su expresión y la singularización de la cubierta; la contigüidad de los módulos en planta, mas no necesariamente en alzado - mediante la alteración tanto de la línea de cornisa como de la del remate inferior- y la voluntad de independizar el espacio habitable con respecto a la cota del terreno. También al parecer alberga pocas dudas con respecto al tipo de cubierta a utilizar ya que siempre la define construida con bóvedas. Incluso en las soluciones ligeras utiliza esta solución constructiva, haciendo la siguiente descripción de la

${ }^{3}$ PETIT, J.(1970). Le Corbusier Lui-même. Éditions Rousseau, Genève. 
misma: "l'une des premières recherches conçues en tôle d'aluminium pliée, la toiture voûtée étant recouverte de béton, de terre et de plantes grasses ".

Recorriendo la información de estos dos proyectos, queda patente la continuidad pero al mismo tiempo la diversidad de la búsqueda. Ésta se hace explícita por ejemplo cuando se constata que en Octubre de 1949 en el 35 Rue de Sèvres, se estaba dibujando la propuesta para la Trouinade construida con muros de tapial y en diciembre de ese mismo año también se avanzaba con la propuesta de Rob, formalizada con el sistema $226 * 226 * 226$ de alveolos de aluminio.

En relación a esto, Le Corbusier escribió en las páginas de su Euvre Complète dedicadas al proyecto de Roq et Rob :

"Les études se sont poursuivies, basées tantôt sur une technicité, tantôt sur une autre, à la recherche d'une type d'habitation et d'exploitation de l'habitation sur les rives de la Côte d'Azur, capable de s'insérer dans le paysage et propre à le vitaliser."

Estos dos proyectos estarán marcados por las búsquedas dispares tanto en torno a la estructura como a la materialidad. No obstante, atendiendo a las palabras de Le Corbusier, es posible intuir que el sentido de éstas trascendía su estricto cometido. Se parte de la hipótesis de que es posible afirmar que tanto en la Sainte-Baume como en $R o q$ et Rob, la búsqueda en torno a la asociación de módulos residenciales -en pro de formar un conjunto coherente y unitario- apunta hacia la voluntad de promover una determinada forma de relación con el paisaje.

Hasta ahora las búsquedas de Le Corbusier relacionadas con la construcción en terrenos naturales se habían centrado en construcciones aisladas, o en todo caso en conjuntos compuestos por construcciones independientes, por lo que resulta posible lanzar la hipótesis de que se trata de las primeras aproximaciones del maestro suizo a este tema. De hecho sus propias palabras consignadas en la reseña del proyecto para la Sainte-Baume en la obra completa nos dan cuenta de ello:

"Tout était déférence au paysage, modulé sur le paysage, expression même du paysage: paysage vue des bâtiments, ou paysage fait de la présence des bâtiments dans une harmonie passionnément désirée." 6

El hecho de enfrentarse a la definición de un conjunto a buen seguro le permitió precisar cuestiones sobre las que antes se dudaba, como por ejemplo el recurso a la bóveda. En algunos croquis para las Maisons Loucheur (1929) (FLC 18354) se puede observar ya la tentación a cubrir con bóvedas los espacios. Estos tanteos tímidos se repiten en la viviendas para la S.P.A en Lannemezan ${ }^{7}$. No obstante, tanto en Roq et Rob como en la SainteBaume esta solución constructiva para la cubierta se asume claramente desde el inicio, ya que le permite fragmentar las distintas partes del conjunto -controlando la escala-, y al mismo tiempo dotar de una imagen homogénea al conjunto mediante su repetición.

\footnotetext{
${ }^{4}$ LE CORBUSIER (1953). CEuvre Complète, Verlag für Arkitektur (Artemis), Zürich,Vol. 5, pag 60

${ }^{5}$ LE CORBUSIER (1953). Euvre Complète, Verlag für Arkitektur (Artemis), Zürich,Vol. 5, pag 60

${ }^{6}$ Ibidem, pag. 25

${ }^{7}$ Una vez más surge la duda sobre si hay errores de catalogación ya que en los DVD plan Vol. 3 y Vol. 7 hay dibujos idénticos en los apartados de las Maisons Loucheur y las viviendas para el complejo SPA.
} 
Las propuestas de 1949 para la Trouinade ${ }^{8}$, dibujadas por Clémot, emplean un módulo base compuesto por dos crujías paralelas de $2.26 \mathrm{~m}$ de ancho y 22.6 metros de longitud, delimitadas por muros de tapial de 0.55 metros de espesor.

Esta métrica retoma, optimizándola, la utilizada en las Maisons Murondins (1940), que parte de dos crujías de 3 metros y tres muros de 0.50 de espesor. La longitud propuesta para estas construcciones es de 40.5 metros, pero dado que por lo general cada construcción está compuesta por dos zonas, cada una de ellas tiene aproximadamente 20 metros. Las Maisons Murondins están pensadas, no obstante -y al contrario que las propuestas para la Trouinade- como un espacio dependiente de su lado largo para abrirse al exterior, actuando como principal responsable de la visión de las mismas. La dimensión de las crujías que las definen surge aunando una dimensión útil para disponer una cama en perpendicular y un paso y una dimensión suficientemente pequeña susceptible de ser cubierta con rondins de madera transportables manualmente.

Aunque las Maisons Murondins surgieron de la necesidad de dar respuesta a una situación de precariedad debida a la guerra, y desde esta óptica se entienden las pautas de su concepción, desde hace varios años Le Corbusier venía haciendo esfuerzos por intentar conciliar lo más avanzado de la industria de su tiempo con un saber hacer y una cultura material ancestrales. Las Maisons Loucheur (1929) son un claro ejemplo de esto y, como continuación de la reflexión de aquellas, el proyecto en Lannemezan (1940) también lo es.

A la par que Le Corbusier reflexiona sobre la métrica y optimiza la distribución de los espacios residenciales, continúa trabajando de manera intensa con la sección para intentar encontrar la manera adecuada de llegar al suelo y de relacionarse tanto con el entorno natural sobre el que el edificio se apoya como con el paisaje lejano con el que se pretende dialogar. En un primer momento, tanto en este proyecto como en los tanteos para Roq et Rob, se asume como premisa básica que las construcciones deben estar levantadas del suelo para favorecer ese diálogo. Esto quizás sea una herencia directa de las Unités d'Habitation, en las que unos de los puntos clave era el tener una mínima ocupación del suelo con una máxima cantidad de viviendas, permitiendo que el terreno libre pasara por debajo de ellas. Sin embargo, en estas pequeñas construcciones el problema es otro y la relación con el paisaje se deberá plantear en términos mas sutiles. Es por eso que veremos cómo a lo largo de la evolución de estos dos proyectos Le Corbusier va realizando tanteos múltiples al respecto.

\subsection{Le Village de Pèlerinage de la Sainte-Baume (1948-1954)}

El proyecto para la Sainte-Baume comparte con Roq et Rob su carácter altruista. En este caso el encargo es promovido por Édouard Trouin, geómetra y propietario de una gran extensión de terrenos en la Sainte-Baume, hermoso paraje montañoso en torno al Plan d'Aups, con el Mont Sainte Victoire como tela de fondo hacia norte. Se dice que en estas montañas, en una gruta a media altura, habitó María Magdalena. Trouin, un apasionado emprendedor, amante de la naturaleza y de lo bello, no quería parcelar sus tierras y borrar así las huellas de un entorno natural privilegiado. Es por esto que se empeñó en la búsqueda de una arquitectura capaz de dialogar con este lugar sin alterarlo, proponiendo construir una basílica dedicada a María Magdalena cuyo proyecto encargó a Le Corbusier.

\footnotetext{
${ }^{8}$ La Trouinade, derivado de Trouin el promotor del proyecto, es otro nombre con el que se conocía el proyecto residencial proyectado en la Sainte-Baume.
} 


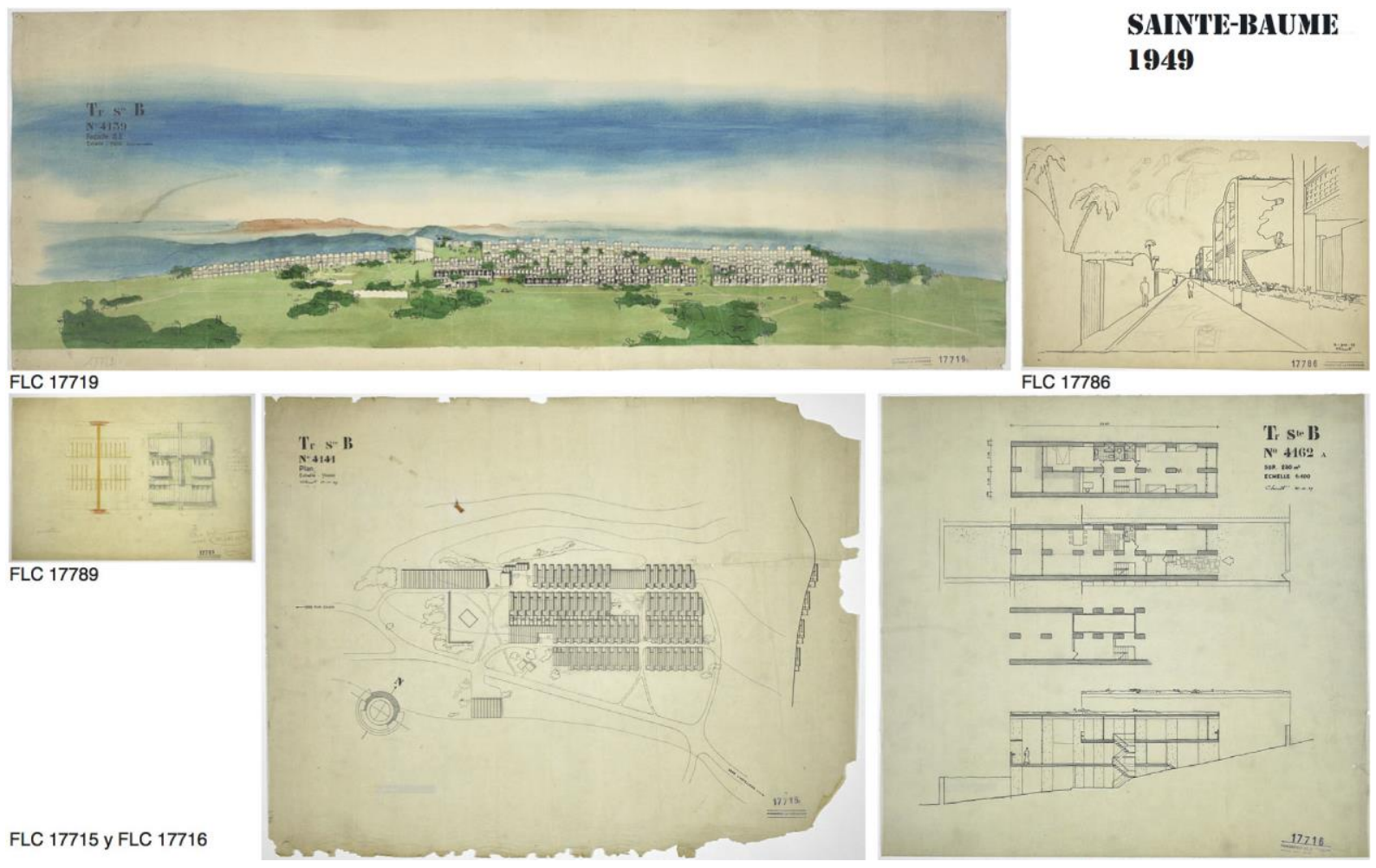

FLC 17719B (NN, NF), FLC 17786 (Clémot, 02-06-1949), FLC 17789 (Samper, 16-11-1949), FLC 17715A (Clémot, 21-101949), FLC 17716 (Clémot, 30-10-1949). Imágenes @FLC-ADAGP.

Junto al proyecto de la Basilique de la Paix et du Pardon (1946-1948) se planteó construir un Village de Pèlerinage en nombre de la paz internacional, que en principio encargó a Perret, quien no pasó de unos esquemas iniciales. Posteriormente, con la aquiescencia de Perret -quien se encontraba inmerso en los trabajos de Le Havre y Amiens- se encargó a Le Corbusier la realización paralela de esta parte del proyecto. Según parece el encargo complementario a la basílica pasó por fases muy diversas, lo que quizás explique la dispersión y diferencia de bocetos.

Los proyectos residenciales para la Sainte-Baume (1948-1954) y algunas de las propuestas para Cap Martin (1949-1956) son coincidentes en el tiempo, compartiendo varias premisas básicas como la de resolver un conjunto residencial de densidad media en un entorno natural con una impactante presencia y en desnivel. Esta coincidencia hace que muchas de las soluciones se planteen de manera casi indistinta, a tal punto que en la clasificación realizada en los DVD Plans hay varios dibujos catalogados de forma indiscriminada en ambos proyectos: dibujos de la Sainte-Baume aparecen en el proyecto de Roq et Rob y viceversa.

En ambos casos se retoma el hilo de varias de las investigaciones realizadas previamente en torno a la vivienda de densidad media construidas a partir de muros de carga como son las Maisons Loucheur (1929), las Maisons Murondins (1940), las Maisons pour Maîtres et Contremaîtres de la S.P.A (1940) y las Unités Transitoires (1944).

En las primeros dibujos para la Trouinade la totalidad del espacio se levanta del suelo debido, según Le Corbusier, debido al desnivel presente en el terreno. No obstante sorprende ver cómo este espacio de aire ni se representa ni se vive como parte de la vivienda. De hecho, en el dibujo en perspectiva seccionada (FLC 17726) se muestra el espacio cortado a nivel de la primera planta interior. 

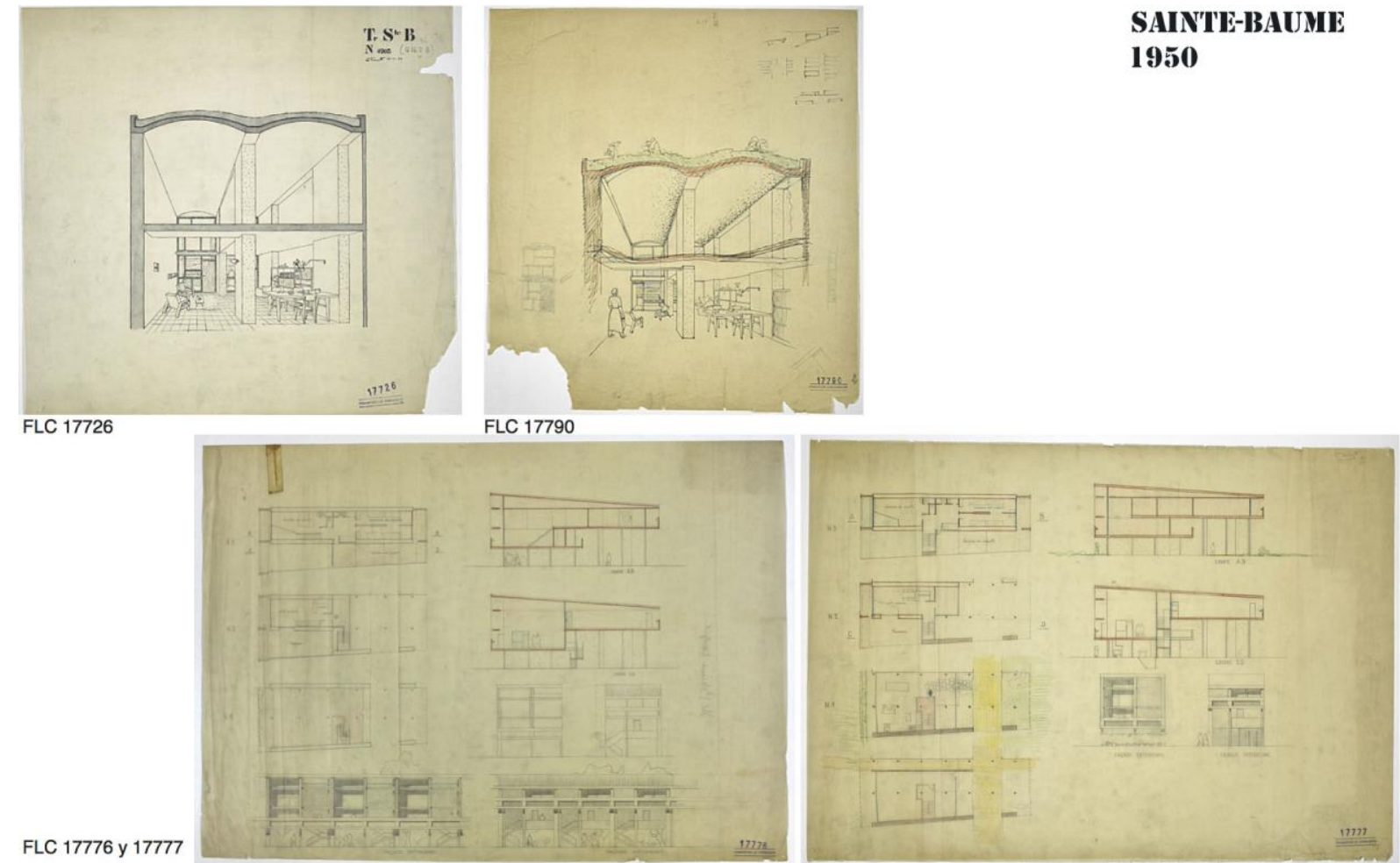

FLC 17726 (Clémot, 19-05-1950), FLC 17790 (Le Corbusier, NF), FLC 17776 (NN, NF), FLC 17777 (Clémot, 19-04-1950). Imágenes $\odot$ FLC-ADAGP.

En la propuesta que data de 1951 sorprende ver cómo se reduce drásticamente el número de viviendas proyectadas, aunque parece claro que se trata de una primera fase de un desarrollo futuro. A pesar de que el esquema resulta análogo al inicial, las particularidades del mismo difieren. Se sigue manejando un esquema de dos crujías paralelas, con la salvedad de que en este caso la línea intermedia de carga está definida por soportes, aparentemente metálicos. La dimensión total de la vivienda se reduce, pasando a dos crujías de 2.26 metros aproximadamente $^{9}$ de ancho por 10 metros de longitud y dos plantas.

Parece que toda la construcción se levanta del suelo al igual que en la propuesta anterior, pero se introduce un cambio sustancial. Tanto en el espacio de acceso a las viviendas como en el ámbito con el que éstas se vinculan con el paisaje se incorporan unos espacios previos, acotados por muros curvos. Si bien en la planta no se obtiene demasiada información sobre estos espacios exteriores, en la sección se puede apreciar la aparición de un árbol dentro de cada uno de ellos y la presencia de un hilo de humo dirigiéndose hacia el cielo, lo que habla probablemente de una vida intensa en el exterior (FLC 17331). Esta operación, aparentemente anodina, supone un cambio conceptual importante. Se pasa de la sección que omite dibujar la planta baja a la creación de un espacio interior al exterior, en el que la mujer y el hombre resguardados a la sombra del edificio (FLC 17730) prolongan el espacio de la vida doméstica disfrutando de su árbol. Con respecto a la relación inversa, lo que se ve desde el paisaje, también se opera una modificación importante: no se confía en la visión de un elemento que se levanta del suelo sino que se busca reproducir las formas de la naturaleza construyendo un paño mineral ondulante que emerge directamente del suelo, como las montañas.

\footnotetext{
${ }^{9}$ No existen cotas en los planos que permiten conocer con precisión sus medidas
} 

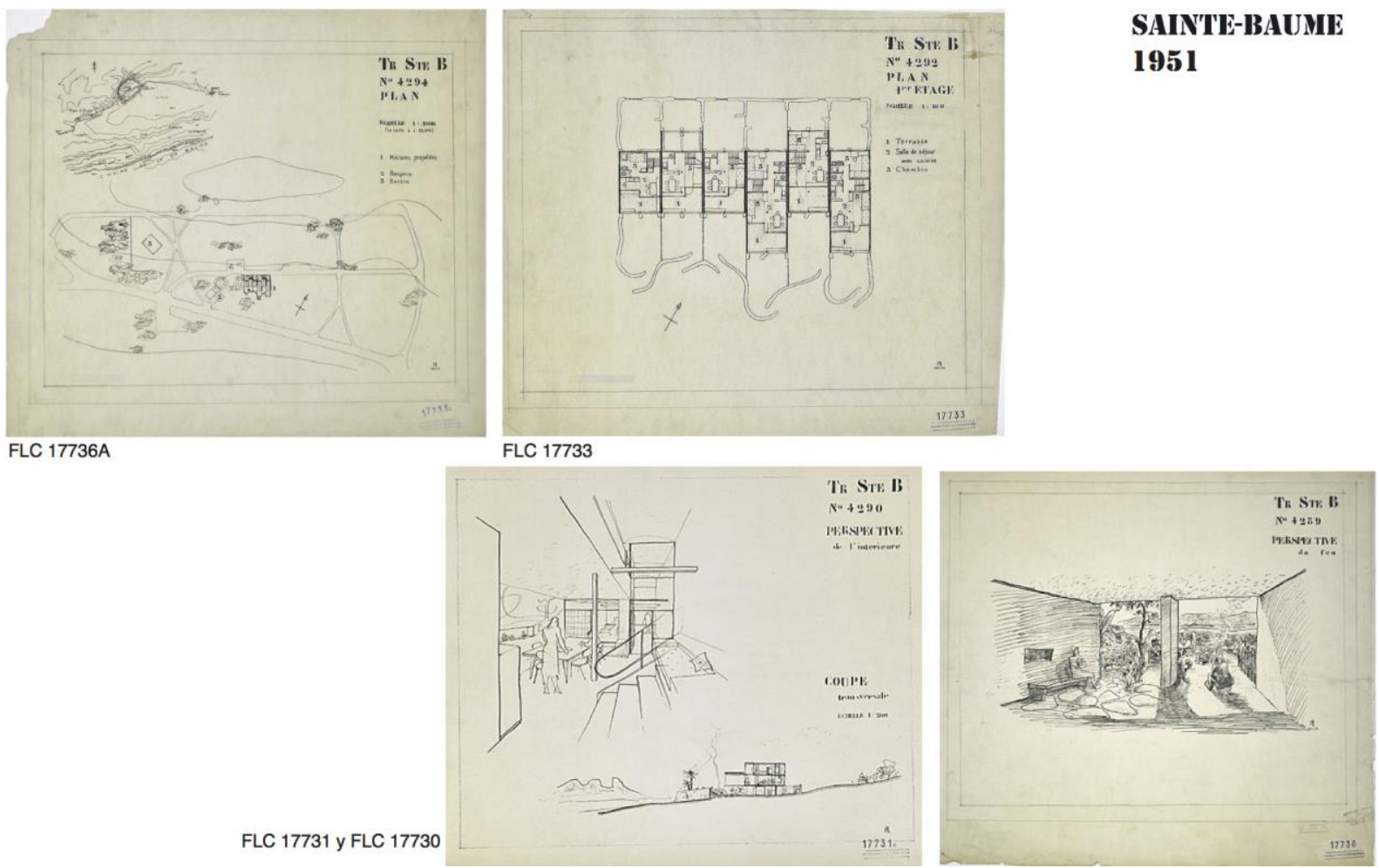

FLC 17736A (Takamasa, 23-02-1951), FLC 17733A (Takamasa, 23-02-1951), FLC 17731B (Takamasa, NF), FLC 17730 (NN, 19-02-1951). Imágenes @FLC-ADAGP

En paralelo a estos tanteos, en 1950 se empieza a gestar otra propuesta que difiere sustancialmente de las anteriores. Responde al esquema de la "barca" con formas de reminiscencias religiosas (FLC 17776, FLC 17777, FLC 17737, FLC 17738, FLC 17794A, FLC 17742, FLC 17781). Durante el proceso de concreción esta forma aparecieron también edificios o conjuntos circulares, que atendiendo a la carta de Trouin archivada en la Fondation Le Corbusier (FLC 17751) pueden responder a una imposición por parte del cliente. No obstante, en los Carnets (D16, fig. 171) figura un boceto de 1950 que muestra la plaza de toros de La Santamaría en Bogotá, en el que se puede leer la siguiente anotación: "La Plaza del Toro// confirmation des anneaux de 200 de la Ste Baume”. En el mismo Carnet figuran mas bocetos de dicho edificio en los que se incide en su diálogo con el paisaje.

En el volumen 5 de l'CEuvre Complète se dice que estaba prevista la construcción de dos tipos de edificios: uno para residencia temporal y otro para residencia permanente. Quizás la diferencia entre las distintas fases del proyecto responda al hecho de que se trate de un tipo de edificio u otro -aunque esto no aparece reflejado en los planos de forma explícita-.

Esta propuesta extraña, al parecer persigue la antítesis de lo que se pretendía en los inicios del proyecto, a saber: la fragmentación de la escala. En este caso se trataba de construir un volumen unitario y con una condición de forma predeterminada y muy condicionante, en la que se hacían esfuerzos sobredimensionados por matizar su impacto. Por su carácter contundente y formalmente autónomo recuerda más las estrategias de relación con el paisaje operada en las Unités d'Habitation que la aproximación que estaba proponiendo para estos conjuntos residenciales. 

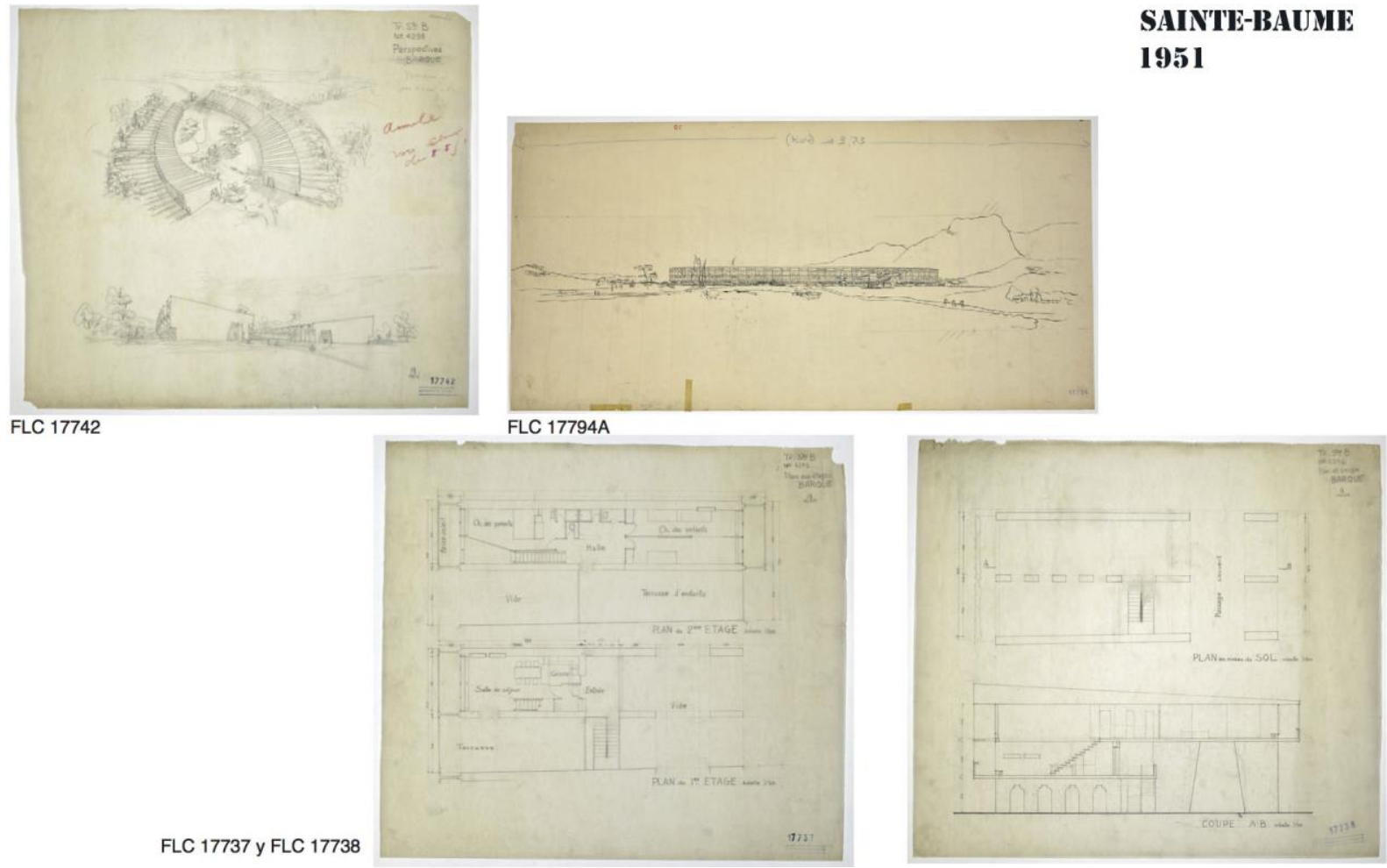

FLC 17742 (Takamasa, 01-03-1951), FLC 17794A (NF, NN), FLC 17737 (Takamasa, 28-02-1951), FLC 17738 (Takamasa, 28-02-1951). Imágenes @FLC-ADAGP.

También cabe resaltar que quizás estos tanteos pudieron coincidir también con la colaboración establecida con "l'Aluminium Français":

"Mais les circonstances avaient permis d'autres rencontres ce fut "l'Aluminium Français” qui, a un moment donné, tendit l'oreille à nos propositions; et des formes d'urbanisme et d'architecture en furent l'effet, conçues en plein voisinage possible et admissible avec le pissé, mais réalisables avec les méthodes les plus aigües d'emploi du métal le plus moderne qui est: l'aluminium "Io

En las carpetas relacionadas con este proyecto aparece una serie de planos sin fechar, dibujados por Germán Samper, que coinciden literalmente con dibujos realizados para Roq et Rob en 1949 y en los que se prescinde de los muros asumiendo por completo la presencia de una estructura ligera. Es posible que éstos hayan servido de base para desarrollar los tipos que daban forma a las primeras propuestas para la Barque (F, 17777 y FLC 17776).

\subsection{Roq et Rob. Cap Martin (1949-1955)}

El proyecto de Rob estaba pensado inicialmente como el conjunto de seis residencias vacacionales para artistas y doce alojamientos para viajeros de paso. Roq era una desarrollo urbanístico más ambicioso que contaba con entre 30 y 80 viviendas según las diferentes versiones. No obstante, y sobre todo en los momentos iniciales, la investigación tipológica con respecto a la célula que definía el tipo de vivienda y sus pautas de construcción fue común (entre ellos y con la Sainte-Baume).

${ }^{10}$ LE CORBUSIER (1953). Cuvre Complète, Verlag für Arkitektur (Artemis), Zürich. Vol. 5 pag. 25. 


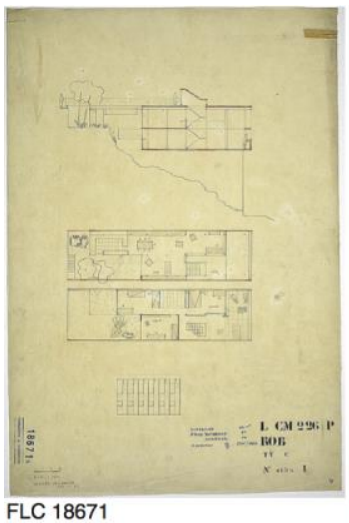

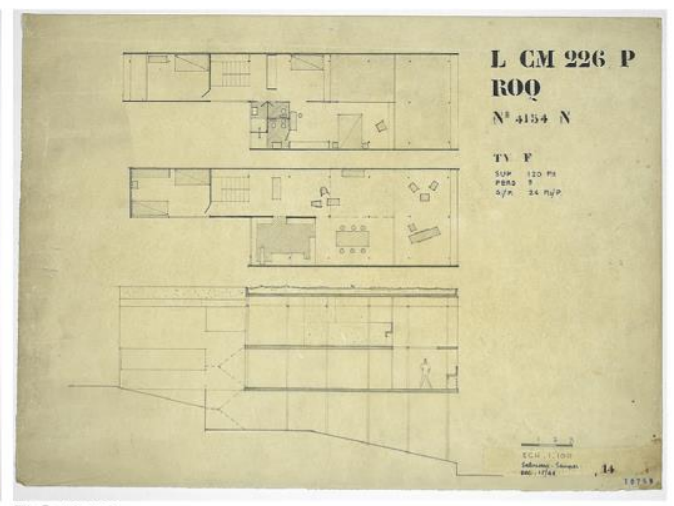

FLC 18759

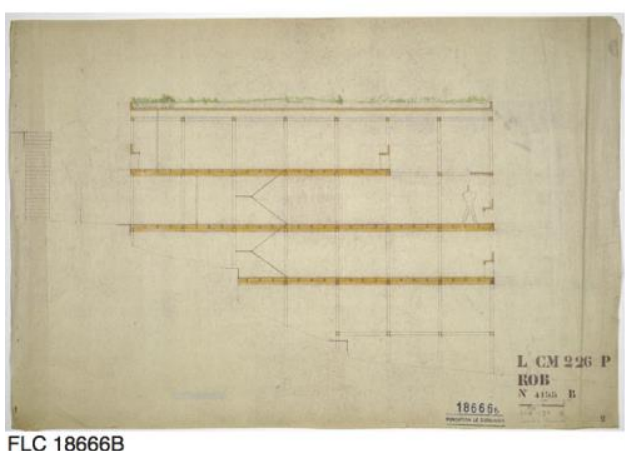

FLC 18666B

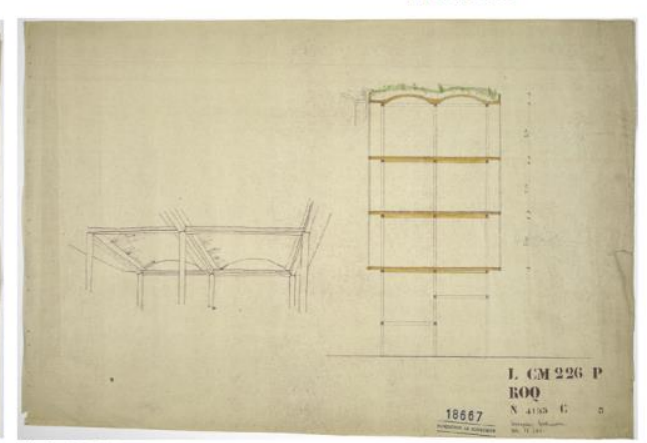

FLC 18667
ROQ ET ROB

1949
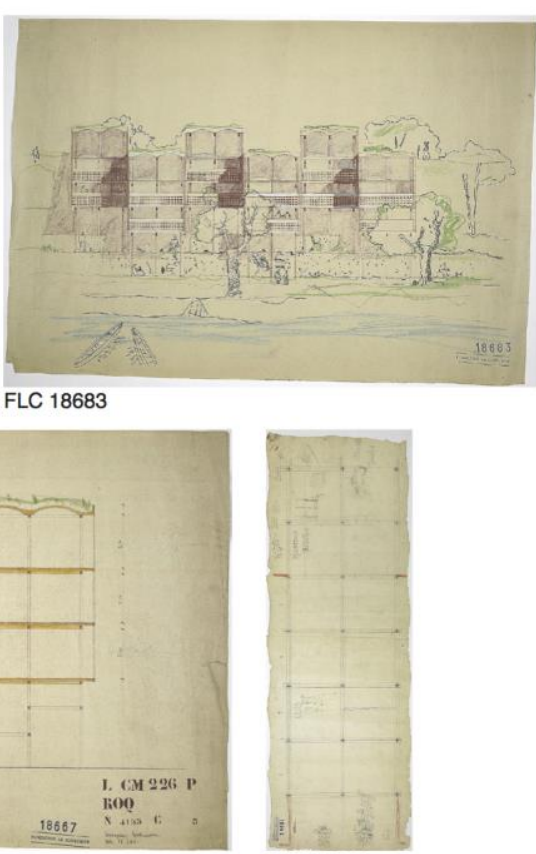

FLC 18948

FLC 18671 (Samper-Salmona, 12-1949), FLC 18759 (Samper-Salmona, 15-12-1949), FLC 18683 (NN, NF), FLC 1866B (Samper, 12-1949), FLC 18667 (Samper-Salmona, 12-1949), FLC 18948 (NN, NF). Imágenes @FLC-ADAGP.

La propuesta para Rob de diciembre de 1949, dibujada por Germán Samper y Rogelio Salmona y cuyos dibujos quizás son los que más han trascendido, exploraba el camino del 226*226*226 de una manera aparentemente muy convincente. Sin embrago vista con detenimiento es una solución que duplica la estructura, ya que la bóveda es un elemento estructural en sí independiente de la retícula de aluminio. El hecho de independizar los soportes verticales de los cerramientos de medianería da lugar a rematar las bóvedas de una forma más armoniosa, estableciendo un doble orden sutil que permite la lectura de cada crujía individualmente, pero que también da cuenta del conjunto dual que constituye la unidad residencial básica. Así mismo, en el encuentro con el suelo conduce a una solución ligera, posibilitando que los módulos de vivienda avancen o se retranqueen con respecto al contiguo con bastante independencia (FLC 18948, FLC 18666B, FLC 18667, FLC 18671A).

En tanteos posteriores dibujados por Yoshizaka Takamasa ${ }^{11}$ entre 1950 y 1951, se observan dos cambios fundamentales. El primero es que las viviendas se reducen claramente en dimensión, pasando a tener 2, 3, 4 ó 5 módulos de 2.26 metros de profundidad en lugar de los 7 que tenían las propuestas anteriores. Este cambio responde a la voluntad de ofrecer la mayor diversidad posible de viviendas, vinculada al número de habitantes que puedan ocuparlas -que oscila desde 2 hasta 2+9+1-. (FLC 18745, FLC 18754). No obstante, estos tanteos parecen haber sido desarrollados fundamentalmente en planta, partiendo de una sección esquemática que ordena los distintos tipos de forma escalonada ajustándose hacia la pendiente y organizando las viviendas de mayor a menor superficie (FLC, 18754). La imagen en alzado, de la cual aparentemente no hay dibujos definitivos, debe

\footnotetext{
${ }^{11}$ Aunque mucho de los dibujos no están firmados, ni tienen fecha, por similitud con otros se intuye que la autoría y las fechas son similares.
} 

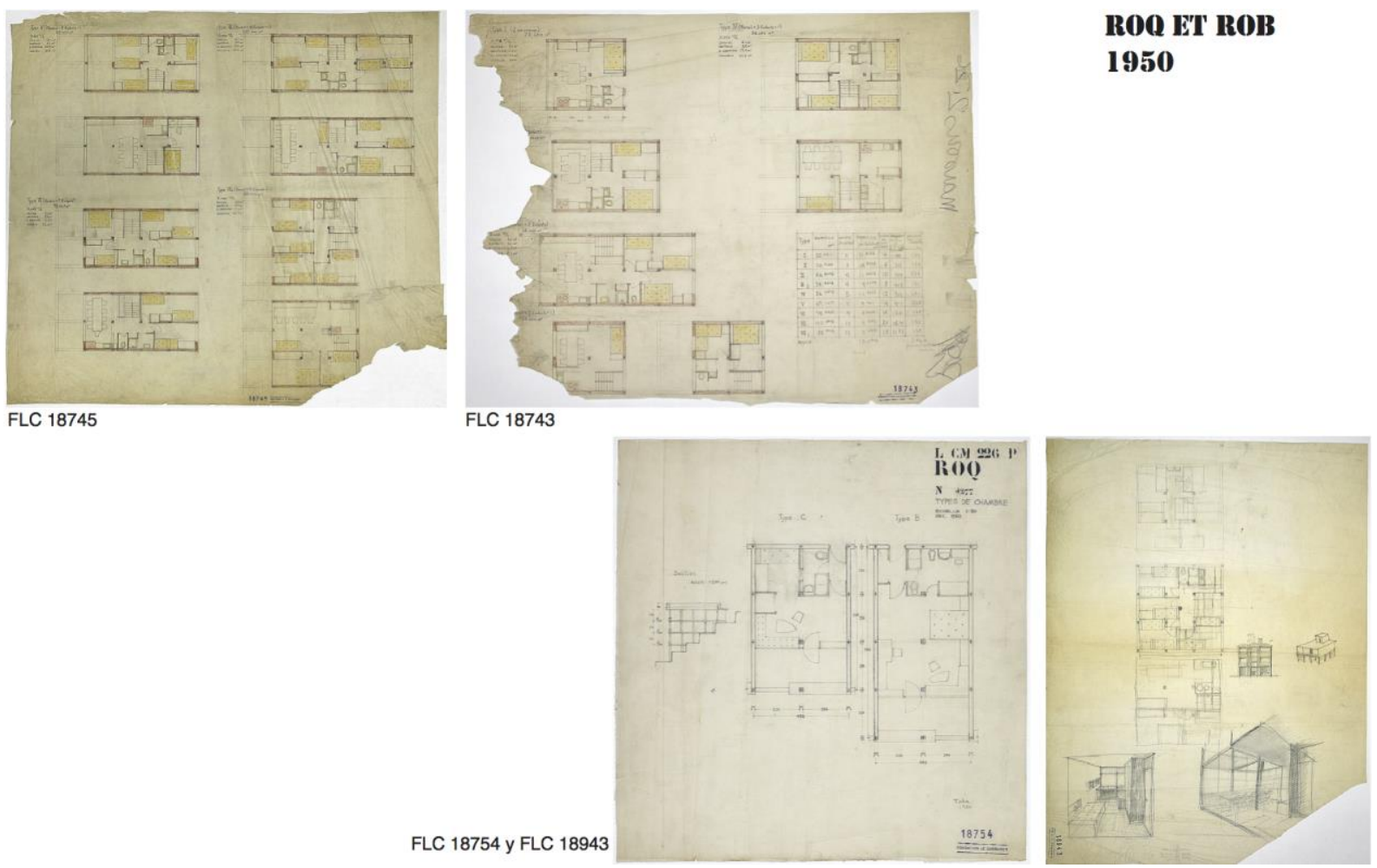

FLC 18745 (NN, NF), FLC 18743 (NN, NF), FLC 18754 (Takamasa, 12-1950), FLC 18943 (NN, NF). Imágenes OFLCADAGP.

asumir cuatro plantas y un frente continuo, lo que genera una escala excesiva para lo que se pretendía. Un tímido croquis quizás da cuenta de ello (FLC 18943).

En estos tanteos desaparece la franja de 53 (o $43 \mathrm{~cm}$ ) que delimitaba el espacio residencial a ambos lados de las dos crujías y que permitía que la bóveda se rematara de forma armoniosa. El módulo de 2.26 metros sigue rigiendo toda la composición y la decisión de duplicar la estructura en la medianera -fruto de la construcción con los alveolos de $2.26 * 2.26 * 2.26$ - parecen ser datos de partida por ahora asumidos.

Takamasa continúa con la búsqueda, planteando en febrero de 1951 otra solución que coincide parcialmente con algunas de las búsquedas para la Sainte-Baume (FLC 18740, FLC 18728). En este caso ya no se trata sólo de un estudio tipológico sino de una propuesta completa. No obstante, la sección induce a pensar que se trata de una solución inicialmente concebida para el territorio de la Sainte-Baume, cuyo desnivel es mucho menos pronunciado que el de Cap Martin. Esta vía exploraba la posibilidad de realizar un cambio entre la estructura que llega al suelo y la de la parte aérea, utilizando muros pesados en la primera y una estructura alveolar de aluminio en la parte superior (FLC 18705, FLC 18706, FLC 18770). En esta propuesta, la llegada al suelo se realiza construyendo con muros sólo los elementos portantes de los extremos, sustituyéndose la línea de carga intermedia por soportes de hormigón. Esta operación, sin duda destinada a liberar la planta baja y hacer menos pesada la imagen de la llegada del edificio al suelo, presenta no obstante ciertas incoherencias. No parece clara la literalidad de mantener las tres líneas de carga, ni tampoco la sustitución de uno de los ejes de encuentro con el suelo por soportes. La decisión de trabajar con muros, además de eventualmente resolver un problema de esbeltez de la estructura de aluminio en las plantas bajas, también a buen seguro partía de una idea de cómo realizar el diálogo con el elemento natural de apoyo. 


\section{ROQ ET ROB}
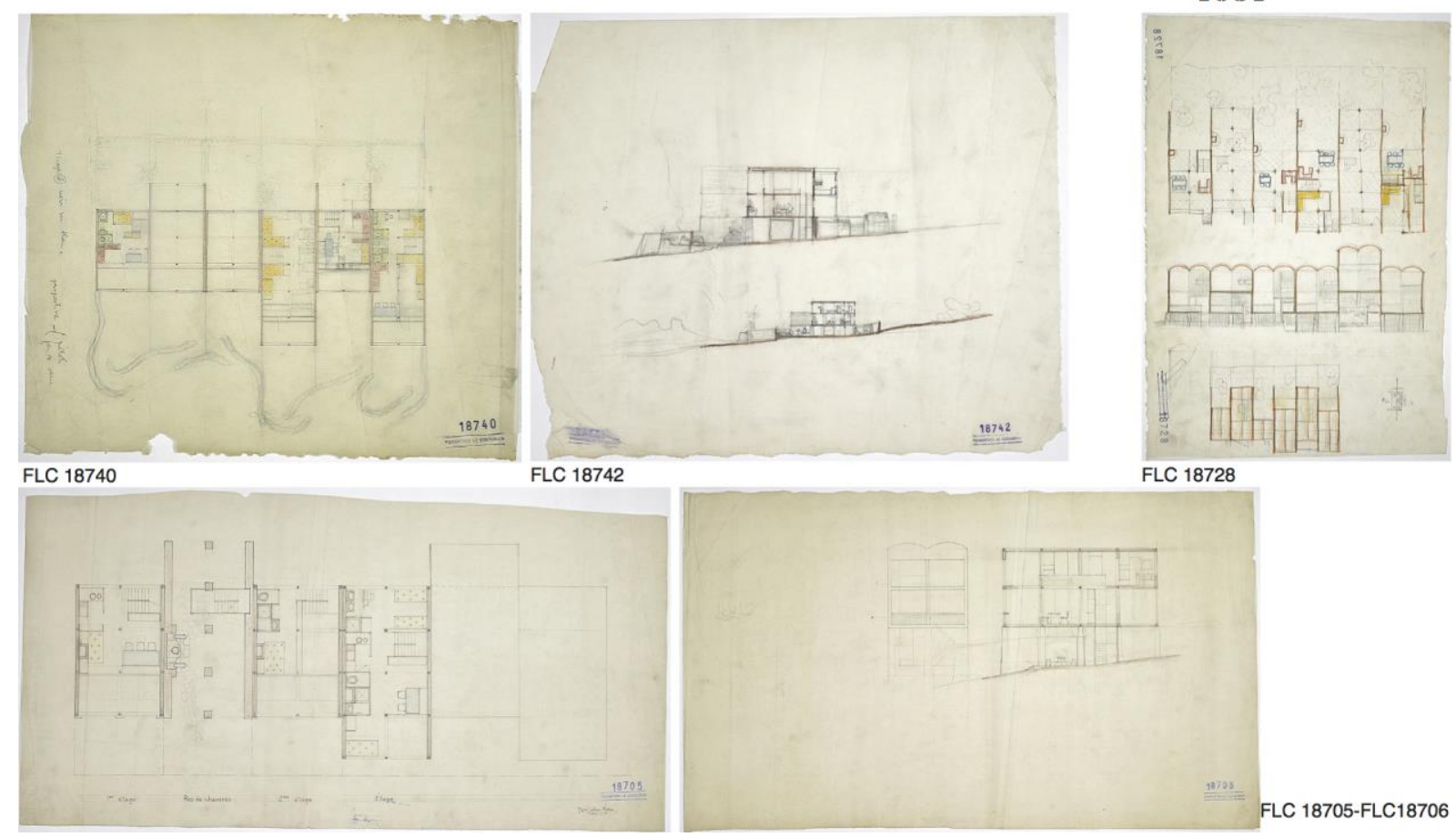

FLC 18740 (NN, NF), FLC 18742 (NN, NF), FLC 18728 (NN, NF), FLC 18705 (Takamasa, 07-07-1951), FLC 18706 (NN,NF). Imágenes @FLC-ADAGP.

A partir de aquí Le Corbusier ensaya otras maneras de resolver esta cuestión. En el dibujo FLC 18704 se pueden observar dos tanteos diferentes, ya adaptados a la topografía de la Costa Azul. En ambos casos se apuesta por una estrategia similar, modificando los tipos de estructura en cada nivel. El segundo dibujo podría coincidir con lo anteriormente visto, en donde perdía importancia la decisión de homogeneizar la altura de la línea inferior del forjado para todas las unidades. Sin embargo aquí, al aumentar la altura del espacio vacío con el fin de adaptarse a la topografía, la solución queda claramente desproporcionada. El primer dibujo apuesta por la creación de una especie de sol artificiel, similar -guardando las distancias- al utilizado en las Unités d' Habitation. En este caso sólo existe estructura vertical en la línea que coincide con el vano intermedio de estructura y la imagen del conjunto, además de resultar relativamente inestable, adquiere una contundencia ajena al planteamiento inicial. En ambas propuestas se unifica la línea inferior de la construcción y, aunque se hacen tanteos modificando la línea de cornisa, el impacto sobre el territorio parece mayor. Finalmente, estas propuestas de unificación del plano de forjado inferior conllevan otra cuestión y es que difícilmente permiten los retranqueos de piezas en planta -otra de las estrategias utilizadas para mitigar la escala del conjunto-.

Como podemos observar la cuestión no es sencilla. Tras esos dibujos tan seductores de Germán Samper y Rogelio Salmona -que no contemplaban de forma concreta las premisas de la construcción- resulta difícil encontrar una opción posible y satisfactoria.

En octubre de 1951 Aphonso realiza otra tentativa, aparentemente cambiando la cota de implantación de la propuesta con el fin de disminuir la altura de la planta baja (FLC 18929) y reduciendo el número de unidades a cinco en lugar de las seis que se habían manejado siempre hasta este momento. En él se muestran de nuevo dos cambios sustanciales: 


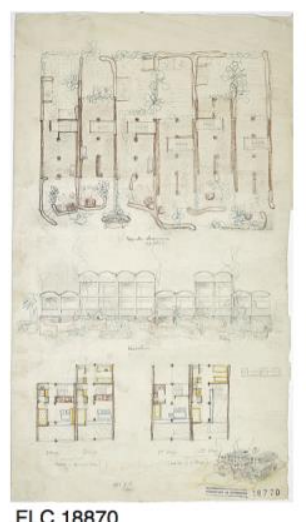

FLC 18870

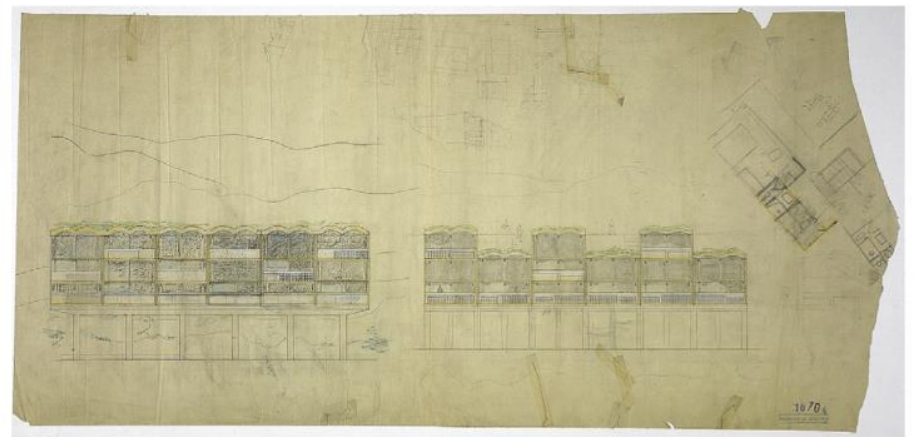

FLC 18704

\section{ROQ ET ROB}

1951

\section{FLC 18909 y FLC 18908}
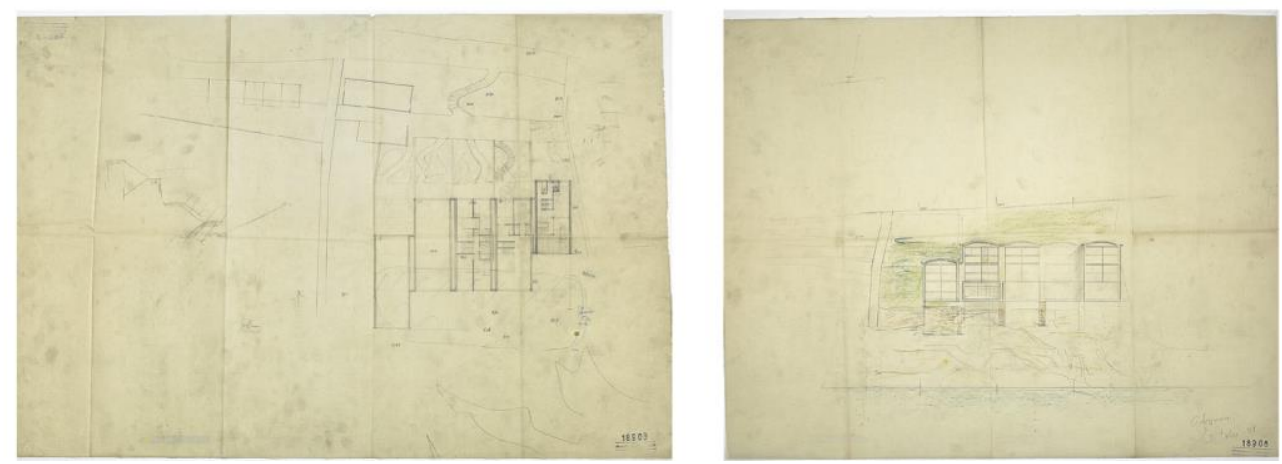

FLC 18770 (Takamasa, 08-02-1951), FLC 18704 (NN, NF), FLC 18909 (NN, NF), FLC 18908 (Aphonso, 10-1951). Imágenes @FLC-ADAGP.

el primero tiene que ver con la construcción y el carácter de la zona aérea y el segundo tiene que ver con la forma de apoyar en el suelo (FLC 18908, FLC 18909).

Por lo que se puede intuir tanto en la planta como en el alzado, en esta fase del proyecto se hace una apuesta contundente por diferenciar de forma clara, mediante sus materialidad y su construcción, el carácter de las dos partes del edificio. El encuentro con el suelo se realiza mediante muros de piedra natural de gran espesor, llegando incluso a cegar la planta baja en el primer vano a la izquierda -el más próximo al acceso- y ofreciendo la visión frontal del muro.

Con el cambio de la cota de apoyo la proporción de la planta baja se reduce, quedando así mucho más proporcionado el conjunto, aunque esto no justifique el cambio de material. Sin embargo, estudiando el dibujo del alzado con una cierta atención, se puede observar cómo la decisión de cegar frontalmente el primer vano puede partir de un deseo de diálogo y continuidad con los muros de contención necesarios para construir el "aterrazamiento", fortaleciendo de esta manera la relación con el entorno natural mediante el material.

El hecho de reducir el conjunto a cinco unidades y de modificar sus desplazamientos relativos también contribuye a logar una mayor armonía con el entorno. En la propuesta dibujada por Aphonso los tres módulos centrales permanece estables, desplazándose sólo aquellos situados en los extremos. De esta forma la percepción del conjunto, cuando se llega por cualquier de los dos laterales, es la de los muros, acotando así un espacio protegido por éstos en la zona frontal de las viviendas. 
Por el contario, la parte superior de la edificación parece asumir con mayor contundencia su carácter de construcción industrializada. Si bien en todas las anteriores aproximaciones a la definición del conjunto el aspecto del mismo parecía obedecer a una cierta voluntad de identificación con las construcciones vernáculas, en este planteamiento se asume con total radicalidad las claves de una construcción ligera: se retoma el espacio entre los módulos, que sin duda permite su ensamblaje y sirve de ajuste métrico entre la dimensión de la piedra y la de los elementos de aluminio, y se modifica incluso el espesor de la cubierta por primera vez y su construcción, planteándose a partir de una plancha curvada recubierta por tierra natural.

\subsection{Les Unités de Vacances. Cap Martin (1952-1954)}

A partir de 1952 se opera un cambio radical en la manera de abordar el proyecto de Rob que al parecer termina convirtiéndose en las Unités de Vacances para las cuales aparentemente se llegó a formalizar un proyecto entre los años 1952, 1953 y 1954. Vale la pena anotar aquí que, si bien parece cierto que el trabajo concreto sobre esta propuesta se llevó a cabo en el 35 Rue de Sèvres a partir de 1952, algunos bocetos de Le Corbusier de que datan de diciembre de 1949 (FLC 19019 P, M, Q, D, E) dan cuenta de que ya entonces el maestro lo tenía en la cabeza. En un documento fechado 4 de julio de 1952 (FLC 18924) quizás se encuentre la clave para este particular ${ }^{12}$. En él Le Corbusier intenta establecer las pautas para la gestión de una copropiedad con Rebutato en relación a los terrenos próximos a L’Étoile de Mer. Según se puede descifrar, Le Corbusier plantea que a cambio de los terrenos aledaños al Cabanon y de la posibilidad de ocupar los terrenos por debajo de éste para implantar las Unités de Vacances, Rebutato podría obtener tanto un edificio para las Unités de Camping y su explotación, como la propiedad de las Unités de Vacances, aunque el uso esté reservado a Le Corbusier y sus colaboradores.

El proyecto está concebido como un lugar de trabajo y el coste de construcción de Las Unités de Vacances correría a cargo de Le Corbusier. Es posible que Le Corbusier decidiera cambiar de estrategia al ver que el proyecto de Roq -de mayor envergadura y que por lo tanto sin duda lograría optimizar los costes de una construcción industrializada- no tenía opciones de salir adelante, ya que de hecho en los últimos años sólo se veían propuestas directamente vinculadas a Rob-. El cambio apunta hacia una simplificación de la construcción y una minimización del espacio, aprovechando la experiencia del Cabanon del cual toma posesión en agosto de 1952. Quizás la necesidad de auto financiar el proyecto lo lleve a se más pragmático, proyectando estrictamente en base a sus necesidades y a una construcción que conoce y domina, con la colaboración fructífera de Barberis en Córcega.

Tras la intensa búsqueda realizada en torno a las viviendas compuestas por dos crujías paralelas, ordenadas mediante el módulo 2,26 y con espacio abovedado, sorprende la solución propuesta para estos módulos, que de alguna manera anula o hace caso omiso de las anteriores investigaciones. Por supuesto también abandona la propuesta para realizar una construcción en aluminio, descartando por el momento llevar a la práctica su brevet $2.26 * 2.26 * 2.26$.

\footnotetext{
${ }^{12}$ Según Bruno Chiambretto en su libro Le Cabanon, pag. 61, Le Corbusier inicia la reflexión sobre este nuevo proyecto en Julio de 1952 en el curso de un viaje, entre Cap Martin y Ajaccio, para supervisar la construcción del Cabanon. En el documento que se cita no es legible el lugar en el que está escrito, pero al existir coincidencia aproximada de fecha bien podría tratarse del mismo momento.
} 


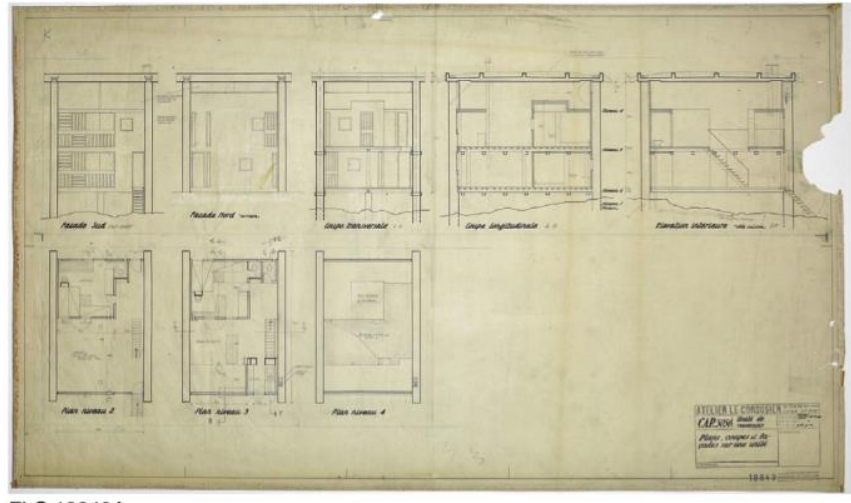

FLC 18849A

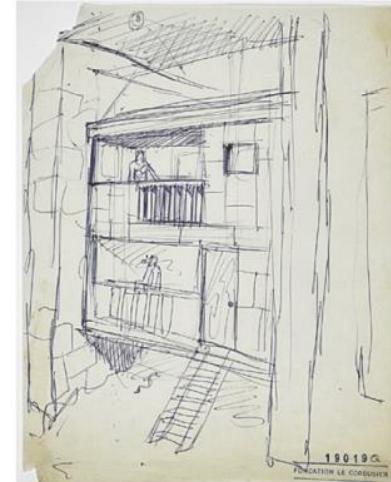

FLC 19019Q

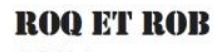

1954

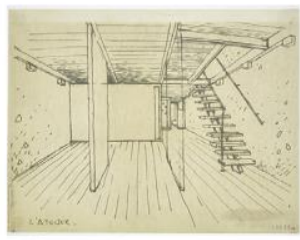

FLC 19036D

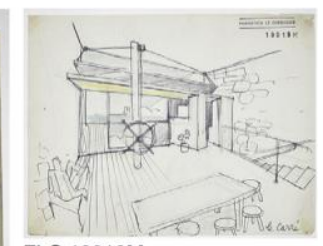

FLC 19019M

\section{A P} IAcuit
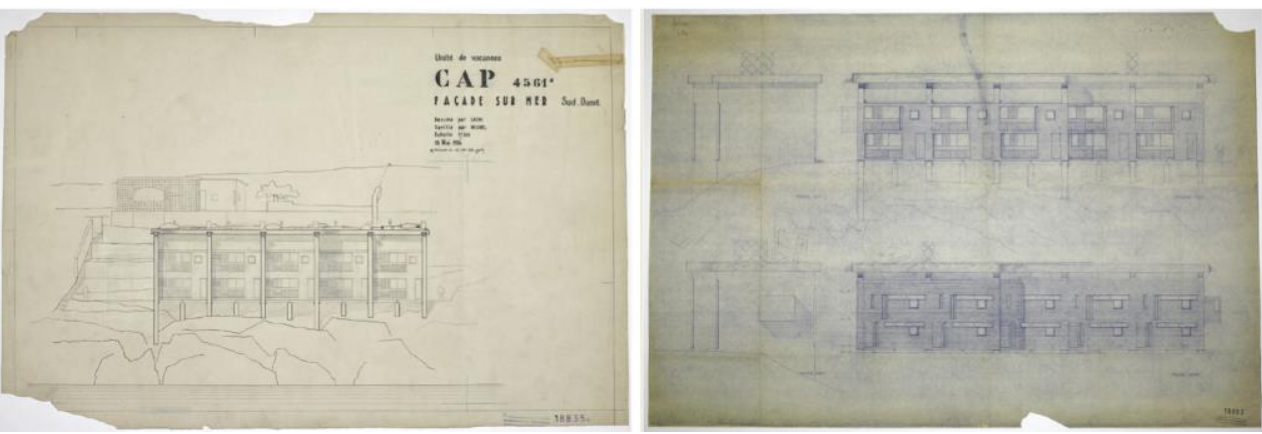

FLC18849A (Michel-Sachinidis, 19-05-1954), FLC 19019Q (NN, NF), FLC 19036D (NN, NF), FLC 19019 M (NN, NF), FLC 18835A (Sachinidis-Michel, 18-05-1954), FLC 18903 (NN, NF). Imágenes @FLC-ADAGP.

El proyecto para las Unités de Vacances se sitúa exactamente en el mismo lugar que estaba previsto Rob, en el terreno inmediatamente inferior a L'Étoile de Mer y el Cabanon y, al igual que las últimas versiones de aquel, está compuesto por cinco unidades, en este caso adosadas en grupos de dos y tres viviendas. Su construcción se prevé mediante muros de carga que no duplican la medianera y una estructura aparentemente de madera apoyada en ellos. La forma cómo se resuelve el programa también varía sustancialmente, ya que si bien las soluciones anteriores apuntaban a viviendas mas o menos convencionales resueltas en dúplex, en este caso realmente se proyecta un espacio para alojar a personas trabajando, y no a familias. El espacio está organizado mediante dos espacios de descanso confinados (3.66*3.66 metros) cada uno de ellos con 4 camas, una mesa y un aseo, una zona común de cocina y descanso y otro gran espacio quizás destinado al trabajo. Existe la posibilidad de disponer de cuatro camas adicionales sobre la cubierta del módulo superior y un espacio de aire que separa la cubierta del resto. La unidades básicas de descanso son una reproducción literal del Cabanon, cuya construcción terminó en Agosto de 1952 (FLC 19012, FLC 18827, FLC 18835, FLC 18836, FLC 18849A).

Si bien la construcción se levanta del suelo, ya no lo hace con una planta o dos, como en los anteriores tanteos, sino tan sólo con ocho escalones. El concepto constructivo se modifica por completo. Unos muros gruesos quizás de piedra (ver bocetos del espacio interior FLC 19019 P) y una cubierta pesada vegetal delimitan el todo. Se pueden apreciar a su vez varios dibujos en los que se hacen pruebas con respecto a la sintaxis entre muros y fachadas. Inicialmente se manifiestan los muros, retranqueándose el plano de fachada y disponiéndose unas gárgolas potentes coincidentes con cada muro (similares a las de Chandigarh) que enfatizan aún más la lectura de las unidades, mientras que en los dibujos de Kim de diciembre de 1953 (FLC 18854, FLC 18858, FLC 18903) se observa cómo se hace pasar la fachada por delante haciendo primar la visión del plano. Al parecer en las últimas versiones Le Corbusier planteaba recubrir las fachadas mediante una plancha de aluminio micro ondulada quizás 
similar a la inicialmente propuesta para el Cabanon. La composición tripartita cuerpo-aire-cubierta pesada recuerda a la estrategia empleada en los edificios lineales de Chandigarh.

Cómo se puede observar, a pesar de la intensidad de la búsqueda por ahora no parece haber conclusiones cerradas. Se podría afirmar que el maestro mantiene como premisas ciertas la permanencia de un ancho de crujía de 2,26 metros como base para la resolución del espacio interior de la vivienda, la voluntad de trabajar de una manera intensa en sus edificios el encuentro con el suelo y con el cielo, la necesidad de una respuesta al paisaje mediante la utilización de elementos que le sean propios y, finalmente, el deseo de aunar el uso de formas de construcción vinculadas a la tradición con las soluciones más innovadoras.

En febrero de 1955 Le Corbusier renunció definitivamente a la construcción de este proyecto bajo el pretexto de que el solar era potencialmente inundable, ya que una fuerte tormenta había causado destrozos recientemente. Es posible que la causa fuera parcialmente esa, pero no cabe despreciar el hecho de que tras seis años de trabajo, altruista, personal y obstinado, Le Corbusier no pareció encontrar una solución para establecer esa simbiosis entre paisaje y arquitectura que le satisficiera. Sólo su Cabanon, cuya principal característica es la ausencia de arquitectura, parecía convencerle.

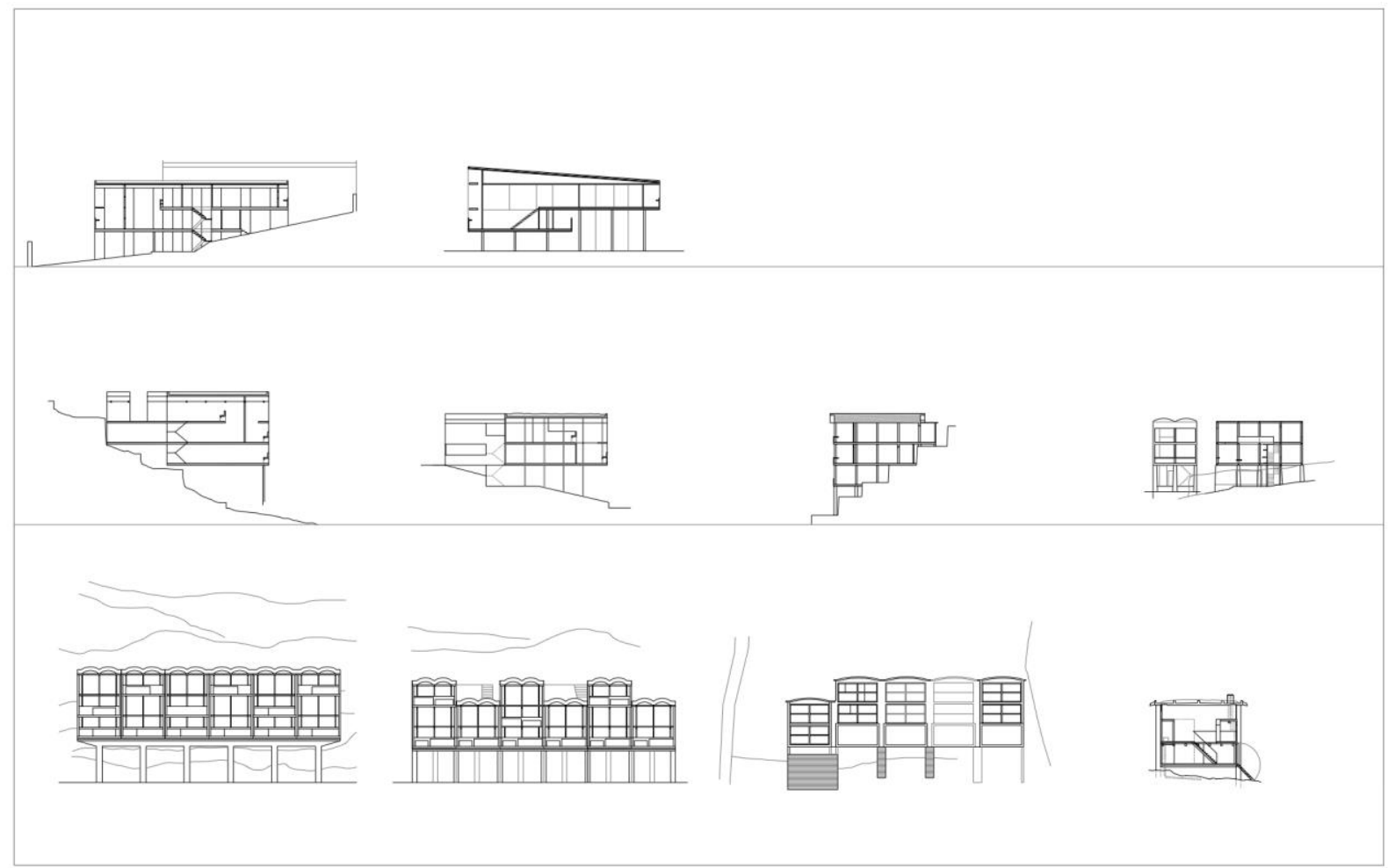

Esquemas comparativos de alzados y secciones para los proyectos de Roq et Rob y el Village de Pèlereniage de la SainteBaume ordenados cronológicamente. Redibujo C. Mejía- J. Deltell.

\section{Bibliografía}

Le Corbusier: Euvre Complète, Vol. 2. Zurich: Verlag für Architektur, Artemis, 1957. Octava edición 1991.

Le Corbusier: Euvre Complète, Vol. 5. Zurich:Verlag für Arkitektur, Artemis.

Le Corbusier: Plans. Paris: Codex Images International, Fondation Le Corbusier, 2005.

Chiambretto, Bruno: Le Corbusier à Cap Martin. Le Cabanon. Marseille: Éditions Paranthèses, 1987, 2006.

Petit, Jean: Le Corbusier Lui-même. Genève: Éditions Rousseau,1970. 


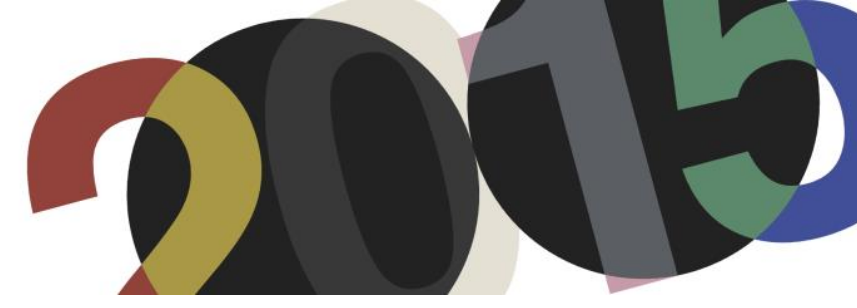

DOI: http://dx.doi.org/10.4995/LC2015.2015.689

\title{
Global Architects: a dialogue between Le Corbusier and Fernando Távora on Architecture Universality
}

\author{
S. Meleiro Lima \\ Faculdade de Arquitectura da Universidade do Porto
}

\begin{abstract}
The aim of this investigation is to present an approach to the notion of a global architect, the universality of his theory and legacy. The investigation is composed in two main stages whose goals are the following: 1) to address the notion of global architect; 2) to demonstrate the role of Le Corbusier to perform the idea of global architect and his influence in others architects, such as Fernando Távora (1923-2005), a portuguese architect recognized as the master of Álvaro Siza. The first stage, we seek to formulate a definition of global architect from the point of view of Le Corbusier's works. During the second stage we analyse and compare the positions of Le Corbusier and Távora and their projects: Ronchamp, Chandigarh and Market at Vila da Feira and Ofir Summer House. Thus, we attempt to analyse the role of Le Corbusier as a global architect and his impact on others colleagues, such as Távora who seeks to achieve the same ideal of global architect and perform a universal vision of architecture.
\end{abstract}

Resumen: El propósito de esta investigación consiste en presentar una aproximación a la idea de arquitecto global, la universalidad de su teoría y su legado. El artículo se compone en dos partes principales cuyos objetivos son los siguientes: 1) hacer una reflexión acerca de el concepto de arquitecto global; 2) aclarar el papel de Le Corbusier como un personaje que personificó el ideal de arquitecto global y mostrar como ha influenciado a muchos arquitectos, como es el ejemplo de Fernando Távora (1923-2005), un arquitecto portugués reconocido como el maestro de Álvaro Siza. En primer lugar, se procura formular una definición de arquitecto global desde el punto de vista de Le Corbusier y sus obras. Durante la segunda parte se analizan y comparan las posiciones de Le Corbusier y Fernando Távora así como sus proyectos: Ronchamp, Chandigarh, Mercado de Vila da Feira y la Casa de Verano en Ofir. Por fin, se trata de analizar la importancia y el papel de Le Corbusier como un arquitecto global y su impacto sobre otros colegas, como es el caso de Fernando Távora que intentaba lograr el mismo ideal de arquitecto global e incorporar una visión universal de la arquitectura.

Keywords: global architect; Le Corbusier; legacy; universalism; Fernando Távora.

Palabras clave: arquitecto global; Le Corbusier; legado; universalismo; Fernando Távora.

\section{Introduction}

The main objective of this investigation is to present an approach to the concept of global architect.

In this research, we aim to demonstrate a multifaceted view of the authors, which aims to transform the concept of the architect to a new ideal of global architect. Le Corbusier and Távora have a universalist point of view as a result of their deep cultural knowledge, architectural evolution and city history in order to operate in different places and circumstances. It is through their knowledge and methodology, which can then transform the place in which they operate.

The first stage, we seek to formulate a definition of global architect from the point of view of Le Corbusier's works. During the second stage we analyse and compare the positions of Le Corbusier and Távora and their projects: Ronchamp, Chandigarh and Market at Vila and Ofir Summer House. 
The latest works Le Corbusier made, allowed us to identify, a new attitude about local issues: in Chandigarh (India) or Ronchamp (France) we can observe his respect and comprehension about the site, the inhabitants culture and its circumstances. He thinks globally to act locally or in other words, he uses the modern architecture but reuses the surroundings and the culture influences in his projects.

Távora, younger architect than Le Corbusier, has met him over the last four CIAM's. In his initial projects we can notice a clear influence of Le Corbusier theories: the Five Points towards a new architecture that were enunciated in 1927 (as the use of pilotis, free floor plan, horizontal or elongated window, free façade and the roof garden), the influence of CIAM Charter toward a new urbanism from 1933 (discussed in CIAM). However, in Távora, we recognize the same attitude: although he has travelled a lot, he was always comparing the city he was visiting with his knowledge of portuguese landscape and circumstances, as we can confirm by the projects from this period, the Market at Vila da Feira or Ofir Summer House, combining the modern and local searching for a synthesis in architecture.

\section{Global Architects: the example of Le Corbusier}

"The world now has 24 solar hours at its disposal. Marco Polo took his time. Nowadays we say: 'Here are your papers Sir, your contract and your airline ticket. Leaving at six to-night, you will be in the antipodes to-morrow, (...) and, if you wish, you can start back the same evening and be home next day". .

The main objective of this investigation is to highlight Le Corbusier's contribute to Modern Architecture, namely his universal perspective through world, which reflected in his disciplinarity, pedagogy and professional field.

We seek to establish relations between universality, humanism and circumstances, their delineations and strains. Besides, this investigation seeks to understand his legacy and his intemporality/timelessness.

Le Corbusier was a French-Swiss Architect (1887-1965) who changed the way we understand dwellings and the city, questioning the house as "a machine à habiter" and how can we plan our cities for tomorrow, exploring projects from Dom-ino scheme to the "immeubles-villa" and "Unité d'Habitation", that perform his first phase and also made the research on urbanism from Athens Charter, ville radieuse to the Plan Voisin planned to Paris. For this study we consider the works of Le Corbusier constructed after the Second World War. It is during the period from 1945 till 1965 that we observe his mature works and masterpieces, such as Ronchamp and La Tourette, both in France or even Chandigarh in India.

Throughout these last works, Le Corbusier was incorporating the lessons from his journeys and was looking for a synthesis between international and local circumstances. As Beatriz Colomina refers, "[...] $i$ viaggi internazionali rappresentano l'educazione architettonica di Le Corbusier, che non ha mai frequentato una scuola di architettura ${ }^{2}[\ldots]$ ”, its through his journeys that he contact with other cultures and incorporate their culture in his projects.

As we have previously mentioned, we identified in Le Corbusier latest works, a new attitude about the local issues: in Chandigarh or Ronchamp his respect and comprehension about the site, the inhabitant's culture and its

\footnotetext{
${ }^{1}$ Le Corbusier, 1960. In: Architects' Journeys Building, traveling, thinking / Los viajes de los arquietectos: construir, viajar, pensar, Ed. Craig Buckley, Pollyanna Rhee, Pamplona: T6 Ediciones, 2011.

2 Colomina, Beatriz. "Verso un architetto globale: Nel dopoguerra Le Corbusier ha transformato la professione dell'architetto. Suo complice: il jet.” In Domus. New York, 30 April 2011.
} 
circumstances. Le Corbusier uses modern architecture but reuses the surroundings and the culture influences in the projects to create a dialogue between global and local circumstances.

In this research, we aim to reveal a multifaceted view of the authors, which aims to transform the concept of the architect to a new ideal of global architect. Both architects, Le Corbusier and Távora have a universalist point of view as a result of their deep cultural knowledge, architectural evolution and city history in order to intervene and operate in different places and circumstances. It is through their knowledge and approach, which can then turn the place in which they operate.

In Távora, we recognize the same attitude: although he has travelled a lot, he was always comparing the city he was visiting with his knowledge of portuguese landscape and circumstances, as we can confirm by the projects from this period, such as the Market at Vila da Feira or Ofir Summer House, or even the Primary School at Cedro.

\section{Dialogue(s) between Le Corbusier and Fernando Távora}

"Cuando eran blancas las catedrales, por encima de las nacionalidades en formación había una idea común [...] Antes de construir universalmente las naves de la nueva civilización, un impulso común del espíritu había unido ya a los pueblos de los tiempos modernos para conducirlos, en medio de dificultades increíbles, a Jerusalén, donde se encontraba el sepulcro de un pensamiento universal ${ }^{3}$ [...]."

We selected two projects from Le Corbusier (1887-1965) last works period, from 1950 till 1965, when he died. This phase is very important to analyse because support our thesis in the scope for universality in architecture, and also is where we observe and discuss the complexity and contradiction on his work. This complexity and contradiction phenomenon was well described and analysed by Robert Venturi in his book Complexity and Contradiction in Architecture, from 1966 and we can observe the same phenomenon in the work of Fernando Távora, that usually say "The contrary in architecture is also possible/ is also true".

Both architects were concerned about synthesis problems, combining modern architecture with local materials, and looking for site integration. Chandigarh is the masterpiece of the respect to local issues: a horizontal city, entirely planned by Le Corbusier and his team. He could have planned high skyscrapers in this capital; with Unité d'habitation models to habitat building zones, but instead he proposed large horizontal buildings that respected the natural landscape. He still plans a radiant city (garden city), with a marked centre, green belts that create leisure zones to recreational activities. His assumptions on urbanism can be identified in this project, but with a few adaptions to the site circumstances.

Fernando Távora (1923-2005) was a Portuguese Architect, younger than Le Corbuiser, who participated in the last four CIAM's and also recognized as the master of Álvaro Siza.

\footnotetext{
${ }^{3}$ Le Corbusier. Cuando las catedrales eran blancas, Colección Poseidon, Ediciones Apostrofe, Barcelona: 1991, p. 53-54. "When the cathedrals were white, above nationalities concerned with themselves, there was a common idea[...]. Already, before constructing everywhere the naves of the new civilization, a common enthusiasm of spirit had brought together the peoples of modem times and had led them, through strange avatars; toward Jerusalem, where there was the seat of a universal thought[...]." Le Corbusier. When the Cathedrals Were White. New York, Toronto, London: McGraw-Hill Book Company, 1964, p. 32. Translated from the French by Francis E. Hyslop Jr.
} 
His design process starts with a process of considering local circumstances, or as Siza prefer to say "The architecture is in the place", extending them beyond the limits of the place itself, seeking to register them in a universal consciousness. His projects since 1953 illustrates the blending of Modernity and Tradition, in a series of experimental projects such the Market at Vila da Feria or the Tennis Pavillion in Matosinhos (1957). These works reflect the criticism made to international architecture.

Távora was interested in the "a-ideological" quality of architecture, and became interested in what is permanent - that makes irrelevant the style and therefore the ideology.

For him Modern Architecture is not a style, but the result of an attitude, that translate exactly the reality that involves. Távora created a tenuous articulation between/among local and global.

For the intention of this investigation, we have selected four case-studies to highlight their positions and critical thinking in Architecture, whose are the following: two projects from Le Corbusier, Ronchamp and Chandigarh, and for Fernando Távora we select other two projects, the Ofir House and the Market at Vila da Feira, both projects in Portugal. The selection of the projects is intentional because we attempt to analyse different project scales. This approach methodology allows us to identify the same attitude and critical thinking used during the creational process of both projects. In Chandigarh's example it is not our intention to analyse the entire project exhaustively, however we still focused on our own research fields, the global architects and their investigation on the dialectics between international and local issues.

\subsection{Chapel of Nôtre Dame du Haut, Ronchamp, 1950 - 1954}

"Architecture is the synthesis of the major arts. Architecture is form, volume, colour, acoustics, and music.",

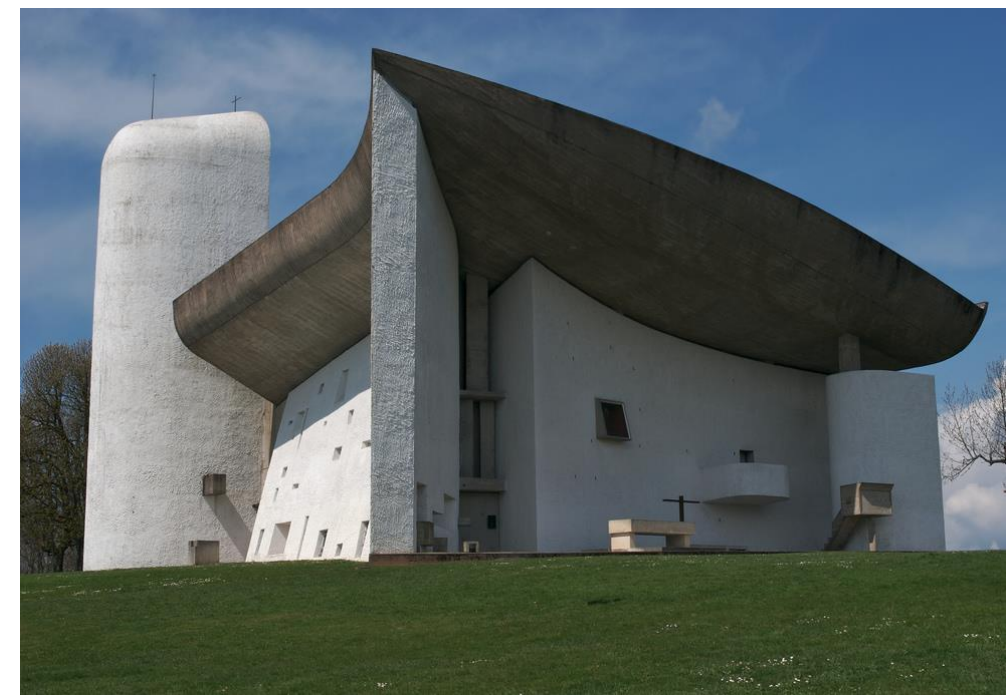

1. Chapel of Notre Dame du Haut, Ronchamp, France, Le Corbusier, 1950. In the east wall there is the open-air chapel.

Ronchamp is a Project for a pilgrimage chapel to accommodate 200 people, on a hilltop in the Vosges Mountains. The building is orientated traditionally, with the altar to the east side and the entrance to the west. The natural light in the building characterizes the space.

\footnotetext{
${ }^{4}$ Le Corbusier, Ronchamp (Carnets de la recherche patiente),17. (Apud: Moos, Stanislaus Von. Le Corbusier: Elements of a Synthesis,(1st Ed. 1979), Revised and expanded, Rotterdam: 010 Publishers, 2009, p. 266).
} 
As Curtis referred, this phase of Le Corbusier works seems to be the search for perennial and unchanging values, this is his primary motivation and let behind his quest for modernity ${ }^{5}$, that characterized all the work he made before. The Chapel of Ronchamp transcends the normal bounds of architecture with their profusion of spirituality and symbolic content, because it is above all sculptural and figurative creation. Lots of metaphors can be identified: the roof as a boat or a mushroom, the light towers as two people hugging each other or as a periscope. The chapel was conceived as a cave where Le Corbusier has used the light and many processes to create different auras as the main process. There are different windows with several colours that perforated a thick and curved wall, a reference to the Gothic Cathedral the symbol of devotion. The penumbra, that characterizes the space, contrast with the light that came from the layer above the roof, creating a filtered sunlight that passes through the glass. As Le Corbusier wrote "is the apotheosis of plastic emotion".

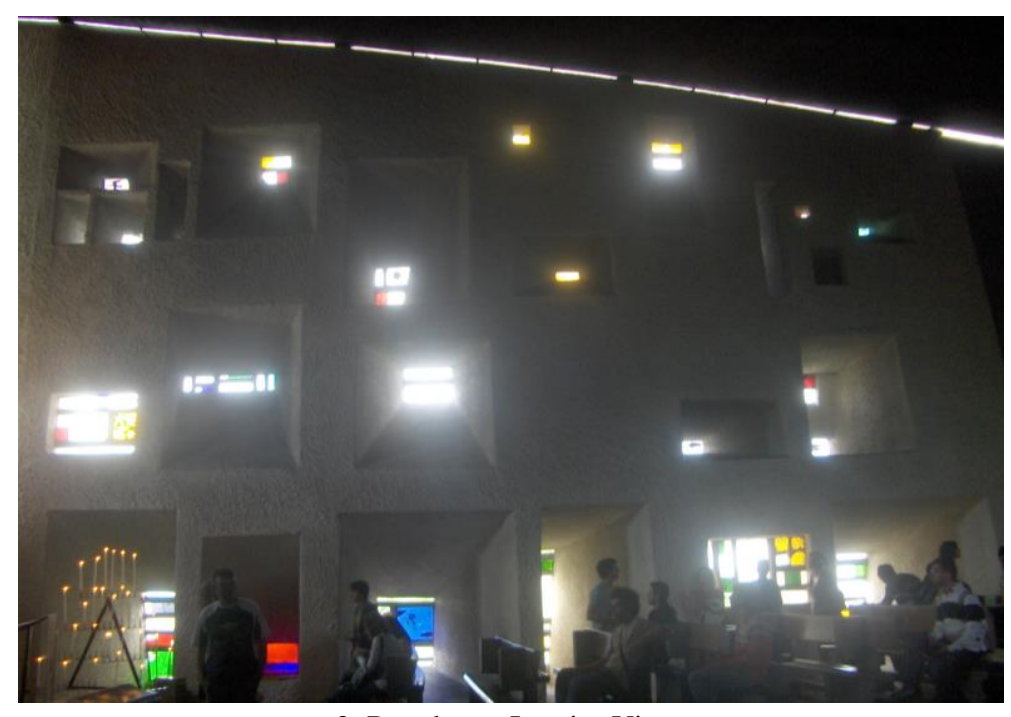

2. Ronchamp Interior View.

Le Corbusier denotes a delicate and sensitive work with light and its meaning. The wall ends before touching the roof and, it is where Le Corbusier puts a glass to create the illusion of suspension of the heavy rooftop. Le Corbusier is sensitive to the spiritual aesthetic of the Chapel, and combines the modern language of architecture with universal questions and meanings. These considerations of cultural and local circumstances were present in several works from this phase of Le Corbusier's Work.

3. Ronchamp Interior View. Fondation Le Corbusier, Paris. FLC 07412. (FLC-ADAGP.

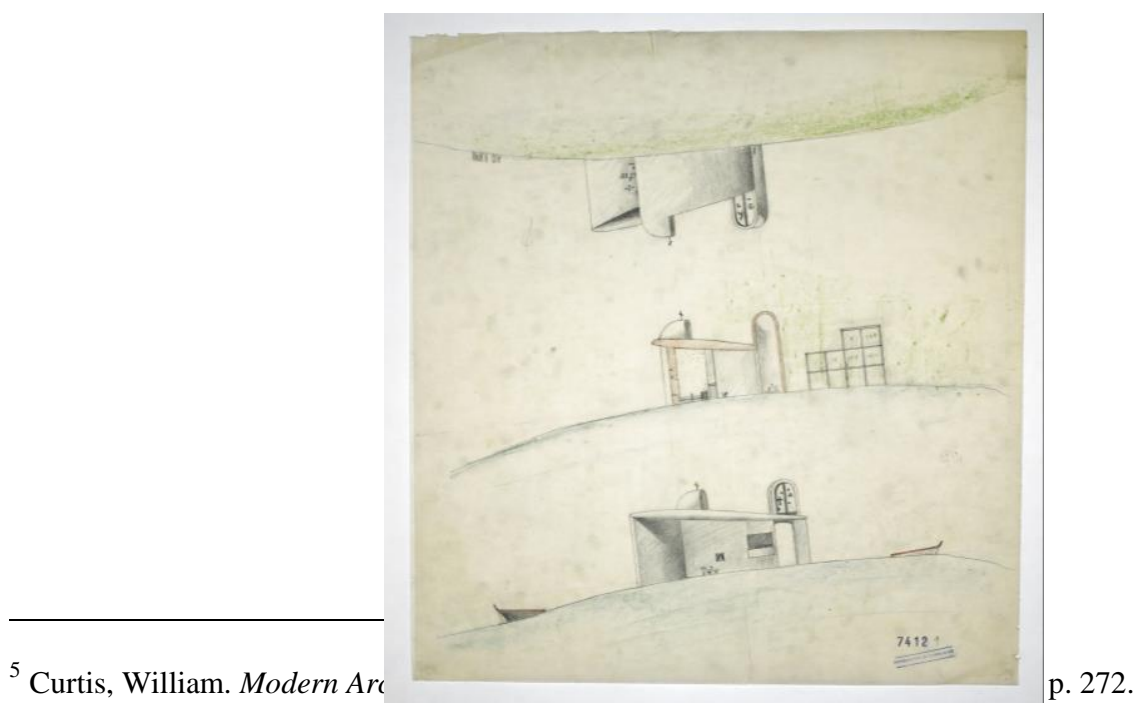




\subsection{Chandigarh as a rethinking of the modern city}

The Chandigarh's design begins with the desire of a new capital for the Punjab state in India. Nehru was the leader who dreamed with this capital, the symbol of democracy and peace. As Von Moos mention, "Le Corbusier's commitment to social harmony may have sounded more familiar to Indians ears than he himself suspected, for the belief in a universal brotherhood of man based upon the blessing of progress and technology ${ }^{6}$ [...]."

The city of Chandigarh was designed to 150000 people and governmental buildings such Parliament, Capitol, High Court and was planned to grow to 500000 people, a natural development to the city capital of the state.

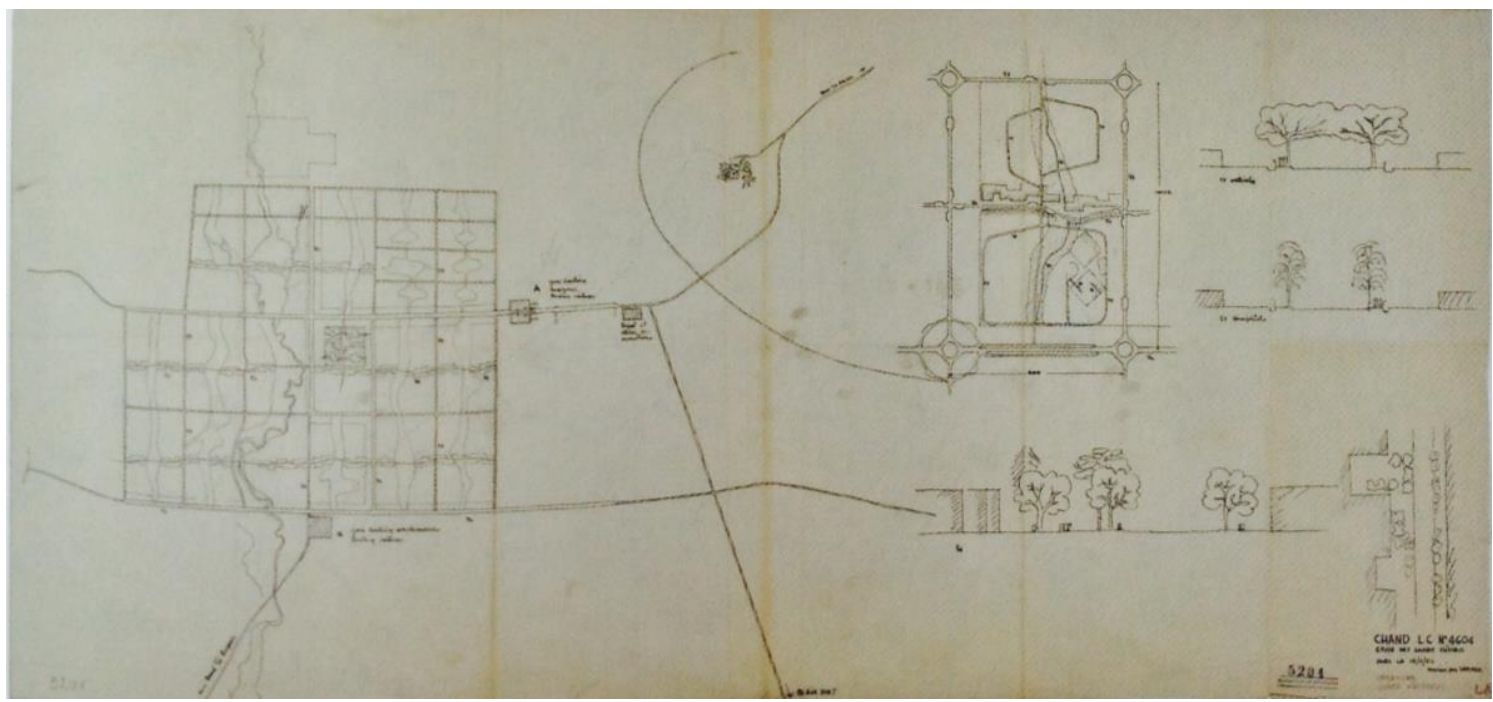

4. Plan of Chandigarh, showing transportation networks. 1951-65. Fondation Le Corbusier, Paris. FLC 05201. OFLCADAGP

Le Corbusier was the city master plan author. He also planned the vast Capitol Complex where major institutions are located, such as the High Court, Assembly, Secretariat and the Governor's Residence that was unbuilt. Jane Drew and Maxwell Fry composed the team responsible for the city conception ${ }^{7}$. The capital was conceived as a horizontal city with an artificial lake Sukhana that reflects the entire city, and also incorporates the layout of the Radiant City (La Ville Radieuse, 1930/5) but without à redent housing block.

It is an idea of his maturation period, as Curtis refers "Moreover [...] the post-war period in Europe was itself marked by pockets of resistance against sterile aspect of internationalism. The attitudes towards the vernacular intrinsic to the late works of Aalto, Le Corbusier and Team X, for example, suggested a more accommodating and flexible strategy with regard to local tradition. ${ }^{8,}$

\footnotetext{
${ }^{6}$ Moos, Stanislaus Von. Le Corbusier: Elements of a Synthesis, (1st Ed. 1979), Revised and expanded, Rotterdam: 010 Publishers, 2009, p290.

${ }^{7}$ Prakash, Vikramaditya. Chandigarh's Le Corbusier: the struggle for Modernity in Postcolonial India. University of Washington Press Seattle \& London, 2002, p13

${ }^{8}$ Curtis, William J.R. Modern Architecture Since 1900, (1st ed. 1982), p.334.
} 


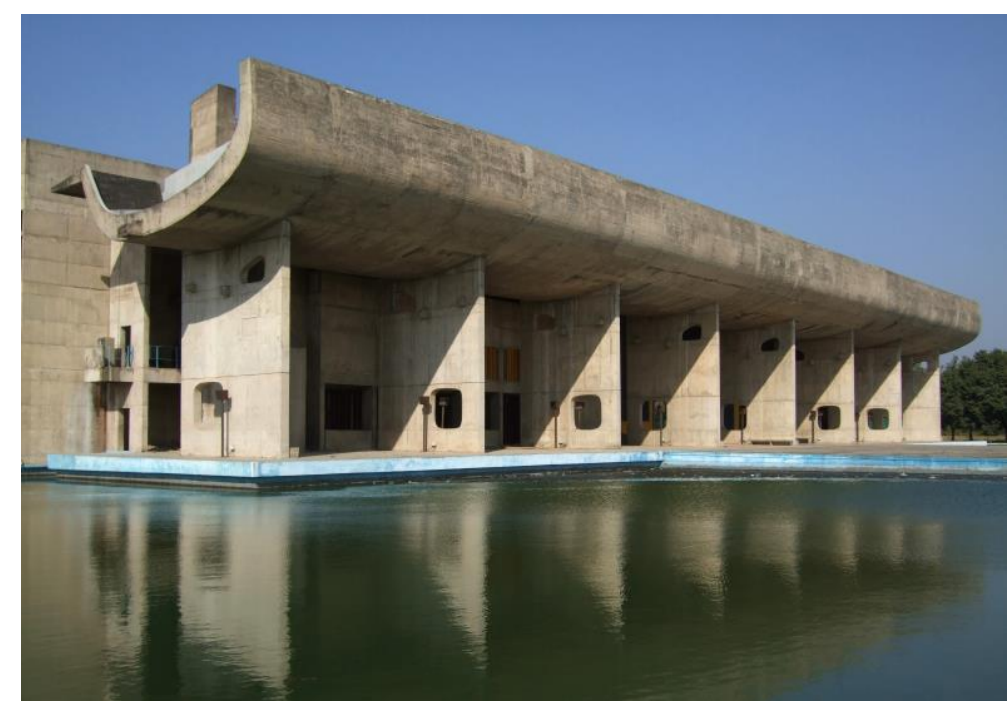

5. Palace of Assembly, Chandigarh. India, 1955. FLC/ADAGP

Chandigarh can be understood as the culmination of the symbolic creation, where Le Corbusier cast an inventory of primordial symbols such as sun, moon, lightening into the monuments but also his philosophical language from the Le Modulor, the harmonic spiral, the solar cycle and the "Open Hand".

However, Le Corbusier's rationalism did not disappear entirely, his concerns after the Second World-War included mathematics and more important The Modulor System. It is important to highlight that in 1946 Le Corbusier wrote "L'architecture et l'esprit mathemathique" and four years later publishes "The Modulor: A Harmonious Measure to The Human Scale, Universally Applicable to Architecture and Mechanics”, which proposed a universal system of measurements for architecture based on golden section proportions.

Le Corbusier worked with typical Indian colours such as pink, colourless yellow, green, all them very different from the primary colours that he used in Unité d'Habitation in Marselha (1945), but in Chandigarh he suggests the coloured indian tissues drying on the sun. Le Corbusier celebrates the genius loci of the place: he incorporates influences from the surrounding area, such the erosional valley that suggests the grid orientation for the entire city in a way to merge landscape and natural environment with architecture and urban design ${ }^{9}$.

Corbusier seems to incorporate universalizing iconography on his works, also combining modern architecture with local culture, materials and methods, in a synthesis process. The balconies created a grid with brise-solei that protected the windows creating the main language of the city complex. He also worked with rugged concrete expression, which became an expression of the surface. The raw concrete finishes and the brise-soleil replaced the thin pilotis and horizontal windows from the beginning period of Le Corbusier.

\footnotetext{
${ }^{9}$ Casciato, Maristella. "Chandigarh: Landscaping a New Capital”, in Cohen, Jean-Louis. Le Corbusier: an atlas of modern landscapes, London: Thames \& Hudson, 2013, p.373.
} 


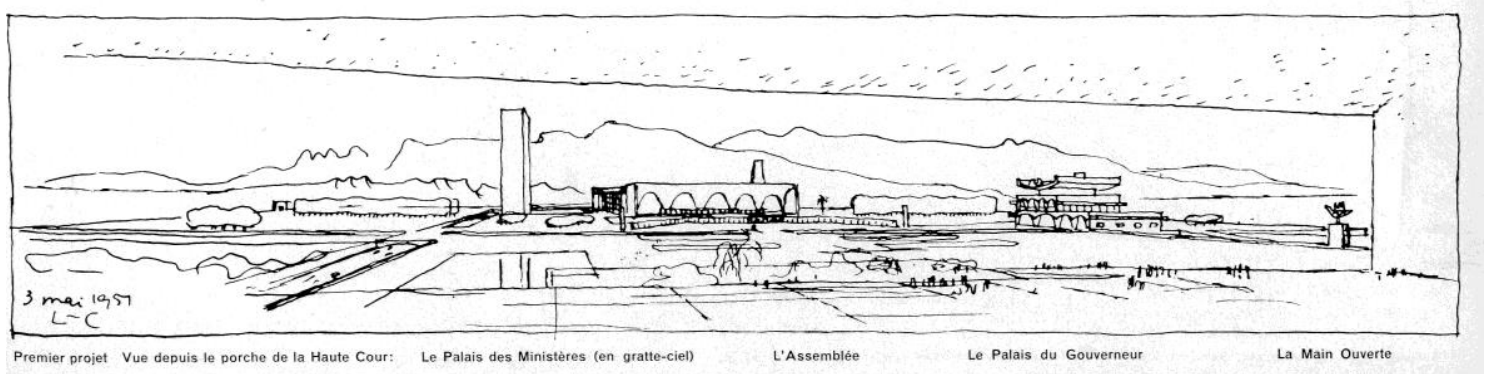

6. Oeuvre Complète, volume5, p.119. (C) FLC/ADAGP

Chandigarh's topography is almost flat with continuous vegetation, the horizontal line prevailing on the skyline. There are no "noble materials", only raw concrete that unite the entire complex, a brutalist experiment. The landscape is punctuated with some buildings and sculptures, which organized and make the delimitation of the site with almost 45 hectares, making them a good example of Land Art.

We can observe a cosmic sense as in Ronchamp Chapel, a building created as an enormous sculpture where a giant pyramid and its truncated conical skylight is combined with other forms, a metaphor of Jantar Mantar of Jaipur, a local blanket. Le Corbusier was careful with indian culture and respect it on his project. Although he still use a rational concept to hierarchize the city traffic road onto seven different types, from the highway till the pedestrian path and organize in several districts with the main functions, we can still identify a more organic plan that respect the local circumstances. Chandigarh seems to be his possibly last opportunity to achieve his target toward a new modern landscape and architecture.

\subsection{Ofir Summer House, (1957-1958) the search of the Third-Way}

Ofir Summer House is a vacation house located in a pinewood near Ofir's beach, in the North of Portugal. This project reflects a synthesis on the Portuguese Architect Fernando Távora path (1923-2005).

"It was through a permanent, magnificent and unforgettable dialogue, where everyone was involved in an attempt to achieve a true compound, that we accomplished our goal. As to its intrinsic value only the future, that great judge, will tell; as to the principle adopted, we have no doubt whatsoever that this is the only on to follow should we want our works, due to their individuality, to be recognized universally". ${ }^{10}$

Távora begins a pathway of permanent search on his formation, where the contradiction has become more persistent. The presence of opposites in architecture become more usual at his work and Távora was conscious about this fact and how it influenced both his works and his thinking. This process was named as Third Way in Architecture ("Terceira Via"/ $3^{a}$ Via). In this attitude we recognize a manifesto of dialectics on international and local issues, or as Távora referred "la arquitectura tiene eso, que lo inverso también es verdade ${ }^{l 1}$ ".

Fernando Távora pursuit the integration of modernity and tradition, and he was always seeking to maintain coherence on his work and never betrayed his thoughts and opinions on architecture.

\footnotetext{
${ }^{10}$ Trigueiros, Luis. Fernando Távora, Blau, Lisboa, 1993, p. 80.

${ }^{11}$ Frechilla, Javier; "Fernando Távora. Conversaciones en Oporto", in Arquitectura 261, Julho-Agosto 1986.
} 


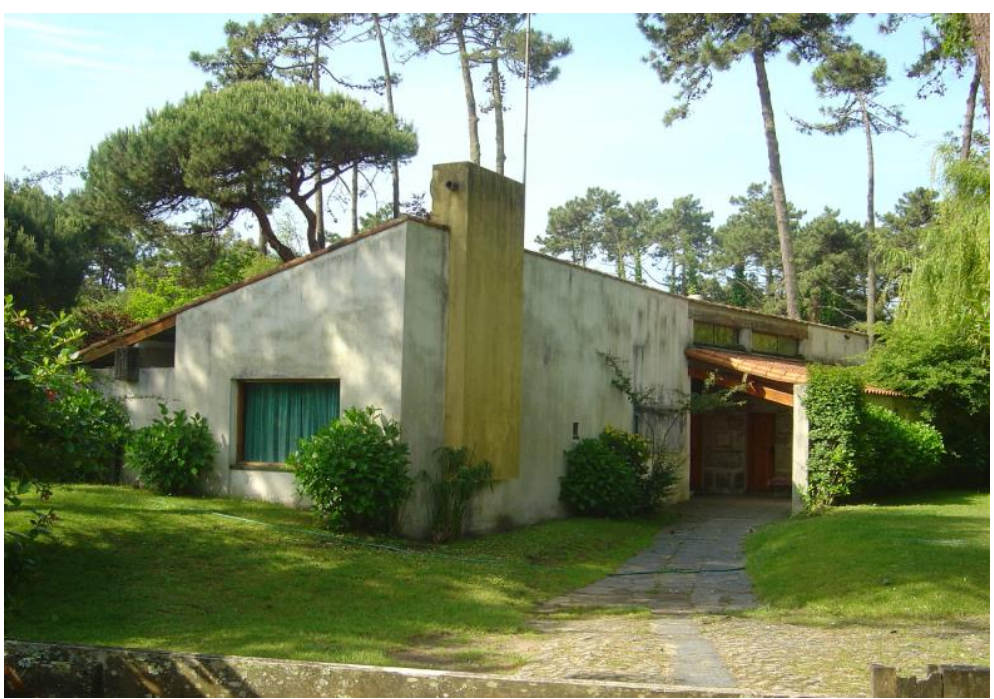

7. Summer House in Ofir. Portugal. Arch. Fernando Távora. View of the house entrance area: the path, the bench, and a little window that brings light into the house interior. It is important to highlight the presence of the yellow colour in the chimney, the only colour used in the house.

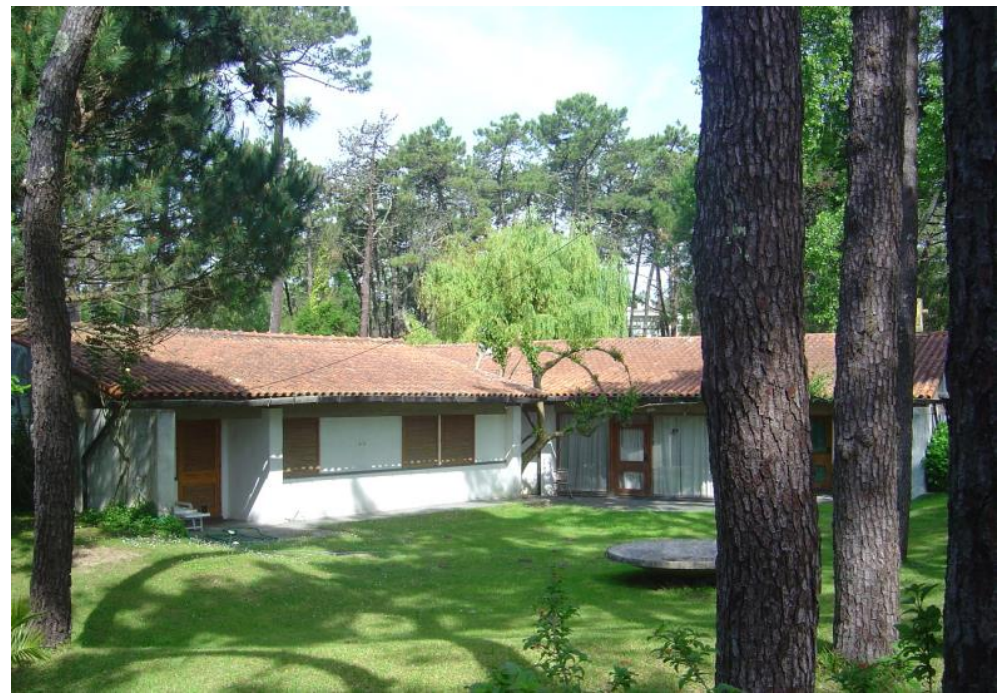

8. View of Ofir Summer House - a house among the trees.

In this summer house, we recognize Le Corbusier's influence in the use of raw concrete on the structure, also in the light effects of the openings such as de niches and windows that perforated the walls that create a tenuous light in the room which allude to the Ronchamp Chapel made by Le Corbusier. Távora blends the modern and the tradition in a synthesis of opposites values. The foundations are in uncovered stone masonry, the brick floor and some elements in large granite cobbles refer to the spontaneous architecture; the roof slopes to interior side and is supported by wooden structures made visible. The thick walls are painted in white and the chimney is in yellow, the only colour used in this project. Like in Ronchamp Chapel, here windows with several dimensions perforate randomly a thick wall.

Távora was aware of the necessary synthesis toward a new architecture, where is more important to blend than to mixture, and take in consideration a multiplicity of circumstances. Távora blends the house with its surroundings, in this case the pinewood, creating a new landscape.

\subsection{Market at Vila da Feira or the space and time contemplation}


The Market (1953-1959) is located in Vila da Feira and it is the expression for a new solution for the public facilities, as a new Market open to everyone, comparable as a Greek Ágora. The market is the result of an intellectual process about the integration of universal and local values ${ }^{12}$, to prove the possibility to synthetize opposites, creating the Third Way ( $3^{\text {rd }}$ Way), that is a Manifesto of articulation between local and global values and influences. Jean-Louis Cohen ${ }^{13}$ named this critical thinking as the "Critical Internationalism" in which rather than reacting defensively to the threat of a homogenizing modernization, the architects made a cautious and calculated decision.

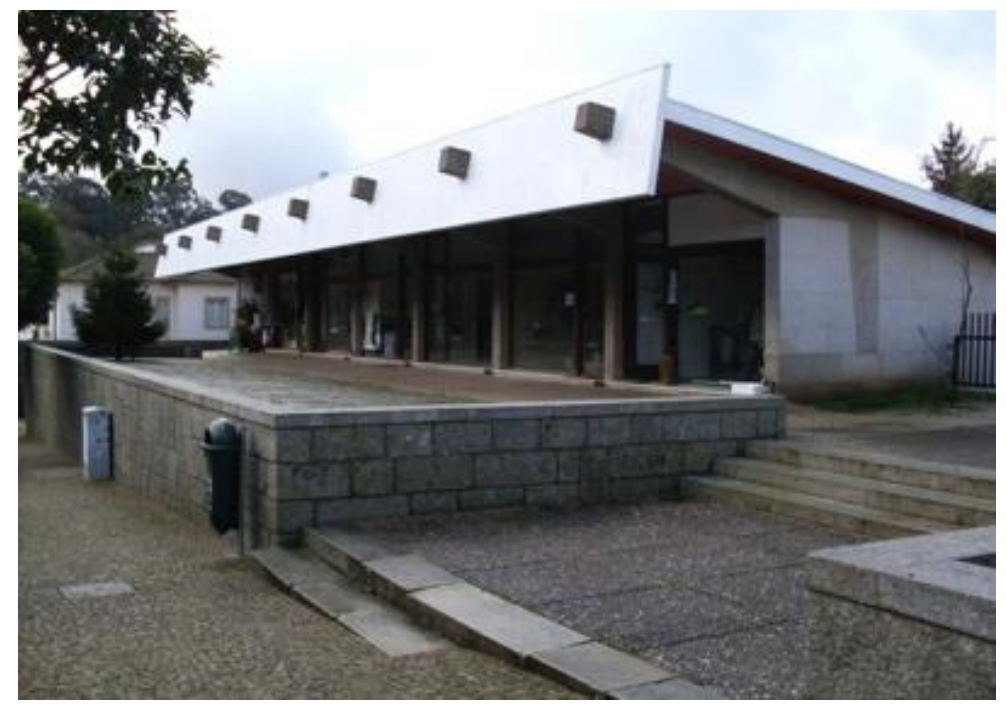

9. Entrance to the Market at Vila da Feira, Portugal. Fernando Távora.

In a 50x50m square lot Távora planned a market, based in an orthogonal grid of 1 by $1 \mathrm{~m}$ that create the geometry of composition. Although a rigid based grid, the volumes composition were fluid and with sober language. The medieval castle emerges in the surroundings. Four volumes distributed by two platforms, configured and delimited the space creating a centre courtyard where is located a fountain surrounded by an octagonal bench that marks the centre, the 'core' of the proposal, and therefore a clear influence of the CIAM VIII at Hoddesdon (1951) adopted in the work of the Arch. Távora.

Távora marks the centre of the place, in a classical gesture, which reveals his doubts about modernism ${ }^{14}$. However, he used the modern language in the structure, his need to mark the centre show us the doubts that he explores to the limits in the projects during the next decades.

We observe a strong reference at the Greek ágora, a place that combine the function of public facilities and also public space. First, we have a program of a market, which means a public space to trading functions, trading goods and ideas. It takes the canon of Greek agora, where besides the market function, also brings together the valences of meeting space for people, exchange ideas, a meeting space and permanence.

The placement is in an interior lot, adjacent to Rua dos Descobrimentos, where Távora proposes the creation of a public space in an interior lot, which one would assume private. The main street Rua dos Descobrimentos is

\footnotetext{
${ }^{12}$ Lima, Susana. "O espaço publico na obra de Fernando Távora - A importância do desenho do espaço público", in Sobre o 'projeto-de-arquitectura' de Fernando Távora; Fernando Távora : minha casal org. coord. Manuel Mendes, Porto: FIAJMS, 2005, p. 194-195.

${ }^{13}$ Cohen, Jean-Louis. The Future of Architecture. Since 1889, London: Phaidon, 2012.

${ }^{14}$ Esposito, Antonio; Leoni, Giovanni. Fernando Távora: opera complete. Milano: Electa, 2005.
} 
slopped allowing the existence of two platforms that organize the space hierarchically, one on the lower level and the other equivalent to the upper level of the market ${ }^{15}$.

The granitic base symbolise the connection to earth, a telluric link and on the other side, the four volumes that contours and organize the space are in concrete material, in a clear contrast with the stone. The concrete has made possible the inverted roof - "butterfly roof" with a large empty space between pillars. As we look at the plan we notice Neoplastic influences on walls dematerialization searching for an atectonic space, organized by the rooftop and pillars. They conform and organize the space, in which Távora inscribe a water-basin with an octagonal bench, as the centre of world. The materials chosen on this project indicate functional aspects but also structural, endurance and even aesthetics issues

The Virtuvian lessons were present on Távora's Works: the utilitas, firmitas and venustas.

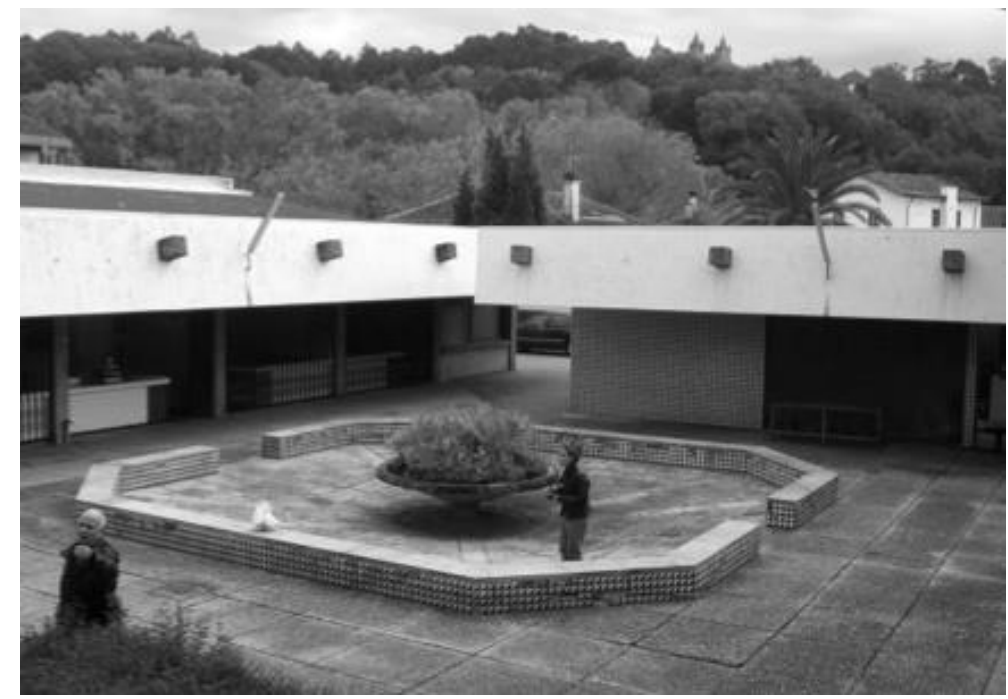

10. Market at Vila da Feira, Portugal. Centre view.

The concrete and steel structured the suspended roof. On other side, the stone and the tile, traditional materials from the north of Portugal enabled the connection to land and the traditional and local circumstances. Távora searched for integration of the modern architecture but questioning their value and made a return to endogenous materials and construction techniques and methods, a return to the origin, as Nietzsche taught.

Aldo Van Eyck analysed this project during the Otterlo Congress (CIAM, 1959), suggesting that the "current notion of time and space should be replaced by the more vital concept of place and occasion ${ }^{16, "}$

Távora explored, on this project, the specific identity of the place without breaking with classical modernism issues such the oppositions between nature and artefact but also the expression of technology. It becomes evident the adhesion to expressive techniques of Le Corbusier work in post war period, such as in the massive expression of the structure and the contrast materials, the use of colours, textures combined.

To sum, this Market results in an enriching expression of modernity, with international scope, because, on the one hand, it proposes a return to historical and cultural origins, on the other it embodies the named Third Way, the way of synthesis.

\footnotetext{
${ }^{15}$ Bandeirinha, J. António. Fernando Távora Modernidade Permanente. Edição Casa da Arquitectura, 2012.

${ }^{16}$ Trigueiros, Luis. Fernando Távora, Blau, Lisboa, 1993, p 56.
} 


\section{Conclusions}

In sum, Architecture is a universal phenomenon. It is more important its ethical function rather aesthetics, because when it is connected to life produce happiness for all inhabitants. These two architects that we have analyze and their works are the demonstration of a great capacity for coordination and synthesis of opposing values, in an integrated view in order to seek the correct and rational form that achieves efficient and beauty the synthesis necessary and possible.

We have chosen the last work from Le Corbusier, in the 1950's because nevertheless they proved to be the most prolific on his career. Ronchamp and even more Chandigarh demonstrate the turn he had taken in his approach to design. Távora inherit this legacy and also have made his own path in the scope for the universality in architecture and the synthesis in Architecture.

The importance of their contribution resides in how they looked at architecture, without refuse modernity and avant gard contributions, with a huge humanism combined with that modern spirit.

\section{Acknowledgements}

The organization acknowledges the directorship of Professor Teresa Fonseca, Fundação Instituto Marques da Silva (a private foundation established by Universidade do Porto) where is accommodated the Fernando Távora Archives, to Paula Abrunhosa, Ana Ramos and Conceição Pratas.

\section{Source of images}

Image 1. Ronchamp. Lima, Susana, 2009.

Image 2. Ronchamp. Lima, Susana, 2009.

Image 3. Ronchamp. Fondation Le Corbusier, Paris. 07412. OFLC-ADAGP.

Image 4. Plan of Chandigarh. Fondation Le Corbusier, Paris. 05201. OFLC-ADAGP.

Image 5. Palace of Assembly, Chandigarh 1. Fondation Le Corbusier, Paris. OFLC-ADAGP.

Image 6. Oeuvre Complète, volume5, p.119. @ FLC-ADAGP.

Image 7. Casa de Ofir. Lima, Susana. Ofir (Esposende), Portugal, 2007.

Image 8. Casa de Ofir, Plan. Lima, Susana. Ofir, 2007.

Image 9. Mercado da Feira. Lima, Susana. Vila da Feira, Portugal, 2013.

Image 10. Mercado da Feira. Lima, Susana. Vila da Feira, Portugal, 2013.

\section{Bibliography/references}

Arquivo Arquitecto Fernando Távora, Fundação Instituto Marques da Silva - Universidade do Porto (AAFT FIMS).

Bandeirinha, J. António. Fernando Távora Modernidade Permanente. Edição Casa da Arquitectura, 2012

Cohen, Jean-Louis. Le Corbusier: an atlas of modern landscapes, London: Thames \& Hudson, 2013.

Cohen, Jean-Louis. The Future of Architecture. Since 1889, London: Phaidon, 2012.

Colomina, Beatriz. "Toward a Global Architect". In Architects' Journeys: Building, traveling, thinking. Pamplona: T6 Ediciones, 2011. 
Colomina, Beatriz. "Verso un architetto globale: Nel dopoguerra Le Corbusier ha trasformato la professione dell'architetto. Suo complice: il jet." In Domus. New York, 30 April 2011.

Curtis, William. Modern Architecture Since 1900. London: Phaidon Press, 1991.

Esposito, Antonio; Leonni, Giovanni. Fernando Távora Opera Conpleta. Milano: Electa, 2005.

Fondation Le Corbusier.

Frechilla, Javier; "Fernando Távora. Conversaciones en Oporto", in Arquitectura 261, Julho-Agosto 1986.

Le Corbusier. Cuando las catedrales eran blancas: viaje al pais de los timidos. trad. Marta Llorente. - Madrid: Apóstrofe, 2007.

Le Corbusier. Le Corbusier, My Work, London: Architectural Press, 1960.

Le Corbusier. When the Cathedrals Were White. New York, Toronto, London: McGraw-Hill Book Company, 1964, p. 32. Translated from the French by Francis E. Hyslop Jr

Lima, Susana. "O espaço público na obra de Fernando Távora - A importância do desenho do espaço público", in Sobre o 'projeto-de-arquitectura' de Fernando Távora; Fernando Távora : minha casal org. coord. Manuel Mendes, Porto: FIAJMS, 2005, p. 188- 213.

Moos, Stanislaus Von. Le Corbusier: elements of a synthesis. $\left(1^{\text {st }}\right.$ Ed. 1968) Rotterdam: 010 publishers, 2009.

Padovan, Richard. Towards universality: Le Corbusier, Mies and De Stijl, 1st ed. - London: Routledge, cop. 2002.

Prakash, Vikramaditya. Chandigarh's Le Corbusier: the struggle for Modernity in Postcolonial India. University of Washington Press Seattle \& London, 2002.

Trigueiros, Luis. Fernando Távora, Blau, Lisboa, 1993. 


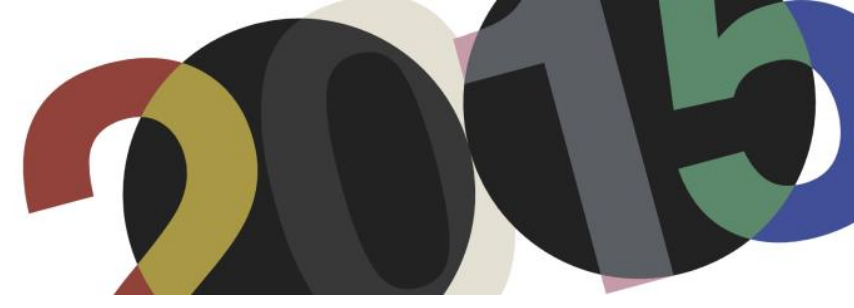

DOI: http://dx.doi.org/10.4995/LC2015.2015.638

\title{
« Histoire d'une Fenêtre ». Le Corbusier y la construcción de la mirada
}

\author{
R. Merí de la Maza, A. Díaz Segura, B. Serra Soriano \\ Escuela Superior de Enseñanzas Técnicas. Universidad CEU Cardenal Herrera. Valencia
}

\begin{abstract}
Resumen: El artículo presenta un estudio de la relación de Le Corbusier con un mecanismo constructivo y de lenguaje arquitectónico fundamental en su obra como es la ventana. Durante ese recorrido se estudian diferentes aspectos que afectan a la definición de la ventana y su relación con la arquitectura que la contiene; en especial centrados en la idea de continuidad espacial y en la disolución conceptual y física de los límites del espacio. Para ello se cruzan enfoques que van desde lo puramente conceptual hasta las relaciones que se establecen entre las soluciones constructivas y sus repercusiones visuales sobre el objeto arquitectónico. Esta breve historia de la ventana en Le Corbusier está centrada en su obra doméstica a través de una secuencia cronológica que permite tener un panorama de la evolución de este elemento en su trayectoria. Podemos ver cómo se produce la transición desde la fenêtre en longueur hasta el pan de verre aménagé, pasando por numerosas aspiraciones, configuraciones y variaciones sobre el propio tema de la mirada y el mecanismo constructivo-visual que la define.
\end{abstract}

\begin{abstract}
The article presents a study of the relationship of Le Corbusier with very a important constructive architectural mechanism in his work as the window is. During that route we study different issues affecting the definition of the window and its relationship to the architecture that contains it; in particular focusing on the idea of spatial continuity and the conceptual and physical dissolution of the limits of space. For that purpose we take different approaches ranging from the purely conceptual to the relationships established between the constructive solutions and their visual impact on the architectural object. This brief history of the Window at Le Corbusier is focused on his domestic work through a chronological sequence that allows an overview of the evolution of the element in his work. We can see how the transition occurs from the fenêtre en longueur to the pan de verre aménagé, through numerous aspirations, configurations and variations on the gaze theme and the constructive mechanism that defines it.
\end{abstract}

Palabras clave: Le Corbusier; Fenêtre; mecanismos constructivos; mirada; ventana.

Keywords: Le Corbusier; Fenêtre; constructive mechanisms; gaze; window.

\section{Introducción}

"Celui qui regarde du dehors à travers une fenêtre ouverte, ne voit jamais autant de choses que celui qui regarde une fenêtre fermée. Il n'est pas d'objet plus profond, plus mystérieux, plus fécond, plus ténébreux, plus éblouissant qu'une fenêtre éclairée d'une chandelle. Ce qu'on peut voir au soleil est toujours moins intéressant que ce qui se passe derrière une vitre ...".

La ventana es un pequeño misterio de la arquitectura, símbolo de continuidad y discontinuidad, intensa en sus variaciones ya etimológicamente hablando, con alternativas que oscilan entre el concepto de paso/perforación y el del elemento que lo cierra. El castellano y el inglés comparten raíces para sus términos con el aire como soporte conceptual (viento-wind) y su origen en el latín ventus o en el antiguo nórdico vindauga (viento-ojo) provienen ambos de la raíz indoeuropea we- (soplar). En estos casos la concepción de la ventana como perforación que permite el paso del viento ha quedado como predominante frente a la mirada, mientras que en

\footnotetext{
${ }^{1}$ Baudelaire, Charles: «Les fenêtres », Petits Poèmes en prose, édition posthume 1869.
} 
las lenguas eslavas es el término okno (ojo) el que se mantiene como primordial. A su vez en el francés (fenêtre) o el italiano (finestra), provenientes del latín feněstra, los vocablos parecen remitirnos a la condición de final de lo externo y, consecuentemente, de principio de lo interno, aunque también se especula con su origen en la raíz griega phainein que significaba igualmente mostrar. Caso aparte es el término portugués janela que se remonta a la pequeña puerta llamada en latín vulgar januella, y que tenía su origen en Iânus (Jano), dios romano de las puertas, el de las dos caras, una mirando hacia fuera y la otra hacia dentro. Esta denominación hace también referencia al objeto que cierra, pero en este caso es el propio elemento de cierre el que toma cuerpo y observa desde su posición los sucesos al tiempo dentro y fuera de la estancia.

La ventana es un tema clave en la arquitectura ya que se significa como la manera de vivir la relación entre interior y exterior, y su definición formal y tecnológica contribuye tanto como las elecciones etimológicas a una determinada percepción del mundo que nos rodea. En ese sentido, la ventana ha sido siempre un objeto de búsqueda vinculado a los paradigmas que la arquitectura pretendía. Proporción, escala, profundidad y posición revelaban las intenciones en su vinculación, o no, con el hombre como habitante del espacio.

La modernidad tuvo uno de sus principios en la posibilidad de separar los diferentes sistemas que integran el hecho arquitectónico. Una de las consecuencias de la desintegración de la unicidad de los sistemas portante, compositivo, volumétrico-formal y espacial fue la posibilidad de modificar la relación entre interior y exterior en la arquitectura. No es de extrañar pues que se convirtiese en tema recurrente de reflexión.

Estas nuevas relaciones van a afectar, evidentemente, a la percepción del exterior desde los espacios interiores, pero también a la construcción de la realidad del espacio interior en su percepción desde el exterior. En esta doble búsqueda de miradas condicionadas del espectador tendrá especial importancia la intensificación del efecto de transparencia literal percibida mayoritariamente desde el interior, pero igualmente clave será la reconstrucción fenomenológica de la realidad y los mecanismos visuales empleados para lograrla también desde el exterior del objeto construido.

En la modernidad, el límite del espacio pierde su condición de frontera para ganar la de horizonte y de esa manera se transmuta tanto la percepción del espacio arquitectónico como las reglas de definición de su límite. Hay que buscar una concreción construida para ese nuevo límite y la definición visual que lo acompaña, y esa búsqueda va a estar presente de manera especialmente intensa en la obra arquitectónica de Le Corbusier.

\section{Histoire d'une Fenêtre}

Hablar de la transformación del límite del espacio y de la construcción de la mirada en Le Corbusier es hacerlo de manera casi directa de la separación entre los diferentes sistemas de la arquitectura que apuntábamos anteriormente. Fue Le Corbusier quien entendió mejor que nadie las consecuencias implícitas de esta disociación, y desde luego fue él quien intentó postular de manera directa cuáles habían de ser sus consecuencias inmediatas en sus cinco puntos para una arquitectura nueva.

Como el propio Le Corbusier escribe "hasta la llegada del cemento armado y el hierro, para construir una casa de piedra, se abrían unas anchas zanjas en la tierra (...) luego, se subian las paredes de piedra. Se establecía un primer piso apoyado sobre los muros, después un segundo y un tercero; se abrían ventanas (...) Abrir ventanas en el muro en el cual se apoyan los pisos es una operación contradictoria; abrir unas ventanas es debilitar el muro. Había, pues, un límite entre la función de sostener los pisos y la de darles luz."2

\footnotetext{
${ }^{2}$ Jeanneret, Charles-Edouard (Le Corbusier): Precisiones, Apóstrofe, Barcelona, 1999, p. 56.
} 
La fenêtre es a la obra de Le Corbusier como los ojos a la expresión de una persona, a su mirada; nos cuenta una historia, nos da pistas sobre su carácter y sus intenciones. Libera el espacio y condiciona al usuario. Este breve recorrido por las "ventanas" de Le Corbusier está principalmente centrado en su obra doméstica, y transita a través de varias de sus obras en una secuencia cronológica que nos permite tener un cierto panorama de la evolución del elemento a lo largo de su trayectoria, sus variaciones. Durante este trayecto nuestro objetivo es desgranar y poner en relación diferentes aspectos que afectan a la definición de la ventana y su relación con la arquitectura que la contiene. En especial nos centraremos en la idea de continuidad espacial y en la permeabilidad conceptual y física de los límites del espacio. Para ello cruzaremos enfoques que irán desde lo puramente conceptual hasta las relaciones que se establecen entre las soluciones constructivas y sus repercusiones visuales sobre el objeto arquitectónico.

\subsection{Maisons Citrohan}

Las casas Citrohan nos van a servir como punto de arranque, cronológicamente hablando, para entender los mecanismos de relación entre interior y exterior de Le Corbusier. Proyectadas en su primera versión en el año 1920, suponen el corolario (al menos etimológicamente hablando) a la idea de la máquina de habitar anticipada desde las páginas de la publicación de L'Esprit Nouveau. La primera versión, implantada directamente sobre el territorio se relacionaba con él desde el interior a través de sus fachadas cortas, ya que la casa estaba direccionada y concebida como un túnel que recogía la luz por sus extremos. Su posicionamiento en la cota del suelo permitía el acceso directo a la sala desde el exterior. Este espacio a doble altura, el corazón de la casa, se relacionaba en toda su dimensión con el exterior mediante un doble ventanal que ocupaba los dos niveles inferiores de la casa. Estos ventanales venían definidos en los dibujos como una serie homogénea y continua de carpinterías verticales partidas en el punto medio de su altura. En el dibujo publicado en el primer volumen de la "Euvre" Complète, observamos como Le Corbusier coloca un elemento ligero de transición y protección solar frente a este gran ventanal que no estaba en las primeras vistas de la casa. (FLC 20707A)

La versión modificada, que se va a presentar al Salón de Otoño del año 1922, muestra ya la incorporación de otra pieza fundamental para entender la relación de las casas de Le Corbusier con el territorio, el pilotis. La relación de la sala se establece con una terraza que envuelve dos de los laterales de la casa, adelantando también en esto otro de los mecanismos de relación con el exterior que Le Corbusier va a poner habitualmente en juego.

Le Corbusier probará con dos versiones de barandilla, una metálica de elementos verticales (FLC 20710), la otra opaca y maciza (FLC 20709) que será la que finalmente adopte en la versión definitiva. En ambos dibujos se mantiene la partición de carpintería en elementos verticales iguales recogida en la propuesta original. Sin embargo en la última versión, los huecos que dan correspondencia a la pared frontal de la sala se mantienen en su configuración a doble nivel e incluso en su partición horizontal interna en el punto medio, mientras que la fenestración varía para transformarse en un menor número de series alternas de ventanas de proporción más ancha, anticipando los estudios posteriores de la casa La Roche. (FLC 20714) 

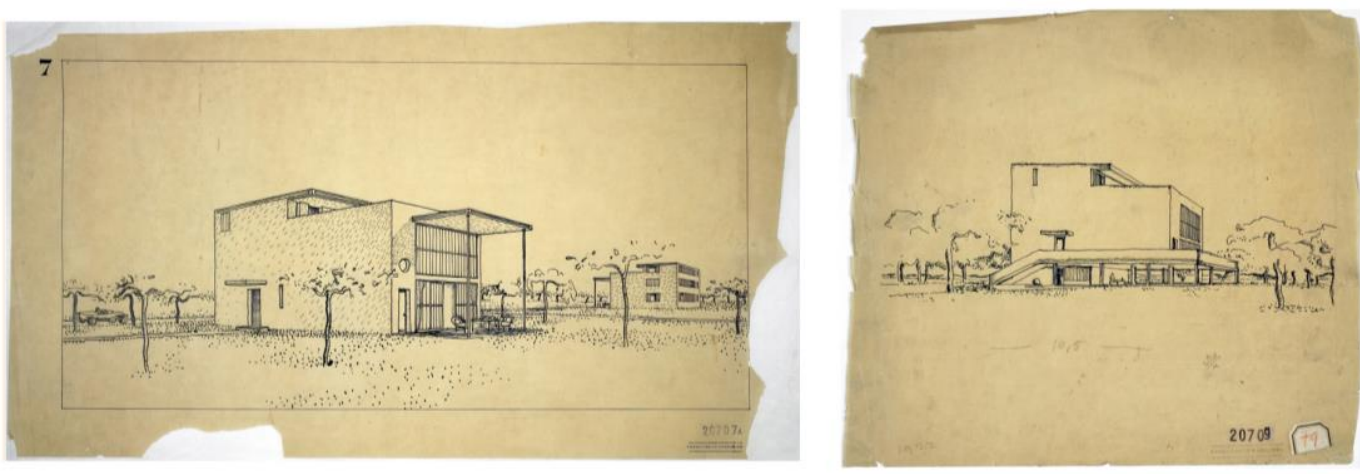

1. Maison Citrohan. FLC 20707A / FLC 20709. OFLC-ADAGP

\subsection{Casa taller para Ozenfant}

A principios del siguiente año, 1923, construirá Le Corbusier la casa-estudio para su amigo y colega el pintor Amédée Ozenfant, en la que debido a las necesidades lumínicas necesarias dará un paso enorme en la disolución de la esquina. Esta labor conceptual de abrir el espacio del volumen del estudio hacia el exterior en tres de las caras del diedro conseguía apropiarse por completo de la luz y del paisaje.

Será en este mismo año cuando Le Corbusier escriba en Vers une architecture el título: "Le dehors est toujours un dedans "’3 y acompañando el capítulo aparecen una serie de bocetos de la Villa Adriana y el Foro de Pompeya en los que el horizonte y los objetos lejanos se perciben enmarcados desde el interior de los espacios.
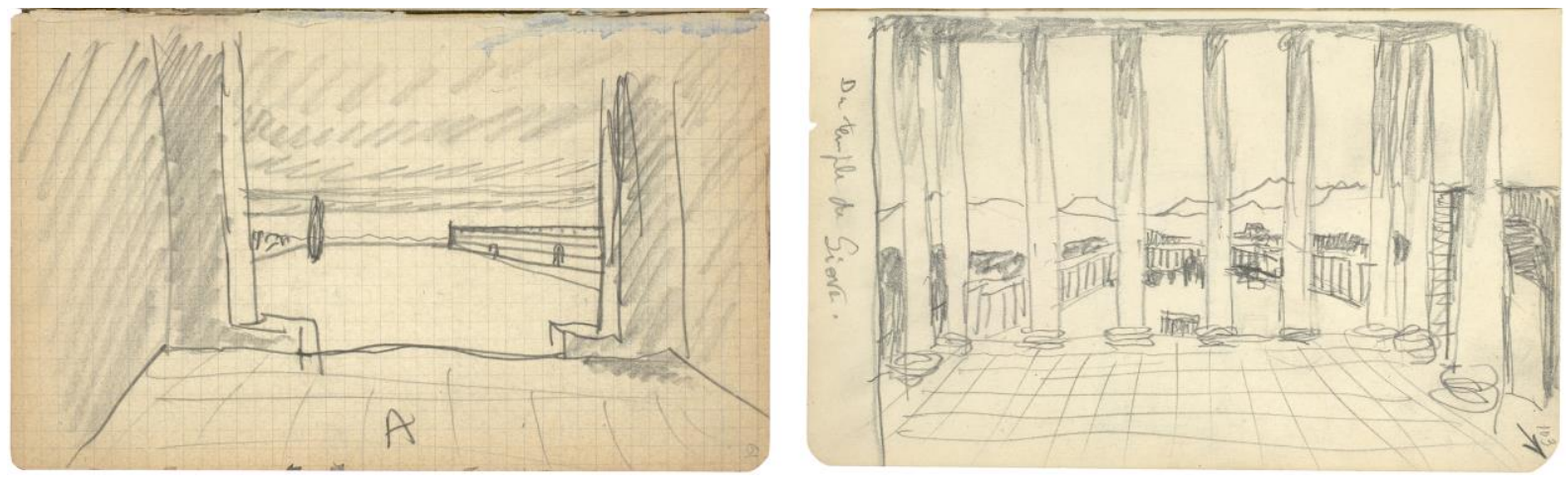

2. Bocetos de la Villa Adriana y del Foro de Pompeya del Carnet voyage d'Orient, incluidos en Vers une architecture. OFLCADAGP

La distribución de la fenestración estaba perfectamente estudiada en su composición por Le Corbusier, como se comprueba en los dibujos de los alzados previos en los que ya están presentes los trazados reguladores para su ordenación (FLC 07848 y FLC 07849), esquema que apenas sufrirá variaciones en su versión definitiva (FLC 07850). Esto se pone de manifiesto en las relaciones que se establecen entre los dos módulos de ventanas existentes en cada alzado. El tercer plano del diedro es el que conforma la fenestración del techo, en el que se ponen en relación ambas modulaciones. La imposibilidad técnica de generar un mecanismo de luz horizontal perfectamente plano al exterior llevó a la colocación de vidrios translucidos en este plano, que eliminaban desde el interior la visión de la solución técnica finalmente adoptada: dos lucernarios en diente de sierra. Su presencia

\footnotetext{
3 “El exterior es siempre un interior”. Le Corbusier-Saugnier: Vers une architecture, Paris, éd. Crès, 1923, p. 154.
} 
caracterizaba la casa en su imagen exterior, pero se negaba desde el interior para potenciar la búsqueda de la abstracción del mecanismo diseñado para establecer la relación con el exterior en la esquina. (FLC 07824)
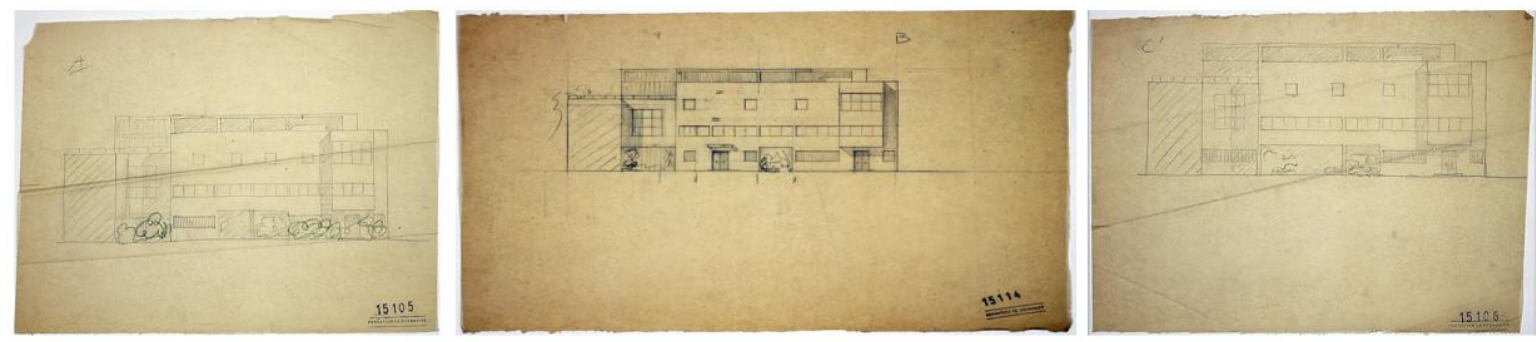

3. Casa estudio para Ozenfant. Alzados FLC 07850 y vista interior del taller. OFLC-ADAGP

La clave estriba en que todas estas operaciones se siguen realizando sobre un contenedor murario, en el cual aún no está presente la estructura como elemento autónomo disociado del espacio. La apertura frontal de las Citrohan se extiende a los planos contiguos del diedro, pero en esencia se trata de la misma disolución plana de los límites del espacio.

\subsection{Maison La Roche-Jeanneret}

Aproximadamente por las mismas fechas comienza a desarrollarse el proyecto para la villa La Roche-Jeanneret también en París. En esta casa, vamos a centrarnos en un único hueco, que es uno de los más complejos proyectados por Le Corbusier en cuanto a sus relaciones con los elementos que lo rodean. La abertura en cuestión es la superior del vestíbulo de la casa La Roche.

El espacio del hall es de por sí especialmente rico; recoge todo el sistema de recorridos de la casa; se abre en cada nivel de una manera distinta a los restantes espacios que lo circundan y queda colonizado por la presencia de la escalera, que a modo de mirador lo invade. Pero, ¿cómo se relaciona con el exterior este espacio? Un único ventanal de grandes proporciones muestra al habitante el espacio exterior de la casa, dándole, según donde se encuentre situado dentro del espacio interior, una percepción diferente de lo que ocurre fuera. Pero este elemento del que hablamos varió considerablemente desde las primeras versiones proyectadas hasta su configuración definitiva.

En las primeras propuestas nos encontramos con un hueco de proporciones cuadradas flotando en el centro del paño opaco y manteniendo una distancia de separación con los límites, tanto laterales como superior, igual al de cada uno de los tres módulos de carpintería que componen el hueco. Estos estudios varían en la configuración del elemento inferior del acceso; la versión A con una puerta centrada sobre el paño opaco (FLC 15105); la versión B completamente abierta (FLC 15114); y la versión C con un hueco horizontal en fenêtre en longueur (FLC 15106 y FLC 15190). 

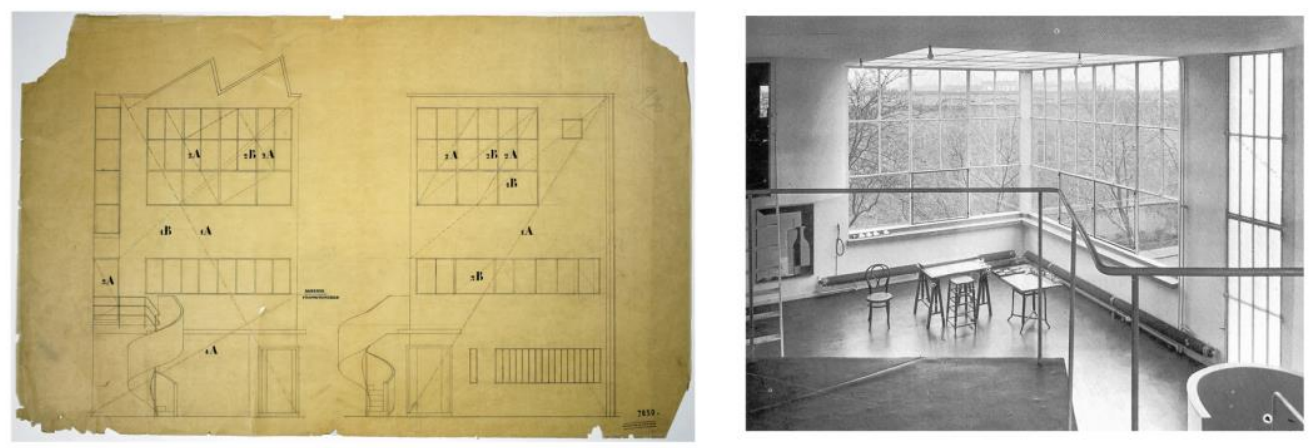

4. Casa La Roche-Jeanneret. Alzados. Versiones A, B y C. FLC 15105, FLC 15114, FLC 15106. OFLC-ADAGP

El 22 de septiembre de 1923, en una segunda versión, el hueco crece horizontalmente, adoptando una configuración más parecida a la final, abarcando completamente los límites del paño (FLC 15274 y FLC 15275). La fenestración conserva aún la disposición de particiones cuadradas iguales repetidas en una matriz que de 3 por 3 elementos crece hasta las 3 filas por 5 columnas, apropiándose del espacio originalmente reservado para el macizo (FLC 15110), y reproduciendo una solución similar a la del taller para Ozenfant.

El 2 de octubre de ese mismo año la configuración de la fenestración va a verse modificada y aparece por primera vez el elemento inferior corrido sin particiones verticales, sobre el que gravitan las particiones superiores que también están sufriendo cambios en su modulación y distribución (FLC 15185). En este punto Le Corbusier, con la excusa de los trazados reguladores del alzado y su relación con la distribución de la carpintería, hace desaparecer nuevamente la extensión del hueco hasta los límites del paño (FLC 15109); desaparición que se verá confirmada en la primera versión de los alzados pasados a tinta en los cuales ya se aprecia claramente una distribución similar a la definitiva, pero conservando una estrechísima franja vertical maciza en ambos laterales del "hиесо" (FLC 15207).
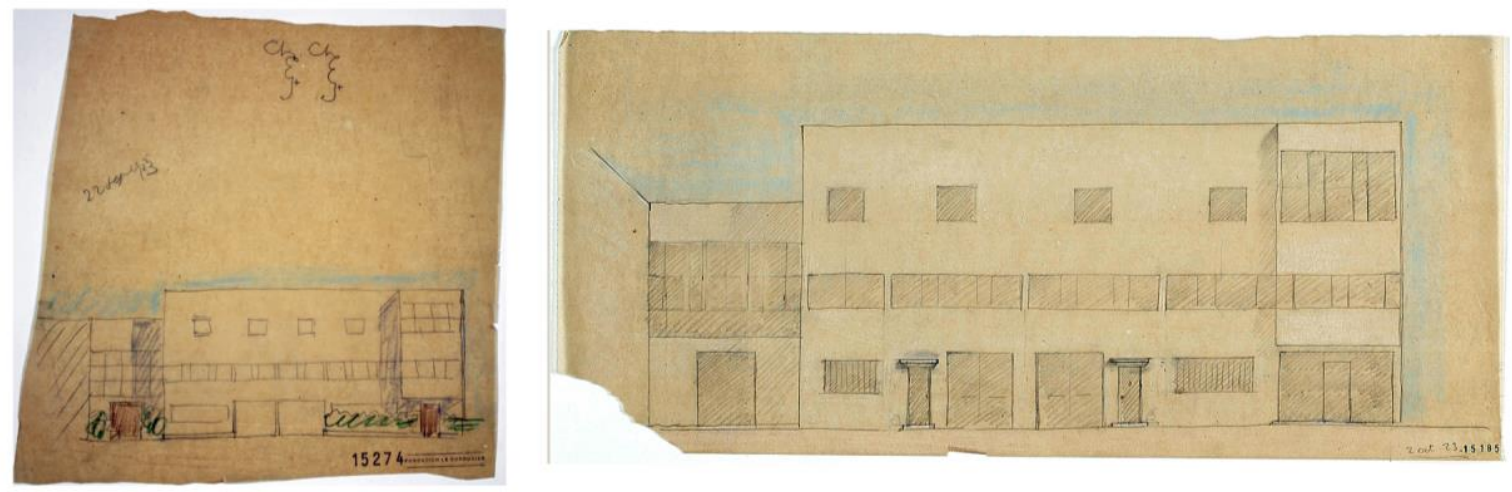

5. Casa La Roche-Jeanneret. Alzados. FLC 15274, FLC 15185. CFLC-ADAGP

La última versión recupera el ancho total del paño hasta las paredes perpendiculares al mismo, y en un primer dibujo, que Le Corbusier anula posteriormente, puede observarse cómo los travesaños horizontales que enmarcan el módulo horizontal inferior adquieren una mayor sección para resolver el problema de la transmisión de cargas de las particiones superiores (FLC 15255). La presencia de una doble línea en la parte inferior del hueco sugiere la posibilidad de un cierto desplazamiento sobre el plano vertical de la fachada, que se reproduce igualmente en el plano pasado a tinta (FLC 15208).

Veamos cómo queda configurada la versión definitiva (FLC 15232). En primer lugar nos encontramos con una pared de cristal de grandes dimensiones que se relaciona con un espacio de corredor que comunica las dos partes de la casa en planta primera. El ventanal arranca desde el suelo del corredor, ofreciendo la sensación de 
continuidad espacial con el exterior desde este punto, en una configuración similar a la que veíamos en la segunda versión de la casa Citrohan, pero invertida. La terraza balcón ha pasado de estar situada al exterior, a actuar a modo de cubierta protectora interior de la puerta de acceso, y el gran ventanal comunica con el exterior la compleja triple altura interior.

El ventanal queda dispuesto abarcando todo el ancho del espacio del hall, pero no abarca en su dimensión vertical toda la altura que dispone dicho espacio. Aquí el volumen es compacto y cerrado, y no existe plano horizontal de techo que se prolongue hacia el exterior. De esta manera, nos encontramos con que la definición superior del ventanal está establecida por un plano blanco que cruza superiormente el espacio, y que apoya tangentemente en los dos planos perpendiculares que han quedado interrumpidos para configurar las barandillas de los dos espacios superiores vinculados al mismo, y que se prolongan en los planos exteriores para enfatizar aún más la continuidad espacial con el exterior. Esta relación de tangencias y apoyos tan extremadamente bien estudiada desmaterializa, desde la percepción interior, la disposición del ventanal como hueco, convirtiéndolo en pura ausencia de plano, percepción que se va a ver incrementada por su división y el tratamiento de las carpinterías. A propósito de esta relación escribe Bruno Reichlin: "La grande finestra sullo square va da parete a parete e non ha stipi; l'architrave poggia direttamente sul parapetto della biblioteca. Architrave, parapetto e finestra sono 'ridotti' alla loro più semplice espressione geometrica: sone delle lastre parallelepipede giustapposte" ${ }^{\natural 4}$.
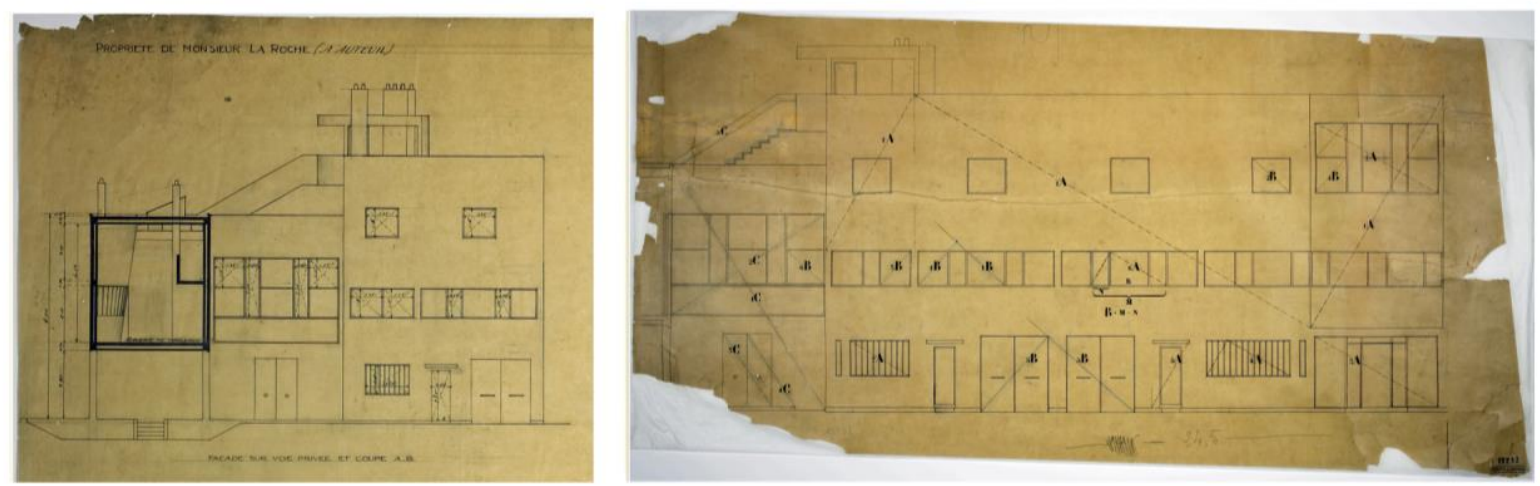

6. Casa La Roche-Jeanneret. Alzados. FLC 15207 (detalle) y FLC 15232. @FLC-ADAGP

El ventanal queda conformado por dos bandas horizontales diferenciadas, que están separadas por el elemento de mayor sección de la carpintería, un perfil en U dispuesto hacia el interior. La banda inferior recoge la altura del alféizar y los dos huecos menores situados junto a ella en los planos perpendiculares. Esta parte tiene vocación de ser continua, dando respuesta invertida al macizo formado por la barandilla interior de la pasarela. Pero la luz es muy grande para que el travesaño horizontal, a pesar de su mayor sección, sea capaz de soportar la sección de ventanal que queda por encima. Así pues, Le Corbusier coloca dos machones verticales que dividen esa banda inferior en tres partes iguales, pero lo hace con los elementos de menor sección visual de todo el conjunto de la carpintería, casi hasta hacerlos desaparecer en el exterior. Estos diminutos parteluces de acero se refuerzan en su cabeza, al interior, con unas pequeñas cartelas que aseguran la transición en profundidad con el travesaño principal.

\footnotetext{
${ }^{4}$ Reichlin, Bruno: "Le Corbusier vs De Stijl: verso la scomposizione in piani della compagine parietale. La Villa La Roche a Auteuil, 1923-1925", en: Dalla "soluzione elegante" all""edificio aperto". Scritti attorno ad alcune opere di Le Corbusier, Mendrisio Academy Press / SilvanaEditoriale, Mendrisio, 2013, p. 65.
} 
La división a tercios la franja establece a su vez varias relaciones. La primera y más evidente con la parte superior de la carpintería; en este caso la relación es de no coincidencia o de discontinuidad, quedando centrados con respecto de las dos particiones menores superiores, que a su vez son los que recorren el resto del ventanal en toda su altura sin interrupción horizontal. Con todo ello, Le Corbusier está marcando la falta de continuidad en los elementos verticales de la carpintería, que no pueden realizar la transmisión directa de las cargas, tensionando visualmente el conjunto y dándole mayor énfasis si cabe a la vocación de continuidad de la pieza de vidrio inferior. Así pues, el travesaño horizontal actúa como barandilla virtual, pero con el peso visualmente invertido al quedar por encima de ella, dando además pie a otra relación visual que se establece con la barandilla metálica interior colocada sobre el macizo opaco de la pasarela hacia la triple altura. Este juego de elementos pesados y ligeros invertidos a ambos lados de la pasarela va a generar una tensión diagonal en el espectador que le lleva a concentrar su atención en la conexión visual desde el volumen vacío superior al interior con el plano de suelo situado al exterior.

Para terminar con el conjunto de correspondencias nos encontramos con el travesaño horizontal que divide a la mitad los tres elementos verticales mayores de la parte superior del ventanal, justo en el punto de concurrencia del límite superior de los dos huecos situados en las paredes perpendiculares, y por supuesto con el dintel de los accesos a la pasarela desde cada uno de sus extremos; tensión de líneas que se va prolongar en el resto de elementos situados en el vestíbulo, ya más lejos del ventanal.
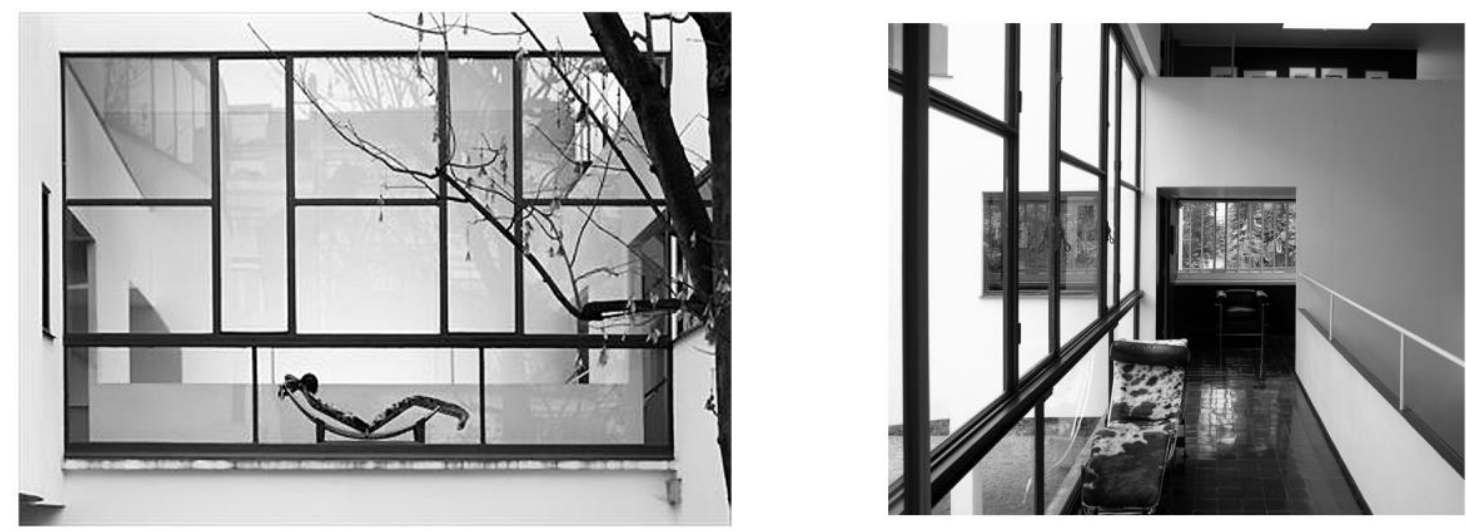

7. Casa La Roche-Jeanneret. Alzados. El ventanal desde el exterior y desde la pasarela.

Le Corbusier, nos ha dejado aquí un juego magnífico de relaciones entre los elementos que definen un espacio, y con ello abre la puerta a un sistema de composición por medio de planos que, aunque no afecta a la volumetría exterior del conjunto, anticipa futuros mecanismos de relación entre interior y exterior.

\subsection{Une Petite Maison}

Vamos a aproximarnos ahora a otro mecanismo fundamental en la definición de la relación entre interior y exterior, la fenêtre en longueur, y lo vamos a hacer partiendo de la casa que proyecta Le Corbusier para sus padres en el lago Léman casi al mismo tiempo que se construía la casa La Roche-Jeanneret. Comencemos por la propia descripción que hace Le Corbusier de la casa: “(...) de cara al Sur, se extiende a lo largo una vivienda de cuatro metros de profundidad, pero cuyo frente mide dieciséis metros. Su ventana tiene once metros de longitud, he dicho 'su'ventana (...) gracias a lo cual se accede a una vista incomparable e inalienable sobre uno de los mas bellos horizontes del mundo. (...) Entramos en la casa. ;La ventana de once metros le otorga categoría! Se 
trata de una innovación constructiva concebida para la posible función de una ventana: convertirse en el elemento, el actor principal de la casa",.

En los primeros dibujos y bocetos de la casa (FLC 09421 y FLC 09438) podemos observar ya la presencia de la larga ventana protagonizando la composición. La modulación presentada es idéntica a la definitiva, con cuatro partes independizadas por el ritmo de la estructura. Sin embargo, aquí la casa mantiene una relación más elevada con el lago y el desnivel se aprovecha para generar una especie de porche bajo la casa soportado por unos protopilotis. Las primeras versiones de la sección constructiva de la ventana presentan una carpintería en acero formada por un marco de perfil en L muy poco desarrollado (FLC 09362 y FLC 09363). La persiana en este caso queda alojada en una hornacina prevista en el interior de la casa, dejando el alzado sin sombra al exterior, y aunque ya se intuye la posición de la estructura esta todavía no tiene una solución definida. En la siguiente versión del alzado (FLC 09367) la planta inferior ha desaparecido y la casa ya queda colocada sobre el lago en una plataforma pero en un único nivel. Una sección constructiva por la ventana (FLC 09373) muestra claramente como un pequeño alero cubre el nicho en el cual queda alojada la persiana provocando una sombra sobre el alzado. La persiana queda vista desde el exterior de la casa, y el plano de la carpintería adelantado en el espesor de la solución pasa continuo por delante de los tubulares de estructura que ya empiezan a prever las placas de anclaje y transición con los elementos de hormigón. Esta solución mantiene la independencia de todas las partes que componen la solución, con cada una de ellas visualmente remarcada.
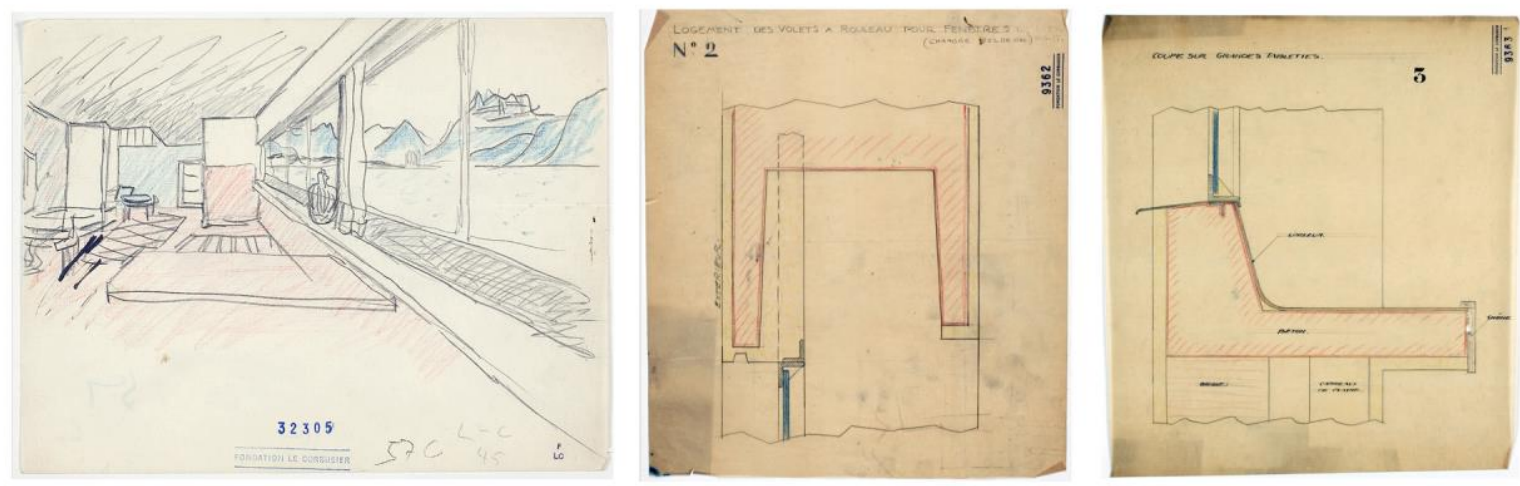

8. Villa Le Lac. Boceto FLC32305 y primeros detalles FLC 09362 y FLC 09363. OFLC-ADAGP

Como explica Le Corbusier, esta casa es una victoria de la ventana sobre el paisaje, sobre el horizonte. Es una victoria de la ventana sobre el espacio interior. La plus grande fenêtre en longueur sur la plus petite maison ${ }^{6}$. Aquí, además, la ventana supone un problema técnico a resolver, y se convierte por tanto en un mecanismo de proyecto, que en este caso lo articula absolutamente todo y se convierte a su vez en el único actor de la fachada.

La solución va a modificarse para la versión definitiva, la ventana recoge ahora en su parte superior externa el cajón de persiana que vuela sobre la fachada generando una sombra sobre el hueco (FLC 09385 y FLC09389), una solución similar pero menos pronunciada sobre la fachada valdrá para la "porte-fenêtre du petit salon", mientras que para el resto de huecos del alzado opuesto al lago se mantiene la solución del cajón hacia la cara interior del cerramiento (FLC09388). Argumenta Le Corbusier que todo está en fijar la altura del dintel y del alféizar; el problema de la estructura se resolverá por medio de esbeltos tubos de acero de $8 \mathrm{~cm}$. rellenos de hormigón. La estructura, en la versión definitiva, se integra en la carpintería de la fachada principal, no se independiza del resto de sistemas (FLC 09387).

\footnotetext{
${ }^{5}$ Jeanneret, Charles-Edouard (Le Corbusier): Una pequeña casa, Infinito, Buenos Aires, 2005.

${ }^{6}$ Jeanneret, Charles-Edouard (Le Corbusier): Une Petite Maison 1923, Birkhauser, Switzerland, 2001.
} 


\subsection{Villa Stein}

En 1925, aproximadamente al mismo tiempo que se terminaba la casa en el lago, Le Corbusier presenta su propuesta para la vivienda moderna en la exposición de París de aquel año, el pabellón del Esprit Nouveau. En él se recogen los planteamientos anteriores de sus Inmuebles Villa, propuesta que incorporaba el espacio exterior a las agrupaciones de vivienda en altura. Este concepto pensado originariamente para unos elementos agrupados, va a incorporarse casi de manera inmediata en la producción de viviendas unifamiliares de Le Corbusier, y supone un paso al frente en la combinación del mecanismo de terraza elevada presentado en la segunda versión de las casas Citrohan, y el mecanismo de gran riqueza espacial que vincula el interior y el exterior en el hall de la villa La Roche.

Su primera formalización con casi todas sus consecuencias se produce en la villa Stein en Garches del año 1927. Aquí se implementa la idea de la terraza exterior elevada como volumen substraído, como espacio contenido y delimitado que sirve de transición entre los espacios interiores domésticos y el mundo exterior. Este espacio queda definido por la construcción de las aristas del diedro, mientras se abre frontalmente hacia el jardín posterior, y parcialmente hacia arriba para conectar con el cielo. Sin embargo en esta ocasión aunque el espacio cumple todos los requisitos necesarios como mecanismo de transición y relación, las estancias interiores de la vivienda apenas si están abiertas al mismo mediante ventanas y puertas más o menos convencionales, desaprovechando la posibilidad de una transparencia transversal del espacio de la sala hacia él. Le Corbusier toma la decisión de potenciar la relación con el exterior del espacio principal de la casa de manera frontal mediante el mecanismo de fenêtre en longueur, que en este caso pliega en las esquinas la distancia justa para mostrar la separación exacta que está retrasada la estructura con respecto al plano de fachada. Se consigue así el efecto de que las láminas blancas opacas, tensas en horizontal, flotan sobre una abertura total que concede 180 grados de visión al habitante de la casa, y visto desde el exterior esta capacidad de dividir la masa del volumen va a tener consecuencias aún mayores en la percepción de conectividad espacial y transparencia.

Colin Rowe y Robert Slutzky presentan una lectura de este espacio desde el punto de vista complementario, infiriendo las propiedades de reconstrucción de la transparencia y la conexión fenomenológica más allá de la mera conexión física de los espacios: “although one can obviously see through his windows, it is not precisely here that the transparency of his building is to be found (...) Le Corbusier proposes the idea that immediately behind his glazing there lies a narrow slot of space travelling parallel to it; and of course, in consequence of this, he implies a further idea - that bounding this slot of space, and behind it, there lies a plane of which the ground floor, the freestanding walls, and the inner reveals of the doors all form a part; and although this plane may be dismissed as very obviously a conceptual convenience rather than a physical fact, its obtrusive presence is undeniable. Recognizing the physical plane of glass and concrete and this imaginary (though scarcely less real) plane that lies behind it, we become aware that here a transparency is effected not through the agency of a window but rather through our being made conscious of primary concepts which interpenetrate without optical destruction of each other" ${ }^{\prime}$.

Van a ser estas aberturas, vistas desde el exterior y con ayuda de los restantes elementos de la composición volumétrica, las que obligan al espectador a deducir otra lectura de la condición del espacio interior. Todos estos efectos dependen en buena medida de la disposición y definición de los elementos de carpintería de las fenêtre en longueur. La especial preocupación por la definición de estas bandas de carpintería queda recogida en una serie de planos tanto de alzado exterior (FLC 10530) como de alzado interior y de planta (FLC 10484), y por

\footnotetext{
${ }^{7}$ Rowe, Colin y Robert Slutzky: “Transparency: literal and phenomenal”, Perspecta no 8, 1964. Aquí extraído de: Rowe, Colin y Robert Slutzky, Transparency, Birkhäuser, Basel, 1997, pp. 36-37.
} 
supuesto de detalle (FLC 10462). Este cuidado en los encuentros entre carpintería y obra será una de las preocupaciones constantes para la eliminación virtual de la presencia del límite en el espacio continuo, y como hemos podido observar, más allá de las consecuencias meramente físicas de la conectividad espacial, pueden lograr grandes efectos perceptuales y fenomenológicos que producen complejas sensaciones espaciales en el espectador.
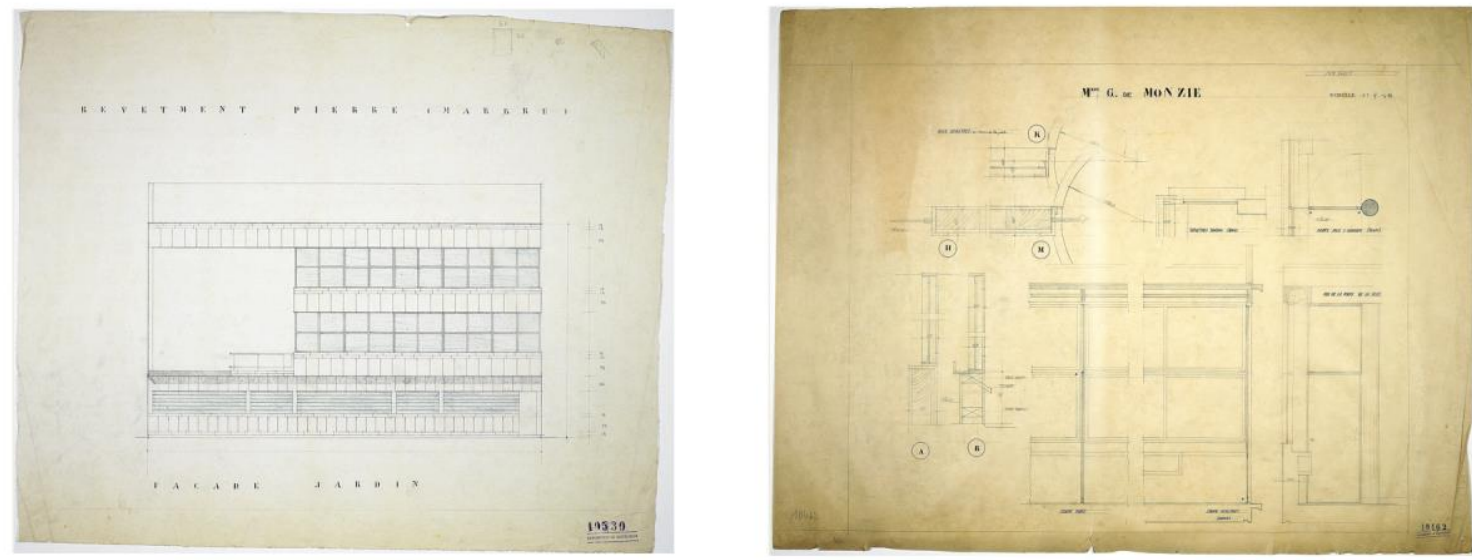

9. Villa Stein. Alzado FLC 10530 y detalles de carpinterías FLC 10462. CFLC-ADAGP

\subsection{Villa Savoye}

La decisión de hacer flotar los volúmenes va a tener otra consecuencia conceptual y formal, que tiene que ver con el reconocimiento mismo de esos cuerpos levantados como volúmenes puros, y no es otra que la imposibilidad de desvanecer completamente los límites exteriores. Le Corbusier escribe al respecto de la villa Savoye: "La casa es una caja en el aire, agujereada a su alrededor, sin interrupción, por una ventana en longitud. (...) Tomando vista y luz del contorno regular de la caja, las diferentes habitaciones van a juntarse, radiando, a un jardín suspendido, que se encuentra allí como si fuese un distribuidor de luz y de sol. Es el jardín suspendido sobre el cual se abren con toda libertad, las paredes correderas de cristales del salón y otras de las diferentes habitaciones de la casa: de esta manera el sol penetra por todas partes, llegando hasta el mismo corazón de la casa",

Le Corbusier puede plantearse interrupciones horizontales continuas en este objeto, pero dado que ha de reconocerse como volumen puro, no puede comunicar el espacio interior de manera completa y directa con el exterior a través de las fachadas. Entonces aplica aquí la solución del vaciado para generar una terraza, a modo de patio, que sea la extensión exterior del espacio principal de la casa. Como al levantarse ha perdido el contacto con el terreno y la naturaleza, convierte entonces la terraza en un jardín elevado. (FLC 19425)

Al disponer este espacio exterior perfectamente acondicionado, Le Corbusier puede abrir de manera franca y directa la sala al exterior, empleando para ello unas carpinterías deslizantes de gran formato que abarcan en altura desde el nivel continuo del pavimento hasta el propio plano interior del techo y, a lo ancho, la dimensión completa de la terraza. Una continuidad totalmente lograda que se va a prolongar hacia el territorio circundante mediante la incorporación completa del horizonte, visible a través de las rasgaduras horizontales que recorren las paredes limítrofes de la terraza.

\footnotetext{
${ }^{8}$ Jeanneret, Charles-Edouard (Le Corbusier): Precisiones, Apóstrofe, Barcelona, 1999, p. 158.
} 
Mientras que las carpinterías son "de acero en las viviendas de Pessac o la casa Ozenfant, las de la villa Savoye o la casa Stein son de madera y acero" (FLC 19480) más cuidadas en sus detalles y en los materiales empleados, sobre todo en lo que se refiere a la gran carpintería deslizante, elemento fundamental de conexión entre la sala y el jardín elevado.

En la primera versión de esta carpintería (FLC 19534) las secciones están constituidas exclusivamente por unos diminutos elementos metálicos, los espesores son casi inexistentes y la propuesta nos presenta unos vidrios que prácticamente se sujetan a ellos mismos. Es importante percibir el deseo de eliminar la presencia de la carpintería para ayudar a entender el concepto de disolución del límite. Esto mismo se remarca en este dibujo con la presencia de una pieza que recoge y esconde el atraque del vidrio fijo contra la pared en uno de los límites de la carpintería, así como la colocación de una U metálica con un listón de madera para recibir el vidrio deslizante. Este elemento a su vez queda emplazado en perpendicular y exterior a la pared, para lograr su desaparición visual desde el interior. Ya estaba presente, en dos pequeños bosquejos atravesados, el rodamiento superior y el mecanismo de polea mediante cadena, aunque aún no se describe la solución de su encuentro inferior. El perfil que recoge el mecanismo de la cadena parece estar sujeto directamente al soporte, ya que no aparecen los tubulares que lo sujetan. Tampoco hay rastro de la persiana exterior.

La segunda versión (FLC 19532) modifica los elementos de la carpintería dándoles un poco más de presencia. Probablemente el deseo colisionó aquí con la realidad constructiva y la necesidad de resolver los numerosos problemas inherentes a un elemento tan complejo como este. Se trata de un bosquejo realizado bastante rápido, y debió de ser un plano de transición hacia los siguientes. Puede verse una composición de perfiles en L y U de acero combinada con orlas, junquillos y otros elementos en madera. Están presentes los tubulares acodados que hacen de pies del elemento horizontal del mecanismo de cierre, y casi desde el principio se marca la presencia autónoma del pilar en los dibujos. Este hecho dará potencia a la realidad de objeto superpuesto a la fachada con la que se construye este mecanismo de cierre.
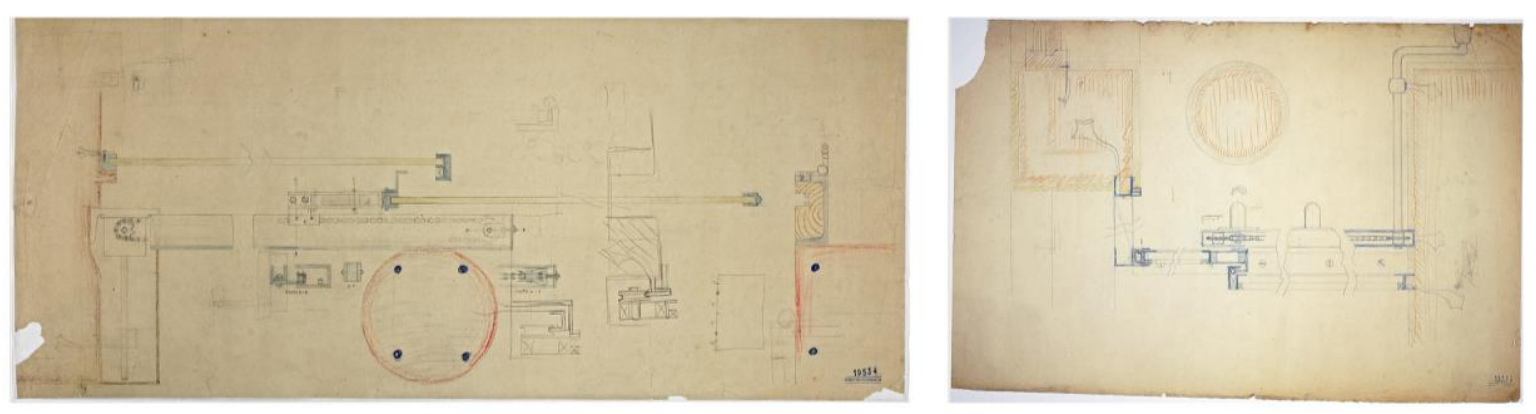

10. Villa Saboye. Detalles de carpinterías FLC 19534 y FLC19532. OFLC-ADAGP

La versión anterior se desarrolla en dos planos de corte vertical (FLC 19535) y horizontal (FLC 19637), en los que todos esos elementos se definen con un poco más de precisión. Cabe destacar la sustitución de la U metálica para la recogida de la hoja deslizante, por otro más complejo, que resuelve los problemas de aislamiento y condensaciones colocando un corcho entre dos chapas de acero. El junquillo que remata el conjunto en el vértice de la obra, contribuye a la desaparición visual del elemento. En la sección vertical vemos la preocupación por realizar un rehundido en la parte maciza de la obra, aunque esta no se encuentre todavía definida; esto se debe a la necesidad de ocultar a la vista todos los elementos del complejo mecanismo que hace funcionar al conjunto, y

\footnotetext{
${ }^{9}$ Torres Cueco, Jorge, Le Corbusier: visiones de la técnica en cinco tiempos, Fundación Caja de Arquitectos, Barcelona, 2004, p. 119.
} 
además aprovecha el rehundido para prever la colocación de las cortinas; el propio cerramiento de obra conforma un tacón que, actuando a modo de goterón, oculta la presencia de la carpintería también desde el exterior. Ya está planteado el sistema de recogida de agua bajo la hoja corredera, y su anclaje al suelo mediante la prolongación de la chapa de acero encajada en la ranura del canalón inferior.

En el siguiente plano (FLC 19502) se estudia por primera vez la incorporación del cajón metálico para resolver la persiana por el exterior, aunque en este caso enrasa con la fábrica por encima del dintel en su cara de fuera, con lo cual queda la duda de si no se tratará de un estudio posterior a los del proyecto de ejecución, e intermedio a la versión última dibujada.
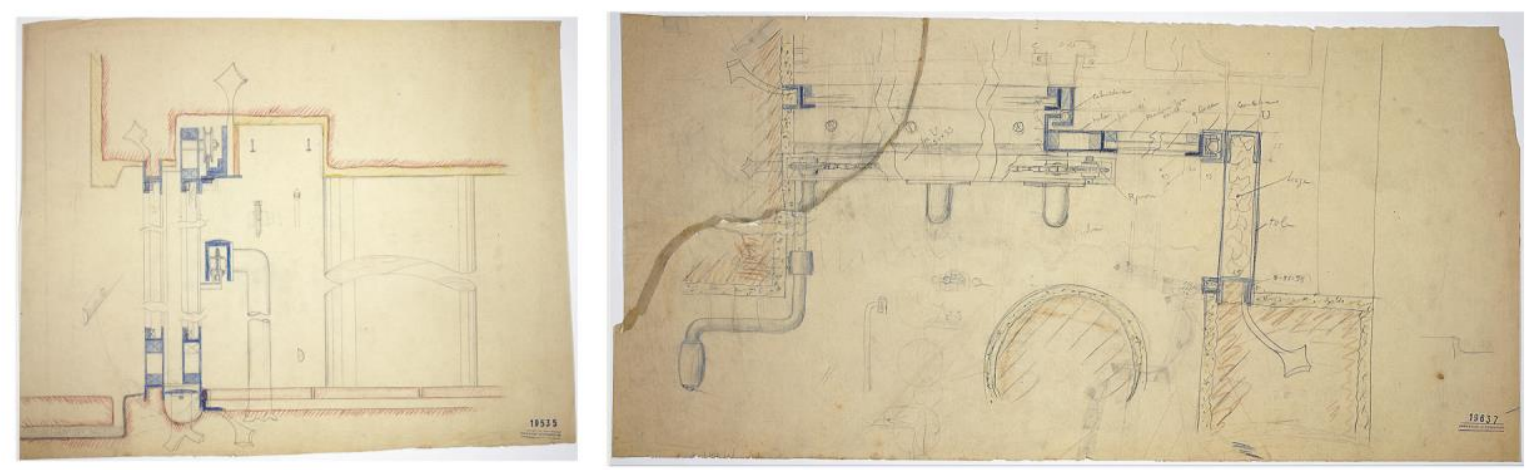

11. Villa Saboye. Detalles de carpinterías FLC 19535 y FLC19637. OFLC-ADAGP

Nos remitimos en este punto a las descripciones que hace Josep Quetglas en su libro sobre la villa Savoye: "El 11 de marzo, Burnham dibuja dos planos de detalle, "Savoye 2090" y "2091" (FLC 19437 y 19438), representando en sección, alzado y planta el mecanismo de deslizamiento y de la persiana de la cristalera de la gran sala, según una invención casi picabiana de Pierre Jeanneret. El bombo de la persiana se proyecta al exterior, en un medio cilindro envuelto en chapa metálica, al modo de las ventanas de la villa Baizeau. La luna deslizante es arrastrada por una cadena continua, movida manualmente con una manivela anclada a un pilar y protegida en una funda metálica que sirve también como barandilla frente a la luna fija" ${ }^{10}$.

Aquí el cajón de la persiana cobra ya todo el protagonismo desde el exterior, al tiempo que resuelve la visión del resto de elementos de la parte superior ocultándolos. La última versión dibujada va a simplificar más aún algunos aspectos.

"El 24 de mayo Frey vuelve a dibujar la sección de la cristalera corredera entre la sala y el jardín, en los planos "Savoye 2137" (FLC 19455) y "2138" (FLC 19456). (...) Por otro lado se simplifican también la carpintería de la cristalera y su mecanismo de deslizamiento, un poco en deterioro de la resistencia y a favor de una más neta definición de las líneas. Puede pensarse que se estiliza aquella manifestación directa del comportamiento de cada pieza, que había en la primera versión del mecanismo, donde se exhibían el manubrio, los ejes de rotación de la cadena y los apoyos de la funda -doblados en codo-, mientras que ahora no se demuestra ningún esfuerzo, sino que el mecanismo queda convertido en pura geometría. Sin duda se trata de un tránsito modélico, desde el gusto de Pierre Jeanneret hasta el de Le Corbusier. Durante la construcción acabará simplificando aún más

\footnotetext{
${ }^{10}$ Quetglas, Josep, Les Heures Claires: Proyecto y arquitectura en la villa Savoye de Le Corbusier y Pierre Jeanneret, Massilia, 2008, p. 212.
} 
este detalle, hasta no ser sino un perfil en $C$, con un sólo tubo metálico en el punto medio de su longitud, como ,11
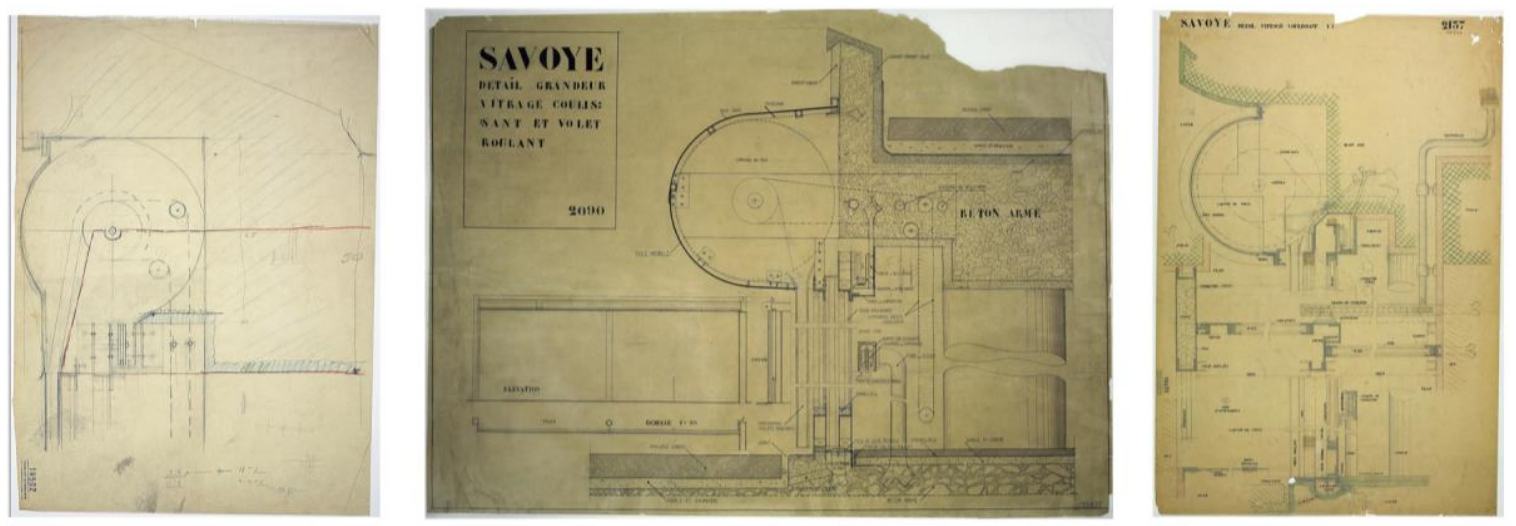

12. Villa Saboye. Detalles de carpinterías FLC 19502, FLC 19437 y FLC 19455. OFLC-ADAGP

Al final del viaje se imponen las tesis de ligereza visual del mecanismo, tal vez en detrimento del comportamiento general de la carpintería, no solo en cuanto a su resistencia sino también por las condensaciones. Este resulta un magnífico ejemplo de la tensión que existió entre lo visual y lo constructivo a lo largo del trayecto que estamos recorriendo, y es que la definición constructiva de los elementos de transición del espacio va a suponer una lucha permanente por alcanzar unos objetivos visuales más allá de los conceptuales.

\subsection{El pan de verre}

En la versión de los cinco puntos incluida en el número 10 de L'Architecture d'Aujourd'hui de 1933, nos encontramos con la substitución de la fenêtre en longueur por la ossature indépendante ${ }^{12}$. Este hecho no puede considerarse circunstancial, y como todo lo que hacia Le Corbusier está perfectamente meditado y direccionado para la consecución de unos objetivos. En primer lugar el concepto de estructura como sistema independiente es mucho más importante, y potente en sus consecuencias, que sus repercusiones en relación con el resto de sistemas recogidas en otros de los puntos. En segundo lugar, Le Corbusier comenzaba a ser consciente de las limitaciones de su propuesta de fenêtre en longueur, y de que ya existían arquitecturas que superaban el lenguaje visual asociado a la modernidad que trataba de representar la misma.

Todo esto dará lugar a la aparición de otro mecanismo que Le Corbusier incorporará a su arquitectura para la definición del límite del espacio, y que no es otro que el del pan de verre: "He construido muchísimas ventanas "en longitud"; mi atención se ha fijado en esos alféizares de ventana, las cuales no me parecen muy francas todavía (...) la ventana es el órgano más costoso de la casa. La ventana corriente es todo un montaje de hierro o de madera, es decir, algo infinitamente delicado, que requiere una construcción cuidada. ¿Y si pudiéramos, con un gesto, repudiar la ventana, pero dando, al mismo tiempo, luz a los pisos? (...) El examen de mi perfil-símbolo me muestra unas fachadas reducidas a algunas bandas de cemento de 30 centímetros de altura. (...) Vamos a sujetar a 25 centímetros por delante de estas bandas de cemento, por medio de cartelas de llanta, unos hierros verticales, bien colocados, que tengan aplomo. Y al través, fuera o dentro, unos hierros horizontales a unas distancias proporcionadas a los cristales o a los vidrios disponibles en el comercio. Por consiguiente, delante de

\footnotetext{
${ }^{11}$ Quetglas, Josep, Les Heures Claires: Proyecto y arquitectura en la villa Savoye de Le Corbusier y Pierre Jeanneret, Massilia, 2008, pp. 250-251.

${ }^{12}$ Lahuerta, Juan José, en el prólogo del libro: Roth, Alfred, Dos Casas de Le Corbusier y Perre Jeanneret, Colegio Oficial de Aparejadores y Arquitectos Técnicos, Murcia, 1997, pp. 9-10.
} 
las fachadas habrá un panel de vidrio. La fachada es un panel de cristal"13. Vemos pues las dudas que finalmente le genera la fenêtre en longueur, y el reconocimiento parcial de que existe un mecanismo mejor, más rotundo, de expresar la separación entre los diferentes sistemas de la arquitectura. Este mecanismo del pan de verre va a estar presente tanto en obras de vivienda colectiva de Le Corbusier, como en bloques de edificios públicos. Desde el Immeuble Clarté hasta el Centrosoyus, pasando por los pabellones Suizo y Brasileño de la Ciudad Universitaria en Paris, las Unité d'Habitation o a proyectos tan significativos como el Immeuble des Invalides en la rue Fabert, el pan de verre va a configurar una manera de relacionarse con el paisaje y el territorio desde las posiciones elevadas de los bloques.

\subsection{Las maisons Jaoul}

Antes de cerrar este recorrido vamos a dar un salto temporal hasta las maisons Jaoul para ver brevemente un último mecanismo operativo sobre el límite del espacio evolucionado conceptualmente desde el pan de verre, que va a tener repercusión en numerosas arquitecturas: le pan de verre aménagé o le quatrième mur.

"Elle témoigne des recherches de Le Corbusier en matière de pan de verre aménagé. Le bois est ici étroitement associé au verre. et le vitrage est comme incorporé à l'ameublement",14.

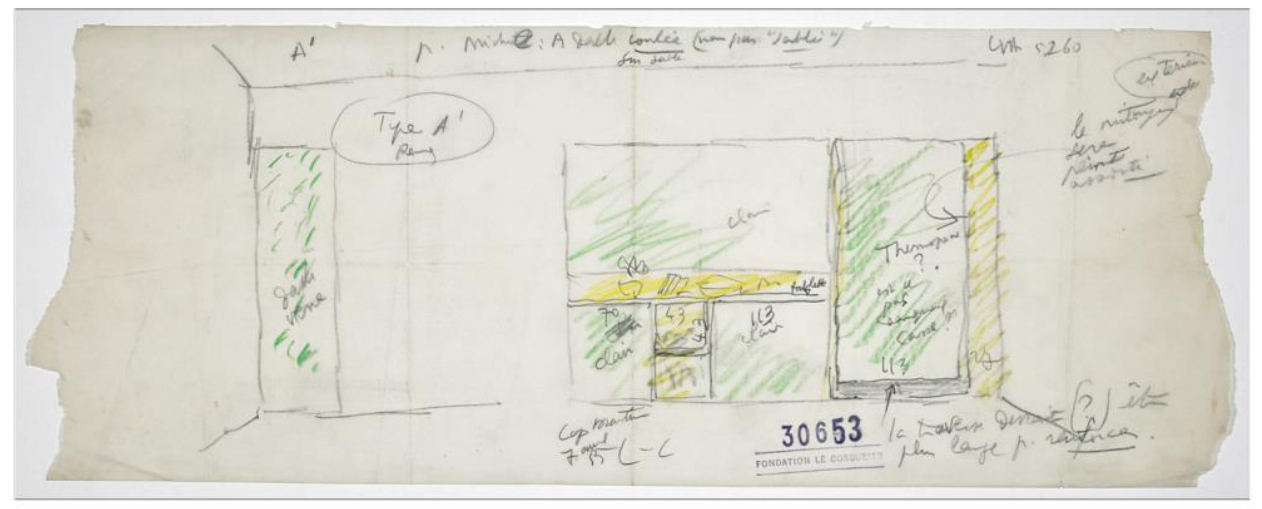

13. Maisons Jaoul. Boceto FLC 30653. CFLC-ADAGP

El paño de vidrio amueblado parece contradecir en sí mismo el principio del que parte. Delimitar el límite del espacio por una lámina transparente para después amueblarla y darle espesor retirándole la esencia misma de membrana resulta cuando menos desconcertante. Pudiera parecer que atribuir a ese mecanismo el nombre de cuarto muro acaba por revertir, semánticamente al menos, su asociación a la disolución del límite del espacio. Sin embargo las soluciones manejadas por Le Corbusier para estas casas y las cinco variables recogidas en el libro de Jules Alazard mantienen una distribución de los elementos opacos en el conjunto de la composición que permite seguir reconociendo el carácter de superposición de este pan de verre aménagé y la percepción de continuidad espacial por la continuidad de las aristas del volumen interior y de los planos que lo conforman. Los vidrios siempre liberan visualmente al menos tres de las esquinas del conjunto, y las partes opacas se componen de tal modo que parecen flotar como inserciones en el paño de vidrio. Le Corbusier habla de la liberación de los puntos estratégicos, de los muros laterales el suelo y el techo. De esa forma conceptualmente toma sentido la expresión de pan de verre aménagé puesto que realmente es el vidrio el que se amuebla y no los muebles los que reciben algunas partes transparentes.

\footnotetext{
${ }^{13}$ Jeanneret, Charles-Edouard (Le Corbusier), Precisiones, Apóstrofe, Barcelona, 1999, p 73.

${ }^{14}$ Alazard, Jules y Jean Pierre Hébert, De la fenetre au pan de verre dans l'oeuvre de Le Corbusier, Collection Actualité du verre $n^{\circ}$ 1, P.V.P. (Dunod), Paris, 1961.
} 
Como indica Caroline Maniaque, Le Corbusier va a retomar las observaciones de Alazard a propósito de la ventana en el Modulor 2: "Quelle évolution minutieuse, méticuleuse, continue de la fenêtre depuis vos articles de l'Esprit Nouveau de 1920 jusqu'à aujourd'hui! Les fenêtres "en longueur" nées de la construction industrielle de bois, de fer ou de béton armé, et des mesures du corps humain. Puis le "pan de verre" qui supprime la "retombée" cô̂teuse sous plafond ainsi que l'allège du sol; il apporte des ressources considérables à l'une des fonctions primordiales de la façade : éclairer. Puis au cours des années le pan de verre devient "le quatrième mur de la chambre"; il n'est pas totalement en verre; certains panneaux sont opaques; des bibliothèques s'y accrochent; des tables s'y appuient; il joue son rôle en éclairant des points stratégiques, les murs latéraux, le plafond et le sol. Puis, c'est le "brise soleil" qui jugule cet ennemi subitement né du pan de verre: l'ardeur solaire. [...] Le vitrage étant désormais à l'abri de la pluie, le bois peut reprendre la place du fer. À ce moment, la fenêtre de bois n'est plus faite d'un châssis à plat, mais de cadres posés "de champ". C'est une nouvelle esthétique de la fenêtre. La fenêtre passe au rang du mobilier, elle peut être architecturée pour elle-même, dedans et dehors..."

Más allá de la separación de los sistemas integrantes de la arquitectura, también las funciones asociadas a la ventana se disocian: aportar la luz y las vistas al exterior, airear y filtrar, prolongar el espacio y dar acceso a la terraza. Cada elemento que compone este nuevo muro de vidrio amueblado responde específicamente a una de esas funciones, y la ventana pasa a ser arquitectura en si misma al interior y al exterior.

Volviendo a las maisons Jaoul, podemos observar como en el alzado interior oeste de la maison $B$ el dibujo de las sombras remarca esa profundidad ganada por el frente del espacio (FLC 09948). En el tramo derecho de la primera planta, la configuración de las zonas opacas parece excavar y recortar el paño de vidrio, dejando, como ya comentábamos anteriormente, tres de las esquinas del conjunto transparentes. De esta forma, las partes de madera parecen esculpirse autónomas en el espesor de la fachada. Esta versión realizada el 16 de abril de 1952 va a sufrir ciertas modificaciones cuando se dibuja nuevamente el 20 de noviembre, la composición de este paño en concreto ha variado ligeramente (FLC 09956). Un rayado rápido indica cuáles son las partes opacas del conjunto, y podemos observar un boceto esquemático de una persona sentada a la mesa asociada al conjunto. Desde el exterior, en los alzados realizados el 21 de noviembre de ese mismo año (FLC 09957) han desaparecido (o probablemente no están reflejados) los elementos ejecutados en madera de esa zona, mientras que en el resto de alzados han sido dibujados con todo el detalle de la veta grafiando el material.
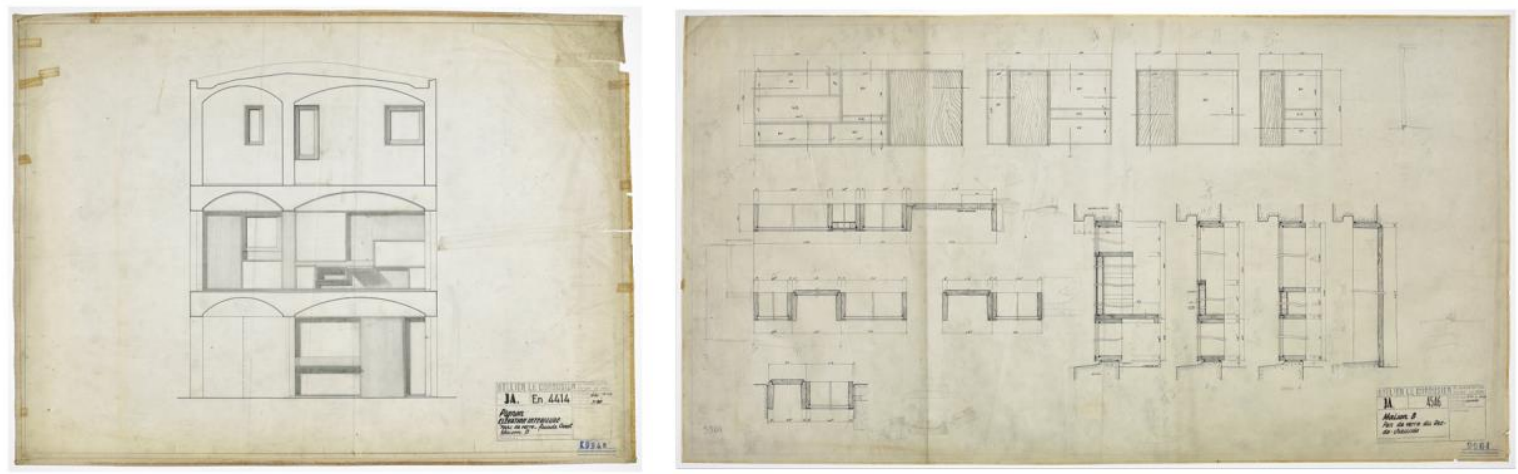

14. Maisons Jaoul. Alzado interior FLC 09948 y detalles de carpintería FLC 09964. CFLC-ADAGP

El plano de detalle de carpintería de los módulos de planta baja de esta casa (FLC 09964) nos muestra cómo se construye este límite espeso mediante unos costales de madera que conforman una profundidad de base de 20

\footnotetext{
${ }^{15}$ Maniaque, Caroline, Le Corbusier et les maisons Jaoul: projets et fabrique, Picard, Paris, 2005, p. 81.
} 
centímetros. Estos elementos van recibiendo alternativamente paños opacos que se abren para ventilar o vidrios dobles fijados mediante los junquillos exteriores. Este módulo crece en profundidad hacia el interior para poder conformar una estantería o prolongarse en una mesa de trabajo asociada al elemento de fachada. De alguna manera, Le Corbusier está logrando fusionar la idea del mobiliario asociado al límite del espacio para incrementar las relaciones entre interior y exterior. El pan de verre aménagé logra algo más que amueblar el límite del espacio, logra que el usuario lo habite y consecuentemente viva en ese lugar intermedio de relación entre el exterior y el interior de la vivienda, modificando una vez más la relación del habitante con el exterior y condicionando su mirada a través de un mecanismo evolucionado de la ventana.

\section{Conclusiones}

"La clé, c'est regarder: regarder, observer, voir, imaginer, inventer, créer""16.

A través de este recorrido podemos deducir que la manera de mirar, de entender la relación entre el interior y el exterior de la arquitectura estuvo permanentemente presente en la búsqueda del maestro suizo. Creador incansable, inventor de nuevas soluciones técnicas, capaz de imaginar nuevos caminos que anticipasen las necesidades formales, compositivas y, sobre todo vivenciales, de la nueva arquitectura. Le Corbusier transitó a lo largo de varias décadas desde la membrana, que disolvía la materialidad de los límites del espacio, hasta su materialización parcial mediante la incorporación de elementos de mobiliario. Durante el trayecto nos dejó ejemplos de cómo recuperar el horizonte incorporándolo al interior del espacio; también se ocupó de enmarcar la mirada en un juego simbólico de relaciones entre lugares que cobraban toda su intensidad por la mera aparición de un hueco ${ }^{17}$; o experimentó con el espesor de la piel para atrapar un espacio intermedio ${ }^{18}$ entre exterior e interior.

Los objetivos conceptuales a lo largo de cada una de las etapas y evoluciones de la ventana en la obra de Le Corbusier dependieron en gran medida de las soluciones técnicas y constructivas de los elementos. La esbeltez de las carpinterías, su configuración formal y compositiva, o la manera en la que se encuentran con los demás elementos constructivos han sido fundamentales para lograr los diferentes objetivos visuales. Las numerosas variaciones y estudios de los detalles constructivos de las ventanas presentes en los planos originales de las obras de Le Corbusier nos han dejado un testimonio fundamental del interés e importancia que la precisión de estos elementos tenía, y de cómo Le Corbusier era plenamente consciente de que solamente desde la experimentación y el avance técnico-constructivo podría alcanzar la depuración deseada.

Lamentablemente no todo cabe aquí. La longitud de este ensayo nos impide prolongar ciertas ideas que simplemente ha quedado enunciadas. Pero dejamos al lector interesado en profundizar en las relaciones apuntadas la tarea de descubrir observar, ver e imaginar más.

\section{Referencias bibliográficas}

Alazard, Jules y Jean Pierre Hébert, De la fenetre au pan de verre dans l'oeuvre de Le Corbusier, Collection Actualité du verre $n^{\circ}$ 1, P.V.P. (Dunod), Paris, 1961.

\footnotetext{
${ }^{16}$ Le Corbusier, Cap Martin, 1963.

17 Ver: Reichlin, Bruno: Dalla "soluzione elegante" all"'edificio aperto". Scritti attorno ad alcune opere di Le Corbusier, Mendrisio Academy Press / SilvanaEditoriale, Mendrisio, 2013, p. 95-97, 330-331.

${ }^{18}$ Ver: Merí de la Maza, Ricardo: "Le Corbusier: Flotando sobre el paisaje con una ventana infinita", en: La casa del principio del mundo. Mecanismos de disolución del límite del espacio en el norte de Portugal, Director: J.M. Moreno, Departamento de Proyectos Arquitectónicos, UPV, Valencia, 2012.
} 
Baudelaire, Charles: «Les fenêtres », Petits Poèmes en prose, édition posthume 1869.

Jeanneret, Charles-Edouard (Le Corbusier): Precisiones, Apóstrofe, Barcelona, 1999.

Jeanneret, Charles-Edouard (Le Corbusier): Una pequeña casa, Infinito, Buenos Aires, 2005.

Le Corbusier -Saugnier : Vers une architecture, Paris, éd. Crès, 1923.

Maniaque, Caroline, Le Corbusier et les maisons Jaoul: projets et fabrique, Picard, Paris, 2005.

Merí de la Maza, Ricardo: La casa del principio del mundo. Mecanismos de disolución del límite del espacio en el norte de Portugal, Director: J.M. Moreno, Departamento de Proyectos Arquitectónicos, UPV, Valencia, 2012.

Quetglas, Josep, Les Heures Claires: Proyecto y arquitectura en la villa Savoye de Le Corbusier y Pierre Jeanneret, Massilia, 2008.

Reichlin, Bruno: Dalla “soluzione elegante” all "'edificio aperto”. Scritti attorno ad alcune opere di Le Corbusier, Mendrisio Academy Press / SilvanaEditoriale, Mendrisio, 2013.

Roth, Alfred, Dos Casas de Le Corbusier y Perre Jeanneret, Colegio Oficial de Aparejadores y Arquitectos Técnicos, Murcia, 1997.

Rowe, Colin y Robert Slutzky, Transparency, Birkhäuser, Basel, 1997.

Rowe, Colin y Robert Slutzky: “Transparency: literal and phenomenal”, Perspecta n 8, 1964.

Torres Cueco, Jorge, Le Corbusier: visiones de la técnica en cinco tiempos, Fundación Caja de Arquitectos, Barcelona, 2004. 
efficacy of its forms that may lay outside the architect's accustomed architectural vocabulary. In themselves, Le Corbusier's "objets à réaction poètique" have no recognizable architectural purpose until they became a necessary factor for the architect, giving direction to the their imagination.

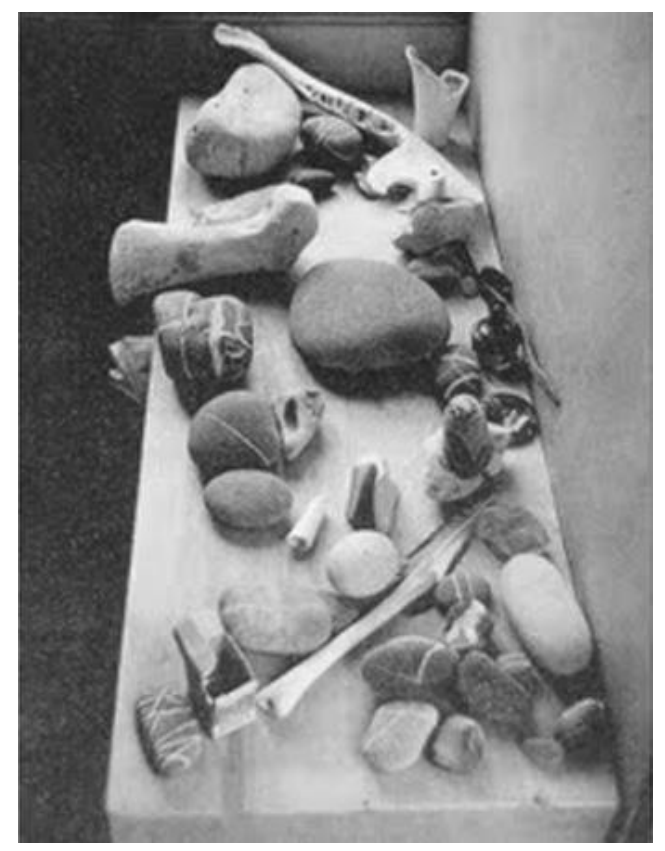

1. Le Corbusier, "Objets à réaction poètique" (objects of poetic reaction), 1925-65.

In the design of architecture, sudden moments of creativity like that Le Corbusier experienced with the crab shell are made possible by what the French chemist and microbiologist, Louis Pasteur described as a "preparedmind," a mind actively engaged in a problem prepared to recognize an everyday object or event as inspiration for architecture. For cognitive scientists, this form of engagement is dependent upon the human capacity to spontaneously shift back and forth between analytic and associative modes of thought. For the Spanish artist Pablo Picasso, Le Corbusier's collections are evidence of a sagacious individual who has learned to harness aberrations in the creative process claiming, "Inspiration exists, but it has to find you working." As evidenced by Le Corbusier's collection of poetic objects, this paper explores the mutability between the everyday and the extraordinary through an examination of the cognitive relationship between the model and its translation to architecture.

\section{Precedents}

Already at an early stage of his career as an architect, Le Corbusier developed an approach to design that was dependent upon a use of precedents for inspiring new architectural ideas. The emulation of classical precedents in antiquity was a dominant pedagogical method amongst European professional schools at the turn of the twentieth century. ${ }^{3}$ At the École des Art Décoratifs in La Chaux-de-Fonds, a small town in the eastern region of Switzerland know as the Jura, Le Corbusier studied the decorative arts under Charles L'Eplattenier, the man he

\footnotetext{
${ }^{3}$ Pierre Saddy, "le passé à réaction poétique," in Pierre Saddy, ed., Le Corbusier: le passé à réaction poétique (Paris: Caisse Nationale des Monuments Historiques et des Sites, 1988), p. 15-27.
} 
would later call his only teacher. ${ }^{4}$ As director of the Ecole, L'Eplattenier was less interested in teaching his students "styles" than an underlying attitude toward nature and art. Rather, L'Eplattenier's goal was to lay the groundwork amongst his students for the development of a regional Jura art inspired partly by local plant forms. It was through L'Eplattenier that Le Corbusier was introduced to Henry Provensal's 1904 published book on art and architectural theory, L'art de Demain (The Art of Today). Along with the guidance of L'Eplattenier, Le Corbusier's approach to design owes a debt to Provensal's writings.

In L'art de Demain (The Art of Today), Provensal proposes the idealistic assumption that there exists perfect formal principles or ideas, which can ultimately be discovered and embodied by the artist. The artist's role for Provensal is to connect man with the eternal principles of the "absolute." Throughout his life, Le Corbusier searched for universal formal principles that as Provensal claimed were found in "nature's crystallized forms" and could bring perfect order into architectural form. ${ }^{6}$ Already during his famous voyage to the Orient, Le Corbusier did not record in his travel log the precise construction and structure of buildings but their origins as squares, cubes, spheres or cylinders with the Parthenon in Athens being a 'cube. ${ }^{7}$ Le Corbusier's preference for geometric forms was fostered by his friendship and ensuing collaboration with the French painter and designer Amédée Ozenfant. An advocate of Cubism, Ozenfant introduced Le Corbusier to modern art, painting and his own art movement, 'purism.' In 1918 (a few months after they met) Ozenfant and Jeanneret published Apres le Cubism. ${ }^{8}$ Their aim was to purify cubism by stripping it of its decorative features and basing their austere geometrical shapes on machine forms. In the third chapter the authors argue that this new art must generalize, must discover the natural laws that both art and science depend. ${ }^{9}$ When properly understood, nature is to be seen as a perfect 'machine' working according to geometric and mathematical principles. Just over a year later Ozenfant and Le Corbusier began publishing an avant-garde magazine on art and architecture called L'esprit Nouveau. ${ }^{10}$ Despite the double signature, the articles on architecture were written primarily by Le Corbusier, which he incorporated into his 1923 published book Vers une Architecture (Towards an Architecture). ${ }^{11}$ In the chapter "The Lesson of Rome" we find Le Corbusier's use of the Roman monuments to argue for an architecture composed of pure geometric forms ${ }^{12}$. Late in his career, Le Corbusier abandoned his pursuit of geometric rationalism for the design of his the chapel, Notre Dame du Haut in Ronchamp, France.

\footnotetext{
${ }^{4}$ H A. Brooks, Le Corbusier's Formative Years: Charles-edouard Jeanneret at La Chaux-De-Fonds (Chicago: University of Chicago Press, 1997), pp. 23-91.

${ }^{5}$ Henry Provensal, L'Art de demain (Paris: Perrin, 1904), p. 143 after Brooks, p. 70.

${ }^{6}$ Provensal, p. 162.

${ }^{7}$ Le Corbusier, Journey to the East, trans. Ivan Žaknić (Cambridge, Mass: MIT Press, 2007), p. 104 and 212.

${ }^{8}$ Amédée Ozenfant and Charles-Edouard Jeanneret, “After Cubism," translated by John Goodman in Carol S. Eliel, L'Esprit Nouveau: Purism in Paris, 1918-1925 (New York: Harry N. Abrams, Inc., 2001), pp.150-158.

${ }^{9}$ Ibid., pp.150-158

${ }^{10}$ Eliel, L'Esprit Nouveau: Purism in Paris, pp. 23-24.

${ }^{11}$ Le Corbusier-Saugnier, Vers une Architecture (Paris: Éditions G. Cres et Cie., 1923).

${ }^{12}$ Le Corbusier, Toward an Architecture, translated by John Goodman (Los Angeles: Getty Research Institute, 2007), p. 200.
} 


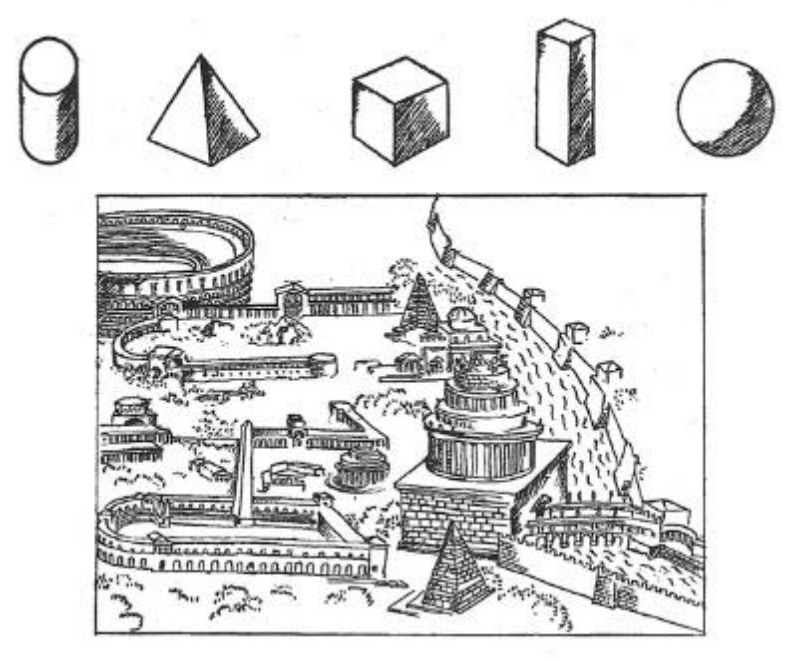

2. Le Corbusier, Sketch of Roman ruins and primary solids in Vers une Architecture, 1923.

Despite its organically determined form, Le Corbusier's chapel at Ronchamp should not be seen as a turn away from his search for universal principles to generate new designs. In Le Corbusier's chapel, three white towers rise up from thick gently curving walls circumscribing and illuminating a space for congregation. Floating $10 \mathrm{~cm}$ above the entirety rests a massive double-shelled curvilinear roof giving the chapel the impression of a white ship or a nun's cowl. In a review of the chapel entitled "Le Corbusier's Chapel and the Crisis of Rationalism," James Stirling noted a change in Le Corbusier's from "forms which have developed from the rationale and the initial ideology of the modern movement are being mannerized and changed into a conscious imperfectionism." ${ }^{13}$ Yet, for Stirling, Le Corbusier has not completely abandoned functional rationality observing how "[a]s a religious building, it functions extremely well. ${ }^{14}$ Rather, in what must be a reference to Le Corbusier's use of precedents, Stirling noted how "travels round the world have stockpiled [Le Corbusier's] vocabulary with plastic elements and objets trouves of considerable picturesqueness. ${ }^{\prime 15}$ Here Stirling seems to be referring to Le Corbusier's use of "objets à réaction poètique." Already in 1943 Le Corbusier lauded their value in the design process. One that he in 1960 claimed could offer him an "eloquent lesson ... bringing a wealth to the mind that it alone cannot detect. ${ }^{" 16}$ But these shells, bones, pinecones, etcetera have their own identities as bits and pieces of natural flotsam and jetsam that alone do not suggest architecture or models for it. Their use requires a mind that is prepared to see them as architecture.

\footnotetext{
${ }^{13}$ James Stirling, "Ronchamp: Le Corbusier's Chapel and the Crisis of Rationalism, ” Architectural Review 119 (1956): 16061.

${ }^{14}$ Ibid.

${ }^{15}$ Ibid.

${ }^{16}$ Le Corbusier, "Les objets à réaction poétique," in Le Corbusier, L'Atelier de la Recherche patiente (Paris: Vincent et Fréal, 1960), p. 209.
} 


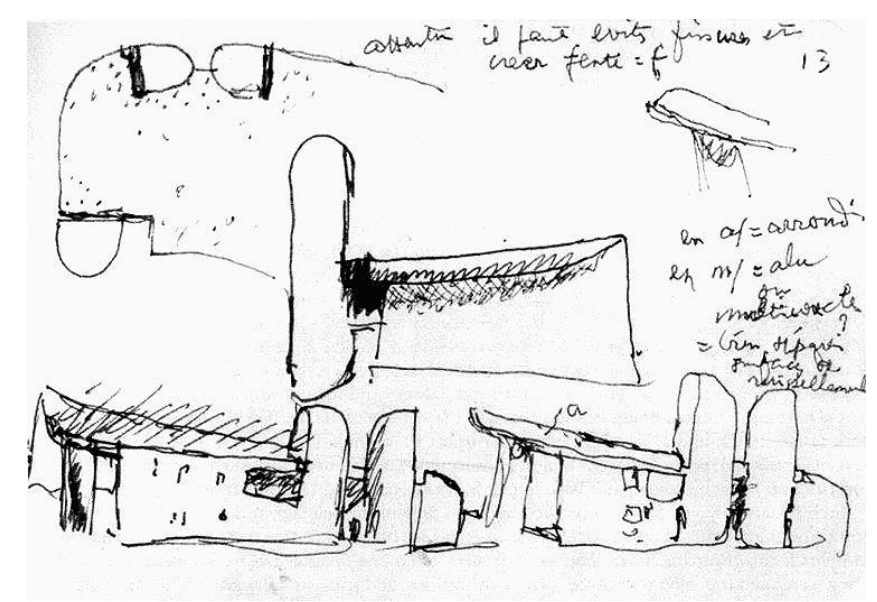

3. Le Corbusier, Studies for Notre Dame du Haut, Ronchamp, c. 1951.

\section{A Prepared Mind for Musement}

To claim moments of inspiration a designer must possesses a 'prepared eye' which is able to take advantage of stimuli they encounter, randomly or intentionally. With every new project, the designer is faced with a new set of requirements and conditions. Although they may avail themselves of all relevant data and information pertaining to the task, this alone will not directly translate into a design solution. Conversely, random trial and error may aid an architect's purposeful search but it cannot act as a substitute for it. As Louis Pasteur remarked in a speech to the Faculty of Sciences at Lille, "fortune favors the prepared mind." ${ }^{17}$ To recognize an everyday object or event as inspiration for architecture, a designer's mind must be actively engaged in a problem. The French architect Le Corbusier kept a collection of found objects in his studio to encourage precisely these random moments of invention that in one case inspired the roof design for his Chapel of Notre-Dame du Haut in Ronchamp, France.

What Le Corbusier's use of the crab shell demonstrates is that accidental moments of creativity are dependent on the designer having experiences upon which they can make hypothetical associations-projections. One can image how standing over his objets à réaction poètique, Le Corbusier uses his shells, bones and other natural objet trouves much like a shaman in an act of divination. For Carl Jung this is likened to "synchronicity" in which the diviner is in a subjective state and finds a meaningful connection between two acausally connected events. $^{18}$

The American philosopher, Charles Sanders Peirce describes the formation of a hypothesis as "an act of insight," which makes the most sense given observed phenomenon or data and based on prior experience. Compared to the creative activity of an architect, Pierce's concept of abduction essentially describes a situation in which the subject is confronted with an observed fact needing explanation. An abductive affordance comes to a subject in a flash which, like Le Corbusier's use of object trouves, "it is the idea of putting together what we had never

\footnotetext{
${ }^{17}$ Louis Pasteur, "Dans les champs de l'observation le hazard ne favorise que les esprits reéparés." Lecture presented at the University of Lille, Douai, France, on December 7, 1854. H. Petersen, ed, A Treasury of the World's Great Speeches (New York: Simon Schuster, 1954), p. 473.

${ }^{18}$ C G. Jung, Synchronicity: An Acausal Connecting Principle, trans. R F. C. Hull (Princeton, N.J: Princeton University Press, 1973),
} 
before dreamed of putting together which flashes the new suggestion before our contemplation." ${ }^{\prime 19}$ To enable our imaginations to shift back and forth between analytic and associative modes of thought, Piece recommended the practice of Musement, an occupation of the mind that searches for "some connection" between two of the three Universes of Experience (Ideas, Brute Actuality, and Signs) "with speculation concerning its cause." 20 Nevertheless, in themselves, Le Corbusier's "objets à réaction poètique," have no recognizable architectural purpose until they became a necessary factor for the architect, giving direction to the their imagination. It is this ability of the imagination to shift between two causes for the same object underlies Le Corbusier's use of precedents.

\section{A Play with Causes}

In everyday practice, architects encounter a variety of sensorial stimuli both familiar and unfamiliar. Yet not every experience may inspire an architectural idea. In a discussion about how humans come to identify the things we experience as men, gold or trees, the seventeenth century English philosopher, John Locke reasoned that simple ideas, like those of a basket, acanthus plant and clay roof tile are invariably produced in our minds by their influence on our sense organs. According to Locke, we go through the world interrogating sensory experience, noticing which primary qualities regularly seem to cluster together-these are a things' size, shape, motion, number, or solidity as a single idea under a single name. ${ }^{21}$ Yet, in the process of acquiring understanding, the imagination is vulnerable to accidental encounters with things and, in order to know them, it must abstract-out the primary from the secondary qualities of a thing - those qualities including color, sound, taste, and odor, which resemble the causes for a thing. ${ }^{22}$

For Aristotle, these accidental discoveries are important events in the work of a designer. In Aristotle's epistemology he places a crucial condition on the certainty of knowledge: we think we have knowledge of a thing only when we have grasped its why, that is to say, its cause. ${ }^{23}$ This account is valid for our study in the sense that it applies to everything that requires an explanation, including artistic production and human action. Here Aristotle recognizes four types of cause that can be given to answer a why-question: the material, formal, efficient, and final cause. However, Aristotle's analysis of causality reaches a critical moment when he asks how those causes that result from chance (tuchē), as the happening by accident as opposed to by design, fit into the division of the four previously mentioned causes. ${ }^{24}$ For Aristotle, those 'accidents' effected by an agent "capable of choosing" are different from what he refers to as automaton — natural accidents like being hit by a randomly falling rock. ${ }^{25}$ In the realm of design, affordances that result from chance (tuchē) are efficient causes, sources "that set processes in motion"- that are not determined by a final cause but whose outcomes are final causes determined by their agent, the designer. ${ }^{26}$

\footnotetext{
${ }^{19}$ Charles Sanders Peirce, "Pragmatism as the Logic of Abduction (Lecture VII)" in The Essential Peirce: Selected Philosophical Writings, Vol. 2 (Bloomington, IN: Indiana University Press, 1998), p. 227.

${ }^{20}$ Charles Sanders Peirce, “A Neglected Argument for the Reality of God,” in Ibid., p. 436.

${ }^{21}$ John Locke, Essay Concerning Human Understanding, (Book II, Section xii, 1) abridged and edited with an introduction by A.D. Woozley (London: Collins, 1964), p. 132.

${ }^{22}$ Ibid., (Book II, Sections ix-xi) pp. 119-134.

${ }^{23}$ Aristotle, The Physics, with an English translation by Philip H. Wicksteed and Francis M. Cornford, Vol. 1 (London: W. Heinemann, 1970), (194 b 17-20). Book 2, chapter 3, p. 129.

${ }^{24}$ Ibid., Book II, chapters 4-6, pp. 138-163.

${ }^{25}$ Ibid. (197b29)., Book II, chapters 6, p. 161.

${ }^{26}$ Ibid. (198a5), Book 2, Chapter 6, p. 163.
} 
This vulnerability is the hallmark of a playful imagination that can shift between different final causes for the same thing and essential to the use of found objects in a playful activity of make-believe. For two children, a game of make-believe begins when an agreement is made that, for example, a pile of snow is a fort. Kendall Walton, a philosopher on the points of coincidence between toys and art, has argued how this fort is a found object that children play with as a "prop" that "prompts" them to imagine what they might not otherwise be creative enough to invent on their own. By interpreting the pile of snow as a prop, they do not merely imagine a fort with turrets, a tower and a moat. Rather, they imagine that the actual heap of snow is itself a fort. ${ }^{27}$ For the German philosopher of hermeneutics, Hans-Georg Gadamer this act of play is particularly strong in the creative arts whereby the artist's (and here we also include the architect) engagement with a thing 'as if' it was a something else permits them to go beyond the limitations and conditions of their own imaginations. ${ }^{28}$ Without entirely dismissing what one already knows about a thing, Le Corbusier, like children with a pile of snow, held the identity of the crab shell in temporary suspense to imagine its material and formal characteristics as something else, the model the chapel roof. Immanuel Kant calls this mental state 'free play' in which our faculties of understanding and imagination cooperate with one another. ${ }^{29}$ That is to say that in the act of makebelieve a child creates a gap between the thing and idea enabling the object to be disengaged from what Paul Ricoeur described as the world behind it, its historical causes. ${ }^{30}$ For Umberto Eco this "disengagement" is particularly strong in the modern world, which generates in all of us "the feeling of senselessness, disorder, or 'discontinuity'." ${ }^{31}$ In this conceptual moat, the imagination is free to posit other possibilities (causes) for everyday objects, including models of architecture, which are open to constant revision.

\section{Conclusion}

Le Corbusier once said that when he obtains a commission, he doesn't immediately start working on the project but lets it sit in his imagination for a few months. It is the mark of an experienced designer to avail themselves of all the issues related to a design project before they start working on it. One may say that the mind of the architect is in this way prepared for the occupation of Musement, a purposeless activity by which the imagination is disengaged, and open to speculate on final causes. The range of experiences an architect may draw upon certainly could also include those of everyday objects like Le Corbuiser's objets de reaction poetique. Yet, the moment of genius, the discovery of a fortuitous idea for putting together what we had never before considered, cannot be predetermined. Behind any strange tale of architectural evolution is a working architect, whose mind is prepared for a moment of inspiration.

\section{Bibliography}

Aristotle: The Physics, with an English translation by Philip H. Wicksteed and Francis M. Cornford, Vol. 1. London: W. Heinemann, 1970).

\footnotetext{
${ }^{27}$ Kendall Walton, Mimesis as make-believe: on the foundations of the representational arts (Cambridge, Mass.: Harvard University Press, 1990), p. 25.

${ }^{28}$ Hans-Georg Gadamer, "The play of art," in The Relevance of the Beautiful and other Essays, trans. Nicholas Walker and ed. Robert Bernasconi (Cambridge: Cambridge University Press, 1986), pp. 124-29.

${ }^{29}$ Immanuel Kant, Critique of Judgment, trans. James Creed Meredith and ed. Nicholas Walker (New York: Oxford University Press, 2009), p. 49.

${ }^{30}$ Paul Ricoeur, "The Hermeneutical Function of Distanciation," trans. David Pellauer, Philosophy Today 17, no. 2 (1973): 139-41.

${ }^{31}$ Umberto Eco, The Open Work, trans. Anna Cancogni (Cambridge, MA: Harvard University Press, 1989), p. xiv.
} 
Brooks, H A. Le Corbusier's Formative Years: Charles-edouard Jeanneret at La Chaux-De-Fonds. Chicago: University of Chicago Press, 1997.

Le Corbusier: The Chapel at Ronchamp. Frederick A. Praeger, 1957.

Le Corbusier: Le Corbusier Talks with Students from the Schools of Architecture. Translated by Pierre Chase. New York: Princeton Architectural Press, 1999. pp. 70-71. First published as Entretien avec les étudiants des écoles d'architecture. Paris: Denoël, 1943.

Le Corbusier: Journey to the East. Translated by Ivan Žaknić. Cambridge, Mass: MIT Press, 2007.

Le Corbusier: L'Atelier de la Recherche patiente. Paris: Vincent et Fréal, 1960.

Le Corbusier: Toward an Architecture. Translated by John Goodman. Los Angeles: Getty Research Institute, 2007.

Le Corbusier-Saugnier: Vers une Architecture. Paris: Éditions G. Cres et Cie., 1923.

Eco, Umberto: The Open Work. Translated by Anna Cancogni. Cambridge, MA: Harvard University Press, 1989.

Hans-Georg Gadamer, "The play of art," in The Relevance of the Beautiful and other Essays. Translated by Nicholas Walker. Edited by Robert Bernasconi. Cambridge: Cambridge University Press, 1986.

Jung, C G: Synchronicity: An Acausal Connecting Principle. Translated by R F. C. Hull. Princeton, N.J: Princeton University Press, 1973.

Kant, Immanuel: Critique of Judgment. Translated by James Creed Meredith and ed. Nicholas Walker. New York: Oxford University Press, 2009.

Locke, John: Essay Concerning Human Understanding. Abridged and edited with an introduction by A.D. Woozley. London: Collins, 1964.

Ozenfant, Amédée; Jeanneret, Charles-Edouard: “After Cubism.” Translated by John Goodman in Carol S. Eliel, L'Esprit Nouveau: Purism in Paris, 1918-1925. New York: Harry N. Abrams, Inc., 2001. pp. 150-158.

Provensal, Henry: L'Art de demain. Paris: Perrin, 1904.

Pasteur, Louis: "Dans les champs de l'observation le hazard ne favorise que les esprits reéparés." Lecture presented at the University of Lille, Douai, France, on December 7, 1854. H. Petersen, ed, A Treasury of the World's Great Speeches. New York: Simon Schuster, 1954. p. 473.

Peirce, Charles Sanders: "Pragmatism as the Logic of Abduction (Lecture VII)" in The Essential Peirce: Selected Philosophical Writings. Vol. 2. Bloomington, IN: Indiana University Press, 1998. p. 226-241.

Peirce, Charles Sanders: “A Neglected Argument for the Reality of God," in The Essential Peirce. p. 434-450.

Ricoeur, Paul: "The Hermeneutical Function of Distanciation.” Translated by David Pellauer, Philosophy Today 17, No 2. 1973. pp. 139-41.

Saddy, Pierre, ed. Le Corbusier: le passé à réaction poétique. Paris: Caisse Nationale des Monuments Historiques et des Sites, 1988.

Stirling, James: "Ronchamp: Le Corbusier's Chapel and the Crisis of Rationalism." Architectural Review, $\mathrm{N}^{\circ}$ 119. 1956. pp. 160-61.

Walton, Kendall: Mimesis as make-believe: on the foundations of the representational arts. Cambridge, Mass.: Harvard University Press, 1990. 


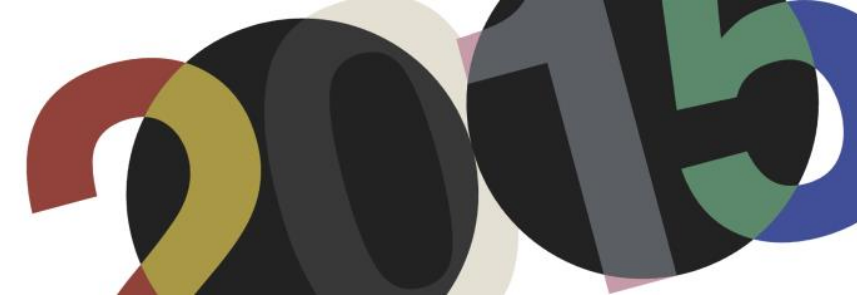

DOI: http://dx.doi.org/10.4995/LC2015.2015.976

\title{
FLC 4932. Lo inesperado en la obra de Le Corbusier. Consideraciones en torno al origen de la promenade
}

\author{
R. Miralles Jori \\ Escuela Técnica Superior de Arquitectura de la Universitat Rovira i Virgili
}

\begin{abstract}
Resumen: Entender la evolución de la idea de la promenade en la crítica corbuseriana. Cómo la idea ha ido pasando de la idea del movimiento al pintoresquismo, a lo cinematográfico y finalmente a la idea de montaje. Leyendo Le Corbusier entender que lo mas relevante de la promenade es la idea de lo inesperado para el espectador. Entender de dónde viene esta idea de lo inesperado a través de la formación de Le Corbusier y, sobretodo, a partir de su formación en la crítica del S.XIX. Especialmente importante para entender la idea de lo inesperado es el libro de Mornings in Florence de Ruskin, en especial su descripción de la capilla de los españoles. Esta capilla también será objeto de estudio por Le Corbusier y, en ella, reconoce la importancia de lo inesperado en arquitectura.
\end{abstract}

Abstract: The first objective of this paper is to understand the evolution of the idea of promenade in Le Corbusier's critic. The paper follows how the idea has changed from the movement to the picturesque, to the cinematographic and finally to the idea of montage. The second objective is to understand that the idea of the unexpected for the spectator is key for the promenade. Then we try to understand where does the idea of the unexpected come in Le Corbusier's formation with special interest in his formation in the nineteenth century critics. And how important to understand the idea of the unexpected is Ruskin's Mornings in Florence, specially his description of the Spanish Chapel. This chapel will be case study for Le Corbusier and in his study he recognises the importance of the unexpected in architecture.

Palabras clave: Promenade, Espacio inesperado, Formación de Le Corbusier, Viajes de Le Corbusier, Capilla de los españoles.

Keywords: Promenade, Unexpected space, Le Corbusier formation, Le Corbusier Travels, Spanish Chapel.

1.

Le Corbusier forjó muchos conceptos arquitectónicos que han hecho fortuna: cubierta jardín, planta libre, promenade, etc. Este último término lo usamos en francés. No traducimos promenade -los anglosajones tampoco- porque algo se pierde en la traducción, cuestión de matiz. No, cuando hablamos de promenade no hablamos sólo de un paseo. Una palabra francesa en el vocabulario que manejamos para hablar de Le Corbusier sirve para entender que la promenade no es sólo un paseo. Le Corbusier para introducir la cuestión de matiz alargaba el término y le añadía el adjetivo architecturale y lo escribía siempre en versales. Cuál es ese matiz que introducimos al hablar de promenade o de promenade architecturale y saber su origen es el objeto de estudio de este artículo.

La idea de promenade architecturale ha tenido muy buena fortuna crítica y goza de muchas definiciones. Sin intención de ser exhaustivos, haremos un breve repaso por las que creo más significativas. En un monográfico reciente sobre el tema, Flora Samuel, empieza dando una definición: "Taken to a basic level the promenade refers, of course, to the experience of walking through a building." La traducción literal; pero Samuel no habría hecho un monográfico sobre el tema si no añadiera un matiz: "Taken at a deeper level, like most things Corbusian, it refers to the complex web of ideas that underpins his work, most specifically his belief in 
architecture as a form of initiation "'. El matiz es complejo. Entendemos que la arquitectura es una disciplina hermética en la que podemos iniciarnos y, según Samuel, Le Corbusier considera que la promenade es la vía. Al leer la definición y el monográfico que le sigue, uno piensa que la autora se refiere más a la fortuna crítica de la palabra que al significado que tenía para Le Corbusier. Esta definición no nos permite entender porqué escribimos promenade en versales o la acompañamos de architecturale pero nos deja con la idea de movimiento.

Tradicionalmente la idea de movimiento se ha asociado a este concepto corbuseriano por el significado propio del término promenade. El profesor Cohen al hablar del paisaje, lo ha explicado como la visión en movimiento ${ }^{2}$. Cohen remite al texto 'vision in motion' de Moholy-Nagy para hacerlo comprensible; aunque, como señala el propio Cohen, sea posterior a la aparición de las 'estrategias de percepción en movimiento' en Le Corbusier. El libro de Moholy-Nagy ${ }^{3}$ empieza definiendo la visión en movimiento. Una definición extensa, de una página, en la que nos hace ver que la visión en movimiento es a la vez percepción simultánea de varios fenómenos que hacen un todo; un nuevo modo de comprender la visión a través de un mismo espacio-tiempo; ver mientras uno se mueve pero también ver los objetos moviéndose - en realidad o a través del arte; también se entiende la visión en movimiento como la proyección dinámica de las posibilidades visionarias. Moholy-Naghy mezcla muchos conceptos que no sé si estaban en la cabeza de Le Corbusier al tratar de acotar el significado de la promenade. En cualquier caso no nos sirve para introducir el matiz que buscábamos porqué es un concepto demasiado amplio.

Cohen, y la tradición a la que hacíamos referencia, lo que hacen es asociar el movimiento no a algo general sino al sujeto que se mueve por dentro de la arquitectura. Esa tradición lo que hace es asociar el nombre de Le Corbusier al del pintoresquismo. Así lo estableció Etlin: "In Le Corbusier's mind, then, the lessons of sequential spaces and balanced picturesque composition taught by Sitte and Choisy and confirmed by the experience of a trip to the East came together to establish the primacy of the architectural promenade while offering guidalines for its realization ${ }^{4}$." La versión de Etlin es en la que el espectador compone unas imágenes que generan composiciones balanceadas, la suma de ellas es la promenade. La duda que a uno le puede venir leyendo a Etlin es en que punto debe el espectador componer la imagen balanceada o si el punto no importa ya que todas las visiones son balanceadas. Esta cuestión la ha tratado de resolver MacArthur quien, en un libro sobre el pintoresquismo dedica un capítulo a Le Corbusier y en un pasaje explica: "As well as being picturesque, we can also understand the promenade as being cinematrographic -the two concepts are not unrelated. In retrospect, we can see the eighteenth-century picturesque as pictoriality with movement added. (...) in the strong cases of the picturesque garden or Le Corbusier's architectural promenade, tries to give space sequence, direction and even narrative ${ }^{5}$.

La visión de MacArthur es la de alguien que teóricamente ha unido el pintoresquismo al movimiento y eso le ha llevado a lo cinematográfico, pero no resuelve el problema que se nos planteaba al leer a Etlin.

\footnotetext{
${ }^{1}$ Samuel, Flora, Le Corbusier and the Architectural Promenade, Birkhäuser, Zurich, 2010

${ }^{2}$ Cohen, Jean-Louis, Le Corbusier: An Atlas of Modern Landscapes, Museum of Modern Art, New York 2013, p.36 - The idea of 'vision in motion', made popular in 1947 by Lazlo Moholy-Nagy, transposes the dynamic caracter of the observational strategies deployed by Le Corbusier. The major breaks that mark his thoughts on city and landscape can be traced back to his discovery of new modes of travel, each one radically altering his perception and method of notation.

${ }^{3}$ Moholy-Nagy, László, Vision in Motion, Theobald, Chicago, 1947, p.12

${ }^{4}$ Etlin, Richard A., Frank Lloyd Wright and Le Corbusier. The romantic legacy, Manchester University Press, Manchester, 1994, p.115

${ }^{5}$ John MacArthur, The Picturesque, Architecture, Disgust and other Irregularities. Routledge (Taylor and Francis group) London, 2007, p.164.
} 
Fue Tim Benton quien probó, empíricamente -cámara en mano-, de filmar la promenade y concluyó: "que tomar la promenade literalmente, como el punto de vista continuamente cambiante de una persona que recorre un edificio, significa no comprender su verdadero sentido ${ }^{6}$. Benton explica que tratando de filmar la promenade en la Villa Savoye, se dieron cuenta de que "una promenade se puede escenificar y rodar, pero las imágenes para ilustrarla deben apartarse del punto de vista del ojo cinético de la persona que se mueve por el edificio. El paseo, en un sentido importante, es virtual más que real; hay que usar la imaginación espacial a medida que uno se mueve por el edificio en lugar del foco monocular de una cámara ${ }^{7}$ ". Esta teoría de que el sentido de la promenade es virtual explica que es el espectador el que tiene que construir en su cabeza las relaciones al ir paseando; como dice Colomina: "That is, the house is not simply constructed as a material object from which certain views become posible. The house is no more than a series of views choreographed by the visitor, the way a filmmaker effects the montage of a film ${ }^{8}$." El tema de la construcción o el montaje para dar un sentido a la promenade es el que desarrollará Martínez de Guereñu en su artículo sobre el montaje en Le Corbusier. Martínez de Guereñu sostiene que los encuadres acaban siendo pares de opuestos -otra vez pintorescos- que los habitantes “debían 'montar' en su mente, producían un juego de relaciones que dotaban a las obras arquitectónicas de una cualidad estética que trascendía las meras construcciones funcionalistas modernas. Porque tal y como demostraron Eisenstein y Le Corbusier insistentemente, la arquitectura también debía permitir la participación del hombre" ${ }^{9}$. Una explicación práctica de esta teoría es el libro de Quetglas sobre la Villa Savoya ${ }^{10}$.

La explicación de lo cinematográfico unido a lo pintoresco no nos resuelve la pregunta de si hay imágenes que son las escogidas o porqué escogemos unas y no otras. El lenguaje cinematográfico cuando quiere remarcar una imagen usa el recurso del tiempo -u otros- para hacernos entender que esa es la importante. ¿Cual es, en el lenguaje arquitectónico, el recurso para hacernos entender, al espectador, cual es la imagen importante?

Entendemos, pues, que la promenade es una sucesión de imágenes que se componen en la mente del espectador al ir transitando por la pieza arquitectónica. Vamos acotando el matiz. Ahora debemos saber qué imágenes escoger y cómo.

2.

Leer lo que se dice de alguien sirve para entender cómo lo han entendido ellos, pero si queremos saber que es la promenade es obligatorio ir a la fuente primaria.

\footnotetext{
${ }^{6}$ Benton, Tim, “Le Corbusier y la promenade architecturale”, En: Arquitectura COAM, Madrid, 1987, n.264-265.

7 op.cit., p. 45

${ }^{8}$ Colomina, Beatriz, Privacy and Publicity. Modern Architecture as Mass Media, The MIT press, 1994. p.312

${ }^{9}$ Martínez de Guereñu, Laura, "LC y el montaje", Massilia 2008, encuentro en Granada, Massilia i Associació de idees, Sant Cugat del Vallès, 2008.

${ }^{10}$ Quetglas, Josep, Les Heures Claires, Massilia, Sant Cugat del Vallès, 2008
} 


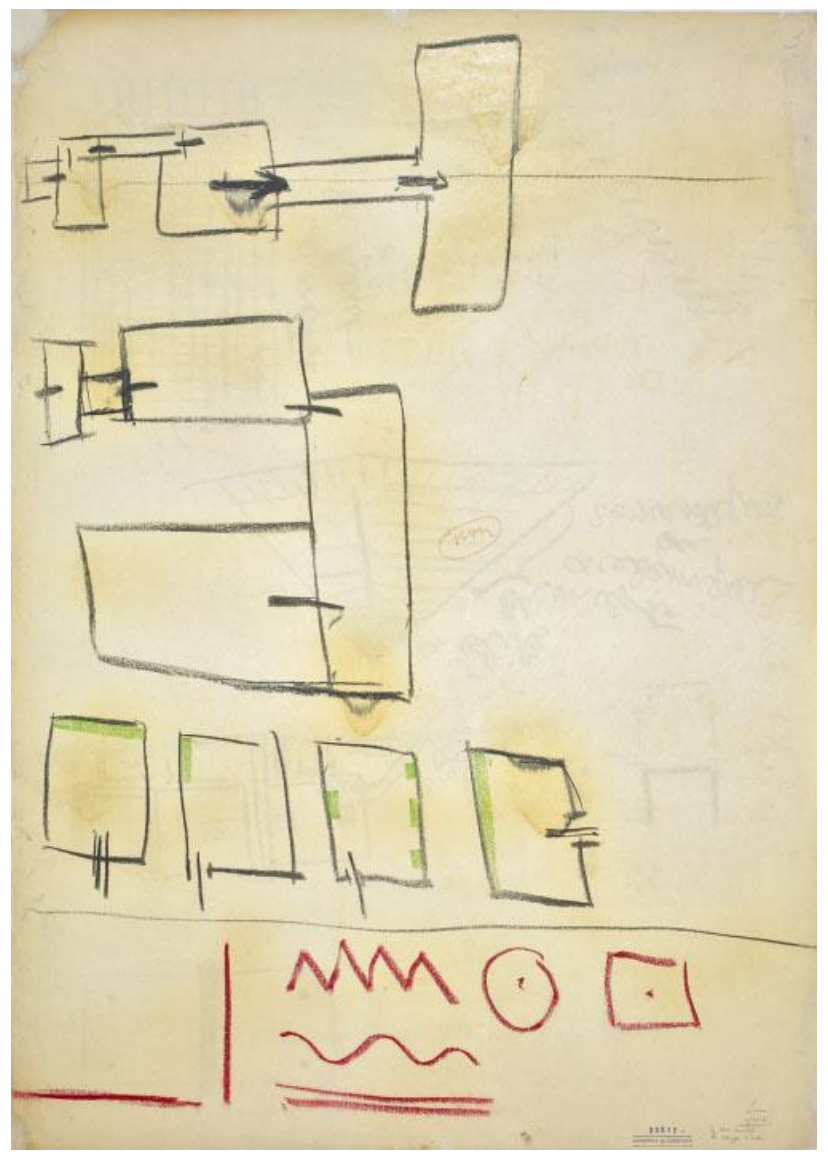

1. Pagina del libro de Precisions dónde se muestra cómo las transiciones son claves para entender el espacio.

La primera vez que Le Corbusier cita la promenade architecturale es en las primeras páginas del II volumen (1929-1934) de sus Oeuvre Complète, a propósito de la Villa Savoye: "Dans cette maison-ci, is s'agit d'un véritable promenade architecturale, offrant des aspects constamment variés, inattendus, parfois étonnants ${ }^{11}$." Es una definición poco canónica de lo que será la promenade porque no explica qué es, explica el efecto que tendrá. Le Corbusier nos anuncia lo que nos proporcionará: aspectos constantemente variados, inesperados, a veces desconcertantes. Sensaciones que se consiguen gracias al movimiento -lo que cualquier lector ya sabe al conocer el significado de promenade, sea arquitectónica o no. El movimiento es importante para poder ir enlazando espacios inesperados, variados, pero es un instrumento, lo relevante es el espacio que el espectador no espera; y la promenade enlaza estos espacios inesperados. Estas imágenes inesperadas serían las que buscábamos antes, las imágenes que al final hay que unir para tener una idea de la arquitectura, las que hay que 'montar' para entender ese edificio.

Le Corbusier hará mucho hincapié en la idea de promenade durante sus primeros años como arquitecto, pero es un concepto que hasta el Carpenter Center encontramos a menudo. Hay una descripción precisa de una promenade, aunque sin nombrarla, en una de las conferencias de Le Corbusier en Argentina:

"On entre: on reçoit un choc, première sensation. Vous voici impressionnés par telle grandeur de pièce succédant à telle autre, par telle forme de pièce succédant à telle autre. Là est l'architecture! ${ }^{12}$."

\footnotetext{
${ }^{11}$ Le Corbusier et Pierre Jeanneret Oeuvre Complète 1929-1934, Grisberger \& Cie, Zurich, 1934. p.29

${ }^{12}$ Le Corbusier. Précisions sur un état présent de l'architecture et de l'urbanisme, ed. Vincent, Fréal, Paris 1960, p.74
} 
En las conferencias Le Corbusier, además de hablar, dibujaba, lo sabemos porque en el libro en que están recogidas las conferencias, Precisions sur un état présent de l'architecture et de l'urbanisme, las explicaciones van acompañadas de dibujos. Cuando uno mira el dibujo que acompaña estas líneas no puede mas que imaginar la secuencia: primero, en silencio, Le Corbusier dibuja las cajas enlazadas que forman unas especies de plantas, los dos dibujos de la parte superior y luego empieza a marcar los puntos de paso cuando dice ciertas palabras clave, "entre", "succédant", "autre”. Por si la gente lo no entiende Le Corbusier trata de ser didáctico y muestra cómo no es lo mismo entrar a una misma habitación por el centro que por un extremo o por el otro (tercer dibujo desde arriba). La sensación que interesa no parece ser la del movimiento sino la de los puntos de transición entre una situación y la siguiente; al principio, como dice Le Corbusier, se recibe un choque que provoca la primera sensación. Cada transición uno imagina que es un choque, un punto clave que queda en la memoria por insospechado. La suma de esos recuerdos son los que forjarán la promenade.

\section{3.}

Hasta aquí hemos explorado la importancia de lo inesperado en la promenade, pero al principio del texto se ha prometido que también se hablaría de dónde procedía ese gusto por lo inesperado. De su etapa de formación sabemos que:

"his taste was not characteristic of the early twentieth century but rather that of the 1860 s and the Gothic Revival. John Ruskin, Owen Jones, Charles Blanc, and Hippolyte Taine were the authors he identified with i spite of having read in Henry Provensal's L'Art de demain that artists should be ahead of their time and must set standards for the future. ${ }^{13,}$

En esta preferencia por la teoría del siglo anterior encontraremos el gusto por lo inesperado en Le Corbusier.

Sabemos por Brooks, Glaseri o Daza de la importancia de los viajes de formación de Le Corbusier y por ellos sabemos también que en el primero Le Corbusier se llevó, como guía, los libros de Baedeker, Taine y Ruskin ${ }^{14}$. Aquí vamos a centrarnos en el libro de Ruskin que compró poco antes de ir de viaje, en 1907, un libro que se acababa de traducir al francés ${ }^{15}$, el “John Ruskin's Les Matins a Florence (Paris 1906; although the first English edition dates from 1875) was extraordinarily important in guiding his steps, his eyes and his mind ${ }^{16 ”}$. El libro de Ruskin fue muy influyente en su formación porque según escribió en una carta a l'Epplatenier, era un libro que enseñaba a mirar ${ }^{17}$. Aprender a mirar es una expresión que explica una determinada sensibilidad, pero como detectarla. En el caso de Le Corbusier a través de cómo él nos enseña a mirar.

\footnotetext{
${ }^{13}$ H. Allen Brooks, Le Corbusier's formative years. Charles-Edouard Jeanneret at La Chaux-de-Fonds. The university of Chicago Press, Chicago 1996. p.96

${ }^{14}$ Según Brooks Cit., Glaseri, cit o Daza, Ricardo, Tras el viaje de Oriente,Fundacion Arquia, Barcelona 2015.

${ }^{15}$ Glaseri, Giuliano, Le Corbusier viaggio in oriente, Marsilio Editori, Foundation Le Corbusier, Venezia 1984., p.104 Nota 54 "L'opera di Ruskin fu acquistata da Jeanneret nell'edizione francese, appena disponibile, poco prima della sua partenza per l'Italia e letta solo durante il viaggio a susidio delle osservazioni da lui raccolte".

${ }^{16}$ Op cit. p.98.

${ }^{17}$ Le Corbusier, carta a L'Epplatenier del 19 de setiembre donde dice: "This Book [Mornings in Florence] 'teaches how to see"'. Recogido en Brooks, cit., p.102
} 

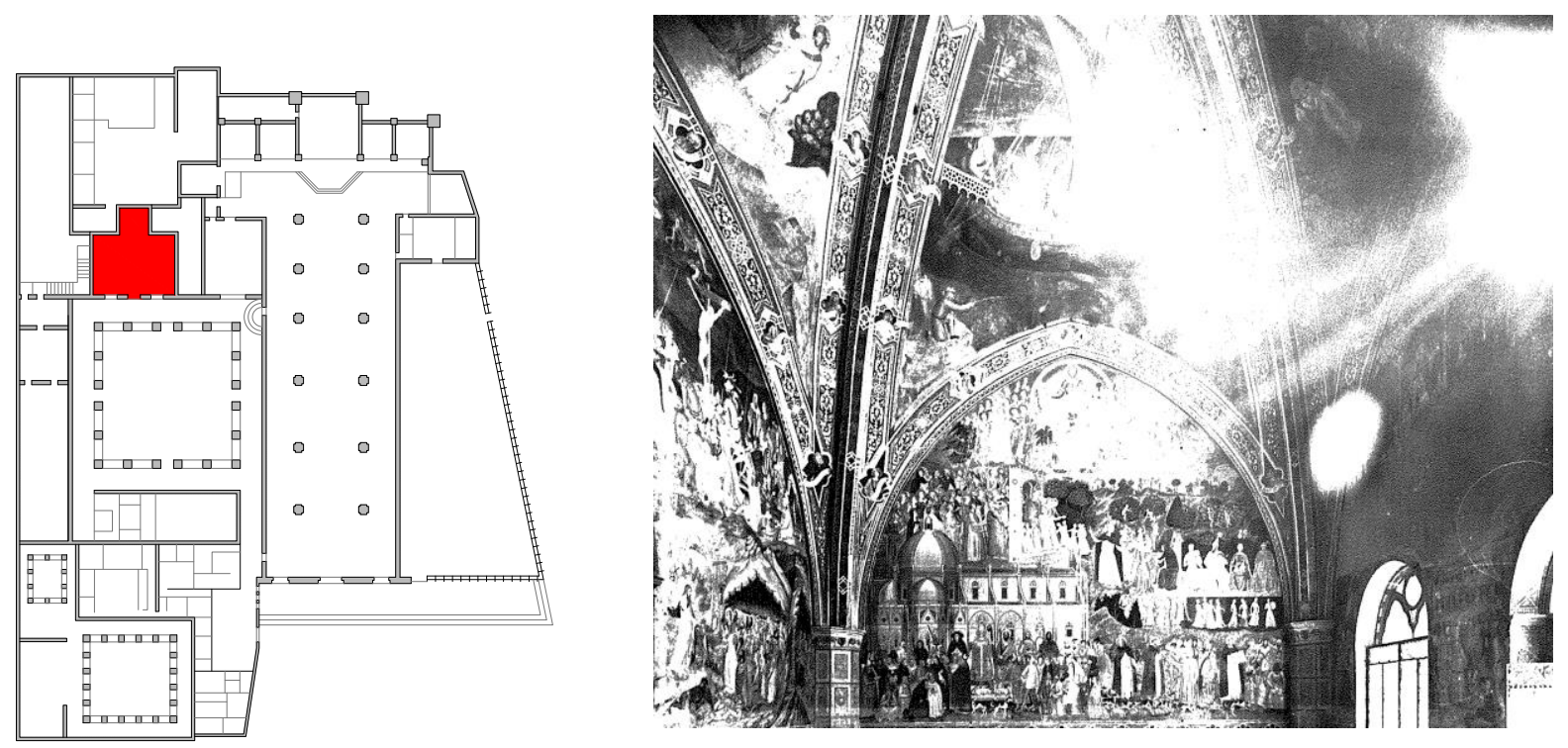

2. Planta de Santa Maria Novella, En rojo, la capilla de los españoles

3. La capilla de los españoles

Le Corbusier ha sido uno de los arquitectos con mas vocación de influencia del siglo XX, su idea de la arquitectura se puede entender tanto mirando sus edificios como leyendo sus numerosos textos. Las dos acciones, proyectar y escribir, explican la mirada de Le Corbusier. En esta ocasión nos centraremos en cómo escribe Le Corbusier ya que es más sencillo compararlo con lo que dice Ruskin que con una obra arquitectónica. Leer a Ruskin o leer a Le Corbusier significa apoyar o rechazar sus argumentos, estar a favor o en contra, no puedes no tomar partido. Ambos usan la escritura para llevarnos a su terreno, un lugar dónde hacer que su mirada sea la nuestra, un lugar dónde convencernos. Le Corbusier ha aprendido a razonar lo que se mira a través de las sentencias de Ruskin y así lo escribirá. En el libro que citábamos, Ruskin explica la capilla de los españoles en Florencia:

"no chapel, whatever, externally manifesting itself as worth entering. No walls, or gable, or dome, raised above the rest of the outbuildings - only two windows with traceries opening into the cloister; and one story of inconspicuous building above. You can't conceive there should be any effect of magnitude produced in the interior, however it has been vaulted or decorated. It may be pretty, but cannot possibly look large ${ }^{18 \%}$.

La descripción no se centra en la superficie o en la decoración o en el estilo arquitectónico, la descripción se encuentra en el efecto que produce la arquitectura al espectador, el efecto de magnitud que sorprende a ese espectador.

Un espectador que viene del exterior, el último estadio donde se encontraba antes de entrar al complejo de Santa María Novella es una plaza de dimensiones considerables; luego uno puede entrar bien a la iglesia o bien por una puerta lateral a la iglesia a un pasadizo que nos llevará al claustro verde. En ambos casos pasaremos de un espacio longitudinal a un claustro; nuestra visión pasará de centrarse en la linealidad y el espacio cerrado en el que estábamos -el contrario de la plaza abierta- a un centro abierto. En esta progresión, al entrar al siguiente espacio, tocaría otro lugar lineal, cerrado. Pero no encontramos eso. Encontramos algo inimaginable, algo de una magnitud insospechada, la capilla de los españoles. Dejarse llevar por ese efecto es lo que hace uno que ha aprendido a mirar con Ruskin.

\footnotetext{
${ }^{18}$ Ruskin, John, Mornings in Florence, The Mersion company, New York, 1897. p. 122.
} 


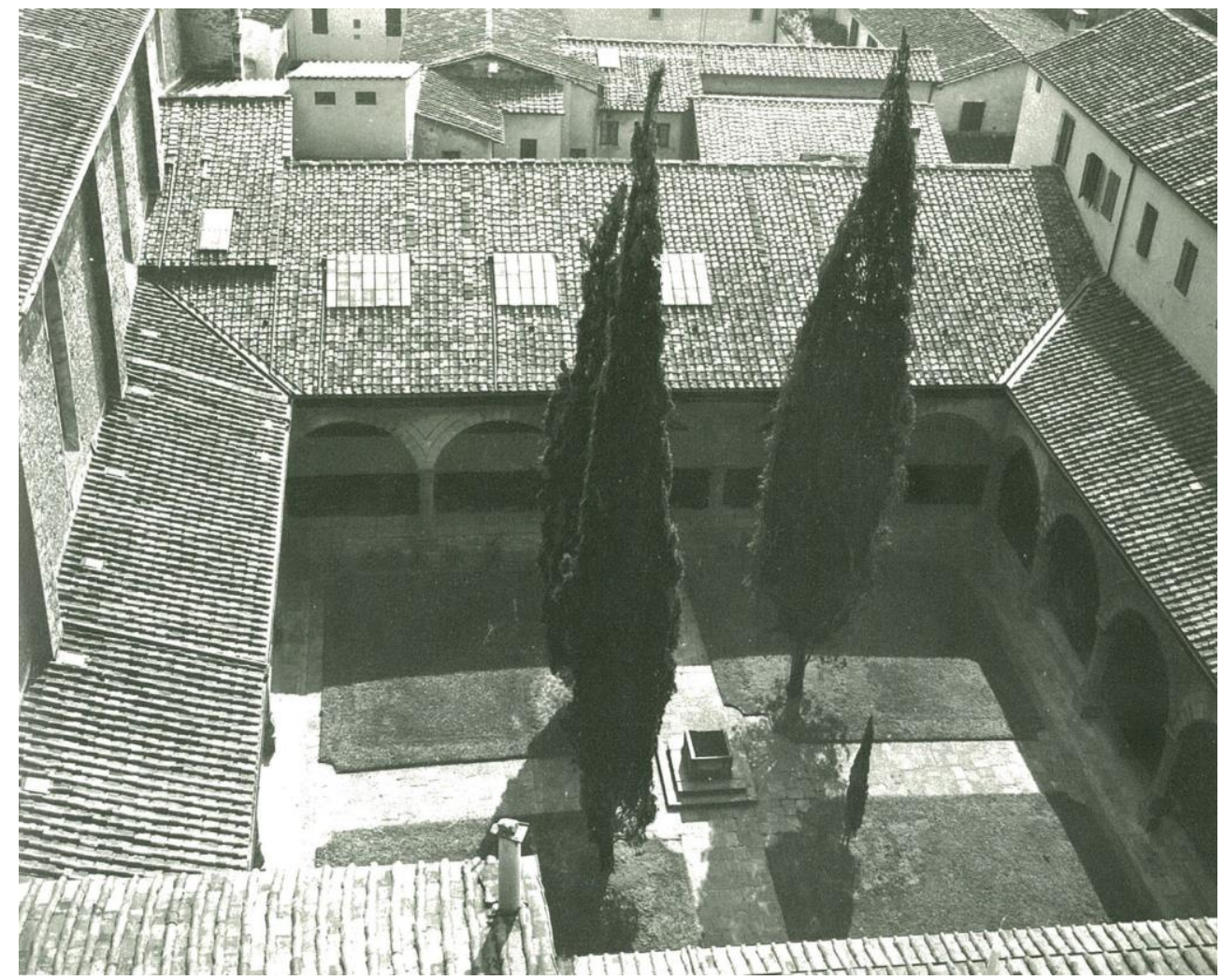

4. Claustro Verde en Santa Maria Novella

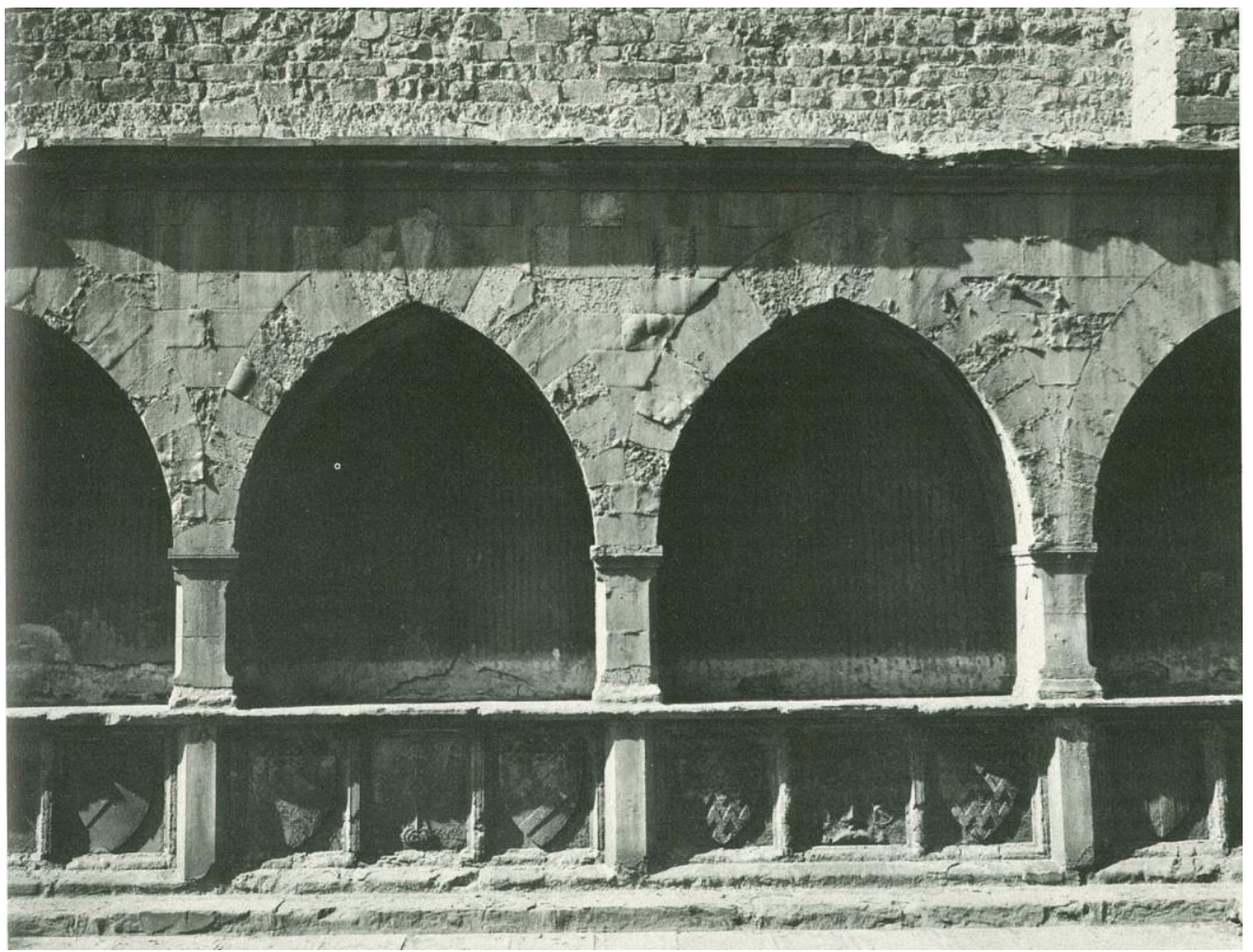

5. Alzado del claustro del cementerio en Santa Maria Novella 


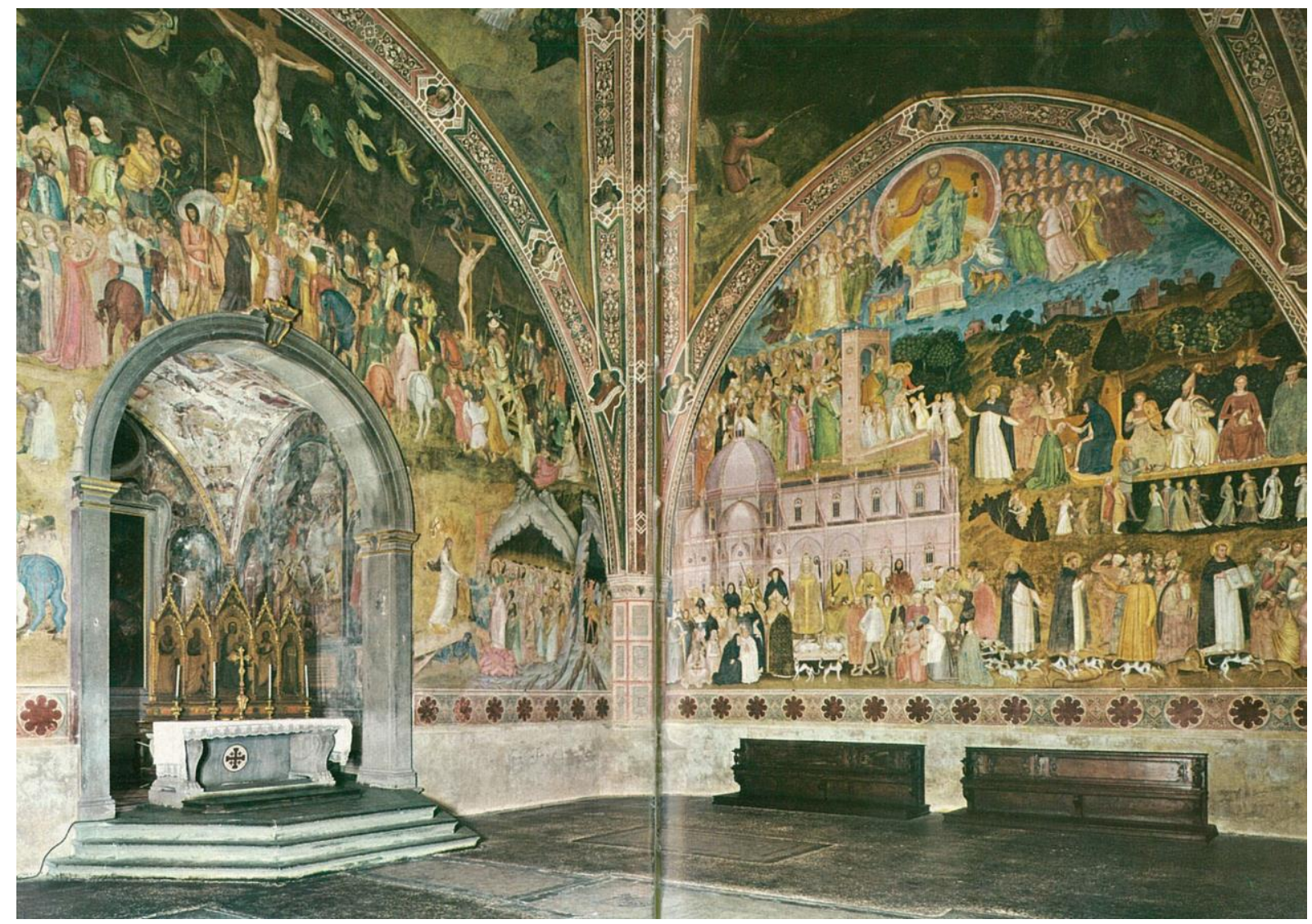

6. Interior de la capilla de los españoles en Santa Maria Novella

Le Corbusier en un papel que dibujó (FLC $4932^{19}$ ), poco después de comprar el libro de Ruskin, hace tres dibujos de la capilla de los españoles. En el primero, a lápiz y repasado a tinta, puede verse una perspectiva del espacio de los cuatro pilares, los arcos y la forma del techo; en el segundo, a lápiz, un alzado que, por la repetición, me atrevería a decir que es del claustro -verde-; el tercero, a tinta con inscripciones a lápiz, es el mas dañado, sólo tenemos un pedazo del dibujo, bastante detallado con algunas cotas y relaciones dimensionales. El dibujo, de mayor tamaño que los otros dos, se puede apreciar un grado de detalle poco habitual en los dibujos de la época de Le Corbusier y está hecho, además, desde el punto de vista del habitante o del espectador mostrando lo que vería este desde dentro de la capilla. El resto del papel está escrito ${ }^{20}$ haciendo referencias a lo que está dibujado.

\footnotetext{
${ }^{19}$ Fue Sekler quién primero miró este trozo de papel poco después de terminar su tesis doctoral y lo incluyó en su versión impresa con algunos comentarios: "Three diagrams and copious anotation concerns an análisis of the spatial arrangement of the Spanish Chapel at Santa Maria Novella in Florence. It is possible that Jeanneret's interest in this space was inspired by Ruskin's discussion of relative size and the effect of decorative tratment in comparing one bay in the Duomo with the space of the Spanish Chapel. p.624 Mary Patricia May Sekler, Early drawings of Charles-Edouard Jeanneret (Le Corbusier), ed. Garland Publishing, Inc. New York and London, 1977.

${ }^{20}$ Una posible transcripción de lo que dice se ofrece a continuación:

Le príncipe de la chapelle des Espagnoles / est celui de tout / ramener à (une) 1 seule / surface partant / depuis le pourtour / de la salle qui en / Somme ne será pas /tres grand, pour vous /recouvrir et vous envoûter comme par / enchantement en se / soient comme bout. Tout / l'art de constructeur / a été de remplir les / angles (,) de les dissimuler, / et l'oeil se promène / du sol jusqu'au bout / opposée, sans rencontrer / (une) 1 seule arête. Le príncipe / de l'éclairage par 2 fenêtres latérales, / placés très près du sol est (donnant( un demande / que la lumière du cloître qui cour / de l'autre côte du mur. Il m'a / paru que la
} 


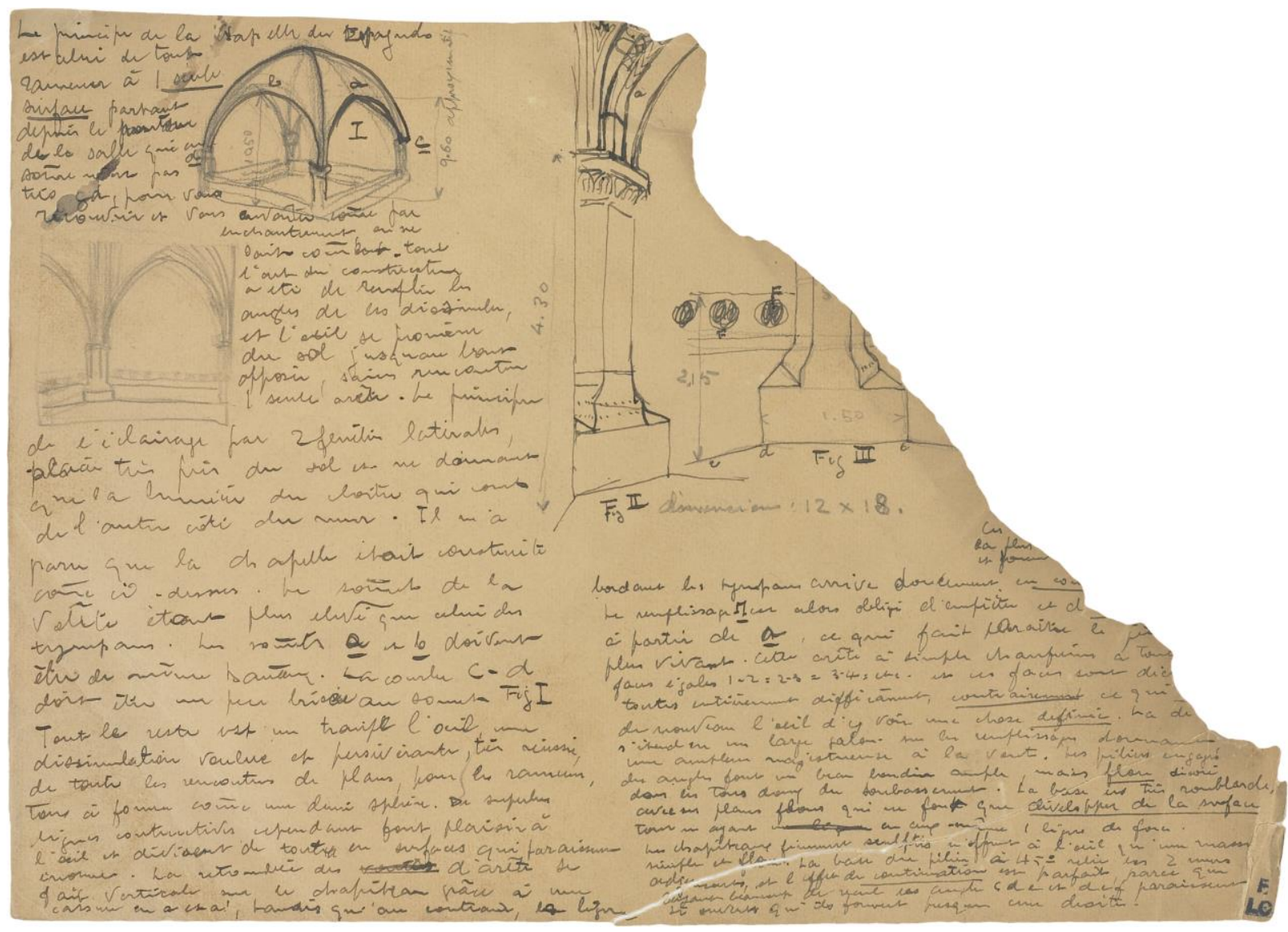

7. FLC 4932

El primer dibujo sirve para comprender el espacio, una especie de axonometría ${ }^{21}$, el tipo de dibujo que uno hace cuando llega a un lugar y quiere entender lo construido, un dibujo analítico. A continuación Le Corbusier traza el segundo dibujo -al que no hace referencia en el texto pero que está escrito antes que el texto, si no el texto no tendría este dibujo. Este dibujo es el que uno hace acordándose de lo que acaba de ver -el claustro- pero sin tenerlo delante, es un dibujo no hecho desde la percepción sino desde el análisis -un alzado ${ }^{22}$. El dibujo de

chapelle était construite / comme ci-dessus. Le sommet de la / voûtre étant plus élevé que celui des / tympans. Les sommets a et $\underline{b}$ doivent / être un même hauteur. La courbe c-d / doit être un peu brisé au sommet. Fig I. / Tout le reste est un trompe l'oeil une / dissimulation voulue et presévérante, très réussi, / de toutes les rencontres de plans, pour les ramener, / touts à forme comme une demi sphère. De superbes / lignes constructives ce pendant Font plaisir à l'oeil et devissent de tout en surfaces qui paraissent / énormes. La retombée d'arête se / fait verticale sur le chapiteau grâce à une /cassure en a est a, tandis qu'au contraire, le ligne // bordant les tympans arrivé doucement en co(...) / Le remplissage II car alors oblige d'empiéter et $\mathrm{d}(\ldots)$ / à partir de a , ce qui fait paraïtre le $(\ldots)$ / plus vivant. Cette arête à simples chapiteau a tout $(\ldots) /$ faces égales $1-2=2$ 3=3-4 etc. et ses faces sont $\operatorname{dic}(\ldots) /$ toutes entièrement diffus comme contrairement ce qui ... / de nouveaux l'oeil d'y voir une chose définis. La de... / s'étant en un large salón sur les remplissages donnant “ une ampleur majestueuse à la voûtre. Les piliers engages / dans angles sont en bras ample mais flanc ivisée / dans les tors du soubassement . La base est très roublarde, / curves ses plans pour qui ne fornt que développer de la surface / tout en ayant en ceux mêmes (une) 1 ligne de forcé / Les chapiteaux firmament sculptes n'offerent à l'oeil qui en mass.. semples et fleurs. La base du pilier à $45^{\circ}$ reliés les 2 mur $/$ adjacentes et l'effet de continuation sont pafraits, parce que / ayant beaucoup de real les courbes $\underline{\mathrm{c}}$ et $\underline{\mathrm{d}}$ est paressent / les ouverts qui les formant persque un cloître.

${ }^{21} \mathrm{La}$ axonometria es el tipo de dibujo que usa Choisy para explicar muchos edificios. Es muy posible que sea el modo en que un discípulo de l'Epplatenier plantea el croquis para entender el espacio. Choisy, Auguste, Historie de l'architecture, 2.vol. Édouard Rouveyre, París 1899.

${ }^{22}$ De hecho al trazar la forma del arco Le Corbusier se equivoca y traza el arco que tiene delante o el que recuerda del claustro del cementerio de la propia Santa María Novella que seguro había visitado unos instantes antes. 
recuerdo aquí actúa como contrapunto, si el primer dibujo es para entender algo que "nos recubrirá y nos cautivará como por arte de magia" el primero es para entender cómo ese mecanismo se desarrolla. Cómo viniendo de un lugar tan falto de espacialidad desde el punto de vista de Le Corbusier, un lugar que se deja cortar por la sombra, que desliga los brazos del claustro dependiendo del momento del sol, entramos en otro que nos cautiva. El primer dibujo sirve para tratar de entender lo que se está viendo (así lo describe en el texto) el segundo para reflexionar de dónde se viene y cómo se ha producido el efecto cautivador. El primero sin el segundo carece de sentido. Es la comprensión de cómo Le Corbusier ha aprendido a mirar leyendo a Ruskin. Ruskin dice que la magnitud la capilla tiene que ver con que uno estando en el claustro verde no espera tal despliegue y Le Corbusier lo dibuja.

Le Corbusier se centra en el texto de FLC 4932, sobre todo, en cómo es la capilla porque el efecto inesperado que "cautiva como por arte de magia" lo ha dibujado. El contraste entre cómo entender, de forma plana, los arcos del claustro choca frontalmente con esos arcos que se entrecruzan para formar el espacio embelesador de la capilla.

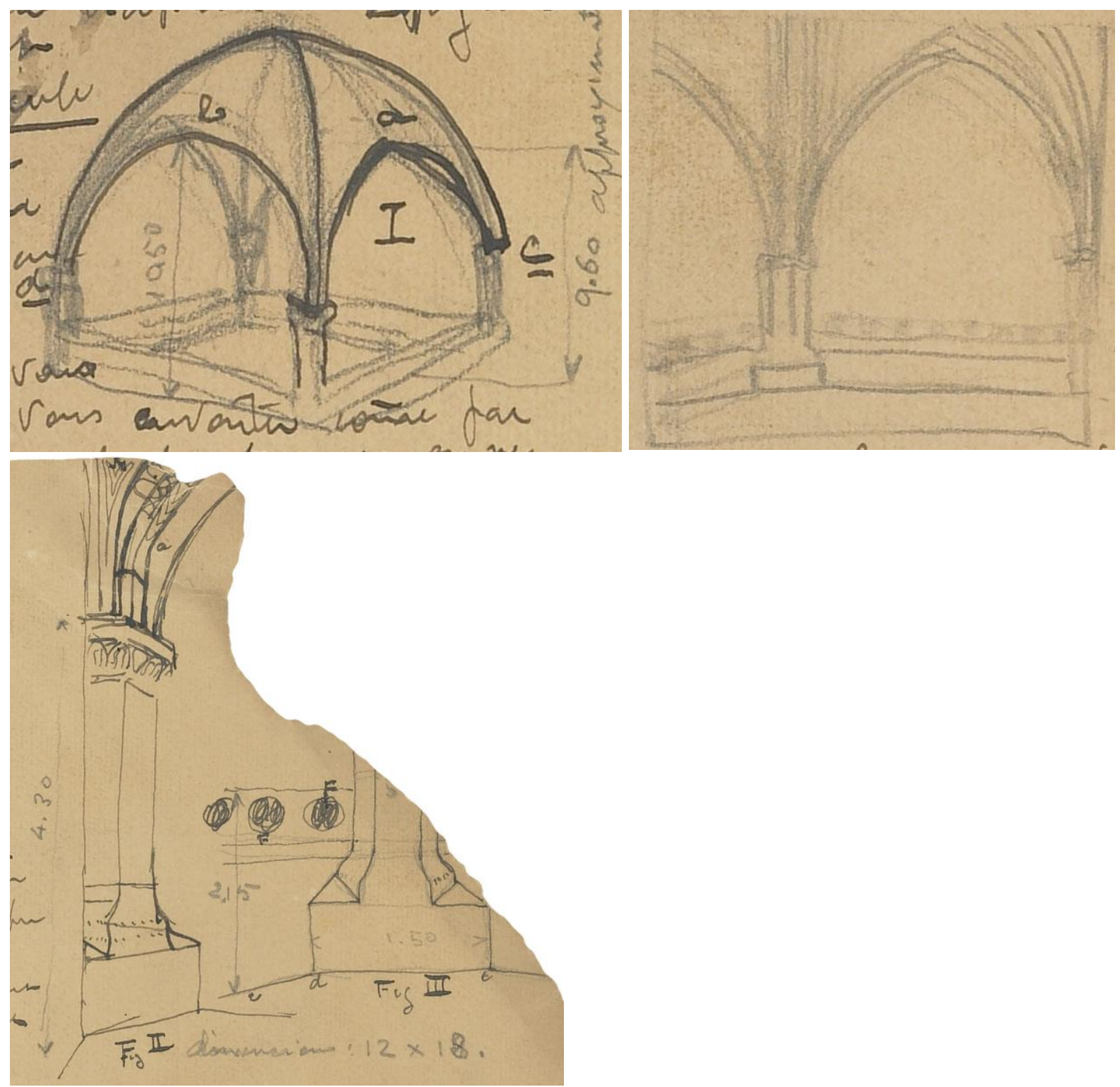

7, 8, 9.- Detalles de FLC 4932 
A la sucesión de esos contrastes, de esos choques, sin los que no aparece el espacio que "cautiva como por arte de magia”, es a lo que Le Corbusier llamará, más adelante, promenade.

Si en el choque radica el origen de la idea de promenade, la arquitectura de Le Corbusier no será sino una sucesión de choques para enseñarnos a mirar lo que tenemos alrededor. De este modo la arquitectura de Le Corbusier no será un paseo para gente amable sino mas bien un paseo lleno de sobresaltos y cosas inesperadas.

\section{Procedencia de las Imágenes:}

Figura 1.- Del libro: Le Corbusier. Précisions sur un état présent de l'architecture et de l'urbanisme, ed. Vincent, Fréal, Paris 1960

Figura 2.- Planta de Santa María Novella, redibujo.

Figura 3/4/5.- Las imagenes son del libro : Busignani, Alberto La chiese di Firenze. (v2) Quartiere di Santa Maria Novella., Sansoni, Firenze, 1979.

Figura 6.- La imágen es de la Guida di Santa María Novella.

Figura 7.- Fondation Le Corbusier.

\section{Bibliografía:}

Benton, Tim, “Le Corbusier y la promenade architecturale”, En: Arquitectura COAM, Madrid, 1987, n.264-265

Brooks, H. Allen Le Corbusier's formative years. Charles-Edouard Jeanneret at La Chaux-de-Fonds. The university of Chicago Press, Chicago 1996

Cohen, Jean-Louis, Le Corbusier: An Atlas of Modern Landscapes, Museum of Modern Art, New York 2013

Coromina, Beatriz, Privacy and Publicity. Modern Architecture as Mass Media, The MIT press, 1994.

Daza, Ricardo, Tras el viaje de Oriente, Fundacion Arquia, Barcelona 2015

Etlin, Richard A., Frank Lloyd Wright and Le Corbusier. The romantic legacy, Manchester University Press, Manchester, 1994

Glaseri, Giuliano, Le Corbusier viaggio in oriente, Marsilio Editori, Foundation Le Corbusier, Venezia 1984

Le Corbusier et Pierre Jeanneret Oeuvre Complète 1929-1934, Grisberger \& Cie, Zurich, 1934

Le Corbusier. Précisions sur un état présent de l'architecture et de l'urbanisme, ed. Vincent, Fréal, Paris 1960

MacArthur, John, The Picturesque, Architecture, Disgust and other Irregularities. Routledge (Taylor and Francis group) London, 2007

Martínez de Guereñu, Laura, "Montage: Le Corbusier y Eisenstein" en Massilia. Annuaire d'Études Corbuseennes. 2008. Encuentro en Granada. Associació d'idees. Centre d'Investigacions Estètiques. Barcelona, 2009, pp.170-185

Moholy-Nagy, László, Vision in Motion, Theobald, Chicago, 1947

Quetglas, Josep, Les Heures Claires, Massilia, Sant Cugat del Vallès, 2008

Ruskin, John Mornings in Florence, The Mersion company, New York, 1897.

Samuel, Flora, Le Corbusier and the arhcitectural promenade, Brikhäuser, Zurich, 2010 


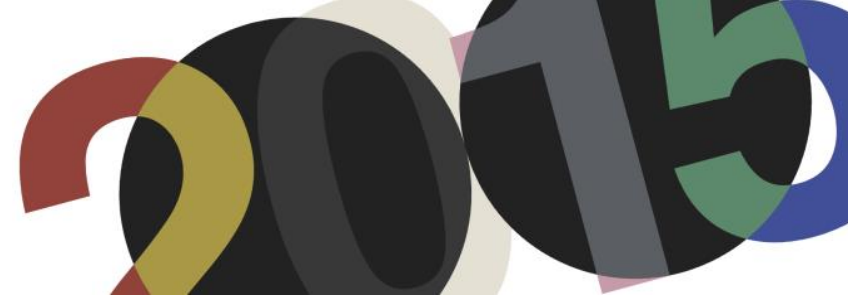

DOI: http://dx.doi.org/10.4995/LC2015.2015.923

\title{
Brise-soleil: principios y transformación en la obra de Le Corbusier
}

\author{
S. Morel Corrêa, R. Anzolch, R. Pedrotti
}

Universidade Federal do Rio Grande do Sul

\begin{abstract}
Resumen: La actitud de Le Corbusier respecto a la superficie epidérmica de sus edifícios cambió en los años 20, cuando se percató de los problemas producidos al construir membranas de escaso espesor con amplias zonas acristaladas. Durante la década de 30, Le Corbusier trabajaba principalmente en países cálidos, y la invención del brise-soleil parecía ser la respuesta a los problemas de ganancia de calor. El brise en la obra de Le Corbusier jugó dos funciones importantes: una como elemento de adaptación al clima y la otra como elemento de composición de fachada. El objectivo del trabajo es rescatar la importancia que Le Corbusier daba a este elemento, para tanto aborda la evolución y la transformación del brise-soleil, en su propia obra. La metodologia del trabajo consiste en analisar las obras elegidas por su relevância en el tema desde un punto de vista medioambiental con base en los estudios de Almodovar, D. Siret y Requena, teniendo en cuenta la orientación y la protección solar en los solsticios de invierno y verano (Le Corbusier defendió que por lo menos hubieran dos horas de penetración solar en el invierno). Del mismo modo, desde el punto de vista arquitectónico se consideran aspectos como la forma arquitectónica, la integración al conjunto, la inserción en la fachada y la importancia en la composición.
\end{abstract}

\begin{abstract}
Le Corbusier attitude on the epidermal surface of buildings changes when he realises, in the 1920s, that the problems caused by membranes of insufficient thick with large glazed areas. During the 1930s decade, Le Corbusier worked mainly in warm countries, and the invention of the brise-soleil seemed to be the answer to the problems of heat gain. The brise-soleil, in the work of Le Corbusier, played two important roles: one as an element of adaptation to the climate and the other as an element of composition of facade. The aim of this paper is to rescue the importance that Le Corbusier gave to this element, so it treats the evolution and transformation of the brise-soleil, in his own work. The methodology of the work consists of an analysis of works chosen for their relevance on the issue from an environmental point of view, based on the studies of Almodovar, D. Siret and Requena, considering the solar orientation and solar shading in the winter and summer solstice (Le Corbusier argued that there were at least two hours of solar penetration in winter). In the same way, from the architectural point of view, it treats aspects such as the architectural form, integration in the whole, insert on the facade and compositional importance.
\end{abstract}

Palabras clave: protección solar; brise-soleil; Le Corbusier.

Keywords: solar shading; brise-soleil; Le Corbusier.

\section{Introducción}

El brise en la obra de Le Corbusier jugó dos funciones importantes: una como elemento de adaptación al clima y la otra como elemento de composición de fachada. En Brasil, a pesar de no haber sido el pionero, el Ministerio de Educación y Salud, contó con la asesoría de Le Corbusier; fue sin duda una de las obras más emblemáticas en relación al empleo del brise-soleil. Si al principio su preocupación se centra principalmente a las limitaciones térmicas, en sus últimas obras, extendió el alcance a los aspectos lumínicos. Por un lado, el brise destruye el sentido de la forma cúbica de las primeras casas, por el otro, Le Corbusier aprovechó la profundidad dimensional del artificio para exhibir los elementos funcionales del interior, como en el edificio de Argel y en otras obras del postguerra, donde en algunos momentos es el tratamiento superficial que da sentido a la forma. El brise soleil fue, desde sus inicios, un elemento compositivo de calidad reconocida en nivel mundial, tuvo su auge en los años 40 hasta los 70, cuando cae en desuso. Hoy vuelve a ser aplicado, sin embargo, de una forma diferente de la fue 
utilizada en el pasado.

El objectivo del trabajo es rescatar la importancia que Le Corbusier daba a este elemento, para tanto aborda la evolución y la transformación del brise-soleil, en su propia obra. De esta manera, se busca entender su complejidad a través del análisis de diferentes tipos de brises y su efecto en el exterior y el interior de los edificios. El estudio presenta la experiencia de Argel, con los edificios de Ponsik y el rascacielo 'biológico' del barrio de la Marina, pasando por el Ministerio de Educación en Rio de Janeiro, la Unidad de Habitación de Marsella, las obras en India: el Secretariado, en Chandigarh, el Edificio de la Asociación de Hilanderos en Ahmedabad - y finalmente el Centro Carpenter para Artes Visuales en Cambridge, Massachussets.

La metodologia del trabajo consiste en analisar las obras, elegidas por su relevancia en el tema, desde un punto de vista medioambiental, con base en los estudios de Almodovar ${ }^{1}$, D. Siret $^{2}$ y I. Requena ${ }^{3}$, teniendo en cuenta la orientación y la protección solar en los solsticios de invierno y verano (Le Corbusier defendió que por lo menos hubieran dos horas de penetración solar en el invierno ${ }^{4}$ ). Del mismo modo, desde el punto de vista arquitectónico se consideran aspectos como la forma, la integración al conjunto, la inserción en la fachada y la importancia en la composición.

El análisis ambiental fue desarrollado a través del software Energyplus ${ }^{5}$, considerando el efecto de la temperatura exterior y teniendo en cuenta los intercambios de aire a través de la ventilación natural. Se consideró un cambio de aire por hora en el período de invierno y cinco cambios horários en el período de verano. Los mapas de iluminación fueron hechos para todos los horários en los solstícios de invierno y verano con cielo despejado. En el análisis lumínico se consideran las relaciones entre los valores de iluminancias mínimas, médias y máximas. Las simulaciones fueron elaboradas con los archivos climáticos del tipo IWEC (International Weather for Energy Calculation), configurados en formato "EPW" (EnergyPlusWeather). Para Argel y Marsella fueran utilizados datos IWEC generados pela American Society of Heating Refrigeration and Air conditioning Engineers, en cuanto que para Dehradun (que representa el clima de Chandigard) y Ahmedabad, los archivos IWEC utilizados son los disponibles de la Indian Society of Heating Refrigeration and Air conditioning Engineers. La excepción fué para Rio de Janeiro, donde fué utilizado arquivo de tipo SWERA (Solar and Wind Energy Resource Assessment).

\section{La evolución del brise-soleil - La experiencia de Argel}

A los finales de los años 20, Le Corbusier se ocupa del tema del sombreamiento, aproximándose instintivamente a la solución teniendo en cuenta el sol, como se constata en los primeros estudios de 1928, para Cartago ${ }^{6}$. En 1930, en el diseño del edificio Clarté, Ginebra, demostró una especie de transición al nuevo enfoque en relación al pan de verre y su protector solar. En este edificio la losa a medios pisos se extendía más allá de la línea de la fachada de vidrio, creando una solución que permite el paso de la luz del sol del invierno y evitando la radiación alta en el verano. Poco después, en 1933, en otro proyecto residencial que no se construyó, en Barcelona, la intención del parasol se hizo más evidente: la planta superior estaba protegida por profundas terrazas y el piso intermedio por venezianas horizontales pivotantes de hormigón.

\footnotetext{
${ }^{1}$ Almodóvar, J. M., 2004.

${ }^{2}$ Siret, D., 2002.

${ }^{3}$ Requena Ruiz, 2011, pp. 215.

${ }^{4}$ Le Corbusier, 1993.

${ }^{5}$ U.S. Department of Energy, EnergyPlus Energy Simulation Software.

${ }^{6}$ Le Corbusier, 1946, p. 108.
} 
En el periodo de 1930-38, Le Corbusier desarrolló una serie de estudios para Argel, incluyendo el edificio de viviendas de Ponsik. En este proyecto, cada una de las fachadas fue correctamente tratada, dependiendo del tipo de insolación recibida: para el lado norte, poco expuestos a la luz solar directa, diseñó grandes paneles de vidrio; para el este con pocas aberturas y para el sur y oeste diseñó brise-soleils. En la fachada oeste, donde la radiación solar tenía bajos ángulos de incidencia e intercepción más difícil, Le Corbusier diseñó lamas verticales u oblicuas ${ }^{7}$. És possible ver en estos bocetos que el elemento está diseñado como una adición al paño de vidrio. (Fig. 1)
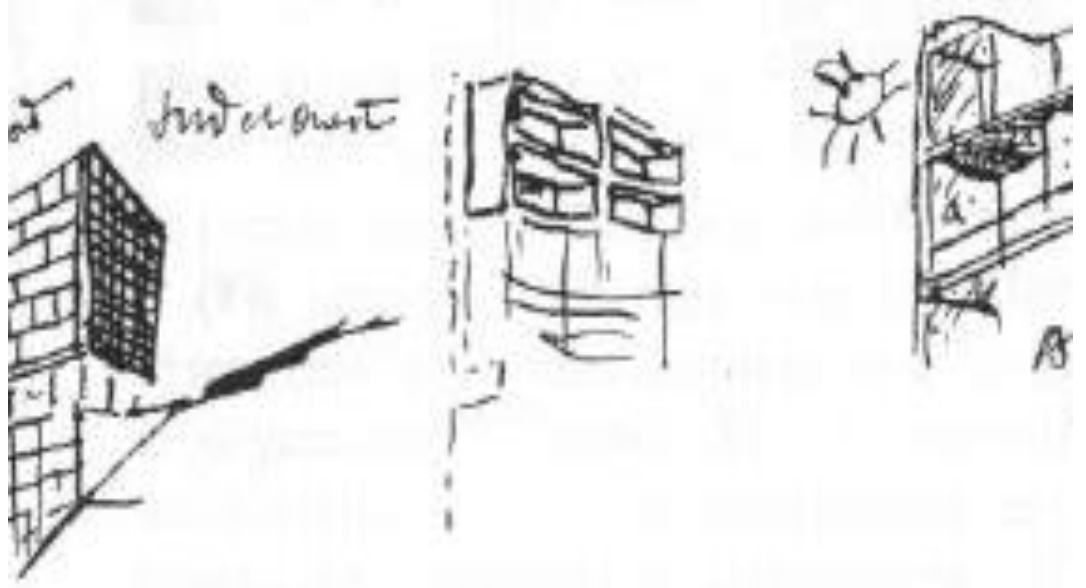

1. Estudios para los apartamentos de alquiler de Ponsik.
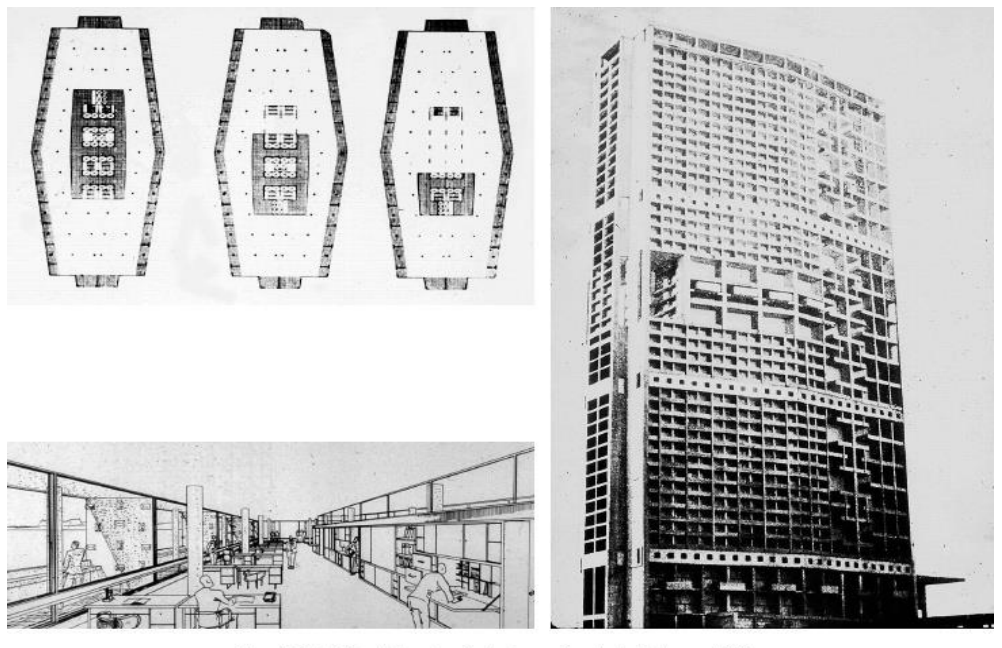

Obus E Project for Algiers Le Corbusier Cap de la Marine 1938

2. Rascacielos del Quartier de la Marine. En las oficinas: estructura de hormigón, pan de verre integral, brise-soleil en loggia.

Continuando con esta investigación, el arquitecto realiza entre 1938 y 1939 un plan de desarrollo para el distrito de la Marina, que aporta una nueva solución constructiva y estética del rascacielos destinado a oficinas comerciales. El rascacielos del Quartier de la Marine no es como en América, de forma accidental. Es un verdadero elemento de biología que contiene con precisión órganos específicos: una estructura independiente, un

${ }^{7}$ Le Corbusier, 1946, op.cit., p. 105. 
recipiente totalmente acristalado con el brise-soleil diseñado para disminuir la ganancia térmica, en las horas calientes y por lo contrario, permitir la entrada de la luz del sol en invierno; un sistema de circulación vertical, un sistema de distribución de peatones y automóviles al lado de los rascacielos y el aparcamiento de $\operatorname{coches}^{8}$.

El brise-soleil se utiliza en forma de una loggia, elemento arquitectónico tradicional reintroducido en la arquitectura moderna. Su expresión regular aparece en dos quintas partes de las fachadas. En el diseño de los brises de la fachada, de acuerdo con el propio arquitecto, alternó ritmos y diferentes espaciamientos, generando una jerarquía inspirada en los fenómenos naturales en una analogía con el pino ${ }^{9}$ (fig. 2). Diversas escalas de distribución, con la multiplicación infinita del sistema hasta los extremos exteriores. Utiliza la section aurea, para producir la envoltura armoniosa del prisma puro y marcado el ritmo proporcional con la escala humana. Así se logran variaciones, con libertad compositiva, estableciendo un principio de composición de abajo hacia arriba. Este rascacielos marca un cambio hacia la plasticidad, el desarrollo maduro de la fachada con textura y enfáticamente proporcionado, hecho posible por el uso del brise-soleil totalmente integrado en un esqueleto de hormigón armado.

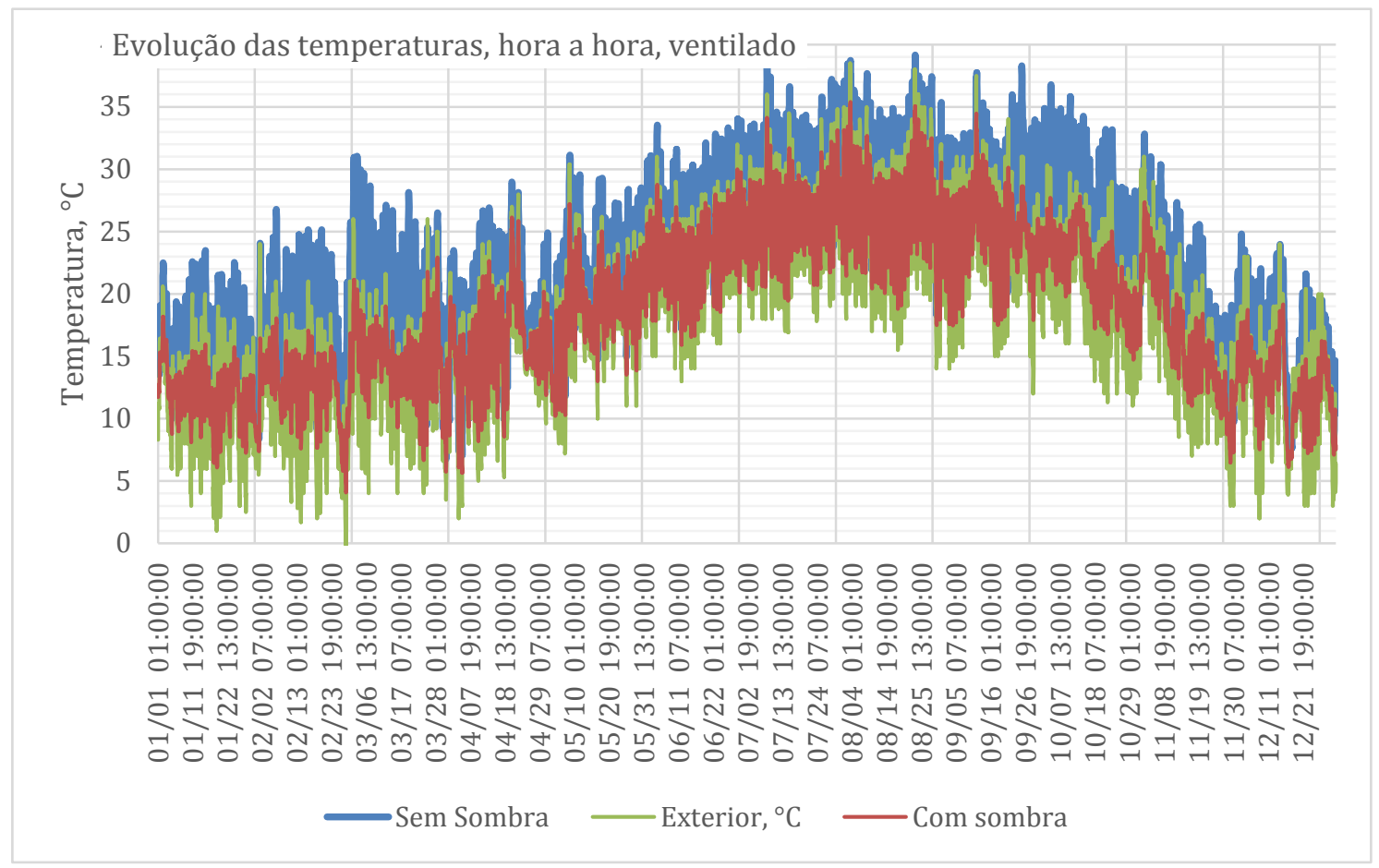

Tabla 1. Argel: Desempeño anual del brise-soleil (en rojo) a través de las temperaturas internas en la habitación, comparado al desempeño de la fachada sin los brises (en azul) y las temperaturas del ambiente exterior (en verde).

Argel está localizada en la latitud $36^{\circ} 46^{\prime} \mathrm{N}$ y longitud 3ㅇ' E. El clima es mediterráneo templado con la estación seca en verano, inviernos suaves y días lluviosos. La proximidad al mar Mediterráneo, influye en la moderación de las temperaturas de la ciudad, siendo las máximas promedio de $31^{\circ}$ y mínimas promedio de $11^{\circ}{ }^{10}$.

Analizando el gráfico de temperaturas anuales, se observa que el brise mitiga el efecto de las altas temperaturas tanto en el verano como en invierno. En el verano, es francamente favorable; sin embargo, el efecto de sombreado, no garantiza el suministro solar deseable en el invierno, produciendo una reducción de 5 a 10 grados, entre lo sombreado y lo no sombreado (Tabla 1).

\footnotetext{
${ }^{8}$ idem, p.50.

${ }^{9}$ ibidem, p.62.

${ }^{10}$ (http://worldweather.wmo.int/en/city.html?cityId=242)
} 
El efecto de los brise-soleil, de acuerdo con los mapas de iluminación natural, sería apropiado en las habitaciones, sin divisiones internas, (que corresponden a los locales de la gran administración), excepto en las primeras horas de la mañana, cuando las relaciones de iluminancia para el 21/6 a las 08:00h son de 128-4011887 lux y para las 16:00h son de 433-1345-5756 lux. Para el 21/12, las relaciones son de 61-240-884 lux a las 8:00h y 325-1579-11334 a las 16:00h.

\section{El Ministério de Educacíon y Salud}

El caso del MES asume relevancia por el hecho de que allí fue la primera obra terminada e inaugurada en 1943, con la implementación del brise-soleil. Aunque Le Corbusier no participó directamente en el proyecto, fue nombrado como asesor por el promotor, el Ministro Gustavo Capanema ${ }^{11}$. El Ministerio es una aplicación pionera de la "planta y fachada libre" en un edificio de oficinas en altura así como por las varias innovaciones y mejoras técnicas. Son notables las losas-hongo forradas con material aislante en su cara inferior, los brises de control manual, que se alejan de la fachada para permitir la circulación del aire y se calibran dimensionalmente para evitar la sensación de rejilla; también se destacan las aberturas que garantizan la ventilación cruzada en los paneles divisorios del piso tipo ${ }^{12}$. La fachada NNO, diferentemente de los otros edificios de Le Corbusier, tiene sólo un tipo de solución para el brise, que se aplica en toda su área, estableciendo un tratamiento superficial sin interrupciones (fig. 3). Aunque le Corbusier había preferido el uso de placas fijas ${ }^{13}$, el equipo de arquitectos brasileños, encabezados por Lucio Costa, optó por elementos móviles como puede verse en el memorial del proyecto:

“[...] Verificamos que la adopción de placas fijas, si bien podría resolver el problema de la asoleación, sería menos satisfactorio en lo concierniente a la iluminación, pues, habiendo sido calculada para días claros, resultaría, por fuerza, deficiente en los sombrios, obligando el uso de luz eléctrica en horas que otros prédios podrían dispensarla. [...] Además de esto, consideramos que siendo la dirección de los rayos solares variable en relación a la fachada, el mejor sistema de evitarlos debería ser móvil. Con esas razones y basados en experiencias con los mejores resultados en el edificio de la Obra do Berço, en la Laguna Rodrigo de Freitas, donde, devido a la orientación, fue adoptado el tipo vertical, decidimos emplear también un proceso semejante que garantice a qualquier hora del día, disposición adecuada a las necesidades do trabajo." 14

El proyecto del brise-soleil dividía la fachada noroeste en módulos de $2 \mathrm{~m}$ con profundidad de 1,30 $\mathrm{m}$, con 3 paneles horizontales fijos en sus costados, $50 \mathrm{~cm}$ frente a las ventanas. Los brises se calcularon para el sol del mediodía del cenit y un sol de invierno a $45^{\circ}$. Debemos tener en cuenta que en los meses más calientes, el promedio de las temperaturas máximas de Río supera los $30^{\circ}$ y la humedad relativa fluctúa en torno al $80 \%$.

Para Almodóvar, en los meses de verano se observa, sin embargo, cómo durante la mayor parte del día, las lamas no reciben radiación solar directa. Como consecuencia su existencia no está justificada como elemento de protección solar, y debido a su color no sería una solución óptima desde el punto de vista lumínico. En los croquis realizados sobre el funcionamiento de las lamas, como se observa en la figura 4, aparecen dibujadas sólo dos, pensandose que estas recibirían sol al medio día en verano ${ }^{15}$.

\footnotetext{
${ }^{11}$ Le Corbusier, op. cit. , p.82.

${ }^{12}$ Comas, Carlos E. D., 2000.

${ }^{13}$ Moos, Stanislau Von, 2013.

${ }^{14}$ Costa, Lúcio, Ministerio de Educação e Saúde, Memorial descritivo, 1962.

${ }^{15}$ Almodóvar, J. M., 2004, op. cit.
} 


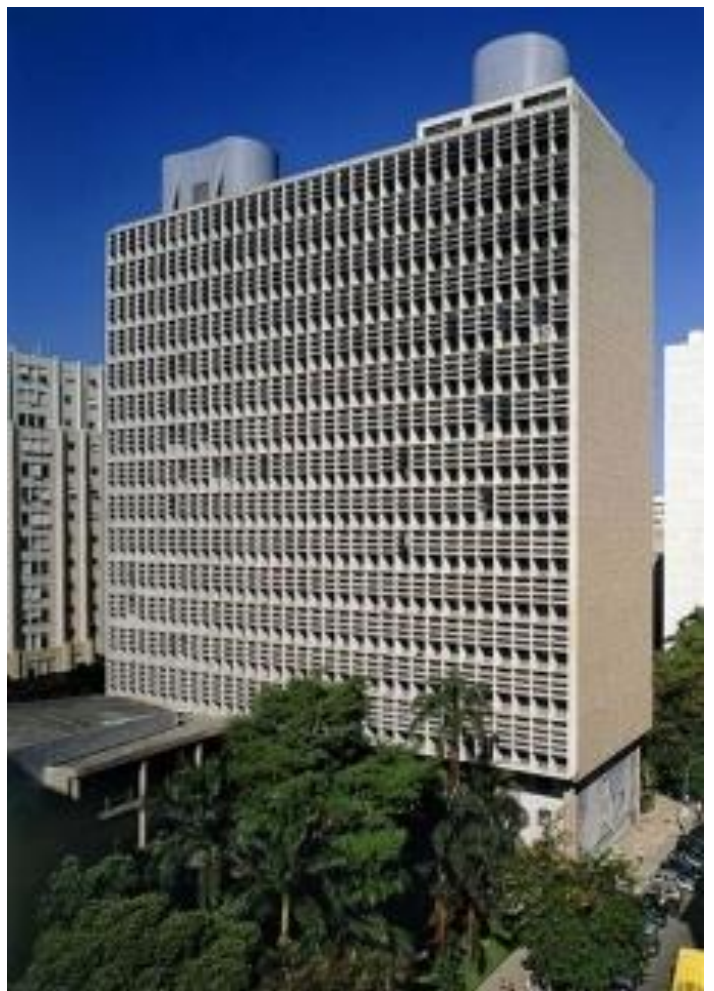

3. Fachada del Ministerio de Educacieon y Salud. Foto Nelson Kon.

El analisis bioclimático de acuerdo con Requena, concluye que las lamas en las tres posiciones tienen una optima adaptación a las lineas de sombra permitiendo controlar la entrada de sol con la inclinación de las mismas. Si analizamos el brise-soleil en sección, podemos observar, que la superficie acristalada se extiende desde aproximadamente un metro de altura hasta el techo (fig. 4). Este es un factor crucial en el desempeño lumínico de los brises, pues la altura mayor del techo garantiza una mayor penetración de luz en las zonas más distantes de la ventana. Según Requena, el nível de iluminancia de 500lux en el plano de trabajo, se consigue en todas las opciones, exceptuando la posibilidad de días nublados, para el fondo de la habitación. Los gradientes entre la parte más próxima a la fachada y el interior evitan los deslumbramientos y garantizan el confort visual ${ }^{16}$. Las lamas se disponen de forma que, sea cual sea su posición, no impidan las vistas de la ciudad. Esta estrategia la consideramos adecuada; la superficie opaca (casi un tercio de la fachada), realmente no produciría un incremento de iluminación aprovechable.

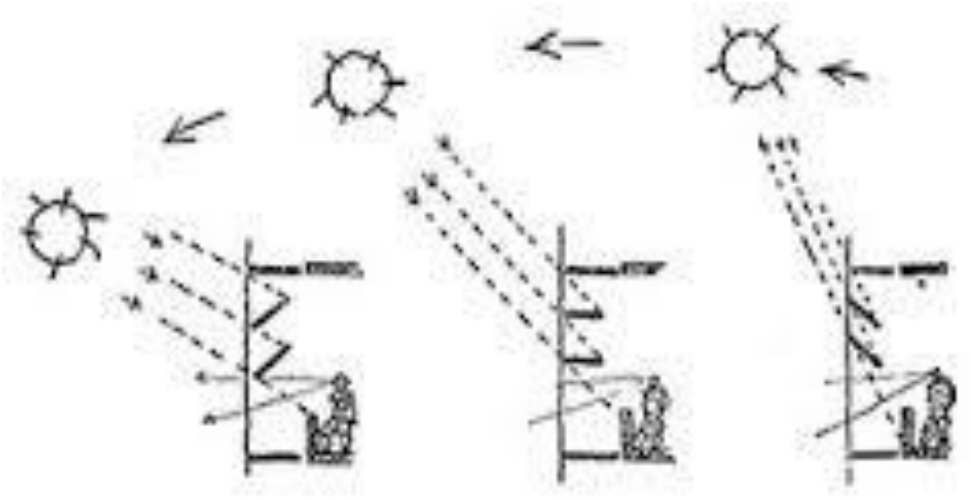

4. Croquis del funcionamiento de las lamas, incluído en el memorial del proyecto. Fuente: Costa, Lúcio, 1962.

${ }^{16}$ Requena Ruiz, I, op. cit. p. 121. 
Según Almodóvar, el coeficiente de reflexión de las lamas es un aspecto crítico en el diseño del brise-soleil. Las lamas con un factor de reflexión de 0,8 o superior (claras) producen mejores resultados lumínicos a la posibilidad de que estas no se utilicen, esto se verifica incluso bajo cielo nuboso. Por tanto, las lamas correctamente dimensionadas y revestidas de color claro en orientación norte (en el hemisferio sur), son una elección segura a la par que necesaria desde el punto de vista lumínico y térmico ${ }^{17}$. Podemos observar también de acuerdo con sus simulaciones, como los campos lumínicos espaciales generados por las lamas son más homogéneos y penetran más profundamente en el ambiente, lo que implica un significativo ahorro de energía.

La simulación de la fachada NNO, demostró el efecto eficaz del brise-soleil, con la disminución de $3^{\circ}$ a $10^{\circ}$ en las temperaturas internas, comparado a la situación sin sombreamiento (tabla 2), durante todo el año. Los mapas de iluminación interna demostraron para el 21/6, invierno en Rio de Janeiro, a las 8:00h relaciones de iluminância de 203-636-2454 lux. Para las 16:00h, los valores son de 2001-5663-18644 lux. En el verano, en el 21/12, a las 8:00h ocurren níveles de 493-1428-5724 lux, y para las 16:00h tenemos 685-1949-7867 lux.

Se concluye que la solución de los brise-soleil para el MES, fué acertada en su implementación en la fachada noroeste, por la combinación de las lamas verticales y horizontales que efectuán la protección en los horarios en los que el sol está bajo. Las temperaturas internas son mucho más leves comparadas al ambiente exterior o si no hubiera el sombreamiento. Sin embargo, la fachada sureste, recibe la luz directa del sol, en la mañana, en el verano, por lo tanto, con gran aporte térmico, así, que necesitaría la protección solar desde el equinoccio. Considerando la iluminación, en los días con cielo despejado, los niveles alcanzados son suficientes y con una buena homogeneidad, para las actividades de las oficinas.

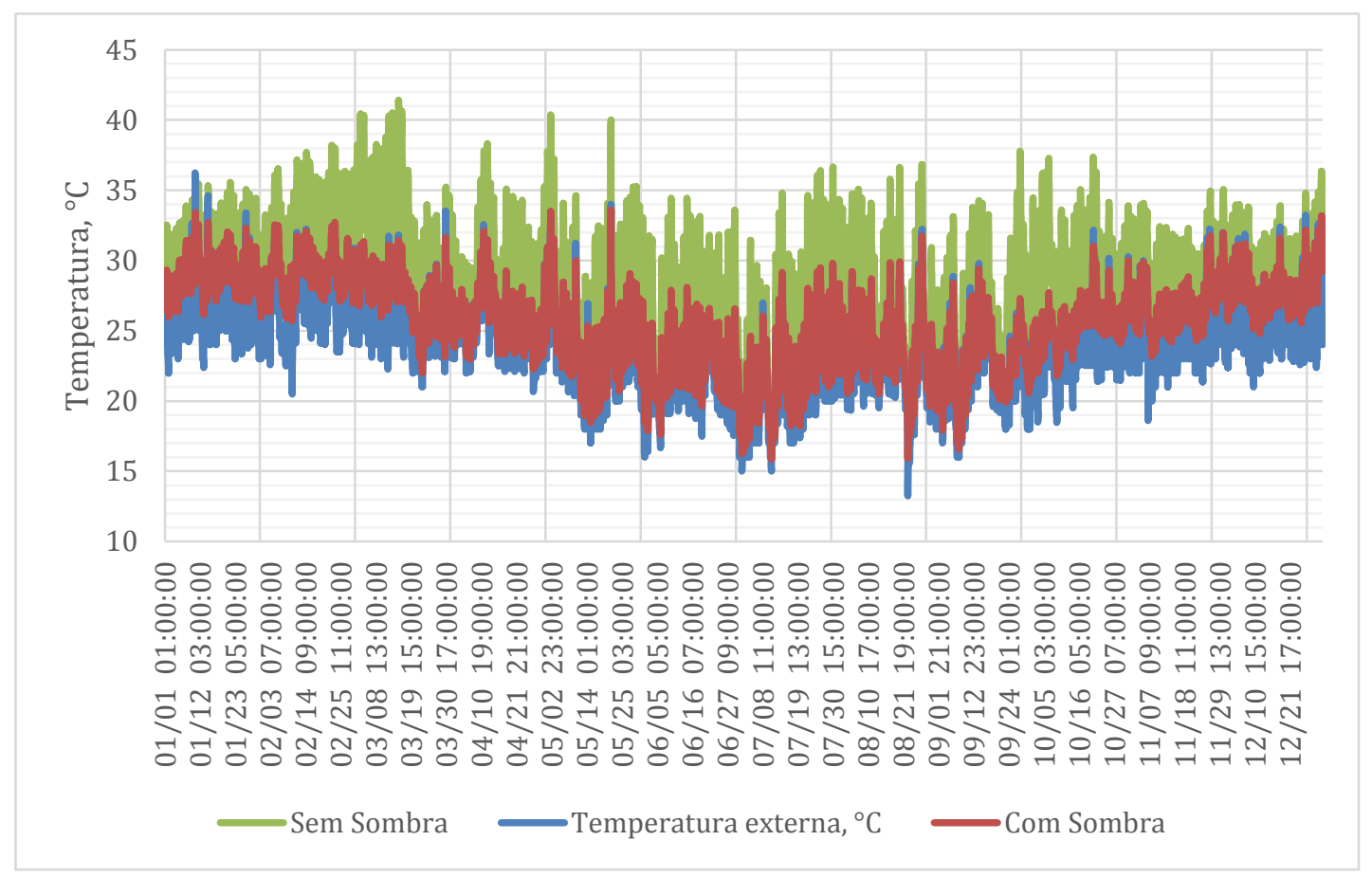

Tabla 2. Rio de Janeiro: Comportamiento anual del brise-soleil (rojo) a través de la temperatura en la habitación en comparación con el rendimiento de la fachada sin brises (azul) y temperaturas de ambiente exterior (verde).

\footnotetext{
${ }^{17}$ Almodóvar, J. M., 2004, op. cit.
} 


\section{La Unidad de Habitación de Marsella}

La Unidad de Habitación de Marsella evoca la imagen de un gran transatlántico, referenciado por Le Corbusier en Vers Une Architecture. Aquí, el arquitecto retoma la fachada especializada del rascacielos de la Marine, en Argel, con la variación de los elementos y creando una textura en la fachada. El brise-soleil en forma de loggía fue la alternativa para los apartamentos y los verticales, para las calles de espacios comerciales y de servicios de la planta intermedia, de modo que es reconocible desde el exterior (fig.5). En este proyecto, Le Corbusier en realidad se enfrenta a una situación compleja: tener que demostrar los méritos de la solución de los brise-soleil en las direciones de donde el sol es menos eficaz. La loggia de Marsella es un prototipo, un dispositivo destinado a generalizarse, a afirmarse y a ser refinado. En la descripción de Wogenscky:

"Una ventana acristalada de 3,66 m. de ancho y 4,80 m. de altura se abre a la sala común sobre el espacio exterior. Entra la luz que fluye en el apartamento hasta la cocina que está en plena claridad. Esta gran vidriera de 3,66 m. se abre, en la longitud y dos metros de altura en una loggia formando una verdadera extensión al aire libre de la sala común. Esta loggia forma el brise-soleil, que es decir, permite que el sol entre profundamente en el apartamento en invierno; en verano, por el contrario, bloquea la penetración." 18

Para Daniel Siret, en Marsella, es evidente que el brise-soleil real trabaja al revés del brise-soleil teórico: en la configuración este-oeste, la loggia mal permite penetrar el sol en invierno y protege poco en verano. En el verano, con las 15 horas solares, la loggia protege sólo la mitad de la fachada oeste, exponiendo la otra mitad a los rayos más calientes de la tarde. La simulación térmica predice un aumento significativo de las temperaturas internas. En invierno, por la tarde, por el contrario, más de la mitad de la fachada está a la sombra de la loggia ${ }^{19}$.

\footnotetext{
${ }^{18}$ A. Wogenscky, apud Siret « Description systématique de ' l'Unité d'habitation Le Corbusier' à Marseille » in Le Corbusier L'Unité d'habitation de Marseille, Le Point (Revue artistique et littéraire), XXXVIII, Novembre 1950, p. 55

${ }^{19}$ Siret, Daniel, 2002, op. cit, p. 5.
} 


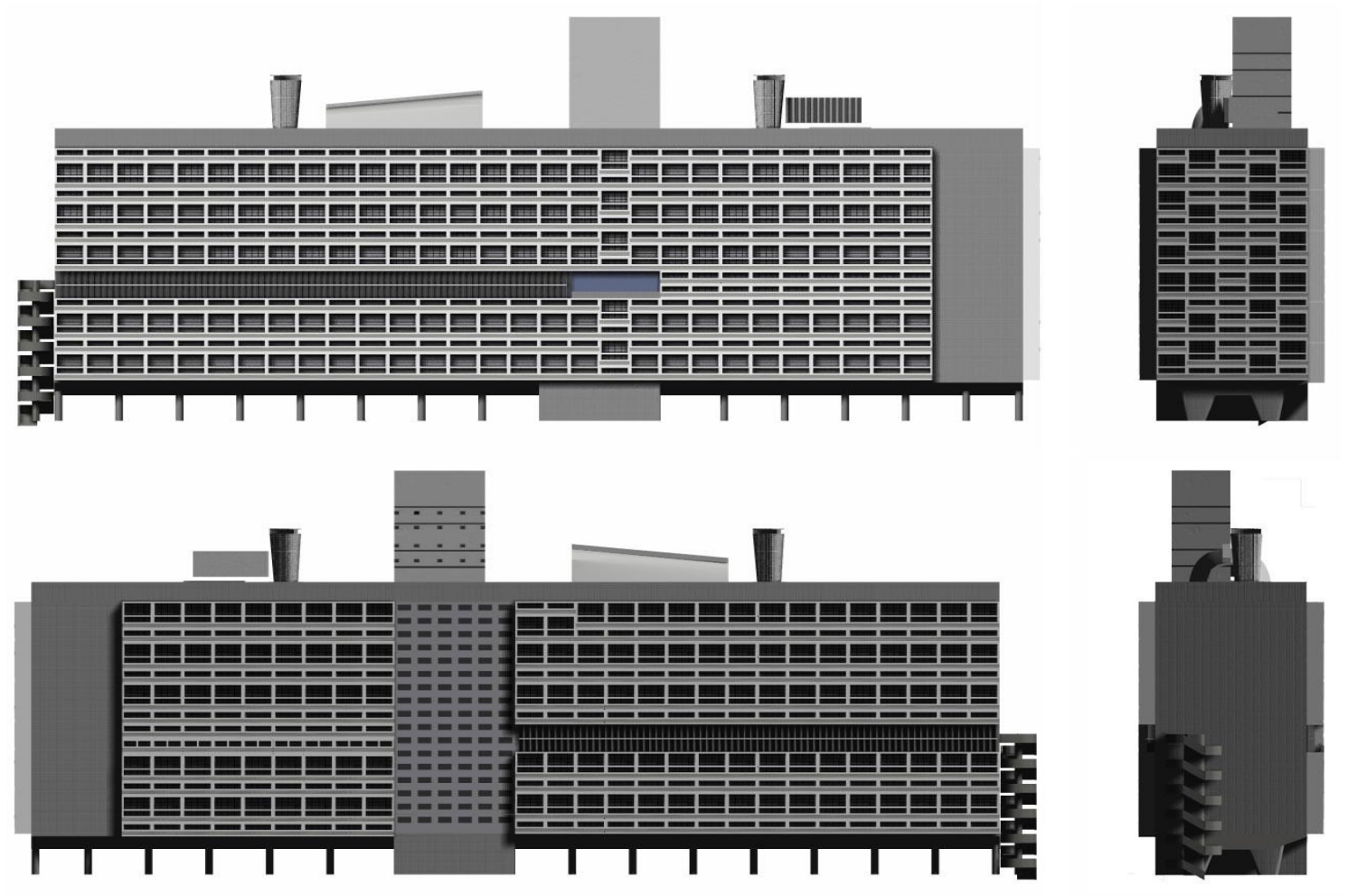

5. Unidad de Habitación de Marsella, arriba: fachadas este y sur, abajo: oeste y norte. Fuente: disponible en: http://misfitsarchitecture.com/tag/unite-dhabitation-marseilles/ acceso en 30/05/2015.

La evidencia del diagrama de sombreado (desarrollado por Olgyay y Olgyay) muestra que la fachada oeste (el lado más largo), permite dos horas de penetración solar de 15:00 a 17:00h en los meses de verano y sólo 20 minutos de luz directa del sol en los meses de invierno. Por el contrario, la máscara de sombra demuestra que la elevación del sur (lado corto) funciona admirablemente, permitiendo hasta ocho horas de penetración de la luz del sol en los meses de invierno y la sombra completa desde abril hasta septiembre. En otras palabras, si el edificio fuese girado en 90 grados los brises trabajarían mucho más efectivamente ${ }^{20}$.

Las simulaciones desarrolladas en este estudio, demostraron que el brise mitiga el efecto de las altas temperaturas tanto en verano como en el invierno. Los gráficos siguientes muestran la comparación de las fachada con y sin sombreamiento, el brise-soleil produce una redución significativa de temperaturas, del orden de 2 a $5^{\circ}$ de amplitud tanto en fachada este cuanto en la oeste (ambas con la ventana a doble altura). Esta redución es favorable en el verano, pero en el invierno las temperaturas son iguales o más bajas que las temperaturas externas, justamente por el sombreamiento que proporcionan (Tabla 3 y 4 ).

El efecto de los brise-soleil considerando la iluminación natural en la doble altura de la fachada oeste, desconsiderando las divisiones internas, (que correponden a los servicios), genera níveles de iluminación elevados desde las primeras horas de la mañana, cuando las relaciones de iluminancias a las 08:00h son de 7391235-1890 lux, para las 16:00h son de 1258-11269-32325 lux en el 21/6. Las similaciones para la tarde, demonstraron la incidencia solar directa desde las 15:00 hasta las 18:00h En el invierno, los niveles son muy bajos por la mañana, con valores de 47-130-261 lux y para las 16:00h, tenemos 493-1668-6673 para el 21/12, sin incidencia solar directa.

\footnotetext{
${ }^{20}$ Mackenzie, Christopher, 1993.
} 
Para la doble altura de la fachada este, los níveles de iluminación ya son muy elevados a las 8:00h de la mañana, con relaciones de 1332-8361-16259 lux y a las 16:00h 795-1278-2001 lux, en el 21/6, presentando relaciones homogéneas por la tarde. Si comparamos las iluminancias de la tarde de la fachada este, con las de la mañana en la fachada oeste, vemos que las condiciones son muy similares. Esto significa que las iluminancias de las habitaciones suelen ser homogéneas, cuando no ocurre la incidencia solar directa. Para el 21/12, tenemos a las 8:00h, 64-202-428 lux y a las 16:00h, 297-532-913 lux. Sin embargo, en las dos fachadas, los brises no comprometen la iluminación natural, debido a la doble altura acristalada que produce una iluminancia promedio muy por encima de los niveles necesarios, excepto en las primeras horas de la mañana en el invierno, en los dos casos.

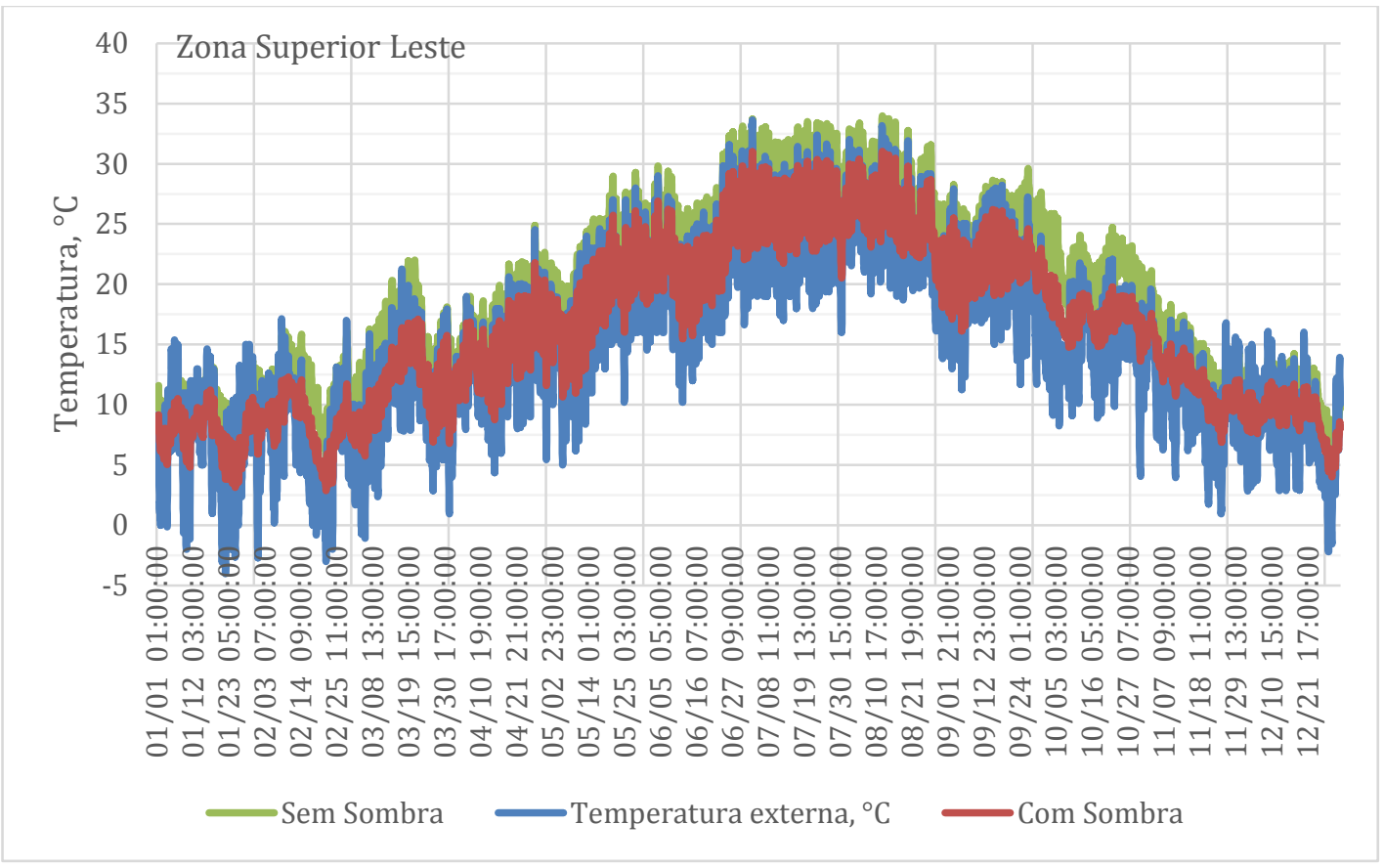

Tabla 3. Marsella: Apartamento de la fachada este con doble altura. Desempeño anual de la zona con el brise-soleil (en rojo) a través de las temperaturas internas comparado al desempeño de la fachada $\sin$ los brises (en verde) y a las temperaturas ambiente exterior ( en azul). 


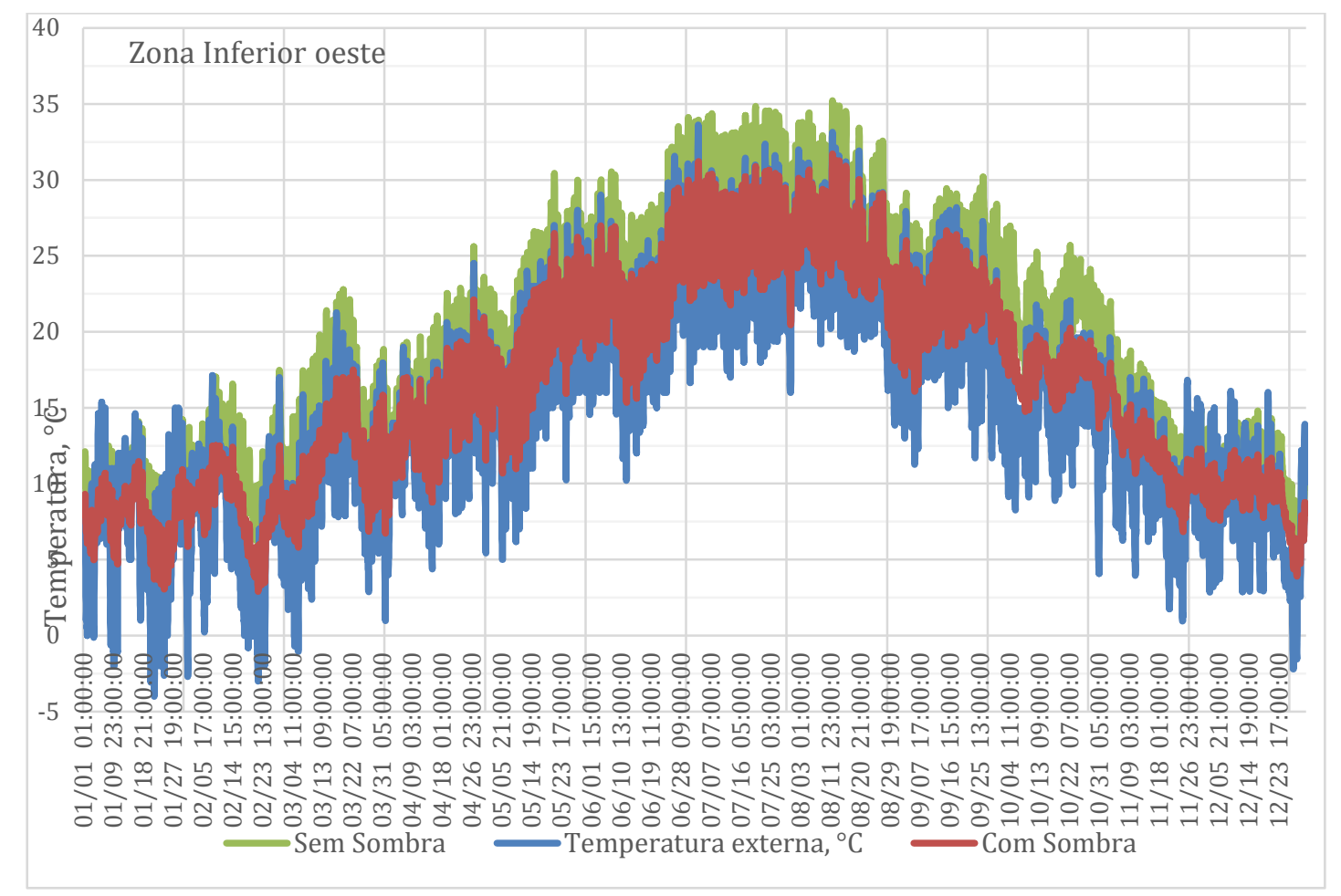

Tabla 4. Marsella: Apartamento de la fachada oeste con doble altura. Desempeño anual de las temperaturas internas con brise-soleil ( en rojo) comparado al desempeño la fachada sin brises (en verde) y a las temperaturas ambiente exterior (en azul).

\section{EI Secretariado de Chandigarh}

En las primeras etapas del proyecto, la complejidad de las técnicas empleadas dificultaba el ajuste de forma y clima, a lo que se sumaron los diferentes requerimientos ambientales en el trópico (Ahmedabad y Chandigarh). Esto llevó a la necesidad de sistematización de los conocimientos previos y a la proposición de métodos más operativos. Con este objetivo, Xenakis, Doshi y Missenard elaboraron el Grille climatique en 1951, donde estudiaban variables relativas al confort humano: temperatura del aire, humedad, velocidad del aire y temperatura radiante. La tabla vinculaba la toma de datos con la combinación necesaria de actuaciones bioclimáticas (radiación solar, ventilación, humedad ambiental e inercia térmica) ${ }^{21}$.

El edificio del Secretariado funciona como sede de los gobiernos municipales de Punjab y Haryana. Es el más grande de los tres edificios administrativos del Capitolio de Chandigarh y marca por el lado izquierdo, el borde del complejo del Capitolio. Tiene una forma alargada, horizontal y maciva de hormigón, 254 metros de largo y 42 metros de altura. Está compuesto por seis bloques de ocho pisos, divididos por las juntas de dilatación, sustentado por dos rampas esculturales, para la circulación vertical a lo largo de los niveles de las instalaciones.

El bloque horizontal de hormigón bruto ha sido objeto de cuidadoso estudio teniendo en cuenta el relieve escultórico dado al hormigón por el efecto de los diferentes tipos de brise-soleil. Por este trabajo compositivo, el edificio tiene semejanzas con el bloque de Marsella y tenía un propósito igualmente elevado: revolucionar el moderno edificio administrativo. El Secretariado estaba entre los primeros edificios diseñados como un "edificio saludable" con cuidadosa atención a la iluminación natural, la ventilación y la eficiencia organizacional.

${ }^{21}$ Siret, D., 2006, p.2 
El Secretariado es la forma simple y convencional donde las variaciones de la estructura y distribución interna no interrumpen su volumen compacto, pero son reproducidas bi-dimensionalmente en un diseño muy elaborado de los brise soleils. Posee la fachada rítmica que crea un deleite para los ojos en un común bloque gris. La jerarquía administrativa se reconoce a primera vista (fig.6). Las oficinas tienen un brise-soleil estandarizado, cuyo elemento principal forma un alto antepecho, donde se reprodujo el mismo esquema de fachada profunda, haciendo accessible la loggia desde el interior. Para reducir visualmente la magnitud de su fachada maciva, el Secretariado fue diseñado como un edificio modular que fragmenta legiblemente la elevación en los elementos del programa. Desplazado en relación al eje de simetría del conjunto, el bloque de los ministros, con doble altura, puede ser fácilmente identificado por su vasta loggia en un contrapunto escultural a la apariencia en serie de los otros despachos (fig. 7).

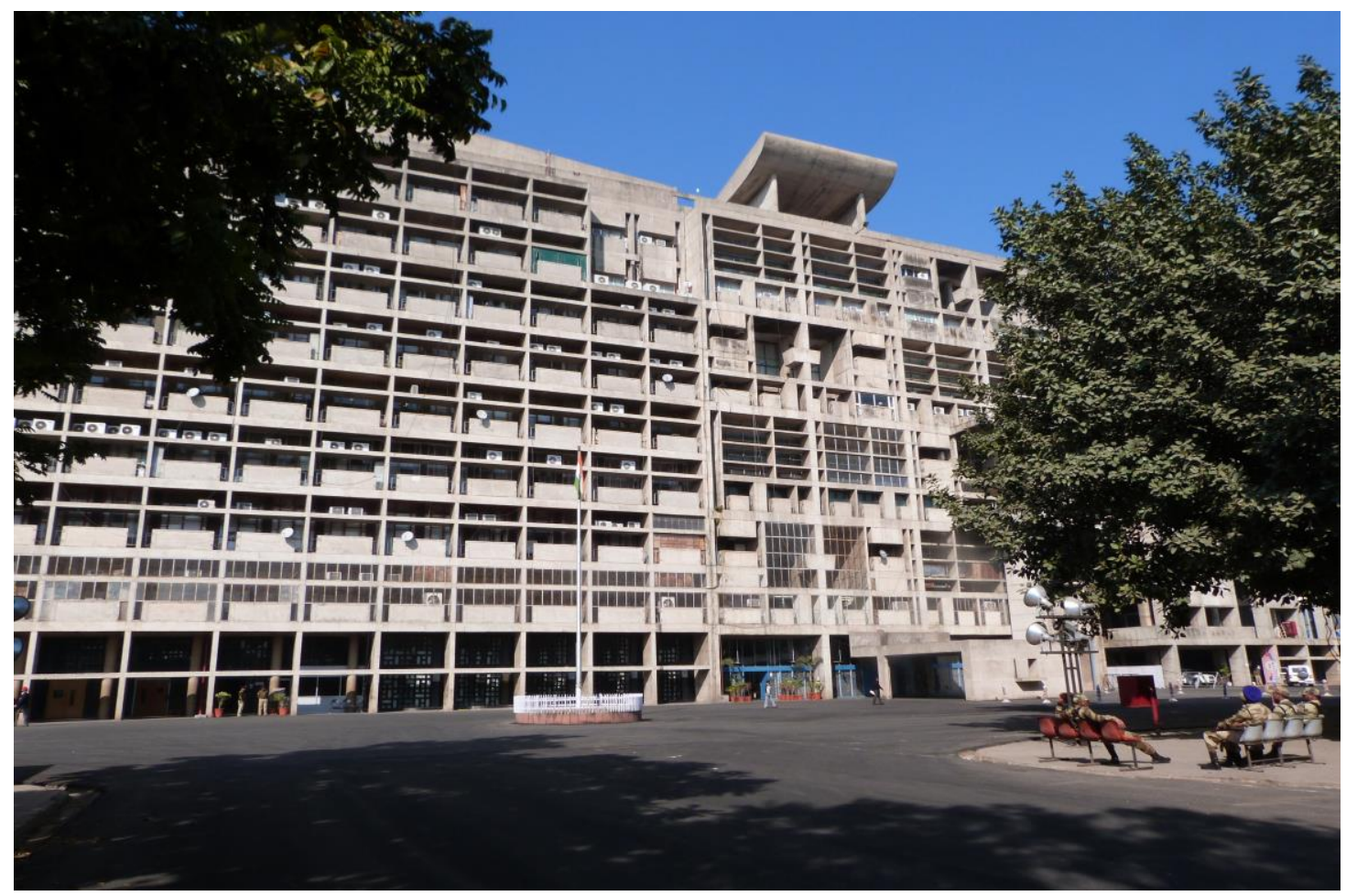

6. Fachada del edifício del Secretariado de Chandigarh.

Para maximizar la iluminación natural y aumentar la ventilación cruzada, se implementó este plano largo y estrecho. Así, el corte de este vasto edificio de oficinas es proporcionado por la protección contra el sol: brisesoleil; contra el calor del aire: respiración natural y artificial; por una modulación rigurosa proporcionada por el Modulor, traendo a todas las cosas una estatura humana ${ }^{22}$. En el Secretariado, el hormigón crudo se interpone en la fenestración de las dos fachadas principales, con elementos verticales y estrechos, 27x7 cm de sección y 366 $\mathrm{cm}$. de altura, constituyen los ondulatoires ${ }^{23}$. Dentro de los panos de vidrio con carpinteria de madera, se introdujeron los aerateurs de entrada. Los de salida estaban conectados a conductos que llevaban el aire hacia la cubierta $^{24}$.

Entre todos los desafíos que tuvo el arquitecto en proyectos llevados a cabo, en India, la adaptación al clima no era el más pequeño. Se trata de hacer la demostración de las virtudes de la arquitectura moderna en un clima

\footnotetext{
${ }^{22}$ Pagnotta, Brian. 2011.

${ }^{23}$ Le Corbusier, 1957. p.78

${ }^{24}$ Requena Ruiz, I., op. cit., p.92.
} 
difícil, que tiene una temporada muy caliente desde marzo a mayo (temperaturas cerca de los 40 grados) y una muy húmeda de junio a octubre ${ }^{25}$.

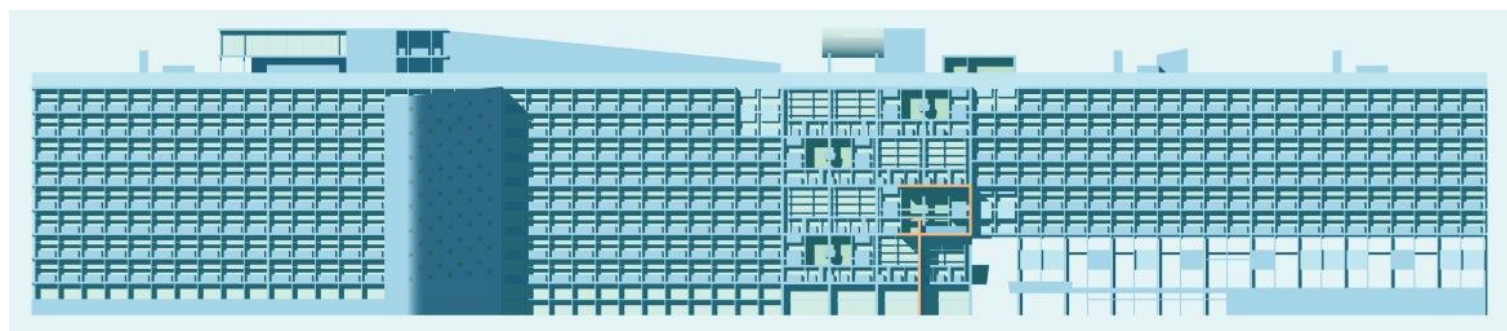

7. Fachada del edifício del Secretariado de Chandigarh. Fuente: disponible en: http://heldinaline.tumblr.com/post/101920384187/secretariat-building-capitol-complex-chandigarh

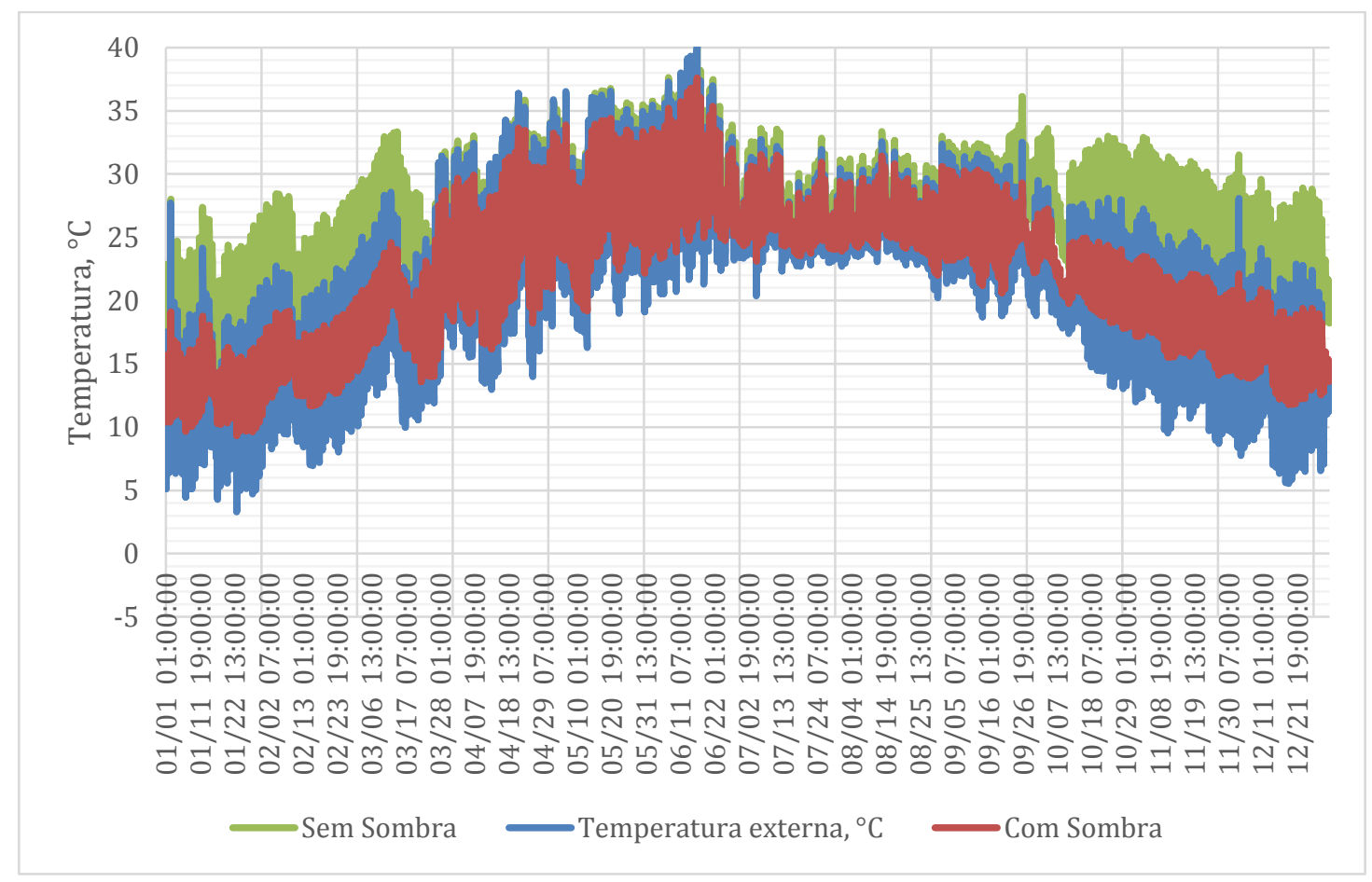

Tabla 5. Chandigarh: Desempeño anual del brise-soleil (en rojo) a través de las temperaturas internas en las oficinas del plano tipo, bloque $\mathrm{C}$, comparados con el desempeño de la fachada sin sombreamiento (en azul) y temperaturas ambiente exterior (en verde).

Las simulaciones demuestran que los brises mitigan las temperaturas, durante todo el año con una amplitud de $2^{\circ}$ a $8^{\circ}$, sin embargo, las amplitudes más grandes ocurren en los meses de octubre a marzo. De marzo a octubre, se presentan temperaturas más elevadas, y las temperaturas internas pueden llegar a los $37^{\circ}$, aunque llegarían a alcanzar los $40^{\circ}$ sin el sombreamento (Tabla 5).

Para la planta abierta, sin considerar las divisiones, los níveles de iluminación ya son adecuados a las 8:00h de la mañana con relaciones de 171-1059-46507 lux y a las 16:00h, 384-3131-175757 lux, en el 21/6. Sin embargo, las zonas de pico son muy puntuales, de modo que el ambiente se puede considerar homogéneo. En el 21/12, los

\footnotetext{
${ }^{25}$ Indian Society of Heating, Refrigeration and Ar condicioning Engineers. Candigarh tiene un clima temperado húmedo, con verano seco y caliente. Para la simulación de Chandigarh se utilizó los arquivos climáticos de la ciudad vecina de Dehradun.
} 
níveles son muy reducidos a las 8:00h com relaciones de 11-89-4634 lux, a las 16:00h tenemos 133-815-34629 lux. El efecto de los brise-soleil considerando la iluminación natural, sería apropiado en las habitaciones, sin divisiones internas, excepto en las primeras horas de la mañana.

\section{La Asociación de Hilanderos en Ahmedabad}

El Edificio de la Asociación de Hilanderos en Ahmedabad, quizá resume lo que se observa sobre el trabajo de Le Corbusier en la India. La estructura es rigorosamente disciplinada, el edificio está orientado de acuerdo con los vientos dominantes. Las fachadas este y oeste tienem sus brises precisamente calculados de acuerdo con la latitud local y el trayecto solar en cuanto que las fachadas norte y sul son prácticamente cerradas ${ }^{26}$. Le Corbusier optó por una arquitectura completamente abierta, donde el aire circulaba de forma natural, una construcción en la que la estructura, los brise-soleils y la envolvente exterior configuraban el suporte base de plantas diáfanas. Los brises-soleils aparecen una vez más como un importante elemento compositivo, concebido como un elemento adicionado a la fachada (fig. 8). En el lado oeste estos aparecen en ángulo para evitar que el temible calor del sol de la tarde penetre profundamente en la planta. Por otro lado, el edificio es una composición espacial osada donde abunda el espacio de circulación, lo cual permite que la brisa del río Sabarmati pase a través de los espacios al aire libre sombreados, ofreciendo un maravilloso refugio dentro de una ciudad hostil y caótica ${ }^{27}$.

La configuración abierta del edificio transformaba la arquitectura en una construcción porosa al paso del aire y protegida de la radiación, dejando las zonas privadas delimitadas por cerramientos específicos. Así como en Chandigarh, también a lo largo de las carpinterias proyectó un aerateur, a cada 1,42 m para garantizar la ventilación cruzada y disipar el calor interior. La buena aireación, acompañada de la gran altura libre (3,66 m) de los espacios, preveía mitigar la sensación térmica en los periodos cálidos del clima tropical. En las obras de los años cuarenta, la construcción indisoluble de la estructura y brise-soleil añadía la inercia y superficie de captación del parasol a la del resto del edificio, comprometiendo la habitabilidad en periodos pico de verano. El calor captado en la fachada era cedido a la estructura y, si carecía de una correcta ventilación, no llegaba a ser disipado en ciclos de menor temperatura. Este efecto fue monitorizado en el edificio de la Casa de Brasil ${ }^{28}$. Con el objetivo de evitar estas deficiencias realizó tres modificaciones en el sistema. En primer lugar, redujo el volumen de hormigón armado expuesto a la radiación solar directa. En según, introdujo una discontinuidad constructiva, entre el brise-soleil y el forjado, quedando unidos puntualmente por ménsulas. El calor, captado y almacenado en el brise-soleil no se transmitía por conducción al forjado interior, evitando aumentar la cesión de energía. La tercera medida fue disminuir al máximo los elementos de hormigón presentes en el plano de fachada con exposición directa al sol, sustituyendo los antepechos unidos a la estructura por barandillas metálicas o piezas de hormigón independizadas.

\footnotetext{
${ }^{26}$ Requena Ruiz, I. 2012, p.5.

${ }^{27}$ Le Corbusier, op.cit., p.144.

${ }^{28}$ Requena Ruiz, I. 2012, op.cit., p. 5.
} 


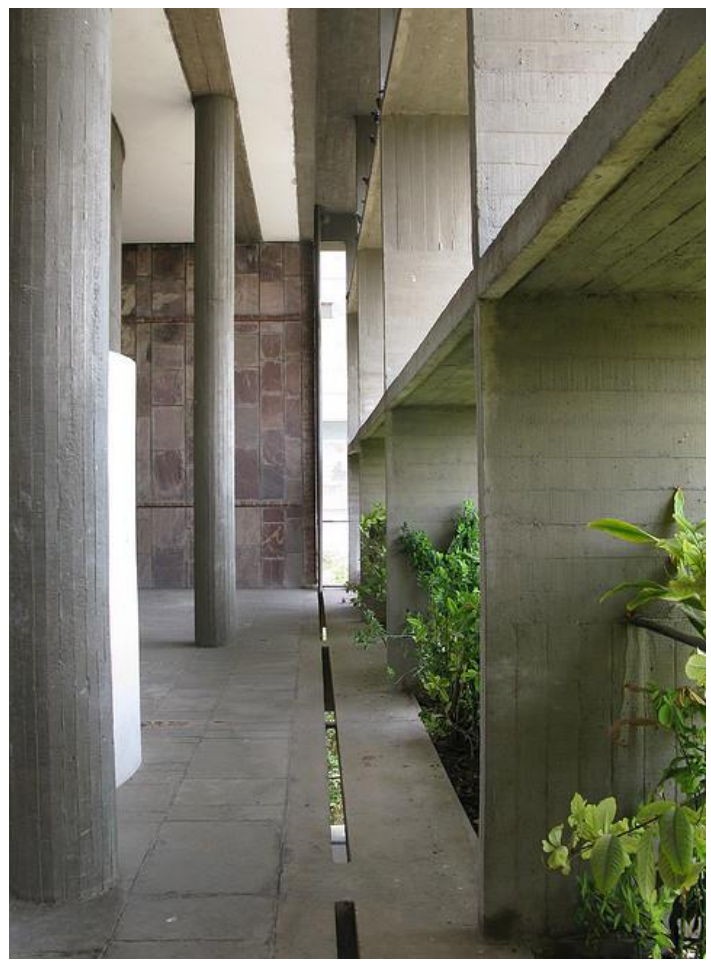

8. Mill's Owners Association - Ahmedabad, Brise-soleil de la fachada este, como elemento compositivo visivelmente separado de la fachada.

Ahmedabad está localizada en la latitud $23^{\circ} 06^{\prime}$ N. y longitud $72^{\circ} 40^{\prime}$ E. El clima es seco estepario cálido, caracterizado por precipitaciones anuales concentradas en periodo de los monzones y temperatura media anual superior a $\operatorname{los} 18^{\circ} \mathrm{C}$. Las máximas diarias en verano superan $\operatorname{los} 40^{\circ} \mathrm{C}$ y las mínimas de invierno no bajan de los $10^{\circ} \mathrm{C}$, combinándose con la estación de monzón intenso, con temperaturas hasta $\operatorname{los} 35^{\circ} \mathrm{C}$ y humedad relativa media superior al $70 \%{ }^{29}$.

Las simulaciones fueron hechas en las salas de conferencias, de las fachada este y oeste. Los gráficos presentan el efecto de los brise-soleil de la fachada este: la mitigación de las temperaturas durante todo el año presentan amplitudes de $2^{\circ}$ a $6^{\circ}$, y en los periodos cálidos de marzo a octubre presentan amplitudes reducidas (Tabla 6). Las diferencias van de $2^{\circ}$ a $4^{\circ}$ en los meses calientes y hasta $6^{\circ}$ en el periodo más frío, lo que no llega a ser un problema, pues las temperaturas invernales son amenas. En la fachada oeste, los picos de temperaturas son más elevados, llegando de $45^{\circ}$ a $49^{\circ}$, donde el efecto de los brises es preciso, con reducciones de hasta $10^{\circ}$ (Tabla 7). Sin embargo, la sensación térmica, en el ambiente interno puede ser más alta debido a la humedad relativa igualmente elevada. En definitiva, esta combinación de factores, no se suele solucionar solamente con estratégias pasivas. Cómo se observa en el comentario anterior, la preocupación y las estratégias de Le Corbusier, en los casos de Índia, fueron focadas en el aporte de calor.

\footnotetext{
${ }^{29}$ India Metereological Department. Fuente: disponible en: http://imdahm.gov.in/ahm.htm, acceso en 5/06/2015.
} 


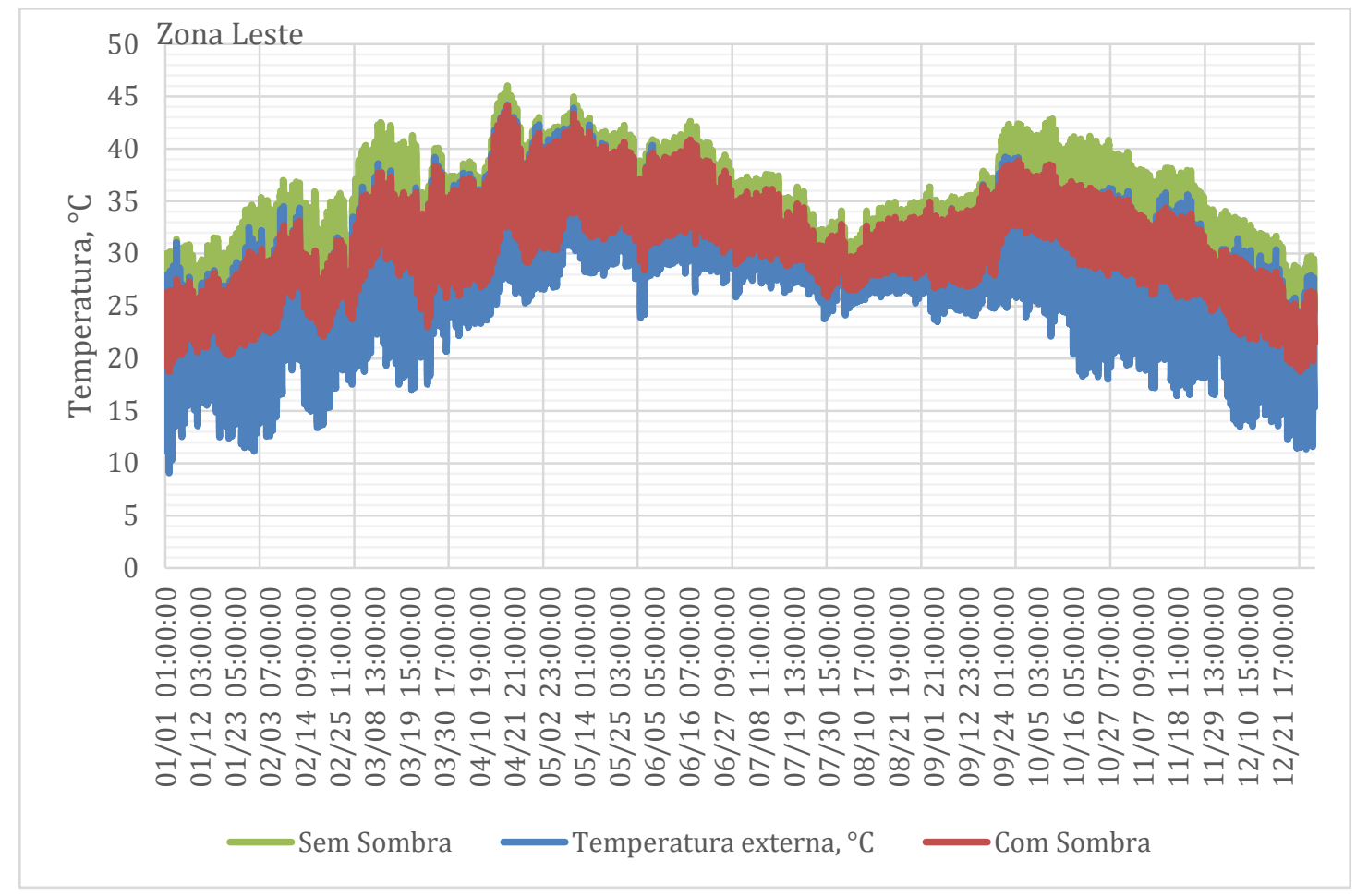

Tabla 6. Ahmedabad: Desempeño anual del brise-soleil (en rojo) a través de las temperaturas internas en la sala de conferencias de la fachada este, comparado al desempeño de la fachada sin los brises ( en azul) y temperaturas ambiente exterior (en verde)

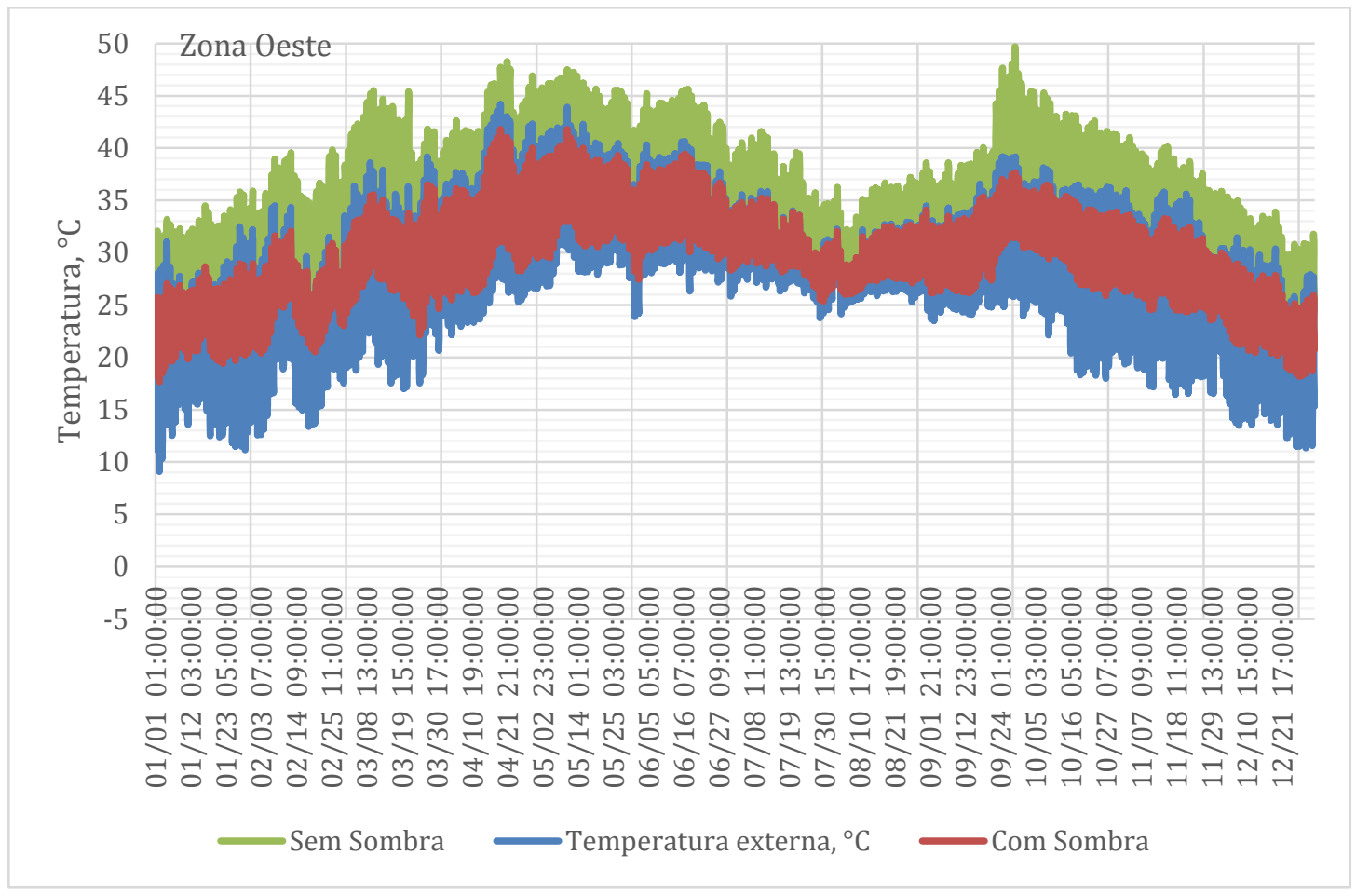

Tabla 7. Ahmedabad: Desempeño anual del brise-soleil (en rojo) a través de las temperaturas internas en la sala de conferencias de la fachada oeste, comparado al desempeño de la fachada sin los brises (en azul) y temperaturas ambiente exterior (en verde). 
Los mapas de iluminación, demostraron para la fachada oeste, a las 8:00h, níveles de iluminación bajos de 39126- 1778 lux, y para las 16:00h, 143-491-6243 lux, sin incidencia solar directa, en el verano (21/6). Para que se tenga una idea más concreta del efecto de los brises, las iluminancias, a las 16:00h serian de 4042-19653-76994 lux, con incidencia solar directa, sin el sobreamiento. En el invierno, los níveles a las 8:00h son de 7-22-220 lux, o sea muy oscuros, y a las 16:00h, tenemos 829-3132- 21479 lux, en el 21/12. Del mismo modo, que en el 21/6, la situación sin el sombreamiento genera una incidencia solar directa muy grande, 2005-7929-28402 lux. Así en términos lumínicos, se observa, que los brise-soleil, son muy efectivos, en este caso.

En la fachada este, a las 8:00h ocurren las relaciones de iluminancia de 1563-7266-127206 lux, y a las 16:00h, 490-1231-31614 lux, en el 21/6. En el 21/12, los níveles para las 8:00h son de 106 -342-7501 lux y a las 16:00h, son de 334-970-23732 lux.

\section{Centro Carpenter para las Artes Visuales in Cambridge, Massachusetts.}

El proyecto del Centro Carpenter proporcionó a Le Corbusier la oportunidad para presentar la síntesis final de sus ideas básicas y teorías sobre arquitectura y arte, en los Estados Unidos. Este edificio fue diseñado para las clases de la Arquitectura, Cine y otras Artes. Su exterior de hormigón tiene un acabado suave y preciso; altas y delgadas columnas rompen sus espacios interiores. Una gran rampa curvilínea divide la estructura y se conecta con la escalera principal y una sala de exposición. Desde el comienzo del proyecto, el Carpenter Center se caracteriza como un paseo arquitectónico conectando las dos calles, a través de un volumen que utiliza formas flexibles.

El arquitecto reeditó la solución ya probada en Chandigarh, Ahmedabad y Villa Shodhan, basada en paneles de hormigón colocados diagonalmente o perpendicular al borde de la construcción, pero con cristal sin marco fijo (fig. 9). Los pisos superiores del edificio, que no tienen aire acondicionado (Le Corbusier culpó el aire acondicionado para la prevalencia de problemas de sinusitis en los Estados Unidos), acumulan, tanto calor durante el verano que las aulas de la cuarta y quinta planta quedan inutilizables ${ }^{30}$. La expectativa del autor, que el edificio podría ser refrescado por los brises-soleil y por las altas y estrechas ventanas operables (aerateurs) no funcionó ${ }^{31}$.

Las aberturas del Centro Carpenter son principalmente de cuatro tipos: ventanas completas de piso a techo (pan de verre), brise-soleil (que también eran muros), ondulatoires (que dieron al espacio una mejor definición, como una pared descontinua en algunos lugares), aérateurs (como láminas pivotantes verticales con anjeos o telas de protección contra insectos incluidas). Todos estos elementos juntos constituyen una gramática de fachada, que es la version actualizada por Le Corbusier de su principio de la fachada libre de los años veinte. La idea era que cada uno de los elementos tenga su propia función y que se integren para simbolizar dicha función.

El Centro Carpenter Center representa la intensificación de sus proyectos anteriores que no sólo incorporan sus elementos arquitectónicos, como buscan nuevas soluciones. Esto queda evidente en el diseño de los brises que están dirigidos para acomodar los rayos del sol en las cuatro estaciones. La construcción es simple, consiste en lamas y pequeñas columnas. Los brises parecen moverse para regular la luz, de tal manera que constituye un avance en el lenguaje arquitectónico probando sus límites en cuanto a lo que podría llegar a ser, en lugar de simplemente simplemente aceptar sus éxitos anteriores.

\footnotetext{
${ }^{30}$ Frampton, Keneth, 2002, p. 186.

${ }^{31}$ Blair Kamin, 2013.
} 


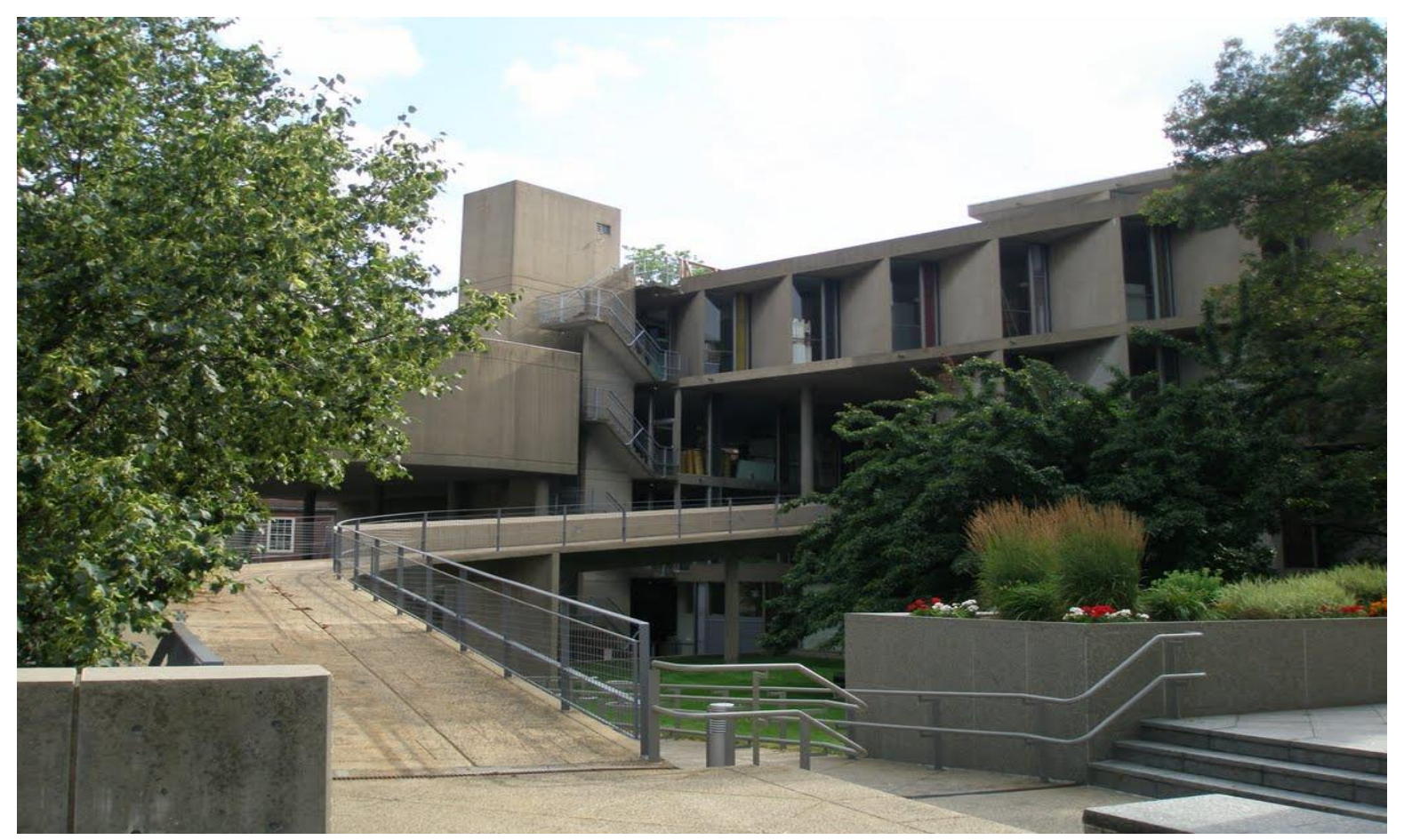

9. Fachada del Centro Carpenter de Artes Visuales.

\section{Conclusiones}

El brise-soleil es el elemento que caracteriza la producción del periodo tardío de la obra de Le Cobusier. Fue un medio de contraponer la vulnerabilidad de la fachada totalmente envidrazada y de evitar la retención de calor sin tener que volver a la tradición de la fachada sólida y perforada. Coherente con la lógica dialéctica de Le Corbusier, la transparencia ideal de la pared externa no fue totalmente abandonada; sus efectos se combinan con la adición de ese nuevo elemento tectónico. Sin embargo el brise-soleil era más que un dispositivo técnico; introdujo un nuevo elemento arquitectónico: una pared gruesa y permeable cuya profundidad y subdivisiones le otorgan a la fachada la morfología y la expresión edicular que se había perdido con la eliminación de la ventana y la pilastra. Por lo tanto, este proceso debe ser visto como un paso en dirección a la tradición monumental, que permitió transformar la lámina o la torre, como en Argel, en el Secretariado, o en Chandigarh, en una forma monumental, cuja superficie podía ser manipulada, creando una jerarquía de escalas, proporcional tanto al ser humano, cuanto al edificio como un todo.

Si en un primer momento el brise-soleil fue un elemento funcional, basado en una aproximación intuitiva, rapidamente pasó a ser un elemento compositivo, como se demuestra en el caso de Argel y en los proyectos siguientes. Sin abandonar los estudios en dirección a la optimización de su eficiencia y apoyándose en consultores, el arquitecto orientó a su equipo a solucionar los problemas específicos de la adaptación climática de cada obra. El deseo de excelencia se expresa ya en los proyectos en la India, como en el caso del Secretariado y finalmente en Cambridge.

Se puede concluir afirmando que le Corbusier creó una doble fachada, lo cual es evidente al observar en los proyectos la línea de adición del brise como un elemento que se acopla a la línea del plano de vidrio y que acaba siendo construido junto a la placa de hormigón. A partir de los proyetos en India, donde la situación climática es más crítica y cuando las investigaciones climáticas tuvieron un avance con la aplicación del método de la malla climática, las aplicaciones de éste generaron una relación con el clima más compleja y abstracta. Cada elemento 
presentaba una función específica: el brise-soleil era calculado y orientado según los requisitos del clima y del programa y los aerateurs según su número y posición, permitían la permeabilidad del aire. En este momento el brise se separa de la fachada en la búsqueda por la eficiencia en su desempeño ambiental.

En todos los casos el diseño de los brises, configura la fachada dupla, lo que de cierta forma no es mas que un muro neutralizador, o sea, un artificio de proyecto para hacer la mediación entre el clima exterior y el interior, un elemento de acondicionamiento natural. Esto se verifica en los ejemplos presentados: Argel y la Unidad de Habitación, caracterizados por la loggia brise-solei, el Ministerio, con su combinación de elementos verticales y horizontales, la diversidad compositiva en Chandigarh, y finalmente por los muros conceptuales de Ahmedabad y Cambridge.

Los resultados de este trabajo evidencian la cuestión central de la dualidad entre el sol del invierno y el sol de verano, así como la dificultad de trabajar en los lugares con climas más rigurosos, los cuales no suelen tener una solución fácil en el proyecto. En el caso de la Unidad de Habitación de Marsella, los brises no impiden una incidencia solar directa de dos horas en las tardes de verano y no permiten el aporte solar en el invierno. En los dos casos de India, las temperaturas internas permanecen muy elevadas en los períodos calientes. Sin embargo, las simulaciones desarrolladas en este estudio demostraron el efecto térmico favorable de los brises en todos los casos, con la mitigación de las temperaturas internas comparado a las condiciones sin el sobreamiento y a las temperaturas ambiente exterior. Aunque en los casos de Ahmedabad, y Chandigarh, no se logra en confort interno con las técnicas pasivas, la reducción de las mismas temperaturas a través de los brises y del conjunto de estratégias pasivas no es despreciable. Con relación al desempeño lumínico el efecto del brise-soleil es igualmente favorable al producir unas relaciones de iluminancias más homogéneas. Sin embargo, no se puede restringir esta apreciación exclusivamente a los brises, sino a la totalidad del sistema espacial propuesto por Le Corbusier, expresado en la conjunción del brise-soleil con las aberturas y la configuración formal del edificio. Estos elementos fueron perfeccionados durante su vida, siendo los factores climáticos los parámetros abstratos generativos de una gramatica formal.

\section{Procedencia de las imágenes}

Fig. 1 - Le Corbusier Le Corbusier - Ouvre Complète 1938-1946. Les Editions d'Architecture Erlenbach-Zurich, 1946. p. 104.

Fig. 2 - ídem, p. 56, 61 y 64.

Fig. 3 - Nelson Kon. [en línea] [fecha de consulta: Mayo,10, 2015] . Disponible en internet: http://www.vitruvius.com.br/revistas/read/minhacidade/08.086/1917

Fig. 4 - Costa, Lúcio. Ministerio de Educação e Saúde, Memorial descritivo. En Sobre Arquitetura, volume 1 (org. Alberto Xavier). Porto Alegre: Centro dos Estudantes Universitários de Arquitetura, 1962

Fig. 5 - [en línea] [fecha de consulta: Mayo,10, 2015] . Disponible en internet: http://misfitsarchitecture.com/tag/unite-dhabitation-marseilles/ acceso en 30/05/2015.

Fig. 6 y 8 - Fotos de la autora.

Fig. 7- [en línea] [fecha de consulta: Mayo,10, 2015] . Disponible en internet: http://heldinaline.tumblr.com/post/101920384187/secretariat-building-capitol-complex-chandigarh

Fig. 9 - [en línea] [fecha de consulta: Mayo,10, 2015] . Disponible en internet: http://www.panoramio.com/photo/62095315.

Tablas $\mathrm{n}^{\mathrm{o}}$ 1, 2, 3, 4, 5, 6 e 7 son originales de los autores. 


\section{Bibliografia}

Almodóvar, José Manuel, De la ventana horizontal al brise-soleil de Le Corbusier: Análisis ambiental de la solución propuesta para el Ministério de Educação de Río de Janeiro, En Arquitextos 051.02, ano 05, set. 2004. [en línea] [fecha de consulta: Mayo, 10, 2015]. Disponible en internet: http://www.vitruvius.com.br/revistas/read/arquitextos/05.051/554.

Comas, Carlos E. D. A máquina para recordar: Ministerio da Educação no Rio de Janeiro, 1936/45. En Arquitextos 005.01, ano 01, out 2000, [Fecha de consulta: Mayo, 18, 2015]. Disponible en internet: http://www.vitruvius.com.br/revistas/read/arquitextos/01.005/967

Costa, Lúcio. Ministerio de Educação e Saúde, Memorial descritivo. En Sobre Arquitetura, volume 1 (org. Alberto Xavier). Porto Alegre: Centro dos Estudantes Universitários de Arquitetura, 1962.

Frampton, Keneth, Le Corbusier - Architect of the Twentieth Century, New York: H. N. Abrams, c2002, p. 186.

India Metereological Department. [en línea] [fecha de consulta: Mayo,31,2015]. Disponible en internet: http://imdahm.gov.in/ahm.htm.

Kamin, Blair. Fifty Years Later, Still Scandalizing the Neighbor. En Architectural Record, 2013. [en línea] [fecha de consulta: Mayo,31,2015]. Disponible en: http://archrecord.construction.com/news/2013/05/130521-onits-50th-anniversary-what-does-le-corbusier8217s-carpenter-center-at-harvard-say-to-us-today.asp (http://worldweather.wmo.int/en/city.html?cityId=242)

Le Corbusier, Le Corbusier et son atelier rue de Sèvres 35- Ouvre Complète 1952-1957. Les Editions d'Architecture Erlenbach-Zurich, 1957. $9^{\circ}$ ed., p.78

Le Corbusier. Le Corbusier - A Carta de Atenas. São Paulo: Hucitec-Edusp, 1993.

Le Corbusier. Le Corbusier - Ouvre Complète 1938-1946. Erlenbach-Zurich: Les Editions d'Architecture, 1946. p. 108

Mackenzie, Christopher, 1993 February: Le Corbusier in the sun. [en línea] [fecha de consulta: Mayo, 24, 2015]. Disponible en internet: http://www.architectural-review.com/1993-february-le-corbusier-in-thesun/8616242.article.

Moos, Stanislau von, Le Corbusier - Elements of a Syntesis, 2013.[en línea] [fecha de consulta: Mayo, 30, 2015] Disponible en internet: https://books.google.com.br/books?id=X_igJKO7y5kC\&pg=PA50\&hl=pt-

$\mathrm{BR} \&$ source $=\mathrm{gbs} \_$selected_pages\# $\mathrm{v}=$ onepage $\& \mathrm{q} \& \mathrm{f}=\mathrm{false}$

Pagnotta, Brian. "AD Classics: Chandigarh Secretariat / Le Corbusier" 26 Sep 2011. [en línea] [fecha de consulta: 25 May 2015]. Disponible en internet: <http://www.archdaily.com/?p=162279>

Requena Ruiz, I. Arquitectura adaptada al clima en el movimiento moderno: Le Corbusier (1930-1960). Tesis doctoral, Universidad de Alicante, Alicante, 2011, pp. 215. [en línea] [fecha de consulta: 25 May 2015]. Disponible en internet: http://rua.ua.es/dspace/handle/10045/23997

Requena Ruiz, I. Bioclimatismo en la Arquitectura de le Corbusier: El Palacio de los Hilanderos. En Informes de la Construcción, Vol. 64, 528, 549-562, octubre-diciembre 2012. [en línea] [fecha de consulta: 25 May 2015]. Disponible en internet:

http://informesdelaconstruccion.revistas.csic.es/index.php/informesdelaconstruccion/article/viewArticle/2425

Siret, Daniel. "1950 - Grille climatique - Chandigarh". Le Corbusier Plans. Paris: Editions Echelle-1 y Fondation Le Corbusier: DVD-ROM, 2006. [en línea] [fecha de consulta: Mayo, 18, 2015]. Disponible en internet: http://www.researchgate.net/publication/236883104_Le_Corbusier_Plans_-_Notice_1950__Grille_climatique_(Chandigardh)

Siret, Daniel. L'illusion du brise-soleil par Le Corbusier, Langages Scientifiques et Pensee Critique, Cerisy, juin 2002, Laboratoire CERMA UMR CNRS 1563, Cerisy, France. [en linea] [fecha de consulta: Mayo, 15, 2015 ]. Disponible en internet: https://halshs.archives-ouvertes.fr/halshs-00580040

Siret, Daniel; Harzallah, Amina. Architecture et contrôle de l'ensoleillement, CERMA - UMR CNRS 1563, Ecole Nationale Supérieure d'Architecture de Nantes, 2006. [en línea] [fecha de consulta: Mayo, 18, 2015]. 
Disponible en internet:

http://www.cafepedagogique.net/communautes/EquipedeRecherchesurlesambiances/Documents/ Architecture $\% 20$ et $\% 20$ contrôle $\% 20$ de $\% 201$ 'ensoleillement.pdf

U.S. Department of Energy, EnergyPlus Energy Simulation Software, [en línea]. [fecha de consulta Mayo, 24, 2015 ]. Disponible en internet: http://apps1.eere.energy.gov/buildings/energyplus/. 


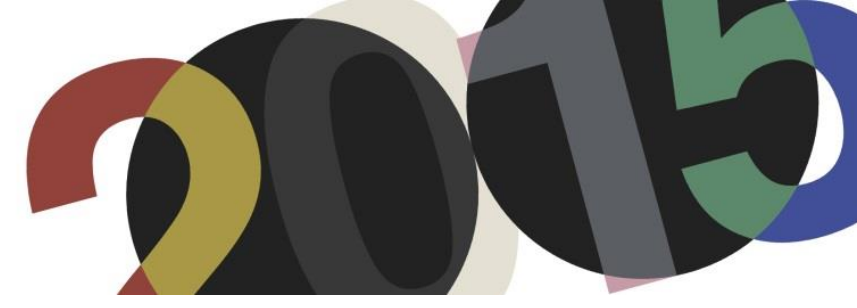

DOI: http://dx.doi.org/10.4995/LC2015.2015.929

\title{
L'Architecture Vivante y Le Corbusier
}

\author{
M.P. Moreno Moreno \\ Escuela Técnica Superior de Arquitectura y Edificación \\ Universidad Politénica de Cartagena. UPCT
}

\begin{abstract}
Resumen: Las publicaciones especializadas de arquitectura facilitan la difusión de ideas, métodos y técnicas del período concreto de su existencia. Sus contenidos, analizados al cabo del tiempo, conforman un atlas de pensamiento capaz de enmarcar la interpretación social de un contexto espacio-temporal bajo el prisma de lo constructivo.

Jean Badovici funda en 1923, junto al periodista Christian Zervos, la revista L'Architecture Vivante (1923-1933) editada por Albert Morancé. La aparición en sus páginas de una arquitectura técnicamente bien definida, acompañada de reseñas redactadas con rigor crítico por su director, o por los propios autores de las obras, hicieron de ella un instrumento prestigioso de propagación de las nuevas ideas entre el público profesional. Una relectura contemporánea de los textos y proyectos publicados, permite detectar el itinerario intelectual llevado a cabo por sus responsables respecto al convulso y cambiante entorno arquitectónico europeo en el que fijaron su mirada. En esa evolución, manifestada en apenas el período de una década, hay que subrayar el protagonismo adquirido por la obra de Le Corbusier que, a partir del cierre de L'Esprit Nouveau en 1925, no dudó en considerarla una excelente herramienta de exposición al debate de sus ideas, incluyendo en ella los proyectos y escritos realizados en pro de una arquitectura moderna.
\end{abstract}

Abstract: The specialized publications in architecture facilitate the diffusion of ideas, methods and techniques of the particular period of its existence. Its contents, analyzed over time, make up an atlas of thought capable of framing the social interpretation of a spatial-temporal context under the prism of the constructive. Jean Badovici founded in 1923, together with the journalist Christian Zervos, the magazine L'Architecture Vivante (1923-1933), edited by Albert Morancé. The appearance on its pages of an architecture technically well-defined, accompanied by critiques written with critical rigor by its director, or for the authors of the works, they did of her a prestigious instrument of spread of the new ideas among the professional public. A contemporary revisiting of the texts and published projects, allows to detect the intellectual itinerary carried out by its persons in charge with regard to the convulsed and changeable European architectural environment in which they fixed its look. In this evolution manifested, in just the period of a decade, we must emphasize the prominence given to the work of Le Corbusier who, from the closure of L'Esprit Nouveau in 1925, did not hesitate in considering it as an excellent tool for exposure to the discussion of his ideas, including in it projects and writings made for a modern architecture.

Palabras clave: Le Corbusier; L'Architecture Vivante; Jean Badovici; revistas; arquitectura.

Keywords: Le Corbusier; L'Architecture Vivante; Jean Badovici; magazines, architecture. 


\section{Introducción}

El arquitecto Jean Badovici ${ }^{1}$ fundó en 1923 -junto al periodista griego Christian Zervos y al editor Albert Morancé- la revista L'Architecture Vivante, de la que se publicaron 42 números estacionales que se agrupaban en volúmenes semestrales, hasta 1933. El subtítulo adoptado por la publicación era “Documents sur l'activité construtive dans tous les pays " $y$ manifestaba tanto su contenido, centrado en el ámbito constructivo, como el amplio ámbito geográfico al que dirigía su foco de atención.

La característica principal del proyecto editorial era exponer la actualidad arquitectónica a través de una información técnica precisa que propiciaba tanto la opinión profesional como la crítica constructiva y el debate intelectual.

La rigurosidad de sus responsables en la recopilación de planos, detalles y fotografías de los proyectos reseñados permitió que el conjunto adoptara una seriedad documental digna para la lectura de especialistas en la materia. La clave fundamental de la revista consistía en una minuciosa labor de búsqueda y selección de lo editado con el objetivo de conseguir la impronta científica a la que se aspiraba.

La información propiamente arquitectónica -dibujos e imágenes- iba acompañada de textos redactados por los protagonistas de la vanguardia del momento donde se abordaban los conceptos que subyacían en la obra publicada. La materialidad constructiva de todo lo expuesto reflejaba el fluido pensamiento del colectivo arquitectónico y las influencias mutuas favorecidas por la difusión en revistas y exposiciones de ejemplos concretos.

El propósito de la revista era hacerse eco de los debates contemporáneos: la vivienda mínima, la policromía en la arquitectura, la prefabricación, la industrialización, el urbanismo o la ciudad.

Teniendo en cuenta el contexto socio-cultural de la publicación (1923-1933), y con la perspectiva que ofrece el paso del tiempo, se puede afirmar que el conjunto conformó, sincrónicamente, un atlas de modelos y tipos arquitectónicos que abordaban el cambio social referido a lo arquitectónico y, diacrónicamente, una herramienta útil para las futuras investigaciones en torno a las incipientes reflexiones aparecidas en aquellos proyectos publicados, todas ellas producto de la asociación de técnica, progreso y pensamiento.

L'Architecture Vivante facilita la relectura de la arquitectura moderna como una disciplina que fue capaz de conformar los escenarios para una nueva vida y de responder desde el mundo del proyecto a la evolución social y económica ocurrida durante el período de entreguerras.

En definitiva, el documento en su totalidad permite enfocar la mirada a un trinomio espacio-tiempo-social concreto desde el prisma de lo arquitectónico y constructivo.

"... una revista con textos críticos e imágenes bien elegidas; si evita el sensacionalismo vulgar se puede convertir incluso en un registro intelectual del estado del mundo visto a través de nuestra disciplina" 2.

\footnotetext{
${ }^{1}$ Jean Badovici, (1893-1956) fue un arquitecto rumano afincado en París dedicado principalmente a la crítica y difusión de la arquitectura moderna a través de la dirección de la revista L'Architecture Vivante. Contribuyó con artículos en otras publicaciones como Cahiers d'Art fundada por Christian Zervos en 1926 o en la revista holandesa Wendingen. Escribió los libros Intérieurs de Süe et Mare (1924), Intérieurs Français(1925), y Grandes Constructions: Béton Armé,Acier, Verre (1931) donde por primera vez, en Francia, se trataba la edificación industrial y fabril como metáfora de la arquitectura moderna.

${ }^{2}$ Fernández Galiano, Luis: "Una mezcla de medios, o una matriz de mediación”. En Arquitectos: Información del Consejo Superior de Arquitectos de España. "Arquitectura mediada”. 2008, N 184. Madrid: CSAE. pp. 47- 48.
} 
Le Corbusier no fue ajeno a la existencia de semejante oportunidad editorial considerándola, desde el primer momento, un adecuado marco propagandístico desde cuyas páginas exponer su propio trabajo para suscitar el debate entre una élite arquitectónica ${ }^{3}$. Sus proyectos -teóricos y construidos- junto con sus escritos, en clave evolucionista, alcanzarán un gran protagonismo, principalmente a partir de 1927. La profusión de su figura, junto a la de Pierre Jeanneret, en la revista respondía tanto a su interés de éstos por estar en el centro de las discusiones arquitectónicas en el ámbito europeo como a la relación intelectual y amistosa de los dos arquitectos con su director, Jean Badovici.

\section{L'Esprit Nouveau versus L'Architecture Vivante}

El período de publicación de L'Architecture Vivante (1923-1933) coincide en dos años con el de la revista L'Esprit Nouveau ${ }^{4}$ (1920-1925). Le Corbusier valoró positivamente la existencia de otro marco de divulgación alternativo en la que se publicara con rigor la arquitectura coetánea acompañada de una crítica inteligente comandada por Jean Badovici.

L'Esprit Nouveau, al contrario que L'Architecture Vivante, era una publicación -cajón de sastre- que abarcaba numerosas temáticas. Su finalidad era mostrar las influencias entre artes y las transiciones transversales de conceptos fundamentales entre las distintas especialidades. Por todo ello el subtítulo adjunto al encabezamiento era muy amplio: 'L'Esprit Nouveau: Revista Internacional Ilustrada de la Actividad Contemporánea, Artes, Letras, Ciencias, Literatura, Arquitectura, pintura, Escultura, Música Ciencias Puras y Aplicadas. Estética Experimental, Estética del ingeniero, Urbanismo, Filosofía, Sociología, Economía, Ciencias Morales y Políticas, Vida moderna, teatro, espectáculos, deportes y eventos".

La contaminación entre campos suponía uno de los paradigmas de la época. El progreso, en clave evolutiva de la sociedad, no era considerado como el producto del sumatorio de cambios parciales sucesivos en cada parcela disciplinar, sino que respondía el resultado de una impulsión única y unidireccional de todo el mundo creativo y social, incluido el de la arquitectura ${ }^{5}$.

Las diferencias entre los enfoques de L'Esprit Nouveau y L'Architecture Vivante ejemplifican el tránsito surgido en los métodos de difusión de la arquitectura. Esta disparidad recuerda el giro hacia el último período de la división de la historia de la publicidad distinguida por Daniel Pope en The Making of Modern Advertising, denominado el de la "era de la fragmentación del mercado". En dicha etapa -datada en la década de los 20- el mercado estaba caracterizado por una "producción para el consumo de masas" que se transforma en una

\footnotetext{
${ }^{3}$ El propio editor, Albert Morancé advierte del propósito de la revista, como libro en evolución, de seguir los esfuerzos realizados por los artistas y considera que dicha publicación está dirigida expresamente a una élite aportando documentos e ideas desde las cuales ellos puedan continuar. "Cette reveu ne s'adresse pas qu'à une élite: elle aporte a ses lecteurs des idées et des documents: à eux d'en tirer partir”, Morancé Albert en L'Architecture Vivante. Primavera-Verano 1926. París: Ed. Albert Morancé. p.6.

${ }^{4}$ L'Esprit Nouveau fue fundada por Charles Édouard Jeanneret-Le Corbusier- y Amédée Ozenfant, siendo inicialmente el editor el poeta Paul Dermée que abandona la publicación en el n⿳⺈,4 al querer convertirla en una revista dadaísta. A partir de entonces el subtítulo cambia de Revue International d'esthétique a Reveu International de l'activité contemporaine, expandiendo su campo temático hacia actividades de la vida cotidiana como el teatro, el diseño, el cine, el deporte etc... Se publicaron un total de 28 números hasta 1925 afirmando entonces Le Corbusier ". ... uno no debe repetirse continuamente. Otros más jóvenes tendrán ideas más jóvenes...”

${ }^{5}$ El maquinismo, punto de partida de Le Corbusier es entendido como un concepto implicado en lo mínimo de cualquier manifestación, fruto del espíritu de una época. "El arte no está separado de la vida; la estética, como la moral, está condicionada por la organización del mundo en la que ésta se desarrolla” Badovici, Jean y (Gray, Eileen): "L'Architecture Utilitaire”. En L'Architecture Vivante. Otoño-Invierno 1926. París: Ed. Albert Morancé. pp.17-24.
} 
"producción para el consumo de un mercado estratificado". Es decir, para subgrupos de consumidores relativamente bien definidos ${ }^{6}$. Este traslado de un público indiscriminado a un público especializado refleja la diferencia sustancial entre estas dos revistas: L'Esprit Nouveau y L'Architecture Vivante. La primera dirigida a un sector amplio de la sociedad con intereses multidisciplinares conectados en el mismo espacio y la segunda enfocada a un público más profesional, capaz de lecturas más técnicas, en este caso arquitectónicas.

El vasto espectro de temáticas abordado por Le Corbusier y A. Ozenfant en L'Esprit Nouveau permitía desdibujar los límites entre el texto y la publicidad. El contraste de imágenes procedentes de productos industriales con dibujos y fotografías de contenido auténticamente arquitectónico posibilitaba establecer metáforas absolutamente intencionadas. El objetivo era dirigir al lector a analogías de ideas como la casa y la máquina, o lo industrial y lo arquitectónico etc... Sin embargo el contenido de L'Architecture Vivante era más restrictivo, centrándose principalmente en lo que de constructivo y técnico tenía la arquitectura.

La concatenación temporal de las dos publicaciones demuestra el desplazamiento impulsado por los responsables de la segunda en el planteamiento editorial; desde un público ${ }^{7}$ diverso, con intereses variados, a un público experto capaz de comprender técnica y científicamente todo lo publicado tanto gráfico como textual.

\section{Objetivos, contenidos y formato de L'Architecture Vivante}

\subsection{Objetivos}

En el primer número de L'Architecture Vivante, J. Badovici cede el protagonismo a Auguste Perret -arquitecto de referencia del momento en París- para explicar tanto el por qué del título elegido como a qué tipo de arquitectura denominarán "Vivante" en la publicación.

"La Arquitectura Viva es aquella que expresa fielmente su época. Buscaremos ejemplos en todos los ámbitos de la construcción y elegiremos las obras que, estrictamente se subordinen a su uso, realizadas con el empleo juicioso de la materia que alcancen la belleza por las disposiciones y proporciones armoniosas de los elementos que las componen"8.

Adjunto a ese texto, y como clave introductora de esa intención, se transcribe una cita pronunciada por el personaje de Phèdre - protagonista del diálogo, "Eupalinos ó el arquitecto" (1922)- de Paul Valéry, que dice:

“¿...no has observado, caminando por esta ciudad, que entre los edificios de la que está poblada, unos son mudos, otros hablan; y otros, los menos comunes, cantan? 9" ( fig.1).

\footnotetext{
${ }^{6}$ Colomina, Beatriz: Privacidad y publicidad. La arquitectura moderna como medio de comunicación de masas. Murcia: Cendeac, 2010. p.130.

${ }^{7}$ En una carta dirigida por Le Corbusier a una filial de los almacenes Printemps denomina Ateliers con el objetivo de hacerse con un contrato de publicidad, aseguraba que únicamente el 24,3\% de los suscriptores eran artistas-pintores y escultores- y el resto era gente con puestos activos en la sociedad, cifrando en $8 \%$ el conjunto de los suscriptores arquitectos. Colomina op. cit pp.133-134.

${ }^{8}$ Perret Auguste en L'Architecture Vivante.. Otoño-Invierno 1923. París: Ed. Albert Morancé. p.6.

${ }^{9}$ Valery, Paul en L'Architecture Vivante. Otoño-Invierno 1923. París: Ed. Albert Morancé. p.6.
} 


\section{L'ARCHITECTURE VIVANTE}
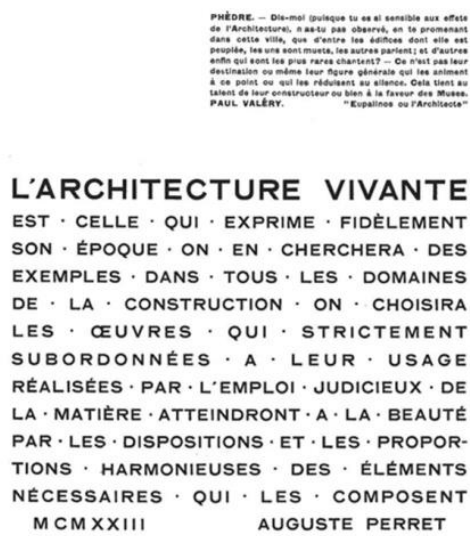

1. Portada: Título y subtítulo de L'Architecture Vivante. Cita de "Eupalinos ou l'architecte" de Paul Valery. Y nota introductora redactada por Auguste Perret. Primer númeno de L'Architecture Vivante, Otoño-Invierno 1923

Esta reflexión, abierta en la primera página desvela, de modo poético, el fin último de la revista: la búsqueda de los edificios que cantan.

El editor Albert Morancé, en el artículo de presentación aclara esa intención manifestada:

"Tratamos de ofrecer la colección más amplia, variada y característica, de documentos que sirvan para realizar el estudio de la arquitectura contemporánea en lo que tenga realmente de novedoso. Examinaremos cada obra en términos de su desarrollo orgánico en cuanto a sus materiales de trabajo, los procesos que se aplican en las nuevas condiciones que se imponen a la arquitectura" 10.

En el reverso de la portada de todos sus números aparece tanto el agradecimiento a los arquitectos que colaboraron con sus obras y publicaciones en la revista, como un texto significativo en el que se describen las pautas fundamentales de la línea editorial perseguida (fig.2):

"L'Architecture Vivante reproducirá edificios de arquitectos franceses ó extranjeros, cuya obra constituya una demostración de investigaciones fecundas del artista contemporáneo, de su claridad de espíritu y de su juicio delicado y seguro. Examinará la base fundamental de sus obras, es decir, la construcción y las numerosas exigencias que implica. Analizará los detalles de utilidad que forman, como dice Delacroix, el punto de partida del arquitecto. Estudiará, al mismo tiempo que la estructura, las formas y la decoración arquitectónica, las artes que contribuyen a embellecer un edificio, indicando con ejemplos aquel espíritu que debe reinar en la colaboración del arquitecto con el pintor o el escultor “

Con estas premisas previas, los objetivos quedaron definidos desde el primer número.

${ }^{10}$ Morancé Albert: “Architectures d'Aujourd'hui“". En L'Architecture Vivante, Otoño-Invierno 1923. París: Ed. Albert Morancé. p.8. 


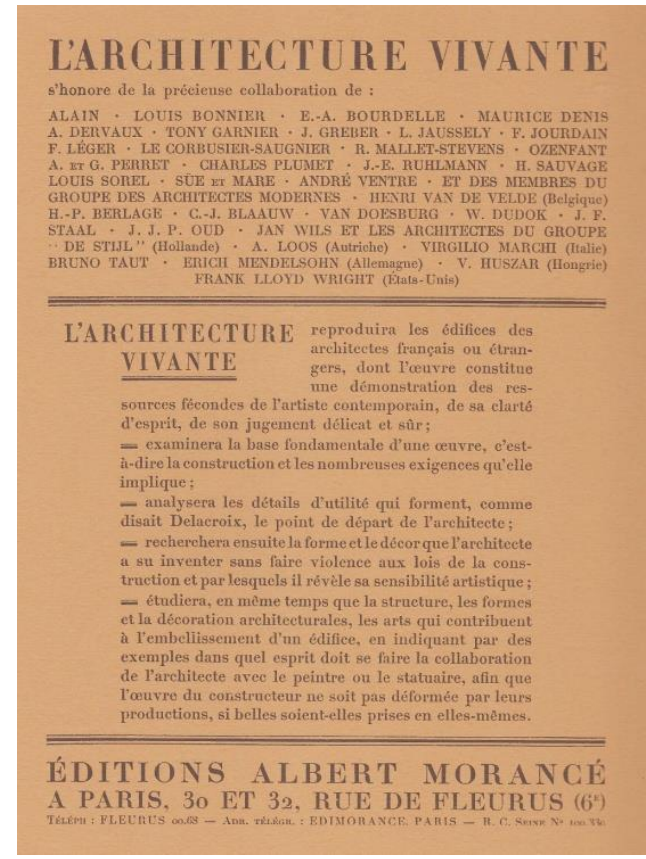

2. Contraportada de L'Architecture Vivante: Agradecimientos y objetivos.

\subsection{Contenidos}

El resultado del conjunto es un complejo documento que mezcla dicotomías asimétricas como el vanguardismo enfrentado al clasicismo, el humanismo combinado con el maquinismo, la individualidad del artista-arquitecto junto a la reivindicación de la experiencia colectiva, el arte con metodologías científicas, o el pragmatismo como colaborador de cualquier tipo de utopía.

El pensamiento subyacente a la amalgama de obras evoluciona en paralelo a las exposiciones, los ideas y las obras más significativas desarrolladas durante la década de su existencia (1923-1933). En la elección de temáticas, obras y protagonistas de sus páginas se refleja la transición intelectual de sus responsables, especialmente de Jean Badovici.

Al principio los contenidos de la revista eran diversos e incluso inconexos, mezclando algunas veces arquitectura con ejemplos de decoración interior, e incluso obras de carácter escultórico-arquitectónico como monumentos ${ }^{11}$. Sin embargo, a medida que avanza en el tiempo, la temática se concentra en la arquitectura, la construcción y el urbanismo.

A partir de 1927, la estrategia editorial gira hacia la publicación de estudios monográficos de arquitectos - Le Corbusier y Pierre Jeanneret (fig.3), Frank Lloyd Wright, Tony Garnier, Erich Mendelsohn- de temáticas concretas - arquitectura alemana, soviética, vivienda mínima ó arquitectura hospitalaria- y por último desarrollos extensos de proyectos de gran envergadura como por ejemplo el Plan d'Aménagement de la Ville d'Alger ó la Exposition de Stuttgart.

\footnotetext{
${ }^{11}$ Un ejemplo de esta diversidad temática es el contenido de los primeros números de Otoño e Invierno de 1923, donde aparecen: el proyecto de la iglesia Notre Dame de Raincy de A.y G.Perret, el Monumento de la Pointe de Grave de Albert Bartholomé y André Ventre, la Perfumería de Rue de Paix de Süe et Maré, el Groupe de Habitation a Bon Marché de la Rue de Aniraux de Henri Sauvage, el Projet pour Institur Royal Hollandais des Sciencies, Lettres et Beaux-Arts de C.van Eesteren, la villa en Vaucresson de Le Corbusier y Pierre Jeanneret y por último la Petite Maison de A. Loos.
} 


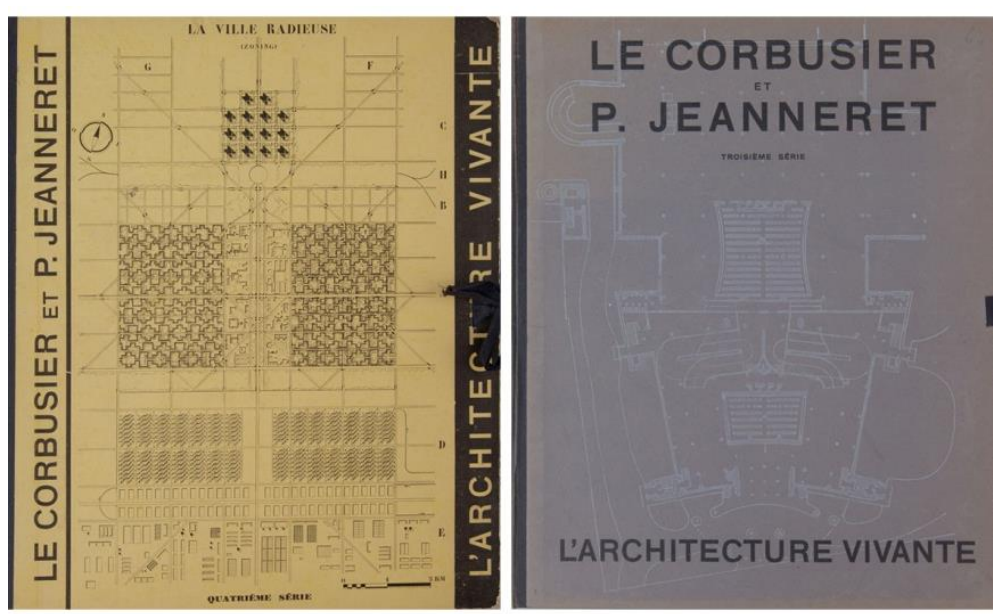

3. L'Architecture Vivante, $\mathrm{n}^{\circ}$ Primavera-Verano 1931. L'Architecture Vivante, $\mathrm{n}^{\circ}$ Primavera Verano 1930

\subsection{Formato}

El formato de la revista era un portfolio de $28 \times 22,5 \mathrm{~cm}$, estructurado en dos secciones: una más iconográfica compuesta por una serie de 25 láminas - envueltas en papel de seda - que contenía imágenes exteriores e interiores y planos escogidos de obras de arquitectura, y otra, a modo de fascículo de 8,16 o 32 hojas, con textos de artistas y arquitectos elegidos por su director acompañados de dibujos y planos, en algunos casos abigarradamente maquetados que corroboraban lo dicho en la redacción de los artículos. Todo ello acompañado de la necesaria e inevitable, pero escasa, publicidad comercial.

\section{Le Corbusier en L'Architeture Vivante}

\subsection{Entretiens sur l'Architecture Vivante}

En el período de 1923 a 1927, Jean Badovici escribía en la revista una sección denominaba "Entretiens sur l'architecture vivante" -conversaciones sobre la arquitectura viva- donde, a modo de reportaje, reseñaba obras significativas del momento. En dicho apartado se aportaba la información gráfica, de proyectos significativos, que iba maquetada, a veces entre el texto, y otras anexas en las láminas -planches- posteriores.

Las primeras referencias de la revista a la obra de Le Corbusier aparecen en dicha sección con la descripción de algunas de las viviendas unifamiliares proyectadas por el arquitecto y Pierre Jeanneret en la década de los 20 como la Villa en Vaucresson, el Atelier d'artiste, la Maison au bord du lac Léman, el atelier allée des Pins ó el Hotel Particulier en la rue Dr Blanche de París.

En "Entretiens sur l'architecture vivante" del primer número de la revista -1923-, Badovici asocia en el mismo epígrafe las tres siguientes referencias, "Petites maison d'Adolphe Loos, Le Corbusier et Pierre Jeanneret. Project pour un Institut Royal Hollandais de C.van Eesteren”. En el texto elogia la común renuncia de estos proyectos a fórmulas anticuadas y la apuesta de sus autores por la búsqueda de una concepción plástica que representara la expresión universal. La alusión a la descentralización de las plantas y al “...juego sabio, correcto y magnífico de los volúmenes bajo la luz" eran, en opinión de Badovici, coincidentes en tan diferentes investigaciones al margen de su concreta ubicación geográfica -Austria, Francia y Holanda-. A continuación, y una vez destacada la confluencia de intenciones de los arquitectos de la nueva generación, Badovici advierte críticamente que ninguno de aquellos ejemplos alcanzaba, a su parecer, la perfección. Aunque auguraba que esos 
mismos autores, en un futuro muy próximo, serían capaces de introducir más orden, razón y equilibrio ${ }^{12}$. La tesis final de aquella agrupación de obras y autores era demostrar que las formas producidas por la humanidad al igual que los deseos, las necesidades y las aspiraciones, no cesaban en su renovación permanente. Y para ejemplificar todo lo dicho eligió adjuntar al texto en la sección de láminas unas imágenes y planos de la Villa Besnos en Vaucresson (1922) de Le Corbusier y Pierre Jeanneret, (fig. 4) y de la Villa Moissi (1923) de Adolf Loos.
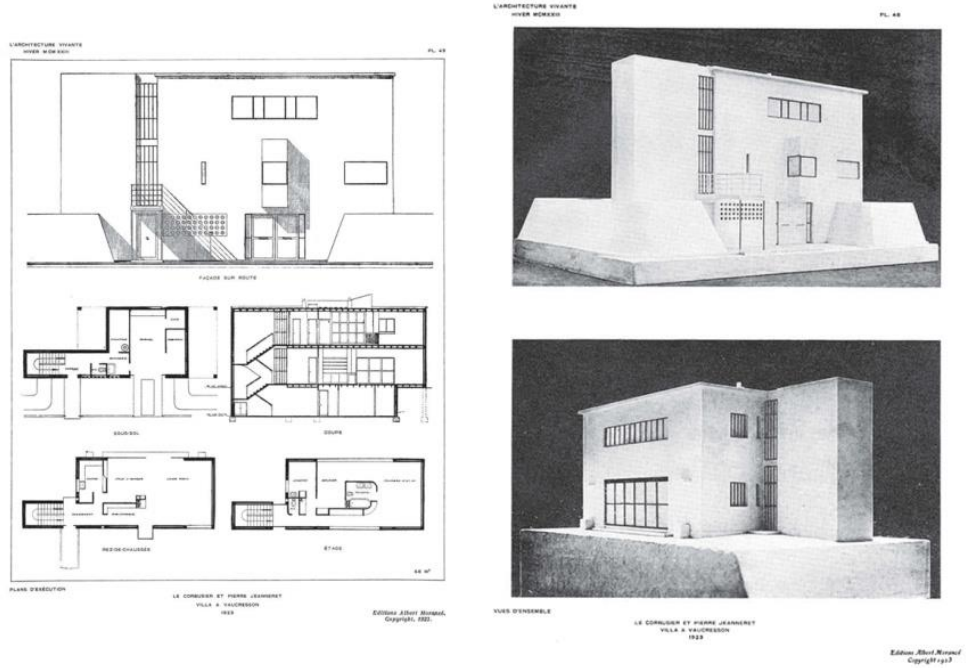

4. Villa en Vaucresson, 1923. Le Corbusier y Pierre Jeanneret en L'Architecture Vivante, Otoño-Invierno 1923. Pl. $48-\mathrm{Pl} .49$

La segunda vez que Le Corbusier aparece en L'Architecture Vivante es en el año 1925.

El pintor A. Ozenfant escribe entonces un artículo titulado, "Sin orden ni concierto"13 contraponiendo el arte creado para el placer frente a la verdadera arquitectura que según él debe ser “...la que satisface en primer lugar a su fin y a nuestra razón sin contener nada superfluo, ni una dimensión, ni una moldura, ni un clavo. Es bella si a pesar de su perfección técnica alcanza la proporción...”. Ozenfant, en aquel texto, explica al arquitecto George su elección de Le Corbusier como encargado del proyecto de su propio estudio-atelier. Y, con el fin de aportar la suficiente información al público lector, Jean Badovici en el apartado "Entretiens sur l'Architecture Vivante" del mismo número de la revista reseña el atelier de A. Ozenfant construido por Le Corbusier y Pierre Jeanneret en 1922 - 83 de la Avenue Reille de París- subrayando que se trata del perfecto ejemplo de aplicación de sus teorías, y alabando tanto el aspecto fabril exterior -fiel reflejo de la idea de lugar de trabajo- como su disposición interior. E invita a realizar un atento estudio de aquella planta del citado atelier que delata la admiración hacia la arquitectura que apuntaba dicho proyecto, “...todas las superficies se establecen con una ciencia impecable, que subordina de una manera absoluta el aspecto exterior al destino del inmueble y a la disposición interior...todos los elementos conforman una unidad orgánica que traduce plásticamente la vida interior y las necesidades del artista... "'I4. En el apartado de láminas, adjunto al final del número, se publicará

\footnotetext{
12 “...que ces ouvres n'aient pas encoré atteint à une perfection certine, cela se comprend, étant donnée la nouveauté de l'effort. Mais lorsque les artistas auron été ramenés au positif par une longue pratique des nouvelles formes, ils introduiront sûrement dans leurs travaux plus de'ordre, de raison, d'équilibre..." Badovici, Jean: "Entretiens sur l'architecture vivante". En L'Architecture Vivante, Otoño-Invierno 1923. París: Ed. Albert Morancé. p.36-37.

${ }^{13}$ Ozenfant, Amédée: “A baton Rompus”. En L’Architecture Vivante. Primavera-Verano 1925, París: Ed. Albert Morancé, pp.5-9

14 Badovici, Jean: "Entretiens sur l'architecture Vivante. Le Corbusier et Pierre Jeanneret. (V.pl 20, 21 et 22)". En L'Architecture Vivante. Primavera-Verano 1925, París: Ed. Albert Morancé, p.16.
} 
una imagen exterior y dos del interior del citado atelier, junto a las plantas, los alzados y la sección, para su completa lectura técnica (fig.5).
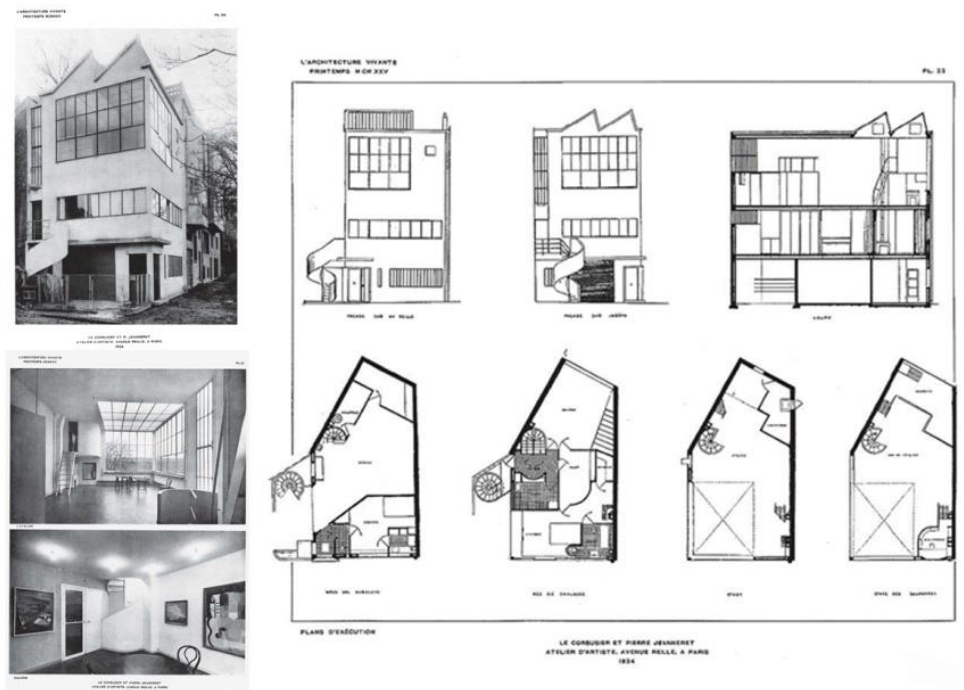

5. Atelier de artiste. Avenue Reille, París 1926. Maison Ozenfant. Le Corbusier y Pierre Jeanneret en L'Architecture Vivante Primavera-Verano 1925. Pl. 20- Pl.22

En el Otoño-Invierno de 1925, las obras de Le Corbusier reseñadas por J.Badovici serán la Villa en CorseauxVevey, situada en el lago Leman (1925), y el Pabellón de L'Esprit Nouveau (1925). De la primera, el director destaca la simplicidad constructiva, la ubicación estratégica de la ventana horizontal y la ingeniosa disposición de las piezas cuyo reparto de volúmenes convierte en inmensa una casa de pequeñas dimensiones objetivas. En los dibujos del proyecto que acompañaban al texto, las secciones de la casa se maquetan junto a ocho perspectivas parciales del interior, que ayudaban a describir la multiplicidad de espacios y rincones conformados por un mobiliario proyectado ad-hoc (fig.6).
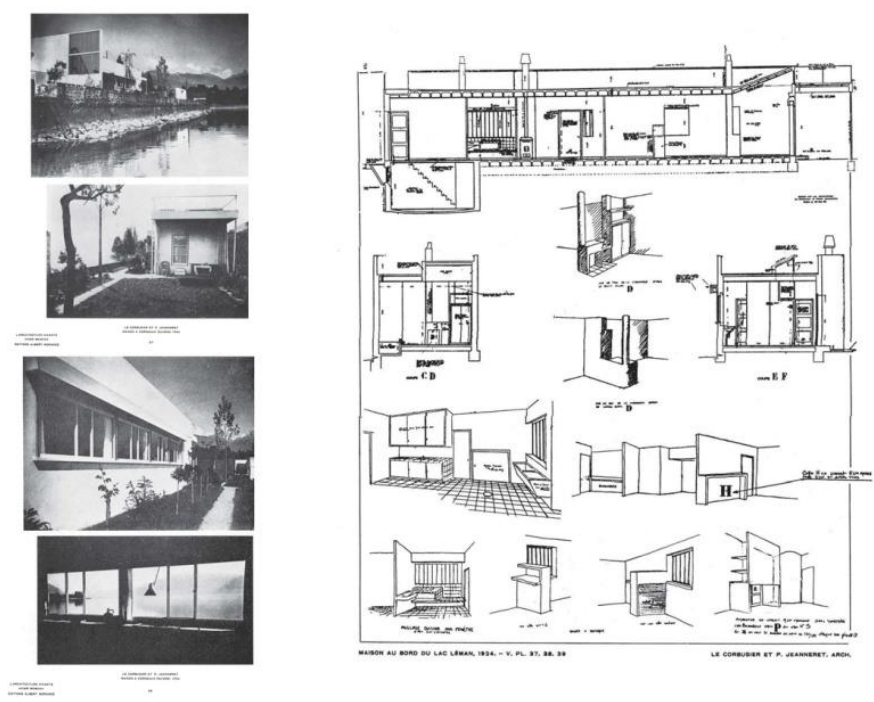

6. Maison en Corseaux (Suisse) 1924. Le Corbusier y Pierre Jeanneret en L'Architecture Vivante. Otoño-Invierno 1925. Pl.37, Pl.38 y p.31 
En cuanto al Pabellón de la Exposición Universal de 1925 en París, Badovici explica su condición de célulatipo de habitación y las posibilidades de desarrollo en su reproducción en los "Inmuebles de Villas" ideados por Le Corbusier. Pero el texto centra su atención en los casier standars expuestos al interior del pabellón, destacando el hallazgo de los arquitectos en la creación de un mobiliario que, con medidas universales de 37,5 75-150 cm, es capaz de dividir espacialmente interiores neutros iluminados y al tiempo permitir el necesario almacenaje doméstico aportando así economía a la construcción.

\subsection{Retrospective}

A partir del número de Primavera-Verano de 1926, desaparece la sección de reseñas "Entretiens sur l'Architecture Vivante". Y en el otoño de1926 Jean Badovici escribe un artículo titulado "Retrospective" 15 que representa el primer encumbramiento de la figura y la obra de Le Corbusier por parte de la revista.

El director recorre la historia de la arquitectura francesa, destacando la voluntad organizadora y la lucidez intelectual heredada de la civilización latina por algunos autores. El propósito central del texto era equiparar los esfuerzos realizados por los constructores románicos y góticos -Bulant, Delorme, Lescot, Du Cerceua, Perraultcon el trabajo, por ejemplo, de Labrouste en la Biblioteca de Santa Geneviève, de A.y G.Perret con el hormigón armado, o de Tony Garnier en la búsqueda de una arquitectura útil. Estas referencias selectivas, que se remontaban a la reciente historia de la construcción, le permiten a Badovici confirmar la existencia de una arquitectura denominada "vivante", que no acusa una temporalidad concreta y que consigue sacar a la luz lo que de "Verdad" tenían aquellas obras como precursoras de lo contemporáneo.

Todo el argumento del artículo desembocaba al final en un elogio a Le Corbusier, refiriéndose a sus investigaciones recientes como la culminación de los variados movimientos precedentes, y a su obra como la verdadera punta de lanza de la arquitectura de vanguardia.

Por primera vez, y sabiendo que sus palabras tienen eco en el lector especializado, la revista, en la voz de su director, erige a Le Corbusier tanto como el heredero de los esfuerzos más significativos de un pasado inmediato, como el creador de una doctrina original y vigorosa, cuyos planteamientos se enfrentan a cualquier rutina constructiva. En definitiva, Badovici entiende el entusiasmo joven de Le Corbusier fundamentado en una ciencia -la arquitectura- que, a su parecer, empieza a estar segura de sí misma.

Para ilustrar las ideas de este artículo, en aquel número, se incluyen planos, detalles y perspectivas de dos obras de Le Corbusier: la Villa Jacques Lipchitz-Miestchaninoff en Boulogne sur Seine de 1926 (fig.7) y la Villa La Roche situada en la calle Docteur Blanche de París, de la que aparecen por primera vez fotografías de paramentos de ladrillos sin enfoscar revelando así el proceso de construcción barata y asequible de la nueva arquitectura propuesta ${ }^{16}$ (fig.8).

\footnotetext{
${ }^{15}$ Badovici, Jean: “Retrospective”. En L'Architecture Vivante. Otoño-Invierno 1926, París: Ed. Albert Morancé, pp.5-7

${ }^{16}$ Las fotos de dicha obra permiten descubrir en la actualidad la preexistencia en la parcela de un árbol respetado en la planta del proyecto por Le Corbusier.
} 


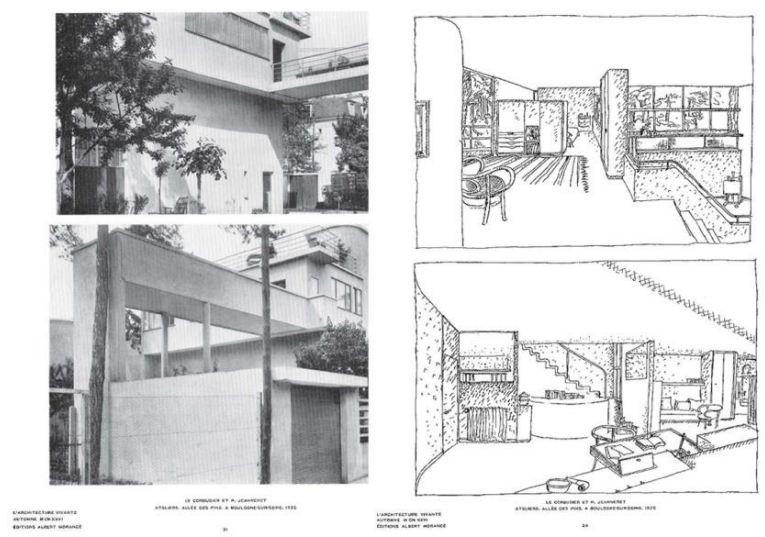

7. Villa Jacques Lipchitz-Miestchaninoff en Boulogne sur Seine de 1926. Le Corbusier y Pierre Jeanneret en L'Architecture Vivante. Otoño-Invierno 1926. Pl. 20-Pl.21
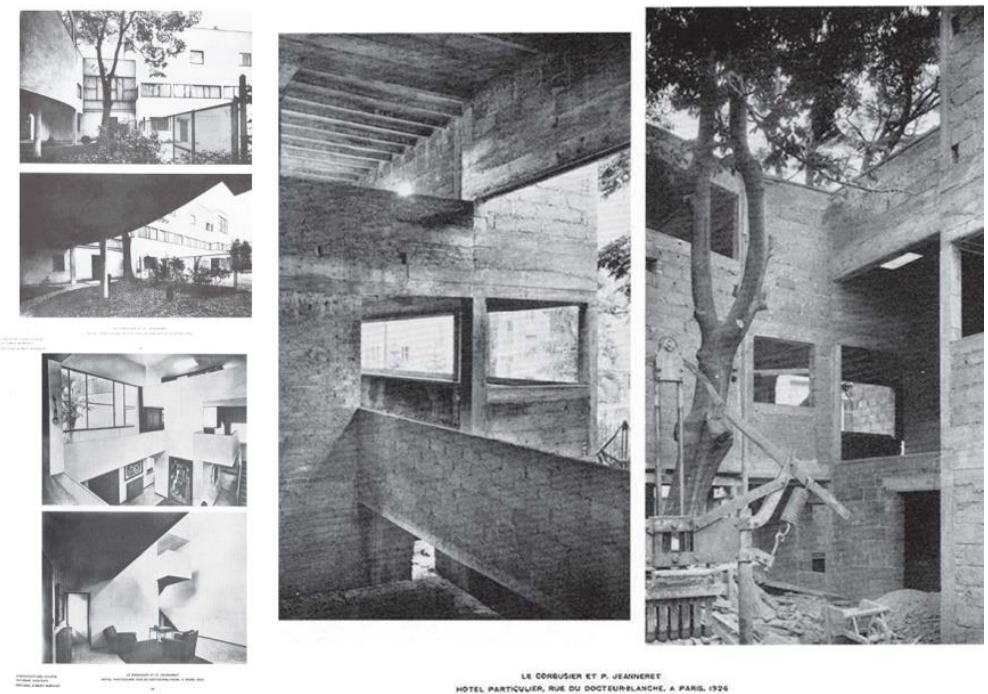

8. Villa La Roche en Docteur Blanche de París, 1926. Le Corbusier y Pierre Jeanneret en L'Architecture Vivante. OtoñoInvierno. Pl.14, Pl.15 y Pl.17

\subsection{Artículos y obras de Le Corbusier a partir de 1927}

La obra de Le Corbusier había aparecido en la publicación con información gráfica de sus proyectos y con reseñas siempre redactadas por Jean Badovici. En 1927, se producen dos cambios sustanciales en la línea editorial de la revista ${ }^{17}$. El primero corresponde a su estructura, y supuso transformar la multiplicidad del contenido en números monógraficos destinados a un tema concreto o a un arquitecto. $\mathrm{Y}$ el segundo, fue su elección de Le Corbusier como referente más habitual, frente a Perret. Y así, a partir de 1927 es el propio Le Corbusier el que publica también sus textos más significativos, convirtiéndose en una de las figuras principales de la revista ${ }^{18}$.

\footnotetext{
${ }^{17}$ Velázquez H, Víctor Hugo: El libro abierto. Sistemas de representación arquitectónica en el libro. Gesamteswerk- Oeuvre Complète Le Corbusier-Pierre Jeanneret 1910-1929. Director: Josep Quetglas i Riusech. Universitat Politècnica de Catalunya. Departament d'Expressió d'Arquitectura de Barcelona. 2012. pp 59-62.

${ }^{18}$ Jannière, Hélène: Les difficultés de la critique dans les années 1930: discours critique des revues et définitiorsn de l'architecture moderne. En Actas de V Congres national d'archéologie et d'histoire de l'art. Bordeaux, INHA(Actas de colloques) 1999, URL: http://inha.revues.org/2344.
} 
Las palabras de Fenolón ${ }^{19}$, transcritas en el número de Primavera-Verano de 1927, suponen un punto de inflexión en la revista y preceden al artículo "L'Esprit Nouveau en Architecture" (fig.9) redactado por Le Corbusier, adelantando el nuevo objetivo de la línea editorial: la visión de la construcción como la Verdad desnuda de la arquitectura ${ }^{20}$ y el concepto de lo bello alcanzable únicamente a través de la lógica constructiva.

DISCOURS A L'ACADEMIE

FRANÇAISE, LE 31 MARS 1693

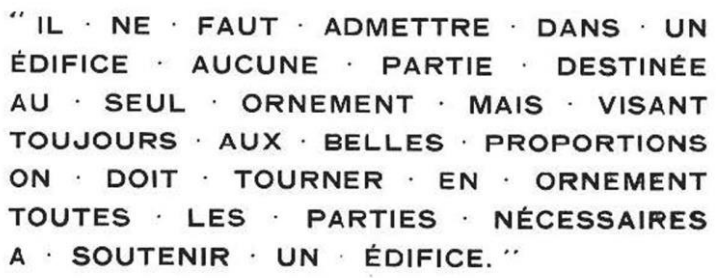

FÉNELON

9. Introducción: Cita de Fénelon en el Discurso a la Academia de 31 de marzo 1693. L'Architecture Vivante. PrimaveraVerano 1927

Aquel año -1927-, y coincidiendo con la exposición de la Weissenhof de Stuttgart, Le Corbusier es el auténtico protagonista de la revista. Y así, en el Otoño-Invierno de 1927, de los cinco artículos publicados en la sección de textos, cuatro de ellos concernían a sus teorías u obras.

Uno, redactado por Jean Badovivi, analizaba Le Palais de la Société des Nations en Ginebra elogiando la estética contemporánea y el rigor en la resolución de los problemas planteados como por ejemplo: la creación de un nuevo tipo de oficinas modernas, el estudio certero de las circulaciones, la iluminación y la acústica adecuada o incluso la previsión de calefacción o ventilación.

Y los otros tres textos estaban firmados directamente por el propio Le Corbusier -L'Esprit de Verité, Oú en est l'architecture y Pessac-. Entre ellos aparecía, casi inédita, ${ }^{21}$ la primera versión de lo que serían posteriormente los famosos "cinco puntos de la nueva arquitectura", que allí eran seis porque incluía la supresión de la cornisa y que más tarde se publicarían en otros medios. Estos artículos se maquetaron junto a numerosos dibujos croquizados del propio Le Corbusier para el adecuado entendimiento de las ideas propuestas (fig.10).

19 "Il ne faut admettre dans un edifice aucune partie destine au seul ornement mais visant toujours aux belles proportions on doit tourner en ornemet toutes les parties necessaries a soutenir un edifice" Metáfora anunciadora de la arquitectura racionalista empleada por Fenolón (1651-1715) a propósito de la belleza de los discursos. Discours á l'Académie Française, le 31 mars 1693. Avril, Jean Louis “Architecture rationaliste” en Dictionnaire des Architectes, Encyclopaedia UniversalisFrance 2013, consultado 20 mayo 2015 http://www.universalis.fr/encyclopedie/architecture-rationaliste/.

${ }^{20}$ Lahuerta Juan José: "Ex quo symmetria efficitur" en L'architecture vivante, el documento arquitectónico del movimiento moderno". Ed. Delegación de Zaragoza del Colegio Oficial de Arquitectos de Aragón, 2003, p.19.

${ }^{21}$ Los puntos se había publicado originalmente en la Europaïsche Revue, en 1927 e inmediatamente después en L'Architecture Vivante, en la entrega de Otoño-Invierno del mismo año. Lahuerta, Juan José: "Ex quo symmetria efficitur", en L'Architecture Vivante, El documento arquitectónico del movimiento moderno, Ed. Delegación de Zaragoza del Colegio Oficial de Arquitectos de Aragón, 2003, p.24. 

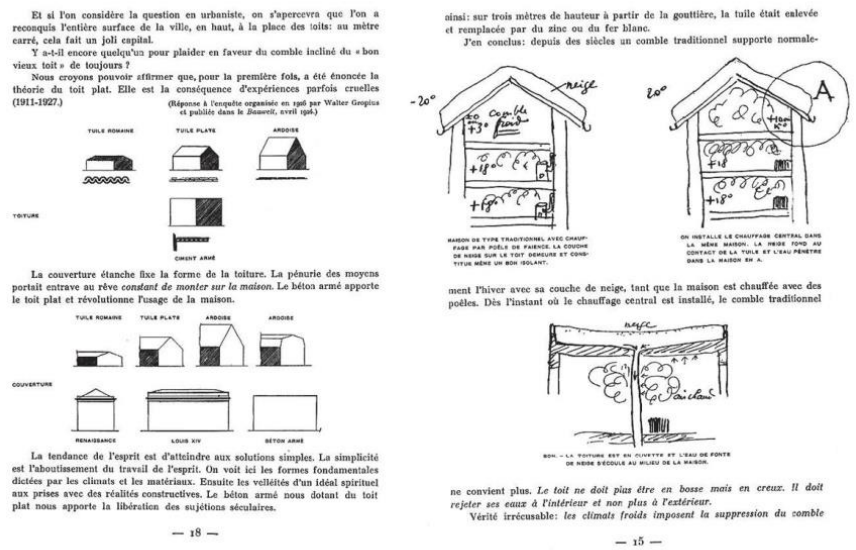

10. Ilustraciones del artículo “Où en est l'architecture?” de Le Corbusier. L'Architecture Vivante. Otoño-Invierno,1927. p 15 y p. 18

El número se complementaba en la sección de láminas con la publicación de imágenes de la Villa Cook (fig.11), Villa La Roche, el Pabellón de L'Esprit Nouveau, el complejo de Pessac (fig.12) y los planos del Concurso de Le Palais de la Société des Nations. Todas estas obras iban acompañadas de proyectos de otros autores, como Mallet-Stevens, Mies van der Rohe, Mart Stam, Sant Elia, Hans Scharoun...

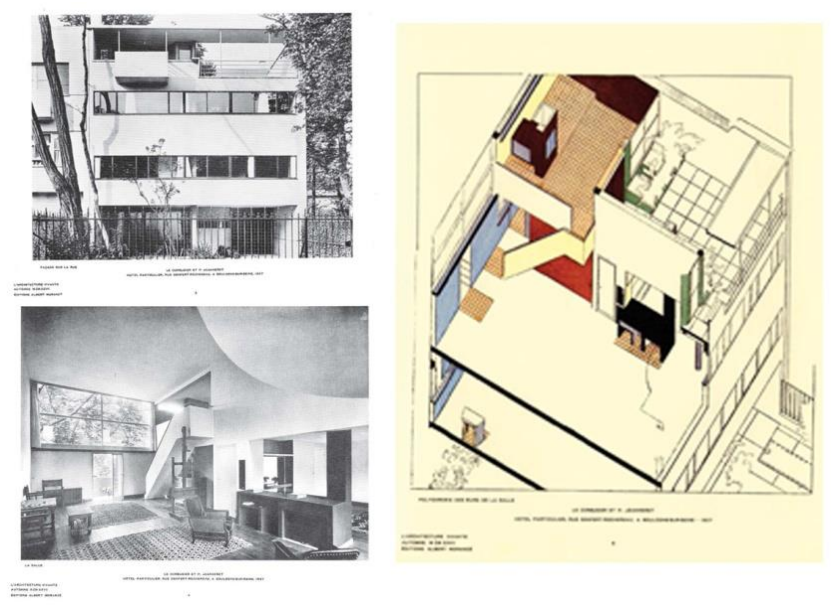

11. Villa Cook, París 1927. Le Corbusier y Pierre Jeanneret. L'Architecture Vivante, Otoño-Invierno1927. Pl. 2, P.14 yPl.5

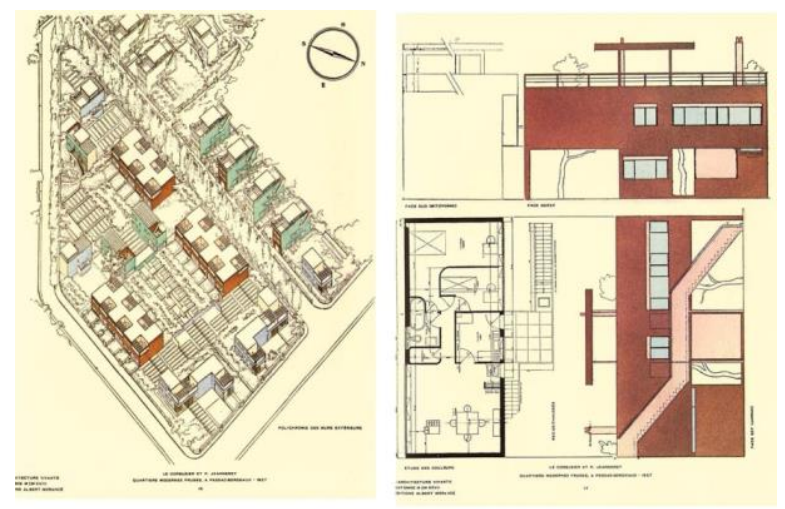

12. Quartiers Modernes Fruges, Pessac 1927 . L'Architecture Vivante, Otoño-Invierno 1927. Pl.15-Pl.17 
En 1928, la revista se hace eco de lo aprendido y observado en la Exposición Weissenhofsiedlung, que había tenido lugar en Stuttgart en 1927, mostrando en su apartado de láminas numerosas imágenes de las proyectos construidos por arquitectos del ámbito europeo incluidos dos realizados por Le Corbusier (fig. 13). Todos ellos introdujeron técnicas novedosas para la construcción.

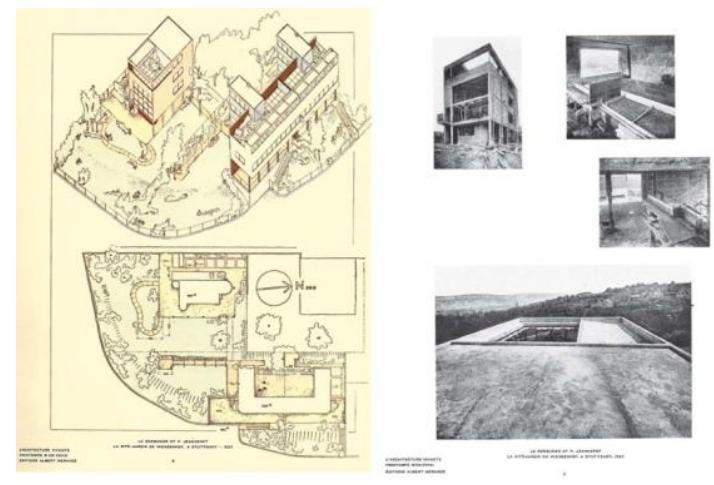

13. La Cité-Jardin du Weissenhof, Stuttgart 1927. Le Corbusier y Pierre Jeanneret. L'Architecture Vivante, PrimaveraVerano 1928. Pl.7-Pl.8

Le Corbusier, en ese mismo número de la , firma dos artículos: La signification de la Cité-Jardin du Weissenhof a Stuttgart y L'Aménagement Intérieur de nos maisons du Weissenhof. Entre los numerosos bocetos y planos que acompañan sus reflexiones destacaban los dibujos esquematizados relacionados en torno a la construcción de los dos proyectos de la exposición. Destacando en ellos el sistema estructural, los elementos prefabricados que hacían de encofrados de pilares con sus armaduras, los detalles de carpinterías, la composición de los forjados y todo ello combinado con dibujos técnicos de plantas, alzados, secciones, junto a perspectivas a mano alzada de espacios interiores planteados en aquellos prototipos (fig.14). El objetivo, tal y como explica el propio Le Corbusier, era que las condiciones sociales y económicas no debían imponer la implantación de unas quiméricas plantas "tipo". Sino más bien que aquellas investigaciones, aplicadas a la arquitectura, debían de manifestarse en sistemas estructurales nuevos concebidos de tal manera que permitieran todas las combinaciones imaginables y respondieran así a las necesidades de variadas categorías de individuos ${ }^{22}$.
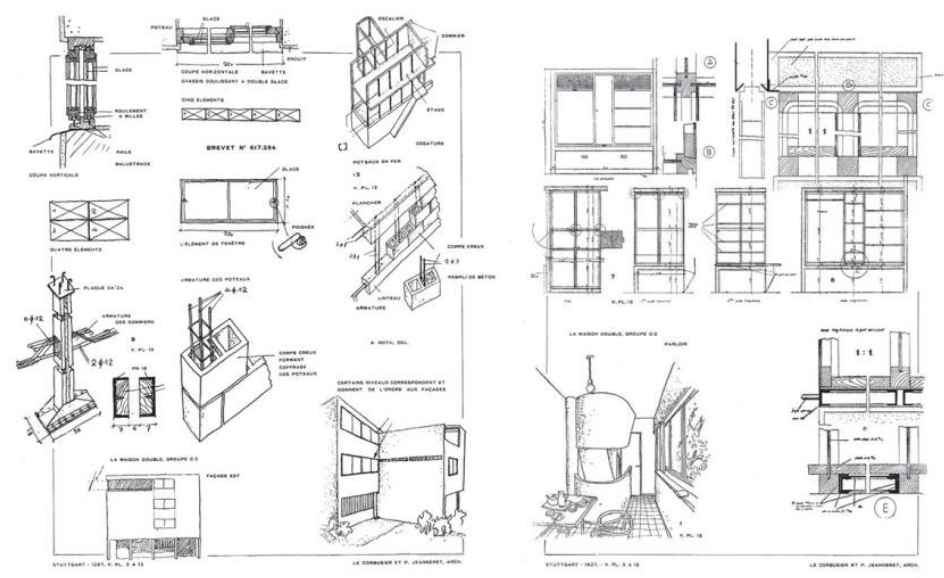

14. La Cité-Jardin du Weissenhof, Stuttgart 1927. Le Corbusier y Pierre Jeanneret. L'Architecture Vivante. PrimaveraVerano 1928. P17 y p.19

\footnotetext{
${ }^{22}$ Le Corbusier: "La signification de la cité-jardin du Weissenhof a Stuttgart", en L'Architecture Vivante. Otoño-Invierno 1928, París: Edition Albert Morancé, pp. 9-15.
} 
En 1929 los responsables de la L'Architecture Vivante realizan el primer monográfico dedicado a la obra de un único arquitecto, siendo el protagonista Le Corbusier.

El número contenía cuatro artículos de los que únicamente el primero- dedicado al I CIAM y firmado por Jean Badovici- no concernía a la obra del suizo. El resto de la publicación abarcaba dos escritos firmados por el propio Le Corbusier: en el primero titulado Janvier 1929, el arquitecto respondía a la cuestión planteada por Jean Badovici en torno a su opinión sobre la Ley Loucheur, y el segundo, Tracés Régulateurs, exponía la importancia de los trazados reguladores como medios geométricos y aritméticos para la composición plástica, ejemplificando su utilización en tres de sus obras - los dos ejemplos construidos para la exposición en Cité-Jardin de Weissenhof y la Villa en Garches-.

El cuarto artículo era una relación de reseñas en torno a diferentes proyectos de Le Corbusier que aparecían en la sección de imágenes del número concernientes a Villas à Carthage, Pavillon Démontable pour les Foires Comerciales, Armée du Salut: Palus du Peuple, Le Palais du Centrosoyus, Mudaneum y Villa à Garches. De esta última hay que destacar la profusión de fotografías aportadas, pese a una polémica surgida entre arquitecto y director. De un total 50 láminas de número, 22 estaban dedicadas a planos-axonómetricas,- y a imágenes de interiores, exteriores e incluso a fotografías durante el período de obra constituyendo unos valiosos documentos, testigos del proceso del proyecto que descubren su construcción tradicional en ladrillo (fig.15).
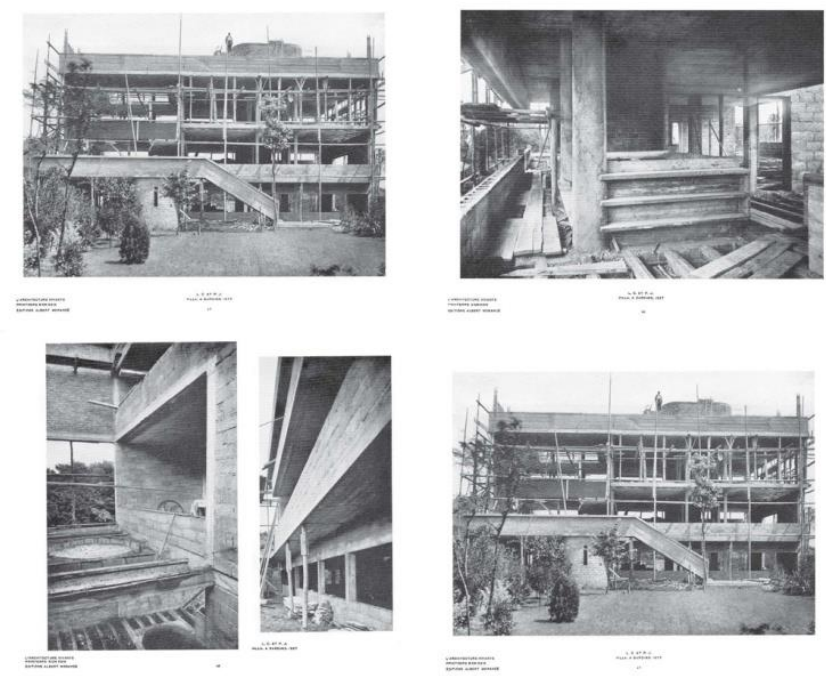

15. Villa à Garches,1927. Le Corbusier y Pierre Jeanneret. L'Architecture Vivante, Primavera-Verano 1927. Pl.6-Pl.10Pl.19-Pl.20

Del contenido de la correspondencia mantenida entre Le Corbusier y Jean Badovici se desprende tanto la relación fluida de amistad entre ambos como los conflictos surgidos en la remisión del material técnico a la revista, por parte del estudio del arquitecto, y la aprobación de las maquetaciones.

El 16 de julio de 1928 Le Corbusier remite al director una misiva ${ }^{23}$ en la que explica no haber recibido las pruebas referidas al proyecto de la Villa Garches que Badovici le había prometido. Por este motivo, y para evitar que sucediera lo que denomina "la aventura de Auteuil", prohíbe firmemente cualquier tipo de reproducción de esa obra en la revista hasta no contemplar él mismo las pruebas definitivas. A pesar de estas duras palabras, se comprometía a no publicar nada de ese proyecto en ningún otro marco de difusión, asegurando así a los responsables de L'Architecture Vivante la exclusiva de la exposición de esa casa.

\footnotetext{
${ }^{23}$ Fundation Le Corbusier E1-5 10T.
} 
El 1 de Agosto de 1928 -quince días después- Jean Badovici contesta a la carta de Le Corbusier, dejando entrever el disgusto que le han provocado sus palabras, “ ...la carta que he recibido no es la carta que se escribe a una amigo que te quiere y te defiende. Es francamente idiota...si no le tuviera una profunda simpatía y admiración, después de esta carta le dejaría de escribir... "24. Realizada una extensa explicación de la confusión en torno a fechas de entrega de imágenes y pruebas, el director deja de manifiesto el desafío que le supone personalmente el seguir publicando obras de Le Corbusier frente a las críticas de la editorial “...os estimo demasiado como para no publicar Garches, a pesar de los ecos que me llegan de Fleurus ${ }^{25}$ : otra vez Le Corbusier!!...”. Estas palabras remiten a un cierto hartazgo por parte del editor sobre la elección de tan numerosa obra del mismo arquitecto en las páginas de la revista.

En la primera mitad de 1930, solventadas aquellas diferencias, la revista publica por dos monográficos, el primero-primavera- de nuevo dedicado a Le Corbusier, y el segundo-verano- a la obra de Frank Lloyd Wright.

Le Corbusier y Pierre Jeanneret aportan entonces el texto “Le problème de la Maison Minimum”, en el que hablan de la estandarización, la industrialización y taylorización en el ámbito constructivo de la vivienda mínima. Para ello apuestan por materiales modernos, como el hierro y el hormigón armado, que permiten la construcción de una estructura independiente del cerramiento, posibilitando la planta y la fachada libre. Como demostración de estas ideas, en las láminas incluyen planos de las diferentes combinaciones posibles del proyecto de viviendas metálicas propuestas, siguiendo la ley Loucheur (fig.16), donde partiendo de casas gemelas simétricas se evoluciona hasta la agrupación en altura de un hotel. También publican Le Palais du Centresoyus de Moscú (1929), L'Assile Flottant de l'Armée du Salut de París (1929), el Salón de Otoño de París de 1929, Maison Cannel (1927), Maison Planeix (1927), Maisons Jumélées metaliques (1920).

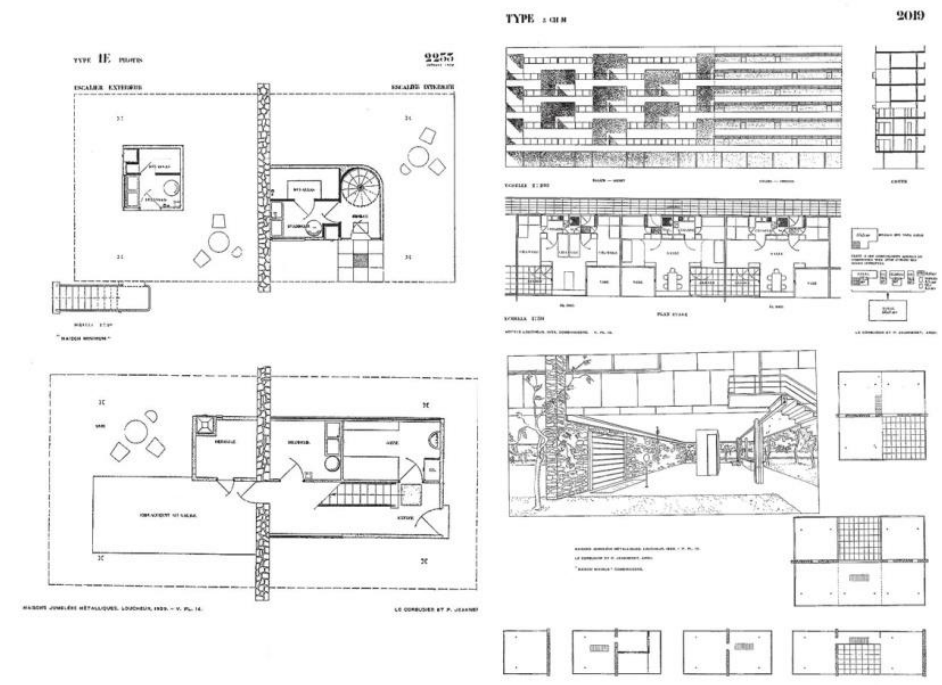

16. Maison Jumélées Métalliques, Loucheur 1929. Combinaisons. Le Corbusier y Pierre Jeanneret. L'Architecture Vivante, Primavera-Verano 1930. Pl.14-Pl.15-Pl.16

En 1931, Le Corbusier aporta por primera vez un texto relacionado con el ámbito del urbanismo y la ciudad, fruto de las reflexiones surgidas en el 3er Congreso Internacional de la Arquitectura Moderna en Bruselas. Y para demostrar sus argumentos, presenta en dicho número la Villa Saboye y su posible agrupación en una

\footnotetext{
${ }^{24}$ Fundation Le Corbusier E1/5/11-12.

${ }^{25}$ Referido a la dirección postal de la Editorial de L'Architecture Vivante. Éditions Albert Morancé, 30-32, rue de Fleurus, à París $\left(6^{\mathrm{e}}\right)$.
} 
ciudad jardín (fig.17), el museo de Artistas Vivos de 1931, la ciudad Refugio de L'Armée du Salut y el Plan Voisin de París (1930)(fig.18).

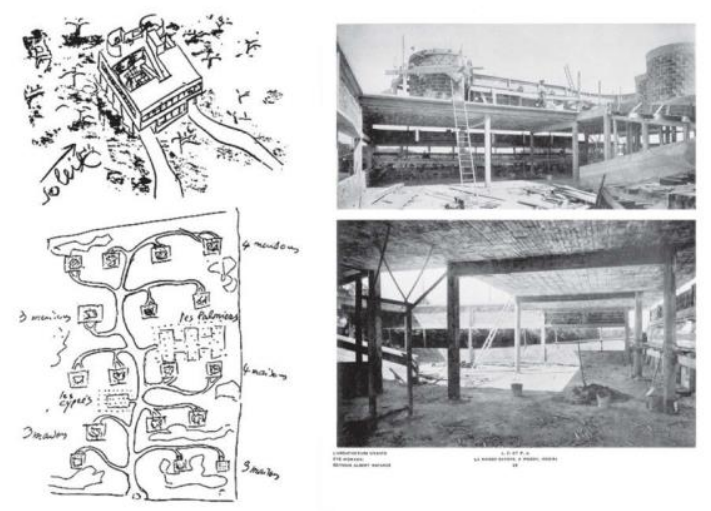

17. Maison Savoye, Poissy, 1929. Le Corbusier y Pierre Jeanneret. L'Architecture Vivante, Primavera-Verano 1931. P.23Pl.29
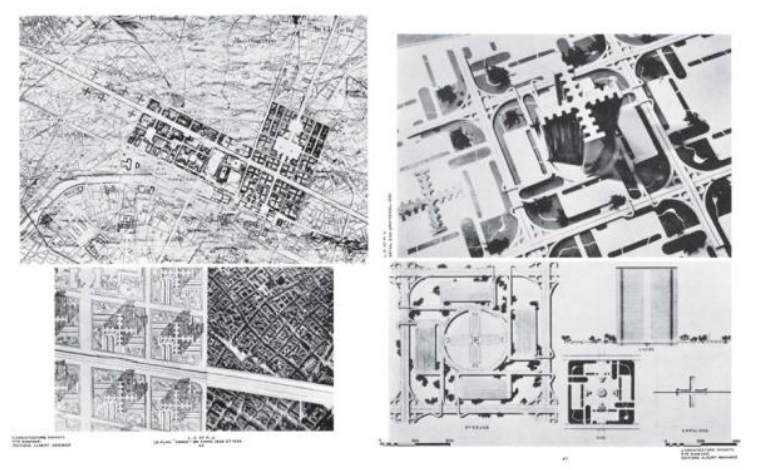

18. Plan Voisin, París 1929-1930. Le Corbusier y Pierre Jeanneret. L'Architecture Vivante, Primavera-Verano 1931. P.43P1.47

Por último, en 1932, expone de nuevo en el ámbito urbanístico el Plan de'Aménagement de la Ville d'Alger y al mismo tiempo muestra el proyecto para el Palais des Soviets en Moscú (fig.19), con sus distintas variaciones de planta.

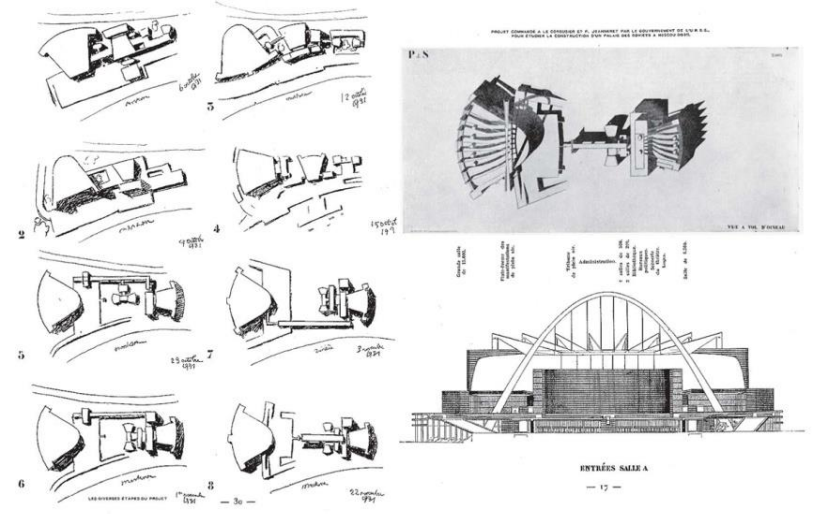

19. Palais des Soviets en Moscú, 1931. Le Corbusier y Pierre Jeanneret. L'Architecture Vivante, Primavera-Verano 1932. P.17-p.30 
En definitiva, durante la década de la existencia de la revista, y principalmente a partir de 1927, los proyectos de Le Corbusier y sus artículos se distribuyeron de manera regular por sus páginas, algunas veces en forma de monográficos sobre el autor y otras referenciados a los textos del número correspondiente.

Toda esta exposición continuada delata la relación de amistad con el director, Jean Badovici, y la importancia que éste último daba a la obra del suizo como precursor y protagonista del movimiento que aquella publicación quería exponer al público selecto.

\section{Adios a la L'Architecture Vivante}

El 26 de Febrero de 1934, con motivo del cierre de la L'Architecture Vivante, Le Corbusier escribe una carta titulada "Au revoir ...à la L'Architecture Vivante," ${ }^{26}$ que se publica en el último número.

Allí califica la revista como "el documento más preciso de investigación de la Arquitectura y el Urbanismo contemporáneo" y destaca la minuciosidad extrema en la publicación de "aquello que constituye la esencia de la arquitectura, los planos, las secciones, los detalles etc...". De sus palabras se desprende el elogio subliminal a la elección, por parte de los responsables, de exponer lo que denomina "la anatomía arquitectónica", reconociendo la dificultad que dicho material técnico tiene para seducir tanto al gran público como a los servicios comerciales, es decir, a la publicidad necesaria.

En la carta de despedida ensalza la selección de los trabajos publicados, valorando la labor de crítica previa a la elección de los proyectos. Y predice que dicho documento, en su conjunto, constituirá la materia prima para las futuras investigaciones que quieran estudiar el movimiento que siguió a la Gran Guerra en el ámbito de la arquitectura.

En sus halagos reconoce, por experiencia propia, lo que representa de disciplina moral y de preocupaciones la confección de una buena revista y califica L'Architecture Vivante como una publicación completamente limpia, clara y estricta. Y por ello afirma que ha sido considerada por el público profesional como "Le Document".

Por último confía en que ese "adiós" que está dando sea realmente un "hasta pronto" esperando que el editor decida en breve reanudar su publicación. Todas estas sinceras palabras finales de Le Corbusier delatan la importancia de la misma para el arquitecto cuya obra fue ampliamente publicada por sus páginas.

\section{Conclusión}

La relectura de L'Architecture Vivante permite, de nuevo al público profesional, admirar el rigor y el cuidado en la publicación del material gráfico como la verdadera anatomía de la arquitectura. Si entonces, para una élite de arquitectos, supuso un formato adecuado para la difusión de proyectos capaces de transmitir de manera técnica los avances de la época. En la actualidad, todo su contenido, especialmente el textual facilita la investigación del el pensamiento cambiante y evolutivo subyacente a aquellas obras, desarrolladas en paralelo a los progresos técnicos en la construcción. La arquitectura de esos años no es un todo armónico y homogéneo sino un conjunto de conflictos y dudas en permanente dialéctica sin meta concreta. Por ello, el hecho de que en sus primeras páginas de la revista fuera Auguste Perret el protagonista de describir los objetivos y, sin embargo, a partir de 1927, la línea editorial apostara mayoritariamente por la obra de Le Corbusier, obedece al posicionamiento crítico de su principal responsable. Jean Badovivi, tanto en sus textos como en la selección de las obras

\footnotetext{
${ }^{26}$ Fundation Le Corbusier U3-5(186-187).
} 
publicadas, siempre desde un frente crítico, corroboró lo que de novedoso tenía la arquitectura de Le Corbusier en la búsqueda del propio autoconocimiento de una época convulsa en lo que a construcción y técnica se refería. Todo ello coloca en la actualidad a L'Architecture Vivante como un inmejorable atlas de pensamiento arquitectónico.

\section{Bibliografía}

Badovici, Jean: "Entretiens sur l'architecture vivante". En L'Architecture Vivante, Otoño-Invierno 1923. París: Ed.Albert Morancé, pp.36-37.

Badovici, Jean: “Retrospective”. En L'Architecture Vivante. Otoño-Invierno 1926, París: Ed. Albert Morancé, pp.5-7.

Badovici, Jean: "Entretiens sur 1'architecture Vivante. Le Corbusier et Pierre Jeanneret.(V.p120,21 et 22)". En L'Architecture Vivante. Primavera-Verano 1925, París: Edition Albert Morancé, p.16.

Badovici, Jean y (Gray, Eileen): “L'Architecture Utilitaire”. En L'Architecture Vivante, Otoño - Invierno 1926, París: Edition Albert Morancé pp.17-24.

Colomina, Beatriz: Privacidad y publicidad. La arquitectura moderna como medio de comunicación de masas. Murcia: Cendeac, 2010, p.130.

Fernández Galiano, Luis: "Una mezcla de medios, o una matriz de mediación”. En Arquitectos: Información del Consejo Superior de Arquitectos de España. “Arquitectura mediada”. 2008, No 184. Madrid: CSAE. pp. 47- 48.

Jannière, Hélène: Les difficultés de la critique dans les années 1930: discours critique des revues et définitiorsn de l'architecture moderne. En Actas de V Congres national d'archéologie et d'histoire de l'art. Bordeaux, INHA(Actas de colloques) 1999, URL: http://inha.revues.org/2344.

Lahuerta Juan José: "Ex quo symmetria efficitur" en L'architecture vivante, el documento arquitectónico del movimiento moderno". Ed. Delegación de Zaragoza del Colegio Oficial de Arquitectos de Aragón, 2003, p.19.

Le Corbusier: "La signification de la cité-jardin du Weissenhof a Stuttgart". En L'Architecture Vivante. OtoñoInvierno 1928, París: Ed Albert Morancé, pp. 9-15.

Morancé Albert: “Architectures d'Aujourd'hui“. En L'Architecture Vivante, Ed. Albert Morancé, París, Otoño Invierno 1923, p.8.

Ozenfant, Amedée: “A baton Rompus”. En L’Architecture Vivante. Primavera-Verano 1925, París: Ed. Albert Morancé, pp.5-9.

Perret Auguste: en L'Architecture Vivante, Ed. Albert Morancé, París, Otoño-Invierno 1923 p.6.

Valery, Paul en L'Architecture Vivante Ed. Albert Morancé, París Otoño-Invierno, 1923 p.6. 


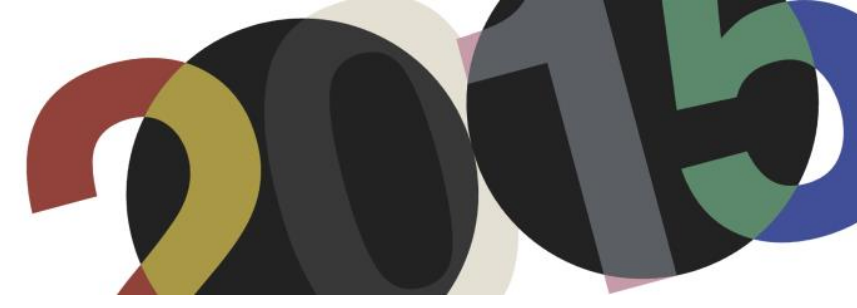

DOI: http://dx.doi.org/10.4995/LC2015.2015.716

\title{
The Thematic Content of Le Corbusier's Musée Mondial: Nature and Perspectivity
}

\author{
D. Motycka Weston
}

University of Edinburgh

\begin{abstract}
The paper considers the possibilities of the genuinely symbolic in modern architecture. It does this by focusing on some aspects of the thematic content of Le Corbusier's and Paul Otlet's Musée Mondial. Of particular interest are the role of nature as a source of the building's forms and of spiritual renewal, and the perspectivity inherent in its privileging of vision. It briefly reflects on the incompatibility of the symbolic and the instrumental concerns of architectural modernity.
\end{abstract}

Resumen: Esta comunicación considera las posibilidades de lo genuinamente simbólico en la arquitectura moderna, concentrándose en algunos aspectos del contenido temático del Museo Mundial de Le Corbusier y Paul Otlet. De interés particular es el papel de la naturaleza como fuente de inspiración de la forma arquitectónica y de renovación espiritual, y la perspectiva inherente a su visión privilegiada. Reflexiona brevemente sobre la incompatibilidad entre lo simbólico y las preocupaciones instrumentales de la modernidad arquitectónica.

Keywords: Le Cobusier, Mundaneum, nature, perspectivity, museum, thematic content.

Palabras clave: Le Corbusier, Mundaneum, naturaleza, perspectiva, museo, contenido temático.

\section{Introduction}

The early decades of the twentieth century were characterized by a deep cultural longing for meaningful symbolic content for the modern age. Artists' fascination with traditional, 'primitive' cultures, in which thematic content was an integral and unproblematic part of all life experience, is one indication of this. The Surrealists, for example, explicitly set about trying to revive or invent a mythology, in order to counteract the prevailing rationalism of their time. ${ }^{1}$ The widespread interest in various branches of the occult in late nineteenth and early twentieth century is another indication of this hunger for lost mystery and meaning. Le Corbusier belonged to this generation, the last one to take myth seriously and to experiment with its restoration. ${ }^{2}$ Already during his formative youthful travels, he expressed a yearning to express himself through a language of symbols. ${ }^{3}$ This preoccupation, explicit in his art, informed also most of his architecture, fusing with his progressivist rhetoric about new technologies and machine production to form a complex vision of modernity. A product of his time, Le Corbusier was deeply informed by both the Enlightenment and Romanticism. An artist as well as a preeminent proponent of technological modernity (industrial production, scientific management and CIAM urbanism), he read poetry and was always inclined to think in terms of analogy and metaphor. He was also deeply aware of the need for architecture to be animated by an ethical dimension, to contain significant symbolic

\footnotetext{
${ }^{1}$ See for example, Louis Aragon, Le Paysan de Paris, Paris, Gallimard, 1926, esp. pp. 9-16.

${ }^{2}$ See Peter Carl and Irena Murray, 'Geometry and Analogy: Le Corbusier's Baghdad Veils,' AA Files, No. 67 (2013), pp. 4960.

${ }^{3}$ Le Corbusier, Journey to the East (orig. 1914), Cambridge, Mass.: MIT Press, 1989, p. 176.
} 
meaning. ${ }^{4}$ All this sometimes produced strange tensions, and never more so than in his search for an appropriate content for his architecture. Typically for him, Le Corbusier infused the Musée Mondial scheme with multiple layers of thematic meaning. In this he was strongly encouraged by the client and co-author of the project, Paul Otlet, who called for a new kind of building, free from the paraphernalia of the traditional museum, an architecture of "speaking stones" where the building, together with material objects, tells the story. ${ }^{5}$ As with the projects of revolutionary architecture parlante, the building itself was to embody and communicate its thematic intentions.

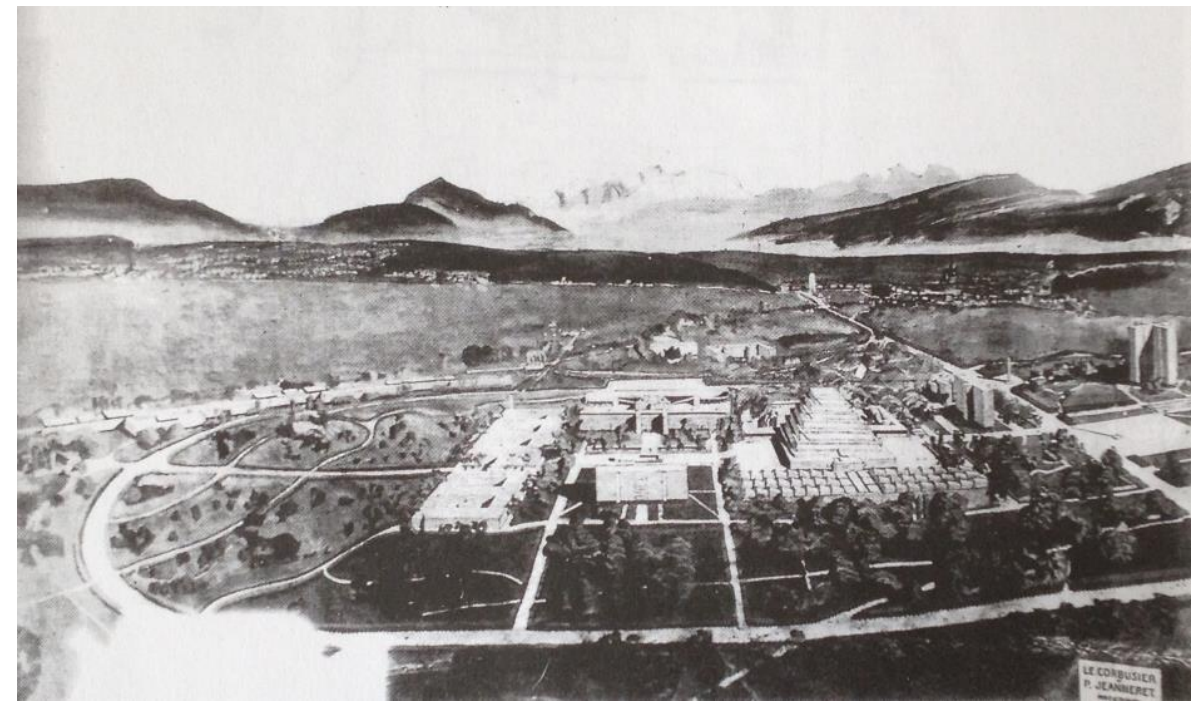

1. Le Corbusier, P. Jeanneret, Mundaneum Diorama, 1929 (Oeuvre Complète 1910-1929)

In this paper I will reflect on some aspects of the thematic content of Le Corbusier and Pierre Jeanneret's design for the Musée Mondial, the World Museum, which formed the focus of the 1928-29 Mundaneum scheme for Geneva $^{6}$ [Fig. 1]. This ambitious project generated lively contemporaneous debate around the themes of appropriate architectural aims and representation. ${ }^{7}$ It gave significant form to the architects' contemporanous thinking about the role of the symbolic in modern architecture. Marking a key step in Le Corbusier's life-long preoccupation with the spiral and museum themes, the project has a richness of iconography which has inspired much subsequent critical interpretation. Among the most authoritative and interesting, Alfred Willis's study discussed the historical sources of the spiral/pyramid form and contains a still useful exploration of Paul Otlet's contributions and of the Musée Mondial as an initiatic centre. ${ }^{8}$ Giuliano Gresleri and Dario Matteoni's work provided cultural context for the world city movement and examined its designs. Gresleri's meticulous research illuminated the architectural development of the project, and his graphic reconstruction of the Musée Mondial filled in some missing detail. He also rightly emphasized Le Corbusier's perennial preoccupation with the theme

\footnotetext{
${ }^{4}$ On Le Corbusier's approach to thematic content in his architecture, see also D. Motycka Weston, 'The Lantern and the Glass: On the Themes of Renewal and Dwelling in Le Corbusier's Purist Art and Architecture,' in I. B. Whyte (ed.) Modernism and the Spirit of the City, London: Routledge, 2003, pp. 146-178, and 'Le Corbusier and the Restorative Fragment at the Swiss Pavilion', in C. Hermansen and M. Hvattum (eds), Tracing Modernity: Manifestations of the Modern in Architecture and the City, London: Routledge, 2004, pp. 173-194.

${ }^{5}$ Paul Otlet and Le Corbusier, Mundaneum, Brussels: Union des Associations Internationales, Palais Mondial, 1928, p. 18.

${ }^{6}$ While Pierre Jeanneret was actively involved in the design of the Mundaneum, I will here, for simplicity's sake, refer to the practice as Le Corbusier.

${ }^{7}$ Le Corbusier's chief challengers on this occasion were Karl Teige and El Lissitzky, the latter's critique being illuminating.

${ }^{8}$ Alfred Willis, 'The Exoteric and Esoteric Functions of Le Corbusier's Mundaneum', Modulus 14, 1980.
} 
of universal, type forms. ${ }^{9}$ Anthony Vidler's work in this area suggested the significance in modern architecture of ocularity and spatial narratives as didactic tools, rooted in the revolutionary architectural culture of the $18^{\text {th }}$ century. ${ }^{10}$ However, it seems to me that, given Le Corbusier's strong feelings and numerous statements on the matter, insufficient emphasis has so far been placed on the role of nature as a redemptive force and the source of transformative panoramic views and archetypal forms in this project. ${ }^{11}$ My reflections here concern mainly the interrelated themes of nature, perspectivity and vision.
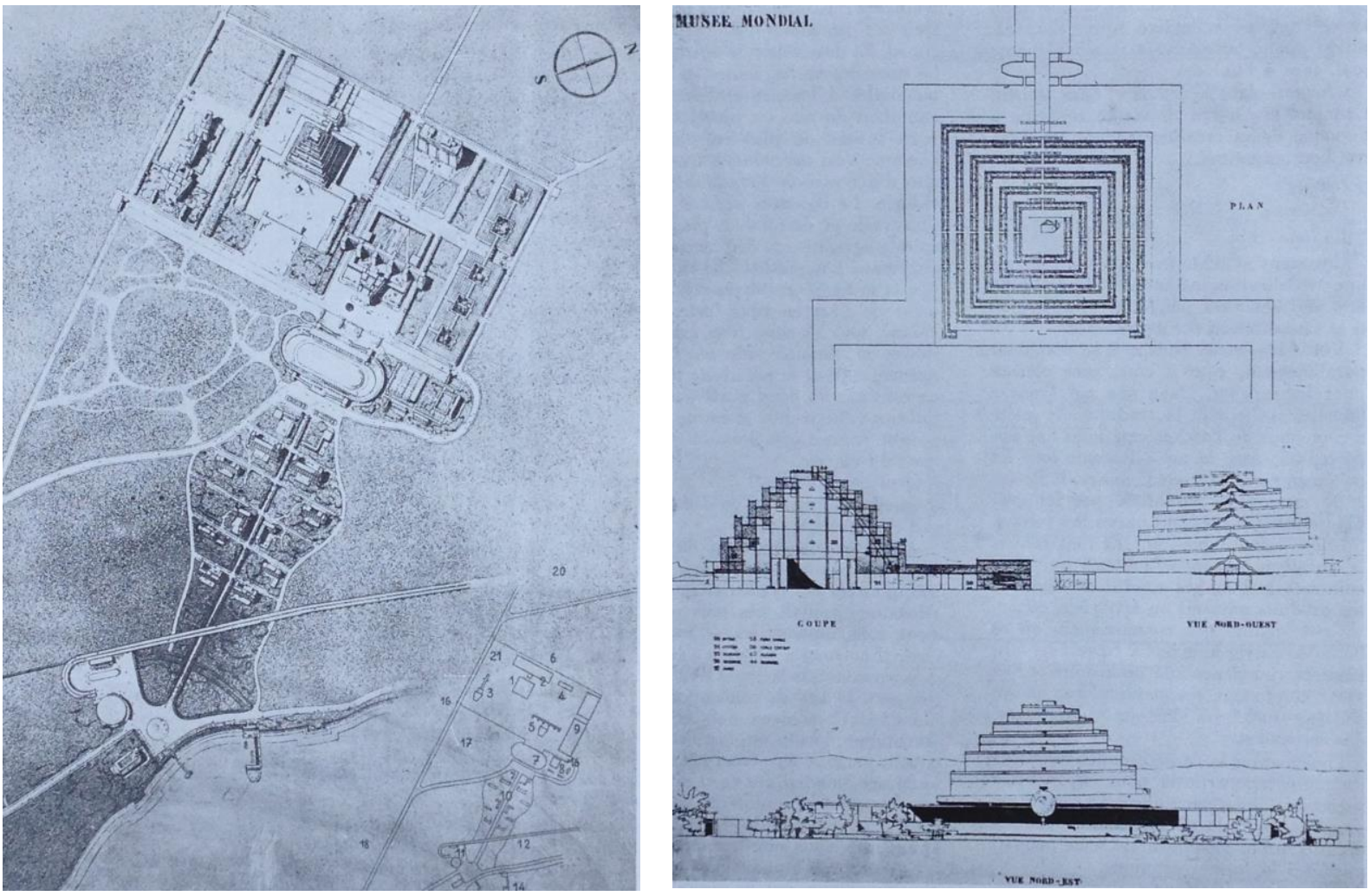

2. Mundaneum plan, Musée Mondial, 1929, plan, section, elevation (Oeuvre Complète 1910-1929)

The design of the Mundaneum is well known. However, for the purposes of this discussion it is necessary to recall some of its main features [Fig. 2]. ${ }^{12}$ The main precinct of the Mundaneum, positioned on a slope

\footnotetext{
${ }^{9}$ Giuliano Gresleri and Dario Matteoni, La città mondiale. Andersen, Hébrand, Otlet, Le Corbusier, Venezia: Marsilio, 1982, and G. Gresleri, "The Mundaneum Plan," in C. Palazzolo and R. Vio, eds, In the Footsteps of Le Corbusier. New York: Rizzoli, 1991, pp. 93-113.

${ }^{10}$ Anthony Vidler, 'The Space of History: Modern Museums from Patrick Geddes to Le Corbusier', in The Architecture of the Museum: Symbolic Structures, Urban Contexts, Manchester: Manchester University Press, 2003, pp. 160-182, and The Writing of the Walls, London: Butterworth, 1989, esp. pp. 165-173. Other valuable contributions to our understanding of Le Corbusier's thought with respect to the Mundaneum include those of Stanislaus von Moos, Pierre Saddy, and Jean-Louis Cohen.

${ }^{11}$ Recent research has looked more closely at the significance of nature and landscape as inspiration for Le Corbusier's (and modernist) work. See Jean-Louis Cohen, ed., Le Corbusier: An Atlas of Modern Landscapes, London: Thames and Hudson, 2013, and Caroline Constant ed., The Modern Architectural Landscape Minneapolis: University of Minnesota Press, 2012.

${ }^{12}$ In addition to the project drawings, the authors' contemporaneous texts are most helpful in imagining what the Musée Mondial would have been like. See Paul Otlet and Le Corbusier, Mundaneum. Most of Le Corbusier's text from this booklet was republished in Architecture Vivante 1929, pp. 27-31. See also Le Corbusier, 'In Defense of Architecture' (1929), Oppositions Reader: Selected Essays 1973-1984, New York: Princeton Architectural Press, 1998, Oeuvre complète 1910-29, Zurich: Girsberger, 1937, pp. 190-97, 214, and Precisions on the Present State of Architecture and City Planning (orig. 1930), Cambridge, Mass.: MIT Press, 1991.
} 
overlooking Lake Geneva, is a Golden Section rectangle. The buildings of the assembled institutions (including a World Library and university as well as the Musée Mondial) are sculptural objects within a park, facing the lake, and with their corners aligned with the cardinal directions. They are laid out within this rectangle by means of abstract geometrical relationships (local symmetries and ideal proportions). While making reference to the layout of holy sites, this is essentially Beaux Arts planning. The visitor's promenade through the Musée Mondial, highlighted in Le Corbusier's accompanying texts, is structured around the dramatic and enveloping views of the mountainous landscape. The prismatic, seven-storey building sits on a large concrete platform reminiscent of a temple precinct, raised above the uneven ground by pilotis. From the car park, the visitor arrives in the parvis to begin his/her pedestrian ascent of the two kilometres of ramps on the exterior of the square spiral of the pyramid, looking out to all four sides. Arriving at its summit, he/she views the 360-degree panorama of the site before entering the museum. The emphasis is on the individual alone, before the spectacle of nature. The exhibition of the history of the world and human culture, which Le Corbusier calls a diorama, then unfolds downward the interior triple-nave sloped galleries, from the genesis of the universe to the modern era, becoming gradually larger and more detailed as it approaches the present. The disorientation and fatigue of the long descent is alleviated along the way by corner balconies, offering the visitor views to the landscape outside. The journey through the museum is completed by a meditative visit to the Sacrarium, a cylindrical chamber nestled under the dark, cave-like hypostyle hall under the pyramid. There he/she encounters the sages of world culture based on Edouard Schuré's Great Initiates. After hours of walking this room offers a few moments of centralized stillness. Light and views of nature once again embrace the visitor as he/she re-emerges into the parvis and face the earth globe and planetarium.
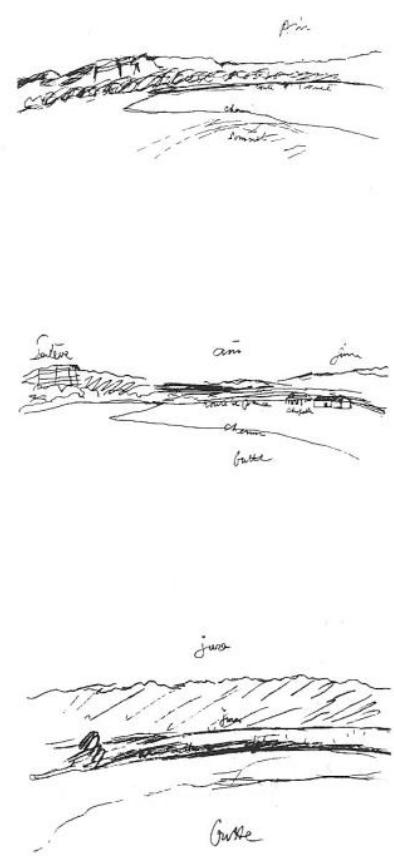

3. Mundaneum Geneva site, Le Corbusier sketches of the views 


\section{Nature, Walking, Promenade architecturale, Natural Themes}

Le Corbusier was often more attentive to the physical context of his buildings than he has been given credit for. The Lake Geneva site, which had already played a key role in his designs for the League of Nations scheme, was also an important generating factor at the Mundaneum [Fig. 3]. In the late 1920s, for strategic reasons, Otlet relocated the Mundaneum project to a sloping field of the Grand-Saconnex on the north edge of Geneva (about to become a world city and centre of global politics), adjacent to the future League of Nations site. Le Corbusier described the site as a "sort of acropolis, dominating the horizon in four marvellous directions, three of different mountain ranges, the fourth of the perspective of the upper lake. The plateau [...] dotted with gigantic trees, the object of Genevan pride."13 Overlooking the Lake of Geneva, this area is remarkable for its highly dramatic views of both the Alps and the Jura mountains, accentuated by contrast to the long flat horizon of the lake. ${ }^{14}$ It had gained fame in the nineteenth century in the art of Ferdinand Hodler and the Swiss Symbolists, and by the 1920 s it was a well known tourist region. ${ }^{15}$ Le Corbusier had made numerous drawings of the area in connection with his projects there, always emphasizing the visual dimension of the spectator's experience. The set of sketches showing the site's ' 4 horizons', the vistas in the four major directions, constitute almost a continuous panoramic view, of the type which Le Corbusier often used for the promotion of his works.

Growing up in the dramatic landscape of the Swiss Jura, Charles Edouard Jeanneret always subscribed to the Romantic idea of nature as a source of profound knowledge, inspiration and moral principles. His youth in La Chaux-de-Fonds (with its Rousseauesque atmosphere and traditions) was permeated by a love of nature, explored on frequent arduous mountain walks with his father or his school group. He even took part in occasional night vigils on mountain tops, spent (probably in some physical discomfort) in quasi-mystical communion with nature. These Jeanneret understood ethically, in terms of sacrifice for his artistic principles. ${ }^{16}$ As he wrote, "Sunday often found us together at the top of the highest hill. It had pinnacles as well as grandly sweeping slopes [....] We were preparing for the future." ${ }^{\prime 17}$ These exhilarating youthful hikes were also important learning experiences - Le Corbusier would later recall his father's reflections at such times on life and the laws of nature. ${ }^{18}$ His design teacher at the Ecole d'Art, Charles L'Eplattenier, emphasized nature on these walks as a source of order and law, unity and diversity, harmony and strength. ${ }^{19}$ Importantly, nature's order was manifest in geometry. L'Eplattenier spoke mystically of the need to build a great monument to nature and to make it their lives' purpose, a vision reminiscent of the prismatic cenotaphs and nature temples of the revolutionary architects. His four-cornered monument, filled with the disciples' works, would be the setting for great annual fire-lit festivals and "incorporate the whole landscape". ${ }^{20}$ The cosmic overtones of such a project are evident.

\footnotetext{
${ }^{13}$ Le Corbusier, Precisions, p. 49.

${ }^{14}$ For a detailed description of the site, see G. Gresleri, 'The Mundaneum Plan,' p. 98-99. See also Le Corbusier, Mundaneum, in Architecture Vivante 1929, p. 28-29, and Oeuvre complète 1910-29, pp. 190-97.

${ }^{15}$ See Stanislaus von Moos, 'Lake Geneva and the Alps' in Jean-Louis Cohen, ed., Le Corbusier: An Atlas of Modern Landscapes, pp. 72-74.

${ }^{16}$ See P. Turner, The Education of Le Corbusier, New York: Garland Publishing, 1977, pp. 89-90. Le Corbusier's father's passion for mountain walking led him to become a leading figure in the Neuchâtel Swiss Alpine Club in the early 1880s.

${ }^{17}$ Le Corbusier, The Decorative Art of Today (orig. 1925), London: The Architectural Press, 1987, p. 194.

${ }^{18}$ Le Corbusier, Modulor 2, Cambridge, Mass.: MIT Press, 1968, pp. 196-97, quoted by A. Brooks, Le Corbusier's Formative Years, p. 10.

${ }^{19}$ Le Corbusier, The Modulor, London: Faber, 1951, p. 25, quoted by Jean-Louis Cohen, Le Corbusier: An Atlas of Modern Landscapes, p. 28.

${ }^{20}$ Le Corbusier, The Decorative Art of Today, p. 195.
} 
Jeanneret's education at the Arts-and-Crafts-infused programme of the Ecole d'Art, led him to study the works of John Ruskin, and to embrace his Romantic philosophy of nature as a source of artistic inspiration and ethical principles. Ruskin's writings celebrate nature as a manifestation of fundamental laws, and link it to the creative artist's redemptive power, self-sacrifice, initiation and even justice. ${ }^{21}$ His view of nature as a profound source of artistic and architectural motifs permeated L'Eplattenier's design course. It was rooted in the Romantic conception of the artist as a prophetic figure, able to transform and redeem society through his moral life and creativity. Immersing himself in nature had a transformative effect on the Romantic individual, with Nature taking the place of God. This idea is memorably embodied by many of the paintings of C.D. Friedrich, where a lone individual stands entranced, gazing at the Sublime panorama of nature [Fig. 4]. It was evoked by Le Corbusier in many of his ecstatic writings on the subject.

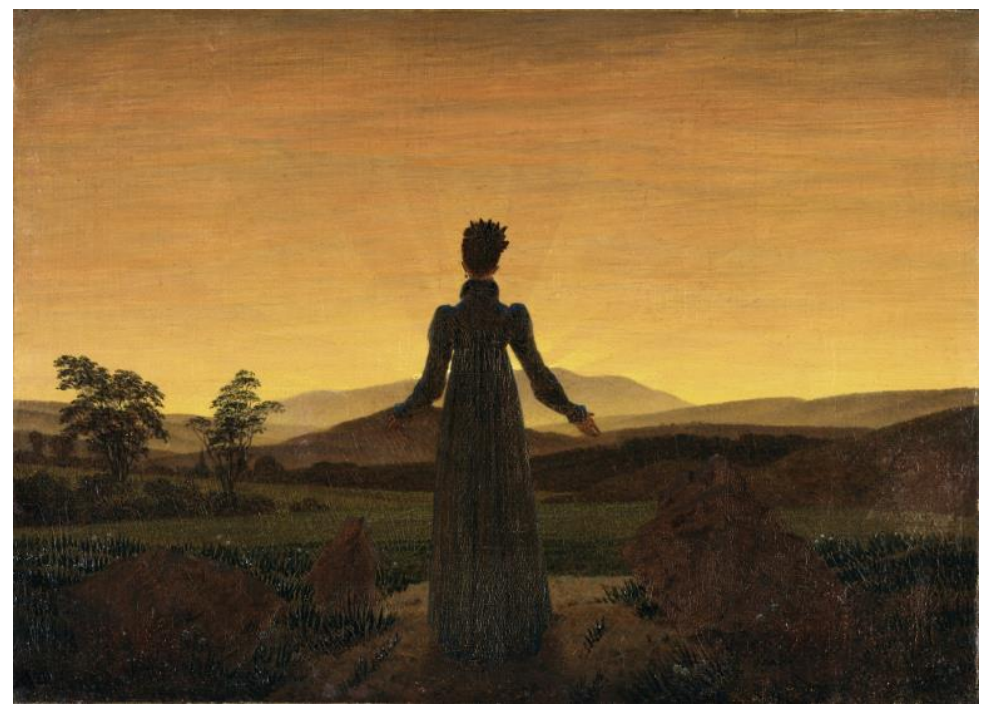

4. C.D. Friedrich, Woman before the Rising Sun (Woman before the Setting Sun), 1818-20, Museum Folkwang, Essen

Such views are rooted in the work of Jean-Jacques Rousseau. For the Genevan philosoher, modern society and its institutions were corrupt, progress was a snare, and civilization had a destructive influence on human beings. He argued that only through a return to unspoilt nature could man regain moral virtue. He thus laid the foundations of the Romantic conception of nature, so influential in the subsequent two centuries. It was here, perhaps, that the ancient reciprocity between culture and nature was first severed. That the two became opposites has had a detrimental effect on modern architecture and especially the city. In his novel La Nouvelle Héloïse, set in the area of Vevey on Lake Geneva, Rousseau draws a parallel between the idyllic nature of the Swiss mountain landscape and the simple goodness of the primary characters. ${ }^{22}$ Rousseau's writings contain numerous references to the landscape around his home city, which would later become the site of the Mundaneum. This conception of nature strongly informed Corbusier's vision of the site's "lyrical order," comprising the skyreaching mountains outlined against the pure horizontal of the lake. It is, I would argue, reflected in the iconic form of the Mundaneum as a high precinct, crowned by a pyramid-mountain, its wide horizontal planes resembling the sea/lake horizon [Fig. 5]. The museum's pyramid form here owes less, it seems to me, to

\footnotetext{
${ }^{21}$ See Mary Patricia Seckler, 'Le Corbusier, Ruskin, the Tree, and the Open Hand,' in Russell Walden, ed., The Open Hand Essays on Le Corbusier, Cambridge, Mass.: MIT Press, 1982, pp. 42-98.

22 J.-J. Rousseau, Julie ou La Nouvelle Hélö̈se. Lettres de deux amants, habitans d'une petite ville au pied des Alpes, Amsterdam: Marc-Michel Rey, 1761. In the early 1920s it was at Corseaux, near Vevey, that Le Corbusier found the site for his parents' future house. In his booklet about the project, La Petite Maison, Zurich: Aux Editions d'Architecture, 1954, he lyrically describes and draws the spectacular mountainous site.
} 
Babylonian ziggurats or towers of Babel than to the archetype on which all such ancient structures were based, the cosmic mountain, the axis mundi or centre of the world. ${ }^{23}$ This symbolic archetype is evoked on the site by the very physical presence of the real mountains. Such a reading is suggested by Le Corbusier's early references to the sacred Mount Athos which he had visited, along with other assorted pilgrims, in 1911. The sketch he made of it then shows a simplified triangular form rising above an expansive sea horizon. In his journal he referred to it as "the pyramid of Athos." 24 The reference to the primary or natural symbol of the mountain is profound and retains its resonance for us. ${ }^{25}$ Such symbols, inexhaustible in their layers of meaning, belong to the natural world of human experience in which we are situated, and which is structured through analogy. The mountain/pyramid draws its power from the orientation of lived spatiality (where 'up', for example, is qualitatively different from 'down') and from the conditions of our embodiment.

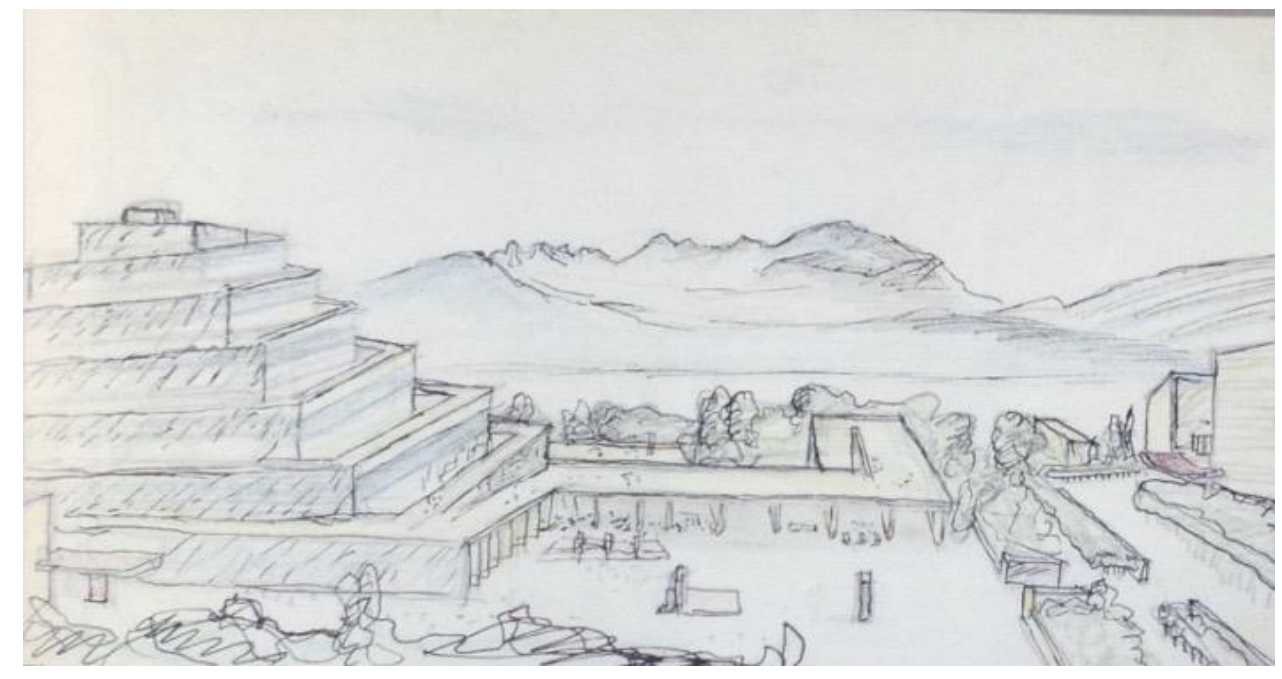

5. Perspective view of Musée Mondial among the mountains (FLC 32114)

\section{Circulation as a Source of Meaning}

The dramatic promenade architecturale which structures the Musée Mondial owes, in my view, a great deal to the significance which Le Corbusier placed on the mountainous context and its meaning. It can usefully be seen in terms of character-forming mountain walks, with their initiatory dimension. Le Corbusier's gradual development of the promenade in his buildings of the 1920s reveals a concern with circulation not merely as an aspect of the buildings' functioning, but as a source of architectural dynamism and symbolic content. This is related to the architect's interest in non-perspectival space, in which movement and embodiment come into play in the formation of the architectural experience and meaning. Some of his other large projects of the time - the Centrosoyus and the League of Nations scheme on the Mundaneum Geneva site - as well as his writings, cast light on his thinking in this respect. In Une Maison - un palais, Le Corbusier devoted a lengthy passage to the occupants' circulation in the latter from their car to the various parts of the building, ending for some of them on the great roof-terrace on top of the Assembly Hall. ${ }^{26}$ There, face to face with Mont Blanc and the Alpine

\footnotetext{
${ }^{23}$ See Mircea Eliade, The Sacred and the Profane, London: Harcourt Brace Jonanovich, 1959, pp. 36-42.

${ }^{24}$ Le Corbusier, Journey to the East, p. 174

${ }^{25}$ On natural symbols, see Karsten Harries, The Ethical Function of Architecture, Cambridge, Mass.: MIT Press, 1997, p. 130-131.

${ }^{26}$ Le Corbusier, Une Maison - un palais, Paris: Crès, 1928, pp. 133-156.
} 
landscape spreading to the south east, they experience a kind of mystical and ethically-charged communion with nature which Le Corbusier himself knew well. This universal, immersive experience, he suggests, can resolve all conflicts, neutralize hatreds, and promote understanding among nations ${ }^{27}$ [Fig. 6]. This dramatic staged encounter between the individual and nature would become a key aim of the promenade architecturale as it gained significance in Le Corbusier's thinking. ${ }^{28}$ It is also evident that at this time he saw the circulation of people which animates the building as a modern, non-elitist alternative to formal Academic composition. ${ }^{29}$ At roughly the same time, circulation (by ramp and lift rather than old fashioned stairs) played a central role in the Centrosoyus, the symbolically significant headquarters of the Soviet proletarian regime's Cooperative movement. ${ }^{30}$ The costly helicoidal ramps in that complex were justified by suggestions of their salutary effects, with the architect likening them to such natural phenomena as rivers and steep mountain paths ${ }^{31}$ [Fig. 7]. In addition to bodily health and vigour, the image of the endlessly circulating inhabitant of modern architecture perhaps ironically recalls the ancient theological topos of the homeless pilgrim, homo viator. ${ }^{32}$ In this, the existential situation of man is seen as that of a perpetual wayfarer on the earth. Alienated from God by the corruption of the world, the penitent pilgrim undertakes an arduous journey in hope of rediscovering divine order and attaining wisdom. In the case of modern architecture, one is reminded also of Rousseau's lamenting of modern industrial man's corrupting alienation from nature, which only a return to it could heal. The epiphanic contact with nature in much of Le Corbusier's architecture, and as the culmination of the promenade architecturale, can perhaps be understood in these terms. This over-optimistic view of the transformative power of nature is a poignant feature of much modernist thought. In the Musée Mondial, the long climb to the pyramid's summit and the didactic descent toward the Sacrarium, punctuated by salutary views of the landscape, are expressive of this. ${ }^{33}$

\footnotetext{
${ }^{27}$ Le Corbusier, Une Maison - un palais, p. 155.

${ }^{28}$ The promenade architecturale first plays a significant role for Le Corbusier at the Maison La Roche in 1923, and becomes codified at the villa Savoye in 1929-31 (Oeuvre complète 1929-34, p. 24). Prior to this, Le Corbusier speaks chiefly of 'circulation.'

${ }^{29}$ Le Corbusier, Precisions, p. 47 and 128.

${ }^{30}$ See Jean-Louis Cohen, Le Corbusier and the Mystique of the USSR. Theories and Projects for Moscow 1928-1936, Princeton, N.J.: Princeton Architectural Press, 1992.

${ }^{31}$ Le Corbusier, Précisions, p. 47, J.-L. Cohen, ed., Le Corbusier: An Atlas of Modern Landscapes, p. 46.

${ }^{32}$ See Gerhart B. Ladner, 'Homo Viator: Mediaeval Ideas on Alienation and Order', Speculum, Vol. 42, No. 2 (Apr., 1967), pp. 233-259. I am grateful to Peter Carl for this insight.

${ }^{33}$ The museum visit is a one-directional journey, staged against the backdrop of nature, recalling the journey of life itself, as well as a survey of all of human history As Le Corbusier noted in connection with museums, "our life on this world is a path on which we can never retrace our steps.” 'Other Icons. The Museums' (c. 1924), The Decorative Art of Today, p.16.
} 


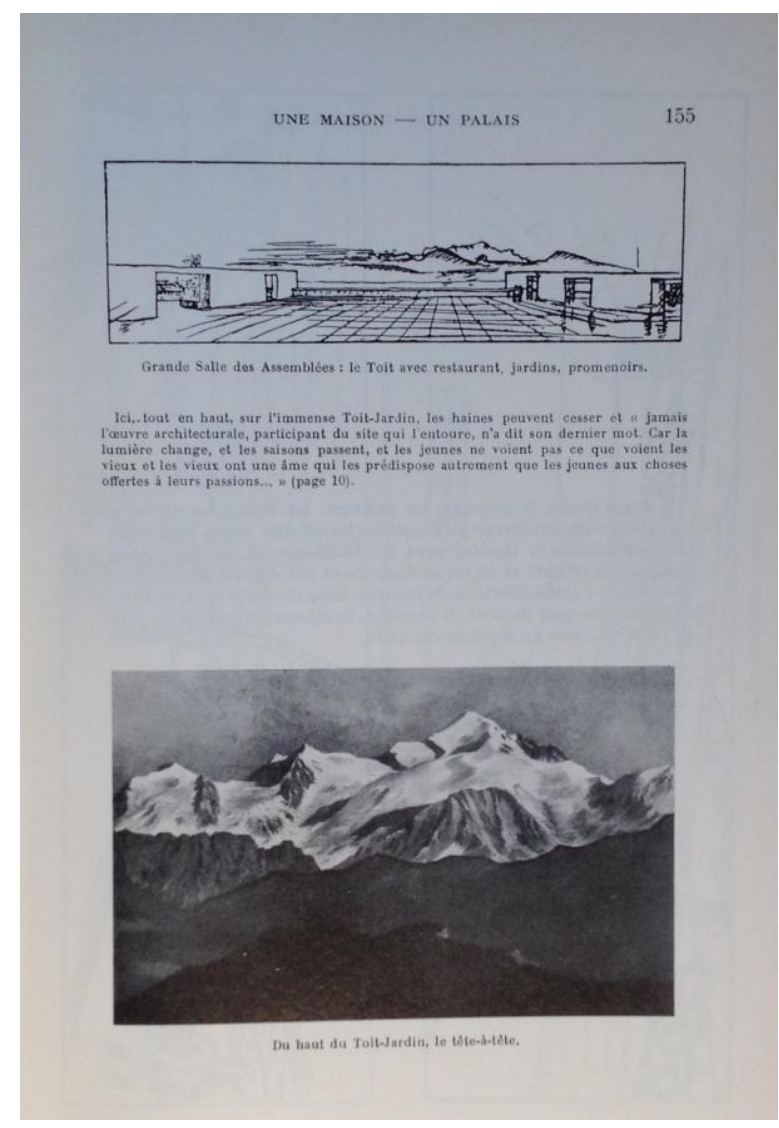

6. Le Corbusier, View of mountains from the roof of Palace of the League of Nations (from Une Maison - Un palais, p. 155)

The invention by Le Corbusier of the 'Law of the Meander' while looking from the air at a winding river in 1929 further illustrates the way in which he often saw such natural configurations as metaphors for themes of human thought; his ease with analogy enabled him to develop many such themes into his signs. A similarly metaphorical approach is evident in the Musée Mondial.

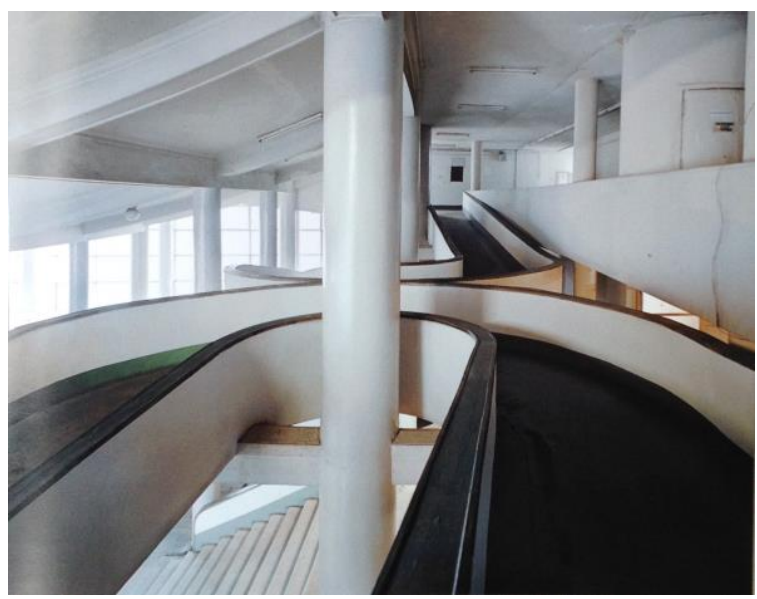

7. Le Corbusier, Ramps at the Centrosoyus (from J.-L. Cohen, An Atlas, p. 156), 


\section{Natural Order}

Another significant way that Le Corbusier's view of nature informs the Musée Mondial design is through his preoccupation with organic forms and growth, as marvellous embodiments of nature's order [Fig. 8]. This order, which must permeate, Le Corbusier believed, any valid modern art and architecture, is manifest in geometry, proportions and number, and in the typicality derived from a kind of evolutionary process. ${ }^{34}$ Following on from his Ecole d'Art days, the geometric order inherent in nature much preoccupied Le Corbusier while he was developing Purism with Amedée Ozenfant. ${ }^{35}$ The right angle, droiture and ideal geometries - all archetypal themes rooted in natural phenomena - became important building blocks of his iconographic system. Significant proportions, such as the Golden Section, were applied to 'verify' paintings and building facades in the form of regulating lines. Buildings were compared to natural organisms. The somewhat spurious idea that objets-type evolve to stable form through machine manufacture in a way that parallels natural selection in evolution was expounded in Purist manifestoes. The works of man, whose body is itself structured according to nature's geometry and proportions, were seen as needing to partake of these principles. Shells, of course, were a frequent point of reference in Le Corbusier's work: in his polemics, art and in his Purist villas. The snail's shell was seen as the perfect model for a dwelling. ${ }^{36}$ Sea shells, such as the beautiful spiral shell of the Nautilus pompilius, had ethical significance for him, stemming from the ideal geometry which they embodied, and which lent them elegance and noble austerity. ${ }^{37}$ Seashells have also traditionally been linked to cosmic fecundity, and so possessed a regenerative dimension. ${ }^{38}$ At the same time as Le Corbusier was working on the Musée Mondial, his painting repertoire was changing to embrace more natural themes. With the advent around 1928 of the objets à réaction poétique, natural objects came to be admired for their intense allusive and metaphoric potential as the marvellous, metamorphic products of geological, climatic and temporal phenomena (erosion, petrification and so forth), touched by chance. Made strange by their displacement from their habitual setting, they provided the artist with fresh inspiration, and architecture with revitalized themes. ${ }^{39}$ The spiral shell, a kind of found objet à réaction poétique, became a metaphor in the Musée Mondial and more emphatically in the Museum of Unlimited Growth a year later. The Golden Section, which is embodied in the spiral shell, became the organizing principle for the whole Mundaneum complex. It is clear that Le Corbusier and Otlet were also aware of architectural precedents - stepped pyramids, temples and spiral minarets and so forth - in the design of the Musée Mondial. It is however interesting that it was natural motifs that the architect emphasized. These represented acceptable modern source material, less susceptible to attack on the grounds of Academic eclecticism.

\footnotetext{
${ }^{34}$ See for example Amédée Ozenfant and C.E. Jeanneret, 'Le Purisme'. L'Esprit Nouveau, no. 4 (January 1921), 371-86. Reprinted in R. Herbert ed. Modern Artists on Art, pp. 59-73. Englewood Cliffs, N.J.: Prentice Hall, 1964.

35 Le Corbusier's thinking on the subject was informed by the influential work of Matyla Ghyka, with whom he was acquainted.

${ }^{36}$ See Le Corbusier, Almanach de l'architecture moderne, Paris: Crès, 1926, p. 29, 147, 182, 199.

${ }^{37}$ See Le Corbusier, The Decorative Art of Today, p. 165 and The City of Tomorrow, p. 197. On the geometry of the spiral shell, see Robert Lawlor, Sacred Geometry, London: Thames and Hudson, 2002.

${ }^{38}$ See A.A. Barb, 'Diva Matrix', Journal of the Warburg and Courtauld Institute XVI, 1953, pp. 193-238. See also Jill Purce, The Mystic Spiral, London: Thames and Hudson, 1974.

${ }^{39}$ Le Corbusier, 'Objets à réaction poétique,' in Jean Petit, ed., Le Corbusier Lui-même, Geneva: Rousseau, 1970, p. 178.
} 


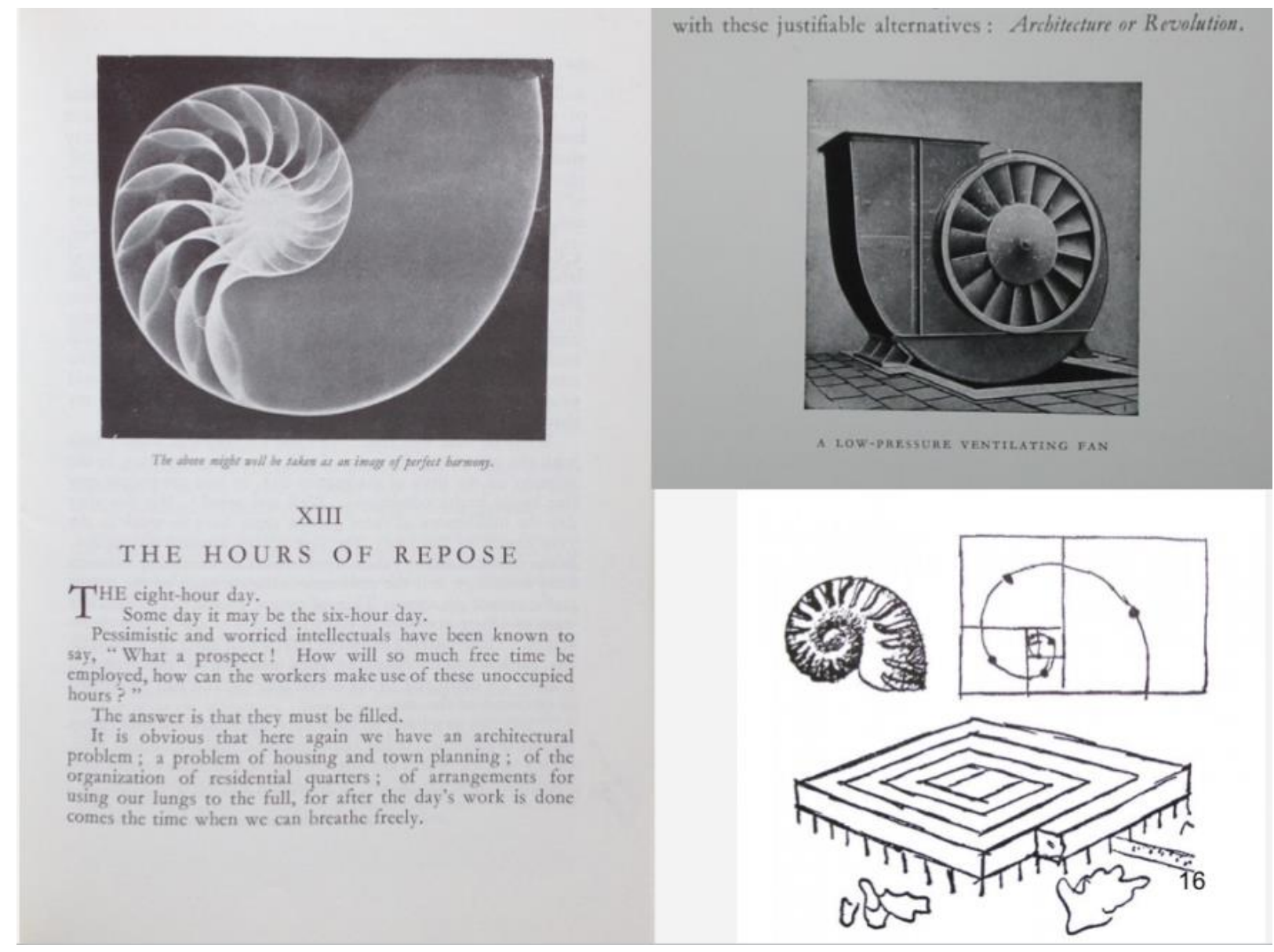

8. Spirals, shells. Le Corbusier, Nautilus pompilius shell (The Decoratieve Art of Today), Ventilating fan (Towards a New Architecture), Museum of Unlimited Growth, 1931.

\section{Scientific Ordering of Museums}

During the later part of the nineteenth century natural history and science museums, with their rationally organized collections, joined the museums of art and antiquities in informing cultural discourse and fashions. ${ }^{40}$ Having evolved from the traditional microcosmic Wunderkammern and cabinets of curiosities during the eighteenth century, such modern museums were characterized by a new scientific sensibility manifest in their stated purpose and the classification of their contents. ${ }^{41}$ Chief among these was the magisterial Muséum national d'histoire naturelle in Paris, with its vast collections of plant, animal and mineral specimens, and a focus on taxonomy and evolutionary history. The idea of progress implicit in the process of evolution is one which was embraced by many different sorts of museums. Such museums, informed now by encyclopaedism, might be seen as a culmination of that culture's dream, the total world collection (an idea which is still present in Le Corbusier's imaginary 'museum of everything' evoked in The Decorative Art of Today). In an architectural context, one is also reminded here of Alexandre Lenoir's Musée des Monuments Français of 1789. Conceived urgently in an effort to rescue some of the royal and ecclesiastic architectural heritage then being destroyed in the revolutionary tumult, Lenoir's museum was organized in a way reminiscent of the scientific rationalism and

\footnotetext{
${ }^{40}$ This can be seen for example in Surrealism in the work of Max Ernst.

${ }^{41}$ See D. Motycka Weston, "'Worlds in Miniature": Some Reflections on Scale and the Microcosmic Meaning of Cabinets of Curiosities', Architectural Research Quarterly, Volume 13, Issue 1, August 2009, pp. 37-48.
} 
progressivist thinking then entering collecting. The story of French architecture was told there through the chronological arrangement of the assembled specimens - fragments desituated by the catastrophic destruction of their original contexts - structuring a didactic narrative journey. ${ }^{42}$ Systematically organized, these could then by analysed by the comparative method of science. Paul Otlet's chronological time-place-object organization at the Musée Mondial manifests a similar sensibility.

Having gained a large portion of his education from personal study in museums, Le Corbusier was among those avant-garde artists, including Max Ernst and André Breton, who found in the dusty cabinet-filled halls of such places a strong dimension of the marvellous. This is arguably linked to the Purist interest in the modern 'theatre' of shop windows which also informed their paintings. These ideas are evident in the Musée Mondial's linear, progressivist organization and its positivist ethos, but also its startlingly imaginative spiral form and collage display technique. That Le Corbusier subscribed to the Romantic conception of nature as a regenerative force and a salvation of the industrial age, using it to inform his buildings, is not surprising. It has to be noted, however, that this idea has an instrumental side, and is thus arguably in conflict with a truly symbolic sensibility.

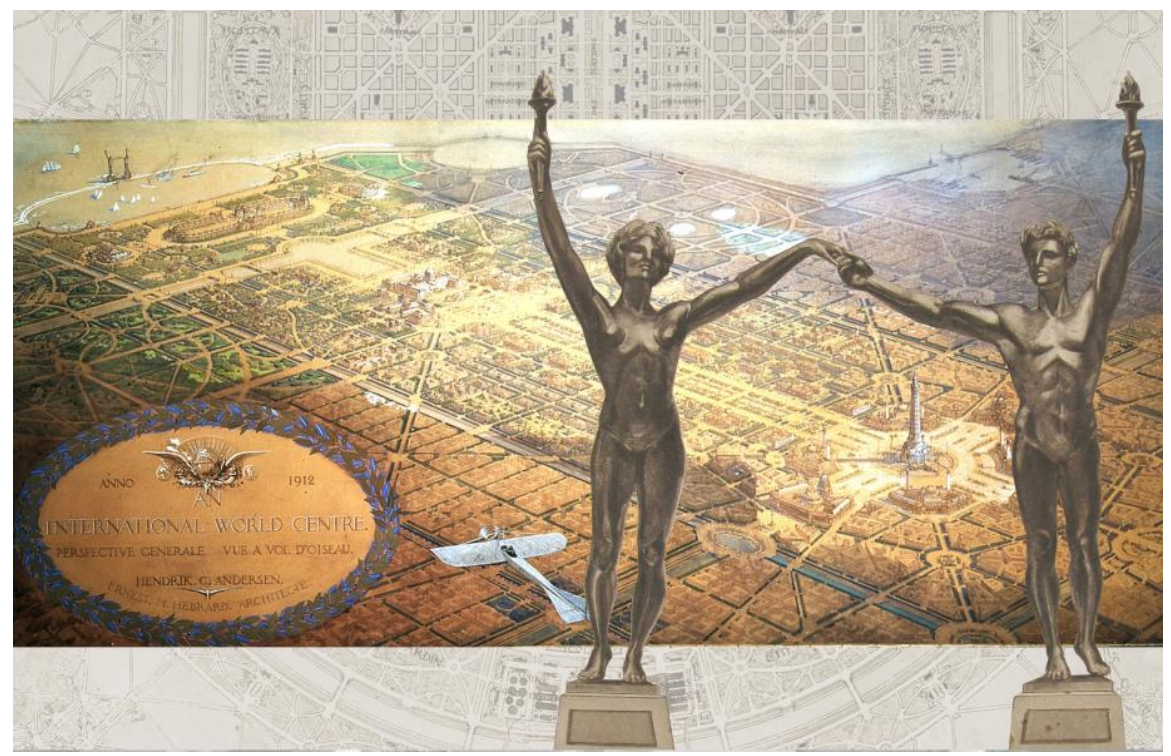

9. Perspectivity of Beaux Arts planning : Andersen, Hébrard, Otlet, World City, 1912

\section{Perspectivity of the spectacle}

The scholarship of recent decades has tended to emphasize the ocularcentric bias of nineteenth and twentieth century culture. Such a bias is also evident in Otlet's and Le Corbusier's thinking underlying the Mundaneum. This is pertinent to a discussion of thematic content; the deep sense of recognition which accompanies genuine symbolic themes must arguably stem from deeper perceptions than just the visual. ${ }^{43}$ As the authors' texts indicate, visuality always played a key role in the conception of the Mundameum, with the Musée Mondial its visual landmark. Providing views to all sides, it was itself visible from afar, resembling, as Le Corbusier said, "a gigantic boundary marker." 44 (Elsewhere, he enthused about the Alpine view framed by the architecture "as in a

\footnotetext{
${ }^{42}$ See Anthony Vidler, The Writing of the Walls, pp. 167-173.

${ }^{43}$ Although the lack of materiality is perhaps inevitable in an unbuilt project.

${ }^{44}$ Le Corbusier, Mundaneum, in Architecture Vivante 1929, p. 27-28.
} 
museum. ${ }^{, 45}$ ) The didactic promenade architecturale, first on the outside and then inside the pyramidal structure, was the focus of Le Corbusier's own contemporaneous descriptions of the project, and combined physical movement with a sequence of largely visual experiences. He called the exhibition within the tripartite nave a "diorama," emphasizing its visual dimension. ${ }^{46}$

For most of the nineteenth century, until the advent of modernism in its final decades, culture was characterized by an adherence to perspectival space, which was understood to equal the spatiality of human experience. In painting this was manifest in perspective illusionism, so effective at creating a sense of visual verisimilitude. In architecture and urban planning, perspectivity - an abstract view of reality - consisted of a reliance on homogeneous, infinitely extending Euclidean space and formal Beaux-arts compositional techniques [Fig. 9]. Since the invention of linear perspective in the Renaissance, the excitement at its ability to create compelling illusions led to a growing prioritization of vision, conceived in terms of a geometrical technique. This process culminated in the nineteenth century, with its ocular bias and its love of all manner of optical apparatuses as ways of looking at and reproducing images of reality. ${ }^{47}$ The problem with this is that perspectival representation is very different from lived spatiality, and can only present an inadequate approximation of manifold direct experience. ${ }^{48}$ Vision alone tends to objectify reality, desituating things from the context of the world. Nevertheless, this time saw an explosion in ever more accurate visual simulacra, from panoramas and dioramas, to photography, to theme park-style reconstructions of whole architectural settings - a process which continues today. ${ }^{49}$

Modern culture's ocular sensibility and the prioritization of the visual was at the root of the phenomenon of Panoramism, the fashion for dioramas, panoramas, and their various other variants, which swept European cities during the first half of the nineteenth century. The essence of a panorama was that it was a geometric construction with an observing eye at its centre. It offered the visiting spectators an all-encompassing, in-theround visual experience. This was made possible by perspectival painting techniques combined with a special curved, top-lit display structure where visitors were completely cut off from the real world outside, and where light and viewpoint could be controlled. ${ }^{50}$ An artificial construct based on optics, it was part of the nineteenthcentury interest in technically enhanced vision. Part fairground attraction, part didactic tool, the immersive nature of the panorama experience was so overwhelming that it sometimes made visitors feel disoriented and nauseous. ${ }^{51}$ The paintings often represented cityscapes or battles, with Sublime Alpine scenery becoming a particularly popular theme [Fig. 10]. With the perfecting of its construction and display techniques, the illusion of the panorama came not just to represent but to replace real experience. Able to 'visit' exotic places, or 'relive' dramatic events through a compelling visual illusion, the visitor was freed from the dangers and expense of

\footnotetext{
${ }^{45}$ Le Corbusier, Precisions, p. 48 . He was talking here of the League of Nations scheme.

${ }^{46}$ Le Corbusier, Oeuvre complète 1910-29, p. 194.

${ }^{47}$ See Jonathan Crary, Techniques of the Observer, Cambridge, Mass.: MIT Press, 1999.

48 See D. Motycka Weston, 'The Restorative Fragment in Early Twentieth-Century Art and Architecture', in Phenomenologies of the City, edited by Henriette Steiner and Max Sternberg, Farnham, Surrey: Ashgate, 2015, pp. 195-212.

${ }^{49}$ Full-scale reconstructions of 'historic streets,' for example, were a popular feature of World Fairs. See Old Edinburgh Street reconstructed just minutes' walk from the actual Old Town at the Edinburgh International Exhibition of Industry, Science and Art of 1886, or the traditional French village at the 1925 Paris Exposition. More recent developments of the this trend have included IMAX cinema, virtual reality, computer generated special effects in film, and sometimes entire new towns.

${ }^{50}$ See Bernard Comment, The Painted Panorama, New York: Harry N. Abrams, 2000.

${ }^{51}$ In a way that occasionally happens today in IMAX cinemas.
} 
actual travel..$^{52}$ As cities came to be thought of as landscapes upon which to gaze, the flâneur, the urban stroller and spectator on the all-enveloping spectacle of metropolitan life, came onto the cultural stage. This figure, often an artist, absorbed experience through watching while walking around the urban topography, without direct participation. He was sometimes seen as a kind of optical device or camera, a detached observer and recorder of scenes or events as a series of linked tableaux. ${ }^{53}$ The idea that experience can be consumed through vision, and its attendant reliance on abstract perspectival space are key features of modernity.

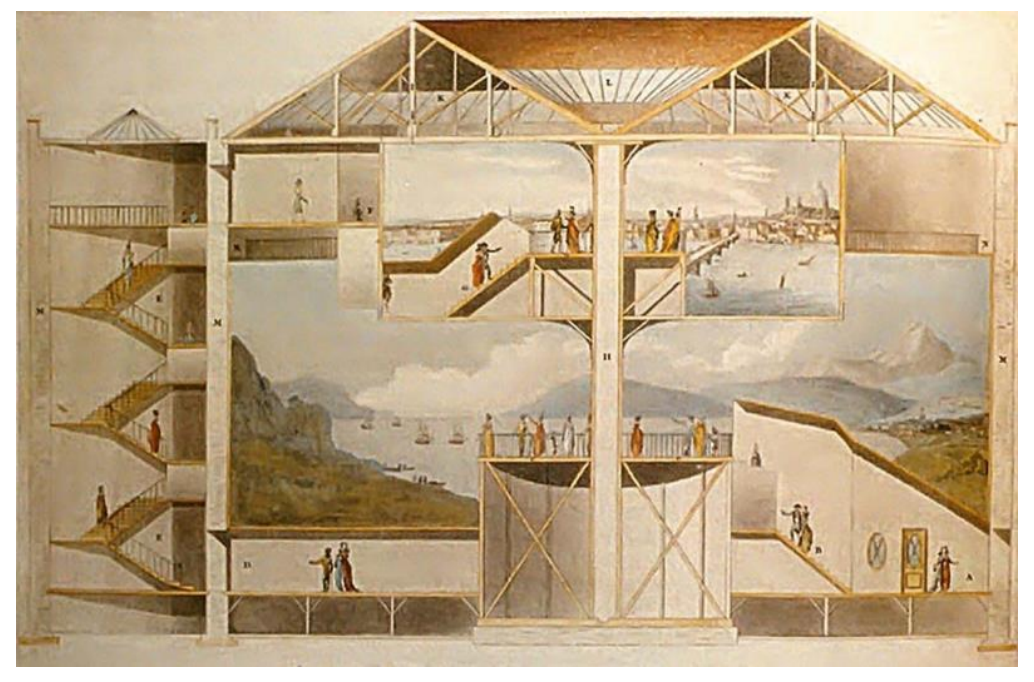

10. Panoramism: The Rotunda, Leicester Square, Robert Barker, 1801 containing panoramas of Alpine scenery and of London.

Anthony Vidler has drawn attention to the striking parallels between Otlet and Le Corbusier's Musée Mondial, and Patrick Geddes' Outlook Tower in Edinburgh. ${ }^{54}$ The biologist and urban planner Geddes was a friend of Paul Otlet, and an active participant in the critique of the elitist and moribund nineteenth-century museum. Believing that evolutionary ideas could be the basis for social progress, from 1892 he set about transforming the Tower into the "world's first sociological laboratory." The building became an optical apparatus in which the panoramic views of the city and its environs would serve as the basis for lessons of history, which could be applied to the society of the present and future. The tower was equipped with a series of optical devices which surveyed the area and collected information which would then be analysed to educational ends. The observatory turret contained a room-sized camera obscura which allowed visitors to view the city and to compare the present panorama with those of the past. Below was a terrace or 'prospect' for direct observation. ${ }^{55}$ Entering the Tower at the top, visitors followed a roughly spiral educational path through a series of rooms downwards, absorbing, as in the Musée Mondial, knowledge through looking and watching. Geddes' tower thus became a kind of mechanical device for learning, a 'thinking machine.' In this way he transformed the whole city into a kind of museum. The feature which is particularly relevant here is the way in which the instrument of vision was used to communicate Geddes's evolutionist theories and to apply them to the social world.

\footnotetext{
${ }^{52}$ Bernard Comment, The Painted Panorama, pp. 130-32.

${ }^{53}$ See Victor Fournel, Ce qu'on voit dans les rues de Paris, Paris, 1867.

${ }^{54}$ See Anthony Vidler, 'The Space of History,' pp. 160-182.

${ }^{55}$ Anthony Vidler, 'The Space of History,' p. 165. There was also an 'episcope', able to 'see' through the Earth at different points, and a globe/planetarium.
} 
A similar perspectival sensibility partly informs, I think, Le Corbusier's promenade architecturale, in its focus on a series of prearranged visual tableaux as a didactic and transformative device. In the Musée Mondial's initiatic journey (from Nature, through the "diorama" of human culture, to the esoteric knowledge of the Sacrarium), Le Corbusier speaks of humanity being transformed "au cours de sa marche". ${ }^{6}$ It is also evident in his constant concern with views in the design of his buildings (through, for example, the strategic placement of openings and the 'horizons' of the ribbon windows, sills and balustrades), to the extent that some of them become instruments for controlling views ${ }^{57}$ [Fig. 11]. The problem with this is that such primarily visual, perspectival focus is a severe reduction of lived spatiality, and thus a poor substitute for direct, participatory experience. The information gained about the world through predominantly visual, perspectival means tends to emphasize its formal aspects, and this is also the problem, in my view, with the Musée Mondial.
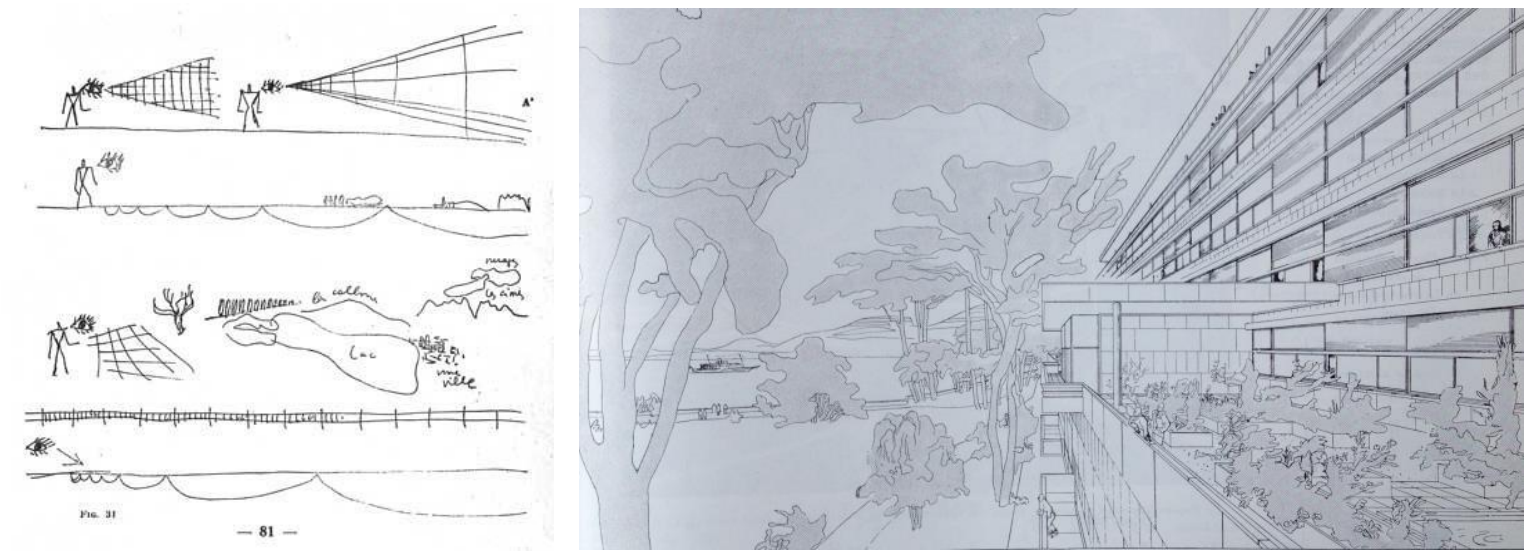

11. Le Corbusier's sketches of vision (from The Modulor), League of Nations perspective (Une Maison - un Palais)

The 360-degree gaze and the control of views through the means of geometry lies at the heart of another modern tendency, Panopticism, exemplified by Jeremy Bentham's panoptical prison as a mechanism of social control. The modern love of panoramic views enjoyed by a detached observer from a privileged viewing point (in a godlike gaze) - while often part of the Romantic appreciation of nature - has a latent, somewhat unsavoury dimension of surveillance and social control. The nineteenth-century adherence to orthogonal planning and to a monumental perspectival order, for example, often had its roots in military strategy as a way of controlling insurgent forces in cities by the efficient deployment of troops. Le Corbusier was deeply interested in the phenomena of live vision, and in the power of non-perspectival spatiality in his paintings and his individual buildings to convey poetic content. At the same time - somewhat paradoxically - he also deployed largely perspectival tools in the design, presentation and publicizing of his city designs. His urban plans of the 1920s geometric and sparse - deploy formal Beaux-Arts-planning-on-a-clean-slate approach, one of the reasons for their failure as real civic settings. The perspective views of the Ville Contemporaine and the Voisin Plan, with their abstract, airplane viewpoint and their eerie accentuation of the horizon, are a memorable example. This tendency culminated with the dioramas displayed in the specially constructed rotunda of the Pavillon de l'Espit

\footnotetext{
${ }^{56}$ Le Corbusier, Mundaneum, in Architecture Vivante 1929, p. 32.

${ }^{57}$ Stanislaus von Moos correctly notes this preoccupation in Le Corbusier's 1923 Petite Maison for his parents at Corseaux near Vevey. 'Lake Geneva and the Alps', in Le Corbusier: An Atlas of Modern Landscapes, p. 75.
} 
Nouveau at the 1925 Exposition des Arts Décoratifs in Paris [Fig. 12].$^{58}$ The Mundaneum was likewise presented in the form of a great diorama, for its exhibition in Geneva [Fig 1].

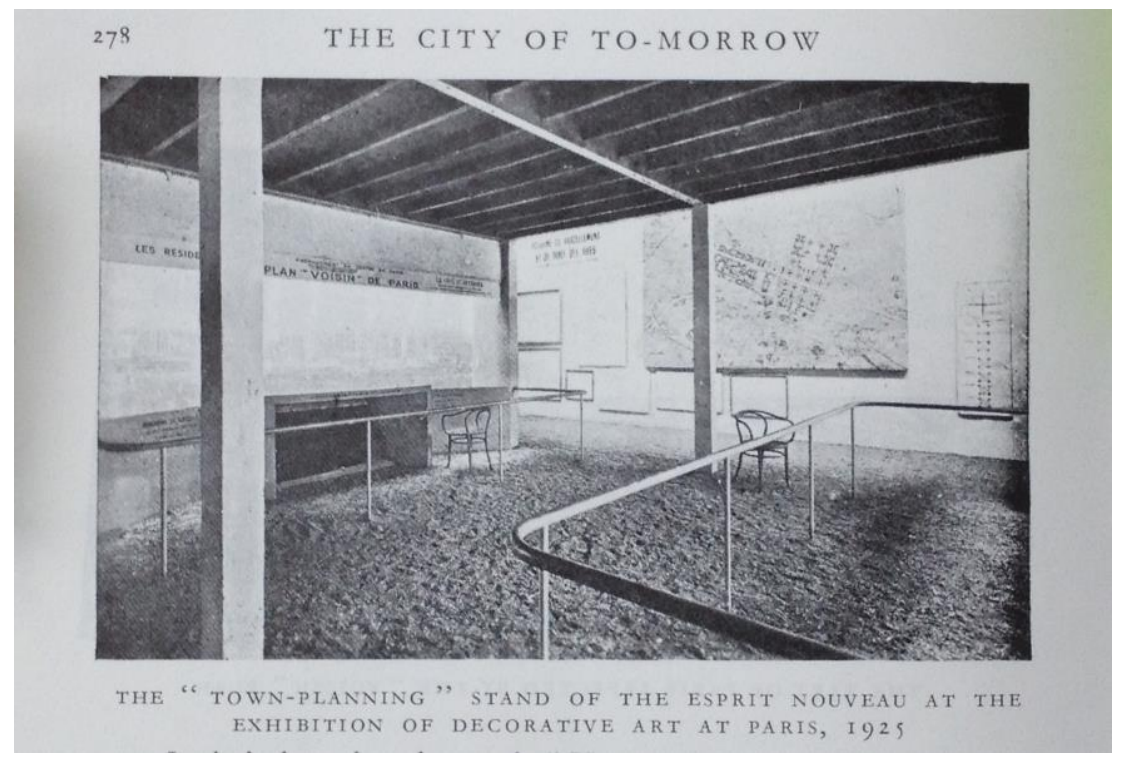

12. Diorama at the Pavillon de l'Esprit Nouveau, Paris, 1925 (Oeuvre Complète 1910-1929, p. 108)

The perspectival sensibility of Panoramism animated, in my view, Le Corbusier's preoccupation with vistas and views as a generative force in his architecture. The presentation perspectives for the League of Nations project, for example, are populated by people gazing at views (and watching each other) from large windows, balconies and terraces. Indeed looking and watching seem to be a chief selling point of this new architecture, verging sometimes on voyeurism. ${ }^{59}$ The person experiencing the views is cast as the lone Romantic individual. In the Musée Mondial this theme is present in Le Corbusier's frequent references to views of the surrounding scenery, and in their careful manipulation. Visitors had unobstructed views on the way up to the museum entrance at the top, the square spiral walk conjuring up a mountain hike. ${ }^{60}$ Once inside the museum, the views became constricted [Fig. 13]. The galleries would have been lit, so far as one can tell from the schematic section, by a continuous clerestory window on the outer side of the tall nave, which would have provided no outside views except for the sky. The downward-expanding diorama of the exhibition on paper sounds somewhat lifeless - a chronological survey, or an exhausting stream of items in a prearranged order. The reality may have been more interesting, however. Le Corbusier's design for the exhibition of French colonial cultures, 'France Overseas', held at the Grand Palais in 1940, may give a better sense of what the Musée Mondial galleries would have been like. ${ }^{61}$ Here one can see that the exhibition spaces would have been far from the arid linear catalogue which Otlet's categories of time, place and object (or Geddes' 'thinking machine' model) would suggest. Instead, in the Paris show, the modern galleries were enlivened by varied heights and lighting conditions. In arranging the

\footnotetext{
58 Nineteenth-century Paris had numerous panoramas. The Pavillon de l'Esprit Nouveau was located on the edge of the exhibition grounds near the Grand Palais. Its site was moments away from an important panorama built in 1858 by Gabriel Davioud in the south gardens of the Champs Elysées (replacing an earlier panorama by Jacques Hittorff).

${ }^{59}$ See for example Le Corbusier, Oeuvre complète 1910-29, pp. 167, 171, Une Maison - un palais, p. 159.

${ }^{60}$ Le Corbusier's drawings are somewhat schematic, and it is often difficult to know with certainty how the windows and balconies on the pyramid would have worked.

${ }^{61}$ Le Corbusier's modern gallery space $(60 \mathrm{~m} \times 12 \mathrm{~m} \times 6 \mathrm{~m}$ high) was apparently built from scratch inside the Grand Palais. The different-height spaces, illuminated by top, indirect light from clerestory windows provided a dramatic setting for the objects, which would have been similar to those contained in the Musée Mondial.
} 
exhibits, Le Corbusier here used his usual technique of the lively juxtaposition of the different fragments to create a rich web of communicative relationships. ${ }^{62}$ The visitor was not a passive observer of a linear spectacle, but was drawn in as a participant in the making of the meaning. A similar situation might have been achieved in the Musée Mondial.
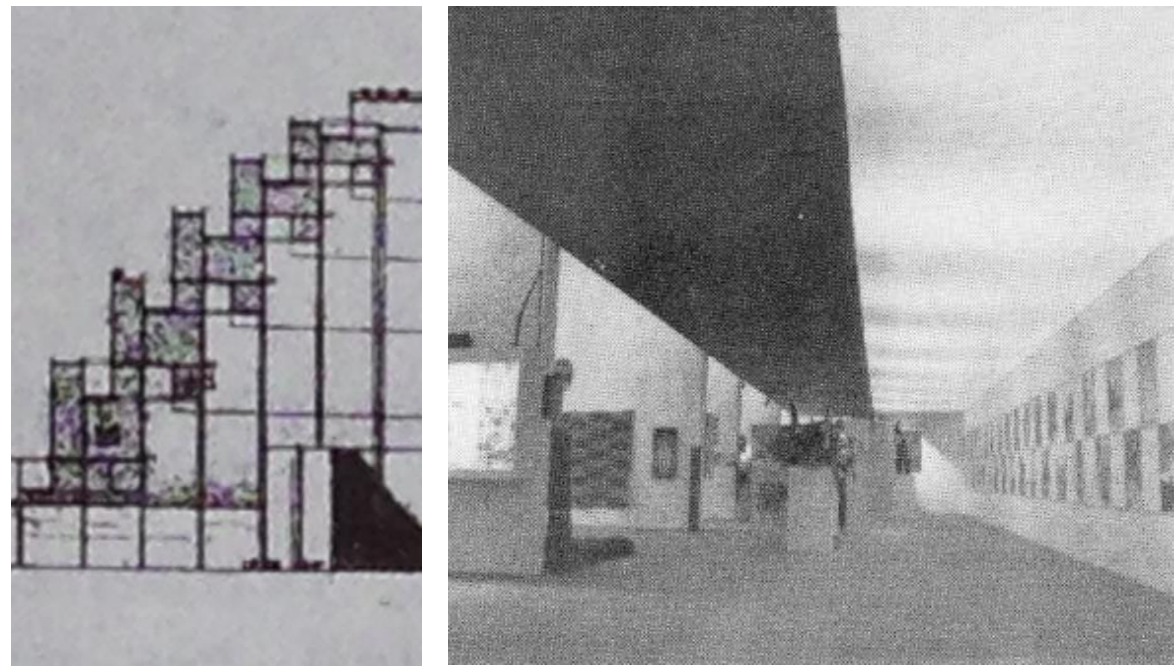

13. Le Corbusier, Musée Mondial pyramid gallery section, France Overseas exhibition (Oeuvre Complète 1938-1946)

According to Le Corbusier, the museum galleries had a glass strip running along the length of the spiral floors, lending light to the hypostyle hall below. It seems unlikely, however, that this would have provided views of this space. The arrival therefore at ground level into this shadowy, cavernous undercroft, with its 'forest' of columns, was probably intended to be a dramatic surprise. Le Corbusier speaks of the Sacrarium 'immersed' in this subaquatic gloom. The atmosphere there may have been reminiscent of the hypostyle Forum at the Palace of Assembly in Chandigarh. Cold, dark and mysterious, this womb-like hall containing the Sacrarium is the one area of the project where clarity of vision is subdued in favour of more primitive kinds of experience. ${ }^{63}$

\section{Conclusions}

The thematic programme of the Musée Mondial is, as we have seen, very complex. In his public statements, Le Corbusier tended to justify all his design decisions there in utilitarian, functional terms characteristic of architectural modernity. Such an emphasis on productive, instrumental knowledge is incompatible with the authentically symbolic. ${ }^{64}$ Some of the strands of the thematic content at the Mundaneum - nature as an antidote to the industrial age, the somewhat prescriptive character of its promenade architecturale, the positivism inherent in the exhibition - are problematic. Inseparably mingled with these, however, are deeper themes, rooted in myth, the cosmological tradition, and the human condition. These include the cosmic mountain, the regenerative dimension of nature, and life as a journey of initiation. Le Corbusier was quite typical of his time in yearning for such thematic content, and like his modern contemporaries, his knowledge of the symbolic was to a

\footnotetext{
${ }^{62}$ See Le Corbusier, Oeuvre Complète 1938-1946. This approach was also memorably used at the Arts Primitifs dans la Maison exhibition of 1933.

${ }^{63}$ In this the underside of the Musée Mondial resembles the lobby of the contemporaneous Villa Savoye, with its subaquatic allusions.

${ }^{64}$ On this problem, see Dalibor Vesely, Architecture in the Age of Divided Representation, Cambridge, Mass.: MIT Press, 2004. On instrumental reason in modernity, see Charles Taylor, Malaise of Modernity, Concord, Ontario: Anansi, 1991.
} 
considerable extent the intellectual product of study. He acquired much of it from books and museums, just as successive generations of architectural historians have relied on symbol dictionaries to 'read' symbols in Le Corbusier's work. This is because the culture which he inhabited was no longer steeped in a living, shared symbolic tradition. The numerous iconographic themes he developed throughout his life (his signs) often have the character of a system - internally consistent, sometimes arbitrary, conceptual. ${ }^{65}$ On the other hand, he was more able than most modern architects to tap into that tradition as it survived latently in the world of direct experience, in poetry, dream and the imagination. Both sides of his enterprise are evident in his synoptic Poème de l'angle droit. The Musée Mondial project, and the discussions about the meaning of modern architecture which it has generated over the years, are very instructive in this context.

\section{Bibliography}

Barb, A.A. 'Diva Matrix’, Journal of the Warburg and Courtauld Institute XVI, 1953, pp. 193-238.

Jean-Louis Cohen, ed. Le Corbusier: An Atlas of Modern Landscapes, London: Thames and Hudson, 2013.

Eliade. Mircea. The Sacred and the Profane, London: Harcourt Brace Jonanovich, 1959.

Gresleri, Giuliano. "The Mundaneum Plan," in C. Palazzolo and R. Vio, eds, In the Footsteps of Le Corbusier. New York: Rizzoli, 1991, pp. 93-113.

Gresleri, Giuliano and Matteoni, Dario. La città mondiale. Andersen, Hébrand, Otlet, Le Corbusier, Venezia: Marsilio, 1982.

Harries, Karsten. The Ethical Function of Architecture, Cambridge, Mass.: MIT Press, 1997.

Ladner, Gerhart B. 'Homo Viator: Mediaeval Ideas on Alienation and Order', Speculum, Vol. 42, No. 2 (Apr., 1967), pp. 233-259.

Le Corbusier, Almanach de l'architecture moderne, Paris: Crès, 1926.

Le Corbusier. The Decorative Art of Today (orig. 1925), London: The Architectural Press, 1987.

Le Corbusier. 'In Defense of Architecture' (1929), Oppositions Reader: Selected Essays 1973-1984, New York: Princeton Architectural Press, 1998.

Le Corbusier. Journey to the East (orig. 1914), Cambridge, Mass.: MIT Press, 1989.

Le Corbusier, Une Maison - un palais, Paris: Crès, 1928.

Le Corbusier. Modulor, London: Faber, 1951.

Le Corbusier, Modulor 2, Cambridge, Mass.: MIT Press, 1968.

Le Corbusier. 'Mundaneum', in Architecture Vivante 1929, pp. 27-31.

Le Corbusier and Jeanneret, Pierre. Oeuvre complète 1910-29, Zurich: Girsberger, 1937.

Le Corbusier, 'Objets à réaction poétique,' in Jean Petit, ed., Le Corbusier Lui-même, Geneva: Rousseau, 1970, p. 178.

Le Corbusier. La Petite Maison, Zurich: Aux Editions d'Architecture, 1954.

Le Corbusier. Precisions on the Present State of Architecture and City Planning (orig. 1930), Cambridge, Mass.: MIT Press, 1991.

\footnotetext{
${ }^{65}$ This is what Peter Carl has aptly called an "algebra of signs."
} 
Motycka Weston, Dagmar. 'The Lantern and the Glass: On the Themes of Renewal and Dwelling in Le Corbusier's Purist Art and Architecture,' in I. B. Whyte (ed.) Modernism and the Spirit of the City, London: Routledge, 2003, pp. 146-178.

Motycka Weston, Dagmar. 'The Restorative Fragment in Early Twentieth-Century Art and Architecture', in Phenomenologies of the City, edited by Henriette Steiner and Max Sternberg, Farnham, Surrey: Ashgate, 2015, pp. 195-212.

Otlet, Paul and Le Corbusier, Mundaneum, Brussels: Union des Associations Internationales, Palais Mondial, 1928

Ozenfant, Amédée and Jeanneret, C.E. 'Le Purisme'. L'Esprit Nouveau, no. 4 (January 1921), 371-86. Reprinted in R. Herbert ed. Modern Artists on Art, pp. 59-73. Englewood Cliffs, N.J.: Prentice Hall, 1964.

Seckler, Mary Patricia. 'Le Corbusier, Ruskin, the Tree, and the Open Hand,' in Russell Walden, ed., The Open Hand Essays on Le Corbusier, Cambridge, Mass.: MIT Press, 1982.

Taylor, Charles. Malaise of Modernity, Concord, Ontario: Anansi, 1991.

Turner, Paul. The Education of Le Corbusier, New York: Garland Publishing, 1977.

Vesely, Dalibor. Architecture in the Age of Divided Representation, Cambridge, Mass.: MIT Press, 2004.

Vidler, Anthony. 'The Space of History: Modern Museums from Patrick Geddes to Le Corbusier', in The Architecture of the Museum: Symbolic Structures, Urban Contexts, Manchester: Manchester University Press, 2003, pp. 160-182.

Vidler, Anthony. The Writing of the Walls, London: Butterworth, 1989.

Willis, Alfred .'The Exoteric and Esoteric Functions of Le Corbusier’s Mundaneum', Modulus 14, 1980. 


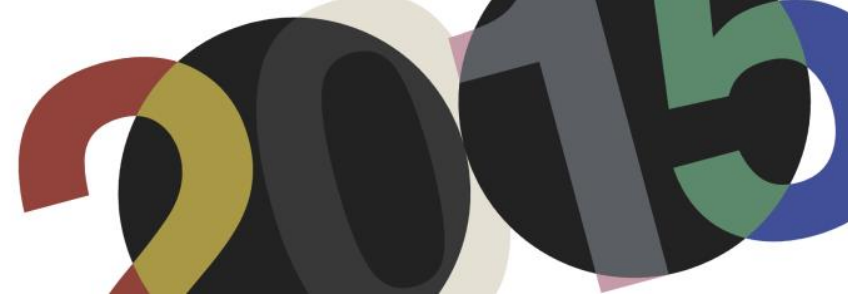

DOI: http://dx.doi.org/10.4995/LC2015.2015.752

\title{
Architecture in Translation: Le Corbusier's influence in Australia
}

\author{
A. Moulis \\ School of Architecture, The University of Queensland
}

\begin{abstract}
While there is an abundance of commentary and criticism on Le Corbusier's effect upon architecture and planning globally - in Europe, Northern Africa, the Americas and the Indian sub-continent - there is very little dealing with other contexts such as Australia. The paper will offer a first appraisal of Le Corbusier's relationship with Australia, providing example of the significant international reach of his ideas to places he was never to set foot. It draws attention to Le Corbusier's contacts with architects who practiced in Australia and little known instances of his connections - his drawing of the City of Adelaide plan (1950) and his commission for art at Jorn Utzon's Sydney Opera House (1958). The paper also considers the ways that Le Corbusier's work underwent translation into Australian architecture and urbanism in the mid to late 20th century through the influence his work exerted on others, identifying further possibilities for research on the topic.
\end{abstract}

Keywords: Le Corbusier; post-war architecture; international modernism; Australian architecture, $20^{\text {th }}$ century architecture.

\section{Introduction}

While there is an abundance of commentary and criticism on Le Corbusier's effect upon architecture and planning globally - in Europe, Northern Africa, the Americas and the Indian sub-continent - there is very little dealing with other contexts such as Australia. Key survey texts on the history of Australian architecture such as J.M. Freeland's Architecture in Australia (1968) and Donald Leslie Johnson's Australian architecture 1901-51: Sources of Modernism (1980) refer only in passing to Le Corbusier's work as formal inspiration to Australian architects of the mid- $20^{\text {th }}$ century, offering little in the way of critical commentary on his influence. ${ }^{1}$ Among them, Australia's most celebrated modernist architect Harry Seidler, whose work is full of references to Le Corbusier that have never been closely examined.

Le Corbusier's links to, and influence in, Australia came about in the dissemination of the architect's works through his publications and through professional journals and magazines; via the travels of Australian architects overseas who witnessed Le Corbusier's work at first hand; through direct contact by architects who had met Le Corbusier or had worked in his atelier and subsequently practiced in Australia and also his own personal contacts with architects and individuals.

The paper will offer a first appraisal of Le Corbusier's relationship with Australia, providing example of the significant international reach of his ideas to places he was never to set foot. It will consider the ways that Le Corbusier's work underwent translation into Australian architecture and urbanism in the mid to late $20^{\text {th }}$ century, evidencing its influence in advancing concepts of modernity.

\footnotetext{
1 J. M. Freeland, Architecture in Australia: a history (Harmondsworth: Penguin, 1972) and Donald Leslie Johnson, Australian architecture, 1950-51: sources of modernism (Forest Grove: Sydney University Press, 1980).
} 


\section{Influence through other architects}

Le Corbusier's architecture and ideas would have impact in Australia through the work of architect's committed to the modernist project he articulated. Chief among them was the celebrated Austrian-born architect Harry Seidler, who attended the Harvard School of Design under Walter Gropius in 1945-46. Wedded to a modernism through his university training, Seidler worked briefly with Marcel Breuer and Oscar Neimeyer before arriving in Sydney in 1948 to design a house for his parents. By his own account Seidler saw modern architecture as a process of form giving pioneered by 'master' architects such as Wright, Gropius, Le Corbusier and Mies van der Rohe. While Gropius provided an intellectual mentor for Seidler it was Le Corbusier's work that provided the strongest formal cues. Seidler held copies of Le Corbusier's serial architectural monographs, the Oeuvre Complète, in his Sydney studio from his first arrival in Australia, which he had brought with him from New York. ${ }^{2}$ The series also provided Seidler with a model for his 1954 monograph Houses, Interiors and Projects and his later collection, Harry Seidler $1955 / 63$ in terms of both presentation and layout. ${ }^{3}$

Seidler's reception of the work of Le Corbusier can be traced to the period in which he worked with Marcel Breuer. While in Breuer's office in 1947 Seidler produced a sketch design for a house with an associate, Rolland Thompson, which was subsequently published in the American journal Arts and Architecture in January $1948 .{ }^{4}$ This project has been acknowledged as substantially the Rose Seidler House, the architect's first Australian work realised the same year - a building heralding the arrival of modernism in the public imagination. ${ }^{5}$ Yet both of these plans are based on Le Corbusier's famous Villa Savoye, pointing directly to Seidler's chief source. An overlay comparison shows that the geometry and layout of the Villa Savoye and the Rose Seidler House are very closely related, indicating that Seidler took his source very seriously, seeking to understand Le Corbusier's proportioning systems from his own careful analysis of the villa's plan such that he could then apply it to his own architecture.

\footnotetext{
2 Ann Stephen, Philip Goad and Andrew McNamara (eds) Modern times: the untold story of modernism in Australia (Carlton, Vic. : Miegunyah Press, 2008), p. 118.

${ }^{3}$ Le Corbusier, Oeuvre Complète Vols 1-4 (London: Thames \& Hudson, 1964), Harry Seidler, Houses, Interiors and Projects, (Sydney: Associated General Publications, 1954).

${ }^{4}$ Harry Seidler and Roland Thompson, 'Preview project', Arts and architecture, 65, (Jan 1948), 32-33.

${ }^{5}$ Kenneth Frampton \& Philip Drew Harry Seidler, 18.
} 


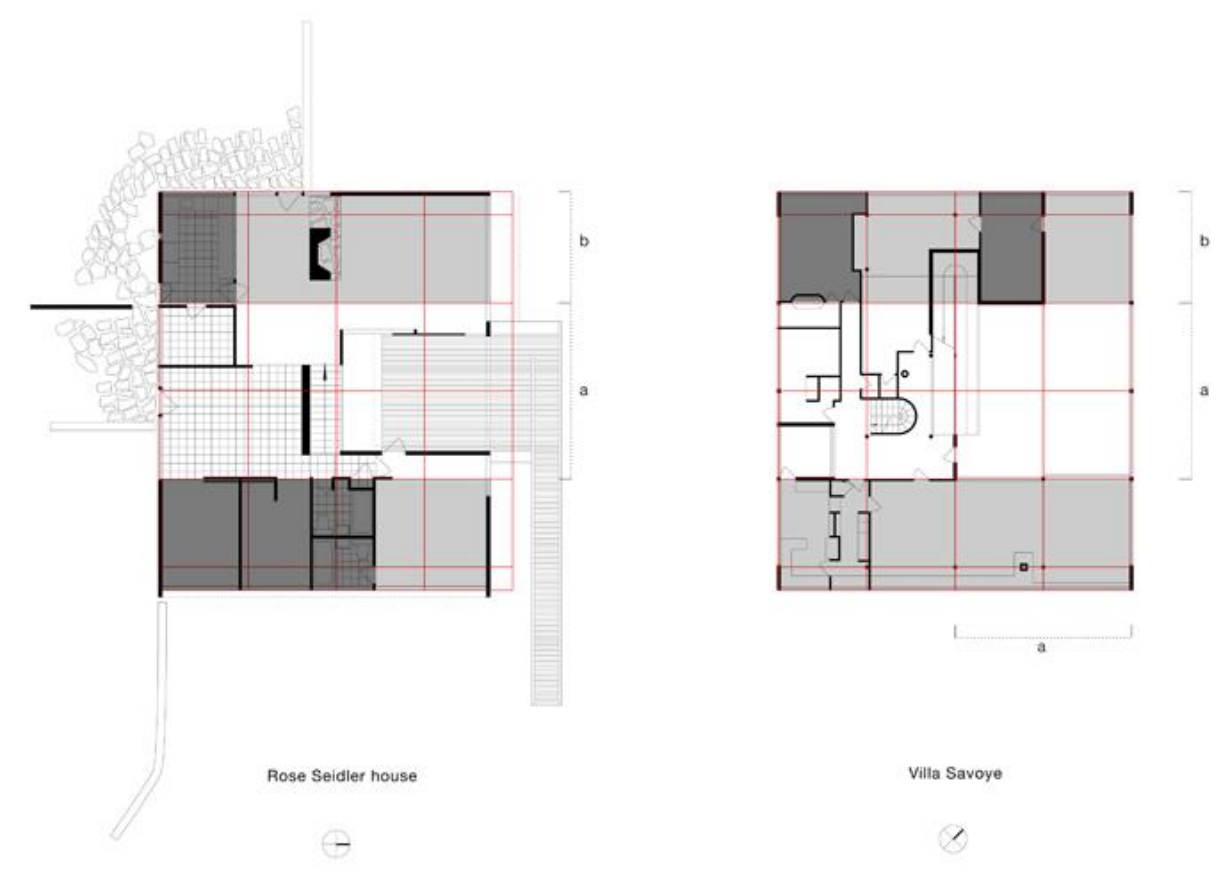

1. Proportional comparison of Villa Savoye and Rose Seidler House plans. [Drawing by I-wen Kuo]

In two projects designed in 1957 Seidler brings a similar analytical method to his appropriation of works by Le Corbusier, specifically from the Oeuvre Complète 1946-1952. For the House in Clifton Gardens (1957) Seidler draws directly upon the form, massing and proportions of Le Corbusier's housing at La Sainte-Baume project (1948) with its distinctive shallow vaulted profile. ${ }^{6}$ At a larger scale but seemly as directly, Seidler draws upon the urban organisation, massing and proportions of Le Corbusier's mid-rise slab blocks for the concourse of Strasbourg project (1951) for his McMahon's Point Development Scheme at North Sydney (1957). ${ }^{7}$

Seidler undertook extensive international tours to witness modernist architecture at first hand and it is clear that visits to the buildings of Le Corbusier were a high priority. ${ }^{8}$ In 1955 Seidler met with Le Corbusier at Chandigarh and was shown through the Secretariat building (1953). ${ }^{9}$ While in Europe on the same tour Seidler also visited Le Corbusier's then recently completed Chapel at Ronchamp (1950-1955). In 1963 Seidler visited Le Corbusier's Carpenter Centre (1961-1964).$^{10}$ This tour also involved a return trip to India with a visit to meet architect B. V. Doshi in Ahmedabad, who had worked with Le Corbusier, and to see Le Corbusier's works there: Shodan House (1951), the Mill owners' Association Building (1954), and the Sarabhai House (1955). Seidler's work would feature characteristic aspects of Le Corbusier's post war architecture such as the adoption of brisesoleil and beton brut finishes in projects including Seidler's own house at Killara, Sydney (1966-67), the Australian Embassy in Paris (1973-77) and the Milsons Point Offices and Apartments (1973-94).

Other architects deserving of attention in understanding Le Corbusier's influence include those that had worked in his atelier and subsequently practiced in Australia. They include the British-born architect and planner Gordon Stephenson, an intern in Le Corbusier's Paris atelier in 1930-32, who arrived in Perth in 1953 and was later Foundation Professor of Architecture at The University of Western Australia, 1960-1972 and Balwant Singh

\footnotetext{
${ }^{6}$ Seidler Seidler 1955/63, 64-67; Le Corbusier, Oeuvre Complète 1946-1952 (Zurich: Girsberger, 1955), 34-35.

${ }^{7}$ Seidler Seidler 1955/63, 194-199; Le Corbusier, Oeuvre Complète 1946-1952, 112-113.

${ }^{8}$ Alice Spigelman, Harry Seidler: Almost full circle (Sydney: Brandl \& Schlesinger, 2001), 199.

${ }^{9}$ Spigelman Harry Seidler, 201.

${ }^{10}$ Letter dated October 31, 1963. NSW Library, Special Collections.
} 
Saini who worked in Le Corbusier's Chandigarh office in the 1950s, becoming Professor of Architecture at The University of Queensland in 1970. Gordon Stephenson, and also Walter Bunning in Sydney, became promoters of the architect's ideas attempting to translate his urban strategies into the national context. Both would have a significant impact on town planning in Australia in the post-war era. Bunning's book on new forms of planning Homes in the Sun (1945) ${ }^{11}$ and Stephenson's Metropolitan Plan for Perth as well as his contribution to planning for the post-war urban expansion of Canberra, are indicative of the diverse ways in which Le Corbusier's ideas suffused not simply architecture but also town planning practice and shaped the developing nation's approach to urban form.

\section{Exhibition of Le Corbusier's art}

On two occasions in the 1950s, artworks by Le Corbusier travelled to Australia to be shown in public exhibitions of modern European art. Three of Le Corbusier's paintings Le Femme au livre (Woman with a Book, 1935), Les deux sæurs (The Two Sisters, 1933-47), and Deux mains et pomme d'or (Two Hands and a Golden Apple, 1948) were included in the travelling show "French Painting Today: Contemporary painters of the School of Paris," which toured every State Gallery in Australia between January and September $1953 .{ }^{12}$ His tapestry work L'Ennui régnait au dehors (Boredom Prevailed Outside, 1954) also appeared in "Contemporary French Tapestry," shown at the Art Gallery of New South Wales (Sydney) in March and April of $1956 .{ }^{13}$ Both exhibitions were overseen by initiatives of the Association Française d'Action Artistique (AFAA, French Association for Artistic Action), an art society first founded under the auspices of the French Ministère des Affaires étrangères (Ministry of Foreign Affairs) and the Ministère de l'Education (Ministry of Education) in $1923 .^{14}$

This showing of Le Corbusier's art may have been small but it was contemporaneous with other exhibitions of Le Corbusier's work - encompassing a span from painting to urbanism - in Europe and North America, literally appearing "at first hand" in Australia as part of a broadly constituted international setting. In Australia, these works clearly had a limited and mixed reception, yet their presence, and the reaction of local audiences to it, mirrored popular and critical attitudes on art and architecture prevalent at the time. As part of the local critical reception of "French Painting Today" Le Corbusier's work received a most direct rebuke. The art critic of Sydney's Daily Telegraph, observing the exhibition's mix of art, singles out the work of Le Corbusier, claimed that the architect's art failed to meet the standard set by the exhibition overall. ${ }^{15}$ That Le Corbusier's work is judged in Australia to be below that of the art of its day accords with judgements of the architect's painting from within cultural circles in Europe at that time but the silence with which the local architecture community greeted Le Corbusier's work is perhaps more surprising.

\footnotetext{
${ }^{11}$ Walter Bunning, Homes in the sun: the past, present and future of Australian housing (Sydney: Nesbit, 1945).

12 Le Corbusier (1887-1965), Le Femme au livre (Woman with a Book, 1935), oil on canvas, 130 x $89 \mathrm{~cm}$, private collection; Les deux sœurs (The Two Sisters, 1933-47), oil on canvas, 100 x $81 \mathrm{~cm}$, private collection; Deux mains et pomme d'or (Two Hands and a Golden Apple, 1948), oil on board, 100 x $81 \mathrm{~cm}$, private collection.

${ }^{13}$ Le Corbusier (1887-1965), L'Ennui régnait au dehors (Boredom Prevailed Outside, 1954), tapestry work, 200 x $256 \mathrm{~cm}$, Mobilier National.

${ }^{14}$ For further discussion see Antony Moulis, “An Active Silence: Le Corbusier's Art in Australia,” Fabrications - Journal of the Society of Architectural Historians, Australia and New Zealand, 17:1, June 2007, 6-17.

15 "French Art in Sydney," Daily Telegraph (Sydney), February 27, 1953.
} 
When the prominent Australian architect and critic Robin Boyd was asked by the Melbourne Herald for his opinion of the exhibition he omitted to mention or comment on the presence of the work of Le Corbusier. ${ }^{16}$ Elsewhere, leading architectural journals such as Architecture in Australia, Art and Architecture and Crosssection failed to note the exhibition at all or the appearance of Le Corbusier's work therein. The reason that Le Corbusier's art received such a cool reception in Australia may have been to do with local debates on the artistic or technological basis of architecture. The perceived failure of functionalism led some to suggest that architecture could achieve renewal through the expression of human and artistic values. Le Corbusier, through his own art and architecture, became an obvious champion. In Australia, however, influential architects such as Boyd were suspicious of the new humanist agenda, preferring to argue that the rational functionalism evidenced in Le Corbusier's pre-war work remained key to the modernist project. ${ }^{17}$

\section{Le Corbusier's Adelaide plan}

In 1950 Le Corbusier made a diagrammatic plan of the City of Adelaide, South Australia, with the assistance of Dr Hugh C. Trumble, a professor of agronomy from the University of Adelaide on secondment to the Food and Agriculture Organization of the United Nations who was traveling through South America. ${ }^{18}$ The drawing, dated 17 September 1950, was made in Bogotà, Colombia, most likely at the Hotel Continental, where the architect stayed while working on his commission for an urban plan for the city. ${ }^{19}$ Clearly marked 'Adelaide, Australia' the drawing is made up of several sections. In the central section there is a simple sketch plan of the southern portion of the city with its grid shown indicatively including its squares. There is a further set of rectangles drawn outside on the top edge of the grid indicating generically the civic buildings along North Terrace. Forming a rough circle around the grid of South Adelaide is a series of dash marks, indicative of the belt of parklands that encircle the city.

A model of British colonial town planning, Adelaide was organized out of theories of systematic development proposed by the politician Edward Gibbon Wakefield in England in the 1830s. Le Corbusier's interest in the city's plan, as it existed in 1950, can be seen in parallel with his then current thinking about architecture and urbanism. It is on his return home from this South American trip that Le Corbusier receives a letter from the Indian Embassy in Paris inviting him to participate in the design of the city of Chandigarh, the modern capital of the Punjab. ${ }^{20}$ This commission, that he later accepts, becomes the most significant of his career. Though the sequence of events that lead to Le Corbusier's drawing of Adelaide are chance events in relation to the Chandigarh commission, the drawing itself provides evidence of knowledge acquired by Le Corbusier that makes a comparison of the two plans potentially significant. ${ }^{21}$

The two plans (as sketches) have obvious similarities in terms of their layout. In both instances the city is drawn as a self-contained rectilinear grid with the major civic buildings located outside it, along an edge of the grid.

\footnotetext{
16 "French Art called vital, courageous," Herald (Melbourne), June 8, 1953.

${ }^{17}$ R. G. Parker, et al., "A Three Sided Debate: Are we at the Beginning, Peak, or End of an Architectural Era?" in Modernism \& Australia, eds. Stephen, McNamara \& Goad, 854-72.

${ }^{18}$ FLC I16177

${ }^{19}$ A letter sent by Le Corbusier, dated 19 September, 1950, is written on stationery of the Hotel Continental, Bogota, Colombia, FLC R11282.

${ }^{20}$ Letter dated 30 September, 1950, FLC P21112.

${ }^{21}$ For discussion of an earlier version of this research of Le Corbusier's Adelaide plan and its value as evidence see Andrew Leach, What is Architectural History? (Cambridge, Polity Press, 2010), p. 89-91.
} 
Both plans feature a city encircled by parks and green space, 'never to be built upon,' and each grid is drawn in relation to a landscape 'backdrop' - the hills or mountains against which it is viewed.

Beyond these similarities, the Adelaide plan drawing also mirrors Le Corbusier's ideology on urbanism. Adelaide's discrete zoning of dwelling, work, transportation and recreation (marked in the drawing) confirms broadly held ideological beliefs about modern urbanism developed by the architect through the CIAM organization, yet here those ideals of planning are represented through the example of a realised contemporary city. Le Corbusier's overtly rhetorical approach to design would not have admitted the plan of Adelaide $-\mathrm{a} 19^{\text {th }}$ century British colonial city founded in southern Australia - as a source or influence for the master plan of Chandigarh yet this drawing provides compelling evidence of a covert connection between the two. ${ }^{22}$

\section{The Sydney Opera House Art commission}

One of the most intriguing aspects of Le Corbusier's contact with Australia is Jorn Utzon's 1958 commissioning of the architect for tapestries and other artwork for the interiors of the Sydney Opera House. ${ }^{23}$ Between 1958 and 1960 Le Corbusier worked actively on the commission producing a 6.5-square-metre wool tapestry, Les Dés Sont Jetés (The Dice Are Cast) and five small enamel works.

Le Corbusier's work began in earnest on June 25, 1959 when he met with Le Corbusier at his home and studio in Paris. During the meeting Le Corbusier made a rough sectional drawing over one of Utzon's drawings indicating where the artworks might be placed in the completed Opera House - a set of enamels to go on a wall of the ground floor corridor and the tapestry to go in the harbour side foyer on the same level. ${ }^{24} \mathrm{At}$ a second meeting on November 1, 1959, details of the production and commission are settled between the two.

\footnotetext{
${ }^{22}$ For more recent discussion see Antony Moulis, “A modern exemplar: Le Corbusier's Adelaide drawing, urbanism and the Chandigarh plan," Journal of Architecture, 17/6 (2012), 871-887.

${ }^{23}$ For earlier discussion see Antony Moulis, "A night at the Opera," AA Files, 64 (Spring 2012), 108-111.

${ }^{24}$ FLC A3/18/179
} 


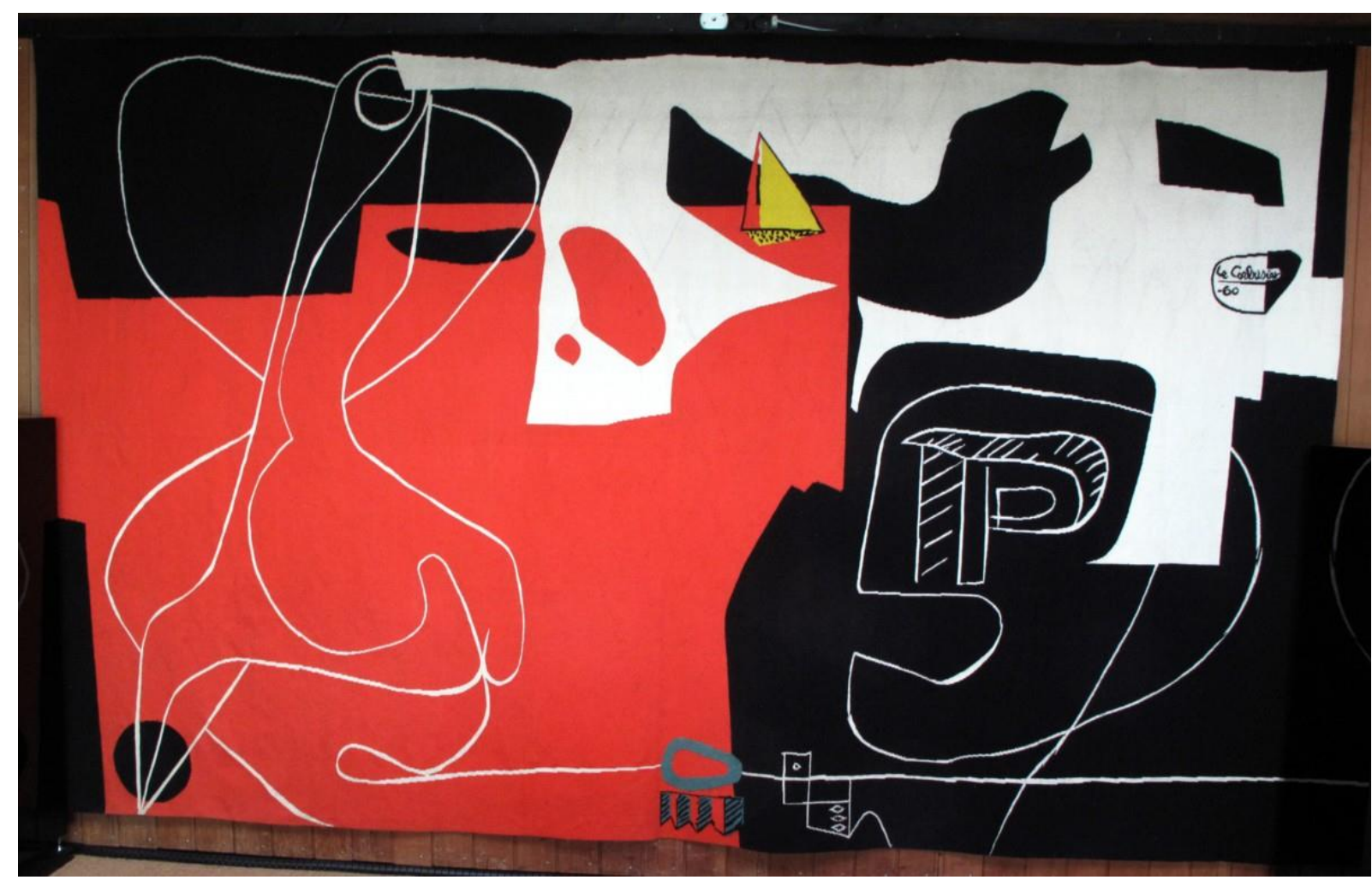

2. Le Corbusier, Les Dés Sont Jetés (The Dice Are Cast), 1960 @FLC-ADAGP

The tapestry, which arrived in Denmark in 1960, contains figurative elements drawn from materials sent to Le Corbusier by Utzon - a copy of his original competition drawings for the Opera House as well as and the 1958 Design Report known as 'The Red Book', which contained developed sketch plans and photographs of preliminary models. The elements Le Corbusier incorporated into the tapestry's composition include a tracing of one of Utzon's models for the famous shells and an outline of the original site plan that included the footprint of the tram depot with its distinctive round-ended plan form, which previously occupied the site. The elements are gathered together with other figures using a collage technique that brings a diversity of elements into relation with one another while obscuring their particular origin in much the same way the architect drew on images of objects - stones and driftwood - converting them into material for his abstract compositions in painting.

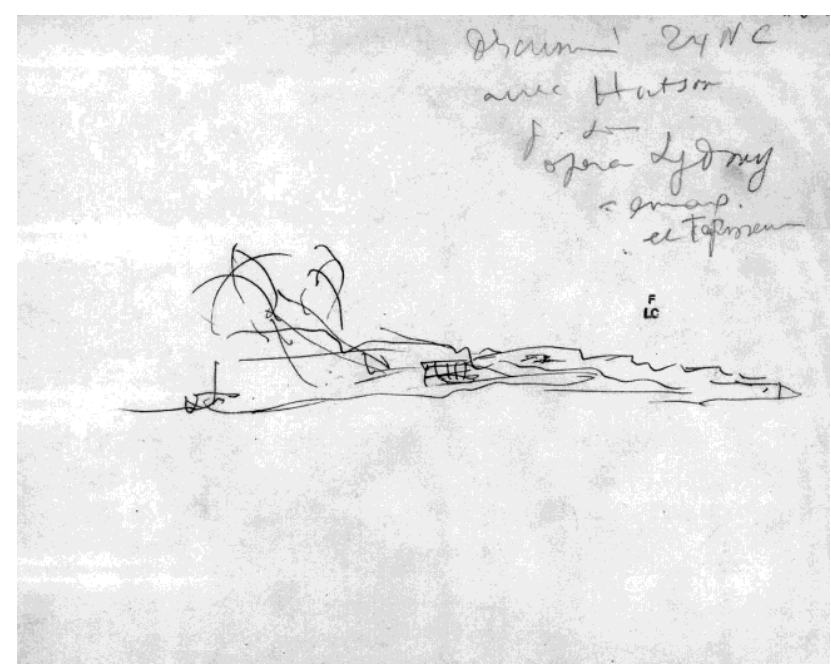

3. Le Corbusier, Sketch of Sydney Opera House, 1959. FLC R3/5/370 @FLC-ADAGP 
One of the most extraordinary images in Le Corbusier's preparatory drawings for the Sydney commission is his own representation of the Opera House pictured in its setting on Bennelong Point. ${ }^{25}$ Drawn as a sketch elevation from the harbour, the image is likely to have been based on the initial Opera House drawings sent by Utzon. It represents a rare moment in Le Corbusier's career in which he privately acknowledges his respect for the work of a fellow architect. The sketch and Le Corbusier's careful approach to the Utzon commission evidences a surprisingly close collaboration between two of the great $20^{\text {th }}$ century architects - one that is until now little studied or known.

After Le Corbusier's death in 1965 and Utzon's resignation from the Opera House project in 1966 the plan to bring the work to Australia fell into obscurity. However, in June, 2015, on the basis of the author's research, the Sydney Opera House Trust purchased the tapestry at auction in Denmark, after it had been held by the Utzon family for over 50 years. The arrival of the work for permanent display in the building will provide testimony to Utzon's original vision for the building's interiors and, at the same time, an entirely unique example of Le Corbusier's synthèse des arts - one realised in surprising moment of collaboration with a fellow architect rather than exclusively in the architect's own terms. ${ }^{26}$

\section{Conclusion}

While the significance of Le Corbusier to the history and theory of 20th modern architecture and urban planning, and their worldwide impact, is well known his connections to Australia have previously been assumed to be nonexistent or indirect at most. Yet there is an account to be made of Le Corbusier's contacts and influence that could add appreciably to the history of modern architecture and urbanism in Australia and provide fresh perspectives to the body of knowledge on Le Corbusier. The dispersed and fragmentary episodes briefly described in this paper touch on significant themes in the architect's post war work - his beliefs regarding modern urbanism, his approach to art practice in relation to architecture, and his performance in collaborating with fellow architects (an aspect of his career that remains little examined). In each case Le Corbusier's contacts with Australia offer opportunities to understand, in microcosm, larger questions and issues. In this sense Le Corbusier's encounters with Australia reveal a two-way exchange, showing the impact of his ideas and projects on Australian-based architects while also revealing counter-influences on Le Corbusier in his post-war career. Despite the fact that the architect never set foot on the island-continent there is more to know of his influence there.

\section{Acknowledgements}

The author acknowledges the assistance of Arnaud AD. Dercelles and the Fondation Le Corbusier with the background research for this paper and also the archives of the University of Adelaide, the National Gallery of Victoria, the Art Gallery of New South Wales and the Mitchell Library, Sydney, and the Sydney Opera House Trust.

\footnotetext{
${ }^{25}$ FLC R3/5/370

${ }^{26}$ Rick Feneley, "Sydney Opera House buys Le Corbusier tapestry 57 years after Joern Utzon commissioned it," The Sydney Morning Herald, June 13, 2015. http://www.smh.com.au/national/sydney-opera-house-buys-lecorbusier-tapestry-57-years-after-joern-utzon-commissioned-it-20150612-ghmgcw.html
} 


\section{Bibliography}

Bunning, Walter, Homes in the sun: the past, present and future of Australian housing, Sydney: Nesbit, 1945.

Freeland, J. M., Architecture in Australia: a history, Harmondsworth: Penguin, 1972.

Johnson, Donald Leslie, Australian architecture, 1950-51: sources of modernism, Forest Grove: Sydney University Press, 1980.

Leach, Andrew, What is Architectural History?, Cambridge, Polity Press, 2010.

Le Corbusier, Oeuvre Complète 1946-1952, Zurich: Girsberger, 1955.

Moulis, Antony, “An Active Silence: Le Corbusier's Art in Australia," Fabrications - Journal of the Society of Architectural Historians, Australia and New Zealand, 17:1, June 2007, pp. 6-17.

Moulis, Antony, "A modern exemplar: Le Corbusier's Adelaide drawing, urbanism and the Chandigarh plan," Journal of Architecture, 17/6, 2012, pp. 871-887.

Moulis, Antony, “A night at the Opera," AA Files, 64, Spring 2012, pp. 108-111.

Seidler, Harry, Houses, Interiors and Projects, Sydney: Associated General Publications, 1954

Spigelman, Alice, Harry Seidler: Almost full circle, Sydney: Brandl \& Schlesinger, 2001.

Stephen, Ann; Goad, Philip and McNamara, Andrew (eds) Modern times: the untold story of modernism in Australia, Carlton, Vic. : Miegunyah Press, 2008. 


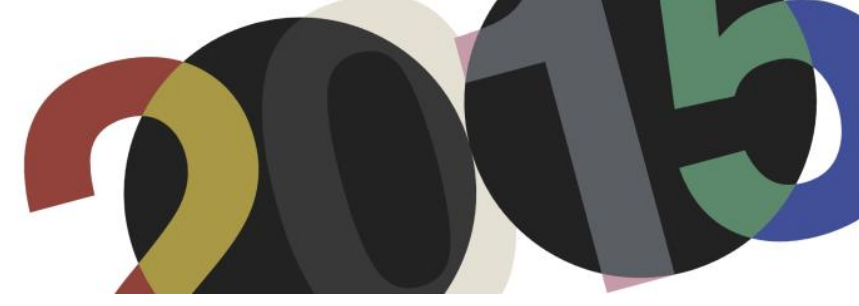

DOI: http://dx.doi.org/10.4995/LC2015.2015.794

\title{
Le Corbusier and the "Lection of the gondola"
}

\author{
A. Mozzato
}

University IUAV of Venice

\begin{abstract}
In light of the reflections developed by Le Corbusier through the "oeuvre plastique" and his intense relationship with the city of Venice, the gondola became the paradigm of an "artistic creation" which, while having to bow to the principles of "utility" linked to the tangible world of the "machinist era" on the one hand, on the other met the expressive requirements of "beauty" connected to the spiritual needs of modern man.

The encounter with the gondola describes this "duality" which pervades all the works of Le Corbusier always in search of a synthesis between "measure" and "lyricism", representing a "plastic manifestation" that points to some theoretical principles and foundations of artistic "action", outlined through the concept of "Outil", the expression and instrument of a necessary "harmony" between mankind and the world.
\end{abstract}

Resumen: A la luz de las reflexiones desarrolladas por Le Corbusier a través de la "obra plástica" y su intensa relación con la ciudad de Venecia, la góndola se convirtió en el paradigma de una "creación artística" que, si bien tiene que someterse, por un lado, a los principios de "utilidad" vinculados al mundo tangible de la "era mecánica", por otro lado cumplía los requisitos característicos de "belleza" relacionados con las necesidades espirituales del hombre moderno.

El encuentro con la góndola describe esta "dualidad" que impregna toda la obra de Le Corbusier, siempre en busca de una síntesis entre "medida" y "lirismo", lo que representa una "manifestación plástica" que apunta a algunos de los principios teóricos y fundamentos de la "acción" artística perfilados a través del concepto de "Outil", la expresión e instrumento de una necesaria "armonía" entre la humanidad y el mundo.

Keywords: Le Corbusier; Gondola; Venice; Plastique acoustique; Outil; Oeuvre plastique; L'angle droit.

Palabras clave: Le Corbusier; Gondola; Venecia; Plástica acústica; Outil; Obra plástica; El ángulo recto. 


\section{Venice is a totality}

On 26 July 1934, on the occasion of the conference organized in the Doge's Palace in Venice by the Institut International de Coopèration Intellectuelle ${ }^{l}$, Le Corbusier participated with a talk entitled "La leçon de la gondole. L'art et les masses contemporaines ${ }^{2}$, .

As Antonio Foscari recounts ${ }^{3}$, the invitation from senator Alfredo Rocco did not receive an immediate positive reply due to his commitments to the Algeri project in that period.

His subsequent interest in the conference can perhaps be attributed to the construction, in progress at the time, of the new industrial centre of Porto Marghera and, above all, of the adjoining residential settlement. This would explain the content of the second part of Le Corbusier's talk which was entirely focused on the topic of housing and its organization within the modern city.

His relations with Luigi Pavan, the director of the port, and Baroness Catherine d'Erlanger, which led him to write a letter dated 25 September to Giuseppe Volpi - promoter of the new industrial and residential settlement of Porto Marghera - show how Le Corbusier foresaw the opportunity to "build a residential city at Porto Marghera which would be a poem like the city of Venice $e^{4,}$, using the theoretical principles of Ville Radieuse (1935), then formalized in the urban development plan for the new city of Antwerp which was partly destroyed by the bombings that took place during the war.

In addressing the topic of the conference, the "relationship between art and contemporary society", after a short introduction on the importance that artistic manifestations assume in human life, Le Corbusier maintained that the establishment of a "new machinist civilization" ${ }^{6}$ " can only occur by "harmonizing new and revolutionary factors with the elements and permanent needs and desires of the human conscience "."

In order for this phenomenon to affect the entire community and not just the corporation of artists it is necessary for "human activities to be brought back through an invisible and profoundly natural force to a unanimous law, a unanimous attitude, total harmony".

Le Corbusier would return to Venice in 1951 for the CIAM summer school ${ }^{9}$. At the opening ceremony he held a conference that highlighted how the lagoon city represented the paradigm of this "totality", described in 1934 as a "unique phenomenon" of "total harmony, complete purity and cultural unity"."

\footnotetext{
${ }^{1}$ On this topic in relation to Le Corbusier's talk see the papers by De Sabbata, Massimo: "Les Arts contemporains et la Réalité. L'Art et l'État”. In Talamona, Maria (Ed.): L'Italie de Le Corbusier. Paris: Édition de la Villette, 2010. pp. 100-109; and Foscari, Antonio: “À Venise en 1934”. In Talamona, Maria (Ed.): L'Italie de Le Corbusier. Op. cit. pp. 200-209.

${ }^{2}$ Le Corbusier: "La leçon del la gondole. L'art et les masses contemporaines". In Tamborrino, Rosa (Ed.): Le Corbusier Scritti. Torino: Einaudi 2003. pp. 233-243.

${ }^{3}$ Foscari, Antonio: “À Venise en 1934”. In Talamona, Maria (Ed.): L'Italie de Le Corbusier. Op. cit.

${ }^{4}$ Ibid. p. 209.

${ }^{5}$ Le Corbusier: La Ville radieuse. Boulogne-sur-Seine: Editions de l'Architecture d'Aujourd'hui. Collection de l'équipement de la civilisation machiniste, 1935.

${ }^{6}$ Le Corbusier: "La leçon del la gondole. L'art et les masses contemporaines". In Tamborrino, Rosa (Ed.): Le Corbusier Scritti. Op. cit. p. 234.

${ }^{7}$ Id.

${ }^{8}$ Ibid. p. 235.

9 For Le Corbusier's talk at the CIAM summer school in Venice in 1952, see the essays of Von Moos and Stanislaus: "À propos de Venise". In Talamona, Maria (Dir.): L'Italie de Le Corbusier. Op. Cit. pp. 76-87; by the same author: "Alla
} 
Among his Venetian experiences, we should remember the project for the New Hospital of Venice ${ }^{11}$, a work commissioned in the summer of 1962 and never completed due to his death on 27 August 1965.

In addition to the "polemical" aspects that had arisen at the time, the scientific literature is unanimous in highlighting the "controversial" character of this project in relation to Le Corbusier's poetics of the period ${ }^{12}$. It is difficult to say if this work, that took place during the dénouement of Le Corbusier's relationship with Venice, would have materialised as planned on paper. Le Corbusier's untimely death would not allow us to provide an answer to this question, anyhow the significance of his complex relationship with the lagoon city cannot be understood by devoting an analysis solely to this project.

This should take place within a reflection inserted in a broader context of reading and understanding of the role that the city assumed for Le Corbusier as part of his overall work. I believe that this is the meaning that should be attributed to the statements in the letter addressed to the engineer Giovanni Favaretto Fisca, then Mayor of Venice, dated 5 October 1962: "L'autorité doit déclarer Venise Ville sacrée "13,", which reduced to a few words the intense interest and deep admiration that the city of Venice, like Paris, stirred up in Le Corbusier as he pursued his rich production and laborious artistic research ${ }^{14}$.

veneziana. Le Corbusier, il turismo e la "crisi dell'utopia". In Talamona, Maria (Ed.): L'Italia di Le Corbusier. Milano: Electa, 2012. pp. 201-217. A part of the talk's transcript has been translated in Italian and published under the title: "À propos de Venise" in Venezia Architettura. $\mathrm{N}^{\circ} 1$. 1952. pp. 6-9.

${ }^{10}$ Le Corbusier: "La leçon del la gondole. L'art et les masses contemporaines”. In Tamborrino, Rosa (Ed.): Scritti. Op. cit. p. 235.

${ }^{11}$ On the project of the New Hospital of Venice see Farinati, Valeria (Ed.): H VEN LC hôpital de Venise Le Corbusier 196370: inventario analitico degli atti nuovo Ospedale. Venezia: IUAV Archivio Progetti, 1999; Petrilli, Amedeo: Il testamento di Le Corbusier: il progetto per l'Ospedale di Venezia, Venezia: Marsilio, 1999; Mattioni, Emilio: "La vicenda del Concorso preliminare per il nuovo Ospedale di Venezia”. In Talamona, Maria (Ed.): L'Italia di Le Corbusier. Op. cit. pp. 377-389; Reichlin, Bruno: "L’Ospedale di Venezia. Congetture sulla genesi del progetto". In Talamona, Maria (Ed.): L'Italia di Le Corbusier. Op. cit. pp. 390-409; by the same author: "L'atelier era un vaso di Pandora". Cinquant'anni di progetti rivisitati da Le Corbusier \& Co. L'Ospedale di Venezia, 1960-1965”. In Reichlin, Bruno: Dalla «soluzione elegante» all'«edificio aperto». Scritti attorno ad alcune opere di le Corbusier. Mendrisio: Mendrisio Academy Press, 2013. pp. 389-414; Sarkis, Hashim (Ed.): Case: Le Corbusier's Venice Hospital and the Mat Building Revival. Munich-London-New York: Harvard University Graduate School of Design, 2001.

12 For further study on the events and figures that contributed to the formulation of the New Hospital project in Venice, see the essays of Reichlin, Bruno: "L'Ospedale di Venezia. Congetture sulla genesi del progetto". In Talamona, Maria (Ed.): L'Italia di Le Corbusier. Op. cit.

${ }^{13}$ Letter dated 3 October 1962 from Le Corbusier to the Mayor of Venice, Giovanni Favaretto Fisca, FLC I2-10.

${ }^{14}$ Several papers described this intense relationship between Le Corbusier and the city of Venice, including Von Moos, Stanislaus: "À propos de Venise". In Talamona, Maria (Ed.): L'Italie de Le Corbusier. Op. cit.; by the same author: "Alla veneziana. Le Corbusier, il turismo e la "crisi dell'utopia". In Talamona, Maria (Ed.): L'Italia di Le Corbusier. Op. cit.; by the same author: "La leçon de Venise". In Le Corbusier: Album La Roche. Milano: Electa, 1996. pp. 24-40; Duboy, Philippe: Le Corbusier, Croquis de voyages et études, Paris. Paris: La Quinzaine littéraire, 2009; by the same author: "L.C.B.N. 1915”. In Casabella. 1987. №531-532. Milano. pp. 94-103; Brooks, A. Harold: Le Corbusier's formative years. Chicago: University of Chicago press, 1997; Von Moos, Stanislaus; Ruegg, Arthur (Ed.). Le Corbusier before Le Corbusier. London: Yale University press, 2002; Gresleri, Giuliano: Viaggio in Toscana (1907). Venezia: Marsilio, 1987; Herausgegeben, von Christoph Schnoor: La Construction des villes. Zurich: gta-Verlag, 2008; by the same author: "L'Italia come modello di spazio urbano: i riferimenti a Venezia, Firenze e Roma ne La Construction des villes". In Talamona, Maria (Ed.): L'Italia di Le Corbusier. Op. cit. pp. 175-187. 


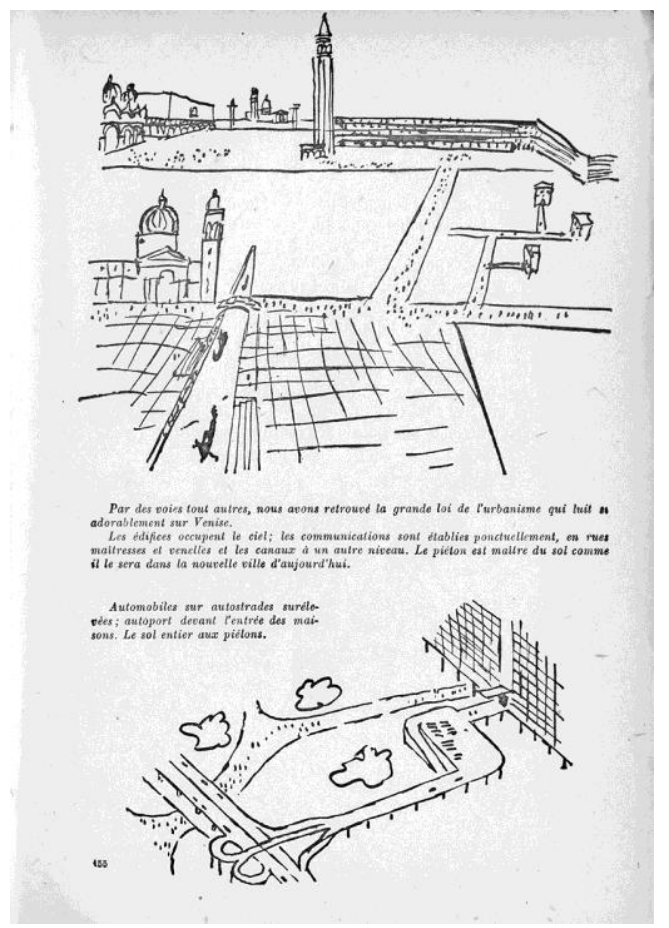

1. Drawing taken from the text by Le Corbusier (in collaboration with François de Pierrefeu): La Maison des hommes. Paris: Éditions Plon, 1942. p. 155, under which he wrote: "By quite different paths we have found the great urban planning principle that Venice illustrates so admirably". CFLC-ADAGP.

\section{A beauty of entirely mechanical origin}

At the conference of 1934, in describing his arrival in the lagoon city, Le Corbusier's admiration was not only directed towards the buildings of Venice but, in turning his gaze to the stairway that led down until it touched the water, his attention rested on one object in particular: the gondola.

"My initial astonishment was provoked not by the romanticism of the gondola, but rather by the impeccable structure of this vehicle, so purely rational ${ }^{15, "}$.

Le Corbusier continued by equating the gondola to an aeroplane in terms of its mechanical aspect and tracing the artistic figure of this object "of abstract art" to a "beauty of entirely mechanical origin" 16 ".

The "machine" is a topic that points to a multitude of meanings and that often, as Le Corbusier himself affirmed, cost him "many reprimands ${ }^{17}$ " due to an often inappropriate and superficial interpretation of its meaning.

Although connected to a specific object, the meaning of the term "machine" first and foremost expresses an aesthetic principle, the content of which must be sought within the pictorial experience, a privileged place of the master's poetic research ${ }^{18}$.

${ }^{15}$ Le Corbusier: "La leçon del la gondole. L'art et les masses contemporaines". In Tamborrino, Rosa (Ed.): Le Corbusier Scritti. Op. cit. p. 235

${ }^{16} \mathrm{Id}$.

${ }^{17}$ Ibid. p. 240. 
At the end of the 19th century, after the theoretical premises connected to impressionist painting most linked - to define them in a nutshell - to the investigation on phenomenal data, thanks to the fundamental analytical mediation of Cézanne and post-Impressionism, as highlighted in the artistic manifesto of purism ${ }^{19}$, the reflection on the phenomenological dimension of the form became predominant ${ }^{20}$.

As regards the iconographic reading of purist compositions, while a series of recurring objects can be recognized - a glass, a pile of plates, a violin, a bottle, a box of matches, an open book - in reality the iconological dimension of the representation does not lie in the intrinsic value of these elements but rather in the system of their relationships specified by the artist within the painting.
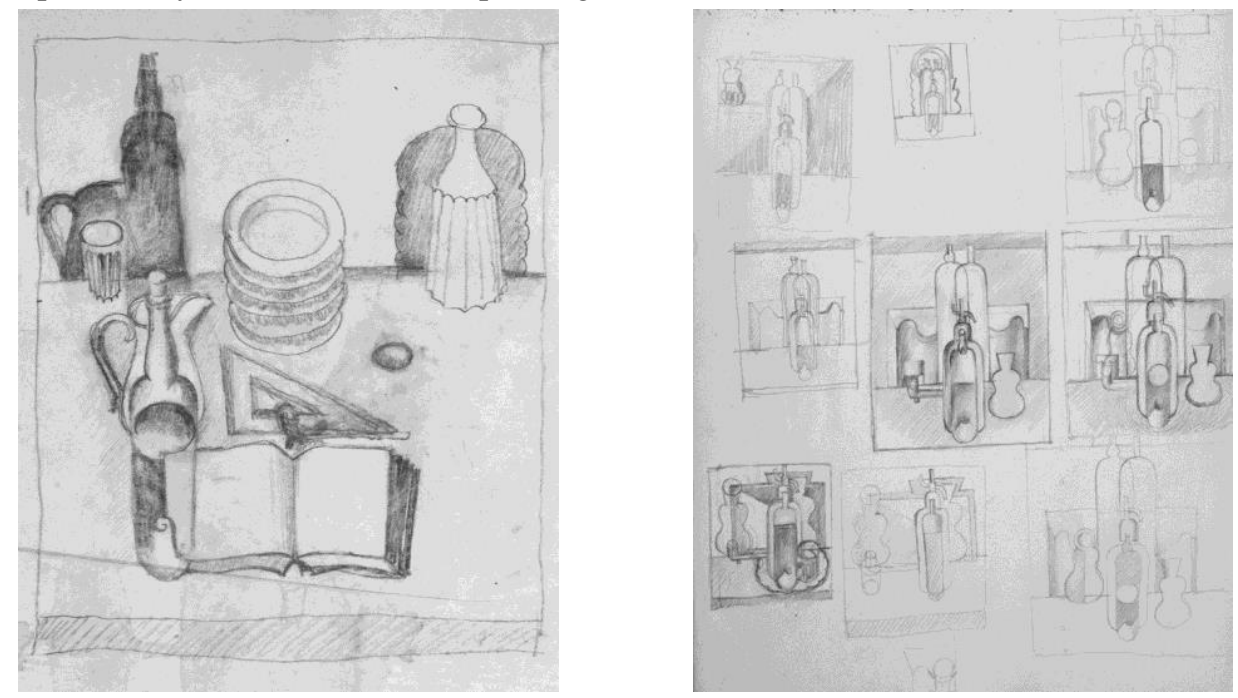

2. Le Corbusier, Preparatory drawing for Nature morte à l'oeuf, 1919 (FLC 1599) and compositional studies of Natures mortes contained in the Album La Roche, 1922. CFLC-ADAGP.

Le Corbusier himself asserted that a work of art is the result of a process of association, common ground for painting and sculpture too:

"A work of art is an association, a symphony of consonant and engineered forms, as much for architecture and sculpture as for painting ${ }^{21, "}$.

${ }^{18}$ In support of this assumption I propound what Le Corbusier wrote: "The basis of my research has its secret in the uninterrupted practice of the plastic arts. There we must find the source of my freedom of spirit and my possibilities of developing". Extract of the text written by Le Corbusier for the exhibition in Palazzo Strozzi, Florence 1963, translated into Italian in Comitato per le Manifestazioni Invernali a Firenze (CMIF): L'opera di Le Corbusier: mostra in Palazzo Strozzi. Firenze: Giuntina, 1963. p. 215.

${ }^{19}$ I refer to the journal: L'esprit nouveau: revue internationelle illustree de l'Activite Contemporaine: arts, lettres, sciences. Paris, 1920-1925.

${ }^{20}$ I refer in particular to the reflection on the structure and the process of specifying the form through its phenomenology which characterized post-impressionism according to the main lines indicated by Rewald, John: Il post-impressionismo da Van Gogh a Gauguin. Firenze: Sansoni, 1967; of the writings consciously dedicated to this topic in painting see Kandinskij Vasilij Vasilevic: Über die Formfrage. In Kandinskij Vasilij Vasilevic; Marc Franz: Der Blaue Reiter. Munich: R. Piper \& Co Verlag, 1914.

${ }^{21}$ Jeanneret, Charles-Edouard; Ozenfant, Amédée: "Le purism". In L'esprit nouveau: revue internationelle illustree de l'Activite Contemporaine: arts, lettres, sciences. N4. Paris 1920-1925. p. 376. 
It is the extreme importance assigned to the process over the final form of the work that allows the meaning of the pictorial representation to be understood.

The purist compositions evince the meaning of an "architecturée 22 " painting in which the subject of the artwork is the system of formal and spatial relationships between the elements in the picture which are exclusively subjugated to the representation of a logical "constructive" structure, where the term "construction", in the fields of painting and architecture, refers to the combination of parts and elements that can comprise a unitary system.

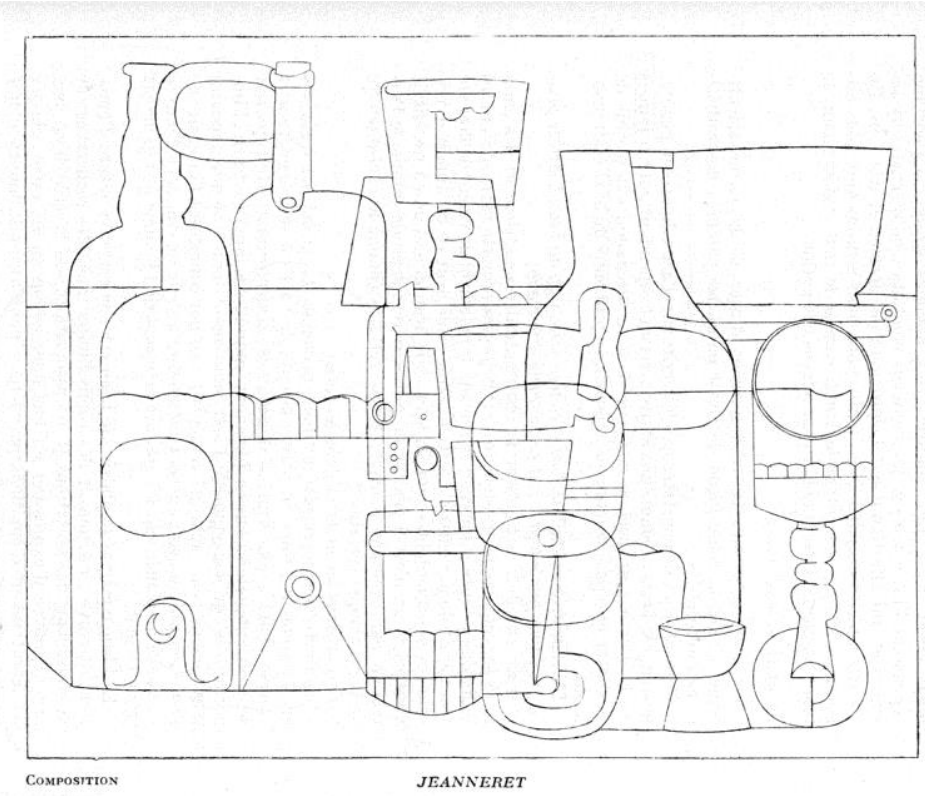

3. Le Corbusier, Composition. (from Jeanneret, Charles-Edouard; Ozenfant, Amédée: "Idées personnelles". In L'esprit nouveau: revue internationelle illustree de l'Activite Contemporaine: arts, lettres, sciences. №27. Paris 1920-1925). OFLCADAGP.

It is in the semantic dimension of the pictorial work that a profound difference with respect to cubist painting can be recognized. Bruno Reichlin ${ }^{23}$ highlights how in Picasso the arbitrary assembly of heterogeneous pieces and parts generates complex forms with one or more external references: guitars, heads and so on. In purist painting, on the other hand, the figures are perfectly recognizable so that the resulting object only consists of its formal and constructive value without external references.

Cubism is still a "representative" artistic experience insofar as the iconological dimension of the work is linked to the object represented. Whereas in purist painting the "constructive" value is represented by that described: the subject is the compositional logic that generates the overall form of the painting.

\footnotetext{
${ }^{22}$ For a more in-depth examination of the meaning this term assumes within the purist pictorial experience of Le Corbusier refer to the text by Mango, Roberto: C. E. Jeanneret-Le Corbusier: la peinture architecturée 1918-1928. Roma: Officina, 1986.

${ }^{23}$ Reichlin, Bruno: “Jenneret-Le Corbusier, painter-architect”. In Blau, Eve; Troy, J. Nancy (Ed.): Architecture and cubism. Cambridge: Canadian Centre for Architecture - Montréal: MIT Press, 1997. pp. 195-218.
} 
Purist poetry expresses very clearly what can be described as the aesthetic principles that the "machine" conveys, transmitting, as Le Corbusier asserted: "an aesthetic of purity, of precision, of the relationships that help to trigger the movement of the mathematical mechanisms of our soul ${ }^{24,}$.

Purists look at the "machine" not as an object in itself but as a system of elements which, through mutual sizing and positioning criteria, constitute a functioning and precise device. In this sense they were interested in understanding and applying its "device" meaning through the reading and transformation of a specific "construction logic" in the pictorial form.

When Le Corbusier claimed that: "an aesthetic, a work of art are first of all systems ${ }^{25}$ ", propounding some reflections of Paul Valery ${ }^{26}$ he was essentially conceiving of the work of art as a "construction" in which analysis, organization, calculation and planning perform a fundamental role.

All human constructions are the result of thinking, humans build for abstraction through the rational organization of the "materials" - which they find in the world they inhabit - in a series of symmetrically and consistently determined relationships and relations.

The great aesthetic revolution set in motion concerned attributing the art placed within the work to the construction of the work. The artistic value of the object is connected exclusively to its "poiesis ${ }^{27}$ " - understood here as everything related to the production of the works - to making as construction, the shaping of a thought, the principle that allows the permanent sovereignty of the artistic form over reality.

\footnotetext{
${ }^{24}$ Le Corbusier: "La leçon de la machine". In Tamborrino, Rosa (Ed.): Le Corbusier Scritti. Op. cit. p. 151.

${ }^{25}$ Jeanneret, Charles-Edouard; Ozenfant, Amédée: "Sur la Plastique". In L'esprit nouveau: revue internationelle illustree de l'Activite Contemporaine: arts, lettres, sciences. N 1 . Paris 1920-1925. p. 48.

${ }^{26}$ I refer in particular to a text by Valery, Paul: "Eupalinos ou l'Architecte”. In La Nouvelle Revue Française. №90, Paris 1921, pp. 237-285, contained within Le Corbusier's personal library (FLC V 112) and of which he wrote "he felt and beautifully translated the same deep and rare things an architect feels when creating". Quotation cited in the paper by Scapolo, Barbara: "Eupalinos o l'architetto", o del fare consistente". In Paul Valéry Eupalinos o l'architetto. Milano-Udine: Mimesis Edizioni, 2011. pp. 89-117.

${ }^{27}$ I am referring to the concepts of "poietica" and "estetica" described in Valéry, Paul: "Discours sur l'Esthétique". In Hytier, Jean (Ed.): Oeuvres. Éditions Gallimard: Paris, 1957. pp 1294-1314.
} 


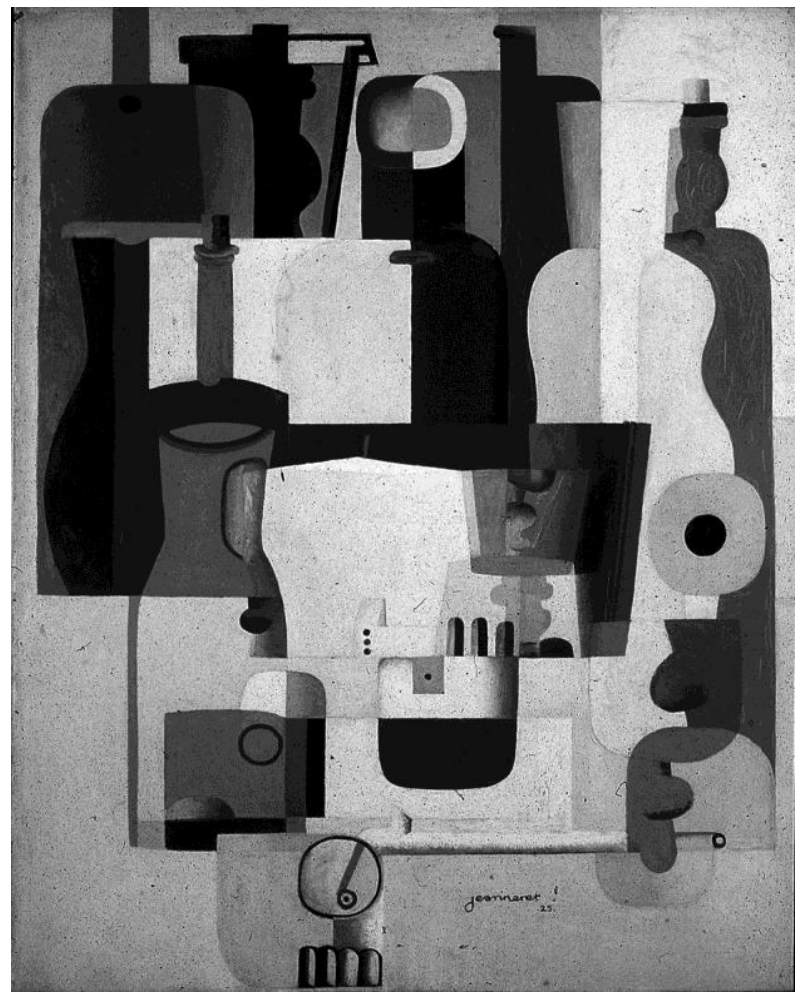

4. Le Corbusier, Nature morte, 1925, Millers Collection, Meridan U.S.A. (FLC 323). @FLC-ADAGP.

\section{Observe these things in their plastic arrangement}

While the "mechanics" of the gondola are proof of the existence of "fundamental links between cause and effect,

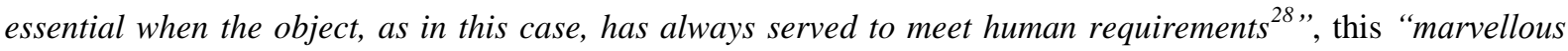

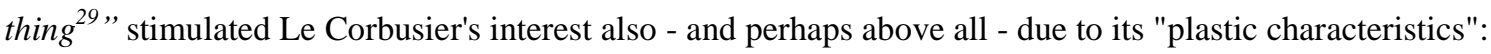

"Gondolas represent, with each element they are comprised of and the juxtaposition and assembly of their forms, wonderfully harmonious and incisive ensembles that arouse emotions like great sculpture 30 ".

The description continues illustrating how the different elements of the structure, the oar support, the curved and tilted carriage of the gondola, and the seat and its metal structure are properly ordered and configured specifying a skillful "plastic arrangement" ".

In the article L'Espace indicible ${ }^{32}$ (1946) Le Corbusier started off by asserting:

"Taking possession of the space is the first gesture of living beings, humans, animals, plants and clouds, the fundamental manifestation of balance and solidity. The first test of existence is that of occupying space ${ }^{33 \text { ". }}$

\footnotetext{
${ }^{28}$ Le Corbusier: "La leçon del la gondole. L'art et les masses contemporaines". In Tamborrino, Rosa (Ed.): Le Corbusier Scritti. Op. cit. p. 235.

${ }^{29}$ Le Corbusier: "A propos de Venise". Op. cit. p. 6.

${ }^{30}$ Le Corbusier: "La leçon del la gondole. L'art et les masses contemporaines". In Tamborrino, Rosa (Ed.): Le Corbusier Scritti. Op. cit. p. 236.

${ }^{31} \mathrm{Id}$.

${ }^{32}$ Le Corbusier: “L'espace indicible”. In L'Architecture d'aujourd'hui numéro hors-série. Paris. 1946. pp. 9-17.
} 
In purist research the topic of space was already of great interest as testified by the reflections explicated in some papers of Esprit Nouveau ${ }^{34}$.

In the Twenties "phenomenal transparency", as described by Colin Rowe and Robert Slutzky ${ }^{35}$, represented a specific compositional technique governing the organization of the elements within the painting. Through the use of several parallel planes perceived simultaneously, the aim was to "construct" the pictorial space, therefore to specify the third dimension through a description of the compositional procedure that generated its form. The three-dimensional nature of the painting is not "represented", but "presented" as the logic of association and organization, thereby indicating a totally abstract space.

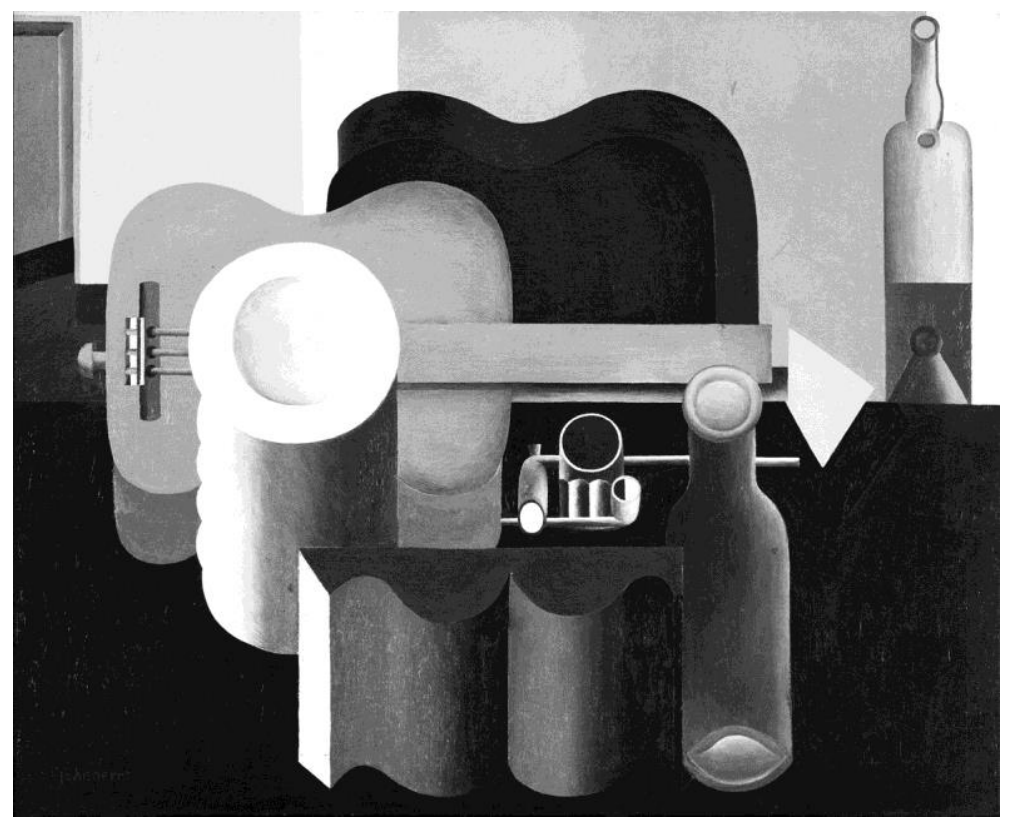

5. Le Corbusier, Nature morte à la pile d'assiette et au livre, 1920, MoMA, New York U.S.A. (FLC 306). OFLC-ADAGP

Around 1927-1928 a profound change occurred which affected linguistic vocabulary on the one hand and, on the other, the syntax that configured the pictorial space.

Previously in the Esprit Nouveau pavilion of 1925 Le Corbusier had exhibited, alongside glassware items - the usual elements that comprise the basic vocabulary of the purist repertoire - shells, pebbles, roots and bark, which he enjoyed collecting here and there during his travels and summer walks along the beach of Cap-Martin.

The article Unite $^{36}$ (1948) describes this unusual interest in objects from the natural world which, in referring once again to some reflections of Paul Valery ${ }^{37}$, indicated the start of a radical renewal of Corbusian poetics.

\footnotetext{
33 Ibid. p. 9.

34 "the purist syntax is the application of constructive and modular means; it is the application of the laws that generate the pictorial space". In Jeanneret, Charles-Edouard; Ozenfant, Amédée: “Le purism”. Op. cit. p. 386.

${ }^{35}$ Rowe, Colin; Slutzky, Robert: Transparence: réelle et virtuelle. Paris: Demi-Cercle, 1992.

${ }^{36}$ Le Corbusier: "Unité". In L'Architecture d'aujourd'hui numéro spécial. Paris. 1948.

${ }^{37}$ In Paul Valéry's Eupalinos dialogue, Socrate recounts the discovery on the seashore to Fedro: "Right there I found one of those objects released by the sea, a white object, of untainted whiteness. Burnished, hard, soft, light, it shined in the sun, on the smoothed sand, dark and sprinkled with sparkles; I picked it up, blew on it, rubbed it on my cape, and its singular form
} 
"From 1918 to 1927 my paintings borrowed the forms of bottles, jugs and glasses, seen on the top of a table of a bistro or restaurant. Strict discipline, harsh but productive discipline: it must be sought and it must be found. Towards 1928 I wished to expand the circle of my pictorial vocabulary and I introduced what I called "objects à réaction poétique", a thousand modest things that contain, summarize and express the laws of nature 38 ",
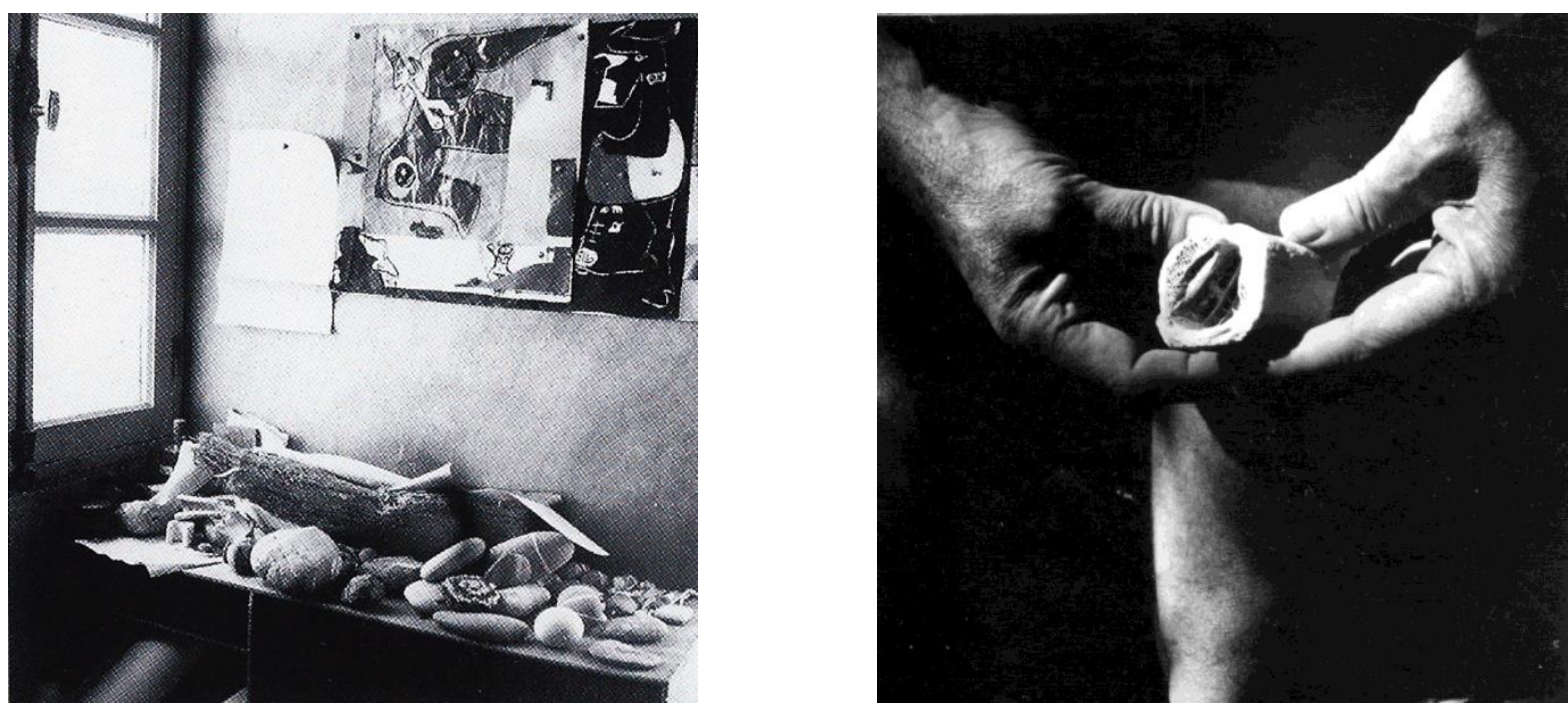

6. "Objects à réaction poétique” at Cap-Martin, photo by Lucien Hervé. (The Getty Research Institute, Los Angeles). (OJ. Paul Getty Trust. Le Corbusier holding a bone in his hand, photo by Lucien Hervé. (FLC Objets à réaction poétique 1-48). CFLC-ADAGP.

In 1940 Le Corbusier was forced to stay for a period in Ozon, in the Pyrenees. During this time a radical transformation of his pictorial research occurred which, through his fascination with the objects à réaction poétique reproduced within the Peinture Acoustique ${ }^{39}$, led to the production of a series of compositions, pictorial first and then sculptural, entitled $\mathrm{Ubu}$, Ozon and Panurge.

The paintings abandoned the rigid geometrization of the forms in favour of more curvy lines; "constructive ${ }^{40 "}$ colours, with homogeneous layering, were replaced with more material tones that accentuated the chiaroscuro contrasts. The black outline appeared which emphasized the figurativeness of the objects represented.

In total purist "abstraction" the elements in the composition - although their recognizability was conserved were denied the chance of any possible reading of their own autonomy of meaning, in this sense becoming "signs", linguistic entities that acquired the value of meaning only insofar as parts of a syntactic construction.

Something different occurred for the objects populating the Peintures Acoustiques which can be attributed a figurative value recognizable precisely in virtue of the use of external references belonging to the natural world.

stopped all my other thoughts. Who made you? I thought”. In Paul Valéry Eupalinos o l'architetto. Op. cit. p. 47. (Original Title. Valery, Paul: "Eupalinos ou l'Architecte". Op. cit. )

${ }^{38}$ Le Corbusier: "Unité”. Op. cit. pp. 45-46.

39 Jornod, Naima; Jornod, Jean-Pierre: Le Corbusier (Charles Edouard Jeanneret): Catalogue raisonné del l'oeuvre peint. Milano: Skira, 2005.

${ }^{40}$ Reference is made to the distinction between "grande gamme, gamme dynamique" and "gamme de trasition", which outlines an eminently "constructive" use of colour within the purist compositions described in the paper by Jeanneret, Charles-Edouard; Ozenfant, Amédée: "Le purism". Op. cit. 


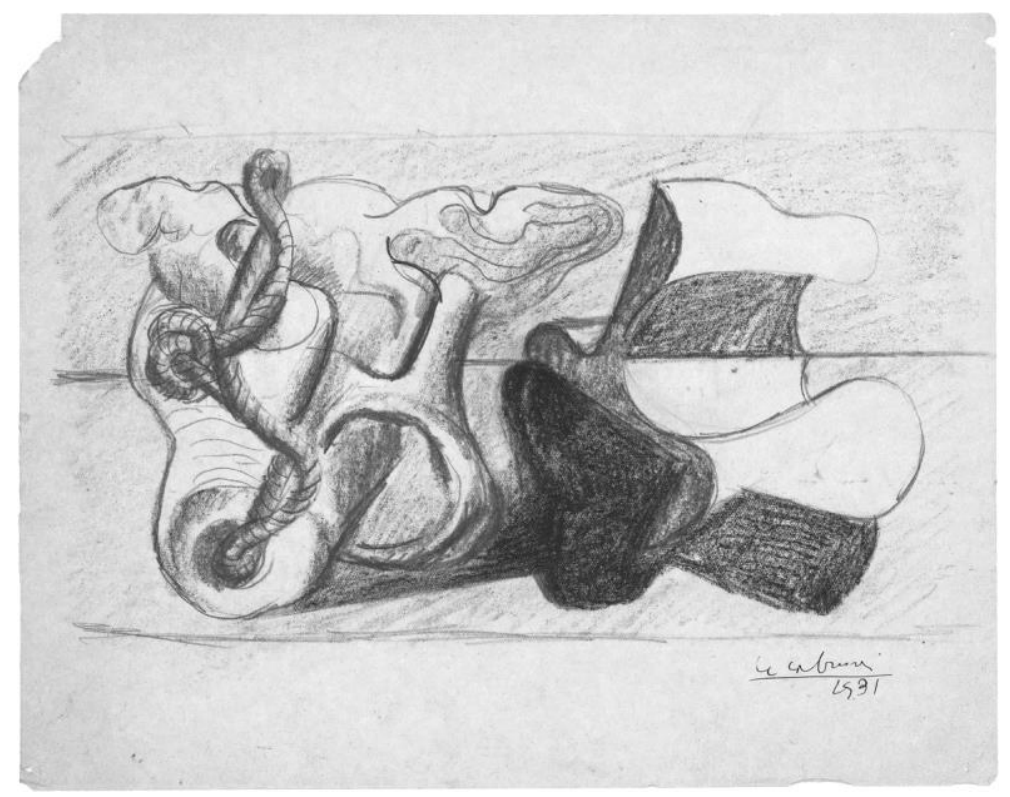

7. Le Corbusier, Racine et cordage, 1931 (FLC 4684). (FLC-ADAGP.

The process of reducing the "figures" to "signs", which characterizes the "abstraction" of the purist period, is not reflected in the Peinture Acoustique or in the subsequent series Ubu, Ozon and Panurge where the objects represented are the bearers of meaning in themselves assuming their own "iconic" character in the composition.

The rhetoric device used in the two periods was completely different: a metonymic directrix was replaced by a metaphoric directrix, the logical presentation of the pictorial fact was replaced by its representation.

In the paper l'Espace Indicible (1946), Le Corbusier clearly explained the characteristics of this new research which aimed to produce a "plastic reality" in direct contact with the space capable of leading to the "indicible ${ }^{4 l} "$ :

"A form that moves away from the dish in order to express the value and to lead (when the debate between intuition and control is over which lasts for the entire time the work is being made) to a sort of plastic painting according to the requirements of the canvas (two dimensions), but that expresses the volume according to the requirements of the spirit ${ }^{42, "}$.

\footnotetext{
${ }^{41}$ Le Corbusier: "L'espace indicible". Op. cit. p. 16 ${ }^{42}$ Id.
} 


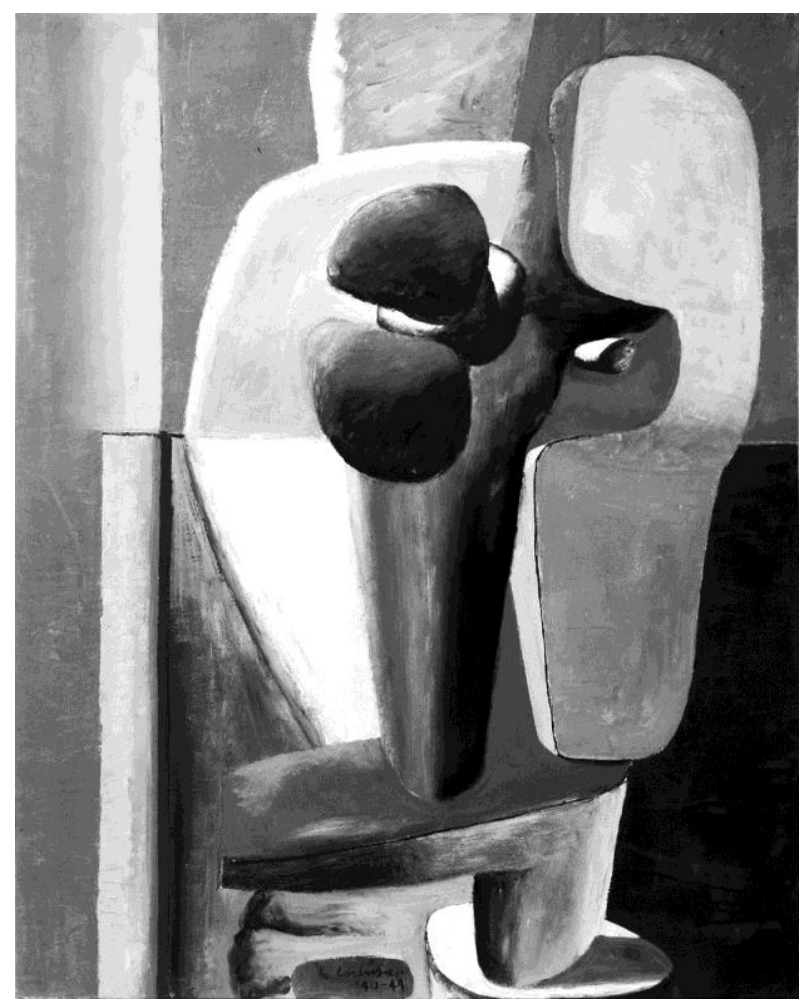

8. Le Corbusier, Ubu IV, 1940-1944, (FLC 126). OFLC-ADAGP.

The forms are no longer two-dimensional, but they express their three-dimensionality in relation to the space of reality as well as the abstract plane of the painting.

Further testimony by Le Corbusier, taken from the paper Unité (1948), is revealing:

"In the autumn of '40 I found myself painting, on sheets of typing paper, some inventions in which drawing became increasingly indispensable, classifying the forms, making them search for a real space ${ }^{43}{ }^{\text {». }}$

The "abstract" qualities of three-dimensionality identified as a logical construct can be replaced with the "plastic" nature of the forms that no longer construct the pictorial space but rather represent it. The object no more assumes just the value and role of a constructive element of the space, but it occupies it, describing its figurative character through its volumetric attributes.

It is no coincidence that, starting from 1944, the Ozon, Ubu and Panurge paintings launched a season of studies for the sculptures referred to as "acoustic" in collaboration with the Breton cabinet maker Joseph Savina ${ }^{44}$.

It should be pointed out how, once again, Venice and the gondola also recurred in this disciplinary area of Le Corbusier's artistic research. As Debora Antonini ${ }^{45}$ recounts, the glass sculpture entitled Harmonies architectoniques - made in 1952 for the exhibition of the Centro Studio Pittori Arte Vetro in Murano - was built

\footnotetext{
${ }^{43}$ Le Corbusier: "Unité”. Op. cit. p. 55.

${ }^{44}$ For a complete overview of the type of operative interaction between the two artists see Le Corbusier: Cuvre complète. Vol. 5. 1946-52. Zurich: Edition Girsberger, 1953. pp. 240-245; Sers, Philppe, Le Corbusier, Savina. Dessins et scultures. Paris: Fondation Le Corbusier, 1984; Le Couédeic, Daniel: “Joseph Savina, l'improbable compagnon de route". In Fondation Le Corbusier (FLC): Le Corbusier l'oeuvre plastique. Paris: Édition de la Villette, 2005. pp. 26-53.

${ }^{45}$ Antonini, Debora: "La sculture de verre”. In Talamona, Maria (Ed.): L'Italie de Le Corbusier. Op. cit. pp. 148-159.
} 
on the model of an $\mathrm{Ozon}^{46}$ sculpture in which it is possible to recognize, among the elements comprising it, a thre-dimensional figure that reproposes the typical form of the oar rest of a Venetian gondola.

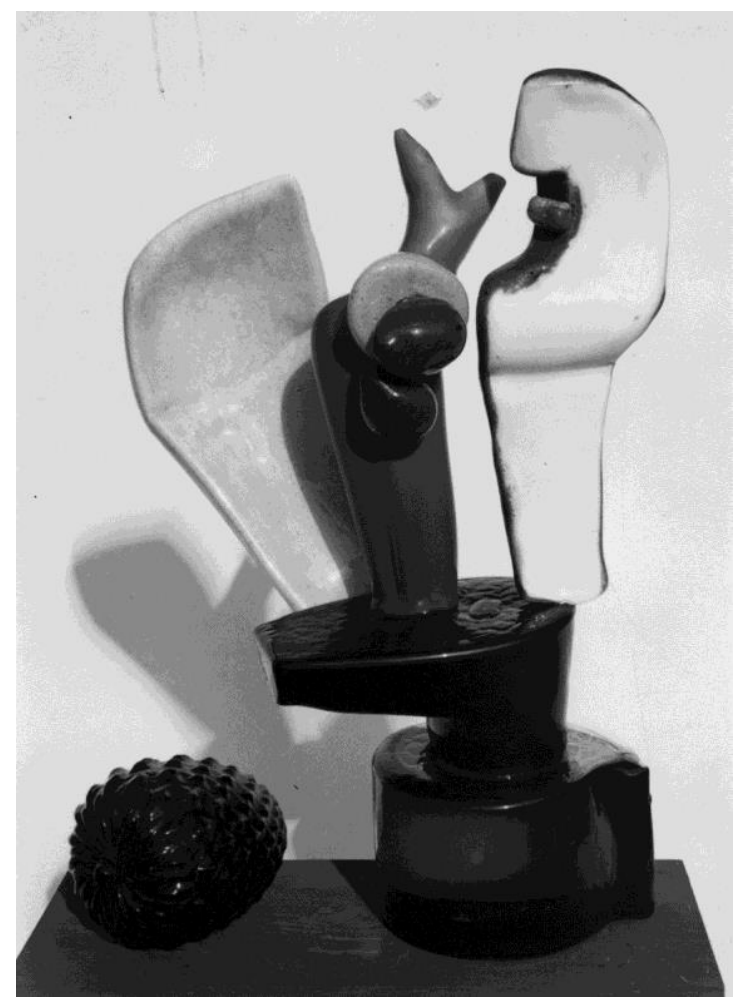

9. Le Corbusier, Harmonies architectoniques, 1952-1953. (FLC C2(10)118). CFLC-ADAGP.

Again in Espace Indicible (1946) Le Corbusier asserted:

"The key to aesthetic emotion is a spatial function" 47 ".

While at the time of the Esprit Nouveau the perception of rational order was enough to meet the requirements of the spirit, the encounter with the objects à réaction poétique expanded the horizon of the plastic and poetic possibilities of the artistic manifestation.

The forms explicated their expressive function through the relationship with the space of the natural world - no longer constructing a totally abstract one - to which Le Corbusier turned his attention in order to investigate those properties capable of exciting and expressing, through the "secret of the form ${ }^{48}$, that poetic phenomenon linked to the "plastique acoustique 49 ".

In that period Le Corbusier abandoned pure abstraction to question the criteria and outcomes of representation. The need for constructive coherence was accompanied by the expressive question, in the knowledge that,

\footnotetext{
${ }^{46}$ Le Corbusier, sculpture no. 3, Ozon, 1940-47, Fondation Le Corbusier, Paris.

${ }^{47}$ Le Corbusier: "L'espace indicible". Op. cit. p. 9.

${ }^{48}$ On this topic refer to the article by Pauly, Danièle: "Il segreto delle forme". In Casabella. 1987. N5531-32. pp. 94-120.

49 "This type of sculpture comes under what I call acoustic plastic, in other words forms that emit and receive". Letter from Le Corbusier to Savina dated 28 August 1947, in Sers, Philippe: Le Corbusier, Savina. Dessins et sculptures. Op. cit. p. 89.
} 
perhaps, the logic of construction was not in itself able to produce that perfection of the form capable of touching the feelings of humans, giving them pleasure and reawakening love and a sense of beauty in them.

Le Corbusier seemed to contribute to the debate described by Robert Klein on whether the work of art consists of a rational organization of the parts that form it or of spiritual enchantment inherent in the sensitive aspect and Gestalt $^{50}$, claiming that:

"L'extraordinaire porte ouverte par le cubisme sur un infini disponible de la manifestation plastique ne se referme nullement sur le trésors de la réalité. Le champ s'étend entre deux extrêmes du support plastique, l'éminentement représentatif et le totalement abstractif ${ }^{51}$ ".

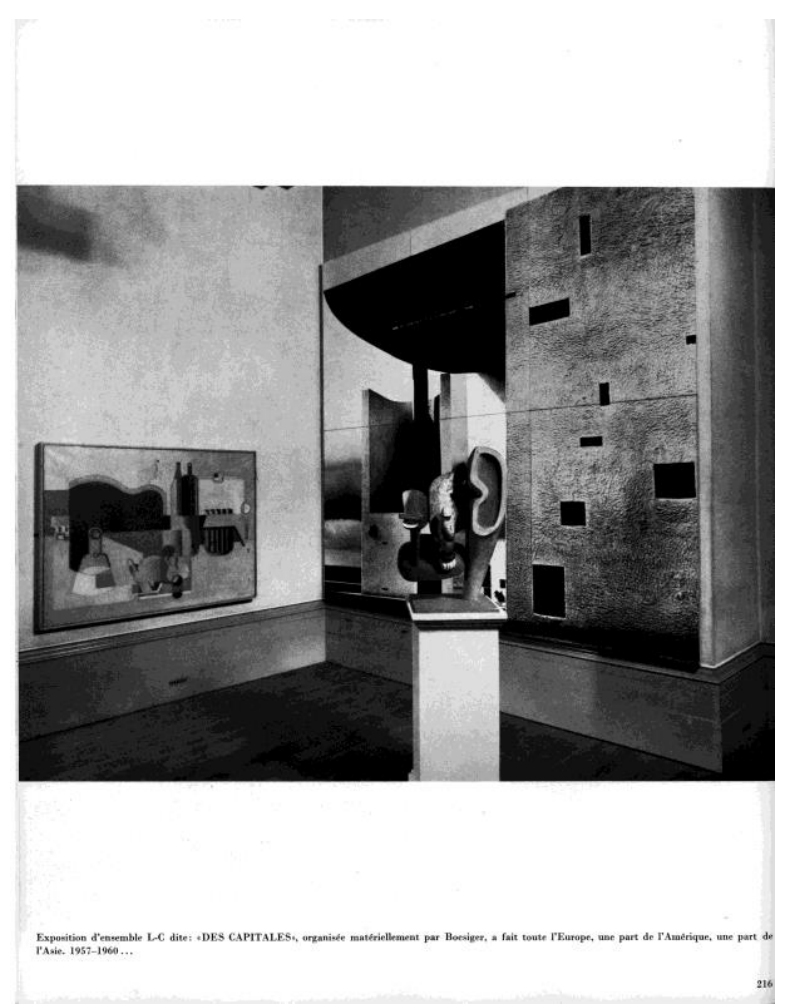

10. Le Corbusier, travelling exhibition "des dix Capitales", 1957-1960. (From Le Corbusier: L'Atelier de la recherche patiente. Paris: Editions Vincent Fréal, 1960. p. 216). CFLC-ADAGP.

\section{The discovery of a magnificent "Outil"}

The gondola, in describing a "purely rational creation" expressive of a "entirely mechanical beauty" and in producing a "plastic invention that seduces by means of an aesthetic quality that only belongs to great art", constitutes a magnificent "Outil $l^{52}$ ".

\footnotetext{
${ }^{50}$ Klein, Robert: La forma e l'intelligibile: scritti sul Rinascimento e l'arte moderna. Torino: Einaudi, 1975. p. 163. (Original Title: Klein, Robert: La forme et l'intelligible, écrits sur la Renaissance et l'art moderne. Paris: Gallimard, 1970).

${ }^{51}$ Le Corbusier: "L'espace indicible". Op. cit. p. 14.

${ }^{52}$ Le Corbusier, Entretiens de Venise, 25-28 July 1934, "Les Art contemporains et la Réalité" and "L'art e l'État" conference organized by the National Institute for International Cooperation and the Italian National Commission for
} 
At the 1934 conference at Doge's Palace in Venice, Le Corbusier described the gondola as an object that represented the most suitable solution to the needs of water-based transport, that emerged when the lagoon city was founded. In French, "outil" does not so much express the meaning of a tool as a "means" through which to achieve a purposel, but the more precise meaning of a "tool" or "instrument", that enables and facilitates human activity within his living reality.

In Je prends Venise a témoin, an introductory essay on the Antwerp plan, as part of La Ville radieuse ${ }^{53}$ (1935), Le Corbusier claims that "Venice in its entirety is made of d'outillage 54 ". On an urban scale, the homes, public buildings, churches, transport tools and their respective parking spaces represent the "equipment of the city", that is the set of "outils" made by man according to his needs. Venice is the paradigm of this composition-design concept that constructs its own inventory of components and parts, combining them according to a plan or a programme in order to represent a "knowing and just outillage 55 ".

At the conference for the CIAM summer school in 1952, describing the "major point of Venice" namely that "Venice is on a human scale $56 "$, the lagoon city once again became the morphological reference for the formulation of the $7 V$ Theory applied to districts of Chandigarh in the new capital of the Punjab.

As in Je prends Venise a témoin, here too Le Corbusier dwells on the need to separate car and pedestrian traffic within the urban structure of the modern city. The "district", a unit in which the space for residential settlements in the new Indian capital is arranged, orders and ranks the seven types of flows by analogy with what happens on the Venetian insule, thanks to the water and pedestrian paths on the ground.
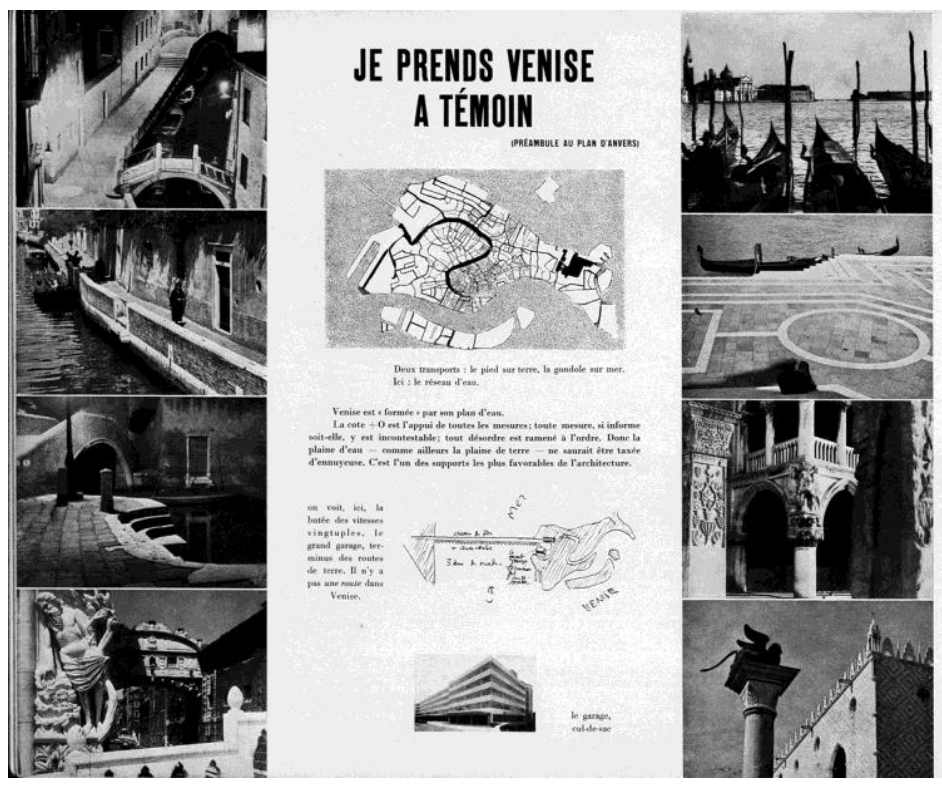

11. Le Corbusier: Je prends Venise a témoin. In La Ville radieuse. Boulogne-sur-Seine: Editions de l'Architecture d'Aujourd'hui. Collection de l'équipement de la civilisation machiniste, 1935. p. 128. OFLC-ADAGP.

Cooperation, with the support of the International Art Biennale of Venice (FLC A3-2). In Talamona, Maria (Ed.): L'Italie de Le Corbusier. Op. cit. p. 10.

${ }^{53}$ Le Corbusier: La Ville radieuse. Op. cit.

${ }^{54} \mathrm{Id}$.

${ }^{55}$ Ibid. p. 269.

${ }^{56}$ Le Corbusier: “À propos de Venise”. Op. cit. p. 7. 
But while the "Outils" are constructed by man as a response to essential practical needs linked to the concept of "utility", they also express their own "formal value". During the conference of 1952 Le Corbusier, drawing some distinctive elements of the lagoon city on the blackboard, commented:

"Venice is made up of elements so clear that all phenomena of architecture and town planning arise and appear, there is a choice of vertical forms, domes, pediments, bridges... there is that extraordinary element, that fantastic thing that is the gondola, an absolutely marvellous centuries-old tool ${ }^{57, "}$.

He then went on to stress:

"The gondola is a miraculous thing! The gondola is one of the most beautiful tools that humans have created, and it has but one master, mankind ${ }^{58, "}$

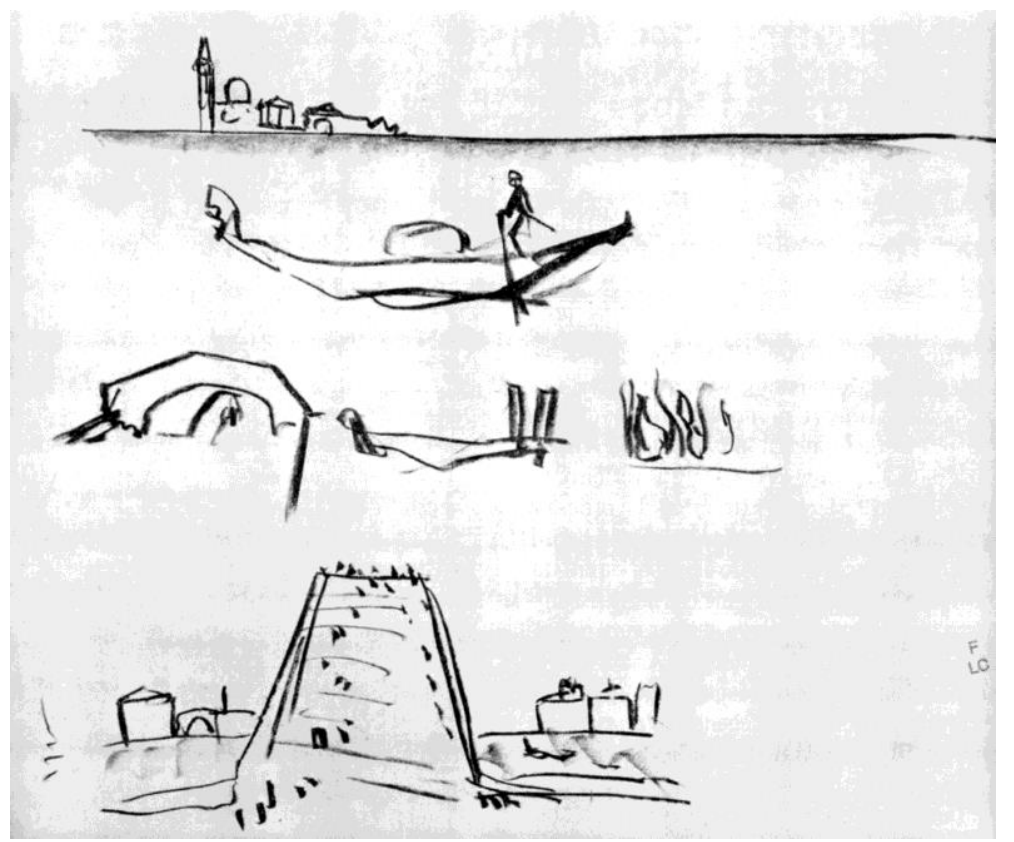

12. Drawings produced by Le Corbusier during the conference held for students of the CIAM school in Venice in 1952 entitled “À propos de Venise”. (From Le Corbusier: “À propos de Venise”. In Venezia Architettura. №1. 1952. pp. 6-9). (cFLC-ADAGP.

As in the case of the "machine", for "outil", the meaning of this term refers to broader discussions on the value and the role of human creativity and on the artist's mission in the world, attributed to some considerations described in Poème de l'angle droit ${ }^{59}$ (1955).

The "outil" constitutes the final lithography of the iconostasis of the poem: the "right angle". The exhaustive critical reading by Juan Calatrava ${ }^{60}$ immediately highlights the metaphorical meaning of this image which summarizes, through the vertical and horizontal line, a dualistic vision of the world, a binary pattern that

\footnotetext{
${ }^{57}$ Ibid. p. 6.

${ }^{58}$ Id.

${ }^{59}$ Le Corbusier: Le Poème de l'Angle droit. Paris: Éditions Tériade, 1955.

${ }^{60}$ Calatrava, Juan: "Le Corbusier e Le Poème de l'Angle droit: un poema abitabile, una casa poetica". In Le Corbusier: Le poème de l'angle droit, Milano: Mondadori-Electa, 2007. pp. 166-185.
} 
pervades the entire work, whose leitmotif leads to the clarification of the relationship between humans and the universe.

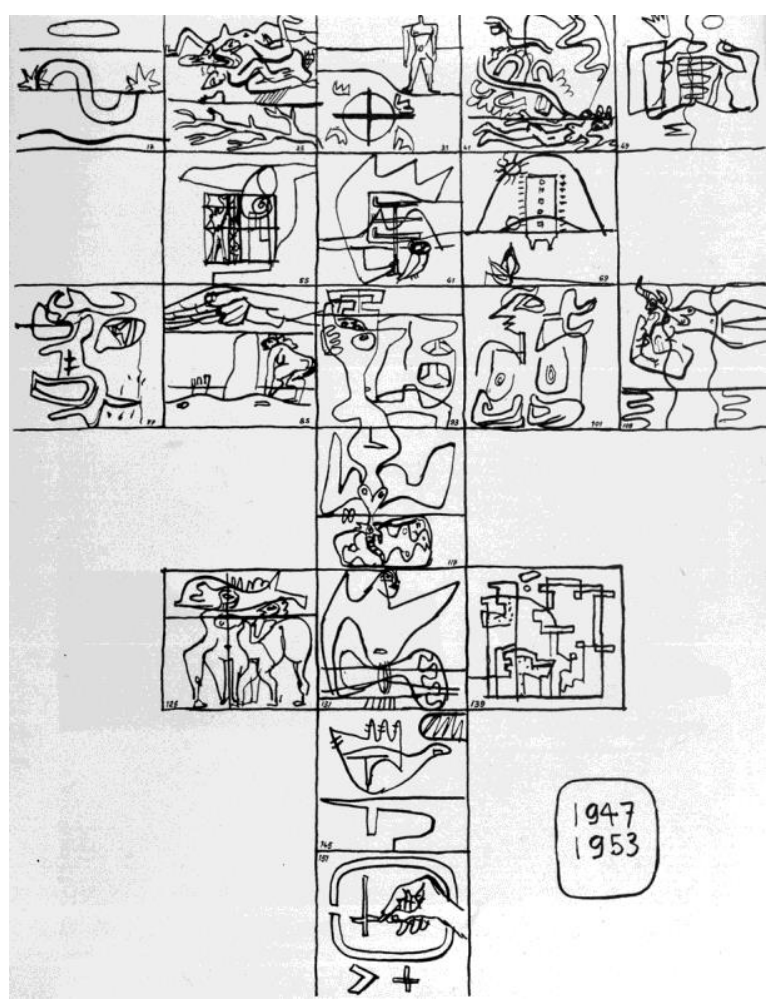

13. Le Corbusier, "iconostasis". (From Le Corbusier: Le Poème de l'Angle droit. Paris: Éditions Tériade, 1955). OFLCADAGP.

As in Venice in 1934, Le Corbusier also dwelt on water in his talk at the CIAM summer school in 1952:

"Venice is like a water level. In the storms of life and in the difficulties of an enterprise, you need to have two things in order to build: a water level and a plumb line ${ }^{61}$,".

Water, "the essential tool in the structure of Venice 62 ", is one of the fundamental themes in the Milieu series of the poem, as it helps to outline three key questions about human creation ${ }^{63}$ : the "level", that represents the unstable balance of fluids by analogy with the precariousness of the human equilibrium; the continuous and cyclic "transformation" of water represented by the different states of water during the day; and finally the "Law of the Meander", a metaphor from his incessant and arduous quest for truth that is found not so much at the end of the process than as during the process itself, represented by the continuous struggle of the current to find its riverbed.

\footnotetext{
${ }^{61}$ Le Corbusier: “À propos de Venise”. In Venezia Architettura. Op. cit. p. 6.

${ }^{62} \mathrm{Id}$.

${ }^{63}$ Contained within the following is a brief summary of the reflections on the Milieu series formulated in the essay of Calatrava, Juan: "Le Corbusier Le Poème de l'Angle droit: un poema abitabile, una casa poetica". In Le Corbusier: The poème de l'angle droit. Op. cit.
} 
The horizontal line, drawn from the water level to its liquid state, is associated, in relation to the meanings connected to the alchemical tradition of the "Philosopher's Stone ${ }^{64 ",}$ with the "feminine principal", the symbol of Nature in which mankind is forced to act. This convergence between the horizontal of the natural world and the vertical of mankind and its works - described through the representation of the "new architectural principles" in the Esprit series of the poem - once again finds its figurative reference in lithography A.3. Milieu of Venice which describes, through the water and its architecture, the perfect synthesis between nature and man.

A relationship emancipated by the dominant character pervading the early reflections on urban planning of $1924^{65}$, to attain a dualistic vision of human activity that asserts a principle of "total harmony" through a criterion of the "reconciliation of opposites" and a "pact of solidarity" with the natural world.

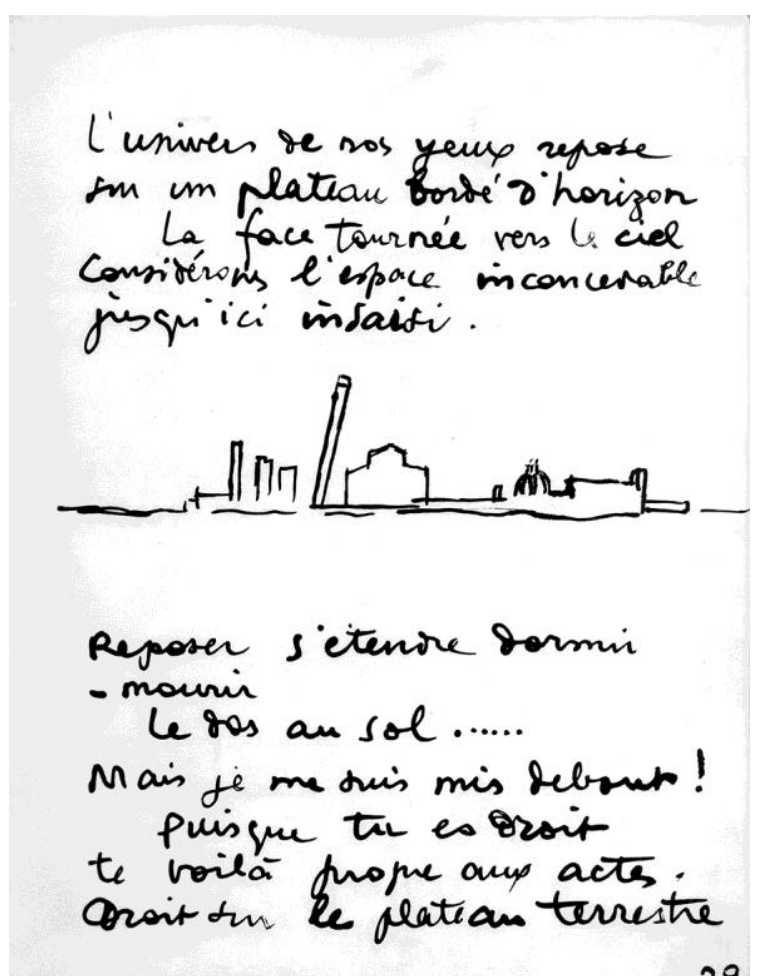

14. Le Corbusier, A.3. Milieu. (From Le Corbusier: Le Poème de l'Angle droit. Paris: Éditions Tériade, 1955). OFLCADAGP.

If the "right angle" becomes an "outil" through which humans specify their rapport with the world, this harmonious relationship with nature is also, and above all, expressed through the construction of "outils". The creative activity becomes a moment of mediation through the cosmos and the human microcosm which occurs through the synthesis between rational order and poetic activity.

\footnotetext{
${ }^{64}$ For a more thorough symbolic interpretation of the Poem of the Right Angle with an esoteric slant refer to the text by Moore, A. Richard: "Alchemical and mythical themes in the Poem of the right angle, 1947-1965". In Oppositions. 1980. N¹9-20. pp. 111-139.

65 "Mankind undermines nature, tears it apart, opposes it, fights it, and settles there". Le Corbusier: Urbanisme. Paris: Éditions Crès, Collection de "L'Esprit Nouveau", 1924. p. 40.
} 
As Le Corbusier asserted in Rome in $1937^{66}$, the object of art conveys a "formal and visible 67 ", intention, the outcome of which is a mental process of abstraction that orders, according to the rules of thought, forms that evoke the feelings of the spirit through the perception of the eye.

The right angle is not only the symbol of primordial harmony between mankind and the cosmos, but it describes the theoretical principles and rules of "making". The "outil", of which the gondola is the most successful paradigm, as well as being an object that meets the requirements of "useful", constitutes a "plastic phenomenon" that arouses emotions through its form.

This desire to combine "nature" and "geometry", "measure" and "lyricism", which pervades the entirety of Le Corbusier's artistic research, also explains the shift from the totally abstract nature of the purist language to the reflections on the "objects à réaction poétique" placing Le Corbusier's work within what can be considered as tension in modern artistic research caught between "abstraction" and "figuration".

The total abstraction undermines the relationship between mankind and nature, not allowing the emotional function connected to the "lyrisme des objects naturels". The objects of the natural world constitute, as Le Corbusier affirms, a set of "emotional elements, because they are the manifestation of the great natural events, of true laws that, if carefully chosen, are themselves factors of extraordinary plasticity and surprising material effects $^{68, "}$

Abstraction and figuration are not just two chronologically distinct moments of Le Corbusier's plastic research, but describe two key aspects of the creative process related to the constructive and expressive issue of the artistic form. The work of art is neither mere imitation, nor is it the absolute denial of reality, but a logical construction of thought that can express meanings only through its manifestation and relationship with the sensitive reality of the natural world.

Through the concept of the "outil", it seems that Le Corbusier wishes to bring the artistic substance of man's work to a broader need for synthesis between "thought" and "form", "material" and "spirit", "immanent" and "transcendental" which is only expressed in the work of man through an unavoidable convergence towards the "Unity" of the two fundamental supports of plastic manifestation: "the imminently representative 69 ", which, through figuration, allows the material and therefore expressive function of the form, and the "totally abstract " $^{70}$ which, through the logic of construction, specifies its material structure.

\footnotetext{
66 "Les tendances de l'architecture rationaliste en rapport avec la collaboration de la peinture et de la sculpture", talk by Le Corbusier at the Conference of the Arts entitled "Rapporti dell'architettura con le arti figurative", held at the Alessandro Volta Foundation on 23-32 October 1936 in Rome. In Tamborrino, Rosa (Ed.): Le Corbusier Scritti. Op. cit. pp. 281-294.

${ }^{67}$ Ibid. p. 284.

${ }^{68}$ Le Corbusier: "Le lyrisme des objets naturale". FLC B2(16)1.

${ }^{69}$ Le Corbusier: "L'espace indicible”. Op. cit. p. 14.

${ }^{70}$ Id.
} 


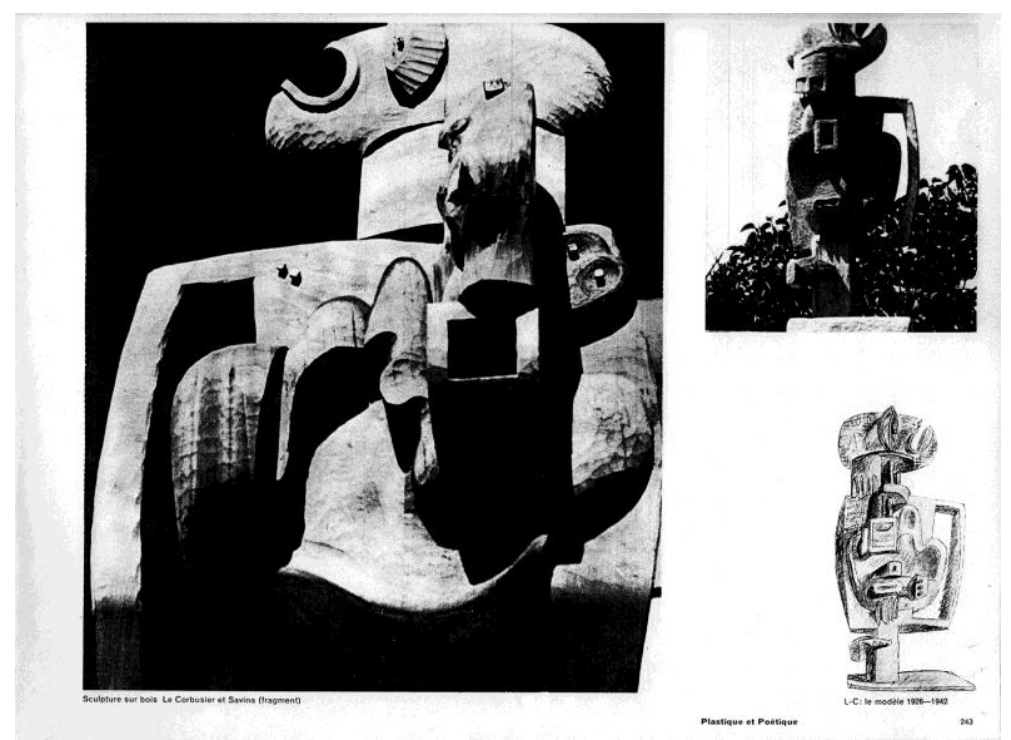

15. Le Corbusier, sculpture Totem, 1950, Paris, FLC. (From Le Corbusier: Euvre complète. Vol. 5. 1946-52. Zurich: Edition Girsberger, 1953. p. 243). (FLC-ADAGP.

\section{Bibliography}

Antonini, Debora: "La sculture de verre". In Talamona, Maria (Ed.): L'Italie de Le Corbusier. Édition de la Villette, 2010. 148-159.

Brooks, A. Harold: Le Corbusier's formative years. Chicago: University of Chicago press, 1997.

Calatrava, Juan: "Le Corbusier e Le Poème de l'Angle droit: un poema abitabile, una casa poetica". In Le Corbusier: Le poème de l'angle droit, Milano: Mondadori-Electa, 2007. pp. 166-185.

Comitato per le Manifestazioni Invernali a Firenze (CMIF): L'opera di Le Corbusier: mostra in Palazzo Strozzi. Firenze: Giuntina, 1963.

De Sabbata, Massimo: “Les Arts contemporains et la Réalité. L'Art et l'État”. In Talamona, Maria (Ed.): L'Italie de Le Corbusier. Paris: Édition de la Villette, 2010. pp. 100-109.

Duboy, Philippe: Le Corbusier, Croquis de voyages et études, Paris. Paris: La Quinzaine littéraire, 2009.

Duboy, Philippe: “L.C.B.N. 1915”. In Casabella. 1987. №531-532. Milano. pp. 94-103.

Farinati, Valeria (Ed.): H VEN LC hôpital de Venise Le Corbusier 1963-70: inventario analitico degli atti nuovo Ospedale. Venezia: IUAV Archivio Progetti, 1999.

Foscari, Antonio: “À Venise en 1934”. In Talamona, Maria (Ed.): L'Italie de Le Corbusier. Paris: Édition de la Villette, 2010. pp. 200-209.

Gresleri, Giuliano: Viaggio in Toscana (1907). Venezia: Marsilio, 1987.

Herausgegeben, von Christoph Schnoor: La Construction des villes. Zurich: gta-Verlag, 2008.

Herausgegeben, von Christoph Schnoor: "L'Italia come modello di spazio urbano: i riferimenti a Venezia". In Talamona, Maria (Ed.): L'Italia di Le Corbusier. Milano: Electa, 2012. 175-187.

Jeanneret, Charles-Edouard; Ozenfant, Amédée: “Le purism”. In L'esprit nouveau: revue internationelle illustree de l'Activite Contemporaine: arts, lettres, sciences. №4. Paris 1920-1925. p. 369-386.

Jeanneret, Charles-Edouard; Ozenfant, Amédée: "Sur la Plastique”. In L'esprit nouveau: revue internationelle illustree de l'Activite Contemporaine: arts, lettres, sciences. $\mathrm{N}^{\circ} 1$. Paris 1920-1925. p. 38-48. 
Jornod, Naima; Jornod, Jean-Pierre: Le Corbusier (Charles Edouard Jeanneret): Catalogue raisonné del l'oeuvre peint. Milano: Skira, 2005.

Kandinskij Vasilij Vasilevic: Über die Formfrage. In Kandinskij Vasilij Vasilevic; Marc Franz: Der Blaue Reiter. Munich: R. Piper \& Co Verlag, 1914.

Klein, Robert: La forme et l'intelligible, écrits sur la Renaissance et l'art moderne. Paris: Gallimard, 1970.

Le Corbusier: “A propos de Venise”. In Venezia Architettura. ํ⒈ 1952. pp. 6-9.

Le Corbusier: "La leçon del la gondole. L'art et les masses contemporaines". In Tamborrino, Rosa (Ed.): Le Corbusier Scritti. Torino: Einaudi 2003. pp. 233-243.

Le Corbusier: La Ville radieuse. Boulogne-sur-Seine: Editions de l'Architecture d'Aujourd'hui. Collection de l'équipement de la civilisation machiniste, 1935.

Le Corbusier: "L’espace indicible”. In L'Architecture d'aujourd'hui numéro hors-série. Paris. 1946. pp. 9-17.

Le Corbusier: “La leçon de la machine”. In Tamborrino, Rosa (Ed.): Le Corbusier Scritti. Torino: Einaudi 2003. p. 145-151.

Le Corbusier: “Unité”. In L'Architecture d'aujourd'hui numéro spécial. Paris. 1948.

Le Corbusier: Euvre complète. Vol. 5. 1946-52. Zurich: Edition Girsberger, 1953.

Le Corbusier: Le Poème de l'Angle droit. Paris: Éditions Tériade, 1955.

Le Corbusier: Urbanisme. Paris: Éditions Crès, Collection de “L'Esprit Nouveau”, 1924.

Le Corbusier: "Les tendances de l'architecture rationaliste en rapport avec la collaboration de la peinture et de la sculpture”. In Tamborrino, Rosa (Ed.): Le Corbusier Scritti. Torino: Einaudi 2003. pp. 281-294.

Le Couédeic, Daniel: “Joseph Savina, l'improbable compagnon de route”. In Fondation Le Corbusier (FLC): Le Corbusier l'oeuvre plastique. Paris: Édition de la Villette, 2005. pp. 26-53.

Mango, Roberto: C. E. Jeanneret-Le Corbusier: la peinture architecturée 1918-1928. Roma: Officina, 1986.

Mattioni, Emilio: "La vicenda del Concorso preliminare per il nuovo Ospedale di Venezia". In Talamona, Maria (Ed.): L'Italia di Le Corbusier. Milano: Electa. pp. 377-389.

Moore, A. Richard: "Alchemical and mythical themes in the Poem of the right angle, 1947-1965". In Oppositions. 1980. $\mathrm{N}^{\circ} 19-20$. pp. 111-139.

Pauly, Danièle: "Il segreto delle forme”. In Casabella. 1987. N5531-32. pp. 94-120.

Petrilli, Amedeo: Il testamento di Le Corbusier: il progetto per l'Ospedale di Venezia, Venezia: Marsilio, 1999.

Reichlin, Bruno: “L’Ospedale di Venezia. Congetture sulla genesi del progetto”. In Talamona, Maria (Ed.): L'Italia di Le Corbusier. Milano: Electa, 2012. 390-409.

Reichlin, Bruno: “L'atelier era un vaso di Pandora”. Cinquant'anni di progetti rivisitati da Le Corbusier \& Co. L'Ospedale di Venezia, 1960-1965”. In Reichlin, Bruno: Dalla «soluzione elegante» all'«edificio aperto». Scritti attorno ad alcune opere di le Corbusier. Mendrisio: Mendrisio Academy Press, 2013. pp. 389-414.

Reichlin, Bruno: “Jenneret-Le Corbusier, painter-architect”. In Blau, Eve; Troy, J. Nancy (Ed): Architecture and cubism. Cambridge: Canadian Centre for Architecture - Montréal: MIT Press, 1997. pp. 195-218.

Rewald, John: Il post-impressionismo da Van Gogh a Gauguin. Firenze: Sansoni, 1967.

Rowe, Colin; Slutzky, Robert: Transparence: réelle et virtuelle. Paris: Demi-Cercle, 1992.

Sarkis, Hashim (Ed.): Case: Le Corbusier's Venice Hospital and the Mat Building Revival. Munich-LondonNew York: Harvard University Graduate School of Design, 2001.

Scapolo, Barbara: "Eupalinos o l'architetto”, o del fare consistente“. In Paul Valéry Eupalinos o l'architetto. Milano-Udine: Mimesis Edizioni, 2011. pp. 89-117. 
Sers, Philppe, Le Corbusier, Savina. Dessins et scultures. Paris: Fondation Le Corbusier, 1984.

Valery, Paul: “Eupalinos ou l'Architecte”. In La Nouvelle Revue Française. N90, Paris 1921, pp. 237-285.

Valéry, Paul: "Discours sur l'Esthétique". In Hytier, Jean (Ed.): Oeuvres. Éditions Gallimard: Paris, 1957. pp 1294-1314.

Von Moos, Stanislaus; Ruegg, Arthur (Ed.). Le Corbusier before Le Corbusier. London: Yale University press, 2002.

Von Moos, Stanislaus: “À propos de Venise”. In Talamona, Maria (Ed.): L'Italie de Le Corbusier. Paris: Édition de la Villette, 2010. pp. 76-87.

Von Moos, Stanislaus: "Alla veneziana. Le Corbusier, il turismo e la "crisi dell'utopia". In Talamona, Maria (Ed.): L'Italia di Le Corbusier. Milano: Electa, 2012. pp. 201-217.

Von Moos, Stanislaus: “La leçon de Venise”. In Le Corbusier: Album La Roche. Milano: Electa, 1996. pp. 2440. 


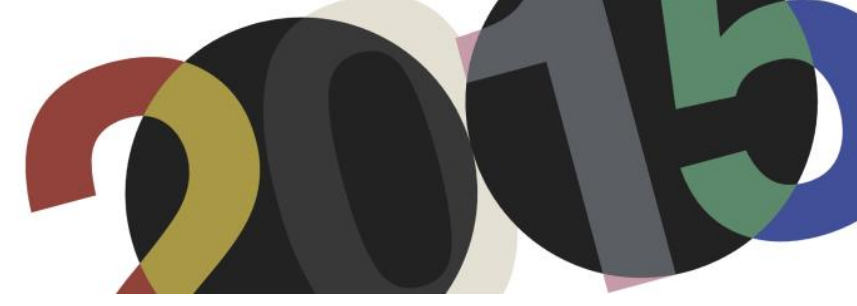

DOI: http://dx.doi.org/10.4995/LC2015.2015.921

\title{
Le Corbusier in Berlin, 1958: the universal and the individual in the unbuilt city
}

\author{
M. Oliveira Eskinazi \\ Faculdade de Arquitetura e Urbanismo, Universidade Federal do Rio de Janeiro. Programa de Pós-Graduação \\ em Urbanismo, Universidade Federal do Rio de Janeiro
}

\begin{abstract}
Among several urban plans designed for Berlin, we find Le Corbusier's project for the Hauptstadt Berlin 1958 competition, which aimed at thinking the reconstruction of the city center destroyed in the II World War. Corbusier's relation with Berlin dates back to 1910, when he arrives at the city to work at Peter Behrens`office. So, for him, the plan for Berlin was a rare opportunity to develop ideas about the city that provided one of the largest contributions to his urban design education, and also to develop ideas he formulated forty years before for Paris'center. Besides that, this project was developed almost simultaneously with CIAM's crises and dissolution, which culminated in the 50's with the consequent appearance of Team 10. At that moment Corbusier's universalist approach to urbanism starts to be challenged by CIAM's young generation, which had a critical approach towards the design methods inherited from the previous generation, associated with CIAM's foundational moment. From the beginning of the 50's on, this new generation balances the universalist ideals inherited from the previous generation with individualist ones they identified as necessary to face the new post war reality. Thus, the main goal of this paper is to analyse Corbusier's design for Berlin and question whether he, at an already mature point of his career, was proposing a plan that answered only the questions that were important to CIAM and to the canonical principles of modern architecture, or if he had also addressed those that belonged to the new generation and Team 10 's agenda, both of them present in the debates of the moment, largely identified as a transitional period.
\end{abstract}

Resumen: Entre varios planes urbanos diseñados para Berlín, esta el proyecto de Le Corbusier para el concurso Hauptstadt Berlín 1958, que tenia como objetivo pensar la reconstrucción del centro de la ciudad, destruida en la II Guerra Mundial. La relación de Corbusier con Berlín se remonta a 1910, cuando llega a la ciudad para trabajar en la oficina de Peter Behrens. Asi que, para él, el plan de Berlín fue una rara oportunidad de desarrollar ideas sobre la ciudad que dio una de las mayores enseñanzas a su aprendizaje en diseño urbano, y también para desarrollar las ideas que formuló cuarenta años antes para el centro Paris. Además de eso, este proyecto se ha desarrollado simultáneamente con la crisis y disolución de CIAM, y con la aparición de Team 10. En ese momento, el enfoque universalista de Corbusier comienza a ser cuestionado por la generación joven de CIAM, que tenía enfoque crítico hacia los métodos de diseño heredados de la generación anterior. Desde el principio de los 50 's, esta nueva generación equilibra los ideales universalistas heredados de la generación anterior con los individualistas necesarios para hacer frente a la nueva realidad. Por lo tanto, lo principal objetivo de este trabajo es analizar el diseño de Corbusier para Berlín y cuestionar si, en un punto ya maduro de su carrera, él propone un plan que respondió sólo las cuestiones que eran importantes para CIAM y a los principios canónicos de la arquitectura moderna, o si también se trataron temas que pertenecian a la nueva generación y a la agenda del Team 10, ambos presentes en los debates del momento, en gran parte identificado como un periodo de transición.

Keywords: Berlin; competition; reconstruction; universal; individual; transitional period.

Palabras clave: Berlín; concurso; reconstrucción; universal; individual; periodo de transición.

\section{Le Corbusier in Berlin}

One among several urban plans designed for Berlin that were never built is Le Corbusier`s project for the Hauptstadt Berlin 1958 competition, which also received projects from Alison and Peter Smithson, Hans Scharoun and others, and aimed at thinking the reconstruction of the city center destroyed in the II World War. But for Le Corbusier it was also a rare opportunity to develop ideas he formulated forty years before for Paris` center. 
Le Corbusier`s relationship with Berlin dates back almost fifty years, when in October 1910 he arrives at the city and starts working at Peter Behrens`office. Nevertheless, his first impression of the city was not a good one, as can be inferred from letters he wrote to his parents:

\author{
"Berlin extended a horrid welcome to me this morning." 1 \\ "Berlin does not win me over, and once you leave the vast avenues, it is just revulsion, pure horror." ${ }^{2}$
}

However, this first impression slowly changes when Le Corbusier gets in touch with the large green areas of the city, both in the Berlins downtown and its suburbs, in future letters to his parents:

"In the Tiergarten, one enjoys anew the impression of great peace in this great forest in immediate proximity to the noisy roads." 3

"So that, when on a spring or summer evening, one takes a walk in any of these suburbs, the visitor arriving from the great furnace of Berlin will be deeply surprised; he will indeed feel himself living in a reviving peace."

But more important to establish his previous relationship with Berlin is the fact that the city provided one of the largest contributions to his urban design education. That happened because in this period he had the opportunity to visit several exhibitions, as the relevant Städtebau-Ausstellung, and participate in sessions of the Werkbund. Besides that, he got in touch with the winning proposals for the Gross-Berlin competition, which aimed at thinking and planning the urban development of the city. So, both the experience of living in Berlin and working at Behrens`office, together with attending exhibitions and sessions of Werkbund`s congress, strengthened the basis of his urban design thinking, in particular his understanding of the perception and modulation of urban space, and consequently in his way of articulating the space in architecture.

Other than that, his project for Berlin was developed almost simultaneously with CIAM`s crises and dissolution, which culminated in the 50`s with the consequent appearance of Team 10. At that moment the design methods associated with CIAM are being questioned. Besides that, Corbusier`s universalist approach to urbanism, which he championed in his Athens Charter, starts to be challenged by CIAM`s young generation, which included the Smithsons, van Eyck, Bakema and Candillis. This generation had a critical approach towards the design methods inherited from the previous one, which was associated with CIAM`s foundational moment, and had among its members, other than Le Corbusier, also Giedion, Gropius and Sert.

Regarding Corbusier`s universalist approach, from the beginning of the 50`s on, this new generation balances the universalist ideals inherited from the previous generation with individualist ones they identified as necessary to face the new post war reality. This group acts towards a way of thinking the city, which prioritizes aspects such as considering the individuality and specific features of the site, including the greatest spatial and social varieties in design, and the development of transitional elements of scale in the configuration of the architectural and urban space. That means that, at the same time that they pay tribute to the previous generation, they question a series of aspects of their contributions. These discussions were fought with greater intensity at CIAM 9, 1953, and CIAM 10, 1956.

\footnotetext{
${ }^{1}$ Jeanneret, letter to his parents, October 18th, 1910, FLC R1-5-67. In: Cohen, Jean-Louis. Le Corbusier: An Atlas of Modern Landscapes. New York: Thames \& Hudson, 2013, pp. 88.

${ }^{2}$ Jeanneret, letter to his parents, October 21st, 1910, FLC R1-5-68. In: Cohen, 2013, op. cit., pp. 88.

${ }^{3}$ Le Corbusier. Les Voyages d'Allemagne, sketchbook 2, pp. 122. In: Cohen, 2013, op. cit., pp. 89.

${ }^{4}$ Jeanneret, Étude sur le mouvement d'art décorativ en Allemagne, p. 48. In: Cohen, 2013, op. cit., pp. 89.
} 
Thus, taking into account both Le Corbusier`s relation to Berlin and his fundamental role in the debates held during CIAM`s congresses, this paper analysis his design for Hauptstadt Berlin 1958 competition. Even though his design was eliminated from the competition, it contains several interesting proposals, such as solutions for the traffic problems, transference of Hauptbahnhof to Friedrichstrasse`s station, transformation of Unter den Linden into a pedestrian promenade, insertion of a grid of eroded blocks around Friedrichstrasse, and the insertion of huge towers near the limits of the intervention area.

Therefore, this paper`s main goal with the analysis of Corbusier design for Berlin is to question whether he, at an already mature point of his career, was proposing a plan that answered only the questions that were important to CIAM and to the canonical principles of modern architecture and urbanism, or if he had also addressed those that belonged to the new generation and Team 10`s agenda, both of them present in the debates of the moment, largely identified as a transitional period.

\section{Le Corbusier and the 50s`agenda}

\subsection{The universal and the individual}

After the end of World War II, relevant theoretical discussions took place. Despite the fact that some of them were never tried out in the practice, they were decisive for architecture and urbanism developments that occurred in the following years. The anxieties and uneasiness that the post-WWII environment provoked to the modern architecture were increasingly debated, especially in the 50`s. From these debates raised an idea of city that paradoxically, at the same time, incorporated and criticized the heritage left by the modern vanguards. A dominant feature of the period between the end of WWII and the beginning of the 60`s, this paradox finds a parallel in the duality of the relationship between the concepts of universal and individual. It is therefore correct to say that the concept of universal is linked to the appropriation of the principals inherited from the modern vanguards and the individual one to its questioning. However, according to Annie Pedret, the concepts of universal and individual were confronted by the third generation of architects in a more subtle way than it is usually depicted, that is, with simplifications and generalizations. That means that, in order to understand an important feature of the changes occurred inside architecture in this period, these concepts require, first of all, to be understood not as opposing ones but as complimentary ones:

“(...) histories of postwar CIAM that do not take a critical view of rhetorical techniques - whether they exist in published statements or even in unpublished official reports and congress minutes - do not accurately represent a comprehensive reflection of historical reality. Team 10 members no longer found it possible to perceive of reality in oppositional terms, thus they replaced the notion of the individual versus the universal with the individual and the universal. This paradigm of duality provided the theoretical basis for the architecture of the 1960 s and added a level of complexity to its characterization from an "either/or" paradigm, to one that accepted "both/and." Writing histories is linked to who the writers are and what agendas they are trying to promote which requires that we, as historians, examine the larger more complex discourse underlying the accepted discourse." 5

Our approach to Le Corbusier`s 1958 project for Berlin is based on this understanding of how a dialect relationship between the concepts of universal and individual is dealt along the 50`s. This allow us to assume

\footnotetext{
${ }^{5}$ Pedret, Annie: Representing history or describing historical reality?: the universal and the individual in the 1950. Conference: Universal vs. Individual: The Architecture of the 1960. Chicago: Illinois Institute of Technology, 2002, pp. 4.
} 
that, despite the fact that Le Corbusier belonged to the first generation ${ }^{6}$ of modern architects and that he defended in several post-WWII CIAM's congresses a more universalist approach in the same line as in the Athena's Chart, he was sensitive to the issues that were being addressed by the new generation and Team 10's agenda, especially if we take in account his presence in the debates of the period. Therefore, it is possible to better assess Berlin`s project in the context of a transitional period. Therefore, this investigation evolved along the ideas of the complementarity of the concepts of universal an individual, the role of CIAM in the postwar and its influence in Le Corbusier`s proposal to the urban development of Berlin`s downtown.

Even before the end of the WWII, there are series of doubts and critics to the planning and project methods used by architects associated with the CIAM. However, this movement increases with CIAM`s first congress after the referred war, CIAM 6, which occurred in Bridgewater, England, 1947, when the group was challenged by a different reality than the one that existed before the war. From then one and throughout the next decade - with impressive strength on the second half of the 50`s - the more universalist approach to urbanism defended by Le Corbusier in the Athena's Chart starts to be challenged by a young generation at CIAM, which criticized the planning and project methods inherited from the previous generation, who were still very attached to the foundation of CIAM.

The more prominent members of this new generation were until 1954 called "young members", but after September 1954 they start to be known as Team 10. These "young members" balanced the universalist ideals inherited by the previous generation with those of individuality which they identified as necessary to face the new reality. Their intervention in the city was directed towards individuality and particular features without nevertheless abandoning completely the universalist ideals, as expressed in the Doorn Manifest of $1954 .^{7}$

This proposal of the new generation, defended by names like Alison and Peter Smithson, Aldo van Eyck, Jacob Bakema, Georges Candillis and John Woelcker, valuing aspects of individuality and the specific characteristics of each place and community, is commonly presented as a opposition to the observations made by the old one, represented by Le Corbusier, Siegfried Giedion, Walter Gropius and Josep Luis Sert, usually linked to more universal ideas. However, the young architects neither placed themselves against the functionalist city designed by the Athens Charter by explicitly questioning its universality. They expressed their disagreement indirectly proposing an alternative method of design that takes into account differences in several orders between things and people - these are social, cultural, historical, geographical, climatic or ethnic differences. And this posture can be verified in the search for a greater variety of typologies and a wider variety of open spaces, creating areas of different features and combinations both spatial and morphological, as social. These design strategies have enabled the modern architecture and urbanism of the 50s to expressing higher degrees of particularity and identity that approach a less universal understanding and therefore more emphasis on features that emphasize individuality.

Among the examples, the most explicit approach to these concepts of individuality and identity was performed by the Smithsons in the projects submitted by them in CIAM 10, $1956 .{ }^{8}$ Each project proposed a different dwelling type for a specific necessity, and so each dwelling should satisfy to individual needs and, at the same

\footnotetext{
${ }^{6}$ Montaner, Josep Maria: Depois do Movimento Moderno. Arquitetura da segunda metade do século XX. Barcelona: Gustavo Gili, 2001.

${ }^{7}$ Smithson, Peter and others: Doorn Manifest. CIAM meeting on 29, 30 and 31 de January, 1954. In: Smithson, Alison: Team 10 Primer. Boston: MIT Press, 1968, pp. 30.

${ }^{8}$ Smithson, Alison: The Emergence of Team 10 out of CIAM: Documents. London: Architectural Association, 1982, pp. 69.
} 
time, respect individual identities, but always starting from common organizational principles. Also Bakemapresents an approach that emphasizes identity-related demands of a time when the individuality of each resident should be considered. The projects developed by him together with Opbouw group to dwell areas in the Netherlands - such as Pendrecht, Alexanderpolder and Nagele, all presented in different editions of the CIAM congress of the 50's - addressed the creation of identity through different approaches to a scheme consisting of formations of housing units that, when grouped, make up the neighborhood units. The housing units of Bakema, as we shall see, resonate in the area south of Unter den Linden in Corbusier`s project for Berlin.

These examples show that architects that belonged to the new generation have done, over the 1950s, important practical trials, based on manifestos, studies and theoretical discourses at the same time valuing features of an individualistic nature, but also challenging the universalist beliefs of CIAM. However, other than the main narratives usually place, they did not abandon one for the other, but dedicated to the task of putting the two ideas relating to and dialoguing with each other. This means that to understand the ideas of modern city designed in the 50s considering all its nuances and complexity, the problem of the universal and the individual must be characterized in less superficial terms, showing the varied aspects that contributed to its development and consolidation.

In the context of this transition period, Le Corbusier, even standing as one of the main representatives of the previous generation, continues to have a significant role, which is also concomitant with the performance of the members of Team 10 and the so called new generation of modern architects. He still defended in the last congresses of CIAM that he participated a point of view that can be theoretically traced back to a more universalist position, that means linked with modern pioneers and the canonical principles of modern architecture, especially with zoning the city into four functions. This position is explained in a series of actions, such as the first session of CIAM 7, chaired by Le Corbusier, who expounded on "Applications of the Athens Charter"; the presentation of works at CIAM 7 stipulated by Corbusier in the form of a grid of CIAM, that is $21 \mathrm{~cm} \times 33 \mathrm{~cm}$ panels forming a grid which was a system to graphically organize information on the projects, so that they could be analyzed comparatively according to the categories set out in the Athens Charter; and his insistence in successive congresses of the postwar CIAM, in the preparation of the Habitat Charter, which would be a continuation of the Athens Charter, among others.

But what this paper aims to show, based on the analysis of the 1958 project for the reconstruction of central Berlin, is that, despite his public defense in theory and in the debates in the congress of the review and continuity of the design principles of the first generation, in practice the project to Berlin begins to demonstrate some solutions that combine universal aspects with individual ones that therefore are consistent with the discussions that have marked this period of transition. Among other solutions, as we shall see, in the Berlin project Corbusier demonstrates a concern with the lack of identity and differentiation of dwelling projects built in previous decades through the creation of buildings with unique shapes composed of irregular volumes, inserting a wide range of building types and configuration of blocks, and the creation of groups of linear buildings based on the idea of combining mirrored structures, forming various open spaces and graduating public and private spaces. Thus, it distinguishes between the different areas, strengthening the individuality of each area and its users. In the same sense is Le Corbusier's approach to open spaces, seeking the coexistence of open spaces with different scales, characters and relationships hierarchy, and with the presence of transitional elements between the public and private domains. 


\subsection{Le Corbusier's role in the CIAMs meetings of the second postwar}

As discussed above, the post-war witnessed a change in discourse and practice within CIAM. To comply with the new society that was born with the end of war, CIAM could no longer guide their progress values and improvements in the human environment by concepts based on rationalist and mechanistic assumptions. This search for a new route - not focusing merely on the functional and rational aspects of architecture and urbanism guided the debates of the period. In this chapter, it will be seen how Le Corbusier standed in this debate inside the CIAM congresses, in order to better understand the influence of his ideas on developing his project to Berlin, which occurred a few years after CIAM 9, when he was removed from the organization of conferences.

The postwar congresses were devoted to issues primarily related to the reconstruction of the cities, covering questions about how to humanize the process of industrialization, as well as the concepts of "core" and "Habitat". The leadership behind this discussion underwent through some changes in the process. From CIAM 9 on, the leadership was transferred from Le Corbusier and Giedion to an international circle of young architects who would form the Team 10. The CIAM 9 was the first moment in the history of this congress that the functional city is put into check; this was also the congress that witnessed closely the changes inside the CIAM.

Between the first two congresses held after World War II - CIAM 6 and 7 - none of them was able to produce consensus about new directions that CIAM should follow from now on in order to maintain its leading position in Europe. CIAM 6, held in Bridgwater, England, in September 1947, was marked by controversial discussions. A major issue was the position of Giedion and Le Corbusier as the main CIAM figures advocating the use of the Charter of Athens, which proposed the "Functional City" as the main purpose of CIAM. By that time, young architects began to challenge the position of the leaders, considering the Charter very "rigid" and "rationalist".

In CIAM 7, held in Bergamo, Italy, in July 1949, it was already clear that the event would not recover the vanguard status that it held before WWII, among other reasons due to conflicts within the organization. The discussions held during the conference showed that the overall focus seemed to be an extension of the ideas of Le Corbusier, who actively participated in the congress. The format itself of the works presented was established by Le Corbusier. He proposed that the projects submitted to CIAM should be on a grid format, in $21 \mathrm{~cm} \times 33 \mathrm{~cm}$ panels forming a grid which was a system to graphically organize information on the projects, so that they could also be analyzed comparatively according with the categories set out in the Charter of Athens. Thus, the CIAM grid started to be used as a matrix, presenting as column headings of the four functions of the Charter - dwelling, work, recreation, and transportation; in the lines of the grid themes were included such as context, volume built, ethical, aesthetic, economic and social impacts, financial, law, among others. According to Le Corbusier, the grid formed by the intersection of these two axes provides a tool for understanding and compare, with a visual method, the different projects. However, despite the fact that the grid proved to be an efficient method to organize project information and was therefore used until CIAM`s dissolution in 1956, there was significant opposition to it. Because it categorized the projects in a limited number of horizontal and vertical lines, it did not represents adequately the conditions in which it was working. This is because, due to its universalist and exclusivist character, the grid predisposed architects to think the city framed in terms of the four functions and preconceived static categories, as opposed to other factors that should be included or at least considered.

In addition, Corbusier advocated that CIAM 7 should have among its objectives the development of the Habitat Charter. The issue eventually continued to draw CIAM`s attention until 1956. The first plenary session held at CIAM 7, chaired by Le Corbusier, dealt with the subject "Charter Athens Applications", and in his introductory speech, Le Corbusier said CIAM should develop a Charter of Habitat for CIAM 7, without stating clearly what 
such Charter might contain 9 .

For the next congress, CIAM 8, held in 1951, Hoddesdon, north London, the title "The Heart of the City" was chosen and this subject reflects a concern of the organizers with interventions in the centers of cities. The theme was relevant especially for the reconstruction of bombed towns - as Berlin after the war. But at that moment it was already evident that the continued application by CIAM of the principles of Athena`s Charter, as desired by Corbusier, was not unanimous, and that was the key issue in the next Congress. The four functions set out in the Charter had initially proved useful for a first analysis of a city, but now were insufficient to capture all its complexity.

The Charter of Habitat, that Le Corbusier wanted to make already in CIAM 7, ended up not being produced. Other than that, the congress showed that, despite that the atmosphere in the postwar was favorable for the development of modern architecture and urbanism, as could be seen in the reconstruction projects being proposed everywhere, the old school of CIAM showed no signs that they would be able to assess realistically the complexities involved with the difficult urban situation resulting from postwar. Thus, in general, the CIAM was unable to regain its leading role in Europe in the first six years after the war. This allowed new generations of architects to claim the Congresses leadership already for the next one, CIAM 9. In a meeting with members of the council held still during the CIAM 8, was suggested by Corbusier that "the occasion of the next Congress would be a good opportunity to 'hand over ' to the younger members" ${ }^{10}$ since 1953 would be the 25 th anniversary of CIAM. The 'hand over' to the new generation represented the official start of efforts to revitalize CIAM, an effort that resulted in the formation of Team 10 after CIAM 9.

With Le Corbusier`s retiring from Congress organization, CIAM 9, held July 1953 in Aix-de-Provence, France, is organized by the old school of CIAM and the French group ASCORAL. The meeting is considered the largest and most diverse CIAM ever. Convened under the title "The Charter of Habitat," the congress was attended by over 3,000 participants, including van Eyck, Bakema, Alison and Peter Smithson, Candilis and Woods - mostly names that would soon become the Team 10 members.

CIAM 9 came, therefore, in order to try to place CIAM relevant again, approaching the reality through the incorporation of ideas that come from a younger generation. However, the connection between the old and the new generation and their ideas did not yield very spontaneously and smoothly. This difficulty was reinforced by the reluctance of the previous generation to include more young people in decisions regarding the future of CIAM, making it clear that the differences between them with regard to ways of thinking the city only increased and favored a sense of division within CIAM. This change of direction was enhanced by Le Corbusier`s doubt on the applicability of the initial ideas of the CIAM in the new postwar scenario. In a letter to Sert, Tyrwhitt writes:

"Corbu said also in the Council meeting that he no longer felt we could be confident about the way men should live in this changing world. He no longer felt he knew what 'a town' should be. The 'Habitat' is clearly an element of living space - Cobu is not sure 'urbanisme' is the correct word - but how it should be organized with the other elements is less and less clear. "'ll

\footnotetext{
${ }^{9}$ Mumford, Eric: The CIAM discourse on urbanism, 1928-1960. Cambridge, Massachussets: Mit Press, 2002, pp. 192.

${ }^{10}$ Mumford, 2002, op. cit., pp. 206.

${ }^{11}$ Mumford, 2002, op. cit., pp. 218.
} 
That is, it was clear to Le Corbusier that, at that moment, the battle of modern architecture to give appropriate responses to architectural and urban problems of the reconstruction period could no longer be engaged on the same basis that worked before WWII. Therefore, the 1953 meeting was characterized by a common desire to both generations, but derived mainly from Le Corbusier and his group, to try once again to produce a Charter of Habitat, a document that, drawn up following 1933 Athens Charter, would provide a continuity to the production of manifestos and should be understood as a letter providing guidance and principles for the development of urbanism since then - as did the Charter of Athens in the pre-war period - and for the production of modern living spaces, one of the four specific functions of the Charter of Athens. However, once again the letter was not formulated.

The young architects, who would soon become members of Team 10, did not like the idea of producing another manifesto. It is without question that they paid tribute to the ideas associated with the Athens Charter, recognizing its value to restore the principles of order in the cities. On the other hand, they challenged the understanding that the organization could go on for another Charter from that same point. For them its principles were now considered inadequate since very abstract and diagrammatic. For this group, it was no longer possible to conceive the "town" and the living spaces from the mono-functional zoning perspective proposed by the Charter of Athens. In contrast, for the young architects, the "town" should henceforth be considered on the basis of human associations, as an attempt to correct the problem of human relations generated by the functional separation proposed in 1933. So it is no surprise that the work program of CIAM 9 points out that the Congress would not be reduced to the study of the four functions, but will focus on housing and everything that revolves around the planning and construction of dwelling.

As in CIAM 7, the studies in CIAM 9 were presented in form of grids $(21 \mathrm{~cm} \times 33 \mathrm{~cm}$ panels $)$, colored by function, and should contain a vertical line at the right edge $(6 \mathrm{~cm})$ containing title, location and author identification, numbering and a brief explanation. A total of forty grids were presented at CIAM 9. Among these, several projects aroused the interest of the younger members, especially those that showed some concern for local conditions and cultural traditions. CIAM 9 was considered the most internationalized and also the most diverse of the congresses so far conducted.

This makes it clear that it was precisely during the CIAM 9 that the generation of young architects starts to have an active participation and criticize, from different approaches, the schematic of the Charter of Athens, suggesting that, to address the issue of Habitat, it would be necessary to adopt a number of new positions such as the introduction of the concept of identity and the investigation of some structural principles of urban growth. And Le Corbusier, although remaining tied with respect to some aspects of the Charter, on the other hand was already showing signs that he understood that this was a period of transition and change paradigms.

Thus, CIAM 9 ends without having succeeded in producing a Charter of Habitat. Moreover, the discussions carried out have led to a split between the new generation and the old school, represented mainly by the figure of Le Corbusier, and that resulted, a few years later, in CIAM '59 and dissolution of CIAM. In the period that followed after the end of CIAM 9, criticism indicating the failure of Congress abounded among the members of the new generation, and began to be directed to CIAM as an institution. So CIAM 9 represents the turning point when CIAM's speech on the functional city, and with it, the validity of the Charter of Athens, were held in check and questioned openly by young architects. And it is from this perspective, claiming the revision of a number of canonical principles of modern architecture through the dwelling, that CIAM 9 plays a key role in understanding the ideas of review and continuity that characterize the theoretical framework where this investigation is made. 


\section{Berlin Hauptstadt 1958, the unbuilt city}

It is in the context of the debates presented above, and in the context of a divided Germany a few years before the effective construction of the Berlin wall in 1961, that Le Corbusier, a few years after attending for the last time a meeting of CIAM, submits his project for Berlin Hauptstadt 1958 contest. The competition solicited proposals for the reconstruction of Berlin`s historic downtown, that was largely destroyed by war. This same period also held other important initiatives of reconstruction of parts of the city destroyed by WW II, both in West and East Berlin. Among the most important, it is worth mentioning the Kollektivplan of 1945, first plan for the reconstruction of Berlin, designed by Hans Scharoun, but not built; among the built ones, are the Stalinallee 1951 in East Berlin, and the Interbau 1957 in West.

Announced immediately after the division of Germanys in 1949, the Stalinallee, today Karl-Marx-Allee, promoted the reconstruction of the Frankfurter Strasse between Strausberger Platz und Frankfurter Tor, and has been object of a competition in 1951. The definite plan puts together ideas of the five prizewinners and of Hermann Henselmann. Following the criteria of socialist realism current at the time of the German Democratic Republic constitution till the end of the 60's, the eclectic-academic architecture will triumph in the $1800 \mathrm{~m}$ long and $80 \mathrm{~m}$ wide avenue. Details evoking Schinkel and its contemporaneous expressed the national character.

The Interbau, example of the best modern architecture and urbanism offered in terms of social housing, promoted the reconstruction of the Hansaviertel, a residential neighborhood from the eighteenth century located in the Tiergarten park. The urban plan was defined by a competition held in 1955, and the exhibition inaugurates in July 1957, with the participation of more than 40 architects. The list of invited includes Le Corbusier, with one Unité d'Habitation, and also Alvar Aalto, Walter Gropius, van den Broek and Bakema, Arne Jacobsen, Oscar Niemeyer, among others. While the monumentality of Stalinallee represented the triumph of socialism in East Germany, the new Hansaviertel would be a replica of the free and democratic society of the West.

On the other hand, the Berlin Hauptstadt 1958 competition was organized even closer to the materialization of the Berlin Wall - only three years before. The competition was planned in October 1955 by the West Berlin government, announced in May 1957, and have received proposals until February 1958. Thus, it stood as a unique opportunity to check the status and then the ideas about the city and its planning.

The notice requested solutions fort the administrative, financial and commercial centers of the city. It gave as a main guideline that the projects should address a future and hypothetical reunified Berlin. The crux of the matter was to think a new urban setting that would allow the future city to be related to the existing city and its vestiges. The program called for the design of a great political and administrative center for the reunified capital, with government offices, ministerial blocks around the Reichstag and a large public area with services, shops and offices; residential areas were excluded from the program - which would represent, if the winning project had been built, a great loss to Berlin`s downtown, which would be configured as an empty area at night and without the mix of functions that characterized it before the destruction and still does, and that is so vital to maintaining the quality of the urban environment. The premise of thinking the reunified city gave the most utopian and progressive features to most of the projects. Reinforcing this, the area in question, covering $10 \mathrm{~km}^{2}$, was limited between the Tiergarten to the west, Alexanderplatz and Museum Island to the east, the river Spree to the north, and the Mehringplatz to the south. It was divided between the two Germanys, since it was located 2/3 in Soviet territory and 1/3 in Allied one. In addition, the area gives rise to important architectural objects, such as the Brandenburg Gate, Museum Island, Humboldt Universität and the Reichstag, seat of the German Parliament, which was in ruins at the time (Image 1). 


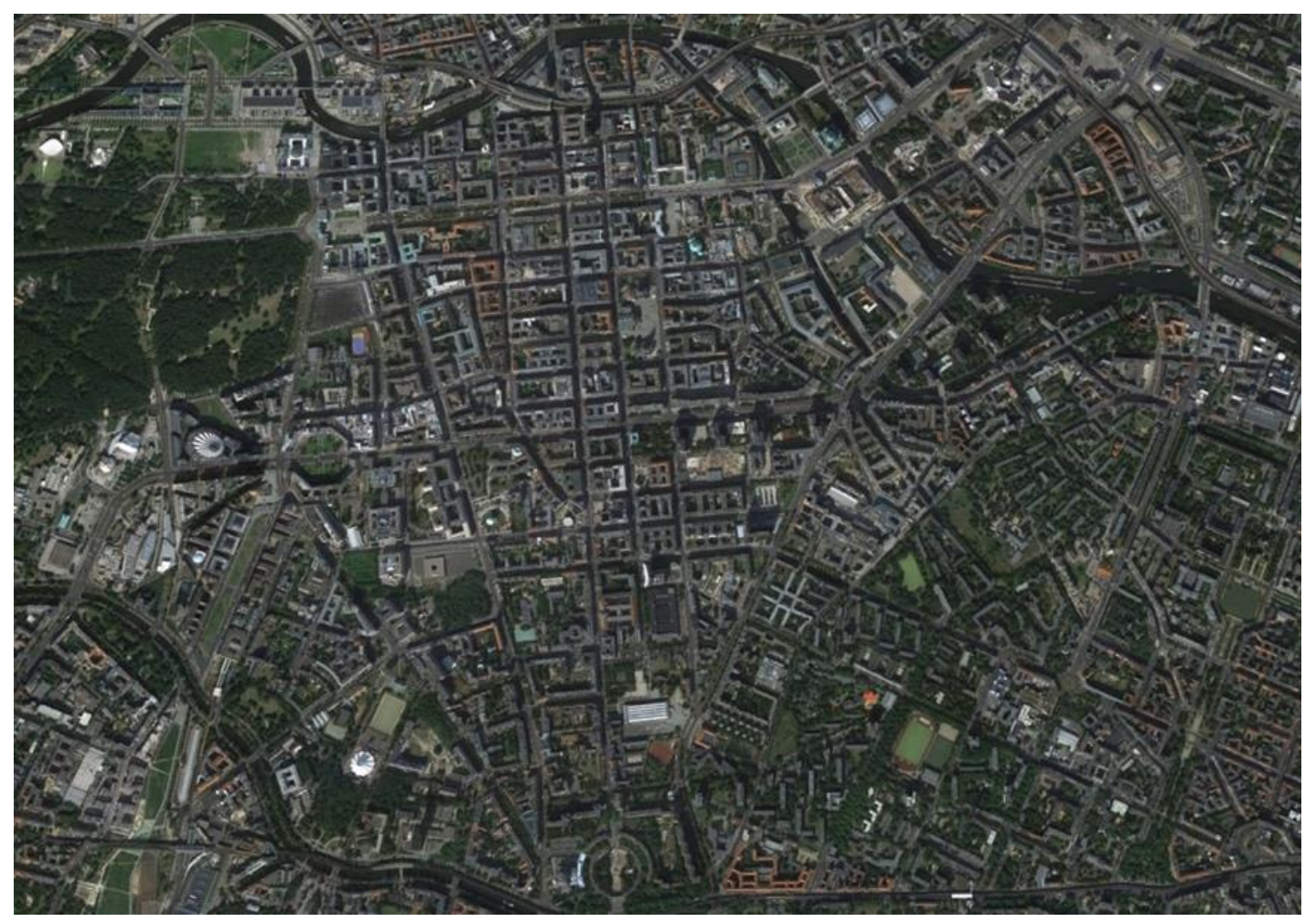

1. Competition area. Source: Google Earth.

The jury included prestigious names like Alvar Aalto, Cornelis van Eesteren and Pierre Vago. Walter Gropius was initially part of the jury and that was one of the reasons that convinced Le Cobusier to accept the invitation to participate in the contest. But for health reasons Gropius was prevented from continuing the function. The competition received 86 proposals from various cities beyond Berlin, such as London, Vienna, Paris and Florence. Of these 86, 13 were eliminated, including Le Corbsuier. Among the proposals submitted, a few stood out, in addition to Le Corbusier`s: Spengelin, Eggelin \& Pempelfort, contest winners; Hans Scharoun, second place; Alison and Peter Smithson together with Peter Sigmond, third place; Jorn Utzon; Sven Markelius; Luigi Piccinato; among others. Soviet architects also sent works to the contest but they could not develop their projects, since their professional association banned its members from participating. While most of the proposals are linked in some way to the principles of CIAM, and the proposals of Hans Scharoun and Alison and Peter Smithson (Images 2 and 3) represented alternative schemes based on new concepts, linked to the agenda of the new generation, the project proposed by Le Corbusier arises along the way, closely linked to the canonical principles of modern urbanism, but also sensitive to some of the concerns that have characterized the debate caught over the 1950s.

Also, it is important to keep in mind that Berlin was, throughout the twentieth century, the subject of proposals and contests that thought solutions to the city, many of them having been only kept on paper, as fragments of utopia. However, the 1958 contest, though also not built, differs from other proposals to Berlin since it would transform the center of Germany`s capital in a planned area, something that was unusual including European level. This condition was made possible by the state of destruction provoked by the bombings of WWII. Thus, Corbusier had the opportunity to work with problems similar to those studied by him to the center of Paris more than thirty years before, without needing to have premised on the destruction of the city center. 


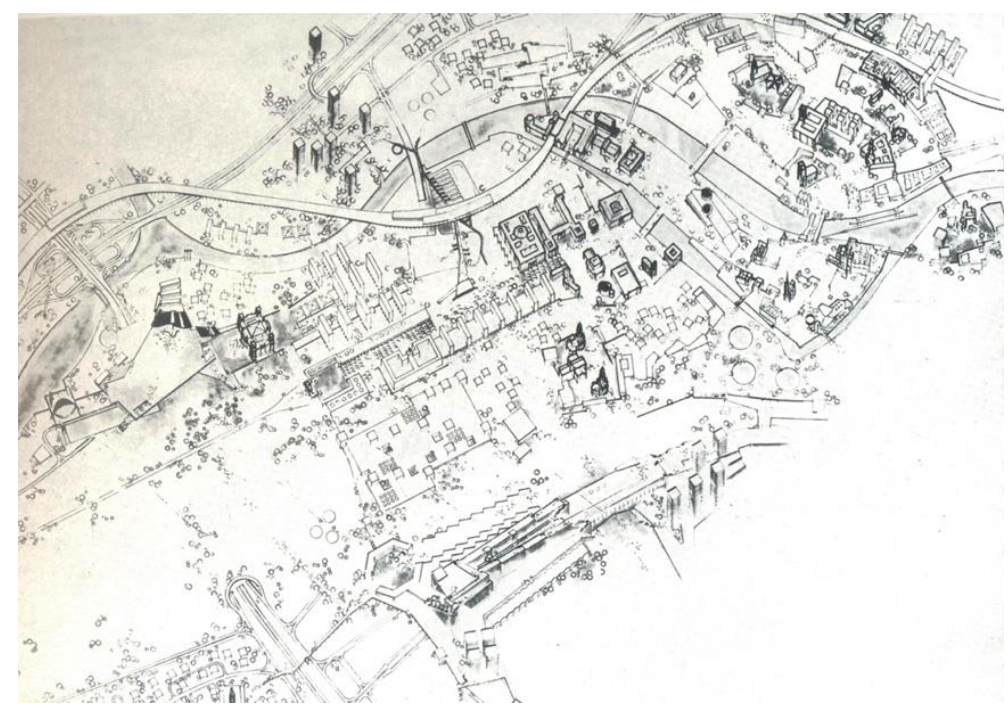

2. Proposal submited by Hans Scharoun for Berlin. Source: Geist, Johann Friedrich; Kürvers, Klaus; Rausch, Dieter: Hans Scharoun. Chronik zu Leben und Werk. Berlin: Akademie der Künste, 1993, pp. 115.

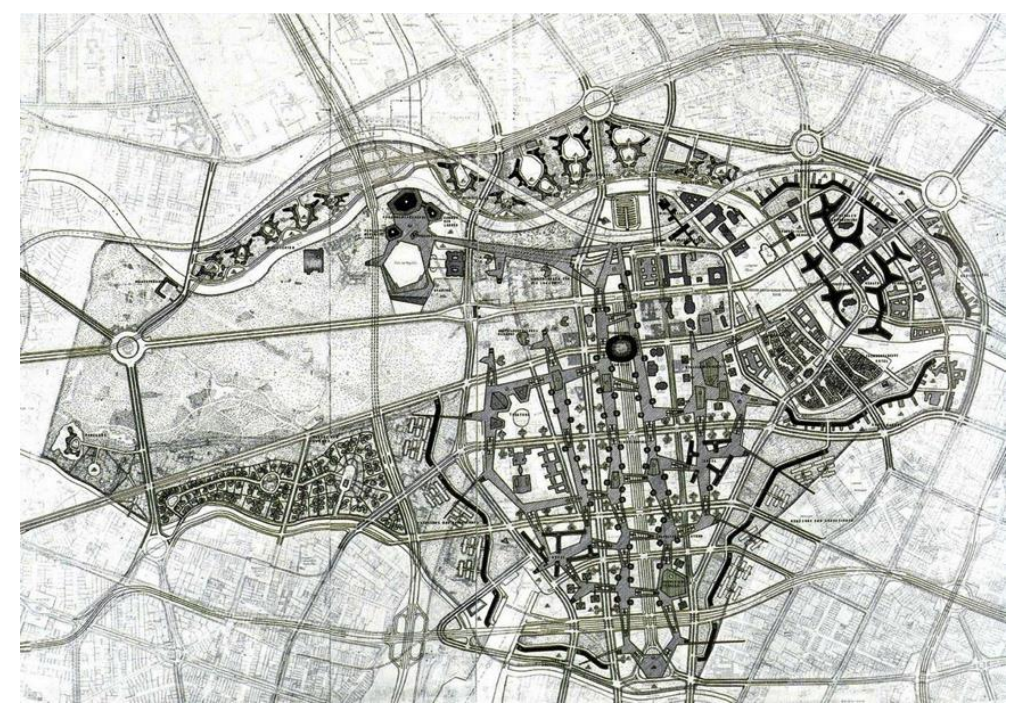

3. Proposal submited by Alison and Peter Smithson for Berlin. Source: Bosman, Jos and others: Team 10 1953-81. In Search of a Utopia of the Present. Rotterdam: NAi Publishers, 2006, pp. 76.

Le Corbusier`s proposal was thought by him more as a scheme of ideas or a master plan, than a widely developed project. Thus, the present analysis was limited to the level of development achieved by the project that was handed out, and was based on a not very wide graphic material found in "Le Corbusier et son atelier rue de Sevres 35 - Oeuvre complete 1957-1965" as well as at the Fondation Le Corbusier site ${ }^{12}$.

Le Corbusier developed the project in his office at Rue de Sevres in Paris; however, as he had lived in Berlin for about a year, he had acquired relative intimacy with the city and its center. Even though he did not went to Berlin at the time of the preparation for the contest, he had a deep knowledge about the peculiarities and characteristics of the area. As his design strategy for the configuration of the area and for the recovery of pre-existing historical center, he used well-outlined urban infrastructure networks as a key element for generating new public spaces. In addition, he incorporates in its proposal some new ideas regarding the treatment of public spaces and their

\footnotetext{
${ }^{12}$ www.fondationlecorbusier.fr
} 
relationship with the existing urban fabric, combining urban elements and equipment of different scales, and thus, creating transitional zones.

Le Corbusier`s premise for the project was to preserve the remaining historic buildings and insert the urban fabric as a sort of overlay, while keeping a continuity with key pathways and structuring lines of the existing track. This stance on existing tissue differs so much from that adopted by Hans Scharoun, as that taken by Alison and Peter Smithson, respectively second and third place, and are, along with Le Corbusier project, among the most published and cited in books and magazines that discuss the contest. While Scharoun completely eliminates the existing urban layout, considering that the original fabric and its road standard lost all meaning they had previously, Smithson propose to interconnect two road systems based on opposing geometries - one at ground level and corresponding to remaining original fabric of the city, and the other superimposed on this, composed of raised platforms by setting a non-orthogonal grid. Thus, one can say that with respect to how to intervene in the existing city, or what remained of it, Le Corbusier project stands midway between Scharoun`s project and Smithson`s, as it keeps in part the existing fabric, and inserts a new urban and road structure at strategic points, but in most cases considering the existing structure and seeking to link with it.

Following the principles of project advocated by CIAM and its most universalizing aspects, Le Corbusier establishes a functional zoning of the area, focusing on the distribution of governmental, administrative, cultural and economic activities. Thus, as shown in Images 4 and 5, it deploys the cultural sector surrounding the Unter den Linden; the economic sector, with shops, offices and services are placed in the southern portion between Unter den Linden and Mehringplatz; adjacent ministries to the Reichstag, the seat of Parliament; diplomatic representations are in the area south of Tiergarten; and the sector for the municipal administrative activities are to the east, near Alexanderplatz. That is, different from common sense about modern urbanism, Le Corbusier implements the activities required by the program considering the characteristic uses of each part of the area and respecting, thereby, the bond of the new proposal with the tradition of the place. The area surrounding the Unter den Linden already covered, before destruction, a number of cultural facilities, as well as the area near the Reichstag also was characterized by government activities, the area south of the Tiergarten had tradition in hosting diplomatic activities, and the area near Alexanderplatz already had activities related to the city.

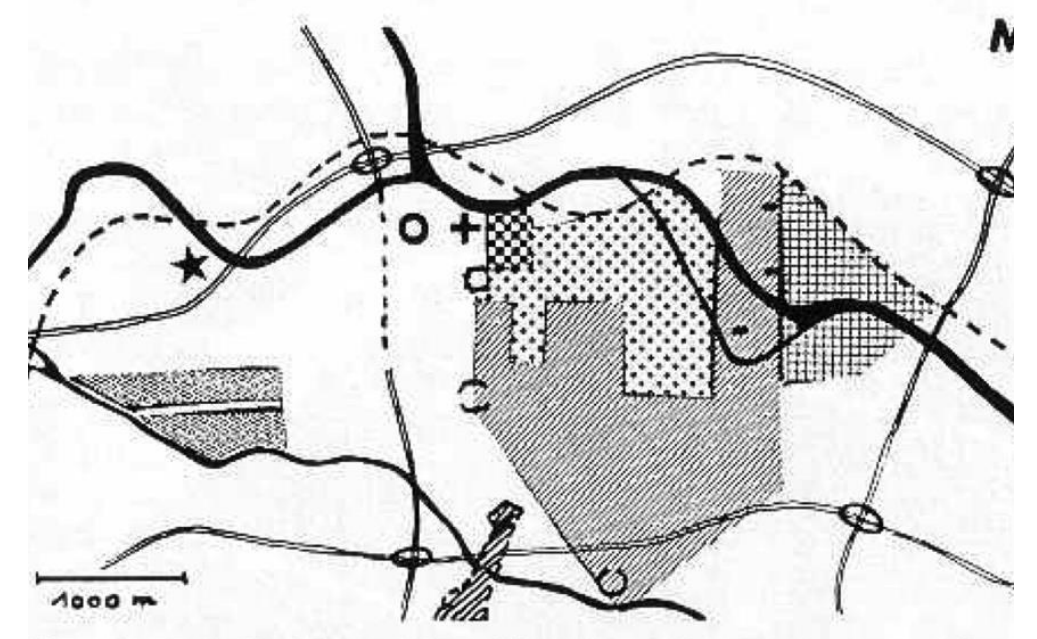

4. Sketch of the functional zoning estabilished by Le Corbusier for Berlin. Source: Boesiger, Willy; Corbusier, Le: Le Corbusier et son atelier rue de Sevres 35: Oeuvre complete 1957-1965. Zurich: Editions d`Architecture, 1966, pp. 230. 


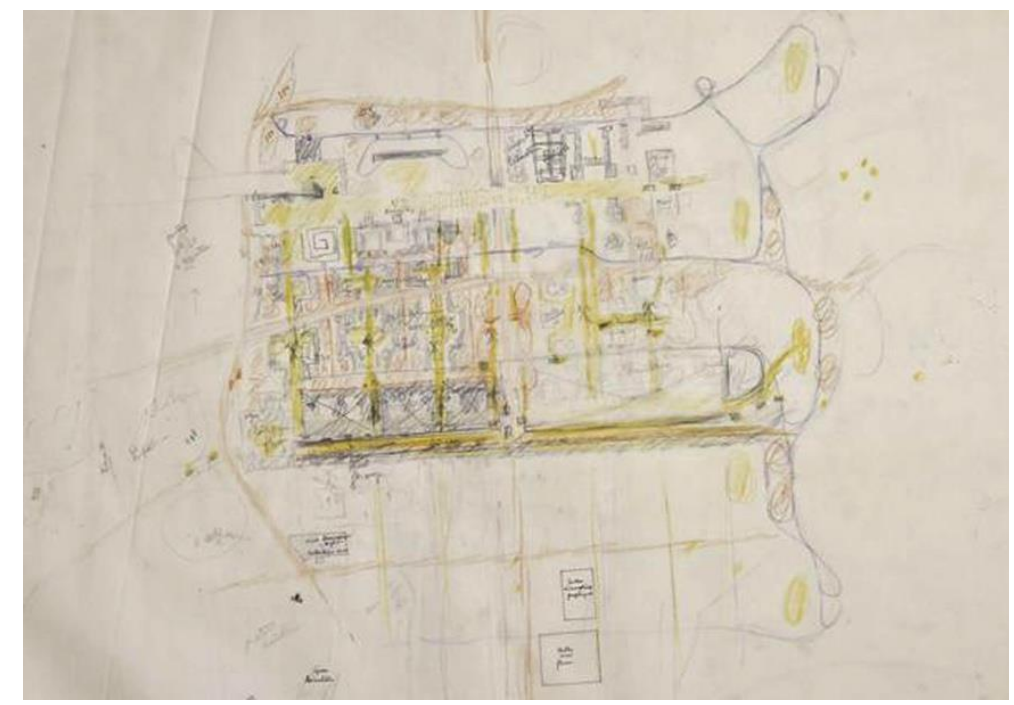

5. Inicial sketch of the plan developed by Le Corbusier for Berlin. Source: www.fondationlecorbusier.fr (Urbanisme, Berlin @FLC-ADAGP 4/7)

In addition, he proposes changes in some of the important urban facilities of the area, as the transformation of Friedrichstrasse station in Hauptbahnhof (Central Station); the implementation of a large roundabout in place of the Hackescher Markt; and placing a series of skyscrapers with plant in a kind of irregular "T" format at strategic points of the plan, concentrated mainly on the east bank area. But among the boldest changes is the proposal to transform Unter den Linden into a pedestrian promenade, increasing the use and enjoyment of the cultural facilities of the area. The car circulation is solved with elevated highways crossing Unter den Linden at specific points related to the main existing roads in the plan, and parking areas are situated in narrow bands in front of buildings. With this gesture, Corbusier intended to rescue the identity and the features that the avenue had in the past, before the appearance of vehicles, when it was an avenue aimed at pedestrians. Furthermore, it also aimed at establishing Unter den Linden as a liaison between the different functions that develop around it and at the same time embrace it as scale transitional element - solutions that present answers to a series of issues debated in recent congresses of CIAM in which he participated. However, this solution displeased the jury, which decreed that Unter den Linden should be used for car traffic.

In the area between south of Unter den Linden and Mehringplatz, the solution adopted by Le Corbusier refers to some extent to the discussions and experiments carried out by the new generation in the congresses of the postwar CIAM with respect to issues related to the urban block configuration. These issues were addressed in architectural design and theoretical framework mainly by members of Opbouw group, the Dutch arm of CIAM led by Bakema, from the approach to the scheme consisting of formations of housing units (or stamps), which grouped form neighborhood units. The housing units were formed by combining groups of different types of housing, so that a significant social and variety of types and sizes of families could live integrally also in diverse areas. When grouping and combined housing units form the neighborhood units, larger units, endowed with shops, schools and recreational areas, which, separated by wooded tracks, play the role of defining the scale of the neighborhood. Thus, the housing unit, to act as recognizable unit of architectural and social composition, which refers to the open block idea, was the originator scheme found by Opbouw to organize the space and at the same time expressing the differences in society and individuals found in a series of housing projects presented by them in successive congresses of CIAM, as Pendrecht (1948-1953), or Alexanderpolder (1953-1956), both in Rotterdam. 
In the area located south of Unter den Linden, even not it is not a program for dwelling, Le Corbusier adopts a similar ordering scheme. He projects open blocks from mirroring two linear buildings in a kind of "C" shape, creating thereby a compositional unit in each block, which is repeated in the plan. Despite the program differences, these units designed by Le Corbusier have parallels in compositional terms and space configuration with Bakema`s housing units, and when grouped they can also refer to the idea of neighborhood units. Moreover, with this configuration, Le Corbusier reaches, within each block, a greater variety of built-up areas and open spaces. Also the character of these areas achieve some diversification, since the inside of each block becomes a semi-public space - and not a private one - with different gradations at every point, and become usable for purposes such as leisure, entertainment and exchange between users. These solutions are in accordance with the idea of achieving greater differentiation and thereby individuality in different parts of the project. This unit, with a repeatable pattern, is evenly distributed in the plane, creating a structure that shows up homogenous but contains internally variety and differentiation. The Images 6,7 and 8 show the final plan.

However, Le Corbusier`s project was among the 13 eliminated by the jury. According to the report issued by the jury, the project solved fully and satisfactorily circulation problems common to large cities, such as Berlin, but Corbusier's decision to deploy one of his skyscrapers between Unter den Linden and the river Spree, hiding a municipal administrative building located on the other side of the river, also angered the jury, which eventually disqualify the project. Nevertheless, this seems like a minor problem, since even without having obtained classification, without having reached a higher stage of development, and without having been built (which joins it to the huge number of projects proposed for Berlin that never got off the ground), the design of Le Corbusier fulfilled the role of proposing a solution that, while linked to some of the canonical principles of modern architecture, also shows sensitive to those raised by the new generation in discussions carried out in the period. Thus, at an already mature point of his career - just seven years before his disappearance - he shows awareness to the theoretical debates of the period as opposed to the common sense regarding his place on modern urbanism.

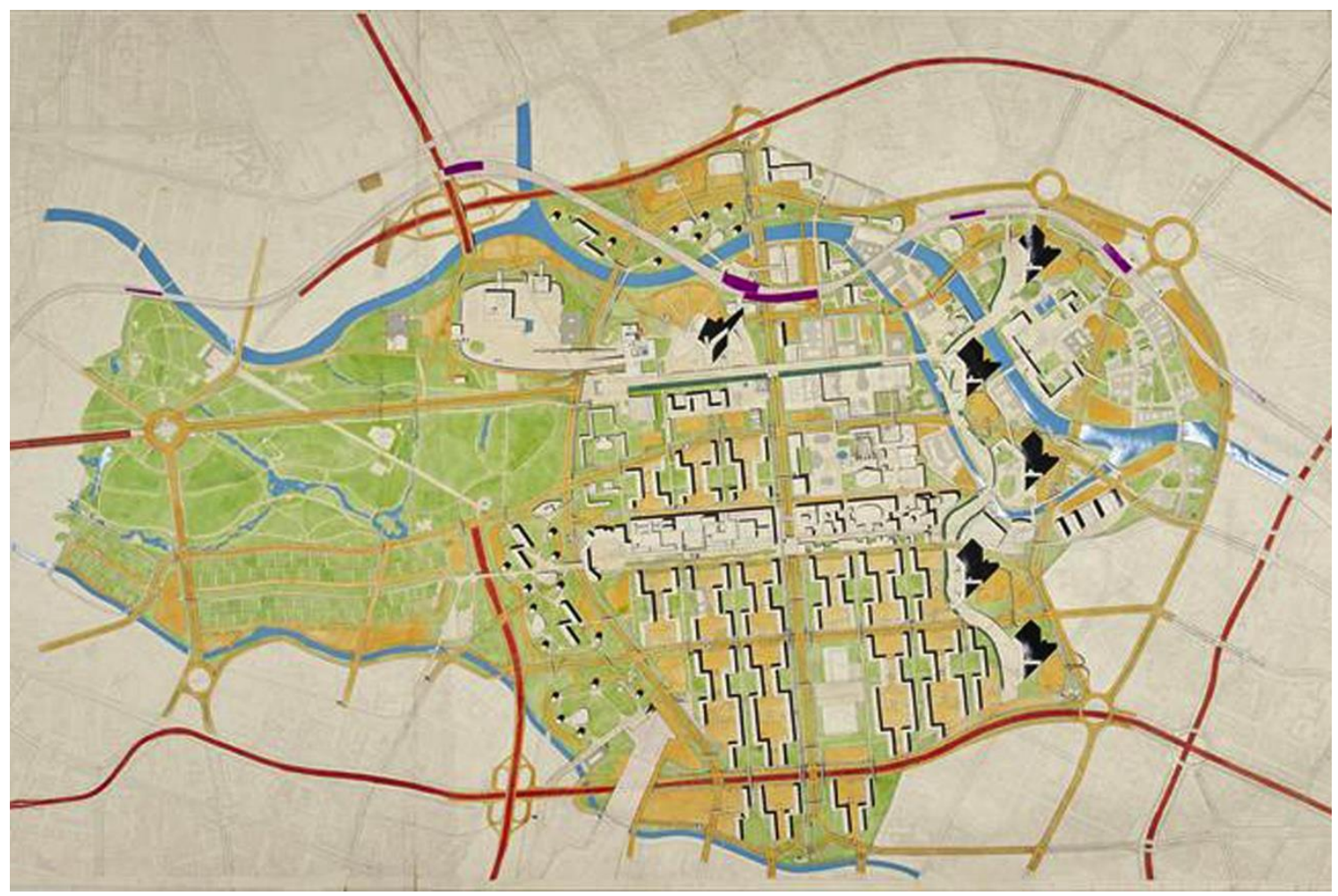

6. Proposal submited by Corbusier for Berlin. Source: www.fondationlecorbusier.fr (Urbanisme, Berlin @ FLC-ADAGP 1/7) 


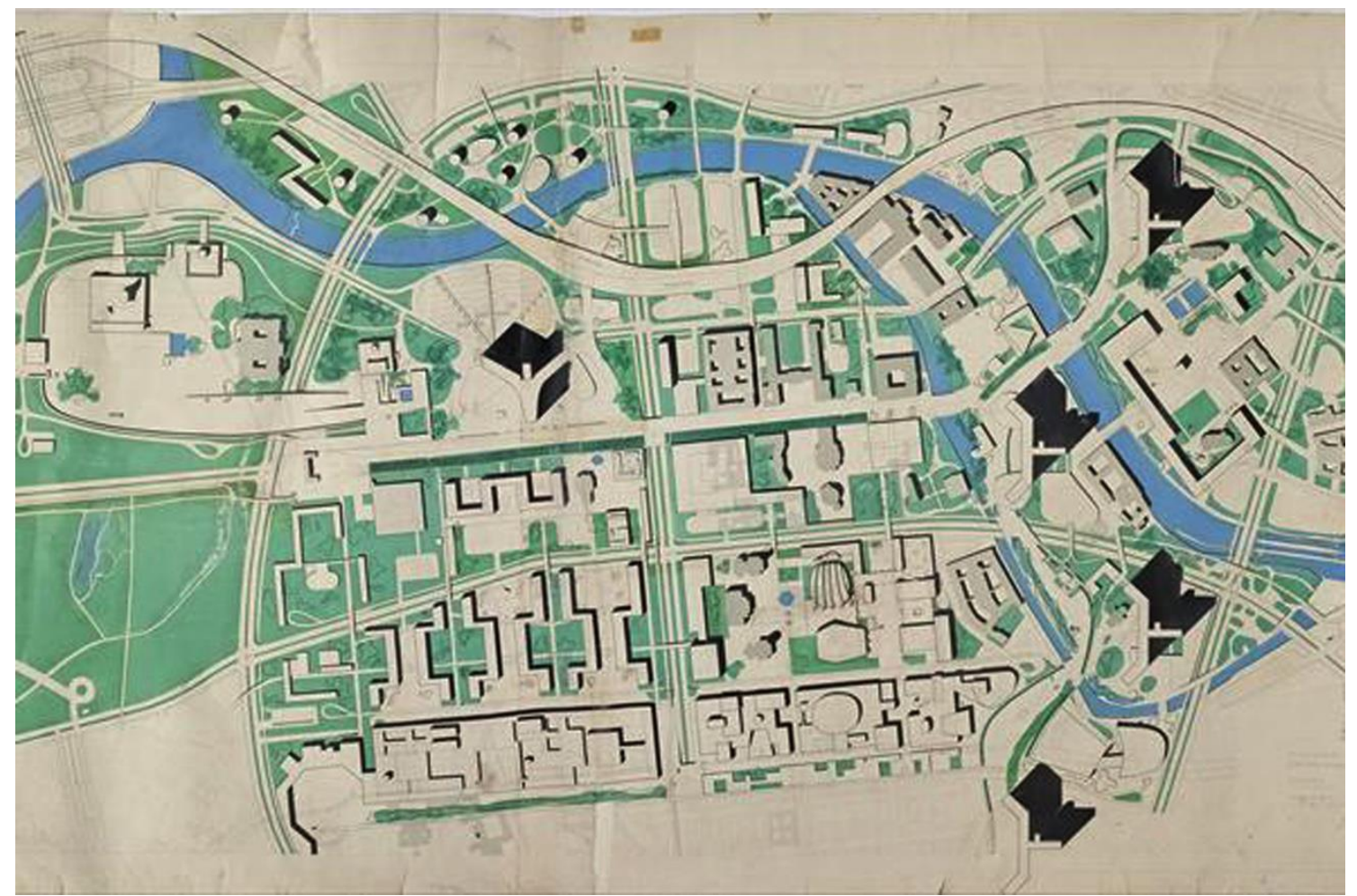

7. Plan of Le Corbusier for Berlin, signalizing in green the green areas. Source: www.fondationlecorbusier.fr (Urbanisme, Berlin @FLC-ADAGP 6/7)

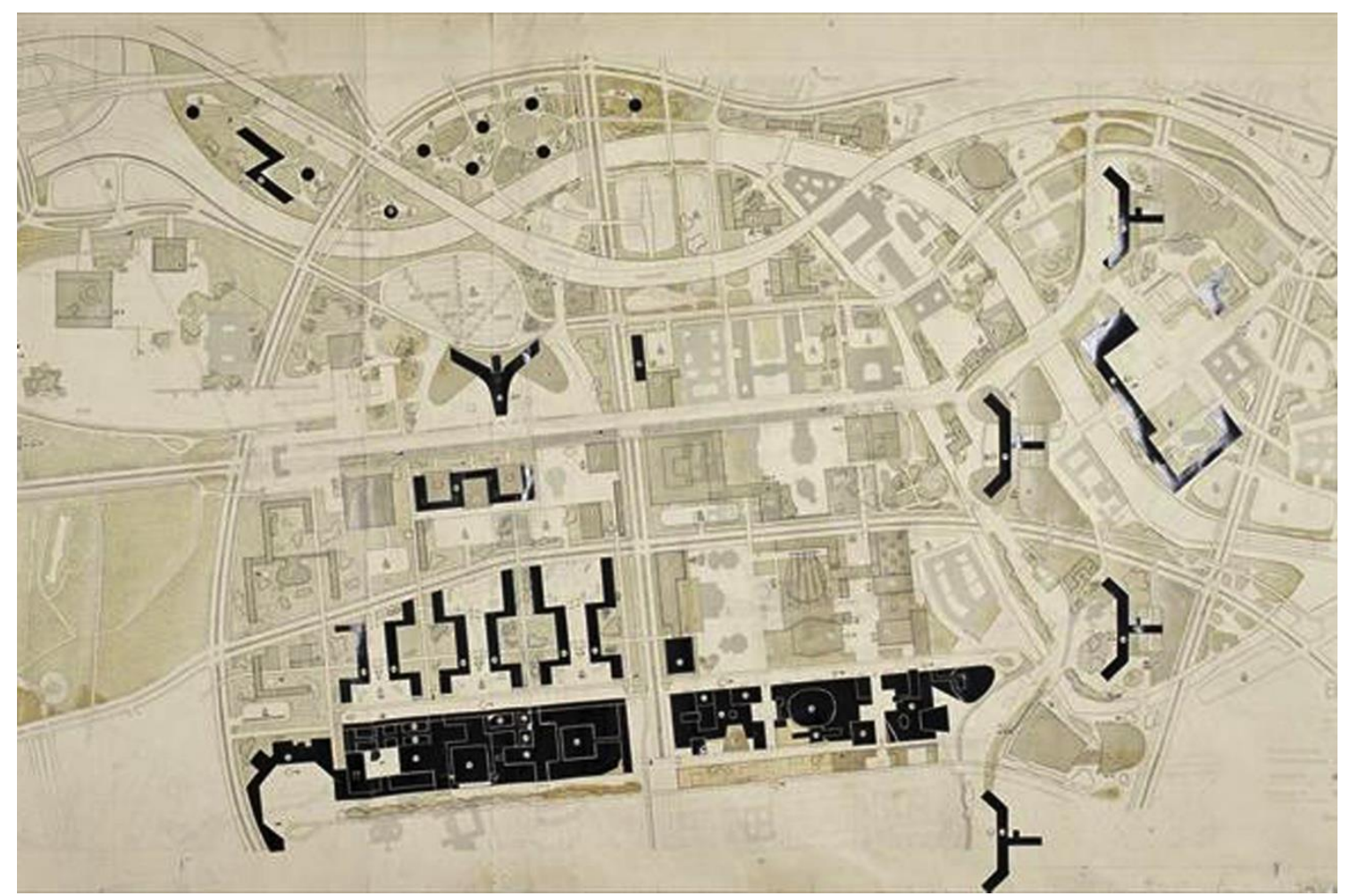

8. Plan of Le Corbusier for Berlin, signalizing in black new buildings. Source: www.fondationlecorbusier.fr (Urbanisme, Berlin @FLC-ADAGP 7/7) 


\section{Conclusions}

More than thirty years after the completion of Plan Voisin, at which Le Corbusier presents its proposal for the center of Paris, he has the opportunity to develop his ideas about architecture, urban planning and modern society to the center of Berlin. Although both represent very optimistic expressions of his time and both being marked by a deep belief in technology and the future of humanity, the project to Berlin differs from the Plan Voisin in that, when touched by the questions posed by new generation of modern architects throughout the transitional period located in the 1950s, he anticipates a number of issues that would be on the agenda of architecture and urbanism in the 1960s. By placing the ideas of universality and individuality acting jointly, Le Corbusier turns out contrary to the common sense and the main narratives dealing with the architectural production of this period, which put both ideas as conflicting ones; similarly, it also defies common sense on his own production in urbanism, whose criticism usually is linked with matters arising out of the canonical principles - and to some extent utopian - adopted on the project to Paris.

On his Berlin project, Le Corbusier adopts, on the one hand, a number of design strategies more linked to CIAM`s booklet and the Athens Charter, such as huge loose towers amid large open areas, and the functional zoning, escaping from the already well established idea of the need for mix of functions. But on the other, he takes others that corroborate the view that his project shows sensitivity to issues addressed in the period in which it was developed. Among them we can mention: an adjustment of scale (especially when compared to Plan Voisin project), connecting with the city scale and limiting the insertion of larger objects to specific points of the plan; the insertion of transitional elements, either of scale, either of function, a strategy that relates to the idea of human association as defended by Smithson in the Statement on Habitat as a basic principle of organization and design tool; the inclusion of a significant typological and space varieties, both for the built spaces and the open ones; concerns about linking his plan with the existing plot, albeit partially; and the adoption of a system for urban blocks configuration that refers to the idea of housing units combinations that generate neighborhood units, a subject widely discussed in CIAMs by the new generation. That is, as seen on Image 9, different than the main narratives usually place, Corbusier did not consider the problem of universal and individual issues as mutually exclusive, but rather devoted himself to the task of putting these two ideas working and dialoguing with one another, explaining, with this, the nuances and complexities of the modern city of the 1950s.

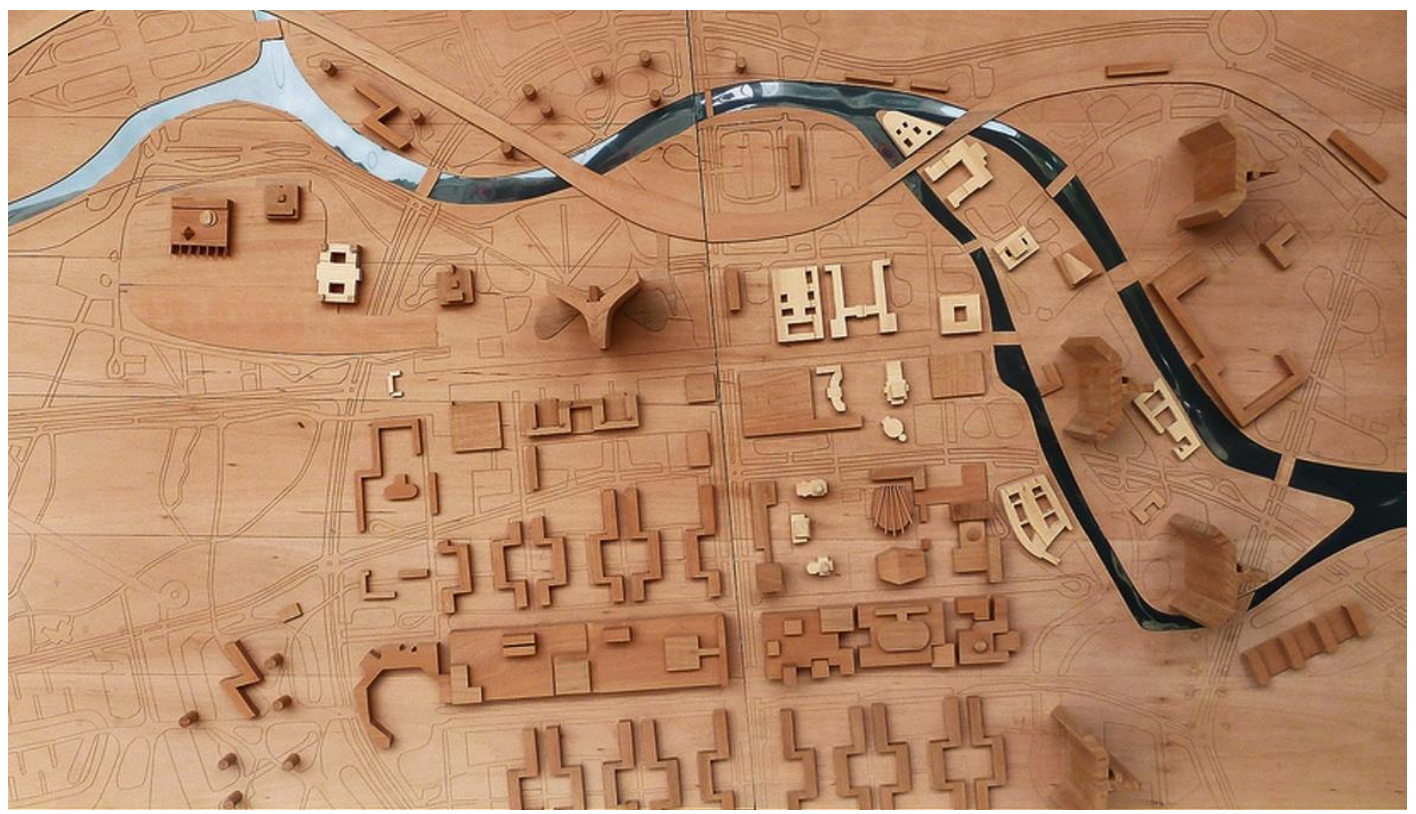

9. Model of the plan submited by Le Corbusier for Berlin. Source: www.flickr.com. 


\section{Bibliography/ references}

Boesiger, Willy; Corbusier, Le: Le Corbusier et son atelier rue de Sevres 35: Oeuvre complete 1957-1965. Zurich: Editions d`Architecture, 1966

Cohen, Jean-Louis: Le Corbusier: An Atlas of Modern Landscapes. New York: Thames \& Hudson, 2013

Montaner, Josep Maria: Depois do Movimento Moderno. Arquitetura da segunda metade do século XX. Barcelona: Gustavo Gili, 2001

Mumford, Eric: The CIAM discourse on urbanism, 1928-1960. Cambridge, Massachussets: MIT Press, 2002

Pedret, Annie: Representing history or describing historical reality?: the universal and the individual in the 1950. Conference: Universal vs. Individual: The Architecture of the 1960. Chicago: Illinois Institute of Technology, 2002

Smithson, Alison. The Emergence of Team 10 out of CIAM: Documents. London: AA, 1982

Smithson, Peter and others: Doorn Manifest. CIAM meeting on 29, 30 and 31 January, 1954. In: Smithson, Alison: Team 10 Primer. Boston: MIT Press, 1968

www.fondationlecorbusier.fr 


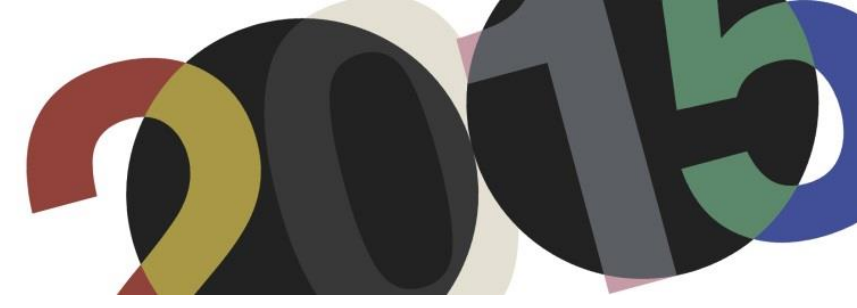

DOI: http://dx.doi.org/10.4995/LC2015.2015.918

\title{
Le Corbusier and The Americas: Affinities, Appropriations and Anthropophagy
}

\author{
D. Ortiz dos Santos
}

Swiss Federal Institute of Technology ETH Zurich

\begin{abstract}
The paper draws attention to Le Corbusier's first trip to the American continent, with a particular focus on his visions and expectations built before the corporeal dislocation to the New World in September 1929. This approach suggests not only an investigation of one single voyage, but of multiple ones, and above all intellectual ones. Voyages that cross biographies, discourses and practices - in a public and intimate scale - which are attentive to a history embodied in its social actors allowing a confrontation of materials that transcends the so called architectural field. It examines one critical moment of ruptures in Le Corbusier's production (1925-1930), and works across the architectural discussions at that time, placing Le Corbusier in a wider web of reciprocal influences and circulation of ideas in order to help to construct a sense of the fragmented, or even silenced, discourses within the artistic and architectural debates in the late twenties. Such an approach not only allows new interpretations but also the establishment of a new periodization on Le Corbusier's knowledge of-and interests in- the Americas, as well as the narratives produced.
\end{abstract}

Resumen: El artículo llama la atención sobre el primer viaje de Le Corbusier al continente americano, con un foco particular en las visiones del arquitecto y sus expectativas construidas antes del 'desplazamiento corpóreo' al nuevo mundo en septiembre de 1929. Desde esta perspectiva, proponemos investigar no sólo un viaje, sino múltiples viajes, y sobre todo los 'viajes mentales'. En otras palabras, examinamos viajes que cruzan biografías, discursos y prácticas, en una escala privada y también pública. Atentos a una historia encarnada en los actores sociales, nos permitimos una confrontación de documentos que extienden el campo de la arquitectura. Analizamos así un momento crítico y de rupturas en la producción de Le Corbusier (1925-1930), situándolo en una amplia red de sociabilidad y debates en los últimos años de la década de 1920, cuyas influencias, afinidades y circulación de ideas se entrelazan. Al trabajar con este abordaje, posibilitamos nuevas interpretaciones y también el establecimiento de una nueva periodización de Le Corbusier y su relación con las Américas.

Keywords: Le Corbusier; Travel; The Americas; Brazil; Blaise Cendrars; Lucien Romier.

Palabras clave: Le Corbusier; Viaje; Las Américas; Brasil; Blaise Cendrars; Lucien Romier.

\section{Introduction ${ }^{1}$}

"Mon cher Giedion, Rentré d'Amérique.(...) pendant tout mon voyage, où j'ai vécu intensément les problèmes d'urbanisme" Le Corbusier, 10 January $1930^{2}$

The choice of naming the most vivid chapter of Précisions (1930) as Prologue Américain, or even Le Corbusier's use of the term 'Amérique' to inform Giedion of his return from Brazil and Argentina seems to be no longer meaningless coincidence, but again critical evidence of Le Corbusier's visions and strategies regarding the new world. By accentuating nuances and complexities in Le Corbusier's networking between 1925-1930, this paper argues that Le Corbusier's construction of the notion of America not only seems to go far beyond the sphere of the United States, but also proves to be changeable and very much influenced by individuals with

\footnotetext{
${ }^{1}$ This paper is based on my doctoral studies in progress at the Institute for the History and Theory of Architecture at ETH Zurich, with support from the Swiss National Science Foundation

${ }^{2}$ Letter from Le Corbusier (LC) to Giedion (SG), 10 Janurary 1930, gta/ETH archives
} 
whom he shared admiration and affinity. I draw attention to Le Corbusier's first trip to the American continent, with a particular focus on his visions and expectations built before the corporeal dislocation to the New World. While the official voyage would originate in Bordeaux on the cruiser Massilia heading for Brazil, Uruguay and Argentina in September 1929, his 'real journey' began long before this transatlantic crossing. This approach suggests then not only an investigation of one voyage, but of multiple ones, and above all intellectual ones. Voyages that crosses biographies, discourses and practices - in a public and intimate scale - that which is attentive to a history embodied in its social actors allowing for a confrontation of materials that transcend the so called architectural field.

The twenties in particular proved to be years of intense circulation among various groups of artists, academics and politicians in France, in Europe and overseas, Brazil included. Le Corbusier's visions of the Americas seem to be deeply affected by these social and intellectual constellations, consequently contributing to reshape his interests and political agenda. Analysis that reassesses the role of some individuals within Le Corbusier's social network in the architect's own practices turn out to be no longer incidental but critical for the studies on Le Corbusier and the new world. This paper examines one critical moment of ruptures in Le Corbusier's production (1925-1930), and works across the architectural discussions at that time, placing Le Corbusier in a wider web of reciprocal influences and circulation of ideas and as so help to construct a sense of the fragmented, or even silenced, discourses within the artistic and architectural debates in the late twenties.

Instead of linking Le Corbusier's discourse on the Americas with major conceptual movements, such as Taylorism or Fordism -already exhaustively explored by a number of scholars and that essentially focused on the 'US sphere' ${ }^{3}$-, I would suggest a more blurred field in which affinities, affections and appropriations, which are fluid and embrace other geographies too, would play a capital role in Le Corbusier's practices and discourse at this time. Such an approach not only allows new interpretations but also the establishment of a new periodization on Le Corbusier's knowledge of- and interests in- the Americas, as well as the narratives produced. As I will show, the second half of the twenties is particularly marked by the introduction of the Southern part of the American continent into Le Corbusier's discourse on America.

\section{Strategies redesigned through America: Impacts of New Alliances on Le Corbusier's Discourse}

"Mon cher Giedion, Nous, les représentants de toute l'Europe technique, nous voyons clair. Nous affirmons, nous réclamons, nous demandons, au nom de l'architecture. Nos voix ont le poids du monde professionnel, etc.(...) Je pourrais d'autre part, vous donner les noms de hautes personnalités enthousiastes, telles que Mal Lyautey, Voisin, Cendrars, Romier etc etc. et les articles déjà parus. Et qu'ainsi nous recommencions, cette foisci d'ensemble, sur un document bien établi, complet, sur lequel s'appuieraient les associations. ” Le Corbusier, 30 December $1928^{4}$

\footnotetext{
${ }^{3}$ The most significant contributions on this issue have been made by McLeod, Passanti, Bacon, and recently Leitner, resulted from their doctoral studies. The seminar and publication on Americanism and Modernity organized by Damisch and Cohen also brings togheter luminous esssays on Le Corbusier's visions of the Americas, focusing on the US sphere. See: McLeod, M. Urbanism and Utopia: Le Corbusier from regional syndicalism to Vichy; Passanti, F. "Des gratte-ciel pour la "ville contemporaine"”, pp.54-65; Bacon, M.: Le Corbusier in America. Travels in the Land of the Timid; Leitner, P. Entre Paris et New York. Dynamiques d'échange pour transformer la métropole 1858-1926

${ }^{4}$ Letter from LC to SG, 30 December 1928, gta/ETH archives
} 
1920-1928: Those would be years of a great amount of 'militant statements' produced by Le Corbusier, in which the use of plural first person pronouns is vastly explored: "Nous affirmons, nous réclamons, nous demandons", he claims in the "name of architecture". His publications and conferences from the twenties have indeed been subject of uncountable studies by scholars. ${ }^{5}$ There is, however, another fragment of Le Corbusier's words of 1928 that appears to be ignored so far. In particular, the list of names of "highly enthusiastic personalities", to borrow Le Corbusier's terms, "representatives of all of technical Europe", who together with Le Corbusier as he describes, also see the paths to be taken "bright and clear". In times of the formation of a group meeting to discuss further directions of the modern architecture, Le Corbusier does not hesitate to relate names of notable figures to Gideon that could support and legitimate the meeting. Voisin, Lyautey, Romier, Cendrars: these are names that despite having been apparently chosen at random by Le Corbusier, deserve some attention.

What could an automobile entrepreneur, a high-ranking military Marshal, an editor of French Newspaper Le Figaro, and a poet have in common in order to have their names pointed out by Le Corbusier? ${ }^{6}$ Why invite such names to join the debates and not others already established within the architectural field? Although these questions may seem straightforward at first glance, answering them poses considerable analysis and demands. As I will shortly show in the following, these four names produced extraordinary work at this time, therefore critically affecting their own 'fields of action'. Further, their practices would echo -in different degrees- complex operations of the French discourse towards the geo-political and economic changes in the first quarter of the twentieth century, relations with the overseas in particular. Le Corbusier's visions of the new world appear to be thus more complex and blurred than those that have been discussed so far.

My intention is not to develop a linear interpretation by proposing such interrogations, but rather to accentuate nuances and complexities in Le Corbusier's networking in the late twenties and how the construction of the notion of the new world is meandering and heterogeneous, transcending the North American discourse too, which has so far prevailed in historiography. ${ }^{7}$

\footnotetext{
${ }^{5}$ Lucan, Benton, Von Moos, Passanti, Cohen among others, whose critical approach to Le Corbusier is based on the architects' files for at least three decades, have strongly contributed to unfold Le Corbusier's discourse, and are therefore names to single out. Amongst their most relevant work: Lucan, J. (Ed.): Le Corbusier: Une Encyclopédie; Benton. T.: Le Corbusier conférencier; von Moos, S.: Le Corbusier: Elements of a synthesis; von Moos, S.: "Urbanism and Transcultural exchanges, 1910-1935: A Survey”, pp. 219-232; von Moos, S.: Le Corbusier und die Industrie, 1920-1925; Von Moos, S., Rüegg, A. (Ed.): Le Corbusier Before Le Corbusier; Passanti, F.: "Des gratte-ciel pour la 'ville contemporaine"”, pp.54-65; Passanti, F.: "Le Corbusier et le gratte-ciel, aux origines du Plan Voisin”, pp.171-190; Passanti, F.: "The Vernacular, Modernism and Le Corbusier", pp.438-451; Cohen, J-L.: Le Corbusier et la mystique de l'URSS. Théories et projets pour Moscou 1928-1936; Cohen, J-L.: Le Corbusier : La planète comme chantier, Paris : Textuel, 2005; Cohen, J-L. (Ed.): Le Corbusier: An Atlas of Modern Landscapes

${ }^{6}$ Pilot and businessman Gabriel Voisin (1880-1973), whose work and ideas had a great impact on Le Corbusier's discourse in early twenties; M ${ }^{\mathrm{al}}$ Lyautey (1854-1934), a former minister of War in France but whose intervention in Morocco and interests in urbanism were familiar to Le Corbusier; Lucien Romier (1885-1944), medieval historian trained at Ecole Nationale de Chartres who became an influential voice on socio-economic affairs policy making in France towards the booming US in the twenties; and poet Blaise Cendrars (1887-1961), a known figure in the French literary world, already very close to artists familiar to Le Corbusier as Sonia Delaunay and Fernand Léger

${ }^{7}$ In Damisch and Cohen's preface to the conference and, later, the book Américanisme et Modernité, the notion of modernity cannot be detached from the idea of the 'New World'. Both call attention to the fact that such processes, very much evident in the twentieth century, are a part of a long historical product wherein varying symbolic and complex features are involved. Despite the attention given to the case of the United States of America, some of their arguments and historical approach may be extended to the context of the whole American Continent. In fact, scholars such as Margareth da Silva Pereira have already called attention to this approach. She insists that the concept of Americanism shall not exclusively encompass the 'North American Sphere' - as presented by Damisch and Cohen. The section dedicated to examine Le Corbusier's and the
} 
By dedicating a few words to these figures mentioned in Le Corbusier's correspondence, I attempt to challenge Le Corbusier's view of the Americas before 1930, and claim that his discourse is much more deeply affected by individuals from his social network than by the commonplace discourse produced in the US and France. I am to demonstrate that the inclusion of Cendrars into such a list sent to Giedion isn't a mere coincidence, but rather a critical evidence of Le Corbusier's visions and strategies towards the new world.

\section{American Utopia associated with the Prosperous US Industry Model: Le Corbusier's encounter with Gabriel Voisin}

Although Reyner Banham in his review on Stanislaus von Moos' publication Avant Garde und Industrie credits the Swiss historian for revealing the association of Le Corbusier to his "notorious patron of the mid-1920s, the ebullient and eccentric industrialist Gabriel Voisin (1880-1973)", 8 such a connection has never been obscured by Le Corbusier himself, precisely after the exhibition of Le Corbusier's urban plan for Paris in 1925 at the exposition internationale des Arts Décoratifs et Industriels modernes, entitled with the industrialist's name. Not to mention the use of car Voisin $14 \mathrm{CV}$ - also owned by Le Corbusier himself, probably received as part of his retribution - to be displayed together with the architect's housing projects in several photos, later published in magazines and Le Corbusier's own books at this same decade. Both cases, including the construction of the Esprit Nouveau Pavilion in 1925 with the sponsorship of Voisin and other industrialist, Henry Frugès, have indeed been subject of studies by Francesco Passanti and his student M. Shaw yet simultaneously Von Moos discloses the peculiar relationship between Voisin and Le Corbusier. ${ }^{9}$ What Von Moos enlightens however in a consistent argument is that the Kreuzbestäubungen (cross-pollination) between avant-garde and industry in the twenties provokes non-homogeneous yet complex outcomes. By focusing on the case of Le Corbusier and Voisin, Von Moos reveals negotiations but interests too, financially and ideologically. Accordingly, he brings light to both actors' shared poetic understanding in arts and architecture -pointing out Voisin's early architectural studies at the Beaux-Arts school in Lyon- as leitmotifs to explore possible geneses of this short but 'fortuitous' encounter. Mostly through Le Corbusier's work from the twenties -as an architect, writer and chef editor of L'Esprit Nouveau - the interest into Voisin's ventures becomes rather evident. Les maisons 'Voisin' published at the second edition of L'Esprit Nouveau (1920) would mark the beginning of a series of celebrations of the industrialist's affairs. Signed by Le Corbusier-Saugnier, the paper applauds the original solution for building a serial production of houses, in accordance with the 'aesthetics of construction" ('l'esthétique de la construction') of that time since the "art of building" is strongly rooted in science. ${ }^{10}$

\footnotetext{
'Americas', which received contributions of Francesco Passanti, Mardges Bacon and Mary McLeod, are entirely focused on the relation between the architect and the U.S.A.

${ }^{8}$ Banham, R.: Avant Garde und Industrie by Stanislaus von Moos, pp. 277

${ }^{9}$ In the early and mid-1980s scholarship began to problematize the issue of Le Corbusier's attention to the affects and effects of the North-American industrialist production and ideology. Almost parallel to Von Moos' work, Francesco Passanti explores Le Corbusier's plan Voisin and the echoes produced by Taylorism and Fordism in the US onto the architects' projects from the twenties. In addition, Mary McLeod investigates Le Corbusier's engagement with politicians and businessmen, as I will further discuss. As shown by Von Moos, and later investigated in-depth by Marybeth Shaw, Voisin would play a significant role for Le Corbusier's concretization of his ideas, not only sponsoring already mentioned the development of the urban plan for Paris and its exhibition, but also the Esprit Nouveau Pavilion, both from 1925

${ }^{10}$ Le Corbusier-Saugnier: "Les Maisons Voisins". In l'Esprit Nouveau, November 1920, vol.2 p.211. Apud Von Moos, S.: L'Esprit Nouveau. Le Corbusier und die Industrie, 1920-1925, p.169
} 
Despite the presence of Le Corbusier's eulogy to Voisin inferring the use of dissimilar written and visual media, and his prodigious enthusiastic letter encouraging Giedion to contact the industrialist for future CIAM debates; in the private sphere, the exchange between Voisin and Le Corbusier seems to have taken place only decades later. $^{11}$

In fact, Gabriel Voisin's overpowering articulation in building more than ten thousand bomber airplanes for the French Army during the Great War, after 1918 having transformed his factory together with his brother into a prefabricated housing company, ran as an automobile company not long thereafter; allowed him to gain not only an extraordinary notoriety in the business and industrial world but also uncountable sympathizers among the French political and intellectual bourgeois circles, Le Corbusier included. In an almost anecdotic episode, Von Moos highlights the social status the Voisin luxurious car would be associated with in the early twenties and how Le Corbusier appreciated not only having one for private matters, but also using it in his architectural discourse to be addressed to the French bourgeois elite. ${ }^{12}$

Eager to establish his profession as an architect in postwar France and as an urban designer too, Le Corbusier would see in Voisin a promising name in which was associated with three critical matters to the architect at this time: (1) an aesthetic discourse that embraced the engineering technologies, (2) a successful undertaking in the business world translating some of the US booming practices of industry into the French terrain, which (3) enabled concrete results entrenched in the French political agenda. Giedion and Le Corbusier's invitation sent to such successful leader in France to sponsor the upcoming conferences in order to discuss the place of modern architecture and urbanism in contemporary society no longer appears to be mere speculation, but rather a solid plan for a broadened understanding of the role of industrial leaders in the construction of a new socio-political agenda.

"Je pense que nous ne devons surtout jamais devenir un "grand Congrès". Nous devons rester "avantgarde", fermé, restreint, aigü, etc ne pas hésiter à traiter, s'il le faut (et c'est fatal) les mêmes questions que d'autres grands congrès. Mais nous devons donner notre point de vue avant-garde, pur, clair, "idéaliste" même. S'il le faut. Nous ne sommes pas la masse, mais le projecteur. " Le Corbusier ${ }^{13}$

In fact, Voisin is not the unique name in the list of figures kept in mind by the organizers of the first meeting. In a letter of 25 July 1928 from Giedion to another automobile industrialist, this time Peugeot director Philipp Girardet, the yet to be secretary of CIAM makes clear that the aims and reasons for the urgency in organizing such a conference, and how industry should be a crucial partner. The goal [of CIAM] was "to replace architecture in its veritable axe, which is economic and sociological". Architecture, Giedion continues, "can be only healed if it works together with industry", whereas "industry needs new architects who know how to codify the secret wishes of our times". He concludes asserting that a "true fruitful development can only take place when architecture and industry commonly collaborate with each other". ${ }^{14}$ It is tempting to make a parallel here with the case of Voisin too; as such discourse on the technological and industrial world seems to be altogether orchestrated by Giedion and Le Corbusier.

\footnotetext{
${ }^{11}$ In Le Corbusier's files, later correspondence of the 1950s revealing words of affection and closeness proved that Le Corbusier and Voisin maintained a mutual admiritation, respect and affinity over many years

${ }^{12}$ Von Moos, S.: "Dans l'antichambre du 'Machine age'”. In Von Moos, S. (Ed.): L'Esprit Nouveau. Le Corbusier und die Industrie, 1920-1925, pp.12-25

${ }^{13}$ Letter from LC to SG, 8 Mai 1929. CIAM Archives, gta/ETH

${ }^{14}$ Letter from SG to Girardet, 25 July 1928, gta/ETH archives
} 
In contrast to the silence of Girardet's name in the final printed version list of Membres du Comité de Patronage of the La Sarraz meeting, other notable French industrialists familiar to Le Corbusier are yet indicated: Henry Frugès, Jean Michelin, and ultimately Gabriel Voisin.

Already in a letter from Gabriel Guevrékian to Karl Moser of 9 June 1928, Voisin's name appears next to an intellectually broad but selective group of names of the French elite who was about to support the meeting, ${ }^{15}$ which include art critics and hommes de lettres as the president of Salon d'Automne Frantz Jourdain; art historian Elie-Faure, who regularly contributed to L'Esprit Nouveau; businessmen such as Le Corbusier's sponsor for dwelling houses in Bordeaux Henry Frugès, Jean Michelin and the head of Crédit du Nord Banking network Administrative Counsel Georges Delebart; engineers as Arthur Fontaine, the president of the International Labour Office; and journalists on politics as Lucien Romier, to whom I will dedicate a few words in a later section.

Although both Giedion and Le Corbusier seem to agree in the capital role of successful industrial production for the legitimation and the establishment of the "new architecture", the construction of their discourses would not share the same references, documents and even methods. At this moment, Giedion's arguments are supported by a critical-historiographic narrative, which claims for the nineteenth-century industrial formation as the genesis of the "new" architecture. For Giedion, such a shift from hand work to industrial production, which affected the contemporary society and architecture too, would take place mainly in European fields and not overseas. Giedion's book Bauen in Frankreich, Bauen in Eisen, Bauen in Eisenbeton, published in $1928,{ }^{16}$ would precisely focus on the French's case ${ }^{17}$ whose introductory words advocate Saint-Simon's concepts of industry and its impacts on urban centers. ${ }^{18}$ As Sokratis Georgiadis indicates, Giedion would devote privileged attention to the images, traveling to Paris in late 1927 with a central purpose of collecting photographic material in the public archives, as well as from the architects' bureau. ${ }^{19}$

In those same years too, Le Corbusier often resorted to particular moments of 'the past' to affirm and support his arguments for modern architecture. Exhaustively he employs graphic and iconographic documentation as part of his discursive strategy. In between texts, Le Corbusier operates a powerful visual appeal: uncountable images of floor plants, cross-sections, isometric drawings and his own sketches of buildings such as the Acropolis in Athens, and Pantheon or the Cathedral of Notre-Dame in Paris; late nineteenth- and early twentieth-century photography of cities or construction sites; and even world city population tables and statistical graphics too. It is a carefully selected iconographic repertoire whose analogy between fragments of the columns of the Parthenon and airplanes would seem not to make sense as a plausibly argument, as demonstrated by Tim Benton. ${ }^{20}$

\footnotetext{
${ }^{15}$ Despite the confirmation of Voisin in supporting the La Sarraz event, absences of Voisin's name in Giedion's archives after 1929 are strong evidences that such encounter between Voisin and the CIAM group haven't progressed. Whether the declination was coming from Voisin or not, so far the surviving material cannot give further acknowledgment, but provide interrogation

16 Originally, the book is a collection of Giedion's articles published in German journal Der Cicerone. For further comprehensive analysis of the production of the book and its context, see Sokratis Georgiadis' introduction of the English vesion of Giedion's Bauen in Frankreich, pp.1-53

${ }^{17}$ In his critical analisys of Bauen in Frankreich, Georgiadis argues that despite choosing France as the field of Giedion's investigation, his "theory had profited mainly from the debate in Germany, which had been going on among architects for eight decades". S. Georgiadis, Introduction of Building in France, Building in Iron, Building in Ferroconcrete by Giedion, p.42

${ }^{18}$ Giedion, S.: Building in France, Building in Iron, Building in Ferroconcrete, pp. 88-89

${ }^{19}$ Ibid, p.45

${ }^{20}$ See: Benton, T.: Le Corbusier conférencier
} 
Unlike Giedion, Le Corbusier, already in his first manifestos on architecture, the most widely known being Vers une Architecture (1923) and Urbanisme (1924), builds a rhetoric which argues that the "new" architecture would have not only its genesis in Europe but also in the American territory. Images and Tables revealing 19th- and 20th industrial production and engineering building of the new continent ${ }^{21}$ place a privileged position in his narratives to rethink architecture in within its present time.

Significantly more interesting to the present proposal is however the modes in which Le Corbusier links past, present and future with America. And, perhaps most critical, is the tenuous but significant narrative that changes between 1928 and 1930, in which the discourse on America is enlarged and sometimes conflicting as well. If the iconographic 'America' of Le Corbusier until 1928 was to a certain extent pending between an eulogy of machinery technologies developed in the precedent century, and an hysteria vis-à-vis the immediate 'cruel' effects of such technologies on people's life (sometimes even announcing a fatalistic attitude towards the future); at the end of the twenties, the European repertoire, which had been so far the main well-founded reference, was gradually giving place to a new inventory of the overseas. America, yet images and texts altogether, turned into a hope and an indication for the future of the inevitable way of living in modern western society, i.e. the city.

In other words, it was a gradual shift from a pure visual appeal of the recent products developed by the advances of science and the engineering of the new world through the 19th and 20th century, to a more poetic, historicaland topographically expanded plastic but also written discourse rooted in new personal experiences and encounters with the new continent. Such encounters, which acted as a potential for Le Corbusier to reconsider a whole new theory on urbanism, began before the transatlantic trip of 1929. But what has been apparently silenced by Le Corbusier is exactly the processes in which such a shift takes place, and how inconsistent and contradictory his practices and discourses became at times. If, on one hand, he criticizes the 'old' and 'dying' Europe in his books, on the other hand, he would stretch alliances with individuals who are precisely claiming for an European 'rebirth', precisely postwar France, on cultural-, economic-, and political levels, as counterpoint to the hegemony coming from the overseas. The cases of Le Corbusier's encounters with French politician Lucien Romier and Swiss-French poet Blaise Cendrars appear to be then exemplary for extending the architect's fluctuating positions and moves in times of an attempt to define and to legitimize modern architecture.

\section{America versus Europe, or France 'on a par with its rivals': Le Corbusier's Ventures between National Politics and International Architecture}

If, on the one hand, there has been certain consensus among scholarship in the necessity to bring light to the relationship between Le Corbusier and industrialist names such as Henry Frugès or even Gabriel Voisin, in order to draw attention to the architect's incorporations of ideas and practices of US industrial utopias as "key to social renewal", ${ }^{22}$ the same cannot be stated with respect to actors from other fields of action, and Marshal Lyautey and journalist Lucien Romier seem to be good examples. For Lyautey, there are only a few texts that establish a link. In this sense, the work of Zeynep Çelik and Jean-Pierre Frey introduces a coherent narrative in exploring both Lyautey and Le Corbusier's relations to North Africa through Said's approach on Orientalism. But what about Lyautey's practices as an urbanist? Why would Le Corbusier correlate him to Giedion on the subject of CIAM?

\footnotetext{
${ }^{21}$ Firstly naming only by country as USA, Canada, Panama in the first volume of the Collection de L'Esprit Nouveau from 1923, but soon afterwards by cities too, like Chicago and New York appearing in Urbanisme in 1924, or Buenos Aires and Rio de Janeiro in Précisions, the last volume of the Collection de L'Esprit Nouveau (EN)

${ }^{22}$ I borrow these words from McLeod who assessed Le Corbusier's understanding of Taylorism. See: McLeod, M. Urbanism and Utopia: Le Corbusier from regional syndicalism to Vichy, p.40
} 
While struggling in France amongst French politicians and the intellectual elite in order to operate within the governmental apparatus and to build, Le Corbusier would claim for international debates and contacts to be held in parallel in order to establish and to legitimize a basis for the modern architecture, in France and abroad. In this sense, the architect seems to be very much aware of the benefits of intersecting the numerous fields and webs of people where he circulates.

“Depuis mon départ de Corseaux, l'affaire PdN suit une marche hors de sentiers de la colère. [...] Mais moi, j'ai tenté de faire autre chose, en jouant sur terrain sûr. Et il se peut que cela n'aille pas mal. Il se peut que maréchal Lyautey (fort épris de mes initiatives) accepte d'être en tête du mouvement." Le Corbusier ${ }^{23}$

After the refusal of his project for the Palais des Nations (PdN) in Geneva, Le Corbusier indicates to his mother that he would hence "play on safe ground", suggesting thus the prominent exchange with seventy-year old Hubert Lyautey, yet Marshal and Commissioner-General of the International Colonial Exhibition that would take place in Paris 1931. Hurbert Lyautey (1854-1934), who being a central name in the first quarter of the 20th century decision making on future developments of French colonies in North Africa, has certainly not escaped the attention of Le Corbusier. Despite being drafted during the trip to Morocco in 1931 together with Pierre Jeanneret and Fernand Léger, Le Corbusier's sketchbook B7 serves as good evidence here. With divagating notes and open analysis on Lyautey's operations in this territory under the French control, Le Corbusier calls up for a "Destin de l'Occident!" (Destiny of the West!) ${ }^{24}$ to create an argument for an inevitable approach towards modernity. ${ }^{25}$

"The destiny of the West", he insists, that is to "act, compose, [and to] create modern life". ${ }^{26}$ What is interesting to us here appears to be the just following sentence, which not only indicates Le Corbusier's awareness of different ways of "creating modern life" but the refusal of models undertook by the Germans and Americans of the United States. ${ }^{27}$ As Paul Rabinow argues, "there was a chance, Lyautey and others believed" -here we could insert Le Corbusier as one of those names- "that through the creation of new social techniques, France could successfully enter the modern world on a par with its rivals". ${ }^{28}$ Le Corbusier's attention to Lyautey has been called while the latter served as Governor-general of Morocco (1912-1925), already addressed in previous paragraphs, but most particularly as a participant of Le Redressement Français, a movement strengthened in late twenties, whose aims were to bring together the industrial and private business elite in order to actively take the leadership in the social-political agenda of the country. ${ }^{29}$ Founded in 1925 by the future head of the French Oil

\footnotetext{
${ }^{23}$ Letter from LC to his mother. January 20 1928, FLC

${ }^{24}$ Le Corbusier carnet B7 (FLC Archives). Apud Franclieu, F.: Le Corbusier Sketchbooks, pp. 436-440

${ }^{25}$ According to De Franclieu and several other scholars, Le Corbusier's notes were as useful memory aid for texts published late 1931 and 1932 in monthly Magazine Plans, whose chief editor was Philippe Lamour. See: Franclieu, F.: Le Corbusier Sketchbooks

${ }^{26}$ Ibid, pp. 437-438

${ }^{27}$ It is indeed very ambiguous Le Corbusier's use of the term 'Americans' in his private and published texts until mid-thirties. Thus a direct link between the term and an assumed meaning calls for caution when looking over his discourse. For this specific case, in which Le Corbusier compares France's socio-, politic- and economic situation in dealing with the global crisis after 1929 with other States that had experience a booming economy too, I assume that he addressed to the cases of Germany and the US only. In fact, Le Corbusier's article "Spectacle de la vie moderne" published in Plans in March 1932 (FLC) embodies precisely these issues and comparisons, however, instead of 'America' Le Corbusier clearly writes 'U.S.A.'

${ }^{28}$ Rabinow, P.: French Modern. Norms and Forms of the Social Environment, p.106

${ }^{29}$ In his studies on Ernest Mercier, Richard F. Kuisel articulates the role of the Redressement in the decisions of French politics in 1928. One example was the money invested by Mercier's organization to fund the election of several French politicians. Kuisel continues, "the Redressement also assumed the task of studying all social and economic measures
} 
Company Ernest Mercier (1878-1955), a name that was included in Le Corbusier's list of personalities he would be 'in contact with' when writing to his mother. ${ }^{30}$

"Au Redressement Français le patron Mercier, est venu exprès pour me dire tout ce qu'il pensait de mon rapport: " Je désirais voir l'homme qui a fait ce rapport". Je déjeunerai ces jours-ci avec le maréchal Lyautey." Le Corbusier ${ }^{31}$

Despite the absence of any concrete action on his part within the CIAM, Lyautey, as representative of the Redressement, is indeed mentioned in one of the very first protocols built just after the meeting of the CIAM delegates that took place in Basel in February of 1929. In between uncountable documents produced after that meeting, this revealing protocol brings light to the heated debates of the encounter in Basel with accuracy, issues which were mainly focused on the content and the format of the second CIAM congress to be held in Frankfurt. For the third day of the program - clearly stated as the most conflictual one amongst the delegates, the question of property and finance is defined to be addressed, and amongst proposed invited speakers, Lyautey. ${ }^{32}$ But more significant than an indication of the appearance of the Marshal's name in the CIAM files, is perhaps arguably the regularity of other names from the Redressement in the documents produced in late twenties by this group, which was in the process of institutionalizing a new agenda for Architecture. ${ }^{33}$

One intriguing protagonist, with whom Le Corbusier would have strengthened his contacts and exchanges with in 1928 and 1929, and who, via the architect's influence, would end up becoming an official member of CIAM's comité de Patronage, is Lucien Romier (1885-1944). The historian and former editor of Le Figaro, having an active voice at the Redressement, insisted that Mercier's organization "had long maintained that housing was the

considered by the legislature in order to advise both its members and the lawmakers. It maintained close contact with a small number of party leaders who sympathized with its views". Kuiser, F.: Ernest Mercier: French Technocrat, Berkeley - Los Angeles: University of California Press, p.85. For further reading on Le Corbusier's engagement with Redressement see: M. McLeod, M.: “Architecture or Revolution: Taylorism, Technocracy, and Social Change”, pp.132-147

${ }^{30}$ Le Redressement also counted on the support of more familiar figures to Le Corbusier such as engineer Louis Loucheur (1872-1931), who being Minister of Labor and Social Welfare encouraged the construction of low-cost housing (Habitations à bon marché). The housing law of 1928 would be a theme of great interest for Le Corbusier, who would have not only published a few texts on this issue in the late twenties, but also aroused debates and attention to his peers in France and abroad. Giedion would be one of Le Corbusier's peers, who was interested in writing on the issue of the Loi Loucheur. The secretary of CIAM would address this theme in the article Weissenhofsiedlung und Paris published in the Stuttgart Journal Werkbund Gedanken. Für Volksbildung, Kunsthandwerk und Industrie, on 20 October 1928. Fragments of the article can be found in an un-published text dated from 18 September 1928, which is addressed to the director of the Journal Lumière under the title La Loi Loucheur et une exposition d'habitation (gta/ETH Archives). I am grateful for Andreas Kapakci for calling my attention of these documents

31 Letter from LC to his mother, January 20, 1928, FLC. Apud Baudouï, R., and Dercelles. A.: Le Corbusier. Correspondance. Lettres à la famille 1926-1946, p. 106

${ }^{32}$ Lyautey is suggested by Le Corbusier to speak about the documentation and stance of the Redressement on recovery of interest and capital gains, and land consolidation. Tim Benton's analysis of Le Corbusier, social housing, Loi Loucheur and the architect's attempts to participate in numerous circles of the French elite involved in this issue shall be singled out here. Benton draws attention to the echoes that Lyautey's terms and decrees in Morocco produced in Le Corbusier's discourse on housing and the divisions of land. In this sense, Benton may be referring to Le Corbusier's talk on the third meeting of CIAM, in which precisely the architect links the success of a modern urbanisation to the necessity of the land repartition. See: Le Corbusier : "Le parcellement du sol des villes", pp.48-57; Benton, T. "La réponse de Le Corbusier à la loi Loucheur", pp. 238-239

${ }^{33}$ This protocol built after the meeting in Basel February 1929, where the name of Lyautey is listed, indeed mentioned other two protagonists from the Redressement: Lucien Romier and the director of Comite des Forges, namely the founder of Redressement Ernst Mercier. Source gta/ETH Archives 
principal problem of the working class in Paris". ${ }^{34}$ Mostly known as the Minister of Petain during WWII, Romier would be an active writer in the late twenties on the question of urban agglomeration and economy in several influential newspapers in France, ${ }^{35}$ and would be present in numerous political organizations and circles such as the National Committee of French Foreign Trade Advisors. ${ }^{36}$

Although apparently discreet amongst the several names and issues raised by Le Corbusier and Giedion between 1928 and 1929, the one concerning Romier is consistently present in their correspondence. Le Corbusier appears to be convinced of bringing the speaker of the Redressement into the CIAM meetings, and the strongest evidence is found in the numerous protocols as well, minutes and reports prepared for the second CIAM congress to be held in September 1929. Later versions of the program shows that it's no longer Lyautey but Romier altogether with Martin Wagner from Berlin who would hold a session on the third day of the congress in Frankfurt. The session, which persisted to focus on the remembrement des sols, ${ }^{37}$ would later disappear from the final version of the program, and the last day of the conference ended up to be dedicated to discussion.

Mary McLeod was pioneer in bringing light to Le Corbusier's professional contacts with Romier. That the speaker of Redressement shall be invited to become a patron of CIAM is given in Le Corbusier's mediation. Nonetheless, the architect's private files show not only that a great admiration and empathy were built between Le Corbusier and Romier, but also an exchange that involved issues of private matters too. His agenda and correspondence with family reveal indeed a relationship, which went beyond professional contacts, such as Romier's encouragement for Le Corbusier to gain French citizenship. In a letter to his mother from November 1928, the architect indicates that once "le cas nationalité (the nationality issue) is solved" - here Le Corbusier's words are clearly associated with concrete plans to marry his French girlfriend Yvonne - the chances for commissioned works in France could advance. ${ }^{38}$

“J'en arrive maintenant à devoir prendre aussi une nouvelle grande décision préálable. J'ai bien réfléchi, depuis des années. Voici: Je vis dans un pays où j'apporte mes idées mais dont aussi je tire toute ma sève. Je suis consideré comme étant à la tête de l'architecture française. Il y a dans le fond équivoque: vous êtes suisse, me dit-on. (...) J'ai causé de cela à Romier. Il estime que je dois me rattacher à la France. Je n'ai jamais eu le sens des frontières. (...) pour réaliser mes intentions avec Yvonne, je veux d'abord liquider le cas nationalité. Dis-moi ce que tu en penses. " Le Corbusier ${ }^{39}$

\footnotetext{
${ }^{34}$ Kuiser, F.: Ernest Mercier: French Technocrat, p. 86

${ }^{35}$ Besides writing for Le Figaro from 1925 until 1927, Romier's texts on France, the US economy would also appear in the monthly magazine Revue des deux mondes between 1927 and 1930. See digital archives of Revue des deux mondes: <http://www.revuedesdeuxmondes.fr/archive/search.php?section\%5B\%5D=ARTICLE\&author=LUCIEN+ROMIER>

${ }^{36}$ In Un milieu libéral et européen, Laurence Badel indicates that Romier received the position of librarian archivist of the the National Committee of French Foreign Trade Advisors. See digital acces in: < http://books.openedition.org/igpde/2217?lang=en>

37 The heated discussions on the remembrement des sols [land management and repartition], the lotissement urbain [town site] and its rationalization, was addressed and recorded in the CIAM delegates meeting of 1929, and was planned to occur in the third day of the CIAM congress. In one of the latest versions of the program, the topics to be examined have been defined with more precision in the draft program of CIAM II entitled Zweiter Internationaler Kongress fuer neues Bauen. Soziale Forderung und Technische Verwirklichung der Kleinwohnung, Meeting of the delegates in Basel 2 February 1929. gta/ETH archives

${ }^{38}$ LC married French model Yvonne Gallis in Paris on the 18th December 1930

39 Letter from LC to his mother, November 28, 1928, FLC. Apud Baudouï, R., and Dercelles. A.: Le Corbusier. Correspondance. Lettres à la famille 1926-1946, p. 194
} 
McLeod's work on Le Corbusier and the Redressement not only draw attention to the fact that Le Corbusier "was enlisted to participate on an urban study committee" headed by Romier, but also argued that the architect's two publications in the group's Bulletin in 1928 were "among Le Corbusier's most explicit espousals of technocratic doctrine", ${ }^{40}$ a clear example of attempt "to influence policy decision while maintaining [a certain] independence from politics". ${ }^{41}$ The scholar built a convincing argument for Le Corbusier's incorporation of US models of industrial productivity in his discourse, such as Taylorism, proving how significant had been the role of major voices of the Redressement for strengthening the construction of texts produced by Le Corbusier in late twenties. Furthermore, McLeod points to a shift in Le Corbusier's understanding of his social role after experiencing failures of such US models of industrial productivity at work, ${ }^{42}$ holding that Le Corbusier's critical look and judgment of these models would only take place from the thirties onwards, at a time when a general refusal of US apparatus and ideas is established amongst the several circles of French society. ${ }^{43}$

If, on one hand Le Corbusier's publications by 1930 are clear evidences of a rupture and hesitation when considering US ideals, a doubtless contribution credited to the investigation of McLeod; on the other hand equally significant here would be to recognize that Le Corbusier's writings of the mid-twenties already indicated certain resistance to the discourses and practices produced in the US and exported worldwide. One of Le Corbusier's criticisms of this period has been precisely the impact of such industrial ideologies upon the urban form of big cities, such as the settlement of skyscrapers in New York. ${ }^{44}$

The book Une maison, un palais serves here as good example. The tone in which Le Corbusier structures the narrative to defend his project of the Palais des Nations, embraces a criticism of the chaotic modern cities, exemplified with the image of New York from above. Published in 1928, the fifth book of the series of L'Esprit Nouveau Collection does not escape from the rhetoric discourse built with images and texts, which also prevailed in Le Corbusier's earlier books from the same collection. ${ }^{45}$ The discourse on the US urban design is, however, slightly different from those others of that collection. Le Corbusier places the drawing entitled "urbanisme américain" in tandem with a picture taken by himself of Versailles entitled "l'escalier de Cent Marches", and argues that the American proposals and ideals are of immeasurable consequence by not having

\footnotetext{
${ }^{40}$ McLeod, M.: “Architecture or Revolution: Taylorism, Technocracy, and Social Change”, p.142

${ }^{41}$ Ibid, p. 144

${ }^{42}$ Ibid

${ }^{43}$ Several authors have pointed out certain homogenous- or even "oversimplified"- visions of the United States built by twentieth-century French society. For example, when examining poet Blaise Cendrars' first impressions of the US, Yvette Bozon-Scalzitti defines in a few but clear words such dominant views. See: Bozon-Scalzitti, Y. "L'Amérique Invisible de Cendrars", p. 150

${ }^{44}$ Although scholars as Passanti, Von Moos and more recently Leitner have shown not only the echoes and 'influences' produced by the debates and writings on the booming construction of skyscrapers in cities as Chicago and New York on Le Corbusier's practices before the great war and the early twenties, in particular when designing the Ville Contemporaine in 1922, but also analysis on the young Le Corbusier's approach and visions of the US; an approach to Le Corbusier's discourse of late twenties, precisely in a time when the architect began to disclose tensions, contradictions and certain suspicion concerning these 'American influences', hasn't been developed in depth. See: Passanti, F. "Des gratte-ciel pour la 'ville contemporaine'", pp.54-65; and Von Moos, S.: "L'Amérique". In Von Moos (Ed.) L'Esprit Nouveau. Le Corbusier et l'industrie 1920-1925, pp.190-193; Leitner, P.: "Le rêve américain de Charles-Édouard Jeanneret", report presented to the Le Corbusier foundation in 2009, which became a chapter of his doctoral dissertation on the exchanges and transformations in Paris and New York from mid-nineteenth century until the first quarter of the twentieth century.

${ }^{45}$ The books are, respectively: Vers une Architecture (1923), Urbanisme (1924), L'Art Décoratif d'Aujourd'hui (1925), and Almanach d'Architecture Moderne (1925)
} 
"the experience" and "not knowing here" [that is, Europe], and for looking at "Versailles without understanding it". 46

In fact, before the establishment of the economic crisis that was marked by the Wall Street crash in October 1929, a number of individuals familiar to Le Corbusier had been already critical to the booming US phenomena, whose writings seemed to have produced echoes on Le Corbusier's visions of the US. Amongst them, Lucien Romier rises as revealing figure in the last two years of 1920s to conjecture the complex universe in which Le Corbusier circulates and operates, and interesting to us, the multifaceted approach towards the New World.

While being a member of the executive committee of the movement Redressement Français, Romier writes between 1927 and 1929 a number of books whose research object announces a shift compared to the earlier work as scholar trained at the Ecole de Chartres to be a political historian of the XVIth century. According to his biographers, ${ }^{47}$ Romier travels to the USA, China, Japan and Central Europe; an experience that allowed the historian "to place great emphasis on the reserves of power [- economic, political and cultural] of the New World", in particular.

In fact, not only Romier's simplistic discourse on the US and the overseas, but also statements on the mores of the modern world seem to be aligned with that of Le Corbusier of the late twenties and early thirties. ${ }^{48}$ In Romier's books, it is not rare to come across flat declarations indicating the "open spirit" or the "promptness of decision making and action" within this "homme nouveau". It is indeed tempting to single out the strong correlation between the French historian and the Swiss architect's employment of particular sentences, terms and parlance in their narratives.

One noteworthy example of Romier's book to the present discussion would be Idées très simples pour les Français, which Le Corbusier possessed. ${ }^{49}$ Short and very concise in words, this publication from 1928 is associated with a conservative stance that, instead of sharing an intellectual approach, compiles a series of statements and instructions, whose aims are, following Romier's words, the finding of effective solutions to make once more France competitive with its rivals.

“(...) il faut que chaque citoyen prenne conscience du retard où nous vivons par rapport à certains peuples étrangers qui sont nos rivaux et nos concurrents, et de la direction à suivre pour regagner notre place, au premier rang. " Lucien Romier ${ }^{50}$

\footnotetext{
${ }^{46}$ Le Corbusier: Une maison, un palais, pp.16-17

${ }^{47}$ François, M.: Lucien Romier, pp.338-355

${ }^{48} \mathrm{La}$ Ville radieuse is perhaps the book whose visual and written discourse produced by Le Corbusier is the most aligned with that of Romier's ideas written in the first part of "Idées très simples pour les francçais", which is mostly devoted to attack the "malaises" of cities and their banlieues. For further analysis on Le Corbusier's discourse of mid-thirties, see McLeod's third chapter of the doctoral dissertation, in which she argued for Le Corbusier's involvement in neo-syndicalist movements, and publications that showed the architect's projects Ville Radieuse and Ferme Radieuse

${ }^{49}$ The two books found at Le Corbusier's private library are the already mentioned Idées très simples pour les Français, whose first edition was published by Le Redressement Français in 1928; and one of Romier's most popular writing L'Homme Nouveau. Esquisse des conséquences du Progrès, from 1929. The latter was dedicated by the author to Le Corbusier. Probable is, however, that Le Corbusier would be also familiar with numerous other writings of Romier, such as the book Qui sera le maître, France ou Amérique? from 1927, whose narrative -sometimes rather repetitive too - aspires to built a polemic through a comparative method between these two societies, in political-, economic- and cultural levels.

${ }^{50}$ Romier, L.: Idées très simples pour les Français, pp. 7-8
} 
Filled with assertive sentences, the speaker of the Redressement builds in three parts a rhetoric that entices readers to urge for political action after exposing one of the author's major concerns, i.e. the question of the masses and the lack of city planning in France.

"Je n'hésite pas à dire que l'aspect des banlieues françaises, quand on les compare à l'aspect des banlieues américaines ou allemandes, est une honte." Lucien Romier ${ }^{51}$

Fragments above are just a few examples of the tone that Romier develops his ideas, not only in books but also in the series of writings published between 1927 and $1929,{ }^{52}$ which not always seems to have had positive reception amongst his peers intellectuals and academics, such as Sigfried Giedion. ${ }^{53}$ Despite Romier's inclination for conservative statements, his examination on the US industrial, political and socio-economic models often pointed to a critical position, instead of insisting on automatic reproduction of these models in other countries. Among many other uniform statements, Romier maintained in 1927 that the US society could not be defined as a "historical nation", neither a "political corpus", but rather an "economic community in its origin", deeply affecting their notions of time and history.

The fact that the resolute hegemonic activities in the US were undermined as such also found acceptance on behalf of Le Corbuiser. Likewise Romier's words, Le Corbusier argues in Une maison, un palais for the lack of experience and historical dimension amongst les Américains. ${ }^{54}$ Le rêve américain, as conceived by the young Le Corbusier before and just after WWI, when building first notions and plans of urban space in particular, appears to be thus challenged after the second quarter of the twentieth century. ${ }^{55}$ It would be precisely in those years of exchanges with Romier, that Le Corbusier establishes a redefinition of his understanding of the New World. Furthermore, as I will show in the following, it would be notably with Cendrars, that Le Corbusier begins to seriously pay attention to 'other' Americas, this time the one located under the Equator.

\section{New Eyes in the New World: the Southern part of the Americas in Le Corbusier's Agenda}

“Cher Ami. Merci de votre Almanach E.N. que je trouve en rentrant d'Amérique (...) ATTENTION: je vous signale que le gouvernement Brésilien veut demander aux Chambres les crédits nécessaires pour la construction de la Capitale Fédérale prévue dans la Constitution (...) 'une ville d'un million d'âmes: PLANALTINA.” Blaise Cendrars ${ }^{56}$

\footnotetext{
${ }^{51}$ Ibid. pp.29

${ }^{52}$ Concerning Romier's analysis on the US, we shall mention a series of texts published in Revue des deux mondes: "Vues sur les États-Unis. I La civilisation de masse" (September 1927), "Vues sur les États-Unis. IL Les moeurs" (September 1927), "Sur la frontière de deux Amériques" (November 1927), "Sur l'impérialisme financier" (July 1928). Some of these texts would also appear in form of chapters of the polemic book "Qui sera le Maître: Europe ou Amérique?" from 1927

${ }^{53}$ In a letter to Karl Moser, Giedion is very critical to Romier and to his book Qui sera le maître: Europe ou Amérique? (1927), attesting that Romier was a "clever and reactionary" type and his book rather "primitive". Letter from Giedion to Moser on March 14 1929, gta/ETH archives. I would like to thank Daniel Weiss for calling my attention to this letter, and Filine Wagner for the precious help in understanding Giedion's hand writing

${ }^{54}$ Here clearly referred to the US residents only

${ }^{55}$ Not just shedding light upon names from Le Corbusier's circles, I have attempted to introduce an intersection between the architect's writings and those produced by individuals, whose affinity and affection had been built, particularly in late twenties, in order to point to an early shift in Le Corbusier's discourse in consideration of his preconceptions of the Americas.

${ }^{56}$ Post Card from Cendrars (BC) to LC, 13 July 1926, FLC
} 
Planaltina is "the city of one million souls" and a "virgin area still". The words from Blaise Cendrars (18871961) to Charles-Edouard Jeanneret that reveals the construction of a new city in Brazil are full of excitement and joy. Cendrars' words attempt to call Le Corbusier attention since the Planaltina project is not any ordinary city project to be built in the overseas. It is in this land, apparently far away from the architect's horizon, that the dream of a new Federal Capital, as "provided in the Constitution" Cendrars notes, is about to take place.

The project to transfer the capital to the interior of Brazil, initially proposed by Jose Bonifacio de Andrada e Silva in 1823, one year after the Brazilian Independence from Portugal, was recovered several times through the nineteenth and the early twentieth century. ${ }^{57}$ In the early 1920 s, the project for the new capital once again became part of the political agenda in Brazil. On 7 September 1922, the date of the 100th anniversary of Brazilian independence from Portugal, the first stone was placed, giving evidence that the dream of the future capital was about to become a reality. Soon this fact and news would not go unnoticed for Cendrars, whose eyes are keen to the American continent, gaining new strength and dimension in particular after 1923, the year when the poet meets the artistic and political circle from Brazil in Paris. The frisson of 'making Planaltina' is not only evoked in Cendrars' letters, but also in other documents, such as on the cover of the book novel L'OR from 1926, offered by the poet to the architect. To Jeanneret, Cendrars writes: "ce bouquin de L'Or en lui souhaitant d'engager en faisant Planaltina". ${ }^{58}$

"En effet, le rêve de "Planaltina" me trotte en tête", Le Corbusier declares to Paulo Prado, the Brazilian entrepreneur who sponsors Cendrars' trips to this country, and who would also promote Le Corbusier's trip in the second semester of $1929 .^{59}$

Written in July 1929, that is, three years after Cendrars' first mention of the Brazilian plans for a new capital, the letter leaves no doubt about Le Corbusier's great interest in new lands such as Brazil. Both architect and poet became in fact obsessive about the idea of making Planaltina. It was indeed an extraordinary chance to construct new ideas in the new world. Despite their engagements, the idea finally did not accomplish concrete results as expected. However, it unfolded new avenues and interests to Le Corbusier, whose impacts would be visible in his discourse right after the stay in Brazil.

Through the surviving letters written to Le Corbusier during the twenties, Cendrars' words are filled with excitement about Brazil and the new possibilities that it may provide to both poet and architect. ${ }^{60}$ On 26 July 1926, Cendrars once again encourages his friend to learn about the projects that are taking place on the other side of the Atlantic. As Margareth da Silva Pereira and Alexandre Eulalio have already shown, it would be however only in 1929, at a time when singular opportunities to build in America (north and south) present themselves to Le Corbusier, that the architect would begin to seriously consider the assistance of his friend, the poet. The first

\footnotetext{
${ }^{57}$ Petropole or Brasilia, these were the two possible suggestions by De Andrada e Silva to name the new capital. In 1920s the name of Planaltina is also suggested within the debates, but Brasilia ended up to be the definitive name, being executed during Juscelino Kubitschek's governance (1956-1961), more than a centenary after De Andrada's project. For a detailed reading on De Andradas' project of the Federal Capital read De Andrada e Silva, J. B.: O Patriarcha da Independência; Magalhães, M.: "Jose Bonifacio's Brasilia in Between Brazil: Multiple Territorial Scales of Planning Collective Life"

${ }^{58}$ The book is part of the Le Corbusier's files, FLC

${ }^{59}$ Letter from LC to Paulo Prado on 28 July 1929, FLC

${ }^{60}$ Although the relationship between Cendrars and Le Corbusier have not been yet an object of study, these two letters mentioned in the present chapter have been already published and mentioned by scholars who have studied the relationship between Le Corbusier and Brazilians. See, Da Silva Pereira, M.: Le Corbusier e o Brasil
} 
attempt of a trip to the Americas, in fact, considered passing through the cities of Rio de Janeiro, São Paulo, Montevideo, Buenos Aires, and Oklahoma city, too. ${ }^{61}$

“C'est décidé, j'irai à Buenos-Ayres (...) Alors, votre amitié me managerait-elle au pays du café? c-à-d pourriez-vous en écrire utilement là-bas, obtenir un engagement, + des conditions (je veux dire: la peine du dérangement!) (...) Pour Buenos-Ayres, on m'attend en août.septembre voyage: Pour mes aises, dites-moi donc quel paquebot, quelle ligne et en deux mots, comment on peut s'ébaudir sur la maison flottante. Voilà! Et merci de tout cour (un type de Oklahoma City USA, nous demande des plans de maisons de série et demande "pour quelle somme on pourrait négocier avec nous"? Dites-moi donc combien nous valons là-bas. Amitiés Ch.E. Jeanneret", 62

In response to Le Corbusier's requests, Cendrars promptly confirms he would contact São Paulo to organize conferences for Le Corbusier in São Paulo and Rio, so he could be introduced to the major of Rio de Janeiro, who has plans to reconstruct the city. ${ }^{63}$ In fact, as well as extending Le Corbusier's networking overseas, the relationship between these two protagonists goes far beyond shared social circles. Cendrars seems to have affected and transformed Le Corbusier's impressions of the Americas, and particularly of Brazil.

Through Cendrars' poems, novels, letters and most probably dinners and encounters in Paris - this would probably explain the reason why so few letters can be found - Cendrars introduced multiple Brazils to Le Corbusier, whose narratives follow neither linear nor logical structures and orders. As a friend, traveler and, of course, as a poet too, Cendrars would have contributed strongly to shaping Le Corbusier's ideas of Brazil, a country which turned to be pivotal in the architect's agenda for the Americas. The mid-twenties would be critical for both figures' encounters. Issues related to the new world, and to Brazil in particular, aren't the only ones that emerged. However, it's been precisely this theme that would become the pivot for their exchange and intellectual shifts. $^{64}$

\section{Blaise Cendrars: la main amie or the Bridge between two Worlds}

On 28 May 1923 Cendrars welcomes two new visitors to his place, Brazilian writer Oswald de Andrade (18901954) and painter Tarsila do Amaral (1886-1973), two key figures, who co-organized the first Modern Art Week in Brazil in $1922 .^{65}$ The meeting seems to have been a success as not only due to a close affinity that grew between them in very short time, but also their work produced henceforth indicates a mutual exchange of influential ideas, and a considerable shift in approach, particularly for Cendrars.

The Parisian stay of the couple Tarsila and Oswald in the early twenties indeed agitates encounters between Cendrars and several other intellectuals -Le Corbusier included- whose engagement with issues related to

\footnotetext{
${ }^{61}$ Notes of LC in his agenda of 1929, FLC

${ }^{62}$ Letter from LC to BC on 7 May 1929, FLC

${ }^{63}$ Letter from BC to LC from 1929, FLC

${ }^{64}$ Le Corbusier Foundation (FLC) and Blaise Cendrars' files at the Swiss Literary Archives in Bern (ALS) offer relevant material that allows us to trace this exchange to a greater extent

${ }^{65}$ The First Art Week hosted a group of participants that advocated for the introduction of a 'new attitude' among the Brazilian Artistic field. This group fought to establish their own understanding of a Brazilian modernity, at home and abroad, as in the case of Oswald Andrade's lecture L'effort intellectuel du Brésil contemporain in May 1923 at Sorbonne, the same institution that housed Le Corbusier's lectures a year before. See, Amaral, A.: Blaise Cendrars no Brasil e os modernistas: Tarsila: sua obra e seu tempo; Rossetti Batista, M.: Anita Malfatti no tempo e no espaço: biografia e estudo da obra; Eulalio, A.: A aventura brasileira de Blaise Cendrars
} 
the modern world and its boundaries, are clearly presented and shared. After the encounter in May, it would not take long for Cendrars to find himself in close contact with Brazilian artistic and political circles based in Paris. The dinner organized in October of the same year by Brazil's Ambassador to France, Luis Martins de Souza Dantas, ${ }^{66}$ which furthermore gathers familiar figures to Cendrars such as Fernand Léger, Darius Milhaud, among others; ${ }^{67}$ has been one of many events that Cendrars attended and at which he felt great empathy with the ideas and revelations that evolved from it.

Through Oswald, Cendrars also meets Paulo Prado (1849-1943) in Paris, a rich and an influential sponsor of modern art in Brazil, who would become one of the poet's dearest friends and paid for Cendrars and Le Corbusier's trips to Brazil. During Prado's long stays in Paris in the mid-twenties, he often met Cendrars and Léger. In 1928, the presence of Le Corbusier in those meetings was sporadic. ${ }^{68}$ Despite not being evident in the survival archival material, but considering the architect's great interest in establishing connections in Brazil, it seems reasonable to assume that Le Corbusier was familiar with social and cultural events organized by the Brazilians who were part of the same circles of Cendrars and Léger, such as Tarsila do Amaral's second individual exhibition in Galerie Percier from May until June 1928, as well as the critic's reviews that had been published. Amongst the paintings exhibited, Antropofagia.

As stated by a number of scholars, Cendrars and Le Corbusier' rapprochement to the Brazilians wouldn't be thus a coincidence, as both sides of the interest in the exchange were present. ${ }^{69}$ From the Brazilians' perspective, the rapport with figures within which efforts to redefine artistic practices in accordance with their time proves fundamental in order to legitimize their discourses in counterpoint to the cultural traditionalism in the country. Yet deciphered by the positions of Cendrars and Le Corbusier's standpoint, Brazil begins to be perceived as a place open to new ideas, whose intellectual autonomy and vision of modernity was not subordinated to any style or "ism", to borrow Cendrars' terms.

\section{The Americas of Cendrars become the Americas of Le Corbusier}

During the twenties in particular, Brazil would then become a great theme to Cendrars. He would not only write on Brazil and together with Brazilians, but also write several of his novels during his stays in the country. Cendrars traveled three times to Brazil, trips lasting usually two to three months. In this travels, the poet discovers São Paulo by car; visits the historical centers of cities in Minas Gerais for example; where there is a

\footnotetext{
${ }^{66}$ Souza Dantas (1876-1954) served as Brazilian ambassador in France for more than twenty years, from 1922 until 1944 , that is, during the Vichy government too. He was not only an important figure who embraced cultural exchanges between Brazil and France, as described in this work, but he also gained international notoriety by granting visas for entry into Brazil for hundreds of people persecuted by the Nazis during the WWII

${ }^{67}$ According to a paper published in the Brazilian Review Ariel by Brazilian writer Sergio Milliet, who was presented in the ambassador's dinner, the list of guests who attended the event were: Léger, Cendrars, Milhaud, Andre Lhote, Jules Romains, Jean Giraudoux and Jules Supervielle, and among Brazilians, Tarsila, Oswald de Andrade, Victor Brecheret, Vicente do Rêgo Monteiro and Pinheiro Júnio. Apud A. Amaral, Tarsila. Sua obra e seu tempo, p. 90

${ }^{68}$ Evidences of these meetings with Leger and Prado are found in Le Corbusier's agenda of 1928 (from 02.28 till 08.1928) and correspondence with family, such as the letter to his mother on July 121928 , FLC

${ }^{69}$ George, W. Tarsila et l'anthropophagie, La Presse, Paris, 5 July 1928. The English version of the fragment published above originally appeared in: Greet, M. "Devouring Surrealism: Tarsila do Amaral's Abaporu”, p.9
} 
high concentration of the most notable Brazilian baroque churches, as well as, buildings and squares; while, once in Rio, he participates in carnival parades, and, just like Le Corbusier in 1929, he joins bohemian rodas de samba (samba dances and social circles) and wanders around in the carioca Favella. Cendrars is profoundly affected by these trips and Brazil becomes a very strong source of inspiration for his poems and other activities for many years to come. The Swiss-French author of la prose du Transsibérien would be engaged to produce not only books based on "Brazilian heroes" and stories such as the baroque artist Aleijadinho, but also film project on Brazil.

"Belle soirée

Le soir tombe sur la côte américaine

Pas un poisson pas un oiseau

Une chaîne continue de montagnes uniformes toutes recouvertes d'une végétation luxuriante

La mer est unie

Le ciel aussi

Je pense aux deux amis que je me suis fait à bord et qui viennent de me quitter à Rio

(...)

Je n'ai jamais autant ri depuis dix ans et ri durant vingt jours j'étais malade de rire et ai augmenté de six kilos Au revoir mes bons amis à bientôt nous nous retrouverons à bord en rentrant en France ou un autre jour à Paris ou à Bruxelles ou ailleurs dans un train qui franchira les Andes ou à bord de l'Emperess qui cinglera vers l'Australie nous aurons toujours le même barman car le monde est bien petit pour d'aussi gais compagnons A bientôt à bientôt"

Blaise Cendrars, Feuilles de Route, 1924

Most of Cendrars' books within Le Corbusier's files - which were published in the twenties (and identified that which Le Corbusier had received or acquired at this same time) - are embedded with stories of Brazil, Cendrars' own experiences in the tropics, and many other experiences the poet had while traveling. Some of them were even written during his stays in Brazilian lands, such as Moravagine (1926) or even Dan Yack (1929). Despite not being found in the architect's library, Cendrars published two texts in the 1920's that had very good chances to be familiar to Le Corbusier. These are the poem Une Nuit dans la Forêt (1929), as well as the publication Feuilles de Route (1924) containing illustrations by Tarsila do Amaral.

"Depuis, j'ai entendu de lui des histoires américaines, des histoires du Brésil, des histoires de serpents de quinze mètres de long, de crocodiles, de fleurs dangereuses, etc... Cendrars n'a jamais manqué d'idées. Il avait le don de la matérialité des faits émotionnels" Le Corbusier ${ }^{70}$

In fact, the poet's representations of the Tropics and the Americas were rather distinct from the imaginary the European artists' had built over the 19th and beginning of the 20th century. Yet, the cities as Rio and São Paulo no longer appeared to be far from the French cities that he was familiar with such as Paris, Nice or London. On the contrary, despite the fact that it happens to be settled thousands of miles away from Europe, São Paulo appeared to be less distant than 'homeland' La Chaux-de-Fonds, for instance.

\footnotetext{
${ }^{70}$ Le Corbusier. "Salut à Blaise Cendrars : Toi, au moins, tu crois à ce que tu fais", FLC
} 
"Saint-Paul

J'adore cette ville

Saint-Paul est selon mon cour

Ici nulle tradition

Aucun préjugé

Ni ancien ni moderne

Seuls comptent cet appétit furieux cette confiance absolue cet optimisme cette audace ce travail ce labeur cette spéculation qui font construire dix maisons par heure de tous styles ridicules grotesques beaux grands petits nord sus égyptien yankee cubiste

Sans autre préoccupation que de suivre les statistiques prévoir l'avenir le confort l'utilité la plus value et d'attirer une grosse immigration

Tous les pays

Tous les peuples

J'aime ça

Les deux trois vieilles maisons portugaises qui restent sont de faiences bleues"

Blaise Cendrars, Feuilles de Route, $1924^{71}$

Through Cendrars' words, ideal denoting Brazil as an 'exotic', 'primitive' and 'wild' land is demoted and replaced by the notions of Brazil as plural, complex and urban; as well as in a constant process of change. As Claude Leroy states, Cendrars "inventoried"72 and brought value to the most current products which were "born and which died daily': the automobile, the train, the airplane, the street etc. The attention he gave to describe, for instance, the car noises of São Paulo city or even the different sounds and languages of its people were evidences of how significant such elements and experiences became for Cendrars.

\section{"SÂO PAULO}

Enfin voici des usines une banlieue un gentil petit tramway

Des conduites électriques

Une rue populeuse avec des gens qui vont faire leurs emplettes du soir

Un gazomètre

Enfin on entre en garde

Saint-Paul

Je crois être en gare de Nice

Ou débarquer à Charring-Cross à Londres

Je trouve tous mes amis

Bonjour

C'est moi"

Blaise Cendrars, Feuilles de Route, $1924^{73}$

The Americas for the poet wouldn't be detached from the notions of 'freedom', 'modernity', and, neither, of from that of 'cannibalism' too. Cannibalism, as defined by Oswald de Andrade, the author of the

\footnotetext{
${ }^{71}$ The poem São Paulo was also published in the catalogue of Tarsila do Amaral's exhibition in Galerie Percier, Paris 1926

${ }^{72}$ See, preface by Claude Leroy in: Cendrars, B. Poésies completes: avec 41 poèmes inédits

${ }^{73}$ See note 71
} 
Anthropophagic manifest (1928), as being the 'inescapable' but a 'most lucid' attitude towards their present time. Such a term embedded with meanings of Montaigne and yet re-appropriated by the "youth of São Paulo", 74 borrowing Le Corbusier's words, not only seduces both poet and architect but also seems to become quickly incorporated in their vocabulary - written and visual. Précisions (1930) and the first sketches made in Brazil, which were published in Le Corbusier's oeuvres complètes (1934), would be the first and most evident publicized signs of the architect's 'appropriation' of such a vocabulary practiced by this group from Brazil. ${ }^{75}$

“Ces pays, Argentine - vieille Castille, - Brésil - vieux Portugal -, sont arrivés à l'heure où ils veulent dessiner leur histoire. L'histoire des peuples n'est jamais que l'expression d'un idéal contemporain, une fabrication spirituelle qui est comme une doctrine, une description de soi-même, une définition de soi. L'histoire n'est pas, on la façonne. (...) on devient Américain en Amérique bien qu'on soit émigrant de partout. Les jeunes de SaintPaul m'ont exposé leur thèse: nous sommes des "Anthropophages" ". Le Corbusier. Prologue Américain, 1929

These Americas re-presented by Cendrars would be the one that most affected Le Corbusier in those years, precisely when the architect would begin to manifest a more critical position towards the hegemonic political and economic discourses produced above the Equator. These Americas: not that of the virile economy where technocracy exercised its power, yet that of other complexities and possibilities instead. One that is associated with the idea of an utopia, with a certain romanticism and naivety too, as it does not intend to challenge the oppressive Eurocentric discourse built over centuries, but that is connected to a notion of modernity shared by a group of individuals, who will leave him room for creation and interlocution.

\section{Acknowledgments}

I would like to acknowledge my appreciation to the staff of the Fondation Le Corbusier in Paris, Michel Richard, Arnaud Dercelles and Bénédicte Gandini, in particular; of the Fonds Blaise Cendrars at the Swiss Literary Archives in Bern (ALS); and of the gta Archives in Zurich. I am grateful to Marie-Thérèse Lathion from the ALS and Prof. Claude Leroy for their generosity in guiding my discovery of Cendrars' files. Also I would like to thank Daniel Weiss, Filine Wagner from the gta Archives and my colleague Andreas Kalpakci, for the open discussions on Giedion, Voisin and Romier. This paper has benefited from discussions at the doctoral seminar organized by Prof. Tim Benton on Le Corbusier at EPFL in Lausanne, and the doctoral colloquia in Architectural Theory organized by Professors Ákos Moravánszky and Laurent Stalder at the ETH Zurich. Prof. Margareth da Silva Pereira, and my colleagues Mário Magalhães and Priscilla Peixoto, whose conversations and writings have been crucial to the formulation of many of the paper's ideas. Finally, Jennifer Robin Caras, who has generously revised and corrected the English manuscript.

\footnotetext{
${ }^{74}$ Le Corbusier, Précisions sur un état présent de l'architecture et de l'urbanisme, Paris: Editions Vincent, Fréal, 1960, p.17

${ }^{75}$ Le Corbusier's drawings of the urban design for the city of Rio de Janeiro, for example - quickly sketched in his private carnets while flying over the city - was immediately transformed into public discourse during his lecture in the same city. In other words, it was while he was traveling through Brazil that Le Corbusier publicized his narratives as a tourist and as an architect in parallel - narratives based on his experiences in loco. This combination of traveller, tourist, architect, urban designer and lecturer is singular in comparison to his previous voyages. In fact, the voyages Le Corbusier carried out in the end of the twenties and beginning of the thirties - in particular to the U.R.S.S., Brazil, Argentina and Algeria - produced a relevant impact on his architectural and written production. Cohen's meticulous investigation on Le Corbusier's trips to the U.R.S.S. calls attention to the architect's expectations before traveling; as well as the confrontation of such expectations once on site and the reception of his ideas among the political and architectural milieu. Nevertheless, it would be in the Brazilian voyage that Le Corbusier would attain the maturity in his discourse and, will establish the year of 1929 as the moment of rupture in his work and concerns regarding Architecture. See, Le Corbusier, 'Oeuvre Complète 1929-1934'
} 


\section{Bibliography/references}

AMARAL, A. Blaise Cendrars no Brasil e os modernistas. São Paulo: Martins, 1970

Tarsila. Sua obra e seu tempo. São Paulo: Perspectiva/Edusp, 1975

BACON, M. Le Corbusier in America. Travels in the Land of the Timid. Cambridge; London : The MIT Press, 2001

Le Corbusier et l'Amérique, première rencontre. In COHEN, J-L and DAMISCH, H. (Ed.) Américanisme et Modernité. L'idéal américain dans l'architecture. Paris : EHESS ; Flammarion, 1993, p. 191-207

BANHAM, R. Avant Garde und Industrie by Stanislaus von Moos. Journal of the Society of Architectural Historians, October 1984, vol. 4, no. 3, p. 277

BAUDOUÏ, R., DERCELlES, A. Le Corbusier. Correspondance. Lettres à la famille 1926-1946. Tome II. Gollion: Infolio, 2013

BENTON. T. La réponse de Le Corbusier à la loi Loucheur. In LUCAN, J. (Ed.) Le Corbusier: une encyclopédie. Paris: Centre Georges Pompidou, 1987. p. 238-239

. Le Corbusier conférencier. Paris: Moniteur, 2007

BOZDOGAN, S. Journey to the East: Ways of Looking at the Orient and the Question of Representation. Journal of Architectural Education, Summer 1988, vol. 41, no. 4, p. 38-45

BOZON-SCALZITTI, Y. L'Amérique Invisible de Cendrars. In CHEFDOR, M. (Ed.) Blaise Cendrars 2. Cendrars et l'Amérique. Paris: Lettres Modernes, 1989, p. 145-176

CENDRARS, B. La Fin du monde filme par l'ange N.D. Paris: Ed. De la Sirène, 1919

Feuilles de Route. Paris : Au Sans Pareil, 1924

L’Eubage. Aux Antipodes de l'unité. Paris: Au Sans Pareil, 1926

. Une Nuit dans la Forêt. Paris: Denoel 1964

Poésies completes: avec 41 poèmes inédits, Claude Leroy (ed.), Paris: Denoël, 2001

COHEN, J-L. Le Corbusier et la mystique de l'URSS. Théories et projets pour Moscou 1928-1936. Paris: Pierre Mardaga Editeur, 1987

Le Corbusier : La planète comme chantier. Paris : Textuel, 2005

(Ed.) Le Corbusier: An Atlas of Modern Landscapes. New York: The Museum of Modern Art, 2013

COHEN, J-L., DAMISCH, H. (Ed.) Américanisme et Modernité. L'idéal américain dans l'architecture. Paris: EHESS; Flammarion, 1993

DA SILVA PEREIRA, M. et al. Le Corbusier e o Brasil. São Paulo: Tessela/Projeto Editora, 1987

EUlAliO, A.; CALIL, A. A aventura brasileira de Blaise Cendrars, São Paulo: Edusp, 2001

FRANCLIEU, F. et al. Le Corbusier Sketchbooks. Vol 1, 1914-1948, London: Thames and Hudson, 1981

FRANÇOIS, M. Lucien Romier. Bibliothèque de l'école de chartres. 1944, vol. 105, p.338-355

GIEDION, S. Building in France, Building in Iron, Building in Ferroconcrete. Santa Monica: The Getty Center for the History of Art and the Humanities, 1995

GREET, M. Devouring Surrealism: Tarsila do Amaral's Abaporu. Papers of Surrealism, Spring 2015, Issue 11, p.1-39

KUISER, F. Ernest Mercier: French Technocrat. Berkeley - Los Angeles: University of California Press, 1967

LE CORBUSIER. Vers une architecture. Paris: Editions G. Crès et Cie, 1923 
. Urbanisme. Paris : Editions G. Crès et Cie. Paris, 1925

. Une maison, un palais. Paris : Editions G. Crès et Cie à Paris, 1928

$\overline{1930}$

Précisions sur un état présent de l'architecture et de l'urbanisme. Paris : Editions G. Crès et Cie à Paris,

La Ville radieuse. Paris : Editions Vincent, Fréal \& C, 1935

. Oeuvre complète 1929-1934, tome 1, publié par W. Boesiger, Girsberger. Zurich: Artémis 1957

. Salut à Blaise Cendrars : Toi, au moins, tu crois à ce que tu fais. La Gazette de Lausanne, March 14, 1960

. Le parcellement du sol des villes, in Rationelle Bebauungsweisen. Ergebnisse des 3. Internationalen Kongresses für Neues Bauen. Nendeln: Kraus, 1979. Copyright 1931 by Verlag Englert \& Schlosser, Frankfurt am Main. p.48-57

Le Corbusier et le livre. Les livres de Le Corbusier dans leurs éditions originelles. Ouvrage publié à l'occasion des expositions produites par le Collegi oficial d'Arquitectes de Catalunya, Barcelona, April 2005

LEITNER, P. Entre Paris et New York. Dynamiques d'échange pour transformer la métropole 1858-1926. Supervisor: Jean-Louis Cohen. Doctoral Dissertation. Université Paris VIII, Vincennes - Saint-Denis, 2009

"Le rêve américain de Charles-Édouard Jeanneret". Report presented to the Le Corbusier Foundation , Paris, 2009

LUCAN, J. (Ed.) Le Corbusier: Une Encyclopédie. Paris : George Pompidou : 1987

MAGALHAES, M. Jose Bonifacio's Brasilia in Between Brazil: Multiple Territorial Scales of Planning Collective Life. Annals of the 16th International Planning History Society Conference, St. Augustine (USA), July 2014

MCLEOD, M. Architecture or Revolution: Taylorism, Technocracy, and Social Change. Art Journal, Summer 1983, vol.43, no.2, p.132-147

Urbanism and Utopia: Le Corbusier from regional syndicalism to Vichy. Supervisor: Kenneth Frampton. Doctoral Dissertation, Princeton University, Princeton N.J, 1985

Le rêve transi de Le Corbusier: 1'Amérique 'catastrophe féerique'. In COHEN, J-L and DAMISCH, H. (Ed.) Américanisme et Modernité. L'idéal américain dans l'architecture. Paris : EHESS; Flammarion, 1993, p.209-228

PASSANTI, F. Des gratte-ciel pour la "ville contemporaine". In VON MOOS, S. (Ed.) L'Esprit Nouveau. Le Corbusier et l'industrie 1920-1925. Strasbourg: Les Musées de la Ville de Strasbourg, 1987, p.54-65

Le Corbusier et le gratte-ciel, aux origines du Plan Voisin. In COHEN, J-L and DAMISCH, H. (Ed.) Américanisme et Modernité. L'idéal américain dans l'architecture. Paris : EHESS; Flammarion, 1993, p.171190

The Vernacular, Modernism and Le Corbusier. Journal of the Society of Architectural Historians, December 1997, vol. 56, no 4, p.438-451

RABINOW, P. French Modern. Norms and Forms of the Social Environment. Cambridge (Massachusetts): The MIT Press, 1989

ROMIER, L. Qui sera le maître, France ou Amérique?. Paris: Hachette, 1927

__. Idées très simples pour les Français, Paris: Simon KRA, 1928

. L'Homme Nouveau. Esquisse des conséquences du Progrès, Paris: Hachette, 1929

ROSSETTI BATISTA, M. Anita Malfatti: no tempo e no espaço. São Paulo: Editora 34, 2006

SHAW, M. Promoting an Urban Vision: Le Corbusier and the Plan Voisin. Supervisor: Francesco Passanti. Master's thesis. MIT, Cambridge, Massachusetts, 1991 
VON MOOS, S. Le Corbusier: Elements of a synthesis, Rotterdam: 010 Publishers, 2009. 1st ed. Published in German Le Corbusier: Elemente einer Synthese, by Huber (1968)

Urbanism and Transcultural exchanges, 1910-1935: A Survey. In ALLEN BROOKS, H. (Ed.) Le Corbusier. Princeton: Princeton University Press, 1987, p.219-232

VON MOOS, S. et al. L'Esprit Nouveau. Le Corbusier und die Industrie, 1920-1925. Berlin: Ernst \& Sohn, 1987

VON MOOS, S., RÜEGG, A. (Ed.) Le Corbusier Before Le Corbusier. New Haven; London: Yale University Press, 2002 


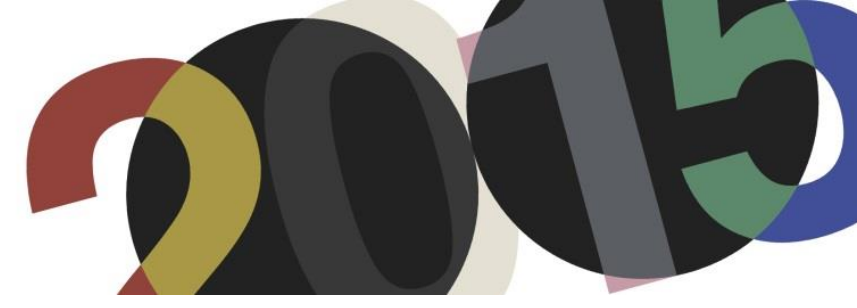

DOI: http://dx.doi.org/10.4995/LC2015.2015.594

\title{
"Who is Le Corbusier?" According to Turkish Architecture
}

\author{
G. Ozorhon, I.F. Ozorhon
}

Faculty of Architecture and Design, Ozyegin University

\begin{abstract}
This study is to focus on the relationship between Le Corbusier and Turkish Architecture and the main question of the study is what Le Corbusier means for Turkish architecture. The method chosen in the research is to seek out answer this question over two main axes (architectural education and architectural practice). Besides a general overview in the section where Le Corbusier is examined within Turkey's architectural education, it was consulted to student opinions and it was mentioned about the topics of master's and doctorate theses conducted as directly related to Le Corbusier. Within Turkey's architectural practice, the projects performed by being inspired of him in Turkey were included and these projects were examined in relation with Le Corbusier's five main principles. The projects examined show that Le Corbusier has become an important guiding spirit in modern Turkish architecture and additionally, the architectural products arising as a conclusion of inspirations are qualified products verifying Turkey's architectural medium. Besides, there is a sub-section titled as Le Corbusier's experiences in Turkey in this section. In this section, by showing reference to Le Corbusier's travels in Turkey and the things engrossed as a result of his travels (with drawings and writings), it is emphasized that the relationship between Le Corbusier and Turkish architecture can be interpreted as a two-way interaction.
\end{abstract}

Keywords: Le Corbusier, Turkey, Architecture.

\section{Introduction}

Who is Le Corbusier? With a little extravagant expression he is one of the most important designers and architects of all times; not only an architect, he has identities of architect, painter, author, architecture philosopher, industrial designer, urban planner, utopist and even public reformist. With this multi-identity structure, Eero Saarinen defines him as the Leonardo da Vinci of our age while Kenzo Tange mixes him up with Michelangelo. Besides, Le Corbusier is the only architect who found the opportunity to design and realize a whole city (Chandigarh) including its public buildings. ${ }^{1}$

The question defining the problem area of the study is "What Le Corbusier (who has well known architectural products in almost every country of the world) expressed / is expressing / will express for the architecture environment of Turkey?" While seeking answer to this question, different environments within architecture should be separately handled.

\footnotetext{
1 Tanyeli, Uğur “Bir Sağırlar Diyaloğu: Le Corbusier'den Türkiye'ye, Türkiye'den Le Corbusier'e” Sanat Dünyamız, 87. İstanbul. 2003. pp.111-121.
} 


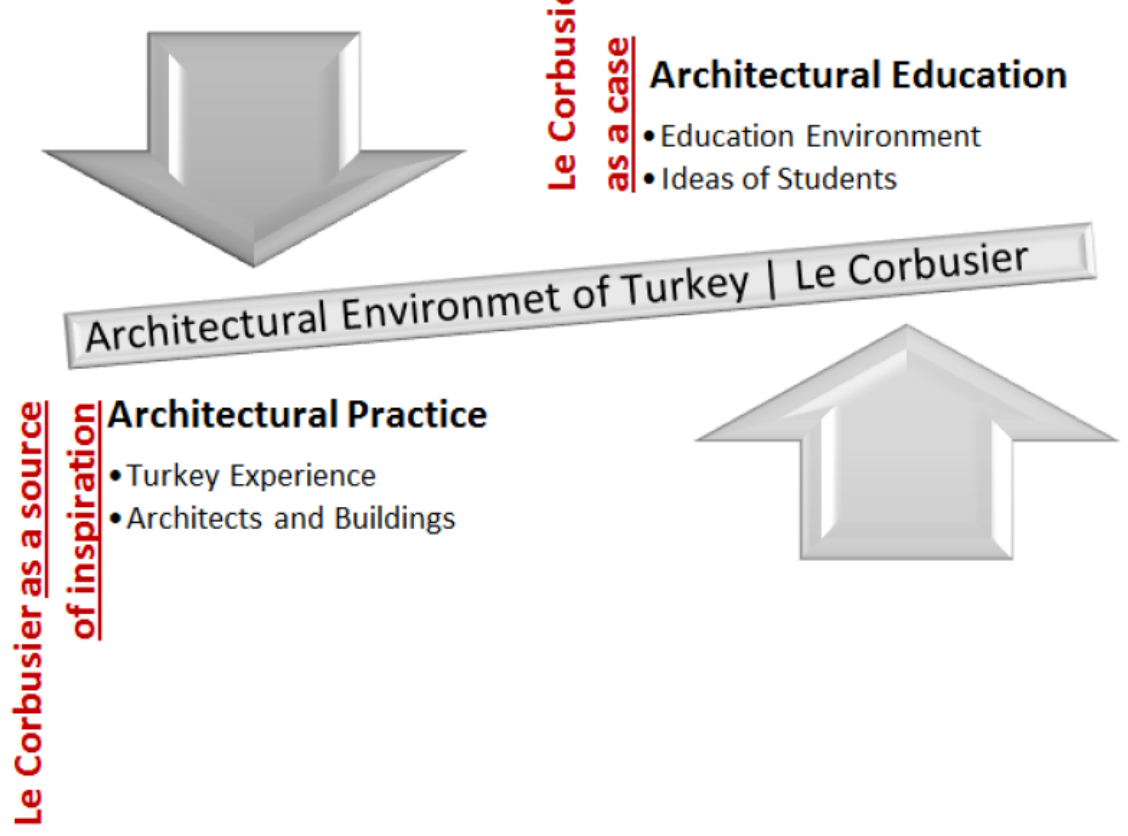

Scheme 1. The method of the survey

For this reason, it was chosen to advance through two main axes in the study. The two mentioned axis (Scheme 1) are architectural education and architectural practice forming the architectural medium. Actually, the answer of the question that "who is Le Corbusier?" can be interpreted differently for these two axes. In this sense, Le Corbusier whose opinions and products are read as an instructive case can be described as a guiding spirit for architectural environment. Within the scope of the architectural education, architectural education and the relationship between architectural practice and Le Corbusier were discussed over their own tools and actors.

\section{Le Corbusier in Turkey's Architectural Education}

\subsection{Le Corbusier as a Case in Architectural Education}

Also for the students of architecture, Le Corbusier is an important figure to whom they encounter from the first days of their education -even long before for some others-. Within architectural education in Turkey, architecture students encounter Corbusier with his different identities in each phase of your education (Scheme 1) and these confrontations are often repeated from the first class to the last during their license education, and then during their master's and doctoral education.

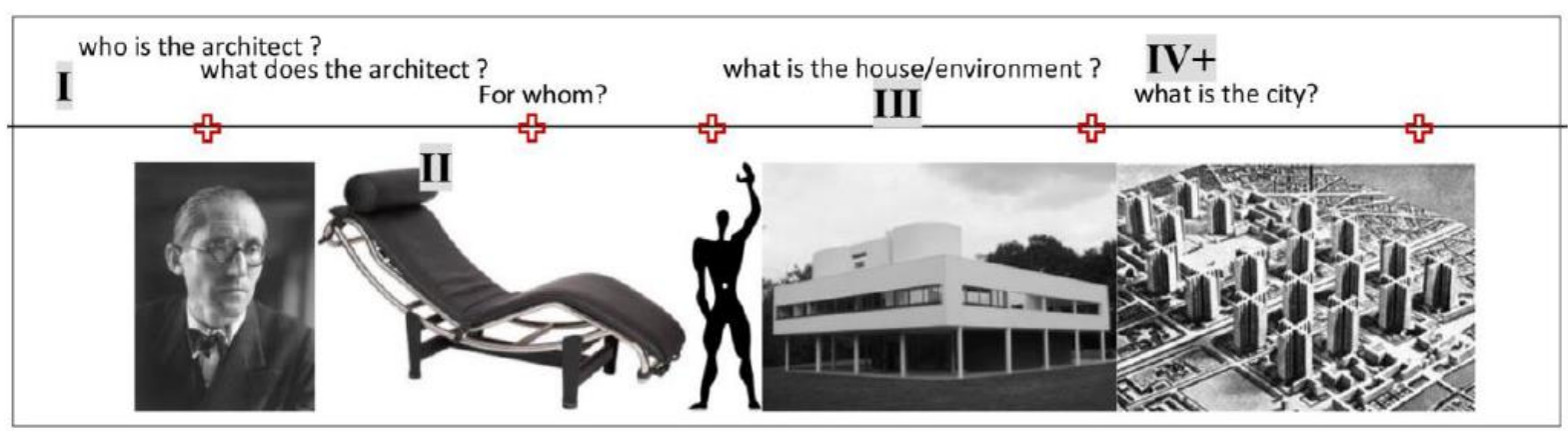

Scheme 2. The Images of Le Corbusier in Architectural Education 
For first-class architecture students, the name of Le Corbusier that comes to their eras from the first days of their education is like the name of a source book to which even the lecturers - who are seen as unachievable in terms of their knowledge and experience of the first days of their education by the students- to be the guides in architecture often consulted. This person is such a person that he is an architect but he is also an artist, designer, writer and philosopher. This multi-identity tells the architecture students about the difficulties of the way they set off on one hand; it reminds the importance of architecture profession where they are candidates on the other hands.

In the first years, Le Corbusier is an important sample given while explaining what is "architect" and "architecture" for architecture students on one hand and he is an important source consulted to while examining the relationship between architecture and human/ human dimensions via "modulor" he developed on the other hand. Architecture students in Turkey encounter with Corbusier repeatedly in terms of different subjects in various courses while their education is advancing following the courses of introduction to the architecture. These confrontations can be experienced in correlation with modernism, housing and even with mobile design. In the courses of urbanism, his designs that can be said revolutionary and even utopic submits an important case while examining the case of the past/now and the future.

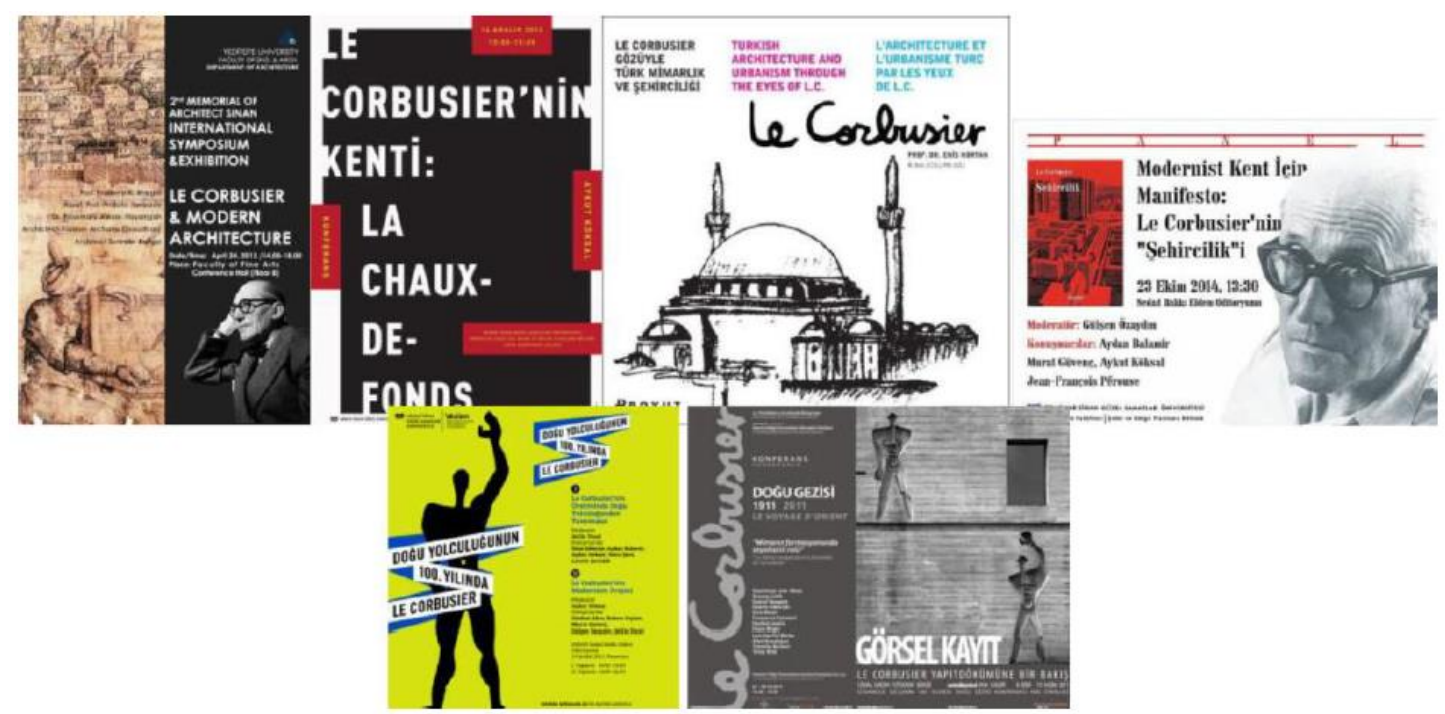

1. The samples from the meetings occurred in Turkey about Le Corbusier in recent years and from the books written about him

Above all, the students of Turkish architecture find the opportunity to look through and understand their own architectural inheritance from his window. They discover the traditional housing of Anatolia and the spatial features of İstanbul and Bursa mosques with the words/drawings of this foreign architect. With Le Corbusier seminars and meetings conducted from time to time (Figure 1) and the books written about him in addition to his own writing, they have a chance to recognize him more closely.

The information about master's thesis conducted about Le Corbusier in Turkey ( 7 master's thesis, 2 doctorate thesis) is seen in Table 1. It was tried to be made visible which these studies focus on in correlation with Le Corbusier through the table. The variety among these subjects refers to the variety of the architect's production on one hand, it indicates to be discussed as a case for many different subjects from the house to the city in the researches conducted in the field of architecture by Corbusier on the other hand. For example; in his thesis, 
Yildırım (2009) ${ }^{2}$ discussed the usage of photography by Le Corbusier as a visual tool. According to Yildırım, the aim of Le Corbusier's photography usage is to reveal not only recording the work and transferring them to the future, but his own point of view - not only in perspective way but the point of view about architecture- to the spectator. In the thesis conducted by Y1lmazer ${ }^{3}$ in 1993, the formations in Turkey constructed dominantly under the inspiration of Le Corbusier were discussed and the similarities between these buildings and Corbusier's buildings were revealed. Except for this, among the subjects discussed in correlation with Le Corbusier, modern architecture, modulor, modular design, house, city, architectural form and architectural language can be listed.

Table 1.* Thesis on Le Corbusier in Architectural Education in Turkey

\begin{tabular}{|c|c|}
\hline Author & Name of the thesis \\
\hline $\begin{array}{l}\text { Y.ISKENDEROĞLU } \\
2009\end{array}$ & An inquiry into the design potentials of Le Corbusier's $\mathrm{d}$ o $\mathrm{m}$ - i n o clusters \\
\hline $\begin{array}{l}\text { E. YILDIRIM } \\
2009\end{array}$ & $\begin{array}{l}\text { P h o t o-s p a c e, photo-story, photo-wall: Architecture of Le Corbusier and its photographic } \\
\text { representation }\end{array}$ \\
\hline A. KÜçüK & The architectural precedent and the diagram: A comparative analysis of Le Corbusier's Villa S a v o y e and R e m \\
\hline $\begin{array}{l}2007 \\
\text { C. SEYHUN }\end{array}$ & $\begin{array}{l}\mathrm{K} \circ \mathrm{o} \mathrm{Ih} \text { a a s' Maison a Bordeaux } \\
\text { The role of the architect and a } \mathrm{u} t \text { o } \mathrm{n} \text { o } \mathrm{m} y \text { of architecture: An inquiry into the position of the early } \mathrm{m} \text { o d e } \mathrm{r}\end{array}$ \\
\hline 2004 & $\mathrm{n}$ architect and architecture: Le Corbusier and Maison $\mathrm{C} \mathrm{u} \mathrm{r} \mathrm{u} \mathrm{t} \mathrm{c} \mathrm{h} \mathrm{e} \mathrm{t}$ \\
\hline $\begin{array}{l}\text { T. S.TAĞMAT } \\
2004\end{array}$ & The maximum architecture can do: Architecture and $\mathbf{u ~} \mathbf{r}$ b a $\mathbf{n}$ i s $\mathbf{m}$ from Le Corbusier to $R$ e $\mathrm{m} \mathrm{Ko} \mathrm{ol} \mathrm{h} \mathrm{a} \mathrm{a} \mathrm{s}$ \\
\hline $\begin{array}{l}\text { S. ÇINAR } \\
2005\end{array}$ & Reading/Unfolding architectural f o $\mathrm{r} \mathrm{m}$ : An inquary into the venice hospital project by Le Corbusier \\
\hline $\begin{array}{l}\text { E. GÖRGÜL } \\
2000\end{array}$ & $\begin{array}{l}\text { An Approach towards the explanation of c o } \mathbf{n ~ t ~ i ~} \mathbf{n ~ u ~ i ~ t ~} \mathbf{y} \text { in architecture' in context through analysis of } \\
\text { theorctical texts Vitruvius, Alberti and Le corbusier }\end{array}$ \\
\hline $\begin{array}{l}\text { S. ÇINAR } \\
1999\end{array}$ & Reconciliation of the irreconcilable: Contradictory I a $\mathbf{n ~ g ~ u ~ a ~} \mathrm{g}$ e of Le corbusiers architecture \\
\hline $\begin{array}{l}\text { P.YILMAZER } \\
1993\end{array}$ & The effects of Le Corbusier on m o dern Turkish Archit e ct ure \\
\hline
\end{tabular}

* it was collected from www.yok.gov.tr.

\subsection{Le Corbusier with the eye of Architecture Students}

In this part of the study, the opinions of architecture students about Le Corbusier are seen as a continuation of the previous section. In this context, four graduate students, one of whom are master's student were asked to briefly explain what Le Corbusier means for them and these opinions were transferred here as it is.

Master's student and research assistant E.Y1ldıhan "That Corbusier takes inspiration from the east was good. That architecture leads to the engineering was good. That he took inspiration from the subjects that I had been aware of but I did not persisted on or from the formations that I had seen before surprised me. This situation ensured me to be more skeptical in project analysis during my education life. I like that he could understand and explain complicated subjects with simple sketches and by using plain language. I thought that this can be like this. So, I tried to understand the subjects about the architecture by drawing that I couldn't understand."

\footnotetext{
${ }^{2}$ Yıldırım, Erdem. Foto-Mekan, Foto-Hikaye, Foto-Duvar: Le Corbusier Mimarlığı ve Onun Fotografik Temsili. Director: Açalya Allmer. unpublished master dissertation. Dokuz Eylül Üniversitesi, İzmir, 2009.

${ }^{3}$ Yılmazer, Pınar. Le Corbusier'nin modern Türk mimarisine etkileri. Director: Kaya Dinçer. unpublished master dissertation. Yıldız Teknik Üniversitesi, İstanbul, 1993.
} 
O.Tekin who is a graduate student describes Le Corbusier like this: "Le Corbusier is seen as the pioneer of modern architecture in architecture history. With architecture, in the formation of physical substructure of the features like urban planner, furniture designer, writer and sculptor, his being wanderer has a big role. Especially in his travels, he admired the architectural features of the Mediterranean and Central Europe peculiar to themselves and being interpreted of this functional, regional architectural features by him has had great contributions to the formation and development of functional viewpoint. He asserted that the beauty concept arose from the relationship between proportional geometry and the function and he explained the proportional geometry with his modular proportional system again, and he fictionalized the relationship of these anthropometric measures with function in buildings and furniture. Le Corbusier inserted the carrier system into our lives as an architectural element and made the mediums and made the facades free as much as it has not been before, he facilitated them and he denuded the concrete as a sculpture, used the roofs as terrace gardens, and has become a touchstone of conventional architectural implementation of today. Le Corbusier brought a breath of fresh air to the architecture with the opinions he produced and the concepts he revealed and he changed the opinion to the architecture with revolutionist applications".

V.Yücel "Le Corbusier... It is the name that has pursued me from the first lesson in the Faculty of Architecture until the moment I have been writing this text. "A machine for living”... There are always these words whenever I opened a book. I think one of the important differences of architecture education from the other academic disciplines is that each year and each period we think to know more things but after some time we realize that we know very few through pleasant or unpleasant ways. For this, is one of the names coming first among this awareness. The first they I started to my faculty, I had an awareness about neither Le Corbusier nor the approach he represents. With the inexperience of the first years of architecture, I tried to have an opinion by looking at the photographs of the works. Even I tried to criticize it. I couldn't understand. I couldn't understand why they are so important, his aesthetics concept and why everybody mentions about him. While getting learnt the approaches, thoughts and wording slowly, those buildings that had no meaning and even I couldn't describe aesthetically and that I couldn't compare the buildings I encountered everyday around me at first have come meaningful for me suddenly. When I turned back, noticing this sharp change in my thoughts about Le Corbusier and my curiosity about him caused him to turn into a passion. According to me, my development in architecture education goes parallel with the change in my point of view about Le Corbusier. I began to buy the books describing him or that he wrote. I was reading the episodes to find the ideal instead of adventure novels. I began to feel that I could reflect the things I learnt from the things I read into all courses I took and every project. Le Corbusier taught me that I shouldn't remain unanswered questions. These questions were not the questions asked by the juries or my teachers of course. These questions are the ones I asked myself. "Why am I doing this? ", "Is this the most ideal solution?", "Can't I find a more logical solution?” ... I'm sure, if I study on a project after years, I will be asking the same questions again and I'm sure one of the most important fellow travellers in the solution of these questions will be Le Corbusier like today."

İ.Y1lan "I learnt the name of Le Corbusier at the first year in the Faculty of Architecture. I have read the books "Towards an Architecture" and "Interview with the Students of Architecture" as all of the architecture students. The connection I have established between the building and the people gave me a new perspective. Besides, that he recorded his travels as sketches and he applied the new things he learnt to his designs encouraged me to see new cities and countries. At the same time examining his thoughts and designs and being aware of the thoughts underlying them ensured me to have a different opinion and to see what I look. Besides I think that the language 
he used in his designs and his approach are timeless and they will have indispensably great contributions to architecture and design history."

\title{
3. Le Corbusier in Turkey's Architecture Profession Practice
}

\author{
"His heart stopped on waters of Mediterranean which he adored \\ A little beyond of his fisher friends and his small home \\ He will lie facing Mediterranean \\ They have poured sacred water from Ganges \\ And soil of Acropolis upon him" \\ Cengiz Bektaş ${ }^{4}$ (2003)
}

The above lines were written by Cengiz Bektaş who is an important Turkish architect. Even only this poem is an indicator of how an important figure is Corbusier in architectural environment both in the world and in Turkey. On the other hand, the relationship between Corbusier who is imitated from his designs to his dressing style and to the thick black-rimmed glasses and who is seen as a source of inspiration with Turkey is interpreted as a twoway interaction by many researches. In other words, the studies showing reference to the travels performed by Corbusier to the cities of Turkey, the things he is recorded within these travels and the things he wrote after his travels defend that Corbusier is significantly affected by Turkish architecture. Aside from these interpretations, it can be easily said that the generic structure of "Turkish house" has actually similar features with the main principles of Corbusier architecture.

\subsection{Corbusier as a Source of Inspiration}

Surely as in many parts of the world and probably to be in the future, Le Corbusier has become an important source of inspiration for Turkey. This part of the study aims to make this visible over building samples. But beforehand, it is required to repeat the question: "who is Corbusier for the architects in Turkey? Why has Corbusier turned into a source and a role model whose opinions it is consulted to? Besides his intellectual artist personality, his mastery of the architecture, drawing and building, his revolutionist opinions and the clarity in sharing their opinions, Turkish architect can find something from themselves. The matter/discussion that Corbusier is affected by Turkish architecture or Turkish architects are affected by him actually points out some partners in both sides. The most important one of these partnerships is a construction mass developing as a reflection from inside-out/of the inside to out. Bektaş expresses as inside-outside matching as an important features of tradition Turkish architecture. Similarly, there is an important part titled "A plan develops from inside to outside" in Towards a New Architecture that is known as Corbusier. On the other hand, the attitude similar to Corbu architecture broking up the structure from the ground with pilotis raises the main spaces of the houses with wooden columns and it is seen in Turkish houses that are placed at the first floor. In also Turkish houses, big windows in Turkish houses just like in Sovaye ensure to be taken of plenty of sunlight into the interior space.

Adolf Max Vogt (1996) ${ }^{5}$ examined the effects of Turkish House on modern thinking and modern architecture and revealed with a detailed comparison. Vogt attracts attention that the principle that at least three of five principles revealed by Corbusier are independent from rising of the building on pilotis, the idea of horizontal window and being independent of external structure of the outer shell from the carriers can be found in Turkish

\footnotetext{
${ }^{4}$ Bektaş, Cengiz “Le Corbusier”. Sanat Dünyamız, 87. İstanbul. 2003. pp.201-203.

${ }^{5}$ Vogt, Alexander Max. Le Corbusier, the Noble Savage: Toward an Archaeology of Modernism. 1996.
} 
houses (Vogt, 1996). Despite having classical styles, Schwob House that Le Corbusier interpreted wooden elements with concrete elements in Ottoman structures is named as "Turkish house" and it carries traces from İstanbul. ${ }^{6}$

On the other hand, as it is mentioned before, Le Corbusier affected many Turkish architect and his works have become the source of inspiration for the designs of their designs. In this part of the study, these inspirations were revealed in correlation with five principles embodied by Le Corbusier in his sample of Villa Savoye through a table (Table 2). The samples discussed here is building block in Hukukçular Site (H. Baysal, M. Birsel/İstanbul), Büyükada Anatolian Club Hotel (T. Cansever, A. Hanci/İstanbul Büyükada) and Cinnah 19 (N.Ersin/Ankara). Each of three buildings is regarded among the main samples of Modern Turkish Architecture with original approaches of his era.

Table 2. Three cases from Turkey that design under the influence of Le Corbusier

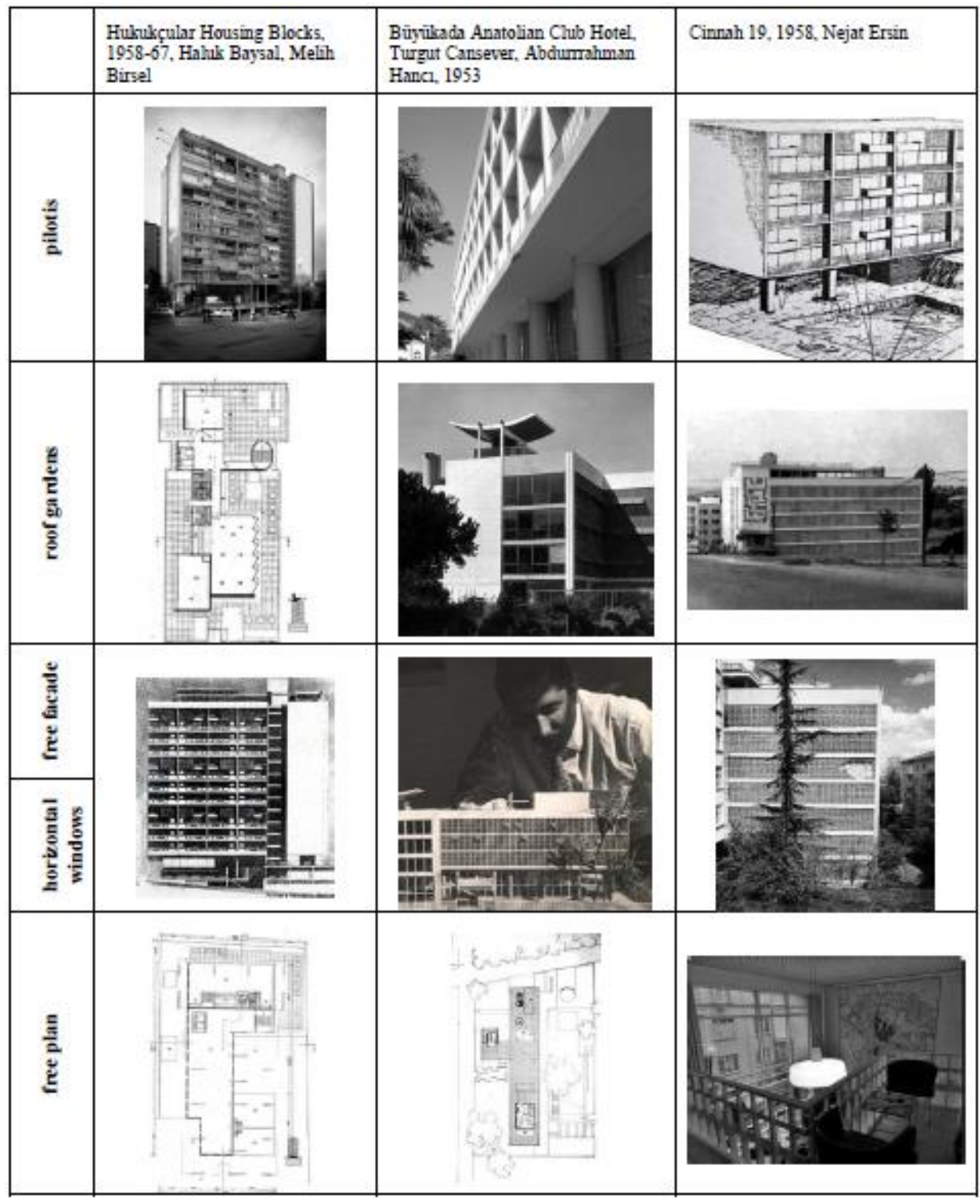

${ }^{6}$ Cohen, Jean Louis. Le Corbusier. Bonn: Taschen, 2006. 
For example; it is possible to follow the effects from Unité d'Habitation in Marseilles by Le Corbusier in Hukukçular Site conducted in İstanbul in 50s. The building rising from the ground with pilotis can be said to display Corbisien architecture in terms of both roof usage and planning understanding. But to use simplex, duplex and half-duplex plan types separate Hukukçular Site from the structure of Unité d'Habitation including only duplex plan solution. Different solutions in the plan can also be read from the aspect of the structure, that is to say it is a continuation for the exterior. The structure including 66 houses on 12 floors was programmed in a style to include site life conditions within it. Commercial activities were designed on the ground and clerestories and the spaces with social usage were designed on the roof.

Anadolu Club Hotel designed by Abdurrahman Hancı and Turgut Cansever exists with reference to a building that is a source of inspiration to him and to a typology (Le Corbusier-Swiss Pavilion). The architects clearly explain that they inspired in the design of this hotel that is among the youth products from Swiss Dormitory Building designed by Le Corbusier in 1925 and from its canonical feature. However, it cannot be mentioned only about a formal transfer here. The power to exceed by criticizing the cultural references hosted by the building and the building they inspired makes him powerful. ${ }^{7}$ In the first period works of Cansever, it is possible to see Corbusien attitude especially in the first period works, but he displayed an original interpretation by blending the things he learnt from Corbusier with the information of Anatolian culture.

In the building design process of Cinnah 19 by Ersin, besides Unite d'Habitation block of Le Corbusier in Marseilles, he was affected by Lucio Costa, Oscar Niemeyer and Edward Durrell Stone. However, as in the other samples, Cinah 19 also was described not as a simple "imitation" of the international trainings dominant in the building but as the product of an "internalized modernism" in a convincing manner. ${ }^{8}$ In this building, three of five elements of Le Corbusier (pilotis, free aspect, free facade, horizontal window and roof garden) were applied. $^{9}$

The samples listed above are shown among the most important works of Modern Turkish Architecture. However, modern attitude in these buildings meeting the modern view of the west affects with local features affected Turkey's architectural environment in further periods. That's to say, the effect of Corbusier to Turkey's architectural environment did not limited only to its own architectural products and saying, but the ones who are in the struggling of understanding and interpreting him displayed architectures to guide the successors.

\footnotetext{
${ }^{7}$ Özorhon, İlker Fatih. Mimarlıkta Özgünlük Arayışları:1950-60 Arası Türkiye Modernliği. Director: Türkan Ulusu Uraz. unpublished PhDdissertation. İstanbul Teknik Üniversitesi, İstanbul, 2008.

${ }^{8}$ Cengizkan, Ali: “Cinnah 19: ütopik mi Gerçek modern mi?”, Modernin Saati, Boyut Yayıncılık, İstanbul, 2002.

${ }^{9}$ Özorhon, İlker Fatih. Mimarlıkta Özgünlük Arayışları:1950-60 Arası Türkiye Modernliği. Director: Türkan Ulusu Uraz. unpublished PhDdissertation. İstanbul Teknik Üniversitesi, İstanbul, 2008.
} 


\subsection{Le Corbusier's Experience in Turkey}

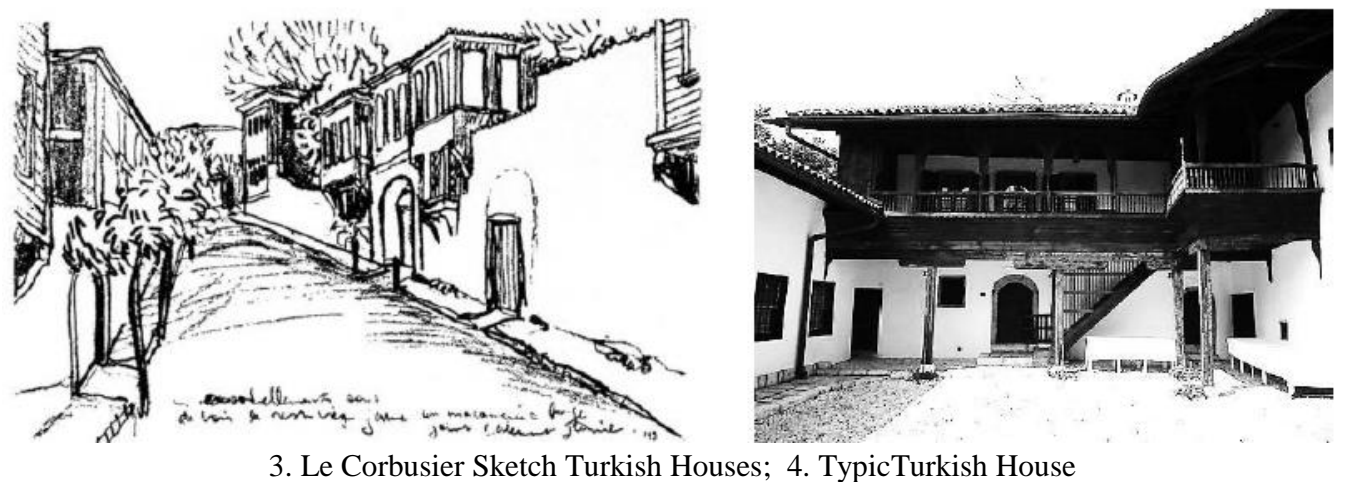

According to some researchers conducted important researches about Corbusier, his visit to Turkey and that he examined Turkish houses during this travel affected his architecture to a great extent. For example, Kortan $(1992)^{10}$ explained this situation as; "Le Corbusier revealed the traditional values existing in Turkish houses with an extraordinary observation skill and submitted some of them as the principles of Modern Architecture. The general principles he found in a Turkish house are these: spaciousness, airiness and brightness were forefront in the houses and in order to provide them, wide and plenty of windows were used: so, plenty of sunlight entered into the houses at the same time and the rooms opened to the landscape. The houses were made in the system of wooden skeleton and they have a light vision. Thanks to this, it was possible to make maximum visible-glasses surfaces. Turkish people separate the ground floor into secondary functions as entrance, garage and cellar and they organize the main spaces of the houses on the first floor built on wooden columns". According to Kortan, Le Corbusier saw many principles like this in a Turkish house and starting from here he suggested five principles that have an important place in modern architecture. The geniuses like him took a lesson from the history of architecture and by being concluded some principles deductively from him, they used them to create a "timeless architecture", "an architecture that is valid and valuable all the times".

However all researches do not share this point of view. However, the most important stubborn fact in this interaction is that Le Corbusier analyzed Turkish architecture and spaces very correctly in conclusion of his travels and even he comprehended and transferred them better than Turkish people. Within this scope, his interpretations about Yeşil Mosque in Bursa are as if he were giving an architectural lesson and they are noteworthy. "A building is like a soap bubble. This bubble is perfect and harmonious if the breath has been evenly disributed and regulated from the inside. The exterior is a result of an interior. In Bursa in Asia Minor, at the Green Mosque, you enter by little doorway of normal human hight; a quite small vestibule produces in you the necessary change of scale so that you may appreciate, as against the dimensions with which it is intended to impress you. Then you can feel the noble size of the Mosque and your eyes can take its measure. You are in a great white marble space filled with light. Beyond you can see a second similar space of the same dimensionsi but it half-light and raised on several steps (repetition in a minor key); on each side a still smaller space in subdued light-turning round, you have two very small space in shade. From full light to shade, a rythm. Tiny doors and enormous bays. You are captured, you have lost the common scale...",II

\footnotetext{
${ }^{10}$ Kortan, Enis: “Çağdaş Türk Evinde Geleneksel Değerlerin Yorumu”. Yapı Dergisi, 130. İstanbul. 1992. pp. 45-50.

${ }^{11}$ Le Corbusier. Towards a New Architecture, The Architectural Press, London, 1927/1972.
} 
Or, Corbusier who emphasized the beauty of pure geometric forms interpreted Turkish mosques in formal term; "An elementary geometry orders these masses: the square, the cube, the sphere. In plan it is a rectengular complex with a single axes. The orientation of the axis of every mosque on Moslem soil toward the black stone of the Kaaba is an aweinspiring symbol of the unity of the faith. " $" 2$ These lines are like a mirror transferred from a couple of eyes looking from outside to writing and reflecting his own architectural history around the world with repeated ans powerful sensitivity.

\section{Conclusion}

Tanyeli ${ }^{13}$ asks "How is life after death of an architect?" and relates the reality assuring that architect continues living after death to the fact that the architect should convert to a role model and the architectural properties that he defined should shape as his public personality after his death. And according to Tanyeli, this came to reality in Corbusier case and he became a role model for architecture world who still continues to be effective. Le Corbusier who is positioned in a separate place from his contemporaries with his act of always taking new steps and trying to produce new solutions, is a pacemaker figure in Turkey books of whom are still read, buildings of whom are observed and copied.

Le Corbusier is an important source whose opinions and projects the architecture students can apply to in many subjects. He is a part of their first education about the subjects who the architect is, where hi is located as a social figure, what the architecture profession is and what it serves or does not serve as an intellectual profession man at the beginning of their education. Le Corbusier is a model shown as a sample by architecture educators in Turkey with his many designs and especially the production of original architecture he conducted as a result of a continuous questioning. The first analysis work of the students is conducted on his buildings and the researches/ thesis and publications are conducted about him. The foreign travels of an architecture school, student or a young architect are formed in a way that can see his buildings.

Le Corbusier was followed for architecture production in Turkey especially after 1950s, his innovative approaches was accepted and repeated by the architects and he has become the source of inspiration of many buildings shown as qualified architectural products within Turkish architecture today. The buildings mentioned within the scope of the study, can be evaluated within this scope. The travels he made to Turkey, his observations and evaluations during these travels are extremely important. For example according to Cansever ${ }^{14}$ (2003), nobody has made the evaluation of Istanbul conducted by Le Corbusier in 1912 when he was only 25 years old. With this feature, Le Corbusier is also separated from the other architects of his age. Although the relationship between Le Corbusier and Turkish architecture is mostly interpreted as a one-way relationship, we think that this explains a two-way interaction. The second aspect of this interaction can be explained with the travels he conducted in Turkey. It can be concluded from his own words that some features of Turkish cities, mosques and houses affected him to a great extent.

\footnotetext{
${ }^{12}$ Le Corbusier. Le Voyage d'Orient, Les Editions Forces Vives, MGB a Meaux, 1966, pp.78.

${ }^{13}$ Tanyeli, Uğur “Bir Sağırlar Diyaloğu: Le Corbusier'den Türkiye’ye, Türkiye'den Le Corbusier'e” Sanat Dünyamız, 87. İstanbul. 2003. pp.111-121.

${ }^{14}$ Cansever, Turgut “Le Corbusier Hala Güncel mi?”. Sanat Dünyamız, 87. İstanbul. 2003. pp.100.
} 
On the other hand, the ones fed/inspired by the opinions and products of Le Corbusier through their opinions and products submitted some work enriching and developing Turkey's architecture environment with the architecture they formed. Within the scope of this study, Hukukçular Housing Block, Anadolu Club Hotel Building and Cinnah 19 are only three of these samples listed f. In this sense, Le Corbusier can be seen as a door opening to the modern world and the architecture of this world in Turkey's architecture environment. Especially after 1930s, making what he has made and design and more importantly to think/question like him is like a way to reach the modern one.

Turkey located between Europe and Asia has a young population who are modern or in a struggle of being modern. In the field of architecture, as a figure standing beside the word of modern Le Corbusier will indispensably continue to be a reference guide with his opinions and works in Turkey's Architecture environment.

\section{References}

Bektaş, Cengiz “Le Corbusier”. Sanat Dünyamız, 87. İstanbul. 2003. pp.201-203.

Cansever, Turgut “Le Corbusier Hala Güncel mi?”. Sanat Dünyamız, 87. İstanbul. 2003. pp.100.

Cengizkan, Ali: “Cinnah 19: ütopik mi Gerçek modern mi?”, Modernin Saati, Boyut Yayıncılık, İstanbul, 2002.

Cohen, Jean Louis. Le Corbusier. Bonn: Taschen, 2006.

Kortan, Enis: “Çağdaş Türk Evinde Geleneksel Değerlerin Yorumu”. Yapı Dergisi, 130. İstanbul. 1992. pp. 45 50.

Le Corbusier. Towards a New Architecture, The Architectural Press, London, 1927/1972.

Le Corbusier. Le Voyage d'Orient, Les Editions Forces Vives, MGB a Meaux, 1966, pp.78.

Özorhon, İlker Fatih. Mimarlıkta Özgünlük Arayışları:1950-60 Arası Türkiye Modernliği. Director: Türkan Ulusu Uraz. unpublished PhDdissertation. İstanbul Teknik Üniversitesi, İstanbul, 2008.

Tanyeli, Uğur “Bir Sağırlar Diyaloğu: Le Corbusier'den Türkiye’ye, Türkiye’den Le Corbusier’e” Sanat Dünyamız, 87. İstanbul. 2003. pp.111-121.

Yıldırım, Erdem. Foto-Mekan, Foto-Hikaye, Foto-Duvar: Le Corbusier Mimarlı̆̆ ve Onun Fotografik Temsili. Director: Açalya Allmer. unpublished master dissertation. Dokuz Eylül Üniversitesi, İzmir, 2009.

Yılmazer, Pınar. Le Corbusier'nin modern Türk mimarisine etkileri. Director: Kaya Dinçer. unpublished master dissertation. Yıldız Teknik Üniversitesi, İstanbul, 1993.

Vogt, Alexander Max. Le Corbusier, the Noble Savage: Toward an Archaeology of Modernism. 1996. 


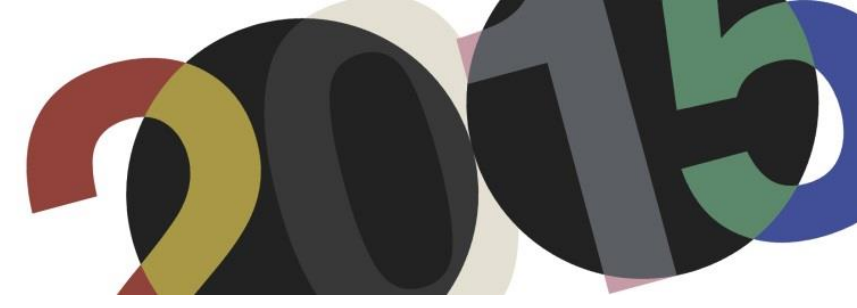

DOI: http://dx.doi.org/10.4995/LC2015.2015.639

\title{
Chandigarh antes de Chandigarh (Cartografía de una idea)
}

\author{
JdelC. Palacios Aguilar \\ Universidad de Lima
}

\begin{abstract}
Resumen: La intención es exponer las ideas que llevaron a Le Corbusier a construir su último y único proyecto urbanistico "Chandigarh";realizar su sueño de construir sobre una ciudad constituida por aquellos elementos prefigurados desde sus libretas, fotografias y textos de sus Viajes a Oriente, 1911 y Sud América, 1929. Le Corbusier encuentra en Chandigarh su ciudad imaginada, aquella configurada en base al constructo de la razón; montañas, paisajes, árboles, cielos, lagos y ríos, etc. y para ello diseñó un mapa en tres dimensiones que contuviese esa razón fundamental de todos sus años de trabajo: "El monumento de la mano abierta" es un lugar donde superpone esa geografia construida (la idealizada con la hallada), diversos dibujos han ido otorgándole en el tiempo esa capacidad de expresar la vocación del tiempo construido . La mano además de serlo- ya no es más un símbolo o un "signo", es un mapa topográfico que contiene sus propósitos esenciales. Chandigarh se construye sobre esa "ciudad imaginada" - siendo sus numerosos dibujos de montañas, ríos y lagos cartografiados desde los botes, trenes, y aviones, - Le Corbusier siempre estuvo a esperaba encontrar un lugar que coincidiera y encajara con todas esas condiciones naturales- alegrías esenciales- y ese lugar fue Punjab (India); alli es cuando se eclipsan realmente por primera vez todos sus elementos configurados. Las montañas del Himalaya y el Lago Suknha más que elementos geográficos - que constituyen los límites del proyecto- son esencialmente imprescindibles para comprenderlo. El monumento de la mano abierta se configura como un recurso ideográfico en la obra de Le Corbusier.
\end{abstract}

\begin{abstract}
The intention is to present the ideas that led to Le Corbusier to build its latest and unique urban project "Chandigarh", realize his dream of building on a city made up of those elements foreshadowed from his notebooks, photographs and texts of his trips to East 1911 South America 1929. Le Corbusier in Chandigarh discovers his imagined city, that set based on the construct of reason; mountains, landscapes, trees, skies, lakes and rivers, etc. and for this he designed a three-dimensional map that contained the fundamental reason for all his years of work: The monument open hand'is a place where overlaps that built geography (the idealized with found), various drawings have been giving at the time that ability to express the vocation of time built. Besides hand the be-is no longer a symbol or a \$ign'is a topographic map containing the essential purposes. Chandigarh is built on the "magined city"- remains his numerous drawings of mountains, rivers and lakes mapped from boats, trains, and planes - Le Corbusier was always expected to find a place to coincide and fit with all those naturales- conditions essential- there was joy and Punjab (India); that's when all set items are really overshadow first. Himalaya Mountains and Lake Suknha than geographic features - which form the boundaries of the project are essentially necessary to understand it. The open hand monument is configured as an ideographic resource in the work of Le Corbusier.
\end{abstract}

Palabras clave: constructo, dibujos, viajes, publicaciones, mano abierta. Keywords: Construct, Drawings, Travels, Publications, Open Hand.

\section{Introducción}

Este texto forma parte de una investigación inicié hace unos meses atrás y quizás el mayor motivo para mi es comprender de mejor manera las circunstancias que han ido elaborando la obra de Le Corbusier.

Nos interesa el paisaje construido (dibujado en el tiempo); no el paisaje físico que observamos sino ese paisaje elaborado desde su experiencia; aquel basado en el constructo de su pensamiento. La idea es exponer los criterios y elementos que pudiesen ayudar a comprender la idea de Chandigarh. Hemos seleccionado algunos 
datos, croquis y fotografías que por el propio interés de ésta investigación nos conducen hacia la construcción de la idea que encierra el proyecto de Chandigarh.

En estos últimos años he estado en contacto con la obra del Maestro y recuerdo tres situaciones fundamentales; la primera fue la vista a la exposición "Rethinking Le Corbusier" en Lisboa, Portugal (2008), la segunda, el viaje a una parte de Estambul (Turkia,2015), Rajasthan (India, 2015), y la tercera quizás la más fundamental fue visitar Chandigarh / Ahmedabad (India, 2015); porque puede visitarlas luego de haber estado casi un mes visitando templos y palacios, y fue así que comprendí las resonancias de su obra.

En la visita a la Exposición "Rethinking Le Corbusier”, descubro un libro -entre otros- que contenía Le Corbusier en su biblioteca personal titulado "Construcción de Ciudades Según principios Artísticos" (Camile Sitte) pude obtenerlo años después. Inevitablemente no pasan desapercibidos dos fragmentos que desde el inicio de la lectura -tanto en el prólogo como en la introducción - le dan un sentido aleccionador al joven Le Corbusier, y que a continuación cito: "Conforme a esta intención, el presente libro no intenta ser, ni una historia del urbanismo, ni un escrito de controversia, sino tan solo ofrecer al técnico material de juicio y derivaciones teóricas; quiere contribuir a la enseñanza estética práctica, aumentando el acervo de experiencias y normas del urbanista, a las que se ciñe en la concepción de sus planos parcelarios l." Quizás ese "material de juicio" sea comprender el universo del que están constituidas las ciudades, y aquellas "normas del urbanista" sean esa fragua que en el tiempo la visión de la experiencia funda. Le Corbusier procuraba en sus proyectos y teorías urbanas continuar con esa unidad ideológica basada en un urbanismo de confluencias naturales, demás esta citar sus planes y proyectos urbanos, pero es importante ahora mirar hacia atrás y comprender como pudo influir este libro en su pensamiento.

Es importante también destacar la influencia que tuvo del escritor, pintor, crítico de arte y de música el suizo William Ritter (1867-1955). ${ }^{2}$, pero la lección de Sitte parece guiarlo también; "Gratos recuerdos de viaje integran nuestros más bellos sueños. Hermosas imágenes de ciudades, monumentos, plazas, panoramas, pasan ante nuestra alma, y otra vez gozamos de aquello a cuyo lado fuimos tan felices al detenernos. ;Detenernos! ¡Cuán a menudo podríamos, en esta o aquella plaza, de cuyas bellezas jamás uno se sacia, y sin duda entonces soportaríamos muchas de angustia, continuando así la lucha eterna de la vida con nuevas fuerzas" ${ }^{3}$. La manera de Le Corbusier de recorrer los territorios y documentarlo no solo gráficamente nos han dejado carnets llenos de experiencias.

Los dibujos de Le Corbusier a mi entender viven tres momentos; el momento en el que dibuja y anota, el momento en el que contiene lo dibujado, y el momento en el que el dibujo transmuta en el tiempo generando un nuevo dibujo (capacidad de observación / constructo). Pero no solo son dibujos, dibuja y fotografía lo que ve, luego proyecta lo que ha aprendido y dibujado, y luego fotografía lo que ha construido; vive un proceso creativo cíclico permanente, algunos dibujos de sus carnets aparecen en sus diseños posteriormente como si estuvieran

\footnotetext{
${ }^{1}$ Sitte, C. La Construcción de Ciudades según principios artísticos. Barcelona, 1929.

${ }^{2}$ Ritter había sido un gran viajero, buen conocedor de la Europa central y su cultura, de la que era un apasionado admirador, por lo que Jeanneret le oiría con frecuencia hablar de los paisajes de Bohemia, de la cultura popular de los Balcanes, o de las bellezas de Constantinopla, despertando y alentando en él un gran deseo de conocer aquellas tierras. [...] Le Corbusier siempre agradecerá la influencia que William Ritter tuvo en su formación en aquel decisivo año de 1911. Dejará constancia de ello en la introducción al primer volumen de su Obra Completa (1930), en la que se referirá a Ritter como el mentor y amigo a quien pudo confiar sus dudas e incredulidades, aquel que le ayudó a encontrarse a sí mismo y a descubrir que en esta vida uno sólo puede contar con sus propias fuerzas. [...] MONTES, C. En el Centenario del Viaje a Oriente. Fotografías, cartas y dibujos. Valladolid, 2011

${ }^{3}$ Sitte, C. La Construcción de Ciudades según principios artísticos, p. 1
} 
emplantillados en su memoria y reproducidos en trazos - casi mecánicamente- por sus manos. Es desde los dibujos de los lugares - y con los alcances de sus pensamientos y escritos- que intentaremos el proyecto de Chandigarh.
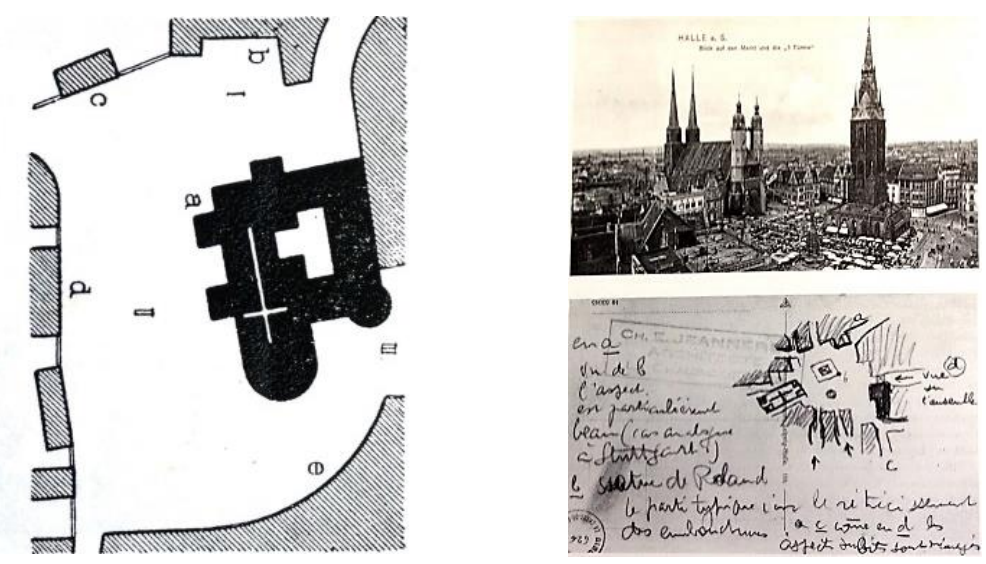

1. Camille Citte "Construcción de Ciudades según principios artísticos" Plaza de la Catedral en Munster. p. 894

2. Postal enviada por Le Corbusier a sus padres_Halles jun 19105

La segunda circunstancia fue la visita a la ciudad de Estambul, ruta hacia Rajasthan (Udaipur, Jodhpur, Jaipur) allí encontré referencias de un Le Corbusier atento que registró todo cuanto vio, como demuestran sus carnets. ${ }^{6}$ En las visitas realizadas a los distintos lugares y templos comprendí las disposiciones de las plazas, espacios entre los edificios, los ingresos a los fuertes y palacios y las alturas que se gozaba desde sus terrazas, luego al visitar Chandigarh pude vivir cercanamente la misma experiencia sensorial.

La tercera circunstancia se ha revelado al visitar y recorrer la ciudad de Chandigarh. Allí se decantan muchas de sus exploraciones teorizadas y explicadas en varias de sus publicaciones; El viaje a Oriente, Hacia una arquitectura, Por las Cuatro Rutas, Cuando las Catedrales eran Blancas, Precisiones, La Ciudad del Futuro, Aircraft, El Poema del Angulo recto, La Pequeña Casa, El Modulor, Mise au Point); intentaremos buscar resonancias que nos permitan clasificar aquellos momentos que han constituido aquella ciudad que tenía pensada.

Es importante mencionar que en el desarrollo del proyecto de Chandigarh (1951-1965) ha habido un elemento que requería insistentemente ser edificado; nos referimos al monumento de la Mano Abierta. El tiempo testigo de sus búsquedas nos permiten ver las posibilidades de ese modelo topográfico desde donde se va construyendo el proyecto que más cercano ha estado de su pensamiento.

\footnotetext{
${ }^{4}$ En el libro de Sitte: "La Construcción de Ciudades según principios artísticos" (1889), está enteramente dedicado al estudio de las ciudades, a la relación entre los edificios, monumentos y plazas, a la disposición y formas de las plazas, estudios sobre la irregularidad, agrupación y disposición de las plazas; y también en el apéndice incluye el empleo de la vegetación en las grandes ciudades. Es un libro lleno de gráficos y análisis desde donde SITTE aborda una conclusión generalista en donde considera que las obras de arte no pueden crearse por comisiones, ni oficinas, sino individualmente, y un plano de ciudad, por debe producir un efecto artístico, es una de tantas. Incluso declara a Constantinopla como un modelo perfecto de ciudad que debemos de imitar; luego comprendemos de qué manera influirá en la visita que Le Corbusier hace en su viaje a Oriente en 1911.

${ }^{5}$ Brooks, A. Le Corbusier's formative years, Charles- Edouard Jeanneret At la Chaux-des-Fonts, Chicago, 1997

${ }^{6}$ El viaje a Oriente que emprendió Charles-Édouard Jeanneret, entre los veintitrés y veinticuatro años, en compañía de su amigo Auguste Klipstein. En un recorrido que comienza el 23 de mayo y termina el 1 noviembre de 1911, el viaje transcurre por la región de Bohemia, (actual Checoslovaquia, creada 1918), Austria, Hungría, Serbia, Rumania, Bulgaria, Turquía, Grecia e Italia. Daza, R. Tras el Viaje de Oriente. Barcelona,2015
} 
Estas aproximaciones aún no contienen la totalidad de las búsquedas, es solo un camino y una pausa sugerente de esta investigación,; el hilo generador de este acercamiento y la documentación hallada me parece que aportan considerablemente a comprender mejor la idea que se propone, idea que está sensiblemente explicada en su último libro, en el mise au point ${ }^{7}$.

La idea de analizar la construcción de una idea sobre Chandigarh y con ello la Mano abierta es para intentar restablecer sus pensamientos formulados y que procuró construir esa evidencia para que no quedara en formulaciones teóricas. La mano abierta representa un pensamiento, no la comprendemos como un signo, sino como una cartografía de su pensamiento, por ello. decodificar esa pieza es de alguna manera codificar nuevamente la obra de Le Corbusier, comprender como se ha ido constituyendo y consolidando un mismo proyecto de arquitectura que comenzó en su viaje a Oriente (1911).

Pero, las preguntas me aparecen al regreso del viaje; ¿Porque son importantes todos los elementos que construyen ese territorio para Le Corbusier?, ¿Porque se repiten los paisajes construidos y dibujados a lo largo de su obra? ¿Cómo es el paisaje que encuentra en Chandigarh, diseña un lugar? o construye sobre él? ¿Porque es importante en la configuración del proyecto el Lago artificial Sukhna? ¿Porque es importante la cordillera Himalaya? ¿Porque la mano abierta debería de ser construida en ese lugar e insistir en ello hasta el final de sus esfuerzos? ¿Es la mano abierta realmente la síntesis de su obra? ¿Es la mano abierta el código de su pensamiento construido por elementos esenciales para la vida del hombre? ¿Representa -la mano abierta- una topografía hecha a partir de una imagen evolucionada de su pensamiento? ¿Contiene el monumento esas "alegrías esenciales" (montañas, caminos, horizontes y lagos) de las que nos hablaba Le Corbusier? ¿Es la mano abierta una cartografía de sus intenciones? ¿Siempre tuvo forma de mano? ¿Es realmente un monumento que refleja toda la síntesis de su obra completa o un signo político?

Intentaremos abordar todas estas interrogantes intercalando los momentos en los que fueron realizados gran parte de sus estudios (dibujos, notas, textos, pensamientos, etc.).

\section{Metodología propuesta para el estudio}

La metodología sitúa en un mismo plano de análisis (por las fechas ${ }^{8}$ en las que se redactó y luego publicó), el Modulor I-II (1950,1955), el Poema del Ángulo Recto (1947-1953) y La Pequeña Casa (1954) como elementos que aparecen durante la gestación de Chandigarh (Punjab, India). La metodología está organizada desde los propios acontecimientos arquitectónicos, algunos en orden cronológico y otros entrelazándose entre sí ayudando a comprender lo que se plantea explicar.

Chandigarh al parecer fue el lugar donde halló todas esas posibles deducciones y contribuciones que dejaría como aporte a la arquitectura no solo desde el Urbanismo sino un lugar donde se desarrolle la vida a favor del hombre.

El segundo factor considerable es la documentación teórica y gráfica reunida en sus viajes; son momentos claves que establecen con el maestro un nexo con la historia y con los lugares que proyectaba; cúmulo de información generada a partir de la observación de sus viaje a Oriente y a Sud América.

\footnotetext{
${ }^{7}$ Torres, J. Pensar la Arquitectura: Mise au point de Le Corbusier. Madrid,2014

${ }^{8}$ Las fechas, datos y toda la documentación que se tiene ha sido consultada directamente de la página web de la fundación Le Corbusier: http://www.fondationlecorbusier.fr
} 
El tercer factor importante es el encargo para el diseño de Chandigarh, donde trabajaron junto a Pierre Jeanneret (primo y encargado del proyecto), Maxwell Fry y Jane Drew ${ }^{9}$. Es fundamental establecer el nexo con su primo Jeanneret ya que anteriormente había colaborado con él - en la que a mi parecer dejaron un ejemplo de urbanismo sintetizado- en los planos de la pequeña casa que se construyó en Suiza, "la pequeña casa fue construida 1923/1924 según los planos de Le Corbusier y de Pierre Jeanneret (N.de.E.) $)^{10}$, luego nos detendremos en ver sobre las implicancias de dicho proyecto y como se hila con la obra de Le Corbusier y Chandigarh.

El cuarto momento está en el pequeño poemario sobre Urbanismo conocido como el Poema del Angulo Recto ${ }^{11}$ que fue elaborado por Le Corbusier entre los años 1948-1955 donde pone de manifiesto las condiciones sobre su trayectoria armónica en la concepción de la arquitectura.
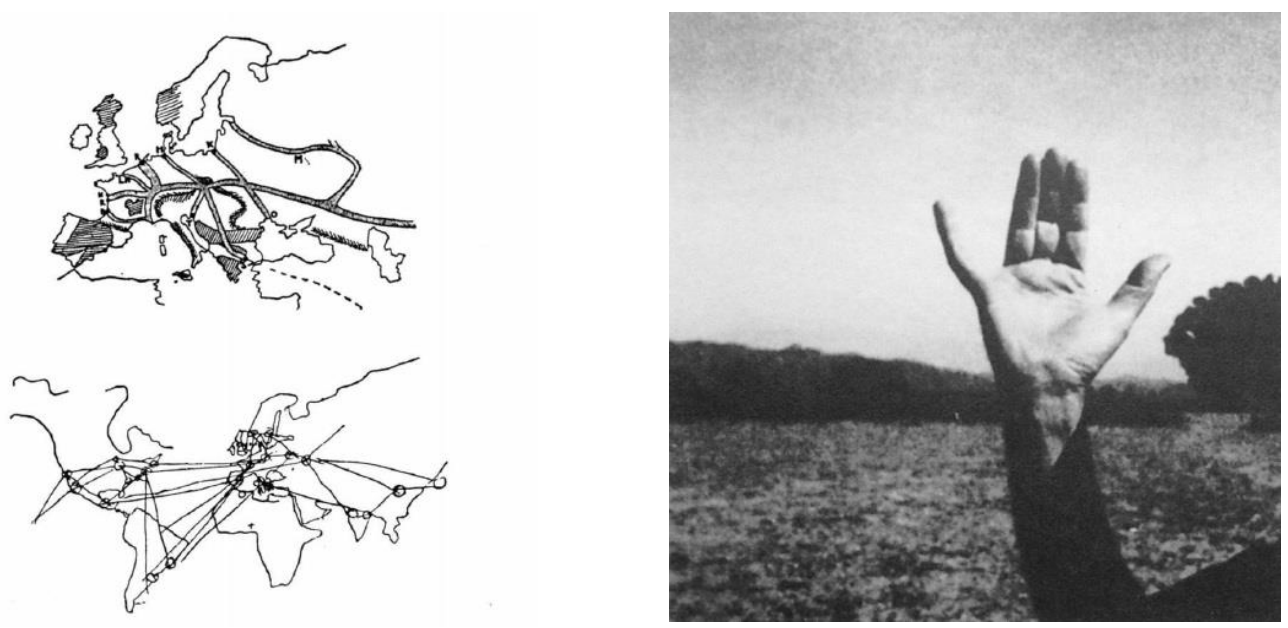

3. Imagen en El Modulor (FLC) p.117, cerrando el capítulo 4 donde se muestra el mapa del viaje a Oriente y seguido el mapa total de todos sus viajes (a Sud América , Europa e India)

4. Le Corbusier's open hand on the Capitol City $1951^{12}$

El quinto propósito lo establece el Monumento de la Mano abierta. Se han escrito innumerables textos y se han querido hallar diversos significados, algunos explicados por el mismo Le Corbusier y sin embargo pensamos que la idea de la mano se ha ido "dibujando" en el tiempo y que finalmente se le ha dado una connotación simbólica, ya que es lo que visualmente evidencia.

\footnotetext{
${ }^{9}$ Huse, M. Le Corbusier, Barcelona, 1986

${ }^{10}$ Le Corbusier. Una Pequeña Casa, Argentina, 2014

${ }^{11}$ AA.VV. Le Corbusier y las Síntesis de las artes; El poema del ángulo recto, Madrid, 2006

${ }^{12}$ Seguin, P. Le Corbusier Pierre Jeanneret (Chandigarh India). Francia, 2014
} 

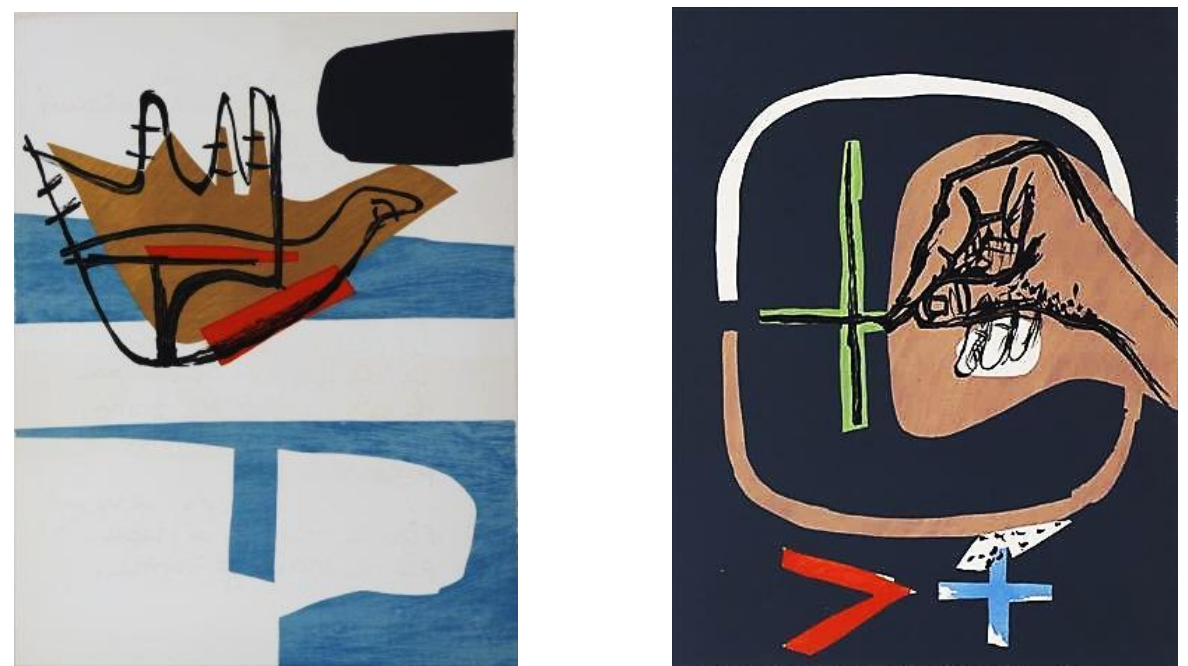

5. El Poema del Angulo Recto p.145_F.L.C Éditions Tériade, Paris, 1955

6. El Poema del Angulo Recto p.151_F.L.C Éditions Tériade, Paris, 1955

La metodología intenta recomponer las ideas que Le Corbusier plantea sobre el diseño de las ciudades que llego a proyectar -solo nos enfocaremos en los proyectos donde hemos encontrado elementos que aparecen coincidentemente en Chandigarh - y que fue componiendo en sus dibujos y escritos, reiterando el entorno hallado, trasponiendo sus condiciones proyectuales y procurando un paisaje-herramienta para el hombre.
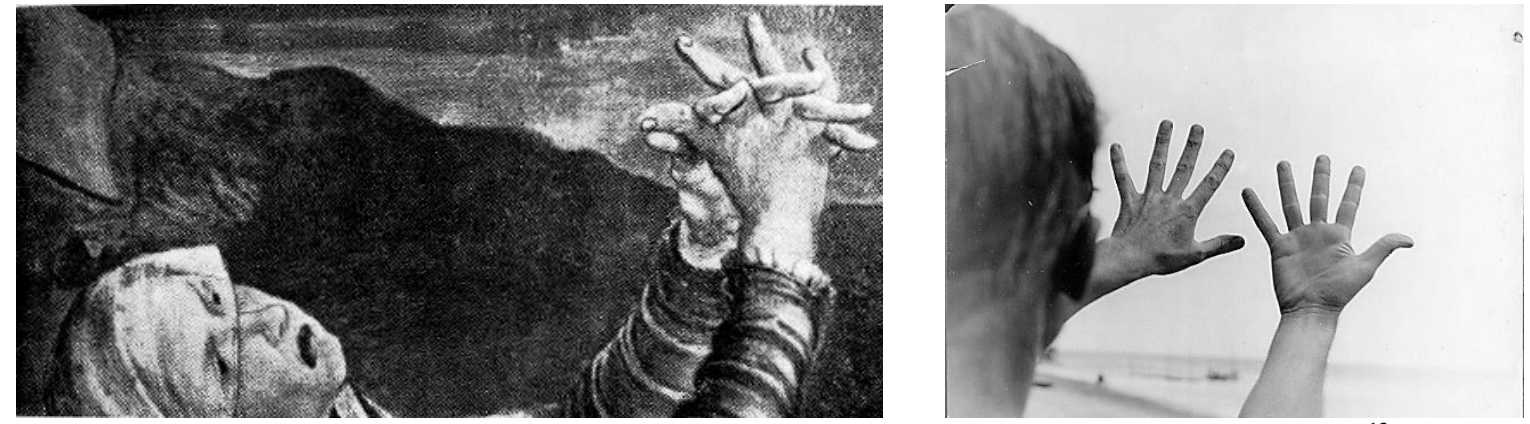

7. Una ilustración de la Maquette établie par Trouin sur l’íconographie Marie-Madeleine, en la Obra Completa ${ }^{\mathbf{1 3}}$ 8. FLC L4.3.27. ${ }^{14}$

Habría que reconfigurar Chandigarh, precisar información sobre su viaje a Oriente, acercarnos a la pequeña casa construida sobre el lago Lemán, atender el manejo de las alegrías esenciales sobre la concepción del urbanismo junto a la regla de las 7 vías y la implicancia directa del Modulor en el estudio de las proporciones.

\section{Resonancias desde el interior}

Esa naturaleza construida que le atrajo tanto -como la que halló al borde del lago Leman (1923) - como el lugar hallado en Chandigarh lo define así: "Estamos en una llanura; la cordillera del Himalaya cierra solemnemente el paisaje por el norte ${ }^{, 15}$ El espacio que concebía como un lugar donde debía desarrollarse una ciudad aparecía nuevamente sobre un fondo montañoso. Quizás le recuerde a los Andes o a los Alpes, pero siempre estaba la idea recurrente "la flor, la planta, el árbol y la montaña se alzan sobre el suelo, viven en un ambiente dado. Si alguna vez llaman la atención por su actitud, verdaderamente firme y soberana, es porque se destacan en su

\footnotetext{
${ }^{13}$ Le Corbusier et Pierre Jeanneret, Euvre complète 1946- 1952 Vol 5 p.27

${ }^{14}$ VV.AA, Le Corbusier, Le Grand, p.458

${ }^{15}$ Le Corbusier. El Modulor/El Modulor 2. Madrid, 2005
} 
presencia, pero provocando resonancias a su alrededor. Nos detenemos, sensibles ante tantos vínculos naturales y contemplamos emocionados por tantas concordancias que orquestan tanto espacio, y consideramos entonces que lo que vemos irradia luz. ",16

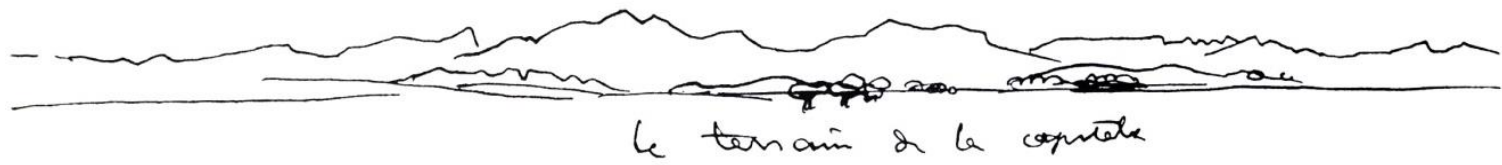

9. Le Terrain de la capitale, $1951^{17}$

En los lugares buscaba esa armonía que encierra un pensamiento y coloca al hombre por encima de lo espiritual. En su libro Como Concebir el Urbanismo (1946) explica esa concepción del lugar; "Existe unidad entre las obras de la naturaleza y las obras del espíritu humano”. Al reconocer la soberanía de la naturaleza, Descartes ha puesto un término a la de la Razón; un término a la primacía del verbo. Lo que cuenta ya no son las palabras sino las realidades" 18 como aguardando ese momento para vaciar su experiencia y voluntad casi siempre son textos que aparecen en la mismas direcciones. En otra de sus publicaciones "La Ciudad del Futuro(1924) aparecen unas condiciones propuestas también desde el paisaje y la vida, que reflejan y mantienen coherentemente esa filosofía planteada en Chandigarh, citando al mismo Le Corbusier ; “ Posiblemente corresponderá al nuevo espíritu arquitectónico, al urbanismo inminente, satisfacer las más remotas funciones humanas, reverdeciendo el paisaje humano y mezclando a nuestra labor la naturaleza" 19 La medida justa entre el hombre y la naturaleza era un motivo fundamental en su arquitectura en éste mismo libro se acerca a las teorías de Sitte y advierte que "La ciudad es un instrumento de trabajo[...]Es la manumisión de la naturaleza por el hombre. Es una acción humana contra la naturaleza, es un organismo humano de protección y trabajo. Es una creación [...]. La poesía es un acto humano: las relaciones concertadas entre imágenes perceptibles" 20 Los elementos debían estar en armonía, el hombre debía de situarse por encima de la naturaleza pero no para dominarla sino para comunicarse con ella y las medidas del hombre "el Modulor" proponían ese encuentro casi nupcial.

En 1937 describe esa relación armoniosa entre el alma del hombre "espíritu” y la naturaleza, las alegría esenciales "Sol. Espacio y árboles; los he comprendido como materiales fundamentales del Urbanismo, portadores de alegrías esenciales al afirmarlo, quiero volver a poner al hombre en sus ciudades, en el corazón mismo de su medio natural, de sus emociones fundamentales" ${ }^{21}$. Siempre por encima de toda arquitectura esta ese propósito de llevar al hombre de situarlo por encima del medio natural-filosófico- pero privarlo de árboles sería destruirlo. Y es que en Chandigarh las montañas que delimitan el paisaje juntos a los espacios verdes -como aquellos vergeles que tanto acuso en Estambul - han configurado esa arquitectura que participa del entorno, lo observa y se reune con él.

\footnotetext{
${ }^{16}$ Ibídem, p225

${ }^{17}$ Seguin, P. Le Corbusier Pierre Jeanneret (Chandigarh India), Francia, 2014

${ }^{18}$ Le Corbusier. Cómo concebir el urbanismo, Argentina 2013

${ }^{19}$ Le Corbusier. La ciudad del Futuro, p.61

${ }^{20}$ Ibidem, p. 15

${ }^{21}$ Le Corbusier, Cuando las Catedrales eran Blancas, Madrid, 2007
} 
El libro "La Pequeña Casa (1923)" se menciona por dos razones ${ }^{22}$; primero porque como mencionamos es un ensayo de menor escala de un urbanismo construido en el espíritu y luego llevado a otra escala, faltaba hallar el lugar. En el caso de Chandigarh el lugar ya estaba, faltaba que Le Corbusier lo mirara para darse cuenta que todo estaba allí, faltaba el Lago Sukhna. Pero volvamos a la Pequeña casa, allí se encuentran realmente todos los motivos antes mencionados, tenemos el Lago Leman, las montañas Neucahtelesas, los árboles, el lugar, el paisaje, la cubierta habitada, el encuadre, los planos que ya estaban hechos, el ángulo recto. Es sabido que la casa fue diseñada para sus padres y que luego se buscó el lugar para edificarla. Es importante mencionar que la "la pequeña casa fue construida en 1923 /1924 según los planos de Le Corbusier y de Pierre Jeanneret.(N.d.E)" ${ }^{23}$ Ambos participaron juntos en la construcción de la ciudad de Chandigarh, por esa coincidencia es que reanudo nuevamente el carácter de esa participación.

En ese mismo año Le Corbusier publica "Hacia una Arquitectura"( 1923) donde aparece coincidentemente el dibujo de la Acrópolis junto al dibujo del Templo de Minerva; analiza las relaciones entre los elementos que conforman la perspectiva, constantemente son reflejadas en el Modulor y trabajadas en Chandigarh en estudios con palos para hallar las distancia armónica entre los edificios. Es importante ver la relación de la planta del dibujo hecho por Le Corbusier del Forum de Pompeya y el de la Pequeña casa por dos razones: la primera es porque toma la configuración de la casa como si de una pequeña ciudad se tratara pero considerando los elementos naturales del paisaje, sin embargo en Chandigarh solo refiere el paisaje como el espíritu del lugar, tomando la historia como un dispositivo y superponiéndolo al lugar. No es tan evidente cuando han pasado muchos años, pero si es evidente que Le Corbusier tenía en la mano todos los trazos que hizo, por ello hay muchas coincidencias entre sus dibujos y sobre lo que proyectó, incluso coincidencias simultaneas.

Si superponemos ambas plantas vemos que guardan una estrecha relación entre sus medidas y orientaciones, el medio que rodea la arquitectura siempre ha estado como condicionante al abordar sus proyectos, incluso desde antes de que se apareciera el lugar se tuvo el proyecto, y es porque ha estado presente en su subconsciente ya su infancia lo revela.
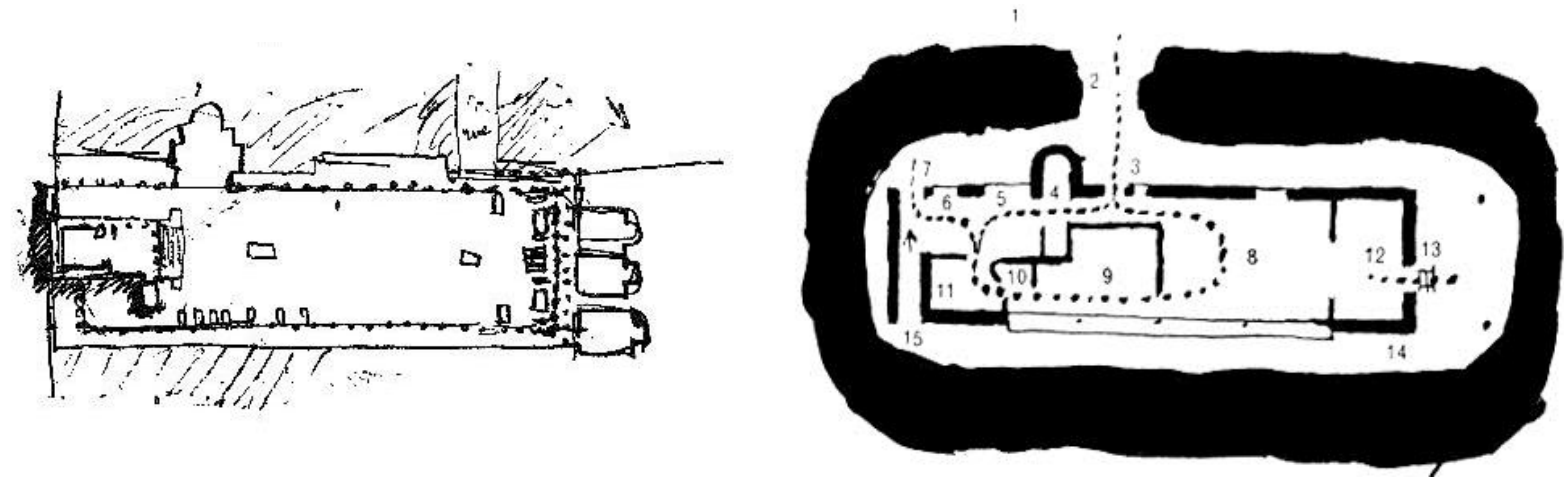

10. Imagen del Foro de Pompeya publicada en "Hacia una Arquitectura", 1927

11. Dibujo de la planta de "La Pequeña Casa", realizada en 1923

La presencia de la naturaleza se hace evidente en La Chaux no solo por sus topografías sino también por el marcado contraste entre el cálido verano y el frío y nevado invierno, debido a su altitud y latitud. De los años transcurridos en La Chaux, Jeanneret (cuyo padre fue presidente del club local de montaña) escribió: "Mi

\footnotetext{
${ }^{22}$ Solo haremos mención a esta casa - por encontrar estrechas relaciones con Chandigarh- porque el libro "la pequeña casa" fue publicado -luego de 21 años de su construcción - en 1954, es relevante que se haya escrito en ese momento, ya que el proyecto de Chandigarh se inicia en 1951.

${ }^{23}$ Le Corbuiser, Una pequeña Casa, p.15
} 
infancia la pase con mis amigos en medio de la naturaleza. Mi padre, además era ferviente devoto de los ríos y las montañas que configuraban nuestro paisaje. Constantemente estábamos entre cimas, siempre en contacto con la inmensidad del horizonte. Cuando la niebla se extendía interminable parecía un verdadero mar, al que nunca había visto. Era el espectáculo supremo. El periodo de la adolescencia fue de curiosidad insaciable, sabía cómo eran las flores, la forma y los colores de los pájaros, comprendía el crecimiento de los árboles y cómo guardaban el equilibrio en medio de una tormenta, en 1925 en L'Art Decoratif d'Aujourd'hui, París ",24

Por estos años iniciales no hay Modulor, pero sí se formaban esas "alegrías esenciales" y relaciones con el paisaje que siempre menciona "Del mismo modo en la Acrópolis de Atenas, espacios y volúmenes dispuestos por la topografía y por una ciencia perfecta, aliados al circo que forman las montañas y frente al mar cubierto de montañas e islas, han convertido este lugar en algo caro para el corazón” ${ }^{, 25}$ y no deja de hacerlo en sus posteriores teorizaciones; en Chandigarh refleja ese mismo espíritu como lo explica Kenneth Frampton "los edificios representativos de los tres poderes-el Tribunal Supremo, la Asamblea y los Ministerios- estaban relacionados no por la configuración del emplazamiento, como en la Acrópolis, sino más bien por líneas abstractas muy lejanas, un escorzo progresivo, cuyos únicos límites parecían estar en las montañas del horizonte" Esas "líneas abstractas "derivan de las medidas del Modulor, de las perspectivas producidas en sus estudios de la Acrópolis y sobre la aplicación de los análisis de movilidad planteados en la conocida "Regla de las 7 vías" y que vio la luz en Chandigarh.

\section{Entre el Himalaya y el lago Sukhna}
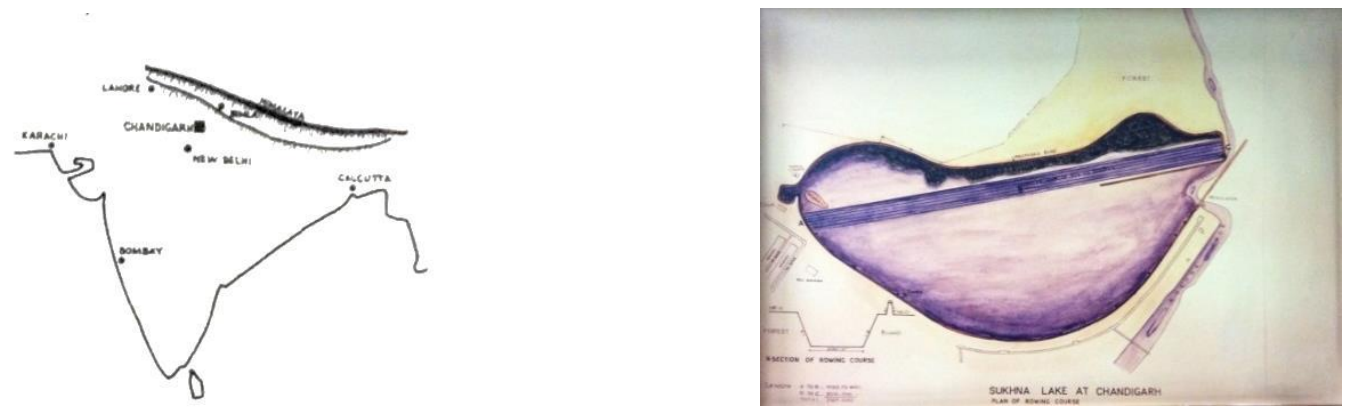

12. Sketch of Chandigarh in the Architect on Buildings News, 6 sep $1951^{26}$

13. Lago Sukhna(1956) ${ }^{27}$

El encargo surge al lograr India su independencia en 1947, con ello la vocación de parte del primer Ministro J. $\mathrm{Nehru}^{28}$ y la de Le Corbusier: "tenía 60 años cuando recibí mi primer y único encargo oficial del Estado, y esto, sin duda! era para reírse un poco! Todo el mundo fue alertado. ; El espíritu, la Edad Media. Después de la Guerra: reconstrucción, para Corbucero" ${ }^{, 29}$. Aquí se refería sobre aquella lejana y ahora cercana posibilidad de elaborar su primer proyecto urbanístico; en otras ocasiones se había truncado por una u otra razón, pero sin

\footnotetext{
${ }^{24}$ Baker, G. Análisis de la forma. Barcelona, 2000

${ }^{25}$ Le Corbusier, Cuando las Catedrales eran Blancas, $p .140$

${ }^{26}$ VV.AA, Le Corbusier, Le Grand, p.455

${ }^{27}$ Fotografía realizada por el autor en el Centre Le Corbusier en Chandigarh (India) 22 enero 2015.

28 "Será una ciudad nueva, un símbolo de la libertad de la India. Firme con las tradiciones del pasado [...], expresión de la confianza del país en el futuro” HUSE, N. Le Corbusier, Barcelona, 1986

${ }^{29}$ Torres, p. 14
} 
embargo este proyecto si se llegó a concretar y allí es donde logra aplicar su experiencia de vida. Al paisaje encontrado en Chandigarh -remarcado por ese fantástico borde montañoso del Himalaya-, le aparece el Lago Sukhna que fue creado para delimitar parte del extenso territorio, de esta manera estaba completando el límite que no tenía su plan ideal (imaginado). El proyecto significaba contener de alguna manera los limites pero dotando a la ciudad de un promenade con árboles y agua tal como está en la actualidad (2015). Un lugar de paseo para los locales y extranjeros, un lugar en donde la naturaleza del lugar permite que se practiquen las regatas cada año y donde se prohibió -desde que Le Corbusier lo propuso- las lanchas a motor para evitar la contaminación y preservar lo natural; la parte superior del paseo marítimo están también prohibidas de tráfico rodado, hasta ahora. A tanto llego el nivel de implicancia con el proyecto y con la integra exposición espiritual de cada uno que cuando fallece Jeanneret -a dos años de fallecer Le Corbusier y a uno de fallecer Jawaharlal Nehru- en 1967 hace que sus cenizas fuesen arrojadas sobre el lago Sukhna. ${ }^{30}$.

La orientación de los edificios estaba regida por los vientos predominantes y la orientación solar, así desde el Lago Sukhna se podía observar la ciudad o divisar parte de los edificios asomarse desde el horizonte, como sucede con las Unités y con el Convento de la Tourette. Pero también encontramos en sus archivos las fotografías que tomo en su viaje por Esztergon ${ }^{31}$ desde donde se aprecia la Catedral desde el Danubio, la imagen es tomada desde un lado del barco y el grado de tranquilidad y contemplación es similar al logrado muchos años después en Chandigarh desde el Lago Sukhna. La fotografía de Chandigarh data de 1965 pero no se tiene el autor. Concuerdan ambas cúpulas, la de la del Palacio de la Asamblea destacando sobre el horizonte, donde la pátina del tiempo no ha envejecido el concreto de los edificios como están ahora.
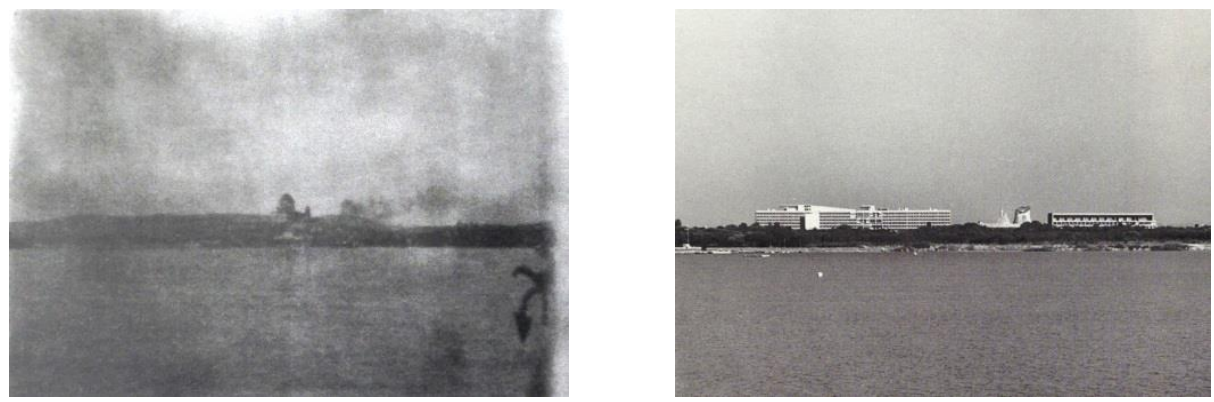

14. Catedral de Esztergon ${ }^{32}$

15. Secretariat, Legislative Assembly and High Court, seen from Sukhna Lake in sector 1,ca.1965 ${ }^{33}$

En sus crónicas escribe una nota que al leer nos hace anticipar lo que realizó en Chandigarh "Aparece Esztergon, extraña silueta: un cubo y una cúpula sostenida por varias columnas. De lejos todo presagia una maravilla. Cubo en el que late un ritmo admirable y que los montes nacientes presentan como una ofrenda sobre el altar que le dedican. "34

El lago Sukhna es fundamental para comprender la nueva concepción de la ciudad de Chandigarh, para Le Corbusier este "Boulevard de Auxs"- There is now a lake, a body of water which has transformed the local climatic condition ${ }^{, 35}$. hoy he podido recorrer el borde del lago y la sensación contemplativa y de gozo esencial

\footnotetext{
${ }^{30}$ Seguin, P. p.43

${ }^{31}$ Daza, El viaje a Oriente, $p .42$

${ }^{32}$ Ibídem

${ }^{33}$ Seguin, P. p.72

${ }^{34}$ Daza, El viaje a Oriente, $p .43$

${ }^{35}$ Le Corbusier et Pierre Jeanneret, Euvre complète 1952- 1957. Vol 6 p.53
} 
es sin duda un gran aporte en la vida de los hindúes, sin embargo no se ha encontrado mayor material que pudiera darnos mayores alcances.

\section{Poemario de Urbanismo y el espacio Inefable ${ }^{36}$}

El ángulo recto referida siempre a la incidencia de la vertical sobre la horizontal y que funda de alguna manera su pensamiento urbanístico, tiene que ver con el recorrido del sol, “El ángulo de incidencia no pasará jamás por la pequeña casa. Alcanza (y deslumbra) a los habitantes de las colinas, ;los de la cota cincuenta o cien! La "gente» ignora el ángulo de incidencia",37 Pero no es sino que a mediados de $1947^{38}$ que inicia el Poema del Ángulo Recto, fue escrito entre los años 1948 y 1955 y abarca parte del periodo en la cual Le Corbusier estaba trabajando en Chandigarh.
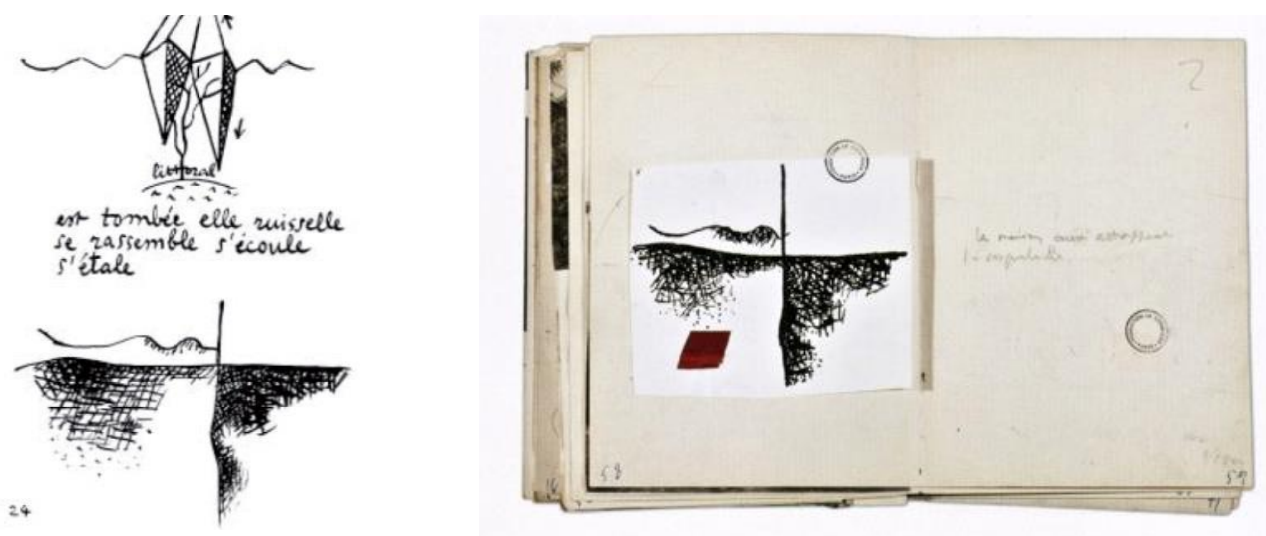

16. Imagen publicada en el Poema del Angulo Recto, p24

17. Imagen de la maquetación del libro La pequeña Casa (1954). ${ }^{39}$

No es casualidad que aparezcan hilos que vinculen las decisiones tomadas en la ciudad previamente prefigurada. Podemos ver que en el libro hay referencias continuas sobre la concepción del espíritu de su obra, nuevamente miramos atrás y comprendemos -ese paisaje concebido desde la experiencia- aquella ciudad que tantas veces reinventó en su mente. "El ángulo recto es el útil necesario y suficiente para actuar, puesto que sirve para fijar el espacio con un rigor perfecto." 40 Esta anotación aparece publicada en 1924 justo cuando proyectaba $L a$ Pequeña Casa y cuando publicaba "Hacia una Arquitectura", 20 años antes de comenzar a escribir el Poema del Ángulo Recto (1947-1953). Le Corbusier nos dice en el mismo libro que el espíritu que anima la naturaleza es un espíritu de orden; aprendamos a saberlo. Por ello, en 1947 cuando inicia el proyecto del Poema del Angulo Recto, (mismo año que la India se independiza) nos continua hablando sobre el horizonte en la composición del paisaje del proyecto: "En el horizonte se dibuja la horizontal; se trata de dos constantes. El ángulo recto es como la integral de las fuerzas que mantienen el mundo en equilibrio. " 41 El libro contiene una estructura que está organizada por medio de imágenes que representan la lucha que el lleva año tras año para poder alcanzar su

\footnotetext{
${ }^{36}$ Espacio inefable traducido en la versión castellana, sin embargo el término en su idioma original es L'espace indicible escrito en 1945 y publicado un año después en Architecture D'Ajourdui; donde exigía una autentica refundación espiritual del entorno humano bajo el signo de la armonía. CALATRAVA, J. Le Corbusier y las Síntesis de las Artes, Madrid, 2006

${ }^{37}$ Le Corbuiser, Una pequeña Casa, p.15

${ }^{38}$ Calatrava, J. Le Corbusier y la Síntesis de las Artes, Madrid, 2006

${ }^{39}$ AA.VV. Construire l'image Le Corbusier et la Photographie, París, 2012

${ }^{40}$ Le Corbusier. La ciudad del Futuro, p28

${ }^{41}$ Ibídem, p.31
} 
pensamiento y llevar a ideliazar sus proyectos. Hay un orden, hay una trama, elementos de Chandigarh de una $u$ otra manera, allí hallamos una imagen que representa el esquema planteado por Le Corbusier en Chandigarh, porque seguramente esta idea configurada formaba parte de sus composiciones respecto al día a la noche, al lugar a los meridianos, a la naturaleza, al parecer ya es una idea que va construyéndose poco a poco en el tiempo.

No nos interesa encontrar simbolismos ni buscar asociaciones entre sí, sino más bien prestar atención a aquellas coincidencias que se vienen dando entre momentos que han sido parte de sus anotaciones en los carnets, fotografías de viaje y luego en los momentos que comenzaron a configurar Chandigarh.

La figura de la pequeña jornada establece el contacto con las 24 horas, con el sol, con la composición de la arquitectura a través del movimiento solar, determinando así el valor de un paisaje marcando el eje de coordenadas mediante una línea vertical. Una imagen más aparece en el Poema del Angulo Recto marcando los 7 momentos de reflexión, aparece el sol coronando el amanecer y quizás la espada está ahí para defender el día precursor de la luz y custodio de la naturaleza, brilla en amarillo porque refleja ese poder del luminoso sol que defiende la vida, aun cuando ya no la quiera el hombre. Esa composición se repite luego páginas más adelante haciendo un poema sobre las visiones que se tiene desde arriba cuando uno sobrevuela por las cordilleras, los Andes y los Alpes. En su viaje a Sur América llenó cuadernos con dibujos de montañas, mares, ríos serpenteantes y cielos diáfanos, todo ello recogido en el Poema, es una oda a la naturaleza, de su espíritu y de la geografía que tanto entusiasmaba.
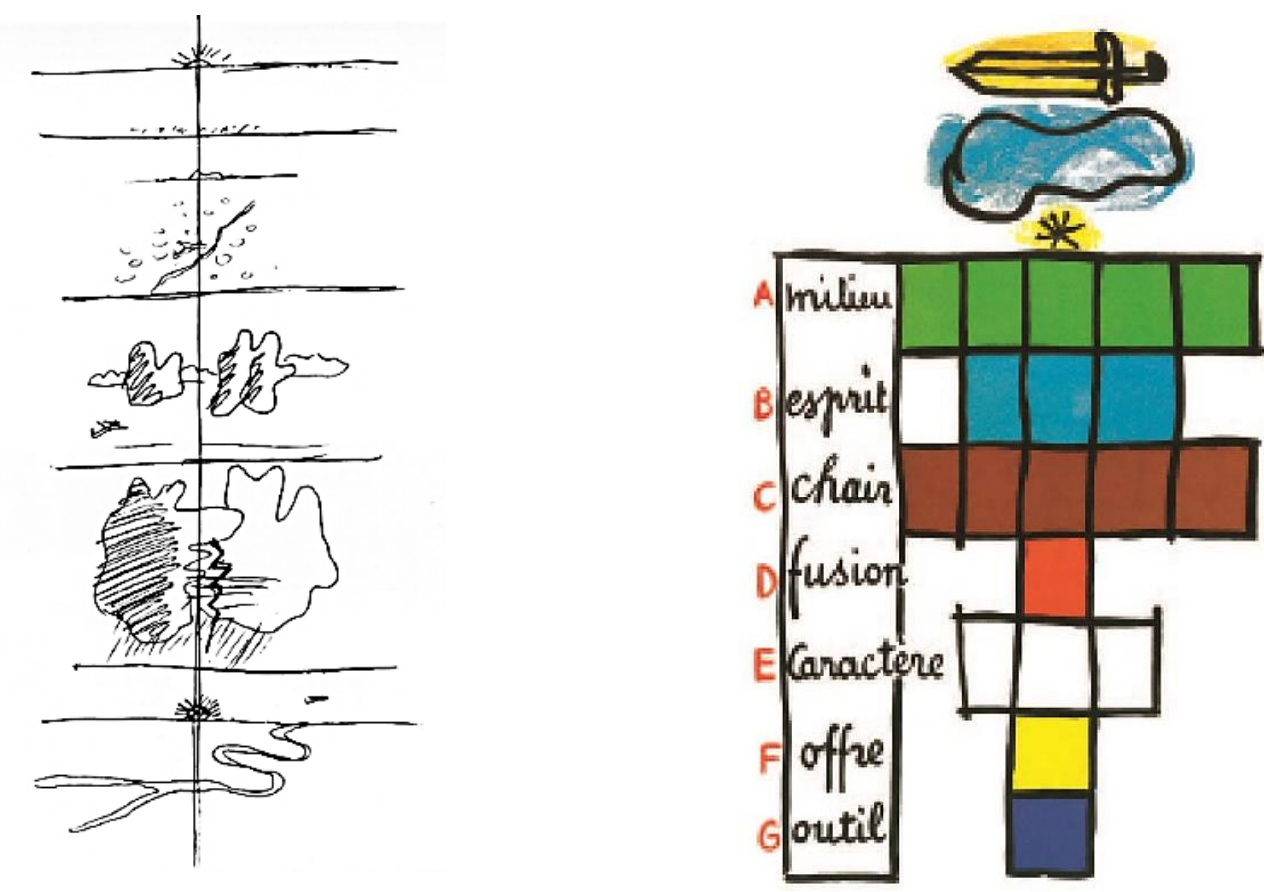

18. Pequeña meditación sobre una jornada completa ${ }^{42}$

19. Poema del Ángulo Recto, p.8

\footnotetext{
${ }^{42}$ Le Corbusier et Pierre Jeanneret, Euvre complète 1957- 1965 Vol 7 _O. Stonorov y W. Boesiger. Zürich: H. R. Grisberger \& Cie, 1937
} 
En la página 39 del Poema del Ángulo Recto aparecen dos gráficos; el superior nos recuerda las estancias sobre las terrazas en los palacios de Jaipur, madre con niño al amparo de la sombra, enmarcando el paisaje, el dibujo inferior esta girado quizás como lo concibió meridionalmente, la orientación del dibujo jerarquiza un orden y una trama que organiza trazando unas líneas como ríos que se entrelazan con la naturaleza. Al lado hemos colocado el mapa de Chandigarh que busca organizarse bajo pautas similares a las graficadas en el Poema del Angulo Recto, vemos la organización reticular. Si fue antes o después no interesa, lo que importa es que este en ese poemario que es parte de la razón que fundamenta su posición frente a la naturaleza y al hombre.

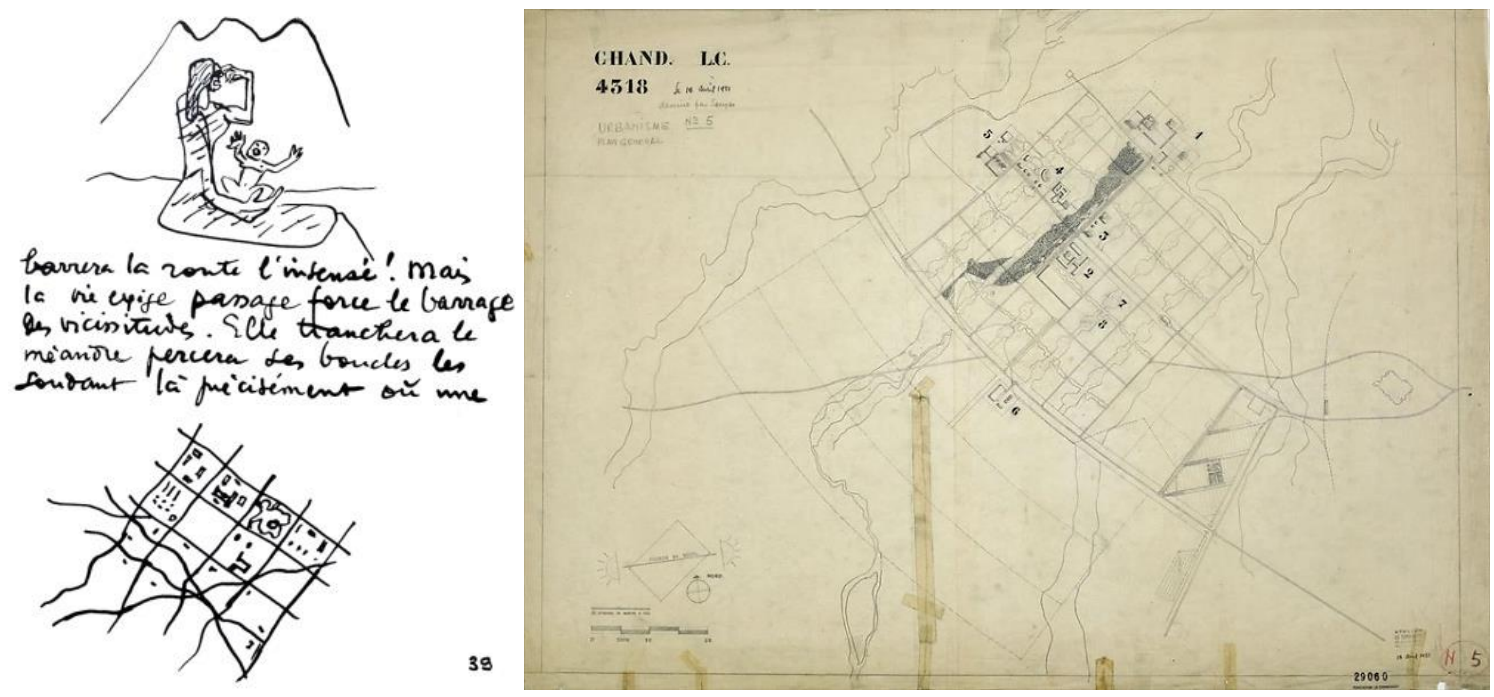

20. El Poema del Ángulo Recto, A-4 Medio, p.38

21. Chandigarh, Plan General n ${ }^{\circ}$. CHD L.C. $4318^{43}$

\section{La mano abierta, una idea de monumento}

Ahora nos toca mirar al monumento, a ver quienes observan y ser nuevamente los observados - como dice Quetglas- quizás en el Panteón de Foch, de 1929, sea la primera ocasión donde Le Corbusier se enfrenta a la idea de monumento "El monumento solemnemente, está aislado. Él también, y puede servir como lección de sensatez" " ${ }^{44}$ El monumento a la mano abierta probamente sea una lección de sensatez porque allí está tallada toda una trayectoria, representa el esfuerzo y la visión de lograr un lugar concebido con la esencia de cada una de sus partes. La mano abierta de alguna manera ya estaba construida -en su mente- cuando Le Corbusier decide colocarla en Chandigarh.

La mano abierta forma parte de ese constructo elaborado durante muchos años con ideas y dibujos de sus viajes. Aparece siempre la voluntad de entender la mano abierta como un signo o símbolo, sin embargo hay motivos para comprender que la mano abierta es una sucesión de dibujos concretos de la mano que va desde 1951-1963, también aparece un texto que pretende justificar su resolución "En un tarde, en la Rest- House en Chandigarh, estando reunidos Jaen Drew, Pierre Janeret, Maxwell Fry y Le Corbuiser, la primera tomo la palabra y dijo; Le Corbusier, usted debe de instalar en el corazón mismo del capitolio, los signos mediante los cuales ha llegado usted a expresar de un lado el urbanismo, y de otro lado su pensamiento filosófico; estos signos merecen ser

\footnotetext{
${ }^{43}$ Seguin, P. p.54-55

${ }^{44}$ Quetglas, J. Pasado a Limpio, II, Girona, 2001
} 
conocidos, son la clave de creación de Chandigarh "45 Pensamos que podría ser una razón, pero pensamos que la razón misma no es la que erigió dicho monumento.

Es sabido que Le Corbusier rechaza en todo momento que dicho se haga una interpretación y declara; "el Monumento a la mano abierta, por ejemplo del que habla Soltan, no es un signo político, una creación de político. Es una creación de arquitecto, un fruto de arquitectura. Hay en esta creación un caso específico de neutralidad humana: lo que crea depende de las leyes de la física, de la química, de la biología, de la ética, de la estética, todas juntas reunidas en una sola gavilla: una casa, una ciudad. [...]Esta mano abierta signo de paz $y$ de reconciliación, debe erigirse en Chandigarh, este símbolo que me preocupa hace muchos años en mi subconsciente debe existir para llevar un testimonio de armonía” [...]Antes de encontrarme un día (más tarde) en las zonas celestes entre las estrellas del buen Dios, seré feliz de ver en Chandigarh, delante del Himalaya que se eleva verticalmente sobre el horizonte, esta mano abierta que marca para el pére Corbu un hecho, una etapa recorrida." 46
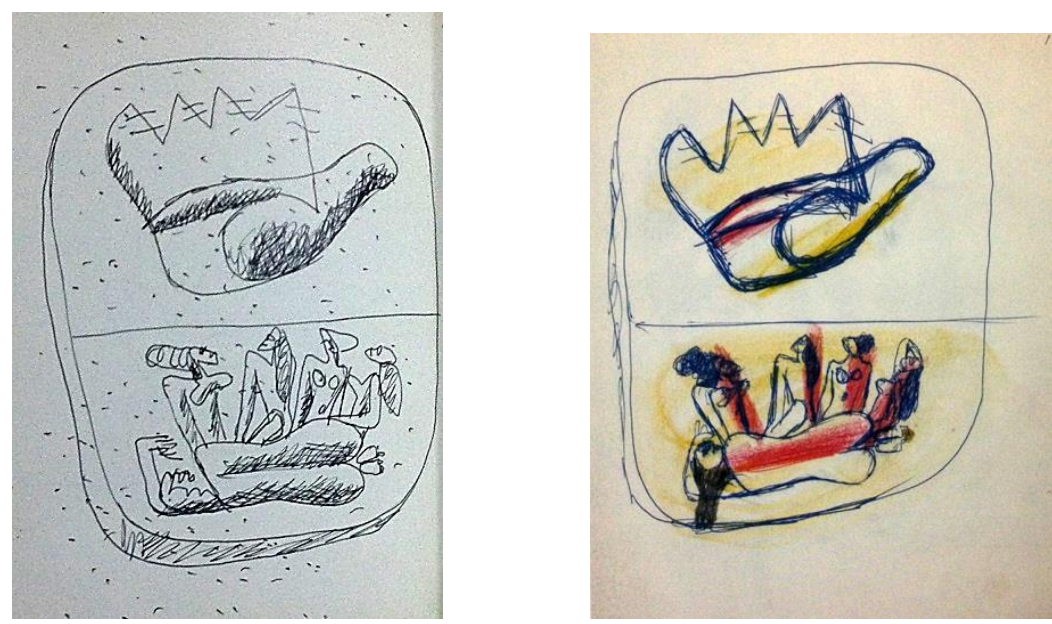

22. Dibujo de la Mano abierta en blanco y negro, $1951^{47}$

23. Dibujo de la Mano abierta en color, $1951^{48}$
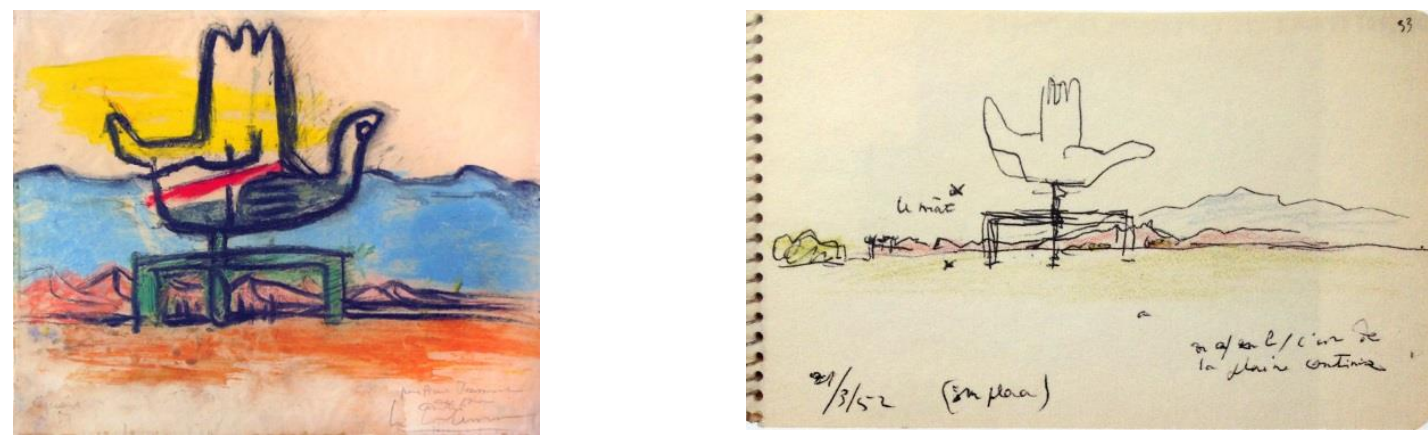

24. Dibujo de la Mano abierta insertado en el lugar dedicado a su primo "Pour Pierre Jeanneret, avec mon amitié", $1951^{49}$ 25. Dibujo de la Mano abierta de los carnets, $1952^{50}$

\footnotetext{
${ }^{45}$ Este comentario no tiene fechada la referencia- el lugar podría ser Chandigarh-pero podría situarse entre los años 19521954 ya que fue el tiempo que estuvieron colaborando en Punjab según los archivos del Centro Le Corbusier en Chandigarh, Le Corbusier 1910-1965, Barcelona, 2005.

${ }^{46}$ Le Corbusier, Mise au Point, Madrid, 2014

${ }^{47}$ VV.AA, Le Corbusier, Le Grand, p.455

${ }^{48}$ Ibídem

${ }^{49}$ ChampetieR, M. Galerie http://www.mchampetier.com/Tecnica_mixta_firmada-Jeanneret-Le.Corbusier-14110quintaesencia.html
} 

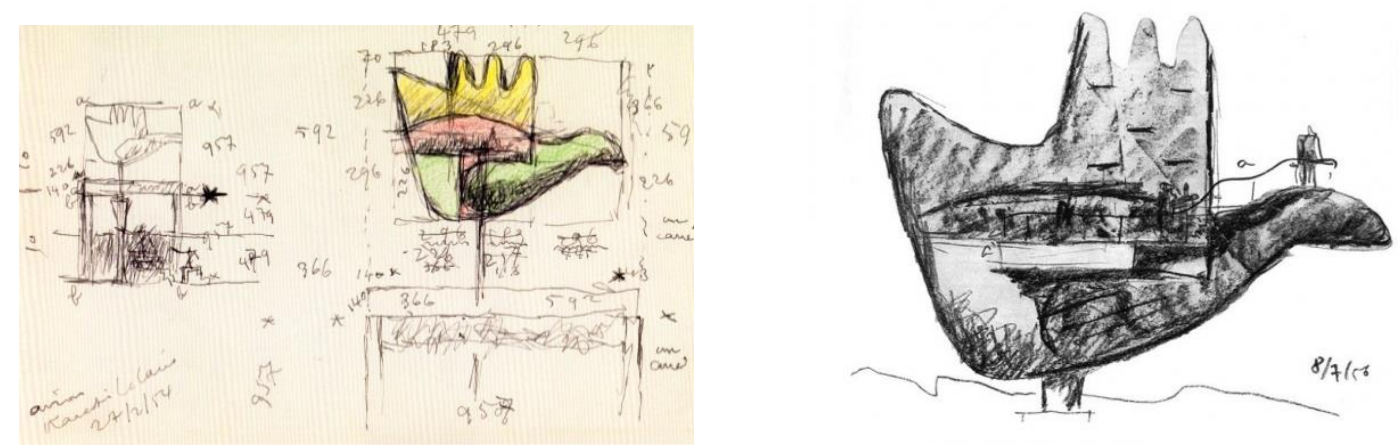

26. Dibujo de la Mano abierta detallando medidas, $1954^{51}$

27. Dibujo de la Mano abierta en blanco y negro, $1956^{52}$

Los dibujos en el tiempo van teniendo distintas representaciones o al menos "derivadas de", incluso se ha llegado a comparar con otros dibujos en donde los dedos aparecen en forma de las montañas como el dibujo del lago Leman. Lo más cercano a su concreción es el mapa elaborado en 1946 para la restructuración urbana de St. Dié podemos ver que tiene casi esa forma, me inclino a pensar que en el hecho de dibujar constantemente algo haya significado cierta pregnancia, claro, es muy reductivo pensar que puede ser solo ello, pero necesitamos armar todas las pesquisas para tener una definición más precisa. En el viaje a Bogotá (1951) aparece un dibujo que podría ser también el origen de este monumento (Fig.20, 21)
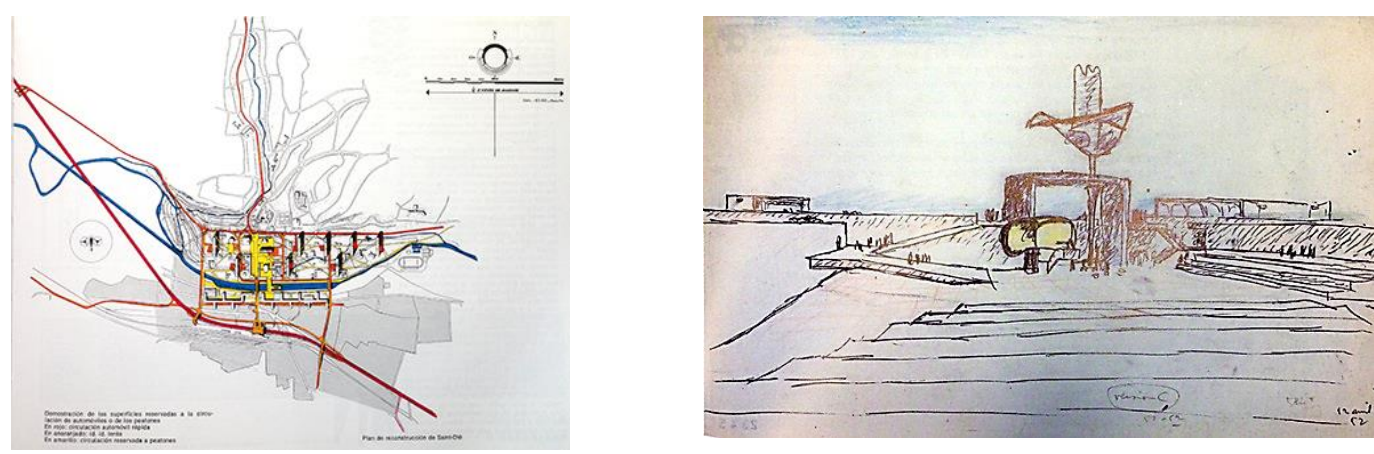

28. St Dié, $1946^{53}$

29. La Mano abierta, 1952

De alguna manera concuerdo con Frampton "en ese contexto, la mano abierta de Chandigarh, sin construir, le obsesionó hasta el último momento. Parecía pensar que no podría morir en paz mientras no fuera realizada. $Y$ es en efecto, su legado último a ese "otro" no eurocéntrico ese Tercer Mundo que le había proporcionado su única oportunidad de construir una ciudad entera, e incluso un nuevo mundo, a partir de la nada o de casi nada. " 54 Y allí radica la voluntad de explicar la idea a partir de que Le Corbusier construyó su obra con todo el material que tenia en mente, con todo lo que haia coleccionado en todo este tiempo, observó, viajó, construyó, anotó cada detalle que vio y con todo ello ha construido la ciudad, por ello iniciaba mi presentación con esta frase; "Quizás la única ciudad que no diseño Le Corbusier fue Chandigarh, tan solo construyo sobre ella".

\footnotetext{
${ }^{50}$ Seguin, P. p.299

${ }^{51}$ VV.AA, Le Corbusier, Le Grand, p.454

${ }^{52}$ VV.AA, Le Corbusier, Le Grand, p.552

53 AA.VV Le Corbusier 1910-1965, Barcelona, 2005.

${ }^{54}$ Frampton K, Le Corbusier, Madrid, 2002
} 
Le Corbusier establece un sentimiento muy fijado a esa voluntad de su viaje instructivo que termina siempre recordándonos a Chandigarh:

$Y$ sin embargo escribo con los ojos que han visto la Acrópolis y vuelvo feliz

$O h !$

Luz!

Mármoles!

\section{Monocromía!}

Frontones abolidos menos el del Partenón, contemplador del mar, masa de otro mundo, el que toma a un hombre y lo coloca por encima del mundo. ¡Acrópolis que acoge que eleva! La alegría de volver acordarme me asalta por completo, y es fortificador el sentimiento de llevarme la vista de esas cosas como una parte nueva de mi existencia, desde ahora inseparable, ${ }^{, 55}$

La última versión de la mano abierta contiene todos los elementos, el hombre por sobre todo; si bien cuando se ha construido no está, Le Corbusier lo ha colocado, incluso en el plano sobre el territorio sujeta con una mano aquel hombrecito de madera que habían elaborado en el estudio. En la versión de 1956 representa al hombre por encima de la creación, en la imagen llega a través de una rampa hasta la falange del pulgar situándose por encima de lo natural reflejado delante del Himalaya, en el fotomontaje la mano intenta calcar el paisaje.
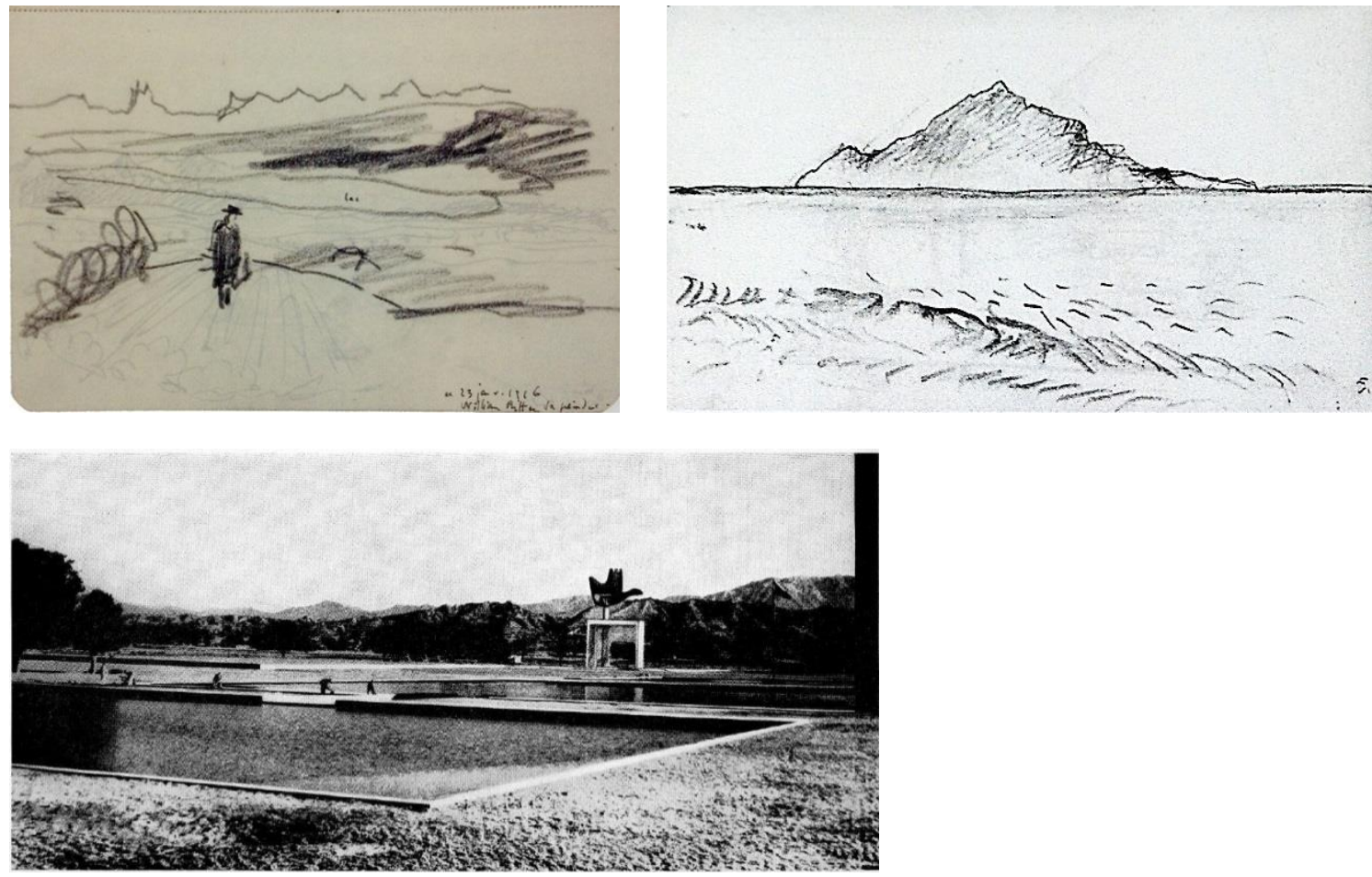

29. Willian Riter va peindre, $1916^{56}$

30. El Monte Athos. Voyage d'Orient. Carnet 3 p. $45^{57}$

31. Photo-collage showing the proposed Monument of the Open Hand before the "Pit of Contemplation" c. $1955^{58}$

\footnotetext{
${ }^{55}$ Le Corbusier. Por las cuatro rutas, Barcelona, 1972

${ }^{56}$ Cohen, J.L. An Atlas of Modern Landscapes. MOMA. New York, 2013

${ }^{57}$ Le Corbusier, Voyage d'Orient, Carnets, Paris, 2002

${ }^{58}$ VV.AA, Le Corbusier, Le Grand, p.461
} 
El ángulo recto - de la prosa a la obra- sujeta ahora el monumento, pero éste se revela y gira sobre su propio eje para mostrar al mundo todos sus lados, redimiéndose al Himalaya, el hombre queda delante, detrás, siempre buscando lo septentrional y lo meridional de lo que está conformado el universo.

\section{Conclusiones}

Son los dibujos y anotaciones realizados en sus viajes (incluso los realizados desde el aire) los que han ido formulando ese amplio constructo - y a lo largo del tiempo han significado a nuestro parecer, más relevantes que los propios proyectos visitados- para construir otras realidades, en este caso específico, Chandigarh.

No es casualidad que cuando Le Corbusier preparaba el Mise au Point (1965) se encontraba corrigiendo los manuscritos del libro de su Viaje a Oriente escrito en 1911; en la nota figuraba "corregido 17 de julio de 1965 ", poco más de un mes antes de su muerte (27 agosto 1965), por ello es importante hilar La Mano abierta con su viaje a Oriente y viceversa, para comprender el viaje que hizo a lo largo de toda su vida.

La pequeña Casa que diseño a sus padres contiene consideraciones muy específicas sobre su voluntad respecto a la arquitectura y al urbanismo. Se hizo y luego se buscó el terreno, el mismo lo explica, “Con el plano en el bolsillo, buscamos largamente el terreno. Seleccionamos varios. Pero, un día, desde lo alto de las colinas, descubrimos el verdadero terreno (1923)" ${ }^{, 59}$ Es importante mencionar que en el mismo libro aparece que los planos fueron elaborados con su primo Pierre Jeanneret coincidentemente con quien colaboró en la formulación del plan para Chandigarh y a quien confió sus designios por así decirlo.

Es en la última versión y definitiva de la mano abierta (contiene las medidas) donde aparecen todos los elementos que conforman la síntesis, la recapitulación de sus pensamientos y de sus ideas en torno a toda su creación artística; alli topográficamente coloca las montañas, el angulo recto que está ligado al horizonte y al poema mismo (Medio, Espíritu, Carne, Fusión, Caracteres, Ofrenda, Útil, instrumento), también a los 5 puntos de la arquitectura que aparecen como líneas horizontales que marcan a modo de escalera el ingreso a su obra de la que siempre se asciende para ingresar.

La mano abierta es el motivo del Poema del Angulo Recto y también como confluyen esas alegrías esenciales, junto a ello se ha configurado ese ideal de urbanismo que tuvo asidero finalmente en Chandigarh. Allí la primera piedra ya estaba colocada solo faltaba un Le Corbusier para explicarla. La mano abierta es una huella del Poema sobre el cielo que pretende explicar en $360^{\circ}$ su relación con el mundo y la sobre la trayectoria del sol.

Las constantes reivindicaciones con la naturaleza dirigidas finalmente en el Poema del ángulo recto (1956) y sus demás teorizaciones desde el urbanismo terminaron por construir un paisaje previo, ese "espacio inefable" habla del primer gesto del hombre por ocupar el espacio y que rehúye casi finalmente al Cabanon en sus últimos días; momentos lleno de circunstancias y de naturalezas ya prefijadas. Cuando apareció el encargo de diseñar Chandigarh tuvo necesariamente que pensar en la porción de agua y así dio origen al lago Sukhna que era lo que le faltaba a su paisaje imaginado. De esa manera preservaría su filosofía y mantendría a salvo sus alegrías esenciales que tanto insistía. El sol, espacio y árboles concebidos como "alegrías esenciales” que explica en “Cuando las Catedrales eran Blancas, 1937” se ven reflejadas en Chandigarh.

\footnotetext{
${ }^{59}$ Le Corbusier, La pequeña casa, p.11

${ }^{60}$ Le Corbusier, El Modulor, p.5
} 
Chandigarh ha sido concebida mediante el constructo de la razón y recorrerla es hallar horizontes que se descubren al acercarse a cada lugar, recorrer las distancias para llegar a cada edificio y manteniendo en todo momento la atención sobre esa compleja concepción de la arquitectura; allí es donde depositó todos sus propósitos por cuanto vivó.

La mano abierta contiene todas las miradas y ángulos posibles, gira, tiene dos lados posibles, el horizonte sigue recto, la mano sobre su ángulo recto seguirá buscando el horizonte, el paso de las 24 horas donde múltiples miradas que hacen al observador del paisaje un nuevo y atento ser.

\section{Referencias bibliográficas}

AA.VV. Le Corbusier y las Síntesis de las artes; El poema del ángulo recto. Madrid, 2006

AA.VV. Le Corbusier 1910-1965. Barcelona, 2005

AA.VV. Le Corbusier / Lucién Hervé Contacts. Italie, 2011

VV.AA, Le Corbuiser Le Grand, New York, 2008

Baker, G. Análisis de la forma. Barcelona, 2000

Brooks, A. Le Corbusier's formative years, Charles- Edouard Jeanneret At la Chaux-des-Fonts. Chicago, 1997

Calatrava, J. Le Corbusier y la Síntesis de las Artes. Madrid, 2006

Cohen, J.L. An Atlas of Modern Landscapes. MOMA. New York, 2013

Daza, R. Tras el Viaje de Oriente. Barcelona, 2015

Huse, M. Le Corbusier. Barcelona, 1986

Le Corbusier. Aircraft. Madrid, 2003

Le Corbusier et Pierre Jeanneret, Euvre complète Volúmenes 5, 6, 7 _ O. Stonorov y W. Boesiger. Zürich: H.

Le Corbusier. El Modulor /El Modulor 2. Madrid, 2005

Le Corbusier, Cuando las Catedrales eran Blancas. Madrid, 2007

Le Corbusier. Cómo concebir el urbanismo. Argentina, 2013

Le Corbusier. La ciudad del Futuro. Argentina ,2013

Le Corbusier. (CH.-E.Jeanneret). Vogaye d'Orient, Carnets. Milano, 2002

Le Corbusier. Una Pequeña Casa. Argentina, 2014

Morel, G. Le Corbusier. Construire la Vie Moderne. París, 2015.

Quetglas, J. Pasado a Limpio, II. Girona, 2001

Seguin, P. Le Corbusier Pierre Jeanneret (Chandigarh India). Francia, 2014

Sitte, C. La Construcción de Ciudades según principios artísticos. Barcelona, 1929

Touchaleaume, E; Moreau,G. Le Corbusier Pierre Jeanneret. L'aventure Indienne. Paris, 2010

Torres, J. Pensar la Arquitectura: Mise au point de Le Corbusier. Madrid, 2014 


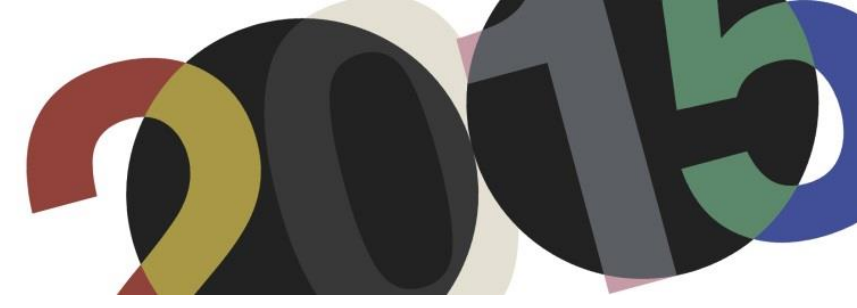

DOI: http://dx.doi.org/10.4995/LC2015.2015.766

\title{
Páginas de un desencuentro: Le Corbusier y L'Architecture d'Aujourd'hui (1930-65)
}

\author{
J. Parra Martínez \\ Área de Composición Arquitectónica. Dpto. de Expresión Gráfica y Cartografía. Universidad de Alicante
}

Resumen: Este trabajo aborda algunos de los hitos en la evolución de la comprometida relación que Le Corbusier y L'Architecture d'Aujourd'hui mantuvieron a lo largo de más de 30 años. Para ello se exploran las razones que explican la selección y el tratamiento de los materiales publicados por la revista, contrastándolos con documentos de archivo y la correspondencia conservada; se incide en los textos críticos y se ahonda en las condiciones de producción de aquellos números de la revista que ayudan a entender mejor esta parte fundamental de su historia.

\begin{abstract}
This paper addresses some landmarks in the evolution of the complicated relation that Le Corbusier and L'Architecture d'Aujourd'hui maintained over more than 30 years. To do so, possible reasons for the selection and for the treatment of the published materials are explored; they are also checked with archival records and the evidences provided by the preserved correspondence; critical texts are examined, as well as, the context in which they produced those issues of the magazine that provide a better understanding of this crucial part of its history.
\end{abstract}

Palabras clave: L'Architecture d'Aujourd'hui; confrontación Le Corbusier-André Bloc; decisiones editoriales; medios; synthèse des arts.

Keywords: L'Architecture d'Aujourd'hui; Le Corbusier-André Bloc confrontation; editorial decisions; media; synthèse des arts.

En febrero de 1987, con ocasión del centenario de su nacimiento, L'Architecture d'Aujourd'hui publicó el tercero de sus números monográficos ${ }^{1}$ dedicados a Le Corbusier. Compiló entonces una selección comentada de extractos y reproducciones facsímiles de algunos de los artículos de referencia que habían ido aparecido en la revista a lo largo de más de tres décadas. Dando entrada a aquella panorámica, un texto ${ }^{2}$ de Bertrand Lemoine defendía que las páginas de L'Architecture d'Aujourd'hui habían estado abiertas en todo momento a las propuestas, "habitualmente polémicas", de Le Corbusier. Sugería asimismo la idea de que un sentimiento de "aprecio y respaldo mutuos" había presidido la relación entre el arquitecto y la revista. Y, aunque Lemoine no escondía que, en ocasiones, aquella relación no había sido precisamente fácil, tampoco entraba en el fondo de esta cuestión. En lugar de ello, adoptaba la versión oficial de André Bloc, fundador y primer director de la revista, quien sostenía ${ }^{3}$ que el distanciamiento progresivo de Le Corbusier de $L$ 'AA había sido fruto de la susceptibilidad y de la intransigencia del maestro, incapaz de aceptar cualquier forma de crítica. Una actitud que, para Lemoine, no sería sino una expresión más de la propia evolución de Le Corbusier como creador ya que, con el paso del tiempo, se había ido replegando sobre sí mismo, orientándose "hacia posiciones defensivas, preocupado por hacer valer y continuar sin discusión alguna la realización de una obra ya consagrada".

\footnotetext{
${ }^{1}$ O podría considerarse el cuarto si, además de los dos anteriores de 1933 y 1948 publicados por L'Architecture d'Aujourd'hui -en adelante también L'AA-, se cuenta el especial que la revista Aujourd'hui consagró a Le Corbusier tras su muerte en 1965.

${ }^{2}$ Lemoine, Bertrand: “Le Corbusier dans L'Architecture d'Aujourd'hui”. En L'AA n²49, especial “Corbu”. Febrero 1987, p.9.

${ }^{3}$ Véanse, por ejemplo, Bloc, André: "Hommage à Le Corbusier". En L’AA no 106. Febrero 1963, p. 2; ó Bloc, André: "Le Corbusier". En Aujourd'hui: art et architecture n51, especial "Le Corbusier”. Noviembre 1965, p.0.
} 

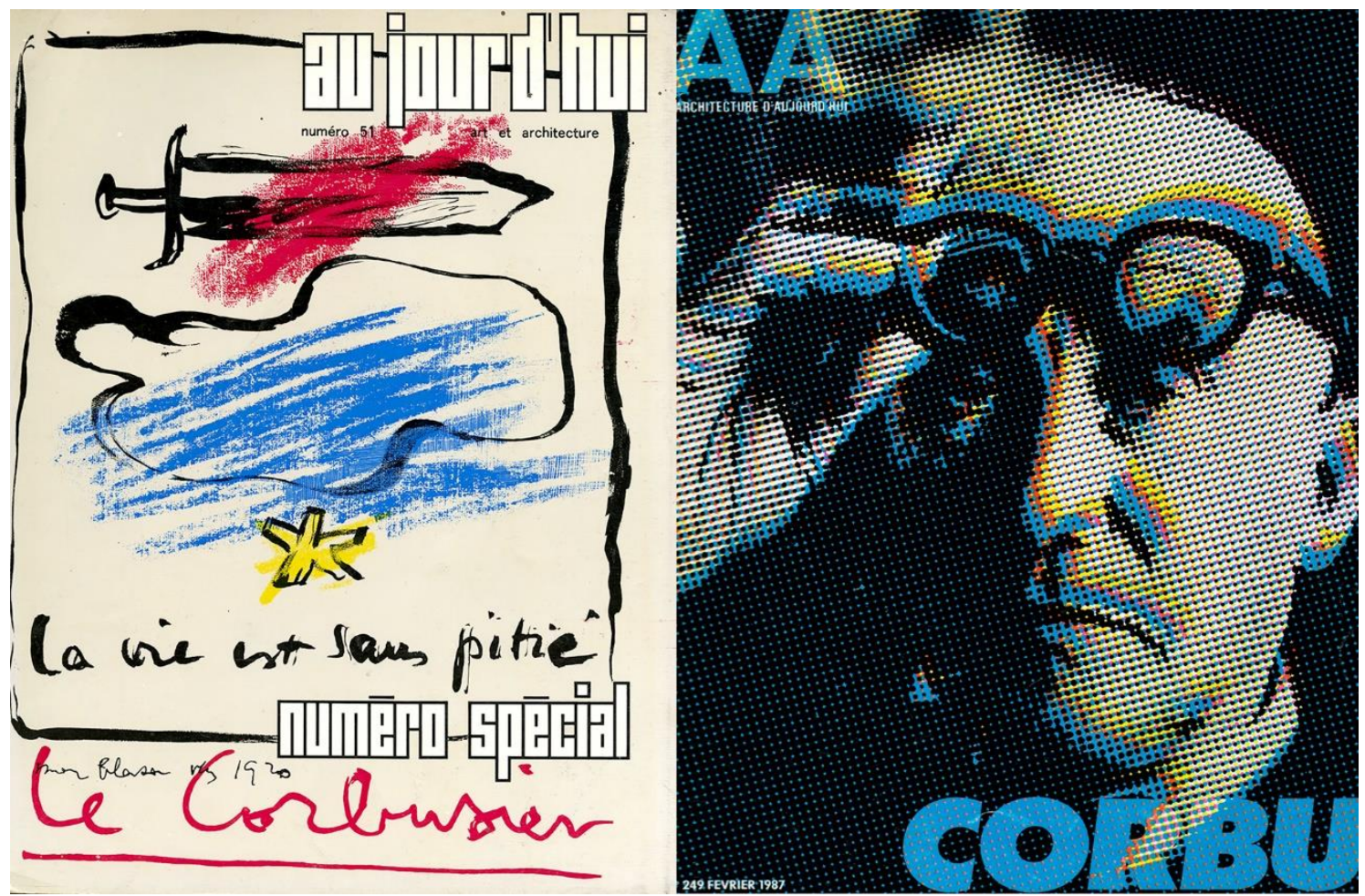

1. Portada del número monográfico publicado por Aujourd'hui en 1965 (izda) y del número especial de $L$ 'AA de 1987 (dcha)

No obstante, conviene matizar estas tesis. Por un lado, porque el soporte que L'Architecture d'Aujourd'hui brindó a Le Corbusier nunca fue unánime sino un foco de amplias controversias entre los miembros de su consejo de redacción. Por otro lado, tampoco parece claro que la pretendida "admiración sin límites" de su director fuera correspondida con aquel "aprecio muto" del que hablaba Lemoine. Más bien, éste se encontró con las suspicacias y el desapego cultivado durante años por un Le Corbusier cada vez más preocupado por la imagen pública y la trascendencia posterior de su obra. Y tampoco sería exacto hablar de un alejamiento progresivo, ni de un enfriamiento del trato. En realidad, se produjo una ruptura y, aunque después se promovieron acercamientos, los afectos, si se dieron, ya no fueron los mismos. La suya fue una relación tormentosa o, mejor, un matrimonio de conveniencia con acuerdos fructíferos, pero también con notorios desencuentros. Ciertamente, hubo momentos estelares, como el monográfico de 1948, películas y varios libros, pero aquellos episodios fueron breves y, casi siempre, resultado de amargas discusiones.

\section{De L'Esprit Nouveau a L'Architecture d'Aujourd'hui}

La extraordinaria influencia ejercida por L'Architecture d'Aujourd'hui como tribuna internacional de la arquitectura moderna fue, en buena medida, resultado del dinamismo intelectual y de la determinación de su creador, el ingeniero y escultor André Bloc quien, a finales de los años 20, había concebido la idea de fundar una nueva revista especializada en arquitectura contemporánea junto a su amigo el galerista Marcel-Eugène Cahen, prematuramente desaparecido semanas antes de su lanzamiento.

El primer número de L'Architecture d'Aujourd'hui ve la luz en noviembre de 1930. Es fruto de una reflexión, aún poco concreta, sobre la realidad del panorama francés: la obsolescencia de la enseñanza de la arquitectura, la escasa formación técnica de los arquitectos o el problema de la vivienda. Aunque su aceptación no fue inmediata, la revista logrará superar la oposición inicial de algunos sectores conservadores, evolucionando hasta 
convertirse en el eje de un ambicioso proyecto editorial alrededor del cual irán gravitando sucesivas publicaciones satélite ${ }^{4}$ que evidencian el compromiso de su director con la cultura técnica, la vanguardia y la integración de las artes.

Interesado por la arquitectura desde su época de estudiante en L'École Centrale, hacia 1920, André Bloc se revela ya como un inquieto fundador de revistas. Poco después de diplomarse, en 1921, se acerca a la obra de Le Corbusier a través de L'Esprit Nouveau, publicación de la que es uno de sus primeros suscriptores ${ }^{5}$ y que va a dejar en él una temprana huella, según sus propias palabras: "uno de los acontecimientos de mi juventud fue la aparición de L'Esprit Nouveau, [...] En un mundo dominado por el conformismo, esta revista trajo un poco de aire fresco, una promesa de renovación. En aquella época nada me orientaba aún hacia las artes plásticas o la arquitectura. [...] Y, sin embargo, no podía resistirme a comprar cada uno de sus números. [...] Estaba fascinado por sus nuevas propuestas" 6 .

Dos años más tarde, en 1923, Bloc escribe ${ }^{7}$ a Le Corbusier exponiéndole sus intenciones de poner en marcha una revista con sus propios medios, se denominaría Les Centraux y tendría carácter trimestral. De nuevo, en 1924 $\operatorname{contacta~}^{8}$ con Le Corbusier para solicitar su colaboración en un artículo, petición a la que el arquitecto consiente ${ }^{9}$ prometiendo enviar un texto e invitándole a visitar su estudio para seleccionar personalmente los materiales que más le interesen. Poco después, Bloc accede a la secretaría del Sindicato del Caucho, donde asume la dirección técnica y financiera de su publicación oficial, La revue générale du caoutchouc, una experiencia en la que es posible descubrir el germen ${ }^{10} \mathrm{de}$ L'Architecture d'Aujourd'hui.

Desde su primer año de vida, $L^{\prime} A A$ se asegura la independencia económica a través de la publicidad y, aunque a veces la revista comprometa la nitidez de su línea editorial para obtener recursos, su solvencia le permite invertir en la promoción de la arquitectura moderna e intensificar su actividad en los más diversos ámbitos, entre ellos, la organización de conferencias, concursos y exposiciones, la cinematografía o el impulso de asociaciones artísticas.

Gracias a sus diferentes fuentes de ingresos, la revista adopta unos acabados y una calidad gráfica al alcance de pocas publicaciones de la época. La característica encuadernación con espiral metálica de los años 30; el contraste entre el clasicismo de la tipografía Didot en el interior con la llamativa rotulación de la portada; y la riqueza visual de sus páginas, privilegiando el uso de la fotografía sobre los planos; son parte de una lógica moderna que, al igual que L'Esprit Nouveau, entiende perfectamente el valor comunicativo de la imagen. Así, por ejemplo, cuando Le Corbusier, en su primer monográfico de 1933, publique sus cinco puntos, la planta y la fachada libres no serán ilustradas con plantas y alzados sino con fotografías de sus villas e, incluso, de la Cité de Réfuge en construcción, utilizando unas inusuales posiciones de cámara que explican de forma más verosímil la independencia entre estructura y cerramiento.

\footnotetext{
${ }^{4}$ En orden cronológico, aparecieron las siguientes revistas satélite Chantiers (1933-35), órgano técnico de L'AA; Art d'Aujourd'hui (1954-65); y, finalmente, Aujourd'hui, art et architecture (1954-67).

${ }^{5}$ En los archivos de la FLC, Bloc aparece en los listados de abonados de la revista desde febrero de 1921 (FLC A2-9-81).

${ }^{6}$ Bloc, André: "Hommage à Le Corbusier". Op. cit., p. 2.

${ }^{7}$ André Bloc: Carta a Le Corbusier, 07.01.1923 (FLC E1-8-45).

${ }^{8}$ André Bloc: Carta a Le Corbusier, 04.03.1924 (FLC E1-8-46).

${ }^{9}$ Le Corbusier: Carta a André Bloc, 29.04.1924 (FLC E1-8-47).

${ }^{10}$ Cfr. Entrevista con Pierre Vago. En Ragot, Gilles: "Pierre Vago et les débuts de L'Architecture d'Aujourd'hui 1930-40". En Revue de l'Art n'89, p 78.
} 
En 1931, se incorpora a la redacción un jovencísimo Pierre Vago, aún estudiante de Arquitectura bajo la tutela de Auguste Perret. Conocedor de varias lenguas y con numerosos contactos en el extranjero, pronto se convertirá en la mano derecha de Bloc. El diligente Vago será uno de los principales activos de L'Architecture d'Aujourd'hui, en la que desempeñará sucesivamente las labores de redactor (1931), redactor jefe (1932-39 y 1945-46) y, desde 1947, presidente de su comité de redacción hasta su dimisión en 1975. Convencido de la vocación internacional de la arquitectura moderna y constatando la habilidad política de su nuevo ayudante, Bloc va a encomendarle la misión de abrir la revista al exterior. Para conseguir este objetivo, Vago se empleará en la creación de una estructura eficaz de corresponsales que, nutriéndose desde el principio de profesionales de la talla de -por ejemplo- Gutiérrez Soto en España, irá creciendo hasta extenderse a todo el mundo.

Paralelamente, con el fin de ampliar su mirada sobre la arquitectura internacional, $L$ ' $A A$ organizará cada otoño un viaje profesional abierto a todos sus abonados. El primer destino, en 1932, será la Unión Soviética, el segundo, en 1933, la Italia de Mussolini. En todas esas expediciones y en las que vendrán después, no sólo se trata de visitar obras realizadas en el extranjero, sino de promover también el debate entre colegas de diferentes países. Para favorecer el intercambio de ideas, en cada viaje la revista celebrará unas jornadas de discusión, las Rencontres Internationales des Architectes (RIA) que, coordinadas por Pierre Vago actuando como secretario general, serán el origen de la UIA, convertida en organismo oficial en 1948.

La vocación internacional de $L^{\prime} A A$ y la reputación de sus contribuidores impulsarán el prestigio de la publicación que, después de la guerra, llegará a ser una de las revistas especializadas de mayor circulación y, al menos en Europa, la más leída ${ }^{11}$. Incluso, en Latinoamérica, en 1947, apareció una versión oficial en castellano, La Arquitectura de hoy, que traducía casi completamente el contenido de los números originales de su revista matriz. Como medida del éxito internacional de $L ' A A$ puede tomarse el incremento anual de sus suscripciones internacionales -más de la mitad fuera de Francia- o, también, la evolución de su tirada, desde los 1.200 ejemplares de 1930 hasta la cifra de 20.000 alcanzada a la muerte de Bloc, ocurrida en un accidente en la India en 1966.

\section{Acción-reacción: $193 X$, hacia una arquitectura de hoy}

Los 30 son años de lucha. El primer número de L'Architecture d'Aujourd'hui inaugura una década convulsa que se inicia, paradójicamente, con la búsqueda de un consenso imposible. Y, probablemente por ello, Le Corbusier es el gran ausente en ese primer número.

En ese momento, la revista es una amalgama de sensibilidades diversas e intereses encontrados. No siendo arquitecto, Bloc pretende asegurar la autoridad de la revista reuniendo en su comité de patronato ${ }^{12}$ a los grandes nombres propios de la cultura arquitectónica francesa. Entre ellos, Frantz Jourdain, Tony Garnier, o Auguste Perret, en torno a cuya figura se va a aglutinar una facción que tendrá un gran peso en los primeros números de la revista, y que se opondrá enérgicamente a las ideas de Le Corbusier. Hay también una generación más joven, representada por André Luçart, H. G. Pingusson o Gabriel Guévrékian, a quienes que se unirán otros como Albert Laprade o Robert Mallet-Stevens, defendiendo unas visiones muy diferentes de la modernidad que la

\footnotetext{
${ }^{11}$ Cfr. Colomina, Beatriz: “1949”. En Somol, R. E. (Ed.): Autonomy and Ideology. Positoning an Avant-garde in Europe. New York: Monacelli Press, 1997. p. 304.

${ }^{12}$ Badouï, Rémi: “D'Hier à Aujourd'hui”. En L'AA n²72. Diciembre 1990, p. 61.
} 
revista no acaba de precisar. Quizás, porque el único punto de encuentro es la técnica, $L$ 'AA apuesta decididamente por ella. Pretenderá ser una plataforma objetiva, pero la centralidad política es una posición difícil de mantener y no exenta de riesgos, como el de desencadenar una querelle entre modernos, incurriendo en las paradojas de defender la autonomía de la arquitectura o la ejemplaridad de las soluciones ingenieriles sin asumir, por ejemplo, el valor ideológico de lo nuevo o la artisticidad de la técnica.

Los primeros números de $L$ 'AA revelan numerosas contradicciones en este sentido. Así, sus lectores encuentran feroces ataques contra Le Corbusier, como los artículos de Marie Dormoy (diciembre de 1931) y Michel RouxSpitz (abril de 1932), que son particularmente llamativos porque, queriendo magnificar su reproche, hasta comparten el mismo título: "Contra el nuevo formalismo". Denuncian el "falso moderno" de su arquitectura blanca, la "exasperación" de sus ventanas alargadas y hasta el esquema Dom-ino, que -de acuerdo con RouxSpitz- nada tiene que ver con la organización racional de una auténtica construcción moderna, como la de los hermanos Perret.

También en 1932, en el número de noviembre, Pierre Vago -conviene recordarlo, discípulo de Perret- advertirá que lejos de representar al ala más progresista de la arquitectura moderna, estas actitudes formalistas no son sino una "reacción disfrazada", una vuelta atrás donde la "preocupación plástica" predomina sobre la lógica y la economía de la razón constructiva.

Con cierta desconfianza, la primera aparición de Le Corbusier tiene lugar en el segundo número de la revista, en enero de 1931. Se trata de una escueta reseña sobre la Villa Savoye en la que su autor, Julius Posener, cuestiona el programa, pone reparos al sobredimensionamiento y a la funcionalidad de sus espacios y concluye que esta obra "original" es "perfecta en todos los aspectos menos en el económico". Teniendo en cuenta que, salvo de forma incidental, la Villa Savoye ya no volvió a aparecer más en la revista, comparado con el interés con que otros medios acogieron la casa, el torpe recibimiento de Le Corbusier en las páginas $L$ 'AA fue, cuanto menos, una ocasión desaprovechada. Además, la difusión, en noviembre de 1931, de la polémica entre Le Corbusier y Joseph Vago, el padre de Pierre y coautor de la propuesta de compromiso del Palacio de las Naciones, tampoco sentó las bases para una relación desprejuiciada por ambas partes.

No sorprende, pues, que, ante las sucesivas invitaciones de André Bloc, Le Corbusier se muestre reticente, decline formar parte del comité de patronato y administre con prudencia sus colaboraciones con la revista. Y tampoco sorprende que, cuando acceda a escribir un texto sobre Auguste Perret para el monográfico dirigido por Pierre Vago en 1932, Le Corbusier se esfuerce en relativizar las contribuciones de Perret a la arquitectura moderna. De él valorará su papel como constructor, pero cuestionará su dimensión como arquitecto porque, según él, "no está a la altura de los tiempos"13. Dirá también que Perret es un "continuador" y "no un revolucionario", atribuyéndose implícitamente a sí mismo esa condición.

La fecha del 14 de diciembre de 1931 adquiere un significado especial en la historia de la revista. A todas luces, es su verdadero acto fundacional. Ese lunes por la tarde, $L$ 'AA convoca a sus abonados en la Sala Pleyel para asistir -según rezaba la invitación- a "una sesión de propaganda de la arquitectura contemporánea" en la que "se podrán escuchar conferencias de varias personalidades y se proyectarán importantes películas inéditas sobre construcciones modernas". Entre ellas, el conocido film L'Architecture d'Aujourd'hui, que toma el

\footnotetext{
${ }^{13}$ Le Corbusier: “Auguste Perret par Le Corbusier”. En L'AA nº7. Octubre 1932, p. 9.
} 
nombre de la revista y que André Bloc había encargado al cineasta belga Pierre Chenal con objeto de publicitar los logros tecnológicos y las posibilidades espaciales de la arquitectura de hoy. Le Corbusier, que había escogido sus escenarios y participado en su guión -y probablemente también en su montaje- se sirvió de esta película aquella noche para apoyar visualmente un discurso dirigido a un auditorio abarrotado y ávido de polémica.

Saliendo al paso de las críticas hacia la paralizante centralidad de su revista, Bloc había planteado el encuentro como un debate entre posturas enfrentadas. Erigió a Le Corbusier en portavoz del frente radical de la modernidad y, como antítesis, a un desprevenido Sauvage que, muy a su pesar, se vio instrumentalizado por los diferentes detractores del arquitecto, desde los seguidores de Perret hasta los representantes de la Academia. De acuerdo con la crónica de Pierre Vago ${ }^{14}$, todos ellos habían acudido al evento para escenificar su oposición a Le Corbusier quien, al impedírsele hablar, abandonó la sala entre aplausos y abucheos. El escándalo, que saltó a la prensa amplificado por una incendiaria campaña de Le Figaro, proporcionó a Bloc la propaganda que pretendía, pero también dejó claro que, tras la soirée Pleyel, ya no habría lugar para la tibieza.

Días después, Le Corbusier respondió por carta ${ }^{15}$ a las excusas del editor, dejando claras sus condiciones para nuevas colaboraciones con la revista: sólo repetiría una sesión similar si estaba dedicada a los estudiantes de arquitectura; no autorizaría la proyección de sus películas junto a las de sus opositores (Fischer, Roux-Spitz y quizás Vago); y, "por su bien y el de la revista”, en futuros trabajos fílmicos, sólo relacionaría su nombre con el de los autores que él juzgase oportuno. Su aceptación por parte de Bloc allanó el camino para la negociación con Le Corbusier de un primer número especial dedicado a su obra, otorgándole carta blanca para decidir y maquetar sus contenidos.

Este primer monográfico, el $\mathrm{n}^{\circ} 10$ de 1933 , consta de 146 páginas donde el arquitecto despliega sus propuestas como cargas de profundidad contra sus enemigos. Le Corbusier combina enunciados teóricos anteriores, como los cinco puntos, con reflexiones urbanísticas recientes, a las que consagra gran parte del número. Entre ellas, el Plan Macià o el Plan de Argel, presentado en forma de "Carta a un alcalde". Hay también proyectos, como el Palacio de los Soviets; discursos, como el de Atenas; y varios textos, como "Concevoir d'abord, construire ensuite", una nueva crítica a la escuela de Perret donde pide vincular su preocupación por las técnicas modernas a una reflexión global acorde a los retos y a la ética arquitectónica de la civilización maquinista.

\footnotetext{
${ }^{14}$ Vago, Pierre: Texto anotado. Archivo de Pierre Vago. Centre d'archives d'architecture du xx ${ }^{\text {ème }}$ siècle. Institute Français d'Architecture (en adelante IFA): 064 IFA 284/2.

${ }^{15}$ Le Corbusier: carta a André Bloc, 18.12.1931 (FLC C3-3-40).
} 

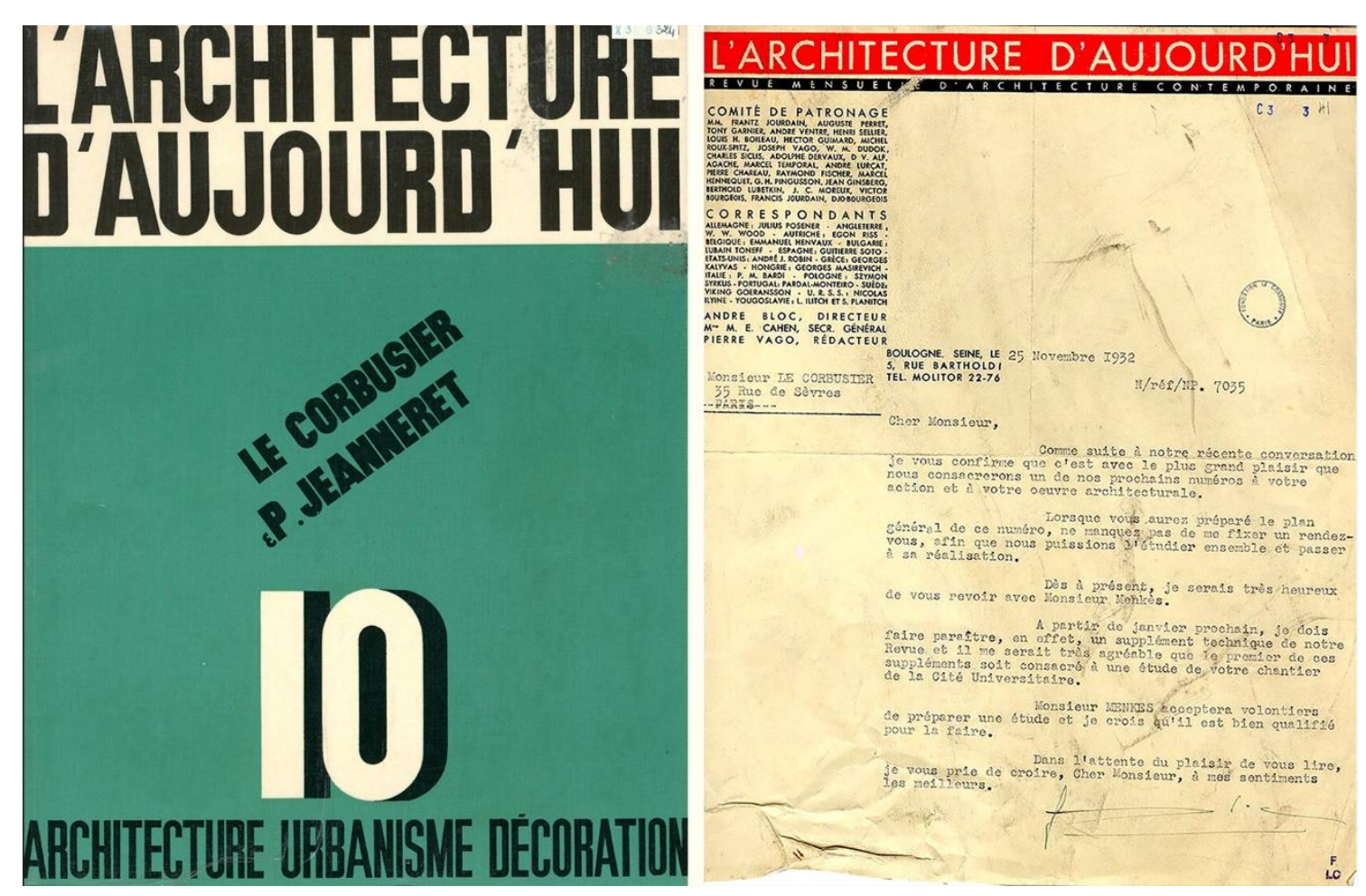

2. Portada de $L^{\prime} A A, \mathrm{n}^{\circ} 10,1933$, primer número monográfico dedicado a LC; carta de André Bloc (25.11.1932) comunicando a LC la decisión de la revista de consagrarle este número (FLC C3-3-41)

El número está precedido por un editorial de tres páginas, firmado por Pierre Vago y titulado "Le Corbusier y L'Architecture d'Aujourd'hui" "16. Es un juego de palabras que no hace referencia tanto a su relación con la revista como al papel central de Le Corbusier en el Movimiento Moderno, cuyas batallas -afirma Vago- "se han librado siempre en torno a su persona". El texto se estructura en tres partes: el maestro, el arquitecto, el líder, apartados en los que trata de desgranar diferentes aspectos de su obra, reconociendo que no es tarea fácil por la transversalidad y rápida evolución de un pensamiento para el que no hay precedentes. Su tesis, "Le Corbusier es un artista, pero no un arquitecto", denuncia una contradicción entre la deriva formalista del arquitecto y su dogmatismo racionalista alegando que, en detrimento de la funcionalidad de sus edificios, muchas de sus decisiones de proyecto "son resultado de una preocupación plástica". Como méritos, Vago valora su "infatigable" capacidad de trabajo y, más especialmente, su habilidad como comunicador, destacando el poder de convicción y el estilo cautivador de Le Corbusier "que atrae a tantos jóvenes entusiastas". Su conclusión, sin embargo, es demoledora: "podremos admirarle a veces, pero no podemos seguir a Le Corbusier".

A pesar de su honestidad intelectual, este texto fue polémico desde su publicación en 1933. El propio Pierre Vago, más de 50 años después, afirmaba haber redactado aquel editorial con sumo cuidado, sintiéndose uno de sus "más sinceros admiradores, que no por ello un incondicional" ${ }^{17}$. Así lo reconoce en diversas notas de su archivo en las que, además de ratificarse en lo que escribiera con 23 años, Vago insistía en que "había querido evitar confundir admiración con adulación" $"$. Algunos autores, como Jean-Claude Vigato ${ }^{19}$, han cuestionado

\footnotetext{
${ }^{16}$ Vago, Pierre: "Le Corbusier et L'Architecture d'Aujourd'hui". En L'AA nº10, "Le Corbusier et P. Jeanneret”. Noviembre 1931, pp. 3-5.

${ }^{17}$ Vago, Pierre: "Retour aux sources. Le Corbusier et $L^{\prime} A A^{\prime}$ ". En $L^{\prime} A A \mathrm{n}^{\circ} 249$. Febrero 1987, p. 7.

${ }^{18}$ Vago, Pierre: Correcciones mecanografiadas de un texto inédito sobre su editorial del $\mathrm{n}^{\circ} 10$ de $L$ 'AA de 1933. Septiembre de 1983. Archivo de Pierre Vago. 064 IFA 284/2.
} 
sus palabras, alegando que declararse admirador en 1987 no sería sino un intento por parte de Vago de minimizar su antigua oposición a Le Corbusier. Para Vigato, aquel texto de 1933, en el que el redactor jefe ponía en guardia a sus lectores contra los contenidos a los que él mismo les enfrentaba, constituye "un episodio antológico en la historia de la edición". No obstante, otros críticos han subrayado la lucidez de la presentación de Vago, entre ellos, Gilles $\operatorname{Ragot}^{20}$, quien ha elogiado su pertinencia y su temprana constatación de la complejidad de un personaje proteico cuyas múltiples facetas son indisociables de su dimensión artística.

Hay evidencias del disgusto de Le Corbusier por el editorial de Vago pues, al reimprimirse pocas semanas después -dado el éxito del número-, el texto fue suprimido por exigencias del arquitecto. De hecho, cada vez que pida a la revista que le envíe más ejemplares para atender sus compromisos, velará porque se trate de su reedición censurada ${ }^{21}$. Le Corbusier sospechaba de Vago; vigilaba atentamente las posibles interferencias de su organización con los CIAM y, sobre todo, recelaba de su ubicua presencia en jurados internacionales. Ante esta antipatía, y en aras de facilitar sus relaciones con la revista, en lo sucesivo, Vago evitará escribir sobre Le Corbusier.

Después de la publicación de este número y, durante meses, Le Corbusier continuará eludiendo las crecientes demandas de la revista. Entre ellas, vuelve a rechazar su entrada en el comité de patronato. Del mismo modo, en 1934, cuando la revista asume la responsabilidad de comisariar las Expositions de l'Habitation que, de forma bianual tendrán lugar en el Grand Palais, Le Corbusier rehúsa ser jurado de los concursos organizados a tal efecto. Tampoco se recoge en la revista ningún otro proyecto del arquitecto hasta septiembre de ese mismo año, cuando divulgue su apartamento del Immeuble Molitor. A partir de entonces y hasta el inicio de la guerra, sus apariciones serán más habituales y habrá reseñas muy positivas sobre su trabajo, como la entusiasta crítica de Pingusson, en abril de 1936, a los planteamientos de Aircraft.

Hacia esa época, André Bloc se muestra ya como un "corbusierano convencido",22 y no esconde su afecto por el arquitecto, como prueba la copiosa correspondencia que mantiene con Le Corbusier. El 17 de junio de 1936, ambos participan en la fundación de la efímera Union pour l'Art y, esa misma semana, Le Corbusier se incorpora finalmente al comité de patronato de la revista, del que será miembro hasta diciembre de 1955.

En 1935, los contactos se habían intensificado con motivo de la preparación del libro La Ville radieuse, que Le Corbusier ofrece a Les éditions de L'Architecture d'Aujourd'hui tras la bancarrota de Crès. Negocia ${ }^{23}$ con Bloc las condiciones para su aparición dentro de la serie L'Équipement de la Civilisation Machiniste, colección en la que también se incluirá Des Canons, de munitions? Merci! De logis... s.v.p. (1938), concebido como el catálogo que debía acompañar al Pavillon des Temps Nouveaux en la Exposición Internacional de 1937. Ambas publicaciones, como las que $L$ 'AA editará en los años 40 vinculadas a la ASCORAL, responden al mismo modo de proceder del arquitecto quien, en su determinación por llevar a cabo personalmente todo el proceso del libro, desde el texto y el diseño hasta su impresión, asume prácticamente el papel del editor, dejando para éste el de

${ }^{19}$ Cfr. Vigato, Jean-Claude: "L'Architecture d'aujourd'hui”. En Lacan, Jacques (Dir.): Le Corbusier, une encyclopédie. Paris: Centre George Pompidou, 1987, pp.47-48.

${ }^{20}$ Cfr. Ragot, Gilles: "Un père de L'Architecture d'Aujourd'hui et un fil d'Ariane". En L'AA n ${ }^{\circ} 275$. Junio 1991, pp. 52-54.

${ }^{21}$ Le Corbusier: carta a André Bloc, 13.4.1934 (FLC U3-13-7).

${ }^{22}$ Vago, Pierre: "Retour aux sources. Le Corbusier et $L$ 'AA". Op. cit., p. 7.

${ }^{23}$ Le Corbusier: carta a André Bloc, 18.02.1935. En ella le ofrece además la posibilidad de ser el editor francés de los CIAM (FLC B2-7-19) 
soporte financiero y depositario de sus derechos. En el caso de La Ville radieuse, Le Corbusier propone la tirada, la proporción de su inversión y de sus beneficios, escoge a sus proveedores y gestiona unilateralmente el trato con ellos. Y, por supuesto, vigila de cerca las ventas y su distribución a través de la revista ${ }^{24}$, exigiendo continuamente a Bloc el envío de libros a todas aquellas personas o instituciones que considera estratégicas. Sólo ese control absoluto y la tenacidad de Le Corbusier para presionar a sus editores explican que, en plena guerra y a pesar de las graves dificultades por las que atravesaba el país, entre 1940 y 1946, consiguiera publicar nueve $\operatorname{libros}^{25}$.
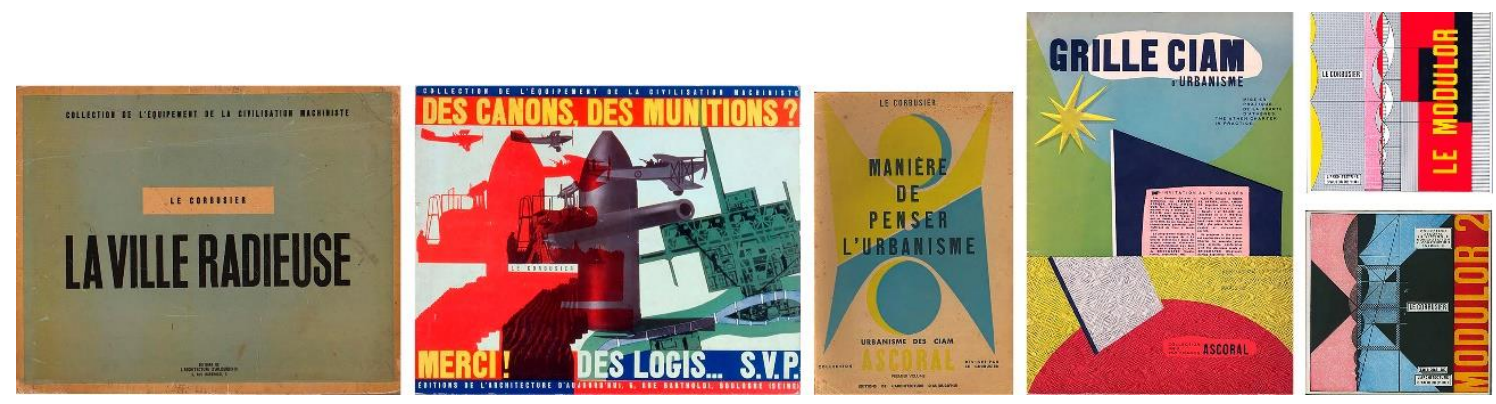

3. Portadas de los libros de Le Corbusier publicados por Les éditions de L'Architecture d'Aujourd'hui entre 1935 y 1955

Con el final de la década, en el seno de la revista afloran diferencias políticas largamente soterradas. En junio de 1940, París es ocupado y la mayor parte de los miembros del comité de $L$ 'AA se ven obligados a abandonar la capital. Comienza así una historia de acusaciones cruzadas que recoge la correspondencia conservada por Pierre Vago. A finales de agosto, André Hermant, colaborador desde 1932 y partidario acérrimo de Perret, escribe a Bloc instándole a "dar a la revista una línea de conducta conforme con la orientación oficial" ${ }^{26}$. En septiembre, las leyes antisemitas excluyen a su director de cualquier actividad de prensa. Ante la censura y las presiones alemanas, Vago considera imposible seguir adelante y, prefiriendo un final digno para la revista, propone su cierre. Coaccionado, en junio de 1941, Bloc se ve forzado a malvender sus fondos y se refugia en zona libre. Perseguido por la Gestapo, Pierre Vago se unirá a la Resistencia. El nuevo propietario, Georges Massé confirma a Hermant en la dirección y los ocupantes exigen cambiar la denominación de la revista. Será el mismo Perret quien proponga ${ }^{27}$ el nuevo nombre: Techniques et Architecture. Entre sus redactores figurará el joven ayudante de Le Corbusier y futuro jefe de su estudio, André Wogensky. Durante el tiempo que su patrón permanezca en Vichy, Wogenscky colaborará con Techniques et Architecture, asegurando sus vínculos con los organismos alemanes $^{28}$.

Le Corbusier regresa a París en el verano de 1942 y reabrirá su atelier en enero de 1943. Durante el final de la Ocupación, sin apenas trabajo, su estudio es el centro de las reuniones de la ASCORAL. Wogenscky toma notas de sus reflexiones y asiste a Le Corbusier en la redacción de los textos que darán lugar a varios libros fundamentales. Denöel editará algunos de ellos, como Les trois établissments humains (1945), mientras que André Bloc se hará cargo de Manière de penser l'urbanisme (1946) y Le Modulor (1950). Les éditions de

\footnotetext{
${ }^{24}$ Alentado por las ventas, en octubre de 1937, Le Corbusier solicita su reimpresión (FLC B2-7-89). Ante la prudencia de Bloc, insiste de nuevo en noviembre (FLC B2-7-105) proponiéndole la idea un pack promocional con De Canons... para ofertarlo a sus lectores.

${ }^{25}$ Cfr. Smet, Catherine de: Le Corbusier, Architect of Books. Baden: Lars Müller Publisher, 2005, p. 17.

${ }^{26}$ André Hermant: carta a André Bloc, 26.08.1940. Correspondence entre MM. Vago, Bloc, Hermant, Bouquet, 1940-44. Archivo de Pierre Vago. 064 IFA 246.

${ }^{27}$ Cfr. Chaslin, François: Un Corbusier. París: Seuil, 2015, p. 242.

${ }^{28}$ Ibíd., pp. 242-243.
} 
L'Architecture d'Aujourd'hui publicarán también la Grille CIAM d'Urbanisme (1948), un proyecto muy querido por Le Corbusier y para cuya difusión sabrá servirse hábilmente del espíritu de cooperación que, en la década de los años 40, va a mantener con la dirección de la nueva revista.

\section{La etapa de posguerra: de la refundación de la revista al segundo número monográfico}

Con la Liberación, André Bloc intentará, sin éxito, recuperar L'Architecture d'Aujourd'hui y su archivo. Ante la negativa de Hermant, que continúa al frente de Techniques et Architecture, reúne a sus más fieles colaboradores para partir de cero con una publicación ${ }^{29}$ en la que hay cambios importantes. En el primer número, de mayo de 1945, el texto de Pierre Vago "Un capítulo se acaba" es una declaración de intenciones que incide en el compromiso ético adquirido tras la guerra. Sus metáforas bélicas y su retórica épica, son dignas del mismo Le Corbusier. A partir de ese momento, la periodicidad de la revista tenderá a ser bimensual y su numeración, en lugar de reiniciarse cada año, será continua. El comité de patronato dará paso a un comité técnico del que Vago asumirá la presidencia. Volcado cada vez más en su producción artística y en el lanzamiento de Art d'aujourd'hui, Bloc va a compartir la dirección de $L$ 'AA con Alexandre Persitz, a quien nombra redactor jefe y con quien alternará la responsabilidad de los números. El inicio de este periodo bicéfalo coincide con el inicio de la etapa de mayor expansión internacional de la revista.

Tras su refundación, $L$ 'AA se vuelca en las soluciones de urgencia y Le Corbusier regresa para ser protagonista en el debate de posguerra. Aparece ya en el primer número de la nueva revista con un artículo sobre la organización del territorio, oportunamente extraído de Les trois établissements humains. De inmediato, el arquitecto se esfuerza para recuperar el papel central que Bloc había querido asignarle a principios de los años 30 y que mantendrá durante esta nueva etapa de entendimiento.

En abril de 1946, se edita Art, el primer especial de la revista después de la guerra. Está consagrado a las artes y Le Corbusier recibe el encargo de diseñar su portada. En su interior, su obra pictórica aparece junto a la de Braque, Léger o Picasso. En la sección de escultura están los autores que más admira: Archipenko, Brancusi, Henri Laurens o su estrecho colaborador, Joseph Savina. Finalmente, en las páginas de arquitectura, el lector se encuentra con "L'espace indicible" ${ }^{30}$ un manifiesto escrito hacia el final del verano de 1945 y que contiene las bases de un nuevo concepto de espacio, crucial durante las décadas siguientes. En "L'espace indicible" las certezas de la primera época dejan paso a intuiciones profundas. Su vocabulario se aleja también de cualquier referencia anterior. Ya no hay eslóganes maquinistas. Le Corbusier habla de "emoción", de "resonancias", de "acústica plástica". El texto se ilustra con un montaje de fotografías y dibujos entre los que, sintomáticamente, no hay ningún edificio terminado, sólo imágenes de proyectos, planes urbanos y obras de arte que representan elocuentemente el proceso de búsqueda y de renovación artística en el que Le Corbusier se hallaba inmerso.

\footnotetext{
${ }^{29}$ Durante algún tiempo convivirán las dos revistas rivales y Le Corbusier formará parte de ambos comités.

${ }^{30}$ Le Corbusier: "L'espace indicible". En $L$ 'AA no especial (hors-série) Art, abril de 1946, pp. 9-17.
} 

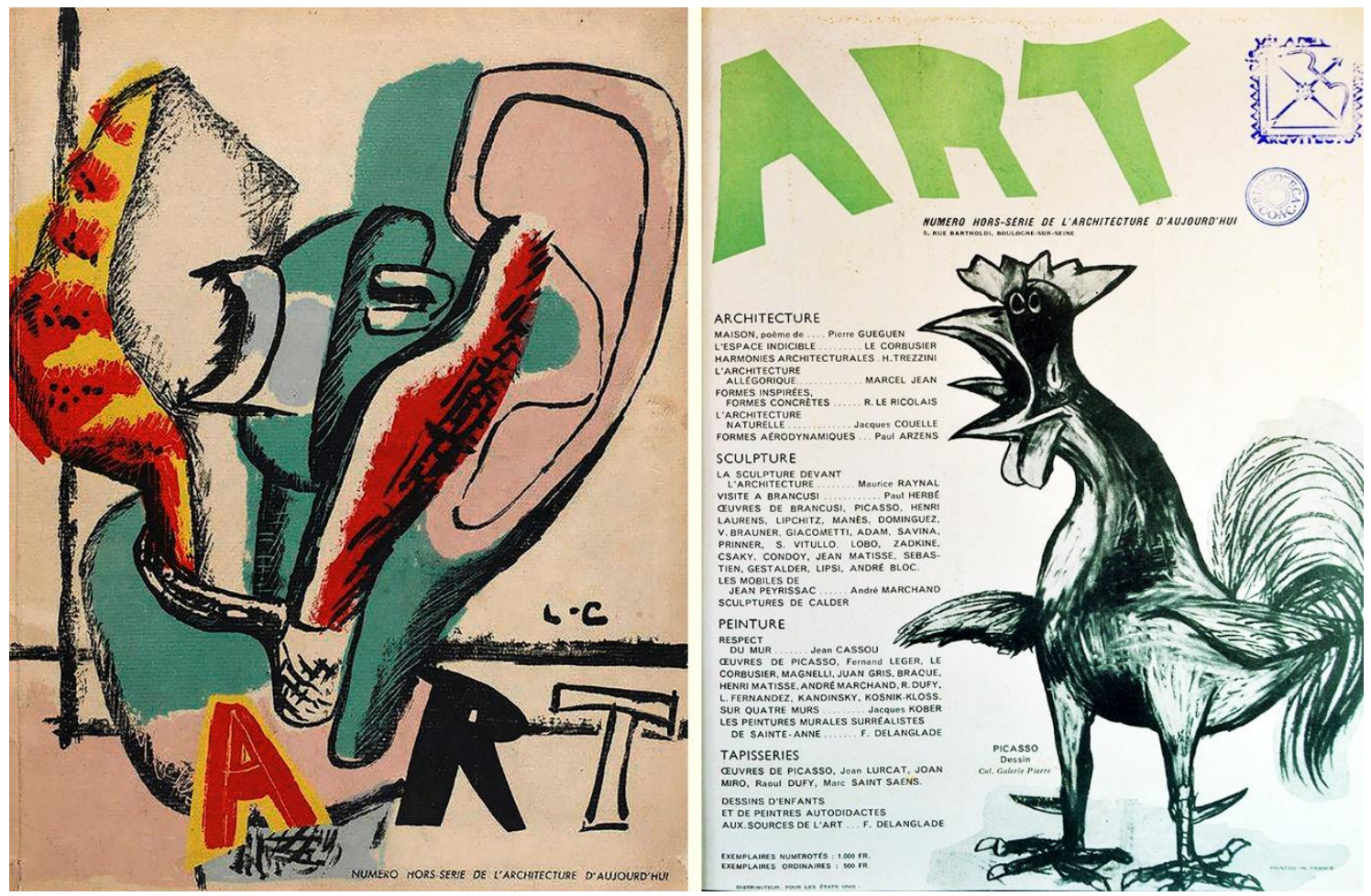

4. Portada de Le Corbusier para el número especial (hors-série) Art, 1946 (izda) y portadilla (dcha) con dibujo de Picasso

También, en 1946, el número de diciembre es importante. En él aparecen las primeras imágenes de la obra de la Unidad de Habitación de Marsella, un proyecto cuya evolución la revista seguirá muy de cerca entre 1946 y 1953. En ocasiones, se trata sólo de breves reseñas con las ideas clave de la propuesta; otras veces, de acciones propagandísticas, como el póster desplegable de agosto de 1949 para la "presentación de la Unidad al [VII] CIAM"; y hay también amplios reportajes con una clara intención pedagógica, como las cuatro páginas dobles del $\mathrm{n}^{\circ} 36$, de agosto de 1951, en las que se explica con todo detalle el funcionamiento de las complejas instalaciones del edificio. Le Corbusier dirige este interés y suma cualquier iniciativa de la revista a su propia campaña promocional con la que trata de responder a la gran oposición pública generada por la construcción de L'Unité. Ciertamente, el episodio de Marsella expresa mejor que cualquier otro cómo el creciente empeño de Le Corbusier por controlar la imagen que los medios difunden de su obra se ha convertido en esta década en una preocupación central.

El tándem Le Corbusier-Bloc parece converger al fin para sumar esfuerzos durante los difíciles años de posguerra. Así, en 1947, cuando L'AA retoma sus ciclos de conferencias, es Le Corbusier quien se encarga de inaugurarlos. Bloc pone a su disposición todos los recursos publicitarios de su plataforma editorial: publicaciones, exposiciones, emisiones radiofónicas, etc., mientras que Le Corbusier, plenamente consciente del potencial mediático de la revista, se involucra como no había hecho hasta la fecha. En aquel momento, ambos cultivan una estrecha relación epistolar y se informan puntualmente de sus respectivos proyectos. Le Corbusier, por ejemplo, envía a Bloc misivas desde Nueva York, poniéndole al corriente de sus contactos con editores americanos o de sus nuevas en la ONU. Bloc, por su parte, le hace saber de sus progresos en Argentina con Guillermo Kraft, el editor en castellano de L'Architecture d'Aujourd'hui. Y los matrimonios Bloc y Le Corbusier hasta intercambian simpáticas postales vacacionales. 

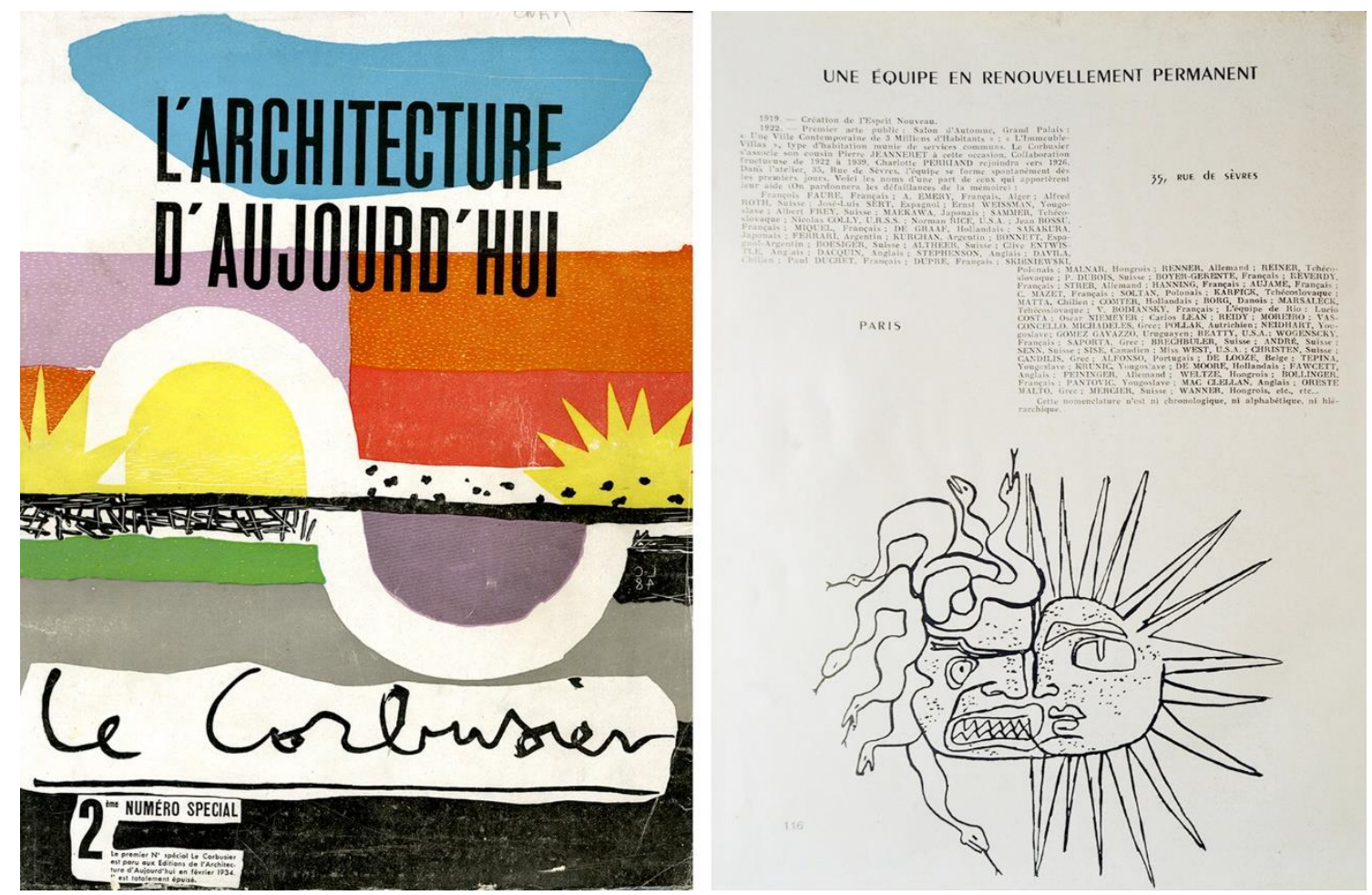

5. LC: diseño de portada y última página del segundo número monográfico de $L$ 'AA de 1948.

En este clima de cordialidad se gesta su segundo número monográfico que ve la luz, fuera de numeración, en abril de 1948. Al igual que en 1933, Le Corbusier tiene plena capacidad para decidir sus contenidos. Preocupado por exponer sus inquietudes de ese momento, Le Corbusier no oculta las contradicciones de su personal exploración artística, cada vez más solitaria frente a las necesidades colectivas de una generación marcada por una guerra aún demasiado reciente. Su polémico artículo central, inicialmente titulado "Synthèse des Arts", pero que terminó apareciendo como "Unité", es una apología de la poética de la construcción y de la dimensión holística de la arquitectura, opuestas a la división de tareas y a la burocracia corporativista que habían inspirado la reciente creación del Ordre des Architectes. Su ataque frontal a esta institución de raíz vichysta provocará un cisma en el comité de la revista que se saldará con la dimisión en bloque del círculo de Perret.

La portada de este número está caracterizada por el esquema del ciclo solar y por la firma de Le Corbusier, que anuncian el gusto orgánico y los símbolos de la ASCORAL que jalonan el monográfico. Concebido más como un libro que como una revista, el diseño de este proyecto editorial se vio beneficiado por su colaboración con el artista gráfico Pierre Faucheux quien, entre 1947 y 1948, trabaja en el estudio de Le Corbusier. El interior desarrolla el principio de heterogeneidad de las imágenes ensayado previamente con el montaje de "L'espace indicible". Respondiendo a esa unité a la que convoca el texto, las imágenes despliegan un mensaje paralelo donde obras de arte, arquitectura y visiones del territorio se funden en un todo. La concepción de la doble página como un espacio coherente de diseño apoya esta misma idea, hasta el punto de que la página se convierte en sí misma en un medio artístico ${ }^{31}$. Igualmente, las nuevas técnicas de impresión posibilitan insólitos hallazgos visuales: esculturas biomorficas trazadas en sepia sobre instantáneas de la Villa Stein; tramas transparentes de color que se superponen sobre planes urbanos... Es la síntesis con la que Le Corbusier quiere expresar los vínculos entre los diversos campos del arte y la unidad de su obra. Todo un hito con el que se cierra la década.

${ }^{31}$ Cfr. Smet, Catherine de: Op. cit., p. 91. 


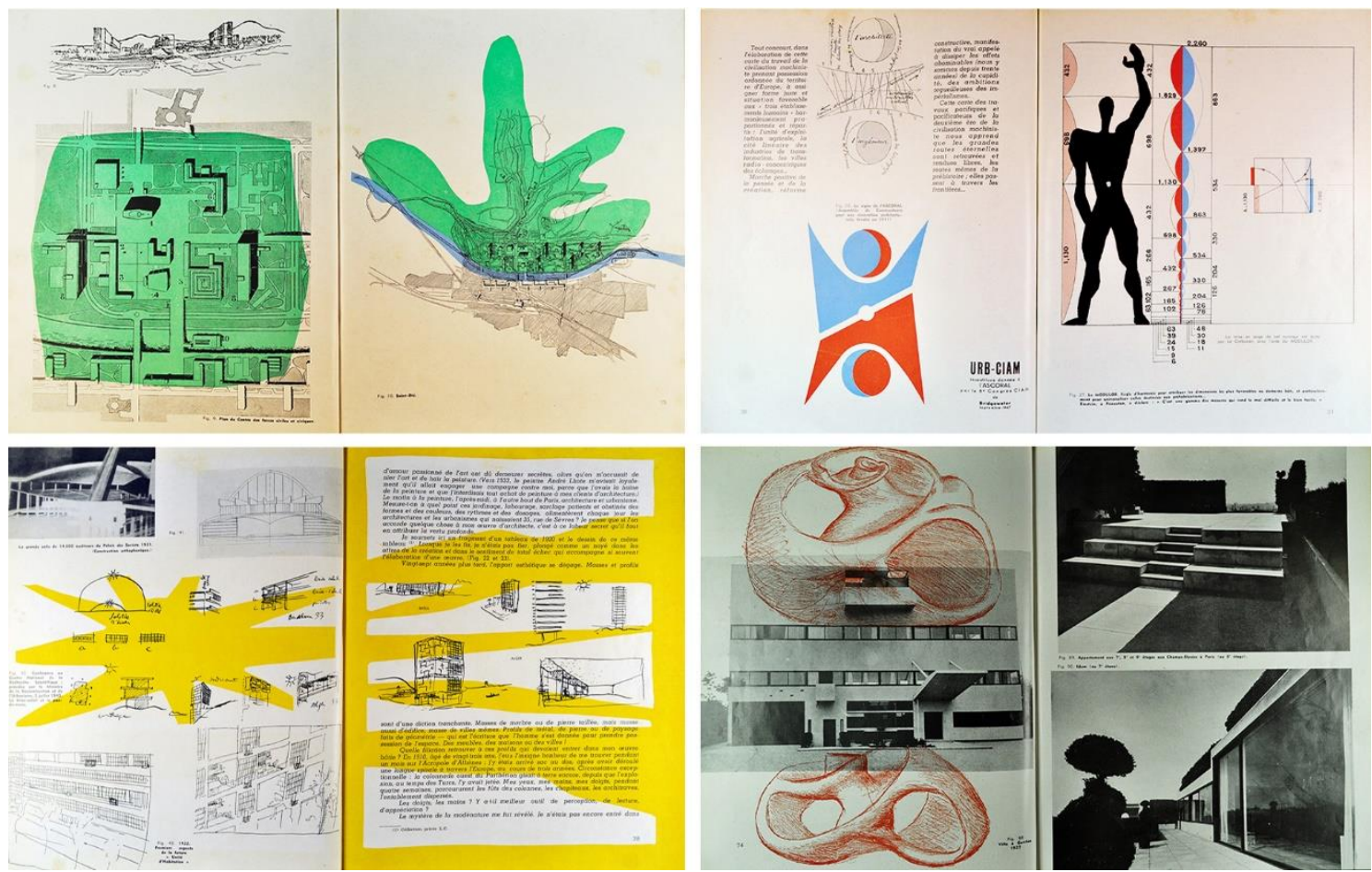

6. LC: páginas dobles del monográfico de $L$ 'AA de 1948 (de izda a dcha 14-15; 30-31; 38-39; y 74-75)

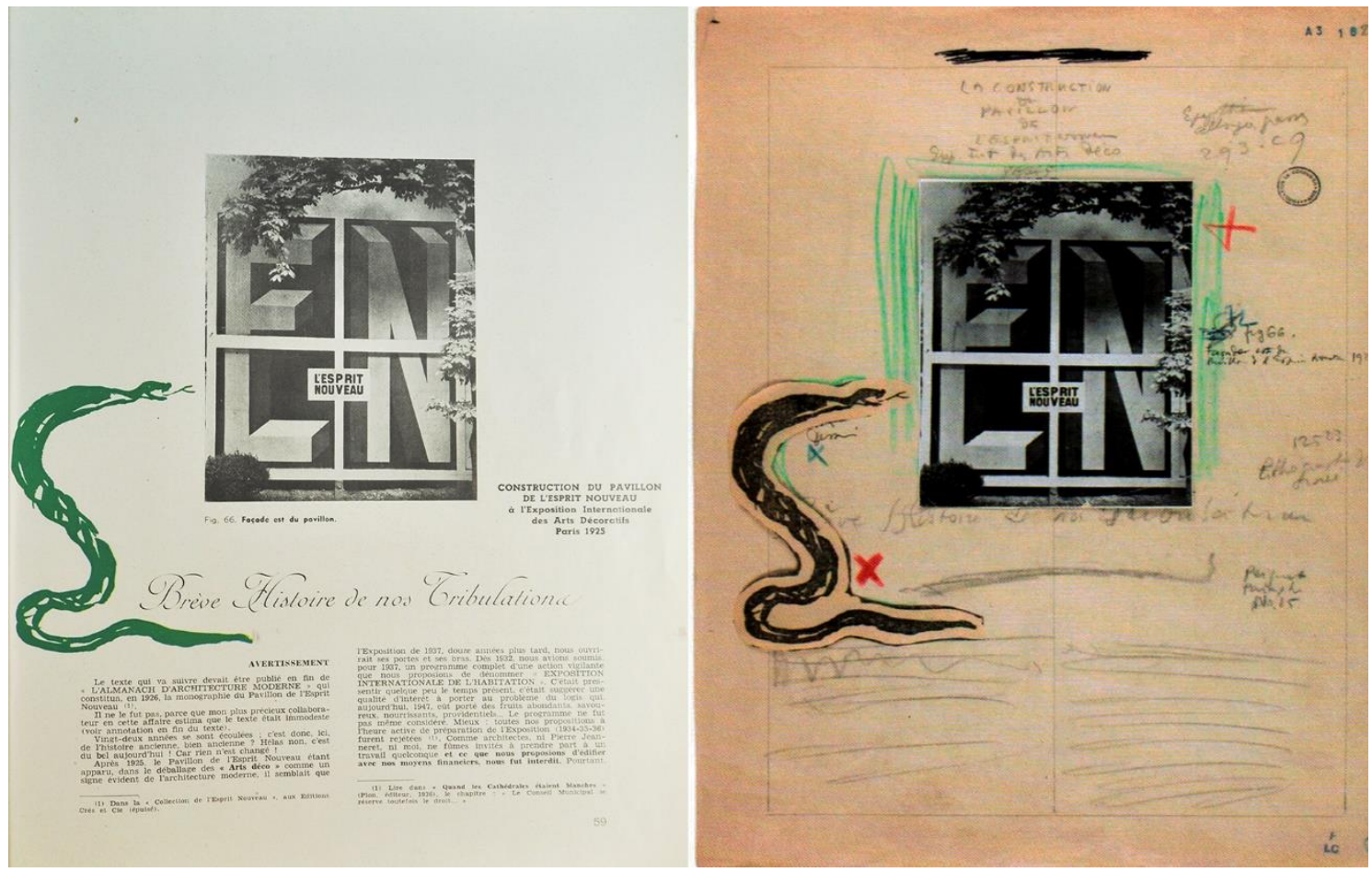

7. LC: diseño final y maqueta de página (59) para el monográfico de $L$ 'AA de 1948 (FLC A3-16-2)

\section{El conflicto: de l'Association pour une Synthèse des Arts al Groupe Espace}

En el marco de un interés largamente compartido, en 1949, Bloc emprende con Le Corbusier un nuevo proyecto, l'Association pour une Synthèse des Arts Plastiques, pero su primera actividad de envergadura, la organización de una exposición en París al año siguiente, desembocará en un enfrentamiento personal que tensará, casi hasta su ruptura, los vínculos entre ambos, perturbando irremediablemente la relación de Le Corbusier con la revista. 
En junio de 1949, Bloc había fundado, junto al pintor Edgard Pillet, la revista L'Art d'aujourd'hui ${ }^{32}$, consagrada a la abstracción, y a la promoción de la función social del arte en el contexto de la Reconstrucción. Aunque en el caso de Le Corbusier sus reflexiones sobre la síntesis de las artes son más antiguas -sus primeros escritos se remontan a principios de la década anterior ${ }^{33}$-, es después de la guerra cuando este asunto cobra especial importancia. En "L’espace indicible" Le Corbusier afirma que la clave de la emoción estética es una función espacial. De este modo, el espacio inefable se convierte en el objetivo de un proceso creativo donde se combinan todas las manifestaciones artísticas: una síntesis de las artes, expresión que, desde ese momento, Le Corbusier utilizará para referirse al conjunto de su obra. La cuestión va a adquirir plena visibilidad en el contexto de la ASCORAL y de los CIAM, en cuyo VII Congreso, en Bérgamo, se forma una comisión permanente denominada Síntesis de las Artes. Por recomendación de ésta, en octubre de 1949, se crea a su vez esta asociación homónima para -de acuerdo con el artículo primero de sus estatutos- investigar y llevar a la práctica "las bases de una colaboración eficaz entre arquitectos, escultores y pintores por todos los medios apropiados, tales como exposiciones, organización de eventos, publicaciones, conferencias, etc."

La asociación se constituye en Boulogne, con la misma sede social de L'Architecture d'Aujourd'hui. Henri Matisse es nombrado presidente y Le Corbusier y Bloc asumen las vicepresidencias primera y segunda, respectivamente. Son ellos quienes toman las principales decisiones y se aseguran de que se escoja a personas de su confianza para los puestos ejecutivos del comité de dirección. El arquitecto Marcel Roux, por parte de Le Corbusier, asume la secretaría general y Renée Diamant-Berger, redactora de $L$ 'AA, es designada secretaria adjunta. Entre sus miembros franceses figuraban arquitectos como Badovici, Bruyère, Prouvé, Wogensky, Zehrfuss o Pierre Jeanneret; los escultores Jean Arp y Henri Laurens; pintores como Braque, Léger o Piccasso; y, entre los consultores extranjeros, Giedion, Niemeyer y Sert.

El grupo se procura un respaldo institucional al más alto nivel. Le Corbusier recaba el apoyo de varios ministerios y de la ciudad de París que, en diciembre de 1949, cede finalmente los antiguos terrenos del Luna Park, adyacentes a la Porte Maillot, para organizar una exposición temporal de arte y arquitectura. Esta exposición, concebida bajo el programa original de synthèse des arts majeurs, debía ser la primera de cuatro muestras temáticas ${ }^{34}$ que, inaugurándose en junio de 1950, continuarían celebrándose con carácter anual hasta 1953.

El arquitecto plantea una primera propuesta, conocida como Proyecto A, que no va más allá de los bocetos realizados entre diciembre de 1949 y enero de 1950. Le Corbusier imagina una serie de pequeños pabellones que, cubiertos con una estructura reticular de madera diseñada a partir de una patente de Le Ricolais, pretendía dar respuesta a la escasez de medios con un sistema de "construcciones ligeras [...] estandarizadas y económicas que formarían una serie de paraguas y parasoles capaces de albergar obras importantes" ${ }^{35}$. Bajo éstos se establecía un circuito museístico a través de patios abiertos entre los árboles con una sugerente indefinición entre interior y exterior. Algunas versiones tempranas del plano de implantación incorporan un

\footnotetext{
${ }^{32}$ Sobre la actividad de esta revista y la creación del Groupe Espace véase la tesis doctoral de Corine Girieud, La revue Art d'Aujourd'hui (1949-1954): Une vision sociale de l'art (2011).

${ }^{33}$ Sobre la genealogía de la síntesis de las artes en la obra de Le Corbusier véase Rivkin, Arnoldo: "Synthèse des Arts. Un double paradoxe”. En Lacan, Jacques (Dir.): Le Corbusier, une encyclopédie. Op. cit., pp.386-91.

34 “Contrat pour le Musée des Arts plastiques Porte Maillot”. Texto mecanografiado, 30.12.1949 (FLC J1-5-138).

${ }^{35}$ Le Corbusier; Boesiger, W. (Ed.): Cuvre Complète, 1946-1952. $7^{\mathrm{a}}$ ed. Zurich: Les éditions d'Architecture, 1976, p. 67.
} 
museo de tipo crecimiento ilimitado, cuya imprecisa relación con el resto de la propuesta pone de manifiesto lo apurado de los plazos.

Diversos condicionantes administrativos obstaculizan el desarrollo de la exposición, a lo que se suma la complicada agenda internacional de Le Corbusier quien, en febrero de 1950, debe viajar a Bogotá. Aunque el proyecto no está listo, insiste en proceder al encargo de los materiales para cumplir así con el compromiso político de disponer del presupuesto asignado antes de finales de marzo. Bloc transmite ${ }^{36}$ sus reservas a Le Corbusier, instándole a convocar una reunión del comité antes de su partida. En el curso de la misma, propone diversas soluciones ${ }^{37}$ : la cancelación de la exposición, su retraso o, incluso, su transformación en otra iniciativa autofinanciada, a lo que Le Corbusier se opone.

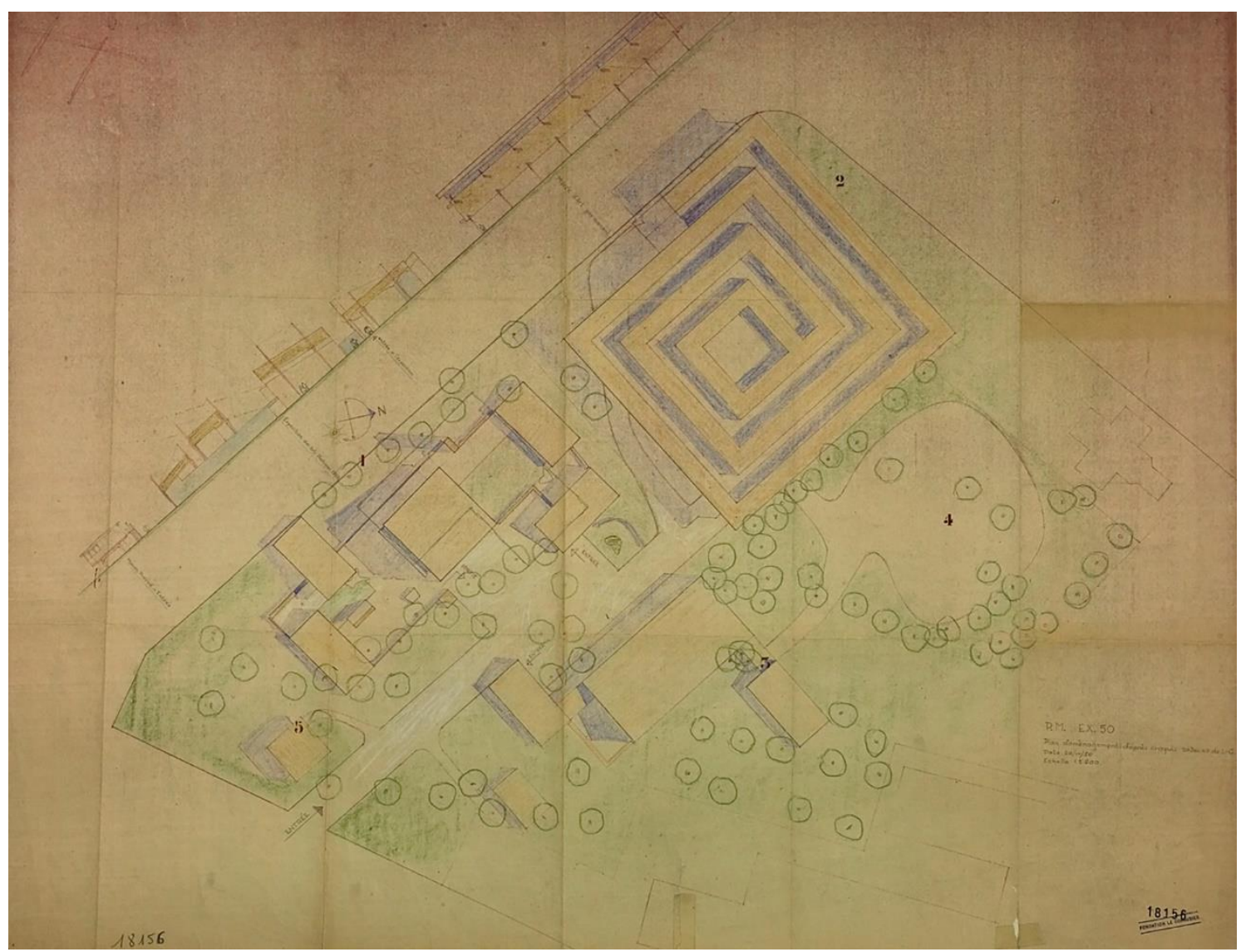

8. LC: Pabellón Synthèse des Arts majeurs. Porte Maillot, París, 1949. Proyecto A. Planta de conjunto. (FLC 18156)

A su regreso de Colombia y desoyendo de nuevo la opinión de Bloc, Le Corbusier decide continuar con otro proyecto y encarga a Jean Prouvé que investigue una solución ligera de paneles y cubiertas de aluminio. Discrepando de la obligación de desmontar periódicamente los pabellones, prefiere concentrar sus esfuerzos en el diseño de una única exposición de mayor envergadura que pueda mantenerse abierta durante varios años. Tratando de superar el carácter local del evento y garantizar su financiación, Le Corbusier sondea sin éxito el

\footnotetext{
${ }^{36}$ André Bloc: Carta a Le Corbusier, 08.02.1950 (FLC J1-5-68).

${ }^{37}$ Cfr. Ragot, Gilles; Dion, Mathilde: Le Corbusier en France. Projets et réalisations. $3^{\mathrm{a}}$ ed. Paris: Le Moniteur, 1997, p. 323.
} 
apoyo de la UNESCO. A pesar de lo que él considera unos “deplorables" medios económicos, su implicación es total.

Su segunda propuesta, el Proyecto B, plantea la ubicación de todos los recintos expositivos bajo una gran cubierta metálica, un sistema universal que permitiría realizar un circuito de exposiciones temporales intercambiables con otras similares procedentes de otros países. Finalmente, ninguna institución aportó fondos extraordinarios, por lo que esta última formalización del Pabellón Synthèse des Arts tampoco fue llevada a cabo. No obstante, su sistema de paraguas metálicos invertidos se convertiría en una referencia a la que Le Corbusier volverá recurrentemente, como en el proyecto del Palais Ahrenberg en Estocolmo (1962), o en la solución construida de la Maison de l'homme para Heidi Weber en Zúrich (1960-65).

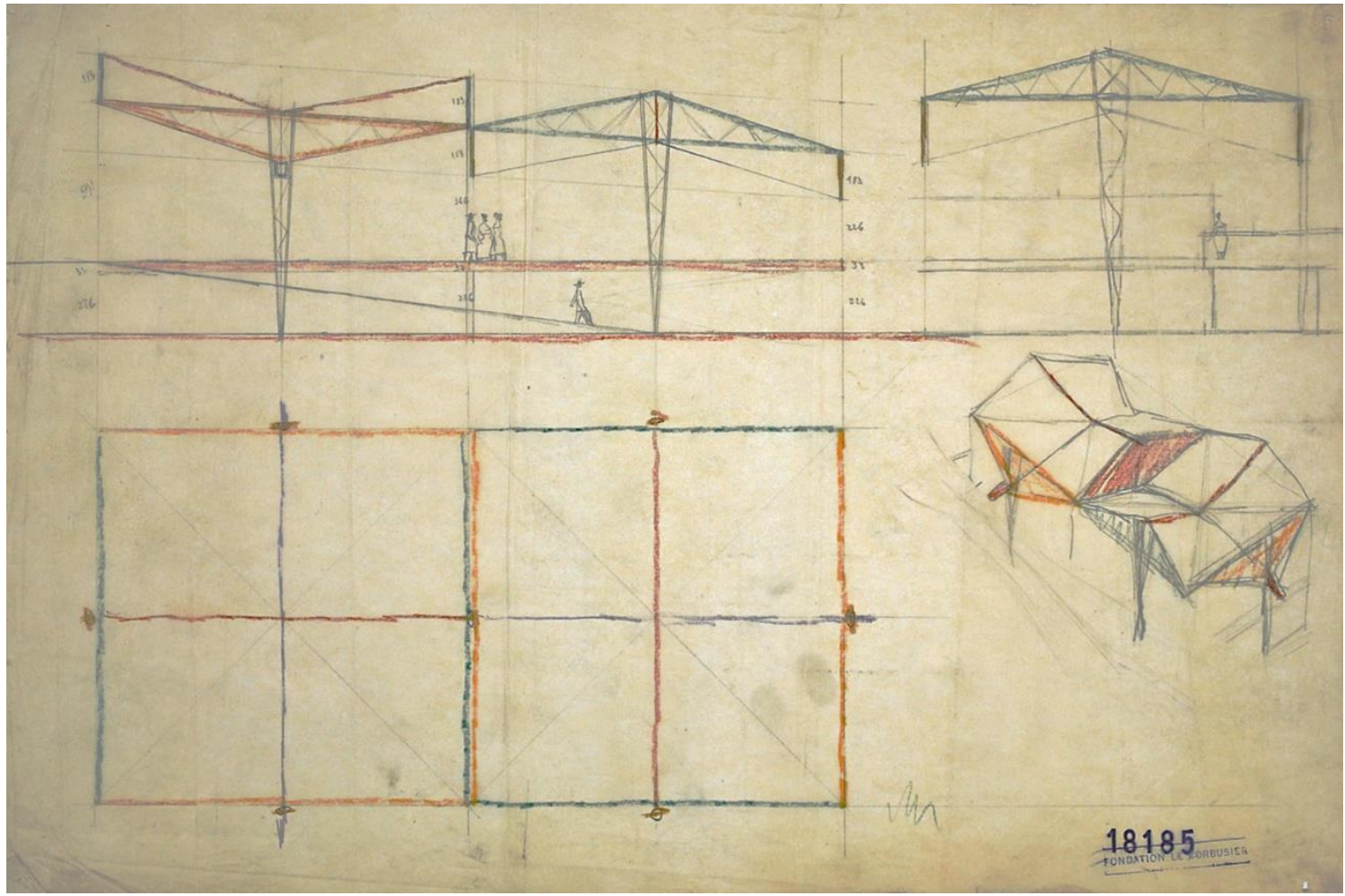

9. LC: Pabellón Synthèse des Arts majeurs. Porte Maillot, París, 1950. Proyecto B. Cubiertas. (FLC 18185)

Para Bloc, las obstinadas exigencias de Le Corbusier fueron la causa del fracaso de la exposición ${ }^{38}$, mientras que éste entendió las objeciones y el desinterés del editor como una deslealtad hacia el proyecto ${ }^{39}$. Sospechando que, durante su nuevo viaje a Colombia, Bloc había maniobrado a sus espaldas con el artista Felix del Marne para fundar otra asociación para la concurrencia de las artes, la creación del Groupe Espace, en octubre de 1950, será interpretada por Le Corbusier como una nueva traición.

\footnotetext{
${ }^{38}$ Cfr. Diamant-Berger, Renée: Notas corregidas por Pierre Vago para el artículo 'De l'Union pour l'Art à l'Association pour une Synthèse des Arts Plastiques et au Groupe Espace", publicado en Aujourd'hui: art et architecture n'59-60, especial "André Bloc", 1967. Archivo de Pierre Vago. 064 IFA 246.

${ }^{39}$ Según notas manuscritas de Le Corbusier sobre la carta citada de André Bloc de 08.02.1950 (FLC J1-5-68).
} 


\section{El periodo final (1950-65): una particular guerra fría}

Diez años después, en junio de 1960, L'Architecture d'Aujourd'hui prepara el número conmemorativo de su trigésimo aniversario. Bajo el amparo de este pretexto, Bloc escribe una carta ${ }^{40}$ a Le Corbusier solicitándole su colaboración en este número donde, según le explica, tiene reservado un puesto de honor. Pero su carta es más bien una justificación. Mientras le interroga indirectamente por la razón de su distanciamiento durante la última década, Bloc habla de tiempos pasados, de proyectos comunes y de cómo ha apoyado su obra en las circunstancias más adversas. Le Corbusier contesta ${ }^{41}$ de forma implacable, le pide que no finja ingenuidad y le recrimina un comportamiento impropio durante la exposición de 1950. Le responde además que, si ha defendido su obra ha sido por su propio interés, pues - dice-cada aparición suya en la revista ha contribuido al prestigio de $L ' A A$, y no al contrario. Tras la réplica de Bloc, Le Corbusier consiente en aparecer en ese número especial, pero con condiciones. Es Persitz quien, meses después, concluye la negociación en la que Le Corbusier exige publicar sólo un fragmento de Les trois établissments humains y el Concurso para la Ordenación Urbana de Berlín, dejando claro que debe indicarse en una nota que su propuesta fue descalificada por un jurado en el que, entre otros, estaba Pierre Vago. El redactor jefe no compartirá su decisión, que encuentra anacrónica e incoherente con los contenidos de ese número emblemático (Panorama 60), pero accede a sus demandas y sale al paso de la situación ante unos desconcertados lectores.

Éste es sólo un ejemplo, quizás el más llamativo, de los que pueden rastrearse en su correspondencia con $L$ ' $A A$ a lo largo de esos años. Por supuesto, la revista no ha dejado de informar sobre Le Corbusier y continúa publicando reportajes sobre su obra, algunos tan exhaustivos como el del número 96, de 1961, sobre La Tourette. Pero el escenario ha cambiado por completo. Para empezar, porque Le Corbusier ahora cobra por ello. Cada proyecto recogido en sus páginas costará a L'Architecture d'Aujourd'hui 100.000 francos, independientemente de la extensión o relevancia del artículo. Así, una vez en la que Le Corbusier recibe un cheque de 30.000 francos por una pequeña reseña del Pabellón Philips lo devuelve solicitando ${ }^{42}$ una rectificación de su importe. Faltan 70.000 francos - replica- y es irrelevante si el edificio ya ha sido difundido por otras revistas o si ilustra una nota sobre el conjunto de la Exposición, el precio lo fija él. A veces Bloc protestará, pedirá llegar a un entendimiento, dirá que sus condiciones son abusivas ${ }^{43}$, pero encontrará siempre la misma respuesta: no es discutible.

Una práctica muy extendida después de la guerra era que los fotógrafos tratasen directamente con las revistas de arquitectura para poner en circulación sus materiales. Así procedía Lucien Hervé quien, desde 1949, va a ejercer como el principal cronista visual de Le Corbusier. Justamente por ello, éste le exigirá personalmente que, siempre que contacte con $L^{\prime} A A$, le informe de sus movimientos. Y cada vez que esto ocurra, Le Corbusier prevendrá inmediatamente a Bloc acerca de publicar cualquier fotografía sin su consentimiento expreso. Igualmente, le prohibirá fotografiar sus edificios. Por ello, en otro episodio en el que Bloc, tratando de encontrar algún subterfugio, pretende tomar imágenes del exterior del Pabellón de Brasil en la Ciudad Universitaria, ambos se enzarzan en una discusión epistolar sobre el derecho o no que tiene para hacerlo. Bloc argumentará ${ }^{44}$ que se trata de un dominio público, pero no verá prudente contrariarle.

\footnotetext{
${ }^{40}$ André Bloc: Carta a Le Corbusier, 02.06.1960 (FLC U3-13-179).

${ }^{41}$ Le Corbusier: Carta a André Bloc, 23.06.1960 (FLC G1-17-415).

${ }^{42}$ Le Corbusier: Carta a André Bloc, 16.09.1958 (FLC U3-13-166).

${ }^{43}$ André Bloc: Carta a Le Corbusier, 18.09.1958 (FLC U3-13-240).

${ }^{44}$ André Bloc: Carta a Le Corbusier, 06.07.1959 (FLC U3-13-171).
} 
Hay momentos, incluso, en los que Le Corbusier parece obsesionado por detectar cualquier aparición suya no autorizada. En febrero de 1960, en una carta enviada a su estudio, escribía: "No tengo ni el tiempo ni el interés para mirar las revistas de arquitectura" ${ }^{45}$. No se refería a L'Architecture d'Aujourd'hui.
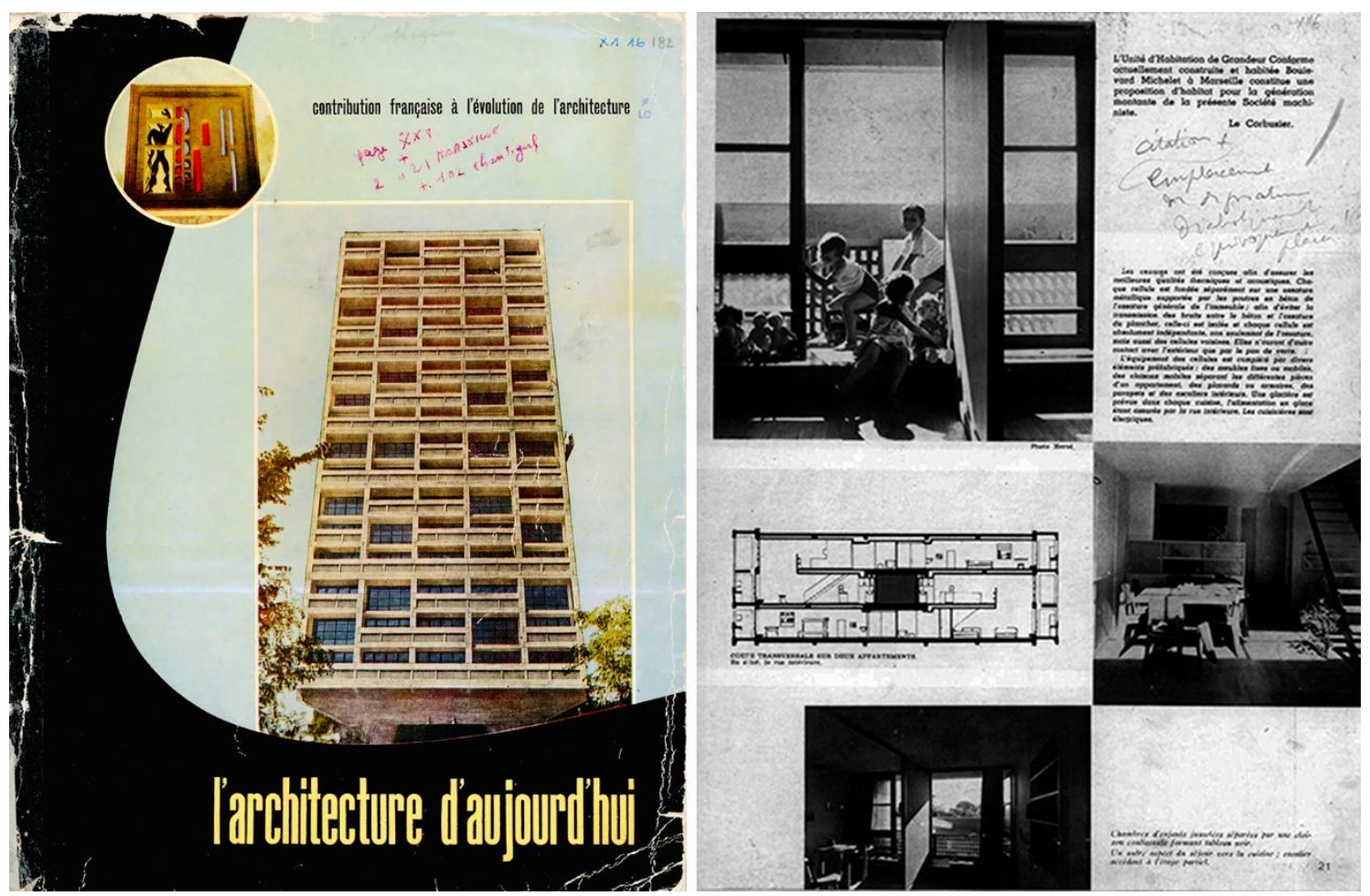

10. L'AA nº46, 1953. Ejemplar de LC (FLC X1-16-182). Portada (izda) y última página del artículo "Unité d'habitation", p.21 (dcha) con texto manuscrito de LC: "cita + colocación de firma diabólicamente equivocadamente situados" (sic)

Le Corbusier exige que se envíe a su estudio cada nuevo número en el que se publique cualquier información sobre él. Antes de ello, solicitará confirmar ${ }^{46}$ la maqueta y, después, efectuará las necesarias comprobaciones para verificar que su impresión se corresponde con aquello que autorizó. Los archivos de su Fundación conservan estos ejemplares de $L \prime A A$ grafiados de su puño y letra. Prueban que han sido cuidadosamente estudiados y que Le Corbusier anotaba todo aquello que le llamaba la atención o que creía que debía contrastar detenidamente. En paralelo, su correspondencia con la revista revela cómo cada desacuerdo se traduce en una o varias cartas expresando su malestar. Esto mismo ocurre con el $\mathrm{n}^{\circ} 46$, de febrero de 1953, Contribution française, que lleva en portada la Unidad de Habitación de Marsella. En este caso, tras recibir el ejemplar, Le Corbusier muestra su contrariedad ${ }^{47}$ al descubrir su firma al final del artículo e insta a Bloc a demostrar que no se trata de un error tipográfico, pues su nombre aparece colocado ambiguamente debajo de un texto, lo que podría confundir - ¿deliberadamente?- a los lectores sobre la autoría del mismo.

Aunque Bloc será siempre el destinatario último de sus misivas, en los años 50, el intercambio con la revista se produce también a través de sus respectivos colaboradores. La secretaria de Le Corbusier y André Wogenscky

\footnotetext{
${ }^{45}$ Le Corbusier: carta a su estudio, 24.02.1960, citada en el editorial del n ${ }^{\circ} 272$ de $L$ ' $A A$ por el entonces redactor jefe de la revista. Chaslin, François: “AA, 1930-1990. Un état critique”. En L’AA n²72. Diciembre 1990, p. 15.

${ }^{46}$ Le Corbusier: carta a André Bloc, 02.04.1953 (FLC B2-14-266).

${ }^{47}$ Le Corbusier: carta a André Bloc, 14.04.1953 (FLC B2-14-291).
} 
escriben desde la rue de Sèvres, mientras que en la redacción de Boulogne, Renée Diamant-Berger o Alexandre Persitz serán quienes desempeñen la difícil tarea de interlocución con un cada vez más irascible Le Corbusier.

Públicamente, el arquitecto tampoco esconde su hostilidad hacia la revista. Evita asistir a eventos promovidos por L'AA y manifiesta su disgusto a terceras personas, como hace en junio de 1959 al escribir a Kenzo Tange a la Embajada de Japón para presentarle sus escusas por no asistir a una cena que la revista organizaba en su honor ya que, según afirmaba, sus "relaciones con los anfitriones ya no son las que eran" 48.

A pesar de sus desencuentros o, precisamente por ellos, en la década de 1960, André Bloc va a brindar diversos homenajes a Le Corbusier. Por ejemplo, en el editorial del número doble 113-114, Un siglo de arquitectura, de abril mayo de 1964, el director subraya la contribución de su revista para situar la obra de Le Corbusier en el lugar histórico que le corresponde como pionero de la modernidad. En este mismo número, Georges Candilis se acerca a su producción a través de una visión panorámica ${ }^{49}$ organizada por décadas. Su antiguo colaborador constata que, a pesar de que se ha escrito mucho sobre Le Corbusier, casi todo está aún por decir, argumentando que los estudios existentes aíslan su obra de su tiempo cuando, realmente, ambos son indisociables pues los avatares del siglo han influido sobre ella y, a la inversa, "Le Corbusier ha marcado decisivamente el espíritu de su época".

Otro de esos reconocimientos, probablemente el más conspicuo de todos, es el "Hommage à Le Corbusier", publicado en el nº106, de febrero de 1963, con ocasión de su retrospectiva en el Musée d'Art Moderne de 1962. Sus ocho páginas de testimonios están precedidas por una afectada nota de André Bloc en la que se esfuerza por hacer valer su antiguo e inquebrantable apoyo a Le Corbusier, insistiendo en que si el arquitecto no siempre le había correspondido del mismo modo había sido porque, seguramente, después de tanta batalla y tanta decepción personal, su carácter se había visto afectado ${ }^{50}$, hasta el punto de no ser "capaz de distinguir a sus verdaderos amigos"

El último tributo de Bloc, ya póstumo, es el número que Aujourd'hui, revista hermana de $L$ 'AA, consagró al arquitecto en noviembre de 1965. Este monográfico fue concebido por Claude Parent y Patrice Goulet, quienes no dejaron a nadie indiferente. El número se abría con un editorial de André Bloc donde aprovechaba, de nuevo, para reiterar su lealtad a Le Corbusier, aunque también para expresar, por primera vez abiertamente, su decepción por algunos episodios del pasado.

\footnotetext{
${ }^{48}$ Le Corbusier: carta a Kenzo Tange, 13.06.1959 (FLC G1-15-499).

${ }^{49}$ Candilis, George: "Le Corbusier et notre époque". En $L$ 'AA nº113-114. Abril-mayo 1964, pp.16-31.

${ }^{50} \mathrm{El}$ mismo argumento que repite en su breve nota necrológica de Le Corbusier, publicada en septiembre de 1965.
} 


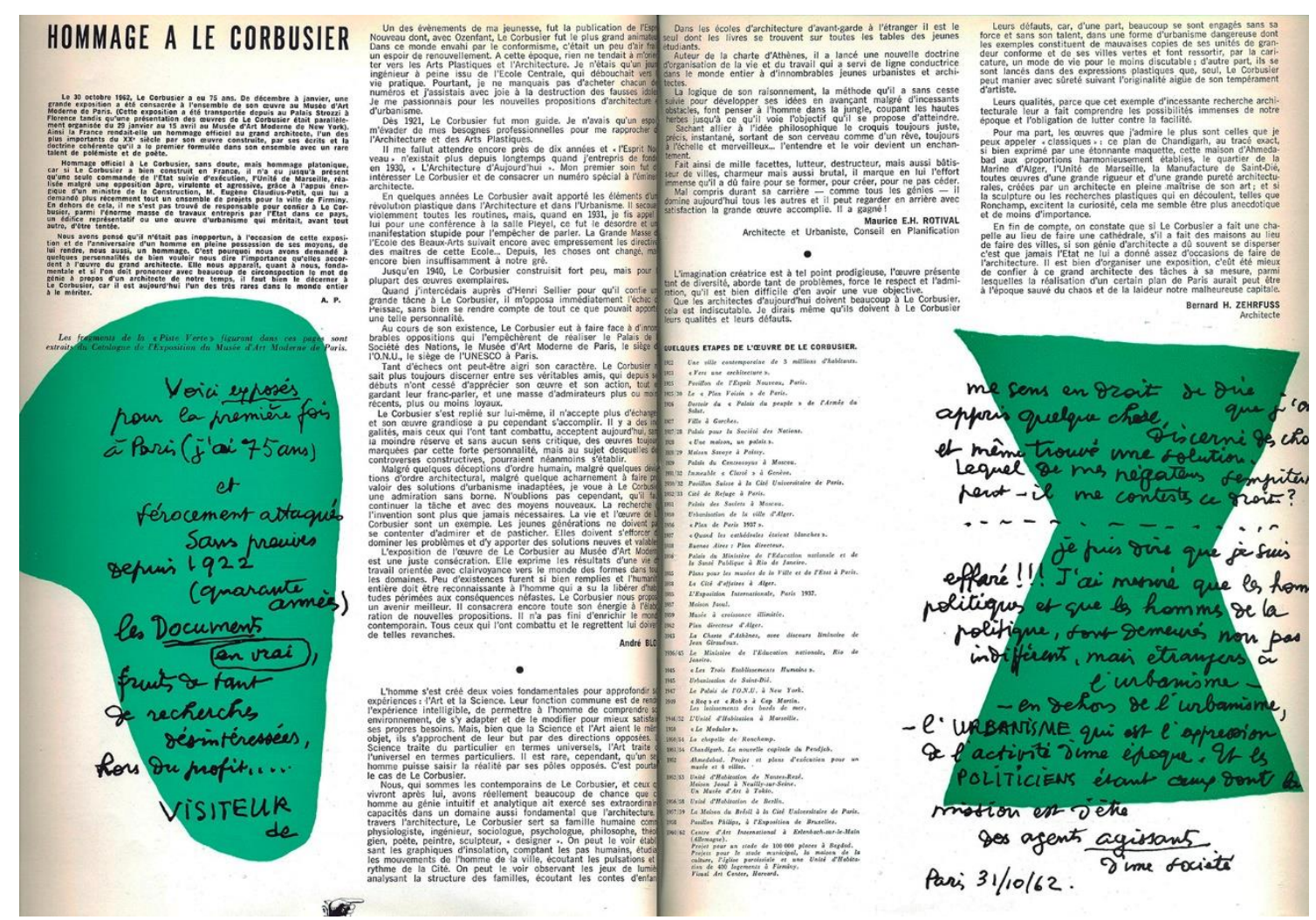

11. $L$ 'AA n ${ }^{\circ} 106,1963$, p.2 y p.9. Primera y última página del "Hommage à Le Corbusier" maquetados con el distintivo de la piste verte de Le Plans de Paris (1956) reciclado en el catálogo de la exposición del Musée d’Art Moderne de1962

Refiriéndose indirectamente a la exposición de 1950, reprochaba a Le Corbusier el "egocentrismo" que le había impedido asumir críticas y aceptar que otros abordasen los mismos temas, como el de la relación entre las artes. “Convencido de que la iniciativa era mía, nunca me perdonó la creación del Groupe Espace. [...] Pese a todo, continué admirando una obra genial a la que, sin duda, debemos lo mejor de la creación contemporánea",51. Curiosamente, este reconocimiento resulta matizado con lo que Bloc afirma, dos párrafos después, al introducir el texto de sus jóvenes redactores: "es demasiado pronto para establecer con justicia el verdadero alcance de la obra de Le Corbusier [pero] Le Corbusier merece mucho más que valoraciones sin espíritu crítico".

Recogiendo el guante, Parent y Goulet proponen un inteligente análisis de la trayectoria de Le Corbusier. Señalan entre sus logros la "visión premonitoria" de una arquitectura que emana de su dimensión territorial, pero inciden también en sus contradicciones, consecuencia del contexto y de la necesidad de cada momento. Su artículo llama a superar las visiones reduccionistas, a las que -recuerdan- tanto recurrió el propio maestro "para resultar convincente" $\mathrm{y}$, por ello, invitan a acercarse a su obra de forma desapasionada dado que -según razonan-su tiempo ha pasado y “Le Corbusier ya no podrá ser la única guía para los jóvenes arquitectos",52.

El número, a pesar de ser ampliamente saludado ${ }^{53}$, ofendió sin embargo a muchos partidarios y amigos de Le Corbusier. El malestar causado por sus artículos de cabecera trascendió el ámbito de $L$ 'AA, extendiéndose la discusión hasta implicar a otros autores fuera de sus círculos, como Michel Ragon o Françoise Choay. Aunque,

\footnotetext{
${ }^{51}$ Bloc, André: "Le Corbusier". En Aujourd'hui: art et architecture n51. Op. cit., p.0.

${ }^{52}$ Parent, Claude; Goulet, Patrice: “Architecture-Urbanisme”. En Aujourd'hui: art et architecture n51. Op. cit., p.3.

${ }^{53}$ Eugène Claudius-Petit: carta a Pierre Vago, 19.09.1966. Archivo de Pierre Vago. 064 IFA 246.
} 
sobre todo, esta controversia desencadenó un enfrentamiento entre Bloc y gran parte del comité de la revista. Candilis, Perriand, Prouvé y otros antiguos colaboradores de Le Corbusier manifestaron ${ }^{54}$ su indignación al considerar que se había convertido un homenaje en una crítica que, incluso, algunos entendieron como una provocación. Entre ellos, Marcel Lods fue el más beligerante. Durante meses mantuvo una insistente correspondencia ${ }^{55}$ con Bloc, Vago y Parent, pidiéndoles explicaciones y exigiendo responsabilidades hasta que, finalmente y tras varias revisiones, Bloc redactó una nota de disculpa asesorado por Vago. Decía escuetamente: "L'AA, que siempre ha combatido al lado de Le Corbusier, comprende estas reacciones que emanan de muchos de sus mejores amigos y viejos compañeros de lucha" ${ }^{\prime \prime 6}$. De nuevo, emergían las metáforas bélicas y, una vez más, el lenguaje de la confrontación que había presidido su relación con la revista.

El corolario de este último número monográfico no puede sino recordar lo sucedido con aquel primer especial de 1933. El círculo se cerraba. A lo largo de todos esos años, Bloc había intentado mantener su posición de centralidad -sin mucho éxito-, respaldando públicamente el trabajo de Le Corbusier y delegando en su elenco de colaboradores más cercanos, desde Pierre Vago a Claude Parent, la responsabilidad de matizar esta adhesión con sus propias críticas, a veces contradictorias, nunca bien recibidas, pero siempre valiosas como expresión de la dificultad para entender, en tiempo real, la vasta dimensión de su legado.

\section{Agradecimientos}

Estoy en deuda con Arnaud Dercelles por su ayuda durante mis visitas a la Fundación Le Corbusier y, después, atendiendo en todo momento llamadas y correos con múltiples cuestiones, en las que ha resultado muy valiosa su pericia para descifrar la caligrafía de Le Corbusier. Agradezco a Gilles Ragot sus comentarios sobre los fondos de L'Architecture d'Aujourd'hui, así como a Alexandre Ragois, responsable de los Archivos del IFA, los contactos facilitados. Deseo asimismo expresar mi gratitud a Claude Parent por su generosa y estimulante conversación. También, y muy especialmente, a Carmen Jordá, mi primera guía cuando, hace ya algunos años, comencé a sumergirme en las páginas de esta revista y a interesarme por su historia. Finalmente, quiero dar las gracias a mis compañeros del Área de Composición de la Universidad de Alicante por todo su apoyo y por poner a mi disposición los recursos del Departamento de los que se ha beneficiado esta investigación.

\section{Créditos fotográficos}

Imágenes 2; 7 (derecha); 8, 9 (planos); y 10 (ejemplar de Le Corbusier del nº46 de L'AA): OFLC-ADAGP Demás imágenes: L'Architecture d'Aujourd'hui y/o revista Aujourd'hui, reproducción de páginas y portadas.

\section{Bibliografía/referencias}

Art. L'Architecture d'Aujourd'hui nº especial (hors-série), 1946.

Badouï, Rémi: “D'Hier à Aujourd'hui". En L'Architecture d'Aujourd'hui n²72, número especial "Soixante années d'Architecture d'Aujourd'hui'. Diciembre 1990, pp. 61-76.

Bloc, André y otros: “Hommage à Le Corbusier". En L'Architecture d'Aujourd'hui nº106. Febrero 1963, pp.2-9.

\footnotetext{
${ }^{54}$ Actas del Comité de L'AA, 24.03.1966. Archivo de Pierre Vago. 064 IFA 246.

${ }^{55}$ Correspondencia Lods-Bloc-Vago-Parent, enero-abril 1966. Archivo de Pierre Vago. 064 IFA 246.

${ }^{56}$ André Bloc (Pierre Vago): Proyecto de nota para L'AA, 01.08.1966. Archivo de Pierre Vago. 064 IFA 246.
} 
Chaslin, François: “AA, 1930-1990. Un état critique”. En L'Architecture d'Aujourd'hui n²72. Diciembre 1990, pp. 12-16.

Chaslin, François: Un Corbusier. París: Seuil, 2015.

Colomina, Beatriz: “1949”. En Somol, R. E. (Ed.): Autonomy and Ideology. Positoning an Avant-garde in Europe. Nueva York: Monacelli Press, 1997. pp. 300-325.

Contribution française à l'évolution de l'architecture. L'Architecture d'Aujourd'hui nº46. Febrero 1953.

Corbu. L'Architecture d'Aujourd'hui n²49. Febrero 1987.

Girieud, Corine: La revue Art d'Aujourd'hui (1949-1954): Une vision sociale de l'art. Director: Serge Lemoine. Université Paris IV-La Sorbonne, París, 2011.

Lacan, Jacques (Dir.): Le Corbusier, une encycplopédie. París: Centre George Pompidou, 1987.

Le Corbusier et Pierre Jeanneret. L'Architecture d'Aujourd'hui nº10. Diciembre 1933-febrero 1934. Boulognesur-Seine, 1934.

Le Corbusier. L'Architecture d'Aujourd'hui no especial (hors-série), 1948.

Le Corbusier; Boesiger, W. (Ed.): Euvre Complète, 1946-1952. $7^{\text {a }}$ ed. Zurich: Les éditions d'Architecture, 1976. Numéro spécial André Bloc. Aujourd'hui: art et architecture n59-60. Diciembre 1967.

Numéro spécial Le Corbusier. Aujourd'hui: art et architecture n51. Noviembre 1965.

Panorama 1960. L'Architecture d'Aujourd'hui nº1-92. Septiembre-noviembre 1960.

Ragot, Gilles: "Pierre Vago et les débuts de L'Architecture d'Aujourd'hui 1930-40". En Revue de l'Art no89. París: Centre André Chastel, Université de la Sorbonne, 1990. pp. 77-81.

Ragot, Gilles: "Un père de L'Architecture d'aujourd'hui et un fil d'Ariane". En L'Architecture d'Aujourd'hui n 275. Junio 1991, pp. 52-54.

Ragot, Gilles; Dion, Mathilde: Le Corbusier en France. Projets et réalisations. $3^{\mathrm{a}}$ ed. París: Le Moniteur, 1997.

Smet, Catherine de: Le Corbusier, Architect of Books. Baden (Suiza): Lars Müller Publisher, 2005.

Un siècle d'architecture. L'Architecture d'Aujourd'hui nº113-114. Abril-mayo 1964.

Vago, Pierre: "Retour aux sources. Le Corbusier et L'AA". En L'Architecture d'Aujourd'hui $\mathrm{n}^{\circ}$ 249, número especial "Corbu". Febrero 1987, p. 7. 


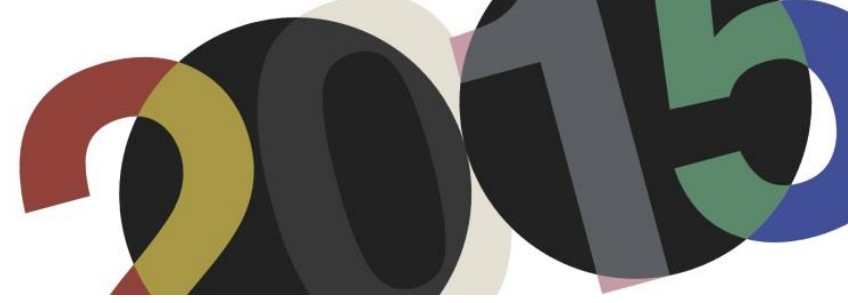

DOI: http://dx.doi.org/10.4995/LC2015.2015.668

\title{
HABITAR EL AIRE
}

\author{
M. Pérez Rodríguez
}

Escuela Superior de Arquitectura de Valencia

\begin{abstract}
Resumen: Existen en las ideas enunciadas por Le Corbusier dos caminos que partiendo aparentemente de mundos paralelos y opuestos, terminarán convergiéndo en un mismo lugar.

Con la construcción del Pavillon de l'Esprit Nouveau, en 1925, se define el nuevo espacio exterior vinculado a la vida moderna. Éste, se dará simultáneamente desde lo colectivo, el immeuble-villa, y desde lo individual, la villa, aunque ambos, se suceden como procesos coexistentes. A este vacío, Le Corbusier lo denominará jardin suspendu, y el orden con el cuál se definirá, será el mismo con el que se constituirá todo el sistema. Desde dentro, este jardin, dejará de ser un exterior para concebirse desde las mismos mecánismos que operan dentro de la casa. Entonces ¿Qué es este espacio?. Simplemente, lo que Le Corbusier trazó, una rica dualidad espacial.

Al otro lado, y opuesto a la casa, surge siempre un exterior, como extensión infinita de lo natural. ¿De qué forma ordenarlo? ¿cómo vincularlo de nuevo al hombre?. Sólo existe una respuesta posible, un único gesto, el arquitectónico, surgido con la construcción de un plano. Con él, asoma la vertical y la horizontal: Aquellas líneas que vinculan de nuevo al hombre con sus leyes. Con ello, el vacío ya no existe, se ha transformado, constituyendo un nuevo espacio. ¿Qué es este espacio?. De nuevo, una rica ambigüedad.
\end{abstract}

Abstract: Into the ideas enunciated by Le Corbusier there are two paths starting apparently from parallel and opposite worlds, but finally coming to converge in a same place.

With the construction of the "Pavillon de l'Esprit Nouveau", in 1925, it is defined the new outside space linked to modern life. This is given simultaneously from the collective with the "immeuble-villa", and from the individual, la villa, although both succeed as coexistent processes. This emptiness was called by Le Corbusier "jardin suspendu", and the order to define it, will be the same used to build the whole system.

From inside, this garden will fail to be an outside to be conceived from the same mechanisms that work into the house. So, what is this space? It is simply what Le Corbusier designed, a rich space duality. In the other side, and opposite the house, an outside emerges always, like a boundless extent of the natural. Which way can it be arranged? How can it be linked again to the human? It exists only one possible answer, one unique gesture, the architectonic one, which emerges with the construction of a plan. With it, vertical and horizontal positions arise: those lines that link again the man with his laws. With it, this emptiness doesn't exists anymore, it has changed becoming in a new space. What is this space? Again, a rich ambiguity.

Palabras clave: immeuble-villa, jardin suspendu, interior, exterior, dualidad especial.

Keywords: immueble-villa, jardin suspendu, inside, outside, space duality.

\section{Introducción}

Con motivo de la l'Exposition des Arts Décoratifs de París de 1925 Le Corbusier construye el Pavillon de L'Esprit Nouveau. Esto supone para él la cristalización de la idea de la cellule d'habitation enunciada en 1922 junto a su prototipo de immueble-villa y, el modelo de Ville Contemporaine de 3 Millions d'Habitants. Con ello, su primer objetivo, integrar urbanismo y arquitectura dentro de una misma disciplina, se cumple, asumiendo así que la concepción del nuevo microcosmos, la cellule, será la base indispensable para lograr tal fin: “[...] expresar el diseño de un edificio de viviendas mediante la construcción de un solo elemento y, utilizarlo para 
demostrar la tesis de la casa moderna", .

La nueva idea, una casa llena de aire, constituye la esencia de muchos de sus futuros trabajos, tanto en lo referente a la vivienda colectiva o el immeuble, como a la villa individual. Basta con recordar las palabras que expresará Gideon tras visitar el Quartier Pessac, donde observará que en las casas de Le Corbusier " el aire circula a través de ellas. El aire se convierte en un factor esencial. Lo que cuenta no es ni el espacio ni la materia, sino las relaciones y las penetraciones [...] No existe ninguna diferencia entre el interior y el exterior",2. Es con relación a este proceso de doble inclusión entre el mundo exterior y el interior, cristalizado en el espacio que él denominará jardin suspendu $u^{3}$, desde donde se aborda el análisis de su obra. Para él, la imagen ya ha quedado grabada en su retina y en su memoria, cuando habla de la Cartuja de Ema: "Cada casa posee de esta manera su propio jardín, en el que la intimidad es perfecta, como en el de los hermanos de la Cartuja de Emaen Galuzzo, cerca de Florencia, visitada por primera vez en 1907, en donde nos sentiamos invadidos por la melancolía. La belleza, la alegría, la serenidad se concentran aqui",4.

Para el Le Corbusier de los años 20, el jardin suspendu será un proceso de racionalización de la naturaleza, un continuo desarrollo que irá en primer lugar a reconocer una visión de la naturaleza opuesta a la casa ${ }^{5}$, y en segundo término -con la búsqueda de un orden ${ }^{6}$ - la definición de un sistema que lo posibilite. Ese será el recorrido para llegar al nuevo espacio exterior de la casa moderna ${ }^{7}$,pero que como en cualquier proceso cíclico, éste germina desde sus primeras obras.

Si atendemos a las palabras utilizadas por Le Corbusier para describir el jardín de la villa Jeanneret-Perret - la Maison Blanche-, construída para sus padres en 1912 en La-Chaux-de-Fonds, fija las ideas que definirán este espacio:"completamente a salvo de miradas indiscretas, con vistas panorámicas de montañas y orientado para permitir una vida constante de la mañana a la noche al abrigo del viento, en un piso de baldosas siempre seco en medio de lechos de flores y praderas de pastos ${ }^{\prime \prime}$. La descripción, como primera aproximación genérica, valdría para cualquiera de sus posteriores jardin suspendu. Para lograr este propósito, se han de cumplir los tres requisitos básicos: se elevarán siempre por encima de la cota cero; se concebirán desde el orden geométrico y

\footnotetext{
1 “[...] d'exprimer la conception d' un bloc d'habitation en construisant un élément isolé et en s'en servant pour faire la démonstration des thèse du logis moderne”. Boesiger, Willy; Stonorov,O: Le Corbusier et Pierre Jeanneret.Oeuvre Complète. 1910-1929, $11^{\circ} \mathrm{Ed}$, Zurich: Les Éditions d'Architecture, 1973. p.92.

${ }^{2}$ Moss, Stanislau Von: Le Corbusier, $1^{\circ}$ Ed, Barcelona: Lumen,1977, p.103. extraído de la cita 59, Bauen in Frankreich, p.8586. Fuentes de Pessac.

${ }^{3}$ Conviene adelantar que la denominación de jardin suspendu, tendrá múltiples acepciones a lo largo de todos los proyectos: jardin suspendu, jardin suspendu et couvert, jardin couvert, terrasse-jardin couverte, terrasse couverte, jardin-terrasse, o jardin supérieur ..etc.

${ }^{4}$ Giuliano Gresleri: Le Corbusier. Viaggio in Oriente, Paris:Foundation Le Corbusier, 1984.p.85

5 "une maison qui soit cette limite humaine, nous entourant, nous séparant du phénomène naturel antagoniste, nous donnant notre milieu humain, à nous hommes”. Le Corbusier: Hacía una Arquitectura,2ed, Barcelona: Apóstrofe, 1998, p.45.

6 "Que voyez-vous se dérouler sous vos yeux, sinon une immense mise en ordre? Lutte contre la nature pour la dominer, pour classer, pour se donner ses aises, en un mot, pour s'installer dans un monde humain qui ne soit le milieu de la nature antagoniste? Un monde à nous, d'ordre géométrique?'. Le Corbusier: Almanach d'Architecture Moderne,Paris:Les éditions G. Cres et Cia.1925 p.26.

7 "Con la terraza-jardin, el visitante aborda el espacio más prestigioso de la villa, el que otorga todo su sentido al proyecto. Lugar de calma y reposo, verdadero "salón a cielo abierto" para las recepciones de verano, este espacio resguardado de las miradas desde el parque, responde a toda una serie de exigencias de proyecto". Sbriglio, Jacques: Le Corbusier. La villa Savoye. Madrid: ABADA editores.2005.p.89

8 "totalement à l'abri des regards extérieurs, avec vue panoramique sur les chaînes de montagnes et orienté de façon à permettre un séjour constant du matin au soir à l'abri du vent, sur un sol dallé toujours sec au milieu de plates-bandes de fleurs et de parterres de gazon " Charles-Edouard Jeanneret, aviso de venta, el 21 de Enero de 1919. http:// www. maisonblanche.ch
} 
espacial del proyecto y; serán siempre un espacio delimitado. Pero aún con estas tres invariantes, este breve estudio analiza, además de los cambios del espacio en sí mismo, su interrelación con la vivienda. Los pequeños cambios no se darán sólo dentro de una misma obra, sino que la investigación en unos implicará la futura materialización de otros, reconociendo con ello, que el proyecto en Le Corbusier es siempre fruto de un un proceso abierto.

\section{Del lleno al vacío: El “Jardin suspendu”.}

\subsection{En el immeuble-villa.}

Cuando Le Corbusier concibe su immeuble-villa, apenas había construído un limitado número de viviendas en su Suiza natal. Pero sin embargo ya había enunciado, lo que sería sin duda la idea más relevante dentro de su obra: la Maison Dom-Ino. Lo más importante de la propuesta no estaba sólo en ofrecer un modelo estructural junto a su amigo Marc Dubois, sino la concepción de un sistema capaz de definir las claves de la vivienda moderna. Éstas se encontraban condensadas en la búsqueda de una heterogenidad y variación interior, en una libertad de su adaptación urbana y, por último, en una nueva forma de relación entre el interior y el exterior. Esta última es la que provocaría la nueva dualidad espacial, una dualidad generada por la utilización de divisiones transparentes y vidriadas, que como bien expresa G.Kepes, lograron "amplificar ópticamente esta integración y crear un espacio vivo y fluido, articulado por dentro y por fuera [...] crear una única unidad viviente".".

Este proceso de inclusión espacial, y de simultaneidad perceptiva, ya estaba presente en otras realizaciones. En el ámbito de lo pictórico, por ejemplificarlo brevemente, esta sincronía ya se manifestaba gracias al uso del entrelazamiento de lineas y planos, o de la combinación entre oscuro y claro. Por ello, tanto Ozenfant como Le Corbusier al final de su primera etapa Purista (1918-28), se valdrán del uso de una línea de contorno común que entrelazará los distintos objetos formales dispuestos en el espacio de la tela. Este nuevo contorno presentaba un significado claro: crear una nueva unidad espacial.

Así será como la cualificación del espacio moderno será aprehendida por el habitante gracias al uso de esta mútua interrelación que, de otro lado, incorporará el espacio exterior como una nueva necesidad vital.

¿Por qué esta inclusión del jardin dentro de la vida urbana?. Una primera intención, sería rememorar "racionalmente" la relación del hombre con la naturaleza, una naturaleza controlada, aunque, conviene matizar, que esta idea de jardin ordenado se nutre también con lo no planificado. Las jardineras geométricas utilizadas por Le Corbusier serán las encargadas de ordenar el espacio del jardin y matizar las relaciones. Junto a esa búsqueda ordenada, la vegetación crecerá libremente en su interior y así lo expresará en su artículo Toitsjardins?:"El viento, los pájaros y los insectos traen semillas. Algunas de ellas encuentran un ambiente favorable. Los rosales se han sublevado y se han convertido en enormes escaramujos. El césped se ha convertido en hierba, en dientes de león. Un cítiso ha nacido, un falso sicomoro. Dos briznas de lavanda se han convertido en matorrales. El sol domina, el viento (allá arriba) domina. Las plantas y los arbustos se orientan y se instalan a su gusto, según sus necesidades. La naturaleza ha recobrado sus derechos. Desde este momento, el jardin está abandonado a su destino., 10

\footnotetext{
${ }^{9}$ Kepes, G: El lenguaje de la visión, $1^{\circ}$ ed, Buenos Aires: Infinito, 1969. p.54.

${ }^{10}$ Boesiger, Willy; Stonorov, O: Le Corbusier et Pierre Jeanneret.Oeuvre Complète. 1910-1929, $11^{\circ}$ Ed, Zurich: Les Éditions d'Architecture, 1973.p.140
} 
Volviendo a la concepción del jardin, además de esta sutil domesticación de lo natural, también cualificará la vida del hombre moderno, individualizándolo de lo colectivo, y permitiendo que la máquina moderna tome aire - le machine à souffler-. Es decir, recuperará el aliento, construyendo el lugar para el ocio y el reposo, al igual que la ciudad moderna, una cavidad, llena de aire y de sol, que horadará sistemáticamente el bloque, como parte fundamental del problema de la vivienda ${ }^{11}$.
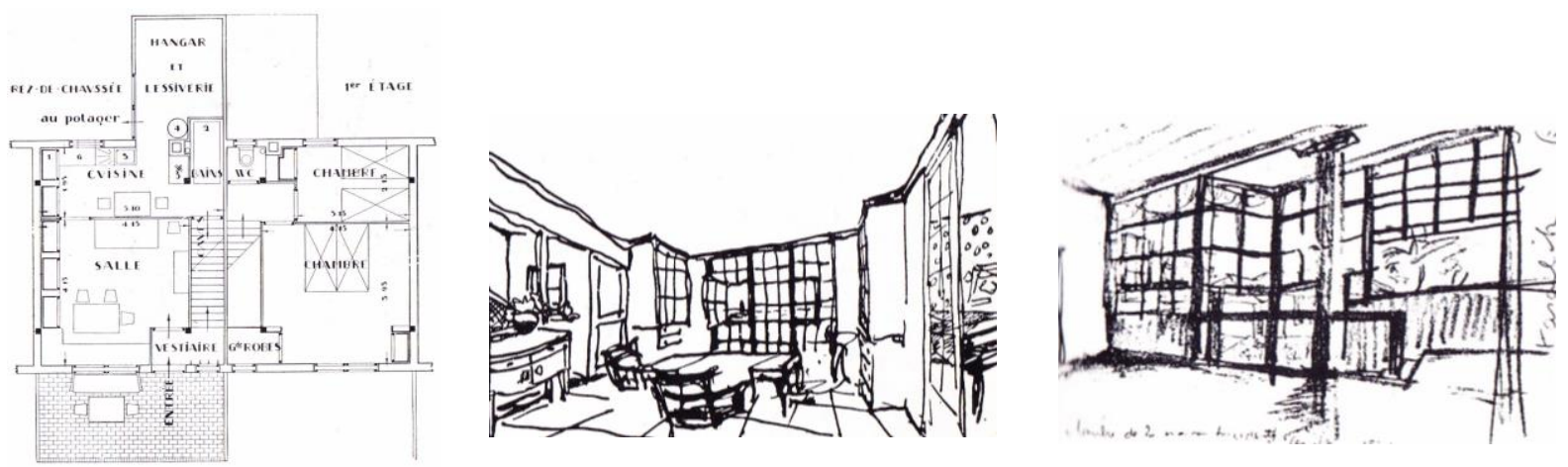

1. Type A (CFLC/ADAGP19176a), Rez-de-Chaussé et $1^{\circ}$ étage, Oeuvre Complète,vol.1, p.25.

2. Croquis $\odot$ FLC/ADAGP intérieur d'une maison dom-Ino, Oeuvre Complète,vol.1, p.25

3. Croquis @FLC/ADAGP5890, intérieur de la maison à Kasanlak, Oeuvre Complète,vol.1, p.17.

¿Cómo se producirá la nueva relación entre el interior y el exterior?. Si analizamos detenidamente los textos y diseños recogidos en su carnet A2, de entre los modelos de viviendas concebidos dentro del sistema dom-Ino, surge el type A (@FLC/ADAGP19176A)(1) como un único espacio construido con una mínima estructura de 4 pilares -una cella moderna del megaron clásico-. Un "Péristyle y hangar”, que tal y como indica J. Quetglas, se convierte en ese "maravilloso anacronismo, que relaciona la casa griega y romana con la arquitectura industrial ",12. Gracias a este peristilo moderno se produce el acceso al type, disponiendo como extensión a él, la terrasse o el espacio exterior. Éste, a su vez, mantendrá una estrecha vinculación con el mundo interior gracias al estudio modular de la fenêtre (2). La propuesta dibujada recuerda bastante al boceto realizado por un joven $C h-\hat{E}$. Jeanneret, en el interior de la maison à Kasanlak (@FLC/ADAGP5890)(3) durante su viaje de 1911 por los Balcanes. Allí expresa y anuncia su interés por "une fenêtre plus longue que haute...",3, es decir, su futura fenêtre en longueur. Incluso, el mismo boceto, es recogido años más tarde en el primer volumen de la Oeuvre Complète $^{14}$. Así será como la superficie límite entre ambas realidades, se convierte en el principal problema a resolver dentro de la arquitectura.

\footnotetext{
11 "un espacio útil al aire libre[...] como uno de los elementos fundamentales en el problema de la vivienda míníma " Aymonino, Carlo: La vivienda racional. Ponencias de los Congresos CIAM 1929-1930. Análisis de los elementos fundamentales en el problema de la "vivienda mínima". Le Corbusier y Pierre Jeanneret, Barcelona:Gustavo Gili, S.A.p.138. 12 "un merveilleux anachronisme qui relie la maison grecque et romaine à l'architecture industrielle”, Quetglas,Josep: Le Corbusier Plans, volumen 1,1905-1926.DVD, Paris:Fundation Le Corbusier, Echelle-1, 2005.

${ }^{13}$ Udovicki-Selb, Danilo François. Les Balkans, génese des cinc points de l'architecture. l'invention d'une architecte. Le voyage en Orient de Le Cobusier, Paris:Editions de la Vilette, cop.2013.p.212

${ }^{14}$ Boesiger, Willy; Stonorov,O: Le Corbusier et Pierre Jeanneret.Oeuvre Complète. 1910-1929, $11^{\circ}$ Ed, Zurich: Les Éditions d'Architecture, 1973,p.17
} 

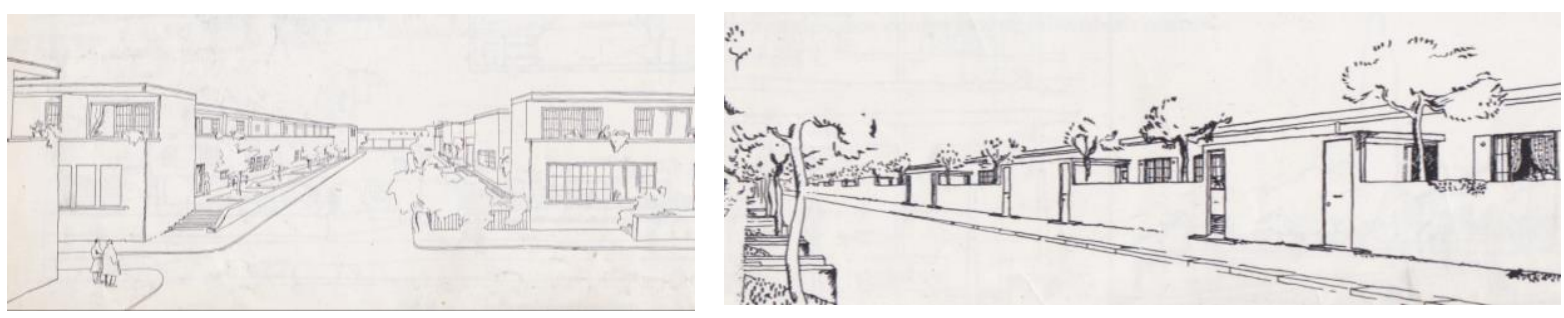

4. CFLC/ADAGP19221 Maison Dom-Ino. Propuesta de ordenación y volumetrías, Oeuvre Complète, p. 26 5.C FLC/ADAGP07856, Alz. propuesta Cité ouvrière, 1920, Oeuvre Complète,p.29

Dentro del grupo de propuestas maison ouvrière que proyectará en los años anteriores a 1922, ya se comprueba el valor que adquieren las decisiones sobre la disposición del espacio exterior, o el tipo de fenestración utilizado. En algunos casos, la solución remite a una composición clásica (@FLC/ADAGP 19221) (4). En otras, como en la Cité Ouvrière en Grand Couronne ${ }^{15}$ de 1920 (CFLC/ADAGP 07856)(5), la colocación de un espacio exterior previo, delimitado y métricamente modulado al resto del proyecto, habla más de la ley de la repetición. Estas indagaciones son, si cabe, un adelanto a los futuros equilibrios plásticos, entre el vacío y el lleno, de las posteriores fachadas del immeuble-villa.

Adentrándonos de nuevo en la cellule del immeuble-villa, y en cómo ese espacio exterior irá transformando su relación con el mundo interior de la casa, el camino arranca con la construcción del Pavillon de L'Esprit Nouveau. Éste se concibe como una villa individual, capaz de ser superpuesta, donde el jardin suspendu se convertirá en la foyer exterior adyacente a la casa.

El espacio medido matemáticamente forma parte de la métrica general del sistema, donde el jardin ocupará la serie BA -en sentido longitudinal- y BBB -en transversal-; constituyéndose la caja de 71/2 x 71/2. En definitiva, un espacio de geometría cúbica, que propicia que el aire penetre hasta el corazón mismo del bloque. Pero además, ese espacio matemático, también será medido "emocionalmente" y de ahí que Le Corbusier, trabaje sobre los límites laterales de esta caja, unos límites que apenas se perforarán.

Esta idea mantiene una de las lecciones aprehendidas por Le Corbusier en su viaje a Pompeia, ya que en su visita a la maison des Dioscures, el arquitecto boceta y describe el salón de la villa como "un único y bello espacio surgido de sus precisas proporciones, y de la masa que lo envuelve” (6).
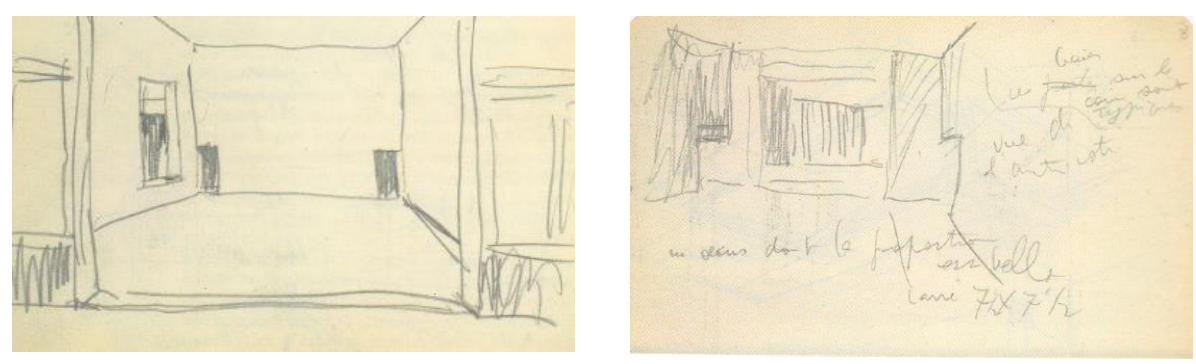

6 y 7.@FLC/ADAGP.Ch.É.Jeanneret, Salon de la Maison des Dioscures, Pompéi, Carnet 4, p.120-121.

\footnotetext{
${ }^{15}$ Única obra de referencia incluída dentro del primer volumen de la Oeuvre Complète.
} 
En el boceto, apenas se dibujan las pequeñas puertas encargadas de perforar la perfecta caja espacial, con lo que se evidencia la importancia del plano por encima del hueco, y así, percibir el espacio en toda su expresión. Le Corbusier lo especifica con más detalle: "les portes baies sur le...coin son typiques...vue de l'autre coté...un oecus dont la proprotion est belle carré 71/2 x 71/2“ (7). Proporción y límites, es la lección aprehendida y reflejada de nuevo en este jardin proyectado. De ello, se desprende toda la configuración final en la disposición y dimensión de los huecos realizados. De entre todos ellos, destaca la pequeña puerta, apenas perceptible, que comunica la estancia con el jardin, manifestando en ese momento, la clara separación entre el mundo interior y el exterior. La importancia de este hecho queda recogido en la fotografía que Le Corbusier realiza para el Pavillon del L'Esprit Nouveau (CFLC/ADAGP L2(13)23(8).
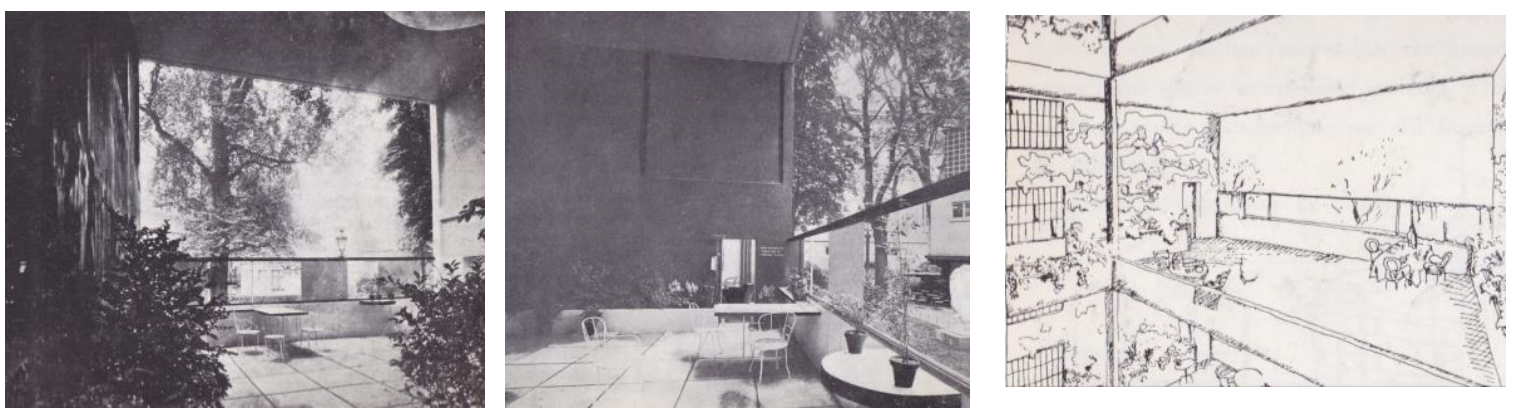

8.CFLC/ADAGP L2(13)23. Le Corbusier, Pavillon de L'Esprit Nouveau, 1925, "le jardin-suspendu”, recogido en la Oeuvre Complète, p.95-103.

9. (OFLC/ADAGP 19097, Le Corbusier, Croquis una terrasse-jardin (le jardin-suspendu).

Allí se evidencia que para conseguir toda la esencia -una caja de aire en perfectas proporciones -, sus planos laterales, apenas perforados, permiten encuadrar la visión del plano frontal. En palabras de Le Corbusier: "En este punto vital de la ciudad, se abre una puerta sobre el jardin. Este jardin es un pensil, cerrado en tres de sus lados [...] se puede pasear con los pies descalzos sin miedo al reumatismo, al resguardo del sol y de la lluvia [...] jardines eficaces, sin mantenimiento. Este jardin, captador de aire, multiplicado a lo largo de vastos bloques de edificios, en efecto constituye una verdadera esponja de aire. "16

Le Corbusier también se ha valido del color sobre el paramento lateral para remarcar este hecho, un color, controlado y elegido dentro de la gama de colores de escala mayor que representará "la unidad y el equilibrio" frente a los colores dinámicos -no válidos para la construcción-. Aunque en Aprés le cubisme, Le Corbusier afirma que "La forma es preeminente, el color no es más que uno de sus accesorios. El color depende enteramente de la forma material: el concepto esfera, por ejemplo, precede al concepto color", ${ }^{\prime 7}$, lo cierto es que aquí, el color juega un importante papel en dirigir e intensificar la mirada hacia el exterior.

Por último, esta terrasse jardin o jardin suspendu, que también aparece representado en el boceto publicado en la Oeuvre Complète 1910-1929 (CFLC/ADAGP19097)(9), terminará percibiéndose como un interior, ya que la visión exterior quedará enmarcada por los elementos que construyen el límite: un antepecho ciego a $86 \mathrm{~cm}$ del suelo, y un perfil paralelo a $183 \mathrm{~cm}$. Ambos serán los mínimos elementos utilizados para redefinir la fenêtre en longueur. Es así como se irá construyendo la rica ambigüedad espacial.

Con la realización del Pavillon -como prototipo construído- y tras su inauguración el 10 de julio de 1925, Le Corbusier considera haber alcanzado uno de sus máximos logros aludiendo "celle-ci est une recherche patiente,

\footnotetext{
${ }^{16}$ Le Corbusier, Precisiones respecto a un estado actual de la arquitectura y el urbanismo,Barcelona:Apóstrofre, 1999, p.99.

${ }^{17}$ Ozenfant, A; Le Corbusier: Acerca del Purismo:Escritos 1918-1926, Madrid:El croquis, 1994. p.76.
} 
obstinée, d' une vérité que nous savons cachée sous la défroque lourde d'un passé écrasant, et celle vérité nous la percevons nettemente" ${ }^{\prime 18}$.

Esta búsqueda paciente y obstinada tiene como primer efecto la transformación del modelo realizado en 1922 al desarrollado en 1925. Le Corbusier trabaja con diversas posibilidades agregativas. Y así, en la propuesta dibujada para Boulogne-sur-Seine (@FLC/ADAGP 28791)(10), el corredor se dispone en una posición central junto al type que cruzará traversalmente el bloque, tanto superior como inferiormente.

Si analizamos, tanto los croquis interiores (CFLC/ADAGP 28797C) (11) como el croquis de la planta del rez-dechausée (@FLC/ADAGP28797D)(12), se observa un nuevo cambio en la apertura al jardin lateral. Esta se hace máxima, generándose un gran hueco que no reniega, ni de la posición, ni de la apertura, que ya existía en el Pavillon de l'Esprit Nouveau. La pequeña puerta continuará existiendo. Con esta nueva perforación en el muro de cierre al jardin, incluso se ha visto modificada la concepción espacial de la doble altura interior. Ahora el boudoir, se colocará, no con relación a la fachada exterior, sino paralelo al jardin suspendu.
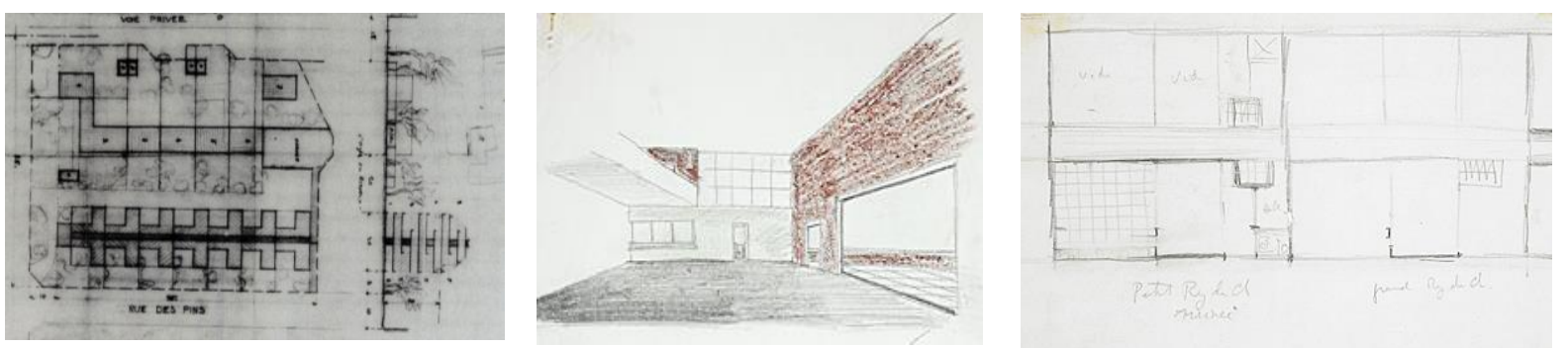

10.CFLC/ADAGP 28791, dessin d'étude en plan d'îlot aménagé et coupe en travers in situ, orientation, numérotation 11. $\odot$ FLC/ADAGP 28797C, Deux croquis en plan, croquis en coupe sur coursive intérieure entre deux types 12.CFLC/ADAGP 28797D, croquis d'étude petit rez-de-chaussée arrivée, grand rez-de-chaussée.
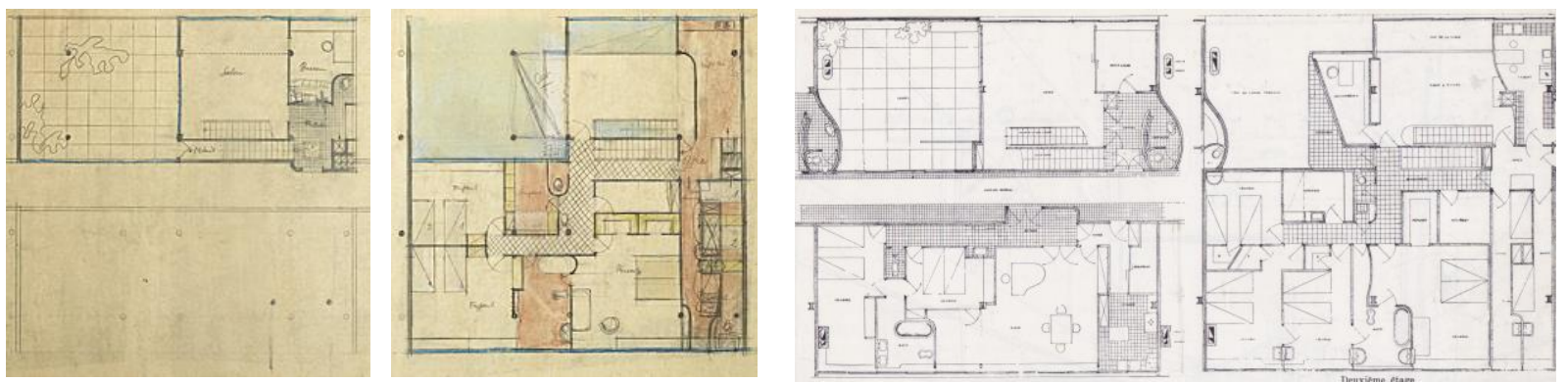

13. (FLC/ADAGP 08680 -Dessin d'étude de trois plans d'étage partiels.

14. (OFLC/ADAGP29659 seire $n^{\circ}$ 1038/OFLC/ADAGP29660 serie $n^{\circ} 1039$ Type d'appartement d'un des grandes immeubles d'habitation, premier étage avec couloir general y deuxiemé etage.

Sin duda, la mayor transformación va a ser con el proyecto para el industrial Wanner, donde además de plantear el uso de la estructura metálica y, la idea de la maison à sec, también se irán precisando los tanteos realizados en los immeuble-villas. Son varios los tipos desarrollados para esta propuesta - type IGS, type 3CHM, type atelier P $o$ W, y type hôtel- , aunque como continuidad más próxima al immeuble-villa, nos centraremos sólo en el que se define como type de petit appartament. Sobre él, las variaciones se suceden, en un doble intento de encaje entre la modulación estructural y el desarrollo del tipo. En el dibujo (CFLC/ADAGP 08680) (13) todavía no se observa la variación métrica definitiva. Incluso, se puede comprobar que se recogen a la vez, dos fases modulares que se suceden durante el proceso del proyecto. Así, en la rez-de-chaussée, correspondiente a la

${ }^{18}$ Le Corbusier: L'Almanache d'Architecture, Les éditions G. Crès et Cie,Paris, FLC, 1925.p.134. 
planta del corredor, la vivienda ocupa la serie $\mathrm{A} 1 \frac{1}{2}-\mathrm{A}-\mathrm{A}-\mathrm{A} \frac{1}{2}$. Mientras que en l'étage supérieur la relación ya ha cambiado, instalándose en una serie A-B-A-B. Finalmente, la propuesta dibujada (CFLC/ADAGP29659 serie $\mathrm{n}^{\circ}$ 1038/@FLC/ADAGP29660 serie n ${ }^{\circ}$ 1039) (14) está dentro de un doble ritmo A, cuyo módulo A, corresponde por igual al jardin suspendu y a la sala.

Además de está continua revisión métrica, lo que si parece definirse es un nuevo volúmen superior que sobresale del plano lateral. En un principio, este volumen, que penetra en la caja espacial del jardin suspendu, aparecerá apoyado - se descubre en el pilar exento que aparece en el croquis de la Oeuvre Complète 1910-1929 (15) y en la organización estructural de l'étage supérieur (@FLC/ADAGP08680) (13) -, para finalmente, resolverse volado sobre el jardin suspendu dentro de la métrica de 2A, tal y como se observa en el croquis publicado en Oeuvre Complète 1910-1929 (16). En éste, se recogen los últimos cambios que afectarán a la relación entre el Jardin suspendu y la vida interior.
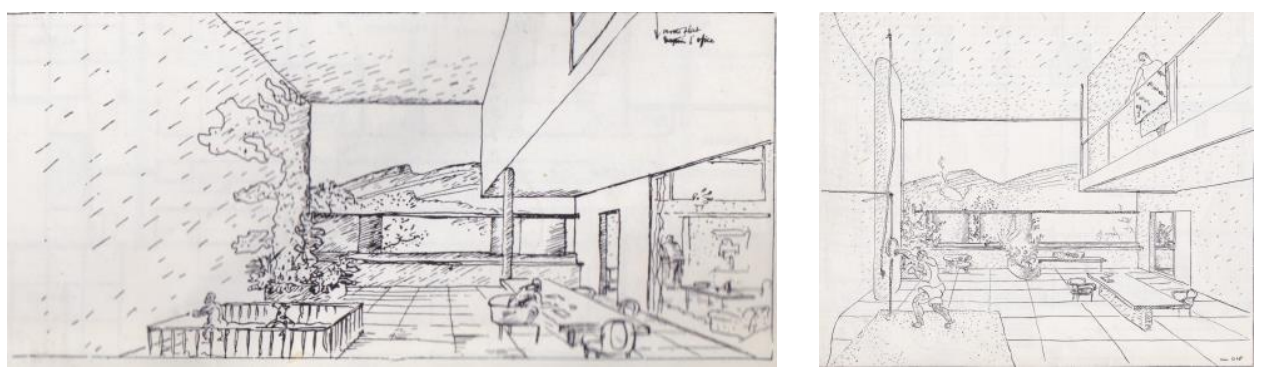

15.CFLC/ADAGP.Un jardin suspendu, Wanner Geneve,1928, Oeuvre Compléte p.183

16.CFLC/ADAGP. Le jardin suspendu d'un appartement, Oeuvre Complète, p.182

Lo primero de todo, es la reducción en la relación espacial interior entre la salle à manger y la salle, a favor de una mayor valoración con el jardin. Sobre éste, recae el pequeño boudoir y la terrasse. Así, parece darse la necesidad de tomar partido por una de las dos relaciones ante el ajuste dimensional que ha provocado el cambio del sistema de agregación. Pero además, añadiría que se ha producido un doble proceso. Por un lado el jardin es la nueva estancia de la casa, aquella que permite - esta vez incluso de manera explícita - el esparcimiento y la actividad física. Por otro lado, es el lugar del que también participará la promenade arquitectónica interior. Basta con imaginar el recorrido de la primera escalera lineal dibujada. Ésta, se toma desde el hall de entrada y niega, desde el punto de arranque, cualquier relación con el jardin. Sin embargo, en su desembarco final, se abre directamente a la galería que vuelca sobre el jardin. Es el nuevo puesto de mando de la casa moderna. Con él, ha cambiado la forma de percibir y de estar. Lejos queda ya la caja espacial de proporciones perfectas que volcaba toda su esfuerzo en enmarcar la relación con el espacio exterior de manera análoga e independiente de la casa. Ahora, la vida ha pasado a un primer plano y el espacio del jardin suspendu se ha convertido en el centro vital al que se abre. Así se percibe en sus dibujos y en los “objetos” dispuestos.

\subsection{En la villa.}

Volviendo al mismo punto de arranque que para el apartado anterior, analizaremos ahora la variante última dibujada del Pavillon transformada en villa independiente para las villas de banlieue. El proyecto apenas ha cambiado en esquema (CFLC/ADAGP 23010)(17), demostrando que el uso del jardin no sólo es válido para la concepción del bloque colectivo sino también para la Villa en la periferia parisina. Características comúnes lo identifican: no se altera la pureza del prisma; el volumen sigue elevándose del plano del suelo; y en el muro 
lateral -sala-jardin-, apenas se perfora. Se evidencia la separación entre el mundo interior y el espacio exterior del jardin. Idea que no tardará en incorporarse a los encargos particulares de sus villas.

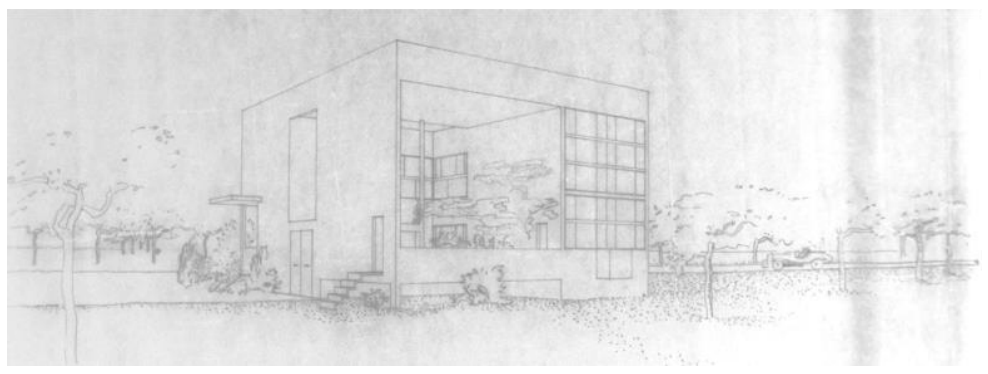

17. (FLC/ADAGP 23010, Perspectiva variante L'esprit Nouveau, 1925.

\subsubsection{La Villa Meyer, 1925}

El proceso que analizamos comienza con la tercera propuesta ${ }^{19}$ dibujada para la Villa Meyer en abril de 1926. Después de abandonar las dos primeros esquemas ${ }^{20}$, Le Corbusier vuelve al prototipo del Pavillon. Su jardin suspendu couvert ${ }^{21}$, es producto de extraer del prisma compacto de Filebo una porción de masa de perfectas proporciones (18)(@FLC/ADAGP10371). De esta forma, se genera la vivienda tipo L que abraza el espacio exterior. Hasta aquí nada nuevo. Sin embargo la villa, al igual que ha sucedido con los immeuble-villa, también se ha visto afectada por las sucesivas exploraciones espaciales, desapareciendo por ello en este caso, el límite entre el jardin $y$ el espacio interior de la casa. Este tanteo se evidencia muy bien en los croquis " 3 " $y$ " 4 " (@FLC/ADAGP 31514) (19) y en la rez-de-chaussée supérieur, donde se constata la gran apertura definida entre ellos, con un único elemento de cierre que permite la total conexión entre los dos mundos. Es claramente un anticipo al complejo mecanismo que surgirá para la villa Savoye; todo un hecho, que permite generar el gran espacio de relación propicio para los actos más sociales ${ }^{22}$.

Pero ¿Por qué esa excepción "ahora” sobre el prototipo?. Aún reconociendo la necesidad para la relación social, lo cierto es que otra idea parece clave para entenderlo. Analizando previamente el caso de la cellule del immueble-villa, o de su prototipo, el Pavillon de l'Esprit Nouveau, sabemos que ambos son herederos del tipo de la maison citrohan $^{23}$, y por ello, la sala asumía, como única posibilidad, la máxima relación con el exterior. Pero además, al tratarse de un modelo para la agrupación colectiva, Le Corbusier entiende que el jardin debe ser el espacio intermedio capaz de responder tanto a lo individual como a lo colectivo, protegiendo al habitante de las miradas indiscretas. De ahí, la escasa apertura de huecos en los planos que delimitan el jardin suspendu. Sin

\footnotetext{
${ }^{19}$ Sobre este punto se han encontrado ciertas discrepancias. En la obra, Le Corbusier et Pierre Jeanneret, Oeuvre complète, 1910-1929, este proyecto se recoge como el segundo, mientras que en las investigaciones de Tim Benton es denominado como el tercer proyecto. El segundo esquema, OFLC/ADAGP 29843, se corresponde con el proyecto e imágenes que Le Corbusier presenta a Meyer por carta.

${ }^{20}$ Benton, Tim: Le Ville di Le Corbusier e Pierre Jeanneret, 1920-1930, Milano:electaarchitettura, 2008.p.166-169.

${ }^{21}$ Boesiger, Willy: Le Corbusier et Pierre Jeanneret, Oeuvre compléte, 1910-1929, Zurich, Les Editions d'Architecture, 1973. croquis 4, OFLC/ADAGP 31514, p.90

${ }^{22}$ Conviene recordar la carta que Le Corbusier escribe a Mme Meyer con motivo de la segunda propuesta dibujada. Aunque se está describiendo una solución arquitectónica diferente, queda clara la necesidad de un espacio para la relación social. “...si l'on veut jouer la comédie,l'on peu s'y vêtir, et deux escaliers permettent de descendre sur la scène, qui est au devant du gran vitrage..." “...si se quiere hacer comedia, sólo hay que vestirse para ello y bajar al escenario que esta ante la gran superficie acristalada ...” . Boesiger, Willy: Le Corbusier et Pierre Jeanneret, Oeuvre compléte, 1910-1929, Zurich, Les Editions d'Architecture, 1973. p.89

${ }^{23}$ Ver Nivet, Soline: Le Corbusier et l'immueble-villas, Stratègies, dispositifs, figures. Wrage, Mardaga cop.,2011
} 
embargo, en la Villa Meyer, la relación se invierte. Ya no existe necesidad de control visual con el interior, más bien al contrario, ya que la privacidad parece ahora necesaria con el mundo exterior. En este caso, será con la Folie Saint-James.
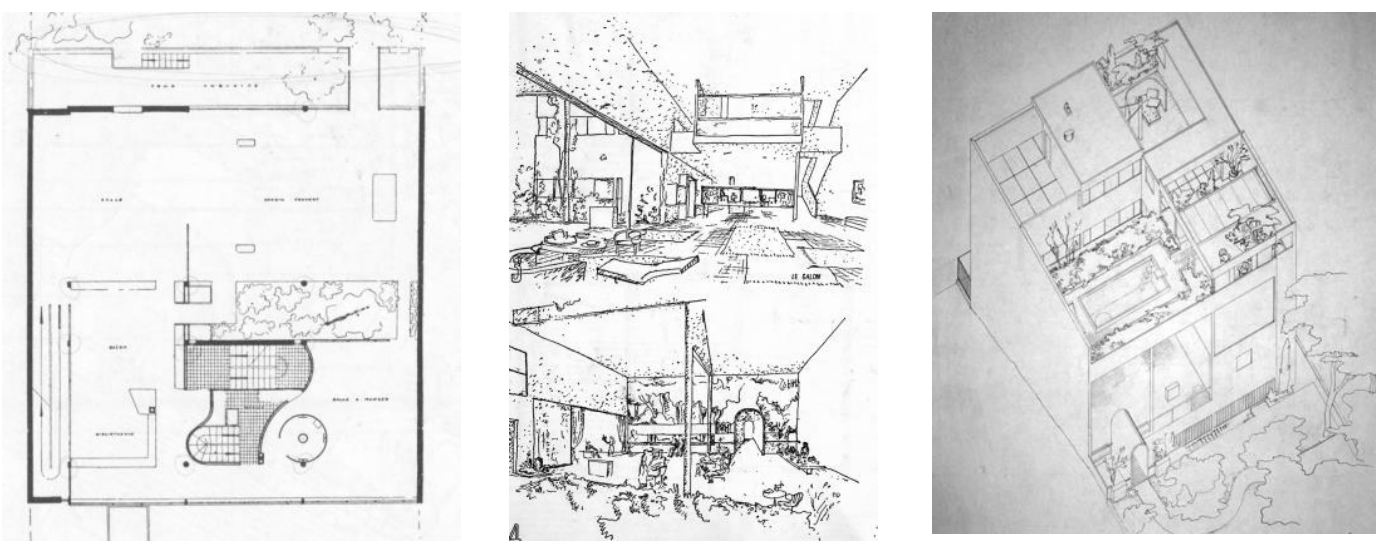

18. (CFLC/ADAGP10371, serie n ${ }^{\circ}$ 666,Villa Meyer, Rez-de-Chaussée suréleve.

19. (CFLC/ADAGP31514, croquis 3y 4, le jardin suspendu couvert.

20. (FLC/ADAGP10380, Axonometría Villa Meyer, vista de la fachada a la Folie Saint-James

Para ello, Le Corbusier se vale de una doble acción: el tratamiento de los límites y la construcción de un patio inglés. Empezando por este último hecho, la decisión permite ventilar e iluminar la rez-de-chaussée inférieur y asegurar la privacidad de la villa, ya que al establecerse una grieta entre la casa y la Folie, la villa se hace solamente accesible a través del pequeño puente cubierto, a modo de muelle de acceso, que el arquitecto proyectará. Como se observa bien en la axonometría (@FLC/ADAGP10380)(20) la villa ya no queda sobreelevada de la cota del suelo, sino más bien, desconectada del mundo exterior. En la misma perspectiva, también se evidencia esta desconexión desde la fachada al jardin, colocando una mínima ventana allí donde antes se abría el balcón del immueble-villa. Dicha ventana ${ }^{24}$, que en el proyecto posterior de la Villa Ocampo no llegará ni siquiera a dibujarse, contrasta con la apertura total superior, una apertura, que permite la visión de la Folie Sain-James a través del boudoir interior ${ }^{25}$. Privacidad y disfrute del habitante están así ahora garantizados.

Métricamente la planta Meyer es, en este momento, un cuadrado de $17 \mathrm{mts}$ de lado. De las tres variantes dibujadas, dentro del esquema estructural CAAA (longitudinal) x $\mathrm{CAB}(\mathrm{A}+\mathrm{B})$ (transversal), el jardin suspendu couvert ocupa un doble módulo A. Esta medida implicará, de manera manifiesta, la construción de la crujía central -como se observa en el croquis 4 - y el pilar en fachada. Algo que no ocurría en el prototipo.

Para la última versión dibujada (@FLC/ADAGP10374)(21) la solución estructural y con ello, la concepción espacial del jardin, se verán transformados. Esta fase no queda recogida en la Oeuvre Compléte, y si lo comparamos con el proyecto definitivo, el cambio se produce al eliminar la cubierta en el último vano. Así, el jardin se separa del cierre lateral oeste (CFLC/ADAGP10378) (22).

\footnotetext{
${ }^{24}$ Incluso esta ventana no aparece tampoco dibujada para la primera variante del tercer proyecto recogido por Benton, Tim: Le Ville di Le Corbusier e Pierre Jeanneret, 1920-1930, Milano: electaarchitettura, 2008.p.174.

25 “...le boudoir voit les feuillages des grandes arbres" “...desde el "boudoir” se ven los follajes de los grandes árboles..." Boesiger, Willy: Le Corbusier et Pierre Jeanneret, Oeuvre compléte, 1910-1929, Zurich:Les Editions d'Architecture, 1973. p.89
} 

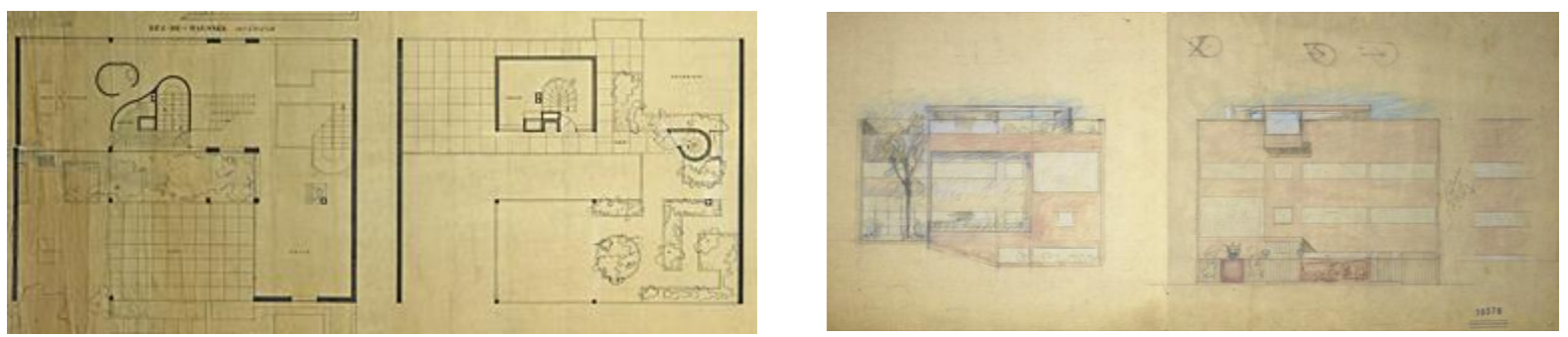

21. (OFLC/ADAGP10374, nº 691, Villa Meyer, etage, terrase. Versión definitiva junio 1926.

22. CFLC/ADAGP10378,dessin d'études de deux façades.Versión definitiva de junio de 1926.

El cambio favorece una mayor inclusión del mundo exterior, ocupando incluso, un módulo A completo. Quizás, se haya vuelto así a los orígenes geométricos que definían el jardin - AB (longitudinal) x AB (transversal)- , pero la decisión ha generado la ruptura de la caja espacial. Ahora, el jardin, que sigue levantándose unos centímetros del terreno natural, ha perdido la claridad de su propósito, entendiéndose más como un espacio exterior de transición.

\subsubsection{Villa Stein-de Monzie, 1927}

El rico proceso en la villa Stein-de Monzie surge principalmente con la serie de diseños preparatorios al segundo proyecto del 20 de julio de 1926. Las perspectivas realizadas entre junio y julio de ese mismo año, en palabras de Tim Benton, son la prueba evidente del intéres de Le Corbusier por la búsqueda de un cierto "gesto teatral" través de la serie de terrasses conectadas (CFLC/ADAGP10587). De ahí sencillamente viene el nombre que coloquialmente se le atribuye a la villa, Les Terrasses, fiel reflejo de la ideología lecorbusierana. En la axonometría a color (CFLC/ADAGP10587) (23) la promenade arquitectónica exterior queda garantizada gracias a la conexión de las terrazas a través del juego de escaleras lineales. Si seguimos observando este recorrido, no se presupone ninguna relación con la vida interior, sino más bien, y debido a la serie de perforaciones en los muros, una múltiple relación con el paisaje circundante. La llegada al jardin superior sólo es posible desde esta promenade exterior. No existe ningún acceso que comunique el interior con el jardin superior. Aún así, la idea no se descartará totalmente y la idea será el germen para las posteriores propuestas.
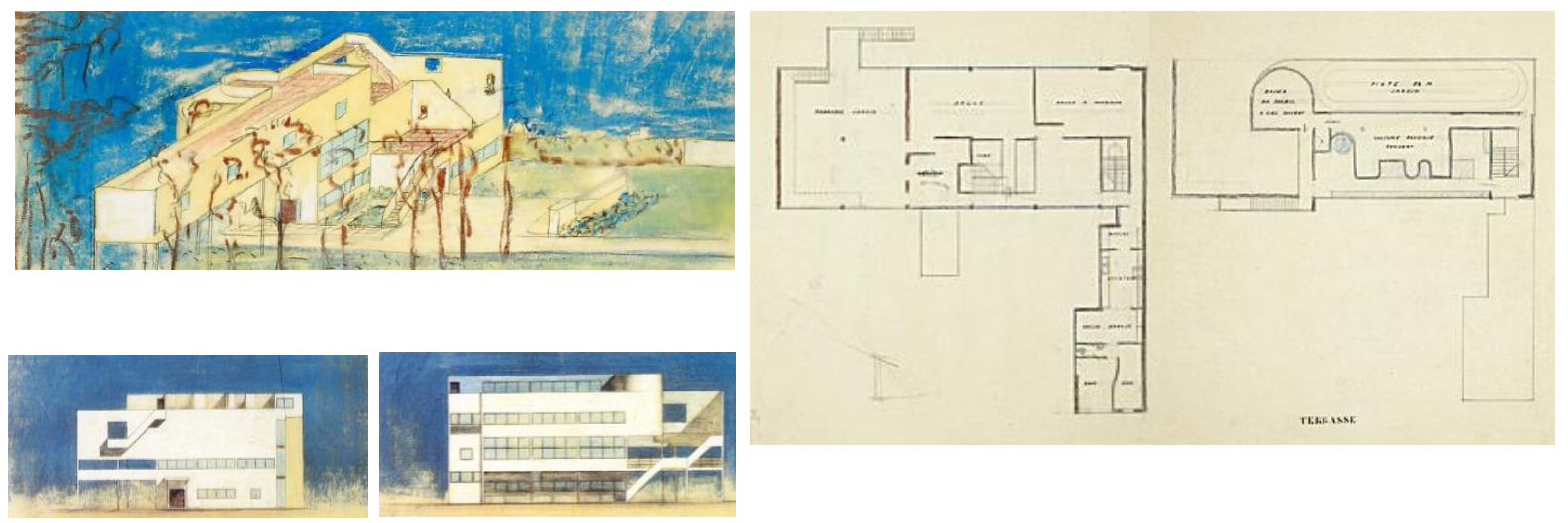

23. $\odot$ FLC/ADAGP10587. Axonometría proyecto preparatorio al 20 de julio de 1926.

24.Proyecto preparatorio 20 de julio de 1926; @FLC/ADAGP10409, plans de rez-de-chaussée supérieur, serie $n^{\circ} 725$ y CFLC/ADAGP 10408, plans de la terrase serie $n^{\circ} 724$.

25. Alzados proyecto 20 de julio 1926:@FLC/ADAGP10406, sur y@ FLC/ADAGP10407, norte. Serie $n^{\circ} 722,723$.

\footnotetext{
${ }^{26}$ Benton, Tim. Le Ville di Le Corbusier e Pierre Jeanneret, 1920-1930, Milano, electaarchitettura, 2008.p.202.
} 
En los siguientes tanteos (@FLC/ADAGP10409 rez-de-chaussée supérieur y (@FLC/ADAGP10408 toitjardin)(24) el proyecto se vuelve más compacto -se ha reducido el ala de servicios en su lado oeste- , y el jardin suspendu o terrasse es colocado al lado este. Con ello, se rompe la simetría de los primeros bocetos. En esa posición el jardin se abrirá totalmente al sur, manteniendo en su lado norte, la relación con "el bosquecillo" que durante un tiempo fué del interés de Le Corbusier. Esta decisión en nada afecta a la promenade arquitectónica y al efecto escenográfico, que vuelve a surgir al conectar la rez-de-chaussée inférieur, la rez-de-chaussée supérieur y el toit-jardin. Para ello, Le Corbusier se vale del sistema de escaleras exteriores tanteado previamente. Éstas, serán concebidas en paralelo a los muros que encierran el jardin, provocando un continuo recorrido peatonal desde lo más público hasta el espacio más privativo - le toit-jardin .(OFLC/ADAGP10406),(@FLC/ADAGP10407)(25).

Este nuevo jardin es una nueva caja espacial abierta cenitalmente. El punto de vista elegido para el croquis denominado jardin surélevé (@FLC/ADAGP31480)(26), se produce desde la posición cubierta que recoge el solarium superior. Quizás por ello, el espacio se asimila más a un interior. Pero también, nacerá de otros mecanismos. Uno de estos, será la configurarán final de sus paramentos. Por un lado, la superficie con relación a la sala, se resuelve al igual que otros referentes construidos, donde apenas se dibujan dos puertas, que ni tan siquiera presentan una relación directa con la estancia principal, sino con dependencias de servicio (@FLC/ADAGP10409 rez-de-chaussée supérieur). En el plano posterior, a norte, la fenêtre en longueur cumpliendo ahora el papel real de rasgar el muro ciego de la fachada, y permitiendo la mirada hacia el jardin exterior. Y por último, al oeste, "la misma" ventana que enmarcará el paisaje, al igual que el final de recorrido peatonal dentro de la villa Savoye.

Con todo ello, y aunque la interrelación con la sala no existe, es cierto que el espacio abierto y acotado del jardin -abierto ahora cenitalmente-, la posibilidad de recorrer los espacios tanto interior como exteriormente, y la búsqueda de enmarcar la mirada hacia el paisaje, puede entenderse - y mucho - como la antesala a las ideas concretadas en la futura Villa Savoye. Aunque finalmente no será la propuesta elegida, si debieron ser importantes para Le Corbusier las investigaciones desarrolladas en esta solución, quedando recogidas en la Oeuvre Compléte.
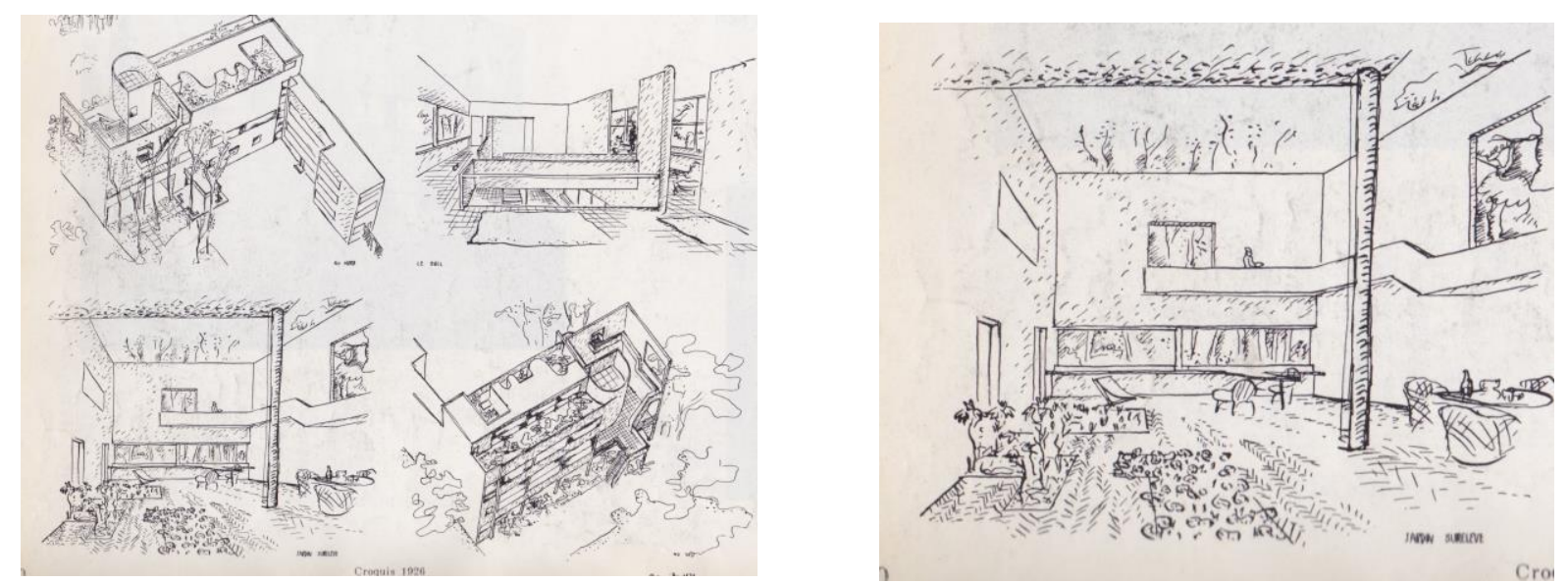

26. (FLC/ADAGP31480 Planche de présentation avec série de perspectives: vue génerale, vue au nord, vue au sud, croquis jardin Surélevé villa Stein,1926.

La solución que finalmente se va a construir, retoma la solución de una volumetría más compacta de los primeros bocetos. Un único volumen donde de nuevo el jardin suspendu cumple la función de vacío rodeado por un tipo $\mathrm{L}$ de vivienda. El esquema final recupera la trama $\mathrm{ABABA}$. Y el jardin ocupa la misma métrica que la establecida en el prototipo del immeuble-villa-BA-. No obstante, llama la atención que para la definición de la 
terrasse-jardin couverte -como la denomina Le Corbusier en este caso-, ésta ya no dispone del elemento verde que matizaba la conexión visual con el ala posterior de la casa y que, al mismo tiempo, reconocía el hueco superior de la cubierta. Será en la villa Stein, donde el pavimiento llegará hasta el límite de la casa (27), ocupando toda la caja espacial. Puede entenderse este hecho, porque aquí, la terrasse-jardin construye el espacio íntimo y privado, elevándose una planta por encima de la cota del suelo y disponiendo previamente de una terrasse exterior que se convierte en la transición entre el jardin exterior y el jardin suspendu.
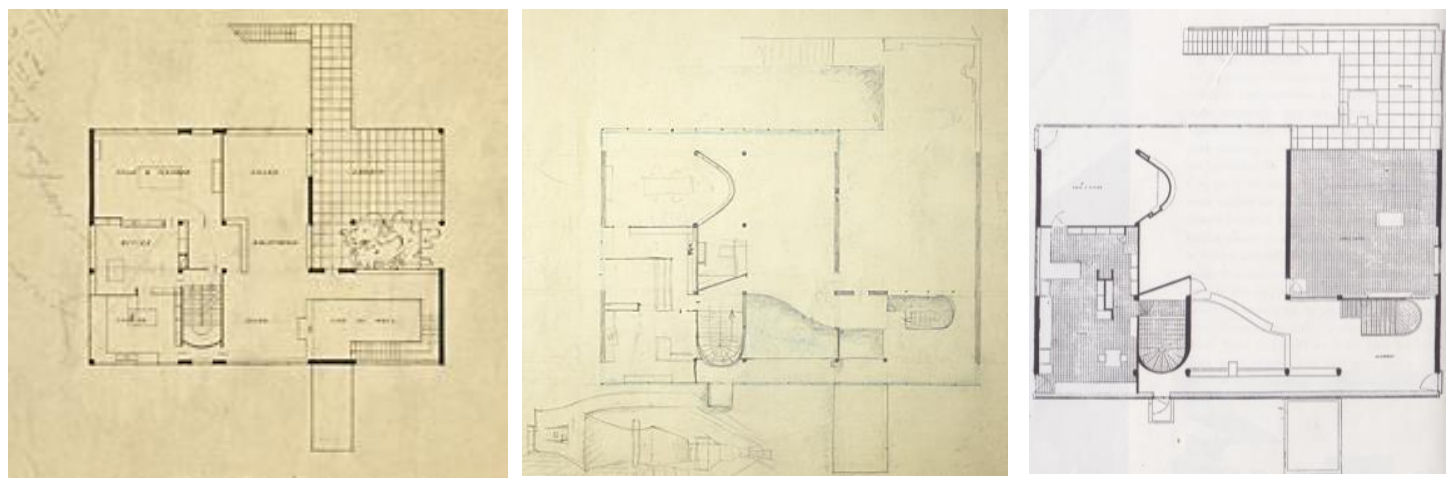

27. CFLC/ADAGP10410 Rez-de-chaussée supérieur, serie $\mathrm{n}^{\circ} 769$, proyecto 7 octubre 1926. villa Stein.

28. $\odot$ FLC/ADAGP10518 Rez-de-chaussée supérieur,esquema previo al proyecto de marzo de 1927.

29.@FLC/ADAGP Rez-de-chaussée supérieur,proyecto definitivo Villa Stein-de Monzie, 1927 publicado en la Oeuvre

Complète p.14

\subsubsection{Villa Savoye, 1928}

De la primera propuesta para la Villa Savoye, Jacques Sbriglio $^{27}$ se preguntaba cómo había sido posible que en un espacio de tiempo tan breve, Le Corbusier fuese capaz de presentar un proyecto tan acabado, pero la respuesta estaba obviamente en todo el proceso iterativo de los trabajos precedentes. Gracias a la experiencia acumulada, y siempre con el objetivo de afianzar las bases de la nueva arquitectura, el primer proyecto para la villa Savoye apenas se distinguirá del definitivo. Su relevancia también queda patente al quedar ambos recogidos dentro de la Oeuvre complète 1910-1929. Vol.1.y 2.
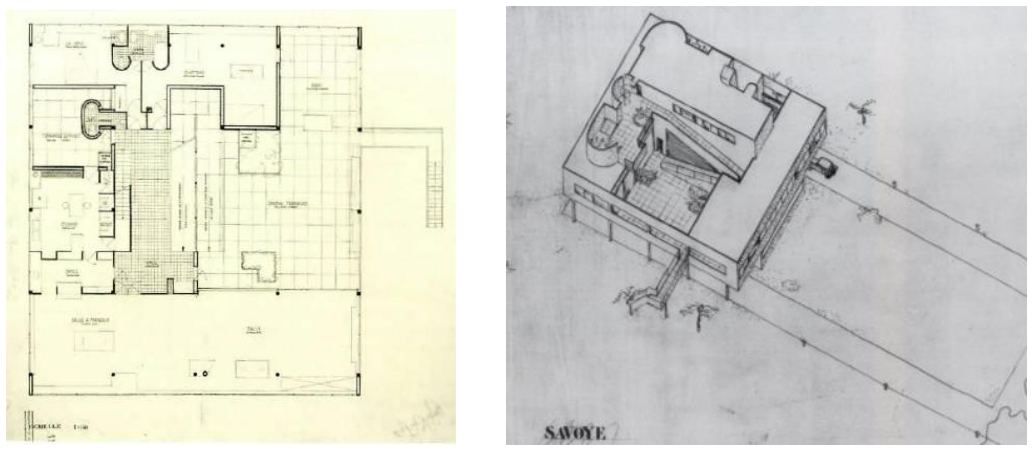

30. CFLC/ADAGP19412, primera propuesta villa Savoye, Rez-de-chaussée supérieur, octubre de 1928.

31. OFLC/ADAGP19423 Axonometría exterior villa Savoye.

\footnotetext{
${ }^{27}$ Sbriglio, Jacques: Le Corbusier. La villa Savoye. Madrid, ABADA Editores, 2005.
} 
En la descripción sobre la visita al emplazamiento, Le Corbusier ya presupone que "la casa no debe tener una única fachada", de ahí que la villa se presente elevada totalmente del plano del suelo ${ }^{28}$, y abierta en todos sus lados. Esto implicaba un cambio con respecto a los proyectos previos que habían sido organizados básicamente a dos fachadas. ¿Cómo concebir ahora el jardin? ¿A dónde abrirse?. (CFLC/ADAGP19412)(30). Comparándolo con los modelos precedentes observamos que éste ha dejado de ocupar una relación tangencial con la villa para convertirse en el lugar central, en "el alma de la villa" 29.

El jardin rodeado por la vivienda, se abrirá a sur y al este, permitiendo en su nuevo acomodo, que la luz irradie hacia todos los recorridos y espacios interiores, principalmente al máximo mecanismo arquitectónico: la rampa. En parte, ella es la que dota a la villa Savoye de toda su esencia espacial. Al igual que aquella promenade arquitectónica exterior que recorría las terrasses de la villa Stein, ahora ésta se verá trasladada al interior, porque la arquitectura, cómo bien explica Le Corbusier, se aprecia “à la marche” ${ }^{30}$. Aún más, desde el eje principal de circulación -la rampa-, dispuesta simétricamente, se avanza internamente para llegar al jardin. Y sin dejar de recorrerlo, se ascendiende hasta el último elemento arquitectónico que definió Le Corbusier. De esta forma, el jardin suspendu parece haberse convertido en parte fundamental, no sólo como espacio para el descanso o la contemplación, que también, sino la razón de la intensidad lograda en uno de los principios que definen la villa: la promenade arquitectónica.

De todas formas, Le Corbusier parace no terminar de rechazar la conexión desde el exterior, y en su primer proyecto, y en los sucesivos tanteos motivados en parte para acortar el dilatado presupuesto, aparecerá siempre una sucinta escalera lineal (@FLC/ADAGP19413) (31) que conecta el jardin con la cota cero, escalera que mantendrá hasta el último momento. Lo que sigue reproduciendo aquí, es el recorrido exterior que descartó para la villa Stein.

Pero ¿Cómo se entiende este nuevo jardin supendu?. Nada queda del espacio "vertical” ideal que se definía en el Pavillon de l'Esprit Nouveau. Éste, ahora, se define con una estructura diferente (AAxAA), y abierto cenitalmente. Para poder aprehenderlo, al igual que ocurría con la propuesta no construida de la villa Stein, se construye todo el muro -horadado por la fênetre en longueur- y que recorre toda la casa. Eso permitirá definir el volumen perfecto de la caja sobre la parcela. Además, y junto a esta solución y su posición elevada, el espacio se ha transformado en una "estancia" de mayor intimidad, al igual que ocurría con los apartamentos de Wanner Geneve - ambos, proyectos coetáneos-. Es un auténtico "belvedere" moderno, razón por la que la sala principal se abrirá totalmente al jardin. Una decisión que se mantiene en todas las propuestas dibujadas. Ya no es necesario protegerse de miradas, más bien al contrario, el jardin es el espacio intermedio, a través del cuál se mira.

En la concepción de ese nuevo "impluvim" de luz y de aire, su localización le requirirá el esfuerzo técnico del gran paño de vidrio construido para la ocasión. Un impulso loable y necesario, pero que seguramente en la

\footnotetext{
28 “si uno está de pie sobre la hierba, no ve muy lejos. Por lo demás la hierba es malsana, húmeda, etc., para habitar en ella en consecuencia el verdadero jardin no estará a nivel del suelo sino por encima de éste, a tres metros y medio : será el jardin suspendido cuyo suelo es seco y solubre, y es desde este suelo desde donde se verá bien todo el paisaje, mucho mejor que si uno estuviera a bajo...” Boesiger, Willy: Le Corbusier et Pierre Jeanneret, Oeuvre compléte, 1910-1929, vol.2, Zurich:Les Editions d'Architecture, 1973. p.24.

${ }^{29}$ Sancho Osinaga, J.C.: El sentido cubista de Le Corbusier, Madrid : Munilla-Lería, 2000

${ }^{30}$ Boesiger, Willy; Stonorov,O: Le Corbusier et Pierre Jeanneret.Oeuvre Complète. 1910-1929, $11^{\circ} \mathrm{Ed}$, Zurich: Les Éditions d'Architecture, 1973.
} 
imaginación de Le Corbusier ${ }^{31}$ la importancia residía en dejar circular el aire, y con ello, que no existiera ninguna diferencia entre el interior y el exterior, convirtiendo la sala en el espacio porticado que se abre al jardin.

\section{Del vacío al lleno.}

Un último apunte, si hasta ahora hemos hablado de la concepción del jardín suspendu, como un proceso de sustracción o, de inclusión del vacío en una masa compacta, ¿de qué otro modo puede volver a construirse ese jardin confinado?.

En su viaje a Italia Jeanneret se detiene a visitar Villa Adriana. Sobre este hecho escribirá más tarde; "Fuera de Roma, al aire libre, construyeron la Villa Adriana. Allí se medita acerca de la grandeza romana. Alli pusieron orden. Es la primera ordenación occidental de importancia”32. En su carnet A4, un joven Jeanneret dibujará uno de los muros más relevantes que constituyen el complejo entramado de Villa Adriana. Este muro es el encargado de delimitar el espacio del Pecile (32) ; una vasta explanada que determina el jardin interior donde la naturaleza se descubre artificialmente domesticada - centro camerelle con el bacino d'acqua-. El límite murario presenta una altura de 9 metros, y una forma totalmente cerrada y paralepipédica. Su lado más largo, de $400 \mathrm{~m}$, está orientado al norte-sur, mientras que el lado corto, se dispone en dirección este-oeste. A la construcción final del muro se le anexionará además una estructura techada y porticada. El conjunto, muro, cubierta y pórtico, permitía realmente los recorridos soleados en los días de invierno y la sombra fresca en los días calurosos. La estructura techada, en el momento en que lo dibuja Le Corbusier, ya ha desaparecido. Y en su visita sólo permanecerá en pie el muro norte. Aún así, para él, la presencia en solitario de este muro, no desmerece en absoluto, más bien al contrario, ya que permite "construir una sombra con la que protegerse del sol excesivo. Construir una sombra tan solo levantando un plano y dándole la orientación precisa. Resolver la cuestión con el gesto mínimo “33.

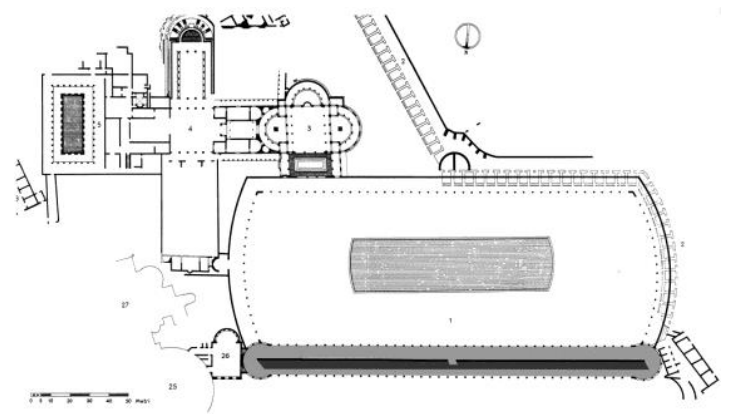

32. Plano del Pecile, Villa Adriana, Tivoli, siglo II d.c., extraído de Crescenzi, Livio; Hurtado de Mendoza, María; Rubini, Mauro, Ed. Ministerio per i Beni Culturali e Ambientali, Soprintendenza Archeologica per il Lazio, Roma, 1996.

Sobre la organización final, surgirá además la excepción en el lado norte del Pecile, dado que es aquí, donde el muro presenta un doble pórtico, uno a cada lado, convirtiéndose entonces éste en la espina central del paseo. Esta dualidad, también predice una nueva situación: la percepción simultánea del interior y del exterior a través

\footnotetext{
31 “ con mi amigo Durafour, dejé Argel una soleada tarde de invierno y volamos sobre el Atlas hacia las ciudades del M'Zab, en el tercer desierto en dirección sur...descubri el principio que rige las ciudades...tras los muros ciegos de las calles había casas risueñas que se abrían con tres amplios arcos a un jardin exquisto”. Le Corbusier: Aircraft, Madrid: ABADA Editores, s.1., 2003. p.34.

${ }^{32}$ Le Corbusier, Hacia una arquitectura, $2^{\circ}$ ed, Barcelona: Apóstrofe, 1998, p.126.

${ }^{33}$ Flores Soto, J.A., El uso consciente de la luz a través de varios espacios romanos, Revista de Humanidades y Ciencias Sociales, No 8, marzo de 2011, ISNN- 1988-3927. p.44.
} 
del recorrido peatonal, ya que en su lado norte el recorrido se abría al paisaje, a la naturaleza, y en su lado sur, al interior del jardín proyectado. Esta misma idea presenta semejanzas a la utilizada por Le Corbusier en la promenade que encierra el jardin suspendu para la segunda propuesta de la Villa Stein.

El muro, despojado de todo la estructura techada, se convierte en una fuerte impresión a la mirada de Le Corbusier y con ello escribe: "las paredes se elevan al cielo en un orden tal que estoy conmovido. Siento vuestras intenciones. Sois dulces, brutales, encantadores o dignos. Me lo dicen vuestras piedras. Me unís a este lugar y mis ojos miran. Mis ojos miran cualquier cosa que enuncia un pensamiento “34. Más aún, con esta visión se intuye la constitución del espacio arquitectónico; "los antiguos construían muros, muros que se extendian y se enlazaban para ensancharse aun más. De este modo creaban volúmenes, base de la sensación arquitectónica, sensación sensorial “35. Pero también aseverará; "lo exterior es siempre un interior"36. Esta afirmación, que aparece en Vers une Architecture, implicará para él que el exterior será la suma de masas y densidades, y de todo lo que le rodea -las casas vecinas, la montaña lejana o próxima, el horizonte bajo o alto -. Todas ellas se traducen en las "masas formidables que actúan con la potencia de un cubo". De esta forma, el exterior es presentido como un espacio limitado, un espacio que Le Corbusier dibuja descubriendo definitivamente la esencia del "édifice cube”, en los “100.000 mètres cubes" que es el exterior. Así la obra ya no está hecha solamente de sí misma, sino que para él, el exterior también existe. Esta idea se vuelve a recoger unos años más tarde en su libro Precisions; "El exterior me encierra en su todo, que es como un aposento" 37.

Estas dos realidades - el muro y el exterior- quedan fuertemente recogidas en el croquis que Le Corbusier levanta del muro Adriano (33). El mismo punto de vista dibujará Piranesi en 1770 para su compendio de "vedute di Rome" (34). Pero las aprehensiones serán bien distintas. Para Piranesi, la vedute del muro, deja subyugado a un hombre ante el esplendor inconmensurable de la ruina. Para Le Corbusier, el observador se encuentra próximo a la superficie muraria, intensificando la aprehensión espacial buscada: un “aposento”. Porque para él, el muro actúa construyendo el mínimo refugio, y define el orden a través del cuál se visualizará el paisaje. Surge así, el invariante arquitectónico, la forma por si misma, alejada de todo referente histórico.
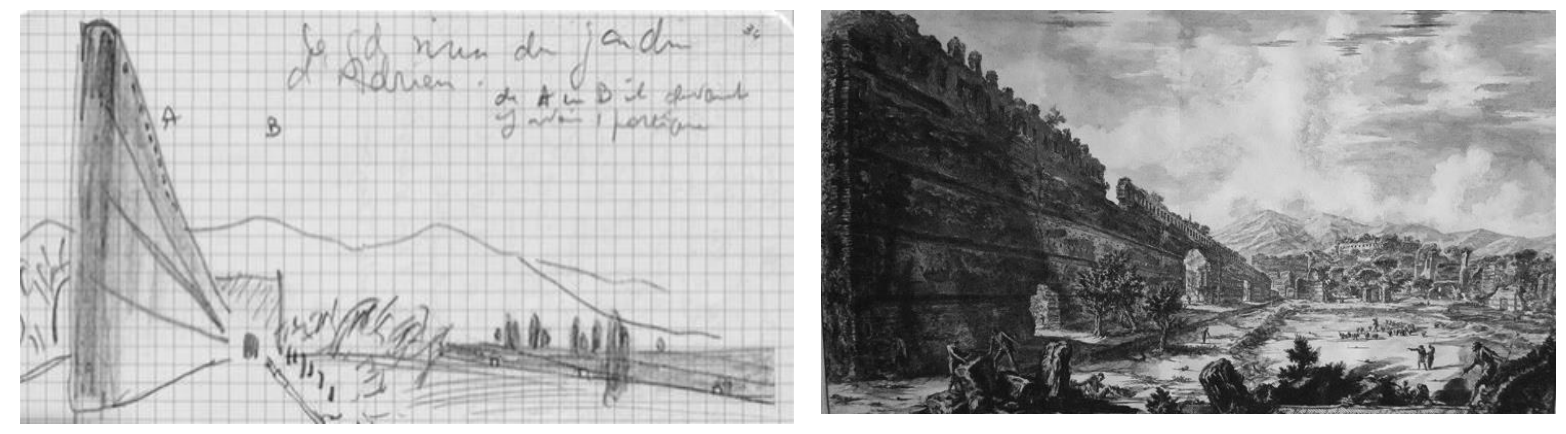

33. CFLC/ADAGP Le Corbusier, Muro del Pecile en villa Adriano, Carnet A4, 1911

34. Piranesi, Vedute de Roma, Muro del Pecile en Villa Adriano. 1770.

\footnotetext{
${ }^{34}$ Le Corbusier, ref. 10, p.123.

${ }^{35}$ Le Corbusier, ref.10, p.150.

36 "El ojo humano, en sus indagaciones, gira siempre, y el hombre también gira simpre a izquierda y derecha, hace piruetas. Se aferra a todo y se siente atraído por el centro de gravedad del lugar entero. De repente, el problema se extiende en torno a él. Las casas vecinas, la montaña lejana o próxima, el horizonte bajo o alto, son masas formidables que actúan con la potencia de su cubo. El cubo de aspecto y el cubo real, son inmediatamente medidos, presentidos por la inteligencia. La sensación cubo es inmediata, primordial; vuestro edificio cubica 100.000 metros cúbicos, pero lo que cuenta son los millones de metros cúbicos que hay alrededor. Luego viene la sensación de densidad: un árbol, una colina, son menos fuertes que la disposición geométrica de formas.". Le Corbusier, ref. 10, p.154.

${ }^{37}$ Le Corbusier: Precisiones respecto a un estado actual de la arquitectura y del urbanismo, Ediciones apóstrofe,p.101.
} 
Le Corbusier realizará unos cuantos bocetos más en su paseo por Villa Adriana. Entre ellos se detiene en el interior de la exedra central, colocada justo simétricamente en el eje este-oeste del Pecile. Desde allí, el dibujo de Le Corbusier vislumbra un doble límite, el hueco de la exedra y el muro del Pecile, ambos, sucesivos límites sobre el límite exterior (35). ¿Y qué es esa visión sino una caja dentro de otra caja?. Claramente es advertido por Le Corbusier, e inseparable de las palabras que Quetglas le otorga a la villa Le Lac, "el cajón de la casa está dentro de otro cajón, el de la parcela, a su vez dentro de otro cajón mayor, el del camino, el sol y de los vientos y el paisaje ${ }^{38}$. Aunque con esta última reflexión nos adelantamos al análisis de la villa Le Lac, si comienza a tener cierto sentido que será esta doble impresión visual la utilizada por el arquitecto.
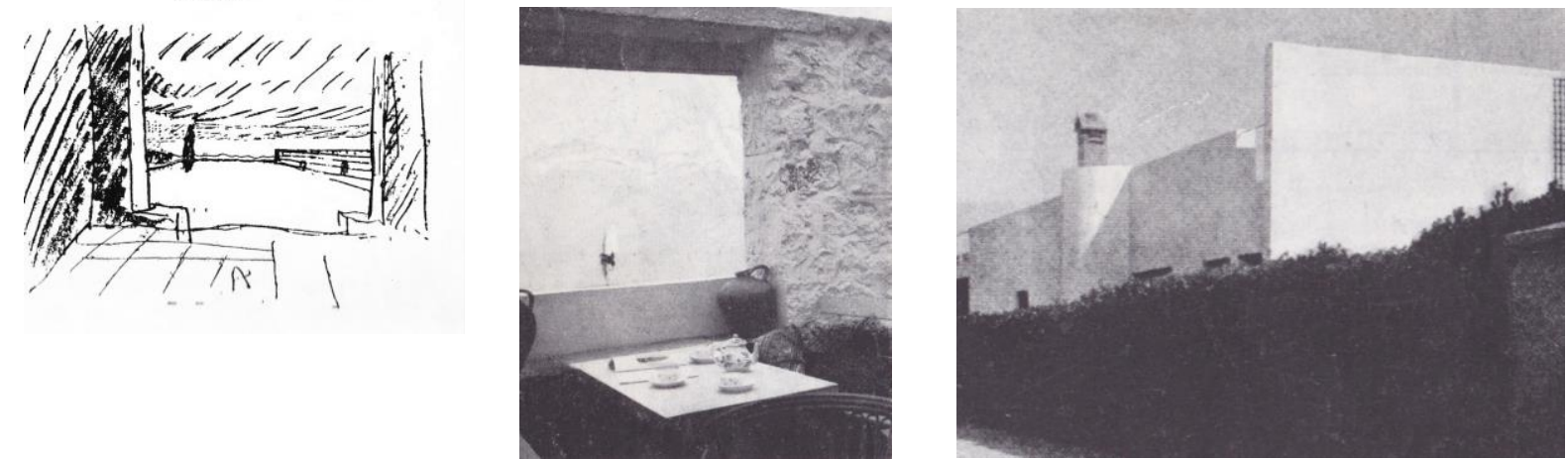

35. (FLC/ADAGP. Croquis Le Corbusier, Muro del Pecile en la exedra central, Carnet A4, 1911

36. ()FLC/ADAGP.Le Corbusier, muro a poniente de la petit villa au bord du Lac Leman, 1925, Oeuvre Complète, p.74

37. (FLC/ADAGPLe Corbuier, muro y ventana a sur de la petit villa au bord du Lac Leman, 1925, Oeuvre Complète, p.74

Le Corbusier construye de nuevo el muro Adriano, o dicho de otra manera, es el muro el que permite la construcción de la primera caja espacial. Este muro adquerirá densidades diferentes, como reacción ante la casa y el lugar - al igual que ocurriría en la villa de Tívoli ${ }^{39}$-. En su lado oeste el muro se ensancha hacía todos los lados, sobresaliéndose de los límites de la casa. La razón, explicada también por Quetglas, es que ese muro “ve llegar al visitante [...] a su vez,[ y definiendo este plano] el lado norte es opaco, y el lado sur es una celosía que deja pasar la luz del sol de atardecida”. A su lado norte, y gracías a que la casa se coloca ligeramente por debajo de la cota de llegada, apenas se eleva, porque con el gesto de colocarse parece que ya se ha hecho todo lo necesario (36). En realidad, sobre este lado, la casa apenas se abre - al igual que la exedra circular que sirve de refugio a Le Corbusier en su visita- . Lo más importante acontece desde el sur y el este. Para ello, la caja-casa, debe posicionarse, y es aquí, donde surge el primer gesto moderno. La casa se situa hacia el poniente y el norte, alejándose de cualquier idea meramente compositiva, para aumentar la superficie en las zonas de mejor soleamiento y vistas ${ }^{40}$. El sol, y el aire, como afirmará tantas veces, son las joyas esenciales desde donde se generará su arquitectura.

Volviendo al muro exterior, es en su lado sur donde reacciona, como límite último de las cajas y el paisaje. El muro es primero apenas un pequeño antepecho, inapreciable desde la fenêtre en longueur interior de la casa, $y$ reconocible, como una fuerte linea horizontal, desde la pequeña loggia exterior ubicada en el lado este de la casa. Por último, en el límite este con la parcela, el muro se levanta por encima de esta primera linea horizontal,

\footnotetext{
${ }^{38}$ Quetglas, J : Le Corbusier. Mise au Point: "Como se construye una casita". Valencia: General Ediciones de Arquitectura, 2012, p.205

${ }^{39}$ igual que hablábamos del muro norte, ciego y que constituye la espina central del doble recorrido, interior y exterior. El muro en su lado oeste, se abrirá al paisaje a través de un continuo sistema de fenestración.

${ }^{40}$ Esta misma lectura sobre su disposición también se recoge en Quetglas, J. : Ref.38.
} 
adquiriendo, desde la distancia, el mismo valor que la casa en cuanto a presencia y definición, y al igual que en ésta, una única ventana permitirá la relación con el paisaje. Con ello, el recinto se hace habitable definiendo el espacio del jardin. Un lugar resguardado de las miradas, y "domesticado" gracias a la incorporación de los mínimos elementos necesarios con los que el hombre moderno habita: ventana, mesa y silla (37). Y un jardin suspendu que se levanta por encima de la cota del lago.

Ha pasado una década desde que Le Corbusier escribiera los principios que constituían el jardin para la casa de sus padres en Le-Chaux-de-Fonds, y todavía, estos siguen construyéndose inalterablemente de nuevo en la villa Le Lac. Sólo la forma es la que parece haber sufrido el proceso de racionalización y esencialización. Ahora parece nacer de un proceso distinto: primero, al confinar el espacio exterior a través del muro, y posteriormente, y en vez de sustraer, a la adicción del "sólido-casa". Entre ambos, surgirá , de nuevo, el vacío habitado: el jardin.

\section{Procedencia de las imágenes}

1. Type A (@FLC/ADAGP19176a), Rez-de-Chaussé et $1^{\circ}$ étage, Oeuvre Complète,vol.1, p.25.

2. Croquis $\odot$ FLC/ADAGP intérieur d'une maison dom-Ino, Oeuvre Complète,vol.1, p.25

3. Croquis @FLC/ADAGP5890, intérieur de la maison à Kasanlak, Oeuvre Complète,vol.1, p.17.

4. (FLC/ADAGP19221 Maison Dom-Ino. Propuesta de ordenación y volumetrías, Oeuvre Complète, p. 26

5.@ FLC/ADAGP07856, Alz. propuesta Cité ouvrière, 1920, Oeuvre Complète,p.29

6 y 7.@FLC/ADAGP.Ch.É.Jeanneret, Salon de la Maison des Dioscures, Pompéi, Carnet 4, p.120-121.

8. OFLC/ADAGP L2(13)23. Le Corbusier, Pavillon de L'Esprit Nouveau, 1925, "le jardin-suspendu", recogido en la Oeuvre Complète, p.95-103.

9. (FLC/ADAGP19097, Le Corbusier, Croquis una terrasse-jardin (le jardin-suspendu).

10. CFLC/ADAGP28791, dessin d'étude en plan d'îlot aménagé et coupe en travers in situ, orientation, numérotation

11.@FLC/ADAGP28797C, Deux croquis en plan, croquis en coupe sur coursive intérieure entre deux types 12. CFLC/ADAGP 28797D, croquis d'étude petit rez-de-chaussée arrivée, grand rez-de-chaussée.

13. OFLC/ADAGP 08680 -Dessin d'étude de trois plans d'étage partiels.

14. CFLC/ADAGP29659 seire $n^{\circ}$ 1038/CFLC/ADAGP29660 serie $n^{\circ} 1039$ Type d'appartement d'un des grandes immeubles d'habitation, premier étage avec couloir general y deuxiemé etage.

15.๑FLC/ADAGP.Un jardin suspendu, Wanner Geneve,1928, Oeuvre Compléte p.183

16.CFLC/ADAGP. Le jardin suspendu d'un appartement, Oeuvre Complète, p.182

17. CFLC/ADAGP 23010, Perspectiva variante L'esprit Nouveau, 1925.

18. OFLC/ADAGP10371,serie nº 666,Villa Meyer, Rez-de-Chaussée suréleve.

19. OFLC/ADAGP31514, croquis 3y 4, le jardin suspendu couvert.

20. OFLC/ADAGP10380, Axonometría Villa Meyer,vista de la fachada a la Folie Saint-James

21. OFLC/ADAGP10374, nº 691, Villa Meyer, etage, terrase. Versión definitiva junio 1926. 
22. CFLC/ADAGP10378,dessin d'études de deux façades.Versión definitiva de junio de 1926.

23. OFLC/ADAGP10587. Axonometría proyecto preparatorio al 20 de julio de 1926.

24.Proyecto preparatorio 20 de julio de 1926; OFLC/ADAGP10409, plans de rez-de-chaussée supérieur, serie nº 725 y $\odot$ FLC/ADAGP 10408, plans de la terrase serie n ${ }^{\circ} 724$.

25. Alzados proyecto 20 de julio 1926:@FLC/ADAGP10406, sur y@ FLC/ADAGP10407, norte. Serie ${ }^{\circ}$ 722,723

26.@FLC/ADAGP31480 Planche de présentation avec série de perspectives: vue génerale, vue au nord, vue au sud, croquis jardin Surélevé villa Stein,1926.

27. OFLC/ADAGP10410 Rez-de-chaussée supérieur, serie nº 769, proyecto 7 octubre 1926. villa Stein.

28. OFLC/ADAGP10518 Rez-de-chaussée supérieur,esquema previo al proyecto de marzo de 1927.

29.@FLC/ADAGP Rez-de-chaussée supérieur,proyecto definitivo Villa Stein-de Monzie, 1927 publicado en la Oeuvre Complète p.14

30. OFLC/ADAGP19412, primera propuesta villa Savoye, Rez-de-chaussée supérieur, octubre de 1928.

31. OFLC/ADAGP19423 Axonometría exterior villa Savoye.

32. Plano del Pecile, Villa Adriana, Tivoli, siglo II d.c., extraído de Crescenzi, Livio; Hurtado de Mendoza, María; Rubini, Mauro, Ed. Ministerio per i Beni Culturali e Ambientali, Soprintendenza Archeologica per il Lazio, Roma, 1996.

33.OFLC/ADAGP Le Corbusier, Muro del Pecile en villa Adriano, Carnet A4, 1911

34. Piranesi, Vedute de Roma, Muro del Pecile en Villa Adriano. 1770.

35. OFLC/ADAGP. Croquis Le Corbusier, Muro del Pecile en la exedra central, Carnet A4, 1911

36. OFLC/ADAGP.Le Corbusier, muro a poniente de la petit villa au bord du Lac Leman, 1925, Oeuvre Complète, p.74

37. OFLC/ADAGP.Le Corbuier, muro y ventana a sur de la petit villa au bord du Lac Leman, 1925, Oeuvre Complète, p.74

\section{Breve Bibliografía}

Amirante, Roberta; Kütükçüoglu, Burcu; Tournikiotis, Panayotis; Tsiomis, Yannis: l'invention d'une architecte. Le voyage en Orient de Le Cobusier, Paris: Editions de la Villette, cop.2013

Aymonino, Carlo: La vivienda racional. Ponencias de los Congresos CIAM 1929-1930. Análisis de los elementos fundamentales en el problema de la "vivienda mínima". Le Corbusier y Pierre Jeanneret,Barcelona:Gustavo Gili, S.A.1973.

Benton, Tim: Le Ville di Le Corbusier e Pierre Jeanneret, 1920-1930, Milano:electaarchitettura, 2008.

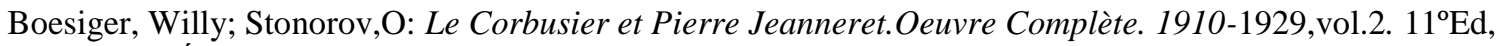
Zurich: Les Éditions d'Architecture, 1973.

Fundation Le Corbusier:Le Corbusier Plans, Volume 1,1905-1926.DVD, $1^{\circ}$ Ed, Paris: Echelle-1, 2005.

Giuliano Gresleri: Le CorbusierViaggio in Oriente, Paris:Foundation Le Corbusier, 1984.

Kepes, G: El lenguaje de la visión, $1^{\circ}$ ed, Buenos Aires: Infinito,1969. 
Le Corbusier: Hacía una Arquitectura,2ºd, Barcelona: Apóstrofe, 1998.

Le Corbusier:Aircraft, Madrid: ABADA Editores, s.1., 2003. p.34.

Le Corbusier: Almanach d'Architecture Moderne,Paris:Les éditions G. Cres et Cia.,1925.

Le Corbusier: Precisiones respecto a un estado actual de la arquitectura y el urbanismo,Barcelona:Apóstrofre, 1999.

Moss, Stanislau Von: Le Corbusier, $1^{\circ} \mathrm{Ed}$, Barcelona: Lumen, 1977.

Nivet, Soline: Le Corbusier et l'immueble-villas, Stratègies, dispositifs, figures. Wrage, Mardaga cop.,2011.

Ozenfant, A; Le Corbusier: Acerca del Purismo:Escritos 1918-1926, Madrid:El croquis, 1994.

Sancho Osinaga, J.C.: El sentido cubista de Le Corbusier, Madrid : Munilla-Lería, 2000

Sbriglio, Jacques: Le Corbusier. La villa Savoye. Madrid: ABADA editores.2005.

Torres, Jorge; y otros: Le Corbusier. Mise au Point.Valencia: General ediciones de Arquitectura, 2012. 


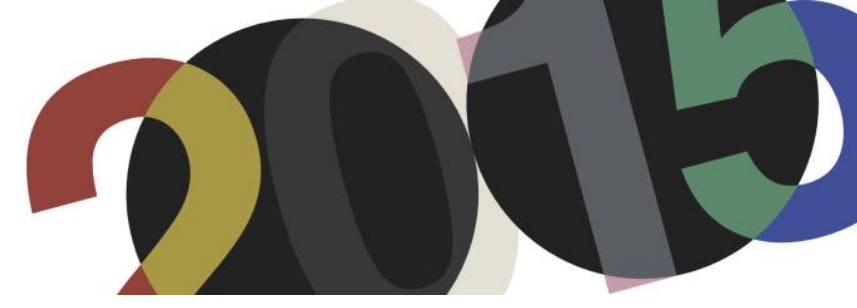

DOI: http://dx.doi.org/10.4995/LC2015.2015.937

\title{
Le Corbusier and São Paulo - 1929: Architecture and Landscape
}

\author{
G. Pianca \\ Faculdade de Arquitetura e Urbanismo da Universidade de São Paulo \\ (Faculty of Architecture and Urbanism of University of São Paulo)
}

\begin{abstract}
This article looks into Le Corbusier's urban proposal for the City of São Paulo, as formulated during his journey to South America in 1929. It highlights the relationship between Architecture and Landscape exposed by Le Corbusier's plan. This paper sets out to investigate the analysis that the innovative Swiss architect performed of the geography and morphology of São Paulo. It contrasts to the works and plans carried out by technicians and engineers at that time. In order to explain how Le Corbusier's treatment of nature and landscape differs from them, we study the extent to which Le Corbusier's plans show design approaches, which were unusual in terms of Western History and Memory. He also looks into the relationship between Le Corbusier's work, on the one hand, and new technological elements and changes in the visual culture at that time, on the other hand, thus seeking to highlight certain obscure spots within Le Corbusier's work.

This study aims at bringing forward some speculations and methods present in the work of Le Corbusier on cities. It deals with contradictory aspects in Le Corbusier's work in order to deepen our understanding of contemporary urban problems.
\end{abstract}

Resumen: Este artículo investiga la hipótesis de proyecto de Le Corbusier para la ciudad de San Pablo, propuesta durante su viaje a América Latina en 1929, focalizando en las relaciones entre arquitectura y paisaje. La primera cuestión analizada en este trabajo es el innovador análisis de la geografia y la morfología de San Pablo propuesto por el arquitecto suizo, que contrasta con la manera con que los técnicos e ingenieros locales desarrollaban sus propuestas en ese momento.

Para explicar dicha diferencia en la manera de lidiar con la naturaleza y el paisaje, el autor de este articulo estudia como el trabajo de Le Corbusier presenta abordajes de proyecto inusuales para la Historia y la Memoria, y su relación con los nuevos elementos tecnológicos y de la cultura visual de la época, procurando así resaltar ciertos puntos oscuros en el trabajo del arquitecto. Esta discusión intenta cuestionar ciertas especulaciones proyectuales y metodologías de trabajo presentes en el trabajo de Le Corbusier sobre ciudades, utilizando sus aspectos contradictorios como modo de profundizar nuestro entendimiento de los problemas urbanos contemporáneos.

Keywords: Modern Architecture; Modern Urbanism; Landscape Architecture; Le Corbusier; São Paulo. Palabras clave: Arquitectura Moderna; Urbanismo Moderno; Arquitectura Del Paisaje; Le Corbusier; São Paulo.

\section{Introduction}

This article investigates Le Corbusier's project for São Paulo, conceived during his visit to South America in 1929. ${ }^{1}$ The plan opens a dialogue between Architecture and Landscape, seeking to bring new components to the

\footnotetext{
${ }^{1}$ A considerable number of surveys, monographs and theoretical reflections about Le Corbusier's journey to Latin America have being carried out since mid-eighties. Among them, it is worth highlighting the pioneering work of Pereira, Margareth Campos da Silva; Santos, Cecília Rodrigues dos, Le Corbusier and Brasil. São Paulo: Tessela/Projeto, 1987. The following works are also worth of mention: Martins, Carlos F., Razón, ciudad y naturaleza. La génesis de los conceptos en el urbanismo de Le Corbusier. Doctoral thesis. Director: Adolfo Gonzalez Amezqueta. Escuela Técnica Superior de Arquitectura de Madrid. Madrid, 1992; the conference: Tsiomis, Yannis (editor). Le Corbusier: Rio de Janeiro, 1929-1936. Rio de Janeiro: Centro de Arquitetura e Urbanismo do Rio de Janeiro/Prefeitura da Cidade do Rio de Janeiro, 1998; and the recent exhibition of the drawings and sketches of Le Corbusier's Conference in South America: Queiroz, Rodrigo; Segawa, Hugo, Le Corbusier, América do Sul, 1929. São Paulo: Mariantonia - Centro Universitário USP, 2012. In addition to these,
} 
debate on the architect's urban visions, as well as to establish the extent to which changes occurring in technology during the twentieth century would have impact on the work of the architect.

We attempt to reconstruct the project's imagery in conjunction with the material conditions of its formulation, and through three research sources. The first is the historical survey of the existing projects for the city of São Paulo. It reveals the urban and social problems that the city was undergoing. Moreover, the facts showed in the survey serve as a means of comparison with the aims of Le Corbusier's hypothesis. Second, the analysis of historical references that Le Corbusier lists on the project's description - such as the aqueduct of Segovia and the Pont du Gard - is relevant to understand why and how these infrastructural elements are present in the plan. Finally, the analysis of the technical and poetic function of the aerial view in the elaboration process of Le Corbusier's plan inscribes this project in a complex visual culture that was being established at that moment.

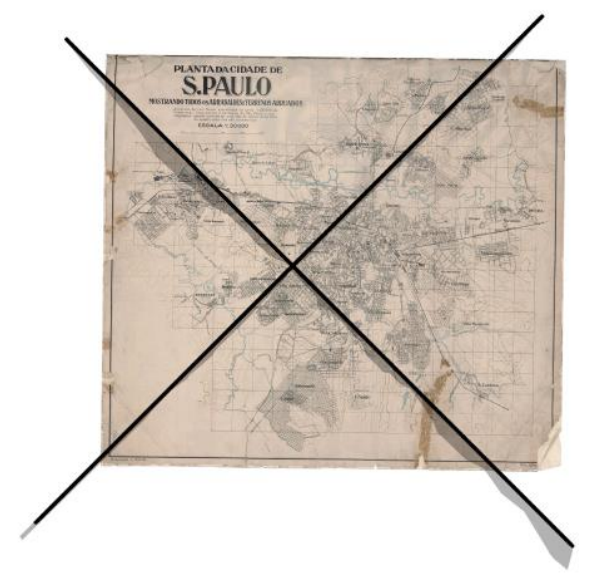

1. Montage of Le Corbusier's plan for São Paulo on cartography, dated from 1924.

The innovative aspects of Le Corbusier's approach to São Paulo are to be found on the radical distinction between traffic routes and water courses. This distinction establishes a relationship of independency between the geomorphology of the circulation system and its buildings. It ascribes to nature a value of enjoyment. It shows the considerable effort of the Swiss architect to recreate signs of great civilizational value, in which diachronic times - the age of the Ancient world and the age of the machine - are combined, in an attempt to reconcile an urban Poieses with the challenges inaugurated earlier in the century. The relationship between Le Corbusier and the aeronautical culture is brought about; it plays a major role in the combination of these two aspects aforementioned. Thereby, it is also necessary to make general characterizations of the period between wars, when this voyage took place. This time embraces a series of social and cultural transformations. The architect was remarkably aware of them, taking part in their debates and undergoing their consequences. Le Corbusier was tracking the development of aviation technology and its use in flightseeing. He was particularly interested in the changes occurring in the relationship between man and its environment, in the new ways for analyzing and understanding territory. ${ }^{2}$ These project characteristics are remarkable in certain later works by Le Corbusier, but they do not remain constant throughout the architect's work.

the recent effort to understand the role of Landscape in Le Corbusier's universe: Cohen, Jean-Louis (editor). Le Corbusier An Atlas of Modern Landscapes. Londres: Thames \& Hudson, 2013.

${ }^{2}$ See Morshed, Adnan, "The Cultural Politics of Aerial Vision: Le Corbusier in Brazil (1929)", in Journal of Architectural Education (1984-), vol. 55, n. 4 (May, 2002), pp. 201-210. 
The great influence of this plan and of other studies to America is generally recognized within authors on the history of architecture. Those plans are circumscribed in a turning point in the trajectory of Le Corbusier, marked by the contrasting directions of the Swiss architect regarding the functional trend of the New Objectivity. It is a widely known fact that Le Corbusier did not attended the II CIAM; instead, he travelled to Latin America, thus allowing himself some valuable time for reflection and research. This moment would be characterized by the radicalization of certain aspects of his thought and practices towards a more sensitive architecture and urbanism, ${ }^{3}$ much closer to the perception of landscape and advocating a broader relation between architecture and nature. ${ }^{4}$ In these plans for the cities of Montevideo, Buenos Aires, São Paulo, Rio de Janeiro, and in the final experience of the "Plan Obus" for Algiers, Le Corbusier formulates, according to some historians such as Manfredo Tafuri, the highest theoretical hypothesis of modern urbanism, one that has not been ideologically or formally surpassed by any other. ${ }^{5}$ Challenging the achievements of Taut, May, Gropius, the Swiss interrupts the continuous sequence architecture-neighborhood-city: the urban structure as such - as a physical and functional unit - is the repository of a new scale of values. And the scope in which these projects are to be understood is the landscape scale.

\section{Le Corbusier's Hypothesis for São Paulo}

A brief introduction to the further description and characterization of Le Corbusier's hypothesis for São Paulo should mention the profound changes the city was undergoing during the first decades of the twentieth century. 1929, the year when Le Corbusier visited São Paulo, is the iconic, exact moment when the contradictions triggered by this process were at full potential.

In 1900, the city of São Paulo can be described as a medium-scale village, with a population of 240,000 inhabitants. Its main economic activity was to serve as a trading post, chiefly for the coffee production in the countryside, and its transport to the port of Santos. During the first decades of the twentieth century, São Paulo turned into an industrialized city; its population increased, amounting to 840,000 inhabitants in $1930 .{ }^{6}$ This steep rise was accompanied by a urban crisis: increasing problems related to traffic and public transportation, the urbanization of areas outside the boundaries of the historic center, increasing sanitation and health problems. However, by that time, public authorities were still formulating their instruments to control these uttered issues .

\footnotetext{
${ }^{3}$ Le Corbusier, "Comotions Sudamericaines. Introduction à un urbanisme sensible”, in La Ville Radieuse. Eléments d'une doctrine d'urbanisme pour l'équipment de la civilisation machiniste. Paris: Ed. L'Architecture d'Aujourd'hui, 1935, p. 220.

${ }^{4}$ Martins, Carlos A. Ferreira, "Uma Leitura Crítica”, in Le Corbusier, Precisões. Sao Paulo: Cosac Naify, 2004, pp. 268-269.

${ }^{5}$ Tafuri, Manfredo, Projecto e Utopia. Lisboa: Presença, 1985, p. 87.

${ }^{6}$ See: Meyer, Regina; Grostein, Marta Dora; Biderman, Ciro, São Paulo Metrópole. São Paulo: Editora da Universidade de São Paulo/Imprensa Oficial do Estado de São Paulo, 2004.
} 


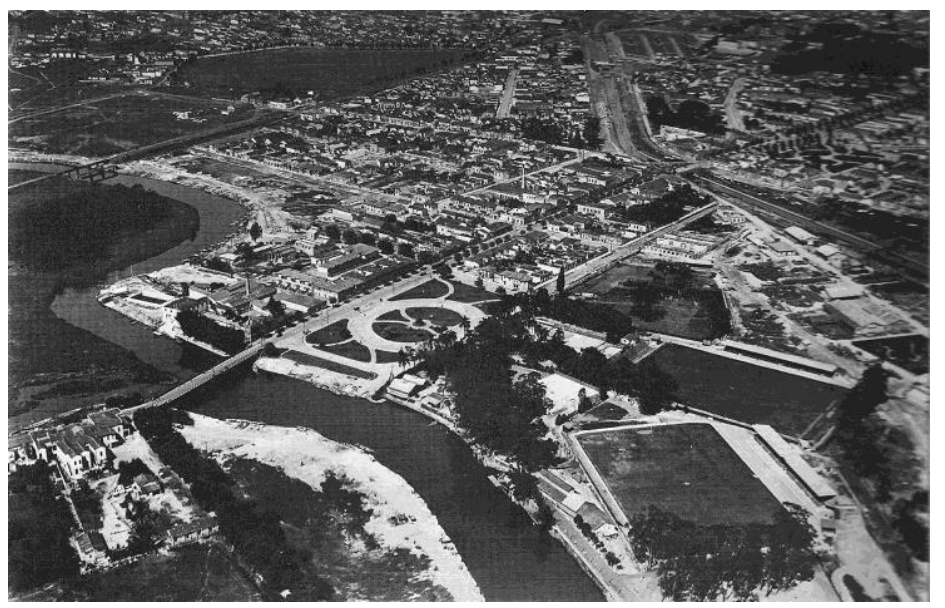

2. Aerial photograph of São Paulo, c. 1930; in the background is Tiradentes Avenue, crossing the now-straightened channel of the Tamanduateí River; in the, foreground the Tietê River follows its original course.

Regarding its physical implementation, the city still consisted mostly of the city's original historic center and its surroundings, limited by the Tamanduateí, the Tietê and the Pinheiros rivers. Beyond these rivers, there were only a few allotments, in which transposition was still precarious. Given these conditions, the city was developing his plans to overcome what would be a major challenge for its growth: the confrontation with its violent hydrography paced by constant floods. ${ }^{7}$

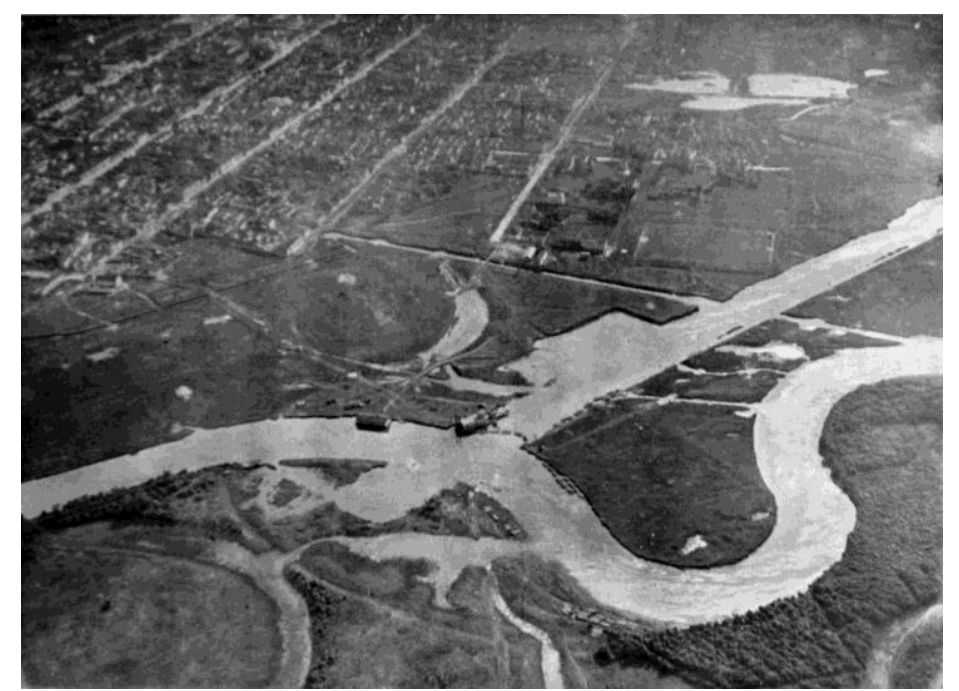

3. The Tietê River's Canalization Process; on the second plan, Bom Retiro district, near downtown, c. 1938.

\footnotetext{
${ }^{7}$ See Seabra, Odette Carvalho de Lima. Os meandros dos rios nos meandros do poder. Doctoral thesis. Department of Geography, FFLCH USP, São Paulo, 1987.
} 
Notoriously, in his text "Corollaire Brésilien", from Precisions, Le Corbusier exposes his perception of the aforementioned conflict:

"Dans le cabinet du préfet de São-Paolo, j'examine avec curiosité, sur le plan mural de la ville, des méandres significatifs. Voici qui est pertinent: ces rues sinueuses passant sous d'autres construites en viaducs. 'Vous êtes', dis-je au préfet, 'en instance de crise de circulation ?'." Le Corbusier ${ }^{8}$

The proposal made by Le Corbusier considered the increasing size of the city of Sao Paulo and its strategic position within the Brazilian territory. It is summed up by two "road axis" set at right angles one to another . One of these axes marks the vector "Rio de Janeiro-Southwest" - connecting the nation's capital at that time. The other axis defined the vector "Northwest-Santos" - the essential link between the coffee production in the countryside and the main port station in Brazil.

Another crucial feature in Le Corbusier's project is the deliverance of transport routes from the crashed topography of the city. It designed these axes as large elevated tracks, able to fully serve the geographical dimension of the city, without deviations or deformations on its course. The main traffic structure of the city would have the physical and material size of São Paulo’s landscape:

"Si l'on faisait ceci: poser de colline à colline, de sommet à sommet, une règle horizontale de quarante-cinq kilomètres puis une seconde même règle, à droit à peu prés, pour desservir les autres points cardinaux. Ces règles droites sont les autostrades de grande pénétration en ville, en réalité de grande traversée. Vous ne survolerez pas la ville avec vos autos, mais vous la 'sur-roulerez'. Ces autostrades que je vous propose sont de gigantesques viaducs. Ne faites pas des arches onéreuses pour porter vos viaducs, mais portez les viaducs sur des structures de béton armé qui constitueront des bureaux au centre de la ville et des logements en périphérie. Le cube de ces bureaux et de ces logements sera immense, pris dans l'air du temps; c'est donc une magnifique valorisation. Un projet précis, un édit. Opération déjà décrit." Le Corbusier ${ }^{9}$

\footnotetext{
${ }^{8}$ Le Corbusier, Précisions sur un état présent de l'architecture et de l'urbanisme. $2^{\text {nd }}$ Edition. Paris: Éditions Vicent, Fréa \& $\mathrm{C}^{\mathrm{ie}}, 1960$, p. 239.

${ }^{9}$ Précisions, op. cit., p. 239.
} 


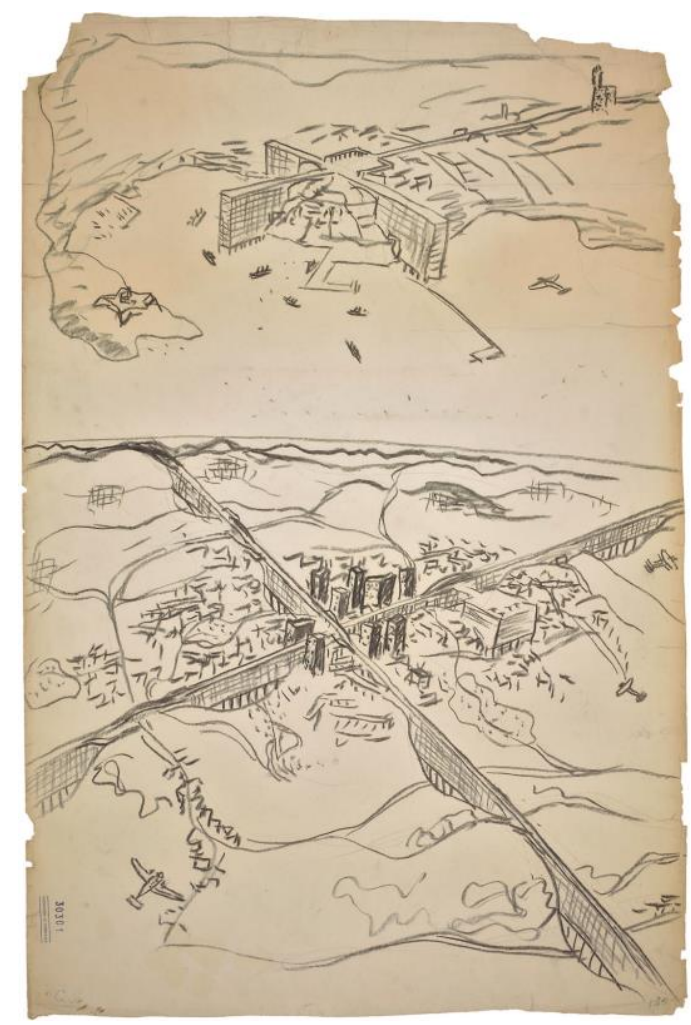

4. Le Corbusier's sketches of his proposals to Montevideo and São Paulo, 1929.

The diagnosis and the proposal for São Paulo present some relevant differences in relation to other urban plans developed on his journey to America. Among four cities, São Paulo is the only one whose picture cannot be grasped from the sea; contrarily to Rio de Janeiro, São Paulo presents no significant topographic component. Due to the fact that the site is marked by a kind of "sea of hills", the recently proper development of the city suggested viaducts as a solution to overcome the numerous small valleys.

In comparison with Le Corbusier's previous formulations, his project for São Paulo has two important distinguishing elements. The first is the removal of the typological difference between the office buildings and residential ones, which now are part of the same macrostructure; the different uses depend solely on the location. Secondly, artificial terrains are no longer created outside the boundaries of the pre-existing city, contrarily to Buenos Aires or Montevideo or to the demolition of a concentrated area, as in the "Plan Voisin" for Paris. ${ }^{10}$

The plan for São Paulo signals a milestone in the transition that the work of Le Corbusier was undergoing in South America. Following a progressive development of the city's abstraction ${ }^{11}$ - in the sense that the urban structure of Buenos Aires deserves a more or less detailed analysis, the interpretation of Montevideo is deducted from the previous one, and the understanding of São Paulo is limited to the verification of the verticalization of the city center and the subtle nuances of the city's geomorphology -, the perspective of Rio de Janeiro seems to be the limit of this process, where nature with its vigor and strength dictates the rhythm and geometry of architecture, paving the way for the subsequent formulation of the "Plan Obus" - the ultimate rupture with the German lines of Architecture and Urbanism.

\footnotetext{
10 "Uma Leitura Crítica", op. cit., p. 285.

${ }^{11}$ Ibid, p. 285.
} 
In São Paulo, the architect cannot avail himself of any sublime horizontal lines in the landscape, any promontories nor any spectacular view of mountains and seas. What is left out to him is the cosmic connection of a large cross, organized by cardinal points. The innovation of this vis-à-vis the previous plans of his journey appears in those gigantic "rules of 45 kilometers" that is not only designed to accommodate business center's offices, but also the residential units in the periphery. This feature anticipates the proposals for Rio de Janeiro and Algiers.

The plan's gigantic dimensions were an innovative aspect of the project, contrasting with the previous project made by the Municipality of São Paulo. In opposition to Le Corbusier's plan, which defines a unity among different territories, such as the floodplains and the top hills, these projects for São Paulo focused primarily on particular issues. They lack a systematic approach. Before looking closely into the relevant and specific elements of Le Corbusier's hypothesis for São Paulo, it is necessary however to look back and make a brief retrospective of the projects that the government of this city had designed to its territory.

\section{São Paulo's problems as seen by local engineers}

São Paulo's engineers were on the margins of the aesthetic debate on the recently inaugurated process of modernization taking place Brazil. Their research and work were associated with the rectification of the Tietê River, carried out in the last decades of the nineteenth century to revert the deterioration of the sanitary conditions of the river's floodplains. It was required due to the critical situation brought about by seasonal floods and especially by the increasing pressure to incorporate new land stocks for the city's expansion. ${ }^{12}$

Given the need to understand the concerns of the engineering in São Paulo, some of these plans will soon be presented. We seek to establish a common genealogy among them regarding the understanding of floodplains as a subject to be dominated by technology, albeit there are considerable differences in landscaping treatment among such studies. It is noteworthy that part of the period when these projects were conceived coincides with the formative years of Le Corbusier and with his early readings about urbanism: many books that the young Charles Eduard Jeanneret consulted in the Bibliothèque nationale of Paris ${ }^{13}$ were read by this generation of Brazilian engineers and laid in the libraries of the Polytechnic Schools. ${ }^{14}$ Some of these books are Der Städtebau by Hermann Josef Stübben, and L'Esthetique des villes by Charles Bulls. Both authors notably played a significant part in the establishment of the theoretical grounds for state engineering in the early twentieth century.

Dating back from the late nineteenth century and the twentieth century, these plans originally aimed at solving sanitation problems. They also attempted to rectify the river, by increasing its steepness and, consequently the speed of the flow of water. It would be an attempt to ward off the sewage from the city's fringes, and to avoid stagnation of water in the urbanized area. Finally, the project conceived the creation of traffic routes adjacent to the canal - in order to deal with the inconstancy of the river. ${ }^{15}$

\footnotetext{
${ }^{12}$ Seabra, Odette, op. cit.

${ }^{13}$ Tafuri, Manfredo, "Machine et mémoire: la ville dans l'oeuvre de Le Corbusier", in. Lucan, Jacques (editor), Le Corbusier une encyclopédie. Paris: Centre Georges Pompidou, 1987, p. 464.

${ }^{14}$ Simões Junior, J. G., “A urbanística germânica (1870-1914). Internacionalização de uma prática e referência para o urbanismo brasileiro", in Arquitextos, Portal Vitruvius. v. 97. São Paulo:

online [http://www.vitruvius.com.br/revistas/read/arquitextos/09.097/134], 2008, pp. 1-11.

${ }^{15}$ For a preliminary research on the projects for São Paulo: Leme, Maria Cristina da Silva (editor), Urbanismo no Brasil. 1895-1965. São Paulo: FAUUSP, FUPAM, 1999.
} 
In 1887, engineer Bianchi Bertoldi conceived the first rectification project for the Tietê and the Tamanduateí Rivers, during the government of President of the Province Visconde de Parnaíba. In 1894, engineer João Pereira Ferraz, through the newly established Comissão de Saneamento do Estado de São Paulo (Sanitation Commission of the State of São Paulo), disposed of the earlier study as a basis for his plan. This project was accomplished thanks to the aid of the first observations and measurements of the river and also to the first accurate topographic surveys of wetlands executed by the Comissão Geográfica e Geológica de São Paulo (Geographical and Geological Commission of São Paulo). The constant threat of floods and pests prompted the first stages of civil work, rectifying three kilometers. However, in 1898 this Commission was extinguished and the works were suspended.

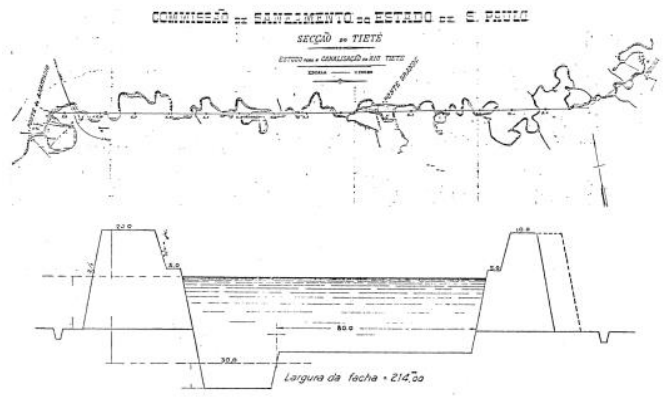

5. Tietê River's channel Section, Eng. João P. Ferraz, c. 1894.

After a long break, engineer Pacheco e Silva make a new proposal to the Municipality in 1913. In the urban field, the Municipality showed more concern with the central area of the remodeling works in the city than with the floodplains, which was still partially occupied by the lower social strata. Only in 1922, a professor of the Polytechnic School on the chair of Ports, Rivers and Canals, professor Fonseca Rodrigues, takes up projects for the rivers, in response to a request made by the Diretoria de Obras Municipais (Municipal Works Agency).

Rodrigues project consisted of two parallel side embankments with waterproofing treatment throughout almost the entire channel length. The space between these embankments measured 108 meters, and its high was 4.5 meters; at their summits two 20-meter wide avenues were planned to be built. Engineer Rodrigues' project was criticized by engineer Victor da Silva Freire, director of the Municipality's Departamento de Obras (Department of Works). According to his argument, the proposal only outlined the hydraulic solution in general terms, and disregarded aspects of the city's embellishment. Engineer João Florence Ulhôa Cintra presented a new plan, focusing on urban embellishment requirements. According to the plan, the height of the dikes is demoted and the width of the largest riverbed is increased; public spaces are placed along riverbanks, and the new channel is set within wide parkways.

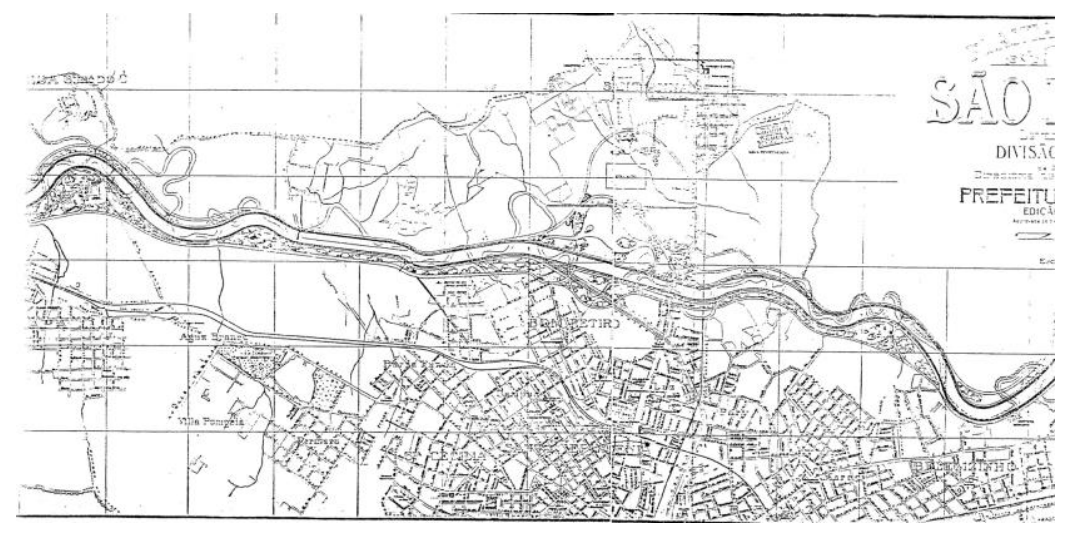

6. Tietê River's Rectification Plan, Eng. João Florence Ulhôa Cintra, c. 1923. 
Two years later, engineer Saturnino de Brito's project combined embellishment criteria and technical aspects with greater maturity and clarity. His plan proposed the increasing of the flow section; the embankment of the lowest areas of margins, which would enable the incorporation of $25 \mathrm{~km}^{2}$ of wetlands into the city; the configuration of two large lakes with a surface of $1.2 \mathrm{~km}^{2}$, which would provide land for landfills and contribute, with its liquid surfaces, to urban embellishment and aquatic sports within the city.

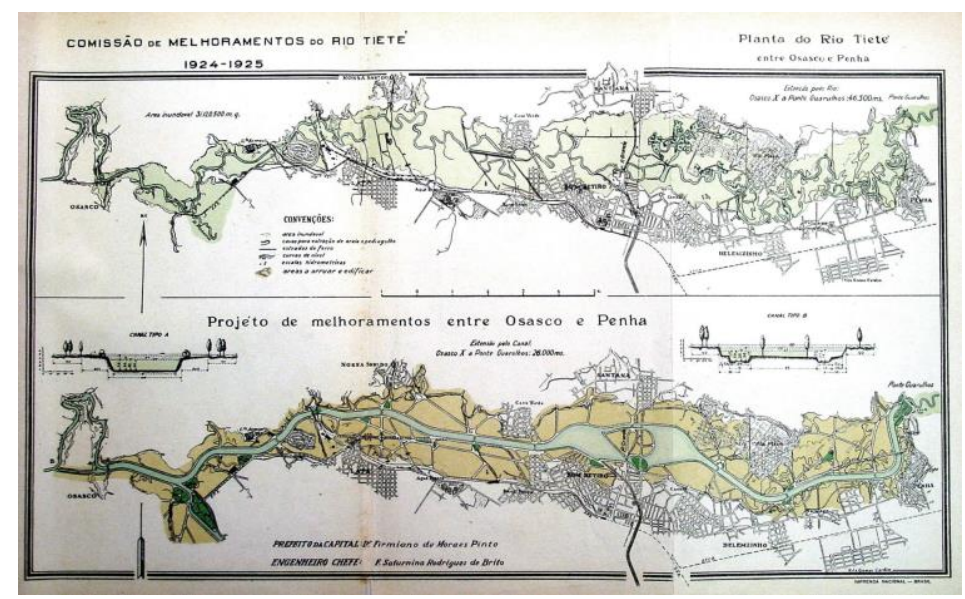

7. Eng. Saturnino de Brito's plan to the Tietê River, c. 1925.

It is remarkable that since 1913 the implementation of marginal avenues around the Tietê River can be seen on these plans. It points out to a major concern with the traffic within the urban debate, and also to the fact that the wealthier classes favored cars. In order to tackle traffic problems, congestion and pedestrian accidents, which could be seen in the city in the twentieth century, Francisco Prestes Maia and Joao Florence Ulhôa Cintra were commissioned by the Municipality to carry out another study.

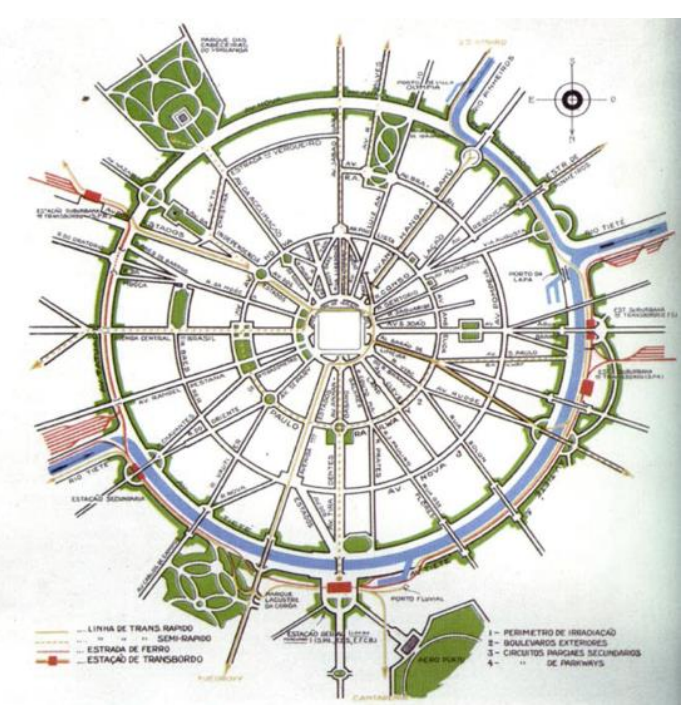

8. Theoretical scheme for Study of a Plan of Avenues to São Paulo, by Prestes Maia and Ulhôa Cintra, c. 1930.

In 1930, the Estudo de um Plano de Avenidas para a Cidade de São Paulo (Study of a Plan of Avenues to the City of São Paulo), as its name implies, combines urban planning issues and the design of avenues, thus highlighting circulation problems as the major urban issue. It considers rivers and nature as nothing else but obstacles to "progress". This plan, unlike the previous ones, was followed by the government and ended up defining the general features of the industrial metropolis into which São Paulo would be turned into in the midtwentieth century. 


\section{Memories of the Past, Memories of Le Corbusier and Memories of the Future}

It is with assertiveness that Le Corbusier conceives the proposal of highways to the plan for São Paulo as well as other proposals for South America and the "Plan Obus". Undoubtedly they can be related to projects like the "Project for Roadtown" by Edgar Chambless, of 1910, to some Russian schemes, and to more specific constructions, such as that by Giacomo Matte-Trucco's in Turin, of 1920-23, with its test course installed on the roof. $^{16}$

The analysis of this constant element found in the Algiers and South American projects usually follows the theoretical lines that regard these highways merely as a futuristic component in these plans. They are associated with the rich collection of historical images and references in Le Corbusier's mind. ${ }^{17}$ The analysis reduces the symbolic value of this component to a pure eulogy of the machine age. ${ }^{18}$ There is still a few analyses that identify the relationship of these highways with monuments of the Western Culture. They see Le Corbusier's project as a parody of a Roman's town diagram on the creation of a cardo and a decumanus, ${ }^{19}$ associating this aspect of the proposal with an imperialist drive to control territories. Rarely it is pointed out that these images and memories of his manifest themselves in certain occasions - thus seeking to create a genealogy of the imagination of these viaducts -, featuring this proposal as a mental dialogue that Le Corbusier has carried out with aqueducts, since his first trip to the East. ${ }^{20}$

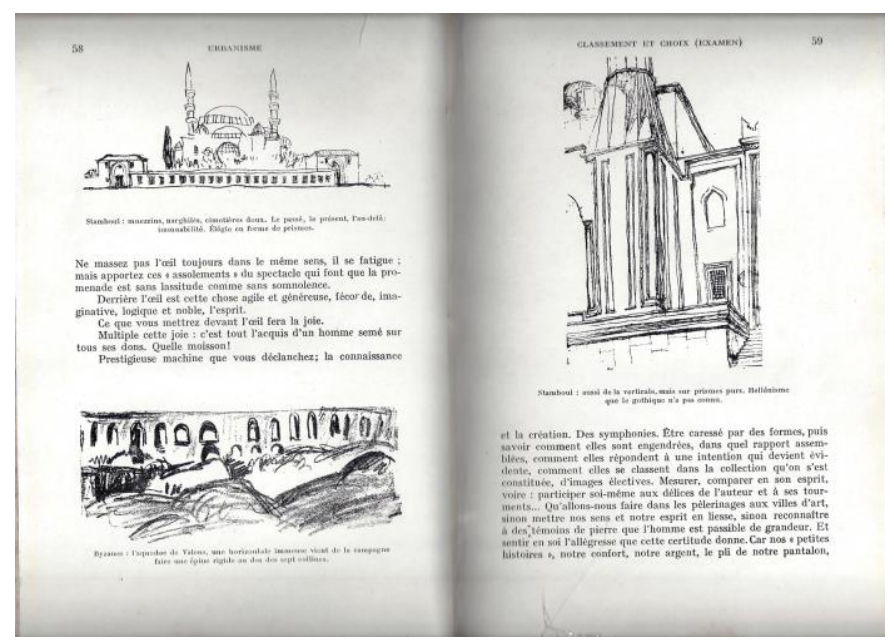

9. Le Corbusier's quotation of Valens on Urbanisme, 1924.

\footnotetext{
${ }^{16}$ Von Moos, Stanislaus, Elements of a Synthesis. Rotterdam: 010 publishers, 2009, p. 199.

${ }^{17}$ Some current research lines seek to associate myths' reconstruction with a fascist tendency within European culture at the beginning of century, which would reverberate in Le Corbusier: Mark Antliff, Avant-Garde Fascism: The Mobilization of Myth, Art, and Culture in France, 1909-1939. Durham, NC: Duke University Press, 2007. For another approach of this subject see the analysis that defines the Swiss architect as a character who cannot renounce the idea that the temporality of the present is not a passageway, but something that remains motionless on the edge of time, getting closer to definitions by Walter Benjamin in Theses on Philosophy of History. See Frajndlich, Rafael Urano, Tafuri: tempo da cidade longinqua, Doctoral Thesis. Director: Mario Henrique D’Agostino. University of São Paulo, Faculty of Architecture and Urbanism, 2014.

${ }^{18}$ Regarding the aforementioned conjunction of highways with buildings, other relevant works deal with this issue: Volker, Ziegler, "Les Chemins de Le Corbusier de l'autodrome à l'autoroute", in: Tsiomis, Yannis (editor), op. cit., pp. 110-115; Weber, Bendicht, "L'architecture d'un viaduc", in Tsiomis, Yannis (editor), op. cit., pp. 64-68.

${ }^{19}$ Oyarzun, Fernando Perez, "Le Corbusier: Latin American Traces", in Cruelty and Utopia. Cities and Landscapes of Latin America. New York: Princeton Architectural Press, 2003, pp. 98-107.

${ }^{20}$ Cabral, Gilberto Flores, "O utopista e a autopista: os viadutos sinuosos habitáveis de Le Corbusier e suas origens brasileiras (1929-1936)”, in Arqtexto, n. 9. Brasil, Porto Alegre: UFRGS, 2006, pp. 54-75.
} 
The attempt to emphasize these images of Antique memories of humanity through the memory and mind of Le Corbusier seems to be required if we need to expand the meanings and reasons of Corbusier's proposal. It is noteworthy to notice that in 1910, in his Voyage à l'Orient, impressed by Valens aqueduct, Le Corbusier drew that monument in charcoal, later including this sketch in Urbanisme, with the caption: "Byzantium: An immense horizontal running through the surrounding country and forming a rigid backbone along the Seven Hills". ${ }^{21}$ The drawing shows to what extent the image of the proposals of 1929 - the viaduct as horizontal joining hills - had been conceived in Le Corbusier's mind, emerging as a manifestation of his creative "subconscious" process that "reused fragments stored in memory for a long time until an opportune resurgence."

Besides the image of the aforementioned Roman aqueduct in Istanbul, in the characterization of the hypothesis for São Paulo the image of two other aqueducts stand out as a synthesis of Le Corbusier's proposal for São Paulo:

“L'aspect magnifique que prendrait tout le site! Quel plus grand aqueduc de Ségovie, quels gigantesques Ponts du Gard! Le lyrisme y trouverait son compte. Y a-t-il rien de plus élégant que la ligne pure d'un viaduc dans un site mouvementé et de plus varié que ses substructures s'enfonçant dans les vallonnements à la rencontre du sol?" Le Corbusier 22

The first ode to Pont du Gard in Le Corbusier's wittings appears in Vers une Architecture, which compares the symbolic value of Pont du Gard with the Pyramids, the Towers of Babylon, the Samarkand Gate, the Parthenon, the Hagia Sophia, the Brunelleschi Cupola, among others. ${ }^{23}$ Below, pictures of the East and the West appear side by side, reinforcing the idea of a slow and suspended temporality as a distinctive trait of Le Corbusier's thought, where these objects are brought back to the present, as if leaps of content were occurring in History.

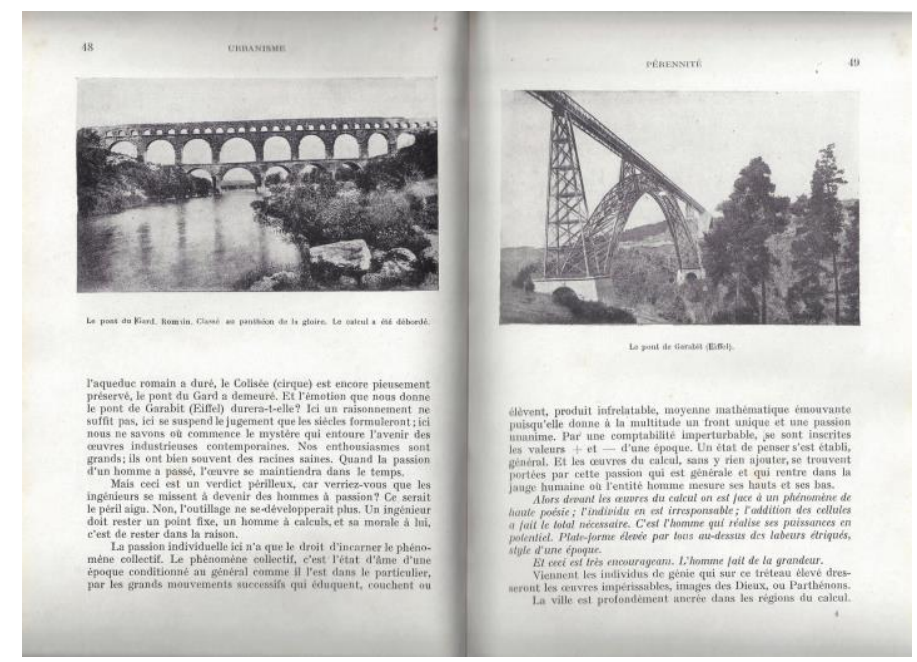

10. Le Corbusier's quotation of Pont du Gard on Urbanisme, 1924.

Besides this aspect, the Pont du Gard represents not only its physical and built limits: it points out to a larger work, the aqueduct of Nîmes, a $50 \mathrm{~km}$ infrastructure built by the Romans as a means of transporting water from a spring at Uzès to the Roman colony of Nemausus. The image of Gard returns in Urbanisme, ${ }^{24}$ now in order to

\footnotetext{
${ }^{21}$ Le Corbusier, Urbanisme. Paris: Editions Crès, 1924, p. 48.

${ }^{22}$ Le Corbusier, "Le Corbusier a Torino" (newspaper interview, 1934), Oeuvre complète, 1929-1934. Zurich: Les Éditions d'architecture Erlenbach-Zurich, p. 202.

${ }^{23}$ Le Corbusier, "Trois Rappels, Le Volume", in Vers une architecture, p. 19.

${ }^{24}$ Urbanisme, op. cit., p. 48.
} 
question the value of masterpieces of modern engineering, and the narrow limits of rationalism that have appeared in the horizon of modernity.

The aqueduct of Segovia, unlike the Pont du Gard, appears as a recent memory of the architect. Le Corbusier visited this Roman aqueduct in Spain during his visit to Madrid in 1928. Initially, this aqueduct did not draw the architect's attention as other works or landscapes did. And it have only been recorded through a postcard that the architect kept in his files together with other postcards, such as the one depicting San Lorenzo Monastery at El Escorial. $^{25}$

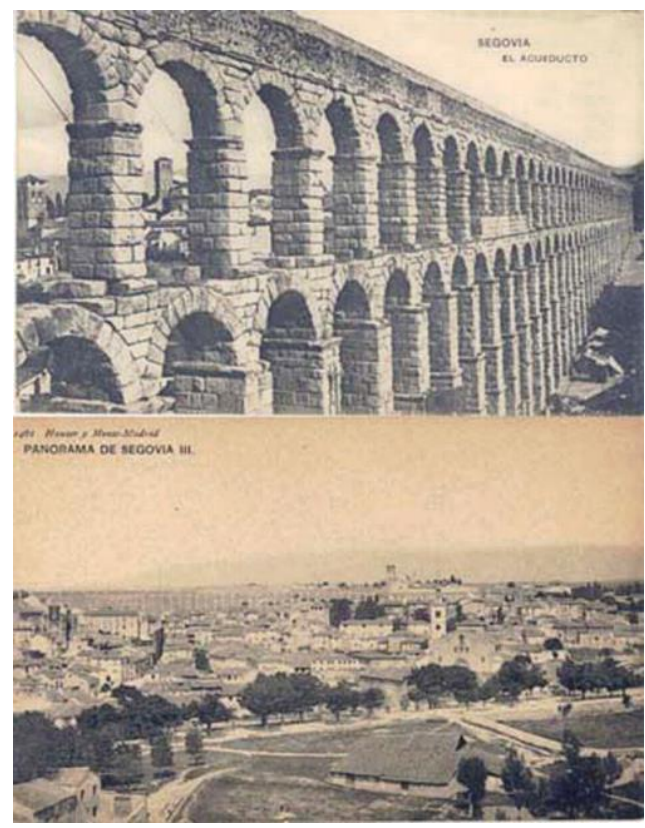

11. Segovia's postcard collected by Le Corbusier on his travel to Madrid and neighboring cities, 1928 .

The spatial configuration between the aqueduct and the city in this example reveals the imaginary that Le Corbusier wanted to introduce to the city of São Paulo: in Segovia, the aqueduct and the valley floor form a large-scale free square (Plaza Azoguejo), where its structure turns out to be of great impact. By the hills where the main structure begins, there are two smaller squares serving as a small centrality in opposite sides of the valley (Plaza de Día Sanz to the south, and Plaza del Avendaño to the north), turning the structure into an articulator between sides cut by the primary geography of the place. ${ }^{26}$ The aqueduct stands out as a technique that acts upon nature, without overlapping it. In addition to acting as a vector, the aqueduct rather relates distant geographical points (very similarly to the project for São Paulo), thus seeking its meaning in the territorial aspects of the landscape.

The importance of these aqueducts is remarkable; we believe that it cannot be ignored if we are to achieve a better understanding of these Latin American proposals. As previously mentioned, the proposals underwent a process of abstraction of "urban form" as opposed to the search for a clear and crystalline dialogue with the continental scale that Le Corbusier faces. Aqueducts in this description are appraised by a certain type of

\footnotetext{
${ }^{25}$ An extensive coverage of Le Corbusier's visit to Madrid and its surroundings can be seen in the exhibition catalogue: Guerrero, Salvador, Le Corbusier, Madrid, 1928: Una casa-un palacio. Madrid: Residencia de Estudiantes de Madrid, 2010.

${ }^{26}$ For more information about the Aqueduct of Segovia see: Casado, Fernando C., "Acueducto de Segovia", in id., Acueductos Romanos en España. Madrid: Consejo Superior de Investigaciones Científicas; Colegio de Ingenieros de Caminos, Canales y Puertos, 2008.
} 
reasoning and intelligence: they represent a strong gesture over territory without merely subjugating nature. They express large infrastructure of continental dimensions, detached from the ground and the earth, covering a not obvious but necessary way for the civilizational milestones that Le Corbusier sees in Romans works.

The civilization value that Le Corbusier always attempted to instill in his projects could be achieved through the description of works such as the Pantheon, the Istanbul Monasteries and other architectural icons. It does not even seem reasonable to apply some urban fabric to America. This study seems to be relevant inasmuch it mentions another aspect of ancient civilizations that also fascinated Le Corbusier: the gesture of the aqueduct is the connection between other civilized territories. It represents the founding of new cities and territories. Le Corbusier seems to search for a state of suspension in which memories of the Antiquity and his personal memories are combined, stressing the relationship between present and tomorrow, creating memories of the future.

Le Corbusier seems to grow apart from the objective issues of São Paulo, using the project in an attempt to solve broader problems, instead. He seeks to create a theoretical methodology of approach to the cities, hoping to reconcile the conflict between humanistic values, which he advocates, and the dashing logic of modernity.

What paths Le Corbusier tried to establish? What were the other assumptions and inputs which enabled Le Corbusier to draw such an original plan during his brief stay in São Paulo, greatly different from the ones previously mentioned, conducted by local engineers? What could justify such a lag between Le Corbusier and the contingencies of the city in question?

\section{The plane and the flight of perception}

The problem of the relationship between architect and engineer functions is a constant theme in the writings of Le Corbusier during the 1920s. Both Vers Une Architecture and Urbanisme are marked by a strong conflict between the purposes of the work of engineers, which Le Corbusier admires, and the aim of arousing the emotion that architects seemed very far from inspiring in their works at that time. ${ }^{27}$ According to him, a new historic moment would be founded when sentimental impulses would be identical to those of reason. He argues that modern industrialism would be the result of abstract reasoning, not of passion, for this process no longer would meet the needs of the "great men" but the limited objectives of the "little men". He claims that this simple opposition between the man of science and the poet is rather illusory, and that the poet must accept and celebrate the end products of this "man of poor fortune", the engineer. ${ }^{28}$

It's possible to state that the "Plan Voisin" did not seek to ultimately solve the problems of the modern city, but rather to raise to a certain level the debate on the topic, thus adhering to the spirit of the time, revealing a certain pessimism regarding the fulfillment of its proposals. Hence, these urban plans by Le Corbusier poses anything but a model in the scientific sense, because they perform a dialectic consisting of the interaction of pragmatism (function) and the ideal order (pure form).

The late twenties and the passage to the thirties is the moment when Le Corbusier radicalized these conflicts, not only theoretically, but also bringing these contradictions into his architectural and urban production. According to Tafuri, this external contradiction becomes internal in Le Corbusier's design for the Apartament of Beistegui. In this project, the Swiss becomes "haunted by metaphorical concerns that come together in a 'open room". Its

\footnotetext{
${ }^{27}$ Colquhoun, Alan, "Arquitetura e Engenharia: Le Corbusier e o paradoxo da razão”, in Modernidade e Tradição Clássica. São Paulo: Cosac Naify, 2004, p. 110.

${ }^{28}$ Urbanisme, op. cit., p. 48.
} 
language tries to reconcile technical and natural features. For the Roman historian, this project refuses both the existing Paris and the Ville Radieuse, where its language and images are transferred to the field of metaphors and dreams. So Tafuri recreates this internal contradiction in the work of Le Corbusier with the question of how to reconcile this poiesis to the needs imposed by the terrestrial myth of rationalization. ${ }^{29}$

To Le Corbusier it seems that what was in question was how to handle the urban phenomenon and its problems, but above all, how to perceive the cities of his epoch sensitively enough, thus rewriting the fundamental questions of urbanism. Notoriously, in the Beistegui's terrace project, the distance interposed between the penthouse and the Parisian panorama is ensured by a technological device, ${ }^{30}$ indicating some hope for the sensitive and poetic use of certain tools and technological possibilities, which could, even in the field of the metaphor, reconcile the conflict mentioned above. The articulating function between the architect and the citylandscape, the instrument-periscope performed in the project for Beistegui, would be reconstituted through the use of aerial view on his journey to South America.

The impact of the incorporation of the aerial view on the imaginary of modernity was notable. For signs of this aerial modernity, we can consider Friedrich Nietzsche's clarion call on Thus Spoke Zarathustra to "kill the Spirit of Heaviness". The personalization that Nietzsche held of this phenomenon brings to mind a set of antinomies, such as light and heavy, air and ground, or even air and space, antinomies that highly pervade a culture of many modern vanguards. ${ }^{31}$ These processes can be seen as creating a new time, as described by Nietzsche, a process able to refund even the name of the Earth: "He who will one day teach men to fly will have moved all boundarystones; all boundary-stones will themselves fly into the air to him, he will baptize the earth anew - as 'the weightless'., ${ }^{32}$ This approach have many similarities to the way Le Corbusier will work at different times on his writings, as we can find on his remark that airplanes are a "sign of new times" advancing forward "in a winged flurry". 33

For some specialists in the visual culture of the aerial view, as Davide Deriu, the practice of modern flight therefore signaled the last escape from the labyrinth of the modern city. The ascent of the planeur, in his words, was implied in the dialectics of spectacle and surveillance: on the one hand, the aerial observation participated in a civilization increasingly mediated by independent representation; on the other hand, it was instrumental to the disciplinary mechanisms of visual detection and inspection. ${ }^{34}$ Certainly both of these aspects can be retained in the thought of Le Corbusier, but above all, the first aspect is more characteristic and remarkable in his thinking. The architect's understanding of this technological impact on the cognitive system can be framed by what writer Roland Barthes realized later on: "The bird's eye view [...] gives us the world to read not only to perceive; this is why it corresponds to a new sensibility of vision; in the past, to travel [...] was to be thrust into de midst of sensation, to perceive only a kind of tidal wave of things; the bird's eye view, on the contrary, [...] permits us to transcend sensation and to see things in their structure." ${ }^{35}$

\footnotetext{
29 "Machine et mémoire", in op. cit., p. 460.

${ }^{30}$ Ibid., p. 460.

${ }^{31}$ Ramirez III, Enrique Gualberto. Airs of Modernity. 1881-1914. Doctoral Thesis. Director: Edward A. Eigen. Princeton University, School of Architecture, 2013, pp. 8-9.

${ }^{32}$ Friedrich Nietzsche, "The Spirit of Gravity", in op. cit., p. 210.

${ }^{33}$ Le Corbusier, Sur les 4 routes. Paris: Gallimard, 1941, p. 125.

${ }^{34}$ Deriu, Davide. "The Ascent of the Modern Planeur: Aerial Images and Urban Imaginary in the 1920s", in Emden, Christian; Keen, Catherine; Midgley, David (editors). Cultural History and Literary Imagination, vol.7; Imagining the City, vol.1. Oxford: Peter Lang, 2006. pp. 189-211.

${ }^{35}$ Barthes, Roland, “The Eiffel Tower”, in Sontag, Susan (editor), A Roland Barthes Reader. London: Vintage, 1993, p. 242.
} 
More than a tool between man and nature, the plane was, for the architect's mind, an object which spirit of creation could be equaled to works of the Western civilization such as the Parthenon: "L'avion a mobilisé l'invention, l'intelligence et la hardiesse: l'imagination et la raison froide. Le même esprit a construit le Parthénon" ${ }^{36}$ During his trip in Latin America, the plane turns into the instrument that allows Le Corbusier to unveil the secrets hidden at ground height. It makes these secrets transparent and leaves those large urban articulations in evidence. Being constituted as a kind of urban inebriation, a vertigo from the heights, in this way it takes hold of Le Corbusier and corresponds, in his city observation strategies, to a second break with the derived method of Camillo Sitte, based on the perspective view, that so much had seduced him, back to 1915 . $^{37}$

As Jean-Louis Cohen points out in his article "L'ombre de l'oiseau planeur", the plane would have been in Le Corbusier's mind a multiple operator, a vector of visual acuity, but also the founder of a civic morality. This urban condenser would have assumed the status of a magical instrument, of a flying camera obscura. It allowed the architect to develop a point of view, which is both material and theoretical, in relation to field of its action and projects. ${ }^{38}$

According to Le Corbusier's hypothesis for São Paulo, the plane is used to attain a new perspective that would allow him to accurately resize and characterize the challenges that the city was facing. Through this visual means to attempt the reconciliation of the contradiction between the constitution of a Poiesis and the terrestrial myth of technology, the Swiss surpasses the theoretical understanding that the set of technicians and local engineers possessed of that territory.

\section{Conclusions}

The innovative and relevant aspects of Le Corbusier's hypothesis for São Paulo are summed up in three items: the accurate understanding of the geomorphology and physical territory of the city, regarding the technical tools and the historic background that local engineers possessed; the radical conjunction of the urban infrastructure, expressed in high freeways, with major uses for the city (housing, services and commerce); at last, the nonbinding of a hallmark of the city, represented through its broad rivers and floodplains, in regard to the set of infrastructure and utility buildings.

This project also refers to to two elements that assemble the foundational imaginary identity of the city of São Paulo, as expressed by the architect:

"Comme des traits, les autos traverseront l'agglomération trop étendue. Du niveau supérieur des autostrades, elles descendront dans les rues. Les fonds des vallées ne seront pas bâtis, mais libres pour le sport et le parquage des autos de petite circulation. Vous y planterez des palmiers à l'abri des vents. D'ailleurs, vous avez déjà créé un début de parc à arbres et à autos au centre de la ville.

Pour vaincre les sinuosités du plateau mamelonné de Saint-Paul, on peut construire des autostrades de niveau, portés sur des gratte-terre." Le Corbusier ${ }^{39}$

\footnotetext{
${ }^{36}$ Le Corbusier. "Des yeux qui ne voient pas... les avions", in Vers une architecture, op. cit., pp. 83-85.

${ }^{37}$ See his manuscript La Construction des Villes, written from 1910 to 1915: Lausanne: L’Âge d'Homme, 1992 (introduction and transcription by Marc E. Albert Emery).

${ }^{38}$ Cohen, Jean-Louis, "L'ombre de l'oiseau planeur", in Yannis Tsiomis (editor), op. cit., 1998. pp. 58-63.

${ }^{39}$ Précisions, op. cit., p. 242.
} 
The primary nature, valleys and rivers, are present in this idea. What is also present in another instance is the domesticated nature, represented through this horizontal ruler, with cars "sur-roulerez" on the highway and buildings being developed according to this plan. It was something very similar to the existing spacial configuration of the Anhangabaú Valley at the time.

In this project, Le Corbusier considers the hydrography a non-productive value, regardless of its major role in leisure. Le Corbusier believes that the vocation of these areas should be associated with the enjoyment of nature. We emphasize that this non-productive character that Le Corbusier ascribes to the floodplain of Tietê is radically distinct from conceptions according to which floodplain rectification projects would be placed on major traffic routes of the city, as shown in the analyzed projects.

This decoupling between floodplains and the city circulation system is paramount in the debate on contemporary urban problems. However distinct the production process and the sphere, means of circulation and its industries are nodal points in the capitalist economy and can be considered the continuation of a production system in and for the circulation process. ${ }^{40}$

The drawing and the building of São Paulo, however, were at odds with the idea of independence between waterways and transport routes: avenues were constructed buffering creeks or rectifying main water courses, associating almost irreversibly the circulation system and the water system, without setting up a system of green areas and leisure. Thus, by combining our rivers and valleys with circulation circuits of goods and capital, we subordinated these natural elements to global processes of the productive system. So, with this close attachment of the circulation process to the production process, in which goods and capital circulation time act as negative limits over the production time, or the amplitude in which a given grandeur of capital functions as a productive capital, always forcing the circulation time so it ideally reaches zero, ${ }^{41}$ São Paulo's history constrained the valleys to be an incessant site of construction of new roads, growing more distant from the primordial aspects of its geography and the former nature in the worst manner.

Le Corbusier's project appears not only as an antipode of the engineering plans of that time, but also of the current situation of São Paulo. His persistent attempt to re-establish the fracture between a poetic vision of the architecture and the aims of technique endures, for almost eighty years since it had first been formulated, as a provocation - a call for reflection on the contemporary city. The reconstruction of the contradictions that lead not only São Paulo but also other cities to the current critical situation, in conjunction with the development of several projects of research that took place, seem to be the way to build a desirable horizon, just as Le Corbusier tried to accomplish.

\section{Source of images}

1. Photomontage, Guilherme Pianca. Cartography of the Urban Development Secretary of the Municipality.

2. Photograph, unknown authorship (A. Salatini private collection), c. 1930. In Reis, N. G, São Paulo: vila, cidade, metrópole. São Paulo: Prefeitura de São Paulo, 2004.

3. Photograph, unknown authorship, c. 1938. In Maria, Francisco Prestes, Os melhoramentos de São Paulo. São Paulo: Prefeitura Municipal de São Paulo, 1945.

4. Drawing, Le Corbusier. Fundação Le Corbusier, Paris. FLC 30301

\footnotetext{
${ }^{40}$ Marx, Karl, O Capital: Crítica da Economia Política. Livro Segundo - O Processo de Circulação do Capital, Barbosa, Regis; F. Kothe, Flávio R. (transl.). São Paulo: Abril Cultural, 1984, p. 110.

${ }^{41}$ O Capital: Crítica da Economia Política. Livro Segundo - O Processo de Circulação do Capital, op. cit., p. 91.
} 
5. Drawing, João P. Ferraz. In Lysandro Pereira, Relatório: Comissão de Melhoramentos do Rio Tietê. São Paulo: Prefeitura do Município de São Paulo, 1950.

6. Drawing, João Florence Ulhôa Cintra. In Lysandro Pereira, Relatório: Comissão de Melhoramentos do Rio Tietê. São Paulo: Prefeitura do Município de São Paulo, 1950.

7. Drawing, Saturnino de Brito. In Saturnino de Brito, F., Melhoramentos do Rio Tietê em São Paulo: relatório. São Paulo: Governo do Estado, 1926.

8. Drawing, Prestes Maia, 1930. In Toledo, B. L., Prestes Maia e as origens do urbanismo moderno em São Paulo. São Paulo: Empresa das Artes, 1996.

9. Excerpt, in Le Corbusier, Urbanisme. Paris: Editions Crès, 1924.

10. Excerpt, in Le Corbusier, Urbanisme. Paris: Editions Crès, 1924.

11. Postcard, unknown authorship (Le Corbusier's private collection). Guerrero, Salvador, Le Corbusier, Madrid, 1928: Una casa-un palacio. Madrid: Residencia de Estudiantes de Madrid, 2010.

\section{Bibliography/references}

Antliff, Mark, Avant-Garde Fascism: The Mobilization of Myth, Art, and Culture in France, 1909-1939. Durham, NC: Duke University Press, 2007.

Barthes, Roland; Sontag, Susan (editor), A Roland Barthes Reader. London: Vintage, 1993.

Cabral, Gilberto Flores, "O utopista e a autopista: os viadutos sinuosos habitáveis de Le Corbusier e suas origens brasileiras (1929-1936)", in Arqtexto, n. 9. Brasil, Porto Alegre: Universidade Federal do Rio Grande do Sul (UFRGS), 2006.

Casado, Fernando C., Acueductos Romanos en España. Madrid: Consejo Superior de Investigaciones Científicas; Colegio de Ingenieros de Caminos, Canales y Puertos, 2008.

Cohen, Jean-Louis (editor), Le Corbusier - An Atlas of Modern Landscapes. Londres: Thames \& Hudson, 2013.

Cohen, Jean-Louis, “L'ombre de l'oiseau planeur", in Yannis Tsiomis (editor), Le Corbusier: Rio de Janeiro, 1929-1936. Rio de Janeiro: Centro de Arquitetura e Urbanismo do Rio de Janeiro/Prefeitura da Cidade do Rio de Janeiro, 1998, pp. 58-63.

Colquhoun, Alan, “Arquitetura e Engenharia: Le Corbusier e o paradoxo da razão", in Modernidade e Tradição Clássica. São Paulo: Cosac Naify, 2004.

Deriu, Davide, "The Ascent of the Modern Planeur: Aerial Images and Urban Imaginary in the 1920s", in Emden, Christian; Keen, Catherine; Midgley, David (editors). Cultural History and Literary Imagination, vol. 7; Imagining the City, vol. 1. Oxford: Peter Lang, 2006, pp. 189-211.

Frajndlich, Rafael Urano, Tafuri: tempo da cidade longínqua, Doctoral Thesis. Director: Mario Henrique D’Agostino. University of São Paulo, Faculty of Architecture and Urbanism, 2014.

Le Corbusier, Vers une architecture. Paris: G. Crès e Cie, 1923.

Le Corbusier, Urbanisme. Paris: Editions Crès, 1924.

Le Corbusier, Précisions sur un état présent de l'architecture et de l'urbanisme. $2^{\text {nd }}$ Edition. Paris: Éditions Vicent, Fréa \& $C^{\text {ie }}, 1960$.

Le Corbusier, Sur les 4 routes. Paris: Gallimard, 1941, p. 125.

Le Corbusier, Oeuvre complète, 1929-1934. Zurich: Les Édition d'architecture Erlenbach-Zurich

Le Corbusier, "Comotions Sudamericaines. Introduction à un urbanisme sensible", in La Ville Radieuse. Eléments d'une doctrine d'urbanisme pour l'équipment de la civilisation machiniste. Paris: Ed. L'Architecture d'Aujourd'hui, 1935.

Martins, Carlos A. Ferreira, “Uma Leitura Crítica”, in Le Corbusier. São Paulo: Cosac Naify, 2004. 
Martins, Carlos A. Ferreira, Razón, ciudad y naturaleza. La génesis de los conceptos en El urbanismo de Le Corbusier. Doctoral thesis. Director: Adolfo Gonzalez Amezqueta. Escuela Técnica Superior de Arquitectura de Madrid. Madri, 1992.

Marx, Karl, O Capital: Crítica da Economia Política. Livro Segundo - O Processo de Circulação do Capital, Barbosa, Regis; F. Kothe, Flávio R. (transl.). São Paulo: Abril Cultural, 1984.

Meyer, Regina; Grostein, Marta Dora; Biderman, Ciro, São Paulo Metrópole. São Paulo: Editora da Universidade de São Paulo/Imprensa Oficial do Estado de São Paulo, 2004.

Morshed, Adnan, "The Cultural Politics of Aerial Vision: Le Corbusier in Brazil (1929)", in Journal of Architectural Education, vol. 55, n. 4, May, 2002.

Nietzsche, Friedrich, Thus Spoke Zarathustra, R. J., Hollingdale (transl.). New York: Penguin, 2003 (1961).

Oyarzun, Fernando Perez, "Le Corbusier: Latin American Traces", in Cruelty and Utopia. Cities and Landscapes of Latin America. New York: Princeton Architectural Press, 2003.

Pereira, Margareth Campos da Silva; Santos, Cecília Rodrigues dos, Le Corbusier and Brasil. São Paulo: Tessela/Projeto, 1987.

Ramirez III, Enrique Gualberto, Airs of Modernity 1881-1914. Doctoral Thesis. Director: Edward A. Eigen. Princeton University, School of Architecture, 2013.

Seabra, Odette Carvalho de Lima, Os meandros dos rios nos meandros do poder. Doctoral thesis. Department of Geography, Faculdade de Filosofia, Letras e Ciências Humanas - Universidade de São Paulo (FFLCH- USP), São Paulo, 1987.

Simões Junior, J. G., “A urbanística germânica (1870-1914). Internacionalização de uma prática e referência para o urbanismo brasileiro", in Arquitextos, Portal Vitruvius, vol. 97. São Paulo: Online [http://www.vitruvius.com.br/revistas/read/arquitextos/09.097/134], 2008, pp. 1-11.

Tafuri, Manfredo, Projecto e Utopia. Lisboa: Presença, 1985.

Tafuri, Manfredo, "Machine et mémoire: la ville dans l'oeuvre de Le Corbusier", in Lucan, Jacques (editor), Le Corbusier une encyclopédie. Paris: Centre Georges Pompidou, 1987, p. 464.

Tsiomis, Yannis (editor), Le Corbusier: Rio de Janeiro, 1929-1936. Rio de Janeiro: Centro de Arquitetura e Urbanismo do Rio de Janeiro/Prefeitura da Cidade do Rio de Janeiro, 1998.

Volker, Ziegler, “Les Chemins de Le Corbusier de l'autodrome à l'autoroute”, in Tsiomis, Yannis (editor), Le Corbusier: Rio de Janeiro, 1929-1936. Rio de Janeiro: Centro de Arquitetura e Urbanismo do Rio de Janeiro/Prefeitura da Cidade do Rio de Janeiro, 1998. pp. 110-115

Von Moos, Stanislaus, Elements of a Synthesis. Rotterdam: 010 publishers, 2009.

Weber, Bendicht, "L'architecture d'un viaduct", in Tsiomis, Yannis (editor), Le Corbusier: Rio de Janeiro, 1929-1936. Rio de Janeiro: Centro de Arquitetura e Urbanismo do Rio de Janeiro/Prefeitura da Cidade do Rio de Janeiro, 1998. pp. 64-68. 


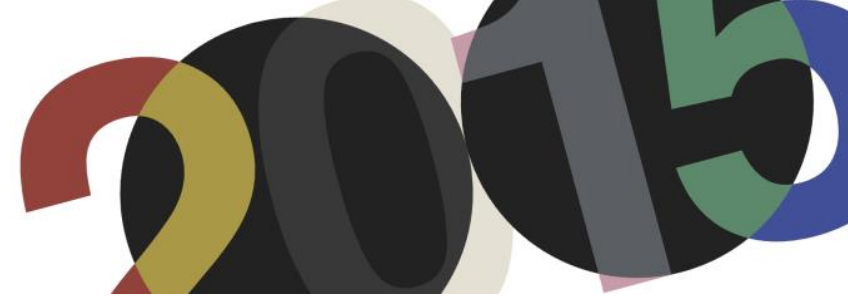

DOI: http://dx.doi.org/10.4995/LC2015.2015.582

\section{La forme du temps à Moscou}

\section{P. Ponce Gregorio}

Escuela Técnica Superior de Arquitectura de Valencia

Resumen: Sería el 2 de septiembre de 1931, mediante carta privada remitida por un tal B. Breslow en calidad de Representante Comercial de la URSS en Francia, cuando Le Corbusier recibe la invitación a participar en el concurso del que sería para muchos el edificio esencial del país, el Palacio de los Soviets de Moscú. Un edificio que en consecuencia, además de encarnar la voluntad de las masas trabajadoras rusas, debía convertirse de manera análoga, alli donde ya se hallaba construida la catedral de El Salvador, en el monumento artístico-arquitectónico de la todavía maltrecha capital soviética. Este y no otro es el punto en el que la presente "forma del tiempo» se inscribe: en el continuo devenir que el proyecto desarrolla dentro del número 35 de la rue de Sèvres de París, a fin de desempolvar parte de aquel rastro creativo velado por la historia, esto es, desandar la linea de los Soviets.

Abstract: It was around september the second, 1931, on a private letter dispatched by some B. Breslow acting as Comercial Representative of the URSS in France, when Le Corbusier received the invitation to participate in the contest of the one that would be for many the essential building of the country, the Palace of the Soviets in Moscow. A building that for that matter would not only enbodies russian's working class will, but also should become in the same way, there where the El Salvador cathedral was built, the artistic-architectural monument of the still struggling soviet capital. This and not else is the point in which the actual Shape of the time'it is enrolled: on the developed by the project inside the number 35 of the rue de Sèvres in Paris, in order to dust off part of that creative trace veiled by history, this is, to walk back along the line of the Soviets.

Palabras clave: Tiempo; composición; simbología; circulación; técnica; Palacio de los Soviets.

Keywords: Time; composition; symbology; circulation; technique; Palace of the Soviets.

\section{Introducción}

Entendemos el proyecto de arquitectura, sin que ello precise remedio, como una fuerza indeleble capaz de construir el pensamiento. Tiene el sentido fundamental de ese «primer esquema o plan de cualquier trabajo que se hace a veces como prueba antes de darle la forma definitiva», según el Diccionario de la Real Academia Española de la lengua. Es por tanto, si nos atenemos al núcleo duro del concepto, cuando encontramos en el proyecto una flamante herramienta para la arquitectura.

Ahora cabría preguntarse qué significa esto de proyecto de arquitectura, pues lejos de ser entendido como mera falacia, las respuestas parecen tener un punto de acuerdo contrapuesto y simétrico: mientras unos hablan de proyecto como realidad ya construida, otros como Zumthor, atendiendo a la etimología de la palabra, escribirán que proyectar significa inventar, un proceso no lineal que, partiendo de la historia de la arquitectura, conduzca, por así decirlo, a un nuevo edificio de un modo lógico y directo ${ }^{1}$.

Este y no otro es el punto en el que la investigación se asienta, en ese espacio de tangencia entre dos esferas tan diferentes como iguales, en esa dimensión donde pentagrama y notas musicales organizan el más ameno de los

\footnotetext{
${ }^{1}$ Zumthor, Peter: Pensar la arquitectura. Barcelona: Gustavo Gili, 2010. pp. 22-23.
} 
conciertos y redactan el mejor de los relatos. Interesa ese punto en el que proyecto y arquitectura estrechan lazos de amistad.

\section{Sobre un proyecto de arquitectura}

Sería en ese momento preciso, una vez entendida la lógica del proyecto, cuando la investigación decidiera viajar a Moscú y acompañar a Le Corbusier en una de sus andanzas por la que entonces era la capital de la URSS. Proyecto y arquitectura debían asentar allí su sede para así, y sólo así, acercar posturas.

Un edificio invisible a la ciudad resultó ser centro de toda mirada, un edificio en la mente proyectado y en el plano construido. El trabajo decidió tropezar con un edificio que, alejado de toda realidad, aún conservara parte esencial de su idea; como si en la no construcción del mismo residiera su propio valor. Decidió tropezar por tanto, con lo que parece no ser nada más que un proyecto de arquitectura, el Palacio de los Soviets.

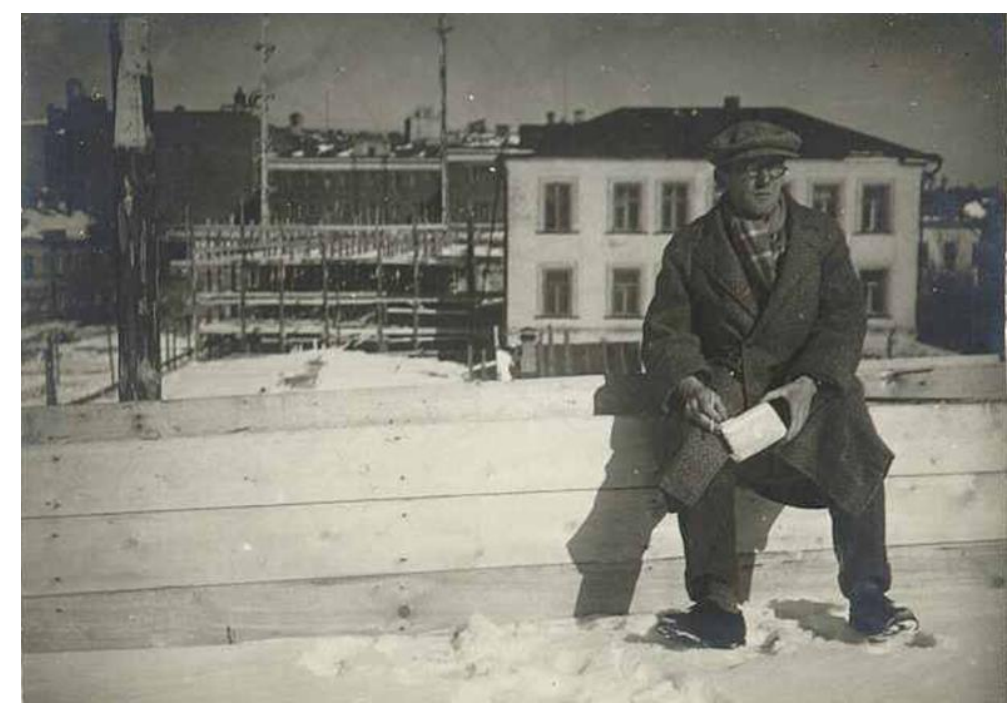

1. FLC_L4-4-162. Le Corbusier tomando anotaciones durante uno de sus viajes a Moscú, marzo de 1930. Fondation Le Corbusier - CFLC-ADAGP.

"Une matinée du mois de mars 1930. La neige couvre encore les immeubles de brique de Moscou. Drapé dans un large manteau de laine, sous une casquette de laine à larges bords et à visière enveloppante, Le Corbusier sourit, un petit carnet à la main. Le carnet est aujourd hui perdu mais, à la place des échafaudages primitifs que l'on aperçoit à l'arrière-plan de la photographie, se dresse encore une construction de béton armé, de métal et de verre: le Centrosojuz, premier grand bâtiment qu'il a l'occasion de réaliser",2.

${ }^{2}$ En castellano (traducción del autor), "Una mañana de marzo de 1930. La nieve cubre todavía los edificios de ladrillo de Moscú. Envuelto en un gran abrigo de lana, bajo una gorra de ala ancha e importante visera, Le Corbusier sonríe, una pequeña libreta en la mano. La libreta se ha perdido pero, en el lugar que ocupan los primitivos andamios del fondo de la fotografía, se alza todavía una construcción de hormigón armado, metal y vidrio: el Centrosoyus, primer gran edificio que tiene la oportunidad de realizar". Fragmento escrito por Jean-Louis Cohen describiendo una fotografía donde Le Corbusier toma notas en su primera visita a Moscú. Véase Cohen, Jean-Louis: Le Corbusier et la mystique de I'URSS. Théories et projets pour Moscou 1928-1936. Bruselas y Lieja: Mardaga, 1987. p. 9. (Fig. 1) 
A través de estas notas rápidas es como Le Corbusier pudo descifrar el código soviético ya desde el principio, pues pronto cayó en la cuenta de que el Palacio de los Soviets era capaz de superar la lógica misma para la que fue gestado. De hecho había quien hablaba de él, con muestras de un anacronismo heredado, como el «edificio esencial del país». Y es que el Palacio debía superar la lógica misma de su edificio, para combinar, con aparente naturalidad, el simbolismo característico de épocas pretéritas con el avance genuino de la modernidad.

Valgan por tanto estas palabras como reunión de ciertas nociones que, amparadas a la sentencia del proyecto, parecen formar parte del ardid ideado por el arquitecto:

\subsection{De la composición}

En marzo de 1991, Alan Colquhoun, quien fuera uno de los críticos de arquitectura más influyentes del último siglo, publica por primera vez su Modernidad y tradición clásica, libro que recopila alguno de los ensayos sin relación aparente escritos por él a lo largo de los años. Es en su segunda parte, bajo el sugestivo título de "Tradiciones y desplazamientos", donde sin ambages, da sus propias pinceladas en torno a Le Corbusier en general y el Palacio de los Soviets en particular.

Es justo ahí donde el autor, en buena lógica, da nombre a aquello de lo que ya apuntaba Choisy cuando precisamente hablaba de «la resolución artística de exigencias imprevistas». Pues la composición del plan corbusierano, según Colquhoun, «requería algo más que simplemente hacer que un edificio se conforme a las líneas limítrofes y a solares de forma irregular. Implicaba hacer entrar en juego un sistema de formas y masas en relación con un observador que ocupa posiciones específicas en el espacio; en una palabra, requería “composición”»".

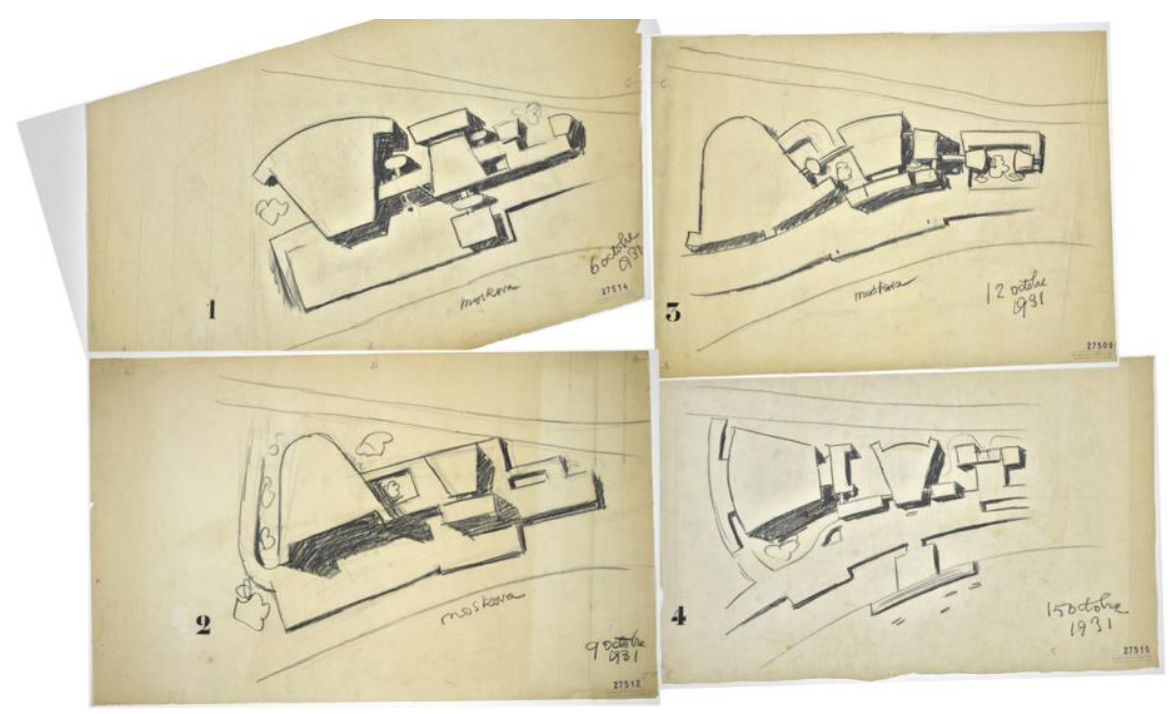

2. Primera parte del panel rotulado como PdS 2824 enviado a Moscú, el 19 de diciembre de 1931, como consecuencia del concurso del Palacio de los Soviets. Aparecen las supuestas cuatro primeras etapas del proyecto, desde el 6 al 15 de octubre de 1931. Los bocetos pueden encontrarse por separado en la Fondation Le Corbusier bajo las siguientes signaturas: FLC_27514, FLC_27512, FLC_27509 y FLC_27510 - OFLC-ADAGP.

\footnotetext{
${ }^{3}$ Colquhoun, Alan: Modernidad y tradición clásica. Madrid: Júcar Universidad, 1991. p. 168.
} 
El análisis de los bocetos y demás planos no cesan en dar indicios fehacientes de lo esquivas que a veces resultan ser las soluciones, pues, las sucesivas deformaciones no son sino huella de un proceso de concepción donde el plan, desprendiéndose de lo sobrante, optimiza el composto ${ }^{4}$ y reduce las formas a rastros elocuentes de un proceso creativo. Le Corbusier se presenta aquí como el arquitecto que proyectando un ideal solventa los pormenores del encaje urbano; la ciudad impone así su condición a una arquitectura que lucha por trascenderla ${ }^{5}$.

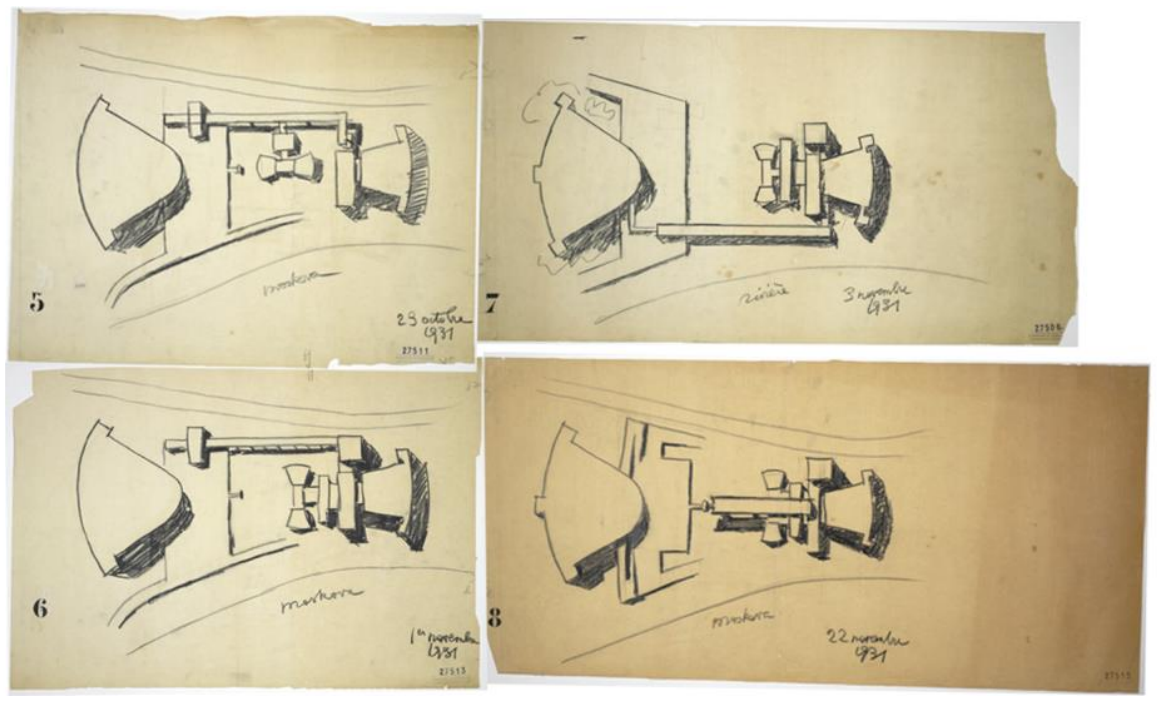

3. Segunda parte del panel rotulado como PdS 2824. Aparecen las cuatro últimas etapas, desde el 23 de octubre al 22 de noviembre de 1931. Los bocetos pueden encontrarse en la Fondation Le Corbusier bajo las siguientes signaturas: FLC_27511, FLC_27513, FLC_27506 y FLC_27515 - OFLC-ADAGP.

Es ahora, a través del trazo tosco y poco cuidado del arquitecto, cuando la composición esboza su discurso y nos avisa de la argucia en la composición pues, si se estudian los planos por separado y se desprenden las fechas de los mismos, es cuando el texto modifica su tono e invierte sus términos. Entendamos ahora que Le Corbusier nos muestra su proceso compositivo desde el final, desde ese elemento óptimo sobre el que la composición se soporta; el último esbozo construido entorno al eje más prosaico que existe, el eje de simetría. Del que escribió en Vers une architecture:

"El eje es, quizás, la primera manifestación humana; es el medio de todo acto humano. El niño que vacila tiende al eje, el hombre que lucha en medio de la tempestad de la vida se traza un eje. El eje es el que pone orden a la arquitectura. Poner orden, es comenzar una obra. La arquitectura se establece sobre ejes. [...] La ordenación es la jerarquía de los ejes, por lo tanto, la jerarquía de los fines, la clasificación de las intenciones "“.

Y es que el eje que vertebra este último boceto es, quizás, lo primero que dibujó el arquitecto en el momento de querer transmitirnos su composición. A partir de ahí, y una vez sentada la base del plan, era cuestión de irle

\footnotetext{
${ }^{4}$ En castellano (traducción del autor), compuesto. Es en el campo del arte y la arquitectura donde el término cobra otro sentido diferente pues, Composto o Bel Composto, término nacido para hablar de los interiores de iglesias, hará referencia a la composición que se genera entre pintura, escultura y arquitectura en el interior de los espacios sagrados.

${ }^{5}$ Castellanos, Raúl: Plan Poché. Barcelona: Arquia/Tesis No 36, 2012. p. 13. En cuyo prefacio se habla de la composición del plan de San Carlo alle Quatro Fontane, Roma, 1635-1641. Obra de Francesco Borromini (1599-1667).

${ }^{6}$ Le Corbusier: Vers une architecture. París: G. Crès, 1923. (Trad. esp.: Hacia una arquitectura. Barcelona: Poseidón, 1977. p. 151).
} 
enturbiando el semblante al proyecto; como si el descomponer formara parte del proceso de composición, pues a veces, cada retroceso no es más que un avance en una dirección distinta.

Es llegados a este punto cuando no deja de extrañar la confianza que el arquitecto encomendaba al trabajo compositivo de la planta, pues tal y como dice Jorge Torres en "La arquitectura es la circulación”, no hay que olvidar que «Le Corbusier recibe la herencia de la tradición académica por la cual le plan, la planta, es la generadora de la arquitectura y la que establece un orden previo. El orden de la planta, garantizaba una concepción precisa» ${ }^{7}$.
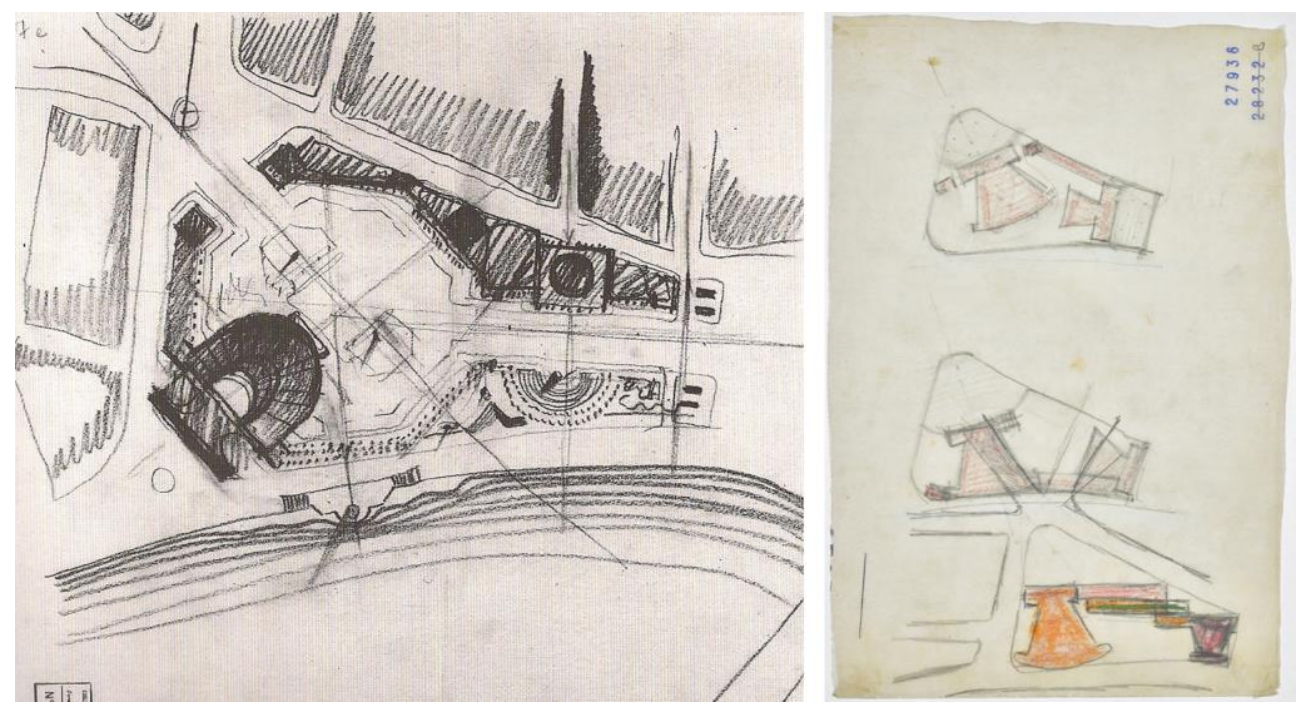

4. Uno de los bocetos iniciales de la propuesta de Auguste y Gustave Perret para la segunda convocatoria -por invitación- del Concurso del Palacio de los Soviets, 1931. Institut Français d’Architecture, París. // FLC_27936B. Tres bocetos iniciales de la propuesta de Le Corbusier, realizados entre el 1 y el 6 de octubre de 1931, en los que se estudian diferentes posibilidades de ocupación dentro de la parcela - OFLC-ADAGP.

Otros como Perret, por volver a la otra propuesta francesa presentada, confiarán también en la planta como mecanismo de composición elemental aunque con criterios aparentemente enfrentados. Pues Perret desde el principio quiso reconocer en su edificio aquella plaza que en su día circundaba la catedral de El Salvador, un espacio que, abrazando a un eje, obliga a la edificación a construir el perímetro que lo delimita. Y es que bien se podría decir que para Perret el eje era lo inevitable a evitar; el eje construía sin ser construido.

En cambio para Le Corbusier, tal y como revelan sus bocetos más incipientes, la construcción entorno al eje habría de ser condición fundamental. Y es que, de no ser esto cierto, a qué se deberían todas esas figuras simétricas gobernadas en algunos casos por líneas que cruzan sus mitades, sino a una suerte de ley que redefine al eje como lo inevitable a no evitar. De hecho, a propósito de la visita que el arquitecto realizara 20 años atrás a la casa del Poeta trágico en Pompeya, asevera en Vers une architecture que todo tiene su eje: «el eje está en las intenciones y en la dignidad que este confiere a las cosas humildes que en él se acomodan. El eje no es aquí un elemento teórico, sino una herramienta capaz de unir los volúmenes capitales» ${ }^{8}$.

\footnotetext{
7 Torres, Jorge: "La arquitectura es la circulación". En Torres, Jorge (Coord.): Le Corbusier. Mise au point. Valencia: General de Ediciones de Arquitectura, 2012. p. 232.

${ }^{8}$ Le Corbusier: Vers une architecture. París: G. Crès, 1923. (Op cit. p. 153).
} 
Es por eso que Le Corbusier, sistematizando la disciplina de la arquitectura hasta la más postrera de sus consecuencias, hallara explicación lógica al decurso de su plan, esto es, concediera a cada pieza del programa un tamaño distinto y preciso donde la planta, reducida ya a formas simples, terminara por conformar una constelación de figuras distribuidas por la mano del arquitecto.

Un eje imaginario, a veces recto, a veces quebrado ${ }^{9}$, sería el encargado por tanto de ordenar los continuos vaivenes del proceso compositivo del plan. Pues tal y como apunta Froebel, el que fuera referente del pequeño Jeanneret, es de esta manera como «el hombre ya desde su infancia busca un punto de unión, una unidad, en esa pluralidad de cosas particulares. Unión y unidad que, fundándose en una ley profunda y necesaria, haga comprensible la multitud desordenada de las cosas». Para más adelante apuntar que «el corazón del niño se tranquiliza con el presentimiento de esa unidad, pero su inteligencia no se satisface hasta que más tarde la descubre y conoce» ${ }^{10}$.
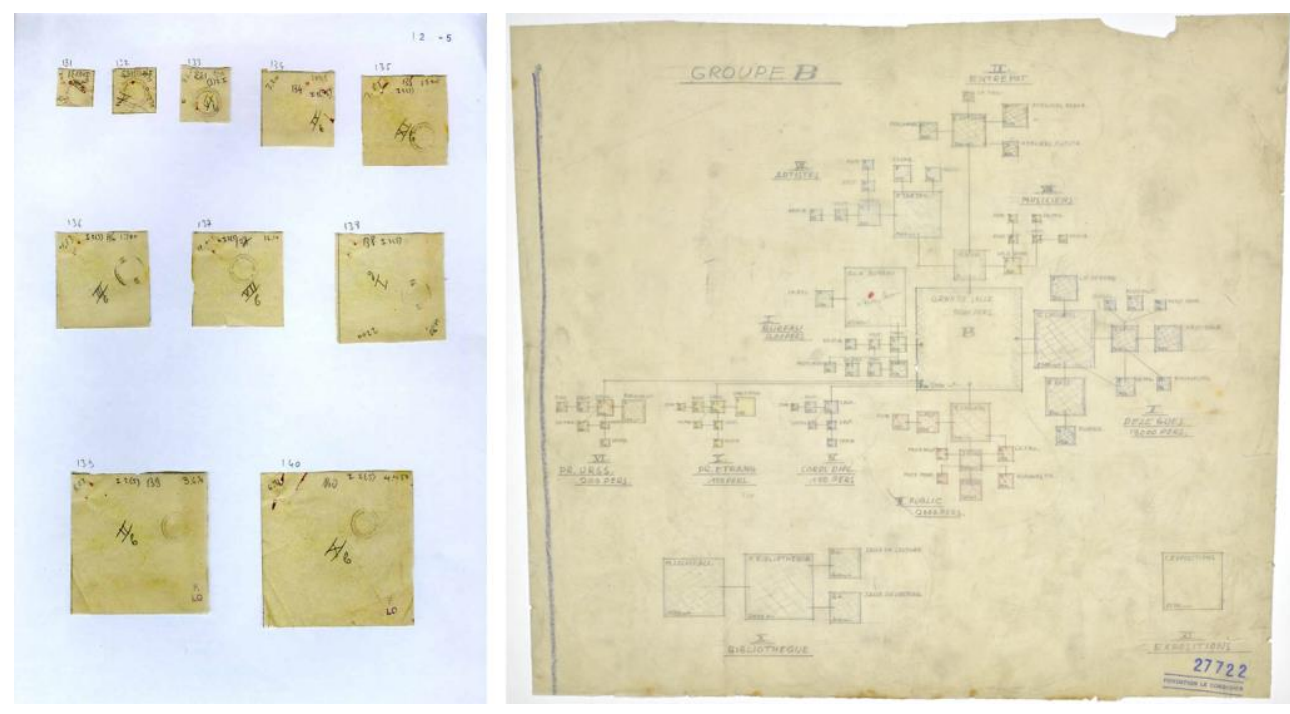

5. FLC_I2-5-104-004. Diferentes piezas recortadas por Le Corbusier correspondientes a los distintos paquetes de programa del grupo B del Palacio de los Soviets, 1931. Fondation Le Corbusier - OFLC-ADAGP. // FLC_27722. Organigrama funcional relativo al grupo B detallado en las condiciones generales de proyecto - OFLC-ADAGP.

Este, o similar, debió ser el exordio que hubo de inspirar a Josep Quetglas en uno de los pasajes de Le Corbusier Plans, donde escribe que «los ocho esquemas de Le Corbusier ayudan a entender el desarrollo intrauterino del proyecto aunque ya avisara de un falso camino para llegar a su arquitectura. La construcción de un violín es muy interesante, y el violín bien hecho está probablemente muy bien, pero no se debe confundir con la música que desprende» ${ }^{11}$.

\footnotetext{
${ }^{9}$ Ibídem, p. 153. Cuando, a propósito de la visita a la casa del Poeta trágico en Pompeya escribe: «todo tiene su eje, pero sería difícil pasar en línea recta. [...] Cuando se visita la casa del Poeta trágico, se constata que todo está en orden. Pero la sensación es rica. Se observan entones las deformaciones hábiles del eje que dan intensidad a los volúmenes».

Froebel, Friedrich: La educación del hombre. Madrid: Daniel Jorro, Editor, 1913. p. 184. El que fuera pedagogo alemán creador de la educación preescolar e inventor de numerosos juegos de «composición elemental» mediante piezas simples como cubos, cilindros y esferas.

${ }^{11}$ Véase: "Le Corbusier. DVD Plans n4". En Quetglas, Josep: L'architecture. París: Fondation Le Corbusier, 2010. pp. 6-7. (Trad. esp.: La arquitectura). Cuando en la segunda parte habla del proceso compositivo corbusierano.
} 


\subsection{De la simbología}

París, 1931. Aquel eje tan manido y conocido procura ahora asir curvatura para a la vez izarse del plano en el que se hallaba recostado; debía desprenderse del seudónimo que le ocultaba, y, manifestando su excelencia, formar parte del mundo contingente de lo vertical. Debía darse a conocer y enaltecer las más puras manifestaciones de la arquitectura; debía ser construido y desvelado su verdadero nombre, arco.

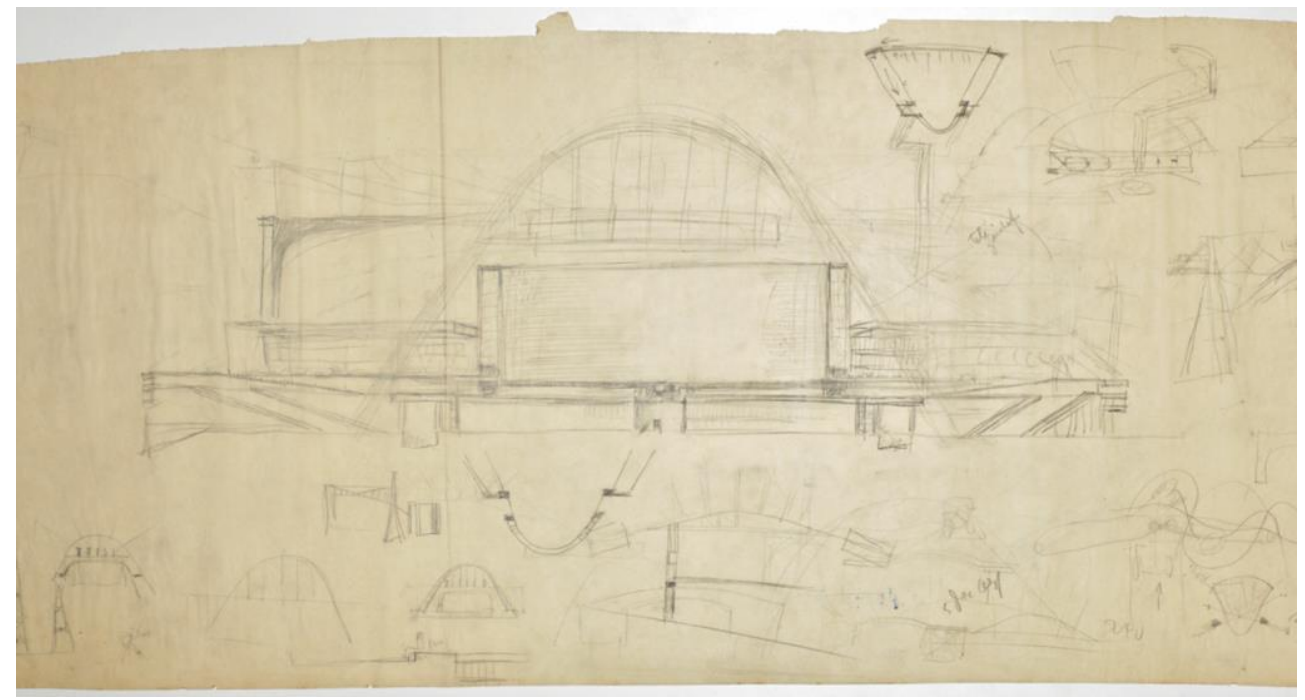

6. FLC_27494. Boceto fechado el 5 de diciembre de 1931 en el que Le Corbusier tantea el arco parabólico - OFLC-ADAGP.

Y es que entender que este trazo que soporta el Palacio es un eje curvado, no es más que obedecer a la etimología que nos educa el pensamiento, pues una de sus acepciones según el Diccionario de la Real Academia Española de la lengua, adoleciendo de cierta retórica, nos advierte a ser «sostén principal de una empresa».

El eje es para Le Corbusier orden y concierto, herramienta generosa; un elemento que sancionado por las leyes de la costumbre, apenas se hubo atrevido a transgredir la dictadura rígida de la composición. Pero el eje es además sinónimo de idea y designio, propósito o finalidad; una regla en torno a la cual se posibilita su entendimiento y construcción, el centro de toda cosa. Es por ello que, lejos de ser entendidos estos por Le Corbusier como trazados estrictos del plan, son realidades consumadas, pues «en la realidad los ejes no se perciben a vuelo de pájaro como los muestra el plano en la mesa de dibujo, sino sobre el suelo, cuando el hombre está de pie y mira al frente. El ojo ve incluso más allá de las intenciones y de las voluntades» ${ }^{12}$.

La vida de las formas no siempre ha avanzado al ritmo de los tiempos, sin embargo parece que en este arco parabólico el proceso sí se ha correspondido; pues surgiendo como consecuencia de la más absoluta necesidad, el arco se ha ido engalanando de alhajas, llenas todas de significado, para pronunciar en el Palacio el más poético de los discursos. Hay quien decía incluso que este arco no era más que mero homenaje a ciertas estructuras que Eugène Freyssinet venía construyendo desde hacía ya diez años: sea el caso de ciertos puentes, o los más que conocidos hangares para dirigibles de Orly; estructuras gestadas como fruto de la más absoluta necesidad parecen tener en el Palacio un significado bien distinto pues, según sostiene Josep Quetglas,

\footnotetext{
${ }^{12}$ Le Corbusier: Vers une architecture. París: G. Crès, 1923. (Op cit. p. 151).
} 

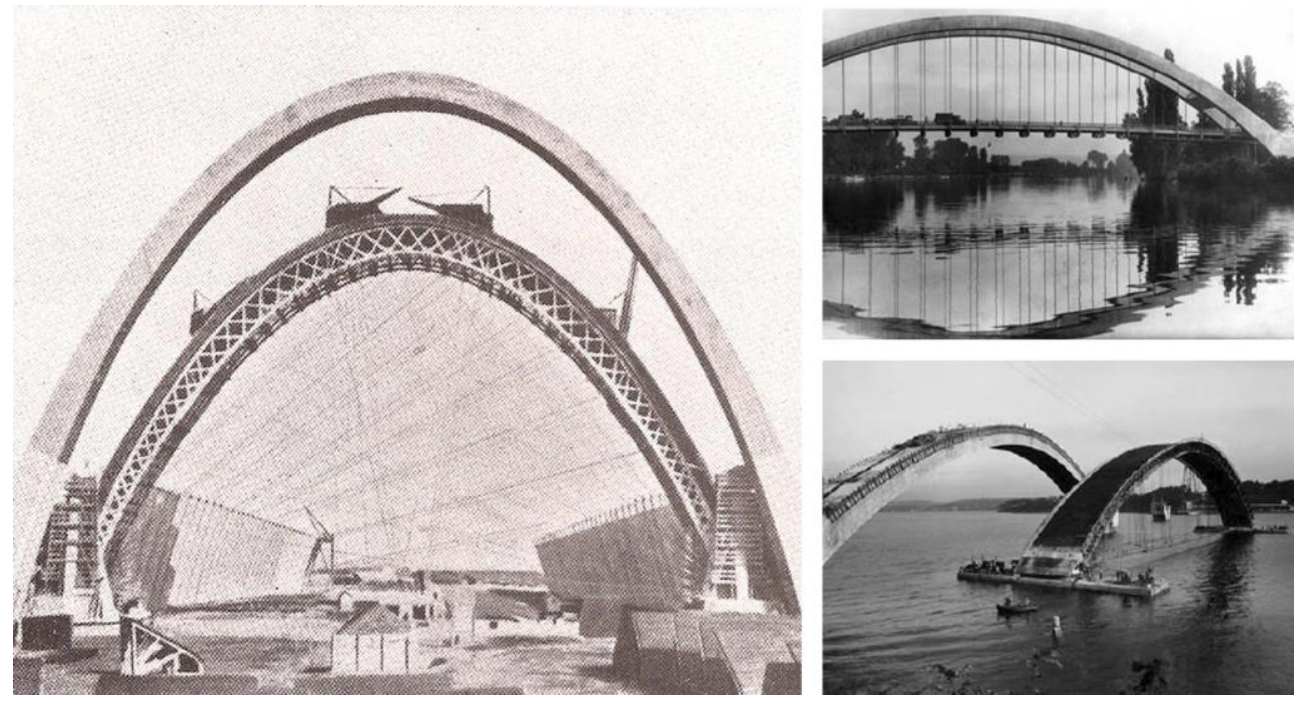

7. Construcción de uno de los arcos que terminarían por conformar los hangares para dirigibles de Orly, 1917-1921. Obra del ingeniero francés Eugène Freyssinet (1879-1962). // Puente de hormigón y acero construido sobre el río Sena a la altura de Saint-Pierre du Vauvray, 1923. // Desplazamiento de la cimbra del puente de Plougastel, 1925-1930.

"para entender la mirada de Le Corbusier sobre el arco de los Soviets hay que olvidar el hormigón y dirigirla a su primer viaje a Moscú, en 1928, cuando pone pie a tierra en la estación de Bielorrusia y dibuja el suelo curvo, los paneles de madera de la acera, la catedral, el arco de triunfo de la victoria sobre Napoleón, la maleta en el suelo, una caja, un carro y ... un caballo, con el collar habitual de las bestias de carga rusas, tanto en el campo como en la ciudad, que sorprenden al occidental. Se trata de un collar de madera clara, curvado en arco parabólico, que no toca el cuello del animal,"13.

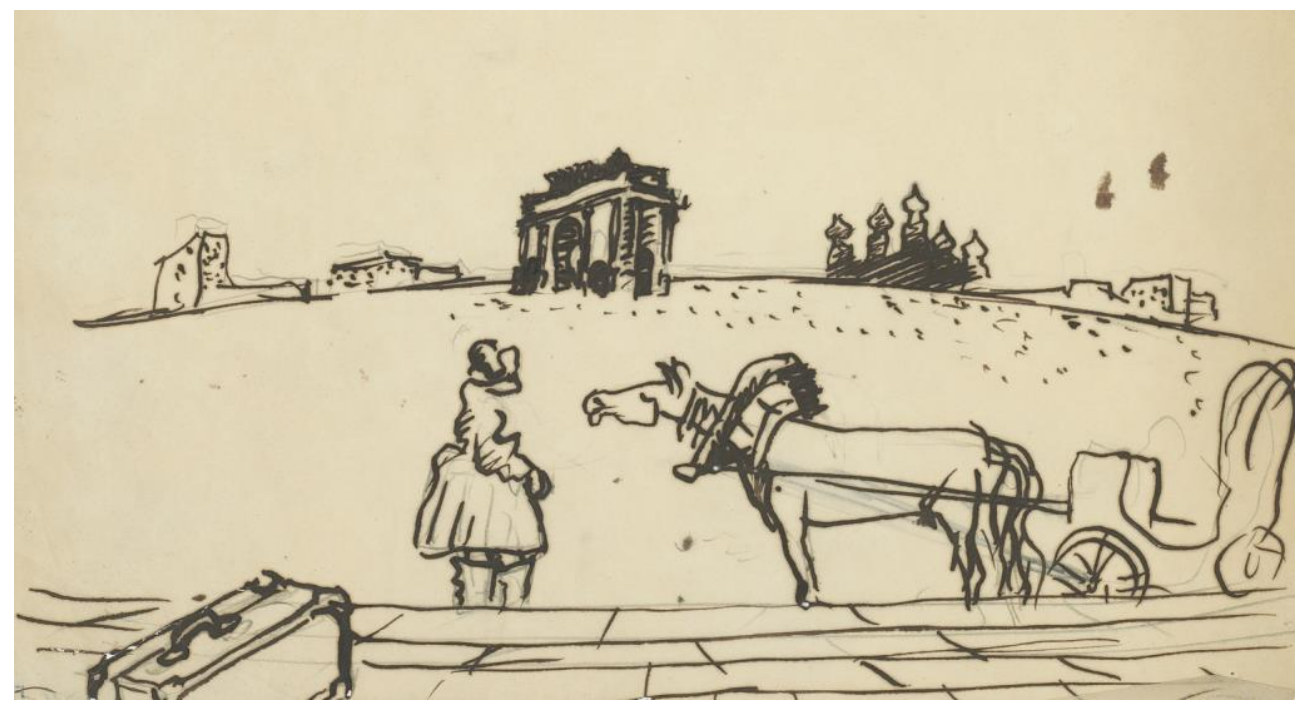

8. FLC_5540. Boceto realizado por Le Corbusier nada más llegar, en octubre de 1928, a la estación de Bielorrusia en Moscú. Donde aparece el Arco de Triunfo Osip Bove de la victoria sobre Napoleón y la silueta del muro del Kremlin junto a la Catedral de San Basilio - CFLC-ADAGP.

${ }^{13}$ Véase: "Le Corbusier. DVD Plans nº4". Op cit. pp. 8-9. (Fig. 8) 
A la vista de un boceto así, es donde uno se sorprende de la capacidad de mirar del arquitecto, pues es que ya desde el primer vistazo parecían estar asentadas las bases del proyecto. Bastaba el horcate que abrazaba el cuello del caballo para ver en ello el «segundo arco de triunfo de la ciudad» y hacer de esta historia una nueva página del libro de Le Corbusier, donde se nos muestra y define como un ser sin voluntad; como si nada fuese con él, con la única pretensión de ser mera hoja en blanco en la que la historia escribe ${ }^{14}$.
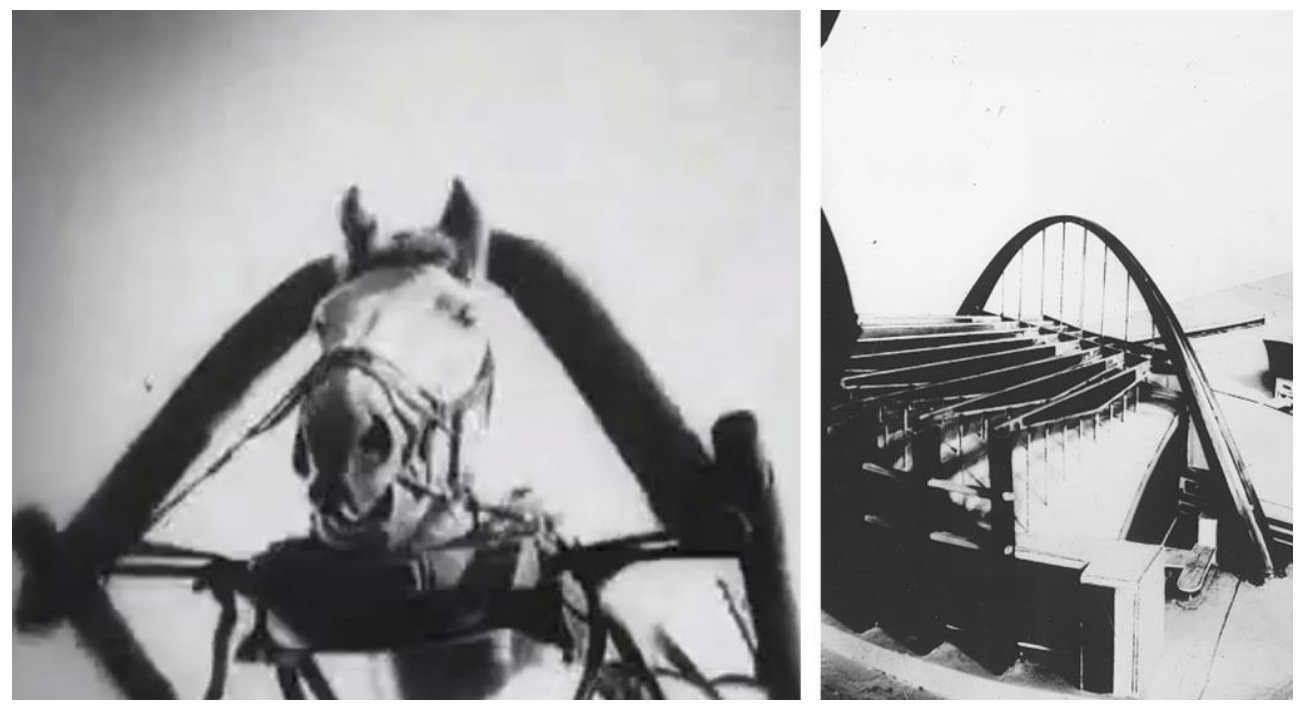

9. Fotograma de la película "La línea general", conocida en español como "Lo viejo y lo nuevo", donde se recalca la importancia del trabajo animal para el avance del hombre (min. 1,43,34), 1929. URSS. Dirigida por Serguéi M. Eisenstein (1898-1948). // FLC_L3-19-53. Fotografía de Lucien Hervé donde se muestra el arco parabólico que soporta la Sala A del Palacio de los Soviets, 1934. Fondation Le Corbusier - OFLC-ADAGP.

Pocos días pasaron desde su llegada «cuando Eisenstein le presentó (a Le Corbusier) unas bobinas de La línea general, donde los carros eran tirados por bueyes enganchados con estos mismos collares hasta pasar por delante de las cooperativas lecheras de arquitectura funcionalista ${ }^{15}$.

Es ahora, haciendo provechoso el trance concedido por esta fortuita convergencia, cuando aquellos arcos de Freyssinet parecen no ser el motivo de la decisión, y sí, un sentimiento de nihilismo controlado el que dotase de luz al sistema, de hecho, es la similitud de ciertos planos de la película con fotografías de la maqueta lo que hace innegable la alianza entre esta arquitectura y el cine.

En efecto, y una vez asociado Le Corbusier a La línea general es cuando nada impide, aprovechando la amplitud que la imaginación siempre nos ofrece, asociar el esqueleto marcado en la piel de un animal todavía vivo con la estructura de las grandes salas de los Soviets; entendidos ambos como ramificaciones dependientes de un elemento regulador, sea la columna vertebral en el animal o el eje simétrico en el plan. En el que caso de que ya llegados a este punto de tangencia, no sean lo mismo.

\footnotetext{
${ }^{14}$ Véase la conferencia titulada "Immeubles-villas de Le Corbusier y arquitectura cartuja: constantes de proporcionalidad" a cargo de la arquitecta portuguesa Marta Sequeira el 24 de octubre de 2013 en la ETSAV; la cual, desmintiendo todo lo dicho por Le Corbusier en torno a la importancia que en él tenía la historia, planteaba la posibilidad de entender sus viajes como ratificación de un modelo ya preconcebido de antemano.

${ }^{15}$ Véase: "Le Corbusier. DVD Plans n4". Op cit. p. 9. (Fig. 9)
} 

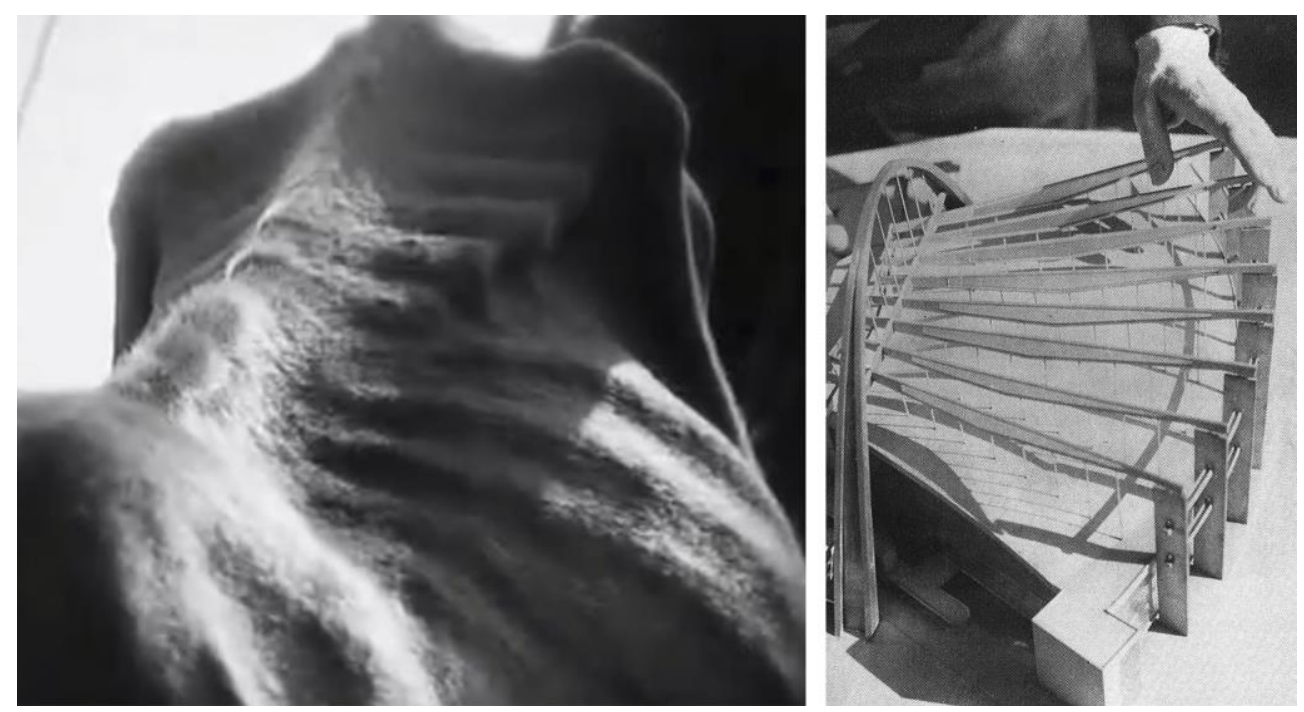

10. Instante de "La línea general" en el que, mediante un plano corto, se pretende mostrar la consecuencia que el trabajo supone a las «bestias de tiro» soviéticas (min. 0,10,18). // Fotografía de André Limot donde Le Corbusier manipula la cubierta de la Sala A del Palacio de los Soviets, 1934. Fondation Le Corbusier - OFLC-ADAGP.

El edificio pues, desde el arco a la estructura misma de las salas, no es otra cosa que reflejo de una sociedad abocada al fracaso que además, dada la contingencia, debía ajustarse el yugo y tirar de la cuadriga para así poder aspirar al más puro e inaccesible de los ideales. Y es que a pesar de los escombros y sucios andamios descuidados por doquier ya parecía alzarse, clara y nítida, la silueta de aquel edificio grandioso. La auténtica torre de Babel, aquella que no pretendía acercar a los hombres al cielo, sino el cielo a los hombres.
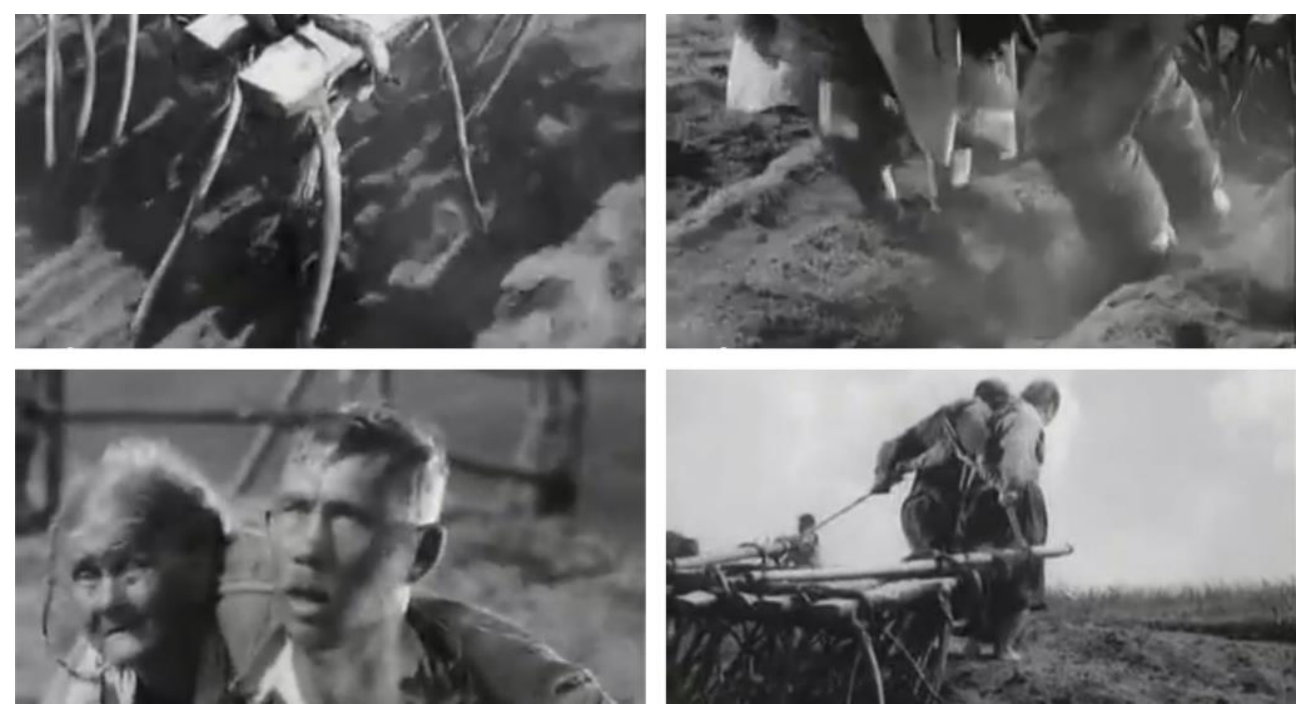

11. Secuencia de "La línea general" en la que se muestra el instante en que dos campesinos se ven obligados a tirar de los aperos de labranza justo después de la muerte de su animal (de arriba abajo y de izquierda a derecha: del min. 0,17,16, al min. $0,17,43$ ). Momento en el que se ejemplifica la precariedad de las formas de trabajo soviéticas y el irrevocable anhelo de la sociedad por alcanzar la más elevada de las aspiraciones.

En este sentido, será de nuevo Josep Quetglas el encargado de manifestar aquel cariz que el Palacio de Le Corbusier quiso entregar al mundo: 
"No importa que el ruso pueda reconocer los trazos en la enorme escala de la URSS, de este nuevo gancho que debía tirar del país. El Palacio de los Soviets: no es un arco de triunfo del tiempo industrial, no es una escenografía pasiva y declamatoria, sino una herramienta para el trabajo y la acción que lleva lejos, una máquina para cambiar el mundo" ${ }^{\prime 6}$.

Pero sería llegados a este punto cuando el arquitecto, en lo que aparenta ser la prueba de un alzado todavía por resolver, dota de una nueva variable a la ecuación que venimos planteando. $\mathrm{Y}$ es que, en uno de los márgenes del papel es donde el yugo se convierte ahora en silla de montar para un Lenin que obligatoriamente debía presidir la composición -tal y como reclamaba aquel Consejo Ejecutivo al que se subordinó la propuesta ganadora-. No es de extrañar entonces que Le Corbusier, obcecado ya por la construcción del Palacio, modificara su discurso y convirtiera aquel horcate que debía tirar del país, en la montura de un Lenin invisible que reposaba sobre un animal encargado de representar el trabajo del hombre soviético, esto es, el Palacio de los Soviets.
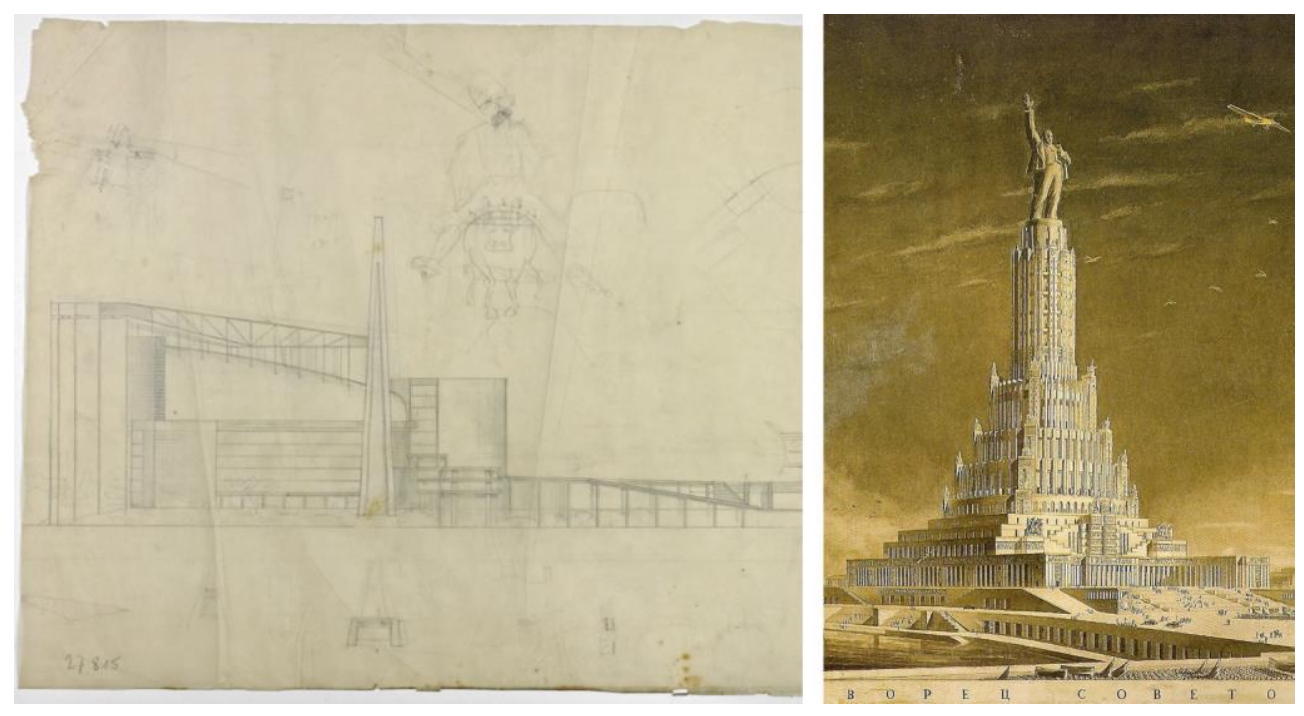

12. FLC_27815. Alzado longitudinal del Palacio de los Soviets visto desde el río Moskova. En el margen superior izquierdo, dibujo de la figura de Lenin sobre uno de los típicos animales de carga soviéticos - OFLC-ADAGP. // Perspectiva. Sexta convocatoria -cerrada-. Propuesta definitiva de Boris M. Iofan, Vladímir A. Shchuko y Vladímir G. Gelfreikh, 1931.

\subsection{De la circulación}

"Dibujo un personaje. Lo hago entrar en la casa; descubre su volumen, tal forma de habitación y sobre todo tal cantidad de luz que entra por la ventana o el panel de cristales. Avanza; otro volumen, otra llegada de luz. Más lejos, otra fuente luminosa; más lejos aún, inundación de luz y penumbra al lado, etc", ${ }^{\prime 1}$.

Circular es caminar, moverse en derredor. Experimentar, descubrir y aprender incluso, es también circular. Un verbo cuya acción, circulación, le ha servido a la arquitectura para definir el interludio que permite poner de acuerdo sus estancias, y es que desde un punto de vista funcional qué es la circulación sino mero vehículo de

\footnotetext{
${ }^{16}$ Ibídem, p. 9.

${ }^{17}$ Le Corbusier: Précisions sur un état présent de l'architecture et de l'urbanisme. París: Éditions Vincent, Fréal et Cie, 1930. (Trad. esp.: Precisiones respecto a un estado actual de la arquitectura y el urbanismo. Barcelona: Poseidón, 1999. p. 154). Dentro del capítulo «El plano de la casa moderna», donde describe los bocetos número 121, 122. (Fig. 13a)
} 
conducción; un artilugio capaz de hacer funcionar la máquina más inexacta. De hecho, será Alexander Klein el que mediante sus estudios gráficos sobre vivienda destacase la importancia de estas circulaciones a la hora de alcanzar el "mínimo existencial" y así ratificar el pensamiento funcional más puro, es por ello que, «espacios de comunicación demasiado grandes y recorridos demasiado largos, derivados de una desfavorable distribución de la planta, provocan un aumento de superficie» ${ }^{18}$.

Podríamos decir entonces que la modernidad peor entendida, quedándose en lo somero de la cuestión, lucha por soltar lastre y desprenderse de aquello que a estas alturas parece no ser más que un trámite entre dos espacios que anhelan entrar en contacto. Como si en la no existencia de este tránsito radicara su propio éxito; para la arquitectura actual en palabras de Jorge Torres, «la circulación es lo inevitable a evitar» ${ }^{19}$.
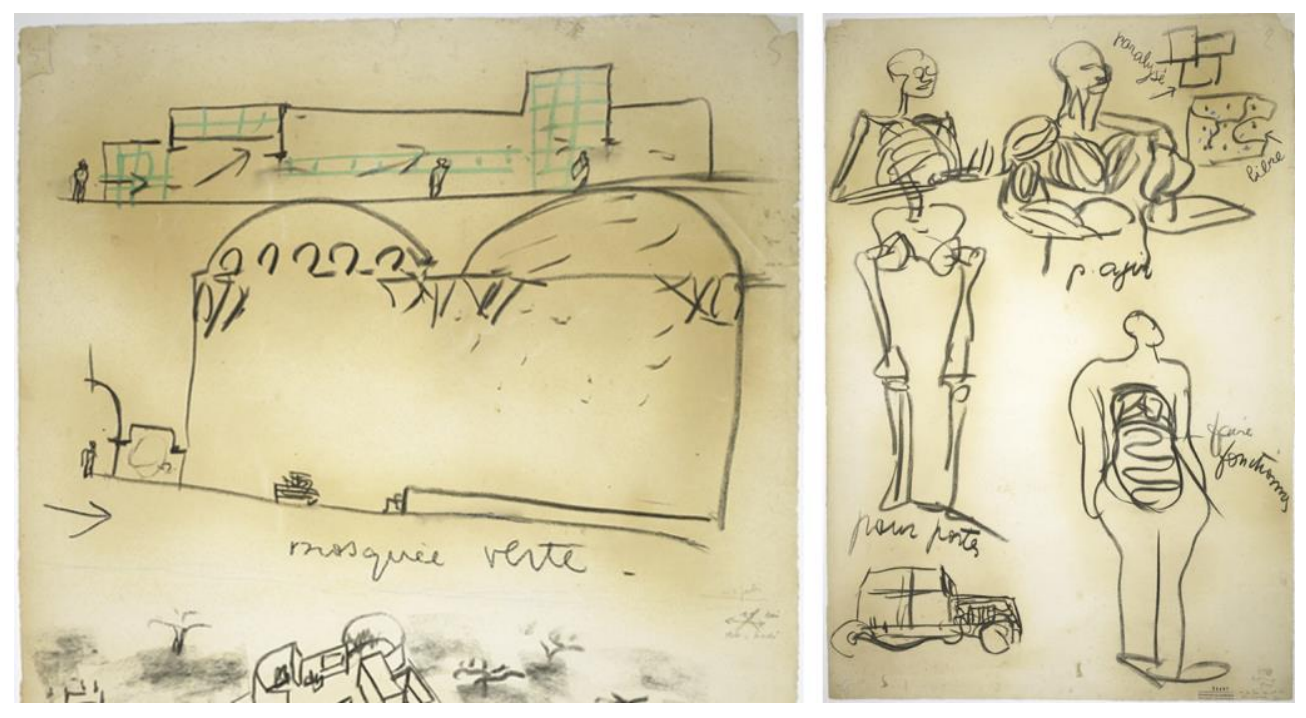

13. FLC_33493. Bocetos en los que Le Corbusier esboza su manera de entender el recorrido arquitectónico tomando como ejemplo la mezquita Verde de Brousse - OFLC-ADAGP. // FLC_33497. Comparativa del plan paralysé de la casa antigua con el plan libre de la casa de la modernidad - OFLC-ADAGP.

El 11 de octubre de 1929 fue viernes. Día de la quinta conferencia que Le Corbusier debía impartir en Buenos Aires a «los amigos de las artes», turno entonces de "el plano de la casa moderna" recogido en Précisions sur un état présent de l'architecture et l'urbanisme, donde el arquitecto, partiendo del plan paralysé ${ }^{20}$ de la casa de piedra, nos revela parte esencial de su parti ideal:

“Un poco de biología previa: este armazón para aguantar, unos rellenos musculares para actuar, esas vísceras para alimentar y hacer funcionar.

\footnotetext{
${ }^{18}$ Klein, Alexander: Vivienda mínima: 1906-1957. Barcelona: Gustavo Gili, 1980. p. 33. Donde aporta un nuevo método de investigación sobre plantas de pequeñas viviendas.

${ }^{19}$ Torres, Jorge: "La arquitectura es la circulación”. Op cit. p. 213.

${ }^{20}$ En castellano (traducción del autor), planta paralizada. De esta manera Le Corbusier habla de la casa de la Academia al inicio de la quinta conferencia pronunciada en Buenos Aires a «los amigos de las artes», fechada el viernes 11 de octubre de 1929, comparándola con la planta libre de la casa de la modernidad.
} 
Un poco de construcción automóvil: un chasis, una carrocería, un motor con sus órganos de alimentación y de evacuación ${ }^{, 21}$.

$\mathrm{Y}$ es que precisamente son esas mismas vísceras, ahora convertidas en ligeros conductos eléctricos y tubos metálicos, las que con intrínseca flexibilidad abrazan los órganos rígidos del vehículo esbozado en la parte inferior, justo en la esquina opuesta a dos plantas que pelean por acercar posturas: donde una, paralizada por el trazado grueso de su poché, se contrapone a la libertad de movimientos de un plan corbusierano amparado a la sentencia de la mobilité. Es ahora, una vez limada la más postrera de las asperezas, cuando se hace evidente la importancia que para el plan libre posee la circulación:

\section{"L'architecture, c'est de la circulation".}

«La arquitectura es la circulación» es el lema conque, mal traducido en la versión castellana como «la arquitectura es circulación», Le Corbusier en su segunda conferencia nos alerta de ella no como elemento a resolver la función, sino como herramienta capaz de otorgar validez a un plan que, a su vez, le permitiera ahondar en el trasfondo de la arquitectura y asentar las bases de su tratado. Cómo se explica sino, la frase que sigue a la ya escrita, y que la consuma diciendo:

“Mediten esta frase, -la circulación- condena los métodos académicos y consagra el principio de los pilotis",22.

Pues son esos mismos pilotis los que elevan el impulso de las intenciones y hacen del plano del suelo un continuum donde lo natural permanece y la poesía queda intacta. Pero el piloti es también «la consecuencia del cálculo y el resultado elegante de la tendencia moderna a la economía -en este punto tomada en su sentido más noble-. Pilote: es atribuir a unos puntos determinados el cuidado de soportar, según un cálculo exacto, unas cargas precisas, sin ningún desperdicio» ${ }^{23}$.

El piloti será, por tanto, elemento sancionador y subversivo de toda creencia aún sujeta a la rigidez de la Academia, siendo la nueva técnica que lo construye, entendida como base misma del lirismo, la que permita esta nueva arquitectura en torno a una circulación libre por la que el hombre se desplaza. Tanto es así que Le Corbusier en 1929, bajo la dirección de Pierre Chenal, supo utilizar el cine como vehículo de explicación de su arquitectura $^{24}$. L'arquitecture d'aujourd'hui de 10,19 minutos de duración, pasó a convertirse en su flamante herramienta donde tratar de desvelar ese nuevo espíritu para la arquitectura y el hombre que la examina. De hecho, en un momento preciso en que la cámara se eleva, es cuando Le Corbusier ratifica el modelo en no más de tres segundos; justo el tiempo que necesita un niño para con su bicicleta, desobedecer el rastro indeleble que el plan dibuja en el suelo, para sólo así, moverse con libertad en una suerte de gesto similar al que el arquitecto hubo de utilizar a la hora de diseñar el Palacio una vez esos mismos rastros ya se hallaban trazados. Y es que,

\footnotetext{
${ }^{21}$ Le Corbusier: Précisions sur un état présent de l'architecture et de l'urbanisme. París: Éditions Vincent, Fréal et Cie, 1930. (Op cit. p. 146). Dentro del capítulo «El plano de la casa moderna», donde describe los bocetos número 111, 112, 113 y 114. (Fig. 13b)

${ }^{22}$ Ibídem. p. 64. Dentro del capítulo «Las técnicas son la base misma del lirismo. Abren un nuevo ciclo de la arquitectura», correspondiente a la segunda conferencia fechada el 5 de octubre de 1929.

${ }^{23}$ Ibídem. p. 68.

${ }^{24}$ Colomina, Beatriz: "Reflexiones sobre la casa Eames". En RA Revista de arquitectura. 2007, Nº. Pamplona: Servicio de publicaciones de la Universidad de Navarra. p. 13.
} 
como ya se apuntaba anteriormente, no hay que olvidar que «Le Corbusier recibe la herencia de la tradición académica por la cual le plan, la planta, es la generadora de la arquitectura y la que establece un orden previo. El orden de la planta, garantizaba una concepción precisa» ${ }^{25}$.
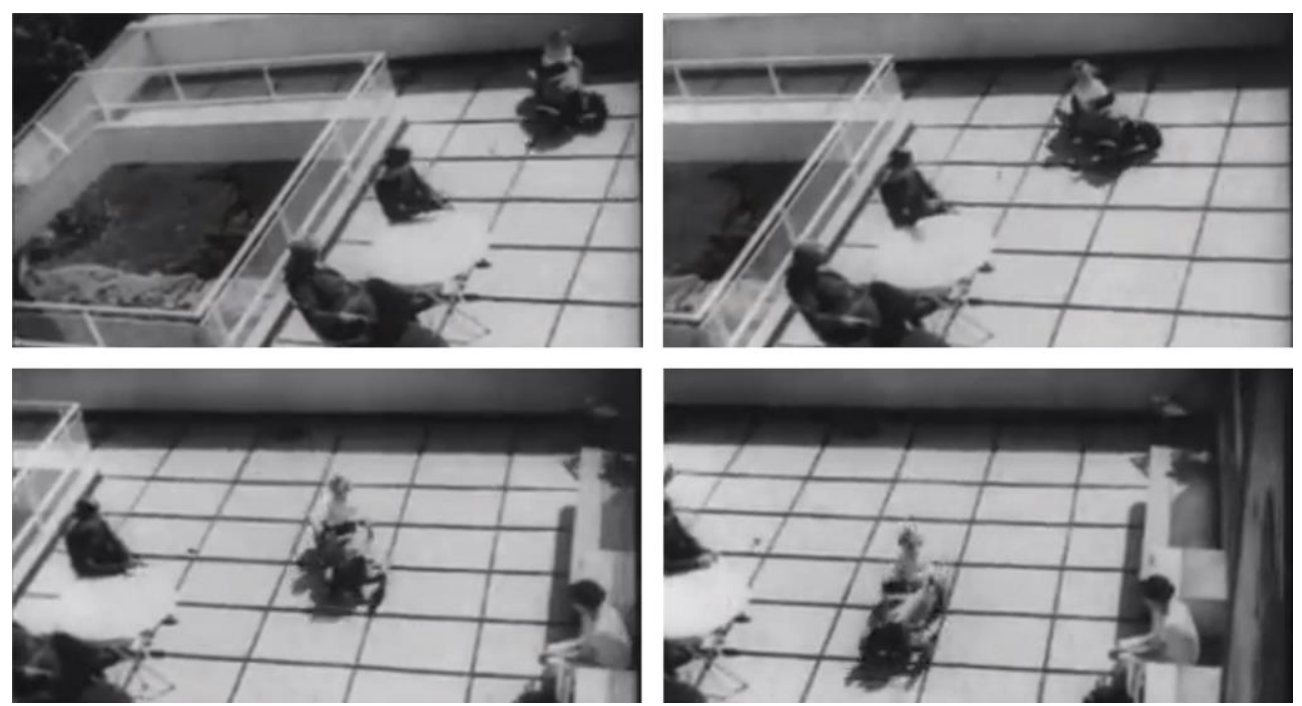

14. Fotogramas del inicio de la película "L'arquitecure d'aujourd'hui", donde se muestra cómo un niño circula con su triciclo por la terraza-jardín de la Villa Stein en Garches (de arriba a abajo y de izquierda a derecha: del min. 0,02,17, al min. 0,02,19). París. 1929. Dirigida por Pierre Chenal (1904-1990) y rodada en la Villa Savoye, la Villa Stein y la Villa d’Avray.

Si el piloti es el principio que posibilita la promenade, la escalera será para Le Corbusier el más torpe y egoísta de los elementos; un ente capaz de someter a todo aquel que aborde sus dominios pues, ya una vez dentro de su lógica, no cabe la distracción. El ser que se enfrenta a la escalera, olvidándose de lo que le rodea acompasa su cuerpo, y como un primoroso diapasón, mediante espasmos, negociará la contingencia que esta le presente.

Es, en el momento de resolver los edificios de gran envergadura cuando Le Corbusier se olvida del enaltecimiento espiritual que comporta la rampa en la casa y hará de ella la más funcionalista de sus herramientas. En esta línea, y a propósito del Palacio de los Soviets, escribe:

"Las escaleras tradicionales han sido reemplazadas por planos inclinados o rampas, único método para alcanzar velocidades suficientes ${ }^{, 26}$.

Llegados a este punto fundamental parece el movimiento para el «cuerpo del hombre», o algo de esto debió mover las leyes del pensamiento corbusierano pues, de no ser esto cierto, a qué se debería esa fuerte pregnancia en el recorrido dentro del que sería su proyecto idealizado; aquel capaz de darle forma al tiempo como esa cuarta dimensión imposible de alcanzar en el dibujo y que necesita por tanto de la palabra para entonces sí, poder expresarse.

La forma del tiempo para Le Corbusier es algo de esto: palabras y dibujos.

\footnotetext{
${ }^{25}$ Torres, Jorge: "La arquitectura es la circulación”. Op cit. p. 232.

${ }^{26}$ Le Corbusier; Jeanneret, Pierre: Projet pour la construction du Palais des Soviets à Moscou. Memoria de presentación. Mecanografiada y correcciones autógrafas. Diciembre de 1931. FLC_H3-6-1-002.
} 
"Pasados los guardarropa, las 14.000 personas se encuentran en un plano inclinado que los conducirá, sin escaleras, con perfecta continuidad, bien sea a la Sala o aquellos lugares más remotos a través de las grandes entradas situadas a izquierda y derecha, o bien al gran Hall-forum situado bajo la sala.

El plano mismo que les conduce hasta allí, continua constante hasta alcanzar el anfiteatro de la misma sala. Este anfiteatro está alimentado por tres arterias -una central y dos laterales-, que se dividen ellas mismas en rutas secundarias horizontales y caminos verticales".

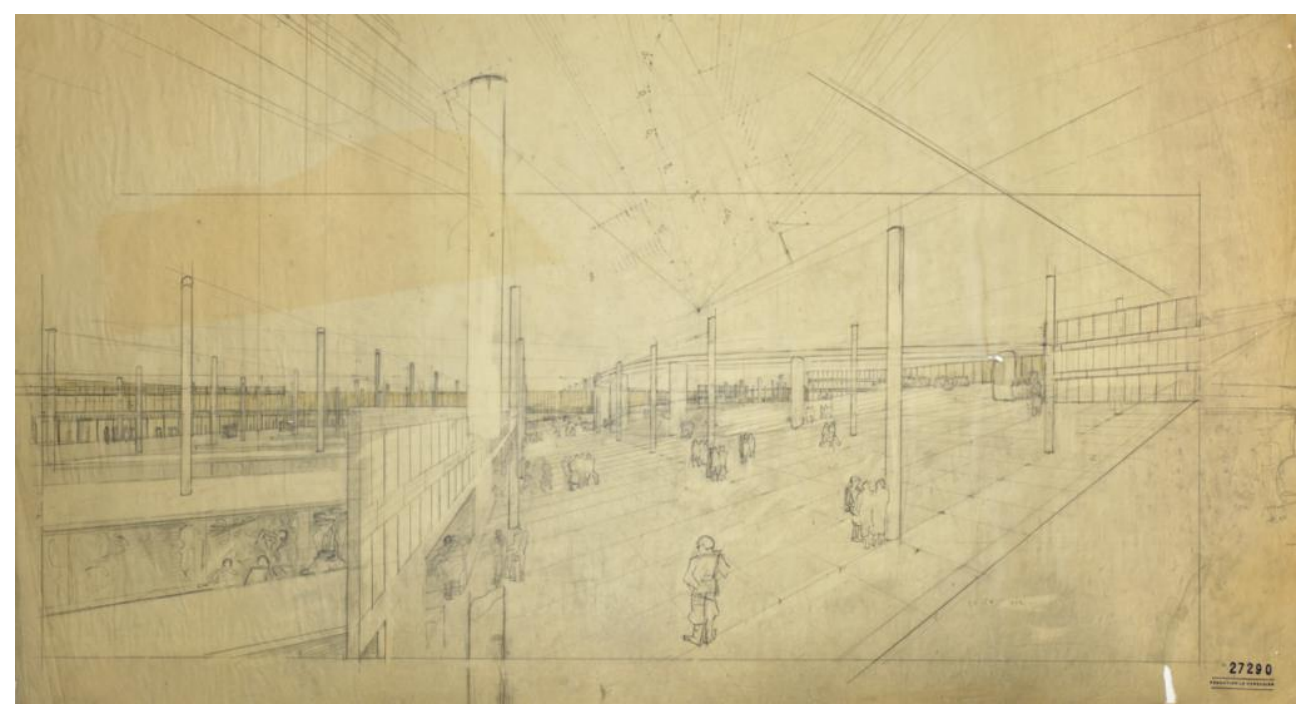

15. FLC_27290. Perspectiva del acceso a la Sala A previa al dibujo definitivo FLC_27251 - CFLC-ADAGP.

Y es, pocas líneas más tarde, cuando aquella biología ya anticipada en Précisions vuelve a entrar en escena, esta vez para comparar la circulación sanguínea del humano con la arquitectónica del edificio:

"La circulación de la sala está basada en un régimen circulatorio normal, con arterias, arteriolas, capilares",27.

Es ahora, si recordamos aquel organigrama que Le Corbusier confecciona a fin de ajustar la función de su edificio, cuando constatamos que el énfasis recae aquí en los contactos que se producen entre estancias, esto es, en el efecto coadyuvante que ejercen cada una de las piezas con sus vecinas más inmediatas. Pues qué duda cabe de que sólo mediante la estrategia representada por Le Corbusier en el dibujo, podría ya imaginarse esto como un procedimiento basado en el control que una serie de figuras dominantes ejercen sobre un sistema encargado de mediar entre la ciudad y el más pequeño de los reductos contenidos en el plan.

Es por tanto ahora, una vez aprendida la lógica del método, cuando el aspecto biológico del esquema no pasa inadvertido para todo aquel que con mirada analítica adivine sus atributos, pues qué es sino un corazón palpitante la silueta colocada en el centro de la composición que riega y dota de flujo al sistema, y qué es lo demás sino consecuencia lógica de la circulación intravenosa de un edificio cuyas estancias, al ritmo de la presión arterial, van reduciendo su escala hasta verse reducidas a mínimas células conectadas por capilares. Y es

\footnotetext{
${ }^{27}$ Ibídem. FLC_H3-6-1-008. (Fig. 15)
} 
que la circulación corbuseriana, desinteresada ya por las escalas que enmarcan a la arquitectura, se define como «una gran palabra moderna. Todo es circulación en la arquitectura y el urbanismo» ${ }^{28}$.

Llegados a este punto, y una vez descrita la arquitectura como "la máquina a habitar", será el urbanismo el encargado de otorgar orden a todo efecto producto del desarrollo azaroso de la ciudad ${ }^{29}$. Aspecto este que Le Corbusier posteriormente describirá en su libro Urbanisme:

"La calle es una máquina de circular; es una fábrica cuyos utensilios deben realizar la circulación. La calle moderna es un órgano nuevo. Es necesario crear tipos de calles que estén equipadas como está equipada una fábrica" ${ }^{, 30}$.
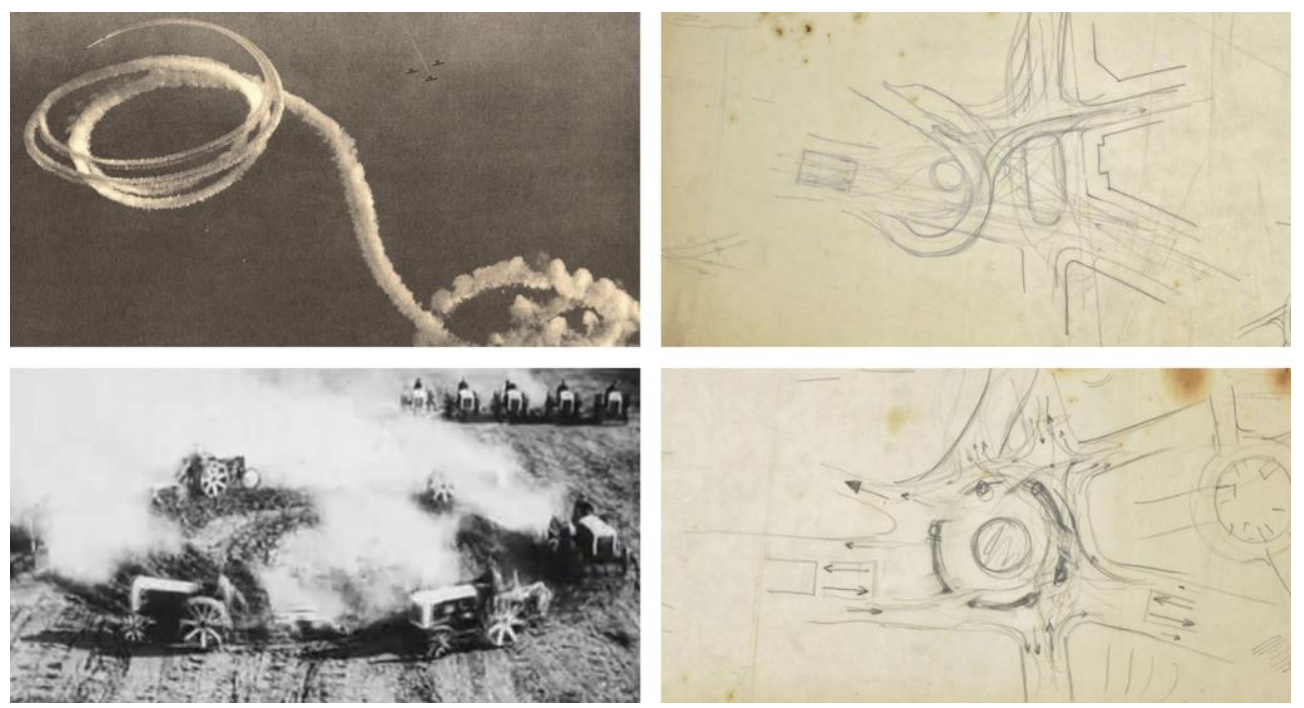

16. En la columna de la izquierda, de arriba a abajo: 1. Aviones italianos trazando anillos de humo: Extraído del libro de Le Corbusier "Aircraft". Madrid: Abada Editores, 2003. img. 83; 2. Tractores arando: min. 1,56,17 de "La línea general”. En la columna de la derecha, de arriba a abajo: FLC_27453 y FLC_27501 - CFLC-ADAGP.

En ese sentido, parece legítimo afirmar que la calle a estas alturas no es más que "la máquina a circular". Una visión novedosa que permitirá a la técnica inmiscuirse en los asuntos más vulgares de la arquitectura, para de manera inapelable, resolver el principal problema que para Le Corbusier evidencia el urbanismo de su época: «reducir los tiempos muertos entre dos funciones fundamentales como son estar en casa -afectividad y descansoe ir a trabajar -oficinas-» ${ }^{31}$.

Y es que no es de extrañar que el ojo ciclópeo de Le Corbusier, observando las más puras manifestaciones técnicas que la física y la naturaleza conceden al mundo, se apoderase de un trazo obsesionado en resolver con movimientos el propio movimiento.

\footnotetext{
${ }^{28}$ Le Corbusier: Précisions sur un état présent de l'architecture et de l'urbanisme. París: Éditions Vincent, Fréal et Cie, 1930. (Op cit. p. 150). Dentro del capítulo «El plano de la casa moderna», donde habla de la «circulación» como uno de los factores fundamentales a desarrollar junto a otros como -clasificación, dimensionamiento, composición y proporcionamiento-, en la revolución arquitectónica todavía por llegar.

${ }^{29}$ Le Corbusier; Jeanneret, Pierre: Projet pour la construction du Palais des Soviets à Moscou. Op cit. FLC_H3-6-1-036.

${ }^{30}$ Le Corbusier: Urbanisme. París: Éditions Vincent, Fréal et Cie, 1930, p. 126. También en L'Esprit Nouveau n²5. París: julio de 1925.

${ }^{31}$ Le Corbusier; Jeanneret, Pierre: Comentaires relatifs a Moscou et a la Ville Verte, marzo de 1930. FLC_H3-6-54-004.
} 


\subsection{De la técnica}

"La arquitectura es la manifestación del espiritu de una época que se aprovechó de sus conquistas técnicas. Confiere a lo que va a ser el rostro de la tierra un aire de juventud y honestidad que vivifica el espíritu, estimula la actividad creativa y establece los nuevos eslabones de la cadena ininterrumpida de la tradición, esa cadena en la que cada pieza es al mismo tiempo un acto de optimismo creativo, un paso adelante y un esfuerzo constructivo ${ }^{, 32}$.

Diríamos que Le Corbusier ve a cada momento cómo la arquitectura no cesa en manifestar aquellas necesidades acuciantes que la debilitan, esto es, se muestra predispuesta a nuevas sugerencias capaces estas de disolver el rastro de su propia involución. De hecho, será el mismo arquitecto el que reconozca en Précisions que sus «ideas revolucionarias están en la historia, en toda época y en todos los países» ${ }^{33}$. Él apenas ha inventado nada, si acaso actualizado todos esos principios de la memoria que siempre han acompañado los pasos de la arquitectura, y es que de no ser esto cierto, cómo se explica sino el título de su segunda conferencia pronunciada el sábado 5 de octubre de 1929 bajo el sugestivo título de "Las técnicas son la base misma del lirismo arquitectónico, abren un nuevo ciclo a la arquitectura" donde precisamente introduce sus cinco puntos como revisión a otros tantos conceptos de carácter no muy distinto.

Es una de sus frases la que, no exenta de contundencia, rubrique la impronta de este nuevo pensamiento:

"La arquitectura es unos pisos iluminados" $"$.

Y es que Le Corbusier, a pesar de no mencionar el término "técnica" a todo momento, hacía en cada una de sus manifestaciones clara alusión a ese espíritu de perfeccionamiento intrínseco en la máquina y la ciencia; lo que para él significaban elementos exactos y precisos. Cómo si no iluminamos pisos de no ser «por el auxilio de la técnica del hormigón y el acero que sustituyen el aspecto macizo del muro por la ligereza de los cerramientos especializados $»^{35}$, pues «las nuevas técnicas nos han traído nuevas palabras y las nuevas técnicas, a las que es imposible resistirse, llaman a nuestra imaginación» ${ }^{36}$.

No sólo nuevas palabras se dieron lugar en el atelier de Le Corbusier, sino también nuevas concepciones hasta entonces inéditas, aparecieron para quedarse y afianzar las bases sobre las que asentar la construcción de esta nueva forma de conocimiento en torno a la técnica.

\footnotetext{
${ }^{32}$ Le Corbusier: Aircraft. Madrid: Abada Editores, 2003. img. 27.

${ }^{33}$ Le Corbusier: Précisions sur un état présent de l'architecture et de l'urbanisme. París: Éditions Vincent, Fréal et Cie, 1930. (Op cit. p. 120). Dentro del capítulo «Una célula a escala humana», donde apunta a la Cartuja d’Ema como fuente de inspiración de sus "inmuebles-villas".

${ }^{34}$ Ibídem. p. 69. Dentro del capítulo «Las técnicas son la base misma del lirismo. Abren un nuevo ciclo de la arquitectura».

${ }^{35}$ Torres, Jorge: Le Corbusier. Visiones de la técnica en cinco tiempos. Barcelona: Arquíthemas N¹3, 2004. p. 127. Donde se habla del arquitecto en torno a cinco tiempos: el progreso, la máquina, la técnica, la construcción y la infraestructura. En este caso concreto se refiere al tercero de ellos: "El ideal de la técnica: arquitectura y tecnología".

${ }^{36}$ Le Corbusier: Précisions sur un état présent de l'architecture et de l'urbanisme. París: Éditions Vincent, Fréal et Cie, 1930. (Op cit. p. 75). Dentro del capítulo «Las técnicas son la base misma del lirismo. Abren un nuevo ciclo de la arquitectura».
} 

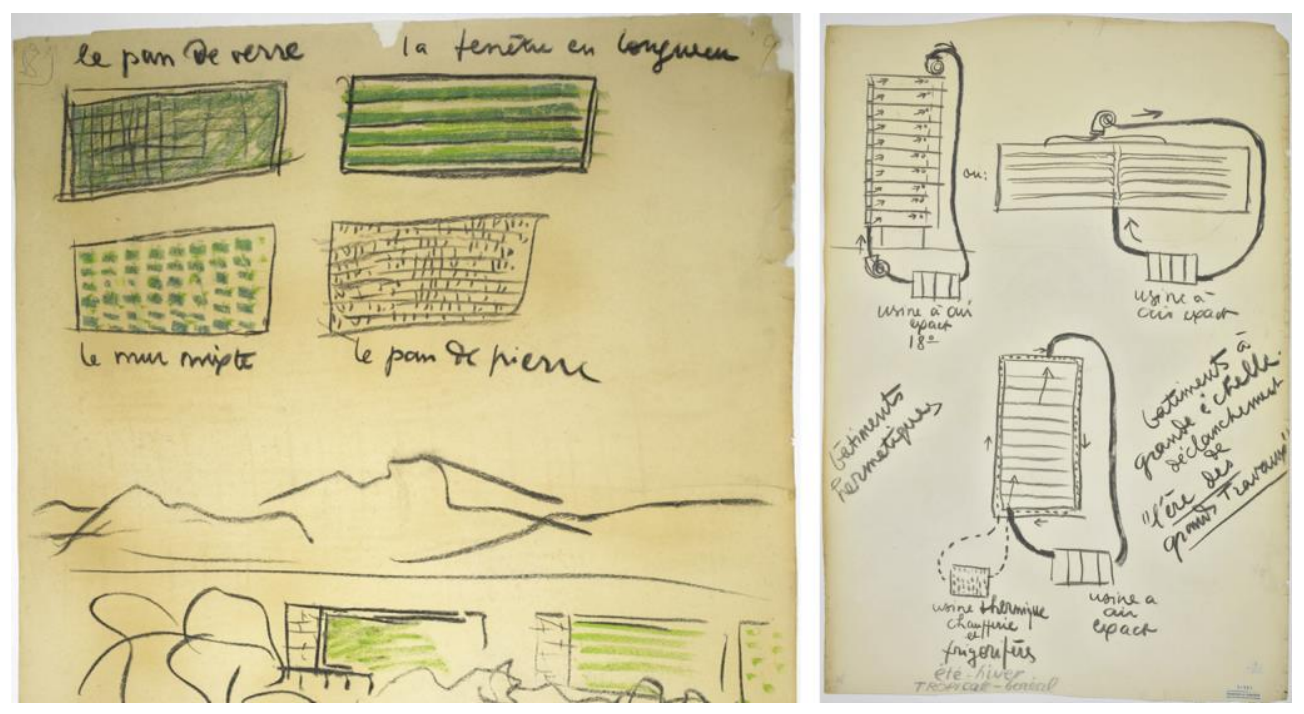

17. FLC_33504. Cuatro procedimientos para cerrar un espacio: le pan de pierre, le mur mixte, la fenêtre longeur y le pan verre - OFLC-ADAGP. // FLC_33527. Bocetos en los que el arquitecto presenta su edificio hermético - OFLC-ADAGP.

Entonces, si lo verdaderamente sustancial radica en iluminar los pisos de la arquitectura, no es de extrañar que sea ahí mismo el punto en el que el arquitecto suizo quisiera centrar su investigación; en esa membrana que, reducida ya por el piloti a la más extrema delgadez, se encargase de ajustar las discrepancias exteriores con las obligaciones propias del interior. Es por eso que la ventana corriente, entendida por el arquitecto como elemento económicamente impropio, se erija como protagonista de este nuevo discurso:

“Un buen día esta verdad aparece: “¡una ventana está hecha para dar luz, no para ventilar!”. Para ventilar, empleamos los aparatos de ventilación; es mecánica, es física”.

A lo que a continuación se pregunta:

“Y si pudiéramos, con un gesto, repudiar la ventana, pero dando, al mismo tiempo, luz a los pisos?”.

Hasta el punto de describir lo que sería el aspecto ideal de este, le pan de verre:

"El examen de mi perfil-símbolo me muestra unas fachadas reducidas a algunas bandas de cemento de 30 centímetros de altura. Bien, pasemos eso por alto, ipasemos adelante! Vamos a sujetar a 25 centímetros hacia delante e estas bandas de cemento, por medio de cartelas de llanta, unos hierros verticales, bien colocados, que tengan aplomo. Y a través, fuera o dentro, unos hierros horizontales a unas distancias proporcionadas a los cristales o a los vidrios disponibles en el comercio. Por consiguiente, delante de las fachadas habrá "un panel de vidrio". La fachada es un panel de cristal ${ }^{\text {37. }}$

Será pues el vidrio, hasta entonces confinado a los límites de la ventana, el encargado de otorgarle a la arquitectura ese nuevo cariz propio de las cosas transparentes y demostrar así, superada la timidez de épocas

${ }^{37}$ Ibídem. p. 73. (Fig. 17) 
pretéritas, la vigencia de un material indudablemente versátil «capaz de resolver la escala arquitectónica desde la base a la cúspide, sin mudar su aspecto, alterar su diseño o modificar su naturaleza» ${ }^{38}$.

Es por eso que, a propósito de esta nueva "arquitectura de vidrio", no resulte extraña la exploración que Le Corbusier incorpora a sus composiciones pictóricas en las que este nuevo material, representado ahora por aquellos elementos más cotidianos -sean botellas o vasos-, se diluya en un espectro de color fruto de la superposición que su propia transparencia autoriza.
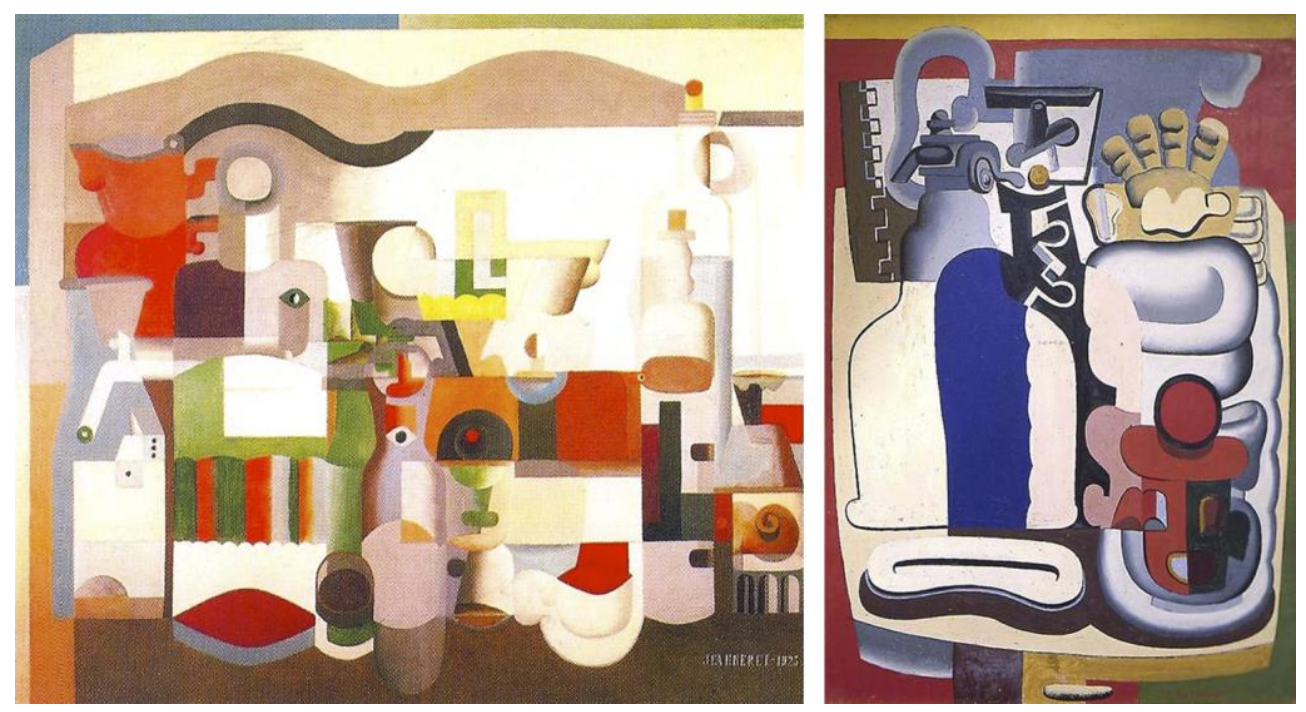

18. FLC_212. Jeanneret, Charles-Édouard: Nature morte au siphon. Óleo sobre lienzo (1,30 x 0,97 m.), 1928 - OFLCADAGP. // FLC_175. Nature morte aux nombreux objects. Óleo sobre lienzo (1,14 x 1,46 m.), 1923 - OFLC-ADAGP.

Sin embargo, no será hasta el momento de enfrentarse a sus grads travaux, allá por los años 30, cuando todos estos principios cobraron una importancia capital y se tiñeron de un cierto aire de universalidad. En este sentido pronuncia: «A esta hora de interpenetración general, de técnicas científicas internacionales, propongo: una sola casa para todos los países y para todos los climas: la casa con respiración exacta» ${ }^{39}$.

Principio este de la respiración exacta posiblemente originado, según Jorge Torres, como consecuencia del viaje que Le Corbusier realizó a Moscú en 1928 a propósito de la construcción del Centrosoyus, donde escribe una nota a Pierre Jeanneret diciendo:

"Pierre, revoir tout le système fenêtres. On pourrait éventuellement tout vitrer et chauffer entre deux. Consulter G. Lyon et laboratoire.

Etudier 1 chauffage à eau chaude pour bureaux - 1 chauffage à air chaud par doublé cloison vitrée pour empêcher le froid"

\footnotetext{
${ }^{38}$ Castellanos, Raúl: "Bloques de hormigón: la dignidad de lo normal”. En Catálogo Verni-Prens. 2010, 4ª edición. Valencia: General de Ediciones de Arquitectura. p. 19.

${ }^{39}$ Le Corbusier: Précisions sur un état présent de l'architecture et de l'urbanisme. París: Éditions Vincent, Fréal et Cie, 1930. (Op cit. p. 85). Dentro del capítulo «Las técnicas son la base misma del lirismo. Abren un nuevo ciclo de la arquitectura».

${ }^{40}$ En castellano (traducción del autor), "Pierre, revise todo el sistema de ventanas. Se podría eventualmente acristalarlo todo y calefactar entre dos. Consultar con G. Lyon y laboratorio. Estudiar 1 calefacción de agua caliente para oficinas - 1
} 
Tres años más tarde, y ya una vez construida la "respiración exacta" del Centrosoyus, será cuando Le Corbusier volviera a aquellos dos conceptos manuscritos para así poder incorporarlos a la futura construcción del Palacio de los Soviets, esto es, mediante la combinación de lo que pasó a denominarse "l'aeration ponctuelle" o sistema Gustave Lyon, encargado de la impulsión de aire; y "les murs neutralisants" o patente Le Corbusier y Pierre Jeanneret, entendidos como acristalamiento doble y hermético por cuyo interior habría de circular aire frío y caliente.

"El principio dice tal que así: los "muros neutralizantes" con su circuito de aire tienen que mantener una temperatura constante de $18^{\circ}$ en la cara interior de las paredes de vidrio; mientras que en oficinas y anexos, necesitan de un circuito especial de ida y retorno -aireación puntual- que permitirá alimentar a todos los locales de aire puro a $18^{\circ}$ y humedad exacta; en las grandes salas, los mismos muros neutralizantes asegurarán la función aislante, mientras que la "aireación puntual" alimentará los pulmones de cada uno de los 6.000 o 15.000 espectadores, $y$ es aqui donde el proceso se vuelve significativo ${ }^{, 41}$.

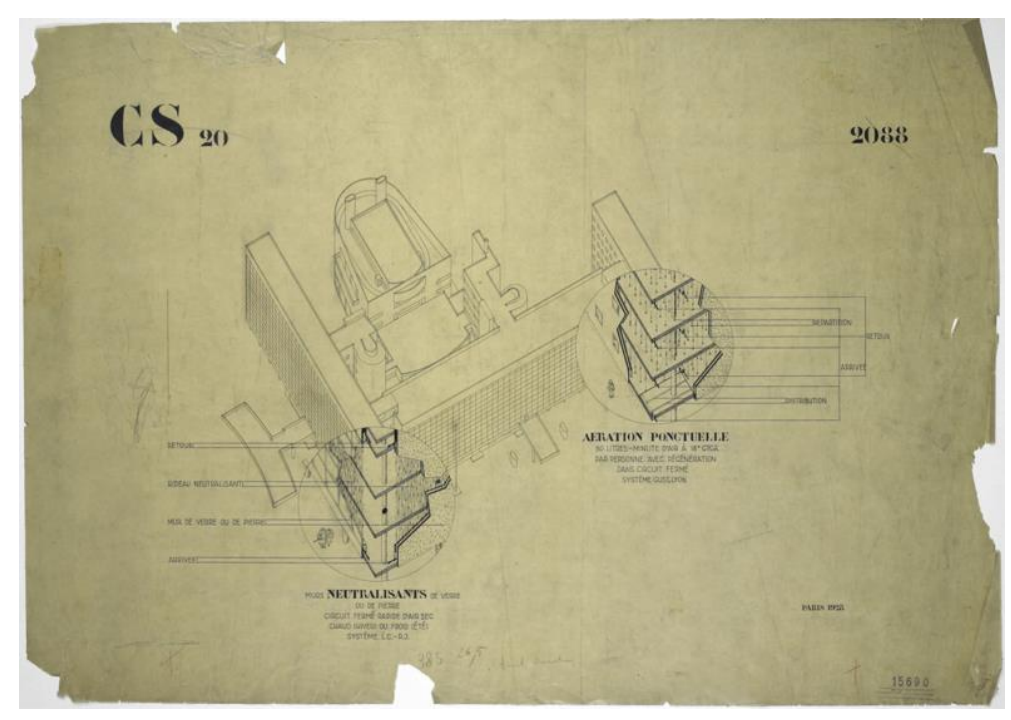

19. FLC_15690. Centrosoyus. Sistema de ventilación compuesto por murs neutralisants - aeration ponctuelle, 1928. Le Corbusier - Pierre Jeanneret - OFLC-ADAGP.

Es de esta manera como Le Corbusier, comprometido con su tiempo, haría de la técnica mera síntesis capaz de abarcar las aspiraciones propias de una antigüedad, que hasta entonces se supo incapaz de advertir tan invisible condición. Mudándola así en algo preciso, perfecto y exacto; un instrumento matemático y riguroso avezado ya en construir las leyes de su propia geometría.

\section{Coda}

Sirvan por tanto estas palabras como reunión a ciertas nociones que, auspiciadas por el proyecto de los Soviets, soportan las coordenadas en las que se encuadra la arquitectura de Le Corbusier. Allí donde la composición, al

calefacción de aire caliente por la doble pared de vidrio para evitar el frío". Fragmento referenciado por Jorge Torres en "Le Corbusier. Visiones de la técnica en cinco tiempos". Barcelona: Arquíthemas No13, 2004. p. 133.

${ }^{41}$ Le Corbusier; Jeanneret, Pierre: Projet pour la construction du Palais des Soviets à Moscou. Op cit. FLC_H3-6-1-029. 
unísono con la simbología, la circulación y la técnica, constituyen el rudimento fundamental de estos, sus grandes trabajos; aquellos en los que el arquitecto nos desvela los entresijos de una promenade cuya forma resulta no ser nada más que materia resultante de su propio tiempo.

Será por tanto en el momento del quehacer, es decir, durante el desempeño de su actividad, cuando el arquitecto suizo, olvidándose de su propia existencia, dote a sus "volúmenes reunidos bajo la luz" de esa cuarta dimensión capaz de poner de acuerdo unos trazados que, multiplicados de manera incesante, parecen no querer nunca encontrar su propia conclusión.

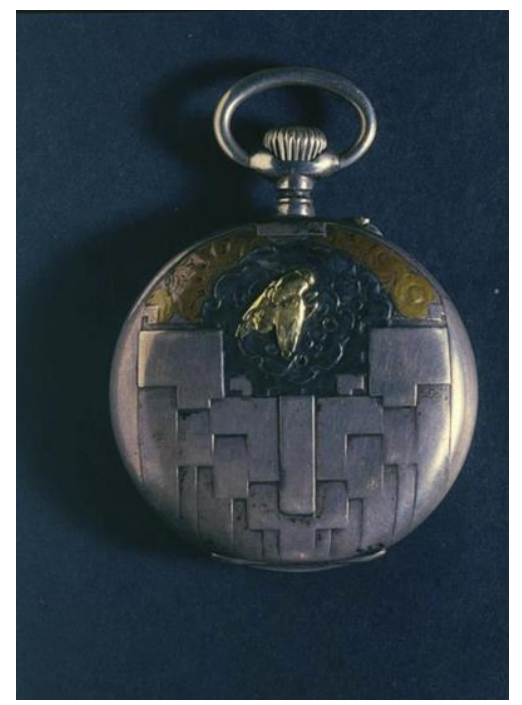

20. Reloj de bolsillo, expuesto en Milán, diseñado y grabado por Charles-Édouard Jeanneret en la Escuela de Arte de La Chaux-de-Fonds bajo la tutela de Charles L Éplattenier (1874-1946), 1906. Fondation Le Corbusier - OFLC-ADAGP.

Y es que el tiempo, encapsulado por el niño en sus inicios, pasará a formar parte de esta arquitectura mudada ya en algo preciso: una suerte de cronómetro donde Le Corbusier, en suma, organiza formas que luchan por acordar su permanencia.

FIN

\section{Agradecimientos}

Este trabajo, iniciado hará algo más de un año, no es más que mera comunión de ciertas notas que en suma, terminarán por conformar la tesis doctoral a la que este escrito precede. Basten por tanto estas líneas para expresar mi gratitud a Jorge Torres, director de la tesis doctoral a la que se alude, por su paciencia y generosidad durante este tiempo.

\section{Créditos de las ilustraciones}

Chenal, Pierre: L'architecture d'aujourd hui. París: Película, 1929: 14abcd

Cohen, Jean-Louis: Le Corbusier et la mystique de I'URSS. Théories et projets pour Moscou 1928-1936. Bruselas y Lieja: Pierre Mardaga, 1987: 7a

Eisenstein, Serguéi: La línea general. Moscú: Película, 1929: 9a, 10a, 11abcd, 16c 
Fernández Alba, Antonio y otros: Eugène Freyssinet. Un arquitecto revolucionario. Madrid: Fundación Esteyco, 2003: $7 \mathrm{bc}$

Fondation Le Corbusier (París): 1, 2abcd, 3abcd, 4b, 5ab, 6, 8, 9b, 10b, 12a, 13ab, 15, 16bd, 17ab, 18ab, 19, 20

IVAM. Centre Julio González: Naum Gabo y el concurso para el Palacio de los Soviets. Moscú 1931-1933. Berlín: Berlinische Galerie, 1993: 4a, 12b

Le Corbusier: Aircraft. Madrid: Abada Editores, 2003: 16c

\section{Bibliografía}

Castellanos, Raúl: Plan Poché. Barcelona: Arquia/Tesis No 36, 2012.

Castellanos, Raúl: "Bloques de hormigón: la dignidad de lo normal”. En Catálogo Verni-Prens. 2010, 4ª edición. Valencia: General de Ediciones de Arquitectura.

Cohen, Jean-Louis: Le Corbusier et la mystique de I'URSS. Théories et projets pour Moscou 1928-1936. Bruselas y Lieja: Pierre Mardaga, 1987.

Colomina, Beatriz: "Reflexiones sobre la casa Eames". En RA Revista de arquitectura. 2007, №. Pamplona: Servicio de publicaciones de la Universidad de Navarra.

Colquhoun, Alan: Modernidad y tradición clásica. Madrid: Júcar Universidad, 1991.

Fondation Le Corbusier: Le Corbusier. DVD Plans. París: Fondation Le Corbusier, 2010.

Froebel, Friedrich: La educación del hombre. Madrid: Daniel Jorro, Editor, 1913.

Klein, Alexander: Vivienda mínima: 1906-1957. Barcelona: Gustavo Gili, 1980.

Le Corbusier: Urbanisme. París: Éditions Vincent, Fréal et Cie, 1930.

Le Corbusier: Hacia una arquitectura. Barcelona: Poseidón, 1977.

Le Corbusier: Precisiones respecto a un estado actual de la arquitectura y el urbanismo. Barcelona: Poseidón, 1999.

Le Corbusier: Aircraft. Madrid: Abada Editores, 2003.

Torres, Jorge: Le Corbusier. Visiones de la técnica en cinco tiempos. Barcelona: Arquíthemas Nº13, 2004.

Torres, Jorge: "La arquitectura es la circulación”. En Le Corbusier. Mise au point. Valencia: General de Ediciones de Arquitectura, 2012.

Zumthor, Peter: Pensar la arquitectura. Barcelona: Gustavo Gili, 2010. 


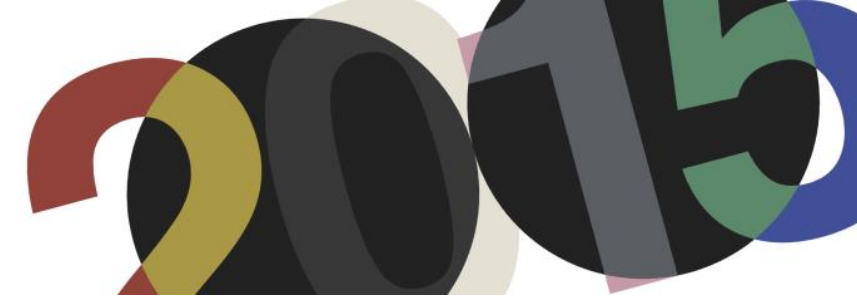

DOI: http://dx.doi.org/10.4995/LC2015.2015.770

\title{
Entre les lignes ou de bouche à l'oreille. Le Corbusier en roumain
}

\author{
R.T. Ponta
}

Université d'Architecture et Urbanisme «Ion Mincu», Bucarest

\begin{abstract}
Résumé: L'article construit l'image de l'auteur de livres Le Corbusier inversée dans le miroir de la culture architecturale roumaine telle que ces éclats permettent de le voir dans une littérature professionnelle qui semble l'avoir obstinément évité. Ainsi la version roumaine de l'auteur Le Corbusier sera le résultat de l'adition de trois images partielles: celle que forme la réflexion des idées corbuséennes dans les æuvres écrites des architectes modernes roumains de l'entre-deux-guerres; celle que propose l'anthologie de textes écrits par Le Corbusier, traduits et édités par Marcel Melicson en 1971 et, en suite, celle avancée par l'exposition de 1987, consacrée à célébrer le centenaire de la naissance de l'architecte. Ensemble ces trois tableaux font preuve des formes insolites que les idées de Le Corbusier assument dans l'histoire récente de la littérature professionnelle roumaine, et montrent les légers déplacements de substance que ces "traductions" engagent.
\end{abstract}

Abstract: The paper focuses on Le Corbusier as author of books and looks at his inverted image such as it is developed in the Romanian architecture culture. The idea arises from the curious fact that the professional literature seems to have programmatically avoided him. In this paper, the Romanian author Le Corbusier will be the uneven sum of three partial images: the first is provided by the reflection of corbusean ideas in the writings of Romanian modern architects between the two World Wars. The second is given by the collection of Le Corbusier's writings, translated and edited by Marcel Melicson in 1971. And finally the third is that of the 1987 centennial exhibition hosted by the Bucharest architecture school. Together these three images testify to the peculiar shapes that Le Corbusier's ideas take in the recent Romanian professional literature and also to the subtle displacement of meaning that these "translations" suggest.

Mots-clés: traductions de Le Corbusier en roumain; affinités personnelles/modèles interdits; circulation et interprétations des idées; synthèses éloignées.

Keywords: translations of Le Corbusier in Romanian; personal affinities/forbidden models; circulation and interpretation of ideas; distant syntheses.

\section{Introduction}

Si l'héritage de Le Corbusier n'est jamais simple à déceler, l'évaluation des reflets de son œuvre écrite en roumain suppose d'un part une manière correcte de considérer le contexte particulier local - le sol fertile ou le rocher dans lesquels les idées de Le Corbusier se sont implantées - et, de l'autre part, un travail de détective dédié à éclairer ce qui n'a jamais étais écrit et ce que l'on n'a jamais prononcé à haute voix. Ainsi l'article essayera de construire l'image de l'auteur de livres Le Corbusier inversée dans le miroir de la culture architecturale roumaine telle que ces éclats permettent de le voir dans une littérature professionnelle qui semble l'avoir obstinément éviter ${ }^{1}$.

Ainsi le travail se propose de reconstituer les contours que la personnalité de Le Corbusier ait occupé dans la conscience professionnelle roumaine comme résultat de l'adition de trois images partielles: celle que forme la réflexion des idées corbuséenes dans les œuvres écrites des architectes modernes roumains de l'entre-deuxguerres; celle que propose l'anthologie de textes écrits par Le Corbusier, traduits et édités par Marcel Melicson

\footnotetext{
${ }^{1}$ En effet la seule œuvre écrite de Le Corbusier qui est parue en entier en roumain est La Charte d'Athènes : Carta Atenei (București : Editura Bucovina, Colecția "Lumea nouă", 1945).
} 
en 1971 et, en suite, celle avancée par l'exposition de 1987, consacrée à célébrer le centenaire de la naissance de l'architecte.

Particulièrement réceptif aux idées de la modernité architecturale européenne, l'entre-deux-guerres roumain a été aussi une période où la culture professionnelle locale ne s'accorde pas aux idées de Le Corbusier d'une manière aussi transparente pour populariser ses ouvrages écrits en les traduisant en roumain. Pour les architectes modernes roumains l'urgence semble avoir été de reprendre ses idées, de les interpréter, de les adapter en les particularisant au contexte local. Quelle est la mesure dans laquelle Le Corbusier inspire leurs réflexions est visible seulement si l'on regarde en confrontant leurs textes, leurs arguments, leurs expressions, ou si l'on suive des formules, des maximes ou des slogans de notoriété. L'article suivra les réverbérations des œuvres écrites par Le Corbusier dans les publications de l'entre-deux-guerres en Roumanie tout en essayant d'expliquer les significations locales de leurs nuances.

La deuxième occurrence des idées de Le Corbusier sur laquelle l'article se concentre - l'anthologie de Melicson de 1971 - surprend et intéresse à la fois grâce à la structure du texte que l'éditeur propose: il prétend façonner l'image complète de Le Corbusier en entremêlant des fragments traduits depuis quinze livres et en ajustant leurs ordre. Cette image totalisante qui emprunte les procédées de l'auteur et qui n'existe que dans le collage de cette traduction partielle sera appréciée en la confrontant aux ouvrages synthétiques écrits par Le Corbusier dans les années 1960 et surtout L'Atelier de la recherche patiente.

Finalement, l'exposition anniversaire qui lui a été dédiée est un prétexte pour présenter comment l'œuvre de Le Corbusier a influencé d'une manière différente une autre génération qui l'a redécouvert. Avec peu de sources et moins de ressources, presque sans aide, à la limite contre le courent officiel, cinq étudiants cherchant une alternative à la schématisation de l'expression architecturale reprennent les livres de Le Corbusier pour y trouver la source pour réinventer une profession dans un contexte soumis de plus en plus au politique.

Ensemble ces trois tableaux font preuve des formes insolites que les idées de Le Corbusier assument dans l'histoire récente de la littérature professionnelle roumaine, et montrent les légers déplacements de substance que ces "traductions" engagent.

\section{Le Corbusier entre les lignes des architectes roumains de l'entre-deux-guerres}

\subsection{Le contexte : l'enjeu des écrits}

La plupart des efforts des professionnels roumains de la fin du XIXe et du début du XXe siècle murissent entre les deux guerres. Ceci se traduit d'un part dans la croissance accéléré du marché du bâti, un volume impressionnant de bâtiments réalisé dans une période assez courte et, de l'autre part, dans un développent urbain sans précèdent d'une capitale assez jeune, désirant se refaçonner à l'Européenne. La croissance du territoire du pays après la première guerre mondiale ${ }^{2}$ a réclamé aussi la mise en question de la manière dont les bâtiments réalisés dans les nouveaux territoires expriment le rattachement symbolique au même centre politique et culturel $^{3}$. En même temps, cet essor de l'architecture et de l'urbanisme a été nourrit par une nouvelle génération d'architectes rapatriés ${ }^{4}$ après des études dans les grands centres universitaires de l'Europe. Ce sont eux qui, en

\footnotetext{
${ }^{2}$ Par l'incorporation de la Dobroudja et de la Transylvanie après le Traité de Paix de Versailles de 1920.

${ }^{3}$ On peut résumer que les positions officielles de l'état et de l'église ont choisi de s'exprimer par un langage architectural traditionnel, imaginé vers la fin du XIXe siècle pour illustrer l'identité de la nouvelle nation roumaine.

${ }^{4}$ Une première génération, qui avait surtout préféré l'Ecole des Beaux-Arts de Paris, était rentrée déjà à la fin du XIXe siècle.
} 
étudiant à Paris, Zürich, Berlin etc. entrent en contact avec les mouvements des avant-gardes artistiques et architecturales européennes.

Du retour au pays natal, parachutés dans un climat fébrile généré par la reprise des efforts de construction après la guerre, ces architectes essayent de disséminer les idées qu'il ont apprises dans un marché hétérogène (en même temps traditionnel et cosmopolite) et par ceci entrent en conflit ouvert avec la génération précédente de professionnels ${ }^{5}$. Menée depuis des positions inéquitables, la querelle entre les avocats du style national roumain et ceux qui défendaient les idées modernes a occupé la scène de l'architecture roumaine de l'entre-deux-guerres. L'arme principale de ce combat a été la parole, écrite ou parlé, parue dans des manifestes, revues d'avant-garde ou conférences publiques. Parmi les architectes les plus présents dans le paysage de l'architecture moderne en Roumanie, Marcel Iancu surgit aisément comme la figure la plus engagée dans les débats, l'auteur le plus fécond et celui dont la biographie l'a rapproché le plus des scènes internationales de l'avant-garde. C'est ainsi que, dans cette première partie de l'article, nous suivront la manière dont Iancu arrive à disséminer les idées de Le Corbusier dans l'espace roumain du débat. Ensuite, pour compléter cette image, nous ferons appel à deux autre contributions qui - à coté de celle de Iancu - forment le volume Vers une architecture de Bucarest, titre qui désigne sans ambiguïté le livre de Le Corbusier comme principale et unique référence.

\subsection{Marcel Iancu - la voix de l'avant-garde européenne à Bucarest}

Marcel Iancu nait à Bucarest en 1895. Il reçoit des leçons de dessin et les expose ou publie dans différentes revues avant d'avoir vingt ans. Il poursuive ses études à Zürich, où, en 1915 il est reçu à l'Eidgenössische Technische Hochschule et rencontre, entre autres, Karl Moser et Hans Arp. C'est avec le dernier, Hugo Ball, Emmy Hennings, Tristan Tzara et Richard Huelsenbeck qu'il pose les bases du mouvement Dada, en février 1916. En même temps, ses œuvres sont présentées au Cabaret Voltaire ou dans autres galléries de prestige à coté de celles de Arp, de Chirico, Klee, Picabia entre autres. ${ }^{6}$

Après avoir essayé de travailler en France, il retourne en Roumanie ou il cherche sa place dans le paysage architectural local, comme il va l'avouer dans sa correspondance : "J'ai décidé de chercher mon chemin propre et de partir en missionnaire de l'art nouveau dans mon pays natal" ${ }^{\prime 7}$. Ce chemin et le travail de missionnaire vont se matérialiser dans l'année qui suive son retour par son engagement dans la presse d'avant-garde locale. Au cours des années et jusqu'en 1941, lorsqu'il va émigrer en Palestine, il aura collaboré à toutes les principales revues d'avant-garde de Bucarest : Contimporanul [Le contemporain], Arta și Orașul [L'art et la ville] - où il joue le rôle de membre fondateur et de directeur artistique, auxquelles il participe avec des textes et des illustrations, et qu'il va occasionnellement financer ${ }^{8}$. Ses articles vont paraître aussi dans d'autres périodiques (Punct [Point], Adam [Adam], Adevărul literar și artistic [La vérité littéraire et artistique], Vremea literară [Le temps littéraire], Oraşul săptămânal [La ville hebdomadaire], Vremea [Le temps], Meridian [Le méridien],

\footnotetext{
5 "In both discourse and tectonics, these dominant trends in the Romanian architectural space were to function in parallel, hermetically sealed off from one another, producing from the very first obviously insurmountable tensions and cleaving the profession into two absolutely disjunctive areas whose severance from one another was for a time to seem absolute." Gabriela Tabacu, "Architect Florea Stănculescu or On Modernism in the Romanian Interwar Architecture as Negotiation Between Genius Loci an Zeitgeist", dans SITA 2 (2014) : 52-76.

${ }^{6}$ Vois la chronologie de Marcel Iancu dans Anca Bocăneț, Nicolae Lascu, Ana-Maria Zahariade, Eds., Marcel Iancu Centenary 1895-1995 (București: Editura Simetria, Uniunea Arhitecților Din România, 1996), 250-255 et Anca Iliescu, "The Architectural Office of Marcel and Iuliu Iancu - A Career in Bucharest Between World Wars", dans Doina Anghel, Red., Marcel Iancu. Biroul de Studii Moderne (București: Editura Simetria, 2008) : 38-55.

${ }^{7}$ Anca Iliescu, "The Architectural Office of Marcel and Iuliu Iancu", 42.

${ }^{8}$ Chronologie dans Marcel Iancu Centenary 1895-1995, 251.
} 
Cultura [La culture]), comme si les occasions de promouvoir les idées de l'architecture et de l'art modernes dans les milieux les plus divers ne sont jamais suffisantes. C'est dans ces revues que vont paraitre ces articles qui évoquent directement ou de biais les idées de Le Corbusier.

Nous allons regarder l'apparition de Le Corbusier filtré dans les écrits de Marcel Iancu dans ces deux hypostases : celles qui citent l'activité de Le Corbusier directement et celles qui reprennent ses arguments et le transposent pour s'accorder à la situation de l'architecture à Bucarest.

\subsubsection{Références directes, citations, articles dédiés à Le Corbusier}

Au début de son activité dans la rédaction du Contimporanul, Iancu ne semble pas attribuer trop d'attention à Le Corbusier. Ceci dit, deux raisons rendent improbable l'hypothèse qu'il ne le connaissait pas encore : le premier tient de la relation que la rédaction de Contimporanul avait établie avec Paul Dermée, comme prouvée par ses contributions dans la revue ${ }^{9}$. Le deuxième se lie au fait que Contimporanul annonce périodiquement l'apparition de L'Esprit Nouveau et même permet aux lecteurs roumains intéressés de contracter des abonnements à la revue française. $(1,2)$

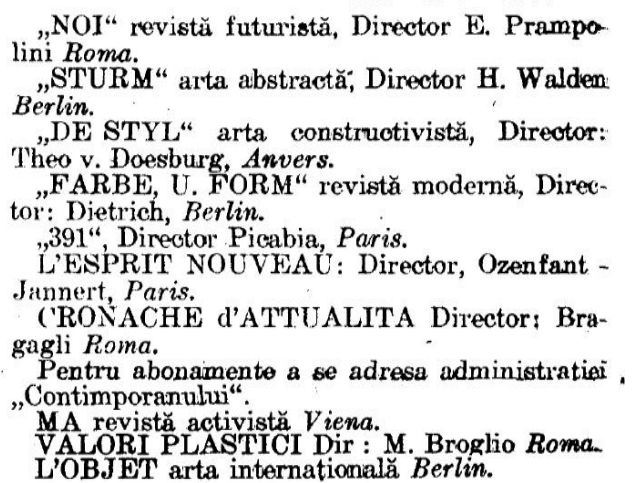

1. Extrait de Contimporanul, 31 (17 fevrier 1923), 4, montrant les revues que la rédaction de Contimporanul recommande à ses lecteurs.

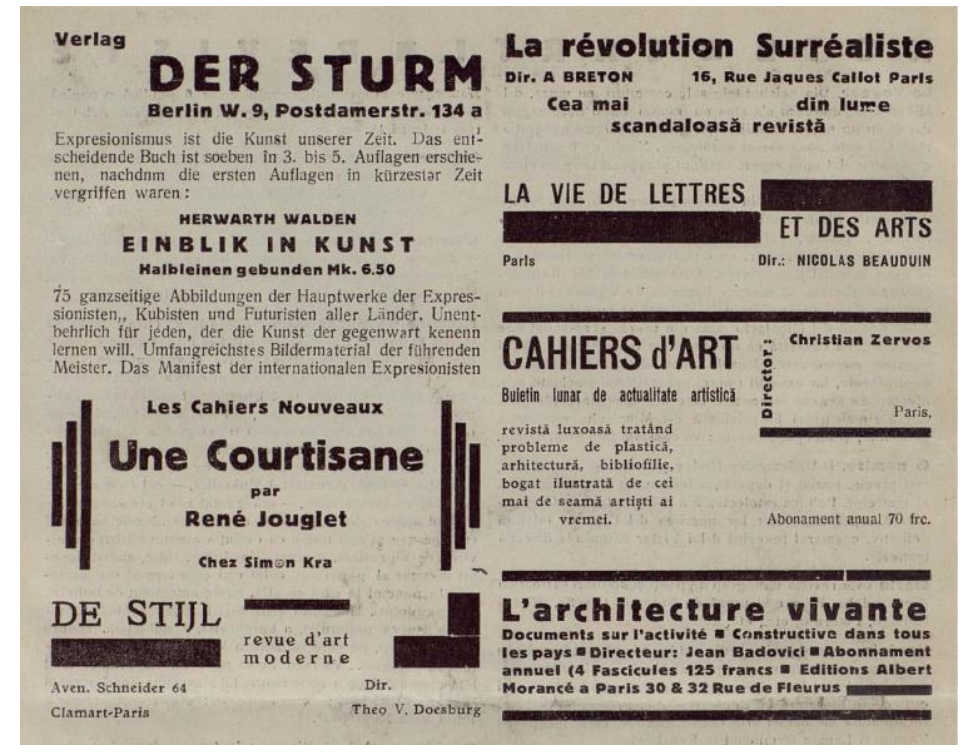

2. Publicité pour L'architecture vivante (entre autres), paru dans 2. Contimporanul, 70 (novembre 1926), 12.

\footnotetext{
${ }^{9}$ Contimporanul, 41 (1923) et Contimporanul, 44 (1923).
} 
Aussi Iancu n'est pas un étranger de la scène artistique parisienne, même s'il semble être plutôt branché au cercle des écrivains surréalistes ${ }^{10}$. C'est seulement en 1925 que Le Corbusier apparaît pour la première fois dans la revue roumaine qui traduit des extraits de Vers une architecture $^{11}(3,4)$.
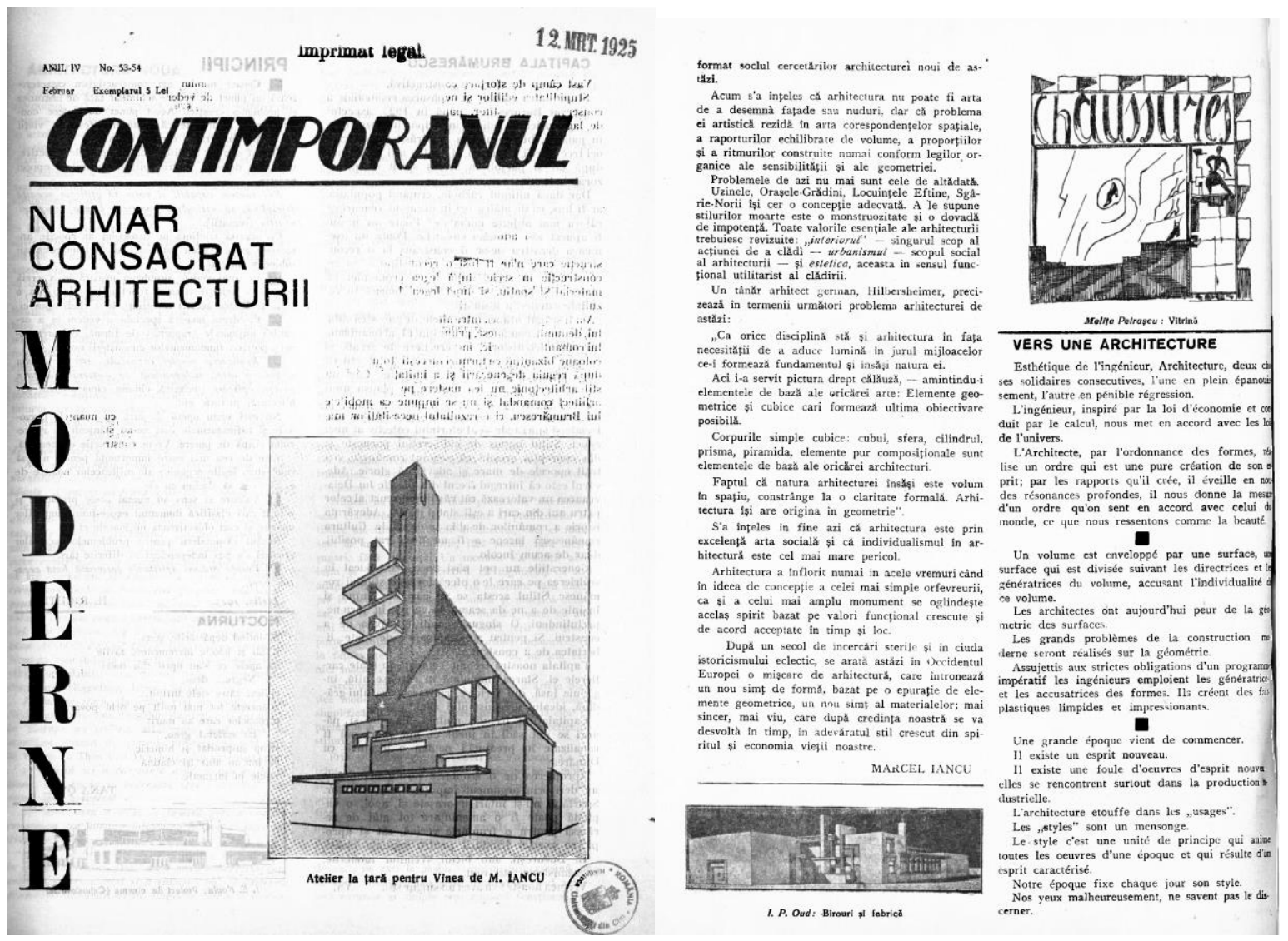

3. - 4. Couverture et page de la revue Contimporanul, 53-54 (février 1925), numéro dédié à l'architecture moderne. La couverture est illustrée par un projet de Iancu; la page montre son article à coté d'une des contributions de Le Corbusier, imprimée en français. L'article signé par Le Corbusier présente dans une forme concentrée les idées de Vers une architecture.

Sinon, la première référence indirecte à Le Corbusier se fait lorsque Iancu évoque l'Exposition des arts décoratifs de 1925 en disant que "Aujourd'hui on constate en France aussi le début d'une alerte."12 Le nom de Le Corbusier apparait pour la première fois dans les écrits de Iancu dans la revue Rampa, dans un article qui annonce l'exposition internationale d'architecture moderne de Stuttgart, Die Wohnung.

Mais l'attention de Iancu pour les œuvres écrits ou bâtis de Le Corbusier semble définitivement attiré après la parution du livre Zwei Wohnhäuser, que Contimporanul présente ainsi:

"Certainement que ces architectes [Le Corbusier et Pierre Jeanneret] sont les chefs de file de l'entière reforme et que leur esprit lucide et critique guide aujourd'hui le mouvement architectural entier. Il suffit de lire ou de

\footnotetext{
${ }^{10}$ Contimporanul, 26 (1926): 6. Iancu échange des lettres ou rend visite à André Breton, Paul Eluard, Georges RibemontDessaignes, Max Ernst, Joseph Delteil, Jean Cocteau. La correspondance de Iancu s'est perdue lors de son émigration en Palestine en 1941.

${ }^{11}$ Il s'agit des numéros 53-54 (février 1925) et 57-58 (avril 1925) de la revue Contimporanul. Nicolae Lascu suppose que la traduction appartient toujours à Marcel Iancu, "Arhitectura în eseurile lui Marcel Iancu", dans Anca Bocăneț, Nicolae Lascu, Ana-Maria Zahariade, Eds., Marcel Iancu Centenary 1895-1995 (București: Editura Simetria, Uniunea Arhitecților Din România, 1996), 212. L'article de Nicolae Lascu est l'ouvrage le plus complet sur l'œuvre écrite de Iancu.

${ }^{12}$ Marcel Iancu, "Arhitectura", dans Geo Șerban, Întâlniri cu Marcel Iancu (București: Editura Hasefer), 108.
} 
feuilleter ce volume pour se rendre compte de leur immense supériorité et du pouvoir de persuasion de chaque détail de leur architecture."13

Dans une seule année, depuis cet article de mars 1928 et jusqu'à celui intitulée "Le Corbusier", de mars 1929, la figure de l'architecte français/suisse arrive à dominer, dans les yeux de Iancu, l'architecture moderne européenne, au fur et à mesure que ses caractérisations parcourent le chemin depuis "chef de file", par "guide malin", à "dirigeant visionnaire" et "prophète"14. Ce dernier article témoigne aussi du détachement de Iancu de l'école moderne allemande et la récupération de l'importance des articles parus dans L'Esprit Nouveau:

"Quand les révolutionnaires allemands, conduits par Gropius, s'efforçaient de dévoiler au monde une nouvelle architecture, [...] Le Corbusier publiait dans "L'Esprit Nouveau" des injonctions sur la route du rationalisme constructif, en annonçant l'adaptation totale à la technique et à l'économie des temps par la standardisation, l'industrialisation et l'objectivation de la forme.

Lorsque J.J.P. Oud [...] projetait des maisons qui étaient des véritables structures ornées et non-constructives, Le Corbusier réalisait la maison d'Ozenfant [...] C'était la première demeure qui exprimait, avec une sincérité brutale, la tendance robuste et large de Le Corbusier.

$[\ldots]$

Le Corbusier est celui qui nous a convaincu, par la ligne de la simplicité impersonnelle, industrielle, de ce que sera l'architecture de l'avenir. L'Europe entière a suivi les pas de ses recherches lucides... ${ }^{15}$

Après 1929, Iancu n'hésite plus à identifier lequel des architectes européens représente le mieux le programme révolutionnaire qu'il soutient lui-même. A partir de ce moment le nom de Le Corbusier apparaît constamment dans les écrits de Iancu, en même temps que les arguments du premier deviennent transparents dans ceux du dernier.

\subsubsection{Les arguments de Le Corbusier entre les lignes}

Si avant 1929 les différentes thèses de l'architecture moderne pouvaient émaner depuis plusieurs sources bibliographiques, après cette année, Iancu semble reprendre les livres que Le Corbusier avait écrits dans les années 1920 et il y demeure, indifférent à ceux publiés entre temps.

Il est certain que les livres écrits par Le Corbusier étaient connus parmi les architectes roumains : ils sont présents dans différentes collections privées et se retrouvent dans plusieurs bibliothèques publiques ${ }^{16}$. Toujours est-il que la plupart de ces professionnels auraient pu lire les livres de Le Corbusier en français, la lingua franca des élites roumaines. Ceci explique aussi la rareté des traductions de Le Corbusier en roumain. Dans ce contexte,

\footnotetext{
${ }^{13}$ Marcel Iancu, "Cărți de arhitectură nouă", dans Geo Șerban, Întâlniri cu Marcel Iancu (București: Editura Hasefer), $127-$ 128.

${ }^{14}$ Dans cette ordre chronologique, dans les articles de Iancu dans Contimporanul, 77 (1928), Contimporanul, 78 (1929), Cuvântul, (17.01.1929), Contimporanul, 80 (1929), dans Geo Șerban, Întâlniri cu Marcel Iancu (București: Editura Hasefer), 127, 130, 131, 133.

${ }^{15}$ Marcel Iancu, "Le Corbusier", Contimporanul 80 (1929), dans Geo Șerban, Întâlniri cu Marcel Iancu (București: Editura Hasefer), 133.

${ }^{16}$ La Bibliothèque de l'école d'architecture de Bucarest enregistre la triade Vers une architecture, Urbanisme, L'art décoratif d'aujourd'hui dans des éditions des années 1920, aussi bien que des traductions en allemand et anglais des premiers deux titres, parus toujours dans la même décade.
} 
le fait que Iancu (aussi que les autres auteurs et architectes roumains de l'époque) ne traduisent pas ses livres en roumain, mais utilisent ses arguments tout en les déformant pour les accorder à la situation particulière locale, indique un travail de popularisation hors du milieu architectural, dans les strates de la société qui ne s'auraient pas intéressé directement au développements de l'architecture en Europe. Parce que la plupart des revues qui reçoivent les textes de Iancu ne sont pas des revues d'architecture, mais rassemblent des contributions diverses littéraires, sur les arts plastiques, le théâtre, le cinéma, l'urbanisme etc. Il existe aussi le cas quand les articles de Iancu apparaissent dans des journaux à grand tirage qui semble confirmer l'intérêt que Iancu porte à la dissémination de ces idées au détriment de l'attribution correcte de leur source.

Parmi ces divers articles, les thèmes où l'emprunt des idées de Le Corbusier est le plus transparent peuvent être organisées dans plusieurs catégories : le changement du mode de vie qui réclame la révolution de l'habitation, la ville contemporaine, l'intérieur de l'habitation, la poésie de la géométrie - le jeux des volumes pures. Ont peut aussi remarquer l'évocation des mêmes images provocatrices telle celle du paquebot, de la voiture ou de l'avion $^{17}$ et l'utilisation des syntagmes devenues monnaie courante comme celle de la machine à habiter ${ }^{18}$.

Parmi ces thèmes Iancu semble avoir vibré particulièrement à la manière dont Le Corbusier énonce les problèmes de l'habitation moderne dans Vers une architecture en accentuant ses valeurs pérennes ("Une maison : un abri contre le chaud, le froid, la pluie, les voleurs, les indiscrets." ${ }^{19}$ ) ou ses formules rhétoriques de Manuel de l'habitation". Ainsi, dans sont article "La nouvelle architecture", Iancu parle d'un maison "pauvre, hygiénique, mais saine... un nid de repos et de santé" en ajoutant que "Notre luxe le plus précieux ne réside plus dans les candélabres et les brocarts, non plus dans les tapis et les soies, des meubles dorés ou des façades en marbre, notre luxe est la lumière et l'air de la maison, la pureté de la ligne et l'image saine de la forme simple. ${ }^{21}$

Similaire au Manuel de l'habitation, Iancu parle directement à l'utilisateur des nouvelles habitations et de la nouvelle ville - l'homme moderne, déterminé par opposition avec l'habitation malsaine qu'il est forcé d'occuper. Ainsi, il ne doit pas être le prisonnier de sa propre maison qui est un "dépôt de meuble", il ne doit pas "tourner en cercle" épuisé par une maison peu pratique en lieu de ce dédier aux activités de l'esprit et ne se lance pas dans des activités sociales frivoles, en les préférant à la vie familiale et cherchant toutes les excuses possibles pour ne pas habiter sa propre maison. Sauf que, en 1930, Iancu constate a posteriori cette évolution implacable de l'architecture et la met en relation avec un changement du mode de vie déjà accompli. Les particularités locales du bâti bucarestois transforment son argument aussi: il oppose les immeubles d'habitation modernes aux maisons patriarcales avec leurs jardins "orientales": "en quelques années, comme par miracle, la ville entière s'est peuplée de hauts palais, bureaux et surtout milliers d'habitations en commun, qui forment les ainsi nommées block-häuser, les vraies phénomènes du développement urbain". ${ }^{22}$ Par ces nouvelles habitations, "sans le moindre soupir et sans regret pour l'ancienne forme de vie", les habitants de la ville font preuve de leur option

\footnotetext{
${ }^{17}$ Marcel Iancu, "Arhitectura nouă", Vremea, III, 142 (1930), dans Geo Șerban, Întâlniri cu Marcel Iancu (București: Editura Hasefer), 143.

${ }^{18}$ Marcel Iancu, "Arhitectura socială", Contimporanul 93-94-95 (1930), dans Geo Șerban, Întâlniri cu Marcel Iancu (Bucureşti: Editura Hasefer), 144.

${ }^{19}$ Le Corbusier, Vers une architecture, (Paris: Flammarion), 89.

${ }^{20}$ Ibid., 96.

${ }^{21}$ Marcel Iancu, "Arhitectura nouă", Vremea, III, 142 (1930), dans Geo Șerban, Întâlniri cu Marcel Iancu (București: Editura Hasefer), 143 à comparer avec Le Corbusier, Vers une architecture, (Paris: Flammarion), 90.

${ }^{22}$ Marcel Iancu, "Cum vedeți Bucureștii de mâine?", Vremea, VIII, 387 (1935), dans Geo Șerban, Întâlniri cu Marcel Iancu (București: Editura Hasefer), 168-169.
} 
pour "une nouvelle vie, plus confortable, plus urbaine, avec du chauffage, des terrasses, des bains et de l'eau chaude..."23

Comme l'argument de Le Corbusier qui exige "une salle de toilette en plein soleil... une terrasse pour bains de soleil ; lavabos en porcelaine, baignoire, douches... le vacuum...le gramophone ou le pleyela... un garage d'auto, de vélo et de moto..." ${ }^{24}$, le confort que l'habitant est censé réclamer est défini par les plus récents progrès en matière de technologie, mais vise surtout la même "économie de vos gestes, de vos ordres et de vos pensées $^{\prime 25}$. Simplifier la vie quotidienne pour pouvoir dédier la plus grande partie du temps aux activités de l'esprit est ce que Iancu trouve lui aussi essentiel : "Ceux qui veulent une habitation vraiment nouvelle doivent vivre la vie réduite dans les formes presque ascétiques d'aujourd'hui. ${ }^{\prime 26}$

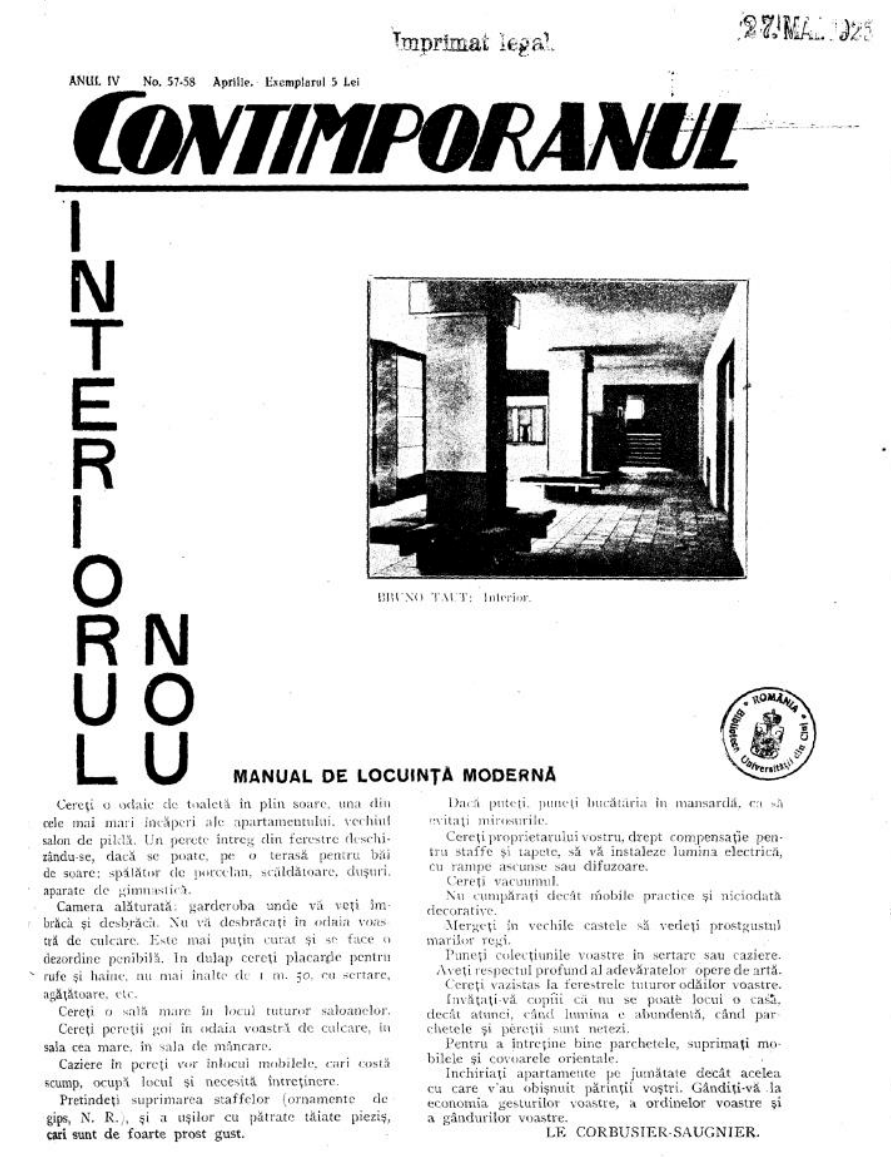

5. Couverture de Contimporanul, 57-58 (avril 1925) numéro dédié au nouveau intérieur qui reproduit Le manuel de l'habitation.

Ecrits dans les années 1930, ces articles ne développent pas des thèmes que Iancu n'avait pas touchés auparavant : dans l'article de 1925 intitulé "L'intérieur" il faisait déjà appel à la considération de l'utilité des meubles et non pas de leurs valeur ornementale, au renoncement à toute forme de décoration inutile : "La nouvelle esthétique... recommande l'enlèvement des tapettes, des tableaux. La pièce moderne demande que les meubles soient petites

\footnotetext{
${ }^{23}$ Ibid.

${ }^{24}$ Le Corbusier, Vers une architecture, (Paris: Flammarion), 96.

${ }^{25} \mathrm{Ibid}$.

${ }^{26}$ Marcel Iancu, "Arhitectură", Contimporanul, 100 (1931), dans Geo Șerban, Întâlniri cu Marcel Iancu (București: Editura Hasefer), 152.
} 
... et rares. ${ }^{\prime \prime 27}$. (5) Aussi avait-il déjà réclamé la simplification de la conception de l'habitation en rapport avec sa fonctionnalité : "L'intérieur moderne met en proportion la hauteur et l'étendue des pièces, selon leurs usages. [...] L'intérieur - place de repos - demande la clarté. ${ }^{28 " . ~ N e ́ a n m o i n s ~ c e ~ q u i ~ p a r a i s s a i t ~ e n ~} 1925$ un manifeste pour la vie moderne engagé, reçoit plus tard de fortes accents rhétoriques ainsi que le ton de l'auteur devient plus aigu et le langage plus violent : "L'esthétique est la peste de l'architecture", "Le pessimisme sclérotique ... du siècle passé...", avec de fortes accents pathétiques : "Jamais la chanson de la géométrie n'a commandé le sentiment de l'homme d'une manière plus intense et plus magnifique." ${ }^{129}$

A cette radicalisation de la forme de ces articles correspond aussi l'accroissement de ses préoccupations pour l'urbanisme doublé par l'adoption explicite de la conception de la ville contemporaine proposée par Le Corbusier. On peut supposer que les milliers d'habitations dont Iancu parle avaient déjà commencé de tracer les contours d'une nouvelle image de la ville, une image que Iancu juge dépourvue de vision. Il condamne cette situation en lui opposant l'exemple des théories de Le Corbusier. Parfois il cite ses références, surtout lorsque la structure de l'article permet l'appel aux exemples européens comme arguments pour les mesures qu'il faut prendre à Bucarest:

"... l'urbanisme doit à Perret, à Le Corbusier et à d'autres génies français, l'idée des villes-tours, qui résolvent d'une manière ingénieuse toutes les problèmes techniques, de l'hygiène, de la circulation, du confort et de l'esthétique dans la ville moderne. Des tours implantés à 500m l'un de l'autre, posés dans des parcs fleuris, qui montent leurs 100 étages... Liés par des autoroutes et des trains volants avec des gares centrales et des aéroports au milieu, ils nous permettent une vision vraie du futur proche. Une populace plus dense que dans les plus tristes foyers infectieux des villes d'aujourd'hui pourra habiter ensemble dans des parcs, sous le soleil, en plein air, en faisant du sport et avec des conditions d'hygiène idéales. ${ }^{130}$ (6)

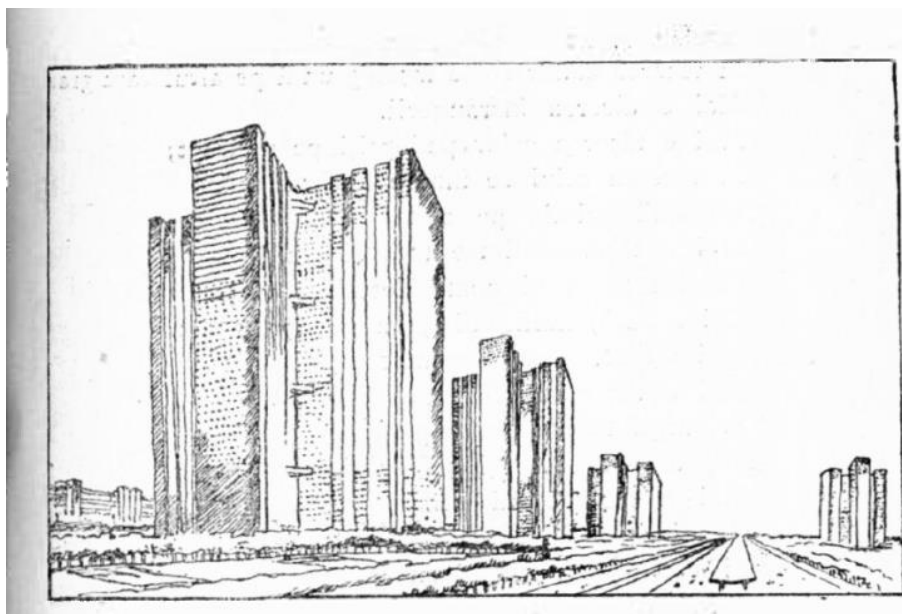

Peret : Cotăfile-Turnuri (desen Saugnier)

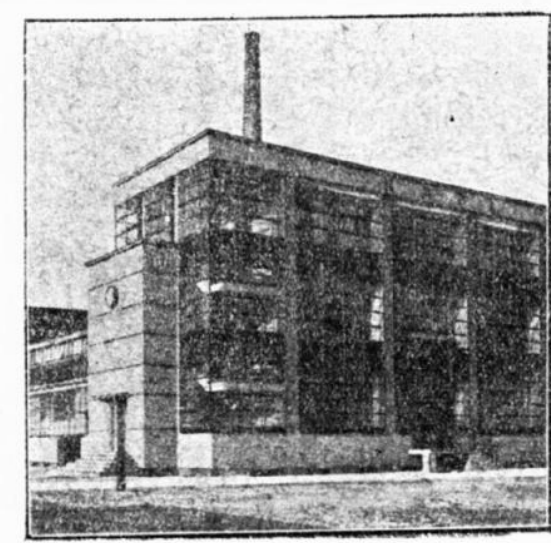

B. Taut : Uzină (Germania)

6. Projet de villes-tours reproduit dans Contimporanul, 53-54 (fevrier 1925), 7, dans le projet est attribué à Auguste Perret et le dessin à Le Corbusier (Saugnier).

\footnotetext{
${ }^{27}$ Marcel Iancu, "Interiorul", Contimporanul, $57-58$ (1925), dans Geo Șerban, Întâlniri cu Marcel Iancu (București: Editura Hasefer), 99.

${ }^{28}$ Ibid.

${ }^{29}$ Dans cette ordre dans Marcel Iancu, "Arhitectura nouă", Vremea, III, 142 (1930), et "Arhitectura socială", Contimporanul, 93-94-95 (1930), dans Geo Șerban, Întâlniri cu Marcel Iancu (București: Editura Hasefer), 143, 144.

${ }^{30}$ Marcel Iancu, "Urbanism, un romantism", Orașul săptămânal, I, 2 (1934), dans Geo Șerban, Întâlniri cu Marcel Iancu (București: Editura Hasefer), 161-163.
} 
Autres fois, quand il propose des solutions pour la situation particulière de la ville de Bucarest, le projet de Le Corbusier se devine caché derrière des indicateurs de densité semblables, l'hauteur à laquelle il aspire ou la distance minimale entre deux croisements de rues etc.

\subsubsection{Vers une architecture de Bucarest}

Nulle part n'est l'influence de Le Corbusier si évidente que dans la conférence que Iancu présente en 1935, à l'invitation de L'Association pour l'urbanisme de Bucarest, dans le cycle Vers une architecture de Bucarest ${ }^{31}$. Le titre est visiblement une référence directe au livre plus fameux de Le Corbusier. (7) Son nom est présent dans toutes les trois conférences qui forment le cycle. Est-ce preuve qu'entre temps Vers une architecture est devenue tellement connu dans les milieux professionnels de Bucarest, que l'affiliation avec son auteur ait fonctionnée pour l'association-hôte comme artifice publicitaire?

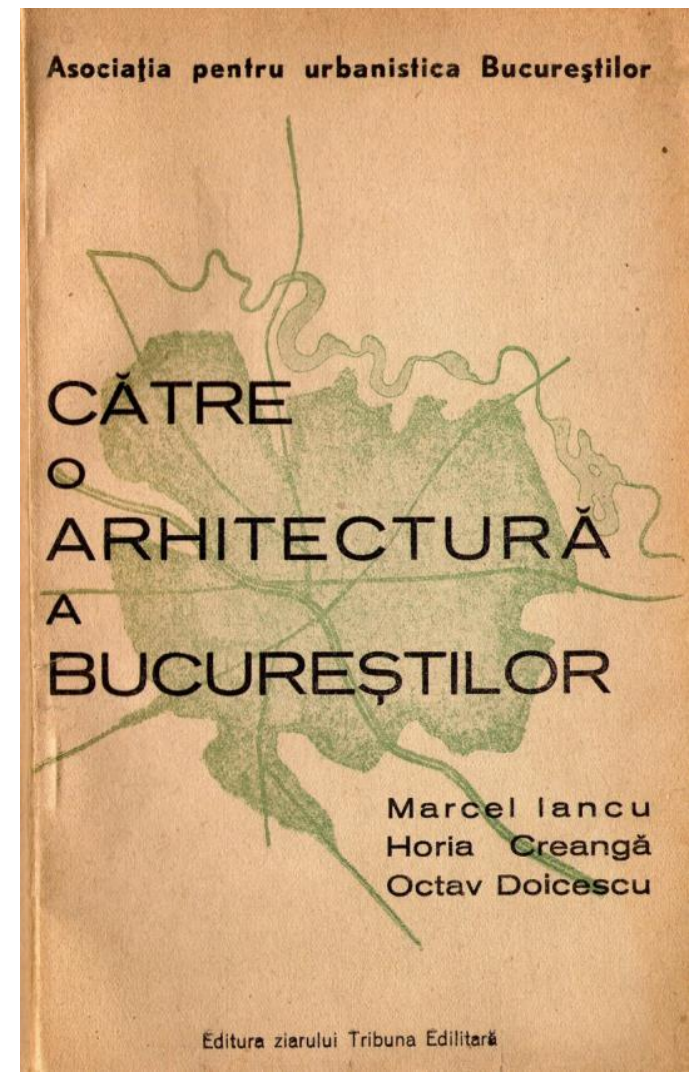

7. Couverture du livre homonyme paru après le cycle de conférences.

Il est possible que L'Association pour l'urbanisme de Bucarest ait cherché gagner du terrain par rapport aux institutions plus établies dédiées à l'urbanisme ${ }^{32}$, d'autant plus que la fabrique de la ville semble avoir refusé entre les deux guerres l'urbanisme libre, en profit d'une modernisation modérée guidée par le modèle de la villejardin. Dans l'entre-deux-guerres la manière dans laquelle Le Corbusier envisage la ville semble avoir enflammé plutôt l'imagination des architectes sans que leurs idées soient entendues comme propositions réalistes.

\footnotetext{
${ }^{31}$ Asociația pentru urbanistica Bucureștilor, Către o arhitectură a Bucureștilor (București: Editura ziarului Tribuna Literară, 1935).

${ }^{32}$ Uniunea Orașelor din România [L'Union des ville de Roumanie], fondée en 1923 et Institutul Urbanistic Român [L'Institut roumain de l'urbanisme] - en 1932. Pour les débuts de l'urbanisme en Roumanie, voit aussi Andreea Udrea, Irina Calotă, "Getting Global, Staying Local. The turmoil of the first steps towards scientific urban planning - the case of Cincinat Sfințescu", dans SITA 2 (2014): 34-51.
} 
D'ailleurs le titre de la conférence de Iancu - Utopia Bucureștilor [L'utopie de Bucarest] - suggère que l'auteur est conscient de la distance qui sépare ses proposition de la réalité bâtie, même si, tout comme Le Corbusier dans Urbanisme, son argument semble hésiter entre la description d'un avenir visionnaire et un projet à attaquer à partir du lendemain.

La structure de son propos est tripartite : l'introduction fait l'histoire des causes qui ont abouti aux problèmes actuels et retient l'occasion pour mettre en évidence les moments qui, inspirés par la géométrie, ont conduit vers des interventions urbanistiques durables: "La où la pensée de l'homme a inventé, où sa main a façonné, vous allez découvrir les lois de la géométrie : la ligne droite, la surface pure, le volume simple." ${ }^{33}$ Continuant la série de parallèles avec la structure de l'Urbanisme, son argument conduit à l'intervention de la machine, des questions édilitaires modernes et des problèmes du foncier liés à la fragmentation du parcellaire : "d'un coup, vers la moitié du siècle dernier, l'ancienne presque-ville est secouée des racines par la machine. La rue devient trop étroite..." ${ }^{34} \mathrm{C}$ 'est ainsi que Iancu arrive à apprécier d'une manière positive le décalage qui sépare Bucarest de la plupart des villes européennes puisqu'il y trouve enfin une opportunité pour guider le développement sur de nouvelles bases : "Le style moderne demande l'urbanisme moderne." 35

La deuxième partie définit "le principe de la ville moderne" en renvoyant directement aux CIAM ${ }^{36}$ et par l'intermédiaire d'une description synthétique de la Ville contemporaine pour trois millions d'habitants ${ }^{37}$.

Enfin la troisième partie parle des mesures qu'il faut prendre pour emmener au bout non pas le projet de Le Corbusier, mais "sa croissance [de Bucarest] vers un tel avenir" ${ }^{38}$. Comme preuve supplémentaire de la similarité de cette structure en trois parts avec celle de l'Urbanisme, où la dernière partie correspondrait au Plan Voisin, Iancu attaque ensuite les problèmes spécifiques de la ville de Bucarest avec des solutions précises pour des situations particulières. Comme Le Corbusier, il choisit ce qu'il faut garder par rapport à ce qu'il faut sacrifier, en classant les différentes opérations antérieures en tant que visionnaires ou impropres aux temps nouveaux. C'est dans le même sens qu'on peut citer la substitution du Parc Monceau ou du Palais Royal ${ }^{39}$ dans l'argument original de Le Corbusier avec les jardins Cișmigiu ${ }^{40}$, qui deviennent ainsi le modèle qui guidera le développement à venir:

"Ne pleurez pas pour le Cișmigiu, car chaque groupement de maisons va recevoir un Cișmigiu dans son cour." ${ }^{41}$

Cet ainsi que Iancu semble reprendre l'argument de Le Corbusier non pas en traduisant les idées du dernier en roumain, mais en les adaptant assez attentivement à la situation particulière de Bucarest.

\footnotetext{
${ }^{33}$ Marcel Iancu, "L'utopie de Bucarest", dans Asociația pentru urbanistica Bucureștilor, Către o arhitectură a Bucureștilor, 8.

${ }^{34}$ Ibid., 12.

${ }^{35}$ Ibid., p.11.

${ }^{36}$ Aucun architecte roumain n'a participé aux CIAM. La référence des Congrès apparaisse une seule autre fois dans les écrits de Iancu dans "Urbanism, un romantism", Oraşul săptămânal, I, 2 (1934), dans Geo Șerban, Întâlniri cu Marcel Iancu (București: Editura Hasefer), 162.

${ }^{37}$ Marcel Iancu, "L’utopie de Bucarest”, dans Asociația pentru urbanistica Bucureștilor, Către o arhitectură a Bucureștilor, $14-16$.

${ }^{38}$ Ibid., 16.

${ }^{39}$ Le Corbusier, Urbanisme (Paris: Flammarion, 1994), 73, 192.

${ }^{40}$ Les jardins Cișmigiu sont les plus vieilles jardins publics de Bucarest, réalisées à partir de 1847, par Wilhelm Meyer, l'ancien directeur des Jardins Impériaux de Vienne.

${ }^{41}$ Marcel Iancu, "L'utopie de Bucarest”, dans Asociația pentru urbanistica Bucureștilor, Către o arhitectură a Bucureștilor, 18.
} 
Avec l'occasion du même cycle de conférences, deux autres architectes modernes, Horia Creangă et Octav Doicescu, ont présenté leurs visions. Le Corbusier est présent dans les deux, mais avec des accents différents.

Le propos de Horia Creangă, intitulé Anarhia stilurilor și arta viitorului [L'anarchie des styles et l'art de l'avenir], est une plaidoirie pour l'architecture moderne comme matériel pour la ville nouvelle. Les grands traits de son raisonnement s'inscrivent dans la ligne de l'argument pour "du chaos, du tumulte dans l'ensemble; de l'uniformité dans le détail ${ }^{\prime \prime 2}$, mais les échos des idées corbuséennes se laissent entendre encore d'avantage lorsque l'auteur plaide pour "simplicité. Des volumes bien proportionnés et tranchants dans l'espace, des lignes droites, des surfaces sans ornements inutiles. Des fenêtres en frise..." ${ }^{\prime \prime 3}$. Mais ces prescriptions montrent surtout l'adhérence de Creangă au programme de l'architecture moderne et non pas forcément qu'il prend son inspiration des livres de Le Corbusier. C'est aussi de même pour l'argument fonctionnel ou la référence à la fameuse triade air-lumière-soleil. Creangă se rapproche le plus de Le Corbusier lorsqu'il dispute l'idée que l'architecture moderne n'est pas représentative, qu'elle n'est pas nationale, en rappelant la simplicité de l'architecture traditionnelle qu'il oppose aux styles historiques : "Notre architecture moderne prend ses sources des besoins généraux du temps et non pas du plaisir de l'imitation. Pourtant cet art des lignes simples a le même âge que le monde [...] Par conséquant, il ne s'agit pas de style, mais d'une conception issue des besoins qui ont affronté les millénaires; il ne s'agit pas de style, car les styles périssent, il s'agit de l'architecture de la simplicité qui demeure immuable. ${ }^{144}$

De l'autre coté, la conférence de Octav Doicescu, Spiritul arhitecturii Bucureștilor [L'esprit de l'architecture de Bucarest], montre explicitement que les architectes locaux étaient au courant avec les livres de Le Corbusier et suggère même que le rôle que Marcel Iancu ait joué pour disséminer ses idées ait été décisif. Doicescu envoie directement au scandale provoqué par le concours pour le Palais des Nations ${ }^{45}$ ainsi qu'aux livres : "Le Corbusier a publié son livre célèbre "Vers une architecture". Il éclaire le chemin de la génération qui pose les bases révolutionnaires de la nouvelle architecture. Ce livre a suscité de l'intérêt et, naturellement, aussi des oppositions. Nous ajouterons le mérite de notre confrère Marcel Iancu qui, avec autres enthousiastes de l'esprit nouveau, a prophétisé à Bucarest la construction qu'on voit aujourd'hui généralisée." 46

L'évocation de la figure de Le Corbusier au début de sa conférence lui sert pour établir la consécration de l'architecture moderne en Europe, pour pouvoir en suite traiter les questions particuliers de sa mise en œuvre à Bucarest. Ainsi, Doicescu identifie plusieurs problèmes: l'inertie du plan de l'habitation qui fait que les bâtiments en apparence modernes abritent des logements où la vie moderne n'a pas encore trouvé sa place ; le manque de compétences techniques qui fait que des façades fausses cachent des charpentes traditionnelles derrière des murs sans logique, offrant seulement l'illusion "des belles harmonies de volumes"; le programme de l'immeuble de rapport et les règlementations urbaines trop permissives qui conduisent vers l'exploitation maximale du terrain plutôt que d'encourager la réduction de la surface du sol occupé par le bâti. Ainsi apparaissent les mêmes "courts et courettes vicieuses et tordues - des vrais puits de lumière, censées d'être

\footnotetext{
${ }^{42}$ Le Corbusier, Urbanisme, 65.

${ }^{43}$ Horia Creangă, "L'anarchie des styles et l'art de l'avenir", dans Asociația pentru urbanistica Bucureștilor, Către o arhitectură a Bucureștilor, 26.

${ }^{44}$ Ibid., 30.

${ }^{45}$ Doicescu était au courant avec plusieurs détails du concours: "Si on l'a décidé que les plans du palais soit exécutés par les représentant de la routine vieilli, on peut affirmer que la nouvelle architecture, par les résultats obtenus - les prix de Le Corbusier et d'autres - a gagné la lutte morale." Octav Doicescu, "L’esprit de l'architecture de Bucarest", dans Asociația pentru urbanistica Bucureștilor, Către o arhitectură a Bucureștilor, 34.

${ }^{46}$ Ibid.
} 
perpétuellement obscures ${ }^{\prime 47}$, et les immeubles, plutôt que se détacher l'un de l'autre, offrent "des murs mitoyens sur 10 étages d'hauteur." 18

Mais toutes ces situations sont appréciées comme autant d'échecs parce qu'ils sont évaluées par rapport à un modèle - "L'exemple théorique esquissé par Le Corbusier"49 - modèle qu'on aperçoit aussi entre les lignes de l'auteur lorsqu'il parle de "la joie du volume rude, bien balancé dans la lumière, simple, sincère" ou de "la grande élasticité des plans". ${ }^{50}$

Au delà de toutes références directes ou des échos lointains des paroles de Le Corbusier, Doicescu surprend surtout la nuance cachée dans le titre même de Vers une architecture, qui envoie à la recherche de l'architecture authentique et propre à son temps telle qu'elle se détache de l'esprit de l'époque ${ }^{51}$. Ainsi il saisit ce que la plupart des traductions des années 1920 de Vers une architecture ont omis ${ }^{52}$ en simplifiant son sens et en le plaçant dans une position d'incongruité avec son contenu. Doicescu suggère en même temps une recherche qui n'est pas encore aboutie ${ }^{53}$, peut-être même une recherche continuelle comme celle qui deviendra la recherche patiente de Le Corbusier, et aussi une démarche que l'appel à l'utilité et à l'emploi des matériaux contemporains ne vont pas pouvoir la soulever aux hauteurs requises à l'architecture comme pure création de l'esprit :

"Beaucoup de ces matériaux ... vont lentement changer aussi cette plastique de la nouvelle architecture avec laquelle nous nous sommes aujourd'hui habitués. L'évolution est longue. La forme ne va pas pouvoir être trouvée dans un temps aussi court. Et peut-être ne la trouvera-t-elle pas encore longtemps si elle se limitera à une expression purement utilitaire et basé seulement sur la plastique des matériaux industriels. ${ }^{54}$

\subsection{Le Corbusier dans le miroir roumain de l'entre-deux-guerres}

En ce qui concerne la réflexion de Le Corbusier dans la littérature professionnelle des années 1920 et 1930, nous pouvons affirmer que ses idées ont parcouru la distance qui sépare la Roumanie de l'Europe occidentale avec un minimum de décalage temporaire et que Marcel Iancu a joué le rôle le plus important dans leurs dissémination. Mais Iancu n'a pas était le seul interprète des idées corbuséennes, non plus était-il le seul à faire preuve de sa lecture subtile. La plupart de l'élite roumaine dans le domaine de l'art et de l'architecture avait accès directement aux livres de Le Corbusier en version originale française. Ainsi nous pouvons supposer que cette connaissance de la langue française a été la principale raison pour laquelle la littérature roumaine n'enregistre pratiquement aucune traduction intégrale de ses œuvres écrits.

\footnotetext{
${ }^{47}$ Ibid., 36.

${ }^{48}$ Ibid., 37.

${ }^{49}$ Ibid., 36

${ }^{50}$ Ibid., 35,36 .

${ }^{51}$ L'argument de Reyner Banham, Theory and Design in the First Machine Age, (Cambridge Massachusetts - London England: The MIT Press, 1980), 246: "the original title V1A, simply says 'Towards an Architecture', and implies, from internal evidence in the book, an absolute or essential architecture..."

${ }^{52}$ Le glissement de la signification du titre original dans les premières traductions allemande et anglaise est remarqué par plusieurs commentaires. Jean-Louis Cohen montre que Le Corbusier avait considéré plusieurs alternatives pour le titre Architecture et révolution ou L'architecture nouvelle, "Introduction" dans Toward an Architecture (Los Angeles: Getty Research Institute, 2007), 40-41.

${ }^{53}$ La maison-outil, la «machine à habiter» est devenue monnaie courante? La machine à habiter comment? [...] Si les installations sanitaires sont en honneur, le sentiment qui habite nos cœurs est-il exprimé... ?, Le Corbusier, Vers une architecture, (Paris: Flammarion), IV.

${ }^{54}$ Octav Doicescu, "L’esprit de l'architecture de Bucarest", dans Asociația pentru urbanistica Bucureștilor, Către o arhitectură a Bucureștilor, 37 .
} 
Dans ce contexte, les échos des livres de Le Corbusier peuvent être lus sur plusieurs paliers : dans le domaine de la théorie, on peut suivre comment ses arguments participent à la définition de l'architecture moderne ou à la description de la relation que celle-ci établie avec les autres arts, avec l'industrie ou avec les nouveaux matériaux et technologies. Sur un autre palier, on constate que la particularité de la manière dont les idées de Le Corbusier ont été reprises et interprétées a été leur instrumentalisation et leur adaptation aux conditions locales de la ville de Bucarest. Ici, le nom de Le Corbusier a fonctionné comme autorité incontestable et son modèle était à suivre surtout dans la manière dont on regarde le développement de la ville. Dernièrement, on peut constater qu'il s'agit des échos des livres que Le Corbusier avait rédigé dans les années 1920 - Vers une architecture, Urbanisme et dans une moindre mesure L'art décoratif d'aujourd'hui et Une maison - Un palais - lorsque les livres parus dans les années 1930 semblent ne pas avoir été autant appréciés par les professionnels roumains de l'époque.

\section{Synthèses rétrospectives}

\subsection{Le Corbusier par Le Corbusier ${ }^{55}$}

Le souci de Le Corbusier pour la présentation unitaire de son activité et, finalement, pour son identification avec la totalité de son œuvre va marquer les derniers vingt années de sa vie. C'est dans ce sens que l'auteur décide dès 1946 l'édition d'une "Synthèse du travail de l'auteur dans le champ de l'art et de l'architecture durant les quarante dernières années. ${ }^{\prime 56}$ Sous divers titres, Space beyond words, L'espace indicible, le livre vas paraître en 1948 comme New World of Space, un titre dans lequel l'auteur veut recueillir "peinture - architecture et urbanisme, mais du seul point de vue lyrisme, beauté, esthétique plastique. ${ }^{157}$

Les livres que Le Corbusier écrira en suite vont se contaminer de cet esprit et témoignent de la recherche des moyens capables à exprimer dans l'espace typographique la synthèse que Le Corbusier cherche d'accomplir. Cette quête se reflète dans la grande diversité des livres publiés dans ces années, dans lesquels on peut discerner des accents distincts, qui nuancent entre les exercices autobiographiques, le journal, la monographie et la synthèse plastique de la forme et du contenu du livre et, finalement, la synthèse de l'œuvre entier et de l'auteur.

Cette direction est soutenue par la parution du Modulor (1950), et renforcée par celles successives de Poésie sur Alger (1951), Le Poème de l'angle droit (Verve, Paris, 1955), Modulor 2 et Les plans de Paris 1956-1922 (1956). En même temps Le Corbusier décide de publier une nouvelle série sous le titre Carnets de la recherche patiente. La syntagme "recherche patiente", que Le Corbusier avait déjà utilisé pour indiquer les activités artistiques de son atelier ${ }^{58}$, désigne sans-doute aussi ce rapport avec le temps, qui fait que le passé soit retracé et intégré dans les réflexions durables de l'auteur. Parallèlement le caractère autoréférentiel de ces réflexions s'exprime par l'entrecroisement des divers milieux et moyens artistiques. Les livres de cette période émanent un autre rythme, libéré de la pression de l'urgence qui avait caractérisé ses livres de jeunesse. Moins préoccupé de motiver la justesse d'une cause, Le Corbusier se penche en revanche sur la lente distillation de la substance de ses livres dans des formes qui reflètent sa personnalité entière. Cette réflexion est présente même dans les publications ayant comme sujet un seul bâtiment comme le montre Une petite maison (1954) ou Ronchamp

\footnotetext{
${ }^{55}$ Le sous-chapitre est basé sur ma recherche doctorale non-publiée Le Corbusier. Teme și forme ale teoriei arhitecturii în secolul XX [Le Corbusier. Thèmes et forme de la théorie architecturale au XXe siècle], soutenue à l'Université d'Architecture et Urbanisme "Ion Mincu" de Bucarest, en 2010.

${ }^{56}$ Catherine de Smet, Vers une architecture du livre. Le Corbusier: édition et mise en pages 1912-1965 (Baden: Lars Müller Publishers, 2007), 83;

${ }^{57}$ Lettre à sa mère et frère datée 14 avril 1946 (FLC, R2-4-85) dans ibid., 84.

${ }^{58}$ Ibid., 123.
} 
(1957), les deux parus dans la collection Carnets de la recherche patiente. La série sera interrompue après ces deux titres jusqu'à la parution de L'Atelier de la recherche patiente, en 1960.

Les dernières pages de L'Atelier de la recherche patiente ${ }^{59}$ montrent un tableau : la surface imprimée du livre ouvert est divisée en six lignes et six colonnes. La première entrée annonce le contenu du tableau comme la bibliographie du livre, mais en regardant de plus près on ne voit que des livres écrits par Le Corbusier lui-même. Ainsi, du haut en bas, de gauche à droite, sont rassemblés trente cinq livres couvrant une période de quarante neuf années, en terminant par le titre du volume que le lecteur est en train de fermer. Ce tableau présente plus que le nombre et les titres des livres que Le Corbusier avait écrits. Comme bibliographie, il contient les références que l'auteur recommande pour son ouvrage. Mais cette série de publications où les seuls autres noms inscrits sont ceux des co-auteurs se termine par le nom de Le Corbusier lui même. Ainsi non seulement se placet-il au bout d'une liste de ses propres œuvres comme si toutes aboutissent avec la personne de l'auteur, mais il s'enferme dans l'espace typographique du volume. (8)

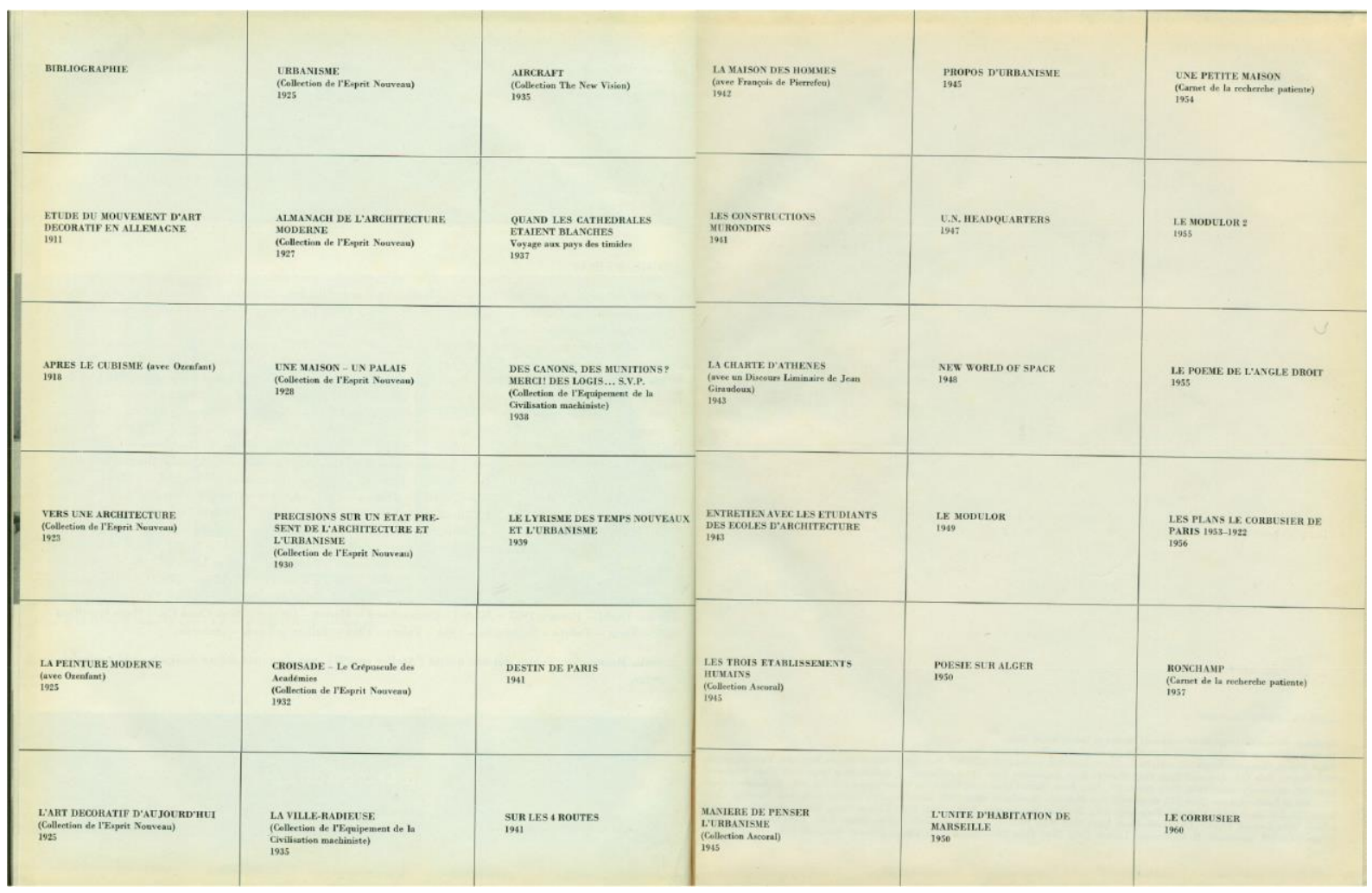

8. Bibliographie pages 310-311 de l'Atelier de la recherche patiente [Le Corbusier, textes et planches], (C FLC/ADAGP

La couverture extérieure indique en apparence l'auteur et le titre, mais cette fois Le Corbusier ne présente plus un carnet de la recherche patiente, mais l'atelier lui-même, le laboratoire dans lequel tous les titres de la bibliographie sont nés. Il se présente. Sur la couverture du livre on retrouve seulement le dessin de la main ouverte. Sur le dos, de nouveau son nom : "Le Corbusier". La page de titre annonce un autre : "Le Corbusier, textes et planches". Sont-ils l'auteur, l'atelier et la totalité des livres interchangeables?

Cette hypothèse est confirmée aussi par le contenu. La table de matières annonce deux parties principales intitulées "Chronologie" et "Un métier" mais, tout en suggérant une biographie et un recueil des œuvres, les deux parties s'avèrent couvrir la même matière : sans reprendre aucune image, sans répéter aucun morceau du

${ }^{59}$ Le Corbusier, Atelier de la recherche patiente [Le Corbusier, textes et planches], (Paris: Vincent Fréal et Cie, 1960). 
texte, la première partie est une chronologie de l'activité de l'auteur, lorsque la deuxième discerne entre les différentes métiers qui compose la vie créative de Le Corbusier. Mais les deux parties sont façonnées par l'entrecroisement des mêmes matériaux - textes, dessins, photographies, plans - et représentent les mêmes sujets - la peinture, la sculpture, l'architecture de Le Corbusier, marquées par son activité de conférencier et celle d'auteur de livres. $(9,10)$

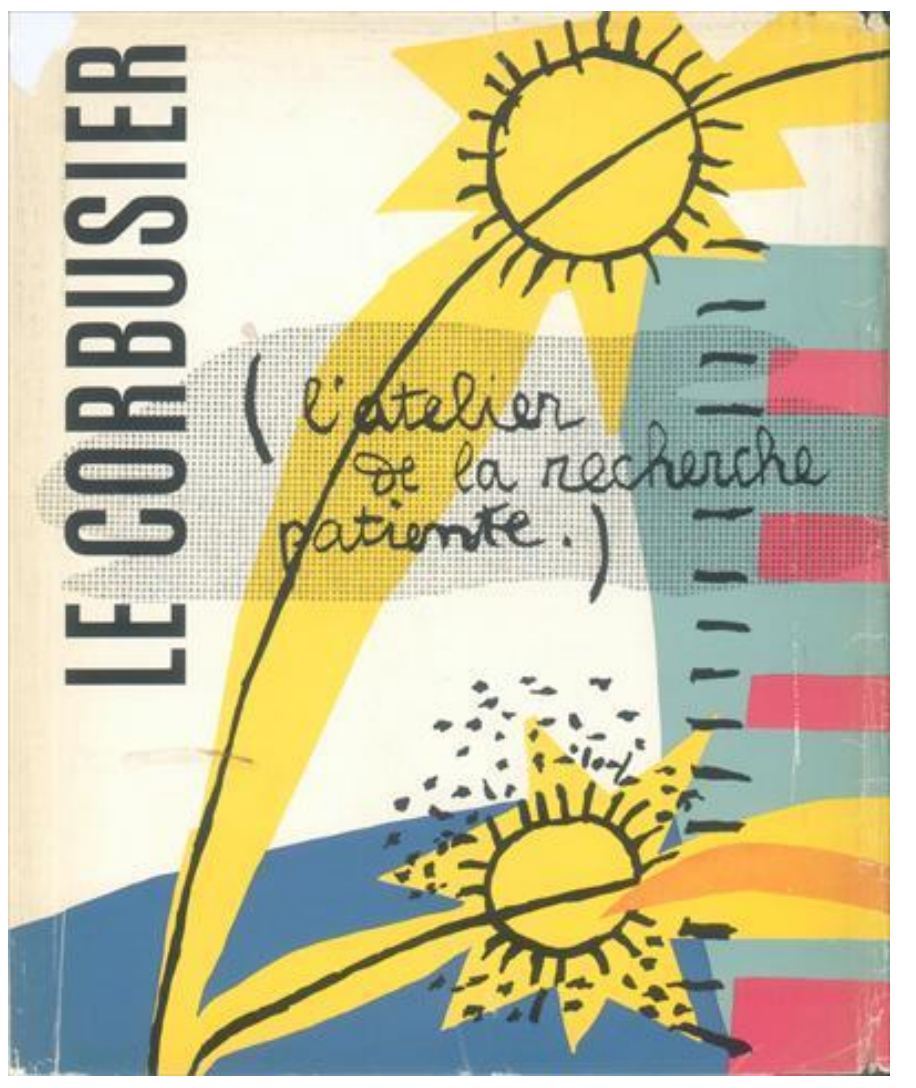

L'Atelier de la recherche patiente, Le Corbusier, 1960

Textes et planches de Le Corbusier

Première Partie: CHRONOLOGIE

Le pays natal

1900-1918

1919-1939

1940-1960

Deuxième Partie: UN MÉTIER

1. L'atelier de la recherche patiente

2. Dessiner (observer - découvrir - inventer - créer)

3. Ni commencement, ni fin

a. La peinture

b. La sculpture

c. Architecture et urbanisme solidaires

4. Le verbe (l'écrit - la parole)

5. Ceux qui ont aidé

Bibliographie

9. - 10. Couverture extérieure et reproduction de la table de matières de Le Corbusier, Atelier de la recherche patiente [Le Corbusier, textes et planches], (C) FLC/ADAGP

Si dans la première partie la peinture, la sculpture et l'architecture s'entremêlent, leurs présentations séparées dans la deuxième partie semblent contredire l'unité que Le Corbusier veut imposer sur son propre œuvre. En revanche, la manière de formuler les sous titres la renforce. Ainsi, le métier s'organise en cinq chapitres sous le signe de L'Atelier de la recherche patiente (cette fois, le titre du chapitre) qui s'ouvre avec une confession qui envoie, derrière les apparences, vers une partie de son œuvre qu'aucune expression publique n'a rendu apparente : "Je pense que si l'on accorde quelque signification à mon æuvre d'architecte, c'est à ce labeur secret qu'il faut en attribuer la valeur profonde. ${ }^{\prime 60}$

En suite, le deuxième chapitre intitulé Dessiner place sous le signe de l'égalité les verbes observer - découvrir inventer - créer et conduit ainsi la compréhension des dessins reproduits. Le chapitre Ni commencement, ni fin rassemble la peinture, la sculpture, l'architecture et l'urbanisme et affirme implicitement les liens indissolubles tissus entre toutes œuvres présentées tout en refusant aucune hiérarchie. Enfin, le chapitre dédié à la parole, $L e$ verbe, porte sur les écrits et les conférences, qu'il situe dans une manière poétique dans la continuité du dessin par l'intermédiaire d'une autre série d'équivalences : à inventer, à composer, à formuler, à dire... C'est ainsi que

\footnotetext{
${ }^{60}$ Ibid., 197.
} 
Le Corbusier place cette partie de son activité dans le domaine de la création ${ }^{61}$ et l'inclut, à coté de ses autres préoccupations, dans un seul projet artistique totalisant.

\subsection{De l'autre part : Le Corbusier vu de loin}

Après la guerre et surtout à partir de 1952 l'architecture en Roumanie est enrégimentée dans les volutes d'un appareil politique qui touche toutes les structures de la société : "le contrôle politique s'établit à toutes les niveaux, depuis l'éducation, à ceux de la théorie et de la pratique [de l'architecture] ${ }^{162}$. L'architecture, dont les thèmes urgentes ont incité des débats ardents dans l'entre-deux-guerres, est réduite soudainement au discours officiel, qui énonce des sujets clairs, scientifiques, d'une voix unique, qui ne tolère pas des commentaires ou des controverses. Si, après une première période calquée sur le modèle stalinien du réalisme-socialiste, à partir de 1958 la surface visible de l'architecture se retourne vers ce qui semble être la continuation de l'expression et des thèses d'avant la guerre ${ }^{63}$, cette transfiguration superficielle n'a pas représenté une véritable porte ouverte pour la libre circulation des modèles entre les deux moitiés de l'Europe.

Dans ce contexte, même s'ils étaient ardemment lus - empruntés, photocopiés, disséminés à tout prix - les livres de Le Corbusier ne pouvaient pas occuper aucune place dans le discours officiel de l'architecture. Même si ses œuvres bâtis étaient prisés, étudiés et émulés dans l'école d'architecture ou dans les rares situations où le programme permettait une plus grande liberté d'expression, ses idées ne devraient pas rivaliser la direction établie par les plans d'état. Il est probable que plusieurs architectes et étudiants lisaient encore Le Corbusier en version originale, ou des articles des revues étrangères qui entraient dans les bibliothèques ${ }^{64}$. Il était certainement connu. Toujours est-il que la principale revue architecturale qui a paru pendant toute la période du régime communiste, Arhitectura, ne lui consacre qu'onze articles, entre 1952 et 1989, dont aucun avant sa mort.

Parmi les onze, trois sont des entrées liées à l'anniversaire centenaire de sa naissance en 1987, deux autres sont des présentations photographiques de ses œuvres, une est un essai sur la promenade architecturale. Le reste de cinq articles sont signés par le même auteur, Marcel Melicson ${ }^{65}$.

Le premier signé par Melicson paraît l'année de la mort de Le Corbusier, dans le dernier numéro de la revue en $1965^{66}$ et reprend ce que l'auteur considère les plus importants projets réalisés par Le Corbusier. Les autres quatre articles font partie d'une série intitulé Fiches pour une histoire de la pensée architecturale contemporaine, que Melicson publie à partir de 1967. Dans cette série, il dédie un article à Frank Lloyd Wright, deux à Adolf Loos, trois à Walter Gropius, quatre à Le Corbusier etc. Tous les quatre articles sur Le Corbusier

\footnotetext{
${ }^{61}$ Une grande partie du travail créatif de L-C s'est élaborée dans ses livres d'une part et, d'autre part, dans ses exposés publics (dans le monde entier, et dès $1920 \ldots$ pendant quarante années), ibid.

${ }^{62}$ Ana-Maria Zahariade, Architecture in the Communist Project (București: Editura Simetria, 2011), 32.

${ }^{63}$ Ce changement d'orientation suive aussi le modèle de Moscou offert par le discours de Nikita Sergueïevitch Khrouchtchev de 1954. En Roumanie, cette modification de direction sera implémentée à partir des années 1958-59. Voit aussi Ana-Maria Zahariade, Architecture in the Communist Project (București: Editura Simetria, 2011), 54-56.

${ }^{64}$ Gabriela Tabacu, "On what and how. Architectural Magazines in the School Library (1945-1989)", dans SITA, I, "Printed in Red. Architectural Writings during Communism" (București: Editura Universitară "Ion Mincu", 2013), 133-148.

${ }^{65}$ Marcel Melicson est architecte et théoricien. Il publie beaucoup dans la revue Arhitectura sur des sujets assez vastes. Il appartient aussi à la rédaction de la revue (après 1958, lorsque la revue énonce les membres de la rédaction) et devient le premier rédacteur en chef à partir de 1963, comme le montre Ana-Maria Zahariade, "Testing the Physiognomy of the Arhitectura Magazine (1952-1989)", dans SITA, 1, "Printed in Red. Architectural Writings during Communism" (București: Editura Universitară "Ion Mincu", 2013): 166.

${ }^{66}$ Marcel Melicson, "Le Corbusier (1887-1965)", dans Arhitectura 6 (1965): 54-57.
} 
seront intégrés dans son prochain livre Le Corbusier. Bucuriile esențiale [Le Corbusier. Les joies essentielles](11).

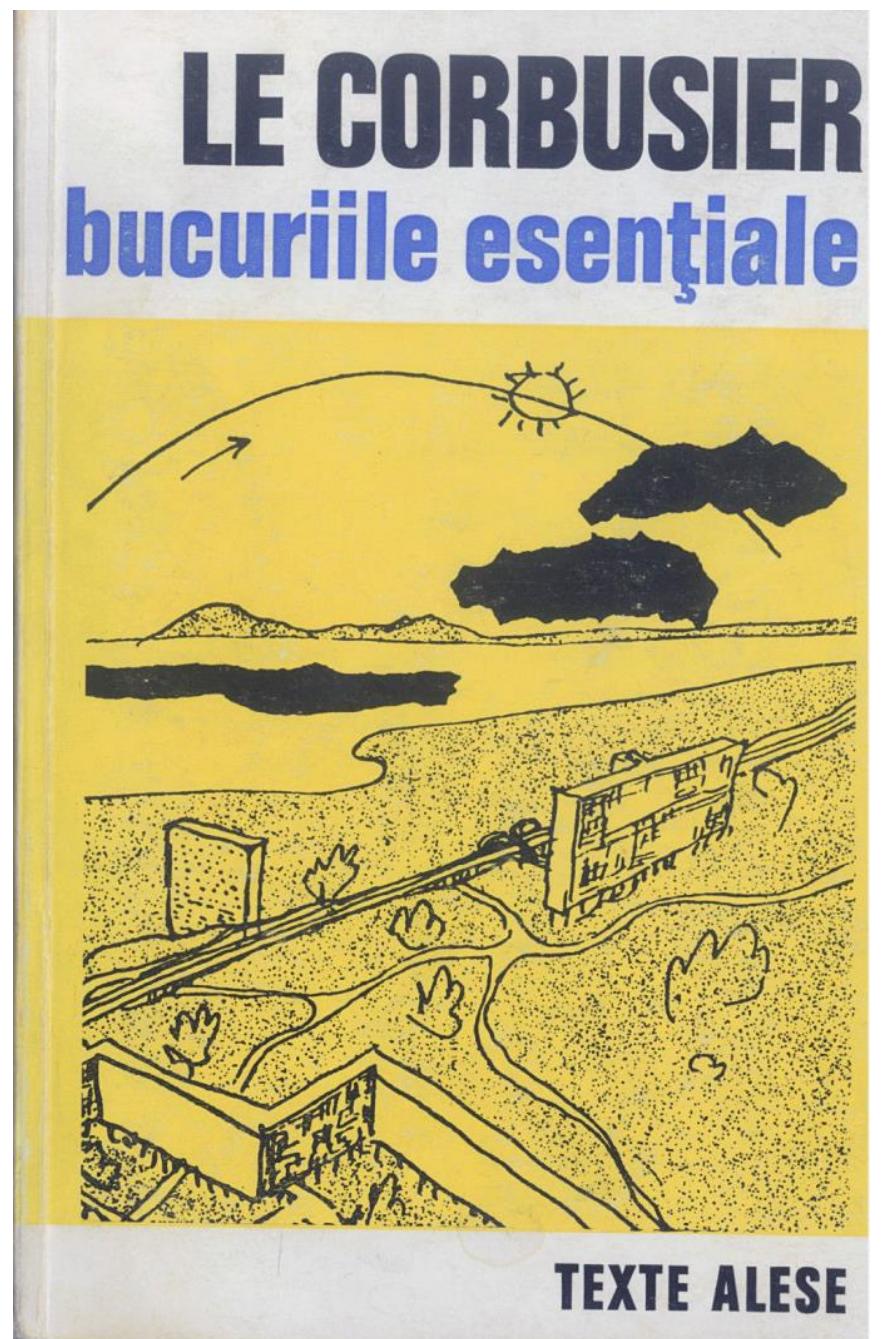

11. Couverture du livre de Marcel Melicson, Le Corbusier. Les joies essentielles.

Paru en 1971, le livre est en effet un recueil de textes choisis depuis quinze livres écrits par Le Corbusier ${ }^{67}$, soigné et introduit par Melicson. Parmi ceux-ci la majorité est représentée par des livres publiés avant 1946, c'est à dire avant que Le Corbusier devient intéressé de réaliser les récits synthétiques de son œuvre. Même si jusqu'à ce moment la base de sélection que Melicson choisit est assez complète, pour décrire la période suivante l'absence du Modulor demeure curieuse et sans explications. Est-il possible que Melicson a évité de son recueil les livres qui auraient pu être interprétés comme lignes directrices pour la pratique architecturale ? Pensait-il que le Modulor et La Charte d'Athènes ${ }^{68}$ sont moins significatifs? Il les connaissait certainement. De toute façon, il semble conscient du risque qu'il assume lorsque - après avertir le lecteur de l'implicite subjectivité de n'importe quelle démarche similaire - il ajoute: "Le problème est de ne pas trahir en aucun cas la pensée et la personnalité de celui qu'on présente. ${ }^{169}$

\footnotetext{
${ }^{67}$ En effet il s'agit de quatorze livres signés par Le Corbusier et le recueil de textes Le Corbusier / Présentation par Sophie Daria. Choix de textes, bibliographie, portraits, facsimiles (Paris: Éditions Seghers, 1964).

${ }^{68}$ La Charte d'Athènes est le seul ouvrage de Le Corbusier traduit en roumain en entier, dès 1945.

${ }^{69}$ Marcel Melicson, Bucuriile esențiale (București: Meridiane, 1971), 29.
} 
L'ouvrage se compose d'une introduction, huit chapitres et une bibliographie. Dans l'introduction Melicson reprend surtout l'activité de l'architecte de l'entre-deux-guerres (dix-huit sur vingt pages). En revanche pour les réalisations d'après guerre il ajoute un commentaire sur les unités d'habitation et cite brièvement Ronchamp et Chandigarh. Même si une grande partie de cette introduction est dédiée aux projets corbuséens, la note méthodologique révèle non seulement l'importance que Melicson accorde à son œuvre écrite, mais aussi la clé de la composition de l'anthologie. Il témoigne ainsi de l'impossibilité de recueillir toute l'œuvre écrite dans un seul volume et, tout en observant que Le Corbusier se répète assez souvent, il propose en revanche une organisation thématique. Les huit chapitres qui en résulte sont: Le Corbusier - l'homme, Le chemin vers l'architecture - La peinture puriste, Le chemin vers l'architecture - L'art décoratif, Architecture: des pierres, une drame, «La civilisation machiniste» et l'architecture, La maison des hommes: un réceptacle de lumière, L'urbanisme ou les joies essentielles de la vie et Bilan: 50 années d'aventures et de catastrophes. Ce que l'on peut remarquer des titres mêmes, est que ces chapitres séparent non seulement les différentes activités artistiques, mais aussi l'architecture (le drame) de la question de l'habitation moderne, de celle de la standardisation, et aussi l'architecture de l'urbanisme. En effet, même si on les regarde de plus près, plusieurs chapitres sont façonnés de fragments enlevés d'un seul livre, comme si l'enjeu serait plutôt de comprimer une grande quantité d'informations dans un petit volume.

Mais Melicson connaissait la formule de synthèse que Le Corbusier propose dans L'Atelier de la recherche patiente; il s'agit de l'avant dernier livre duquel il extrait les passage qui compose son anthologie. Encore, Melicson transcrit la bibliographie de la fin du livre de Le Corbusier qu'il recommande lui-aussi, plutôt que les livres qu'il a utilisé lui-même. Mais là où Le Corbusier avait préféré la forme du tableau, Melicson choisit la formule plus ordinaire de la liste bibliographique.

Dans quelle mesure peut-on lire comment, entre la présentation de l'homme et le bilan du recueil de Melicson, la personnalité de Le Corbusier encadre toute cette série d'aventures et de catastrophes, tout comme dans L'Atelier de la recherche patiente la bibliographie aboutissait au nom de l'auteur-même? Dans ce sens, on peut remarquer que les passages repris de ce dernier livre composent surtout le premier et le dernier des chapitres de l'ouvrage de Melicson. Si dans le premier ils sont surtout utilisés pour remémorer les commencements, les passages inclus dans le chapitre final permettent à Le Corbusier d'énoncer son propre bilan ("Ma recherche, tout comme mes

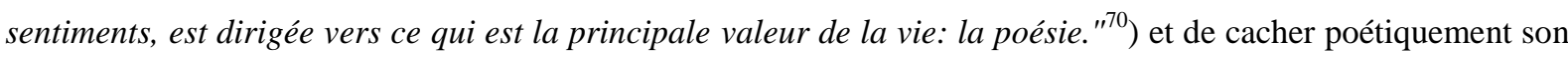
existence entière derrière la métaphore de l'acrobate ${ }^{71}$.

Les joies essentielles demeure jusqu'aujourd'hui l'anthologie la plus complète des textes écrits par Le Corbusier et traduits en roumain, une totalité curieuse, construite suivant les règles du maitre, mais en dehors de son accord. Dans mon opinion le recueil ne rate pas l'image de Le Corbusier en entier, mais aboutit à dessiner un portrait plus facile à comprendre parce qu'il n'essaye pas de surprendre ses aspects les plus discordants. Ceci dit, il reste discutable si Melicson présente une image aussi complète qu'il prétend. Si le portrait issu montre des similarités frappantes avec l'original, c'est comme s'il était le résultat correct d'un problème, sans la preuve de la démonstration. En revanche, si l'on se demande quels sont les manques les plus manifestes, ils seront certainement à trouver dans la forme du livre même : un livre plutôt traditionnel, avec un argument linéaire, sans beaucoup d'illustrations et qui groupe la plupart des images dans des sections qui interrompent le texte. Plutôt que de manquer de présenter une idée que Le Corbusier ait eu et que cette "traduction" cache, ce qui se perd est

\footnotetext{
${ }^{70}$ Ibid., 179 et Le Corbusier, Atelier de la recherche patiente [Le Corbusier, textes et planches], 300.

${ }^{71}$ Marcel Melicson, Bucuriile esențiale, 181 et Le Corbusier, Atelier de la recherche patiente [Le Corbusier, textes et planches], 197.
} 
surtout l'entrecroisement particulier du texte et des images, le mélange contrôlé qui évoque la peinture, la sculpture, l'architecture, l'urbanisme et l'art typographique par les moyens du dernier.

\subsection{Epilogue : la transcription du dessein}

En 1987, deux ans avant les changements politiques qui allaient ouvrir de nouveau la profession aux débats sur son présent aussi que sur son histoire, cinq étudiants en an terminal de l'école d'architecture de Bucarest décident de monter une exposition anniversaire Le Corbusier. Les cinq - Ana Dornescu, Maria Mureșan, Haytam Zeki, Florian Stanciu et Radu Teacă - se mettent à copier des plans, des coupes, façades, suivant du plus près le dessein du maître. Ils y ajoutent les copies des dessins, des esquisses, des tapisseries, des textes... Ils travaillent sur du papier épais, collé aux planchettes de sorte que les feuilles ne gonflent pas à cause de la technique en tempera. La reproduction de ces dessins vibrants représente pour eux le déchaînement par rapport aux représentations techniques, arides que l'école impose à l'époque pour préparer les étudiants à la vie professionnelle qui les attend dans les instituts de l'état ${ }^{72} .(12,13)$

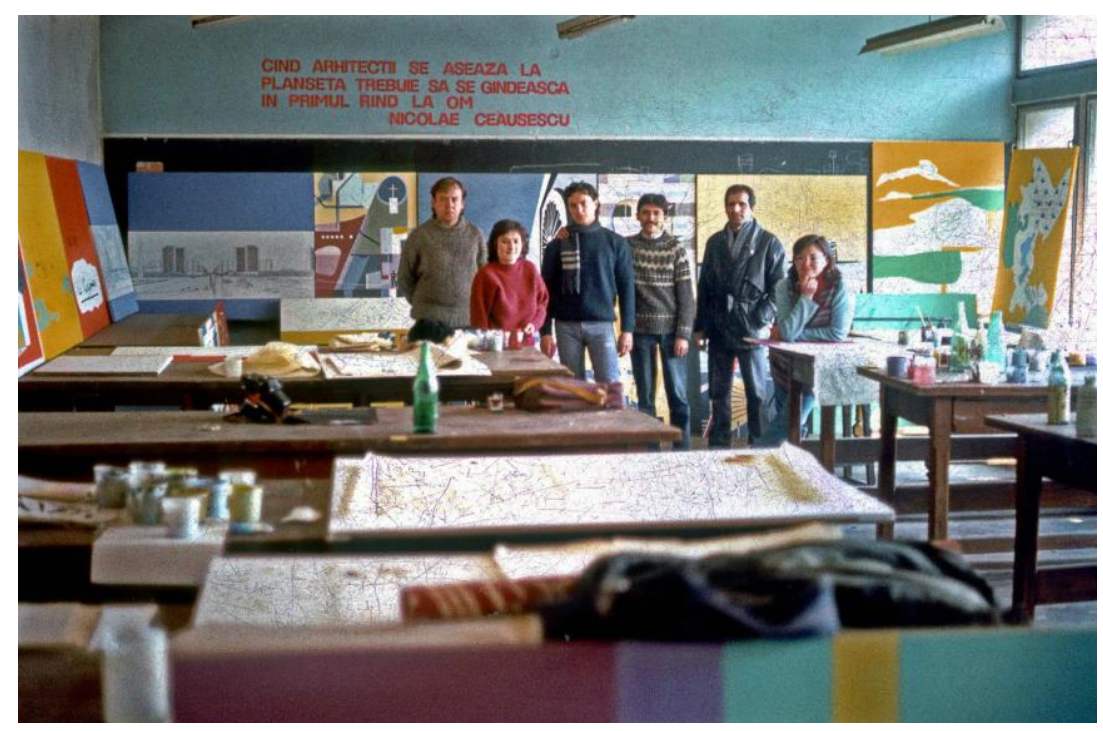

12. Image du travail préparatoire de l'exposition. Sur le mur derrière les auteurs la suivante citation du président de la république, Nicolae Ceaușescu : Lorsque les architectes se mettent au travail, ils doivent réfléchir premièrement à l'homme.

\footnotetext{
${ }^{72}$ Toutes les informations proviennent d'une interview accordée par Florian Stanciu, en février 2015.
} 


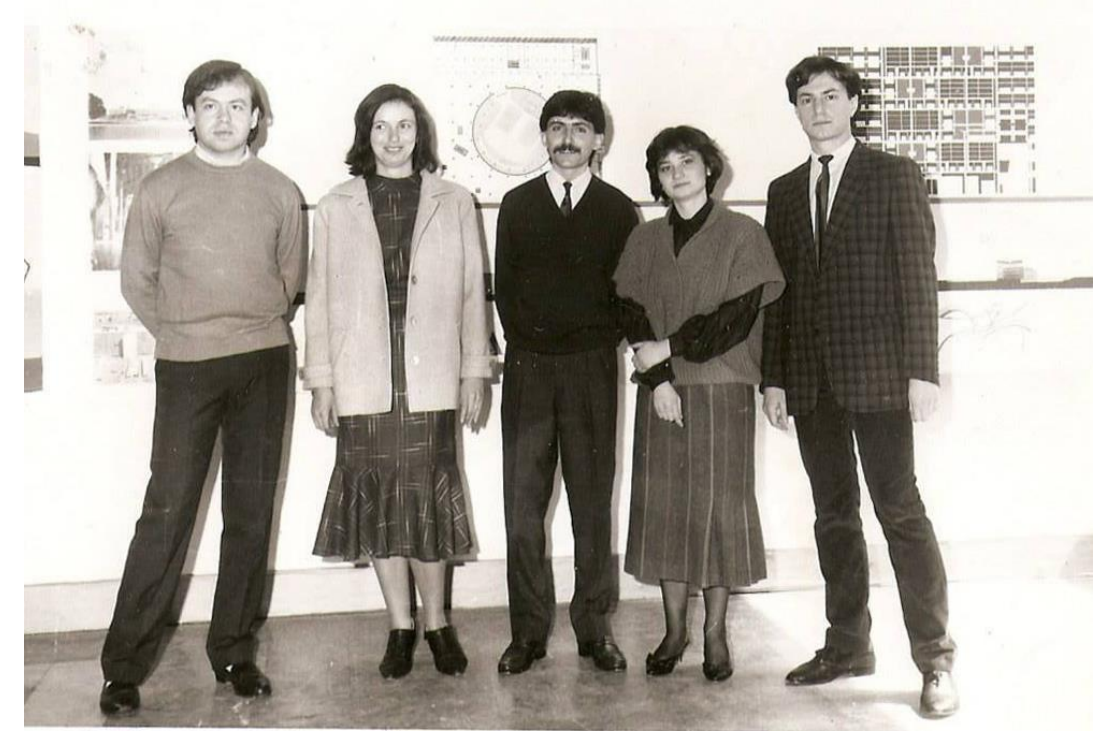

13. Photographie des auteurs à l'occasion du vernissage de l'exposition.

Ils ont commencé à travailler non pas en cachette, mais non plus officiellement et sans aucune garantie qu'ils vont pouvoir exposer. Ils reçoivent l'aide de quelques jeunes assistants ou de professeurs avec plus d'expérience : les uns leurs donnaient des idées, d'autres leur facilitaient l'accès à une copieuse ou leurs apportaient de la nourriture ${ }^{73}$. Un professeur entreprend les démarches pour transformer leur initiative indépendante (et par ceci intolérable) dans une entreprise assumé officiellement par l'école : qu'ils puissent ouvrir l'exposition au public. La censure consent, non pas sans réserves, et le vernissage a lieu, le 17 avril 1987 dans la présence du recteur de l'école, de l'ambassadeur de la France et du consul Suisse à Bucarest.

Après quelques années, après la révolution, lorsque plusieurs des auteurs sont devenus à leur tour jeunes assistants à la même école, en faisant la critique d'un projet, un des auteurs de l'exposition se rend compte qu'il s'est taché de tempera bleue : en tournant la planchette il retrouve un des panneaux de l'exposition de 1987. Depuis Le Corbusier était devenu sujet des cours de l'histoire de l'architecture, ses projets - des exemples à présenter. Et la témérité de leur démarche - désuète.

\section{Sources des images}

Les images (1), (2), (3), (4), (5), (6) et (7) sont reproductions des couvertures ou des pages des revues et des livres mentionnés, provenant de la Bibliothèque Métropolitaine de Bucarest: http://www.digibuc.ro.

L'image (8) est une reproduction de la table de matières de Le Corbusier, L'Atelier de la recherche patiente [Le Corbusier, textes et planches], (C) FLC/ADAGP.

Les images (9) et (10) sont reproduites depuis la page internet de la Fondation Le Corbusier, (C) FLC/ADAGP http://www.fondationlecorbusier.fr/corbuweb/morpheus.aspx ?sysId=13\&IrisObjectId=6450\&sysLanguage=frfr\&itemPos=16\&itemSort=fr-fr_sort_string1\%20\&itemCount=47\&sysParentName=\&sysParentId=25.

L'image (11) représente la couverture de Marcel Melicson, Bucuriile esențiale (București: Meridiane, 1971).

L'image (12) est reproduite par l'amabilité de M. Haytam Zeki.

L'image (13) reprend l'illustration de l'article "Le Corbusier 100" paru dans la Arhitectura, № 3 (1987), 4-5 et est reproduite par l'amabilité de L'Union des Architectes de Roumanie.

\footnotetext{
${ }^{73}$ L'article "Le Corbusier 100" dans Arhitectura 3 (1987): 4-5, évoque les professeurs Ion Lucăcel, Mircea Stănculescu et Sorin Vasilescu.
} 


\section{Références bibliographiques}

"Le Corbusier 100". Dans Arhitectura. 1987, № 3. București: Uniunea Arhitecților Din România. 1987. pp 4-5.

Apostol, Eugen: "Le Corbusier și Uzina Verde". Dans Arhitectura. 1976 № 1. București: Uniunea Arhitecților Din România. 1976. pp 51-52.

Asociația pentru urbanistica Bucureștilor: Către o arhitectură a Bucureștilor. București: Editura ziarului Tribuna Literară, 1935.

Banham, Reyner: Theory and Design in the First Machine Age, Cambridge Massachusetts - London England: The MIT Press. 1980

Beldiman, Alexandru; Cârneci, Magda: Bucharest In The 1920s-1940s Between Avant-garde and Modernism. București: Editura Simetria. 1994

Bocăneț, Anca; Lascu, Nicolae; Zahariade Ana-Maria: Marcel Iancu Centenary 1895-1995. Marcel Iancu In Interwar Romania Architect, Fine Artist, Theorist. București: Editura Simetria, Uniunea Arhitecților Din România, Editura Meridiane. 1996

Cohen, Jean-Louis: "Introduction". Dans Le Corbusier: Toward an Architecture. Los Angeles: Getty Publications, 2007. pp. 1-78.

De Smet, Catherine: Vers une architecture du livre. Le Corbusier: édition et mise en pages 1912-1965. Baden: Lars Müller Publishers. 2007

Iliescu, Anca: "The Architectural Office of Marcel and Iuliu Iancu - a Career in Bucharest between the World Wars". Dans Anghel, Doina: Marcel Iancu. Bureau of Modern Studies. București: Editura Simetria, 2008. pp. 38-55.

Ispir, Mihai: "Corbusier Omagiat". Dans Arhitectura. 1987, № 4. București: Uniunea Arhitecților din România. 1987. pp 80-81.

Lascu, Nicolae (Ed.): Funcţiune şi formă. București: Editura Meridiane. 1989

Lascu, Nicolae: Horia Creangă. 1892-1992 Centenar Horia Creangă. București: Uniunea Arhitecților din România. 1992

Le Corbusier: Textes et Planches. Paris; Editions Vincent, Fréal \& Cie. 1960

Le Corbusier: Urbanisme. Paris: Éditions G.Grès et Cie. 1925. Réimprimé par Éditions Artaud, Paris 1980. Reimprimé par Flammarion, Paris, 1994

Le Corbusier: Vers Une Architecture. Paris: Éditions G.Grès et Cie. 1923. Réimprimé par Librairie Artaud, Paris 1977. Réimprimé par Flammarion, Paris, 1995

Melicson, Marcel: " Fișe pentru o istorie a gîndirii arhitecturale contemporane VIII". Dans Arhitectura. 1968 N $^{\circ}$ 2. București: Uniunea Arhitecților din România. 1968. pp 85-96.

Melicson, Marcel: " Fișe pentru o istorie a gîndirii arhitecturale contemporane IX". Dans Arhitectura. 1968 No 3. București: Uniunea Arhitecților din România. 1968. pp 97-108.

Melicson, Marcel: " Fișe pentru o istorie a gîndirii arhitecturale contemporane X". Dans Arhitectura. 1968 N 4. București: Uniunea Arhitecților din România. 1968. pp 109-120.

Melicson, Marcel: "Fișe pentru o istorie a gîndirii arhitecturale contemporane XI". Dans Arhitectura. 1968 Nº 5. București: Uniunea Arhitecților din România. 1968. pp 121-132.

Melicson, Marcel: "Le Corbusier 1887-1965". Dans Arhitectura. 1965 № 6. București: Uniunea Arhitecților Din România. 1965. pp 54-57.

Melicson, Marcel: Le Corbusier. Bucuriile Esențiale. Texte Alese. București: Editura Meridiane. 1971 
Ponta, Radu Tudor. Le Corbusier. Teme şi forme ale teoriei arhitecturii în secolul XX. Directeur de thèse AnaMaria Zahariade. Universitatea de Arhitectură și Urbanism "Ion Mincu", 2010.

Șerban, Geo: Întâlniri cu Marcel Iancu. București: Editura Hasefer. 2011

Tabacu, Gabriela: "Architect Florea Stănculescu or On Modernism in the Romanian Interwar Architecture as Negotiation Between Genius Loci and Zeitgeist". Dans SITA. "Indigenous Aliens. Mediators of Architectural Modernity". 2014, Nº 2. București: Editura Universitară "Ion Mincu". 2014. pp. 52-76.

Tabacu, Gabriela: "On what and how. Architectural Magazines in the School Library (1945-1989)". Dans SITA. "Printed in Red. Architectural Writings during Communism". 2013, No 1. București: Editura Universitară "Ion Mincu". 2013. pp. 133-148.

Udrea, Andreea; Calotă, Irina: "Getting Global, Staying Local. The Turmoil of the First Steps towards Scientific Urban Planning - The Case of Concinat Sfințescu". Dans SITA. "Indigenous Aliens. Mediators of Architectural Modernity". 2014, Nº 2. București: Editura Universitară "Ion Mincu". 2014. pp. 34-51.

Zahariade, Ana-Maria: "Testing the Physiognomy of the Arhitectura Magazine (1952-1989)". Dans SITA.

"Printed in Red. Architectural Writings during Communism". 2013, No 1. București: Editura Universitară "Ion Mincu". 2013. pp. 161-184.

Zahariade, Ana-Maria: "Twelve Years After: Thoughts on Marcel Iancu's Architecture". Dans Anghel, Doina: Marcel Iancu. Bureau of Modern Studies. București: Editura Simetria, 2008. pp. 18-37.

Zahariade, Ana-Maria: Architecture In The Communist Project. Romania 1944-1989. București: Editura Simetria. 2011 
DOI: http://dx.doi.org/10.4995/LC2015.2015.548

\title{
Dattiers Andinos y la Búsqueda Paciente en Rue de Sèvres, 1948-1959 ${ }^{1}$
}

\author{
I. Quintana Guerrero \\ Universidad de São Paulo
}

\begin{abstract}
Resumen: Con la Unidad de Habitación marsellesa, el Atelier Le Corbusier transformaba su personal y métodos. Recurrentemente, se ha denominado a ésta como la fase del Grand Atelier, en cuyo ocaso surgieron nuevos desafios y elementos para un "espacio inefable". De límites imprecisos, esa Búsqueda Paciente implicaba un estado de ánimo transicional que confrontaba a Le Corbusier con sus propios métodos y con algunos de sus colaboradores, a los que peyorativamente atribuyó el apodo de dattiers (datileras), debido a su presunta arrogancia y baja productividad. Este trabajo reconstruye los principales aspectos del paso de algunos colaboradores suramericanos de Le Corbusier por París entre 1948 y 1959. Su participación fue larga e intensa, alcanzando en ocasiones el estatus de coordinadores y abordando obras en todas las escalas. Aún cuando, entre ellos, sólo Augusto Tobito fue directamente calificado como dattier, sus colegas colombianos compartían algo de su rebeldía, autonomía o destreza; de ahi que les hagamos extensivo ese apelativo. Así pretendemos construir un relato que contrarreste las abundantes narrativas sobre proyectos e influencia del franco-suizo en territorio andino.
\end{abstract}

Abstract: With Marseille Housing Unit, the Atelier Le Corbusier began a transformation of its staff and methods. Frequently, this phase is known as Le Grand Atelier, receiving new challenges during its ending, and conceiving new elements for an "ineffable space". With undefined boundaries, the Patient Research involved a transitional frame of mind opposing Le Corbusier to his own proceedings and to some of his collaborators. Pejoratively, the master named them as dattiers (datepalms), due to their alleged arrogance and low productivity. This work reconstructs several aspects of the internship of some South American collaborators on Le Corbusier at Paris between 1948 and 1959. Their participation was extended and intense, allowing them to reach, in some cases, the status of coordinators, and engaging works in all the scales. Even though just Augusto Tobito was directly called as dattier, his Colombian coworkers shared his rebellion, autonomy or skills. That is why we also use that adjective for them. We intend to create a complementary story for plenty of narratives about projects and influences of the French-Swiss architect in the Andes territory.

Palabras clave: Le Corbusier; arquitectos modernos suramericanos; planes urbanos; proyectos de habitación. Keywords: Le Corbusier; South American Modern architects; urban plans; housing project.

\section{Introducción}

El Atelier Le Corbusier tuvo diversos matices durante sus 42 años de existencia, comenzando por los "años heroicos" 2 (previos a la Segunda Guerra Mundial), de camaradería entre un joven arquitecto y sus escasos colaboradores. Debido a la exigüidad de documentos, es difícil establecer la acción de algunos de ellos, cuyo paso por el taller fue breve. Dicha documentación se hizo sistemática ante la cantidad de asalariados y proyectos

\footnotetext{
${ }^{1}$ Trabajo derivado de una investigación doctoral sobre los colaboradores latinoamericanos de Rue de Sèvres durante sus fases. Se confrontaron fuentes primarias como planos, bocetos, correspondencia y entrevistas (consultados, principalmente, en las Fundaciones Le Corbusier (FLC) y Rogelio Salmona, en los archivos de Germán Samper y en las colecciones especiales de Frances Loeb Library - Harvard University), con publicaciones sobre cada uno de los actores; disertaciones y tesis doctorales sustentadas durante los últimos 10 años, así como algunas obras que abordan la metodología de trabajo en el Atelier.

${ }^{2}$ Sterken, Sven: Iannis Xenakis: architecte et ingénieur. Dirección: Bart Verschaffel. Tesis doctoral. Universiteit Gent, 2004.
} 
abordados, número nuevamente reducido durante la que el propio Corbusier llamó como Étape 72 (su edad en 1959, comienzo de esta etapa).

El clímax del taller, en cuanto a cantidad de encargos y obras ejecutadas, acaeció entre ambas instancias. Gracias a proyectos de la postguerra -reconstrucción urbana y viviendas masivas- el taller superó los cien miembros; de ahí su denominación como Grand Atelier. La consagración de "Corbu” como figura mundial atrajo candidaturas de jóvenes abiertos a cualquier condición laboral de con tal de obtener un lugar en el estudio de arquitectura más célebre entonces. La complejidad en sus operaciones, asumiendo paralelamente los estudios técnicos para Marsella y otras obras a través de un órgano adjunto, el ATBAT (Atelier des Bâtisseurs), incitó tácitamente el establecimiento de jerarquías y, por ende, de inevitables roses del maestro con quienes alcanzaron relevancia al interior del equipo. No obstante, la alta rotación de mano de obra y el paso ineludible de los meses suscitaron fluctuaciones del Grand Atelier.

Como hilo conductor subyace la idea de Búsqueda Paciente, con la que "Corbu" designó su taller casi desde sus comienzos, y que en ocasiones ha sido identificada con el ocaso de su carrera y la materialización de un "espacio inefable" y de un lenguaje brutalista. Esa búsqueda también estaría vinculada a un état d'âme, cuestionando certezas cultivadas durante las últimas décadas. La presencia de colaboradores más maduros, curtidos en los procedimientos lecorbusierianos e incluso tan temperamentales como su jefe, contribuyó a este aspecto. A tres de ellos, Xenakis, Maisonnier y Tobito, atribuyó el apelativo de dattiers royaux ${ }^{3}$ (datileras reales), y apartó de su servicio, sin previo aviso, luego del verano de 1959.

Tobito, venezolano, se recibió como arquitecto en Bogotá, donde construyó sus primeras obras y conoció a Le Corbusier. Menos divulgado que el impacto del viaje sobre el imaginario lecorbusieriano ha sido el paso del venezolano, junto al de cuatro colombianos, por el taller; hecho sorprendente si se considera que dos de ellos, Rogelio Salmona y Germán Samper, tuvieron colaboraciones prolongadas en Rue de Sèvres, con carácter y desempeño equiparables a los de los dattiers.

\section{Rogelio Salmona (París, 1927 - Bogotá, 2007)}

Primer colaborador andino, le petit Salmoná (como le llamaban sus colegas) conoció al maestro durante su primera visita a Bogotá, en 1947, como su traductor oficial y anfitrión en una cena ofrecida por su padre. Fue entonces cuando "Corbu" mencionó que sólo en su taller era posible aprender arquitectura y que allí esperaba a Roger. Con apenas 20 años y tres semestres en la Universidad Nacional, éste debió regresar a París, tras la revuelta popular que azotó a Bogotá en abril de 1948. Ya en Rue de Sèvres, fue rechazado por Le Corbusier, quien ni siquiera recordaba a su padre. El joven se impondría en una primera disputa, al hacerse contratar como gratteur (pasante sin pago), abandonando la École des Beaux Arts, donde estaba inscrito. En compensación, hizo cursos de sociología del Arte con Pierre Francastel, motivando su paulatino alejamiento ideológico del maestro.

Los seis años y tres meses del franco-colombiano en el taller atañen 29 proyectos, organizados en tres ejes temáticos: vivienda social masiva y planes de reconstrucción urbana; casas individuales para élites y algunos proyectos para Chandigarh ${ }^{4}$.

\footnotetext{
${ }^{3}$ « $[\ldots]$ chacun de vous est un dattier royal ! // [...] c'est l'eau et le soleil qui ont le dessus. // Leur destin est d'être là, toujours présents. // Mais on les engueule toujours : ce soleil est trop chaud, cette pluie mouille ». Nota de 11/07/1957 (FLC U3-8-207).

${ }^{4}$ En este documento apenas incluimos tres imágenes seleccionadas entre el vasto material que sustenta los relatos. En el caso de los planos, proporcionamos códigos de algunos de ellos, atribuidos por la FLC, para su consulta abierta tanto en esa institución como en la colección de DVDs Le Corbusier: Plans (Paris: CodexImages International, 2005). La sigla FGJF
} 


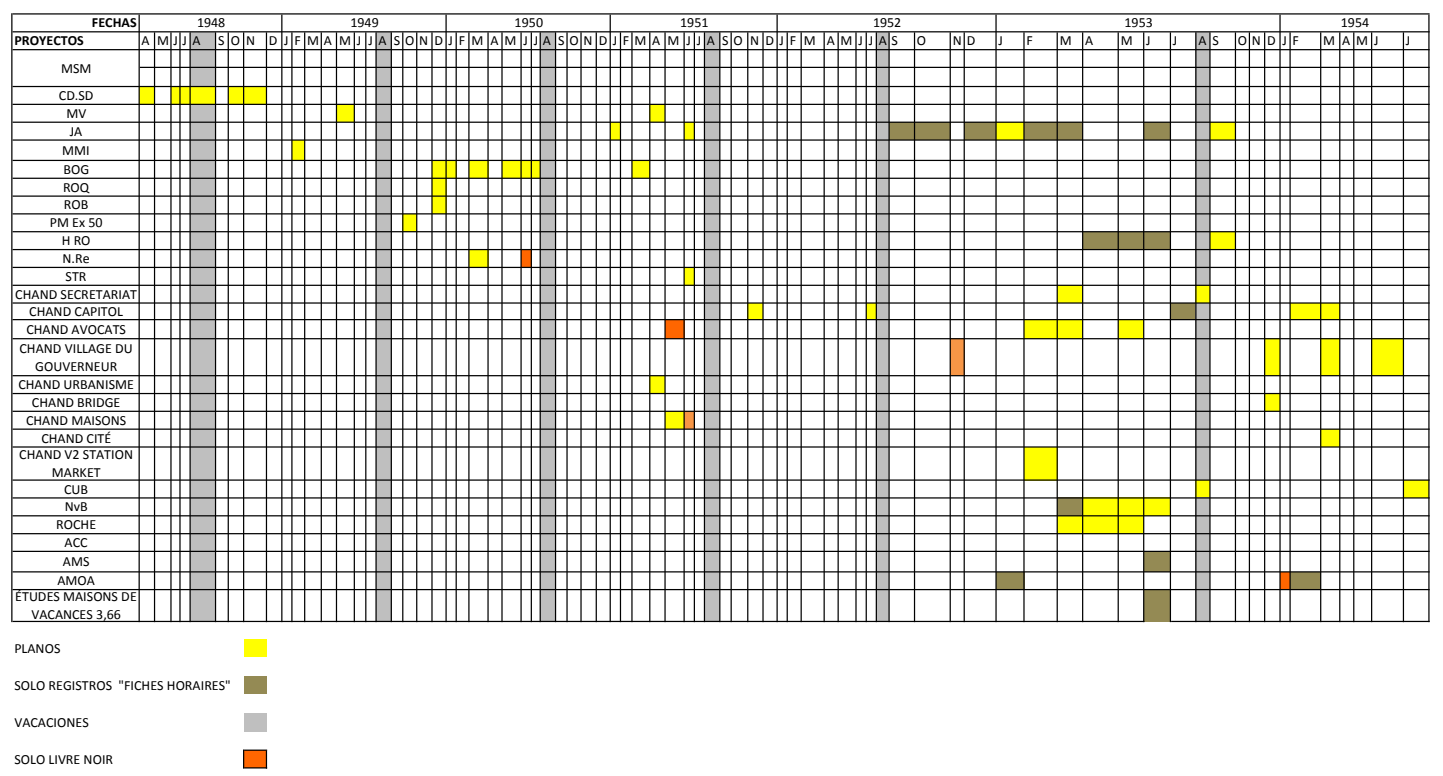

1. Tabla de proyectos lecorbusierianos con documentación relativa a Rogelio Salmona. Fuente: La autora, basada en archivos de la FLC.

\subsection{Laboratorios HBM}

La Unidad de Marsella (MMI) fue ejecutada por el ATBAT, con contribuciones esporádicas de Salmona, quien, junto con Samper y Justino Serralta, visitó la construcción en 1949 y 1950. Los colombianos participaron en otros proyectos urbanos: Marseille Veyre (MV) y Marseille-Sud-Michelet (MSM; colina que ilustraron en una perspectiva aérea - FLC 23110). En el segundo (FLC 30202) habría un anillo verde para recreación, circundado por bloques à redent y vivienda de baja densidad, apelando a las tres joies essentielles a la vida urbana divulgadas en los CIAM (a cuya sexta versión asistieron los colegas): luz, espacio y verdor.

La creación de Habitations Bon Marché (HBM) no era solamente una prioridad del estado francés sino de cooperativas privadas. Una de ellas solicitó al franco-suizo una unidad para Rezé-les-Nantes (NRe), en 1951 (FLC 01519). De menor presupuesto que su antecesora, su plano de implantación fue hecho por Salmona, quien, paralelamente, ejecutó varias planchas de las unités para un barrio de 800 viviendas en Estrasburgo, Rotterdam (STR). Reinaldo Valencia (Quibdó, 1922 - Chalonnes-sur-Loire, 1994), colombiano que llegó al atelier 16 meses después que Roger, permaneciendo otros 20 meses, dibujó las plantas generales del conjunto, con sus sistemas hidráulico y eléctrico (FLC 30667A; FLC 30708). Vale la pena abrir un paréntesis para comentar que Valencia había contribuido más que sus compatriotas en el desarrollo de la Unidad marsellesa, especialmente en el estudio de policromía de las fachadas (febrero de 1951; FLC 25643 - FLC 25646).

\subsubsection{LC BOG}

Rotterdam se benefició del Plan Regulador de Bogotá. Sin ánimo de ahondar en ese proyecto, vale la pena mencionarlo como tentativa gubernamental de planear esa capital a futuro y reconstruir su centro histórico, devastado en abril de 1948. Junto a otros miembros del taller como Carlos Clémot (Uruguayo) y Valencia (que

corresponde al fondo Guillermo Jullian de la Universidad Católica de Chile (Centro de Originales Sergio Larraín GarcíaMoreno), mientras que IFA corresponde al archivo de Arquitectura Moderna del Institut Français d'Architecture y GS al archivo personal de Germán Samper. 
trabajó específicamente con Salmona en el estudio de densidades), Roger elaboró el Informe Técnico, presentado en Septiembre de 1950 bajo el formato de la Grilla CIAM, con base en el protocolo elaborado por Le Corbusier y las autoridades colombianas en Roquebrune-Cap-Martin (agosto de 1949). A pesar de su desacuerdo, Salmona dibujó axonometrías del Centro Cívico (FLC 31561), que conservaría escasos inmuebles y acogería nuevas unités y edificios ministeriales, en el marco de la Plaza Principal. Con Samper, trazó borradores para la implementación del sistema de las 7 vías, mas calles peatonales (FLC 33686) ${ }^{5}$.

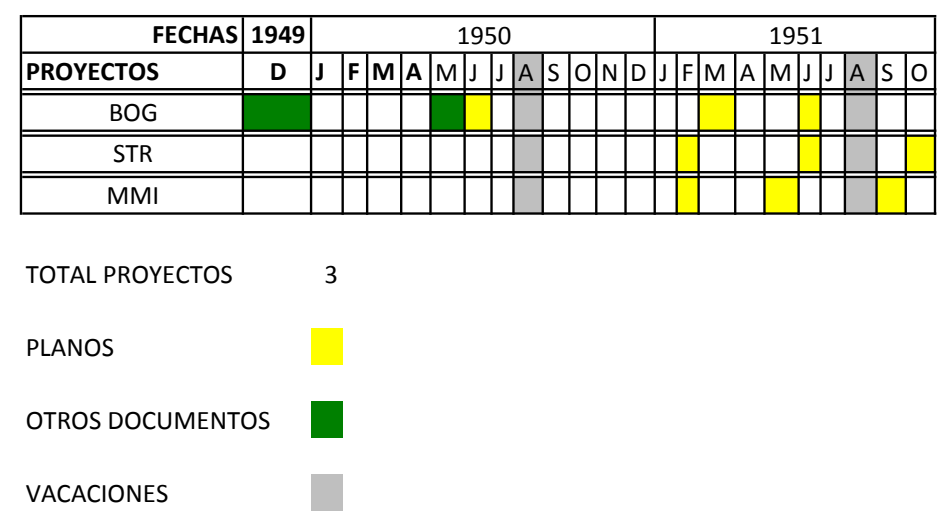

2. Tabla de proyectos lecorbusierianos con documentación relativa a Reinaldo Valencia. Fuente: La autora, basada en archivos de la FLC.

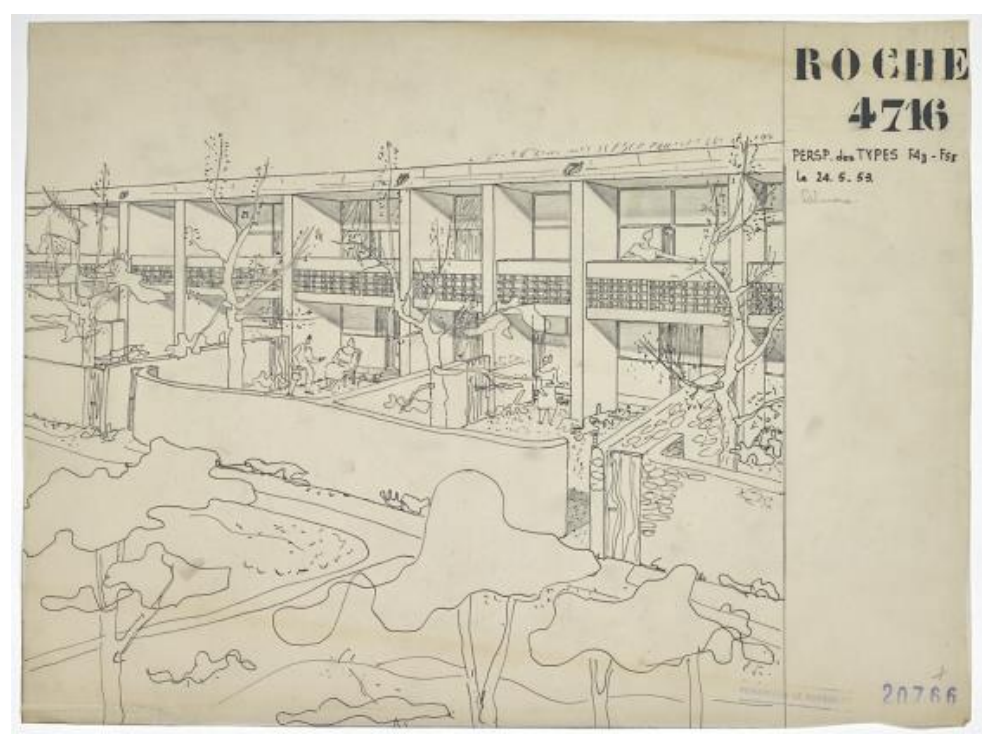

3. Plano $N^{o}$. 4716: perspectiva casas tipo La Rochelle en La Citadelle. Fuente: FLC (20766).

\footnotetext{
${ }^{5}$ Según Salmona, él propuso un octavo tipo de vía, exclusivo para bicicletas, inspirado en ciclorrutas de Ámsterdam. Tarchópulos, Doris: Las Huellas del Plan para Bogotá de Le Corbusier, Sert y Wiener. Dirección: Joaquín Sabaté, José María Ezquiaga. Tesis doctoral. Universitat Politécnica de Catalunya, 2010, p. 138.
} 


\subsubsection{Barrios experimentales}

En junio de 1953, Roger contribuyó a un proyecto experimental para Roubaix: HEM (HRo), donde se implementarían, entre varias alternativas, casas tipo La Rochelle (usadas en Bogotá), de dos pisos y cubiertas inclinadas, basadas en las "mesopotamiens" lecorbusierianas de 1939. Allí también se concibió una nueva tipología: Rez-de-chaussée, resuelta en una única planta, de $81.65 \mathrm{~m}^{2}$ (FLC 20829). La Citadelle (ROCHE), proyecto sin lote determinado, evolucionaba el esquema La Rochelle (FLC 20762); en él, perspectivas internas de Salmona recrean sus condiciones espaciales, semejantes a las de las células en las unités (Fig. 3). Idénticas imágenes se usaron para Neuve-Ville-Briey (NvB), nuevo suburbio de la ciudad minera de Briey (IFA/PINGU/C/53), proyectado por Georges-Henri Pinguisson, quien invitó a Le Corbusier a construir una Unité (BrF). Su propuesta, de abril de 1953, incorporaba otras unidades de 12 y 17 pisos y un grupo de casas La Rochelle, con plantas y cortes del franco-colombiano (FLC 20770).

\subsection{Casas individuales}

En Chandigarh, Le Corbusier había propuesto un tipo de casa para peones, dibujado por Salmona y eventualmente por Tobito $^{6}$, además de las residencias para funcionarios de más alto rango mencionadas más adelante. A diferencia de éstas, donde se privilegiarían las técnicas de construcción manual locales, la maison du péon estaría cubierta por un sistema mixto, con bóvedas prefabricadas de concreto apoyadas en muros de mampostería (FLC 29113). Con contribuciones menores de Salmona, “Corbu”también compuso tres casas en Ahmedabad (FLC 30244; FLC 06426B). Dos de ellas, Sarabhai (AMS) y Shodhan (ASH), seguían líneas enunciadas por "Corbu" y derivadas de los prototipos Citrohän ("masculino") y Monol ("femenino"). El segundo caso apela nuevamente a la bóveda como elemento distintivo del espacio doméstico lecorbusieriano, luego adoptado en la propia arquitectura de Salmona.

En noviembre de 1949, Roger y Samper desarrollaban un conjunto de casas vacacionales en Roquebrune-CapMartin, Roq et Rob. Se contemplaron varias posibilidades para su construcción (no ocurrida), como un sistema estructural metálico, llamado 2.26 × 2.26 × 2.26 (dimensión básica del Modulor) o Le Brevet. El partido básico de las diferentes de casas Roq y Rob era muy similar al de La Rochelle (células alargadas), también con tres niveles, aunque escalonados, obedeciendo a la accidentada topografía (FLC 18667- FLC 18676). Una serie de perspectivas elaboradas por el dúo colombiano evidencia las bóvedas de concreto como sistema para las cubiertas (FLC 18758). Poco tiempo después (junio de 1951), la familia Jaoul encargaría a "Corbu" dos casas en Neuilly-sur-Seine. Mientras Samper estudió la implantación de las casas, Salmona elaboró parte de los planos de ejecución, junto a Kim y Sachi, en marzo de 1953. Roger también supervisó dibujos de un cuarto colombiano en el taller, cuya estada (de apenas seis meses) aun resulta misteriosa: Alberto Peña.

A diferencia de las casas Roq et Rob, en las Jaoul las bóvedas rebajadas parten de una hoja de piezas cerámicas planas (rasilla) fijadas con yeso, recubierta con una pequeña lámina de concreto - solución calculada por el ingeniero Domenec Escorsa (FLC 09956) tras la visita de Le Corbusier a la casa que Francisco Pizano construyó para su padre en Bogotá, apelando a una solución de naturaleza semejante para la escalera. Los primeros croquis de las fachadas también muestran la disposición pareada de las casas, rápidamente substituida por un esquema en "L” de Samper (FLC 10365). Luego del regreso a Colombia de éste, en 1953, Salmona permaneció 9 meses más junto al maestro, contribuyendo para algunas casas de funcionarios de alto nivel en la Aldea del Gobernador de

\footnotetext{
${ }^{6}$ Según nota del Carnet J35 (24 de febrero de 1955). De Franclieu, Françoise (Ed.): Le Corbusier: Sketchbooks. New York, Cambridge: MIT Press, 1981. 3v, p. 254.
} 
Chandigarh: secretarios de gobierno y militares (tipo V; FLC 05556), asistentes (tipo X; FLC 29098/99) y empleados senior (tipo XI; FLC 05566/67).

\begin{tabular}{|c|c|c|c|c|c|c|c|c|c|c|c|c|}
\hline FECHAS & & & & 195 & & & & & & 1953 & & \\
\hline PROYECTOS & M & & J & A & $S$ & 0 & \begin{tabular}{|l|l}
$N$ & $D$
\end{tabular} & \begin{tabular}{|l|l|l|l}
$J$ & $F$
\end{tabular} & M & $|\mathrm{A}| \mathrm{N}$ & \begin{tabular}{l|lll}
$M$ & $J$ & $J$ \\
\end{tabular} & J A \\
\hline$J A$ & & & & & & & & & & & & \\
\hline CHAND CAPITOL & & & & & & & & & & & & \\
\hline $\begin{array}{c}\text { CHAND } \\
\text { SECRÉTARIAT } \\
\end{array}$ & & & & & & & & & & & & \\
\hline CHAND GRILLE & & & 189 & & 98 & 72 & & & & & & \\
\hline $\mathrm{N} . \mathrm{Re}$ & & 92 & 14 & & & & & & & & & \\
\hline $\mathrm{MMI}$ & & 12 & & & & 27 & & & & & & \\
\hline
\end{tabular}

TOTAL PROYECTOS

6

PLANOS

SOLO REGISTROS "FICHES HORAIRES"

4. Tabla de proyectos con documentación de Rue de Sèvres, relativa a Alberto Peña. Fuente: La autora, basado en archivos de la FLC.

\subsection{Urbanismo en Chandigarh}

Junto con Samper, Salmona fue architecte projetteur de las primeras exploraciones urbanas en Punjab ${ }^{7}$. No todos los lineamientos propuestos fueron acogidos, aunque su recepción por parte de las autoridades locales fue mucho mejor que la del Plan Director de Bogotá, proveyendo elementos para Chandigarh: una grilla cartesiana con rigurosa implementación de la regla de las 7V, privilegiando los rápidos desplazamientos. El 23 de abril de 1951, Salmona trazó plantas y perfiles de algunos tipos de vías, complementando las investigaciones sobre arborización de Samper (FLC 05289). La nueva capital indiana también contaría con un Centro Cívico, lejano del corazón de la ciudad: la Explanada del Capitolio fue parcialmente construida, e incluso alterada después de la muerte de "Corbu". Salmona contribuyó en los perfiles que ilustran de la modificación de la topografía original mediante "colinas artificiales" que dialogan con los Montes Himalaya y con las pintorescas siluetas de los nuevos edificios institucionales ${ }^{8}$ (FLC 05291). De entre ellos, el Secretariado y el anexo de Abogados, dos prismas rectangulares configurando las esquinas opuestas de la explanada, poseen trazos de Roger. Los planos del edificio anexo (febrero y marzo de 1953; FLC 04742 - FLC 04756) muestran 6 oficinas de magistrados junior, dividiendo el edificio en sendos módulos (similar estrategia a la adoptada para el Secretariado). Brisesoleils en la fachada sur y una cubierta suspendida (aunque totalmente plana) recuerdan a la propia Alta Corte; mientras que la fachada norte, de ladrillo, sería ciega, similar a la del Museo de Ahmedabad.

\footnotetext{
7 « Pour mener à bien la construction de Chandigarh, Le Corbusier met en place [...] hiérarchie très stricte des tâches, s'alignant sur les conventions de travail de l'époque : calqueur, dessinateur, projeteur, chef d'exécution, inspecteur des travaux, chef d'études et des travaux, chef d'équipe ». Papillault, Rémi: Chandigarh et Le Corbusier, création d'une ville en Inde 1950-1965. Toulouse: Poïsis, 2011, p. 80.

${ }^{8}$ Salmona hizo una poética descripción de la creación del Capitolio, junto a Le Corbusier, en: Arcila, Claudia Antonia: Tríptico Rojo. Conversaciones con Rogelio Salmona. Bogotá: Taurus, 2007, pp. 129-130.
} 


\subsection{La partida de Salmona}

Además de sus discrepancias con el maestro, Salmona consideraba que su experiencia en Rue de Sèvres había sido demasiado teórica. Por eso envió su candidatura a Bernard Zehrfuss, quien proyectaba el CNIT en La Défense. Al ser admitido, presentó su renuncia a "Corbu". Como regalo de despedida, éste lo invitó a descender al sótano para escoger uno de los cuadros de su autoría. Como un último acto de rebeldía en el taller, el francocolombiano prefirió quedarse con un Juan Gris.

\section{Germán Samper (Bogotá, 1924 - )}

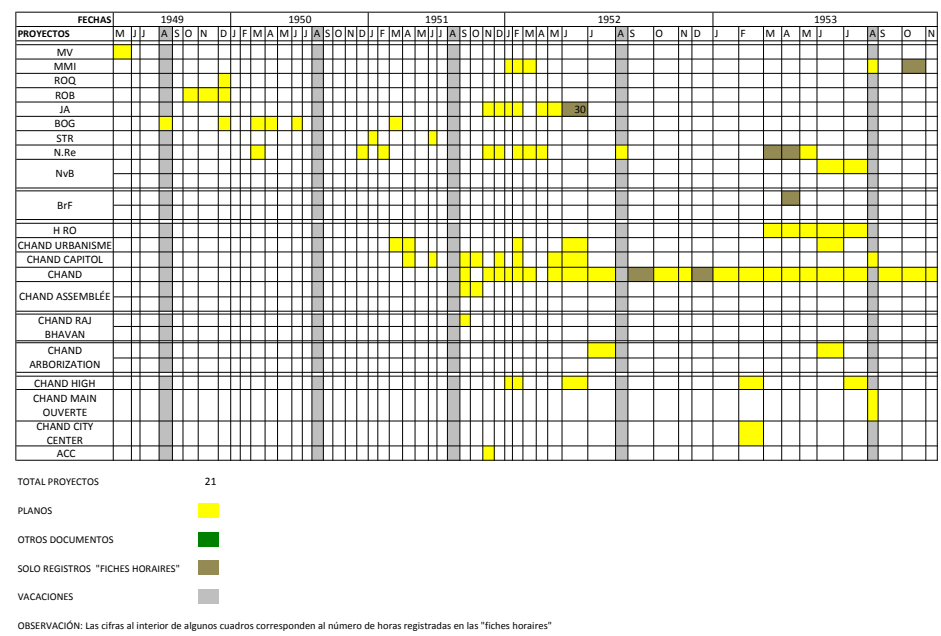

5. Tabla de proyectos lecorbusieriana con documentación relativa a Germán Samper. Fuente: La autora, basada en archivos de la FLC.

Recién graduado de la Universidad Nacional, Samper, con un grupo de estudiantes, recibió al franco-suizo en el aeropuerto de Bogotá, en 1947. Sus conferencias, así como la lectura de sus principales manifiestos, impulsaron al colombiano para postular a una beca del francesa y, en noviembre de 1948, embarcar hacia París. Entonces se presentó espontáneamente al taller, buscando una pasantía no remunerada, inicialmente negada. Mientras tanto, se inscribió en el Instituto Francés de Urbanismo y, como Salmona, en los seminarios de Francastel. Finalmente, gracias a su compatriota y a Georges Candillis, fue reclutado sin que el maestro lo supiese, para elaborar algunas grillas del Plan La Rochelle-Pallice, presentadas en el sexto CIAM.

Consagrado dibujante, Samper recorrió y esbozó proyectos lecorbusierianos en Île-de-France mientras esperaba una oportunidad con "Corbu"; una práctica común entre sus admiradores. Sin embargo, la interacción directa con él y el cambio de lenguaje en los nuevos encargos del taller harían cambiar la concepción idílica de Samper, quien fue llamado por su patrón como Lion, mientras que, por su astucia, Salmona recibió el apodo de Gazelle. Esto denotaba una relación mucho más próxima entre Le Corbusier y Samper; de hecho, la designación del segundo como dessinateur se dio rápidamente.

\subsection{Algunos proyectos urbanos}

Además de los planes para Marsella, Samper también contribuyó al barrio Rotterdam con plantas del complejo (FLC 30663/64); elevaciones y detalles de su unité (FLC 30665/66). Aunque su poder de decisión fue menor para el Plan Director de Bogotá, Samper registró minuciosamente cada una de sus fases en su cuaderno, abordando el estadio previo de la ciudad y la necesidad de fortalecer sus nodos de intercambio comercial y 
conexiones internacionales aéreas, conforme a los Tres Establecimientos Humanos. Un segundo cuaderno contiene borradores del Informe Técnico y de estudios de densidades (se esperaba aumentar, en promedio, a 4600 habitantes por hectárea en el área urbana); distribución de las cuatro funciones urbanas a lo largo de la capital y de las unidades barriales (barras intercaladas y articuladas por una vía vehicular), con un centro de servicios. Finalmente, esbozó casas longitudinales “Gaitán”, inspiradas en los lotissement Barcelona y en Roq et $R o b$, y firmó planos relativos a las intersecciones viarias, dentro de la regla de las $7 \mathrm{~V}$.

\subsubsection{Viviendas en la reconstrucción}

La acción de Samper para la unidad marsellesa fue mucho mayor que la de Salmona, concentrada en una serie de planchas ATBAT, del primer trimestre de 1952 (plantas de los niveles 4, 7 y 8 - FLC 25313/14; detalles de bancos, ventanas y divisiones en la guardería - FLC 25806, FLC 30762). En sus visitas a la obra, el colombiano la registró externa e internamente, con colores y dimensiones detalladas del mobiliario doméstico. Este aprendizaje fue útil en la contribución de Samper para Rezé (1952), también enfocada en detalles constructivos. Junto al panameño Efraín Pérez Chanis, estudió de las diferentes tipologías de apartamentos, especificadas tanto en las plantas tipo como en minúsculas axonometrías (desde $76 \mathrm{~m}^{2}$, células no "traversantes"; FLC 02167); secciones de la caja sur de circulaciones verticales (FLC 02144); planos del sistema hidráulico (FLC 01510; FLC 01687) y estudios para la fachada principal (FLC 02145).

Junto a salmona, Samper también desarrolló las casas Rez-de-Chaussée para Neuve-Ville-Briey, supervisando los planos de Sachi para los subtipos F3 y F5, en escala 1:50, basados en sus propios croquis. Las planchas $\mathrm{N}^{\circ}$. $4739^{9}$ (FLC 20818B); 4742 (FLC 20821B); 4743 (corte, FLC 20822B) y 4740 (FLC 20819B) se repiten en Roubaix. Otros dibujos del dossier HEM fueron firmados por Samper en Marzo de 1953, representando las conexiones viales y topografía de la conurbación Lille-Roubaix-Tourcoing (FLC 20900/03), así como la distribución de zonas verdes y cuerpos de agua dentro de la urbanización (FLC 20914). Una localización dibujada posteriormente por Samper se muestra más densa que la propuesta inicial (FLC 20817).

\subsubsection{El aprendizaje de Jaoul}

Además de las planchas oficiales firmadas junto a Salmona, Samper elaboró un "Estudio de normalización de las casas alargadas" para Roq et Rob: páginas sueltas con esquemas del "volumen alveolar habitable", ceñido a los patrones del Brevet: materialización de la existenzminimum. El interés del colombiano sobre esa patente estaba en sus posibilidades como medio de construcción masiva.

En lo que se refiere al proyecto para los Jaoul, mencionamos anteriormente la participación de Samper en su primera fase. El pequeño presupuesto, el lote reducido, la dificultad de excavar en el mismo y la estricta normativa urbana obligaron a una alteración importante del programa en noviembre de 1951, aunque persistía la independencia entre las viviendas. Al respecto, estudios para su implantación fueron consignados en su cuaderno GS10, incluyendo croquis del propio Corbusier con diferentes alternativas. Llama la atención aquella desarrollada por Samper en diciembre, con ambas unidades paralelas, separadas por un patio (FLC 10315/19). En ese mismo mes comenzó la investigación para las bóvedas: en las notas del colombiano aparecen cálculos de las vigas y muros de carga que las soportarían. Samper ya participaba de reuniones técnicas con Wogensky para determinar éstas y otras especificaciones (tipos de revestimientos del suelo, sistema de desagües de las cubiertas, juntas de dilatación entre elementos prefabricados, etc.) necesarios para la elaboración de detalles técnicos, a incluir en el "permiso de construcción", de marzo de 1952 (FLC 09896/902). Durante el mes siguiente, elaboró

\footnotetext{
${ }^{9}$ Numeración consecutiva de planos en el Cuaderno de Dibujantes o "Livre Noir”.
} 
curiosas elevaciones internas de la casa $\mathrm{B}$, describiendo la disposición interna de los pan-de-verre (FGJF PLR 025 003). Finalmente, en su cuaderno se destacan largas tablas descriptivas y presupuestos estimados de los elementos arquitectónicos, organizadas por capítulos y piso: techo, divisiones internas; fachadas ciegas; carpintería; equipamientos sanitarios y sistemas hidráulicos; calefacción y otros equipos eléctricos.

\subsection{Un bogotano en el proyecto de Chandigarh}

La lista de obras indianas que contaron con la participación de Samper es extensa, comenzando por los estudios urbanos generales, entre los cuales señalamos el Capitol y la Grilla de Arborización (clasificación morfológica de las especies, posibilidades de agrupación y estudios climáticos; FLC 05983). En febrero de 1953, trazó esquemas para el City Center: sector con galerías comerciales en los primeros pisos de edificios de oficinas, finalmente diseñado por arquitectos locales. Además, el colombiano contribuyó en el estudio de las líneas de transporte público urbano (autobuses), que circularían por las V2, V3 y V4, conectando la capital con el nuevo aeropuerto extra-muros y el mundo rural (FLC 05201; FLC 05277).

\subsubsection{El Capitol y sus edificios}

Además de la definición del skyline (FLC 05140), prácticamente todos los edificios previstos en la nueva explanada contaron, en mayor o menor medida, con contribución del colombiano. La serie de plantas $\mathrm{N}^{\circ} .4361$ (FLC 05141/42) ilustra un espacio público más convencional que la versión construida, con una secuencia simétrica de espejos de agua a lo largo del eje que conectaría el Palacio de Justicia con la Asamblea. Habría una torre en lugar del edificio longitudinal del Secretariado, perpendicular al eje. En una alusión a sus investigaciones sobre los volúmenes platónicos, Le Corbusier incluyó un cubo rematando la composición, correspondiente al Raj Bavhan (desarrollado posteriormente por Tobito) -que desaparecería en bocetos y collages subsecuentes, también firmados por Samper-, además de nuevas zonas verdes y alteraciones topográficas.

Samper tuvo una participación intensa para el primer esquema para la Asamblea, publicado en el volumen $\mathrm{V}$ de la Euvre Complete. Las mayores transformaciones tuvieron lugar en la forma en herradura de la "Lower House" (FLC 03103; FLC 03016). A su vez, la "Upper House", inicialmente propuesta como un hexágono flotante, replicaba al fallido Palacio de los Soviets ${ }^{10}$. Fachadas reticulares con transparencias también fueron dibujadas por el colombiano, así como secciones indicando la iluminación cenital a través de tímidas claraboyas. Tanto para éste proyecto (FLC 03324/25) como para la Alta Corte (FLC 04354; 05146A), el "León" construyó diagramas conceptuales del programa y flujo de actividades (en el segundo caso, instancias ceremoniales, residencias de visitantes y apartamento del gobernador).

Su contribución al diseño del Palacio de Justicia estuvo vinculada a una fase avanzada del proyecto, dibujando las fachadas posterior y laterales, en escala 1:100 (FLC 04521; FLC 04556/58). En ésta, el pórtico monumental de acceso, apoyado sobre tres gigantescos pilares coloridos, exhibe la nueva e intensa policromía plasmada en la paleta de colores Salubra 2, de 1959 (desarrollada con colaboración de Tobito). Samper también trazó esquemas del sistema de ventilación de los tribunales: un ducto de altura triple, que sobresale del volumen central sin irrumpir en la cubierta en "V", recapturando el aire caliente por un segundo ducto y enfriándolo con un sistema frigorífico (FLC 04764). Por último, esbozó las primeras elevaciones para el monumento de la Mano Abierta, construido en la década de los 80 y cuya relación con el paisaje himalayo ha sido ampliamente discutida- y de las rampas y escaleras hacia la Fosa de la Consideración (FLC 0583/35).

\footnotetext{
${ }^{10}$ Papillault, Rémi: Chandigarh et Le Corbusier, création d'une ville en Inde 1950-1965. Toulouse: Poḯsis, 2011.
} 


\subsubsection{Coordinando el Secretariado}

Teniendo a su cargo el trabajo de colegas como Peña o el chileno Emilio Duhart, Samper asumió la coordinación de la sede para 9 ministerios de Punjab, en septiembre de 1951, actuando como interlocutor entre "Corbu" y la firma calculista Schaud \& Metz. La cantidad de originales conservados por el arquitecto merece un estudio detallado; aquí apenas mencionamos algunas fases que contaron con su participación exhaustiva:

- Desarrollo del esquema longitudinal (sugerencia del ingeniero Thapar): una barra de $254 \mathrm{~m}$ de largo; yuxtaposición de 6 módulos estructurales y volúmenes externos para escaleras (posteriormente reemplazadas por rampas), los cuales, junto a los monumentales brise-soleils, rompieron su monotonía. Un reporte detallado del colombiano (febrero de 1952) denuncia las dificultades técnicas no sólo por causa de las dimensiones del edificio, sino por el flujo de trabajadores al interior de oficinas en doble crujía, quienes comenzarían y terminarían su jornada simultáneamente. La Grille Climatique y sus estudios solares fueron otro de los aportes definitivos del "León" al Secretariado. Tras el clima inclemente del lugar, era fundamental un sistema de ventilación natural, explicando en el "corte fundamental" transversal de un piso tipo, de $2.26 \mathrm{~m}$ de altura libre, el (FLC 02640; FLC 03435). La fachada más afectada (sureste) fue intensamente estudiada por Samper en enero de 1952, considerando cuatro pan-de-verre diferentes en el módulo intermedio del edificio (bloc $n$. 4, salas de ministros; FLC 02654A /B y FLC 03433).

- En junio de 1952, y con eventual colaboración de Peña (FLC 02869, FLC 02884) Samper elaboraría incontables versiones de esa elevación basada en el patrón 3.66 del Modulor, ajustando el "tejido" (como él mismo lo denominó) de los balcones brise-soleil, cuyo anclaje a la estructura principal se dificultaba por la desproporción de su voladizo. Le Corbusier ordenó dibujar columnas exentas según el ritmo de la estructura principal (en primera instancia, Samper se rehusó, sin prever la riqueza proporcionada por la superposición de ambos ritmos ${ }^{11}$ ). Posteriormente, en su cuaderno bocetó dos pérgolas de acceso (una curva, la que se construyó, y otra convencional; GS8099, GS8100) y las primeras perspectivas internas del vestíbulo, antecedido por un espacio abierto bajo el piso artificial del nivel 1. El año de 1953 sería aun más arduo, definiendo las fachadas laterales y nuevas versiones de todas las plantas, en escala 1:200, con la coparticipación de Kim (FLC 02669; FLC 02668; FLC 03404). La configuración de esas plantas aun dependía del establecimiento de los ejes estructurales por parte de los ingenieros.

Algunas perspectivas y axonometrías coloridas de Samper ilustran la calzada excavada entre al Secretariado con la Asamblea (Fig. 6). En julio, éste profundizó en la composición del club sobre el toit-jardin (FLC 02786): un prisma horizontal predominantemente de vidrio y cubierta en "V", apoyado sobre pilotis y religado a la cubierta mediante una rampa. En octubre de 1953, nuevas exploraciones en planta de ese espacio y esquemas estructurales para la loggia del Gobernador soportada mediante un sistema estructural diferente para cada una de sus tres caras, constituían las últimas contribuciones al dossier de Samper (FLC 29120A; FLC 29120C). Éste viajaría a India en 1961, constatando el fruto de su trabajo para el Secretariado, inaugurado en 1958.

\footnotetext{
${ }^{11}$ Samper, Germán: Le Corbusier de cerca. Revista Camacol, N ${ }^{\circ}$. Especial Le Corbusier 100 años, 1987, p. 63.
} 


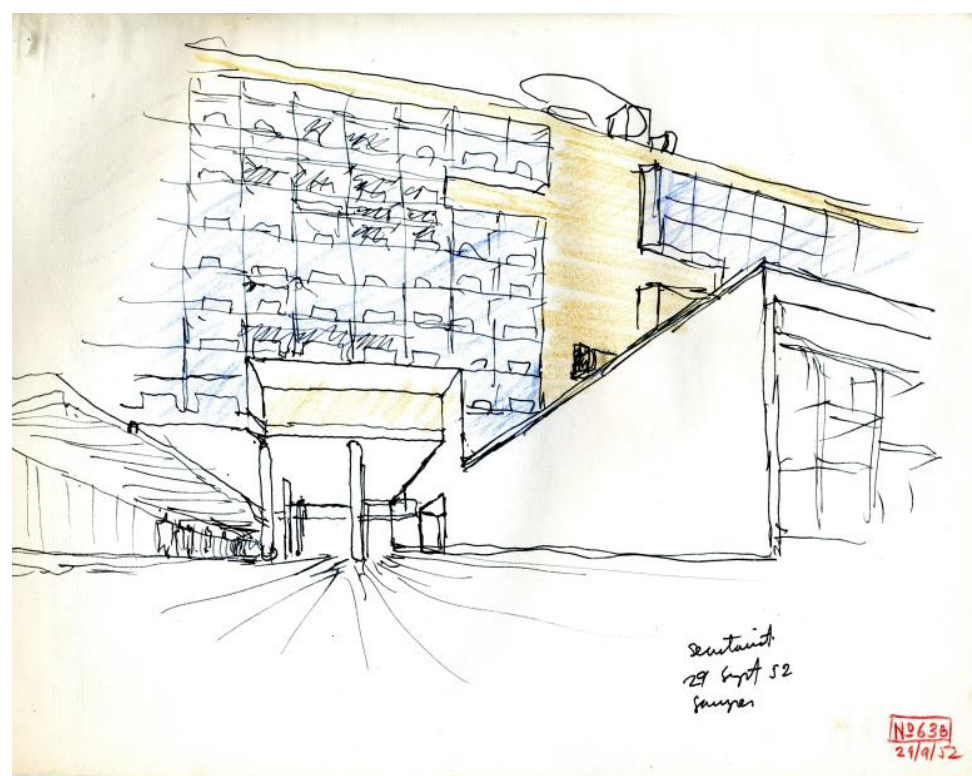

6. Perspectiva peatonal del acceso y fachada principal del Secretariado. Fuente: GS (8075).

\subsection{Regreso a Colombia}

Debido a uno de los viajes de Le Corbusier a Chandigarh, Samper no logró despedirse, dejando apenas una carta (05/11/1953). El último certificado laboral emitido para el colombiano expresa todas sus cualidades esenciales: precisión, sangre fría, orden y capacidad de invención. Días antes, "Corbu” también le regaló una famosa ilustración de una de las actitudes cotidianas ineludibles, según él, delante de la vida: como el Quijote, era necesario combatir contra molinos de viento. A su regreso a Bogotá, Samper mantuvo contacto con París, representando a Rue de Sèvres para la construcción del Banco Francés e Italiano (no desarrollado). Por su parte, el franco-suizo le expresó su deferencia al incluirlo en la lista de posibles miembros de la FLC.

\section{Augusto Tobito (Rubio, 1921 - Ginebra, 2012)}

Tobito había trabajado en Bogotá antes de llegar a Rue de Sèvres, como arquitecto y como docente en la Universidad de los Andes. También hizo parte del CIAM Colombia, según la lista registrada en su séptima versión, y participó del proyecto urbano para Tumaco, dirigido por Town Planning Associates. Como Salmona y Samper, conoció a Le Corbusier en su primer viaje a Bogotá, como miembro de la Sociedad Colombiana de Arquitectos. Los detalles de la contratación de Tobito en París serían concertados desde enero de 1953, pero su efectiva incorporación se dio dos meses después, cuando apareció sorpresivamente en el taller sin que hubiese sido expedido su permiso de trabajo. Trabajó en un número importante de proyectos (27) y entabló una relación cercana con Xenakis. Sumado a la melancolía por el fallecimiento de Yvonne Gallis en 1957, su maestro comenzaba a sentir molestia por la prolongada permanencia de los dos, lo que lo llevó a atribuirles el estatus de dattiers $^{12}$. Tobito ${ }^{13}$ narra diferencias metodológicas con relación a sus antecesores latinos: “[...] el colaborador iniciaba una solución y Le Corbusier trataba de comprender la proposición hecha e iba introduciendo ideas personales en el camino que había de seguir el proyecto [...]. También sucedía que de pronto encontrase una falla en la solución propuesta y entonces daba un giro completamente nuevo a la solución inicial o bien la

\footnotetext{
${ }^{12}$ En la última página de L'Atelier de la Recherche Patiente (Paris: Éditions Vincent Fréal, 1960) aparece: «Xénakis [sic], Tobito et Maisonnier, qui ont quitté l'atelier en 1959, ont demandé à être désignés : architectes chef d'études ».

${ }^{13}$ Tobito, Augusto: Le Corbusier: Gigante del siglo XX. Punto. №. 25, 1965, pp.19-20.
} 
transformaba paulatinamente a lo largo de las sesiones que dedicaba a esos proyectos". El propio Corbusier en carta al ministro de desarrollo iraquí, justificaría el retardo en el proyecto del estadio de Bagdad en esta nueva y más paciente manera de proceder ${ }^{14}$.

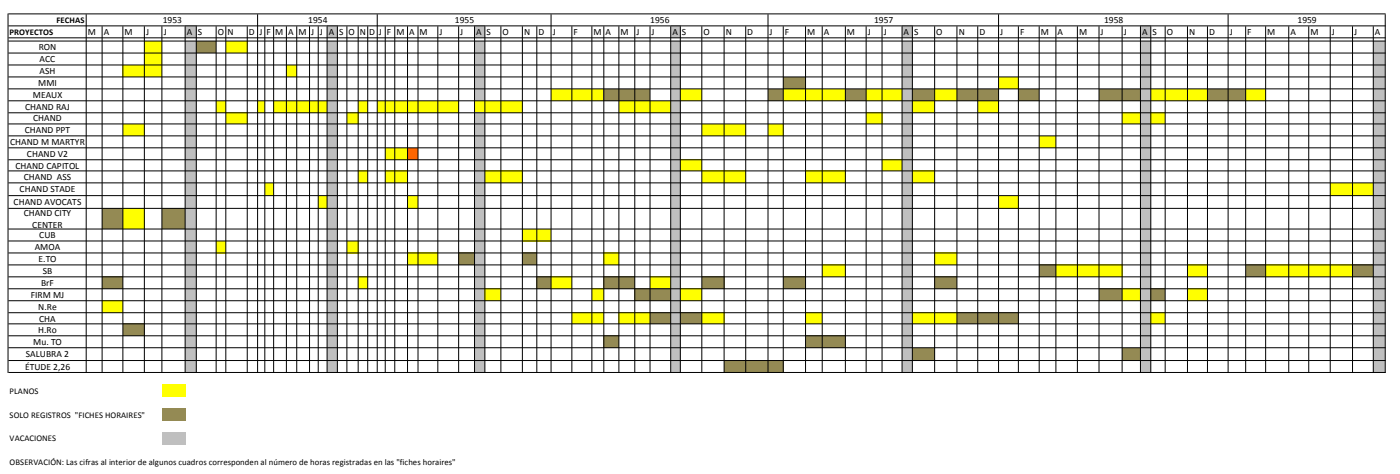

7. Tabla de proyectos lecorbusierianos con documentación relativa a Augusto Tobito. Fuente: La autora, basada en archivos de la FLC.

\subsection{Proyectos Indios y Arquitectura Simbólica}

La participación del venezolano en el atelier comenzó justo donde la de los colombianos terminaba: en propuestas para Chandigarh: Capitol; City Center y Edificio de Abogados. En éste, Tobito modificó la volumetría dibujada por Salmona, proponiendo un prisma bajo, apenas conectado a la barra principal por una galería abierta (FLC 04684/86). Para City Center, dibujó un conjunto de edificios de oficinas en altura a escala 1:100, cuyos basamentos configurarían una especie de bazar turco (FLC 05123/24). Tobito también dibujó las fachadas para el PTT Building, uno de los extraños rascacielos previstos para la capital de Punjab. Su particularidad: la inclusión de pan-de-verres ondulatoires (FLC 29138), característicos de otro proyecto en el que el dattier tuvo una participación fugaz: el convento de La Tourette (FLC 01066/69). Como reemplazo de Samper en la coordinación del Secretariado en septiembre de 1953, efectuó transformaciones importantes en la distribución de las salas de ministros (FLC 02848/49) y en la composición de sus fachadas (FLC 03517), al alternar vitrales con bloques de vidrio.

\subsubsection{Raj Bahvan}

El Palacio del Gobernador fue el único de los cuatro grandes edificios del Capitol no ejecutado. El gobernador Nehru rechazó un primer esquema debido a sus dimensiones, sobrepasando el presupuesto y oponiéndose al espíritu austero democrático. Los primeros croquis en planta del dattier denotan instancias sinuosas, dispuestas sin orden aparente (especialmente en el último nivel, donde se dispondría el apartamento principal. FLC $03896-$ FLC 04104/8) en medio del perímetro cuadrado del edificio. Éste soportaría una red estructural de pilares cruciformes (Fig. 8). Resalta una serie de siluetas que Tobito hizo con el pintoresco perfil del Raj Bahvan (FLC 04148): coronando el basarti, en el quinto nivel, se levantaría una cubierta a manera de platón, presuntamente relacionada con los motivos taurinos de la pintura lecorbusieriana. La fenestración del lado suroeste del cubo, en el segundo nivel, evoca la fachada de acceso de Ronchamp (FLC 03791), así como de la Villa Shodhan, con vitrales visibles en las secciones-fachada del salón de esa casa, también dibujadas por el venezolano (FLC 07496/97). En abril de 1955, los estudios estructurales se vieron afectados por la presión de las autoridades

\footnotetext{
${ }^{14}$ Marefat, Mina: “Mise au point for Le Corbusier's Baghdad Stadium”. En Docomomo, Nº 41, 2003, p. 36.
} 
indias, quienes retuvieron buena parte del pago. Eso desencadenó un atraso y posterior charrette $^{15}$ en junio, produciendo el primer conjunto completo de planos para el palacio (FLC 03777/84). En los cortes 3 y 4 (FLC 03801; FLC 03814), entre el cuarto y quinto piso, el dattier dibujó una especie de bóveda, también proyectada en las fachadas sureste y noreste, donde se percibe mejor su complejidad volumétrica (se incorporaba una ametralladora para la entrada de luz cenital; FLC 03811/13). Entre los últimos dibujos de Tobito para el Palacio, cuya construcción fue descartada en junio de 1957, hay secciones transversales de los brise-soleils (FLC 03823).

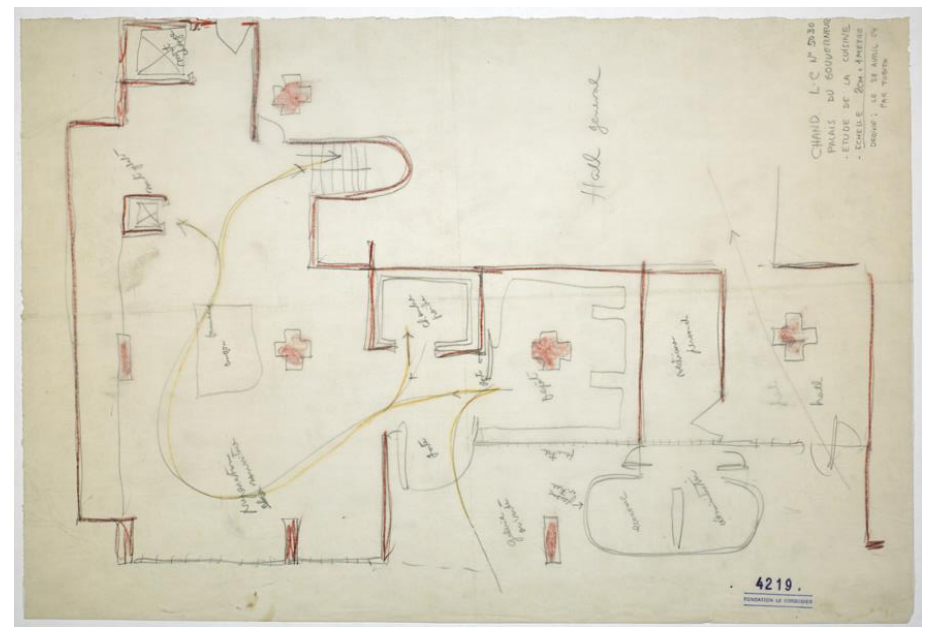

8. Esquema del hall general del Raj Bahvan, por Tobito. Fuente: FLC (04219A).

\subsubsection{Asamblea}

Luego de pasar frente a los reactores de una central nuclear en Lorraine, Le Corbusier pidió a Maisonnier y Tobito descartar los estudios de Samper para la Asamblea y desarrollar un monumental hiperboloide truncado como sala de diputados, cuya altura duplicaba la del conjunto de oficinas administrativas, en el perímetro de la propuesta (FLC 02903). Las secciones y plantas de los cinco pisos fueron elaboradas por el venezolano en septiembre de 1955, ilustrando una de las alas de la Asamblea nacida del nivel excavado y vinculada al acceso vehicular por piso abierto, con pilotis, rampas y algunos cubículos (FLC 02965). El acceso ceremonial se daría por la fachada oriental, luego de franquear la pasarela sobre el espejo de agua. Esbeltas columnas rodearían la hipérbole en la sala de pasos perdidos. La planta de la cubierta, también elaborada por Tobito, exhibe la proyección de la claraboya para la sala principal, cuya distribución interna, en escala 1:100, redibujó en marzo de 1957 (FLC 02929). En octubre, el venezolano trazó las cuatro fachadas del edificio: la oriental ostentaba una pérgola de acceso distinta a la construida, no curva sino oblicua (FLC 03034). Junto a Xenakis, también construyó una maqueta en la que incluye la pirámide en la terraza-jardín. Cerrando la producción del venezolano, una versión definitiva de esa planta (FLC 03089) ilustra las nervaduras de la nueva pérgola.

\subsection{Repensando las unidades habitacionales}

El dattier tuvo una participación fugaz en los dossiers de algunas unités como Rezé-les-Nantes, dibujando una perspectiva sur de la unidad, con un lago en primer plano (FLC 02316A/B). Una plancha idéntica, marcada con nomenclatura de Briey-en-Forêt (FLC 17327), fue firmada por él, junto a otros 13 dibujos en enero de 1956:

\footnotetext{
${ }^{15}$ Jerga francesa comúnmente usada en el taller para designar un momento de presión extrema en su producción.
} 
fachadas del edificio (FLC 30434A/B) y de la terraza-jardín (FLC 17335) la cual finalmente carecía de los componentes de sus antecesoras.

\subsubsection{Meaux o la multiplicación de unités}

Paralelamente al desarrollo de Rezé, Le Corbusier asumió un estudio para 2000 viviendas en un suburbio industrial al oriente parisino, promovido por la compañía Renault. Éste complementaría la Fábrica Verde propuesta por el maestro del otro lado de la autopista nacional $\mathrm{N}^{\circ}$. 3. Tobito dibujó los primeros esquemas de implantación, con cinco unidades idénticas e inmuebles à redent para equipamientos (FLC 21560). Como en Estrasburgo, dos torres cilíndricas alojarían solteros. En los meses sucesivos, consideró más posibilidades de organización del sector a partir de los mismos elementos, presentadas mediante una grilla CIAM en febrero de 1956 (FLC M3-12-488).

Ante el rechazo de la propuesta por parte de sus clientes, “Corbu” planteó una intervención mayor, abarcando parte del rio La Marne; creando una zona de explotación agrícola y considerando 20 unidades para aumentar la densidad del centro urbano (FLC 21568). Posteriormente, Tobito desarrolló un esquema de tan sólo 17 unités (FLC 21690); una tercera alternativa, de marzo, reduciría su número a 8 (FLC 21730). Para subsanar las viviendas faltantes, se proponían barras sinuosas, evocando el proyecto lecorbusieriano para Alger (1930). La siguiente versión de Meaux sólo contaría con 800 habitaciones, entre células y casas Rez-de-Chaussée, organizadas por una trama urbana diagonal delimitada por una carretera perimetral. El dattier se concentró en el estudio de la zona industrial (norte), deslindada por una vía férrea (FLC 21888A/B/C). En noviembre de 1955, detalló las plantas de las unidades (FLC 21443; FLC 21894), simplificando la estructura de las unités precedentes, con cuatro y no tres mega-pórticos en el sentido transversal ${ }^{16}$. Dos planos simples, inclinados, convergirían en cada pilar en "V". La posibilidad de construcción serializada de unidades gestó un equipo técnico al interior de Rue de Sèvres, el EQUIPBA (Équipe de Bâtisse), liderado por Xenakis, con participación eventual de Tobito y Maisonnier, investigando el montaje en seco de células. Se convocó a la Renault para formular el Sistema Meaux, de principio cercano al Brevet, combinando concreto armado en los nudos de amarre, plástico y acero. Ante la presión de la automotriz para su comercialización, el maestro abandonó la idea. Antes, Xenakis y Tobito desarrollaron estudios comparativos entre las diferentes unidades, derivados en módulos cúbicos de $2.26 \mathrm{~m}$ para Meaux (carpeta FLC M3-4). También se plantearon viviendas de baja altura bajo el mismo patrón, suscitando propuestas morfológicamente complejas, que quedaron abandonadas como el resto del proyecto, en el verano de 1960.

\subsubsection{Unidad Typ-Berlin}

La unidad berlinesa nació de la invitación a Le Corbusier para participar en la Interbau, exposición de arquitectura moderna. Inicialmente de 400 células (aumentadas posteriormente a 557) ésta no se construiría en Hansaviertel, barrio de la muestra, sino en Charlottenburg, al oeste de Berlín. Tobito se encargó de estudiar la implantación de la propuesta, al adaptar a la topografía y trazado original del terreno mediante la creación de una plataforma curva y semienterrada, con estacionamientos y cuartos de máquinas (FLC 23683). Los cortes generales de la unidad dibujados por el venezolano corresponden a muros estructurales similares a los propuestos para la unidad de Briey, transformados en pilares en "V" al contacto con el terreno (FLC 23689 A/B). En septiembre y octubre de 1956, Tobito también contribuyó con sus estudios para la guardería en el toit-jardin,

\footnotetext{
${ }^{16}$ Calafell, Eduard: Les unités d'habitation de Le Corbusier: aspectos formales y constructivos. Barcelona: Fundación Caja de Arquitectos, 2000.
} 
cuyo patio de recreo se instalaría justo por encima del volumen de aulas (no construido por cuestiones presupuestales; FLC 23685A/B). También esbozó la caja de ascensores, colinas artificiales, y un anfiteatro al aire libre (FLC 23694A/B). Los problemas comenzaron cuando las autoridades rechazaron la medida básica de $2.26 \mathrm{~m}$, exigiendo $2.5 \mathrm{~m}$ como altura mínima libre, lo que implicó ajustes del prototipo, buscando su armonía con el Modulor. La confrontación entre París y Berlín no se hizo esperar, tras modificaciones arbitrarias en obra, denunciadas en el volumen VI de la Euvre Complète ${ }^{17}$.

\subsection{Cultivar el Cuerpo y el Espíritu}

Concomitantemente a las iniciativas culturales de postguerra lanzadas por el gobierno francés, se encontraba una red de casas culturales: en Firminy, ésta fue encargada a Le Corbusier (1953). Con la alteración posterior del programa por parte del alcalde Petit, la propuesta fue integrada a un proyecto más ambicioso, con instalaciones deportivas, consolidando la cuarta función de la ciudad moderna: cultivo del cuerpo y del espíritu. Finalmente denominada como la Casa de la Juventud, la barra de 112 metros de largo, separada del estadio por taludes, fue laboratorio de un nuevo lenguaje técnico y formal. Contó con participación casi autónoma de Tobito y Xenakis en lo referente al estudio en sección de la cubierta inclinada (FLC 16826; la versión definitiva denota una curva invertida), cuya semejanza con la Escuela Júlia Kubitschek en Diamantina (Brasil), construida por Oscar Niemeyer en 1954, es indiscutible. De hecho, en el último volumen de su Euvre Complète ${ }^{18}$, Le Corbusier acusó sutilmente a sus colaboradores de propiciar un supuesto plagio.

\subsubsection{La crisis de Bagdad y el ocaso de los dattiers}

Tobito y Xenakis trabajaron mancomunada e intensamente en la solución estructural del Estadio de Bagdad, entre abril y julio de 1958, continuando las investigaciones técnicas y funcionales de Firminy. El estadio de planta circular albergaría 50000 espectadores y una pista olímpica, además de algunas excentricidades "a la romana" como una fosa para festivales y cuatro vomitoriums (FLC 00166). Ambos dattiers elaboraron estudios comparativos de equipamientos deportivos en otras capitales y, en abril de 1958, comenzaron a dibujar elevaciones de más de 20 tipos de contrafuertes de concreto (FLC 29507): pantallas (voiles) de hasta 3 pisos de altura $(8 \mathrm{~m})$ dispuestas radialmente en todo el perímetro del estadio. La dupla también esbozó el palco cubierto para el rey: un volumen cúbico, aislado, a media altura de las graderías (FLC 29519-22; FLC 29526). En junio de ese año, Tobito dibujó en solitario todo el complejo, "en limpio", así como circulaciones verticales dentro del equipamiento y una plataforma para periodistas y vestuarios, coincidiendo con las tres líneas más bajas de graderías (las líneas superiores aparecen en voladizo; FLC 00250). La solución de la cubierta, en concreto armado, tensores de acero y lonas plásticas, fue formulada por el ingeniero Georges Presenté ${ }^{19}$, quien terminaría de desarrollar el proyecto, ejecutado póstumamente.

\subsection{Entre los fieles}

Desde marzo de 1959, "Corbu" contemplaba el despido de sus dattiers, tras la exigencia de un aumento de salario. Una nota genérica anunció su retiro cinco meses después; justificado por la necesidad de darles alas para

\footnotetext{
${ }^{17}$ Boesiger, Willy (Ed.): Le Corbusier et son atelier rue de Sèvres 35. CEuvre Complète 1952-1957. Zürich: Les Éditions d'Architecture, 1957. v6, p. 192.

${ }_{18}$ Boesiger, Willy (Ed.): Le Corbusier et son atelier rue de Sèvres 35. Euvre Complète 1957-1965. Les Éditions d'Architecture. Zürich: 1966. v7.

${ }^{19}$ Ragot, Gilles: Le Corbusier à Firminy-Vert, manifeste pour un urbanisme moderne. Paris: Éditions du Patrimoine-Centre des monuments nationaux, 2011, p. 136.
} 
volar por sí mismos ${ }^{20}$, y por diferencias de opinión respecto a la forma general y rampas externas del estadio de Bagdad $^{21}$. Un mes antes, el maestro había solicitado a su contador la liquidación para los tres colaboradores. El venezolano apenas regresaría a su país en noviembre de ese año, para ejercer como docente de la Universidad Central en Caracas. El día 5 de ese mes, Le Corbusier le había regalado un dibujo de su autoría, con la nota "“...] merci de votre gentillesse naturelle ${ }^{, 22}$. Poco antes de su fallecimiento, en julio de 1965, el maestro recibió en su apartamento una visita del venezolano: «J'étais heureux de revoir Tobito, qu'il poursuivait, qu'il était parmi les fidèles. Lorsque nous nous sommes quittés [...], j’ai dit à Tobito que qui pensait revenir me voir l'année prochaine $»^{23}$. En retorno a su gentil despedida, el dattier ${ }^{24}$ escribió con motivo de la muerte del maestro: “ $A U d$. El Hombre cabal, en postrer homenaje, con el adiós de los amigos: ¡Adiós, monsieur Le Corbusier!’.

\section{Conclusiones}

De entre los andinos, quizás por su juventud, desinterés o brevedad de la pasantía, ni Salmona, ni Valencia ni Peña parecen haber incidido en las adaptaciones metodológicas del taller. No obstante, el papel del primero, como articulador entre empleados más recientes y la lógica proyectual del maestro, es innegable, evidenciado por la cantidad de proyectos en los que participó y perspectivas que dibujó. Transformaciones en las herramientas proyectuales (collages, diagramas de flujos, dibujos ingenuos y coloridos), tradicionalmente vinculadas a la llegada del chileno Guillermo Jullian al taller, se vislumbran en la abundante documentación aportada por Samper, particularmente en los relacionados al proyecto del Secretariado. Por otra parte, la mayoría de los proyectos lecorbusierianos que contaron con la contribución de latinoamericanos están ligados con la vivienda masiva y su papel en los nuevos planes urbanos: incluso temas como la nueva policromía (explorada desde la fachada de Marsella); el apelo constante a los patrones del Modulor; el uso recurrente de los vitrales; la creación de formas alegóricas del universo pictórico lecorbusieriano y su diálogo a diferentes escalas con la geografía circundante, abordadas en mayor o menor medida por los dattiers, contribuyeron a la creación de ese espacio inefable, consolidado en Chandigarh con antecedencia a la llegada de Jullian. Se eximía así la indispensable presencia de obras artísticas de diferente índole, lo que Le Corbusier dejó entrever al definir" ${ }^{25}$ : " $L a$ quatrième dimension semble être le moment d'évasion illimitée provoquée par une consonance exceptionnelle juste des moyens plastiques mis en ouvre et par eux déclenchée. [...] une victoire de proportionnement [sic] en toutes choses - physique de l'ouvrage comme aussi efficience des intentions contrôlées ou non, saisies ou insaisissables, existantes toutefois et redevables à l'intuition [...] Alors une profondeur sans bornes s'ouvre, efface les murs, chasse les présences contingentes, accomplit le miracle de l'espace indicible [...] couronnement de l'émotion plastique".

La Búsqueda Paciente, llena de incertidumbres, sólo se detuvo con la muerte de "Corbu", aquel verano de 1965. En contraste con el efímero paso de otros colaboradores latinos por el taller, estos dattiers aprehendieron del maestro esa virtud, en aras de explorar una idea hasta sus últimas consecuencias (caso Secretariado y la contribución de Samper), incluso si la esperanza de materializar dicha búsqueda era casi nula (caso Meaux y la intervención de Tobito). Su resistencia efectiva, sólo se dio en la propia acción profesionales de estos personajes

\footnotetext{
${ }^{20}$ Carnet IV (28 août 1959). De Franclieu, Françoise (Ed.): Le Corbusier: Sketchbooks. New York, Cambridge: MIT Press, $1981.5 \mathrm{v}$.

${ }^{21}$ Loach, Judi: L'Atelier LC, un centre européen d'échanges. Monuments Historiques, v. III-IV, No. 180. 1992, p. 76.

${ }^{22}$ Archivo personal Bárbara Bradley.

${ }^{23}$ Boesiger, Willy (Ed.): Le Corbusier: Les dernières Euvres. Zürich: Artemis, 1969. pp. 168-169.

${ }^{24}$ Tobito, Augusto: Le Corbusier: Gigante del siglo XX. Punto. $\mathrm{N}^{\mathrm{o}} .25,1965, \mathrm{p} .11$.

${ }^{25}$ Le Corbusier: L'espace indicible. L'Architecture d'Aujourd'hui, $\mathrm{N}^{\mathrm{o}}$. hors série, 1945.
} 
en sus lugares de origen: Salmona como principal exponente de la arquitectura del ladrillo; Samper como edificador de miles de casas de crecimiento progresivo y autoconstrucción por parte de las propias comunidades obreras; Tobito como docente reformista y experto en asuntos bioclimáticos.

\section{Referencias bibliográficas}

Arcila, Claudia Antonia: Tríptico Rojo. Conversaciones con Rogelio Salmona. Bogotá: Taurus, 2007.

Boesiger, Willy (Ed.). Le Corbusier et son atelier rue de Sèvres 35. Cuvre Complète 1952-1957. Zürich: Les Éditions d'Architecture, 1957. v6.

Boesiger, Willy (Ed.): Le Corbusier et son atelier rue de Sèvres 35. CEuvre Complète 1957-1965. Les Éditions d'Architecture. Zürich: [s.n.], 1966. v7.

Boesiger, Willy (Ed.): Le Corbusier: Les Dernières Euvres. Zürich: Artemis, 1969.

Calafell, Eduard: Les unités d'habitation de Le Corbusier: aspectos formales y constructivos. Barcelona: Fundación Caja de Arquitectos, 2000.

De Franclieu, Françoise (Ed.): Le Corbusier: Sketchbooks. New York, Cambridge: MIT Press, 1981. 5v.

Le Corbusier: L'Atelier de la Recherche Patiente. Paris: Éditions Vincent Fréal, 1960.

Le Corbusier: "L’espace indicible". En L'Architecture d'Aujourd'hui, $\mathrm{N}^{\mathrm{o}}$. hors série, 1945.

Le Corbusier: Plans. Paris: CodexImages International, Fondation Le Corbusier, 2005.

Loach, Judi: "L'Atelier LC, un centre européen d'échanges". En Monuments Historiques, v. III-IV, Nº 180. 1992 ,

Marefat, Mina: Mise au point for Le Corbusier’s Baghdad Stadium. En Docomomo, No . 41, 2003.

Papillault, Rémi: Chandigarh et Le Corbusier, création d'une ville en Inde 1950-1965. Toulouse: Poïésis, 2011,

Samper, Germán: "Le Corbusier de cerca". Revista Camacol, N . Especial Le Corbusier 100 años, 1987.

Sterken, Sven: Iannis Xenakis: architecte et ingénieur. Dirección: Bart Verschaffel. Tesis doctoral. Universiteit Gent, 2004.

Tarchópulos, Doris: Las Huellas del Plan para Bogotá de Le Corbusier, Sert y Wiener. Dirección: Joaquín Sabaté, José María Ezquiaga. Tesis doctoral. Universitat Politécnica de Catalunya, 2010.

Tobito, Augusto: "Le Corbusier: Gigante del siglo XX". En Punto, No. 25, 1965. 
philosophical standpoint. The focus will be on Sanctuaires d'Orient, a book by Édouard Schuré, ${ }^{1}$ because it shows the extent to which Le Corbusier was exposed to an idealistic line of thought based on key notions of the German philosophical tradition.

\section{Schuré's Sanctuaires}

Charles L'Eplattenier, Le Corbusier's teacher and mentor at the school of arts of La Chaux-de-Fonds, provided Le Corbusier with a Ruskinian education, permeated by the notion of a mythical South, behind which stood Rousseau's notion of origins. ${ }^{2}$ German philosophical idealism and Hegelian aesthetics were added to this education through indirect sources such as Henry Provensal's L'art de demain. ${ }^{3}$ This eclectic book on art theory, rooted in German idealism, argues for the unity of spirit and matter and of art and science as the way to overcome the decadent state of contemporary art and create a new art expressing the moral and spiritual needs of the new emerging society. The artist is presented as the one who is tasked with creating a new society, bringing together the "truth of the past and that of the future" through a new art, thus giving continuity to the "invisible chain" that, uniting Man to the infinity of Universe, resolves the Absolute. Art is seen as the expression of a given thought-the idea-being attained through abstraction and symbolic dimension: cubic forms which, expressing universal laws underlying nature, have informed all great periods of art. Le Corbusier found similar ideas in Les Grands initiés, by Schure, ${ }^{4}$ given to him by L'Eplattenier when he departed on his initiatory trip to Italy in 1907. He started reading it in Italy and finished it in Vienna. ${ }^{5}$ The book explores the same ideas of esoteric knowledge or a universal truth that traverses history, and of the need for a spiritual revival of modern civilization. The focus shifts from art and artists to religion and an elite of mystical prophets, who were the guardians of the "eternal truth" at the base of the great periods of civilization. This background was preparatory to the reading of Sanctuaires d'Orient during the Viennese sojourn in $1908 .^{6}$

Schuré (1841-1929) was a playwright, novelist and music critic. ${ }^{7}$ He had an extensive knowledge of German philosophical idealism, maintaining personal contacts with Richard Wagner and Friedrich Nietzsche. Inspired by Wagner's dream of revitalizing mythology through drama, Schuré himself attempted to stage his own sacred dramas and probed into music writing. He was an evocator more than a man of erudition, a specialist or an objective historian, as Alain Mercier has put it. Underlying the esoteric tone of Sanctuaires d'Orient, however, one finds an idealistic world-view comprehensively expounded, through which Le Corbusier could frame the rather esoteric discourses of his previous readings.

The book is an account of his journey to the East-Egypt, Greece and Palestine. It is divided into four main sections, the first devoted to Muslim Egypt, the second to ancient Egypt, the third to ancient Greece, and the last one to the Holy Land. The main arguments are that, despite their diverse expressions, all religions are rooted in a single, universal religion, and that an independent spiritual movement of a transcendental nature must rise from within the lay world in order to put an end to the antagonism between the Christian Church and the University.

\footnotetext{
${ }^{1}$ All subsequent citations refer to the 1907 edition.

${ }^{2}$ For a comprehensive work on Le Corbusier's early years see Brooks, Formative Years. On the influence of Rousseau see Vogt, Le Corbusier, passim.

${ }^{3}$ On the influence of this book in Le Corbusier see Turner, Education, p. 10-24.

${ }^{4}$ All subsequent citations refer to the 1921 edition. See also Turner, Education, p. 24-29.

${ }^{5}$ Le Corbusier to parents, 8 October 1907 and 31 January 1908, repr. in Correspondance, p. 49, 137.

${ }^{6}$ Le Corbusier to parents, 31 January 1908, repr. in ibid., p. 137.

${ }^{7}$ For a comprehensive work on Schuré see Mercier, Édouard Schuré.
} 
The aim is to retrieve this universal religion through a synthesis of religion, science and art, a synthesis to be found in the lost pagan relationship between Man and the divine forces of the natural world-the "unité primordiale et finale." What is more, the retrieval of this original existence will be accomplished by applying the old tradition and symbols to a new universal meaning.

Based on these premises, Schuré explores the three countries he considers to be the great sources of the tradition and symbols of the Occident, and of its intellectual, artistic, moral and social life. Ancient Egypt is seen as the heir to the pagan understanding of the universe, having expressed this sacred ontology through symbols. One of these is the pyramid, which expresses the Absolute through abstraction and geometric laws, and by combining science and religion within a perfectly built geometric form. ${ }^{8}$ The other is the sphinx, the Guardian of the rising Sun. Facing east, it allegedly was originally crowned with a golden disk lit by the first rays of the sun, reconciling the vertical, cosmic axis with the horizontal, pantheistic axis. ${ }^{9}$ We recognize here two major icons of Hegel's theory on Egyptian art.

Schure then traces the history of the split of this original pagan religion into several branches through the debate on Greece and Palestine. Concerning Greece, Romantic imagery is discussed, from the theme of an ideal society to that of the Greek fighter and of an existence transfigured by art, in a peaceful relationship with a mythic landscape. It echoes Hegel's theory on ancient Greek Kunstreligion (Art-as-religion), filtered by the Wagnerian notion of Gesamkunstwerk, which Schuré expresses through the concept of vie intégrale (complete life). As for Palestine, Schuré stresses the coexistence of Judaism, Christianity and Islam. While Judaism and Christianity are the two sides of the epistemological schism of the universal religion, he argues, Islam was founded upon both, reuniting the ontological values. Particular emphasis is given to the mosque of Omar (generally known as the Dome of the Rock) in Jerusalem, built on the site of Solomon's temple. Its dome is discussed in similar terms to those employed for the Egyptian pyramid: a perfectly built geometric form uniting science and religion. Schuré sees it as a symbol of the "invisible chain" that started in ancient Egypt, reconciling the Orient and the West. This explains the first section devoted to Muslim Egypt, in which he argues for the role of Islam in drawing forth a future synthesis of science, religion and art.

The historical account of the ontological transmission of pagan religion, extending beyond the bounds of this paper, ends with what Schuré considers to be the last attempt to re-establish a universal religion: the crusades of the Order of the Temple of Solomon. With this last assumption, Schuré completes the three stages of Hegel's philosophy of art-symbolic (Egyptian), classical, and romantic (Gothic) art.

\section{Philosophical Background}

The central assumption underlying Schuré's discourse consists of an evolutionary conception of history expressed at three levels: the history of civilization itself, of religion, and of art. Historical teleology is expressed in Schuré's faith in a new emerging era which, under the impulse of social and intellectual development, would fulfill historical destiny. The view of history as a chronological process of cultural development and progress towards a higher state of perfection has its roots in positivist thinking. ${ }^{10}$ In the face of growing knowledge of the Eastern world, this evolutionary principle had to deal with the evidence that values change with different

\footnotetext{
${ }^{8}$ Schuré, Sanctuaires, 83-86.

${ }^{9}$ Ibid., p. 88-91.

${ }^{10}$ On the theories of history I rely on Meinecke, Historism.
} 
historical and environmental contexts. This is particularly evident in the artistic field. With Montesquieu, Voltaire, and later Winckelmann, art came to be seen as an expression of a particular people and their life as a whole, and thus dependent on specificities such as climate, political constitution, national character and the spirit of the age. This relativizing of history did not eschew the idea of historical development, however. The Enlightenment had proposed what has been called the "life cycle theory," which explained the course of human events through the notion of the growth, maturity and decline of human creation. The correlation between these cycles became the focus in the nineteenth century. Early in 1821, Wilhelm von Humboldt conceived of history as a chain of events linked to each other in space and time. ${ }^{11}$ This process, he argued, was governed by particular laws (e.g., of geography and climate) and by a more powerful active principle: original and eternal ideas which, not being directly visible because they lie outside the compass of the finite, impart impetus and direction to world history. It is the historian's task to reveal the essence of history by unveiling the idea or hidden spirit beneath the surface of historical events, just as the artist's task is to reveal the ideal form beneath the variable forms of the visible world. The nineteenth-century saw the nurturing of this belief in historical events driven by an eternal, original idea common to all cultures. Its most extreme vision is found in Hegel's philosophy of history and his belief that all socio-cultural phenomena are historically determined by final causes-a universal will.

Schuré's call to retrieve the universal religion is informed by these ideas of a driving force giving purpose to history. True, the positivist view of historical development was associated with the notion of a straightforward narration of progress from the religious to the secular. However, as men like David Hume and Kant show us, ${ }^{12}$ the process of secularization never led to a total severing of connections with religion. While religious practices, institutions, and the nature of God where being questioned, religion tended to be seen as the state in which Man finds himself in relation to the world, such as in Hume's "natural religion." The rationalist conception of nature as order and as a system of a priori rules became gradually associated with a Neo-Platonic understanding of the world. This view is expressed early on with Giambattista Vico (1668-1744), who supported the idea of the existence of interior forces of an immaterial nature hidden beneath the visible mechanistic framework of cause and effect, through which God calls life into being. ${ }^{13}$ All this paved the way for the counter-Enlightenment doctrines of pantheism and the related belief in an immaterial driving force hidden beneath the contingent factors of historical events.

This counter-Enlightenment positioning comes as no surprise. Questioning Christian theology required its replacement with new moral and social systems. Hegel's is the first comprehensive attempt to synthesize every aspect of existence into one such system. ${ }^{14}$ Rejecting the atheism of positivist thinking, Hegel sees religion as a fundamental issue of human consciousness. Placing himself on the threshold between the religious and nonreligious world, he brought Christianity into the realm of the secular, firstly by considering it historically-that is, as a historical expression of an idea-and secondly by dissolving the idea in a pantheistic philosophical system. Rather than transcendence, God concerns Man's inner spirit and self-consciousness. In other words, God is the Absolute, immanent in the finite.

\footnotetext{
${ }^{11}$ Von Humboldt, "On the Historian's Task".

${ }^{12}$ See Minois, Histoire de l'athéisme, chap. XII

${ }^{13}$ On Vico see Meinecke, Historism, p. 37-53.

${ }^{14}$ Minois, Histoire de l'athéisme, chap. XVII
} 
Both Hegel's "doctrine of pantheism in the shape of humanity as an evolving God"15 and the more general pantheistic doctrines that saw nature as a manifestation of the Divine, of the Absolute, and as a revelation of the infinite, were reactions against the positivist "disenchantment of the world," as Max Weber termed it. Through them, the Romantics conceived of God as the Absolute, immanent in nature and history. This implied two notions that interest us here. First, the notion of the secular-sacred, a peaceful, pantheistic existence in harmony with the natural world, resurfacing in imagery such as that of pagan religion and of nature as Mother Earth, profusely explored by Schuré and his contemporaries. Second, the idea that, freed from Christian theology, man could give continuity to history and achieve a higher state, the iconic image of which is Nietzsche's Übermensch (Superman, or more precisely, over-human). ${ }^{16}$ In terms of historical development, these notions relate to two poles. On one pole is the myth of a golden age and of the Primitive, involving an original pantheistic existence, fusing reason and intuition. On the second, we find a renewed Christianity, which, to recall Hegel's conception, consists of the consummate or absolute religion, the religion of reconciliation. Judaism and Islam, in their turn, were seen as religions of the western Orient, forming a transition from pure oriental religions to Christianity.

Such is the basis of Schuré's renewed Christianity, a universal religion uniting science, religion and art, aiming at a higher state of mankind by retrieving a secular-sacred existence and an art expressing this fundamental lived experience. In fact, in the teleological principle of idealism, the emergence of a new era implied a return to a primitive identification with nature, a return to the primitive Absolute. It is this identification, understood as an ideal that traverses history beneath historical events, that underlies Schuré's notion of the "unité primordiale et finale" and Provensal's assertions on the "invisible chain" that brings together the "truth of the past and that of the future," uniting Man to the infinity of Universe.

Finally, this historical and religious perspective runs parallel with the theories of art history. Art, I have mentioned, came to be seen as an expression of a given culture and of its relation to the world, thus depending on contingent factors. However, as with the theories of history, a universal will was believed to lie beneath the contingent. With the impulse of Winckelmann, the nineteenth-century looked at art as a symbol and revelation of the divine. All great periods of art therefore shared the same fundamental symbols. Also, beauty was understood as something apprehensible more through impression than through reason, implying experience rather than $\grave{a}$ priori laws. Thus understood, symbols were a means to an epistemological experience, acquiring a key role in the development of art history. This explains Schuré's call for the study of symbols in loco (from ancient Egyptian to Muslim and Christian architecture), and of its purpose: to unveil through an experience of reason and intuition the eternal, original idea that, hidden beneath these symbols, traverses history and will allow a new society and its artistic expression to emerge.

In sum, through the reading of Schuré's Sanctuaires d'Orient in 1908, Le Corbusier was exposed to a consistent philosophical reasoning based on German idealism. The book clarified and broadened the Romantic discourse of his previous readings, allowing him to conceive of an idealistic world-view based on an evolutionary conception of history, given purpose by the idea of a secular-sacred existence, and in which the experience of mythic symbols is a vital means of re-enacting that existence and creating a new architectural style expressing the zeitgeist.

\footnotetext{
${ }^{15}$ Meinecke, Historism, p. 506.

${ }^{16}$ Note that Le Corbusier read Nietzsche's Thus Spake Zarathustra in 1908/1909 and was struck by Nietzsche's conception of the Übermensch, which has much in common with Provensal's elite of artists and Schuré's Initiates. Turner, Education, p. 56-61.
} 


\section{Schuré and Le Corbusier}

In order to evaluate the influence of Schuré on Le Corbusier's subsequent period of travel, I will focus on the three points initially raised: his rejection of architectural schools, his approach to Notre-Dame, and the itinerary of the journey to the East.

An immediate manifestation of Schuré's influence concerns religion and universities. When, in 1908, Le Corbusier went home for Christmas, his father noted in his journal the complete modification of his son's beliefs and religious faith, which nonetheless coexisted with a feeling of confidence in the future. ${ }^{17}$ This signifies that Le Corbusier was abandoning his Protestant education and adhering to Schuré's lay movement and arguments on the revival of an original existence. Inklings of this had resurfaced by the end of the Viennese stay. In a letter to his brother Albert, ${ }^{18}$ he speaks of Italy as "la Terre sacrée", imbued with an ideal to which he should be faithful. Moreover, this ideal is about to be revealed with the emergence of a renewed society:

“... ces phénomènes de transmission de la pensée à travers des pays entiers, s'observent de nos jours toujours plus nombreux (paraît-il). On devine-là une force inouïe qui va un jour se révéler; la force qui a fait les miracles des prophètes, des prêtes égyptiens, indoux (sic) ou persans. Schuré le constate comme une force terrible, des plus dangereuses ou d'une influence quasi-divine suivant les cas." 19

The modification of his beliefs was consistent with his rejection of university, which in his case meant architectural schools. Le Corbusier's repeated refusal to continue his education at architectural school, and the fact that this was a contentious battle-ground between him and L'Eplattenier from the time of his arrival in Vienna until his German sojourn between 1910 and 1911, illuminates the extent to which he absorbed Schuré's critique of the antagonism between the Christian Church and the University.

This is already felt in Vienna, where we also find the idea of historical development and of a universal ideal underlying it. During the school years at La Chaux-de-Fonds, Le Corbusier had acquired the notion of three great historical periods: ancient Egypt, ancient Greece and the Middle Ages. ${ }^{20}$ This idea was mainly associated with ornament through authors such as Owen Jones. ${ }^{21}$ A letter to Albert reveals that, during the reading of Schuré, he came to see these historical periods as major expressions of philosophical ideas, upon which a new modern architecture should be built. Confessing his doubts on the Viennese modern movement, he wrote:

“... l'étude sérieuse ferait placer en première ligne l'Égypte puis la Grèce et tout au bout la Chrétienté pour l'expression des idées de grande philosophie !"22

\footnotetext{
${ }^{17}$ Quoted in Dumont, ed., Lettres à Charles L'Eplattenier, p. 194.

${ }^{18}$ Le Corbusier to Albert, 2 February 1908, repr. in Correspondance, 147-149.

${ }^{19}$ Le Corbusier to parents, 11 February 1908, repr. in ibid., p.150-154.

${ }^{20}$ Le Corbusier wrote about L'Eplattenier's teaching: "Pour lui, trois grandes périodes demeurent: l'Égypte avec le lotus, la Grèce avec l'acanthe, le Gothique avec les fleurs et les bêtes des bois...” Le Corbusier, L'Art décoratif, p. 198.

${ }^{21}$ Copying artistic motifs from Jones's Grammaire de l'ornement was a routine exercise in the school of arts. Ibid., 135. Motifs ranged from the ancient cultures of Egypt, Asia and Greece to the middle ages and the Renaissance. While suggesting an evolutionary succession of these styles, Jones saw the architecture of ancient Egypt as a pure original style. See Jones, Grammar, 22.

${ }^{22}$ Le Corbusier to Albert, 15 December 1907, repr. in Correspondance, p. 103-104
} 
If we accept the above, consequences in his subsequent approach to architecture are to be expected. The earliest paradigmatic example is his reaction to Notre-Dame during his sojourn in Paris and the preparatory readings associated with it. Instead of enrolling in an architectural school, Le Corbusier devoted the first months of his stay to studying at the Bibliothèque Sainte-Geneviève, where he paid particular attention to Edouard Corroyer's $L^{\prime}$ Architecture romane. ${ }^{23}$ The book is a study of the genesis and development of the Christian church, the aim of which was to understand the genesis of the Gothic, dealt with in a second volume. The historical account, building upon Viollet-le-Duc, gives continuity to a historical approach that extends back to Julien-David Le Roy's Histoire de la disposition des formes différentes que les chrétiens ont données à leur temples depuis Constantin le Grand jusqu'à nous (Paris, 1764). ${ }^{24}$ It explains the genesis of the Romanesque, ranging from the influence of the Orient-from Syria to Byzantium-to the early Catholic appropriations of the Roman basilica and Romanesque architecture. The gradual evolution is explained in terms of the functional needs of Christian ritual, exploring the technical solutions and principles that characterize the distinct typologies.

In functional and spatial terms, Corroyer presents the problem as the tension between longitudinal and centralized plans. Romanesque architecture, he posits, emerged directly from Byzantine and Roman architecture (a statement copied by Le Corbusier in his sketchbook ${ }^{25}$ ), having undergone a process of wavering between a longitudinal development of space and a centralized plan. This process ultimately led to their reconciliation in the cross plan with a dome of the Gothic church. In compositional and technical terms, emphasis is put on the association between the typological definition and building system, discussed as a set of distinct ways of assembling structural elements with simple geometric forms-from domes to columns and arches-and with each combination corresponding to a different spatial and formal result.

Le Corbusier summarized the main historical steps presented by Corroyer in his sketchbook, in an attempt to understand the association between the structural solutions and simple forms of architectural elements. This is particularly explicit in the pages devoted to Hagia Sophia. He copied Corroyer's illustration (fig.1) and translated the description of the conceptual and building principles into a scheme of assembled structural forms: four large piers with four arches and a central dome, the transition between the square and the circle being achieved by means of pendentives.

The technical principles are nevertheless seen as the means of achieving a given spatial solution, in this case the prevailing of the longitudinal direction. Next to the plan and cross-section Le Corbusier wrote:

"Ste Sophie a voulu se souvenir de la basilique (surtout celle de Constantin de Rome) par la tendance à revenir au plan rectangulaire-les bas côtés par contre sont bien sacrifiés."

\footnotetext{
${ }^{23}$ Note that the word "romane" means Romanesque in French, whereas the word for ancient Roman would be "Romaine".

${ }^{24}$ Continuing a discourse which started with the Abbé Jean-Louis de Cordemoy and the Graeco-Gothic ideal, Leroy traces the gradual unfolding process of architecture that had led to the Christian church, from the Roman basilica to Hagia Sophia, St. Mark in Venice, or St. Peter in Rome. On Le Roy see Middleton, Introduction to Le Roy, The Ruins.

${ }^{25}$ Corroyer, L'Architecture romane, 156; Le Corbusier, Carnet A2-19-108, p. 47-48.
} 
He then copied Corroyer's statement:

"La Construction de $S^{\text {te }}$ Sophie est une merveille, car nulle part on n'à appliqué av. tant de hardiesse et de franchise les principes de l'architecture rationnelle." 26

Technique is thus seen as the means of attaining a given spatial solution. Moreover, Schure allowed him to look at the spatial solution not in functional terms, but as a meaningful experience. The point to be made here is that rationalism meant not an end in itself, but an objective means of attaining the idea. This reconciling principle of rationalism and idealism is revealed in his annotations about Notre-Dame.

Apart from reading Corroyer, Le Corbusier had bought Viollet-le-Duc's Dictionnaire raisonné, where he certainly recognized the source of Corroyer's arguments. ${ }^{27}$ The time he devoted to both was preparatory to his study of Gothic architecture. ${ }^{28}$ Allen Brooks has noted that his sketchbook of Notre-Dame does not show a concern with structural problems, but rather with visual effects and decoration. ${ }^{29} \mathrm{He}$ was seeking to learn how art forms embody an idea, Brooks adds, endeavoring to deduce from medieval art how to apply a controlling idea to modern architecture. This is shown by a note in which Le Corbusier writes about "the subjective impression rendered by the idea." Anne Prache, on the other hand, has noted that the sketchbook annotations reveal Le Corbusier's sensitiveness to the environment of the cathedral and to the prospect it offers. ${ }^{30}$ In fact, these annotations reveal that his study of the Gothic focused on the emotional experience of space. He writes on how the illusion created by the raw stone and light filtered by the stained-glass windows reaches its paroxysm, constituting the "internal raison d'être" of the cathedral $;{ }^{31}$ and this raison d'être, or idea-the illusion-is seen as a product of reason. This paroxysm, he writes, can be translated into mathematics, as the "common measure and means; a point at which materials are linked to each other in an invisible way." ${ }^{32}$ This passage echoes Provensal's assertions on a synthesis of science and art through mathematical rapports and mystical numerology: art manifests the divine through universal laws of unity, number and harmony, appealing to both the physical senses and mind. At a more general level, however, it resonates with Schuré's synthesis of science, religion and art, the ultimate aim of which is to attain the idea.

Le Corbusier was thus searching for a synthesis of spirit and matter, and looking at the rationalist discourse on the Gothic in light of Schuré's assertions on the Egyptian pyramid: an expression of the Absolute combining science and religion within a perfectly built form. If this is so, the insight into the medieval structure of Violletle-Duc's Dictionnaire and Le Corbusier's interest in visual effects must be seen as complementary rather than contrasting concerns-a synthesis in which rationalism is an objective means of attaining a given "subjective

\footnotetext{
${ }^{26}$ Le Corbusier, Carnet A2-19-108, p. 33; Corroyer, L'Architecture romane, p. 124-25.

${ }^{27}$ See "Architecture," in Viollet-le-Duc, Dictionnaire, vol.1, p.116-452.

28 “Ayant fini l'étude du style roman et ayant bien compris toutes les phases de son développement, je poursuis par l'étude du gothique et, parallèlement à l'étude des livres, je fais l'étude pratique en passant des heures précieuses sur Notre-Dame, le chef-d'œuvre incontestable et le monument unique de l'art pendant vingt siècles." Le Corbusier to parents, 14 June 1908, repr. in Correspondance, p. 188.

${ }^{29}$ Brooks, Formative Years, 171-172. The sketchbook, hereafter cited as Notre-Dame Carnet, belongs to a private collection. For its content I rely on Brooks and on the several quotations in Prache, "Begegnung mit Notre-Dame".

${ }^{30}$ Prache, "Begegnung mit Notre-Dame," p. 276.

${ }^{31}$ Le Corbusier, Notre-Dame Carnet, p. 14, 16, 18, quoted in ibid., p. 277-279.

${ }^{32}$ Ibid.
} 
impression." 33 Furthermore, we might expect this subjective impression to concern a fundamental experience-an ahistorical idea. Notre-Dame provided the paradigmatic Parisian laboratory for understanding this synthesis because, as Schuré had written, Gothic architecture expressed the last attempt to re-establish a universal religion. Hence the word "antique" to characterize Notre-Dame, ${ }^{34}$ revealing Schuré's historical conception and view of the Gothic as descended from Egyptian art.

Viollet-le-Duc's ideas and the rationalism of the French discourse on the Gothic, it must be stressed, were quite compatible with, and complementary to, the idealism of Schuré. All shared several key aspects. First, as we have seen, an evolutionary conception of history which, finding its roots in the orient, should be accomplished by the modern era. Second, an idealistic view in which rationalism is the means of achieving something deeper, that is, an artistic expression, understood as a spiritual concept and manifestation of an ideal. ${ }^{35}$ Third, an experiential and symbolic understanding of architecture, which, being conceived by the spirit, should provoke an essential emotive response: Schuré emphasized the pure geometry and rigorous construction of the ancient symbols of Egypt as the means for an epistemological experience; Viollet-le-Duc saw the Gothic as a model for a new human-centered architecture, connecting man and God. ${ }^{36}$

In order now to better understand the relevance of this dialectical interaction between rationalism and idealism and its links with the journey to the East it is worth demonstrating that we find the same essential attitude towards architecture during the trip. Hagia Sophia is a paradigmatic example. From Corroyer and Viollet-le-Duc, Le Corbusier was aware that the building constituted a key moment in the evolutionary process of western architecture. The Parisian sketch after Corroyer shows that Le Corbusier was attentive to the technical solutions and compositional principle based on assembled simple forms. This resurfaces in the Turkish sketches, where Le Corbusier attempts to reconstruct the original volumetric expression of the exterior composition. The annotation on one of the sketches (fig.2) reads:

"ce sont les cubes qui agissent et l'embrochement"

\footnotetext{
${ }^{33}$ The attempt to explain subjective experience through objective means can be found in several discourses in the nineteenth century. This is the case of the idealistic attempts to create a kunstwissenchaft, or a science of art, the most radical expression of which is probably Gottfried Semper's comparative method. It permeated discourses on, for example, the theories of Einfühlung (empathy), which Le Corbusier would become aware of during his stay in Germany, as well as the architectural debate of nineteenth-century France, namely Viollet-le-Duc's approach to the Gothic. For the influence of the theories of Empathy during the German stay see Passanti, "Architecture," p. 83-85. On resonances of these ideas on Viollet-le-Duc see, for example, his Entretiens, vol.1, p.17-19, 22.

34 " D'autre part à côté de l'abstraction des mathématiques pures, je lis Viollet-le-Duc, cet homme si sage, si logique, si claire et si précis dans ses observations. J'ai Viollet-le-Duc et j'ai Notre-Dame qui me sert de table de laboratoire pour ainsi dire. Dans cette merveilleuse bâtisse je contrôle les dires de V. le Duc, et j'y fais mes petites observations personnelles. C'est là aussi que je vais faire mes séances de dessin 'd'après l'antique'(!) ..." Le Corbusier to L'Eplattenier, 3 July 1908, repr. in Lettres à L'Eplattenier, p. 171.

35 "Nous ne parlerons donc que du style qui appartient à l'art considéré comme conception de l'esprit ... Qu'est-ce donc que le style? C'est, dans une œuvre d'art, la manifestation d'un idéal établi sur un principe." Viollet-le-Duc, Dictionnaire, vol.8, p.478.

${ }^{36}$ Ibid., vol. 1, p. 147-148.
} 
By contrast, and despite his efforts, he found it hard to deal with the interior:

"L'intérieur de Ste Sophie me porterait volontiers à blasphémer. Mais je ne risque pas l'enfer légèrement, j'attends. ${ }^{37}$

Why this difficulty in interpreting the interior? The crux of the problem was the deciphering of the idea, or of the fundamental experience underlying the architectural solution and its rational principles. By the time Le Corbusier visited Hagia Sophia-and this is still so today-the correspondence between structure and form was much clearer inside than outside, where the Ottoman additions attached to the original building compromise the perception of assembled forms. Therefore, his endeavor to comprehend the interior did not consist of a rationalist reading of structure, form and function, which he read in the compromised exterior. Rather, it consisted in deciphering the subjective dimension attained through it. The problem, as in Notre-Dame, was how to explain subjective experience through objective means.

How he understood this subjective dimension can be deduced from his interpretation of the classical mosques of Istanbul, the typology of which was strongly marked by the Byzantine basilica. Auguste Klipstein, his traveling companion, described the mosques of Istanbul in his journal as

"eternal representations of Hagia Sophia, yet ingenious and often brilliant repetitions, which very often surpass the original." 38

This shows that Le Corbusier was well aware of the connections between Hagia Sophia and the typology of the classical Ottoman mosque. He could therefore easily interpret the experiential and symbolic dimension of the former through latter.

As happened with Hagia Sophia, he struggled to comprehend the Ottoman mosques (fig. 3). In an article published in two parts in the periodical Feuille d'Avis, ${ }^{39}$ after having left Turkey, he summarized the mosques as an ordering of elementary geometric forms with a square plan, a central dome (high so that prayers may rise) and the mihrab on the opposite side to the entrance (a door to the Kaaba). Underlying these words is the view of a play of elementary forms submitted to a vertical and horizontal axis.

Again, the mediating key to understanding this interpretation is Schuré, his assertions on the meaningful reconciliation of the horizontal and vertical axes in the Egyptian sphinx, and his view of the reuniting of the ontological values in Islam. Schuré had argued that worshippers in Muslim rituals, in turning towards Mecca, also turn towards the rising sun, marking the path of the sun. ${ }^{40}$ What is more, in discussing geometry and axial arrangement as the means for an epistemological experience uniting science and religion, he had discussed the meaning of this axis in Ayran worship as an immaterial light that traverses all ancient religions through the cult of the sun. ${ }^{41}$ Le Corbusier saw the classical Ottoman mosque as a sphinx, with its dome as a majestic disc, ${ }^{42}$ and

\footnotetext{
${ }^{37}$ Le Corbusier to L'Eplattenier, 18 July, 1911, repr. in Lettres à L'Eplattenier, p. 277-279.

${ }^{38}$ See Ivan Zaknic, Eastern Journeys, chap. 1. I would like to thank Ivan Zaknic for an advance view of the manuscript of this chapter.

${ }^{39}$ Le Corbusier, “Les Mosquées," Feuille d'Avis, 22 and 25 November 1911; repr. in Voyage d'Orient with minor changes.

${ }^{40}$ Schuré, Sanctuaires, p. 40, 60-61.

${ }^{41}$ Idem., Les Grands initiés, p. 293-294.
} 
argued that the orientation of the axis of every mosque towards the Kaaba is an awe-inspiring symbol of the unity of the faith. ${ }^{43}$ Millions of faithful face Mecca, he wrote, radiating the same adoration when boundless horizons bite into the bloody disc of the sun. ${ }^{44}$ It is only reasonable to interpret this reference to an "aweinspiring" symbol and to the "unity of the faith" in terms of Schuré's arguments on an ontological solar religion, and in terms of his view of the vertical and horizontal axes as symbols of the "invisible chain" (or universal will) that traverses history.

Between Paris and Istanbul, then, Le Corbusier shows the same idealistic attitude towards architecture, searching for a subjective dimension attained through rationalism, common to the main periods of historical development. Also through Schuré, he came to look at the vertical and horizontal axes as a symbol of this universal truth. Be it in Hagia Sophia or the Ottoman mosque, rationalism was to resolve the association between these axes, ordering elementary forms, and the epistemological experience of architecture. It was this "eternal" subjective dimension attained through rationalist means that Le Corbusier searched for during these years and the years to come.

Looking at the itinerary of the journey to the East in light of Schuré's book and Corroyer and Viollet-le-Duc's conception of architectural history, his decision to extend the initial plans to travel to Rome comes as no surprise. Even if it was Klipstein who challenged him to travel to Istanbul, Le Corbusier did have a purpose in expanding the itinerary to include Turkey, Mount Athos, Greece and the south of Italy. Byzantine, Muslim, ancient Greek and ancient Roman architecture were part of a broad transitional context in the history of western architecture, ranging from ancient Syria to the Renaissance, the study in situ of which was necessary for the foundation of a new modern architecture. Significantly, he wished to visit the Egyptian pyramids and the Dome of the Rock, although both were eventually dropped. ${ }^{45}$

Le Corbusier's repeated refusal to enroll in an architectural school, his endeavor to comprehend Notre-Dame as a rationalist means of attaining a subjective impression, the itinerary of the journey to the East and his association of the Ottoman mosque with the Egyptian sphinx, illustrate how Le Corbusier's autodidactic agenda during his formative years followed a consistent idealistic world-view largely absorbed through reading Schuré's Sanctuaires d'Orient.

\section{Idealism and Le Corbusier's Architecture}

The lasting influence that nineteenth-century idealism exerted upon Le Corbusier is too vast and complex to be discussed here. To conclude, then, I will briefly discuss one single aspect of it: the right angle. Let me start with his Croisade; ou, le crépuscule des académies.

Le Corbusier's lifelong rejection of the Academies is well known. In his Croisade, the view of his own work as a crusade reminds us of Schuré's arguments on the last attempt to re-establish a universal religion by the lay knights of the Order of Temple. The connection goes far beyond the title. Ideas such as a "broad emerging crusade towards the universal thought," a "renewed life form," or the search for a new "balance of spirit and

\footnotetext{
${ }^{42}$ Le Corbusier, "Les Mosquées," 25 November 1911.

${ }^{43}$ Ibid., 22 November 1911.

${ }^{44}$ Idem., "Constantinople III," Feuille d'Avis, 18 November 1911; repr. in Voyage d'Orient.

${ }^{45}$ Le Corbusier to L'Eplattenier, 18 July 1911, repr. in Lettres à L'Eplattenier, p. 279.
} 
matter" to be found in a "millennial relationship between man and nature,"46 clearly go back to Schuré's call to retrieve an original relationship between Man and nature and to the nineteenth-century conception of history as an evolutionary process. Le Corbusier saw himself as the artist whose task it was to fulfill historical destiny.

Fulfilling historical destiny implied retrieving the "millennial relationship between man and nature," to use his words. This implied the recovery of its symbols: the vertical and horizontal axes. We have seen that, in associating the vertical and horizontal axes of Ottoman mosque with the Egyptian sphinx, Le Corbusier recognized the reuniting of ontological symbols in Islam. Moreover, Corroyer and Viollet-le-Duc, who presented the Gothic as a final stage of the evolutionary process of the typology of the Christian church, reconciling the longitudinal and vertical axes, may well have helped him to look at these symbols as a constant in all great periods of art. Thus he saw the Parthenon in similar terms: a cube extending the vertical thrust of the Acropolis and facing the sea. ${ }^{47}$ This established the basis for the exploration of the theme of the right angle throughout his work.

His Poéme de l'angle droit, published in the fifties, shows how he incorporated Schuré's discourse into his poetic world. The connection is first revealed in 1924. In the article "L'Angle Droit" published in L'Esprit Nouveau, the right angle is presented as the key issue of modern art, articulating the main themes of Schuré's idealistic worldview. The article calls for a sense of the sacred through a laicized "hiératisme" to be attained through the spirit of order of the right angle in art. Defined by a vertical and a horizontal axis, the right angle is a sign or conventional symbol. Its roots are to be found in the art of the past (ancient Egypt provides the epitome) but it traverses all great periods of art history. The constancy of this symbol is explained by the applicability of constant laws to the work of art of all times. These laws are the vertical axis, a primary instinct established by gravity, and the horizontal axis, defined by the movements of the human body, from which proceeds Man's knowledge of the world. Because these axes are a result of the constancy of the human body (the physical and sentimental organization of Man), they act upon the senses and satisfy the imperative of Man's sensibility, independently of historical time. The right angle, it is posited, is a universal fact. Contemporary art cannot therefore stand in opposition to this primary instinct of human nature. It must incorporate the spirit of order of the right angle and accomplish the aim of the new cycle that started with the Enlightenment: to attain a period of "hiératisme" ("knowledge of the means, choice of signs and spirit of geometry"), meaning the state of mind (état d'esprit) attained by a civilization after leaving the empiricist period and acquiring consciousness of what previously had only been felt (Schuré's complete life).

In this article, then, we find the main points of Schuré's idealism: the belief in a universal truth that traverses history and the evolutionary conception of history associated with it, permeated by the "life cycle theory"; the call for a lay movement in order to re-establish an existence fusing science, religion and art; the view of art as a means to an epistemological experience and its capacity to re-establish the ideal existence; and the belief in a new emerging society and art. All this is symbolized by the right angle, ultimately related to the symbols of ancient Egypt.

Schuré's discourse on the Egyptian sphinx, I mentioned, feeds upon Hegel's aesthetics, involving a reductive translation of form into meaningful geometry and axes. For Hegel, the sphinx is the symbol of the symbolic

\footnotetext{
${ }^{46}$ Idem., Croisade, p. 17-18, 25-26.

${ }^{47}$ Idem., Voyage d'Orient, p. 153-154.
} 
itself, the "objective riddle" par excellence. With a human head, it expresses the will of the human spirit to break free from the dull weight of matter. This pressure for self-conscious spirituality and its links with the notion of universal will were expanded by Arthur Schopenhauer's discourse on free will $l^{48}$ and translated by Gottfried Semper into visual physical terms in his Style $e^{49}$ by exploring the symbolic meaning of the vertical and horizontal axes in the creation of form. The vertical axis, Semper argues, expresses the struggle of the organic vital force against matter (gravity). The horizontal axis expresses the freedom of will and movement. The right angle, defined by both and expressed in the human head, is the symbol of absolute free will.

Le Corbusier had become aware of Semper's arguments, at least through Charles Blanc, as far back as his school years. ${ }^{50}$ Following on from Semper, Blanc discusses how the axes are reflected in the human face, their meaning in terms of spiritual and moral values, and the applicability of this principle in art. What the 1924 article shows us is how these discourses were preparatory to, and enriched, Le Corbusier's interpretation of Schuré's discourse.

Indeed, the meaning that Le Corbusier attributed to the right angle expresses the lifelong influence of nineteenthcentury idealism and of the German philosophical tradition: the absolute free will of the modern man and the renewed life form of modern society. Cases such as the unité d'habitation of Marseilles illustrate well how Le Corbusier constructed his architecture upon this idealistic legacy, incorporating the right angle both in symbolic terms and as a proposal for the new way of life of the Übermensch of an emerging society (fig. 4). Architecture, with its vertical impulse and orientation towards the rising and setting sun, expresses the ontological symbol and enacts its experiential pantheistic dimension.

\footnotetext{
${ }^{48}$ Schopenhauer, Will and Representation.

${ }^{49}$ Semper, "Prolegomena," in Style, p. 83-96.

${ }^{50}$ Blanc, Grammaire, p. 26-37. Blanc's book was a recurrent reading of Le Corbusier at least since 1907.
} 


\section{Figures}
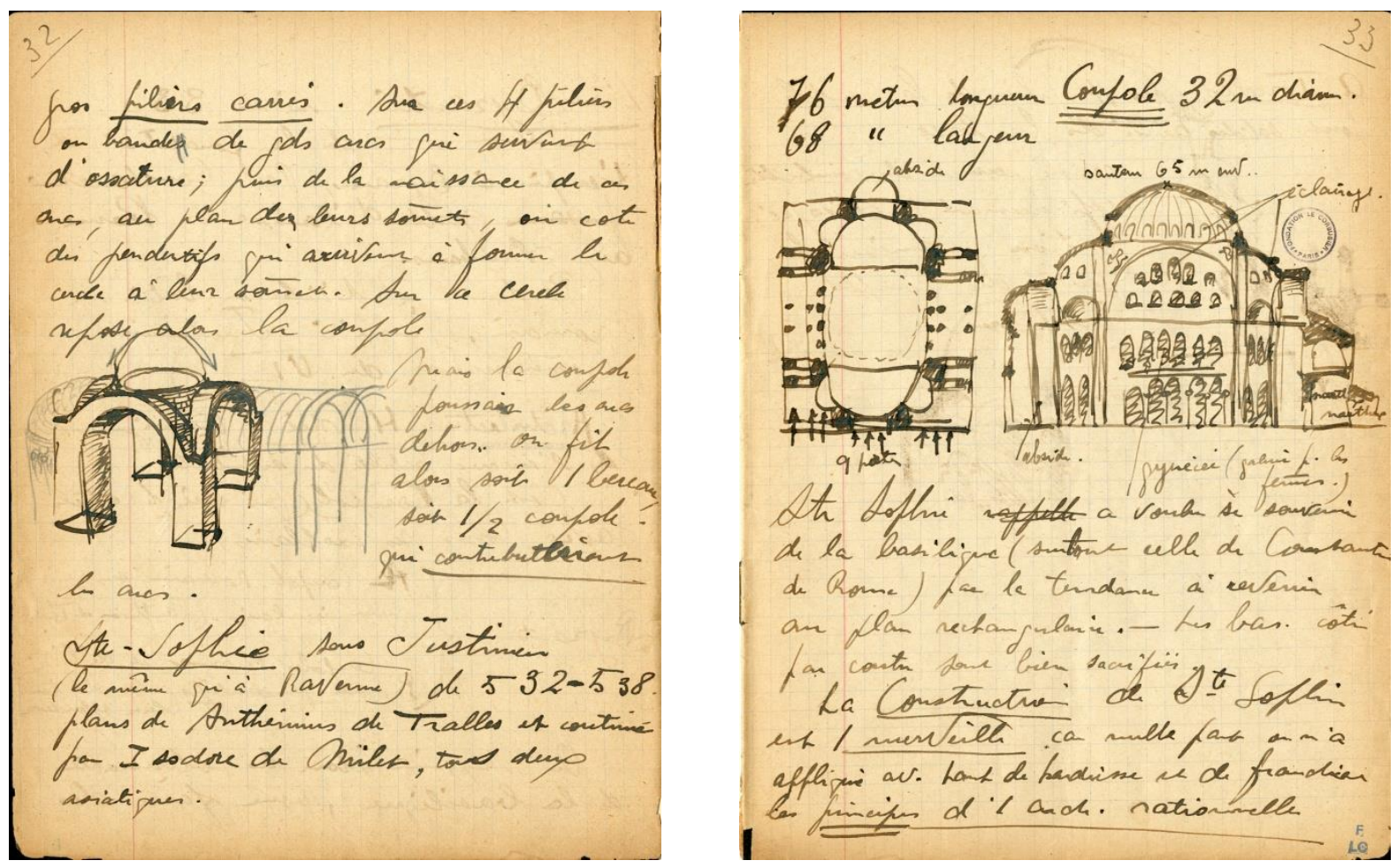

1. Le Corbusier. Notes after Corroyer's L'Architecture romaine. Hagia Sophia. Structural principle, plan and cross-section. FLC A2-19-108, 1908, p. 32, 33. 


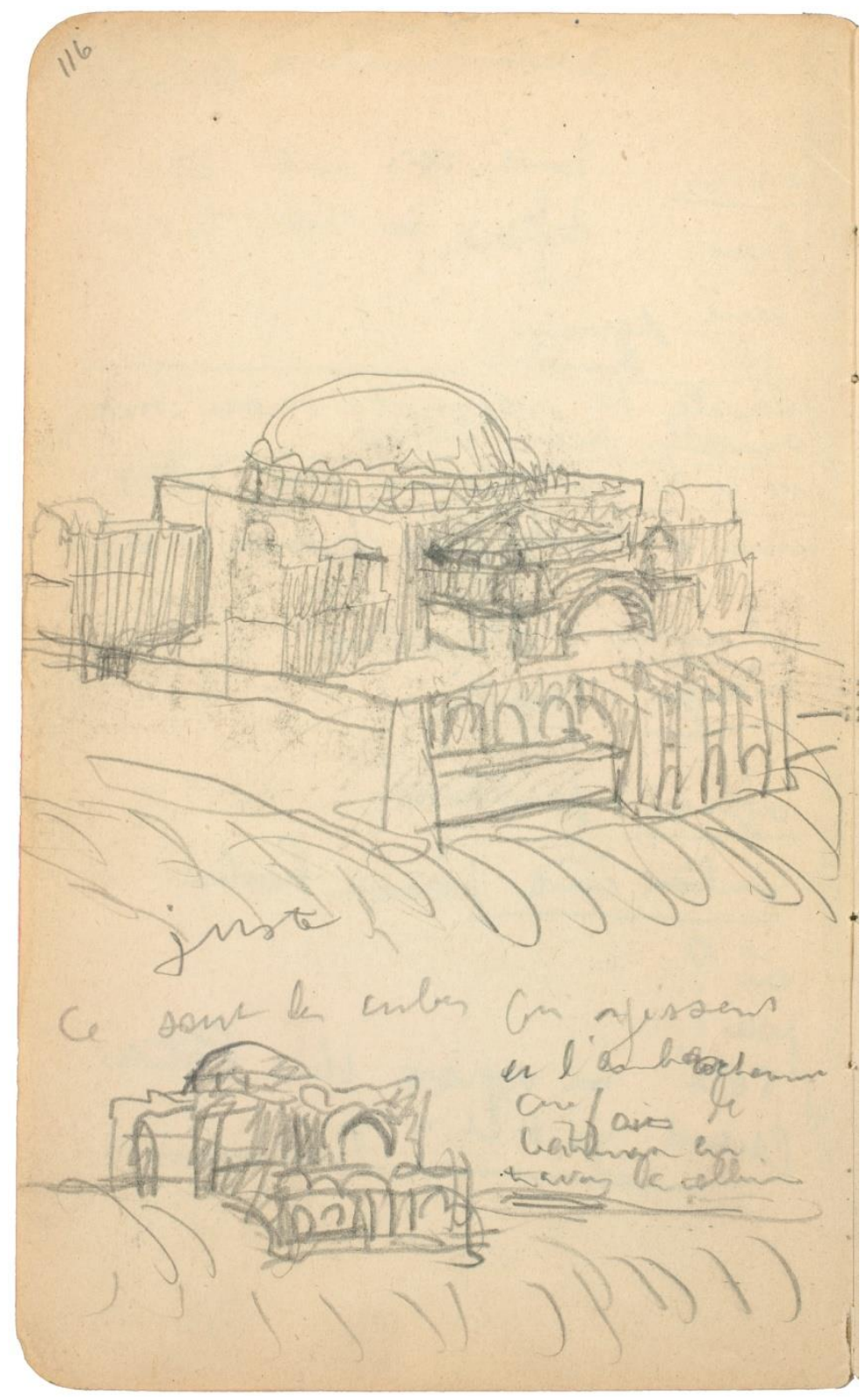

2. Le Corbusier. Hagia Sophia, 1911. Sketchbook 2, p. 116. 


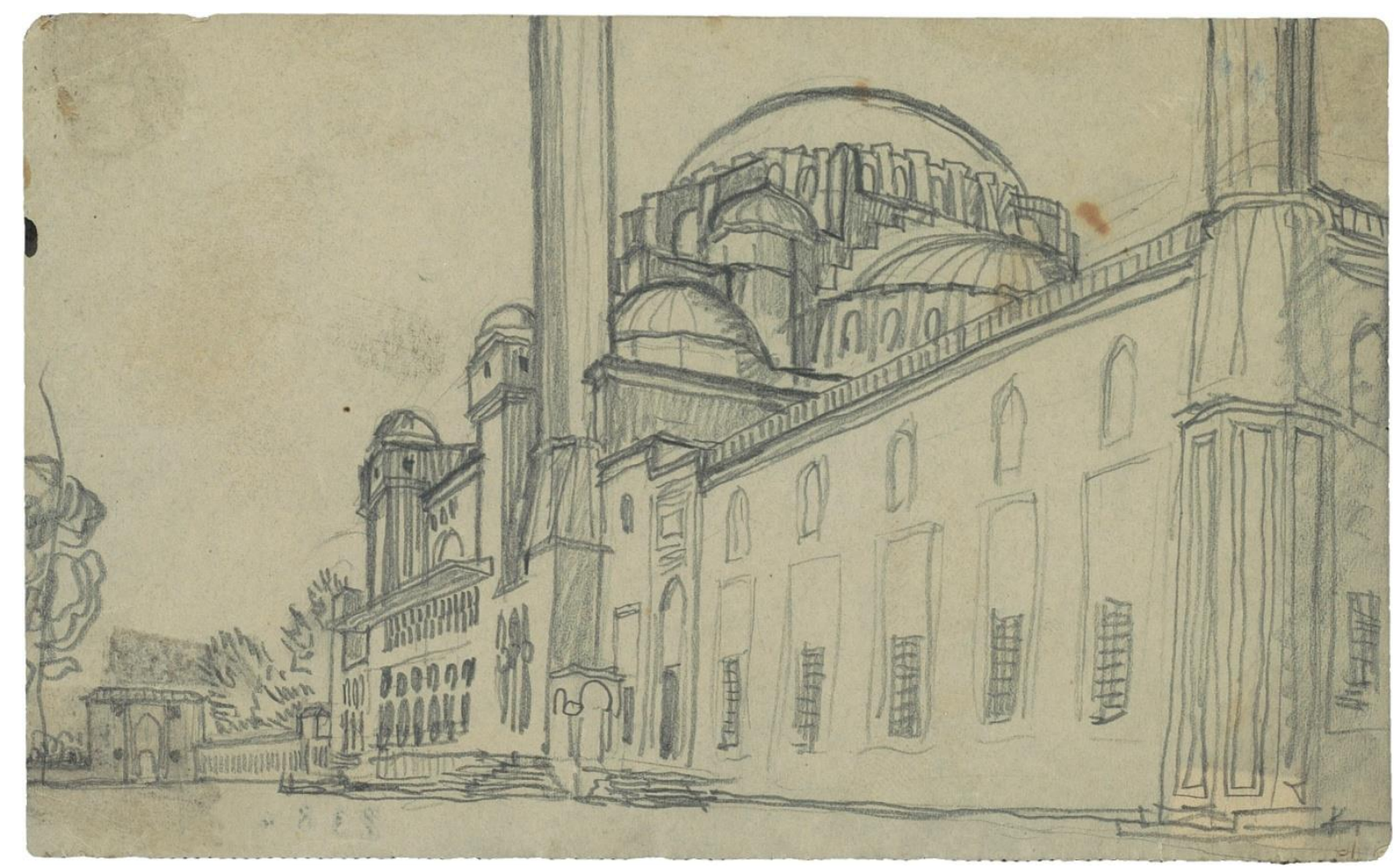

3. Le Corbusier. Süleymaniye mosque. Sketch, 1911. FLC 2384. 


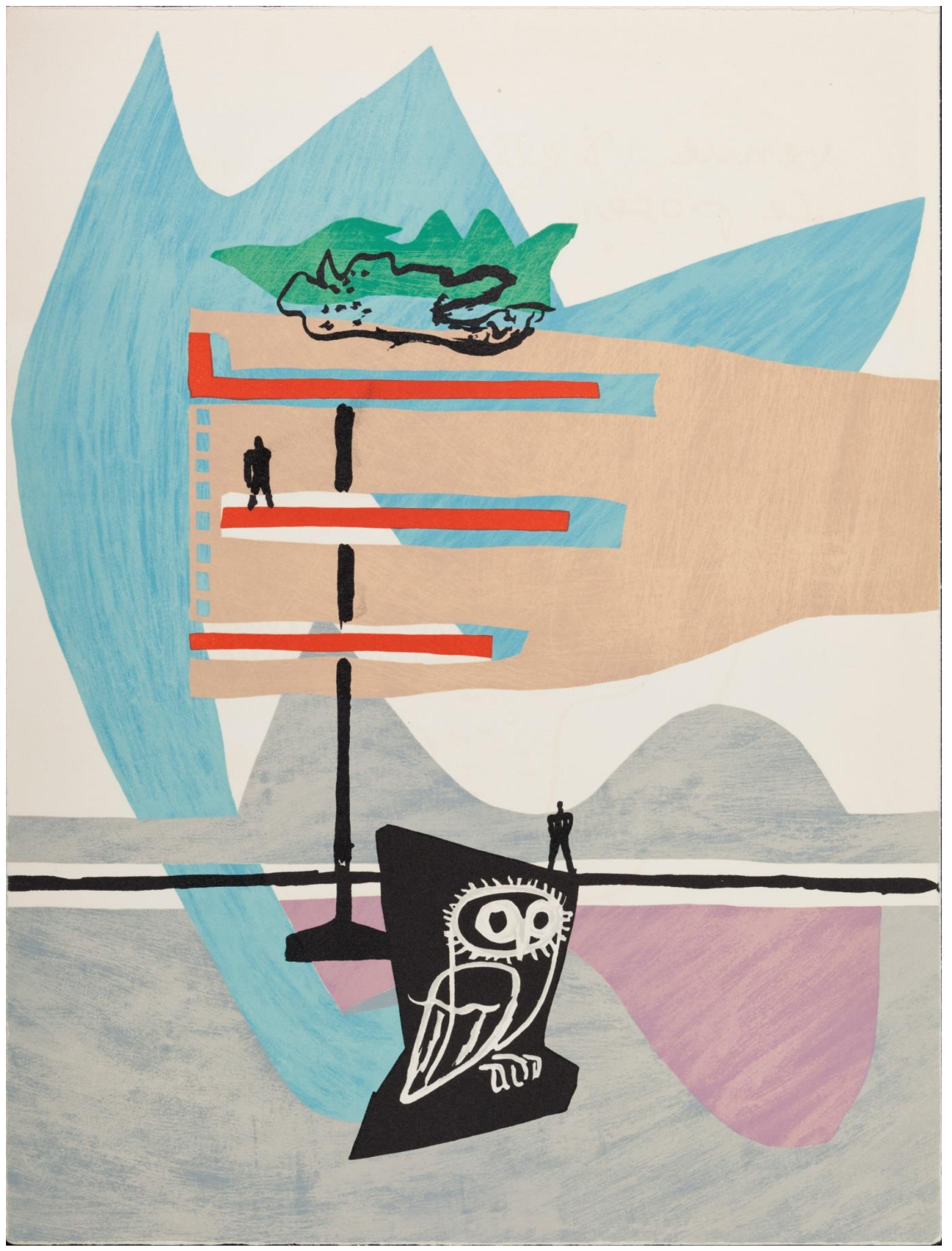

4. Le Corbusier. From Le Poème de l'angle droit, p. 61. 


\section{References}

Baudouï, Rémi; Dercelles, Arnaud (Ed.). Le Corbusier, Correspondance: lettres à la famille 1900-1925, vol. 1. Paris: Fondation Le Corbusier - Infolio, 2011.

Blanc, Charles. Grammaire des arts du dessin, architecture, sculpture, peinture. Paris: Jules Renouard, 1867.

Brooks, H. Allen. Le Corbusier's Formative Years: Charles-Edouard Jeanneret at La Chaux-de-Fonds. Chicago: University of Chicago Press, 1997.

Corroyer, Edouard. L'Architecture romane. Paris: Quantin, 1988.

Dumont, Marie-Jeanne (Ed.). Le Corbusier, lettres à Charles L'Eplattenier. Paris: Linteau, 2006.

Hegel, Georg Wilhelm Friedrich. Aesthetics: Lectures on Fine Art. Translated by T.M. Knox. New York: Oxford University, 1988.

Jones, Owen. The Grammar of Ornament. London: Bernard Quaritch, 1868.

Le Corbusier. L'Art décoratif d'aujourd'hui. Paris: Crès, 1925.

Le Corbusier. Croisade; Ou, le crépuscule des académies. Paris: G. Crès, 1933.

Le Corbusier. “Constantinople III”. In Feuille d'Avis, 18 November 1911.

Le Corbusier. "En Orient. Constantinople, Les Mosquées”. In Feuille d'Avis, 22 and 25 November 1911.

Le Corbusier; Ozenfant, Amédée. “L'Angle droit”. In L'Esprit nouveau, №18 (1924). n.p.

Le Corbusier. Le Voyage d'Orient. Paris: Forces vives, 1966.

Meinecke, Friedrich. Historism: the Rise of a New Historical Outlook. New York: Herder and Herder, 1972.

Mercier, Alain. Édouard Schuré et le renouveau idealiste en Europe. Lille: Atelier reproduction des thèses, Université de Lille III - Paris: Diffusion honore champion, 1980.

Middleton, Robin. Introduction to Julien-David Le Roy, The Ruins of the Most Beautiful Monuments of Greece. Los Angeles: Getty Research Institute, 2004. pp.1-199.

Minois, Georges. Histoire de l'athéisme. Paris: Fayard, 1998.

Passanti, Francesco. "Architecture: Proportion, Classicism and Other Issues". In Le Corbusier Before Le Corbusier: Applied Arts, Architecture, Painting, Photography, 1907-1922. Edited by Stanislaus von Moos and Arthur Rüegg. New Haven: Yale University Press, 2002. pp. 68-97.

Prache, Anne. "Le Corbusiers Begegnung mit Notre-Dame in Paris." In Bau-und Bildkunst im Spiegel internationaler Forschung, Festschrift zum 80 Geburtstag von Prof.-Dr. Edgar Lehmann. Berlin: VEB Verlag für Bauwesen, 1989. pp. 276-279.

Provensal, Henry. L'Art de demain: vers l'harmonie intégrale. Paris: Perrin, 1904.

Schopenhauer, Arthur. The World as Will and Representation. Translated by E. F. J. Payne. New York: Dover Publications, 1966.

Schuré, Édouard. Les Grands initiés: esquisse de l'histoire secrète des religions. Rama, Krishna, Hermès, Moïse, Orphée, Pythagore, Platon, Jésus. Paris: Perrin, 1908).

Schuré, Édouard. Sanctuaires d'Orient: Égypte, Grèece, Palestine. Paris: Perrin, 1898. 
Semper, Gottfried. Style in the Technical and Tectonic Arts; or Practical Aesthetics. Translated by Harry Francis Mallgrave and Michael Robinson. Los Angeles: Getty Reseach Institute, 2004.

Turner, Paul Venable. The Education of Le Corbusier. New York: Garland Essays, 1977. Viollet-le-Duc. Entretiens sur l'architecture. Paris: A. Morel \& C ${ }^{\mathrm{ie}}, 1863$.

Viollet-le-Duc, Eugène-Emmanuel. Dictionnaire raisonné de l'architecture française du XIe au XVIe siècle. Paris: A. Morel \& C $C^{\text {ie }}, 1875$.

Viollet-le-Duc, Eugène-Emmanuel. Entretiens sur l'architecture. Paris: A. Morel \& C ${ }^{\text {ie }}, 1858$.

Vogt, Adolf Max. Le Corbusier and the Noble Savage: Towards an Archaeology of the Modernism. Translated by Radka Donnel. Cambridge: MIT Press, 1998.

Von Humboldt, Wilhelm. "Über Die Aufgabe Des Geschichtschreibers" (Prussian Academy, 1821). Translated into English as “On the Historian's Task.” In History and Theory 6 N. ${ }^{\circ} 1$ (1967). pp. 57-71.

Zaknic, Ivan. Eastern Journeys, 1911. The Dual Diaries and Legacies of Auguste Klipstein and Le Corbusier. Book-length manuscript in progress, 2015. 


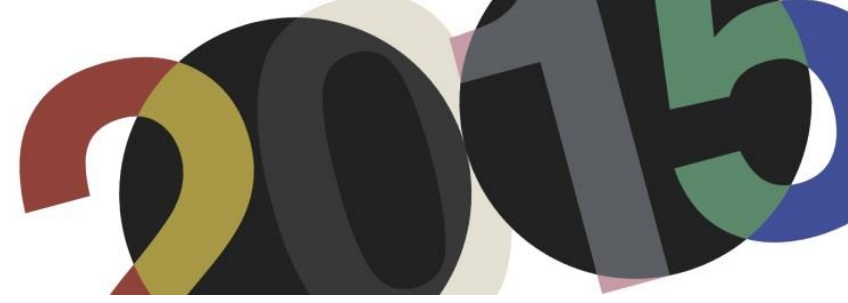

DOI: http://dx.doi.org/10.4995/LC2015.2015.784

\title{
Le Corbusier in Chandigarh: A Search for the Natural Order
}

\author{
A. Ramesh \\ Department of Architecture and Planning, Visvesvaraya National Institute of Technology, Nagpur, India
}

\begin{abstract}
This paper is an attempt to analyse and decode Le Corbusier's application of his exceptionally singular and complex understanding of the order of the natural world in his urban masterpiece-Chandigarh City. It was Le Corbusier's strong belief that architecture was a personal search for truth, a truth that was contained in the organic harmony of nature. He was convinced that with the advent of the machine in the $19 t^{h}$ century, ties between man and nature had been severed. For the sake of the citizen's physiological and psychological health, he felt it was essential that future cities focus on reconnecting man to nature through large green parks open to the sky, unpolluted by the machine. His own formative years in the lush forests of the Swiss countryside, sketching and abstracting natural forms helped him observe and internalise the inherent logic in their geometry. Over the years, a deeper study of mathematical proportions of the human body led Le Corbusier to propose the Modulor as a standard for the human scale in architecture. This only further cemented his belief that there was no separate natural order and man-made order; man was a part of nature and therefore a part of the natural order as well. However, it was the spiritual aspect of city planning that fascinated Le Corbusier the most. After a life long study of natural forms, he was fully convinced that this Spirit was hidden in the geometries of nature. To him, it was essential that the twentieth century city employ this spiritual order as a means restore harmony between man, nature and the cosmos.
\end{abstract}

Resumen: Este trabajo conforma un intento para analizar y decodificar la aplicación de Le Corbusier en su comprensión excepcionalmente singular y compleja del orden del mundo natural en su obra maestra urbana - La Ciudad de Chandigarh. La firme creencia de Le Corbusier era que la arquitectura constituía una búsqueda personal de la verdad, una verdad establecida en la armonía orgánica de la naturaleza. Estaba convencido de que con el surgimiento de las máquinas en el siglo XIX, los lazos entre el hombre y la naturaleza se habían roto. Por el bien de la salud fisiológica y sicológica de los ciudadanos, sentía que era fundamental que las ciudades futuras se enfocaran en reconectar al hombre con la naturaleza a través de grandes parques verdes abiertos al cielo, sin ser contaminados por máquinas. Sus propios años de formación en los frondosos bosques del campo Suizo, esbozando y captando formas naturales lo ayudaron a observar e internalizar la lógica inherente en su geometría. Con el transcurso de los años, un estudio más profundo de proporciones matemáticas del cuerpo humano, llevaron a que Le Corbusier propusiera el Modulor como un estándar para la escala humana en arquitectura. Esto sólo consiguió consolidar aun más su creencia de que no había una separación entre el orden natural y el hecho por el hombre; el hombre era parte de la naturaleza y por lo tanto parte del orden natural también. Sin embargo, fue el aspecto espiritual de la planificación de la ciudad lo que más fascinó a Le Corbusier. Luego de un estudio de formas naturales a lo largo de la vida, se convenció por completo acerca de que este Espíritu estaba escondido en las geometrías de la naturaleza. Para él era primordial que la ciudad del siglo veinte empleara este orden espiritual como un medio para restaurar la armonía entre el hombre, la naturaleza y el cosmos.

Keywords: Chandigarh; City Planning; Capitol Complex; Modulor Man; Open Hand; Natural Order.

Palabras clave: Chandigarh; Planificación de la ciudad ; Capitol Complex; Modulor Man; Open Hand; Orden del Mundo Natural. 


\section{Introduction}

"I ask a simple question, an architectural question: what will become of the cities, New York, London, Paris, gigantic stretched to breaking point, full of mistakes and scorched by hot breath of the machine age? Tomorrow must provide an answer." 1

In 1951, Le Corbusier was given the opportunity to bring his answer from the drawing board to reality, the opportunity to design and construct a new capital for Punjab at the foothills of the Himalayas. The new capital, named Chandigarh, was meant to be an administrative city for the state of Punjab and was designed to eventually house up to 500,000 inhabitants, primarily refugees, who had fled to India during the violence of the India Pakistan partition in 1947. Le Corbusier aimed at providing all of Chandigarh's future residents with a pleasant social atmosphere along with all the amenities of modern living.

Appointed Chief Advisor for the project, Le Corbusier was engaged in generating the general and detailed urban layout, with the hierarchal arrangement of roads, the demarcation and placement of various zones, the styles of all buildings, various types of dwellings for the city's residents as well as the architecture of the Capitol Complex - the administrative center with ministries, High Court and a Governor's Palace. The architectural vision that he evolved for Chandigarh was an amalgam of the Mughal palaces of ancient India, the vernacular styles in Punjab, the rules of composition of Classical buildings of Europe that he admired as well as the learnings from his personal search for the Spirit of the natural world.

While critics often misunderstand the rigid orthogonal urban layout and the rugged concrete buildings of the Capitol because of their brutal physical appearance, the truth of the matter is that Le Corbusier's Chandigarh is rooted deep in his awareness of a universal natural order. Through the study of various aspects of the city's design, this paper will establish that Le Corbusier's design for Chandigarh was a masterful attempt to provide a New India with a city in equilibrium with the ancient spirit and the modern machine.

\section{Methodology}

In previous studies, Le Corbusier's theories and designs for cities, his use of symbols and his proposal for the Modulor have been studied in great depth and detail. The most significant study on the symbolism of Chandigarh is found in 'Le Corbusier: Ideas and Forms' by William J.R Curtis where he analyses and critiques Le Corbusier's vision for the city. An in-depth analysis of Le Corbusier's use of the Modulor and Golden Section in Chandigarh can be referred to in Klaus-Peter Gast's 'Le Corbusier, Paris-Chandigarh'. Sangeet Sharma, an architect working in Chandigarh, documents the history of Chandigarh and life in the city in the present day context. Chronicling his discussions with seven renowned architects who visit the city, Sharma wittily describes the forces that brought Chandigarh to life.

Le Corbusier's understanding of nature and the cosmic order has been analysed in Emma Dummett's thesis titled 'Green space and cosmic order: Le Corbusier's understanding of nature'. According to her, Le Corbusier's understanding of nature has within itself “...both evidence of a underlying, primordial order and a terrifying

\footnotetext{
${ }^{1}$ Corbusier, Le: “Introduction”, Boesiger, Willy (Ed.): Le Corbusier: oeuvre complète 1946-1952. Zurich: Éditions d'Architecture, 2006.
} 
morass of disorder; it was both a static image and a realm of experiential possibility.. "2. Dummett's analysis provided a direction for this paper by pointing to Le Corbusier's holistic view of man's relationship with nature.

The present study focuses solely on the city of Chandigarh and aims to demonstrate how Le Corbusier's understanding of nature has both physical and spiritual manifestations in the city. For the purpose of this paper, only the designs that Le Corbusier fully realised in Chandigarh will be studied, thereby omitting his unbuilt designs for the Governor's Palace and several monuments in the pedestrian plaza of the Capitol Complex.

\section{Physical Manifestations of the Natural Order in Chandigarh}

For Le Corbusier, "the aim of taking man back to nature"3 was foremost in his designs for future cities. The most conspicuous route to achieve this was by interweaving the tangible dimensions of the natural world with the city's form.

\subsection{Open Space, gardens and greenery}

In the City of Tomorrow, Le Corbusier envisions the urban landscape of the future city as such: “ The whole city is a Park. The terraces stretch out over lawns and into groves. Low buildings of a horizontal kind lead the eye on to the foliage of the trees... Here is the CITY with its crowds living in peace and pure air, where noise is smothered under the foliage of green trees...Here, bathed in light, stands the modern city ...There are gardens, games and sports grounds. And sky everywhere, as far as the eye can see."

This vision is there for all to see even today in Chandigarh where one is struck by the abundance of parks, gardens and open spaces in all parts of the city.

In a deliberate attempt to set Chandigarh apart from the squalor, congestion and poor levels of hygiene in the traditional Indian cities of the 1950s, Le Corbusier included extensive landscaping and verdure into the city's layout plan. Within the vast green belts, plentiful city parks and neighbourhood gardens, Le Corbusier wished for a vibrant public realm where the residents would have myriad opportunities for close contact with other humans as well as ample space for meditation and solitude. He envisioned people living an active and healthy life in the open green spaces where they were sheltered from the 'speed' of the modern city.

In Chandigarh, the continuous strips of green criss cross through the city's layout in the form of the Leisure Valley and special gardens at the city level, the central greens at the sector level, the small tot lots around which clusters of houses are arranged at the community level and individual courtyards for each dwelling at the smallest scale. Rows of trees line the roads, their species and shape determined by the orientation and function of the road in the hierarchy of V7 road network.

\footnotetext{
${ }^{2}$ Dummett, Emma: Green space and cosmic order: Le Corbusier's understanding of nature. Advisors: D. Weston, I. Boyd Whyte. Doctoral thesis, University of Edinburgh, 2007, p. 216

${ }^{3}$ Le Corbusier: The Marseilles Block. Sainsbury, Geoffrey (Trans.). London: Harvill Press,1953, p. 24. First published as Unité d'habitation Marseille, Le Point 38, November 1950 quoted in Green space and cosmic order: Le Corbusier's understanding of nature, p. 4.

${ }^{4}$ Corbusier, Le: The City of Tomorrow and Its Planning, Etchells, Frederick (Trans.). London: The Architectural Press, 1971. First published as Urbanisme, Editions Crès et Cie, Paris, 1924
} 


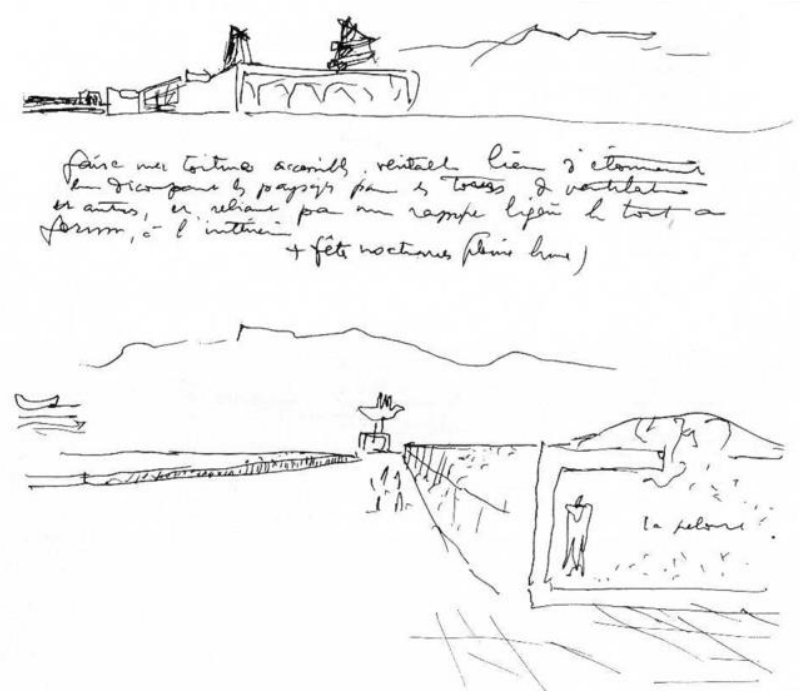

1. Le Corbusier's sketches of the vistas in the Capitol Complex from two different vantage points show the outline of the Himalayas drawn in the background.

While it is widely accepted that the Garden City movement played an influential role in Le Corbusier's design for abundant greenery within modern cities, his formative years in his hometown of La Chaux-de-Fonds in the Jura mountains of the Swiss countryside were the most profound influence. The experience of growing up in a well planned town with abundance of shared green space made him attempt to combine the benefits of life in the city with life in the rural countryside in his designs for Chandigarh.

Le Corbusier believed that by providing easy access to the basic pleasures such as sunlight, greenery and open space within the city, he could positively impact both the physiological and psychological aspects of man's well being. In the Radiant City, he talks of the future cities with their vast green spaces as those which will "enable the human spirit to draw strength from its active collaboration with the forces and beauties of nature.",5

\subsection{The Signature of the Himalayas}

A study of Le Corbusier's sketches of Chandigarh reveal one recurring theme - the silhouette of the majestic Himalayan skyline as the backdrop. Right from his initial sketches of the terrain to the final few of the Capitol Complex, the mountains reappear almost like they have become a part of the architectural composition.

Despite claiming to prefer the calm seas over the overwhelming mountains, “our loft wrinkles - the Alps, the Andes and the Himalayas ", had always enchanted Le Corbusier. Beginning from his project for his parents' lake house in 1925 to the Marseilles Unite, he made a wilful attempt to the lure the natural world into the private realm of the inhabitants. He follows this through in Chandigarh, only on a much larger urban scale.

A walk on the long vistas in the first phase of the city offer unobstructed views of the high hills of the Himalayas. However, the more scenic panorama is from the Leisure Valley - the most prominent of the green spaces in the city of Chandigarh that sprawls from the North-East to the South-West along a seasonal rivulet.

${ }^{5}$ Corbusier, Le: The Radiant City: elements of a doctrine of urbanism to be used as the basis of our machine-age civilisation. New York: Orion Press, 1967.

${ }^{6}$ Corbusier, Le: The Poem of the Right Angle. Hylton, Kenneth (Trans.). Paris: Fondation Le Corbusier and Editions Connivences, 1989. 
Here the spectacle of the mountains, framed by the the open skies and the vast expanse of greenery, prove to be a sanctuary from the fast moving machines of the modern city, a safe place to meditate and contemplate the natural world.

Even within the office blocks of the Secretariat building in the Capitol Complex, Le Corbusier finds ways to anchor man to the surrounding mountainous landscape. He explains his reasons for installing large coiling vertical ramps versus lifts in the building saying, “ Three thousand employees must climb forty metres once or twice a day. If we put in lifts they will have one or two overwhelming rush hours each day, and will contribute nothing at any other time...The motivating force is there to be taken in the feet and in the energy of each of the three thousand employees. In installing a beautiful ramp (and) making a magnificent viewing point onto the landscape, the city and the Capitol itself, we will give to those employees for ten months at least the possibility of a wonderful morning walk. "7

Even at first glance, it becomes clear that Le Corbusier was finely attuned to the fact that despite advances of the industrial age, man had an innate desire for a meaningful connect with nature. It may seem that Le Corbusier greatly simplified this human desire and therefore only used nature in a mere instrumental manner through the abundance of greenery and framed panoramic mountain scenes at the urban scale. The truth however is that this was just the first step in his grand plan to restore the harmony between modern man and the natural world.

His own journey of understanding nature began in the lush forests of the Swiss countryside, observing, sketching and abstracting natural forms. After a life long study of the natural world, Le Corbusier was fully convinced that in order to create the ideal city, the elusive Spirit that animated all of nature should be deciphered and applied by man to his own creations.

"Nature presents itself to us as a chaos; the vault of the heavens, the shapes of lakes and seas, the outlines of hills. The actual scene which lies before our eyes, with its kaleidoscopic fragments and its vague distances, is a confusion. There is nothing there that resembles the objects with which we surround ourselves, and which we have created. Seen by us without reference to any other thing, the aspects of Nature seem purely accidental...But the spirit which animates Nature is a spirit of order; we come to know it. We differentiate between what we see and what we learn or know. ",

\section{Le Corbusier's Symbols and the Spirit of Chandigarh}

On the occasion of the inauguration of the city of Chandigarh in 1953, Pandit Jawaharlal Nehru, independent India's first Prime Minister said to the crowd gathered in front of the High Court, "Let this be a new town, unfettered by the traditions of the past... and expression of the nation's faith in the future." 9

\footnotetext{
7“"Trois milles employés doivent monter jusqu'à 40m. une ou deux fois par jour. Si on installe les ascenseurs ceux-ci auront une ou deux heures de pointe formidables, puis ne serviront plus à rien. / La force motrice est à prendre dans les pieds et dans l'énergie de chacun des 3000 employés. En installant une belle rampe faisant point de vue magnifique sur le paysage, sur la ville et sur les beautés du Capitol lui-même, on donne à ce personnel, pendant dix mois au moins la possibilité d'une promenade matinale magnifique." Le Corbusier to Jane Drew, 11 June 1952, FLC P2-11-175 as translated and quoted in Green space and cosmic order: Le Corbusier's understanding of nature, p. 110.

${ }^{8}$ The City of Tomorrow and Its Planning

${ }^{9}$ Singer, Milton: Semiotics of Cities, Selves and Cultures: Explorations in Semiotic Anthropology. Berlin: Walter de Gruyter, 1991
} 
In Chandigarh, Le Corbusier saw the need to create a city that spoke to the emerging spirit of a nascent independent nation in the post colonial world. The language he chose to communicate his vision for Chandigarh was a series of abstract symbols intricately woven into the urban fabric. As a Purist painter and sculptor, Le Corbusier was well-versed in the language of the abstract and had intimate knowledge of the deep meanings that could be conveyed through the simplest of forms.

Through his travels in India, he filled his sketchpad with wiry drawings of the rural Indian people, their lifestyles, the animals they domesticated and the landscape they inhabited. In the untouched countryside, he saw the peasants as a society of people living in the rural idyll that the industrialised societies of the west romanticised. Then on, the most challenging task in Chandigarh was to build a modern city that did not focus on the transient themes of its own period and the immediate past but remained in touch with the long-standing primeval ethos of India.

"At the end of 1951, in Chandigarh: the possibility of getting in touch with the essential joys of Hindu principles: a brotherhood of relationships between the cosmos and all living things: stars, nature, sacred animals, birds, monkeys, and cows, and in the villages, children, adults, and still active older people, the pond and the mango trees, all present and all smiling, poor but in proportion ",10

Initially, Le Corbusier wrote to Pandit Nehru hoping to learn of a few contemporary symbols that would easily express the ethical, socio-cultural and political ideologies of Indian culture ${ }^{11}$. When this search returned no results, he had no option but to rely on his own resources to find an appropriate set of symbols to represent the spirit of the natural world in a city of the second machine age.

A majority of the symbols he conceived for Chandigarh were abstract pictorial representations of man, his hands and foot prints, the native animals inhabiting the surrounding landscape- the birds in the sky, the domesticated bull on land, the fish, turtles, snakes living in the water and, most importantly, all of the natural world that he could perceive- the forces of nature, the mountains, the the sun, the stars and the moon. The idea of nature as sacred, was deep rooted in Le Corbusier's mind and it was this notion that impelled him to elevate familiar scenes of daily life to a quasi-religious status through his abstract symbolic language.

Le Corbusier's oeuvre of symbols were not limited to the two dimensional murals that adorned the walls, ceilings, tapestries and doorways. From the upturned arc of the recurrent parasol roof, that was a mere sculptural abstraction of the bull's horns to the more philosophically rooted Open Hand monument, Le Corbusier developed these symbols into a full fledged architectural language and conscientiously incorporated them into the three dimensional design of the buildings of the Capitol Complex and the city itself.

\subsection{The Rhythm of the Sun}

In the tropical climate of India, Le Corbusier saw the sun as the driving force of life where man's activities were dictated by the daily and annual rhythm of the solar cycle. Fascinated by this primal pulse of the natural world,

\footnotetext{
${ }^{10}$ Corbusier, Le: The Final Testament of Père Corbu.A Translation and Interpretation of Mise au point by Ivan Zaknic. Ivan Zaknic (Ed.). New Haven - London: Yale University Press, 1997

${ }^{11}$ Le Corbusier to Jawaharlal Nehru, 25 September 1961, FLC P1-6-264. Reproduced in Krustrup, Mogens: Porte email : Le Corbusier, Palais de l'Assemblée de Chandigarh $=$ Emalje porten $=$ La porte emaillée $=$ The enamel door. Copenhagen: Arkitektens Forlag, Kunstakademiets Forlag, 1991 in Green space and cosmic order: Le Corbusier's understanding of nature, p. 164.
} 
Le Corbusier, in his poetry, compares the sun to a machine whose laws have been in place since time immemorial.

\author{
" Punctual machine turning \\ since time immemorial \\ engenders every instant of the \\ Twenty four hours cycle the gradation \\ the nuance the imperceptible \\ almost providing a rhythm.. ",12
}

While his sine curve symbol for the 24-hour cycle of the sun is commonly found in Chandigarh, Le Corbusier also united with the laws of the solar cycle, the play of light and shadow in his buildings. The parasol roof, brise soleil and the 'undulatories' found on the facades of his buildings in the Capitol Complex can be understood as functional symbols of the solar cycle, designed to naturally shade the interior spaces during the day while the sun moves through the sky.

A more symbolic representation of his fascination with the solar cycle is the pavilion of the Tower of Shadows. One of the few monuments to have been realised completely, its purpose is to map the path of the sun through shadows cast on the inside as well as the outside of its perforated walls. Oriented to face the ordinate points at 45 degrees off of the axes of the Capitol Complex, each wall and level of this Tower corresponds to the calculated angles of incidence.

The building of the Legislative Assembly played host to his most sincere effort to symbolise the daily as well as the annual rhythms of the sun. The fenestrations in the Tower of the Assembly Hall are a marriage of machine and myth. Le Corbusier's inspirations lay in the ancient Indian tradition of mapping the sun with large observatories called the Jantar Mantar. On visiting the Jantar Mantar in New Delhi, he commented, "They point the way; bind men to the cosmos ...the precise adaptation of forms and organisms to Sun, rain, air etc. "'13. In a similar attempt, The Tower of the Assembly Hall was meticulously designed so that the window openings at the very top of the Tower would 'reflect the summer sun, to receive the winter sun and to reflect the sun of the equinoxes onto the interior surfaces of the hyperboloid'. Bathed in optimum natural light, the Assembly hall would create the ideal milieu for the representatives of the people to discuss affairs of national importance.

\title{
4.2 The Relevance of the Right Angle
}

The initial plan of Chandigarh, developed by American architect Albert Mayer and his assistant Mathew Novicki, was in a fan pattern with the curvilinear roads of the city located in the valley between the two seasonal rivulets. The most significant change made to this initial layout by Le Corbusier was his relocating the city's sectors within an orthogonal grid of $800 \mathrm{~m} \times 1200 \mathrm{~m}$.

With the recurring orthogonal grid, Le Corbusier boldly resisted what was hitherto considered acceptable, that only curvilinear forms were natural. Corbusier's critics say his repeated use of the rigid right angle in the city plan was a forceful imposition of a machine-made order onto an organic world. Contrary to this commonly held

\footnotetext{
${ }^{12}$ The Poem of the Right Angle

${ }^{13}$ Tungare, Amit: Le Corbusier's Principles of City Planning and their Application in Virtual Environments. Advisor: Andonian, Greg. Masters thesis. Faculty of Graduate Studies and Research, School of Architecture Carleton University, Ottawa, Ontario, May, 2001, p. 67
} 
belief, Le Corbusier was an architect whose lifelong quest was to understand the underlying laws of natural world and embrace the universal harmony of nature in his architecture . A deeper reading of his designs for Chandigarh, allow us to see that he applied his learnings from nature to his designs for cities.

In his letters to his mother, Le Corbusier admits that openness of the site - "a limitless plain unroll(ing) itself over the hills and the foothills of the Himalayas ${ }^{, 14}$ was what drew him to the project. The gentle slope at the foothills compelled him to develop the grid plan as a response to the vast site. The grid itself works in tandem with the natural features of the site because of its flexibility, adjusting when required to accommodate the large river valley running through the site.

The right angle itself was derived from a keen observation of nature. In the Poem of the Right Angle, Le Corbusier writes,

"Erect on the terrestrial plain

of things knowable you

sign a pact of solidarity

with nature: this is the right angle..." 15

When he saw the horizon, he perceived it to form the right angle in conjunction with the vertical axis of gravitational force. The constant character of the right angle that kept the natural world in equilibrium intrigued him. To him, the right angle was a metaphor to express the underlying unity in man, nature and the cosmos.

\subsection{The Golden Section and the use of the Modulor}

Even early in his career, Le Corbusier perceived nature as ordered and organised within itself. What he was not able to resolve until later on was the role of man and his creations- the machine and modern buildings, in this natural world. Influenced by his work on regulating lines and proportional grids at the office of Peter Behrens in Berlin, he looked to mathematics and geometry for solutions to this problem.

It was during this search that Le Corbusier came across the works of Matila Ghyka, a Romanian mathematician and writer who published extensively on the origins and presence of the Golden Section in nature, art, architecture, music, and literature ${ }^{16}$. For Le Corbusier, the mathematics of the Golden Section seemed to hold a single answer to two separate questions under study- one was the search for a modular measurement for all components of a building and the second was a mathematical grounding that linked the proportions of the human body to the organising principles of nature.

The Modulor, which Le Corbusier described as a "range of harmonious measurements to suit the human scale, universally applicable to architecture and to mechanical things ${ }^{\prime 17}$, was born as a culmination of decades of research into these questions. By applying this system of "divine proportions",18 from the Golden Section to the

\footnotetext{
14“"Une plaine illimitée s'appuyant sur des collines et un fond d'Himalaya." Le Corbusier to his mother, 12 March 1951, in Jenger, Jean (Ed.), Le Corbusier, Choix de Lettres. Berlin: Birkhäuser - Editions d'Architecture, 2002, p. 342 as quoted in Green space and cosmic order: Le Corbusier's understanding of nature, p. 37.

${ }^{15}$ The Poem of the Right Angle

${ }^{16}$ Cohen, J-L 2014: Le Corbusier's Modulor and the Debate on Proportion in France. Architectural Histories, 2(1): 23, pp. 114, DOI: http://dx.doi.org/10.5334/ah.by

17“"The Modulor", Le Corbusier: oeuvre complète 1946-1952

${ }^{18}$ Corbusier, Le: A Timely Book. Hendricks, Genevieve (trans.) as in Le Corbusier's Modulor and the Debate on Proportion in France
} 
built form, Le Corbusier wanted the human psyche to easily relate to the man-made and machine-made surroundings conspicuously at the physical level as well as latently at the primitive aesthetic and psychological level. With the Modulor, he ensured that buildings were designed to suit the scale of the human body and function as an extension of the limbs. The proportioning system was meant to affect the human mind at a much deeper level, where the inhabitant would intrinsically sense the beauty arising from the use of the Golden Section.

The repeated appearance of Le Corbusier's Modulor Man in the plazas and on the walls, tapestries and doors of Chandigarh is a small percentage of the symbolic value of the Modulor. For the city of Chandigarh, Le Corbusier envisaged a "full scale application of mathematics in building: three dimensional urbanism (on ground and in space)" ${ }^{\prime \prime}$. He imagined a city where the Modulor would be used as a measuring tool that influenced design at both large and small scales, "everything (from) pilotis, highways and roads, swimming pools, buildings, from top to bottom and in every object of interior, car parks... ${ }^{, 20}$.

The Capitol Complex in Chandigarh was by far Le Corbusier's grandest achievement. Even at this monumental scale, the Modular played a vital role during the design process. The entire Capitol Complex is located within a square with a dimension of 800 meters on each of its sides. Obelisks on four corners of this square marks the extreme boundaries of the Complex. Keeping in mind the proportions of the Modulor, Le Corbusier divided this large square further. He positioned his architectural masterpieces - the Secretariat, the High Court, the Assembly and the unbuilt Governor's Palace at specific points corresponding to the geometry of the Golden Section. While the relevance of this grandiose arrangement does not reveal itself at once to the human eye, Le Corbusier justified it saying, "the site is united with the imperceptible

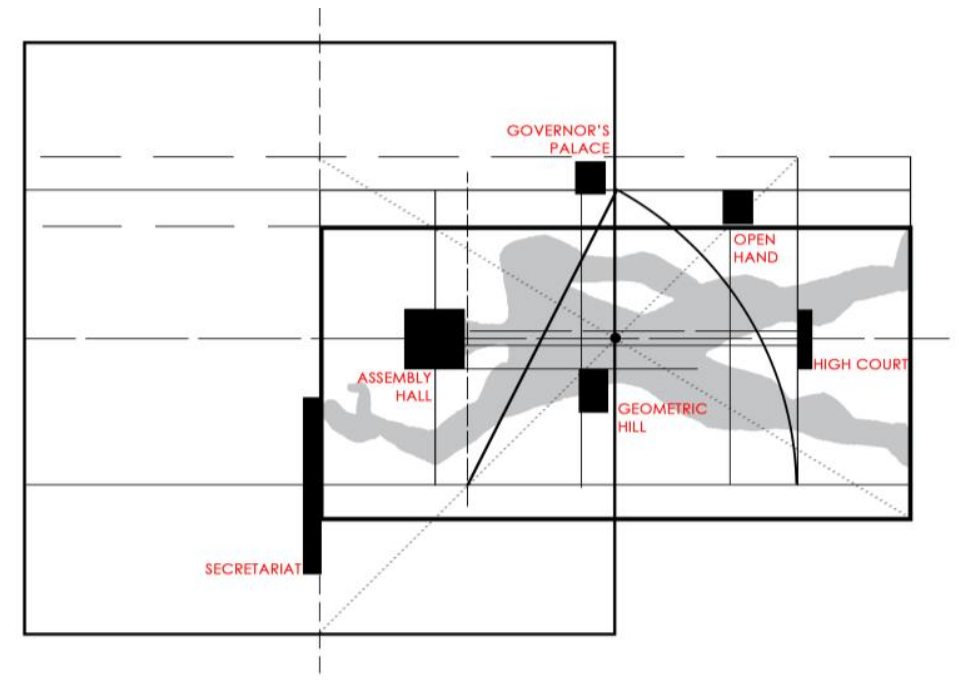

2. The Plan of the Capitol Complex as derived from the proportions of the Golden Section and the Modulor.

\footnotetext{
${ }^{19}$ Corbusier, Le: The Modulor. London: Faber and Faber, 1954 as quoted in Steyn, Gerald: Le Corbusier and the human body. Art Historical Work Group of South Africa, 2012

${ }^{20}$ Ibid.,

${ }^{21}$ Sharma, Sangeet: Corb's Capitol: (a journey through Chandigarh's architecture). w/o.pl. Abhishek Publications, 2009.
} 
From Klaus- Peter Gast's book Le Corbusier, Paris - Chandigarh, it is clear that the sculptural architectural forms of the Secretariat, the High Court and the Assembly buildings were all regulated with extensive use of the Modulor $^{22}$. For example, it is seen that the basic form of the Secretariat is based on the Modulor and Golden Section. Beginning with a simple rectangle, Le Corbusier divided it further into six proportional parts. He then derived a double square projected on the central axis and used the vertical axis dividing the lines between the square to establish the position of the wall within the rectangle. The system of proportioning and progressions further establish the positions of the pilotis, brise soleil on the facade, the location of dividing walls, room heights in sections as well as the dimensions of the open plans for the interiors. In Sangeet Sharma's book, Corb's Capitol: (a journey through Chandigarh's architecture), he narrates an incident where the Indian engineer on site was at a loss for why he could not use a beam 2' in depth in the High Court, forcing the architect in charge to explain that only a depth of $1^{\prime}-7 \frac{1}{2}$ " or 2 ' $-1 \frac{1}{2}$ " would suit the dimensions of the Modulor ${ }^{23}$.

In the Edict of Chandigarh, Le Corbusier expresses his deep belief in the Modulor, its sacrosanct goals and explains his ambitions to the future citizens, "The city of Chandigarh is planned to human scale. It puts in touch with the infinite cosmos and nature. It provides us with places and buildings for all human activities in which the citizens can live a full and harmonious life. Here the radiance of nature and heart are within our reach. ${ }^{, 24}$

\subsection{The Anthropomorphic city plan}

Even prior to the development of the Modulor, Le Corbusier thought of man as a symbolic representation of the entire universe; a thought that could be traced back to the times of Da Vinci's Vitruvian Man. Since his early years, he had shown a keen interest in the study of biology and it was this interest that influenced his ideas for anthropomorphic future cities. To him, cities and towns were "biological phenomena",25 and he drew a direct likeness between the city form and the human body. In his mind, the city had a head, a heart, lungs and a circulatory system that were as essential to the city as they were to the human body. Extending this analogy further, he contended that if the city was left uncared for it would lose its vitality and energy deteriorating to the extent of disarray.

Le Corbusier had extensively applied this similarity between the city and the human body in his previous projects such as his design for the Radiant City. In the City of Tomorrow, he refers to the parks and gardens as the "lungs" of a city and conveys the revolutionary idea of a living, breathing city, thus forever transforming the way people look at man's most complex creation- the city. In his sketches, he anthropomorphised the dwellings by drawing a single eye on each of them. He did this because he pictured the built form of the dwelling taking on the human persona of its residents, imagining each building to be gazing peacefully at the surrounding landscape.

Inspired by the rationality and harmony in the functioning of systems of the human body, Le Corbusier's Chandigarh was a symbol of the organising principles that nature had created for the human body. While Mayer's and Novicki's plan of Chandigarh also indicated the head and body of the city, it was Le Corbusier's

\footnotetext{
${ }^{22}$ Gast, Klaus-Peter: Le Corbusier, Paris-Chandigarh. Basel, Birkhaüser, 2000

${ }^{23}$ Corb's Capitol: (a journey through Chandigarh's architecture)

${ }^{24}$ Edict of Chandigarh, Chandigarh: The City Beautiful, The official website of the Chandigarh Administration, http://chandigarh.gov.in/knowchd_edict.htm accessed on $1^{\text {st }}$ June,2015

${ }^{25}$ Corbusier, Le: Concerning Town Planning. Entwistle, Clive (trans.). London: The Architectural Press, 1947, p. 11. First published as Propos d'Urbanisme, Paris: Editions Bourrelier et Cie, 1946 as quoted in Green space and cosmic order: Le Corbusier's understanding of nature, p. 81
} 
deeper understanding of this symbolism that allowed him to connect the two separate parts. He envisaged the city of Chandigarh with the Capitol Complex, Sector 1 as the head, the City Center Sector-17 became the heart, the Leisure valley and other green open spaces were the lungs providing a breath of fresh air to the city's residents, the cultural and educational institutions stood for the intellect, the industrial areas formed the viscera and lastly the hierarchy of roads in the V7 network acted as the circulatory system of the body.

His parallel of the city and the human body did not end at this scale; he even looked at the cell for inspiration. The cells, basic building blocks of all living things, provide order and structure to the whole body. He saw the cell as a self-sufficient organism, interacting with other cells to ensure the proper and smooth functioning of the body. Analogous to the cell, each sector in the urban layout of Chandigarh city was self-sufficient, having shops, schools, health centres and places of worship and recreation within itself. Similar to the cells in the natural world, each sector had its designated role to play in the smooth functioning of the whole - the city. This analogy to the cell justifies his need to standardise the dimensions of the sector and reproduce it multiple times to fill the city's layout plan.

While the large city has no obvious physical similarities to a human's body, it remains symbolic of the order of the natural world. In the words of the architect himself, "If the creation is ordered, it lasts throughout time and remains an object of admiration in every mind. This is the work of art, the human creation which, while no longer bearing any of the evident aspects of Nature, yet submits to the same laws. ${ }^{26}$

The immense thought put into the anthropomorphic design of Chandigarh makes the city itself a symbol. By applying the laws of the human body to the ordering of human habitation, Le Corbusier attempted to infuse the city with a primeval spirit that was until then buried deep within each individual.

\subsection{The Spirit of the Open Hand}

"The Open hand is the only political act of my life..The Hand is open to give and receive. It is a sign of optimism in this world of catastrophe. ${ }^{27}$

The Monument of the Open Hand crowns the Pit of Contemplation at the far north of the Capitol Complex. The Pit is 5 meters deep and consists of two amphitheaters, a speaker's platform and ramp that leads up to ground level. From its sunken depth, every perspective is dominated by the 28 meters tall Open Hand sculpture. The abstract human hand sculpture is placed atop a slender column acting as the axis of the ball bearings on which the sculpture rotates.

In a video interview, Le Corbusier describes this monument as a place to discuss the affairs of the people without the interference of those in power, much like the Greek democracies of the past. The two amphitheaters represent the idea that there would always be two sides to any debate. Similar to a tree whose branches swayed with the wind, the Open Hand was designed "like a weather cock, not to show the incertitude of ideas, but to indicate symbolically the direction of the wind (that is the state of affairs).

\footnotetext{
${ }^{26}$ The City of Tomorrow and Its Planning

${ }^{27}$ Recorded video interview of Le Corbusier, https://www.youtube.com/watch?v=UmcR9jU6SPw, accessed on $1^{\text {st } J u n e, ~} 2015$

28 “ The Open Hand”, Le Corbusier: oeuvre complète 1946-1952.
} 


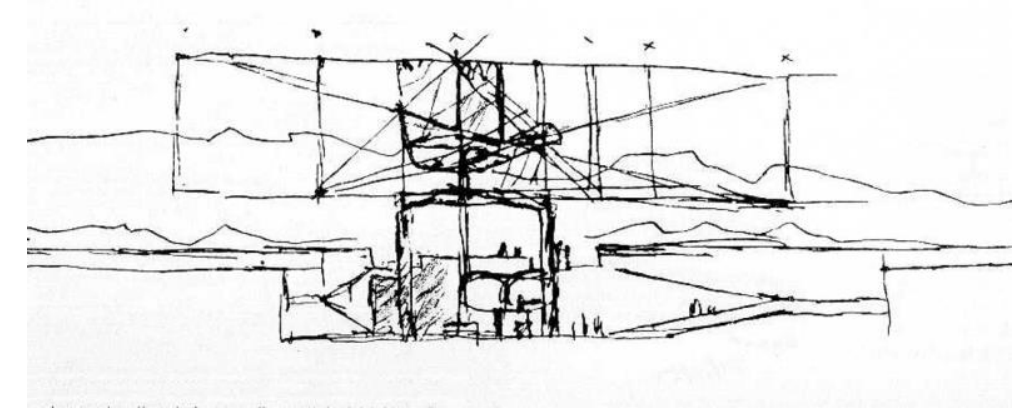

3. Le Corbusier's sketch of the Open Hand Monument superimposed with the proportioning lines of the Golden Section and the Modulor. The outline of the Himalayas are drawn in the background.

The inspiration for the form has been debated innumerable times- "The reverent see in the Open Hand a pancultural significance, a cross between a Buddhist gesture for dispelling fear and a hovering Picasso Peace Dove. ${ }^{29}$ However, the most intriguing answer is from Xavier Monteys who perceives the Open Hand as a series of mountain peaks ${ }^{30}$. As noted before, Le Corbusier was particularly fascinated by the mountain peaks whether they were the Alps, where he first drew their silhouettes, the Andes, where he perfected his drawing of the Open Hand or the Himalayas, where his vision was finally brought to life. Monteys suggests that Le Corbusier himself was only subconsciously aware of this resemblance as he spontaneously drew the form of the Open Hand with the Himalayas as a backdrop. He goes on to question whether the Open Hand was in reality a "Monument to the men or a Monument to the Mountain?",31.

While the symbol of the Open Hand has appeared time and again in Le Corbusier's previous sketches and paintings, the proportions of the Open Hand Monument in Chandigarh were subject to the Golden Section, a mathematical law that he related to the universal order. In a sketch dating $6^{\text {th }}$ April, 1952, the Open Hand Monument is shown superimposed by the proportioning rectangles of the Golden Section and the Modulor ${ }^{32}$. While it is certain that Le Corbusier wished for the Open Hand to follow the sound aesthetic principles derived from the Modulor, this rigorous use of the Modulor even in this stand-alone sculpture can be seen as a reflection of his deep-rooted need to follow the laws of a universal natural order.

At the end of his life long search, Le Corbusier still remained doubtful if he had been able to unearth the hidden laws that governed the natural world. However, what he was unequivocally sure of was that whatever be these elusive laws, the end result was always universally harmonious. The Open Hand Monument was Le Corbusier's

\footnotetext{
${ }^{29}$ Curtis, William J.R. : Le Corbusier: Ideas and Forms. London - New York: Phaidon Press Limited, 2001. First published in 1986

${ }^{30}$ Monteys, Xavier: Alpes, Andes, Himalaya. Massilia: anuario de estudios lecorbusierianos, 2004 bis, p. 136-143. http://hdl.handle.net/2099/9268

31 “Monumento a los hombres o a la Montãna?” translated from Alpes, Andes, Himalaya

${ }^{32}$ Le Corbusier: oeuvre complète 1946-1952.
} 
call to arms, a timeless symbol reminding not only the people of Chandigarh, but the entire human race to rise above the "feelings of anguish and disharmony which separate mankind, and so often create enemies. ",33

"I let the others find a solution now, for it's a tragic moment! ",34

With this altruistic gift, Le Corbusier urges the people to set off on their own search for the natural order, a search that would no doubt result in an understanding of themselves, their surroundings and also lead the way for a state of harmony and accord.

\section{Image Sources}

Corbusier, Le: "Chandigarh, the new capital of Punjab”, Boesiger, Willy (Ed.): Le Corbusier: oeuvre complète 1957-1965. Zurich: Éditions d'Architecture, 2006.

Sketch by Author

Corbusier, Le: “The Open Hand”, Boesiger, Willy (Ed.): Le Corbusier: oeuvre complète 1946-1952. Zurich: Éditions d'Architecture, 2006.

\section{Bibliography/references}

Boesiger, Willy (Ed.): Le Corbusier: oeuvre complète 1946-1952. Zurich: Éditions d'Architecture, 2006.

Cohen, J-L 2014: Le Corbusier's Modulor and the Debate on Proportion in France. Architectural Histories, 2(1): 23, pp. 1-14, DOI: http://dx.doi.org/10.5334/ah.by

Corbusier, Le: The City of Tomorrow and Its Planning, Etchells, Frederick (Trans.). London: The Architectural Press, 1971. First published as Urbanisme, Editions Crès et Cie, Paris, 1924

Corbusier, Le: The Radiant City: elements of a doctrine of urbanism to be used as the basis of our machine-age civilisation. New York: Orion Press, 1967.

Corbusier, Le: The Poem of the Right Angle. Hylton, Kenneth (Trans.). Paris: Fondation Le Corbusier and Editions Connivences, 1989.

Corbusier, Le: The Final Testament of Père Corbu.A Translation and Interpretation of Mise au point by Ivan Zaknic. Ivan Zaknic (Ed.). New Haven - London: Yale University Press, 1997.

Curtis, William J.R.: Le Corbusier: Ideas and Forms. London - New York: Phaidon Press Limited, 2001. First published in 1986.

Dummett, Emma. Green space and cosmic order: Le Corbusier's understanding of nature. Advisors: D.

Weston, I. Boyd Whyte. Doctoral thesis, University of Edinburgh, 2007

Gast, Klaus-Peter: Le Corbusier, Paris-Chandigarh. Basel, Birkhaüser, 2000

Monteys, Xavier: Alpes, Andes, Himalaya. Massilia: anuario de estudios lecorbusierianos, 2004 bis, p. 136-143. http://hdl.handle.net/2099/9268

Sharma, Sangeet: Corb's Capitol: (a journey through Chandigarh's architecture). w/o.pl. Abhishek Publications, 2009.

Singer, Milton: Semiotics of Cities, Selves and Cultures: Explorations in Semiotic Anthropology. Berlin: Walter de Gruyter. 1991.

\footnotetext{
${ }^{33}$ Ibid.

${ }^{34}$ Recorded video interview of Le Corbusier, https://www.youtube.com/watch?v=UmcR9jU6SPw, accessed on $1^{\text {st }}$ June, 2015
} 
Tungare, Amit: Le Corbusier's Principles of City Planning and their Application in Virtual Environments. Advisor: Andonian, Greg. Masters thesis, Faculty of Graduate Studies and Research, School of Architecture Carleton University, Ottawa, Ontario, May, 2001

Edict of Chandigarh, Chandigarh: The City Beautiful, The official website of the Chandigarh Administration, http://chandigarh.gov.in/knowchd_edict.htm accessed on 1st June,2015

Recorded video interview of Le Corbusier, https://www.youtube.com/watch?v=UmcR9jU6SPw , accessed on 1st June, 2015 


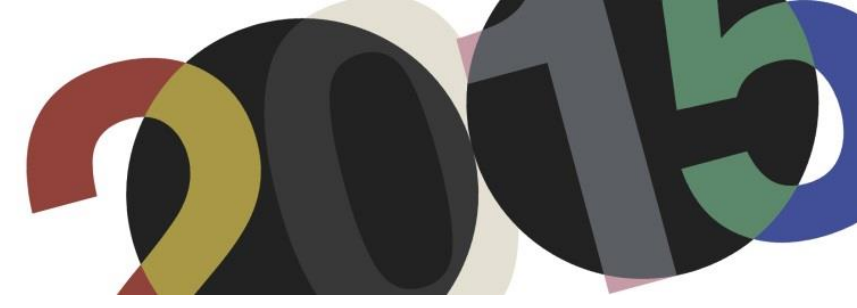

DOI: http://dx.doi.org/10.4995/LC2015.2015.899

\title{
The mur neutralisant as an active thermal system: Saint Gobain tests (1931) versus CFD simulation (2015)
}

\author{
C. Ramírez-Balas*, J.J. Sendra *, R. Suárez*, E.D. Fernández-Nieto**, G. Narbona-Reina** \\ * Instituto Universitario de Arquitectura y Ciencias de la Construcción, Escuela Técnica Superior de \\ Arquitectura, Universidad de Sevilla \\ ** Departamento de Matemática Aplicada I, Escuela Técnica Superior de Arquitectura, Universidad de Sevilla
}

\begin{abstract}
At the same time as the initial development of air conditioning systems for indoor climate control in buildings were occurring in USA, Le Corbusier and Lyon made truly innovative proposals for different projects he was working on in Europe. These served to generate homogenous thermal environments and focused on the combined effect of his mur neutralisant and respiration exacte. The clearest example of their shortcomings is the City of Refuge in Paris (1930-33). Given the technological and economic mistrust towards these proposals, as it was impossible to execute these according to the original plan these were not pursued. CFD simulations carried out by our research team confirm that the mur neutralisant and respiration exacte for the City of Refuge in Paris would have functioned together if they had been executed following the original plans. The main aim of this paper is to confirm the validity of the mur neutralisant as an active thermal system for buildings. Firstly, the results of the tests carried out by the engineers of Saint Gobain are compared to the results of the CFD simulations. Based on the comparison of the results from the physical models tested in Saint Gobain laboratories and CFD energy model simulations, a possible calibration is proposed for CFD which might prompt the establishment of other operation hypotheses.
\end{abstract}

Keywords: Le Corbusier; mur neutralisant; The City of Refuge; Active Façade System; Computational Fluid Dynamics (CFD); Numerical Simulation.

\section{Introduction}

In the 20th century, air conditioning systems gained success first in the United States and then in Europe, and their use became increasingly widespread throughout the century. In contrast, the proposals from Le Corbusier and Lyon, based on the combination of the mur neutralisant and respiration exacte (figure 1) as an active thermal system, only provoked technical and financial mistrust so that they were not followed up and could not be executed as planned. However, in the late 20th century these reappeared as predecessors of active façade systems. The best-known example of their failure is the City of Refuge in Paris (1930-33), designed as Salvation Army accommodation for between 500 and 600 homeless people.

However, simulations carried out by our research team using Computational Fluid Dynamics (CFD) programs confirm the combined effect of the mur neutralisant and respiration exacte on the temperature control of the main dormitory in the City of Refuge of Paris if the system had been executed following the original designs of Le Corbusier and Lyon ${ }^{1}$. The main aim of this study is to establish the suitability of the mur neutralisant as an active conditioning system for buildings. In the 1930s Saint Gobain engineers Lebel and Le Barbier carried out

\footnotetext{
${ }^{1}$ Ramírez Balas, C.; Fernández Nieto, E.D.; Narbona Reina,G.; Sendra, J. J.; Suárez, R. "Numerical simulation of the temperature evolution in a room with a mur neutralisant. Application to 'The City of Refuge' by Le Corbusier". Energy and buildings. 2015. 86. pp. 708-722.
} 
laboratory tests on physical models to ascertain the suitability of the mur neutralisant as an active heating system in extreme outdoor temperatures and without solar radiation ${ }^{2345}$. Our research group has compared these with the results obtained in 2015 using energy models and CFD simulations of the same operation and outdoor environmental conditions.

Following the comparison and adjustment of both models, other hypotheses have been established regarding the operation of the energy models and subsequent CFD simulation of the design of a south-facing mur neutralisant for the main dormitory in the City of Refuge. The operation of the mur neutralisant has been assessed as an active heating system for cold winter days with and without sunlight, including the influence of solar radiation, which was neglected in the Saint Gobain tests, and as an active cooling system on hot summer days, an operation mode which Saint Gobain also failed to test.

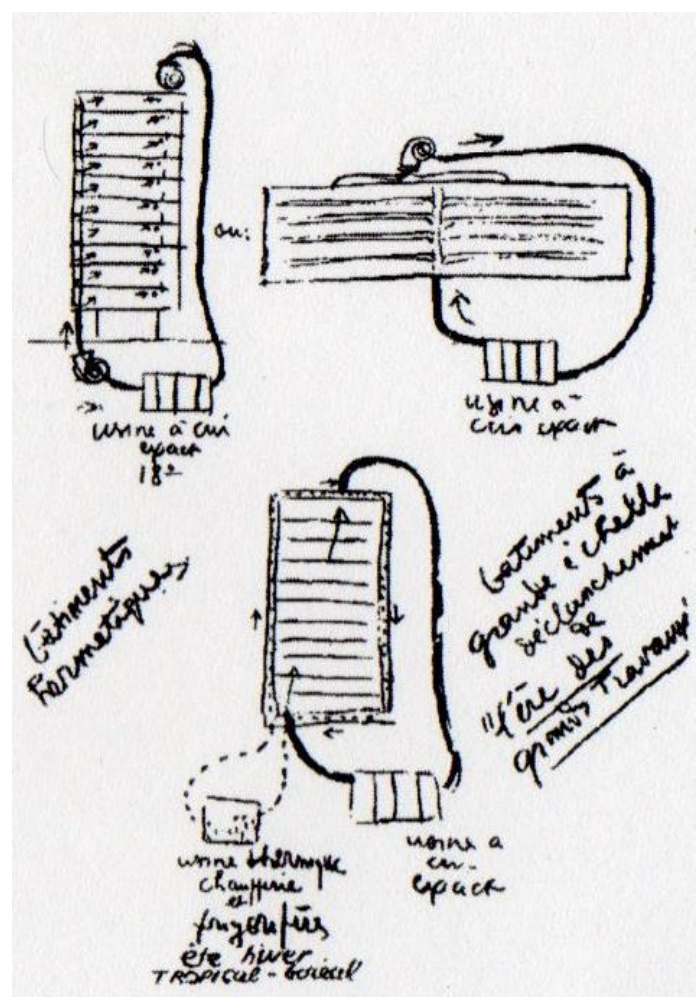

1a. Diagram by Le Corbusier of the operation of the mur neutralisant ${ }^{6}$.

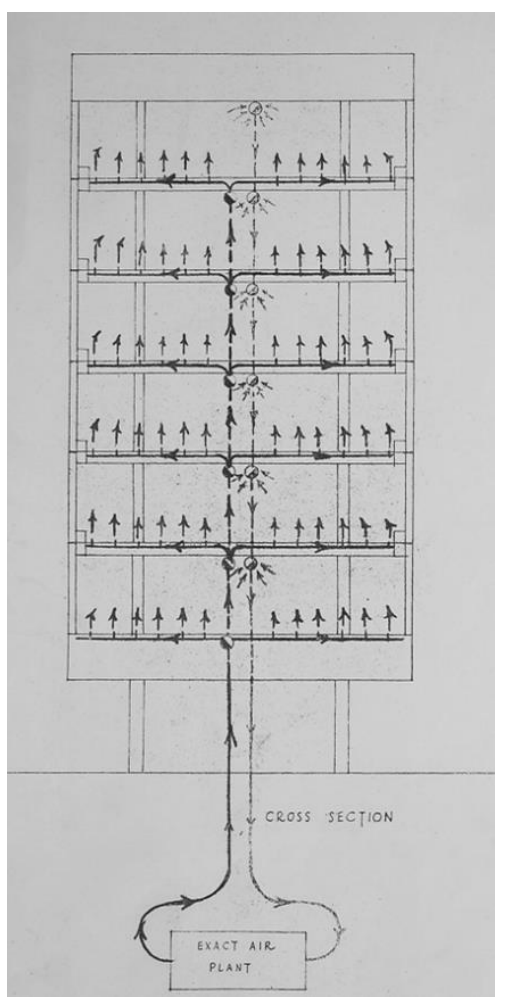

1b. Drawing by Le Corbusier of the mur neutralisant and respiration exacte ${ }^{7}$.

1. Proposal by Le Corbusier for the mur neutralisant and respiration exacte.

\footnotetext{
${ }^{2}$ Le Braz, J. "La transmission de la chaleur gràverâ travers le verre: Des idées nouvelles sur le chauffage des habitations." Glaces et Verres. 1933. № 20. pp. 13.

${ }^{3}$ Brian Brace, T. "Le Corbusier, the city of refuge, Paris 1929-33". Chicago: University of Chicago Press. 1987.

${ }^{4}$ Cuadernos de Postgrado. La respuesta de la American Blower Corporation. 24 January 1930.

5 Bryan, Harvey. "Le Corbusier and the 'Mur Neutralisant': An Early Experiment in Double Envelope Construction." Proceedings of the Ninth International PLEA Conference. 1991. pp. 257-62.

${ }^{6}$ Le Corbusier. El edificio hermético. "Croquis de Précisions".

${ }^{7}$ Foundation Le Corbusier. FLC 15720. (FLC-ADAGP.
} 


\section{Saint Gobain tests}

On Le Corbusier's instructions, Saint Gobain engineers carried out numerous tests over a two-year period, recording them in two documents on 25 June $1931^{8}$ and 11 March $1932^{9}$.

The test room (figure 2) consisted of two rooms with a $0.5 \mathrm{~m}$ intermediate space and $7 \mathrm{~mm}$ double glazing in a wooden frame with an air cavity varying between 3 and $20 \mathrm{~cm}$ in width. The room known as the hot room representing the interior space, measured $2.04 \times 1.64 \mathrm{~m}$ and was $2.72 \mathrm{~m}$ high. It needed to maintain an indoor temperature of $18{ }^{\circ} \mathrm{C}$ to ensure minimum thermal comfort conditions in winter. Another "cold" room, measuring $0.8 \times 1.4 \mathrm{~m}$ and $2.4 \mathrm{~m}$ high, represented the outdoor space. The temperature in this cold room could be maintained at different low winter levels.

Walls, ceilings and floors were built using $12 \mathrm{~cm}$ thick expanded cork insulation panels in the hot room, while those used in the cold room were $24 \mathrm{~cm}$ thick. On two of these walls the panels were in contact with a brick enclosure. All openings were sealed and a $22 \times 22 \mathrm{~cm}$ window (K) was used to review the installation without opening the door. Figure 2 shows the following elements: a $2.5 \mathrm{~m}$ long conduct, used to measure the fan-driven airflow, which varied between 0 and $150 \mathrm{l} / \mathrm{s}$; an air heater consisting of a series of electric resistances which could bring the temperature up to $50^{\circ} \mathrm{C}$; a device consisted of a shell with holes on top, placed at the bottom of the air cavity between both glass panes and distributing air inside the cavity. The hot air passing between both glass sheets was expelled through a hole at the top of the air cavity. Finally, four temperature sensors were placed: (a) at the centre of the hot room; (b) at the centre of the cold room, $1.22 \mathrm{~m}$ from the glass; (c) in the hot air conduct, prior to air entry to the cavity; and (d) at hot air outlet, at the top of the air cavity.
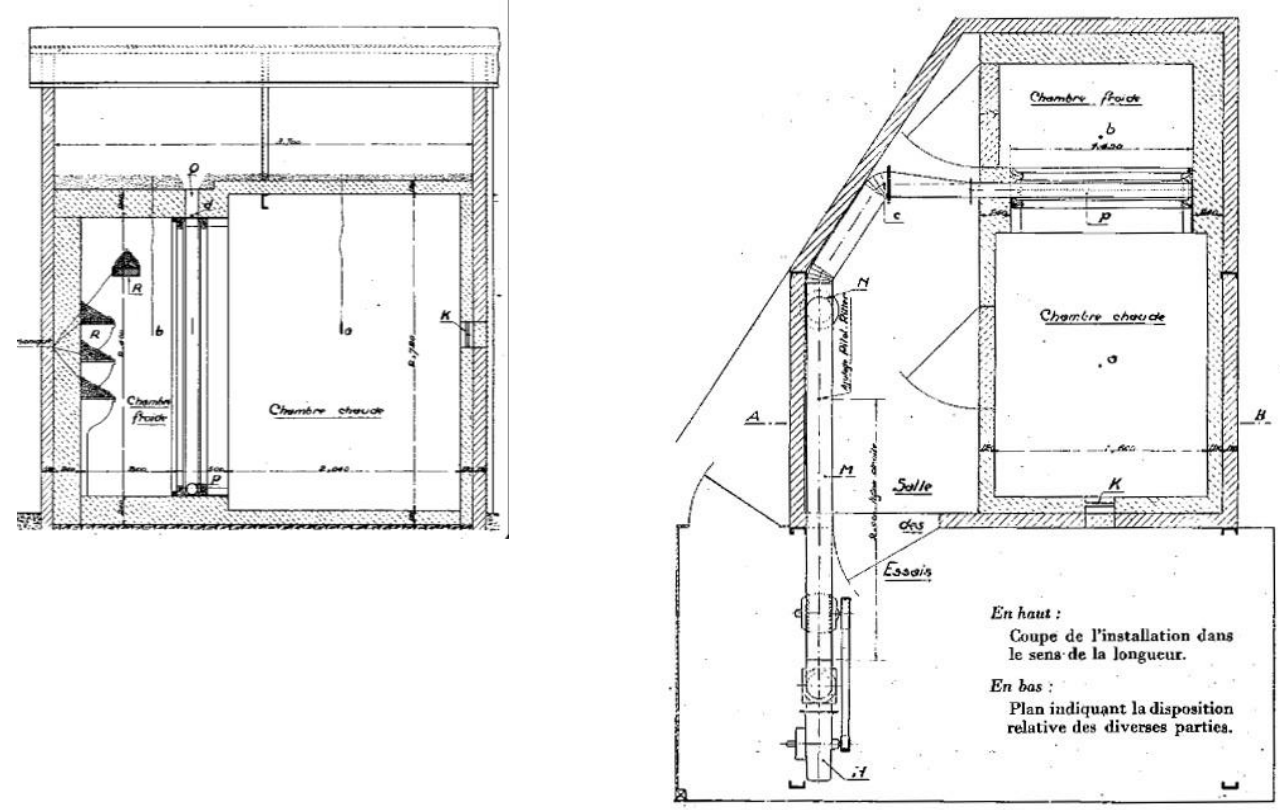

2. Horizontal and vertical section of the Saint Gobain test room ${ }^{10}$.

\footnotetext{
${ }^{8}$ Lebel, H.; Le Barbier, M. Société Anonyme des Manufactures des Glaces et Produits Chimiques de Saint-Gobain, Chauny et Cirey. Note sur les essais de transmission de la chaleur à travers les glaces, efectués à l'Annexe du Comptoir de Vente, 23 rue Boucry, Paris du 3 Avril au 8 Mai 1931. Letter of 25 June 1931.

${ }^{9}$ Lebel H.; Le Barbier, M. Société Anonyme des Manufactures des Glaces et Produits Chimiques de Saint-Gobain, Chauny et Cirey. Note sur la seconde série d'essais effectués pour la mesure de la transmission de la chaleur à travers les glaces à l'Annexe du Comptoir de Vente, 23 rue Boucry, Paris du 23 Novembre au 21 Décembre 1931. Letter of 11 March 1932.
} 
Various tests proposing different hypotheses were carried out on a $7 \mathrm{~mm}$ double glazed mur neutralisant. The width of the air cavity, airflow and duration of the test were modified. The main aim was to obtain a low transmission coefficient $(\mathrm{Q})$ for the mur neutralisant in winter with a view to maintaining an indoor room temperature of $18^{\circ} \mathrm{C}$ in very low outdoor temperatures with no solar radiation.

Between 3 April and 8 May 1931 an initial series of tests was carried out for three air cavity widths: $20 \mathrm{~mm}, 70$ $\mathrm{mm}$ and $120 \mathrm{~mm}$, with no hot airflow through the cavity (table 1). The $\mathrm{Q}$ values obtained were 2.80, 3.36 and $3.92 \mathrm{kcal} / \mathrm{h} \mathrm{m}^{2}{ }^{\circ} \mathrm{C}$, respectively. Accordingly, the decision was made to continue the tests with a hot airflow of $100 \mathrm{l} / \mathrm{s}$ into the air cavity (active chamber), at different temperatures and cavity widths between 11 and $12 \mathrm{~cm}$. An initial run of three tests on the $12 \mathrm{~cm}$ active chamber was carried out with different airflow temperatures suited to the cold room temperature (case 1, table 2), followed by a second three-test run with the same airflow, varying the cavity widths to $11 \mathrm{~cm}$ (case 2, table 3), and with cold room and hot airflow temperatures also differing from earlier ones. In both cases the hypotheses were numbered following the chronological order of tests.

\begin{tabular}{|l|c|c|c|}
\hline & 13 April & 15 April & 14 April \\
\hline Test duration & $2 \mathrm{~h} \mathrm{30}$ & $2 \mathrm{~h} 45^{\prime}$ & $2 \mathrm{~h} \mathrm{30}$ \\
\hline Active chamber width & $12 \mathrm{~cm}$ & $7 \mathrm{~cm}$ & $2 \mathrm{~cm}$ \\
\hline Mean T hot room: Tc & $+18^{\circ} \mathrm{C}$ & $+18^{\circ} \mathrm{C}$ & $+18^{\circ} \mathrm{C}$ \\
\hline Mean T cold room: Tf & $-7.5^{\circ} \mathrm{C}$ & $-22.5^{\circ} \mathrm{C}$ & $-15.5^{\circ} \mathrm{C}$ \\
\hline Mean ambient T: Ta & $+12.8^{\circ} \mathrm{C}$ & $+13{ }^{\circ} \mathrm{C}$ & $+12.2^{\circ} \mathrm{C}$ \\
\hline Value of Q $\left(\mathrm{kcal} / \mathrm{hm}^{20} \mathrm{C}\right)$ & 2.80 & 3.36 & 3.92 \\
\hline
\end{tabular}

Table 1. Tests on mur neutralisant with different chamber widths and no heating.

\begin{tabular}{|l|c|c|c|}
\hline Case 1: $12 \mathrm{~cm}$ & Hypothesis 1 & Hypothesis 2 & Hypothesis 3 \\
\hline & 27 April & 28 April & 29 April \\
\hline Test duration & $1 \mathrm{~h} \mathrm{30}$ & $1 \mathrm{~h} 15^{\prime}$ & $2 \mathrm{~h} 45^{\prime}$ \\
\hline Active chamber width & $12 \mathrm{~cm}$ & $12 \mathrm{~cm}$ & $12 \mathrm{~cm}$ \\
\hline Mean T hot room: Tc & $+19^{\circ} \mathrm{C}$ & $+16.2^{\circ} \mathrm{C}$ & $+16^{\circ} \mathrm{C}$ \\
\hline Mean T cold room: Tf & $-6{ }^{\circ} \mathrm{C}$ & $-8.8^{\circ} \mathrm{C}$ & $-17.5^{\circ} \mathrm{C}$ \\
\hline Mean ambient T: Ta & $+14^{\circ} \mathrm{C}$ & $+15^{\circ} \mathrm{C}$ & $+13.5^{\circ} \mathrm{C}$ \\
\hline Inlet T mur neutralisant & $+20.25^{\circ} \mathrm{C}$ & $+20.2^{\circ} \mathrm{C}$ & $+22.7^{\circ} \mathrm{C}$ \\
\hline Outlet T mur neutralisant & $+17.5^{\circ} \mathrm{C}$ & $+16.5^{\circ} \mathrm{C}$ & $+17.5^{\circ} \mathrm{C}$ \\
\hline Airflow & $100 \mathrm{l} / \mathrm{s}$ & $100 \mathrm{l} / \mathrm{s}$ & $100 \mathrm{l} / \mathrm{s}$ \\
\hline Value of Q $\left(\mathrm{kcal} / \mathrm{hm}^{2 \circ} \mathrm{C}\right)$ & 5.95 & 6.78 & 6.70 \\
\hline
\end{tabular}

Table 2. Test on 7+120+7 mm mur neutralisant with hot airflow inside the active chamber and with the same flow.

\begin{tabular}{|l|c|c|c|}
\hline Case 2: $11 \mathrm{~cm}$ & Hypothesis 1 & Hypothesis 2 & Hypothesis 3 \\
\hline & $8 \mathrm{May}$ & $8 \mathrm{May}$ & $8 \mathrm{May}$ \\
\hline Test duration & $50^{\prime}$ & $4 \mathrm{~h} 15^{\prime}$ & $55^{\prime}$ \\
\hline Active chamber width & $11 \mathrm{~cm}$ & $11 \mathrm{~cm}$ & $11 \mathrm{~cm}$ \\
\hline Mean T hot room: Tc & $+18^{\circ} \mathrm{C}$ & $+18^{\circ} \mathrm{C}$ & $+18^{\circ} \mathrm{C}$ \\
\hline Mean T cold room: Tf & $-28^{\circ} \mathrm{C}$ & $-20^{\circ} \mathrm{C}$ & $-13^{\circ} \mathrm{C}$ \\
\hline Mean ambient T: Ta & $17^{\circ}$ & $17^{\circ}$ & $17^{\circ}$ \\
\hline Inlet T mur neutralisant & $+38^{\circ} \mathrm{C}$ & $+31.5^{\circ} \mathrm{C}$ & $+27.5^{\circ} \mathrm{C}$ \\
\hline Outlet T mur neutralisant & $+28.5^{\circ} \mathrm{C}$ & $+24^{\circ} \mathrm{C}$ & $+22^{\circ} \mathrm{C}$ \\
\hline Airflow & $1001 / \mathrm{s}$ & $1001 / \mathrm{s}$ & $1001 / \mathrm{s}$ \\
\hline Value of Q $\left(\mathrm{kcal} / \mathrm{hm}^{2 \circ} \mathrm{C}\right)$ & 6.60 & 7.00 & 6.60 \\
\hline
\end{tabular}

Table 3. Test on 7+110+7 mmmur neutralisant with hot airflow inside the active chamber and with the same flow.

\footnotetext{
${ }^{10}$ Le Braz, J. "La transmission de la chaleur gràverâ travers le verre: Des idées nouvelles sur le chauffage des habitations". Glaces et Verres. 1933. № 20. pp. 13.
} 
Between 23 November and 21 December another three tests were carried out with different flows and hot airflow temperatures in the $12 \mathrm{~cm}$ active chamber, depending on the temperature of the cold room (case 1, table 4).

\begin{tabular}{|l|c|c|c|}
\hline Case 1: $12 \mathrm{~cm}$ & Hypothesis 4 & Hypothesis 5 & Hypothesis 6 \\
\hline & 26 November & 18 December & 18 December \\
\hline Test duration & $1 \mathrm{~h}$ & $1 \mathrm{~h} \mathrm{30}$ & $1 \mathrm{~h} 45^{\prime}$ \\
\hline Active chamber width & $12 \mathrm{~cm}$ & $12 \mathrm{~cm}$ & $12 \mathrm{~cm}$ \\
\hline Mean T hot room: Tc & $+17.2^{\circ} \mathrm{C}$ & $+18.1^{\circ} \mathrm{C}$ & $+18^{\circ} \mathrm{C}$ \\
\hline Mean T cold room: Tf & $-11.5^{\circ} \mathrm{C}$ & $-11.8^{\circ} \mathrm{C}$ & $-10.5^{\circ} \mathrm{C}$ \\
\hline Mean ambient T: Ta & $+13^{\circ} \mathrm{C}$ & $+7.5^{\circ} \mathrm{C}$ & $+8^{\circ} \mathrm{C}$ \\
\hline Inlet T mur neutralisant & $+35.7^{\circ} \mathrm{C}$ & $+35.5^{\circ} \mathrm{C}$ & $+43.7^{\circ} \mathrm{C}$ \\
\hline Outlet T mur neutralisant & $+29.2^{\circ} \mathrm{C}$ & $+29.7^{\circ} \mathrm{C}$ & $+32.5^{\circ} \mathrm{C}$ \\
\hline Airflow & $1501 / \mathrm{s}$ & $1201 / \mathrm{s}$ & $851 / \mathrm{s}$ \\
\hline Valueof Q (kcal/hm $\left.{ }^{2 \circ} \mathrm{C}\right)$ & 6.98 & 6.34 & 5.35 \\
\hline
\end{tabular}

Table 4. Test on 7+120+7 mm mur neutralisant with hot airflow inside the active chamber and with different flows.

On 12 December 1931 a test was carried out using an electric radiator inside the $13 \mathrm{~cm}$ cavity in order to determine the influence of hot air convection within this active chamber (case 3 , table 5).

\begin{tabular}{|l|c|}
\hline Case 3: $13 \mathrm{~cm}$ & 12 December \\
\hline Test duration & $1 \mathrm{~h} 30^{\prime}$ \\
\hline Active chamber width & $13 \mathrm{~cm}$ \\
\hline Mean T hot room: Tc & $+18.5^{\circ} \mathrm{C}$ \\
\hline Mean T cold room: Tf & $-10.2^{\circ} \mathrm{C}$ \\
\hline Mean ambient T: Ta & $+2.7^{\circ} \mathrm{C}$ \\
\hline Mean T cavity & $+42.1^{\circ} \mathrm{C}$ \\
\hline Value of Q $\left(\mathrm{kcal} / \mathrm{hm}^{2 \circ} \mathrm{C}\right)$ & 5.49 \\
\hline
\end{tabular}

Table 5. Test on 7+130+7 mm mur neutralisant with intermediate heating from electric radiator.

Finally, in late 1931 a further two tests were executed with a mur neutralisant configuration consisting of three 7 $\mathrm{mm}$ panes, with a $65 \mathrm{~mm}$ separation between the outer glazing and the intermediate glazing, and $120 \mathrm{~mm}$ between the intermediate and the inner glazing, with no hot airflow in the two air chambers (table 6).

\begin{tabular}{|l|c|c|}
\hline & 1 December & 16 December \\
\hline Test duration & $1 \mathrm{~h} 26^{\prime}$ & $2 \mathrm{~h} \mathrm{3}$ \\
\hline Width of cavity between inner glazing and intermediate glazing & $12 \mathrm{~cm}$ & $12 \mathrm{~cm}$ \\
\hline Width of cavity between intermediate glazing and outer glazing & $6.5 \mathrm{~cm}$ & $6.5 \mathrm{~cm}$ \\
\hline Mean T hot room: Tc & $+17.6^{\circ} \mathrm{C}$ & $+18^{\circ} \mathrm{C}$ \\
\hline Mean T cold room: Tf & $-10.9^{\circ} \mathrm{C}$ & $-11.5^{\circ} \mathrm{C}$ \\
\hline Mean ambient T: Ta & $+6.2^{\circ} \mathrm{C}$ & $+7.4^{\circ} \mathrm{C}$ \\
\hline Value of Q $\left(\mathrm{kcal} / \mathrm{hm}^{2 \circ} \mathrm{C}\right)$ & 1.65 & 1.71 \\
\hline
\end{tabular}

Table 6. Tests on 7+65+7+120+7 $\mathrm{mm}$ mur neutralisant without heating.

\section{Numerical model proposed for the simulation of the mur neutralisant}

Current CFD energy simulation systems make it possible to evaluate the energy behaviour of the mur neutralisant solution proposed by Le Corbusier. In fact, our research group has developed a CFD model not only reproducing the behaviour of Le Corbusier's mur neutralisant, but also its behaviour when combined with 
respiration exacte ${ }^{11}$. The numerical calculation model drawn up using mathematical codes and ways of resolution was implemented and subsequently simulated using FreeFem++ (hereafter FF++) ${ }^{12}$.

Figure 3 clearly shows the energy flows within the mur neutralisant, which were taken into account in the design of the model. Of the total incident solar radiation $\left(\mathrm{I}_{\mathrm{o}}\right), 7 \%$ was reflected to the exterior $\left(\xi_{\text {eg }}\right)$ and $14 \%$ absorbed by the outer glazing $\left(\alpha_{\mathrm{eg}}\right)$. The remaining $79 \%$ of energy incides on the inner glazing $\left(\tau_{\mathrm{eg}}\right)$, with $7 \%$ transmitted to the air cavity through reflection $\left(\xi_{\mathrm{ig}}\right), 14 \%$ absorbed by the inner glazing $\left(\alpha_{\mathrm{ig}}\right)$ and finally, $58 \%$ of incident solar energy which is transmitted to the room $\left(\tau_{\mathrm{ig}}\right)$.

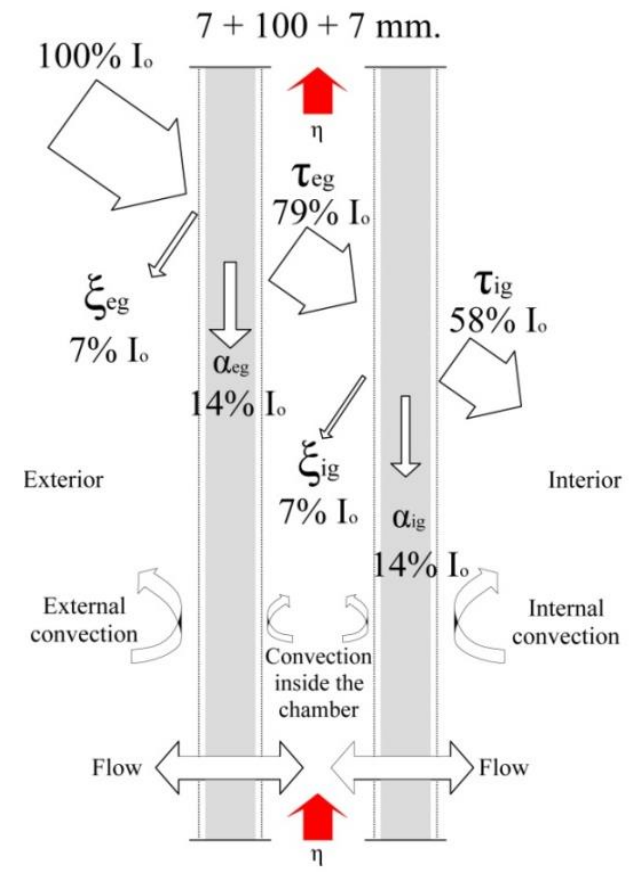

3. Scope and detail of physical phenomena in the mur neutralisant.

The numerical model proposed resolves the following system of partial differential equations:

$$
\left\{\begin{array}{c}
(\rho c V)_{f} \frac{\partial T_{f}}{\partial z}=-\eta c \frac{\partial T_{f}}{\partial z}+U_{c} A\left(T_{e g}-T_{f}\right)+U_{c} A\left(T_{i g}-T_{f}\right) \\
(\rho c V)_{e g} \frac{\partial T_{e g}}{\partial t}=U_{e x t} A\left(T_{e x t}-T_{e g}\right)+U_{c} A\left(T_{f}-T_{e g}\right)+\sigma \varepsilon_{e g}\left(T_{e x t}^{4}-T_{e g}^{4}\right)+\alpha_{e g} I_{o}+Q_{e g} \\
(\rho c V)_{i g} \frac{\partial T_{i g}}{\partial t}=U_{i n t} A\left(T_{i n t}-T_{i g}\right)+U_{c} A\left(T_{f}-T_{i g}\right)+\sigma \varepsilon_{i g}\left(T_{i n t}^{4}-T_{i g}^{4}\right)+\alpha_{i g} \tau_{e g} I_{o}+Q_{i g}
\end{array}\right.
$$

with $z \in[0, L], \mathrm{L}$ is the length of the mur neutralisant and $t \in\left[\mathrm{t}_{0}, \mathrm{t}_{\mathrm{M}}\right]$ time.

${ }^{11}$ Ramírez Balas, C.; Fernández Nieto, E.D.; Narbona Reina,G.; Sendra, J.J.; Suárez, R. "Numerical simulation of the temperature evolution in a room with a mur neutralisant. Application to 'The City of Refuge' by Le Corbusier". Energy and buildings. 2015. Vol. 86. pp. 708-722.

12 FreeFem++ v.-3.37-1. Available from: http://www.FreeFem.org/ff++/ (22.05.15). 
The model designed can calculate in both winter and summer conditions as it makes it possible to introduce the absorption, transmission and reflection of solar radiation and the convection flows in the glazing due to incidence of solar radiation and exterior temperature.

The model was validated with the models proposed by Ismail and Henríquez ${ }^{131415}$. This research focused exclusively on the study of the effects of the mur neutralisant. The complete development of the numerical model can be consulted in ${ }^{16}$.

\section{Numerical model vs. Saint Gobain tests}

The initial proposal was the comparison of the results of the 1930s Saint Gobain tests (hereafter SG) with the FF++ simulation results of the Computational Fluid Dynamics numerical models design (hereafter CFD), with only the mur neutralisant in operation.

The CFD model reproduces the Saint Gobain test room, respecting the measurements and characteristics of the room and the mur neutralisant under study (Fig. 4). The mesh density in the CFD model was adjusted to ensure reliable results and a minimum margin of error (Fig. 5).

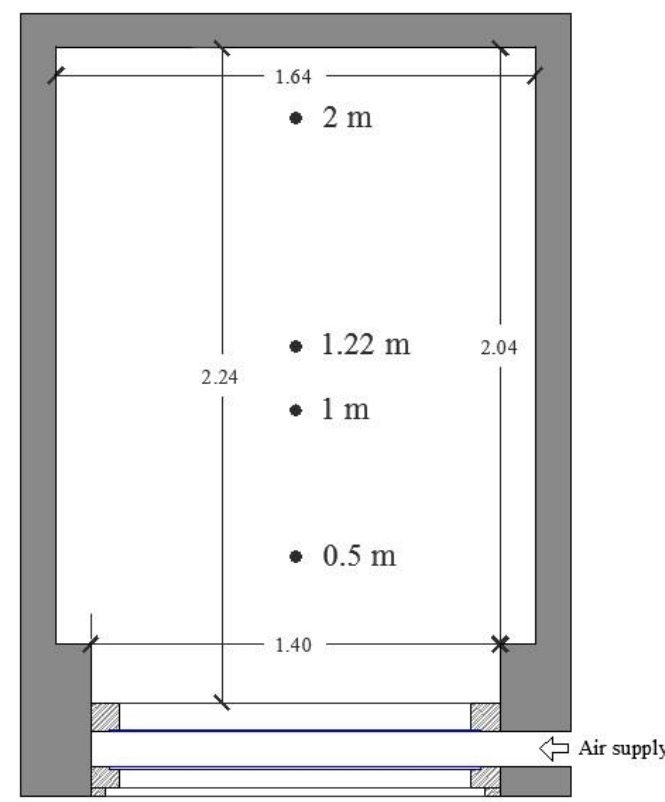

4. Dimensions and points of measurement for the SG room.

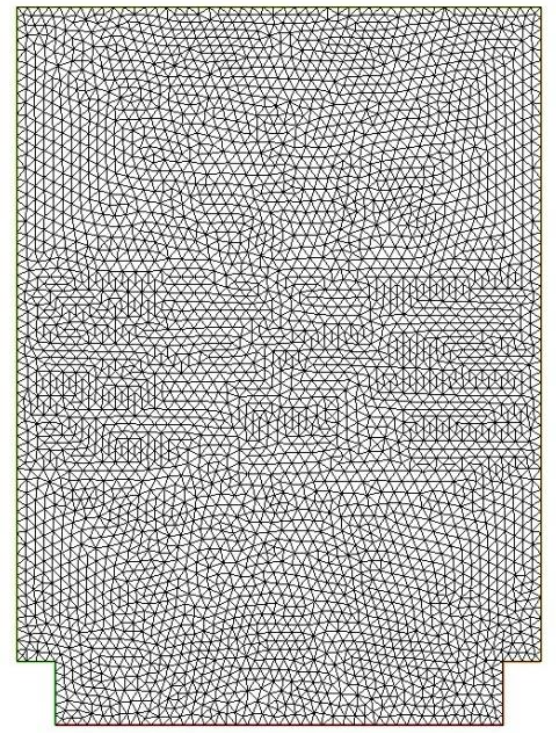

5. Density of the SG room mesh for CFD model.

\footnotetext{
${ }^{13}$ Ismail, K.A.R.; Henríquez, J.R. "Modeling and simulation of a simple glass window", Solar Energy Materials \& Solar Cells. 2003. 80. pp. 355-374.

${ }^{14}$ Ismail, K.A.R.; Henríquez, J.R. "Two-dimensional model for the double glass naturally ventilated window", International Journal of Heat and Mass Transfer. 2005. 48. pp. 461-475.

${ }^{15}$ Ismail, K.A.R.; Henríquez, J.R. "Simplified model for a ventilated glass window under forced air flow conditions". Applied Thermal Engineering. 2006. 26. pp. 295-302.

${ }^{16}$ Ramírez Balas, C.; Fernández Nieto, E.D.; Narbona Reina,G.; Sendra, J. J.; Suárez, R. "Numerical simulation of the temperature evolution in a room with a mur neutralisant. Application to 'The City of Refuge' by Le Corbusier". Energy and buildings. 2015. 86. pp. 708-722.
} 
Test 2, with a 7+110+7 mm mur neutralisant in the Saint Gobain hypothesis, was taken as reference for the comparison of the results of both models for two main reasons. It was the test with the longest duration, $4 \mathrm{~h} 15$ $\mathrm{m}$, to maintain the room at $18{ }^{\circ} \mathrm{C}$ and it established an air flow of $100 \mathrm{l} / \mathrm{s}$ in the chamber. Saint Gobain established this value after analysing the effect of different flows, such as $120 \mathrm{l} / \mathrm{s}$ and $150 \mathrm{l} / \mathrm{s}$. It was shown that with the reduction of airflow to $100 \mathrm{l} / \mathrm{s}$ there was a considerable reduction in the heat transmission coefficient due to less turbulence in the air chamber and less active exchanges between the hot air and the cold outer glazing.

Table 7 shows the results of the CFD model simulation at hourly intervals from the first to the fourth hour, recording the evolution of the different temperatures both in the room and the mur neutralisant itself. As with the SG model, the simulation was carried out in the absence of solar radiation. In addition, figure 6 shows the output of the results of the CFD model for the same hourly intervals. Based on these results, a graph was produced to show the distribution of the indoor room temperature in relation to the room depth (Fig. 7).

\begin{tabular}{|l|c|c|c|c|c|}
\cline { 3 - 7 } \multicolumn{2}{c|}{} & \multicolumn{5}{c|}{ Test duration FF++ (CFD) } \\
\hline Room under study & $60 \mathrm{~min}$ & $120 \mathrm{~min}$ & $180 \mathrm{~min}$ & $240 \mathrm{~min}$ \\
\hline $0.5 \mathrm{~m}$ Room temperature & T $0.5 \mathrm{~m}$ & 20.15 & 21.50 & 22.29 & 22.74 \\
\hline $1 \mathrm{~m}$ Room temperature & T $1 \mathrm{~m}$ & 18.82 & 19.35 & 19.65 & 19.82 \\
\hline $1.22 \mathrm{~m}$ Room temperature & T $1.22 \mathrm{~m}$ & 18.53 & 18.87 & 19.07 & 19.18 \\
\hline $2 \mathrm{~m}$ Room temperature & T $2 \mathrm{~m}$ & 18.07 & 18.12 & 18.15 & 18.16 \\
\hline Mur neutralisant & & $60 \mathrm{~min}$ & $120 \mathrm{~min}$ & $180 \mathrm{~min}$ & $240 \mathrm{~min}$ \\
\hline Exterior glazing temperature & Teg & -3.38 & 3.76 & 6.41 & 7.41 \\
\hline Interior glazing temperature & Tig & 21.89 & 25.24 & 27.10 & 28.47 \\
\hline
\end{tabular}

Table 7. Temperatures of the room and mur neutralisant following CFD simulations with air heating.

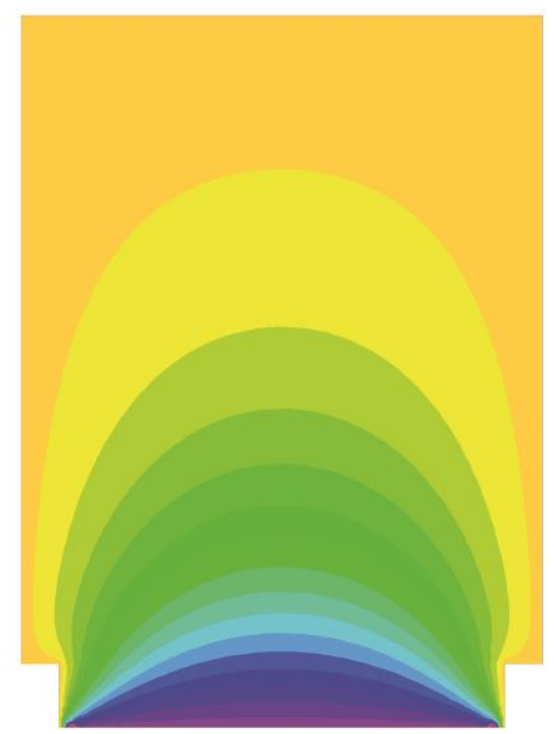

6a. $60 \mathrm{~min}$.

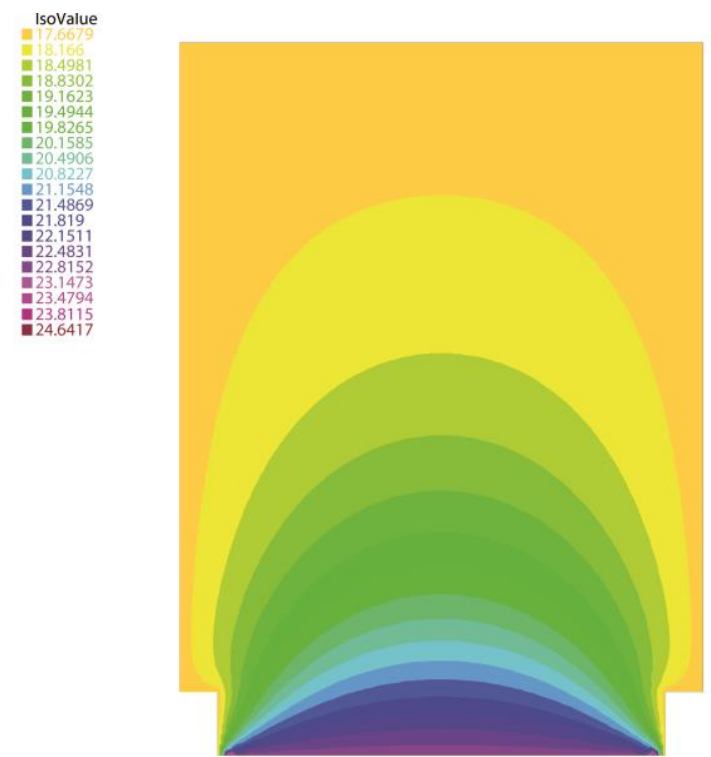

6b. $120 \mathrm{~min}$. 


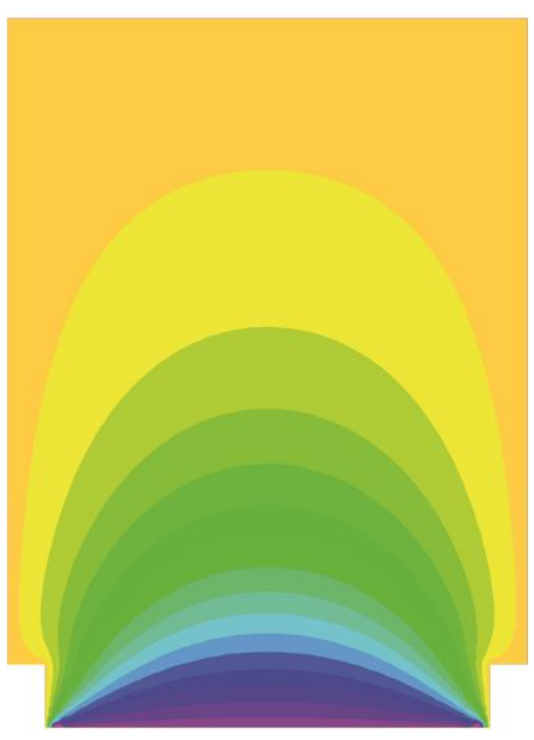

6c. $180 \mathrm{~min}$.
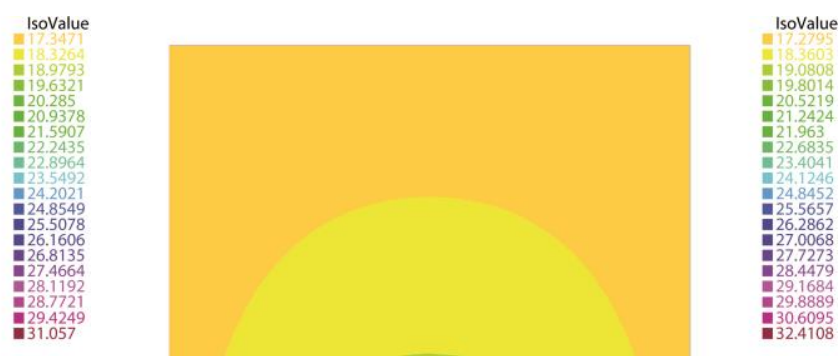

6d. $240 \mathrm{~min}$.

6. Results of the CFD simulation at hourly intervals (horizontal model section) with air heating.

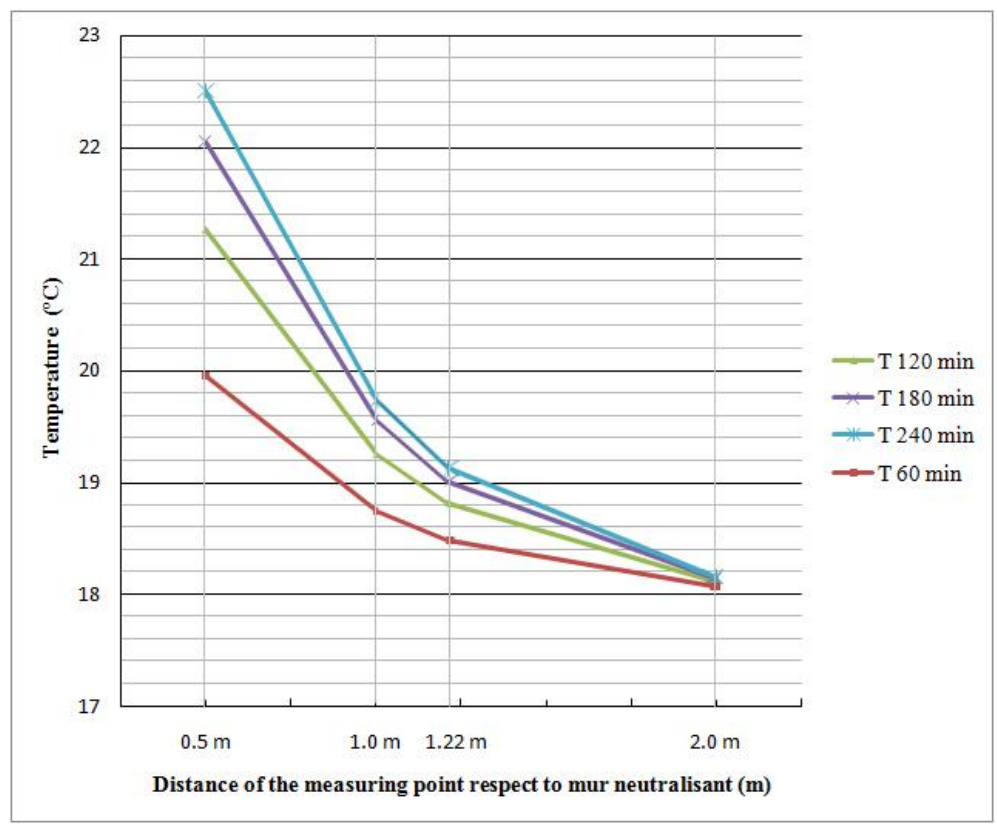

7. Evolution of indoor temperature at different points of the room over 4 hours with air heating.

Figure 7 shows that with the same flow temperature in the active chamber as the SG model, $31.5^{\circ} \mathrm{C}$, and the mass flow from the same airflow in the chamber, $100 \mathrm{l} / \mathrm{s}$, the temperature $1.22 \mathrm{~m}$ deep where Saint Gobain placed temperature probes is around $19^{\circ} \mathrm{C}$, a degree higher than that of SG. Convergence at $18^{\circ} \mathrm{C}$ takes place 2 $\mathrm{m}$ from the mur neutralisant. Therefore, with this temperature and flow the values occurring in the room are similar to those Saint Gobain regarded as comfort level in winter, or even slightly higher. 
As is to be expected the indoor and outdoor surface temperature of the glazing in the mur neutralisant evolve over time, increasing perceptibly to values around $7^{\circ} \mathrm{C}$ outdoors and $28.4^{\circ} \mathrm{C}$ indoors. Therefore, given that the difference in temperature between both models is around $5 \%$, it can be considered that in winter conditions without solar radiation there is adjustment between them.

\section{Establishment of other hypotheses on environmental conditions and the operation of the mur neutralisant}

Once the adjustment between both models was established, different hypotheses were proposed for environmental and operation conditions of the mur neutralisant, but the CFD model of the test room was replaced with a model of the main dormitory of the City of Refuge (figure 8) (hereafter CR model), with a surface area of $297.67 \mathrm{~m}^{2}$. Figure $9 \mathrm{a}$ shows this model and figure $9 \mathrm{~b}$ shows the meshing applied to it. The southfacing façade of the Parisian CR model is a mur neutralisant $37.20 \mathrm{~m}$ long and $2.80 \mathrm{~m}$ high, with a surface area of $104.16 \mathrm{~m}^{2}$ and a $110 \mathrm{~mm}$ cavity with $7 \mathrm{~mm}$ double glazing $(7+110+7)$.

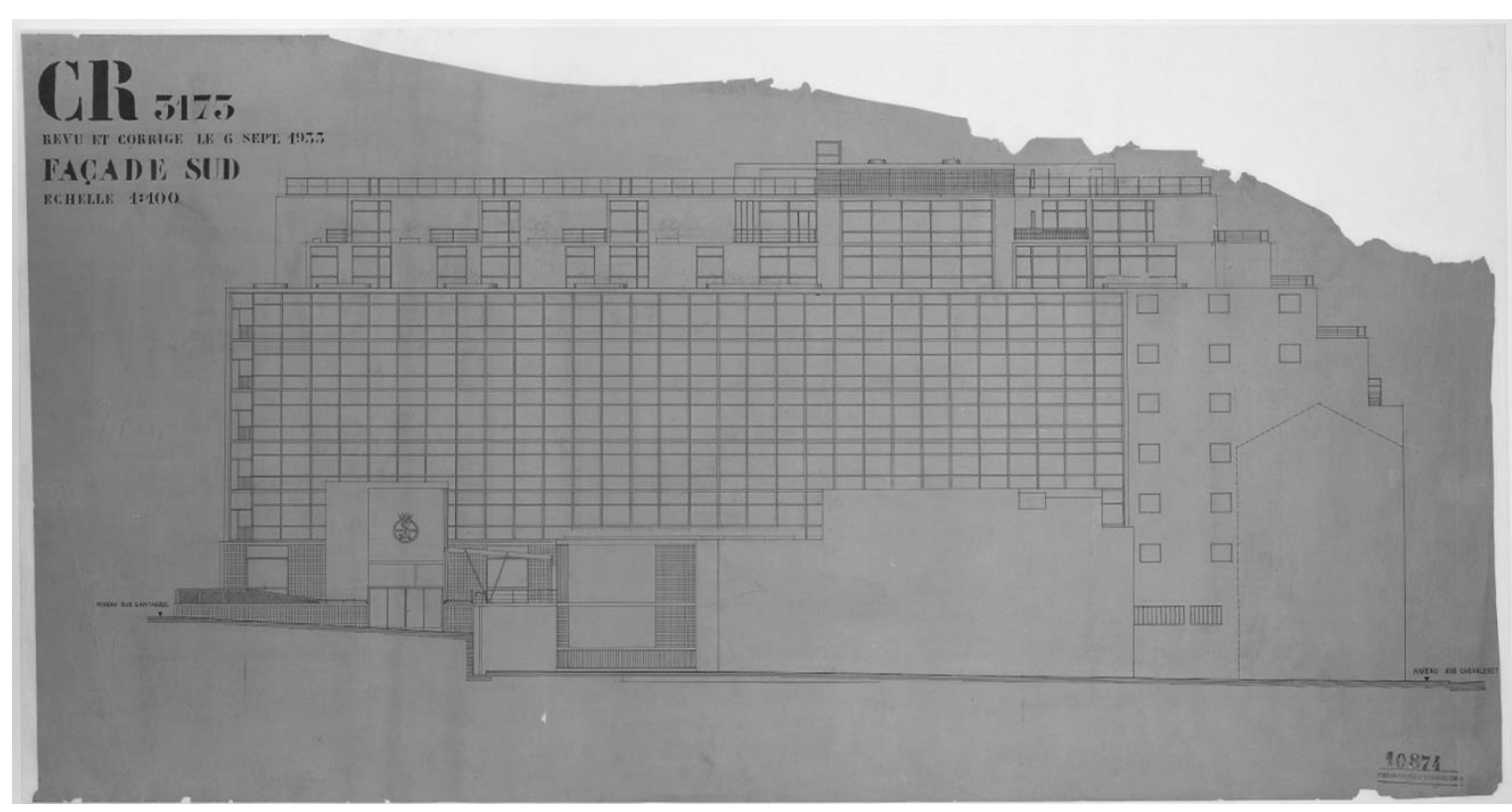

8a. South façade of the City of Refuge ${ }^{17}$.

\footnotetext{
${ }^{17}$ Fundation Le Corbusier. CR 3173. FLC 10874. OFLC-ADAGP
} 


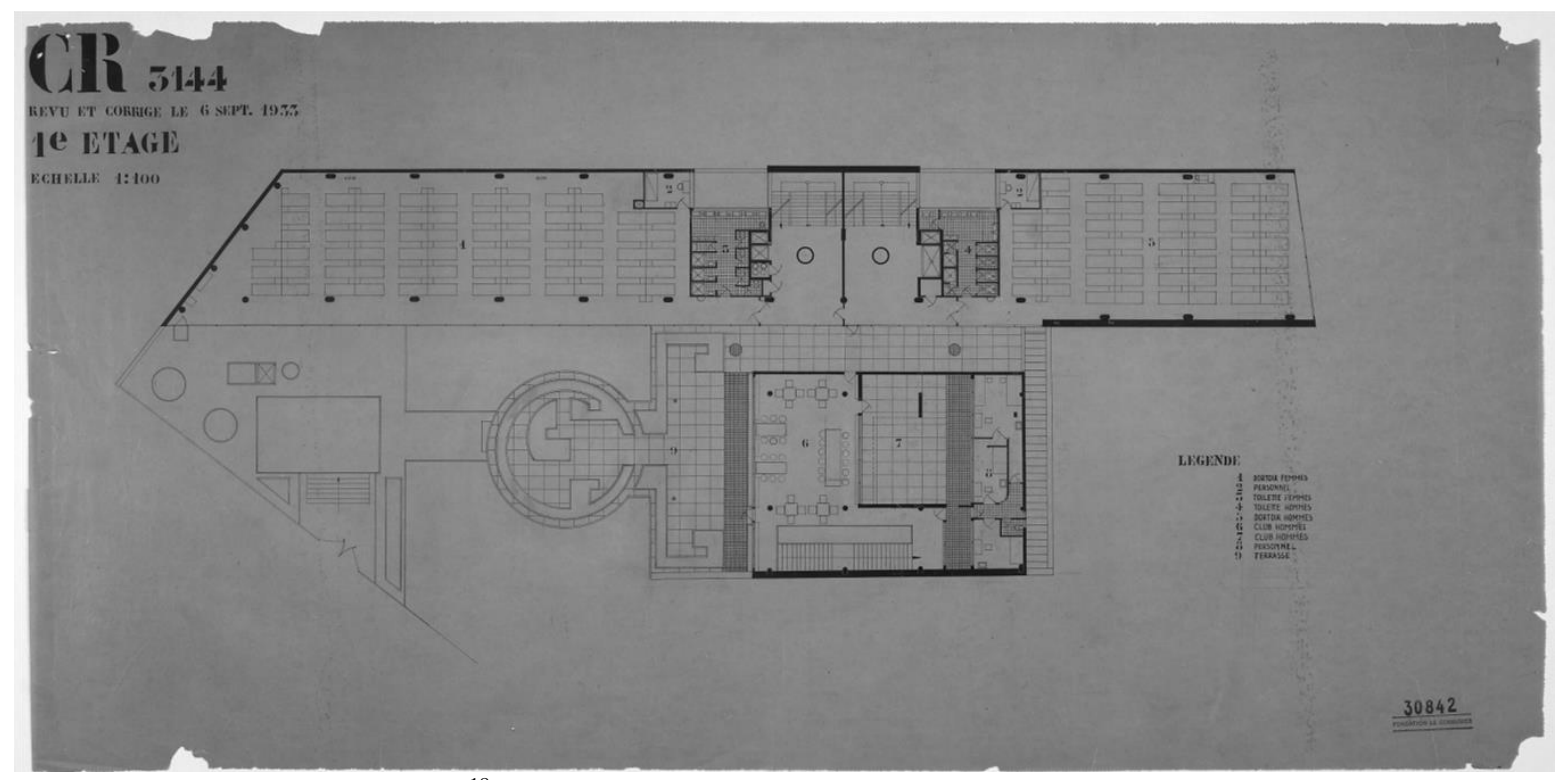

8 b. First floor of the City of Refuge ${ }^{18}$.

8. Drawings of the City of Refuge. 6 September 1933.

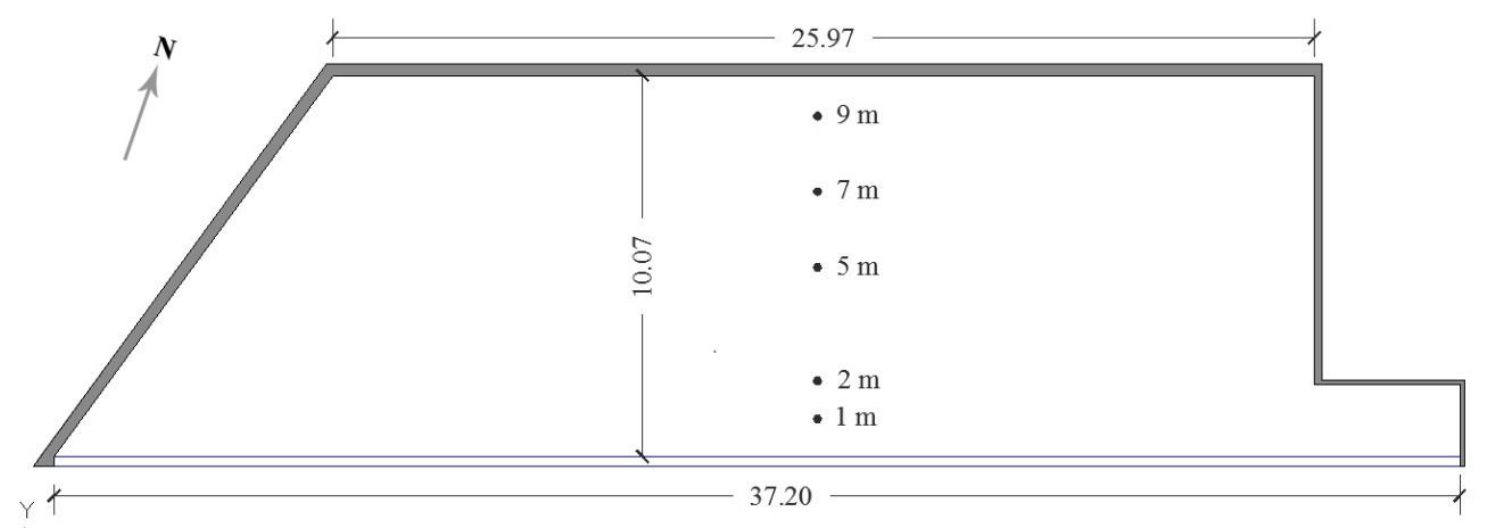

9a. Dimensions and points of measurement in the room in the City of Refuge.

${ }^{18}$ Fundation Le Corbusier. CR 3144. FLC 30842. OFLC-ADAGP 


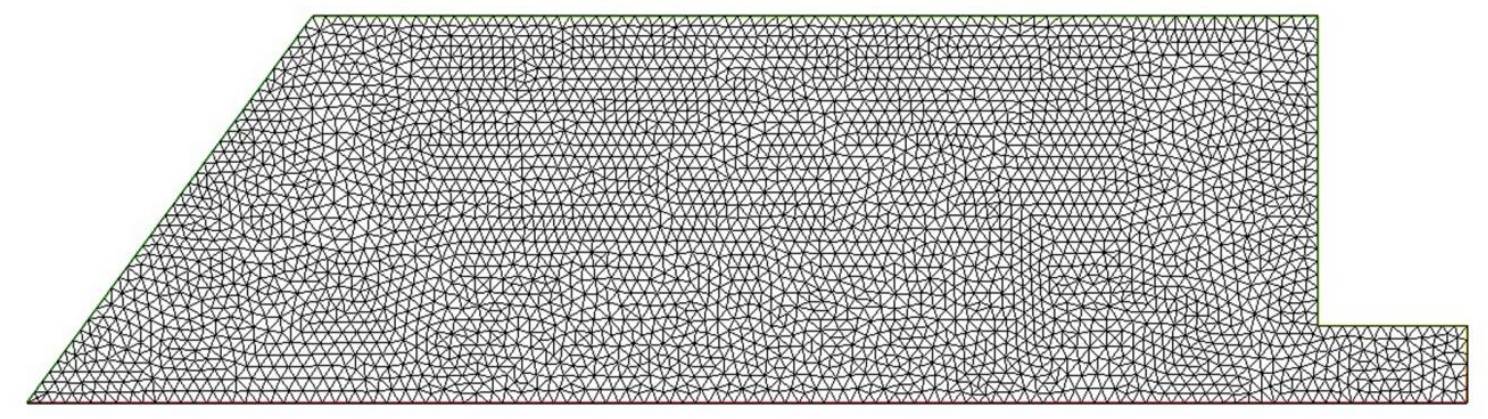

9b. CFD mesh density in the room in the City of Refuge.

9. CFD Model.

\subsection{CFD simulations in the City of Refuge model in winter with absence and presence of solar radiation}

Simulations were carried out on the CR model from the 27 to 31 December, but the only results specified here are those of the third and coldest day, 30 December, with an outdoor temperature ranging from $-6{ }^{\circ} \mathrm{C}$ at $8: 00 \mathrm{~h}$ to $1{ }^{\circ} \mathrm{C}$ at $15: 00 \mathrm{~h}$ (table 8 ), once the operating conditions of the thermal system were stabilised. Both the presence and absence of solar radiation -not included by Saint Gobain in the tests- were simulated, in order to assess solar incidence on the evolution of indoor temperatures. The airflow used in the cavity was 100 1/s per metre along the mur neutralisant, as recommended by Saint Gobain engineers following the tests. The heat coefficient value $(\mathrm{Q})$ used was the same as that calculated by Saint Gobain engineers for this configuration of mur neutralisant and airflows. The following formula, proposed by Lyon, and based on outdoor temperature was used to calculate airflow temperature:

$$
\theta_{E}=21.6-\frac{T f}{5}
$$

where $\theta_{\mathrm{E}}$ equals airflow temperature and $\mathrm{T}_{\mathrm{f}}$ the outdoor temperature, both in ${ }^{\circ} \mathrm{C}$.

However, unlike constant airflow temperature criteria followed in the Saint Gobain tests, a simplification which could be considered as valid given the test duration, our simulations have considered a variable airflow temperature based on outdoor temperature, with no variation given the limited thermal inertia of the mur neutralisant. These calculations were spread out over four days, with day-night thermal oscillations, and a maximum value of $7^{\circ} \mathrm{C}$ was reached on the third day (30 December). Therefore, applying Lyon's formula to each hour of these days, the airflow temperature varies depending on the outdoor temperature.

\subsubsection{Simulation with solar radiation}

Table 8 shows the results for simulations with solar radiation. The fifth and sixth columns show the respective surface temperatures of the outer and inner glazing of the mur neutralisant. The fourth column of the table gives the variable hot airflow temperature in the active chamber, values oscillating from $22.8{ }^{\circ} \mathrm{C}$ at $8: 00 \mathrm{~h}$ to $21.4^{\circ} \mathrm{C}$ at 15:00h. These are relatively low values given the outdoor temperatures and the relatively low airflow, 100 1/s per metre along the mur neutralisant, and provide an idea of the efficiency of the thermal system. 
Figures 10 and 11 show the results in a horizontal section at 8:00 $\mathrm{h}$ and 15:00 $\mathrm{h}$, when the respective minimum and maximum outdoor temperatures are reached. In addition, figure 12 includes a series of graphs of the evolution of the temperature inside the room on the third day at hourly intervals depending on the distance from the mur neutralisant as well as its relationship to the outdoor temperature.

As can be seen, the maximum indoor temperatures are reached at 15:00 $\mathrm{h}$ and the minimum ones at 7:00 $\mathrm{h}$. The temperatures reached at the same distance from the mur neutralisant are fairly uniform throughout the day, with temperature differences between the two test hours of $1.14^{\circ} \mathrm{C}$ at $1 \mathrm{~m}, 0.95{ }^{\circ} \mathrm{C}$ at $2 \mathrm{~m}, 0.49{ }^{\circ} \mathrm{C}$ at $5 \mathrm{~m}, 0.26{ }^{\circ} \mathrm{C}$ at 7 $\mathrm{m}$ and $0.09^{\circ} \mathrm{C}$ at $9 \mathrm{~m}$. This uniformity of temperature therefore increases throughout the day with the distance from the mur neutralisant. The thermal uniformity on the outdoor glazing of the mur neutralisant is also significant. Although outdoor temperature varied by $7^{\circ} \mathrm{C}$ on that day, the superficial temperature of the outdoor glazing only varied by $2.58^{\circ} \mathrm{C}$.

As was to be expected, there is less thermal uniformity in the room, although all its points fall within the temperature comfort band during the day, with a maximum temperature value of $23.73{ }^{\circ} \mathrm{C}$, at $1 \mathrm{~m}$ from the mur at 15:00 h, and a minimum value of $18.49^{\circ} \mathrm{C}$, at $9 \mathrm{~m}$ from the mur from 7:00 to 9:00 h. At 15:00 h the difference in temperatures $1 \mathrm{~m}$ from the wall and $9 \mathrm{~m}$ from the wall (end locations in the room) is $5.15^{\circ} \mathrm{C}$, and at 7:00 $\mathrm{h}$ it is $4.10^{\circ} \mathrm{C}$. The difference in the half of the room closest to the mur neutralisant is more pronounced, as the differences in temperature $5 \mathrm{~m}$ from the mur neutralisant and $9 \mathrm{~m}$. from the mur neutralisant are $2.41{ }^{\circ} \mathrm{C}$ at 15:00 $\mathrm{h}$ and 2.01 at 7:00 h.

As stated by our research group in the CFD simulations using a numerical model of the combined effect of the mur neutralisant and respiration exacte, the function of respiration exacte is not merely limited to improving indoor air quality but also contributes to greater thermal uniformity in the room, thus improving the comfort conditions of the thermal system ${ }^{19}$.

\footnotetext{
${ }^{19}$ Ramírez Balas, C.; Fernández Nieto, E.D.; Narbona Reina,G.; Sendra, J. J.; Suárez, R. "Numerical simulation of the temperature evolution in a room with a mur neutralisant. Application to 'The City of Refuge' by Le Corbusier". Energy and buildings. 2015. 86. pp. 708-722.
} 


\begin{tabular}{|c|c|c|c|c|c|c|c|c|c|c|}
\hline 30-Dec & $\begin{array}{c}\text { Io } \\
\mathrm{W} / \mathrm{m}^{2}\end{array}$ & $\begin{array}{l}\text { Text } \\
{ }^{\circ} \mathrm{C}\end{array}$ & $\begin{array}{l}\text { Timp } \\
{ }^{\circ} \mathrm{C}\end{array}$ & $\begin{array}{l}\text { Teg } \\
{ }^{\circ} \mathrm{C}\end{array}$ & $\begin{array}{l}\text { Tig } \\
{ }^{\circ} \mathrm{C}\end{array}$ & $\begin{array}{c}\mathrm{T}(1 \mathrm{~m}) \\
{ }^{\circ} \mathrm{C}\end{array}$ & $\begin{array}{c}\mathrm{T}(2 \mathrm{~m}) \\
{ }^{\circ} \mathrm{C}\end{array}$ & $\begin{array}{c}\mathrm{T}(5 \mathrm{~m}) \\
{ }^{\circ} \mathrm{C}\end{array}$ & $\begin{array}{c}\mathrm{T}(7 \mathrm{~m}) \\
{ }^{\circ} \mathrm{C}\end{array}$ & $\begin{array}{c}\mathrm{T}(9 \mathrm{~m}) \\
{ }^{\circ} \mathrm{C}\end{array}$ \\
\hline 1:00 & 229 & -3.8 & 22.36 & 11.92 & 22.53 & 22.68 & 22.16 & 20.58 & 19.54 & 18.51 \\
\hline 2:00 & 228 & -4 & 22.4 & 11.78 & 22.5 & 22.66 & 22.13 & 20.56 & 19.53 & 18.51 \\
\hline 3:00 & 232 & -3 & 22.2 & 11.73 & 22.47 & 22.62 & 22.11 & 20.55 & 19.52 & 18.51 \\
\hline 4:00 & 227 & -4.2 & 22.44 & 11.61 & 22.45 & 22.61 & 22.09 & 20.53 & 19.51 & 18.50 \\
\hline 5:00 & 228 & -4 & 22.4 & 11.53 & 22.44 & 22.59 & 22.07 & 20.52 & 19.50 & 18.50 \\
\hline $6: 00$ & 224 & -5 & 22.6 & 11.39 & 22.44 & 22.59 & 22.07 & 20.51 & 19.49 & 18.50 \\
\hline 7:00 & 225 & -4.8 & 22.56 & 11.29 & 22.44 & 22.59 & 22.07 & 20.50 & 19.49 & 18.49 \\
\hline $8: 00$ & 221 & -6 & 22.8 & 11.13 & 22.47 & 22.61 & 22.08 & 20.50 & 19.49 & 18.49 \\
\hline 9:00 & 226 & -5 & 22.6 & 11.11 & 22.49 & 22.63 & 22.09 & 20.51 & 19.49 & 18.49 \\
\hline $10: 00$ & 287 & -4.3 & 22.46 & 11.31 & 22.64 & 22.71 & 22.14 & 20.52 & 19.50 & 18.50 \\
\hline 11:00 & 628 & -4 & 22.4 & 11.72 & 22.95 & 22.92 & 22.28 & 20.56 & 19.51 & 18.50 \\
\hline $12: 00$ & 865 & -2 & 22 & 12.34 & 23.30 & 23.20 & 22.50 & 20.64 & 19.55 & 18.51 \\
\hline $13: 00$ & 1017 & -0.1 & 21.62 & 12.98 & 23.59 & 23.46 & 22.72 & 20.76 & 19.61 & 18.53 \\
\hline 14:00 & 932 & 0 & 21.6 & 13.44 & 23.78 & 23.65 & 22.91 & 20.89 & 19.68 & 18.55 \\
\hline $15: 00$ & 861 & 1 & 21.4 & 13.69 & 23.78 & 23.73 & 23.02 & 20.99 & 19.75 & 18.58 \\
\hline $16: 00$ & 531 & 0 & 21.6 & 13.60 & 23.62 & 23.66 & 23.01 & 21.05 & 19.80 & 18.59 \\
\hline $17: 00$ & 279 & -1 & 21.8 & 13.34 & 23.41 & 23.51 & 22.92 & 21.06 & 19.82 & 18.60 \\
\hline 18:00 & 237 & -2 & 22 & 13.05 & 23.23 & 23.37 & 22.80 & 21.02 & 19.81 & 18.60 \\
\hline 19:00 & 236 & -2.3 & 22.06 & 12.80 & 23.09 & 23.24 & 22.69 & 20.96 & 19.78 & 18.59 \\
\hline 20:00 & 240 & -3 & 22.2 & 12.56 & 22.98 & 23.14 & 22.59 & 20.89 & 19.74 & 18.58 \\
\hline 21:00 & 244 & -4 & 22.4 & 12.30 & 22.91 & 23.07 & 22.52 & 20.84 & 19.70 & 18.57 \\
\hline $22: 00$ & 250 & -3.6 & 22.32 & 12.13 & 22.84 & 23.00 & 22.46 & 20.79 & 19.67 & 18.56 \\
\hline 23:00 & 257 & -3 & 22.2 & 12.04 & 22.78 & 22.94 & 22.40 & 20.75 & 19.65 & 18.55 \\
\hline $24: 00$ & 261 & -2 & 22 & 12.05 & 22.71 & 22.87 & 22.34 & 20.71 & 19.63 & 18.54 \\
\hline
\end{tabular}

Table 8. Results of the temperatures for the mur neutralisant and different points of the room on 30 December, with solar radiation.

IsoValue

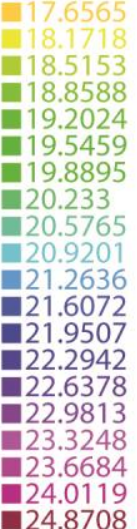

10. Results of the CFD simulation (horizontal section of the model) with air heating and solar radiation: 30 December, 8:00 h. 


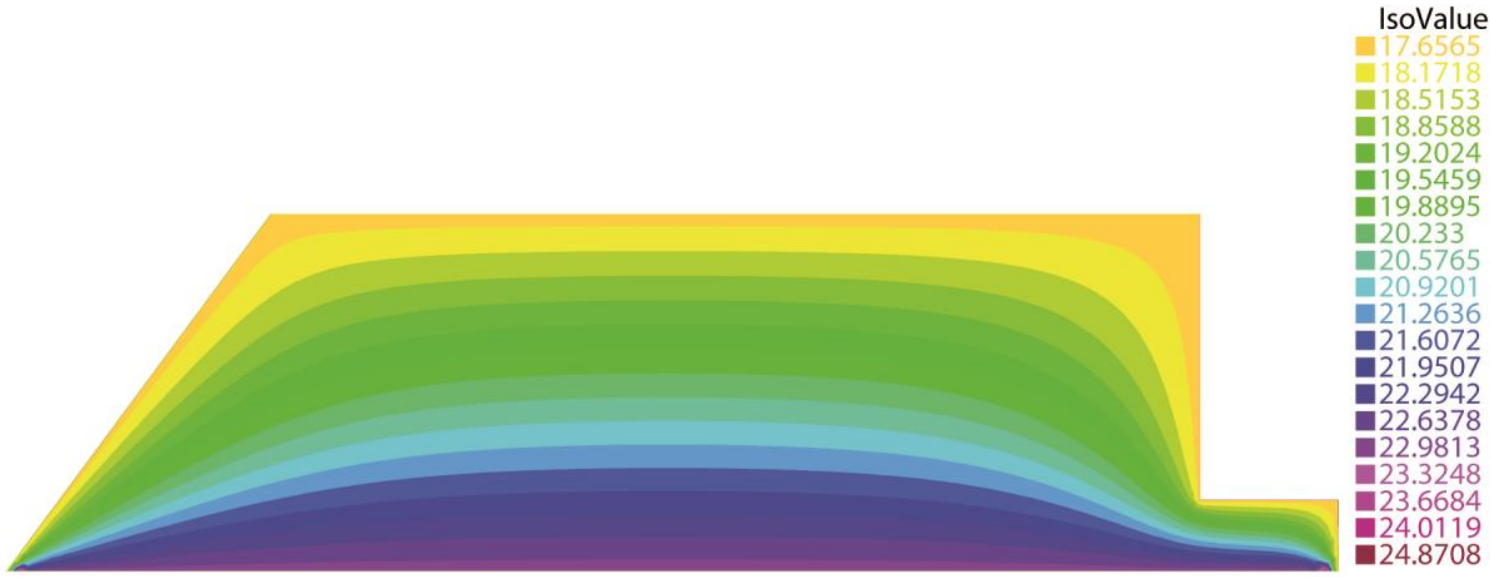

11. Results of the CFD simulation (horizontal section of the model) with air heating and solar radiation: 30 December, 15:00 h.

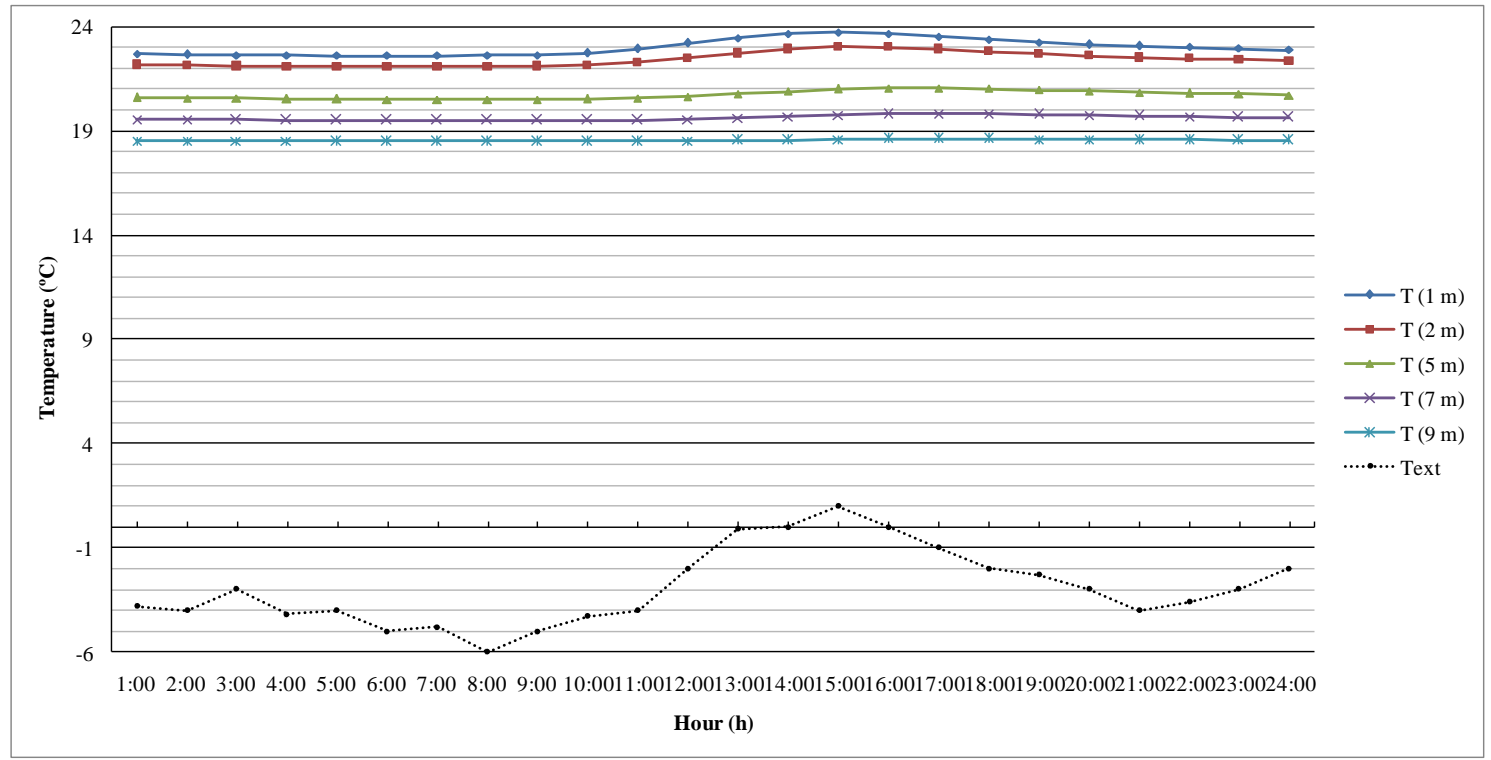

12. Evolution of indoor temperature at different points in the room for 30 December, with solar radiation, with airflow q=100 $1 / \mathrm{s}$ and a variable airflow temperature in the active chamber.

\subsubsection{Simulation without solar radiation}

Table 9 and figures 13,14 and 15 show the same results in the absence of solar radiation, confirming the influence of solar radiation on the operation of the system. Without radiation uniformity throughout the day was very pronounced. In figure 15 the graphs showing the evolution of indoor temperatures at different distances from the mur neutralisant are almost straight lines. The maximum difference is $0.12{ }^{\circ} \mathrm{C}$ at $1 \mathrm{~m}$ from the mur compared with $1.14{ }^{\circ} \mathrm{C}$ occurring with solar radiation. Uniformity in the surface temperature of the outer glazing is also more pronounced: there is a maximum oscillation of only $0.99{ }^{\circ} \mathrm{C}$ in the exterior surface temperature compared with the $7^{\circ} \mathrm{C}$ variation in outdoor temperature.

Equally, thermal uniformity in the room is more pronounced without solar radiation. The maximum indoor temperature is $21.18^{\circ} \mathrm{C}$ at $15: 00 \mathrm{~h}$ and $1 \mathrm{~m}$ from the mur neutralisant, and the minimum is $18.32{ }^{\circ} \mathrm{C}$ at $1: 00 \mathrm{~h}$ and $9 \mathrm{~m}$ from the mur neutralisant. There is therefore a difference of only $2.86{ }^{\circ} \mathrm{C}$ for these positions and 
extreme hours. At 15:00 h, the difference between indoor temperature at $1 \mathrm{~m}$ and $9 \mathrm{~m}$ from the mur neutralisant is $2.82{ }^{\circ} \mathrm{C}$, compared with a difference of $5.15^{\circ} \mathrm{C}$ occurring with solar radiation.

As regards the temperature values reached in both hypotheses it can be observed that at 15:00 $\mathrm{h}$ (day), this difference is $2.65^{\circ} \mathrm{C}$ at $1 \mathrm{~m}, 2.18^{\circ} \mathrm{C}$ at $2 \mathrm{~m}, 1.20^{\circ} \mathrm{C}$ at $5 \mathrm{~m}, 0.68^{\circ} \mathrm{C}$ at $5 \mathrm{~m}$ and $0.18^{\circ} \mathrm{C}$ at $9 \mathrm{~m}$, while at $1: 00 \mathrm{~h}$ (night) the difference is $1.33^{\circ} \mathrm{C}$ at $1 \mathrm{~m}, 1.20^{\circ} \mathrm{C}$ at $2 \mathrm{~m}, 0.77^{\circ} \mathrm{C}$ at $5 \mathrm{~m}, 0.46^{\circ} \mathrm{C}$ at $5 \mathrm{~m}$ and $0.16^{\circ} \mathrm{C}$ at $9 \mathrm{~m}$.

It should be noted that based on the solar radiation values extracted from the climate table, 30 December was a fairly sunny day. On an overcast day, the worst case scenario for winter, the results for both hypotheses simulated would be quite similar.

\begin{tabular}{|c|c|c|c|c|c|c|c|c|c|c|}
\hline 30-Dec & $\begin{array}{c}\text { Io } \\
\mathrm{W} / \mathrm{m}^{2}\end{array}$ & $\begin{array}{l}\text { Text } \\
{ }^{\circ} \mathrm{C}\end{array}$ & $\begin{array}{l}\text { Timp } \\
{ }^{\circ} \mathrm{C}\end{array}$ & $\begin{array}{l}\text { Teg } \\
{ }^{\circ} \mathrm{C}\end{array}$ & $\begin{array}{l}\text { Tig } \\
{ }^{\circ} \mathrm{C}\end{array}$ & $\begin{array}{c}\mathrm{T}(1 \mathrm{~m}) \\
{ }^{\circ} \mathrm{C}\end{array}$ & $\begin{array}{c}\mathrm{T}(2 \mathrm{~m}) \\
{ }^{\circ} \mathrm{C}\end{array}$ & $\begin{array}{c}\mathrm{T}(5 \mathrm{~m}) \\
{ }^{\circ} \mathrm{C}\end{array}$ & $\begin{array}{c}\mathrm{T}(7 \mathrm{~m}) \\
{ }^{\circ} \mathrm{C}\end{array}$ & $\begin{array}{c}\mathrm{T}(9 \mathrm{~m}) \\
{ }^{\circ} \mathrm{C}\end{array}$ \\
\hline 1:00 & 0 & -3.8 & 22.36 & 10.82 & 21.52 & 21.10 & 20.72 & 19.65 & 18.98 & 18.32 \\
\hline $2: 00$ & 0 & -4 & 22.4 & 10.73 & 21.33 & 21.14 & 20.76 & 19.67 & 18.99 & 18.33 \\
\hline 3:00 & 0 & -3 & 22.2 & 10.70 & 21.54 & 21.16 & 20.78 & 19.69 & 19.00 & 18.33 \\
\hline 4:00 & 0 & -4.2 & 22.44 & 10.62 & 21.51 & 21.19 & 20.81 & 19.71 & 19.01 & 18.34 \\
\hline $5: 00$ & 0 & -4 & 22.4 & 10.54 & 21.69 & 21.22 & 20.84 & 19.73 & 19.02 & 18.34 \\
\hline 6:00 & 0 & -5 & 22.6 & 10.43 & 21.64 & 21.26 & 20.87 & 19.74 & 19.03 & 18.34 \\
\hline 7:00 & 0 & -4.8 & 22.56 & 10.34 & 21.85 & 21.30 & 20.90 & 19.76 & 19.04 & 18.35 \\
\hline 8:00 & 0 & -6 & 22.8 & 10.20 & 21.66 & 21.34 & 20.94 & 19.78 & 19.05 & 18.35 \\
\hline 9:00 & 0 & -5 & 22.6 & 10.17 & 21.53 & 21.38 & 20.97 & 19.81 & 19.07 & 18.35 \\
\hline $10: 00$ & 0 & -4.3 & 22.46 & 10.19 & 21.47 & 21.39 & 20.99 & 19.82 & 19.08 & 18.36 \\
\hline $11: 00$ & 0 & -4 & 22.4 & 10.24 & 21.21 & 21.40 & 21.00 & 19.84 & 19.09 & 18.36 \\
\hline $12: 00$ & 0 & -2 & 22 & 10.42 & 21.17 & 21.38 & 20.99 & 19.84 & 19.09 & 18.36 \\
\hline $13: 00$ & 0 & -0.1 & 21.62 & 10.69 & 21.10 & 21.32 & 20.95 & 19.84 & 19.09 & 18.36 \\
\hline $14: 00$ & 0 & 0 & 21.6 & 10.92 & 21.04 & 21.25 & 20.90 & 19.81 & 19.09 & 18.36 \\
\hline $15: 00$ & 0 & 1 & 21.4 & 11.16 & 20.97 & 21.18 & 20.84 & 19.79 & 19.07 & 18.36 \\
\hline $16: 00$ & 0 & 0 & 21.6 & 11.28 & 21.00 & 21.13 & 20.79 & 19.75 & 19.05 & 18.35 \\
\hline $17: 00$ & 0 & -1 & 21.8 & 11.29 & 21.19 & 21.09 & 20.76 & 19.72 & 19.03 & 18.34 \\
\hline 18:00 & 0 & -2 & 22 & 11.23 & 21.24 & 21.09 & 20.74 & 19.70 & 19.02 & 18.34 \\
\hline $19: 00$ & 0 & -2.3 & 22.06 & 11.16 & 21.36 & 21.09 & 20.74 & 19.69 & 19.01 & 18.34 \\
\hline 20:00 & 0 & -3 & 22.2 & 11.05 & 21.54 & 21.11 & 20.75 & 19.69 & 19.01 & 18.33 \\
\hline 21:00 & 0 & -4 & 22.4 & 10.90 & 21.45 & 21.14 & 20.77 & 19.69 & 19.01 & 18.33 \\
\hline $22: 00$ & 0 & -3.6 & 22.32 & 10.82 & 21.34 & 21.17 & 20.79 & 19.70 & 19.01 & 18.33 \\
\hline 23:00 & 0 & -3 & 22.2 & 10.81 & 21.15 & 21.18 & 20.81 & 19.72 & 19.02 & 18.34 \\
\hline 24:00 & 0 & -2 & 22 & 10.86 & 21.12 & 21.18 & 20.81 & 19.72 & 19.02 & 18.34 \\
\hline
\end{tabular}

Table 9. Results of the temperatures of the mur neutralisant and the room at the different points measured for 30 December, without solar radiation. 
IsoValue

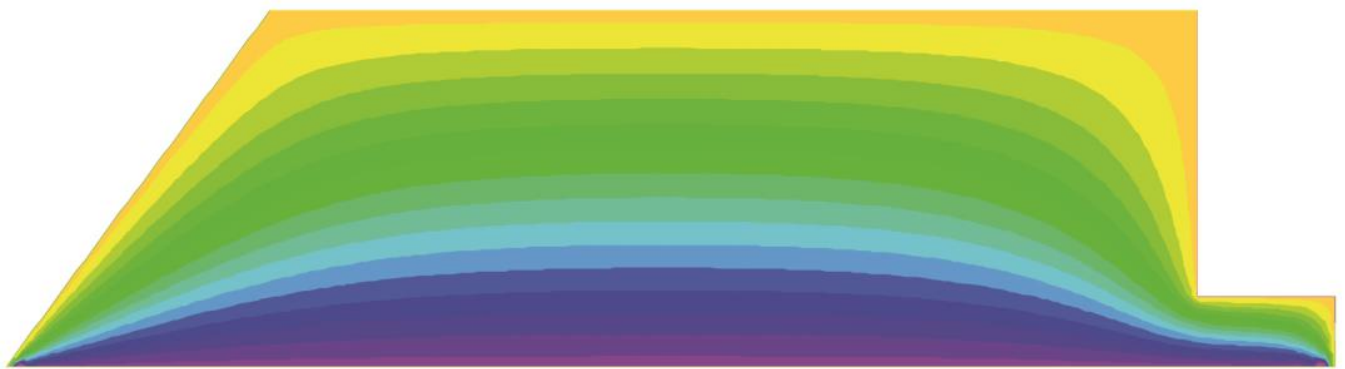

19.6294

$-19.8801$

20.1308

20.3814

20.6321

20.8828

$-21.3842$

$-21.6348$

21.8855

- 22.1362

22.3869

23.0136

13. Results of the CFD simulation (horizontal section of the model) with air heating and no solar radiation: 30 December, 8:00 h.

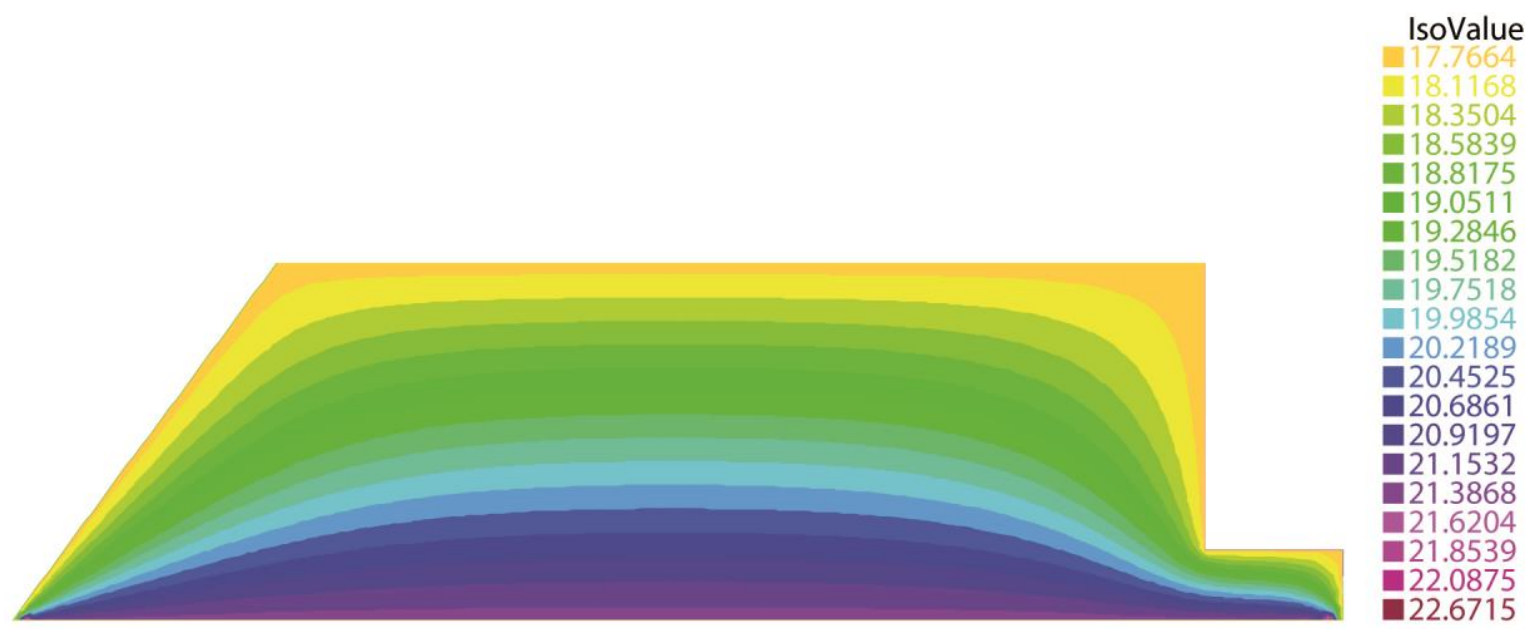

14. Results of the CFD simulation (horizontal section of the model) with air heating and no solar radiation: 30 December, 15:00 h. 


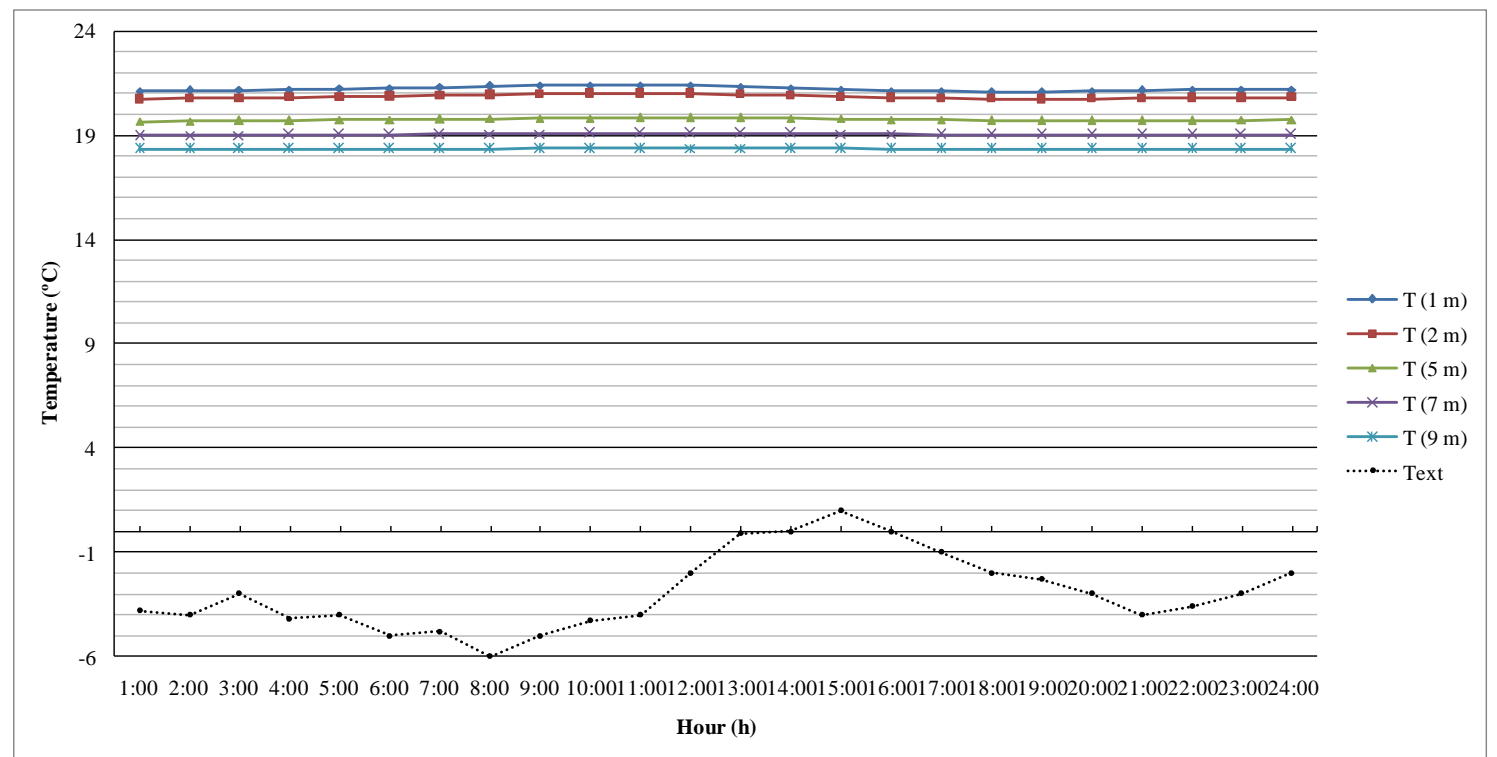

15. Evolution of indoor temperature at different points in the room on 30 December, without solar radiation, with airflow $\mathrm{q}=100 \mathrm{l} / \mathrm{s}$ and variable airflow temperature in the active chamber.

\subsection{CFD simulations of the City of Refuge model in the summer}

Simulations were carried out on the CR model from 29 June to 3 July, but as in the case of winter, only the results for the third and hottest day, 2 July, were specified once the operating conditions of the thermal system were stabilised. In this case only solar radiation was simulated. The airflow selected in the air cavity was also 100 1/s per metre along the mur neutralisant. Lyon's formula was also used to calculate the airflow temperature, which was still considered variable depending on outdoor temperature.

Table 10 shows the results for the simulations with solar radiation. The respective surface temperatures of the outer and inner glazing of the mur neutralisant are shown in the fifth and sixth columns. The fourth column of the table shows the variable hot airflow temperature in the active chamber, with values ranging from $18.2^{\circ} \mathrm{C}$ at 6:00 $\mathrm{h}$ to $15.6^{\circ} \mathrm{C}$ at 14:00-15:00 $\mathrm{h}$. These are quite high values given the outdoor temperatures and relatively low airflow, 100 l/s per metre along the mur neutralisant, and provide an idea of the efficiency of the thermal system.

Figure 16 shows the results in a horizontal section at 15:00 h, when the maximum exterior temperature is reached. In addition, figure 17 includes a series of graphs showing the evolution of the temperature inside the room on the third day at hourly intervals, depending on the distance from the mur neutralisant and its relationship with the outdoor temperature.

As can be observed the maximum indoor temperatures are reached between 15:00 and 18:00 $\mathrm{h}$ and the minimum temperatures between 6:00 and 8:00 h. Relatively uniform temperatures are obtained throughout the day at the same distance from the mur neutralisant, although logically this homogeneity is less pronounced than in winter given the greater incidence of solar radiation and the greater variability in outdoor temperatures, with differences at these extreme times of $3.39{ }^{\circ} \mathrm{C}$ at $1 \mathrm{~m}, 2.92{ }^{\circ} \mathrm{C}$ at $2 \mathrm{~m}, 1.73{ }^{\circ} \mathrm{C}$ at $5 \mathrm{~m}, 1.01{ }^{\circ} \mathrm{C}$ at $7 \mathrm{~m}$ and $0.34{ }^{\circ} \mathrm{C}$ at $9 \mathrm{~m}$. Therefore, as in winter, the uniformity of these temperatures increases throughout the day along with the distance from the mur neutralisant. The thermal uniformity on the outer glazing of the mur neutralisant is also significant. Although outdoor temperature varies by $13{ }^{\circ} \mathrm{C}$ on 2 July, the surface temperature of the outer glazing only varies by $6.33^{\circ} \mathrm{C}$, slightly less than half the previous value. 
Although there was less thermal uniformity in the room throughout the day, all points in the room were within the comfort band, with a maximum temperature value of $23.80^{\circ} \mathrm{C}, 1 \mathrm{~m}$ from the mur neutralisant at 15:00 h, and a minimum value of $18.27^{\circ} \mathrm{C} 9 \mathrm{~m}$ from the mur neutralisant and from 7:00 to 8:00 $\mathrm{h}$, values very similar to those obtained in winter at the same points in the room and at the same time. This shows the potential of the thermal system to maintain similar environmental conditions inside, regardless of the outdoor temperature. At 15:00 $\mathrm{h}$ the difference in temperatures $1 \mathrm{~m}$ from the mur and $9 \mathrm{~m}$ from the mur (extreme locations in the room) was $5.25^{\circ} \mathrm{C}$, and at $6: 00 \mathrm{~h}$ it was $2.13^{\circ} \mathrm{C}$. This difference is more pronounced in the half of the room closest to the mur neutralisant, as the differences in temperature $5 \mathrm{~m}$ from the mur neutralisant and $9 \mathrm{~m}$. from the mur were $2.38^{\circ} \mathrm{C}$ at $15: 00 \mathrm{~h}$ and $1.10^{\circ} \mathrm{C}$ at $6: 00 \mathrm{~h}$.

As was already stated in the discussion of results for winter with solar radiation, respiration exacte contributes to greater thermal uniformity in the room, thus improving the comfort conditions of the thermal system.

\begin{tabular}{|c|c|c|c|c|c|c|c|c|c|c|}
\hline 02-Jul & $\begin{array}{c}\text { Io } \\
\mathrm{W} / \mathrm{m}^{2}\end{array}$ & $\begin{array}{l}\text { Text } \\
{ }^{\circ} \mathrm{C}\end{array}$ & $\begin{array}{l}\text { Timp } \\
{ }^{\circ} \mathrm{C}\end{array}$ & $\begin{array}{l}\text { Teg } \\
{ }^{\circ} \mathrm{C}\end{array}$ & $\begin{array}{l}\text { Tig } \\
{ }^{\circ} \mathrm{C}\end{array}$ & $\begin{array}{c}\mathrm{T}(1 \mathrm{~m}) \\
{ }^{\circ} \mathrm{C}\end{array}$ & $\begin{array}{c}\mathrm{T}(2 \mathrm{~m}) \\
{ }^{\circ} \mathrm{C}\end{array}$ & $\begin{array}{c}\mathrm{T}(5 \mathrm{~m}) \\
{ }^{\circ} \mathrm{C}\end{array}$ & $\begin{array}{c}\mathrm{T}(7 \mathrm{~m}) \\
{ }^{\circ} \mathrm{C}\end{array}$ & $\begin{array}{c}\mathrm{T}(9 \mathrm{~m}) \\
{ }^{\circ} \mathrm{C}\end{array}$ \\
\hline 1:00 & 344 & 19.9 & 17.62 & 22.13 & 21.16 & 21.103 & 20.874 & 19.967 & 19.222 & 18.414 \\
\hline 2:00 & 339 & 19 & 17.8 & 21.64 & 20.97 & 20.89 & 20.664 & 19.806 & 19.119 & 18.379 \\
\hline 3:00 & 339 & 19 & 17.8 & 20.83 & 20.66 & 20.706 & 20.486 & 19.67 & 19.031 & 18.349 \\
\hline 4:00 & 335 & 18.2 & 17.96 & 20.57 & 20.57 & 20.555 & 20.336 & 19.556 & 18.957 & 18.323 \\
\hline 5:00 & 334 & 18 & 18 & 20.22 & 20.48 & 20.434 & 20.215 & 19.46 & 18.895 & 18.301 \\
\hline 6:00 & 369 & 17 & 18.2 & 20.2 & 20.5 & 20.415 & 20.158 & 19.386 & 18.844 & 18.284 \\
\hline 7:00 & 715 & 18.7 & 17.86 & 20.54 & 20.72 & 20.559 & 20.227 & 19.359 & 18.814 & 18.272 \\
\hline 8:00 & 1127 & 20 & 17.6 & 21.12 & 21.12 & 20.881 & 20.442 & 19.4 & 18.819 & 18.27 \\
\hline 9:00 & 1557 & 22 & 17.2 & 21.85 & 21.85 & 21.341 & 20.789 & 19.523 & 18.869 & 18.283 \\
\hline 10:00 & 1840 & 23.4 & 16.92 & 22.76 & 22.4 & 21.872 & 21.219 & 19.718 & 18.965 & 18.311 \\
\hline 11:00 & 2046 & 26 & 16.4 & 23.77 & 22.88 & 22.412 & 21.68 & 19.963 & 19.097 & 18.353 \\
\hline $12: 00$ & 2180 & 28 & 16 & 24.76 & 23.21 & 22.919 & 22.131 & 20.23 & 19.251 & 18.402 \\
\hline 13:00 & 2231 & 29.4 & 15.72 & 25.62 & 23.9 & 23.351 & 22.536 & 20.497 & 19.41 & 18.455 \\
\hline $14: 00$ & 2138 & 30 & 15.6 & 26.23 & 23.8 & 23.66 & 22.852 & 20.738 & 19.562 & 18.506 \\
\hline 15:00 & 1923 & 30 & 15.6 & 26.51 & 24.03 & 23.803 & 23.041 & 20.929 & 19.69 & 18.551 \\
\hline $16: 00$ & 1591 & 29.8 & 15.64 & 26.53 & 24.08 & 23.777 & 23.085 & 21.046 & 19.781 & 18.585 \\
\hline $17: 00$ & 1360 & 29 & 15.8 & 26.32 & 23.87 & 23.635 & 23.014 & 21.087 & 19.826 & 18.603 \\
\hline 18:00 & 1140 & 30 & 15.6 & 26.04 & 23.12 & 23.362 & 22.832 & 21.056 & 19.828 & 18.607 \\
\hline 19:00 & 855 & 29 & 15.8 & 25.57 & 22.84 & 22.976 & 22.542 & 20.955 & 19.788 & 18.597 \\
\hline 20:00 & 588 & 28 & 16 & 24.99 & 22.54 & 22.518 & 22.174 & 20.792 & 19.708 & 18.574 \\
\hline 21:00 & 411 & 26 & 16.4 & 24.32 & 22.09 & 22.064 & 21.782 & 20.583 & 19.596 & 18.539 \\
\hline 22:00 & 384 & 25.4 & 16.52 & 23.76 & 21.37 & 21.654 & 21.413 & 20.358 & 19.466 & 18.497 \\
\hline 23:00 & 380 & 24 & 16.8 & 23.21 & 21.01 & 21.307 & 21.087 & 20.139 & 19.334 & 18.453 \\
\hline 24:00 & 382 & 24 & 16.8 & 22.78 & 20.79 & 21.004 & 20.802 & 19.94 & 19.21 & 18.411 \\
\hline
\end{tabular}

Table 10. Results of the temperatures of the mur neutralisant and the room at the different points measured on 2 July. 


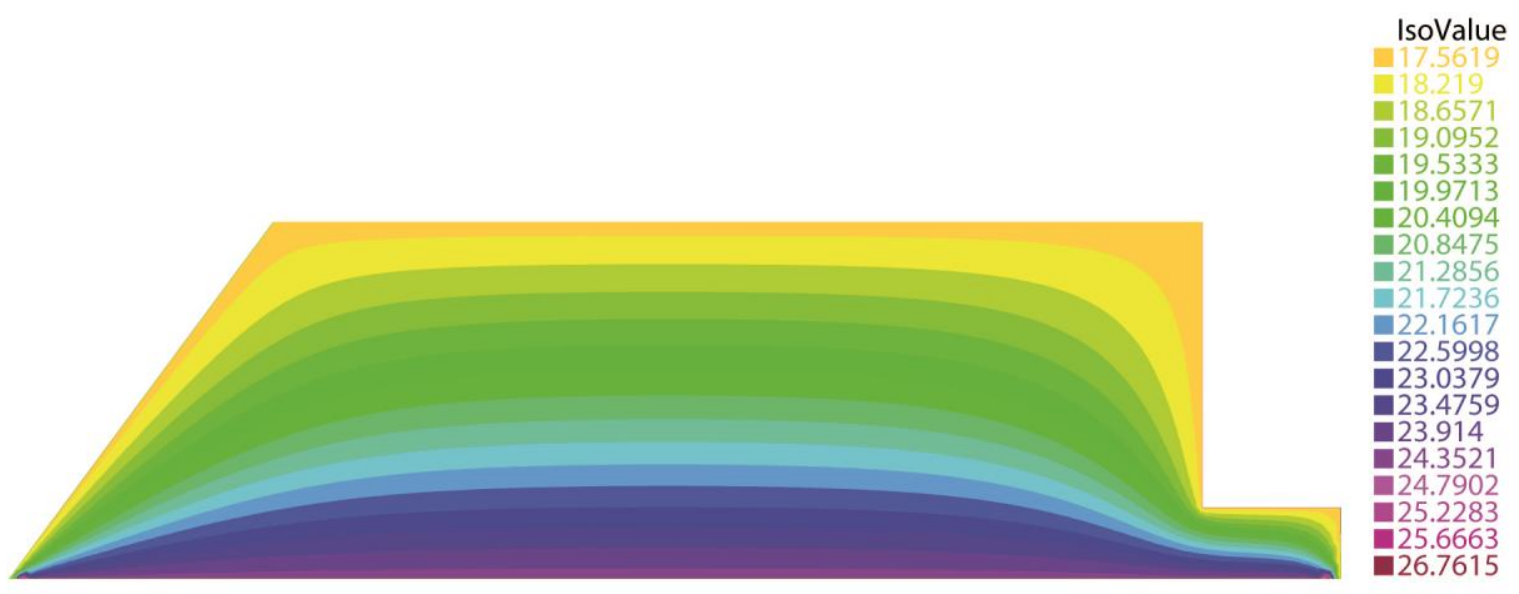

16. Results of the CFD simulation (horizontal section of the model) with air heating and solar radiation: 2 July, 15:00 $\mathrm{h}$.

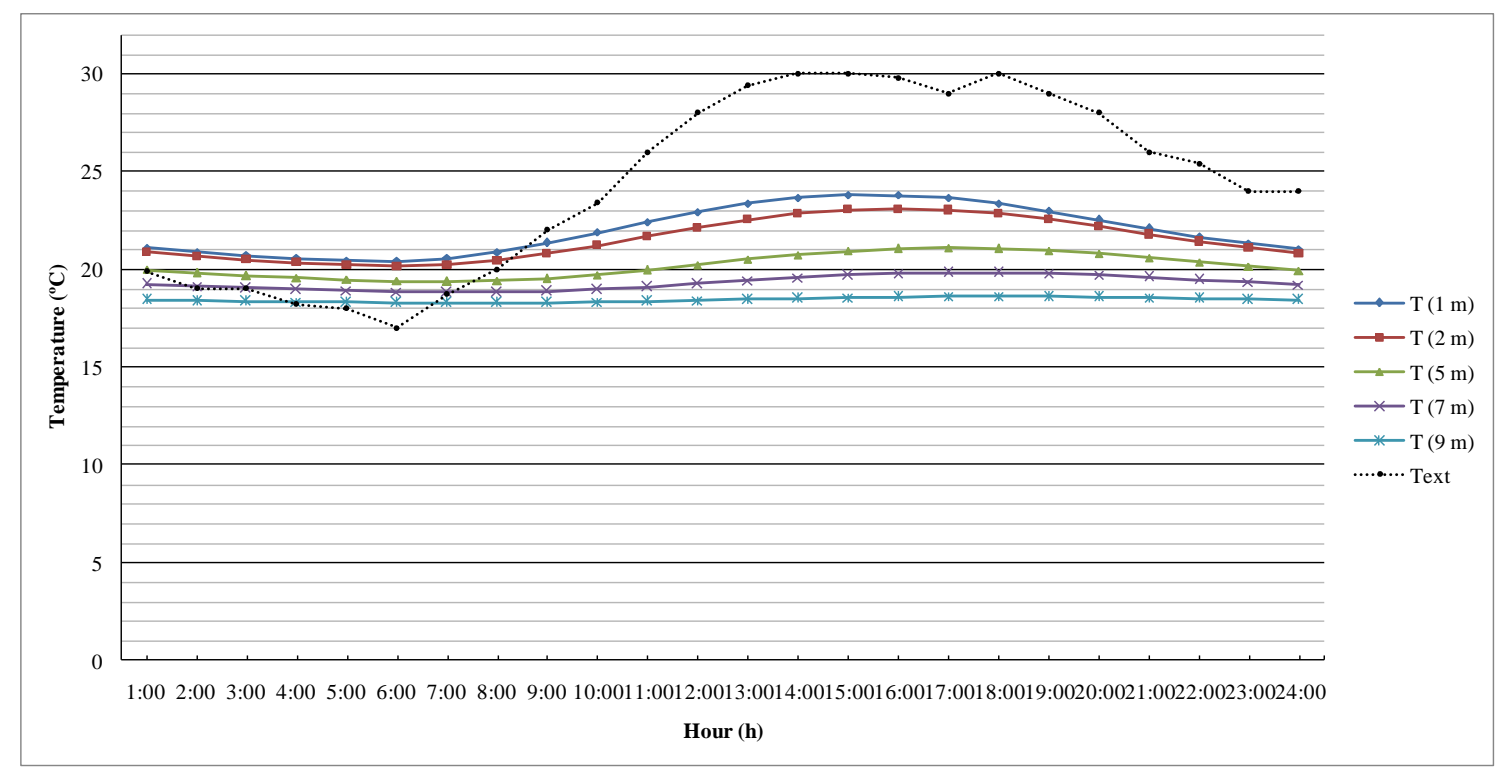

17. Evolution of the indoor temperature at different points in the room on $2 \mathrm{July}$, with solar radiation, with airflow q=100 l/s and variable airflow temperature of the active chamber.

\section{Conclusions}

The combined technological innovation of the mur neutralisant and respiration exacte proposed by Le Corbusier, with the help of G. Lyon, constituted a new interpretation of the mechanisation of the environment to solve the control of indoor climate in Modern Movement. Based on the data and conclusions of the mur neutralisant tests carried out by Saint Gobain engineers on physical models in test rooms in the 1930s, a numerical model was validated and implemented using the CFD-based program FreeFem++. This made it possible to observe the behaviour the mur neutralisant in the City of Refuge would have displayed under different environmental and operating conditions had the original design been completely carried out. 
The numerical model allows the energy simulation of the south-facing mur neutralisantof the main dormitory in the City of Refuge. The mur neutralisant is made up of two sheets of $7 \mathrm{~mm}$ glass with a $110 \mathrm{~mm}$ active air chamber, a hypothesis which is very similar to that proposed in the original project by Le Corbusier. Airflow in this mur was $100 \mathrm{l} / \mathrm{s}$ per metre along the mur neutralisant at a temperature which varied according to outdoor temperature. In winter conditions, represented by a sunny winter's day in Paris, with outdoor temperatures oscillating between and $-6^{\circ} \mathrm{C}$ and $1{ }^{\circ} \mathrm{C}$ on the same day, and with an airflow temperature in the chamber varying between $22.8{ }^{\circ} \mathrm{C}$ and $21.4^{\circ} \mathrm{C}$, notably uniform indoor temperatures occur in the room throughout the day at the same distance from the mur neutralisant. These temperatures decrease along with the increased distance from the mur neutralisant from a mean value of $23{ }^{\circ} \mathrm{C} 1 \mathrm{~m}$ from the mur neutralisant to a value of $18.5^{\circ} \mathrm{C} 9 \mathrm{~m}$ from the mur, that is to say, at the far end of the room. Despite low winter temperatures, the fact that comfort temperatures are reached in the room with an active air chamber and relatively low airflows (for heating in winter), gives some idea of the energy efficiency of the mur neutralisant as a heating system.

In summer conditions, represented by one of the hottest days of the representative climate year in Paris, with outdoor temperatures which on one day oscillate between $17^{\circ} \mathrm{C}$ and $30^{\circ} \mathrm{C}$, the airflow temperature in the chamber decreases to values between $18.2{ }^{\circ} \mathrm{C}$ and $15.6{ }^{\circ} \mathrm{C}$. The increase in solar radiation entails less thermal uniformity throughout the day compared with the winter day at the same distance from the mur neutralisant, although the difference in the middle of the room $(5 \mathrm{~m}$ from the mur neutralisant $)$ is $1.7^{\circ} \mathrm{C}$. The difference in temperature with respect to the distance from the mur neutralisant is more pronounced, with mean values ranging from $22^{\circ} \mathrm{C}$ at a distance of $1 \mathrm{~m}$ from the mur neutralisant to $18.5^{\circ} \mathrm{C}$ at $9 \mathrm{~m}$ from the mur, values potentially equivalent to those obtained in winter for the same distances. This demonstrates the potential of the thermal system which results in thermal uniformity at the same distance from the mur neutralisant throughout the year. As in the case of the heating operation mode, the relatively low airflow and relatively low airflow temperatures (for cooling in summer) show the energy efficiency of the mur neutralisant as a cooling system.

Therefore, the operating conditions of the mur neutralisant and the indoor temperature values obtained in both winter and summer confirm that the active thermal system proposed by Le Corbusier for controlling indoor temperatures makes it possible to obtain an isothermique thermal environment with similar indoor comfort conditions throughout the year, regardless of outdoor temperature and solar radiation. The energy efficient integrated system of temperature control was incorporated into the building envelope. This comprehensive interpretation of the relationship between architecture and energy was practically half a century ahead of environmental control systems with active façade systems designed with a view to building sustainability and energy efficiency. Had the mur neutralisant been executed following the original designs of Le Corbusier and Lyon, it would probably have posed serious competition to the air conditioning systems developed in the 20th century with great success and barely any technological competition.

\section{Acknowledgements}

The authors wish to thank the Le Corbusier Foundation and researcher Jorge Torres from Universitat Politècnica de València for the information and documentation provided for this study.

\section{References}

Brian Brace, T. "Le Corbusier, the city of refuge, Paris 1929-33". Chicago: University of Chicago Press. 1987.

Bryan, Harvey. "Le Corbusier and the 'Mur Neutralisant': An Early Experiment in Double Envelope Construction". Proceedings of the Ninth International PLEA Conference. 1991. pp. 257-62. 
Cuadernos de Postgrado. La respuesta de la American Blower Corporation. 24 January 1930.

FreeFem++ v.-3.37-1. Available from: http://www.FreeFem.org/ff++/ (22.05.15).

Ismail, K.A.R.; Henríquez, J.R. "Modeling and simulation of a simple glass window". Solar Energy Materials \& Solar Cells. 2003. 80. pp. 355-374.

Ismail, K.A.R.; Henríquez, J.R. "Simplified model for a ventilated glass window under forced air flow conditions". Applied Thermal Engineering. 2006. 26. pp. 295-302.

Ismail, K.A.R.; Henríquez, J.R. "Two-dimensional model for the double glass naturally ventilated window". International Journal of Heat and Mass Transfer. 2005. 48. pp. 461-475.

Le Braz, J. "La transmission de la chaleur gràverâ travers le verre: Des idées nouvelles sur le chauffage des habitations". Glaces et Verres. 1933. 20. pp. 13.

Lebel H.; Le Barbier, M. Société Anonyme des Manufactures des Glaces et Produits Chimiques de SaintGobain, Chauny et Cirey. Note sur la seconde série d'essais effectués pour la mesure de la transmission de la chaleur à travers les glaces à l'Annexe du Comptoir de Vente, 23 rue Boucry, Paris du 23 Novembre au 21 Décembre 1931. Letter of 11 March 1932.

Lebel, H.; Le Barbier, M. Société Anonyme des Manufactures des Glaces et Produits Chimiques de SaintGobain, Chauny et Cirey. Note sur les essais de transmission de la chaleur à travers les glaces, efectués à l'Annexe du Comptoir de Vente, 23 rue Boucry, Paris du 3 Avril au 8 Mai 1931. Letter of 25 June 1931.

Ramírez Balas, C.; Fernández Nieto, E.D.; Narbona Reina,G.; Sendra, J. J.; Suárez, R. "Numerical simulation of the temperature evolution in a room with a mur neutralisant. Application to 'The City of Refuge' by Le Corbusier". Energy and buildings. 2015. 86. pp. 708-722. 


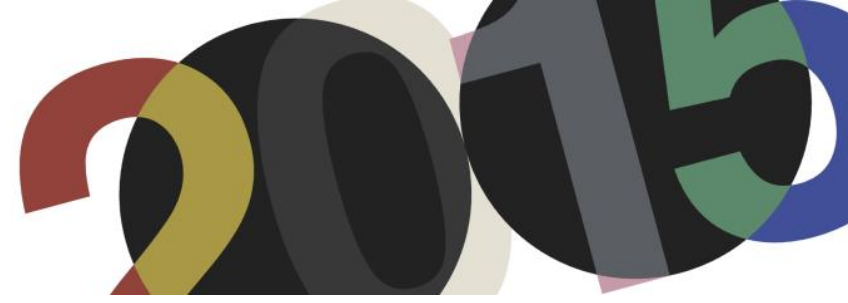

DOI: http://dx.doi.org/10.4995/LC2015.2015.1067

\title{
Le Corbusier, Missenard et Le Climat
}

\section{J. Redondo Morán}

\author{
Escuela Superior de Arquitectura de A Coruña
}

\begin{abstract}
Resumen: La obra de Le Corbusier no puede ser entendida sin la influencia directa que han tenido los colaboradores durante toda su vida. Pensadores, ingenieros y arquitectos, especialistas en todas las disciplinas relacionadas con la arquitectura. Esta visión, ayuda a entender tanto su pensamiento como su obra. Todos ellos, personajes de extraordinarias cualidades, ocultos en mayor o menor medida tras la figura del maestro, aunque muchos pasarían a la historia como parte de los mejores arquitectos del siglo $X X$.

Uno de estos colaboradores y quizá el más olvidado, fue André Missenard, colaborador aparentemente menor según las clásicas visiones de la historiografía de la arquitectura, siendo recogido en escasa bibliografía. Sin embargo, es el más importante a la hora de abordar la visión medioambiental propugnada por Le Corbusier en los años 50 y 60. Desde la documentación original de los proyectos, donde son continuas las alusiones a Missenard hasta sus aportaciones sobre ventilación natural, humedad, temperatura ambiental, superficies radiantes, calefacción, etc. Parte importante en los estudios climáticos realizados para el plan de Chandigarh, como la importante Grille Climatique.
\end{abstract}

Abstract: Le Corbusier's work can not be understood without the direct influence that all employees had throughout his life. Thinkers, engineers and architects, specialists in all disciplines related to architecture. This view helps to understand his thinking and his work. All of them, had extraordinary qualities, hidden in varying degrees after the figure of Le Corbusier, though many would go down in history as some of the best architects of the twentieth century.

One of these partners and perhaps the most forgotten, was André Missenard, seemingly minor contributor by conventional visions of historiography of architecture, being collected in scant literature. However, it is the most important in addressing environmental vision espoused by Le Corbusier in the years 50 and 60. Since the original project documentation, which are continuous allusions to Missenard up their contributions on natural ventilation, humidity, environmental temperature, radiant surfaces, heating, etc. Important part in climate studies for the plan of Chandigarh, as the important Grille Climatique.

Palabras clave: sostenibilidad; clima; arquitectura; Chandigarh; Missenard; ventilación.

Keywords: sustainability; weather; architecture; Chandigarh; Missenard; Ventilation.

\section{Introducción}

La figura de Le Corbusier, para ser entendida, ha de mirarse desde una posición más distante. Acercándose con cautela a su tan extensa obra teórico-práctica. Teniendo especial interés en la lista interminable de colaboradores, tanto dentro como fuera del Atelier Le Corbusier.

André Missenard fue uno de esos colaboradores, que aun sin pertenecer al Atelier, jugó un papel fundamental en el desarrollo de los proyectos de Le Corbusier y en el mundo de las instalaciones de la primera mitad del siglo $\mathrm{XX}$.

\section{La figura de A. Missenard}

André Missenard (1901-1989) fue un ingeniero mecánico francés, físico de vocación. Antiguo alumno de l'Ecole Polytechnique, miembro de jurado de l' Ecole Nationale Superieure des Beaux Arts y presidente de honor del Comité Cientifico Técnico de la industria, de calefacción y ventilación. 
En el año 1928 recibe el premio Hermann Rietschel ${ }^{1}$, gracias a las investigaciones sobre la temperatura ambiental, base de las aplicaciones de calefacción radiante desarrolladas a lo largo de su carrera profesional en la firma Missenard-Quint, empresa líder en Francia de ingeniería e instalaciones.

Para entender el pensamiento de A. Missenard, hay que tener en cuenta la figura de Alexis Carrel ${ }^{2}$, amigo y colaborador. Se conocieron antes de la II Guerra Mundial, cuando A. Carrel escribió el prefacio del libro de A. Missenard "L'homme et le climat"3 publicado en 1937 en París.

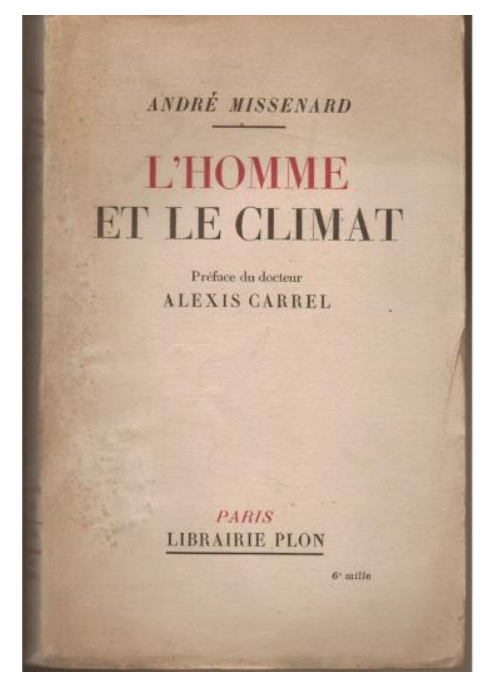

1. Portada del libro "L'Homme et le Climat”, A. Missenard 1937, ed. Plon.

Participó en la segunda guerra mundial, donde fue llamado como Capitán en el $17^{\circ}$ Regimiento de Artillería del ejército francés, toda su vida homenajeará a los valientes que lucharon bajo su mando. Era muy consciente desde la declaración de Guerra de la falta de preparación que tenían tanto él como los demás altos cargos del ejército francés.

A. Missenard y A. Carrel coincidieron de nuevo en la Fundación francesa para el estudio de los problemas humanos, conocida como la "Fundación Carrel", donde este último era regente además de colaborador con el gobierno de Vichy. Esta etapa le llegó a marcar de por vida, y fue aquí donde se empapó del pensamiento higienista del Doctor Alexis Carrel. Como Le Corbusier manifiesta en una carta del 22 de Mayo de 1956, es en este momento donde comienza su relación con A. Missenard, ya que además el mismo Le Corbusier, habla sobre su colaboración con dicha institución.

Tras la II Guerra Mundial, prosiguió su trabajo en la firma de ingeniería Quint et Flamant, y es en el año 1949 cuando pasa a llamarse Missenard-Quint ${ }^{4}$, conservando el mismo nombre en la actualidad.

Desde los comienzos A. Missenard mostraba un especial interés por el desarrollo industrial, haciendo hincapié en los temas energéticos.

\footnotetext{
${ }^{1}$ Medalla Hermann Rietschel de la Federación de ingenieros de calefacción y aire acondicionado de Alemania.

${ }^{2}$ Biólogo, médico e investigador científico francés, premio Nobel de medicina en 1912, claro exponente de la corriente higienista junto con el doctor Pierre Winter.

${ }^{3}$ Missenard, André: L'Homme et le climat. París: ed. Plon, 1937.

${ }^{4}$ Empresa de ingeniería francesa fundada por Henri Martin en 1945, bajo el nombre Maison Henri Martin.
} 


\section{3. "Architecture d'Aujourd'hui"}

En el año 1935, redactaría un artículo en el número 5 de "Architecture d'aujourd'hui". Titulado, "IIIL'Utilisation de la chaleur. Convection et Rayonnement'.

“(...)La sensación de calor está íntimamente ligada a todos los intercambios de calor corporal con la atmósfera, es comprensible que una persona pueda sentir la misma impresión térmica en dos recintos que difieren en la temperatura de sus paredes, la velocidad y temperatura del aire. (Para completar, también se debe incluir sudoración de la piel, pero vamos a eliminar estas variables, asumiendo que el vapor de agua sea igual en ambos casos $)(\ldots)^{5, "}$

Esta reflexión pone de manifiesto, que el confort de un individuo en un ambiente concreto no está únicamente ligado a la temperatura, en la búsqueda de confort intervienen más factores, las corrientes de aire, el contenido de humedad, las temperaturas radiantes de los elementos y también las actividades que el individuo desarrolla en cada momento. La necesidad fisiológica de mantener una temperatura corporal de $37^{\circ} \mathrm{C}$ provoca que nuestro organismo intercambie calor mediante convección y radiación, con el aire y los elementos con los que estamos en contacto.

Cuando un individuo se desplaza rápidamente o por el contrario está realizando una actividad sedentaria; lleva ropas de abrigo ó por el contrario ropas ligeras; las condiciones de temperatura de los elementos que componen ese hábitat momentáneo son completamente diferentes.

Si bien todas estas investigaciones fueron desarrolladas de manera teórica en Francia, fue en Estados Unidos donde se verificaron y confirmaron.

Para su desarrollo se realizaron comprobaciones en dos locales diferentes; A: calefactado con muros radiantes y una temperatura interior del aire de $14^{\circ} \mathrm{C}$ y B: con paredes frías de vidrio y temperatura interior del aire de $22^{\circ} \mathrm{C}$. La sensación de confort era la misma. Hay que tener en cuenta que los termómetros eran ordinarios y por lo tanto no median el calor por radiación, únicamente influenciables por la temperatura del aire. Para comprobar que ambos ambientes se encontraban en igualdad, se desarrollaron termómetros envueltos por un material absorbente y termométrico, destinado a tener en cuenta la radiación fría o caliente de las paredes. Lo que hoy llamamos termómetro de bulbo húmedo, que mide la sensación térmica de un lugar, mucho más importante que la simple temperatura del aire.

\section{Publicaciones}

Las investigaciones sobre la radiación de los elementos, llevarían a A. Missenard a la publicación del libro “Conductivité Thermique. Des solides, liquides, gaz et de leurs melanges”(A. Missenard, 1965). Donde desarrolla las condiciones térmicas de los materiales, sólidos, laminares, etc. poniendo especial énfasis en el hormigón, y cómo varía de manera sustancial la conductividad térmica final del elemento constructivo.

La capacidad térmica de un hormigón depende de numerosos factores: en particular de la naturaleza del cemento y de su conductividad, de la dosificación, de la proporción de agua de mezcla, de la naturaleza y la conductividad del agregado, la compacidad del hormigón, y por último las condiciones de secado.

${ }^{5}$ Missenard, André: The radiant heating. Architecture d'Aujourd'hui, $n^{o}$ 5, p.36. París: Architecture d'Ajourd'hui 1935. 
Pero como conclusión final A. Missenard expone como condiciones esenciales en la variación de la capacidad térmica: La conductividad del cemento, y su dosificación, la conductividad de los agregados, y la compacidad.

Algo totalmente comprobado, y extendido en la actualidad, es la utilización de arcillas hidroexpansivas, aditivos aireantes, etc. A parte de reducir el peso del material final, de todos es sabido el incremento de su capacidad aislante. Siempre desde la prudencia, la introducción de estos componentes mejorará la conductividad térmica del elemento sin poner en peligro la capacidad portante.

El interés por la radiación de los elementos constructivos y su aportación a la calefacción de un local, no es algo que se haya inventado recientemente. Ya se utilizaba en el Hypocaustus romano, padre de la "gloria" castellana, donde el suelo era calentado mediante conductos por los que se hacía discurrir aire caliente. Algo poco eficiente ya que no permitía la calefacción de locales de gran tamaño. Fue en el S. XIX cuando se propuso como calefacción para grandes superficies.

Ya a comienzos del S. XX se desarrollo comercialmente con la aparición de diferentes patentes. Un claro ejemplo es el edificio de la Ecole de plein air de Suresnes de Eugène Beaudouin y Marcel Lods. Diseñado con principios higienistas, donde la calefacción se realizaba con tuberías embebidas en el suelo, por donde discurría agua a presión.

Los problemas de polución de las ciudades, por el alto consumo de carbón en las estufas de los habitantes, provocó el desarrollo de infraestructuras locales de calefacción, el llamado "district heating" 6 . Se introdujo en Europa en la ciudad de Dresde, y posteriormente se realizaron intervenciones de este tipo en numerosas ciudades, con el fin de dotar de calefacción a las viviendas sociales y barrios de obreros, centralizando la producción de calor en una única unidad de producción.

Las consecuencias económicas devenidas de la guerra mundial y la gran crisis económica que asolaba a Europa paró el desarrollo de estos sistemas hasta casi los años 50.

En el libro "Cours superieur du Chauffage”(A. Missenard, 1937-1943), entre otras cosas, A. Missenard propone una serie de pautas para la elección correcta del modelo de calefacción.

"Inmuebles regularmente habitados.- Para los locales ocupados permanentemente, no hay ninguna duda, en el estado actual de la técnica, el modo de calefacción más apropiado y económico es la utilización de agua caliente a baja presión. No solamente es más higiénico que la calefacción a vapor de agua a presión, sino que la instalación de calefacción será más regulable. "7

Si bien habla de un coste superior de la instalación por agua caliente, el rendimiento de esta hace que se amortice en unos pocos años de explotación.

Explica también que dentro del programa funcional de una vivienda, hay que calefactar los locales de más uso, el salón o el comedor, y habla de cómo la ventilación de los otros locales de las viviendas pueden favorecer el flujo de aire caliente hacia ellas, calentando de manera suficiente estas estancias.

En los años 50 se desarrollan diferentes estrategias de calefacción por radiación, por un lado el suelo radiante, el más utilizado y eficiente. Por otro lado numerosos proyectos con plafones de techo radiantes, más económicos y

\footnotetext{
${ }^{6}$ District heating: Sistema de calefacción urbana, puesto en práctica por primera vez en Nueva York en 1880.

${ }^{7}$ Missenard, André: Cours Superieur de Chauffage Ventilation et Conditionement de l'air, vol. 1. París: Librairie de L'Enseignement Technique, 1943.
} 
fáciles de modificar y reparar, pero con condiciones de habitabilidad infinitamente diferentes. El calor tiende a quedarse en capas superiores provocando altas temperaturas a la altura de la cabeza del individuo, algo que en años posteriores se demostrará que no es conveniente.

Se desarrolla otra alternativa, más económica, con un rendimiento más que aceptable. La disposición de radiadores. Algo que se desarrollará en los innumerables barrios obreros europeos como una respuesta económica a los problemas higienistas de la sociedad y la arquitectura.

"Salas de reuniones, colegios, oficinas.- Durante largo tiempo se ha considerado el vapor bajo presión conveniente especialmente para sistemas de calefacción intermitentes necesarios para los locales únicamente ocupados en jornada laboral." 8

También la aparición de los radiadores, contribuyó a modificar ligeramente esta disposición en favor de la calefacción por agua caliente, ya que la entrada en régimen del sistema es mucho más rápida y por lo tanto se necesita menor cantidad de energía para acondicionar los locales.

A. Missenard pone de manifiesto el problema de la ventilación, ya que en lugares en los que se acumulan muchos individuos trabajando es necesario renovar el aire de los locales frecuentemente. Esto perjudica enormemente el rendimiento de este tipo de calefacción, lo que provocará la aparición de sistemas de calefacción por aire caliente, combinándolos con una ventilación mecánica. Él lo llama "rudimentario" en la publicación, pero nos consta a día de hoy, la mejor eficiencia respecto a los otros métodos de calefacción en este tipo de locales.

En la actualidad uno de los principios del Estándar Passive House ${ }^{9}$, es la hermeticidad de los edificios, para evitar pérdidas de energía por infiltraciones o malos aislamientos, y renovar el aire interior calentándolo cuando sea necesario. Se instalan sistemas de intercambio de calor, en los que se atempera en primera instancia el aire que entra del exterior, con el aire interior que se desecha, después de esta acción se calefactará si es necesario para llevarlo a la temperatura que deseemos. Principio esencial del modelo de "respiration exacte" de Le Corbusier, acompañado del muro neutralizante.

"El rápido desarrollo de la Técnica permite actualmente, en cualquier lugar, sin importar el clima, al menos reducir la sensación de calor, la humedad y la composición del aire. Como es el caso generalmente, los problemas humanos fueron superados por la mecánica, y de aquí a una treintena de años, no sabremos muy bien cual es la influencia de los factores climáticos sobre el comportamiento de los hombres, y por tanto cuales serán las condiciones deseables para los locales. Gracias a los estudios y a las observaciones desarrolladas simultáneamente en América, en Inglaterra, en Alemania y en Francia, tenemos derecho a pensar que la pregunta está un tanto desgastada. Tenemos todas las razones para creer que evolucionará rápidamente. En efecto, la técnica de los climas artificiales, una vez limitada a la calefacción, campo de los artesanos en lugar de los ingenieros, recurre cada vez más a los hombres con una formación científica sólida, que les permite, cuando se desea, asimilar las nociones de biología y psicología necesarias para el estudio de esta nueva disciplina.

\footnotetext{
${ }^{8}$ Missenard, André: Cours Superieur de Chauffage Ventilation et Conditionement de l'air, vol. 1. París: Librairie de L'Enseignement Technique, 1943.

${ }^{9}$ El origen del término proviene del libro de Edward Mazaria "Passive Solar Energy Book" 1979.
} 
Espero, por último, que el programa de investigaciones sobre perros de raza pura, que había elaborado con A. Carrel en 1938, sea reanudado, para sentar las bases sólidas, de nuestro conocimiento de la climatología natural y artificial." 10

Llama la atención como un hombre de técnica, en un momento como este, con un continuo desarrollo industrial, era capaz de interesarse por la respuesta primitiva de las especies a los diferentes climas. En las investigaciones llevadas a cabo con Alexis Carrel, siempre sobre el hombre, se estudiaban los comportamientos de las diferentes culturas, etc. Pero para A. Missenard, el modelo humano como elemento de investigación biológico de respuesta al clima, ya estaba agotado.

Centran la investigación en las razas puras de perros y sus orígenes. Cómo estos cánidos, todos ellos de la misma familia, han dado respuesta evolutiva a los diferentes hábitats y condiciones en los que se encontraban.

Pone de manifiesto su inquietud sobre cómo la construcción de climas artificiales oculta los factores climáticos exteriores. Hoy conocemos los graves problemas de este desaforado desarrollo tecnológico que nos ha llevado a la colonización de innumerables lugares no habitables por el ser humano. Siempre apoyándonos en la técnica, en los combustibles, destruyendo los hábitats en los que nos asentamos y por tanto empeorando las condiciones de habitabilidad que en ellos había.

Como intento de respuesta a estos problemas, ya que es imposible parar el desarrollo humano solucionar todos los problemas técnicos que se presentan, nace la inquietud de minimizar el impacto de todas nuestras acciones sobre la Tierra, lo que desembocaría en la segunda mitad del S.XX, en el Desarrollo Sostenible y la Sostenibilidad Arquitectónica.

Esto supone un punto de inflexión en el mundo de las instalaciones, y una preocupación por acondicionar los diferentes locales conforme al uso y las actividades a las que se destinarán, teniendo en cuenta el clima y las condiciones atmosféricas en las que se desarrollará.

\section{Le Corbusier y André Missenard.}

Le Corbusier inicia en torno a 1930 el desarrollo de su arquitectura bioclimática. Un período en el que pone en marcha mecanismos de adaptación de la arquitectura al entorno. Preocupándose por el soleamiento, el control de la ventilación y la humedad, construcción con sistemas naturales, recuperando la coherencia arquitectónica mostrada por las construcciones vernáculas.

Desarrollará en los años 40 el prototipo "heliotécnico", como respuesta a la influencia del soleamiento sobre los hábitats interiores, utilizando tanto los "brise soleil" como el "pan de verre ondulatoire" Xenakis $^{12}$. Las diferencias entre los lugares en los que se asienta cada edificación daba como resultado diferentes versiones del prototipo heliotécnico.

Para intentar simplificar la complejidad de los cálculos asociados a cada prototipo, en 1951 Xenakis, elaboró un nuevo procedimiento los "Epure du soleil”, donde se resumían en un solo dibujo los cálculos gráficos de asoleo.

\footnotetext{
${ }^{10}$ Missenard, André: Cours Superieur de Chauffage Ventilation et Conditionement de l'air, vol. 4. París: Librairie de L'Enseignement Technique, 1943.

${ }^{11}$ Pan de verre ondulatoire: Solución racional a la vidriera moderna modulada según elementos prefabricados de hormigón armado.

${ }^{12}$ Iannis Xenakis, compositor musical y arquitecto francés de orígenes griegos, miembro de l'Atelier Le Corbusier.
} 
El desarrollo de nuevos proyectos en latitudes cercanas a los trópicos con climatologías más restrictivas, llevo a replantear el modelo de actuación. Gracias a la relación que existía con A. Missenard ampliaron el rango de las investigaciones más allá del soleamiento, incluyendo otros factores climáticos como son: la lluvia, ventilación de mañana, sol de verano, sol de invierno, ventilación de tarde, iluminación, etc.

De esta manera vería la luz la en 1951 "La Grille Climatique" de L'Atelier Le Corbusier. Una rejilla mediante la cual se enumeran, coordinan y analizan las condiciones del clima de un lugar definido por su latitud. Con el fin de materializar diferentes estrategias arquitectónicas como respuesta a necesidades biológicas humanas. De esta manera se puede regularizar y rectificar climas excesivos y darse cuenta, a efectos arquitectónicos, de qué condiciones pueden mejorar la habitabilidad.

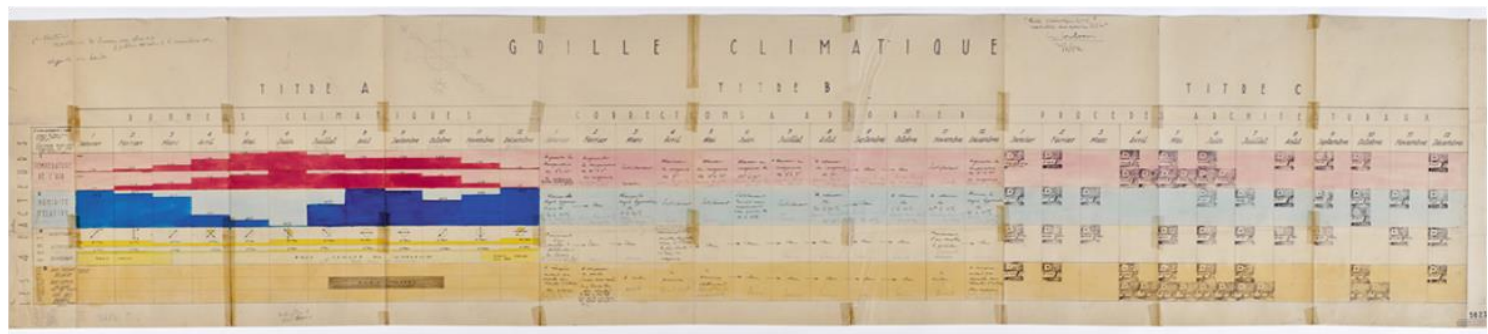

2. Grille Climatique de Chandigarh. Fuente: Fundación Le Corbusier FLC 05623. Autor: I. Xenakis y B.V. Dosh, 1951.

"Title A", Condiciones climáticas. Cada clima se expresa de cuatro formas esenciales: A) temperatura (rojo); B) grado de humedad del aire (azul); C) vientos y direcciones; y C) radiación térmica.

Este apartado de la "Grille" posee cuatro bandas horizontales, que servirán para visualizar las variaciones de cada uno de los cuatro factores mencionados durante el período definido. De esta manera con un simple vistazo comprendemos las condiciones climáticas en cada uno de los meses del año.

“Title B”, Correcciones y rectificaciones biológicas necesarias para mejorar las condiciones de habitabilidad.

En este segundo apartado se citarán las rectificaciones o correcciones que consideran necesarias, y la lectura de este segundo panel justificará la intervención del arquitecto.

"Title C", Soluciones Arquitectónicas. Se proponen soluciones arquitectónicas adecuadas a cada momento y condición, correlativas con las correcciones y rectificaciones necesarias del "Title B". La marca con un sello azul con la letra D y un código numérico, evidencia la existencia de un dibujo explicativo de la solución estratégica a seguir.

Se adjunta a dicha rejilla un dossier en el que se encuentran todos estos dibujos. Representan la respuesta del arquitecto. Gracias a estas explicaciones, unas más detalladas que otras, de las estrategias a seguir hace de la "Grille" un documento practico y visual. 


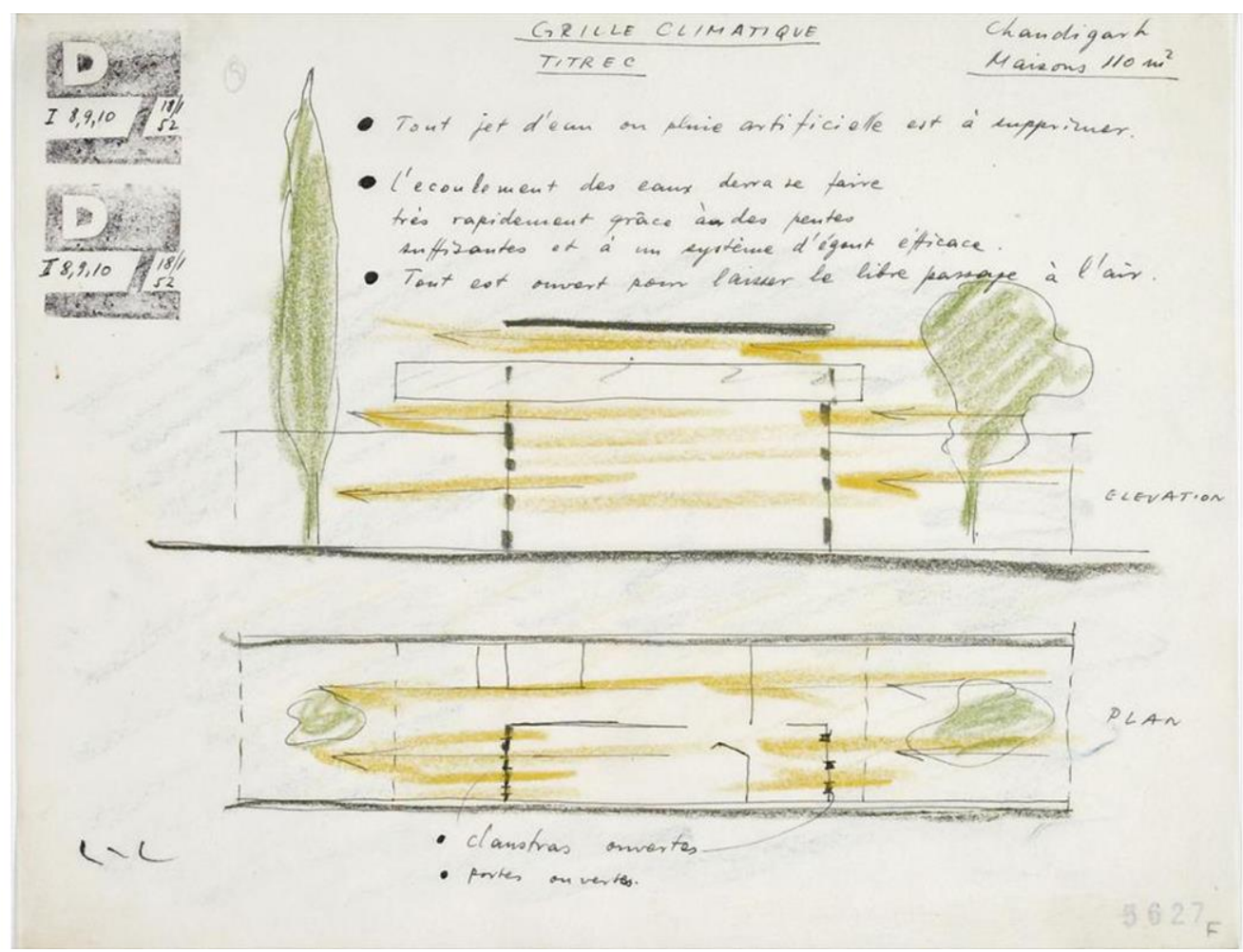

3. Dibujo adjunto a la Grille Climatique de Chandigarh, Maisons de Peon $110 \mathrm{~m}^{2}$. Fuente: Fundación Le Corbusier FLC $05627(6 / 14)$

Las aplicaciones de este método permitieron el desarrollo de los proyectos de Le Corbusier en Chandigarh, cada elemento que lo componía era correctamente calculado, desde los "brise soleil" hasta los "pan de verre ondulatories", tratando de paliar los efectos de la radiación solar en este clima tan cálido.

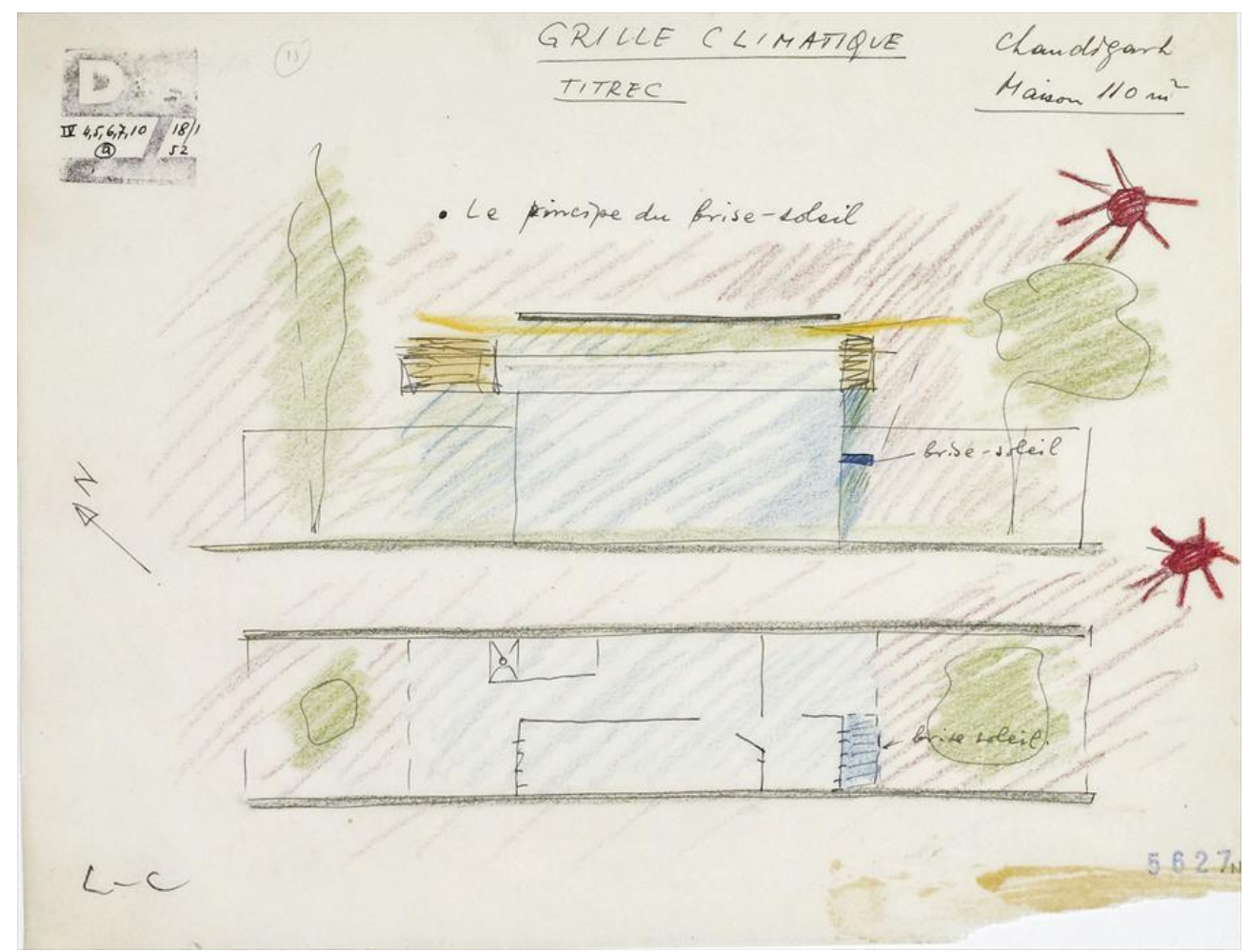

4. Dibujo adjunto a la Grille Climatique de Chandigarh, Maisons de Peon $110 \mathrm{~m}^{2}$. Fuente: Fundación Le Corbusier FLC $05627(8 / 14)$. 
Se desarrollan propuestas ya planteadas con anterioridad, y se definen estrategias de diseño pasivo que ayudan a hacer más confortable el espacio habitable. Desarrollo de aleros, colocación de vegetación para la reducción del soleamiento, ventilaciones cruzadas, cubiertas ventiladas, etc.

Un elemento que desarrollará de manera muy detallada, aunque en estos primeros esquemas no quede del todo clara su disposición, son los aerateurs. Estos aireadores, son compuertas que permiten la apertura de un hueco de suelo a techo en la fachada principal y en su opuesta de similares dimensiones. Permitiendo así el barrido de aire en todos los estratos interiores.

El proyecto de Chandigarh, trajo muchos quebraderos de cabeza a Le Corbusier, ya que durante la construcción de los edificios, estos sufrieron innumerables modificaciones, fruto de la falta de entendimiento entre las partes y del intento de reducción de costes. Un claro ejemplo son las discusiones entre Le Corbusier y P. L. Varma ${ }^{13}$.

En una carta de 1952, Le Corbusier, tras haber discutido sobre los acristalamientos propuestos, se niega a que estos sufran ninguna modificación. Él plantea acristalamientos fijos para el edificio, colocando aerateurs opacos de suelo a techo como única hoja practicable en la fachada.

Para la justificación de las decisiones tomadas en el desarrollo de sus proyectos, consulta a su "amigo" A. Missenard, al que presenta como un especialista técnico de alto nivel. Dicha carta se redacta como resumen de una reunión mantenida entre ambos. Donde tratan numerosos temas de diseño pasivo y activo de la edificación, exponiendo las estrategias a seguir.

Propone como solución más correcta la instalación de aire acondicionado, pero plantea la posibilidad si los recursos son escasos, de aprovechar los vientos mediante aberturas en las fachadas, y en los momentos en los que estos sean de baja intensidad, apoyar este movimiento con la instalación de ventiladores. Se estudia también otra solución para la ventilación interior, instalar en el corredor interior unos conductos de ventilación que comunicados a unas chimeneas verticales provoquen una depresión de aire y por lo tanto una corriente ascendente, ya sea por diferencia de presiones o por efecto Venturi, que favorezca esta renovación de aire en el interior de los locales.

Se preocupan por dotar al interior de un confort mayor, por eso no recomienda la instalación de ventiladores de techo ya que esto provoca una evaporación de la sudoración, y con el incremento de la humedad del aire llegaría a perjudicar la respiración.

Junto con dicha carta se incluye un dossier Técnico redactado por André Missenard, en el que se exponen las características y movimientos del aire, así como la justificación de las propuestas de Le Corbusier.

Se establece la disposición de aerateurs en fachada cada 2,26m, para el caso del edificio del Secretariado, suficiente para que el aire se mezcle, con una altura igual a la altura interior del espacio.

${ }^{13}$ P. L. Varma, Ingeniero jefe del Punjab durante las obras de Chandigarh. 


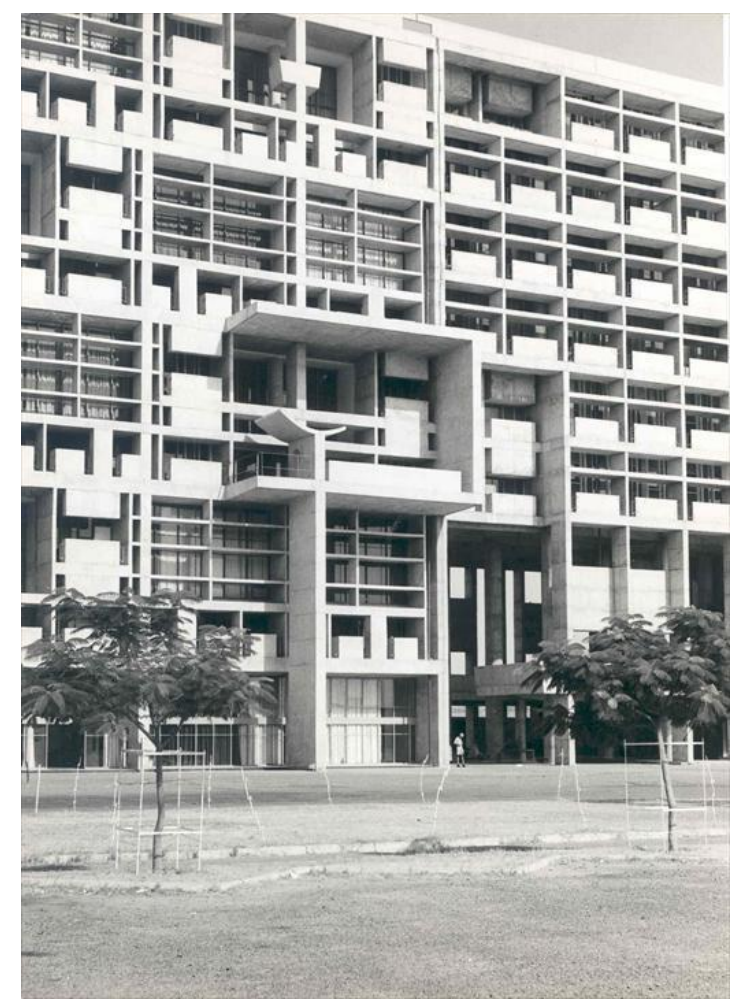

5. Imagen de la fachada del Secretariado de Chandigarh, donde se pueden observar los huecos que permitirían pasar el aire en toda la altura de la misma. Fuente: Fundación Le Corbusier FLC.

"Les pido a ustedes, ingenieros, y a ustedes, arquitectos, que resuelvan del modo más inteligente posible el problema concreto que plantea el Secretariado; es decir, la instalación de las vidrieras llamadas "ondulatorias". Tienen delante el más bello problema de fabricación: alrededor de 15.000 piezas de hormigón, exactamente iguales, y alrededor de 100.000 piezas de vidrio, en cuatro o cinco formatos, todos semejantes. Hace ya dos años declaré que la economía que había que alcanzar en el Secretariado sólo podía provenir de las vidrieras. Ustedes me han planteado todas las oposiciones posibles. Discutí amistosamente con ustedes y les prometí que consultaría a un técnico de alto nivel. Mi propuesta ha sido admitida totalmente por él y aceptada como eficiente. Por lo tanto, cuento con ustedes para cerrar la discusión y, en aras de la mayor eficacia, pasar sin más tardanza a la realización.

Les agradezco de antemano su colaboración y les ruego, señores administradores, ingenieros, arquitectos, que reciban mi consideración más distinguida.

Le Corbusier ${ }^{, 14}$

Queda claro tanto el interés de Le Corbusier y su Atelier como el de A. Missenard por solucionar los problemas devenidos por la adaptación de los edificios al clima. Y como el apoyo únicamente en la técnica no sería una solución adecuada. Elevados costes, elevado mantenimiento, y eficacia cuestionable, frente a coherencia de las soluciones arquitectónicas.

\footnotetext{
${ }^{14}$ Le Corbusier. Carta entre Le Corbusier y P.L. Varma, FLC P1-10-306.
} 


\section{Conclusión}

Podemos establecer por lo tanto un claro paralelismo entre el momento arquitectónico actual y el que vivía Le Corbusier en sus proyectos de mediados de siglo. Cómo tras un período de gran desarrollo industrial y bonanza económica la arquitectura se olvida de la racionalidad y no se preocupa de las consecuencias y problemas de la desmesura de determinados modelos arquitectónicos. No es, hasta la aparición de una crisis económica y financiera, el momento en que estos aspectos vuelven a tenerse en cuenta.

Las investigaciones climáticas que se desarrollan en el Atelier Le Corbusier, están totalmente vigentes, y son totalmente coherentes. El desarrollo de la Arquitectura sostenible actual, deviene de estas investigaciones. Antes de adentrarse en la definición de los proyectos, se realizan innumerables análisis climatológicos, que tienen como primer resultado la correcta orientación de las fachadas principales de los edificios previstos.

Se tienen en cuenta, al igual que tenían en cuenta en la "Grille Climatique", el aprovechamiento de las características climáticas existentes. Y tras su estudio se desarrollan las diferentes propuestas arquitectónicas y el diseño de los elementos de protección. Lo que hoy llamamos arquitectura pasiva.

Las ventilaciones cruzadas, los efectos chimenea, la instalación de vegetación en fachadas y cubiertas, están a la orden del día. También con el aprendizaje de otras culturas se ha llegado a incorporar estrategias de diseño pasivo como el aprovechamiento del refrescamiento evaporativo, claro ejemplo de esto es la arquitectura islámica y sus innumerables patios con estanques y piscinas, que aprovechan el intercambio de temperatura entre las brisas calientes y las superficies de agua, provocando un descenso de la temperatura en este discurrir de aire.

Pero para adaptar la arquitectura de manera correcta al clima es necesario garantizar una condiciones de confort interior para las que se necesita un apoyo tecnológico, lo que hoy se llaman estrategias activas.

El problema aparece cuando intentamos definir el confort interior de un local. No podemos pretender tener temperaturas interiores inferiores a $22^{\circ} \mathrm{C}$ en los meses de verano, y superiores a $21^{\circ} \mathrm{C}$ en los meses de invierno.

Una temperatura interior correcta en invierno sería $18-19^{\circ} \mathrm{C}$, y en verano $24-25^{\circ} \mathrm{C}$. Sin suponer ningún perjuicio hacia el individuo, esto conllevaría un ahorro energético considerable, que incluso en la mayoría de los casos podría estar garantizado por el desarrollo de las estrategias pasivas que con anterioridad comentábamos.

“(...) Como es el caso generalmente, los problemas humanos fueron superados por la mecánica, y de aquí a una treintena de años, no sabremos muy bien cual es la influencia de los factores climáticos sobre el comportamiento de los hombres, y por tanto cuales serán las condiciones deseables para los locales.(...)"15

Tanto Le Corbusier como A. Missenard eran conscientes de ello, y centraban el desarrollo de sus investigaciones en la minimización de las estrategias activas en la arquitectura. El individuo y el edificio han de dar una respuesta simbiótica y coherente al clima y al lugar.

\section{Agradecimientos}

La organización agradece a Nathalie De Romance, nieta de A. Missenard, por facilitar información acerca de la biografía de su abuelo, y a la Fondation Le Corbusier.

\footnotetext{
${ }^{15}$ Missenard, André: Cours Superieur de Chauffage Ventilation et Conditionement de l'air, vol. 4 (conclusión). París: Librairie de L'Enseignement Technique, 1943.
} 


\section{Bibliografía/referencias}

Ábalos, I. y Herreros, J. “Técnica y arquitectura en la ciudad contemporánea”. Madrid: Nerea, 2000.

Fondation Le Corbusier. “Le Corbusier Sketchbooks 1954-1957”. Paris: Fondation Le Corbusier.

Le Corbusier (1938) "Problèmes de l'ensoleillement". En: Le Corbusier y Jeanneret, P. (1938) Oeuvre Complète (1938-1946). Zurich: Les Editions d'Architecture, p.103-107.

Le Corbusier (1965) “Oeuvre complète 1957-1965”. Zurich: Les Èditions d'Architecture.

Missenard, André: “A la recherche de L'homme”. Istra, 1954.

Missenard, André: "Le chauffage et le rafraîchissement par rayonnement". París: Eyrolles, 1954.

Missenard, André: 'L'Homme et le Climat”. París: ed. Plon, 1937.

Missenard, André: "Cours Superieur de Chauffage Ventilation et Conditionement de l'air". París: Librairie de L’Enseignement Technique, cuatro tomos, 1937-1943.

Missenard, André: "Condictivité Thermique. Des solides, liquides, gaz et de leurs mélanges". París: ed. Eyrolles, 1965.

Missenard, André: “The radiant heating” Architecture d'Aujourd'hui, nº5, p.36.

Requena Ruiz, Ignacio: “Arquitectura adaptada al clima en el Movimiento Moderno: Le Corbusier (19301960)". Director: Juan Calduch Cervera. Universidad de Alicante, Departamento de Expresión Gráfica y Cartografía, 2011.

Ruiz-Larrea, Miguel Ángle (traductor): “Música de la arquitectura. Iannis Xenakis”. Madrid: Akal, 2009. 


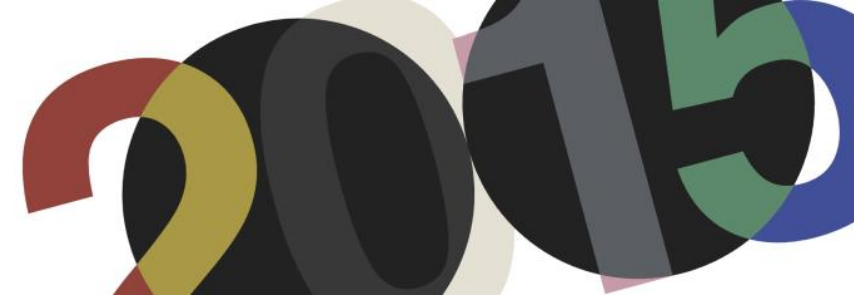

DOI: http://dx.doi.org/10.4995/LC2015.2015.659

\title{
Construcciones ambientales para el hábitat moderno: Le Corbusier y André Missenard (1937-57)
}

\author{
I. Requena, D. Siret \\ CRENAU - UMR CNRS-MCC-ECN 1563 Ambiances Architectures Urbanités. École Nationale Supérieure \\ d'Architecture de Nantes (Francia)
}

\begin{abstract}
Resumen: Desde final de los años 30, la formulación de una nueva sensibilidad cultural, tecnológica y política hacia el clima, entendido en un sentido amplio, replanteó la relación entre el cuerpo humano y su entorno. El presente artículo confronta la obra de Le Corbusier ante dicha hipótesis de evolución del paradigma higienista previo. A partir de una investigación original en los archivos de la Fondation Le Corbusier, el objeto principal es el estudio de los intercambios teóricos y los aportes técnicos entre el arquitecto y André Missenard. El ingeniero, referente en el entorno científico, industrial y político de la época, resulta una pieza clave para entender la relevancia de la dimensión ambiental del hábitat propugnado por Le Corbusier durante los años 50. En particular, este trabajo aborda tanto los métodos de ideación (Grille Climatique) como su materialización espacial, técnica y sensorial (Unités d'habitation y Maison du Brésil). Las conclusiones del artículo muestran la evolución de los postulados habitacionales de Le Corbusier, que partiendo de la "Ville Radieuse", acabó por integrar las ideas de la "Science des climats artificiels" en el proyecto arquitectónico, buscando "Rétablir les conditions nature" en el hábitat moderno.
\end{abstract}

\begin{abstract}
Since the late-1930s, the emergence of a renewed cultural, technological and political approach towards the notion of climate reformulated the relationship between bodies and their milieux. This article analyses the works of Le Corbusier through the lens of this hypothesis of the hygienist paradigm's evolution. Based on an original research at the archives of the Fondation Le Corbusier, this paper focuses on the theoretical discussions and the technical collaboration of the architect with André Missenard. This engineer, a key figure in the scientific, industrial and political environment of his time, played a main role to understand the relevance of the ambient dimension in Le Corbusier's housing proposals in the 1950s. In particular, this paper deals with the design methods (Grille Climatique), as well as their spatial, technical and sensory materialization (Unités d'habitation and Maison du Brésil). The conclusions of the article show the evolution of Le Corbusier's postulates, which beginning from his early proposal for the "Ville Radieuse", managed to integrate the contributions of the "Science des climats artificiels" in architectural design looking for "Rétablir les conditions nature" in modern housing.
\end{abstract}

Palabras clave: André Missenard; climas artificiales; control ambiental; Le Corbusier. Keywords: André Missenard; artificial climates; thermal ambiances; Le Corbusier.

\section{Introducción: control ambiental y modernidad}

Desde finales del s. XIX, el enfoque higienista en medicina, arquitectura e ingeniería marcó la manera de construir los espacios destinados al trabajo, la salud o a la habitación. Diversas investigaciones actuales ${ }^{1}$ muestran la importancia en este periodo de la accesibilidad de luz solar y aire limpio como métodos de purificación ambiental en un sentido medicinal, social e incluso moral. No obstante, la constatación del aumento

\footnotetext{
${ }^{1}$ En particular: Campbell, M., What Tuberculosis Did for Modernism; Hobday, R., The Light Revolution; Siret, D., Les sensations du soleil dans les théories architecturales et urbaines.
} 
de la polución en el medio urbano ${ }^{2}$, entre otros aspectos, hizo aflorar a principios del s. XX nuevos ingenios técnicos que prometían purificar el aire del interior de los edificios. Sirvan de ejemplo el Climatogène de Bontemps (1901), la Air-conditioning unit de Carrier (1902) o el "Appareil pour laver l'air" de Richet (1910). Estos dispositivos nos indican el comienzo de una etapa donde las nuevas técnicas de control ambiental, unidas a los estudios fisiológicos sobre el sistema termorregulativo del cuerpo humano y a un medio social e industrial en busca de atmósferas interiores asépticas y reguladas, produjeron nuevas derivas del pensamiento higienista que tuvieron su traducción en la arquitectura de décadas posteriores.

Durante la primera mitad del s. XX, tal como Fleming y Jankovic indican ${ }^{3}$, dicho efecto se manifestó a través de una mayor relevancia científica y cultural de la noción de clima. Por una parte, al clima a gran escala, capaz de influir sobre la sociedad, la técnica y la cultura, como revelan por ejemplo la publicación de Civilization and Climate de Huntington (1924), la creación de la American Air Force Weather Service (1937) o la fundación de la World Meteorological Organization WMO de las Naciones Unidas (1951).

Por otra parte, el clima a escala del cuerpo humano, así como su control mediante las técnicas modernas. Apoyándose en la analogía del cuerpo-maquina, productor e intercambiador de energía con su medio, numerosos médicos, economistas, físicos, geógrafos e ingenieros ${ }^{4}$ desarrollaron investigaciones interdisciplinares que alimentaron la ambición de construir climas artificiales a medida. Una primera aproximación se construyó según el concepto de "air-conditioning (aire acondicionado)", definido por Carrier como el "control de las condiciones

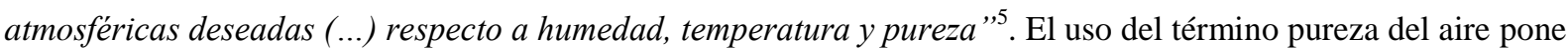
de manifiesto la continuidad entre sus objetivos iniciales y los del pensamiento higienista. Superados los debates heredados sobre la concentración de $\mathrm{CO}_{2}$ y sus efectos en la salud o en la eficiencia de trabajadores y escolares, la investigación científica se orientó hacia el análisis de la percepción sensorial individual in vitro de ambientes térmicos. La nueva meta era encontrar las condiciones ambientales de mayor eficiencia biológica y mental, considerando así al cuerpo humano como un simple receptor de estímulos pasivo, cuya situación ideal se encontraba en la neutralidad sensorial o la ausencia de estimulación ambiental. El avance tecnológico y comercial del aire acondicionado reconfiguró la percepción social de espacios como salas de cine, galerías comerciales o edificios de oficinas, cuyo atractivo residía además en sus cualidades térmicas.

A final de los años 20, Le Corbusier se hizo eco del mecanismo de ventilación Aération ponctuelle del ingeniero Gustave Lyon (1857-1936) con el objetivo de desarrollar su Respiration exacte. Combinada con un sistema de aislamiento activo, el Mur neutralisant, inspirado a su vez en la Maison isotherme de Raoul Decourt (1925), la propuesta climático-arquitectónica pretendía encarnar la utopía moderna de fabricar "todo el año aire exacto, renovado, desinfectado, exactamente humidificado y llevado a la temperatura constante de $18{ }^{\circ} \mathrm{C}$ " 6 . Proyectos como el Centrosoyuz (Moscu, 1928) o la Cité de Refuge (Paris, 1929) fueron reflejo de un punto de vista que ya estaba presente de manera conceptual en Vers une architecture (1923): "una casa que sea ese límite humano, que nos envuelve, que nos separe del fenómeno natural antagonista, que nos de nuestro medio humano, a

\footnotetext{
${ }^{2}$ Simonnet, C., Brève histoire de l'air.

${ }^{3}$ Fleming, Roger; Jankovic, Vladimir: Rivisiting Klima.

${ }^{4}$ Ackermann, M., Cool Comfort: America's Romance with Air-Conditioning.

${ }^{5}$ Cooper, G., Air-Conditioning America: Engineers and the Controlled Environment, 1900-1960.

${ }^{6}$ Cita original: "fabriquer toute l'année de l'air exact, dépoussiéré, désinfecté, exactement humidifié et porté à température constante de $18^{\circ}$ environ". Cf. Le Corbusier, La ville radieuse : eléments d'une doctrine d'urbanisme pour l'équipement de la civilisation machiniste, p. 42.
} 
nosotros, los hombres ${ }^{\text {,7 }}$. Tal como Torres Cueco $^{8}$ señala, para Le Corbusier esta casa completamente regulada constituía un agente protector frente a un ambiente natural desordenado que dificultaba el desarrollo de la vida humana.

En paralelo al air-conditionning, profesionales de diverso ámbito defendieron una segunda tesis basada en las mismas bases científicas: la evolución de las nuevas técnicas de control ambiental permitiría crear en espacios interiores auténticos Climats artificiels en toda su complejidad, cuya interacción con el cuerpo humano sería aprovechada positivamente. La atmosfera interior no pretendía remplazar al clima natural, sino construirse íntimamente ligada a él y modularlo en sus condiciones más extremas. Desde los años 20, diversas aportaciones reflejaron esta articulación, por ejemplo la patente de vidrio Vitaglass permeable a los rayos UVA $^{9}$, los ventiladores de velocidad variable y la ionización del aire ${ }^{10}$ o incluso la vacunación aérea. En definitiva, los Climats artificiels proponían una noción de atmósfera interior aumentada que, conservando las características de heterogeneidad y variabilidad del clima natural, permitiría mejorar la eficiencia biológica del Homme Nouveau.

En 1937 el ingeniero francés André Missenard (1901-1989), colaborador de Le Corbusier desde 1942, acuñó por primera vez el término de la Science des climats artificiels. Missenard tenía como objetivo devolver al ser humano a unas condiciones habitables próximas al clima natural que, según él, resultaba fisiológicamente idóneo para el desempeño de sus tareas vitales y sociales. Por lo tanto: "para la gran mayoría de seres humanos aclimatados a su hábitat, la solución mas racional, aunque parezca paradójico, sería cambiar su clima natural

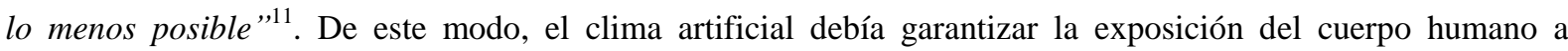
variaciones ambientales semejantes a las del clima exterior, lo cual impediría el acomodamiento del sistema termorregulador y reforzaría la respuesta inmunológica, haciéndolo más vigoroso. Missenard defendió que las técnicas de control ambiental debían ir más allá de la mera regulación térmica, debiendo aspirar a la creación de climas interiores $^{12}$. La Science des Climats artificiels se alineaba técnicamente con el término de climatización empleado en el mundo anglosajón: "conjunto de procedimientos que permiten realizar, en un local, un clima artificial caracterizado por el nivel de la sensación térmica, la pureza del aire, el nivel de la sensación sonora, la presencia de iones, la presión, etc ${ }^{\prime 13}$. En definitiva, el clima artificial articuló los conocimientos de diversas disciplinas interesadas en las atmósferas del hábitat cotidiano y su papel en la construcción del proyecto de la modernidad.

\footnotetext{
${ }^{7}$ Cita original: "une maison qui soit cette limite humaine, nous entourant, nous séparant du phénomène naturel antagoniste, nous donnant notre milieu humain, à nous hommes". Cf. Le Corbusier, Vers une architecture.

${ }^{8}$ Torres Cueco, J., Pensar la arquitectura: Mise au point de Le Corbusier, p. 103.

${ }^{9}$ Sadar, J., The Healthful Ambience of Vitaglass: Light, Glass and the Curative Environment.

${ }^{10}$ Cooper, G., Ob. Cit.

${ }^{11}$ Missenard, A., L'homme et le climat.

${ }^{12}$ Missenard, A., Le conditionnement des locaux.

${ }^{13}$ Ibidem.
} 

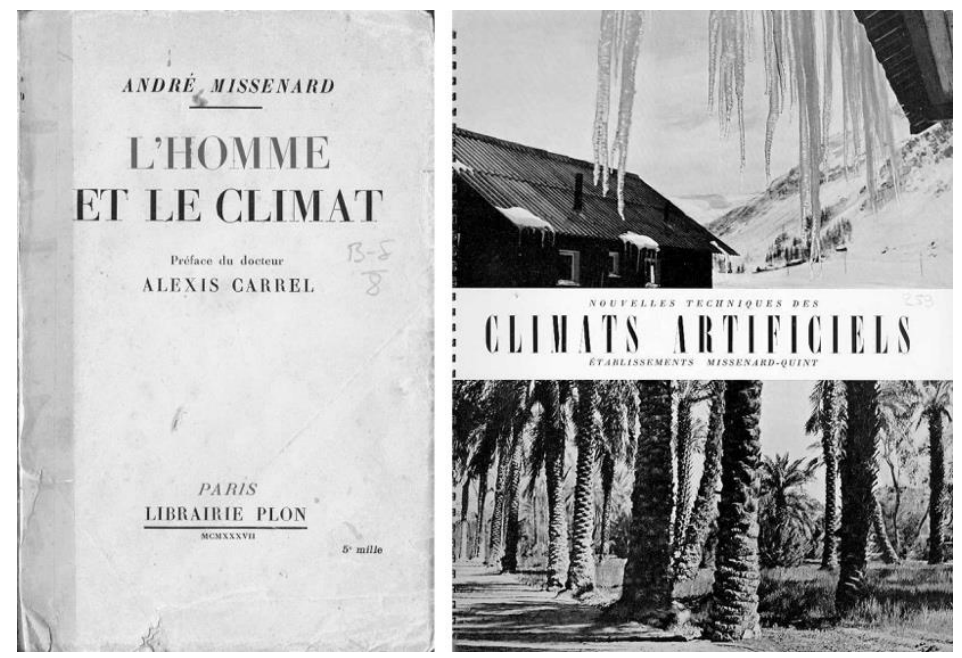

1. L'homme et le climat de André Missenard, prologado por Alexis Carrel, y tríptico publicitario de Ets Missenard-Quint en 1957 (FLC Q1-15-259). Fuente: ( ) FLC-ADAGP.

En este contexto, la noción de clima transcendió su dimensión climatológica vinculándose a conceptos de naturaleza cultural o política, como el confort, la eficiencia o la ergonomía. Si bien el primer aspecto es visible en los trabajos de Corbin o de la Soudière ${ }^{14}$, el segundo ha sido especialmente subrayada por Sloterdijk ${ }^{15}$. La capacidad de controlar el clima a pequeña escala redefinió tanto los modos de ocio, de trabajo y de habitación propugnados por la modernidad, como los ambientes donde estas actividades debían llevarse a cabo. La arquitectura de la vivienda, en consecuencia, sirvió para operar una utopía climático-terapéutica de amplias implicaciones sociales. Reflejo de ello fue la introducción de la temática Climats artificiels en los comités pluridisciplinares de vivienda de la Sociedad de Naciones y de la Fondation Française pour l'Etude des Problèmes Humains ${ }^{16}$. El interés de Le Corbusier por estas cuestiones quedó patente en sus continuos intercambios y colaboraciones con médicos e ingenieros especializados (thermiciens) desde final de los años 30 hasta final de los 50, los cuales se detallan a continuación.

\section{Le Corbusier y los climas artificiales}

En su publicación L'Homme et le climat (1937), Missenard indicó por primera vez la necesidad de asentar las bases de una nueva disciplina: la Science des climats artificiels. A modo de manual el libro realiza un estado del arte de los fenómenos ambientales conocidos y sus efectos sobre la salud, la productividad o el comportamiento humano. Aunque Le Corbusier no conocería personalmente a Missenard hasta 1942, su biblioteca personal conservada en la FLC contiene una edición de L'Homme et le climat de 1937. El libro, posiblemente su primer contacto directo con las ideas de Missenard, revela a través de copiosas anotaciones el interés del arquitecto por la dimensión ambiental en la arquitectura y el urbanismo modernos. Además, el documento constata su intención de vincular los postulados técnico-científicos de Missenard con el proyecto de la Ville Radieuse (1934), instrumentalizando afirmaciones sobre el soleamiento, la ionización del aire, la ventilación natural o el apoyo a un modo de vida físicamente activo, a favor de un nuevo urbanismo.

\footnotetext{
${ }^{14}$ Véanse: De la Soudière, M., Au bonheur des saisons; Corbin, A., La pluie, le soleil et le vent.

${ }^{15}$ Sloterdijk, P., Esferas III - Espumas, Esferología plural.

${ }^{16}$ Marino, G. « Some Like It Hot ! » Le confort physiologique et ses dispositifs dans l'architecture du XXè siècle.
} 
Otra punto de acceso a las ideas subyacentes en la noción de clima artificial fue el círculo social común con Missenard, con personalidades como el biólogo y cirujano Alexis Carrel (1873-1944), premio nobel en medicina (1912), convencido defensor del eugenismo ${ }^{17}$ y presidente de la Fondation Française pour l'Etude des Problèmes Humains. También cabe destacar la figura de Pierre Winter (1891-1952), médico, biólogo e higienista francés, igualmente unido al movimiento eugenista, que fue amigo y vecino de Le Corbusier en el 24 rue Nungesser et Coli. El doctor era un convencido de la importancia de la arquitectura para la salud de la sociedad moderna y militaba por el enfoque ambiental de Missenard sobre el medio construido.

En Junio de 1937, Winter realizó una intervención en el V CIAM en Paris, titulada "Logis et loisirs (vivienda y ocio)". La ponencia recogió de manera general los requerimientos medicinales exigidos a las soluciones habitacionales modernas, dado que, en su opinión, para los médicos era imposible "cumplir correctamente su misión de 'reducir las enfermedades al mínimo estricto, construir cuerpos robustos y harmoniosos sin viviendas saludables, sin ocio organizado, sin la reconstrucción de las fabricas, de las oficinas, sin la creación de todo el equipamiento de salud" "18. Winter basaba su propuesta en la idea de obtener el máximo aprovechamiento de los beneficios biológicos del clima del lugar sobre el cuerpo humano, corregido mediante la arquitectura en caso de ser necesario. Por ejemplo, refiriéndose al soleamiento, Winter destacó la obligación de maximizar la captación de luz natural evitando la orientación Norte o aplicando correcciones arquitectónicas en caso necesario. Según su opinión la luz en la ciudad moderna estaba enferma: "disminución de rayos U.V. (ineficacia de la helioterapia urbana), disminución de los infrarrojos (calorificos) y perdida de elementos vitalizantes (...) El pan de verre, en la ciudad actual contaminada, es lo mejor que podemos desear; para las ciudades con aire puro, daremos todas las facilidades para el contacto directo entre la piel y la luz. "19 Sin embargo, aparte de indicaciones generales sobre orientación solar o ventilación, su proyecto no entraba en el detalle ni científico ni técnico sobre su materialización.

Como veremos a continuación, la relación profesional entre Le Corbusier y Missenard aportó un mayor grado de concreción en la dimensión técnica y fisiológica de los climas artificiales, asociándolo al uso de estrategias o dispositivos arquitectónicos. En consecuencia, su trabajo colaborativo durante los años 50 se convirtió en un laboratorio de soluciones ambientales para el hábitat moderno ${ }^{20}$.

No obstante, si bien Le Corbusier y Missenard parecían coincidir en los principios esenciales, sus puntos de vista divergían en cuanto a la manera de materializarlos. El trabajo de Le Corbusier intentaba acercar a los habitantes a unas condiciones naturales idealizadas, lo cual podía ocurrir dentro o fuera de la arquitectura, o como él mismo lo dijo en su articulo Aux approches d'une synthèse $e^{21}$, hacer que a través de la arquitectura moderna "les conditions de nature sont reconquises !’. Al contrario, Missenard pensaba que el clima artificial no debía ni suplir ni imitar el contacto real con la naturaleza, enfoque que le llevó a criticar la arquitectura de Le Corbusier: “es preocupante que los ventanales alargados de Le Corbusier, 'incorporando el paisaje en la vivienda', creen la peligrosa ilusión de la vida al aire libre ${ }^{, 22}$.

\footnotetext{
${ }^{17}$ Su libro L'Homme, cet inconnu publicado en 1935 se convirtió en un manifiesto reconocido internacionalmente.

${ }^{18}$ Winter, P., "Logis et loisirs", Junio 1937, FLC D2.11.557.

${ }^{19}$ Winter, P., "Logis et loisirs", Junio 1937, FLC D2.11.561.

${ }^{20}$ Requena-Ruiz, I.; Siret, D. Experiments on Thermal Comfort and Modern Architecture.

${ }^{21}$ Le Corbusier, Aux approches d'une synthèse. Aboutissement de vingt années consacrées à la recherche d'une doctrine du domaine bâti.

${ }^{22}$ Missenard, A., A la recherche de l'homme, p. 2.
} 


\section{La Grille Climatique: la regulación climática y el hábitat moderno}

La colaboración profesional Le Corbusier-Missenard se inició de forma efectiva tras su vuelta del segundo viaje a Chandigarh (India) en Noviembre de 1951. Le Corbusier escribió al ingeniero en busca de consejo experto, dado que la nueva serie de encargos en la India suponían un desafío de adaptación a un clima distinto. Consciente de la importancia del clima en estos proyectos, el arquitecto aprovechó el viaje para solicitar la información climatológica al Institute of Fundamental Research of Bombay ${ }^{23}$. Su carta a Missenard revela una ambición mayor: desarrollar un método de ideación que le permitiera obtener condiciones ambientales idóneas en la arquitectura para cualquier clima. Dado que la rigidez de las normativas en los países europeos dificultaban la experimentación a este respecto, Le Corbusier concebía sus proyectos en la India como una oportunidad de explorar otras soluciones de control ambiental: "Las reglamentaciones en relación a esta nueva capital implican la toma de decisiones respecto a las leyes de higiene (de diferente naturaleza a nuestras reglamentaciones conformistas y fruto de todos los compromisos) ${ }^{, 24}$.

El proceso de concretización del método se continuó de manera intensiva con la ayuda del ingeniero griego Iannis Xenakis (1922-2001), quien estableció el "Programa de estudios de las condiciones climáticas óptimas y de los medios arquitectónicos de corrección" 25 . En el texto Xenakis especificó cuatro variables del "ambiente climático" (temperatura, humedad relativa, velocidad del aire y temperatura de los muros) que determinarían "las variaciones ambientales óptima y teórica para conservar o incrementar el mejor rendimiento VITAL”,26. El 20 de diciembre de 1951, Xenakis dibujó un diagrama titulado “Grille d’hygiène climatique”,27, aunque el término higiene se eliminó en diagramas posteriores ${ }^{28}$. La evolución de la terminología utilizada evidencia la influencia de Missenard en su elaboración" ${ }^{29}$. En paralelo, Samper elaboró un plano llamado "Esquisse générale

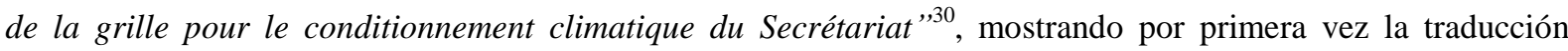
arquitectónica de los criterios físicos y fisiológicos indicados en la Grille Climatique.

A fecha 31 de enero de $1952^{31}$, el equipo de proyecto documentó el método de ideación en el dosier Grille Climatique, el cual además se complementó con un catálogo de soluciones aplicado en el proyecto de viviendas Maisons des péons $110 \mathrm{~m}^{2}$ (1952) en Chandigarh. Los autores lo describieron como un modo de visualización que permitiría enumerar, coordinar y analizar los datos climatológicos de un emplazamiento definido, con el objetivo de guiar la investigación arquitectónica hacia soluciones mas próximas a las necesidades de la biología

\footnotetext{
${ }^{23}$ Le Corbusier, carta a Pran Nath Thapar, 9 de Diciembre de 1951, FLC P2.17.183.

${ }^{24}$ Le Corbusier, carta a André Missenard, 3 de Diciembre de 1951, FLC E2.16.14. Cita original: "Des réglamentations concernant cette nouvelle capitale impliquent des decisión à prendre concernant les lois de l'hygiène (de tout autre natura que nos règlamentations conformistes et fruits de tous les compromis)".

${ }^{25}$ Xenakis, I., "Programme d'études des Conditions Climatiques Optima et des Moyens Architecturaux de correction," 16 de Diciembre de 1951, FLC P2.1.1.

${ }^{26}$ Ibidem. Cita original: "les variations optima et théoriques de l'ambiance pour conserver ou accroître le meilleur rendement VITAL".

${ }^{27}$ Denominación original: "Grille d'Hygiène Climatique", cf. Le Corbusier, carta a Jane Drew, 20 de Diciembre de 1951, FLC, G2.11.26.

${ }^{28}$ Le Corbusier, carta a Jane Drew, 21 de Diciembre de 1951, FLC P2.1.9.

${ }^{29}$ Siret, D. Grille Climatique, 1951.

${ }^{30}$ Samper, G., "Esquisse générale de la grille pour le conditionnement climatique du Secrétariat", 21 de Diciembre de 1951, FLC 2642.

${ }^{31}$ Atelier Le Corbusier, "Grille climatique”, 31 de Enero de 1952, FLC P2.1.3.
} 
humana. A través de estrategias y dispositivos arquitectónicos diversos, su interés residía en la regulación y corrección efectiva de los excesos del clima para crear las condiciones de bienestar y el confort ${ }^{32}$.

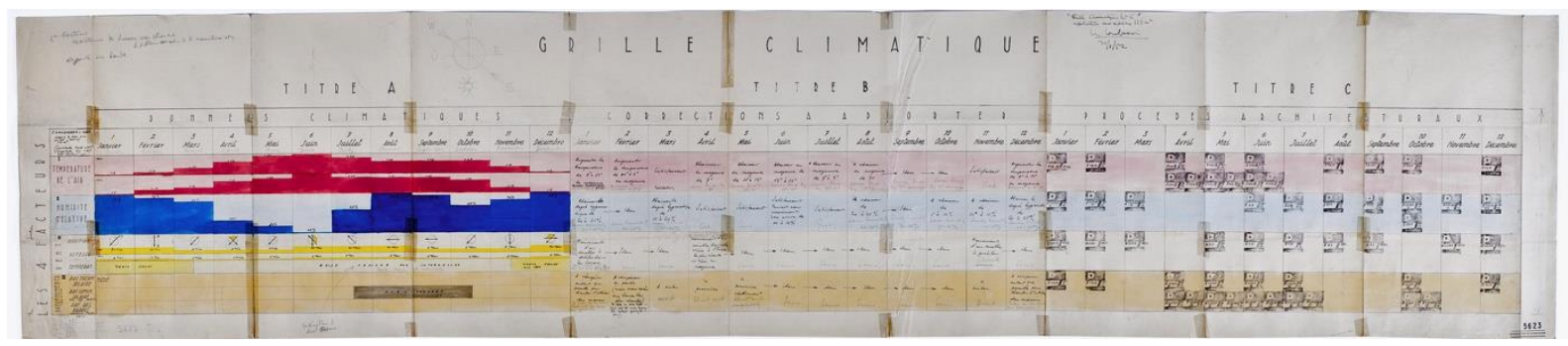

2. Grille Climatique según los datos climatológicos de Chandigarh (FLC 5623). Fuente: @ FLC-ADAGP.

El esquema definitivo quedó compuesto por tres columnas. La primera, titulada "Datos climáticos" (con anterioridad "Condiciones de ambiente”), recogía la información climatológica correspondiente a los cuatro factores ambientales propuestos originalmente por Missenard: temperatura del aire, humedad relativa, dirección y velocidad del viento, así como soleamiento y radiación térmica de las construcciones. La segunda columna fue llamada "Correcciones a ofrecer" (previamente "Correcciones en vista del confort y el bienestar"), remplazando la expresión del "mejor rendimiento vital” de la versión precedente. Según las instrucciones escritas, esta fila debía ser rellenada por un "físico-biólogo"33, quien determinaría un programa de condiciones ambientales que serviría de apoyo a la intervención de los arquitectos. La tercera columna fue titulada "Procedimientos arquitectónicos" (antes "Soluciones arquitectónicas"), teniendo como cometido indicar la existencia de una solución técnico-formal aconsejada.

La identificación de dichas propuestas se hizo mediante un sello con la letra D seguida de un código numérico, haciendo alusión a un conjunto de dieciséis croquis específicos personalmente realizados y firmados por Le Corbusier $^{34}$. Por medio de una sección y una planta para cada propuesta, los arquitectos ilustraron las soluciones primarias y sus combinaciones: control solar, regulación de la humedad, control de la ventilación cruzada y construcción con alta inercia térmica. El proyecto elegido, las Maisons des péons $110 \mathrm{~m}^{2}$, se trataba de un conjunto de viviendas unifamiliares en hilera basado en otro proyecto previo no construido de prototipos de viviendas para el plan urbano de Bogotá (Colombia, 1950). El principal valor de este trabajo no realizado en la India fue, precisamente, servir de ejemplo para la aplicación de estrategias pasivas de climatización en el hábitat social moderno.

\footnotetext{
${ }^{32}$ Ibidem.

${ }^{33}$ En el primer y único ejemplo de la Grille Climatique, fue Missenard quien rellenó estas notas en tanto que "physicobiologiste". Cf. Missenard, "Corrections désirables dans les locaux," 16 de Enero de 1952, FLC, P2.1.27.

${ }^{34}$ Conservados en el conjunto de dibujos con la cota FLC 5627.
} 

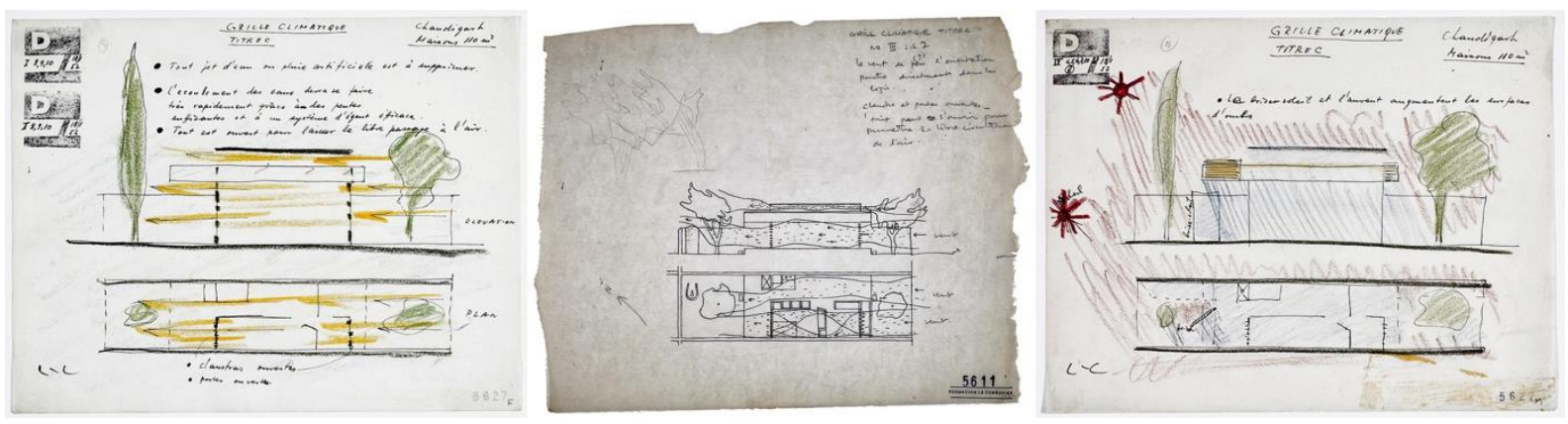

3. Serie de croquis adjuntos a la Grille Climatique. Fuente: (C) FLC-ADAGP.

Finalizado el periodo intensivo de reflexión metodológica, la Grille climatique desapareció de los trabajos del Atelier 35S, aunque Le Corbusier insistió con posterioridad en su interés para Chandigarh: "Pero esta Grille Climatique no ha sido tenida en consideración en Chandigarh y yo lo lamento amargamente (...) Habiendo sido perdida esta Grille yo estoy dispuesto a hacer establecer una nueva y a enviarla a Chandigarh si me lo solicitan ${ }^{, 35}$. No obstante, las estrategias de intervención propuestas en las citadas viviendas formaron parte del argumentario proyectual del Atelier $35 S$ en sus grandes proyectos públicos (e.g., Secretariado Chandigarh 1950, Alta Corte Judicial Chandigarh 1950, Palacio de los Hilanderos Ahmedabad 1956), pero también en sus proyectos de vivienda individual (e.g., Villa Sarabhai Ahmedabad 1955, la Villa Shodan Ahmedabad 1956) y colectiva (e.g., Convento de la Tourette Eveux-sur-l'Arbresle 1959 o la Casa de Brasil Paris 1959).

\section{Sistemas radiantes y prototipos climático-espaciales}

A lo largo de los sucesivos estados del arte realizados por Missenard para alimentar el corpus teórico de la Science des Climats Artificiels, los estudios de las técnicas de regulación ambiental y la reacción fisiológica desencadenada mostraron el interés del ingeniero por los sistemas radiantes. Una elección que venía justificada por diversos motivos: la baja temperatura de calefacción que minimizaría los movimientos del aire, reduciendo la difusión de microbios en comparación a otros sistemas; la libertad de instalación respecto a las particiones y los cerramientos; la posibilidad de mantener temperaturas de aire bajas, supuestamente más saludables para los pulmones; y la durabilidad de la instalación, dado que quedaría protegida dentro del hormigón ${ }^{36}$. Paradójicamente, Missenard era escéptico a la tesis defendida por algunos de sus colegas ingenieros, que equiparaba la calefacción radiante al modo natural por el cual recibimos la radiación solar desde el cielo (calefacción en el techo) o desde el terreno (suelo radiante). Aunque aceptaba que la radiación se asemejaba en mayor medida a la manera natural en la que el cuerpo humano recibe la energía calorífica, no coincidía en que su artificialización tuviera las mismas propiedades que la radiación luminosa y calorífica del Sol ${ }^{37}$.

Durante los años 40, Missenard desarrolló una patente de calefacción por suelo radiante: el Système Missenard. El método consistía en una instalación de tuberías de diámetro medio integradas en la losa de hormigón, convirtiendo el elemento estructural a la vez en calefactor. Sin embargo, hacia final de la década la compañía Ets Missenard-Quint no solo explotaba su patente, sino que también era concesionaria para Francia de la patente de

\footnotetext{
${ }^{35}$ Le Corbusier, carta a Varma, 22 de Mayo de 1956, FLC P1.10.303. Cita original: "Mais cette Grille Climatique n'a pas été prise en consideration à Chandigarh et je le regrette amérement (...) Cette Grille ayant été perdue je suis prêt à en faire établir une nouvelle et à l'envoyer à Chandigarh si on me la demande".

${ }^{36}$ Missenard, A., A la recherche du temps et du rythme.

${ }^{37}$ Missenard, A., Le Chauffage et la rafraichissement par rayonnement.
} 
superficies radiantes de la multinacional inglesa Richard Crittall \& Co, que a su vez era concesionaria del Système Missenard para el resto de Europa ${ }^{38}$. A diferencia de la licencia Missenard, la patente de Crittall se realizaba mediante tuberías de pequeño diámetro y se instalaba en la capa superficial de techos o muros. La conexión entre las dos empresas manifiesta su disposición a emprender en técnicas modernas de acondicionamiento ambiental, así como su interés en la relación entre la técnica y la arquitectura modernas. Sirva de ejemplo el hecho de que los sistemas de Richard Crittall \& Co fueron utilizados, entre otros, por el ingeniero finés Carl Rosenqvist, colaborador de Alvar Aalto ${ }^{39}$. Finalmente, cabe destacar que, tras varios debates entre los ingenieros y el Atelier $35 S$ relativos a la calefacción de las Maisons Jaoul (Neuilly-sur-Seine, 1951-5), el menor coste del Système Missenard provocó que fuera el único ejecutado en las obras de Le Corbusier, como la Maison du Brésil (Paris, 1953-59) o las Unités d'habitation desde Rezé (1949-56).
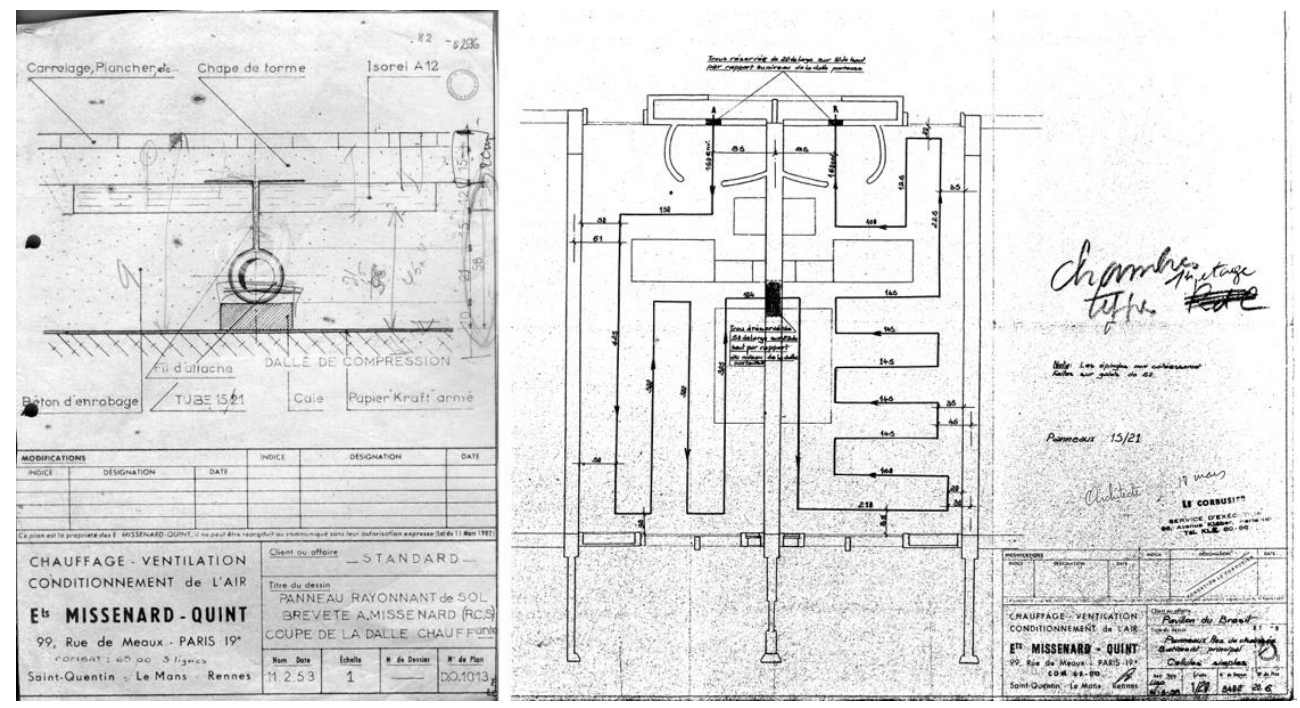

4. Esquema del Système Missenard y plano instalación de planta baja en la Casa de Brasil. () FLC-ADAGP.

La adaptación de un sistema de calefacción radiante, basado en los principios de gran inercia térmica y temperatura constante en su periodo activo, a los requisitos de variabilidad exigidos según los criterios de la Science des climats artificiels, fue abordada por Missenard de diversas maneras. En primer lugar, la diferenciación de los circuitos de alimentación en fluido calorífico según la orientación y las pérdidas térmicas de la zona, estrategia empleada en las Unités d'habitation a partir de Rezé o en la Maison du Brésil. Si tomamos de ejemplo el caso de Rezé, la instalación cuenta con cinco circuitos de calefacción diferentes no delimitados a cada vivienda sino al grado de exposición. Los circuitos se definieron entonces como: fachada este, fachada oeste, fachada sur, planta primera y planta ático. En segundo lugar, la temperatura del fluido calorífico se regulaba de manera continua a través de una sonda interior y otra exterior para cada circuito, especialmente desarrolladas por Ets Missenard-Quint ${ }^{40}$ para permitir la adaptación a las oscilaciones térmicas exteriores. La regulación se realizaba de manera centralizada según los criterios establecidos por la ingeniería, no permitiendo la interacción con los habitantes. En tercer lugar, la temperatura de cada espacio se pensó en base al uso del

\footnotetext{
${ }^{38}$ Prueba de la importancia de este acuerdo es su presentación en el encabezado del papel oficial de Ets Missenard-Quint en los años 50 con la leyenda "Concessionnaire des Brevets Internationaux de Chauffage par Rayonnement. Licence Crittall”. Cf. Bernard Morel, carta a André Wogenscky, 27 de Febrero de 1953, FLC N4.1.38.

${ }^{39}$ Linnanmäki, S., Aalto's Ideas on Air-Conditioning - How Finland Became a "Fanland"?

${ }^{40}$ Dupuy, R., et al. Régulation automatique; Monnier, M., Le Corbusier 1955-2005, Rezé-les-Nantes.
} 
mismo y de su situación en el trayecto diario de los habitantes en el edificio. Como demuestra el proyecto de instalación de la Maison du Brésil, el desfase térmico interior-exterior se amortiguaría creando una transición desde las habitaciones calefactadas a $18{ }^{\circ} \mathrm{C}$, el corredor interior no calefactado, la planta baja calefactada de manera general a $15{ }^{\circ} \mathrm{C}$ y la cámara de transición vidriada con doble puerta de entrada. Por último, la yuxtaposición de múltiples sistemas de calefacción facilitaría una mayor precisión de control térmico, ejemplo que podemos ver en el mismo proyecto: sistema general de calefacción por suelo radiante para garantizar una temperatura de base mínima; radiadores-convectores en zonas más expuestas de planta baja, planta primera y ático; e impulsión de aire acondicionado en el salón de actos.

Al igual que ocurrió con el mur neutralisant respecto a las fachadas en los años 20, el suelo se convirtió durante los años 50 en un elemento de múltiple funcionalidad en la arquitectura de Le Corbusier, sumando a su cometido estructural las dimensiones sensorial térmica, técnica y plástica. El trabajo realizado sobre los solados de edificios como la Maison du Brésil o las Unités d'habitation así lo evidencia. Las plantas residenciales se realizaron en linóleo según la patente Dalami en formato de losetas adheridas de 30x30x1 cm, elegido por su acabado superficial así como por sus propiedades de transmisión térmica y resistencia a dilataciones. Si bien la composición del material con asbestos resulta problemática actualmente por cuestiones sanitarias, en el momento de la construcción fue una propuesta innovadora en la construcción de viviendas. La planta baja, a diferencia, se realizó en solado de pizarra pulida montada según un despiece en bandas paralelas de diferentes dimensiones. La forma de reflejar las luces y de radiar el calor desde la instalación inmediatamente inferior otorgan al suelo de este espacio continuo una presencia térmica y visual que envuelve al usuario. Cabe remarcar, además, que las características formales de tal espacio (continuidad espacial, altura de techo variable y cerramientos curvos) habrían sido difícilmente viables con otro sistema de calefacción. El dispositivo espacial-sensorial descrito no fue una aportación puntual en el trabajo de Le Corbusier, si no que se extendió a otras proyectos de hábitat colectivo, como las Unités d'habitation de Rezé (1949-56), de Briey-en-Forêt (1956-60) y en Firminy (1959-68), o incluso parcialmente en el Convento de la Tourette.

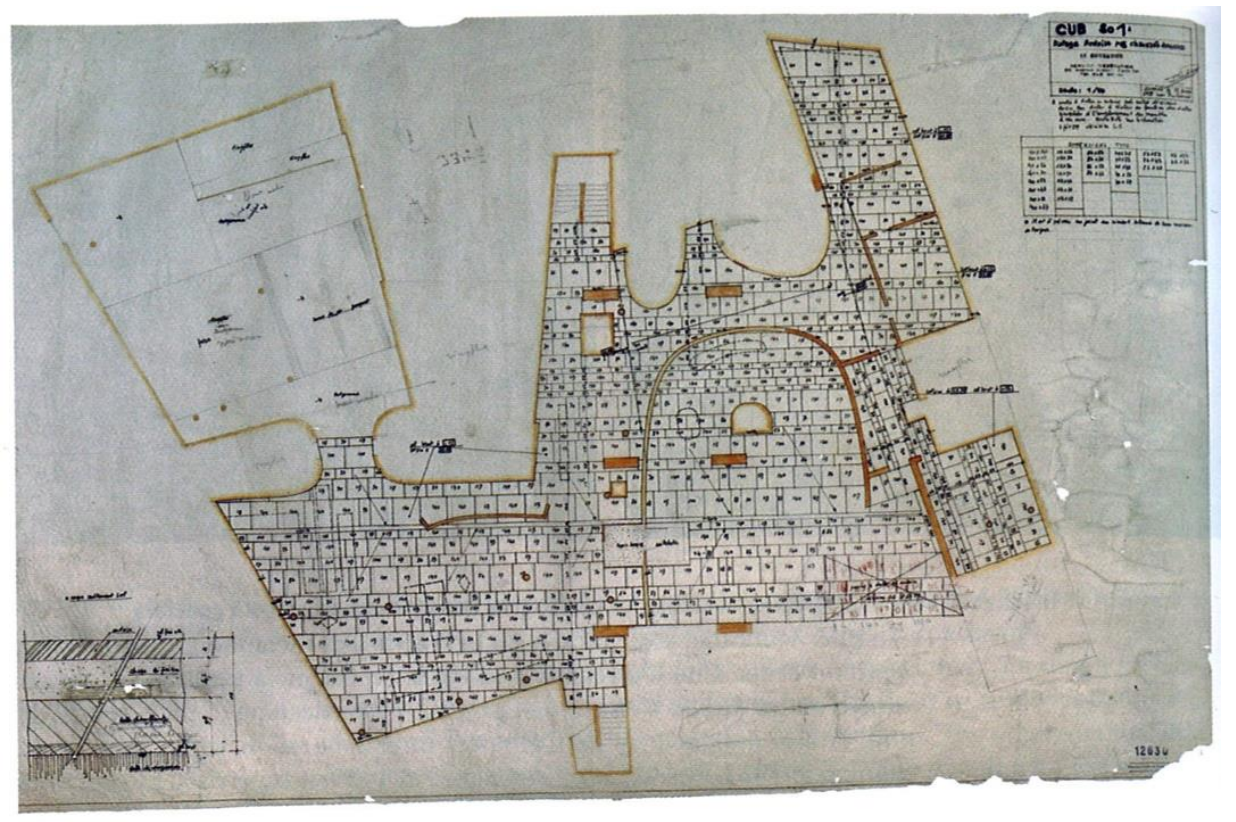

5. Casa de Brasil, planos de despiece de solado de pizarra y trazado de instalación de suelo radiante (FLC 12630). C FLCADAGP. 
La radiación calorífica fue también motivo de experimentación en el proyecto de la Ecole Maternelle de la Unité d'habitation en Firminy. En este caso, la conexión directa del edificio a la red de calefacción urbana fue aprovechada para independizar totalmente el sistema de calefacción en la última planta. La distribución en serie de las aulas sirvió para insertar paneles radiantes integrándolos en la zona inmóvil de las particiones. Los ingenieros se apoyaron en una patente de la Escuela Politécnica de Varsovia con paneles de hormigón conectados directamente a la red. El dispositivo estaba compuesto por un serpentín metálico y una armadura de acero embebidos en el hormigón. Publicado en los Annales del ITBTP en 1957, el citado método aprovechaba la inercia térmica del hormigón al tiempo que permitía explorar el valor plástico del radiador como objeto que formaba parte de las composiciones espaciales de Le Corbusier desde el principio de su practica profesional ${ }^{41}$.

En resumen, la dimensión térmica de las soluciones habitacionales de Le Corbusier en los años 50 revela, de una parte, una interacción más rica y compleja entre clima, arquitectura y cuerpo humano en comparación con sus propuestas de los años 20. Por otra parte, nos indica igualmente una imbricación de las instalaciones de acondicionamiento ambiental en la experiencia espacial y sensorial de la arquitectura de Le Corbusier, evolucionando desde una percepción óculo-céntrica del espacio hacia una percepción más envolvente.

\section{Conclusión: una arquitectura que restablece las condiciones naturales}

Como resultado de un periodo de experimentación conceptual y aplicada a la vez, la comprensión de la arquitectura como una construcción ambiental, especialmente en su dimensión térmica, pasó a formar parte de las propuestas teóricas de Le Corbusier. Desde que en 1945 publicó la primera edición de su teoría de Les Trois Etablissements Humains, la influencia de Winter y Missenard resultaron mas explicitas. En concreto, su interpretación teórica pasó por la afirmación de un medio físico capaz de restituir unas condiciones vitales mas próximas a un ideal natural. Le Corbusier introdujo inicialmente este aspecto bajo el paraguas general de las condiciones de trabajo que, según el, habían desconectado al hombre de su medio primigenio. El clima natural constituía en sus propias palabras un "juego fértil de reacciones favorables al mantenimiento de la máquina humana, muscularmente y nerviosamente (...) La diversidad se imponia, poniendo al hombre en un estado permanente de acomodamiento, de defensa, de mantenimiento, de reforzamiento, de recuperación ",42. Si Les trois établissements humains pretendía resolver eficazmente los problemas de ocupación del territorio de la civilización maquinista, el restablecimiento de las Conditions de nature en el marco vital del ciudadano permitiría fabricar las condiciones ambientales idóneas para el individuo moderno.

El arquitecto suizo-francés desarrolló este punto de vista en mayor profundidad en el artículo "Rétablir les conditions nature", publicado en 1957 en la revista de paisajismo Espaces verts et jardins. En él, Le Corbusier comenzó explicando cómo la técnica había esclavizado al ser humano determinando un nuevo entorno vital. Una idea anteriormente preconizada por Missenard, quien trató de explicar los peligros del uso descontrolado de las técnicas de acondicionamiento ambiental: "conviene levantarse contra la tendencia actual de realizar climas artificiales de una manera desordenada (...) combatiendo los efectos nefastos de las condiciones artificiales o

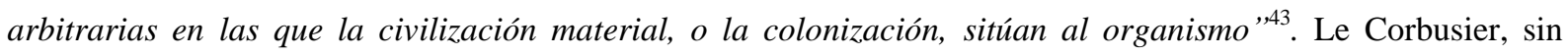
embargo, no se apoyó en trabajos ajenos para defender tal conclusión, si no que para él era el resultado de

\footnotetext{
${ }^{41}$ Nam, S., Le radiateur chez Le Corbusier.

${ }^{42}$ Le Corbusier, Les trois établissements humains, p. 63.

${ }^{43}$ Cita original: "il convient de s'élever contre la tendance actuelle à réaliser des climats artificiels d'une façon désordonnée (...) en combattant les effets fâcheux des conditions artificielles ou arbitraires dans lesquelles la civilisation matérielle, ou la colonisation, place l'organisme”. Cf. Missenard, A., L'homme et le climat, p. 253.
} 
"cincuenta años de investigaciones en arquitectura y urbanismo donde se sucedieron y mezclaron el buen 'Hombre', su hogar, su trabajo, su tiempo libre, su ciudad, su cuerpo, su espíritu y su corazón"44. Como resultado, el arquitecto sostuvo el restablecimiento de las condiciones naturales, lo cual aparece en el texto a modo de evolución de cinco postulados ya presentes en la Ville Radieuse: les 24 heures solaires, le sport au pied des maisons, la nature est entrée dans le bail, la ville verte y les techniques modernes s'y prêtent.

El texto considera la necesidad de restablecer las condiciones ambientales próximas a la naturaleza como parte del proyecto urbano global y no exclusivamente de los espacios de trabajo. El hábitat, en consecuencia, se encuentra directamente afectado por la idea de Rétablir les conditions de nature en calidad de elemento creador de ese medio idealizado. De manera diferente a Missenard, para Le Corbusier la naturaleza debía entrar en la vivienda permitiendo crear la impresión de vivir integrado en ella, para lo cual su propuesta pasaba por maximizar el soleamiento directo, vincular la vista al paisaje, favorecer la renovación del aire interior y controlar su temperatura respecto a las variaciones del clima exterior.

En Julio de 1961, Le Corbusier impartió una conferencia en la Facultad de Medicina de París, titulada "Conditions nature, urbanisme efficace et efficient". El arquitecto preparó una conferencia generalista, explicando su contribución personal a la interacción entre la arquitectura y el clima exterior. Véase por ejemplo la presentación del brise-soleil y los problemas derivados al no utilizarlo, ejemplificados en los edificios de la ONU y de la UNESCO, o su propuesta de ventilación natural para el Secretariado de Chandigarh. Posteriormente, el texto de la conferencia ensalza de nuevo el contraste existente entre los ritmos naturales de la vida, variables y adaptativos, respecto al ritmo único y continuo de la máquina. En palabras de Le Corbusier: "la alternancia que es un fenómeno de naturaleza humana. Todo lo que es humano es alternante: el marchar, el parpadeo de los ojos, la palabra, los labios que hablan, todo lo que ustedes quieran, me da igual, es alternante, mientras que la máquina, ella, es continua "45. Afirmación que, una vez más, podemos considerar análoga al texto de Missenard en 1937: "en una época donde podemos considerar realizar, artificialmente, todos los climas, es conveniente llamar la atención sobre el peligro y la responsabilidad que comporta la generalización, sin precauciones, de estas condiciones artificiales ahora, en permanencia, lo que consideramos estar en el confort ideal ${ }^{, 46}$. En consecuencia, el hábitat se convirtió en un método para la creación de climas artificiales, considerados como ambientes heterogéneos capaces de estimular e interactuar con el cuerpo y la percepción de los habitantes.

La publicación póstuma del libro Mise au point por Jean Petit en $1965^{47}$, sirvió para insistir en la importancia del argumento de restablecer las condiciones naturales como eje fundamental de sus propuestas arquitectónicas y urbanas. La arquitectura moderna tenía para Le Corbusier la responsabilidad de luchar contra la progresiva desnaturalización del entorno vital del ser humano debida al mal uso de las técnicas modernas, entre ellos los sistemas de acondicionamiento ambiental. Su colaboración con Winter y Missenard, unida a la creciente necesidad de vivienda tras la Segunda Guerra Mundial, hizo de su obra un campo de experimentación donde el

\footnotetext{
${ }^{44}$ Le Corbusier, Rétablir les conditions de nature.

${ }^{45}$ Cita original: "l'alternance qui est un phénomène de nature humaine. Tout ce qui est humain est alternatif: la marche, le battement des yeux, la parole, les lèvres qui parlent, tout ce que vous voudrez, ça m'est égal, c'est alternatif alors que la machine, elle, est continue". Cf. Le Corbusier, "Conditions de nature, urbanisme efficace et efficient", Conferencia en la Facultad de Medicina de París, Julio de 1961, FLC C3.10.46.

${ }^{46}$ Cita original: "À une époque où l'on envisage de réaliser, artificiellement, tous les climats, il convient donc d'attirer l'attention sur le danger et la responsabilité que comporte la généralisation, sans précautions, de ces conditions artificielles maintenant, en permanence, ce qu'on estime être le confort idéal'. Cf. Missenard, A., L'homme et le climat.

${ }^{47}$ Le Corbusier, Mise au point.
} 
objetivo era construir un hábitat, en sus dimensiones sensorial, ambiental y física, que transcendiera la función básica de alojamiento y cumpliera un objetivo social más amplio en el conjunto del proyecto de la modernidad.

\section{Agradecimientos}

Los autores desean agradecer a la Fondation Le Corbusier y a la Bibliothèque Nationale de France por el acceso a sus fondos documentales. La presente investigación ha sido financiada con el apoyo de la Fondation Le Corbusier - Bourses pour Jeunes Chercheurs 2013.

\section{Bibliografía/referencias}

Ackermann, Marsha E.: Cool Comfort: America's Romance with Air-Conditioning. Washington: Smithsonian Institution Press, 2002.

Campbell, Margaret: "What Tuberculosis Did for Modernism: The Influence of a Curative Environment on Modernist Design and Architecture". En Medical History. Octubre 2005, n 49. pp. 463-88.

Cooper, Gail: Air-Conditioning America: Engineers and the Controlled Environment, 1900-1960. Baltimore: The John Hopkins University Press, 1998.

Corbin, Alain: La pluie, le soleil et le vent : une histoire de la sensibilité au temps qu'il fait. Paris: Aubier, 2013.

De la Soudière, Martin: Au bonheur des saisons. Voyage au pays de la météo. Paris: Grasset, 1999.

Dupuy, R.; Broida, V.; Marmillot, A.; Touzard, P.; Raussou, J: Régulation automatique. Annales de l'Institut Technique du Batiment et des Travaux Publiques. N 60. 1952.

Fleming, Rodger; Jankovic, Vladimir: "Revisiting Klima". En Osiris. $\mathrm{N}^{\circ}$ 26. Chicago: The University of Chicago Press, 2011. pp. 1-16. doi:10.1086/661262.

Hobday, Richard: The Light Revolution: Health, Architecture, and the Sun. Forres: Findhorn Press, 2006.

Le Corbusier: "Aux approches d'une synthèse. Aboutissement de vingt années consacrées à la recherche d'une doctrine du domaine bâti". En Boesinger, Willy; Le Corbusier. (Ed.): Le Corbusier. CEuvre Complète 19381946. Zurich: Les éditions d'architecture, 1947. $7^{a}$ ed. 1977. pp. 66-68.

Le Corbusier: La ville radieuse: eléments d'une doctrine d'urbanisme pour l'équipement de la civilisation machiniste. Boulogne-sur-Seine: L'Architecture d'aujourd'hui, 1935.

Le Corbusier: Les trois établissements humains. Paris: Editions Denoël, 1945.

Le Corbusier: Mise au point. Paris: Forces Vives, 1965.

Le Corbusier: "Rétablir les conditions de nature". En Espaces verts et jardins, № 7. 1957. pp. 33-43.

Le Corbusier: Vers une architecture. París: Crès, 1923.

Linnanmäki, Seija: “Aalto's Ideas on Air-Conditioning - How Finland Became a 'Fanland'?". En Working papers - Alvar Aalto Researchers' Network. Seinäjoki: Alvar Aalto Museum, 2012.

Marino, Giulia: “'Some Like It Hot!' Le confort physiologique et ses dispositifs dans l'architecture du XXè siècle : histoire et devenir d'un enjeu majeur.” Director: Franz Graff. École Polytechnique Fédérale de Lausanne, Faculté de l'environnement natural, architectural et construit, 2014.

Missenard, André: Le chauffage et le rafraichissement par rayonnement. París: Eyrolles, 1959.

Missenard, André: À la recherche de l’homme. París: Librairie Istra, 1954.

Missenard, André: À la recherche du temps et du rythme. París: Plon, 1940.

Missenard, André: L'homme et le climat. París: Librairie Plon, 1937. 
Missenard, André: "Le conditionnement des locaux. Conceptions et réalisations modernes". En La technique moderne. $\mathrm{N}^{\circ} 7.1934$.

Monnier, Marilyne: Le Corbu 1955-2005 Rezé-Les-Nantes. Rezé: Marilyne Monnier, 2005.

Nam, Sung-Taeg: "Le radiateur chez Le Corbusier”. En Massilia 2012. Annuaire d'études corbuséennes. La boite à miracles - Le Corbusier et le théâtre. Marsella: Éditions Imbernon, 2012. pp. 17-42.

Requena-Ruiz, Ignacio; Siret, Daniel: "Experiments on Thermal Comfort and Modern Architecture: The Contributions of André Missenard and Le Corbusier". En Rosso, Michela. (Ed.): Third EAHN International Meeting. Investigating and Writing Architectural History: Subjects, Methodologies and Frontiers. Torino: Politecnico di Torino, 2014. pp. 651-62.

Sadar, John: "The Healthful Ambience of Vitaglass: Light, Glass and the Curative Environment". Architectural Research Quaterly. №12. 2008. pp. 269-81. doi:10.1017/S1359135508001206.

Simonnet, Cyrille: Brève histoire de l'air. Versailles: Editions Quæ, 2014.

Siret, Daniel: “Grille climatique, 1951". En Fondation Le Corbusier (Ed.). Le Corbusier Plans, vol. 11. Paris: Echelle-1 \& Fondation Le Corbusier, 2005.

Siret, Daniel: "Les sensations du soleil dans les théories architecturales et urbaines : de l'hygiénisme à la ville durable". En Krampl, Ulrike; Beck, Robert; Retaillaud-Bajac, Emmanuelle. (Eds.). Les cinq sens de la ville du moyen âge à nos jours. Tours: Presses universitaires François-Rabelais (PUFR), 2013. pp. 105-117.

Sloterdijk, Peter: Esferas III - Espumas, esferología plural. Madrid: Ediciones Siruela, 2006.

Torres Cueco, Jorge: Pensar la arquitectura: Mise au point de Le Corbusier. Madrid: Abada Editores, 2014. 


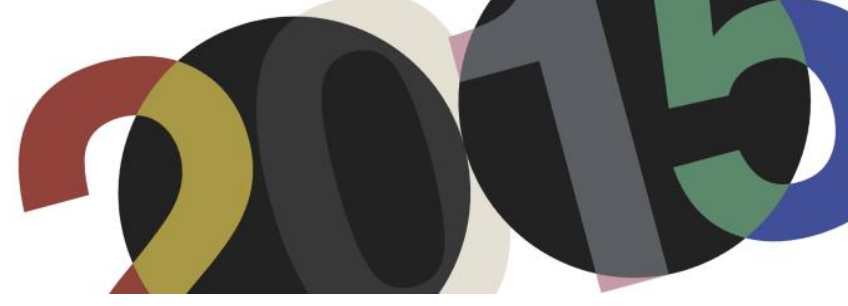

DOI: http://dx.doi.org/10.4995/LC2015.2015.719

\title{
Notre Dame du Haut, Ronchamp, the shape of a listening. A whole other generative hypothesis
}

\author{
L. Ribichini \\ Università di Roma "Sapienza" Facoltà di Architettura. Dipartimento di Storia, Disegno e Restauro \\ dell'Architettura
}

\begin{abstract}
The article will examin one of Le Corbusier's more emblematic works: the Ronchamp Chapel. The aim is to discover some of the intentionalities hidden within the design of this work by the swiss architect. It will start with the following considerations of Le Corbusier about the Ronchamp chapel: "it began with the acoustics of the landscape taking the four horizons as a reference...to respond to these horizons, to accomodate them, shapes were created...” And: " Shapes make noise and silence; some speak and others listen..."And again: "Ear can see proportions. It's possibile to hear the music of visual proportion" (Le Corbusier).

The article sustains that the church is nothing but a giant acoustic machine dedicated to Virgin Mary which main purpose is the listening of the prayers. Infact in the Christian religion Mary is the very vehicle between God and man, she has a human but also divine nature since she is the mother of Jesus. To get in contact with the divine it is necessary to pray Mary, she can listen to man's prayers but she can also pass down God's word to man. In support of this hypothesis there stands an analogy between the chapel's map and the image section of a human ear, highlighting the coincidence between the altar position and that of cochlea, which shape is so dear to le Corbusier that he makes use of it very often in his work.
\end{abstract}

Keywords: Ronchamp; acoustic landscape; human ear, architecture as chrystallized music.

"Why do I draw? And why do I teach drawing at the university? Because I express myself by drawing and so the first thing I teach my students is how to draw. "

Oscar Niemeyer

\section{Introduction}

As the author teaches drawing, there can be little doubt that he has come to view architecture from his own particular standpoint. Thus, he is convinced that architects, through graphic representation, not only express the process whereby their intentions take concrete shape, but also materialize certain assumptions about the meaning of their creative action, including the sources of inspiration and the guiding ideas, the doubts, the rethinking and the second thoughts. In this sense, the plan views, elevations, sections, perspective and axonometric projections, as well as the preparatory drawings and earliest sketches of the nascent idea, all help us - in a way that can be seen as essential - to understand the genesis and significance of the spatial solutions that are adopted.

The paper stems from a close observation of Le Corbusier's drawings of the chapel of Notre-Dame-du-Haut in Ronchamp and an analysis of his statements about this work. The result has been a sort of "vivisection" of the drawn object - on the architectural scale but also that of landscape -, looking for clues about what could have influenced the architect in the transition from the "intangible" idea, prefigured in the mind, and the "tangible" result that came into being on the sheet of paper. 
In actuality, as was also the case in other circumstances, ${ }^{1}$ Le Corbusier left some indications that can help us understand his work and the motives that inspired it. We will thus start from several of his writings linked to the chapel and the name of the site where it was built, before turning our attention to the building as drawn and the key to interpreting it.

\section{Inspiration, listening, designing}

Two months after Notre-Dame-du-Haut was inaugurated, Le Corbusier wrote: "My inquiries into plastic form led me to see an acoustic intervention in the domain of forms. An implacable mathematics and physics can and should reign over the forms presented to the eye, ... Their concordance, their repetition, their interdependence, and the spirit of unity or of family which binds them together to form an architectural expression, is a phenomenon which is as supple, subtle, exact and implacable as that of acoustics. I began with the acoustics of the landscape, taking into account the four horizons: the Saône plain facing the Ballons d'Alsace and the two small valleys on either side. I then created forms to respond to these horizons, to embrace them". ${ }^{2}$ This was in 1955; two years later, he added: "Forms create noise and silence; some speak, others listen". ${ }^{3}$ Once again, as earlier for the Villa Savoye, the thinking of Paul Valèry resonates throughout Le Corbusier's reflections. ${ }^{4}$ Indeed, Valèry's Eupalinos distinguishes buildings that are "muets" from those that are "parlent" and those that are "chantent": mute buildings are devoid of interest, those that speak only tell the story of why they were built, but those that can sing reveal their close relationship with their creator and the latter's capacity to represent himself in them. ${ }^{5}$

Proceeding obliquely, Le Corbusier links this meditation - all centering on an "environmental ear" in harmony with the "acoustic horizons" - with his cherished themes of the metaphysical and the divine. Were it not for the fact that more than thirty years had gone by since the interiors designed by Hermann Finsterlin, the chapel of Notre-Dame-du-Haut would make us think of a transposition in architecture of those organic spaces, which never got beyond the draft stage, that seem almost as if they "emerged from nature or were exuded by man and developed, like the human body, from the body of being". ${ }^{6}$ Like Finsterlin, Le Corbusier visualizes "mental meanders which, like the ramifications of fluidifying ectoplasms, appear to be a paraphrase of the transmission of nervous energy", 7 but by contrast with the wild, animal nature of Finsterlin's sketches, Le Corbusier's references to the organic world do not seem to involve any desecrating tension.

\footnotetext{
${ }^{1}$ For the Villa Savoye in Poissy, close scrutiny of Le Corbusier drawings of the plan view reveals the outlines of a woman's face, seen full on, the result of a unique repertory of sources of inspiration. In this connection, see: RIBICHINI, Luca. Il volto e l'architetto. Roma: Gangemi, 2008.

${ }^{2}$ LE CORBUSIER. "La chiesa di 'Notre-Dame-du-Haut' a Ronchamp”. Casabella-continuità. 1955, n’ 207, p. 7.

${ }^{3}$ Ibid. p. 89.

${ }^{4}$ For the influence exerted by Valéry's philosophy on the architecture of Villa Savoye, see RIBICHINI. Il volto e l'architetto, op. cit. and Chapter 2, pp. 41-58 in particular. Le Corbusier, in Almanach d'une architecture moderne, published in 1926, wrote that in Eupalinos ou l'Architecte, Paul Valéry "as a poet, he has written things about architecture that a professional whose lyre is not tuned to this music - could not say: he has felt and admirably interpreted the same profound and rare things that an architect feels when he creates".

${ }^{5}$ VALÉRY, Paul. Oeuvres. Vol. II. Paris: Gallimard, 1957-1960, p. 93.

${ }^{6}$ FINSTERLIN, Hermann. Nuovi scritti. In: BORSI, Franco. Hermann Finsterlin. Idea dell'architettura. Firenze: Libreria Fiorentina, 1969, p. 157.

${ }^{7}$ FAGIOLO, Marcello. Architettura \& Massoneria l'esoterismo della costruzione. Roma: Gangemi, 2006, p. 372.
} 
If, then, the architectural form is able to collect and transmit both light and sound, the chapel of Notre-Dame-duHaut - as Ruggero Pierantoni maintained when he investigated the "sisterhood" of auditory and visual sensation ${ }^{8}$ - is indeed capable of building " a bridge cast between two ancient provinces of the spirit [that of the acoustic forms and that of the forms of light] kept apart for far too long by Pythagorean misconstruction".

In any case, as Frampton suggests, "Le Corbusier's interest in the sculptural 'resonance' of a building with its site was first formulated in 1923, when he characterized the Acropolis and its Propylaeum by identifying the point 'in which nothing can be taken away, nothing can be left, if not these closely interlinked and intense elements which tragically ring crystal-clear like brass instruments'. This passionate description of the Acropolis, communicating a sense of unity just before being broken, constantly resurfaces all through his life and becomes increasingly imbued with pathos towards the end of his career. This was the concept behind the 'acoustic vision' in Ronchamp; it also inspired the shape of the miniature volcanos and mountains of the community facilities on the roof of the Unite'". ${ }^{9}$ It is perhaps in the name of an acoustic/visual device with which to shape the form of this construction in Ronchamp that the architect refers to an image of strong symbolic value, destroying "rationalist principles, grammer and syntax. With a generosity unprecedented in history, he contradicts himself and his 1921 theories, the pilotis as a roof garden, the grid and the Modulor, he breaks rules and codes without replacing them, leaving his disciples Niemeyer, Candilis, Wogenscky and thousands of followers all over the world speechless and lost". 10

What, then, could have been the design method that Le Corbusier used to develop such a unique idea? According to Danièle Pauly, ${ }^{11}$ the sketches for Ronchamp contain the basic design idea in nuce. This probably depended on the fact that Le Corbusier's first visit to the site came long after he was assigned the project, and this was a sort of "incubation" period during which the process ripened and matured. Part of the architect's research took place during this incubation period, and was crucial in gaining a mastery of all of the problems involved. Thus, he collected information about the site, the pilgrimages, Marian devotion and Catholic rituals, elaborating them in more complex terms thanks to his grounding in sacred art and his discussions with the clergy. A true process of sedimentation that starts with the things seen and fixed in the mind through drawing: "Once things enter through the tip of a pencil, they stay inside you for the rest of your life; written and inscribed. To draw something by hand, to follow an outline, to fill a space or understand volumes means, first and foremost, being able to perhaps observe, perhaps discover [...] and only then will the creative event take place". ${ }^{12}$

In designing, Le Corbusier uses many different sources of inspiration, from recollections of his travels, his own life or even ideas stemming from techniques that, once impressed in his memory through drawing, were transferred straight to the design, influencing it in unfathomable ways. As he himself wrote, the first step in this acoustic intervention was to find a way of transcoding visual form and audible effect. As in music, architecture which aspires to a connection with sound must rely on mathematical relationships, tutelary guardians of perfection and harmony. Indeed, Le Corbusier had long been convinced that: "To recognize the presence of an acoustic phenomenon in the domain of form, we don't need to be initiated in the use of difficult words, but an

\footnotetext{
8 PIERANTONI, Ruggero. La trottola di Prometeo. Roma-Bari: Laterza, 1996. Pierantoni discusses the acoustique paysagiste of the chapel in Ronchamp in his Chapter XLI, pp. 359-368, illuminatingly entitled “... aussi subtil, aussi exact, aussi implacable que celui de l'acoustique...". Le Corbu, Encore, per cemento solo.

${ }^{9}$ FRAMPTON, Kenneth. Storia dell'architettura moderna. $3^{\mathrm{a}}$ ed. Bologna: Zanichelli, 1993, pp. 270-271.

${ }^{10}$ ZEVI, Bruno. Il manifesto di Modena: Paesaggistica e grado zero della scrittura architettonica. Venezia: Canal \& Stamperia, p. 23.

${ }^{11}$ PAULY, Danièle. La cappella di Ronchamp come esempio del processo creativo di Le Corbusier. In: BROOKS, Harold Allen (a cura di). Le Corbusier 1887-1965. Milano: Electa, 1993, p. 164.

${ }^{12}$ LE CORBUSIER. L'atelier de la recherche patiente. Paris: Vincent Fréal \& Cie, p. 37.
} 
individual who is sensitive to the things of the universe. The eye can 'see' proportions. We can 'listen' to the music of visual proportions". ${ }^{13}$

As we know, the design was developed starting from the plan view, which according to Le Corbusier is the force that generates all his architecture. As Francesco Tentori realized, in a letter written to Bruno Zevi in 1956, after a visit to the chapel: "here the 'borrowed form' [...] has an inherent symbolic value. [...] Further confirmation of the symbolism that pervades the chapel's entire architectural form is provided by the plan, which suggests the image of a bell or, perhaps, that of a human ear". ${ }^{14}$ an immense white cement ear thrown on the ground and, moreover, showing "a curious insistence on certain anatomical details" where, if a line is drawn across the face at the level of the ear, the cochlea is located. As for the profile adopted for the roof to ensure stable statics, Le Corbusier tells us that he was inspired by the organic form of a crab shell - picked up on a beach Long Island in 1947 and kept along with other objets trouvés - whose structural strength he had tested by standing on it with his full weight.

\section{El juego del revés...}

In ancient times, the Bourlémont hill - exactly where Le Corbusier built the chapel of Notre-Dame-du-Haut in 1955 - was dotted with pagan temples. Later, during the Roman occupation of Gaul, it became the site of an army camp. The existence of this settlement suggests an explanation of the place name "Ronchamp", as deriving from the Latin Romanorum campus and its French version "champ des Romains". 16

Bearing this in mind will help us understand the logical structure of the complicated "backwards game" whereby Le Corbusier seeks to give shape to the "aural" space of Notre-Dame-du-Haut, which would otherwise remain undescribed, perhaps to some extent because of a code of architectural representation that is better suited to visual experience than to hearing. Indeed, it was not until much later that ideas about the audible dimension of architecture, as an esthetic component of the built space or even as a "design material" began to circulate, ${ }^{17}$ first stemming from John Cage's "visual scores" and then, in the Seventies, culminating in Raymond Murray

\footnotetext{
${ }^{13}$ LE CORBUSIER. Modulor 2. Boulogne-sur-Seine: Éditions de l'Architecture d'Aujourd'hui, 1950, p. 154.

${ }^{14}$ TENTORI, Francesco. "Le Corbusier e Picasso (lettera a B. Zevi)”. L'architettura - cronache e storia. 1956, n ${ }^{\circ}$., p. 808. The author would like to thank Prof. Antonella Greco for drawing his attention to this work.

15 PIERANTONI, La trottola di Prometeo, op. cit., p. 368. This was also taken up and analyzed by other authors. In particular, see: PETRILLI, Amedeo. Le traiettorie acustiche di Le Corbusier. In: MAZZOCUT-MIS, Maddalena (a cura di). Immagine forma e stile. Milano: Mimesis, 2001, pp. 215-231; PETRILLI, Amedeo. Acustica e architettura. Spazio, suono, armonia in Le Corbusier. Venezia: Marsilio, 2001; FIOTTI, Francesco. "Multiversi. Percorsi possibili fra spazio e suono". Le Carré Bleu. $\mathrm{n}^{\circ}$ 2. 2007, p. 52-53.

${ }^{16}$ From the $7^{\text {th }}$ century onwards, the site was dedicated to the Marian cult, and in particular to the Birth of the Virgin Mary. The most reliable information, however, dates only to the $13^{\text {th }}$ century, when the site, already a popular place of prayer, finally became a place of pilgrimage. In 1944, German bombs severely damaged the church on the site, which had in turn been built on the ruins of another chapel destroyed by fire in 1913. The Diocesan Commission for Sacred Art in Besançon decided to build a new chapel and commissioned Le Corbusier to draw up the plans. In addition to the 200-seat chapel, the commission also included landscaping the surroundings to accommodate the flow of approximately 12,000 pilgrims normally expected during the two most important Marian feast-days: August 15 (feast of the Assumption) and September 8 (feast of the Nativity).

${ }^{17}$ Though as Roberta Lucente argues: "The question of the relationship between Music (as formally structured and codified sound) and Architecture (as formally structured and codified space) has arisen periodically since the earliest times, at the critical, methodological and creative levels, and has been marked by occasions and works that can be taken as milestones for measuring the distance between the two spheres at the time in question" (LUCENTE, Roberta. "Suono e architettura: isomorfismi e nuove aperture disciplinari”. Le arti del suono. 2013. $\mathrm{n}^{\circ} 7$, p. 13).
} 
Schafer's theories of the soundscape and the acoustic life of a community. ${ }^{18}$ And right in the middle of a book that Le Corbusier wrote, and sent to press, to celebrate the inauguration of the chapel, we find the following exhortation, enigmatically combining music and architecture: "Observe the play of shadows, learn the game ... Precise shadows, clear cut or dissolving. Projected shadows, sharp. Projected shadows, precisely delineated, but what enchanting arabesques and frets! Counterpoint and fugue. Music, great music! Try to look at the pictures upside down, or on their side. You will soon discover the Game!". ${ }^{19}$

Only if we accept this invitation will we be given the key, the fundamental key, to understanding Le Corbusier's design. At the time of his first visit to the site at Ronchamp, in fact, he wrote: "June 1950. I spent three hours on the hill to get a feel for the land and the horizons: I let it all soak in. The bullet-blasted chapel is still standing". ${ }^{20}$ Perhaps inspired by the site's name, which seems to have been guessed in a sort of backwards charade from "Champ des Romains", where the place name ron-champ is morphed from the earlier, popular form rom-champ, the architect organizes a game that is not all that different from the game mentioned a moment ago - Le Corbusier's attention to the names of his creations is well known -, to invite the viewer to turn the blueprint on its side, or even upside down, so as to be able to read the space's audible characters that otherwise would risk remaining unexpressed.

At this point, Tentori's suggestion that the chapel's floorplan recalls the shape of a bell or perhaps a human ear, takes on new vigor and force. "It is in the figurative arts - i.e., pure creation - that I find the lifeblood of my architecture", ${ }^{21}$ as Le Corbusier loved to repeat. And so, when presented with his client's requests, he responded in his usual way by turning the spatial dynamics that were to give character to the church into basic elements. At this point, the question is whether the immense stylized ear lying on the hillside in Bourlémont is or is not the result of an organic approach to the spatial design of the church in which the architect uses forms "shaped" with heterogeneous techniques rather than "planned" with the canonical methods of design. If, as Le Corbusier maintains, architecture develops from the floorplan, we still have to understand why the plan of Notre-Dame-duHaut seems to coincide perfectly with the cross section - the coronal section - of part of the face at ear level, thus emphasizing the mechanical organs of hearing. The floorplan is oriented according to the cardinal points and, from west to east, shows remarkable analogies first with the form of the external part of the right ear, then its canal, and finally the spiral shape of the cochlea. ${ }^{22}$ This is the exact point where the main altar is located: the fulcrum on which contact between human beings and the heavens turns, the channel through which man's words ascend to God and the word of God descends to earth.

And it is the word of God, or rather, His voice, that Western culture and Christianity associate with the sound of the bell. ${ }^{23}$ It is no coincidence that the Poème électronique - the composition on which Le Corbusier collaborated with Edgar Varèse in 1958 and whose initial sequence is emblematically entitled "Genesis" - opens with a tolling bell, as sound, the "beginning of everything", is the element from which all of creation originates. $^{24}$

\footnotetext{
${ }^{18}$ SCHAFER, Raymond Murray. Il paesaggio sonoro. Lucca: Ricordi e LIM Editrice, 1985, p. 285.

${ }^{19}$ LE CORBUSIER, Ronchamp. Milano: Edizioni di Comunità, 1957, pp. 46-47.

${ }^{20}$ Ibid. p. 155.

${ }^{21}$ JENGER, Jean. Le Corbusier. L'architettura come armonia. Torino: Electa Gallimard, 1997, p. 89.

${ }^{22}$ The sense organ that converts sounds from the outside world into nerve impulses which it transmits to the brain.

${ }^{23}$ As Saint Pope John Paul II said, "The church bells remind us not to forget that Sunday is the Lord's day; they represent the 'voice of God' for those who believe and are a message for those who do not believe. It's so beautiful to hear the sound of the bells that sing the glory of the Lord to all creatures. [...] Each of us bears a very sensitive bell. This bell is called the heart. The heart plays a sound and I hope that your heart will always play beautiful memories".

${ }^{24}$ Indeed, our universe began with a sound, the colossal explosion that was the "Big Bang".
} 
In the process of creating Ronchamp, the bell also played a fundamental part, with its richly evocative symbology. Thus, there is reason to believe that Notre-Dame-du-Haut sprang from two primal ideas: the bell, a shape for housing the sounds and harmony of creation, and the ear, an organ for listening to an audible environment, and even to the voice of God. Just as happens in our own psyche, ${ }^{25}$ the two shapes have fused as they constructed each other, each with the other's aid, creating an architectural image in which we can still see the tracks ${ }^{26}$ of both shapes; to discover them (as the architect suggests) all we need to do is "play" with the floorplan, looking at it upside down, or turning it on its side. It is as if Le Corbusier had set in motion a procedure where he watches a form take shape without intervening, or only taking very limited action, but doing so with the help of an expressive toolkit based entirely on the discipline of architectural representation.

\section{Musical facades}

One last word - but no less important for all that - should be devoted to the facades of Notre-Dame-du-Haut. While it is true that this church is an immense ear, reclining on the ground to listen to the voice of God, it should also not surprise us that the space also calls to mind a massive pipe organ (a great musical and harmonic machine), where the functional element of listening is preeminent, and the facades, or rather, the openings in the facades, are the expression of a fully-fledged study in musical composition. ${ }^{27}$

Ranged across the facades, these openings recall the perforated roll used in player pianos between the late nineteenth and early twentieth centuries, while the elevation as a whole is reminiscent of a sheet of music, notes writ large on the surface of the walls. Starting from this simple observation, we traced a map of the many openings in the wall, to piece together the musical score they represent.

This musical map of the facades has a parallel in the experiments conducted in the Fifties by the composers Edgard Varèse and Karlheinz Stockhausen; nor must we forget the revolutionary work with the sounds of nature by John Cage and Buckminster Fuller. In this new system of expression, musical notation had abandoned the usual coded marks on the staff in favor of a new mode of representation. Thus, in 1953, Stockhausen's KontraPunkte No. 1 for 10 instruments identifies the notes with "sound points", apparently isolated, and assigns a different color to each instrument (bars 148-198): green for the flute, sky blue for the clarinet, light blue for the bass clarinet, orange for the bassoon, dark blue for the trombone, red for the violin, purple for the cello. Black is for the piano, which covers all the registers, grey for the harp, and so forth.

Accordingly, after mapping the "openings" on the chapel walls, we arranged them in a grid with time on the abscissa $(x)$ and the height of the musical notes on the ordinate $(y)$; taking a diagram of the piano keyboard as a

\footnotetext{
${ }^{25}$ Here, images overlap, often merging and mixing, fusing and confusing, resulting in what Sigmund Freud described in 1930 as: "a stratification that is the memory, or rather, the story that each of us constructs about a given place" (FREUD, Sigmund. Il disagio della civiltà e altri saggi. Torino: Bollati Boringhieri, 2012, pp. 204).

${ }^{26}$ The track, or more specifically the impression, is inherent to the concept of individuality. Through a track, or in other words the marks left on the ground, we can identify an unknown subject. We could thus think of the sound of the bell as the first track - the opening notes, recorded acoustically and then allowed to germinate architecturally - that presented itself to Le Corbusier during his first visit to Ronchamp: "I remember that June 4 was Sunday, the Lord's day, when the bells ring out in celebration" (LE CORBUSIER, Ronchamp, op. cit., p. 89).

${ }^{27}$ A suggestion in this connection comes to us from Johan Wolfgang Goethe - a major influence for the Bauhaus's experiments in design - who, in a letter dated March 23, 1829, wrote to his friend Johann Peter Eckermann: "I found a note among my papers: in it I defined architecture as crystallized music. And there is some truth in this; the atmosphere that emanates from architecture comes close to the effect of music" (TROCON, Renzo. Johan Wolfgang Goethe. La teoria dei colori. Introd. di Giulio Carlo Argan. Milano: il Saggiatore, 1987, p. 185).
} 
reference, the horizontal grid was divided into half notes with a range of around eight and a half octaves. This information was then entered into modern music software, obtaining a result in line with the musical trends current at the time the chapel was designed in the 1950s.

Though the investigation in this area continues, the findings so far permit us to state that - as was to be the case for the Philips Pavilion at Expo '58 in Brussels - Notre-Dame-du-Haut not only acts as the sounding box for the tones that arise inside the chapel, but is itself the origin of the sound; almost as if to testify that architecture and music can coincide in harmony.

\section{Images}

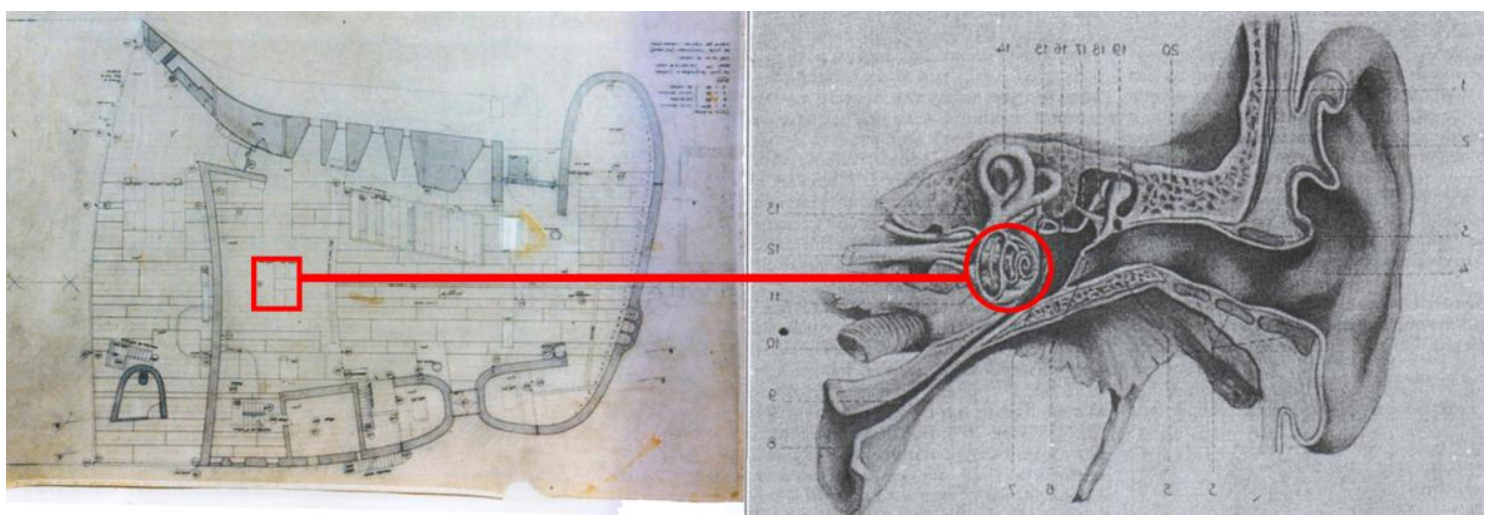

0. FLC7196 - Parallels between the architectural organism (the floorplan of Ronchamp) and the organ of hearing. Note that the position of the altar, where prayers are received, coincides with that of the cochlea, where sound impulses are received.

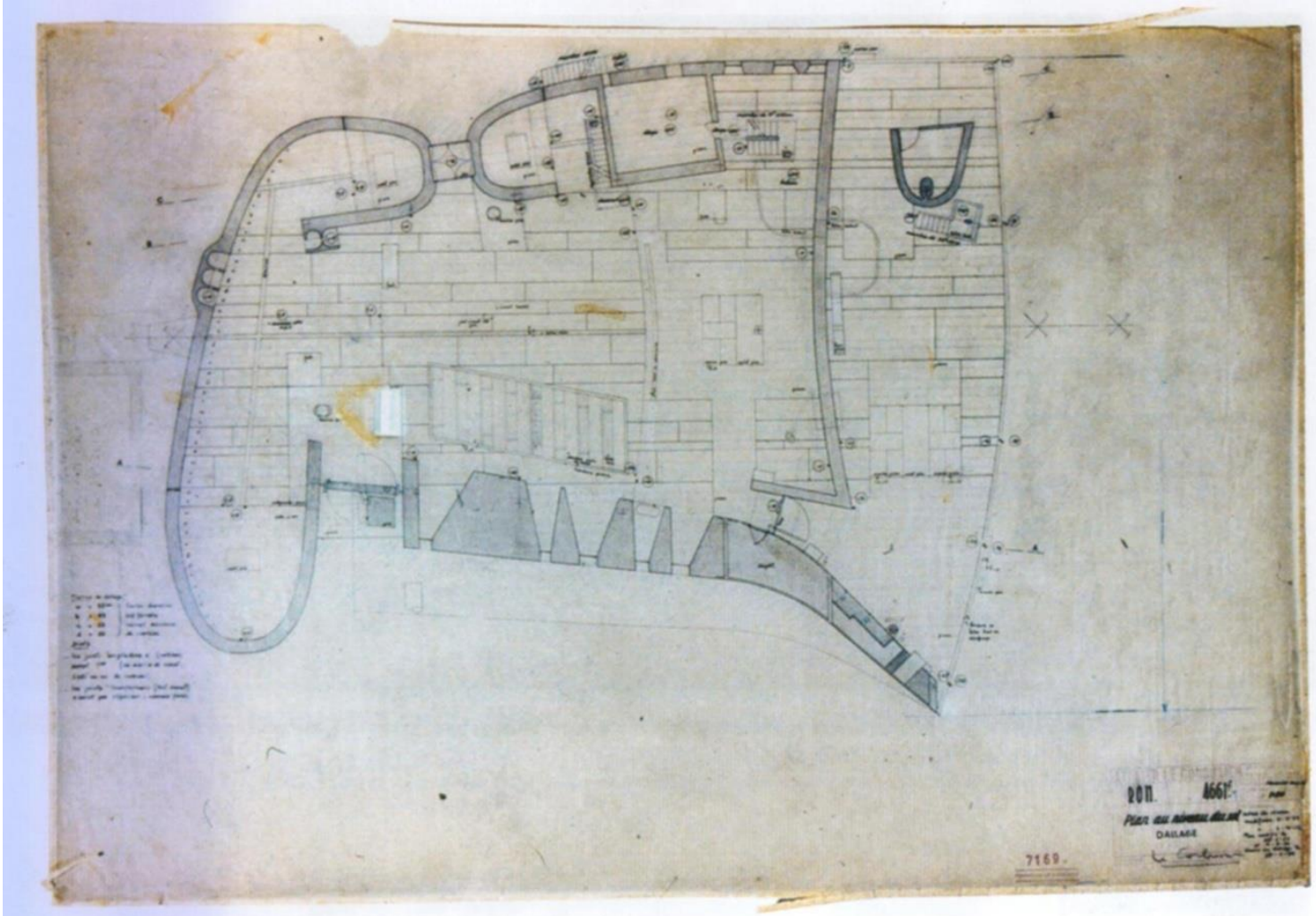

1. FLC7196 - Floorplan of the Ronchamp chapel, in the correct viewing position with the title block on the right. 


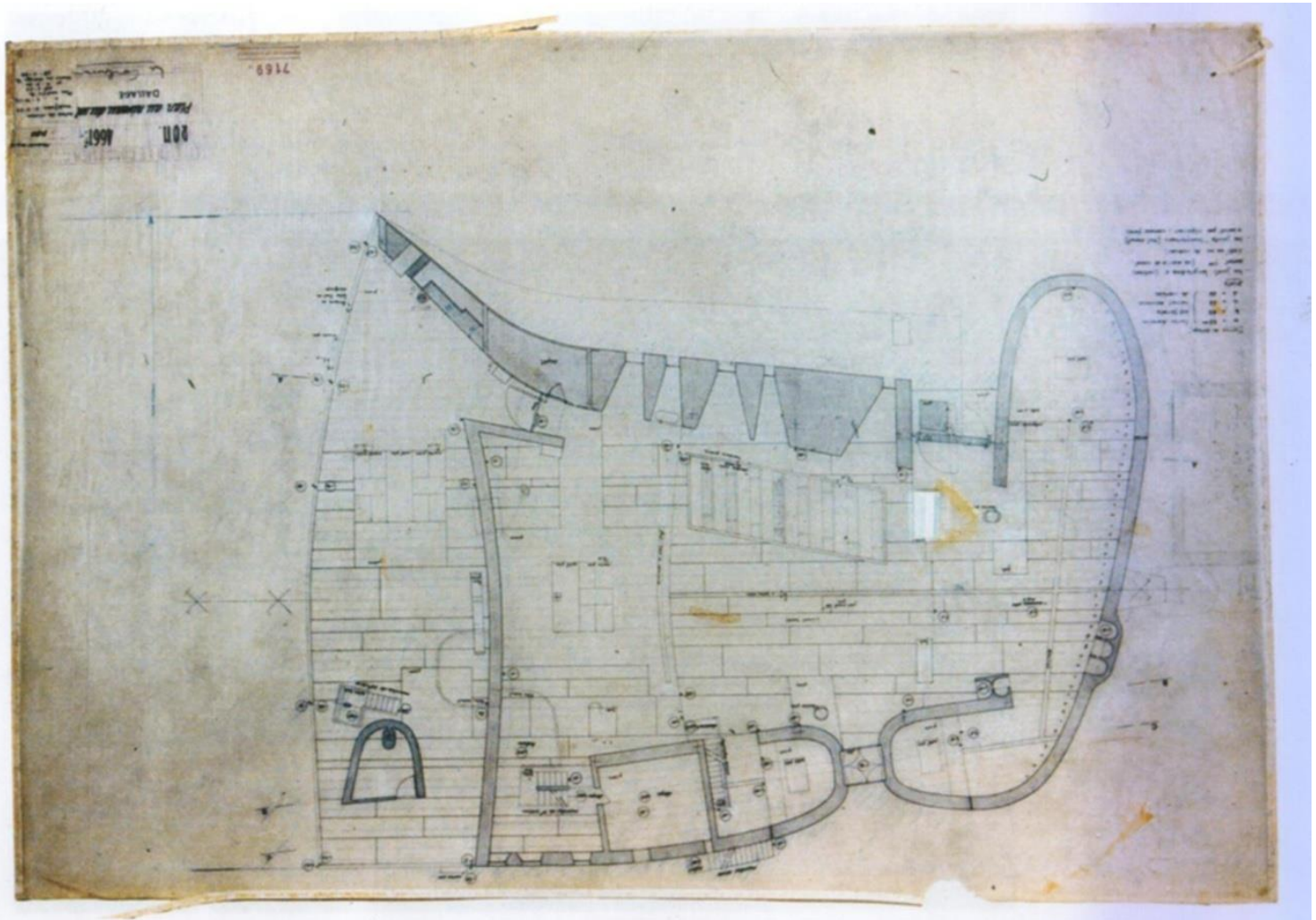

2. FLC7196 - Floorplan turned upside down.

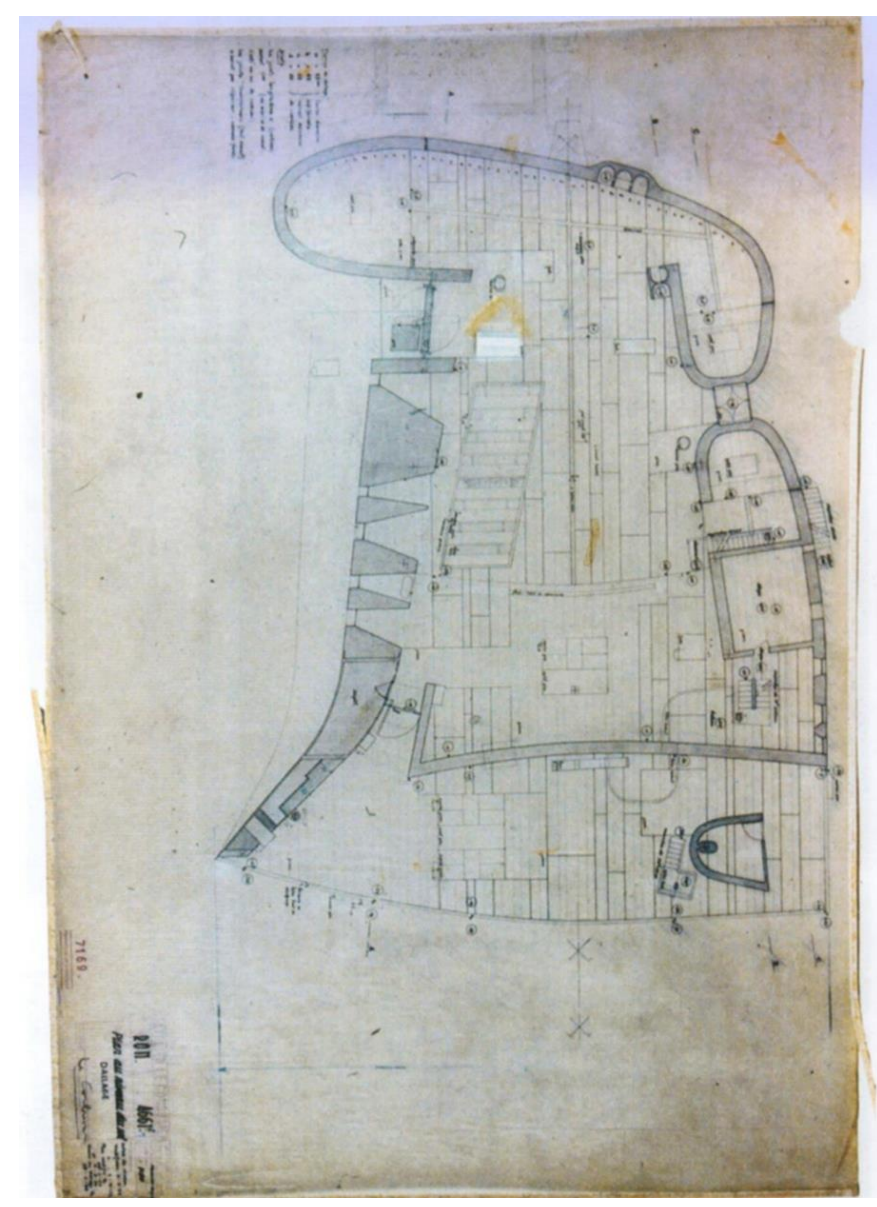

3. FLC7196 - Floorplan turned on its side (bell) 


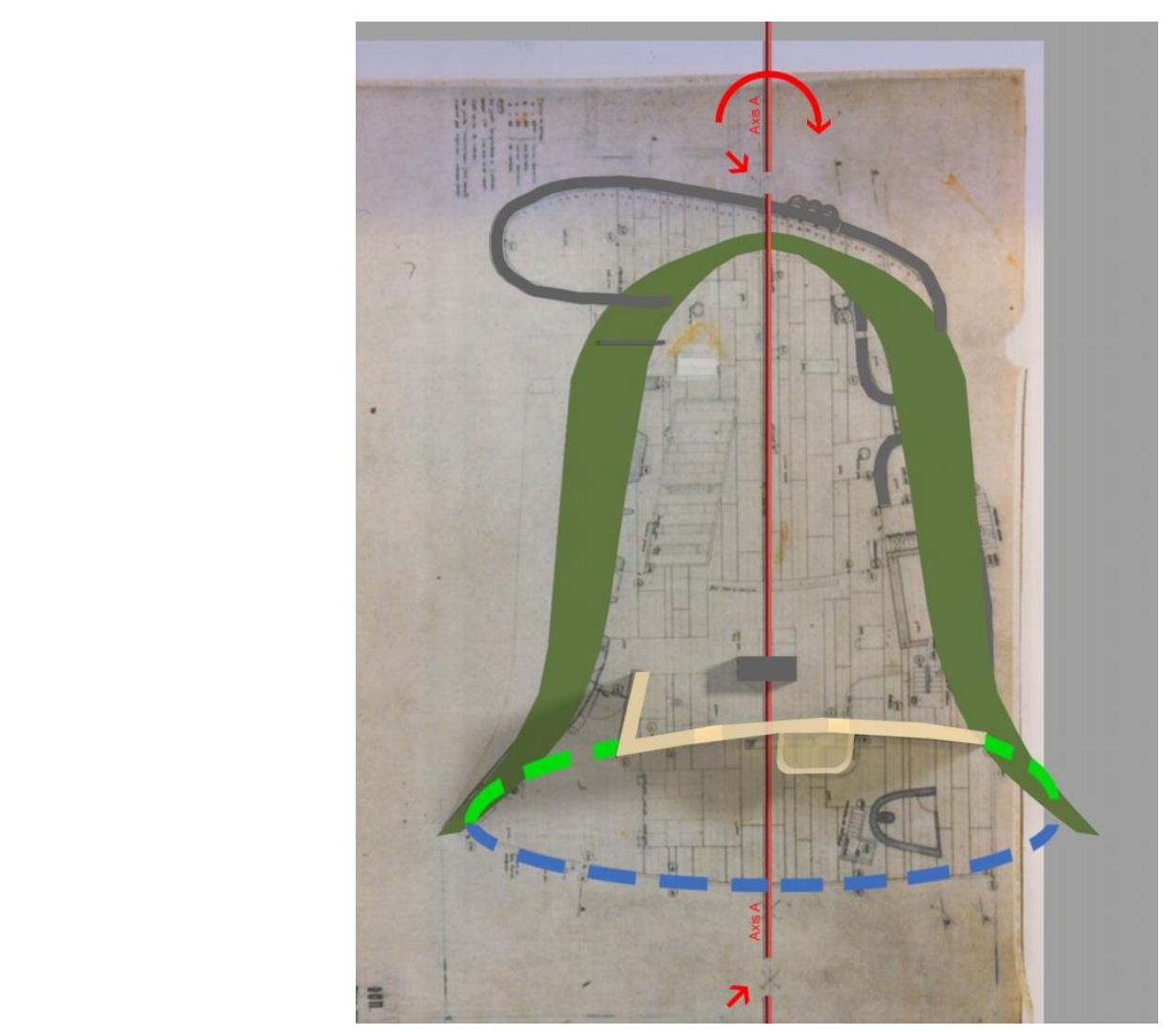

4.1 Rotation around the axis A

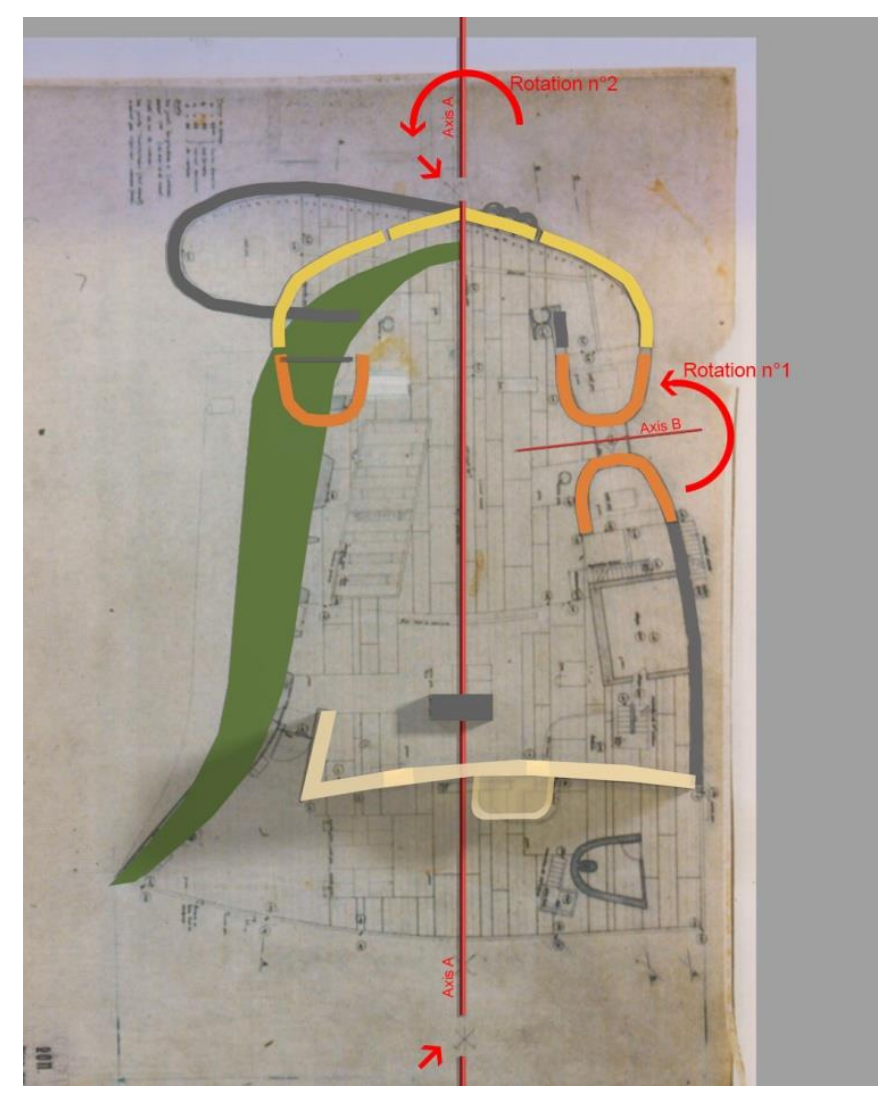

4.2 Rotations around the axis $\mathrm{A}$ and axis $\mathrm{B}$ 


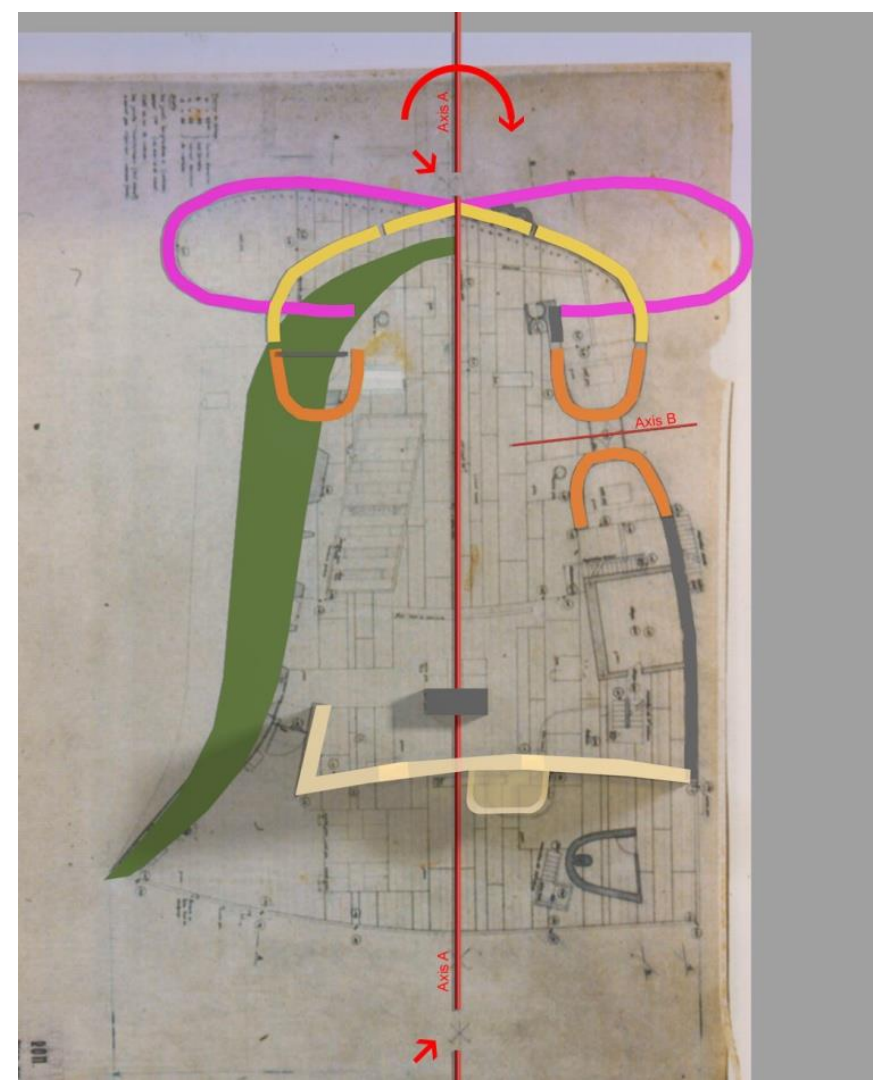

4.3 Rotation around the major axis

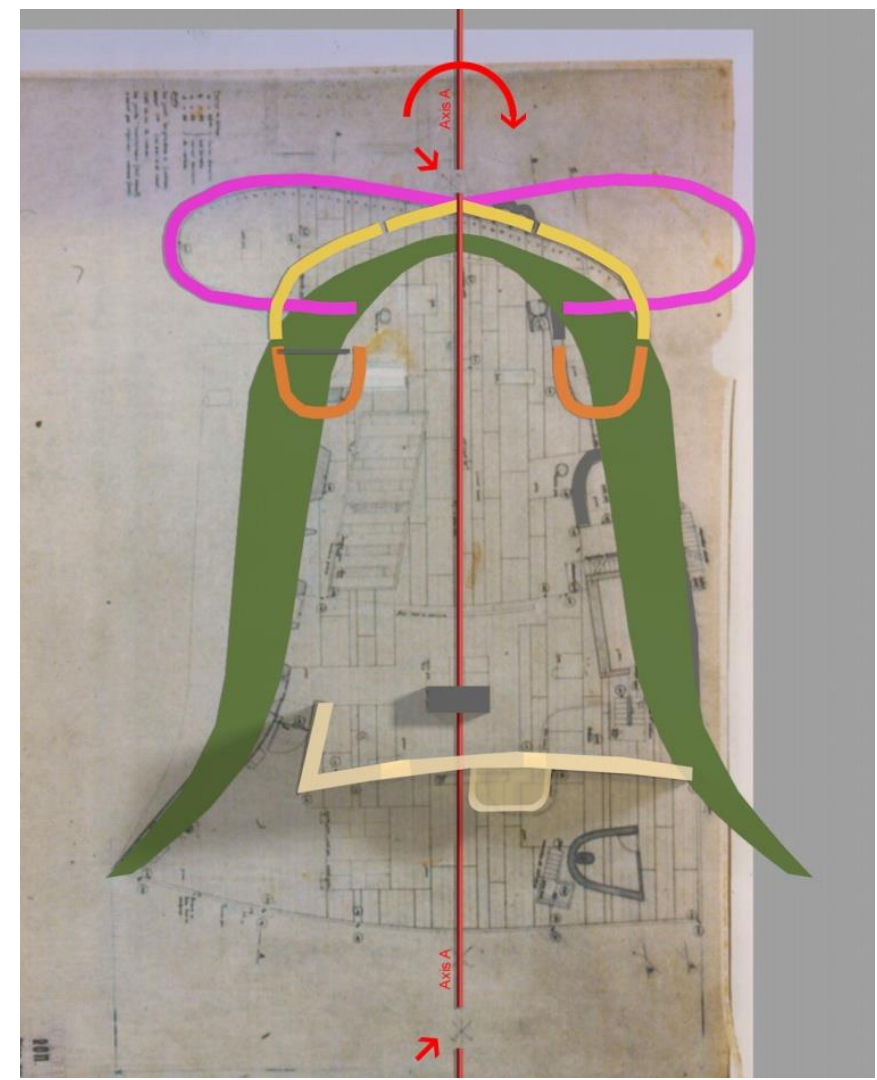

4.4 Rotation around the major axis (suggestion of shape of bell) 


\subsection{Closing of bow}
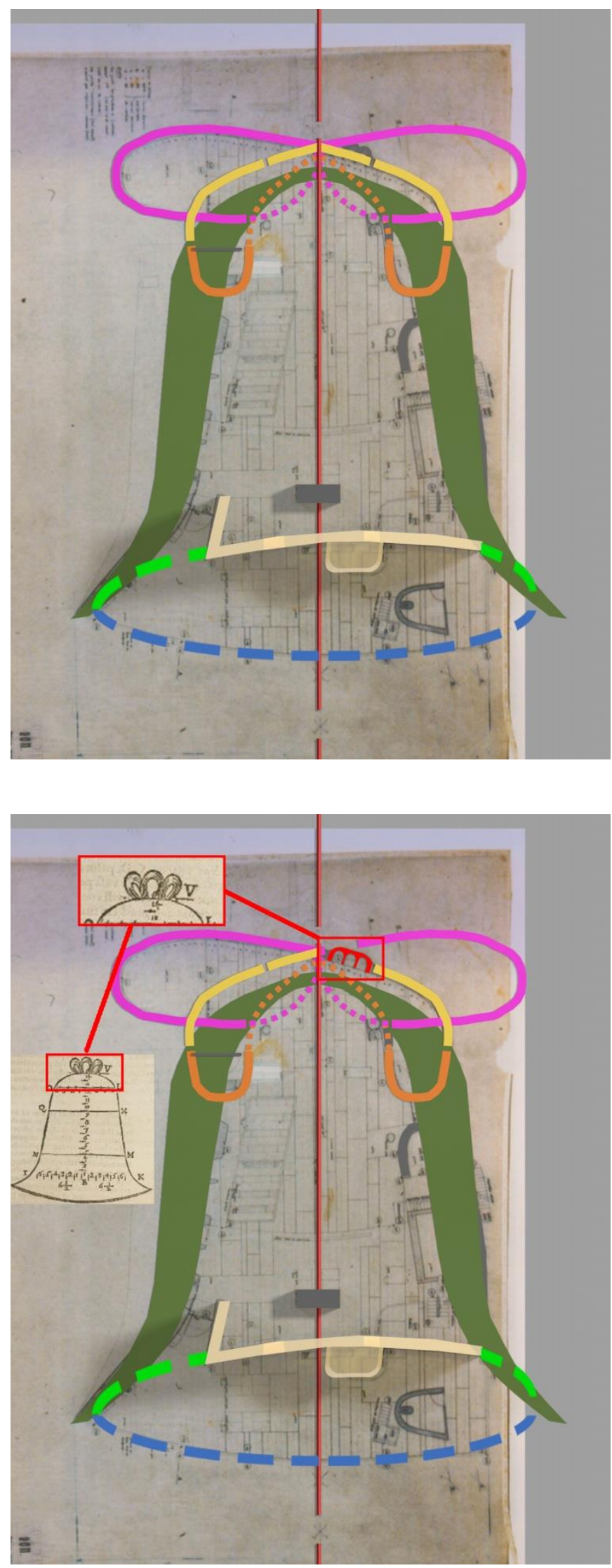

4.6 


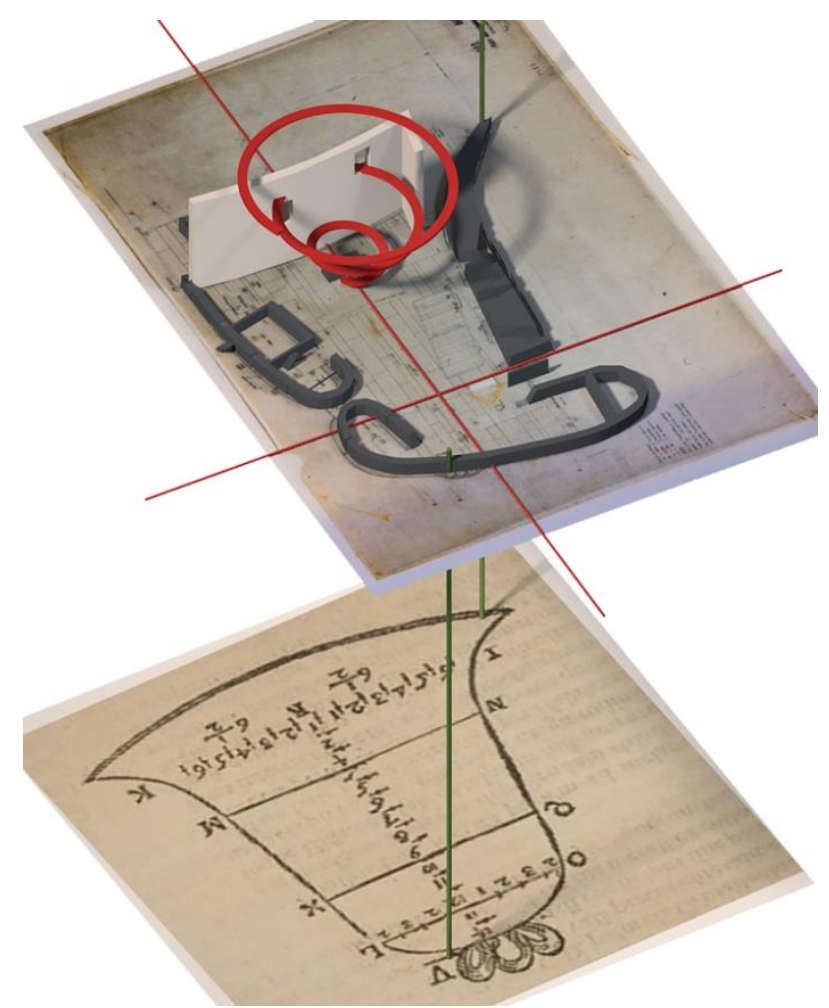

5. Organization and overlapping of figurative references

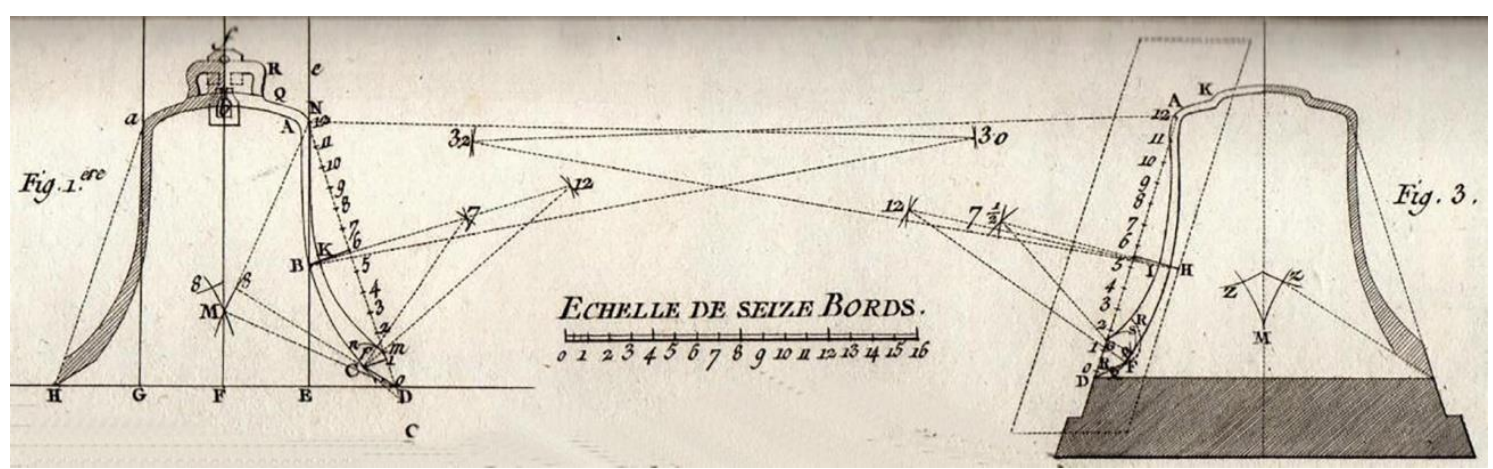

6. Illustration from the Encyclopédie by Denis Diderot and Jean-Baptiste Le Rond d'Alembert 


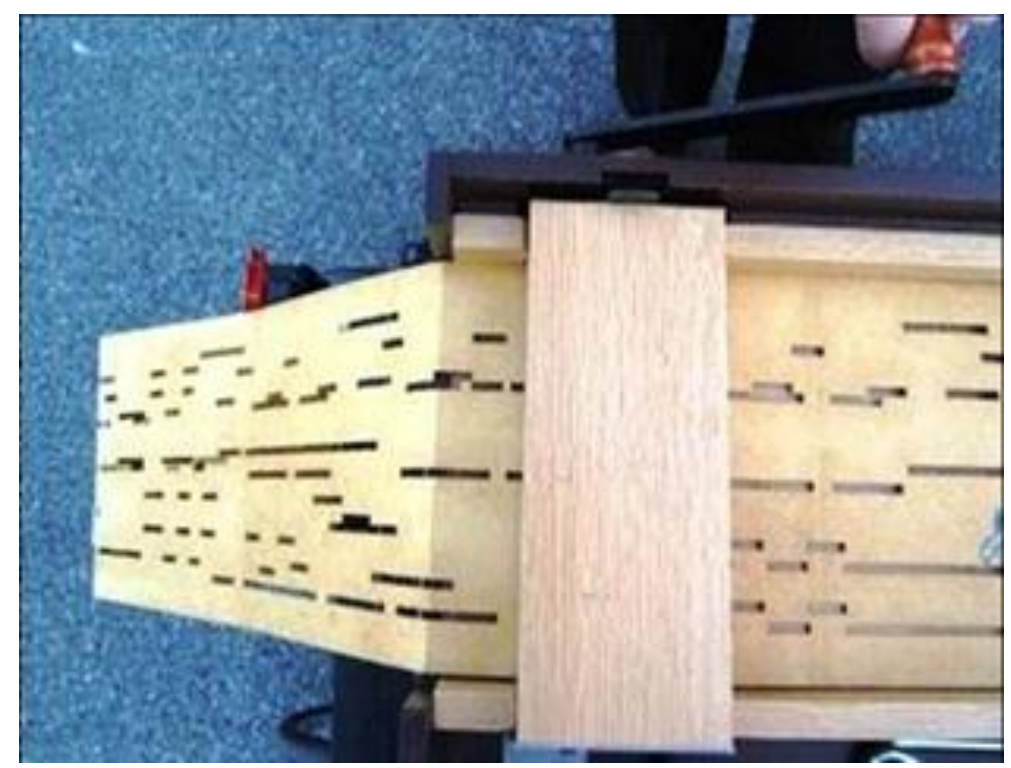

7. Mechanical layout of a barrel organ

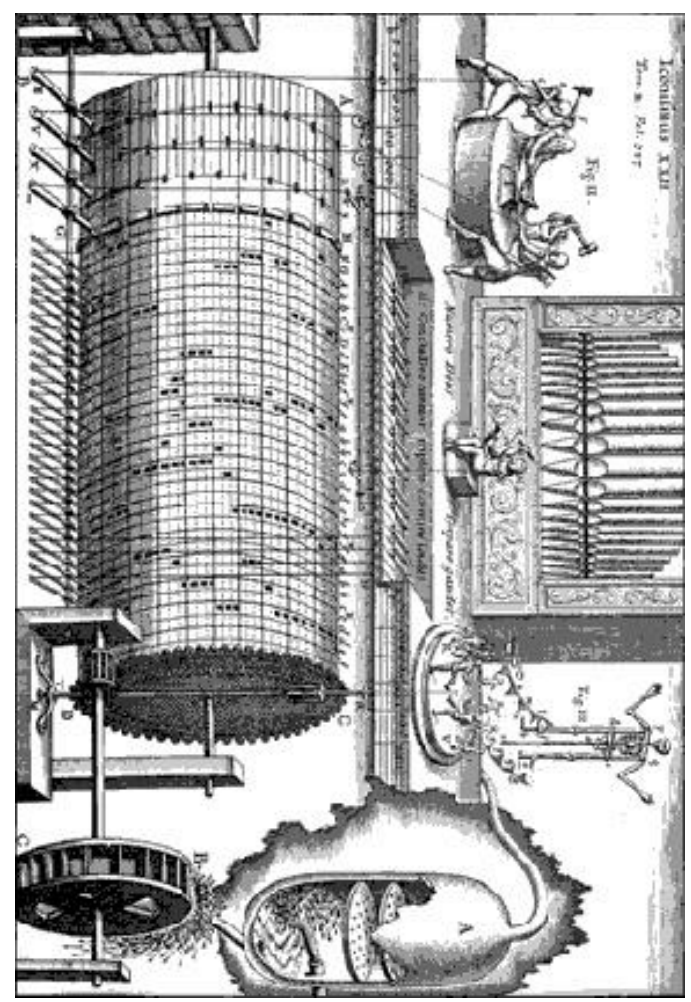

8. Father Athanasius Kircher, hydraulic organ with automata (from A. Kircher, Musurgia universalis, Rome 1650, II. IC. XXII) 

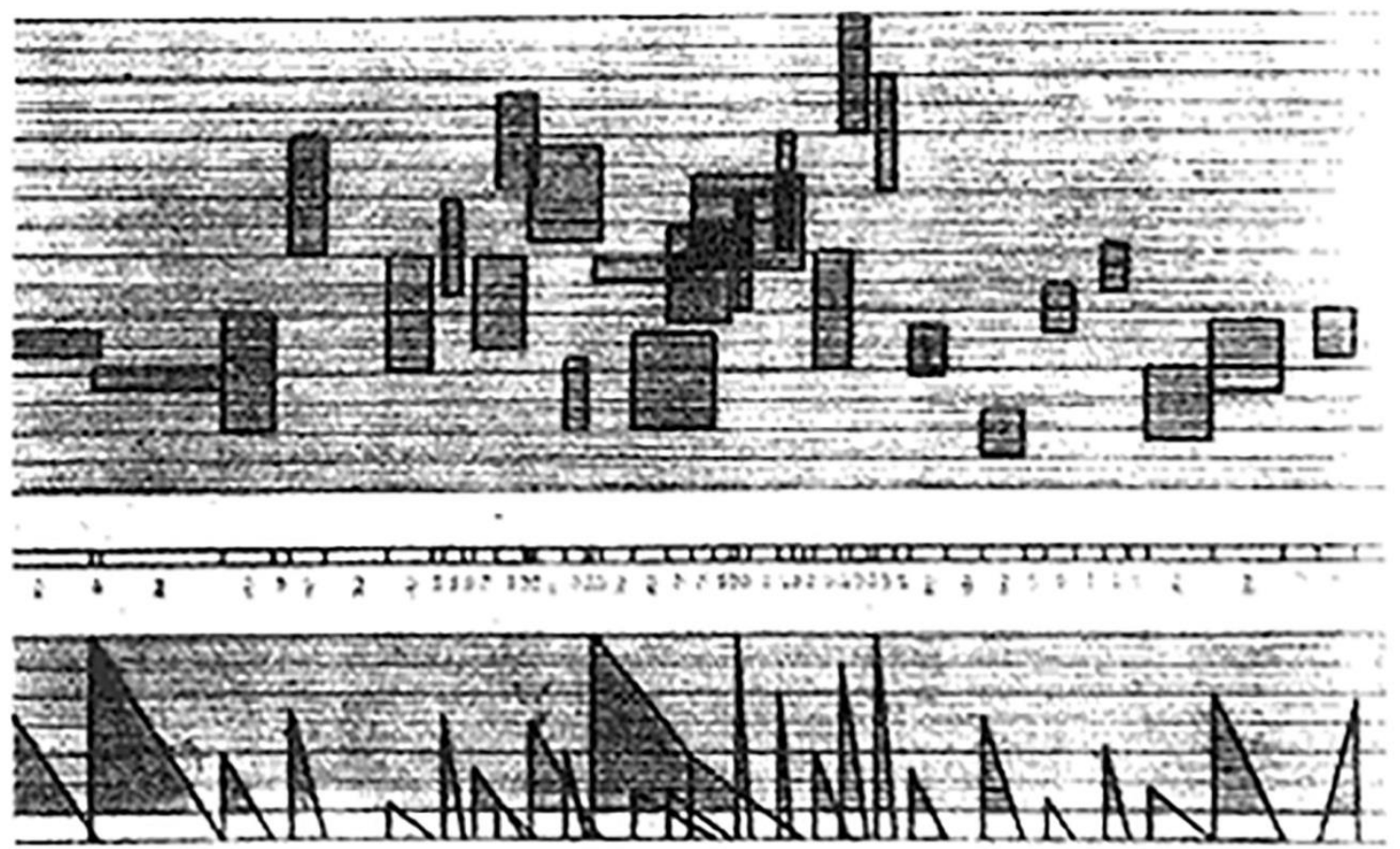

9. Karlheinz Stockhausen, Studie II, 1954

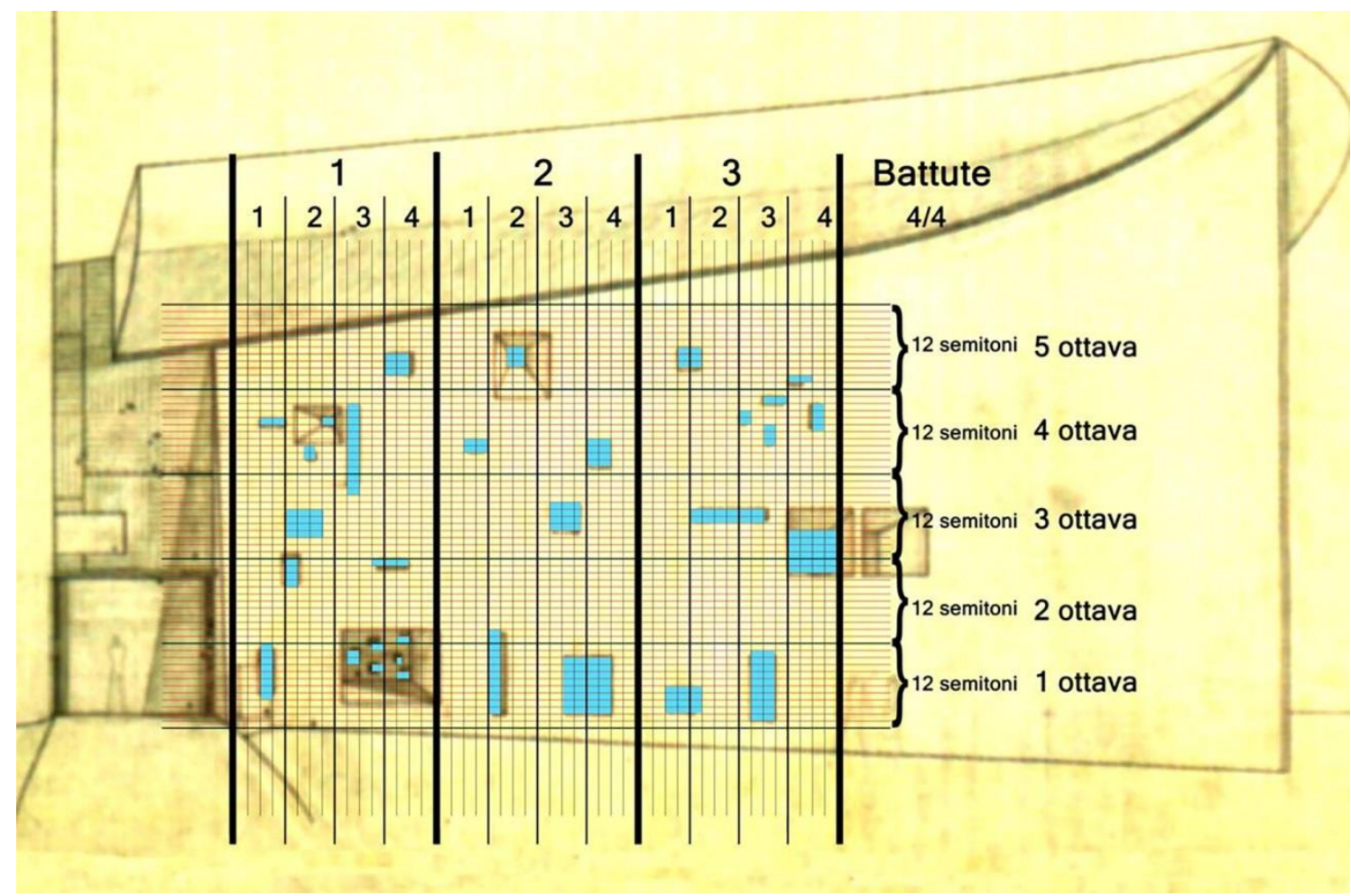

10. Score, south façade of Ronchamp 


\section{Bibliography}

FAGIOLO, Marcello. Architettura \& Massoneria l'esoterismo della costruzione. Roma: Gangemi, 2006.

FINSTERLIN, Hermann. Nuovi scritti. In: BORSI, Franco. Hermann Finsterlin. Idea dell'architettura. Firenze: Libreria Fiorentina, 1969.

FIOTTI, Francesco. "Multiversi. Percorsi possibili fra spazio e suono". Le Carré Bleu. n 2. 2007. Also posted on http://www.francescofiotti.com/03multiversi.pdf

FRAMPTON, Kenneth. Storia dell'architettura moderna. $3^{\text {a }}$ ed. Bologna: Zanichelli, 1993.

FREUD, Sigmund. Il disagio della civiltà e altri saggi. Torino: Bollati Boringhieri, 2012.

JENGER, Jean. Le Corbusier. L'architettura come armonia. Torino: Electa Gallimard, 1997.

LE CORBUSIER. Modulor 2. Boulogne-sur-Seine: Éditions de l'Architecture d'Aujourd'hui, 1950.

LE CORBUSIER. "La chiesa di 'Notre-Dame-du-Haut' a Ronchamp". Casabella-continuità. 1955, nº 207.

LE CORBUSIER. Ronchamp. Milano: Edizioni di Comunità, 1957.

LE CORBUSIER. L'atelier de la recherche patiente. Paris: Vincent Fréal \& Cie, 1960.

LUCENTE, Roberta. "Suono e architettura: isomorfismi e nuove aperture disciplinari". Le arti del suono. 2013. $\mathrm{n}^{\circ} 7$.

PAULY, Danièle. La cappella di Ronchamp come esempio del processo creativo di Le Corbusier. In: BROOKS, Harold Allen (a cura di). Le Corbusier 1887-1965. Milano: Electa, 1993.

PETRILLI, Amedeo. Acustica e architettura. Spazio, suono, armonia in Le Corbusier. Venezia: Marsilio, 2001b.

PETRILLI, Amedeo. Le traiettorie acustiche di Le Corbusier. In: MAZZOCUT-MIS, Maddalena (a cura di). Immagine forma e stile. Milano: Mimesis, 2001a.

PIERANTONI, Ruggero. La trottola di Prometeo. Roma-Bari: Laterza, 1996.

RIBICHINI, Luca. Il volto e l'architetto. Roma: Gangemi, 2008.

SCHAFER, Raymond Murray. Il paesaggio sonoro. Lucca: Ricordi e LIM Editrice, 1985 (orig. ed. The Tuning of the World. Toronto: McLelland and Stewart Limited, 1977).

TENTORI, Francesco. "Le Corbusier e Picasso (lettera a B. Zevi)". L'architettura - cronache e storia. 1956, n 6.

TROCON, Renzo. Johan Wolfgang Goethe. La teoria dei colori. Introd. di Giulio Carlo Argan. Milano: il Saggiatore, 1987.

VALÉRY, Paul. Oeuvres. Vol. II. Paris: Gallimard, 1957-1960.

ZEVI, Bruno. Il manifesto di Modena: Paesaggistica e grado zero della scrittura architettonica. Venezia: Canal \& Stamperia, 1998. 


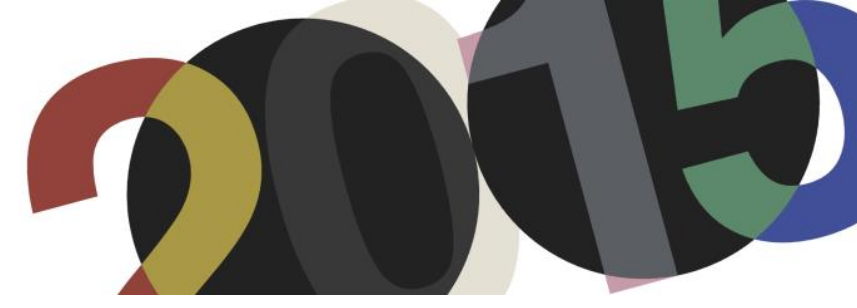

DOI: http://dx.doi.org/10.4995/LC2015.2015.1007

\title{
La lección del embalse. Le Corbusier y los aprovechamientos hidroeléctricos
}

\author{
A.S. Río Vázquez \\ Grupo de Investigación en Historia de la Arquitectura de la Universidade da Coruña
}

\begin{abstract}
Resumen: El interés de Le Corbusier por los aprovechamientos hidroeléctricos es una constante a lo largo de su vida, sobre todo como inspiración y referencia para proyectar su arquitectura, dando forma a una lección del embalse que veremos enfocada de diferentes maneras y en distintos momentos, desde su descubrimiento durante el trabajo en Vienne (Francia) para la Société d'applications du bétón armé hasta el intento de materialización con la obra de Bhakra en la India, pasando por etapas sucesivas en las que se va exponiendo, publicando o compartiendo, mediante conferencias, textos teóricos o encuentros en viajes, como el realizado a los Estados Unidos en 1946, cuando visita el macroproyecto de la Tennessee Valley Authority y deja constancia en la primera edición americana de Quand les catedrales étaient blanches: voyage au pays des timides. A través de sus palabras, de sus dibujos y de sus proyectos vamos revelando las dos caras de la lección del embalse: la que se desprende de manera inmediata desde las realidades encontradas, que tendrá su impulso final paralelo a la construcción de Chandigarh con la implicación en la presa sobre el Sutlej; y la cara oculta, desvelada como aportaciones e influencias progresivas en su arquitectura. Ambas caras permanecerán como el testimonio de la fértil relación entre Le Corbusier y los aprovechamientos hidroeléctricos.
\end{abstract}

Abstract: The interest of Le Corbusier on hydroelectric industry is a constant throughout his life, especially as inspiration and reference to project its architecture, shaping a lesson of the dam that we will see focused in different ways and at different times, from their discovery while working in Vienne (France) for the Société d'applications du bétón armé to the attempt to materialize the work of Bhakra in India, through successive stages in wich he will be in exposing, publishing or sharing through conferences, theoretical texts and encounters on trips, like the one made to the United States in 1946, when he visits the macro project of Tennessee Valley Authority and describes it in the first American edition of Quand les cathedrals étaient blanches: voyage au pays des timides. Through his words, his drawings and his projects we will reveal the two faces of the lesson of the dam: the one which follows immediately from the facts found, which will find the final attempt parallel to the construction of Chandigarh with the involvement at the dam on Sutlej; and the other side, unveiled as inputs and progressive influences in its architecture. Both sides remain as the testimony of the fertile relationship between Le Corbusier and hydroelectric industry.

Palabras clave: Arquitectura; Siglo XX; Le Corbusier; agua; industria; embalse. Keywords: Architecture; 20th Century; Le Corbusier; water; industry; dam.

\section{Introducción}

Las obras de los aprovechamientos hidroeléctricos, con la presa como elemento principal, se convirtieron en un referente constante a lo largo de la trayectoria arquitectónica —y también vital— de Le Corbusier, convirtiéndose en un lugar donde aprender, dando forma a una lección de arquitectura que se va concretando de diferentes maneras en cada momento.

Presente desde su etapa de formación, cuando encuentra en la construcción de embalses la optimización de la técnica y el ideal de un espíritu nuevo en arquitectura, se va apareciendo una y otra vez durante su vida: textos, imágenes, viajes, conferencias... en ocasiones como encargo, otras veces por interés personal, el embalse se busca y se estudia, hasta coincidir plenamente en el norte de la India, con la participación en el proyecto de la 
presa de Bhakra sobre el río Sutlej (1), auténtica obra total que persigue integrar arte, ingeniería y arquitectura a todas las escalas y se convierte en el mejor testamento posible de esa lección permanente.

Si rastreamos la presencia de los embalses en la biografía de Le Corbusier ${ }^{1}$, no nos encontraremos con grandes hallazgos construidos — es más una lección de ausencias y deseos que de realidades—. Sin embargo, es en esas aproximaciones, en esas visiones tangentes o en las huellas dejadas en otros proyectos, donde alcanza su valor como enseñanza. Nos proponemos revisar esos pasos sucesivos, ese itinerario de varios momentos que nos puede servir tanto para conocer mejor la obra del arquitecto como para remarcar la importancia que las estructuras de este tipo han tenido para la modernidad.

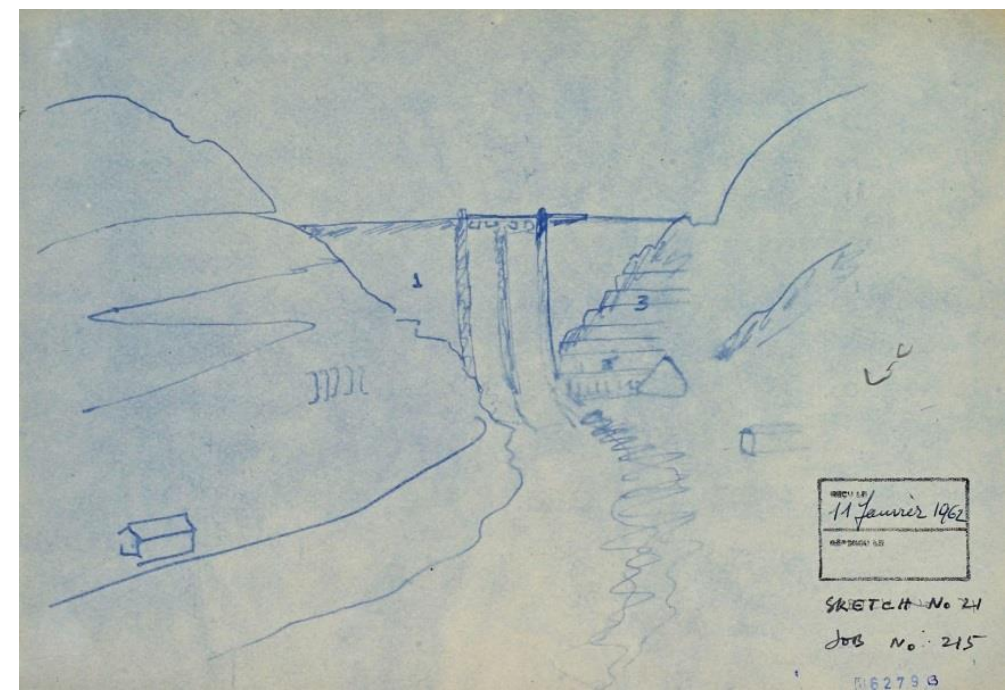

1. Le Corbusier: boceto de la presa de Bhakra sobre el Sutlej, 11 de enero de 1962 (FLC 6279 CFLC-ADAGP)

No por casualidad nos encontraremos que, en ocasiones reiteradas, los ejemplos escogidos como emblema del nuevo espíritu en arquitectura son presas, comenzando por un inmenso embalse en construcción en los Alpes, «en el fin del mundo, lejos de toda estación y de todo camino» ${ }^{2}$, como afirma Le Corbusier. «Una obra semejante —decimos—es la grandiosa premisa de los tiempos próximos» ${ }^{3}$.

\section{Vienne. La lección descubierta}

La relación de Le Corbusier con los embalses se inicia en una fase temprana de su formación, a partir del traslado a París en 1917 y el comienzo del trabajo en la Société d'applications du bétón armé (SABA) administrada por Edgard Louis Bornand. SABA se dedicaba la construcción de edificios, fábricas, presas y realizaba los postes de hormigón empleados para las líneas de electricidad ${ }^{4}$. En una carta fechada el 7 de abril de 1917 Bornard certifica al arquitecto Charles Edouard Jeanneret como supervisor para la empresa de los trabajos de construcción de la central eléctrica de Saintes y las obras hidroeléctricas en l'Isle Jourdain (Vienne, Francia) ${ }^{5}$. Construidas entre 1917 y 1921, la presa y la central hidroeléctrica de l'Isle Jourdain (2) motivaron la primera

\footnotetext{
${ }^{1}$ Sobre la relación de Le Corbusier y los fluidos vid. Sánchez-Pombo, Marina: «La arquitectura de los fluidos. Le Corbusier y los ríos». En Massilia. Anuario de Estudios Corbusierianos. 2004bis. Barcelona: Associació d'idees, 2005, pp. 48-69

2 Trad. del autor. En orig.: «Cette vallée est au bout du monde, loin de toutes gares et de tout chemin». Le Corbusier: Urbanisme. París: Crés, 1925, p. 138

${ }^{3}$ Trad. del autor. En orig.: «Un tel chantier, disons-nous, est la prémisse grandiose de temps proches». Id., p. 142

${ }^{4}$ Vid. Allen Brooks, Harold: Le Corbusier's Formative Years. Chicago: The University of Chicago Press, 1996, p. 473

${ }^{5} I d .$, p. 475
} 
mirada hacia el embalse como arquitecto. Y, aunque el esfuerzo profesional se centró en el proyecto de los edificios complementarios a la obra de ingeniería, como la fábrica o las viviendas para trabajadores, no podemos obviar un encuentro iniciático que, de algún modo, motivará los sucesivos encuentros posteriores.

Mientras el joven Jeanneret trabaja en los distintos equipamientos de la zona, allí se levanta la presa de la Roche, parte de un gran proyecto promovido por la Société des forces motrices de la Vienne, que concibe tres embalses con sus correspondientes centrales para asegurar el abastecimiento eléctrico. La Roche no es una estructura con un carácter monumental. Su baja altura y su directriz recta hacen que se integre con naturalidad en el entorno, destacando la presencia del edificio de la central en superficie próximo a la presa. Como en una representación, l'Isle Jourdain supone la introducción de los protagonistas a Jeanneret, y el joven arquitecto intuye las posibilidades de acción que permiten los diferentes elementos de los aprovechamientos hidroeléctricos: las presas, las centrales, las estaciones de transformación y los poblados para trabajadores. Dejando a un lado la especificidad de la vivienda obrera — analizada reiteradamente en la trayectoria de Le Corbusier-, el problema fundamental lo plantea el diálogo que establecen las presas y las centrales (3): entre sí y con el territorio y el paisaje. Las características propias de cada emplazamiento, así como las soluciones adoptadas para la presa y para los edificios auxiliares — de escala tan distinta y tan difícil solución formal—ofrecen un campo apropiado para la colaboración profesional entre ingenieros y arquitectos, que Jeanneret descubre gracias a su trabajo en l'Isle Jourdain.

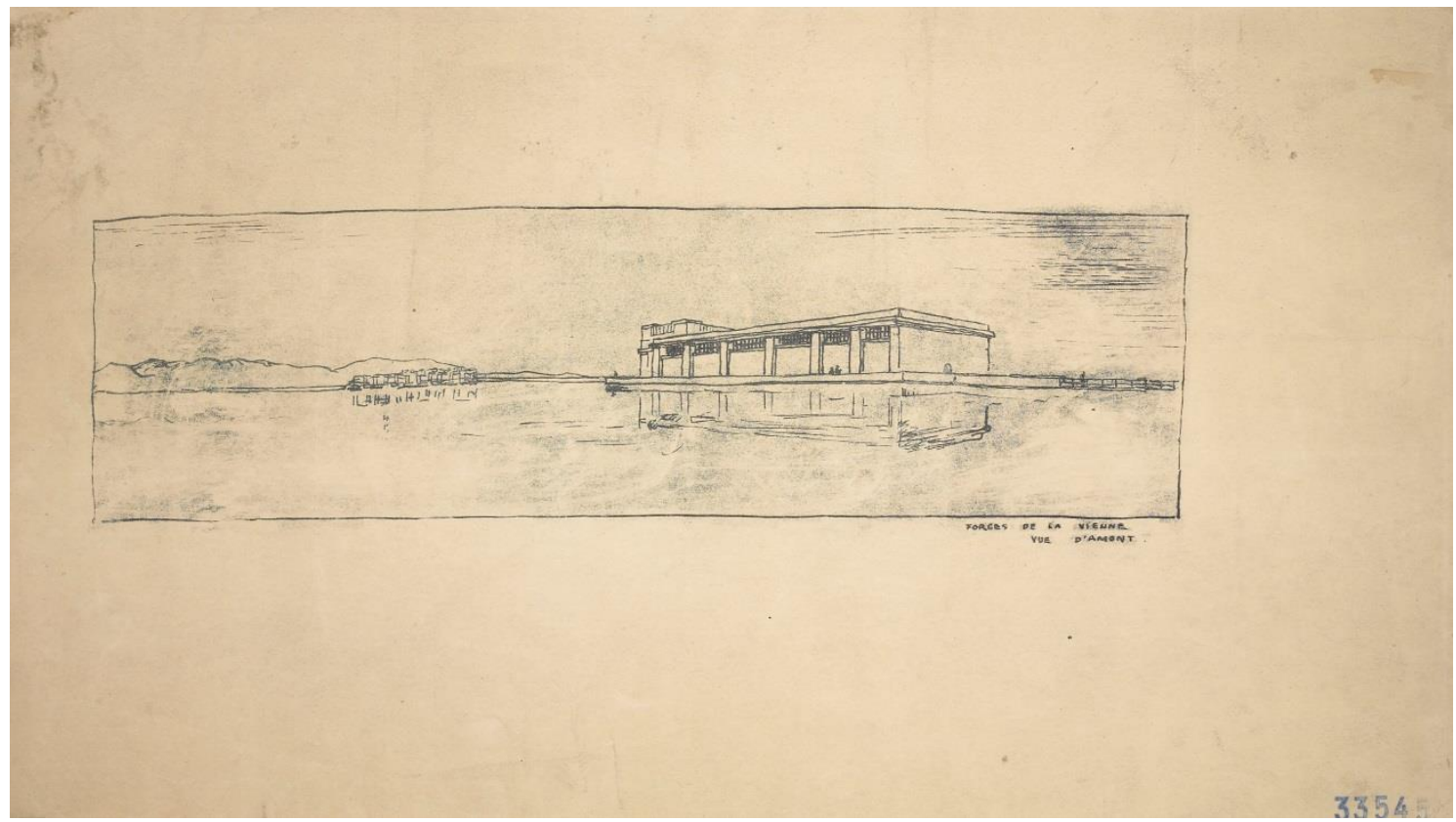

2. Le Corbusier: dibujo de la central hidroeléctrica de l'Isle Jourdain, 1917 (FLC 33545 OFLC-ADAGP)

Años más tarde, con la publicación de Urbanisme (1925), encontramos la primera referencia explícita a la lección del embalse. El décimo capítulo, titulado «Nuestros métodos» comienza con un esquema del sistema constructivo empleado en el embalse Barberine, situado en el cantón suizo de Valais ${ }^{6}$. Le Corbusier lo titula «La Presa», explicando la dimensión y la complejidad de la estructura utilizada. Más adelante explica que se trata de una inmensa presa que se está construyendo en los Alpes: «Un problema técnico sencillo: paciencia y precisión

\footnotetext{
${ }^{6}$ Esta presa de gravedad, construida entre 1919 y 1925, está situada en el lago Emosson. Fue sustituida por otra mayor entre 1969 y 1975, quedando sumergida en las aguas del embalse. Se convertirá en la imagen canónica de la lección del embalse en las conferencias de 1924 y en el libro Urbanisme.
} 
para ajustar los niveles del valle y sus vertientes. Una multiplicación para cubicar el de agua del lago que se creará. Una poco de regla de cálculo para resolver algunas fórmulas relativamente simples. Se saca la conclusión: hay que levantar una presa que tenga tantos metros de largo, de tantos metros de altura; que tenga tal espesor en la base, tal otro en el extremo superior, y el empuje sobre la presa será de tanto. Cualquier espíritu medio puede resolver todos estos cálculos: etapa insignificante» ${ }^{7}$.

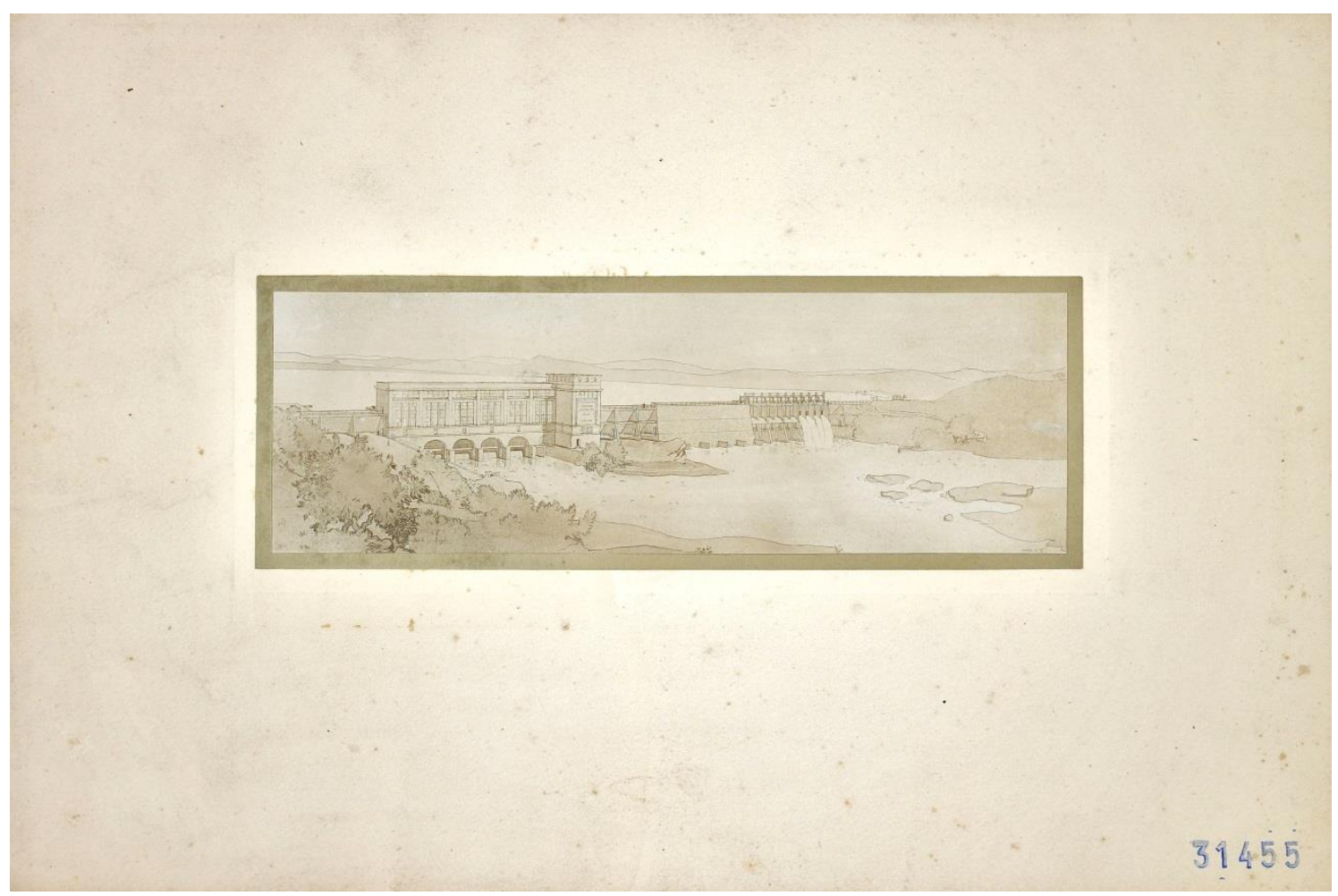

3. Le Corbusier: dibujo de la central hidroeléctrica de l'Isle Jourdain, 1917 (FLC 31455 OFLC-ADAGP)

Es después cuando comienza lo interesante, cuando los números resultantes son abrumadores y la obra debe hacerse a 2.500 metros sobre el nivel del mar, en el fin del mundo (4). Las dramáticas condiciones, donde solo llegan los escaladores del club alpino, son bien conocidas por Jeanneret, pues son próximas al ambiente donde se desarrolló su infancia y al recuerdo de los paseos por la montaña con su padre. El desarrollo de la titánica obra es descrito con emoción y admiración: «Todo el valle ronronea suavemente» ${ }^{8}$. Escucha atento el proceso: «Tiende el oído a esa música melodiosa, experimenta una sensación de bienestar, seguridad, de norma» ${ }^{9}$. Se maravilla tanto por el resultado como por la evolución y la tecnología empleada ${ }^{10}$.

\footnotetext{
${ }^{7}$ Trad. del autor. En orig.: «Problème techique simple: de la patience et de l'exactitude pour relever les niveaux de la vallée et de ses versants. Une multiplication pour cuber l'eau du lac artificiel qui sera créé. Un peu de règle à calcul pour résoudre quelques formules relativement simples. On conclut: il faut élever un barrage de tant de mètres de long, tant de mètres de haut; il aura telle épaisseur à la base, telle au sommet, la poussée sur le barrage étant de tant. Un esprit moyen peut faire le tour de ces calculs: étape insignifiante». Le Corbusier: Urbanisme, p. 138

${ }^{8}$ Trad. del autor. En orig.: «Toute la vallée ronronne doucement». Id., p. 140

${ }^{9}$ Trad. del autor. En orig.: «on tend l'oreille à cette musique mélodieuse, et l'on en a un sentiment de bien-être, de sécurité, de règle». Id., p. 141

${ }^{10}$ La experiencia de la visita a la construcción de la presa también es recordada en Sur les 4 routes: «Produce una sensación maravillosa observar, junto a la obra, la construcción de un embalse con los ruidos, los martillazos, las cadenas de transporte, las perforadoras y los estallidos de la dinamita». Trad. del autor. En orig.: «Quelles joies merveilleuses offre le chantier d'un barrage quand on arrive à pied d'oeuvre, en pleins travaux, dans le bourdonnement, le martèlement et le
} 
Comienza a pensar en trasladar estas ideas a la construcción de ciudades, y entonces nos presenta la lección del embalse, resumida en tres puntos o principios: la regla de cálculo — que resuelve las ecuaciones del universo-, la supervisión estricta y la presencia del gran capitán del embalse. Guía y ejecutor de la obra «es uno de esos hombres, muy poco comunes, que siempre controlan con rigor, con precisión, el domingo, las semanas... y que nunca han cometido un solo fallo» ${ }^{11}$. Le Corbusier, como ese capitán alpino, tiene en sus manos las herramientas que pueden dar forma al nuevo mundo: «Podemos hacer grandes cosas» ${ }^{12}$. Y concluye finalmente: «He aquí la lección del embalse» ${ }^{13}$.

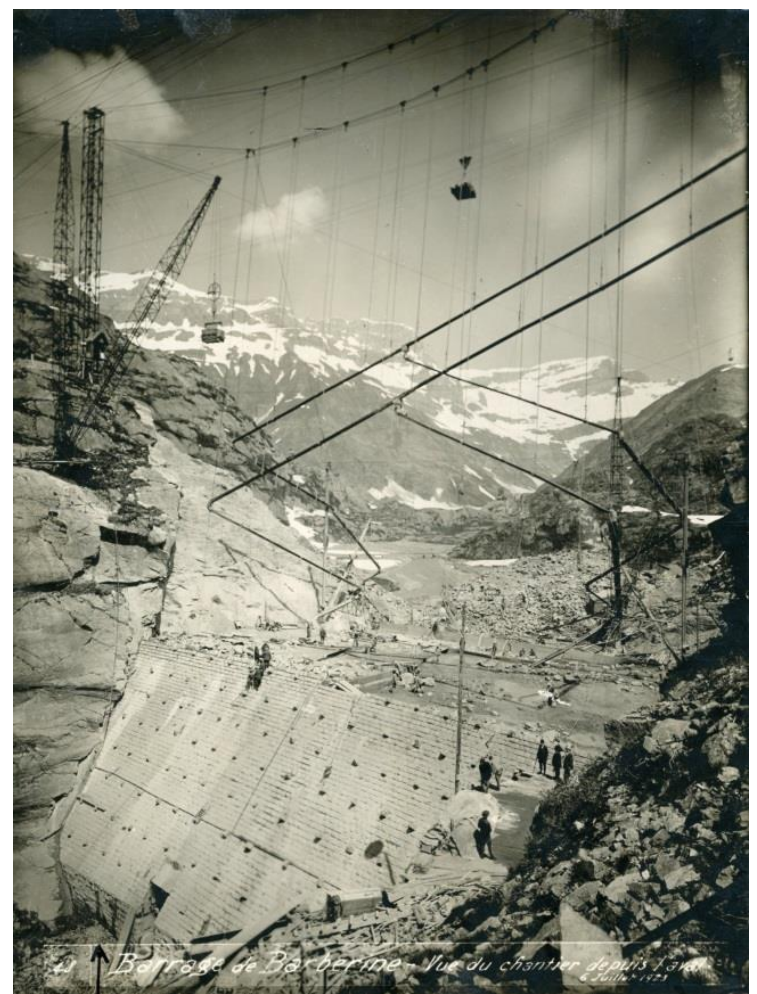

4. Le Corbusier: «la Presa». Fotografía de la construcción de la presa Barberine publicada en Urbanisme, p. 139, 1925 (CFLC-ADAGP)

\section{Barberine. La lección expuesta}

Aunque Urbanisme supone la introducción de la lección del embalse en uno de los textos teóricos fundamentales para entender la trayectoria de Le Corbusier, las ideas ya estaban presentes durante esos años, como prueban las conferencias impartidas en Lausana y París contemporáneas a la preparación del libro. Pero, en la exposición al público, sucede un cambio relevante: la presa genérica de Urbanisme se convierte en un caso concreto y real situado en el entorno próximo. En Urbanisme interesaba el objeto y su construcción por encima de los nombres, que solo conocemos por datos externos. Era denominada «la Presa», con mayúscula. En sus conferencias, se habla específicamente de la experiencia en Barberine, acercando la lección al público local y, al mismo tiempo,

déchirement des chaînes transporteuses, des concasseurs, des éclatements de mines». Le Corbusier: Sur les 4 routes. París: Gallimard, 1941, p. 160

${ }^{11}$ Trad. del autor. En orig.: «Cet homme est un de ces hommes — très rares-qui contrôlent toujours, avec rigueur, précision, le dimanche, la semaine, et qui jamais n'ont une défaillance». Id., p. 143

${ }^{12}$ Trad. del autor. En orig.: «nous puvons faire des choses grandes». Ib.

${ }^{13}$ Trad. del autor. En orig.: «Voilà la leçon du barrage». Ib. 
apropiándose del lugar y de sus cualidades más allá del objeto. Un lugar que seguirá presente durante años: una cabaña situada en Barberine se nos mostrará nuevamente mediante la reproducción de una tarjeta postal en Une Maison - Un Palais (1928) ${ }^{14}$. Lausana y el lago Léman se sitúan a medio camino entre La Chaux-de-Fonds y la presa Barberine, por lo que se convierte también en una suerte de lugar vital, donde entran en juego la proximidad al origen familiar y el anhelo de universalidad del ponente. La presa se transforma en el enlace con lo conocido, pero también en la manera de distanciarse de ello.

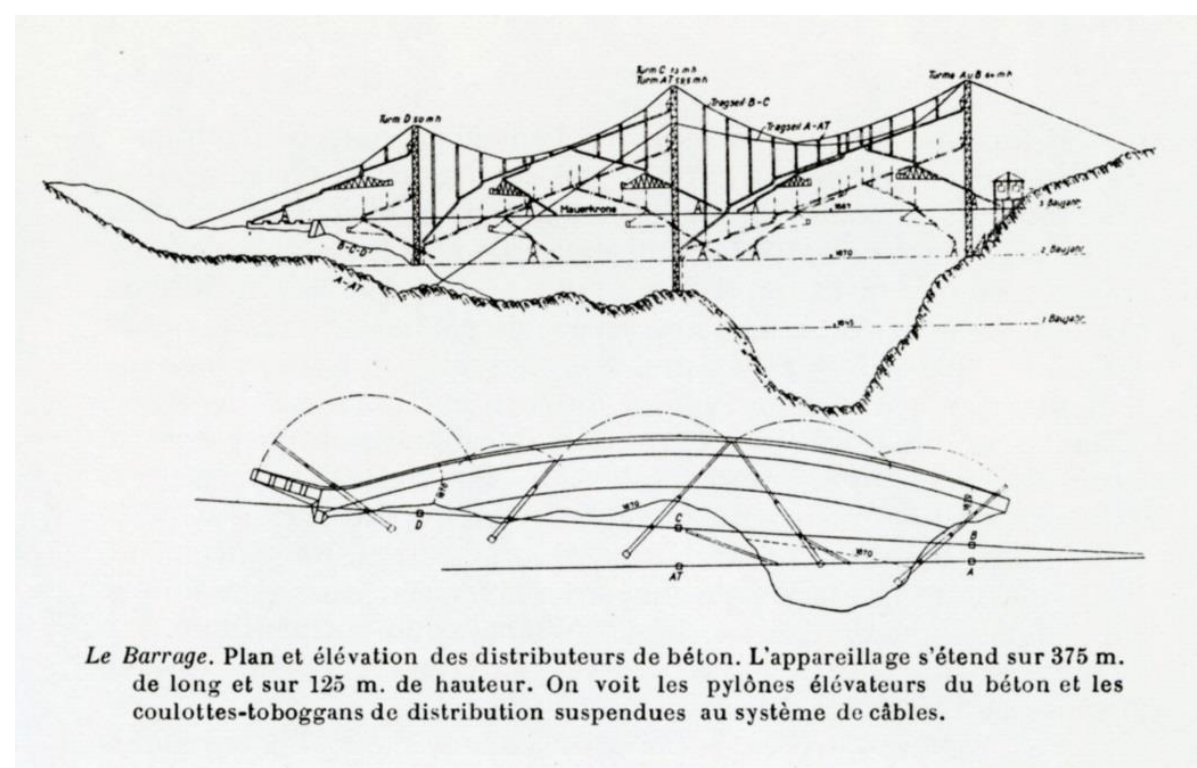

5. Le Corbusier: «La Presa». Alzado y planta del sistema de distribución del hormigón publicados en Urbanisme, p. 137, 1925 (@FLC-ADAGP)

Cuando imparte la conferencia en Lausana, el 18 de febrero de 1924, sigue incidiendo en la importancia del hecho constructivo (5) y, frente al tratamiento dado en Urbanisme, comienza a destacar también la relevancia del paisaje resultante, ese paisaje vivido desde la infancia donde la obra del hombre y la naturaleza se complementan. La presa Barberine vuelve a ocupar un lugar clave en el discurso, recordando la emoción que le había producido la visita a la obra con su amigo Paul Budry en octubre de $1923^{15}$, e introduciendo otros aspectos que avanzan sobre lo desarrollado en Urbanisme: «Al día siguiente buscamos a los ingenieros; les transmitimos nuestra admiración, que aceptaron complacientes. Después de una breve charla, la explicación de mis ideas [construir rascacielos en el interior de las ciudades] les provocó cierta risa, y cuando protesté exclamaron: 'Pero usted va a destruir la belleza de las ciudades al construir sus rascacielos'. Esas personas, capaces de crear esa inmensa grandeza, eran incapaces de comprenderla» ${ }^{16}$. La decepción ante la mentalidad de los ingenieros ante la lección que estaban construyendo, sigue patente en la conferencia de la Salle Rapp en París del mismo año: «Ellos [los ingenieros] eran totalmente diferentes a nosotros, precisamente por su mentalidad. Solían concebir y

\footnotetext{
${ }^{14}$ Vid. Burriel Bielza, Luis: Le Corbusier. La passion des cartes. Bruxelles: CIVA, 2013, p. 120

${ }^{15}$ Benton, Tim: Le Corbusier conférencier. París: Éditions du Moniteur, 2008, p. 56

${ }^{16}$ Trad. del autor. En orig.: «Nous sommes allés trouver le lendemain les ingénieurs; nous leur avons dit notre admiration qu'ils accueillirent avec une calme tranquille; après discussions nous arrivâmes à ceci c'est qu'en leur exprimant mes idées je réussis à soulever un éclat de rire général et devant cette manifestation, leur posant la question, ils me répondirent: 'Mais vous allez tuer la beauté des villes en faisant des gratte-ciel.' Ces gens capables de faire une grandeur immense ne se rendent pas compte de cette grandeur». Id., p. 57
} 
ejecutar sus construcciones basándose únicamente en el cálculo, se nos revelaron como incapaces de imaginar, en un campo diferente al suyo, las consecuencias de su actividad; permanecieron como hombres del pasado» ${ }^{17}$.

En la intervención persiste la exaltación de la técnica y la confianza en que el progreso de la ingeniería sirva para transformar la arquitectura, pero a diferencia de las generalidades de Urbanisme, esta revolución se empieza a plantear en lugares concretos, reconocibles; en un territorio de acción que se mueve desde el paisaje hasta la casa, temas ya trabajados en Vienne. Pero, mientras Vienne se había convertido en un laboratorio de integración profesional, con una leve presencia en el entorno, Barberine es la gran vela de cemento que corta el valle, la respuesta contundente a la naturaleza, la transformación del lugar conocido desde la infancia.

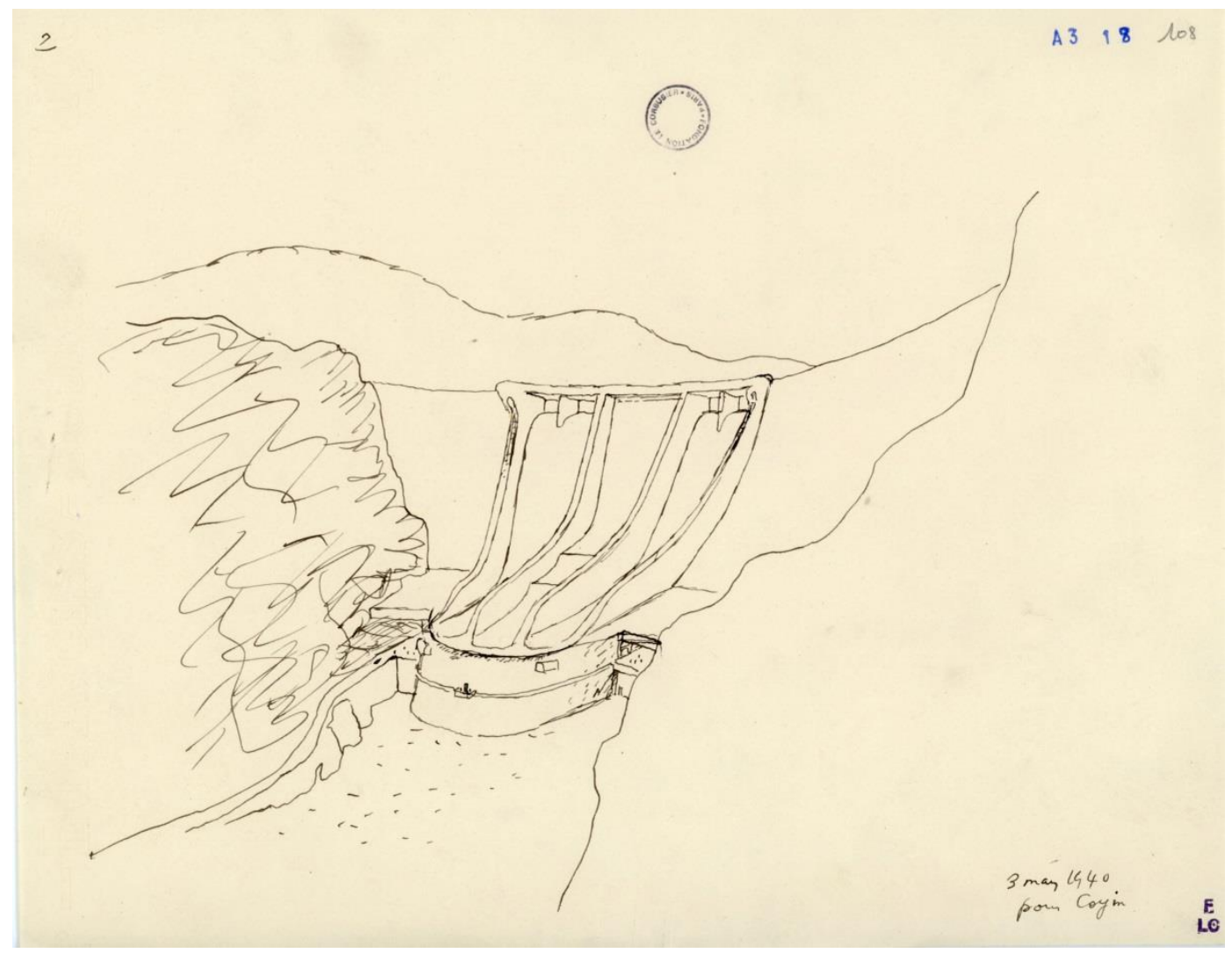

6. Le Corbusier: «Una primera aproximación de la arquitectura y de los fluidos...». Boceto de la presa de l'Aigle (FLC A3(18)108 OFLC-ADAGP)

Al trasladar la dimensión, ya no solo tecnológica, sino también paisajística del embalse hacia la arquitectura y la experiencia vital, y haciendo hincapié en esa arquitectura del hogar, de lo cotidiano y concreto, Le Corbusier expone y transmite la posibilidad de hacer real el espíritu nuevo. Comienza entonces a plantearse la materialidad de la lección del embalse. Su interés queda patente a través de las palabras pronunciadas en Lausana que, por primera vez, identifican y localizan el origen del aprendizaje: «He estado en los Alpes y he visto una de las creaciones más hermosas que puede alcanzar la iniciativa humana: la presa Barberine ${ }^{18}$.

\footnotetext{
${ }^{17}$ Trad. del autor. En orig.: «Ils [les ingénieurs] étaient totalement différents de nous, en vertu même de leur état d'esprit: habitués à concevoir et à exécuter des oeuvres de pur calcul, ils se sont révélés à nous, incapables d'imaginer, dans un domaine différent du leur, les conséquences de leur activité même; ils étaient demeurés des hommes d'autrefois». Ib.

${ }^{18}$ Trad. del autor. En orig.: «Je me suir trouvé dans les Alpes à voir l'une des plus belles choses que puisse faire le travail humain: le barrage de Barberine». Id., p. 202
} 


\section{Tennessee Valley Authority. La lección compartida}

En el año 1935 Le Corbusier viaja por primera vez a los Estados Unidos ${ }^{19}$. Uno de los resultados de ese viaje fue el texto Quand les catedrales étaient blanches: voyage au pays des timides, publicado en 1937. En 1939 queda maravillado con las presas proyectadas por André Coyne (París 1891- Neuilly-sur-Seine, 1960) «uno de esos ingenieros capaces de apreciar la armonía». ${ }^{20}$ En lugar de separar la presa de la central, como se venía haciendo, Coyne integró los dos elementos: «solidarizó la fábrica con la presa, la convirtió en un ser único, dotado de una biología sana y clara» ${ }^{21}$. Le Corbusier dibuja la presa de $1^{\prime} \operatorname{Aigle}^{22}$ (6) y escribe «En 1939 yo había intentado una primera aproximación de la arquitectura y de los fluidos (presa del Sr. Coyne). Y en ese año de 1945 todavía más (presa de Chastang ${ }^{23}$ )» ${ }^{24}$, incluyendo otro boceto (7).

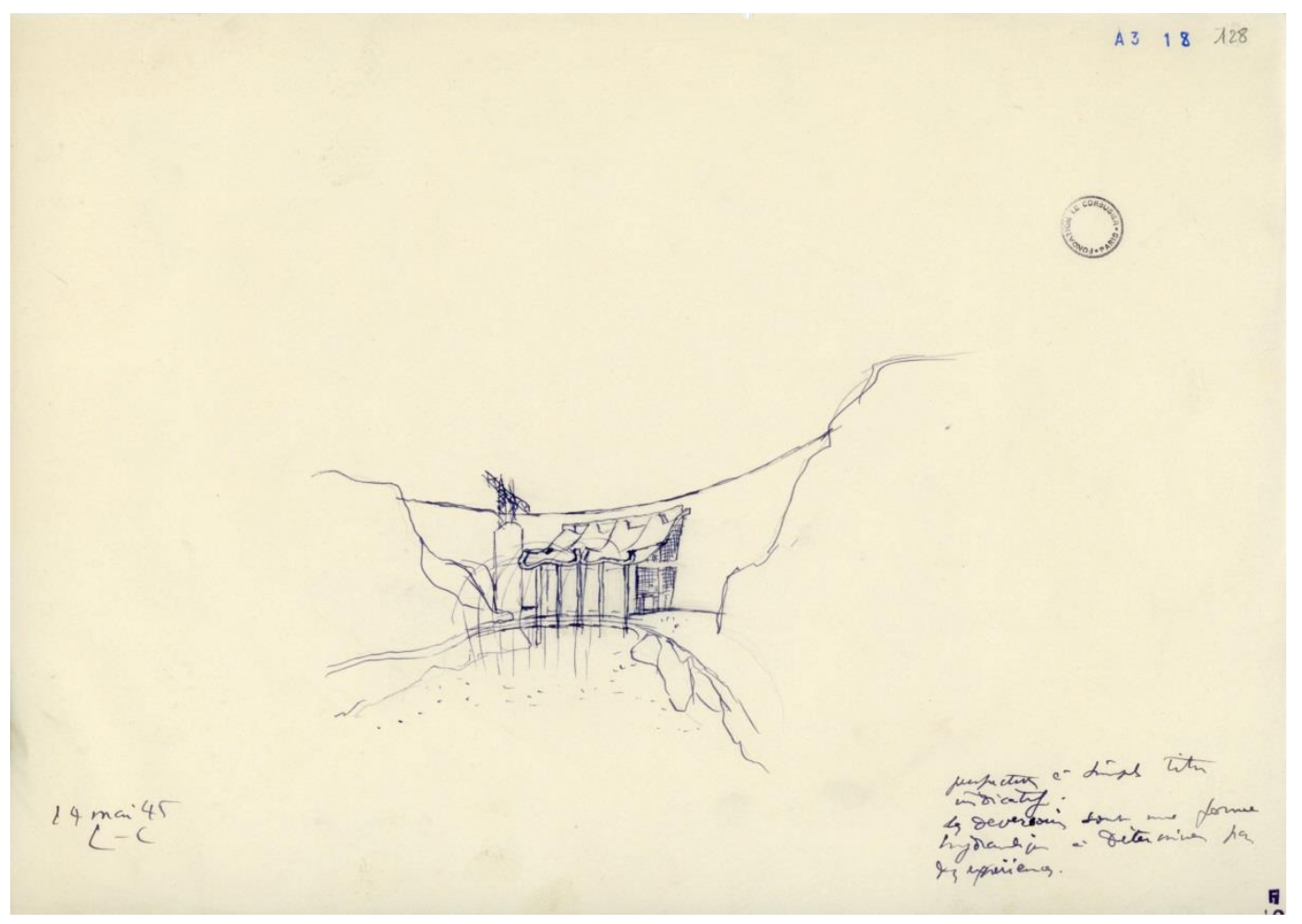

7. Le Corbusier: «Y en ese año de 1945 todavía más...». Boceto de la presa de Chastang (FLC A3(18)128 CFLC-ADAGP)

Regresa de nuevo a Nueva York en 1946 para integrar el equipo de proyecto del edificio de las Naciones Unidas. Coincidiendo con ese viaje, la editorial Reynal \& Hitchcock publica la edición americana del libro, que incluye una introducción del autor preparada específicamente para la nueva traducción, fechada el 21 de mayo de 1946

\footnotetext{
${ }^{19}$ Sobre este primer viaje, vid. Bacon, Mardges: Le Corbusier in America. Travels in the Land of the Timid. Cambridge: The MIT Press, 2001

${ }^{20}$ Trad. del autor. En orig.: «l'un de ces ingénieurs, aptes à goûter l'harmonie». Le Corbusier: Propos d'Urbanisme. París: Bourrelier, 1946, p. 50

${ }^{21}$ Trad. del autor. En orig.: «solidarisa l'usine et le barrage, en fit un être unique, doté d'une saine et claire biologie». Ib.

${ }^{22}$ Proyectada por Coyne y construida entre 1941 y 1946, está situada en la baja Normandía, sobre el Dordoña. También se conoce como «La presa de la Resistencia». Le Corbusier introdujo el boceto en el cuarto volumen de la Oeuvre Complète además de en Propos d'Urbanisme.

23 También proyecto de Coyne (1947-1952) sobre el Dordoña. Al igual que la anterior, integra la presa y la central hidroeléctrica. Su dibujo se repite en la Oeuvre Complète y en Propos d'Urbanisme junto a l'Aigle.

${ }^{24}$ Trad. del autor. En orig.: «J'avais essayé en 1939, un premier rapprochement de l'architecture et des fluides (barrage de M. Coyne). En cette année 1945 davantage encore (barrage du Chastang)». Le Corbusier: Propos d'Urbanisme, p. 50
} 
en Nueva York. En ella habla sobre los diez años transcurridos desde el primer viaje, enfrentando la situación entre Europa y América y celebrando que el público americano haya esperado una década para recibir esa traducción, pues lo sucedido hasta entonces permite entender y potenciar el contenido del texto. Y, entre esos hechos, destaca uno de manera especial: el proyecto de la Tennesse Valley Authority (TVA) desarrollado desde principios de la década de los treinta: «En torno a 1935 se inició el trabajo de la TVA. En enero de este año 46, fui a ver sus efectos. El hombre y la naturaleza, las leyes de la naturaleza y los cálculos que también expresan las leyes del mundo, imaginación humana en busca de la armonía... La negligencia había desatado eventos catastróficos en el valle. Las cosas iban de mal en peor. La naturaleza fue tomada de la mano y, finalmente, su ira fue calmada; una vez más se volvió maternal. El flujo cíclico de agua ha provocado una regeneración maravillosa; los hombres se encuentran de nuevo con la abundancia y la promesa de la felicidad. Y también, en el dominio de la naturaleza, se sentían orgullosos por haber creado las grandes presas que son portadoras de esplendor físico y espiritual» ${ }^{25}$.

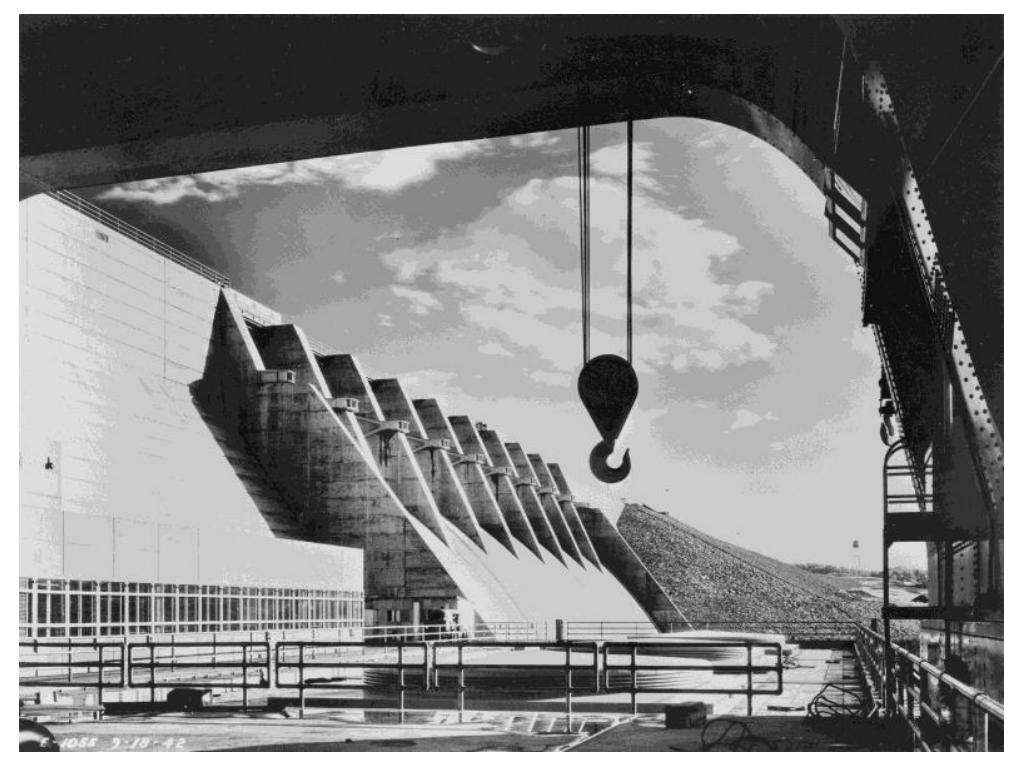

8. La presa Cherokee de la TVA en construcción, Tennessee, h. 1945 (Library of Congress Prints and Photographs Division, LC-USW33- 015646-ZC)

El programa de la TVA (8) fue una de las grandes acciones del New Deal promovido por Roosevelt en los Estados Unidos. Creado el 18 de mayo de 1933, su objetivo principal era la obtención de energía eléctrica y el control de las riadas del Tennessee en una región que abarcaba siete estados ${ }^{26}$. El cerebro intelectual de la operación fue el líder político David Lilienthal que, junto al científico Albert Einstein y al capitán de la industria naval Henry J. Kaiser fue una de las personas que marcaron el segundo viaje norteamericano de Le Corbusier. Del encuentro con Lilienthal dejó constancia en uno de sus textos más conocidos: El Modulor (1948): «Mi segunda visita fue a Lilienthal, en Knoxville, director general de Tennesse Valley Authority (TVA), admirable

\footnotetext{
${ }^{25}$ Trad. del autor. En orig.: «About 1935 the work of the TVA was begun. In January of this year, '46, I went to see its effects. Man and nature, laws of nature and calculations which also express the laws of the world, human imagination in search of harmony... Neglect had unloosed catastrophic events in the valley. Things were going from bad to worse. Nature was taken by the hand and finally her anger was calmed; once again she become maternal. The cyclic flow of water brought about a wonderful regeneration; men found again abundance and the promise of joy. And also, in mastering nature, they felt pride in having created the great dams which are bearers of physical and spiritual splendor». Le Corbusier: When the cathedrals were white. Nueva York: Reinald and Hitchcock, 1947, p. XIX

${ }^{26}$ Vid. Zarza, Daniel: «TVA (Tennesee Valley Authority). "Electricity for all”». En Formas de Arquitectura y Arte. Marzo 2008, No 18. Ciudad Real: Colegio de Arquitectos de Ciudad Real, 2008, pp. 132-151
} 
animador del gran proyecto de armonía respaldado por el presidente Roosevelt: diques del Tennessee, nuevas ciudades, salvación y renacimiento de la agricultura. La conversación fue realmente amistosa porque mi regla áurea hablaba de armonía. Y toda la obra de Lilienthal tiende a la armonía. Su rostro sonreía ante este dulce pensamiento: hacer reinar la armonía... mediante la ejecución de los más gigantescos trabajos y a través de la coordinación de los más vastos proyectos: agua, fuerza motriz, abono de tierras, agricultura, transportes, industria. Objetivo: un territorio tan grande como Francia arrancado al deterioro que, con angustiosa rapidez, cubría con un sudario desértico las tierras cultivadas. Y la vida victoriosa volvía a tomar posesión de estas tierras salvadas para realizar una de las mayores síntesis de la organización moderna» ${ }^{27}$.

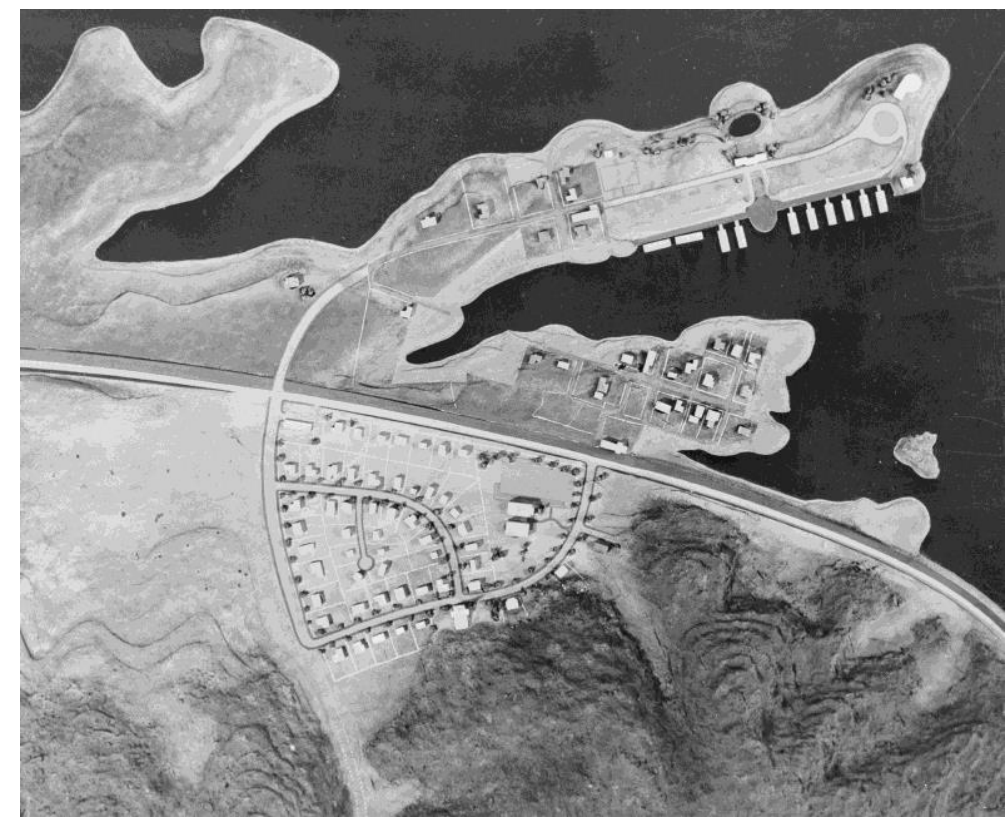

9. Maqueta de planeamiento urbanístico de la TVA, h. 1945 (Library of Congress Prints and Photographs Division, LCUSW33-015607-ZC)

La obra total de la TVA lleva al límite la idea de integración profesional observada por primera vez en l'Isle Jourdain. Ya no son simplemente grandes presas — como la emblemática de Norris-, con sus centrales hidroeléctricas, edificios auxiliares y poblados obreros. Aquí aparece el paisajismo, la explotación agrícola, la accesibilidad territorial, el diseño de asentamientos completos (9)... dentro de un amplio proyecto que, con sus logros y sus fracasos, ponía de manifiesto la auténtica dimensión técnica, funcional y estética de los embalses.

La lección del embalse era, al otro lado del Atlántico, compartida pero, sobre todo, ampliada hacia una sublime integración de ingeniería y arquitectura, donde tenía presencia desde el diseño de la propaganda hasta las

\footnotetext{
${ }^{27}$ Trad. del autor. En orig.: «Ma seconde visite fut pour M. Liliental, à Knoxville, directeur général de la Tennesse-ValleyAuthority (T.V.A.), animateur admirable de ce grand plan d'harmonie épaulé par le Président Roosevelt: les barrages du Tennessee, les villes neuves, le sauvetage et la renaissance de l'agriculture. La conversation fut véritablement amicale, car ma régle d'or parlait d'harmonie. Et toute l'ouvre de M. Liliental est tendue vers l'harmonie. Son visage, d'ailleurs, souriait à cette douce pensée: faire régner l'harmonie... par l'entreprise des plus gigantesques travaux, par la coordination des plus vastes projets: eau, force motrice, engrais, agriculture, transport, industrie. Couronnement: un territoire grand comme la France arraché à l'érosion qui, avec une rapidité angoissante, drpait d'un linceul de désert lest étendues cultivées. Et la vie victorieuse reprenait possession de ces terres sauvées pour y réaliser l'une des plus grandes synthèses de l'organisation moderne». Le Corbusier: Le Modulor. París: L'Architecture d'aujourd'hui, 1950, p. 53
} 
viviendas para las familias del entorno. El territorio, entendido como soporte de acción y posibilidades de proyecto del arquitecto moderno gravitaban alrededor del embalse. Sólo restaba su materialización plena.

\section{Bhakra. La lección construida}

Será al final de su vida, casi cincuenta años después de la primera experiencia en l'Isle Jourdain, cuando Le Corbusier se enfrente a la realidad de la lección del embalse. Será en la India, al mismo tiempo que el gran proyecto de Chandigarh, y le llegará, al igual que en el encargo de la capital, por la intervención de Nehru.

La presa de Bhakra, una de las mayores del momento, se sitúa sobre el río Sutlej, en la frontera del Punjab (10).

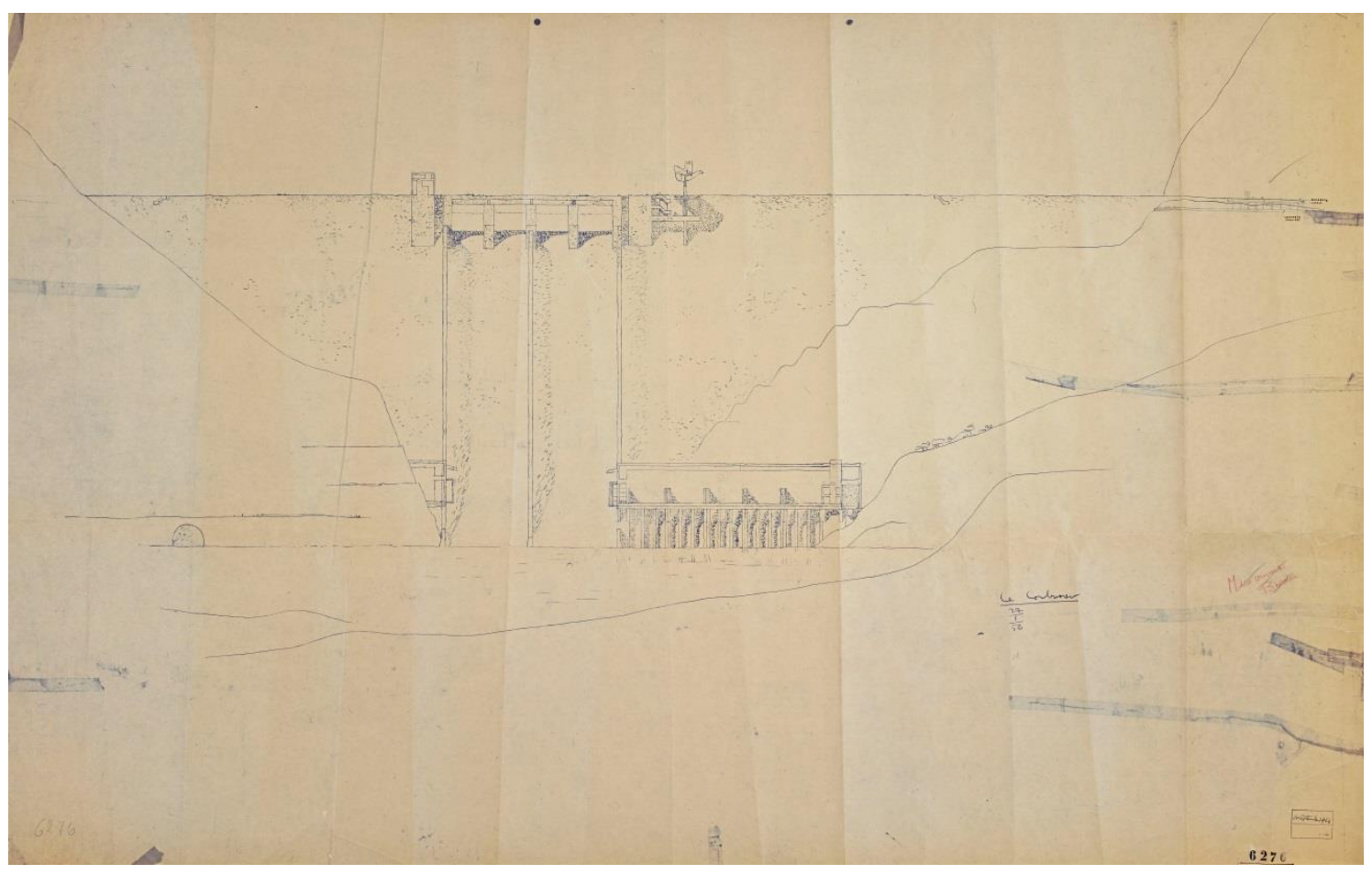

10. Le Corbusier: Alzado de la presa de Bhakra aguas abajo, 27 de marzo de 1956 (FLC 6276 CFLC-ADAGP)

Desde su origen, se pretende crear un elemento simbólico para la nueva nación más allá de su funcionalidad inmediata, como sucedería con la ciudad de Chandigarh, situada $100 \mathrm{~km}$ al sur de la presa. Ciudad y presa pueden entenderse como dos proyectos contemporáneos y complementarios, promovidos por el primer ministro con la intención de modernizar la joven nación, calificando a Bhakra como el nuevo templo de la India resurgente.

Los trabajos preliminares comienzan a finales de la década de los cuarenta. El 17 de noviembre de 1955 se celebra el inicio del hormigonado de la presa con la presencia de Nehru y, un año después, se contacta formalmente con Le Corbusier, con la intención de involucrar a aquellos artistas y arquitectos que estaban trabajando en el proyecto de la capital. Le Corbusier no solo manifiesta su plena disponibilidad para afrontar el encargo sino que muestra un interés especial, al encontrar en la presa india la oportunidad para dar forma a la lección del embalse anhelada desde su juventud. 
Con la estructura principal ya definida y en construcción, la labor del arquitecto se concentra en el aspecto final, especialmente en la introducción de ese factor simbólico y conmemorativo buscado por Nehru ${ }^{28}$. Se trabaja por lo tanto, en los temas más superficiales: fachadas de la central, situada al pie de la presa; diseño de las áreas públicas, incluyendo un centro de visitantes y mirador en la parte superior; y tratamiento de la pequeña escala como las luminarias o las barandillas ${ }^{29}$, al tiempo que realiza un proyecto similar de menor dimensión en los elementos de contención y de ocio del lago Sukhna en Chandigarh. Más tarde se ocupa también de los aspectos paisajísticos: vías de acceso, arbolado, iluminación del entorno... combinando todas las escalas del diseño como había sucedido en la experiencia de la TVA.

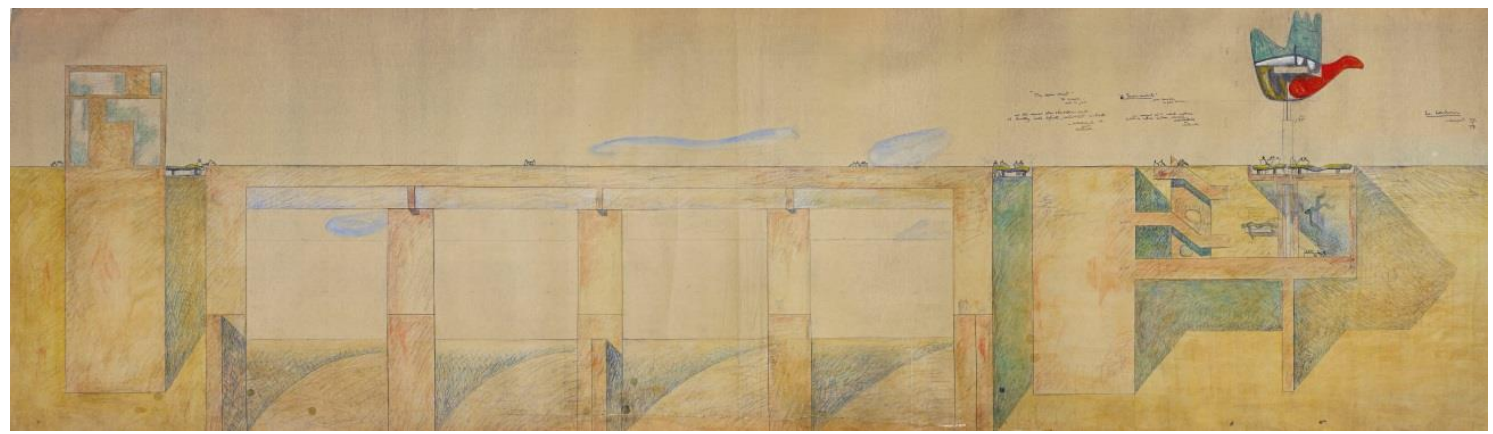

11. Le Corbusier: Detalle de la coronación de la presa de Bhakra con el mirador para visitantes y la Mano Abierta, 1958 (FLC 6272 ○FLC-ADAGP)

Diversas razones, fundamentalmente de tipo económico, van privando a Le Corbusier de ver su presa ideal materializada. Aun así, el afecto hacia la obra y la enorme responsabilidad que sentía hacia ella se ponen de manifiesto en los múltiples croquis con los que va concretando cada parte: la gran escenografía del conjunto, vista de aguas abajo con la problemática de relacionar presa y central eléctrica — aquellos elementos con los que comenzó a descubrir la lección del embalse —; la zona de coronación — la más trabajada en sucesivos ensayos, y dónde plantea la escultura de la Mano Abierta (11) — y, sobre todo, el programa simbólico ${ }^{30}$. Como había avanzado Nehru, Le Corbusier entiende que está trabajando en un auténtico templo de la modernidad: «No se permitirá que los automóviles transiten por encima de la Presa; la Presa es exclusivamente para peatones. La gente con prisas no debería traer aquí el desorden a aquellos que han venido desde muy lejos para meditar. Es

\footnotetext{
${ }^{28}$ Sobre el proyecto de Bhakra, vid. Antonini, Debora: «Barrage». En Le Corbusier Plans. París: Fondation Le Corbusier, 2010, caja 4, volumen 14

${ }^{29}$ Sobre la escala del diseño en el embalse, resulta revelador un fragmento de Sur les 4 routes: «Me encontraba en el Congreso de los C.I.A.M., en el embalse de Marathon, en Grecia. La ingeniosa obra desplegaba su enorme potencia. Estaba en la parte alta del embalse, apoyado en la baranda. Era una baranda indigna, de "estilo". Bastaba esa baranda en lo alto del embalse para profanar toda la obra. Las turbinas hacían su trabajo fielmente, el embalse acopiaba las aguas, sólo la baranda estaba fuera de lugar. Y las montañas y sus pinos y aquella misma piña, matemática pura, que rodaba a mis pies denunciaba el atentado contra la unidad» Trad. del autor. En orig.: «Nous étions au congrès des C.I.A.M. au barrage de Marathon, en Grèce. L'ouvre ingénieuse déployait dans le site ses grands événements. Mais nous, nous étions au sommet du barrage, appuyés à la seule chose en contact, le parapet. Ce parapet était ignoble, en "style" et l'oeuvre entière en était profanée. Oui, un parapet y suffit; c'est la couronne du barrage. Les turbines turbinent fidèlement; le barrage barre; mais le parapet pète de fatuité. Et les montagnes et les pins des montagnes, et cette pigne de pin qui roule sous nos pieds, sont là pour dénoncer la faute; la pigne de pin, mathématique parmi les plus pures, dénonce le crime de lèse-unité». Le Corbusier: Sur les 4 routes. París: Gallimard, 1941, p. 158.

${ }^{30}$ Vid. Antonini, Debora: «Bhakra Dam, un haut lieu en Inde». En Antonini, Debora y otros: Le symbolique, le sacré, la spiritualité dans l'ouvre de Le Corbusier. París: Éditions de la Villette, 2004, pp. 84-95
} 
una cuestión de dignidad, de calidad espiritual» ${ }^{31}$. Resulta significativo que se evoque la experiencia trascendente vivida en los Alpes, y que Bhakra se convierta, igual que entonces, en «la Presa» con mayúscula.

A pesar del reiterado rechazo a sus propuestas para la presa, Le Corbusier siempre se sentirá como el arquitecto del embalse, defendiendo que Chandigarh y Bhakra eran entidades hermanas en orden y pensamiento. Podríamos pensar que se pierde la última oportunidad de hacer realidad la lección del embalse tanto tiempo deseada. Sin embargo, ya al final de su vida, no se percibe esa idea. Y, si no es en Bhakra... ¿Dónde se ha construido?

Si analizamos los años previos a Bhakra, no encontramos otros proyectos vinculados a aprovechamientos hidroeléctricos, por lo que podemos pensar que la lección del embalse se ha materializado en otros lugares, de maneras y formas muy distintas, más veladas que evidentes, como debería suceder con toda buena lección. Así, en la capilla de Ronchamp, el modo de plantear la cubierta y la evacuación de agua, pero también la contención e introducción de la luz, tienen mucho que ver con la arquitectura de las presas ${ }^{32}$. No puede ser casual que Sud-Est Travaux et Construction (SETC), la empresa constructora escogida para dar forma al convento de la Tourette, estuviera especializada en la realización de presas hidráulicas en los Alpes ${ }^{33}$. Incluso, de proyectos anteriores como el Palacio de la Sociedad de Naciones (Ginebra, 1926), se ha dicho: «Si pudiésemos atribuir al espacio las cualidades del agua, el edificio de Le Corbusier podría ser comparado a la presa que contiene el espacio, lo ordena, lo horada, le abre compuertas, para regar finalmente los informales jardines situados junto al lago» ${ }^{34}$.

Le Corbusier nunca completó el proyecto de un aprovechamiento hidráulico en plenitud, pero definió y practicó la lección del embalse en su arquitectura. Lo hizo a través de textos teóricos y obras construidas, donde dejó los rastros más fecundos de esa lección. Le interesó hasta los últimos años de su vida, como prueba la tarjeta postal de la presa sobre el río Çubuk (Turquía) conservada en su archivo y fechada en torno a $1964^{35}$. Y quiso legarla a futuros aprendices: en su Entretien avec les étudiants des Ecoles d'Architecture dejó escrito: «podría tratarse de una casa de fin de semana o de un palacio inmenso, de una presa hidráulica o de una fábrica, la llamada a la imaginación permanece constante» ${ }^{36}$.

\section{Conclusiones}

Desde los años veinte hasta el final de su vida, los aprovechamientos hidroeléctricos se convirtieron en un referente constante en la trayectoria de Le Corbusier, dando forma a una lección de arquitectura que se fue concretando en tiempos y maneras diferentes. El trabajo en Vienne para la Société d'applications du bétón armé,

\footnotetext{
${ }^{31}$ Trad. del autor. En orig.: «Les voitures n'ont pas le droit de rester au sommet du Barrage; le Barrage est réservé aux piétons. Les gens pressés n'ont pas à venir ici apporter leur fièvre à ceux qui sont venus de si loin pour se recueillir! Question de dignité, de qualité d'esprit». Antonini, Debora: «Barrage». En Le Corbusier Plans. París: Fondation Le Corbusier, 2010, caja 4, volumen 14

${ }^{32}$ Vid. Antonini, Debora: «L-C "around" RON». En Massilia. Anuario de Estudios Corbusierianos. 2004. Barcelona: Associació d'idees, 2004, pp. 182-191

${ }^{33}$ Potié, Philippe: Le Corbusier: Le Couvent Sainte Marie de la Tourette. Basilea: Birkhäuser, 2001, p. 80

${ }^{34}$ Trad. del autor. En orig.: «If we could attribute to space the qualities of water, then his building is like a dam by means of which space is contained, embanked, tunneled, sluiced, and finally spilled into the informal gardens alongside the lake». Rowe, Colin; Slutzky, Robert: «Transparency: Literal and Phenomenal». En Perspecta. 1963, vol. 8. New Haven: Yale School of Architecture, 1963, p. 54

${ }^{35}$ Construida entre 1930 y 1936 en una relación similar con la capital a la que tendría posteriormente Bhakra con Chandigarh. Vid. Burriel Bielza, Luis: Le Corbusier. La passion des cartes. Bruxelles: CIVA, 2013, p. 126

${ }^{36}$ Trad. del autor. En orig.: «Il peut être question aussi bien d'une maison de week-end que d'un palais immense, d'un barrage hydraulique que d'une manufacture; l'appel à l'imagination demeure constant». Le Corbusier: Entretien avec les étudiants des Ecoles d'Architecture. París: Minuit, 1957, p. 37
} 
en su etapa de formación, condujo a su descubrimiento; el texto de Urbanisme sirvió para su exposición teórica, defendida públicamente en conferencias como la de Lausana en 1924. Así, la lección del embalse se va desarrollando y mostrando progresivamente, al tiempo que se encuentran nuevos referentes como la experiencia de la Tennessee Valley Authority en los Estados Unidos, que amplía la dimensión y el territorio del proyecto.

Ya en los años cincuenta, la participación en la obra de Bhakra le permite ensayar la construcción de lo aprendido previamente, aunque no consigue hacer realidad sus intenciones para la presa (12). Sin embargo, el valor de la lección del embalse se desvela a través de las palabras, del dibujo y de la arquitectura, especialmente aquella de carácter más simbólico, donde permanece como el testimonio de la fértil relación entre Le Corbusier y los aprovechamientos hidroeléctricos.

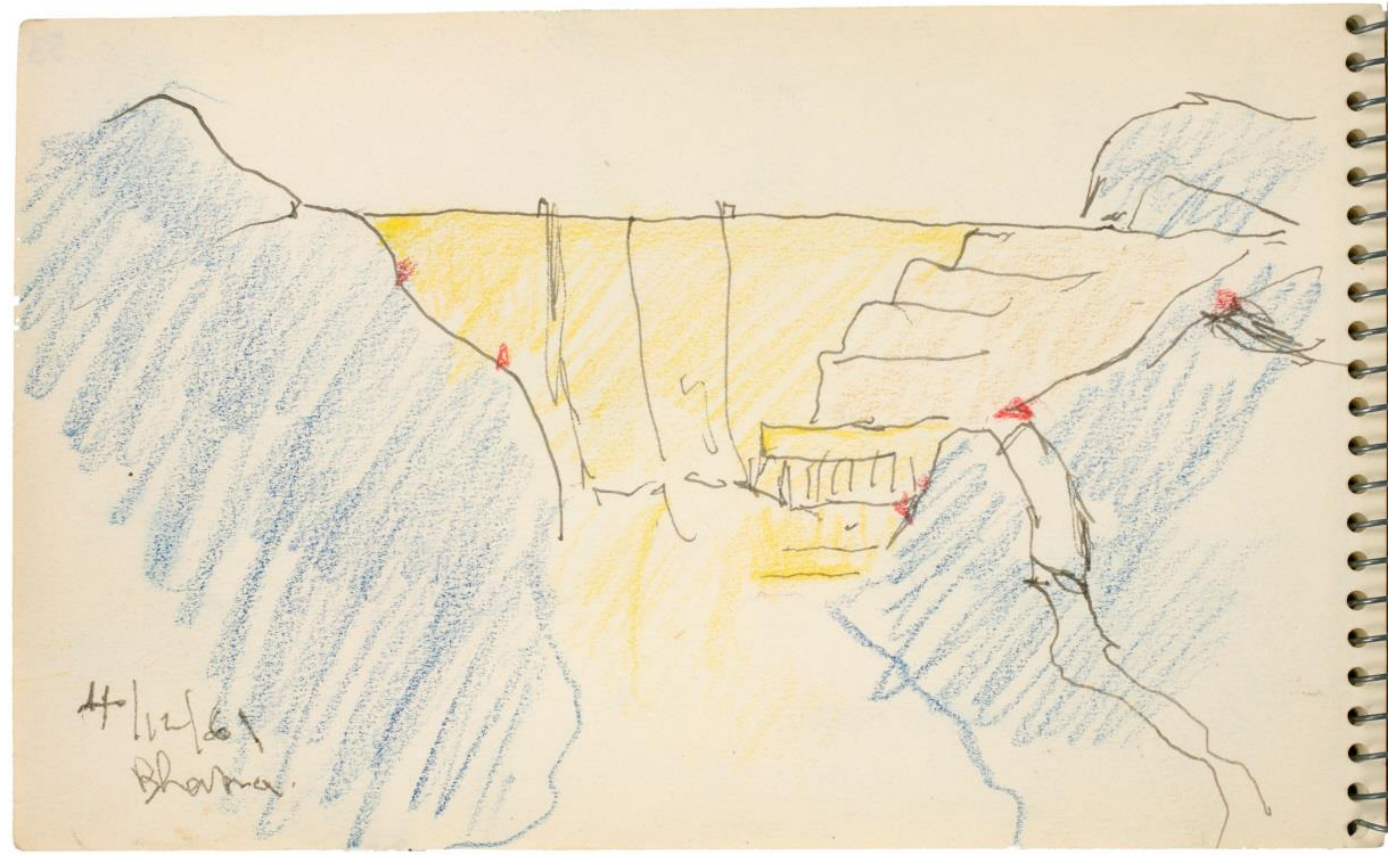

12. Le Corbusier: Boceto con la iluminación nocturna de la presa de Bhakra, 4 de diciembre de 1961 (FLC Carnet_R65_820 (cFLC-ADAGP)

\section{Referencias bibliográficas}

Allen Brooks, Harold: Le Corbusier's Formative Years. Chicago: The University of Chicago Press, 1996

Antonini, Debora: «Barrage». En Le Corbusier Plans. París: Fondation Le Corbusier, 2010, caja 4, volumen 14

Antonini, Debora: «Bhakra Dam, un haut lieu en Inde». En Antonini, Debora y otros: Le symbolique, le sacré, la spiritualité dans l'ouvre de Le Corbusier. París: Éditions de la Villette, 2004, pp. 84-95

Antonini, Debora: «L-C “around” RON». En Massilia. Anuario de Estudios Corbusierianos. 2004. Barcelona: Associació d'idees, 2004, pp. 182-191

Bacon, Mardges: Le Corbusier in America. Travels in the Land of the Timid. Cambridge: The MIT Press, 2001

Benton, Tim: Le Corbusier conférencier. París: Éditions du Moniteur, 2008

Burriel Bielza, Luis: Le Corbusier. La passion des cartes. Bruxelles: CIVA, 2013

Le Corbusier: Carnets 4 1957-1964. Milán: Electa, 1982

Le Corbusier: Entretien avec les étudiants des Ecoles d'Architecture. París: Minuit, 1957 
Le Corbusier: Le Modulor. París: L'Architecture d'aujourd'hui, 1950

Le Corbusier: Oeuvre Complète Volume 4 1938-46. Zurich: Girsberger, 1950

Le Corbusier: Propos d'Urbanisme. París: Bourrelier, 1946

Le Corbusier: Sur les 4 routes. París: Gallimard, 1941

Le Corbusier: Urbanisme. París: Crés, 1925

Le Corbusier: When the cathedrals were white. Nueva York: Reinald and Hitchcock, 1947

Potié, Philippe: Le Corbusier: Le Couvent Sainte Marie de la Tourette. Basilea: Birkhäuser, 2001

Rowe, Colin; Slutzky, Robert: «Transparency: Literal and Phenomenal». En Perspecta. 1963, vol. 8. New Haven: Yale School of Architecture, 1963, pp. 45-54

Sánchez-Pombo, Marina: «La arquitectura de los fluidos. Le Corbusier y los ríos». En Massilia. Anuario de Estudios Corbusierianos. 2004bis. Barcelona: Associació d'idees, 2005, pp. 48-69

Zarza, Daniel: «TVA (Tennesee Valley Authority). "Electricity for all”». En Formas de Arquitectura y Arte. Marzo 2008, N 18. Ciudad Real: Colegio de Arquitectos de Ciudad Real, 2008, pp. 132-151 


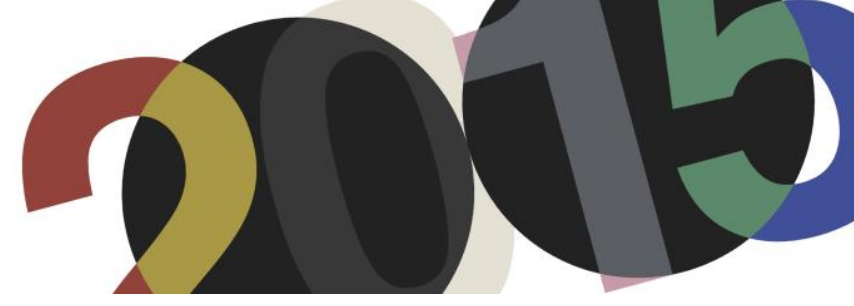

DOI: http://dx.doi.org/10.4995/LC2015.2015.880

\title{
Le Corbusier et le Brésil : une Synthèse des Arts Majeurs, et aussi des Arts Mineurs
}

\author{
C. Rodrigues dos Santos
}

Faculté d'Architecture et d'Urbanisme, Université Presbytérienne Mackenzie, SP, Brésil

Resumé: Ce travail examine les discours des architectes Lucio Costa et Le Corbusier sur la Synthèse des Arts, et les analyses faites à partir de l'application de ces idées dans les projets d'Architecture Moderne Brésilienne des années 1940, en particulier le projet du siège du Ministère de l'Éducation et de la Santé à Rio de Janeiro. L'objectif du présent travail est alors de révéler et de mettre l'accent sur la collaboration entre Le Corbusier et les architectes brésiliens ainsi que sur les Arts mineurs, représentés ici par l'art de l'azulejo, dans le processus de Synthèse des arts, comme supports et véhicules des expressions artistiques des Arts majeurs ou Beaux-arts.

Abstract: The objective of this work is, mainly through the speeches of Lucio Costa and of Le Corbusier on the "Synthèse des Arts" and the analysis of the application of these ideas to the works of the Modern Architecture in the years 1940 in Brazil, to reveal and to emphasize the important role of the Arts Mineurs and the Industrial Design in the process of the Synthesis of the Arts, as "vehicles" of the biggest expressions of the art intended to be integrated to the architecture, considering elements like ceramic tiles.

Mots-clés: Synthèse des Arts; Arts Majeurs et Arts Mineurs; Architecture Moderne Brésilienne. Keywords: Synthesis of the Arts; Major Arts and Mineurs Arts; Modern Brazilian Architecture. 
Le Corbusier entra en relation avec Lucio Costa et les architectes brésiliens lors de son premier voyage au Brésil, en 1929. Le pays vivait, à ce moment, un contexte de modernisation et de maturation de la discussion sur l'identité nationale ${ }^{1}$. Il s'agissait d'une relation complexe, qui se répercuta sur le travail du maître suisse et de ses disciples américains et fut bien plus profonde qu'une simple influence de Le Corbusier sur l'Architecture Moderne Brésilienne, comme l'a montré Carlos Eduardo Comas : "L'architecture de Le Corbusier ne se présente pas comme un système fermé, c'est comme un jeu de dominos. Ce que les Brésiliens Lucio Costa et Oscar Niemeyer font, c'est comprendre les règles de ce jeu, en capturer le mécanisme, la 'structure profonde' de l'œuvre de Le Corbusier (...) ne signifie pas une soumission, mais une culture de l'identité (...). Les architectes brésiliens ont compris Le Corbusier suffisamment et ont été en mesure d'infléchir son travail, et l'inverse sera également vrai"'2; pour Lucio Costa, il s'agissait d'associer ses propres initiatives à celles de Le Corbusier, ayant en vue le renouveau de l'architecture brésilienne ${ }^{3}$. Le dialogue établi entre Costa et Le Corbusier sur les questions de la Synthèse des Arts, et la place que tous deux accordaient dans ce débat aux dits Arts Mineurs, n'est que l'un des chapitres de cette relation complexe et sophistiquée ${ }^{4}$.

Le déplacement de Le Corbusier de Paris à Rio de Janeiro, lors de son deuxième voyage au Brésil, en $1936^{5}$, dure cinq jours. A bord du dirigeable Hindenburg, l'architecte écrit le texte "L'Architecture et les Arts Majeurs" "Les tendances de l'architecture rationaliste en rapport avec la collaboration de la peinture et de la sculpture. L'étude de la tendance qui règne, bien au contraire, dans l'architecture rationnelle, d'exclure, en tant que superflus d'après une logique rigoureuse, les concours des arts figuratifs" ${ }^{6}$. Ce texte ne sera publié, en portugais, qu'en 1984 par la Revista do Patrimônio Histórico e Artístico Nacional, avec préface de Lucio Costa, le gardien zélé du texte durant toutes ces années. L'article est traduit en portugais par Lucio Costa lui-même, qui l'intitule: "Arquitetura e as Belas-Artes"7 - "As tendências da arquitetura racionalista relativamente à colaboração da

\footnotetext{
${ }^{1}$ Sur les voyages de Le Corbusier au Brésil, voir : SANTOS, Cecilia R. dos ; PEREIRA, Margareth da S.; PEREIRA, Romão da S.; SILVA, Vasco C.. Le Corbusier e o Brasil. São Paulo, Projeto/Tessela, 1987.

2 BAPTISTA, Luis S.; VENTOSA, Margarida. "Prospectivas críticas - Herança de Le Corbusier", Architectura e Arte, $\mathrm{n}$. 50/60, julho/agosto 2008, Lisboa, Portugal.

${ }^{3}$ SANTOS, Cecilia. et alii. Op. cit., pp. 106-120.

${ }^{4}$ Lorsqu'on lui demanda pourquoi Le Corbusier avait reçu l'invitation pour aller au Brésil, en 1936, et pas un autre architecte en vue de cette époque, Walter Gropius par exemple, Lucio Costa expliqua: "Le Corbusier était le seul qui considérait le problème sous trois aspects : le sociologique (...), l'adaptation à la technologia nouvelle et l'approche plastique. C'est cela qui m'a frappé le plus, c'est là qu'il était différent de tous (...); l'approche de Le Corbusier séduisait beaucoup (...) il avait le don de la parole (...) et une foi énorme dans la rénovation, au bon sens du terme, une force qui contagiait les jeunes". Quand on lui demanda encore si Le Corbusier avait, d'une façon ou d'une autre, profité de son séjour au Brésil, Costa ajouta : "avec cette sensibilité impressionnante qu'il avait, il absorvait toujours quelque chose, dans n'importe quel pays. Sa richesse était là, exactement : il était sensible au régionalisme et était cosmopolita en même temps". In: "Presença de Le Corbusier" interview en 1987 à Jorge Czjkowsky, Maria Cristina Burlamaqui et Ronaldo Brito. In: COSTA, Lucio. Registro de uma vivência. São Paulo, Empresa das Artes, 1997, pp. 144-155.

${ }^{5}$ Le Corbusier arrive à Rio de Janeiro à l'aube du 13 juillet 1936, et reste au Brasil un peu plus d'un mois, jusqu'au 15 août. En 1929, il avait voyagé pour son compte, mais en 1936, "il répond objectivement, à une proposition de collaboration professionnelle avec des architectes locaux qui avaient déjà l'expérience d'un certain nombre de projets de caractère moderniste. Le Corbusier n'est donc pas venu au Brésil pour y fonder un nouveau mouvement architectonique, mais pour ratifier et d'une certaine façon accélérer le processus, déjà en cours, de rénovation de l'architecture brésilienne" (In: SANTOS, Cecilia et alii. Op. cit., p. 112). Le Corbusier fut invité par le Ministre de l'Éducation et de la Santé, Gustavo Capanema, à participer à un projet pour la Cité Universitaire de Rio de Janeiro et à donner une série de conférences à l’École des Beaux-arts; l'insistance de l'architecte lui-même lui permit de participer aussi, comme consultant, au projet du nouveau siège du Ministère de l'Éducation et de la Santé - MES.

${ }^{6}$ LE CORBUSIER. "A arquitetura e as Belas-Artes". Revista do Patrimônio Histórico e Artístico Nacional. Rio de Janeiro, IPHAN, n. 19 / 1984, pp. 53 a 69.

7 “L'Arts Majeurs" est traduit par Lucio Costa comme "Belas-Artes", "Beaux-Arts" en français.
} 
pintura e da escultura. $\mathrm{O}$ estudo da tendência que, ao contrário, impera na arquitetura racional de excluir como supérfluo, seguindo uma lógica rigorosa, o concurso das artes figurativas".

Les questions relatives à la Synthèse des Arts, discutées par Le Corbusier, sont tributaires des débats qui ont eu lieu en Angleterre au XIXe siècle, dans le cadre des Arts \& Crafts de W. Morris, ainsi que des propositions du premier Bauhaus et des discussions sur les métiers d'art ${ }^{8}$ et de la production industrielle en Allemagne, qu'il étudiera in situ pour faire publier, en 1912, le texte "Étude sur le mouvement d'art en Allemagne". En 1925, dans son livre Almanach d'Architecture Moderne, à propos du Pavillon de L'Esprit Nouveau, Le Corbusier écrit: "Nous ne sommes pas, à l' heure actuelle, partisans de la fresque, de la frise, de la métope. Il est mieux que l'ouvre peinte ou sculptée ne soit pas une 'commande' mais un produit direct de l'imagination. (...) Nous détachons du mur la sculpture et la peinture et les laissons seules, agir avec le radium qu'elles peuvent contenir" ${ }^{\prime \prime}$. La même année, Le Corbusier publie le livre L'art décoratif d'aujourd'hui, sur les relations entre l'art (et l'architecture), le folklore et les arts décoratifs à "l'âge de la machine", esquissant les idées qui seront à l'origine du corpus de la Synthèse des Arts, mûries dans les œuvres ultérieures. En reprenant les registres de son voyage d'Orient en 1911, Le Corbusier définit des relations entre l'art décoratif, le décor, l'art figuratif, l'art industriel et le folklore (le folklore traditionnel et "notre folklore aujourd'hui", selon ses propres termes), pour indiquer quel décor serait compatible avec "les temps nouveaux", au détriment de l'art décoratif, de son déclin et de sa mort dont il se croit le héraut ${ }^{10}$.

Le décor ne devrait être envisagé, selon Le Corbusier, que s'il cherche son inspiration, sans imitations, dans les civilisations du passé légitimées par l'Histoire ainsi que dans la culture matérielle d'héritage européen représentée par des objets utilitaires d'origine archéologique (étrusques ou grecs, par exemple) ou d'origine régionale relatifs au folklore, aux arts populaires et à l'ethnographie (de la vallée du Danube ou de la Hongrie et de la Serbie, par exemple) ${ }^{11}$. Dans le dernier chapitre de L'Art décoratif d'Aujourd'hui, qu'il intitule "Confession", Le Corbusier publie une carte avec l'itinéraire de son voyage d'Orient, sous-titrée "Le voyage utile", où chaque destination porte les lettres $\boldsymbol{C}$ - Culture, ou $\boldsymbol{F}$ - Folklore ou $\boldsymbol{I}$ - Industrie ; il explique : "L'architecture me fut révélée. L'architecture est le jeu magnifique des formes sous la lumière. (...) L'architecture n'a rien à voir avec le décor. L'architecture est dans les grandes cuvres, difficiles et pompeuses, léguées par le temps, mais elle est aussi dans la plus petite masure, dans un mur clôture, dans toute chose sublime ou modeste qui contient une géométrie suffisante pour qu'un rapport mathématique s'y installe. (...) Il n'y a pas de décor qui fasse jaillir l'émotion du voyageur : il y a l'architecture qui est forme pure, intégrale, - structure plastique -, et il y a les ouvres d'art: Phidias ou le pot du potier serbe des Balkans" ${ }^{\prime 2}$. Il appartient à l'architecture de créer l'atmosphère pour l'œuvre d'art, puisque son but est de "créer des rapports"13. Il ne s'agit pas encore d'une Synthèse, mais bien d'un rapport entre les arts. Et il ne s'agit pas d'un rapport entre les Arts Majeurs, puisque sont regroupées des œuvres qui vont des antiquités grecques aux céramiques serbes du XXe siècle. Lors de son passage en Hongrie, en 1911, Le

\footnotetext{
8 FERNANDES, Fernanda. "A síntese das Artes e a moderna arquitetura brasileira dos anos 1950". consulté: www.iar.unicamp.br/dap/vanguarda/.../fernanda_fernandes.pdf - ; voir aussi: "El concepto de Síntesis de las Artes" e "La irrupción de las sombras", consulté: www.tdx.cbuc.es/TESIS_UPC/../TDX...//04

${ }^{9}$ LE CORBUSIER, Almanach d'Architecture Moderne. Paris, G. Grès, 1925, pp.145-146.

${ }^{10}$ Voir aussi: TSIOMIS, Yannis. «Le Corbusier, L'Art décoratif d'aujourd'hui et 'La loi du ripolin' ».

${ }^{11}$ Au sujet de la discussion sur l'ethnographie et le folklore et sur l'affirmation des identités nationales à cette époque en Europe et au Brésil, voir : SANTOS, Cecilia H G Rodrigues dos. Mapeando os lugares do esquecimento : ideias e práticas na origem da preservação do patrimônio no Brasil. Thèse de doctorat, Faculté d'Architecture et Urbanisme, Université de São Paulo, 2007.

${ }^{12}$ CORBUSIER. L'Art Décoratif d'Aujourd'hui. Paris, G. Grès, 1925, pp.210-217.

${ }^{13}$ Idem, p. 128.
} 
Corbusier annonçait déjà, dans une lettre aux amis de l'atelier d'art de La Chaux-de-Fonds, le devoir de fuir de "l'européanisation envahissante et sale" jusque dans les refuges tranquilles où survit la grande tradition populaire $^{14}$.

Le Corbusier s'intéresse au folklore qui met en valeur le travail anonyme, l'œuvre lointaine qui remonte à plusieurs siècles et se perfectionne sur l'échelle de l'émotion humaine pour devenir unanime et donc collective, "susceptible de l'universalité", pour, à son tour, "fournir sa sève" au travail individuel ${ }^{15}$. Le folklore, ainsi défini, apparaît comme "concis, bref, économique, intense, essentiel"16, les mêmes attributs que Le Corbusier valorise dans le décor et dans l'architecture. L'objet contemporain moderne devrait être conçu selon un objectif et exécuté à la perfection en vue d'une utilisation certaine, pareil aux manufactures traditionnelles : "l'objet parfait est un organisme vivant, animé d'esprit de vérité". La critique de l'architecte se dirigée vers l'art décoratif, le "folklore usurpé par les paresseux et les stériles" pour être reproduit à grande échelle par la "machine à déformer", celle qui fabrique des objets qui semblent avoir été faits à la main, mais ne comptent plus ni avec "l'inquiétude de l'inexplicable", caractéristique du folklore traditionnel, ni avec la "sérénité de la connaissance", attribut de l'art ${ }^{17}$. À Rio de Janeiro, en 1936, Le Corbusier note dans son carnet: "Il n'y a pas d'Art décoratif. Il y a l'art. L'art, c'est l'harmonie et non pas le décor. L'expression la plus désintéressée et la plus expressive du lyrisme se réalise dans les Arts Majeurs" ${ }^{18}$.

Selon la tradition des Beaux-Arts, seules l'architecture, la sculpture et la peinture méritent le titre d'Arts Majeurs, alors que les activités et les "choses" de la vie quotidienne, telles que les meubles, lampes, tissus, vaisselle, dont la confection est confiée à l'art des artisans ou des techniciens, rentrent dans la catégorie des Arts Mineurs. Pour Jenny Dreyfus ${ }^{19}$, la division et la hiérarchisation de l'art en Arts mécaniques ou industriels (concernant le travail manuel) et Arts libéraux (fruits de l'esprit et de l'imagination), vont provoquer la division, encore adoptée en France par l'Académie au moment où l'auteure écrit son livre (1946-1949), entre Arts Majeurs ou Beaux-Arts (y compris l'architecture -l'Art Majeur par excellence-, la sculpture et la peinture) et les Arts Mineurs ou arts appliqués ou arts rétrospectifs ou arts décoratifs: "Les Arts mineurs sont le résultat de produits normaux du travail humain, qui n'ont pas atteint la figure de proue des grands arts mais présentent cependant un aspect esthétique associé à un caractère d'utilité qui leur est essentiel" ${ }^{\prime 20}$. Aucune dépréciation des Arts Mineurs ne se justifierait, selon la muséologue, car ils renvoient à des artefacts qui eux aussi ont des qualités, telles que la solidité, la maîtrise de la forme et la perfection de la finition. Mais Jenny Dreyfus reconnaît que "l'art de la parure $^{\prime 21}$ peut être considéré comme inférieur dans la hiérarchie des Beaux-Arts, ainsi que les différents types d'objets considérés comme appartenant aux arts décoratifs, comme les meubles, l'argenterie, l'orfèvrerie, le

\footnotetext{
${ }^{14}$ LE CORBUSIER. Viagem do Oriente. São Paulo, Cosacnaify, 2007, pp. 17-28. Dans la présentation de l'édition de la Cosacnaify, en portugais, Margareth da Silva Pereira nous rappelle que ce livro, révisé par Le Corbusier l'année de sa mort, et dont la publication fut posthume, peut être considéré comme son premier et dernier livre, un texte qui nous fournit la clé pour comprendre l'œuvre de l'architecte.

${ }^{15}$ LE CORBUSIER. L'Art Décoratif d'Aujourd'hui. Paris, G. Grès, 1925, pp.33 et 211.

${ }^{16}$ Idem p. 32

${ }^{17}$ Ibidem, p. V et pp. 27-32.

${ }^{18}$ Notes sur feuilles séparées, numérotées de 1 à 6 , portant l'en-tête "Cabinet do Ministère de l'Éducation et de la Santé Publique”, Fondation Le Corbusier, A2-19. In: SANTOS, Cecilia et alii. Op. cit., p. 149

${ }^{19}$ DREYFUS, Jenny. Artes Menores. São Paulo, ANHAMBI, 1959. J. Dreyfus (1890-1977) a été conservatrice du Musée Historique National à Rio de Janeiro, et professeure de la matière "Arts mineurs" dans le Cours de Muséologie.

${ }^{20}$ Idem, p. 09

${ }^{21}$ Parure est le motif décoratif basé sur le dessin, qui sert à enjoliver ou orner des objets ou choses dans la structure desquels il soit intégré harmonieusement (In: DREYFUS. Op. cit., p. 15)
} 
textile, la tapisserie, la céramique, le verre, et encore les mosaïques, les carrelages, les vitraux - "tous les objets qui entourent l'homme et son foyer ${ }^{\prime 22}$.

Les arts appliqués à l'industrie ${ }^{23}$ - bronze, meubles, orfèvrerie, céramique, mosaïque, tapisserie, vitraux - étaient classés sans hésitation comme arts décoratifs ; cependant, lorsqu'il s'agissait de la peinture et de la sculpture, associées ou intégrées à l'architecture - sous forme de fresques, peintures murales, vitraux, ornementation architecturale, bas-reliefs, médaillons ou statues - l'encadrement comme art décoratif ou Art Mineur devenait plus difficile, ce que l'on découvre déjà dans les textes de Le Corbusier. Dans le chapitre "L'heure de l'Architecture", du livre L'Art décoratif d'Aujourd'hui, Le Corbusier fait l'histoire critique de la fin du XIXe siècle et, tout en y situant sa formation n'oublie pas d'en attribuer les crédits à Ruskin, Grasset, Owen Jones, William Morris et Walter Crane et de reconnaître dans leurs travaux "un superbe effort, un courage condidérable, une hardiesse très grande, une révolution véritable". Et il souligne encore «qu' "en 1900, l'incendie s'allume dans les esprits. On se met alors à parler d'Art décoratif. Et des escarmouches s'engagent : grand art, arts mineurs. Deux camps. ${ }^{24}$.

Dans l'article "La sainte alliance des Arts Majeurs ou le grand art en gésine", publié dans la revue La Bête Noire en juillet 1935, Le Corbusier annonce la possibilité d'une relation efficace entre les trois Arts Majeurs architecture, sculpture et peinture - et de ceux-ci avec les moyens d'expression ${ }^{25}$. En octobre 1936, peu après son retour du Brésil, il participe à Rome à la "Sixième Réunion VOLTA". Il y reprend le thème dans son texte intitulé "Les tendances de l'architecture rationaliste par rapport à la collaboration de la peinture et de la sculpture" ${ }^{26}$, où il met l'accent sur le parallélisme entre l'architecture et les deux autres Beaux-arts, et définit ce mouvement comme une "symphonie d'événements" et la "synthèse de la pensée" sur l'architecture ${ }^{27}$.

Le Corbusier ne reprendra ce débat que dix ans plus tard, après la fin de la guerre, dans le texte "L'Espace Indicible" publié dans la revue Architecture d'Aujourd'hui: "Ce texte doit être situé par le lecteur à sa juste place. L'an 1945 compte des millions de sinistrés sans abri, tendus désespérément vers l'espoir d'une transformation immédiate de leur situation. (...) Prendre possession de l'espace est le geste premier des vivants (...), manifestation fondamentale d'équilibre et de durée. (...) J'ignore le miracle de la foi, mais je vis souvent celui de l'espace indicible, couronnement de l'émotion plastique. (...) Architecture, sculpture, peinture, la marche du temps et des évènements les conduit indubitablement, maintenant, vers une synthèse" ${ }^{\prime 2}$. Deux ans plus tard, en 1948, il publie un autre article dans la même revue, intitulé "Unité" : "Le corps du domaine bâti est l'expression des trois arts majeurs solidaires". Et il ajoute, en expliquant que la Synthèse ne devrait pas être envisagée comme simple subordination de la peinture et de la sculpture à l'architecture, ni non plus comme subordination inverse : "Il s'agit davantage de trouver le moyen de parvenir à une unité sans compromettre l'autonomie de la construction, du tableau ou de la sculpture. Chacun des trois arts a sa propre fonction et

\footnotetext{
${ }^{22}$ DREYFUS, J.. Op. cit., ps. 09 e 10.

23 “Arts appliqués à l'industrie" est l'équivalent de "Industrial Design" en anglais.

${ }^{24}$ LE CORBUSIER. L'Art Décoratif d'Aujourd'hui. Paris, G. Grès, 1925, pp. 133-140.

25 Voir: "El concepto de Síntesis de las Artes" et "La irrupción de las sombras", consultés sur www.tdx.cbuc.es/TESIS_UPC/...TDX...//04 ; Voir aussi: Archives de la Fondation Le Corbusier, consulté sur : http://www.fondationlecorbusier.fr/ConfCONF1(2).htm

${ }^{26}$ MOOS, Stanislaus von. Le Corbusier - une synthèse. Marseille, Parenthèses, 2013, p. 317.

${ }^{27}$ LE CORBUSIER. «L'Espace Indicible ». Architecture d'Aujourd'hui, avril 1946. In : JENJER, Jean. Le Corbusier l'architecture pour émouvoir. Paris Gallimard, 1993, ps. 138-141.

${ }^{28}$ Idem
} 
poétique et aucun n'a besoin, pour se justifier, d'un accord symphonique dans l'œuvre d'art totale" ${ }^{29}$. Pendant l'automne 1949, par recommandation du CIAM VII (1947) au Congrès de Bridgewater en Angleterre, où l'on avait discuté de la Synthèse des arts, est fondée l'Association Synthèse des arts plastiques ${ }^{30}$. Cependant, en ce qui concerne le travail de l'architecte Le Corbusier, ces idées n'ont de répercussion que sur des fresques qui couvriront "les murs des maisons de certains de ses amis, profitant soit de l'admiration qu'ils lui vouent, soit de leur absence provisoire ${ }^{\prime 31}$. Comme, jusqu'en 1946, les grands projets de l'architecte ne s'étaient pas concrétisés, il ne lui restait qu'à s'occuper de petits projets pour des maisons, des villas et pavillons, qui seront devenus les laboratoires de la Synthèse des Arts $^{32}$. En 1947, lorsque Le Corbusier entame la construction de l'Unité d'Habitation de Marseille, il s'interroge: "Où commence la sculpture? et la peinture? et l'architecture? ".

La réponse est donnée, cette même année, avec l'inauguration à Rio de Janeiro du siège du Ministère de l'Éducation et de la Santé - MES, une célébration compétente et précoce de la Synthèse des Arts, projet auquel Le Corbusier n'avait participé que comme consultant lors de son séjour au Brésil en $1936^{33}$. Parmi les nombreux principes corbuséens préconisés pour l'architecture moderne, le MES a inauguré la Synthèse des Arts en orchestrant le travail d'architectes (Oscar Niemeyer, Afonso Reidy, Jorge Moreira, Carlos Leão et Ernani Vasconcelos, sous la coordination de Lucio Costa), de sculpteurs (Jacques Lipchitz, Bruno Giorgi, Celso Menezes), du peintre Candido Portinari, de muralistes qui ont travaillé sur les panneaux de carrelage (Candido Portinari et Paulo Rossi Osir) et de l'architecte paysagiste Roberto Burle Marx ${ }^{34}$. Le ministre de l'Éducation et de la Santé, Gustavo Capanema, assume lui-même la défense de la Synthèse des Arts dans ce projet, dans une lettre qu'il adresse au président Getúlio Vargas, le 14 juin 1937. Le ministre y expose les raisons d'avoir fait appel à une collaboration entre sculpteurs et peintres pour la réalisation du projet pour le siège de son ministère ${ }^{35}$, ce qui, d'une certaine manière, rend "officielle" l'idée de la Synthèse des Arts au Brésil: "Les architectes, qui ont organisé le projet du palais pour le Ministère de l'Éducation et de la Santé, y ont mis de l'effort, du travail, du soin et du goût. Ils l'ont longuement fait et refait, afin de nous rendre finalement un travail sûr et beau (...) qui fonctionne de manière rationnelle (...), un modèle technique du bâtiment. Mais ils ont aussi voulu faire une œuvre d'art. Ce souci de faire de l'architecture, des ouvres d'art, n'a jamais cessé d'être un signe de la culture entre les nations. (...) Dès lors, on ne pouvait que les inviter à coopérer à la réalisation de l'ouvrage, de la sculpture et de la peinture. Ces deux arts sont complémentaires de l'architecture qui, à son tour, ne peut pas

\footnotetext{
${ }^{29}$ MOOS. S., op. cit., p. 319. Dans le même livre, en post-scriptum du chapitre 7 (pp. 372-375), Moos contextualise ce chapitre, "Éléments d'une synthèse", en expliquant que la première édition était sortie de presse quelques années à peine après la mort de Le Corbusier et que le sous-titre, "Éléments d'une synthèse" reflète encore la rhétorique optimiste du programme de l'architecte, en continuation directe de l'esprit des années cinquante. Les architectes modernes avaient dû relever alors un double défi : libérer l'architecture de son image techniciste et éviter les pièges des formules éculées de l'académicisme. La 'synthèse des arts' était à cet égard une alternative intéressante. Il s'agissait de retrouver une aura culturelle capable de replacer l'architecture sur le même plan que le monde de l'art et le mécénat de prestige.

${ }^{30}$ Henri Matisse était président de la section CIAM de Synthèse des Arts Plastiques, Le Corbusier était premier viceprésident et André Bloc deuxièmevice-président ; le siège social était celui de L'Architecture d'Aujourd'hui. In : RIKVIN, Arnoldo. "Un doble paradoxe". In : LUCAN, Jacques (org.). Le Corbusier - une encyclopédie. Paris, Centre Georges Pompidou, 1987, ps. 386-391.

${ }^{31}$ MOOS, S. Op. cit., p. 317.

${ }^{32}$ Idem, p. 319.

${ }^{33}$ À propos de la polémique suscitée par Le Corbusier au sujet du créateur du projet et des honoraires reçus, voir: SANTOS, Cecilia et alii. Op. cit., pp.106-217.

${ }^{34}$ Voir: SEGRE, Roberto. Ministério da Educação e Saúde - Ícone urbano da modernidade brasileira (1935-1945). São Paulo, Romano Guerra, 2013.

${ }^{35}$ On peut considérer comme certaine la participation de Lucio Costa à la rédaction de cette exposition des motifs signée par le ministre.
} 
exister sans eux pleinement. Les grandes époques de l'art montrent comment l'architecture, la sculpture et la peinture se sont réunies pour la composition d'une même œuvre. Ainsi ont été prévus par les architectes, lors du projet, quelques travaux qui sont strictement déterminés, de sculpture et de peinture. Ces cuvres n'ont pas été conçues de manière aléatoire, avec un souci d'ornement. Bien au contraire. Ils seront destinés à accorder à l'ensemble le signe de son destin, de sa finalité. (...) Ils ne seront donc non pas des artifices luxueux et inutiles, mais des parties complémentaires, conséquentes et nécessaires" ${ }^{36}$.

Si la Synthèse des Arts se concrétise pour la première fois au Brésil, dans le projet du siège du Ministère (19361945/1947), le débat à son sujet se définit et s'approfondit dans une étroite collaboration intellectuelle entre Lucio Costa et Le Corbusier. Les deux architectes, qui ont mûri ces questions dans leurs travaux et publications dès le milieu des années 1930, élargissent la discussion à la Conférence Internationale des Artistes, organisée par l'UNESCO à Venise, en 1952. Lucio Costa y présente "L'architecte et la société contemporaine" ${ }^{37}$ et donne comme référence le texte que Le Corbusier lui avait laissé au Brésil en 1936. Mais il cite bientôt son propre travail, "Raisons de la nouvelle architecture" ${ }^{38}$, qu'il date lui-même de 1933 à 1935: "l'œuvre d'art acquiert une voie précise et unanime : l'architecture, la sculpture et la peinture sont un ensemble cohérent, un organisme vivant dont la désagrégation est impossible". Le Corbusier, à son tour, présente à Venise une communication intitulée "Chantiers de synthèse des arts majeurs" ${ }^{39}$, qui se termine par la déclaration suivante: "Cette note n'a pas hésité à soutenir la communication de M. Lucio Costa, lue le 24 Septembre 1952 en session du Comité des Arts plastiques" ${ }^{40}$. À Venise, Lucio Costa prend son temps pour remettre en question "les agissements de certains peintres qui n'utiliseraient l'architecture que comme scénario de leurs auvres, sans tenir compte d'une approche d'intégration" ${ }^{41}$, mais Le Corbusier préfère aborder la question en faisant appel à la reprise du contact de l'architecture avec les autres arts, à l'occasion d'une réunion qui ait lieu en faisant de l'associé une présence sur la réalité concrète du chantier. "Ouvrir des chantiers", répète-t-il avec insistance ${ }^{42}$.

Étant donné la participation de Lucio Costa au débat sur la Synthèse des Arts, et sa profonde connaissance de la langue française, nous pouvons dire que le choix du titre qu'il a donné au texte que lui avait confié Le Corbusier en 1936 n'a pas été accidentel ni occasionnel. Traduisant "Arts Majeurs"43 par «Belas Artes», "Beaux-Arts" en français, Lucio Costa semble d'une part chercher avant tout une association entre le grand débat qui se tient à l'époque en Europe et auquel Le Corbusier faisait référence dans son texte - "orner ou ne pas orner, décorer ou ne pas décorer, enrichir ou ne pas enrichir, ennoblir ou ne pas ennoblir, etc" - et d'un autre côté les tâches nécessaires pour intégrer les trois Beaux-Arts que Costa définira au long de ses réflexions: "l'intention plastique (...) est précisément ce qui distingue la construction simple de l'architecture (...), une fois établis les liens

\footnotetext{
${ }^{36}$ LISSOVSKY, Mauricio; SÁ, Paulo Sérgio Moraes de. Colunas da Educação - A construção do Ministério da Educação e Saúde. Rio de Janeiro, CPDOC/IPHAN, 1996, pp. 224-225.

${ }^{37}$ In: XAVIER, Alberto (org.). Lucio Costa: sobre arquitetura. Porto Alegre, Edit. UniRitter, 2007. D'après une note de l'organisateur, ce texte présente des extraits d'un autre texte de l'auteur "Considérations sur l'Art contemporain", daté de la même année.

${ }^{38}$ COSTA, Lucio. "Raisons de la nouvelles architecture". In: XAVIER, Alberto (org.). Lucio Costa: sobre arquitetura. Porto Alegre, Edit. UniRitter, 2007, p. 20.

${ }^{39}$ In: SANTOS, Cecilia; et alii. Op. cit., pp. 239 a 241.- Fundation Le Corbusier - U3.10.449/450.

${ }^{40}$ Idem.

${ }^{41}$ FERNANDES, F., Op. cit

${ }^{42}$ SANTOS, Cecilia et alii. Op. cit., pp. 239 a 241.

${ }^{43}$ Majeur = plus grande; plus important; opposé a mineur. Dictionnaire de La Langue Française - Petit Robert.
} 
nécessaires d'intention en plastique avec les autres facteurs essentiels en cause (...), (elle) justifie sa classification traditionnelle dans la catégorie des beaux-arts" ${ }^{\prime 44}$.

Sans accepter la hiérarchie des arts dans sa traduction en portugais, et en refusant la classification des arts en majeurs et mineurs, Lucio Costa se permet d'introduire les questions "d'identité" et de "tradition" qui ne sont pas explicites mais à peine suggérées dans le discours écrit de Le Corbusier : "(...) Nous pouvons déjà voir des aspects "indigènes" de l'architecture moderne, d'apparence significativement différenciée quoiqu'obéissant aux mêmes principes de base et se servant de matériaux et de techniques communs. Non seulement parce que, sur les conseils de Le Corbusier lui-même, on peut voir la recherche délibérée de faire revivre, dûment intégrée à la nouvelle conception, l'expression de quelques souvenirs de parti général ou de détail de fond traditionnel toujours valables, et surtout parce que le caractère national lui-même s'exprime par la collaboration architecturale d'artistes authentiques, préservant ainsi ce qu'il y a d'impondérable, mais d'authentique et d'irréductible dans le caractère différent de chaque peuple ${ }^{\prime 45}$. Lucio Costa renforce donc l'appel insistant de Le Corbusier pour placer l'architecture "au-delà de l'utilité" ou l'importance de l'intention plastique en architecture, toujours rattachée à l'identité nationale. En même temps, Costa ouvre un espace qui permet de considérer quelle partie de la tâche de Synthèse entrerait dans les arts dits "artisanaux", "utilitaires" ou "mineurs", véhicules ou supports des expressions majeures qu'ils se proposent d'intégrer. Des éléments tels que azulejos ${ }^{46}$, mosaïques, fresques, vitraux, cobogós ${ }^{47}$, entre autres, qui sont des références dans les traditions coloniale et vernaculaire, fréquentent toujours davantage les travaux de l'architecture moderne brésilienne, ajoutant par ailleurs un sens de brésilienneté aux codes architectoniques de l'Architecture Moderne Internationale.

Parmi tous ces éléments, nous nous arrêterons ici à la fabrication traditionnelle de l'azulejo qui a été incorporé au projet du MES, par suggestion de Le Corbusier: "Ils ont entendu du professeur illustre les leçons qui tendent à mettre en valeur des matériaux locaux comme les granits cariocas à la place de marbres importés, plantes et arbres désuets comme le palmier royal (...), comme les azulejos qu'il avait appris à admirer lors de longues visites à l'église de la Glória do Outeiro" ${ }^{48}$. Dans son témoignage pour la revue Módulo, Lucio Costa confirme que la suggestion provenait de Le Corbusier, et qu'elle avait eu un accueil favorable de la part des Brésiliens: "Nous acceptons vos recommandations concernant la mise en place des azulejos dans les clôtures de rez-dechaussée et du gneiss dans les encadrements et les pignons". Costa expliquera plus tard qu'il avait envisagé d'utiliser dans le projet un genre de pierre de couleur paille-brûlée, le grès d'Ipanema, mais Le Corbusier avait insisté sur l'utilisation du gneiss - "ce granit est si beau, on dirait la peau d'un jaguar" - une pierre méprisée pendant la période coloniale au profit d'autres granits plus nobles, utilisée notamment pour paver certains

\footnotetext{
${ }^{44}$ COSTA, Lucio. "L'architecte et la société contemporaine" (en portugais). In: XAVIER, Alberto (org.). Lucio Costa: sur l'architecture. Porto Alegre, Editora UniRitter, 2007, p. 245.

${ }^{45}$ Idem, p. 243

${ }^{46}$ Le mot azulejo désigne en Espagne et au Portugal un carreau de faïence décorée, un carreau céramique. Simple matériau de couverture des surfaces murales, il est de plus investi d'ambitions artistiques.

${ }^{47}$ Le cobogó est un bloc décoratif ajouré, de béton ou de céramique, employé pour la construction de murs et de parois, qui filtrent le soleil et la luminosité ; développé dès le début du XXe siècle et largement utilisé dans l'architecture brésilienne moderne, il a comme références les muxarabis et les persiennes de l'architecturea traditionnelle.

${ }^{48}$ LEMOS, Carlos. "Azulejos décorés dans la modernité arquitectonique brésilienne". In: Revista do Patrimônio Histórico e Artístico Nacional. Rio de Janeiro, IPHAN, n. 20/1984, p. 171. Localisée au sommet d'une colline, l'église de Notre-Dame de la Glória do Outeiro fut terminée en 1739. Le projet est attribué au lieutenant-colonel José Cardoso Ramalho, et sa structure en pierre contraste avec le chaulage, avec les panneaux d'azulejos bleu-et-blanc à l'intérieur, attribués au maître en carreaux d'azulejo Valentim de Almeida, et avec la taille des retables. Consulté sur: http://outeirodagloria.org.br/igreja
} 
trottoirs de Rio de Janeiro et pour l'encadrement des portes des bâtiments du XIXe siècle ${ }^{49}$. Dix ans plus tôt, Le Corbusier avait encensé le folklore - "si intense le folklore, que tous, nous y sommes immédiatement sensibles (...), chose magnifique que le folklore (...), où le temps et la masse ont apporté la pureté" ${ }^{50}$ - attiré comme il l'était lors de ses voyages par "ces mélodies, ou alors ces vases, ces fétiches, ces maisons qui ne sont pas l'œuvre d'un certain Monsieur $X^{\prime \prime}{ }^{51}$ et dont il étend les qualités au "folklore d'aujourd'hui", défini, comme le folklore traditionnel, comme "œuvre de perfection, digne et durable, conforme à nos besoins et répondant à notre pensér ${ }^{\prime \prime 52}$, et conforme aussi à l'économie, à la tradition et aux techniques de traitement des matériaux locaux. Pendant son séjour à Rio en 1936, Le Corbusier note dans un de ses carnets: "Au Brésil, recherche, étude et sauvegarde des folklores" ${ }^{\prime 53}$.

L'azulejo, une tradition dans les églises brésiliennes construites surtout dans le nord et le nord-est du Brésil au XVIIe et au XVIIIe siècles, ira également recouvrir au cours du XIXe siècle les façades des "sobrados", maisons urbaines à étages, surtout dans les villes du littoral. Plutôt que des motifs d'ordre esthétique, ce sont des raisons économiques et d'autres dues à la conservation et au confort thermique qui furent décisives dans ce choix, un fait qui, selon Costa, a particulièrement plu à Le Corbusier, qui observait attentivement les façades revêtues d'azulejos lorsqu'il se promenait à Rio de Janeiro. L'intérêt qu'il portait au granit et aux azulejos, encore fréquents dans l'architecture de Rio à cette époque, et la suggestion qu'il a faite que ces deux éléments figurent dans le projet du MES, sont enregistrés à trois reprises dans son carnet de voyage ${ }^{54}$. Paulo Osir, chargé de la fabrication de ces azulejos, confirme en avoir reçu une pièce, retirée de l'Eglise de la Glória ${ }^{55}$ - dont les panneaux magnifiques avaient particulièrement enchanté Le Corbusier - comme modèle du ton de bleu souhaité dans les panneaux conçus par Portinari. Et pour en finir avec les doutes concernant l'auteur de l'idée d'incorporer les références coloniales à l'architecture moderne du MES, par des matériaux et techniques des Arts Mineurs «d'appartenance nationale pure», Lucio Costa confirme : "Celui qui vient de l'étranger est toujours plus sensible et observe. Nous ne pensions pas à cela, ce n'était qu'un revêtement qui existait là. Et lui est arrivé avec la richesse d'une autre approche ${ }^{\prime \prime 56}$.

D'origine arabe, l'azulejo est une plaque de format régulier, carrée ou rectangulaire, en argile cuite, dont une des surfaces est émaillée ou vitrifiée. À l'origine, la fabrication se développa notamment en Espagne, au Portugal, en Italie et plus tard aux Pays-Bas, grâce à l'amélioration des techniques traditionnelles de préparation et de la peinture, ainsi qu'à l'utilisation de la polychromie et des motifs figuratifs interdits chez les musulmans. Les premiers azulejos fabriqués au Portugal remontent au XVIe siècle et, dès le XVIIe, les pièces bleu-et-blanc commencèrent à prédominer en prenant la porcelaine chinoise comme modèle.

\footnotetext{
${ }^{49}$ In: Revue Módulo, n. 40, 1975, apud: SILVEIRA, Marcele Cristiane da. OL'azulejo dans la modernité architectonique (en portugais). Maîtrise, Faculté d'Architecture et Urbanisme - Université de São Paulo, 2008, p. 135.

${ }^{50}$ LE CORBUSIER. L’Art Décoratif d'Aujourd hui. Paris, G. Grès, 1925, p.36.

${ }^{51}$ Idem, p. 33.

${ }^{52}$ Ibidem, p. 32 .

${ }^{53}$ Notes sur feuillets séparés, avec en-tête du "Cabinet do Ministère de l'Éducation et de la Santé Publique". In: SANTOS, Cecilia et alii. Op. cit., p. 150

${ }^{54}$ Sur les carnets de route, Rio de Janeiro : une page avec deux croquis pour l'édifice, et le commentaire : "Palais Ministère, granit, azulejos bleu-et-blanc", Carnet C12-736, In: SANTOS, Cecilia . Op. cit, p. 167; un croquis, vue générale avec l'église de la Glória, Carnet C12-754, In: SANTOS, Cecilia et alii. Op. cit. p. 116; un croquis de la latérale de l'église de la Glória avec indications sur le dessin pour du "gneiss rose" et "blanc", et le commentaire: "= force, + mathé, + diamant", Carnet C12-755, In: SANTOS, Cecilia et alii . Op. cit. p. 197.

${ }^{55}$ LISSOVSKY, M.; SÁ, P. S. M. Op. cit, , p. 272

${ }^{56}$ In: "Presença de Le Corbusier". Op. cit. ps. $144-155$
} 
Au Brésil, on trouve des azulejos surtout dans l'architecture coloniale de Bahia, Pernambouc, Maranhão et Rio de Janeiro ; pendant la période coloniale, la plupart des pièces venaient du Portugal. On les trouve avant tout dans les églises et les monastères, mais aussi dans des résidences, en panneaux de scènes religieuses ou profanes, ou comme "tapis". Au milieu du XIXe siècle, on commença à les appliquer comme revêtement des façades extérieures $^{57}$. Carlos Lemos et José Wasth Rodrigues s'accordent pour attribuer aux Brésiliens, et pas aux Portugais, l'idée de recouvrir d'azulejos les parois extérieures des maisons urbaines, en particulier celles situées à la côte, une tradition qui perd de sa force dès la moitié du XIXe siècle. Il s'agirait d'un choix motivé par les conditions climatiques, car l'azulejo est fait d'un matériau imperméable qui protège de l'humidité et diminue la température interne des immeubles ${ }^{58}$. Dans les premières décennies du XXe siècle, en réintégrant l'azulejo dans l'architecture, dans l'esprit des barres, des "tapis" et des médaillons d'architecture coloniale, et pas encore dans les façades revêtues, l'architecture néocoloniale fournit une demande nouvelle à une industrie de la céramique, jeune et sans l'expérience nécessaire pour faire face à un grand volume de combustion de pièces peintes à la main. Les panneaux d'azulejos de l'architecture néocoloniale privilégiaient des thèmes historiques et patriotiques, déjà marqués par un fort caractère "nativiste" 59 .

Suivant donc les indications de Le Corbusier, l'équipe d'architectes du bâtiment-siège du Ministère de l'Éducation et de la Santé décida d'inclure des parois d'azulejos sur certains murs non structuraux du rez-dechaussée. Ces panneaux seront le support de la nouvelle expression plastique de Candido Portinari, "les premiers azulejos qui marquent cette réviviscence d'un art presque abandonné ", selon les termes de Joaquim Cardozo ${ }^{60}$. Il existe sept panneaux d'azulejos dans le bâtiment du MES, "six sont dûs à Portinari, les deux principaux étant situés sur les façades du hall des fonctionnaires, l'un en face de la Rue Graça Aranha et l'autre sous les pilotis, face au hall principal. Le panneau de la cage de l'escalier secondaire fut conçu par Paolo Rossi, dont la firme Osirarte fabriqua tous les azulejos. (...) Portinari et Paulo Rossi choisirent des motifs marins comme thème des panneaux d'azulejos, peut-être parce que le bâtiment, à l'époque de sa construction, se situait en face de la Baie de Guanabara, car le remblai de Flamengo et les bâtiments frontaliers n'existaient pas encore" ${ }^{\prime 61}$.

Roberto Segre, qui a analysé la composition des panneaux, met en évidence les thèmes marins et les éléments unitaires, simples et répétitifs, poissons, étoiles de mer, sirènes, hippocampes, coquillages, escargots anthropomorphes, coraux ou crabes, ce qui permet à Portinari de créer sur les surfaces des panneaux de "maillages aux textures qui varient selon la prédominance d'une figure ou d'une autre, perceptibles comme formes sur un pan proche ou comme un tissu à distance" ${ }^{\prime \prime 2}$. Les azulejos créent un effet de dématérialisation des surfaces par le jeu de captation et réflexion de la lumière, qui accorde de la légèreté aux grande surfaces des murs et cloisons aveugles, pour recomposer plus tard, géométriquement, les mêmes surfaces à l'aide du traitement plastique, de la perspective et de l'application de la couleur. Grâce à l'azulejo, écrit G. C. Argan,

\footnotetext{
${ }^{57}$ RODRIGUES, José Wasth. Documentário Arquitetônico - Relativo à antiga construção civil no Brasil. São Paulo, Itatiaia - USP, 1979 , p. 224. Au cours de plusieurs années de voyages, d'études et de documentation de l'architecture coloniale au Brasil, José Wasth Rodrigues (1891-1957) réunit une collection de dessins d'édifices, de détails de constructions et d'éléments décoratifs, publiés dans cet ouvrage. Aux pages 224 à 227, il reproduit 23 modèles d'azulejos trouvés au Brésil, de diverses provenances.

${ }^{58}$ LEMOS, C., Op. cit., pp. 168 e 169.

${ }^{59}$ Voir: BREFE, Ana Claudia Fonseca. O Museu Paulista. São Paulo, Editora UNESP, 2003; KESSEL, Carlos. Arquitetura Neocolonial no Brasil. Rio de Janeiro, Jauá, 2008

${ }^{60}$ CARDOZO, Joaquim. Azulejos no Brasil, p. 106. Apud SEGRE, R. Op. cit., p. 431.

${ }^{61}$ RIBEIRO, Paulo Eduardo Vidal Leite. "Palácio Gustavo Capanema - Processo de restauração e revitalização" Consultado em :http://www.docomomo.org.br/seminario\%203\%20pdfs/subtema_B1F/Paulo_eduardo_ribeiro.pdf

${ }^{62}$ SEGRE, R. Op. cit., p. 414.
} 
"l'homme a restitué au ciel la lumière qui en provenait, mais remplie de sens humain". Il ajoute : "C'est un art des pauvres, la céramique : faite d'un peu de terre, d'un peu de couleur, et de feu. Mais ce n'est pas un art pauvre : plus simples sont sa matière et son artifice et plus somptueuse est sa vue. Mais c'est précisément parce que les matériaux sont pauvres que la splendeur de la couleur et de l'émail s'en trouve plus rehaussée. C'est presque une victoire de la richesse de la fantaisie sur la richesse matérielle" ${ }^{63}$.

Toutefois, comme le souligne Carlos Lemos, "en peu de temps (...), les raisons de Le Corbusier furent oubliées et de nombreux architectes modernistes, voire certains critiques, justifièrent rapidement l'utilisation d'azulejos décorés à peine comme éléments d'identification nationaliste, une question rattachée à l'identité culturelle" ${ }^{64}$. Associé à Oscar Niemeyer dans son bureau de São Paulo dans les années 1950, Lemos affirme que ce n'est pas cette idée qui aurait conduit l'architecte carioca, "conscient de ce qu'il faisait", à reprendre dans le complexe architectural de Pampulha ${ }^{65}$, à Minas Gerais, des panneaux aux azulejos bleu-et-blanc dessinés par Portinari. Lemos interrogea Niemeyer à ce sujet et celui-ci fit part de son désaccord avec ceux pour qui la présence de panneaux d'azulejos était presque devenue une "obligation moderniste", une "marque brésilienne indicative de notre architecture moderne, toujours répétée, associée à l'utilisation ici et là des treillis sur les vérandas et les balcons", traitée comme signe obligatoire de la modernité native. Niemeyer réaffirmera l'aspect rationnel et fonctionnel de l'utilisation d'azulejos sur les façades, comme un matériau qui résiste bien aux intempéries, sans mentionner des raisons pouvant suggérer des liens avec la tradition constructive brésilienne, ou comme signe obligatoire de la modernité native.

Pour la réalisation des grands panneaux d'azulejos du MES, Portinari va trouver Paulo Rossi Osir à São Paulo, et lui demande d'agrandir ses dessins sur des cartons et de les peindre sur les carreaux d'azulejos. Pour répondre à ce défi, l'artiste italo-brésilien crée, en 1940, l'Atelier d'Azulejos Osirarte, entreprise fondée pour fabriquer les pièces de revêtement de murs extérieurs du siège du Ministère ${ }^{66}$. En 1943, lors d'une exposition sur son travail, en fonction de cette première commande, Paulo Rossi explique: "Nous avons, bien sûr, une tradition d'azulejo, héritée des Portugais qui l'ont appliquée avec tant de soin à l'époque coloniale et qui s'est retransmise jusqu'à nos jours, au long de la période impériale et contemporaine (...). Mon ambition était, et est toujours, celle de suivre certaines lignes directrices, à la fois en ce qui concerne les questions techniques et les sujets, et de contribuer à créer un art décoratif à nous, indépendant, enraciné dans notre histoire, dans nos coutumes, bref, dans notre vie de tous les jours. Seul un ensemble d'artistes, dans une sorte de reconstitution de l'artisanat, $m$ 'a semblé en mesure d'accomplir ce projet" ${ }^{67}$.

Rossi décida d'utiliser la technique de peinture sur l'azulejo non émaillé pour la fabrication des 47.000 carreaux placés dans les panneaux du MES. Le dessin est d'abord exécuté sur la surface poreuse, qui absorbe l'encre très

\footnotetext{
${ }^{63}$ Lettre de G. C. Argan a Rafael Salinas Caiado. In: Revista Oceanos, n.36/37, octobre1998/mars1999, p. 235. Apud SILVEIRA, M. Op, cit., p. 125.

${ }^{64}$ LEMOS, C.. Op. cit., p. 171.

${ }^{65}$ L'ensemble architectonique de la Pampulha, à Belo Horizonte, Minas Gerais, fut un projet d'Oscar Niemeyer, à la suíte d'une commande du maire de la ville, Juscelino Kubitschek. Il fut construit entre 1942 et 1944. Il s'agit d'un ensemble de bâtiments, casino, église, salle de bal, club et hôtel entourant le lac artificiel de la Pampulha.

${ }^{66}$ Une série de commandes d'autres architectes et de particuliers, et la bonne acceptation des azulejos décoratifs créés par la firme Osirarte, prolongèrent l'existence de l'entreprise jusqu'à la fin des années 1950. Selon Paulo Almeida, “en un processus dialectique et entraînés par les propres courants rénovateurs, on cherchait un certain sens de modération et d'équilibre, en reprenant le fil des traditions légitimes, une fois rétablie la foi dans les connaissances techniques et dans le métier, comme éléments indispensables pour la réalisation d'œuvres d'art de longue vie" (ALMEIDA, Paulo Mendes de. De Anita au Musée. São Paulo, Perspectiva, 1976, p. 161).

${ }^{67}$ LISSOVSKY, M.; Sá, P. S. M. de. Op. cit., p. 272.
} 
rapidement, ce qui exige une grande exactitude du tracé. Les azulejos de 15 x $15 \mathrm{~cm}$ sont alors stockés puis envoyés à l'émaillage et la cuisson. De longues recherches et des essais effectués pendant trois ans dans le studio Osiarte témoignent de la mise en valeur du processus de fabrication et du métier de l'artiste : "Pendant quatre mois, j'ai mélangé des couleurs susceptibles de résister à des températures supérieures à 1.200 degrés, en essayant d'obtenir ce bleu intense particulier des azulejos portugais de l'église de la Glória. Mais je n'ai pas réussi. Mes recherches m'ont permis quand même de trouver un bleu intense, transparent et attrayant, qui a satisfait partiellement les exigences" ${ }^{68}$.

En 1953, un an après le Congrès de Venise, où se rendirent Le Corbusier et Lucio Costa, intéressés par le discours de la Synthèse des Arts, Max Bill, alors de passage à Rio de Janeiro, donna une interview au magazine Manchete, dans laquelle il critiqua l'architecture moderne brésilienne, en se référant aux panneaux d'azulejos du Ministère : "La beauté des plantes qui y sont présentes est plus que suffisante comme décoration. Les azulejos brisent l'harmonie de l'ensemble, ils sont inutiles et, de ce fait, ne devraient pas avoir été placés là. (...) Je suis contre la peinture murale dans l'architecture moderne. Le mural n'a eu sa raison d'être qu'à une époque où peu de gens savaient lire ; sa fonction a toujours été illustrative, c'est-à-dire de raconter par des images facilement reconnaissables ce que la plupart des gens ne pouvaient pas apprendre par la langue écrite (...), ce qui veut dire qu'il est inutile, et l'inutile est toujours antiarchitectural" ${ }^{69}$. Dans sa réponse au critique suisse, Lucio Costa se reporte tout d'abord à l'intégration des panneaux d'azulejos au projet du bâtiment, pour ensuite mettre en valeur cette solution, d'inspiration brésilienne, qui se sert de la tradition ancienne des panneaux d'azulejos comme support pour des œuvres d'art, enrobant les murs d'une œuvre de l'architecture moderne. (...). "Il trouve aussi inutiles et nuisibles les azulejos. Or, le revêtement d'azulejos au rez-de-chaussée et le sens fluide adopté dans la composition des grands panneaux ont la fonction très claire d'amortir la densité des murs afin de leur enlever toute impression de support puisque le bloc supérieur ne s'appuie pas sur eux, mais sur les colonnes. Puisque l'azulejo est un des éléments traditionnels de l'architecture portugaise, il était le nôtre, et il nous a paru opportun d'en renouveler l'application"70 .

La discussion tourne une fois de plus autour de la manufacture, de l'Art Mineur, critiqué ou prisé pour sa participation à l'Architecture Moderne Brésilienne, tantôt comme élément de la composition, ou comme technique de construction adaptée aux conditions tropicales, tantôt comme signe de brésilienneté ou comme référence à la tradition, ou encore por alimenter le travail des artisans. Pour Niemeyer, l'aspect d'imperméabilité et de confort thermique fournis par les revêtements d'azulejos s'avèrent prioritaires et sont les véritables signes de la modernité, qu'il faut transmettre ; et pour Lucio Costa, les panneaux d'azulejos du MES renforcent et surtout éclairent les caractéristiques structurelles et constructives du bâtiment. Les questions qui associent l'application des azulejos à celle des origines indigènes, à la récupération de l'architecture traditionnelle n'apparaissent qu'au deuxième plan, malgré tous les efforts demandés à l'Osiarte pour récupérer la technique de fabrication et l'intensité exacte du bleu d'origine. Peu à peu, va prévaloir le sens originel suggéré par Lucio Costa et par Le Corbusier, faire revivre, dûment intégrée à la nouvelle conception, l'expression de quelques souvenirs d'une partie générale ou d'un détail de fond traditionnel, toujours valable, expression propre du «caractère national».

\footnotetext{
${ }^{68}$ Idem

69 "Occasion perdue" (interview de Max Bill au magazine Manchete et réplique de Lucio Costa). In: XAVIER, Alberto (org.). Lucio Costa: sobre arquitetura. Porto Alegre, Editora UniRitter, 2007, ps. 252 a 259.

${ }^{70}$ Idem.
} 
Ainsi, en une véritable opération de Synthèse des Arts, des Arts Majeurs et ausi des Arts Mineurs, le bâtiment du MES inaugure cette importante série d'œuvres émaillées qui garnissent les murs extérieurs de ce monument, qui allait devenir l'un des principaux de l'Architecture moderne. Il s'agissait de mettre à jour l'emploi, la thématique, le dessin et les techniques de la fabrication traditionnelle des azulejos, un art mineur qui marque et distingue l'architecture portugaise et l'architecture brésilienne coloniale. Ensemble, architectes, artistes et aussi artisans, ont réalisé un grand projet de Synthèse des Arts, mais aussi d'affirmation de la modernité nationale. Si la voie de la Synthèse discutée par Le Corbusier et Lucio Costa conduisait bien à essayer de récupérer une source poétique commune pour les Arts Majeurs ${ }^{71}$, les raccourcis empruntés passeront loin des schémas beaux-arts, et récupéreront d'autres traditions comme références, toujours à la recherche d'une nouvelle unité pour les temps nouveaux. Concision, vérité, économie, intensité, essence, universalité figurent parmi les qualités identifiées par Le Corbusier et Lucio Costa dans les processus de création des expressions du folklore, du vernaculaire et des Arts Mineurs, autant de qualités qui finiront par atteindre les températures élevées de fusion nécessaires pour que la Synthèse des Arts soit accomplie, au-delà du discours. Dans un art dit "mineur", dont l'expression technique et esthétique est rattachée à la tradition, un rôle plus grand se révèle peut-être ici, même s’il n'est pas toujours reconnu et est souvent sous-évalué.

\section{Références Bibliographiques.}

ALMEIDA, Paulo Mendes de. De Anita ao Museu. São Paulo, Perspectiva, 1976.

BAPTISTA, Luis S.; VENTOSA, Margarida. "Prospectivas críticas - Herança de Le Corbusier", Architectura e Arte, n. 50/60, julho/agosto 2008, Lisboa, Portugal.

BREFE, Ana Claudia Fonseca. O Museu Paulista. São Paulo, Editora UNESP, 2003.

CALATRAVA, Juan. «Un autre Le Corbusier : l'idée de la synthèse des arts majeurs ». La lettre du Collège de France, $\mathrm{n}^{\circ} 28,28$ avril 2010. Consultado em : http://lettre-cdf.revues.org/1049

COSTA, Lucio. "O arquiteto e a sociedade contemporânea". In: XAVIER, Alberto (org.). Lucio Costa: sobre arquitetura. Porto Alegre, Editora UniRitter, 2007.

COSTA, Lucio. "Razões da nova arquitetura". In: XAVIER, Alberto (org.). Lucio Costa: sobre arquitetura. Porto Alegre, Editora UniRitter, 2007.

DREYFUS, Jenny. Artes Menores. São Paulo, ANHAMBI, 1959.

"El concepto de Síntesis de las Artes", consultado em :www.tdx.cbuc.es/TESIS_UPC/...TDX...//04

FERNANDES, Fernanda. "A Síntese das Artes e a moderna arquitetura brasileira dos anos 1950". Consultado em: www.iar.unicamp.br/dap/vanguarda/.../fernanda_fernandes.pdf -

"La irrupción de las sombras", consultado em : www.tdx.cbuc.es/TESIS_UPC/...TDX...//04

JENJER, Jean. Le Corbusier - l'architecture pour émouvoir. Paris, Gallimard, 1993.

JUNIOR, Juscelino H. C. Machado. A poética do vernáculo - Os paineis de Geraldo Queiroz no Triangulo Mineiro. Dissertação de mestrado, Instituto de Artes - Universidade Federal de Uberlandia, 2011.

KESSEL, Carlos. Arquitetura Neocolonial no Brasil. Rio de Janeiro, Editora Jauá, 2008.

LE CORBUSIER. "A arquitetura e as Belas-Artes". Revista do Patrimônio Histórico e Artístico Nacional. Rio de Janeiro, IPHAN, n. 19 / 1984.

\footnotetext{
${ }^{71}$ Voir aussi : CALATRAVA, Juan. "Un autre Le Corbusier : l'idée de la synthèse des arts majeurs". La lettre du Collège de France, $n^{\circ}$ 28, 28 avril 2010. Consulté sur : http://lettre-cdf.revues.org/1049.
} 
. A arte decorativa. São Paulo, Martins Fontes, 1996.

. «L'Espace Indicible », Architecture d'aujourd'hui, avril 1946. In : JENJER, Jean. Le Corbusier

- l'architecture pour émouvoir. Paris Gallimard, 1993, ps. 138-140.

A viagem do Oriente. São Paulo, Cosacnaify, 2007.

LEMOS, Carlos. "Azulejos decorados na modernidade arquitetônica brasileira". In: Revista do Patrimônio Histórico e Artístico Nacional. Rio de Janeiro, IPHAN, n. 20/1984.

LISSOVSKY, Mauricio; SÁ, Paulo Sergio Moraes de. Colunas da Educação - A construção do Ministério da Educação e Saúde (1935-1945). Rio de Janeiro, CPDOC/FGV-IPHAN, 1996.

MOOS, Stanislaus von. Le Corbusier - une synthèse. Marseille, Parenthèses, 2013.

"Oportunidade perdida" (entrevista de Max Bill à revista Manchete, e réplica de Lucio Costa). In: XAVIER, Alberto (org.). Lucio Costa: sobre arquitetura. Porto Alegre, Editora UniRitter, 2007.

"Presença de Le Corbusier" - entrevista de Lucio Costa a Jorge Czjkowsky, Maria Cristina Burlamaqui e Ronaldo Brito, 1987. In: COSTA, Lucio. Registro de uma vivência. São Paulo, Empresa das Artes, 1997, ps. 144 -155 .

RIBEIRO, Paulo Eduardo Vidal Leite. "Palácio Gustavo Capanema - Processo de restauração e revitalização" Consultado em:

http://www.docomomo.org.br/seminario\%203\%20pdfs/subtema_B1F/Paulo_eduardo_ribeiro.pdf

RIKVIN, Arnoldo. "Um doble paradoxe”. In : LUCAN, Jacques (org.). Le Corbusier - une encyclopédie. Paris, Centre Georges Pompidou, 1987.

RODRIGUES, José Wasth. Documentário Arquitetônico - Relativo à antiga construção civil no Brasil .São Paulo, Itatiaia - USP, 1979.

SANTOS, Cecília Rodrigues dos. "A Arquitetura e as Artes Menores". Atas/Proceedings VIII SEMINÁRIO DOCOMOMO BRASIL - Cidade Moderna e Contemporânea: Síntese e Paradoxo das Artes. Rio de Janeiro, 2009.

Mapeando os lugares do esquecimento: ideias e práticas na origem da preservação do patrimônio no Brasil. Tese doutoramento, Faculdade de Arquitetura e Urbanismo Universidade de São Paulo, 2007.

SANTOS, Cecilia Rodrigues dos; PEREIRA, Margareth da Silva; PEREIRA, Romão da Silva; SILVA, Vasco Caldeira da. Le Corbusier e o Brasil. São Paulo, Projeto/Tessela, 1987.

SILVEIRA, Marcele Cristiane da. O azulejo na modernidade arquitetônica. Dissertação de mestrado, Faculdade de Arquitetura e Urbanismo - Universidade de São Paulo, 2008.

TSIOMIS, Yannis. «Le Corbusier, L'Art décoratif d'aujourd'hui et 'la loi du ripolin' ». Consultado em maio de 2015, em : http://books.openedition.org/pupo/2422.

XAVIER, Alberto (org.). Lucio Costa: sobre arquitetura. Porto Alegre, Editora UniRitter, 2007.

http://www.fondationlecorbusier.fr/ConfCONF1(2).htm

http://www.itaucultural.org.br/aplicExternas/enciclopedia_IC/index.cfm?fuseaction=termos_texto\&cd_verbete= 334 


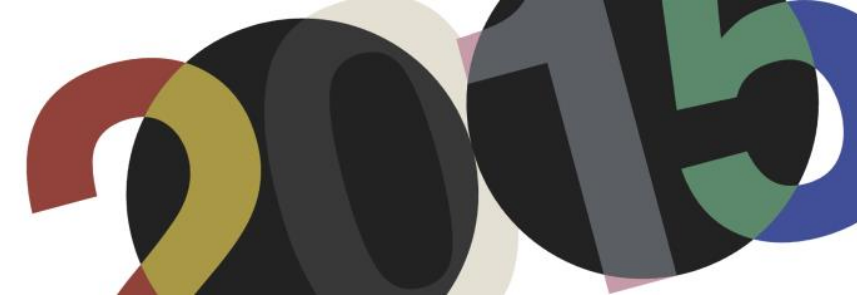

DOI: http://dx.doi.org/10.4995/LC2015.2015.661

\title{
"L'emploi du quatrième mur sur le pan de verre". Apariciones del concepto de cuarta pared en los libros, textos y documentos de Le Corbusier
}

\author{
J.A. Rodríguez Casas \\ Escuela Técnica Superior de Arquitectura de Madrid
}

\begin{abstract}
Resumen: La cuarta pared de Le Corbusier es un modelo teórico que ve por primera vez la luz en La Ville Radieuse en 1935. Su aparición, tras la fachada libre, abre el campo de posibilidades de diseño del cerramiento de los edificios tras la fachada libre. Desde su primer enunciado, la teoría tiene un carácter eminentemente práctico, ya que define con claridad un conjunto de instrucciones y una herramienta de proyecto. Esta herramienta permite el diseño de cerramientos de vidrio divididos de acuerdo a la geometría del Modulor, siendo capaz cada una de estas divisiones de asumir una función diferente (ventilación, iluminación, vistas). Además, mediante el aumento del espesor de la fachada, la herramienta de la cuarta pared posibilita alojar módulos de equipamiento en su interior, disponer el vidrio en distintas posiciones de protección o exposición e incluso colocar pantallas y capas de protección dentro del espesor del cerramiento. Aunque tuvo escasas apariciones en los escritos de Le Corbusier, la teoría fue en su vertiente práctica de uso frecuente en el estudio de Rue de Sèvres, 35 tanto en proyectos como en edificios construidos. El presente trabajo recorre la presencia de la cuarta pared en los escritos del arquitecto y analiza el contenido de la misma, intentando desentrañar el "manual de instrucciones" que supone. El artículo sintetiza además la deriva que sufrió la cuarta pared a lo largo de la carrera del arquitecto, poniendo de manifiesto su capacidad de adaptación al avance técnico constante en su arquitectura.
\end{abstract}

\begin{abstract}
Le Corbusier's fourth wall is a theoretical model that first appears in "La Ville Radieuse" in 1935, opening, after the free façade, a full range of possibilities to the design of the building's envelope. It has mainly a practical character from its first wording, as the fourth wall clearly defines a set of instructions and a tool for projecting, The tool allows for the enclosures to be divided according the Modulor's geometry, with each of these divisions being able to take on different functions (ventilation, illumination or views). In addition to this, the fourth wall's tool is able to accommodate equipment modules inside the façade by increasing its thickness, place the glass in different protection or exposure positions or even placing screens or protection layers inside the building envelope's thickness. While the theory seldom appeared in Le Corbusier's writings, it was frequently used by the Rue de Sèvres 35 office due to its practical implications, either in projects or in completed buildings. The present work visits and analyses the fourth wall's few appearances in the architect's theoretical documents and attempts to untangle its "instruction manual. The article summarises as well the drift that the fourth wall theory experimented through the architect's career, evidencing its ability to adapt to the constant technical development of his architecture.
\end{abstract}

Palabras clave: quatrième mur, cuarta pared, façade libre, fachada libre, pan de verre. Keywords: quatrième mur, fourth wall, façade libre, free façade, pan de verre.

\section{Introducción. Objetivos y antecedentes.}

El presente trabajo toma como objeto de estudio la figura de la cuarta pared de Le Corbusier. Se trata de una teoría o modelo que abrió el campo de posibilidades de diseño del cerramiento de los edificios en el contexto de la entonces reciente introducción del concepto de la fachada libre, no sujeta ya a las servidumbres de su tradicional función estructural. El artículo tiene la voluntad de sentar la base documental sobre la que acometer un estudio más profundo de la teoría, que venga a paliar en la medida de lo posible la desproporción entre la poca atención recibida por la misma y el extenso uso que se hizo de la misma a modo de herramienta de proyecto en la práctica del estudio del 35, Rue de Sèvres. 
La cuarta pared de Le Corbusier no ha tenido hasta la fecha un tratamiento monográfico de relevancia, encontrándose tan solo alusiones aisladas a la teoría, en su mayor parte en monografías de obras de Le Corbusier en cuyo diseño el papel de la herramienta de la cuarta pared fue decisivo ${ }^{1}$, si bien nunca han supuesto un estudio de profundidad sobre la herramienta. Recientemente la teoría ha aparecido mencionada en estudios sobre el arquitecto no centrados en una obra concreta, sino desde su componente de estrategia de introducción del equipamiento de la vivienda en el cerramiento en Le Corbusier, Furniture and interiors 1905-65 y desde el punto de vista de sus características plásticas y materiales en Le Corbusier: Béton Brut and ineffable space ${ }^{3}$.

Existe de todos modos una excepción a esta situación, y es a partir de la misma que este trabajo toma forma. En la tesis doctoral La densidad del limite. Le Corbusier y Mies Van Der Rohe del equipamiento al sistema de objetos $^{4}$ de Carmen Martínez Arroyo, se realiza un ejercicio de análisis y formulación de la teoría de la cuarta pared $^{5}$, fruto del estudio del cerramiento del edificio en la arquitectura moderna focalizado en (pero no limitado a) las figuras de Le Corbusier y Mies van der Rohe. El presente artículo se encuentra englobado dentro de la investigación de mi tesis doctoral La cuarta pared de Le Corbusier, sistema de densificación del cerramiento del edificio, codirigida por Carmen Martínez Arroyo y planteada como continuación de la mencionada línea de investigación de su tesis, a modo de spin-off..

\section{El manifiesto oculto de le quatrième mur $^{6}$ en La Ville Radieuse ${ }^{7}(1935)$.}

La cuarta pared de Le Corbusier no fue presentada de manera concisa y directa, ni arropada en una conferencia o artículo sobre el particular que comunicara con claridad su contenido y naturaleza. Al contrario que en muchas otras ocasiones en la labor teórico-propagandística de Le Corbusier, la presentación de la teoría o herramienta se realiza de manera callada, casi subrepticia. La cuarta pared aparecerá como un simple dibujo a línea en página

\footnotetext{
${ }^{1}$ A destacar los apartados dedicados al particular en los trabajos monográficos Maniaque, Caroline: Le Corbusier et Les maisons Jaoul. Projets et fabrique Paris: Éditions A. \& J. Picard, 2005, pp. 76-83 y Sbriglio, Jacques, Immeuble 24 N.C. et Appartement Le Corbusier. Basel: Birkhäuser, 1996, pp.64-66.

${ }^{2}$ Rüegg, Arthur, Le Corbusier, Furniture and Interiors 1905-1965. Zürich, Verlag Scheidegger and Spiess, 2012

${ }^{3}$ Gargiani, Roberto; Rosellini, Anna: Le Corbusier: Béton Brut and Ineffable Space, 1940-1965: Surface Materials and Psychophysiology of Vision. Lausanne: EPFL Press - Oxford: Routledge, 2011

${ }^{4}$ Martínez Arroyo, Carmen: La densidad del límite. Le Corbusier y Mies Van Der Rohe del equipamiento al sistema de objetos. Director: Manuel de las Casas. Universidad Politécnica de Madrid, Escuela Técnica Superior de Arquitectura de Madrid, Departamento de Proyectos Arquitectónicos, 2005

${ }^{5}$ Ver también resumen de la tesis en el artículo Martínez Arroyo, Carmen: "La densidad del límite". En Arquitectos n¹74, Volumen 05/2. Madrid: CSCAE 2005

${ }^{6}$ Se opta en adelante por la traducción la cuarta pared frente a la más literal del cuarto muro en atención a la memoria de significado teatral del término le quatrième mur en la cultura francesa en el momento de la aparición de la teoría. El término hacía referencia a una hipotética cuarta pared dentro de la caja escénica coincidente con la separación de escenario y platea, y plantea una completa teoría escénica en función del uso que se hacía de la cuarta pared, bien desarrollándose la acción teatral como si dicho muro fuera real, o bien forzando su ruptura mediante la interpelación directa de los actores a la audiencia extendiendo la acción más allá de los límites físicos de la caja escénica. El termino se considera acuñado por André Antoine en el siglo XIX pero ya Diderot lo describía en sus escritos un siglo antes; en cualquier caso la ruptura de la cuarta pared es un hecho teatral establecido ya desde el teatro clásico mediante la acción del coro que se dirige directamente a la platea.

${ }^{7}$ Le Corbusier: La Ville Radieuse; éléments d'une doctrine d'Urbanisme pour l'équipement de la civilisation machiniste. Boulogne-sur-Seine: Éditions de l'Architecture d'aujourd'hui, 1935.
} 
par con dos anotaciones manuscritas sin alusión alguna en el texto ni referencia en ningún otro elemento de la publicación (Imagen 1).

La obra, publicada en el año 1935, y que de manera testimonial y tangencial va a suponer el primer vehículo de publicitación de la herramienta de la cuarta pared, supone un tratado completo de urbanismo de composición heterogénea, en el que las técnicas modernas que han de construir el nuevo modelo de ciudad ocupan una parte importante. Es precisamente en esa segunda parte del libro, Les techniques modernes, más concretamente en la página 44 de su cuarto apartado, La respiration exacte, donde aparecerá el concepto de cuarta pared en forma de ilustración con notas manuscritas.

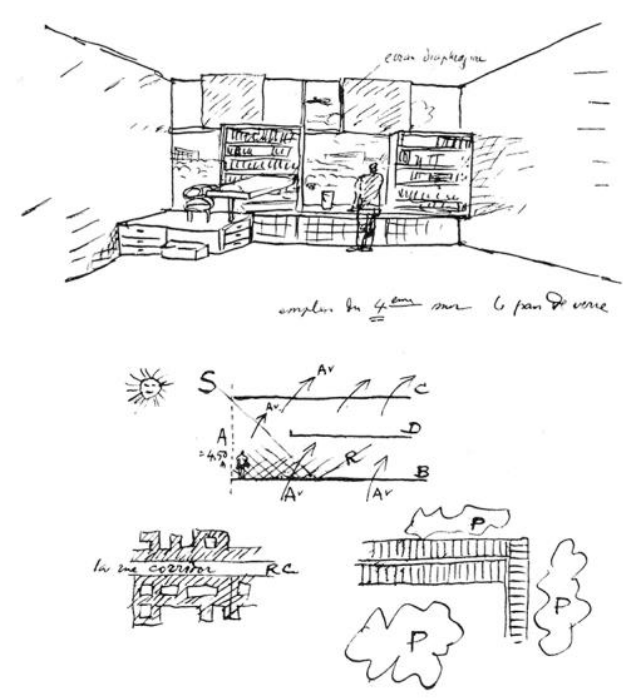

1. Le Corbusier. La Ville Radieuse. OFLC-ADAGP. Croquis inaugural de la teoría de la cuarta pared.

En la ilustración que aparece justificada en el margen izquierdo de la página 44 del libro se distinguen dos partes diferenciadas: en la parte superior se representa una perspectiva frontal de una habitación tipo con un único punto de fuga, introduciendo de manera gráfica el concepto de cuarta pared. En la parte inferior, unos esquemas sitúan en planta y en sección dicha estancia dentro del bloque y describen en sección el impacto de la radiación solar en dicha estancia.

La parte inferior de la imagen es la única que enlaza con el texto del capítulo que acompaña a la ilustración, donde se indica que la fachada será enteramente de vidrio y hermética, quedando la estancia climatizada mediante el sistema de tratamiento de aire de la respiration exacte. La parte superior de la ilustración, la que define el empleo del concepto de le quatriéme mur en el pan de verre, no encuentra referencia alguna en el texto, limitándose su alcance a lo expresado mediante medios gráficos. En este sentido la elección de la vista frontal garantiza por un lado la claridad geométrica y dimensional de lo representado y centra la atención sobre el plano del cerramiento en la abstracción de la estancia arquitectónica universal que define.

El dibujo tal y como aparece reproducido es monocromo y de trazo lineal, la superficie de la ilustración superior es 8 × $5 \mathrm{~cm}$. El trazo a mano alzada tiene un alto grado de detalle, y define una serie completa de códigos, 
elementos y relaciones entre los mismos esenciales para la transmisión de las leyes básicas de la teoría de la cuarta pared. La interpretación del nuevo concepto de quatrième mur depende por tanto del análisis cuidadoso del contenido del croquis.

La característica principal del croquis es la división del pan de verre en fragmentos de distintas medidas, de acuerdo a una geometría ortogonal, no basada en una malla previa homogénea en ninguna de las dos direcciones del plano, similar a la usada por los suprematistas en la división del lienzo en sectores con diferentes características plásticas.

Establecida la división en partes, cada uno de los elementos resultado de la división tiene un tratamiento diferenciado. Cada elemento tiene un grado de transparencia-opacidad, para lo cual el arquitecto se esfuerza en usar los reducidos mecanismos gráficos del dibujo a línea monocromo para dejar claro el material de cada uno de los elementos. Un rayado en cuadrícula representa la franja inferior en vidrio armado, habitual en sus construcciones sobretodo en la parte inferior de los pan de verre de sus proyectos de la época; la ausencia de trazos indica la opacidad de la pieza; y las vistas cercanas o lejanas (paisajes urbanos, nubes, aviones) informan de la transparencia de los distintos elementos.

Adicionalmente, algunos de los módulos en los que se divide el plano de fachada aparecen equipados. Por un lado se introducen elementos tipo casier proyectados en voladizo hacia el interior de la vivienda. Se dibujan alojando libros, mecanismo gráfico que permite subrayar su funcionalidad y aclarar la escala del mismo, si bien el tamaño con el que parecen representados es mayor del habitual en los diseños de Charlotte Perriand de esa misma época. Adicionalmente en la esquina inferior izquierda del mismo se dispone una plataforma materializada por la adición de dos módulos de cajonera que abren hacia dos direcciones diferentes, enfatizando su carácter de ocupación del espacio y de su capacidad de definición de uso del mismo. Junto a la plataforma, un escalón define el acceso a la misma, explicitando la posibilidad de uso de la misma por parte del usuario, representado cerca acogido por el dispositivo espacial que supone el cerramiento de cuarta pared.

Sobre la plataforma equipada se disponen dos elementos de mobiliario estándar: una silla y una mesa. Esta operación define la influencia del cerramiento de cuarta pared sobre el sistema de objetos contenido en la estancia que lo alberga. El cerramiento equipado "imanta" el mobiliario suelto de la habitación, definiendo su posición. Esta polarización transforma de hecho algunos de estos elementos de mobiliario, como en el caso de la mesa que ve reducido su número habitual de apoyos a uno, ya que el tablero de la misma descansa también sobre la balda inferior de uno de los casier incorporados al cerramiento. El elemento trasformado queda por tanto a medio camino entre el objeto de mobiliario independiente (el caso de la silla) y el módulo de equipamiento completamente integrado en el cerramiento (el caso del casier). 
En relación con esta disposición del equipamiento dentro del pan de verre, recientemente Arthur Ruegg en su libro Furniture and Interiors ${ }^{8}$ yuxtapone la imagen de le quatrième mur que nos ocupa a la imagen de la unidad de estudio (plataforma-cajonera, mesa y silla, Imagen 2) de la ampliación de la Maison du Lac del año 1931 y describe el croquis de la cuarta pared como la generalización a la totalidad del pan de verre de la operación de equipamiento llevada a cabo en el cuarto de invitados de la casa. Fija además el origen de la disposición del mobiliario sobre un estrado en los studioli de los cuadros renacentistas, la silla como perteneciente al estudio del padre del arquitecto y la disposición de doble apoyo en pata y muro trasunto de la disposición observada en las celdas de los monjes del Monasterio de Ema.

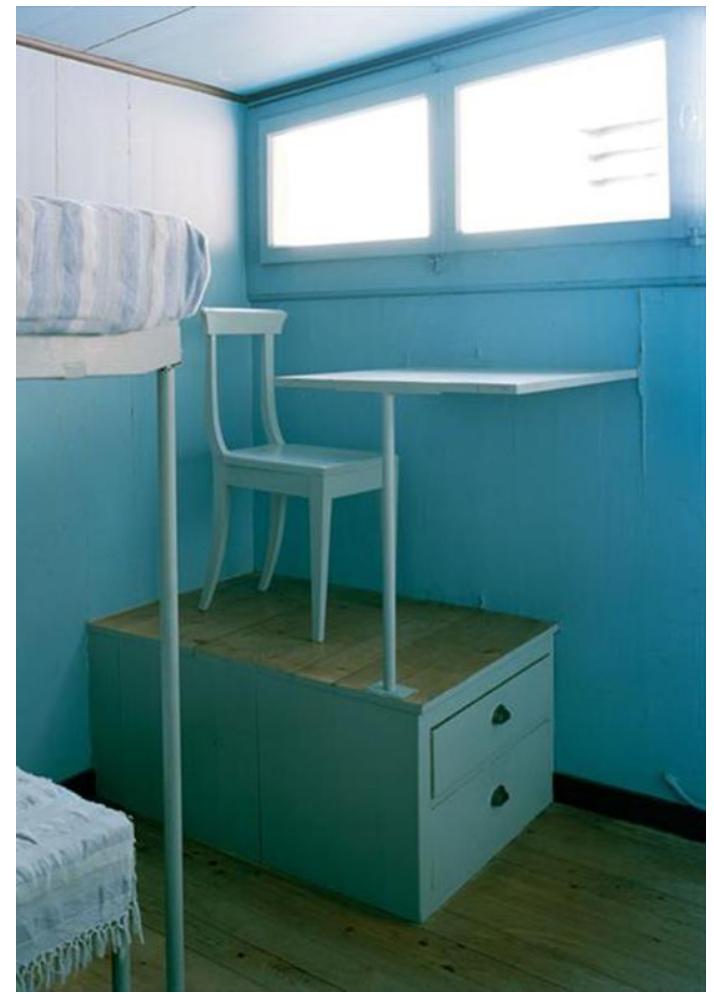

2. Olivier Martin- Gambier, OFLC-ADAGP. Unidad de estudio de la ampliación de la Maison du lac, 1931

La hipótesis del cambio de escala para la definición de la teoría de la cuarta pared es plausible, si bien la existencia de un croquis (Imagen 3) datado en 1930 perteneciente al proceso de diseño del Proyecto Wanner en el que ya se enuncia la teoría de manera gráfica similar a la que se muestra en el dibujo de La Ville Radieuse publicado en 1935, hace pensar más en un proceso de continuo enriquecimiento del esquema, en el que el croquis aparecido en La Ville Radieuse supondría una versión enriquecida respecto al de 1930, al que se habría incorporado una unidad de estudio completa como la de la ampliación de la Maison du Lac (1931).

Continuando con el análisis de la ilustración, observamos que el pan de verre que representa la figura no es plano, sino que ha adquirido espesor, debido a la introducción de elementos que no le son habituales. Este espesor no queda definido con claridad. En ocasiones parece proyectarse hasta adquirir el espesor de una tabla en continuidad con los costados de los casiers, en otros salvan el desplazamiento de dos partes no coplanarias, como en el caso del estante que se forma entre la base de vidrio armado translucido interior y el hueco transparente inmediatamente superior. En cualquier caso, este crecimiento de grosor permite introducir piezas de

${ }^{8}$ Rüegg, Arthur: Le Corbusier, Furniture and Interiors 1905-1965. Zürich, Verlag Scheidegger and Spiess, 2012, 
equipamiento, dotar de relieve al cerramiento y colocar el vidrio en diferentes posiciones con diversos grados de protección solar.

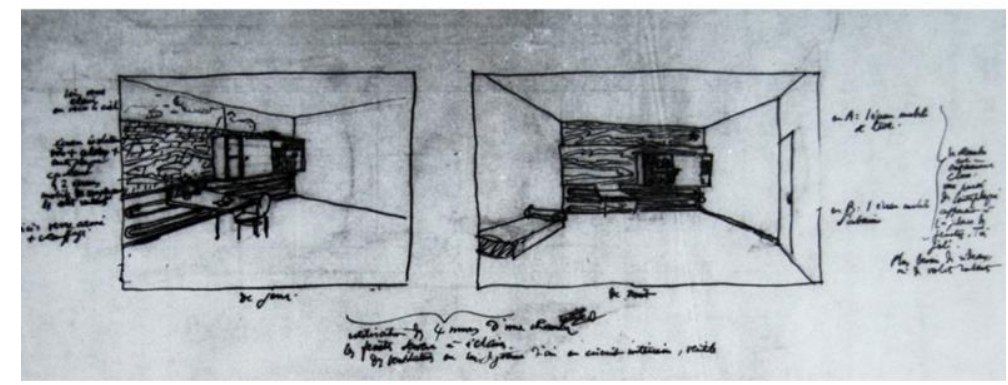

3. Le Corbusier. 8664 OFLC-ADAGP. Cerramiento en clave de cuarta pared en posiciones día-noche perteneciente al proyecto del Immeuble Wanner, 1930

El esquematismo y la simplicidad de la técnica del dibujo no le impide a Le Corbusier introducir apuntes sobre el tipo de iluminación obtenida mediante la disposición del cerramiento de cuarta pared en una estancia tipo. El dibujo de sombras arrojadas localizadas y diversos trazos indicando una cierta tamización de la luz nos indican la capacidad de la cuarta pared de seguir proporcionando luz natural a la vez que protege de la exposición solar excesiva.

Además de los elementos gráficos ya descritos el dibujo cuenta con dos anotaciones manuscritas, de vital importancia para su entendimiento y en definitiva el único ancla del mismo al nombre de la teoría: “l'emploi du quatrième mur dans le pan de verre", quedando a modo de título o slogan del dibujo y resumiendo su naturaleza. De manera adicional, en la parte superior de la ilustración encontramos una anotación puntual referente a un elemento del dibujo: "écran diaphragme”. Ambas son de gran importancia en el entendimiento del contenido de la ilustración. Analicémoslas por partes:

"l'emploi" (empleo, uso): la elección del término nos introduce el carácter de herramienta de la cuarta pared. Se presenta así con entidad de estrategia o proceso de generación de cerramiento. Modo de hacer o conjunto de instrucciones al servicio del arquitecto para la definición de un cerramiento complejo.

“du quatrième mur" (de la cuarta pared): el nombre otorgado a la herramienta es a la vez poético y contundente, ya que enlaza con la abstracción de estancia que representa el dibujo, al mismo tiempo que introduce, a través de sus reminiscencias teatrales, su papel articulador de dos espacios o realidades diversas, el interior de la habitación y el exterior de la ciudad

"dans le pan de verre" (en la fachada de vidrio): la localización de toda la serie de operaciones descritas en el dibujo en la fachada de vidrio describe la preocupación por los problemas que presenta la misma, expuesta al sol y a cuyas consecuencias ya se enfrentado tras la terminación de los trabajos de La Cité de Refuge. El texto del capítulo ya habla de la necesidad de disposición del brise-soleil y de la necesidad de disponer elementos de bloqueo de la radicación solar, lo que enlaza con la segunda inscripción manuscrita de la ilustración: 
"écran" (pantalla o filtro): superpuesto al vidrio, ya sea por su interior o por su exterior. Será estrategia habitual en las cuartas paredes diseñadas por Le Corbusier y adoptará diversas formas constructivas. Mediante la anotación, el arquitecto añade a la teoría una operación de especialización por capas a la de especialización por partes que es más patente en la ilustración.

diaphragme (diafragma): remarca el hecho de que la pantalla es capaz de obturar la apertura del hueco al que corresponde dentro de la cuarta pared en cuestión e introduce el concepto de obturador dentro d ela teoría, que como veremos será algo recurrente.

La desconexión de la imagen del texto con la obra que la acoge no permite sacar más conclusiones que las que son fruto del análisis del dibujo si bien hemos podido comprobar que el conjunto de instrucciones que contiene es fácilmente deducible mediante la observación y análisis de la misma.

\section{Le Corbusier, Euvre complète $1938-46^{9}(1946)$. Primera puesta a punto de la teoría}

Diez años después de la primera aparición pública de la teoría de la cuarta pared, y sin haberse construido ningún pan de verre diseñado según sus parámetros, la teoría es revisitada y puesta al día con la publicación de la conferencia Problèmes de l'ensoleillement, en el cuarto tomo de la obra completa del arquitecto.

En la década transcurrida entre ambas publicaciones, la teoría se ha empleado y con bastante recurrencia además en el trabajo del estudio de la Rue Sèvres. Basta repasar los planos de los proyectos desarrollados en aquella época para encontrar numerosos ejemplos de frentes de vidrio en clave de cuarta pared: Les immeubles locatifs du aménagement de la place de la mairie, Boulogne-sur-Seine, France, (1939), donde el pan de verre se realiza a base de variaciones de piezas estándar tipo casier, los proyectos de Maisons pour ingénieurs et contremaîtres, S.P.A., Lannemezan, France, (1940), donde los frentes de pan de verre equipados en carpintería de madera entre muros de mampostería responden a los dictados de la teoría ya de manera plena y aparecen de manera clara como frentes completos de cuarta pared enclavados en la envolvente estructural, al igual que en los casos de las Unités d'habitation transitoires, (1944) o de la Résidence Peyrissac, domaine agricole, Cherchell, Algérie, (1942). En todos estos casos los frentes de cuarta pared son concebidos como elementos de construcción seca en carpintería de madera y engloban frentes completos a modo de cierre de una estructura realizada en construcción muraria por artesanos locales.

La herramienta goza ya de unos años de puesta en práctica en los proyectos del estudio cuando se publica la conferencia. El texto de la misma supone una recapitulación completa sobre el problema del cerramiento a lo largo de la carrera de Le Corbusier, partiendo de la necesidad intrínseca a su urbanismo construido con sol, espacio y vegetación, de dotar a sus edificios de luz natural a través de la disposición del pan de verre y la consecuente aparición del problema de la exposición solar. La conferencia llega a su punto clave y Le Corbusier centra entonces el problema a resolver: Il faut diaphragmer le pan de verre.

Comienza entonces un repaso pro las soluciones habidas ya en su recorrido arquitectónico: el vuelo de 1,5 metros de los forjados del Immeuble Clarté, Géneve, Suisse (1930), el esqueleto independiente de los frentes de vidrio retranqueados de la Villa Baizeau, Carthage, Tunisie, (1928), las soluciones a tres niveles de logia, lamas y retranqueo de vidrios de Barcelona y las soluciones de logia y de brise-soleil de Alger, puestas en práctica más tarde en Brasil.

\footnotetext{
${ }^{9}$ Le Corbusier: Problèmes de l'ensoleillement . Le brise-soleil. En L'Euvre complète 1938-46. Zurich: Girsberger, 1946
} 
$\mathrm{Y}$ es entonces cuando introduce en este nuevo paradigma de la superposición de la logia al pan de verre, lo que va denomina una auténtica conquista arquitectónica, "le quatriéme mur": ...cette solution qui s'appelle "brise soleil" porte un nom significatif. En fait, cést un briseur de toutes sortes de difficultés; on lui ajoindra le "brisevent" par la possibilité de constituer des parois hermetiquesvitrées translucides, transparents, opaques si l'on veut. Une conquête architecturale será faite: l'exploitation du quatrième mur de la chambre ${ }^{10}$.Le Corbusier

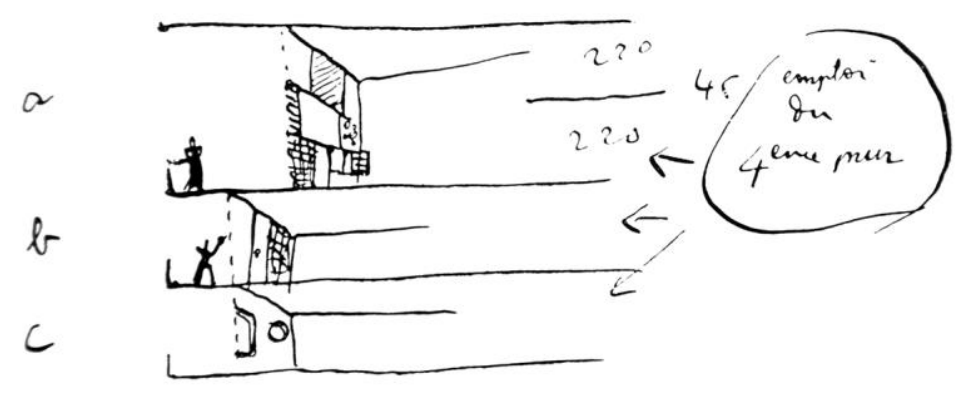

4. Le Corbusier. Euvre complète 1938-46. OFLC-ADAGP. Ilustración que acompaña el texto de la conferencia Problèmes de l'ensoleillement

A partir de ahí desarrolla la explicación de la cuarta pared en dos direcciones, la coincidente con la teoría presentada en La VIlle Radieuse, si bien en este caso son las palabras de Le Corbusier las que describen las operaciones que se pueden realizar en el pan de verre que diez años antes debíamos deducir del análisis de la ilustración y por otro lado la actualización de la teoría al nuevo paradigma de la interposición de la logia habitable, que introduce una nueva variable que transforma en cierta medida la herramienta del quatriéme mur.

La nueva ilustración (Imagen 4) representa una sección esquemática similar a la que ya se presentaba diez años atrás en La Ville Radieuse. De la comparación de ambas descubrimos los nuevos parámetros añadidos al modelo. La cuarta pared ya no se dispone como un cerramiento al borde de la edificación sino que se retranquea, y lo hace en función de la altura del mismo, para optimizar su grado de exposición solar en función de las condiciones higrométricas de la localización donde se trabaje.

En paralelo se establecerá un porcentaje de relación de partes opacas y transparentes en el compacto de cuarta pared que actúa de cerramiento y su valor dependerá también de la orientación y localización del mismo, de la necesidad de bloqueo de la radiación solar. Ambas variables juntas funcionan como un diafragma de una cámara fotográfica, en la que se puede controlar el retranqueo del diafragma y su apertura para encontrar la solución óptima a cada situación de exposición.

Le Corbusier destaca además las ventajas de esta nueva situación, la posibilidad de limpieza con facilidad por parte del usuario del pan de verre, tanto por dentro como por fuera, la posibilidad de que el usuario personalice el frente de su vivienda sin alterar la imagen general del edificio, salvaguardada por el gran orden de logia brisesoleil.

\footnotetext{
${ }^{10}$ Le Corbusier: Problèmes de l'ensoleillement . Le brise-soleil. En L'Euvre complète 1938-46. Zurich: Girsberger, 1946
} 
La nueva incorporación a la cuarta pared, fruto de la nueva posición que ocupa en la edificación, es lo que Le Corbusier denominará trou d'homme, el paso entre el interior de la vivienda y la logia exterior que s e incorporará como un elemento más a las divisiones de la cuarta pared. El pan de verre es por fin practicable, si bien el arquitecto no abandona la idea del mur neutralisant ni de la respiration exacte, que sigue publicitando como posibilidad de instalación en el nuevo orden de fachada de vidrio tras la logia brise-soleil. Si observamos la ilustración que ilustra la conferencia (Imagen 4) donde se representa este juego de retranqueos de los elementos de cuarta pared en función de la altura de la sección, el nivel grafiado con la $c$ se reserva a la solución de mur neutralisant, mientras que los niveles $a$ y $b$ disponen de aperturas y ventilación natural.

\section{Le Modulor $I^{11}(1950)$. Primera presentación de resultados. La reforma del frente oeste de 24NC.}

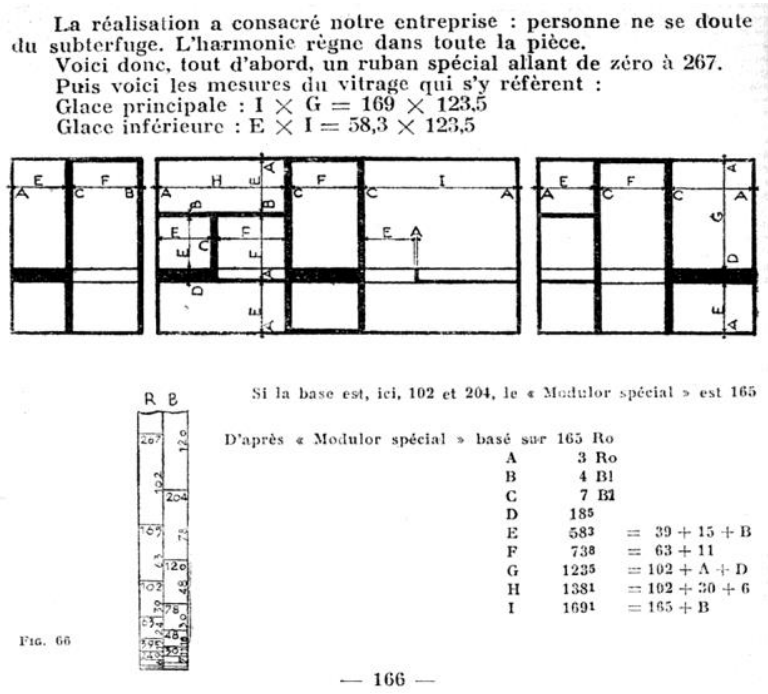

5. Teodoro González de León. Le Modulor. OFLC-ADAGP. Ilustración Une nouveau pan de verre de bois, primera cuarta pared construida.

La publicación del Modulor servirá como vía de propagación del primer resultado construido de la teoría de la cuarta pared. La publicación se limita a presentar la reforma del frente oeste del apartamento del arquitecto como un mero ejemplo de modulación de un frente de vidrio y madera de acuerdo al nuevo sistema de medidas. El proyecto se incluye dentro de la segunda parte del texto, Realidades prácticas, en la selección de proyectos que constituyen el capítulo quinto del libro, Primeros ejemplos de utilización. No menciona el uso de la teoría como tal, ni lo publicita como ejemplo de resultado de la misma. En la representación del mismo se explicitan en un dibujo del cerramiento relleno de negro las medidas del uso del nuevo sistema de medidas, si bien para la ocasión se empleó una escala alterada, Modulor spécial (Imagen 5), ya que por temas normativos la altura del frente a acristalar era de $204 \mathrm{~cm}$. en vez de los 226 canónicos de altura libre que marca la escala canónica del Modulor. El arquitecto, lejos de ver tal eventualidad como un posible síntoma de poca flexibilidad del sistema, lo toma como una prueba de su versatilidad y capacidad de adaptación a distintas situaciones de proyecto. En futuras intervenciones utilizará el Modulor estándar de 226 de manera sistematica.

\footnotetext{
${ }^{11}$ Le Corbusier: Le Modulor: essai sur une mesure harmonique à l'échelle humaine alicable universellement à l'architecture et á la méchanique. Boulogne-sur-Seine: Éditions de l'Architecture d'aujourd'hui, 1950
} 
En el dibujo no se aprecian realmente las operaciones del equipamiento del frente, ni de su potencial como dispositivo capaz de definir el uso del espacio que cierra, los mecanismos gráficos expresivos en esta ocasión potencian el uso de la medida humana en el cerramiento. La publicación sirve por tanto como proyecto hito que pone de manifiesto la voluntad del arquitecto de operar sobre el frente equipado de cuarta pared a escala humana. Las consecuencias derivadas de la introducción del sistema de medida en el uso de la teoría de la cuarta pared en la definición de los cerramientos desde este momento va a ser decisiva principalmente en dos aspectos.

En primer lugar, la utilización de un sistema de medidas a escala humana potenciará en gran medida la facilidad de introducir equipamiento a la medida del usuario con mayor facilidad. Las consecuencias se pueden comprobar desde esta primera aplicación, las medidas de los elementos de la cuarta pared constituida mediante medidas del Modulor dan unidad a todos los elemento sueltos de mobiliario y al equipamiento del frente de vidrio, con lo que la capacidad de la cuarta pared de ordenar el uso del espacio que se define se ve potenciado en gran medida. Este imantado, o ordenación del entorno cercano se va a dar ya en una doble dirección, hacia el exterior de la vivienda y hacia el interior de la misma, actuando como articuladora la cuarta pared de los dos espacios domésticos y poniéndolos en relación, no solo a nivel de circulaciones, comunicación visual y uso de sus respectivos espacios, sino relacionando el equipamiento de ambos, creando una relación visual entre elementos de ambos espacios.

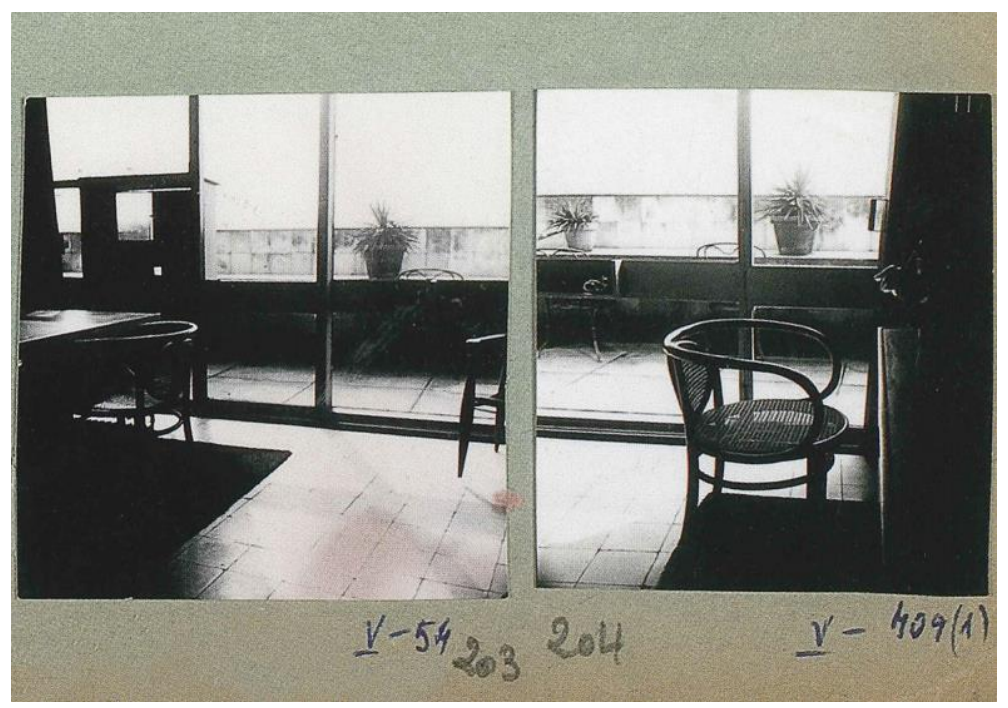

6. Lucien Hervé. OFLC-ADAGP. El frente oeste del apartamento de Le Corbusier

Esto se observa en las imágenes del espacio del comedor del apartamento de Le Corbusier tras la reforma del frente acristalado que nos ocupa (Imagen 6). El elemento de tabla de refuerzo que recorre toda la longitud del cerramiento tiene otra propiedad, y es la de conectar visualmente los planos de la mesa exterior corrida que equipa el peto de la vivienda y la del interior, la mesa de mármol con reborde inspirada en las mesas funerarias egipcias con patas de elefante. La conexión visual hace aparecer el espacio como una verdadera machine à habiter donde todos los elementos encajan, están relacionados visualmente y ordenan el uso que se hace del mismo con precisión.

En segundo lugar la importancia del uso de las medidas del Modulor en la cuarta pared radicará en la rápida sistematización de soluciones que traerá consigo. Este fenómeno no debe entenderse como una pérdida de grados de libertad en las posibilidades de definición de los espacios habitables que cierran los elementos de cuarta pared, sino una progresiva sistematización y optimización de los mismos, que apunta hacia la taylorización 
buscada por el arquitecto. En este sentido es reveladora la lectura de la patente conocida como del Modulor ${ }^{12}$, cuyo nombre real es Breveté Perfectionnements apportés aux ensembles à usage humain constitués para la juxtaposition d'éléments.

La patente define la definición de la escala de medidas y viene acompañada de figuras gráficas a modo de ejemplo. En el texto de la misma se encuentran unas instrucciones breves de cómo aplicar el sistema de medidas a la división de frentes acristalados en cuadrados y rectángulos a los que correspondan materiales diversos e incluso piezas de equipamiento encastradas. Le Corbusier introduce de este modo unas breves instrucciones de cuarta pared en la patente que registra el sistema de medidas del Modulor, quedando su utilización como primera aplicación ligada al nuevo sistema de medidas.

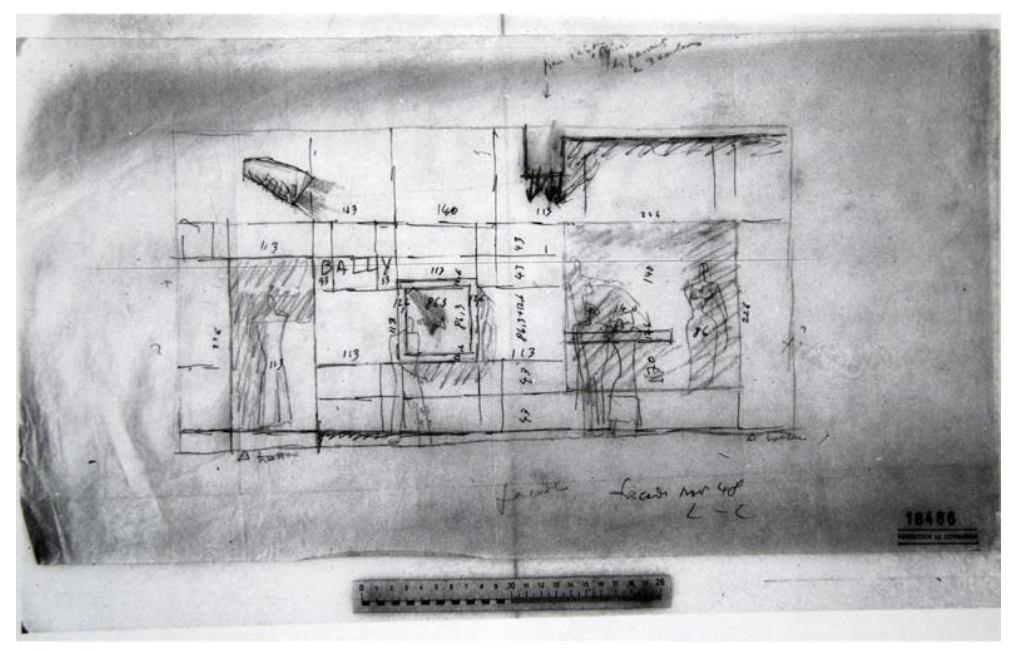

7. Le Corbusier. 18486 OFLC-ADAGP. Estudio de medidas para la fachada del Magasin Bally (1948)

Finalmente, quedaría por citar otro proyecto que aparece publicado en las paginas del Modulor y que en su cerramiento podemos considerar adscrito al modo de hacer de la cuarta pared. Se trata del proyecto del cerramiento del Magasin Bally (1948), que aparece dentro del capítulo 7. Comprobaciones materiales y coda de la publicación. Se trata de un frente para el comercio del Boulevard Madeleine construido en entramado metálico y compartimentado de acuerdo a las medidas del Modulor, donde se abren tres huecos de distintas características, medida, función y posición dentro del espesor del cerramiento (Imagen 7). Se trata de una cuarta pared con todo el juego de posibilidades que la caracteriza, con una mayor proporción de partes opacas respecto a las transparentes debido al uso, diferente al de vivienda y con unas necesidades específicas de exposición, iluminación y control.

${ }^{12}$ Le Corbusier: Breveté Perfectionnements apportés aux ensembles à usage humain constitués para la juxtaposition d'éléments. BSGDG N 996.664 - 15/05/1945, délivré le 05/09/1951, publié le 24/12/1951 


\section{Le Corbusier, Euvre complète $1946-52^{13}$. Segunda presentación de resultados. Los compactos de la fachada de L'Unite de Nantes Rezé. La definición breve de la teoría.}

La siguiente aparición de la cuarta pared en las publicaciones y escritos de Le Corbusier tendrá lugar en el quinto tomo de la obra completa, donde se publica la Unité d'habitation Rezé-les-Nantes (1952-53), en cuyo artículo se dedica una página completa a la reproducción de los cinco elementos tipo prefabricados en madera por el tándem Barberis-Alazard ${ }^{14}$ que se ocupó ya de la construcción de la primera cuarta pared en la reforma del frente oeste del apartamento de Le Corbusier.

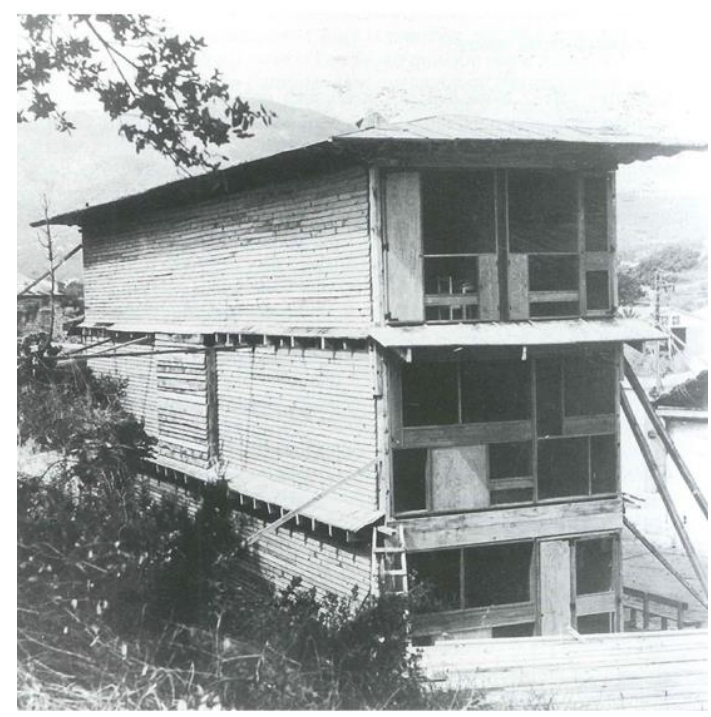

8. OFLC-ADAGP. Prototipo a escala real de los prefabricados de cuarta pared para la Unité de Rezé

El dibujo del alzado de los prefabricados se acompaña de la descripción del espacio de logia anexo y de un breve comentario que aporta dos nuevos datos a añadir al ideario de cuarta pared del que estamos haciendo inventario. En primer lugar Le Corbusier nos da la definición breve de cuarta pared: Le $4^{\text {ème }}$ mur de la pièce: le pan de verre aménagé. La definición mantiene intactas las características que desde el inicio hemos atribuido a la teoría, pero su dimensión más importante está en la amplitud que coge el nombre, y su complemento de la piéce, que nos indica el entendimiento de la pieza de cierre inseparable del espacio que cierra. Ya hemos visto en varias ocasiones que la cuarta pared ordena el espacio que cierra y que desde la llegada del espacio exterior de logia amplía su área de influencia al espacio exterior de la misma manera. La dirección que toma ahora es la de empezar a definir un sistema de módulo habitable y cierre equipado del mismo. En ese sentido la trayectoria del proyecto de L'Unité de Nantes ha supuesto un avance en esa dirección. Las limitaciones económicas del mismo en comparación a Marsella han hecho primar la seriación y simplificación de los elementos de cierre, que se reducen a 5 diferentes, un único compacto para las habitaciones de los niños y dos pares de compactos que configuran el cierre del espacio de salón, dormitorio principal y escalera de manera simétrica.

\footnotetext{
${ }^{13}$ Le Corbusier: Euvre complète 1946-52. Zurich: Girsberger, 1953

${ }^{14}$ EL corso Charles Barberis, carpintero y Jules Alazard antiguo colaborador de Rue de Sévres y a la sazón industrial
} 
De hecho, en el texto que acompaña a la ilustración Le Corbusier recalca que los representados son les seuls éléments standard composant toutes les façades d'appartaments. De esta forma deja claro el valor de la simplificación y optimización de la respuesta en clave de cuarta pared, de máxima economía. Esta depuración afectaba al esquema inicial de la estructura, más cercano si cabe que el finalmente ejecutado al concepto de célula habitable y cierre de la misma con elemento compacto de cuarta pared. El Beru system que finalmente se ejecutó consistía en 2 muros de hormigón ligero de $3 \mathrm{~cm}$ de espesor con $20 \mathrm{~cm}$. interiores de hormigón in situ con armado ligero sobre muros en $\mathrm{M}$ y en V que sustituían a los pilotis originales de Marsella. Las opciones que se barajaron antes seguían el concepto de las boîtes a chaussures, tras el botellero marsellés, una de ellas objeto incluso de una patente, prueba del interés de Le Corbusier por la definición en paralela de la célula habitable y su mecanismo de cierre.

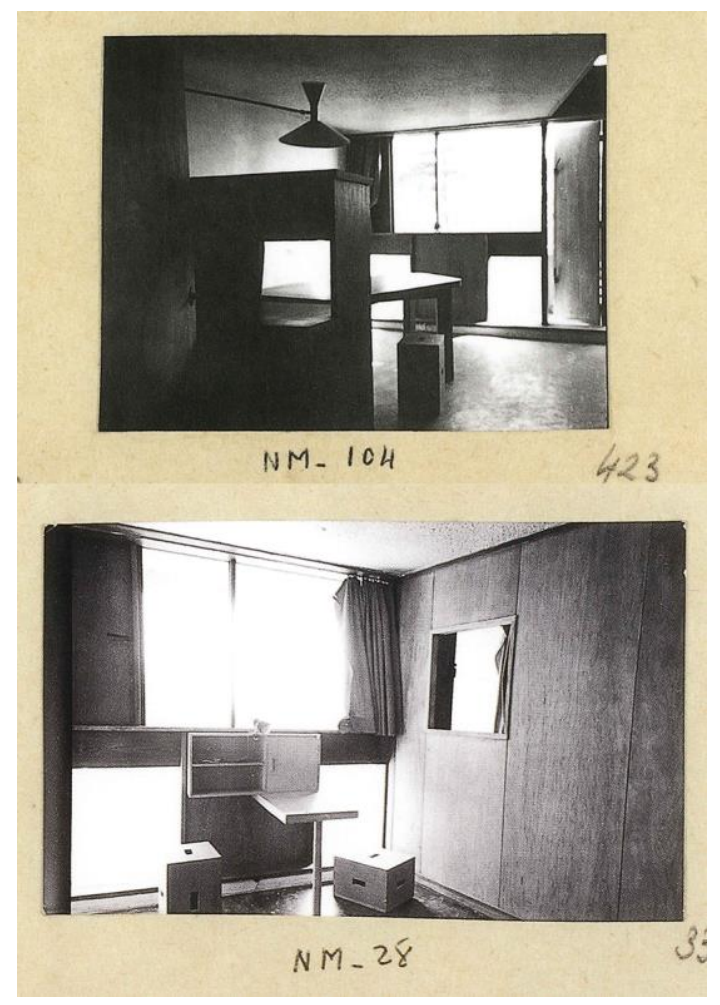

9. Lucien Hervé. (FLC-ADAGP. Vista interior del prefabricado de cuarta pared de las habitaciones infantiles

\section{Modulor $2^{15}(1955)$. Segunda actualización de la teoría y recapitulación.}

La aparición de la teoría en el Modulor 2 sirve de recapitulación de la historia del cerramiento en su obra por parte de le Corbusier reproduciendo un diálogo con Jules Alazard en el que repasan las fases de la evolución del cerramiento en su obra: fenêtre en longeur, pan de verre, le quatriéme mur y le brise-soleil. A estas figuras ya conocidas añade una nueva fase que se identifica con su reciente experiencia india: la separación de funciones.

Al referirse a la cuarta pared realiza un resumen de la misma coincidente con las otras descripciones presentes en su obra, y hace hincapié en el hecho de que la carpintería se realiza en madera ${ }^{16}$ a base de tablas de canto, en

\footnotetext{
${ }^{15}$ Le Corbusier: Modulor 2 (La parole est aux usagers) Suite de "Le Modulor 1948”. Boulogne-sur-Seine: Éditions de l'Architecture dàujourd 'hui, 1955

${ }^{16}$ La elección de la madera como material para la construcción de los frentes de pan de verre, enmarcado en la escasez de acero de la posguerra, momento que supone el pistoletazo de salida para los proyectos fundamentales del arquitecto tiene
} 
vez de tratarse de un bastidor plano, lo que da rango de mobiliario al cerramiento de la vivienda. Destaca además que su disposición bajo al protección de la logia brise-soleil permite que la madera no sea afectada por la lluvia ${ }^{17}$ y su mantenimiento sea sencillo y realizable por el propio usuario.

El diálogo entre Le Corbusier y Jules Alazard tiene lugar a la salida de la visita de obra de las Maisons Jaoul ${ }^{18}$, la obra en la que la estrategia de la cuarta pared junto a la definición de una estructura alveolar 226x226 constituye ya la estrategia completa del proyecto, elevando la teoría de la cuarta pared a tema principal en la definición de su arquitectura.

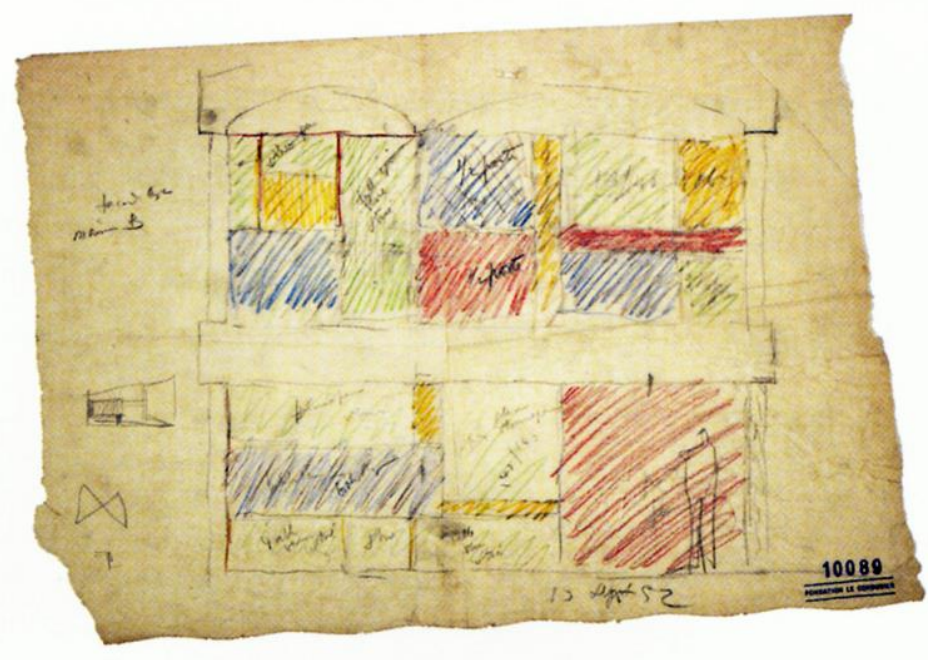

\section{Le Corbusier. 10089 OFLC-ADAGP}

El último punto de la evolución narrada por el arquitecto se refiere a la separación de funciones de iluminar y ventilar que define el arquitecto en uno de sus viajes a al India tras una toma de datos en el hotel Taj Mahal y que recoge en el Carnet Nivola II (Imagen 11). En él establece un nuevo modelo de quatriéme mur que hace un tratamiento del frente de pan de verre mediante una triple aproximación:

efectivamente un papel fundamental en la utilización de la teoría de la cuarta pared, que se adapta con facilidad a la versatilidad de ese material y potencia su carácter de mobiliario

${ }^{17}$ El cerramiento del frente oeste de su apartamento, expuesto a la lluvia, sí se vio afectado, la madera se pudrió y el agua entraba en la cámara del acristalamiento y en el año 1962 se sustituyó por otro en aluminio. Existe constancia de una petición de presupuesto de brise-soleil prefabricado para la protección del frente de madera tras su construcción, pero nunca fue llevado a cabo.

${ }^{18}$ El frente oeste de $24 \mathrm{NC}$, les Maisons Jaoul y L’Unité Nantes, las tres llevadas a cabo por el tándem Barberis-Alazard forman lo que podríamos denominar un cánon de quatriéme mur, respondiendo a tres escalas, la del tratamiento independiente de un frente en clave de cuarta pared, la de hacer de la cuarta pared la estrategia general de proyecto y la de seriación de los módulo de cerramiento. 


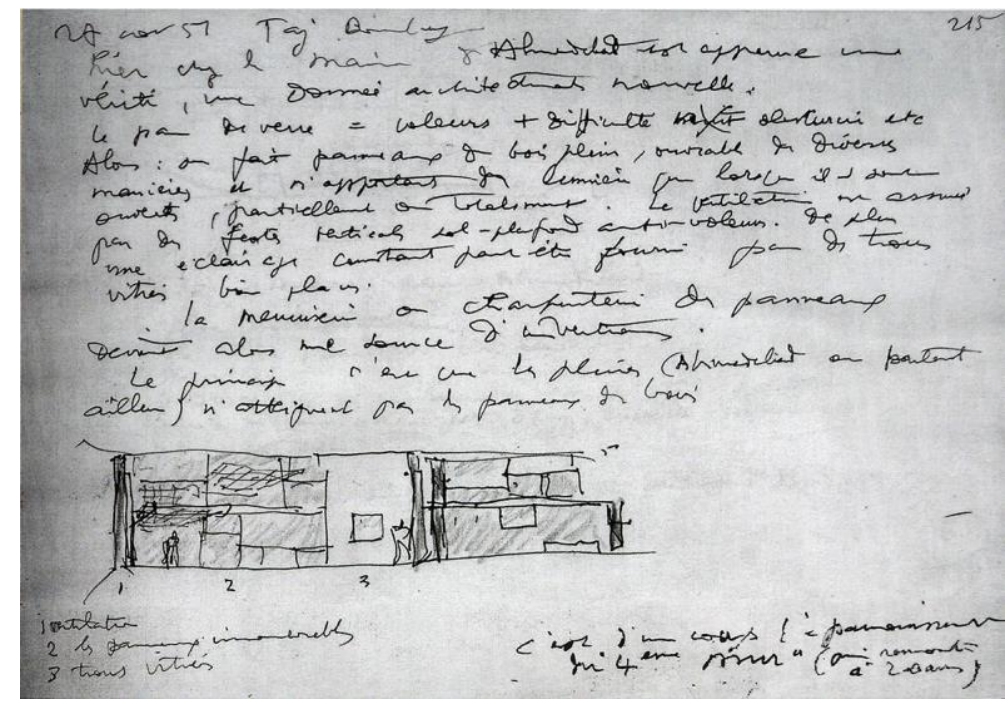

11. Le Corbusier. OFLC-ADAGP. Manuscrito Carnet Nivola II cuya ilustración aparece en el Modulor 2.

Alors: on fait panneaux du bois plein, ouvrables des diverses manières et n'apportant du lumière que lorsque ils sont ouverts, partiellement ou totalement. La ventilation est assuré par des fentes verticales sol-plafond antivoleurs. De plus un éclairage constant peut être fourni par des trous vitrés bien placés. La menuiserie ou charpenterie des panneaux devient alors une source d'inventions.

1 Iluminación mediante paneles practicables

2 Ventilación asegurada por ranuras verticales de suelo a techo anti ladrones

3 Iluminación constante a través de huecos con vidrio fijo

Esta disposición, además de introducir en el catálogo de Le Corbusier la solución de aérateur supondrá la base de la composición del cerramiento de sus proyectos indios, en especial de las villas de Ahmedabad.

\section{De la fenêtre au pan de verre dans làrchitecture de Le Corbusier ${ }^{19}(1959)$. La voluntad de industrialización del sistema.}

A modo de epílogo de la deriva de le quatriéme mur en el universo teórico de Le Corbusier, en 1959 se publica una versión "en limpio" de la evolución del cerramiento en su obra referida en el Modulor 2, supervisada por el arquitecto y realizada a modo de publicación promocional empresarial por Jules Alazard.

La publicación, bajo el título De la fenêtre au pan de verre dans làrchitecture de Le Corbusier presenta documentada con las referencias habituales ya vistas en publicaciones anteriores la evolución en 5 fases ya vista en el Modulor 2. La única aportación o diferencia respecto a su precedente es que la última fase, la separación de funciones no se ilustra ya con el croquis indio que dio lugar al aérateur, sino que viene representado con la definición de unos módulos de quatriéme mur 226 x 226 que presentan la consabida separación de funciones en distintos elementos (ventana transparente para iluminar el área de trabajo, aérateur opaco y verical de suelo a techo, hueco de paso a la logia exterior, hueco de iluminación inferior translúcido, etc) Estos compactos (Figura 12) son la depuración y síntesis de los utilizados en proyectos de la década anterior: Roq et Rob, la celda de la

\footnotetext{
${ }^{19}$ Jules Alazard: De la fenêtre au pan de verre dans l'œuvre de Le Corbusier: étude conçue et rédigée avec l'accord de Le Corbusier. Paris: Dunod, 1959
} 
Tourette, la versión de proyecto de la habitación de estudiante de la Maison du Brasil por citar los más significativos. (Imágenes 13, 14 y 15)

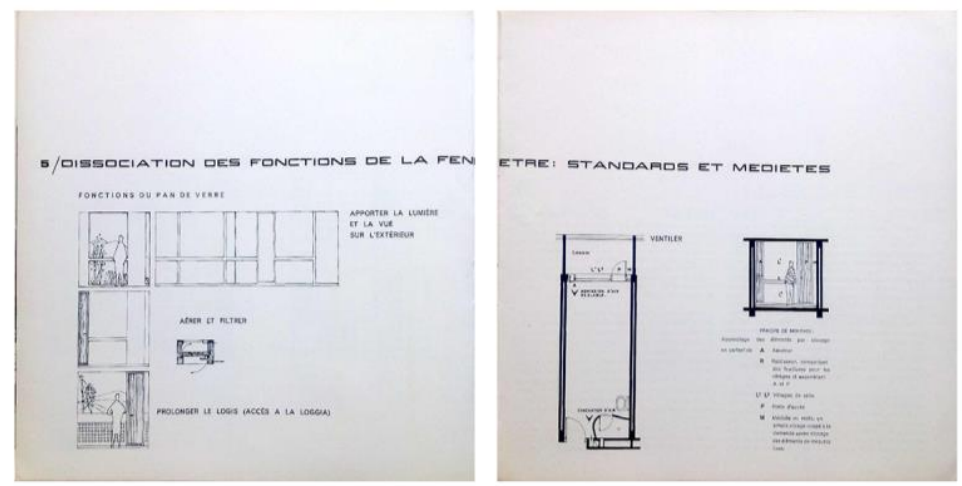

12. Le Corbusier. OFLC-ADAGP. Capítulo 5 del libro De la fenêtre au pan de verre dans l'œuvre de Le Corbusier. Definición de compacto de cuarta pared 226×226 con separación de funciones

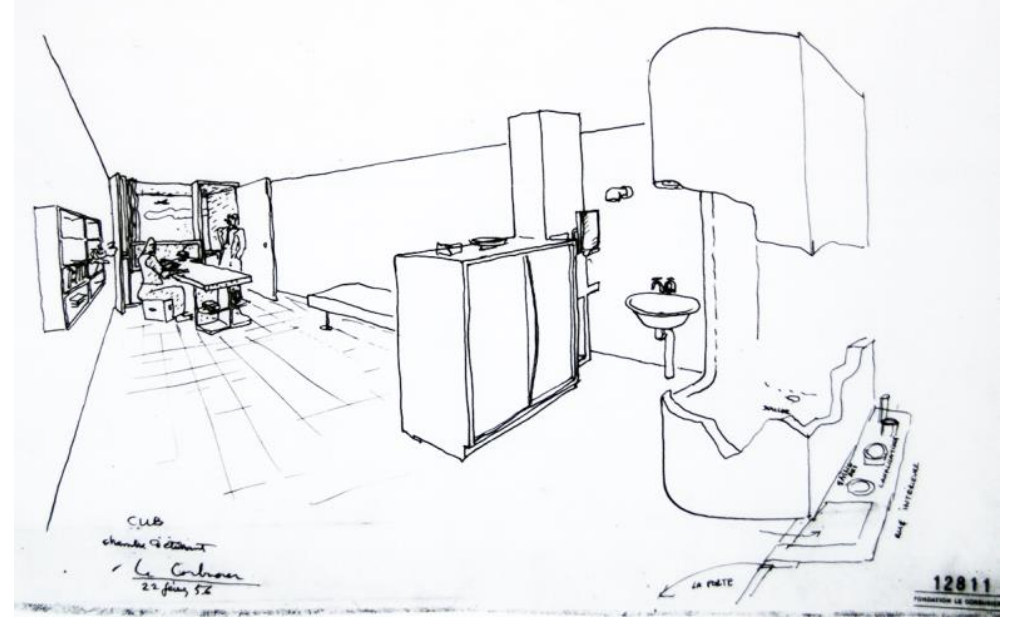

13. Le Corbusier. 12811 CFLC-ADAGP. Versión de proyecto de los cerramientos de las habitaciones de estudiantes de la Maison du Brésil.

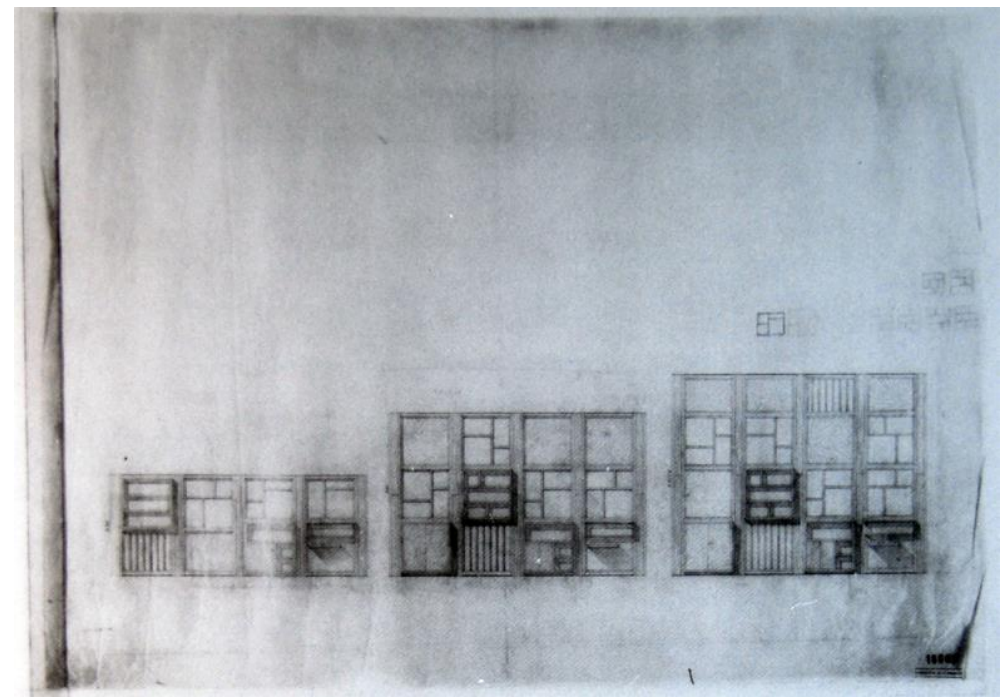

14. Le Corbusier. 18867 OFLC-ADAGP. Estudio de fachadas en compactos de cuarta pared 226 x 226 para Roq et Rob. 


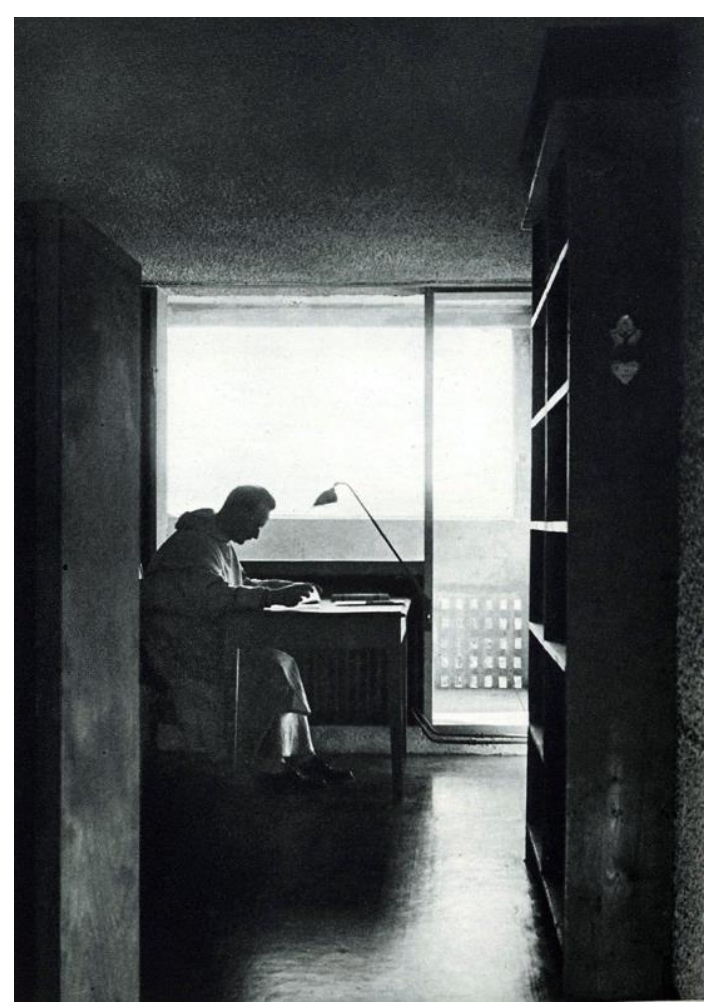

15. J.Caps. L'Art Sacré, "Le Corbusier: Un couvent dominicain”, Mars-Avril 1960, nº-8. Paris: Éditions du Cerf, 1960. pp 21-32. Un dominico estudia en la cuarta pared de su celda.

El origen de este dibujo se encuentra en el acta de una reunión que mantuvieron el industrial y el arquitecto, En ella se puede leer: 27 juillet 57. 24NC Jules Alazard + L-C. Thème: Le 4ème mur, Éléments type L-C \& mettre en vente. Conclussion: L'Unité modular est 226/226.

El contenido del acta deja claro el entendimiento por parte del arquitecto de un sistema de producción de soluciones habitacionales a base de la doble componente de estructura alveolar 226/226 y compactos de cerramiento tipo quatriéme mur. Se dejan además dibujados con indicaciones para su elaboración posterior e inclusión en la publicación del industrial con vistas a su comercialización. Es la culminación de un proceso de depuración de las soluciones de cuarta pared comenzado con un dibujo en La Ville Radieuse.

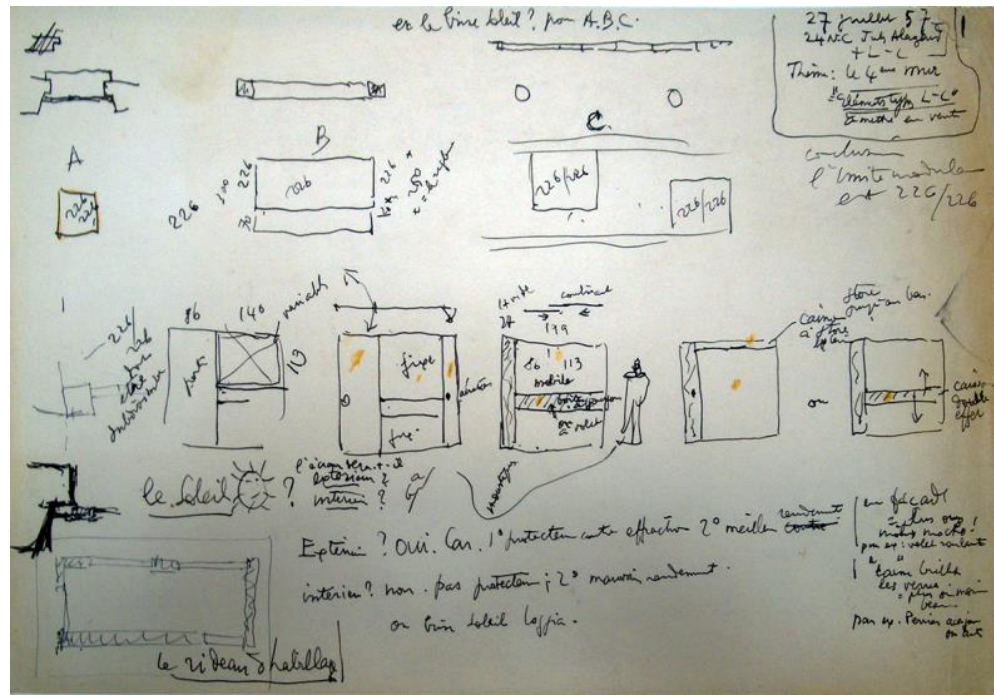

16. Le Corbusier. Centro Canadiense de Arquitectura. Acta Reunión. Tema: L $4{ }^{\text {ème }}$ mur "Elements type L-C" \& mettre en vente. Asistentes: Le Corbusier, Jules Alazard. Lugar: Apartamento de Le Corbusier, 24NC, Paris. Fecha: 27 julio 1957. 


\section{Conclusiones}

El recorrido establecido desde la primera aparición de la teoría en La Ville Radieuse hasta el acta de la reunión en 24 NC con Jules Alazard nos ha permitido entender el papel de la teoría de la cuarta pared como aglutinador de técnicas referidas al cerramiento de la edificación con el pan de verre. El repaso de los documentos relativos a la teoría ha servido para identificar las instrucciones de la herramienta de proyecto de cuarta pared y que se resumen en tres grandes grupos: operaciones de especialización del cerramiento por partes mediante la división del cerramiento de acuerdo a la geometría del Modulor; operaciones de especialización por capas mediante la superposición de pantallas y por último operaciones de especialización funcional mediante la incorporación de equipamiento.

Los elementos de cierre de cuarta pared actúan como dispositivos de la máquina de habitar con dos funciones principales:

- La primera función es la de definir el uso espacial de la célula habitable que cierran, articulando la relación interior y exterior, asimilando en su interior el equipamiento esencial de la pieza y ordenando el resto de mobiliario.

- La segunda es la de actuar como diafragmas, y en conjunción con el elemento exterior de logia adoptar un grado de opacidad y un retranqueo suficientes para conjugar las necesidades de la pieza ofreciendo la protección solar que la orientación y situación de la misma demandan

Finalmente la teoría de la cuarta pared junto con la investigación paralela de una estructura alveolar 226/226 configuran un sistema de producción del hábitat a escala humana.

\section{Procedencia de las imágenes}

Imagen 1. Le Corbusier. La Ville Radieuse. CFLC-ADAGP. Croquis inaugural de la teoría de la cuarta pared.

Imagen 2. Olivier Martin- Gambier, CFLC-ADAGP. Unidad de estudio de la ampliación de la Maison du lac,

Imagen 3. Le Corbusier. 8664 CFLC-ADAGP. Cerramiento en clave de cuarta pared en posiciones día-noche perteneciente al proyecto del Immeuble Wanner, 1930.

Imagen 4. Le Corbusier. Euvre complète 1938-46. CFLC-ADAGP. Ilustración que acompaña el texto de la conferencia Problèmes de l'ensoleillement.

Imagen 5. Teodoro González de León. Le Modulor. CFLC-ADAGP. Ilustración Une nouveau pan de verre de bois, primera cuarta pared construida.

Imagen 6. Lucien Hervé. CFLC-ADAGP. El frente oeste del apartamento de Le Corbusier

Imagen 7. Le Corbusier. 18486 CFLC-ADAGP. Estudio de medidas para la fachada del Magasin Bally (1948) 11

Imagen 8. CFLC-ADAGP. Prototipo a escala real de los prefabricados de cuarta pared para la Unité de Rezé . 12

Imagen 9. Lucien Hervé. CFLC-ADAGP. Vista interior del prefabricado de cuarta pared de las habitaciones infantiles 
Imagen 11. Le Corbusier. CFLC-ADAGP. Manuscrito Carnet Nivola II cuya ilustración aparece en el Modulor 2.

Imagen 12. Le Corbusier. CFLC-ADAGP. Capítulo 5 del libro De la fenêtre au pan de verre dans l'œuvre de Le Corbusier. Definición de compacto de cuarta pared 226×226 con separación de funciones. 16

Imagen 14. Le Corbusier. 12811 CFLC-ADAGP. Versión de proyecto de los cerramientos de las habitaciones de estudiantes de la Maison du Brésil.

Imagen 13. Le Corbusier. 18867 CFLC-ADAGP. Estudio de fachadas en compactos de cuarta pared 226 x 226 para Roq et Rob.

Imagen 15. J.Caps. L'Art Sacré, "Le Corbusier: Un couvent dominicain”, Mars-Avril 1960, n7-8. Paris: Éditions du Cerf, 1960. pp 21-32. Un dominico estudia en la cuarta pared de su celda.

Imagen 16. Le Corbusier. Centro Canadiense de Arquitectura. Acta Reunión. Tema: L 4 ème mur "Elements type L-C” \& mettre en vente. Asistentes: Le Corbusier, Jules Alazard. Lugar: Apartamento de Le Corbusier, 24NC, Paris. Fecha: 27 julio 1957

\section{Bibliografía/referencias}

Gargiani, Roberto; Rosellini, Anna: Le Corbusier: Béton Brut and Ineffable Space, 1940-1965 : Surface Materials and Psychophysiology of Vision. Lausanne: EPFL Press - Oxford: Routledge, 2011

Jules Alazard: De la fenêtre au pan de verre dans l'œuvre de Le Corbusier: étude conçue et rédigée avec l'accord de Le Corbusier. Paris: Dunod, 1959

Le Corbusier: Breveté Perfectionnements apportés aux ensembles à usage humain constitués para la juxtaposition d'éléments. BSGDG N 996.664 - 15/05/1945, délivré le 05/09/1951, publié le 24/12/1951

Le Corbusier: La Ville Radieuse; éléments d'une doctrine d'Urbanisme pour l'équipement de la civilisation machiniste. Boulogne-sur-Seine: Éditions de l'Architecture d'aujourd'hui, 1935

Le Corbusier: Le Modulor: essai sur une mesure harmonique à l'échelle humaine alicable universellement à l'architecture et á la méchanique. Boulogne-sur-Seine: Éditions de l'Architecture d'aujourd'hui, 1950

Le Corbusier: Modulor 2 (La parole est aux usagers) Suite de "Le Modulor 1948”. Boulogne-sur-Seine: Éditions de l'Architecture dàujourd'hui, 1955

Le Corbusier: Euvre complète 1938-46. Zurich: Girsberger, 1946

Le Corbusier: Euvre complète 1946-52. Zurich: Girsberger, 1953

Le Corbusier: Problèmes de l'ensoleillement . Le brise-soleil. En Techniques et architecture VOL VI, 1946, Nº11 , pp26-28

Maniaque, Caroline: Le Corbusier et Les maisons Jaoul. Projets et fabrique Paris: Éditions A. \& J. Picard, 2005

Martínez Arroyo, Carmen: "La densidad del límite". En Arquitectos n¹74, Volumen 05/2. Madrid: CSCAE 2005

Martínez Arroyo, Carmen: La densidad del limite. Le Corbusier y Mies Van Der Rohe del equipamiento al sistema de objetos. Director: Manuel de las Casas. Universidad Politécnica de Madrid, Escuela Técnica Superior de Arquitectura de Madrid, Departamento de Proyectos Arquitectónicos, 2005

Rüegg, Arthur, Le Corbusier, Furniture and Interiors 1905-1965. Zürich, Verlag Scheidegger and Spiess, 2012

Sbriglio, Jacques, Immeuble 24 N.C. et Appartement Le Corbusier. Basel: Birkhäuser, 1996 


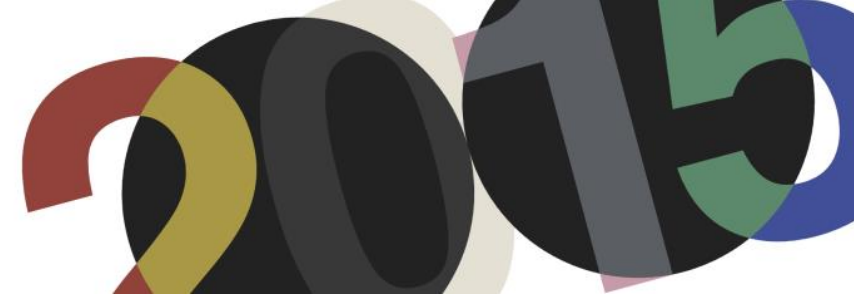

DOI: http://dx.doi.org/10.4995/LC2015.2015.711

\title{
Le Corbusier en 'Líneas Simples’: Toyo Ito
}

\author{
M. Rodríguez Fernández
}

Gerald D. Hines College of Architecture University of Houston

Resumen: Desde principios de la década de 1980, Toyo Ito asumió la misión de traducir el mensaje mecanicista de Le Corbusier en la era de la electrónica. Anhelaba superar la referencia a la máquina únicamente como inspiración estética, así como abolir la relación entre forma y función, de acuerdo a la nueva era digital. La experimentación doméstica de Ito, a lo largo la primera mitad de la década, le llevo a concebir finalmente una 'arquitectura de líneas simples'. Desde el Proyecto Dom-ino (1980) hasta la Casa en Magomezawa (1986), se da una paulatina liberación de la formalidad lecorbuseriana - basada en una sociedad de la producción — en favor de una arquitectura sin forma —en consonancia con una sociedad del consumo. El proyecto que supone un punto de inflexión en esa evolución fue la Casa en Hanakoganei (1983), que introducía una serie de maniobras arquitectónicas que Ito implementó posteriormente en Silver Hut (1984), Pao I (1985) y en la Casa Magomezawa. Estos tres proyectos aglutinan las características que definen la arquitectura de Toyo Ito desde mediados de los 80 y que en última instancia impulsan 'la aventura doméstica de los 80 en Japón', la cual vuelve su mirada hacia las artes decorativas. La aspiración última de Ito - al igual que la de su 'alter ego'Le Corbusier seis décadas antes-fue diseñar una 'nueva arquitectura' acorde con los avances tecnológicos del momento, para ello Ito ensayó las siguientes estrategias arquitectónicas: desmaterialización, permeabilidad interior-exterior, indefinición funcional, provisionalidad, liberación formal respecto de la estructura, ligereza, arquitectura como vestido y anti-monumentalidad.

Abstract: Toyo Ito took on the mission of translating Le Corbusier's mechanistic message for the electronic age at the beginning of the 1980s. He desired to go beyond the reference of the machine only as aesthetic inspiration, as well as to abolish the relationship between form and function, visible in the new digital era. Ito's domestic experimentation, during the first half of the decade, finally led him to conceive an 'architecture in simple lines.' From the Dom-ino Project (1980) to the House in Magomezawa (1986), there is a gentle liberation of the Corbusian formality-based on a society of production-in favor of an architecture without form - in accordance with a society of consumption. The House in Hanakoganei (1983) is as milestone in this evolution, where Ito introduced a series of design techniques that he later implemented in Silver Hut (1984), Pao I (1985), and in the Magomezawa House. These three projects congeal the characteristics that define Ito 's architecture from the middle of the 1980s and, ultimately, give impulse to the 'domestic adventure of the 80s in Japan,' that turns its eye to the decorative arts. Toyo Ito's goal, similar to that of his 'alter ego' Le Corbusier six decades earlier, was to design a 'new architecture' in harmony with the technological advances of the time, which led him to try the following design strategies: dematerialization, interior-exterior permeability, undefined function, provisionality, formal liberation of the structure, lightness, architecture as a dress, and anti-monumentality.

Palabras clave: Le Corbusier; Toyo Ito; Máquina; Electrónica; Hanakoganei; Pao I. Keywords: Le Corbusier; Toyo Ito; Machine; Electronic; Hanakoganei; Pao I. 


\section{Era de la Electrónica versus Era de la Maquina}

“Le Corbusier emitió un enorme mensaje hacia el cuerpo de la era mecánica. Mi tarea es traducir estos mensajes a la era electrónica, ésa es la versión de la arquitectura de Le Corbusier con toda su robustez, en líneas simples" Toyo Ito ${ }^{l}$

Toyo Ito (n. 1941) se formó en los años 60, en plena efervescencia del Movimiento Metabolista. Terminó su etapa universitaria coincidiendo con las Olimpiadas de Japón, en pleno apogeo de la figura de Kenzo Tange. Trabajó con el metabolista Kiyonori Kikutake hasta el año 1969. En 1971, tras el fracaso de las ideas utópicas del Movimiento Metabolista en la Expo'70, Ito inició su trayectoria independiente creando su oficina Urban Robot. Era un tiempo de crisis para la arquitectura japonesa, el propio Arata Isozaki afirmaba en aquel momento que 'los arquitectos japoneses ya no tenían futuro'. Mientras que Isozaki enfrentaba la década de manera pesimista, Kazuo Shinohara-considerado anti-metabolista-la veía como una oportunidad para la experimentación a escala doméstica. Pronto Toyo Ito se dejó influir por las ideas 'revolucionarias' de Shinohara, uniéndose a una generación de arquitectos muy críticos con la ciudad como proyecto. Negaron con su arquitectura introvertida no solo la ciudad sino también cualquier relación con la sociedad. A su vez, Toyo Ito criticaba al Metabolismo porque consideraba que sus ideas seguían dentro del ámbito estético de la máquina. Al final de la década, en 1979_coincidiendo la publicación del famoso libro Japan as number one $e^{2}$ - Ito cambió el nombre a su oficina a Toyo Ito \& Associates. Comenzaría así la década de mayor esplendor para el país nipón de la historia moderna, tanto desde el punto de vista económico, como tecnológico y social y por ende arquitectónico.

En plena euforia de la era de la electrónica, cuando Tokio era visto como 'la ciudad del futuro', Toyo Ito se cuestionó la vigencia de las teorías arquitectónicas modernas de principios de siglo basadas en el culto a la máquina. Al igual que Le Corbusier a principios de la década de 1920, Ito se preguntó a principios de la década de 1980, ¿qué clase de arquitectura sería acorde con los desarrollos tecnológicos del momento?.

El 'mundo de las máquinas' ejerció una fascinación particular en la mayoría de los arquitectos modernos. Desde principios de los años veinte, Le Corbusier se apoyó en la estética de la máquina para idear una 'nueva arquitectura'. Coincidiendo con el inició la década, Le Corbusier se asoció con el pintor Amédée Ozenfant y desarrollaron sus Teorías Puristas a través de la publicación de artículos en la revista que ambos fundaron: L'Esprit Nouveau. En 1923 Le Corbusier recopiló sus artículos en un libro titulado Vers une architecture, como introducción a sus teorías acerca de una Nueva Arquitectura en la Era de la Máquina. Lo cual se traducía en la aplicación del taylorismo a la arquitectura doméstica, con su famoso eslogan 'La casa es una máquina para habitar', a la vez que definía el concepto de 'equipamiento' en sustitución de los términos mobiliario y decoración.

En los 80, Japón asumió el liderazgo en alta tecnología, en las áreas de electrónica de consumo, la industria de fabricación del automóvil e incluso robótica. Era el momento de la Era de la Información en una sociedad movida por el consumo. El concepto de información al que se refiere Toyo Ito se encontraba en el corazón de esa

\footnotetext{
${ }^{1}$ Ito, Toyo: "Simple lines for Le Corbusier". En Maffei, Adrea (Ed.): Toyo Ito. Works, projects, writings. Milano: Electa Architecture, 2002. pp. 340-341.

${ }^{2}$ Vogel, Ezra F.: Japan as Number One: Lessons for America. Cambridge, MA: Harvard University Press, 1979.
} 
ciudad cambiante, convertirse en super-Tokio fue la transformación de Tokio en información. Tokio representaba el futuro que Ridley Scott imaginaba en Blade Runner (1982): una ciudad virtual o de individuos virtuales. Poco antes, Paul Virilio en su Esthétique de la disparition (1980), afirmaba que "la vivienda es tan solo la anamorfosis de un umbral. Mal que les pese a los nostálgicos de la historia, Roma no está ya en Roma; la arquitectura no mora en la arquitectura sino en la geometría, en el espacio-tiempo de los vectores; la estética de lo edificado se disimula en los efectos especiales de la máquina de comunicación, artefactos de transferencia o transmisión "’3. Roma estaba entonces en Tokio y así lo reflejaba el cine americano desde principios de los 80 .

En un estado cambiante de las cosas, Toyo Ito se fijó en la fascinación que el 'mundo de las máquinas' ejerció sobre Le Corbusier y asumió que esa relación cercana entre arquitectura y tecnología era deseable. A principios de los años 80, cuando la tecnología de vanguardia era la electrónica, Ito decidió asumir la misión de traducir el mensaje mecanicista de Le Corbusier en la era de la electrónica.

Mientras que Le Corbusier aspiró a concebir 'edificios como máquinas’—donde la forma sigue a la función—, la arquitectura que Ito buscaba diseñar, acorde con la tecnología de la electrónica-donde la relación entre forma y función desaparece-, era una arquitectura sin forma, que se desmaterializaba o incluso desaparecía. Ito aspiraba a proyectar una arquitectura de líneas simples. Con la ambición de 'construir una sociedad de la modernidad', en consonancia con los avances de la industria, basada en la producción y apoyada en la familia, Le Corbusier llegó a considerar a las máquinas modelo para su arquitectura racional y paradigma de belleza. En el mundo acelerado y fluctuante de los 80 en Japón, con una sociedad cada vez más individualista y hedonista, Ito aspiraba a satisfacer los deseos de aquella sociedad consumista gracias a una nueva arquitectura en consonancia con una tecnología que se aproxima a lo virtual. Toyo Ito pretendía proyectar 'la imagen física de la era digital'.

Toyo Ito publicó una serie de artículos, desde mediados de los años 80, donde explicaba sus teorías de nueva arquitectura para la era de la electrónica: "Hacia la arquitectura del viento" (1985), "Una arquitectura que pide un cuerpo androide" (1988), "Un jardín de microchips. La imagen de la arquitectura en la era microelectrónica" (1993) o "Arquitectura en una ciudad simulada" (1991) entre otros. En todos ellos, Ito mencionó reiteradamente a Le Corbusier, evidenciando que su actividad había estado siempre ligada a él, desde su formación universitaria hasta pasados los ochenta. Sin embargo, el momento de transmutación de la arquitectura formalista de Le Corbusier en la arquitectura de líneas simples de Ito fue a lo largo de la primera mitad de la década de 1980. Esta liberación de la rigidez impuesta por las teorías lecorbusierianas se reflejó en los diseños de vivienda de Ito, desde el Proyecto Dom-ino (1980) hasta la Casa en Mamomezawa (1986), con el hito importante de la Casa en Hanakoganei (1983)

\section{Dom-ino de Toyo Ito versus Dom-ino de Le Corbusier}

"Se considera a Le Corbusier el arquitecto moderno más influyente en la historia de Japón"4. Sus teorías mecanicistas rigieron los postulados de la arquitectura japonesa por más de medio siglo. A pesar de que no visitó el país hasta 1955, su filosofía de diseño estuvo presente en Japón desde los años 20, primero a través de sus

\footnotetext{
${ }^{3}$ Virilio, Paul: Esthétique de la disparition. Paris: Balland, 1980. p. 111.

${ }^{4}$ Yatsuka, Hajime: Entrevista personal con Marta Rodríguez. Tokio, 21 de diciembre de 2012.
} 
publicaciones $^{5}$ y más tarde a través de sus aprendices formados en París. Kunio Maekawa, Junzo Sakakura o Takamasa Yoshizaka trabajaron en el Atelier rue de Sèvres; Kenzo Tange se inspiró en el maestro francés para liderar el Movimiento Metabolista; Kisho Kurokawa proyecto su Nakagin Capsule Tower (1972) basado en el sistema que Le Corbusier ideó para la Unite d'habitation de Marsella (1946-1952); formalmente siguió inspirando a arquitectos japoneses desde Kazuo Shinohara hasta Tadao Ando; más velada pero no menos crucial es su huella en la trayectoria profesional de Toyo Ito o Kazuyo Sejima.

Mientras que en los años 70 Toyo Ito siguió postulados próximos a Shinohara, diseñando una arquitectura formalista e introvertida que negaba la ciudad y la sociedad - cuyo ejemplo paradigmático fue la Casa White $U$ (1976)_, en 1980 decide abrirse a la sociedad con su Proyecto Dom-ino. Si la Casa White U se inspiró formalmente en la Villa Saboye (1929)—como Kikutake advirtió6_el Proyecto Dom-ino (1980) de Ito se apoyó conceptualmente en la Maison Dom-ino de Le Corbuiser de 1914.

"Para mí, este proyecto (Dom-ino) fue el punto de arranque para comenzar a revisar una vez más la ciudad que iba cambiando rápidamente, y para considerar de nuevo la arquitectura desde el punto de vista de la vida urbana" Toyo Ito ${ }^{7}$

Justo en 1980 Ito decidió abrirse a la sociedad, buscando 'recuperar la idea de moral urbana' y para ello volvió su mirada a Le Corbusier. La Dom-ino de Le Corbusier aglutinaba sus 'cinco principios de la nueva arquitectura' y encerraba la posibilidad de producción en serie. Ito se interesó en el proyecto de Le Corbusier por el hecho de que ofrecía la oportunidad al usuario de elegir. Consciente del creciente poder femenino en el Japón de los 80 y cuestionado su papel como arquitecto 'autor', Toyo Ito publicó su Proyecto Dom-ino en la revista femenina Croissant $^{8}$. Su entonces becaria Kazuyo Sejima diseñó los folletos de promoción del proyecto, publicado en una revista que en aquel tiempo estaba enfocada a mujeres trabajadoras treintañeras.

El Proyecto Dom-ino de Ito "tenía el propósito de intentar la comercialización de una vivienda pequeña hecha de hormigón armado y bajo coste". . A raíz del éxito de la publicación, Ito diseñó una serie de proyectos, entre ellos la Casa en Koganei (1980) y la Casa en Umegaoka (1981-1982), que continuaban fieles a los postulados estéticos de Corbusier. El único proyecto construido fue la Casa en Umegaoka, similar formalmente a la Maison du Tonkin (1924) — donde por vez primera Le Corbusier puso a prueba su sistema de Dom-ino — y a la Casa Guiette (1926).

\footnotetext{
${ }^{5}$ La obra de Le Corbusier viajó a Japón a través de sus numerosas publicaciones. L'Art décoratif d'aujourd'hui (1925) de Le Corbusier fue traducido por Kunio Maekawa en 1930. Los clientes japoneses se vieron influidos por la arquitectura exterior a través de Kenchiku-zasshi (revista de arquitectura) que ilustraba la arquitectura occidental desde 1913. Para más información consultar: McNeil, Peter: "Myths of Modernism: Japanese Architecture, Interior Design and the West, c. 1920-1940". En Journal of Design History, Vol. 5, No. 4, pp. 281-294.

6 "Hay un collage en el cual se superponía una fotografía de una porción del segundo piso de la villa Saboya con su Casa White U. El dia que White U apareció en las revistas, recibi una llamada de Kikutake quien decía: 'Esa casa es fantástica. Me recuerda a la Villa Saboya.' Esa es la razón por la cree el fotomontaje en el momento de la exposición”. Ito, Toyo. Toyo Ito 1971-2001. Tokyo: TOTO Publishing, 2013. p. 39.

${ }^{7}$ Ito, Toyo: "Líneas Simples para Le Corbusier". En Torres Nadal, José María (Ed.): Toyo Ito, Escritos. Murcia: Colegio Oficial de Aparejadores y Arquitectos Técnicos Librería Yerba, 2000. pp. 151-160.

${ }^{8}$ Croissant, Heibon Shuppan, No. 94, 1981.

${ }^{9}$ Ito, Toyo: "Hacia una Arquitectura del Viento". En Torres Nadal, José María (Ed.): Toyo Ito, Escritos. Murcia: Colegio Oficial de Aparejadores y Arquitectos Técnicos Librería Yerba, 2000. pp. 21-44.
} 
Tras la Primera Guerra Mundial, Le Corbusier se dio cuenta de que la gran prioridad era el realojamiento de la población y para ello era fundamental la racionalización de la construcción a través de viviendas estandarizadas de bajo costo. Esto fue lo que le motivó a desarrollar patentes sobre diversos sistemas de construcción prefabricados de hormigón. El resultado más significativo de este interés fue el llamado sistema Dom-ino (1914), que consistía en una losa horizontal de hormigón lisa, con pilares de hormigón retranqueados desde el borde de la losa, de manera que las fachadas pudieran ser independientes. El sistema implicaba la posibilidad de planificación libre del interior, así como la apertura (o cierre) de la fachada de acuerdo al antojo del usuario. Aquello interesó especialmente a Ito, quien llegó a proponer en su Proyecto Dom-ino (1980) distintas opciones de amueblamiento y de soluciones para la cocina. El Proyecto Dom-ino (1980) supuso el inicio de la ansiada liberación de la manipulación formal impuesta por la función. La Dom-ino de Corbusier pretendía desarrollar 'una nueva moral urbana'; la Dom-ino Toyo Ito trataba de descubrir cómo deberían ser 'las casas de la nueva era'.

Si la Dom-ino de Le Corbusier buscaba afrontar las ruinas de la ciudad tras el desastre de la guerra, el Dom-ino de Ito aspiraba a afrontar las ruinas de las ciudades japonesas tras la crisis de las utópicas propuestas urbanas metabolistas. Toyo Ito, no sólo se inspiró en la patente de Le Corbusier sobre sistemas de construcción prefabricados de hormigón, sino que utilizó el mismo nombre, 'Dom-ino', el cual parece derivar de la combinación de las palabras domicilio e innovación. A pesar de la aspiración inicial de Ito de abrirse a la sociedad y ofrecer libertad al usuario, el Proyecto Dom-ino (1980) derivó en una arquitectura introvertida en relación con la ciudad.

\section{Casa HanaKoganei versus el Diario de Adèle}

"Fue en la primavera del año 83 cuando se terminó la Casa de Hanakoganei. Creo que en esta obra pude, por primera vez, realizar un proyecto sin estar sujeto a manipulaciones formales" Toyo Ito ${ }^{10}$

Durante la construcción de la Casa en Umegaoka (1981-1982), Ito comenzó a diseñar la Casa Hanakoganei (1982-1983). Este proyecto marcó un punto de inflexión en la relación de Ito con Le Corbusier-liberándose de la formalidad impuesta por la máquina-y en la transformación de su obra en líneas simples. A su vez, en la Casa en Hanakoganei, Ito introdujo una serie una serie de estrategias - como la apertura hacia el exterior-que implementaría posteriormente en los proyectos Silver Hut (1983-1984) y Casa en Magomezawa (1985-1986).

Toyo Ito empleó dos sistemas estructurales en la Casa Hanakoganei, uno pesado en la planta baja (hormigón armado) y otro ligero para el resto (madera y metal). Al mismo tiempo, la vivienda estaba compuesta por dos espacios, uno abierto bajo una cubierta en bóveda rebajada, y un espacio cerrado con un tejado a dos aguas. Lo interesante es el espacio abierto, dado que por vez primera Ito utiliza una bóveda y se abre al exterior, tanto a la ciudad como a la naturaleza. Otro aspecto muy interesante que esta vivienda introduce es una componente de temporalidad, tanto en la forma como en la materialidad de la cubierta de la zona abierta. La estructura metálica confeccionaba una cubrición con aspecto provisional, como los hangares o invernaderos, antecedente de las cubiertas de Silver Hut y la Casa en Magomezawa.

\footnotetext{
${ }^{10}$ Ito, Toyo: "Hacia una Arquitectura del Viento". En Torres Nadal, José María (Ed.): Toyo Ito, Escritos. Murcia: Colegio Oficial de Aparejadores y Arquitectos Técnicos Librería Yerba, 2000. pp. 21-44.
} 
Lo intrigante es que, en el año 1984 Toyo Ito publicaba las imágenes y planos de la Casa en Hanakoganei en la revista Japan Architect, junto a un artículo bajo el título “Adéle’s Dream” "11, donde escribía:

"El croquis había sido garabateado en un apartamento en París en un sombrío día de invierno. Un fuerte deseo de un resplandeciente sol y aire fresco debió haber ocupado la mente de Adèle. Mi imaginación comenzó a estimulares. ¿Conocería a Le Corbusier? La sensación provocada por el croquis originó otra similar a la deslumbrante frescura que debió de haber tenido la Maison La Roche de Le Corbusier al concluirse (...)Tratando de crear un espacio abierto, un espacio como el que soñó Adèle, donde fluye abundantemente los rayos de sol y el viento sopla a través como si se tratará del exterior" Toyo Ito ${ }^{12}$

Justo en 1983, Ito inició un grupo de investigación privado en su oficina, junto a otros arquitectos de su generación, que duró hasta 1984. Entre los arquitectos que participaron en aquellas reuniones denominadas Aderu no kai (reuniones Adèle ${ }^{13}$ ) estaban, Itsuko Hasegawa, Kijo Rokkaku, Osmu Ishiyama y Rinken Yamamoto. El objetivo del grupo era reflexionar acerca de mobiliario y nuevos estilos de vida en la ciudad de Tokio. Para ello estudiaron los diseños de una colaboradora de Le Corbusier en los años 20 y 30 en París, "alguien como Perriand", en un café parisino que Le Corbusier y Picasso frecuentaban. La Casa en Hanakoganei era 'la casa soñada por Adèle', cuyos bocetos Ito encontró en su diario.

“Cuando trabajaba para Toyo Ito, él y otros hacían un proyecto ficticio llamado Casa de Adèle (Aderu no ie)" Kazuyo Sejima ${ }^{15}$

El interés de la sociedad japonesa por el interior doméstico en la década de 1980 — fruto del despegue del consumismo del arte de la vida-motivó el redescubrimiento de la figura de Charlotte Perriand entre los arquitectos y diseñadores en Japón ${ }^{16}$. Los arquitectos japoneses buscaban referentes para afrontar el diseño de su arquitectura doméstica y la aportación de la postura de Perriand había sido crucial desde antes de la Guerra ${ }^{17}$. Su papel de arquitecta/diseñadora francesa, colaboradora de Le Corbusier, vínculo entre Occidente y Japón ${ }^{18}$; su

${ }^{11}$ Ito, Toyo: "Adèle's dream; architects: Toyo Ito, Architect and Associates". En Japan architect, 1984 Mar., v.59, no.323, pp. 49-54.

${ }^{12}$ Ito, Toyo: “Adèle's dream; architects: Toyo Ito, Architect and Associates”. En Japan architect, 1984 Mar., v.59, no.323, pp. 49-54.

${ }^{13}$ Adèle Hugo era el nombre de la hija de Victor Hugo, cuya historia de vida real se cuenta en la película "L'Histoire d'Adèle H." (1975).

${ }^{14}$ Ito, Toyo: Entrevista personal con Marta Rodríguez, Tokio, 20 de diciembre de 2012.

${ }^{15}$ Sejima, Kazuyo: Entrevista personal con Marta Rodríguez, Tokio, 25 de diciembre de 2012.

${ }^{16}$ Zenno, Yasushi: Entrevista personal con Marta Rodríguez, Tokio, 27 de diciembre de 2012.

17 "Perriand estableció un verdadero diálogo o intercambio con Japón durante casi medio siglo. Colaboró con Maekawa y Sakakura desde finales de los años 30; con Sori Yanagi, su asistente durante su primera visita a Japón; trabajó con Ren Suzuki, su cooperador después de la guerra; con Kenzo Tange a finales de la década de 1950, en quien dejó una importante huella, llegando a participar en las reuniones previas a la consolidación del Movimiento Metabolista a finales de los años 50; resurgió como importante referente en la década de 1980, llegando a influir en Toyo Ito o Kazuyo Sejima" Rodriguez, Marta: "Transnational Architecture: Charlotte Perriand \& Kazuyo Sejima”. En Gallego, Pedro L. (Ed.): Arquitectura Contemporánea en Japón. Valladolid: Universidad de Valladolid - Fundación Japón, 2015. pp. 47-58.

${ }^{18}$ Aunque normalmente se les atribuye a Sakakura y a Maekawa el papel de emisarios de las teorías de Le Corbusier en 
actitud de integración de las ideas mecanicistas de Le Corbusier con la filosofía del Movimiento Mingei; y su 'vida de arte', se presentaron en los 80 en Japón como nicho de inspiración para la creación de mobiliario, nuevos modos de vida y arquitectura. Entonces, Toyo Ito se fijó en Perriand-quien a principios de 1928 transformó el espacio de la galería de la Maison La Roche de Le Corbusier-coincidiendo con su ambición de crear 'nueva arquitectura' como superación de la era de la máquina y liberación de su 'alter ego' Le Corbusier.

Curiosamente las teorías mecanicista de Le Corbusier tuvieron detractores en Francia, desde principios de los años 30, entre las filas de los miembros de la UAM, instigadas por su propia colaboradora Charlotte Perriand. Las afinidades de apreciación sensual de los miembros de la UAM manifestaban un retorno común a 'elementos sensoriales', en contraste con el dogmatismo rígido impuesto por Le Corbusier ${ }^{19}$. En particular, Perriand, argumentaba que Le Corbusier estaba demasiado interesando en asociaciones estéticas y simbólicas con la máquina, en lugar de enfocarse en la exploración de nuevas posibilidades técnicas o experimentación con las propiedades físicas de los materiales.

\section{Pao I: Icono de la Era de la Electrónica.}

"Fruto de aquella investigación (Aderu no kai), Ito desarrolló su concepto Pao I para la Chica Nómada de Tokio en 1985 " Nagisa Kidosaki ${ }^{20}$

Mientras que el 'problema de la época' en la Francia de los años 20 era 'la producción', en el Japón de los años 80 era 'el consumo'. Le Corbusier describió la 'Casa-Máquina' ${ }^{21}$ como un objeto de producción en masa, inspirado en la industria del automóvil y basado en el mecanismo de la familia. Aplicó un análisis taylorista a los componentes del interior, proponiendo el concepto de 'equipamiento' en sustitución de la palabra mobiliario, con el fin de eliminar lo decorativo del hábitat humano. En el Tokio de los 80, ciudad efímera y provisional, pueblo ficticio, donde la vida parecía pseudo-real, la existencia era nómada. Toyo Ito habló entonces de conceptos como la libertad (individual), la comodidad o el placer, de acuerdo a una sociedad cada vez más hedonista. La Casa Nómada era en realidad la negación de la necesidad de una casa para la sociedad japonesa de mediados de los ochenta, basada en el individuo aislado. Según Toyo Ito, la casa había perdido todo su

Japon, sin embargo, Charlotte Perriand se convirtió en la verdadera embajadora de las ideas del maestro francés en el país nipón, especialmente acerca de arquitectura domestica. Perriand estableció un diálogo o intercambio con Japón durante casi medio siglo. Contratada por el Ministerio de Comercio e Industria Japonés, sucesora de Bruno Taut en Japón, su postura de integración de las ideas mecanicistas de Le Corbusier con la filosofía del Movimiento Mingei se hizo evidente en la exposición Contribución al equipamiento interior de la vivienda, Japón 2601. Selección, Tradición, Creación, que Perriand organizó junto a Junzo Sakakura en 1941. En 1955 - coincidiendo con la visita de Le Corbusier a Japón con motivo del encargo del Museo de Arte Occidental de Tokio, Perrian organizó la Exposición Proposition d'une Synthèse des Arts, París 1955: Le Corbusier, Fernand Léger, Charlotte Perriand. La exposición mostraba la obra de Le Corbusier, junto a la de Fernand Léger y Charlotte Perriand en los grandes almacenes Takashimaya de Tokio y marcó un interés renovado por el arquitecto francés y su obra en Japón. El 'broche final' sería la conferencia que Perriand dio en Japón en 1987, con motivo del centenario de la muerte de Le Corbusier, junto a exposición organizada en su nombre en Tokio. Para más información, consultar: Rodriguez, Marta: "Charlotte Perriand. Un mestizaje Japón-Europa”. En Garcés, Pilar; Terrón, Lourdes (Ed.): Itinerarios, Viajes y Contactos Japón-Europa. Berna: Perter Lang AG, 2013. pp. 775-785.

${ }^{19}$ Para ampliar información, consultar: Constant, Caroline: Eileen Gray. London: Phaidon, 2000. p. 139.

${ }^{20}$ Kidosaki, Nagisa: Entrevista personal con Marta Rodríguez. Berkeley, 10 de agosto de 2012.

${ }^{21}$ La fórmula de las "máquinas de habitar" ayudó a Le Corbusier y algunos otros arquitectos a reconsiderar el diseño y la construcción de la casa. Le Corbusier defendía "el problema de la vivienda es el problema de la época". Le Corbusier: Vers Une Architecture. Paris: G. Cres, 1923. p. 210. 
significado y podría ser únicamente una simple tienda de campaña.

En lugar de la maquina de habitar, Toyo Ito - que compartía con Marshall McLuhan (1911-1980) la idea de que la arquitectura debe funcionar como la forma extendida de la piel—propuso el concepto de la casa nómada o casa como vestido: cubrición o envolvente metálica a la manera de un ropaje. El individuo se liberaba de la rigidez formal y funcional de la casa máquina, dado que simplemente necesita una envolvente ligera. Ito planteó una nueva arquitectura como protección metálica liviana y abstracta que no ejercía presión sobre el cuerpo y superaba el concepto de arquitectura ciborg de Kurokawa y la arquitectura androide de Archigram.

"De Toyo Ito aprendí a concebir la arquitectura como una capa extensión del cuerpo (...) primero pensar de lo que rodea o envuelve al cuerpo, como la ropa, una bufanda, y luego la cubierta de la vida (...) El concepto de Pao era ropa, como una bufanda, un vestido y cubierto con un paraguas" Nagisa Kidosaki $^{22}$

Justo en el ecuador de la década de 1980, Ito diseñó Pao I: Prototipo de instalaciones compactas para la mujer nómada de Tokio. El proyecto se mostró en 1985, con motivo de una exposición en los grandes almacenes Seibu, en la zona comercial de Shibuya en Tokio. Pao I incorporaba tres tipos de '(pre)mobiliario inteligente': para la moda, para el aperitivo y para la inteligencia. La casa explotaba, desaparecía en un sumatorio de muebles inteligentes, que no sólo se abrían a la ciudad sino que se dispersaban por ella: la ciudad era la casa.

El concepto de Pao se movió entre lo real y lo virtual y entre lo primitivo y lo tecnológico. Con la pretensión de la desaparición del objeto arquitectónico, Pao I se fabricó con alambre colgado, anillos de tubo de acero y tela translúcida. La arquitectura se desmaterializaba para albergar a un sujeto con un cuerpo virtual. Pao I (1985) representó el paradigma de la arquitectura de líneas simples, que se caracterizaba por su naturaleza efímera. El proyecto Pao I se convirtió en icono de la era de la electrónica, por tratarse del paradigma de una arquitectura sin forma. Una cubrición, que consistía en un armazón metálico de cables con retales de tela translúcida, permitía una total permeabilidad entre exterior e interior (social y urbana). Era un paraguas que no protegía de la lluvia, del sol o del viento y se alejaba de la formalidad de la Casa Paraguas (1961) de Shinohara.

La abstracción del círculo y lo ergonómico, asociado a lo corporal, estaban en el origen de la concepción de Pao I. Ito utilizó el círculo en un sentido purista, como generador tanto de los objetos como de la cubrición o envoltura de tela, a la manera en la que Le Corbusier, Jeanneret y Perriand lo usaron para diseñar la Chaise Longue $^{23}$. Al igual que Le Corbusier encomendó a Charlotte Perriand el diseño de la Chaise Longue (1928) icono de la era de la máquina ${ }^{24}$ —, Toyo Ito puso a Kazuyo Sejima al frente del diseño de Pao I (1985) — icono de la era de la electrónica- . Tanto Perriand como Sejima posaron como modelos habitando ambos objetos, con el fin de promocionarlos.

\footnotetext{
${ }^{22}$ Kidosaki, Nagisa: Entrevista personal con Marta Rodríguez. Berkeley, 10 de agosto de 2012.

23 "El círculo se utiliza de manera casi obsesiva en un desplazamiento vertical que genera todo el conjunto. Los círculos dialogan con el cuerpo humano, se acoplan, parten de él o lo envuelven. Tanto el armazón como los objetos tienen una dimensión antropométrica y las formas se distancian del cuerpo para permitir su movimiento como un ropaje tridimensional" Rodriguez, Marta: Arquitectura Petite: Charlotte Perriand \& Kazuyo Sejima. Una Historia Transnacional. Directores: Juan Antonio Cortés y Luis A. Gutiérrez. Universidad Politécnica de Madrid, ETSAM, 2013.

${ }^{24}$ Para más información, consultar: Rodriguez, Marta: "Petite Architecture". En Jones, Denna (Ed.): Architecture: The Whole Story. London: Thames \& Hudson, 2014. pp. 460-461.
} 
"Pienso que al cuerpo nómada que flota por el medio urbano de hoy día, el aspecto provisional de la cubrición de este edificio le proporciona sensación de confort cosa que no se obtiene con la arquitectura monumental que perdura" Toyo Ito ${ }^{25}$

Pao I representó la conquista de la arquitectura en era de la electrónica, donde se daba una disociación entre forma y función. Su carácter provisional y ligero implicaba la movilidad, como residencia transportable, de acuerdo a una tecnología digital cambiante. Ito propuso una revolución del espacio doméstico: el espacio privado que se desarrolla en el espacio público. Diseñado para un tipo de vida informal, el de la mujer liberada japonesa que anhelaba un nuevo lugar desde donde posicionarse frente al mundo, su casa se desperdigaba por la ciudad para favorecer el consumo. Aquellos nómadas ${ }^{26}$, a los que Toyo Ito aludía, sólo necesitan su ropa para su deriva a través de la megalópolis de Tokio, su nomadismo era a través de los espacios de la moda y vivían su vida cotidiana como un sueño. La arquitectura de Pao I adquirió la simplicidad a la que Toyo Ito aspiraba, como refugio temporal para los miembros de la nueva sociedad japonesa integrada por nómadas urbanos habitando una enorme desiring machine (Tokio) ${ }^{27}$.

\section{Silver Hut y la Casa en Magomezawa: Arquitectura de Líneas Simples.}

Toy Ito definió el 'cuerpo real' como la suma del ser corporal, y el 'cuerpo virtual' formado por la acción de la información. Mientras que Pao era la vivienda para los habitantes urbanos que disponían de cuerpo virtual, Ito describía en su artículo "Líneas Simples para Le Corbusier" que su intención había sido que "Silver Hut estuviera precisamente en el punto de cruce de la vivienda de los residentes con cuerpo real y, por otro lado, del pao donde viven los nómadas" 28 .

"Es en mi obra Silver Hut donde yo quería que se plasmara, precisamente, la diferencia entre mi obra y la de Le Corbusier" Toyo Ito ${ }^{29}$

Toyo Ito comenzó a diseñar Silver Hut (1983-1984)—su propia casa—poco después de la Casa Hanakoganei (1982-1983). La casa supuso una evolución es su liberación de la formalidad funcionalista lecorbusieriana. Silver Hut se posicionó justo en el solar contiguo de la Casa White U (1976). Frente a un proyecto cerrado, Ito construyó uno abierto a la sociedad y al entorno, con una cubierta que flotaba. La condición desmontable y temporal impregnaba el conjunto, gracias a una estructura, cubierta y cerramiento metálicos. "Ito, por aquel entonces, estaba interesado en la ligereza y en la luz (lightness and light), le interesaba el color plata (silver), el

\footnotetext{
${ }^{25}$ Ito, Toyo: "Una arquitectura que pide un cuerpo androide". En Torres Nadal, José María (Ed.): Toyo Ito, Escritos. Murcia: Colegio Oficial de Aparejadores y Arquitectos Técnicos Librería Yerba, 2000. pp. 45-66.

${ }^{26}$ El concepto 'nómada' inspirará su Restaurante Nómada (1986), escenario idóneo para Blade Runner (1982), construido en sólo dos meses y derribado tras poco más de medio año.

${ }^{27}$ Toyo Ito toma prestado el término nómada y su nueva interpretación a partir de los escritos de los filósofos franceses Gilles Deleuze y Félix Guattari, como Mil mesetas: Capitalismo y esquizofrenia, y lo aplica a las condiciones urbanas japonesas. Para más información, consultar: Bognar, Botond. Beyond the Bubble: The New Japanese Architecture. London: Phaidon Press Ltd., 2008. p. 39.

${ }^{28}$ Ito, Toyo: "Líneas Simples para Le Corbusier”. En Torres Nadal, José María (Ed.): Toyo Ito, Escritos. Murcia: Colegio Oficial de Aparejadores y Arquitectos Técnicos Librería Yerba, 2000. pp. 151-160.

${ }^{29}$ Ito, Toyo: "Líneas Simples para Le Corbusier”. En Torres Nadal, José María (Ed.): Toyo Ito, Escritos. Murcia: Colegio Oficial de Aparejadores y Arquitectos Técnicos Librería Yerba, 2000. pp. 151-160.
} 
cual refleja la luz, da luz y es ligero. De hecho su casa es Silver porque es como el brillo del sol, el color más claro porque es un color brillante, no es blanco o negro, es el color más luminoso „30.

Las aspiraciones de Toyo Ito, a lo largo de media década, tuvieron su culminación en la Casa en Magomezawa (1985-86). Esta casa se liberaba de la formalidad impuesta por la estructura. Un andamiaje provisional construía la imagen final de la casa y generaba espacios de indefinición funcional, a medio camino entre interior y exterior. La Casa en Magomezawa estaba dividida en dos estructuras, una de hormigón enterrada y otra metálica, más ligera y simple que en la Casa en Hanakoganei. A su vez, la fachada como andamiaje provisional y estructural, se disociaba de la forma del edificio, como evolución de Silver Hut. En la Casa en Mogomezawa había una mayor simplicidad en la estructura y la forma desaparecía. "Era una expresión de mi deseo de envolver nuestros cuerpos con ingrávida comodidad, similar a la ropa" "31, afirmaba Toyo Ito. La confusión entre interior y exterior era total, la casa se abría a la ciudad y a la sociedad y se liberaba de la relación entre forma y estructura. El aire y la luz atravesaban el edificio confeccionado por líneas simples. De hecho, se asemejaba a un diagrama construido que aglutinaba todas las características de la arquitectura de líneas simples de Toyo Ito.

Kazuyo Sejima ayudó a Toyo Ito en su misión de traducir la era de la máquina en la era de la electrónica, durante el periodo que va de 1980 a 1986. Ella colaboró en los cinco proyectos que definieron la transfiguaración de 'Le Corbusier en Líneas Simples': Dom-ino, Casa en Hanakoganei, Silver Hut Pao I, y la Casa en Magomezawa. Sejima se había formado estudiando la obra corbuseriana, gracias a su profesor Yuzuro Tominaga (n. 1943). Con Tominaga como director de su tesis fin de master, Sejima se concentró en la realización de copias de 44 proyectos de Le Corbusier, desde sus de casas unifamiliares hasta de sus edificios públicos de gran escala ${ }^{32}$. Conocedora de la obra de Le Corbusier y de Eleen Gray, Sejima no sólo inspiró y estuvo al cargo del diseño de Pao I, sino que también fue responsable del proyecto de la Casa Hanakoganei (la casa para sus padres) ${ }^{33}$. Kazuyo Sejima se interesó por Charlotte Perriand gracias a Toyo Ito y curiosamente inició su carrera profesional independiente en 1987, año en que Perriand dio una conferencia en Japón, con motivo de la exposición "Le Corbusier's Architectural Models".

\section{En resumen}

"No sé por qué pero mi actividad transcurre siempre al lado de Le Corbusier" ${ }^{34}$, así comenzaba Toyo Ito su artículo "Simple lines for Le Corbusier", escrito en 1994. Sin embargo, ya desde principios de la década de 1980, Ito había 'asumido su misión' de idear una nueva estética, de acuerdo con la era de la electrónica y en sustitución de la era de la máquina.

La década de 1980 en Japón, al igual que la década de 1920 en Francia, fue un momento de esplendor económico, desarrollo tecnológico y revolución social, que demandaba experimentación en el ámbito arquitectónico. Le Corbusier y Toyo Ito iniciaron ambas décadas, respectivamente, con la ambición de crear

\footnotetext{
${ }^{30}$ Kidosaki, Nagisa: Entrevista personal con Marta Rodríguez. Berkeley, 10 de agosto de 2012.

${ }^{31}$ Ito, Toyo: Toyo Ito 1970-2001. GA Architect 17. Tokyo: A.D.A. EDITA Tokyo, 2001. p.39.

${ }^{32}$ Akagi, Kanako: Vision and Mission through the Eyes of Kazuyo Sejima. Career and works of a female Japanese Architect. Thesis (MArch). The University of Auckland, 2005. p. 14.

${ }^{33}$ Hattori, Kazuaki: Entrevista con Marta Rodríguez, Tokio, 28 de diciembre de 2012.

${ }^{34}$ Ito, Toyo: "Simple lines for Le Corbusier". En Maffei, Adrea (Ed.): Toyo Ito. Works, projects, writings. Milan: Phaidon Press, 2006. pp. 340-341.
} 
'nueva arquitectura' de acuerdo a los nuevos estilos de vida. A principios de los años 20, Le Corbusier enunció una revolución en la concepción del espacio doméstico: ‘máquinas de habitar' y 'equipamiento', en lugar de casas y muebles. Toyo Ito, por su parte, afrontó la década de los 80 , proponiendo arquitectura para la era de la liberación de ese espacio: 'casa como vestido' y 'pre-mobiliario inteligente'.

En un contexto volátil, la arquitectura de Toyo Ito incorporaba condiciones sensoriales a la vez que se libera de su existencia formal. Se detectan una serie estrategias o características que Ito utilizó para concebir sus edificios, acordes con la era de la electrónica, que definían su arquitectura de líneas simples. ¿Cómo habitar en líneas simples? Sería lo contrario a morar en la caverna que ofrece protección. La arquitectura de líneas simples debía ofrecer libertad! La gran aspiración de Ito fue diseñar una arquitectura sin forma que buscaba desaparecer, para ello, el arquitecto japonés se apoyó en la ambigüedad formal y funcional: si se anula la forma, se anula su relación con la función y viceversa. La materialidad también es un aspecto clave, si la arquitectura se desmaterializa pierde su forma; frente a la formalidad del hormigón, las líneas simples del metal, que confieren translucidez y transparencia. La apertura del interior al exterior y la permeabilidad del objeto ante los agentes atmosféricos o la vegetación también posibilitan la confusión formal. La experimentación a escala doméstica cuestiona la monumentalidad arquitectónica y su durabilidad; temporalidad frente a permanencia, el carácter de provisionalidad de estructuras propias de hangares o de invernaderos así como la idea de habitar la cabaña urbana. Liberación de la relación entre forma y estructura, o estructura como andamiaje temporal que se disocia del espacio habitado y crea espacios intermedios con indefinición formal y funcional. Rotura, no sólo de la fachada, sino también de la cubierta que flota; frente al eslogan lecorbuseriano, "L'architecture est le jeu magnifique des formes sous la lumière" ${ }^{\prime 35}$, la luz y el aire atraviesan los edificios de Toyo Ito. Colores y materiales reflectantes y futuristas: el color plateado refleja la luz, a la vez que es ligero. Finalmente, Ito propone arquitectura como ropa cómoda, "que ejerce la menor presión posible sombre el cuerpo" ${ }^{\text {, }}$, membrana ligera que envuelve al individuo como una cortina.

En última instancia, "'Toyo Ito cambió la manera de diseñar casas en Japón', bajo la convicción de que la casa había perdido su significado. Su proximidad a poderosos diseñadores de interiores fue crucial en su papel protagonista en la aventura doméstica japonesa de la década de 1980",37.

\section{Bibliografía/referencias}

Akagi, Kanako. Vision and Mission through the Eyes of Kazuyo Sejima. Career and works of a female Japanese Architect. Thesis (MArch). The University of Auckland, 2005.

Bognar, Botond: Beyond the Bubble: The New Japanese Architecture. London: Phaidon Press Ltd., 2008

Constant, Caroline: Eileen Gray. London: Phaidon, 2000

Ito, Toyo: “Adèle's dream; architects: Toyo Ito, Architect and Associates". En Japan architect. Vol.59. No.323. Tokyo. Marzo 1984. pp. 49-54.

\footnotetext{
${ }^{35}$ Le Corbusier: L'Art décoratif d'aujourd'hui. Paris: Éditions G. Crès, 1925.

${ }^{36}$ Ito, Toyo: "Silver Hut (1989)". En Ito, Toyo: Tarzans in the Media Forest. London: Architectural Association, 2011, pp. 56-57.

${ }^{37}$ Rodriguez, Marta: "The Domestic Adventure of the 1980s in Japan”. En Proceedings of the SAH Annual Conference in Chicago. Chicago: Society of Architectural Historians, 2015.
} 
Ito, Toyo: "Hacia una Arquitectura del Viento". En Torres Nadal, José María (Ed.): Toyo Ito, Escritos. Murcia: Colegio Oficial de Aparejadores y Arquitectos Técnicos Librería Yerba, 2000. pp. 21-44.

Ito, Toyo: “Líneas Simples para Le Corbusier”. En Torres Nadal, José María (Ed.): Toyo Ito, Escritos. Murcia: Colegio Oficial de Aparejadores y Arquitectos Técnicos Librería Yerba, 2000. pp. 151-160.

Ito, Toyo: "Silver Hut (1989)". En Ito, Toyo: Tarzans in the Media Forest. London: Architectural Association, 2011, pp. 56-57.

Ito, Toyo: Toyo Ito 1971-2001. Tokyo: Toto, 2013

Ito, Toyo: "Una arquitectura que pide un cuerpo androide". En Torres Nadal, José María (Ed.): Toyo Ito, Escritos. Murcia: Colegio Oficial de Aparejadores y Arquitectos Técnicos Librería Yerba, 2000. pp. 45-66.

Le Corbusier: Vers Une Architecture. Paris: G. Cres, 1923

Le Corbusier: L'Art décoratif d'aujourd'hui. Paris: Éditions G. Crès, 1925

Maffei, Adrea (Ed.): Toyo Ito. Works, projects, writings. Milan: Phaidon Press, 2006

McNeil, Peter: "Myths of Modernism: Japanese Architecture, Interior Design and the West, c. 1920-1940". En Journal of Design History. Vol. 5, No. 4. 1992. DOI: 10.1093/jdh/5.4.281. pp. 281-294.

Rodríguez Fernández, Marta. Arquitectura Petite: Charlotte Perriand \& Kazuyo Sejima. Una Historia Transnacional. Directores: Juan Antonio Cortés y Luis A. Gutiérrez. Universidad Politécnica de Madrid, ETSAM, 2013.

Rodríguez, Marta: “Charlotte Perriand. Un mestizaje Japón-Europa”. En Garcés, Pilar; Terrón, Lourdes (Ed.): Itinerarios, Viajes y Contactos Japón-Europa. Berna: Perter Lang AG, 2013. pp. 775-785.

Rodriguez, Marta: "The Domestic Adventure of the 1980s in Japan”. En Proceedings of the SAH Annual Conference in Chicago. Chicago: Society of Architectural Historians, 2015.

Rodriguez, Marta: “Petite Architecture". En Jones, Denna (Ed.): Architecture: The Whole Story. London: Thames \& Hudson, 2014. pp. 460-461.

Rodriguez, Marta: “Transnational Architecture: Charlotte Perriand \& Kazuyo Sejima”. En Gallego, Pedro L. (Ed.): Arquitectura Contemporánea en Japón. Valladolid: Universidad de Valladolid - Fundación Japón, 2015. pp. 47-58.

Virilio, Paul: Esthétique de la disparition. Paris: Balland, 1980

Vogel, Ezra F.: Japan as Number One: Lessons for America. Cambridge, MA: Harvard University Press, 1979 


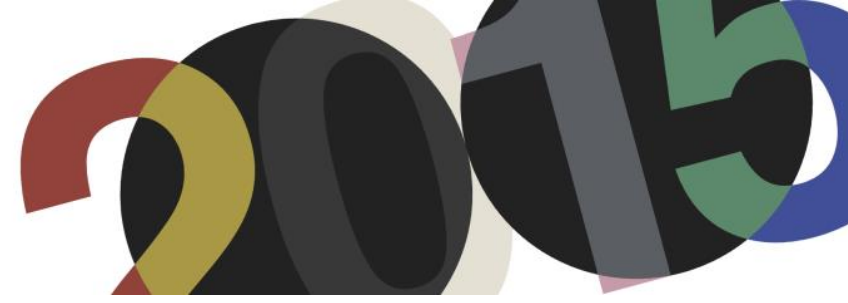

DOI: http://dx.doi.org/10.4995/LC2015.2015.591

\title{
METÁFORAS OBSESIVAS E IDEOGRAMAS [marcas del surrealismo en la construcción del discurso de Le Corbusier]
}

\author{
L. Rojo de Castro
}

Escuela Técnica Superior de Arquitectura de Madrid, UPM

\begin{abstract}
Resumen: El reciente interés académico en el Movimiento surrealista constituye una revisión de largo alcance, habiéndose ampliado el campo de análisis con evidente ambición multidisciplinar. Su estratégica relación con otras disciplinas, la impostación de sus derivas urbanas como prácticas sociales y etnográficas, la profundización en las técnicas de manipulación de la fotografía y la escritura, la naturalización de la fragmentación asociada al montaje y, finalmente, la revisión de la imprecisa naturaleza del objeto surrealista en sus distintas versiones (objet trouvé, objet à réaction poétique, objet-type, ready-made, etc.) y su función seminal en lo contemporáneo, facilitan un escenario de investigación complejo y abierto.

Un escenario en el que la obra de Le Corbusier se dibuja en una nueva perspectiva.

Le Corbusier adoptó técnicas afines al surrealismo, como la fotografía, el montaje y el caligrama, con el objeto de ampliar el significado de los paradigmas asociados a la racionalidad productiva y tecnológica, en particular los que construyen el espacio doméstico. El uso tales medios discursivos y de divulgación asociados con el surrealismo facilitó la contaminación de su discurso con las estrategias desestabilizadoras y conflictivas características del Movimiento.
\end{abstract}

Abstract: The recent academic interest in the surrealist movement is a far-reaching review, having widened the scope of analysis with evident multidisciplinary ambition. Its strategic relationship with other disciplines, the imposture of their urban drifts as social and ethnographic practices, the deepening on the manipulation techniques of photography and writing, the naturalization of fragmentation associated with montage and, finally, the review of the imprecise nature of the Surrealist object in its different versions (objet trouvé, objet à réaction poétique, objet-type, ready-made, etc.) and its seminal role in the contemporary facilitate an open and complex research scenario.

A scenario within which the work of Le Corbusier is perceived in a new perspective.

Le Corbusier adopted techniques related to surrealism, such as photography, montage, automatism and the calligram, in order to expand as well as undermine the meaning of canonical paradigms associated to productive and technological rationality, in particular those related to the domestic milieu. The use of such display of discursive instruments facilitated the contamination of his editorial and architectural work with the destabilizing and conflicting strategies that characterize the Movement.

Palabras Clave: Surrealismo, metáforas obsesivas, montaje, automatismo, analogía, arbitrariedad.

Keywords: Surrealism, obsessive metaphors, montage, automatism, analogy, arbitrariness.

\section{Introducción}

“Todavía vivimos bajo el imperio de la lógica, y precisamente a eso quería llegar. Sin embargo, en nuestros días, los procedimientos lógicos tan solo se aplican a la resolución de problemas de interés secundario." 1

André Breton, 'Primer Manifiesto Surrealista'

1 Breton, André: Manifeste du surréalisme. Paris: Gallimard, 1924. 2ª Ed. 1966. Traducción: Manifiestos del Surrealismo. Visor Libros, Madrid, 2002, pp. 20 
Los Surrealistas reconocieron su hábitat más afín en la ciudad, -París en particular-, apropiándose de sus imágenes para construir el escenario de una transformación radical de la experiencia urbana -de los ciclos cotidianos, la ocupación de los espacios públicos o de la arquitectura como soporte. Expusieron, bajo la aparente continuidad de los hechos, una versión distinta aunque construida de objetos familiares, lugares emblemáticos y fragmentos de la memoria colectiva, esforzándose en revelar la 'anormalidad en la normalidad'.

Ajenos a la utopía o los modelos abstractos, hicieron de la ciudad el laboratorio de sus experimentos, alcanzando un nivel de infiltración al que era difícil sustraerse. Creyeron descubrir en la heterogénea e impredecible actividad del paisaje urbano los elementos para activar otro modo de percepción predicado en la continuidad onírica, la desconexión del automatismo y el azar de los encuentros involuntarios.

Y pertrechados con tales herramientas, se propusieron superar la contraposición entre las cualidades simbólicas y físicas del espacio imaginario frente a las del espacio real o, dicho de otra manera, la oposición clásica entre sueño (irracional) y acción (racional).

Pero, a diferencia de otras Vanguardias, no aspiraron a una transformación material/literal de la realidad que los rodeaba, sino una intensificación de su relación con esta, apropiándose de las técnicas del flâneur y del coleccionista -caracteres urbanos propios de su tiempo moderno- haciendo de la experiencia urbana el soporte de su identidad.

Con tal fin, provistos del ojo mecánico del fotógrafo/voyeur y de las técnicas de des-familiarización del etnógrafo/coleccionista, se emplearon a fondo en perturbar la integridad y estabilidad de los códigos, fueran estos urbanos, sociales, morales o visuales. La experiencia urbana y el desmembramiento de sus soportes simbólicos, iconográficos y semánticos se identifican en el ideario surrealista para construir otra realidad a partir de sus elementos constitutivos -desmembrados, desfigurados o desplazados- por medio de procesos ajenos a la creación o la novedad.

\section{“...el esfuerzo humano, que tiende a variar sin cesar la disposición de elementos existentes, no puede ser aplicado a producir un solo elemento nuevo." ${ }^{2}$}

Las propuestas surrealistas para el 'embellecimiento irracional de París, ${ }^{3}$-cuya vocación era desvelar los escenarios surreales subyacentes bajo la aparente continuidad de las apariencias-, se caracterizan por la constante alteración de sus referencias emblemáticas, así como la desestabilización de su memoria colectiva. La manipulación y el trastorno de lo conocido permitía romper el sistema cotidiano de relaciones -el entorno estable de referencias-, emancipándose del principio de realidad pero sin escapar de la misma.

Así lo ponen de manifiesto los relatos urbanos de Louis Aragon y André Breton. Tanto en Le paysan de París (1926) como en Nadja (1928), los personajes deambulan sin aparente propósito o argumento por una ciudad que se esfuerzan en no reconocer. Una ciudad desmembrada en múltiples fragmentos y sometidos a una azarosa espera, aguardando ser 'descubiertos' [trouvaille], recuperados y, solo entonces, dotados de un nuevo significado y función construido en la azarosa circunstancia del encuentro.

\footnotetext{
2 Breton, André (1924): opus cit

3 Eluard, Paul: 'Sur certaines possibilités d'embellissement irrationnel d'une ville'. Surréalisme au Service de la Révolution $n^{\circ}$ 6. París 1933
} 
Sin embargo, se ha dicho que la arquitectura no formaba parte de las preocupaciones del surrealismo, que sus intereses se centraban en las artes plásticas, la fotografía y la literatura. ${ }^{4} \mathrm{Y}$, aunque es razonable afirmar que no hay una arquitectura surrealista como tal, como tampoco un modo surrealista de hacer arquitectura, recientemente se han aportado instrumentos alternativos para comprender en profundidad la compleja relación entre surrealismo y arquitectura.

Desde este nuevo punto de vista, y a pesar de la inexistencia de una arquitectura surrealista, la arquitectura sería el instrumento adecuado para cuestionar las estructuras estables de las convenciones, la representación, el lenguaje, la ocupación y producción del espacio, de la ciudad y de sus imágenes o la producción de objetos e ideas, las prácticas sociales, la función simbólica de la técnica, etc. ${ }^{5}$

En este nuevo escenario crítico, la arquitectura -la ciudad- no sería el fin en sí mismo sino el instrumento, la herramienta del surrealismo. La arquitectura sería el 'medio' y no el mensaje: tal es el cambio fundamental de paradigma crítico.

Así lo constatan los escritos de Apollinaire, Breton o Aragon, en los que la actividad surrealista se concentra en dos escenarios paradigmáticos del cambio de Siglo: el interior doméstico como instrumento de construcción de la identidad privada, y el paisaje urbano, en el que se expresan y representan los conflictos de una vida moderna en gestación. Y así lo corrobora Walter Benjamín, cuyo escepticismo con el diletantismo surrealista no le impide reconocer la función estructural y alegórica de la desestabilización de ambos paradigmas.

El reciente interés académico en el Movimiento surrealista constituye una revisión de largo alcance, habiéndose ampliado el campo de análisis con evidente ambición multidisciplinar. ${ }^{6}$

Su estratégica relación con otras disciplinas, la impostación de sus derivas urbanas como prácticas sociales o etnográficas, la profundización en las técnicas de manipulación de la fotografía y la escritura, la naturalización de la fragmentación asociada al montaje y, finalmente, la revisión de la imprecisa naturaleza del objeto

\footnotetext{
${ }^{4}$ Nos referimos al 'estado de la cuestión' a final de los 80, cuando la revista inglesa AD publicó un número monográfico sobre arquitectura y surrealismo editado y dirigido por D. Vaseley: 'Surrealism and Architecture'. Architectural Design $n^{o}$ 5\&6. Londres, UK, 1978

5 “... a pesar del aparente desinterés de los surrealistas por la arquitectura, la arquitectura parecería el más prometedor de los instrumentos para una verdadera práctica surrealista." Vidler, Anthony (2003): Fantasy, the Uncanny and Surrealist Theories of Architecture', keynote speech given at the conference "Fantasy Space: Surrealism and Architecture", Manchester, Whitworth Art Gallery, September 12, 2003. El interés de A. Vidler por la relación entre surrealismo y arquitectura viene de lejos, sirva como muestra el libro The Architectural Uncanny: Essays in the Modern Unhomely. Cambridge, Mass: MIT Press, 1992

${ }^{6}$ Sirvan de ejemplo los siguientes libros, listados por orden alfabético: Adamowicz, Elza: Surrealist Collage in Text and Image. Dissecting the exquisite corpse. Cambridge University Press, 1988. Caws, Mary Ann: The surrealist look. An erotic of encounter. Cambridge, Mass: MIT Press, 1997. Clifford, James: The Predicament of Culture. Twenty-Century Ethnography, Literature and Art. Cambridge, Mass: Harvard University Press, 1988. Fijalkowski, Krzysztof: Un salon au fond d'un sac. The domestic spaces of surrealism. Surrealism and Architecture. New York: Ed Thomas Mical, Routledge, 2005. Foster, Hal: Compulsive Beauty. Cambridge, Mass: MIT Press, 1993. Krauss, Rosalind: Corpus delicti, L'Amour fou, New York/London: Abbeville Press, 1985. Krauss, Rosalind: The optical unconscious. Cambridge, Mass: October Book, MIT Press, 1993. Krauss, Rosalind \& Bois, Yve-Alain: Formless. A user's guide. New York: Zone Books. 1997. Malt, Johanna: Obscure Objects of Desire. Surrealism, Fetishisim and Politics. Oxford University Press, 2004. Mileaf, Janine: Please Touch. Dada and Surrealist objects after the readymade. Lebanon, NH: Darmouth College Press, 2010. Tythacott, Louise: Surrealism and the Exotic. New York: Routledge, 2003
} 
surrealista en sus distintas versiones (objet trouvé, objet à réaction poétique, objet-type, ready-made, etc.) y su función seminal en lo contemporáneo, facilitan un escenario de investigación complejo y abierto. Un escenario en el que la obra de Le Corbusier se dibuja en una nueva perspectiva.

Le Corbusier compartió el espacio y el tiempo con los surrealistas, el inquieto París de la posguerra. Pero también las técnicas productivas con las que inundaron el ambiente social, intelectual y cultural de la ciudad: la afición por desplazar objetos y conceptos en el espacio y en el tiempo fuera de su lugar de origen, por forzar la aproximación de realidades dispares y ajenas, o por manipular estructuras estables -como el lenguaje, el marco, la geometría, la anatomía o el espacio doméstico- para erosionar sus fundamentos hasta la desfiguración, pero cuidándose de no perder la referencia de los mismos.

Adoptó otras técnicas afines al surrealismo, como la fotografía, el montaje y el caligrama, con el objeto de ampliar el significado de los paradigmas asociados a la racionalidad productiva y tecnológica, en particular los de la máquina. Y las empleó para construir, finalmente y a través de la edición y manipulación de textos e imágenes en libros, conferencias, revistas y otros medios de divulgación, una versión deformada de su propia obra.

Y es precisamente el uso simultáneo de tal conjunto extenso de medios discursivos y de divulgación, y su particular utilización por el autor, lo que facilitó la contaminación de su discurso con las estrategias desestabilizadoras y conflictivas del surrealismo y que nos proponemos analizar.

\section{El montaje}

Así ocurre en los fotomontajes con los que Le Corbusier ilustra la potencial transformación de la casa y la ciudad -de lo doméstico y lo urbano- con los nuevos principios maquinistas, pero que comparten con el surrealismo técnicas y recursos tanto conceptuales como productivos.

En una sola operación gráfica y literal, el imponente 'Aquitania' se incrusta no sin violencia en la ciudad para demostrar su monumental superioridad como icono y como paradigma: un objeto convexo cuya potente lógica interna, predicada en la flotación, le permite ser independiente del lugar y de su contexto. Y, como consecuencia, las convenciones de la arquitectura se sustituyen por la ley de Arquímedes, un principio matemático universal, racional por definición, capaz de producir 'objetos técnicos' dotados de una coherencia interna autónoma y objetiva.

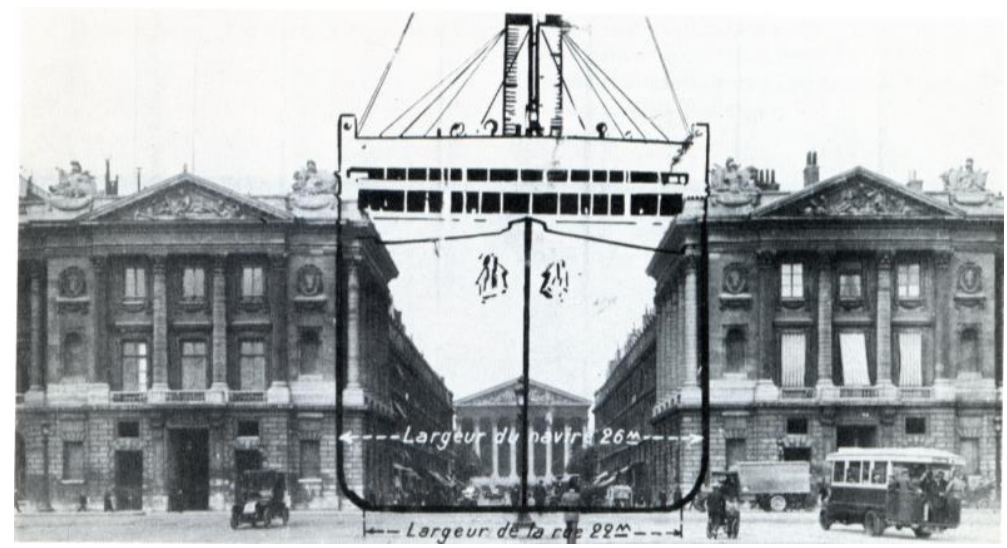

1. Le Corbusier (1935): 'La Ville Radieuse, éditions de l'Architecture d'Aujourd'hui', Collection de l'équipement de la civilisation machiniste, Boulogne-sur-Seine, pag 123 FLC-ADAGP 
Sin embargo, a pesar de la vocación racional contenida en la admiración por el 'parquebote', su imagen superpuesta en la Plaza de la Concordia nos enfrenta a un desplazamiento icónico de gran envergadura cuyas implicaciones exceden las meramente funcionales o tecnológicas.

La fragmentación asociada con esta operación, -el desplazamiento de un objeto fuera de su contexto y su ubicación en un lugar ajeno, fuera de escala y de relación-, traslada a la construcción de la ciudad las técnicas discontinuas del montaje tal y como los concebían los surrealistas: no como operación material sino como una actividad eminentemente semiótica, consistente en la manipulación y desplazamiento de mensajes icónicos y verbales previamente formados o emitidos.

El trasatlántico representa el paradigma de la transformación tecnológica asociada al pensamiento racional: es un producto de la 'ley de la causa y el efecto', en palabras de Le Corbusier. Sin embargo, su abrupta ubicación en la Plaza de la Concordia responde a las técnicas surrealistas del shock, de los desplazamientos oníricos y de la desestabilización de las convenciones físicas, sociales o simbólicas. Y, lo que es más significativo, la desestabilización de la lógica invocada por el propio Le Corbusier.

Y, sí es inevitable relacionarlo con el redimensionamiento de la arquitectura por medio de las leyes de la nueva eficacia industrial y productiva, igualmente ofrece coincidencias sustanciales con las propuestas desestabilizadoras del paisaje urbano realizadas por André Breton y sus compañeros de 'deriva'.

A pesar de sus fundamentales desencuentros con los surrealistas, en los fotomontajes de Le Corbusier puede detectarse una paradójica coincidencia con la máxima de Breton:

“...se considera menos interesante una estatua en un pedestal que en un hoyo." 7

Es decir, la experiencia de todo objeto o cuerpo conocido se ve intensificada como consecuencia del desplazamiento y la descontextualización.

En el fotomontaje realizado para ilustrar el texto 'Tres Advertencias a los señores arquitectos', publicado en el primer número de L'Esprit Nouveau, la imagen del Aquitania se recorta contra le Tour Saint-Jacques, la catedral de Notre Dame, el Arco de Triunfo y la Ópera, precisamente los monumentos elegidos por la revista Le Surréalisme au Service de la Révolution en su cuestionario a los miembros del Movimiento Surrealista para proponer un 'embellecimiento irracional' de París a través de la alteración, modificación o desfiguración de sus monumentos más emblemáticos.

La indirecta respuesta de Le Corbusier al cuestionario de la revista surrealista -al que no había sido invitado a participar- es rotunda: la trivialización de los monumentos enfrentados 'vis a vis' a la imagen imponente y superpuesta de un objeto fuera de lugar y de contexto y cuya coherencia interna no es más relevante que su arbitrario desplazamiento.

Definitivamente, su presencia en la imagen no responde a su funcionalidad como máquina u objeto técnico, sino como icono desestabilizador, como fetiche de significado inestable fruto de la descontextualización y el montaje. Varado en la Plaza de la Concordia, el Aquitania es una ruina contemporánea.

\footnotetext{
${ }^{7}$ Breton, André: Ouvrés complètes II. Paris, Gallimard, 1992. pag 305 [‘...une statue est moins intéressante à considérer sur une place que dans une fosse.']
} 
En el discurso de Le Corbusier, el 'Aquitania' y sus potentes imágenes se asemejan tanto al instrumento técnico predicado en la lógica productiva como al objeto surrealista descrito por Breton:

"En cuanto a la experiencia del objeto, su significado convencional se subordina a su valor dramático, es decir, a su poder de evocación y su imagen más pintoresca." 89

Contaminada por los modelos del objet chance y el automatismo, la analogía, en manos de los surrealistas, abre el discurso al azar de las relaciones arbitrarias, pero controladas dentro de los límites estructurales de una sintaxis o de una anatomía, poniendo de manifiesto que su propósito no es mostrar conexiones o parecidos existentes -por poéticos que estos sean-, sino construir otros sistemas de relaciones que des-familiaricen, transformen o modifiquen nuestra percepción y entendimiento del mundo que nos rodea sin necesidad de alterarlo físicamente.

Aragón escribe en 'El desafío a la pintura' (1930):

"Una lámpara eléctrica se transforma para Picabia en una jovencita. Aquí vemos que los pintores utilizan los objetos verdaderamente como palabras." 10

No se trata, sin embargo, de un mero intercambio de objetos o de su mecánico desplazamiento en el espacio, en el tiempo o en la imaginación. Estamos ante la distorsión de los códigos de significación, como afirma Foucault, hasta el punto de superar las diferenciaciones más fundamentales entre la imagen y la palabra, precisamente aquellas que le permiten a Le Corbusier hablar y dibujar simultáneamente, expresarse indistintamente con textos y figuras, con formas y palabras, ideas e ideogramas.

La manipulación del Aquitania adelanta la aplicación de las técnicas del montaje y la distorsión de la analogía no solo a la construcción de la realidad y de la ciudad, sino también y fundamentalmente, del discurso. Por ello, no pueden ser reducidas a meras analogías maquinistas ni figuras poéticas.

En una inadvertida coincidencia con las técnicas surrealistas, las imágenes construidas por Le Corbusier visuales, literarias o metafóricas-, y puestas en circulación en libros, conferencias y revistas, no se soportan en parecidos o continuidades reales, sino en la construcción, por medio de las técnicas del montaje, de conexiones visuales o semióticas que, por su naturaleza imprevista o arbitraria, incentivaran relaciones potenciales ajenas a los objetos y su función, a su identidad u origen.

"La imagen es una creación pura del espíritu, y no puede nacer de la comparación sino del acercamiento de dos realidades más o menos lejanas. Cuanto más lejanas y escasas las concomitancias entre ambas realidades objeto de aproximación, más fuerte será la imagen..." 11

\footnotetext{
8 Le Corbusier: Vers une architecture. París: Flammarion, 1923. Reeditado 1991, pag 92

9 Breton, André: Surrealism and Painting. París: Editions Gallimard, 1928. MFA Publications, Boston 2002

10 Aragon, Louis (1930): Los collages. El desafío a la pintura. Madrid, Editorial Síntesis,

11 Reverdy, Pierre: Nord-Sud No Marzo, París, 1918
} 
Los surrealistas se caracterizan por intensificar la experiencia por medio de relaciones metafóricas y metonímicas en las que las intersecciones analógicas construidas entre los elementos tienden a cero. Y es precisamente la falta de coherencia entre los elementos involucrados en la relación analógica lo que obliga al espectador a comprometerse, y a la realidad a deformarse.

Una intensificación de la experiencia que diseminan tanto por el espacio de la ciudad como del conocimiento, a la producción de imágenes y de textos, en la poesía y en la conversación de café. Y, como consecuencia de esta práctica, barcos y ciudades, coches y casas, urinales y objetos domésticos, tipografías, titulares y fragmentos de catálogos comerciales se ensamblan inesperadamente en un discurso construido de conexiones cuya arbitrariedad es altamente productiva.

"La llave de la prisión mental solo se encuentra en las rupturas que nos traen otros modos irrisorios de conocer: reside en el juego libre e ilimitado de las analogías...", escribe Breton. ${ }^{12}$

Las imágenes construidas por Le Corbusier se apropian de tales mecanismos, construyendo la nueva arquitectura con medio de fragmentos literalmente extraídos de otras áreas o disciplinas ajenas a la arquitectura, objets trouvés procedentes de escenarios tan dispares como la producción industrial, los nuevos útiles de oficina, la ingeniería naval o los artefactos más precisos producidos por la tecnología bélica. Conexiones improbables, incluso forzadas, cuya extrema potencia icónica, procedente de una obsesión recurrente, se asocia con la inestabilidad semántica propia de la paradoja y ajena a la razón.

Bajo la influencia de la sensibilidad surrealista, tanto la vida urbana de París como el discurso de Le Corbusier se saturan de fetiches, objetos cuyo significado trasciende su cualidad y apariencia material, su función aparente o convencional, para convertirse en iconos sometidos a constante deformación.

\section{El caligrama}

La página 27 del libro Une Maison, un Palais $(1928)^{13}$ muestra una fotografía del lago Leman tomada desde el aire. En ella se muestran una vía del ferrocarril que corre paralela y junto al lago, la superficie plana del agua y la densa red de bancadas escalando la montaña. Al fondo un imponente pico rocoso se levanta cerrando con rotundidad el espacio de la fotografía. En el centro de la imagen un barco atraviesa la neblina, navegando junto a la orilla por la que discurren las vías del tren.

Al pie de la foto Le Corbusier escribe: 'une maison'. Sin embargo, en la imagen no aparece una casa. De hecho, la arquitectura como tal está ausente.

\footnotetext{
${ }^{12}$ Breton, André: Le Surréalisme et la peinture. París, Gallimard, 1965. ['La clé de la prison mentale ne peut être trouvée qu'en ruptures avec ces façons dérisoires de connaître: elle réside dans le jeu libre et illimité des analogies.']

${ }^{13}$ Le Corbusier: Une Maison-une Palais. París: Editions Convences, 1928
} 


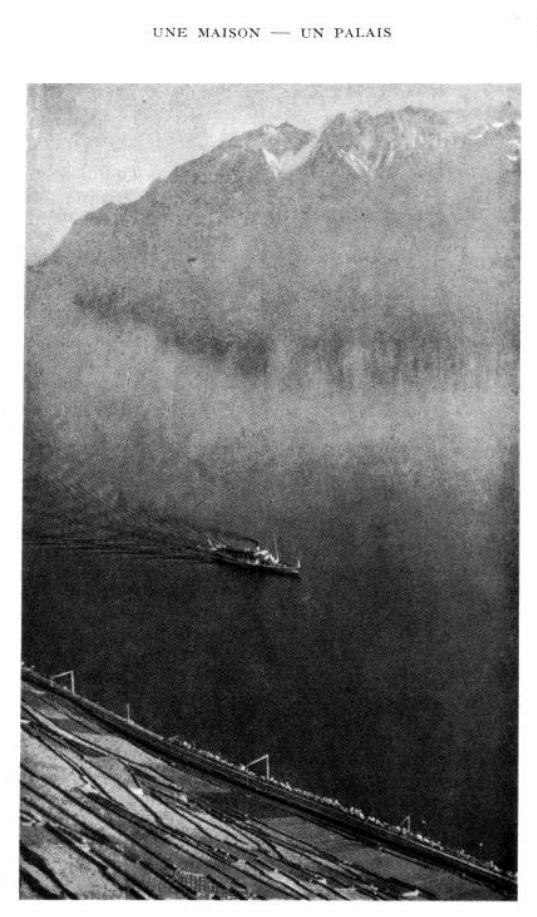

2. Le Corbusier (1928) 'Une Maison, un Palais’ Éditions Crès Collec. "L'Esprit Nouveau", Paris, pag 27 FLC-ADAGP

Las dos palabras escritas bajo de la fotografía nos enfrentan a una paradoja similar a la planteada en el caligrama 'la trahison des images (1928) ${ }^{14}$, cuidadosamente delineado por Magritte.

La aparente continuidad entre ambos medios de expresión -imagen y texto-, confiada a la figura integradora del marco que las contiene -la página del libro-, revela una primera y fundamental fractura: aquello que aparece en la imagen no es una casa, es un barco. Si Magritte escribió bajo el dibujo de la pipa "ceci n'est pas une pipe", aquí debería escribirse, con la misma letra redonda y escolar, "ceci n'est pas une maison."

Atendiendo al exhaustivo análisis realizado por Foucault, ${ }^{15}$ el mensaje del caligrama, icónico y enfático, nos enfrenta con la duda de sí estamos llamados a mirar o a leer para, finalmente, darnos cuenta que el mensaje no está completo, ya que carece de suficiente unidad y articulación para ser descodificado de forma clara y unívoca. El 'espacio coherente de la lectura' se ve alterado por la analogía construida entre el barco y la casa, en la que las intersecciones entre los elementos comparados son mínimas, la conexión tan tenue que debe ser necesariamente intensificada por el lector.

Estamos, de hecho, ante una metonimia disociativa, una metáfora obsesiva construida entre dos objetos a pesar de sus fundamentales diferencias: la casa y el transatlántico. El uno, estable y estático; el otro, ajeno a un lugar y en constante movimiento; el primero, un instrumento básico en la formación material, social y cultural de la identidad y la memoria colectiva; el segundo, un artefacto tecnológico predicado en la eficacia técnica y la inestabilidad propia de la flotación.

\footnotetext{
${ }^{14}$ René Magritte, 1928. Óleo sobre lienzo. 63 x $93 \mathrm{~cm}$. Los Ángeles County Museum of Art, LA

15 Foucault, Michel: Ceci n'est pas une pipe. Montpellier: Fata Morgane, 1973. Traducción: Esto no es una pipa. Barcelona, Editorial Anagrama, 1981
} 
Si nos atenemos al parecido en la localización - una casa en la orilla del lago-, podemos aventurar que Le Corbusier está pensando en la Petite Maison. Sin embargo, no son más que especulaciones que intentan cerrar la fractura inscrita en el caligrama, reconstruir una continuidad entre texto e imagen para cerrar la incertidumbre que se cierne sobre el lenguaje mismo.

Para aquellos 'ojos que no ven' ${ }^{16}$ la contradicción contenida en el caligrama facilita la intensificación del mensaje a través de la doble condición icónica y metonímica del barco, cuya función es iniciar una cadena de asociaciones, directas e indirectas, con otros objetos o ideas, introduciendo un alto grado de indeterminación a pesar de su potente concreción física.

La analogía así concebida está inscrita en la raíz del surrealismo, caracterizada por multiplicar exponencialmente las relaciones al no requieren del fundamento de un parecido o de una conexión estructural. La analogía surrealista potencia la arbitrariedad en las conexiones para intensificar el significado, adentrándose en terrenos vedados al control de las convenciones disciplinares o de la razón. Y, siguiendo de hecho las técnicas del 'Cadavre Exquis', ${ }^{17}$ permite construir un cuerpo híbrido formado con partes inconexas, más propio del autómata que de la máquina.

Perdida la necesidad de una justificación intrínseca o extrínseca en la analogía, el poeta surrealista Paul Eluard estaría en lo correcto: Todo es comparable a todo.

Y así ocurre en la portada del segundo capítulo de L'Art décoratif d'aujourd'hui (1925), donde el montaje de imagen, tipografía y texto no deja lugar a la duda: la maquetación de la página guarda las marcas de la edición comercial contemporánea -los catálogos de venta que interesaron tanto a Max Ernst como a Le Corbusier, pero también las marcas del surrealismo: los recursos del collage y la escritura automática que permiten unir 'sobre un soporte inapropiado ${ }^{18}$ diversos medios de expresión y técnicas de representación para provocar relaciones fortuitas e inconexas capaces de desvelar y transmitir ideas con mayor rotundidad.

La edición de L'Art décoratif d'aujourd'hui conserva las marcas provenientes de las agrupaciones indexadas de los catálogos comerciales que construyen el discurso por agregación, así como de la construcción de mensajes icónicos propios de la publicidad urbana y la prensa diaria, o de la naturalización del montaje a partir de fragmentos de la ciudad moderna.

Pero, en su potencia y refinamiento, muestra igualmente las marcas del surrealismo: La apariencia de una sintaxis en la tipografía, el orden vertical de la lectura y la potente figura del marco anuncian una legibilidad que finalmente no se proporciona, poniendo en cuestión las convenciones de la lectura, la sintaxis y el marco.

La sinuosa figura del bidé introduce, en el discurso institucional del museo y de las artes decorativas, un objeto cotidiano vinculado al espacio privado del aseo, la representación de las formas antropomórficas y al cuerpo femenino - el fetiche surrealista por derecho.

\footnotetext{
${ }^{16}$ Le Corbusier (1923): Ibid. pag 65

${ }^{17}$ Brotchie, Alastair: A book of Surrealist games. London: Redstone Press, 1991.

${ }^{18}$ Lucien Duchase, Isidore, Conde de Lautréamont (1896): Los Cantos de Maldoror, Madrid: Editorial Pretextos, 2000
} 
El bidé - un signo aislado que flota en la superficie blanca de la página- posee las cualidades de 'objet trouvé, operando simultáneamente como 'objet type' -predicado en la racionalidad del objeto instrumental- y como fetiche sexual -asociado a la irracionalidad incontrolada del subconsciente.
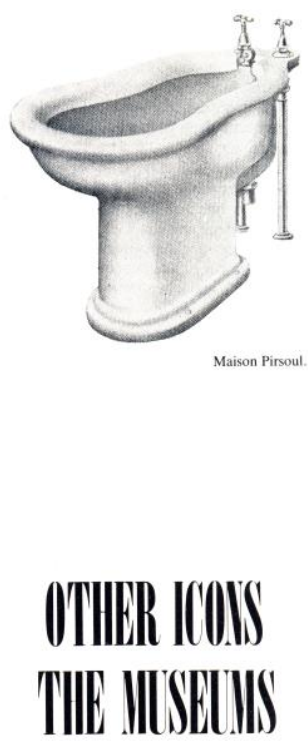
There are good museums, and bad. Then there are those with the good and
bad together. But the museum is a sacred entity which debars judgement.

3. Le Corbusier (1925) 'L'Art décoratif d'aujourd'hui', Éditions Crès, Collec. "L'Esprit Nouveau” pag 15 FLC-ADAGP

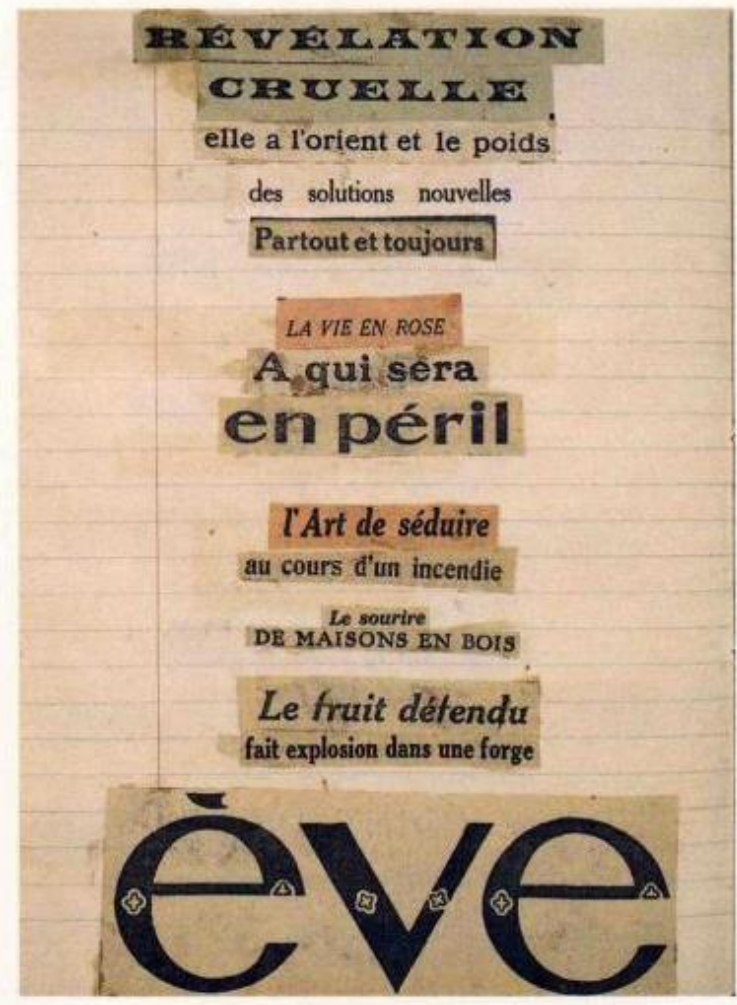

4. André Breton (1924): 'Poème' 
Entendido como 'objet type', reafirma las cualidades instrumentales y funcionales de los objetos racionalmente concebidos como 'extensión' y suplemento de la anatomía del cuerpo y fabricados con las técnicas productivas características de la industrialización; como 'fetiche', representa la difícil construcción de la identidad privada en el espacio público y abierto de la nueva arquitectura y de la transparencia social.

Su presencia en la página como icono capaz de desestabilizar la institución del museo es el resultado de un desplazamiento desde el espacio privado de lo doméstico, asociado al cuerpo femenino, al discurso disciplinar de la arquitectura contemporánea, pero aún lo es más la desconexión entre la imagen y el texto situado al pié de la imagen: "Outres icones. Les musées" [Fig 3]

No en vano, el bidé es uno de los 'objetos contemporáneos' que deberían exhibirse en el 'verdadero museo', tal y como lo describe Le Corbusier en L'Art décoratif d'aujourd'hui. El verdadero museo es un fragmento de la realidad formado, a su vez, de otros tantos fragmentos, un instante de la ciudad en el que se acumulan los instrumentos de la vida diaria.

\section{"Un lugar que lo contenga todo", 19}

Su colección no está formada por obras de arte, objetos valiosos o piezas excepcionales. Muy al contrario, acumula sombreros y zapatos junto a bombillas, bidets y sillas Thonet.

El Museo imaginado por Le Corbusier es más parecido al mercadillo de Saint-Ouen que al Louvre. O quizá su modelo fuera el Museo Etnográfico del Trocadero, cuya colección de artefactos tribales constituía, al igual que el mercadillo, el modelo alegórico surrealista no solo de la experiencia de lo urbano, sino de toda experiencia. Ambos lugares, el Trocadero y Saint-Ouen, fueron los verdaderos laboratorios de experiencias surreales.

Los libros escritos, montados y editados por Le Corbusier, a pesar de su pedigrí racionalista y enérgica voz de manifiesto a favor de la transformación de la realidad con los nuevos procedimientos industriales de producción y reproducción, se muestran finalmente contaminados por las técnicas del surrealismo: las conexiones paradójicas, el montaje y el azar automático.

Así ocurre en la página 31 de Ver une architecture. ${ }^{20}$ Su edición se asemeja a los poèmes objet, 'construidos' en el círculo de Breton como juegos colectivos usando frases sueltas y descontextualizadas, titulares de periódicos o proverbios, unidos azarosa o automáticamente. Es el caso de Poème, ${ }^{21}$ formado por agregación de frases impresas, tomadas de libros y periódicos, cortadas y pegadas sobre el papel. [Fig 4]

El uso de la yuxtaposición como mecanismo dominante dificulta la intención inicial de 'leer' el poema como unidad lingüística y de significado, tropezándonos constantemente con sus fracturas materiales y semánticas. El

\footnotetext{
${ }^{19}$ Le Corbusier: L'Art décoratif d'aujourd'hui. París : Editions G Cres, 1925. pag 17

${ }^{20}$ Le Corbusier (1923): Ibid

21 Breton, André (1924): Poeme. Según Alastair Brotchie (1991), el 'poème objet' es uno de los juegos surrealistas, en parte como escritura automática y en parte como objeto surrealista. Como tal, se define como un poema en el cual una parte de los términos o elementos son tratados como objetos, en lugar de cómo palabras. También puede considerarse como la aplicación de la técnica del 'cadavre exquis' a la escritura o la construcción de un texto.
} 
collage surrealista es, en definitiva, una actividad eminentemente semiótica -más que una operación material o formal- consistente en la distorsión de mensajes icónicos y verbales previamente formados o emitidos.

Aun siendo paradójico, puede afirmarse que la lógica aplastante del discurso maquinista de Le Corbusier se construye con técnicas compartidas con los collages surrealistas de Max Ernst y de la escritura automática propuesta por Breton: uniendo fragmentos extraídos directamente de la realidad, de los catálogos comerciales e industriales, de imágenes icónicas del pasado, aproximadas en una aparente continuidad que no deja trazas de sus fracturas, predicada no en la articulación coherente sino en la conexión arbitraria.

\title{
4. La analogía
}

En el Primer Manifiesto del Surrealismo, publicado en 1924 y contemporáneo de los textos en L'Esprit Nouveau, André Breton aborda la tarea de describir las cualidades de las imágenes surrealistas.

\begin{abstract}
"Los innumerables tipos de imágenes surrealistas exigen una clasificación', escribe Breton. 'No voy a ocultar que para mí la imagen más fuerte es aquella que contiene un alto grado de arbitrariedad, aquella que más tiempo tardamos en traducir a lenguaje práctico, sea debido a que contiene en si una enorme dosis de contradicción, sea a causa de que uno de sus términos esté curiosamente oculto, sea porque tras haber presentado la apariencia de ser sensacional se desarrolla débilmente, sea por porque de ella se derive una justificación formal irrisoria, sea por que pertenezca a la clase de las imágenes alucinantes, sea porque preste de un modo muy natural la máscara de lo abstracto a lo que es concreto, sea por todo lo contrario, sea porque implique la negación de alguna propiedad física elemental, sea porque dé risa." 22
\end{abstract}

En su deambular por la ciudad, el fotógrafo surrealista -mitad flâneur mitad coleccionista- intensifica la atención sobre lo que le rodea, iluminando en encuentros fortuitos objetos capaces de reavivar una imagen, un destello, un recuerdo, un temor o una obsesión.

La fotografía es el instrumento para capturar aquellos fragmentos de la realidad que operan como agitadores de la conciencia, de la memoria y de las convenciones. Al igual que la 'escritura automática', la inmediatez mecánica de la fotografía, ajena a las limitaciones de la representación, se emplea como mecanismo de introspección que facilita la exposición de los conflictos entre objeto y sujeto, entre el ciudadano y la ciudad, o entre el hombre y la nueva civilisation machiniste.

Fotografía y escritura automática permiten ver y escribir sin las limitaciones de una construcción cultural o social. Por ello, Breton afirma:

\section{"La escritura automática es la verdadera fotografía del pensamiento." 23}

El ojo de Brassaï constituye un ejemplo paradigmático de la visión surreal de la ciudad. Y no sólo por su afición a retratar aspectos sórdidos y ambientes marginales de la ciudad: sus imágenes introducen un modo de mirar contrario a toda naturalidad.

22 Breton, André: Manifeste du surréalisme. París: Gallimard, 1924

23 Bretón, André (1924): Ibid 
Se apropia de escenas y objetos que encajaban intencionadamente en la categoría del cliché urbano o doméstico, forzando su desfiguración o tornando irreconocible lo familiar -bien por el exceso de proximidad, por la tergiversación del punto de vista o centrándose con tal grado de detalle, de obsesión, sobre los objetos, que es imposible reconstruir su contexto-, alterando los soportes de la memoria colectiva y de la identidad.

El ojo de Brassaï -su cámara- no actúa como un órgano biológico predispuesto a restituir una razón coherente en la apariencia de las cosas, sino como una máquina de aislar, desmembrar y fragmentar, enfrentándonos a un enigma tras otro.

En sus manos, la fotografía es un mecanismo de trastornar, turbar y conmover, "une machine à bouleverser le monde, ${ }^{24}$ en palabras de Aragon.

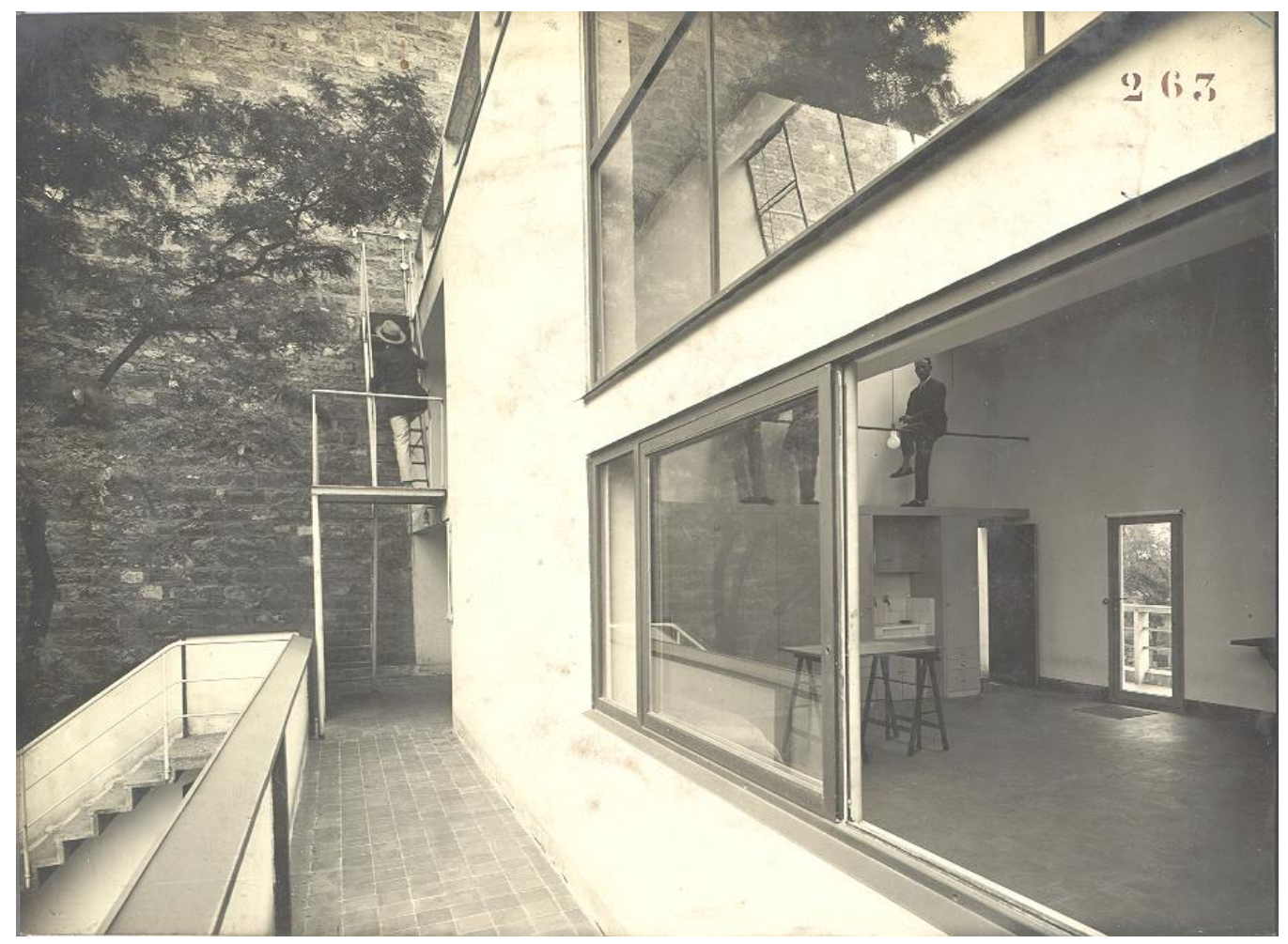

5. Le Corbusier + Jeanneret_Maison Planeix (1929) en 'L'Architecture Vivante' $3^{\mathrm{e}}$ série, printemps, Editions Albert Morancé, París (1930) FLC-ADAGP

El ojo de Le Corbusier reproduce la misma pauta. Su mirada, intencionada y oblicua, deforma la realidad a través de las imágenes con la intención de alterar su recepción y comprensión, simulando una nueva versión a partir del original.

La fotografía de la fachada interior de la Maison Planeix (1927/29), publicada por Morancé (1930), nos introduce en un espacio confinado y sin horizonte. La sensación es la de estar en un recinto interior, confinado como una habitación. El plano vertical divide la imagen en dos partes equivalentes. A la derecha, el estudio; a la izquierda, el jardín. Como sí de una imagen especular se tratara, ambos lados se compensan en la fotografía,

\footnotetext{
24 Aragon, Louis (1923) Le grande saison Dada. Opus Internacional 123-24 (Abril-Mayo 1991), pag 109 [Una máquina de trastornar (conmover) el mundo]
} 
fomentando la idea de una duplicación, de una equivalencia intensificada por la transparencia de las ventanas. Incluso las figuras de los personajes que parecen flotar en el aire como acróbatas, elevados sobre el suelo y a la misma altura, responden a la simetría especular de un reflejo. [Fig 5]

La mirada de Le Corbusier no es frontal sino oblicua. El ojo -la cámara- se ha situado próximo a la pared, mirando simultáneamente dentro y fuera del Estudio a través de la ventana. Y debido a la oblicuidad de la mirada y su sesgada perspectiva, ambos espacios, el interior del estudio y el exterior del jardín, se perciben como semejantes, continuos e interiores.

El marco y el punto de vista anulan las diferencias, equiparándolos a pesar de sus evidentes diferencias, intensificando la simetría y la continuidad entre ambos, haciéndonos creer que podrían ser alternativamente exteriores o interiores, pero no distintos entre sí.

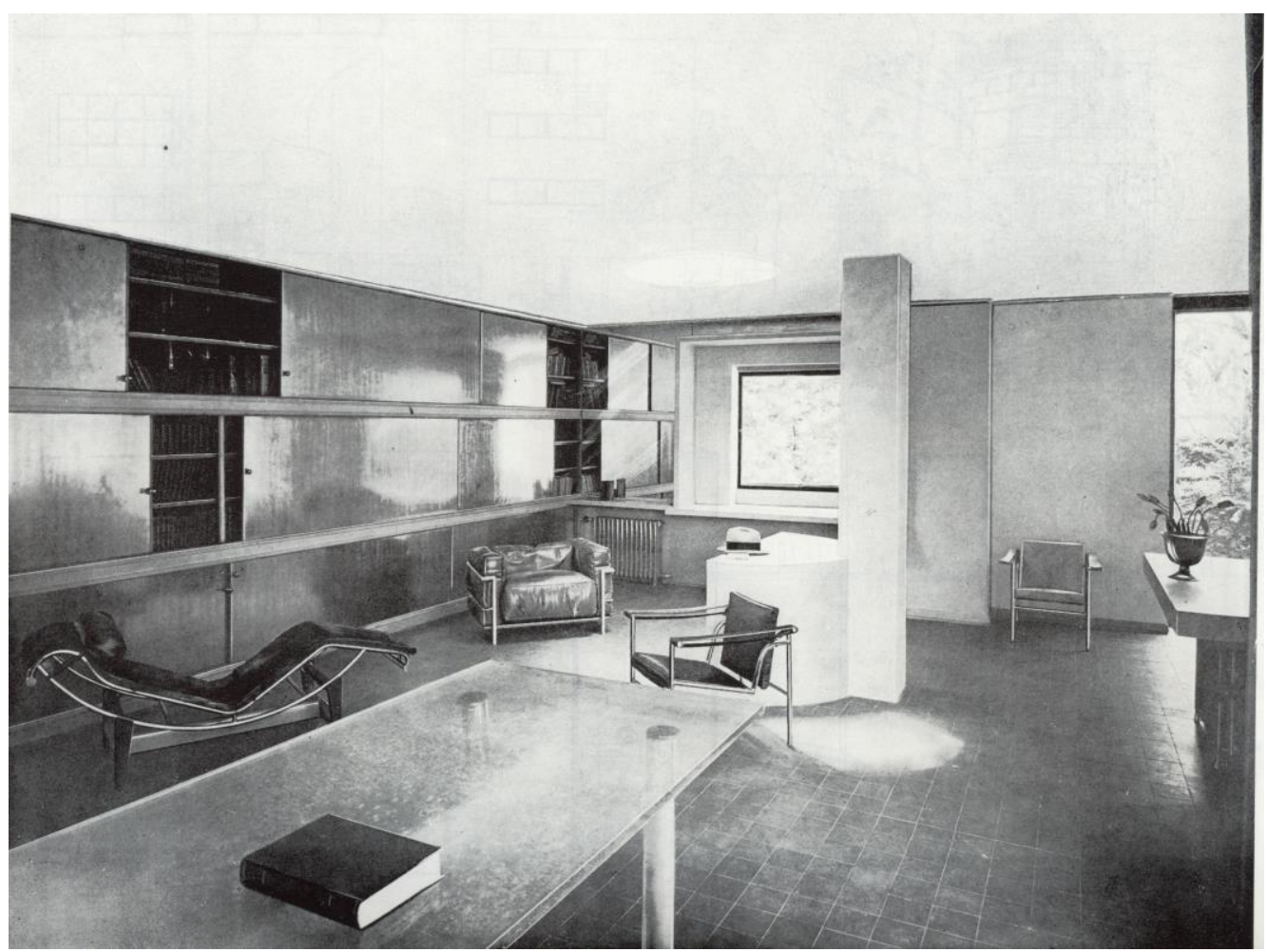

6. Le Corbusier + Jeanneret_ Ville D'Avray, (1929) en 'L'Architecture Vivante' $3^{\mathrm{e}}$ série, printemps Editions Albert Morancé, París (1930) FLC-ADAGP

Si estamos ante una implementación del aforismo "el exterior es siempre un interior," ${ }^{25}$ no lo es con carácter metafórico o poético sino paradójico. Entregadas a la búsqueda de lo sublime en lo real, siguiendo la máxima de Aragon, las imágenes surrealistas no son descriptivas sino interrogativas: “...si la realidad es la ausencia aparente de contradicción, lo sublime es la manifestación de la contradicción en la realidad."

La fotografía de Maison Planeix elegida por Le Corbusier para su primera publicación en L'Architecture Vivante pertenece a la categoría de lo interrogativo, empeñada en la desestabilización de las categorías y las

25 Le Corbusier (1923): Ibid. pag 154 ['Le dehors est toujours un dedans. '] 
convenciones. La doble condición fenomenológica y conceptual simultáneamente asignada a los espacios en la fotografía -cerrados y abiertos, interiores y exteriores, continuos y discontinuos- coincide con la preferencia de Breton por aquellas imágenes que "contienen en si una enorme dosis de contradicción, sea a causa de que uno de sus términos esté curiosamente oculto..."

En la fotografía de la biblioteca de la Ville d'Avray (1928/29) publicada en la Oeuvre complète Le Corbusier intensifica de nuevo la manipulación de la realidad física a través de su reproducción fotográfica. A la derecha, un ventanal de suelo a techo sin carpintería se abre sobre el jardín. Es el paradigma de la transparencia, el 'pan de verre', el muro de vidrio por definición. Sin embargo, muy próximo y a su izquierda, una ventana rectangular -su alter ego- enmarca una vista sobre el jardín. [Fig 6]

El marco exento encuadra la imagen como si de un lienzo se tratara, y través del vidrio, la vista sobre el jardín se recorta como un paisaje tradicional. Sin embargo, en la fotografía el marco flota en la pared. Parece no tener trasera, no apoyar en una pared, no tener soporte: es, en realidad, un efecto visual, un engaño provocado por el espejo con que Le Corbusier ha empanelado la pared. Y, como consecuencia, la vista sobre el jardín a través del marco de la ventana se torna engañosa: en la fotografía, detrás de la pared no parece haber un jardín sino otra habitación -otro espacio interior-, equivalente e igual que la habitación en la que estamos.

El encuadre, cuidadosamente elegido por Le Corbusier, ${ }^{26}$ enfatiza el equívoco, aprovechando la ambigüedad para acentuar la doble condición abierta y cerrada de la habitación. En esta ocasión, un espacio interior que se 'representa como si fuera exterior', como si careciera de algunos de sus límites -el techo, la pared, etc.

Estamos ante un efecto óptico, un trompe l'œil. El prominente marco de la ventana -una representación de la ventana tradicional y una analogía de la representación pictórica-, flota artificiosamente en el espacio reflejado de la habitación como una imagen dentro de otra imagen.

La fotografía de la Biblioteca de la Ville d'Avray comparte con los collages en 'Une semaine à bonté,27 mecanismos de manipulación de la percepción, enfrentándonos a contradicciones visuales cuyo objetivo trasciende más allá de la crisis de los sistemas de representación, llegando a cuestionar la naturaleza del espacio interior o su capacidad para representar la identidad privada del sujeto. [Fig 7]

${ }^{26}$ Existen diversas versiones de esta imagen, tomadas desde diversos puntos de vista pero muy próximos entre si. Algunas revelan el engaño o trompe l'oxil y otras lo ocultan.

27 Ernst, Max (1934): Une semaine à bonté: The Original Collages. Catálogo de la exposición, Museo de Orsay, Paris 2006 


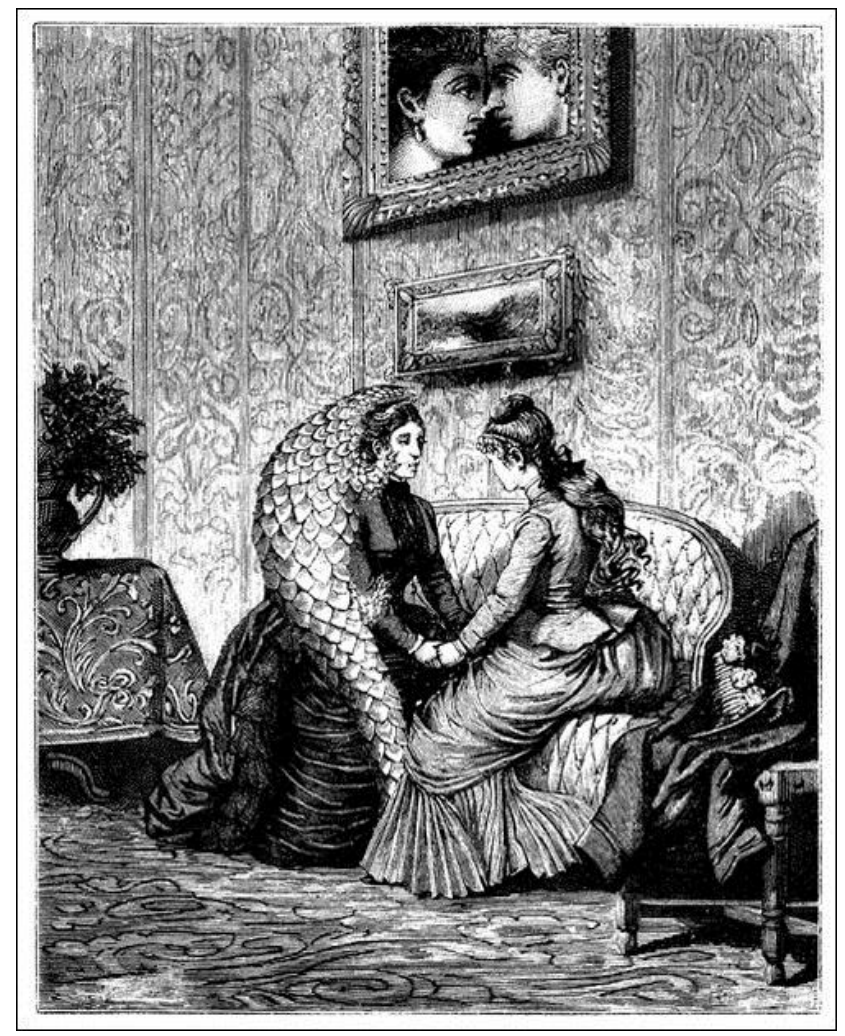

7. Max Ernst (1934), 'Une semaine à bonté, ou les sept éléments capitaux', Tercer Libro, Martes, Paris: Editions Jeanne Bucher.

En la fotografía, el espacio exterior del jardín y el espacio interior de la biblioteca se superponen en una paradoja física, pugnando por ocupar simultáneamente el mismo lugar. Y, para intensificar la ambigüedad, las líneas horizontales de la estantería y su alternancia de paneles y huecos se prolongan en la imagen reflejada, atravesando la pared y trasladándonos al otro lado de la fachada, enfrentándonos a una contradicción visual, espacial y conceptual. En palabras de Breton, una imagen será surrealista “... porque implique la negación de alguna propiedad física."

En los collages de Ernst, los lienzos enmarcados en la pared también se abren a otros espacios, a otras escenas que se suceden simultáneamente. Otras escenas tan reales o tan imaginarias como aquella en la que estamos participando. En ambos casos, Ernst y Le Corbusier, la coherencia visual ha sido destruida, interrogándonos sobre la naturaleza de las imágenes y sobre su contenido, pero también sobre las convenciones utilizadas para su construcción y comprensión.

La reproducción mecánica - la fotografía- no ha sustraído únicamente el aura a la realidad, sino también su estabilidad. Y, a través de técnicas de manipulación fotográfica, cada fragmento entra, a través de su imagen, en un proceso de edición y trastorno capaz de desfigurar su identidad.

Tal y como sugiere Breton, estas imágenes 'prestan una máscara abstracta a lo que es concreto y viceversa', Enfrentarnos a dos realidades dispares pero construidas a partir de un mismo objeto, estaríamos ante un proceso de naturaleza 'crítico paranoica' descrito por Dalí, caracterizado por la duplicación de un hecho real o de un objeto sin mediar una alteración física del mismo, tan solo de su contexto, del sistema de relaciones en el que se presenta inmerso: 
"Mediante un proceso claramente paranoico ha sido posible obtener una imagen doble, es decir, la representación de un objeto que, sin la menor modificación figurativa o anatómica, sea al mismo tiempo la representación de otro objeto absolutamente diferente, representación, esta última, que también está exenta de todo tipo de deformación o anormalidad...." 28

Si la fotografía, tal y como la emplean Brassaï o Le Corbusier, sirve no para describir el objeto sino para modificarlo, para alterar el sistema de categorías en el que se inscribe, esta puede identificarse como una técnica para producir no imágenes sino 'objetos surrealistas', cuya función es ensanchar y ampliar nuestra entendimiento de la realidad.

La desfiguración de la realidad y el trastorno de los sistemas de relaciones, ensayado inicialmente a través de la fotografía y de su manipulación, se trasladan finalmente desde la edición y manipulación de las imágenes a la realidad misma, a la arquitectura, para proponer configuraciones capaces de dislocar los sistemas de convenciones, los clichés de la arquitectura, sus fundamentos

Le Corbusier introduce el trastorno de los códigos en el corazón mismo de la arquitectura: en la configuración de la nueva domesticidad moderna. Pero, siguiendo una vez más las técnicas surrealistas -de distorsión dentro de sus límites estructurales para asegurar la comprensión de su deformación dentro de las reglas, dentro de su propia sintaxis- elige estratégicamente, para su manipulación, paradigmas característicos de lo doméstico en su tiempo: el marco, el estuche y, sobre todo, el interior.

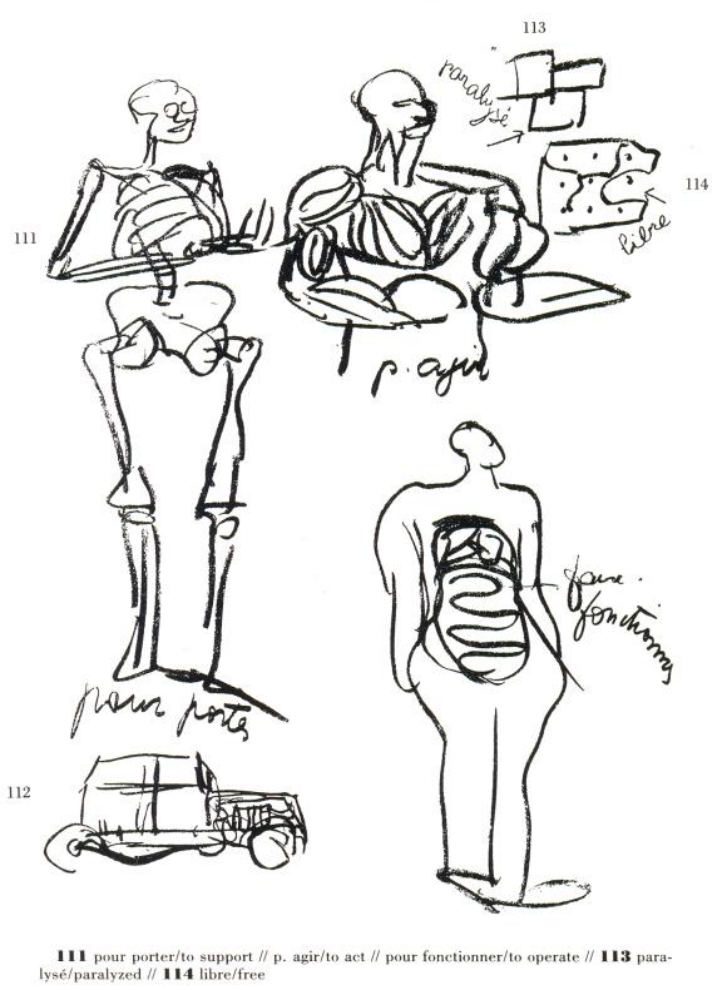

8. Le Corbusier (1930), 'Précisions...' Éditions Crès, Collec. "L'Esprit Nouveau", Paris pag 125 FLC-ADAGP

28 Dalí, Salvador: 'Interprétation paranoïaque-critique de l'image obsédante «L'Angélus» de Millet'. París: Reviste Minotaure, 1933 


\section{Conclusiones: contigüidades difíciles de resolver}

Solo en este contexto de apropiación de la paradoja como instrumento productivo, simultáneamente incubado y descubierto por el surrealismo en la ciudad, es posible entender el complejo significado asignado por Le Corbusier a los mecanismos del marco, el estuche, la estructura anatómica, el chasis o las vísceras, operativos simultáneamente en su discurso como instrumentos conceptuales y como figuras, es decir, como ideas icónicas y como objetos metonímicos.

Es el caso, por ejemplo, de las vísceras humanas, una analogía repetidamente empleada por Le Corbusier:

"Desde hace años nos hemos acostumbrado a ver plantas tan complicadas que parecen hombres que llevan sus vísceras por fuera. Nosotros defendemos que las vísceras queden dentro, clasificadas, ordenadas, que solo aparezca una masa límpida. ¡Pero no es tan fácil! A decir verdad, esa es la gran dificultad de la arquitectura: hay que poner las cosas en orden." ${ }^{29}$ [Fig 8]

El texto construye una metáfora en apariencia: la relación analógica entre las vísceras humanas, informes en sí mismas pero contenidas y limitadas dentro del orden estructural de músculos y esqueleto, y los elementos arquitectónicos del interior doméstico.

\section{C.INAIN}

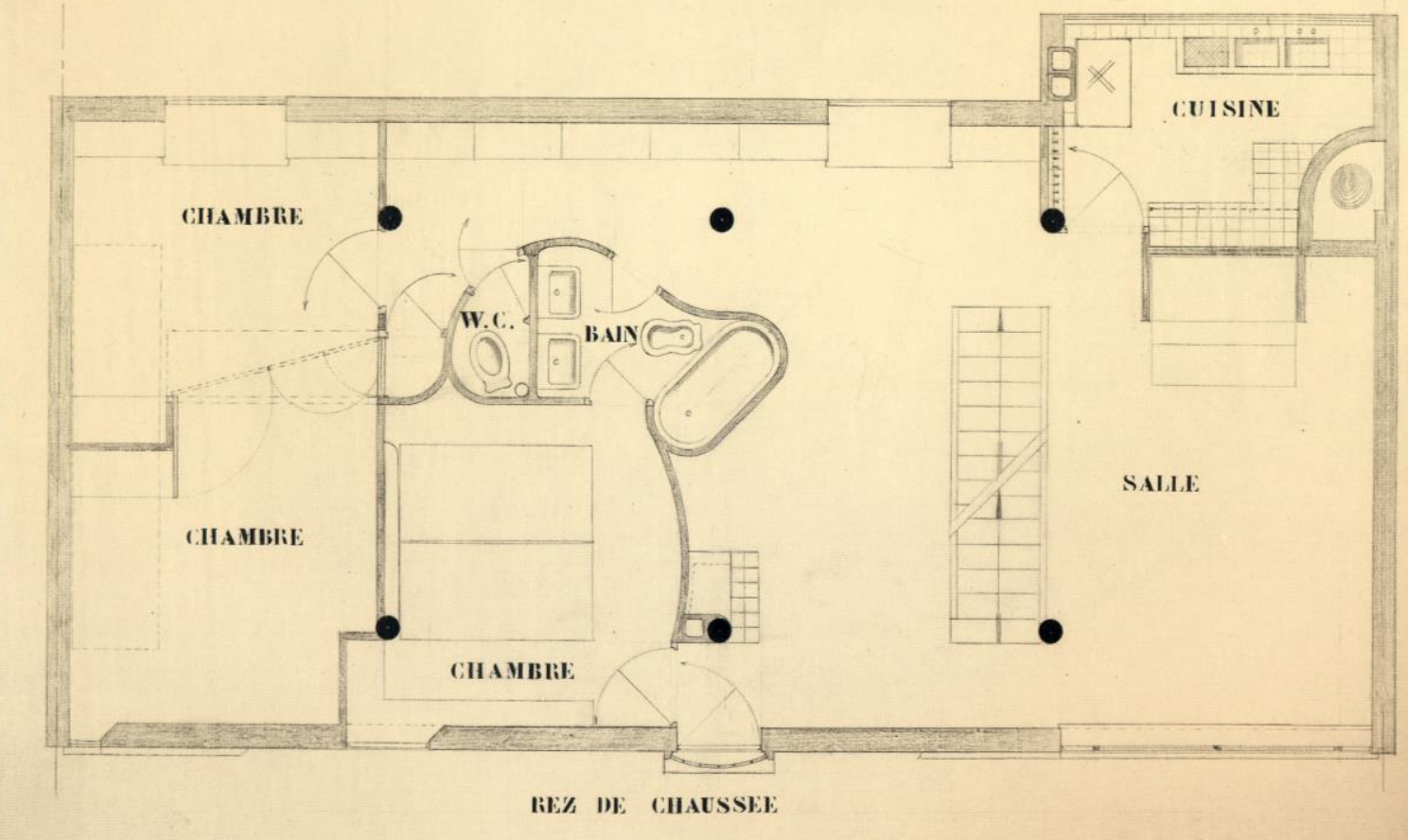

9. Le Corbusier, Planta de la Maison Canale, Boulogne-sur-Seine, 1924 FLC-ADAGP

29 Carta manuscrita enviada a Madame Meyer en octubre de 1925. Publicada en Euvre Complète Volumen 1 1910-1929. Zurich: Boessinger y Stonorov Les Editions d'Architecture, 1964. pag 89 [On est accoutumé depuis des années à voir des plans qui sont si compliqués qu'ils donnent l'impression d'hommes portant leurs viscères au -dehors. Nous avons tenu à ce que les viscères soient dedans, classés, rangés, et que seule une masse limpide apparût. Pas si facile que cela! A vrai dire c'est là la grande difficulté de l'architecture: faire rentrer dans le rang.] 
La abstracción del estuche en la caja -su transformación en un contenedor genérico y estándar, ajeno a la identidad especifica de su habitante-, se superpone con la imagen de las vísceras del cuerpo -“les viscères soient dedans, classes, rangés, et que seule une masse limpide apparû"t- que llenan el interior doméstico. Un interior que creíamos vaciado de todo rastro de identidad -de objetos y muebles, de recuerdos y souvenirs- para ser ocupado, en su lugar, por un 'equipamiento doméstico' ordenado según las leyes de la eficacia y la utilidad, y en el que ahora se dibujan las figuras simuladas de un cuerpo, una anatomía y sus vísceras.

La improbable relación entre ambos campos semánticos, así como la distancia existente entre ellos, responden a las técnicas surrealistas de desestabilización de las relaciones analógicas por medio de conexiones arbitrarias predicadas en las técnicas del montaje 'de realidades más o menos lejanas'.

Le Corbusier aprovecha el potencial de las tres figuras (esqueleto, musculatura y vísceras) como analogías disociativas capaces de construir conexiones sin un soporte semántico plausible, pero de gran efectividad icónica y conceptual. Y, por medio de la articulación fortuita de fragmentos independientes entre sí, introduce las técnicas del montaje en el centro del discurso de la arquitectura doméstica.

La planimetría de las villas Canale, Meyer y Stein de-Monzie nos sorprenden, sin embargo, con una figuración literal: las curvas y contra-curvas que rodean los aparatos sanitarios exceden el eco antropomórfico adherido a su función para contagiar a la arquitectura un parecido literal con las vísceras.

En el interior de la potente caja rectangular, el contraste entre la malla regular de pilares circulares racionalmente ubicados y las formas libres y sinuosas de las 'vísceras domésticas' no dejan lugar a dudas: si la nueva domesticidad está predicada en la lógica, esta no es ni única ni unívoca. [Fig 9]

Le Corbusier nos enfrenta abiertamente a un dilema: no a la dificultad de elegir, sino a la falta misma de necesidad de hacerlo. O, por el contrario, a la necesidad de aceptar la complejidad paradójica como un valor estructural de lo contemporáneo, su seña de identidad. Aquello que lo aproxima a nuestro tiempo y a nuestra sensibilidad.

Solo así puede explicarse que, incluso en la pequeña planta de la villa Canale (1924), se superpongan, al menos, tres lógicas: la geometría regular de la caja (el marco), la lógica estructural del hormigón armado (anatomía) y la de la continuidad espacial de la nueva domesticidad (el estuche), cada una coherente en si misma pero ajena a su articulación e integración en un sistema unitario.

Intensificadas por la inestabilidad semántica y figurativa, las figuras del marco, la anatomía del cuerpo y del estuche doméstico introducen en la arquitectura de Le Corbusier múltiples desplazamientos metonímicos. Y, precisamente por su inestabilidad y polisemia, sitúan en el centro del discurso de la 'casa moderna' las semillas de su alter ego.

La configuración de lo doméstico es, en 1920, el escenario más propicio para la escenificación del conflicto que afecta a la construcción de la identidad de la arquitectura, del individuo contemporáneo y de una unidad coherente entre ambos. Le Corbusier se implica en esta tarea de búsqueda de una domesticidad contemporánea, aparentemente predicada en la coherencia reclamada por la razón productiva asociada con la mecanización y la industrialización. En 1925 describe este proceso de cambio que, 'como un huracán', es responsable de una transformación imparable y profunda: 


\begin{abstract}
"Durante los últimos años hemos asistido a las sucesivas etapas de un acontecimiento: con la construcción metálica, la disociación entre la decoración y la estructura. Luego la moda de destacar la construcción, indicadora de la nueva formación. Luego, la admiración por la naturaleza, revelando el deseo de reencontrar (a través de que extraño rodeo!) las leyes de lo orgánico. Finalmente, la manía por lo sencillo, el primer contacto con las verdades de la máquina, llevándonos de vuelta al sentido común y a la instintiva manifestación de una estética de nuestra era." 30
\end{abstract}

Sin embargo, la presencia decisiva de objets à réaction poétique - a menudo asimilables por su función icónica a objets trouvés surrealistas- que alteran la estabilidad de las imágenes y de su reivindicada abstracción sugiere un uso de las técnicas del shock y la contradicción de modo consistente e intencionado.

Así se pone de manifiesto, por ejemplo, en el diagrama de la 'Planta Libre' o en las plantas de la Villa Stein deMonzie, por ejemplo. El conflicto inscrito en el dibujo planimétrico trasciende los problemas de la representación y nos enfrenta a la difícil convivencia entre el espacio fluido y la arquitectura de las habitaciones. El conflicto de su 'superposición sobre un único soporte', expresado a la manera de Ernst.

El proceso de concepción, dibujo y construcción de la villa Stein-de Monzie (1927) tiene un particular interés no solo por la complejidad en su programa - puede describirse alternativamente como una vivienda compartida o como dos viviendas unidas-, sino también porque representa el ensayo más riguroso y complejo de los paradigmas manejados por Le Corbusier en la década de 1920/30 y la gestión del conflicto. [Fig 10]

"Al interior, la planta es libre, cada piso tiene una distribución totalmente independiente, rigurosamente adaptadas a unas funciones específicas: las separaciones no son más que membranas. La impresión de riqueza no la proporciona el lujo de los materiales, sino simplemente la disposición interior y sus proporciones. Toda la casa obedece a los trazados reguladores que condujeron a modificar, a la medida de $1 \mathrm{~cm}$., las dimensiones de cada partición. La matemática aporta aquí verdades reconfortantes: dejamos su obra con la certeza de haber llegado a la cosa exacta." 31

\footnotetext{
${ }^{30}$ Le Corbusier (1925): L'Art décoratif d'aujourd'hui. París: Editions G. Crès, 1925

31 Le Corbusier. Descripción de la Villa Garches (1927) en CEuvre complète Vol 1 1910-1929, Zurich : W. Boessinger y O. Stonorov Les Editions d'Architecture, 1964. pag 144
} 


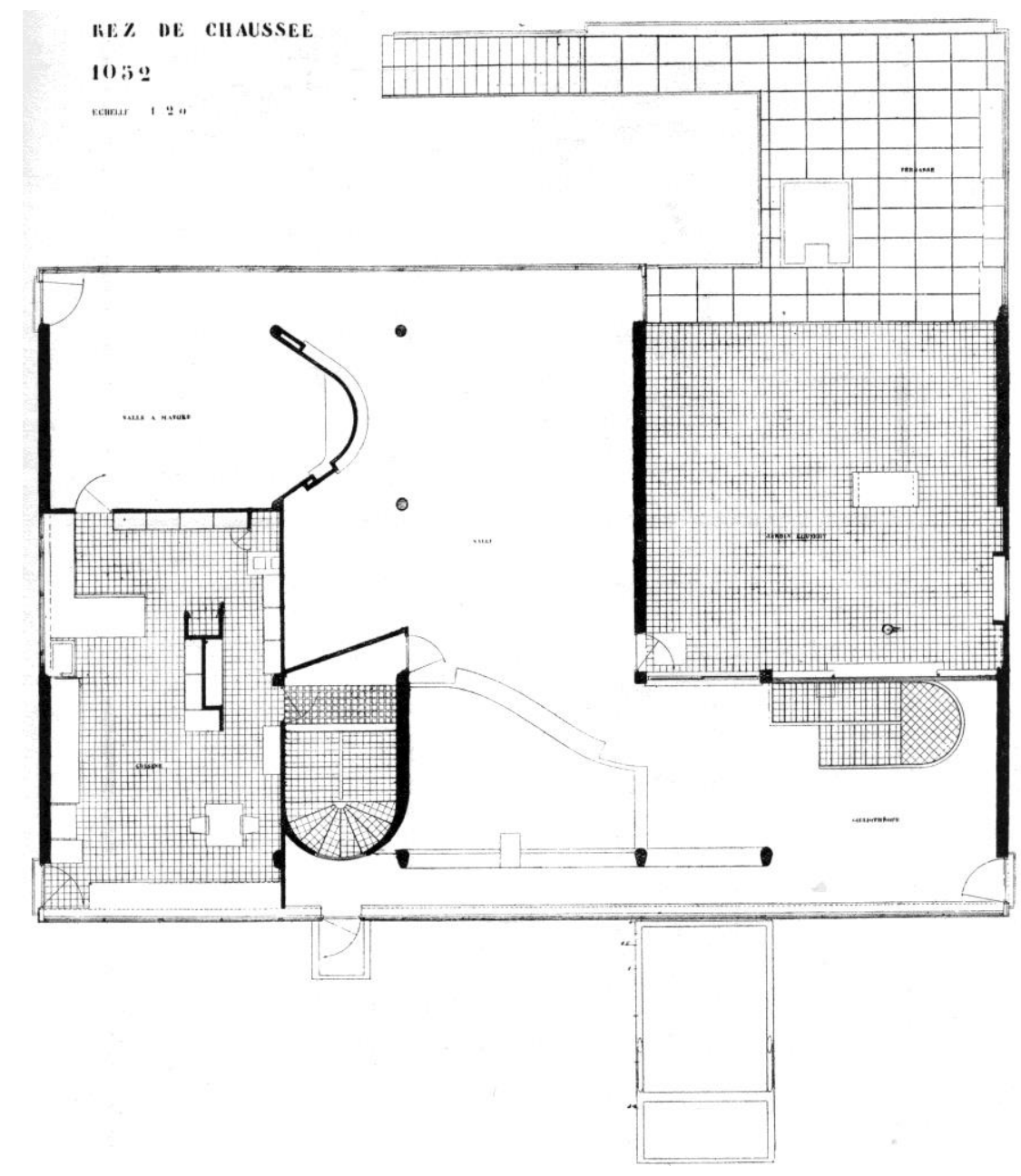

10. Le Corbusier, Planta de la Villa Stein De-Monzié, Garches, 1927 FLC-ADAGP

Aunque propone confiar la coherencia formal, estructural y espacial de la Villa Stein-de Monzie a la proporcionalidad armónica inscrita en los trazados reguladores, el orden matemático es sólo uno de los medios puestos en práctica para alcanzar una unidad que lo es solo en apariencia. Una unidad amenazada por la constante distorsión introducida por la potencia icónica de las figuras derivadas de la especificidad funcional, el respeto de convenciones domésticas propias de la clase social de los Stein y de la señora de Monzie -asociadas a la privacidad del mundo femenino y a una idea de lujo entendido como bienestar físico del cuerpo- pero, sobre todo, por la continua articulación implementada para encadenar la experiencia del interior en una secuencia capaz de restaurar la unidad.

El conflicto advertido por Tafuri entre los objets à réaction poétique -icónicos por definición- y la abstracción derivada del vaciamiento propio de la planta libre, junto con la distorsión diagonal y escenográfica impuesta por una circulación panorámica que recorre la casa, condicionan la estabilidad y dificultan la unidad prometida. Simultáneamente plano y profundo, único y estratificado, continuo y fragmentario, el espacio de la villa Stein-de Monzie acoge cualidades dispares y contrapuestas, no tan diferentes de las que agitan los collages de Ernst o de los montajes de Picasso. 
"Señora", escribe Le Corbusier, "hemos soñado con haceros una casa que fuera tersa y uniforme como un cofre de bellas proporciones y a la que no ofendieran los múltiples accidentes que crean un ambiente pintoresco, artificial e ilusorio y que rechinan bajo la luz, añadiendo más ruido al ruido. Nosotros nos oponemos a la actual moda que castiga a este país y en el extranjero de casas complicadas e hirientes. Pensamos que la unidad es más fuerte que las partes. Y no crea usted que la simplicidad es fruto de la pereza; por el contrario, es el resultado de un plan largamente madurado. Lo simple no es fácil." 32

La afirmación 'nous pensons que l'unité est plus forte que les parties' señala un punto de inflexión y nos orienta sobre las diferencias entre la volumetría agregada de la Maison la Roche y la forma rotunda y compacta que caracteriza las villas Meyer, Cook y la que nos ocupa.

Las tensiones espaciales, programáticas y estéticas se ven definitivamente confinadas dentro de un volumen abstracto y regular, y un entramado estructural igualmente abstracto y regular. Las 'vísceras' del organismo doméstico vuelven al interior del cuerpo, ordenadas y clasificadas. La compresión hacia el interior -la interiorización total del programa domestico dentro del cofre, de un estuche en la terminología de Benjaminobliga no solo a reordenar los elementos y reconsiderar sus jerarquías sino, y más importante, a aproximar elementos dispares, fomentando la continuidad en la contigüidad, 'trabajando a favor de la unidad aparente y en contra de la fragmentación pintoresca'.

Sí el marco y el orden estructural imponen una unidad abstracta, la distribución interior, por agregación de elementos independientes, construida por acumulación de incidencias, es ajena a un principio unitario. Incluso la terraza/jardín deja de ser el elemento central, diferenciador y articulador entre los dos apartamentos, para transformarse en una 'habitación interior' mas, engarzada en la secuencia de contigüidades que intentan conciliar la fragmentación en habitaciones y espacios interiores privados y la continuidad de un recorrido interior panorámico que articula las múltiples vicisitudes en una secuencia, como si de del movimiento por un jardín, un paisaje o una ruina se tratara.

La imposición del marco -de una envolvente regular y abstracta- es una decisión radical: un límite geométrico y sin accidentes que obliga a contener en su interior todos los elementos y sus relaciones. Una vez tomada esta decisión, toda la arquitectura será interior; y, del mismo modo, todas las relaciones serán de intensa contigüidad dentro de los límites del marco.

"Para que surja la poesía de estos temas arquitectónicos son necesarias contigüidades claras difíciles de resolver." 33

El espacio se construye como articulación de las piezas autónomas, de los fragmentos. Una articulación que nos obliga a circular entre y alrededor de las piezas para re-construir una unidad -un sistema de relaciones- cuya presencia intuimos pero que no es legible. Una experiencia accidentada y discontinua que debe ser reconstruida uniendo los fragmentos por medio de las técnicas del montaje. Una dificultad a la que hace referencia C. Rowe

32 Carta manuscrita de Le Corbusier, enviada a Madame Meyer en Octubre de 1925. Publicada en Cuvre complète Volumen 1 1910-1929. Zurich: Boessinger y Stonorov Les Editions d'Architecture, 1964. pag 89

33 Le Corbusier (1964): Euvre complète Volumen 1 1910-1929 Zurich: Boessinger y Stonorov Les Editions d'Architecture, 1964. pag 89 
(1947) cuando afirma que conceptualmente todo está claro pero, desde el punto de vista de la experiencia, es profundamente paradójico.

En definitiva, Le Corbusier potencia iconos distintivos del mundo doméstico -formas antropomórficas y figuras reconocibles asociadas con la domesticidad y la privacidad- paradójicamente inscritos en espacios abstractos, manipula las técnicas del poché para resolver las necesidades de la domesticidad contemporánea en una planta abierta y sin compartimentación, e intensifica la interiorización del espacio privado al tiempo que potencia la continuidad espacial asociada con el movimiento.

Se apropia igualmente de la inversión entre lo doméstico y lo público por medio de la exacerbación de la circulación -de la experiencia fragmentaria del interior-, como si de un recorrido a lo largo de una ruina o un paisaje se tratara. Predicado en el movimiento, el espacio doméstico se abre necesariamente y, al hacerlo, expone el conflicto entre continuidad y discontinuidad o entre transparencia y compartimentación.

Al igual que ocurre en los montajes de Max Ernst, los espacios domésticos construidos por Le Corbusier entre 1920 y 1935 se debaten entre la unidad y la fragmentación, entre la envolvente geométrica que encierra y protege el espacio privado del interior y la fluidez espacial del recorrido que abre la casa al exterior y la transforma en un paisaje.

Un debate latente que no solo no concluye ni se resuelve, sino que se potencia y aprovecha.

Aunque la racionalización y la industrialización a la que hace constante referencia son responsables de una transformación profunda, lo que distingue la arquitectura de Le Corbusier es el atrapamiento entre ambos modelos espaciales y domésticos: su superposición. En la arquitectura de Le Corbusier, el espacio doméstico es simultáneamente abierto y envolvente, transparente y compartimentado, continuo y discontinuo. O, en sus palabras, interior y exterior. Es, por tanto, conflictivo por definición o, en palabras de Breton, sublime y, por tanto, ajeno a la simplificación racional o a la ley de 'la causa y el efecto'.

Para los surrealistas, la manifestación de los aspectos sublimes de la realidad requiere la presencia simultánea del paradigma y de su deformación, de su forma estable y su fractura. Sea este paradigma el lenguaje -garante de la coherencia semántica por medio de la estructura sintáctica-, el marco -el mecanismo para diferenciar la realidad de su representación- o la estructura anatómica -sobre cuya apariencia se sustenta la naturalidad orgánica o, al menos, se representación.

"Rather than reducing the disjunctions of the parts, the englobing term as stage, frame, box or anatomy simple displays the merveilleux as a space of paradox. Such dissociative metonymies tease the imagination without ultimately yielding to the cognitive process of decoding." 34

34 Adamowicz, Elza: Surrealist Collage in Text and Image. Dissecting the exquisite corpse. Cambridge University Press, 1998. pag 83 
En una improbable aunque innegable coincidencia con el surrealismo, Le Corbusier aprovecha los conflictos latentes para construir un discurso más ambicioso que el de la razón, superponiendo estrategias e instrumentos contrapuestos. Y la sensibilidad surrealista que invade la experiencia de Paris en los años de la posguerra le ofrece los recursos para integrar el conflicto en el discurso de la arquitectura como conexiones improbables e imprevistas entre 'realidades más o menos lejanas'.

\section{Bibliografía}

Adamowicz, Elza: Surrealist Collage in Text and Image. Dissecting the exquisite corpse. Boston, MASS: Cambridge University Press, 1988

Aragon, Louis: Los collages. El desafío a la pintura. Madrid: Editorial Síntesis, 1930

Aragon, Louis: Le grande saison Dada. Opus Internacional 123-24. París: s.e. 1923

Breton, André: Manifeste du surréalisme. Paris: Gallimard, 1924. Traducción: Manifiestos del Surrealismo. Madrid: Visor Libros, 2002

Breton, André: Ouvrés complètes II. París: Gallimard, 1992

Breton, André: Surréalisme et la peinture. París: Editions Gallimard, Paris 1928 (2 Ed. 1965). Surrealism and Painting Boston: MFA Publications, 2002

Brotchie, Alastair: A book of Surrealist games. Londres: Redstone Press, 1991

Dalí, Salvador: “Interprétation paranoïaque-critique de l'image obsédante «L'Angélus » de Millet”, Reviste Minotaure. París, 1933

Eluard, Paul: "Sur certaines possibilités d'embellissement irrationnel d'une ville", Surréalisme au Service de la Révolution $n^{\circ}$ 6. París, 1933

Ernst, Max (1934): Une semaine à bonté: The Original Collages. París: Catálogo de la exposición, Museo de Orsay, 2006

Foucault, Michel (1973): Ceci n'est pas une pipe. Montpellier: Fata Morgane, 1973. Tradución: Esto no es una pipa. Barcelona: Editorial Anagrama, 1981

Le Corbusier: Une Maison-une Palais. París: Editions Convences, 1928

Le Corbusier: Vers une architecture. París: Flammarion, 1923

Le Corbusier: L'Art décoratif d'aujourd'hui. París: Editions G Cres, 1925

Le Corbusier: Euvre complète Volumen 1 1910-1929. Zurich: Boessinger y Stonorov Les Editions d'Architecture, 1964

Lucien Duchase, Isidore, Conde de Lautréamont (1896): Los Cantos de Maldoror. Madrid: Editorial Pretextos 2000

Reverdy, Pierre: Nord-Sud Marzo. París, 1918

Vaseley, Davilor: “Surrealism and Architecture”. Architectural Design nº 5\&6, London UK, 1978

Vidler, Anthony (2003): "Fantasy, the Uncanny and Surrealist Theories of Architecture", keynote speech given at the conference "Fantasy Space: Surrealism and Architecture", Manchester, Whitworth Art Gallery, September 12, 2003. UK

Vidler, Anthony: The Architectural Uncanny: Essays in the Modern Unhomely. Cambridge, MASS: MIT Press, 1992 


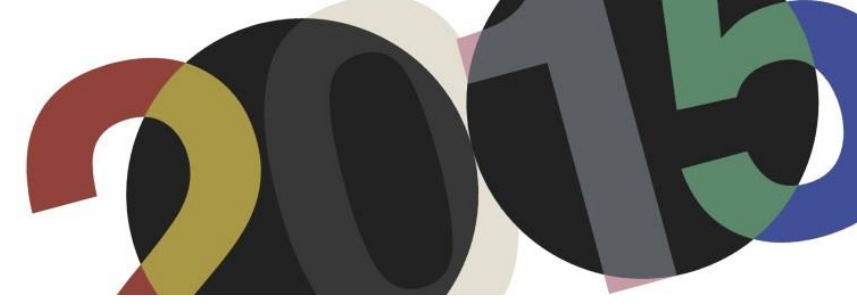

DOI: http://dx.doi.org/10.4995/LC2015.2015.728

\title{
Possibles liens avec le monde Antique. La suggestion des ruines dans les œuvres de Le Corbusier: de l'architecture Romaine au bâtiment de la Haute-Cour de Justice de Chandigarh
}

\author{
C. Roma
}

PhD candidate in Architecture - Theories and Project, Sapienza Università di Roma

Résumé: La recherche s'intéresse à la formation de Le Corbusier et à sa capacité d'abstraction au travers des mémoires, images liées à la connaissance du monde antique; un approfondissement qui traite le lien entre les æeuvres du Maître et l'étude de l'architecture romaine, soulignant ainsi deux clés de lecture: une liée à l'archétype des modèles classiques, et une seconde liée aux ruines et à son paysage archéologique. Si la première laisse apparaitre clairement la composante rationnelle, volonté de poursuivre une architecture universelle, dans laquelle s'affirme l'utilisation de la raison que seuls les archétypes peuvent enseigner; la seconde tente de délimiter la relation entre le pouvoir évocateur de la ruine et les suggestions personnelles de l'architecte. Parcourant les phases de sa formation, la recherche se concentre sur les connaissances que le jeune Jeanneret acquiert durant son séjour allemand (1910-1911), première phase d'étude de l'architecture romaine qui alimente un intérêt destiné à se développer grâce à l'expérience du Voyage d'Orient et à l'approfondissement de certaines sources, tels que les vues de Piranesi. Cet approfondissement se retrouve dans de nombreux dessins et réflexions contenus dans les carnets 4 et 5 rédigés durant le séjour romain. Ces expériences représenteront une source d'inspiration pour sa production architecturale et théorique, présuppositions qui semblent apparaitre dans certaines cuvres de l'architecte y compris la Haute Cour de Justice de Chandigarh en 1952.

\begin{abstract}
The research focuses on Le Corbusier educational process and on his ability to abstract, through his memories, the images related to the knowledge of the Ancient World; a study that addresses the clear connection between the works of Le Corbusier and his knowledge of Roman architecture, outlining two interpretations: the first one linked to the archetype of classic models, and the second one to ruins and archaeological landscape. The first interpretation clearly illustrates the rational perspective, the will to pursue an universal architecture distinguished by use of reason, that only archetypes can teach, whereas the second interpretation attempts to outline the relationship between the evocative influence of the ruin and the personal suggestions of the architect. Retracing the steps of his educational process, the research investigates the knowledge acquired by the young Jeanneret during his German stay (1910-1911). This is the first phase of the study of Roman architecture, that inspires him an interest that will be pursued later through the experience of the Voyage d'Orient and the study of some sources, such as Piranesi's views. This learning is reflected in numerous drawings and reflections contained in Carnet 4 and in Carnet 5, elaborated during his stay in Rome. These experiences will be a source of inspiration for his architectural production and theoretical assumptions, and they seem to be reflected in some works of the architect, as the Chandigarh Haute Cour of 1952.
\end{abstract}

Mots-clés: ruines; architecture Romaine; Villa Adriana; Haute Cour.

Keywords: ruins; Roman architecture; Villa Adriana; Haute Cour.

\section{Introduction}

Cet article affronte le rapport d'intérêt et d'étude que Charles Edouard Jeanneret a tissé, dès les premières années de sa formation, avec l'architecture Romaine, dès les premières années de sa formation, qui deviendront source de suggestion et d'inspiration qu'il reproposera dans son œuvre. Sont prises en considération les sources primaires, Vers une Architecture, Le poème de l'angle droit, Euvre complète, Le Voyage d'Orient et les Carnets d'où l'on perçoit l'intérêt qu'il a eu, durant sa formation, pour les ruines de l'architectures romaines, manifesté à 
travers l'étude des textes Les Entretiens de la Villa de Rouet de Alexander Criniglia-Vaneyre, deux volumes, les œuvres de Pierre Gusman, Dictionnaire raisonné de l'architecture française du XIe au XVIe siècle de Viollet-leDuc, et le dessin de la ruine romaine et le détail du Praetorium de Villa Adriana.

Ce même sujet est recherché dans les sources secondaires, en considérant comme texte basilaire le volume L'Italia di Le Corbusier de Maria Talamona, édité en 2012, représentant une récente et exhaustive de la formation de l'architecte en Italie, tant par son approche que par sa connaissance du paysage archéologique italien. Un deuxième texte, Le Corbusier a Villa Adriana, par Eugenio Gentili Tedeschi et Giovanni Denti (sous la direction de Annalisa Mauri) représente le lien essentiel pour reconstruire la visite à la Villa de Adriano.

L'analyse des sources conduit à supposer un fructueux système de relation entre Le Corbusier et l'architecture romaine, à travers la figure de Piranesi, dont Le Corbusier découvre les vues d'abord à travers les textes, ensuite durant la visite au Unterrichtsanstalt des Königlichen Kunstgewerbemuseum et enfin à Rome. Ce rapport définit un double intérêt, renforcé dans l'admiration pour la rigueur géométrique de l'architecture classique, qui sera théorisée dans un similaire ordre géométrique Moderne, et dans la fascination pour les ruines sous la forme dans laquelle elles sont parvenues à l'époque récente. La duplicité d'intérêt pour l'architecture Antique, et en particulier pour Villa Adriana, se reflète aussi dans sa production architecturale sous forme d'inspirations diverses mais coexistantes, dans un mélange d'ordre, de pureté formelles et de rugosité épidermique, comme montré dans le projet de la Haute Cour de Chandigarh.

\section{Les acquis du Monde Antique}

"Pleine main j'ai reçu...Pleine main je donne"

L'interprétation que Le Corbusier, donnait de sa capacité à donner et recevoir du monde qui l'entourait, se concrétise dans une déclaration contenue dans le dernier chapitre du poème Le Poème de l'Angle Droit ${ }^{2}$. La main ouverte est un geste d'altruisme, un signe de paix pour l'humanité - la main "ouverte pour donner, ouverte pour recevoir",3.

Ce concept est l'une des plus importantes pensées que Le Corbusier développe durant l'âge mûr à l'occasion de la rédaction du texte cité. Ce concept est élaboré alors qu'il réalise le projet de la cité de Chandigarh. La grande sculpture, emblème proposé pour le développement de la nouvelle ville, est porteuse de nombreuses significations: elle interprète les débats politiques du pays, la difficile recherche d'indépendance que l'Inde est en train de conquérir, et la philosophie professée par Gandhi ${ }^{4}$.

Mais la main ouverte semble aussi rappeler le sens d'altruisme d'un homme qui a su recevoir d'autres cultures, et qui, grâce à sa capacité d'évolution, a su répondre à travers son engagement démontré dans les dynamiques architecturales développées au cours du XIX ${ }^{5}$.

\footnotetext{
${ }^{1}$ Le Corbusier, Le poème de l'angle droit, Paris: 1ed., Editions Verve, 1955

${ }^{2} i d$.

${ }^{3}$ id.

${ }^{4}$ Kurtis, W.JR., Il moderno e l'arcaico, o le ultime opere, p. 297 in Abram, J.; Bancon, M.; Baudouï, R., et al., Enciclopedia Le Corbusier, Milano: Electa, 1988. Argumentations sur les possibles connections entre l'emblème de la "main ouverte" et les questions liées aux évènements politiques qui secouent l'Inde après l'indépendance anglaise.

${ }^{5}$ Tentori, F., I viaggi come una mano aperta, pp.62-69 dans Gravagnuolo, B., Le Corbusier e l'Antico. Viaggi nel Mediterraneo, Napoli: Electa, 1997
} 
L'image de la Main Ouverte, est la métaphore qui montre le mieux l'aspect humain du Maître ; elle va outre les superstructures culturelles qui ont rendu l'architecte emblème incontesté de la rationalité. Il en ressort donc une sensibilité plus intime, qui embrasse son engagement pour les complexes évènements d'un pays qui se prépare à renaître.

Transposant le terme recevoir aux questions liées à la première phase d'apprentissage de l'architecture, et soulignant certains moments fondamentaux de la croissance du jeune architecte, on peut reparcourrir les premières élaborations théoriques vouées à l'identification des archétypes architecturaux ; terrain fertile sur le quel le jeune Charles-Edouard Jeanneret basera ses premières convictions qui convergeront dans les articles rédigés pour la revue $L^{\prime}$ Esprit Nouveau ${ }^{6}$ et qui mieux se concrétisent dans le texte Vers une architecture ${ }^{7}$.

\section{La rencontre avec l'Architecture Romaine}

Jeanneret est un peu plus qu'un garçon quand, sous le conseil de son maître Charles L'Eplattenier, il décide, le 12 juin 1905, d'interrompre les études commencées dans l'École d'Art à Chaux-de-Fonds, en dépit de son engagement et d'excellents résultats obtenus au cours des trois premières années de sa formation. Bien que ses études auraient dû faire de lui un graveur-ciseleur pour des caisses d'horloge, lui assurant un emploi dans l'industrie du pays, le jeune Jeanneret, abandonne l'école et poursuit un rêve plus grand, l'étude de l'architecture ${ }^{8}$.

Après ce changement, il fait ses premiers pas dans le monde de l'architecture dans son pays natale, grâce au contact d'un architecte locale, fourni par son maître; c'est alors que le jeune réalise les premiers dessins de détails constructifs, selon la méthode rationaliste décrite par Viollet-le-Duc ${ }^{9}$.

Enfin l'Eplattenier encourage le jeune Charles-Edouard Jeanneret à entreprendre le Grand Tour le 3 septembre 1907, voyage qui, pendant quatre ans, le conduira dans les principaux centres de culture européen. Les séjours commencent avec l'étude théorique de l'architecture que le jeune entreprend en Allemagne. Moments cruciaux durant lesquels il mûrit le penchant pour l'étude des architectures romaines qui semble l'éloigner du premier intérêt pour les composantes plus décoratives, héritage de la première formation suisse cultivé en occasion de son premier voyage en Toscane, en $1907^{10}$.

La relation que Jeanneret établit avec l'Italie, et en particulier avec l'architecture romaine, a été amplement explorée par Marida Talamona, en particulier lors de l'organisation de l'exposition L'Italia di Le Corbusier ${ }^{11}$. Les études et recherches dérivant de cette initiative ont fourni de soigneuses reconstructions sur les années dédiées, par Le Corbusier, à l'étude et à l'analyse des antiques architectures romaines, outils qui ont soutenu l'analyse ici proposée.

Effectuant une reconstruction des évènements qui soudent les rapports entre les architectures antiques et la production architecturale de Le Corbusier, il apparaît le caractère du paysage archéologique romain perçu non

\footnotetext{
${ }^{6}$ Revue d'art "L'Esprit Nouveau" fondée en mars 1920 à Paris par Charles Edouard Jeanneret - qui lors de cette occasion prendra le pseudonyme de Le Corbusier - avec l'artiste Amédée Ozenfant; comme outil de communication du manifeste Après le Cubisme

${ }^{7}$ Le Corbusier, Vers une architecture, Paris, 1923

${ }^{8}$ Petit, J., Le Corbusier lui-même, Paris: 1ed. qui était Le Corbusier, 1968 pp. 24-44. et Dumont, M.-J., Dall'art Nouveau all'avanguardia, tasselli di una formazione, dans L'Italia di Le Corbusier, par Talamona M., L'Italia di Le Corbusier, Milano: Mondadori Electa S.p.A, 2012, pp. 19-30

${ }^{9}$ id., p 24

${ }^{10}$ Passati, F., Toscana, p. 41-50, dans Talamona, M., 2012 op.cit.

${ }^{11}$ Exposition, L'Italia di Le Corbusier, de Marida Talamona, Roma: MAXXI Museo delle Arti del XXI secolo, 2012
} 
seulement comme une extraction des archétypes des constructions classiques. Mais apparait aussi l'inspiration d'un paysage confus, constitué de ruines qui s'accumulent à l'intérieur des murs de l'Urbe, et qui respirent dans la campagne romaine de Villa Adriana à Tivoli.

En souhaitant effectuer une reconstruction des premiers contacts que le jeune Jeanneret a eu avec la connaissance des architectures classiques, il faut tenter de reparcourir les connaissances acquises à travers les textes consultés durant les études de jeunesse, du moins les plus significatifs, mais bien plus encore la préparation entamée en vue du voyage. Durant le printemps de 1908 son intérêt est captivée par le livre L'architecture romane de Edouard Corroyer (1888) au point de lui dédier un cahier entier, rempli de croquis et notes pour la compréhension de l'antiquité ${ }^{12}$.

Il entre en contact avec le lettré William Ritter ${ }^{13}$ - figure significative pour la maturation de tels intérêts - qui conseil au jeune l'étude de Les Entretiens de la villa de Rouet ${ }^{14}$ de Alexander Criniglia-Vaneyre, œuvre qui "marquera un tournant dans sa formation et le passage de la tradition gothique à celle classique"15.

"Notre âme est classique, en effet elle ne peut qu'évoluer vers une formule gréco-latine (...) j'avais étouffé tout ce qui pouvait m'éloigner du Sud, de Rome et la Méditerranée; le salut était dans la culture classique"16.

C'est peu être la première fois que le jeune architecte entre en contact avec l'exaltation de la culture classique, et intègre les motivations de l'auteur, au point d'en commenter les raisons avec enthousiasme, expliquant aux marges du même texte: "... entièrement d'accord avec l'esprit général et génial (...) En ce qui me concerne, ce livre vient aider favorablement mon orientation. Il provoque, l'examen, les déductions normales, claires, lumineuses; relâche la poignée allemande. Dans un an, à Rome, je le relirai, et avec des croquis je fonderai ma discipline du Jura, de Neuchâtel"17. Durant cette phase se précise la volonté d'étudier personnellement les architectures romaines et cela se confirme dans sa correspondance, du 2 décembre de la même année avec la famille ${ }^{18}$ et dans une lettre expédiée un peu plus tard à L'Eplattenier. "...c'est la mon révolution (...) j'ai aussi un livre splendide de dorique, de ionien, de corinthien, de cet art romain fait de voutes colossales et de grands murs pleins. Et, depuis des mois, mes idées se fixent. Je n'irai point en Amérique, ni en Flandres. Mais je resterai ici jusqu'à ce que je sache la langue, abrégeant peut-être mon séjour chez Behrens pour aller à Dresde pour bâtir chez Tessenow l'Institut Jacques Dalcroze, suivant la proposition qui m'à été faite. Puis je ferai mon voyage d'études en Allemagne et ensuite irai me recueillir. Ou? À Rome"19.

Dans une lettre successive du 10 janvier 1911 à L'Eplattenier, Jeanneret faisait référence à deux volumes inhérents à l'architecture romaine: "J'ai, ici, un splendide livre sur cet art romain, fait de voutes colossales e de grands murs pleins (...) Puis je ferai mon voyage d'études en Allemagne et ensuite irai me réfugier. Où? Á

\footnotetext{
${ }^{12}$ Talamona, M., “L'ai décidé de finir mes études...sans le rêve. J'avais pour cela songé à Rome”, p. 117, p. 134 n. 18. dans Talamona, M., 2012, op.cit.

${ }^{13}$ Dumont, M.-J., Dall' Art Nouveau all'avanguardia, tasselli di una formazione, p. 29 dans Talamona, M., 2012, op.cit.

${ }^{14}$ Turner, P. V., La formazione di Le Corbusier, idealismo e Movimento Moderno, Milano: Editoriale Jaca Book SpA, 2001, pp. 59, 112-118

${ }^{15}$ Talamona, M., "L'ai décidé de finir mes études...sans le rêve. J'avais pour cela songé à Rome”, p.112 dans Talamona, M., 2012, op.cit.

${ }^{16}$ Criniglia-Vaneyre, A., Les Esentretiens de la villa di Rouet, Genève, 1908, p. 9, dans Turner, P. V., La formazione di Le Corbusier, idealismo e Movimento Moderno, Milano: Editoriale Jaca Book SpA, 2001, p. 113

${ }^{17}$ Criniglia-Vaneyre, A., Les Esentretiens de la villa di Rouet, Genève, 1908, p. 69 dans Turner, P. V., 2001, p.113 op.cit.

${ }^{18}$ Baudouï, R., Dercelles A., (éditer par) Le Corbiusier correspondances. Lettres à la famille 1900-1925 vol I fondation Le Corbusier / Paris-Gollion: infolio Editions, 2011 p. 335 dans Talamona, M., 2012, p.115 op.cit.

${ }^{19}$ Jeanneret, C.-E., lettre à Charles L'Eplattenier, 16 janvier 1911, dans Dumont, M.-J., Lettres a Charles L'Eplattenier, Paris: Editons du Linteau, 2006, p. 258-260 dans Talamona, M., 2012, p.115 op.cit.
} 
Rome. Alors, si vous me voudrez encore... Ah, cher maître, la constatation de mon esthétique aboutie est la seule chose qui me permet encore de faire cette vie" ${ }^{\prime 20}$.

Giuliano Gresleri a identifié dans les deux volumes les œuvres de Pierre Gusman: "Chargé de la Mission archéologique en Italie par le Ministre de L'instruction publique et des Beaux-Arts" ${ }^{\prime 21}$ contenues, selon l'érudit, dans la bibliothèque de l'école de Le Chaux-de-Fonds. Les textes sont dédiés à Pompéi et à Villa Adriana. Durant la description des volumes on peut remarquer la présence de représentations des environnements de Pompéi et de la Villa Adriana, "lithographies produites à partir de photos et aquarelles réalisés par l'auteur ou par des élèves de Villa De Médicis qui «perfectionnaient» actualisant les dessins de Pirro Ligorio e Piranesi"22.

Donc, il se pourrait que ce soit la première fois que Jeanneret rencontre Piranesi, même si indirectement. Les représentations reportées dans le texte et transmises par les gravures devaient probablement conserver et transmettre les caractéristiques physiques des objets en question, tout comme les encadrements en perspective et, malgré l'inévitable synthèse, les traits essentiels du langage piranésien.

Un autre élément qui contribue à stimuler son intérêt pour l'architecture romaine, vient toujours de Berlin; durant la visite au Unterrichtsanstalt des Königlichen Kunstgewerbemuseum (1911) Jeanneret a la possibilité d'observer certaines gravures de Piranesi et note une déclaration qui documente son grand intérêt: "tout ce ci gravures de Piranesi admirable. Mais voir à Rome la collection complète et choisir les meilleurs" ${ }^{\prime 23}$. Son attention a été captivé par les architectures exposées, mais peut être aussi par la capacité expressive des œuvres piranésiennes.

Peu après cet événement le jeune Jeanneret entreprend son Voyage d'Orient qui le conduit à travers de nombreuses villes pour rejoindre enfin Rome le 14 Octobre 1911.

C'est une occasion pour se dédier à la découverte des œuvres architecturales et artistiques majeures de la ville, qui est envahie par de nombreuses manifestations pour la célébration du cinquantenaire de l'Unité d'Italie.

Parmi les évènements artistiques auxquels adhère Jeanneret on rappelle la série d'expositions rétrospectives à Castel Sant'Angelo, où se trouve l'exposition topographique romaine, qui contient une ample collection de vues de Rome. Parmi les œuvres on trouve des peintures de Canaletto, Van Wittel, les œuvres de Vasi, Pannini et Piranesi $^{24}$ et les aquarelles de la Roma Sparita de Ettore Roesler Frantz ${ }^{25}$, dont Jeanneret acquiert certaines reproductions; une série d'œuvres qui pour la plupart présentaient les vues d'une Rome qui suintait de paysages mélancoliques, représentant l'aspect dévasté de la ville Eternelle.

\section{Les ruines dans le paysage romain}

Durant le séjour romain de nombreuses architectures attirent l'attention de Jeanneret, qui passe ces journées à noter sur ses cahiers croquis et impressions sur les architectures qui l'intéressent plus. L'ensemble des données

\footnotetext{
20 Jeanneret, C.-E., lettera a Charles L'Eplattenier, 10 Janvier 1911, AFLC dans Gresleri, G., Dalla Villa alle Ville: Jeanneret e Adriano, dans Talamona, M., 2012, p. 138 op.cit.

${ }^{21}$ Gresleri, G., Dalla Villa alle Ville: Jeanneret e Adriano, in L'Italia di Le Corbusier, dans Talamona, M., 2012., p. 138 op.cit.

22 id., p. 138

${ }^{23}$ Jeanneret, C.-E., Voyage d'Orient. Carnets, Milano: Electa, 1987, p. 17 dans Talamona, M., "L'ai decidé de finir mes études...sans le rêve. J'avais pour cela sogné à Rome”, dans Talamona, M., 2012, p. 117 op.cit.

${ }^{24}$ Guida generale delle Mostre Retrospettive di Castel Sant 'Angelo, Istituto Italiano di Arti Grafiche, Bergamo 1911 dans Talamona, M., 2012, p. 117 op.cit.

${ }^{25}$ Talamona, M., "L'ai décidé de finir mes études...sans le rêve, p.124 J'avais pour cela songé à Rome”, p. 124 dans Talamona, M., 2012, p. 117 op.cit.
} 
récoltées dans le $4^{\circ}$ et $5^{\circ}$ Carnet - dédiés aux expériences architecturales - et les correspondances échangées durant cette période communiquent une alternance d'émotions opposées provenant de l'expérience du paysage romain. Dans une des lettres adressées à Auguste Klipstein, en décrivant le bilan des lieux visités durant le Grand Tour il affirme : "Rome n'a pas de silhouette, pas d'âme. Oh Istanbul! Oh Athènes! Mais Rome a les vieux Romaines de la brique cuite, et le bon Dieu a permis que tous les revêtements de marbre aient été volés. Alors c'est magnifique, unique, subjuguant. Ça, c'est du musée pour architecte" ${ }^{\prime 26}$.

Au rejet dédaigneux de l'image urbaine correspond la révélation de la ruine, exaltée en vertu du pouvoir qu'elle a d'extrapoler ceux qui sont, selon le jeune, les contenus le plus authentiques et significatifs de l'architecture romaine. Les ruines révèlent en effet les masses dénudées, épurées des revêtements décoratifs. Ces déclarations semblent faire écho, à distance de cinquante ans, à certaines réflexions laissées par Viollet-le-Duc: “...Les ruines des monuments vraiment romains, c'est-à-dire édifiés suivant la donnée romaine, ont du style. Restaurez la plupart de ces ruines, remettez en place les ordres, les encadrements, les bandeaux, les ornements enlevés par les barbares ou par le temps, vous verrez le style propre à ces grandioses constructions s'effacer, à mesure que vous y replacerez ces applications empruntées à un autre art, à un autre ordre d'idées, à un autre principe de structure (...), ${ }^{, 27}$.

Ces concepts refont surface lors de l'étude de certaines architectures mieux conservées, comme le Colisée, durant laquelle Jeanneret copie certaines vues du Piranesi et affirme: "pourrait servir de base à une discussion sur l'unité monumentale où il n'y a qu'utilité ou (il n'y a) point d'ordres d'architecture mais seulement une belle expressivité architecturale ${ }^{, 28}$. Encore une fois les ruines en tant que telles sont objet de réflexions utiles à comprendre la valeur de la masse isolée, bien exprimée dans les vues évocatrices de Piranesi. Ces amas émergent dans le paysage urbain et deviennent une autre occasion pour une réflexion sur le paysage - "un paysage urbain à composé, 29 - contribuant à la formation des principes contenus dans le texte Vers une architecture.

La fascination de Le Corbusier pour le paysage archéologique romain trouve, dans l'interprétation qu'en donne Piranesi, un intérêt renouvelé vers la forme phénomènique telle qu'elle se présente. L'attitude déjà manifestée par l'architecte envers le dessin des ruines, à coté des dessin des précises reconstitutions historiques, souligne cette attention; Piranesi renforce la nature des ruines, et il rende clairement lisible les éléments qui avaient déjà fasciné Le Corbusier: ces amas ruinés laissent apprécier la pure venustas de l'architecture, dénudés par le temps de la firmitas et de la utilitas.

"Face aux antiquités Romaines ou Grecques ou de la Renaissance, (l'architect) arrive à s'isoler de chaque stéréotype de langage pour saisir à l'état pur les émotions suscitées par une séquence d'espaces, par un particulier effet de clair-obscur, par le jeu des volumes, par la texture des matériaux, par les relations avec le paysage, par les signaux par lesquels les formes témoignent les présences des hommes ou stimulent l'imagination de l'observer à les penser" ${ }^{\prime 30}$.

\footnotetext{
${ }^{26}$ Jeanneret, C.-E., lettera a August klipstein, 28 Ottobre 1911, BV LC/102/1267 dans Talamona, M., L'ai decidé de finir mes études...sans le rêve. J'avais pour cela sogné à Rome, p. 131, dans Talamona, M., 2012, op.cit.

${ }^{27}$ Viollet-le-Duc, E.-E., Dictionaire raisonné dell'architecture française di XIe au XVIe siècle, Paris, 1866, Tom. $8^{\circ}$, ad vocem "Style"

${ }^{28}$ Jeanneret, C.-E., doc. FLC B2 (20) 245, dans Cohen, J.-L., Roma come lezione, dans Talamona, M., 2012 p. 188 op.cit.

${ }^{29}$ Jeanneret, C.-E., Carnet 4, Milano: Electa, 1987, p. 140, Le Corbusier, Vers une architecture, Parigi, 1923, p. 128 et Talamona, M., 2012, p. 131 op.cit.

${ }^{30}$ Tedeschi, E. G., Le lezioni di Tivoli, dans Mauri, A. (sous la direction), Le Corbusier a Villa Adriana, un atlante, Bologna: Alinea editrice s.r.l., 1999 p.10
} 
Le paysage archéologique de la Villa Adriana se présente, ainsi, dans sa forme brut, comme matière de projet et référence spatial, comme "ensemble monumental, très structuré, dans lequel s'intègrent sans rupture de continuité épisodes sans cesse variés, qui offrent surprises en boucle, organisations spatiaux de énorme effet, grâce à une régie très savante, dont les résultats surclassent souvent la qualité architecturale spécifique des éléments particuliers ${ }^{\prime \prime 31}$.

La vision de l'archéologie donne à Le Corbusier une leçon qui complète la mathématique perfection de l'antique, et plonge, au contraire, dans l'imperfection des fragments et l'effritement perceptif des rigoureuses matrices du projet. L'espace inspiré à l'espace archéologique est un espace absolu, détaché de son lien avec le plein, un "corps atmosphérique immatériel traversé par corps architecturaux de mesure inférieure lui subordonnés",32.

Son héritage, que Franco Purini ressente dans la "antiquité virtuelle,33 de la ville des Lumières, caractérisé par la fragmentation d'une unité perdue, par la stratification des bâtiments construits et reconstruits, par l'effritement dimensionnel d'un forma urbis perdue, se retrouve dans une "échelle urbaine réduite à peu environnements résiduelles, hétérogènes et contradictoires" 34 et dans une "espace complexe, au même temps continu et discontinu (...) indéchiffrable, trop variés dans ses composantes pour être considéré comme quelque chose doté encore de spécifiques matrices génératrices, ${ }^{35}$.

Les considérations sur la ville reflètent les composition du Maître vénitien, que recherche sa réalité virtuel sur la base de la structure logique de le espace archéologique. Les pièces sont des éléments isolés, combinés "niant le connexions syntaxiques entre les parties en faveur des libres associations thématiques",36 selon une procédure paratactique, innée dans la réalité visible du paysage archéologique, et exalté dans les œuvres de Piranesi.

"Dans la Villa Adriana plans horizontaux établis en entente avec la plaine romaine; montagnes qui ferment la composition établie, d'ailleurs, par rapport à eux",37: la réflexion de Le Corbusier "n'est pas, naturellement, un élément objectif, inhérent à la façon de bâtir romaine connaissable par une analyse philologique des ruines; elle est, plutôt, une interprétation ciblée, la découverte d'un artiste-architect auquel n'intéresse pas la reconstruction philologique, mais le sens que la culture moderne peut donner au héritage de l'histoire ${ }^{\text {,38. }}$.

\section{De la Villa Adriana à la Haute Cour de Justice à Chandigarh}

Parmi les plus importantes annotations sur le séjour romain duré onze jours (du 14 au 28 octobre, 1911) ${ }^{39}$ l'intérêt est captivé par la visite de Villa Adriana à Tivoli et certaines réflexions sur Villa d'Este. Le jeune Jeanneret dédie trois jours à l'étude de l'architecture et des ruines, qui se concluent avec cinquante-neuf pages de dessins et notes, contenues en partie dans le Carnet 4 et dans le Carnet 5 tout entier.

Les réflexions sur l'ensemble des antiquités de Villa Adriana sont nombreuses, tout comme les ambitions qu'il transporte dans sa successive production architecturale et théorique. Celles-ci seront présentées en premier plan

\footnotetext{
${ }^{31} i d .$, p. 10

${ }^{32}$ Purini, F., Attualità di Giovanni Battista Piranesi, Melfi:Libria, 2008, p. 23

${ }^{33}$ id., p. 9

${ }^{34} i d .$, p. 11

${ }^{35} i d .$, p. 11

${ }^{36} i d .$, p. 12

${ }^{37}$ Le Corbusier, Verso una Architettura, Cerri P.; Nicolin P. (sous la direction) Milano: Longhesi, 5 ed., 2003, p. 159

${ }^{38}$ Denti, G., La ricerca delle leggi e dell'ordine, dans Mauri, A., 1999, p. 13 op. cit.

${ }^{39}$ Petit, J., Le Corbusier. Lui-même, Genève: Edition Rousseau, 1970, pp. 24-44
} 
durant la publication du projet de Sainte-Baume dans l'Euvre Complète ${ }^{40}$ et dans d'autres réalisations telles que Ronchamp et Chandigarh" ${ }^{41}$ En outre "la Villa Adriana figure, même si pas expressément mentionnée, dans des croquis illustratifs de Urbanisme: l'intérêt n'est pas donné par leur relation avec le contexte, mais en tant que signe de la présence de ce monument dans les souvenirs de Le Corbusier, comme preuve de l'importante impression qui il a suscité à l'auteur,"42.

Les nombreux croquis effectués durant le séjour clarifient l'attente de la visite: le jeune produit de nombreux dessins de ruines, parcourant les diverses parties du complexe, et évoque les encadrements en perspectives présents dans les images de Pierre Gusman, dans lesquels l'auteur retravaille les gravures de Pirro Ligorio et Piranesi. Ces éléments sont utiles à Jeanneret pour fixer dans la mémoire le souvenir des masses romaines, comme dans la représentation du mur du Pecile, où est utilisé le même encadrement en perspective qui de manière synthétique met en lumière les géométries originales du complexe et leurs rapports avec le paysage naturel ${ }^{43}$ (image 1).

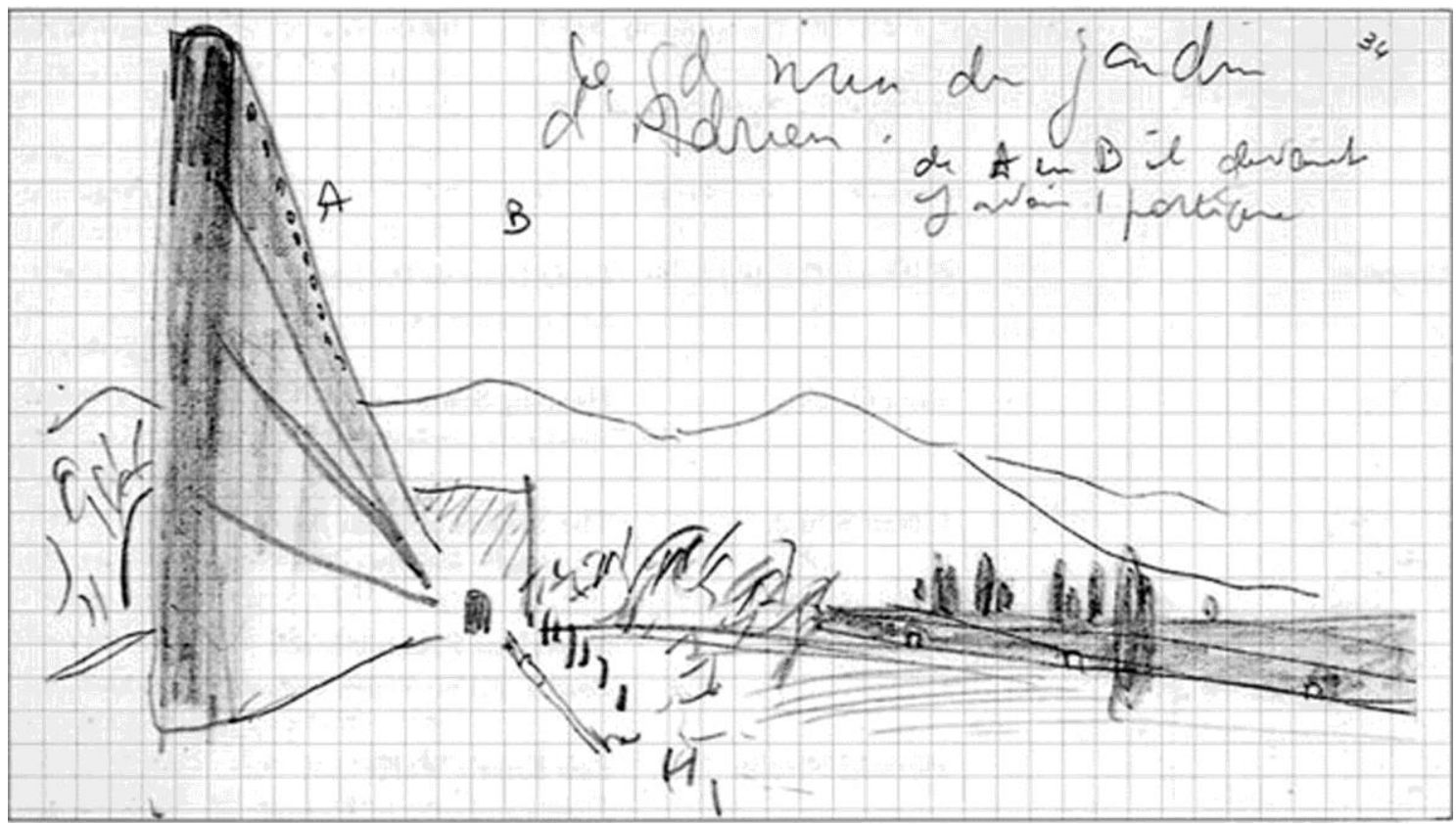

1. Jeanneret, C.-E., Carnet 5, p. 34: Esquisse de Villa Adriana, 1911.

Le deuxième croquis (image 2) représente le Praetorium ${ }^{44}$ - logements des Gladiateurs - avec un dessin précis des géométries originales de la structure, dépouillé de l'étage supérieur originel dans lequel exaltent les gigantesques arches; dans le dessin suivant ${ }^{45}$ (Carnet 5 , p. 79) il rappelle ce qu'il reste de l'antiquité, en soulignant le caractère de la ruine. Une représentation qui suggère la volonté d'emprisonner la mémoire de la ruine en tant que telle, où la fragmentation de l'étage supérieur et la présence de la nature captivent son intérêt tout autant que les géométries compositrices précédentes. Une confirmation supplémentaire qui pourrait étayer

\footnotetext{
${ }^{40}$ Le Corbusier, Oeuvre Complète 1957-1965 Vol. VII, Zurich: Les editions d'architecture, 1967 et Gresleri, G., Dalla Villa alle Ville: Jeanneret e Adriano, dans Talamona M., 2012, p. 149 op.cit.

${ }^{41}$ Gresleri, G., Dalla Villa alle Ville: Jeanneret e Adriano, dans Talamona, M., 2012, p. 149 op.cit.

${ }^{42}$ Tedeschi, E. G., Le lezioni di Tivoli, dans Mauri, A., 1999, p.11 op. cit.

${ }^{43}$ Gresleri, G., Dalla Villa alle Ville: Jeanneret e Adriano, dans Talamona, M., 2012, pp. 140-141 op.cit

${ }^{44}$ Jeanneret C.-E., Carnet 5, Milano: Electa, 1987, p. 78, dans Gresleri G., Dalla Villa alle Ville: Jeanneret e Adriano, dans M. Talamona, 2012, p. 146 op.cit.

${ }^{45} i d .$, p. 79
} 
l'hypothèse d'une reprise d'une vue piranésienne, Rovine di uno degli alloggiamenti dé Soldati presso ad una delle eminenti fabbriche di Adriano nella sua Villa di Tivoli ${ }^{46}$ (image 3), que Jeanneret a vue indirectement dans les textes de Pierre Gusman ou durant la série d'expositions rétrospectives à Castel Sant' Angelo, visitées depuis peu.

La représentation du croquis du jeune et l'image de Piranesi contiennent la volonté de maintenir le caractère actuel de l'antiquité. On pourrait supposer que Jeanneret se soit à nouveau penché, en direct, sur l'architecture qu'il avait déjà vue précédemment dessinée, et dont il assimile la connaissance des constructions et aussi la capacité évocatrice des ruines.

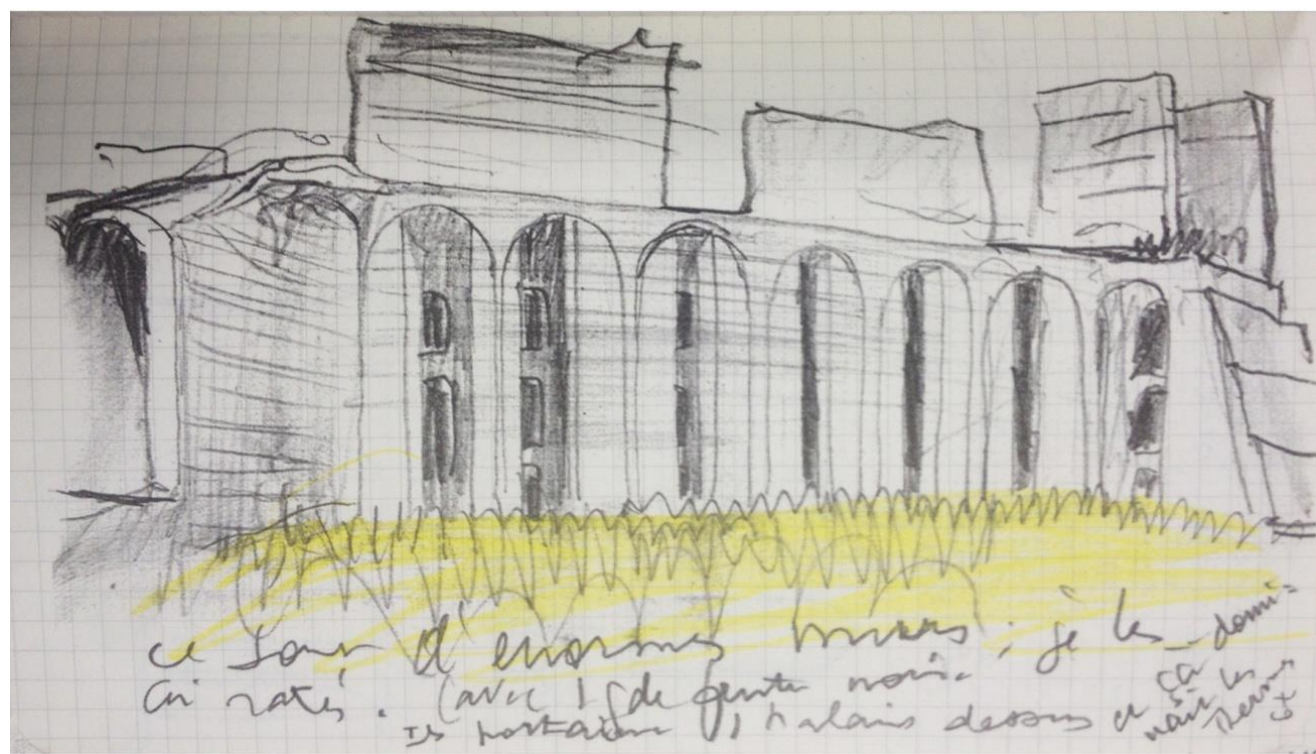

2. Jeanneret, C.-E., Carnet 5, p. 79: Esquisse de Villa Adriana, Le Praetorium, 1911.

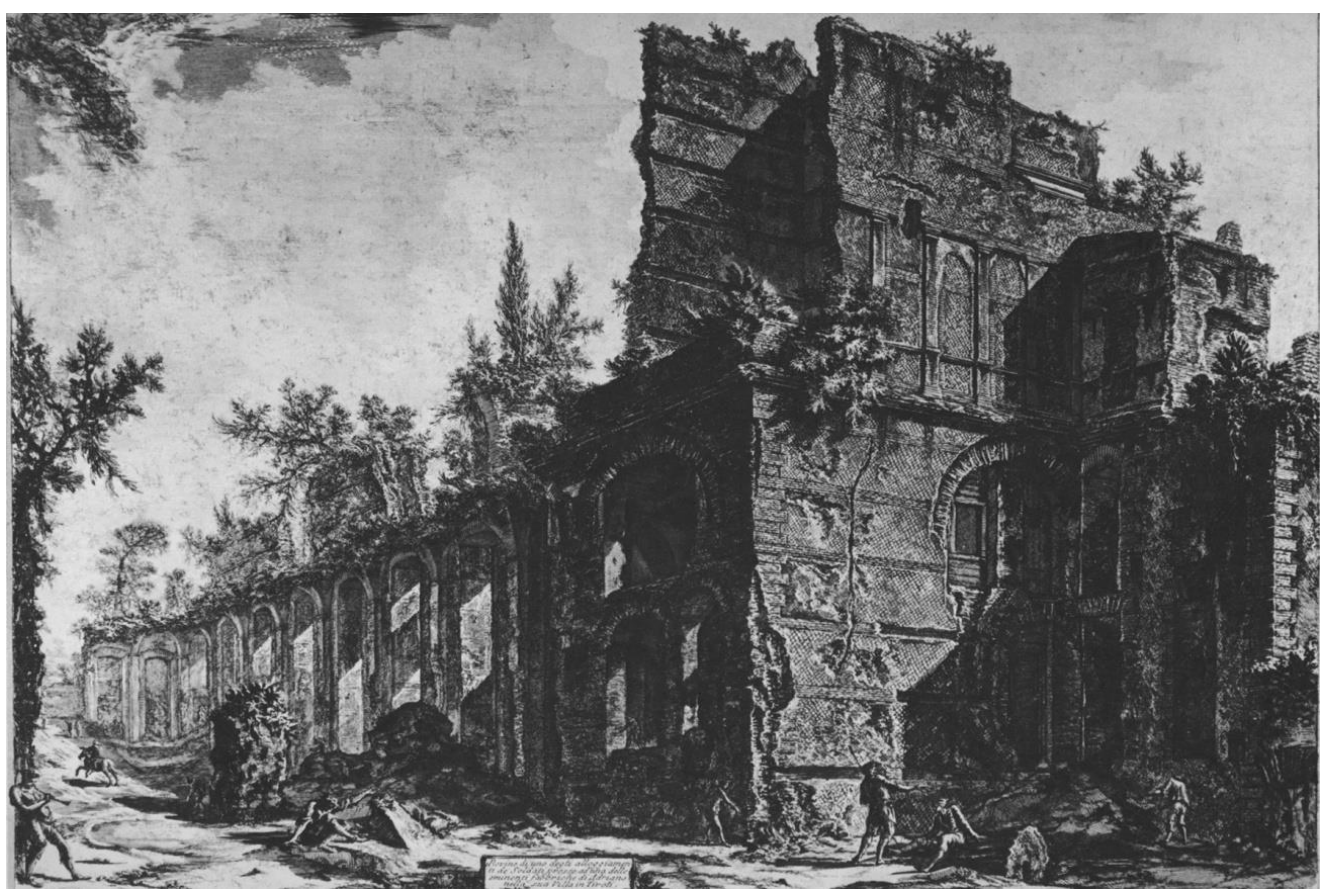

3. G. B. Piranesi, Rovine di uno degli alloggiamenti dé Soldati presso ad una delle eminenti fabbriche di Adriano nella sua Villa di Tivoli.

${ }^{46}$ Conti V.; Piranesi F., Piranesi, vedute e antichità di Tivoli, Roma: Centro Stampe de Vittoria, 1996, Tav. 22 
Le croquis du Praetorium resurgit, inspirant la composition de Ronchamp et les grandes arches qui composent l'édifice de la Haute Cour à Chandigarh" ${ }^{47}$. "Si le souvenir de Villa Adriana est rappelé ainsi, soudainement, ce n'es pas seulement parce que Le Corbusier est allé à Tivoli et a regardé longtemps ce lieu si suggestif, mais, surtout, parce que il choisit de dessiner ce qui assume effectivement le rôle de souvenir pour l'Architect" ${ }^{\prime 48}$. L'architect, donc, retrouve dans ses souvenirs "un microcosme qui réunit types de bâtiment et caractères spatiaux significatifs de la façon de construire romaine: les techniques des murs en briques et des voutes en béton, l'articulation et l'ouverture des enveloppes qui établissent les rapports entre intérieur et extérieur, la captation de la lumière qui valorise l'espace interne et donne un significat suggestif aux espaces sous-sol" 49 (image 4).

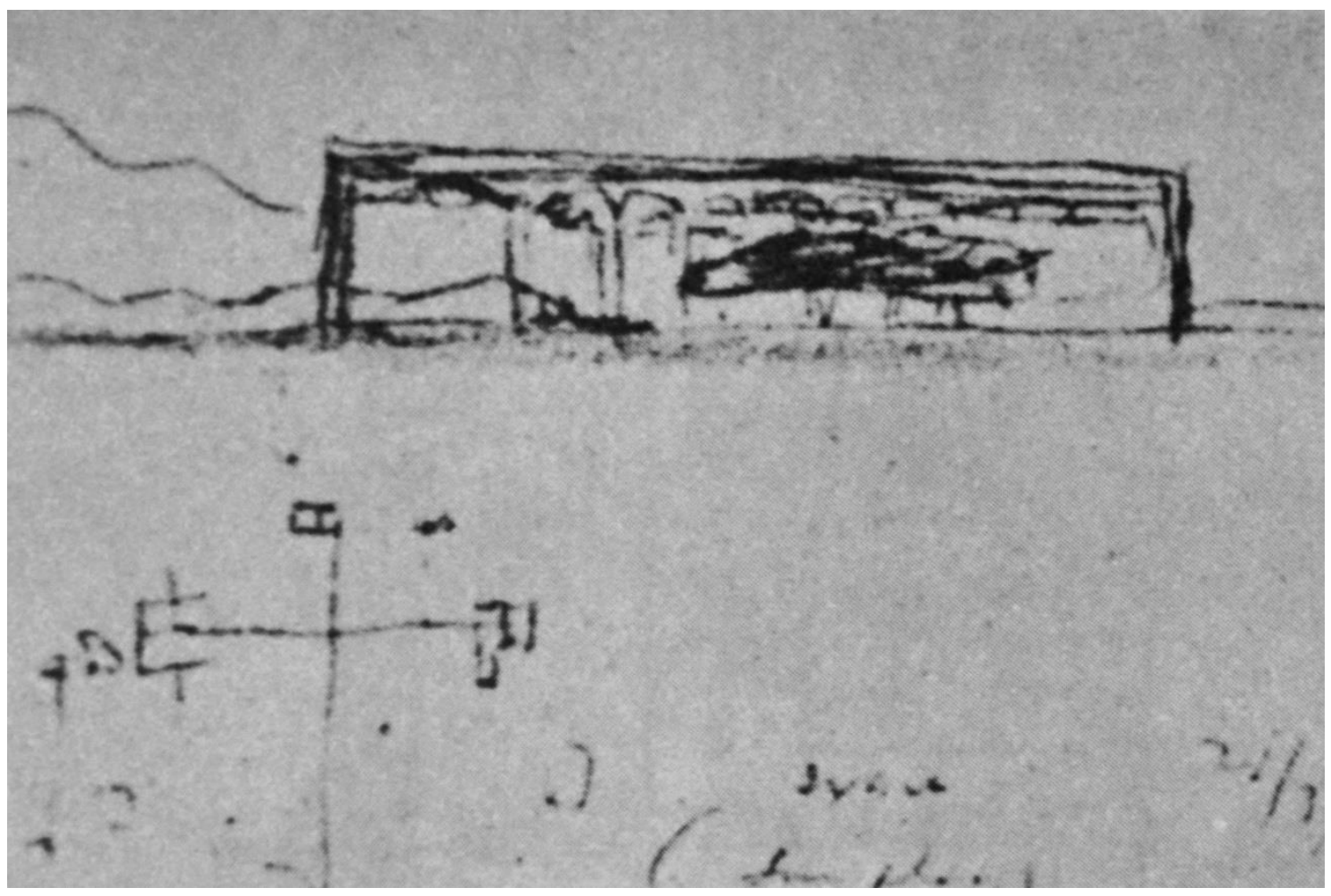

4. Le Corbusier, Premier croquis conceptuel de la Haute Cour de Chandigarh.

La géométrie de la forme de la façade de la Haute Cour (image 5), définie par le subtil parallélépipède qui embrasse et ferme l'édifice grâce à un signe pur, bloque le système continu des puissantes arches romaines. Ce signe précis encadre la structure et crée une friction avec le vide intérieur, où l'on perçoit la fluidité spatiale des voutes.

L'image du Praetorium gravée par Piranesi exalte la légèreté de la construction, accentuant les faisceaux lumineux qui traversent la structure; un mécanisme qui laisse pressentir une spatialité complexe, au-delà de la première couche de pierre du Praetorium.

\footnotetext{
${ }^{47}$ Gresleri, G., Dalla Villa alle Ville: Jeanneret e Adriano, dans M. Talamona, 2012, p. 136-150 op.cit.

${ }^{48}$ Danièle P., la cappella di Rochamp, come esempio del processo creativo di Le Corbusier, dans: AA.VV. Le corbusier 18871965, Mialno: Electa, 1993, p. 168

${ }^{49}$ Denti, G., La ricerca delle leggi e dell'ordine, dans Mauri, A., 1999, p. 12 op. cit.
} 


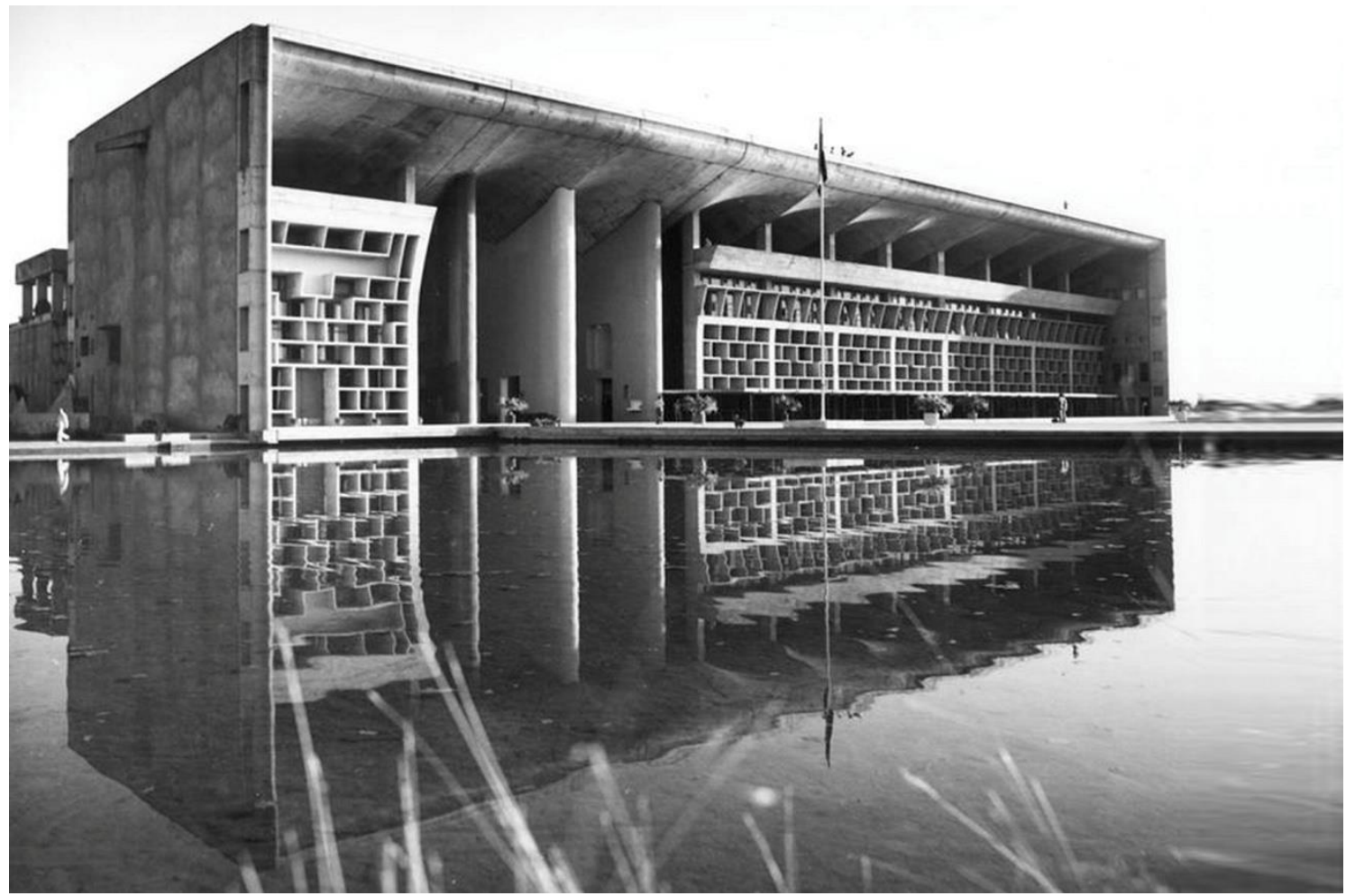

5. Le Corbusier, Haute Cour de Chandigarh, 1952.

Cet espace interne vit des éléments menus, apposés au grand édifice, qui d'un coté suggèrent la fragmentation et l'effritement de l'ensemble, caractéristique primaire des ruines, et d'un autre avivent le gigantisme de la figure qui frise l'infini vers l'horizon. De la même façon, l'Haute Cour naît comme un ordre géant d'arcades creuses qui laissent regarder au-delà, et qui révèlent les organismes fonctionnels greffés sur leur structure, générant une relation osmotique avec l'extérieur. Le système du vide qui traverse l'espace interne et externe, particularité de toutes les architectures en ruine, est accentué dans l'Haute Cour: le bâtiment manque de façade, d'un dispositif architectonique de construction du front, mais au contraire caractérise son aspect extérieur par la visibilité de sa nature intérieure. Le système de vide laisse traverser ses éléments par le soleil, tout comme à Villa Adriana "la lumière modèle les formes de la nature et l'architecture, et leur relation mutuelle intéresse Le Corbusier, qui la souligne dans ses croquis" ${ }^{\prime 50}$ (image 6).

Grâce à l'espace ouvert sous-jacent les arcades, le bâtiment de l'Haute Cour cherche une relation avec le milieu extérieur et son paysage bâti, un lien émotif avec les parties d'un ensemble dilaté et hétérogène, selon une volonté déjà invoquée lors de la conception du projet de l'ensemble du Capitole, quand, en 1951, "l'architecte signe la grande prospective où l'on voit, sous le grand cadre parasol de la Haute Cour, une vue piranésienne sur laquelle se détachent les bâtiments" ${ }^{\mathrm{N} 1}$ (image 7), manifestant l'intention de construire un système composé par éléments décousus, paratactiquement approchés, libres dans l'espace atmosphérique décrit de l'Himalaya à l'arrière-plan. Une liste de vibrations qui se détachent dans l'espace indicible de l'écoute.

\footnotetext{
${ }^{50}$ id., p. 12

${ }^{51}$ Papillault, R., Chandigarh et Le Corbusier, Creation d'une ville en Inde, 1950-1965, Toulouse: Edition Poesis, 2011, p.234
} 


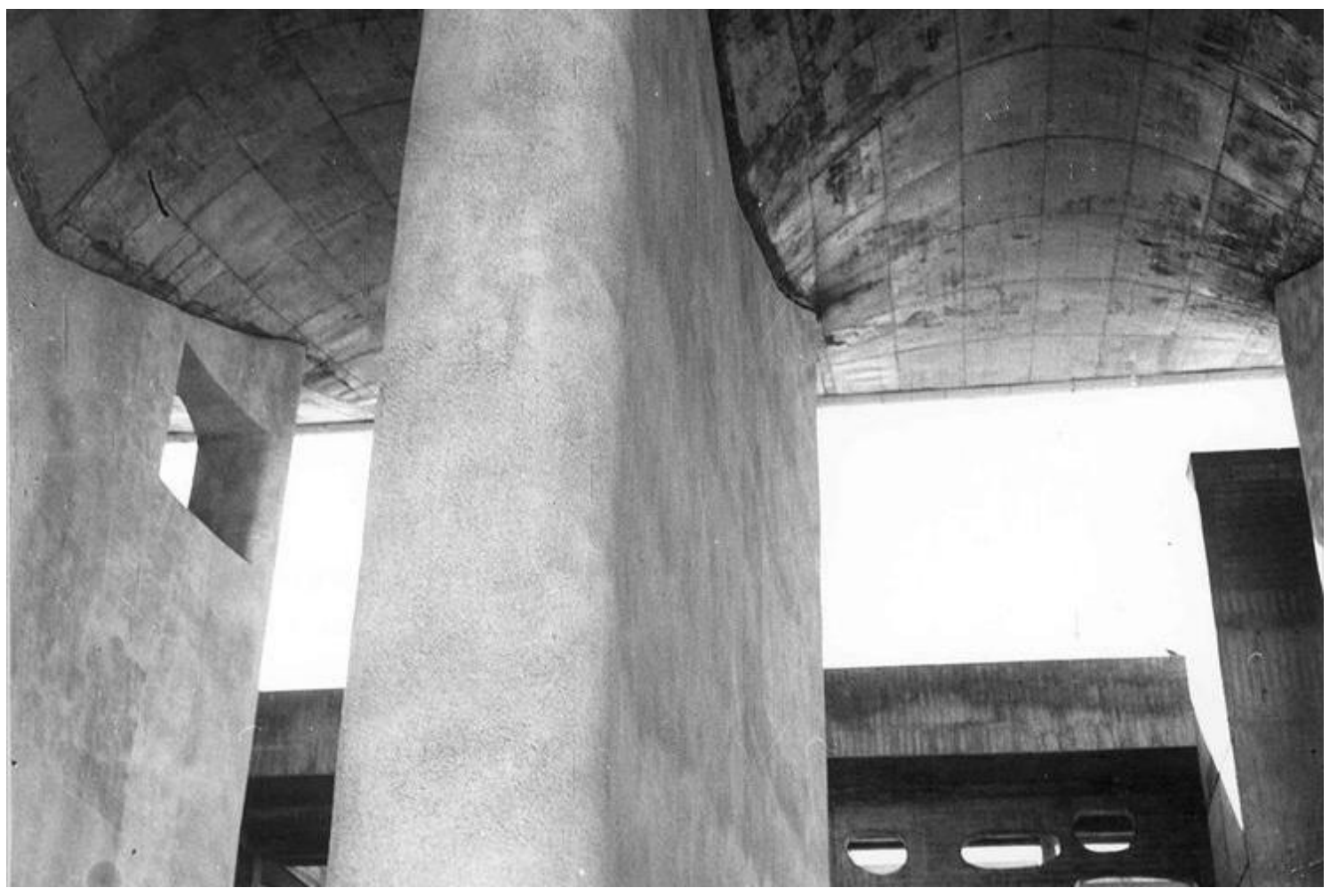

6. Le Corbusier, Haute Cour de Chandigarh, 1952.

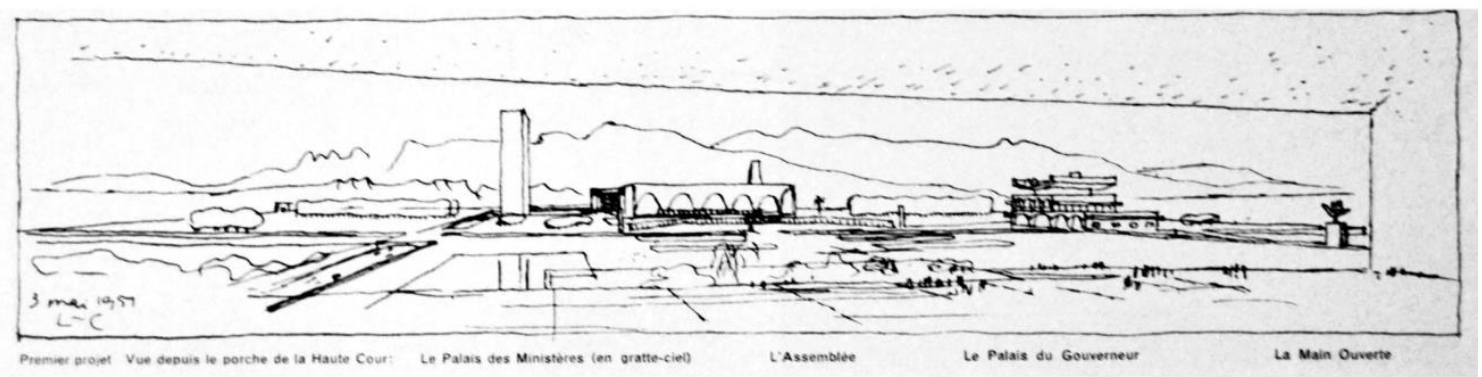

7. Le Corbusier, Perspective sur le Capitole signé Le Corbusier (le Sécretariat est encore une tour, l'Assemblée présente une élévation à arcades, le Palais du Gouverneur et la Main Ouverte ont leur forme presque définitive), 3 mai 1951.

Le Corbusier lie le bâtiment au sol, le dépouillant du socle supposé au début ${ }^{52}$, de façon que les douze piliers qui définissent le rythme des treize travées paraissent enracinés à terre. L'accentuation de l'espace module l'insertion des volumes fonctionnels, coincés entre les butées et renfermés en haut par un évident plancher, dessinés par un système de façade constitué d'une grille irrégulière de ciment qui crée un "lien visuel entre l'observateur et l'édifice",53. Les sept cours sont accueillies en cinq étages dans le volume inséré entre les travées, positionné asymétriquement. Une asymétrie qui travail avec les corps fonctionnels à la base de l'édifice, éléments indépendants par rapport au système vouté qui semblent suggérer la présence d'éléments moyenâgeux superflus, qui seraient des systèmes superposés à la pure géométrie recherchée dans l'architecture romaine. Ceux-ci déséquilibrent la structure principale, en définissant une superfétation majeure, et déterminent une arythmie des travées coïncidente avec l'entrée. De l'autre coté, marqué par une seule travée plus grande, l'autre plein de la

\footnotetext{
${ }^{52} i d$.

${ }^{53}$ Serenyi, P., Senza tempo ma del suo tempo: l'architettura di Le Corbusier in India, dans Brooks, H. A., Le Corbusier, Milano: Electa, 2001, p. 202.
} 
composition se place près le vide de l'entrée, manifestant une rupture entre les parties. Le vide du hall, souligné par les travées latérales plus étroites, est l'occasion pour créer un espace à toute hauteur, vertigineux, où sont visibles les "chainettes ${ }^{\prime 54}$ des arcades, en souvenir des substructions romaines. Dans cet espace creux s'inscrit un mur à l'arrière-plan, qui rend la majestueuse entrée semi-ouverte. Le mur au fond, plein linéaire percé par des ouvertures difformes, est structure de la rampe, et crée une complexité spatiale interne peu prévisible de loin, dramatisée par le soleil filtrant. La rampe serpente entre les galeries à différentes étages qui distribuent les fonctions, posés a l'arrière et enveloppés par un épais brise-soleil qui concourent au dessin di front postérieur, sur lequel s'imprime le volume de la salle des pas perdus.

De l'autre côté, le brise-soleil qui module le front antérieur, orienté vers les autres édifices du Capitole, se recourbe pour chercher un dialogue, pour suggérer ainsi une tension, grâce à une déformation qui reste toujours ouverte, qui ne se referme pas dans la géométrie du bâtiment. "Les trois grands objets désireux cherchent de briser leur solitude (...) L'Haute Cour à travers l'inflexion des brise-soleil "55 essaye de évoquer une unité perdue, de faire allusion aux autres éléments qui constituent l'espace du Capitole, comme les reins d'un arc effondré renvoient à leurs complément (image 8).

C'est précisément en ce système d'émergences solitaires que s'accomplit la suggestion du paysage archéologique, l'inachèvement propre des fragments, produits d'une matrice difficilement intelligible, où "rien n'aide l'œil à se situer par rapport à ces trois personnages, (...) pas d'allusions prospectives, pas de triangulations formelles, qui établissent une conversation dont l'oreille humaine n'est adéquate à saisir que faibles et déformés échos ${ }^{\prime \prime 56}$.

La matrice géométrique du projet laisse de la marge à la correction sensible, à l'émergence de la sensibilité de l'architecte à travers des mailles de la structure logique dont lui même s'était équipé. L'effort initial pour le Capitole, sur lequel il concentra les attentions majeurs, en laissant aux lignes tracées par Mayer l'organisation du plan urbain, convergea en une composition orientée sur grands axes et carrées pour structurer le projet de l'espace ouvert et les éléments le composant, suivant le système métrique-proportionnel du Modulor.

Dans la recherche de tracer des références spatiales, de reconnaître des pierres angulaires pour projeter la grande esplanade représentative du Capitole indien, Le Corbusier recourt à sa mémoire intérieure, émotionnelle, aux lointains souvenirs de sa jeunesse, pas pour le remaniement de figures et des allusions mécaniques à architectures déjà vue, mais pour rechercher la même charge émotionnelle évoquée par les ruines du paysage $\operatorname{archéologique~}^{57}$, innée dans la composition de la Villa Adriana, dans la magnificence de l'ensemble comme elle est apparue à ses yeux.

\footnotetext{
${ }^{54}$ Papillault, R., 2011, p. 232 op. cit

${ }^{55}$ Tafuri, M. Macchine e Memoria, dans Brooks, H. A., 2001 p. 255 op. cit.

${ }^{56}$ id., p. 252

${ }^{57}$ Bellini, F., Il conflitto irriducibile tra raziocinio e natura primordiale, dans Casciato, M., Le Corbusier e Chandigarh, ritratto di una città moderna, Roma: Edizioni Kappa, 2003, pp. 107-116
} 


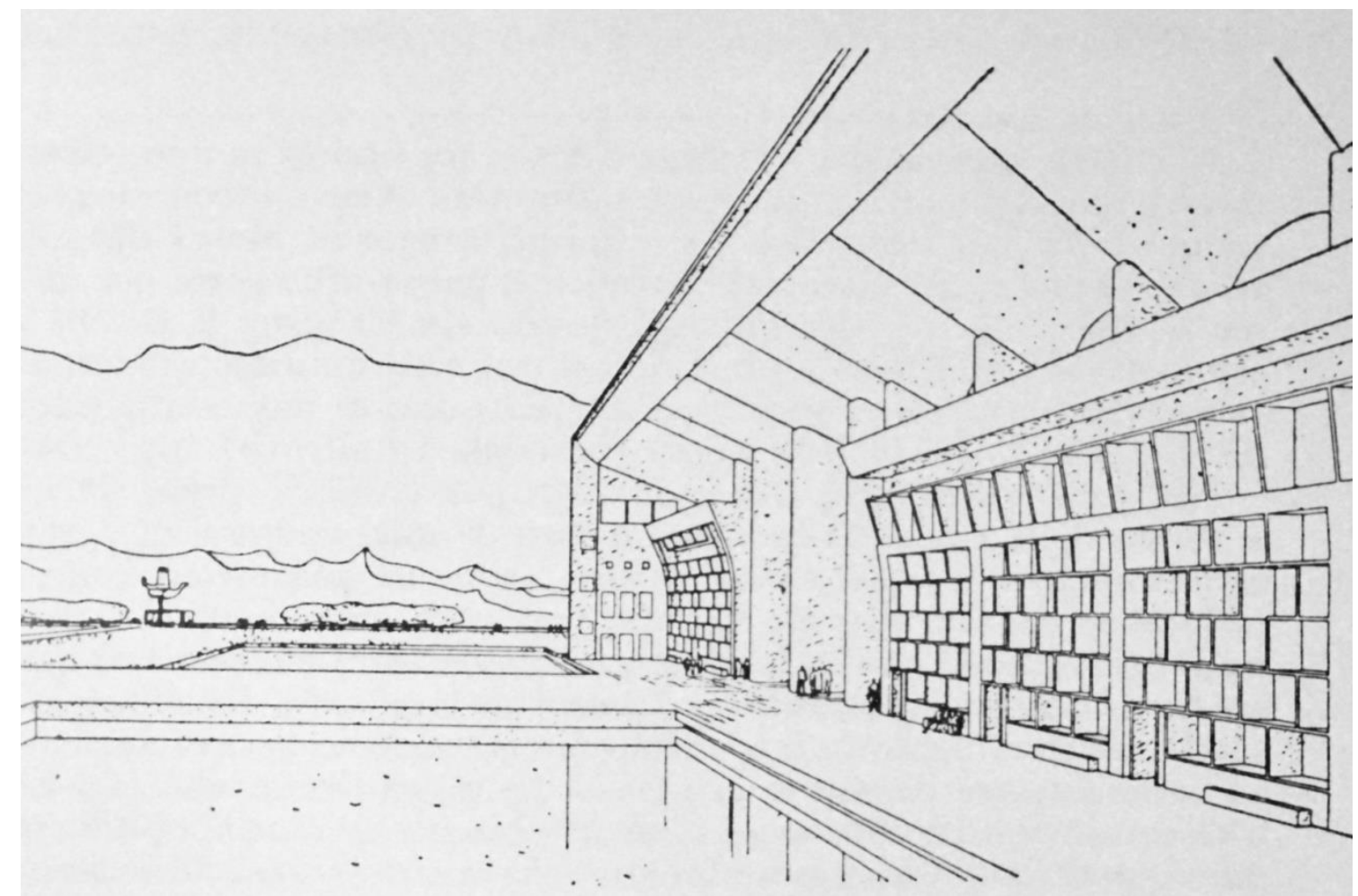

8. Le Corbusier, Perspective de la Haute Cour de Chandigarh.

Il ne s'agit plus seulement de la géométrie proportionnelle, des grandes axes générateurs faisant allusion à un schéma mental mathématicien presque parfaite, qui conduisent la conception du projet: il décide de sous-tendre la rigueur géométrique à une géométrie déclarée qu'en partie. Comme cela arrive dans les architecture fragmentées par le temps, qui expriment les émotions juste grâce à l'absence des pièces, à la perte de la vérité géométrique présente dans leur conception originale, comme les lignes-guide qui structurent la composition du Capitole.

La volonté de construire un paysage architectural qui se base sur des objets isolés, met en évidence sous la lumière l'uniformité de la matière du ciment brut qui devient écho de la matérialité de la ruine, contenue dans les masses romaines laissées à l'abandon ${ }^{58}$; et comme les masses antiques, à Chandigarh les édifices se décomposent sur le plan horizontal, souvenirs de la composition ouverte du complexe de Villa Adriana qui manifeste un "urbanisme organique" et "géographique" ${ }^{\text {"59 }}$ fait de gigantesques mégastructures linéaires qui suivent un paysage primordial.

\section{Conclusion}

L'intérêt pour les ruines du monde antique, qu'il a approché aussi grâce à l'étude des dessins de Piranesi, a guidé sa sensibilité d'architecte et, en particulier, les expériences faites durant la visite de Villa Adriana ont été pour le jeune Jeanneret un enseignement important, auquel il dédiera en 1922 une précise pensées: "Rome s'occupait de conquérir l'univers et de gérer. (...) Hors de Rome, ayant de l'air, ils ont fait la Villa Adriana. On y médite sur la grandeur romaine. Là, ils ont ordonné. C'est la première grande ordonnance occidentale. Si l'on évoque la

\footnotetext{
${ }^{58}$ Von Moos, S., «L'Europe après la pluie» ou le brutalisme face à l'Histoire, dans J. Sbriglio, Le Corbusier et la question du Brutalisme, Paris: Edition Parenthèses, 2013, pp. 66-87

${ }^{59}$ Colquhoun A., Il significato di Le Corbusier, dans Brooks, H. A., 2001, p. 44 op. cit.
} 
Grèce à cette jauge, on dit: "Le Grec était un sculpteur, rien de plus" mais attention, l'architecture n'est pas que d'ordonnance. L'ordonnance est une des prérogatives fondamentales de l'architecture. Se promener dans la Villa Adriana et se dire que la puissance d'organisation qu'est "Rome" n'a encore rien fait, quel tourment pour un homme qui se sent participer, complice, à ce raté désarmant! $!^{60,}$

Les croquis et les réflexions dédiés par l'architect à l'ensemble archéologique de Tivoli, à côté des analyses des vues de Piranesi, manifestent un intérêt vers l'Antique et vers la tension spatiale du paysage archéologique. L'analyse du projet de Chandigarh, et de l'Haute Cour de Justice notamment, montre des suggestions spatiaux et lumineuses, et des éléments de la composition, qui représentent une modalité par laquelle émerge l'empreinte reçue par les architectures Romaines. Cette orientation se superpose à la recherche d'ordre, harmonie et proportion, qui marque la plupart de sa production architecturale et théorique: la fascination des ruines, pour la réaction poétique qu'ils génèrent, au delà du sens et de la fonction de l'architecture, émerge comme composante plastique et irrationnelle plusieurs fois dans ses projets, pour trouver son achèvement dans les œuvres de la maturité, dont le Capitole de Chandigarh.

\section{Crédits des illustrations}

Image 1. Esquisse de Villa Adriana, dans: Jeanneret, C.-E., Voyage d'Orient. Carnet 5, Milano: Electa, 1987, p. 34

Image 2. Esquisse de Villa Adriana, Le Praetorium, dans: Jeanneret, C.-E., Voyage d'Orient. Carnet 5, Milano: Electa, 1987, p. 79

Image 3. Rovine di uno degli alloggiamenti dé Soldati presso ad una delle eminenti fabbriche di Adriano nella sua Villa di Tivoli, dans: Conti, V.; Piranesi, F., Piranesi vedute e antichità di Tivoli, Roma: 1ed. Centro Stampe de Vittoria, 1996.

Image 4. Premier croquis conceptuel de la Haute Cour de Chandigarh, dans: Papillault, Rémi, Chandigarh et Le Corbusier, Création d'une ville en Inde, 1950-1965, Toulouse: Edition Poesis, 2011, p. 215

Image 5. Photo de l'Haute Cour de Chandigarh, dans: www.fondationlecorbusier.fr.

Image 6. Photo de l'Haute Cour de Chandigarh, dans: www.fondationlecorbusier.fr.

Image 7. Perspective sur le Capitole signé Le Corbusier (le Sécretariat est encore une tour, l'Assemblée présente une élévation à arcades, le Palais du Gouverneur et la Main Ouverte ont leur forme presque définitive), 3 mai 1951, dans: Papillault, Rémi, Chandigarh et Le Corbusier, Création d'une ville en Inde, 1950-1965, Toulouse: Edition Poesis, 2011, p. 234

Image 8. Perspective de la Haute Cour de Chandigarh, dans: Le Corbusier, E. Saurwein (sous la direction), Modulor 2, Milano: Gabriele Marzotta Edizioni s.r.l., 1974

\section{Bibliographie}

Abram, Joseph; Bancon Mardges; Baudouï, Rémi, et al., Enciclopedia Le Corbusier, Milano: Electa S.p.a. Milano, 1988

Baudouï, Rémi; Dercelles, Arnaud, Le Corbusier. correspondance. Lettres à la famille 1900-1925 vol I Fondation Le Corbusier, Paris-Gollion, Infolio Editions, 2011

Brooks, Allen H., Le Corbusier 1887-1965, Milano: 1ed. Electa, 1993

Casciato, Maristella, Le Corbusier e Chandigarh, ritratto di una città moderna, Roma: Edizioni Kappa, 2003

\footnotetext{
${ }^{60}$ Le Corbusier-Saugnier, «Architecture, la leçon de Rome », l'Esprit Nouveau, n14 ${ }^{\circ}$ janvier 1922 dans Duboÿ P., Croquis de voyage et étude, Paris: La Quinzaine Littéraire, 2009, pp. 124-125
} 
Conti, Vincenzo; Piranesi, Francesco, Piranesi vedute e antichità di Tivoli, Roma: 1ed. Centro Stampe de Vittoria, 1996

Duboÿ, Philippe, Croquis de voyage et étude, Paris: 1ed. La Quinzaine Littéraire, 2009

Gravagnuolo, Benedetto, Le Corbusier e l'Antico. Viaggi nel Mediterraneo, Napoli: 1ed. Electa,1997

Jeanneret, Charles-Édouard, L’Esprit Nouveau, Paris: 1 ed., 1920.

Jeanneret, Charles-Édouard, Voyage d'Orient. Carnets, Milano: 1ed. Electa, 1987

Le Corbusier, Le poème de l'angle droit, Milano: 5rd. ed. Electa, 2007

Le Corbusier, Euvre Complète 1957-1965 Vol. VII, Zurich: 2rd. Ed. Les éditions d'architecture, 1967

Le Corbusier, Vers une architecture, Milano: 11rd.ed. I Marmi, 2013

Papillault, Rémi, Chandigarh et Le Corbusier, Création d'une ville en Inde, 1950-1965, Toulouse: Edition Poesis, 2011

Petit, Jean, Le Corbusier lui-même, Paris: 1ed. qui était Le Corbusier, 1968

Purini, Franco, Attualità di Giovanni Battista Piranesi, Melfi: Libria, 2008

Sbriglio, Jacques, Le Corbusier et la question du Brutalisme, Pairs: 1ed. Edition Parenthèses, 2013

Talamona, Marida, L'Italia di Le Corbusier, Milano: Mondadori Electa S.p.A., 2012

Tedeschi, Eugenio Gentili; Denti, Giovanni, Mauri, Annalisa (sous la direction), Bologna: Alinea editrice s.r.l., 1999

Turner, Paul V., La formazione di Le Corbusier, idealismo e Movimento Moderno, Milano: 1ed. It. Editoriale Jaca Book SpA, 2001

Viollet-le-Duc, Eugène Emmanuel, Dictionnaire raisonné de l'architecture française di XIe au XVIe siècle, Saint Julien: 13rd. Ed. Editions de Sancey, 1978-1979 


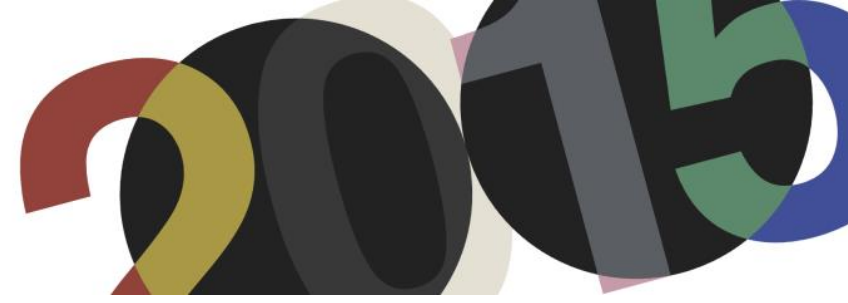

DOI: http://dx.doi.org/10.4995/LC2015.2015.682

\title{
Le Corbusier y la autonomía de la arquitectura
}

\author{
A. Rubio Garrido
}

Escuela Técnica Superior de Arquitectura de Valencia

\begin{abstract}
Resumen: Tres han sido los intentos de vincular la obra de Le Corbusier con la "autonomía de la arquitectura".
El primero, aquel formulado por Emil Kaufmann en 1933, reposa en una analogía ética conducida por medio de ciertos mecanismos compositivos. El segundo lo alentó Johnson durante la posguerra e identifica en Le Corbusier un sistema de composición autorreferencial pretendidamente ajeno a todo condicionante exterior que enfatiza el purismo de sus operaciones formales. El tercero fue conducido por un grupo de autores englobados en el "autonomy project" que vio en su obra la posibilidad de entender la arquitectura simultáneamente como hecho social y producto formal.

Cada intento ensalzó ciertas características de Le Corbusier y obvió otras en la medida en que se adscribieron a las diversas, y por momentos divergentes, interpretaciones de la autonomía de la arquitectura.

En este texto defenderé que la aparente multiplicidad de las interpretaciones de la obra de Le Corbusier que derivan de estos intentos puede superarse atendiendo al sentido filosófico originario de "autonomía" y su incorporación al arte. A la postre, remiten a una paradoja difícilmente superable y que puede identificarse como consustancial a la modernidad arquitectónica: la dialéctica entre la forma y la función.
\end{abstract}

Abstract: There have been three attempts to link Le Corbusier's work with the "autonomy of architecture".

The first one, the one conducted by Emil Kaufmann in 1933, lies in an ethical analogy through some compositional mechanism. Johnson encouraged the second one during the postwar. He identified in Le Corbusier a system of self-referential composition, supposedly alien to all outside constraint, which emphasizes the purity of its formal operations. The third was led by a group of authors, members of the "autonomy project". They saw in his work the possibility of understanding architecture simultaneously as a social fact and formal product.

Each attempt praised certain features of Le Corbusier and others were disregarded, following the pattern of controversial interpretations of the autonomy of architecture.

In this paper I will argue that this apparent multiplicity of interpretations of Le Corbusier's work can be overcome taking the original philosophical sense of "autonomy" and its incorporation into art. In the end, they refer to an insurmountable paradox, which can be identified as integral to modern architecture: the dialectic between form and function.

Palabras clave: Le Corbusier, autonomía de la arquitectura, compromiso, formalismo, dialéctica. Keywords: Le Corbusier, autonomy of architecture, commitment, formalism, dialectics.

\section{Introducción}

A lo largo del siglo XX, tres han sido los intentos de vincular la obra de Le Corbusier y la "autonomía de la arquitectura".

El primero reposa en una analogía ética. Apenas tres meses después del incendio del Reichstag, Kaufmann propone en su publicación Von Ledoux bis Le Corbusier. Ursprung und Entwicklung der autonomen Architektur una continuidad entre los valores democráticos y republicanos de la Revolución Francesa con la arquitectura de Le Corbusier, "el más autoconsciente protagonista" de la nueva arquitectura, "den Führer des jungen Frankreich". Respaldado por su teoría del pavillonsystem, Kaufmann encuentra en Ledoux el precedente de una arquitectura paradigmáticamente reflejada en Le Corbusier. La lucha por la autonomía se entiende en este primer 
sentido como la lucha de la autodeterminación contra el dictado de la necesidad externa, la razón contra la contingencia, lo sintético contra lo orgánico, lo puro contra lo corrupto.

El segundo está marcado por el giro que impone Kaufmann a su producción teórica a partir de su exilio en Estados Unidos de América. Durante su debut en 1942 en la American Society of Architectural Historians, Kaufmann obvia toda referencia al republicanismo revolucionario en su producción teórica (y los vínculos establecidos con Kant o Rousseau) e invierte la prioridad entre la forma y sistema en beneficio de lo que llamará el "new individualism". Toda mención al carácter emancipatorio y su analogía entre Ledoux y Le Corbusier desaparece, dando lugar a un tipo de formalismo abiertamente deudor del legado de Durand y Dubut que será explotado con profusión por Johnson, entre otros. Este constituye la segunda versión del vínculo entre Le Corbusier y la autonomía de la arquitectura: un sistema de composición autorreferencial, pretendidamente ajeno a todo condicionante exterior, que enfatiza el purismo de sus operaciones formales.

En tercer lugar, diversos autores reunidos en torno a lo que se llamó el "autonomy project" intentaron en los años setenta rehabilitar la "autonomía de la arquitectura" desde la premisa de la necesidad de incorporar una orientación social. Esta motivación inicial llevó, a la postre, a una combinación de los dos postulados anteriores, de suerte que vieron en la obra de Le Corbusier la posibilidad de entender la arquitectura simultáneamente como hecho social y producto formal.

Tras una breve introducción del concepto de autonomía desde su originaria concepción filosófica y los desafíos concretos que esta implica para la arquitectura, presentaré en los tres apartados siguientes una genealogía de las interpretaciones que han caracterizado la recepción de la "autonomía de la arquitectura" a través de la obra de Le Corbusier: el compromiso ético defendido por Kaufmann, el formalismo de Johnson y, finalmente, una suerte de relativismo condensado en el "autonomy project". Mostraré cómo, a la postre, todas remiten a una paradoja difícilmente superable y que no es otra que aquella a la que nos aboca necesariamente la asunción de la modernidad en la arquitectura: la dialéctica entre la forma y la función.

\section{La "autonomía de la arquitectura"}

como la arquitectura no es sólo autónoma, sino que al mismo tiempo es funcional, no puede negar simplemente a los seres humanos tal como son, aunque tiene que hacer esto en tanto que autónoma.

Adorno $^{1}$

En un sentido amplio, se entiende por "autonomía" la no dependencia de algo o alguien a la hora de determinar sus propias leyes. Así, se dice de alguien que es autónomo en la medida en que se vale por sí mismo; referido a un estado, autónomo es aquel que tiene la potestad de regirse mediante normas y órganos propios; y así en adelante. En sintonía con esta acepción, en la tradición filosófica cabe distinguir, al menos, dos amplios sentidos en su uso. En un primer sentido, que podría ser llamado ontológico, la autonomía responde a la propiedad de ciertas esferas de la realidad de regirse por leyes propias, esto es, distintas de las de otras esferas de la realidad. Aquello que distinguiría esta propiedad de la independencia sería el hecho de que, junto con estas leyes que remiten a esta esfera (aunque no forzosamente de forma exclusiva), pueden coexistir otras consideradas de rango más fundamental que, a su vez, pertenecen a otras esferas. El segundo sentido en el que se emplea la autonomía pertenece al ámbito ético. Procede originariamente del área política -y a partir del siglo

\footnotetext{
1 Adorno, Theodor W.: Teoría estética. Obra completa $n^{\circ} 7$. Rolf Tiedemann (Ed.). Jorge Navarro Pérez (Trad.). Madrid: Akal, 2004. p. 342.
} 
XVII también jurídica- y no será hasta principios de la Edad Moderna cuando puede encontrarse mención explícita en referencias aisladas de diferentes autores. En líneas generales se habla de una ley moral autónoma cuando "tiene en sí misma su fundamento y la razón propia de su legalidad". 2

En cualquier caso, es a partir de Kant cuando la autonomía ocupa una posición central como concepto filosófico ${ }^{3}$ y cobra un sentido enfático. En efecto, Kant sitúa el concepto de "autonomía" en el centro de su filosofía práctica. Afirma que la razón humana es una fuente autónoma de principios de conducta, a cubierto de los halagos de inclinación sensual, tanto en sus determinaciones de valor como en sus decisiones de actuar. Así, la autonomía humana es el valor más alto y la condición de posibilidad de todos los otros valores y la "autonomía de la voluntad" [Autonomie des Willens] es entendida como supremo principio de la moralidad. ${ }^{4}$ Sería este un primer sentido de autonomía en la obra de Kant: uno indisolublemente ligado a la filosofía práctica.

Adicionalmente, puede rescatarse un segundo sentido -quizás más laxo- de autonomía en Kant. Pese a que sólo pueda aplicarse el sentido estricto de "autonomía" al dominio de la razón práctica, Kant sí defiende la autonomía del juicio del gusto como facultad del alma respecto del entendimiento y de la razón. Así, la estética sería autónoma respecto del conocimiento (no aporta conocimiento) y de la moral (es desinteresada). Es más, la producción en este ámbito, es decir, la obra de arte y la movilización de una técnica propia, tiene unos fundamentos y aspira a cierta objetividad que no son ni la del entendimiento (cuyos principios son conceptos determinantes) ${ }^{5}$ ni de la razón (cuyo principio es un ideal de perfección moral fundamentado en el imperativo moral). ${ }^{6}$ En primer lugar, la producción artística se basa en el principio de la "finalidad sin fin" mediado por la figura del genio, quien se da a sí mismo las reglas para la producción artística de tal forma que se pueda producir como si lo producido fuera obra de la naturaleza. ${ }^{7} \mathrm{Y}$, en segundo lugar, el juicio del gusto tiene por fundamento un sentimiento subjetivo desinteresado y aspira a una cierta universalidad diferente a la de las leyes naturales y la de los imperativos morales. Se fundamenta antes bien en el consenso que cabría esperar en un colectivo de gusto educado, lo que podría provocativamente llamarse una "objetividad subjetiva". ${ }^{8}$ Luego, en un sentido no tan estricto como el moral, sí puede hablarse en Kant de un tipo de autonomía del arte en la medida en que no es ni conocimiento ni moral. Esto evidenciaría una insalvable diferencia entre las producciones humanas que, como es el caso de la artesanía, no son propiamente autónomas, puesto que están orientadas a un fin. Pero puede incluso ampliarse a otras producciones como la gastronomía que, aún siendo independientes de la ciencia o de la moral, no por ello son autónomas en el sentido en que lo es el arte.

En definitiva, son igualmente identificables en Kant los dos sentidos de autonomía filosófica reseñables en el conjunto de la filosofía moderna, de suerte que puede achacársele tanto la responsabilidad de haber otorgado a la autonomía un papel central en el desarrollo del arte occidental como de posibilitar su intrínseca ambigüedad. De hecho, esta indeterminación dará lugar en la tradición estética a dos corrientes no siempre claramente diferenciables que atravesarán la exposición de este trabajo. En el primer caso, la autonomía es interpretada como libertad e independencia de cualquier manifestación artística respecto de restricciones socioculturales e

\footnotetext{
2 Véase la entrada "autonomía” en Ferrater Mora, José: Diccionario de filosofía. Buenos Aires: Editorial Sudamericana, 1964. Tomo I, p. 161.

${ }^{3}$ Ritter, Joachim (Ed.): Historisches Wörterbuch der Philosophie. Basilea: Schwabe, 2007. pp. 702-703.

${ }^{4}$ En su Fundamentación de la metafísica de las costumbres de 1785, la autonomía de la voluntad se define como "el estado por el cual ésta [la voluntad] es una ley para sí misma, independientemente de cómo están constituidos los objetos del querer”. Véase Kant, Immanuel: Fundamentación de la metafísica de las costumbres. Madrid: Espasa Calpe, 1990. p. 120.

${ }^{5}$ Véase Kant, Immanuel: Crítica del Juicio. Manuel García Morente (trad.), Madrid: Tecnos, 2007. p. 143

${ }^{6}$ Ibíd., pp. 121-122.

${ }^{7}$ Ibíd., pp. 232-234.

${ }^{8}$ Ibíd., p. 129.
} 
institucionales (estado, sociedad, Iglesia, partidos...). Es característica de la lucha por la liberación del arte y los artistas en la Edad Moderna e Ilustración respecto de todo ámbito que no sea específicamente artístico, que no tenga propiamente fines artísticos. Atiende, pues, a la exigencia de la delimitación de las esferas de la cultura. En el segundo caso, la autonomía en el arte adquiere un impulso ético. Constituiría el requisito necesario para poder establecer una nueva utopía ajena a la sociedad doliente: sólo constituyéndose el arte como autónomo, puede proponer o proporcionar alternativas a las dinámicas socioculturales que se entienden como perniciosas. Este presupuesto es propio del pensamiento revolucionario que centra todos sus esfuerzos en la transformación de las condiciones materiales de la sociedad. Aunque su desarrollo más maduro llegará con las estéticas marxistas, ya en Schiller puede identificarse este compromiso con la sociedad desde el arte.

Si esto es así en el caso del arte en general, hay que reconocer que la arquitectura establece un particular desafío a las teorías estéticas. Por sus cualidades propias, es indudable que la arquitectura constituye un caso singular entre las artes. Y es que, en tanto que arte particular, la arquitectura arrastra una serie de determinaciones internas que parecen imponer limitaciones a su autonomía, tanto en el plano formal (por su orientación funcional y por ser un arte político), como en el plano disciplinario (en tanto que arte de conjunto y arte público). ${ }^{9}$ Luego, desde la consolidación del discurso autónomo en la cultura occidental y atendiendo a las dos corrientes antes mencionadas, la arquitectura ha de enfrentarse por fuerza a una conflictiva decisión: o bien asumirse como parte indisoluble de la sociedad que le da lugar, corriendo el riesgo de mimetizarse con ella y perder, así, el carácter crítico que toda aproximación moderna exige; o bien, asumirse como autónoma, desprenderse de la sociedad y autolegitimarse. Ambos polos entrañan altos riesgos. Si confundirse con la sociedad, es decir, desprenderse de toda instancia a la que recurrir frente a los medios de presión del momento (culturales, económicos, institucionales) vulneraría el principio básico de mejorar la sociedad a la que sirve, erigirse como autónoma y desde ahí imponer una soberanía estética en "el mundo de la vida" instauraría un tipo de autoritarismo contrario a su naturaleza social. ${ }^{10}$

Pese a esta ineludible conflictividad, a principios del siglo XX se constituyó una corriente de práctica y teoría arquitectónica que tenía como eje vertebrador un decidido empeño por fundar algo así como una "arquitectura autónoma". Fue sin lugar a dudas Emil Kaufmann el responsable de este insólito auge. Heredero de la célebre Escuela de Viena de Historia del Arte, mantuvo en sus trabajos el característico énfasis de esta tradición académica en el desarrollo de aproximaciones políticas y sociales a la teoría del arte. En este ambiente, entre profesores como Max Dvorak y Hans Semper y con el legado aún candente de las lecciones impartidas por Alois Riegl ${ }^{11}$ y Franz Wickhoff, cabe situar el periodo de formación de Kaufmann. La novedosa orientación de la historia de la arquitectura desarrollada por estos maestros -que fijaron su atención en periodos de transición o

\footnotetext{
${ }^{9}$ Estoy adaptando libremente lo que entiende Roger Scruton por "distinguishing features of architecture": literalmente, su "utility or function", su "highly localized quality", su "character as a public object" y su "continuity with the decorative arts, and the corresponding multiplicity of its aims". Véase Scruton, Roger: The Aesthetics of Architecture. Londres: Methuen \& Co., 1979. pp. 1-20.

${ }^{10}$ Sobre esto he tenido ocasión de profundizar en Rubio Garrido, Alberto: "El desafío de la expresión. Una aproximación desde la polémica de la autonomía de la arquitectura”. En Campillo, Antonio y Manzanero, Delia (Coord.): Los retos de la Filosofía en el siglo XXI. Valencia: PUV, 2015. Vol. III, pp. 49-61.

11 En Riegl puede rastrearse un primer compromiso con la autonomía en la arquitectura, aunque no se mencione explícitamente. En su obra defiende que el valor del arte ha de medirse en relación a las técnicas y a los procedimientos aplicados, a la inmanencia del trabajo que contiene él mismo, a la transformación que el tiempo hace sufrir a los modelos espaciales. El arte, desde esta perspectiva, es la expresión del Wollen característico de una época. Las técnicas de realización de la forma (que hacen el lenguaje) son convencionales y por lo tanto equívocas, sujetas a transformación. El Kunstwollen se entiende como principio que informa la obra en el plano formal en el dominio de la pura visibilidad donde, aislados, entran en juego "el contorno y el color, en el plano o el espacio".
} 
decadencia obviados por la imposición de los grandes estilos- posibilitó la reivindicación de los momentos de quiebra, de ruptura, en la historia de la arquitectura como periodos merecedores de ser estudiados sin supeditarse a la evolución del arte anterior o posterior, al tiempo que se formulaban alternativas para el arte de su tiempo. Este contexto académico llevaría a Kaufmann a investigar sobre la transición del barroco al neoclasicismo ya desde su trabajo de doctorado y, simultáneamente, a posicionarse respecto de la arquitectura de sus contemporáneos.

\section{La analogía ética: Le Corbusier comprometido}

Kaufmann menciona por primera vez a Le Corbusier en una nota al pie del artículo "Die Stadt" (1931). ${ }^{12}$ En concreto, se remite a tres extractos de L'Architecture considerée sous le rapport de l'art, des moeurs et de la législation y destaca las similitudes entre postulados centrales de Ledoux y el libro de 1923 Vers une architecture. Estas citas, pese a no mencionarlo explícitamente, señalan una llamativa cercanía con el manifiesto lecorbusierano:

1. “Le sentiment apprécié d'un plan est à l'abri de toute domination. Il émane du sujet, il doit adapter à la nature des lieux et des besoins". ${ }^{13}$ La confianza expresada sin ambages por Le Corbusier en la capacidad generatriz de los planes combina, al igual que en esta cita de Ledoux, el carácter de autodeterminación del sujeto (que se traslada a la obra de arquitectura por medio de los procesos de abstracción) y la capacidad de estos mecanismos de ordenación de transmitir emociones: "Si ces volumes sont formels et non dégradés par des altérations intempestives, si l'ordonnance qui les groupe exprime un rythme clair, et non pas une agglomération incohérente, si les rapports des volumes et de l'espace sont faits de proportions justes, l'œil transmet au cerveau des sensations coordonnées et l'esprit en dégage des satisfactions d'un ordre élevé: c'est l'architecture". ${ }^{14}$

2. “Tout détail est inutile, je dis plus, nuisible, quand il devise les surfaces par des additions mesquines ou mensongères. "15 Con esta cita, Kaufmann alude a la dialéctica, con frecuencia conflictiva, que se establece en la arquitectura entre el volumen y las superficies que lo envuelven. A este tenor, el reto para Le Corbusier estriba en que estas segundas no "dévorent le volume et l'absorbent à leur profit", 16 como denuncia ser el caso en su época. En las superficies, pues, predomina el carácter utilitario (como es el caso en las edificaciones industriales) y toda adición (superflua, esto es, inútil) ha de ser entendida en este sentido como un engaño.

3. “Toutes les formes que l'on décrit d'un seul trait de compas sont avouées par le goût. Le cercle, le carré, voilà les lettres alphabétiques que les auteurs emploient dans la texture des meilleurs ouvrages. ${ }^{\prime 17}$ Las referencias a la idea de que las formas primarias son las formas bellas abundan en Vers une architecture. Además, coincidirían Ledoux y Le Corbusier en justificarlo aduciendo la preeminencia de lo visual en el juicio sobre la arquitectura. Para Ledoux, sus proyectos "parlent aux yeux",18 y, así, para Le Corbusier en su célebre dictum: "L'architecture est le jeu savant, correct et

\footnotetext{
${ }^{12}$ Kaufmann, Emil: "Die Stadt des Architekten Ledoux”. En Kunstwissenschaftliche Forschungen, vol. 2, 1933. p. 141.

${ }^{13}$ Ledoux, Claude-Nicolas (1804): L'Architecture considerée sous le rapport de l'art, des moeurs et de la législation. París, calle Neuve d'Orléans: imprenta de H-L-Perroneau. Vol. 1, p. 65.

${ }^{14}$ Le Corbusier: Vers une architecture. $11^{\mathrm{a}}$ edición. París: Les éditions Crès et $\mathrm{C}^{\mathrm{i} a}, 1925$. p. 35.

${ }^{15}$ Ledoux, op. cit., 1804. p. 91.

${ }^{16}$ Le Corbusier, op. cit., 1925. p. 25.

${ }^{17}$ Ledoux, op. cit., 1804. p. 135.

${ }^{18}$ Véase, por ejemplo, ibíd., pp. 52 y 115.
} 
magnifique des volumes assemblés sous la lumière. Nos yeux sont fait pour voir les formes sous la lumière; les ombres et les clairs révèlent les formes; les cubes, les cônes, les sphères, les cylindres ou les pyramides sont les grandes formes primaires que la lumière révèle bien; l'image nous en et nette et tangible, sans ambigüité." 19 Insistirán ambos, asimismo, en la capacidad para resolver los grandes problemas de la construcción moderna por medio de purismos geométricos. ${ }^{20}$

Luego, de una forma un tanto genérica, Kaufmann apunta con estas citas a tres lugares comunes de la arquitectura de Le Corbusier de entreguerras condensados en "Las tres advertencias a los señores arquitectos" de su personal manifiesto (aunque en orden inverso): el plan, la superficie y el volumen. Estas máximas aún no están explícitamente vinculadas a la autonomía de la arquitectura, aunque, como veremos en breve, ya apuntaban hacia alguna de sus características más notables. De hecho, por aquel entonces, Kaufmann todavía no había desarrollado el corpus teórico que le llevaría a ser considerado el padre putativo de la autonomía de la arquitectura. $^{21}$

Es fundamentalmente a partir de la publicación en 1933 de Von Ledoux bis Le Corbusier. Ursprung und Entwicklung der autonomen Architektur cuando queda ya irremisiblemente sellado el matrimonio entre estos dos arquitectos con la bendición del novedoso concepto de "autonomía de la arquitectura". Por aquel entonces, Kaufmann disponía no sólo ya de la versión francesa de Vers une architecture, sino que Urbanisme había sido traducida [Städtebau] y hay constancia de su adquisición del primer volumen de Oeuvres complètes. ${ }^{22}$ En este breve libro, apenas tres meses después del incendio del Reichstag, Kaufmann traza una continuidad entre los valores democráticos y republicanos de la Revolución Francesa con la arquitectura de Le Corbusier. Y, en esta línea de pensamiento, identifica a Ledoux como el precursor de un cambio de época que cristaliza heroicamente en las vanguardias arquitectónicas. La identificación del pavillonsystem en la obra de Ledoux permite a Kaufmann seguir el rastro de lo que posteriormente llamará las "configuraciones revolucionarias", pasando por la obra de Durand, Dubut, Loos, Gropius y Neutra. Esta fundación geométrico-funcional del "sistema de pabellones" en Ledoux abre la posibilidad de la supervivencia de los principios modernos más allá de los cambios de apariencia, achacados a los gustos y estilos de cada época.

Sin entrar en consideraciones relativas a la veracidad y precisión de sus análisis o, muy especialmente, de la analogía entre la arquitectura de Ledoux y aquella de Le Corbusier, es importante reseñar aquí la deliberada superficialidad con la que Kaufmann analiza la obra de Le Corbusier, tanto escrita, como construida. Así se justifica él:

Llevar a cabo una interpretación de la esencia de la arquitectura actual no puede ser objeto de un trabajo de investigación histórica. Una demostración circunstanciada del dominio de autonomía en el siglo XX parece, además, tan superflua como necesaria fue la comprobación de su existencia en el XIX. Los testimonios del modo de pensar arquitectónico de la era Le Corbusier [esto es, la era de "la arquitectura autónoma"] aparecen con tan consumada nitidez ante nuestros ojos, con una claridad tan meridiana, que hacen vanos los análisis minuciosos al respecto. ${ }^{23}$

\footnotetext{
${ }^{19}$ Le Corbusier, op. cit., 1925. p. 16.

${ }^{20}$ En la segunda advertencia: "La surface". En ibíd., pp. 25-29.

${ }^{21}$ El concepto de "autonomía de la arquitectura" apenas si había sido mencionado en un breve estudio sobre la iglesia de Chaux de Ledoux en Kaufmann, Emil: “C.N. Ledoux under der klassizistische Kirchenbau”. En Kirchenkunst, 3, 1931. p. 62.

${ }^{22}$ Véase Vidler, Anthony: Histories of the Immediate Present: Inventing Architectural Modernism, Cambridge: The MIT Press, 2008. p. 40.

${ }^{23}$ Kaufmann, Emil: De Ledoux a Le Corbusier. Origen y desarrollo de la arquitectura autónoma. Barcelona: Gustavo Gili, 1982. pp. 93-94.
} 
No es de extrañar, pues, la práctica ausencia de este presunto protagonista en la publicación. De hecho, aparece fugazmente ya terminado el texto y sin la reproducción (que contrasta con la profusión gráfica del caso de Ledoux) de ninguno de sus proyectos. Pero, más allá de la aducida evidencia del paralelismo entre Ledoux y Le Corbusier, como bien señala Vidler, diríase que su omisión en la argumentación responde a otras motivaciones. ${ }^{24}$ La teoría de la "arquitectura autónoma" de Kaufmann fue inicialmente concebida para legitimar a los arquitectos de vanguardia frente tanto al auge del neoclasicismo de parada defendido por Albert Speer, como a los críticos de la Neue Sachlichkeit (bien en su versión conservadora como Sedlmayr, bien desde el régimen estalinista). Luego, por una parte, el análisis concreto de la obra de Le Corbusier no se encontraba entre sus objetivos y de ahí que aparezca en apenas tres páginas como la cristalización de una nueva era, como el representante más autoconsciente de una incipiente revolución en la arquitectura. Y, por otra parte, al querer extrapolar su tesis al conjunto de la arquitectura amenazada por los totalitarismos, el protagonismo efectivo de Le Corbusier (más allá del meramente representativo) quedó diluido en favor de una pluralidad desde Loos y Berlage, hasta Gorpius y Neutra. Así explicitó en sus conclusiones:

la continuidad del desarrollo de la arquitectura postrevolucionaria es demostrable hasta el comienzo de nuestra propia era, que se inicia hacia 1900 con el holandés Berlage y el austriaco Adolf Loos y que puede ser caracterizada con la máxima precisión con sólo nombrar a su más conocido adalid, el líder de la joven Francia, Le Corbusier [den Führer des jungen Frankreich]. ${ }^{25}$

Más allá de estas consideraciones, como podremos comprobar en breve, la mención a Le Corbusier en su provocativo manifiesto tuvo repercusiones notables a lo largo del siglo XX en lo que respecta a su recepción. Sintéticamente, Kaufmann encuentra en Ledoux, por analogía, al liberador del régimen feudal y absolutista del barroco al incorporar en su arquitectura las concepciones morales y prácticas de la naciente burguesía francesa, como son el individualismo y el republicanismo. Es en este sentido en el que Kaufmann llega a considerar su arquitectura como "revolucionaria". Su lucha por la autonomía era la lucha de la autodeterminación contra el dictado de la necesidad externa, la razón contra la contingencia, lo sintético contra lo orgánico, lo puro contra lo corrupto. Esta debe ser considerada, en opinión de Kaufmann, la máxima aportación del periodo revolucionario. Y esta será, en definitiva, la herencia por los jóvenes arquitectos vanguardistas que él quiso enfatizar con el término "arquitectura autónoma" y con la apelación a Le Corbusier:

La semejanza de la era Ledoux con nuestro tiempo no se limita -y sea dicho esto a modo de conclusión-a los aspectos formales y temáticos. Esta similitud no nace únicamente del hecho de que, ahora como entonces, el vasto y nuevo problema de la cuestión social irrumpe con intransigencia, ávido de fuertes estímulos hacia soluciones independientes, incidiendo de manera decisiva sobre toda actividad arquitectónica. Independientemente de las nuevas exigencias de la realidad, es detectable en una y otra época un renovado idealismo, que aparece en L'Architecture de Ledoux y en los escritos de Le Corbusier, en el concepto de la Ciudad Ideal del primero y acaso en la Cité Mondial del segundo. En este idealismo, basado en un modo de entender la moralidad y el derecho completamente transformado, nos parece que estriba la verdadera $y$ última razón de la renovación arquitectónica. ${ }^{26}$

\footnotetext{
${ }^{24}$ Vidler, op. cit., 2008. pp. 37-41.

${ }^{25}$ Kaufmann, op. cit., 1982. p. 93.

${ }^{26}$ Kaufmann, op. cit., 1982. pp. 94-95.
} 
De ahí que Kaufmann critique el abuso de lugares comunes en la recepción de Le Corbusier, como serían su "fascinación por la línea recta" o el "regreso a los principios fundamentales de la esfera, el cubo y el cilindro" 27 y reivindique la restauración del cambio de paradigma en la arquitectura: un arte comprometido con la sociedad, dispuesto a aliviar sus necesidades, a proporcionar nuevas perspectivas de desarrollo tanto personal como social, a mejorar, en definitiva, el estado de la cuestión.

Puesto que Le Corbusier cree tanto en este nuevo arte como podría hacerlo Ledoux, puesto que en uno y otro se percibe una íntima unión entre arte y vida por todo ello, debe mencionarse al arquitecto cuya obra supone la plena afirmación de los nuevos principios al lado de aquel otro cuyas facultades creadoras marcaron su comienzo. ${ }^{28}$

\section{Le Corbusier formalista}

Tras el Anschluss de marzo de 1938, Kaufmann tuvo que exiliarse a Estados Unidos tanto por su condición de judío como por las ideas expresadas en sus publicaciones. En su debut en 1942 en la American Society of Architectural Historians, ${ }^{29}$ en una decidida apuesta por agradar a su audiencia -nuevo entorno en el que iba a desarrollar toda su futura obra académica-, obvia toda referencia al impulso ético de su precedente teoría de la "arquitectura revolucionaria" e invierte la prioridad entre la forma y sistema en beneficio de lo que llamará "new individualism". ${ }^{30}$ Toda mención al carácter emancipatorio de la analogía establecida entre Ledoux y Le Corbusier desaparece en beneficio de un tipo de formalismo que será explotado con profusión por sus anfitriones. Por otra parte, y en coherencia con ello, su atención prioritaria al ensalzamiento de los arquitectos de vanguardia será en lo sucesivo sintomáticamente sustituida por estudios historiográficos de la arquitectura europea del siglo XVIII y principios del XIX. ${ }^{31}$ Ciertos autores han visto en este giro una suerte de renuncia a sus primeras tesis, explícitamente orientadas hacia los valores revolucionarios franceses. Sea así o no, lo cierto es que esta versión despolitizada de su concepto de “autonomía de la arquitectura” será la que llegará con más fuerza al auditorio estadounidense, ansioso por redefinir las máximas hasta ahora heredadas del viejo continente. Serán otros, por lo tanto, los que insistan en la analogía entre Le Corbusier y las teorías sobre la "arquitectura autónoma".

Muy tempranamente, Phillip Johnson se vio atraído por la teoría de la autonomía en la arquitectura del historiador vienés y, en 1942, presentó públicamente el Von Ledoux bis Le Corbusier en la American Society of Architectural Historians en Cambridge. El individualismo, la creatividad y la originalidad defendidas por Kaufmann encajaban con su manera de entender la modernidad arquitectónica. Pero no sólo. Desde su personal

\footnotetext{
${ }^{27}$ Podría incluso interpretarse este pasaje como un ajuste de cuentas personal, en la medida en que casi contradice literalmente la primera e inmediatamente anterior alusión a Le Corbusier en "Die Stadt". En una nota al pie, dice oponerse al análisis de Stonorov y Boesiger en Le Corbusier \& P. Jeanneret de 1930.

${ }^{28}$ Kaufmann, op. cit., 1982. p. 95.

${ }^{29}$ Publicado como Kaufmann, Emil: "Claude-Nicolas Ledoux: Inaugurator of a New Architectural System”. En Journal of the American Society of Architectural Historians 3, 1943. pp. 12-20.

${ }^{30}$ Véase Mertins, Detlef: "System and Freedom. Sigfried Giedion, Emil Kaufmann, and the Constitution of Architectural Modernity". En Somol, Robert E. (Ed.): Modernity and Ideology: Positioning an Avant-Garde in America. Nueva York: The Monacelli Press, 1997. pp. 212-231.

${ }^{31}$ Estos estudios se plasmarán a lo largo de su carrera en sus dos publicaciones de mayor impacto: Three Revolutionary Architects: Boullée, Ledoux, Lequeu (1952) y su magnus opus póstuma Architecture in the Age of Reason: Baroque and PostBaroque in England, Italy, and France (1955).
} 
interpretación de Kaufmann, este postulado sintonizaba con su trayectoria profesional y, en especial, con su empeño de centrar toda discusión sobre la arquitectura en una suerte de indeterminación ideológica.

Desde la exposición "Rejected Architects" de 1931, Johnson había espoleado una controversia en Estados Unidos de América que no tardaría en llegar a su momento culminante. Como atestiguan diferentes críticos de la época, la exposición se entendió como una intromisión de outsiders en la arquitectura y dinámicas culturales estadounidenses que los desviaban de sus objetivos que remitían a una tradición de profunda raigambre social. Douglas Haskell, por ejemplo, reivindicó el compromiso nacionalista y la tecnocracia local frente a esos "postulados extranjeros". De forma más explicita, Catherin Bauer plasmaba su preocupación al constatar que apenas se percibían en la exposición compromiso con la sociedad, de no ser por los representantes locales Alfred Claus y George Daub. ${ }^{32}$ Así pues, desde entonces, en un amplio sector de la crítica arquitectónica de esa época se vinculó el protagonismo de Le Corbusier a la figura del arquitecto ajeno a las demandas de la sociedad, y a Kaufmann y Johnson, sus adalides, como su embajador. La tan aclamada International Style Exhibition de 1932 del Museum of Modern Art de Nueva York, organizada y catalogada por Henry-Russel Hitchcock, Alfred Barr y Phillip Johnson, supuso la culminación de esta agitada polémica, llevando a sus autores a instalarse en un radicalismo formal inédito hasta entonces. Como Johnson afirmará años más tarde: "the functionalist part and the Marxian part [de la arquitectura moderna] left me cold, because to me architecture is a pure art, and it's art that interests $m e " .{ }^{33}$ En detrimento del compromiso con lo social que enarbolaron explícitamente las vanguardias europeas, la "autonomía de la arquitectura" que Kaufmann defendió para justificar la obra de, entre otros, Le Corbusier se interpretó en el entorno de Johnson como una revolución, sí, pero exclusivamente lingüística. Con su acostumbrada vehemencia, recordaba así su fascinación por la arquitectura europea de entreguerras: "In fact, we did not have the slightest idea what the avant-garde was. [...] At the Museum of Modern Art, we were ignorant of the political dimension of the art; for us it was revolutionary, but only aesthetically". ${ }^{34}$ Su pretendida falta de compromiso apela a una falta de interés por las implicaciones sociales del hecho arquitectónico. Lo que realmente interesaba a Johnson era el desarrollo de un lenguaje arquitectónico propio, "puro", en sus propios términos, que vinculaba a la tradición desempolvada por Kaufmann. ${ }^{35}$

Con la publicación del catálogo International Style: Architecture since 1922, quedó meridianamente claro cuáles eran los puntos a rescatar de las vanguardias arquitectónicas. Destacaron tres principios básicos que venían avalados por las obras expuestas de Le Corbusier. ${ }^{36}$ En primer lugar, haciendo uso de los progresos tecnológicos, los edificios modernos podían pasar a ser "mere planes surrounding a volume", a diferencia de las construcciones clásicas, donde los muros servían tanto como estructura como divisoria espacial. Con la incorporación del acero y del hormigón armado a la arquitectura se permitió la separación entre la fachada y la planta. En este sentido, el efecto de masa de la arquitectura tradicional se sustituyó por "plane surfaces bounding a volume". ${ }^{37}$ En segundo lugar, la regularidad atendía simultáneamente a los requerimientos de tipo económico e industrial y al principio impuesto de fragmentación por el cual cada una de las funciones han de ser

\footnotetext{
${ }^{32}$ Véase Baco, Mardges: Le Corbusier in America: Travels in the Land of the Timid. Cambridge: The MIT Press, 2001. p. 22.

${ }^{33}$ Lewis, Hilary y O’Connor, John: Philip Johnson: the architect in his own words. Nueva York: Rizzoli, 1994. p. 174.

${ }^{34}$ Somol, op. cit., 1997. p. 42.

${ }^{35}$ En 1950, publicará un artículo en The Architectural Review donde argumenta que la forma de su Glass House es heredera de la pureza geométrica de Ledoux. Véase Schulze, Franz: Philip Johnson. Life and Work. Nueva York: Knopf, 1994. pp. $157-158,194-196$ у 216.

${ }^{36}$ Como muestra del reconocimiento al protagonismo de Le Corbusier en "Modern Architecture: International Exhibition", mostraron fotografías y dibujos de sus casas de la Weissenhof Siedlung de Stuttgart, el pabellón suizo en la Cité Universitaire de París y varias villas. Pero, por encima de cualquier otra, tanto en la exposición (y su icónica maqueta) como en el catálogo (ocupando la portada como única representación gráfica) la indiscutible protagonista fue la Villa Savoye.

${ }^{37}$ Somol, op. cit., 1997. p. 56.
} 
identificables por sí mismas, sin requerir de la mediación de otras para justificarse. Así, por ejemplo, las ventanas, que anteriormente tenían valor de contraste con la masa del muro, pasaron a ser superficies acristaladas de grandes dimensiones. ${ }^{38}$ Por último, y coherentemente con este principio de fragmentación, los detalles constructivos en la modernidad así interpretada por Johnson (y Hitchcock) adquieren valor arquitectónico: las barandas, las ventanas, los parapetos dejan de estar afectados por el tradicional intrusismo de otras disciplinas como la escultura o la pintura y, en definitiva, dejan de estar sobreimpuestos al volumen. ${ }^{39}$

La "architecture as Volume" en lugar de la arquitectura entendida como masa, la "regularity" y "the avoidance of applied decoration" o la no intromisión de otras disciplinas recuerdan los primeros postulados de Kaufmann (luego tan duramente criticados por él mismo) recogidos de Vers une architecture en 1931. En este sentido, puede considerarse International Style: Architecture since 1922 como el acta fundacional de una nueva manera de entender la autonomía de la arquitectura, en la que sus paradigmas quedan reducidos a operaciones de tipo formal desprovistas ya de toda carga ética.

El impacto de esta exposición y su catálogo es público y notorio, de suerte que este giro en la recepción de Le Corbusier y su explícito vínculo con las teorías de la arquitectura autónoma impregnará notablemente la recepción anglosajona de la obra de Le Corbusier respecto de su relación con la autonomía en las décadas siguientes. Como muestra de ello, autores como Hilberseimer o Gandelsonas (en diversas publicaciones de Oppositions) seguirán insistiendo en las cualidades autorreferenciales de la arquitectura de Le Corbusier, enfatizando el purismo de sus operaciones formales. Es significativo a este respecto cómo se erigirá la Maison Dom-ino a paradigma de sus postulados. Así lo defendió Gandelsonas en 1976:

But are any or all these variations anything more than geometry? And even in terms of their use as floor levels and the necessity to enclose them so as to provide shelter, are they anything more than a set of geometric relationships plus this use, which together in some way approximate what we have always thought architecture to be? And if we answer in the affirmative that they do constitute architecture, then do all such variations of these elements when combined with their uses constitute architecture? And if it immediately appears clear that not all of the examples qualify, then how do we begin to distinguish between those that do not?. ${ }^{40}$

Por su parte, Hilberseimer reunió en Contemporary Architecture (1964) el constructivismo ruso, el neoplasticismo holandés y el "lecorbusierano purismo" bajo el concepto de "arquitectura autónoma".

\section{Le Corbusier y el fin de los grandes relatos}

Si esto es así entre aquellos que confiaron -incluso durante los años 70- en la aproximación formal heredada de Johnson, cabe ahora recordar los movimientos contestatarios que operaron a lo largo de esas décadas y, muy especialmente, a partir del 68 .

Por aquel entonces, el malestar en la disciplina era patente a un lado y otro del Atlántico. Desde muy diversos posicionamientos predominaba la crítica a la reinterpretación dogmática de la modernidad arquitectónica, monopolio que había degenerado en un "estilo desenraizado, intelectualizado y superficial”. En este contexto, al igual que el "funcionalismo", la idea de una arquitectura intelectual, elitista, universal o sobre-impuesta, la

\footnotetext{
${ }^{38}$ Ibíd., p. 73.

${ }^{39}$ Ibíd., p. 85.

${ }^{40}$ Gandelsonas, Mario: “Aspects of Modernism: Maison Dom-ino and the Self-Referential Sign”. En Oppositions, vols. 1516, The Institute for Architecture \& Urban Studies, 1976. pp. 188-199.
} 
"autonomía de la arquitectura" fue objeto de duras críticas. La estrategia de Johnson no garantizó a ojos de la nueva generación -salvo contadas excepciones- ${ }^{41}$ una alternativa al imparable auge de las lógicas postindustriales y, por otra parte, había consolidado un problemático alejamiento de la arquitectura respecto de las necesidades sociales.

La radicalización de las posiciones llevó al cultivo de los extremos, según los cuales la arquitectura ha de anteponer su autonomía como disciplina a su integración en la sociedad; y el opuesto, según el cual la arquitectura antes que nada es social y, si quiere llevar a cabo su misión crítica, ha de desprenderse del aislamiento al que le llevó el discurso autónomo formal. En cualquier caso, tanto los defensores de la posible recuperación del proyecto de autonomía en la arquitectura como sus detractores, partieron de la necesidad de incorporar un giro social a la arquitectura. Así, para unos, el compromiso social suponía la recuperación del proyecto de vanguardia de formación de estilos de vida: el objetivo de orientar la arquitectura hacia la reforma de la sociedad, de responder a sus necesidades. Autores como Summerson o Banham abrazaron, pues, el carácter mesiánico del movimiento moderno (en crítica directa a la recepción de Johnson y el "Internationnal Style"), ${ }^{42}$ es decir, la necesidad de orientar la arquitectura según fines ajenos a ella, hacerse social a costa de perder su singularidad, renunciando por supuesto a su autonomía. Para otros, en cambio, la implementación de la crítica en la arquitectura suponía por fuerza la recuperación del proyecto ilustrado de autonomía más propiamente kantiano. ${ }^{43}$ En última instancia, este posicionamiento veía en las vanguardias arquitectónicas el riesgo constatado en la posguerra- de confundirse con aquello contra lo cual se disponían a luchar. La no delimitación clara de las fronteras de la arquitectura respecto de otras prácticas y de otros factores sociales podía llevar a una complicidad con los responsables de aquello que se quería transformar. En consecuencia, esta tendencia de la década de los 70 -con el explícito apelativo de autonomy project- tuvo que enfrentarse en primer lugar a la delimitación de dichas fronteras con el fin de evitar su disolución en lo social. Así lo sintetizaba K. Michael Hays en el monográfico de Perspecta veinte años después:

The various researches into architecture's autonomy can now be understood in their historical trajectory as nothing quite so much as attempts to recode, to reterritorialize, to reinvent the boundaries and specificities that delimit the discipline. ${ }^{44}$

Considerar la arquitectura simultáneamente como un arte autónomo y como parte de la sociedad (en la terminología corriente en estas discusiones, como "formal product" y como "cultural act") fue la estrategia ampliamente consensuada para superar el aislamiento en el que había caído en la posmodernidad y poder simultáneamente recuperar su capacidad transformadora de la sociedad. Desde diferentes presupuestos, y a modo de mera contextualización, autores como K. Michael Hays, Diana Agrest, Stanford Anderson, Peter Eisenman, Alan Colquhoun o Anthony Vidler defendieron cómo al ser parte de la cultura y servirle, la arquitectura detenta

\footnotetext{
${ }^{41}$ Obviando aquellos que, aún siendo activos a finales de los 60 y las décadas siguientes, pertenecían a la generación anterior, sólo la "escuela formalista" siguió defendiendo la autonomía de la arquitectura desde una gramática rígida de las formas autorreferentes (una aproximación cercana a la de Rossi, por otra parte).

${ }^{42}$ Banham, Reyner: “Actual Monuments”. 1988. En Banham, Mary y otros (Ed.). A Critic Writes Selected Essays by Reyner Banham, Los Angeles: University of California Press, 1999. p. 285.

${ }^{43}$ Véase Hays, K. Michael: "Prolegomenon for a Study Linking the Advanced Architecture of the Present to that of the 1970s through Ideologies of Media, the Experience of Cities in Transition, and the Ongoing effects of Reification". En Perspecta: the Yale Architectural Journal, vol. 32, Cambridge: Yale University, 2001. pp. 100-107.

${ }^{44}$ Hays, K. Michael: "Twenty Projects at the Boundaries of the Architectural Discipline Examined in Relation to the Historial and Contemporary Debates over Autonomy". En Perspecta: the Yale Architectural Journal, vol. 33: Minning Autonomy, Connecticut: Yale University, 2002. p. 55.
} 
un potencial de transformación de lo social, sin por ello tener que renunciar a su autonomía. Las diferencias entre tan variados referentes son, por supuesto, notables en lo que respecta a la elaboración de un programa alternativo para la autonomía de la arquitectura. No obstante, adentrarnos en este complejo panorama excede el propósito de este texto. Por tanto, me limitaré en lo que sigue a apuntar someramente dos de las principales corrientes que siguieron enarbolando la obra de Le Corbusier - aún con llamativas diferencias- en favor de una rehabilitación de los paradigmas autonomicistas, sin llegar a matizar como cabría en otro contexto qué se entiende en cada caso por "autonomía de la arquitectura".

Desde una perspectiva escorada del lado del "formal product", para Alan Colquhoun la modernidad supone entender la forma en la arquitectura como indisoluble de una "idea" que emerge desde sus valores propios:

Composition therefore was able to stand for an aesthetic of immanence in which art became an independent kind of knowledge of the world and was no longer, as it had been both in the medieval and the classical traditions, the means by which certain "truths" or concepts were given rhetorical clothing. ${ }^{45}$

La forma arquitectónica, pues, albergaría por derecho propio sus valores estéticos, independientes de toda realidad externa a ella misma. De ahí que vea en Le Corbusier un privilegiado representante de este nuevo potencial, en la medida en que formuló las innovaciones tecnológicas, por ejemplo, con medios inherentes a la arquitectura. Su conocida fórmula de "la casa es una máquina de vivir" no sólo apuntaría en este sentido a las posibilidades técnicas, sino que enfatiza sus ramificaciones estéticas:

It was not to annex architecture to a branch of empirical science, but to use the machine as a model for a work of art whose form and structure were determined by laws internal to itself. The laws which applied to technology were different from those which applied to architecture, the first being directed to the solution of practical problems, the second to the creation of states of mind. In both cases, however, the desired results could only be obtained by understanding the laws which controlled their production. From this point of view Le Corbusier's famous statement can be interpreted as a metaphor for an aesthetic theory... ${ }^{46}$

Sería legítimo, en este sentido, incorporar a la disciplina arquitectónica elementos ajenos, tales como la técnica o los requerimientos funcionales, siempre y cuando se haga en clave arquitectónica. Colquhoun insiste así en la unificación en el seno de la arquitectura de la ciencia y el arte, y como muestra de ello se refiere a la comparación de Le Corbusier entre el Partenón y un automóvil moderno en las páginas de Vers une architecture: estos dos elementos, en principio ajenos el uno al otro, revelan propiedades comunes como el orden o la invariabilidad, propiedades que forman parte de los valores estéticos de la arquitectura.

En segundo lugar, desde una perspectiva materialista y, por tanto, que insiste en el carácter de "cultural act", la arquitectura no debería ser evaluada como un "passive agent of culture" que simplemente refleja las fuerzas sociales e históricas dominantes, sino como una entidad activa que tiene un lugar en la cultura "as an architectural intention with ascertainable political and intellectual consequences" ${ }^{47}$ Luego, la arquitectura

\footnotetext{
${ }^{45}$ Colquhoun, Alan: Modernity and the Classical Tradition: Architectural Essays, 1980-1987. Cambridge: MIT Press, 1989. p. 34.

${ }^{46}$ Colquhoun, Alan: "The Significance of Le Corbusier". En Brooks, H. Allen (Ed.): Le Corbusier: the Garland Essays. Nueva York: Garland, 1987.

${ }^{47}$ Hays, K. Michael: "Critical Architecture: Between Culture and Form”. En Perspecta: the Yale Architectural Journal, vol.
} 
constaría de diferentes niveles, alguno de los cuales tiene propiedades interiores y otros que requieren la comunicación con la realidad exterior. Ambos niveles se relacionan entre sí, dando lugar a una arquitectura espacial y temporalmente localizada: la "social formation". Dado que sus diferentes niveles se comunican con las realidades sociales y culturales, la arquitectura no puede ser totalmente independiente de lo social:

At a different level of autonomy thesis there appears a key concept from Louis Althusser, that of the "semi-autonomy" of "levels" or "instances" within an ideological field -the economic, political, juridical, cultural, aesthetic realms (and so on). The autonomy of each disciplinary level allows the development and advance of that discipline's particular techniques. But each level also feels pressure from all the others and exerts influence on all the others. What results is a set of insides and outsides that are reciprocally constituted and related by way of their ultimate structural difference and distance from one another rather than their identity, all held together by the "structural totality" of a social formation. ${ }^{48}$

Esta línea de pensamiento, tan abiertamente althusseriana, fue recogida con mucha más literalidad por Stanford Anderson. En tanto que disciplina, la arquitectura ha de enfrentarse al hecho de que no puede liberarse totalmente de la función (como exterioridad) y, por otra parte, no puede operar de forma totalmente funcional: "what we have is a spectrum that has to be analyzed for the attitudes of the architects, for theresponse that we expect relative to a particular kind of problem that the building is addressing”. Para salvar esta dificultad, Anderson propone la distinción entre "discipline" y "profession" en la arquitectura. La primera debería ser considerada como un "collective body of knowledge that is unique to architecture and which, though it grows over time, is not delimited in time or space”. La profesión, en cambio, estaría vinculada a las condiciones reales y temporales de la arquitectura. ${ }^{49}$ La disciplina de la arquitectura gozaría, pues, de un carácter temporal y espacialmente indefinido. Posteriormente, con el concepto de "quasi-autonomy", Anderson evaluará la autonomía de la arquitectura como un rango de posibilidades que pueden revelarse de diferentes formas autónomas o no-, como resultado de la intención de los arquitectos combinada con las circunstancias sociales y culturales que el edificio tiene que satisfacer, diluyendo por tanto el intento metódico de delimitar las fronteras disciplinares. En este sentido, Anderson da especial énfasis en "Quasi-Autonomy in Architecture" a la capacidad de cambio de estilos de vida. Referido al Carpenter Center de Le Corbusier:

First, he [Le Corbusier] made the building itself an active participant in the problem situation rather than a retiring, effortless framework. Secondly, the visitor and Harvard are forced to recognize that illiteracy about art is not a matter of vision alone. In this building art is not a spectator sport; all of one's senses and the whole of one's perception are engaged. One feels that the Carpenter Center is a world, a context, a problem, and we have the happy opportunity to form ourselves against it. ${ }^{50}$

Desde su tesis, la arquitectura es parte de la cultura, no una parte independiente como quiso entender Johnson, sino dependiente de ella, insertada en ella. Reivindica el valor de compromiso con lo social del Carpenter Center, la capacidad transformadora de lo social de la arquitectura, en la medida en que participa de los problemas que

21, Cambridge: Yale University, 1984. p. 20.

${ }^{48}$ Hays, op. cit., 2001, pp. 100-107.

${ }^{49}$ Anderson, Stanford: "Types and Conventions in Time: Toward a History for the Duration and Change of Artifacts". En Perspecta: The Yale Architectural Journal, vol. 18, Cambridge: Yale University, 1982. p. 115.

${ }^{50}$ Anderson, Stanford: "Quasi-Autonomy in Architecture: The Search for an 'In-between'”. En Perspecta: the Yale Architectural Journal, vol. 33: Minning Autonomy, Connecticut: Yale University, 2002. pp. 30-37. 
se dan lugar en su localización. En este sentido, es una exigencia para la arquitectura, defiende Anderson, no retraerse, no quedar al margen de lo que le convoca. Es más, insiste, la arquitectura es propiamente "fundadora de mundo". En su intervención, el arquitecto es capaz de traer el arte a la vida, de hacerlo presente. De suerte que el edificio, el Carpenter Center en este caso, forma a su vez parte de ese mundo en el que la arquitectura, el arquitecto y el espectador han de tomar partido, participando simultáneamente del problema y la solución. Esta posición de Anderson sintetizada en el explícito "Quasi-Autonomy of Architecture” comparte el carácter pragmático y moderado -si lo comparamos con las dos precedentes- que abundó durante estas décadas (como Solà-Morales y su “Arquitectura débil” o Kenneth Frampton y la idea del “Critical Regionalism”).

Aunque el autonomy project no reclamaba un papel utópico, como fue el caso en la arquitectura de vanguardia, la exigencia de autonomía de la arquitectura en los 70 no pretendió únicamente redefinir la disciplina sino también ganar resonancia social. En otras palabras, tras de la explícita intención por parte de la arquitectura en la década de 1970 de reinventar su territorio, los límites de su especificidad como disciplina, aflora la redeterminación de su función cultural. Los arquitectos del autonomy project abandonaron el papel heroico de la vanguardia arquitectónica (entendida como heteronomía) y trataron de recuperar la autonomía de la arquitectura renunciando a la pretensión de transformar la vida, así como cualquier responsabilidad sobre el destino del mundo. El proyecto era un decidido intento de apartar a la arquitectura de la ideología dominante y de resistencia frente al status quo, así como un empuje para volver a alcanzar un lugar en la sociedad y recuperar la labor crítica de la arquitectura moderna. No obstante, la autonomía así entendida llevó a la fragmentación de la arquitectura: internamente supuso una exigencia de descifrado esencialista y de recodificación, y externamente un dilema respecto de su terreno de intervención en otros ámbitos sociales -bajo la prohibición de una propuesta utópica y con la exigencia de una orientación social basada en la necesidad de reestructurar el presente-. En definitiva, esta fragmentación llevó a posicionamientos o bien directamente contrarios a la autonomía sensu stricto (como Anderson y su "quasi-autonomy") o intentos de recuperar una unidad perdida por medio de las teorías estructuralistas o lingüísticas (como es el caso de Colquhoun).

\section{Conclusiones}

Más allá de exponer los usos interesados de la obra tanto escrita como construida de Le Corbusier para justificar su vínculo con la autonomía de la arquitectura, el objetivo de este texto ha sido defender su centralidad en estas discusiones.

En la irrupción de la problemática asunción teórica del postulado autonomicista, Kaufmann defendió la obra de Le Corbusier como un exponente ejemplarizante del intrínseco movimiento emancipador que cabe esperar de la arquitectura en tanto que arte comprometido con la sociedad. Vio en el Mundaneum la cristalización de este postulado. Por su parte, el relevo abanderado por Johnson redujo la cuestión a una pregunta por la "forma" arquitectónica. La autonomía se entendió así como un problema de lenguaje arquitectónico, un proyecto de desarraigo y de abstracción formal. En este sentido, obras como la Villa Saboye o la Maison Dom-ino fueron erigidas como sus paradigmas. En el tercer periodo analizado, los intentos de rehabilitación de la autonomía de la arquitectura se vieron en mayor o menor medida enfrentados a la imposibilidad del proyecto y los más resolvieron tal aporía con la negación de uno de los polos: o bien se caía del lado de una autonomía restrictiva de la arquitectura, o bien se intentaba rescatar una concepción esencialista de la arquitectura. O, en otras palabras, durante el tercer periodo no se introdujeron propiamente nuevos elementos a la discusión, sino que se entendió que la salida a los fracasos anteriores estribaba en una combinación de ambos polos. En este caso, por ejemplo, Anderson encontró en el Carpenter Center una muestra de ello. 
A la vista del significado fundacional de la autonomía, no sorprende la ductilidad de los posicionamientos, pese a que se remitan en principio a una misma tradición. Todas las interpretaciones responden a la duplicidad del significado de autonomía detectado ya en Kant. Así, tanto el "Le Corbusier comprometido" como el "Le Corbusier formalista" atienden, por sorprendente que pueda resultar, a un mismo paradigma. En efecto, de esta inestable relación entre Le Corbusier y la autonomía de la arquitectura se desprende una paradoja difícilmente salvable: o bien se suscribía la tesis formalista según la cual el compromiso con lo social se establece "despolitizando" la arquitectura, o bien se recuperaba la naturaleza social de la arquitectura, reivindicando su capacidad de transformación de la sociedad. La caída de los grandes relatos que implementó el tercer periodo no es otro que un intento de no renunciar a ninguno de los extremos.

En un sentido amplio, visto como síntoma, diríase que la autonomía apela a la necesidad de establecer un principio a priori para la arquitectura una vez hecho experiencia de la quiebra de sus fundamentos: con la perdida su razón de ser espontánea provocada por la Ilustración y sus procesos de racionalización, la arquitectura pierde su legitimidad esencial. Es llamativo en este sentido cómo las discusiones en torno a la autonomía de la arquitectura han coincidido con momentos de crisis en la disciplina que exigían su redefinición y, aun más, un posicionamiento respecto de la deriva moderna en la sociedad. Frente a la amenaza de los totalitarismos, Kaufmann inauguró el debate en 1933 con su Von Ledoux bis Le Corbusier; tras la Segunda Guerra Mundial y la crisis del modelo de vanguardia, Johnson apeló a la autonomía para refundar los códigos formales y lingüísticos de la arquitectura de posguerra; con el agotamiento de la modernidad, a lo largo de los sesenta y setenta, la autonomía tuvo que enfrentarse simultáneamente a la amenaza del populismo y a la del elitismo.

Como señala Moneo en el prólogo a la edición española de Architecture in the Age of Reason de 1974, al margen del análisis concreto que presentó Kaufmann de la arquitectura "revolucionaria", cabe reconocerle el mérito de haber planteado la hipótesis de continuidad entre la Ilustración y la arquitectura de vanguardia. Así, su acierto más destacado quizás fue el de entender la modernidad en la arquitectura como un proyecto social y la autonomía en el sentido kantiano del término como estrategia de relación entre lo social y lo formal: haciéndose autónoma, esto es, atendiendo exclusivamente a las reglas que le son propias, la arquitectura se hace hecho social. Y, en esta línea de reflexión, bien podemos defender ahora que, en estas tentativas que se prolongaron a lo largo del siglo veinte, Le Corbusier ocupa un papel central. Su obra ejemplifica, en definitiva, la modernidad arquitectónica entendida como una ineludible y paradójica dialéctica entre la forma y su función social, enlazando así con una de sus provocaciones más acertada: "Architecture ou révolution, on peut éviter la révolution?".

\section{Bibliografía}

Adorno, Theodor W.: Teoría estética. Obra completa $n^{\circ} 7$. Rolf Tiedemann (Ed.), Jorge Navarro Pérez (Trad.), Madrid: Akal, 2004

Anderson, Stanford: "Types and Conventions in Time: Toward a History for the Duration and Change of Artifacts". En Perspecta: The Yale Architectural Journal, vol. 18, Cambridge: Yale University, 1982

Baco, Mardges: Le Corbusier in America: Travels in the Land of the Timid. Cambridge: The MIT Press, 2001

Brooks, H. Allen (Ed.): Le Corbusier: the Garland Essays. Nueva York: Garland, 1987

Colquhoun, Alan: Modernity and the Classical Tradition: Architectural Essays, 1980-1987. Cambridge: MIT Press, 1989

Hays, K. Michael: “Critical Architecture: Between Culture and Form”. En Perspecta: the Yale Architectural Journal, vol. 21, Cambridge: Yale University, 1984 
Hitchcock, Henry Russell y Johnson, Philip: The International Style: Architecture Since 1922. W. W. Norton, Incorporated, 1932

Kant, Immanuel: Fundamentación de la metafísica de las costumbres. Madrid: Espasa Calpe, 1990

Kant, Immanuel: Crítica del Juicio. Manuel García Morente (Trad.), Madrid: Tecnos, 2007

Le Corbusier: Vers une architecture. $11^{\text {a }}$ edición. París: Les éditions Crès et $C^{\text {ia }}, 1925$

Ledoux, Claude-Nicolas: L'Architecture considerée sous le rapport de l'art, des moeurs et de la législation. Vol. 1. París, calle Neuve d'Orléans: imprenta de H-L-Perroneau, 1804

Perspecta: the Yale Architectural Journal, vol. 33: Minning Autonomy

Somol, Robert E. (Ed.): Modernity and Ideology: Positioning an Avant-Garde in America. Nueva York: The Monacelli Press, 1997

Vidler, Anthony: Histories of the Immediate Present: Inventing Architectural Modernism, Cambridge: The MIT Press, 2008 


\section{Le Corbusier's Collaborators in the Paris Studio.}

In the considered times, among the asistants in Le Corbusier's Studio, besides Xenakis and Sołtan, were Roggio Andreini, Roger Aujame, Georges Candilis ${ }^{1}$, Nicos Chadzidakis, Fernand Gardien, Andre Maisonnier and Andre Wogenscky. ${ }^{2}$ The Studio played a significant role in spreading ideals of modernism worldwide. Many prodigious adepts were invited to take part in the process of establishing contemporary architecture through the hands of visionary Le Corbusier.

\subsection{Xenakis in the Paris Studio.}

Xenakis $^{3}$ was not initially interested in architecture. He started working for Le Corbusier simply to earn a living. Considering his dramatic context of arrival to Paris (1947), those reasons are perfectly understandable. It is worth to remember that at the end he was sentenced to death in absentia by Greek government in $1948^{4}$. Having no legal documents, heading to USA, he needed to find a way to live in Paris for some period of time. His main interest was in music and he only needed a day job to be able to pursue his ambition.

Xenakis claimed himself, that his consciousness on contemporary architecture practically did not exist. He gained all of the needed knowledge and experience through Le Corbusier: "[he] was the one who taught me to think in architectural terms[...] The main thing I learned form Le Corbusier was the way he solved problems and his attitude to architecture."

In ATBAT Xenakis was an engineer responsible for calculating the resistance of reinforced concrete. As he stated in one of his articles - that work opened his eyes to "the bewildering imperialism of technique over architecture" . He described how easily he could have shaped architectural views in the Studio with his judgements on their structural realisability ${ }^{7}$.

Xenakis was engaged in several important undertakings. He was, inter alia, the main designer of so called Undulating Glass Panes, which was one of the most significant outcomes of Le Corbusier-Xenakis cooperation and resulted in a patent application in 1955. Earier he participated in works upon the Modulor. ${ }^{8}$

After a while his interest in architecture grew stronger and he asked Le Corbusier to be responsible for an overall project. Thus, he was made a project manager of the La Tourette convent and, later on, for a Philips Pavilion for the Expo'58 exhibition, which will be discussed later in this paper.

\footnotetext{
${ }^{1}$ Georges Candilis, due to their mutual Greek friend, was an indirect cause of lannis Xenakis' employment in ATBAT. (compare with Xenakis \& Kanach, 2008, p. 3)

${ }^{2}$ compare with Sven Sterken's lannis Xenakis' Architectural Projects: Catalogue raisonne, in: Kanach, Sh, (ed.), Music and Architecture by lannis Xenakis, p. 294.

${ }^{3}$ Iannis Xenakis (1922-2001) was a Greek contemporary music composer. He graduated in engineering from the Athens Polytechnic Institute, which enabled him to take a job at ATBAT. He developed in architecture through experience with Le Corbusier during 12 years of employment in his Paris studio.

${ }^{4}$ Xenakis participated as a leader in student's demonstrations of Greek Resistance against the Germans in 1941, then in 1945 lost left eye from shrapnel during fighting with the British in Athens.

${ }^{5}$ Xenakis in Balint Andras Varga. Conversations with lannis Xenakis (London: Faber \& Faber, 1996), p. 20-22.

${ }^{6}$ Xenakis article in Le Fait culturel (Paris: Fayard, 1980), ed. by Gerard Montassier p. 213-228. English version in: Xenakis\&Kanach, 2008, p. xvi.

${ }^{7}$ Ibidem, p. xvi.

${ }^{8}$ More in: Xenakis \& Kanach, 2008, p. 11-48.
} 


\subsection{Xenakis' impact on contemporary music - background.}

Cooperation between Le Corbusier and Xenakis appears as a highly mutual transaction. Both played major roles in constituting and converting their domains (architecture and music). Both had a wide and recognised impact on their followers. Despite of belonging to different generations without a doubt they were the icons of dynamics of the XX century.

As Le Corbusier's influence is widely discussed and commonly known to architects, it is crucial to shortly present the impact of Xenakis on contemporary music. That will allow an understanding of what kind of an artistic personalities were confronted at 35 rue de Sèvres.

The Greek composer is a canonical figure in his primary field of interest, which is musical composition, for several reasons. Most importantly he introduced indeterminancy to music. Even though there were instances of such experiments before, it was for the first time that a composer envisaged form of the composition (here with a use of a particular stochastic mathematical model), which was indeterminate in detail. Metastasis (1953-54) definitively breaks with a static linear thinking (horizontal-melodic / vertical-harmonic) in musical composition, establishing new spatial relationships, which can be regarded only as a whole. It exposes the raw sound material (choice of instruments) while rejecting orchestration (tone color formation) as a separate layer. As a result, a passionate musical work is created, highly expressive, emanating a direct energy. The analogy to Le Corbusier's methodology in this case is clear.

To summarize, Xenakis' importance in the domain of music lays in the conversion of musical form, which from that moment cannot be considered in previously operating terms. Although stochastics are in the center of its justification, the core result lays in widening of emotional expression. "Mathematical formulas are important primarily for the purpose of analysis of the creative process. Xenakis rightly held that even using traditional instrumental means of expression it is possible to create new sound effects. The important value is in sonoristic properties of a form. Analogous results can be achieved without using mathematical formulas, by purely spontaneous creativity".

\subsection{Jerzy Soltan's experience with Le Corbusier's Studio: “Mais mon cher Soltan, il faut que ce soit beau"}

Jerzy Sołtan started his adventure with Le Corbusier with a book "Quand les Cathedrales etaient blanches" which he got from his fiancee's mother and he felt obliged to read ${ }^{10}$. During the war, as a prisoner of war in Geramn POW camps, he established a correspondence with Le Corbusier, which he considered the "true advanced studies", along with conversations held with other imprisoned Polish intellectuals. He confronted it with academic studies that he completed in Warsaw University of Technology. It was also in POW where he really understood the essence of creative teamwork. ${ }^{11}$

On the $1^{\text {st }}$ of July 1945 Jerzy Sołtan arrived at Paris and became a collaborator of Le Corbusier. In ATBAT, as it was mentioned before, he encountered the times of work upon the Modulor and the Unite d'Habitation. Among other aspects, he was delegated to be a project manager of the town plan of La Rochelle.

\footnotetext{
9 Chomiński, Józef; Wilkowska-Chomińska, Krystyna, Formy muzyczne, Vol.2: Wielkie formy instrumentalne, Warszawa: Polskie Wydawnictwo Muzyczne, 1987, p. 820.

${ }^{10}$ Braniewski, W., Amerykańskie impresje, in: Introduction to Polish edition of Quand les Cathedrales etaient blanches Kiedy katedry były białe. Podróż do kraju ludzi nieśmiałych, Warszawa: Fundacja Centrum Architektury, 2013, p. 18.

${ }^{11}$ Gola, Jola, Jerzy Sołtan. Monografia, Warszawa: Wydawnictwo Akademii Sztuk Pięknych, 1995 , p. 316.
} 
Sołtan stayed in Paris only for 4 years (in comparison to Xenakis' 12-years-experience in ATBAT), but that time determined his whole professional career.

After terminating in Le Corbusier's studio Jerzy Sołtan formed a spectacular architectural team back in Warsaw. It was constructed according to the ideals that he had learned in Paris - multidisciplinarity of its members enabled complex coding in architetcural design and diverted their concerns onto spatial beauty insted of the form-follows-function commandment that was at that times firmly taught in schools.

In 1961 Jerzy Sołtan received an extremely prestiguous proposition to become a Chairman of the Department of Architecture at Harvard University (until 1958 occupied by Walter Gropius and then left vacant for several years). Difficulties mounted by the Polish authorities postponed taking this position until 1967.

\section{World's Fare in Brussels - The Story of two Pavlions.}

As interesting as it is elegant, there is a extraordinary occasion to compare the influence of Le Corbusier on both Polish and Greek architect. They were commissioned a parallel architectural projects - pavilions for the same exhibition in Brussels - Expo'58. Both buildings are completely different in form, but show an intriguing sameness in consistency and multileveled artistic disposition. For the sake of grasping the means in which they are composed according to the similar principles, a short presentation and analyses of those instances is required.

\subsection{The Philips Pavilion by Xenakis.}

Although research upon the Philips Pavilion is vast and widely known ${ }^{12}$ in the society of architectural historians, for the purposes of analysis and furtherly employed comparison with the Polish National Pavilion, it is needed to shortly introduce the principal issues.

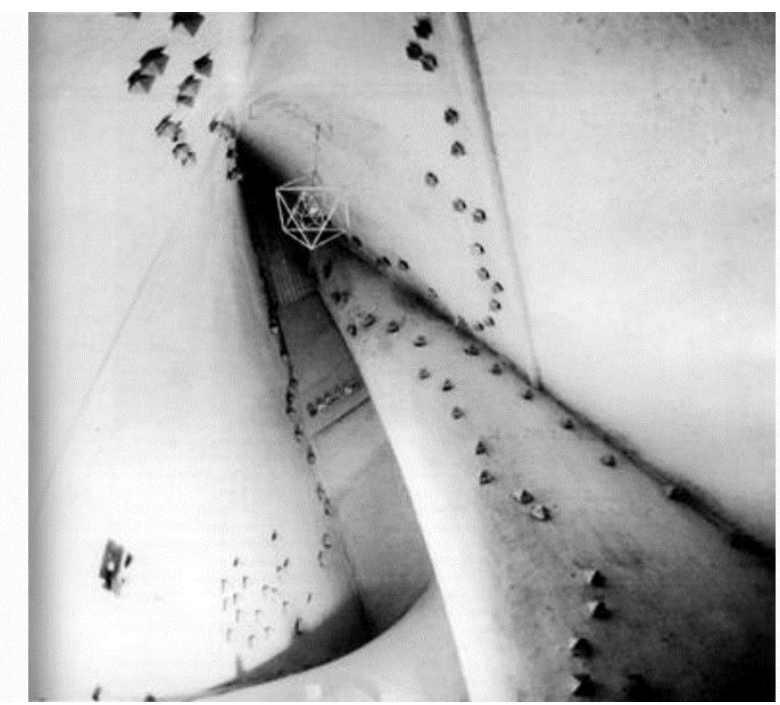

1. Philips Pavilion inner surface of the hyperbolic paraboloid structure with a view on so-called mathematical object, 1958.

Le Corbusier was commissioned to design a Philips Pavilion for the World's Fares Expo'58 by the Artistic Director of the Philips Company, Luis Kalff in 1956. The architect was concentrated on an eight-minute

\footnotetext{
12 Exhausting study is presented in: Treib, M., Space Calculated in Seconds. (Princeton: Princeton University Press, 1996), The Philips Technical Review, vol. 20 n¹, Eindhoven, 1958/59.
} 
spectacle called Poème électronique, while the architectural design was delegated entirely to Xenakis ${ }^{13}$. It is worth to notice that Le Corbusier was at that time deeply involved with the Chandigarh Project and, thus, 34year-old Greek was left free-handed in designing a spatial disposition of the Pavilion.

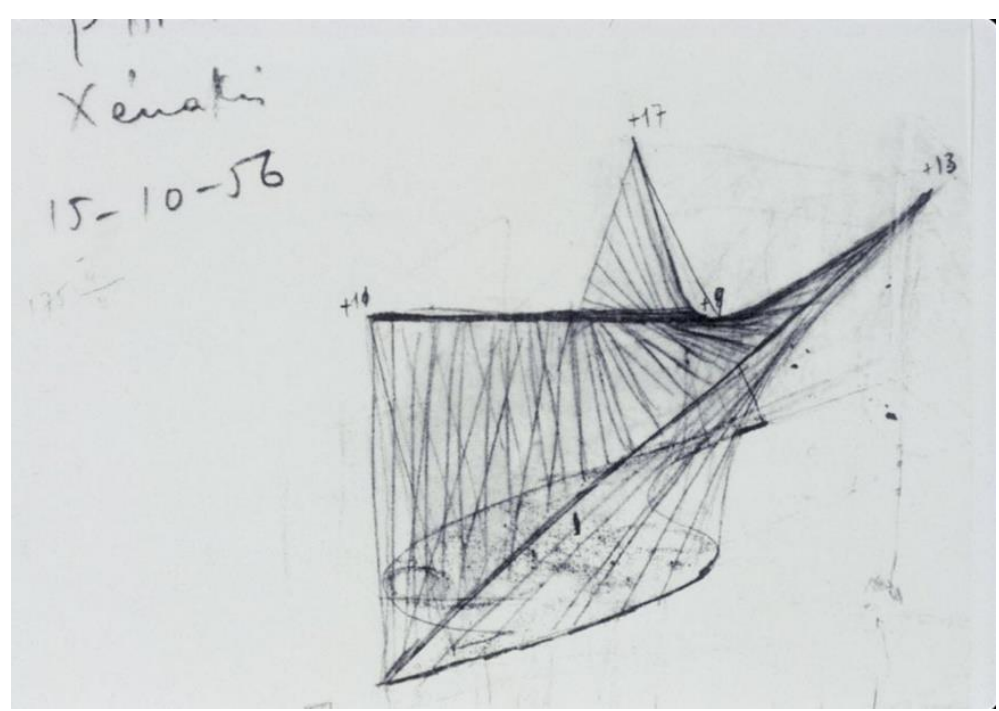

2. Xenakis' initial sketches for the Philips Pavilion, 1956.

\subsubsection{The structure, the material and the mathematical model.}

When one sees the preliminary sketches made by Xenakis for the Pavilion, a stunning impression is as if they were made spontaneously, even instinctively. Those hyperbolic paraboloids, despite of being unambiguously defined and precise, produced a tensive spatial relationships that was highly emotional and expressive. Nonetheless, its strictness brought a clear structural solutions that were possible to be developed in reinforced concrete. It certainy pushed the limits of engineering of that time. The only way for structural design of the Pavilion was to work on scale models, by trial and error. ${ }^{14}$ It was the same in the case of The Polish National Pavilion, which will be discussed later in this paper.

Here, the final reinfoced concrete slabs that formed an outer shell of the building were $5 \mathrm{~cm}$ thick and were spanned like a tent on a steel cables that formed a self-supporting surfaces of 22-meters high. Such a structure became an adequate "envelope" for a spectacle, that was composed to present the cutting-edge sound and light technology of a commissioning company.

It is worth to emphasize that in the Philips Pavilion mathematical model were explored explicitly and were the basis for a form of the building. The use of math in the Polish case is different and will be presented later.

\subsubsection{Fusion of stimuli.}

For the purpose of the Philips Pavilion, Edgar Varese ${ }^{15}$ was asked to compose a piece of electronic music which was meant to be played in the Pavilion along with diverse visualisations and light spectacles. The inner surface of the shell was packed with sound equipment of 425 speakers in the form of diamonds that enabled the show. The sound was complemented with projections of intriguingly juxtaposed images.

\footnotetext{
${ }^{13}$ Description and information based on: Kanach, S. [2008], pp. 93-118.

${ }^{14}$ Xenakis \& Kanach, 2008, p. 94.

${ }^{15}$ Edgar Varese (1883-1965) French-born innovative composer of electronic music.
} 
Along with noticing the beauty of the particular aspects of that spectacle, authors wish to reflect upon a specificity of an approach itself. The unbounded flow of stimuli, synaesthesia and the unity of arts were the dream of Le Corbusier himself and was the grounds of Xenakis' furtherly explored research in music and architecture.

As in the scenario for the Poème électronique, in the building of Philips Pavilion there is no separate elements. All issues are regarded in an inherent context. The Vitruvian triadic notions cannot be isolated - form, function and structure are intertwined in the sublime interdependence.

Same can be seen in an approach of the Polish crew, led by Jerzy Sołtan, in an independent project of The Polish National Pavilion. That was symptomatic and shows plausible grounds to speculate upon the manner of an influence that Le Corbusier had upon his apprentices.

\subsection{The Polish National Pavilion by Jerzy Soltan and partners.}

When Poland was invited to participate in the World's Fare Expo'58 in Brussels (first such an exhibition after the War), in 1956 an open competition was held for a project of a pavilion. Among the 100 submitted works the one titled BX 58 made by Jerzy Soltan received a special award and has been assigned for realization. From the very beginning in was known that it will be a true intermedial opus that will combine the space, cutting-edge technology, visual art, video, changing illumination and sound - avant-garde musique concrete. A free nonhierarchical plan with no predefined way and time of exploration in conjunction with an open structure, was a direct application of an innovative approach.

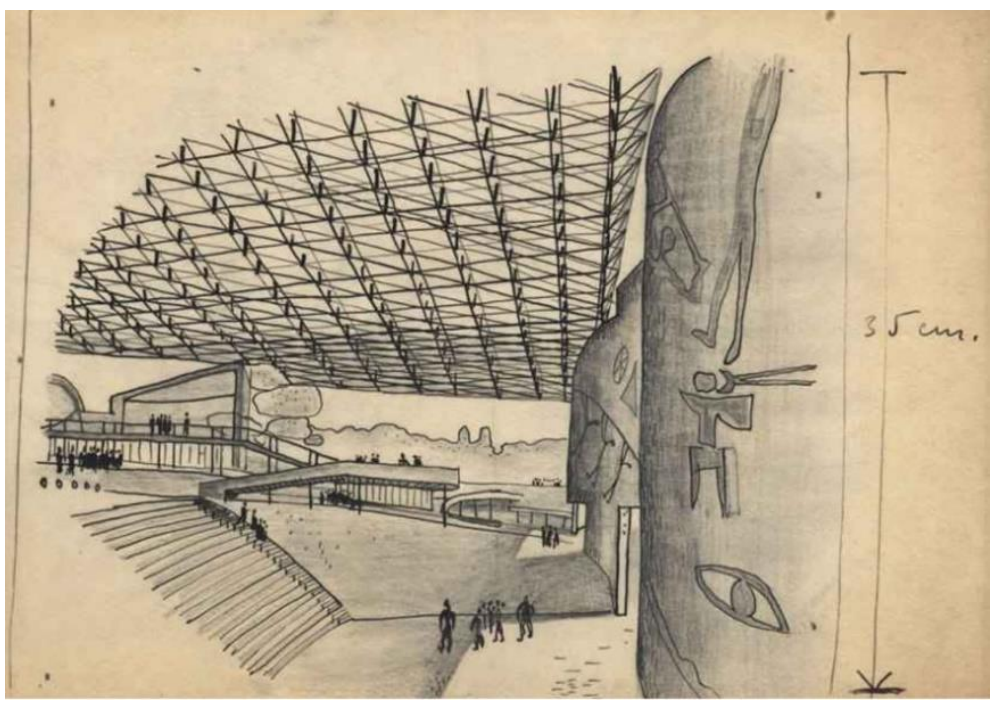

3. The view on the southern wall and the entrance to The Polish National Pavilion for Expo'58, Drawing by Jerzy Sołtan, 1956.

The pavilion enabled entering from every direction, the main entrance was not designed. Thanks to the openness and transparency the space was free from oppressiveness. The assigned plot was a part of a park. For the sake of preservation of all existing trees, the team proposed the use of spatial structure as roofing, which allowed to keep openings for tree crowns, as well as a free distribution of supporting columns.

Nevertheless, the precedent aim was to create a space that is acting on the senses directly and in a multi-threaded manner. The engaged tool for such a task was - a synthesis of all arts. Abstract graphics on the main façade was designed according to the variation of mathematical curves and was casted on a folding façade. Such an approach can be ascribed to the participation of a mathematician - structural designer in the Sołtan's team. At 
night, to emphasize the plastic expression, façade was to be illuminated by moving reflectors. According to the drawings of Wojciech Fangor (a part of the team), it is possible to judge that such a play with light could have been very powerful.

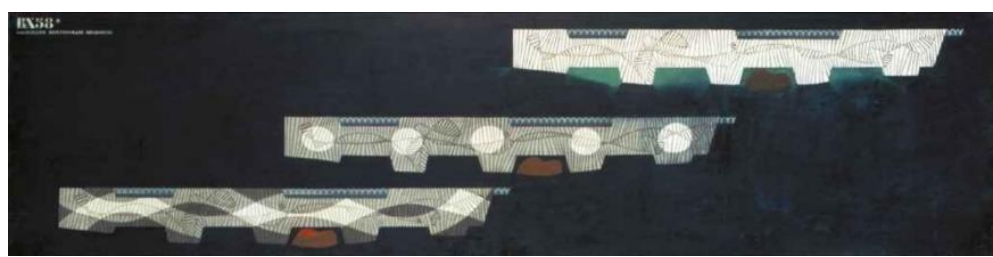

4. The project of a floating illumination with mobile headlights - the Polish National Pavilion. Drawing by Wojciech Fangor, 1956.

After the political changes that followed the year 1956, the vast savings program was introduced in Poland, and project funding has been stopped. The only element that was realized (for the sake of research upon material and structural strength) was a fragment of roofing structure. An alternative simplified project was later on commissioned, but due to the substantial limitation in funding the expressive power of the design significantly diminished. Soltan's wrote in his notes: "And then - the slow drying up of the venture....Its smaller version...and its death for... financial reasons.It is obvious that in this project we were not focusing on the shell or on the framing of the exhibit items or on the 〈〈architecture〉> of the exhibit box, but on the issue of COMMUNICATION or on transmitting to the visitor nformation and the mood in the most direct manner. We wanted to use all the means of communication, assaulting simultaneously the largest number of human senses"16

The process of that collapse initated an increasing misunderstanding of highly innovative assumptions of the BX 58. The team was forced to reply to strong criticism not only of the unsufficiency and ineffectiveness of a structural design, but also of the inadequate emotionality of the project. It is worth to mention that Jerzy Sołtan fought for his views forcefully: "Architecture lacking emotion is not architecture but building. While every work of building that produces emotions becomes "ipso facto" architecture..."17

\section{Is there a common spirit of the apprentices of Le Corbusier?}

As it is easy to notice in all compositional parallels in presented above pavilions, the manner in which Le Corbusier was forming their architectural partners proved to be very powerful. Surely he did not tend to transmit fixed solutions in architectural design. The reason why Sołtan can be recognized as his apprentice lays more in the way the Polish architect was constructed in the means of an approach to architecture regarded as an abstract phenomenon. Recalling his mentioned earlier in this paper statement upon architecture and emotions, one can purely hear the voice of his Master, when he emphasizes that: "Architecture has another meaning and other ends to pursue than showing construction and responding to needs (and by "needs" I mean utility, comfort and practical arrangement). Architecture is the art above all others which achieves a state of platonic grandeur, mathematical order, speculation, the perception of the harmony which lies in emotional relationships. This is the AIM of architecture ${ }^{, 18}$

Xenakis was maybe more independent in his convictions on architecture, despite the fact that, as he admited, before the experience with Le Corbusier at his studio in Paris, he had known very litte of it. Nevertheless, in the

\footnotetext{
${ }^{16}$ Sołtan, J., Correspondence to Biszo, in: Gola, 1995, p. 320.

17 Sołtan, J., Fangor, W., Ihnatowicz, Z., Tomaszewski, L., 1956, Reply to criticism concerning the design in: Gola, 1995 , p. 175.

${ }^{18}$ Le Corbusier, Towards a new architecture, Dover Publications, New York, 1986, p. 110-111.
} 
conscious affirmation of the manner on which the Studio conducted their research, he showed the grand formative significance of those 12 years at 35 rue de Sèvres. He wrote about Le Corbusier: "his way of working was a liturgy, a secret transmutation. Metric proportion, but also the power of space, and functionality, as well as materials, not to mention light, colour, technique... all in a dazzling carrousel of interdependence" ${ }^{\text {"19. }}$

It was probably this interdependence, that was the most powerful factor in the ferment of Le Corbusier's Studio.

\section{Summary - why Corbu's Hands?}

Le Corbusier ATBAT was not just another architectural studio. It was a monastery, where space was contemplated. The new face of contemporary architecture was developed, realised and felt through a direct experience engaging all senses in respond to the full gamut of stimuli.

Xenakis and Soltan found their individual creative means, developed very different curricula. But authors wish to present one extraordinary rendezvous of those two personas that happened years later. It explains how both artists were formed and deeply structuralised by an experience of being Le Corbusier's assistants - Cobru's Hands.

„And thus with the our first project in the atelier - linked with all its design investigations is a search for the ineffable space (espace indicible), that Le Corbusier wrote and spoke so much about.

It seems to me now that I feel that post-cubist space, there at Mokotów, was experienced simultaneously from all sides, and not gradually, as in a step by step process. I don't know of any other larger spatial realization in Poland that would evoke similar feelings in the viewer. Iannis Xenakis felt and understood those visual events when we visited the stadium together. The spatial sensibility and training of this Corbuserian architect and composer produced faultless reaction. It seems to me, however, that what to a Xenakis was not only a pleasant but also intellectually clear experience, remains for those less initiated simply the pleasure of being there with its causes left unconsidered." ${ }^{20}$

\section{Source of images:}

1. Philips Pavilion inner surface of the hyperbolic paraboloid structure with a view on so-called mathematical object, 1958. Source: http://ad009cdnb.archdaily.net/wp-content/uploads/2011/08/1312860839-image-3.jpg, access: 8-6-2015.

2. Xenakis' initial sketches for the Philips Pavilion, 1956. Source: http://www.iannisxenakis.org/images/archi/philips2.jpg, access: 8-6-2015.

3. The view on the southern wall and the entrance to The Polish National Pavilion for Expo'58, Drawing by Jerzy Sołtan, 1956. Source:

http://www.muzeum.asp.waw.pl/collective/pawtucket/index.php/Detail/Object/Show/object_id/403, access: : 86-2015.

4. The project of a floating illumination with mobile headlights - the Polish National Pavilion. Drawing by Wojciech Fangor, 1956. Source:

http://www.muzeum.asp.waw.pl/collective/pawtucket/index.php/Detail/Object/Show/object_id/413, access: 8-62015.

\footnotetext{
19 Xenakis, I., Concerning Le Corbusier 1965, in: Xenakis, I., Music and Architecture, ed. Kanach, S., Pendragon Press, Hillsdale, New York, 2008, p. 121.

${ }^{20}$ Sołtan, J., Correspondence to Biszo, in: Gola, 1995, p.319
} 


\section{Bibliography}

Braniewski, Waldemar, Wstęp. Amerykańskie impresje, in: Kiedy katedry były białe. Podróż do kraju ludzi nieśmiatych (Quand les Cathedrales etaient blanches), Warszawa: Fundacja Centrum Architektury, 2013.

Chomiński, Józef; Wilkowska-Chomińska, Krystyna, Wielkie formy instrumentalne, Warszawa: Polskie Wydawnictwo Muzyczne, 1987.

Gola, Jola (ed.), Jerzy Soltan. Monografia, Warszawa: Wydawnictwo Akademii Sztuk Pięknych, 1995.

Le Corbusier, Towards a new architecture, Dover Publications, New York, 1986.

Xenakis, Iannis; Kanach, Sharon, Music and Architecture. Architectural projects, texts, and realizations, Hillsdale, New York: Pendragon Press, 2008. 


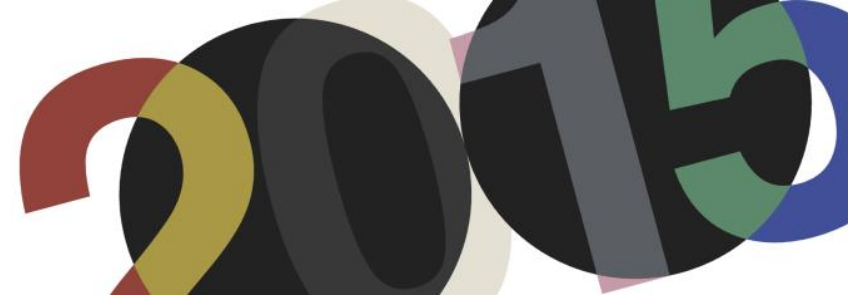

DOI: http://dx.doi.org/10.4995/LC2015.2015.1018

\title{
Le Corbusier et Christian Zervos dans Cahiers d'art
}

\author{
M.P. Sabella \\ Università degli Studi di Cagliari - DICAAR Dipartimento di Ingegneria Civile, Ambientale e Architettura
}

\begin{abstract}
The search has as purpose to notice the importance of Christian Zervos (Argostoli 1889 - Paris 1970), a greek art historian and founder of the magazine and publishing house Cahiers d'art, that lived in Paris from 1907 to the end of his life) with Le Corbusier, inserted in the contest of Cahiers d'art.

The exceptional versatility of Zervos's mind had allowed him to realize, through Cahiers d'art, a intellectual environment that exceeded the ordinary publishing house of that period, beacuse it was enchanted and nourished by all sector of knowledge. Zeros, inside the Cahiers d'art, made Le Corbusier protagonist of the section of Architecture, that submits to Sigfried Giedion. In fact since the first number of Cahiers d'art the work of Le Corbusier was broadly taken in examination. The articles related to the work of the Architect have gone since 1926 to 1954; the themes that touch these texts can be separate in four major topics: design, private house, great public buildings, painting.

La recherche a le but de relever l'importance de Christian Zervos (Argostoli 1889-Parigi 1970), historien de l'art et fondateur des Éditions Cahiers d'art, qui vécut à Paris depuis 1907 à sa mort, et Le Corbusier, insérée dans le contexte de Cahiers d'art. L'exceptionnel éclectisme de Zervos a permis de réaliser dans Cahiers d'art un excellent milieu intellectuell qu'il va au-delà des Éditions, car uni et nourri par chaque domaine de la connaissance. Dans les Cahiers d'art, Zervos rend Le Corbusier le protagoniste de la section d'architecture, soignée par Siegfried Giedion
\end{abstract}

Keywords: Cahiers d'art; Christian Zervos; projects.

\section{Introduction}

L'attention de Christian Zervos pour l'architecture et pour Le Corbusier était présent aussi pendant son activité près les Edition Albert Morancé.

En trois articles ${ }^{1}$ de Les Arts de la maison sont reportées des réflexions sur l'œuvre et sur l'influence qui exerça sur la contemporanéité, et comme celle-ci fut caractérisée par l'architecture de Le Corbusier.

En outre Zervos à l'intérieur des Cahiers d'art fit protagoniste de la section d'architecture, qu'il confie à Siegfried Giedion, Le Corbusier. Depuis le premier numéro des Cahiers l'œuvre de Le Corbusier vint amplement prise en examen.

Les articles relatifs à l'œuvre de l'architecte vont de 1926 au 1954. En totale les articles qui traitent de Le Corbusier sont vingt-et-un, deux signé par Siegfried Giedion, treize par Christian Zervos, et six par l'architecte

\footnotetext{
${ }^{1}$ Zervos C., Réalisations et projets. Le Pavillon de l'Esprit Nouveau, «Les arts de la maison», Automne \& hiver, Éditions Albert Morancé, Paris, 1925, pp. 15-18; Zervos C., "La leçon de l'Exposition des arts décoratifs et industriels de 1925", Les arts de la maison, Automne \& hiver, Éditions Albert Morancé, Paris, 1925, pp. 27-29; ZERvos C., "Réalisations et projets. Le Corbusier et Pierre Jeanneret. Intérieurs", Les arts de la maison, Printemps \& été, Éditions Albert Morancé, Paris, 1926, pp. $14-16$.
} 
même. Les sujets qui traitent ces textes peuvent se divisent en quatre macros domaines, c'est-à-dire: le design d'intérieurs, ${ }^{2}$ l'habitation privée, ${ }^{3}$ les grands bâtiments publics, ${ }^{4}$ la peinture. ${ }^{5}$

\subsection{Design d'intérieurs}

Zervos se met de façon critique à l'égard de sa contemporanéité, en ayant assisté au venir moins du «faire le nouveau». ${ }^{6}$ ${ }^{2}$ Zervos C., Architecture intérieure enquetes, «Cahiers d'art, Bulletin mensuel d'actualité artistique publié sous la direction
de Christian Zervos», n' ${ }^{\circ}$, janvier, Paris, 1926, pp. 14-15.
${ }^{3}$ LE CORBuSIER, Notes à la suite, «Cahiers d'art, Bulletin mensuel d'actualité artistique publié sous la direction de Christian
Zervos», III, Paris, 1926, pp. 46-52; GIEDION S., "Le problème du luxe dans l'architecture moderne. A propos d'une nouvelle
construction a Garches de Le Corbusier et Pierre Jeanneret", in Cahiers d'art, Revue d'art paraissant dix fois par an-
Directeur: Christian Zervos. Peinture- sculpture-Architecture-musique-mise en scène-disques-cinéma, V-VI, Paris, 1928, pp.
254-256; Giedion Siegfried, "Le Corbusier et l'architecture contemporaine par S.Geidion", in Cahiers d'art, Revue d'art
paraissant dix fois par an- Directeur: Christian Zervos. Peinture- sculpture-Architecture-Art ancien-ethnographie-cinéma,
IV, Paris, 1930, pp. 205-215; ZeRvos C., "Immeuble «Clarté» a Genève par Le Corbusier et Pierre Jeanneret", in Cahiers
d'art, Revue paraissant dix fois pas an - Directeur: Christian Zervos - Peinture, Sculpture, Architecture, Art ancien,
Ethnograpgie, Cinéma, Editions «Cahiers d'art», 14, rue du Dragon, Paris (IV arrondissement), VI-VII, Paris, 1932, pp. 289-
294; Zervos C., "Jeunes architectes. A propos de leur ex position à la Galerie des "Cahiers d'art" Février-Mars 1935", in
Cahiers d'art, Revue paraissant dix fois pas an- Directeur: Christian Zervos - Peinture, Sculpture, Architecture, Art ancien,
Ethnograpgie, Cinéma, I-IV, Paris, 1935, pp.75-93.

${ }^{4}$ Zervos C., Projet pour le palais de la S.D.N. à Genève, par Le Corbusier et Pierre Jeanneret, «Cahiers d'art, Peinture, sculpture, Architecture, musique. Directeur: Christian Zervos», IV-V, Paris, 1927, pp. 175-182; Zervos C., "Qui batira le palais des nations a Genève? Étude-manifeste de «Cahiers d'art» en faveur d'un projet moderne", Cahiers d'art, Peinture, sculpture, Architecture, musique. Directeur: Christian Zervos, IX, Paris, 1927, pp. I-VIII; ZeRvos C., "Qui batira le Palais des Nations? II. La situation actuelle", Cahiers d'art, Peinture, sculpture, Architecture, musique. Directeur: Christian Zervos, IX, Paris, 1927, pp. IX-XVI; Zervos C., "Qui batira le Palais des Nations? III. Decisione del jury", Cahiers d'art, Peinture, sculpture, Architecture, musique. Directeur: Christian Zervos, n9, Paris, 1927; Zervos Christian, "Qui batira le Palais des Nations? IV. Le Conseil des Nations va statuer", Cahiers d'art, Revue d'art paraissant dix fois an-Directeur: Christian Zervos. Peinture- sculpture-Architecture-musique-mise en scène-disques-cinéma, II, Paris, 1928, pp. 84-88; LE CORBUSIER, "La Salle Pleyel. Une preuve de l'évolution architecturale", Cahiers d'art, Revue d'art paraissant dix fois anDirecteur: Christian Zervos. Peinture- sculpture-Architecture-musique-mise en scène-disques-cinéma, II, Paris, 1928, pp. 8990; Zervos C., "Un projet de centre mondial a Genéve", Cahiers d'art, Revue d'art paraissant dix fois par an-Directeur: Christian Zervos. Peinture- sculpture-Architecture-musique-mise en scène-disques-cinéma, VII, Paris, 1928, pp. 307-312; LE Corbusier, "Maison de l'Union des cootives de l'U.R.S.S. a Moscou par Le Corbusier et Pierre Jeanneret", Cahiers d'art, Revue d'art paraissant dix fois par an-Directeur: Christian Zervos. Peinture- sculpture-Architecture-musique-mise en scène, IV, Paris, 1929, pp.162-163; Zervos C., "Pour la création a Paris d'un Musée des artistes vivants", Cahiers d'art, Revue d'art paraissant dix fois par an-Directeur: Christian Zervos. Peinture- sculpture-Architecture-Art ancien-ethnographiecinéma, I, Paris, 1930, pp. 337-339; Zervos C., "Pour la création a paris d'un musée des artistes vivants(II). Réponse et projet d'aménagement et d'organisation, par Le Corbusier et Pierre Leanneret", Cahiers d'art, Revue d'art paraissant dix fois par an-Directeur: Christian Zervos. Peinture- sculpture-Architecture-Art ancien-ethnographie-cinéma, $\mathrm{n}^{\circ}{ }^{1}$, Paris, 1931, pp. 1-9; Le CORBUSIER, "Projet pour la construction du palais des Soviets par Le Corbusier et Pierre Jeanneret", in Cahiers d'art, Revue paraissant dix fois pas an - Directeur: Christian Zervos - Peinture, Sculpture, Architecture, Art ancien, Ethnograpgie, Cinéma, Editions «Cahiers d'art», 14, rue du Dragon, Paris (IV arrondissement), I-II, Paris, 1932, pp. 74-77; ZeRvos C., "Le futur palais des Soviets à Moscou", in Cahiers d'art, Revue paraissant dix fois pas an - Directeur: Christian ZervosPeinture, Sculpture, Architecture, Art ancien, Ethnograpgie, Cinéma, I-IV, Paris, 1934, p.114.

${ }^{5}$ Le Corbusier, Zervos C., Les peintures révélées par Igor Grabar, «Cahiers d'art, Revue d'art paraissant dix fois par anDirecteur: Christian Zervos. Peinture- sculpture-Architecture-musique-mise en scène-disques-cinéma», X, Paris, 1928, pp.427-428; Le Corbusier, Léger, «Cahiers d'art», III-IV, Éditions Cahiers d'art, Paris, 1933, pp. 110-111; Zervos C., Expositions. Le Corbusier, peintre (Musee National d'Art Moderne), «Cahiers d'art», $29^{\circ}$ Anno, éditions «Cahiers d'art», 14, rue du Dragon, Paris, 1954, pp.5-12. 
À l'Exposition de 1925 on réprimande «d'abord la conception générale qui a réglementé son organisation. Conçue comme une manifestation éphémère, cette exposition a empêché l'artiste de travailler sur des réalités. L'effort dans le vide ne l'a pas obligé à se mettre en face de responsabilités propres à imposer à son esprit cette mesure et cette circonspection qui nous viennent des problèmes pratiques». ${ }^{7}$

Au lieu d'organiser une inutile «foire en carton-pâte, les organisateurs de l'exposition auraient pu élever dans un coin de la région parisienne une cité modèle où tous les problèmes de l'urbanisme, de l'architecture, de l'hygiène et du confort eussent été mis à l'étude sur la base des données scientifiques les plus récentes». ${ }^{8}$

Zervos rappelle l'attention sur le donnée le plus considérable de l'exposition: «l'esprit [...] qui prévaut, c'est la tendance somptuaire. Tout est destiné aux classes favorisées par la fortune. Partout un luxe provoquant, souvent du plus mauvais goût. Des objets de peu d'utilité et d'un prix exorbitant», ${ }^{9}$ et il n'est présent «aucune mesure dans les proportions. Point de goût dans le choix de la forme. Des façades vides de toute sensibilité. Nulle humanité dans l'aspect de l'ensemble». ${ }^{10}$

Pour Zervos il est répréhensible «méconnaître l'admirable leçon de l'américain Wright, toute de bon goût, de sobriété et de sens constructif» comme aussi l'avoir perdu de vue l'exemple de la «jeune architecture hollandaise, celle qui réagit contre les tendances de l'Ecole d'Amsterdam et qui, avec l'aide des pouvoirs publics, a su se manifester d'une façon étonnante»; ${ }^{11}$ et il est encore honteux «méconnaître l'œuvre des architectes autrichiens et l'enseignement du grand théoricien Adolphe Loos. C'est vouloir ignorer les constructions des architectes tchécoslovaques, qui depuis vingt ans réalisent des édifices aux formes pures, débarrassées de l'ornament, et selon des règles d'une logique impeccable. C'est enfin négliger l'effort de certains architectes allemands et des constructivistes russes dont les ouvres mériteraient une étude très attentive». ${ }^{12}$

Zervos trouve beaucoup pauvre l'architecture de l'Esposition et, à l'exception du Théâtre de Perret «l'œuvre la plus consolante de l'Exposition», ${ }^{13}$ on peut citer «malgré certaines restrictions, comme œuvres modernes que le Pavillon des Renseignements de Rob. Mallet-Stevens et le villa de Le Corbusier et Pierre Jeanneret». ${ }^{14}$ En ligne générale il y n'avait pas une «Modernité vraie» ${ }^{15}$ en entendant chose différente de la «Nouveauté morphologique», ${ }^{16}$ car la plus grande partie des artistes a donné priorité à la forme.

Dans la production des meubles on peut retrouver la même tendance qu'on est relevé en architecture: «on a changé la 'forme' d'un meuble pour une autre forme souvent bien moins heureuse et bien moins pratique. Aux styles anciens on n'a opposé que des semblants de style nouveau», ${ }^{17}$ exception fait, s'entende, pour Le Corbusier, Francis Jourdain, Pierre Chareau, Marcel Guilleminault.

\footnotetext{
${ }^{6}$ Zervos C., La leçon de l'Exposition des arts décoratifs et industriels de 1925, «Les arts de la maison», Automne \& hiver, Éditions Albert Morancé, Paris, 1925, p. 27-28.

${ }^{7}$ Ivi, pp. 27.

${ }^{8}$ Ibidem.

${ }^{9}$ Ibidem.

${ }^{10}$ Ibidem

${ }^{11}$ Ibidem.

12 Ibidem.

${ }^{13}$ Ibidem

${ }^{14}$ Ibidem.

${ }^{15}$ Ibidem.

${ }^{16}$ Ibidem.

${ }^{17}$ Ivi, p. 29 .
} 
Ces rares artistes ont été capables de suivre «la leçon d'économie donnée par les constructeurs d'automobiles, de wagons et de paquebots et qui ont adapté cette leçon à l'étude des portes, des fenêtres, notamment à l'étude de l'ensemble intérieur en vue de suppléer par une organisation raisonnée, aux dimensions exiguës de la demeure contemporaine». ${ }^{18}$

Mais malgré celui-ci, selon Zervos, l'avènement de l'Exposition Internationale des Arts Décoratifs et Industriels Modernes de 1925, il ne résoulut pas le problème de l'architecture et du management des intérieurs, en partageant l'opinion de quelques artistes qui «sont unanimes à proclamer la nécessité absolue d'accorder l'œuvre avec la spiritualité de la vie moderne, ses nécessités sociales, ses inventions mécaniques». ${ }^{19}$ Ils diffèrent, pour leur avis, aussi en «ce qui concerne le sacrifice de la personnalité. Quelques-uns soutiennent l'effort des sensibilités individuelles. D'autres voient dans ces sensibilités une orientation vers l'analyse et l'expression aiguüe due moi qui retarde ou paralyse l'évolution nécessaire. Ils préfèrent les créations d'ensemble qui leur paraissent mieux répondre aux besoin du présent». ${ }^{20}$

Par contre, autres préfèrent «se soumettre à une discipline collective qui impose des contructions élémentaires propres à satisfaire aux nécessités actuelles». ${ }^{21}$ Et celà, selon Zervos, «c'est pourquoi les premiers sont partisans du meuble, tandis que les seconds, inspirés de la tradition grecque, romaine et médiévale veulent remplacer le meuble par l'utilisation rationnelle des murs». ${ }^{22}$

Les nouvelles et importantes solutions autant pour l'architecture générale que pour la gestion intérieure de l'habitation, Zervos écrit, furent introduites pendant l'Exposition par Le Corbusier que «est le prophète de la standardisation à outrance. Il poursuit la création d'une maison-type» ${ }^{23}$ dans lequelle «chacune des pièces ayant une fonction déterminée, elle doit comporter un outillage approprié [...] sur un autre plan esthétique». ${ }^{24}$

Il est pour celà qui lui définit Le Corbusier et Pierre Jeanneret «deux artistes qui comptent parmi les meilleurs novateurs d'aujourd'hui» ${ }^{25}$ et il reconnaît dans le projet pour le Pavillon de l'Esprit Nouveau un instrument valide pour apporter nouvelles et importantes solutions soit du point de vue architectural soit du management de la espace intérieure.

Ainsi dans l'entretien qui Le Corbusier accordé à Zervos, intitulé Un seule corps de métier, on été examinées des sujets relatifs à la standardisation industrielle, et de la différence qu'il doit exister entre les parties de la maison et leur fonction, et surtout l'emploi du nouveau matériel de construction, le béton armé.

Le Corbusier suppose «un seul corps de métier» ${ }^{26}$ en chantier, le maçon, en imaginant que «le menuisier ne met plus les pieds dans le batiment et il ne retarde plus désespérément les travaux. Ses produits n'entrant dans la maison que lors de l'emménagement, dans des murs secs ». ${ }^{27}$ Pas plus donc les vieilles étagères, qui constituent les armoires, approximativement projetées mais, par cette collaboration à la distance des techniciens spécialisés,

\footnotetext{
${ }^{18}$ Ibidem.

${ }^{19}$ Zervos C., Architecture intérieure enquetes, «Cahiers d'art, Bulletin mensuel d'actualité artistique publié sous la direction de Christian Zervos», n ${ }^{\circ}$, janvier, Paris, 1926, p. 14.

${ }^{20}$ Ibidem.

${ }^{21}$ Ibidem.

${ }^{22}$ Ibidem.

${ }^{23}$ Ibidem.

${ }^{24}$ Ibidem.

${ }^{25}$ Zervos C., Réalisations et projets. Le Pavillon de l'Esprit Nouveau, «Les arts de la maison», Automne \& hiver, Éditions Albert Morancé, Paris, 1925, p. 15.

${ }^{26}$ Ibidem.

${ }^{27}$ Ivi, pp. 15-18.
} 
on pourra avoir «une porte, une fenêtre ou un casier standard» ${ }^{28}$ réalisés pour être inséré dans l'œuvre créée parfaitement par le maçon. Le rôle du projeteur sera 'seulement' de «ordonner et proportionner». ${ }^{29}$

Pour Le Corbusier le plan de la maison moderne doit être économe de la place; à chaque outil devra être assigné sa placé et donc les meubles devront être conçus pour des usages bien précis. Alors tout ceci fut possible grâce à l'emploi du béton armé, à ses qualités spécifiques de être modelé et aux les formes multiples que peut assumer.

Zervos rappelle comme le Pavillon de l'Esprit Nouveau constitue le modèle architetturale d'un style d'habitation, d'une cellule susceptible de vitalité et qui peut se développer librement dans la réalité urbaine.

Il est important de remarquer comme Zervos considère valides seulement peu études parmi ceux exposés à la Exposition internationale des arts décoratifs et industriels modernes de 1925, quand fut montré le Pavillon de l'Esprit Nouveau.
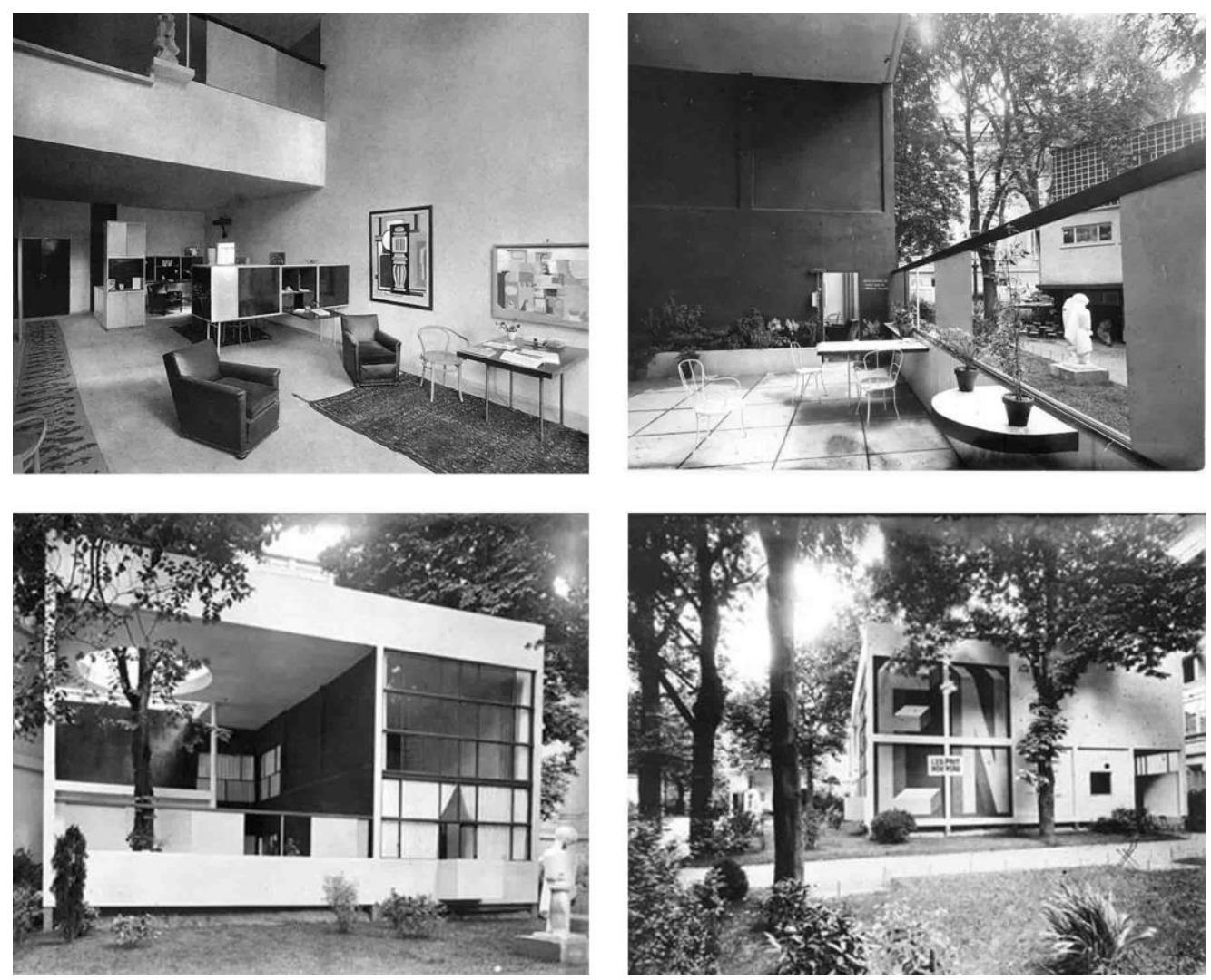

1. Pavillon de l'Esprit Nouveau , 1925.

Zervos est conscient de combien la recherche de Le Corbusier consacrât beaucoup d'attention à l'habitation privée. Un entretien relâché au éditeur grec révèle combien l'architecte fût intéressé à résoudre les problèmes relatifs à la vie dans la maison moderne. En dix-huit points Le Corbusier dédie beaucoup d'attention à la définition confort, éclairage et meubles, et en rappelant comme le verbe construire soit synonyme de faire durer, que structurer soit de résoudre les données pratiques d'un problème de comfort, et que le but de l'architecture soit prétendre émouvoir.

\footnotetext{
${ }^{28}$ Ibidem

${ }^{29}$ Ibidem.
} 
Dans le premier point Le Corbusier déclare que «l'architecture est fonction de la lumière; c'est un phénomène plastique dans la lumière. Sans lumière, on ne voit pas. Ne voyant pas, on ne sent pas. Pas d'émotion architecturale sans lumière ${ }^{30}$ et il est dans cette circonstance qu'on situe «le phénomène architectural plus profondément encore dans le fait de la lumière: nous nous éveillons à la lumière, nous voyons, discernons, nous agissons, travaillons, pensons». ${ }^{31}$ Et à l'homme plaît que «le soleil entre dans la maison, car nous vivons sédentairement dans la grande ville ${ }^{32}$ puisque $« 1$ 'homme est un animal de lumière». ${ }^{33}$

Un animal de lumière et sa «maison est un abri» ${ }^{34}$ et «plus nous devenons sédentaires, plus nous cherchons le confort»; $;^{35}$ par les fenêtres «le béton armé apporte des trésors de soleil» ${ }^{36}$ et «avec le béton armé, il n’y a plus de trumeau imposé. Le fenêtre peut toucher aux deux murs latéraux et les éclairer d'un bord à l'autre». ${ }^{37}$ Ainsi «nous avons conquis par la technique la base primordiale de la sensation architecturale: la lumière». ${ }^{38}$

En regardant «les murs éclairés et colorés de nos maisons» ${ }^{39}$ il est possible de remarquer l'«eloquence des proportions: géométrie, épurement, classification, hiérarchie données par la couleur» ${ }^{40}$ qu'en les réfractant sur les murs nous invite «à participer d'un phénomène architectural». ${ }^{41}$

Le Corbusier a plusieurs fois proposé la nécessité de standardiser les meubles de la maison, en proposant des étagères standardisées comme aussi tables standardisées, dont les proportions pourront avoir valeur universelle. Et non seulement, mais en les rapportant aux autres éléments d'enrichissement d'une maison, il fait une réflexion sur les tableaux, en désapprouvant la nouvelle réalité que «s'imposait dans la maison moderne: la bibliothèque à tableaux». ${ }^{42}$ Pour Le Corbusier le tableau est un panneau mobile dans lequel il faut regarder pour déchiffrer le discours qui y est écrit dedans: «un tableau est un livre, il contient quelque chose; on ne peut pas lire quarante livres à la même minute». ${ }^{43}$

Le Corbusier releve que si «on accroche de multiples tableaux, d'innombrables tableaux partout ${ }^{44}$ il se verra «finie l'eurythmie de la maison ${ }^{45}$ et l'œuvre perdra sa fonction réelle.

Élément de grande importance pour lui qui se considere «un supréme épicurien. Parce qu'un véritable épicurien recherche la jouissance pure». ${ }^{46} \mathrm{~L}$ 'architecte rappelle que

${ }^{30}$ Zervos C., Notes à la suite, «Cahiers d'art, Bulletin mensuel d'actualité artistique publié sous la direction de Christian Zervos», n³, Paris, 1926, pp. 46-52.

${ }^{31}$ Ibidem.

${ }^{32}$ Ibidem.

${ }^{33}$ Ibidem

${ }^{34}$ Ibidem.

${ }^{35}$ Ibidem.

${ }^{36}$ Ibidem.

${ }^{37}$ Ibidem.

${ }^{38}$ Ivi, p. 47.

${ }^{39}$ Ivi, p. 49.

${ }^{40}$ Ibidem.

${ }^{41}$ Ibidem.

${ }^{42}$ Ivi, p. 52.

${ }^{43}$ Ibidem.

${ }^{44}$ Ibidem.

${ }^{45}$ Ibidem.

${ }^{46}$ Ivi, p. 51. 
«Epicure proposait pour but à l'homme, le bonheur, mais il le plaçait dans les jouissances de l'esprit et du cœur plus encore que dans celles des sens, dans l'exercise de la raison, dans la santé du corps et de l'âme, dans les plaisirs calmes qui ne doivent ni nous priver de plaisirs plus grands ni nous causer de pénibles lendemains». ${ }^{47}$

Le Corbusier conclut ainsi: «j'ai fait mes études de construction, trés sérieusement, assez loin pour un architecte; ensuite depuis vingt années, j'ai porté un intérêt passionné à ce déroulement prestigieux d'une technique nouvelle de la construction qui nous affranchissait de servitudes séculaires». ${ }^{48}$

\subsection{Habitations privées}

En prenant en examen l'Immeuble Clarté à Genève, projet de Le Corbusier et Pierre Jeanneret, Zervos met en contraste le tentative de faire de l'immeuble «une forme d'habitation vivante». ${ }^{49}$

Une donnée significative est constituée par le fait que «l'immeuble de Genève réalise l'idée toujours mise en avant par Le Corbusier de rompre la division uniforme en étages jusque pour la vie privée». ${ }^{50}$

Le Corbusier développe typologies différentes d'habitation, qui vont «depuis le simple studio jusqu'à l'appartement de neuf pièces, et en arrive ainsi à creer des pièces de dimensions extraordinaires, occupant par exemple toute la profodeur de l'immeuble, soit quinze mètres. Ces pièces sont divisées en parties s'adaptant à divers usages et offrant des hauteurs de plafond différentes. [...] Ce sont les appartements de deux étages à deux ou trois pièces qui offrent le plus de possibilités de développement». ${ }^{51}$

La nouvelle lecture de l'espace on obtient à travers «la rupture avec la division traditionnelle en étages ${ }^{52}$ même si «l'architecte doit faire en sorte non seulement de ménager des pièces élevées, mais de les disposer sur des plans différents». ${ }^{53}$

En outre «il est étonnant de voir comment les pièces, malgré les parois vitrées, sont faciles à meubler: il existe, en effet, de grands emplacements pour les meubles qui rétablissent l'équilibre». ${ }^{54}$ Cependant le paroi vitrée reçu des critiques pas dans le demaine économique, mais «dans certaines réactions psychiques. La crainte de ne pouvoir s'isoler suffisamment de l'espace extérieur, on le sait d'expérience, existe bien plus ches l'architecte auteur du plan que chez le futur locataire. [...] La crainte des parois vitrées est étroitement liée à la notion d'architecture. My house in my castle». ${ }^{55}$

Giedion affirme que «les maisons de Le Corbusier sont la réalisation du point de vue moderne. C'est ce qui explique que la langue architecturale de Le Corbusier figure, comme élément quasi anonyme, dans l'œuvre de tant de ses contemporains». ${ }^{56}$ Selon l'historien de l'architecture «toute l'œuvre de Le Corbusier a pour but de

\footnotetext{
${ }^{47}$ Ibidem.

${ }^{48}$ Ibidem.

${ }^{49}$ Zervos C., Immeuble 'Clarté' a Genève par Le Corbusier et Pierre Jeanneret, «Cahiers d'art, Revue paraissant dix fois pas an - Directeur: Christian Zervos - Peinture, Sculpture, Architecture, Art ancien, Ethnograpgie, Cinéma», Éditions «Cahiers d'art», 14, rue du Dragon, Paris(IV arrondissement), nº6-7, Paris, 1932, pp. 289-294.

${ }^{50}$ Ivi, p. 289.

${ }^{51}$ Ivi, pp. 289-290.

${ }^{52}$ Ivi, p. 291.

${ }^{53}$ Ibidem.

${ }^{54}$ Ivi, p. 294.

${ }^{55}$ Ibidem.

${ }^{56}$ GiEdion S., Le problème du luxe dans l'architecture moderne. A propos d'une nouvelle construction a Garches de Le Corbusier et Pierre Jeanneret, "Cahiers d'art, Revue d'art paraissant dix fois par an- Directeur: Christian Zervos. Peinturesculpture-Architecture-musique-mise en scène-disques-cinéma», n ${ }^{\circ}$-6, Paris, 1928, pp. 254.
} 
détruire la maison en tant que 'fortesse' et d'ériger à sa place un bâtiment léger presque transparent comme ceux qu'ont rêvé les meilleurs architectes du siècle dernier lorsque, pour la première fois ils créèrent leurs merveilleuses halles en fer et en verre». ${ }^{57}$

Pour Giedion «le luxe, au sens d'autrefois, n'est plus réalisable ${ }^{58}$ et vraiment «pour la première fois dans l'histoire nous nous trouvons devant ce singuilier phénomène: ce n'est plus la classe la plus favorisée, mais au contraire la classe la moins favorisée, qui est le facteur dominant dans la création du style moderne». ${ }^{59}$

Ce fait ne dépend pas de raisonnements sentimentaux mais se trouve dans chaque problème de la production: «nous savons très bien que l'architecture moderne n'aura acquis la stabilité et l'universalité à laquelle nous croyons, que lorsque sa plus petite cellule aura été modelée de la façon la plus méticuleuse». ${ }^{60}$

Selon Giedion l'architecture contemporaine doit être analyzée an relation avec un période spéciale, celle de la «production industrielle ${ }^{61}$ dans lequelle est fort «la nécessité de tenir compte dans une large mesure des besoins humains», ${ }^{62}$ dont l'importance implique «que la nouvelle architecture n'est possible que par la collaboration des disciplines les plus diverses». ${ }^{63}$

À ce point Giedion reporte une définition d'Architecture de Le Corbusier, c'est-à-dire «Architecture signifie pour moi: agir par construction spirituelle». ${ }^{64} \mathrm{Il}$ s'agit d'une définition qui se complète dans le modus operandi typique de Le Corbusier qui «a su tirer parti du squelette de béton armé transmis par la science. Nous ne songeons pas aux formes de ses constructions, mais à la façon dont il fit servir l'armature aux fonctions nouvelles de l'habitation». ${ }^{65}$

Pour Giedion «c'est dans cette adaptation de la sèche construction de béton armé à l'élaboration de l'habitation moderne réclamée par l'époque ${ }^{66}$ qu'il réside l'élément fécond de l'œuvre de Le Corbusier, pour lequel est d'importance capitale que l'on renoncé «une fois pour toutes à ces murailles de mœllons entassés à la main, et qui font de non maisons d'effroyables prisons», ${ }^{67}$ en soulignant que «le facteur décisif n'est pas le progrès dans les formes, mais la méthode de construction». ${ }^{68}$

En ce qui concerne les méthodes constructives «l'armature qui s'est substituée aux murailles portantes permet un afflux de lumiere jusqu'ici inconnu» ${ }^{69}$ en rendant possible un innovant accord entre «les exigences de la biologie qui s'accordent avec celles de la construction». ${ }^{70}$

\footnotetext{
${ }^{57}$ Ibidem.

${ }^{58}$ Ibidem.

${ }^{59}$ Ibidem.

${ }^{60}$ Ibidem.

${ }^{61}$ GiEdion S., Le Corbusier et l'architecture contemporaine par S. Geidion, «Cahiers d'art, Revue d'art paraissant dix fois par an. Directeur: Christian Zervos. Peinture, Sculpture, Architecture, Art ancien, Ethnographie, Cinéma», n ${ }^{\circ}$, Paris, 1930 , pp. 205-212.

${ }^{6}$ Ivi, p. 205.

${ }^{63}$ Ibidem.

${ }^{64}$ Ibidem.

${ }^{65}$ Ibidem.

${ }^{66}$ Ibidem.

${ }^{67}$ Ibidem.

${ }^{68}$ Ibidem.

${ }^{69}$ Ivi, p. 206.

${ }^{70}$ Ibidem.
} 
Maintenant la fenêtre prend «une importance qu'elle n'avait jamais eue. Tout naturellement, les constructions à armature de béton armé ou de fer, permettent des baies larges ou même, selon la position des piliers, des ouvertures occupant toute la largeur de la façade. [...] De la conception générale de la nouvelle construction, Le Corbusier tire l'idée de la fenêtre horizontale coulissante qui peut glisser dans les ouvertures correspondantes». ${ }^{71}$

Autre rappel à un des points de l'architecture de Le Corbusier est donné par «l'adaptation de la construction à armature aux fonctions nouvelles de l'habitation ${ }^{72}$ que «comporte également une transformation rationnelle du toit et l'utilisation de l'espace laissé libre par les piliers du rez de chaussée» ${ }^{73}$ et enfin «l'articulation du cube rigide et massif, telle que l'a tentée Le Corbusier dans la Villa De Monzie à Garches». ${ }^{74}$
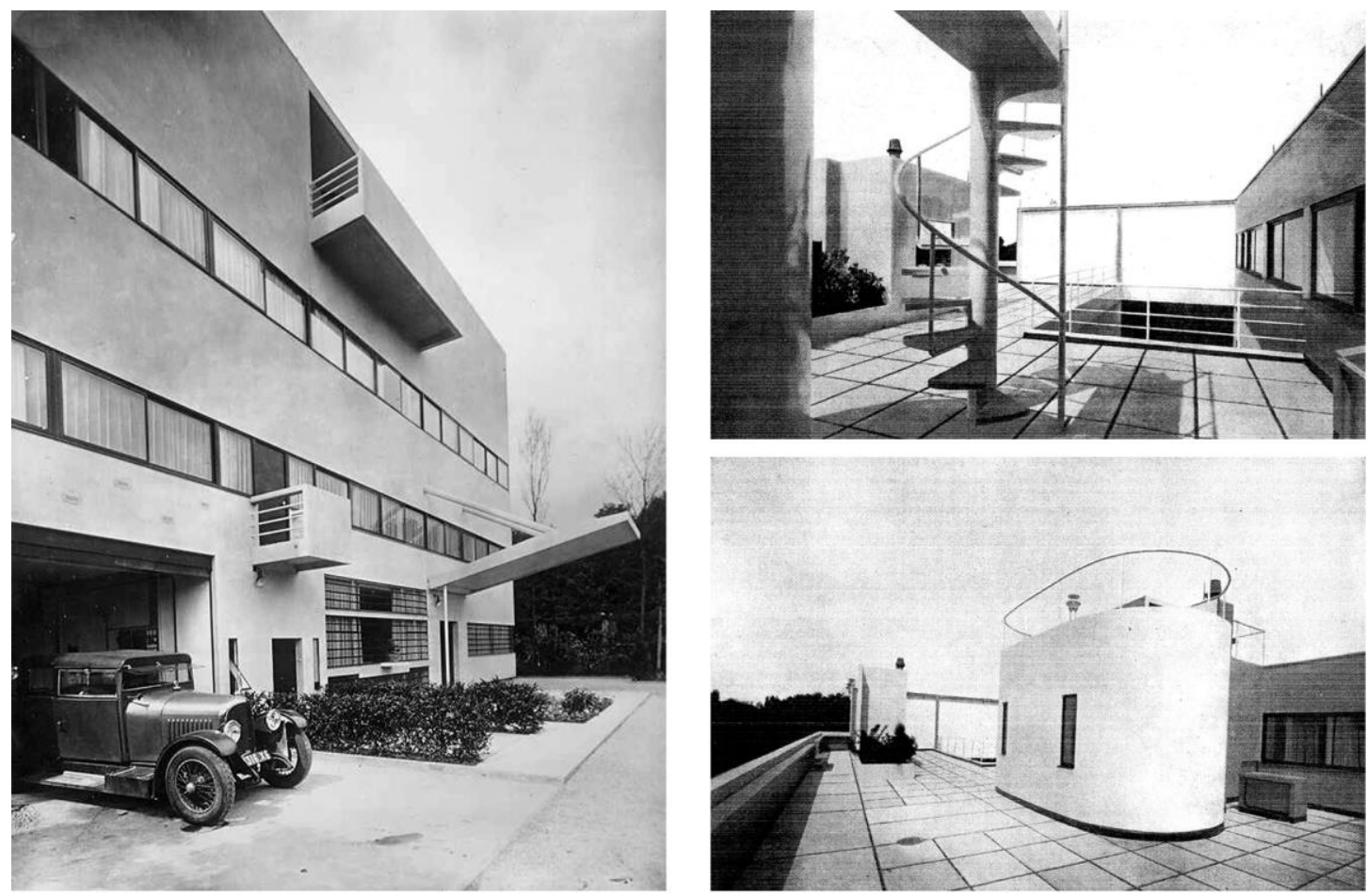

2. Villa De Monzie à Garches, 1928.

Giedion définit cette villa «un essai consistant à alléger non seulement la base, mais encora la partie supérieure et à laisser largement pénétrer l'air par la façade qui n'est plus compacte». ${ }^{75}$

Pour Giedion, Le Corbusier réalise «une architecture planante». ${ }^{76}$ Tremper son architecture demande à l'homme la création de «un nouveau sens de l'équilibre. Les recoupement, les interpénétrations, aspirent le monde extérieur». ${ }^{77}$ Et les terrasses et les ponts qui entourent presque le volume de la maison «sont du luxe. Mais en même temps leur réalisation exprime le fait que la vie privée, fermée, perd de plus en plus sa justification». ${ }^{78}$

\footnotetext{
${ }^{71}$ Ibidem.

${ }^{72}$ Ibidem.

${ }^{73}$ Ivi, pp. 206-207.

${ }^{74}$ Ibidem.

${ }^{75}$ Ivi, p. 211.

${ }^{76}$ Ibidem.

${ }^{77}$ Ibidem.

${ }^{78}$ Ibidem.
} 
Le luxe de la Villa à Garches consiste dans un «luxe de volume d'air, qui par son harmonie réalise la nouvelle conception. C'est l'exprérience hardie d'un visionnaire qui est ici réalisée; et cette expérience nous fait apercevoir le seul moyen qui permette aujourd'hui de faire du luxe une force productive». ${ }^{79}$

«Toutes les maisons de Le Corbusier ont pour but de créer un habitat pour les habitudes de vie en voie de formation ${ }^{80}$ comme aussi Villa Savoye. Le problème qui Le Corbusier se met c'est toujours d' «ouvrir la maison, cette maison qui se ferme craintivement, et créer de nouvelles possibilités de liaison entre l'intérieur et l'extérieur». ${ }^{81}$ Contrairement à les précédentes villes de Le Corbusier, construites sur un terrain resserré, Villa Savoye possède une place spéciale puisque se trouve complètement isolée. Le problème à résoudre ici «pour tout homme ayant quitté son travail et cherchant à reprendre contact avec la nature organique, avec les plantes, le ciel et le paysage». ${ }^{82}$
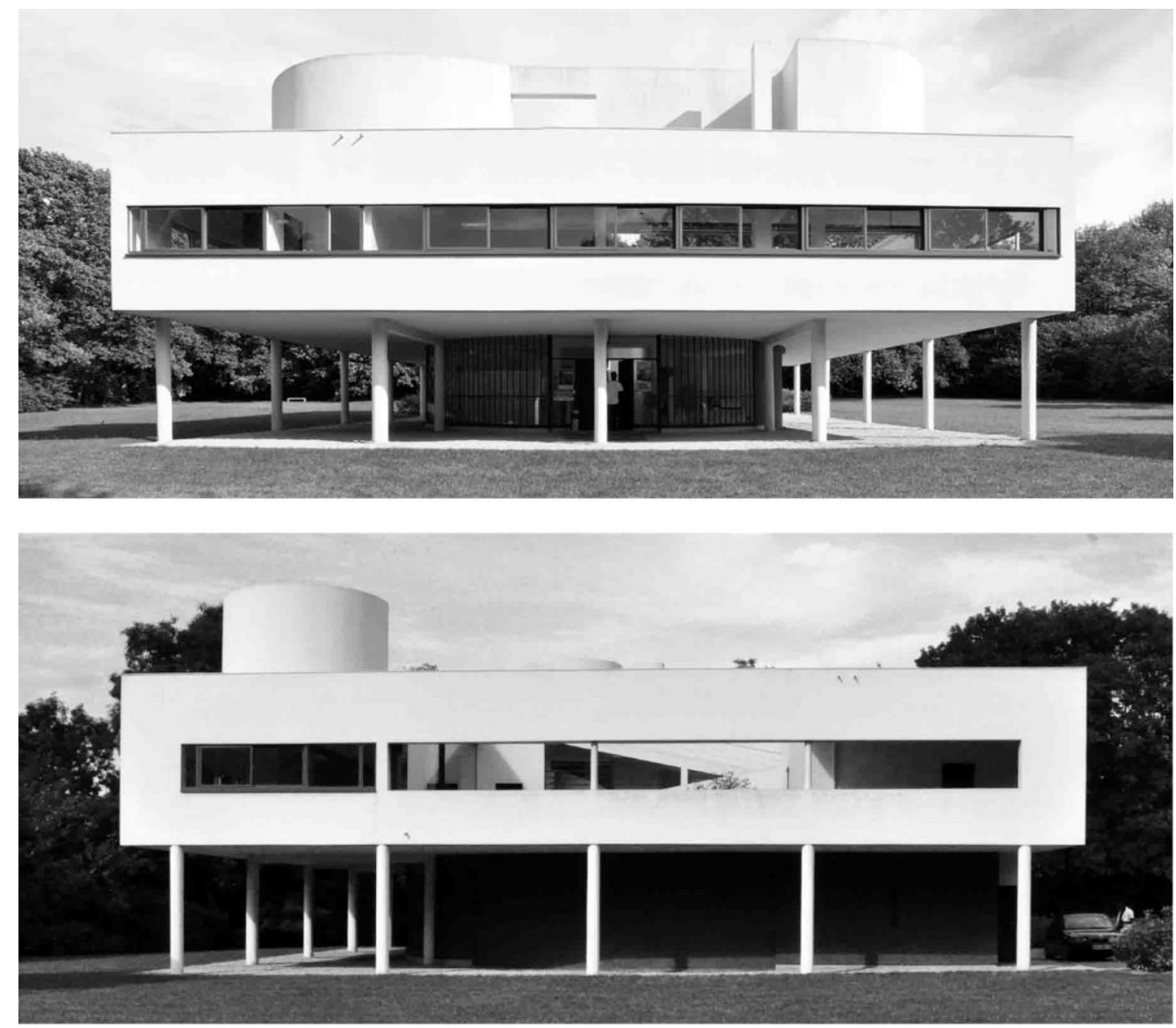

3. Villa Savoye, 1929.

Il est important de souligner comme le «notre attitude est toute différente aujourd'hui vis-à-vis de la nature. Il s'agit moins de s'adapter passivement au sol lui-meme que de s'unir avec tout le paysage: avec le ciel, et surtout avec l'air». ${ }^{83}$

\footnotetext{
${ }^{79}$ Ibidem.

${ }^{80}$ Ivi, p. 212 .

${ }^{81}$ Ibidem.

${ }^{82}$ Ibidem.

${ }^{83}$ Ibidem.
} 
«La maison repose sur pilotis et les véritables appartements se trouvent au premier étage»; ${ }^{84}$ le particulier «auquel est destinée la construction, aspire à dominer le paysage plutôt qu'à se trouver en proximité des arbres et des plantes. Il veut jouir du panorama, du vent et du soleil». ${ }^{85}$

Giedion décrit la maison comme «un cube reposant sur pilotis. Le cube n'est pas une masse pleine, mais évidé dans la direction du Sud-Est et du Sud-Ouest, et de telle sorte que le soleil levant n'effleure pas seulement les surfaces extérieures mais pénètre jusque dans l'intérieur de la maison». ${ }^{86}$

En outre «il n’y a pas de façade, pas de devant ni de derrière, car la maison s'ouvre de tous côtés». ${ }^{87}$

\subsection{Grands bâtiments publics}

Le projet pour le Palais de la Société des Nations à Genève, conçu par Corbusier et Pierre Jeanneret est «une leçon très complète d'architecture moderne. De nombreux problèmes d'ordre esthétique et d'ordre technique et pratique s'y trouvent résolus». ${ }^{88}$

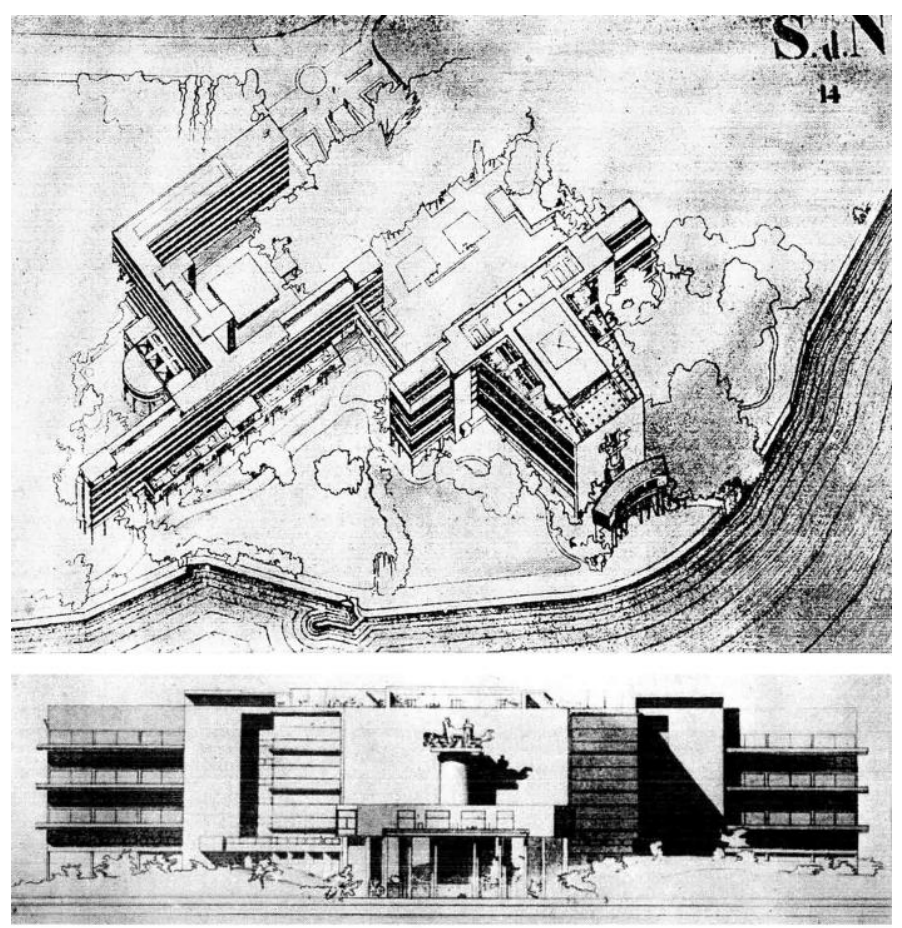

4. Projet pour le Palais de la Société des Nations à Gèneve, 1927.

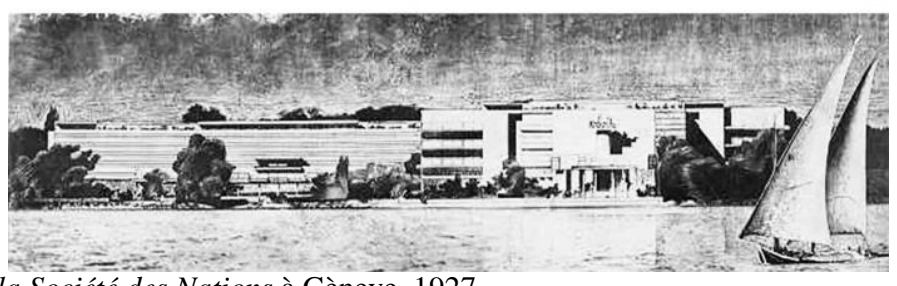

${ }^{84}$ Ibidem.

${ }^{85}$ Ibidem.

${ }^{86}$ bidem.

${ }^{87}$ Ibidem.

${ }^{88}$ Zervos C., Progetto per il Palazzo della S.D.N. a Ginevra, a cura di Le Corbusier e Pierre Jeanneret, «Cahiers d'art. Peinture, sculpture, architecture, musique. Directeur: Christian Zervos», IV-V, Paris, 1927, p. 175. 
Avant tout les deux architectes ont analysé soigneusement «le site où ce Palais doit s'élever, contrairement aux habitudes des architectes qui réalisent sur le papier des monuments passe-partout» ${ }^{89}$ pour rendre le projet $«$ partie intégrante du site». ${ }^{90}$

Du point de vue topographique ce projet «évite les espaces morts en mettant les bâtiments au travers de tout le terrain». ${ }^{91}$ En outre «s'oppose au 'Système fermé'; procède par 'redents' très ouverts à la vue, à la lumière, au soleil» ${ }^{92}$ et «ne touche pas au terrain, évite le déplacement des terres en vue du terrassement ou en vue des fouilles». 93

Les bâtiments «étant tous au même niveau et occupant des places très différentes du terrain accidenté, ils seraient construits sur des poteaux 'pilotis' de hauteurs variables. Les vastes espaces couvertes ainsi crèés sont utilisés pour faire des garages» ${ }^{94}$ et la circulation des autos «se fait à sens unique». ${ }^{95}$

Élément capital du bâtiment fut la fenêtre et cette «solution technique, fenetre à double vitrage coulissante latéralement et fermeture hermétique par excentrique serrant automatiquement les châssis contre une nervure médiane, est assurée par un type existant déjà et appliqué avec succès ». ${ }^{96}$

L'éditeur grecque met en évidence comme «le bâtiment de la Grande salle s'avance en proue vers le lac, jusqu'au bord de l'eau. La vue de la terrasse est donc tout à fait exceptionnelle. La salle est étudiée à fond au point de vue acoustique, aération, ventilation, chauffage, purification de l'air». ${ }^{97}$

Le système d' «aération ponctuelle' qu'ils se sont proposés d'appliquer dans la grande salle, chauffe de l'air à $18^{\circ}$ [...] pénètre dans le locaux de purification et d'ozonification, il est, soit réchauffé, soit réfrigéré, de façon à être maintenu constamment à $18^{\circ}$, été comme hiver». ${ }^{98}$

Élément innovant se revela celui-là «d'accord avec les travaux de Gustave Lyon, de la Salle Pleyel»; ${ }^{99}$ Le Corbusier et Pierre Jeanneret ont conçu une salle «d'après les lois rigoureuses de l'acoustique, qui permettent de diriger les ondes sonores et de faire état de murs projecteurs et de murs réfléchisseurs». ${ }^{100}$

Avec la Salle Pleyel on était atteint «la Chimère de l'acoustique avait été poursuivie depuis l'antiquité par les voies incertaines et, en l'occurence, inopérantes de l'empirisme. Mais, aujourd'hui, le monde de la construction sait dorénavant qu'en peut résoudre scientifiquement l'acoustique des grandes salles». ${ }^{101}$

L'innovation, nécessaire surtout en architecture, c'est fondamental et sert à desserrer «pour le monde crédule, la vérité [...]. Mais voici qu'aujourd'hui, la salle Pleyel, c'est la vérité aussi, la vérité de fait, la vérité

\footnotetext{
${ }^{89}$ Ibidem.

${ }^{90}$ Ibidem.

${ }^{91}$ Ibidem.

${ }^{92}$ Ibidem.

${ }^{93}$ Ibidem.

${ }^{94}$ Ibidem.

${ }^{95}$ Ibidem.

${ }^{96}$ Ivi, pp. $175-176$.

${ }^{97}$ Ivi, p. 176.

${ }^{98}$ Ibidem.

${ }^{99}$ Ibidem.

${ }^{100}$ Ibidem.

${ }^{101}$ Le CORBUSIER, La Salle Pleyel. Une preuve de l'évolution architecturale, «Cahiers d'art, Revue d'art paraissant dix fois an. Directeur: Christian Zervos. Peinture, Sculpture, Architecture, Musique, Mise en scène, Disques, Cinéma», n², Paris, 1928, pp. 89-91.
} 
fonctionnante, s'opposant à la vérité factice de l'Institut; et l'Institut s'incline devant cette nouvelle vérité irréfutable». ${ }^{102}$

Confiant en l'arriver et dans la sensibilité qui tôt ou tard devront émerger, l'architecte déclare que «il est à prèsumer que dans le monde entier, tout futur tenancier de salle exigera le maximum de sécurité acoustique. Et le nombre des salles Pleyel se multipliera». ${ }^{103}$

Il est ainsi que Le Corbusier argue sur «le valeur historique de la Salle Pleyel: sans ambiguité ni restriction, elle est vraie, comme est vrai l'avion qui vole et le poisson qui nage». ${ }^{104}$

Le Corbusier met en garde les lecteurs en déclarant que «ces nouvelles salles seront modernes. L'étant, voici la résultante tragique: impossible de dessiner, ni meme de concevoir, dans de telles salles, le moindre ordonnance dite classique: pilastres, colonnes, entablements, coupoles, moulures, bref, tout ce qui se dessine, et tout ce qui, en fait, remplit les manuels d'histoire de l'art. nous ne sommes plus ici, dans un système orthogonal rappelant l'un quelconque des systèmes architecturaux du passé; nous sommes dans un systeme biologique, où tout est plans gauches, surfaces gauches, insaisissables, incapables de recevoir le moindre système de décor orthogonal». ${ }^{105}$

Pour Zervos «il s'agit de la lutte de l'ancien contre le moderne. Cette lutte intéresse toutes les élites, parce que l'objet, le Palais de la Société des Nations, est une œuvre capitale et que l'issue de cette bataille comptera en plus ou en moins dans l'histoire de l'évolution contemporaine». ${ }^{106}$

Le tableau d'honneur du concours international pour la construction de le Palais de Genève fut rendu public dans le mois de mai 1927, accolé par «le laconique rapport du jury», ${ }^{107}$ et dans le mois suivant il eut lieu l'exposition des projets de «377 cabinets d'architecture d'Europe et d'Amerique». ${ }^{108}$

Selon Zervos «il y avait véritablement là, la somme des puissances architecturales» ${ }^{109}$ de l'époque, et «deux tiers des envois constituaient la contribution de l'académisme le plus fin comme aussi le plus plat». ${ }^{110}$

Le palmares représentait de manière admirable «dans une diversité incohérente, la totalité des manifestations architecturales d'aujourd'hui: École des Beaux-Arts de Paris, emphase archéologique italienne, distinction néoclassique scandinave, superficialité 'moderne' d'un côté de la production germanique, modernisme rationel et digne de la France d'avant-garde». ${ }^{11}$

Devant à une manifestation si vaste et différente de l'architecture, comme il pouvait être le jury capable de comprendre et évaluer un «tel éclectisme», ${ }^{112}$ et avec un palmares que «comportait neuf premiers prix, neuf

\footnotetext{
${ }^{102}$ Ivi, p. 89.

${ }^{103}$ Ibidem.

${ }^{104}$ Ibidem.

105 Ivi, p. 90.

${ }^{106}$ Zervos C., Qui batira le palais des nations a Genève? Étude-manifeste de 'Cahiers d'art' en faveur d'un projet moderne, «Cahiers d'art, Peinture, sculpture, Architecture, musique. Directeur: Christian Zervos», n 9 , Paris, 1927, p. I.

${ }^{107}$ Ivi, p. II.

${ }^{108}$ Ibidem.

${ }^{109}$ Ibidem.

${ }^{110}$ Ibidem.

${ }^{111}$ Ibidem.

${ }^{112}$ Ibidem.
} 
deuxième prix, neuf troisième prix, contrairement au programme qui prévoyait: un première prix, deux deuxièmes prix, un troisième, quatrième, cinquième, sixième et septième prix». ${ }^{113}$

Zervos énumère les événements qui caractérisèrent le cours des soixante-quatre séances du jury, en relevant comme à la soixante-troisième le projet numéro 273, celui de Le Corbusier et Pierre Jeanneret «était mis au premier rang et recommandé avant tout autre à l'attention du Conseil. Pendant toute le durée des déliberations qui furent extraordinairement laborieuses, le projet Le Corbusier fut le seul qui réunit constamment les suffrages de quatre architectes de reputation mondiale qui siégeaient au jury». ${ }^{114}$

Ce qui pressait Zervos était l'imprévu qu'il rencontra au dernier moment et qu'il concernait une règle contenu à l'intérieur du statut qui semblait interdire l'usage des «moyens mécaniques». ${ }^{115}$ Les plans de Le Corbusier et Pierre Jeanneret, «dessinés à l'encre comme tous les autres, avaient été reproduits pour plus de netteté, à la presse d'imprimerie» ${ }^{116}$ et ceci fournit l'occasion de contestation de la part de quelque juré; malgré cela «il devenait difficile de tirer hors de pair le projet Le Corbusier, et comme aucun des autres ne s'imposait, le jury se tira d'affaire en classant les meilleures, mettant ainsi la Société des Nations dans un embarras dont elle n'est pas près de sortir». ${ }^{117}$

Pour Zervos on peut se demander s'il est admissible «qu'un projet de haute valeur ait été ainsi refoulé pour des raisons qui n'ont rien à voir avec l'architecture». ${ }^{118}$

Un autre aspect important du problème du projet 273 ère constituée par le coût: «le projet 273 (Le Corbusier et Pierre Jeanneret) indique la somme de 12 milions; les autres fournissent tous les chiffres de 13 millions», ${ }^{119}$ seuil déclaré explicitement dans l'avis du concours.

L'unique objection enlevé fut celle qui mettait en évidence comme «si huit projets coûtent de 17 à 50 millions, comment se peut-il qu'un projet chiffre à 12 millions? Ce projet doit être incomplet; il est incomplet». ${ }^{120}$

Le Corbusier il défendit le caractère exhaustif du projet, comme le devis qui fut rédigé par les «meilleures entreprises suisses», ${ }^{121}$ en soulignant que rester à l'intérieur des limites du concours est dû au fait qu'il concevait «l'architecture sur d'autres bases». ${ }^{122}$ Le projet en effet «correspond rigoureusement aux nécessités d'exploitation intérieure de la Société des Nations et cela par une économie caractéristique de l'espace dont l'effet est de faciliter l'usage des bâtiments et ed déterminer un cube restreint des bâtiments. Ensuite, contrairement aux autres, il contient toutes les indications de structure dans les moindres détails; si l'on voulait, l'exécution pourrait commencer dès demain, sur les plans qui sont dans les caisses, au secrétariat de la Société des Nations». ${ }^{123}$ Le Corbusier précise que si le prix est autre «c'est que [...] nos procédés de structure sont intièrement standardisés et que notre ossature de béton porte les services requis avec exactitude et économie, et que rien dans toute notre étude, n'est inutile. Ce sont là des bases entièrement neuves, conformes à tout ce qui régit le travail contemporain dans tous les domaines autres que celui de l'architecture et ces bases sont opposées

\footnotetext{
${ }^{113}$ Ivi, pp. II-III.

${ }^{114}$ Ivi, p. III.

${ }^{115}$ Ibidem.

${ }^{116}$ Ibidem.

117 Ibidem.

${ }^{118}$ Ivi, pp. III-IV

${ }^{119}$ Ibidem.

${ }^{120}$ Ivi, p. IV.

${ }^{121}$ Ibidem.

122 Ibidem.

${ }^{123}$ Ivi, pp. V-VI.
} 
à celles qui ont servi à établir les projets coûteux où l'emphase seule a préoccupé les auteurs, au détriment le plus fatal des services de la Société des Nations». ${ }^{124}$

La commission des cinq membres, à laquelle enfin tous les pouvoirs étaient délégués, n'arriva pas à une conclusion à la fin de la session et pour éviter un rapport à l'Assemblée de 1928, pour obtenir des nouveaux crédits «faisait augmenter de $50 \%$ la somme de 13 millions fixée aux conditions du concours», ${ }^{125}$ prise de position que «bouleverser les juristes et les gens de bonne foi». ${ }^{126}$

Zervos écrit que «le projet Le Corbusier et Pierre Jeanneret occupe tous les esprits. Et cela à un tel point, que devant un danger immanent dont le sentiment pouvait bien être éveillé par la confusion des discussions de la dernière session de Genève, les élites de tous pays sont émues. Et les associations professionnelles ont décidé de faire entendre leur voix à Genève». ${ }^{127}$

Pour Zervos tel «bataille n'est pas du tout entre tels ou tels des neufs projets primés en premier. C'est une double bataille de principe: d'hégémonie (bataille diplomatique) et d'esprit ancien contre esprit moderne». ${ }^{128}$ Une bataille diplomatique qui risque ne pas trouver «un instant où seront débattues de questions d'architecture». ${ }^{129}$

Ce qui préoccupe Zervos c'est de savoir qui pourrait triompher à la dernière minute entre la stupeur générale «à la barbe de l'Angleterre et de l'Italie [...] le 'Palais Nénot' président de l'Academie des Beaux-Arts et de l'Institut de France». ${ }^{130}$

L'éditeur reporte comme «cette histoire du Palais est devenue, dans l'élite, le prétexte à proclamer l'avènement d'un esprit neuf». ${ }^{131}$

Mais le jury, composé de «Adatchi, Osuski, Sir Hilton Young, Politis, Urruta, a décidé que le Palais des Nations serait construit par Nénot, Prix de Rome, Membre de l'Institut, Prèsident du Salon des Artistes Français». ${ }^{132}$

La pensée de Nenot qu'il croit l'architecture de Le Corbusier une 'barbarie', c'est pour Zervos comme une offense aux propres temps, un outrage à l'inclinaison contemporaine et un désir évident de freiner chaque type de tension vers la recherche du nouveau.

Zervos ayant pris partie active au débat sur le Palais des Nations croit que la revue Cahiers d'art, considerant tout ce qui il est arrivé, pour sa raison d'être «se trouve fortement mêlée. [...] Revue qui, dans les œuvres de l'art, défend l'esprit moderne». ${ }^{133}$

Cependant «depuis l'ouverture de la Session de la Société des Nations à Genève, des membres du Conseil, les principales délégations de l'Asseblée, le Secrétariat général, ainsi que les autorités génevoises et la population de

\footnotetext{
${ }^{124} I v i$, p. V.

${ }^{125}$ Ibidem.

126 Ibidem.

${ }^{127}$ Ivi, p. VIII.
}

${ }^{128}$ Zervos C., Qui batira le Palais des Nations? II. La situation actuelle, «Cahiers d'art, Peinture, Sculpture, Architecture, Musique. Directeur: Christian Zervos», n 9 , Paris, 1927, p. IX.

${ }^{129}$ Ibidem.

${ }^{130}$ Ibidem.

${ }^{131}$ Ivi, p. X.

${ }^{132}$ Zervos C., Qui batira le Palais des Nations? III. La situation actuelle, «Cahiers d'art, Peinture, sculpture, Architecture, musique. Directeur: Christian Zervos», nº10, Paris, 1927, p. XI.

${ }^{133}$ Zervos C., Qui batira le Palais des Nations? IV. Le Conseil des Nations va statuer, «Cahiers d'art, Revue d'art paraissant dix fois an. Directeur: Christian Zervos. Peinture, Sculpture, Architecture, Musique, Mise en scène, Disques, Cinéma», n², Paris, 1928, p. 84 . 
Genéve, on été saisis par l'Union des Associations Internationales, représentée par Paul Otlet, sénateur de Bruxelles, du projet d'édifier à Genéve un centre mondial». ${ }^{134}$

Le projet du Mundaneum dessiné par Le Corbusier et Pierre Jeanneret, «Architectes à Paris, lauréats du concours du Palais des Nations», ${ }^{135}$ a été montré dans l’Université de Genève et «exposé aux délégués et au public génevois, le projet de la Cité Mondiale, qui serait à la fois Quartier Général pour les Associations, Congrès, libres mouvements internationaux et centre scientifique, documentaires, éducatif, réalisant au degré mondial et avec la coopération des organismes officiels: les cinq grandes institutions traditionnelles du Travail Intellectuel: Bibliothèque, Musée, Association scientifique, Université, Institut». ${ }^{136}$

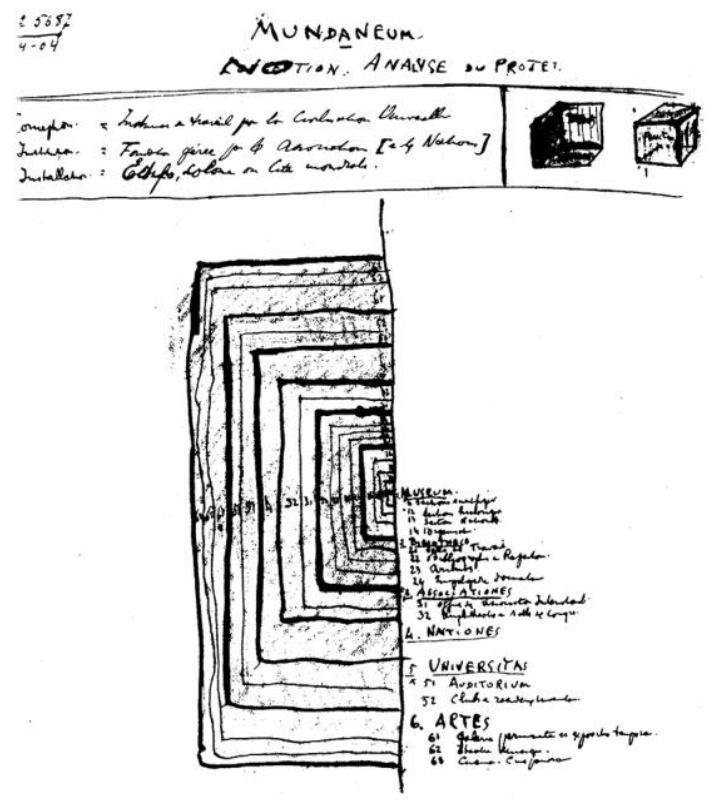

\section{Dessin du Mundaneum.}

Le Corbusier soutient que «le but du Mundaneum est d'exposer et de faire connaitre par l'écrit, par l'objet et par la parole: Comment les Hommes, de leurs humbles origines, se sont élevés jusqu'à la splendeur de leurs Génies, de leurs Héros et de leurs Saints. Comment la Terre a été dècouverte et, ses Forces ayant été soumises, presque entièrement habitée. Comment se sont élevées et les Villes, et les Nations, et le Civilisations. Comment les êtres humains, au nombre de centaines de millions, sont parvenus ò vivre en communauté sur la planète. Comment, depuis que le temps et l'espace ont été graduellement vaincus, toutes les idées et tous les actes, s'enchainent, ont leurs répercussions du Nord au Sud, de l'Orient à l'Occident, et constituent désormais une Pensée collective faite de toutes les pensées particuliéres, une Activité générale faite de toutes les pensées particuliéres, une Activité générale faite de toutes les activités spéciales. Comment, après que la Famine et la Peste durent reculer, hier, devant le Travail et la Science, à son tout la Guerre, aujourd'hui, doit céder devant une Paux voulue et organisée.

${ }^{134}$ Zervos C., Un projet de centre mondial a Genéve, «Cahiers d'art, Revue d'art paraissant dix fois par an. Directeur: Christian Zervos. Peinture, Sculpture, Architecture, Musique, Mise en scène, Disques, Cinéma», n7, Paris, 1928, p. 307-311. ${ }^{135}$ Ibidem.

${ }^{136}$ Ibidem. 
Comment, enfine, l'Esprit l'emportant sur la Matière, il faut que l'Idéal préside aux destinées, et que, sur la Terre aussi, il se réalise sous les formes élevées qu'ont définies les siècles: Vérité, Beauté, Bonté; Foi, Espérance et Charité; Justice et Perfection; Liberté, Égalité, Fraternité». ${ }^{137}$

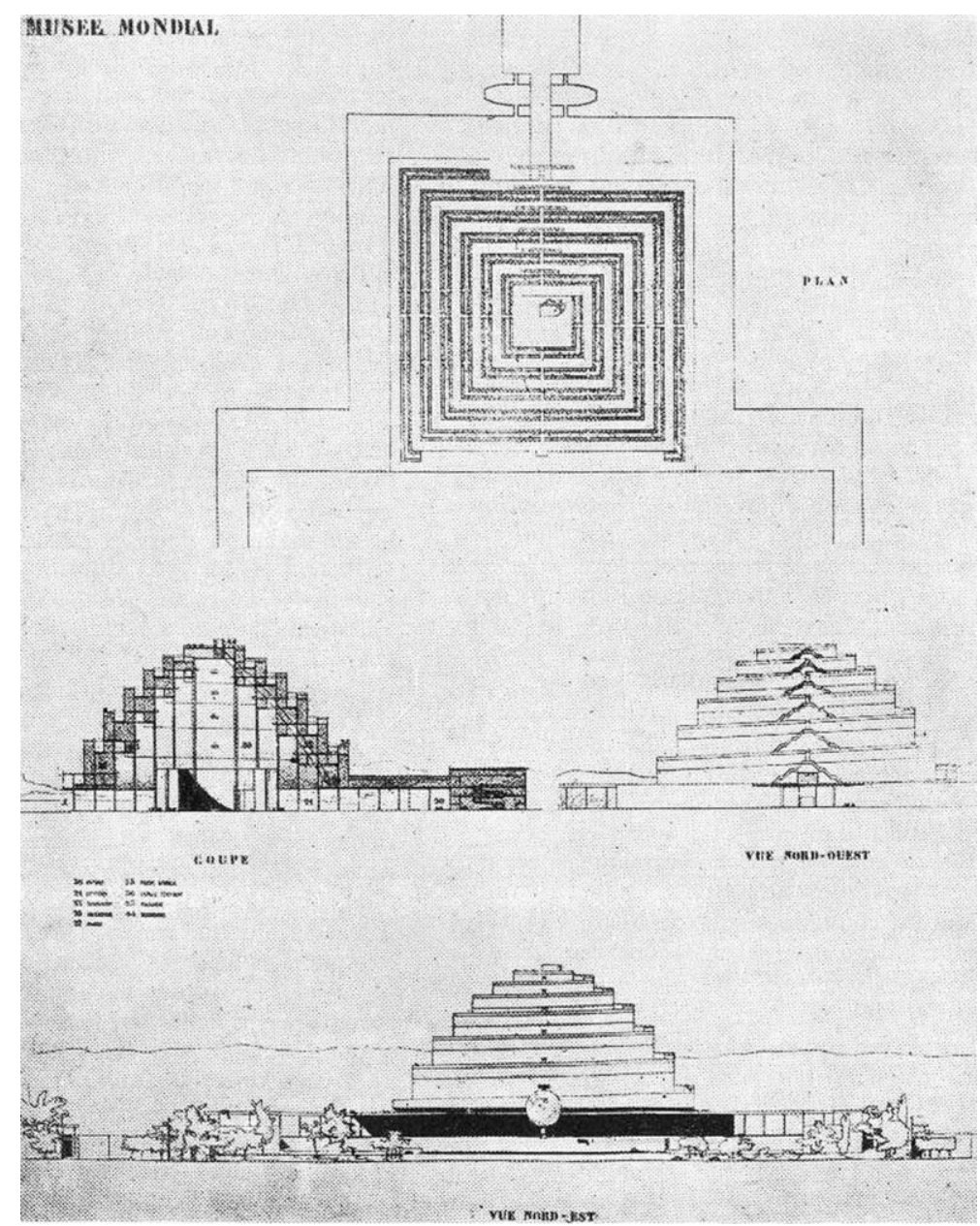

6. Projet du Mundaneum.

Le désir de Le Corbusier était que «en un point du Globe, l'image et le signification totales du Monde puissent être perçues et comprises; que ce point devienne un lieur sacré, inspirateur et coordinateur de grande idées, de nobles activités. Qu'il y soit formé un Trésos, fait de la somme des oeuvres intellectuelles, apporté comme une contribution à la Science et à l'Organisation Universelle, comme un élément de l'immense Épopée et de l'Aventure magnifique poursuivies à travers les âges par l'Humanité». ${ }^{138}$

Zervos est convaincu que «le monde trouverait là le lieu où s'élève au plus haut, le sens de la solidarité humaine, où se démontrent les conséquences des fautes et des bienfaits, où l'analyse fournit ses informations précises, où la synthèse montre les directions, où les moyens de coordination et d'harmonisation sont présents». ${ }^{139}$

\footnotetext{
${ }^{137}$ Ibidem.

${ }^{138}$ Ivi, p. 308.

${ }^{139}$ Ivi, p. 311.
} 
Dans les mêmes ans du projet pour le Palais des Nations, Le Corbusier et Pierre Jeanneret furent engagés dans l'étude pour un autre concours international, pour la construction de le Palais de l'Union des Coopératives de l'U.R.S.S. à Moscou. Les deux architectes «viennent d'être chargés de l'exécution de ce travail sur l'insistance de l'association des architectes modernes de Moscou auprès des pouvoirs». ${ }^{140}$
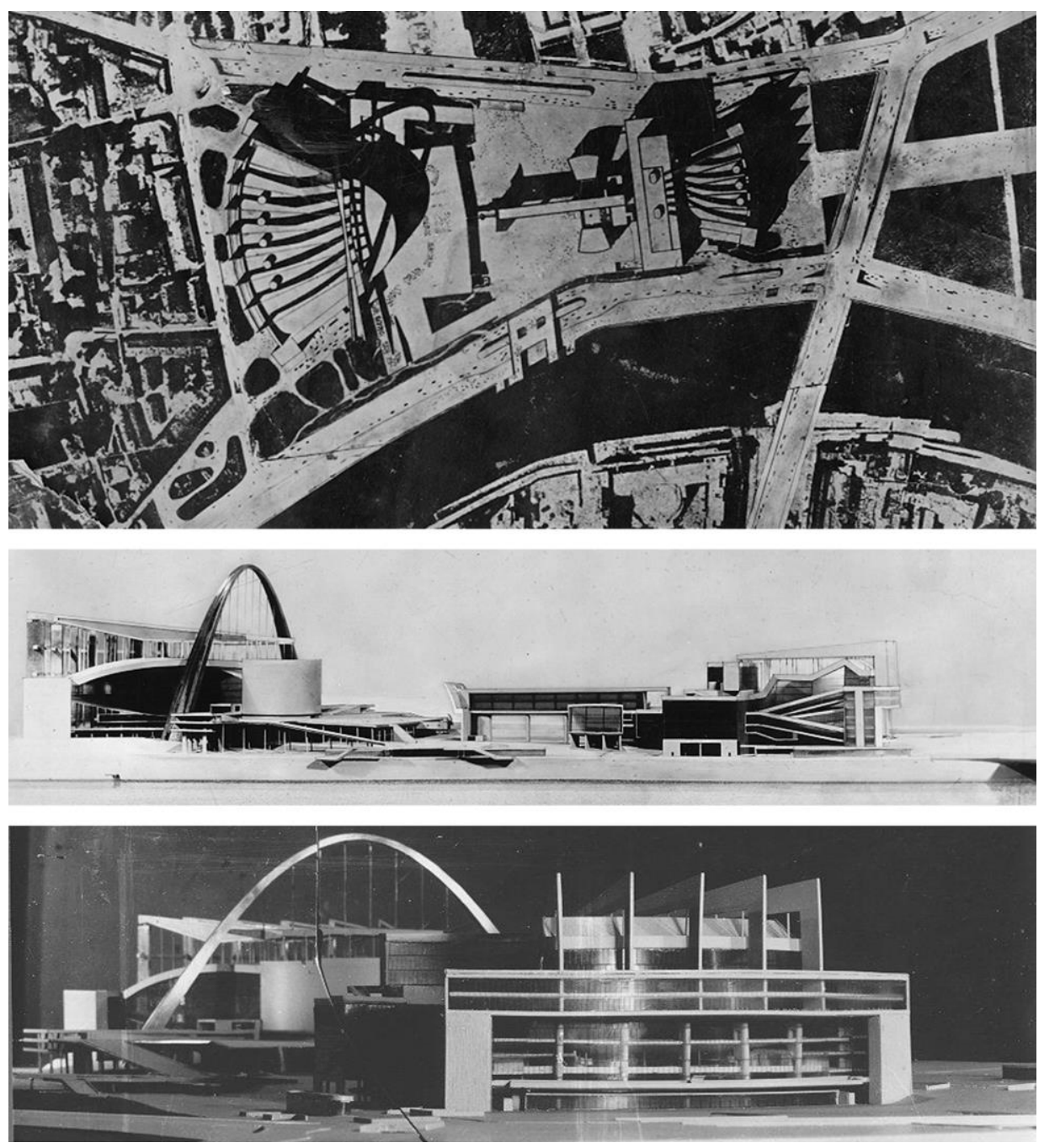

8. Projet pour la Maison de l'Union des Cootives de l'U.R.S.S.

La second phase du concours, en 1928, devait «fourni à Moscou une nouvelle série de plans émanant de cabinets d'architecture notoires d'Autriche, d'Allemagne, de France et d'Angleterre». ${ }^{141}$ Le projet de Le Corbusier et Pierre Jeanneret vint tout de suite tenu en grande considération, autant que «Le Corbusier partit pour Moscou en octobre 1928, et sur place, dut faire un second projet tenant compte très exactement des conditions locales. Enfin en février 1929 le plan définitif était adopté». ${ }^{142}$

\footnotetext{
${ }^{140}$ Zervos C., Maison de l'Union des Cootives de l'U.R.S.S. a Moscou par Le Corbusier et Pierre Jeanneret, «Cahiers d'art, Revue d'art paraissant dix fois par an. Directeur: Christian Zervos. Peinture, Sculpture, Architecture, Musique, Mise en scène», n4, Paris, 1929, p. 162-163.

${ }^{141}$ Ibidem.

${ }^{142}$ Ibidem.
} 
La remise donnée aux architectes des dirigeants du concours de Moscou était celle d'apporter au projet pour le Palais de l'Union des Coopératives de l'U.R.S.S. «tout ce que la technique moderne a créé d'efficace dans l'industrie du bâtiment». ${ }^{143}$

Le but était de mettre d'une manière beaucoup à l'avant-garde et parfaitement en syntonie aux demandes imposées. Le projet qui conçurent «gràce aux libertés apportées à l'art de bâtir par le ciment armé» ${ }^{14}$ garantit la solution de la «respiration à l'intérieur de l'édifice». ${ }^{145}$

En outre la conjonction du «brevet Gustave Lyon (aération ponctuelle) et du brevet Le Corbusier et Pierre Jeanneret (murs neutralisants), transforme du tout au tout les traditions du chauffage des immeubles». ${ }^{146}$

Selon Zervos telles méthodes de construction «entraînent des conséquences architecturales impératives», ${ }^{147}$ quel la réalisation de bâtiments type, par exemple 'type bureau', 'type assemblée' et «leur enveloppe est réduite à des plans lisses (doubles membranes). Ces plans sont tout de verre, tout de pierre ou mixtes, suivant la destination des locaux». ${ }^{148}$

Un couple important d'éléments est constitué par le toiture «plate avec écoulement des eaux pluviales ou de fonte des neiges à l'intérieur» ${ }^{149}$ et par le soutien des «corps de batiments qui sont sur pilotis, avec circulations diverses des voitures ou des piétons au-dessous». ${ }^{150}$ De telle manière surgit «un complexe plan architectural nouveau, entièrement inédit, imposant à l'architecture un système esthétique nouveau». ${ }^{151}$

Pour Zervos «l'architecture est faite de rapports émouvants. Ce qui permet la perception des rapports, ce sont des volumes, des surfaces, des lignes limpides et lisibles clairement. Ce qui apporte l'émoi artistique c'est la qualité des rapports que ces éléments géométriques ont entre eux». ${ }^{152}$

Zervos dans les Cahiers d'art de quelque an après, remarque que cependant le «Conseil du Bâtiment du Palais des Soviets a pris dernièrement la décision de faire exécuter le projet élaboré par des architectes russes», ${ }^{153}$ et conclut l'article en écrivant que «si nous approuvons l'organisation intérieure de ce palais, nous élevons absolument contre son expression plastique». ${ }^{154}$ Il comprenait que les Soviet eussent voulu ériger en hauteur un monument pour commémorer les luttes et la victoire du prolétariat russe, mais il ne se comprennais pas comme, pour les exprimer, les architectes n'eussent pas été capables de trouver autre chose que des souvenirs archéologiques sans importance.

\footnotetext{
${ }^{143}$ Ibidem.

${ }^{144}$ Ibidem.

145 Ibidem.

${ }^{146}$ Ivi, p. 163.

${ }^{147}$ Ibidem.

${ }^{148}$ Ibidem.

${ }^{149}$ Ibidem.

${ }^{150}$ Ibidem.

${ }^{151}$ Ibidem.

152 Ibidem.

${ }^{153}$ Zervos C., Le futur palais des Soviets à Moscou, «Cahiers d'art, Revue paraissant dix fois pas an. Directeur: Christian Zervos. Peinture, Sculpture, Architecture, Art ancien, Ethnograpgie, Cinéma», n¹-4, Paris, 1934, p.114.

${ }^{154}$ Ibidem.
} 


\section{Bibliography/references}

Giedion, Siegfried, "Le Corbusier et l'architecture contemporaine par S.Geidion", in Cahiers d'art, Revue d'art paraissant dix fois par an- Directeur: Christian Zervos. Peinture- sculpture-Architecture-Art ancienethnographie-cinéma, IV, Paris, 1930

Giedion, Siegfried, "Le problème du luxe dans l'architecture moderne. A propos d'une nouvelle construction a Garches de Le Corbusier et Pierre Jeanneret", in Cahiers d'art, Revue d'art paraissant dix fois par anDirecteur: Christian Zervos. Peinture- sculpture-Architecture-musique-mise en scène-disques-cinéma, V-VI, Paris, 1928

Le Corbusier, "La Salle Pleyel. Une preuve de l'évolution architecturale", Cahiers d'art, Revue d'art paraissant dix fois an- Directeur: Christian Zervos. Peinture- sculpture-Architecture-musique-mise en scène-disquescinéma, II, Paris, 1928

Le Corbusier, "Maison de l'Union des cootives de l'U.R.S.S. a Moscou par Le Corbusier et Pierre Jeanneret", Cahiers d'art, Revue d'art paraissant dix fois par an-Directeur: Christian Zervos. Peinture- sculptureArchitecture-musique-mise en scène, IV, Paris, 1929

Le Corbusier, "Projet pour la construction du palais des Soviets par Le Corbusier et Pierre Jeanneret", in Cahiers d'art, Revue paraissant dix fois pas an - Directeur: Christian Zervos - Peinture, Sculpture, Architecture, Art ancien, Ethnograpgie, Cinéma, Editions «Cahiers d'art», 14, rue du Dragon, Paris (IV arrondissement), I-II, Paris, 1932

Le Corbusier, Notes à la suite, «Cahiers d'art, Bulletin mensuel d'actualité artistique publié sous la direction de Christian Zervos», III, Paris, 1926

Zervos, Christian, "Immeuble «Clarté» a Genève par Le Corbusier et Pierre Jeanneret", in Cahiers d'art, Revue paraissant dix fois pas an - Directeur: Christian Zervos - Peinture, Sculpture, Architecture, Art ancien, Ethnograpgie, Cinéma, Editions «Cahiers d'art», 14, rue du Dragon, Paris (IV arrondissement), VI-VII, Paris, 1932

Zervos, Christian, "Jeunes architectes. A propos de leur ex position à la Galerie des "Cahiers d'art" Février-Mars 1935", in Cahiers d'art, Revue paraissant dix fois pas an-Directeur: Christian Zervos - Peinture, Sculpture, Architecture, Art ancien, Ethnograpgie, Cinéma, I-IV, Paris, 1935

Zervos, Christian, "Le futur palais des Soviets à Moscou", in Cahiers d'art, Revue paraissant dix fois pas an Directeur: Christian Zervos- Peinture, Sculpture, Architecture, Art ancien, Ethnograpgie, Cinéma, I-IV, Paris, 1934

Zervos, Christian, "Pour la création a Paris d'un Musée des artistes vivants", Cahiers d'art, Revue d'art paraissant dix fois par an- Directeur: Christian Zervos. Peinture- sculpture-Architecture-Art ancienethnographie-cinéma, I, Paris, 1930

Zervos, Christian, "Pour la création a paris d'un musée des artistes vivants(II). Réponse et projet d'aménagement et d'organisation, par Le Corbusier et Pierre Leanneret", Cahiers d'art, Revue d'art paraissant dix fois par anDirecteur: Christian Zervos. Peinture- sculpture-Architecture-Art ancien-ethnographie-cinéma, $\mathrm{n}^{\circ} 1$, Paris, 1931

Zervos, Christian, "Qui batira le palais des nations a Genève? Étude-manifeste de «Cahiers d'art» en faveur d'un projet moderne", Cahiers d'art, Peinture, sculpture, Architecture, musique. Directeur: Christian Zervos, IX, Paris, 1927

Zervos, Christian, "Qui batira le Palais des Nations? II. La situation actuelle", Cahiers d'art, Peinture, sculpture, Architecture, musique. Directeur: Christian Zervos, IX, Paris, 1927

Zervos, Christian, "Qui batira le Palais des Nations? III. Decisione del jury", Cahiers d'art, Peinture, sculpture, Architecture, musique. Directeur: Christian Zervos, n 9, Paris, 1927

Zervos, Christian, "Qui batira le Palais des Nations? IV. Le Conseil des Nations va statuer", Cahiers d'art, Revue d'art paraissant dix fois an-Directeur: Christian Zervos. Peinture-sculpture-Architecture-musique-mise en scène-disques-cinéma, II, Paris, 1928 
Zervos, Christian, "Réalisations et projets. Le Corbusier et Pierre Jeanneret. Intérieurs", Les arts de la maison, Printemps \& été, Éditions Albert Morancé, Paris, 1926

Zervos, Christian, "Un projet de centre mondial a Genéve", Cahiers d'art, Revue d'art paraissant dix fois par an-Directeur: Christian Zervos. Peinture-sculpture-Architecture-musique-mise en scène-disques-cinéma, VII, Paris, 1928

Zervos, Christian, Architecture intérieure enquetes, «Cahiers d'art, Bulletin mensuel d'actualité artistique publié sous la direction de Christian Zervos», $\mathrm{n}^{\circ} 1$, janvier, Paris, 1926

Zervos, Christian, Projet pour le palais de la S.D.N. à Genève, par Le Corbusier et Pierre Jeanneret, «Cahiers d'art, Peinture, sculpture, Architecture, musique. Directeur: Christian Zervos», IV-V, Paris, 1927

Zervos, Christian, Réalisations et projets. Le Pavillon de l'Esprit Nouveau, «Les arts de la maison», Automne \& hiver, Éditions Albert Morancé, Paris, 1925, pp. 15-18; ZERVOS C., "La leçon de l'Exposition des arts décoratifs et industriels de 1925”, Les arts de la maison, Automne \& hiver, Éditions Albert Morancé, Paris, 1925 


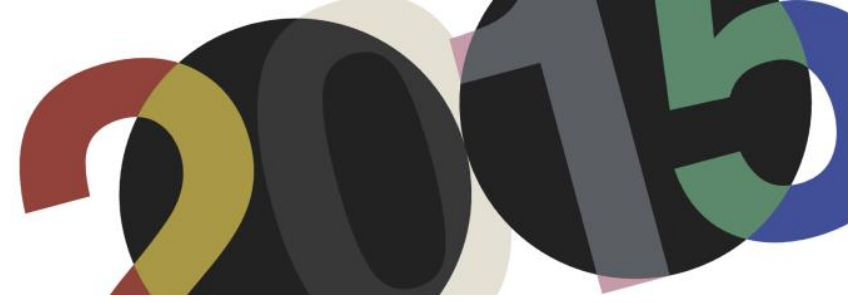

DOI: http://dx.doi.org/10.4995/LC2015.2015.834

\title{
CAPRICCI NO CAPRICHOSOS: copy_paste de Le Corbusier; o los inesperados saltos de la cabra
}

\author{
M. Salazar Valenzuela
}

Escuela Técnica Superior de Arquitectura de Madrid

\begin{abstract}
Resumen: Un dibujo 'a capriccio' de Le Corbusier desvela diferentes operaciones que lo emparentan con el capriccio arquitectónico como un dispositivo analítico, crítico y proyectual, caracterizado por los copy paste, algunas veces de su propia arquitectura, y otras, modificando diferentes principios de arquitecturas precedentes inscritas en la tradición. Con esto, creando nuevas realidades arquitectónicas ideales, a partir de "los saltos inesperados" del capriccio arquitectónico, en proyectos urbanístico, principios arquitectónicos, o arquitecturas singulares como su propia tumba. De esta manera, posicionando el 'capriccio' como proceso plausible de proyectación arquitectónica, que aunque esté enmarcado en el siglo 18, con sus principales exponentes: Canaletto o Piranesi, se propone como una lectura novedosa y contemporánea con su relación al procedimiento de ideación a partir de copiar, desplazar y combinar en la realidad múltiples arquitecturas.
\end{abstract}

Abstract: Le Corbusier's architectural drawing 'a capriccio' reveals different operations that link he with architectural capriccio as an analytical device, critical and project, characterized by copy_paste, sometimes of his own architecture, and other modifying different principles of architectural precedents registered in the tradition. With this, creating new architectural ideal realities from "unexpected jumps", architectural Capriccio in urban projects, architectural principles, or unique architecture as his own grave. In this way, takes up a stance 'Capriccio' as reasonable process of architectural design, although it is belongs to the 18th century, with its main exponents: Canaletto or Piranesi, is proposed as a new and contemporary interpretation with connection to conception's process from copy, move and combine in actually multiple architectures.

Palabras clave: capriccio arquitectónico; copy paste; Canaletto; Berlín; Rogelio Salmona; tumba de Le Corbusier. Keywords: architectural capriccio; copy paste; Canaletto; Berlin; Rogelio Salmona; Le Corbusier's grave.

Hay un dibujo realizado en 1952 por Le Corbusier que podríamos considerarlo perteneciente al género pictórico de los 'capricci'. En él se desarrolla una escena propia de un capricho goyesco y, simultáneamente, otra de un Capriccio Arquitectónico canalettiano por la combinación de edificios desplazados de su lugar. En el primer plano de la escena un cuervo carga a un burro y un burro carga a un cuervo, semejando el Capricho 42 de Goya llamado “Tú que no puedes”; Le Corbusier escribe bajo su dibujo: “¿El genio carga al burro o el burro carga al genio?" . En el fondo de esta escena hay un templo sobre un promontorio análogo al Partenón; en el centro, el conjunto de Pisa; y a la derecha, hacia donde van dichos animales se encuentra la Villa Savoye [1].

Así, la doble lectura que tiene este capriccio genera múltiples conexiones, que se concretan de manera plausible como un proceder proyectual, analítico y crítico, más que como una simple diatriba. Dado que los capricci acontecen como un complejo dispositivo crítico de información, que tienen un tema visible arbitrario, y otro oculto e inesperado más trascendental. Como sucede por ejemplo, en el capriccio del gran canal con la catedral

\footnotetext{
${ }^{1}$ Le Corbusier escribe en el dibujo "Le génie porte-t'il l'âne, ou l'âne porte-t-il le génie?". Hace parte de la carta que envía en 1952 desde Chandigarh a Giedion, que es publicado en el conocido libro de Giedion "Espacio, Tiempo y arquitectura" en relación al tema -de algunos fracasos proyectuales- de Le Corbusier y sus clientes. Ver, Christine Boyer, Le Corbusier. Homme de Lettres. Princenton Architectural Press: New York. 2011, páginas 35 y 688. Traducción del autor.
} 
de San Pablo de Marlow ${ }^{2}$, en los capricci de Canaletto, las Invenzioni Capric di Carceri de Piranesi, o Los Caprichos de Goya.

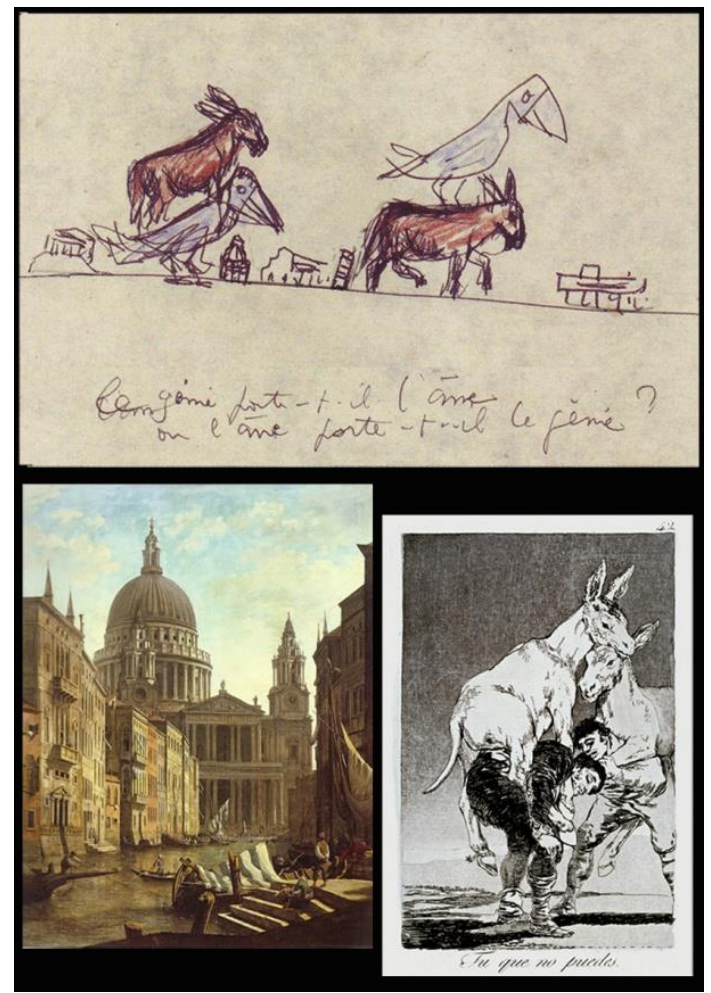

1. Capricci de Le Corbusier, Marlow y Goya.

De esta manera, el Capriccio Arquitectónico, es uno de los géneros pictóricos, que más destaca la capacidad proyectual de la arquitectura, porque desde sus inicios ha sido un medio para crear y representar figuraciones arquitectónicas ideales, las cuales subrepticiamente contienen loables reflexiones en torno al proyecto y a la crítica arquitectónica, que se propagaron en el apogeo del siglo XVIII con el Grand tour mostrando su mixtura cultural de arquitecturas y lugares. Así, el porqué, el interés y originalidad del estudio del capriccio arquitectónico, surge de detectar que sus procedimientos básicos que colaboran en la creación de la 'realidad arquitectónica ideal' son análogos o devienen en las operaciones contemporáneas colectivamente reconocibles de copiar, cortar y pegar; que -se utilizan y- utilizaron como una metodología que generaba y contenía complejas experimentaciones sobre la arquitectura, y que encuentran correspondencia proyectual, analítica y critica con arquitecturas lecorbusierianas.

En consonancia con lo anterior, Le Corbusier realiza a lo largo de su obra arquitectónica y pictórica, diversas operaciones capriccio, las cuales contienen lo sistemático de este género pictórico, que etimológicamente deriva de la palabra capra $^{3}$ (cabra), por los inesperados saltos de dicho animal. Saltos que en el capriccio

\footnotetext{
${ }^{2}$ Una crítica política, de la realidad ideal de Venecia exiliada en la capital de la monarquía británica. "Michel Liversidge, dio una fascinante explicación, que se acentúa con lo que dijo André Corboz sobre la obra de Canaletto, considerando que la pintura puede leerse como una suerte de reivindicación de la libertad perdida por la Republica de Venecia justo en el momento en que Francia la cedía a Austria, en 1797" -misma fecha del capriccio-. En, AA.VV. Arquitecturas pintadas del Renacimiento al siglo XVIII. Madrid: Museo Thyssen-Bornemisza. 2011, p. 361

3 "Etymologically, two origins have been proposed for the word capriccio, whose existence dates perhaps to the seventeenth century; one derives it from the Italian word for goat, capra, and suggests that animal's arbitrary or willful behavior -goatlike, in other words; the second combines the Italian word for head, capo, with riccio, or hedgehog, evoking a person with their hair standing on end-thus shocking, surprising, or fearful. Both sources are tied to animal imagery, the first source
} 
arquitectónico se caracterizan, principalmente, en el procedimiento de 'copiar', al transponer, combinar, desplazar proyectos, lugares o fragmentos existentes, y 'pegarlos' (copy_paste) de manera experimental no referencial, como un collage figurativo o abstracto, transgrediendo con esto, el concepto de lugar y emplazamiento fijo que tiene la arquitectura, así como la lectura lineal de lo real e ideal.

De esta manera, el procedimiento copy_paste del capriccio, que acompañan nuestra contemporaneidad y vida cotidiana, automatizando actividades y procesos de creación, también de manera análoga acompañó a Le Corbusier, que se sirvió del acervo cultural e histórico de la arquitectura para hacer de su imitación -copia-y consecuente trasgresión -pegado-, el paradigmático y copioso legado arquitectónico que ha dejado, que como escribe Alan Colquhoun: "Esta es la razón por la que, al comenzar el proceso creativo de Le Corbusier, es legítimo hablar de desplazamiento de los conceptos. Se trata de un proceso de reinterpretación y no de creación a partir de un vacío cultural"4.

En Le Corbusier, la reinterpretación que se puede hacer a partir del 'capriccio del viaje del burro y el cuervo por el Partenón, Pisa y la Villa Savoye' genera un doble salto, que podemos asociar a su manera de proyectar: El primero, - canalettiano- se da cuando con el copy_paste, desplaza arquitecturas y objetos desligándolos de su lugar, para ser combinados y emulados, sin que pierdan su identidad en otro lugar, así creando nuevas realidades y enlaces que se concretan de manera específica en un proyecto e inquietud teórica. El segundo, -goyescocuando con el copy_paste se invierte o transgrede de forma crítica, específicos elementos y partes de arquitecturas precedentes, logrando con ello que se altere su significado común, y constituyan, una 'invención' de conceptos genéricos de proyectación.

Los dos saltos antes expuestos, constituirán la metodología, y camino que seguiremos, en donde, el primero, más propio del capriccio arquitectónico (Partenón-Pisa-Villa Savoye) expondrá el argumento general, sobre el desplazamiento, copia y combinación de arquitecturas en lugares disímiles. Y el segundo, destaca la trasgresión e inversión de las reglas (el cuervo carga al burro, el burro carga al cuervo) como una formulación presente en los “5 puntos para una nueva arquitectura", así como tránsito de su legado en la contemporaneidad.

\section{El salto del lugar}

En cuanto al primero, Le Corbusier con los procedimientos de desplazar y combinar arquitecturas y lugares disímiles, que configuran una nueva realidad, pareciera encontrar, en el capriccio arquitectónico, el dispositivo preciso para trasmitir dicha realidad ideal de su complejo pensamiento crítico, artístico y arquitectónico. De igual manera, se destaca como el "virtuosismo" que caracteriza el término capriccio, desde sus orígenes, sustenta la obra lecorbusieriana.

Es así, que la virtuosa habilidad (copy_paste) de desplazar y combinar arquitecturas y lugares, por parte de Le Corbusier, está presente en lo que corresponde al sencillo, pero complejo 'capriccio arquitectónico del Partenón-Pisa-Villa Savoye', reiterado de manera análoga en su otro dibujo “Des produits standard de la pensée

more directly, the latter metamorphically; it could also be said one describes the cause, the other the effect, of a capriccio." En, Steil, Lucien. The Architectural Capriccio, memory, fantasy and invention. Burlington: Ashgate. 2013, p. 5

4 "Desplazamiento de conceptos en Le Corbusier" En, Colquhoun, Alan. Arquitectura moderna y cambio histórico. Barcelona: Ed. GG, 1978, p. 114

${ }^{5}$ El virtuosismo en el capriccio, trascendió de la música al arte, designando una extraña e inesperada, composición, que implicaba una habilidad extraordinaria sobre una técnica, y sobre la manera de yuxtaponer múltiples variables en una única obra o lugar. Con esto no podemos relacionar los capricci de Beethoven, Paganini, Goya, Canaletto o Piranesi, al sentido familiar y banal de la palabra 'caprichoso'. 
humaine: le temple antique, la cathédrale gothique, l'église de la Renaissance, la maison de béton arme "6 [2], en donde se evidencia el procedimiento lecorbusieriano de combinatoria racional, que se extiende a su arquitectura 'real' de capricci no caprichosos.

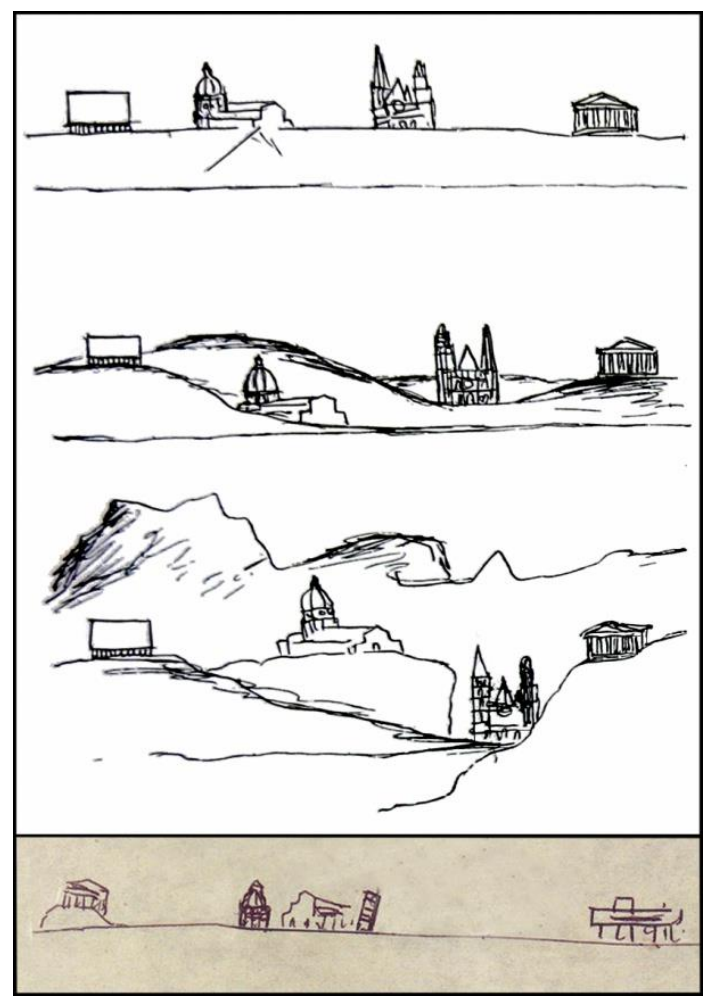

2. Desplazamiento de la arquitectura sin especifidad del lugar. Le Corbusier. Euvre complète Vol 4 1938-1946'. Zurich: Les Editions d'Architecture, 1964, p. 153

De ahí que estos dos dibujos capriccio se complementan en la similitud de los temas que circunscriben: en el centro los edificios cristianos, y en los extremos el templo griego y el edificio lecorbuseriano. Con esto mostrando que la especifidad del lugar pasa a un segundo plano, para destacar que en la adaptabilidad de los saltos y combinatoria de dichas arquitecturas, se concibe pragmáticamente la idea de arquitecturas genéricas e isótropas para cualquier realidad topográfica; como enuncia Le Corbusier: "Les quatre qualités d'esprit habitent parfaitement bien ce même et unique paysage”.

\footnotetext{
6 "Ce croquis montre, à trois reprises, des produits standard de la pensée humaine: le temple antique, la cathédrale gothique, l'église de la Renaissance, la maison de béton arme, situés à chaque fois dans les conditions uniformes de plaine, de collines ou de montagnes sauvages. Les quatre qualités d'esprit habitent parfaitement bien ce même et unique paysage. Mais la leçon porte aussi fortement dans l'autre sens: les quatre qualités de pensée bâtie conviennent, a chaque fois, aussi bien à la plaine qu'aux collines et qu aux sauvages montagnes". En (volumen 4), Le Corbusier. Cuvre complète Vol 41938 1946'. Zurich: Les Editions d'Architecture, 1964, p. 153
} 


\section{El salto al revés}

Otras imágenes proyectuales que podemos designar como capriccio arquitectónico, son las combinaciones que suceden a partir de una "confirmación" como Le Corbusier las califica. En donde, la yuxtaposición de dos equivalencias arquitectónicas idealizan la realidad de la arquitectura -copia- de referencia. Sin embargo, estas 'confirmaciones' son un copy_paste al revés: alcanza su característica de copia sin conocer a priori el original copiado. La "confirmación" es un déjà vu que Le Corbusier detecta inesperadamente, y que le afirma un camino proyectual tomado, así como también amplia el alcance de la realidad ideal de un proyecto específico.

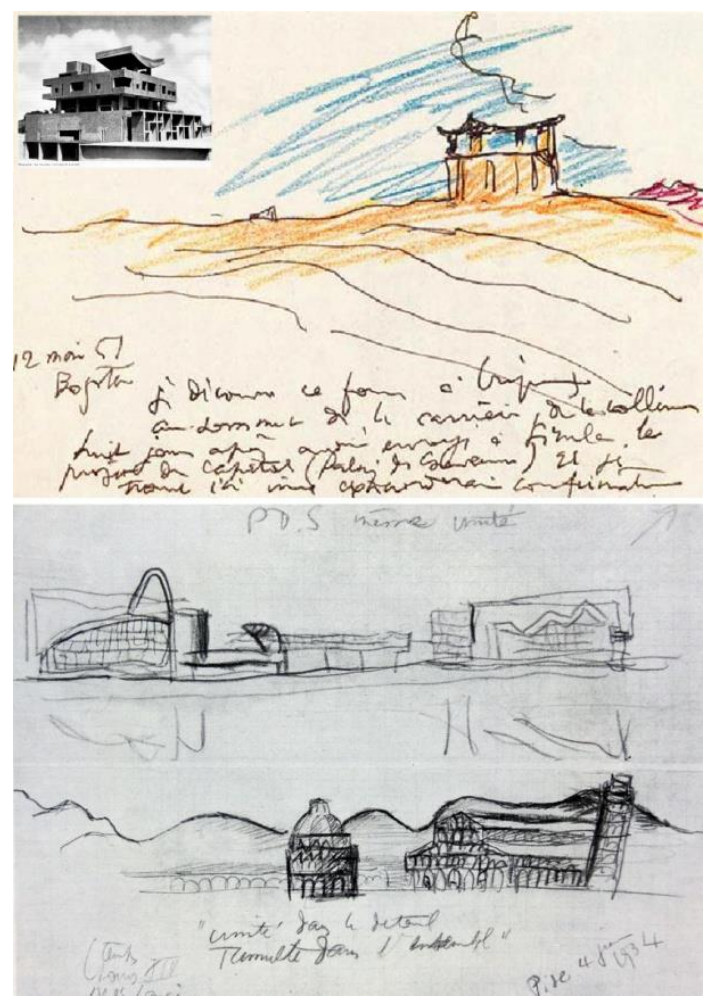

3. Saltos al revés o "confirmaciones". Le Corbusier, Carnets, Vol. II, E-20, Graf. 431@FLC-ADAGP. Le Corbusier. Euvre complète 1929-1934.

De esta manera, el 'copy_paste al revés', déjà vu o "extraordinaire confirmation"] [3], que tuvo con el proyecto del Palacio del Gobernador, al detectar en una pequeña fábrica de ladrillos en Bogotá, la similitud a posteriori de la formalización lograda en el proyecto de la India, enlaza mentalmente Chandigarh y Bogotá. Así mismo, como la "confirmación" del Palacio de los Soviets en Moscú se enlaza con el -representado reiteradamente por Le Corbusier- conjunto de Pisa, el cual, en su heterogeneidad inesperada y organización informal, pareciera ser para Le Corbusier un 'capriccio arquitectónico real', de escala y complejidad ideal, plausible a copiar y emparentar con sus proyectos. Diría, para argumentar su copy_paste al revés, la anécdota de cómo reconoce los mismos principios arquitectónicos de formación, que rigen el proyecto de Moscú y Pisa: "nuestro Palacio de los Soviets de 1931 y su confirmación vista desde las ventanillas del rápido Paris-Roma, el 4 de junio de 1934, a la derecha

\footnotetext{
7 "12 de mai $51 \backslash$ Bogotá \je découvre ce four à briques au sommet de la carrière, de la colline huit jours après avoir envoyé à Simla le projet du Capitol (Palais du Gouverneur) Et je trouve ici une extraordinaire confirmation.” En, Le Corbusier, Carnets, Vol. II, E-20, Graf. 431. (FLC-ADAGP
} 
el Campo-Santo de Pisa, todo esto denuncia el deseo de una organización molecular de la cosa edificada sobre medida armónica a la escala del hombre" ${ }^{\circ}$.

\section{El salto de la ciudad ideal}

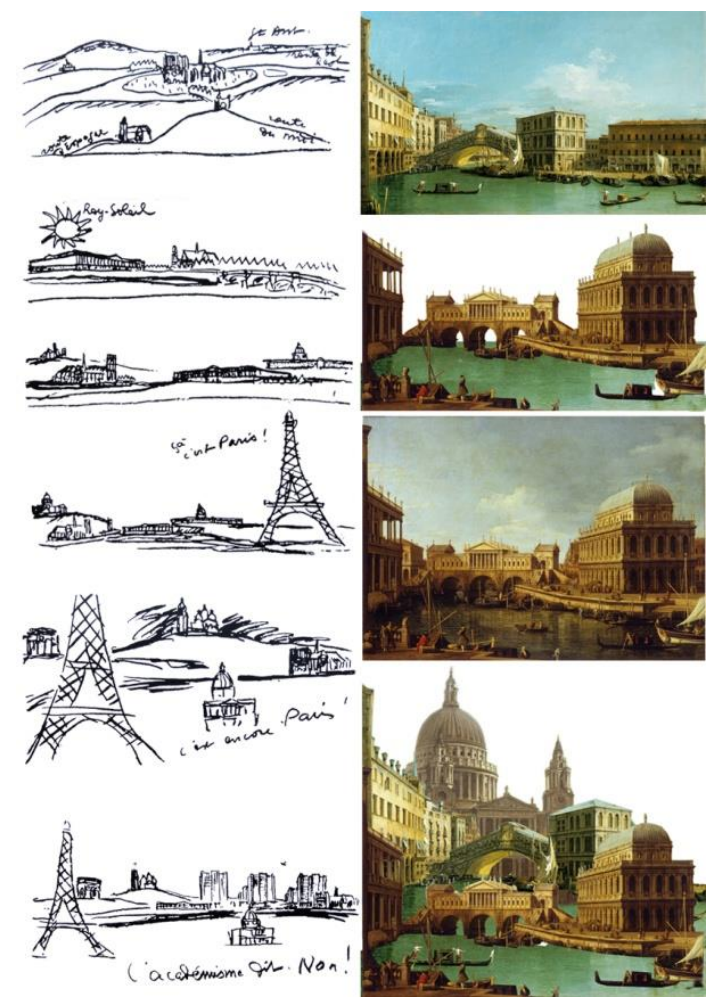

4. Storyboard idealización de la realidad de la ciudad con el capriccio. Le Corbusier. Precisiones. Barcelona: Apóstrofe, 1999; Collage de capricci arquitectónicos, Imágenes del autor.

No obstante, en Le Corbusier las anteriores 'confirmaciones', se presentan más como análisis comparativos y teorías que describen su pensamiento arquitectónico, que como concretas formalizaciones proyectuales. Sin embargo, algunos de sus proyectos por la respuesta proyectual que proponen, se relacionan más directamente al capriccio arquitectónico canalettiano, por la hiperrealidad idealizada y 'espacio absoluto' e isótropo que generan. Así, como el proyecto del Plan Voisin para Paris de $1925^{9}$, autocopia, de las ideas propuestas en el proyecto de la Ville Contemporaine, que emula la organización de centro y periferia de la Ciudad Ideal renacentista. El Plan Voisin, es insertado en una vista que representa parís en sus edificios icónicos (Tour Eiffel, Arco del triunfo, Sacré-Coeur, el Panteón de Paris y Nôtre-Dame), como lo haría Canaletto al insertar, el proyecto rechazado para el puente del Rialto de Palladio, argumentando con su capriccio arquitectónico que la ciudad con aquel proyecto no construido, constituía la continuidad y actualización histórica que hubiera idealizado a Venecia, así como Le Corbusier lo manifestó con el proyecto de París: “¡Esto es París!. Siento que el mundo tiene sus ojos sobre París, espera de París el gesto que ordene, que cree y eleve, dentro del orden, el

\footnotetext{
${ }^{8}$ Le Corbusier, El Modulor. Barcelona: Editorial Poseidón, 1980, p. 155

${ }^{9}$ André Cordoz, al descubrir la influencia del 'espacio absoluto' newtoniano en los cuadros de Canaletto, cita al Plan Voisin de Le Corbusier, como una proyección de aquel espacio isótropo. Corboz, André. Canaletto, Una Venezia Immaginaria, Volumen I y Volumen II. Milán: AlfieriElecta. 1985, p.173
} 
hecho arquitectónico que iluminara todas las demás ciudades. Creo en Paris. Tengo esperanza en Paris. Suplico a París que haga hoy, de nuevo, ese gesto de su historia: ¡continuar!. El academicismo grita: ¡No!’”I0.

Sin embargo, en el Plan Voisin, primer proyecto urbanístico de le Corbusier, no busca su semejanza formal con la Ciudad Ideal renacentista, no es un proyecto pensado en planta. Es una 'ciudad idealizada' que en el "montaje mental" de su storyboard justifica como la realidad trasciende como nueva realidad ideal -real-, constituida por el capriccio arquitectónico: como la Roma ideal de Piranesi en el Campo Marzio, y la Venecia inventada de Canaletto -y Marlow-, que constituyen por las conexiones entre memoria, ciudades, preexistencias urbanas y arquitecturas en ausencia, la ciudad ideal y análoga [4].

\section{Los saltos a Berlín: una ciudad imaginaria posible de construir}

Al igual que las vedute y los capricci arquitectónicos canalettianos, que más que representar vistas reales de la ciudad, inventan su realidad, con ello creando "una Venecia imaginaria": el Plan Voisin y el proyecto urbanístico para la reconstrucción de Berlín en 1958, inventan la realidad ideal para Paris y Berlín.

El proyecto para Berlín -último planteamiento urbanístico de Le Corbusier-, constituye un 'capriccio arquitectónico archivo' ${ }^{11}$, ya que en él se almacenan, como si fuera una caja de memoria, proyectos lecorbusierianos creados para otros lugares concretos, como el Palacio de la Asamblea de Chandigarh, el Museo de Tokio, o el Pabellón Philips de Bruselas, entre otros. De esta manera, constituyendo con este planteamiento urbanístico, de autoeclecticismo y auto copy_paste el proyecto más virtuoso de capriccio arquitectónico lecorbusieriano, como otrora haría Piranesi con las copias de sí mismo que hace en las Carceri.

Le Corbusier, a partir de audaz desplazamientos y combinaciones de edificios -rechazados- para otros lugares, pareciera buscar en este proyecto la última oportunidad para construirlos, como sucede con el Rascacielos Cartesiano, el Rascacielos Triaxial, el Museo de Crecimiento Ilimitado, el Palacio de los Soviets, el Palacio de Congresos y la Torre Circular para Estrasburgo, y los edificios redents. No obstante, algunos de sus copy_paste, por su ubicación y gran escala como es el caso de los rascacielos, fueron unas de las principales razones para que el jurado del concurso, entre los que se encontraba Aalto y Gropius, eliminaran la propuesta lecorbusieriana para Berlín $^{12}$. La crítica al veredicto no tardaría, como otrora lo haría Le Corbusier con respecto al Plan Voisin y el Secretariado de las Naciones de Ginebra. Le Corbusier argumentó en su diatriba titulada “Le crime?",13, que "el hecho de pensar un urbanismo en tres dimensiones fue considerado como un crimen" "14 así como explicó, que su proyecto era un planteamiento acorde al tiempo moderno, y que el principio generador más importante del mismo, era la peatonalización de la avenida Unter den Linden, y creación de otros paseos promenade, que enlazarían los rascacielos y demás edificios propuestos, con la ciudad, todo esto a favor de quitar las calles a los automóviles, para devolverlas a las personas y, de manera subrepticia, brindar un Grand tour de equivalencias y contrastes lecorbusierianos. [5]

\footnotetext{
${ }^{10}$ Le Corbusier. Precisiones. Barcelona: Apóstrofe, 1999. p. 200

${ }^{11}$ Taxonomía del 'Capriccio' propuesta a partir del tema de tesis doctoral del autor (Enlaces, Archivo, Collage, Fragmento)

${ }^{12}$ Tenreiro, Oscar. "The Berlin Comedy. Le Corbusier and the 1958 Competition for the Recosntruction of Central Berlin". En, Massilia 2002, anuario de estudios Lecorbusierianos. Barcelona: Fundación Caja de Arquitectos, 2002

${ }^{13}$ Le Corbusier; (Ed) W. Boessinger. Le Corbusier et son atelier rue de Sèvres: 'CEuvre complète 1957-1965'. BasileaBoston-Berlin: Editions d'Architecture Artemis, 1985, p. 235

${ }^{14}$ Ibidem, p. 230. "Mais le fait de penser à un urbanisme à trois dimensions fut considéré comme un crime. Sur 86 projets, treize furent retenus; le treizième était celui de Le Corbusier. Il fut éliminé. (...) Inutile de préciser que les plans primés n'exprimaient pas l'urbanisme à trois dimensions."
} 


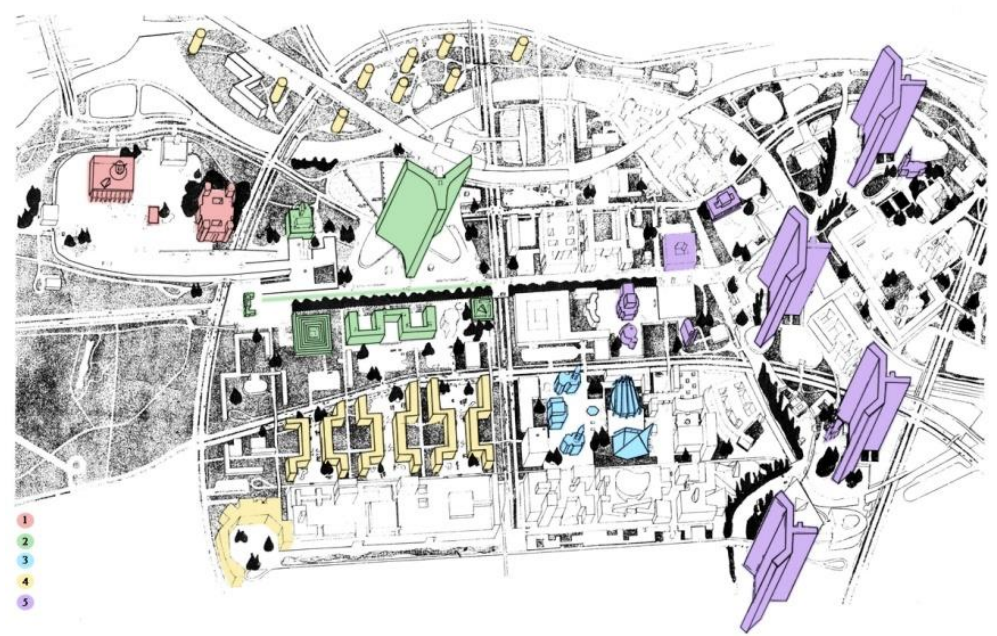

5. Propuesta de Le Corbusier para Berlín. Edición, 'Gradiente' de enlaces capriccio. 'Euvre complète 1957-1965'

De esta manera, las combinaciones que se configuran en el copy_paste de proyectos de Le Corbusier con los edificios más representativos de la ciudad, la podemos organizar a partir de un gradiente de cinco grupos de enlaces, que muestran como este 'capriccio arquitectónico de Berlín' tiene un grado de equivalencias que destaca cierta continuidad y adaptabilidad de la realidad local con la foránea; y otro grado, de contrastes y discontinuidades entre las mismas.

Así, el primero, y más destacado grupo proyectual, corresponde al conjunto conformado en la Platz der Republik entre el edificio del Reichstag y el Palacio de la Asamblea de Chandigarh [6]. Esta agrupación que destaca las notorias equivalencias y continuidades inesperadas entre el Reichstag y la Asamblea de Chandigarh, ya que con el cascarón hiperbólico, que sobresale por encima del edificio, que representa fielmente el espacio interior en su formalización exterior, actualiza el concepto de 'cúpula' del edificio neoclásico del Reichstag, presentando por asociación, con su edificio una plausible 'cúpula moderna' sin parangón, que seguiría experimentando, hasta llegar a abarcar todo un proyecto, como es el caso de la Iglesia de Saint-Pierre en Firminy.

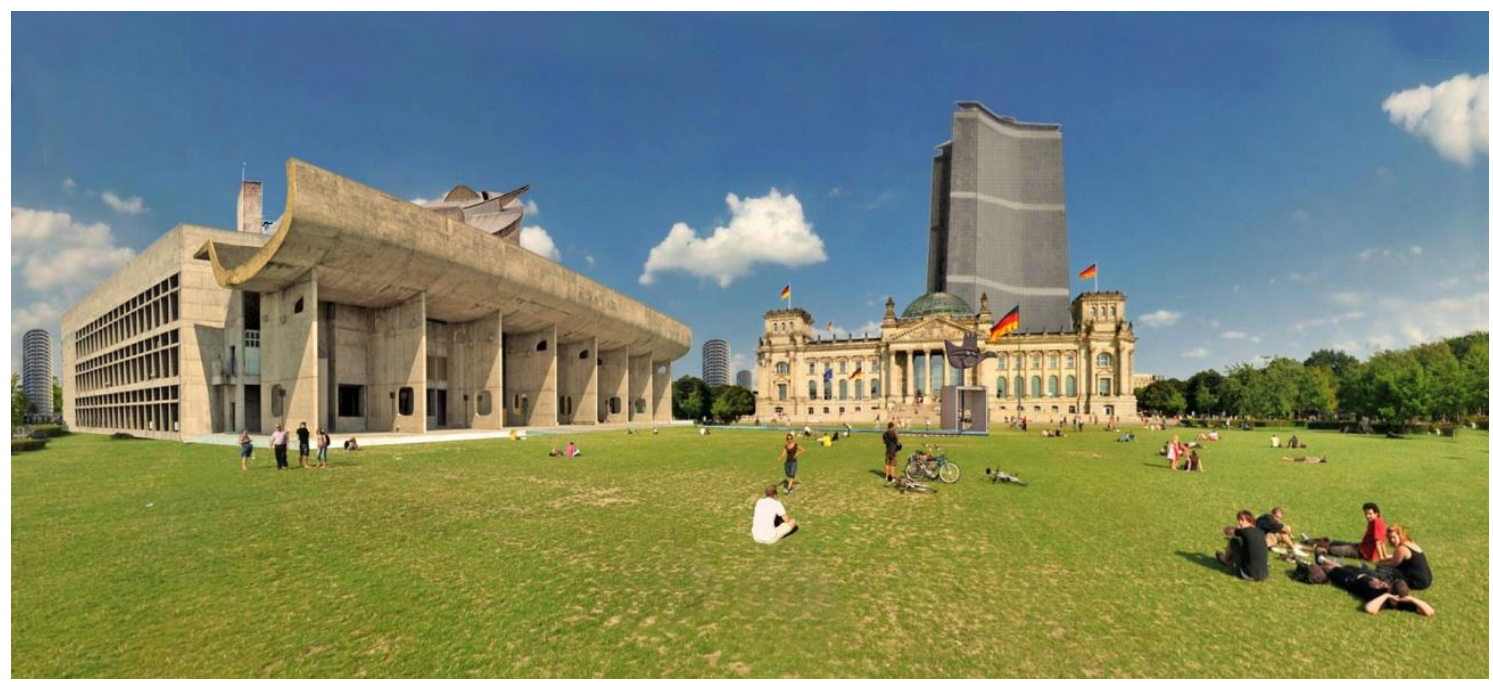

6. Propuesta de Le Corbusier para Berlín: Capriccio arquitectónico de Chandigarh en Berlín. Collage del autor.

La equivalencia del copy_paste, en el segundo grupo compuesto por la Puerta de Brandeburgo, la avenida Unter den Linden, el Museo de Crecimiento Ilimitado, el Palacio de Congresos en Estrasburgo, el Museo de Tokio, y el Rascacielos Triaxial -análogo al propuesto en 1937 en La Marine de Argel-, están fundadas por el espacio 
peatonal informal entre estos edificios, que como en la ciudad de Chandigarh, huye por entre los edificios aislados, sin posibilidad de delimitarse al no estar constituidas claramente calles o plazas, como sucede con el gran espacio en derredor del Rascacielos Triaxial que compensa las relaciones con la ciudad por su elevada altura. Cuestiones diferentes con el anterior grupo, en donde Le Corbusier, a partir de la plataforma sobre la que apoya el copy_paste análogo al Palacio de Congresos en Estrasburgo ${ }^{15}$, genera un gran muro curvo que contendría el Reichstag y el Palacio de la Asamblea de Chandigarh.

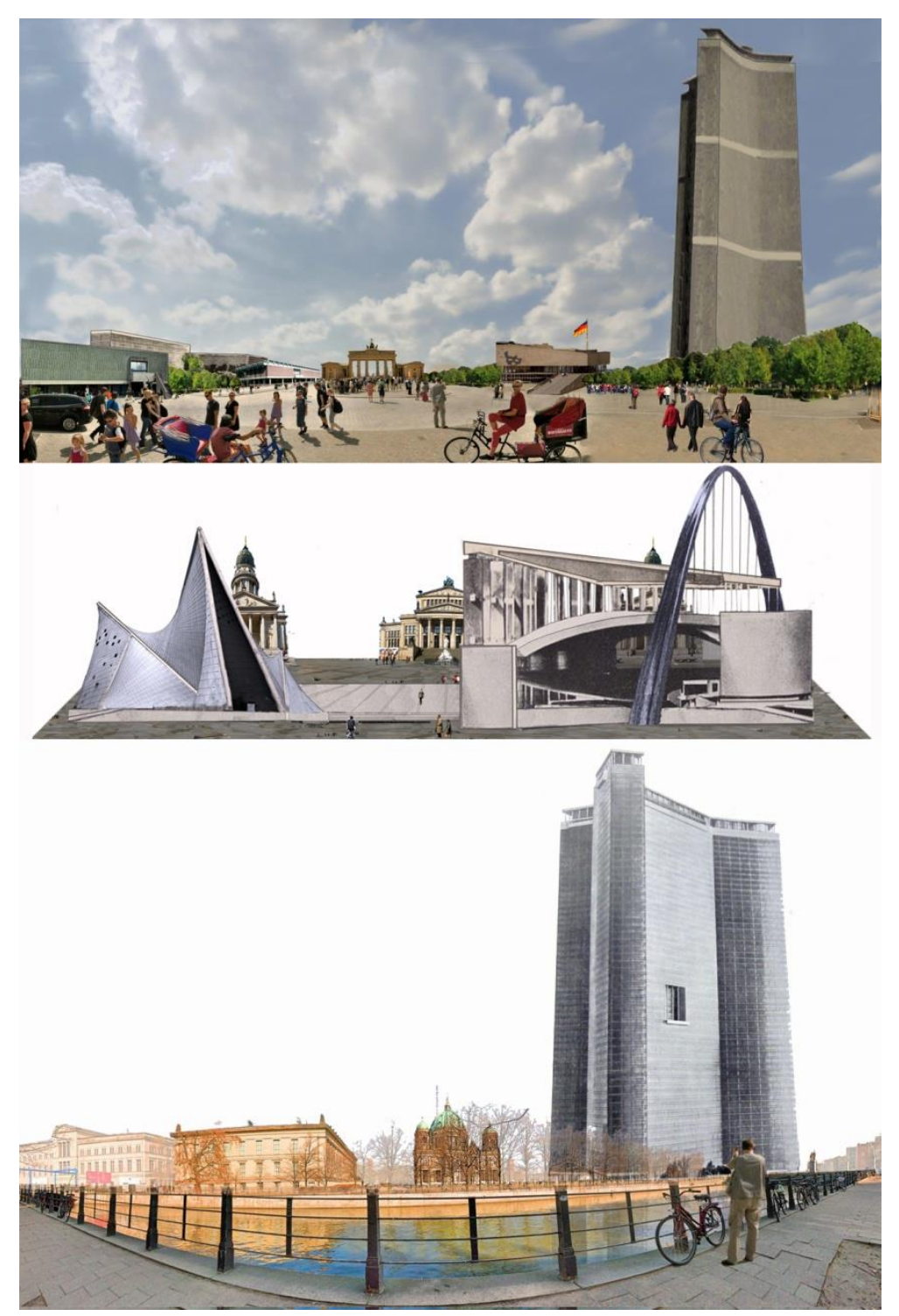

7. Propuestas de Le Corbusier para Berlín: Capricci arquitectónicos (grupos 2, 3 y 5). Collage del autor

El salto a Berlín, de una parte del Palacio de los Soviets de Moscú, y el Pabellón Philips, conforma el tercer grupo que recuerda la "confirmación" entre el proyecto de Moscú y el conjunto de Pisa. Ya que Le Corbusier expande la contigua plaza Gendarmenmarkt, que contienen los tres edificios aislados de la Deutscher Dom, el Konzerthaus y la Französischer Dom; para ubicar la propuesta de una nueva sala de conciertos, formalizada con el Palacio de los Soviets, y otro edificio cultural análogo al Pabellón Philips. Con esto constituyendo un espacio equivalente al campo santo de Pisa, con edificios exentos en su interior, por entre los cuales se genera una red de

\footnotetext{
15 Tenreiro, Oscar. passim
} 
recorridos. Esta plausible característica, contrasta con las propuestas de los primeros puestos otorgados en el concurso (Spengelin, Harmann, Scharoun, y Alison y Peter Smithson), en donde los tres edificios históricos son prácticamente ignorados.

En el cuarto conjunto, los bloques redents en direccionalidad norte-sur, hacen que "Le Corbusier básicamente seguido por la vieja grilla, elimine las diagonales (wilhemstrasse y Lindenstrasse) "'l6. No obstante, genera una nueva grilla peatonal con líneas verticales rectas y horizontales en zigzag; que son atenuadas por el conjunto trasversal de edificaciones que proponen unir la octogonal Leipziger Platz, y el rio Spree. Esta configuración longitudinal y trasversal, destaca por el contraste con las edificaciones verticales del siguiente conjunto.

El último grupo de enlaces, está caracterizado por el contraste y oposición de escalas. Así, las Torres Circulares para Estrasburgo (1951) ubicadas de manera aleatoria, en parte de la periferia del centro de Berlín, quedan “ordenadas” por extraños bloques 'rayo' de ángulos agudos - con cierta relación al contemporáneo museo judío de Libeskind-, con esto estableciendo una alteración al orden general de la propuesta urbanística, y a la relación que pudieran entablar las Torres Circulares con el conjunto del Reichstag.

Sin embargo, el contraste de oposición de escalas más paradójico es el producido por la proximidad, de algunos de los cinco Rascacielos Cartesianos (1937), con representativos edificios históricos de la ciudad, como es el caso del Zeughaus, la Marien kirche, o los edificios de Schinkel, como la Friedrichswerdersche kirche, y el paradigmático Altes Museum, este último, quedando disminuido por uno de los rascacielos lecorbusierianos, que supera en diez su altura [7].

Con lo anterior, pareciera consiente la creación de dicha oposición escalar entre el edificio del Neoclasicismo y el Moderno, que pareciera contribuir en alejar las semejanzas existentes entre su obra y la de Schinkel, que posteriormente pondría de manifiesto Colin Rowe ${ }^{17}$, mostrando la equivalencia entre la planta del Altes Museum y la planta del Palacio de la Asamblea en Chandigarh. No obstante, al Le Corbusier trasladar el edificio de Chandigarh a Berlín, tal vez, inspira, anula o completa dicho paralelismo establecido por Rowe, ya que como antes se ha dicho: el Palacio de la Asamblea en Chandigarh, al relacionarse también en planta y alzado, con el Reichstag que no enmascara, como el Altes Museum su cúpula interior con un volumen ortogonal. Así, el proyecto de Le Corbusier se convierte en un paradigma, copy_paste y actualización de dicha configuración y estilo arquitectónico.

Es particular, la manera en que Le Corbusier reitera, que el concurso urbanístico de Berlín, es una síntesis, de lo que él ha estudiado por décadas. De igual manera, es consciente de lo 'caprichoso' que pudieran parecer sus propuestas, diría en la memoria para el concurso:

"Todo lo que ya en cuarenta años ha sido declarado quimérico, utópico, «Fácil de imaginar en la luna», encontrará aquí en Berlín el lugar, [...] Aquí en Berlín esto es posible. Incluso parece (antes de la evidencia de los planes) que no podemos tener dudas sobre eso!" 18 , y finaliza de manera similar, "Este programa tiene en sí mismo una gran esperanza urbana. Todo lo que ha sido estudiado por nosotros desde cuarenta años ahora está inscrito en esta ciudad y su historia. [...] El esplendor de la arquitectura y el urbanismo fusionado: urbanismo en tres dimensiones. "19

\footnotetext{
${ }^{16}$ Tenreiro, Oscar.,op. cit. p. 90

17 “addenda de1973” en, Rowe, Colin. Manierismo y arquitectura moderna y otros ensayos. Barcelona: Gustavo Gili, 1978

${ }^{18}$ Tenreiro, Oscar.,op. cit. p. 131

${ }^{19}$ Ibídem, p. 133
} 
En consecuencia, los diferentes saltos de arquitecturas lecorbusierianas, que hemos mostrado a partir del 'capriccio arquitectónico del Partenón-Pisa-Villa Savoye', y que abrió el camino para descubrir el 'Capriccio arquitectónico de Berlín”, argumenta como Le Corbusier pone de manifiesto las relaciones internas del sistema urbano, y la misma sustancia de la ciudad real como una ciudad posible y deseada. En donde el capriccio arquitectónico no aparece como un dispositivo optimista de la historia, ya que no se celebra un pasado y glorioso esplendor sino que anticipa un ambiente contemporáneo. Crea una nueva realidad para una sociedad regenerada y, sin lugar a dudas, más cívica, multicultural y moderna, gracias a los saltos inesperados combinados en la capricciosa propuesta lecorbusieriana.

\section{El salto copy_paste del legado lecorbuseriano}

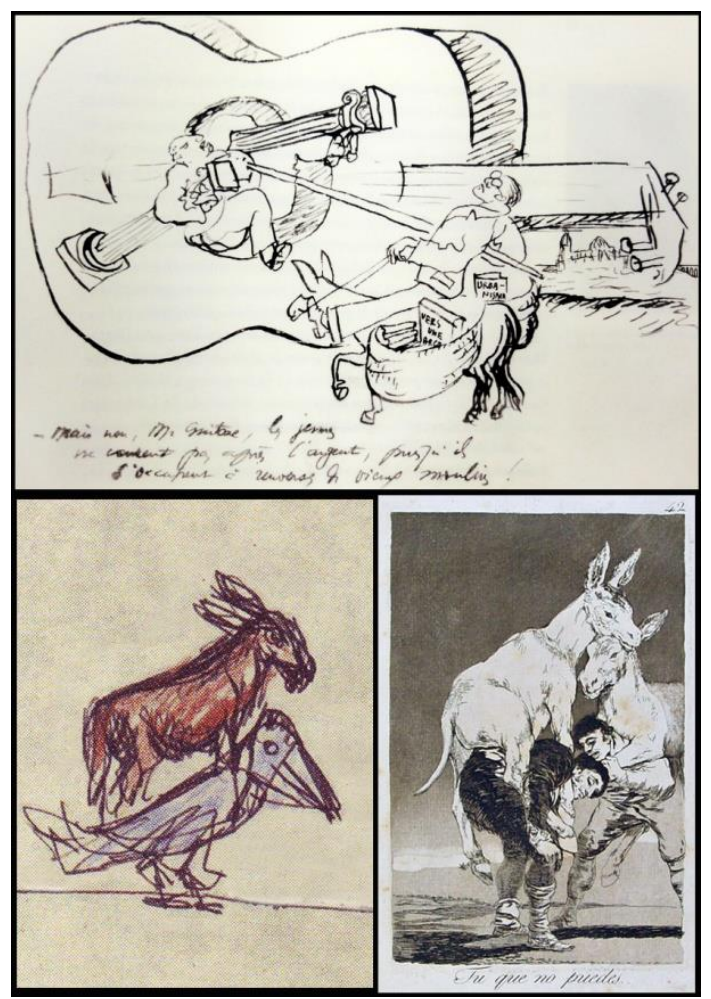

8. Relación de la 'inversión' lecorbusieriana del 'capriccio del cuervo y el burro' y "Sr. Guitarra” con la serie de asnerías de Goya.

El 'capriccio del viaje del burro y el cuervo por el Partenón, Pisa y la Villa Savoye', ha servido como medio para analizar algunos desplazamientos y combinaciones - copy_paste-de arquitecturas en la obra de Le Corbusier. No obstante, lo más arbitrario e inesperado de dicho capriccio se encuentra en la escena con que Le Corbusier le da su nombre: “El genio carga al burro o el burro carga al genio?”. Esta imagen es análoga a otro dibujocapriccio (Sr. Guitarra) [8], que realizó en 1928 en Madrid, en la cual -ya no como cuervo- se autorretrata montado sobre un burro, que cerca de la catedral y viaducto de Segovia, embiste quijotescamente contra la Academia $^{20}$.

\footnotetext{
${ }^{20}$ Escribe en este dibujo, «-No, Sr. Guitarra, los jóvenes / no corren detrás del dinero, / jestán ocupados en derribar los viejos molinos!», Le Corbusier lleva sus dos libros Vers une architecture y Urbanisme, y embiste contra un señor cargado con dos columnas clásicas - una jónica y otra corintia-. En el fondo, del perfil de una ciudad emerge un edificio que podría ser la catedral de Segovia, lugar que visitó en su permanencia en Madrid.
} 
De esta manera, la reiteración por parte de Le Corbusier de la figura del burro como medio elocuente para manifestar alguna reflexión en concreto, se destaca, por la relación directa que establece con la 'serie de Asnerías' -37 a 42-, único tema sucesivo en los Caprichos de Goya. En esta serie, Goya hace un copy_paste de la tradición satírica y moralizante del burro utilizada en la literatura ${ }^{21}$, sin embargo, hace a partir de ello una invención: el burro en Goya es un mecanismo que representa la 'inversión' de la razón y las funciones morales en la sociedad. En consecuencia, Le Corbusier emula de dicha serie el Capricho 42, que es anterior al célebre 43 "El sueño de la razón produce monstruos". El Capricho 42, "Tu que no puedes" corresponde a la primera parte del refrán español, que finaliza "llévame a cuestas”, en él se presenta la 'inversión' funcional entre dos personas que cargan a dos burros; con esto relacionándose al dibujo de Le Corbusier 'capriccio del viaje del burro y el cuervo por el Partenón, Pisa y la Villa Savoye' que “revela un fuerte sentido de la herencia y de los modelos de control del pasado visto desde la distancia, en un giro irónico. Tales giros o vueltas son una reminiscencia de la forma en que se invierte la historia ${ }^{, 22}$.

Del mismo modo, Le Corbusier hace un copy_paste en donde 'invierte' aspectos concretos del sistema de reglas de la arquitectura tradicional, como argumenta de manera magistral Alan Colquhoun. Así, "cada uno de los cinco puntos de Le Corbusier parte de un aspecto concreto de la practica precedente y procede a invertirlo. El uso de piloti es una inversión del podium clásico; acepta el principio clásico de separar el piano nobile del suelo, pero interpreta esta separación en términos de vacío y no de masa. La fenêtre en longueur es una contradicción de la clásica ventana edicular; la terraza en cubierta se opone al techo a dos aguas y sustituye el ático por una habitación al aire libre; La fachada libre sustituye la disposición regular de los huecos por la de una superficie de libre composición; la planta libre se opone al principio según el cual la distribución estaba limitada por la necesidad de paredes de carga verticalmente ininterrumpidas y lo reemplaza por el de una distribución de tabiques determinada sólo por las conveniencias funcionales

Así, la anterior síntesis de los cinco puntos lecorbusierianos a partir de diferentes inversiones, y que hacen parte de su legado arquitectónico, lo expondremos a la luz de las inversiones y subrepticios copy_paste, que hace, paradójicamente, su discípulo con la arquitectura, en apariencia, más antagónica a Le Corbusier: Rogelio Salmona.

De igual manera, Salmona como Le Corbusier genera una serie pictórica de capricci arquitectónicos, en donde pone en evidencia la herencia y modelos de arquitecturas precedentes que influyeron su obra. Pone como Le Corbusier, en uno de sus capricci, un proyecto propio (Las Torres del Parque), el Partenón, y a diferencia de Pisa, una pirámide mesoamericana; y en el primer plano de la escena, personajes griegos en oposición y sincretismo (Apolo, las musas y Dionisos). Por el contrario, en la arquitectura de Salmona, es paradójico que aunque él haya estado por casi una década como discípulo de Le Corbusier, no se haya percibido ninguna influencia de él, en cambio, se destacan marcadas alusiones a otros maestros modernos, como Wright, Kanh, Aalto y Scharoum, sin olvidar, la influencia de la arquitectura precolombina, clásica griega y romana, entre otras [9].

\footnotetext{
${ }^{21}$ Helman, Edith. El trasmundo de Goya. Madrid: Alianza Forma. 1963. Reimpresión, 1986. p.73

${ }^{22}$ Boyer, Christine.,op. cit. p. 36

${ }^{23}$ Tenreiro, Oscar.,op. cit. p. 114
} 

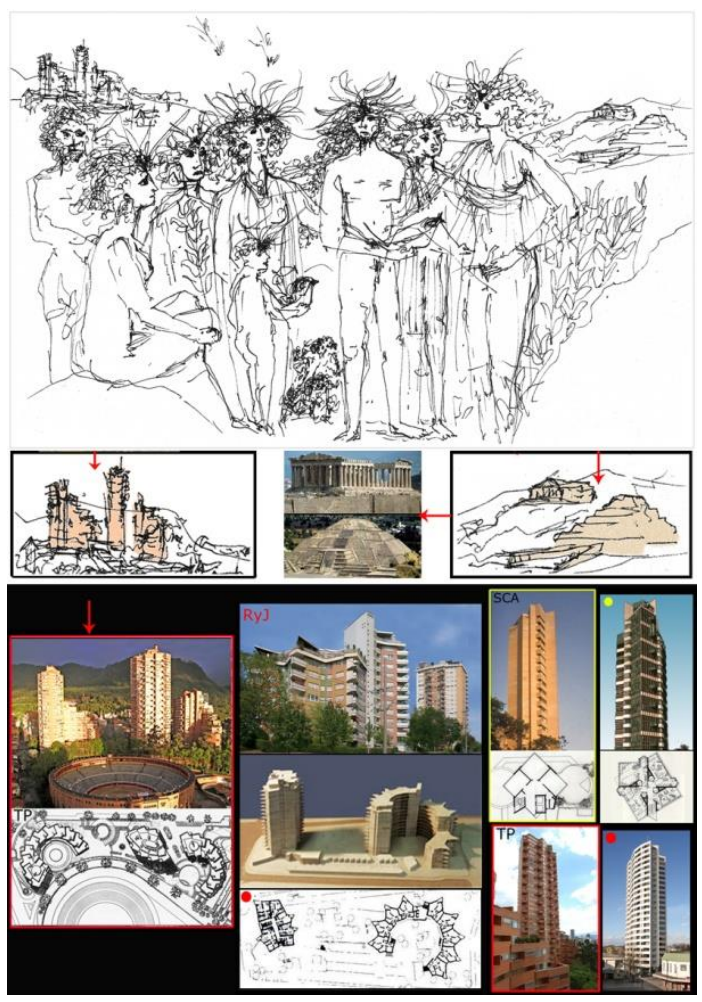

9. Capriccio arquitectónico de Salmona, e influencia de Wright, Aalto y Scharoum en el conjunto Torres del Parque.

Así, el distanciamiento de Salmona contrasta con la cercanía formal de la mayoría de discípulos hacia Le Corbusier, los cuales se encargaron de manera leal de difundir formas y el 'expresionismo' lecorbusieriano. No obstante, Salmona pareciera tomar distancia para ver de lejos, más claramente, 'lo esencial' de su maestro y, con esto, de manera velada acercarse a él. Es por ello, que algunos de los principios lecorbusierianos, como los cinco puntos de una nueva arquitectura y la promenade, son emulados por Salmona, transformándolos y avanzando en ellos mediante un 'copy_paste experimental' o “recreación” de los mismos, como advierte: “Siento además que continúo una tradición de recrear lo que otros a su vez han recreado. No invento. Continúo",24 "Lo entiendo como un acto de rememoración. Es recrear, continuar en el tiempo lo que otros, los que me antecedieron, han a su vez recreado. [...] conviene mirar atrás antes de dar un paso hacia delante. [...] claro que conviene mirar hacia atrás, pero hay que saber retirar la mirada en el momento oportuno: se trata de recrear y transformar. No de copiar ${ }^{, 25}$

De esta manera, al exponer brevemente como Salmona continua, o 'recrea' ocultamente en su arquitectura, algunos de los cinco puntos de Le Corbusier, descubriremos simultáneamente el valor subyacente de legado lecorbusieriano.

\footnotetext{
${ }^{24}$ Entrevista por Fontane, Claudio, “Un'azione a favore della città: Rogelio Salmona”. En, Costruire in Laterizio, nro. 95, Architettura latino americana, Settembre/Ottobre 2003. pp 42. Traducción del autor.

25 "Entre la mariposa y el elefante" En, Rogelio Salmona, espacios abiertos / espacios colectivos. Bogotá: Ministerio de Cultura, SCA. 2006, p. 89
} 


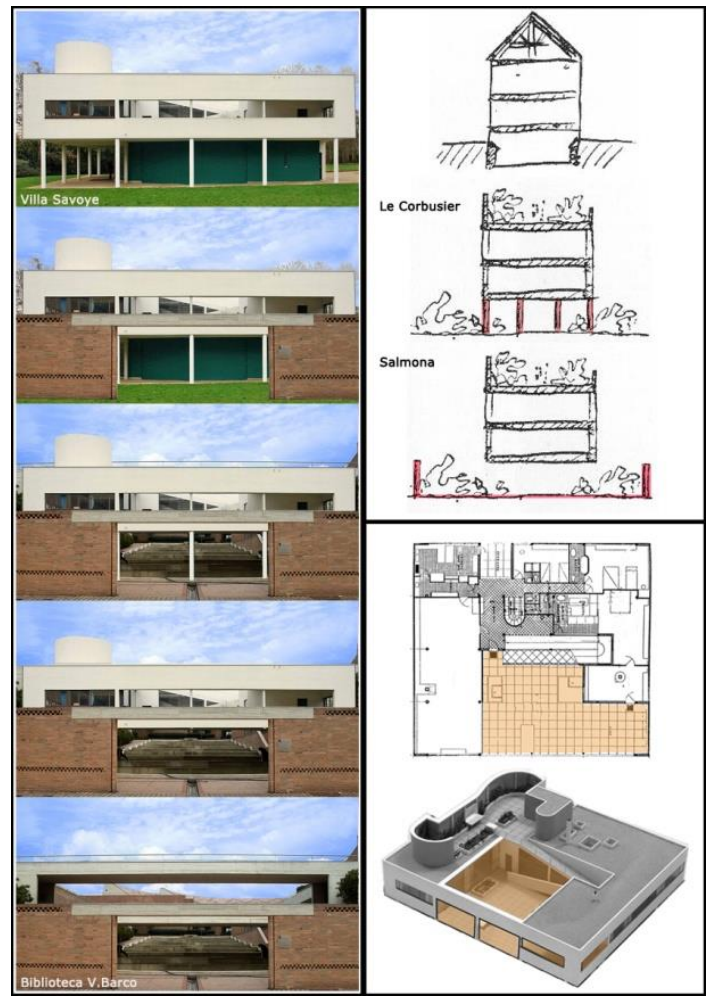

10. Relación Le Corbusier-Salmona: planta baja sobre pilotis y patio.

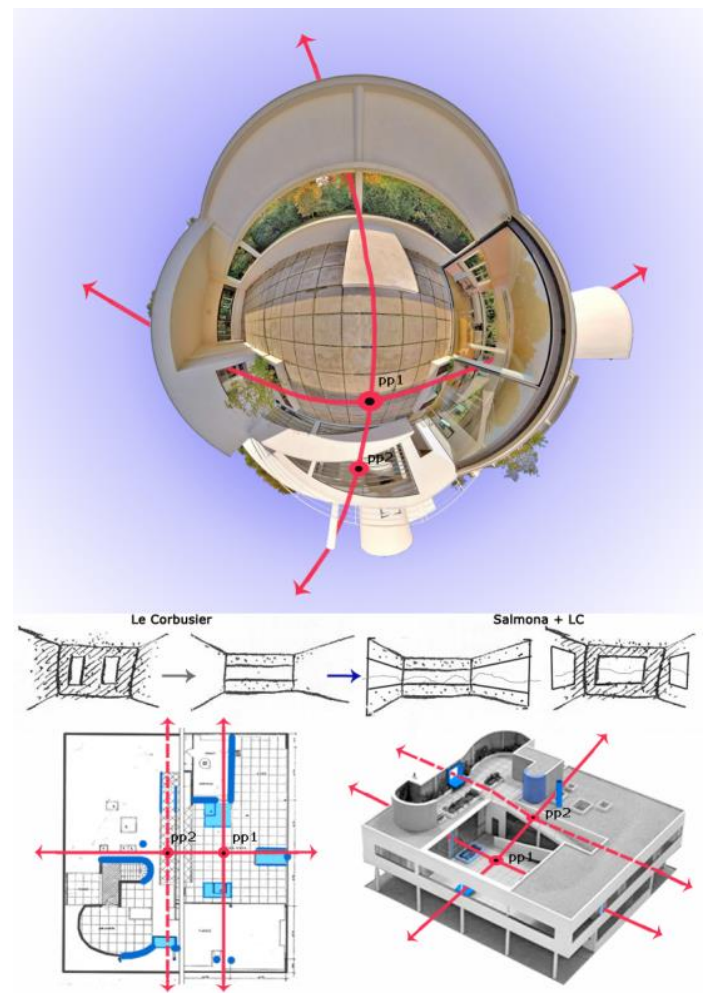

11. Relación Le Corbusier-Salmona: ventana corrida y panóptica. 
El uso de piloti y la liberación de la planta baja [10], se 'recrea' con su valor como estructura conceptual que sostiene el proyecto, y que da continuidad al plano del suelo. De esta manera, la estructura que sostiene los proyectos de Salmona, es el "patio" que da continuidad a la planta baja haciendo que 'entre el afuera' en el edificio, con esto prevaleciendo el recorrido 'público' del peatón -y del agua- antes que el del coche como en la Villa Savoye. No obstante, si eliminamos los pilotis de la Villa Savoye, vemos esta 'esencia' del proyecto lecorbusieriano, en donde el 'patio' también es el elemento estructurador, que además de acceso y continuidad, le otorga a la Villa Savoye un carácter universal y tradicional, que destaca como la contraposición entre patio y piloti caracteriza la obra lecorbusieriana; así como en los edificios de Salmona se vislumbra en el patio de acceso la Villa Savoye.

La fenêtre en longueur [11], en Salmona es asumida como un potente panorama de Barker, de visión libre a 360 grados, con un punto panóptico que desde el interior del edificio se apropia del entorno visual exterior. Aunque, como el anterior punto, Salmona con su planteamiento, hace que descubramos este fenómeno panorámico en la 'esencia' de la Villa Savoye, en la cual, hay un punto panóptico y cruce visual geométricamente creado por Le Corbusier: marcado entre la mesa-ventana en el patio y la abertura -frontal- en el nivel superior constituida por el piloti de ventilación y el volumen curvo que emerge de la escalera; los cuales se cruzan perpendicularmente, por la tensión entre la ventana del habitáculo posterior y la abertura en el salón entre el piloti y el ducto de la chimenea, el cual en la promenade a la planta superior, es sustituido por la rampa y otra ventana-mesa en la cubierta jardín. De esta manera la Villa Savoye no se refiere a la fenêtre en longueur como funcional ventana de iluminación, sino como dispositivo panóptico que irradia miradas desde el interior hacia el exterior cruzando el edificio y conectándolo con el entorno.

La cubierta-jardín [12], es el factor más evidente del 'copy_paste experimental' o "recreación” lecorbusieriana en la arquitectura de Salmona. Sin embargo, en su obra avanza, en el sentido de lo público, ya que propone la 'cubierta-plaza', con la intención de prolongar o trasladar el espacio público de la ciudad al edificio, como manifiesta: "La primera calidad que debe tener nuestra arquitectura es permitir que el espacio sea apropiado por la comunidad entera aunque la propiedad no le pertenezca y que la arquitectura tenga unidad, pero que se trasforme y dé una imagen diferente según el sitio de la ciudad donde se le mire" ${ }^{26}$ Salmona hace más accesible la cubierta, al semienterrar en medios niveles sus proyectos, acercando cubierta-plaza y suelo, para que se encadenen con los patios públicos, y así darle a la cubierta-jardín un carácter público.

La cubierta-plaza, al igual que la cubierta-jardín en Le Corbusier contiene variados y singulares elementos, que se disponen para producir diferentes acontecimientos cuando se habite. Así, dos de los más destacados, y que relacionan la obra de Salmona a la lecorbusieriana, son el planteamiento del 'ascenso del paisaje' y 'el teatro en la cubierta'.

El primero, se refiere a como con el jardín sugiere su ascenso y reconstitución del suelo ocupado por el edificio en la cubierta, como por ejemplo, en el Convento de la Tourette, en donde una 'cubierta jardín inclinada' sugiere el ascenso al gran campo verde del último nivel. Esta característica en particular la encontramos como 'copy_paste' de Salmona en el Edificio de Posgrados en la Universidad Nacional de Colombia, en el cual hay una 'Cubierta jardín inclinada' análoga a la lecorbusieriana, además, porque en los dos proyectos es un vestíbulo que conecta diferentes recorridos, así como sugiere el ascenso a la terraza, o un ascenso hacia el cielo.

\footnotetext{
${ }^{26}$ Gaitán, Gloria. Arquitectura Liberal. Bogotá: Editorial Arco, 1990, p.65
} 
El teatro y graderío sobre la cubierta, en la obra de Le Corbusier surge de manera sutil en la Unité d'Habitation en Marsella, y pasa luego, a la de Nantes-Rezé, pero su pequeño tamaño no lo particulariza como lugar principal en la cubierta-jardín; contrario a los grandes ‘teatro-mirador' públicos de Salmona, que son una 'recreación' del Teatro de Delfos por su amplitud visual al paisaje lejano.

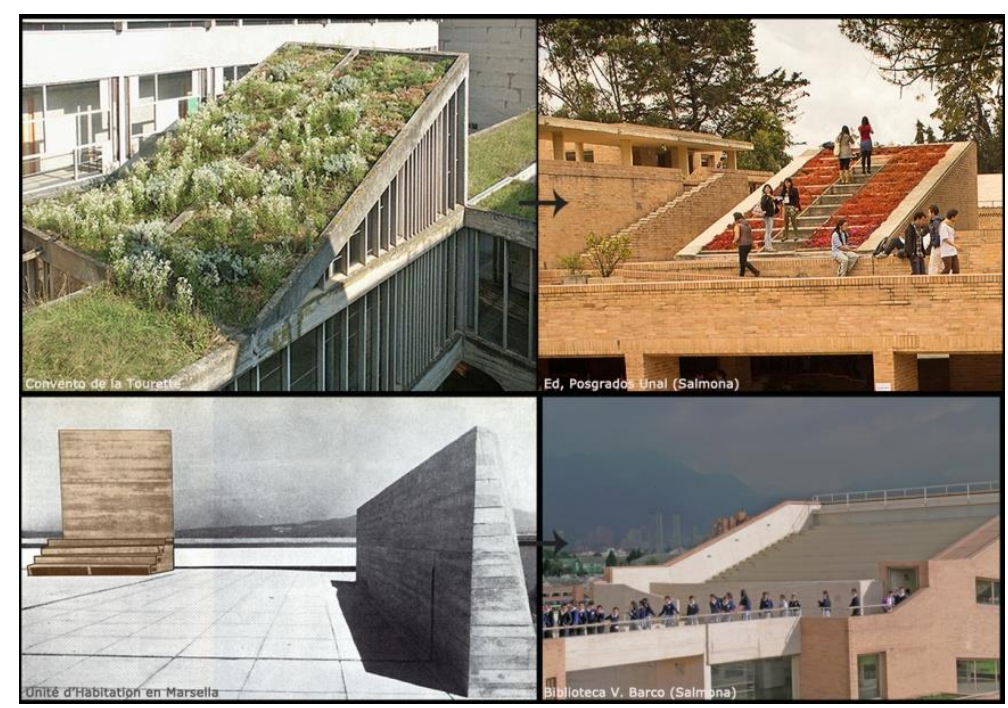

12. Relación Le Corbusier-Salmona: cubierta jardín y cubierta plaza

Luego de la 'recreación' de los tres ‘puntos' antes expuestos (la planta baja sobre pilotis, la ventana corrida, y la cubierta ajardinada), otro de los principios arquitectónicos que caracteriza el enlace Le Corbusier-Salmona, es la promenade arquitectónica, que "significa la experiencia temporal del interior de un edificio que ya se ha grabado en la mente como una unidad espacial y conceptual",27, que Salmona evoluciona, alargando el tiempo con recorridos oblicuos, y al volverla más dependiente de quien recorre el edificio, y no de los recorridos establecidos por la arquitectura. La redefine como "Errancia arquitectónica", en la cual, como no hay un único recorrido, se descubren y conectan elementos nuevos en cada errar por el proyecto. Dicha 'Errancia' se configura mediante un preciso diagrama de lugares de 'recorrido y congregación ${ }^{28}$, dos actividades complementarias que invitan e inducen la voluntad cinética de entrar en el edificio público, errar y apropiarse de él.

Otra cuestión que caracteriza la Promenade y la Errancia, es que la primera tiene una condición de frontalidad "Le Corbusier tendia a organizar las superficies internas y externas de hecho que formasen una serie de planos (reales o figurados) en ángulo recto con la línea de movimiento del observador" 29 . En cambio, en la 'Errancia' Se organizan los lugares y espacios de manera oblicua, como sucede en el portal de acceso del Edificio de Posgrados que es ocupado por un gran árbol preexistente, y que es una "confirmación" del portal de acceso del Convento de la Tourette, también con el "Point de vue dans l'axe de l'arbre"30 que da inicio al viaje por el edificio.

De acuerdo con todo lo anterior, los saltos de asociaciones y copy_paste de Rogelio Salmona han servido como medio para conocer y desvelar nuevos aspectos en la arquitectura de Le Corbusier y su legado. De igual manera,

\footnotetext{
${ }^{27}$ Colquhoun, Alan., op. cit. p. 118

${ }^{28}$ Para ampliar sobre el tema ver, Salazar, Mauricio. Lugares dentro de lugares, el rito de la memoria en la composición arquitectónica. Centro Cultural Gaitán: Rogelio Salmona. Bogotá: Punto aparte, UNAL. 2011. p.176

${ }^{29}$ Colquhoun, Alan., op. cit. p. 118

30 «Point de vue dans l'axe de l'arbre», Quetglas, Josep. AA.VV. Massilia 2004bis, anuario de estudios Lecorbusierianos. Barcelona: Fundación Caja de Arquitectos, 2004
} 
el tránsito de arquitecturas por entre los diferentes saltos del capriccio -del lugar, al revés, de la ciudad ideal, y el de Berlín-, se presenta como el principal argumento: el capriccio arquitectónico es en Le Corbusier un dispositivo que permite comprender el 'virtuosismo' analítico, proyectual y crítico de su obra. Así, como permite crear equivalencias entre su proceso de ideación, el de Canaletto, Goya, y nuestra contemporaneidad, en el proceso de reproducción racional 'copy_paste', que Le Corbusier pareciera anticipar, en la virtud para 'pegar' elementos propios, y aprehendidos de otros lugares a sus proyectos.

No obstante, lo importante no son tanto los elementos copiados (Partenón, Pisa, Villa Savoye; el burro y el cuervo...Chandigarh), sino el sinfín de conexiones que suscita un viaje mental por ellos. Así, como argumenta Tafuri: "Tanto los Capricci de Canaletto como las Vedute, las Carceri o el Campo Marzio de Piranesi son, a su manera, 'invitaciones al viaje' [...]. En el viaje, se ha de ser consciente de que la aventura buscada, para ser total, no ha de tener límites, y que por ellos el viaje se ha de prolongar hasta el infinito, [...] el viaje induce a un 'montaje' mental'31.

De igual manera, como la obra de Le Corbusier, que se presenta como una invitación infinita al viaje, que revela en su camino la eficacia del capriccio arquitectónico: mostrar múltiples lugares y culturas en un mismo lugar. Así, manifestando -anticipadamente- a la contemporaneidad, que el potencial complejo de la arquitectura, está en las migraciones, combinaciones y copy_paste, capaces de expresar múltiples significados culturales: una mixtura cultural en una serie de saltos a capriccio de manera no caprichosa.

\section{Coda: la tumba como capriccio arquitectónico}

En 1957, la muerte de Yvonne, esposa de Le Corbusier, acaeció en un período de máxima creatividad lecorbusieriana, ya que se encontraban en proceso algunos de sus más paradigmáticos proyectos, como el Convento de la Tourette y el Plan Director en Chandigarh con sus singulares edificios. Estos proyectos de la década de los 50's, que junto con la Unité d'Habitation en Marsella, El Poema del Ángulo Recto, o La Iglesia de Ronchamp, caracterizarían este período como un 'punto de inflexión' y maduración en la obra lecorbusieriana; el cual pudo influir en el 'proyecto' de la tumba para Yvonne, que Le Corbusier acompañaría con su fallecimiento en 1965.

En relación con el salto que pudieran dar otros proyectos en la concepción de la tumba para Yvonne y Le Corbusier, es Le Poème de l'Angle Droit (1947-54), la obra que muestra en el principio y el final la relación exacta con el procedimiento 'capriccio': el copy_paste y los saltos inesperados de la -alada mujer- cabra. En cuanto a lo primero, es irrefutable la correspondencia directa que tiene la imagen que abre el 'Poema' con la tumba, ya que en ella se representa - de manera purista- un prisma triangular junto a un fragmento de columna cilíndrica, que sería el copy_paste que arquitecturiza Le Corbusier como su tumba. Con respecto a lo segundo, en la última imagen que cierra el 'Poema' con un 'iconostasio' a manera de índice, descubrimos una anomalía en la casilla (D3) correspondiente al tema "Fusión", en donde se "invierte" de izquierda a derecha la figura, con respecto a la imagen en color de la misma en la página 117. Dicha imagen del inesperado salto capriccioso es caracterizada - pareciera de manera intencional- con la mixta figura lecorbusieriana de Licorne, una alada mujer cabra, asociada a su esposa Yvonne, quien nació bajo el signo zodiacal de capricornio representado por la cabra. Así, Licorne salta por varias páginas de 'El Poema del Ángulo Recto', y otras obras pictóricas de Le Corbusier (el mural del Pabellón suizo, etc.), convirtiéndose en una imagen nómada -capriccio- en constante salto por la obra artística lecorbusieriana. [13]

\footnotetext{
${ }^{31}$ Tafuri, Manfredo. La esfera y el laberinto: vanguardias y arquitectura de Piranesi a los años setenta. Barcelona: Editorial Gustavo Gili, 1984. p. 52
} 


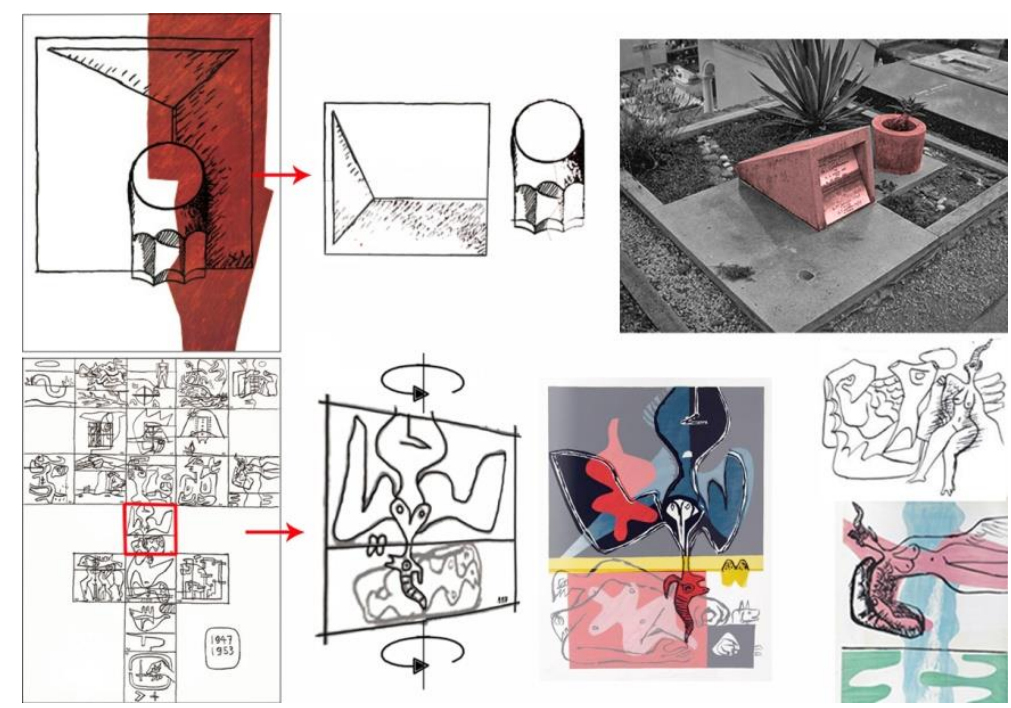

13. Le Poème de l'Angle Droit (1947-54) y el proyecto de la tumba: copy_paste, inversión y desplazamiento nómada

De igual manera, que en dichos saltos de Licorne, Le Corbusier realizaba autocopy_paste, desplazamientos de arquitecturas, e inversiones de conceptos de la tradición para constituir la esencia de muchos de sus proyectos. Como por ejemplo, la escala de Chandigarh a partir del contraste con Versalles ${ }^{32} \mathrm{o}$, de manera destacada, el copy_paste de la 'regla espacial de la cartuja ${ }^{33}$ en el Convento de la Tourette, que lo estructura en torno a tres espacios, que hacen compatible el aislamiento individual y la celebración de ritos colectivos: el patio de ingreso, el claustro menor y el claustro mayor. Así, el 'patio de ingreso' en el convento de la Tourette es la plataforma delimita entre el portal de acceso y el parapeto que mira al espacio central. El 'claustro menor' como el cartujo está contiguo al volumen de reunión colectiva: la capilla. Y el 'claustro mayor' es delimitado por las celdas de los monjes, y es un espacio sacro de introspección por las tumbas de los cartujos dispuestas allí.

Algo semejante sucede, de manera, subrepticia en el Convento de la Tourette. La tumba de Yvonne y Le Corbusier, está representada en la emulación de los volúmenes al interior del 'claustro mayor’ del edificio: en la loable composición del prisma triangular -del lucernario del vestíbulo- y el cilindro -de la escalera helicoidal-, que parecen "confirmaciones" de los dos volúmenes de la tumba en el cementerio de Roquebrunne. Así mismo, la presencia del oratorio piramidal, enlaza con el tema de la tumba, que Le Corbusier en 1951 abordaría en un proyecto para una capilla funeraria, en la que piden "que pensara en determinar el lugar para su propia tumba «sea cuando sea que el momento llegue» ${ }^{34}$

\footnotetext{
32 Comenta Salmona: "Pasaron algunos días, Le Corbusier no volvió a la mesa de dibujo, estaba atareado en otros menesteres, pero yo sabía que el plan de la capital -del Punjab- seguía vigente en su cabeza. Finalmente una mañana helada de invierno se presentó a mi mesa, detalló los dibujos, los midió y me dijo: "Vamos a Versalles". En su pequeño automóvil iniciamos el viaje. Al llegar se puso delante del castillo y miro detenidamente el parque y la concavidad que lo conformaba. Lo observaba fascinado, cuando repentinamente me dijo: "Tout ça c'est petit" (todo esto es pequeño). Al regreso al taller, le dobló la escala a los planos que había dibujado y nació en ese momento, me pareció a mí, sólo en ese momento, la capital del Punjab Chandigarh". En, Arcila, Claudia. Tríptico rojo. Conversaciones con Rogelio Salmona. Bogotá: Taurus. 2007. p. 131

${ }^{33}$ Rogelio Salmona, Organizaba todos sus proyectos rigurosamente a partir de la 'regla espacial cartuja'. En, Salazar, Mauricio. Lugares dentro de lugares, el rito de la memoria en la composición arquitectónica. Centro Cultural Gaitán: Rogelio Salmona. Bogotá: Punto aparte, UNAL. 2011. P. 206

34 "La Pirámide y el Muro: notas preliminares sobre una obra inédita de Le Corbusier en Venezuela". Lapunzina, Alejandro. AA.VV. Massilia 2002, anuario de estudios Lecorbusierianos. Barcelona: Fundación Caja de Arquitectos, 2002, pág. 148-161
} 


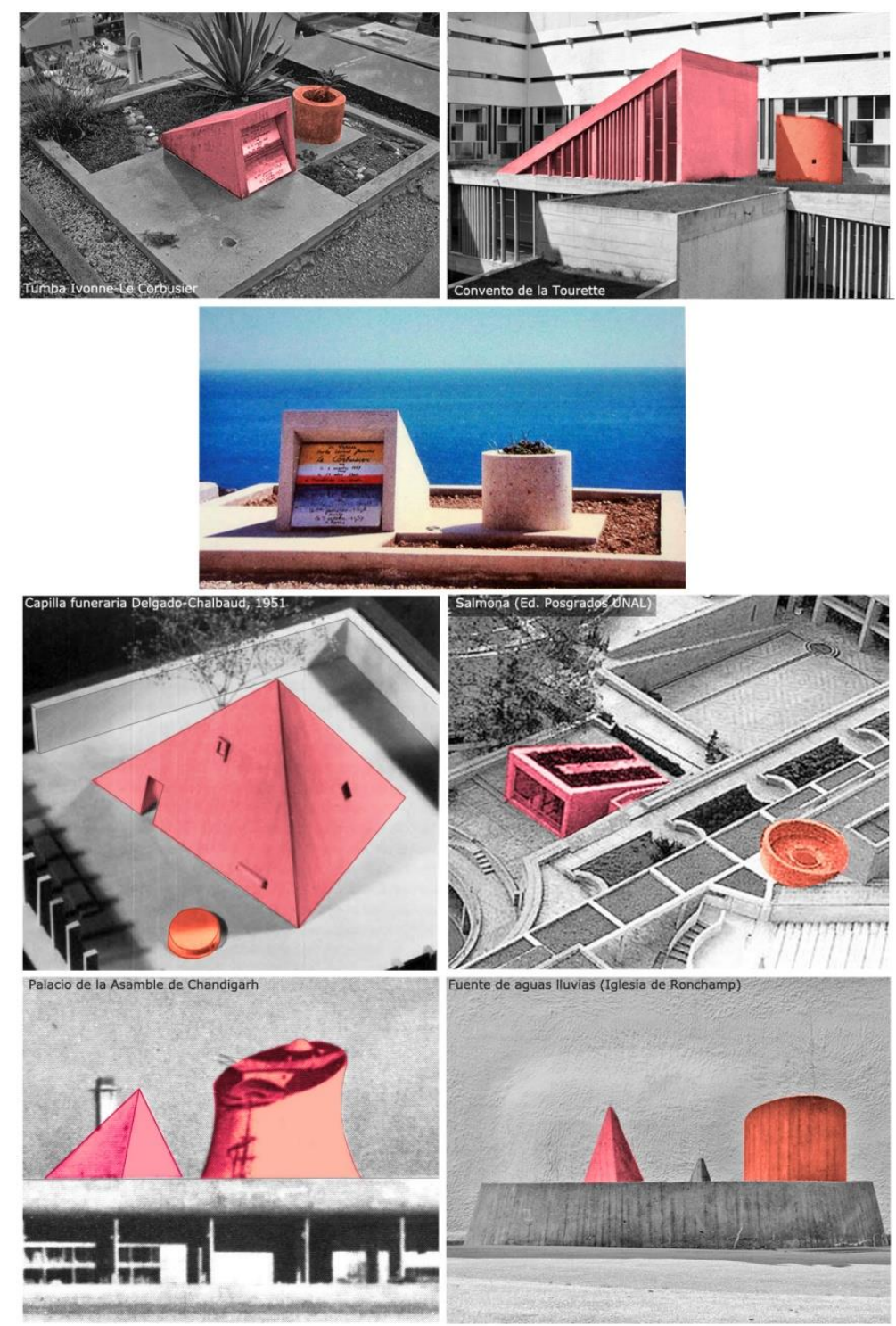

14. Inquietud formal, capriccio y ubicuidad de la tumba de Yvonne y Le Corbusier. Fuentes, (Capilla funeraria DelgadoChalbaud) en "La Pirámide y el Muro: notas preliminares sobre una obra inédita de Le Corbusier en Venezuela". Lapunzina, Alejandro; (foto en color de la tumba de Le Corbusier y de Yvonne Gallis, 1958) FLC L3(5)62CFLC-ADAGP. (Asamblea Chandigarh) Euvre complète 1957-1965’, pág. 96. Otras fotografías del autor.

De acuerdo con lo anterior, al examinar la obra completa de Le Corbusier, encontramos que la formalización de su tumba, se presenta como un 'diagrama' e inquietud proyectual, que se reitera tomando diferentes matices que, no obstante, no distan de los dos volúmenes de su prototipo fúnebre: el de alusión triangular y cilíndrica sobre una base cuadrada. Así, en la Capilla funeraria de Delgado-Chalbaud (1951), una pirámide -Cestia- delimitada en un recinto cuadrado es acompañada inesperadamente de una "plataforma cilíndrica para sentarse",35, la cual en la tumba para Yvonne es un cilindro -maceta- que consigue una proporción equivalente con el prisma triangular - con las placas epitafio-, como en la Tourette. De igual modo, el tránsito de estas dos formalizaciones es evidente en la cubierta de la Asamblea de Chandigarh, en donde el prisma triangular del lucernario de la Tourette, se trasforma, con una silueta igual, en el lucernario piramidal de la Sala del Consejo; y el volumen

35 Ibídem, p. 154 
cilíndrico, ahora toma un protagonismo monumental en el cascarón hiperbólico de la Sala de la Asamblea; del cual podemos seguir su desplazamiento hasta el cascarón troquelado de la Iglesia en Firminy, acompañada del bloque inclinado del Centro Juvenil y Cultural, que podría hacer alusión al prisma triangular de la tumba. Sin embargo, es en la Iglesia de Ronchamp, en donde parece iniciarse la formalización de la tumba lecorbusieriana, en la compleja fuente ovalada que contiene dos volúmenes piramidales y uno cilíndrico, que por su carácter primitivo, carga de atemporalidad la tumba de Yvonne y Le Corbusier [14].

Los anteriores saltos a otros proyectos del ubicuo 'proyecto' de la tumba lecorbusieriana, evidencian que no es fortuito el encuentro y "fusión" de dicha dupla formal, ya que como antes se ha relacionado, también trasciende como legado arquitectónico en su -antagónico- discípulo Rogelio Salmona, que favoreció el tránsito de estas dos formas esenciales del Convento de la Tourette, al saltar funcional y formalmente al Edificio de Posgrados de la Unal. Así, con esta emulación se hace furtivamente un homenaje a la tumba de Le Corbusier, suscitando el encuentro de ellos como maestros, que redefinieron el copy_paste como un plausible homenaje y capriccio arquitectónico, que propicia el goce colectivo que trasciende a lo poético.

Le Corbusier, parece crear con el proyecto nómada de la tumba en Roquebrunne, una nueva realidad ideal que se desplaza por múltiples arquitecturas, en la "fusión" poética de opuestos que se complementan, del prisma triangular y el cilindro; de la muerte y la vida; de lo femenino y lo masculino ${ }^{36}$, de la razón y el capriccio: en suma, la fusión de Yvonne y Le Corbusier en el silencio elocuente de la ubicuidad de su tumba.

\section{Fuentes de las imágenes}

1. Capricci de Le Corbusier, Marlow y Goya. Fragmento del Dibujo de LC en, Boyer, Christine. Le Corbusier. Homme de Lettres. New York: Princenton Architectural Press, 2011, p. 688 (figura 1.14), edición. procedente de Le Corbusier, Maler Og Arkiteckt (Copenhagen: Fonden til udgivelse af Arkitekturtidsskrift B, 1995), 21; Goya y Lucientes, Francisco de. Caprichos de Goya: colección de ochenta estampas grabadas al agua fuerte con agua de resina. Madrid: Calcografía Nacional, 1868; Capriccio de Marlow en la Tate gallery en Londres.

2. Desplazamiento de la arquitectura sin especifidad del lugar. Le Corbusier. Euvre complète Vol 4 1938-1946'. Zurich: Les Editions d'Architecture, 1964, p. 153

3. Saltos al revés o "confirmaciones”. Le Corbusier, 1951, Carnets, Vol. II, E-20, Graf. 431. CFLC-ADAGP. Le Corbusier. Euvre complète 1929-1934. p.132

4. Storyboard idealización de la realidad de la ciudad con el capriccio. Le Corbusier. Precisiones. Barcelona: Apóstrofe, 1999, p.199. Collage de capricci arquitectónicos, imágenes del autor.

5. Propuesta de Le Corbusier para Berlín, imagen editada con 'Gradiente' de enlaces capriccio. 'Cuvre complète 1957-1965’ pág. 235, edición.

6. Propuesta de Le Corbusier para Berlín: Capriccio arquitectónico de Chandigarh en Berlín. Collage del autor.

7. Propuestas de Le Corbusier para Berlín: Capricci arquitectónicos (grupos 2, 3 y 5). Collage del autor

8. Relación de la 'inversión' lecorbusieriana del 'capriccio del cuervo y el burro' y "Sr.guitarra" con la serie de asnerías de Goya. En, Guerrero, Salvador. Le Corbusier : Madrid 1928 : una casa-un palacio [exposición], Residencia de Estudiantes, mayo-julio 2010 p.58; Goya y Lucientes, Francisco de. Caprichos de Goya: colección de ochenta estampas grabadas al agua fuerte con agua de resina. Madrid: Calcografía Nacional, 1868.

9. Capriccio arquitectónico de Salmona, e influencia de Wright, Aalto y Scharoum en el conjunto Torres del Parque. Fundación Rogelio Salmona; imágenes del autor en Salazar, Mauricio. Lugares dentro de lugares, el rito de la memoria en la composición arquitectónica, Centro Cultural Gaitán: Rogelio Salmona. Bogotá: Punto aparte, UNAL. 2011, p.241 y 300

\footnotetext{
${ }^{36}$ Página 111 (D3) en, Le Pòeme de l'Angle Droit
} 
10. Relación Le Corbusier-Salmona: planta baja sobre pilotis y patio. Imágenes del autor

11. Relación Le Corbusier-Salmona: ventana corrida y panóptica. Imágenes del autor

12. Relación Le Corbusier-Salmona: cubierta jardín y cubierta plaza. Imágenes del autor. (Marsella) 'CEuvre complète 1946-1952’ pág. 223, edición.

13. Le Poème de l'Angle Droit (1947-54)@FLC-ADAGP y el proyecto de la tumba: copy_paste, inversión y desplazamiento nómada. Le Corbusier y la Síntesis de las Artes, El Poema del Ángulo Recto. Madrid: Círculo de Bellas Artes-Fondation Le Corbusier, 2006. (Imagen primera página; Iconostasio de esquemas p.155; D3 Fusion p.117; C5 Chair). Imágenes editadas.

14. Inquietud formal, capriccio y ubicuidad de la tumba de Yvonne y Le Corbusier. (Capilla funeraria DelgadoChalbaud, en "La Pirámide y el Muro: notas preliminares sobre una obra inédita de Le Corbusier en Venezuela”. Lapunzina, Alejandro. AA.VV. Massilia 2002, anuario de estudios Lecorbusierianos. Barcelona: Fundación Caja de Arquitectos, 2002, pág. 152, edición; (foto en color de la tumba de Yvonne Gallis, Le Corbusier ,1958) FLC L3(5)62@FLC-ADAGP. (Asamblea Chandigarh) Euvre complète 1957-1965', pág. 96, edición. Otras fotografías del autor.

\section{Bibliografía}

AA.VV. Arquitecturas pintadas del Renacimiento al siglo XVIII. Madrid: Museo Thyssen-Bornemisza, 2011

AA.VV. Le Corbusier y la Síntesis de las Artes, El Poema del Ángulo Recto. Madrid: Círculo de Bellas ArtesFondation Le Corbusier, 2006

AA.VV. Massilia 2002, anuario de estudios Lecorbusierianos. Barcelona: Fundación Caja de Arquitectos, 2002

AA.VV. Massilia 2004bis, anuario de estudios Lecorbusierianos. Barcelona: Fundación Caja de Arquitectos, 2004

AA.VV. Massilia 2006, anuario de estudios Lecorbusierianos. Barcelona: Fundación Caja de Arquitectos, 2006

Arcila, Claudia. Tríptico rojo. Conversaciones con Rogelio Salmona. Bogotá: Taurus, 2007

Boyer, Christine. Le Corbusier. Homme de Lettres. New York: Princenton Architectural Press, 2011

Colquhoun, Alan. Arquitectura moderna y cambio histórico. Barcelona: Ed. GG, 1978

Corboz, André. Canaletto, Una Venezia Immaginaria, Volumen I y Volumen II. Milán: AlfieriElecta. 1985

Helman, Edith. El trasmundo de Goya. Madrid: Alianza Forma. 1963. Reimpresión, 1986

Le Corbusier, El Modulor. Barcelona: Editorial Poseidón, 1980

Le Corbusier. Euvre complète Vol 2 1929-1934'. Zurich: Les Editions d'Architecture, 1964

Le Corbusier. Euvre complète Vol 4 1938-1946'. Zurich: Les Editions d'Architecture, 1964

Le Corbusier. (Ed) W. Boessinger. Le Corbusier et son atelier rue de Sèvres: 'CEuvre complète 1957-1965'. Basilea-Boston-Berlin: Editions d'Architecture Artemis, 1985

Le Corbusier. Precisiones. Barcelona: Apóstrofe, 1999

Rowe, Colin. Manierismo y arquitectura moderna y otros ensayos. Barcelona: Gustavo Gili, 1978

Salazar, Mauricio. Lugares dentro de lugares, el rito de la memoria en la composición arquitectónica, Centro Cultural Gaitán: Rogelio Salmona. Bogotá: Punto aparte, UNAL. 2011

Steil, Lucien. The Architectural Capriccio, memory, fantasy and invention. Burlington: Ashgate, 2013

Tafuri, Manfredo. La esfera y el laberinto: vanguardias y arquitectura de Piranesi a los años setenta. Barcelona: Gustavo Gili, 1984 


\title{
1. Espacio de reflexión
}

El CCVA de Harvard, como muchos otros proyectos de Le Corbusier, comienza con un largo período de reflexión. Tanto el edificio, como el proceso de diseño tienen un espacio y un tiempo de espera. En el edificio, es una plaza cubierta de recibimiento (imagen 1), en el proceso de diseño (1959-1961), son largos tiempos de espera, antes de dibujar. Una "búsqueda paciente"1, como él mismo llamó a su taller en los últimos años. Por recuentos sobre Ronchamp, sabemos que después de iniciado un encargo, el arquitecto se prohibía a sí mismo elaborar dibujos durante varios meses. ${ }^{2}$ En el caso del CCVA, tres meses después de su visita a Cambridge, Sert le pregunta por el proyecto y Le Corbusier le dice: "el silencio es de oro (como dice el proverbio), en el momento estoy almacenando los datos del problema en mi central telefónica interna (mi cerebro)" ${ }^{3}$ Luego le dice que ha mandado a construir algunas maquetas del sitio; de las que no parece haber registro alguno. Sin embargo, esta prohibición de dibujar no parece ser tan estricta como parece, pues durante la primera visita al sitio escogido, del 12 al 15 de Noviembre de 1959, sí escribe dos frases que definirán el proyecto, donde ya menciona este espacio de reflexión que mostramos en la primera imagen.

\begin{abstract}
Attention Boston
Il faut qu'il ait un cavedji (à la Turque) pour établir eontrats. // contacts // Boston // Il y a du granit gris // La spirale du toit du mussée doit devenir une piste de jardins et rocailles dressée dans le paysage et formant un paysage. ${ }^{4}$
\end{abstract}

Como dice aquí, "es necesario que haya un cavedji (a lo turco)". Pero el cavedji no es un café turco (cofeeshop) como suele traducirse, sino que es la cava aedium, o cavaedium, elemento arquitectónico que simboliza una cueva que une la casa Romana con el Hades, y que está ubicado exactamente en el patio, o Atrium, con el que a menudo se confunde. Varios cavedjis pueden verse en los cuadernos de su Viaje a Oriente de 1911, posiblemente en Istambul. Cuando se encontraba en esta ciudad, como cuenta Giuliano Gresleri: "Le Corbusier visitaba las mezquitas, los bazares, y los cementerios (...) vestido como Turco, razonando como Turco, y "deviniendo" Turco, gracias a una estadía lo suficientemente duradera como para simular una residencia." ${ }^{5}$ Esta plaza enterrada de recibimiento, y que en ocasiones especiales se integra al lobby del edificio, es un espacio silencioso que escoge quien no ha optado por la rampa que atraviesa el edificio, un camino al parecer más corto. Como continua diciendo Le Corbusier, el cavaedium, es un lugar para "establecer contratos, (o) contactos". Se puede ver que ha tachado contratos, y que parece haberlo traicionado su subconsciente. En la segunda frase se dibuja la imagen de un espiral con un jardín de rocas formando un paisaje. Y esto mismo, es lo que le espera al visitante

\footnotetext{
${ }^{1}$ LE CORBUSIER, L'Átelier de la Recherche Patiente, Paris: Éditions Vincent Fréal, 1960.

${ }^{2}$ PAULY, Danièle, Le Corbusier: The Chapel at Ronchamp p 128. Citado por KELLETT, Ron, "Le Corbusier's design for the Carpenter Center: a documentary analysis of design media in architecture", En: Design Studies, Volume 11, Issue 3, July, 1990, pp. 164-179.

${ }^{3}$ SEKLER, Eduard F., CURTIS, J. William, Le Corbusier at work. The genesis of the Carpenter Center for the Visual Arts, Cambridge, MA: Harvard University Press, 1978. p. 58 Carta del 15 de febrero de 1960 (traducida por el autor).

${ }^{4}$ Le Corbusier Sketchbooks Vol. 4, 1957-1964, notes by FRANCLIEU Françoise, Cambridge, MA: the MIT Press, Fondation Le Corbusier and the Architectural History Foundation. Sketchbook P59. Imagen 447.

${ }^{5}$ GRESLERI, Giuliano, "The Rediscovered Carnets", En: Le Corbusier (Ch.-E.Jeanneret), Voyage d'Orient. Carnets, English edition, Milano: Fondation Le Corbusier, 1987, p. 13.
} 
después de este espacio de recibimiento: una espiral; que como veremos más adelante, tendrá varias rutas posibles, según lo que se venga a buscar en el edificio.

Tres meses después de las dos frases iniciales, Le Corbusier escribe otra descripción verbal del proyecto, y se la envía en un memorando oficial a Guillermo Jullian de la Fuente, el 2 febrero de 1961. Allí dice:

Il faudra préparer une route de traversée du bâtiment par les étudiants entre les heures de cours. Une route touristique peut être en spirale si nous faisons monter le bâtiment.

Des sonneries électroniques seront composées et réalisées pour 1, 2, 3 émissions par jour, à heures fixes, émission de nature formidable de douceur ou de puissance.

Ces émissions seront selon une route sonore, stéréophonique,

-en spirale montante, descendante.

-en verticale montante, descendante. En mettant du sonore au sol et au ciel.

Aquí se habla de una "ruta de travesía" o de una "ruta turística", y aunque no se ha dibujado todavía, ya se establece como un componente duradero del proyecto. En post data Le Corbusier le pide a Jullian, extraer una copia de las notas tomadas en su cuadernillo de Boston en Noviembre de 1959. En la imagen 2 podemos ver el extracto hecho por Jullian. En un proceso en el que hasta ahora no ha aparecido ningún dibujo, resulta extraño ver un círculo en el extracto de Jullian, que no aparece en la notas Le Corbusier. Este dibujo fue publicado por el propio Jullian años más tarde en el catálogo de una exposición en la Universidad de Kentucky, junto con otras notas y dibujos enviados a él por Le Corbusier, entre los que se encuentra también una hermosa tarjeta de "mejoría". ${ }^{6}$ El círculo dibujado por Jullian aparecerá sin embargo durante los dibujos iniciales, como veremos más adelante. Antes veamos lo que se ha dicho sobre esta metodología en Le Corbusier.

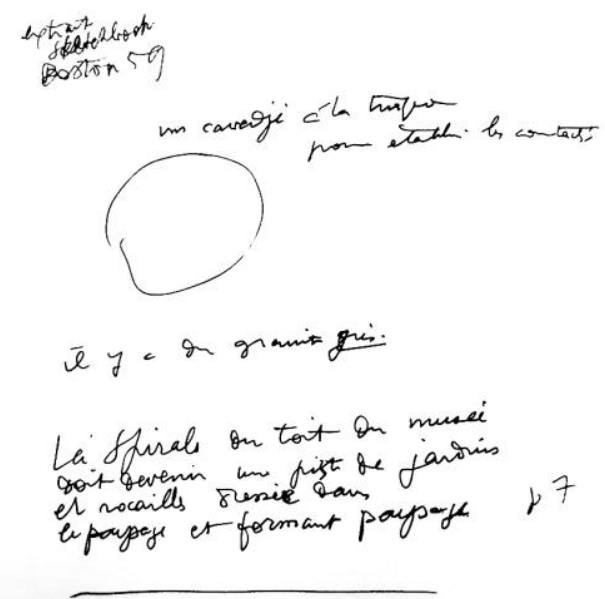

2. Extract Sketchbook Boston 59, Guillermo Jullian de la Fuente, 1960, Ink on translucent paper, 27.1 x $21.1 \mathrm{~cm}$, Fonds Guillaume Jullian de la Fuente, Collection Centre Canadien d'Architecture/Canadian Center for Architecture, Montréal.

\footnotetext{
${ }^{6}$ JULLIAN DE LA FUENTE, Guillermo and EARDLEY, Anthony, Atelier rue de Sèvres. An exhibition of project sketchesand notes from Le Corbusier to Guillermo Juliian de la Fuente while working in the Atelier Le Corbusier between 1959 and 1965, Lexington, Ky.: College of Architecture, University of Kentucky, Art Gallery, 1975.
} 


\section{Sintaxis y diagrama}

El nacimiento del CCVA ha sido a través de enunciados, que se van construyendo y sumando. Luego aparecen los dibujos. Este tipo de proceso ha sido identificado por Anthony Vidler como un proceso diagramático, que opera "entre la forma y la palabra, el espacio y el lenguaje", (...) que "es a la vez constitutivo y proyectivo; es performativo en vez de representativo." ${ }^{7}$ Refiriéndose al edificio en cuestión, unos años antes, Stan Allen afirmaba: "los diagramas no son esquemas, tipos, paradigmas formales, u otros dispositivos reguladores, sino simplemente marcadores de posición, instrucciones para la acción, o descripciones contingentes de posibles configuraciones formales. Ellos trabajan como máquinas abstractas y no se parecen a lo que producen." 8 Resumiendo, el diagrama se presenta como un estado de cosas "abierto", a la vez "verbal y visual", que es como tal y se repite como tal, y al cual se vuelve en momentos de dudas. Bruno Reichlin también habla del CCVA como una obra "abierta"; tanto a influencias externas de diversos órdenes, como la colaboración de los miembros del Atelier, o de los constructores, así como a la interacción en el proyecto, de las condicionantes climáticas y de las influencias del sitio. Reichlin también se refiere a la arquitectura de la última fase de Le Corbusier como cada vez más "informe" y esquemática, y sobretodo "dialógica", es decir, en la que siempre existe un diálogo entre una dimensión verbal o conceptual, y una dimensión visual, o de formalización. ${ }^{9}$

Ron Kellet en un artículo de 1990 sobre el CCVA, también menciona el uso de los "cartons découpés", y de la libre manipulación de áreas previamente recortadas ${ }^{10}$, así como el uso estratégico del color para definir circulaciones, zonas públicas y zonas privadas. Sin embargo Kellet no menciona la sintaxis espacial. Paul Emmons es quien ha escrito sobre los "diagrammme à bulles" de Le Corbusier, aunque tampoco menciona la sintaxis. Según Emmons, estos diagramas comienzan a aparecer durante las conferencias de Le Corbusier por Sur América en 1929, siendo popularizados por arquitectos como Percy Nobbs sólo a partir de los años $40 .{ }^{11}$ Un poco más temprano el mismo año, también se puede observar un diagrama de burbujas utilizado en el prototipo Loucheur (Imagen 3). En ese diagrama todos los espacios convergen alrededor de la sala de estar, aunque no existen indicaciones de dónde pueda existir un acceso. En una hoja aparte se enumeran las áreas respectivas para cada uno de los espacios.

En los estudios para los servicios comunes de los primeros prototipos de Unités Le Corbusier llama a estos diagramas:"shema(s) de organisation"12 y en los DVD Plans aparecen como:"organigrammes". Aunque podemos observar los diagramas burbuja en varios de sus proyectos, su uso no es tan común, y solo aparecen en

\footnotetext{
${ }^{7}$ VIDLER, Anthony, "Diagrams of Diagrams: Architectural Abstraction and Modern Representation", En: Representations, No. 72 (Autumn, 2000), pp. 1-20. Se le agradece a uno de los revisores anónimos del congreso por la sugerencia de esta lectura.

8 ALLEN, Stan, "Diagrams Matter", En: ANY: Architecture New York, "Diagram Work: ATA MECHANICS FOR A TOPOLOGICAL AGE", No. 23, (1998), pp. 16-19

${ }^{9}$ REICHLIN, Bruno, «L'œuvre n'est plus faite seulement d'elle-même », En : REICHLIN Bruno et MOREL JOURNEL Guillemette (dir.), En: Cahiers de la Recherche Architecturale et Urbaine "Le Corbusier. L'atelier intérieur: L'intertextualité à l'oeuvre", n. 22-23, février 2008, pp. 119-150."(...) l'approche dialogique du projet a développé chez lui la perception de deux nivaux distincts dans le processus de projet: l'un, conceptuel, s'exprime et se transmet par de diagrammes, des symboles, des métaphores et des instructions verbales; l'autre, concernant la mise en forme, procède par essais et ajustements répétés autant de fois que nécessaire sur la base d'une expérience visuelle et d'une et d'une mémoire formelle." $\mathrm{P}$. 150

${ }^{10}$ KELLETT, Ron, op. cit.

${ }^{11}$ EMMONS, Paul "Embodying networks: bubble diagrams and the image of modern organicism", En: The Journal of Architecture, 11:4, 2006, 441-461.

${ }^{12}$ FLC 27145, Le Courbusier Plans, DVD 8.
} 
momentos donde se necesita mayor eficiencia del espacio, como en las cocinas de las Unité de Marseille; o en el Pavillion des Temps Nouveaux, de la Expo. 1937 $7^{13}$, así como en la fábrica Claude et Duval de 1946. Paul Emmons llama la atención sobre otros diagramas donde lo funcional se mezcla con lo biológico, como el realizado para la sede de la compañía suiza Rentenanstalt, en Zürich, durante 1933, donde las principales funciones de la compañía son representadas como las partes vitales de un organismo, conectándose por líneas de flujos.

Otro ejemplo de la importancia por los planes de organización también la podemos ver en el texto que escribe para la casa de sus padres en el lago Léman. Lo primero que tiene claro es la ubicación geográfica de la casa: el lago Léman, sin embargo, antes de buscar la parcela ya ha pensado el plano y la organización de la casa. " $E l$ plano antes que el terreno? El plano de una casa para encontrarle un terreno? Sí. (...) Con el plano en el bolsillo hemos buscado por largo tiempo el terreno". ${ }^{14}$ La razón principal de esto es que teniendo una organización previa de la casa con sus requerimientos mínimos, se puede buscar la posición más adecuada de todas las funciones con respecto al sol y al sitio en general. Las actividades de la casa se establecen en forma de "circuito", como él mismo lo llama; en un ordenamiento que sigue a su vez el circuito sol.

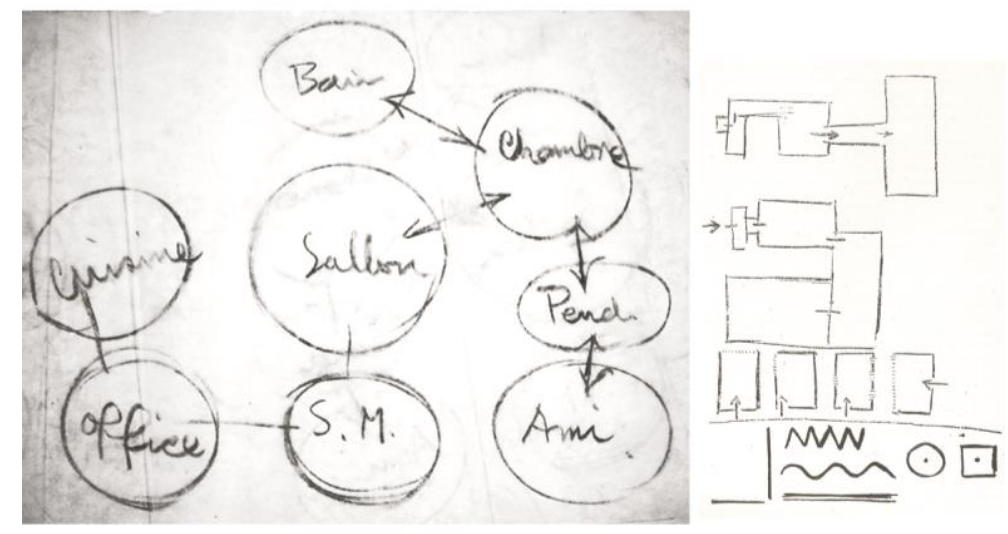

3. a. Organigramme Maison Loucheur 1929; b. Diagrama de ritmos, Précisions, p. 75

Haciendo uso de los diagramas con burbujas, para evitar la distracción de la forma, Bill Hillier en los años 70 se propone entender la relación de un edificio con el espacio público, mediante lo que llamó la sintaxis espacial. Su objetivo principal era observar la "permeabilidad de (los) sistema(s)" a partir de estos diagramas ${ }^{15}$. La sintaxis del espacio se refiere al análisis de las diferentes posiciones que asume cada una de las funciones del "sistema" arquitectónico. Hillier también llama a esto su profundidad. Las tres posibilidades estructurales que este autor encuentra son: 1. la galería (enfilade), o sucesión de espacios 2. la planta arborescente o jerárquica y 3. la planta en red; además de sus posibles combinaciones. Tanto a Nobbs como a Hillier los caracteriza un estricto funcionalismo, en el que la forma no importa, solo las funciones y su encadenamiento, como es el temprano diagrama para la casa Loucheur.

\footnotetext{
${ }^{13}$ FLC 30820C, Le Corbusier Plans, DVD 7.

${ }^{14}$ LE CORBUSIER, Une Petite Maison, Zurich, Editions Girsberger, Les Carnets de la Recherche Patiente No.1, 1954, p. 911 .

${ }^{15}$ HILLIER, Bill, The Social Logic of Space, 7th ed., Cambridge: Cambridge University Press, 1984, p. 14.
} 
Habría otra tradición paralela, y quizá más antigua que ésta. Aquella donde la forma de las diferentes partes que componen la sucesión sí importa. En esta tradición el diagrama se entendería como secuencia sentimental y "erótica", a diferencia del diagrama estrictamente funcional. Dentro de esta tradición sentimental, si seguimos a Robin Middleton ${ }^{16}$, se encuentra Nicolas Le Camus de Mézières (1721-1789) como uno de los pioneros. Como dice Middleton: "el manejo del espacio, o más bien, el de la secuencia de espacios, para determinado efecto sensual fue primero analizado por Le Camus de Mézières. Esta fue su contribución a la teoría de la arquitectura." ${ }^{17}$ También podríamos incluir dentro esta tradición erótica los escritos de Rob Krier o de Bernard Tschumi en los años 70 y $80^{18}$. Estas dos posibilidades, una sentimental y la otra funcional, nos recuerdan los famosos conceptos de circulation en caso de eficiencia máxima y promenade, en caso de dilatación de un recorrido $^{19}$.

La sintaxis espacial ha sido utilizada en investigaciones recientes, como la de Kim Doovey y compañía, sobre el Educatorium de $\mathrm{OMA}^{20}$, lo que ha permitido ejemplificar y avanzar en su aplicación. Sin embargo, surgen ciertas dificultades al momento de aplicarla en Le Corbusier. Una de ellas es que este arquitecto concibe los recorridos, no sólo en términos funcionales, sino también a través de las múltiples sensaciones que estos evocan, como se puede ver en su Précisions (1930) (imagen 3B.) Los cambios de sensación como han observado Josep Quetglas y otros, suelen ser sutiles y pequeños, un tapete, un escalón, el marco de una puerta, un cambio de color $^{21}$, por lo que abstraernos de ellos iría en contra de la arquitectura. Sin embargo, no podremos ver estos detalles sino a modo conclusivo, y siempre relacionándolos a la sintaxis. Otra dificultad al emplear la sintaxis espacial es la representación de los espacios semi-abiertos, aquellos que están afuera y adentro al mismo tiempo como el cavedji, o cavaedium del CCVA (imagen 1). Estos se representarán con líneas punteadas. Quizá la dificultad mayor en relación a la sintaxis espacial es la representación de la flexibilidad, como ocurre por ejemplo con los salones para seminarios, que en el primer proyecto se encuentran dentro del auditorio o dentro de los talleres.

\section{Simulacros de sintaxis (dos escuelas)}

Sólo un año después de su construcción, Sigfried Giedion critica el edificio por sus espacios tipo bodega y por otros espacios "difíciles de animar". Como él mismo dice: "De alguna manera, Le Corbusier ha sentido la comprensible incompletud del programa. Ésta surgió bajo los plásticamente sobresalientes espacios de taller, bajo los pilotis, y cavidades, los cuales son difíciles de animar. Sin más, Le Corbusier habría encontrado la posibilidad de incorporar un aula espaciosa, faltante en el gran volumen de la construcción." ${ }^{22}$ Esta temprana

\footnotetext{
${ }^{16}$ LE CAMUS DE MÉZIÈRES, Nicolas, (int.) MIDDLETON, Robin, The Genius of Architecture; or, The Analogy of that Art with our sensations, Santa Monica, CA: The Getty Center for the History of Art and the Humanities, (1780) 1992.

${ }^{17}$ Middleton menciona a Serlio como un posible antecesor de Le Camus. Idem, p. 31.

18 "Eroticism is a constituent part of architectural choreography. Anyone who disputes this, has not yet enjoyed life to the full". KRIER, Rob, Architectural Composition, London, Academy Editions and Rob Krier, 1988, p.24 Ver también TSCHUMI, Bernard, "Sequences", En: Architecture and Disjunction, 1996: Boston, MIT press. pp. 153-173

${ }^{19}$ PÉREZ-DE-ARCE, Rodrigo, "El Atajo y la Promenade", En: Massillia: annuario de estudios lecorbusierianos, \# 2007,"Guillermo Jullian de la Fuente", pp. 138-153.

${ }^{20}$ DOVEY, Kim., DICKSON, Scott, "Architecture and Freedom? Programmatic Innovation in the Work of Koolhaas", En: Journal of Architectural Education, Vol. 56, No. 1 (Sep., 2002), pp.4-13

${ }^{21}$ Ver QUETGLAS, Josep, Les Heures Claires. Proyecto y Arquitectura en la Villa Savoye de Le Corbusier y Pierre Jeanneret, Sant Cugat del Vallès, Associació d'Idees. Centre d'investigacions Esthètiques, 2009.

22 "Irgendwie hat Le Corbusier die begreifliche Unvollständigkeit des Proramms empfunden. Es entstanden unter den plastisch hervortretenden Werkstatträumen, unter den Pilotis, Hohlräume, die schwer zu beleben sind. Ohne weiteres
} 
crítica, se debe a que Giedion no pudo ver el edificio en uso posteriormente, pues éstos espacios han sido utilizados por estudiantes y artistas invitados para exhibir sus obras. El cavedji, o plaza de recibimiento ha sido particularmente importante para este propósito, albergando entre otros, un pequeño teatro efímero para marionetas, diseñado por Pierre Huyghes. En una fotografía de 1969 ya lo podemos ver animado con pinturas. (Imagen 1.)

La "incompletud del programa" tampoco es muy cierta. Como vemos en los anexos ${ }^{23}$ del libro de William J. Curtis, el programa está completamente detallado. Fue redactado por el propio Comité para la práctica de las Artes Visuales en Harvard, cuyo presidente era Josep Lluís Sert, y en él participaron el escultor Mirko Basaldella, primer profesor invitado del centro, y Eduard F. Seckler, su primer director. Como observa Curtis, el programa fue dejado intencionalmente abierto por este comité, "casi la mitad del espacio total fue adjudicada a estudios y talleres, una cuarta parte a exposiciones, y el resto al lobby vestíbulo, una sala de conferencias, salones para seminarios, oficinas, almacenamiento y servicios (...) las funciones fueron luego distribuidas en una estructura de tres niveles con sótano". ${ }^{24}$

El análisis del edificio a través de la sintaxis espacial, nos mostrará los diferentes tipos de organización y de uso previstos durante el proceso de diseño. Antes de pasar a éste, veamos cómo se usaría el método de la sintaxis espacial en dos escuelas también dedicadas al arte, y diseñadas en tiempos diferentes por Le Corbusier: la escuela para Artistas Reunidos en la Chaux-des-fonds de 1910 y la Escuela para Arte y Arquitectura de Chandigarh de 1961. Las dos se estructuran alrededor de un patio central. Las dos son paralelepípedos. Pero en términos de programa y de sintaxis, la segunda es más grande y compleja que la primera. La Escuela de Artistas Reunidos que proyectó Charles-Édouard Jeanneret a los veintitrés años, bajo la supervisión de su maestro L'Épplatenier, aunque tiene un acceso principal, también tiene accesos independientes para los talleres de los artistas, lo cual produce un esquema en red en la primera planta. Al interior del edificio, accediendo por la parte central se llega a un gran salón de cursos a doble altura, el cual funciona como un espacio arborescente y de control por parte de los docentes en el nivel superior. La suma de los dos conforma un sistema híbrido, en el que se hace uso tanto del sistema en red para el trabajo independiente de cada artista, como del sistema arborescente para el funcionamiento arquitectónico del saber.

La escuela de Arte y Arquitectura de Chandigarh, cuyo diseño proviene de los módulos para enseñanza de Chandigarh de 1951, propone un esquema arborescente, con el gran lobby galería ocupando casi toda una cara del paralelepípedo. Éste funciona como un espacio de circulación, de control, pero también de exposición. El lobby, repartidor y estancia a la vez, remata a cada lado en dos espacios jerárquicos que son: el salón de conferencias a la derecha, y las oficinas administrativas a la izquierda. Al gran lobby-porche se le adosan dos corredores con doble crujía que conducen a las diferentes dependencias de la escuela. Los talleres de diseño se encuentran al fondo, conectados en galería (enfilade), por lo que podemos ver un sistema que se inicia arborescente y se combina con circulaciones en red y galería, pero cuyo genotipo principal es el árbol. Lo más profundo del sistema lo ocupa la biblioteca, antes de la cual se debe atravesar un segundo lobby. Claramente éste es el lugar más secreto del edificio, y por la tanto el más jerárquico, allí donde se guarda el saber.

hätte Le Corbusier die Möglichkeit gefunden, eine fahlenden, geräumigen Hörsaal in das grosse Bauvolumen einzugliedern." (traducción de Andrés Otalvaro y del autor), GIEDION, Sigfried, "Das Carpenter Center for Visual Arts der HarvardUniversität in Cambridge (MA)", En: Bauen+Wohnen, Vol. 18 \#8, Zurich, (August 1964), p. 332

${ }^{23}$ Ver appendix 1 en SECKLER y CURTIS, op.cit. p.281

${ }^{24}$ Idem. p. 41 


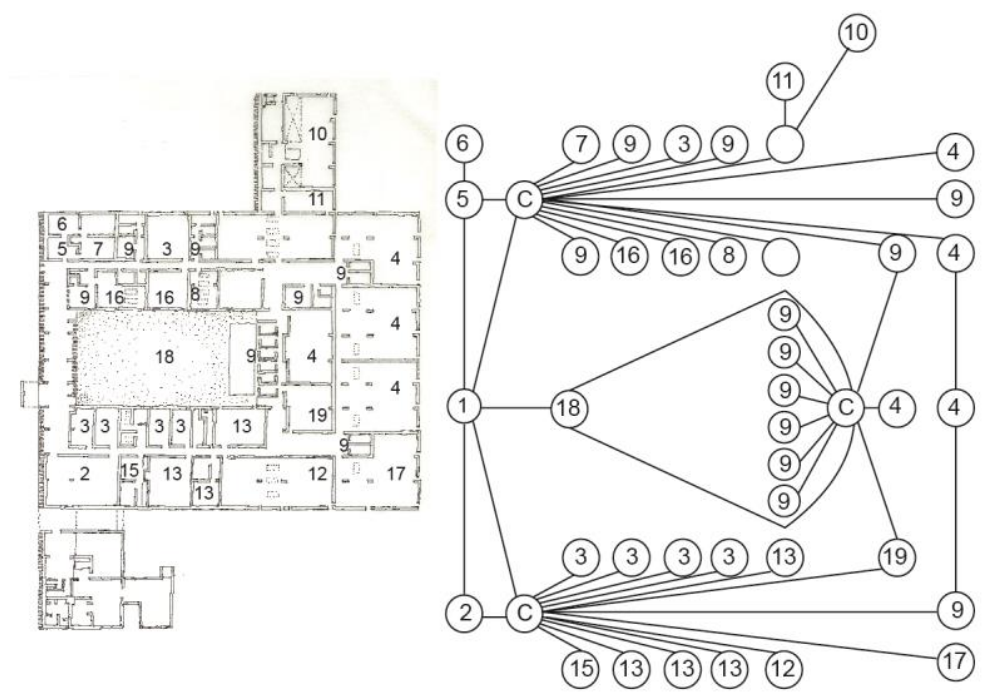

4. a. Calco Escuela de Arte y Arquitectura de Chandigarh, 1961. b. Sintaxis: 1. Lobby- porche; 2. Auditorio; C. Corredor; 3. Salones de conferencias; 4. Talleres; 5. Sala de espera; 6. Sala de Comité; 7. Oficina principal; 8. Células de investigación; 9. Profesores; 10. Biblioteca; 11. Hemeroteca; 12. Taller; 13. Almacén; 14. WC; 15. Fotografía; 16. Oficinas; 17. Museo; 18. Patio; 19. Cuarto de arte.

\section{Primer Proyecto}

El proyecto es iniciado con dos frases que aparecen durante la primera visita al sitio, entre el 12 y 15 de Noviembre de 1959. Éstas parecen registros de un sueño, visiones, o viejos recuerdos de Istambul. El 2 de febrero Le Corbusier le escribe un memorando oficial a Jullian, con otra descripción verbal del proyecto. Allí le pide que haga un extracto del cuaderno de notas de Boston, y Jullian parece añadir un círculo, que tiende a ser una espiral, y que Le Corbusier parece nunca haber dibujado. En esta fase del proyecto, como indica la correspondencia con Sert del 10 de febrero de 1960, también se elaboran maquetas del sitio en el Atelier, cuyas piezas y elementos, al parecer son móviles. ${ }^{25}$

El primer dibujo para el CCVA aparece el 1 de Abril, cinco meses después de la visita al sitio. Una versión idéntica del dibujo es copiada en el cuaderno que guarda la secretaria del Atelier ${ }^{26}$. En este diagrama se le adjudica a cada componente del programa definido por Harvard, un nivel del edificio. El nivel I es ocupado por los "pilotis totaux" (pilotis totales). Sus funciones son: lobby-vestíbulo, una sala de conferencias, salones para seminarios, oficinas, almacenamiento y servicio. El nivel II es para los talleres de "sculpture" (escultura). El nivel III es dedicado a la "peinture" (pintura). Y finalmente el nivel IV es para "exposition" (exposición), con un ascenso por la "route ascensionelle" (ruta ascendente). Con color amarillo se marcan dos flujos que atraviesan el proyecto, uno por la ruta ascendente y otro por el primer nivel. Aunque todavía no se puede observar la disposición interior del espacio, sí podemos decir que este es un diagrama en red, con dos accesos independientes, que conectan el espacio al interior.

\footnotetext{
${ }^{25}$ Ver KELLET, Ron, op. cit.

${ }^{26}$ VER. FLC 30397, LC PLANS, DVD VOL. 16. CCVA.
} 


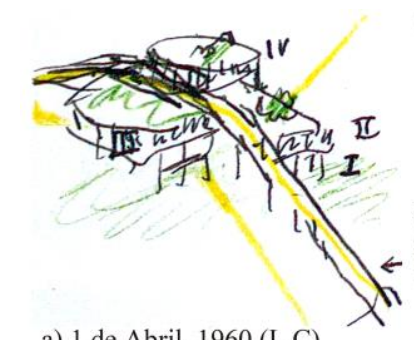

a) 1 de Abril, 1960 (L.C)

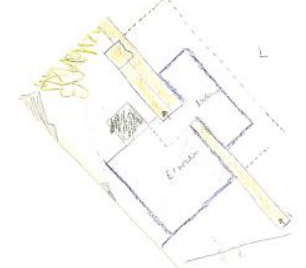

d) 10 de Abril, 1960 (Jullian)

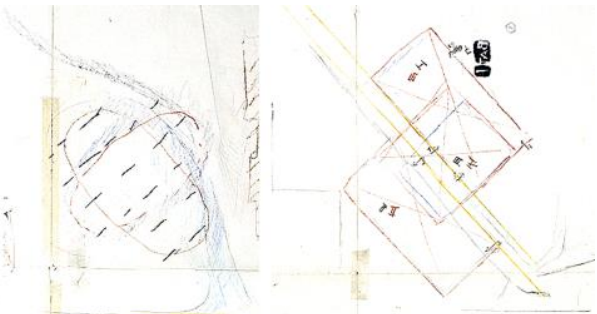

b) 7 de Abril, 1960 (L.C) c) 7 de Abril, 1960 (L.C)
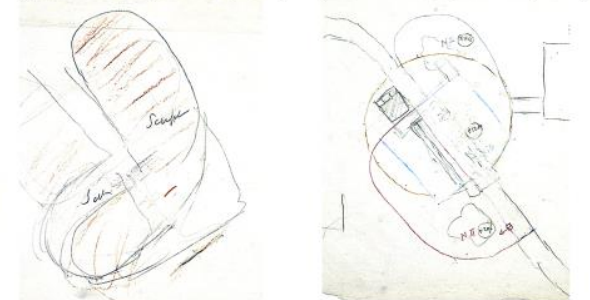

e) 11 de Abril, 1960 (L.C) f) 14 de Abril, 1960 (L.C)

5. Proceso primer proyecto

El primer proyecto evoluciona durante el mes de abril. El 7 de abril (Fig. 7b) Le Corbusier realiza un dibujo en planta conformado por dos óvalos yuxtapuestos, y atravesados por una rampa en espiral. William J. Curtis llama a este espacio: "un campo de fuerza" ${ }^{27}$. Este dibujo contrasta con otro que Le Corbusier realiza el mismo día a partir del recorte de las áreas previamente requeridas por el programa, y que se hace en planta y corte a la vez (C). Como dice Curtis, mientras el uno parece ser "el equivalente simbólico a la experiencia original del movimiento a través de la vegetación (...) el segundo plano hecho el mismo día es un estudio esquemático de la relación principal de los dos amplios estudios requeridos en el programa y del espacio para estudio más pequeño" ${ }^{28}$ Vemos aquí entonces, un dibujo fluido encaminado a recrear su idea del espiral y un acercamiento estrictamente funcional.

El 10 de Abril, Jullian continúa desarrollando los planos y cortes (D) hechos por Le Corbusier con áreas previamente recortadas (o "papiers découpés") (C), que según Curtis, citando entrevistas con Andreini y Jullian de la Fuente, era "el método que siempre usaba Le Corbusier en el Atelier." ${ }^{29}$ Como narra Curtis, parafraseando las entrevistas: "los recortes eran cambiados de lugar en un plano del sitio (buscando) formas y relaciones funcionales experimentales hasta que el arquitecto estaba satisfecho, y luego él simplemente trazaba sobre el borde del recorte y procedía, como en este caso, con su dibujo". ${ }^{30}$

El 12 de abril, Le Corbusier parece dibujar sobre las áreas previamente recortadas, usándolas como guía, aunque retornando a las formas ovoides (E). El 14 de abril, como si se juntaran las dos opciones contrastadas, surgen los contornos casi definitivos del edificio construido (F). En los días siguientes, Jullian le adapta el sistema estructural de pilotis a estas formas, calculando a la vez alturas en corte y los gradientes de la rampa. El proyecto que presenta Le Corbusier en el Harvard Hall a finales de junio de 1960, es dibujado por Jullian y terminado el 7 de junio de 1960 (G).

\footnotetext{
27 "(...) Le Corbusier's idea of a building as a "field force" affecting its surroundings". Curtis, op. cit. p 61

${ }^{28}$ Idem. p. 63

${ }^{29}$ Idem, p. 63 note 13 .

${ }^{30}$ Ibidem.
} 
La sintaxis del primer proyecto permanece casi idéntica a la del boceto del 1 de abril. Es una sintaxis en red, con ciertos elementos arbóreos, como el manejo de múltiples vestíbulos. En primer lugar se podría acceder por la rampa (6.1), o "travesía turística", llegando exclusivamente a la sala de exposiciones que cuenta con dos niveles conectados por otra rampa interna. La otra opción para entrar sería a través del lobby principal (6.2), que se abre a la plaza de recibimiento o cavedji, y que conduce luego a la sala de conferencias (6.3). Ésta tiene dos disposiciones posibles según la afluencia, y se encuentra en galería conectada con el estudio de luces y sonido (6.4), con la posible intención de hacer grabaciones de las conferencias y de los eventos. Una última entrada es provista en frente del elevador de carga (6.7), a través del cual se conecta el edificio verticalmente en uno de sus costados. La conexión al otro lado la establece una torre dotada con elevadores (6.11), baños (6.12), y escaleras (6.13). El lobby también se conecta con el sótano, donde se encuentran áreas destinadas al almacenamiento (6.6), así como también, una conexión subterránea con el museo Fogg. Las funciones a las que se les da importancia a través del recorrido son: la sala de exposiciones en el tercer piso, y la sala de conferencias; la función más profunda y privilegiada es el estudio del artista en el quinto nivel (6.37), rodeado de un "jardín de rocalla", inaccesible al turista común, si no es en caso de exhibiciones. En el libro de Curtis podemos ver algunas fotos de Bassaldella en 1964, sentado junto a la ventana, y al lado de la terraza jardín cubierta de nieve, en ese espacio sólo accesible para el artista, con una vista de Cambridge al fondo.

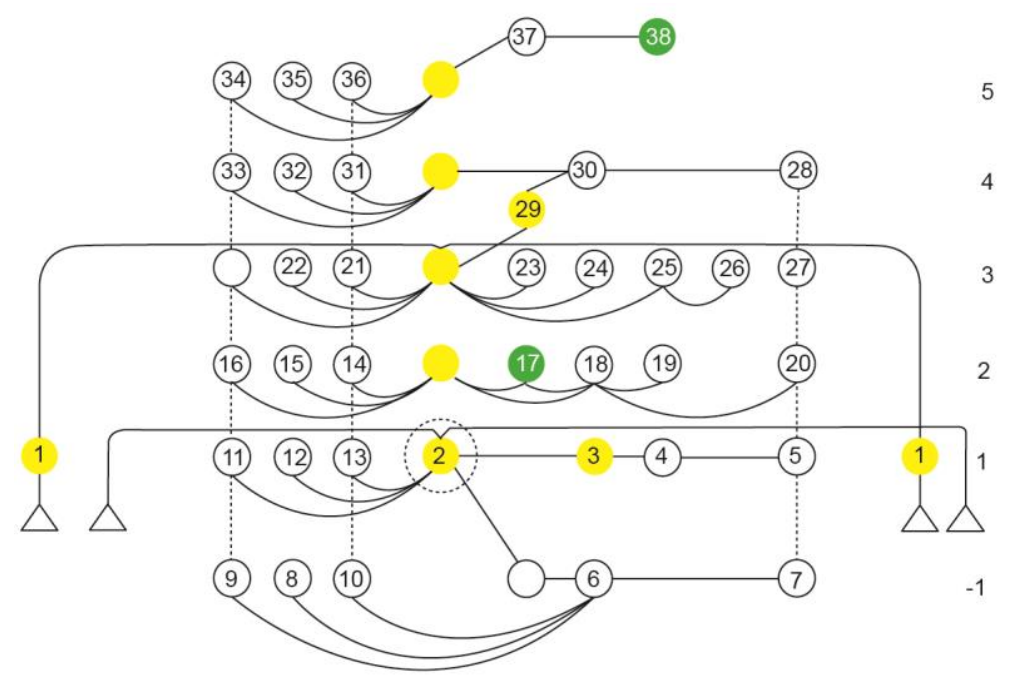

6. Sintaxis Primer proyecto:

1. Rampa; 2. Lobby; 3. Sala de Conferencias; 4. Estudio; 5. Montacargas; 6. Lobby -1; 7. Montacargas $-1 ; 8$. Lockers; 9. Elevadores; 10. Escaleras; 11. Elevadores; 12. WC; 13. Escaleras; 14. Escaleras; 15. WC; 16. Elevadores; 17. Espacio abierto complementario; 18. Taller de 3D; 19. Almacenamiento; 20. Montacargas; 21. Escaleras; 22. WC; 23. Taller $2 \mathrm{D} ; 24$. Almacenamiento; 25. Oficinas administrativas; 26. Oficina del director; 27. Montacargas; 28. Montacargas; 29. Rampa; 30. Exhibición; 31. Escaleras; 32. WC; 33. Elevadores; 34. Elevadores; 35. WC; 36. Escaleras; 37. Studio; 38. Terraza

\section{Segundo Proyecto}

El segundo proyecto surge principalmente por requerimientos técnicos exigidos por el cliente durante la primera fase de diseño y por problemas de circulación no resueltos, como el acceso al montacargas y la rampa de la sala de exhibición entre el tercer y cuarto nivel, la cual nunca fue construida. Durante la visita que Le Corbusier hace en junio a Boston para presentar el proyecto, realiza nuevamente un diagrama en su cuadernillo (7.b), en el que enfatiza la vista del edificio sobre el conjunto del campus, "l'ensemble du campus". Esta es la 
vista más lejana y la primera que tiene el visitante cuando se acerca desde la estación de metro atravesando Harvard Yard. Después de las vacaciones de verano, mientras Jullian trabaja resolviendo el punto más apropiado para el montacargas pero además el sótano y la sala de exhibición en el tercero y cuarto nivel, Sert se encuentra trabajando con sus asociados en Boston, principalmente sobre el sótano y el primer nivel (7.c). Las indicaciones de Sert llegan en octubre a Paris, y es sólo en enero de 1961 que Jullian resuelve estos problemas (7 d), para después ejecutar los planos que estudian Sert y Asociados en la primavera de ese mismo año (7 e).

La sintaxis final que establece el segundo proyecto será muy similar a la del edificio construido, a excepción de algunos movimientos, de la suma de requerimientos del cliente, y de la incorporación de ciertas normas para la construcción del estado de Massachusetts. Las funciones principales que cambian de localización son: 1. Las oficinas de la administración, que pasan del tercer al primer nivel (requerimiento del cliente) (fig. 8.10; 8.3; 8.4; $8.5 ; 8.6)$ y 2 . La sala de conferencias, a la cual se llega ahora por el sótano, después de atravesar el lobby principal, y que cuenta en este proyecto con una salida de emergencia (fig. 8: 16). También desaparece la rampa del tercer al cuarto nivel, con lo que se anula la comunicación con el cuarto nivel. El montacargas se ubica en un punto definitivo y contiguo a este aparecen escaleras de emergencia, conectadas por un corredor (fig. 8. 8; 8.9)
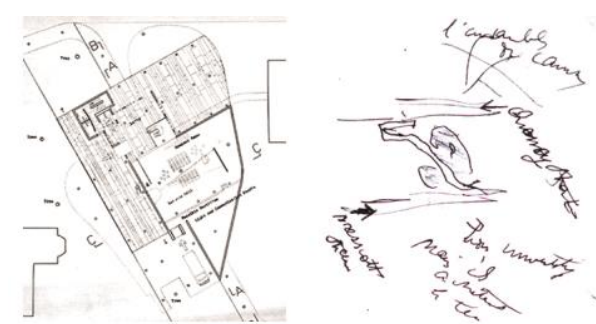

a) 7 de Junio, 1960 (Jullian)
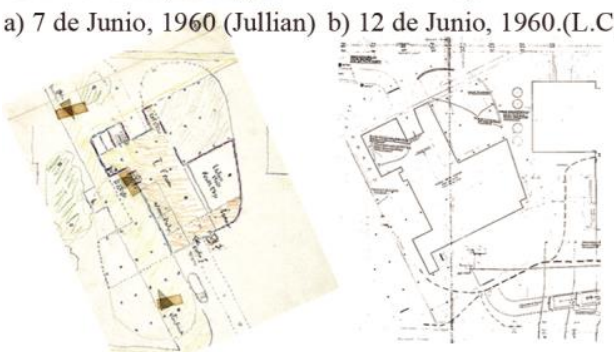

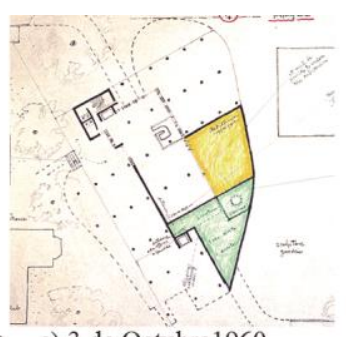

c) 3 de Octubre 1960 .
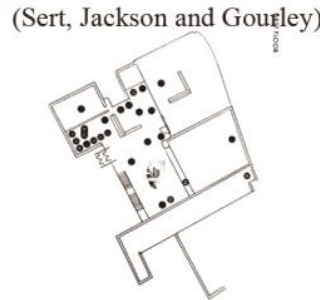

d) 11 de Enero, 1961 (Jullian) e) 5 de Octubre, 1961 (Jullian) f) Brute Catalog, 2013.

7. Proceso segundo proyecto

La sintaxis del sistema sigue siendo una red, con la posibilidad de ciertos recorridos en espiral al interior del edificio, como quería el arquitecto en un comienzo. Se puede observar también que existen tres modos de ingreso, aunque no todos con la misma función. Los dos ingresos principales, por la rampa, y por debajo del edificio, como se observa en un dibujo del 18 de enero de 1961 elaborado por Jullian (fig.9), tienen dos condiciones diferentes, uno está marcado: "étudiants" y el otro "public". Uno es para el estudiante, otro es para el turista. Además se encuentra el ingreso de servicio, en la parte trasera hacia Prescott Street. También aparecen dos salidas de emergencia, una en la sala de conferencias, que no se construyó, y otra por la escalera de emergencia. 


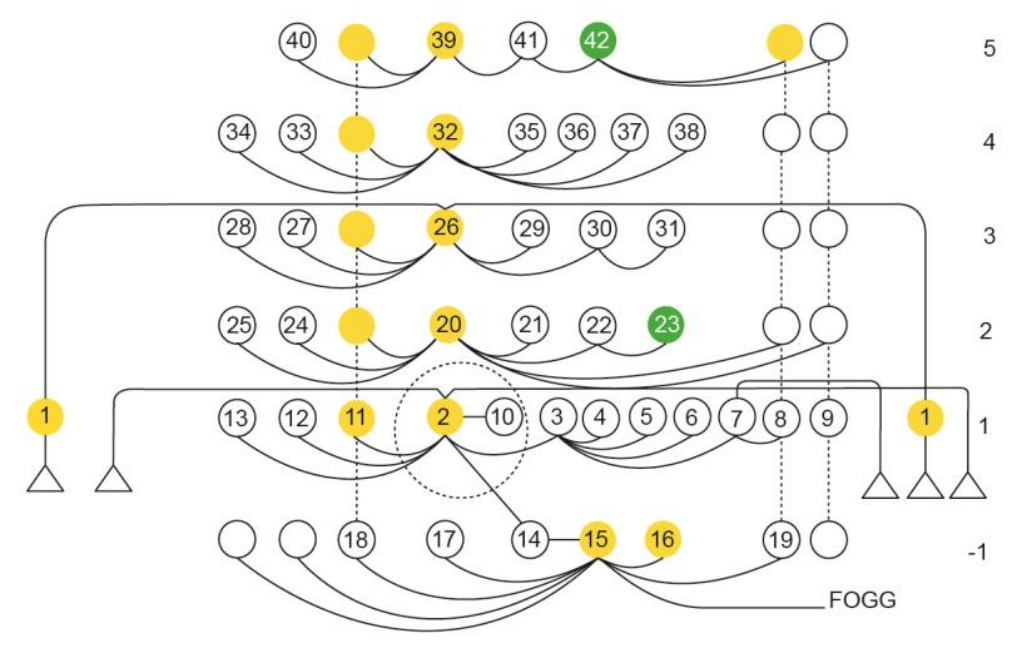

8. Sintaxis segundo proyecto

1. Rampa; 2. Lobby; 3. Secretariado; 4. Facultad; 5. Facultad; 6. Oficina del director; 7. Corredor; 8. Escaleras; 9. Elevadores; 10.Facultad (actual director); 11. Escaleras; 12. WC; 13. Almacenamiento; 14. Escaleras; 15. Lobby; 16. Sala de Conferencias; 19. Elevadores; 20. Lobby 2; 21. Taller 3D; 22. Escultura; 23. Jardín interior; 24. WC; 25. Oficinas; 26. Lobby $3 ; 27$. WC; 28. Oficinas; 29. Pintura; 30. Galería Sert; 31. Terraza; 32. Lobby 4; 33. WC; 34 Oficina; 35 . Talleres independientes; 36. Salón de seminarios; 37. Salón de seminarios; 38. Salón de seminarios; 39. Lobby 5; 40. WC; 41. Studio; 42. Terraza.

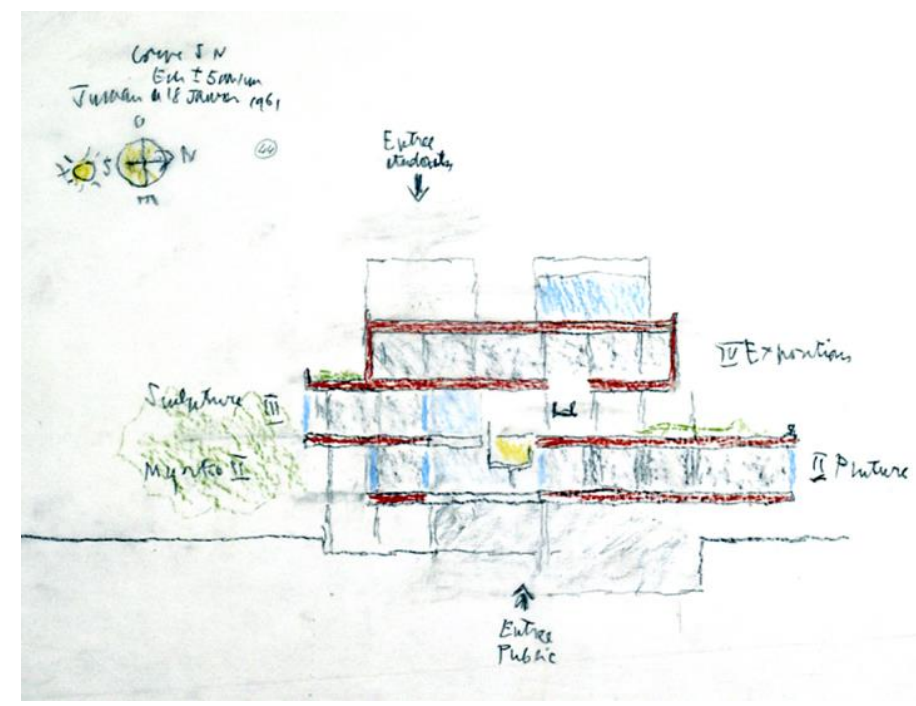

9. Sección Sur Norte. Guillermo Jullian, Enero 18, 1961.

\section{Posibilidades de sintaxis, o de promenade architecturale}

Como se puede observar en el proyecto construido y en el diagrama de sintaxis del último proyecto, las tres formas de ingreso pueden desembocar en una gran variedad de recorridos al interior del edificio. Sin embargo, como muestran los dibujos del proceso, desde un inicio estaban proyectados dos tipos de ruta, que en los dibujos finales se especifican como para "étudiants" y "public", y en el primer boceto se identifican con dos rayas amarillas, una por debajo y otra por la rampa. En relación con la teoría y la utilización de la promenade architecturale de Le Corbusier, habría que insistir que a estas múltiples posibilidades se les debe sumar la 
descripción de cada una de las formas, colores y texturas que va encontrando a su paso la persona que experimenta el edificio, y que bien puede ser un estudiante, o un turista.

Después de la pausa que provee el cavedji, en comunicación con el lobby y con una oficina para facultad (que ahora ocupa el director del centro), el visitante entrará al edificio por el lobby principal, o por la rampa, buscando la salida de este espacio sin acceso. Una vez dentro del edificio, como lo muestran claramente algunos dibujos en sección, elaborados en la última fase del proyecto, el visitante podrá recorrer los sitios públicos, es decir los lobby de cada piso que hacen parte de la torre de servicios, pero no tendrá acceso a los talleres. Aunque sí puede recorrer la sala de exposiciones en el tercer nivel, por la rampa o por la torre de escaleras, quizá el modo más común de terminar la "ruta turística" sea en el auditorio, donde se encuentra el tapete de Le Corbusier "La Femme et le Moineau", de $1957^{31}$. El estudiante y el artista son quienes más se beneficiarán con las sensaciones del espacio. Aunque el artista tiene a su disposición toda la terraza del quinto nivel, el estudiante también puede terminar su promenade architecturale, bien sea en el salón de seminarios integrado al taller del tercer nivel, o bien sea en los salones del seminario del cuarto, cuyos tragaluces marcan un momento sublime del recorrido, y donde el estudiante recibirá por parte de sus docentes y del espacio mismo las enseñanzas del 'saber habitar'. El primero es el espacio de las enseñanzas de la mano y del cuerpo, es redondo y oblicuo, el segundo es el de la enseñanza de la mente, es cuadrado y demasiado pequeño para su tragaluz, el cual se encuentra desfasado con respecto a las paredes del salón.

Con respecto a "los espacios difíciles de animar" de los que hablaba Sigfried Giedion, podemos ver que estos se han usado desde muy temprano en la historia del centro, como vimos en la primer imagen, hasta hoy en día, como lo han dejado ver varias exhibiciones en la plaza de recibimiento, desde Arquitecturas Inflables, Teatros de Marionetas, hasta exposiciones recientes como Brute en 2013, en la que se usó casi todo el Carpenter Center, incluyendo los estudios y terrazas del quinto nivel, e incluso la oficina del director (fig. 7f). Este uso del edificio a través del arte merece ser profundizado en una investigación posterior.
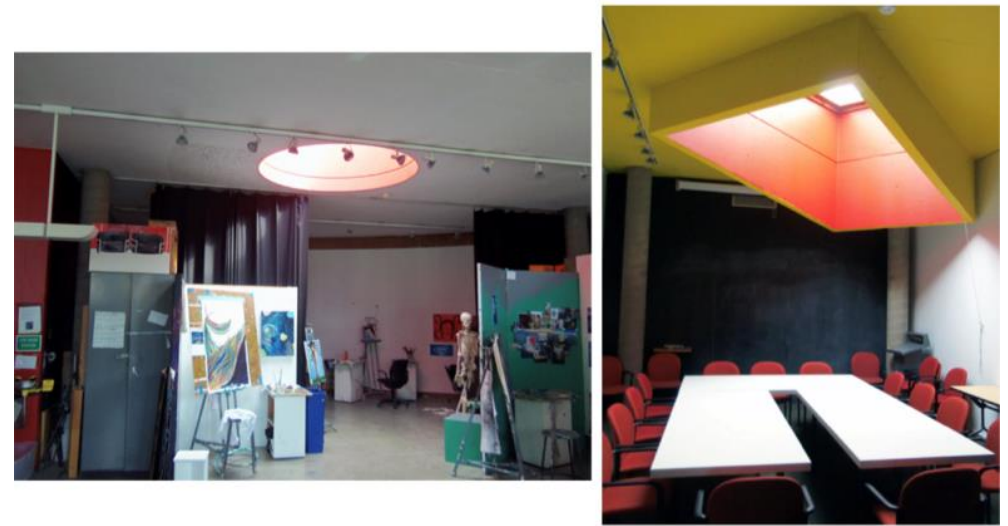

10. Espacios para seminarios, foto del autor, Abril 2015.

\footnotetext{
${ }^{31}$ MATHIAS, Martine, Le Corbusier: Oeuvre Tissé, Paris: Philippe Sers éditeur, 1987
} 


\section{Agradecimientos}

El autor le agradece muy especialmente a James Voorhies, director del Carpenter Center for the Visual Arts y a Timothy Driscoll, del Harvard University Archive, por su generosidad y ayuda con los archivos del edificio; a Caroline Dagbert del Centre Canadien d'Architecture, Montréal; a Isabelle Godineau y Arnaud Dercelles de la Fondation Le Corbusier; a Carlos Jullian de la Fuente y su hija Anne-Laure y a Anne Pendleton-Jullian, por su valiosa colaboración. Infinitos agradecimientos también a Maximo Kitever por su ayuda en Paris, a Andrés Otálvaro por las traducciones y a Beatriz Ramírez por su ayuda con las ilustraciones y las correcciones.

\section{Lista de imágenes}

1. "Mirko 1969-1970" Exhibition, Fotógrafo desconocido, 19724, Box 13, Harvard University Archives.

2. Extract Sketchbook Boston 59, Guillermo Jullian de la Fuente, 1960, Ink on translucent paper, $27.1 \times 21.1 \mathrm{~cm}$, Fonds Guillaume Jullian de la Fuente, Collection Centre Canadien d'Architecture/Canadian Center for Architecture, Montréal.

3a. Croquis et organigramme d'un logement/ FLC 18318 - Numéro 41. LC PLANS vol.3. Maison Loucheur, 1929.

3b. Diagrama de ritmos (imagen sin título), LE CORBUSIER, Précisions sur un État Présent de l'Architecture et de l'Urbanisme, Paris: Éditions Vincent, Fréal \& Cie, 1935, p. 75.

4a. Planta de la Escuela de Arte y Arquitectura de Chandigarh (calco del autor)

4b. Sintaxis. Dibujo del autor

5. Proceso del primer proyecto:

5a. Sketch de Abril 1, 1960, Le Corbusier. Le Corbusier Sketchbooks Vol. 4, 1957-1964, notes by FRANCLIEU Françoise, Cambridge, MA: the MIT Press, Fondation Le Corbusier and the Architectural History Foundation. Sketchbook P59. imagen 447.

5b. Sketch studies of shematic site plan in color with party wall, Le Corbusier, Abril 7, 1960, FLC 31197. LC Plans vol. 16. Carpenter Center for the Visual Arts.

5c. Sketch studies of plan with longitudinal section through ramp opposite, principle, Le Corbusier, Abril 7 , 1960, FLC 31318.

5d. Boston First floor, Guillermo Jullian, Abril 10, 1960, FLC 31208.

5e. Sketch studies of shematic floor plan in color (exposition) with captions, Le Corbusier, Abril 11, 1960, FLC 31213.

5f. B // Sketch Studies of floor plan in situ with ramp, party wall / Color, captions, heights / Stamp BAT I, Le Corbusier, Abril 14, FLC 31217.

6. Sintaxis del primer proyecto. Diagrama del autor.

7. Proceso del segundo proyecto:

7a. 5657 / I // Floor plan with interior layout, paving, Guillermo Jullian, junio 7, 1960, FLC 31254.

7b. L'ensemble du campus, Sketch de Le Corbusier, junio 12, 1969, Le Corbusier Sketchbooks Vol. 4, op. cit. imagen 500.

7c. Proposition ground level, Sert, Jackson and Gourley, Octubre 3, 1960, FLC 31315.

7d. Drawing no. 2 // Three sketch studies of floor plan level 1, 2, 3 with captions, Guillermo Jullian, Enero 11, 1961, FLC 31343.

7e. VAC \& Fogg Museum, Jullian, Octubre 5, 1961, FLC 30336.

7f. Floor plan disposition from Brute! Exhibition catalog, 2013, 19724, Box 11, Harvard University Archives.

8. Sintaxis segundo proyecto. Diagrama del autor. 
9. Section south-north // Sketches of transverse section with captions, orientation / Colot / No. 44, Guillermo Jullian, FLC 31349.

10. Salones de seminario, fotos del autor, 2015.

\section{Bibliografía}

ALLEN, Stan, "Diagrams Matter", En: ANY: Architecture New York, "Diagram Work: ATA MECHANICS FOR A TOPOLOGICAL AGE", No. 23, (1998), pp. 16-19

DOVEY, Kim, DICKSON, Scott, "Architecture and Freedom? Programmatic Innovation in the Work of Koolhaas", En: Journal of Architectural Education, Vol. 56, No. 1 (Sep., 2002), pp. 4-13

EMMONS, Paul "Embodying networks: bubble diagrams and the image of modern organicism", En: The Journal of Architecture, 11:4, 2006, 441-461.

GIEDION, Sigfried, "Das Carpenter Center for Visual Arts der Harvard-Universität in Cambridge (MA)", En: Bauen+Wohnen, Vol. 18 \#8, Zurich, (August 1964), p. 332

GRESLERI, Giuliano, "The Rediscovered Carnets", en: Le Corbusier (Ch.-E.Jeanneret), Voyage d'Orient. Carnets, english edition, Milano: Fondation Le Corbusier, 1987, p. 13.

HILLIER, Bill, The Social Logic of Space, 7th ed., Cambridge 1984: Cambridge University Press, p. 14.

JULLIAN DE LA FUENTE, Guillermo and EARDLEY, Anthony, Atelier rue de Sèvres. An exhibition of project sketches and notes from Le Corbusier to Guillermo Juliian de la Fuente while working in the Atelier Le Corbusier between 1959 and 1965, Lexington, Ky.: College of Architecture, University of Kentucky, Art Gallery, 1975.

KELLETT, Ron, "Le Corbusier's design for the Carpenter Center: a documentary analysis of design media in architecture", En: Design Studies, Volume 11, Issue 3, July, 1990, pp. 164-179.

KRIER, Rob, Architectural Composition, 1988: London, Academy Editions and Rob Krier,

LE CAMUS DE MÉZIÈRES, Nicolas, MIDDLETON, Robin (int.), The Genius of Architecture; or, The Analogy of that Art with our sensations, Santa Monica, CA: The Getty Center for the History of Art and the Humanities, (1780) 1992.

Le Corbusier Sketchbooks Vol. 4, 1957-1964, notes by FRANCLIEU Françoise, Cambridge, MA: the MIT Press, Fondation Le Corbusier and the Architectural History Foundation. Sketchbook P59. imagen 447.

LE CORBUSIER, Précisions sur un État Présent de l'Architecture et de l'Urbanisme, Paris: Éditions Vincent, Fréal \& Cie, 1935 (1930).

LE CORBUSIER, Une Petite Maison, Zurich, Editions Girsberger, Les Carnets de la Recherche Patiente No.1, 1954 ,

LE CORBUSIER, L'Átelier de la Recherche Patiente, Paris: Éditions Vincent Fréal, 1960.

MATHIAS, Martine, Le Corbusier: Oeuvre Tissé, Paris: Philippe Sers éditeur, 1987.

PÉREZ-DE-ARCE, Rodrigo, "El Atajo y la Promenade", En: Massillia: annuario de estudios lecorbusierianos, \# 2007, "Guillermo Jullian de la Fuente", pp. 138-153.

QUETGLAS, Josep, Les Heures Claires. Proyecto y Arquitectura en la Villa Savoye de Le Corbusier y Pierre Jeanneret, Sant Cugat del Vallès, Associació d'Idees. Centre d'investigacions Esthètiques, 2009

REICHLIN, Bruno, «L'œuvre n'est plus faite seulement d'elle-même », in REICHLIN Bruno et MOREL JOURNEL Guillemette (dir.), En: Cahiers de la Recherche Architecturale et Urbaine "Le Corbusier. L'atelier intérieur: L'intertextualité à l'oeuvre", n. 22-23, février 2008. 
SEKLER Eduard F., CURTIS, J. William, Le Corbusier at work. The genesis of the Carpenter Center for the Visual Arts, Cambridge, MA: Harvard University Press, 1978. p. 58 Carta del 15 de febrero de 1960 (traducida por el autor).

TSCHUMI, Bernard, "Sequences", En: Architecture and Disjunction, Boston: MIT press, 1996.

VIDLER, Anthony Vidler, "Diagrams of Diagrams: Architectural Abstraction and Modern Representation", En: Representations, No. 72 (Autumn, 2000), pp. 1-20. Se le agradece a uno de los revisores anónimos del congreso por la sugerencia de esta lectura. 


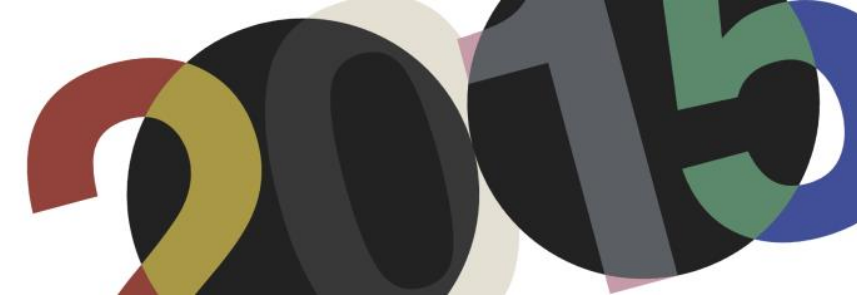

DOI: http://dx.doi.org/10.4995/LC2015.2015.680

\title{
Dibujando La Casa Peyrissac
}

\author{
A. Saseta Naranjo \\ Doctoranda en el Departamento de Proyectos Arquitectónicos de la ETSA de Barcelona (UPC, España) y \\ Lecturer en Dar Al Uloom University (Riad, Arabia Saudí)
}

\begin{abstract}
Resumen: Se trata de imaginamos en la piel de un empleado de Le Corbusier al que se le encomienda la misión de pasar a limpio unos croquis relativos al proyecto de una casa. Los croquis mencionados son realizados por Le Corbusier en 1942, durante su estancia en Argel, y hacen referencia a una casa diseñada para una propiedad agrícola cerca de la Montaña Chenoua perteneciente a la familia Peyrissac. Disponemos de dichos croquis gracias a la Fundación Le Corbusier y también contamos con la información ofrecida por La Cuvre Complète, aunque en su mayoría consiste en una selección de los mismos dibujos acompañados de algunas notas aclaratorias. Por razones de operatividad se ha optado por recurrir a la tecnología actual, de esta manera todos los dibujos han sido realizados por ordenador. Básicamente nos hemos centrado en una serie de dibujos, que consideramos son los últimos cronológicamente hablando y que representan la planta baja, primera y de cubiertas, una sección transversal de la casa, y sendas axonometrías. También hemos prestado atención al resto de la documentación existente, especialmente a los dibujos que hacen referencia a la implantación de la casa en su entorno, a la organización global y al programa de necesidades, así como cualquier información concreta sobre dimensiones. Hemos insertado la casa en la parcela original, previa búsqueda de la misma, hemos dibujado la planta baja, la planta primera, y una sección transversal, todo ello atendiendo a la información prestada por los dibujos originales del maestro. Como ejercicio hemos dibujado una hipótesis de detalle constructivo de cubiertas.
\end{abstract}

Abstract: It is imagined to be a Le Corbusier employee who is commissioned to draft a house based on some original drawings. These drawings are made by Le Corbusier in 1942, during his stay in Algeria, and refer to a house designed for an agricultural property near the Mountain Chenoua which belongs to Peyrissac family. The original drawings have been provided by Le Corbusier Foundation. Also, The Euvre Complète provides information for this project, although mostly consists of a selection of the same drawings accompanied by some explanatory notes. For operational reasons it is decided to use current technology, so all drawings have been made by computer. Basically it has been focused on a series of drawings, which it is believed are the last ones and represent the ground, first floor plan and the roof, also a cross-section of the house, and two axonometrics. It has been paid attention to other existing documentation, especially drawings that refer to the implementation of the house in its surrounding, the organization and the program requirements, as well as any specific information about dimensions. The house has been inserted in the original plot and the ground floor, first floor, and a cross section have been drawn, based on the information provided by the original drawings of the Master. As an exercise, a hypothetical construction detail of the roof has been drawn.

Palabras Clave: Le Corbusier; Peyrissac; Chenoua; Argel; Croquis; Casa. Keywords: Le Corbusier; Peyrissac; Chenoua; Argel; Sketch; House.

\section{Introducción}

El cuerpo de este trabajo se realiza como ejercicio de curso, en el seminario titulado Análisis de Obras y Proyectos, impartido por Josep Quetglas en los Cursos de Doctorado del Departamento de proyectos Arquitectónicos, en el año 2005. Para este congreso, el trabajo ha sido revisado y ampliado significativamente.

El ejercicio consiste en imaginarnos en la piel de un empleado de Le Corbusier al que se le encomienda la misión de pasar a limpio unos croquis relativos al proyecto de una casa. Sin muchas explicaciones, se le 
proporciona una carpeta llena de bocetos a mano alzada y se le pide que delinee la casa completa. Tendremos que averiguar la cronología de los croquis, analizar cada dibujo y cada anotación, y resolver las posibles contradicciones típicas del método prueba-error de las primeras fases de un proceso de diseño. Como somos un empleado veterano, instruido en el modus operandi del maestro, nos podremos apoyar en soluciones adoptadas en otros proyectos.

Los croquis mencionados son realizados por Le Corbusier en 1942, durante su estancia en Argel, y hacen referencia a una casa diseñada para una propiedad agrícola cerca de la Montaña Chenoua, perteneciente a la familia Peyrissac.

Por razones de operatividad se ha optado por recurrir a la tecnología actual, de esta manera todos los dibujos han sido realizados por ordenador.

Siendo el objetivo del trabajo "pasar a limpio" la información existente en los croquis originales, después de un análisis y clasificación de los mismos, nos hemos centrado en una serie de dibujos, que consideramos son los últimos cronológicamente hablando, y que representan la planta baja, primera y de cubiertas, una sección transversal de la casa, y sendas axonometrías. También hemos prestado atención al resto de la documentación existente, especialmente a los dibujos que hacen referencia a la implantación de la casa en su entorno, a la organización global y al programa de necesidades, así como a cualquier información concreta sobre dimensiones.

\section{Dibujando La Casa Peyrissac}

\subsection{Clasificación y análisis de los croquis originales}

Lo primero que hemos hecho ha sido analizar la información original existente relativa a La Casa Peyrissac, la cual consiste en 36 croquis originales a los que hemos tenido acceso en su totalidad gracias a La Fundación Le Corbusier ${ }^{1}$, y a 8 Páginas de La Euvre Complète ${ }^{2}$ dedicadas a dicha casa, que consisten, básicamente, en la reproducción de algunos de los croquis previamente mencionados a los que se le han añadido anotaciones, en algunos casos muy esclarecedoras.

Después de analizar los 36 croquis previamente mencionados, hemos asociado a cada uno de ellos diferentes temáticas y los hemos relacionado en una tabla. Las temáticas mencionadas son: La implantación en la parcela, la relación de la casa con las principales vistas, con el límite de la propiedad, con el camino comunal y con la disposición de la piscina; las cotas de nivel, el programa de necesidades, las plantas, las secciones, las fachadas, la estructura, la cubierta, la volumetría definitiva y todo lo relativo a dimensiones generales y materiales. Por último, hemos señalado cada detalle que nos puede ayudar a encontrar la parcela dentro de la planimetría de Argel.

\footnotetext{
${ }^{1}$ Colección de 36 croquis originales dibujados por Le Corbusier en relación a La Casa Peyrissac y facilitadas por La Fundación Le Corbusier. Ver listado, clasificación y análisis de los mismos en las tablas 1, 2, 3, 4 y 5.

${ }^{2}$ Le Corbusier CEuvre Complète Volume 4. 1938-46. 14a ed. Birkahauser, Basel: W. Boesiger, 2013.
} 
A continuación se adjunta una tabla con el listado de imágenes y su clasificación según temáticas, así como 4 tablas más con los croquis originales agrupados. Por cuestiones de espacio se han omitido 4 croquis que no se han considerado relevantes para este trabajo.
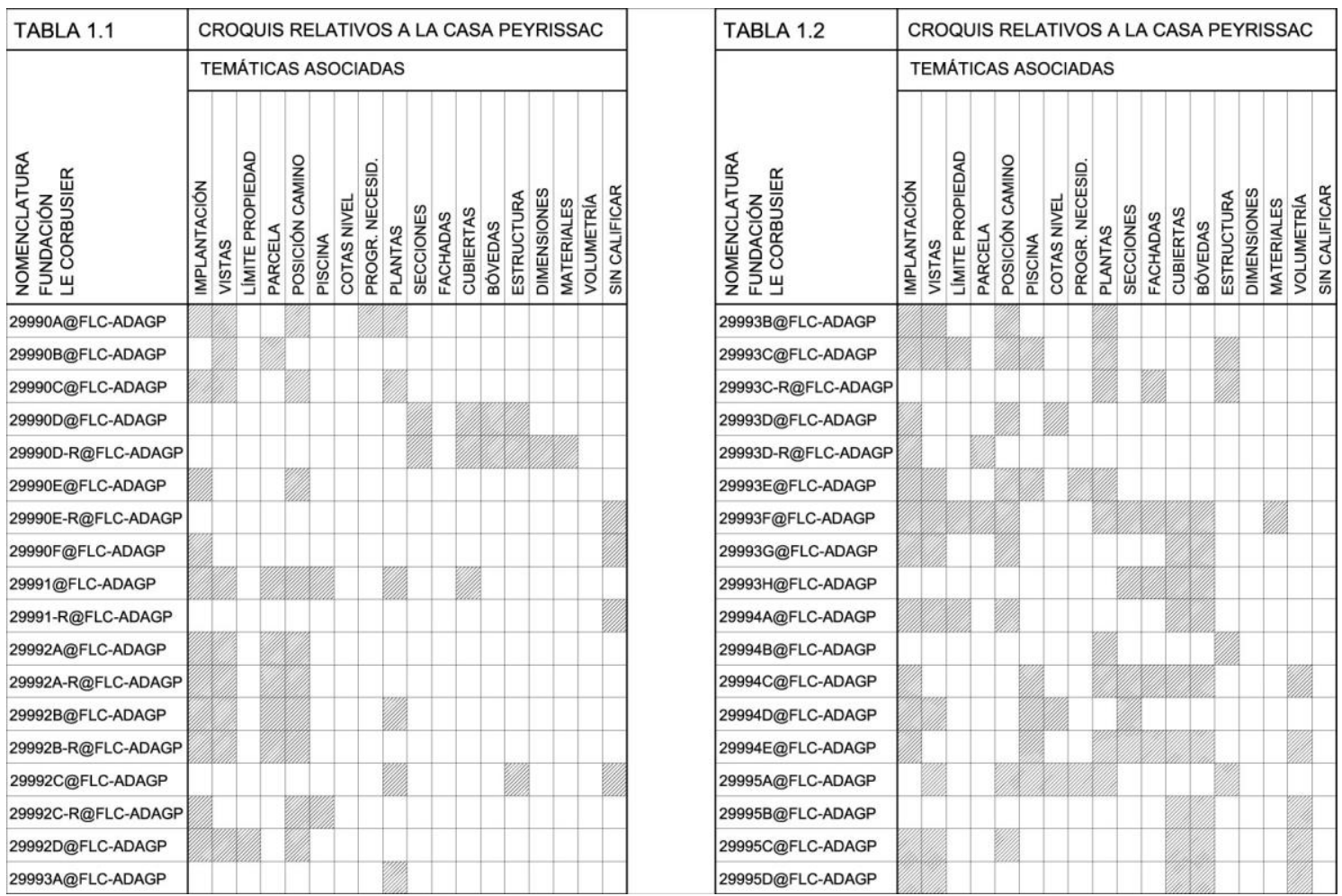

Tabla 1. Clasificación y análisis de los croquis originales.

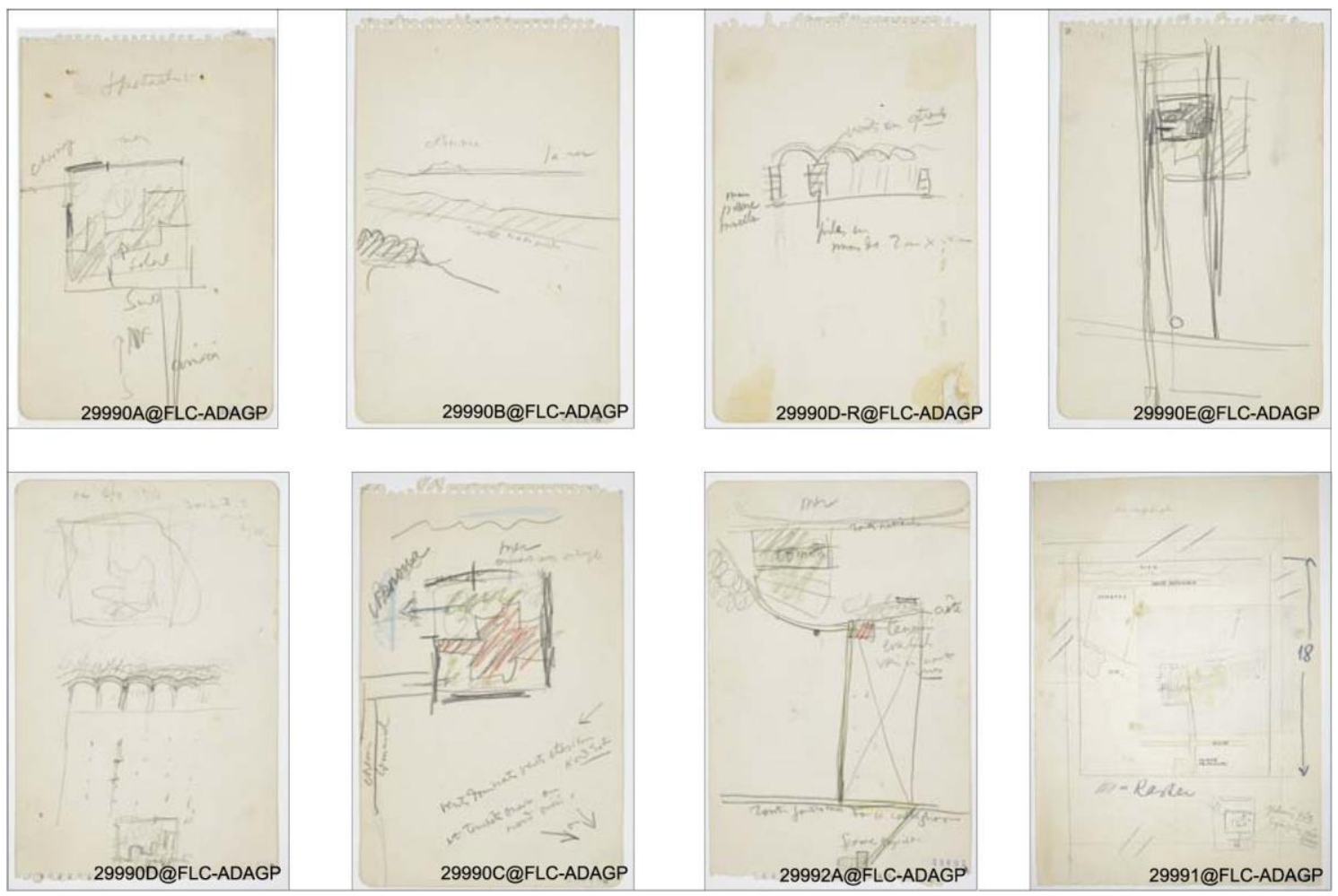

Tabla 2. Relación de croquis originales. 


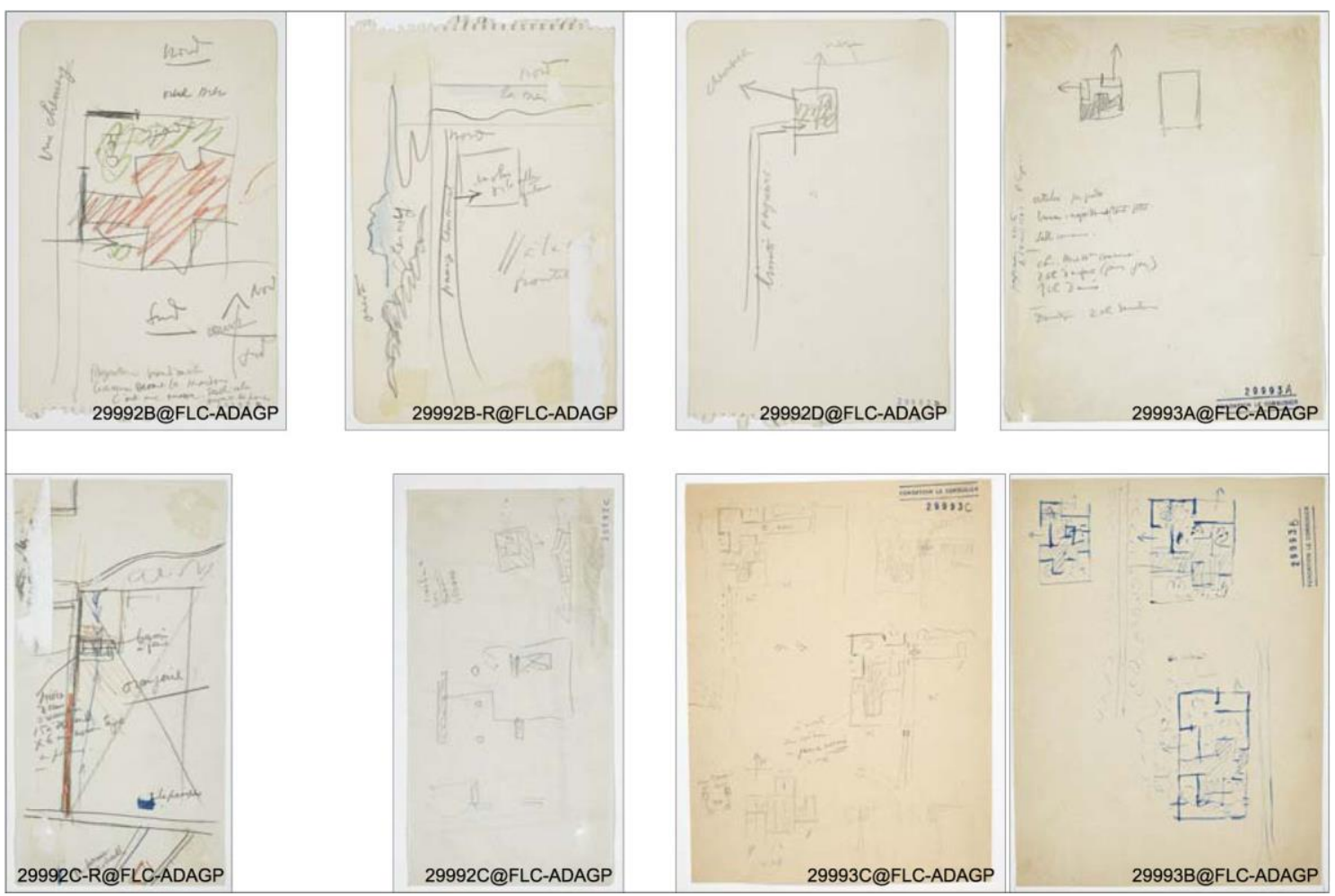

Tabla 3. Relación de croquis originales

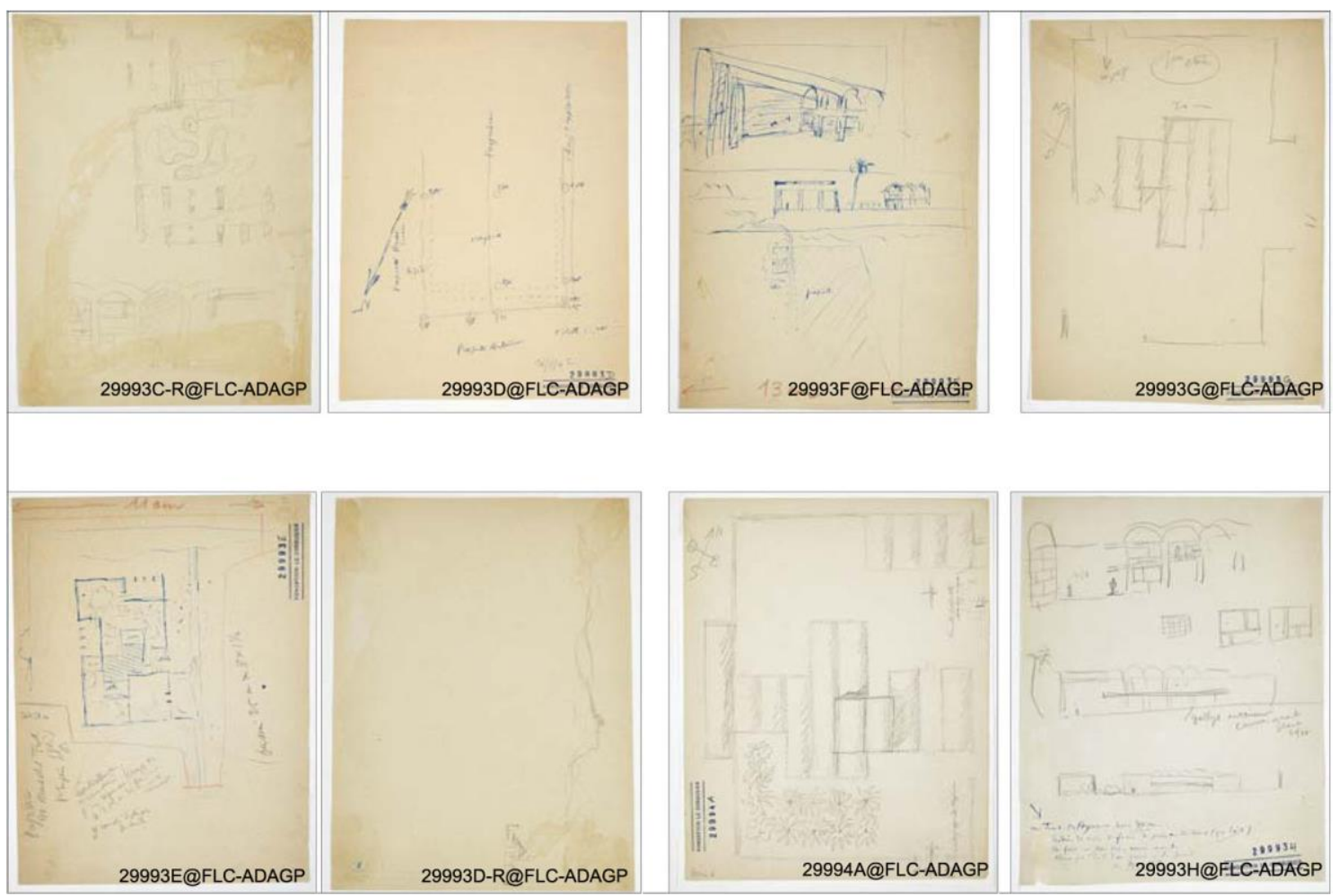

Tabla 4. Relación de croquis originales. 


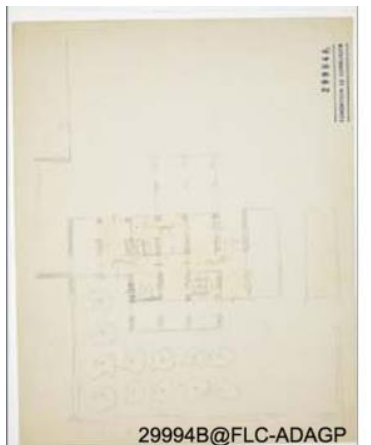

29994B@FLC-ADAGP
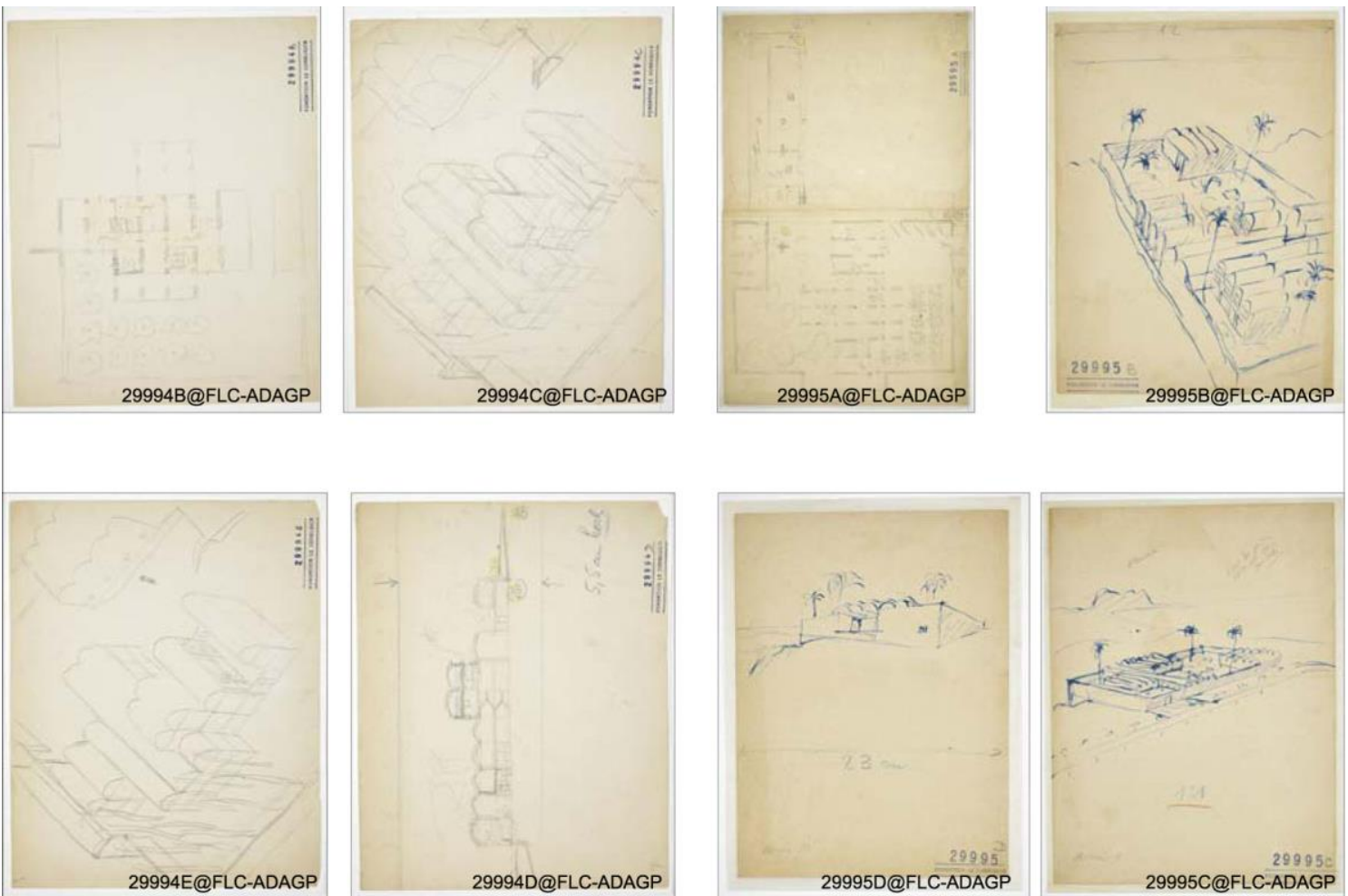

Tabla 5. Relación de croquis originales.

\subsection{La configuración general de la casa}

Desde los primeros croquis, Le Corbusier dibuja la Casa Peyrissac contenida en un perímetro rectangular con sólo parte de su superficie interior construida, y dos grandes aberturas al norte y al oeste (gabinetes de vistas). En las primeras versiones dicho rectángulo es en realidad un cuadrado y las aberturas ocupan aproximadamente la mitad del lado del cuadrado, estando situadas una en el este del lado norte del cuadrado y la otra en el norte del lado oeste del mismo, apuntando cada una de ellas, como bien se anota en los dibujos, a las mejores vistas, la abertura del norte mirando al mar y la del oeste a la Montaña Chenoua. En todos estos primeros dibujos, dentro del recinto cuadrado, aparece un polígono irregular que se representa tramado, e identificamos con el área techada de la casa, cuya silueta es en cada dibujo diferente pero en todos ocupa aproximadamente un $40 \%$ de la superficie del cuadrado, y se desarrolla de oeste a este, llegando a tocar los correspondientes perímetros en dichos puntos cardinales. Esta primera configuración la encontramos en los croquis 29990A@FLC-ADAGP, 29990C@FLC-ADAGP, 29990E@FLC-ADAGP, 29992B@FLC-ADAGP, 29992D@FLC-ADAGP y por último el 29993A@FLC-ADAGP, donde aparece un cuadrado con las características anteriores, con la diferencia de que los gabinetes de vistas se representan como sendos rectángulos acoplados al muro perimetral. En este dibujo también se detalla el programa de necesidades y aparece un rectángulo vacío cuyas proporciones son el cuadrado anterior más la mitad del mismo, constituyendo el primer pensamiento del maestro en cuanto a un cambio de proporción en la forma prevista.

En el croquis 29993B@FLC-ADAGP aparecen tres dibujos muy similares de la planta. El recinto es un rectángulo de proporciones diferentes en cada uno de ellos. La parte construida se representa tramada a rayas y se desarrolla de oeste a este tocando dichos perímetros. El perímetro sur aparece exento, sin ninguna construcción adosada al mismo. Los gabinetes de vistas se representan como sendos rectángulos añadidos al perímetro, ambos con una abertura lateral desde lo que se supone es el patio interior. Por primera vez, hay una 
intención constructiva en el grosor con el que se dibuja el perímetro de la casa, representado como un muro que, cuando llega a la abertura destinada a los gabinetes de vistas, se retranquea hacia el interior, dejando un rectángulo que representa un volumen sin cerrar, quedando expuesto a las inclemencias del entorno y a las virtudes de las vistas. Observando el croquis 29995D@FLC-ADAGP entendemos mejor las intenciones plásticas del maestro.

Al cambiar las proporciones del cuadrado al rectángulo, el gabinete de vistas oeste cambia de posición, encontrándose ahora, aproximadamente, en el centro del lado oeste de dicho rectángulo, adosado a la parte techada de la casa.

Los croquis siguientes confirman los presupuestos formales y de proporciones realizados hasta ahora, preocupándose el maestro a partir de ahora por otras cuestiones como: Los elementos estructurales de la casa, la configuración del programa de necesidades, las dimensiones generales y la posición de la casa respecto al camino comunal que llega a la parcela.

\subsection{Los elementos estructurales}

En La Euvre Complète, página 122, se menciona que la estructura está constituida por pilastras cuadradas, muros y medios muros.

En la esquina inferior izquierda del croquis 29993C@FLC-ADAGP, encontramos un esquema en el que se propone una distancia entre ejes de 4 metros y muros de 50 centímetros de espesor, quedando una distancia libre de 3,5 metros. Esta información se confirma en el mismo croquis, ya que a la derecha del dibujo anterior hay otro esquema en el que aparecen 7 crujías acotadas en un total de 28 metros. Aunque arriba en el mismo croquis encontramos información contradictoria, acotándose el ancho de la casa en 25 metros, entendemos que este último esquema es una aproximación realizada antes de haber hecho la reflexión sobre cuál podría ser la distancia óptima entre ejes. En el croquis 29992C@FLC-ADAGP observamos un dibujo que aparenta ser una trama de elementos estructurales, variando desde elementos cuadrados a rectangulares de dos tamaños, pudiéndose interpretar dichos elementos como pilastras, muros y medios muros. El croquis 29993C@FLCADAGP representa una vista parcial de la planta de la casa, donde aparece la esquina sur-oeste y el gabinete de vistas oeste, y donde claramente confirmamos la existencia de tres tipos de elementos estructurales.

Los siguientes dos croquis a analizar serían el 29995A@FLC-ADAGP y el 29994B @FLC-ADAGP. Como se menciona en La Euvre Complète, páginas 120 y 121, dichos dibujos corresponden a la planta baja y primera respectivamente. En ambos croquis aparecen todos los elementos estructurales, confirmándose la existencia de las pilastras, los muros y los medios muros.

Después de este análisis previo, empezamos a dibujar. El primer paso que se ha dado consiste en pasar a limpio la información existente para la planta baja. Insertamos el croquis 29995A @FLC-ADAGP en el programa de dibujo y proporcionamos dicho croquis, teniendo en cuenta una trama de ejes separados 4 metros en el sentido transversal, de oeste a este. En el croquis que estamos usando de referencia en nuestro dibujo aparecen 10 crujías longitudinales, si el ancho de las mismas es de 4 metros, el ancho total de la casa resulta 40 metros. Este hecho resulta contradictorio con los 28 metros anteriores que nos indicaba la anotación del croquis 29993C@FLCADAGP, sin embargo, lo damos por válido apoyándonos para ello en el siguiente razonamiento: Si observamos el croquis 29993G@FLC-ADAGP vemos que se propone una primera etapa en la construcción del proyecto, 
consistente en cinco crujías, acotadas un ancho total de 20 metros, lo cual confirma la tesis de que el ancho de cada crujía se debe mantener en 4 metros.

Teniendo fijado el ancho, el siguiente paso es acotar la longitud de las crujías. Observando el croquis 29995A@FLC-ADAGP se intuye claramente que podríamos superponer una trama perpendicular a la anterior, cuya separación entre ejes fuera también de 4 metros. Esta segunda trama nos ayudaría a situar los principales elementos de la casa. De esta manera, obtenemos una malla ortogonal de 4 x 4 metros. El primer indicio del éxito de esta operación es comprobar que los centros de gravedad de las pilastras cuadradas coinciden con puntos de intersección de la trama, así como que la posición de los muros perimetrales de la casa y de las líneas generales que definen la plataforma, donde se sitúa la piscina, entran dentro de la lógica geométrica que la trama propone.

El siguiente paso consiste en fijar la posición y dimensiones tanto de los elementos estructurales como de los muros perimetrales. Para la definición de los elementos estructurales nos apoyamos en los siguientes argumentos: el ancho lo consideramos fijado en 50 centímetros (25 centímetros a cada lado del eje), y el largo lo definimos basándonos en que los elementos estructurales consisten en pilastras cuadradas, muros y medios muros, y atendiendo a la información brindada por el croquis 29990D-R@FLC-ADAGP, en el cual se dibuja un esquema en sección donde aparecen unos muros de ladrillo que sustentan bóvedas. De uno de los muros sale una flecha con una anotación que dice: "Pilastras y muros de 2 metros x 50 centímetros" 3 . En el croquis 29995A@FLC-ADAGP, efectivamente, se han dibujado tres tipos de soportes estructurales, siendo perfectamente coherente suponer que las pilastras cuadradas son de 50 x 50 centímetros, situadas, como hemos mencionado anteriormente, con su centro de gravedad coincidiendo con las intersecciones de la trama ortogonal. Los medios muros los fijamos en 2 metros de largo, y los situamos teniendo en cuenta que sus dos esquinas más cercanas a los puntos de intersección de la trama deben distar de dichos puntos 25 centímetros tanto en la dirección X como en la Y. Por último, los muros enteros los consideramos del largo total del módulo que propone la trama, es decir 4,5 metros, ya que entendemos que para seguir una retícula lógica han de distar cada una de sus esquinas 25 centímetros, en los ejes X e Y, de los puntos de intersección de la trama.

El muro perimetral lo hemos dibujado en concordancia con las proporciones que el croquis 29995A@FLCADAGP nos sugiere, utilizando de guía los ejes correspondientes propuestos en la trama ortogonal. De esta manera obtenemos que la casa está contenida en un recinto rectangular de 36,50 metros de ancho por 52,50 metros de largo.

El gabinete de vistas norte permanece en su posición inicial, constituyéndose como un recinto rectangular con apertura a la plataforma de la piscina y separado del conjunto de la casa. Sin embargo el gabinete de vistas oeste mantiene su posición en el eje Y, pero avanza hacia el exterior del perímetro de la casa en el eje X, quedando adosado al rectángulo que conforma el perímetro de la casa como un saliente de 4 metros de ancho por 12,50 metros de largo, situado a 16 metros en el sentido longitudinal de la esquina sur oeste de dicho rectángulo.

\footnotetext{
${ }^{3}$ Todas las anotaciones que acompañan los dibujos originales, y que se han usado en la presente comunicación, han sido traducidas del francés por la autora.
} 


\subsection{La piscina}

En el croquis 29995A@FLC-ADAGP la piscina aparece situada en una plataforma que tiene continuidad con el gabinete de vistas norte. Esta plataforma está acotada como un rectángulo de las siguientes dimensiones: en el sentido transversal, de oeste a este, 8 metros, más 25 metros, más una longitud que no está definida, y que, según las proporciones generales, debería ser precisamente 4 metros. En el sentido longitudinal se vuelven a acotar tres medidas, de norte a sur, 8 metros más 8 metros, que corresponde a la piscina, más 1 metro. Al comprobar las medidas, dentro de la lógica del dibujo, encontramos que los primeros 8 metros están desproporcionados y que más bien corresponderían a 4 metros. De esta manera la piscina adquiere unas dimensiones de 25 metros por 8 metros y se inserta a su vez en un rectángulo de 36 metros por 13 metros. Este rectángulo se adosa al gabinete de vistas situado al norte mediante una segunda plataforma, en continuidad física con la anterior, que se acota en el dibujo en 4 metros transversales, de oeste a este, por 8 metros longitudinales, de norte a sur, y de la cual observamos que las medidas coherentes son exactamente las inversas: 8 metros transversales por 4 metros longitudinales.

Siguiendo la cronología de los croquis existentes en la fundación Le Corbusier, la primera vez que aparece la piscina es en el croquis 29991 @FLC-ADAGP, donde podemos apreciar la posición de la casa en relación a los principales elementos de su entorno, la piscina se encuentra situada en el extremo superior este de la casa adosada a ella como un apósito. Sin embargo, más tarde demostraremos que este dibujo es posterior y que el maestro reflexionó sobre la piscina antes de llegar a la configuración que en este dibujo propone. Nos paramos en el dibujo 29992C-R@FLC-ADAGP, según nuestro juicio, anterior al mencionado y donde por primera vez aparece una anotación referente a la piscina que dice: "Tamaño del pozo 15 a 20 x 6m debajo del suelo". La siguiente referencia aparece en el croquis 29993C@FLC-ADAGP, y es la primera vez que la piscina aparece dibujada en posición y dimensiones similares a las que encontramos en el croquis de referencia 29995A@FLCADAGP. En este dibujo, la piscina está separada de la casa por el camino comunal, tema que discutiremos más tarde, y se acota en 25 metros para la piscina y 3 metros para un elemento que tiene continuidad geométrica con la misma y se encuentra situado al este. Este mismo elemento lo habíamos acotado anteriormente en 4 metros, siguiendo la lógica geométrica del dibujo, pero al encontrar un dato preciso, decidimos dibujar su ancho en 3 metros.

La siguiente referencia es el croquis 29993E@FLC-ADAGP donde encontramos una anotación que dice: "Piscina $25 \times 8 \times 1$ 1/2". Medidas que son perfectamente coherentes con nuestro dibujo. Respecto a la anotación encontrada en el croquis 29992C-R@FLC-ADAGP, donde se hace referencia a un pozo, podemos olvidarnos gracias a una anotación encontrada en La Euvre Complète, página 120, que dice: "La piscina sirve de sistema de riego para la plantación",

\subsection{El camino comunal y la necesidad de comprar la parcela colindante}

El camino comunal que llega a la parcela es un elemento de estudio recurrente desde los primeros croquis. Llama la atención el hecho de que la posición de la casa varía respecto al camino varias veces a lo largo del proceso. En los primeros croquis el maestro se muestra dubitativo, dibujando el camino al este o al oeste de la casa, en algunos casos muriendo en la esquina sur-este del recinto, y en otros dejando que transcurra paralelo a la casa al

\footnotetext{
${ }^{4}$ Todas las citas tomadas de La CEuvre Complète y que se han usado en esta comunicación han sido traducidas por la autora.
} 
oeste de la misma, pegado o separado de ella. Observamos este hecho en los croquis clasificados como 29990E@FLC-ADAGP y 29992A-R@FLC-ADAGP donde, a modo de garabato, podemos ver el recinto de la casa con las dos opciones de caminos posibles.

Entendemos la duda del maestro cuando llegamos al croquis 29993C@FLC-ADAGP, donde hay varios dibujos de la planta de la casa; en un primer dibujo observamos el recinto rectangular de la casa, con la piscina adosada a la esquina superior del lado este y el camino muriendo en la esquina sur-oeste. A la derecha, encontramos un segundo dibujo donde se representa otra vez el recinto de la casa, pero esta vez con el camino situado entre la casa y la piscina y acompañado de una anotación que dice: “A comprar para asegurar vistas". En el croquis anterior 29992D@FLC-ADAGP encontramos una anotación al este del camino que dice: "Límite Peyrissac". Por último observando el croquis 29993F@FLC-ADAGP encontramos un esquema de la situación de la casa en su entorno donde se representan tres elementos: la propiedad, el camino y la villa, estando la villa fuera de la propiedad. Por todo ello concluimos que Le Corbusier propuso a su cliente comprar la parcela colindante al oeste porque, por razones que veremos más adelante, esta parcela tenía mejores vistas que la del propio Peyrissac.

Una vez tomada la decisión de comprar la parcela colindante, el camino siempre aparece al este de la casa, transcurriendo paralelo a la misma, sin embargo, esta configuración dejaba la piscina separada de la casa, razón por la cual entendemos que el maestro decidió finalmente hacer morir el camino en la esquina este del lado sur del recinto de la casa, y poner la entrada a la misma en ese punto. En el croquis 29994A@FLC-ADAGP el camino queda perfectamente acotado en 5 metros de ancho situado a 1 metro al oeste del límite de la propiedad Peyrissac. Esta información se confirma en el croquis 29995A@FLC-ADAGP, el cual es la referencia última de nuestro dibujo.

Es imposible analizar si efectivamente la parcela colindante al oeste tiene mejores vistas sin ubicar primero la propiedad Peyrissac en la planimetría de Argel. A continuación vamos a estudiar la información que tenemos para tratar de localizar la propiedad.

En La CEuvre Complète, página 116, se describe perfectamente las virtudes del lugar: "La vista del horizonte está abierto sólo a dos puntos: al norte, el océano; al oeste la Bahía de Cherchell y la magnífica Montaña Chenua; los dos gabinetes de vistas quedarán expuestos al sol y el viento. Una gran plantación de naranjas y tomates en una meseta, limitada por un acantilado que muere en la orilla del mar. La residencia se instalará en la parte superior del acantilado para disfrutar de las dos vistas mencionadas”.

El croquis 29991@FLC-ADAGP representa la casa en relación a todos los elementos de su entorno. Por su clasificación este croquis debería ser uno de los primeros de la serie, sin embargo advertimos que es posterior ya que en él se observan decisiones que se han tomado casi al final del proceso: El camino está situado en la esquina sur-este del recinto de la casa; la piscina está situada, como un apósito, en el norte del lado oeste; las dimensiones generales de la casa y la piscina, así como la posición de los gabinetes de vistas, son similares a lo propuesto en el croquis 29995A@FLC-ADAGP; incluso podemos advertir las diferentes crujías con sus ejes. Por otro lado, este es el dibujo que Le Corbusier eligió para explicar la situación de la casa en La Euvre Complète. Por todo lo dicho, concluimos que es un dibujo considerado definitivo donde deberían estar todos los elementos del contexto que afectan al diseño de la casa, y, además, nos pueden dar información relevante para encontrar la parcela en la planimetría de Argel. 
Analizando el croquis anterior sabemos que nuestra parcela está situada en una zona agrícola, orientada norte-sur pero con una ligera inclinación hacia el oeste, que al norte se encuentra el mar y al oeste la Montaña Chenoua, que la carretera nacional queda al norte, que entre la parcela y la carretera nacional no hay conexión, que a la parcela llega un camino comunal que viene del sur y conecta con una carretera regional, que a su vez nos lleva a otra finca perteneciente a la familia Peyrissac. A pesar de que el lado norte del perímetro de la casa está adosado a una línea con cierta curvatura que continúa tanto al este como al oeste, el hecho de que esta línea represente el borde de un acantilado no queda claro hasta que en La Euvre Complète, página 118, leemos una anotación que dice: “La composición termina en el borde del acantilado". Volvemos a los croquis y vemos que la línea que representa el borde del acantilado es un elemento recurrente en todos los dibujos que presentan la casa en su entorno y nos paramos en el croquis 29993D-R@FLC-ADAGP, donde se dibuja un perfil del terreno a gran escala en el que vemos el recinto de la casa en el borde del acantilado.

Con todos estos datos nos vamos a la planimetría de Argel y buscamos una parcela en una zona agrícola al este de la Montaña Chenoua, orientada norte-sur con una ligera inclinación al oeste, limitada por un acantilado en su linde norte y por un camino comunal en su linde oeste ${ }^{5}$. La característica determinante es que la parcela que colinde con ella al oeste tenga el suficiente atractivo para que Le Corbusier insistiera en que era necesario comprar un trozo para situar allí la casa.

Tras explorar la zona, concluimos que la parcela debe estar situada entre Le Chenoua y el pueblo de Fouka, donde hay una zona agraria con bastantes parcelas de características compatibles con la que estamos buscando. Para localizar la nuestra nos hemos apoyado en una anotación encontrada en La Euvre Complète, página 119, aparece una planta de la casa, anterior a la que estamos usando de referencia para nuestro dibujo, y arriba de la misma se escribe: "el mar" y abajo: "Le Chenoua, La Tumba de la Cristiana”. La tumba de la Cristiana es el nombre que en francés, traducido en este caso, se le otorga al Mausoleo Real de Mauritania, el cual es un monumento funerario que se encuentra entre Le Chenoua y Fouka, exactamente en el área donde estamos buscando nuestra parcela.

Efectivamente, al norte del Mausoleo, al otro lado de la carretera, encontramos una parcela con características compatibles a la nuestra en términos de orientación, situación al borde del acantilado y flanqueada por un camino comunal al oeste, en la cual nos fijamos precisamente por la morfología de la parcela que linda con ella al oeste. Dicha parcela tiene un entrante del acantilado que, a su vez, la separa de la parcela más al oeste haciendo que su extremo termine en un pequeño promontorio, que, al situar la casa en el mismo, garantizaría las vistas de la Montaña Chenoua al este. Más adelante, cuando dibujemos el plano de situación, comprobaremos si la casa encaja o no en este promontorio.

\subsection{Las cotas altimétricas}

El siguiente paso es estudiar los diferentes niveles de la planta baja y para ello lo primero que hacemos es analizar las cotas altimétricas originales del terreno. La planimetría de la zona de la cual disponemos está representada a escala 1:50000, limitándose la información sobre cotas altimétricas a unas curvas de nivel que a

\footnotetext{
${ }^{5}$ Para buscar la parcela se ha utilizado Google Earth y también un plano topográfico de Argel fechado en Octubre de 1942, perteneciente al U.S. Army Map Service. Washington D.C. y localizado en el sitio web de la Universidad de Texas dentro de la Perry-Catañeda Library Map Collection.
} 
esa escala poco pueden ayudarnos. Consideramos mejor estrategia centrarnos en la información recogida por el propio Le Corbusier.

Existe un croquis clasificado como 29993D@FLC-ADAGP en el que se realiza un intento de detallar la topografía del terreno. Tan sólo está dibujada la finca propiedad de Peyrissac, ya que el dibujo orientado al norte, se acaba en el camino comunal, situado al oeste. Entendemos que la superficie a la cual hace referencia el dibujo, es la franja de tierra, en el norte de la parcela, donde estaba previsto ubicar la casa. Vemos que el camino empieza teniendo una cota de +1.80 metros, sube a +2.48 metros para volver a bajar en el extremo a +1.82 metros. Los mismos puntos desplazados a la derecha del camino son +2.70 metros,+3.70 metros y +3.21 metros. Existen otros tres puntos similares más al este que decidimos obviar ya que suponemos que una vez establecida la decisión de situar la casa en la propiedad colindante carecen de interés.

Volvemos al croquis 29995A@FLC-ADAGP que estamos usando como referencia para nuestro dibujo y representa la planta baja. La información es confusa, pero podemos sacar cosas en claro. Aparece una primera cota de +1.80 metros en la entrada de la casa, precisamente donde muere el camino. Dentro del gabinete de vistas norte y en el extremo este de la plataforma de la piscina aparece una segunda cota, que se repite en ambos casos, y es +3.70 metros. Estas dos cotas son significativas, ya que resultan coherentes con la información obtenida en el croquis 29993D@FLC-ADAGP. Encontramos dos cotas más: +2.48 metros al sur del gabinete de vistas norte $\mathrm{y}+3.70$ metros al oeste de la plataforma de la piscina, fuera de la misma.

La cota que se encuentra al sur del gabinete de vistas norte y que es +2.48 metros la identificamos como la segunda cota del camino vista en el croquis 29993D@FLC-ADAGP. Si la parte sur de la casa se encuentra a +1.82 metros y la norte a +2.48 metros, supondría que la casa debería tener una pendiente aproximada del $1.5 \%$, lo cual es improbable, ya que su uso se tornaría muy incómodo; por otro lado, tampoco existe ninguna escalera que indique que pueda haber un cambio de cota. Es más lógico suponer que Le Corbusier pensara dejar toda la planta baja en una superficie plana a la cota de entrada, +1.80 metros, a excepción del gabinete de vistas norte y la plataforma que contiene la piscina que estarían ambos a +3.70 metros de altura.

En el croquis 29995A@FLC-ADAGP observamos como del extremo sur-oeste de la plataforma de la piscina sale una pasarela en la dirección este oeste de ancho 1 metro. Según el dibujo en planta, en un momento determinado, la pasarela se convierte en escalera para después volver a ser plana y morir en otra escalera. Entendemos que este elemento supone la unión física entre la casa, la piscina y el gabinete de vistas norte, al cual sólo se puede acceder desde la piscina. La cota +2.48 metros anteriormente mencionada, situada al sur del gabinete de vistas norte, pudiera referirse al segundo tramo de la pasarela anteriormente comentada.

Para comprobar esta información nos vamos al croquis 29994D@FLC-ADAGP, donde se representa una sección transversal de la casa. Por un lado aparecen dos cotas superpuestas +1.80 metros y +2.48 metros en el extremo este de la casa, a la altura del camino, por otro lado aparece +3.70 metros en lo que debería ser la proyección de la plataforma de la piscina, y debajo de esta vuelve a aparecer de nuevo +3.70 metros, esta vez superpuesta con +2.70 metros. Todas las cotas están rodeadas con un círculo amarillo, excepto +1.80 metros y +2.70 metros, rodeadas en azul. Comprobamos en el croquis 29993D @FLC-ADAGP que ambas cotas pertenecen a la parte sur de la antigua parcela y concluimos que la posición de las mismas en la dirección norte-sur debe ser el criterio para rodearlas de distinto color. Como no hay información determinante al respecto, nosotros seguimos con nuestra idea de dejar la planta baja a rasante de la cota +1.80 metros y el gabinete de vistas norte junto con la 
plataforma que contiene la piscina a +3.70 metros. Respecto a la pasarela, vemos en la sección que no se ha realizado ningún escalón, sino que la unión de ambas cotas se plantea como una rampa, para que esto sea factible necesitamos una longitud de al menos 20 metros. En el dibujo en planta la segunda escalera acaba aproximadamente a la altura del segundo eje en dirección este-oeste, desde ese punto al borde de la piscina son exactamente 20 metros, con lo cual, la elijamos o no, la opción de sustituir las dos escaleras por una rampa es perfectamente coherente con la lógica geométrica del conjunto.

\subsection{Forjados de planta baja y primera}

En planta baja hemos sombreado lo que consideramos el interior de la vivienda, la superficie que suponemos se pretendía pavimentar en madera, tal como se menciona en La Euvre Complète, página 116, entendiendo que el resto se quedaría como suelo de tierra compactada. En principio, hemos considerado que las carpinterías están en los límites de la superficie sombreada, siguiendo los ejes transversales a los elementos estructurales, pero es muy probable que en una fase posterior del proyecto se decidiese retrasar alguna, dejando espacio cubierto a modo de porche.

Para delimitar el forjado de planta primera se ha estudiado el croquis 29995A@ @LC-ADAGP, que representa la planta baja, pero en el cual aparece superpuesta la proyección del forjado de planta primera, reconocible porque la superficie contenida por dicha proyección está tramada. La Euvre Complète, página 120, hay una anotación junto al dibujo al cual nos referimos que dice: "La zona gris indica las áreas con baja altura: 2.20m, quedando el resto a 4.50m”. El croquis 29994B@FLC-ADAGP, donde se detalla la planta primera viene a confirmar la información del croquis 29995A@FLC-ADAGP. Por último el croquis 29994D@FLC-ADAGP que representa la sección nos confirma las suposiciones iniciales. Concluimos que las crujías, que están divididas en más de una planta, son, contando en la dirección oeste-este, la 3,4,5,6,7 y 10, estando esta última dedicada al servicio. Las crujías 4,5 y 6 no están divididas en toda su longitud, quedando espacios a doble altura tanto en la delantera como en la trasera de la casa. El resto del espacio tiene doble altura. En la sección anterior podemos observar también que las crujías 6 y 7 tienen una segunda y tercera altura, que no aparece en ninguna planta pero que por una anotación que aparece en La Euvre Complète, página 12, se destina a cuarto de invitados y aljibe respectivamente. El croquis 29994A@FLC-ADAGP corresponde a una planta global de cubiertas, en el que vemos claramente un volumen cuadrado que sobresale y que corresponde a la prominencia de las crujías 6 y 7 . También confirmamos esta cuestión en los croquis 29994E@FLC-ADAGP y 29994C@FLC-ADAGP que corresponden a sendas axonometrías.

\subsection{Planta de cubiertas y vegetación}

Atendiendo a la lógica constructiva de las bóvedas en sección y al propio dibujo de Le Corbusier procedemos a dibujar la planta de cubiertas, para ello seguimos las directrices establecidas en la planta baja y primera.

Finalmente obtenemos 9 bóvedas longitudinales dirección norte sur que cubren todas las crujías que conforman la casa excepto la crujía 9 que está descubierta. Adicionalmente, separadas del cuerpo principal de la casa, tenemos cuatro bóvedas paralelas a las anteriores que constituyen la cubierta del gabinete de vistas norte.

Relativo a la dirección de las bóvedas hay una contradicción entre los dibujos que queremos aclarar y tiene que ver con los croquis 29993H@FLC-ADAGP y sobre todo con el 29993F@FLC-ADAGP donde se representan sendas secciones generales de la casa y podemos ver como la dirección de las bóvedas en el cuerpo principal de 
la casa es perpendicular a la que adquieren en el gabinete de vistas norte. Este hecho se confirma en las volumetrías 29995B@FLC-ADAGP y 29995C@FLC-ADAGP, en los cuales las cubiertas del cuerpo principal de la casa y del gabinete de vistas oeste se representan como bóvedas longitudinales en dirección este-oeste y la cubierta del gabinete norte como bóvedas longitudinales perpendiculares a las anteriores. Sin embargo en los dibujos de la última serie constituidos por el 29995A@FLC-ADAGP que representa la planta baja, el 29994B@FLC-ADAGP, que representa la planta primera, el 29994A@ @ FLC-ADAGP, que representa la planta de cubiertas y los croquis 29994C@FLC-ADAGP y 29994E@FLC-ADAGP, que representan sendas axonometrías, la dirección de las bóvedas es norte-sur tanto para la casa como para el gabinete de vistas norte. En último momento el maestro decidió que todas las bóvedas deberían desarrollarse en la misma dirección, quizás por simplicidad estructural o quizás porque los flujos de la casa funcionaban mejor en dirección norte-sur.

En el croquis 29995A@FLC-ADAGP Le Corbusier esboza la vegetación alrededor de la casa. Por un lado, fuera del recinto de la casa al este de la misma y al sur de la piscina, se dibuja una retícula ordenada de árboles, en lo que representa una típica plantación de naranjos y que es acorde con el uso previo de la finca. Dentro del recinto de la casa, en el patio delantero, al sur-oeste de la misma se sitúa una trama de palmeras, muy ordenadas, situadas cada una de ellas en las intersecciones de la continuación de la trama ortogonal usada para la estructura. En el extremo norte de la casa, se plantea otro tipo de vegetación, lo que parecen ser árboles de copa generosa, se sitúan de forma anárquica en el patio trasero.

\subsection{Plano de situación}

Vamos a proceder a situar la casa en el contexto que estaba prevista y presentarla en un plano de situación. Podemos decir que esta es la "prueba de la verdad", ya que nos confirmará o por el contrario nos dejará en entredicho todas las hipótesis establecidas hasta ahora. Para ello disponemos del croquis 29991 @FLC-ADAGP, donde aparece la casa en relación a todos los elementos de su entorno y de la planimetría de Argel, donde, como se ha explicado anteriormente, ya hemos localizado la parcela.

En La Euvre Complète, página 116, encontramos la siguiente afirmación: "Este primer proyecto se elaboró con total precisión y encaja perfectamente en el lugar". Para insertar la casa en su entorno atendemos a la información que se da en el croquis 29994A@FLC-ADAGP, en el cual se detalla la planta de cubiertas. En la esquina sur este del recinto de la casa, donde muere el camino, se indica que el mismo debe estar en el eje de simetría de la crujía 9, que su ancho es 5 metros y que está situado a una distancia horizontal de 1 metro del límite de la propiedad Peyrissac. En el mismo croquis, al sur del gabinete de vistas norte encontramos una anotación que indica que el límite de la propiedad está a 10 metros de algo que no vemos. Deducimos que ese elemento que no vemos es el límite de la plataforma de la piscina.

Siguiendo las consideraciones anteriores insertamos la casa en la parcela y observamos que encaja perfectamente, tanto es así que su arista norte es idéntica al lado norte de la parcela, y la casa en conjunto queda perfectamente encajada en la protuberancia indicada.

\subsection{Interior de la vivienda y programa de necesidades}

A continuación nos centramos en el interior de la vivienda. En primer lugar situamos la escalera y vemos si es viable en el espacio que se le destina. Ya sabemos por una anotación de La Euvre Complète vista anteriormente que la altura libre de suelo a techo es 2.20 metros que corresponde a "la altura de un hombre con el brazo 
levantado" y que es la utilizada por Le Corbusier antes del Modulor. Por otro lado en la última página de $L a$ Euvre Complète aparece un dibujo de fachada que por su definición, muy superior al resto de los dibujos, consideramos que pertenece a otro proyecto, a la cual se le añade una anotación que dice: "Una fachada (dos veces $2.20 \mathrm{~m}=4.50 \mathrm{~m}$ )". Escaneando dicha fachada y escalándola en el programa de dibujo nos damos cuenta que 4.50 metros es la distancia hasta el arranque de la bóveda. Para que todo encaje el forjado debería ser una pieza muy fina de madera de 10 centímetros de espesor. Vemos como una escalera de 12 escalones de 30 centímetros de huella y 19 centímetros de contrahuella cabe de forma holgada en dos tramos dejando un paso previo y un descansillo de 1 metro.

No tenemos información relativa a las carpinterías exteriores, cómo hipótesis se ha dibujado un esquema muy básico en planta que nos permitiese acotar los espacios interiores.

En cuanto a los tabiques de división interior nos hemos limitado a dibujar lo sugerido por Le Corbusier. En $L a$ Euvre Complète, página 116, encontramos lo siguiente: “... Los divisiones dentro de estos espacios pueden variar entre compactas, transparentes y paneles translúcidos, según las necesidades.” Sin embargo no tenemos indicios gráficos de dichos paneles, ya que apenas hay dibujadas particiones separando usos.

Para entender el interior de la vivienda habría que analizar el programa de necesidades. En La Euvre Complète, página 121, encontramos una anotación que dice: "Planta baja: recepción. Planta primera: apartamentos. Planta segunda: habitación de invitados. Planta tercera: depósito de agua”. En el croquis 29993A@FLCADAGP se detalla una lista con el programa de necesidades que dice: "Taller no grande, despacho de mayordomía, sala común, habitación del señor y de la señora, 2 habitaciones de jóvenes, 1 habitación de amigos, 2 habitaciones de servicio doméstico". Para entender cómo se distribuirían los usos tenemos que irnos a croquis posteriores. En el croquis 29993E@FLC-ADAGP donde se representa una primera versión de la planta baja, el taller se encuentra en el área sur de la casa, hay dos salones, uno en el área norte y otro al oeste pegado al gabinete de vistas y por último el servicio se encuentra en el área este de la casa. En el último croquis dibujado para la planta baja, el 29995A@FLC-ADAGP, el salón se mantiene en el área norte, ocupando parte de las crujías 5 y 6, el taller se sitúa al oeste, pegado al gabinete de vistas, el despacho de mayordomía en el área sur de la crujía 7, la cocina ocupa la crujía 8 y el área de servicio está situada en la crujía 10, separado por el paso descubierto que conforma la crujía 9. En este último dibujo apenas se sugiere unas particiones que separan el despacho de mayordomía, la cocina y el taller del resto de la zona social. En cuanto al mobiliario todo queda en un mueble en la cocina y unos muebles modulares en el taller.

Si nos vamos al croquis 29994B@FLC-ADAGP, que representa la planta primera, encontramos unas divisiones que dividen los tres dormitorios, el del padre, el del hijo y el de la hija, quedando una zona diáfana en el desembarco de la escalera. Se insinúan dos núcleos húmedos que podrían corresponder a los baños asociados al dormitorio de los padres y al del hijo. Como mobiliario tan solo aparece situada la cama matrimonial.

\subsection{Geometría de las bóvedas, sección transversal y detalle constructivo}

Para dibujar la geometría de las bóvedas en sección hemos partido de la imagen de fachada que aparece en $L a$ Euvre Complète, página 122, y que cómo hemos comentado anteriormente, consideramos que pertenece a otro proyecto. Es la única información que tenemos al respecto, por lo cual la usamos. Insertamos la imagen en el programa de dibujo y la escalamos, dándonos cuenta de que si la distancia entre ejes de muros es 4 metros, la 
distancia del suelo al arranque de la bóveda es exactamente 4,5 metros, concluyendo que si efectivamente la imagen pertenece a otro proyecto, las dimensiones mencionadas estaban bien arraigadas en la mente del maestro.

Utilizamos la geometría obtenida de la imagen de fachada respecto a una de las crujías en sección para dibujar la sección transversal completa de la casa, para ello insertamos en el programa de dibujo el croquis 29994D @FLCADAGP, que representa la sección, lo escalamos, superponemos la geometría obtenida anteriormente y dibujamos el resto de las crujías de la casa. Nos damos cuenta de que la sección, aparentemente un dibujo rápido a mano alzada está perfectamente proporcionada y al igual que las plantas encaja perfectamente con las medidas generales y la lógica geométrica de la casa.

Cómo ejercicio vamos a dibujar una hipótesis de detalle constructivo de cubierta. En La Euvre Complète, página 116, encontramos información sobre los materiales y sistemas constructivos a usar: "... El edificio debe ser construido por nativos y se debería usar la piedra local para pilares, muros o medios-muros". Y también "... Los pisos deben ser de madera y las bóvedas de ladrillo hueco, también hecha por nativos..." Apoyándonos en este texto sabemos que los muros están construidos de mampostería de piedra local y las bóvedas de ladrillo hueco. Aunque no se especifica en ningún lado entendemos que es necesario un dintel que transmita las cargas de las bóvedas a los muros, el cual pudiera ser de hormigón armado o, en escasez de este, de madera. También en La Euvre Complète, página 122, encontramos la siguiente anotación donde se habla de los materiales en el interior de la vivienda: "Resumen: juego de tres materiales: mampostería vista, bóvedas acabadas en cal, particiones de madera". Con lo cual ya sabemos cuál es la terminación interior de las bóvedas y para la exterior probablemente deducimos que se pudiera tratar de una solería cerámica o la misma cal del interior. Entre el ladrillo hueco y la terminación exterior de la bóveda podríamos suponer que hubiera una capa de adobe.

En cuanto al desagüe de la cubierta resulta lógico pensar que fuera mediante canalones longitudinales en las intersecciones de las bóvedas y que terminasen en gárgolas, como sugiere el dibujo de fachada de Las Obras Completas anteriormente mencionado. Para rematar el testero de las bóvedas es necesario un elemento que pudiera ser un parapeto y que a su vez recogiese el canto de los dinteles. Siguiendo este razonamiento se ha dibujado una hipótesis de detalle constructivo, en el cual las dimensiones están tanteadas de forma aproximada. 


\section{Los dibujos}

A continuación se presentan los dibujos que hemos realizado basándonos en los croquis del maestro.

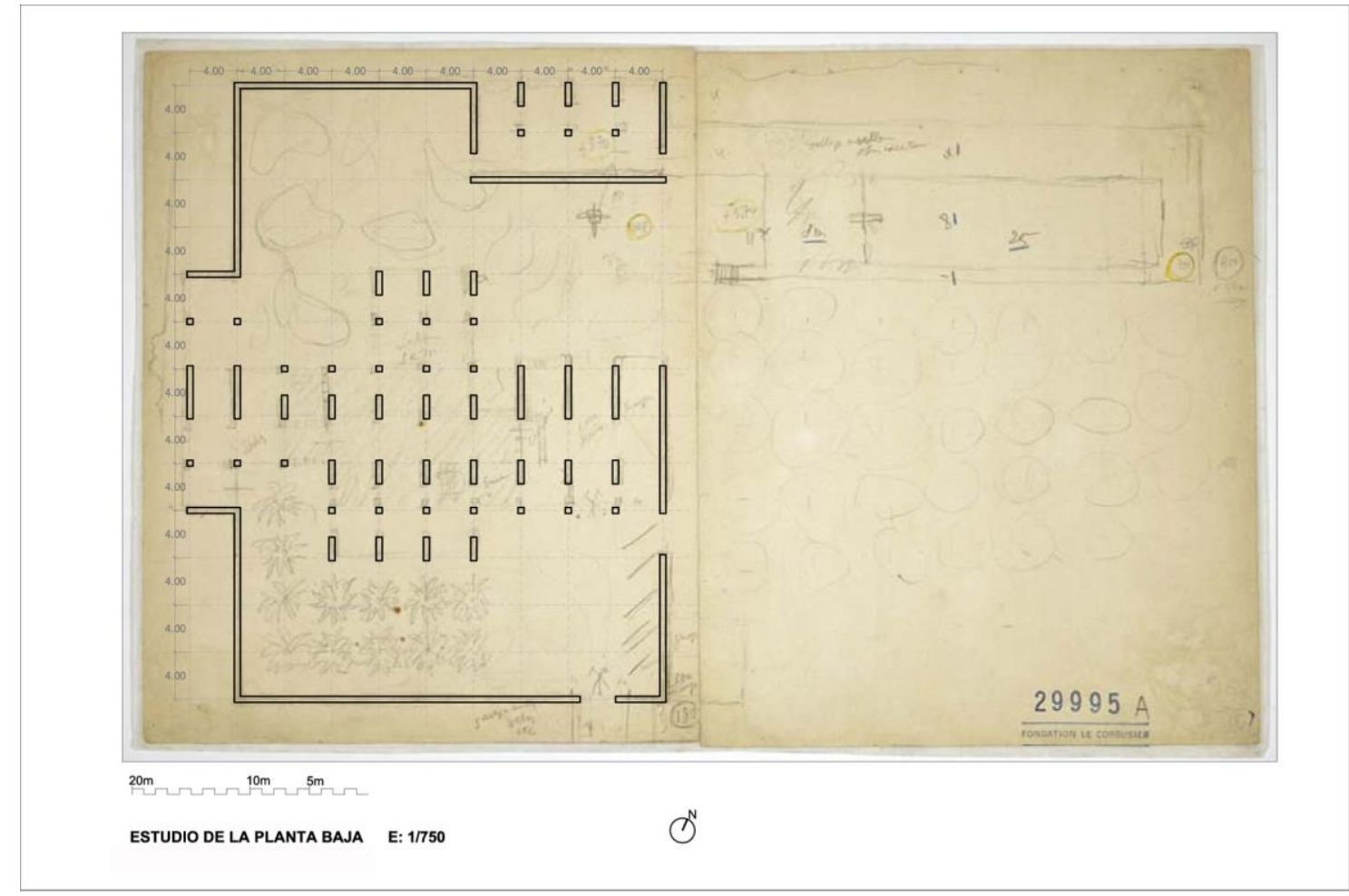

1.Estudio de la Planta Baja. Superposición sobre el croquis 29995A.

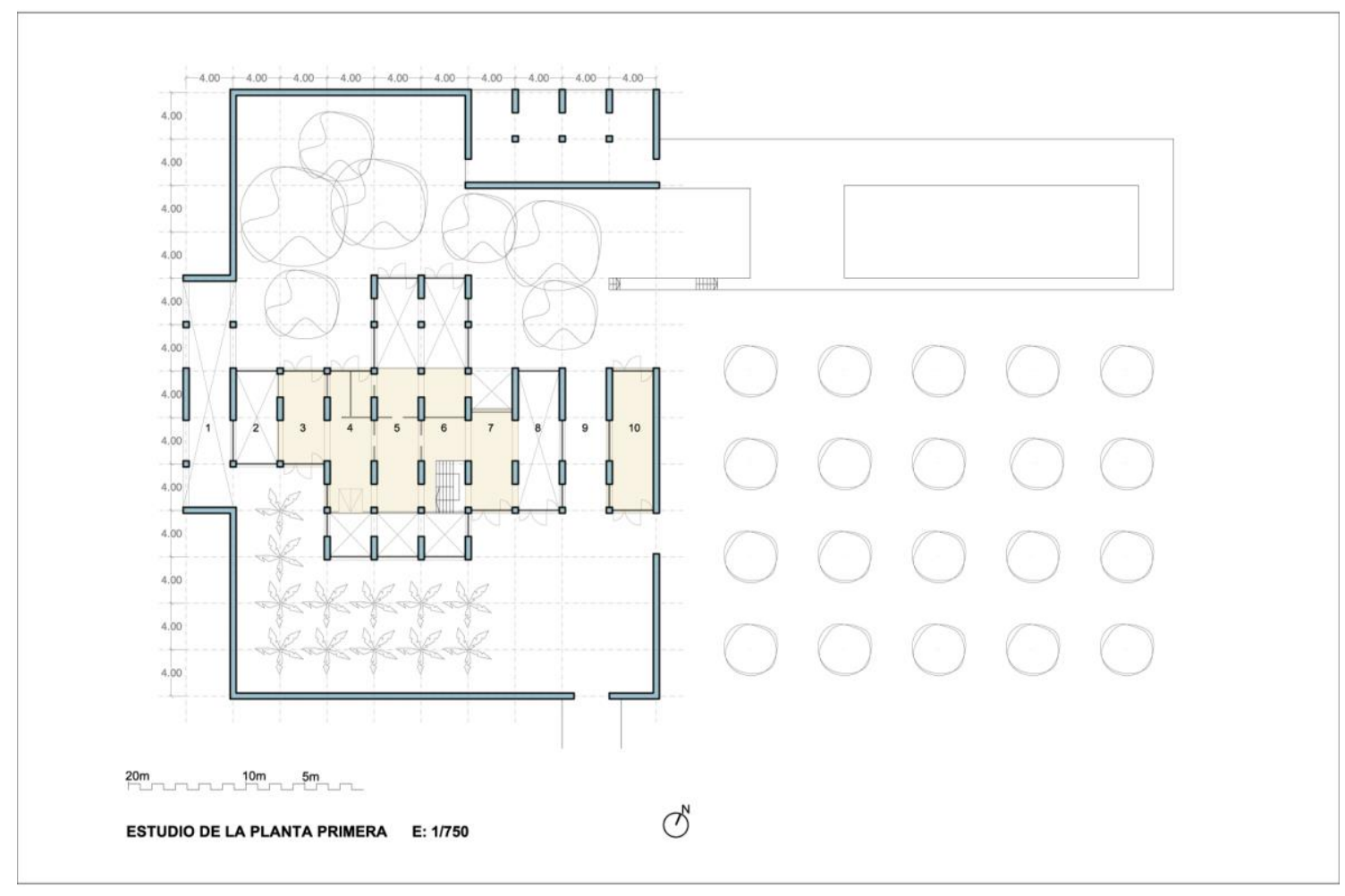

2. Estudio de la Planta Baja con todos sus elementos. 


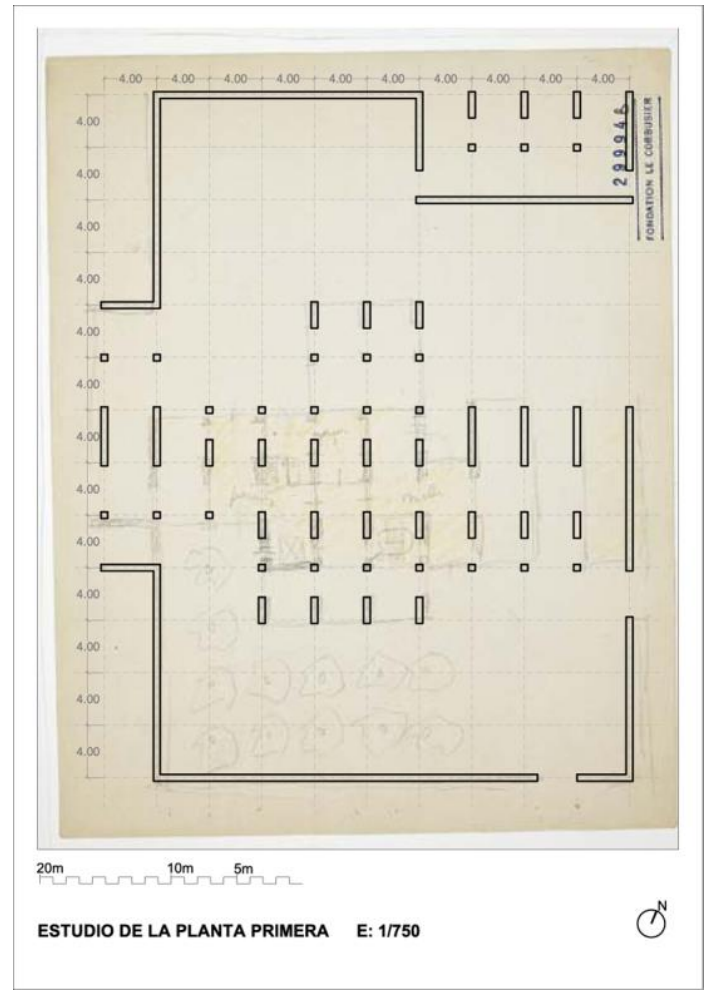

3.Estudio de la Planta Primera. Superposición sobre el croquis 29994B.

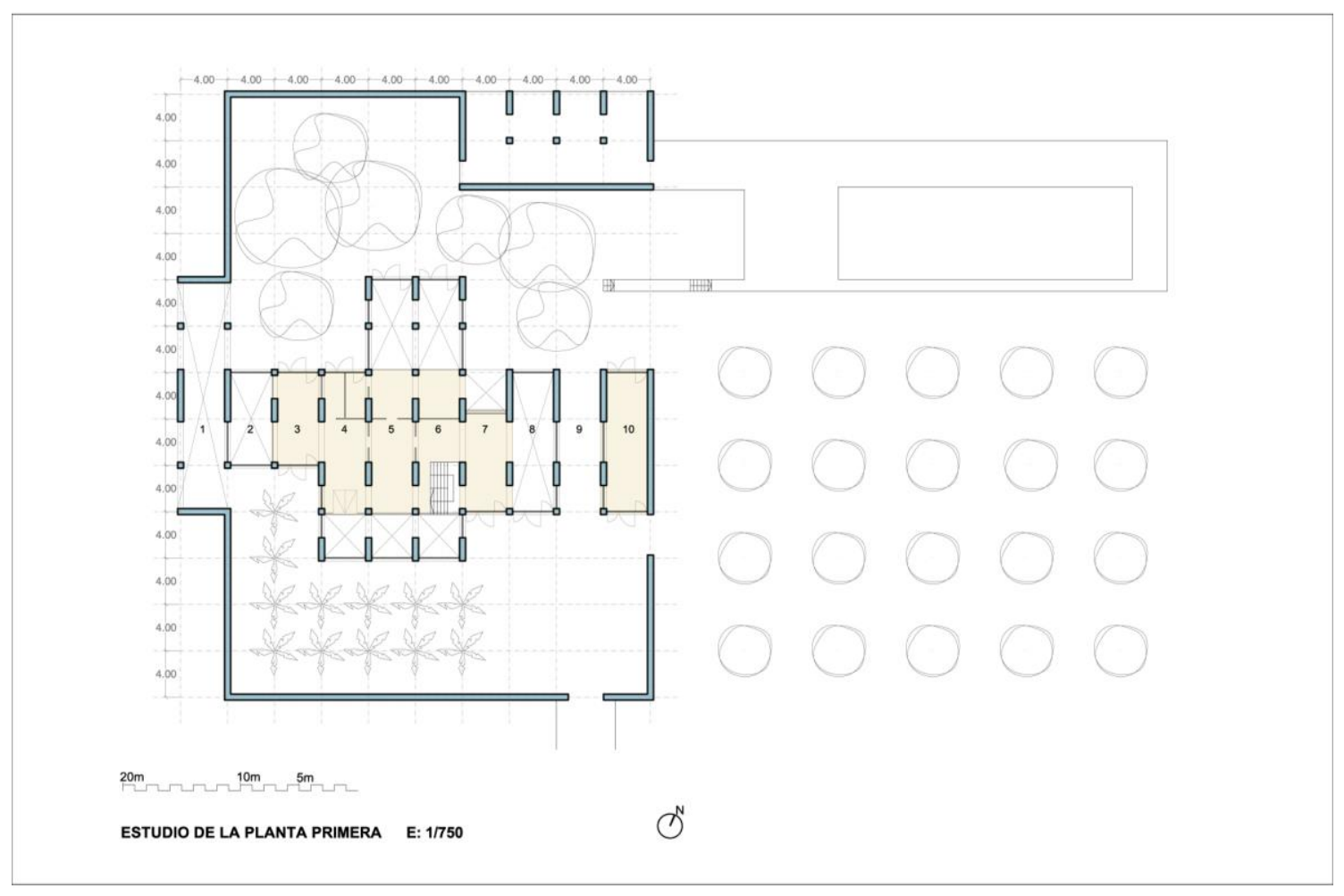

4. Estudio de la Planta Primera con todos sus elementos. 


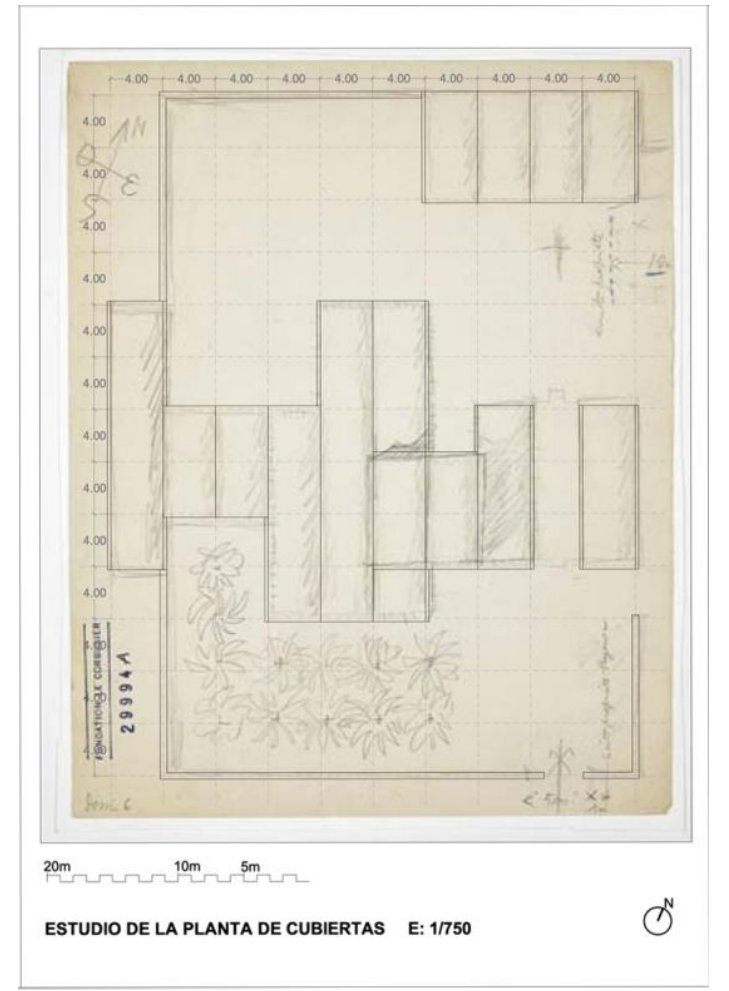

5. Estudio de la Planta de Cubiertas. Superposición sobre el croquis 29994A.

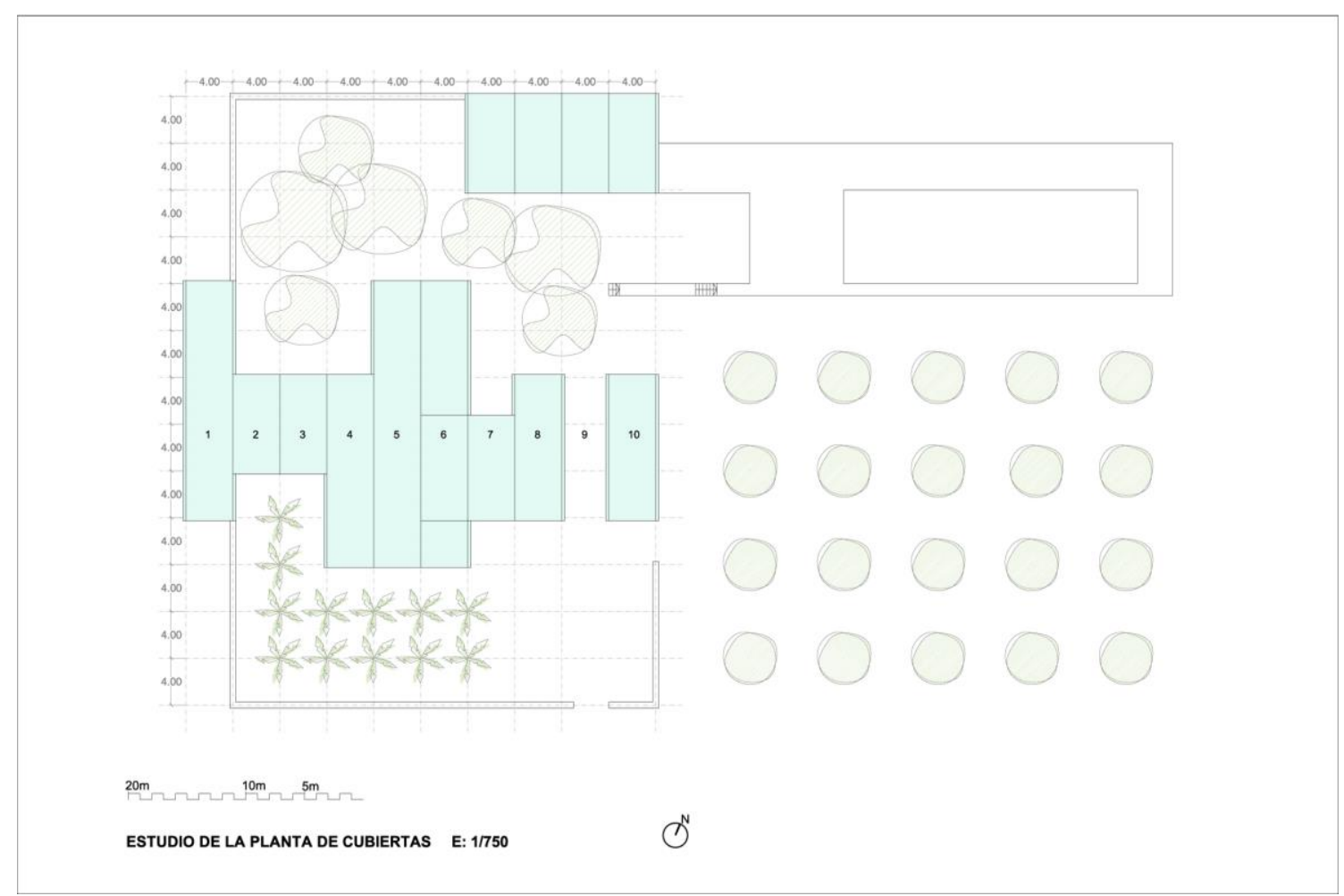

6. Estudio de la Planta de Cubiertas y la vegetación. 

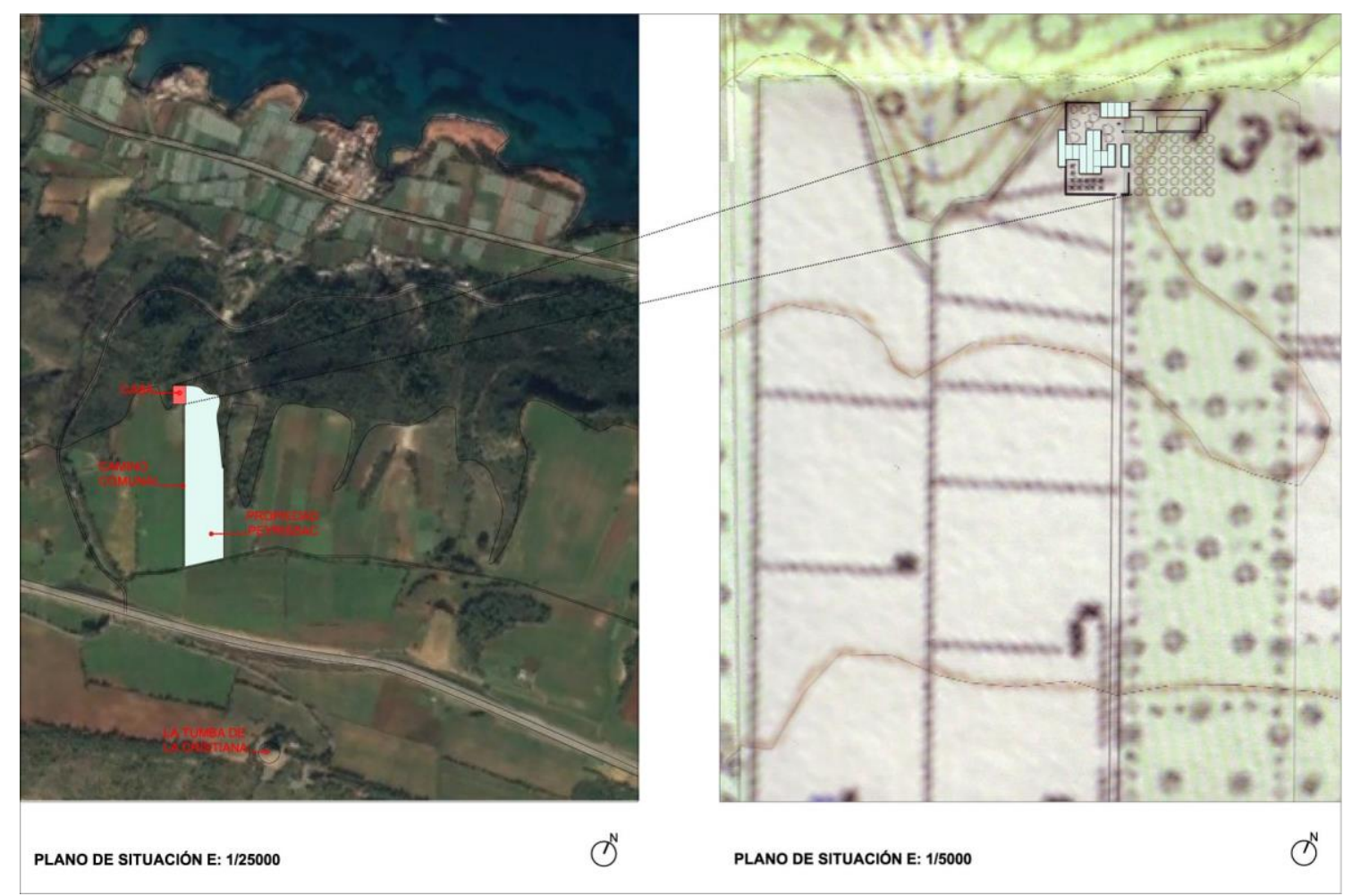

PLANO DE SITUACIÓN E: $1 / 25000$

$\infty^{N}$

PLANO DE SITUACIÓN E: 1/5000

7. Situación de la parcela.

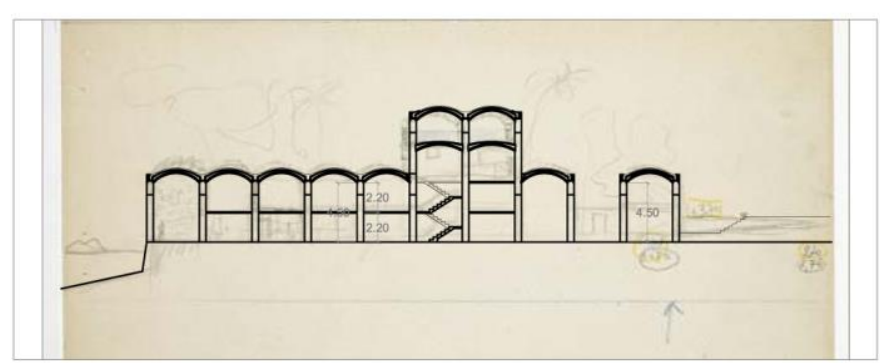

ESTUDIO DE LA SECCIÓN E: 17750

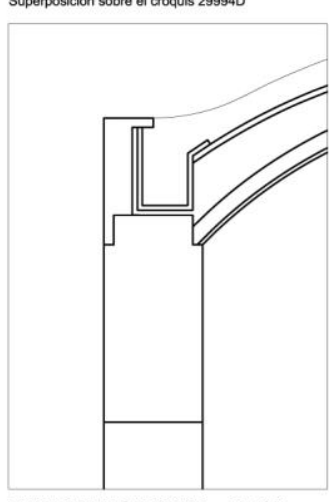

DETALLE DE CUBIERTA
Encuentro con el dintel de borde

Encuentro con el dintel de borde

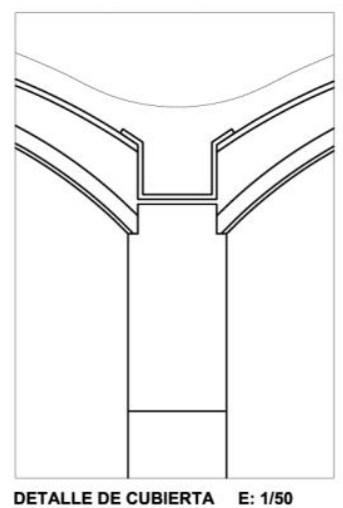

DETALLE DE CUBIERTA E: $1 / 50$ Intersección entre bovedas

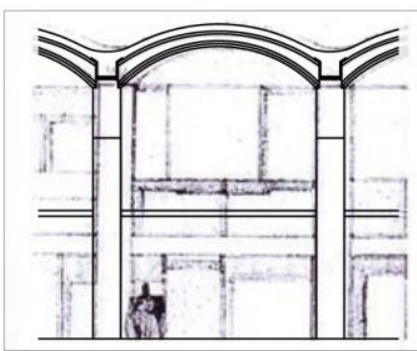

ESTUDIO DE LA GEOMETRIA DE LA BÓVEDA

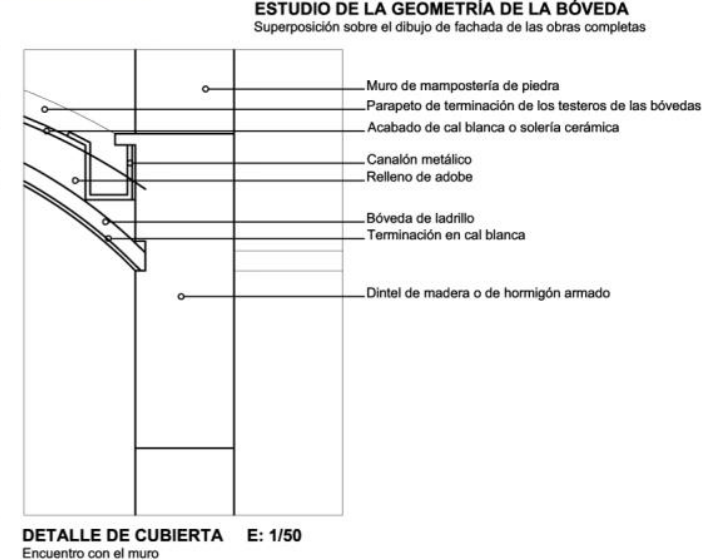

8. Sección y detalle constructivo. 


\section{Conclusiones}

Para realizar los dibujos nos hemos limitado a seguir las indicaciones que los croquis originales del maestro nos daban, sorprendiéndonos el hecho de que todas las piezas encajaban como si se tratara de un puzle. Ayuda el hecho de que el diseño de la casa se basa en un sistema geométrico y constructivo extremadamente sencillo, con la cualidad de no por ello restarle riqueza espacial al conjunto.

Teniendo en cuenta que vamos por detrás del maestro, hemos parado de dibujar cuando se nos ha acabado la información. Quedan varios temas por resolver: cuestiones básicas de distribución y mobiliario, como una más lógica distribución de los núcleos húmedos, la ubicación de las particiones interiores y sus diferentes grados de opacidad, las carpinterías exteriores, tanto en planta como en alzado, y por último profundizar en el sistema constructivo.

De la misma forma que hemos supuesto cómo debería ser el detalle constructivo de cubierta y lo hemos dibujado, se podrían establecer hipótesis relativas a los temas referentes a distribución interior y carpinterías, utilizando ejemplos de otras obras de Le Corbusier o simplemente apropiándose del proyecto.

\section{Listado de imágenes}

Colección de 36 croquis originales dibujados por Le Corbusier en relación a La Casa Peyrissac y facilitadas por La Fundación Le Corbusier. Ver listado, clasificación y análisis de los mismos en las tablas 1, 2, 3, 4 y 5.

Imágenes $1,2,3,5,6$, y 8 , realizadas como resultado del análisis de los croquis originales.

Imagen 7, realizada a partir de una imagen de Google Earth y de un parcelario de la zona.

\section{Bibliografía}

Le Corbusier Ouvres Complètes Volume 4. 1938-46. 14ª ed. Birkahauser, Basel: W. Boesiger, 2013.

Tipasa. Algeria 1:50,000. Series P741, U.S. Army Map Service, 1941. Perry-Castañeda Library Map Collection. University of Texas. 


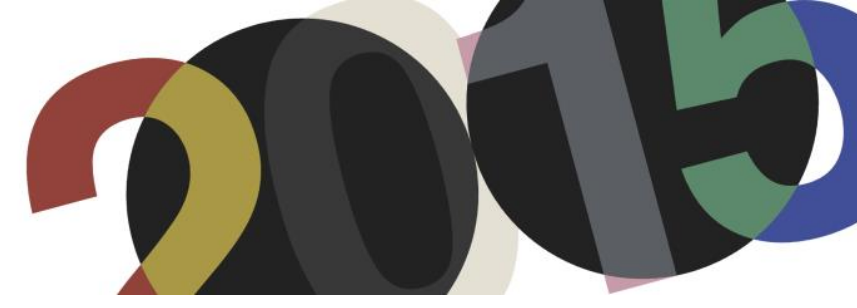

DOI: http://dx.doi.org/10.4995/LC2015.2015.1600

\title{
Le Corbusier's early urban studies as source of experiential architectural knowledge
}

\author{
C. Schnoor
}

Unitec Institute of Technology, Auckland, New Zealand

\begin{abstract}
In the year between April 1910 and March 1911 Le Corbusier - then Charles-Edouard Jeanneret - composed maybe the most comprehensive piece of writing of his career: a manuscript entitled "La construction des villes" which took on to systematically investigate the architectural elements that the city is made from. Taking Camillo Sitte's Der Städte-Bau nach seinen künstlerischen Grundsätzen of 1889 as his intellectual starting point, Jeanneret developed a complex and convincing thesis within several months, however never published it himself. One of the topics that appear throughout Jeanneret's manuscript is the quality of space as enclosure. This paper takes this observation as a starting point to ask how the manuscript that was put aside after March 1911 (and only shortly picked up again by Jeanneret in 1915) may have influenced Le Corbusier's architectural thinking. In order to achieve this, the chapter "The Illusion of the Plan" from Vers une architecture is investigated as a link between La construction des villes and Le Corbusier's houses. Finally, the Maison La Roche-Jeanneret and the Villa Savoye are read as buildings that very strongly incorporate aspects of thinking urban space in a way that way that closely relates to his studies back in 1910.
\end{abstract}

Keywords: La construction des villes; Städtebau; urban space; architectural space; Maison La Roche-Jeanneret; Villa Savoye.

\section{Introduction: The space of Le Corbusier's house designs and La construction des villes}

The well-known opening lines of Le Corbusier's Urbanisme contain a strong rebuttal of his earlier investigations of urban design. He suggests that he had been led on a false path by Camillo Sitte's ideas of a "sentimental past on a small and pretty scale, like the little wayside flowers" ${ }^{\prime}$, in fact that it had been the path of the pack-donkey who meanders - instead of man's direction who walks in a straight line: “The Pack-Donkey's Way has been made into a religion. The movement arose in Germany as a result of the book by Camillo Sitte on town-planning, a most wilful piece of work; a glorification of the curved line and a specious demonstration of its unrivalled beauties",

For the informed reader it is clear that Le Corbusier criticizes himself for being the pack-donkey, for following the winding path - and that he prompts himself to now walk in a straight line. But although he evokes the impression that his studies of Sitte and other urban design authors had been a waste of time, Le Corbusier knew better. He had, over the period of about a year from April 1910 to March 1911, composed a manuscript of astonishing clarity and rigour on questions of urban design, called La construction des villes, based on Camillo Sitte's book and on many other writings.

In my own research on La construction des villes, now more than ten years ago, I saw the first task in clarifying what Le Corbusier had really said - and to trace his writing back to his own sources, while attempting to identify

\footnotetext{
${ }^{1}$ Le Corbusier, The City of To-Morrow and its Planning, transl. Frederick Etchells (New York: Parson and Clarke, 1929), p. XXV. Originally published as Urbanisme. Paris: Crès, 1925.

${ }^{2}$ Le Corbusier, The City of To-Morrow, p. 8.
} 
his positions on these urban questions back in 1910 (the period which he speaks so condescendingly about in 1925). In Urbanisme, Le Corbusier suggests that he put everything to the side that he had read and erroneously believed in 1910. This paper therefore undertakes to take the knowledge gained from our study of Le Corbusier's urban design education a step further and to ask how it might have not been put to the side, despite his strong argument to the contrary, but how much and in which way his own knowledge, gained from the intense study of German language urban design literature and the direct experience of towns and cities at first hand was able to shape his formation as an architect. This can only be done in sketch format here but it might act as a useful starting point for further investigations. This paper thus follows Stanislaus von Moos' question in his foreword to the German/French edition of La construction des villes: "What happened to the text, after it had been shelved for the time being, respectively had been recast into the form of Urbanisme, which, in terms of its content, was mostly distorted into its contrary?"3

\section{The space of Le Corbusier's houses and La construction des villes}

With his unfinished manuscript "La construction des villes", Le Corbusier - still Charles-Edouard Jeanneret at that time - undertook an immense piece of writing - and learning - in 1910/11. ${ }^{4}$ He developed, probably more unwittingly than planned, a veritable treatise on urban design that, had it been published, would have added worthily to the contemporary writings on urban theory ${ }^{5}$. Requested by his teacher Charles L'Eplattenier, Jeanneret's task was to develop an argument for the aesthetic, or architectural reconsideration of the layout and organisation of his hometown La Chaux-de-Fonds which was to host the Assemblée générale des délégués de l'Union des villes suisses, scheduled to take place on 24 and 25 September 1910. But instead of providing a text for this convention he began to develop what might, under different circumstances, have become his academic thesis. He collected material, read about eighty books and journal articles, translated texts from German, wrote chapters and had about 600 pages of chapter texts and material ready by early 1911 - but no text for the September meeting in La Chaux-de-Fonds. In the end, L'Eplattenier published his own text. ${ }^{6}$ After abandoning the manuscript in early 1911, Jeanneret briefly took up work on it again in 1915, when he researched, in the Bibliothèques Nationales in Paris, further material for the intended book. But he never incorporated this material into the already written body of chapters. ${ }^{7}$

In his foreword to the first complete edition of La construction des villes, Stanislaus von Moos described it as a Steinbruch - a quarry - of Le Corbusier's work. ${ }^{8}$ And indeed, it is. Since he so meticulously put together his thesis, we can follow his intellectual, literary workmanship almost step by step from reading to note-taking to

\footnotetext{
3 "Was geschah mit dem Text, nachdem er fürs Erste ad acta gelegt bzw. in die sachlich mindestens über weite Strecken ins Gegenteil verdrehte Form von Urbanisme umgegossen worden war?" Stanislaus von Moos, "Vorwort. Im Steinbruch der Vormoderne", In Christoph Schnoor (ed.), La Construction des villes. Le Corbusiers erstes städtebauliches Traktat von 1910/11 (Zurich: gta, 2008), p. 13. Translation by author.

${ }^{4}$ Christoph Schnoor (ed.), La Construction des villes. Le Corbusiers erstes städtebauliches Traktat von 1910/11 (Zurich: gta, 2008).

${ }^{5}$ A closer comparison of La construction des villes with the Handbuch des Städtebaues by Cornelius Gurlitt, written in 1914 but only published in 1920 (Berlin: Architekturverlag Der Zirkel), reveals a surprising closeness in structure and argument.

${ }^{6}$ Charles L'Eplattenier, "L'esthétique des villes", in [Résumé de l'intervention de Charles L'Eplattenier à l'] Assemblée générale des délégués de l'Union des villes suisses réunis à la Chaux-de-Fonds à l'Hôtel de Ville, les 24 et 25 septembre 1910, Compte-rendu des délibérations de l'assemblée générale des délégués de l'union des villes suisses, 1910 ; Beilage zum schweizerischen Zentralblatt für Staats- und Gemeinde-Verwaltung 11 (1910), p. 24-31.

${ }^{7}$ It was Marc Albert Emery who published a first, albeit incomplete, edition of La construction des villes in 1992: Marc Albert Emery, Charles-Edouard Jeanneret, La Construction des villes (Lausanne: L:Age d'Homme, 1992).

${ }^{8}$ Von Moos, "Im Steinbruch der Vormoderne", p. 13.
} 
composing text. But this is only one aspect of the 'quarry' quality of La construction des villes. This manuscript holds a multitude of clues and suggestions for explaining Le Corbusier's later work.

Jeanneret studied recent German language theories of urban design, under the German term Städtebau (which translates into French as construction des villes). This was first promoted by architect Camillo Sitte in Vienna, whose volume Der Städte-Bau nach seinen künstlerischen Grundsätzen of $1889^{9}$ had been both popular as a piece of writing and influential in terms of developing the new discipline of designing cities. Sitte demanded to develop cities in a way that re-connected to the best historical periods of city-building, and thus to learn from old masters. However, Sitte did not study famous architects' works in order to come to an understanding of cities, instead he travelled, surveyed historic towns and cities, mostly in Italy and Germany, and derived his conclusions in a more phenomenological way than by arguing historically. Sitte's idea of a City Planning according to Artistic Principles ${ }^{10}$, taken up in German cities, was understood not so much as engineering or technical 'planning' but as a deeply architectural task and as such of vivid interest for Jeanneret who used Sitte as a starting point but extended his reading far beyond Sitte.

Rather than investigating in detail the content of La construction des villes ${ }^{11}$, this paper attempts to show how Le Corbusier's urban studies of 1910/11 did not just lay the foundations of his later urban design theory and practice but how they may have provided essential lessons on the design of architecture by his reading on - and grappling with - the form, structure and passer-by's perception of urban space. The paper argues that this substantially aided Le Corbusier's deep understanding of architecture, of architectural rhythm, space, proportion and circulation, not least the promenade architecturale. The paper will indicate how Jeanneret understood urban situations with the sense of spatial volume, of Raum, in mind ${ }^{12}$, and then compare elements of his 1910 writing to a chapter from Vers une architecture and investigate a few selected houses of the 1920s in order to demonstrate how aspects of La construction des villes seem to have aided Le Corbusier's architecture to evolve.

Why should we attempt to locate Jeanneret's urban research in his later houses - and not search for continuity between La construction des villes and Urbanisme? One answer is: this will be done elsewhere ${ }^{13}$; but more importantly, there is very little that, in an experiential sense, connects the spatial density and complex quality of Le Corbusier's houses with his (grand) urban designs. This paper now offers an answer to that problem by suggesting that, while of course elements of his research for La construction des villes went into the making of Urbanisme, another main (indirect?) outcome of this research is the quality of his houses. In an Albertian sense: the house is a small city.

\subsection{In La construction des villes, the notion of space as volume is ever-present}

Over a period of about seven months from April to November 1910 - mostly in Munich, with a journey to Berlin and (editorial) summer holidays in La Chaux-de-Fonds - Jeanneret incessantly read and took notes, translated excerpts, wrote chapters. Camillo Sitte was the intellectual starting point [Fig. 1] but by no means the only book he read. It has been possible to establish a bibliography of book titles and journal papers which Jeanneret read

\footnotetext{
${ }^{9}$ Camillo Sitte, Der Städte-Bau nach seinen künstlerischen Grundsätzen (Vienna: Graeser, 1889).

${ }^{10}$ This is the English title given to Sitte's book: Camillo Sitte, City Planning According to Artistic Principles, transl. George Collins and Christiane Crasemann-Collins (New York: Random House, 1965).

${ }^{11}$ This can be done through the forthcoming English edition; translated by Kim Sanderson, London: Ashgate, ca. 2016.

${ }^{12}$ Christoph Schnoor, "Le Raum dans La construction des villes de Le Corbusier. Une traduction aux multiples strates linguistiques et culturelles”, in Jean-Sébastien Cluzel (ed.), Traduire l'architecture (Paris 2015), pp. 120-29.

${ }^{13}$ Christoph Schnoor, "Le Corbusier and the Influence of Classicist Urban History", forthcoming in Armando Rabaça (ed.), Le Corbusier: History and Tradition (University of Coimbra, 2016).
} 
and worked with in 1910 that contains ca. 80 titles. ${ }^{14}$ All in all, while instigated by L'Eplattenier, this was nevertheless a thoroughly self-directed introduction into the new area of Städtebau ${ }^{15}$. Chapter by chapter, Jeanneret established what one could call a treatise of Städtebau questions, systematically investigating topics such as roads, perimeter blocks, public squares, parks, and applying his newly gained knowledge to his hometown, La Chaux-de-Fonds.

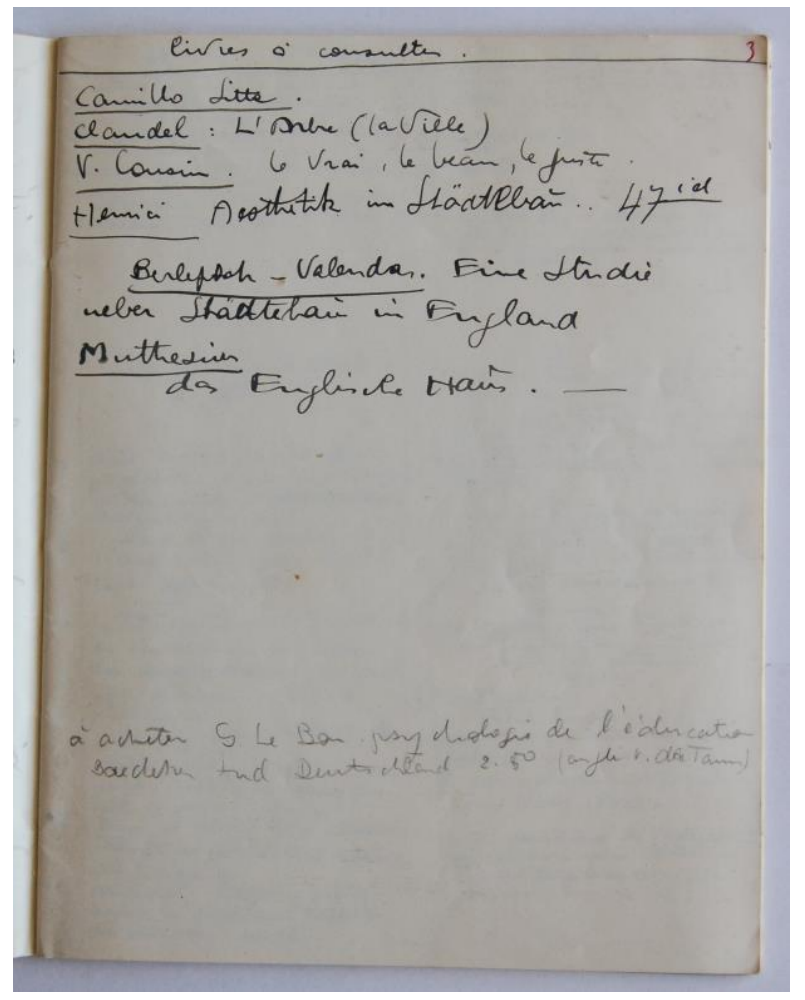

1. "La construction des villes", Cahier C.3, p. 52 (Lcdv 426). Reading list, early April 1910.

The remarkable and specific aspect to focus on for this paper is the consistency with which Jeanneret explored how urban space was generated - space in the sense of enclosure, even volume. It seems that he even 'invented' a new term for this, by using the French term corporalité, an underutilized French word, as synonym for the German word Raum, or space, but in the sense of the spatial enclosure of a chamber. ${ }^{16}$ It may be important to set this notion in comparison to a claim that Kurt Forster made in his groundbreaking analysis of the La RocheJeanneret houses in Paris. Forster says about the La Roche house: "The most conspicuous curvatures, the swelling body of the La Roche gallery and the softly rounded stairwell giving onto the rear terrace, reassert Le Corbusier's explicit distinction between volume and space [highlighted by author]"17. Forster bases this judgement on his combined reading of Purisme, the rappels in Vers une architecture, and Le Corbusier's theory on tools as body extensions, as laid down in L'Architecture décoratif d'aujourd'hui. Pointing at the "membrane-

\footnotetext{
${ }^{14}$ See Schnoor (ed.), La Construction des villes, pp. 615-17.

${ }^{15}$ Städtebau had just recently become a discipline in Germany - the Technische Hochschule Charlottenburg had introduced the first chairs of Städtebau, with Professors Joseph Brix and Felix Genzmer in 1903 and 1904.

${ }^{16}$ Cf. Christoph Schnoor, "Le Raum dans La construction des villes de Le Corbusier. Une traduction aux multiples strates linguistiques et culturelles", in: Traduire l'architecture, ed. Jean-Sébastien Cluzel, Paris 2015.

17 Kurt Forster, "Antiquity and Modernity in the La Roche-Jeanneret Houses of 1923", in K. Michael Hays (ed.). Oppositions. Selected Readings from a Journal for Ideas and Criticism in Architecture 1973-84 (New York: Princeton Architectural Press, 1998), p. 471.
} 
like nature of spatial envelopes" "18, Forster further asserts: "Le Corbusier built this experiential distinction between the organic form of the human body and the geometric structure of spatial abstractions into his architecture. In moving through the house, gesturing into space, or retreating to the 'hidden places' where purely utilitarian equipment modelled on the human body has been installed in compact volumes, one experiences the dialectic opposites of conceptualized space and bodily presence. Space comes to represent abstract totality, equipment the reality of need"19.

If we were to follow Forster's claim, Le Corbusier's notion of space could only be an abstract totality while it was the bodily volumes of curved elements that asserted themselves in space. This dichotomy however overlooks an aspect which lets Le Corbusier's space appear as less of a dichotomy, but instead introduces a tension that cannot be resolved. The fact that the curved volumes contain spaces that seems to have, in themselves, been shaped by the human body who uses them ${ }^{20}$, adds another, a poetic dimension of the space held by walls that is not explained by the notion of the membrane but instead sees the space itself as volume.

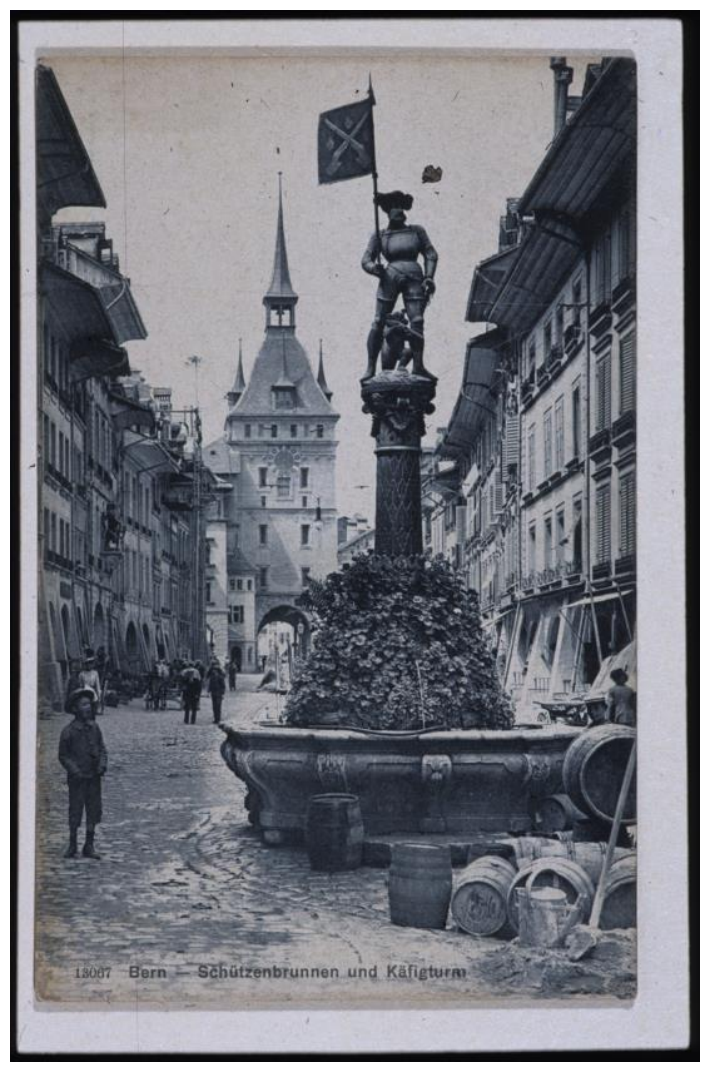

2. Marktgasse in Berne, L5-9-46 FLC

For this to be explained, Le Corbusier must be heard first; in La construction des villes, he analysed urban space generated by streets [Fig. 2], concluding: "We have all experienced the enchanting Marktgasse in Berne, having been through the passageway under the Käfigturm tower; [...]. The beauty of this street is generally attributed to the very edifices which frame it, to the superb fountains which enliven it. This is erroneous. The beauty arises

\footnotetext{
${ }^{18}$ Forster, "Antiquity and Modernity”, p. 471.

${ }^{19}$ Forster, "Antiquity and Modernity", p. 475.

${ }^{20}$ Cf. Christoph Schnoor, "Space and the Body: Concepts of the Corporeal in Le Corbusier's Work", in Kirsten Wagner and Jasper Cepl (eds.), Images of the Body in Architecture. Antropology and Built Space (Berlin: Wasmuth, 2014), pp. 99-130, here pp. 109-113.
} 
from the feeling of perfect volume in the street, and only subsequently - as a result of this - can the façades pay an effective tribute". ${ }^{21}$ Indeed, it is throughout La construction des villes that Le Corbusier uses the term "volume" in such a way that it can be read as synonymous with space. This may have to do with the fact that, inspired by Sitte's approach, Jeanneret very carefully studied what made spaces feel enclosed, which elements added to this condition and how this was perceived by the passer-by, the user of a city.

\subsection{Public urban space as enclosure}

In the general context of Jeanneret's investigation of künstlerischer Städtebau (Camillo Sitte's approach towards urban design that had architectural, artistic intent) it is not surprising that Jeanneret would have studied very carefully the various conditions Sitte discussed that make a public urban space feel spatially enclosed. However, it is remarkable with what persistence Jeanneret extended this search for spatial enclosure to his investigation of streetscapes, indeed of walls of enclosure ("Murs de Clôture"). Even in his excerpts and sketches for the chapter on cemeteries, a sense of spatial enclosure is brought out very strongly - on the one hand through the notion of the wall as enclosing element (Pisa), and on the other hand through plants as creating walls [Fig. 3]. This was fostered by contemporary architects' understanding of the garden as an architectural space, as Jeanneret would see at first hand in Peter Behrens' office. ${ }^{22}$
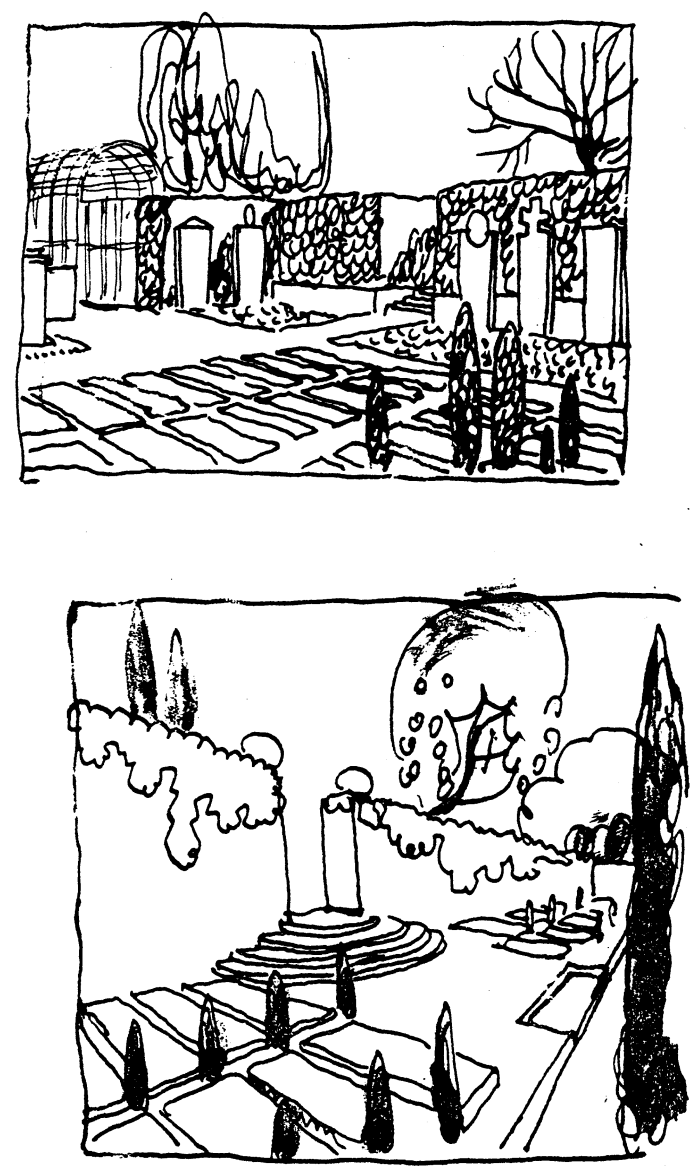

3. "La construction des villes", Cahier C.9, p. 250 (Lcdv 298)

\footnotetext{
${ }^{21}$ Charles-Edouard Jeanneret, "La construction des villes”, Lcdv 104, in Schnoor (ed.), La Construction des villes, p. 302.

${ }^{22}$ Barry Bergdoll, "Das Wesen des Raums bei Mies van der Rohe", in Barry Bergdoll and Terence Riley (eds.), Mies in Berlin (Munich: Prestel, 2001), pp. 66-105.
} 


\subsection{Theory of perception of space - static and in motion}

In terms of this paper's argument, the other crucial element for Le Corbusier's architectural formation is the flâneur's perception of urban space. Although Le Corbusier seems to not have read any of the theories on architectural space that had been developed by art historians just two decades earlier - neither August Schmarsow nor Heinrich Wölfflin are mentioned in his notes - he nevertheless learned about the applications of these theories through the practical aesthetics of architects and art historians. Jeanneret specifically studied writings by architects Karl Henrici and Paul Schultze-Naumburg and by art historian Albert Erich Brinckmann in depth.

Henrici, in his Beiträge zur praktischen Ästhetik im Städtebau ("Contributions to a Practical Aesthetic in City Planning"), laid down rules for the 'correct' design of streetscapes, so as to prevent them from appearing tedious for the passer-by who experienced the city by walking. ${ }^{23}$ Similarly, Paul Schultze-Naumburg, in the volume Der Städtebau, as part of his nine-volume Kulturarbeiten, explored how streetscapes were unfolding in front of the passerby's eye, and through that implicitly formulated the notion of an architectural movie in the flâneur's perception. ${ }^{24}$ Albert Erich Brinckmann, in his work Platz und Monument ("Square and Monument") of 1908 took a slightly different approach. ${ }^{25}$ While he also referenced Sitte's book as a starting point, he used a historical approach to investigate urban squares in Europe throughout history, arguing that the "Raumgefühl"26, the spatial feeling of each epoch, was different and required different architectural responses. He insisted on understanding the human scale in urban design. ${ }^{27}$ Brinckmann placed a strong emphasis on the square of the French kings and thus inspired Jeanneret in turn to research French urban developments of the 1600s and 1700s. It was also Brinckmann's Platz und Monument that introduced Laugier's writings to Jeanneret.

\section{3. "The Illusion of the plan" as continuation and transformation of Le Corbusier's urban studies of 1910}

The argument here is that through all these aspects of understanding the city and its visually and physically experienced elements, Jeanneret was provided with a set of tools of inquiry, with design tools that would enable him to better understand architectural space. This happened to such a degree that during his Voyage d'Orient, he would have found parallel spatial aspects in the buildings he visited to the urban spaces he had studied through books and through personal, physical experience. It is therefore fascinating to read the chapter of Vers une architecture, "The Illusion of the Plan" 28 , that in many ways refers directly back to his Voyage d'Orient, with the knowledge of Jeanneret's reading of Sitte and other Städtebau writers in 1910: it is almost palpable how his reading of urban design literature in combination with his direct visual experience of the Acropolis, Pompeii and Tivoli generated profound insights on the nature of architecture and in the generation of touching architectural space.

\footnotetext{
${ }^{23}$ Karl Henrici, Beiträge zur praktischen Ästhetik im Städtebau (Munich: Callwey, 1904).

${ }^{24}$ Paul Schultze-Naumburg, Der Städtebau. Kulturarbeiten vol. 4 (Munich: Callwey, 1906).

${ }_{25}$ Albert Erich Brinckmann, Platz und Monument. Untersuchungen zur Geschichte und Ästhetitk der Stadtbaukunst in neuerer Zeit (Berlin: Wasmuth, 1908).

${ }^{26}$ Brinckmann, Platz und Monument, p. 153.

${ }^{27}$ Brinckmann, Platz und Monument, passim.

${ }^{28}$ Le Corbusier, "The Illusion of the Plan”, in Toward an Architecture, transl. by John Goodman (Los Angeles: Getty, 2008), pp. 213-230, originally published as Vers une Architecture (Paris: Crès, 1923).
} 


\subsection{The garden as an outside room, a piece of architecture}

It seems that the sharp distinction that exists in Le Corbusier's work between the over-scaled urban designs and the often intimate and intricate spatiality of his architectural works is overcome at this very point where he stresses: "Considering the impact of a work of architecture on its site, I will show that here again the outside is always an inside ${ }^{\prime 29}$. With this remark, Le Corbusier brings together the urban space with the space of architecture, and one feels not only reminded of Alberti's sense of the house as a city but also of Hermann Muthesius' remark that the garden is a continuation of the rooms of the house into the outside. Jeanneret had not only read Muthesius' Das englische Haus in 1910, but had translated long passages about the relationship between house and garden into French, of which this sentence seems crucial: "The garden is seen as a continuation of the rooms of the house, almost a series of separate outdoor-rooms, each of which is selfcontained and performs a separate function. Thus the garden extends the house into the midst of nature ${ }^{, 30}$. And while he was taking excerpts from Georges Riat, L'Art des Jardins, a history of gardens that provided him with many poetic images of famous gardens through all times, Jeanneret commented to himself: "I should say that the garden adjoining the house shall not be a reminder of nature but a continuation of rooms, hallways, etc., of sunrooms or rooms of fresh air" ${ }^{\prime 31}$. In fact, some of the excerpts from Georges Riat were in turn citations of Hyppolite Taine's Voyage en Italie, in which Taine describes Italian gardens as pieces of beautiful and serene architecture. In this context Jeanneret also copied an illustration from Riat, entitled "Xyste et Triclinium sous une treille de la maison de Salluste ${ }^{, 32}$, at Pompeii [Fig. 4].

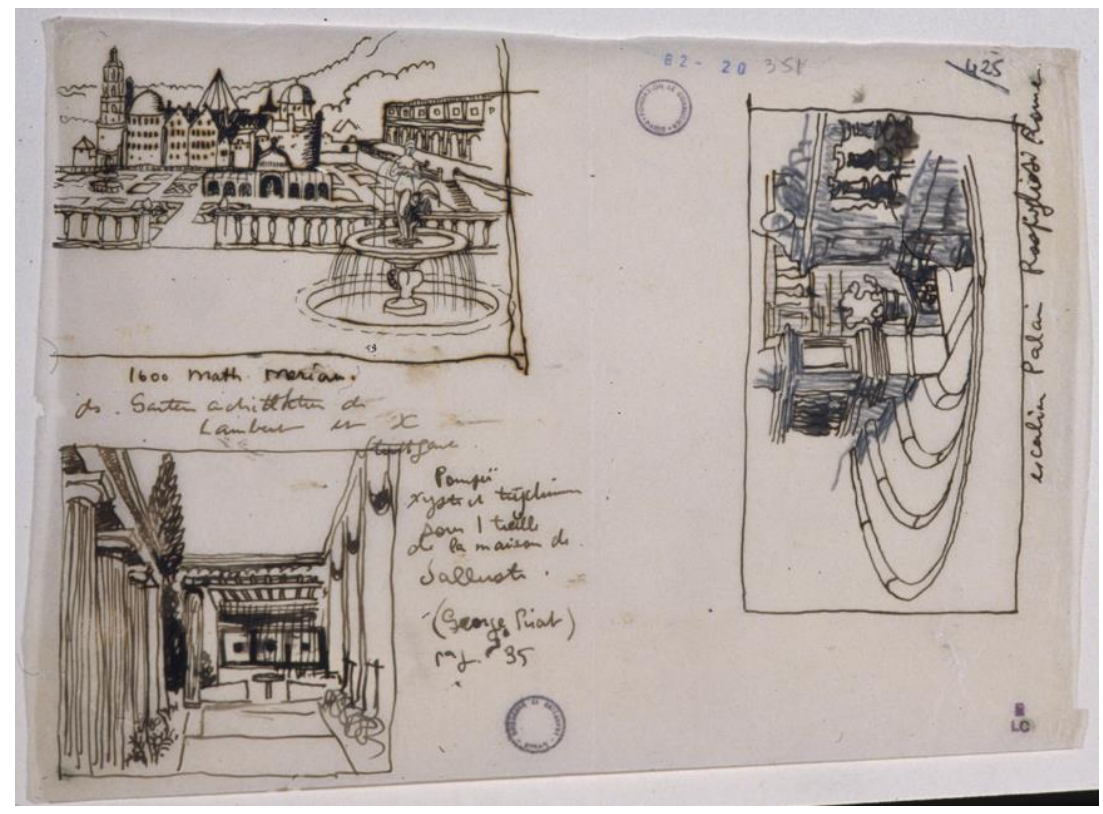

4. B2-20-351 FLC

\footnotetext{
${ }^{29}$ Le Corbusier, "The Illusion of the Plan", p. 216.

${ }^{30}$ Hermann Muthesius, The English House, ed. and introduction by Dennis Sharp, preface by Julius Posener, translated by Janet Seligman (New York: Rizzoli, 1979), 107. The original is Hermann Muthesius, Das englische Haus, Part II, p. 85: "Man erblickt im Garten eine Fortsetzung der Räume des Hauses, gewissermaßen eine Reihe einzelner Außenräume, von denen jeder in sich geschlossen eine gesonderte Bestimmung erfüllt. So erweitert der Garten das Haus in die Natur hinein.” 31 "Dire que le jardin attenant à l'habitation ne doit pas être un rappel de nature, mais une continuation des salles, vestibules etc., des chambres de soleil ou de fraîcheur." Jeanneret, "La construction des villes", Lcdv 246, in Schnoor (ed.), La Construction des villes, p. 406. Translation by author.

${ }^{32}$ B2-20-351 FLC, from Georges Riat, L'Art des Jardins (Paris: L. Henry May, 1900) p. 35.
} 
This very compressed collection of literature on gardens might serve to indicate how, in 1910, Jeanneret had laid the foundation for his own explorations, during his Voyage d'Orient, of Pompeii and its houses, and of the notion, which he would fully embrace in his own architectural projects, that the garden could be, in fact, another room of the house. Such a treatment of the garden is visible in the Pavillon de l'Esprit Nouveau - and in his designs for the Immeuble-villas, in which the garden manifests itself as an integral part of the architecture, as a 'garden of stone ${ }^{, 33}$. An approach to this notion already shows in his first house for his parents, the Maison Blanche in La Chaux-de-Fonds of 1912, in which the garden closely follows inspirations from Schinkel (the pergola), Schultze-Naumburg (for the pavillon at the edge of the garden) and Muthesius - in the way that it is set on a socle or plinth [Fig. 5].

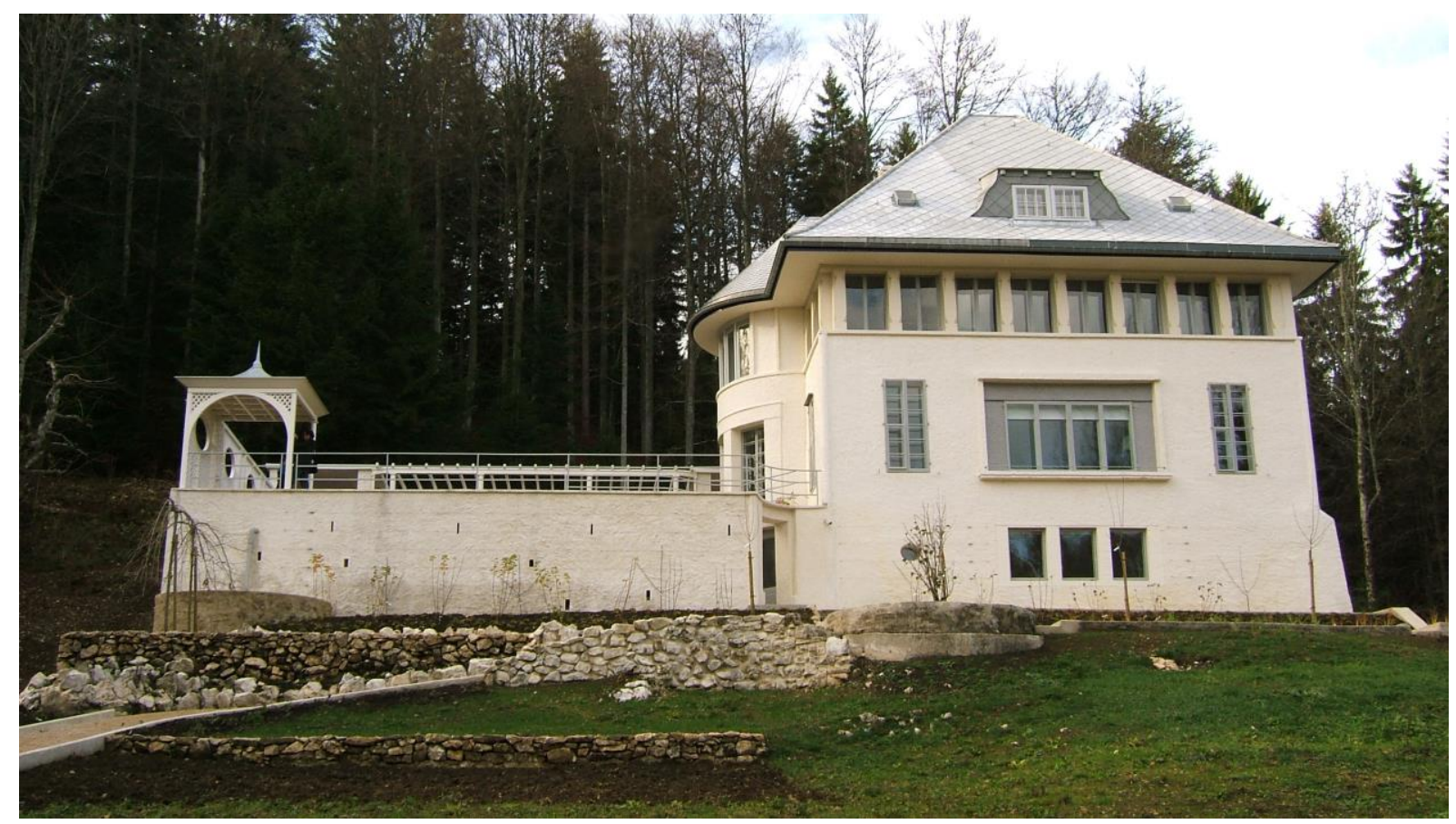

5. Maison Blanche (photo Christoph Schnoor)

\subsection{The admiration of the wall in urban situations and in Pompeian houses}

In the chapter "The Illusion of the Plan", Le Corbusier further asserts: "Architecture has as its goal to make us cheerful or serene. Have respect for walls. The Pompeian does not put holes in his walls; he has devotion for walls, a love for light. Light is intense if it is between walls that reflect it. The man of antiquity made walls, walls that extend and join together to make for still larger walls. Thus he did create volumes, the foundation of architectural sensation, of sensory sensation" 34 . The wall is paid due respect in what forms one of the magnificent discoveries within La construction des villes: a very short chapter that Jeanneret devoted to the idea of the wall in an urban context. He calls this chapter "Murs de Clôture", walls of enclosure, and it is almost

\footnotetext{
${ }^{33}$ See Christoph Schnoor and Claudia Kromrei, "Immeuble-villas between Albert Gessner and Le Corbusier", in Andrew Leach and Alexandra Brown (eds.), OPEN. Proceedings of the 30th Annual Conference of the Society of Architectural Historians, Australia and New Zealand SAHANZ. Griffith University, Gold Coast, Australia. pp. 807-22.

${ }^{34}$ Le Corbusier, "The Illusion of the Plan", p. 220.
} 
entirely based on passages in Paul Schultze-Naumburg's Städtebau. ${ }^{35}$ Schultze-Naumburg praises the beauty of the enclosure and, as a reader, one feels the spatial sense of enclosure as an almost bodily tangible feeling of being held: "The wall is not just a rigid and unyielding enclosure which incidentally is very ugly [...], but it is rather the most noble and beautiful kind of enclosure altogether. Only the wall allows one to carry the sensation of being at home and between ones own four walls, out under the open sky" "36. Not only is this an emotional argument for a simple and everyday piece of built structure, but one feels reminded of Jeanneret's note to himself, penned in his notebook on gardens: "I should assert this: for the GARDENS, that they are rooms - in fact, floor, wall and ceiling, and not houses. And that one should create volumes in which one feels inside and not outside oneself ${ }^{, 37}$. This - at its end rather enigmatic - statement makes more sense when read in parallel with Schultz-Naumburg's affirmation of the wall's qualities before: it might be that Jeanneret was aiming at expressing exactly that sensation of feeling 'at home while outside'. Based on Schultze-Naumburg's words and his own experiences from Pisa and Paris, Jeanneret had written in 1910: "A wall is beautiful, not just through its sculptural beauty, but also through the impressions it can evoke. It speaks of comfort, it speaks of delicacy, it speaks of power and of brutality: it is forbidding or it is welcoming; sometimes it holds a mystery. A wall is suggestive of feelings ${ }^{\prime 38}$. Jeanneret praised the wall of the Archives Nationales in Paris as well as the powerful wall around the Cathedral, Baptistery and Cemetery in Pisa, and in particular the wall of the Camposanto Monumentale itself $^{39}$. It even seems that he was ascribing a paradise-like peace to this particular piece of architecture. This does not mean to claim that Jeanneret had only developed a sense of the spatial quality of walls through reading Schultze-Naumburg, as it seems that he had already been aware of them during his first visit to Pisa in 1907. But from the similarity of his words with Schultze-Naumburg's formulations one is tempted to see the latter as having sharpened Jeanneret's sense of the spatial quality of walls.

Judging from Le Corbusier's design 'template' of the Maison Dom-Ino, one might get the impression that Le Corbusier's architecture - at least in the 1920s - was all about horizontality and the free plan, but no more than that. As Max Risselada claimed: "In the work of Le Corbusier, the distance between floors seems no longer important; only by way of stairs and ramps can the vertical dimension be realized". ${ }^{40}$ But this is not the case. Risselada's interpretation might be more suitable for many of Mies van der Rohe's spaces. Colin Rowe analysed many of Mies' spaces as what he termed "International Style Space" - a space sandwiched between two horizontal planes, with the specific requirement that the underside of the ceiling be uninterrupted so as to fully convey the smooth sensation of a space sliced horizontally, and extending into the distance ${ }^{41}$. On the other hand,

\footnotetext{
${ }^{35}$ Paul Schultze-Naumburg, Der Städtebau. Kulturarbeiten vol. 4 (Munich: Callwey, 1906).

36 "Die Mauer ist eben nicht bloss eine steife, starre Umwehrung, die im übrigen sehr hässlich [...] ist [...]. Sondern sie ist die edelste und schönste Art der Umwehrung überhaupt. Sie allein ermöglicht es, dass man das heimische Gefühl, zwischen seinen vier Wänden zu sein, auch unter freien Himmel hinausträgt [...]." Paul Schultze-Naumburg, Der Städtebau, Kulturarbeiten vol. 4, 1906/09, p. 429. Translation by author.

37 "Il faudrait bien affirmer ceci: pour JARDINS, c'est que ce sont des chambres, - en effet, plancher, parois et plafond, et non pas des maisons. Et qu'il faut créer des volumes ds lesquels on se trouve dedans et non pas situés hors de soi." Jeanneret, "La construction des villes", Lcdv 244, in Schnoor (ed.), La Construction des villes, p. 405. Translation by author.

38 "Un mur est beau, non seulement de sa beauté plastique, mais aussi des impressions qu'il peut éveiller. Il parle de confort, il parle de délicatesse, il parle de puissance et de brutalité : il est rébarbatif ou il est accueillant ; - il détient le mystère parfois. Un mur est évocateur de sentiments." Jeanneret, "La construction des villes", Lcdv 228, in Schnoor (ed.), La Construction des villes, p. 395. Translation by author.

${ }^{39}$ Jeanneret, "La construction des villes", Lcdv 310, in Schnoor (ed.), La Construction des villes, p. 446-47.

${ }^{40}$ Max Risselada, "Free Plan vs. Free Façade. Villa Savoye and Villa Baizeau revisited," in: Raumplan versus Plan Libre (Rotterdam: 010 Publishers, 2008), p. 85.

${ }^{41}$ Colin Rowe, "Neo- 'Classicism' and Modern Architecture II", in The Mathematics of the Ideal Villa and Other Essays (Cambridge, Mass.: MIT Press, 1976), 143.
} 
in "The Mathematics of the Ideal Villa", Rowe analysed Le Corbusier's space in the Villa Stein/de Monzie as centrifugal but always pushing against walls: "by introducing inversive gestures alongside expansive ones, he again makes simultaneous use of conflicting strategies ${ }^{, 42}$. Through its relentless verticality, the wall - and this is not just the rough stone wall which appears in Le Corbusier's architecture from circa 1930 onwards - is a strong counterpoint to the notion of crisp and clean horizontality. It is for this very reason that the careful establishment of Le Corbusier's appreciation of walls is worth re-considering here. Quite obviously, he did not lose his interest in the vertical boundary of a building but continued to explore the tension between the horizontal and the vertical. For this reason it is so valuable to see the continuation of Le Corbusier's appreciation of the wall from "La construction des villes" through to his modernist buildings of the 1920s and beyond.

\subsection{The axis}

On the surface the central argument of the chapter "The Illusion of the Plan" is of course Le Corbusier's argument that an axis, drawn in plan, may look beautiful but: "In reality, axes are not perceived in bird's-eye views shown in plan on the drawing board, but from the ground, by a man standing erect and looking before him "43. Thus, Le Corbusier asserts that the experience in space is what counts, rather than the beauty of the drawing. Such a notion he had already explored, in detail, in the introductory chapters of La construction des villes. Inspired by the way in which Städtebau responded to the Genius Loci and was considered in an architectural manner, Jeanneret claimed that throughout history, a good method of planning cities had prevailed: "The first method was design in space. Streets and squares were designed by considering the topography of sites. [...] The planner was a sculptor because he saw in 3 dimensions; he was a poet, because he created landscapes made by human hand, in which beauty, fully impregnated with the laws of Nature, could make staying in cities agreeable and charming" ${ }^{44}$. And he asserts, as the final lines of the chapter: "Beauty of a drawing on a sheet of paper, naive admiration of a fine graphic, this, in short, is the whole error which each page of this study will combat ${ }^{, 45}$.

In "The Illusion of the Plan", Le Corbusier applies his knowledge of urban spaces - both from his reading and from the experience in space - to the House of the Tragic Poet in Pompeii, confirming the subtle qualities of an axis that is present but does not intrude through an overly direct assertion: "Everything relates to an axis but you'd have a hard time drawing a straight line through it. The axis is in the intentions, and the splendour given by the axis extends to the humble things that the latter affects with a skilful gesture (the corridors, the main passage, etc.), through optical illusions. The axis here is not a dry theoretical thing; it links the crucial volumes yet spells them out and differentiates them from one another" ${ }^{\text {"46. }}$.

He further points out the difficulty of placing objects directly on axis, saying: "The fountain to the rear is in the corner of the garden. An object placed in the centre of a room often ruins the room since it prevents your placing yourself in the centre of the room and having the axial view; a monument in the centre of a square often ruins

\footnotetext{
${ }^{42}$ Colin Rowe, "The Mathematics of the Ideal Villa", in The Mathematics of the Ideal Villa and Other Essays (Cambridge, Mass.: MIT Press, 1976), 12.

${ }^{43}$ Le Corbusier, "The Illusion of the Plan", p. 221.

${ }^{44}$ Jeanneret, "La construction des villes", Lcdv 43-44, in Schnoor (ed.), La Construction des villes, p. 258. Translation by Kim Sanderson.

${ }^{45}$ Jeanneret, "La construction des villes", Lcdv 46, in Schnoor (ed.), La Construction des villes, p. 259. Translation by Kim Sanderson.

${ }^{46}$ Le Corbusier, "The Illusion of the Plan”, p. 223.
} 
the square and the buildings around it - often, but not always; every such case has its own logic ${ }^{, 47}$. This is Sitte at his finest. In La construction des villes, Jeanneret had most carefully studied and reproduced Sitte's argument for the so-called point mort ${ }^{48}$, the argument that a monument should not be erected in the centre of the square but in the 'dead corner', since this was the space that passers-by could refer to [Fig. 6]. It gave the monument a scale while being out of the way of the traffic. Sitte used the example of Michelangelo's argument to place his David at the corner of the Piazza dei Signoria and not in its middle, and he quoted the Forum in Pompeii as an example ${ }^{49}$.

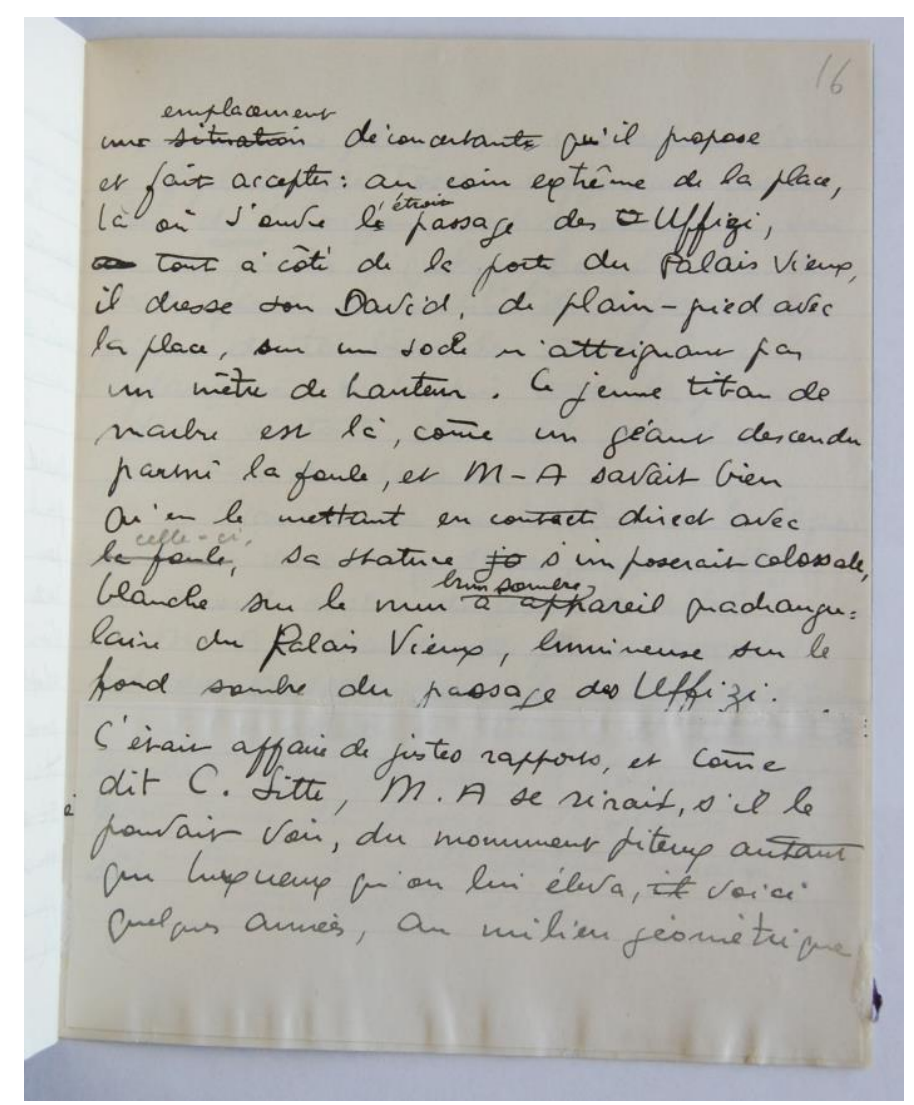

6. "La construction des villes", chapter text on squares (Lcdv 185), explaining Michelangelo's placing of the David sculpture.

To summarize: the Voyage d'Orient substantiated Jeanneret's newly gained - theoretical and experiential knowledge on urban spaces and added further, related aspects of the same topics. Le Corbusier's chapter on "The Illusion of the Plan" acts as another joint between the urban and the architectural space: not just houses figure in it, but also the Forum of Pompeii, which had served as an important argumentative device for Camillo Sitte in his Städte-Bau, and a point that Jeanneret had already picked up in his writings of 1910. Thus it evolves that many of the intellectual investigations begun in 1910 are still present in Vers une architecture, as much as in fact many of his assertions in Vers une architecture are best explained through the link back to the urban design investigations of more than ten years earlier.

\footnotetext{
${ }^{47}$ Le Corbusier, "The Illusion of the Plan", p. 224.

${ }^{48}$ Sitte, Der Städte-Bau, chapter "Das Freihalten der Mitte”, pp. 24-37.

${ }^{49}$ Sitte, Der Städte-Bau, pp. 21-23.
} 


\section{Villas La Roche-Jeanneret \& Savoye as realization of urban design principles}

Having established above that in "The Illusion of the Plan", important topics that Jeanneret had investigated and intellectually developed in La construction des villes, had not disappeared at all but had matured, the hypothesis is now taken further via an interpretive look at elements of the houses La Roche-Jeanneret and Villa Savoye.

In his analysis of the Maison La Roche-Jeanneret, Kurt Forster has made us aware of Le Corbusier's active borrowings from antiquity ${ }^{50}$, as an enquiry into architecture on a most fundamental level, as Anthony Vidler put it: "the forms of Greek temples, Roman monuments, and Pompeian houses as illustrated by Le Corbusier in his canonical text Vers une architecture do not refer to any already formulated Humanist tradition. Instead they stand for the origin of 'architecture' itself. That is, they are not so much to be measured and encoded into copybook lexicons as they are to be experienced in their essence" ${ }^{\text {, }}$. Jeanneret's visit of Pompeii then can be seen as a continuation of his urban studies where, as Leo Schubert observed, "all interiors had been turned into exteriors. [...] The atria, with their fountains and colonnades, became little plazas, and rooms became patios "52. Thus, Pompeii by its very nature may have suggested to Jeanneret a transition between the urban and the architectural spaces.

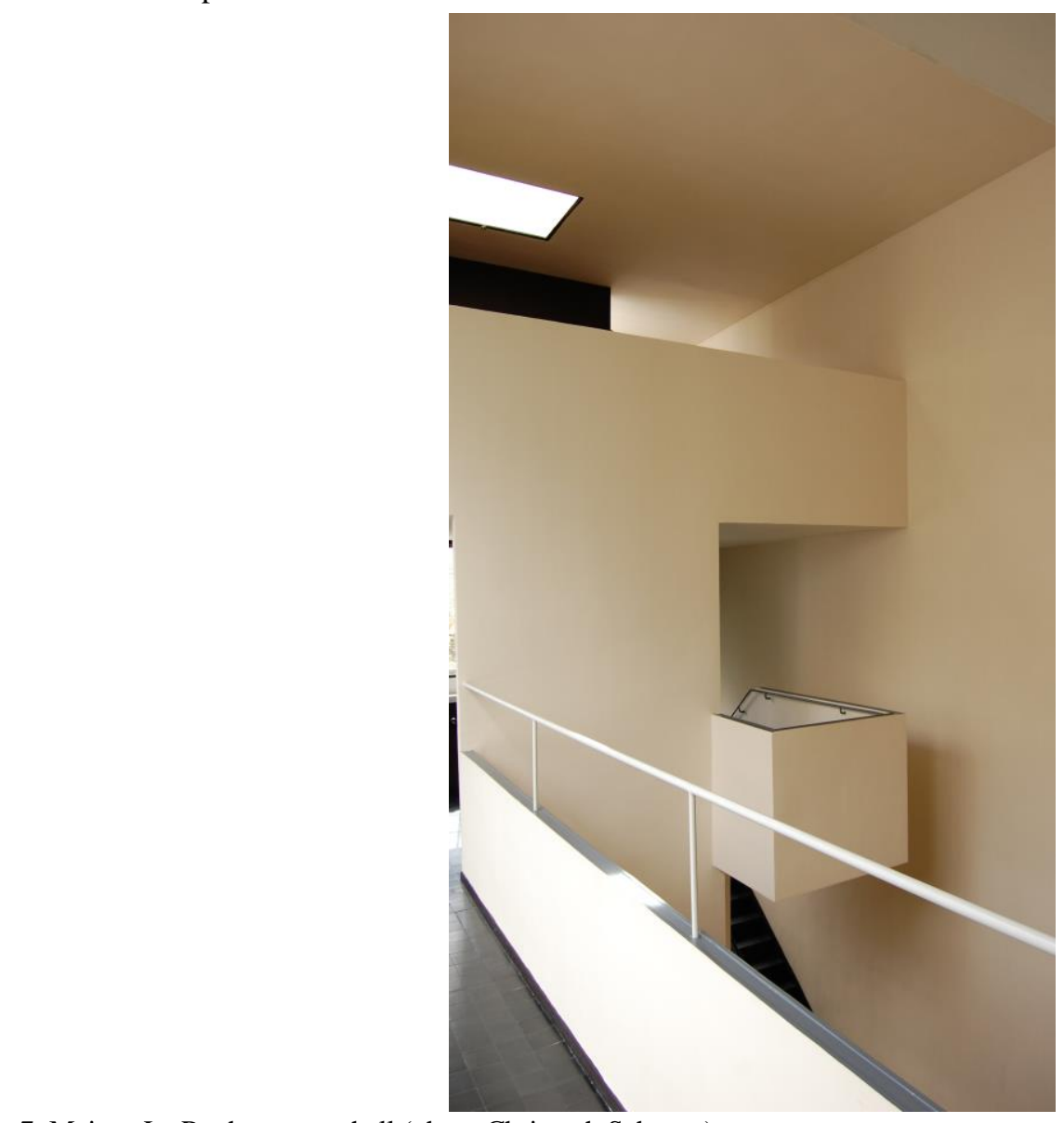

7. Maison La Roche - entry hall (photo Christoph Schnoor)

\footnotetext{
${ }^{50}$ Forster, “Antiquity and Modernity”, pp. 463-85.

${ }^{51}$ Anthony Vidler, "The Abstraction of History", in K. Michael Hays (ed.): Oppositions. Selected Readings from a Journal for Ideas and Criticism in Architecture 1973-84 (New York: Princeton Architectural Press, 1998), p. 461.

${ }^{52}$ Leo Schubert, "Jeanneret, the City, and Photography", in Stanislaus von Moos and Arthur and Rüegg (eds.), Le Corbusier before Le Corbusier (New Haven - London: Yale University Press, 2002), p. 64-65.
} 
Le Corbusier's houses of the 1920 s can be read as incorporating elements of the urban design studies, written down in La construction des villes, of 1910. In the Maison La Roche-Jeanneret [Fig. 7], the entry hall is like a public square on several levels. It is a tightly compressed space, it fulfils the client's demands for a social space - in fact it is a space like a theatre or one of the many stage-like public spaces in Venice. The visitor stands on the ground floor and imagines himself holding a glass of champagne while greeting someone who is in conversation with a friend on the first floor. People look down from the library and greet: it is a such a wellcomposed space to celebrate 'seeing and to be seen'. And in this, it feels not like an indoor room but indeed like a public urban space, a space in which the inside is always an outside, to take up and invert Le Corbusier's own phrase from "The Illusion of the Plan": the wall with balcony on the left side of the entrance might as well be the façade of a house - and, as Forster has shown in his analysis, it is almost virtually an outside since the interior balcony is the counterpart to the second balcony outside the gallery. ${ }^{53}$ This is an important point because I would like to assert here that I believe scales, for Le Corbusier, were mutable. Architecture and urban design then are not too distant spheres that cannot intermingle, but as this paper attempts to show, they interchange in $L a$ construction des villes itself, and, for Le Corbusier, experiences from the urban realm are allowed to enter his architecture.

Of course, almost the whole La Roche part of the house is also a promenade architecturale. And while Richard Etlin has already pointed at the link between picturesque urban design and the notion of the promenade, and Bruno Reichlin has delivered an inspiring reading of the promenade based on a comparison with Le Corbusier's purist paintings ${ }^{54}$, it should be emphasized here that Jeanneret's urban design studies of 1910/11 had a lasting influence of the development of the idea of the promenade. As Jeanneret carefully studied Henrici's and Schultze-Naumburg's elaborations on the effect that a well-designed streetscape has on the passer-by, these studies helped him develop the notion of the promenade with ever-changing views.

But the ramp itself takes us back to the matter of the pack-donkey. It is, in fact, Karl Henrici who had put the idea of the pack-donkey into Jeanneret's head in 1910, by suggesting that for humans (!) and beasts of burden (such as the pack-donkey) alike, winding paths uphill were much easier to negotiate and that serpentines were the right choice, rather than continuous gradients. Jeanneret had, in many words, taken up this suggestion and formulated a lengthy passage in his chapter on roads, in which he asked that 'the donkey's lesson should be remembered. In fact, if this beast with its long ears had been in the planners' office, it would have suggested: 'When it comes to streets sloping upwards, my dear planners, consider as much as you can ourselves, the poor beasts condemned to bear very heavy burdens. We do not like your continuous slopes which you draw so very straight ${ }^{, 55}$.

\footnotetext{
${ }^{53}$ Forster, “Antiquity and Modernity”, p. 469.

${ }^{54}$ Richard A. Etlin, Frank Lloyd Wright and Le Corbusier: The Romantic Legacy Manchester and New York: Manchester University Press, 1994), pp. 106-18; Bruno Reichlin, “Jeanneret - Le Corbusier, Painter - Architect”. In Eve Blau and Nancy Troy (eds.), Architecture and Cubism (London - Cambridge, Mass.: MIT Press, 1997), pp. 195-218.

55 "La leçon de l'âne est à retenir. En effet, si la bête aux longues oreilles, si elle eût fait partie du bureau du cadastre eût proposé ceci: 'Quand il s'agit dess rues montantes, messieurs les géomètres, pensez pour autant qu'il será posible à nous autres, pauvres bêtes condamnées à tirer des fardeaux bien lourdes. Nous n'aimons pas vos pentes continues que vous tirez si bien droites [...]". Jeanneret, "La construction des villes", Lcdv 117, in Schnoor (ed.), La Construction des villes, pp. 319 20. Lcdv 117. Transl. Kim Sanderson.
} 


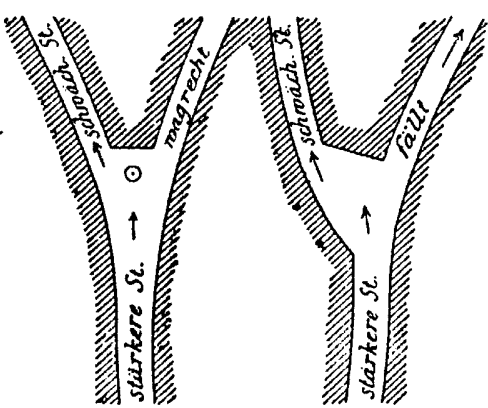

$\Lambda$ bbild. $1-4$.

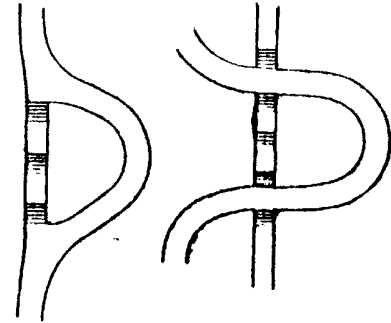

Abbildg. 5 u. 6.

8. Karl Henrici, Beiträge, p. 102-103, figs. 1-6. Figures 5 and 6 indicate the intertwined street and stairs.

In his further explanations on this topic, Henrici propounds how, on sloping sites, paths for pedestrians and streets should be entwined: “... if one has reason and opportunity to design such routes for pedestrians, and interrupts these with rest stops, then [...] the stepped or terraced form runs alongside or intertwines with the hairpin bend. The relevant example is a street designed for traffic which runs up in large bends to the crest of a hill, crossed by a footpath following a shorter line ${ }^{" 56}$. Henrici further demands that the connection between those two motifs be visible: "With such open site, it is important for the overall impression given that the connection between the two motifs, the sinuous route and the steep ramp, steps or terrace, be recognisable [Fig. 8]; lively intersections of the various lines arise, and the impact can be heightened fully by introducing architectural pieces, sculptural or garden ornaments ${ }^{\prime, 57}$. This, as one cannot fail to notice, is exactly what Le Corbusier achieved in the Villa Savoye. Ramp and circular stairs are the two means of vertical transport, the ramp as horizontal and therefore as easy as possible, the stairs as vertical as feasible. The two are placed in close proximity so that the effect of interweaving is very noticeable for the visitor entering the Villa [Fig. 9].

\footnotetext{
56 “...und wenn man Gelegenheit und Veranlassung hat, solche Richtewege für Fussverkehr anzulegen, und diese mit Ruhepunkten unterbricht, dann ergibt sich [...] eine Durchdringung oder Nebeneinander der Treppen- oder Terrassenform mit der Serpentine. Das Vorbild dafür liefert jede Fahrstrasse, die in grossen Windungen zu einer Berghöhe hinaufführt, mit dem Fusspfade, der sie in kurzer Linie durchkreuzt”. Henrici, Beiträge, p. 103-104. Translation by Kim Sanderson.

57 "Bei solchen offenen Anlagen ist es für den Eindruck von Bedeutung, dass man die beiden Motive, das der Serpentine und das der steilen Rampen-, Treppen- oder Terrassenbildung, in ihrem Zusammenhange erkennt; da ergeben sich belebende Überschneidungen der verschiedenartigen Linien, und durch einzuführende Architekturstücke, durch bildnerischen oder gärtnerischen Schmuck lässt sich die Wirkung auf das Höchste steigern." Henrici, Beiträge, p. 102-103. Translation by Kim Sanderson.
} 


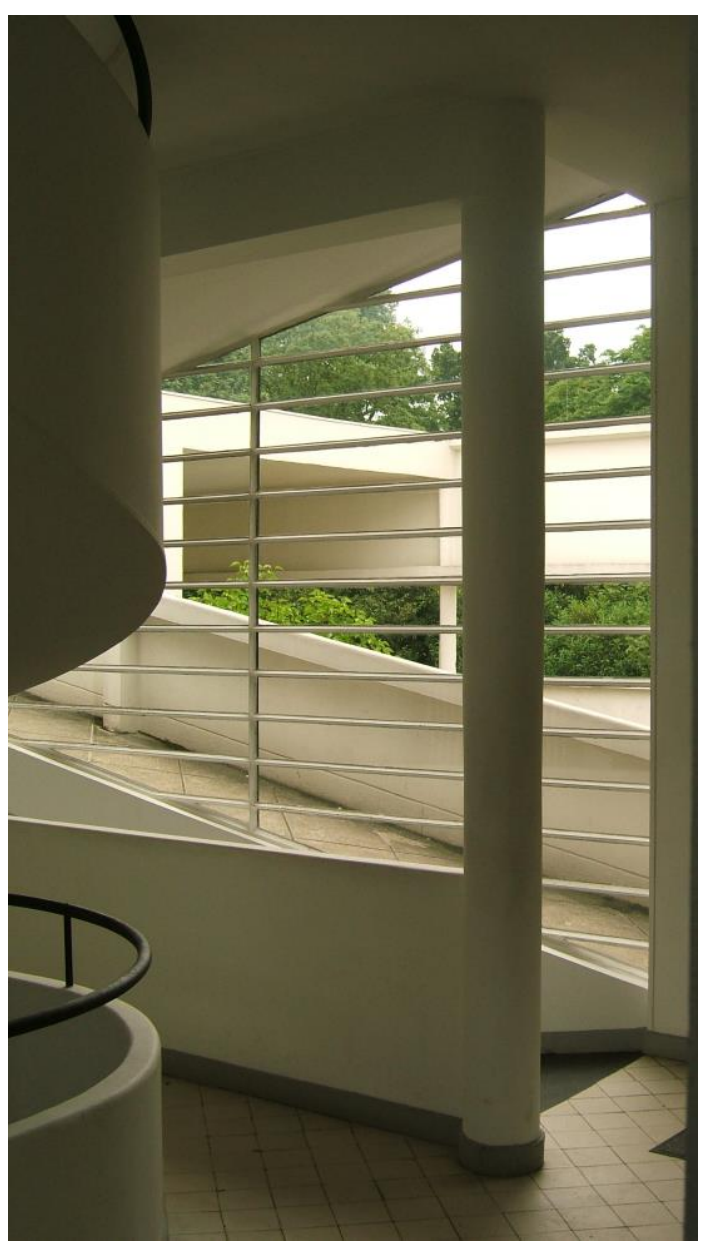

9. Villa Savoye: ramp and stairs (photo Christoph Schnoor)

\section{Conclusion}

By comparing passages from La construction des villes with the chapter "The Illusion of Plans" and selected houses from the 1920s, this paper has attempted to show that Le Corbusier enabled himself to learn, through his urban studies of 1910/11, as much about architecture as he learned about urban design. In fact I believe that it was through his thorough investigation of the qualities of urban space and its manifold conditions that Le Corbusier enabled himself to shape his extraordinary understanding of the many characteristics of architectural space.

\section{Bibliography}

Bergdoll, Barry. "Das Wesen des Raums bei Mies van der Rohe”. In Barry Bergdoll and Terence Riley (eds.). Mies in Berlin. Munich: Prestel, 2001. pp. 66-105.

Brinckmann, Albert Erich. Platz und Monument. Untersuchungen zur Geschichte und Ästhetitk der Stadtbaukunst in neuerer Zeit. Berlin: Wasmuth, 1908.

Emery, Marc Albert Emery. Charles-Edouard Jeanneret, La Construction des villes. Genèse et devenir d'un ouvrage écrit de 1910 à 1915 et laissé inachevé. Lausanne: L:Age d'Homme, 1992.

Etlin, Richard A. Frank Lloyd Wright and Le Corbusier: The Romantic Legacy. Manchester - New York: Manchester University Press, 1994, pp. 106-18. 
Forster, Kurt. “Antiquity and Modernity in the La Roche-Jeanneret Houses of 1923”. In K. Michael Hays (ed.). Oppositions. Selected Readings from a Journal for Ideas and Criticism in Architecture 1973-84. New York: Princeton Architectural Press, 1998. pp. 463-85.

Gurlitt, Cornelius. Handbuch des Städtebaues. Berlin: Architekturverlag Der Zirkel, 1920.

Henrici, Karl. Beiträge zur praktischen Ästhetik im Städtebau. Munich: Callwey, 1904.

L'eplattenier, Charles. "L'esthétique des villes". In [Résumé de l'intervention de Charles L'Eplattenier à l'] Assemblée générale des délégués de l'Union des villes suisses réunis à la Chaux-de-Fonds à l'Hôtel de Ville, les 24 et 25 septembre 1910, Compte-rendu des délibérations de l'assemblée générale des délégués de l'union des villes suisses, 1910 ; Beilage zum schweizerischen Zentralblatt für Staats- und Gemeinde-Verwaltung no. 11, 1910. pp. 24-31.

Le Corbusier. "The Illusion of the Plan". Toward an Architecture, transl. by John Goodman. Los Angeles: Getty, 2008, pp. 213-230. Originally published as Vers une Architecture. Paris: Crès, 1923.The first version of this text: Le Corbusier-Saugnier, “Architecture II, L’Illusion des plans”, in Esprit Nouveau, no. 15, February 1922. pp. 1767-80.

Le Corbusier. The City of To-Morrow and its Planning. Transl. Frederick Etchells. New York: Parson and Clarke, 1929. Originally published as Urbanisme. Paris: Crès, 1925.

MuthesiuS, Hermann. The English House. Dennis Sharp, ed. and introduction, preface by Julius Posener, translated by Janet Seligman. New York: Rizzoli, 1979. Originally published as Das englische Haus. Entwicklung, Bedingungen, Anlage, Aufbau, Einrichtung und Innenraum. Berlin: Wasmuth, 1904-11.

Reichlin, Bruno. "Jeanneret - Le Corbusier, Painter - Architect”. In Blau, Eve, and Troy, Nancy (eds.). Architecture and Cubism. London - Cambridge, Mass.: MIT Press, 1997. pp. 195-218.

Riat, Georges. L'Art des Jardins. Paris: L. Henry May, 1900.

Risselada, Max. "Free Plan vs. Free Façade. Villa Savoye and Villa Baizeau revisited”. In Max Risselada (ed.). Raumplan versus Plan Libre. Rotterdam: 010 Publishers, 2008. pp. 84-94.

Rowe, Colin. The Mathematics of the Ideal Villa. Cambridge, Mass.: MIT Press, 1976.

Schnoor, Christoph (ed.). La Construction des villes. Le Corbusiers erstes städtebauliches Traktat von 1910/11. Zurich: gta, 2008.

Schnoor, Christoph. "Le Raum dans La construction des villes de Le Corbusier. Une traduction aux multiples strates linguistiques et culturelles". In Jean-Sébastien Cluzel (ed.). Traduire l'architecture, Paris 2015. pp. 12029.

Schnoor, Christoph. "Space and the Body: Concepts of the Corporeal in Le Corbusier's Work". In Kirsten Wagner and Jasper Cepl (eds.). Images of the Body in Architecture. Antropology and Built Space. Berlin: Wasmuth, 2014. pp. 99-130.

Schnoor, Christoph; Kromrei, Claudia. "Immeuble-villas between Albert Gessner and Le Corbusier". In Leach, Andrew and Brown, Alexandra (eds.). OPEN. Proceedings of the 30th Annual Conference of the Society of Architectural Historians, Australia and New Zealand SAHANZ. Griffith University, Gold Coast, Australia. pp. 807-22.

Schubert, Leo. "Jeanneret, the City, and Photography". In von Moos, Stanislaus, and Rüegg, Arthur (eds.). Le Corbusier before Le Corbusier. New Haven - London: Yale University Press, 2002. pp. 55-67.

Schultze-Naumburg, Paul. Der Städtebau. Kulturarbeiten, vol. 4. Munich: Callwey, 1906.

Sitte, Camillo. City Planning According to Artistic Principles. Transl. George Collins and Christiane Crasemann-Collins. New York: Random House, 1965.

Sitte, Camillo. Der Städte-Bau nach seinen künstlerischen Grundsätzen. Vienna: Graeser, 1889. 
Vidler, Anthony. "The Abstraction of History". In K. Michael Hays (ed.). Oppositions. Selected Readings from a Journal for Ideas and Criticism in Architecture 1973-84. New York: Princeton Architectural Press, 1998. p. 461.

von Moos, Stanislaus. "Vorwort. Im Steinbruch der Vormoderne". In Schnoor, Christoph (ed.). La Construction des villes. Le Corbusiers erstes städtebauliches Traktat von 1910/11. Zurich: gta, 2008. pp. 7-13. 


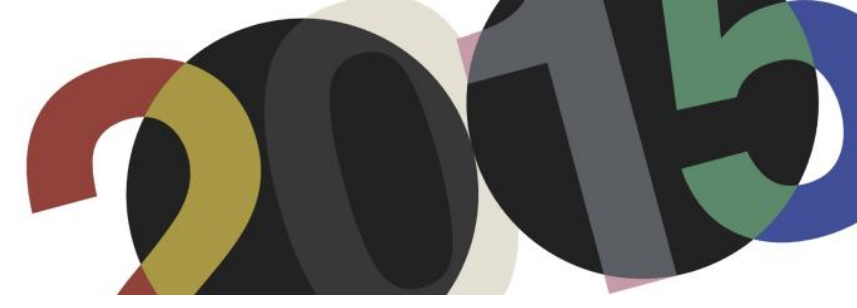

DOI: http://dx.doi.org/10.4995/LC2015.2015.567

\title{
Le Corbusier y el edificio del Ministerio de Educación y Salud
}

\author{
L. Scottá
}

Faculdade de Arquitectura da Universidade do Porto

\begin{abstract}
Resumen: Este artículo presenta una reflexión acerca del edificio del Ministerio de Educación y Salud, en Rio de Janeiro/ Brasil - un proyecto de varios arquitectos brasileños con la colaboración de Le Corbusier. El objetivo es analizar el procesos de la obra a partir de la comparación de tres publicaciones: Cuvre Complete 1934-1938, Brazil Builds: Architecture New and Old: 1652-1942 y Euvre Complete 1938-1946. Con el análisis de estos tres libros se presenta una visión completa desde el proceso de diseño hasta el final de la construcción. Es decir, puede ser vista la creación de un edificio. Mientras que el primer libro muestra un proyecto incipiente, en la etapa de progreso de ideas y propuestas, el segundo - Brazil Builds - presenta la construcción en proceso. Finalmente, el último libro muestra el diseño final y las fotografias del edificio ya construido, sólo un año después de su finalización
\end{abstract}

\begin{abstract}
This paper discusses the Ministry of Education \& Health building in Rio de Janeiro/Brazil - a project developed by several Brazilian architects in collaboration with Le Corbusier. The aim is to analyze the working process by comparing three publications: Euvre Complete 1934-1938, Brazil Builds: Architecture New and Old: 1652-1942 and Euvre Complete 1938-1946. The analysis of these three books presents a complete outlook of the building's design, from its beginning up to its construction. In other words, one can see the creation of a building. While the first book introduces the project in an incipient stage, going through the progress of elaborating ideas and proposals, the second - Brazil Builds - presents the construction process of the building. Finally, the last book presents the final design and photographs of the building already built, just a year after being finished.
\end{abstract}

Palabras clave: Brazil Builds; Le Corbusier; Arquitectura moderna brasileña. Keywords: Brazil Builds; Le Corbusier, Brazilian Modern Architecture.

\section{El proyecto del Ministerio de Educación y Salud}

La primera mitad del siglo XX condujo a Brasil a un gran progreso en varias áreas. Fue una época de crecimiento y evolución. Como afirma Williams: "A mediados del siglo XX, Brasil fue un ejemplo de desarrollo moderno. Durante este período no es exagerado decir que Brasil fue el país más moderno del mundo"1 ${ }^{\text {El }}$ Ministerio de Educación y Salud (MES), diseñado en 1936, se convirtió en el emblema ${ }^{2}$ del proceso de desarrollo del modernismo en la arquitectura brasileña. En abril de 1935, se convocó un concurso de proyectos para la construcción de la sede del Ministerio. Las normas del plan urbano de Río de Janeiro, que deberían ser respetadas, recomendaban: "retranqueo homogéneo de la edificación en relación a los límites del terreno (alineación), la construcción de edificios como bloques con zonas internas para ventilación e iluminación, además de entradas por las cuatro caras ${ }^{\prime \prime 3}$. El jurado eliminó fulminantemente los proyectos que contravinieron las reglas, quedando tres proyectos que tendrían un período adicional para su desarrollo hasta la decisión final. El

\footnotetext{
${ }^{1}$ WILLIANS, Richard: Brazil - Modern Architectures in history. Londres: Reaktion Books Ld, 2009. p.7. (Traducción del autor)

${ }^{2}$ Ibidem. p.8 .

${ }^{3}$ LISSOVSKY, Maurício; MORAES DE SÁ, Paulo Sérgio: Colunas da Educação. A construção do Ministério da Educação e Saúde. Rio de Janeiro: MINC/IPHAN, Fundação Getúlio Vargas/CPDOC, 1996.p. 13. (Traducción del autor)
} 
proyecto elegido fue el del arquitecto Archimedes Memória, entonces director de la Escuela Nacional de Bellas Artes. Se pagó el premio al arquitecto, pero el Ministro Gustavo Capanema decide no construir el proyecto ganador y, por medio de Carlos Drummond de Andrade, invita a Lucio Costa para preparar una propuesta para el MES el día 25 de marzo de 1936. Lucio Costa forma un equipo constituido por Oscar Niemeyer, Affonso Eduardo Reidy, Carlos León, Jorge Moreira, Ernani Vasconcelos y por él mismo. Al mismo tiempo, por sugerencia de Lucio Costa, el equipo se puso en contacto con Le Corbusier para que visitase Brasil para dar su opinión sobre el proyecto en curso para el MES, sobre los planes de la Cidade Universitária do Brasil y para que promoviese un ciclo de conferencias sobre arquitectura moderna.

En mayo, el equipo de arquitectos presentó una memoria descriptiva donde se percibe la influencia de los principios de la nueva arquitectura de Le Corbusier. Proyectado con una estructura independiente del cerramiento que dotaba a las fachadas de libertad, fue diseñado un volumen principal de 7 plantas conectado a dos alas de 5 plantas, todos apoyados sobre pilotis y un bloque anejo que albergaba una sala de conferencias.

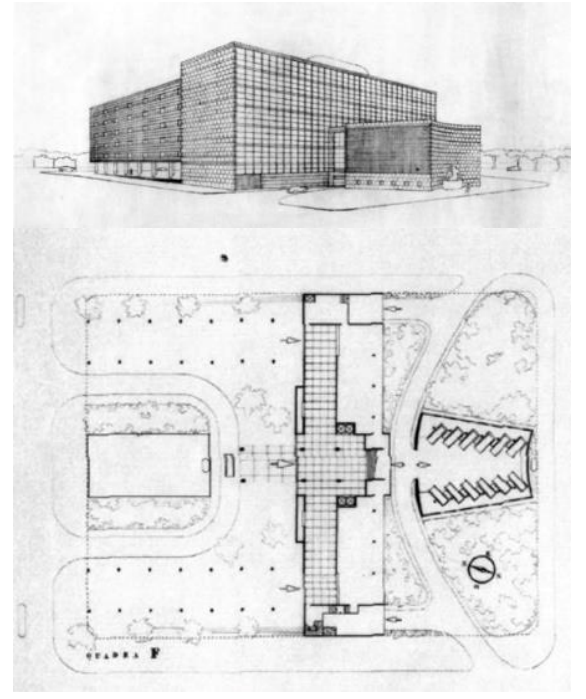

1.Primera versión del Ministerio de Educación y Salud. Proyecto del equipo de arquitectos brasileños.

En una carta a Gustavo Capanema, Le Corbusier mostraba su excitación por el viaje a Río de Janeiro: "Creo que sería una gran alegría para un arquitecto como yo encontrar en este magnífico paisaje la oportunidad de construir una obra de madurez capaz de revelar las posibilidades de la arquitectura moderna" ${ }^{4}$. Quería vincular su visita al desarrollo de alguna obra arquitectónica. Dijo:

"Estoy en una edad que ya no me permite desplazarme tan lejos para simplemente dar conferencias a estudiantes. Es indispensable para mí el poder crear obras arquitectónicas, ya sean pequeñas o grandes, aunque significativas. Expongo el problema de manera muy nítida, dejando claro que no puedo dar cursos de arquitectura y urbanismo en Río a menos que sea asegurada formalmente mi participación en una obra de arquitectura o urbanismo, en colaboración con los arquitectos brasileños ${ }^{\prime 5}$.

\footnotetext{
${ }^{4}$ LE CORBUSIER apud LISSOVSKY, Maurício; MORAES DE SÁ, Paulo Sérgio: Colunas da Educação. A construção do Ministério da Educação e Saúde. Rio de Janeiro: MINC/IPHAN, Fundação Getúlio Vargas/CPDOC, 1996.p. 59. (Traducción del autor)

${ }^{5}$ Idem.
} 
Después de hacerse oficial la llegada de Le Corbusier, Lucio Costa y él intercambiaron algunas cartas. Los temas fueron la arquitectura moderna, sus obstáculos en Brasil y el envío de las propuestas del equipo brasileño a Le Corbusier. Costa dijo que la mayoría de la gente no entiende completamente la arquitectura moderna y apenas oyeron hablar de la "máquina de habitar", y que había mucho por conocer aún. Cuenta que a él mismo le llevó algún tiempo entender las ideas de Le Corbusier, y que cuando éste llegó a Brasil por primera vez en 1929, tampoco lo entendió. En una carta del 26 de junio de 1936, Lucio Costa escribe:

"Durante su visita a Río de Janeiro en 1929, asistí a su conferencia: llegué a mitad del acto, la sala estaba llena - cinco minutos más tarde me fui escandalizado, convencido sinceramente de que había visto a un 'charlatán'. Entiendo muy bien, por tanto, el malentendido que persiste, ya que la mayoría aún está en esa etapa" ${ }^{6}$.

No obstante, en la misma carta, aclara un poco más tarde, que, cuando ya es director de la Escuela de Bellas Artes de Río de Janeiro,

"Se produjo un cambio profundo - el 'tradicionalista' que solía ser, en el mal sentido de la palabra, había sido capaz de superar gradualmente la repugnancia que sus libros me producían y de repente, como una revelación, toda la conmovedora belleza de su espíritu me impresionó. En 'estado de gracia' y con la fe inquebrantable de los recién convertidos, ;traté de 'salvar' a los jóvenes de la Escuela!" 7 .

En el mismo texto, Lucio Costa explicó la realización del concurso para la construcción del MES y el proyecto ganador y no construido, así como toda la red de contactos que se establecieron, resultando finalmente en la idea de un proyecto de arquitectos brasileños con el asesoramiento de Le Corbusier. En virtud de eso le hizo una cuidadosa petición:

"Apenas una sola cosa más. Una de sus tareas, junto al ministro, será la de dar su opinión sobre el proyecto del cual envío fotografías. Si le desagrada, díganoslo sin contemplaciones, pero por favor, no le diga de una manera seca al Sr. Capanema: 'Es feo... ellos no me entendieron' - porque entonces estaríamos perdidos sin remisión, ya que los 'otros' ya lo condenaron y por eso solicitamos su opinión ${ }^{\prime 8}$.

La situación era delicada. La evaluación de Le Corbusier tenía que ser favorable, aunque fuese sólo en parte. Fue necesario un proceso de aceptación de la modernidad. Los esfuerzos de Gustavo Capanema, Carlos Drummond de Andrade, Lucio Costa y de todos los otros arquitectos habrían sido en vano si Le Corbusier no hubiese reconocido su doctrina en el edificio, o simplemente rechazase el proyecto. No servirían de nada todos los discursos en favor del modernismo que se habían hecho hasta aquel momento en Brasil si Le Corbusier no avalase los intentos de los arquitectos.

\footnotetext{
${ }^{6}$ LUCIO COSTA apud LISSOVSKY, Maurício; MORAES DE SÁ, Paulo Sérgio: Colunas da Educação. A construção do Ministério da Educação e Saúde. Rio de Janeiro: MINC/IPHAN, Fundação Getúlio Vargas/CPDOC, 1996. p. 93. (Traducción del autor)

${ }^{7}$ Idem.

${ }^{8}$ LUCIO COSTA apud LISSOVSKY, Maurício; MORAES DE SÁ, Paulo Sérgio: Colunas da Educação. A construção do Ministério da Educação e Saúde. Rio de Janeiro: MINC/IPHAN, Fundação Getúlio Vargas/CPDOC, 1996. p. 93. (Traducción del autor)
} 
Le Corbusier llegó a Río de Janeiro el 12 de julio. Desde el 31 de julio hasta el 14 de agosto se habían programado seis conferencias sobre arquitectura moderna ${ }^{9}$. Antes de llegar a Brasil, Le Corbusier ya había recibido el proyecto desarrollado por el equipo brasileño y lo había considerado como prometedor. En su informe al Ministro menciona la aplicación de las teorías modernas de la arquitectura que defendió, elogiando la buena orientación, la solución de la estructura del edificio y el esquema de iluminación. Afirma que "este proyecto se puede clasificar por su valor arquitectónico entre los mejores de la historia que se hayan hecho hasta hoy sin importar en cual país ${ }^{\prime 10}$ y admitiendo algunas reservas desde el punto de vista plástico en cuanto a la simetría, sostenía que el terreno contenía algunas características que podrían haber limitado las soluciones. Por lo tanto - en relación con el lugar elegido en la Esplanada do Castelo - sostuvo que "sería desolador soportar los costes de un edificio tan bien diseñado"11 en un terreno con una mala localización. Afirmó que "el principio y la esencia de una obra arquitectónica reside en su ubicación. La ubicación es equivalente a más de la mitad del diseño arquitectónico y es claramente decisiva" ${ }^{12}$, proponiendo "no corregir el proyecto, que es excelente, sino a cambiar la localización, que es inadecuada"13. En el mismo informe, Le Corbusier refiere que puso en duda la elección del terreno, obteniendo la respuesta de que "toda la libertad era aún posible"14. Por ello, estaba dispuesto a colaborar en la búsqueda de otro terreno, decidiéndose, más tarde, por una zona junto al mar.

Para el nuevo terreno, situado cerca del mar y próximo al aeropuerto, presenta una propuesta que afirma que no es nueva, sino una reelaboración del diseño de los arquitectos brasileños. Le Corbusier escribe:

"Insisto en que este no es un nuevo palacio, sino el mismo, cuyas alas se abren. En consecuencia, el nuevo palacio tiene las mismas secciones constructivas, los mismos locales y, en principio, la misma disposición. En compensación, los servicios de la sala de conferencias y del vestíbulo mejoraron de manera significativa" ${ }^{\prime 15}$.

Este proyecto se muestra en Euvre complète 1934-38. La propuesta es de un edificio en bloque horizontal, más bajo que la propuesta de los brasileños y con vistas privilegiadas hacia la Bahía de Guanabara.

\footnotetext{
${ }^{9}$ LISSOVSKY, Maurício; MORAES DE SÁ, Paulo Sérgio: Colunas da Educação. A construção do Ministério da Educação e Saúde. Rio de Janeiro: MINC/IPHAN, Fundação Getúlio Vargas/CPDOC, 1996.

${ }^{10}$ LE CORBUSIER apud LISSOVSKY, Maurício; MORAES DE SÁ, Paulo Sérgio: Colunas da Educação. A construção do Ministério da Educação e Saúde. Rio de Janeiro: MINC/IPHAN, Fundação Getúlio Vargas/CPDOC, 1996. p. 109. (Traducción del autor)

${ }^{11}$ Ibidem, p. 110.

${ }^{12}$ Idem.

${ }^{13}$ Idem

${ }^{14}$ Ibidem. p. 109.

${ }^{15}$ LE CORBUSIER apud LISSOVSKY, Maurício; MORAES DE SÁ, Paulo Sérgio: Colunas da Educação. A construção do Ministério da Educação e Saúde. Rio de Janeiro: MINC/IPHAN, Fundação Getúlio Vargas/CPDOC, 1996. p. 112. (Traducción del autor)
} 


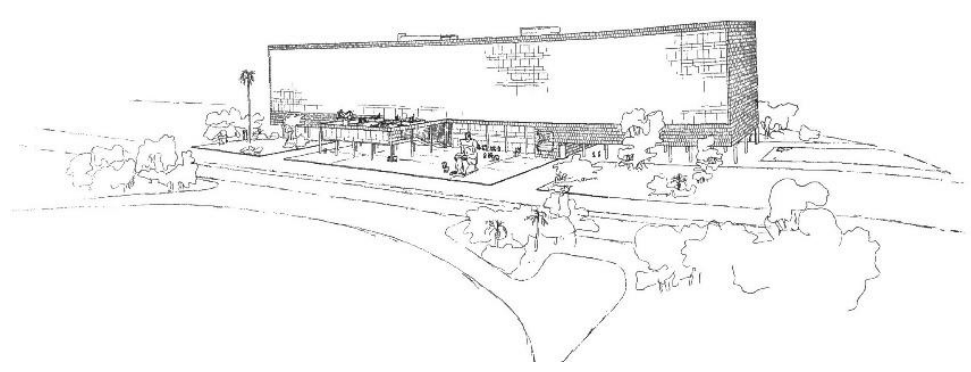

2. Propuesta de Le Corbusier para el nuevo terreno elegido por él. Publicado en Euvre complète 1934-38.

A lo largo de su estancia en Río de Janeiro, Le Corbusier se dedica a concretar el cambio de terreno, destacando las posibilidades arquitectónicas que se perderían si fuese ubicado en el terreno de la Esplanada do Castelo. Si esto ocurriera, Le Corbusier temía que se convirtiese en "un conjunto arquitectónico de tal naturaleza que de ninguna manera, a pesar de toda la perfección del edificio, fuese posible conseguir una impresión de nobleza y grandez $a^{\prime \prime 16}$. No obstante, por diversas razones administrativas, no fue posible modificar el terreno, siendo uno de los problemas principales su proximidad al aeropuerto, donde la altura requerida para los edificios era demasiado baja. Por ello, volvieron al terreno de la Esplanada do Castelo, para el cual el proyecto diseñado por Le Corbusier no era factible. Al mismo tiempo, la permanencia de Le Corbusier en Brasil había llegado a su fin. Gustavo Capanema consiguió que Le Corbusier dejase algunos dibujos, hechos a última hora, para el terreno original. El arquitecto mantuvo un volumen principal horizontal en uno de los lados del terreno, conformando una plaza de acceso con el bloque de servicios perpendicular al volumen horizontal.

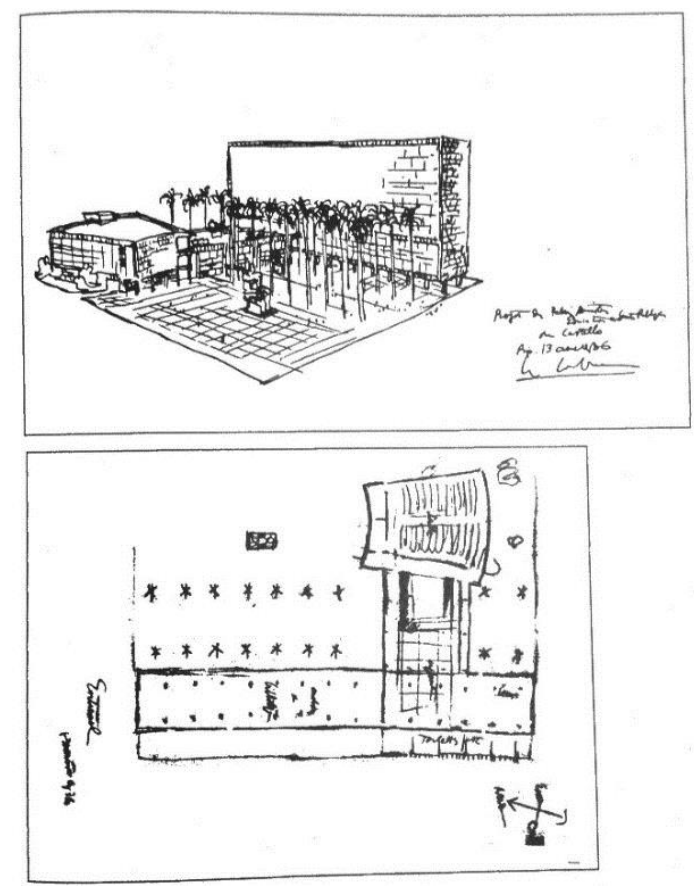

3. Propuesta de Le Corbusier para el terreno original.

${ }^{16}$ Ibidem, p. 19. 
Aun así, el proyecto brasileño siguió obteniendo opiniones de diversos profesionales e incorporando las sugerencias de Le Corbusier, con el fin de llegar a un proyecto definitivo. Los brasileños no querían construir su proyecto inicial, pero no estaban satisfechos con la propuesta dada por Le Corbusier. Fue necesario mucho trabajo para llegar a un acuerdo final basado en el diseño dejado por el maestro, pero cambiando la relación entre los tres volúmenes propuestos. Lucio Costa escribe el 3 de julio 1937 a Le Corbusier:

"Reconocida la imposibilidad de construir en el magnífico terreno que elegiste - porque tendría que ser mucho más bajo y sin la posibilidad de desarrollarlo inmediatamente debido a su proximidad al aeropuerto; y confirmado, por otro lado, que la 'momia'[17] estaba bien muerta - hicimos un nuevo diseño, inspirado directamente en sus croquis" ${ }^{\prime 18}$.

La respuesta de Le Corbusier es recibida el mismo mes:

"Su edificio del Ministerio de Educación y Salud me parece excelente. Incluso me atrevería a decir: animado por un espíritu clarividente, consciente de los objetivos: servir y emocionar. No tiene estos vacíos o barbarismos que a menudo vemos en otras obras modernas y que muestran que no se sabe lo que es la armonía. ¿Se está construyendo? ¿Sí? Entonces mucho mejor, y estoy seguro de que será hermoso. [...] Mi enhorabuena, mi 'OK' (como usted quería)"19.

El 30 de diciembre, Le Corbusier escribió a Gustavo Capanema: "Recibí hace unas semanas los planos y las fotografías del Ministerio, actualmente en construcción. Sigo detestando el terreno en el que lo construyen, pero creo que el espíritu innovador que anima a este edificio, con el paso del tiempo, lo convertirá en una cosa excelente $^{\prime 20}$.

El proyecto estuvo marcado por el racionalismo y funcionalismo predicado por Le Corbusier, y siguió los cinco principios: los pilotis, la planta libre, el jardín-terraza, la fachada libre y la piel de vidrio. Se le dio una gran importancia a la integración con obras de arte, integrando revestimientos de azulejos, frescos y esculturas. El Ministerio de Educación y Salud no estuvo exento de críticas, pero al mismo tiempo se divulgó en el extranjero con gran interés por varias publicaciones como el New York Times en 1943, y L'Architecture d'Aujourd'hui en $1947^{21}$. Más tarde, fue renombrado como Palácio da Cultura y fue inaugurado el 3 de octubre $1945^{22}$.

\section{Euvre complète 1934-38}

En este trabajo, publicado por Max Bill, y con textos de Le Corbusier en 1939, el Ministerio de Educación y Salud aún estaba en construcción. El texto menciona la invitación al arquitecto franco-suizo realizada por el Ministro de Educación y Salud y por el Comité de arquitectos responsables por el proyecto. Muestra que Le

\footnotetext{
${ }^{17}$ Nombre dado por Le Corbusier al primer proyecto del equipo brasileño.

${ }^{18}$ LUCIO COSTA apud LISSOVSKY, Maurício; MORAES DE SÁ, Paulo Sérgio: Colunas da Educação. A construção do Ministério da Educação e Saúde. Rio de Janeiro: MINC/IPHAN, Fundação Getúlio Vargas/CPDOC, 1996. p. 137. (Traducción del autor)

${ }^{19}$ LE CORBUSIER apud SEGAWA, Hugo: Arquiteturas no Brasil: 1900-1991.São Paulo: Edusp, 2010. p.91. (Traducción del autor)

${ }^{20}$ LE CORBUSIER apud LISSOVSKY, Maurício; MORAES DE SÁ, Paulo Sérgio. Op.cit.. p. 140. (Traducción del autor)

${ }^{21}$ CAVAlCANTI, Lauro (org.): Quando o Brasil era Moderno - Guia de Arquitetura 1928-1960. Rio de Janeiro: Aeroplano, 2001, p. 373.

${ }^{22}$ LISSOVSKY, Maurício; MORAES DE SÁ, Paulo Sérgio. Op.cit. p. 12.
} 
Corbusier se mostró inflexible en la sustitución del terreno, eligiendo otro para el cual elaboró planos con los arquitectos del Comité.

El principal proyecto está diseñado para el terreno cerca del mar elegido por Le Corbusier. Se publican una perspectiva general del edificio (ver Figura 2), un diseño del paisaje donde se implantaría, un esquema de circulaciones y varias imágenes de cómo sería el interior del edificio y su integración con el exterior (ver figura 4).

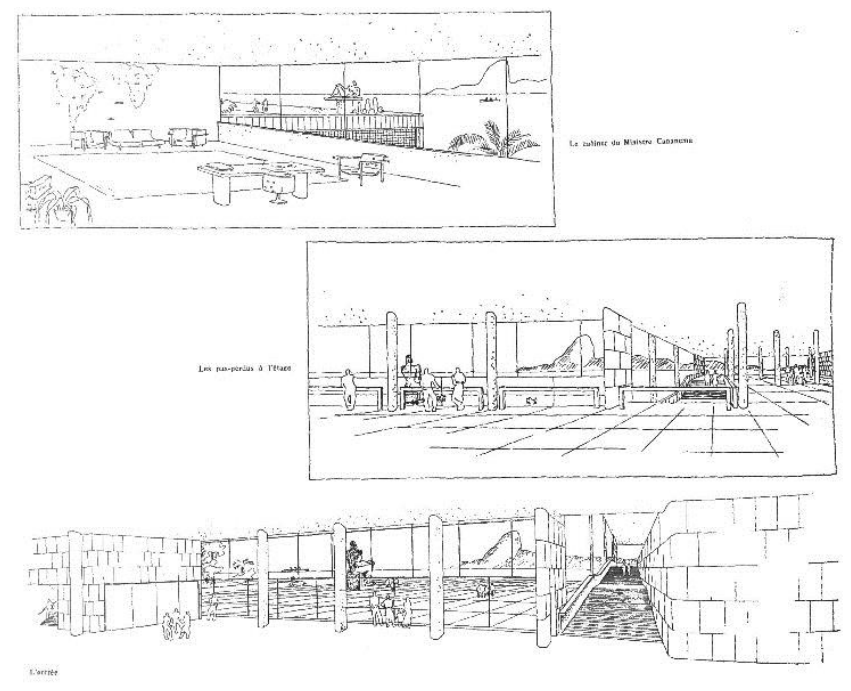

4. Propuesta de Le Corbusier para el nuevo terreno elegido por él. Publicado en Euvre complète 1934-38.

El texto continúa con la revelación de que no fue posible el cambio de terreno ${ }^{23}$, y se tuvo que volver al terreno original. Así que, en la víspera de su partida, Le Corbusier tuvo que ofrecer una propuesta al Ministro Capanema $^{24}$, pero estos diseños no aparecen en el libro, son los que se muestran anteriormente (Figura 3).

Lucio Costa resume los hechos, diciendo que Le Corbusier

"Hizo, así, varios intentos de adaptar el diseño al terreno de la Esplanada do Castelo, pero las variantes propuestas eran insatisfactorias. Cuando partió, nos quedamos con la tarea de elaborar el nuevo proyecto, basado en su proyecto inicial para la bahía, manteniendo lo esencial, pero modificando la implantación, la dirección (norte-sur en lugar de este-oeste), y aumentando la altura.

Cuando terminamos el proyecto, le enviamos copias y la foto de la maqueta, a lo que respondió enalteciendo el diseño. Lo que creó la confusión fue el trazo que Le Corbusier hizo después, calcado en la fotografía de la maqueta, divulgado en una publicación de Zurich"25.

\footnotetext{
${ }^{23}$ LE CORBUSIER \& JEANNERET, Pierre. Euvre complète. Vol 3. 1934-1938. Zürich: Les Éditions d'Architecture, 1995. (Publicado originalmente en 1938) p. 78.

24 “Avant son départ, Le Corbusier dut fournir au ministre une proposition d'adaptation de ser plans sur le terrain antérieurement choisi. On voit sur la gauche du croquis de droite l'usage habituel des terrains en question, à Rio: façades sur rues étroites et cours intérieures. Le projet actuellement en exécution constitue une grande novation urbanistique; il permettrait de tirer un parti admissible des tracés fâcheux de rues et de blocs ed d'introduire à nouveau l'espace dans le site Urbain, ainsi que des moyens efficaces de circulation”. LE CORBUSIER \& JEANNERET, Pierre. Euvre complète. Vol 3. 1934-1938. Zürich: Les Éditions d'Architecture, 1995. (Publicado originalmente en 1938) p. 78.
} 
Las tres últimas imágenes muestran el diseño final para el Ministerio de Educación y Salud y causan una cierta confusión. En la primera gran perspectiva (Figura 5) la leyenda sugiere que esta sería la propuesta hecha en el último momento ${ }^{26}$ por Le Corbusier, y, sin embargo, es el esbozo del proyecto final que se construyó después de meses de trabajo y con las modificaciones hechas por los arquitectos brasileños, sobre la base de la propuesta dejada por Le Corbusier.

Según Bruand hubo una gran polémica: "En lugar de ser el proyecto original de Le Corbusier el que había servido de base para el posterior desarrollo del proyecto construido, en realidad era un dibujo hecho, a posteriori, en función de los planos definitivos, que Lucio Costa y el equipo enviaron a Le Corbusier en 1937"27.

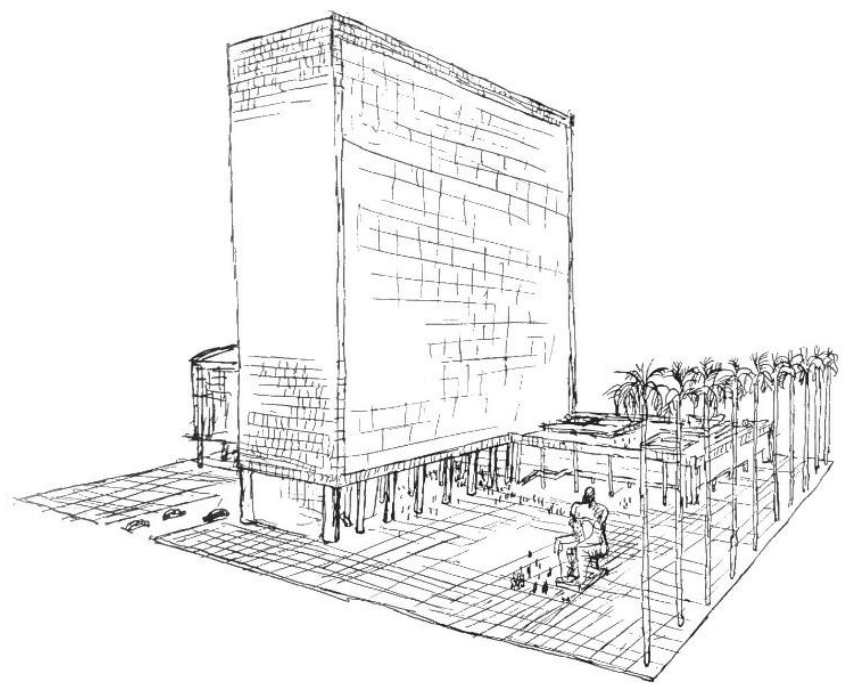

5. Propuesta final del equipo de arquitectos brasileños, basado en las indicaciones y dibujos dejados por Le Corbusier. Publicado en Euvre complète 1934-38.

En Cuvre complète 1934-38, el texto concluye indicando que el proyecto está en ejecución y será una gran innovación urbana, mientras muestra, en uno de los dibujos, la gran diferencia entre la forma tradicional de ocupar una manzana urbana en contraste con la implantación moderna del proyecto propuesto.

\footnotetext{
25 “ “Ele nos deixou um presente...” Entrevista com Lucio Costa”. Arquitetura e Urbanismo. São Paulo: outubro e novembro de 1989. p. 25. Disponível em http://www.jobim.org/lucio/bitstream/handle/2010.3/4103/VIII\%20A\%200204143\%20L.pdf?sequence=2. Acesso em 07 jun. 2015. (Traducción del autor)

26 "Adaptation sur le terrain adopté en dernière heure des aménagementes de projet de la page 78." LE CORBUSIER \& JEANNERET, Pierre. Euvre complète. Vol 3. 1934-1938. Zürich: Les Éditions d'Architecture, 1995. (Publicado originalmente en 1938) p. 81.

${ }^{27}$ BRUAND, Yves: Arquitetura contemporânea no Brasil. São Paulo: Perspectiva, 1981. p.85. (Traducción del autor)
} 


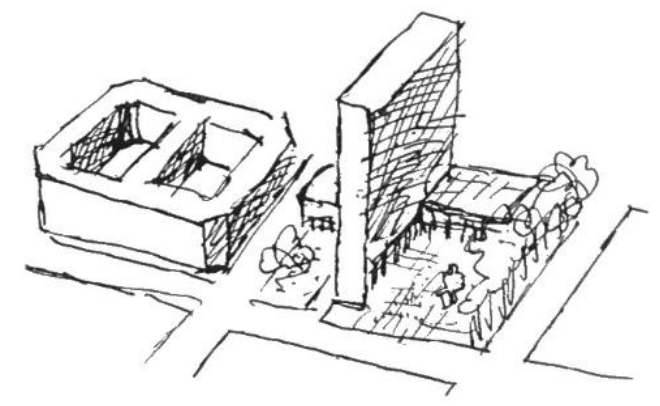

6. Ministerio de Educación y Salud. Publicado en Euvre complète 1934-38.

\section{Brazil Builds - Architecture New and Old: 1652 - 1942}

La producción arquitectónica en Brasil durante las primeras décadas del siglo XX fue significativa, y esto llamó la atención del Museo de Arte Moderno (MoMA) de Nueva York, que decidió realizar una exposición, seguida de un libro llamado Brazil Builds: Architecture New and Old: 1652-1942. Aunque también mostró alguna arquitectura antigua, era la arquitectura moderna y sus innovaciones las que tuvieron más éxito. Uno de los aspectos más destacados en este libro es el Ministerio de Educación y Salud, la primera gran obra del modernismo brasileño junto a obras destacadas como la sede de la ABI y el aeropuerto Santos Dumont. Brazil Builds fue el principal vehículo para la difusión de la arquitectura moderna brasileña en el exterior. El autor comenta sobre la obra en cuestión:

"En 1936, Le Corbusier fue invitado a ir a Río por un grupo de arquitectos encargados de la construcción del Ministerio de Educación y Salud. En esta obra se refleja su influencia de una manera muy acentuada, no obstante, lo más importante es que en ella se manifiestan libremente la imaginación del diseño y la reprobación del antiguo camino oficial. Mientras que el clasicismo de los edificios federales en Washington, lo arqueológico de la Real Academia de Londres y el clásico nazi en Múnich dominan triunfantemente, Brasil tuvo el coraje de romper con la rutina y tomar un nuevo rumbo dando como resultado el que Río de Janeiro poseyese los más bellos edificios públicos del continente Americano" ${ }^{28}$.

Philip Goodwin escribió que el gran aporte de la arquitectura brasileña fueron los sistemas de control solar y de calor en los edificios a través de la utilización del brise-soleil:

"Ya en 1933, Le Corbusier recomienda el uso del brise-soleil móvil, externos, como lo eran en su proyecto no construido en Barcelona, pero fue en Brasil donde por primera vez esta teoría se pone en práctica. Tal y como los arquitectos de Brasil los han desarrollado, estos parasoles son a veces horizontales, a veces móviles, o fijos. Quebra-sol es el nombre que se les da, pero el término francés brise-soleil es más comúnmente utilizado"29.

\footnotetext{
${ }^{28}$ GOODWIN, Philip: Brazil Builds - Architecture New and Old 1652 - 1942. New York: Museum of Modern Art, MoMa, 1943. p. 91. (Traducción del autor)

${ }^{29}$ Ibidem, p. 85.
} 
Explicó que el lado sur no tenía ninguna protección, ya que está menos expuesto, mientras que el lado norte estaba protegido por el sistema de persianas horizontales móviles de los cuales había diagramas ilustrativos (Figura 6). También hay dibujos de las distintas disposiciones de los volúmenes ensayadas sobre el terreno hasta que se encontró la solución definitiva. El libro muestra nueve imágenes del edificio, dos de ellas ocupan la página entera y muestran ambos lados del edificio (Figura 7 y 8), cuatro detalles más aproximados, un detalle de la pared de azulejos de Portinari y dos fotografías de los parasoles.

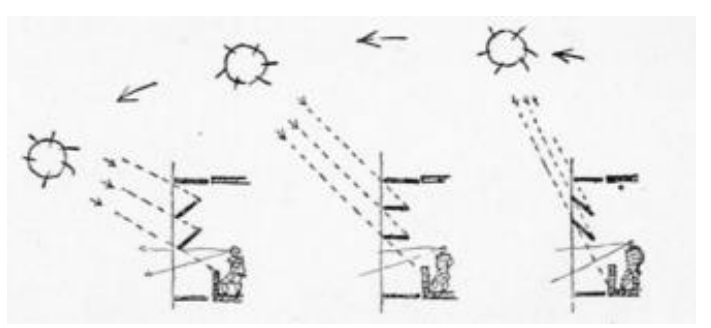

7. El funcionamiento del sistema de brise-soleil del Ministerio de Educación y Salud. Publicado en Brazil Builds.

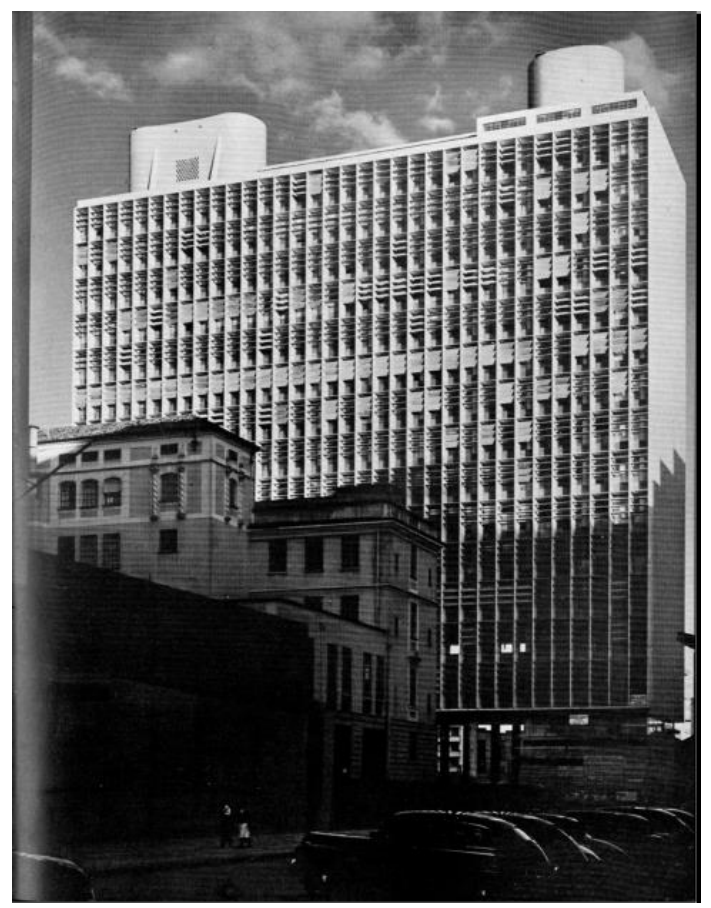

8. Ministerio de Educación y Salud. Publicado en Brazil Builds. 


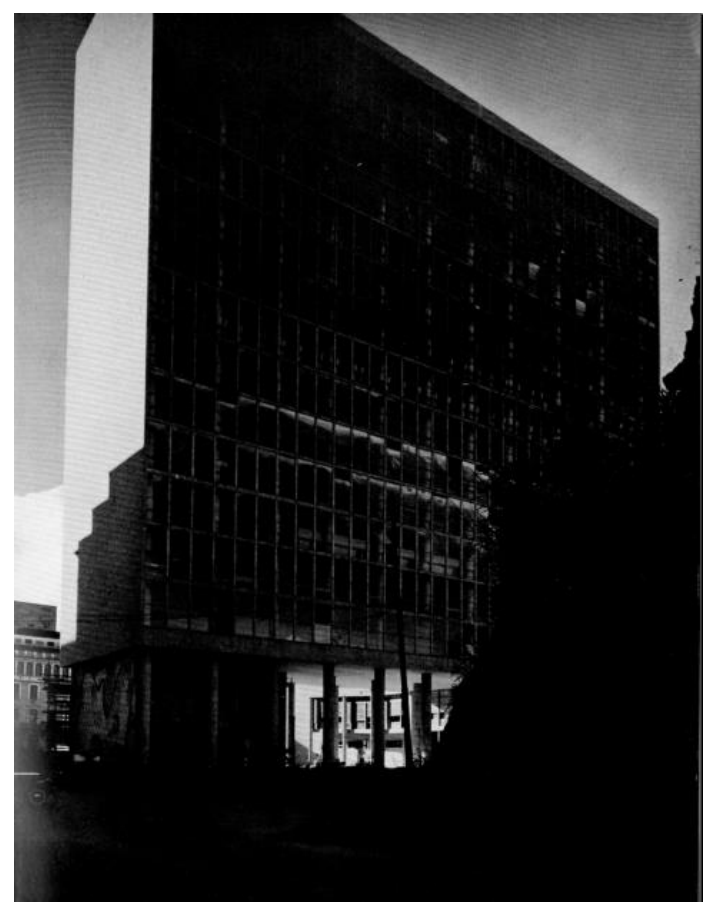

9. Ministerio de Educación y Salud. Publicado en Brazil Builds.

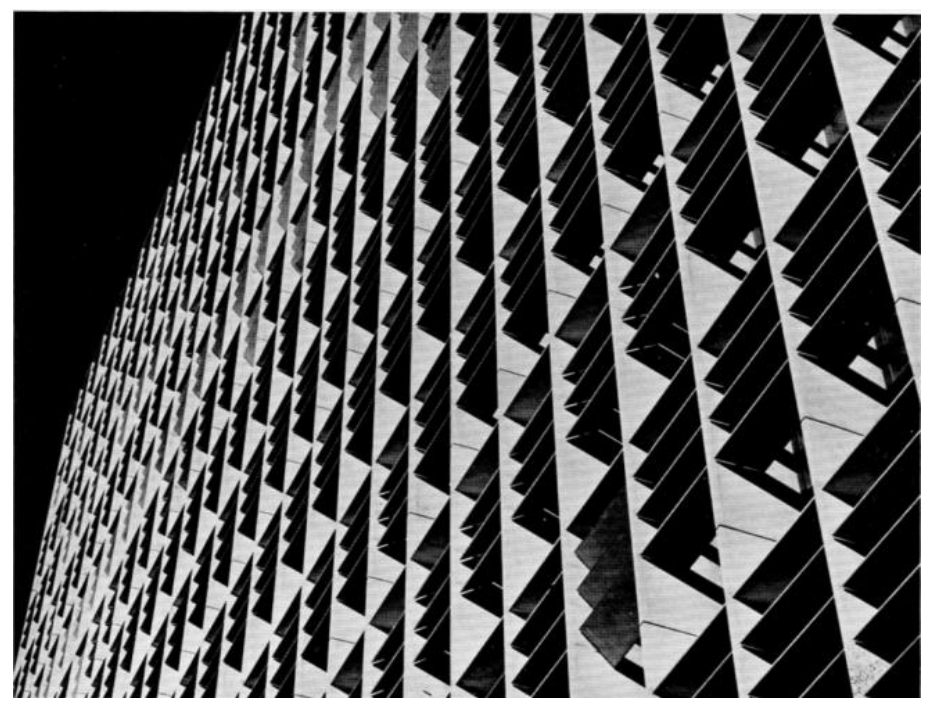

10. Brise-soleil del Ministerio de Educación y Salud. Publicado en Brazil Builds.

Goodwin informó de que el Ministerio de Educación y Salud se localizaba en la Avenida Graça Aranha, en la ciudad de Río de Janeiro. Los responsables fueron los arquitectos Lucio Costa, Oscar Niemeyer, Afonso Reidy, Carlos León, Jorge Moreira y Ernani Vasconcelos; así como el arquitecto consultor Le Corbusier. Se comunicó que el trabajo se había iniciado en 1937, aunque todavía estaba en proceso de construcción en el otoño de 1942. El arquitecto escribió: "Aquí no hay tan sólo belleza superficial. Cada detalle original es consecuencia de un estudio atento y cuidadoso de los más complicados problemas de la construcción moderna" ${ }^{30}$ y destacó las

${ }^{30}$ GOODWIN, Philip: Brazil Builds - Architecture New and Old 1652 - 1942. New York: Museum of Modern Art, MoMa, 1943. p. 106. (Traducción del autor) 
innovaciones de la construcción: "La estructura interna de hormigón permitió que las fachadas norte y sur fuesen completamente revestidas con vidrio, sin interrupción por las piezas de soporte. Las paredes laterales estrechas de los lados este y oeste, así como las columnas que sostienen el bloque principal, están revestidas con granito autóctono rosáceo-gris ${ }^{\prime \prime 31 . ~ E l ~ v o l u m e n ~ p r i n c i p a l ~ f u e ~ d e d i c a d o ~ a ~ o f i c i n a s . ~ E l ~ c a t a ́ l o g o ~ m e n c i o n o ́ ~ q u e ~ e n ~}$ su terraza una 'estructura de líneas curvas' fue destinada a la maquinaria de los ascensores y depósitos de agua. Otro volumen también forma parte del edificio:

"Bajo el edificio principal, en ángulo recto con él, se encuentra un bloque bajo donde están localizados el auditorio y las salas de exposición. Las paredes son de azulejos blancos y azules, especialmente diseñados para el edificio. En la cubierta existe una terraza-jardín, para uso del Ministerio. Otros azulejos forman un gran mural sobre la base de la pared oeste del edificio principal ${ }^{\prime 32}$.
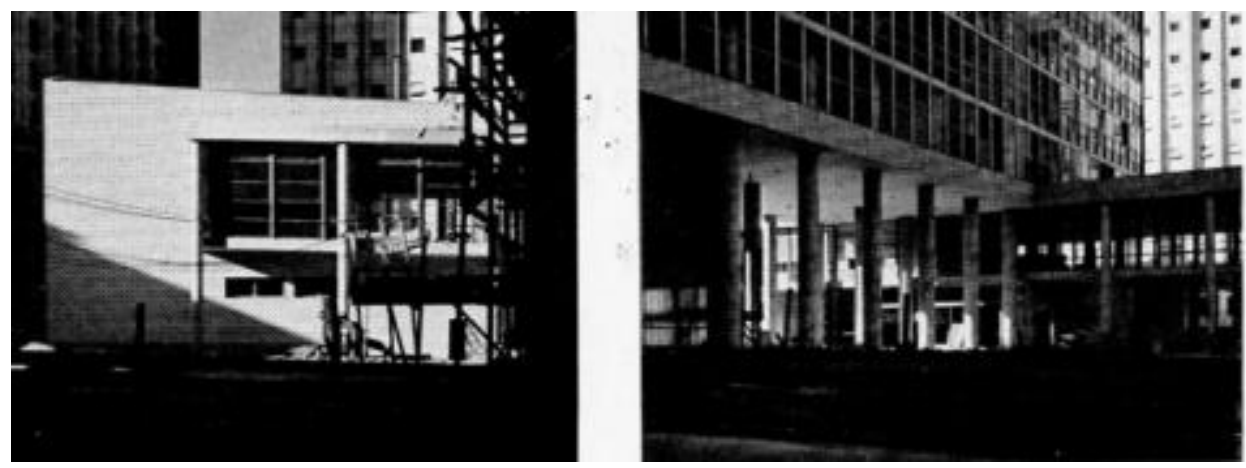

11. Vistas del Ministerio de Educación y Salud. Publicada en Brazil Builds.

Una parte del edificio ya tenía un mural diseñado por Cândido Portinari. También se muestran las plantas bajas, el segundo, tercero, cuarto y el decimoquinto piso.

\footnotetext{
${ }^{31}$ Idem

${ }^{32}$ Ibidem. p. 108.
} 


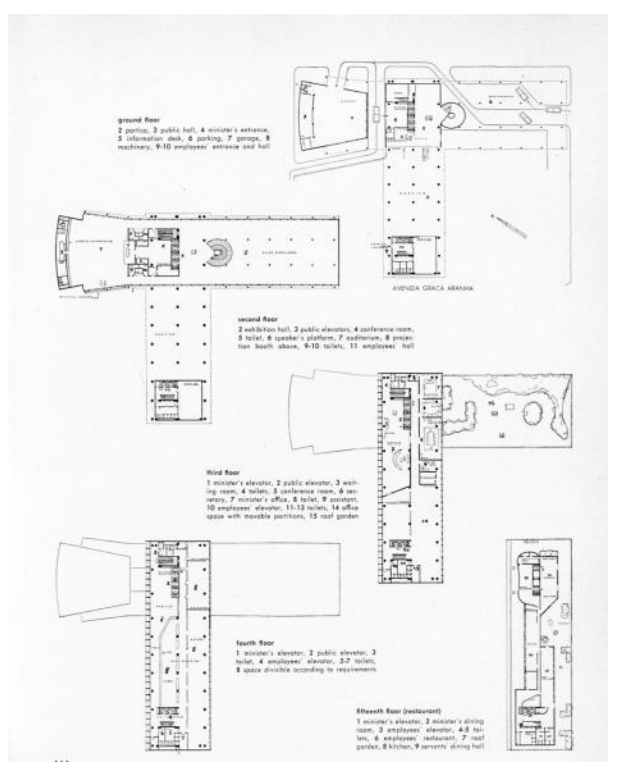

12. Plantas bajas del Ministerio de Educación y Salud. Publicado en Brazil Builds.

\section{Euvre complète 1938-46.}

En Euvre complète 1938-46 se incluyen una foto y un croquis con la descripción emocionante del paisaje de Río de Janeiro y la posibilidad de obtener hermosos encuadres a través de la arquitectura.

13. Croquis de Rio de Janeiro Euvre complète 1938-46

Aparecen los nombres de los arquitectos brasileños y de Le Corbusier como arquitecto consultor, invitado por Gustavo Capanema para revisar los planos para el Ministerio de Educación y Salud y hace una referencia a Euvre complète 1934-38, que había publicado parte del material. Se refería brevemente la cuestión del cambio de terreno que no llegó a materializarse, y se destacó el hecho de que el edificio, en un terreno estrecho, tuviese una implantación contraria a los usos tradicionales y liberase el suelo.

El texto refiere un importante libro publicado en medio de la guerra: Brazil Builds, y cita varios pasajes:

"Francia siempre tuvo una gran influencia en la cultura brasileña, tanto en el campo de la educación, como en el campo de la literatura, así como en la ciencia y las artes. Las ideas revolucionarias del gran arquitecto franco-suizo Le Corbusier fueron recibidas con simpatía especial por los jóvenes arquitectos brasileños, y sus enseñanzas se pusieron en práctica con especial brillo en el Ministerio de Educación y en otras obras en Belo Horizonte" 33.

\footnotetext{
${ }^{33}$ GOODWIN, Philip: Brazil Builds - Architecture New and Old 1652 - 1942. New York: Museum of Modern Art, MoMa,
} 1943. p. 81. (Traducción del autor) 
El desafío era el de encontrar soluciones para la incidencia del sol en los edificios

"Su gran aportación a la nueva arquitectura son las innovaciones para evitar el calor y los reflejos luminosos en las superficies de vidrio, a través de brise-soleils externos especiales. En América del Norte es una cosa poco conocida. Teniendo que soportar el sol de las tardes de verano, los grandes edificios, en general, son como un horno, a causa de la insuficiente protección de sus ventanas de hojas semi-cerradas. Las oficinas modestas, entonces, tienen que elegir entre una de dos alternativas posibles: o bien asarse, o bien protegerse ligeramente a través de toldos o persianas; una protección débil porque no funcionan contra los reflejos del sol en los vidrios. Y es curioso ver cómo los brasileños lidiaron con un problema muy importante cuyo estudio fue el que originó nuestro viaje ${ }^{\prime 34}$.

También se refiere al hecho de que Le Corbusier ya había recomendado el uso de los brise-soleils en Barcelona (como expliqué anteriormente), pero Brasil fue el primero en ponerlo en práctica. Menciona otras contribuciones de Le Corbusier al edificio, como la recomendación de usar el granito existente en Río de Janeiro, y no encargar piedra de Borgoña, como se hacía hasta entonces. Y sugirió que se utilizasen cerámicas portuguesas, vinculadas a los orígenes brasileños, para crear un contraste con el granito y el vidrio ${ }^{35}$. Repite dibujos que se publicaron en Euvre complète 1934-38: La primera perspectiva aparece como: 1936 - $1^{\text {o }}$ proyecto - Le Corbusier (Figura 2), la visión general del edificio con el subtítulo: 1936-1937 Segundo proyecto de Le Corbusier, adaptado para la ejecución en un terreno tradicional de Río (Figura 5), utiliza la comparación entre la implantación tradicional en la manzana y la implantación moderna del Ministerio (Figura 6), con la recomendación de que se ignoren los edificios vecinos, pues son fruto de una mala planificación urbana.

Las otras imágenes son fotografías y plantas bajas del edificio, probablemente ya finalizado.

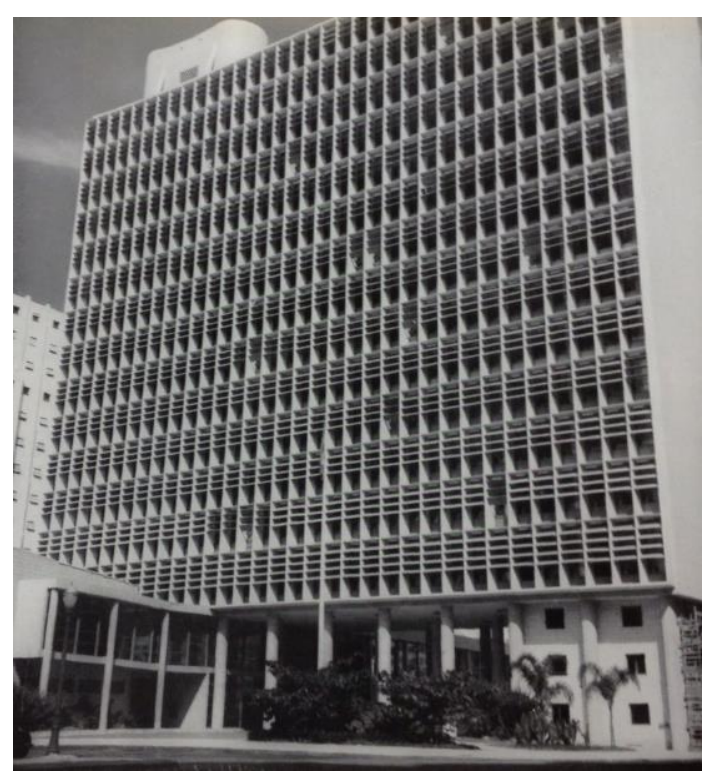

14. Ministerio de Educación y Salud. Publicado en Euvre complète 1938-46

\footnotetext{
${ }^{34}$ GOODWIN, Philip: Brazil Builds - Architecture New and Old 1652 - 1942. New York: Museum of Modern Art, MoMa, 1943. p. 85. (Traducción del autor)

${ }^{35}$ LE CORBUSIER \& JEANNERET, Pierre. Euvre complète. Vol 4. 1938-1946. Zürich: Les Éditions d'Architecture, 1995. (Publicado originalmente en 1946).
} 


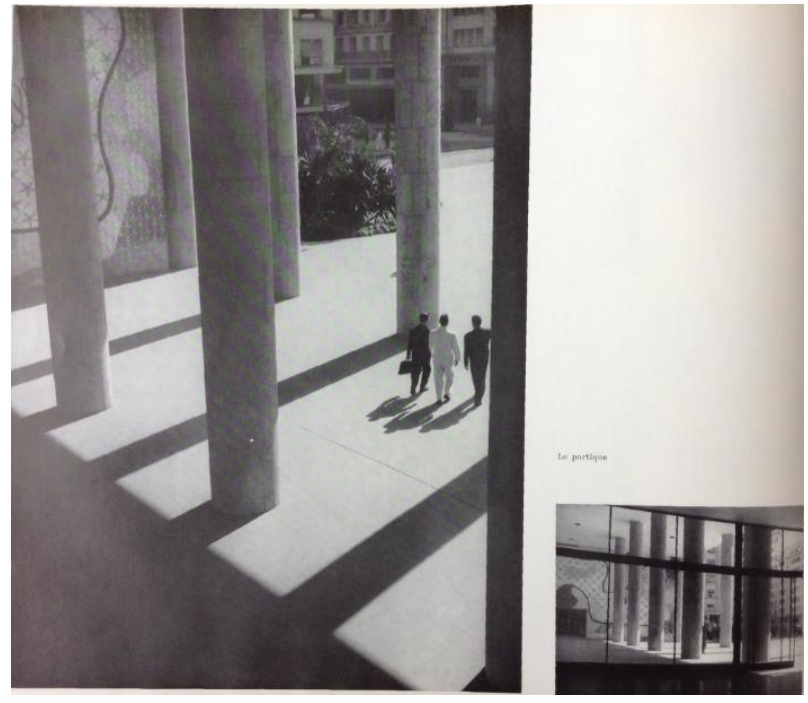

15. Ministerio de Educación y Salud. Publicado en Euvre complète 1938-46

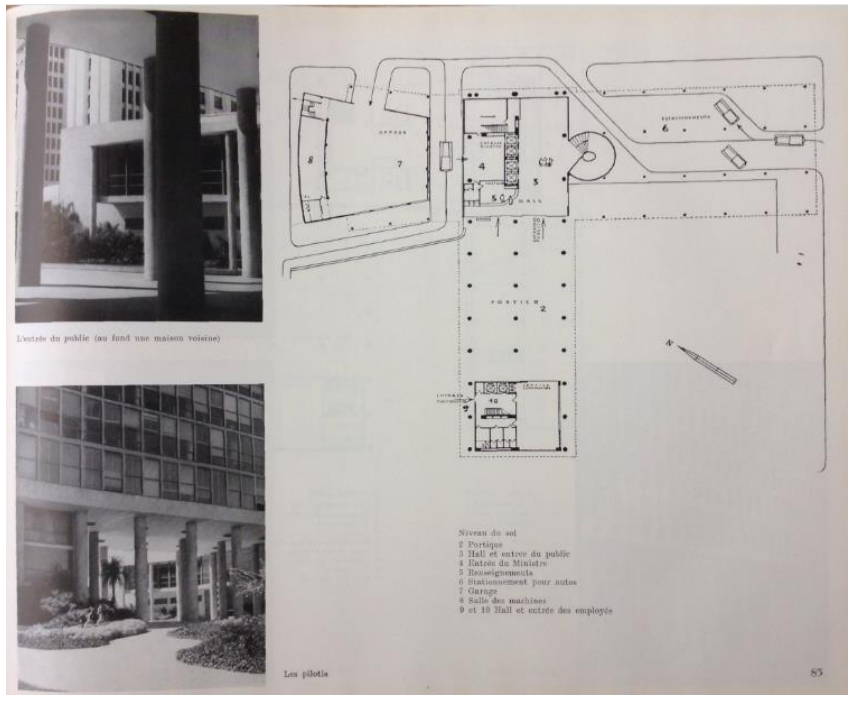

16. Ministerio de Educación y Salud. Publicado en Euvre complète 1938-46 


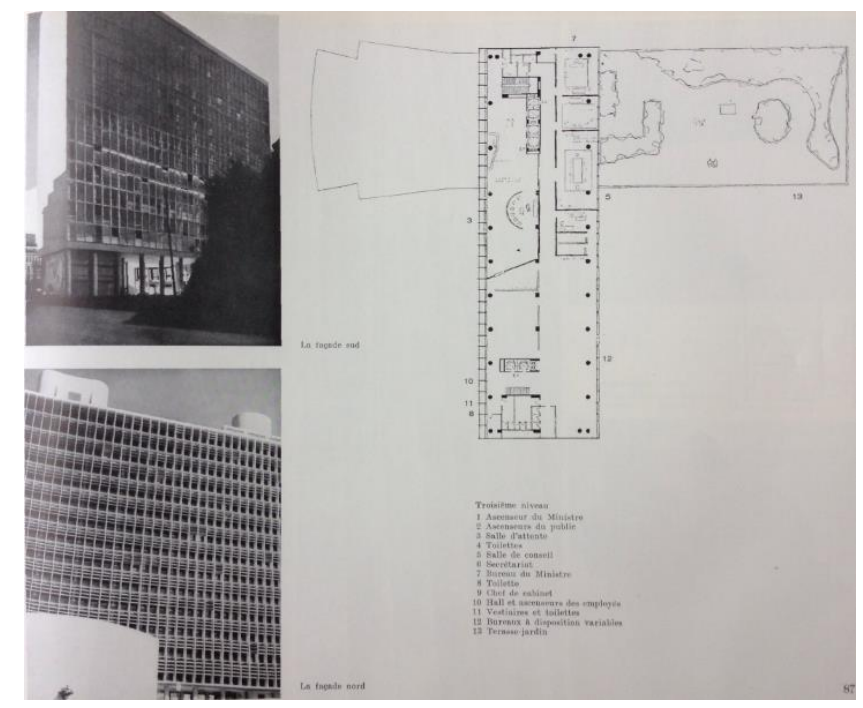

16. Ministerio de Educación y Salud. Publicado en Euvre complète 1938-46

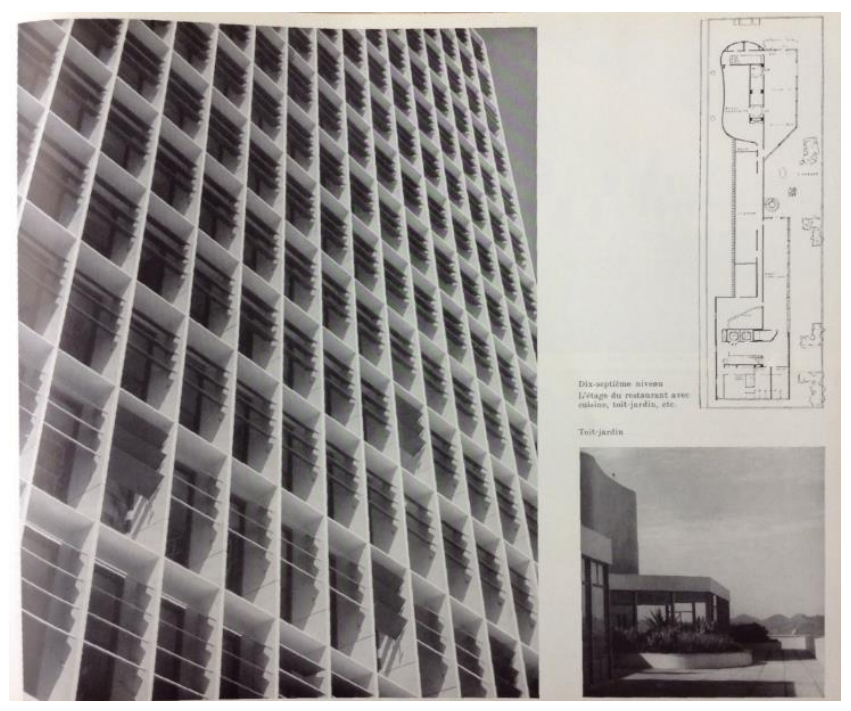

17. Ministerio de Educación y Salud. Publicado en Euvre complète 1938-46

\section{Consideraciones finales}

Durante todo el proceso se nota un gran compromiso de Le Corbusier con el terreno que desea cambiar. El trabajo propuesto para el terreno elegido cerca del mar fue detallado, con diseños de paisaje, con esquemas de circulación y croquis de perspectivas internas. A través del material mostrado en estos libros podemos ver hasta qué punto los trabajos avanzaron, antes de que tuviera que ser cancelado por la imposibilidad de cambiar de terreno. Durante el período en el que Le Corbusier estuvo en Brasil, los arquitectos y él mismo se dedicaron a este proyecto creyendo que sería construido. Por tanto, debe haber sido un shock cuando tuvieron conocimiento de la imposibilidad de construir en el terreno idealizado. Le Corbusier pasó toda su estancia proyectando el edificio para el terreno que le agradaba. Y en la víspera de su partida le presentaron el terreno anterior (rechazado por él) como la única alternativa. 
Con poco tiempo, Le Corbusier consigue hacer una propuesta con algunos dibujos y vuelve a Francia, probablemente frustrado. Estos dibujos fueron la base del proyecto final realizado por los arquitectos brasileños, que con los cambios de escala y de intercambio de bloques lograron llegar a un resultado definitivo que fue construido. No obstante, esta propuesta de Le Corbusier para la Esplanada do Castelo no forma parte de las publicaciones sobre el edificio.

En Euvre complète 1934-38, aparecen los diseños para el primer proyecto en el terreno cerca del mar, y luego pasan al diseño final, con perspectivas y maqueta del proyecto desarrollado por los brasileños basado en la propuesta dejada por Le Corbusier. En Brazil Builds, el Ministerio de Educación y Salud fue la gran sorpresa. Junto a otras obras, destacó con sus medidas de protección contra el sol. Las fotografías publicadas eran todavía de un edificio en construcción, pero ya se podía entrever el edificio en el que se convertiría.

En Euvre complète 1938-46 la narración comienza describiendo Río de Janeiro y las hermosas vistas que ofrece. El libro cita Euvre complète 1934-38, y especialmente Brazil Builds, que había logrado un gran éxito. Aquí se publican más fotos, detalles y planos de plantas bajas, de la obra ya inaugurada. Pero los dibujos publicados fueron de nuevo los del primer proyecto del terreno junto al mar, y como segunda propuesta, el diseño final, omitiendo la propuesta para la Esplanada do Castelo hecha por Le Corbusier en el último día. Siendo para un terreno difícil y con un tiempo muy limitado, su omisión puede significar que el arquitecto no estaba muy satisfecho con el resultado, no obstante, esta es una parte importante para la comprensión del proceso y lo esclarecería en gran medida, ya que es una etapa intermedia entre las dos soluciones.

Con el análisis de los tres libros se obtiene una visión general del proceso de diseño desde el principio del proyecto hasta el final de la construcción, es decir, se puede entender la creación de un edificio. Mientras que el primer libro muestra las primeras aspiraciones, y cuenta con planos y dibujos lo que sería el edificio, el segundo muestra la construcción en curso, detalles por terminar, y atisbos del futuro por imaginar. Y finalmente, el tercero muestra toda la historia, los diseños y las fotografías del edificio finalizado.

\section{Lista de imágenes}

1. Comas, Carlos Eduardo . Projeto arquitetônico, obra coletiva: o caso do Ministério da Educação. In: Projetar II Seminário sobre Ensino e Pesquisa em Projeto de Arquitetura, 2005, Rio de Janeiro. Anais do Projetar II. Rio de Janeiro: PROARQ UFRJ, 2005. v. 1. p. 5 y 6

2. Le corbusier \& Jeanneret, Pierre. Euvre complète. Vol 3. 1934-1938. Zürich: Les Éditions d'Architecture, 1995. (Publicado originalmente en 1938) p. 78.

3. Lissovsky, Maurício; MORAES DE SÁ, Paulo Sérgio: Colunas da Educação. A construção do Ministério da Educação e Saúde. Rio de Janeiro: MINC/IPHAN, Fundação Getúlio Vargas/CPDOC, 1996. p.115.

4. Le Corbusier \& Jeanneret, Pierre. Euvre complète. Vol 3. 1934-1938. Zürich: Les Éditions d'Architecture, 1995. (Publicado originalmente en 1938). p. 80.

5. Le Corbusier \& Jeanneret, Pierre. Euvre complète. Vol 3. 1934-1938. Zürich: Les Éditions d'Architecture, 1995. (Publicado originalmente en 1938) p. 81.

6. Le Corbusier \& Jeanneret, Pierre. Euvre complète. Vol 3. 1934-1938. Zürich: Les Éditions d'Architecture, 1995. (Publicado originalmente en 1938) p. 81.

7. Goodwin, Philip: Brazil Builds - Architecture New and Old 1652 - 1942. New York: Museum of Modern Art, MoMa, 1943. p. 85.

8. Goodwin, Philip: Brazil Builds - Architecture New and Old 1652 - 1942. New York: Museum of Modern Art, MoMa, 1943. p. 107. 
9. Goodwin, Philip: Brazil Builds - Architecture New and Old 1652 - 1942. New York: Museum of Modern Art, MoMa, 1943. p.109.

10. Goodwin, Philip: Brazil Builds - Architecture New and Old 1652 - 1942. New York: Museum of Modern Art, MoMa, 1943. p. 84.

11. Goodwin, Philip: Brazil Builds - Architecture New and Old 1652 - 1942. New York: Museum of Modern Art, MoMa, 1943. p. 108.

12. Goodwin, Philip: Brazil Builds - Architecture New and Old 1652 - 1942. New York: Museum of Modern Art, MoMa, 1943. p. 111.

13. Le Corbusier \& Jeanneret, Pierre. Euvre complète. Vol 4. 1938-1946. Zürich: Les Éditions d'Architecture, 1995. (Publicado originalmente en 1946). p. 80 e 81.

14. Le Corbusier \& Jeanneret, Pierre. Euvre complète. Vol 4. 1938-1946. Zürich: Les Éditions d'Architecture, 1995. (Publicado originalmente en 1946) p. 83.

15. Le Corbusier \& Jeanneret, Pierre. Euvre complète. Vol 4. 1938-1946. Zürich: Les Éditions d'Architecture, 1995. (Publicado originalmente en 1946) p. 84.

16. Le Corbusier \& Jeanneret, Pierre. Euvre complète. Vol 4. 1938-1946. Zürich: Les Éditions d'Architecture, 1995. (Publicado originalmente en 1946) p. 85.

17. Le Corbusier \& Jeanneret, Pierre. Euvre complète. Vol 4. 1938-1946. Zürich: Les Éditions d'Architecture, 1995. (Publicado originalmente en 1946) p. 86.

\section{Bibliografía}

Arquitetura e Urbanismo. São Paulo: outubro e novembro de 1989 . Disponível em http://www.jobim.org/lucio/bitstream/handle/2010.3/4103/VIII\%20A\%2002-04143\%20L.pdf?sequence=2.

BRUAND, Yves: Arquitetura contemporânea no Brasil. São Paulo: Perspectiva, 1981.

CAVALCANTI, Lauro (org.): Quando o Brasil era Moderno - Guia de Arquitetura 1928-1960. Rio de Janeiro: Aeroplano, 2001.

COMAS, Carlos Eduardo. Projeto arquitetônico, obra coletiva: o caso do Ministério da Educação. In: Projetar II Seminário sobre Ensino e Pesquisa em Projeto de Arquitetura, 2005, Rio de Janeiro. Anais do Projetar II. Rio de Janeiro: PROARQ UFRJ, 2005. v. 1.

GOODWIN, Philip: Brazil Builds - Architecture New and Old 1652 - 1942. New York: Museum of Modern Art, MoMa, 1943.

LE CORBUSIER \& JEANNERET, Pierre. Euvre complète. Vol 3. 1934-1938. Zürich: Les Éditions d'Architecture, 1995. (Publicado originalmente en 1938)

Euvre complète. Vol 4. 1938-1946. Zürich: Les Éditions d'Architecture, 1995. (Publicado originalmente en 1946)

LISSOVSKY, Maurício; MORAES DE SÁ, Paulo Sérgio: Colunas da Educação. A construção do Ministério da Educação e Saúde. Rio de Janeiro: MINC/IPHAN, Fundação Getúlio Vargas/CPDOC, 1996.

SEGAWA, Hugo: Arquiteturas no Brasil: 1900-1991.São Paulo: Edusp, 2010.

WILLIANS, Richard: Brazil - Modern Architectures in history. Londres: Reaktion Books Ld, 2009. 


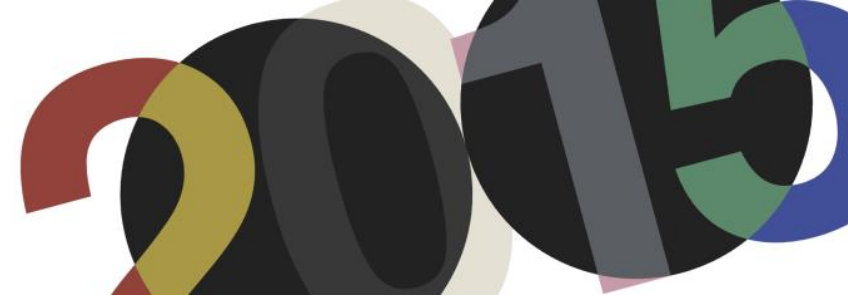

DOI: http://dx.doi.org/10.4995/LC2015.2015.938

\title{
Garder mon aile dans ta main: The genesis of the Open Hand
}

\author{
G. Sepe Camargo
}

Faculdade de Arquitetura e Urbanismo da Universidade de São Paulo

\begin{abstract}
The main hypothesis of this paper is that in the image of the Open Hand it is possible to find the reconciliation between two significant themes of the symbolic universe engendered by Le Corbusier: instrumentality and detachment. The genesis of the Open Hand is therefore to be seen as grounded among his late 1940s plastic works, which notably display the gradual movement of certain elements of figuration toward an iconic role. The hand appears as a crucial theme to Le Corbusier. Unlike other themes that have been set as pictograms - as the meander, the solar journey of 24 hours, and the bull figure -, the hand will not find its definitive form until very late in the architect's work. The hand's "other" seems to be another image from his painting: the winged figure, half woman and half animal, that appears in a wall at the Pavillion Suisse (mural, 1948) and illustrates the cover of Poésie sur Alger (1951). The image suggests an alienation from the worldly experience and the tragedy represented by the historical time, related to the volatility of natural phenomena. These two figures seem to synthesize the two attitudes governing the work of Le Corbusier thereafter. It is in Le Poème de L'Angle Droit (1947-1953) that the core of the symbolic system of Le Corbusier is found. The duality achieves its final result in the figure of the Open Hand, elected as the synthesis of the entirety of his symbolic system.
\end{abstract}

Resumen: La principal hipótesis de este trabajo es que en la imagen de la Mano Abierta es posible encontrar la reconciliación entre dos temas importantes del universo simbólico engendrada por Le Corbusier: instrumentalidad y el desapego. Por tanto, la génesis de la Mano Abierta es ser visto entre sus obras plásticas finales de 1940, que sobre todo muestran el movimiento gradual de ciertos elementos de la figuración hacia un papel icónico. La mano aparece como un tema crucial para Le Corbusier. A diferencia de otros temas que se han establecido como pictogramas - como el meandro, el viaje solar de 24 horas, y la figura del toro -, la mano no encontrará su forma definitiva hasta muy tarde en la obra del arquitecto. El "otro" parece ser una imagen de su pintura: la figura alada, mitad mujer y mitad animal, que aparece en el Pabellón Suisse (mural, 1948) e ilustra la portada de Poésie sur Alger (1951). La imagen sugiere una alienación de la experiencia mundana y la tragedia representada por el tiempo histórico, relacionado con la volatilidad de los fenómenos naturales. Estas dos figuras parecen sintetizar las dos actitudes que rigen la obra de Le Corbusier a partir de entonces. Es en Le Poème L'Angle Droit de (1947-1.953) que el núcleo del sistema simbólico de Le Corbusier se encuentra. La dualidad logra su resultado final en la figura de la Mano Abierta, elegido como la síntesis de la totalidad de su sistema simbólico.

Keywords: Open Hand; Le Poème de L'Angle Droit; Chandigarh; instrumentality; detachment.

Palabras clave: Open Hand; Le Poème de L'Angle Droit; Chandigarh; instrumentalidade; desapego.

\section{Introduction}

This paper looks into the hypothesis that the plastic work of Le Corbusier contains the genealogy of a highly elaborate symbolic system that permeates every moment of his intellectual activity. The image of the Open Hand is its decisive moment. This symbolic system is rooted in the structural change underwent by his painting in the end of the 1930s, and finds a clearer formalization in the period between 1947 and 1953.

This constellation of symbols, added to a fabric of distinct realms - such as architecture, painting, sculpture reveals one particular attribute: that this laboratory, the recherche patiente, is never detached from the figurative art, its driving force. 
The figurative is associated with personal records, travel notes, the exercise of memory, studies. Ultimately, when endowed with an iconic quality, it relates to a communicative quest. This new status seems to be embodied with a unique and radical attribute, to such extent that Le Corbusier sets out to think through painting, especially between 1947 and 1953.

As an itinerary for this paper, we track down the establishment of his symbolism in the preceding moment, illustrated by the project for the monument in memory of Vaillant-Couturier. This early moment intertwines painting and architecture - a certain painting and a certain architecture.

The reason for mentioning this particular project is twofold. First, its formalization displays symbolic concerns and also works as a counterpoint to the next period. Second, the presence of an image in the monument allows us to demonstrate the subsequent development in Le Corbusier's thinking, from the figurative to the iconic.

We then set out to exemplify the structural changes in his paintings occurring from 1938. For this purpose we describe the execution of Grafitte at Cap-Martin.

From this point, the analysis focus on the symbolism that emerges in the years between 1947 and 1953 , considering the murals in the atelier at 35 rue de Sèvres and the Pavillon Suisse in the brief interval between March and October 1948. It was a turning point, when the plastic work played a new role. The themes of these two murals are premonitory of a more precise definition, which can be found in Le Poème de L'Angle Droit. Besides this, the fact that these two murals and the publication of the text Unité $e^{l}$ can be situated very closely in time indicates that at this point the architect was more effectively carrying out his plastic activity. In the text, published in a special issue of L'Architecture d'aujourd'hui (1948), Le Corbusier for the first time openly reproposes a chronology in which architecture and painting are not antagonists, but appear as different moments of the same research. Thereafter, the evaluation of his painting and graphic work will be increasingly frequent, and inseparable from his architectural work.

The analysis seeks to move freely across the textile established by various realms - architecture, painting, graphic art. We understand that so do symbols - even if they remain tied to the fundamental warp of the painting, seen here as an ordering matrix.

\section{An initial attempt}

It is the very nature of the symbolism labored by the architect that allows the continuous shift of themes from different linguistic domains. This symbolism is fixed in precise images. The hand is one of them.

As pointed out by Juan Calatrava, for Le Corbusier "the hand is the point of contact between the artist and the world", ${ }^{2}$ a symbol opposing the idea of hierarchy and the distinction between idea and execution bequeathed by the classical tradition.

In 1937, that image appears highlighted in the project to the monument in memory of Paul Vaillant-Couturier (Fig. 01), the socialist editor of the newspaper L'Humanité, for the town of Villejuif, near Paris

\footnotetext{
${ }^{1}$ L'Architecture d'aujourd'hui. Special issue "Le Corbusier". Paris: Editions L'Architecture d'aujourd'hui, 1948.

${ }^{2}$ Calatrava, Juan. "La plastica de un arquitecto". In: Salvador Guerrero (Ed.), Una Casa-Un Palacio. Madrid 1928. Exhibition catalog. Madrid: Publicaciones de la Residencia de Estudiantes, 2010, pp. 182-183.
} 


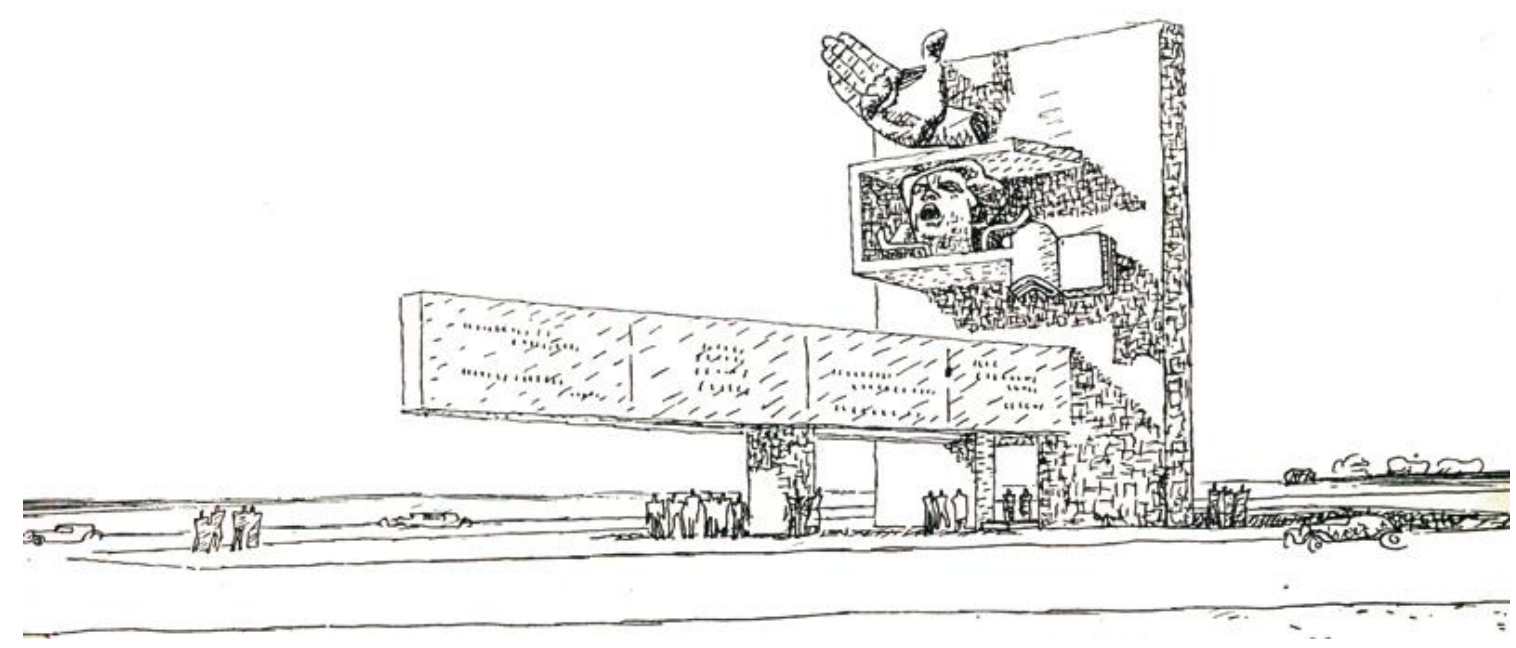

1. Monument in memory of Vaillant-Couturier. In: Mein Werk/L'Atelier de la recherche patiente. $1^{\text {st }}$ ed. Paris: Ed. Vincent Fréal, 1960

The monument consists of a concrete wall, with an equivalent proportioned volume protruded in the horizontal direction. Three images are molded in concrete: a face, an open book and a hand. The arrangement of these images, emerging from the wall, with the open hand on top of the composition, ensures a dramatic dynamism to the monument whenever it is seen by an observer in motion, from an automobile for instance.

The composition echoes the assemblage of objects characteristic of paintings such as Siphon et gants (FLC 210), from 1927: each object keeps its autonomy, as desired by the objectivity of purism. The contours of the face attached to the monument are similar to those of female figures depicted in oil paintings such as La femme au guéridon et au fer à cheval (FLC 145), from 1928. In both cases Le Corbusier is concerned about demarcate the hues from the incidence of light on the purity of the geometry that constitutes the figures. The interweaving of the objects is achieved through the consistency of the material in both cases; oil patches in contrasting colors on the paintings are comparable to the homogeneity of the concrete in the monument. The images overlap one another in a collage, maintaining the independence of the theme.

In the case of the monument, it is worth noticing the ambiguous nature of the gesture alluded to by the image of the hand, which crowns the composition. It does not match any assertive gesture of protest, which supposedly accompanies the outcry of the face below. Designed as the final image of the composition, the hand reinforces the disjunction between the elements. The hand gently juts skyward like an intermission.

This early appearance still does not conceal the subsequent role of the hand. In retrospect, it is significant of the structural change of the symbolism alluded to. A structural evolution of his art will be required to reposition the meaning of this particular figure within a larger system.

\section{Structural changes}

After his forays in the Casbah of Algiers in 1931, the compositions depicting female figures became a recurring theme in Le Corbusier's studies. 
Earlier that year, the architect had been invited by the company Amis d'Alger to deliver two lectures in the city. Although he received no official charge, the interest in Algiers prompted the drafting of the Plan Obus, presented in the following year. Between 1931 and 1942, the architect returned several times to the city and produced a significant number of other proposals, none of them executed. ${ }^{3}$

As demonstrated by Von Moos, ${ }^{4}$ in his first visit to Algiers Le Corbusier had the opportunity to make rapid sketches of female nudes. He worked on this set of drawings continuously during the subsequent years; their purpose, a larger wall composition, has never been carried out.

In several studies, the architect proceeds similarly. Each figure was individually modeled and subsequently transferred over a translucent paper sheet. The various overlapping sheets of paper allowed a better fit of the composition before the final drawing. The name mariage des contours was given to this procedure, which origins can be traced back to the still lifes of purist research.

The most accurate transposition of this working method, although not matching the previously intended project, is the panel done in 1938 for the summer house drawn by Irish designer Eileen Gray (1878-1976) for the editor of the magazine L'Architecture Vivante, Jean Badovici (1893-1956), in Roquebrune-Cap-Martin. Le Corbusier was a frequent visitor of the house during the 1930s.

Graffite at Cap-Martin (Fig. 02), carried out without the consent of Gray, incorporates the elements that had been tested since 1931.5

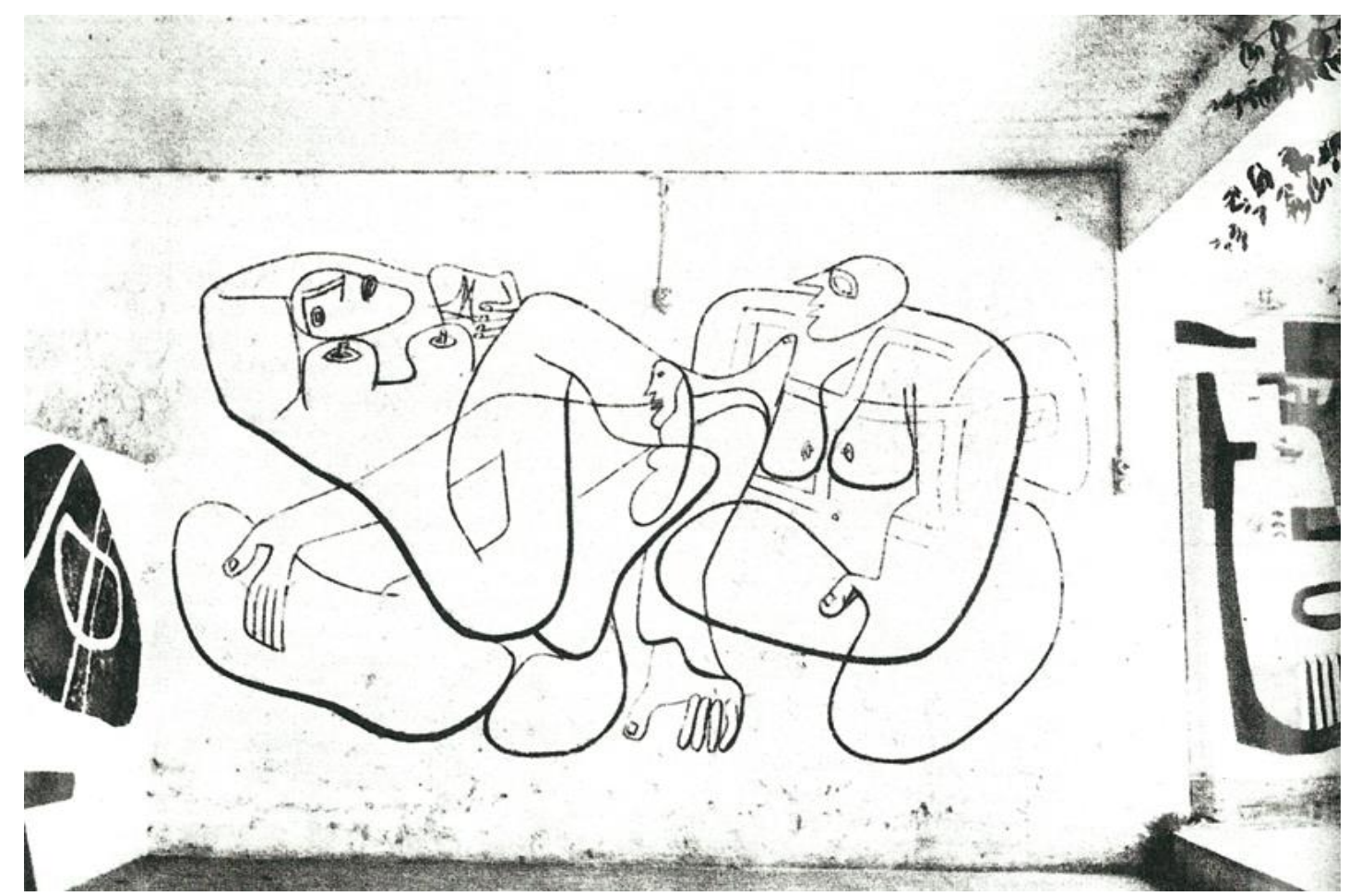

2. Graffite at Cap-Martin. In: Mein Werk/L'Atelier de la recherche patiente. $1^{\text {st }}$ ed. Paris: Ed. Vicent Fréal, 1960

\footnotetext{
${ }^{3}$ For a detailed account of Le Corbusier experience in North Africa, see: Mary McLeod "Le Corbusier and Algiers"In: Oppositions 19-20. Cambridge, Massachusetts: MIT Press, 1980, pp. 55-85.

${ }^{4}$ Von Moos, Stanislau. “Mariage des Contours”. In: Oppositions 19-20. Cambridge, Massachusetts: MIT Press, 1980, pp. $87-$ 107.

${ }^{5}$ For a detailed account of this episode, see: Colomina, Beatriz. Privacy and Publicity. Architecture as Mass Media. $1^{\mathrm{st}} \mathrm{ed}$. Cambridge, Massachusetts: MIT Press, 1996.
} 
On the wall, the detailing of the hands contrasts with the strong line that delineates the three images. The hands seem to define the limits of the composition: the four fixed points or pivots around which the images are organized.

The mural also illuminates the internal hierarchy of the elements in Le Corbusier's paintings from that period. Von Moos points out that the exposure of Guernica in the Spanish Pavilion at the International Fair of Paris, held in the year preceding the preparation of Graffite at Cap-Martin, had strongly impressed Le Corbusier, especially because Picasso did not resort to polychrome. ${ }^{6}$

Graffite at Cap-Martin was remarkable in its refusal to the use of polychrome. More importantly, it points to the separation of color and drawing on the picture plane. This last feature will be a constant thereafter.

These procedures will bring about a change in the structure of the works.

The sinuous calligraphy of the figures is inscribed over the color patches. Formally, this separation implies that preeminence is given to the drawing against the background, over which it appears to float. Through this solution, the figure is enhanced, thus appearing as an independent, outlined element on the surface. As a result, certain elements of the figuration tend gradually toward an iconic role.

\section{Dualism: the other}

As displayed extensively by Le Corbusier in several publications and lectures, images of "the solar journey of 24 hours", "the Modulor", "the law of the meander", "the diagram of the essential joys" are recurrent, both in his paintings and architecture.

These diagrams, sketches and synthetic drawings had been set as icons or symbols since an early age. As modern glyphs, derived from a crude stroke of color, usually black, its origins are not the graphic exercise, but the concept. They illustrate necessary abstractions in the architectural and urban debate that dates back to the 1930s. They clearly play a communicative role. These glyphs had first appeared in publications; later on, they invaded other spheres.

Unlike these, the image of the hand will not achieve a final result until very late. In various manifestations of the period, it appears intertwined, in a clear allusion to communion. It is often accompanied by rocks, shells, bones, small objects and, on many occasions, by the curved lines of the female body.

The touch, the handle of forms of the natural world by the hands, the perception of textures, the measurement of weight seem to be the privileged way to apprehend the environment chosen by the architect, as if it demanded a reunion with something more primal and fundamental. ${ }^{7}$

We notice that a radical change has been brought about, especially when we consider the prominent place given to vision and optics during the 1920s in L'Esprit Nouveau, the desired purist objectivity for painting and the architecture seen as "the masterful, correct, and magnificent play of volumes brought together in light".

The dualism that dominates his art elects a companion to the image of the hand: the female body, a privileged object to knowledge. Dualism was a permanent attribute of Le Corbusier thought, which origins are far beyond the concerns of this paper. However, it is important to note that a dualistic view of the world, related to natural

\footnotetext{
${ }^{6}$ Id., p. 4.

${ }^{7}$ The presence of tactile attributes in the work of Le Corbusier is differently developed by Monteys, Xavier. "Tres apuntes sobre la presencia de lo tactil en la obra de Le Corbusier". In: Torres, Jorge (Ed.). Le Corbusier Mise au Point. Memorias Culturales. Valencia: General de Ediciones de Arquitectura, pp. 182-194.
} 
processes and in accordance with a form of primitive thought - mythical and circular —, seems to emerge more forcefully in his art during the postwar period, as an alternative to progress, speed, visual stimuli, and the arrow of time of the civilisation machiniste.

In view of the image of the hand, the other seems to be a figure also found in his paintings, the winged figure, half woman and half beast (Fig. 03), emerging from the recollection of the North African experience. ${ }^{8}$

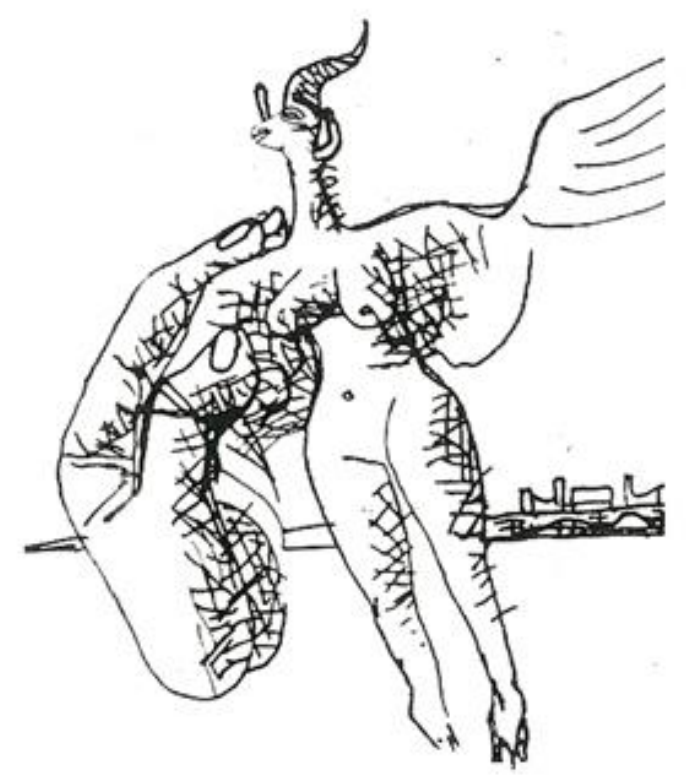

3. Cover of Poésie sur Alger. $1^{\text {st }}$ ed. Paris: Falazie, 1951

In the posterior lithographic album Petites Confidences, printed in 1957, the architect called this figure a Licorne, but this name is inaccurate. Its genesis clearly seems to be derived from the increasingly frequent exercises on the female body. It also resonates "les meandres" that so much impressed the architect.

Usually horizontally outlined, with its wings safeguarded on its body, the design does not correspond to a figure in flight, but to an indelicate suspension, as if it was carried by the wind. The rigidity of the image was very similar to that found in the series of sculptures Icône, made together with Joseph Savina in later years ${ }^{9}$.

Similarly to Walter Benjamin's description of Paul Klee's Angelus Novus, Le Corbusier outlines the figure always facing back towards the wind that drives in the opposite direction. However, unlike Klee's painting, nothing suggests the storm "that irresistibly impels the future to which his back is turned, while the pile of debris grows to heaven". ${ }^{10}$ In Le Corbusier the meaning is different. The images suggest a detachment of the worldly

\footnotetext{
${ }^{8}$ Von Moos, Stanislau. "Mariage des Contours". In: Oppositions 19-20. Cambridge, Massachusetts: MIT Press, 1980, pp. 87107.

9 To a analysis of this collaboration see Le Couédic, Daniel. Joseph Savina, l'improbable compagnon de route", in Le Corbusier : L'œuvre plastique, Paris, Fondation Le Corbusier et Éditions de La Villette, 2005, p. 26-53

${ }^{10}$ Benjamin, Walter. "Sobre o conceito de História". Magia e técnica, arte e política: ensaios sobre literatura e história da cultura. $7^{\text {a }}$ ed. São Paulo: Brasiliense, 1994, p. 226.
} 
experience and the tragedy represented by the historical time. It appears subject to the volatility of natural phenomena.

As indicated by Tafuri, ${ }^{11}$ the detachment from the worldly experience, implied by the over-flight vision, is a theme dear to Le Corbusier. It is recurrent since his first experiences with airplanes during the voyage to South America in 1929.

The importance of the flight experience has been extensively pointed out as a catalyst of a new attitude toward urban phenomenon: the changes on the scale of its urban plans, the confrontation between building and landscape, the comprehension of architecture in a territorial sense. However, very little attention has been given to the flight as a cognitive experience defined by a particular time.

We clearly see that the contemplation of the physical environment from an airplane is marked by a "relative slowdown in look" - as if it had occurred during a longstanding period, when the vicissitudes of the everyday experience were almost indifferent to the observer. The perspective provided by the airplane implies an "apparent suspension of speed" that equals the activities of human labour and primitive nature.

Also the incidence of sunlight on the surfaces seen from above works differently from that observed from the ground. The shades and shadows seem to blur the clear distinctions between architecture and nature, as if all phenomena were unified and reduced to a geological scale: scars, breaks and stratification on a heterogeneous surface.

It is no accident that the extensions observed from the top of the mountains in the Jura during his formative years are an emotional bond that anticipates this process. The memory will favor a realistic attitude toward the phenomena of nature, away from any esoteric bindings or surrealistic overtones.

Would it not be significant that the abandonment of the objectivity of the visual experience of purism - to the detriment of an appreciation of the tactile aspects of the world mediated by the hand - coincides with a new statute of "looking", marked by the contemplation of the extensions and the awareness of the quality of surfaces?

Would it not be the games with scales - so characteristic of his work - a means to make sense of these two extremes, analogous to the photos of water and sand taken on the beach of Le Piquey (Fig.04), which resemble the descriptions of landscapes seen above?

Le Corbusier seems to suggest that the nature and the technical problem should be unified in a common time.

It is not at this precise period that the role assigned to nature as a homogeneous background to his architecture was abandoned in favor of an active incorporation, almost resonant, such as the coverage of the Unité in Marseille so much testifies?

Are the paths leading to this consciousness of the story of the winged figure?

\footnotetext{
${ }^{11}$ Tafuri, Manfredo. "Machine et mémoire: The City in the Work of Le Corbusier". In: Brooks, Allen H. (Ed). Le Corbusier BROOKS, Allen H. (ed). Princeton, New Jersey: Princeton University Press, 1987, pp. 203-228.
} 


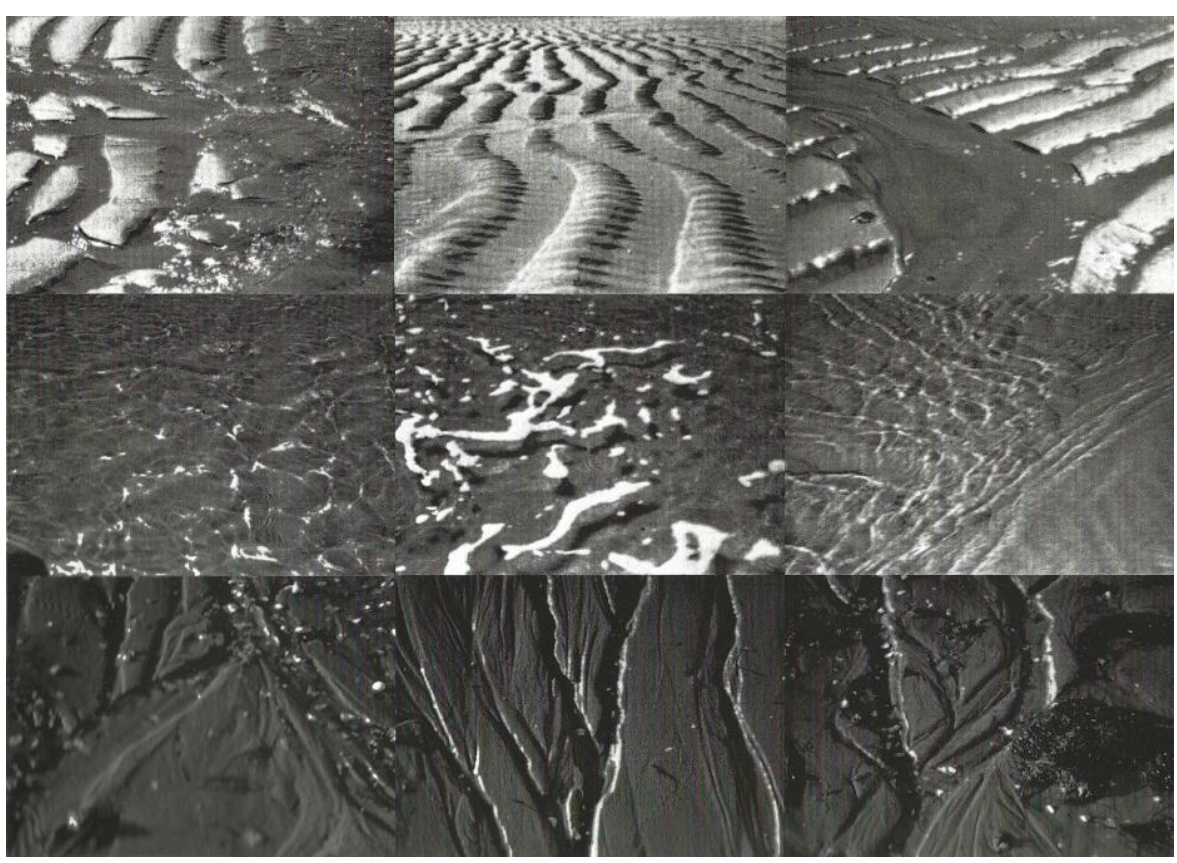

4. 16mm film camera. Le Piquey between 1936-37. FLC

\subsection{Two panels}
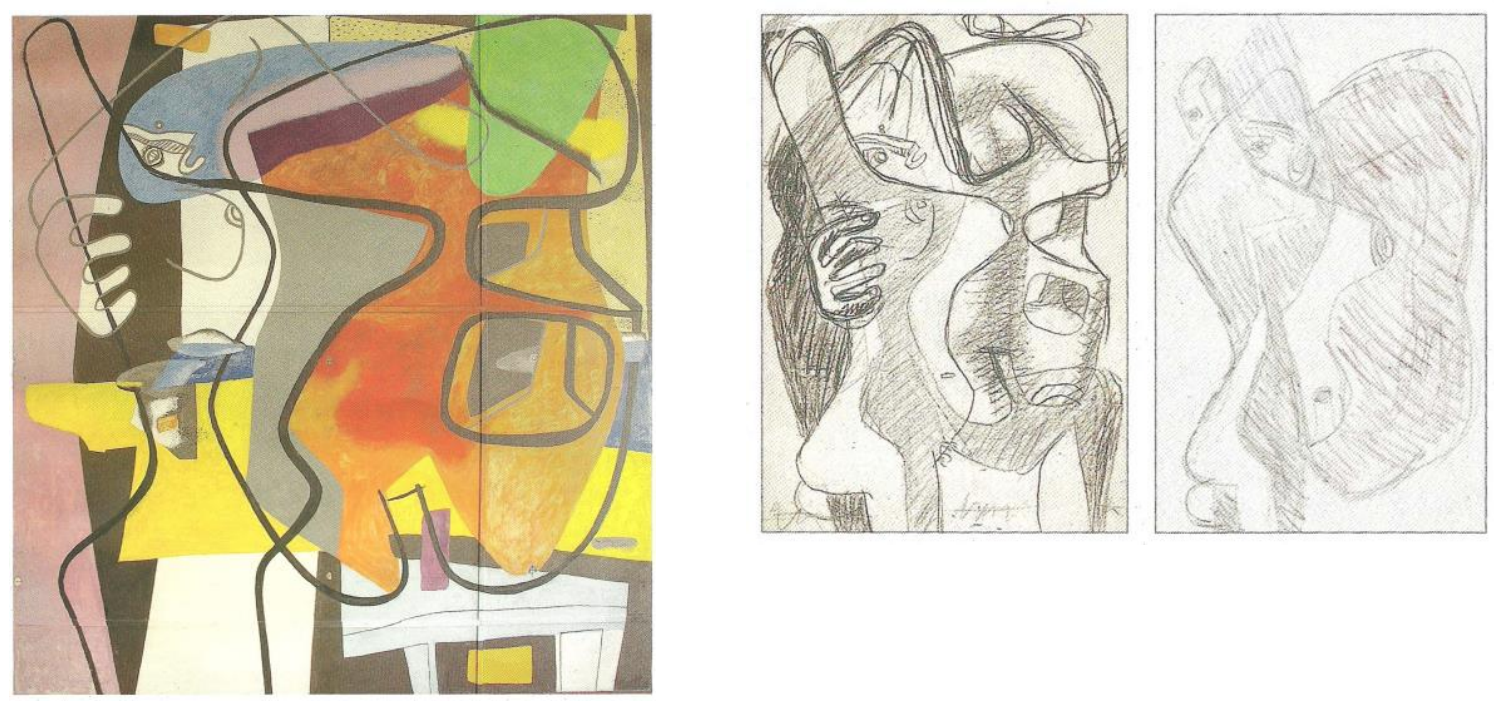

5. Mural at 35 rue de Sèvres. Photo: Marie-Odile Hubert, 2006

6. Étude de la gravure pour 5 femmes. FLC 4028

7. Étude Femme et coquillage. Crayon on paper. FLC 4202

After the Easter holidays of $1948,{ }^{12}$ the employees of the atelier at 35 rue de Sèvres were surprised by a painting (Fig. 05) of $3.82 \times 3.50 \mathrm{~m}$ on the backplate that covered the end wall of the workspace.

The panel was derived from a series called Femme et coquillage (Figs. 06 and 07), widely documented in sketches in pencil and crayon and later reproduced on other media such as engraving and oil.

\footnotetext{
${ }^{12}$ As told by Roger Aujame in "La Peinture murale, 35 rue de Sèvres à Paris". Foundation Le Corbusier.
} 
The dualism is evident. The contours - the mariages des contours - merge the irregular and sinuous shapes of a female figure with a shell. Wrapped in a hug, anchored by a hand that rests or deliver, the female figure occupies the side with nocturnal colors, close to blue and purple, whereas the shell is demarcated with a solar and lively orange.

The theme of the mural at the Pavillon Suisse of the Cité universitaire in Paris in 1948 (Fig. 08) was more elaborate.

With massive dimensions of $10.63 \times 3.42 \mathrm{~m}$, one half of the wall is occupied by the representation of the myth of the Minoan labyrinth. As a metaphor for architecture itself, the labyrinth serves as remembrance of a troubled, irregular path, in a clear allusion to the tribulations of human experience.

It would be appropriate to think of the labyrinth as an antagonist to the meander's law. The meander illustrates the operation of natural laws, the relentless force of nature that overcomes any obstacle. The labyrinth points to the uncertainties and dilemmas of the worldly experience in which men intended to get lost.

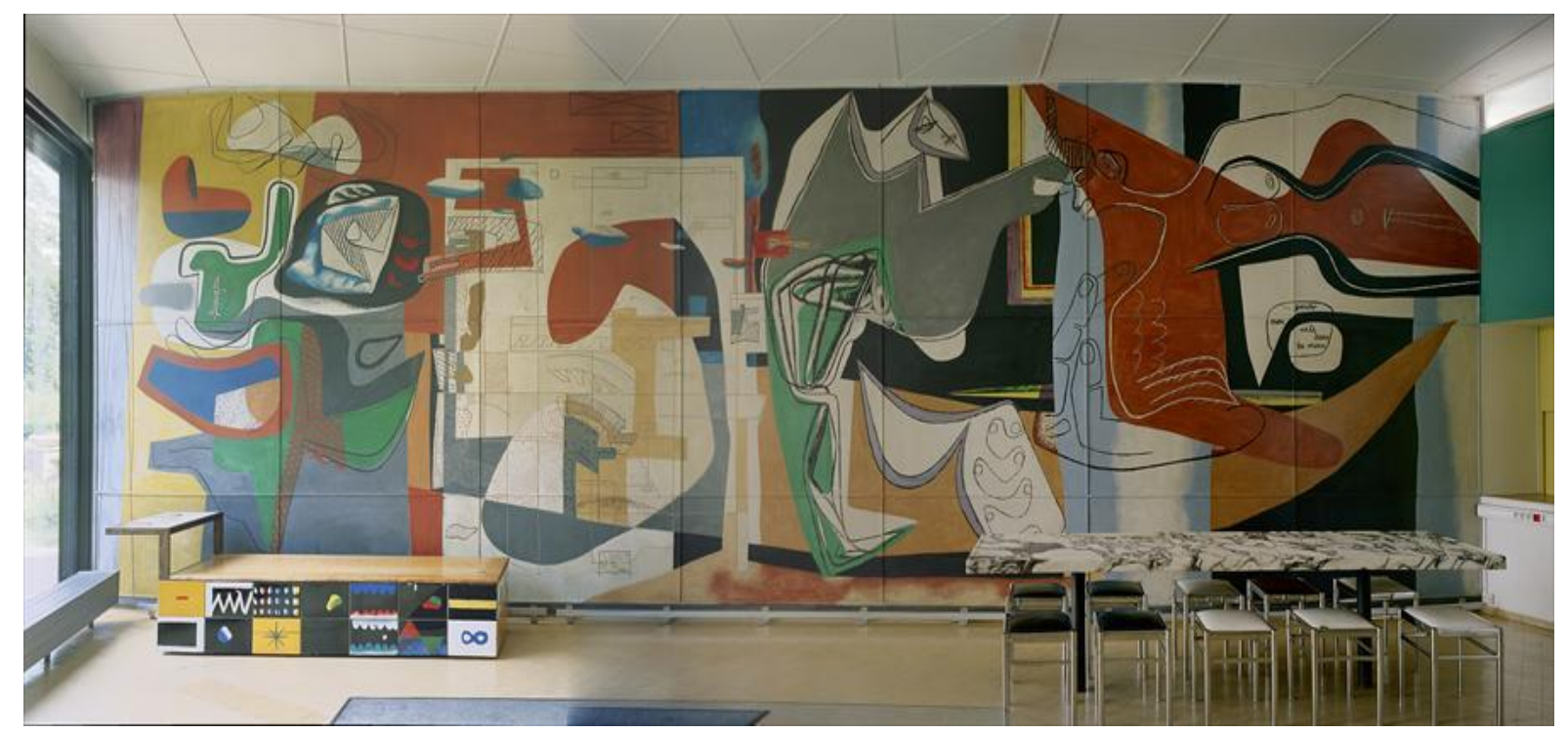

8. Cité universitaire, Pavillon Suisse. FLC/DAGP.

The bull and woman, separated by the labyrinth, re-propose most clearly the dualism presented through the wall in rue de Sèvres. This dualism, however, has deeper nuances. Half bull, half man, the beast that inhabits the labyrinth, the Minotaur, was the result of the incestuous relation between Pasiphaë, the Queen of Crete, and the bull sent by Poseidon as an offering to King Minos. This unholy genesis would not have gone unnoticed to Le Corbusier.

Richard A. Moore suggests that the female figure is Pasiphaë, the Queen of Crete and the goddess of the moon. ${ }^{13}$ Although the shape of the head resembles a crescent moon, it is worth noticing that in his hands lies the ball of thread associated with Ariadne. As retold through the myth, the thread was provided by Ariadne to guide Theseus through the labyrinth, so he could kill the Minotaur. Even when confronted with the subsequent lithography, Ariane et Pasiphaë (1961), the similarity in the design of the figures does not allow us to definitely denominate her.

\footnotetext{
${ }^{13}$ Moore, Richard A. "Alchemical and Mythical Themes in the Poem of the Right Angle". Oppositions (Winter 1980): 110114 Cambridge : MIT Press for The Institute for Architecture and Urban Studies, 1980.
} 
The other half of the panel is dominated by a delicate arrangement of the image of a winged female resting on one hand. It suggests a more generous communion between opposites, in a clear opposition to the violent dualism of the Minoan myth.

The prominent position of these two figures within the symbolic system of Le Corbusier is reinforced by the passage taken from the initial strophe of the poem Autre Eventail Mme. Mallarmé, by poet Stéphane Mallarmé. It is inscribed alongside the figures: "Garder mon aile dans ta main". ${ }^{14}$

The unusual resort to a literary reference explicitly reaffirms that the nature of the game developed by the two images has a symbolic horizon that craves for definition. ${ }^{15}$

These images seem to synthesize the two attitudes that govern the work of Le Corbusier thereafter.

On the one side, there is the need to anchor the plastic work in a sphere related to the expression of human labor, which is symbolized by the hand. On the other extreme, the need to provide the plastic work with a final horizon different from the contingency of the present. This is symbolized by the winged figure in flight.

\section{Le Poème de L'Angle Droit}

In Le Poème de L'Angle Droit (Fig. 09) we can find the key elements of Le Corbusier's symbolic system. The poem organizes the constellation of symbols that permeates his work.

It was written between 1947 and 1953, when the production of the two murals also took place. Its subjects will be fully incorporated into the lithographs of the book.

The tone of this work is confessional, as suggested by the architect's calligraphy and ink sketches. The book records the notes and drawings made during successive trips between Paris, Marseille and Chandigarh.

Le Corbusier uses the idea of iconostasis to spatially organize the 19 lithographs that make up the poem.

Iconostasis is a set of religious icons organized within an interchangeable orthogonal grid, arranged between the nave and the altar of Orthodox churches. In a way, it marks the separation between the mundane sphere, the ship, and the sacred sphere, the altar. In this orthogonal grid the position of each icon is precisely determined by the religious narrative to which the group relates. The intention of the architect seems to be similar.

\footnotetext{
${ }^{14}$ The complete strophe in Mallarmé's poem reads as follows: "O rêveuse, pour que je plonge,/ Au pur délice sans chemin,/ Sache, par un subtil mensonge,/ Garder mon aile dans ta main".

15 On the relationship between literature and architecture in the work of Le Corbusier, see: Calatrava, Juan. "Referentes literários en el pensamiento de Le Corbusier". In: Torres, Jorge (Ed.). Le Corbusier Mise au Point. Memorias Culturales. Valencia: General de Ediciones de Arquitectura, pp. 126-161.
} 


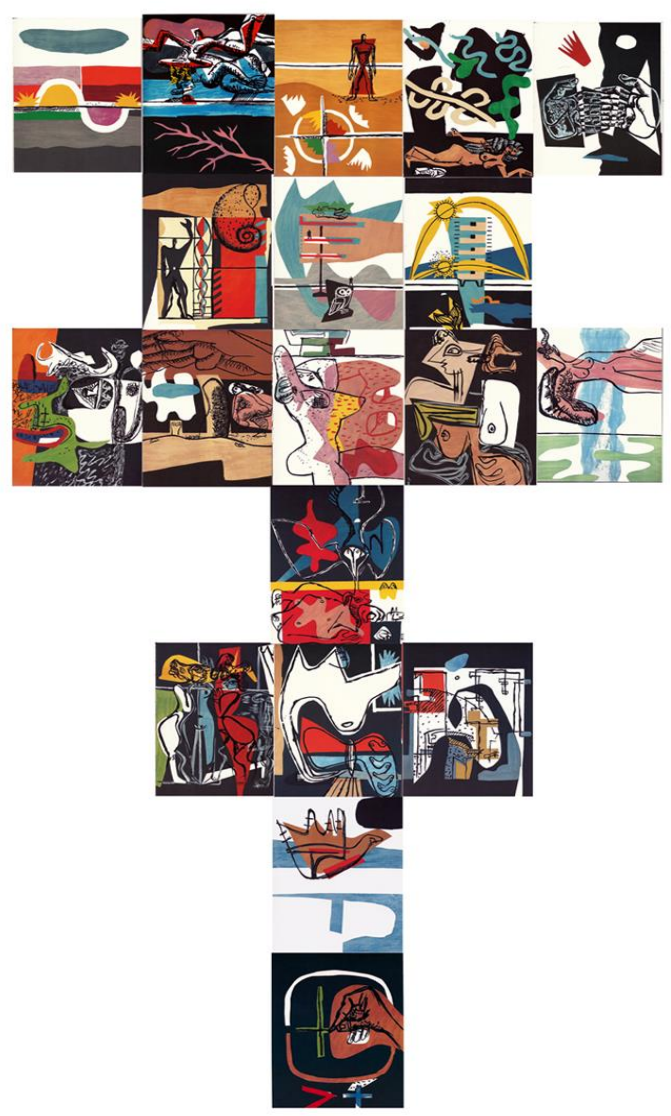

9. Le Poème de L'Angle Droit, author's montage.

The poem's iconostatic matrix is composed by seven lines, corresponding to the seven themes guiding the arrangement of the lithographs: environment, spirit, flesh, fusion, character, offering, and instrument.

The organization of the poem suggests successive synthesis from top to bottom.

It evolves around the duality represented by the dominant images of the hand and the winged woman, and is complemented by the previously elaborated symbols such as the sinuous calligraphy of the "law of the meander", the solar journey of 24 hours, the diagram of the essential joys and the Modulor.

On top we can see the eternal succession of natural-geological phenomena indifferent to human labor - for which architecture appears as a more accurate metaphor.

Below we see the record of the unpredictability of everyday life and the vicissitudes of the human condition.

The lithographs of the Femme et coquillage series, of the bull, the labyrinth, and of Pasiphaë/Ariadne attend fully in the iconostasis.

The presence of these figures suggests an even more intimate connection, especially when we think that the third row of the iconostasis, once ordered, displays an arrangement which is similar to the one on the wall of the Pavillon Suisse: the bull on the far left, Femme et coquillage replacing Pasiphaë/Ariadne, and the winged figure resting on a hand at the far right.

If we consider that the lines follow one another in successive syntheses, we have the first three re-proposing the dualism previously studied, with the Modulor and the principles of modern architecture and urban planning as a 
link or interface between the man's faith in instrumentality and the nature's call for detachment of the everyday experience.

However, from the fourth line, called fusion, we move into the territory where these images will be reworked, and we arrive at the genesis of the icon, which is our matter of concern in this paper.

The duality finds its form in the figure of the Open Hand (Fig. 10), elected as a synthesis of the entire symbolic system, and precedes a new operability proposed in the last lithograph, the right angle.

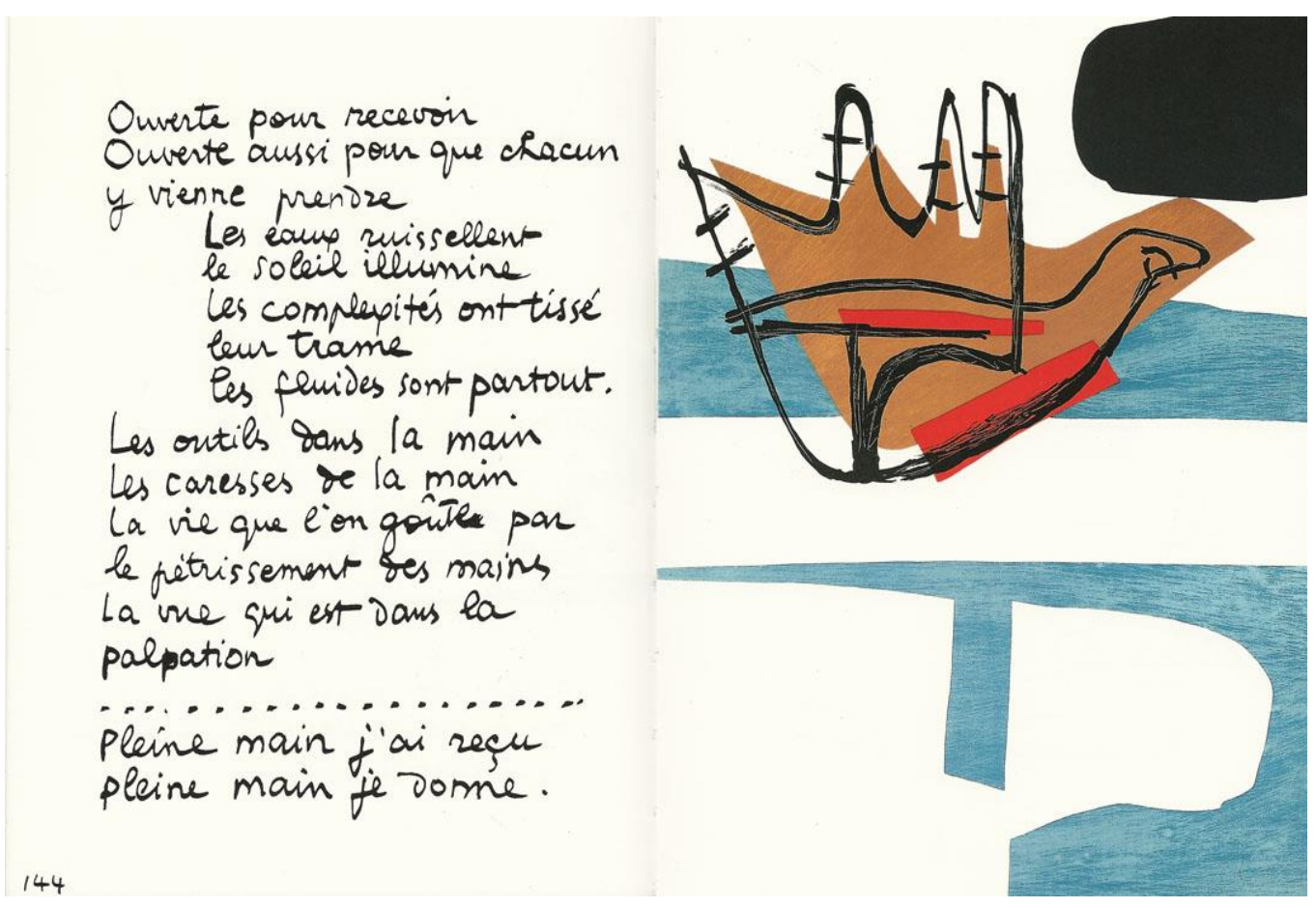

10. The Open Hand. Le Poème de l'Angle Droit. $1^{\text {st }}$ ed. Paris: Verve, 1955.

The hand is drawn in suspension. The three intermediate fingers are set vertically, and the edge fingers are opposed to them.

This opposition of extreme fingers does not correspond to the natural position of a hand, as in the design of the winged figure on the wall of the Pavillon Suisse. This strange position — almost impossible — incorporates his double, the winged figure: a hand appears suspended in the air like the silhouette of a flying bird.

The poem thus retells the genesis of this figure, drawn as a to reconcile the two different attitudes having mastery over his work.

A drawing dating back to the 1950s (Fig. 11) suggests another genesis for the image of the Open Hand. This drawing is on one of the notebooks that the architect had brought to Bogota during the commission of the city's Pilot Plan. The Open Hand appears to derive from a sketch depicting a group of five women gathered in circle, one of them lying on the front. 


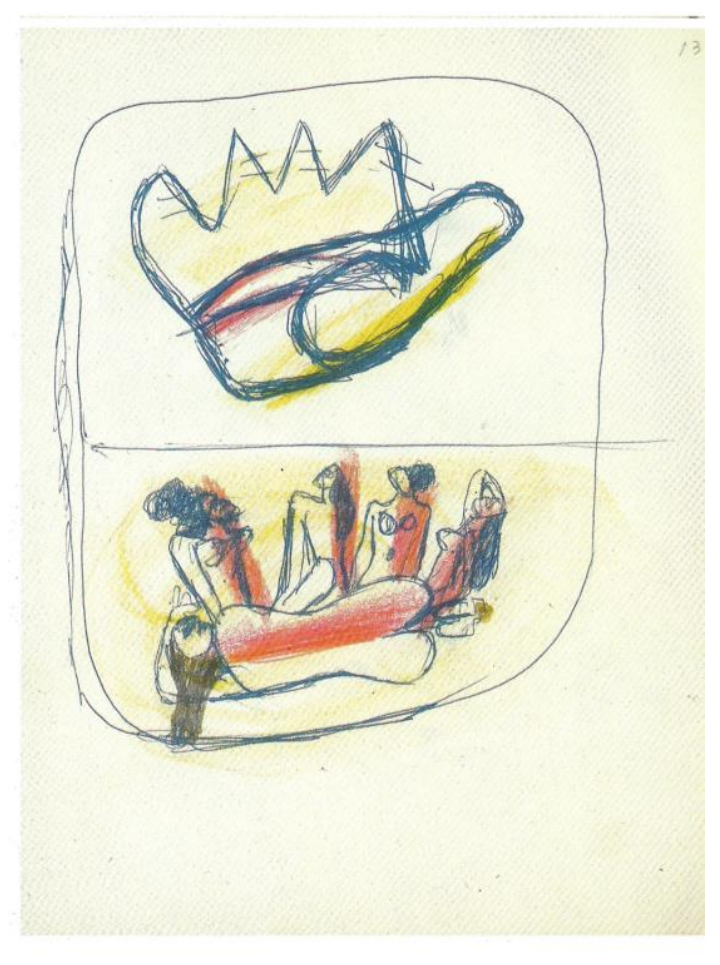

11. Sketch from the Bogota's notebook. FLC.

This genesis does not fit the narrative outlined in Le Poème de L'Angle Droit and in the mural at the Pavillon Suisse in the Cité universitaire.

What is suggested here is that the precise definition of this drawing indicates an earlier formulation. The nature of the scene seems to confirm that the intention underlying the hand symbol is similar to the transmission of experience that can be deduced from the congregation wheel. It has a communicative intent.

The poem's tone is personal, whereas the poem's structure is, conversely, highly elaborate. The iconostasis suggests a textile in which the symbols are collected, retold and worked. Path of the memory and intellectual adventure at once, it is not related to any defining moment, nor is contaminated by any particular place and time - as an example, it incorporates attributes collected from the Indian landscape, but excludes those symbols explicitly bound to the Hindu tradition, like the Ashoka Chakra and the swastika, symbols that later on will be incorporated into the works of Chandigarh.

Is not it strange that no technical apparatus appear? No plane or automobile, no factory or a modern buildingjust an ordinary fishing boat instead of an ocean liner?

The need to move the language, passing successively from one image to another, dominates the nature of the symbolism permeating Le Corbusier's work.

Clarity of language cannot be claimed. On the contrary, the structure of the poem appears as a metaphor for the labyrinth. A labyrinth without Ariadne's thread. 


\section{Garder mon aile dans ta main}

The architectural works belonging to the period of the development of the poem (1947-1953) seem to reflect the oscillation between these two extremes. The expression owes much to the antagonistic struggle between the materiality of the gross artifact and the spatiality avid to expand its boundaries beyond the object itself.

As demonstrated in Le Poeme de L'Angle Droit, what governs the symbol in the work of Le Corbusier is its particular experience. It is no coincidence that the poem's tone is confessional, and that the travel records dominate various drawings accompanying lithographs. The trip works as a metaphor for personal experience. Its importance is reaffirmed several times since Le Corbusier's trip to Asia Minor and Eastern Europe in 1916, the so-called Journey to the East. This symbolism is fed by these experiences, but mostly by the voyages to South America, North Africa and especially India.

The image of the open hand would appear materialized as a monument in the Plan for Chandigarh's Capitol, in Punjab, India (Fig. 12).

Le Corbusier took on the task of designing the representative buildings of the city: the Secretariat, the General Assembly, the High Court and the Government Palace, the latter ending up not being built. These buildings make up the capitol city, located on the outskirts of the urban plan.

The city plan, originally developed by American urban planner Albert Mayer, was just reviewed by the architect, and was implemented by Pierre Jeanneret and the couple formed by English urban planner Maxwell Fry and the anthropologist Jane Drew, the last two associated with the MARS Group (Modern Architectural Research Group), the English section of the CIAM.

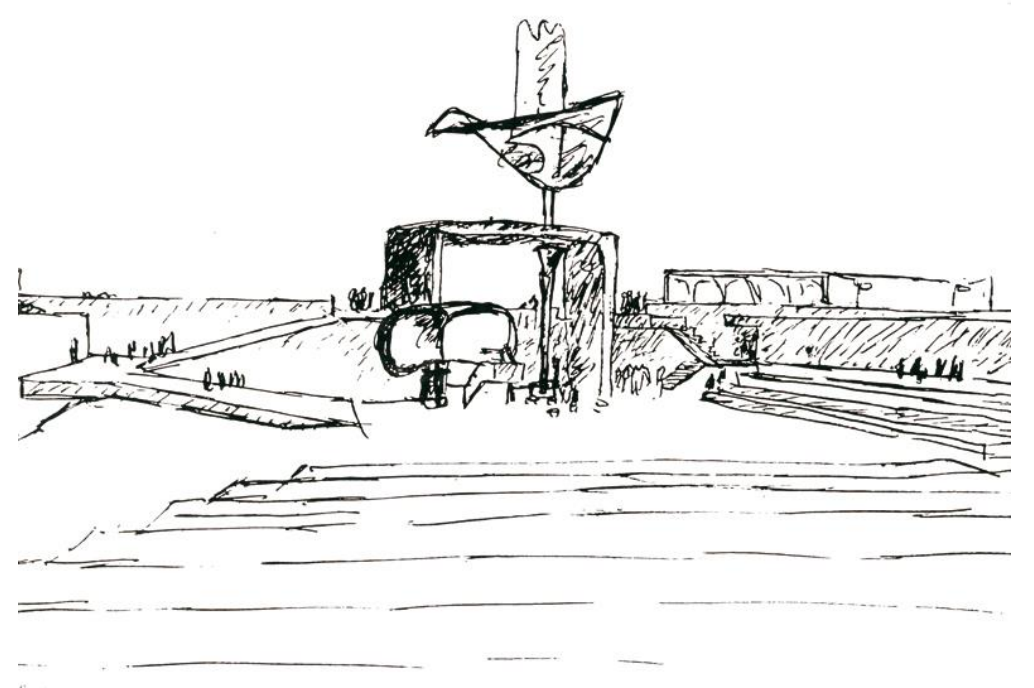

12. Sketch of the Open Hand in Chandigarh.

In: Mein Werk/L'Atelier de la recherche patiente. $1^{\text {st }}$ ed. Paris: Ed. Vincent Fréal, 1960

The difficulties and specific political connotations that this symbol assumed in the Indian context are not within the concerns of this paper. Its realization would take more than twenty years after the end of the main buildings of the capital, after the death of the architect and the Prime-Minister Nehru. We are more concerned with the political connotations intended by the architect, its internal position in the body of his work, as the culmination of its iconic and symbolic concerns. 
The architecture of Chandigarh's monument Open Hand was intended as a metaphor for the contradictions upon which the architect's work is anchored.

The symbol emerges as a consciousness that his creative activity, as opposed to what his work could have suggested until the mid-1940s, could no longer be anchored in the technical dimension of the industrial civilization. The work of art should point to a time different from that of the machinist civilization. The univocal time when all processes will be unified, the perfect image of the machine, would be incompatible with the fullness of human experience to which his architecture pretends.

Language should look for other purposes, a new, open instrumentality.

Not accidently, another monument — as the former in memory of Vaillant-Couturier (Fig. 01) — concentrates the dilemmas faced by Le Corbusier during the long and patient research. The intent of the architect in both cases is communication. It is significant of his change of attitude towards the possibilities opened by modernity.

In 1937, Villejuf, intended with the speed provided by the automobile, generates the dynamism of the composition and breaks away with the immobility of disinterested contemplation.

In Chandigarh, the detachment from the surroundings and other visual stimulus that allows contemplating the wind transform one image into another.

Suspended on a metal pole, its position in the Capitol marks the space symbolically called Pit of Consideration. It is detached from the immediate surroundings and alludes to the necessary halt before action.

This is the context for the Open Hand monument. Its design reaffirms the initial directions described in the poem, as well as the genesis suggested herein.

The pole rests on a metal roller that allows the sculpture to move freely, driven by the wind.

The constant change in the wind direction is responsible for the transformation from one image into another: the imperious gesture of the hand marking their presence along the skyline, and the delicacy of the wing that moves in the wind.

In "garder mon aile dans ta main".

\section{Acknowledgements}

Prof. José Tavares Correia de Lira (FAUUSP — São Paulo, Brasil).

Guillherme Pianca, Stephanie Guerra and Bruno Schiavo, for their comments.

\section{Source of images}

01, 02. extract from: : Mein Werk/L'Atelier de la recherche patiente. $1^{\text {st }}$ ed. Paris: Ed. Vincent Fréal, 1960.

03. extract from: Poésie sur Alger. $1^{\text {st }}$ ed. Paris: Falazie, 1951.

04. 16mm film camera. Le Piquey between 1936-37. FLC

05. Marie-Odile Hubert, 2006. FLC. DAGP.

06. Foundation Le Corbusier. FLC 4028

07. Foundation Le Corbusier. FLC 4202

08.Foundation Le Corbusier. FLC/DAGP

09. author's montage using the pages of Le Poème de l'Angle Droit. $1^{\text {st }}$. ed. Paris: Verve, 1955. 
10. extract from: Le Poème de l'Angle Droit. $1^{\text {st }}$. ed. Paris: Verve, 1955.

11. Sketch from the Bogota's notebook. Foundation Le Corbusier.

12. extract from: : Mein Werk/L'Atelier de la recherche patiente. $1^{\text {st }}$ ed. Paris: Ed. Vincent Fréal, 1960.

\section{Bibliography/References}

Benjamin, Walter: "Sobre o conceito da História". Magia e técnica, arte e política: ensaios sobre literatura e história da cultura. ed.7. São Paulo: Brasiliense, 1994. p.226

Besset, Maurice (org.). Le Corbusier sketchbooks. Nova Iorque : Architectural History Foundation Cambridge, Mass. : MIT Press, 1981

Brooks, H. Allen. Le Corbusier's Formative Years. 1.a ed. Chicago. University of Chicago Press, 1997

Calatrava, Juan. "La plastica de un arquitecto". In: Salvador Guerrero (Ed.), Una Casa-Un Palacio. Madrid 1928. Exhibition catalog. Madrid: Publicaciones de la Residencia de Estudiantes, 2010, pp. 182-183

Calatrava, Juan. "Referentes literários en el pensamiento de Le Corbusier”. In: Torres, Jorge (Ed.). Le Corbusier Mise au Point. Memorias Culturales. Valencia: General de Ediciones de Arquitectura, pp. 126-161

Cohen, Jean-Louis (org.). Le Corbusier - An Atlas of Modern Landscapes. Londres: Thames \& Hudson, 2013.

Colomina, Beatriz. Privacy and Publicity. Architecture as Mass Media. $1^{\text {st }}$ ed. Cambridge, Massachusetts: MIT Press, 1996

Corbusier. Doctoral thesis. Director: Adolfo Gonzalez Amezqueta. Escuela Técnica Superior de Arquitectura de d'Aujourd'hui, 1935

Eléments d'une doctrine d'urbanisme pour l'équipment dela civilisation machiniste. Paris: Ed. L'Architecture Foundation Le Corbusier: “La Peinture murale, 35 rue de Sévres à Paris” Foundation Le Corbusier, 2009 general bibliography:

L'Architecture d'aujourd'hui. Special issue “Le Corbusier”. Paris: Editions L'Architecture d'aujourd'hui, 1948

Le Corbusier. "Cornotions Sudamericaines. Introduction à un urbanisme sensible", in La Ville Radieuse.

Le Corbusier. Aircraft. 1.a ed. Madrid: ABDA, 1987

Le Corbusier. Ouevre complète, 1929-1934. Zurich: Les Édition d'architecture Erlenbach-Zurich;

Le Corbusier. Precisions sur le état présent de L'architecture et de urbanisme.1.a ed. Paris: G.Crés et Cie., 1930

Le Corbusier: Le Poème de l'angle droit. 1st ed. Paris: Verve, 1955

Le Corbusier: Mein Werk/ L'Atelier de la recherche patiente. 1st ed. Paris: Ed. Vincent Fréal, 1960

Le Corbusier: Poésie sur Alger. 1st ed. Paris: Falazie, 1951

Le Couédic, Daniel. Joseph Savina, l'improbable compagnon de route", in Le Corbusier : L'œuvre plastique, Paris, Fondation Le Corbusier et Éditions de La Villette, 2005, p. 26-53

Lucan, Jacques. Le Corbusier. Une encyclopedie. 1.a ed. Paris. Centre Georges Pompidou, 1987

Madrid. Madri, 1992

Mark Antliff, Avant-Garde Fascism : The Mobilization of Myth, Art, and Culture in France, 1909-1939. Durham, NC: Duke University Press, 2007

Martins, Carlos A. Ferreira. Razón, ciudad y naturaleza. La génesis de los conceptos em El urbanismo de Le 
Mary McLeod “Le Corbusier and Algiers”In: Oppositions 19-20. Cambridge, Massachusetts: MIT Press, 1980 , pp. $55-85$

Monteys, Xavier. "Tres apuntes sobre la presencia de lo tactil en la obra de Le Corbusier". In: Torres, Jorge (Ed.). Le Corbusier Mise au Point. Memorias Culturales. Valencia: General de Ediciones de Arquitectura, pp. 182-194

Moore, Richard A. "Alchemical and Mythical Themes in the Poem of the Right Angle". Oppositions (Winter 1980): 110-114 Cambridge : MIT Press for The Institute for Architecture and Urban Studies, 1980

Tafuri, Manfredo. Projecto e Utopia. Lisboa: Presença, 1985

Tafuri, Manfredo. Teorias e História da Arquitectura. 2.a ed. Lisboa: Editorial Presença,1988

Tafuri, Manfredo: "Machine et mêmoire: The City in the Work of Le Corbusier". in, Le Corbusier. Brooks, Allen H.1st ed. Princeton University Press. Princeton, New Jersey, pp.203-228

Valéry, Paul. Introdução ao Método de Leonardo da Vinci. 1.a ed. São Paulo: Editora 34, 1998

von Moos, Stanislau: "Mariage des Contours". in.Oppositions 19-20. Cambridge, Massachusetts: MIT Press, 1980. pp. $87-107$

Von Moos, Stanislaus. Elements of a Synthesis. Rotterdam: 010 publishers, 2009 


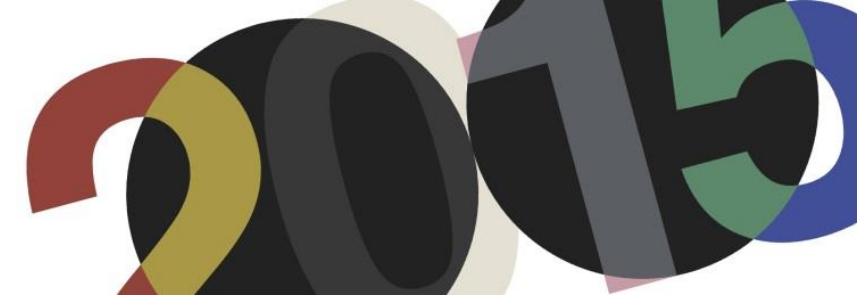

DOI: http://dx.doi.org/10.4995/LC2015.2015.570

\title{
Criterios de combinación de colores para la arquitectura en Salubra I: estudio de tonos
}

\author{
J. Serra, J. Llopis, A. Torres y M. Giménez
}

Escuela Superior de Arquitectura de Valencia

Resumen: Realizamos un nuevo estudio de las combinaciones de colores seleccionados por Le Corbusier en los 'claviers' para la empresa de papeles pintados Salubra en 1931, mediante su análisis en el espacio de color Natural Color System NCS, que permite comprender las variables perceptivas de los colores (tono, negrura y cromaticidad) y sus criterios de armonía.

En este artículo discutimos las gamas tonales seleccionadas y aquellas que están ausentes., e intentamos desentrañar el orden subyacente en las combinaciones de colores mediante el estudio de las similitudes y contrastes de sus tonalidades en NCS. De manera gráfica, se demuestran algunos principios de armonía como el recurso habitual de contrastar tonos fríos con cálidos, algo que difiere ligeramente del tradicional contraste de complementariedad. El trabajo completo ha sido publicado en Color Research and Application (C) Wiley Periodicals. Color combination criteria in Le Corbusier's Purist architecture based on Salubra claviers from 1931. DOI: 10.1002/col.21940.

Abstract: We have carried out a new study of the color combinations selected by Le Corbusier in the 'claviers' for the Salubra wallpaper company in 1931, by analyzing them in the Natural Color System NCS, which allows us to understand the perceptive variables of colors (hue, blackness and chromaticness) as well as their combination criteria.

In this paper, the selected hue ranges are discussed, and those absent ones. We aim to find out the underlying order in the color combinations by studying the similarities and contrasts of their hues in NCS. We demonstrate graphically some principles in Le Corbusier's color preferences, such as the usual resource of contrasting cool with warm colors, something slightly different to the traditional contrast of complementary colors. The complete work has been published in Color Research and Application (C) Wiley Periodicals. Color combination criteria in Le Corbusier's Purist architecture based on Salubra claviers from 1931. DOI: 10.1002/col.21940.

Palabras clave: color, armonía; Le Corbusier; Salubra; arquitectura; Natural Color System. Keywords: color; harmony; Le Corbusier; Salubra; architecture; Natural Color System.

\section{Introducción}

En 1931 la empresa de papeles pintados Salubra, con sede en Basilea (Suiza), encarga a Le Corbusier confeccionar una primera carta de colores para la arquitectura que se completa en 1959 con una segunda versión. La primera de estas colecciones estaba pensada como una serie armónica, de manera similar a como se organizan los sonidos en un piano, de ahí su denominación como "claviers de couleurs" (fig. 1). En 1997, ambas colecciones de colores se reeditan junto con el texto inédito de Le Corbusier Polychromie Architecturale fechado entre finales de 1932 y principios de $1933^{1}$, sin duda el documento más importante para comprender el color en la obra del arquitecto suizo.

\footnotetext{
${ }^{1}$ Le Corbusier: "Polychromie architecturale". En Rüegg, Arthur (Ed.): Polychromie architecturale: Le corbusier's color keyboards from 1931 and 1959. Basel: Birkhäuser, 1997. pp. 94-143.
} 
Son varios los autores que han estudiado detenidamente las cartas de color Salubra I: JL. Caivano explica su organización y funcionamiento ${ }^{2}$; M. Colli la ordenación de los colores en los claviers $^{3}$; A. Ruegg analiza en profundidad las cartas junto con su texto Polychromie Architecturale ${ }^{4}$; y J. de Heer ${ }^{5}$ desarrolla un estudio exhaustivo de los aspectos cromáticos en los escritos y la arquitectura Purista de Le Corbusier, evidenciando el alto grado de libertad con el que finalmente disponía los colores en la obra construida más allá de los claviers de color Salubra I.

Sin embargo, existe un asunto que no se ha trabajado hasta la fecha, que consiste en un análisis de las combinaciones de colores seleccionados en los teclados empleando un espacio de notación del color estándar como Natural Color System (NCS), que permite comprender las características colorimétricas de los colores (tono, negrura y cromaticidad) y sus criterios de armonía. En este artículo nos centramos en el estudio de los tonos de los colores, aunque también se han estudiado la negrura y la cromaticidad ${ }^{6}$.

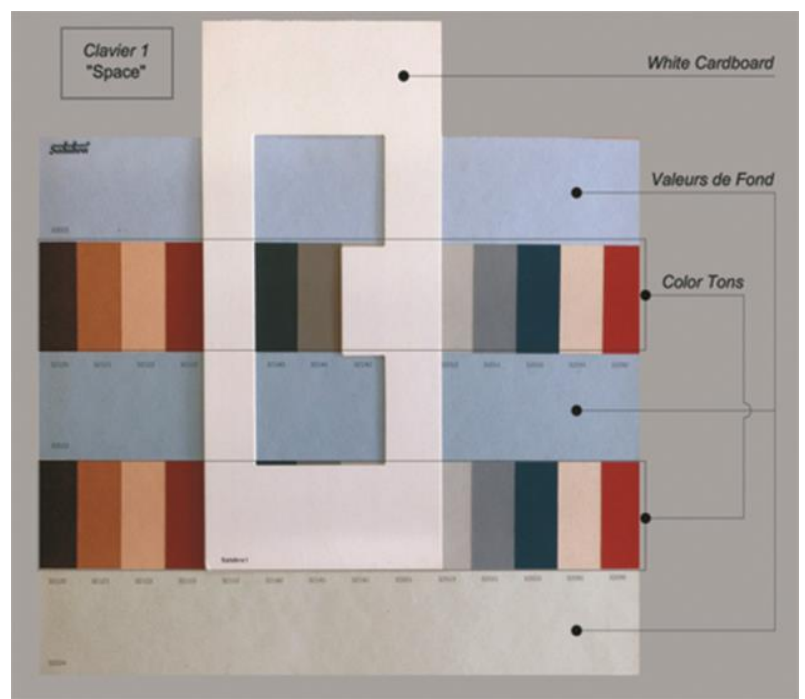

1. Foto del clavier 'Espace' de la colección Salubra I (1931), indicando los valeurs de fond y los color tons, así como el cartón blanco para ayudar a seleccionar cada combinación.

Este análisis es coherente con el pensamiento de Le Corbusier, al menos en su etapa Purista a la que pertenece esta colección de colores, quien consideraba que la belleza en la arquitectura respondía a una serie de leyes basadas en los números que podían ser conocidas y estudiadas ${ }^{7}$. En este sentido, su aproximación a la belleza

\footnotetext{
${ }^{2}$ Caivano, José Luis: La compleja relación con el color de uno de los maestros de la arquitectura moderna: Nueva edición de la Policromía Arquitectónica de Le Corbusier”. En Luminotecnia. N N 84. Mar de la Plata (Argentina): Editores SRL, 2007. pp. 58-61.

${ }^{3}$ Colli, Luisa Martina: "Hacia una policromía arquitectónica”. En Lucan, Jaques (Ed.): Le Corbusier, une encyclopédie. Paris: Centre de Crêation Industrielle, 1987. pp. 97-100.

${ }^{4}$ Rüegg, Arthur: "Le Corbusier's Polychromie architecturale and his Color keyboards from 1931 and 1959". En Rüegg, Arthur (Ed.): Polychromie architecturale: Le Corbusier's color keyboards from 1931 and 1959. Basel: Birkhäuser, 1997. pp. 12-93.

${ }^{5}$ Heer, Jean de: The architectonic colour: polychromy in the Purist architecture of Le Corbusier. Rotterdam: 010 Publishers, 2009.

${ }^{6}$ Serra Lluch, Juan y otros: "Color combination criteria in Le Corbusier's purist architecture based on Salubra claviers from 1931”. En: Color Research and Application. Enero 2015 (Early view). Wiley Periodicals, 2015. DOI: 10.1002/col.21940

${ }^{7}$ Dempsey, Amy: Estilos, escuelas y movimientos: guía enciclopédica del arte moderno. Barcelona: Blume, 2002.
} 
ideal responde a lo que podemos considerar un paradigma positivista ${ }^{8}$ y se fundamenta en criterios racionales de orden y proporción. No obstante, Le Corbusier no concibe las cartas Salubra I como un sistema abierto que sirviera para combinar cualquier color de la naturaleza, sino como una especie de manual muy bien delimitado de sólo 43 colores que tienen todas las garantías de ser adecuados para la arquitectura y establece cómo combinarlos. Le Corbusier no busca un sistema de clasificación de todos los colores posibles, sino más bien un instrumento que permita restringirlos y que garantice las posibilidades de armonía. De ahí que las cartas de color se construyan al modo del teclado de un piano, en el que las teclas son limitadas pero suponen la base de cualquier armonía musical.

En todo caso, Le Corbusier limita el margen de libertad según un criterio de armonía absolutamente personal, que sólo puede ser explicado desde su sensibilidad como arquitecto y como pintor, así como desde su deseo de racionalizar la mayor parte de sus procesos creativos.

\section{Método}

El estudio se realiza partiendo de la documentación disponible en la Fundación Le Corbusier en París, donde las cartas de color originales se han evaluado visualmente y con instrumental técnico (espectrofotómetro de contacto modelo Kónica Minolta CM 700d, colorímetro Munsell y NCS) ${ }^{9}$.

Nos centramos en la carta Salubra I de 1931 porque responde a inquietudes que Jeanneret y Ozenfant empezaron a investigar seis años antes en su texto Nature et création $^{10}$, donde consideraban que la belleza se basaba en el orden y la claridad formal.

Nuestra metodología ha consistido en extraer todas las combinaciones posibles de colores de la colección, que resultan ser 312 combinaciones de 4 colores (1.248 parejas de colores) y representarlas en el espacio de color tridimensional NCS, que tiene forma de doble cono invertido. Esta representación es un modelo virtual navegable que permite ser observado desde cualquier punto de vista (fig. 2), identificando si existen criterios de armonía o contraste, o sea coincidencias o divergencias con respecto a los tonos de los colores o a sus valores de negrura y cromaticidad.

\footnotetext{
${ }^{8}$ O’Connor, Zenna: “Colour Harmony Revisited”. En: Color Research and Application. № 35 (4). Wiley Periodicals, 2009. pp. 268-273.

${ }^{9}$ En los casos en los que el paso del tiempo había deteriorado el color de las muestras, como en el caso del azul 32040, se extrajeron las características colorimétricas de las cartas publicadas en 1997, pues se considera que son una buena reinterpretación de los colores originales.

${ }^{10}$ Jeanneret, Ozenfant: "Nature et creation”. En: L'Esprit Nouveau. N 19. Paris: Ed. de L'Esprit Nouveau, 1923. s.p.
} 


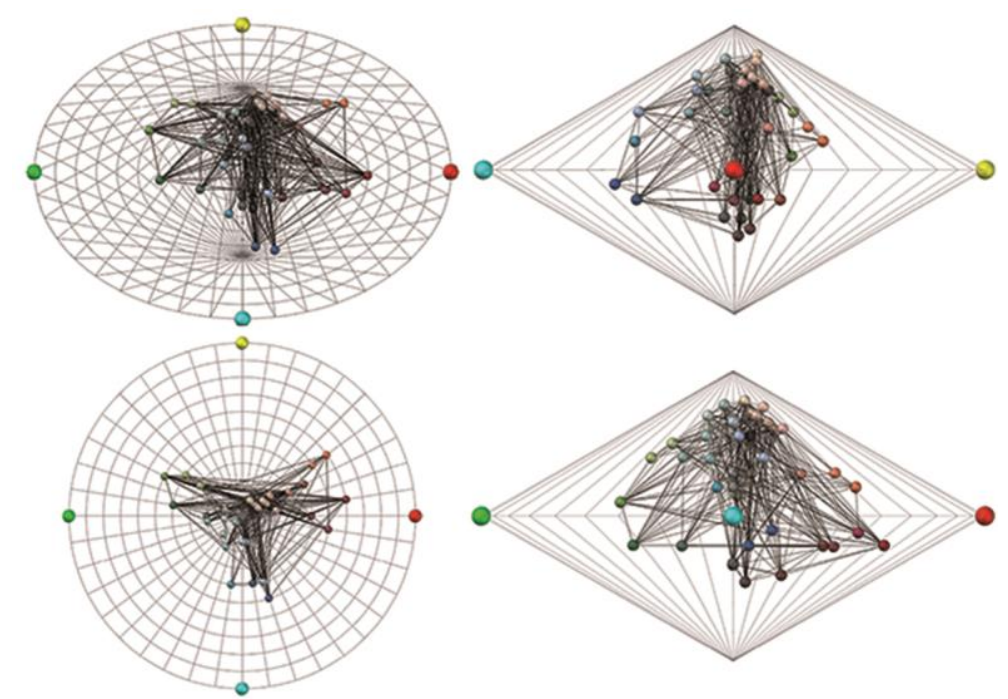

2. Modelo virtual navegable en 3D con indicación de todas las parejas de colores Salubra I (1931) en el espacio de color NCS. Las líneas que unen las esferas indican colores emparejados.

A nivel teórico, la búsqueda de los criterios de combinación de los colores se ha llevado a cabo siguiendo los modelos habituales del paradigma positivista, que son los más cercanos al pensamiento de Le Corbusier. Por un lado la búsqueda de similitudes entre los colores, como proponía A. Munsell ${ }^{11}$ o posteriormente J. Itten ${ }^{12}$; por otro la búsqueda de equilibrios entre fuerzas oponentes, como sostenía el propio A. Munsell, Chevreul ${ }^{13}$ ó Goethe $^{14}$, entre otros. Es cierto que todos los modelos de agrupación de colores basados en similitudes y contrastes son limitados, sobre todo cuando aspiran a dar respuestas estéticas universales, válidas para cualquier contexto o cualquier observador, como advierte muy bien la arquitecta Z. O'Connor ${ }^{15}$. La intención de Le Corbusier no era la de predecir la respuesta humana ante sus combinaciones de color sino establecer su propio criterio de agrupación, basado en sus preferencias personales. En este sentido, nuestro objetivo es comprender mejor unas combinaciones de color que el propio Le Corbusier ya ha considerado apropiadas para la arquitectura. En todo caso, es difícil caer en el error de considerar las cartas Salubra I como la solución universal al problema de las armonías de color, cuando ni siquiera el propio Le Corbusier parece que las empleara de manera estricta.

\section{Análisis de los tonos NCS}

Los 43 colores de la colección Salubra I se organizan en 12 colecciones denominadas claviers. Cada una de ellas consta de tres colores de fondo (valeurs de fond) y dos bandas horizontales de color tons colocados en una secuencia que asemeja a un teclado. Para facilitar la selección de los colores, las cartas se acompañan de unos cartones de color blanco que permiten aislar dos valeurs de fond junto con uno o dos color tons, de modo que los

\footnotetext{
${ }^{11}$ Munsell, Albert: A grammar of colour. Mittineague, Massachusetts: The Strathmore paper company, 1921.

${ }^{12}$ Itten, Johannes: Kunst der Farbe. Ravensburg: Otto Maier Verlag, 1961. Versión inglesa por: Hagen, E. The elements of color. NY: Van Nostrand Reinhold, 1970.

${ }^{13}$ Chevreul, Michel Eugène: De la loi du contraste simultané des couleurs et de l'assortiment des objets colorés. Paris: Gauthier-Villars et fills; 1839. p 750. Traducción inglesa: Martel, C: The principles of harmony and contrast of colors and their applications to the arts. London: Longman, Brown, Green and Longmans, 1855.

${ }^{14}$ Goethe, Johann Wolfgang: Materialien zur Geschichte der Farbenlehre, Zur Farbenlehre. Tubingen: Cotta, 1810. Traducción inglesa: Eastlake, C.: Goethe's theory of colours. London: J. Murray, 1840.

${ }^{15}$ O'Connor. Op. cit., p. 268.
} 
colores seleccionados, con un máximo de cuatro, deben ser observados aislados con un cartón blanco. En las distintas cartas de color parece evidente que los valeur de fond son los que dan el "timbre" a cada clavier y se asocian de algún modo con los nombres propios que los identifican: Espace, Ciel, Velour I y II, Sable I y II, Mur I y II, Paysage y Bigarrées I, II y III. Mediante un "proceso de asociación", los valeurs de fond se vinculan a un concepto, a una idea de orden secundario. Así, a los colores azules corresponde la idea asociada de "cielo" y "espacio", a los ocres la "arena", a los rojos la "pared" y a los verdes el "paisaje". Este papel asociativo del color es evidente en proyectos como las viviendas en Pèssac, donde el verde se asocia a la idea de bosque lejano o de cubierta ajardinada, el azul al fondo del cielo, y el rojo se emplea para "fijar" una fachada como "pared" y reforzar su presencia.

Los 43 colores en la colección Salubra I derivan de 14 colores iniciales a los que denominamos colores principales. A partir de cada uno de estos colores principales, Le Corbusier obtuvo varias familias de colores a base de añadir pigmento blanco y así desplazar los colores principales a una versión más suave en tres o cuatro pasos. Así pues, encontramos grupos de colores que se originan a partir de un mismo color principal y diremos que pertenecen a la misma familia de color-pigmento (azules cobalto o rojos bermellón, por ejemplo). Cada uno de los colores de la colección original Salubra I se denotaba con un número de tres dígitos, correspondiendo a los colores principales los siguientes: 001, 010, 020, 030, 040, 050, 060, 080, 090, 100, 110, 120, 130 y 140. Las unidades de cada número de referencia indican aproximadamente la negrura y cromaticidad del color, mientras que las decenas y centenas identifican cada una de las 14 familias de color-pigmento. Siguiendo la denominación de M. colli para cada familia de color-pigmento: $\approx$ blanco $^{16}$ (primeros dos dígitos 00: 001), grises (001, 010, 011, 013), azules ultramar (primeros dos dígitos 02: 021, 022, 023, 024), azules cobalto (primeros dos dígitos 03: 030, 031, 032, 033, 034), verdes veronés (primeros dos dígitos 04: 040, 041, 042), verdes amarillentos (primeros dos dígitos 05: 050, 051, 052, 053), naranjas (primeros dos dígitos 08: 080, 081, 081), rojos bermellón (primeros dos dígitos 09: 090, 091), carmines (primeros dos dígitos 10: 100, 101, 102), ocres rojizos (primeros dos dígitos 11: 110, 111, 112); sienas (primeros dos dígitos 12: 120, 121, 122, 123), marrones (primeros dos dígitos 13: 130, 131) y sombras (primeros dos dígitos 14: 140, 141, 142, 150).

\footnotetext{
${ }^{16}$ Colli llama a este primer color "blanco", aunque no pertenece estrictamente a los colores neutros en NCS (S0510 Y30R). Para evitar confusiones, denominamos a esta familia de color-pigmento con un solo miembro " $\approx$ blanco".
} 


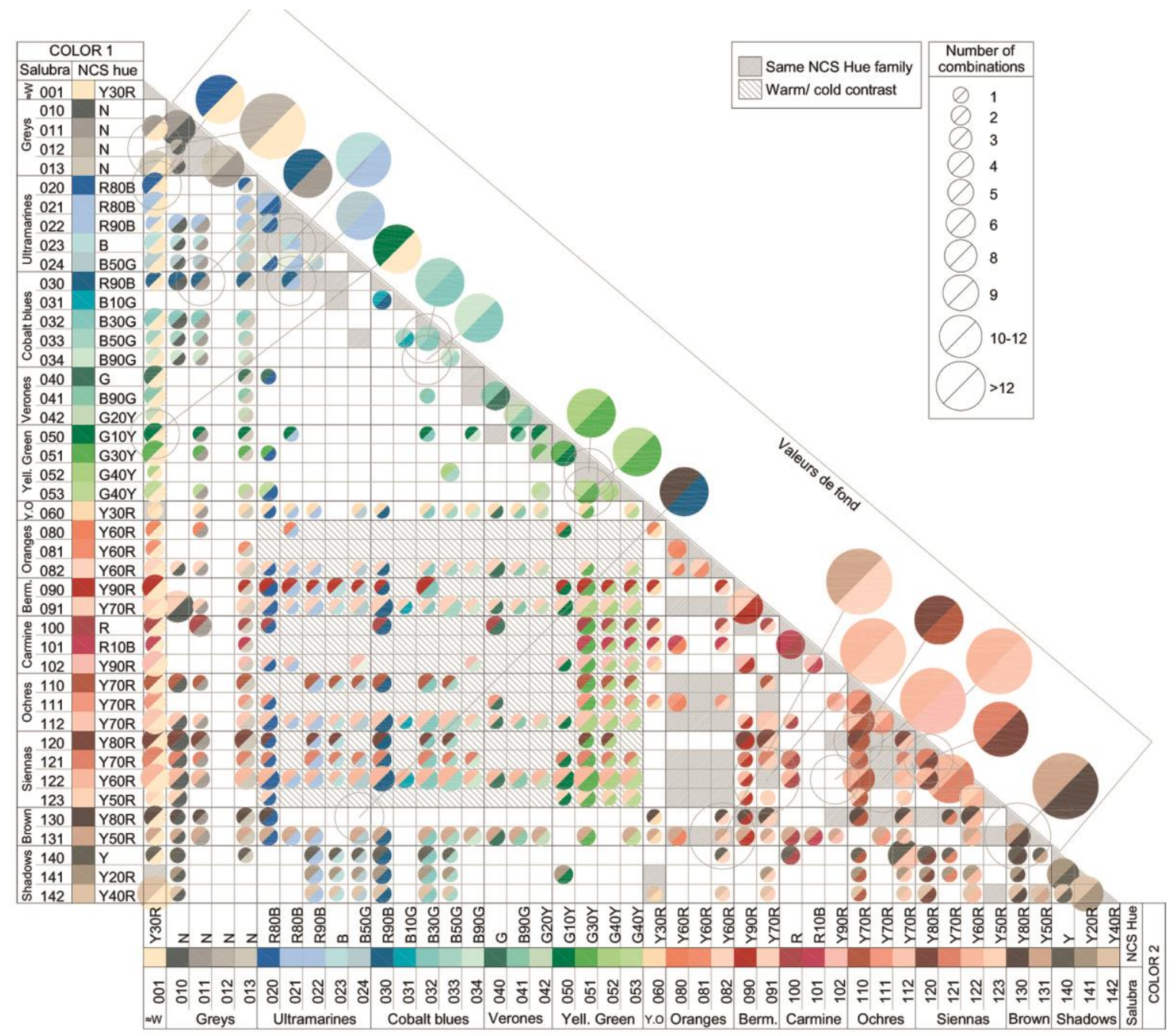

3. Representación de todas las parejas de colores Salubra I (1931). En abscisas y ordenadas se muestran los 43 colores con su notación NCS. El número de veces que se repite una pareja en los claviers se indica con el tamaño del círculo. Aquellas parejas correspondientes a dos colores de fondo (valeurs de fond) se representan al margen, por ser mucho más numerosas. El tramado denso de rayas indica el lugar geométrico de las combinaciones de colores de igual tono en NCS. El tramado de rayas menos denso indica el lugar geométrico de las combinaciones de colores con contraste frío/ cálido ${ }^{17 .}$

Al seleccionar estas 14 familias de color-pigmento y no cualesquiera otras, Le Corbusier quiere evitar aquellos colores que no sean plenamente "arquitectónicos" y que por lo tanto puedan neutralizar el efecto visual de la forma arquitectónica. En el ámbito de la pintura de caballete, Ozenfant y Jeanneret daban prioridad a los volúmenes y el dibujo de las formas frente al color y deseaban evitar el carácter destructivo del color que criticaban en otros movimientos artísticos como De Stijl. También en la arquitectura debía evitarse todo efecto impresionista del color que pudiera distorsionar la geometría de las formas puras.

\footnotetext{
${ }^{17}$ Téngase en cuenta que el patrón de color impreso puede haber sufrido modificaciones respecto al color verdadero a causa del proceso de impresión. Refiérase siempre a cartas originales NCS.
} 


\subsection{Colores presentes}

En el texto Le Purisme ${ }^{18}$, previo a la primera colección de colores Salubra I, Ozenfant y Jeanneret describían tres gamas de color para la pintura de caballete. La primera de ellas era la grande gamme que contenía todos aquellos colores 'constructivos' que fueron empleados por los grandes pintores de la historia del arte desde Miguel Ángel o Ingres, pasando por Seurat o Cezanne, hasta los cubistas Picasso o Gris. Son pintores bien considerados porque todos ellos, en opinión de Le Corbusier, subordinaron el color al dibujo y dieron prioridad a la construcción de la forma mediante el claroscuro. Optaron por el disegno frente al colore, siguiendo la oposición entre estos dos conceptos que se inicia en época Renacentista con Vasari y se extiende hasta finales del s. XIX en Francia. La grande gamme incluye el amarillo, ocre rojizo, colores tierras, blanco, negro ultramar y los colores derivados de ellas. La segunda es una gamme dynamique y a diferencia de la anterior contiene colores que no son "estáticos", sino que dan la sensación de continuo cambio de plano. A ella pertenecen el amarillo limón, los naranjas, el rojo bermellón, verde veronés o el azul cobalto claro. La tercera es una gamme de transition que contiene al verde esmeralda y los colores esmaltados, sin cualidades constructivas. Le Corbusier da a entender que sólo desea emplear la grande gamme.

En el texto Polychromie Architecturale, el criterio para seleccionar los colores también responde a un deseo de restringirlos a sólo aquellos que sean "verdaderamente arquitectónicos" ${ }^{19}$, pero esta vez Le Corbusier habla de la selección de un gamme noble ${ }^{20}$ : blanco, negro, ultramar, azul, verde inglés, ocre amarillo, tierra siena natural, bermellón, carmín, rojo inglés y tierra siena tostada. Se abandona por lo tanto la distinción inicial entre tres gamas de color y se observa que para Salubra I Le Corbusier suma sin dificultad a la grande gamme algunos colores que pertenecen a la gamme dynamique, la "gama ágil e inquieta que da la sensación de continuo cambio, 21 .

Si observamos los 43 colores seleccionados en Salubra I vemos que aproximadamente la mitad de ellos (17) pertenecen a familias comprendidas entre NCS R10B y Y80R, o sea colores fríos, y la otra mitad (17) pertenece a familias ubicadas entre NCS G40Y y R80B, o sea colores cálidos. Quedarían al margen los colores grises y sombras (9). Debe señalarse que las gamas de colores cálidos incluyen sólo seis tonos NCS organizados alrededor del rojo Y80R mientras que las gamas frías contienen el doble de tonos NCS, seis alrededor del azul R80B y seis alrededor del verde G30Y. Por lo tanto los colores cálidos que están excesivamente próximos al amarillo o al violeta se evitan. Como discutiremos más adelante la oposición entre tonos fríos y cálidos fue importante en el pensamiento de Le Corbusier.

Además las gamas cálidas que Le Corbusier elige son mayoritariamente marrones y grises, es decir colores terciarios que se corresponden con porcentajes pequeños de cromaticidad en NCS. Estos colores pueden ser explicados por el deseo de Le Corbusier de conectarlos con los pigmentos naturales. Para Le Corbusier son estos colores derivados de la tierra los que han acompañado a la arquitectura desde sus orígenes. Son colores "eternos" que se distinguen de los pigmentos sintetizados químicamente, tan populares en la pintura de la segunda mitad del siglo XIX y que Le Corbusier consideraba demasiado saturados y no arquitectónicos. Aun así las investigaciones recientes de los centros históricos de muchas de las ciudades, al menos en el arco mediterráneo,

\footnotetext{
${ }^{18}$ Jeanneret, Ozenfant. Op. cit., p. 382 ff.

19 'éminemment architecturales', Le Corbusier, Polychromie Architecturale, Op. cit. p 94.

${ }^{20}$ Ibid., p. 134.

${ }^{21}$ Jeanneret, Ozenfant. Op. cit., p. 384.
} 
demuestran que la arquitectura tradicional contenía gamas más amplias de tonos en NCS, con más gamas amarillentas, próximas a los tonos NCS Y30R ó Y40R, y en general con menos negrura $\mathrm{NCS}^{22}$.

\subsection{Colores ausentes}

Es interesante detenerse a observar no sólo los colores seleccionados para Salubra I sino también los ausentes. Uno de ellos es el color negro, que se sustituye por otros colores bastante oscuros pero que en realidad pertenecen a otras familias de color-pigmento: marrón y siena. Sí que existen cuatro colores grises pero sólo dos de ellos pertenecen a los colores neutros N en NCS $(011,012)$. Estos cuatro colores grisáceos tienen distintos porcentajes de negrura, sin embargo el color más oscuro corresponde con un marrón (130) equivalente al tono NCS Y80R.

Resulta llamativa también la ausencia del blanco, siendo el color más parecido el 001, un tono amarillento de la familia NCS Y30R. El color blanco está ausente precisamente porque tiene un estatus excepcional. El blanco es previo a la policromía, es el color necesario para purificar la mirada hacia la forma arquitectónica, como señala Wigley $^{23}$. Le Corbusier considera que el blanco es fondo necesario para que el resto de colores asuman su significado. Así lo señala a propósito de la Villa Albert Jeanneret (París, 1923-1925): “La base será blanca, pero pintaremos dos de las paredes de rosa pálido (tierra siena tostado claro) y otra que se oponga, verde pálido; el resto blanco, el techo blanco" 24 . El color blanco es el del estuco o el de la pintura que se aplica directamente a los techos y a los fondos de las paredes, y no es necesario incluir un papel pintado de color blanco en la colección Salubra I. Volvemos a señalar que los cartones para seleccionar los colores de los claviers son de color blanco y no un gris medio como podría ser recomendable para evitar el fenómeno de los contrastes simultáneos a la hora de observar un color. Sobre el blanco es donde hay que visualizar la policromía arquitectónica, pero aún se puede ir más allá, pues Le Corbusier no sólo menciona el blanco como el fondo necesario sino también como el fin en sí mismo de toda la organización cromática. Así, señala Le Corbusier a propósito del Pabellón de l'Esprit Nouveau: "la cal brilla a consecuencia de la superficie de la pared que está en sombra (tierra sombra tostada o natural) a consecuencia de la pared que es cálida (ocres), a consecuencia de la pared que cede su protagonismo (sombras azuladas, etc.). Una casa completamente blanca parecería un pastel"25. En esta afirmación Le Corbusier parece querer trabajar al modo de los pintores impresionistas, quienes disponían acentos de color alrededor del blanco para destacar su luminosidad.

También llama la atención la ausencia de varias familias de color correspondientes a los amarillos verdosos y amarillos anaranjados y cuya nomenclatura correspondería con los números 06 y 07 en notación Salubra I. Efectivamente no existen colores entre los tonos NCS G40Y y Y60R, a excepción de cuatro colores sombra (060, 140, 141 y 142). Parece que Le Corbusier desplaza las gamas de amarillo cadmio hacia unos colores tierra, más bien oscuros y las gamas de amarillos verdosos hacia unos verdes escasamente amarillentos. Existe también

${ }^{22}$ García Codoñer, Ángela y otros: La arquitectura tradicional de Ontinyent: El color histórico. Valencia: Ajuntament d' Ontinyent, 2010.

${ }^{23}$ Wigley, Mark: White walls designer dressess: the fashioning of modern architecture. Cambridge: MIT press, 1995.

24 "La base sera le blanc; mais on peindra deux des murs en rose pâle (terre de Sienne brûlée claire), un autre qui fait vis-àvis, en vert pâle; le reste blanc, le plafond blanc." Le Corbusier, Polychromie Architecturale, Op. cit. p. 122.

25 'Le 'lait de chaux' étincelle à cause de ce pan de mur qui est sombre (terre d'ombre brûlée ou naturelle), de ce mur qui est chaud (ocres), de ce mur qui fuit (bleus, etc.). Entièrement blanche la maison serait un pot à crème." Le Corbusier: Almanach d'architecture moderne. Paris: Ed. Connivences, 1926. p. 146. 
una ausencia evidente en las familias de tonos ubicadas entre la NCS R20B y la R80B, es decir los violetas, que son descartados de su consideración arquitectónica Purista.

En 1951 Le Corbusier corrige estas ausencias de familias tonales en su nueva paleta de colores, los types couleurs, que empleó en las Unité d'Habitation o el Pabellón Suizo ${ }^{26}$. En esta paleta se representan todos los colores del espectro incluyendo un amarillo vivo, el violeta y el negro. Cuando ocho años después se publica la paleta de colores Salubra II encontramos algunos de estos colores ausentes en la primera versión: el color negro (4320E), un amarillo cadmio de tono NCS Y10R (4320W) y también un verde amarillento muy saturado NCS G80Y (4320F). En general se proponen colores con más porcentajes de negrura y cromaticidad NCS. Se abandonan los colores suaves por otros más llamativos.

Como señala Ruegg ${ }^{27}$ la arquitectura de Le Corbusier posterior a la II GM está dominada por una fuerte coloración, a veces en forma de "acentos cromáticos". El negro puro se dispone ahora cerca del blanco cuando al principio difícilmente aparecía como una superficie (exceptuando ciertos suelos fabricados con baldosas negras) y en general las texturas de los materiales empiezan a cobrar importancia. Sin duda una evolución evidente de la policromía arquitectónica que se hace menos rígida y más expresiva.

\section{Combinaciones de colores basadas en el contraste de tono NCS}

Un posible criterio de armonía reside en el empleo de colores que se encuentren en posiciones opuestas en el círculo cromático y que sean, por tanto, colores complementarios. Chevreul, Goethe, Munsell o Itten, estudiaron ya este principio de armonía que tuvo gran influencia en los pintores impresionistas y postimpresionistas como Signac o Seurat. Le Corbusier era conocedor sin duda de estas leyes de la complementariedad del color, pero sus cartas Salubra I no se construyen con un sistema ordenado de colores en el que se pueda observar la existencia de colores oponentes o complementarios siguiendo el criterio de Itten: rojo-verde, azul-naranja y amarillovioleta. Entre estos pares de complementarios, el amarillo-violeta ha de ser rechazado por no existir violetas en Salubra I. El naranja-azul podría ser algo significativo y el rojo-verde el mayor de ellos, pero en términos generales las combinaciones de Le Corbusier no parecen estar elegidas siguiendo una oposición estricta entre colores complementarios.

Tampoco se adecuan a los pares de colores oponentes que sostienen la construcción del espacio de color NCS: rojo-verde, azul-amarillo y negro-blanco. Si se proyectan sobre un plano bidimensional los colores y combinaciones Salubra I, se observa que pocas líneas pasan exactamente por el centro del círculo cromático NCS (fig. 2). Las relaciones entre los colores dibujan una figura con una geometría parecida a triángulos con una serie de vértices que corresponden con los colores principales de cada familia tonal, aquellos con más cromaticidad y negrura NCS.

Sin embargo, parece que existe un criterio de combinación que persigue un equilibrio entre colores cálidos y fríos y no un criterio estricto de complementariedad o de pares oponentes perceptivos. Heer ${ }^{28}$ asegura que azul y

\footnotetext{
${ }^{26}$ En la paleta de colores para la Maison du Pelerin en Ronchamp, se muestran dos colores amarillo cadmio, junto a un azul ultramar y un gris que nada tienen que ver con la escasa presencia de los amarillos en Salubra I. Este documento se encuentra en la Fundacion Le Corbusier (FLC Q1- 7. 118).

${ }^{27}$ Ruegg. Op. cit., pp. 66-83.

${ }^{28}$ Heer, Op. cit., p. 91.
} 
rojo fueron los pares básicos del sistema de color de Le Corbusier y que formaban un contraste que más allá de la pura óptica, respondía a cuestiones psicológicas, asociativas y arquitectónicas. Le Corbusier mismo señalaba que "La clasificación en dos grandes categorías de tonos fríos y cálidos aporta orden: cada color (tono y valor) se dirige bien hacia el lado luminoso (calidez, alegría, gozo, violencia) o hacia el lado sombrío (frescura, serenidad, melancolía, tristeza). [...] El rojo (y sus combinaciones de marrones, naranjas, etc...) fijan la pared, afirman su posición exacta, su dimensión, su presencia. Además, al azul se vinculan sensaciones subjetivas, de suavidad, calma, de agua natural, mar o cielo. Al rojo se asocian sensaciones de fuerza, de violencia. El azul actúa como un calmante del cuerpo, el rojo como un estimulante. Uno es descanso, el otro acción ${ }^{, 29}$. Hay que señalar además que esta dualidad entre dos colores oponentes rojo-azul en términos de luz-sombra, calidezfrescura, alegría-serenidad, gozo-melancolía, violencia-tristeza, es una traslación literal de la teoría del color de Goethe $^{30}$ y sus parejas de oponentes amarillo-azul, a quienes asignaba las cualidades de distancia-cercanía, poder-blandura, repulsión-atracción y demás. Le Corbusier sustituye simplemente el amarillo del esquema de Goethe por el rojo.

El equilibrio entre colores fríos-cálidos explica bien los criterios de armonía para muchas de las combinaciones presentes en la colección Salubra I. En la figura 3 se ha señalado con un rayado el lugar geométrico de las combinaciones que manejan pares de colores opuestos frió-cálido y en ella se encuentran un gran número de muestras. Hemos considerado como colores fríos las familias de colores-pigmento del azul ultramar, azul cobalto, verde-amarillento y verde veronés; y como colores cálidos las familias del naranja, rojo bermellón y carmín. Los colores fríos pertenecen al rango entre NCS R80B y G40Y, y los colores cálidos al rango entre NCS Y30R y R10B. No incluimos ocres, sienas ni marrones entre los colores cálidos pues aunque pueden tener una proporción importante de rojo poseen poca cromaticidad NCS. Cualquiera de estos colores apagados combinado con un color frío destacará antes por su contraste de negrura o cromaticidad que por su tono. Los consideramos colores neutros en la oposición frío-cálido, junto con los grises.

En su estudio de las cartas Salubra I, Colli ${ }^{31}$ consideraba las gamas de la familia de color-pigmento verdeamarillento como colores cálidos, mientras que los carmines eran considerados colores fríos. Efectivamente el verde amarillento es un color más cálido que el verde veronés y eso explica que Le Corbusier prefiera combinar el verde amarillento junto al carmín, que es más frío, que no junto al rojo bermellón. Pero nosotros consideramos que tanto bermellón como carmín forman familias de color-pigmento cálidas, y que verde amarillento y verde veronés deben ser consideradas familias de colores fríos. Esto se debe a que la oposición de color frío-cálido en Le Corbusier es más conceptual que perceptiva. Si al rojo corresponde el papel de "fijar la pared", esta descripción se ajusta tanto para el carmín como para el bermellón y ambos deben ser considerados colores cálidos, a pesar del ligero contenido de azul en el caso del carmín. Examinando los colores verdes, tanto el verde amarillento como el verde veronés responden a la idea de "dar espacio" y deben ser considerados ambos colores fríos, a pesar de la ligera proporción de amarillo en el caso del verde-amarillento.

\footnotetext{
29 "La classification en deux grandes categories de tons chauds et tons froids apporte l'ordre: toute couleur (ton \& valeur) se dirige soit du côté lumière (chaleur, gaîté, joie, violence), soit du côté ombre (fraîcheur, sérénité, mélancolie, tristesse). [...] Le rouges (et ses composes bruns, oranges, etc. ...) fixe le mur, affirme sa situation exacte, sa dimension, sa présence. De plus, au bleu s'attachent des sensations subjectives de douceur, de calme, de paysage-eau, meu or ciel. Aur rouge s'attachent des sensations de force, de violence. Le bleu agit sur l'organisme comme un calmant, le rouge comme un excitant. l'un est au repos, l'autre est action". Le Corbusier. Polychromie architecturale. Op. cit., pp. 98, 115.

${ }^{30}$ Goethe. Op. cit. p. 158.

${ }^{31}$ Colli, Luisa Martina: "Le Corbusier e il colore: i Claviers Salubra”. En Storia Dell'arte. № 43. s.1.: s.e., 1981. p. $272-285$.
} 
4. Los cuadros representan cada uno de los claviers de Salubra I (1931). En abscisas se muestran en orden los color tons con su
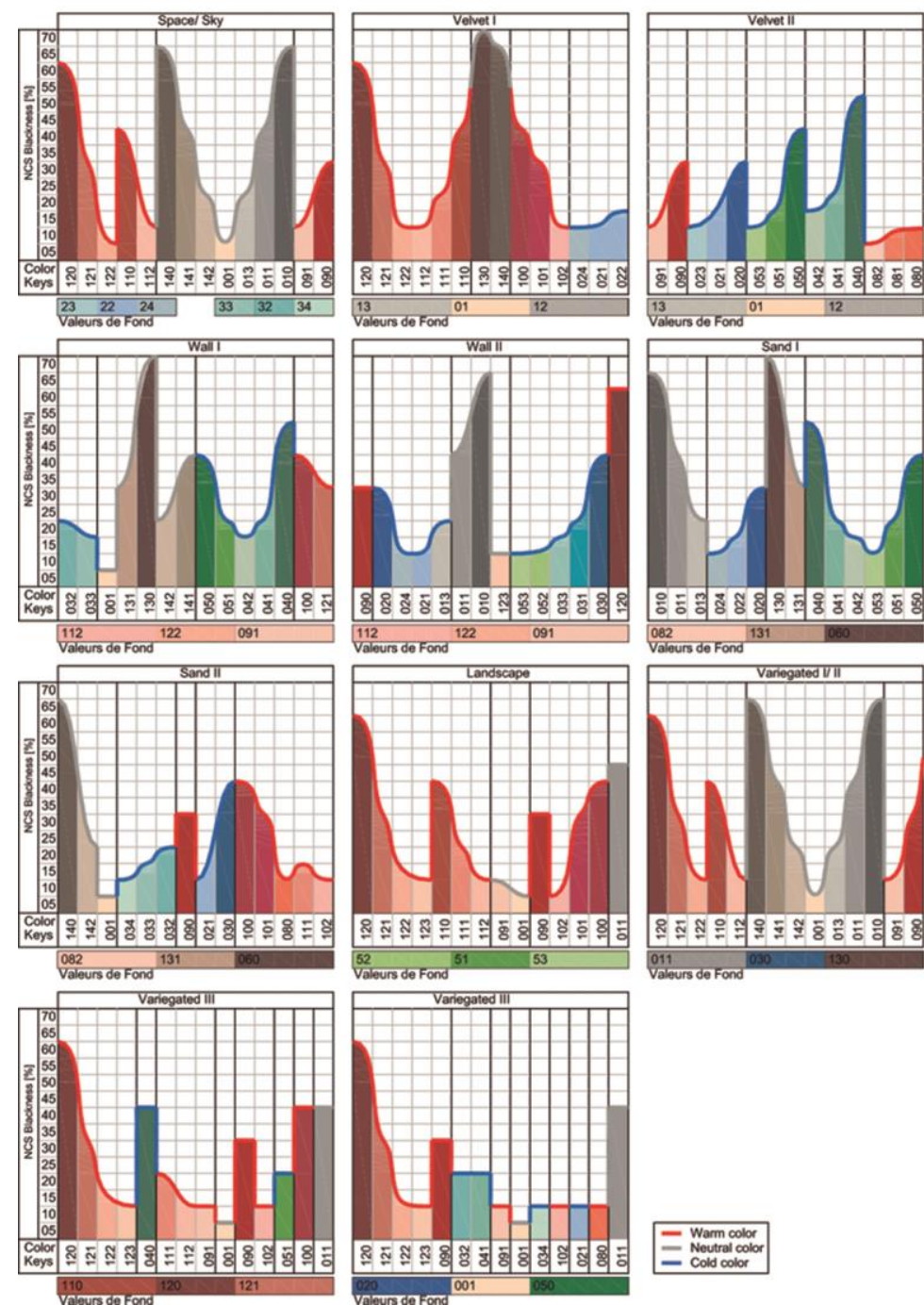

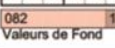
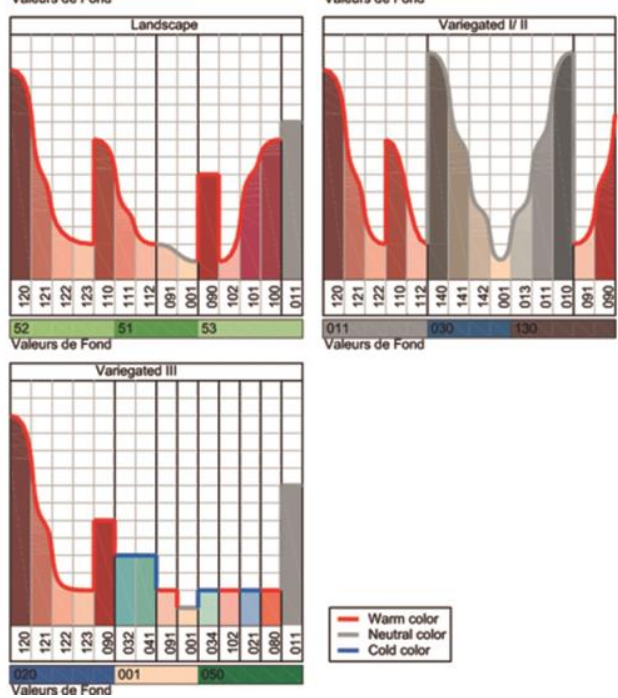

identificación Salubra I, así como los valeurs de fond en fila aparte. En ordenadas se indica el porcentaje de negrura NCS. Una arista roja, azul o gris indica si el color en cuestión es cálido, frío o neutro, respectivamente. Aristas negras verticales indican contrastes frío/cálido/neutro entre colores adyacentes. Se evidencian las secuencias y discontinuidades en la ordenación de los colores por Le Corbusier. This work is licensed under a Creative Commons 4.0 International License (CC BY-NC-ND 4.0)

En la figura 4 se representan los color tons de los 12 claviers, indicando en la secuencia de cada uno de ellos el valor de negrura NCS de cada color y su pertenencia a los tonos fríos, cálidos o neutros. La finalidad es observar en ella los puntos de inflexión en los valores de negrura, así como las transiciones entre colores fríos y cálidos. Como si de una especie de línea de armonía se tratara podemos ver la presencia de pautas, simetrías o saltos, sin olvidar los valeurs de fond, que dan idea del timbre general de la composición. Vemos que el color rojo bermellón (090) sirve a menudo para resolver la transición entre gamas conflictivas o que no son preferidas: se interpone entre los azules cobalto y azules ultramar en Sable II, así como entre los sienas y carmines en Paysage. También en Bigarrée III se interpone entre los azules cobalto y los sienas. Llama la atención la escasa presencia de verdes y azules en claviers como Bigarrée III, así como entre los color tons de aquellos claviers donde los valeurs de fond son fríos (Espace, Ciel y Bigarrées I, II, III). 


\section{Conclusiones}

Hemos realizamos un nuevo estudio de las combinaciones de colores seleccionados por Le Corbusier en los claviers para la empresa de papeles pintados Salubra I en 1931, mediante su análisis en el espacio de color Natural Color System NCS, que permite comprender las variables perceptivas de los colores (tono, negrura y cromaticidad) y sus criterios de armonía.

Centrándose en el estudio de los tonos hemos observado que los 43 colores se deducen a partir de 12 colores principales a los que se añade blanco en distinta proporción. Al margen los 9 colores grises y neutros, la mitad de los restantes pertenecen a tonos fríos (NCS R80B a G40Y) y la mitad a tonos cálidos (NCS Y30R a R10B). Destaca la diferencia de estos colores amarronados y poco saturados con los propios de la arquitectura tradicional, a pesar del deseo de Le Corbusier de vincularlos con los "colores eternos".

Para completar el círculo cromático faltan colores en la gama de los amarillos (G40Y a Y60R) y los violetas (R10B a R80B). Tampoco aparecen el blanco, que se presupone para la arquitectura, ni el negro. Algunas de estas ausencias se suplen en las cartas Salubra II de 1959 y en edificios construidos después de la II GM.

Con respecto a los criterios de armonía se demuestra que las armonías de colores basadas en la similitud de tono son habituales, sobre todo si se consideran las parejas de dos color tons, y son especialmente significativas para las familias tonales del naranja, verde veronés e incluso carmín, donde parece ser un criterio de armonía preferido frente a otros. También existen gran cantidad de parejas de colores cuya armonía se basa en el contraste de tono, pero no tanto de colores complementarios y opuestos en el círculo cromático, sino de colores fríos y cálidos. La oposición entre colores fríos-cálidos fue señalada por el propio Le Corbusier y explica muchas de las combinaciones presentes en la colección Salubra I de 1931. Azul y rojo son considerados antónimos a nivel visual, psicológico, simbólico y arquitectónico.

En un estudio comparado del contraste frío-cálido y del claroscuro, se demuestra la presencia de ritmos y pautas en los claviers, habitualmente porque a un color principal suelen acompañarle otros colores de la misma familia tonal. Además se observa que el rojo bermellón sirve para resolver la transición entre gamas conflictivas o que no son preferidas.

\section{Agradecimientos}

Los autores agradecen especialmente la ayuda de la catedrática Ángela García Codoñer, directora del Grupo de Investigación del color de la UPV, por su profundo conocimiento del color. También la ayuda del catedrático José Herráez Boquera en el manejo de valores numéricos y su posterior dibujado en CAD; la ayuda del Dr. Pedro Cabezos Bernal en el modelado 3D en formato .pdf y la ayuda de Isabelle Godineau en la localización de documentos en la Fundación Le Corbusier. Además, este trabajo ha sido posible gracias a la financiación del Vicerrectorado de Investigación de la Universitat Politècnica de València (UPV, PAID-06-2012).

\section{Bibliografía/ Referencias}

Caivano, José Luis: La compleja relación con el color de uno de los maestros de la arquitectura moderna: Nueva edición de la Policromía Arquitectónica de Le Corbusier”. En Luminotecnia. № 84. Mar de la Plata (Argentina): Editores SRL, 2007. pp. 58-61. 
Chevreul, Michel Eugène: De la loi du contraste simultané des couleurs et de l'assortiment des objets colorés. Paris: Gauthier-Villars et fills; 1839. p 750. Traducción inglesa: Martel, C: The principles of harmony and contrast of colors and their applications to the arts. London: Longman, Brown, Green and Longmans, 1855.

Colli, Luisa Martina: “Le Corbusier e il colore: i Claviers Salubra”. En Storia Dell'arte. No 43. s.l.: s.e., 1981. p. $272-285$

En Lucan, Jaques (Ed.): Le Corbusier, une encyclopédie. Paris: Centre de Crêation Industrielle, 1987. pp. $97-$ 100 .

Colli, Luisa Martina: "Hacia una policromía arquitectónica". En Lucan, Jaques (Ed.): Le Corbusier, une encyclopédie. Paris: Centre de Crêation Industrielle, 1987. pp. 97-100.

Dempsey, Amy: Estilos, escuelas y movimientos: guía enciclopédica del arte moderno. Barcelona: Blume, 2002.

García Codoñer, Ángela y otros: La arquitectura tradicional de Ontinyent: El color histórico. Valencia: Ajuntament d' Ontinyent, 2010.

Goethe, Johann Wolfgang: Materialien zur Geschichte der Farbenlehre, Zur Farbenlehre. Tubingen: Cotta, 1810. Traducción inglesa: Eastlake, C.: Goethe's theory of colours. London: J. Murray, 1840.

Heer, Jean de: The architectonic colour: polychromy in the Purist architecture of Le Corbusier. Rotterdam: 010 Publishers, 2009.

Itten, Johannes: Kunst der Farbe. Ravensburg: Otto Maier Verlag, 1961. Versión inglesa por: Hagen, E. The elements of color. NY: Van Nostrand Reinhold, 1970.

Jeanneret, Ozenfant: “Le Purisme”. En: L’Esprit Nouveau. No 4. Paris: Ed. de L'Esprit Nouveau, 1920. pp 382 ff.

Jeanneret, Ozenfant: “Nature et creation”. En: L'Esprit Nouveau. N 19. Paris: Ed. de L'Esprit Nouveau, 1923. s.p.

Le Corbusier: "Polychromie architecturale". En Rüegg, Arthur (Ed.): Polychromie architecturale: Le corbusier's color keyboards from 1931 and 1959. Basel: Birkhäuser, 1997. pp 94-143.

Le Corbusier: Almanach d'architecture moderne. Paris: Ed. Connivences, 1926. p. 146.

Munsell, Albert: A grammar of colour. Mittineague, Massachusetts: The Strathmore paper company, 1921.

O’Connor, Zenna: “Colour Harmony Revisited”. En: Color Research and Application. No 35 (4). Wiley Periodicals, 2009. pp 268-273.

Rüegg, Arthur: "Le Corbusier's Polychromie architecturale and his Color keyboards from 1931 and 1959". En Rüegg, Arthur (Ed.): Polychromie architecturale: Le Corbusier's color keyboards from 1931 and 1959. Basel: Birkhäuser, 1997. pp. 12-93.

Serra Lluch, Juan y otros: "Color combination criteria in Le Corbusier's purist architecture based on Salubra claviers from 1931”. En: Color Research and Application. Enero 2015 (Early view). Wiley Periodicals, 2015. DOI: $10.1002 / \mathrm{col} .21940$

Wigley, Mark: White walls designer dressess: the fashioning of modern architecture. Cambridge: MIT press, 1995. 
architecture through his publications. ${ }^{2}$ It is conspicuous that Le Corbusier in the same period established collaboration with a photographer who had not previously specialised in architectural photography. ${ }^{3}$ Interestingly, Hervé was in this period engaged in promoting photography as an art form. ${ }^{4}$

Many of the Hervé photographs Le Corbusier chose to publish in Ronchamp are in a non-representational mode. The distorted views, bold cropping and/or vigorous tonal contrasts of the photographs are typical of Hervé's oeuvre, and may recall the New Photography movement of the late 1920s and 1930s (Ill.1). ${ }^{5}$ Notably, the book is the anti-thesis of the didactic, and more "rational", presentation form of Oeuvre Complete, in which The Chapel of Ronchamp was presented in both volume 5 and 6. The completed building was presented in Oeuvre Complete, 1952-1957, vol. 6, which was published the same year as the photo book. Most of the photographs in this presentation were shot by Bernhard Moosbrugger, and are total shots from the exterior and interior of the building. ${ }^{6}$ Their compositions are in line with classical architectural photography, i.e. the use of parallel verticals, even lighting, and wide angle, in order to contain as much of the building as possible within the picture frame. ${ }^{7}$ Whereas the monographic series primarily targeted practising architects, the photo book was aimed at a largely lay audience, readers with a special interest in art and architecture. A comparison of these two publications of The Chapel of Ronchamp indicates a distinction between parallel communication strategies targeting different audiences, which also entailed selecting photographs by different photographers.

Moreover, the photo book has the quality of an artistic object in its own right. The mock-up for the book indicates that the double-page spreads were designed as entities, in which the white space surrounding the photographs had an important role in the composition. ${ }^{8}$ The graphic design played an essential role in the architect-editor's endeavour to create pairs of photographs. Before examining this issue more thoroughly, the organization of the main photographic sequence of the book should be addressed.

\footnotetext{
${ }^{2}$ Pearson, Christopher, "Integrations of art and architecture in the work of Le Corbusier. Theory and practice from ornamentalism to the "Synthesis of the Major Arts", Dissertation, Stanford University, 1995, p.17.

${ }^{3}$ For accounts on how Hervé and Le Corbusier's collaboration started, see: Bergdoll, Barry, "Les deux modernismes architecturaux de Lucien Hervé", in Lucien Hervé : L'œil de l'architecte, Brussels : CIVA, 2005, 11; Béatrice Andrieux, "The encounter between two visionaries of modernity", in Sbriglio, Jacques (ed.), Le Corbusier \& Lucien Hervé: The architect \& the photographer. A dialogue, London: Thames and Hudson, 2011, pp. 20-21.

${ }^{4}$ Hervé, Lucien, “A propos de la photographie d'architecture", Aujourdhui : Art et Architecture, September 1956, no 9, pp. 29-31.

${ }^{5}$ Elwall, Robert, "New eyes for old: Architectural photography", Twentieth Century Architecture, British modern: Architecture and design in the 1930s, 2007, n ${ }^{\circ}$ 8, pp. 54-55.

${ }^{6}$ Le Corbusier, "La chapelle de Ronchamp", Oeuvre Complete, 1952-1957, volume 6, Zürich: Girsberger, 1957, pp. 16-43.

${ }^{7}$ Herschman, Joel and Robinson, Cervin, Architecture Transformed: A History of Buildings from 1839 to the Present, New York: The architectural league of New York, 1988, p.10.

${ }^{8}$ FLC B 1-2-243.
} 

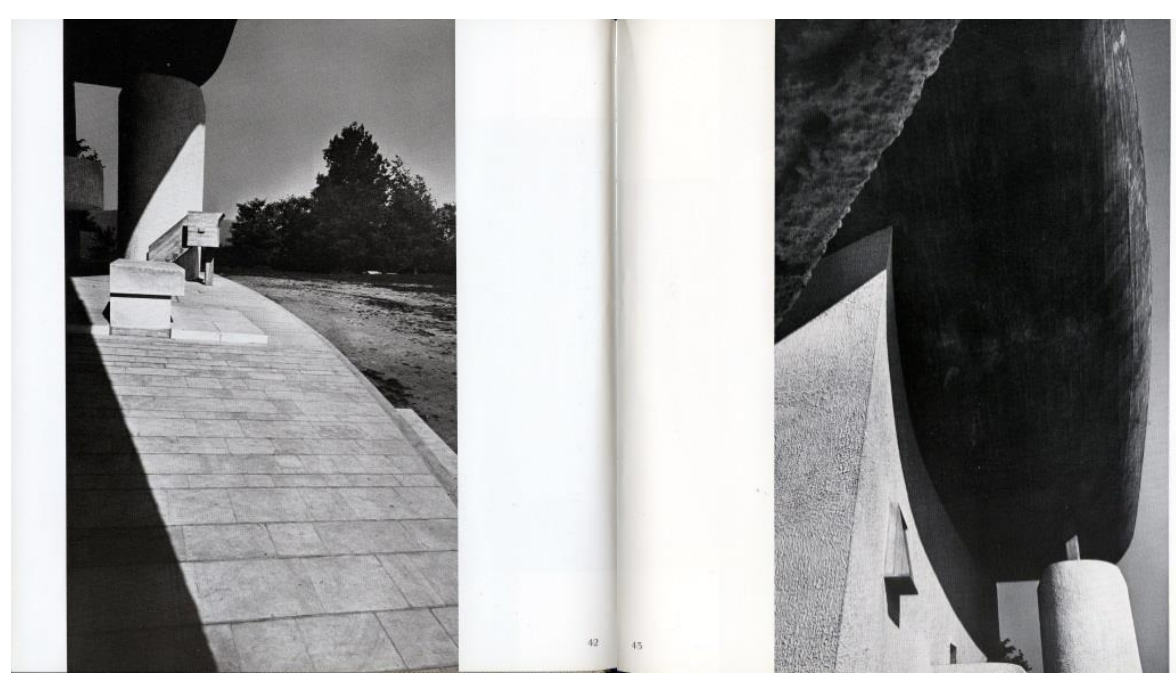

1. Double page-spread from the second chapter of the book Ronchamp. Photo: Lucien Hervé. (Le Corbusier, Ronchamp, Stuttgart, Verlag Gerd Hatje, 1957, pp 42-43) (ㄷ FLC- ADAGP)

\section{Slow-motion and cross-cutting: Interweaving promenades}

The concept of the architectural promenade was a key term in many presentations of The Chapel of Ronchamp in the professional press, and was used as a narrative device in written accounts or in the organisation of illustrations. ${ }^{9}$ In the Ronchamp book, however, the photographic sequences of the first and third chapter deny any chronological progression completely. Contextual jumps create a clearly incoherent representation of time, and the reader's ability to presume what comes next is obstructed. The dramaturgy of the photographic sequence of the second chapter, which is the main part of the book, is more complex. It includes sections with motifs that roughly imitate a visitor's route through and around the building. The chronological progression is, however, interrupted by double-page spreads in which views of elements that are far apart from each other in the building are juxtaposed.

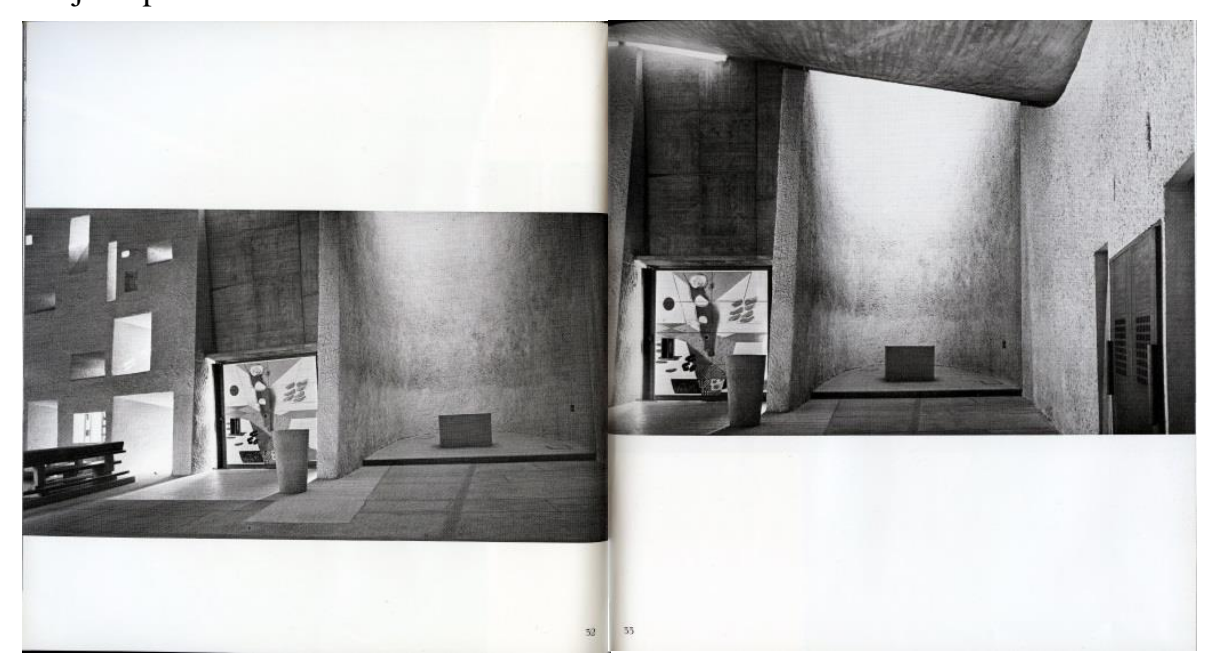

2. Double page-spread from the second chapter of the book Ronchamp. Photo: Lucien Hervé. (Le Corbusier, Ronchamp, Stuttgart, Verlag Gerd Hatje, 1957, pp 32-33) (@ FLC- ADAGP)

\footnotetext{
${ }^{9}$ See for instance Guéguen, Pierre, "Le testament poétique de Le Corbusier“, Aujourd'hui: Art et Architecture, 1955, n 4, pp.54-60.
} 
If these pages deliberately fracture the linear narrative, other double spreads are characterised by their emphasis on continuity. The book has several examples of double-page spreads in which photographs of similar motifs are visually linked without any vertical division in the form of a white space between them (Ill.2). They invite associations of a film camera panning horizontally from right to left, or zooming in from a wide view to a close-up. Furthermore, they may recall Le Corbusier's description of the promenade, particularly how he highlighted the cinematic quality of the architectural experience:

"We enter, we walk around, we look at things while walking around and the forms take on meaning, they expand, they combine with each other. Outside: We approach. We see, our interest is aroused, we stop, we appreciate, we turn around, we discover. We receive a series of sensory shocks, one after the other, varying in emotion: the jeu comes into play. We walk, we turn, we never stop moving or turning towards things. Note the tools we use to perceive architecture...the architectural sensation we experience stems from hundreds of different perceptions. It is the 'promenade', the movement we make that act as the motor for architectural events". 10

As Claire Zimmerman has pointed out, what film does in a continuous layered montage, photography approximates through seriality and repetition. ${ }^{11}$ The double page-spreads in question may give the impression that selected "scenes" have been extended in slow motion, through the juxtaposition of similar motifs and the visual linking of the photographs. The quasi-cinematic effect would maybe more accurately be compared to a "long take", an uninterrupted shot without cuts. It is as if the depicted architectural forms "expand" and "combine with each other", as Le Corbusier formulated it in his description of the promenade (Ill.3). What he essentially highlighted was a perception in movement, something the double-page spreads with visually linked photographs may also evoke.

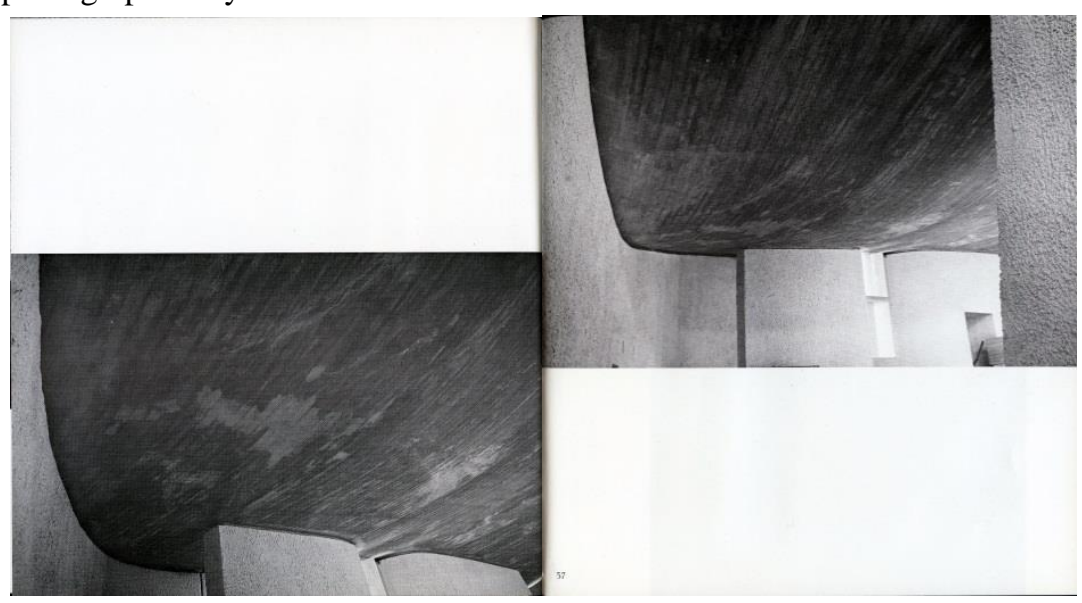

3. Double page-spread from the second chapter of the book Ronchamp. Photo: Lucien Hervé. (Le Corbusier, Ronchamp, Stuttgart, Verlag Gerd Hatje, 1957, pp 36-37) (@ FLC- ADAGP)

The most extensive part of the second chapter comprises the sequence of exterior photographs. It includes various views of each of the façades that are presented successively, starting and ending at the East side of the building. A characteristic of this section is its alternation between details of fragments of the building from various perspectives, and more inclusive views that show larger part of the facades. It is as if the sequence combines views from various promenades. If the section of exterior photographs, seen as an entity, can be

\footnotetext{
${ }^{10}$ Le Corbusier, Speech at conference at the Reale Accademia d'Italia, Rome, 1936. FLC Archives, published in Architecture Vivante, Paris 1936, p. 7.

${ }^{11}$ Zimmerman, Claire, "The monster magnified: Architectural photography as visual hyperbole", Perspecta, Monster, 2008, vol.40, p. 138.
} 
interpreted as one coherent walk around the building, it involves a continuous shifting of positions; from observing the building from a distance, to moving towards it to scrutinize a particular element more closely, only to back away again to attain the larger perspective of the building in its surroundings.

However, the book may also appear as an attempt to overwhelm the readers with an excessive flow of images. By the time Le Corbusier made the photo book, The Chapel of Ronchamp was controversial among architectural critics. Early reviews of the building repeatedly stressed with obvious disdain that Le Corbusier had left behind the rationalism of his earlier functionalist work. ${ }^{12}$ Considered as an architectural publication, the book at once reads as an advocacy of the building and as a persistent aestheticization of the architectural subject through an abundance of photographs and graphic design. If the photographic sequence partly was an attempt to overstimulate readers' visual apparatus, helping to silence any sceptical commentators, one can assume the book was made with a rather friendly audience in mind. In one sense the book presents itself to the readers as an assertion that criticism of the building would no longer affect the architect. In the preface of the book, Le Corbusier stated:

"Never in my life have I 'explained' a painting. The painting will go out and will be loved or hated, understood or not. Do you think that that bothers me! (How could that bother me). ",13

\section{Exposing the medium: The expanse of blank space}

The expanse of blank spaces surrounding or separating the photographs characterizes the double spreads of the book. Le Corbusier's dedication to balance the proportions of white areas around or between the photographs is underlined by the mock-up. Particularly, his annotations "blanc vide" (white space) between photographs testifies to the importance of the unprinted areas in his conception of the composition of the different pages. In the second chapter of the book, some of the pages approximate the rule of thirds, in which the unprinted areas are essential elements in the composition. The white parts of the pages help emphasize the alternations between vertical and horizontal orientation of the images. Moreover, the demarcations of the unprinted areas introduce vertical and horizontal lines that influence the perception of the images. Either they highlight the curving lines of the building or they create a contrast to the diagonal lines that often dominate the compositions of Hervé.

White spaces also accentuate the cropping of the photographs, of which some deviate radically from standard photographic formats of the period. By highlighting the unconventional format and edited quality, the blank parts of the pages intensify what Rosalind Krauss has succinctly pointed out about the perceptual effect of cropping: "Photographic cropping is always experienced as a rupture in the continuous fabric of reality." ${ }^{14}$ Attention is drawn to the quality of photographs as images. The layout ardently accentuates the photographer's semi-abstract compositional approach, praising the photographs as creative expressions relatively independent of the architectural subject they present. The architect-editor's re-composition of the photographs demonstrates the fact that there is no pure perception, by stressing the necessity of recognizing the frame as a structure by which perception is organized. ${ }^{15}$

\footnotetext{
${ }^{12}$ Stirling, James, "Ronchamp: Le Corbusier's chapel and the crisis of rationalism", Architectural Review, 1956, n 3, p.161; Pevsner, Nicolas, An outline of European architecture, $6^{\text {th }}$ ed., Baltimore: Penguin Books, 1960, p. 508.

${ }^{13}$ Le Corbusier, Ronchamp, p. 7.

${ }^{14}$ Krauss, Rosalind, The Originality of the Avant-Garde and Other Modernist Myths, Cambridge, MA: MIT Press, 1996, p. 115.

${ }^{15}$ Emerling, Jae, Photography: History and Theory, London: Routledge, 2012, p. 48.
} 


\section{The editor as curator}

A desire to let the lines in one photograph be continued by the shapes depicted in the photograph on the facing page apparently guided the selection of photographs, and the decision to juxtapose or place them in a diagonal relation to each other. The architect-editor acted as a curator, creating a dialogue between the images. The manner in which pairs of images are separated, linked and/or rather framed by the blank spaces, underlines the impression of the composition of the page spreads as a curation of images. Yet another function of the white areas is to show readers that it is not the individual photographs to which they should respond, but the visual play between two images. They call attention to the logic of the space of the double spread (Ill. 4).

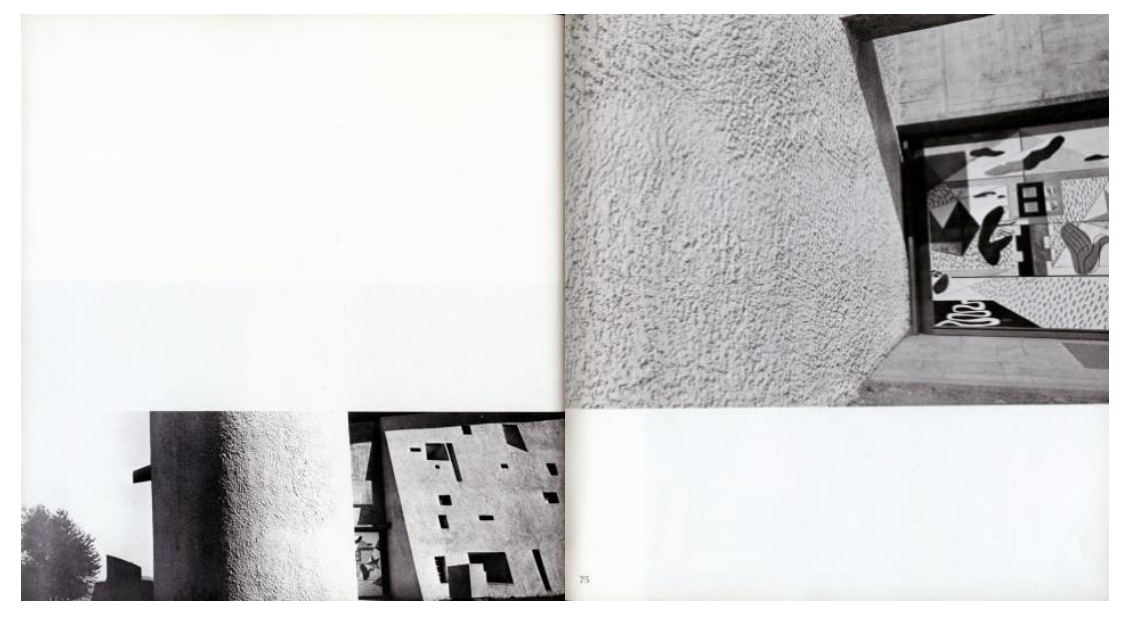

4. Double page-spread from the second chapter of the book Ronchamp. Photo: Lucien Hervé. (Le Corbusier, Ronchamp, Stuttgart, Verlag Gerd Hatje, 1957, pp 74-75) (@ FLC- ADAGP)

Some of Hervé's close-ups of concrete surfaces may evoke a tactile imagination and an embodied spectatorship. They enhance intimacy and nearness by referring to bodily encounters, whereas the architect-editor's layout creates a distance. The graphic design is clearly motivated by a wish to create an aesthetically pleasing reader experience. This contrast between the respective impacts of individual motifs and layout plan recalls the alternation in the sequence between sections that roughly imitate a visitor's route around the building and double spreads introducing contextual jumps between contrasting motifs. Notably, there is a tension in the book - it may even appear as a conflict - between evocations of experiential aspects and the overt exhibition of the mediation of the experience of architecture. The presence of the photographer and the editor is always felt by the readers (IIl.5). Le Corbusier never intended to make the media transparent, but rather to display their intervening agency. The editorial composition of the book exposes an artistic manner of re-composing architectural photography. Christopher Pearson has argued that Le Corbusier's conception of the synthesis of the arts was oddly conservative in its choice of media, ignoring film and photography in favour of more traditional means of expression. ${ }^{16}$ The hybrid nature of Ronchamp, part architectural representation and part photographic art book, to some extent challenges this conception of the synthesis.

\footnotetext{
${ }^{16}$ Pearson, "Integrations of art and architecture in the work of Le Corbusier", p. 389.
} 


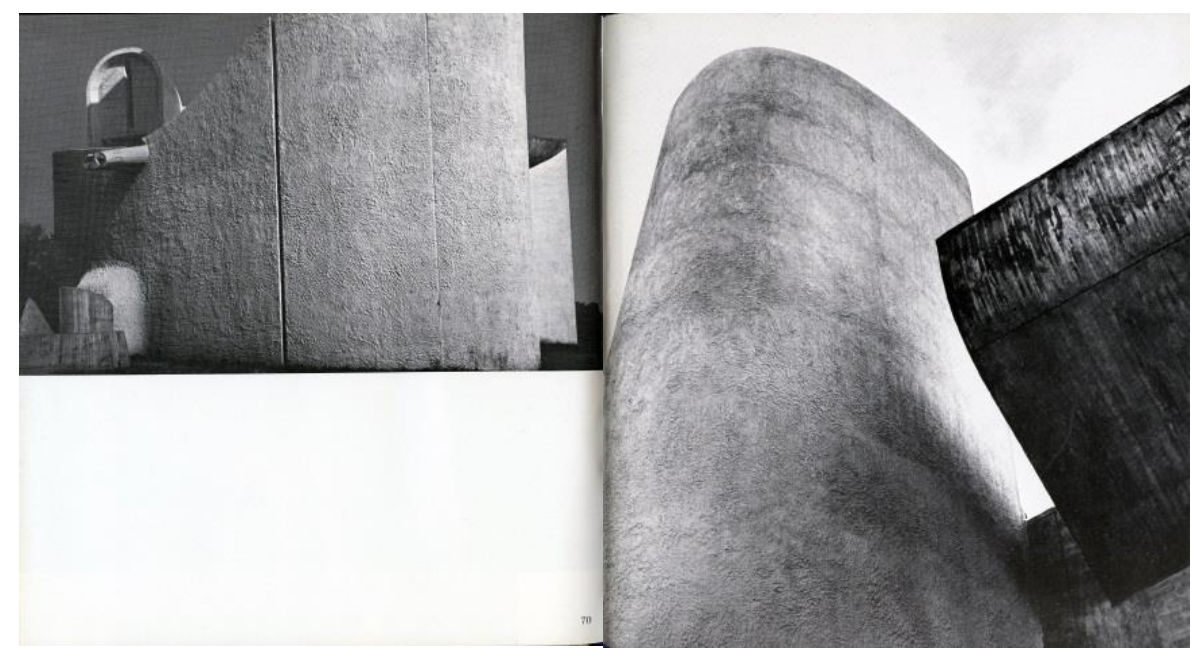

5. Double page-spread from the second chapter of the book Ronchamp. Photo: Lucien Hervé. (Le Corbusier, Ronchamp, Stuttgart, Verlag Gerd Hatje, 1957, pp 70-71) (@ FLC- ADAGP)

\section{5. "Bravo pour le collage !!": Hervé's contact sheets as editorial impulse}

Hervé's contact sheets bear witness to a careful process of selection and composition, as has been noted by Quentin Bajac. ${ }^{17}$ They may be seen in relation to the interest in the series as form, an avant-garde predilection since the 1930s. Furthermore, both Hervé and Le Corbusier were inspired by the medium of film. ${ }^{18}$ More particularly, they shared an interest in the work of the Russian film director Sergei Eisenstein. ${ }^{19}$ The manner in which Hervé catalogued his photographs is characterised by a cinematic sensitivity. Working on his contact sheets, he would often juxtapose motifs that indicate only a slight movement by the photographer/camera (Ill.6). ${ }^{20}$ It is noteworthy that the sequentiality of Herve's contact sheets seems to have influenced Le Corbusier's editing of Ronchamp, particularly the composition of the double spreads that may be compared to "slow motion" scenes or "long takes".

\footnotetext{
${ }^{17}$ Bajac, Quentin, "Expressing architecture", in Sbriglio (ed.), Le Corbusier \& Lucien Hervé: The architect \& the photographer, p. 13.

${ }^{18}$ Obrist, Hans Ulrich, Lucien Hervé - Une Conversation, Paris : Manuella Éditions, pp.14-15.

${ }^{19}$ Le Corbusier met Eisenstein in Moscow in the 1920s. Cohen, Jean-Louis, Le Corbusier and the mystique of the USSR : Theories and projects for Moscow 1928-1936, translated by Kenneth Hylton, Princeton, N.J. : Princeton University Press, 1992.

${ }^{20}$ The cinematic effect is undoubtedly the result of the composition of the contact sheets. Photographs that are juxtaposed on the contact sheets were in most cases evidently not successive shots during a photo shoot, as is confirmed by Hervé's catalogue codes that refer to the numbers of the original contact prints from which the photographs are cut.
} 


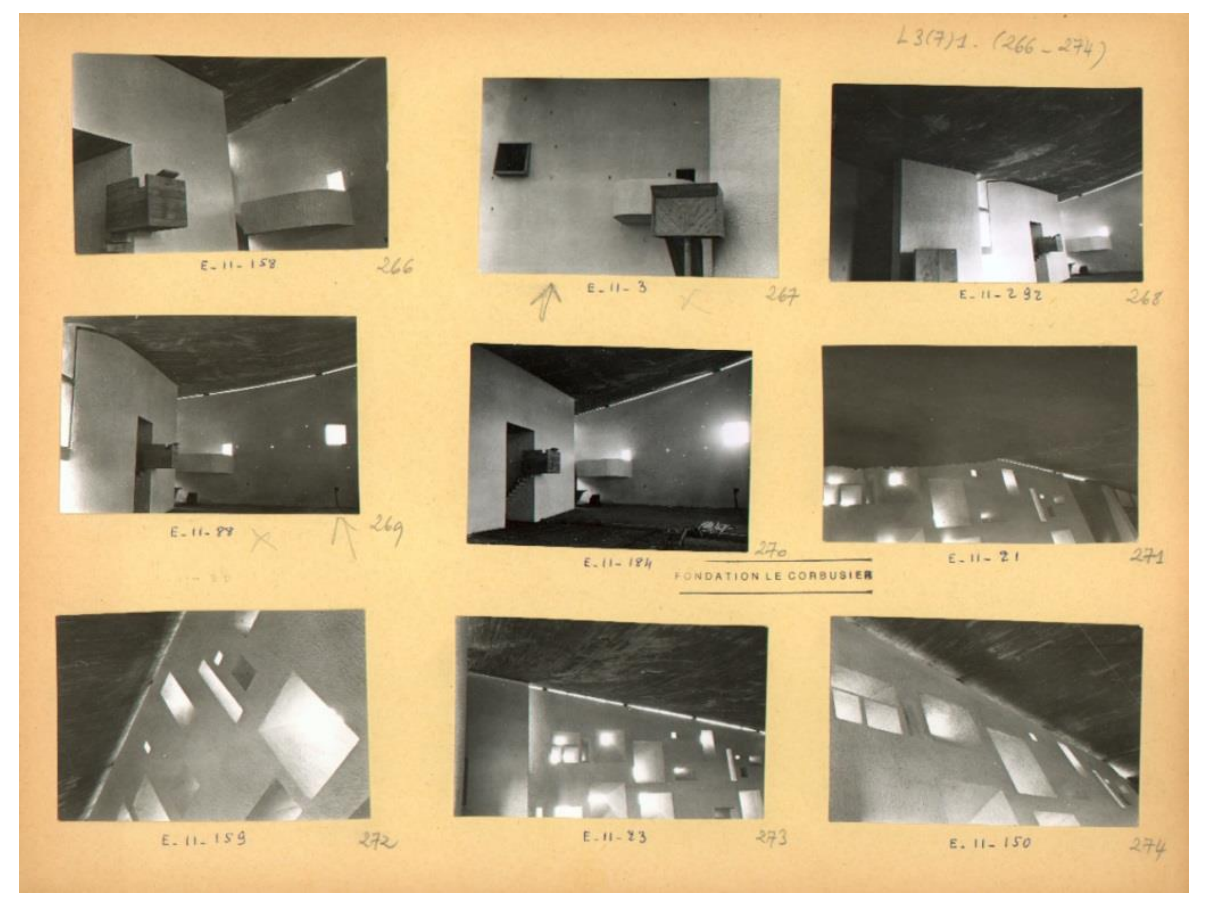

6. Contact sheet with photographs by Lucien Hervé, compiled by the photographer. FLC L-3-3-70 @ FLC - ADAGP

Hervé would also sometimes rotate images before pasting them on the planches. A contact sheet with photographs of The Chapel of Ronchamp contains the following note by Le Corbusier under a photograph from the East façade, placed sideways on the sheet: "Bravo pour le collage !! Ca a créé un nouveau lieu saint...".21 This is another aspect of Hervé's work on the contact sheets that may have inspired the architect-editor at an early stage of the design process of the book, inasmuch as the mock-up shows that some of the images were initially rotated on the page. In an interview, Hervé stated that he always photographed in such a way that the pictures could be viewed inverted. ${ }^{22}$ Indeed, it was something he had "discussed at length" with Le Corbusier with respect to painting: "For us it is not the theme that is important, it is not the subject, but essentially the plastic expression." 23 Notably, Le Corbusier, like Fernard Léger, would flip over his paintings to see them afresh. $^{24}$

Hervé's 1965 article "Concerning architectural photography" undertakes several comparisons of that medium to painting. ${ }^{25}$ What complicated such an exercise in comparison was the photographer's dual role, as an artist, but also as an interpreter of the work of another artist. According to Hervé, it would be better to compare the ethical and aesthetic endeavour entailed in this act of interpretation to the work of a conductor or a musician:

"Like a conductor of an orchestra or a pianist, he selects the sounds and tones of the instruments to remake to his own taste the purest of harmonies, while at the same tine scrupulously respecting the intensions of the composer, in this case, the architect. ${ }^{26}$

\footnotetext{
${ }^{21}$ FLC L3-3-110.

${ }^{22}$ Naegele, Daniel, “An Interview with Lucien Hervé”, Parametro, January-February 1995, vol. 1-2, no 206, p. 7.

${ }^{23}$ Lucien Hervé quoted in Naegele, "An Interview with Lucien Hervé”, p. 76.

${ }^{24}$ Quetglas, Josep, "Ronchamp: A landscape of visual acoustics", in Cohen, Jean-Louis (ed.), An Atlas of Modern Landscapes, London: Thames and Hudson, 2013, p. 212.

${ }^{25}$ Hervé, “À propos de la photographie d'architecture”, pp. 29-31.

${ }^{26}$ Hervé, "À propos de la photographie d'architecture”, 31
} 
The article expresses Hervé's determination to promote photography as an art form. The manner of seeking to elevate the position of photography by reference to music is a long-standing strategy among artists, especially since the late nineteenth century, as they sought to musicalize their own media. ${ }^{27}$ Indeed, the technique was frequently used by Le Corbusier himself. ${ }^{28}$

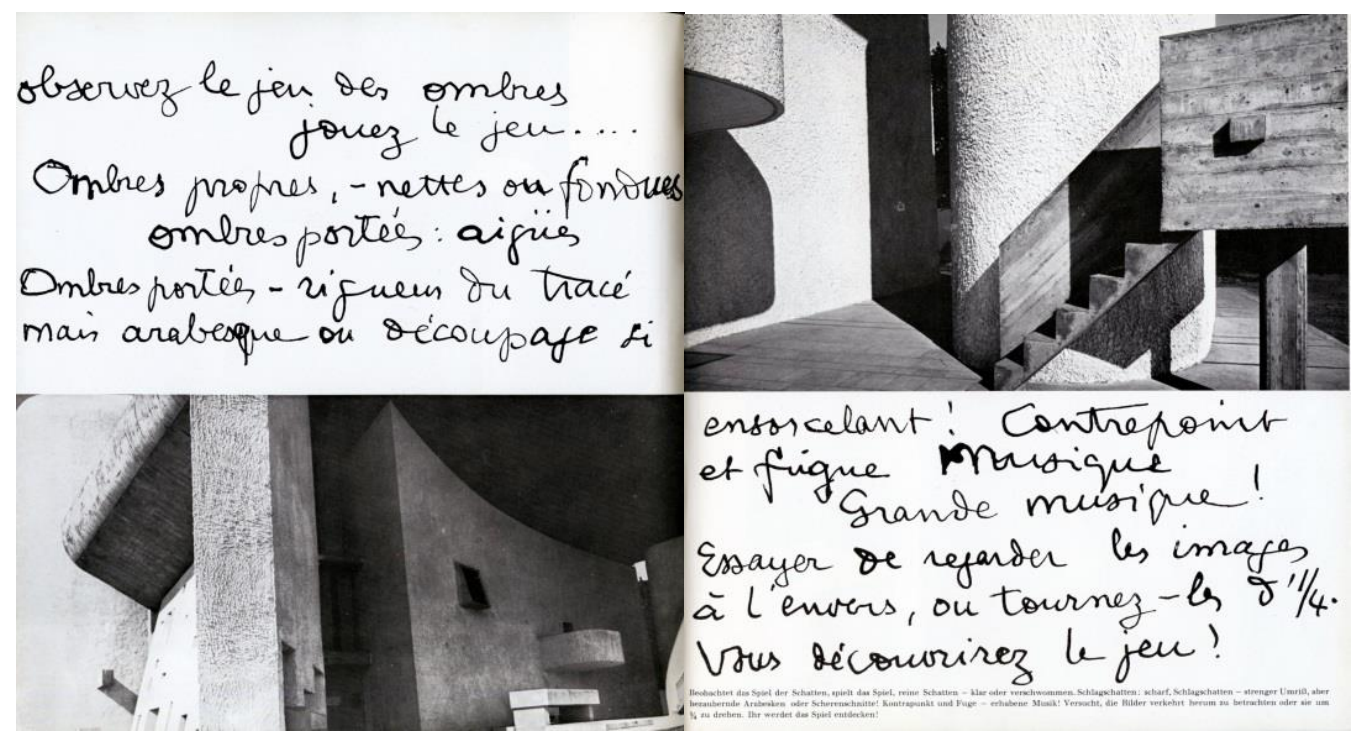

7. Double page-spread from the second chapter of the book Ronchamp. Photo: Lucien Hervé. (Le Corbusier, Ronchamp, Stuttgart, Verlag Gerd Hatje, 1957, pp 46-47) (@ FLC- ADAGP)

\section{Musicalization}

In his Precisions from 1930, Le Corbusier described architecture and music as "intimate sisters". ${ }^{29}$ Nevertheless, The Chapel of Ronchamp was the first architectural project in which music was stated as playing a part in the design conception. ${ }^{30}$ Le Corbusier initially wanted strident electronic music by the composer Edgar Varèse to play automatically at regular intervals from the chapels towers. In his book on the chapel, Jean Petit quoted the architect on his ideas for the readers (IIl. 7):

"I have one more idea to bring Ronchamp to perfection, and that is that there should be music (even if there were no one to hear it)-automatic music coming from the chapel at regular hours, addressing, inside and outside, the unknown occasional listener. ${ }^{, 31}$

The musical programme was rejected, after clerical opposition. ${ }^{32}$ In the book Ronchamp, however, there is a trace of the idea of letting the aural component be essential in the experience of the visitor. The book apparently

\footnotetext{
${ }^{27}$ Carpenter, Patricia, "Musical form regained", The Journal of Philosophy, January 21, 1965, vol.62, n 2, p. 42.

${ }^{28}$ Peter Bienz's doctoral dissertation is the most thorough account of Le Corbusier's involvement with music. Bienz, Peter, "Le Corbusier und die music", Bauwelt Fundamente 120, Braunschweig: Vieweg, 1998.

${ }^{29}$ Le Corbusier, Precisions on the present state of architecture and city planning, originally published in 1930, Cambridge, MA: MIT Press, 1991, p. 11.

${ }^{30}$ Pearson, "Integrations of art and architecture in the work of Le Corbusier", p. 386.

${ }^{31}$ Le Corbusier cited in Petit, Jean, La Chapelle Notre-Dame-du-Haut, Ronchamp : Les Cahiers Forces vives, Paris : Forces Vives, 1956, pp. 20-21.

${ }^{32}$ Pauly, Danièle, The Chapel at Ronchamp, Basel: Birkhäuser; Paris: Fondation Le Corbusier, 2008, p. 96.
} 
aspires to musicalize the reader's experience. The most explicit musical reference appears in a reproduction of a handwritten note by Le Corbusier, at a double spread with two photographs from the outdoor chapel:

"Observe the play of shadows, play the game... Precise shadows, clear cut or dissolving. Projected shadows, sharp. Projected shadows, precisely delineated, but what enchanting arabesques and frets. Counterpoint and fugue. Great music! Try to look at the pictures up-side down or sideways. You will discover the game. ${ }^{, 33}$

The text strengthens the non-representational aspect of the photographs. The encouragement to turn the book sideways increases the distance from the referent, the architectural subject, and calls the readers' attention to the graphic operations of the photographs. In music, a fugue is a composition technique in which one or two themes are imitated by successively entering voices. It is contrapuntally developed in a continuous interweaving of the voice parts. In Ronchamp, much of the photographic sequence unfolds as a play of straight and curved lines forming abstract shapes. Shadows echo the architectural shapes and create mirroring surfaces in the images. This visual counterpoint rhythm is observed by leafing through the pages of the book.

Paraphrasing Roland Barthes, one might say that the handwritten text serves as an anchorage for the readers' interpretation of the photographic sequence.$^{34}$ It invites readers to see the book as an adaption of musical form. However, the musical reference quoted above goes beyond the visual compositions of the photographs. Repetition is a key principle of the editorial construction that links it to the structure of a musical composition. Notably, the repetition of similar motifs enforces their effect in the sequence. A reiterated page design, with identical placement of pictures and blank areas, serves to link double-page spreads containing contrasting photographic motifs. It creates a unity. At the same time, a shifting rhythm is established through the sequence, by the contrast between the repeated interruptions of white space separating photographs and the continuation implied by visual linking of photographs. The white space could be regarded in this sense as analogous to the function of silence in a musical piece, understood as the complement to music rather than the opposite. Like a moment of silence, the white space at once underlines the preceding section of the photographic sequence and calls attention to the succeeding part of its composition.

In Le Corbusier's Le Modulor from 1950, music serves as a symbol of measure and proportions. ${ }^{35}$ This publication was his fullest theoretical statement of the relationship between architecture and music, and reflects his faith in the Renaissance project of establishing humanistic measure. ${ }^{36}$ Whereas Le Modulor partly expresses a rational approach to music as a system of flexible and adaptable principles, the effect of adapting Ronchamp to musical principles is to call attention to music as an art form progressing in time. In music, time becomes aestheticized. ${ }^{37}$ Readers are reminded of this in their reading of the book, an activity that itself is a temporal experience. Only implicitly does the book suggest a musicalization of architectural perceptions. The manner in which the photographic sequence combines views from various promenades, by letting them overlap and be intertwined, might be compared to the relationships of repeated melodic intervals in a musical piece. It appears

\footnotetext{
${ }^{33}$ Le Corbusier, Ronchamp, pp. 46-47.

${ }^{34}$ Barthes, Roland, "Rhetoric of the Image", in Barthes, Roland, Image - music -text, London: Fontana Press, 1977, pp. 3251.

${ }^{35}$ Le Corbusier, Le Modulor, Boulogne: Éditions de l'Architecture d'Aujourd'hui, 1950.

${ }^{36}$ Graham, James, "Musique en fer forgé: Erik Satie, Le Corbusier and the problem of aural architecture", AA Files, 2014, n ${ }^{\circ}$ 68, pp. 9-10.

${ }^{37}$ Stambaugh, Joan, “Music as a temporal form”, The Journal of Philosophy, April 23, 1964, vol.61, n 9, p. 274.
} 
as the carrying over of one theme to another. One of Le Corbusier's declarations may come to mind: "Music, like architecture, is time and space". ${ }^{38}$

While Le Corbusier was making the mock-up for the book, in the summer of 1956, he had started working on the Poème électronique..$^{39}$ This was the multimedia show he curated for the Philips pavilion, which he designed together with Iannis Xenakis for the Brussels Fair of $1958 .{ }^{40}$ When he asked Varèse to compose the music for the show, Le Corbusier described what he had in mind: "a scenario to be created wholly from relationships; light, plasticity, design, and music." ${ }^{41}$ The show was Le Corbusier's most explicitly formulated idea about the synaesthetic experience, and was related to an abstract idea of a synthesis of the arts. $^{42}$ It is interesting that it coincided with his work on the book Ronchamp, which to some extent evokes aural and tactile perceptions. It is, however, primarily through references to principles of musical composition that the book manifests its own ambition of going beyond the mere documentary report on the building. Whereas musical analogies are widespread in Le Corbusier's architectural writings, the book can be regarded as a visual, and more subtle, manner of highlighting the relationship between architecture and music, through the mediation of photography inspired by musical composition. One might say that the book offers a more abstract aestheticization of the architectural experience.

\section{Une pot-pourri : Photographic sequentiality}

In the 1950s, Le Corbusier worked to strengthen the artistic character of his Oeuvre Complete series, as the correspondence concerning the production of volumes five and six illustrates. In his letters to the publisher and editor he insisted on the inclusion of polychrome illustrations as one of the means to achieve this goal. ${ }^{43}$ More important in the present context, is that while working on the sixth volume Le Corbusier developed another concept of communicating his architectural works through photography, in which sequentiality purposefully would arouse musical associations.

The same year as Ronchamp appeared in print, he told the editor Willy Boesiger that he wanted volume six to include a separate section of photographs of some of his buildings. He called it a "pot-pourri", and attached several sketches as a mock-up for a particular section of the volume. ${ }^{44}$ The photographs would be by Hervé alone, and The Chapel of Ronchamp would have a central position. Apparently, this photographic sequence was intended to illustrate his concept of the synthesis of the arts, and it is interesting to note that his formulations further suggest a musical analogy. Le Corbusier referred to it as a "Séquence Symphonique des Arts Majeurs", and listed some of the projects to be included:

\footnotetext{
${ }^{38}$ Le Corbusier cited in Wogenscky, André, Le Corbusier's hands, translated by Martina Millà Bernad, London: The MIT Press, 2006, p. 74.

${ }^{39}$ Le Corbusier started making the mock-up at Cap-Martin from August 1956. FLC U 3-1-7, letter from Le Corbusier's secretary to Gerd Hatje, 30 July 1956.

${ }^{40}$ Treib, Marc, Space calculated in seconds: The Philips pavilion, Princeton, N.J. : Princeton University Press, 1996.

${ }^{41}$ FLC J2-19-86, letter from Le Corbusier to Edgar Varèse, 25 June 1956.

${ }^{42}$ Pearson, "Integrations of art and architecture in the work of Le Corbusier", p. 389.

${ }^{43}$ FLC F3- 20-12, letter from Le Corbusier to Girsberger, 4 November 1948; U 3-14-52, Note from Le Corbusier to Boesiger, 21 December 1956; FLC U3-14-68, letter from Le Corbusier to Boesiger, 15 June 1957; FLC U3-14-65, letter from Le Corbusier to Girsberger, 23 April 1957.

${ }^{44}$ The attachments to the letter are not in the archive. FLC U3-14-65, letter from Le Corbusier to Boesiger, 23 April 1957.
} 
"Pot-pourri = Ronchamp/Chandigarh/Ahmedabad/Nantes-Rezé/Marseille-Michelet/ Jaoul. etc.../ showing the comprehensive and inventive symphonic concept of the architect. "45

Analogous to montage, the word potpourri refers to a mixture of elements, and often implies a collection of unrelated or disparate items. As a description of a principle of combining photographs of various buildings on the double page-spreads of a book, it suggests a condensed form of presentation for which comparability would be essential. Although Le Corbusier did not expand on how this potpourri should be organized, the term he used implies that he wanted to create a diversified and complex series of images. One can imagine it appearing as a fragmented, but congruous, photographic sequence that generated a new context for the perception of the projects presented. It was presumably conceived as a means of pursuing the goal of raising the artistic quality of the volumes of Oeuvre Complete. By adopting an experimental approach to a purely photographic sequence, it would traverse the artistic ambitions for volume five, which had primarily centred on inclusion of polychrome illustrations. ${ }^{46}$ The principle would have introduced a new model on which to organise the photographic sequences in the monographic series. The fact that it was suggested only a few months after Le Corbusier had finished the mock-up for Ronchamp, suggests that the experience of creating the sequence of Hervé photographs for the book was crucial for his development of the pot-pourri concept. ${ }^{47}$

Catherine de Smet has identified demonstrative juxtapositions as a characteristic principle of the graphic design of New World of Space. ${ }^{48}$ Reproductions of his paintings and buildings were combined in double page-spreads of the book, rhetorically underlining the unity of his creations within different artistic disciplines. ${ }^{49}$ What De Smet has referred to as "synthetic" layout, ${ }^{50}$ entailed the superimposition of sketches of natural objects onto photographs of his built works, with a view to implying sources of influence. The proposed pot-pourri concept would assumedly, in condensed form, also privilege demonstrative confrontations. It was supposedly intended to work as a method of isolating selected elements of each project, inviting the readers to draw parallels and extract formal aspects shared by the different projects presented. In this sense, it seems to have been informed by his earlier graphic strategies, which had depended on the juxtaposition of different media. However, it primarily illustrates another aspect of the role photography, in particular, played in the everlasting process of Le Corbusier's conceptual engagement with his projects. ${ }^{51}$

If it was intended to promote his aim of the synthesis of the arts, the concept also shed light on his use of intermedial references to music to communicate his architecture through photography. Considered as a strategy to emphasize the aesthetic quality of architectural expressions, it applies to Ronchamp. According to Irina O. Rajewsky, an intermedial reference should be understood as a meaning-constitutional strategy that contributes to a media product's overall signification. ${ }^{52}$ The given media product constitutes itself partly or wholly in relation to the work or system to which it refers. In Ronchamp, the adoption of musical forms helps shape and constitute

\footnotetext{
${ }^{45}$ FLC U3-14-65, letter from Le Corbusier to Boesiger, 23 April 1957.

${ }^{46}$ FLC F3- 20-12, letter from Le Corbusier to Girsberger, 4 November 1948.

47 The final mock-up was sent to Hervé in January 1957, for him to prepare the photographs to be published. FLC E2-4-374, letter from Le Corbusier's secretary to Lucien Hervé, 7 January 1957.

${ }^{48}$ De Smet, Catherine, Vers une Architecture du Livre: Le Corbusier. Edition et mise en pages 1912-1965. Baden: Lars Müller Publishers, 2007, pp. 86-88.

${ }^{49}$ De Smet, Vers une Architecture du Livre, pp. 83-90.

${ }^{50}$ De Smet, Catherine, Le Corbusier: Architect of Books, Zurich: Lars Müller Publishers, 2007, p. 91.

${ }^{51}$ Colomina, Beatriz, "Le Corbusier and photography", Assemblage, October 1987, no 4, pp. 6-23.

${ }^{52}$ Rajewsky, Irina O., "Intermediality, intertextuality, and remediation: A literary perspective on intermediality", Revue Intermédialités, no.6, Autumn (2005), p. 53.
} 
the book as an artistic object. However, as a hybrid of a photo book and an architectural monograph, it is never perceived in isolation from the architectural subject it presents. Through the intermedial reference it thematises and reinvigorates architectural expressions in relation to musical form.

\section{A voluntary sculpture}

Another intermedial reference that can be identified in the book serves to illustrate other aspects of Le Corbusier's use of photography (in publications and his own photographic practice), as well as contemporary conventions for photographing sculpture and architecture. The structure of the main photographic sequence of the book, combining views from multiple promenades around the building, together with the many tilted views and close-ups recalls an established practice in the photographic documentation of sculpture, which included movements encircling the work of art to create series of different views. ${ }^{53}$ In a 1949 handbook on photographing architecture and sculpture, Helmut Gernsheim wrote: "Success depends ... on the photographer's ability to acquire the sculptor's faculty of seeing and thinking all round his model."

The manner in which Le Corbusier organised the Ronchamp photographs may encourage a perception of the architectural work as a sculpture. As part of his self-conscious campaign to shape his persona as the universal plasticien, Le Corbusier may have consciously have sought to evoke the documentation technique of another artistic discipline to heighten the status of the building as an art work, implicitly downplaying its utilitarian role. Seen in the context of the hostility many architectural critics had expressed, the book may be regarded as an invitation to consider the project as a work of art, one to be judged as a work of formal innovation in the service of aesthetic renewal.

However, the photographic sequence also points to Le Corbusier's own photographic procedures of working in series $^{55}$ Tim Benton's research on the photographic practice of Le Corbusier has revealed how the architect became preoccupied at an early stage with working in series, taking several photographs of the same or of similar objects. ${ }^{56}$ In the book Le Corbusier: Secret Photographer Benton pointed out that it became an obsession for Le Corbusier to work in series, particularly in the 1930s when he primarily photographed with his movie camera. For him, the series enabled a methodical analysis of form.

It is worth noting that Le Corbusier's photographs of natural objects, of his "objets à réaction poétique", has a parallel in the work of surrealist artists of the 1930s. Their photographic practice expressed an interest in ways of manipulating photographic conventions to create sculptures from objects and fragments that were not originally conceived of as works of art. ${ }^{57}$ The resulting pictures were called "involuntary sculptures". Under this heading Gyula Brassaï and Salvador Dalì published photographs of a fragment of soap and a crumpled up bus ticket in Minotaure in $1933 .{ }^{58}$ Briony Fer has interestingly discussed this as a moment in the history of Modernism when

\footnotetext{
${ }^{53}$ Di Bello, Patrizia, "Photography and Sculpture: A light touch", in Di Bello, Patrizia and Koureas, Gabriel (eds), Art, History and the Senses: 1830 to the Present, Farnham: Ashgate, 2010, p. 29.

${ }^{54}$ Helmut Gernsheim, Focus on architecture and sculpture: An original approach to the photography of architecture and sculpture, London: The Fountain Press, 1949, p. 38.

${ }^{55}$ Benton, Tim, LC Foto. Le Corbusier: Secret Photographer, Baden: Lars Müller Publishers, p. 405.

${ }^{56}$ Benton, Le Corbusier: Secret Photographer, pp. 405-406.

${ }^{57}$ Johnson, Geraldine A., "Introduction: Sculpture and photography: Envisioning the third dimension", in Johnson, Geraldine A. (ed.), Sculpture and photography: Envisioning the third dimension, Cambridge; Cambridge University Press, 1998, p. 13.

${ }^{58}$ The photographs were by Gyula Brassaï. Gyula Brassaï and Salvador Dalì, "Sculptures involontaires", Minotaure, 1933, $\mathrm{n}^{\mathrm{o}} 3-4$, p. 68.
} 
the distinctions between sculpture and photography became blurred. ${ }^{59}$ The connection to the Herve photographs that Le Corbusier published in the book Ronchamp, is the photographer's dedication to explore and expose plastic shapes through the medium of photography. In the book, links to photographs of sculpture can be identified as operating at two levels: in the photographic sequence and in the individual photographs. Hervé's compositions emphasise the sculptural qualities of the building, particularly through framing and lighting.

Whereas the idea of modern sculpture as a significant historical development gathered momentum relatively late, in the $1930 \mathrm{~s}$, it peaked in the $1950 \mathrm{~s}$ with a spate of publications dedicated to the subject. ${ }^{60}$ Moreover, sculptural photo books from the post-war period represent a particular type of photographic object. ${ }^{61}$ In his handbook, Gernsheim urged the architectural photographer to take a "rational" approach: "The picture must be taken in such a way as clearly to show the structure of the building." 62 Through the pictures, the photographer should "intelligently relate the general plan of a building to its parts and give a correct interpretation." 63 In contrast, the imperative for the photographer of sculpture read as follows: "The photographer must try to infuse his work with life, and in lighting the photographer has a powerful means at his disposal for his interpretation photographing ... photographing sculpture is modelling with light." 64 The many oblique angles in Hervé's photographs in Ronchamp obstruct the readers' ability to relate the views to the plan of the building. If readers follow the architect-editor's instruction to turn the book sideways or upside down, the "irrationality" of the photographs, in terms of conventions of architectural representation, reaches a climax. This aspect of the reader experience would obviously have been emphasized if the initial idea to rotate some of the photographs, as indicated by the mock-up, had been realized.

\section{Representing architecture as drama}

Hervé's compositions depend on the use of shadows to mould the architectural shapes in dramatic fashion. This aspect, in particular, relates his photographs in Ronchamp to those he shot of the Cistercian abbey of Le Thoronet, and that were published in the book La Plus Grande aventure du monde: L'architecture mystique de Cîteaux. ${ }^{65}$ Le Corbusier wrote the preface for this book. After receiving a copy of the completed book, Le Corbusier sent a letter to Hervé to express his enthusiasm for the published photographs:

"Received your magnificent book, you have done truly creative work here. It is very beautiful...It is not photogenic, it is photography to the highest degree. "66

This compliment may recall Le Corbusier's characterisation of the photographer Frédéric Boissonnas as a plastic artist when publishing his pictures of Parthenon in Vers une Architecture (Ill.8). ${ }^{67}$ Nevertheless, he included

\footnotetext{
${ }^{59}$ Fer, Briony, “The space of anxiety: Sculpture and photography in the work of Jeff Wall”, in Johnson (ed.), Sculpture and photography, p. 239.

${ }^{60}$ Potts, Alex, The sculptural imagination: Figurative, modernist, minimalist, New Haven and London: Yale University Press, 2000, p. 103.

${ }^{61}$ Di Bello, Patrizia, "Sculpture, photograph, book: The sculptures of Picasso (1949)", in Di Bello, Patrizia; Wilson, Colette and Zamir, Shamoon (eds), The photobook : From Talbot to Ruscha and beyond, London : I.B. Tauris, 2012, pp.91-109.

${ }^{62}$ Gernsheim, Focus on architecture and sculpture, p. 33.

${ }^{63}$ Gernsheim, Focus on architecture and sculpture, p. 31.

${ }^{64}$ Gernsheim, Focus on architecture and sculpture, p. 38.

${ }^{65}$ Hervé, Lucien, La plus grande aventure du monde : L'architecture mystique de Cîteaux, with texts by François Cali Paris : Arthaud, 1956.

${ }^{66}$ Letter from Le Corbusier to Lucien Hervé, quoted in Naegele, “An Interview with Lucien Hervé”, p. 75.

${ }^{67}$ Le Corbusier, Vers une architecture, Paris: Crès \& Cie., 1923, p. 181.
} 
Boissonnas' pictures in the publication primarily to praise the work of the Greek architect Pheidias as a sculptor. "The Parthenon is a drama", Le Corbusier noted in the preface to Ronchamp. ${ }^{68}$ Determined to highlight his own capacity as a sculptor, the abundance of Hervé photographs in the book would hopefully serve a parallel purpose to the Boissonnas photographs of Acropolis he had earlier published:

"With contour modulation one acknowledges the plastic artist; the engineer steps aside and the sculptor works.... It is Pheidias who made the Parthenon, Pheidias the great sculptor. "69

\section{Bibliography}

Andrieux, Béatrice. "The encounter between two visionaries of modernity". In Sbriglio, Jacques: Le Corbusier \& Lucien Hervé. The architect \& the photographer. A dialogue. London: Thames and Hudson, 2011, pp. 19-22.

Bajac, Quentin. "Expressing architecture". In Sbriglio, Jacques: Le Corbusier \& Lucien Hervé: The architect \& the photographer. A dialogue. London: Thames and Hudson, 2011, pp. 11-16.

Barthes, Roland. "Rhetoric of the Image". In Barthes, Roland. Image - music-text. London: Fontana Press, 1977, pp. 32-51.

Benton, Tim. LC Foto: Le Corbusier. Secret Photographer. Baden: Lars Müller Publishers, 2013.

Bergdoll, Barry. "Les deux modernismes architecturaux de Lucien Hervé “. In Bergdoll, Barry; Boone, and Puttemans, Pierre. Lucien Hervé: L'œil de l'architecte. Brussels: CIVA, 2005, pp. 9-17.

Bienz, Peter. "Le Corbusier und die music“. Bauwelt Fundamente 120. Braunschweig: Vieweg, 1998.

Boesiger, Willy (ed.). Oeuvre Complete, 1952-1957, volume 6, Zürich: Girsberger, 1957.

Brassaï, Gyula and Dalì, Salvador. "Sculptures involontaires". Minotaure, 1933, nº 3-4, p. 68.

Carpenter, Patricia. "Musical form regained". The Journal of Philosophy. January 21, 1965, vol. 62, no 2, pp. 3648.

Cohen, Jean-Louis. Le Corbusier and the mystique of the USSR. Theories and projects for Moscow 1928-1936. Translated by Kenneth Hylton. Princeton, N.J.: Princeton University Press, 1992.

Colomina, Beatriz. "Le Corbusier and photography”. Assemblage. October 1987, nº 4, pp. 6-23.

De Smet, Catherine. Vers une Architecture du Livre: Le Corbusier. Edition et mise en pages 1912-1965. Baden: Lars Müller Publishers, 2007.

. Le Corbusier: Architect of Books. Zurich: Lars Müller Publishers, 2007.

Di Bello, Patrizia. "Photography and Sculpture. A light touch". In Di Bello, Patrizia and Koureas, Gabriel (eds). Art, History and the Senses: 1830 to the Present. Farnham: Ashgate, 2010, pp. 19-33.

. "Sculpture, photograph, book: The sculptures of Picasso (1949)". In Di Bello, Patrizia; Wilson, Colette and Zamir, Shamoon (eds). The photobook. From Talbot to Ruscha and beyond. London : I.B. Tauris, 2012, pp. 91-109.

Elwall, Robert. "New eyes for old: Architectural photography". In Twentieth Century Architecture. British modern, Architecture and design in the 1930s. 2007, n⿳0 8, pp. 54-55.

Emerling, Jae. Photography: History and Theory. London: Routledge, 2012.

\footnotetext{
${ }^{68}$ Le Corbusier, Ronchamp, p. 6.

${ }^{69}$ Le Corbusier, Vers une architecture, p. 178; 180.
} 
Fer, Briony. "The space of anxiety. Sculpture and photography in the work of Jeff Wall". In Johnson, Geraldine A. (ed.). Sculpture and photography. Envisioning the third dimension. Cambridge: Cambridge University Press, 1998, pp. 234-246.

Gernsheim, Helmut. Focus on architecture and sculpture: An original approach to the photography of architecture and sculpture. London: The Fountain Press, 1949.

Graham, James. "Musique en fer forge. Erik Satie, Le Corbusier and the problem of aural architecture". $A A$ Files. 2014, n ${ }^{\circ}$ 68, pp. 3-15.

Gueguen, Pierre. "Notre-Dame-du Haut à Ronchamp. Le testament poétique de Le Corbusier". Aujourd'hui : Art \& Architecture. September 1955, n ${ }^{\circ} 4$, pp. 54-60.

Herschman, Joel and Cervin Robinson. Architecture Transformed: A History of Buildings from 1839 to the Present. New York: The architectural league of New York, 1988.

Hervé, Lucien. “A propos de la photographie d'architecture”. Aujourdhui : Art et Architecture. September 1956, $\mathrm{n}^{\circ}$ 9, pp. 29-31.

La plus grande aventure du monde: l'architecture mystique de Cîteaux. With texts by François Cali. Paris: Arthaud, 1956.

Johnson, Geraldine A. "Introduction: Sculpture and photography. Envisioning the third dimension". In Johnson, Geraldine A. (ed.). Sculpture and photography: Envisioning the third dimension. Cambridge: Cambridge University Press, 1998, pp. 1-20.

Krauss, Rosalind. The Originality of the Avant-Garde and Other Modernist Myths. Cambridge, MA: MIT Press, 1996.

Le Corbusier. Vers une architecture. Paris: Crès \& Cie., 1923.

. Precisions on the present state of architecture and city planning. First published in 1930. Cambridge, MA: MIT Press, 1991.

. Speech at conference at the Reale Accademia d'Italia, Rome, 1936. FLC Archives, published in Architecture Vivante (1936), p. 7.

. Le Modulor. Boulogne: Éditions de l'Architecture d'Aujourd'hui, 1950.

Ronchamp: Les Carnets de la recherche patiente 2. Stuttgart: Verlag Gerd Hatje, 1957.

Naegele, Daniel. “An Intervju with Lucien Hervé”. Parametro 1-2, January -February 1995, n 206, pp. 74-83.

Obrist, Hans Ulrich. Lucien Hervé - Une Conversation. Paris : Manuella Éditions, 2011.

Pauly, Danièle. The Chapel at Ronchamp. Basel: Birkhäuser - Paris: Fondation Le Corbusier, 2008.

Pearson, Christopher. "Integrations of art and architecture in the work of Le Corbusier. Theory and practice from ornamentalism to the "Synthesis of the Major Arts", Dissertation, Stanford University, 1995.

Petit, Jean. La Chapelle Notre-Dame-du-Haut, Ronchamp : Les Cahiers forces vives. Paris: Forces Vives, 1956.

Pevsner, Nicolas. An outline of European architecture. Sixth edition. Baltimore: Penguin Books, 1960.

Potts, Alex. The sculptural imagination. Figurative, modernist, minimalist. New Haven and London: Yale University Press, 2000.

Quetglas, Josep. "Ronchamp. A landscape of visual acoustics". In Cohen, Jean-Louis: An Atlas of Modern Landscapes. London: Thames and Hudson, 2013, pp. 212-218.

Rajewsky, Irina O. "Intermediality, intertextuality, and remediation: A literary perspective on intermediality". Revue Intermédialités. Autumn 2005, nº 6, pp. 43-64.

Stambaugh, Joan. “Music as a temporal form”. The Journal of Philosophy. April 1964, vol. 6, n 9, pp. 265-280. 
Stirling, James. "Ronchamp: Le Corbusier's chapel and the crisis of rationalism". Architectural Review. 1956, $\mathrm{n}^{\circ}$ 3, pp. 156-161.

Treib, Marc. Space calculated in seconds: The Philips pavilion. Princeton, N.J.: Princeton University Press, 1996.

Wogenscky, André. Le Corbusier's hands. Translated by Martina Millà Bernad. London: The MIT Press, 2006.

Zimmerman, Claire. "The monster magnified: Architectural photography as visual hyperbole". Perspecta. Monster. 2008, vol. 40, pp. 136-147. 


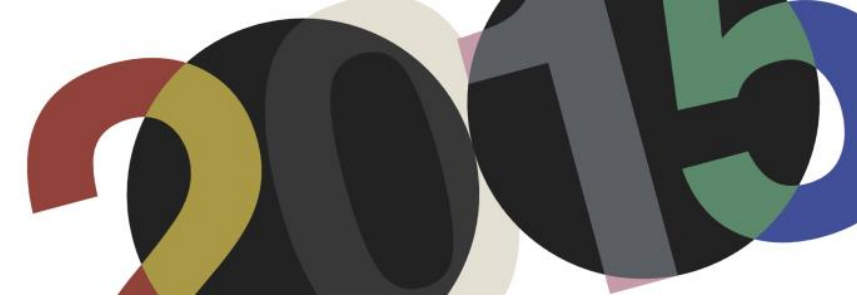

DOI: http://dx.doi.org/10.4995/LC2015.2015.1545

\title{
La poética del urbanismo de Le Corbusier: arte y función en la ciudad moderna
}

\author{
A. Soler Machado, E. Gehlen Bregolin
}

FAUFRGS

\begin{abstract}
Resumen: El objetivo de este artículo es demostrar que existe una poética en el urbanismo de Le Corbusier y que el tema se mantiene y se transforma en sus modelos teóricos y sus derivaciones. Desde el punto de vista teórico-metodológico, parte-se del presupuesto de que esa poética es el resultado de la dualidad entre arte y función presente en su pensamiento, originada en su formación personal y el momento histórico en el que produce su obra. El analisis se estructura con la agrupación de su produción urbanística en cuatro fases: 1-los años 1920: el Plan Ideal; 2-1929-38: las ciudades de América del sur y los viaductos; 3-1930-50: la Ville Radieuse; 4-Después de la Segunda Guerra Mundial: la ciudad de los 7V y la Unité d'habitation. La reflexión final retoma la visión general de su produción urbanística y la vincula al concepto de utopia.
\end{abstract}

Abstract: The goal of this article is to demonstrate that there is an aspect of poetics in Le Corbusier's urbanism and that this theme is maintained and you can see it being transformed through the theoretical models and its derivations. From the methodological and theoretical point of view, we make the assumption that the poetics is the result of the duality between art and function present in his thought, which comes from the historical moment in which his work was made and from his personal background. This analysis is structured by grouping his urban planning works in for phases; the 1920s: the Ideal City; 1929-38: the cities of South America and the viaduct; 1930-50: the Ville Radieuse; after the II World War: the city of $7 \mathrm{~V}$ and the Unite d'habitation. The final considerations bring back the general vision of his urban planning works and tie it to the concept of utopia.

Palabras clave: Le Corbusier; Urbanismo; Poética; Arte; Función. Keywords: Le Corbusier; Urbanism; Poetics; Art; Función.

\section{Introducción}

"El poeta (...) evalúa y da cuenta de la calidad duradera de las palabras. Se encuentra en el polo opuesto de las calculadoras y sigue la curva ondulante de las pasiones. Además de la utilidad, se da cuenta de lo imperecedero - el hombre". Le Corbusier ${ }^{1}$

El urbanismo de Le Corbusier está teñido de las diferentes visiones de la modernidad arquitectónica expresadas en su obra. Tiene ecos de su postura idealista y de todas sus experiencias, cada una de ellas un aprendizaje, consciente o no, registrado en bocetos, fotografías, escritos, pinturas, esculturas y proyectos. Todo lo que hizo en la vida se convirtió en materia prima de su trabajo futuro.

Su concepción de la ciudad moderna divide las opiniones. Por un lado, es vista como un esqueleto sin carne, un estricto sistema teórico racional, funcional y científico, en el que todas las relaciones son abstractas y se reducen a la cantidad. Por otro lado, "la ciudad de Le Corbusier es cualquier cosa menos un discurso científico. Es una

\footnotetext{
${ }^{1}$ Le Corbusier: "Por una Arquitectura". São Paulo: Editora da Universidade de São Paulo, 1973. p. 7.
} 
imagen completa, totalmente trabajada en cada detalle. (...) ¿sería ella científica, neutral y refutable o artística, ideológica e irrefutable? Todo apunta a la segunda interpretación" ${ }^{2}$.

El objetivo de este artículo es demonstrar que existe una poética en el urbanismo de Le Corbusier y que el tema se mantiene y se transforma en los modelos teóricos (propuestas ideales sobre terrenos hipotéticos) y en sus derivaciones: adecuaciones de los modelos a situaciones geográficas y culturales específicas.

La hipótesis que se quiere explicitar es que la tensión establecida entre la doble dimensión, funcional y artística de su urbanismo resulta en una poética: por definición, un replanteamiento semántico de ciertos elementos con aspectos metafísicos - intentos para describir los fundamentos, condiciones, leyes, estructura básica, significado y propósito de la realidad en su conjunto o de los seres en general; creación, crítica o defensa de la realidad.

Desde el punto de vista teórico-metodológico, se parte del presupuesto de que la dualidad de su pensamiento se deriva del momento histórico en el que su obra se produce y de su formación personal: en La Chaux de Fonds, donde nació, en París, donde vivió desde los 29 años, en sus lecturas y viajes.

El análisis se estructura con la agrupación de la producción urbanística de Le Corbusier en cuatro fases que corresponden a diferentes posturas urbanísticas: 1-los años 1920: el Plan Ideal; 2-1929-38: las ciudades de América del sur y los viaductos; 3-1930-50: la Ville Radieuse; 4-Después de la Segunda Guerra Mundial: la ciudad de los 7V y la Unité d'habitation.

La reflexión final retoma la visión general de su producción urbanística y la vincula al concepto de utopía.

\section{De la dualidad del pensamiento corbusiano}

El pensamiento de Le Corbusier toma forma en su tierra natal, después en París, a partir de los 29 años y en sus viajes. Le Corbusier nació en La Chaux-de-Fonds, el 06/10/1887, época en la que la ciudad se convirtió en un ambiente de talleres pequeños, y sus relojes ganaron reconocimiento internacional. De la familia calvinista, recibió una educación moral que acentuaba los contrastes entre el bien y el mal. Con el padre relojero, realizó paseos por la región, explotando la flora y la geología, y aprendiendo la lógica de los relojes, en la que cada parte cumple una función. Con la madre pianista, desarrolló su sensibilidad poética.

Con L'Eplattenier, en la École d'Art, aprendió la doctrina religiosa artesanal de Ruskin, a abstraer las estructuras de la naturaleza y a pensar en la creación natural como revelación de un orden espiritual que se debe trasladar al design ${ }^{3}$. Conoció el movimiento arts and crafts y las teorías del ornamiento de Owen Jones, originadas en una tradición que pensaba en términos de un significado contingente y no universal, y que buscaba una renovación de la arquitectura por medio del ornamiento y de la artesanía. Más tarde se aparta de esa visión, acercándose a una concepción universalista de la arquitectura ${ }^{4}$. A partir de la historia de la región del Jurá, hecha de sendas revoluciones, políticas y religiosas, Le Corbusier construye un pedigree para sí mismo: una tradición de pensamiento libre 5 .

A los 29 años, Charles-Édouard Jeanneret hace de Paris su morada espiritual, donde continúa su aprendizaje y adopta su nuevo nombre: Le Corbusier. Sus numerosos viajes por Europa y el mundo le posibilitan hacer

\footnotetext{
${ }^{2}$ Colqhoun, Alan: "Modernidad y tradición clásica". São Paulo: Cosac 7 Naify, 2004. pp. 113-117.

${ }^{3}$ Curtis, William: "Le Corbusier: ideas and forms". London: Phaidon, 1986. p. 19.

${ }^{4}$ Colqhoun, Alan: “Modernidad y tradición clásica”. São Paulo: Cosac 7 Naify, 2004. pp. 102-103.

${ }^{5}$ Curtis, William: "Le Corbusier: ideas and forms". London: Phaidon, 1986. p. 19.
} 
contacto con la historia y aportan lo esencial para su formación. Sus croquis y acuarelas registraran su observación de elementos del pasado, de lo típico detrás del incidente, y preocupaciones morales convertidas en geometrías según su propia terminología. Si los ornamentos podían ser microcosmos, más adelante en su vida, cuadros, edificios y planes urbanos también podrían serlo ${ }^{6}$. Del 1907 al 1912, hace contacto con tres tipos de escenarios: los centros de la cultura, de la industria y del folclore ${ }^{7}$. Como Proust, sus recuerdos se mezclan con sus vivencias y proyectos.

El momento histórico en el que produce su obra también es importante para entender su pensamiento. Se caracteriza por la ruptura de la arquitectura con las demás artes y por su enlace con la ciencia y las dinámicas sociales, un cambio que comienza en los siglos XVIII y XIX, cuando la arquitectura queda dividida en sus funciones constructivas y científicas y sus funciones artísticas y de representación, siendo la razón reservada a la primera y la emoción a la última. Con el crecimiento del utilitarismo, la razón científica queda dirigida cada vez más a la eficacia instrumental ${ }^{8}$. Por ende, el funcionalismo, con sus dos tradiciones, el a priori y lo empírico, se convierte en el medio por el cual la vanguardia de los años 1920, a la que se vincula Le Corbusier, combate el historicismo.

El pensamiento de Le Corbusier contiene, pues, de un lado las preocupaciones científicas del funcionalismo; de otro, la tradición racional, moralizante y didáctica del clasicismo francés. A partir de esa dualidad, construyó sus fundamentos teóricos, los más elaborados del movimiento moderno. Encuanto que para Gropius la teoría era lo instrumental y el diseño su producto directo, para Le Corbusier la teoría era su justificación ${ }^{9}$.

En Por una arquitectura, Le Corbusier intenta una conciliación entre idealismo y racionalismo constructivo, estableciendo la distinción entre la ingeniería y la arquitectura: según el mismo, el ingeniero provee lo que es útil, muestra el camino de la verdad; el arquitecto despierta la emoción, torna la verdad palpable ${ }^{10}$. Al discutir la estética, la divide entre lo espiritual, - lo que agrada a la gente culta: la armonía y la proporción -, y lo sensorial, lo que agrada a las personas simples: la decoración y el color ${ }^{11}$.

La dualidad de su pensamiento se expresa en su obra por medio de la tensión entre el sólido y el vacío, la luz y la sombra, el movimiento horizontal y el vertical, los elementos del pasado y de la era de máquina. En el urbanismo, se revela en cuatro fases que corresponden a diferentes posturas a ser examinadas a continuación. Esa tensión es lo que genera su poética.

\section{Las cuatro fases del Urbanismo de Le Corbusier}

\subsection{Los Años 1920: El Plan Ideal}

Esta fase se caracteriza por la búsqueda de un Plan Ideal racionalista como solución a los problemas urbanos de la nueva sociedad industrial, capaz de mejorar los individuos y regular el comportamiento humano, dando lugar a una era de armonía.

\footnotetext{
${ }^{6}$ Curtis, William: "Le Corbusier: ideas and forms". London: Phaidon, 1986. p. 24.

${ }^{7}$ Cohen, Jean-Louis: "Le Corbusier 1887-1965: El lirismo de la arquitectura en la era mecánica”. Madrid: Tasken, 2009. p. 7.

${ }^{8}$ Colqhoun, Alan: "Modernidad y tradición clásica”. São Paulo: Cosac 7 Naify, 2004. pp. 69-72.

${ }^{9}$ Colqhoun, Alan: "Modernidad y tradición clásica". São Paulo: Cosac 7 Naify, 2004. p. 99.

${ }^{10}$ Colqhoun, Alan: "Modernidad y tradición clásica". São Paulo: Cosac 7 Naify, 2004. p. 106.

${ }^{11}$ Colqhoun, Alan: "Modernidad y tradición clásica". São Paulo: Cosac 7 Naify, 2004. p. 107.
} 
En los años 1920, Le Corbusier sintetiza las ideas de sus años de formación en un vocabulario personal arraigado en las condiciones de la sociedad industrial, cuyo contenido simbólico era la creación de un nuevo modelo de vida $^{12}$. Para Le Corbusier, la era maquinista exigía la superación de la pequeña construcción privada. El nuevo desafío era pensar el habitar a escala colectiva de la ciudad y del territorio. El desarrollo de la ciencia y de la técnica, del principio del siglo XX, ofrecía la posibilidad de reencuentro con las leyes perennes de la belleza ideal y de atender en una nueva escala a la necesidad del máximo rendimiento - funcional y emocional - de la ciudad y de la casa.

Le Corbusier era simpatizante de la tendencia cultural iniciada en fines del siglo XIX, direccionada a romper con el pasado por medio de la industria y el arte de vanguardia, la práctica, la eficacia, la concepción austera, racional y universal de belleza, el orden y la geometría: la llamada utopía del futuro, definido por Choay como urbanismo progresista ${ }^{13}$. Unido a los constructivistas rusos y sus propuestas utópicas, y a Gropius con respecto a sus ideas de la vivienda mínima, adhiere al funcionalismo substituyendo los criterios anteriores de la ciudad jardín por las ideas de la Cité Industrielle de Garnier.

La idea del Plan Ideal nace de su visión, idealista y pragmática: la definición de los tipos ideales era el camino para la transformación de las estructuras urbanas incompatibles con el nuevo ambiente económico y social industrial caracterizado por la presencia de la fábrica y sus sectores de vivienda. La vida moderna, relacionada a las necesidades colectivas exigía un nuevo plan, generado por una nueva concepción de la vivienda colectiva formada por la suma de células individuales. En un texto de 1952, "El regalo de las técnicas" Le Corbusier declara que la casa, - ahora con servicios que muestran el grado de civilización, es el punto de partida y fin último de la urbanística ${ }^{14}$.

La metáfora mecanicista y artística de la máquina de habitar en conjunto con la posibilidad de industrialización de la arquitectura genera la noción de standard y de la casa como principio formador de la ciudad-máquina. Los dos conceptos convergen para la noción de zonificación funcional en escalas distintas, de la casa a la ciudad. Su concepción del espacio mínimo desarrollado en el esquema Dom-inó y en el Pabellón de 1925, y la concomitante redefinición de los servicios domésticos, desplazados de la esfera individual a la colectiva, originaran el Immeuble-Villa, un superbloque semejante a un hotel, a partir del cual Le Corbusier propone la Ville Contemporaine, su primer modelo teórico de ciudad, una propuesta ideal sobre un sitio hipotético y plano.

En el Salón de Otoño de 1922, el organizador Marcel Temporal le pide a Le Corbusier que le diseñe una fuente. El acepta la propuesta con la condición de que en torno de ella se ubique una ciudad de tres millones de habitantes, la solución teórica para los problemas de París de la primeira post-guerra: vivienda en gran escala, espacios abiertos, centro de negocios y tránsito. Eso no es una broma, sino la historia que expone la ansiedad de Le Corbusier por exponer sus nuevas concepciones urbanas, aprovechando al máximo la oportunidad que se le presentaba.

Su concepción de La Ville Contemporaine de 1922 es un collage de ideas y contradicciones: incluye las ideas positivistas de una nueva sociedad, de St. Simon, la sociología newtoniana de Fourier y principios de Provenzal: el ideal de la belleza como expresión de la mente y del espíritu y no de los sentidos físicos ${ }^{15}$; y la concepción de la arquitectura a la escala del pensamiento -- lugar de lo colectivo --, y no sólo a la escala del cuerpo humano,

\footnotetext{
${ }^{12}$ Curtis, William: "Le Corbusier: ideas and forms". London: Phaidon, 1986. p. 60.

${ }^{13}$ Choay, François: "El Urbanismo”. São Paulo: Ed. Perspectiva, 1979. p. 160.

${ }^{14}$ Monteys, Xavier: "La gran máquina: la ciudad en Le Corbusier”. Barcelona: Ediciones del Serbal, 1996. pp. 11-12.

${ }^{15}$ Colqhoun, Alan: "Modernidad y tradición clásica". São Paulo: Cosac 7 Naify, 2004. p. 101.
} 
lugar pasajero en el que el individuo abriga su existencia ${ }^{16}$. Por otra parte, une la ideología progresista a referencias históricas: la estructura espacial centralizada, organizada en torno de las torres de planta cruciforme de 60 pisos de la Cité d'affaires, pone la modernidad industrial y la burocrática capitalista a nivel de una ley universal. Su forma urbana inspirada en la ciudad ideal de Bruno Taut contiene la cuadrícula utilitaria de Manhattan, la jerarquía clásica de París, la geometría simbólica de Pequim y de las ciudades ideales renascentistas.

Los tipos residenciales poseen referencias igualmente ambiguas, de la era industrial y de la historia: los Immeubles-Villas evocan las cabinas del transatlántico y las células monásticas de la Cartuja de Emma; y los edificios residenciales en redents se asemejan al falansterio de Fourier. La relación de la arquitectura con el paisaje, expresada en la línea de recorte de las masas edificadas contra el cielo, es tanto una reinterpretación de su visualización de las torres verticales de las mezquitas de Istambul en el horizonte, registrada en bocetos, cuanto la representación de una unidad cósmica y de un optimismo ingenuo respecto de las potencialidades del mundo industrial. La zonificación rígida convive con la libertad de las Unidades Vecinales de 400 por 400 metros de lado, dotadas de áreas verdes, servicios y equipamientos de uso colectivo, y de un sistema jerarquizado de vías de acceso elevadas sobre un parque continuo ${ }^{17}$. Aunque exista un enfoque humanista, la Ville se concentra más en los aspectos relativos al sistema de movimientos: a la circulación y a la velocidad.

El Plan Voisin, 1925, es la aplicación del esquema de la Ville Contemporaine a la región central de París, entonces con tres millones de habitantes. El plan se concentra en la orilla derecha del rio Sena y tiene los mismos principios y contradicciones que la Ville Contemporaine, presentados ahora, de manera aún más impactante. La demolición de gran parte del centro de París para la implantación de la grilla ortogonal que estructura sus torres y redents, y el mantenimiento de los principales monumentos históricos como objetos de una exposición contra el fondo de la arquitectura moderna, representan el conflicto entre modernidad y tradición.

Desde el punto de vista del tráfico, el plan pone al coche como la salvación de la metrópoli demoliendo la propia metrópoli. Le Corbusier se justifica con el argumento del mejoramiento de tráfico de París, lo que aumenta el valor de la tierra y fomenta a los inversores extranjeros a establecerse allí. Esa intervención pretensiosa y audaz, incompatible con la urbanidad mixta y la complejidad social de la ciudad que el mismo tanto admiraba ${ }^{18}$, no es aceptada, pero Le Corbusier logra su principal ambición en relación al plan: enunciar los problemas urbanos de París - el tráfico y la inadecuación de la vivienda y del sector administrativo - a través de sus ideas formales y de su postura innovadora de que la concentración y la densificación en altura de los edificios son el requisito previo para el progreso cultural. El Plan Voisin abre la oportunidad de discutir la planificación urbana racionalizada en gran escala, normalizada en 1928, cuando Le Corbusier funda el CIAM con Gropius, Karl Moser y Sigfried Giedion.

\footnotetext{
${ }^{16}$ Martins, Carlos: "Una Lectura Critica de Precisiones". En: Le Corbusier: Precisiones sobre un estado presente de la arquitectura y del urbanismo. São Paulo: Cosac \& Naify, 2004. p. 276.

${ }^{17}$ Monteys, Xavier: "La gran máquina: la ciudad en Le Corbusier”. Barcelona: Ediciones del Serbal, 1996. pp. 42-48.

${ }^{18}$ Curtis, William: "Le Corbusier: ideas and forms". London: Phaidon, 1986. p. 65.
} 


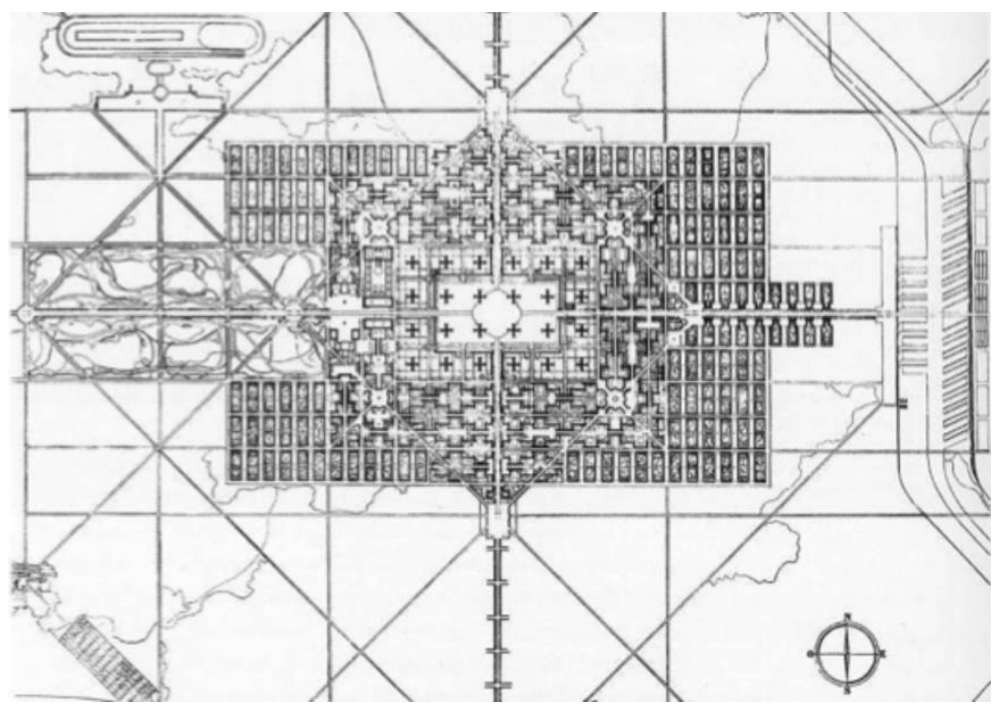

1. Le Corbusier, Ville Contemporaine, $1922^{19}$.

\subsection{9-38: las ciudades de América del Sur y los viaductos}

Esa fase marca un giro importante en su sensibilidad y visión de mundo. Invitado por los intelectuales argentinos a dar conferencias sobre diversos temas, y seducido por la inminente construcción de una nueva capital para Brasil, Le Corbusier conoce la región entre el Rio de la Plata y el sureste de Brasil en 1929.

En el vuelo entre Buenos Aires y Asunción, mira el paisaje desde una nueva perspectiva: el avión cambia radicalmente su percepción de las ciudades y del mundo, aumentando su comprensión a cerca de las escalas de la arquitectura y las formas de la naturaleza ${ }^{20}$. El avión es también un símbolo de la teoría de la visión general, una noción hegeliana en la que el poeta-filósofo es capaz de entender toda la historia y ver en ella la operación de la razón. El contexto cósmico avistado en el vuelo, de pliegues y ondulaciones, se tradujo en la "teoría del meandro," en el concepto de una "quinta fachada" y en una nueva propuesta urbana: el edificio-viaducto, una estructura que contiene fracciones de su repertorio, como autopistas, rascacielos y líneas de vivienda.

Si el propósito funcional del mega-edificio era resolver el aumento de la población y facilitar el flujo de personas y mercancías por los puntos de salida de la ciudad, su propósito artístico se expresó en la audacia de la inmensa escultura sobre el paisaje sinuoso, haciendo referencia tanto al "Roadtown," como al Lingotto de Turín. Los viaductos gigantescos que resolverían todos los problemas relacionados con la zonificación, la circulación, la preservación y expansión de las ciudades de América del Sur se mantuvieron sólo en sus bocetos, pero demuestran su nueva sensibilidad a las condiciones geográficas y culturales locales.

\footnotetext{
${ }^{19}$ Le Corbusier: "Le Grand”. London: Phaidon, 2014. p.130.

${ }^{20}$ Cohen, Jean-Louis: “Le Corbusier 1887-1965: El lirismo de la arquitectura em la era mecânica”. Madrid: Tasken, 2009. p.
} 11. 
La atmósfera de descubrimientos, junto con su talento mágico de metamorfosear el mundo, de acuerdo a sus propias fantasías, dio lugar a las intervenciones urbanas de Montevideo, Sao Paulo, Río de Janeiro y después en $\mathrm{Argel}^{21}$. En Montevideo y Sao Paulo los viaductos se convierten en ejes y su intersección establece el sector de negocios de la ciudad (Cité d'affairs). Las propuestas de Río de Janeiro, donde el viaducto gana la topografía peculiar a través de curvas y túneles, tiene sus legados brasileros: los edificios de vivienda "Pedregulho" y "Gávea" de Affonso Eduardo Reidy, son fragmentos de esta ciudad lineal de Le Corbusier. Las ideas, los planes y las historias experimentadas en este viaje, como el encuentro con la cantante estadounidense Josephine Baker, a bordo del transatlántico Giulio Cesare hacia Buenos Aires, compiladas en Précision, produjeron una gran influencia en su trabajo futuro.

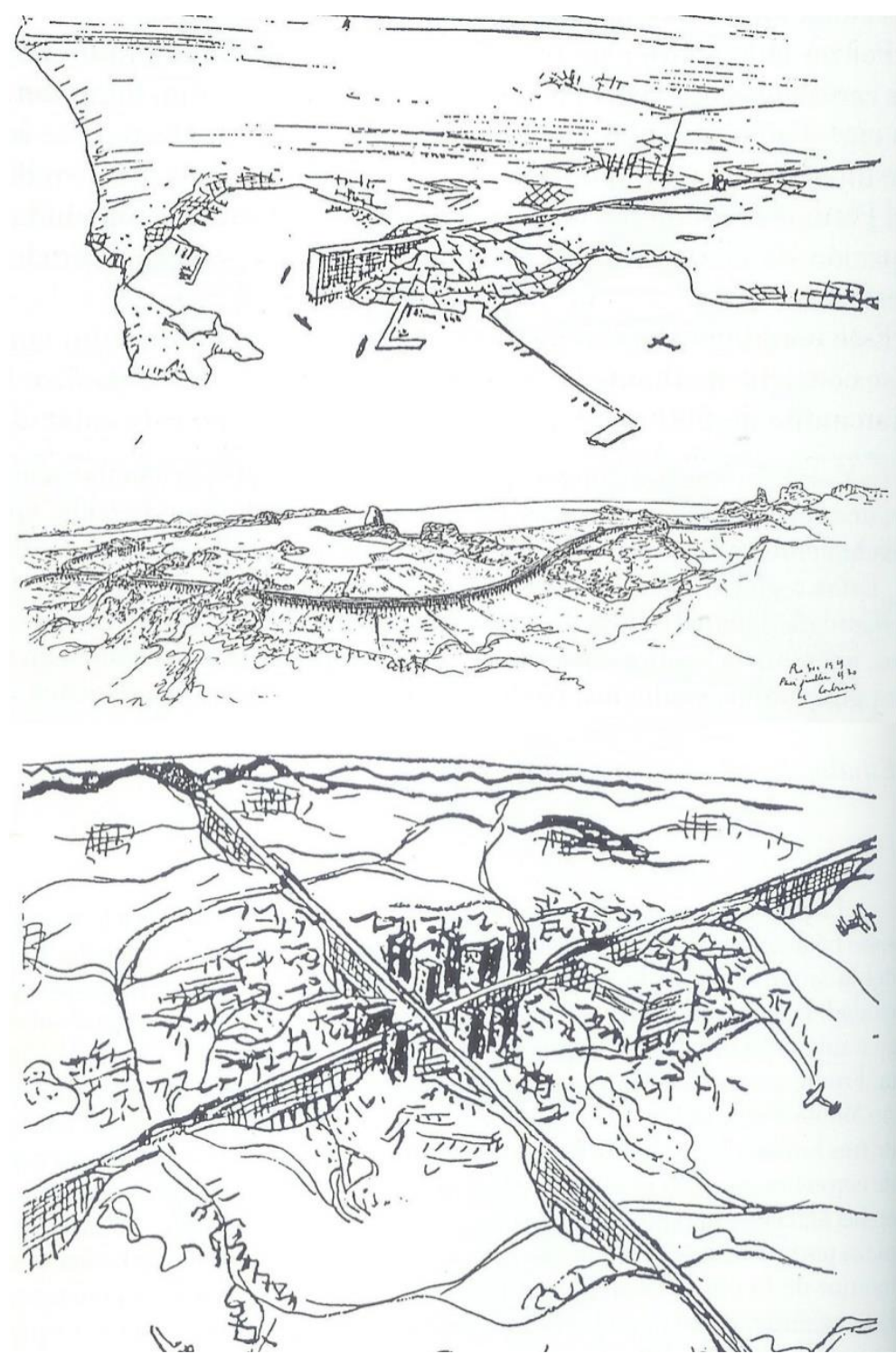

2. Le Corbusier, Propuestas para Río de Janeiro, Montevideo y Sao Paulo, $1929^{22}$.

\footnotetext{
${ }^{21}$ Curtis, William: "Le Corbusier: ideas and forms". London: Phaidon, 1986. p. 123.

${ }^{22}$ Monteys, Xavier: "La gran máquina: la ciudad en Le Corbusier”. Barcelona: Ediciones del Serbal, 1996. pp. 182, 178 y 180.
} 


\subsection{0-50: la Ville Radieuse}

Esa fase se caracteriza por el desarrollo de la nueva sensibilidad respecto a los lugares y la historia adquirida por Le Corbusier en el viaje por América del Sur, expresada en la formulación de un nuevo modelo teórico caracterizado por la humanización del programa original racionalista: la Ville Radieuse, el modelo de referencia de la mayor parte de su obra urbana, que abarca un período desde 1930 hasta la Segunda Guerra Mundial.

Le Corbusier no cambia sus antiguas convicciones, sino que revela una cierta desilusión con la máquina, con las promesas de los tiempos modernos y los ideales estilísticos previstos en la década de 1920, sustituyendo la creencia en el triunfo de la era maquinista por el deseo de un futuro menos doctrinario, donde sería posible la convivencia entre técnicas primitivas y avanzadas.

La sensibilidad del fin del ensueño, es una sensibilidad que acepta y celebra el artificio, la máscara, la convención, el territorio secreto, la ilusión, la contradicción y la complejidad, la grieta y el fragmento, la ironía y la paradoja.

La Ville Radieuse, el segundo modelo teórico de Le Corbusier, diseñado entre 1924 y 1935, es una respuesta a las acusaciones de Moscú de que sus planes anteriores eran mecanismos capitalistas. El plan es una evolución de la Ville Contemporaine, donde intenta lograr un equilibrio entre los órdenes, individual, familiar y público; entre la forma construida y el espacio abierto; y entre la ciudad y la naturaleza ${ }^{23}$.

Su esquema antropomórfico diseñado a partir de dos mallas giradas a 45 grados, formada por líneas de uso paralelas inspiradas en el modelo racional de Ciudad Lineal de Nikolay Alexandrovich Milyutin, evita cualquier núcleo de poder central y es expandible: la metáfora perfecta para el desarrollo de una sociedad igualitaria donde se elimina la diferencia entre el campesinado y el proletariado.

Tipológicamente, los bloques en redents de la Ville Radieuse representan una mejora en comparación con el modelo anterior, haciendo más evidente la relación entre la casa y el hombre. Su visión de que la ciudad arranca del hogar, es la más antropológica y tal vez la más humana de entre sus contemporáneos ${ }^{24}$.

En esta etapa, Le Corbusier proyecta 13 ciudades, donde demuestra la capacidad de adaptación de los modelos, de la Ville Radieuse - y los viaductos, en el caso de Argel - a las circunstancias geográficas y culturales específicas.

El sector de negocios (Cité d'affaires) se hace cada vez más independiente en las propuestas que siguen y, con el tiempo, Le Corbusier llega a reconocer el papel de la antigua ciudad como el centro, al que se unen otros componentes. Los medios de transporte también se someten a cambios.

Las estaciones puestas simbólicamente cerca del centro de negocios, en las primeras propuestas, se desplazan, en las siguientes, a las zonas de servicio. La industria presente en la periferia de la Ville Contemporaine y de la Ville Radieuse, abandona la ciudad y se instala en las rutas de conexión.

En las ciudades ubicadas en la orilla de un lago o mar, la Cité d'affaires se ubica siempre a su lado (Argel, Barcelona, Ginebra, Río de Janeiro, Buenos Aires y Nemours).

\footnotetext{
${ }^{23}$ Curtis, William: "Le Corbusier: ideas and forms". London: Phaidon, 1986. p. 119.

${ }^{24}$ Monteys, Xavier: "La gran máquina: la ciudad en Le Corbusier”. Barcelona: Ediciones del Serbal, 1996. p. 16.
} 
Los principios de la Ville Radieuse se aplican en 1930, en el plan de Moscú, Rusia; en 1932, en el Plan Maciá de Barcelona, España y en el plan de Ginebra, Suiza; en 1933, en los planes de Estocolmo, Suecia y Amberes, Bélgica; en 1934, en el plan de Nemours, Argelia; en 1935, en los planes de Nueva York, EE.UU., Roma, Italia y Zlin, República Checa; en 1936, en los planes de Hellocourt, Francia y Addis Abeba, Etiopía; y en 1937, en el nuevo plan de París, Francia.

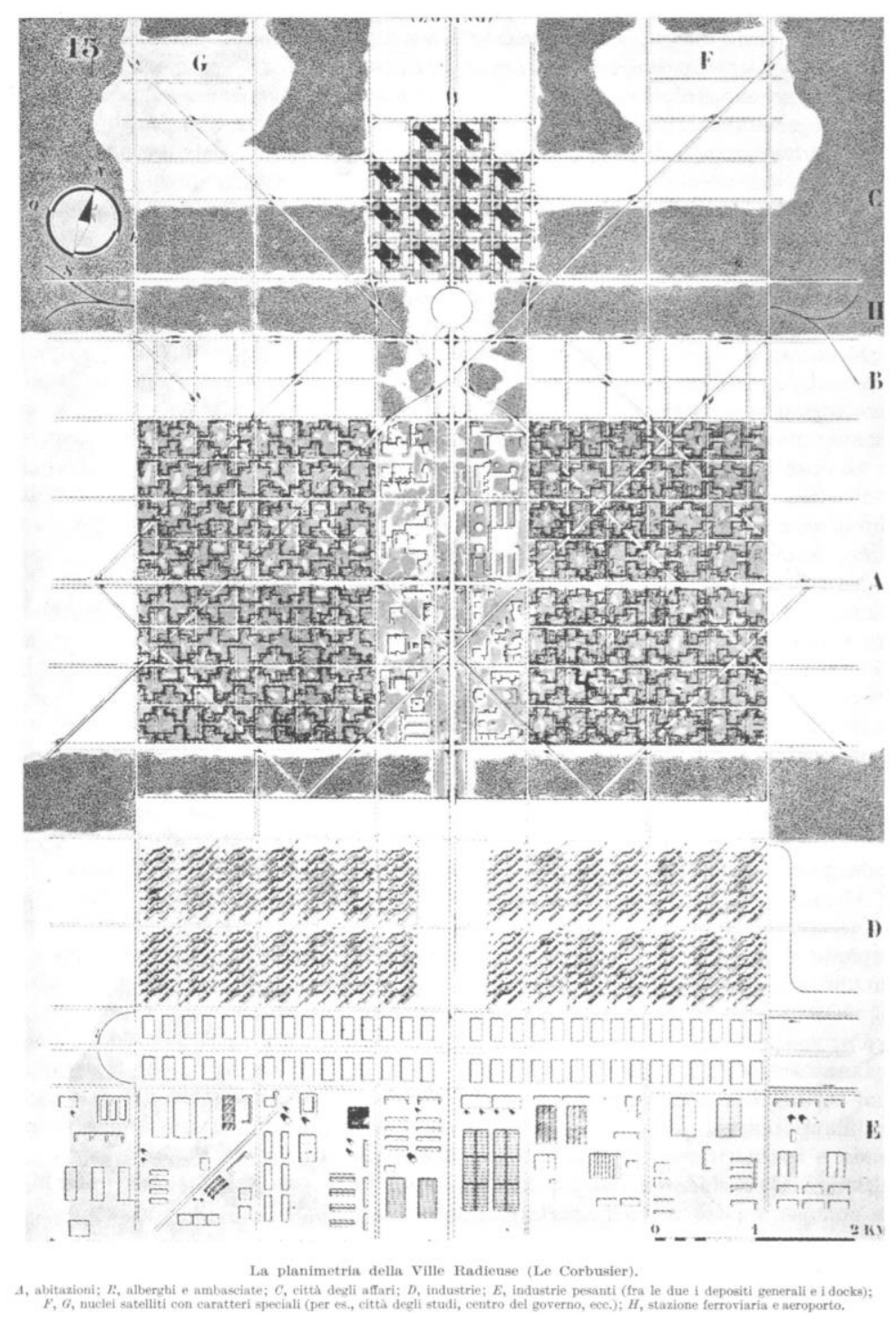

3. Ville Radieuse, $\operatorname{Plan}^{25}$.

\footnotetext{
${ }^{25}$ Monteys, Xavier. "La gran máquina: la ciudad en Le Corbusier”. Barcelona: Ediciones del Serbal, 1996. p. 40.
} 


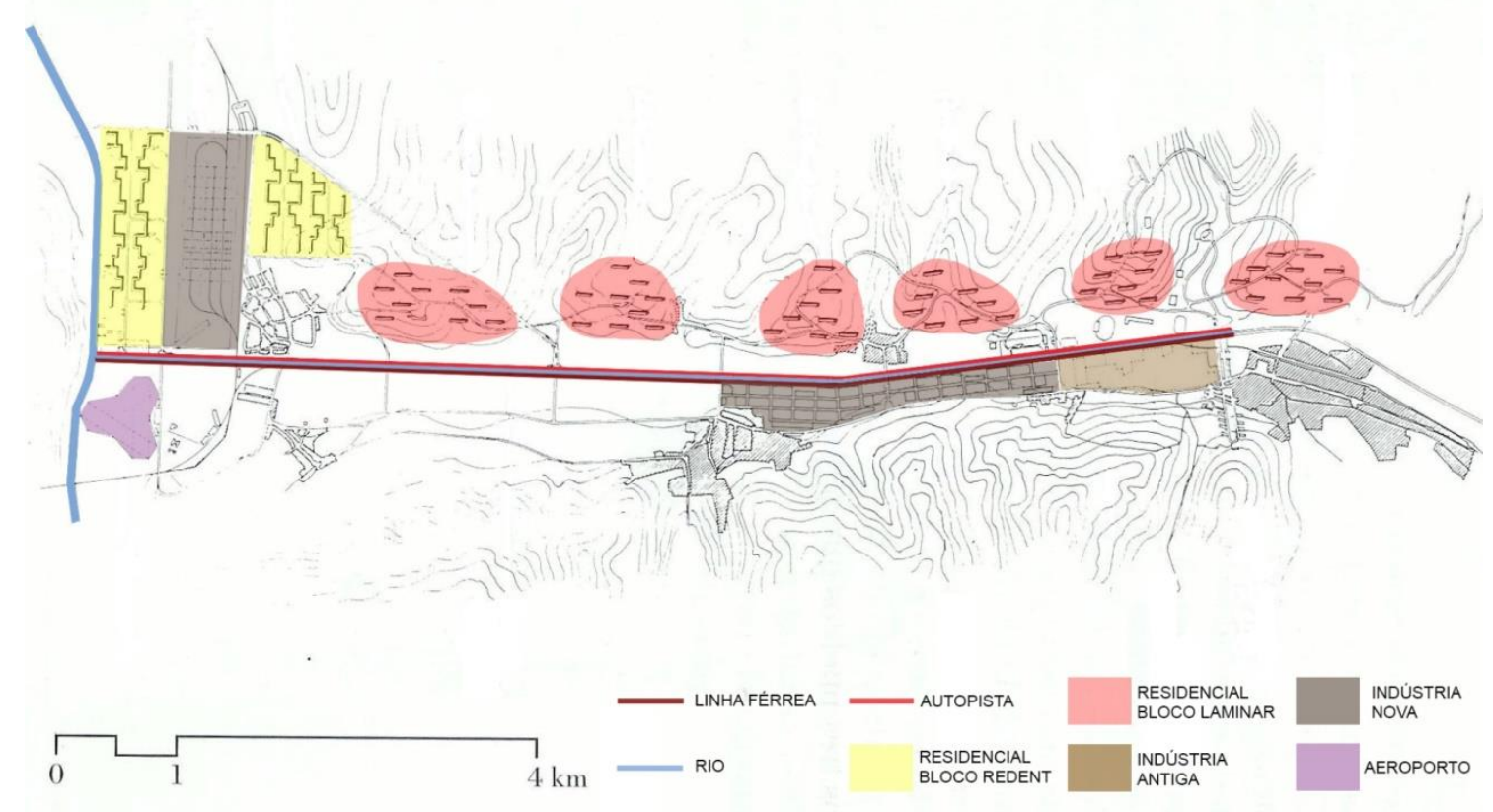

4. Le Corbusier, Plan de Zlin, $1935^{26}$.

De 1930 a 1942, Le Corbusier trabaja en el Plan Obus, haciendo la transposición de los principios de la Ville Radieuse y de la propuesta de Río de Janeiro a un contexto específico, geográficamente similar a la capital carioca: un rango estrecho, emparedado entre el mar y las montañas, donde era necesario hacer hincapié en la idea de crecimiento orgánico.

En el plan para Argel, capital de Argelia, la idea de ciudad lineal con viaductos se expresa en cuatro elementos principales, orquestados de manera escultórica: la Cité d'affaires; el conjunto de apartamentos curvados de clase media alrededor del Fuerte de L'Empereur; la alta ruta que une a estos dos elementos al casco antiguo colonial; y un enorme viaducto por sobre una ruta que se extiende a lo largo de la costa.

El Plan Obus es, quizás, su proyecto urbano con más contenido artístico y poético: la malla rígida anterior reemplazada por una abstracción de las curvas femeninas de la mujer brasileña, y del paisaje montañoso de Río, expresa la magia fructífera y sensual de Argelia y evoca tanto la caligrafía mística de sus bocetos, cuanto las paredes onduladas de las terrazas de Favre-Jacot, planeadas veinte años antes.

La poética está presente en el nombre mismo del plan: "Obus" significa cáscara explosiva y la propuesta recuerda la trayectoria curva de un proyectil que se choca con la curva de la costa, y que estalla en fragmentos alrededor de las colinas y el casco antiguo ${ }^{27}$.

La estrategia revela un arquitecto interesado en la cuestión del contexto y en las condiciones humanas en diferentes circunstancias. Pero, paradójicamente, expresa. tanto la idea social utópica de la fusión del hombre con la naturaleza, como la idea de una sociedad elitista. Las diversas versiones presentadas fueron consideradas poco realistas y rechazadas.

\footnotetext{
${ }^{26}$ Monteys, Xavier: “La gran máquina: la ciudad en Le Corbusier”. Barcelona: Ediciones del Serbal, 1996. p. 238 y análisis de los autores.

${ }^{27}$ Curtis, William: "Le Corbusier: ideas and forms". London: Phaidon, 1986. p. 123.
} 

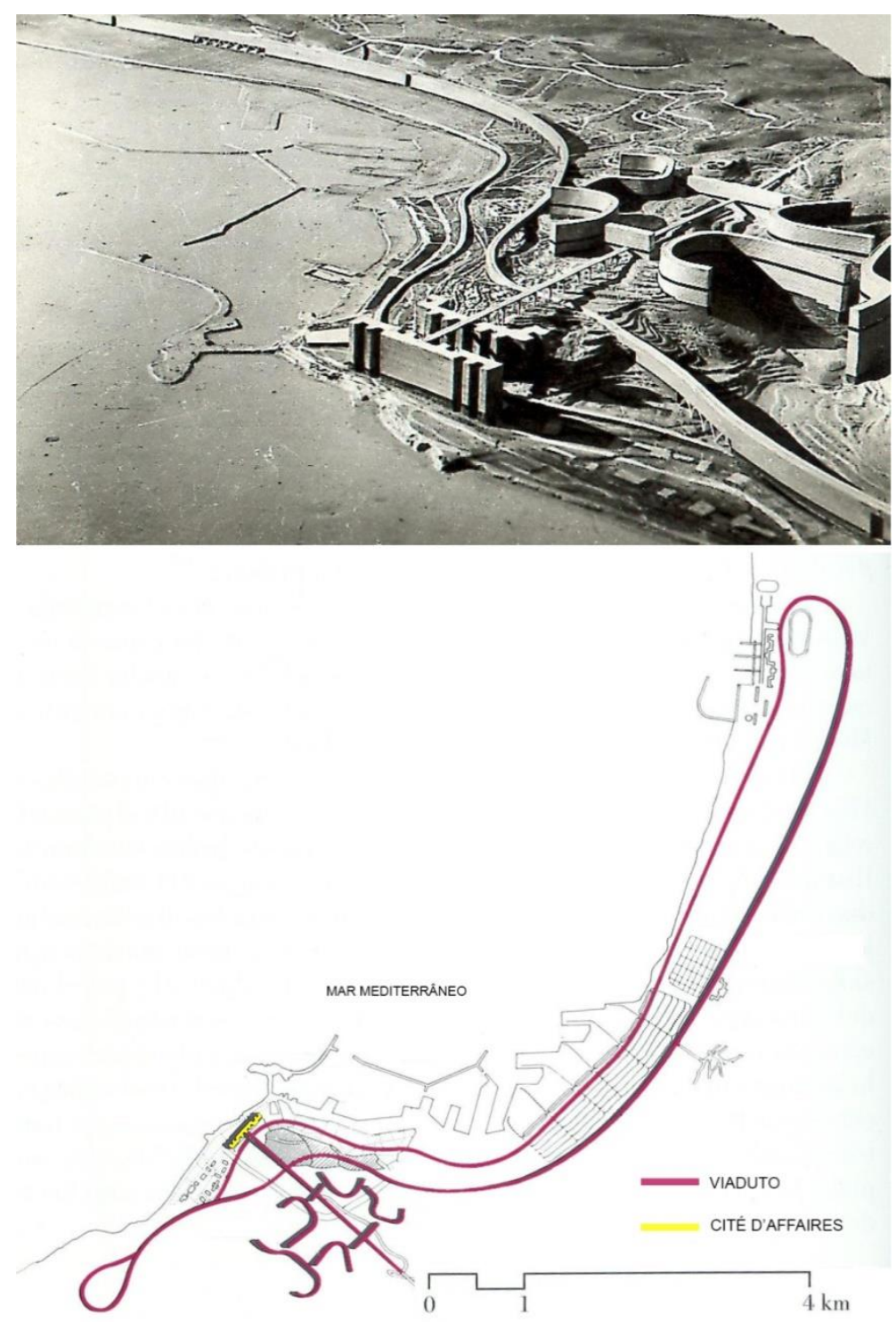

5. Le Corbusier, Plan de Argel, $1942^{28}$.

\subsection{Después de la Segunda Guerra Mundial: la ciudad de las $7 \mathrm{~V}$ y la Unité d'habitation}

La obsesión de Le Corbusier con respecto a la fabricación de la vivienda en serie encuentra en la Europa de la post-guerra, en la cual la necesidad de viviendas alcanzó un nivel sin precedentes, un campo fértil. Al mismo tiempo, su reflexión estética se expresa ahora en forma de poema, Le Poème de l'angle droit, escrito entre 1947 e 1955. En una parte se nota su concepción cósmica y poética de la geometría:

"El universo de nuestros ojos descansan

en una bandeja del horizonte

El lado que mira hacia el cielo

\footnotetext{
${ }^{28}$ Monteys, Xavier: "La gran máquina: la ciudad en Le Corbusier”. Barcelona: Ediciones del Serbal, 1996. p. 186 y análisis de los autores.
} 
Consideremos el espacio inconcebible

Justo aqui imperceptible

Descansar se acostar dormir

- Mourir

La espalda al sol ...

Pero me levanté!

Puesto que usted tiene razón

Estás lista a los actos.

Derecho sobre la plataforma terrestre

Las cosas asombrosas usted

contracta con la naturaleza el

pacto de solidaridad: es el ángulo recto

De pie frente al mar vertical

ahí estás en tus pies ${ }^{29}$ ".

En sus últimos cinco proyectos urbanos, Le Corbusier no descarta los modelos anteriores, pero aplica su tercer modelo teórico, la Ciudad Lineal Industrial, o Regla de las 7 Vías, que surgió de la formulación de Le Trois Etablissements Humaines de 1945, donde define los tres tipos de asentamientos esenciales del hombre: la Unidad de Granja, la Ciudad Concéntrica Radiante de Intercambios y la Ciudad Lineal Industrial.

Estos planes se caracterizan por la adopción en filas alternadas de la Unité d'habitation, su última tipología de vivienda, una evolución de los tipos anteriores, cuyo aislamiento es compensado por la incorporación de los servicios urbanos ${ }^{30}$.

La comunidad ideal es una especie de síntesis de toda la obra de Le Corbusier y reafirma la dualidad entre el arte y la función, y entre referencias técnicas e históricas. La Unité es una ciudad jardín vertical y una metáfora del

\footnotetext{
${ }^{29}$ L'univers de nos yeux repose sur un plateau bordé d'horizon La face tournée vers le ciel Considérons l'espace inconcevable jusqu'ici insaisi.

Reposer s'étendre dormir

- mourir

Le dos au sol...

Mais je me suis mis debout!

Puisque tu es droit

te voilà propre aux actes.

Droit sur le plateau terrestre

des choses saisissables tu

contractes avec la nature un

pacte de solidarité : c'est l'angle droit

Debout devant la mer vertical

te voilà sur tes jambes.

Le Corbusier: "Le Poème de l'angle droit: A3 MILIEU". 1955. Disponíble en: $<$ http://www.fondationlecorbusier.fr/corbuweb/morpheus.aspx?sysId=13\&IrisObjectId=6474\&sysLanguage=frfr\&itemPos=19\&itemSort=fr-fr_sort_string $1 \% 20 \&$ itemCount=47\&sysParentName=\&sysParentId=25>. Aceso en 6 jun 2015.

${ }^{30}$ Frampton, Kenneth: "História Crítica da Arquitetura Moderna”. São Paulo: Martins Fontes, 2003. p. 274.
} 
transatlántico, pero es narrativa como en el tiempo de Víctor Hugo y contiene las lecciones de Roma, registrados en sus bocetos de viaje.

Tiene la misma relación dual greco-romana de encuadramiento y destaque del paisaje, y se estructura a partir de la idea de promennade vertical que conduce a la terraza, cuyo diseño evoca los objetos del cubismo y reinterpreta tanto el Lingotto, cuanto Delfos, el circus romano, la Piazza Navona, el Foro de Pompeya y Villa Adriana. La Unité es uno de los supuestos más importantes de la cultura urbana contemporánea ${ }^{31}$.

Entre 1945 y 46, Le Corbusier elabora los planes franceses de Saint-Die, Saint-Gaudens, La Rochelle-Pallice y Marseille Vieux-Port; en 1948, el plan de Izmir, Turquía; en 1950, el plan de Bogotá, Colombia; en 1951, los planes para el sur de Marsella, Francia y Chandigarh, India; en 1956, el plan de Meaux, Francia y en 1958, el plan de Berlin Centro, Alemania.

En consonancia con otros giros y paradojas en su carrera, el mayor proyecto urbanístico de Le Corbusier se ubicaba lejos de los países industriales de Occidente: en la India, donde el clima caliente y las limitaciones de la tecnología local exigieron la adecuación de sus soluciones típicas.

Con la separación de Pakistán de la India, el estado de Punjab se divide y su capital queda en el lado paquistaní de la frontera, por lo que se hace necesario la construcción de una nueva capital a ser implantada en un punto donde la llanura empieza a doblarse, formando las bases de la cordillera del Himalaya. Chandigarh debería ser una ciudad eficiente, con espacios limpios y abiertos para liberar a los indios de la tiranía de las ciudades súper pobladas y sucias y del confinamiento de una vida en la agricultura.

En el plan de 1951, la organización formal básica con retícula ortogonal y carreteras axiales, sigue el esquema de la Ville Radieuse, con el Capitolio - abrigo de la democracia - materializando la cabeza de la figura antropomorfa, en lugar de los rascacielos del modelo ${ }^{32}$. La jerarquía de calles de diferentes tamaños en función de su uso, creando los sectores rectangulares de las comunidades urbanas autónomas, surge de la Regla de las $7 \mathrm{~V}$.

\section{La poética del Urbanismo de Le Corbusier}

"La ciudad es una imagen poderosa que acciona nuestro espíritu. Porque la ciudad no seria, aún hoy día, fuente de poesía". Le Corbusier ${ }^{33}$

Al articular el arte y la función, el Urbanismo de Le Corbusier constituye una poética, cuya metafísica, es una utopía ambigua: concibe el mundo moderno como un momento de retorno y prefiguración de un orden universal ideal, símbolo de nostalgia de la era histórica, pero también, de su superación por la era tecnológica en la que se confunden el progreso y el destino ${ }^{34}$.

\footnotetext{
${ }^{31}$ Monteys, Xavier: "La gran máquina: la ciudad en Le Corbusier. Barcelona: Ediciones del Serbal, 1996. p. 147.

${ }^{32}$ Curtis, William: "Le Corbusier: ideas and forms". London: Phaidon, 1986. pp. 190-194.

${ }^{33}$ Le Corbusier: "Urbanismo". São Paulo: Martins Fontes, 2011. p. VII.

${ }^{34}$ Argan, Giulio Carlo: "Proyecto y Destino”. São Paulo: Editora Ática, 2001. p. 23.
} 


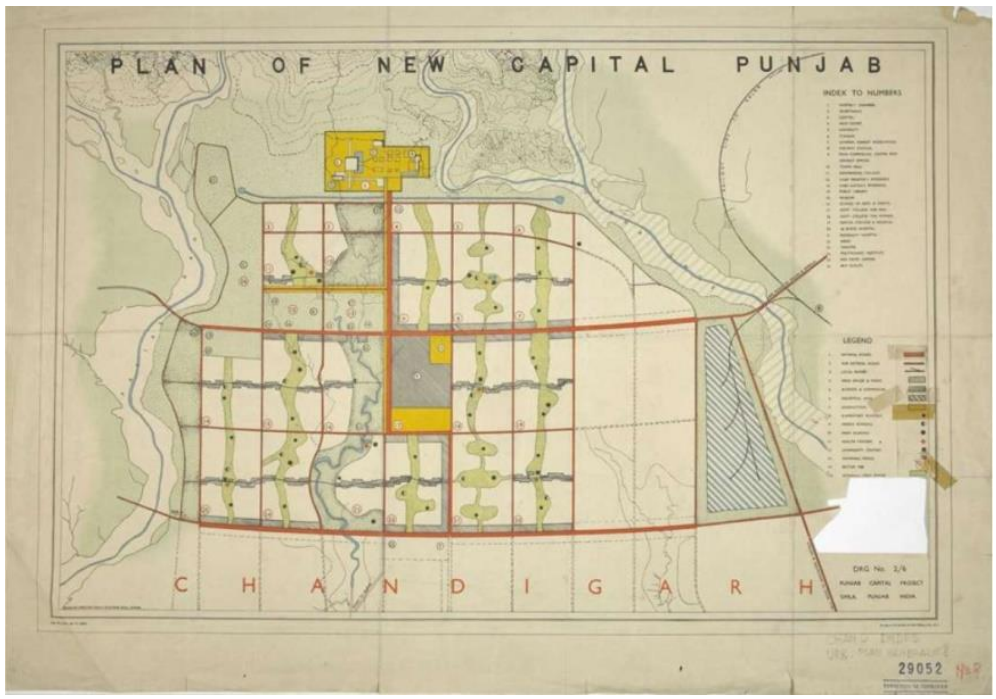

6. Le Corbusier, Plan de Chandigarh, $1956^{35}$.

Los rasgos utópicos del urbanismo corbusiano se deben a la asociación entre una organización social perfecta y un espacio nuevo de doble dimensión: una funcional, el modelo, referente a sus trazos reproducibles y una artística, el retrato, referente a sus particularidades:

"La primera imagen, que llamaré retrato porque pinta los rasgos espaciales que hacen de la Utopía una individualidad única, es el resultado, hasta en la particularidad de sus edificios, de las contingencias de su geografía y de la historia. La segunda imagen, que llamaré modelo porque conserva de la Utopía solamente características espaciales mal ubicadas y reproducibles, depende, por el contrario, sólo del orden humano y de un estricto sistema de normas culturales. Estas dos imágenes siguen siendo distintas (...), bajando de la escala del territorio a la ciudad y la casa, ${ }^{, 36}$.

El modelo es lo que sirve de objeto de imitación, corresponde a generalidades y se expresa en los conceptos y las formas de sus formulaciones teóricas (Ville Contemporaine, Ville Radieuse, Viaductos y Ciudad de las 7V). Los conceptos incluyen los ideales de universalidad, reproducibilidad y zonificación de usos; las formas, los trazados reguladores esquemáticos cartesianos con referencias de la tradición clásica francesa y la morfología abstracta que se opone a la tradición. El retrato corresponde a la adaptación y transformación de los modelos de acuerdo a contextos específicos, generando una multitud de posibilidades ilustradas por las ciudades que se presentan.

La concepción corbuseana de la ciudad como máquina habitable es tecnicista y funcional y aparentemente contraria a la concepción heideggeriana, según la cual la poesía hace el habitar ${ }^{37}$, originada en la poiésis griega, en referencia al acto poético como un momento de éxtasis, la poesía haciendo del habitar una vivienda. La técnica se deriva de téchne, que significaba "técnica" y "arte". En la era moderna, el arte se aparta de la técnica, ahora confundida con funcionalidad, un requerimiento arquitectónico que se refiere al uso -- la utilitas de Vitruvio.

\footnotetext{
${ }^{35}$ Disponible en: <http://architizer.com/blog/changes-in-store-for-chandigarh/>. Acceso en 4 jun 2015.

${ }^{36}$ Choay, François: "A regra e o Modelo: Sobre a Teoria da Arquitetura e do Urbanismo". São Paulo: Editora Perspectiva, 1985. p. 153.

${ }^{37}$ Heidegger, Martin: "Poéticamente habita el hombre". 1958.

Diponible en: 〈http://olimon.org/uan/heidegger-poeticamente_habita_el_hombre.pdf>. Acceso en: 4 jun 2015. p. 2.
} 
Le Corbusier las reúne aproximándo-se a Heidegger e incluso a Aristóteles: si la Poética del pensador griego es un conjunto de notas sobre el tema de la poesía y el arte, la poética corbuseana es el conjunto de sus obras y planes, cada cual una demonstración de la posible tensión entre el arte y la función.

La poética de su urbanismo surge de la condición transversal de su trabajo creativo, característica sobresaliente de su carrera; es una construcción intelectual hecha a partir de los vínculos establecidos entre las ideas y las imágenes, entre las artes visuales y la arquitectura, entre la historia y la modernidad, entre las vivencias y los deseos; y se traduce en modelo, metáfora y poética para pensar la ciudad. Emerge de las paradojas y contradicciones no resueltas.

Para Le Corbusier, la simple oposición entre el hombre y el poeta de la ciencia es ilusoria ${ }^{38}$. El espacio corbuseano contiene una dimensión funcional y otra artística: la concepción tecnicista del diseño urbano combinada con una visión poética del ser.

En la mayor parte de sus obras, Le Corbusier da expresión artística al conflicto entre la idea clásica de un orden ideal a priori y la noción pragmática (función) que heredó de las tradiciones historicistas y positivistas, expresadas como lo funcional, lo accidental y lo contingente ${ }^{39}$.

Le Corbusier ocupó uno de esos raros momentos en la historia en que parecía que la opinión del artista y del hombre de pasiones convergían hacia un mito colectivo, pero fue más exitoso en la conciliación de sus ideas conflictivas en sus edificios que en su teoría o en sus proyectos urbanos ${ }^{40}$.

En el Congreso CIAM de 1933, sobre el tema de la Ciudad Funcional, las ideas urbanas de Le Corbusier fueron retiradas de su visión poética original y peligrosamente aceptadas e incorporadas en la Carta de Atenas como recomendación normativa, causando un gran impacto en la planificación urbana en su conjunto y paralizando la investigación sobre otros tipos de vivienda después de la Segunda Guerra Mundial ${ }^{41}$.

El nuevo paradigma urbano que propone un nuevo orden formal del espacio social con fuertes rasgos utópicos, influye en la planificación de muchas ciudades del mundo a partir de la segunda mitad del siglo XX. En Brasil, el mejor ejemplo es el Plan Piloto de Brasilia, diseñado por Lucio Costa en 1957.

Hoy en día, las ideas de Le Corbusier, aceptadas o criticadas, pueden ser vistas como un laboratorio urbano ${ }^{42}$ y deben ser reinterpretadas pero nunca olvidadas.

\section{Agradecimientos:}

Este trabajo se realizó con el apoyo de FAPERGS.

\footnotetext{
${ }^{38}$ Colqhoun, Alan: “Modernidad y tradición clásica”. São Paulo: Cosac 7 Naify, 2004. p. 109.

${ }^{39}$ Colqhoun, Alan: "Modernidad y tradición clásica". São Paulo: Cosac 7 Naify, 2004. pp. 86-87.

${ }^{40}$ Colqhoun, Alan: "Modernidad y tradición clásica". São Paulo: Cosac 7 Naify, 2004. pp. 122-182.

${ }^{41}$ Curtis, William: "Le Corbusier: ideas and forms". London: Phaidon, 1986. p. 122.

${ }^{42}$ Von Moss, Stanislaus: "Le Corbusier, Elements of a Syntesis". Rotterdam : 010 Publishers, 2009. Diponible en: $<$ http://books.google.com.br/books?id=X_igJKO7y5kC\&pg=PA50\&hl=pt-

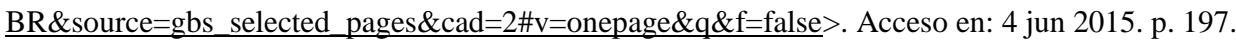




\section{Listado de las imágenes:}

1. Le Corbusier, Ville Contemporaine, 1922. Le Corbusier: Le Grand. London: Phaidon, 2014. p.130.

2. Le Corbusier, Propuestas para Río de Janeiro, Montevideo y Sao Paulo, 1929. Monteys, Xavier: "La gran máquina: la ciudad en Le Corbusier. Barcelona: Ediciones del Serbal, 1996. pp. 182, 178 y 180.

3. Le Corbusier, Ville Radieuse, Plan. Monteys, Xavier. "La gran máquina: la ciudad en Le Corbusier". Barcelona: Ediciones del Serbal, 1996. p. 40.

4. Le Corbusier, Plan de Zlin, 1935. Monteys, Xavier: "La gran máquina: la ciudad en Le Corbusier. Barcelona: Ediciones del Serbal, 1996. p. 238 y análisis de los autores.

5. Le Corbusier, Plan de Argel, 1942. Monteys, Xavier: "La gran máquina: la ciudad en Le Corbusier. Barcelona: Ediciones del Serbal, 1996. p. 186 y análisis de los autores.

6. Le Corbusier, Plan de Chandigarh, 1956. Disponible en: $<$ http://architizer.com/blog/changes-in-store-forchandigarh/>. Acceso en 4 jun 2015.

\section{Referencias Bibliográficas:}

Argan, Giulio Carlo: "Proyecto y Destino”. São Paulo: Editora Ática, 2001.

Choay, François: “El Urbanismo”. São Paulo: Ed. Perspectiva, 1979.

Choay, François: “A regra e o Modelo: Sobre a Teoria da Arquitetura e do Urbanismo”. São Paulo: Editora Perspectiva, 1985.

Cohen, Jean-Louis: “Le Corbusier 1887-1965: El lirismo de la arquitectura en la era mecánica”. Madrid: Tasken, 2009.

Colqhoun, Alan: “Modernidad y tradición clásica”. São Paulo: Cosac \& Naify, 2004.

Curtis, William: “Le Corbusier: ideas and forms”. London: Phaidon, 1986.

Heidegger, Martin: "Poéticamente habita el hombre". 1958. Diponible en: <http://olimon.org/uan/heideggerpoeticamente habita_el_hombre.pdf>. Acceso en: 4 jun 2015.

Le Corbusier: "Por una Arquitectura”. São Paulo: Editora da Universidade de São Paulo, 1973.

Le Corbusier: "Urbanismo”. São Paulo: Martins Fontes, 2011.

Le Corbusier: "Le Grand”. London: Phaidon, 2014.

Frampton, Kenneth: "História Crítica da Arquitetura Moderna”. São Paulo: Martins Fontes, 2003.

Fondation Le Corbusier. Disponiblel en:〈http://www.fondationlecorbusier.fr $>$. Acceso en 4 jun 2015.

Monteys, Xavier: “La gran máquina: la ciudad en Le Corbusier”. Barcelona: Ediciones del Serbal, 1996.

Martins, Carlos: "Una Lectura Critica de Precisiones". En: Le Corbusier: Precisiones sobre un estado presente de la arquitectura y del urbanismo. São Paulo: Cosac \& Naify, 2004.

Von Moss, Stanislaus: "Le Corbusier, Elements of a Syntesis". Rotterdam : 010 Publishers, 2009. Diponible en: $<$ http://books.google.com.br/books?id=X_igJKO7y5kC\&pg=PA50\&hl=pt-

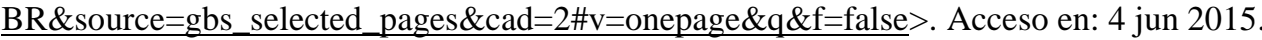




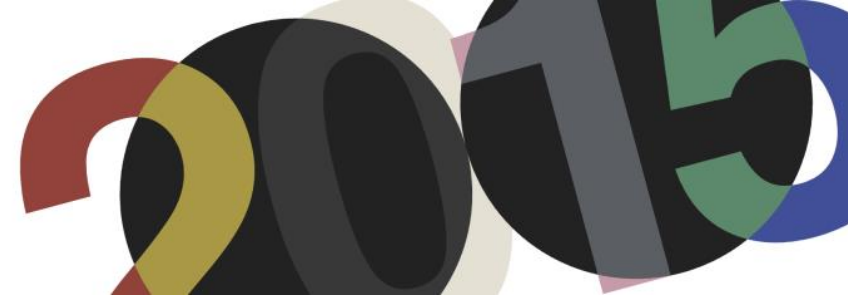

DOI: http://dx.doi.org/10.4995/LC2015.2015.827

\title{
Complejidad y contradicción en Le Corbusier
}

\author{
R. Such Sanmartín
}

Escola Tècnica Superior d'Arquitectura de Barcelona

Resumen: En 1966 Robert Venturi publica Complexity and Contradiction in Architecture. Este libro representa uno de los alegatos más severos contra las limitaciones de la arquitectura moderna. Concebido como un ensayo visual, mediante una colección de ejemplos de épocas y lugares muy heterogéneos, las tesis de Venturi denotan una fuerte animadversión hacia las posiciones funcionalistas de la ortodoxia moderna. De entre todas las obras que lo ilustran, Le Corbusier aparece paradójicamente como el arquitecto al que más se alude y la Villa Savoye, por sorpresa, como la obra de referencia. Frente a la lectura establecida y canónica de la arquitectura de Le Corbusier, el análisis de Venturi supone una mirada fresca y alternativa de sus posiciones teóricas. A través de sus estrategias basadas en la fenomenología de la complejidad y la contradicción, Venturi descubre la arquitectura tensa y vibrante de Le Corbusier que, sin renunciar nunca a sus convicciones modernas, tampoco sucumbió ante ellas.

Abstract: In 1966 Robert Venturi publishes Complexity and Contradiction in Architecture. This book represents one of the most serious allegations against the limitations of the modern architecture. Conceived as a visual essay, with a collection of examples from different times and places, the text of Venturi denotes a strong hostility against the functionalist positions of the orthodox Modern architecture. Paradoxically, in the book of Venturi, Le Corbusier appears as the most mentioned architect and the Villa Savoye -by surprise- as the most quoted work. In opposition of the classical view of Le Corbusier's work, the analysis of Venturi represents a new fresh look and alternative view of his theoretical positions. Through his multiple strategies based on the phenomenology of complexity and contradiction, Venturi discovered the intense and vibrant architecture of Le Corbusier who, without ever renouncing his modern convictions, he didn't succumb to them.

Palabras clave: Le Corbusier, Venturi, Complejidad y contradicción, Norma y transgresión. Keywords: Le Corbusier, Venturi, Complexity and Contradiction, Norm and Transgression.
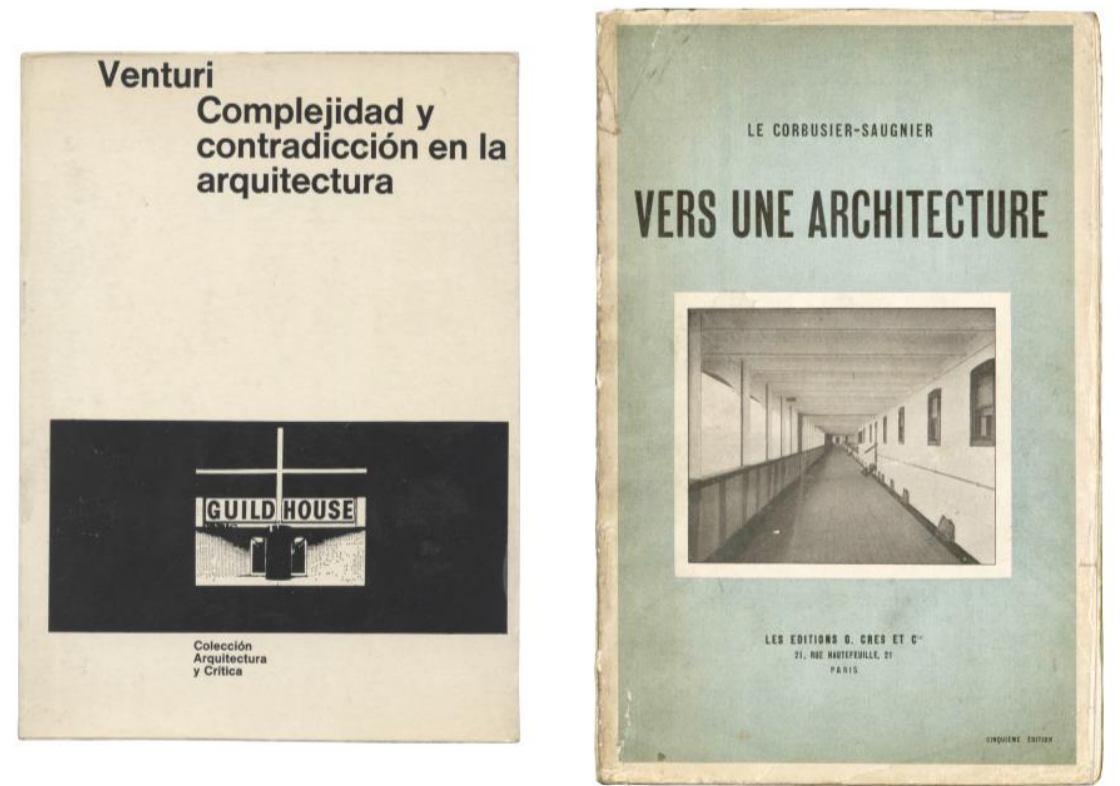

1. Venturi, Robert: Complejidad y contradicción en la arquitectura. Barcelona: Gustavo Gili, 1974 (portada) y Le Corbusier: Vers une architecture. Paris: Crès, 1923 (portada). @ FLC-ADAGP 


\section{Introducción}

En 1966, un año después de la muerte de Le Corbusier en Roquebrune-Cap-Martin, Robert Venturi publica Complexity and Contradiction in Architecture ${ }^{1}$. Este libro, presentado literalmente por su autor como "una defensa en favor de una arquitectura equívoca", significa uno de los reproches más severos a la pureza y simplificación de la arquitectura moderna. Trazado mediante el análisis comparativo de obras de toda la historia, con una especial inclinación por la arquitectura del Manierismo, Barroco y Rococó, el libro se levanta contra las posiciones reduccionistas modernas, en defensa de una arquitectura basada en la fenomenología de la complejidad y la contradicción. Las tesis de Venturi finalmente muestran su contraste con los principios de la ortodoxia moderna y todo el libro denota una especial animadversión hacia sus figuras insignes. De las 253 obras que lo ilustran ${ }^{3}$, Le Corbusier aparece paradójicamente como el arquitecto al que más se alude y la Villa Savoye, por sorpresa, como la obra más referenciada.

Vincent Scully, autor de la introducción, es el primero en señalar esta tensión entre ambos a través de la comparación del libro con Vers une architecture. Le Corbusier representa el arquitecto heroico de principios de siglo, conducido por el rigor cartesiano y la precisión geométrica, y que encuentra en el templo griego y el referente de la máquina el paradigma del ideal moderno. Venturi, por el contrario, en contraste con el purismo moderno, se apega a una cultura del fragmento y lo coyuntural, y descubre, en las antiguas fachadas de las ciudades de Italia, el arquetipo de un modelo opuesto.

Las posiciones de Venturi y Le Corbusier representan los dos extremos de la arquitectura del siglo XX y, aunque a priori, sus principios aparentan ser dos modelos irreconciliables, ya desde los primeros compases del libro, el propio Venturi se cuida de desmentirlo. Para él, la arquitectura de Le Corbusier finalmente se distingue del resto de la ortodoxia moderna y se coloca en el territorio de la ambigüedad, como una de las que mejor ejemplifican las tesis de su libro. ¿Pero a qué se refiere Robert Venturi cuando alude a la noción de complejidad y contradicción en Le Corbusier?

\section{Vers une architecture y Complexity and Contradiction in Architecture}

Vers une architecture y Complexity and Contradiction in Architecture son probablemente los dos libros más importantes e influyentes de Le Corbusier y Robert Venturi. Ambos están escritos como un manifiesto y, por distintos caminos, representan un punto y aparte respecto a las posiciones culturales anteriores. En la

\footnotetext{
1 Robert Venturi publica Complexity and Contradiction in Architecture en 1966 aunque como se indica en los agradecimientos del libro lo redacta mayoritariamente en 1962, gracias a una estancia en Roma patrocinada por la Graham Foundation for Advanced Studies in The Fine Arts. La edición norteamericana corre a cargo del Museo de Arte Moderno de Nueva York en colaboración con la Graham Foundation y se reedita de nuevo en 1977 y en 2002, con algunas modificaciones en el formato y el tamaño de las ilustraciones. En 1972, se publica por primera vez la versión en castellano, editada por Gustavo Gili y con una compaginación distinta de la versión norteamericana pero respetando en todo momento su espíritu original. Para la elaboración de este artículo, tanto para los textos como para las imágenes, se ha utilizado la segunda edición en castellano de 1974.

${ }^{2}$ Venturi, Robert: Complejidad y contradicción en la arquitectura. Barcelona: Gustavo Gili, 1974. pp. 25.

${ }^{3}$ El libro cuenta con 350 ilustraciones repartidas en once capítulos. En los diez primeros capítulos Robert Venturi desarrolla las tesis principales del libro y se sirve de 253 ilustraciones. En el último capítulo se expone íntegramente la obra del despacho Venturi-Scott Brown Associates con 97 ilustraciones. Le Corbusier aparece ilustrado en los diez primeros capítulos hasta en once ocasiones y, junto con Miguel Ángel y Alvar Aalto, es el arquitecto más referenciado.
} 
introducción del libro de Venturi, Vincent Scully llega a afirmar que se trata del texto "más importante sobre arquitectura desde Vers une architecture”, y sugiere con ello, la comparación entre ambos. (Fig. 01).

Vers une architecture se publica en 1923 como una serie compilada de artículos escritos por Le Corbusier y Amédeé Ozenfant para la revista L'Esprit Nouveau. El texto no es tanto un ensayo de crítica como un manifiesto ideológico sobre la arquitectura de su tiempo. Está escrito con mensajes directos y concisos, y viene articulado por numerosas ilustraciones que, a modo de eslóganes, infunden un fuerte tamiz ideológico. Le Corbusier pone un gran acento en la medida y formato de estas ilustraciones, pero sobretodo en su selección: edificios industriales como almacenes, elevadores de grano o silos, se combinan con los grandes avances de la máquina como automóviles, aviones o barcos. Continuamente se incentiva a la analogía entre las formas de la industria con las grandes formas monumentales del pasado. En la selección de Le Corbusier, se destila su predilección por las formas primarias, geométricas y regulares de la Antigüedad en conjunción con la precisión y exactitud del mundo de la industria. Con ello, se evoca una arquitectura heroica y monumental.

Complexity and Contradiction in Architecture se publica en 1966 a través del patrocinio del Museo de Arte Moderno, aunque se escribe mayoritariamente en 1962 gracias a una beca que recibe Venturi de la Graham Foundation para la Academia Americana de Roma. El libro es fundamentalmente un ensayo de crítica arquitectónica basado en el método comparativo entre obras. En la heterogénea selección que propone Venturi se yuxtaponen arquitecturas nuevas con otras antiguas, proyectos de escalas muy dispares y obras afectadas por todo tipo de contextos, en una actitud coleccionista de acumulación y mezcla que contrasta con la selección iterativa y metódica de Le Corbusier ${ }^{5}$.

No hay ninguna duda de que la historia es el referente conceptual de ambos libros y, en determinados pasajes, llegan incluso a coincidir en obras, sitios o personajes comunes, como es el caso de la ciudad de Roma, Santa María Cosmédin o la obra de Miguel Ángel ${ }^{6}$. Una relación con la historia y el pasado que transita sin embargo por direcciones opuestas. Mientras Le Corbusier se detiene en la mirada serena y monumental de la Antigüedad, en la geometría de las grandes construcciones del pasado, Venturi se interesa en cambio en los edificios complejos e irregulares, afectados por las situaciones urbanas donde se inscriben. Uno comprende la ciudad desde su dimensión urbana y monumental, como el conjunto de formas abstractas que la completan, mientras que el otro se deja seducir por la irregularidad de su trama, experimentando la ciudad como un tejido complejo y entrelazado. El primero aprende de la proporción, el ritmo o la geometría de las grandes obras, mientras que el segundo se interesa en su dimensión colosal, la desproporción o el gigantismo. No es de extrañar, entonces, que los ejemplos negativos del Barroco que Le Corbusier denunció en Rome des horreurs ${ }^{7}$ fueran probablemente los que más pudiesen cautivar a Venturi.

Con todo, Vers une architecture y Complexity and Contradiction in Architecture representan, cada uno desde sus posiciones, dos miradas confrontadas y opuestas de la arquitectura del siglo XX. La primera consolida la lectura arquetípica del Movimiento Moderno, impregnada por el referente de la máquina y la idealización del pasado; mientras que la segunda, a través de la fenomenología de la complejidad y la contradicción, se confronta

\footnotetext{
${ }^{4}$ Venturi, Robert: Complejidad y contradicción en la arquitectura. Barcelona: Gustavo Gili, 1974. pp. 9.

${ }^{5}$ En sus respectivos libros, Le Corbusier y Venturi reflejan dos actitudes contrapuestas en la selección y el tratamiento de sus ilustraciones. De la misma manera, también es opuesta la relación con su obra propia. Mientras Le Corbusier intercala obras y proyectos en el discurso teórico del libro, Venturi lo excluye, y concentra la obra en un último capítulo independiente.

${ }^{6}$ Monteys Roig, Xavier: Robert Venturi: Complexity and Contradiction in Architecture (1966). Més no és menys. Conferencia dentro del curso Construït amb paraules: Teories i textos d'arquitectes del segle XX, 2009.

${ }^{7}$ Le Corbusier: Hacia una arquitectura. Barcelona: Ediciones Apóstrofe, 1998. pp.139.
} 
con ella. Como veremos, Le Corbusier, en tanto que uno de los principales portavoces de las posiciones modernas, aparece un primer momento en el foco de las críticas de Venturi para finalmente, colocarse en el centro de gravedad de su tesis.

\section{Tensión y contradicción. Robert Venturi y el análisis de la arquitectura de Le Corbusier}

No es una coincidencia que Robert Venturi apoye las principales tesis de su libro en la obra de Le Corbusier. Si bien, a priori, su arquitectura representa muchas de las simplificaciones contra las que Venturi arremete, una aproximación más profunda revela cómo esta se fundamenta en el contrario, en conceptos cargados de contradicción y complejidad. A la simplificación inicial que sugieren sus volúmenes puros y sus formas platónicas, su arquitectura yuxtapone una fuerte complejidad en su funcionamiento interno, en la organización del programa o en los mecanismos que despliega para recorrerla. Esta doble tensión entre lo que a primera vista promete y lo que finalmente acontece despierta la atención de Venturi y desencadena el análisis de sus principales estrategias proyectivas. Tras reparar en una primera cuestión sobre la "percepción de la arquitectura", el análisis de Complexity and Contradiction in Architecture se detendrá en la dualidad entre el interior y el exterior, el papel de la estructura como orden configurador y en la fuerte contradicción que algunos de los principios teóricos de Le Corbusier acaban manifestando.

\subsection{Percepción y ambigüedad}

La primera clasificación de Complexity and Contradiction in Architecture se detiene en la fenomenología de la percepción o la contrariedad que producen algunas arquitecturas cuando son experimentadas. Se trata de un concepto que Venturi denomina ambigüedad perceptiva o la discrepancia que se detecta entre "lo que una imagen es y lo que parece ser" ${ }^{\prime 8}$. Venturi observa cómo detrás de la claridad que aparentan las geometrías regulares y las formas puras de Le Corbusier, se esconde una interesante ambigüedad geométrica, que no hace sino enriquecerlas. En relación a la geometría de la Villa Savoye, Venturi se cuestiona: "La Villa Savoye: ¿es una planta cuadrada o no?"' (Fig. 02).

Desde sus primeros proyectos en los años veinte hasta sus últimas propuestas para la India o Venecia, la precisión matemática y la exactitud geométrica han sido una constante que ha recorrido toda la arquitectura de Le Corbusier. Si hay alguna cosa que emparenta sus distintos tipos de producción a lo largo de su trayectoria es precisamente este interés disciplinar por lo regular y lo exacto, por las formas ideales que derivan del cálculo. Son numerosos y conocidos los sistemas que Le Corbusier puso en marcha para garantizar este control sobre la proporción y la geometría; desde los Trazados Reguladores, "Les 4 compositions" o el sistema de proporciones Modulor, por citar algunos de los mecanismos más conocidos. Para Le Corbusier, la búsqueda de la precisión se convirtió finalmente en un ideal que perseguir, aunque, como veremos, para él no fue tan importante alcanzarlo como conseguir aparentarlo.

En Complexity and Contradiction in Architecture, Venturi es el primero en señalar cómo esta búsqueda de la precisión por parte de Le Corbusier no está absenta de contradicción. Mientras que, efectivamente, a primera vista, su arquitectura parece responder a un trazado geométrico y regular, donde un fuerte sentido de la proporción y lo racional parece gobernar todo el proyecto, sus obras terminan finalmente por incorporar

\footnotetext{
${ }^{8}$ Venturi, Robert: Complejidad y contradicción en la arquitectura. Barcelona: Gustavo Gili, 1974. pp. 33.

${ }^{9}$ Venturi, Robert: Complejidad y contradicción en la arquitectura. Barcelona: Gustavo Gili, 1974. pp. 35.
} 
impureza y adaptación, distorsionando sutilmente su trazado original. Venturi constata cómo las geometrías claras y regulares de sus proyectos están continuamente deformadas por las numerosas adaptaciones que todo encargo debe afrontar.
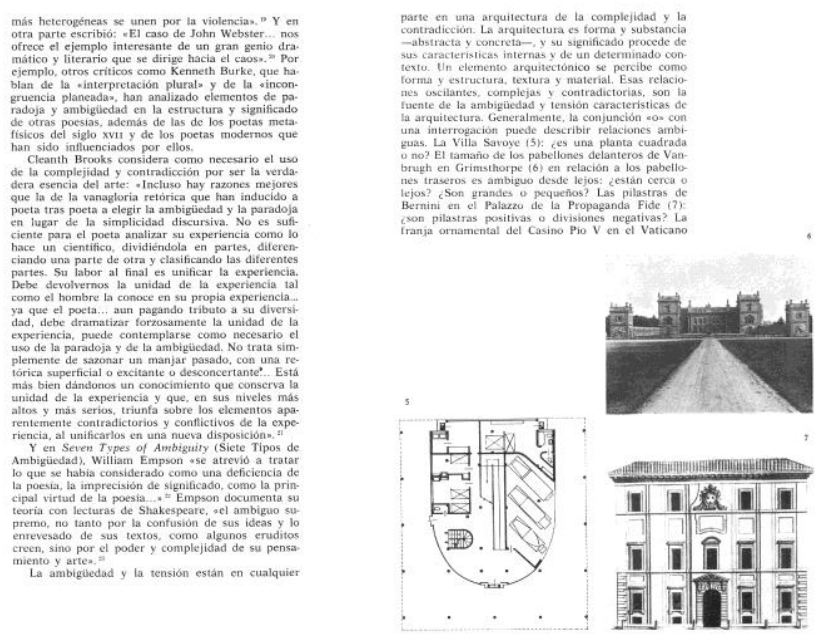

2. Venturi, Robert: Complejidad y contradicción en la arquitectura. Barcelona: Gustavo Gili, 1974, pp. 34 y 35.

En algunas ocasiones, estas adaptaciones vienen determinadas por el sitio o las condiciones dificiles del programa, mientras que, en otras, son producto de una cierta inconsistencia técnica que el propio Le Corbusier llegó a reconocer. En definitiva, se trata de numerosas variables que finalmente alteran la pureza inicial con la que sus geometrías habían sido concebidas en origen pero que no modifican sin embargo el aspecto general de precisión y regularidad de toda la obra. Con todo, la tesis de Venturi acaba por desvelar cómo la arquitectura de Le Corbusier no está tan interesada en la precisión matemática de las formas puras sino en tratar de aparentarla. Se podría afirmar, entonces, que Le Corbusier no persigue tanto el rigor geométrico que deriva del cálculo exacto, sino la capacidad que este tiene para evocar un nuevo vocabulario simbólico -técnico, exacto, precisoque sirva para expresar el lenguaje de la nueva arquitectura ${ }^{10}$.

\subsection{Dualismo: interior y exterior}

Al margen de estas primeras observaciones sobre "percepción" y "ambigüedad", el texto de Venturi también distingue otras estrategias proyectivas de Le Corbusier que parecen fundamentarse en fenómenos contradictorios. Uno sobre el que se detiene más vivamente es la fuerte dualidad que se experimenta en la gran mayoría de sus obras. En relación a este fenómeno, Venturi describe: “La casa Shodan de Le Corbusier es cerrada, aunque es abierta; un cubo cerrado por sus esquinas pero abierto por sus superficies; su Villa Savoye

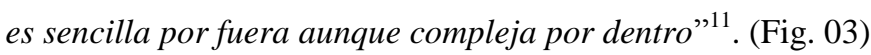

\footnotetext{
${ }^{10}$ Torres Cueco, Jorge: Le Corbusier: visiones de la técnica en cinco tiempos. Barcelona: Fundación Caja de Arquitectos, 2004. pp. 11.

${ }^{11}$ Venturi, Robert: Complejidad y contradicción en la arquitectura. Barcelona: Gustavo Gili, 1974. pp. 37.
} 
En términos generales, la arquitectura de Le Corbusier expresa una fuerte tensión entre lo que acontece en el exterior y en el interior del proyecto, es decir, entre la percepción exterior del volumen y la experiencia interior del espacio. Como ya se ha observado, desde fuera, su arquitectura se define a través de volumetrías simples y formas regulares; una complexión compacta y prismática que viene contrastada por unos interiores entretejidos y complejos, cargados de una fuerte profundidad espacial.
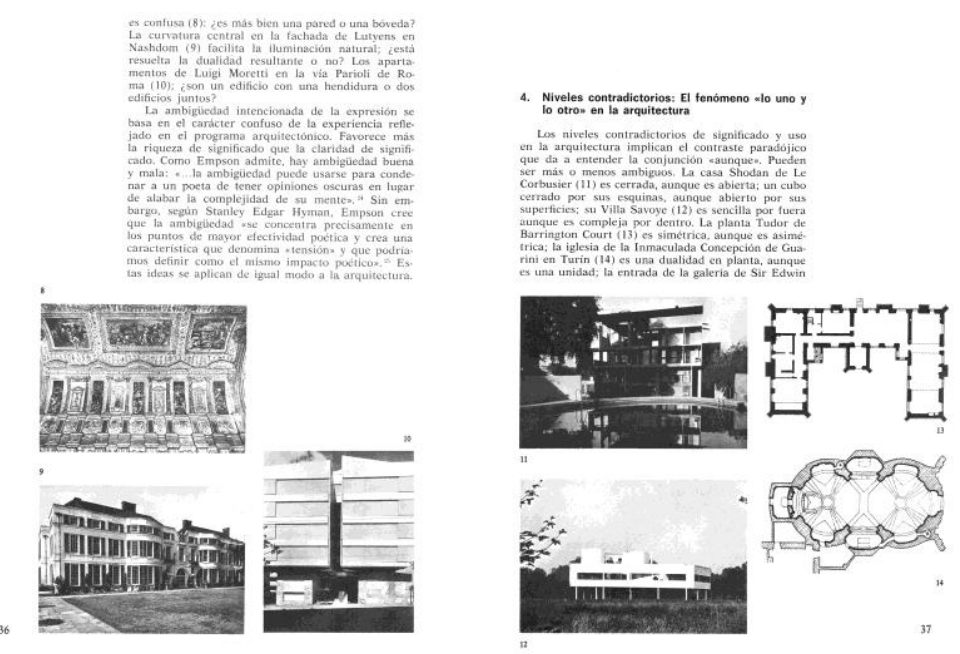

3. Venturi, Robert: Complejidad y contradicción en la arquitectura. Barcelona: Gustavo Gili, 1974, pp. 36 y 37.

Basta con pensar en alguno de sus primeros proyectos como la Villa Savoye o la Villa Stein para dar cuenta de esta circunstancia: mientras que por fuera la arquitectura se articula como piezas compactas y cerradas, "cajas prismáticas", sus interiores, en cambio, son abiertos y complejos, formas curvas, espacios a doble altura, rampas en trazado diagonal, etc. Venturi lo describe así en la Villa Savoye: "Su severo exterior, casi cuadrado, rodea una confusa configuración interior que se vislumbra a través de aberturas y de los salientes de arriba. En este contexto la imagen tensa de la Villa Savoye por dentro y por fuera muestra una resolución contrapuntual con una envoltura rígida parcialmente interrumpida y un interior complejo parcialmente revelado" ${ }^{2}$.

Este sentido de la dualidad entre interior y exterior no será, no obstante, un invariable en la arquitectura de Le Corbusier y, a lo largo de su trayectoria, se puede ir rastreando su evolución y progreso. Le Corbusier irá transformando el carácter cúbico y cerrado de sus primeras volumetrías de los años veinte para incorporar progresivamente, en las obras maduras, distintos grados de apertura y porosidad, hasta el punto de confirmar que, entre unas y otras, se invierten sus características formales, y se muestran posiciones simétricamente opuestas. $^{13}$

En Complexity and Contradiction in Architecture, Venturi dedica numerosos pasajes a esta cuestión de la envolvente, y pone precisamente el acento en los numerosos recursos compositivos que utiliza Le Corbusier: el subrayado de las aristas del perímetro, el perfilado de las esquinas o los salientes en cubierta que contrapuntúan el volumen general. Asimismo, es sobradamente conocido cómo, en ocasiones, todo el volumen se levanta del

\footnotetext{
${ }^{12}$ Venturi, Robert: Complejidad y contradicción en la arquitectura. Barcelona: Gustavo Gili, 1974. pp. 111.

${ }^{13}$ Un aspecto que ha sido desarrollado en: Cortés, Juan Antonio: "La caja y el parasol”. En Cortés, Juan Antonio (Comp.): Lecciones de equilibrio. Barcelona: Fundación Caja de Arquitectos, 2006. pp. 78-95.
} 
suelo natural para enaltecer esta condición de "objeto aislado" y ensimismado. Pero esta atención sobre la envolvente no surge exclusivamente como un recurso plástico o expresivo sino que, como detecta Venturi, se convierte también en un verdadero mecanismo de control y unidad de la propuesta. De esta forma, la envolvente continua actúa como un verdadero marco rígido que garantiza la estabilidad formal del proyecto al tiempo que permite el despliegue espacial de su interior. En el caso de la Villa Savoye, por ejemplo, las cuatro fachadas casi idénticas- caracterizadas por sus rasgadas ventanas apaisadas, no solamente definen la envolvente exterior sino que regulan la compleja red de espacios y elementos que la configuran. La casa no renuncia entonces a un programa ambicioso y diverso, de una alta complejidad espacial, pero tampoco a la claridad exterior de un proyecto unitario y sereno. Venturi lo define así: "La planta de la Villa Savoye es un ejemplo de contención de muchas complejidades dentro de un marco rígido. Algunas plantas de otras casas suyas de los años 20 nos sugieren que se empezó a trabajar por la estructura para pasar luego al interior"14. Y continúa: "Su orden interior se adapta a las funciones múltiples de una casa, a escala doméstica y al misterio parcial inherente a la sensación de privacidad. Su orden exterior expresa la unidad del concepto de casa en una escala apropiada para el terreno que dominaba y para la ciudad que probablemente un día formará parte de ella "15.

\subsection{Orden e irregularidad}

Uno de los rasgos más significativos de la obra de Le Corbusier, y probablemente sobre el que más ha insistido la crítica, es su elevada capacidad de sistematización. "No hay ninguna obra de arte sin un sistema" 16 , parafrasea Venturi sobre Le Corbusier, a propósito de esta condición de su arquitectura. Al revisar cualquiera de los proyectos u obras construidas de Le Corbusier, uno descubre numerosos principios y reglas metodológicas que gobiernan las trazas de su arquitectura. Al margen de su inagotable instinto creativo, en Le Corbusier se reconoce una sólida actividad reflexiva que le sirvió continuamente de alimento y sustrato teórico. Una actividad que cultivó de manera persistente durante toda su trayectoria y que se concretó en numerosos ensayos y escritos de arquitectura, pero que, en sus proyectos, también tomó la forma de un sistema de reglas y principios procedimentales: un sistema normativo. Leonardo Benevolo ya había advertido sobre ello al descubrir que se trataba del "único arquitecto moderno que definió la arquitectura en términos de un sistema reglas" " Sin ninguna duda, en Le Corbusier podemos hablar de una preceptiva poética, es decir, un conjunto de directrices y reglas de procedimiento que sirvieron de marco epistemológico y sustento teórico de su arquitectura.

Entre las numerosas aportaciones teóricas que Le Corbusier desarrolló a lo largo de su trayectoria destaca la sistematización que llevó a cabo en el plano del espacio y la estructura y, más concretamente, en las ambiciosas propuestas de la pareja Dom-ino y Citrohan y los Cinco puntos para una nueva arquitectura. Sin ninguna duda, en estas dos propuestas se destilaron una serie de principios estructurales y espaciales que sentaron las bases de toda su producción posterior.

Esta dimensión sistemática y metodológica no pasó tampoco inadvertida para Robert Venturi y en Complexity and Contradiction in Architecture se refiere a ella en numerosas ocasiones. Venturi descubre cómo en la obra de Le Corbusier existe un fuerte principio axiomático que rige la gran mayoría de sus obras. Se trata de una especie de método dominante basado en la malla o la retícula organizativa. Venturi se refiere a ella a través de la célebre

\footnotetext{
${ }^{14}$ Venturi, Robert: Complejidad y contradicción en la arquitectura. Barcelona: Gustavo Gili, 1974. pp. 116.

${ }^{15}$ Venturi, Robert: Complejidad y contradicción en la arquitectura. Barcelona: Gustavo Gili, 1974. pp. 111.

${ }^{16}$ Venturi, Robert: Complejidad y contradicción en la arquitectura. Barcelona: Gustavo Gili, 1974. pp. 64.

${ }^{17}$ Colquhoun, Alan: "Desplazamiento de conceptos en Le Corbusier". En Colquhoun, Alan (Comp.): Arquitectura moderna y cambio histórico. Barcelona: Gustavo Gili, 1978. pp. 113-175.
} 
confrontación del par retícula-gesto, donde se puede discernir entre el orden geométrico y estructural de la malla de pilares y la compartimentación libre que fluctúa entre ellos. En su escrito, Venturi lo explica a través de la comparación: "Le Corbusier en la Villa Savoye adapta las irregularidades circunstanciales y excepcionales a un método, por otro lado rígido y dominante [la retícula]. Pero Aalto, en contraste con Le Corbusier, casi parece crear el orden de las irregularidades, como puede verse en el centro Cultural de Wolfsburg, (...) Mies no permite que nada se introduzca en la regularidad de su orden del punto, línea y plano",I8.

El método dominante y rígido al que se refiere Venturi alude directamente a la idea de la retícula organizadora y, por consecuencia, a uno de los grandes sistemas teóricos que Le Corbusier desarrolló a principios de los años veinte: el sistema Dom-ino de losas de hormigón apoyadas sobre pilares. Como es conocido, de este sistema estructural deriva todo el corolario compositivo de los Cinco puntos para una nueva arquitectura, entre los que se encuentra la malla ordenadora que permite la planta libre. Así, Venturi otorga la condición de "método" a la retícula estructural, consciente que determina todo el aparato compositivo-espacial de la arquitectura de Le Corbusier.

Pero en el mismo momento que Venturi enuncia la importancia de construir un método - una norma-, expresa simultáneamente la necesidad de transgredirla. "Uno levanta un orden y luego lo destruye"19. Para Venturi, el método que gobierna cualquier proyecto debe ser dominante pero no inflexible y este finalmente debe adaptarse a la realidad con la que convive. "Un orden válido se adapta a las contradicciones circunstanciales de una realidad compleja ${ }^{, 20}$. Venturi ejemplifica algunas de estas transgresiones otra vez a través de la Villa Savoye: "En la Villa Savoye las posiciones de algunas de las columnas en el sistema regular de intercolumnios se ajustan ligeramente para adaptarse a las necesidades espaciales particulares: una columna se desplaza y otra se suprime. (...) Hoy Le Corbusier es un maestro de la excepción significativa, (...). Rompe el orden de los intercolumnios de la planta baja de la Villa Savoye moviendo una columna y removiendo otra, como he mostrado, para adaptar las circunstancias excepcionales implicadas en el espacio y la circulación. En este elocuente compromiso, Le Corbusier hace más viva la regularidad dominante de la composición "21.

En la Villa Savoye, la transgresión a la malla regular de pilares es precisamente lo que permite absorber las condiciones difíciles del programa. En el garaje, efectivamente, una de las columnas se desplaza, y permite, de este modo, la entrada de coches, y en la parte central de su planta, la retícula se desdobla para incorporar la rampa. Se trata, entonces, de dos distorsiones a la malla que cancelan su regularidad, pero que finalmente refuerzan su carácter ortogonal. "El significado puede reforzarse si se rompe el orden; las excepciones indican la presencia de la regla”22. De esta manera, Venturi descubre cómo la transgresión a la norma, más allá de contradecir la regla, acaba finalmente por reforzar su significado y, con ello, de nuevo se confirma que, para Le Corbusier, la adaptación del método, su capacidad para ajustarse a la realidad, vuelve a ser más trascendente que el método en sí mismo.

\footnotetext{
${ }^{18}$ Venturi, Robert: Complejidad y contradicción en la arquitectura. Barcelona: Gustavo Gili, 1974. pp. 64.

${ }^{19}$ Venturi, Robert: Complejidad y contradicción en la arquitectura. Barcelona: Gustavo Gili, 1974. pp. 63.

${ }^{20}$ Venturi, Robert: Complejidad y contradicción en la arquitectura. Barcelona: Gustavo Gili, 1974. pp. 63.

${ }^{21}$ Venturi, Robert: Complejidad y contradicción en la arquitectura. Barcelona: Gustavo Gili, 1974. pp. 77.

${ }^{22}$ Venturi, Robert: Complejidad y contradicción en la arquitectura. Barcelona: Gustavo Gili, 1974. pp. 64.
} 


\subsection{Grados de contradicción: combinación y mezcla}

La arquitectura de Le Corbusier nunca renunció a nada. A diferencia de otros contemporáneos suyos, su obra se experimenta desde un pensamiento inclusivo, sin restricciones, con una clara voluntad de incorporar en ella el máximo de situaciones y elementos simultáneos posibles. Como postula Venturi, su obra parece admitir lo uno y lo contrario, en una especie de dualismo integrador sobre el que ya se ha insistido. Algunos de los ejemplos de los que se sirve Venturi en Complexity and Contradiction in Architecture apuntan claramente hacia esta dirección, y reflejan su vocación contradictoria. Otros, sin embargo, parecen incluso ir un poco más allá, registrando nuevas situaciones de naturaleza inusitada.

Hasta el momento nos hemos detenido en aquellos aspectos contradictorios que subrayan las transgresiones sobre el método: la excepción a la regla. (Pensemos de nuevo en el desplazamiento de pilares que permite la entrada de coches en el garaje de la Villa Savoye y que hemos descrito anteriormente). Pero en Le Corbusier existen también otros aspectos que parecen sugerir una idea de contradicción más ambiciosa y profunda, pero igualmente productiva: la combinación entre sistemas. En efecto, en Le Corbusier no solamente hay transgresiones sobre el método, sino que también se superponen o combinan en un mismo proyecto varios métodos operativos; como si dos órdenes de naturaleza distinta pudiesen convivir en un mismo escenario.

En relación a este tipo de combinaciones, Venturi utiliza el Palacio de la Asamblea de Chandigarh -una de las obras maduras de Le Corbusier- para ejemplificarlo. En este proyecto, Venturi destaca como la retícula de pilares regulares debe convivir con otra estructura de naturaleza distinta, como es la producida por la gran sala cónica de la Asamblea. En este caso, la retícula no se distorsiona como en la Villa Savoye, sino que se ajusta con arreglo con la sala interior. Al revisar con atención la planta del proyecto, uno detecta cómo Le Corbusier yuxtapone a la malla de pilares, el gran cilindro murario de la sala, y hace convivir así en un mismo proyecto dos estructuras distintas: pilares puntuales con muros de carga, o dicho en otras palabras: una estructura de muros de carga dentro de una planta libre Dom-ino. Así lo describe: “En el palacio de Le Corbusier de las Dos Asambleas en Chandigarh el hall de la asamblea cónica, apretujado en la malla rectangular, representa una supercontiguidad tridimensional de un tipo muy violento"23. Y continúa: "En el edificio de la Asamblea aunque la red de columnas también se ajusta a la excepcional forma plástica de la sala de la Asamblea, en la yuxtaposición de ambas la sala y la red de columnas no se adaptan: la yuxtaposición es violenta y sin concesiones mutuas, no solo en planta sino también en sección, donde se puede apreciar que la sala ha sido violentamente colocada en la retícula,"24. (Fig. 04)

Venturi denomina, a este tipo de yuxtaposición, contradicción adaptada, puesto que se superponen violentamente sistemas de naturaleza diferente. Se empieza a detectar entonces que la arquitectura de Le Corbusier no solamente es capaz de admitir deformaciones e inflexiones en su estructura, -transgresiones sobre el método-, sino que también permite la convivencia de sistemas de naturaleza contraria, como el que se expresa en el proyecto de Chandigarh. Muros y pilares conviven en este proyecto con naturalidad, haciendo más viva la percepción del espacio y manifestando uno de los casos más tensos de contradicción estructural.

\footnotetext{
${ }^{23}$ Venturi, Robert: Complejidad y contradicción en la arquitectura. Barcelona: Gustavo Gili, 1974. pp. 88.

${ }^{24}$ Venturi, Robert: Complejidad y contradicción en la arquitectura. Barcelona: Gustavo Gili, 1974. pp. 64.
} 

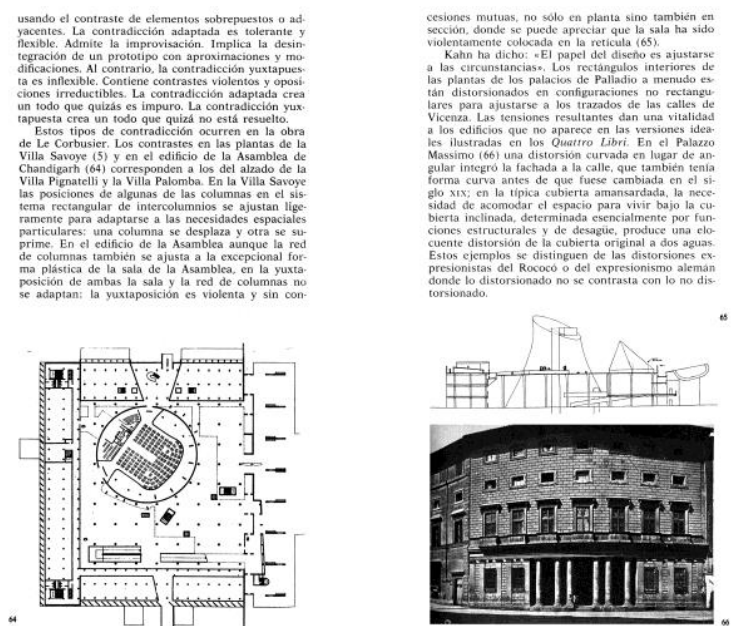

4. Venturi, Robert: Complejidad y contradicción en la arquitectura. Barcelona: Gustavo Gili, 1974, pp. 74 y 75.

Al observar este tipo de combinaciones, no obstante, uno no puede dejar de asombrarse por el cinismo o la capacidad de autoengaño que manifestaba Le Corbusier en sus proyectos. Resulta especialmente sorprendente comparar las combinaciones de sistemas que se producen en algunas de sus obras más importantes en relación con los principios ideológicos que él mismo había defendido en origen. Así, al volver la mirada sobre sus primeras declaraciones teóricas, encontramos un Le Corbusier inquebrantable, puro, incapaz de admitir superposiciones; donde los principios teóricos son formulados de manera destilada y analítica: sin contradicciones. Basta con pensar, por ejemplo, en la tabla de los Cinco puntos y la intransigencia que muestra Le Corbusier en relación a la posibilidad de utilizar muros de carga para alcanzar una arquitectura verdaderamente moderna.

Pero mientras el ideario teórico de Le Corbusier discurre por un camino, su puesta en práctica, en cambio, transcurre por otro. Así, mientras que las posiciones teóricas de Le Corbusier invalidan cualquier posibilidad de combinación, su obra en cambio, la acepta con naturalidad y de manera inclusiva. No es necesario repasar la cantidad de proyectos donde esta mezcla de sistemas -Dom-ino y Citrohan- aparece en combinación. Con todo, emerge de nuevo el contraste entre el Le Corbusier de sus posiciones teóricas -axiomático, purista, analítico--, en contraposición al Le Corbusier que tanto apreció Venturi en sus obras -sincrético, vitalista, contradictorio-.

\section{Conclusiones}

Complexity and Contradiction in Architecture aparece en escena en un momento histórico en el que los principios del Movimiento Moderno ya están consolidados y son ampliamente difundidos. La imagen canónica de Le Corbusier, encarnado en el gran héroe moderno, termina de apuntalar los cimientos de la denominada ortodoxia moderna. Frente a esta mirada reduccionista y estereotipada, en su libro, Robert Venturi opone una lectura renovada y sin complejos de la arquitectura de Le Corbusier, mucho más interesada en los conceptos que despliegan sus obras que no en las ideas puristas que este finalmente pretendió defender en sus escritos.

Desde esta perspectiva, las tesis del libro, lejos de interpretarse como otra crítica más a los principios de la modernidad, pueden ser vistas, entonces, como el mejor de sus complementos a lo largo del tiempo ${ }^{25}$. El propio

\footnotetext{
${ }^{25}$ Venturi, Robert: Complejidad y contradicción en la arquitectura. Barcelona: Gustavo Gili, 1974. pp. 9.
} 
Venturi, ya había insistido en esta dirección al considerar recientemente la Villa Savoye como su "edificio favorito del siglo $X X^{\prime 26}$. Con esta reveladora apreciación final, la obra más paradigmática del Movimiento Moderno se convertía, al mismo tiempo, en la ilustración complementaria de las posiciones contrarias defendidas por Venturi, y alcanzaría con ello una suerte de reconciliación.

En el análisis de la obra de Le Corbusier, Robert Venturi descubre una arquitectura tensa y vibrante que se aleja de los principios reduccionistas modernos con los que a primera vista parecía estar formulada. Venturi es uno de los primeros teóricos en señalar cómo Le Corbusier finalmente no renuncia a sus convicciones modernas, pero tampoco cede ante ellas, y sus proyectos, si bien tienen un método dominante y de apariencia rígida, admiten numerosas dosis de complejidad y contradicción. Se revela entonces, que mientras su arquitectura se levanta a través de un sólido andamiaje teórico, de apariencia científica e inequívoca, su puesta en práctica acepta con naturalidad las irregularidades y tensiones a las que le obliga la propia realidad de cada encargo.

Lo que en última instancia la tesis de Venturi termina por desvelar es el importante vacío que se produce entre los enunciados teóricos y su desarrollo práctico. En la distancia que Le Corbusier recorre entre sus posiciones ideológicas y su puesta en práctica -en esta contradicción latente e inconfesada- se encuentra uno de los procesos creativos más fértiles del maestro suizo y una de las formas de investigación más importantes del proyecto de arquitectura.

\section{Procedencia de las imágenes}

Fig. 01 Venturi, Robert: Complejidad y contradicción en la arquitectura. Barcelona: Gustavo Gili, 1974 ; y Le Corbusier: Vers une architecture. Paris: Crès, 1923. () FLC-ADAGP

Figs. 02-04 Venturi, Robert: Complejidad y contradicción en la arquitectura. Barcelona: Gustavo Gili, 1974.

\section{Bibliografía}

Banham, Reyner: Teoría y diseño en la primera era de la máquina. Barcelona: Paidós Estética, 2014.

Colquhoun, Alan: "Desplazamiento de conceptos en Le Corbusier". En Colquhoun, Alan (Comp.): Arquitectura moderna y cambio histórico. Barcelona: Gustavo Gili, 1978.

Cortés, Juan Antonio: "La caja y el parasol". En Cortés, Juan Antonio (Comp.): Lecciones de equilibrio. Barcelona: Fundación Caja de Arquitectos, 2006.

Le Corbusier: Vers une architecture. Paris: Crès, 1923.

Le Corbusier: Hacia una arquitectura. Barcelona: Ediciones Apóstrofe, 1998.

Monteys Roig, Xavier: Robert Venturi: Complexity and Contradiction in Architecture (1966). Més no és menys. Conferencia dentro del curso Construït amb paraules: Teories i textos d'arquitectes del segle XX, 2009.

Scott Brown, Denise; Venturi, Robert: Architecture as Signs and Systems for a Mannerist Time. Londres: The Belknap Press of Harvard University Press, 2004.

Torres Cueco, Jorge: Le Corbusier: visiones de la técnica en cinco tiempos. Barcelona: Fundación Caja de Arquitectos, 2004.

\footnotetext{
${ }^{26}$ Scott Brown, Denise; Venturi, Robert: Architecture as Signs and Systems for a Mannerist Time. Londres: The Belknap Press of Harvard University Press, 2004. (Capítulo I.2, 14).
} 
Venturi, Robert: Complexity and Contradiction in Architecture. Nueva York: Museum of Modern Art, 1966. Venturi, Robert: Complejidad y contradicción en la arquitectura. Barcelona: Gustavo Gili, 1974.

Von Moos, Stanislaus: Le Corbusier. Elements of a Synthesis. Róterdam: 010 Publishers, 2009. 


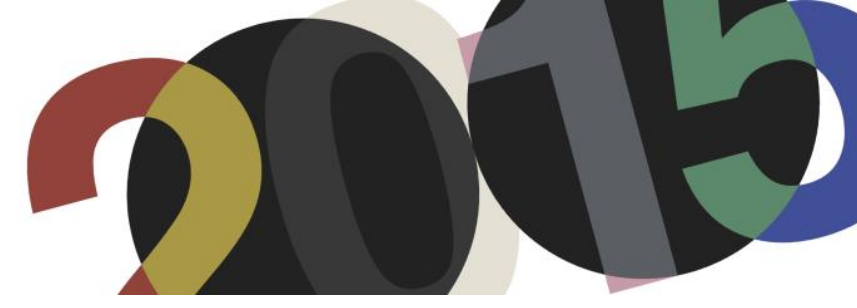

DOI: http://dx.doi.org/10.4995/LC2015.2015.891

\title{
Let's play with Le Corbusier
}

\author{
B. Świt-Jankowska \\ Institute of Architecture, Urban Planning and Heritage Protection, Faculty of Architecture, Poznan University \\ of Technology
}

\begin{abstract}
The research focuses on the possibility of transferring theoretical ideas of Le Corbusier into educational programs of the very young children - between three and six. The worldwide development of civilization changed the natural environment of the human. For the average European citizen a city is more natural place for living than a forest. Simultaneously, in these days many inhabitants present an extremely conformist approach to life and to the surrounding space. The participation of members of the society in the shaping of public spaces is possible only through the involvement and practice, but the democratic responsibility does not appears out of nowhere. It must be fostered and nurtured as early as in childhood. According to developmental psychology, children in the age of 3-6 are very susceptible to the acquisition of new skills and learn it in an intuitive way. The proper education program using Le Corbusier's lectures and theory could help them to understand the space better. The seeming simplicity of above rules is an advantage in this case - thereby it can be explained to even such an audience as small children. On the other hand, some kind of abstract and hidden difficulty included in this theory becomes an opportunity to create a very absorbing and stimulating workshops that follow the needs of younger and older children. Le Corbusier's legacy includes not only physical issues and can be used in many different ways. As Pablo Picasso once stated: every child is an artist, the problem is staying an artist when you grow up. For those reasons, incorporating such an innovative strategy for kids'education reveals a great potential.
\end{abstract}

Resumen: Los estudios realizados enfocan en comprobar las posibilidades de usar las ideas teóricas de Le Corbusier en los programas educativos para niños de tres a seis años. El desarrollo de la civilización ha cambiado el entorno natural del ser humano - una ciudad para el ciudadano promedio de Europa es un lugar más natural para vivir que el bosque. Al mismo tiempo, hay que reconocer que muchas personas muestran el enfoque muy conformista a la vida, tanto al espacio circundante. Esta situación se podría mejorar mediante la participación consciente de los miembros de la sociedad en la creación del espacio público, su compromiso y la práctica. Pero la responsabilidad democrática no aparece sola, se debe estimularla y nutrir ya en la infancia. De acuerdo con la psicología del desarrollo, los niños de 3 a 6 años son muy susceptibles a la adquisición de nuevas habilidades y aprenden de una manera intuitiva. Programa educativo que utiliza los cursos y la teoría de Le Corbusier puede ayudarles a entender mejor el medio ambiente. La aparente sencillez de los principios proclamados por él en este caso es una ventaja. La abstracción y escondidas dificultades incluidas en ellos,nos permiten a crear actividades estimulantes que correspondan a las necesidades de los niños pequeños, tanto y mayores. Como afirmo Pablo Picasso: "Todo niño es un artista. El problema es cómo mantenerse siendo niño una vez que se ha crecido".

Keywords: Architectural education, children, Le Corbusier.

Palabras clave: Enseñanza de la arquitectura, los niños, Le Corbusier.

"The child is both a hope and a promise for mankind"

Maria Montesorii

\section{Introduction}

Due to the worldwide development of civilization the natural environment more often is being replaced by the build-up areas. The architecture - buildings, streets and towns - becomes the background of contemporary human and affects every part of his live: reactions, emotions, relationships; the way of thinking and behaviour. Therefore, interest in issues related to space and architecture should be normal - in spite of that, most of the 
people turn around from the problems of nearest surrounding. "Someone else should take care of this" - it is a common opinion on this subject. As a result cities are full of chaotic public spaces, ugly buildings and angry, dissatisfied people. Alain de Botton ${ }^{1}$ wrote that good architecture can stimulate enthusiasm and teach people to look at things more consciously. But, as in the case of poetry or other arts, to begin to be fascinated by the architecture, it is necessary to understand its meaning for an individual user in a particular moment of his live. At the beginning it is unclear what to look for, what is important, what is worth an attention. Through a careful observation of space and time in architecture, it gradually becomes possible to enjoy a building or a public space with a growing understanding and fascination.

One of the big problems of modern polish architecture (and perhaps not only polish) is the lack of acceptance of the role and work of an architect. Gone are the days when, as in case of Le Corbusier, designer was a Demiurge shaping lives of ordinary people through the architecture and urban planning. Contemporary investor rarely has the appropriate education of architecture and art and often agrees with the arguments in the field of economics than aesthetics. Why is that? What can be done with it?

The participation of members of the society in the shaping of common spaces is possible only through the involvement and practice, but the democratic responsibility does not appear out of nowhere. It must be fostered and nurtured as early as in childhood - by spontaneous action and design ${ }^{2}$. The most important issues like terms of shaping the form of buildings, harmony and composition, selection of materials, colours and textures, respect for cultural heritage or environmental awareness can be inculcated in a simple way through fun and games. According to developmental psychology, the best time to learn spatial abilities for children is the period between 3-6 years. In this age children are susceptible to the acquisition of new skills and learn it in a very intuitive way.

Regrettably, educational programs in many countries (including Poland ${ }^{3}$ ) treated architectural teaching extremely superficially. Polish legislative acts, like The Education Act (dated 7 September 1991) and Regulation of the Minister of Education (dated 27 August 2012) on the core curriculum of pre-school education and general education in particular types of schools specify only general dispositions:

- to disseminate among children and adolescents knowledge of the principles of sustainable development and shaping the attitudes favouring its enforcement at the local, national and global communities (The Education Act);

- to build children's knowledge about the social, natural and technical world the core curriculum of preschool education);

- to stimulate interest in painting, sculpture and architecture, including green architecture and interior design (the core curriculum of pre-school education);

- to teach how to identify selected fields of art: architecture, painting, sculpture and graphics (the core curriculum of primary school education);

- $\quad$ to teach how to identify selected works representing various fields of art, including architecture (the core curriculum of general school education);

- $\quad$ to distinguish between styles and trends of architecture and art (the core curriculum of general school education);

- to participate in culture through contact with monuments (the core curriculum of general school education).

\footnotetext{
${ }^{1}[2]$, p. 19.

$2[5]$.

${ }^{3}$ Except the Nordic countries.
} 
As it is clear from the foregoing list the proposed by authorities actions concentrate on passive teaching methods: recognition, differentiation, description. Current experience and research on development and education of children prove that only practical actions can achieve intended purpose - to develop the children's sensitivity to spatial issues. It is very important especially for the youngest. One of the major problems associated with the transmission of knowledge of architecture and related issues is the lack of adequate trainings for teachers in kindergartens and primary schools. Admittedly some children attend extra classes developing theirs artistic and spatial skills - but these are often children of parents associated with arts or architecture. Most children gradually lose the natural interest in space, treating it as something obvious and devoid of significance.

Conducted research on Architectural education of the youngest focused on ability to translate the key issues of the theory of architecture into basic set of guidelines understandable to the layman. Properly constructed program of architectural activities mixed with theoretical problems clearly and simply explained can be a useful didactic aid for kindergarten's and primary school's teachers. A systematic but flexible methodology aimed to improve educational practices through three-stage activity: analysis/exploration, design/construction and evaluation/ implementation.

This paper is a presentation of parts of the research that verifies possibility of transferring theoretical ideas - in this case Le Corbusier's ${ }^{4}$ - into educational programs of the very young children between three and six.

\section{The synthesis of Le Corbusier's theory in a context of architectural education of the youngest}

It goes without saying that Le Corbusier (Charles-Édouard Jeanneret) is still one of the most important and influential architectural personalities of the twentieth century. Although until his death in the Mediterranean Sea nearly fifty years have already passed, his works, books and individuality exert enormous influence on subsequent generations of architects. The name of Le Corbusier raises mixed emotions: from uncontrolled delight to crushing criticism, but all roads of modern architecture lead either to or from him. Admired or hated, Le Corbusier is unavoidable. His specific way of arguing, polemical tactics and drawings permanently entered into the language of architectural education. Le Corbusier's legacy includes not only physical issues. The influence he was able to exert was in part due to his lectures and publications. One of the best known (and, as Tim Benton ${ }^{5}$ writes, the least understood book in twentieth century) was Vers une architecture (1923). Between 1924-1926 Le Corbusier published four following books containing his most important theoretical ideas - Five Points of Architecture, a Modulor concept, a purifying white, a sequential way of shaping space. The simple rules hard to use in practise but absolutely powerful.

The fundamental issue during implementation of research study was to isolate key principles and theories of Le Corbusier and to translate them into language understandable to very young children. Due to the large difference in the development of children in the studied period (3-6 years), in this case target age group was limited. Proposed educational program has been adapted to five-year-old children.

The previously mentioned three-stage activity corresponds to three conventional parts of workshops (classes prepared according to the so-called project method). Duration of each part has been adapted to the five-year's old pre-school children:

\footnotetext{
${ }^{4}$ The conducted research assumes analysis of the theory of architecture for possible use the achievements of other great architects-theorists, not only Le Corbusier's.

${ }^{5}[1]$.
} 
- $\quad$ introduction (5-10 minutes);

- $\quad$ activity (20-30 minutes);

- $\quad$ conclusion (5-10 minutes).

\subsection{The first phase: analysis/exploration}

The content, structure, and instructional approaches was firstly identified through a literature review and the input of experts and practitioners. A preliminary literature review was conducted with the purpose of identifying the main objectives to be achieved and principles that have the potential to be useful for the work with children. The author analysed both the texts written by Le Corbusier as well as a series of analytical positions about his work. This study revealed a multiplicity of research being conducted constantly based on his works. The choice of the leading idea is always burdened with subjective preferences. Finally, it was decided to highlight the specific role of human in Le Corbusier's designs and theoretical considerations. A human being was for Le Corbusier the beginning and the end of the design. The architecture became a reflection of existence - both literally and metaphysically. Moreover, a reference point to every realization and theoretical project was a man typical, but not without its own individuality.

According to Le Corbusier, a return to anthropomorphism, as the basis of design, should restore human scale in space, which idea was lost during the French Revolution. The metric system based on speculative method of measurement seems to be responsible for the dislocation and perversion in the architecture, and designers should turn away from him and return to the sources - the human body. In manifest published in 1949 called The Modulor: A Harmonious Measure to the Human Scale - Le Corbusier wrote that for a good composition it is only necessary to guarantee a few elements, but each of them should be a personality of strong personality ${ }^{6}$. All arithmetic is written using ten digits, all music is saved with six notes - everything is the result of conjugated agendas, both cosmic and human. It's like keyboard, on which a great number of different scales is possible to play, but each element engages with its neighbours in one unit ${ }^{7}$. Le Corbusier left the metric system and created his modular system of proportions. The starting point was the proportions of the male body as a basic canon. Le Corbusier superposed Vitruvian dimensions scheme with the golden section represented geometrically or with a use of an analytical formula.

The second concept - The machine for living in (machine à habiter) - raises the question of the means of relation between the user and the building - subordination and the supremacy. For Le Corbusier was clear that the aim of creation in architecture is "to accommodate a man". In spite of many critical comments and controversies which affect his legacy at the present time, this simple principle is still valid. Furthermore, Le Corbusier was extremely interesting as a human. A costume consisting of "bow-tie, starched collar, and bowler hat; rhetorical style combining discipline, enthusiasm, ironic wit and moral outrage" ${ }^{\text {, }}$ made him perfectly standard for the times. Even his adopted name - Le Corbusier - sounded like an object-type. Simultaneously the way he spoke, the conviction of the rightness of his judgements, independence and individuality - all that made him almost a character from a fairy tale: black-and-white, pure and intransigent.

\footnotetext{
${ }^{6}[6]$.

${ }^{7}$ [7], p. 14.

${ }^{8}$ [4], p. 31.
} 
The most known concept of Le Corbusier heritage, Five Points of Modern Architecture, in combination with previous ones may become a buckle unifying seemingly unrelated issues: a human and a machine, individuality and standardization.

The use of the form of Modulor, The Machine for living in and Five Points of Modern Architecture, as a leading themes during workshops with children have some evident advantages:

- $\quad$ firstly, it refers to the well-known concepts, which will be elaborated later on it this paper;

- $\quad$ secondly, it affects the imagination;

- $\quad$ thirdly, it stimulates desire for individual experience.

This part of theory had to be transformed into a manner understandable for children.

The target group forced a particular approach to explaining Le Corbusier's theory; a child of five is very physically fit and independent: can jump on one leg, is able to build a complex building with blocks, speaks correctly and fluently. It gladly imitate adults playing their roles. This is a good opportunity to dialogue with child and to focus its attention on the selected issues. It should be remembered that at the same time the energy level of the child at this age is high. Young children have relatively short attention spans, though, and generally behave best when alternating activities is adopted: those requiring sitting still and focusing with those that allow for physical movement. Interest and engagement in the lesson is the key way of holding their attention. Small groups of children may be able to play together for 15 minutes or up to a $1 / 2$ hour if they are engaged in novel, interesting playful activities ${ }^{9}$. The introduction of new issues must be based on past experience - theory or history of architecture is a subject relatively rarely taken up in conversations with children. Therefore, some parts of knowledge should be simplified, but not distorted.

The analysis of the works of Le Corbusier with additional regards of developmental possibilities and limitations of five year olds and a preliminary interview in a selected group of children provided detailed feedback for an opening: a history of a man who wanted to find a recipe for a home.

Therefore, firstly, was made a reference to the well-known concepts: a home (a place to living in) and a recipe (selected group participated earlier in the program Preschoolers are cooking). Secondly, it affects the kids imagination: dressed in black man who stirred the pot with big spoon to do a "home soup". Thirdly, it stimulates desire for individual experience - everyone wants to participate in such a "cooking".

From a scientific point of view, the above story can convey the most important elements of the Le Corbusier's theory in a very simple way: a Modulor concept as a soup of ingredients, Five Points of Modern Architecture as a recipe. The human is both demiurge and component in a Machine for living in.

\subsection{The second phase: design/construction}

The theoretical analysis was essential for understanding the heart of the matter and for workshops preparation. The active phase had to meet several another requirements: the classes should be interesting, immersive, involving all, changing in time, tailored to the age of the children, and primarily - not boring.

\footnotetext{
${ }^{9} \mathrm{http}: / /$ www.earlyinterventionsupport.com/qa-normal-attention-span/
} 
- $\quad$ The first level of difficulty (a scale 1:1):

After short introduction children was exposed to the concept of Modulor by working with their own bodies. It was action on a scale of one to one - they learned about the theory through direct experience, feelings and emotions. The pupils compared the dimensions of their own body parts - with each other and in the context of the space around them. The physical activity gave them the opportunity to individual observations - they discovered for themselves the spatial relationships between objects, furniture, items of equipment (like windows, doors, basins, toilets, mirrors, etc).

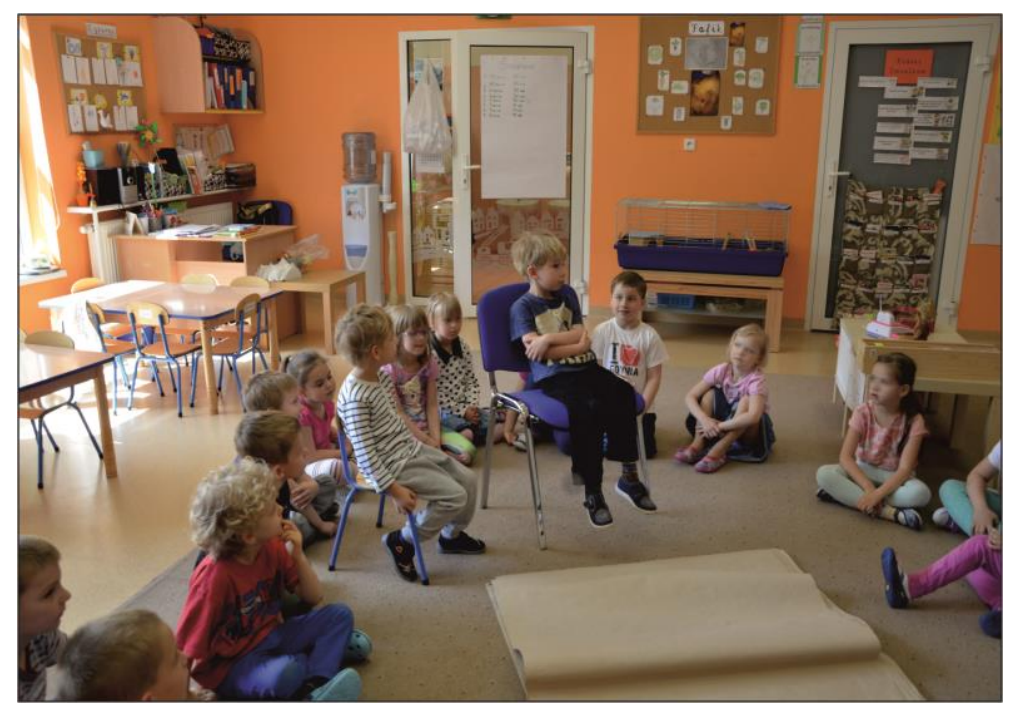

1. Who's chair is more comfortable? Workshop in kindergarten, Poznan, May 2015.

Then for each child its own Modulor was made. On large pieces of brown paper personalized shapes appeared. This caused great joy to children and was the reason of many ridiculous comments. It was also a time for rest and relaxation.

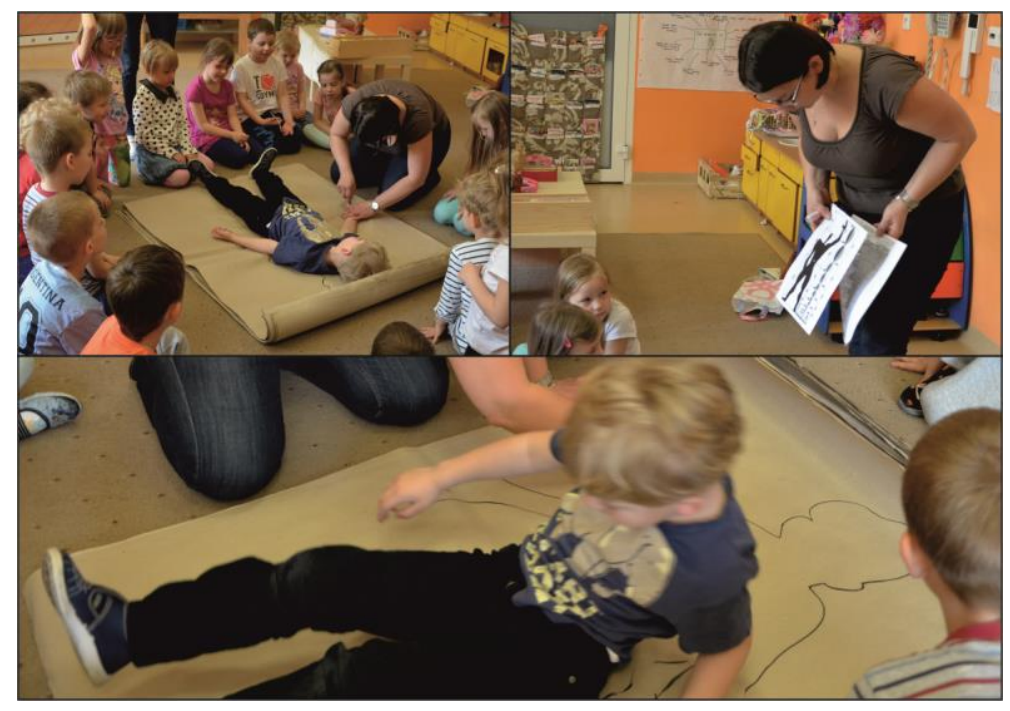

2. My own Modulor. Could I take him home? Workshop in kindergarten, Poznan, May 2015. 
- $\quad$ The second level of difficulty (a scale 1:22):

By comparing their own experiences and the possibility of moving the wooden puppet children familiarized themselves with the issues of scale. They explored its abilities, the range of motion and wondered what it would need for life.

Afterwards, the children were divided into four groups and they started "cooking". The main component was a matchbox as the primary equipment of each of the apartment. For the role of the boiling pot white, cardboard boxes with pre-cut holes were picked.

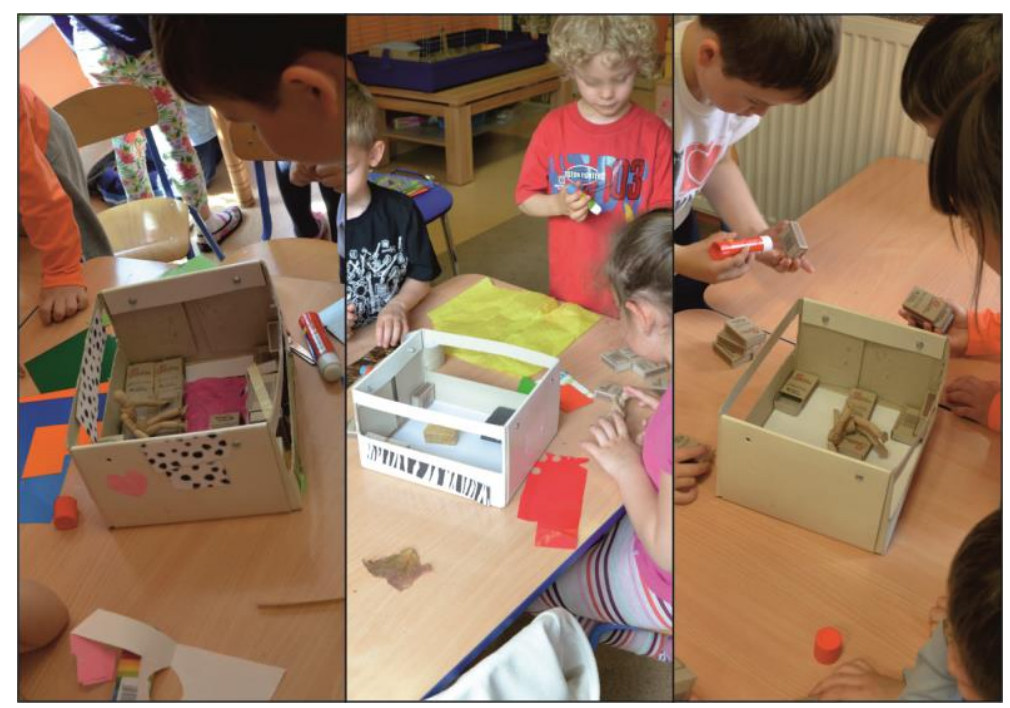

3. The "cooking" process. Workshop in kindergarten, Poznan, May 2015.

Each group presented the individual approach and their own interpretation of the module. The only role of the teacher was to draw children's attention to problems of dimensions of a human model - for example, that furniture should be appropriate to wooden puppet. Children ware allowed freedom and flexibility in completing the arrangement: they furnished and decorated their homes according to own aesthetic preferences - colorful scraps of materials, paper, sponges, or colored pencils filled the purist white boxes. This outcome allowed the extension of pre-planned objectives on an additional issue - Le Corbusier's reply upon learning that the housing project he had designed at Pessac had been altered by its inhabitants. In response to the changes he said: "You know, it is life that is right and the architect who is wrong"

The summary of this phase was based on the presentation of apartments, during which both utilitarianism and repeatable solutions, and individualism was emphasized.

\subsection{The third phase: evaluation/ implementation}

The third phase was connected with another level of difficulty: an abstract approach. The "ready-machine" built in the previous step was transformed into a housing unit. It made possible to raise the global issues associated with the growing population of people in the world, lack of green spaces, and traffic problems. The children ware able to explore different settings of blocks - hints of the teacher led them to the solution close to Marseilles's unit. Finally, recalling Five Points of Modern Architecture as a recipe allowed for a discussion about children's own experience - the place they lived in.

10 "Vous savez, c'est la vie qui a raison, l'architecte qui a tort", [3]. 


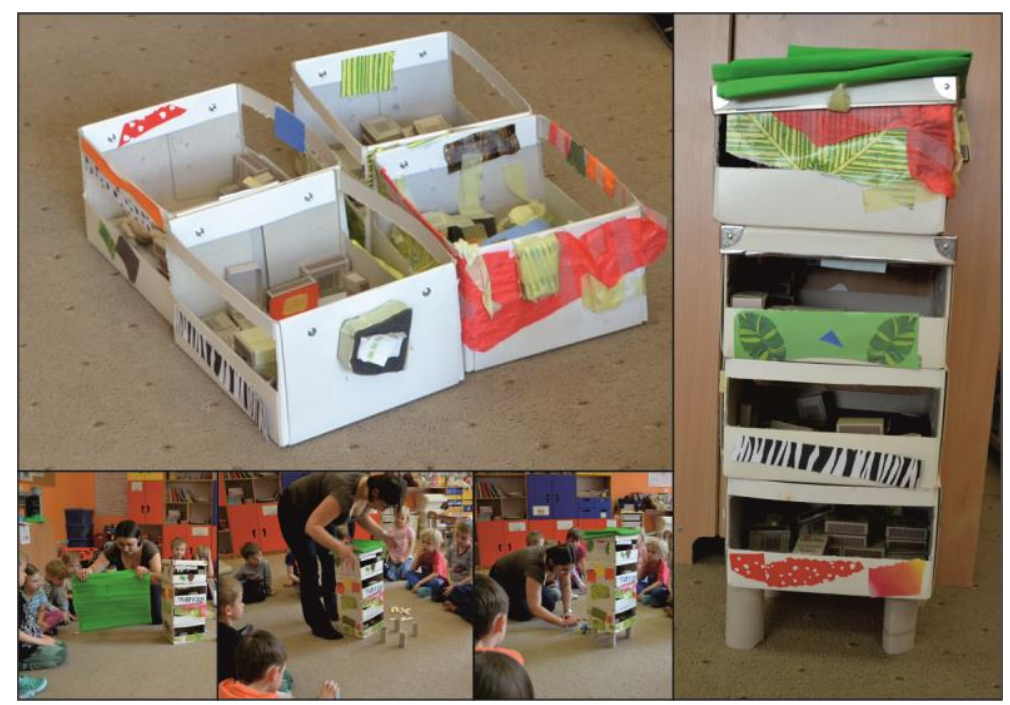

4. Five Points of Modern Architecture - how to make a home-soup. Workshop in kindergarten, Poznan, May 2015.

These activities show the abilities of using a simplified version of Le Corbusier's theory through the cooking analogy. It helped to create personalized spaces that with the use of repetition and module could become a major component of the "greater cuisine", namely housing unit.

As "a homework assignment" that would consolidate knowledge it is recommended to apply further observation of the surroundings or drawing from nature and from memory.

\section{Conclusions}

The Architectural education of the youngest project originated in the desire of an architect to tackle the growing problem of the decreasing quality of town space. It consists of various activities, both theoretical and practical. Roger A. Hart wrote: "We must work with educational authorities to change their conception of schooling. Currently they fear too much the collapse of control which would result from practising democracy. While we work on this slow and difficult process, we must continue to work with non-governmental organizations which, throughout the world, have been providing most of the creative examples for effecting children's participation" ". Architectural workshops engage children of all ages in the design process. They draw the attention of young audiance into the surrounding space and develop interest in the built and natural environment. Working with spatial models efficiently develops such skills as creativity and creative thinking. Participation in the design workshops sensitize children and young people to the use of the simplest materials and techniques for innovative, unconventional solutions. It allows to gain knowledge on architecture, ecology and sustainable development and introduces the concepts such as context, cultural heritage, dialogue with the environment.

The above workshop was held in May 2015, in one of the Poznan (Poland) kindergartens.

It was organized as a single meeting conducted by an architect. Large interest of children and teachers, theirs active participation, and the obtained results confirms the thesis, which is that the proper education program using Le Corbusier's lectures and theory could help children to understand the space better. The simplicity of the Le Corbusier's vision of modern architecture allows to use it not only in design and theoretical discussions, but in other areas too. The seeming accessibility of above rules is an advantage in this case - thereby it can be

\footnotetext{
${ }^{11}[5]$, p. 37.
} 
explained to even such an audience as small children. On the other hand, some kind of abstract and hidden difficulty included in this theory becomes an opportunity to create a very absorbing and stimulating workshops that follow the needs of younger and older children. Ultimately, the proposed activities should be prepared in such a way that they can be carried out by the preschool staff and flexibly adapted to other teaching activities. Depending on the needs, the program of activities can be expanded and extended in time. Pre-schools teachers, who usually do not have adequate training in architecture, can develop skill and expand their knowledge together with children. Suggested activities can both complement daily educational activities and be a separate element that have a potential to impact the selection of other educational content.

The next step of conducted research is to prepare the course and source materials for kindergarten teachers (in collaboration with experts in the field of early childhood education and artistic education) which will allow them to personally lead classes related to architecture.

\section{Acknowledgements}

This paper is part of the research carried out at the Faculty of Architecture at Poznan University of Technology within the research project entitled "Architectural education of the youngest - phase 2" financed by the Polish Ministry of Science and Higher Education in Warsaw (2015).

\section{Source of images}

All images ware took during the workshops by Ms. Agnieszka Jaskuła, May 2015.

\section{Bibliographical references}

Benton, Tim: The Rhetoric of Modernism: Le Corbusier as a Lecturer. Basel - Boston - Berlin: Birkhäuser, 2009

de Botton, Alain: The architecture of happines. London: Hamish Hamilton, 2006

Boudon, Philippe: Lived-In Architecture: Le Corbusier's Pessac Revisited. London: Lund Humphries, 1969

Gans Deborah: The Le Corbusier Guide. rev. ed. New York: Princeton Architectural Press, 2000

Hart, Roger A.: Children's participation: from tokenism to citizenship Graphics layout: S. Selim Iltus. Florence: UNICEF International Child Development Centre. Spedale degli Innocenti, 1992

Le Corbusier; de Francia, P.; Bostock, A. trans.: The Modulor: A Harmonious Measure to the Human Scale Universally Applicable to Architecture and Mechanics. London: Faber \& Faber, 1956

Sołtan, Jerzy: Modulor, system wymiarowania. Warszawa: Koło Naukowe Wydziału Arch. Wnętrz ASP, 1946

Von Moos, Stanislaus: Le Corbusier: Elements of a Synthesis. Rotterdam: 010 Publishers, 2009 


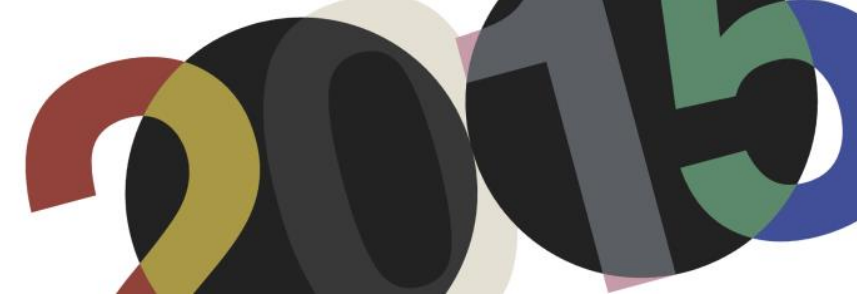

DOI: http://dx.doi.org/10.4995/LC2015.2015.821

\title{
Visions "humaines" ou "infernales": les moyens de transport et la perception de la ville chez Le Corbusier
}

\author{
S. Talenti
}

Université de Salerne, Italie

\begin{abstract}
Résumé: Les représentations des villes depuis la mer ont eu, à partir du XVe siècle, un grand succès dans l'iconographie urbaine des voyageurs. Depuis 1911, Le Corbusier a pris l'habitude d'esquisser dans ses carnets de croquis les paysages urbains découverts au cours de son voyage en Orient. Villes, remparts ou monuments significatifs sont souvent représentés depuis la mer ou les fleuves, car l'arrivée en bateau autorise une perception progressive et globale du site. Suite à son séjour en Amérique du sud en 1929, l'architecte exprime ouvertement son appréciation pour la perspective obtenue depuis le bateau au milieu des baies, car ce point de vue lui permet de contextualiser immédiatement ses propositions d'aménagement urbain. De simple connaissance des villes, cette pratique iconographique devient, chez Le Corbusier, un instrument d'élaboration du projet. Mais la vue horizontale est bientôt accompagnée du procédé de survol des centres urbains pour appréhender la grandeur du paysage naturel et construit. À travers l'analyse des nombreuses images - dessins, croquis, photos - élaborées par Le Corbusier à partir des différents moyens de transport, ainsi que des commentaires accompagnant ces documents iconographiques et de quelques textes publiés, on essayera de mieux comprendre le rapport entre l'échelle de ces visions panoramiques et la nouvelle approche territoriale mise au point par Le Corbusier à partir des années Trente.
\end{abstract}

\begin{abstract}
The representations of cities viewed from the sea have had, since the fifteenth century, a great success in urban iconography. From 1911, Le Corbusier began drawing urban landscapes in his sketchbooks, which he discovered during his trip to the Orient. Cities, fortifications or significant monuments are often depicted from the sea or rivers, because the arrival by boat allows a gradual and overall perception of the site. After his stay in South America in 1929, the architect openly expressed his appreciation for the panoramic view obtained from the boat in the middle of the bay. This point of view allows him to contextualize his urban development proposals immediately. This iconographic practice is no longer a simple function of knowledge, but it has become an instrument for realising the project. However, the horizontal view was soon accompanied by the process of flying over urban centres to understand the magnitude of the man-made and natural landscape. Through the analysis of the many images - drawings, sketches, photos - developed by Le Corbusier using different means of transport, of comments accompanying these iconographic documents and of some published texts, the paper aims to better understand the relationship between the scale of these panoramic visions and the new territorial approach developed by Le Corbusier from the Thirties onwards.
\end{abstract}

Mots clés: moyens de transport; avion; bateau. Keywords: means of transport; airplane; boat.

\section{Introduction}

"Suddenly... we have been endowed with THE BIRD'S EYE VIEW".

Les représentations des villes depuis la mer ont eu, à partir du XVe siècle, un grand succès dans l'iconographie urbaine des voyageurs. L'approche graduelle de la côte, autorisée par le transport maritime, devient l'occasion pour de nombreux architectes, de découvrir lentement les agglomérations, mais surtout de saisir leur insertion dans le contexte du paysage. Depuis 1911, Le Corbusier a pris l'habitude d'esquisser dans ses carnets de croquis les paysages urbains découverts au cours de son voyage en Orient. Villes, remparts ou monuments significatifs

\footnotetext{
${ }^{1}$ Le Corbusier: Aircraft. London: The Studio, 1935, p. 6.
} 
sont souvent représentés depuis la mer ou les fleuves, car l'arrivée en bateau autorise une perception progressive et globale du site. Suite à son séjour en Amérique du sud en 1929, l'architecte exprime ouvertement son appréciation pour la perspective obtenue depuis le bateau au milieu des baies, car ce point de vue lui permet de contextualiser immédiatement ses propositions d'aménagement urbain. De simple connaissance des villes, cette pratique iconographique devient, chez Le Corbusier, un instrument d'élaboration du projet. Mais la vue horizontale est bientôt accompagnée du procédé de survol des centres urbains pour appréhender la grandeur du paysage naturel et construit: "De l'avion, j'ai vu des spectacles qu'on pourrait appeler cosmiques",2. La vision aérienne serait, à son avis, la vue que tout concepteur de ville devrait privilégier afin de mieux comprendre le territoire et ses caractères. En particulier, lors de la conception du Plan Obus pour Alger, la vue d'en haut aurait influencé, selon lui, l'abandon de toute grille orthogonale ${ }^{3}$. Dans la capitale algérienne, où il est invité en 1931, Le Corbusier va tester les différentes façons de voir et de représenter la ville: la vision frontale obtenue depuis le paquebot qui lui permet de mettre l'accent sur l'horizontalité du front de mer; la vue plongeante qui autorise la saisie de la dimension territoriale et enfin celle propre au promeneur qui découvre, en flânant et en pénétrant dans le dédale de la Casbah, le véritable cœur de l'agglomération et sa complexité urbaine. Il s'agit de trois différentes appréhensions de l'espace construit, complémentaires mais basées sur une même saisie relativement lente des données. Le Corbusier est désormais convaincu que seul le paquebot, l'avion et le "pied du marcheur sur la route" peuvent permettre d'apprécier le "spectacle", en produisant des "visions humaines" et globales, contrairement à celles "inhumaines et infernales" engendrées par les trains et les voitures ${ }^{4}$. À travers l'analyse des nombreuses images - dessins, croquis, photos - élaborées par Le Corbusier à partir des différents moyens de transport, ainsi que des commentaires accompagnant ces documents iconographiques et de quelques textes publiés, on essayera de mieux comprendre le rapport entre l'échelle de ces visions panoramiques et la nouvelle approche territoriale mise au point par Le Corbusier à partir des années Trente. Ceci permettra de vérifier jusqu'à quel point les représentations effectuées depuis la mer ou les vues aériennes ne sont pas seulement un moyen de connaissance, mais aussi un outil très important dans la conception de projets d'architecture et d'aménagements urbains qui jaillissent comme des véritables révélations. Les résultats de cette étude ne prétendent pas être exhaustifs, la recherche pouvant encore s'enrichir, un jour, grâce au réexamen de l'œuvre écrite de Le Corbusier ainsi que de sa correspondance privée.

\section{Vision frontale et panoramique}

Pendant le voyage en Orient en 1911, Le Corbusier commence à changer l'orientation de ses carnets de croquis, afin de mieux saisir l'horizontalité des paysages urbains. "Nous sommes venus par la mer, classiquement, pour voir se dérouler les choses". . Les premières impressions depuis le bateau se traduisent en skylines et panoramas, à même de représenter au mieux la spécificité de chaque ville. Nombreux sont les dessins qui, par quelques traits, fixent sur le papier les caractères des grandes agglomérations comme Istanbul, mais aussi de réalités urbaines plus modestes, comme la ville hongroise d'Esztergom dessinée depuis le Danube ${ }^{6}$. Le jeune architecte utilise aussi l'appareil photo pour prendre ses premiers clichés panoramiques depuis l'embarcation: des

\footnotetext{
${ }^{2}$ Le Corbusier: Précisions sur un état présent de l'architecture et de l'urbanisme. Paris: G. Crès et Cie, 1930, p. 4. Cf. Lemonnier, Aurélien: "Des yeux qui accusent: Le Corbusier et la ville vue d'avion". In Lampe Angela (Dir.): Vues d'en haut. Metz: Centre Pompidou, 2013, pp. 258-261.

${ }^{3}$ Cf. Bonillo, Jean-Lucien (Dir.): Le Corbusier. Visions d'Alger. Paris: Editions de la Villette, 2012.

${ }^{4}$ Le Corbusier: Précisions... op. cit., p. 8.

${ }^{5}$ Le Corbusier: Le voyage d'Orient. Marseille: Parenthèses, 1987, p. 67.

${ }^{6}$ De la ville hongroise d'Esztergom dessinée depuis le Danube, Le Corbusier avait également fait une photo en juin 1911: cf. Le Corbusier: Il viaggio d'Oriente (Le voyage d'Orient). Faenza: Faenza Editrice, 1974, p.164 ainsi que Mazza, Barbara: Le Corbusier e la fotografia. La vérité blanche. Firenze: Firenze University Press, 2002, fig. 29.
} 
photosqui visent à saisir les points forts des villes des Balkans ou de quelques citadelles fortifiées, par l'enregistrement de leurs silhouettes.

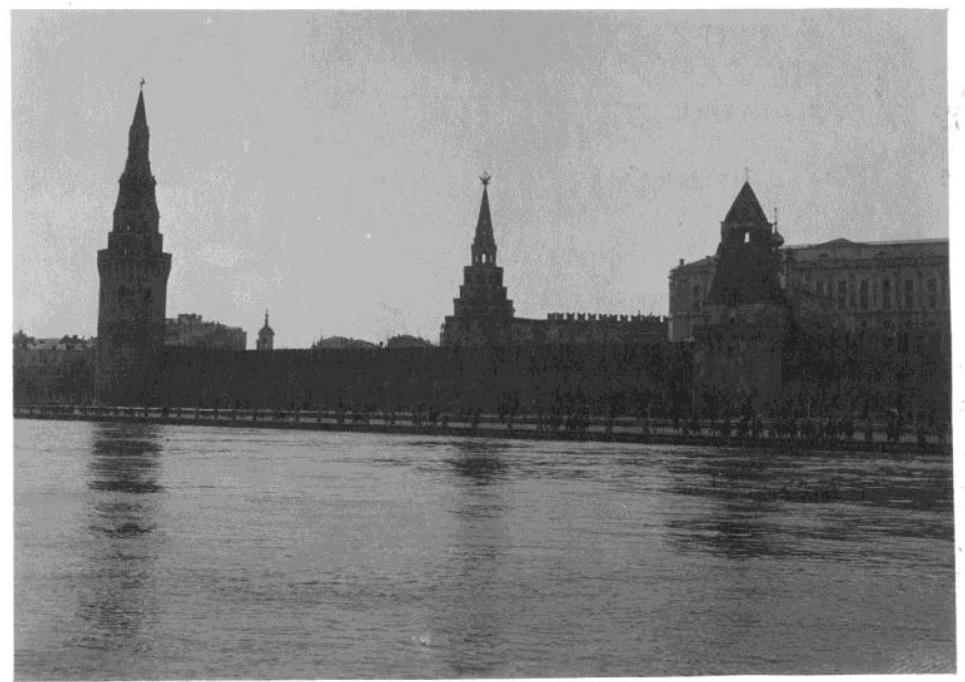

1. La forteresse de Smederevo. Photographie 1911. FLC, L5-1-124.

La forteresse du XVe siècle de la ville serbe de Smederevo est saisie depuis le Danube à travers une image suggestive et séduisante où l'enceinte fortifiée se détache à l'horizon en soulignant l'étendue et l'ampleur de la citadelle $^{7}$. Même les profils noirs et bidimensionnels des villes sont captés dans le but de cristalliser la première image d'un site, selon une approche visuelle qui deviendra une démarche cognitive amplement utilisée par Le Corbusier.

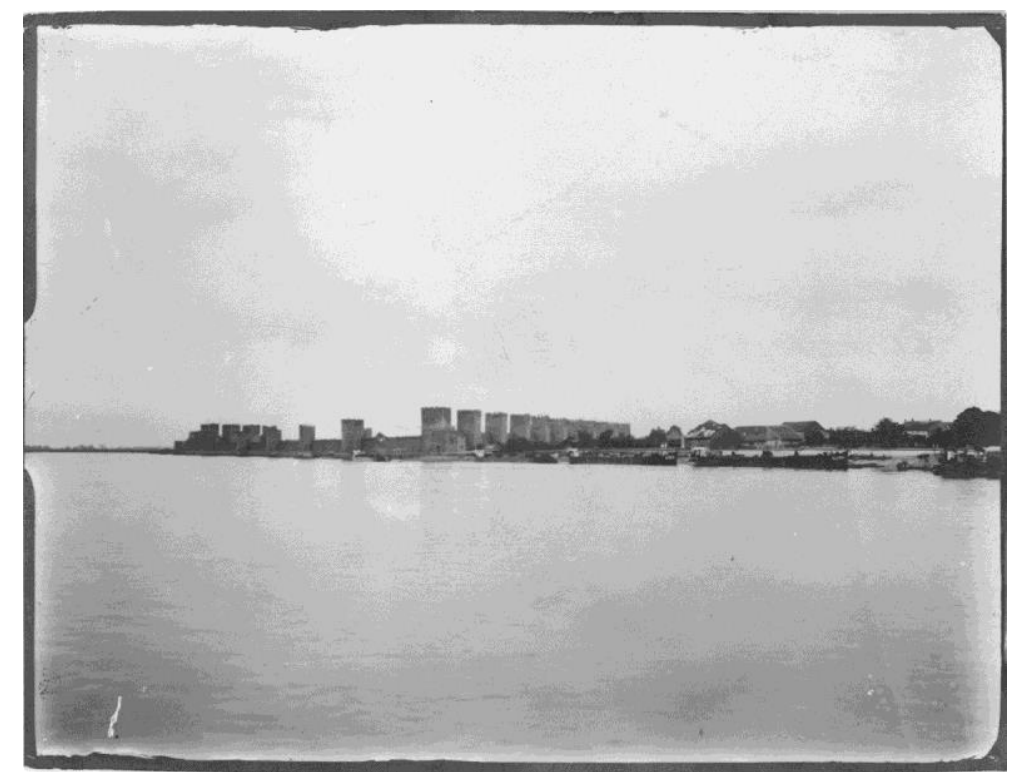

2. Photo prise lors du voyage dans les Balkans en 1911. FLC, L4-20-170.

Le medium photographique ne remplacera toutefois pas le dessin, en particulier dans la saisie des sensations, comme Le Corbusier l'affirme clairement dans une interview des années Soixante “...je me suis aperçu qu'en confiant mes émotions à un objectif j'oubliais à les faire passer par moi, ce qui était grave, alors j'ai laissé

\footnotetext{
${ }^{7}$ Fondation Le Corbusier: Voyages de jeunesse: L5-1-124.
} 
tomber la Kodak et j'ai pris mon crayon et depuis, j'ai toujours dessiné tout et n'importe où"8. Quoi qu'il soit l'outil d'enregistrement, Le Corbusier semble déjà appréhender, lors de son voyage dans les Balkans, les avantages d'un point de vue suffisamment éloigné et détaché, à même de mieux faire comprendre les relations entre l'architecture et le milieu naturel/urbain dans lequel elle s'insère. Ces différentes images ne contiennent pas encore de propos liés au projet de transformation du site, l'objectif étant, pour l'instant, celui de la documentation, voire de la compréhension sans visée opérationnelle. Les croquis et les dessins du jeune architecte fixent, par des traits rapides, les lignes principales du paysage dans toute son étendue. Dans l'un des nombreux panoramas d'Istanbul, par exemple, Le Corbusier souligne par des rayures horizontales la mer et quelques collines, alors que les lignes verticales sont essentiellement réservées aux bâtisses, telles que mosquées ou bâtiments remarquables par leur profil $1^{9}$. La présence, au premier plan, de l'eau, semble prendre un sens bien précis. En effet, les vues représentées depuis le bateau en mer - à moins qu'il s'agisse, parfois, de dessins élaborés depuis la côte d'en face - accordent une place énorme à cette surface plane et immobile, accentuant parlà, non seulement la distance physique de la terre, mais aussi le détachement de l'observateur et sa capacité à saisir l'essentiel de façon synthétique, comme en témoigne un second panorama d'Istanbul ${ }^{10}$.

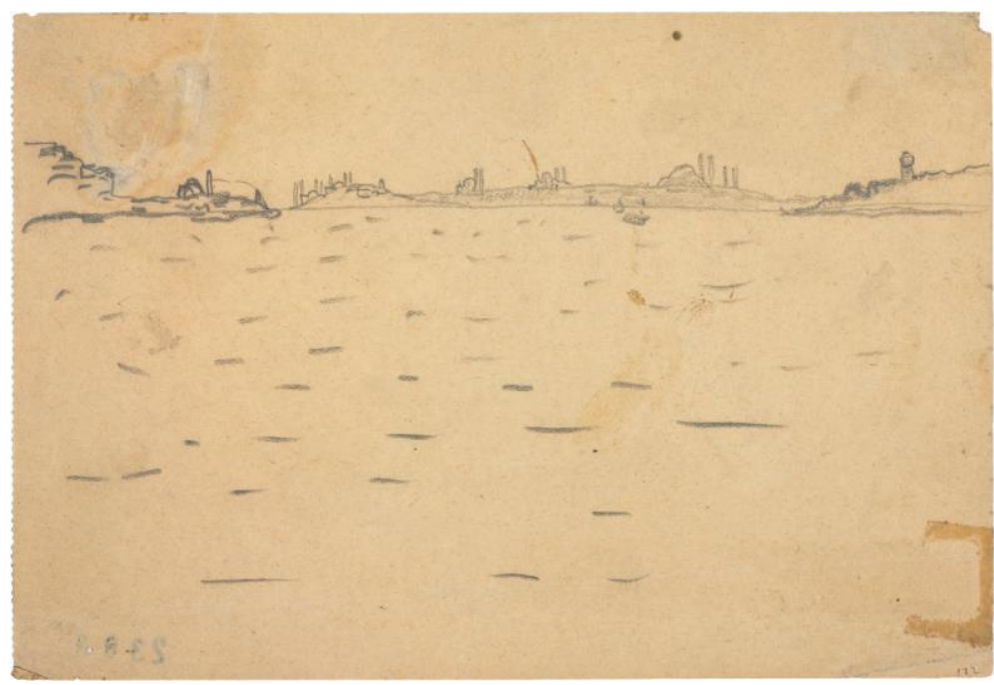

3. Panorama d'Istanbul, 1911. FLC, 2383.

Dans celui-ci le cadrage repousse très loin la ligne de l'horizon avec le skyline bidimensionnel de la ville sur le Bosphore. Le Corbusier utilise la plus grande partie de carnet pour y dessiner la mer par quelques touches de crayon. Une surface qui n'est donc presque jamais exploitée pour ses reflets séduisants, mais qui ne sert qu'à faire reculer le profil urbain au fond du dessin. Le ciel et la mer occupent ainsi la plus grande partie des croquis élaborés par le Corbusier depuis un bateau. Le skyline de la ville qui surplombe l'eau devient juste une trace horizontale au milieu d'un environnement naturel qui l'entoure totalement. En ce qui concerne Rio, Le Corbusier écrit en 1930 "La ville s'annonçait par une ligne qui, seule, est capable de chanter avec le caprice véhément des monts: l'horizontale"

Son approche et son appréhension des agglomérations surplombant l'eau, deviennent de plus en plus liées et conditionnées par le moyen de transport maritime ou fluvial qui façonne le premier aperçu visuel. L'élaboration des énormes infrastructures surélevées envisagées pour Rio ou Alger, trouve en effet son origine dans cette ligne

\footnotetext{
${ }^{8}$ Cité par Benton, Tim: “Le Corbusier photographe secret”. In Herschdorfer, Nathalie et Umstätter, Lada (Dir.): Construire l'image. Le Corbusier et la photographie. Paris: Textuel, 2012, pp. 30-53, cit. p. 49.

${ }^{9}$ Panorama d'Istanbul, 1911, FLC 2459.

${ }^{10}$ Panorama d'Istanbul, 1911, FLC 2383.

${ }^{11}$ Le Corbusier: Précisions...op. cit., p. 245.
} 
d'horizon toujours accentuée dans ses premiers relevés. Bien qu'il s'agisse d'interventions de grande envergure et d'une emprise à échelle territoriale, la démarche qui les sous-tend paraît être celle qui veut le moins modifier et altérer le sol ainsi que le visage et la silhouette générale du site saisis depuis la mer, en s'étendant essentiellement sur l'horizontalité. Les skylines sont alors dessinés par Le Corbusier, non seulement pour fixer le premier aperçu d'une ville, mais aussi pour vérifier la correcte insertion du projet. La démarche utilisée à Rio de Janeiro, avait déjà été expérimentée lors d'un projet, en 1927, pour un autre site surplombant l'eau. C'est ainsi que la vue du Palais des Nations élaborée depuis le lac de Genève a l'avantage d'être le fruit d'un relevé pris avec précision depuis une place suffisamment reculée pour pouvoir souligner, comme l'explique la légende, que "la géométrie des formes architecturales entre en symphonie avec les richesses naturelles du site" ". En même temps, la représentation du projet vu du lac vise à accentuer, par le biais de l'eau qui sépare l'ensemble architectural du bateau (imaginaire ou réel), la distance spatiale et mentale entre l'observateur et l'objet en question. Cette recherche de distance objectivante s'aligne parfaitement avec la représentation pleine-page à travers la vue cavalière plongeante que Le Corbusier utilise pour illustrer ce projet: une axonométrie à même de renforcer l'effet d'abstraction et de séparation. Cette mise à distance recherchée par l'architecte depuis ses premiers voyages en bateau, trouvera son aboutissement naturel, comme on aura l'occasion de voir, dans les survols des villes en avion. La séquence sténographique reprise depuis le bateau près de Manhattan et publiée en 1937 en guise de conclusion dans Quand les cathédrales étaient blanches veut aussi souligner le "paysage émouvant" de la ville américaine ${ }^{13}$. La réalisation des huit croquis dans lesquels se croisent les éléments de l'embarcation avec la silhouette des gratte-ciels, a été rendue possible par le rythme lent du moyen de transport.

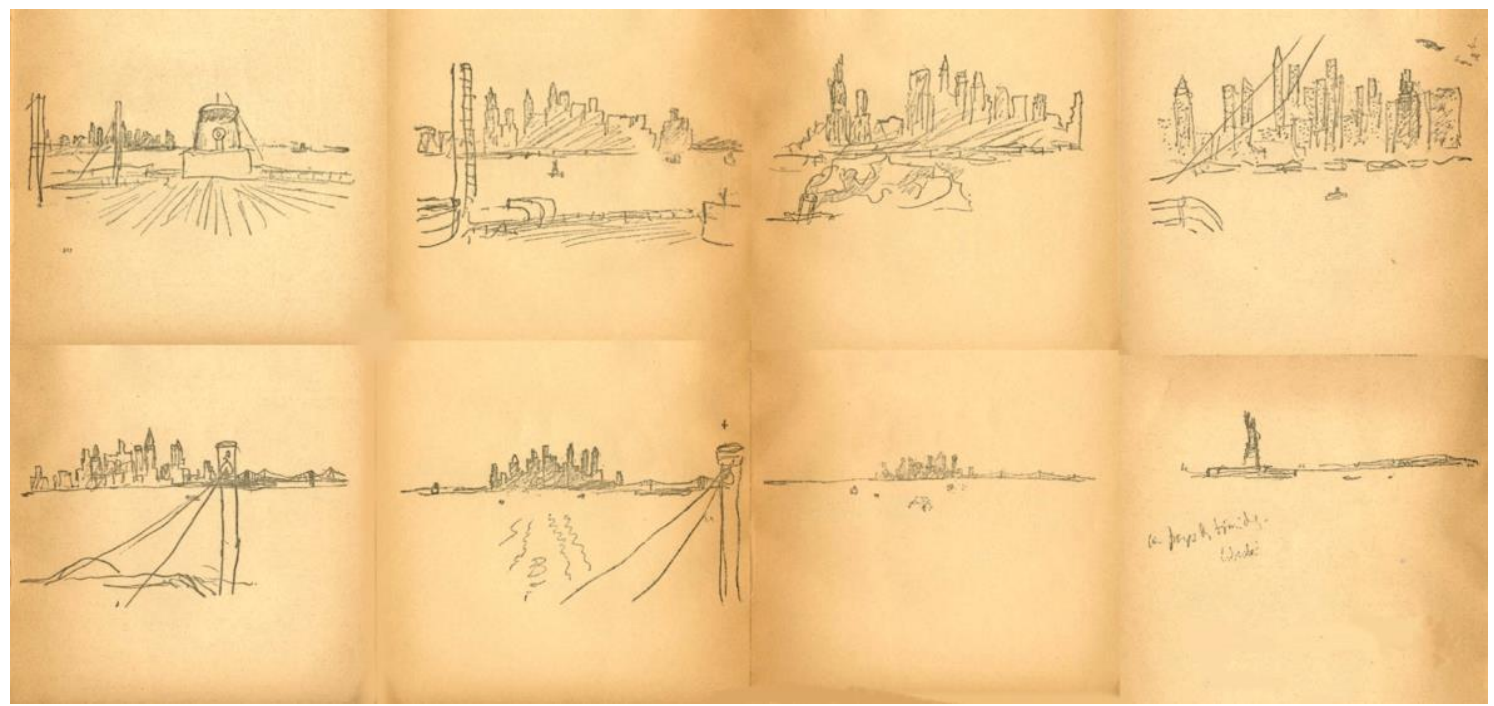

4. Séquence sténographique de Manhattan. Le Corbusier: Quand les cathédrales étaient blanches. Voyage au pays des timides. Paris: Plon, 1937, pp. 315-322.

Le procédé qui semble viser la "vue panoramique animée" sera repris en 1936, par un outil iconographique différent, lorsque Le Corbusier, de retour du Brésil, réalisera des photos prises en séquence depuis le paquebot Conte Biancamano ${ }^{14}$. Le lien avec le medium cinématographique devient de plus en plus évident.

La vue depuis les bateaux, ne permet pas seulement à Le Corbusier d'élaborer une première impression fixée sur le papier ou la pellicule photo à travers les lignes quelque peu abstraites du skyline de la ville qui

\footnotetext{
${ }^{12}$ Le Corbusier: Vers une architecture. Paris: Arthaud, 1977, p. XIV. Cf. le chapitre «Température », ajouté en 1928 à l'occasion de la troisième édition.

${ }^{13}$ Le Corbusier: Quand les cathédrales étaient blanches. Voyage au pays des timides. Paris: Plon, 1937, pp. 315-322.

${ }^{14}$ Cf. Benton, Tim: LC Foto: Le Corbusier Secret Photographer. Zürich: Lars Müller, 2013.
} 
appréhendent les relations entre architecture historique, projet, espace urbain, paysage, territoire. Elle autorise aussi, une fois que le navire s'approche de la côte, une vision plus rapprochée où les principales émergences architecturales sont enregistrées afin de noter les points fragiles et délicats où il faudra intervenir. Il s'agit toujours de visions frontales, mais capables, par leur proximité au front de mer, de faire jaillir des considérations ponctuelles sur l'aménagement urbain actuel et futur. Cette approche déjà riche en propositions, devra toutefois être validée et confrontée par les "pieds du marcheur" avec la découverte des espaces plus cachés et retirés de la ville, ainsi que par le survol aérien que Le Corbusier découvre à la fin des années Vingt. C'est en suivant ces deux étapes que se déroule, par exemple, son approche de la côte newyorkaise à bord du Normandie. Sa première impression depuis le paquebot attendant la "quarantaine" est celle d'une ville fantastique, "quasi mystique": le "temple du nouveau monde"." Puis, lorsque l'embarcation atteint une distance réduite du front de mer, "l'apparition se transforme en image d'une brutalité et d'une barbarie inouïe"16. Le premier skyline permet d'élaborer un aperçu visuel principalement lié aux sensations et aux émotions; la vision frontale rapprochée autorise les jugements et les commentaires critiques que la promenade en ville accomplie le soir et les photos aériennes qui accompagnent la publication de Quand les cathédrales étaient blanches pourront confirmer ou contredire.

Il s'agit donc d'un regard qui sous-tend déjà une approche analytique et critique du site, traduit par des croquis où nombreuses sont aussi les annotations écrites, souvent à mi-chemin entre constat et projet. Les vues de Barcelone depuis la mer tracées en 1932 constituent peut-être la démonstration la plus évidente que ces représentations accompagnées de commentaires - ne font plus vraiment partie de la culture du voyage, comme l'a justement souligné Giuliano Gresleri ${ }^{17}$. Le Corbusier note sur l'un de ses croquis: "Il faudrait gratte-ciel même hauteur que Monjuich"18.

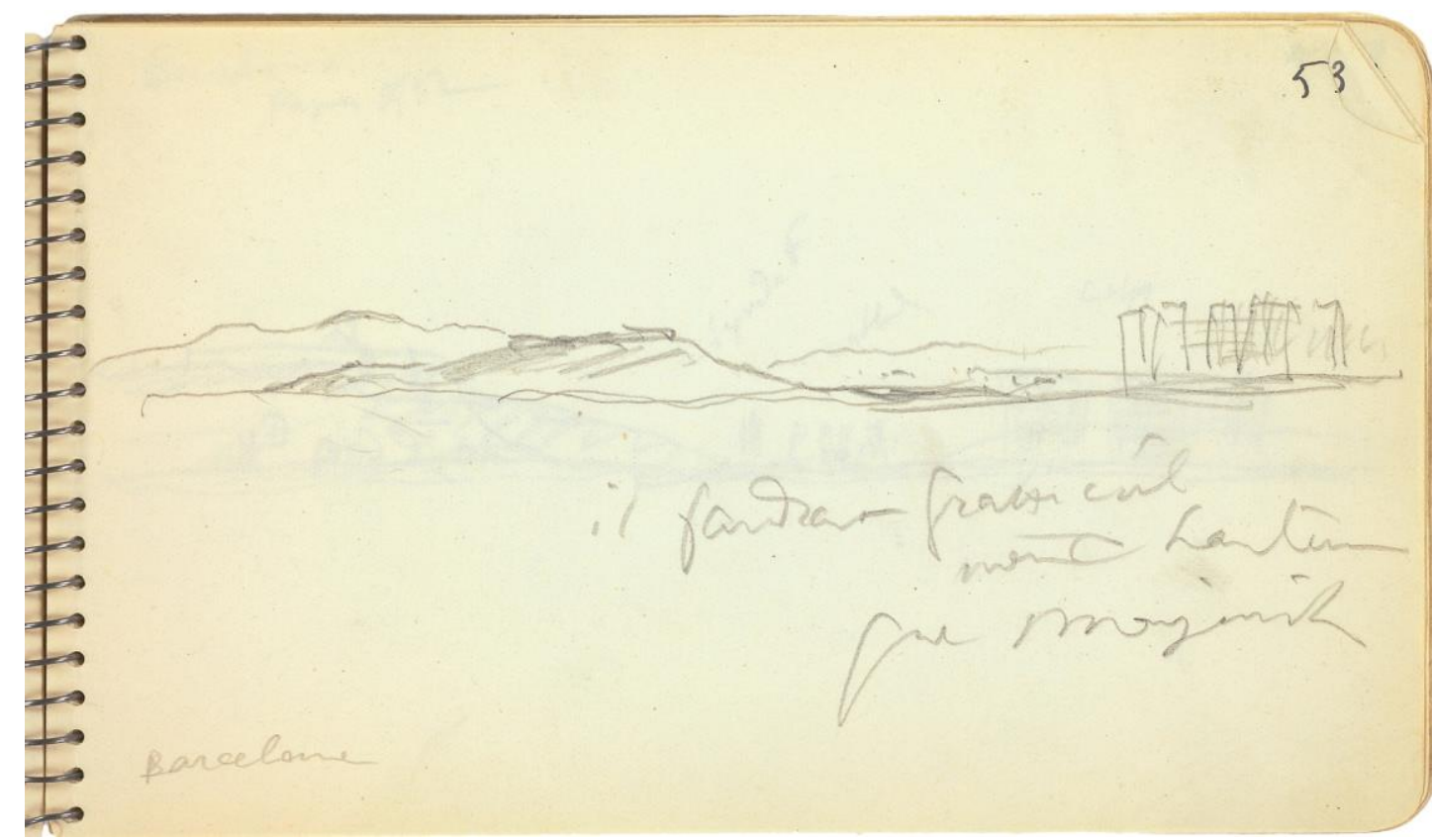

5. Vue de Barcelone depuis la mer, 1932. FLC, carnet C10, n. 636.

\footnotetext{
${ }^{15}$ Le Corbusier: Quando le cattedrali erano bianche. Faenza: Faenza editrice, 1975, p. 42.

${ }^{16}$ Ibid., p. 42

${ }^{17}$ Cf. l'interprétation par Gresleri: Gresleri, Giuliano: "Dal diario al progetto. I Carnet 1-6 di Le Corbusier". In Lotus, N. 68. 1991, pp. 6-21.

${ }^{18}$ FLC, carnet C10, n. 636
} 
La même visée opérative est très explicite dans le dessin où l'architecte esquisse le skyline de la ville catalane avec ses différentes hauteurs ${ }^{19}$, ou dans celui qui représente Rio de Janeiro en $1936^{20}$ où se lisent les différentes émergences architecturales et naturelles, ainsi que leur impact sur le paysage global du front de mer. Dans le compte rendu de son séjour brésilien, Le Corbusier déclare apprécier la perspective obtenue depuis le bateau au milieu de la baie: "Or, du large de Rio, j'ai repris mon carnet de dessin; j'ai dessiné les monts et, entre les monts, l'autostrade future et la grande ceinture architecturale qui la porte... Les paquebots qui passaient, immeubles magnifiques et mouvants des temps modernes, trouvaient là-bas, suspendus dans l'espace au-dessus de la ville, une réponse, un écho, une réplique"21.

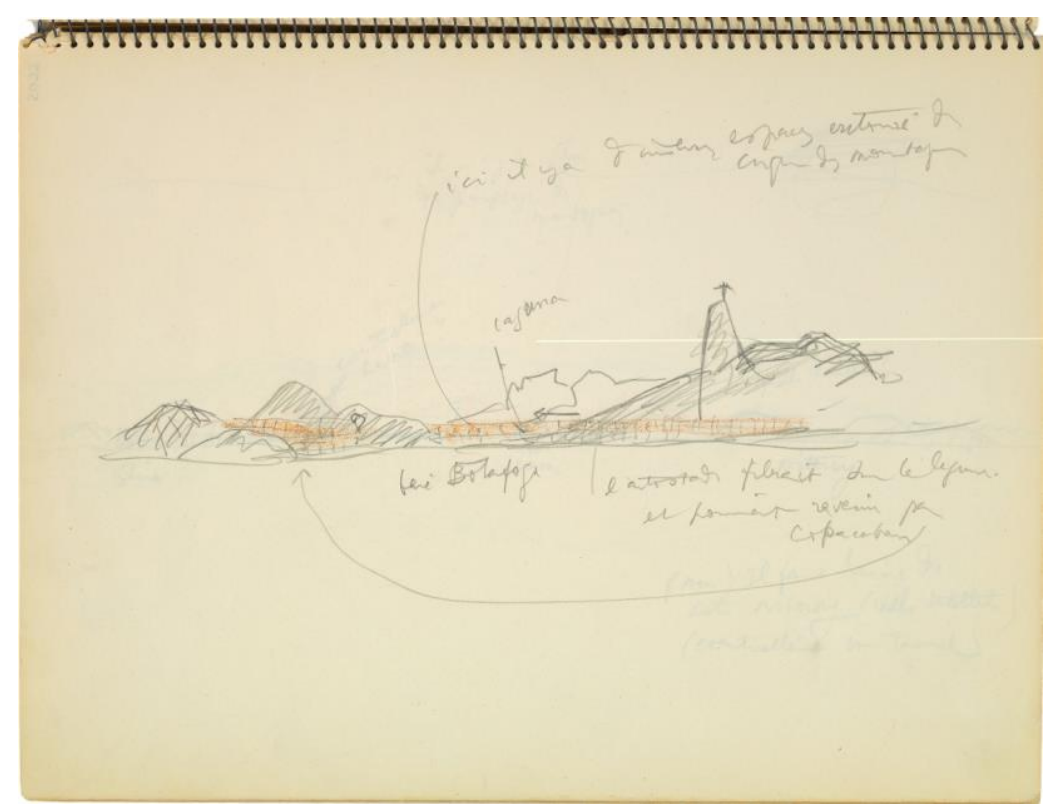

6. Un des premiers croquis pour Rio de Janeiro. FLC, dessin 5033.

Cette sorte de résonnance acoustique qui se crée entre le navire et l'architecture semble confirmer à Le Corbusier que son projet remplit toutes les conditions pour aboutir. Elle lui permet aussi de réfléchir sur la complémentarité de l'approche maritime et du survol aérien qui se disputent gentiment le rôle principal dans l'appréhension et l'interprétation des lieux urbains grâce à un enregistrement des données qui se produit de façon systématique et calme: "Du large, j'ai vu dans mon esprit la ceinture ample et magnifique des bâtisses, avec le couronnement horizontal de l'autostrade frappant de mont en mont et tendant la main d'une baie à l'autre. L'avion est prêt à en devenir jaloux; de telles libertés lui semblaient réservées" ${ }^{22}$. Mais si la vue horizontale de la ville maritime autorisée par le bateau est à même d'enregistrer l'insertion dans le site et l'unité paysagère, la perception du haut d'un avion est manifestement celle qui permet de comprendre l'échelle territoriale, en devenant, pour Le Corbusier, la seule capable de dévoiler les véritables secrets et les grandes leçons que l'esprit humain pouvait élaborer seulement de façon intuitive ${ }^{23}$.

\footnotetext{
${ }^{19}$ FLC, carnet C10, n. 637

${ }^{20}$ FLC, carnet C12, n. 731.

${ }^{21}$ Le Corbusier: Précisions... op. cit., p. 244.

${ }^{22}$ Ibid., p. 244.

${ }^{23}$ Dans une note prise en 1955 en survolant l'Inde, Le Corbusier écrit : "De même que des perspectives de rivières-méandres étaient du Léonard (sic! Piero della Francesca). Il y a eu des scénarios de nuages que certains ont peint, les ayant imaginés vus du haut des airs" (FLC, carnet J39, n. 448).
} 


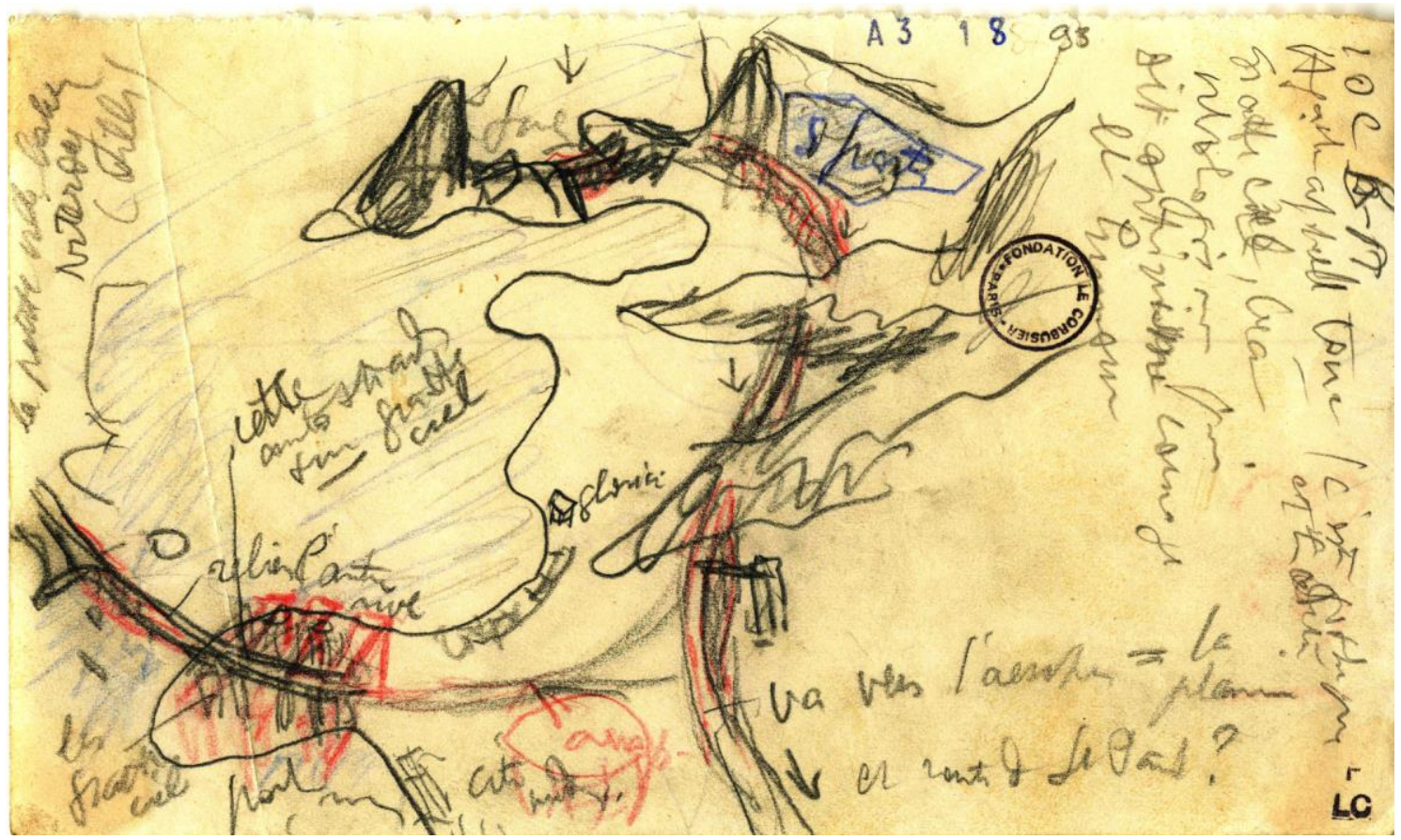

7. Rio de Janeiro, vue depuis l'avion avec croquis de son projet pour la ville. FLC, A3.18.98.

\section{Comment découvrir les secrets d'une ville}

À partir de ses premiers voyages, Le Corbusier commence à apprécier la vue privilégiée déjà par Montaigne lors de sa découverte des villes. À Naples, par exemple, après avoir visité l'église du Jésus, il se dirige vers les hauteurs, en direction de la route de Posillipo, depuis laquelle il peut contempler - comme le suggérait le célèbre guide d'Italie de Baedeker utilisé par beaucoup de voyageurs de l'époque - "les plus magnifiques points de vues, tout particulièrement beaux au coucher du soleil; aucun étranger ne devrait négliger d'y faire une promenade"24. Depuis cette colline Le Corbusier est désormais à même d'admirer toute la partie orientale du golfe et de signaler les quelques opérations ponctuelles - comme le site industriel de l'Ilva - venues altérer l'horizontalité du paysage ${ }^{25}$. À Rio de Janeiro, en 1936, il va jusqu'à réaliser une séquence de deux minutes de film depuis la plateforme sommitale du Morro da Providencia, en enregistrant le paysage de la grande baie ${ }^{26}$. Ses achats de cartes postales avec des vues plongeantes ou aériennes répondent aussi, comme on le verra, à ce besoin d'embrasser d'un coup d'œil le panorama construit et naturel. Dans ses publications, Le Corbusier commence également à faire appel aux photographies prises du haut ou depuis les appareils qui s'envolent au-dessus des villes. Dans le n. 18 de l'Esprit nouveau, par exemple, il publie deux clichés, dont l'un représente une vue aérienne de New York ${ }^{27}$. Pour le frontispice de L'art décoratif d'aujourd'hui (1925) Le Corbusier a recours à la photo zénithale publiée par la revue $S t a v b a^{28}$. La même année, il utilise pour un chapitre d'Urbanisme une carte postale dont le titre est déjà révélateur: Paris au début du XXe siècle. Une promenade en dirigeable ${ }^{29}$. Le Corbusier est déjà pleinement conscient que l'aviation ne constitue pas seulement un progrès technique, mais qu'elle sera à l'origine d'une

\footnotetext{
${ }^{24}$ Baedaker, Karl: L'Italie des Alpes à Naples. Paris: Ollendorgg, 1909, p. 393.

${ }^{25}$ Cf. Fatigato, Orfina: "À travers Naples". In A.A.V.V.: L'invention d'un architecte. Le voyage en Orient de Le Corbusier. Paris: Éditions de la Villette, 2013, pp. 426-439.

${ }^{26} \mathrm{Cf}$. Prelorenzo, Claude: "Gammes cinématographiques". In Le Corbusier. Aventures photographiques. Paris, Éditions de la Villette, 2014, pp. 70-87.

${ }^{27}$ Cf. l'article "L'ordre" écrit par Le Corbusier dans le numéro 18 de l'Esprit nouveau. À ce sujet cf. Mazza, Barbara: Le Corbusier... op. cit., p. 98.

${ }^{28}$ Mazza, Barbara: Le Corbusier... op. cit., p. 99.

${ }^{29}$ Ibid, p. 101.
} 
nouvelle manière de voir le monde. Ce n'est pas un hasard s'il envisage la publication - malheureusement jamais réalisée - d'un paragraphe/chapitre entier consacré aux vues depuis l'avion. La Fondation Le Corbusier conserve en effet un précieux document où l'on lit "faire 1 paragraphe sur la vue d'avion nouvel état de chose dans l'esthétique urbaine comme sensation architecturale. Montrer alors quelques vues d'avions (service topographique) de Paris ${ }^{\prime 30}$. Les trois croquis qui accompagnent ce propos, représentent des vues plongeantes - aucune vue zénithale du même genre que celle utilisée dans son frontispice de 1925 n'y figure - semblables à celles qu'un avion en phase d'atterrissage ou de décollage pourrait enregistrer. Des images qui, tout en saisissant l'étendue des différentes villes, visent à faire ressortir les volumes et les silhouettes des bâtiments principaux de la trame urbaine, de façon très réaliste et peu géométrisée. Dans un dessin l'on croit apercevoir les toits de Notre-Dame et du Panthéon, alors qu'un autre, légendé Chicago, affiche un seul gratte-ciel au milieu de lignes à peine ébauchées.

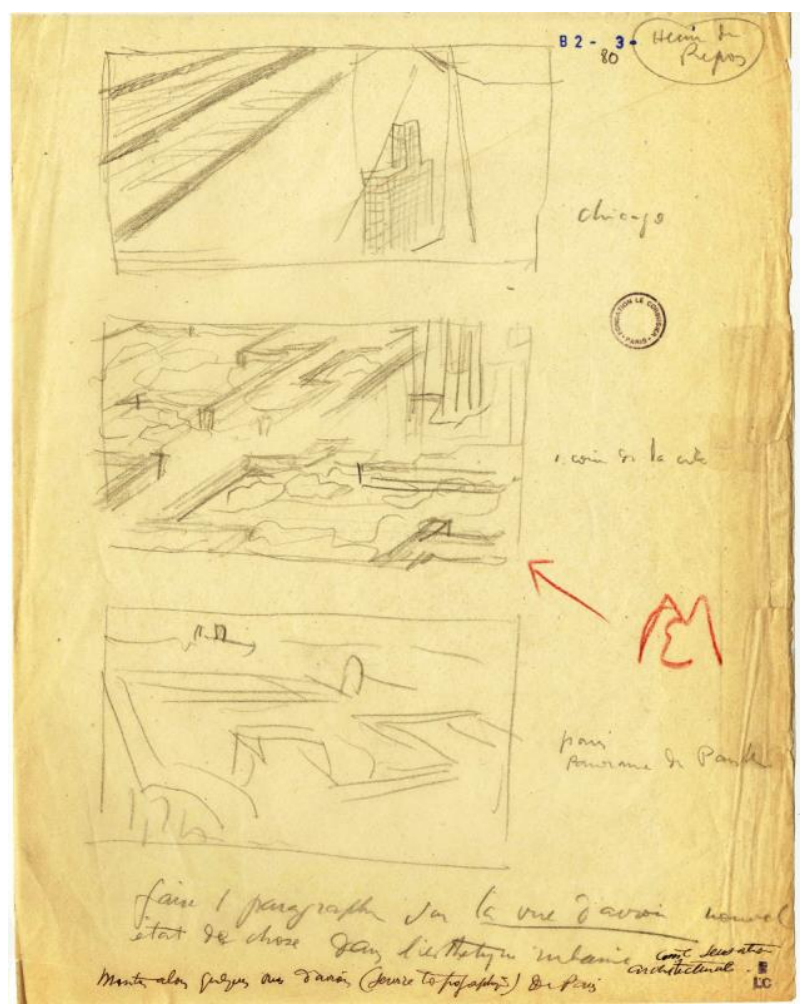

8. Feuille esquissant le projet de rédiger un chapitre d'Urbanisme sur la vue d'avion

Le Corbusier n'a pas encore découvert par ses propres yeux le vol en avion et ses dessins ressemblent davantage aux vues perçues depuis le sommet d'une colline (ou d'un édifice) qu'aux visions territoriales et planétaires dont il fera l'expérience quelques années plus tard. En effet, son rêve de voler se concrétise une première fois en 1928 lors d'un voyage en avion en direction de Moscou, mais trouve son véritable exaucement au cours des années 1929-1933 grâce aux nombreux survols des villes et du territoire de l'Amérique du sud et de l'Algérie. Les enregistrements aussi bien sur ses carnets de croquis que sur la pellicule photo ne se feront pas attendre. Des images qui, comme les notes qui très souvent les accompagnent, atteignent une plus grande capacité de synthèse et de concision. Entre ses phrases lapidaires, ses esquisses à peine ébauchées, ses photos instantanées et la vitesse du nouveau moyen de transport, existe sans doute un lien très fort ${ }^{31}$. La réalité est enregistrée sans médiations, dans son authenticité et avec promptitude. Ce qui ne signifie absolument pas que la saisie perde en précision. Tout au contraire, la vision d'avion est, selon l'architecte "la plus calme, la plus régulière, la plus

\footnotetext{
${ }^{30}$ FLC, B2-3-80.

${ }^{31}$ Cf. Bruno Pedretti: “Il volo dell'etica”. In Casabella. No 531-532. Janvier-Février 1987, pp. 74-85.
} 
précise qu'on puisse désirer: on apprécie le pelage tacheté ou rouge ou noir d'une vache. Tout prend la précision d'épure, le spectacle n'est pas hâtif mais très lent, sans rupture... "32. Car au fond la vitesse de l'aéroplane, sa "course foudroyante... donne la sensation étrange de la presque immobilitê" ${ }^{33}$.

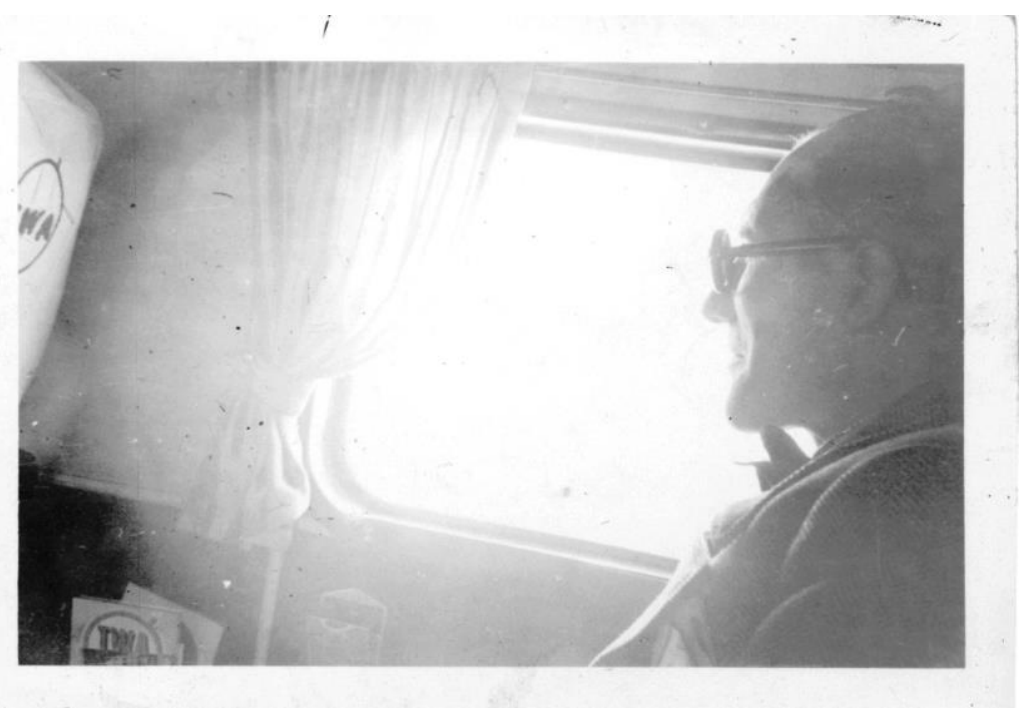

9. Le Corbusier lors d'un voyage en avion. FLC, L5-2.41.

La compréhension profonde des villes et des territoires de la part de Le Corbusier se fera par les deux modalités de perspective aérienne, complémentaires: celle "des paquebots de l'air qui foncent à 6000 mètres d'altitude par-dessus océans, savanes, sierras ou cordillères" et qui de très haut saisit la morphologie et les grands signes du territoire, mais aussi celle qui est autorisée par l'avion dans ses phases de décollage ou d'atterrissage ou bien par les petits appareils ou encore par ce qu'il nommera 1"“aéronautique verticale", à savoir les hélicoptères qui, “jouant à l'hippocampe des aquariums, montent et descendent de-ci de-là des montagnes sans aéroport, sur des aires d'atterrissage minuscule" ${ }^{\text {34 }}$. A titre d'exemple, il suffit de rappeler la demande de l'architecte adressée au pilote lui montrant Sao Paulo depuis l'avion, à savoir de voler aussi bas que possible. Dans ce cas précis le but était d'arriver à apprécier les hauteurs et la spatialité du tissu urbain, avec ses volumes et ses imbrications, l'important étant toujours d'appréhender au mieux le site survolé. Une expérience semblable est relatée par le Corbusier en 1935: le pilote qui l'avait accompagné en mars 1933 au-dessus du Mzab, ne se serait pas limité à survoler le territoire algérien, mais serait descendu sur les villes pour montrer à l'architecte "the principle of the towns ${ }^{\prime 35}$. C'est alors, du haut de l'avion, que le Corbusier découvre le secret des villes du désert avec les jardins et les arcades dont se composent les maisons locales ${ }^{36}$.

\footnotetext{
${ }^{32}$ Le Corbusier: Précisions... op. cit., p. 8.

${ }^{33}$ Le Corbusier: Sur les 4 routes. Paris: Denoël, 1970 (1 $1^{\text {èr }}$ éd. 1941), p. 42.

${ }^{34}$ Le Corbusier: "Urbanisme et Aéronautique". In Techniques et Architecture. № 9-12, 1947, reproduit in: Duboy, Philippe: Le Corbusier. Croquis de voyages et études. Paris: La Quinzaine Littéraire-Louis Vuitton, 2009, p. 320-323, cit. p. 322.

${ }^{35}$ Le Corbusier: Aircraft... op. cit., p. 12.

${ }^{36}$ Ibid. p. 12.
} 


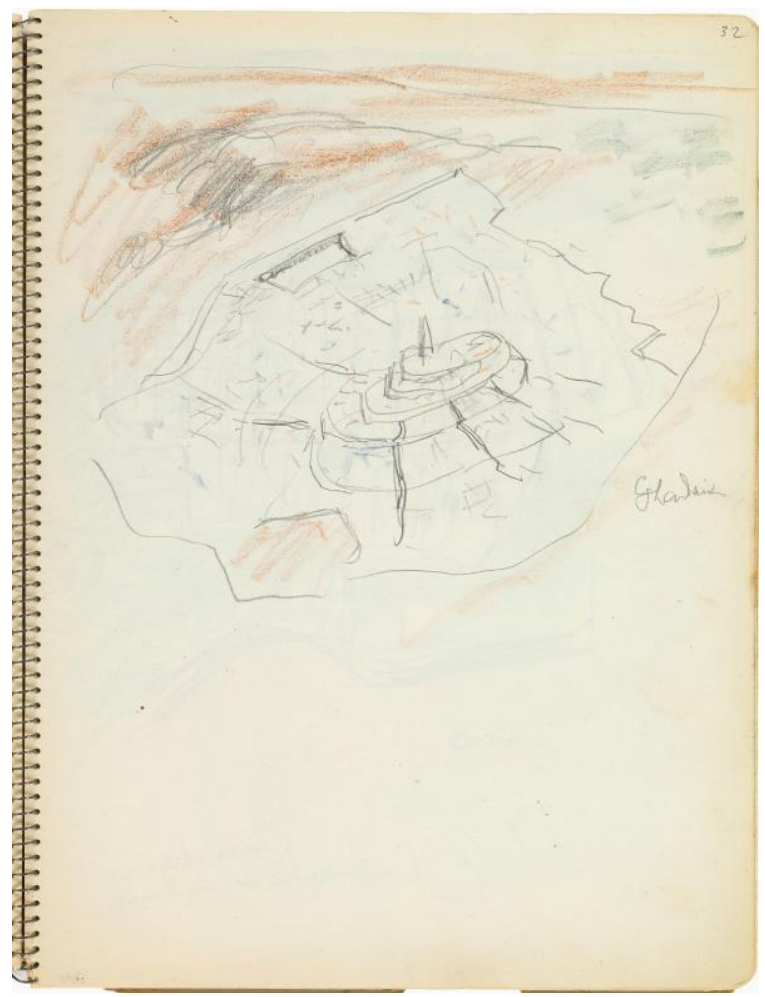

10. Vue aérienne d'une ville du désert, 1933. FLC, dessin 5010.

Par ailleurs, Le Corbusier revendique la nécessité de "voir" et de ne pas se limiter à l'acte, qu'il juge passif, du simple regard. Il semble partager avec l'un de ses plus célèbres prédécesseurs, Viollet-le-Duc, la conviction que "voir c'est savoir" suisse aboutit à la conclusion que "l'avion ... voit tout minutieusement" ${ }^{38}$ et qu'il s'avère être, probablement, le seul moyen capable de découvrir les secrets des villes. Le meilleur outil d'enregistrement de ces visions "actives" et "conscientes" demeure, selon lui, le dessin: un geste manuel mais aussi un acte intellectuel de connaissance et de sélection, qui n'est pas sans rappeler, encore une fois, les réflexions du célèbre théoricien français du XIXe siècle pour qui dessiner trouvait une équivalence dans l'étude et non dans la simple reproduction. "Je n'existe dans la vie qu'à condition de voir", écrit le Corbusier de retour du Brésil en $1929^{39}$. C'est d'ailleurs peut-être cette conviction que la vue aérienne puisse conduire à appréhender le sens le plus profond des choses, qui intensifie le plaisir du voyage en avion chez Le Corbusier au point de l'entendre affirmer "me voici au Paradis dans l'air comme un oiseau"40 ou encore "je ne suis jamais si tranquille que dans l'avion. Cosmos et solitude amicale et bénéfique" ". Ses lectures, pendant ses traversées européennes aussi bien que transatlantiques, traduisent parfaitement cet état d'esprit voué à la méditation, aux réflexions sur le sens de la vie et de l'univers entier. Rabelais, définis comme "homme qui apporte le courage et la pensée, ${ }^{, 2}$, Machiavel et $\mathrm{Brecht}^{43}$, ne constituent que quelques exemples des auteurs qui accompagnent l'architecte à 5000-6000 mètres de hauteur. Don Quichotte se retrouve souvent entre ses mains, l'incitant peut-être à lire la réalité avec d'autres yeux. Et le regard de Le Corbusier se fait de plus en plus attentif,

\footnotetext{
${ }^{37}$ Viollet-le-Duc, Eugène-Emmanuel: Histoire d'un dessinateur. Comment on apprend à dessiner. Paris: Hetzel, 1879, p. 302.

${ }^{38}$ Le Corbusier se trouve sur l'avion Bombay-Dehli en 1955: FLC, carnet J39, 439.

${ }^{39}$ Le Corbusier: Précisions... op. cit., p. 8.

${ }^{40}$ Le Corbusier: Carnets 2. 1950-1954. Paris: Herscher, 1981, n. 934.

${ }^{41}$ FLC, carnet E20, n. 422

${ }^{42}$ FLC, carnet J36, n. 268.

${ }^{43}$ FLC, carnet L47, n. 881 .
} 
sélectif, analytique, précis, étendu, au point de balayer l'espace cosmique et d'en tirer des conclusions graphiques ou écrites qui peuvent parfois paraître laconiques et lapidaires à cause de leur synthèse poussée à l'extrême.

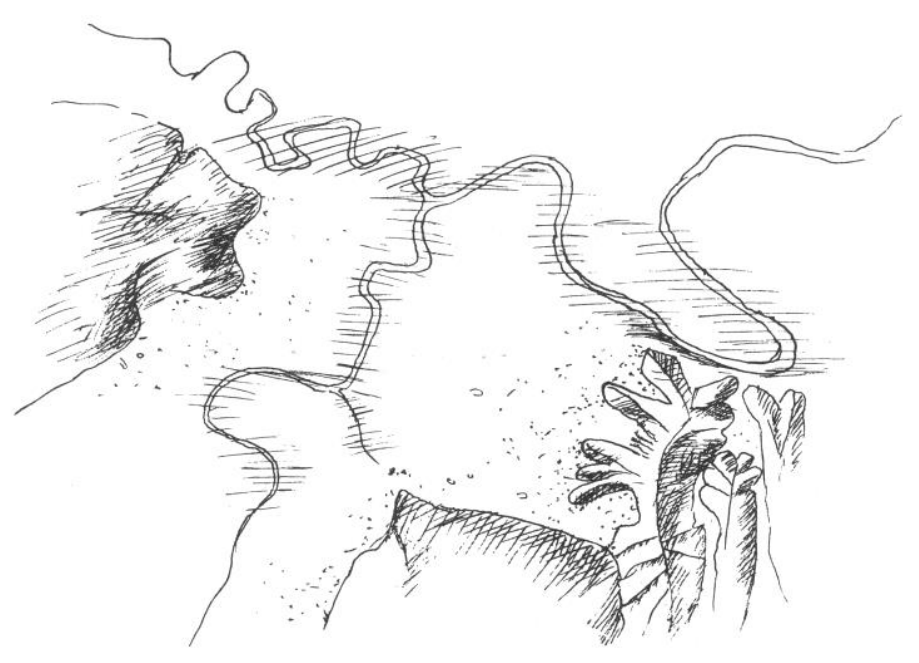

11. Paysage algérien depuis l'avion, 1933. Le Corbusier: Aircraft. London: The Studio, 1935, p. 116.

\section{Analyse et projet: la naissance d'une nouvelle échelle}

La précision autorisée par la vue aérienne devient, chez Le Corbusier, le point de départ d'une série de projets de transformation d'une réalité qui lui apparait, du haut de l'avion, particulièrement riche en contradictions. Le spectacle offert par l'aéroplane - "Quel sinistre bilan!" et de l'aménagement urbain. En 1930, dans Précisions l'architecte avait souligné la capacité de l'avion d'entrer "dans l'intimité de la ville" et de lui arracher "d'un simple coup d'œil d'oiseau planeur tous les secrets qu'elle cachait si facilement au pauvre terrien sur ses deux pieds" ${ }^{\prime 45}$. Mais la compréhension se transforme très rapidement en jugement critique. Les considérations que l'architecte formule en 1935 dans le texte qu'il écrit pour accompagner les photos que la célèbre maison d'édition anglaise The Studio envisageait de publier dans un volume consacré à la vision aérienne, sont très éloquentes à ce propos ${ }^{46}$. "The airplane is an indictment. It indicts the city. It indicts those who control the city. By means of the airplane, we now have proof, recorder on the photographic plate, of the rightness of our desire to alter methods of architecture and town-planning" ${ }^{\text {"47 }}$. Ce nouvel état de lucidité incite "to change something in the present world" et ne peut aboutir qu'à la recommandation de démolir les vieilles villes et de les reconstruire. La vision claire et lucide constitue l'acte préalable à l'intervention: "The airplane has given us the bird's-eye view. When the eye sees clearly, the mind makes a clear decision"49. Très nombreuses sont les annotations qui accompagnent les croquis de Le Corbusier effectués lors de ses voyages en avion dans lesquelles il exprime ses pensées, voire ses condamnations des solutions urbaines adoptées dans le monde entier. La France figure comme l'un des pays le plus incriminé où le "parcellement actuel des terres" est

\footnotetext{
${ }^{44}$ Le Corbusier: Sur les $4 \ldots$ op. cit., p. 150.

${ }^{45}$ Le Corbusier: Précisions... op. cit., p. 235.

${ }^{46}$ Le Corbusier: Aircraft... op. cit.

47 Ibid, p. 11.

${ }^{48} \mathrm{Ibid}, \mathrm{p} .11$.

${ }^{49}$ Ibid, p. 13.
} 
“affolant", "désastreux" "50. En 1962, en survolant la capitale il note "la banlieue de Paris vue d'avion est un scandale, une maladiel/ toutes maisons se touchent mais se voient, s'entendent..." ${ }^{.51}$. La vieille Europe, en générale, n'échappe pas à ses critiques féroces: des expériences allemandes des cités jardins (à Frankfort par exemple) ${ }^{52}$ à "l'extrême cacophonie" de Barcelone ${ }^{53}$. Malgré l'emploi de matériaux de construction peu modernes, Le Corbusier semble préférer les solutions adoptées dans les pays du Moyen Orient qu'il découvre en avion comme par exemple la ville d'Abadan, en Iran: située près d'un "fleuve majestueux", elle est une "ville moderne en torchis mais d'une géométrie et ordonnance totale (du logis)" où même les "tanks aluminiumés groupés par quatre... [sont] dans un ordre magnifique ${ }^{\text {} 54}$. Font aussi partie de cette appréhension des villes et du territoire survolés, les remarques et les observations sur la couleur de la terre, des sites, de l'horizon. Dans ses dessins, mais surtout dans les notes qui les accompagnent, Le Corbusier transcrit et commente les gradations et les couleurs lui permettant de mieux comprendre l'humidité du sol et par là "toute une biologie", toute cette "vie organique" qui se dévoile à ses yeux à 5000-6000 mètres de hauteur". L"“herbe brulée de l'horizon", de l'estuaire de l'Indus ${ }^{57}$, contribuent à saisir la spécificité du territoire examiné depuis le ciel. Une fois que l'architecte pense avoir réussi à entrer "dans le corps et le cour de la ville" et avoir "compris une part de son destin..." "58, jaillit alors la "joie de la création",59. Un sentiment qui vient remplacer la "joie des sens",60 provoquée par la vision du monde à ses pieds.

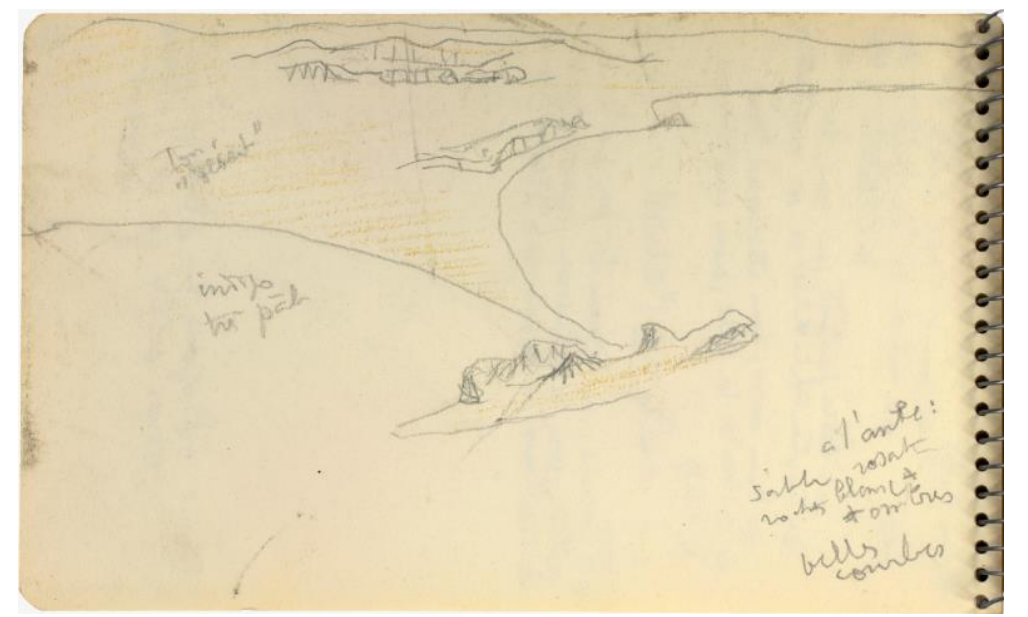

12. Depuis l'avion, Le Corbusier note les couleurs des territoires survolés, 1958. FLC, carnet J37, n. 334.

Du retour d'Amérique du sud en 1929, à bord du paquebot qui le ramène en Europe et où il est en train d'écrire Précisions, Le Corbusier aboutit à des conclusions claires et rigoureuses concernant son devoir d'architecte du XXe siècle. Depuis qu'il a découvert un pays "dimensionné pour l'avion"61 pour lequel il a élaboré des projets de grande envergure à échelle territoriale - à Buenos Aires comme à Rio de Janeiro - il estime que son attention et ses préoccupations devront désormais s'adresser essentiellement aux questions urbaines et aux territoires

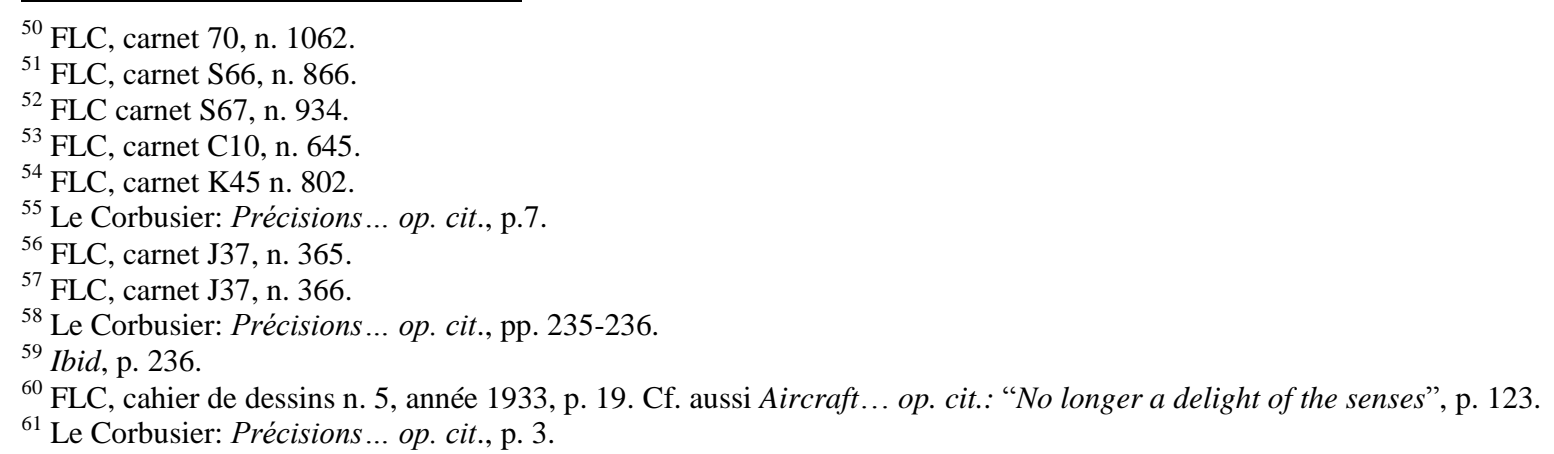


métropolitains. Le Corbusier est de plus en plus conscient que grâce à ce nouveau moyen de transport "on est devenu un animal nouveau sur la planète ${ }^{, 62}$ et que ce genre de vision depuis les hauteurs ne peut plus utiliser les catégories analytiques traditionnelles mais demande une nouvelle approche du regard. Dans une note prise en 1962 sur le vol Nice-Paris, il réfléchit à la naissance d'une nouvelle d'appréhension du monde, qui n'est plus proportionnée à la hauteur du piéton qui marche et qui voit les arbres, les murs des fermes etc. ${ }^{63}$.

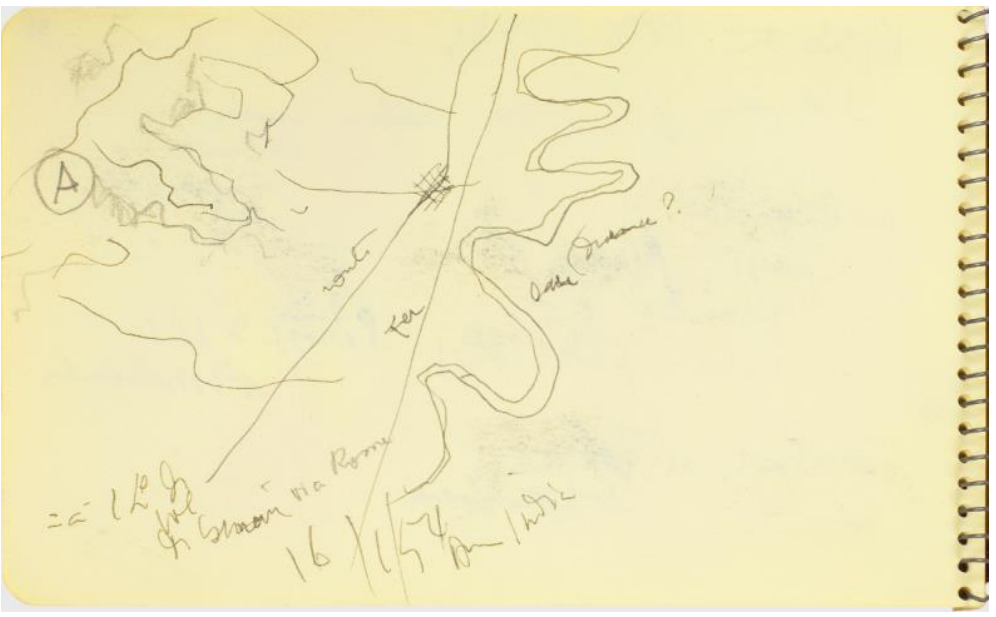

13. Les trois routes (terre, eau, fer) vues de l'avion. FLC, carnet H30, n. 1030.

Il ne s'agit pas seulement d'un changement d'échelle d'observation, mais de transformation de sa nature qui atteint presque un statut métaphysique: grâce à l'avion “nous réalisons, dans le réel, ce qui jusqu'ici n'avait été qu'une vue de l'esprit ${ }^{364}$. Les croquis de Le Corbusier saisissant la morphologie des pays survolés, se composent parfois de quelques lignes seulement: des traits qui représentent de façon dépouillée et concise les estuaires, les méandres des fleuves, les différentes voies de communication - les trois routes: terre, eau, fer - qui s'alignent parallèlement etc. ${ }^{65}$. Des images graphiques, presque abstraites, capables néanmoins de fournir "une leçon de hydrographie, de physique",66. Entre la petite échelle des grains de sable déplacés par la mer et photographiés en 1936 par Le Corbusier sur la plage du Piquey ${ }^{67}$ et celle des grandes érosions, des méandres infinis et des estuaires des villes de l'Afrique du nord ou de l'Amérique du sud, la différence ne réside que dans la dimension des objets représentés. Le processus naturel d'évaporation et condensation de l'eau qui régit la planète entière comparée depuis l'avion à un œuf poché6 ${ }^{6}-$, devient pour Le Corbusier l'une des questions essentielles sur laquelle réfléchir, peu importe l'échelle de ses effets.

\footnotetext{
${ }^{62}$ FLC, carnet P60, n. 501.

${ }^{63}$ FLC, carnet S67, n. 928.

${ }^{64}$ De Pierrefeu, François et Le Corbusier: La maison des hommes. Paris: Plon, 1942, p.141.

${ }^{65}$ FLC, carnet H30, n. 1030 ou encore carnet P60, n. 503.

${ }^{66}$ FLC, carnet J38, n. 439.

${ }^{67}$ Cf. Benton, Tim: LC Foto... op. cit.

${ }^{68}$ Le Corbusier: Précisions... op. cit., p. 5 : "Comme l'œuf poché, la terre est saturée d'eau en surface".
} 


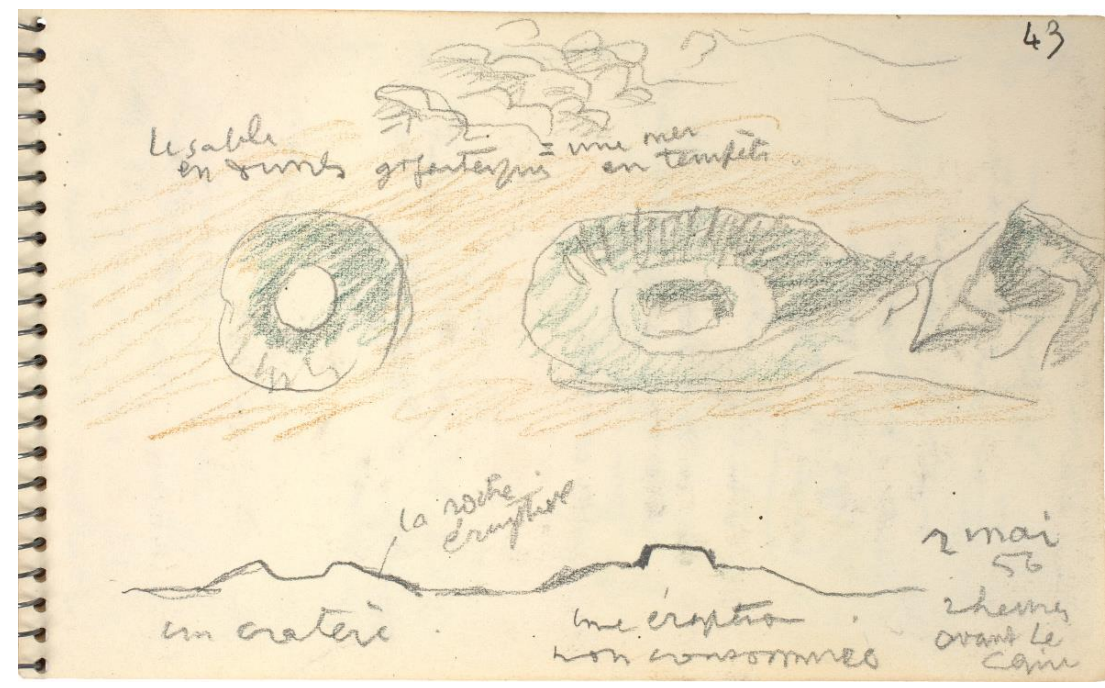

14. Sable, dunes, roches depuis l'avion, 1956. FLC, carnet K42, n. 634.

La vision aérienne ainsi que la vue plongeante qui se pose sur quelques centimètres carrés de sable, permettent de découvrir l'un des mystères de notre terre qui, avec ses ondulations, ses roches et ses petits ou grands mouvements, est capable de provoquer en nous "la notion de sublime" ${ }^{69}$. Pas étonnant alors que dans un dessin de 1933 - année pendant laquelle il survole avec Louis Durafour le désert allant d'Alger à Laghouat et Ghardaïa - Le Corbusier note cette petite équation: "avion=philosophie/spectacle à thèse" "70. Ce moyen de transport a la capacité de soulever des questions et des problèmes essentiels concernant le cadre de vie des hommes et la vue sans fin qu'il autorise d'un "horizon sans rupture limite du disque terrestre" 71 accorde à Le Corbusier une sérénité et une fusion avec le cosmos: "Je suis dans un état de parfait équilibre, de parfaite sérénité, presque effusion, à $6000 \mathrm{~m}$ d'altitude..."72.

\section{Les cartes postales entre panoramas urbains et territoriaux}

On ne connait pas très bien l'emploi que Le Corbusier faisait des cartes postales, en dehors du lien avec son œuvre picturale ou de leur intégration dans ses textes publiés ${ }^{73}$. D'après un examen de la collection, il paraît toutefois que les vues panoramiques depuis les hauteurs ainsi que celles depuis les avions occupent une part importante du fonds concernant l'architecture et l'espace urbain. D'une part elles ont probablement servi d'“aide-mémoire" au sein d'un processus d'apprentissage et de connaissance, d'autre part elles semblent être le miroir parfait de sa conscience qu'une nouvelle échelle de lecture du territoire terrestre va désormais orienter la vision humaine. C'est peut-être pour travailler sur cette nouvelle perception de la ville autorisée par l'aviation, que Le Corbusier achète des cartes postales reproduisant l'île de Manhattan ou San Francisco photographiées depuis le ciel, mais jamais à une hauteur trop importante, afin de pouvoir saisir la ville dans son contexte naturel (montagne, mer etc.) ainsi que ses reliefs. La vue aérienne du grand carrefour Slussen à Stockholm réalisé dans les années 1930, fait partie de la collection ${ }^{74}$. L'infrastructure est photographiée depuis un angle à même de saisir les différents niveaux routiers entrelacés, ainsi que la contiguïté au centre urbain. Les espaces liés au monde du transport suscitent chez le Corbusier depuis toujours une attention spéciale. Cette carte postale rappelle en effet

\footnotetext{
${ }^{69}$ Ibid., p. 15.

${ }^{70}$ FLC, cahier de dessins, n. 5, 1933, p. 19.

${ }^{71}$ FLC, carnet J39, n. 448.

${ }^{72}$ Le Corbusier: Carnets 2...op. cit., n. 934.

${ }^{73}$ Cf. Burriel Bileza, Luis: Le Corbusier. La passion des cartes. Bruxelles: Mardaga, 2013, p. 22.

${ }^{74}$ FLC, cartes postales, L5-9-18.
} 
les différents clichés photographiques pris par l'architecte au cours de l'un de ses voyages en avion à Anvers, dans lesquelles il avait fixé le port et ses alentours ${ }^{75}$.

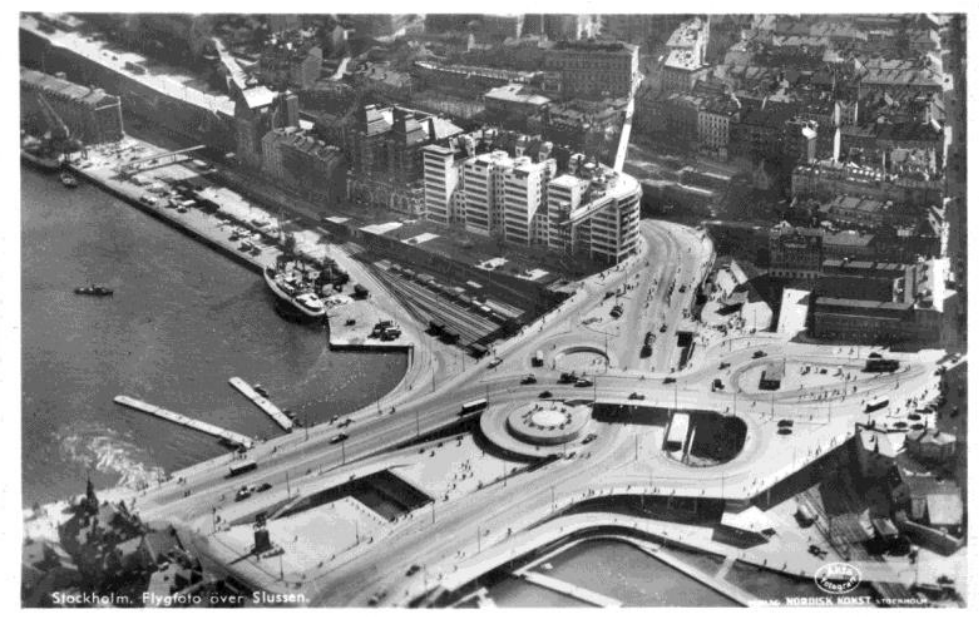

15. Carte postale représentant une vue aérienne du grand carrefour Slussen de Stockholm. FLC, L5-9-18.

Mêmes les cartes postales des remparts d'Aigues Mortes (cliché de la Compagnie Aérienne Française) ou des denses tissus urbains de Venise offrent des vues plongeantes très réelles et peu abstraites ${ }^{76}$. La présence de quelques vues aériennes nocturnes (Rio de Janeiro, New York etc.) témoigne également de l'intérêt de Le Corbusier pour l'effet que l'éclairage électrique pourrait susciter auprès d'un voyageur découvrant ces agglomérations. Dans ses notes prises au cours de ses voyages en avion il a aussi souvent fait allusion à la vision nocturne des villes et au rôle des lumières électriques dans l'appréhension de la grille urbaine, de la géométrie du tracé (à Téhéran par exemple) aussi bien que dans la révélation de 1"“affiche de bienvenu" des villes, comme lorsqu'il affirme, en 1960, que "l'arrivée de nuit sur Bombay est saisissante" avec ses bords de mer "ceinturés... de lumière" ". Nombreuses sont aussi les cartes postales conservées dans cet immense fonds iconographique, reproduisant le skyline des villes européennes ${ }^{78}$.

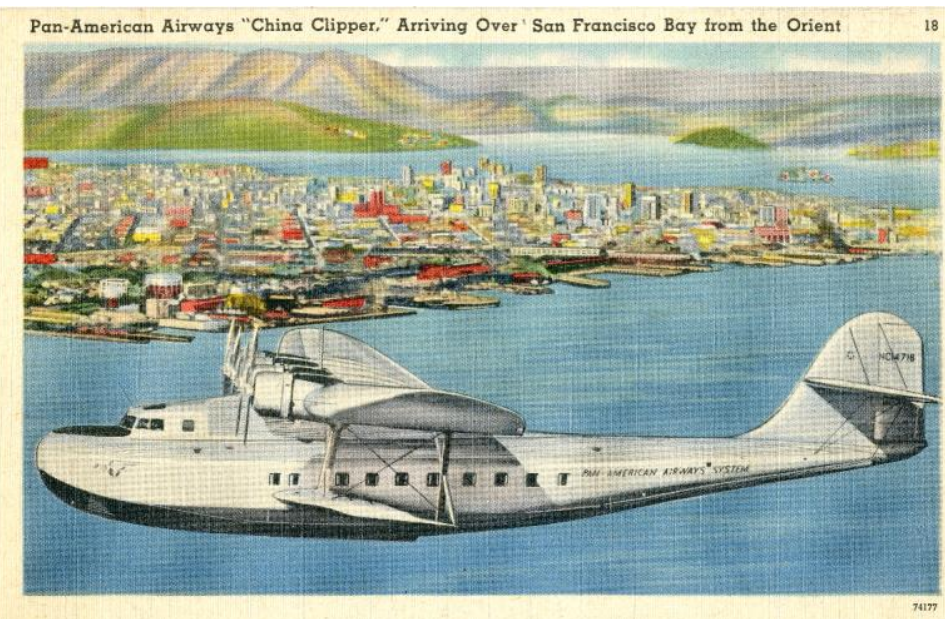

16. Carte postale avec une vue aérienne de San Francisco. FLC, L5-4-80.

\footnotetext{
${ }^{75}$ FLC, L5-2-39 e L5-2-40

${ }^{76}$ FLC, L5-5-6; L5-5-215, L5-8-287.

${ }^{77}$ FLC, carnet P60, n. 500.

${ }^{78}$ Cf. Burriel Bileza, Luis: Le Corbusier... op. cit.
} 
Le choix de cadrage de ces cartes postales qui comprennent aussi une vue de New York depuis le Hudson River, est en parfaite résonance avec les silhouettes dessinées ou photographiées par l'architecte - parfois depuis un bateau - depuis le temps de ses voyages de jeunesse. Par ailleurs, le format de ses carnets de croquis, employés à l'horizontale, ressemble étrangement à celui des cartes postales. Deux moyens de figuration qui témoignent du même intérêt pour l'effet que la silhouette d'une ville peut provoquer sur le touriste/spectateur/acheteur. Qu'il s'agisse de photos prises par lui-même, d'annotations ou de cartes postales achetées, Le Corbusier ne privilégie jamais les images représentant les centres urbains depuis la verticale, mais des panoramas visant à donner le premier aperçu de la ville qu'on s'apprête à découvrir. Un aperçu visuel que l'architecte a toujours considéré comme important, et qui devient un véritable leit motiv à partir de ses voyages dans les des années Trente.

\section{De la vision humaine à $1,60 \mathrm{~m}$ à celles infernales des trains et des automobiles}

“...il n'est, avec l'avion, que le paquebot en mer et le pied du marcheur sur la route, qui permettent ce qu'on pourrait appeler des visions humaines: on voit, l'œil transmet calmement" ${ }^{379}$. Le danger des eaux, par exemple, que le colon qui habite en Uruguay ne comprend pas, peut devenir clair seulement grâce à la vue depuis l'avion. Mais c'est la vue à 1,60 m de hauteur qui vient confirmer et compléter les premières impressions engendrées par l'arrivée par bateau ou par aéroplane. En effet, l'œil du piéton qui a "conservé des jambes et des yeux à 1,60 m $d u$ sol" saisit les traces naturelles de manière assez différente de l'avion qui "a gagné des ailes" ${ }^{\text {" }}$ : si la vue des prairies, des fleuves, des forêts vierges confère au marcheur des sensations de "noblesse, d'exubérance, d'opulence, de vie", la même vue, depuis le ciel, n'apparait que de la "moisissure"81.

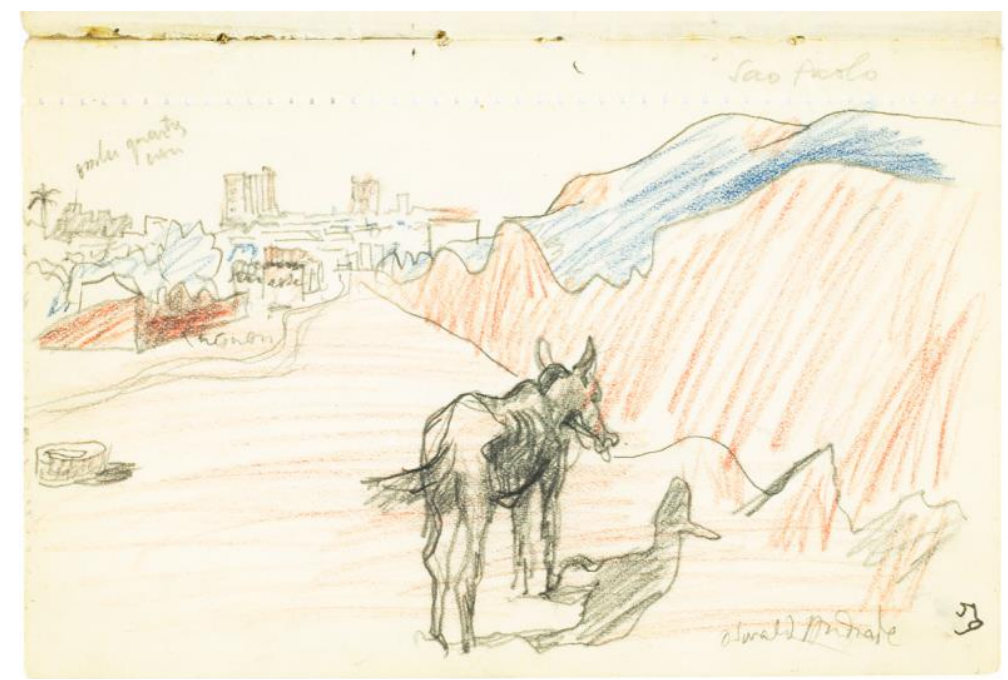

17. Vue de Sao Paulo depuis la route. FLC, carnet B4, n. 260.

La promenade en ville prévoit généralement de monter sur les sommets pour scruter le tissu urbain depuis les hauteurs et souvent du point de vue opposé à celui offert par la vision depuis la baie. "Du haut des «Favellas» on voit toujours la mer, les rades, les ports, les îles, l'océan, les montagnes, les estuaires; le nègre voit tout cela...; une fierté est dans l'œil du nègre qui voit tout ça; l'œil de l'homme qui voit de vastes horizons est plus hautain, les vastes horizons confèrent de la dignité; c'est une réflexion d'urbaniste..." ${ }^{\Perp 2}$. Parallèlement, les pieds du marcheur permettent aussi de pénétrer dans le cœur des villes et de découvrir les différentes solutions

\footnotetext{
${ }^{79}$ Le Corbusier: Précisions... op. cit., p. 8.

${ }^{80}$ FLC, carnet F26, n. 846.

${ }^{81}$ Le Corbusier: Précisions... op. cit., p. 7.

${ }^{82}$ Ibid, p. 235.
} 
de l'habitat historique et/ou moderne. À Buenos Aires, “j'ai parcouru à pied nombre de rues... J'ai regardé, $v u$ et compris..." ${ }^{, 3}$. Le dessin de Sao Paulo depuis la route témoigne de la vision calme et paisible que la vitesse du pas humain ou animal autorise: Le Corbusier a le temps de dessiner aussi, à côté du paysage, l'âne qui l'accompagne ${ }^{84}$.

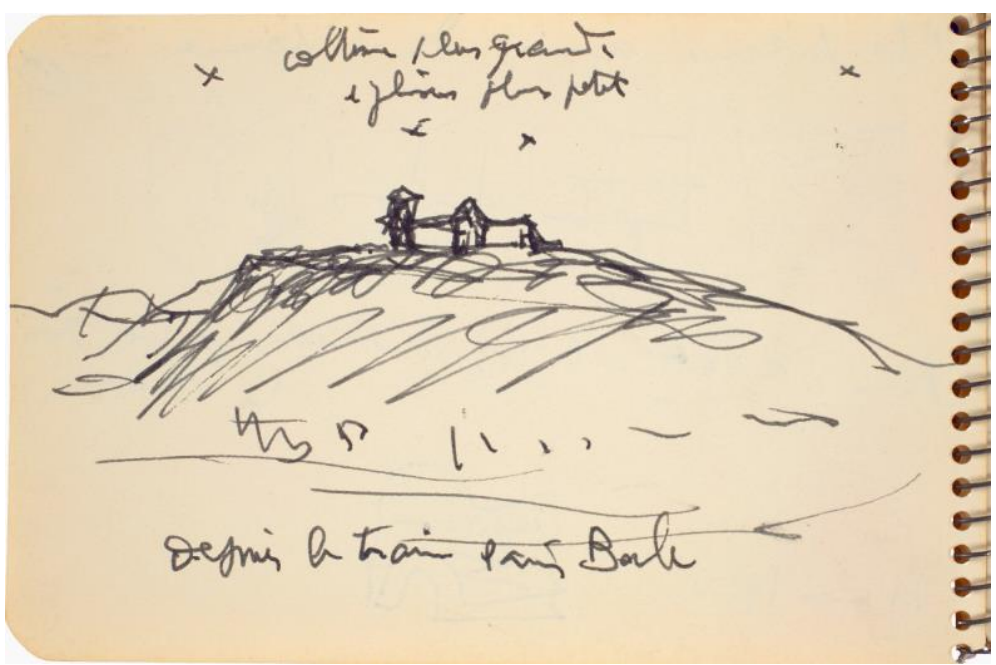

18. Esquisse de Ronchamp depuis le train, 1950. FLC, carnet D17, n. 272.

À Alger, l'architecte se balade dans la Casbah; à Rio de Janeiro il esquisse les maisons et signale leur ancrage au sol ainsi que les magnifiques panoramas visibles par leurs fenêtres ${ }^{85}$. À ces visions humaines, Le Corbusier oppose celles “inhumaines et infernales ... offertes d'un train ou d'une auto, même d'une bécane"86. L'architecte ne semble pas tellement aimer les chemins de fer. D'une part car ils ont remplacé la traditionnelle entrée en ville qui se faisait "en pompe étincelante par le pont-levis et les portes des rois (porte Saint-Denis, porte Saint-Martin, seules demeurées) et la sente millénaire jusqu'au cour de la cité, où sont les cathédrales et les hôtels de ville" ${ }^{87}$ par "la lèpre qui s'étale autour du cliquetis du train sur les aiguillages" ${ }^{88}$. D'autre part, car les chemins de fer ont déversé en ville une foule épouvantable, en contribuant à la rendre invivable. Mais c'est aussi la vitesse de ce transport qui est mise en cause, puisqu'elle a supplanté le rythme lent et naturel des êtres vivants et de leurs moyens de transport, sans pour autant être à même d'entrainer une nouvelle façon d'appréhender la ville. Les premières esquisses de Ronchamp élaborées en mai 1950 “depuis train Paris-Bâle" ${ }^{\text {} 89}$ constituent les rares exemples de saisie/insertion d'une architecture au milieu de son contexte paysager pris depuis ce moyen de transport.

Mais la pensée de Le Corbusier semble parfois hésiter et se brouiller lorsqu'il analyse les quatre routes (automobile, avion, bateau, chemin de fer) et les visions qu'elles ont entrainées. Si la rapidité symbolise la civilisation machiniste et a fait "considérer d'un ceil nouveau la planète"90, celle qui appartient proprement aux trains est considérée toutefois par l'architecte comme une "vitesse... [qui] brouille le paysage", alors que celle des avions échappe à cette critique, car leur "course foudroyante" donnerait "la sensation étrange de la presque immobilité" " ${ }^{\text {pl }}$. Les diagrammes réalisés lors de la sixième conférence tenue à Buenos Aires en 1929

\footnotetext{
${ }^{83}$ Le Corbusier: Précisions... op. cit., p. 35.

${ }^{84}$ FLC, carnet B4, n. 260.

${ }^{85}$ Le Corbusier: Précisions... op. cit., p. 10.

${ }^{86}$ Le Corbusier: Ibid, p. 8.

${ }^{87}$ Le Corbusier: Sur les 4 ... op. cit., p. 113.

${ }^{88}$ Ibid, pp. 113-114.

${ }^{89}$ Le Corbusier: Carnets 2...op. cit., n.272-273.

${ }^{90}$ Le Corbusier: Sur les 4 ... op. cit., p. 40.

${ }^{91}$ Ibid, pp. 41-42.
} 
dans lesquels Le Corbusier esquisse la courbe de la vitesse qui, depuis 1850, a augmenté de façon exponentielle grâce aux "chemins de fer, paquebots, avions, dirigeables, automobiles T.S.F., téléphone",92, mérite notre attention.

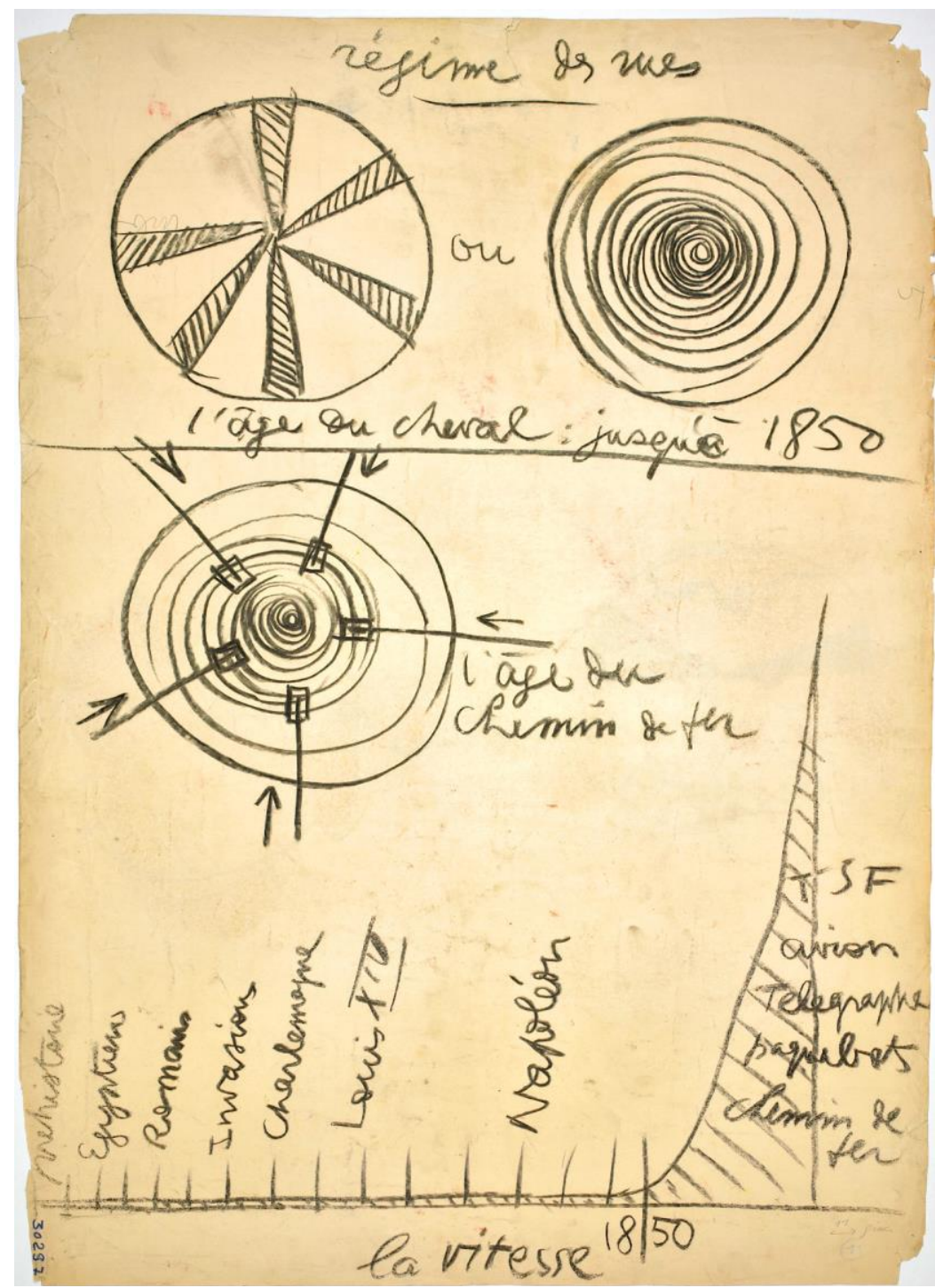

19. Diagramme de la vitesse. Esquisse élaborée lors de la sixième conférence tenue à Buenos Aires en 1929. FLC plan 30297A.

La conception de la route moderne comme axe de circulation très rapide est certainement à l'origine de la définition de vision inhumaine et infernale, élaborée par le Corbusier en 1930. La célérité, dont le but est celui de faire baisser les encombrements, autorise une vision cinétique qui s'accommode peu à un enregistrement fidèle de la réalité. L'automobile peut seulement aider à la perception de la topographie du terrain parcouru: "en auto, nous avons fait des expériences: celle par exemple du temps considérable qu'il faut pour aller d'un point à un autre: vallonnements, contours, pentes, etc." ${ }^{\prime 3}$. Ou, dans le meilleur des cas, elle permet à Le Corbusier de se faire une idée sommaire de la construction des maisons et du mode de l'habitat, comme lorsqu'il voyage en 1951 sur sa jeep de Chandigarh à New Dehli ${ }^{94}$.

\footnotetext{
${ }^{92}$ Cf. Benton, Tim: Le Corbusier conférencier. Paris. Editions Le Moniteur, 2007, pp. 184-185. Un des deux croquis a été publié dans Le Corbusier: Précisions... op. cit., p. 148.

${ }_{93}^{93}$ Le Corbusier: Précisions... op. cit, p. 240.

${ }^{94}$ FLC, carnet E18, 343-346.
} 


\section{Conclusion}

Pour Le Corbusier, voir - et ne pas simplement regarder - depuis un bateau ou un avion, entraine une approche cognitive et interprétative de la ville et de ses caractères urbains et paysagers que nul autre moyen de transport n'autorise. Il s'agit de visions (avec la vue à 1,60 m de hauteur) qui trouvent dans la complémentarité, le couronnement de leurs objectifs. La grande distance depuis l'objet autoriserait, selon l'architecte, une perception davantage globale, précise et objective, tout en permettant de prendre des décisions rapides dans le domaine de la conception du projet architectural et urbain. En particulier, l'aéroplane est désormais devenu la métaphore d'un regard nouveau. La prédilection pour une vision lente et presque "immobile" consentie par un paquebot ou un avion révèle une démarche accordant à la première découverte d'un site - silhouette, trame, morphologie etc. une importance sans précédent. Mais l'approche essentiellement visuelle que l'on peut avoir depuis une embarcation arrivant à proximité de la côte, trouve son véritable aboutissement grâce à la contemplation depuis le ciel. "The bird's eye view" 95 est désormais capable non seulement de déclencher une nouvelle échelle d'appréhension du monde, des sensations inédites, mais aussi d'engendrer une nouvelle philosophie de vie.

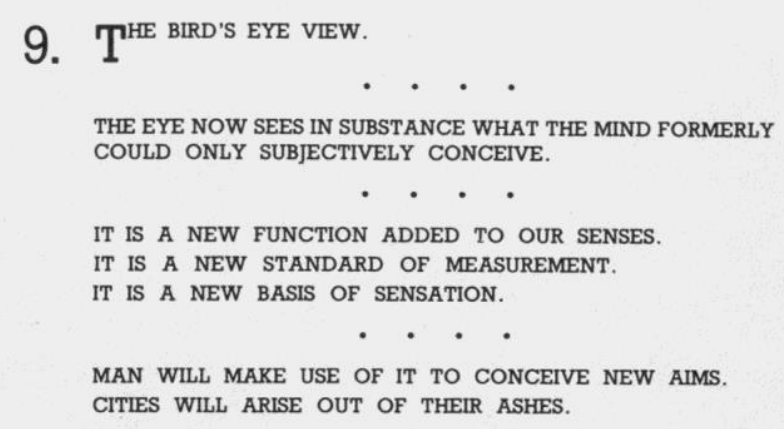

20. Extrait de Aircraft, 1935. Le Corbusier: Aircraft. London: The Studio, 1935, p. 96.

\section{Liste des images}

1. La forteresse de Smederevo. Photographie 1911. FLC, L5-1-124.

2. Photo prise lors du voyage dans les Balkans en 1911. FLC, L4-20-170.

3. Panorama d'Istanbul, 1911. FLC, 2383.

4. Séquence sténographique de Manhattan. Le Corbusier: Quand les cathédrales étaient blanches. Voyage au pays des timides. Paris: Plon, 1937, pp. 315-322.

5. Vue de Barcelone depuis la mer, 1932. FLC, carnet C10, n. 636.

6. Un des premiers croquis pour Rio de Janeiro. FLC, dessin 5033.

7. Rio de Janeiro, vue depuis l'avion avec croquis de son projet pour la ville. FLC, A3.18.98.

8. Feuille esquissant le projet de rédiger un chapitre d'Urbanisme sur la vue d'avion FLC, B2-3-80.

9. Le Corbusier lors d'un voyage en avion. FLC, L5-2.41.

10. Vue aérienne d'une ville du désert, 1933. FLC, dessin 5010.

11. Paysage algérien depuis l'avion, 1933. Le Corbusier: Aircraft. London: The Studio, 1935, p. 116.

\footnotetext{
${ }^{95}$ Le Corbusier: Aircraft, op. cit., p. 96.
} 
12. Depuis l'avion, Le Corbusier note les couleurs des territoires survolés, 1958. FLC, carnet J37, n. 334.

13. Les trois routes (terre, eau, fer) vues de l'avion. FLC, carnet H30, n. 1030.

14. Sable, dunes, roches depuis l'avion, 1956. FLC, carnet K42, n. 634.

15. Carte postale représentant une vue aérienne du grand carrefour Slussen de Stockholm. FLC, L5-9-18.

16. Carte postale avec une vue aérienne de San Francisco. FLC, L5-4-80.

17. Vue de Sao Paulo depuis la route. FLC, carnet B4, n. 260.

18. Esquisse de Ronchamp depuis le train, 1950. FLC, carnet D17, n. 272.

19. Diagramme de la vitesse. Esquisse élaborée lors de la sixième conférence tenue à Buenos Aires en 1929. FLC, plan 30297A.

20. Extrait de Aircraft, 1935. Le Corbusier: Aircraft. London: The Studio, 1935, p. 96.

\section{Bibliographie}

A.A.V.V.: L'invention d'un architecte. Le voyage en Orient de Le Corbusier. Paris: Editions de la Villette, 2013.

Benton, Tim: "Le Corbusier photographe secret”. In Herschdorfer, Nathalie et Umstätter, Lada (Dir.): Construire l'image. Le Corbusier et la photographie. Paris: Textuel, 2012, pp. 30-53.

Benton, Tim: LC Foto: Le Corbusier Secret Photographer. Zürich: Lars Müller, 2013.

Benton, Tim: Le Corbusier conférencier. Paris. Éditions Le Moniteur, 2007.

Bonillo, Jean-Lucien (Dir.): Le Corbusier. Visions d'Alger. Paris: Éditions de la Villette, 2012.

Burriel Bileza, Luis: Le Corbusier. La passion des cartes. Bruxelles: Mardaga, 2013.

Casabella. № 531-532. Janvier-Février 1987.

De Pierrefeu, François et Le Corbusier: La maison des hommes. Paris: Plon, 1942.

Duboy, Philippe: Le Corbusier. Croquis de voyages et études. Paris: La Quinzaine Littéraire-Louis Vuitton, 2009.

Gresleri, Giuliano: “Dal diario al progetto. I Carnet 1-6 di Le Corbusier”. In Lotus. N.68. 1991, pp. 6-21.

Le Corbusier: Aircraft. London: The Studio, 1935.

Le Corbusier: Le voyage d'Orient. Marseille: Parenthèses, 1987 (1 ${ }^{\text {ère }}$ éd. Paris: Les Éditions Forces Vives, 1966 ; éd. it. Il viaggio d'Oriente. Faenza: Faenza Editrice, 1974).

Le Corbusier: Précisions sur un état présent de l'architecture et de l'urbanisme. Paris: G. Crès et Cie. Coll. "L'esprit nouveau", 1930.

Le Corbusier: Sur les 4 routes. Paris: Denoël, 1970 (1 $1^{\text {ère }}$ éd. 1941).

Le Corbusier: Vers une architecture. Paris: Arthaud, 1977 (1 $1^{\text {ère }}$ éd. 1923).

Le Corbusier. Aventures photographiques. Paris, Éditions de la Villette, 2014.

Le Corbusier: Quand les cathédrales étaient blanches. Voyage au pays des timides. Paris: Plon, 1937 (éd. ital. Quando le cattedrali erano bianche. Faenza: Faenza editrice, 1975).

Lemonnier, Aurélien: “Des yeux qui accusent: Le Corbusier et la ville vue d'avion”. In Lampe Angela (Dir): Vues d'en haut. Metz: Centre Pompidou, 2013, pp. 258-261.

Mazza, Barbara: Le Corbusier et la fotografia. La vérité blanche. Firenze: Firenze University Press, 2002. 


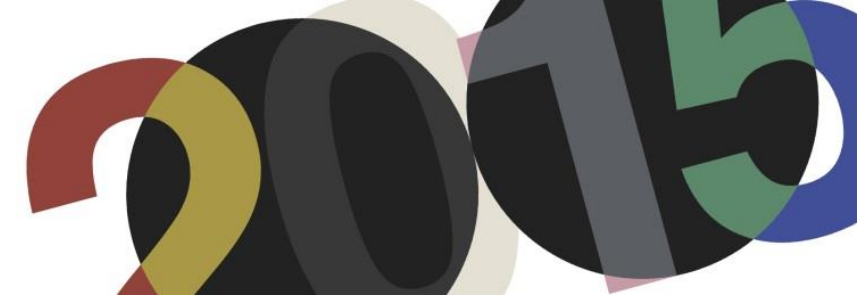

DOI: http://dx.doi.org/10.4995/LC2015.2015.947

\title{
The eye of the architect. Le Corbusier and the photograph: demonstrate, learn, remember
}

\author{
A. Teodosio \\ Department of Civil Engineering, University of Salerno (Italy)
}

\begin{abstract}
The relationship between Le Corbusier and the visual arts (drawing, photography and cinema) is deep and complex and, although the subject of numerous publications and research since the late 60s, still arouses much interest, as evidenced by the many events organized in the last years - "Le Corbusier. Vue sur la mer ", Maison La Roche, Paris, 2012; "Construire the image: Le Corbusier et la Photographie", Musée des Beaux-Arts, the Chaux-de-Fonds, 2013; or the recent "Le Corbusier and photography", IUAV, Venice, May 2015-. The paper, starting out from the researches already developed, proposes a further reflection on the relationship between the Swiss architect and the photography, paying particular interest to the shooting made in first person. The study analyzes the different approaches and the different subjects photographed in the course of his life and it is proposed to include the work of Le Corbusier in the broader cultural context of the twentieth century, a period in which the relationship between architecture and visual communication, thanks to the many possibilities offered by technological innovations, it becomes increasingly close and inevitable.
\end{abstract}

Resumen: La relación entre Le Corbusier y las artes visuales (dibujo, fotografía y cine) es profunda y articulada y, aunque es objeto de numerosas publicaciones y investigaciónes desde el finales de los años 60es, todavía despierta mucho interés, como lo demuestran los diversos eventos realizados en los últimos años - "Le Corbusier. Vue sur la mer", Maison La Roche, Parìs, 2012; "Construire l'image: Le Corbusier et la photographie”, Musée des Beaux-Arts, la Chaux-de-Fonds, 2013; o la más reciente "Le Corbusier e la fotografia", IUAV, Venezia, mayo 2015-. El artículo, a partir desde investigación ya desarrollado, propone una reflexión más sobre la relación entre el arquitecto suizo y la fotografía, prestando especial interés a las realizata en primera persona. El estudio analiza los diferentes enfoques y diferentes sujetos fotografiados en el curso de su vida y se propone de insertar la obra de Le Corbusier en el contexto cultural más amplio del siglo XX, un período en el que la relación entre la arquitectura y la comunicación visual, gracias a las muchas posibilidades que ofrecen las innovaciones tecnológicas, se vuelve cada vez más estrecha e inevitable.

Keywords: Le Corbusier; photography; representation of architecture.

Palabras clave: Le Corbusier; fotografia; representaciones de la arquitectura.

\section{Introduction}

Since the beginning of '900 journalists, critics and writers, but also many architects, make an extensive use of photography. The historiography traces back to the 30's already a deep and direct relationship between modern architecture and the new way to observe it. Many architects build personal archives that include images of ancient monuments but also of contemporary works and industrial buildings. As noted by the critic and theorist British Banham, the Modern Movement, for the first time in the history of art, is based almost exclusively on "photographic evidence" rather than on personal experience and direct survey ${ }^{1}$. The historic Pevsner, in his Pioneers of Modern Design (1936), makes extensive use of photographs to illustrate the texts and puts the accent

\footnotetext{
${ }^{1}$ Banham Reyner, A Concrete Atalantis. U.S. Industrial Building and European Modern Architecture, Cambridge-London: Mit-Pr 1986, p.18, work quoted by Fanelli Giovanni, Storia della fotografia di architettura, Roma-Bari: Laterza, 2009 , p.394
} 
on the power of the image by emphasizing the role of the photographer that, with his operational choices, is able to valorize or destroy the shooted handiwork of which, in a sense, becomes also author.

Also Le Corbusier bestows great importance to the expressiveness of his photographic work. Since the Twenties, he need the contribution of many photographers wherewith weaves deep associations: among them Charles Gérard, Georges Thiriet, Marius Gravot, which claims to have "elective affinities", Klaus Kinold, Lucien Hervé in which finds "an architect's soul". The architect works closely with professionals of lens and often influences their choices and their creative process. Some images, such as the famous atelier of Ozenfant ${ }^{2}$, become true icons of the Modern Movement and, as Giedion says, constitute a kind of self legitimization of modernism.

The photography for Le Corbusier is a vehicle to demonstrate his theses in Vers une architecture (1923); a propaganda for his work Oeuvre complète (1930-55), the first catalog made by an architect about his work; becomes a decorative element and the characterization of the interior space in the Swiss Pavilion in the University City of Paris, where 44 enlargements in black and white, rectangular or square, placed side by side seamlessly, give rise to a "fresque photographique"

The interest of Le Corbusier for the photographic representation is demonstrated by the large number of postcards purchased during his travels: images of landscapes and monuments, but also of modern architecture or projects that constitute material for subsequent studies or publications - as La construction des villes (1910) or, sometimes, the basis for drawings, sketches or notes. In this regard, very interesting is the postcard with the view of Notre-Dame of Paris, preserved by the Le Corbusier Foundation in Paris, on which he traces the proportional scheme of the facade and the cut margins for publication.

The evolution of the instruments and shooting techniques and the spread of portable appliances, lighter and easier to handle, allows architects to use firsthand photography to collect impressions and personal notes. Even Le Corbusier, starting from his youth travels, combines the traditional representations (written notes, sketches and drawings) with the photo shoots. He produces about 6000 shots that tell about the discovery of distant countries and cultures in the youthful period, exploratory trips preparatory for the implementation of projects such as the one in Brazil (1936) -, or intimate memories - as the summer holidays in Piquey, in the Bassin d'Arcachon -.

\section{Photographs of an architect in journey}

Le Corbusier, like Wright, is more prone to the drawing ${ }^{4}$. It seems to have no particular talent for photography, for which he declares to prove even embarrassment. In his writings he does not fail to underline its limits, saying that it cannot go beyond the crudest documentary aspect, and criticizes the fact that often it is delegated to the camera the task of looking at the world. Entrusting the emotions to the lens, you risk to forget to watch because, while the drawing presupposes long times of implementation and observation, the fleeting pressure on the button of a camera does not imply participation and does not gives time to fix the memory.

\footnotetext{
${ }^{2}$ Paris, atelier Ozenfant, photography by Charles Gérard, about 1924, published in Le Corbusier. Oeuvre complète, II, 1934.

${ }^{3}$ Definition used by Le Corbusier in his Oeuvre complète, II, 1934, p.77.

${ }^{4}$ Zannier Italo, "Nota a margine su Le Corbusier fotografo", in Giuliano Gresleri, Le Corbusier, Viaggio in Oriente. Charles, Edouard Jeanneret fotografo e scrittore, Venezia-Parigi: Marsilio-Fondation Le Corbusier, 3rd ed. 1995, pp. 479-482.
} 
However, the discovery and systematization of a rich photographic collection ${ }^{5}$, of which Le Corbusier is author, opens new glimmers on this personality so varied and complex, and broadens the interest from the simple analysis of the architectural work to the intellectual figure in its entirety. The large number of images retrieved, despite their unpretentious technique, demonstrate unequivocally that to the initial sense of rejection towards the photography, indeed, it joins together the attraction towards it. Also, they give impetus to a number of specific studies $^{6}$, thematic events and a heated debate on the relationship between the architect, the visual culture in general and the photograph in particular.

The photographic production of Le Corbusier can be divided into two major sections: that of his youth travels in Germany, Switzerland and Italy (1907) and in the East in 1911 - in which he made about 450 shots; and that of his maturity, of the '30s, in which the shooting makes sense and meaning profoundly different.

\subsection{From the city to the architecture...}

Despite his overt skepticism, Le Corbusier makes extensive use of photography not only in his publications, but also during his travels. Probably the first camera that he owns is a Kodak of small format that, as he wrote in some letters, only allows shooting of small size and poor quality, as those made in Italy, dark, blurred and that offering a distorted perception of the places ${ }^{7}$. In 1910 he buys a new camera for his trip to Germany. The drawings, still very close to the teachings of Sitte, the notes and the photographs reflect the search for new rules for the construction of the modern city and his personal insights ${ }^{8}$. In the many German cities he visits, he photographs urban hubs such as squares, widening and fountains, rather than individual monuments.

In May of 1911, before leaving for his trip to the Orient with his friend and student of art history August Klipstein, he buys a Cupid 80 camera, a professional device of which boasts the technical quality, and produces pictures in postcard format. From the early stages of this long "Grand Tour" his method of representation evolves: the drawings become drier and basic but rich in details and notes useful for his future work; the photograph, instead, is becoming increasingly important, and he will shoot approximately 450 pictures of which often is referenced in Carnets $^{9}$. Even the represented subjects change: gradually the focus shifts from the built to details (frames, shelves, overhangs) that become a source of inspiration for his architecture. As noted by

\footnotetext{
5 In 1982, the Fondation Le Corbusier entrusts to Gresleri the reordering of Le Corbusier iconographic material that converges in the text: Giuliano Gresleri, Le Corbusier, Viaggio in Oriente. Charles, Edouard Jeanneret fotografo e scrittore, Parigi: Fondation Le Corbusier, 1984.

${ }^{6}$ From the aforementioned study of Gresleri of 1984, which provides an initial assessment of photographs of Le Corbusier in his youth; to the essay by Thomas Schumacher "Deep space, Shallow space" published in Architectural Review (1987) with considerations on the photographic representation of architecture corbusiane in Oeuvre complète; to the studies by Beatriz Colomina "Le Corbusier und die Fotografie" and Stanislaus Von Moss "Im Vorzimmer des Machine Age" about photography as a means of propaganda of his ideas and his work published in the exhibition catalog L'Esprit Nouveau. Le Corbusier und die Industrie 1920-25, del 1987; to the work by Barbara Mazza, Le Corbusier e la fotografia. La vérité blanche (2002), that addresses comprehensively the complex relationships between the architect and photography; until the recent publication of Tim Burton, Le Corbusier, Secret Photographer (2013) which analyzes in detail the photographic production of the master.

${ }^{7}$ For a depth study based on detailed analysis of documents on equipment owned by Le Corbusier see: Cusano Federica, "Les voyages d'Italie", in AAVV, Le Corbusier. Aventures photographiques, Paris: Fondation Le Corbusier, 2014, pp. 3145.

${ }^{8}$ In this period Le Corbusier starts working at La construction des villes, work written between 1910 and 1915 and left unfinished.

${ }^{9}$ Mazza Barbara, Le Corbusier e la fotografia. La vérité blanche, Firenze: University Press, 2002, pp.23-24.
} 
Gresleri, you can trace a link between the attention paid to the double glazing of Malá Strana in Prague and the windows of the Maison Domino and villa Meyer ${ }^{10}$.

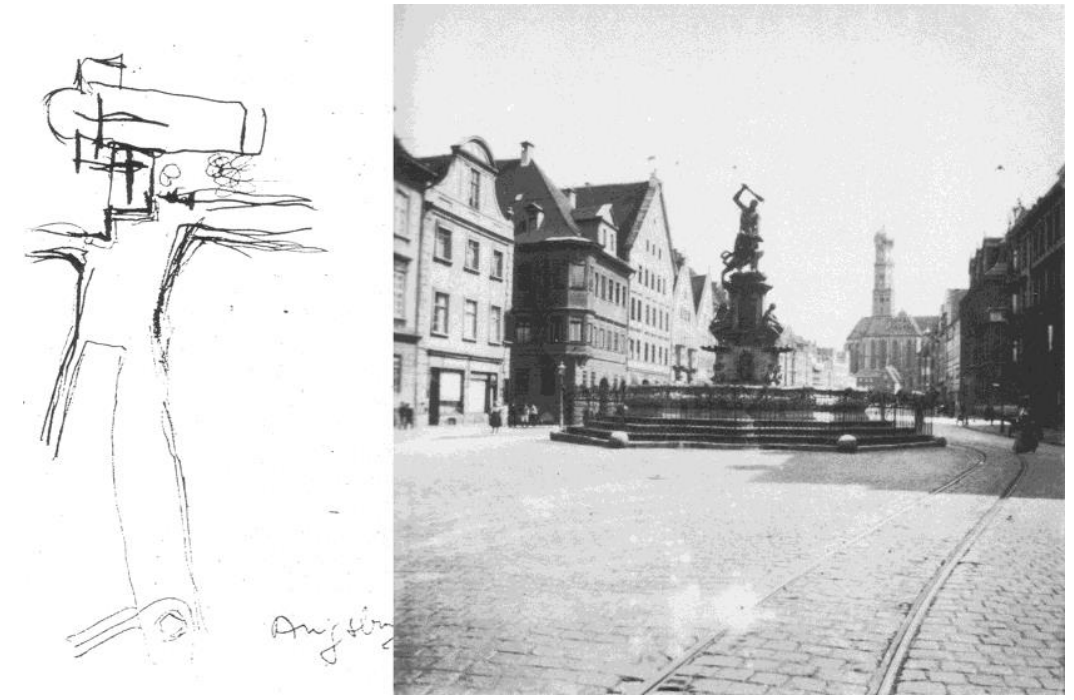

1. Le Corbusier, Augsburg (June 1910). Study of the site of Maximillianstrasse (from Le Corbusier, Carnet du Voyage d'Allemagne 2, p.143); view of Maximillianstrasse and of Sam Ulrich Cathedral (from G. Gresleri, Le Corbusier, Viaggio in Oriente., Charles, Edouard Jeanneret fotografo e scrittore, Venezia-Parigi: Marsilio-Fondation Le Corbusier, 3rd ed. 1995, pp. 156 e 157).

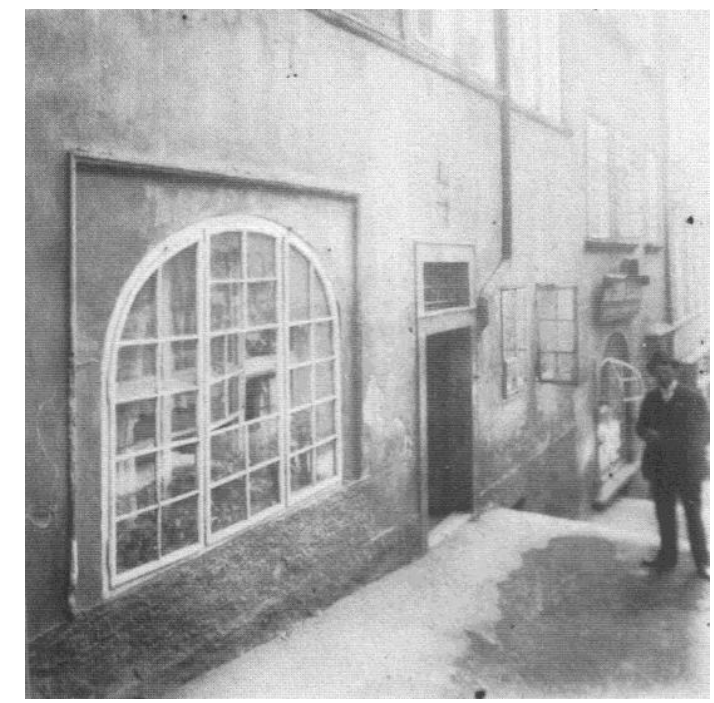

2. Le Corbusier, Prague (May 1911). Window on the stairs of Malá Strana (in Gresleri G., Op. Cit. p. 175).

If lacking images of Vienna, very documented is the route along the Danube and through the Balkans. Le Corbusier was very fascinated by the Hungarian, Bulgarian and Romanian countryside. He portrays the landscape with quick sketches, while reserves more precise technical drawings and spontaneous photographs to the architecture of the villages farmers. Numerous photos show simple traditional houses with large windows, porches and balconies; pergolas with vines and surrounding walls that hide courtyards filled with trees and plants. For the first time, ordinary people and scenes of peasant life are taken from his lens, while they are completely absent images of the Palace of Sinaia with its famous paintings by El Greco that, as is clear from his

${ }^{10}$ Gresleri G. (1995), Op. cit., p.61. 
diaries, he certainly sees. Unequivocal sign of the fact that his interests are changing and reflection turns increasingly to the simplicity of the places, forms and ways of living that have been lost elsewhere.

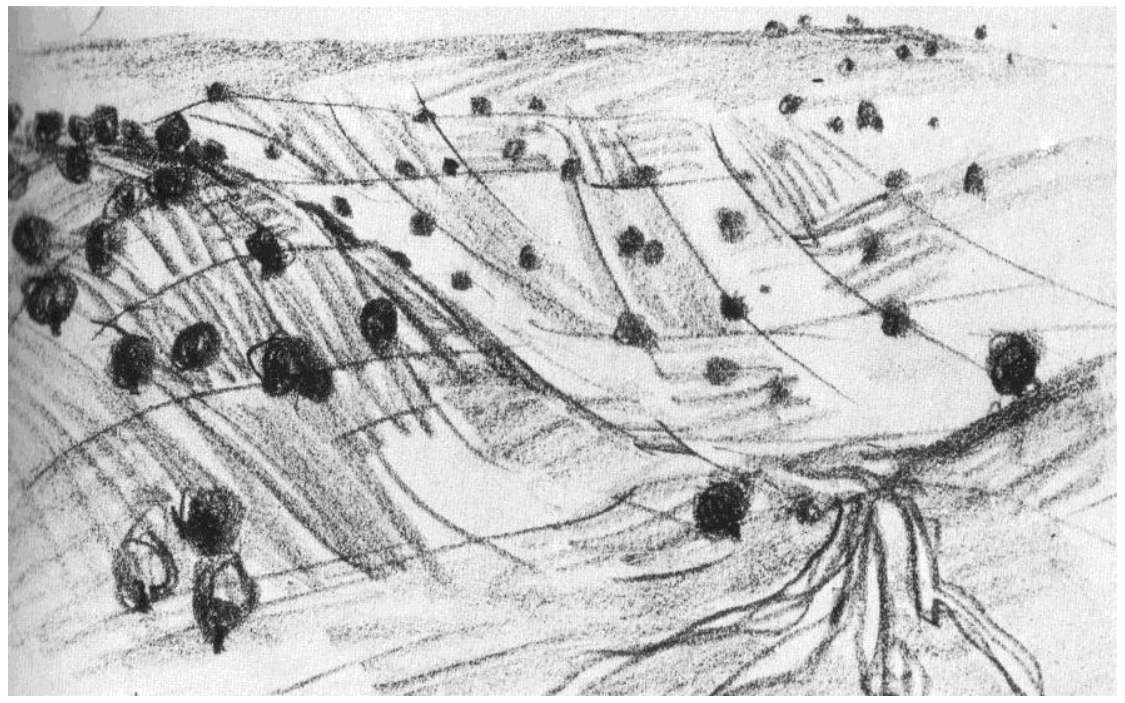

3. Le Corbusier, Bulgarian countryside (end of June 1911). Landscape with fields and trees. Pencil, pastel green and brown with traces of yellow, AFLC 6129 (from Gresleri.G, Op. Cit. p. 193).

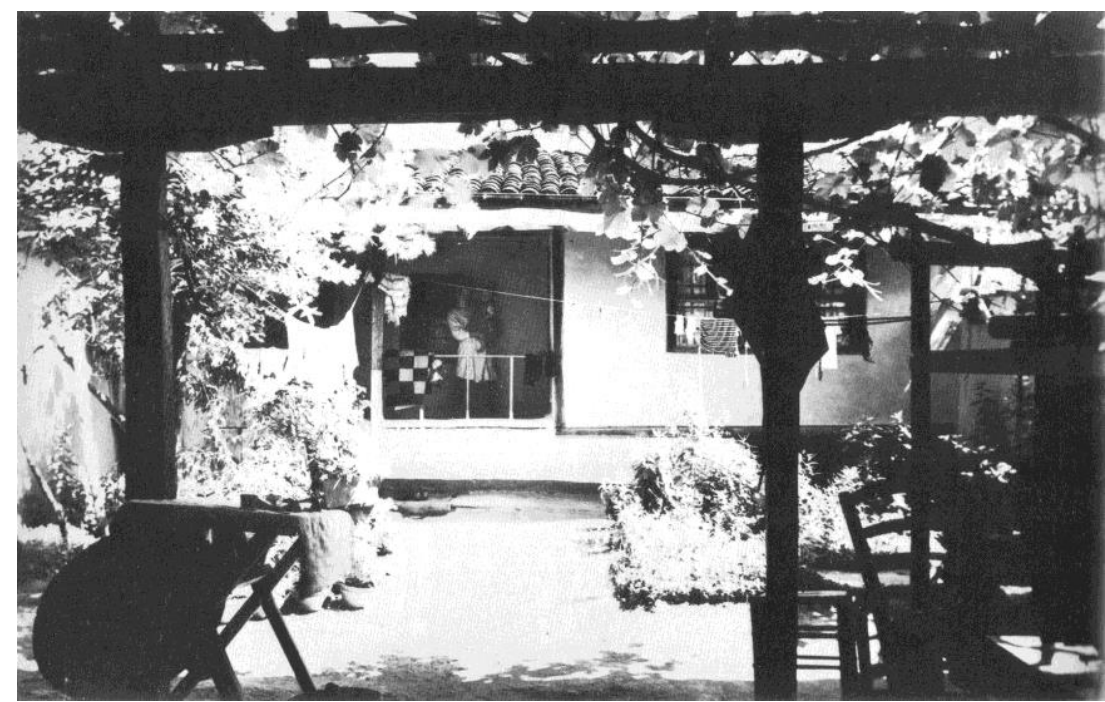

4. Le Corbusier, Kazanluk (July 1911). Courtyard with pergola and figure of a woman with child,. (from Gresleri G., Op. Cit. p. 206).

In Istanbul he wanders around the city without a predetermined path and prefers to entrust his feelings to the written description. Photographs the city from afar, from the west of Pera. From here, his camera placed on the window sill of his room, accidentally catches the blaze overnight in the city on 24 July 1911: "Tragic night! Great show, made of fire, people impassive and people upset, shouting and tears"11. Only Santa Sofia is an exception: the building is broken down and analyzed for parts, through the use of photography. As demonstrated by the shots taken, the architect shows a greater interest in the complex combination of volumes of facades rather than for the sensual interior decorations.

\footnotetext{
${ }^{11}$ Le Corbusier, Il disastro di Stambul, carnet July 2011, published in Gresleri G. (1995), Op.Cit., p.247.
} 


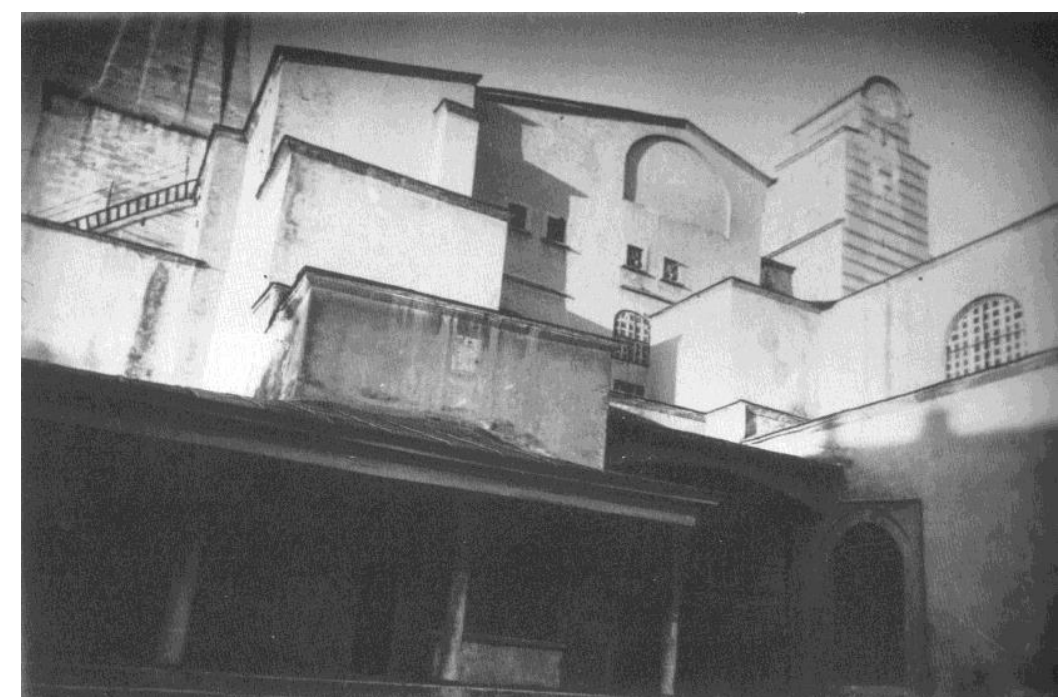

5. Le Corbusier, Instanbul (July, 1911). Santa Sofia, the spurs of the main entrance, south side. (from Gresleri G., Op. Cit. p. 272).

In Athens Le Corbusier photographs architectural details and even sculptural particulars preserved in the museum of the Acropolis, while leaving to the drawings the representation of the temples as part of a complex made up of natural elements and built.

In October 1911 in Naples he buys a Kodak Brownie with which he made about 120 shots of the city but also of Pompeii, Rome, Pisa. The images are lower quality but, as stated in one of his Carnet, he feels the need for a lighter instrument, which does not require a tripod, convenient to use and recharge. In Pompeii he takes numerous photos, often dark and out of focus: glimpses of streets and villas integrate technical drawings with dimensions and hypothetical reconstructions and reflections on living space. In Rome he photographs the ancient monuments, but with a glance very personal and functional to his interests. He tries to extract details of the architecture of Michelangelo in St. Peter's; he snaps a lot of stairs (from Piazza di Spagna to Villa Medici), a recurring theme in his iconography.

In Florence he photographs details of Santa Maria Novella and of the Giotto's bell tower, the side of the Cathedral and the Belfry, without worry of the scene, while he entrusts the representation of monuments in their context to the pencil sketches. In Pisa he photographs details and produces a poetic glimpse of the Baptistery which is reflected in the wet churchyard of the Duomo anticipating, in a sense, those effects of transparency and reflection that often he will seek for the representations of his architecture for future publications.

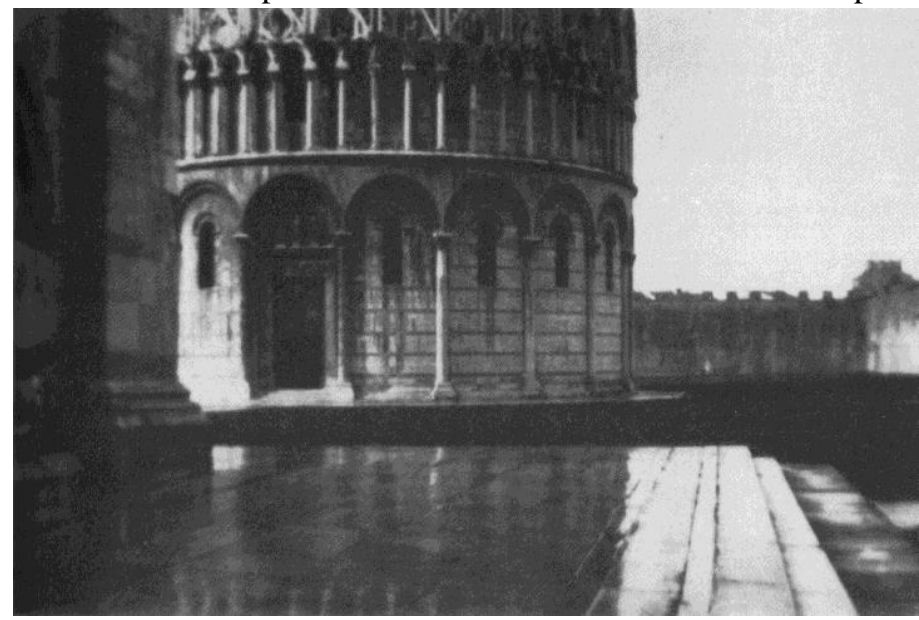

6. Le Corbusier, Pisa (October, 1911). Baptistery seen from the parvis of the cathedral (from Gresleri G., Op. Cit., p. 385). 


\section{2 ...to the nature}

In 1936 Le Corbusier shall provide itself with a cutting edge camera, the Siemens B16mm, and within two years produces about 120 shots and 6000 snaps that, as states Tim Benton, show a hidden aspect of the architect ${ }^{12}$. From this moment on, the photograph becomes an expression of personal emotions and a plastic and artistic search tool. Its use is increasingly connected to cinematographic experiments and, in this period, the architect also begins to check the possibilities of exchange and interaction between drawing, photography and cinema. Experiences that will converge, many years later, into the realization of the Philips Pavilion in Brussels (1958) in which photos, movies and music give rise to a Poéme élecronique ${ }^{13}$. A sort of concretization of what MoholyNagy had already guessed in 1922 when in his article "Produktion-Reproduktion", published in De Stijl, talks about new forms of production and representation, consistent with the technological age, based on the interaction of cinema, music and photography, can reveal previously unknown realities ${ }^{14}$.

In the '30s the subjects of the photographs by Le Corbusier change profoundly. The urban areas, buildings and architectural details of his early works characterized by the search for references to the practical work, leave room to snaps more intimate and personal. Pictures of loved ones (mother, girlfriend, friends and even his dog), resorts (as Piquey in the Bassin d'Arcachon, where he spends the holidays) seafaring themes, boats, fishermen, common items and building materials, natural elements become protagonists of his representations.

The so-called "objet trouvé" of the artists of the early Twentieth century, "objects à réaction poétique" for Le Corbusier, - found objects, waste and scrap loads of history, biological forms, signs and footprints in the sand arouse emotions and anxieties and they are the source of inspiration for many of his paintings and even for his architectures.

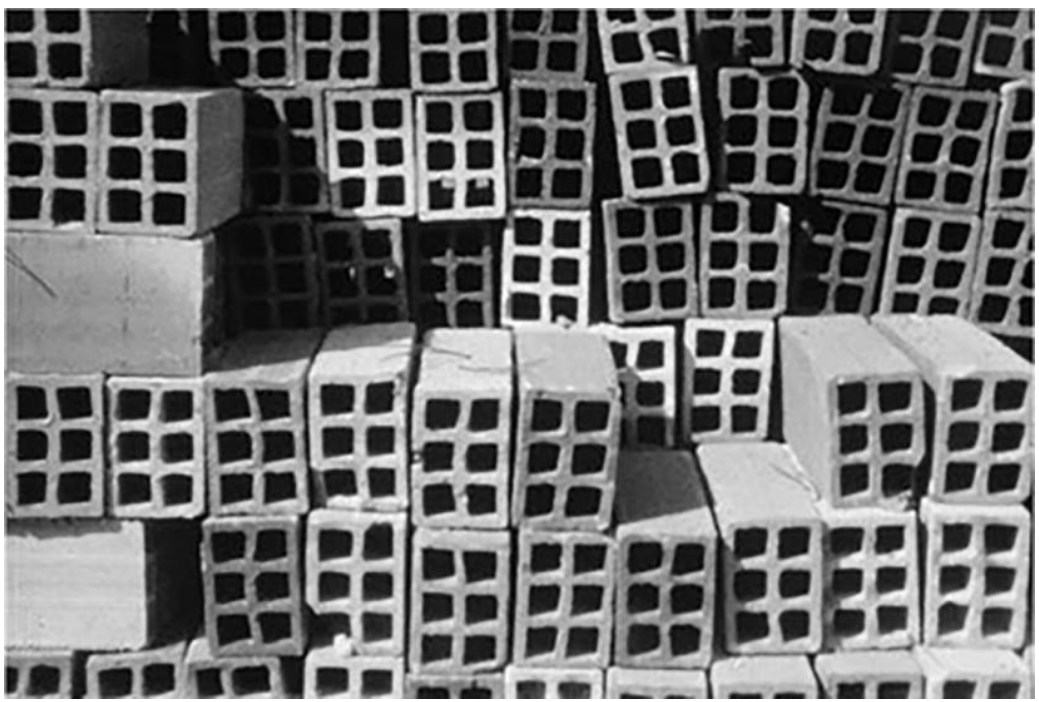

7. Le Corbusier, Piquey (1936-37). Industrial building materials (from AAVV, Construir...p.51).

\footnotetext{
${ }^{12}$ Benton is the author of several studies on Le Corbusier photographer. Here: Benton Tim, "Le Corbusier. Photographe secret”, in AA. VV. Construire l'image. Le Corbusier et la photografie, Paris: Éditiòn Textuel, 2012, p.32.

${ }^{13}$ Fanelli Giovanni, Storia della fotografia di architettura, Roma-Bari: Laterza, 2009, p.430-32.

${ }^{14}$ Moholy-Nagy Lásló, Produktion-Reproduktion, in “De Stijl”, V, 1922, n.7, pp. 98-100, opera citata in Mazza B. (2002), Op. cit., p.70.
} 


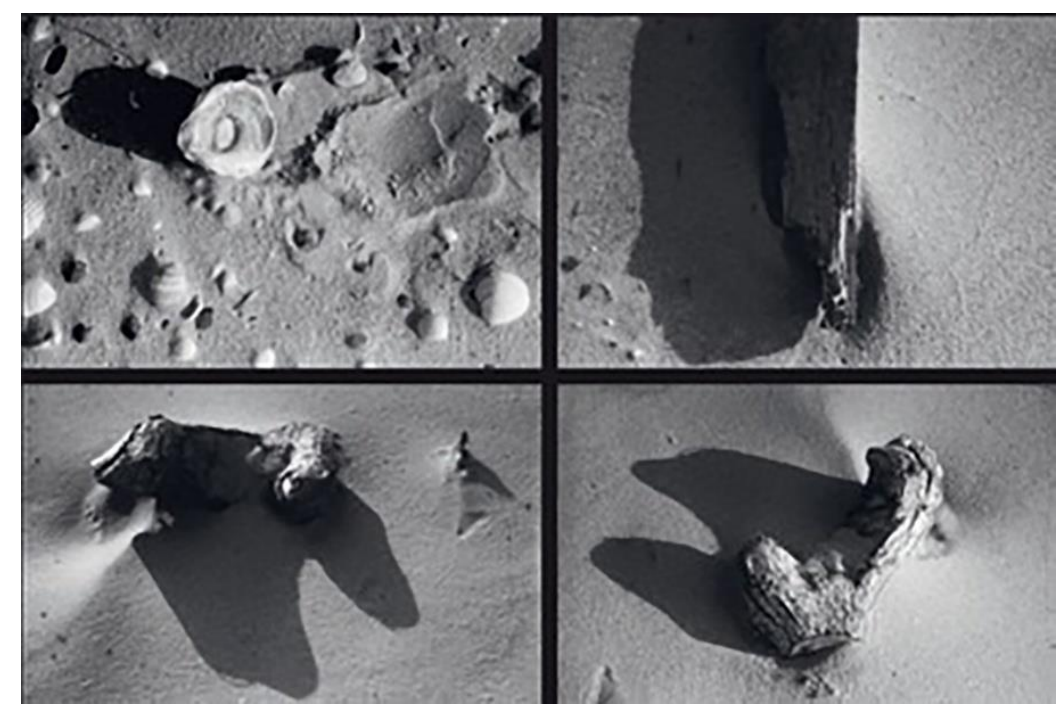

8. Le Corbusier, Piquey (September 1936). "Objects à réaction poétique" on the beach (from AAVV, Le Corbusier. Aventures...p.61).

Bones, shells, stones, pieces of bark, roots and mechanical parts, are collected, photographed and drawn repeatedly to reveal the beauty of form, the precision of the work of nature and their structure.

The eye of the painter seems more present than ever and the compositions become more and more abstract and symbolic also through the use of image sequences separated by white or black banding or in continuous succession. Horizontal or vertical bands that demonstrate a clear link with the cinema and tell the architecture but also what draws the attention of Le Corbusier photographer and artist. Exemplifying is the sequence of about 500 shots made on board the ocean liner Conte Biancamano during the traveling in Brazil (1936), images that explore the details and mechanics of the ship.

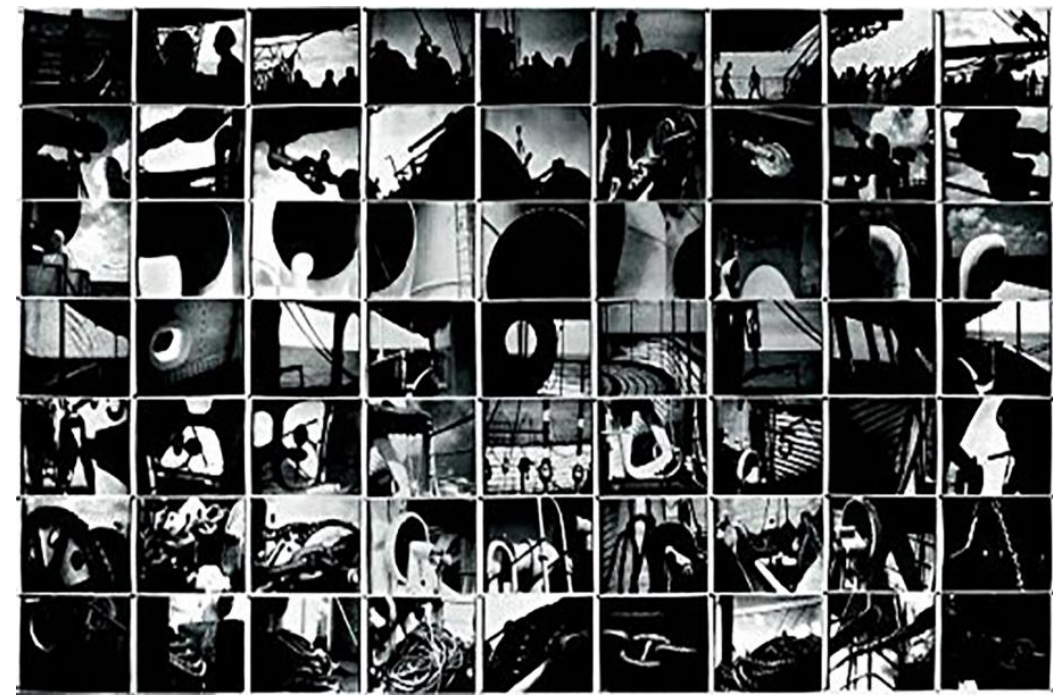

9. Le Corbusier, (August 1936). Collage of 63 photographs taken aboard the ocean liner Conte Biancamano, (from AAVV, Le Corbusier. Aventures...p.66).

The detachment from any reference dimensional, chased so many years before during the Journey to the East, when the architect, reflecting on St. Sophia and on the Galata Tower in Istanbul, asserts that to achieve a monumental and grandiose appearance it should avoid any reference to human scale and elements that can bring 
to $i^{15}$, now is functional to the dematerialization of shooted objects. The photographed objects, losing every real connotation, become generator centers of the surrounding space and have a strong emotional charge, a rich and imaginative aesthetic potential that becomes a source of inspiration for a new architecture.

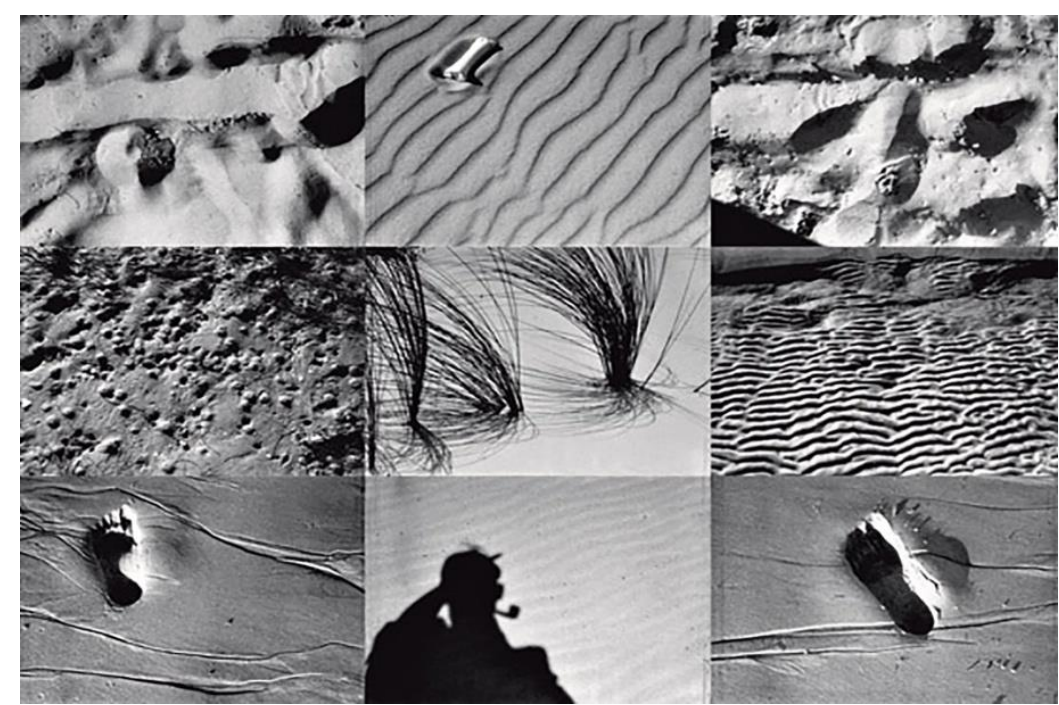

10. Le Corbusier, Piquey (1936-37). Photographs of the sand on the beach (from AAVV, Construir...p.47)

The growing interest in natural elements, in fact, corresponds to a progressive evolution of the architectural language: from the purism of the first period Le Corbusier switches to the style more "organic" that characterizes some emblematic works of the '50s. The turning point in the poetics of the architect seems to have already introduced by the proposals for the expansion plans of Rio and Algiers, with their flexuous configuration, the progressive abandonment of the abstract and austere style of the purist aesthetics, the loss of confidence in the progress made by the industrial technology.

From the rediscovery of the natural order of things spring the works called "brutalist" for the use of materials such as the coarse gravel, the unfinished wood, the brick facades and the béton brut. These are architectures with a free form, in which coexist elements inspired by the spontaneous construction techniques and advanced technology solutions. Among the most prominent examples: the Maison Errazuriz (1930) in Chile, with a sloping roof and built of wood and stone; the Petit Maison de Weekend (1935) built in Paris, with roofing in rough concrete vaults. Among the most mature and complex outcomes of the new brutalist aesthetic we find the Unité d'Habitation (1947-1952) of Marseilles and his buen retiro Le Cabanon (1952), a "castle" of $3.66 \mathrm{~m}$ to $3.66 \mathrm{~m}$ in French Riviera made exclusively of wood and natural materials.

${ }^{15}$ Mazza B. (2002), Op. cit., p. 42. 


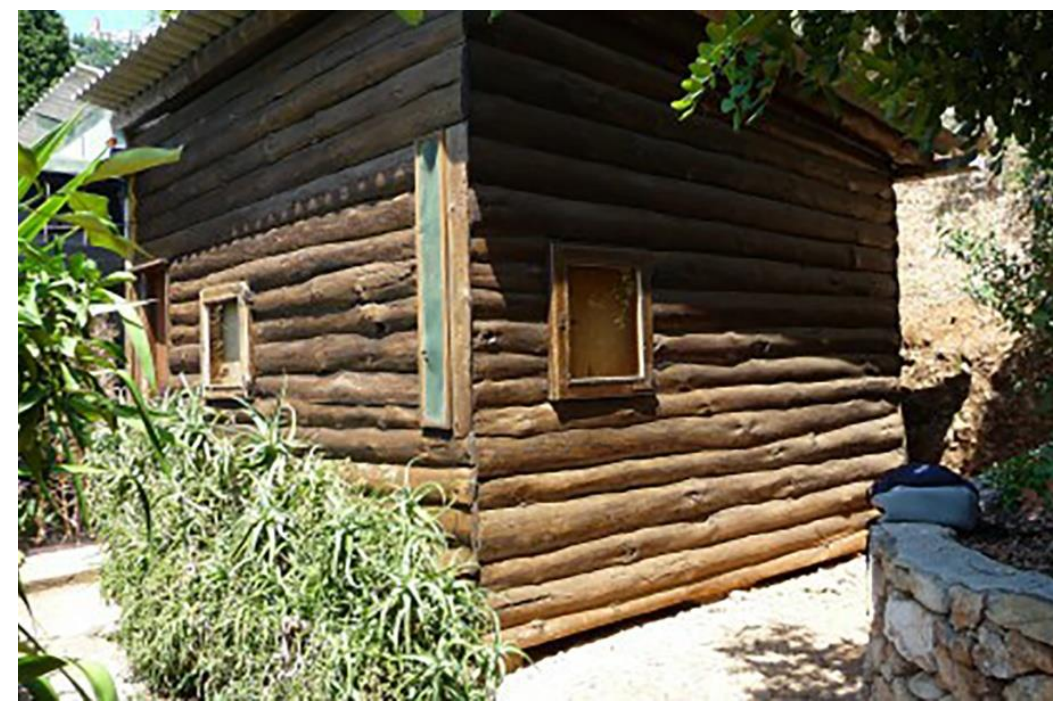

11. Le Corbusier, Roquebrune-Cap-Martin (1952). Vacation home Le Cabanon, (https://en.wikipedia.org/wiki/Cabanon_de_vacances\#/media/File:Cabanon_Le_Corbusier.jpg)

But the work that more than any other symbolizes the achievement of the "ineffable space" is certainly the Chapel of Ronchamp (Notre-Dame-du-Haut, 1950-1955), an architecture with sculptural forms, whose curves, turning to the four cardinal points, generate the space by wrapping the churchgoers inside and by embracing the natural universe on the outside. A work that many critics have metaphorically just assimilated to a shell, the shape so dear to Le Corbusier since his childhood.

\section{Conclusions}

Despite his initial preclusions, it is evident that also Le Corbusier is fascinated by photography and he immediately comprises its importance and validity as an analytical, communicative and informative tool.

Already from his youth "the eye of Jeanneret seems able to grasp from all that is built and from all fact of custom the particularity that constitutes the uniqueness of the work, its essence, its all"16. And perhaps the search for this essence is the thread that connects all the conspicuous photographic production of the Swiss master: from the youth shots that intend to retain the exact memory of locations and fragments of reality, to those of maturity that aim to the abstraction and to the complete dematerialisation of the shooted object

Beyond the different objectives of his shots, Le Corbusier never uses passively the camera but try to master the instrument and enslave it to his practical needs or to his artistic poetry ${ }^{17}$. His shots, regardless of poor technical quality, show immediately a very personal character for the chosen subjects and for their compositional structure. Photography for him is a kind of private note and rarely he publishes his shots. And is in this fact that finds confirmation and explanation the term coined by Benton's of "secret photographer" ${ }^{18}$.

\footnotetext{
${ }^{16}$ Gresleri G. (1995), Op. Cit., p.12.

17 The subjects and the unusual shots of his photos of travel and the many manipulations of images for studies and publications of his own or others' architectures respond to this logic: photomontage, collage, retouching, printing on the reverse or rotated to show the value of an architectural composition balanced and well calculated, regardless of the direction of observation, games of optical and spatial illusionism.

${ }^{18}$ Benton Tim, Le Corbusier Secret Photographer, Zurich: Lars Müller Publishers, 2013.
} 
The relationship between Le Corbusier and photography, therefore, is very long and controversial, passes through all his long personal and professional life and undergoes significant transformations that, such as in a hall of mirrors, reflect the evolution of his thought and of his artistic and architectural poetics.

\section{Images sources}

1. Gresleri G., Le Corbusier, Viaggio in Oriente. Charles, Edouard Jeanneret fotografo e scrittore, VeneziaParigi: Marsilio-Fondation Le Corbusier, 3rd ed. 1995, pp. 156 e 157.

2. Gresleri, Le Corbusier, Op.cit., p. 175.

3. Gresleri, Le Corbusier, Op.cit.,p. 193.

4. Gresleri, Le Corbusier, Op.cit., p. 206.

5. Gresleri, Le Corbusier, Op.cit, p. 272.

6. Gresleri, Le Corbusier, Op.cit, p. 385.

7. AAVV, Construire l'image: Le Corbusier et la photographie, Paris: Thames \& Hudson/Textuel, 2012, p.51.

8. AAVV, Le Corbusier. Aventures photographiques, Paris: Fondation Le Corbusier, 2014, p.61.

9. AA VV., Le Corbusier. Aventures...p.66.

10. AAVV, Construir...p.47.

11. https://en.wikipedia.org/wiki/Cabanon_de_vacances\#/media/File:Cabanon_Le_Corbusier.jpg

\section{Bibliography}

AAVV, Construire l'image : Le Corbusier et la photographie, Paris : Thames \& Hudson/Textuel, 2012.

AAVV, Le Corbusier. Aventures photographiques, Paris: Fondation Le Corbusier, 2014.

Banham Reyner, A Concrete Atalantis. U.S. Industrial Building and European Modern Architecture, CambridgeLondon: Mit-Pr 1986.

Benton Tim, Le Corbusier Secret Photographer, Zurich: Lars Müller Publishers, 2013Fanelli Giovanni, Storia della fotografia di architettura, Roma-Bari: Laterza, 2009.

Gresleri Giuliano, Le Corbusier, Viaggio in Oriente. Charles, Edouard Jeanneret fotografo e scrittore, VeneziaParigi: Marsilio-Fondation Le Corbusier, 3rd ed. 1995.

Mazza Barbara, Le Corbusier e la fotografia. La vérité blanche, Firenze: University Press, 2002.

Zannier Italo, "Nota a margine su Le Corbusier fotografo", in Le Corbusier, Viaggio in Oriente. Charles, Edouard Jeanneret fotografo e scrittore, edizione di Giuliano Gresleri, Venezia-Parigi: Marsilio-Fondation Le Corbusier, 3ed 1995, p. 479-482. 


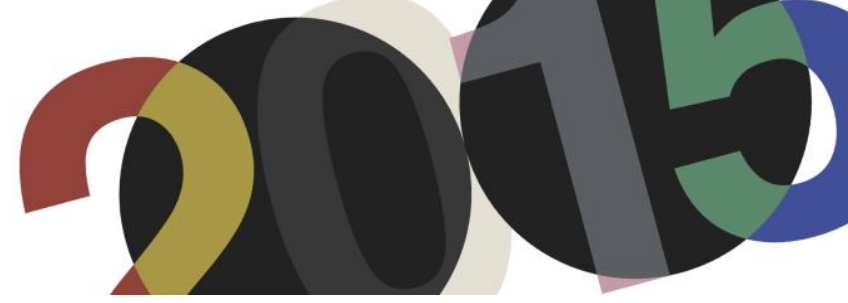

DOI: http://dx.doi.org/10.4995/LC2015.2015.1033

\title{
In Quest of Modernity: Le Corbusier's Project for the New Civic Hospital in Venice
}

\author{
I. Tolic
}

University of Bologna

\begin{abstract}
The paper deals with Le Corbusier's unbuilt project for Venice analyzing the meaning of the Civic Hospital within the cultural context between 1954, the year in which the new master plan started to take shape, and 1966, when an extraordinary 'acqua alta' put an end to city's contemporary ambitions. In Venice's quest for modernity, the master plan (1954-1962), the national competition for the San Giuliano district (1959), the national competition for the Hospital (1963) and the international one for the Tronchetto Island (1964-1965) represent key events in which conservatives and modernists found themselves face to face, and in relation to which Le Corbusier's project has not yet been studied. Even though Le Corbusier's Hospital was presented to the public opinion as a courageous and innovative project, this paper seeks to demonstrate that it was actually more in line with the conservative front because it brought back the "problem of Venice" to its insular dimension after more than a decade of attempts to solve it considering a wider regional frame.
\end{abstract}

Resumen: El articulo trata sobre el proyecto, no cumplido, por Le Corbusier para Venecia incluyéndolo en el contexto cultural desarrollado entre el año 1954, en el que el nuevo master plan empezaba a coger forma, y el 1966, cuando una extraordinaria 'acqua alta' cortó los anhelos de modernidad del tiempo. Los acontecimientos clave de este periodo fueron: el master plan, el concurso nacional para el barrio de San Giuliano, el concurso nacional para el Hospital y el concurso internacional para la Isla de Tronchetto. Con respecto a estos el proyecto de Le Corbusier no había todavía estado analizado. El Hospital de Le Corbusier había estado presentado, en su tiempo, como un proyecto innovador. Lo que este articulo quiere demostrar es que, en realidad, representó una posición conservadora, pues volvió a llevar el problema de Venecia en sus medidas insulares después de mas diez años de intentos para solucionarlo a escala regional.

Keywords: Venice; Civic Hospital; Le Corbusier; modernity; center and periphery.

Palabras clave: Venice; Civic Hospital; Le Corbusier; modernidad; centro y periferia.

\section{Introduction}

In the last five decades, life and work of Le Corbusier have been analyzed from many and different points of view. The considerable amount of publications - impossible to summarize - demonstrates on one side the richness of his accomplishments and on the other, the never abating interest of scholars towards them. Among publications and events dedicated to Le Corbusier only in the last years, it might be worth mentioning the exhibition which took place at Museo Nazionale delle Arti del XX Secolo [MAXXI] in Rome, which investigated architect's relationship with Italy throughout his career ${ }^{1}$. For however long and articulated, it was only in the last phase of his productive life that Le Corbusier got the chance to work in the country, even though none of his projects was accomplished. In fact, he was commissioned a Church in Bologna (1962), the Olivetti Electronic Center in Rho $(1963)^{2}$ and the Civic Hospital in Venice ${ }^{3}$. The last project has attracted the interest of scholars which have investigated it thoroughly probing its assonances with the earlier formulations of the

\footnotetext{
${ }^{1}$ Talamone, Marida (Ed.): LItalia di Le Corbusier (exhibition catalogue: Rome, October 18, 2012 - February, 17, 2013). Milan: Electa, 2012.

${ }^{2}$ Bodei, Silvia: Le Corbusier e Olivetti. La Usine Verte per il Centro di calcolo elettronico. Macerata: Quodlibet, 2014.

${ }^{3}$ Gresleri, Giuliano; Gresleri, Glauco: Le Corbusier. Il programma liturgico. Bologna: Compositori, 2001.
} 
"musee à croissance illimitée",; analyzing it as an epitome of the "mat-building" type ; attempting to identify its origin in relation to a wider international contemporary architectural discourse ${ }^{6}$; or studying its structural formulation in comparison to the medieval urban configuration of the city of Venice ${ }^{7}$ - to mention just a few. What still seems to be missing is an attempt to analyze the meaning of Le Corbusier's project for and within contemporary Italian cultural context. The project for the Civic Hospital in fact belongs to a period which saw the national competition for the new masterplan of Venice (1954-1962), the national competition for the residential district of San Giuliano in Mestre (1959), the national competition for the new Civic Hospital (1963) and the international one for Tronchetto Island (1964-1965). In each of these competitions, architects and urban designers tried to solve the so-called "problem of Venice", historical center and its urban expansions on mainland. Which was Le Corbusier's role within these debates and in relation to the very future of Venice? Why, in spite of the national competition for the new Civic Hospital, he was assigned the task? And, even more relevant, what this choice and his presence in Venice meant within that period?

The following paper is also a part of a larger research dealing with the Civic Hospital of Venice and a rich series of unbuilt or partially built projects which characterize its history between the end of the Republic (1797) and today. On one side, unbuilt projects reveal about clients' aspirations as much as any built structure (and possibly even more due to their existence only on paper). On the other side, the surprising number of proposals prepared for the Civic Hospital allows us to consider the ever evolving relationship between health care and architecture to the study of which Le Corbusier's project and the national competition for San Giobbe offers material for further deepening. Moreover, the history of the Civic Hospital is strongly interwoven with Venice's quest for modernity, in relation to which Le Corbusier's project assumes a particular meaning. In fact, instead of considering it as a part of a series of unbuilt projects for Venice ${ }^{9}$, the goal of this paper is to reverse the point of view thus explaining the meaning of the Hospital in relation to the debates which made the proposal possible and which are to be intended as attempts to solve the above mentioned "problem of Venice". Even though the choice of Le Corbusier was presented to the public opinion as a courageous act aimed at city's modernization, the paper seeks to demonstrate that, aside contemporary propaganda, the Hospital affaire has actually an extremely complex background. By bringing back the "problem of Venice" to its insular dimension (after more than a decade of attempts to consider it within a wider regional frame), Le Corbusier's project reconciled two opposite visions of the future of Venice bypassing one of the most pressing issues discussed within the national cultural scene, and namely the conflicting relationship between historical centers and new peripheries.

\footnotetext{
${ }^{4}$ O’Byrne Orozco, María Cecilia. El proyecto para el hospital de Venecia de Le Corbusier. Director: Josep Quetglas. Universidad Politécnica de Cataluña, Escuela Superior de Arquitectura de Barcelona, 2007.

${ }^{5}$ Sarkis, Hashim (Ed.), Le Corbusier. Venice hospital and the Mat building revival. Munich: Prestel, 2002.

${ }^{6}$ Reichlin, Bruno: "L’Ospedale di Venezia. Congetture sulla genesi del progetto". En Talamone, Marida (Ed.): L'Italia di Le Corbusier (exhibition catalogue: Rome, October 18, 2012 - February, 17, 2013). Milan: Electa, 2012. pp. 390-409.

${ }^{7}$ Shah, Mahnaz: Le Corbusier's Venice Hospital Project. An Investigation into its Structural Formulation. Farnham: Ashgate, 2013.

${ }^{8}$ Comune di Venezia; Fondazione Giorgio Cini: Atti del Convegno internazionale "Il problema di Venezia". Venice: w/o.pub, 1964.

${ }^{9}$ Puppi, Lionello; Romanelli, Giandomenico (Ed.): Le Venezie possibili: da Palladio a Le Corbusier. Milan: Electa, 1985.
} 


\section{Le Corbusier and "the problem of Venice"10}

Towards mid-1960s, a series of debates and discussions about the future of Venice has created an increasingly tense atmosphere which was about to result in an open conflict between conservators and innovators. Precisely before that moment, between April 8 and 14, 1965, Le Corbusier visited the lagoon for the second time since the beginning of the Hospital affaire and his permanence was recorded by the Italian National Television (RAI) ${ }^{11}$. The video represents a rare document in which the project was explained for the benefit of non-specialists and in which the issue at stake was defined by the very protagonists of the story.

Le Corbusier was interviewed while standing on Saint Mark square, having the church of San Giorgio Maggiore, designed by Andrea Palladio, as a background. The choice of the location allows a suggestive interpretation, creating a symbolic link between the old master, who centuries ago left his unmistakeable mark on the city, and the new one, ready to embark on a similar task. Le Corbusier said: "All the beauties of Venice are already known. But what will happened with Venice within the contemporary internationalization processes? I think it is extremely necessary to find a way to preserve the physical, spiritual and intellectual unity which has determined its history ${ }^{\prime \prime 2}$. What emerges from these words is a concern towards Venice's future, and an operative indication. According to these words, the new Hospital of Venice may be seen as Le Corbusier's answer to debates regarding the relationship between modern architecture and the historical context.

Within the same video document in fact, Giuseppe Mazzariol explained to the audience that the project for the new Hospital had "unanimously been interpreted as an example of innovation that respects the history and the art of Venice". The hospital was to replace the Slaughterhouse - "a small neoclassical building" - and a "complex of houses built at the beginning of the 20th Century located on the other side of Rio di San Giobbe. It will stretch out into the lagoon on pilotis for 60 meters [...]. There, there will be a sort of dam at the end of which a small chapel will be built. The chapel will be the first thing that those arriving in Venice from terraferma will see". The project, "that harmoniously interacts with city's urban tissue, represents Le Corbusier's own interpretation of Venice. He has been able to renounce completely to his architectural language. [...] He has renounced to everything in order to give us an architecture made entirely of open spaces and in fact, through the pilotis, it will be possible to see Venice [...]. Le Corbusier, who has always built in height, has now designed a small, low and humble architecture which is in perfect harmony with the city. In other words, he was influenced by the city [...] just like Longhena and Palladio before him" ${ }^{\prime 13}$. The tune of the interviews following Mazzariol's speech are more or less the same, stressing the affinities between the project for the Hospital and the city, constantly reassuring the national audience that no damage will be done and that the city could only benefit from Le Corbusier's project.

The video document deals then with a different topic, focusing on the problems of the Hospital hosted within the monumental complexes of San Zanipolo. The discussion revolves around the rapid evolution of medical science and the impossibility to adopt further the preexisting buildings to contemporary health care standards. From this point of view, Le Corbusier's project was presented as innovative given that "the new hospital reserves for each patient an individual cell in which he will be cured far from any sort of degrading and mortifying promiscuity. In

\footnotetext{
${ }^{10}$ Comune di Venezia; Fondazione Giorgio Cini: Atti del Convegno internazionale "Il problema di Venezia". Venice: w/o.pub, 1964.

${ }^{11}$ Ciacci, Leonardo (Ed.): Venezia è una città. Un secolo di interpretazioni del cinema documentario. Venice: Marsilio, 2004. pp. 53-61.

12 Ibid, p. 53

${ }^{13}$ Giuseppe Mazzariol. En Pellegrini, Glauco: Servizio sulla presentazione del progetto di Le Corbusier per il nuovo Ospedale di Venezia, "L'Approdo", RAI, May 11, 1965.
} 
the history of architecture and in that of hospitals, Le Corbusier's project - labeled as the modern machine for healing - opens an entirely new chapter,"14.

"But will Venice find help and support for the realization of such an important work, which can solve all the inconveniences and chronic shortcomings of an inadequate health care system?" the voice-over asks rhetorically. The answer is provided by Giovanni Favaretto Fisca, the mayor of Venice, who said that "the city administration has already done its job. And I think that the institution I represent will continue to do it also in future .15. The president of the Hospital Carlo Ottolenghi, on the other side, mentioned the fact that there might problems with the bureaucratic iter, which is particularly complex: "I keep on my bedside table the Old and the New Testament, but also a list of authorizations that my secretary has prepared and that are necessary for accomplishing the project" ${ }^{\text {"16 }}$. In fact, a long list of unbuilt projects prepared for the Hospital during the previous decades testifies the difficulties that the Hospital administration had already encountered and which were now imposing a cautious approach.

As for the architectural and urban qualities of Le Corbusier's project, the video document reports the opinion of Giuseppe Samonà who stated that "this work of art irradiates with balance and meanings so high that it creates an environment within the environment, without ever imposing itself. It creates a new balance and harmony. And when it comes to somebody who is ingenious like Le Corbusier, this harmony has been reached with such understanding of all historical architectures of Venice that it is astonishing. You understand that [...] this project will grow and gradually irradiate a new harmony that this urban tissue needs in order to renew itself with modern vigor [... " ${ }^{, 17}$. Again, the audience was reassured: the Hospital was designed in full respect of Venice's character, and thus there was no need to fear any unwanted consequence.

The RAI registration is an important document which bears witness of the opinion of all parties involved in the Hospital affair. However, what the document doesn't explain is the caution of the interviewed, the too frequent references to the historical character of Venice and the contemporary cultural context. In order to understand that, it is necessary to take into consideration a wider chronological span which allows for a better comprehension of the meaning of the project in relation to the so-called "problem of Venice".

\section{The new master plan and the role of Venice within}

In 1954, the Ministry of Public Works published a list of cities which - according to Article 8 of the Planning Law of 1942 - were obliged to define and adopt a new master plan within five years ${ }^{18}$. Venice was among those cities and was, two years later, also at the center of a legislative action aimed at preserving its monumental character: the so-called Special Law for Venice defined ways in which private and public funds could be

\footnotetext{
${ }^{14}$ Ignazio Muner. En Pellegrini, Glauco: Servizio sulla presentazione del progetto di Le Corbusier per il nuovo Ospedale di Venezia, "L’Approdo", RAI, May 11, 1965.

${ }^{15}$ Giovanni Favaretto Fisca. En Pellegrini, Glauco: Servizio sulla presentazione del progetto di Le Corbusier per il nuovo Ospedale di Venezia, "L'Approdo", RAI, May 11, 1965.

${ }^{16}$ Carlo Ottolenghi. En Pellegrini, Glauco: Servizio sulla presentazione del progetto di Le Corbusier per il nuovo Ospedale di Venezia, "L'Approdo", RAI, May 11, 1965.

${ }^{17}$ Giuseppe Samonà. En Pellegrini, Glauco: Servizio sulla presentazione del progetto di Le Corbusier per il nuovo Ospedale di Venezia, "L’Approdo", RAI, May 11, 1965.

${ }_{18}$ Approvazione del primo elenco dei Comuni obbligati a redigere il piano regolatore dei rispettivi territori. Gazzetta Ufficiale della Repubblica Italiana. № 120. May 26, 1954. Rome: Istituto Poligrafico dello Stato. p. 1621.
} 
synergically used in order to solve urgent hygienic and maintenance problems the city was facing ${ }^{19}$. The two actions are to be intended not as independent from each other, but as a result of a larger concern regarding on one side the preservation of historical and artistic heritage of the past and on the other the future of it, in relation to the role of the city within a larger territorial context. In fact, the new master plan would result in the first planning document to take into consideration both the historical center and its counterparts on terraferma ${ }^{20}$.

At the time the above mentioned laws were published, Venice was already discussing the possibility to hold an international competition for the new master plan and had already invited individual experts to join a special Commissione Redazionale that was asked to prepare the necessary documentation ${ }^{21}$. However, two years later, in June 1956, probably because of the delicacy of the argument but certainly because of the limited time available, the participation was allowed only to national planners who were given 120 days to prepare their proposals ${ }^{22}$. On September 10 of the same year, the participants were given 99 more days being the new deadline postponed to January 15, 1957. Roberto Tognazzi, the major of Venice, stressed several times the importance for Venice to rethink its role within the larger geographical context: "Venice suffers a crisis because of the needs born out from the modern development, and because the limits of its historical center make it impossible for the city to host necessary services and infrastructures. That's why the city has expanded towards terraferma and the estuary, and hence today the need to guide this development transforming this expansion into [...] a vital element for the city thanks to which the historical center will be able to articulate and improve itself within and for the modern society ${ }^{, 23}$.

The Jury ${ }^{24}$ decided to award five proposals (among the 13 presented), assigning the first prize to a group led by Giorgio Amati. The second prize went to a group led by Giovanni Astengo, the third to that led by Daniele Calabi, the fourth to that led by Ludovico Quaroni and the fifth to Lavinio Bellemo. It was Jury's opinion that each of these proposals presented a number of interesting solutions especially regarding the relationship between the center and terraferma. The task to prepare a definitive version of the masterplan was assigned to the before mentioned Commissione Redazionale ${ }^{25}$, the members of which comprised among others Giuseppe Samonà and

\footnotetext{
${ }^{19}$ Provvedimenti per la salvaguardia del carattere lagunare e monumentale di Venezia attraverso opere di risanamento civico e di interesse turistico. Gazzetta Ufficiale della Repubblica Italiana. No 103. April 28, 1956. Rome: Istituto Poligrafico dello Stato.

${ }^{20}$ Back in 1954, the planning tools Venice could count on were a Piano Regolatore del Quartiere Urbano di Marghera dating back to 1926, a Piano di Ricostruzione di Mestre (1950), a Piano di Risanamento di Venezia Insulare (1939), and a never adopted Piano regolatore dell'Abitato di Mestre (1939, 1942). Consiglio Comunale: Resoconto Stenografico della Seduta. Relazione Dorigo. February 14, 1958. Archivio Storico Comunale, Venezia. p. 1.

${ }^{21}$ Elementi per il concorso internazionale per il piano urbanistico. February 22, 1954. 1948/X-1-2. Archivio Storico Comunale, Venezia.

${ }^{22}$ Comune di Venezia: Concorso nazionale di idee per la impostazione del piano regolatore generale del Comune di Venezia. June 9, 1956. 1948/X-1-2. Archivio Storico Comunale, Venezia.

${ }^{23}$ Relazione del Sindaco Avv. Roberto Tognazzi nella seduta del 26 ottobre 1956 sul programma dell Amministrazione Comunale per il quadriennio 1956-1960. Archivio Storico Comunale, Venezia.

${ }^{24}$ Members were Roberto Tognazzi, Gino Luzzatto, Giuseppe Samonà, Attilio Vismara, Wladimiro Dorigo, Giovanni Padoan, Edoardo Detti, Gino Greggio, Armando Melis, Antonino Rusconi, Cesare Valle, Giovanni Bazzuoli, Giuseppe Befani, Giovanni Stecconi, Giuseppe Caporioni, Pietro Zampetti, Ugo Boffa as reported in Approvazione del Piano Regolatore Generale del Comune di Venezia. March 20, 1965. Consiglio Comunale. Archivio Storico di Venezia, Venezia. p. 2.

${ }^{25}$ Commissione was formed on December 14, 1956 with the goal to "prepare a general program for the restoration of the historical center, indispensable both for the master plan and for the detailed plan (piano particolareggiato) that the Municipality had to present according to art. 4 of the new Special Law for Venice". Members were Roberto Tognazzi, Armando Gavagnin, Giuseppe Samonà, Innocenzo Gasparini, Luigi Piccinato, Virgilio Vallot, Benedetto Panciera, Bruno Venturini, Giovanni Padovan, Mario Nono, Pietro Torta, Wladimiro Dorigo, Giorgio Zecchi, Raoul Sartorio, Giovanni
} 
Luigi Piccinato. The drafting process was paralleled with passionate debates in the City Council ${ }^{26}$, in spite of which works were concluded in 1959. Commissione stated in its report that any alterations of the historical center should be avoided, except for the 19th Century areas, in which it was necessary to intervene "in order to provide form and content to the historical center itself" ${ }^{27}$. Among these areas, Commissione identified also the North-Western front of Venice (San Giobbe, Baia del Re and Sant'Alvise), e.g. the areas in which the new Hospital was to be located. In fact, Commissione described the existing Hospital at SS. Giovanni e Paolo as a complex in which "all the services are concentrated in old buildings, and therefore the Hospital can not be considered neither adequate nor efficient; the irrational location of services and the impossibility to restructure the complex in modern terms provides an inadequate response to contemporary necessities ${ }^{28}$. Commissione identified the area of San Giobbe ("well exposed, healthy and immune to toxic fumes" ${ }^{\text {"29) }}$ as an adequate location for the construction of a modern Hospital with a capacity of 1.000 beds.

The final version of the master plan, approved by the local authorities on the 20th of March 1959 and by the national Ministry of Public Works on the 17th of December 1962, affirmed the regional dimension of Venice by setting some main goals to be achieved: a new touristic district was to be accomplished on Punta Sabbioni; a new housing district for 35.000 inhabitants was to be built on mainland, in the area of San Giuliano; a new industrial district was to be located near Porto Marghera; a brand new business district was to be hosted in the area comprised between Piazzale Roma and the Giudecca Canal (considered at that time "the trump card of the masterplan ${ }^{, 30}$ ); and a new Hospital was to be built on the area of San Giobbe ${ }^{31}$. The goals set by the master plan envisioned a reorganization of the city within a regional frame, providing the areas around Ponte della Libertà on its both ends with a brand new role: these were meant to "free" the historical center from its insular dimension triggering at the same time a process of integration between the historical center and terraferma. In fact, it was precisely these areas that future competitions took into consideration.

\section{Le Corbusier's message to the city administrators: "Don't kill Venice,"32}

About the time the new masterplan of Venice was ready (October 1962), an international seminar was organized on the island of San Giorgio Maggiore with the aim to find a solution to "the problem of Venice",33. The goal of the seminar was, as declared in the opening speech of the mayor, "to bring to the attention of the world the problems of Venice" because it "is not only an Italian problem, but of all those who believe in the destiny and the universal values of humankind" ${ }^{34}$. The occasion was described by the local press as "a consultation of

Stecconi, Giuseppe Caporioni, Pietro Zampetti, Giuseppe Stomeo and Marcello Maggia. Consiglio Comunale: Resoconto Stenografico della Seduta. Relazione Dorigo. February 14, 1958. Archivio Storico Comunale, Venezia. p. 22.

${ }^{26}$ Comune di Venezia: Piano Regolatore Generale. Relazione. Venezia: w/o, 1959. p. 47.

${ }^{27}$ Ibid, p. 38.

${ }^{28}$ Ibid, p. 40.

${ }^{29}$ Ibid, p. 136

${ }^{30}$ Consiglio Comunale: Resoconto Stenografico della Seduta. Relazione Dorigo. February 14, 1958. Archivio Storico Comunale, Venezia. p. 24.

${ }^{31}$ Ospedali Civili Riuniti: I progetti preliminari per il nuovo ospedale di Venezia. Venezia: Stamperia di Venezia, 1964. s.p.

${ }^{32}$ Le Corbusier: Letter to Giovanni Favaretto Fisca, October 3, 1962. En Comune di Venezia; Fondazione Giorgio Cini: Atti del Convegno internazionale "Il problema di Venezia". Venice: w/o.pub, 1964. pp. 491-493.

${ }^{33}$ Comune di Venezia; Fondazione Giorgio Cini: Atti del Convegno internazionale "Il problema di Venezia". Venice: w/o.pub, 1964.

${ }^{34}$ Favaretto Fisca, Giovanni: "Saluto del sindaco di Venezia". En Comune di Venezia; Fondazione Giorgio Cini: Atti del Convegno internazionale "Il problema di Venezia". Venice: w/o pub, 1964. p. 4. 
international doctors around a patient of great importance, 35 . Within the title of the congress may be found all the preoccupations about the future of Venice which have exponentially grown since the new masterplan has started to take shape. The city was undoubtedly going through a particularly delicate period, but it has also to be mentioned that the debates about the future of Venice were perfectly in tune with contemporary ongoing international debates, which saw experts engaged in discussions about the future of historical centers in general: the National Congress on Preservation and Renewal of Historical Centers in Gubbio (1960), the International Seminar on Urban Renewal organized by the European Comité de l'Habitat in Geneva (1961) and the International Congress on the Enhancement of Monuments organized by the Fédération Internationale pour l'Habitation, l'Urbanism et l'Aménagément des Territoires in Santiago de Campostela (1961) are only some of the occasions in which the topic was addressed and which took place around the same period. The Venetian congress, organized at Fondazione Cini, is therefore to be understood as a part of this larger national and international debate, within which the case of Venice was particularly significant due to its peculiar urban condition. It would be impossible to summarize all the speeches given during the congress, but it may be interesting to recall the words of Giuseppe Samonà, one of the authors of the master plan, who invited the general public to finally "acknowledge city's regional dimension" and therefore "treat the problems within that larger context ${ }^{, 36}$.

If we attempt to judge the event by looking only at the names of those that were present, and the list of which was published on the first pages of the conference proceedings, than we would surely deduce that the event was a huge success. But there was also an absentee, the participation of which would have been particularly significant: Le Corbusier in fact had kindly declined the invitation to attend the meeting but sent un message, in which Venice was described as "Ville Sacrée”, "ville fermée”, "le plus prodigious évènement urbanistique existent sur terre" and "ville harmonieuse". These epithets of the city appear somehow in contrast with the second part of the letter, in which Le Corbusier stated: "Ce que vous avez à reconstruire, faites-le d'une architecture la plus moderne possible. [...] Employez le béton armé pour établir ces standards et ne cherchez pas à copier la vieille brique faite à la main du vieux Venise. Vous pouvez metro au monde des frères et sours des 'Palais Ducals', 'Procuraties', etc. etc. ... de la famille illustre de Venise: des lieu et des locaux (des vases accueillant les functions ou des êtres vivants) ${ }^{\prime 37}$. Le Corbusier's words were addressed to both conservators and modernists: in fact, while affirming city's uniqueness and untouchability on one side, he was also inviting the audience to accept modernity as an unavoidable part of Venice's future. With this message, the architect probably prepared the ground for himself, avoiding momentarily to take part in the discussions. In order to understand the calibrated sharpness of Le Corbusier's words, it is necessary to look at the proposals that were presented for the city around the same period and to understand how the problem of Venice was dealt with by national planners.

\footnotetext{
${ }^{35}$ Ivi. p. 3.

${ }^{36}$ Samonà, Giuseppe: "Centro storico e centro direzionale. Città insulare e terraferma". En Comune di Venezia; Fondazione Giorgio Cini: Atti del Convegno internazionale "Il problema di Venezia". Venice: w/o pub, 1964. pp. 103-111.

${ }^{37}$ Le Corbusier: Letter to Giovanni Favaretto Fisca, October 3, 1962. En Comune di Venezia; Fondazione Giorgio Cini: Atti del Convegno internazionale "Il problema di Venezia". Venice: w/o pub, 1964. p. 492.
} 


\section{Three competitions and some (unaccomplished) solutions to the problem of Venice}

On May 15, 1959, a national competition for a residential neighborhood to be built on San Giuliano's barene (salt marshes) was held ${ }^{38}$. The competition was organized by the Comitato di Coordinamento dell'Edilizia Popolare, who asked planners for a urban district provided with all the necessary civic services. The operation was aimed at managing the flight from Venice towards Mestre, a flight mainly due to the precarious condition of Venetian houses which in the previous decades had resulted in an uncontrolled urban expansion on terraferma. In order to provide directions for further growth, it had become mandatory to configure a comprehensive urban plan and initiate a dialogue regarding the housing problem which interested both the mainland and its insular counterpart $^{39}$. Fifty-seven planners took part in the competition, among which Luigi Piccinato, Giuseppe Samonà, Giovanni Astengo, Ludovico Quaroni as well as the winner: Saverio Muratori ${ }^{40}$. While the latter attempted to configure the new urban complex looking for inspiration at the historical center, the other planners accepted the "vitality of the task",41 offering with their proposals a significant contribution to another problem, and namely "the industrial squalor of Mestre" ${ }^{42}$. Ludovico Quaroni and his team had probably more clearly than others put Mestre in the condition to face the historical center without subjection. The proposal was brave and touched some of the most delicate issues of the contemporary debates regarding the housing problem and, above all, the relationship between historical centers and new peripheries. With the semi circular forms of the business district to be located on the lagoon banks, Quaroni attempted to imposed a new formal configuration to the entire area which comprised 2600 residential units. The project was characterized by a strong internal formal coherence, thus opening a dialogue with both the existing settlements on terraferma and the historical center itself. In other words, Quaroni’s proposal embodied a urban discourse in which the regional dimension of Venice was acknowledged ${ }^{43}$ highlighting the need for "an active and dynamic interpretation of each new urban settlement, to be intended as an element of an all-comprehensive urban system ",44.

\footnotetext{
${ }^{38}$ Ministero dei lavori pubblici: Quartieri coordinati. Rome: Editalia, 1960. pp. 106-110. See also Dolcetta, Bruno: "Edilizia pubblica, città piano”. En Barbiani Elia (Ed.), Edilizia popolare a Venezia. Storia, politiche, realizzazioni dell Istituto Autonomo per le Case Popolari della Provincia di Venezia. Milan: Electa, 1983. pp. 93-111.

${ }^{39}$ Dubbini, Renzo: "San Giuliano e San Giobbe". En Zucconi, Guido (Ed.): La grande Venezia. Una metropoli incompiuta tra Otto e Novecento. Venice: Marsilio, 2002. pp. 111-117.

${ }^{40}$ Benevolo, Leonardo: Un consuntivo delle recenti esperienze urbanistiche italiane. Casabella-Continuità, $\mathrm{N}^{\circ} 242$. August 1960. p. 33.

${ }^{41}$ Ibid, p. 32.

${ }^{42}$ Colquhoun, Alan: Formal and Functional Interactions: A Study of Two Late Projects by Le Corbusier. Architectural Design. May 1966. p. 221.

${ }^{43}$ Benevolo, Leonardo: Un consuntivo delle recenti esperienze urbanistiche italiane. Casabella-Continuità, $\mathrm{N}^{\circ} 242$, August 1960. p. 33.

${ }^{44}$ L.S.: Il concorso per il quartiere residenziale alle Barene di S. Giuliano, Venezia-Mestre. Casabella-Continuità, $\mathrm{N}^{\circ} 242$, August 1960. p. 32.
} 


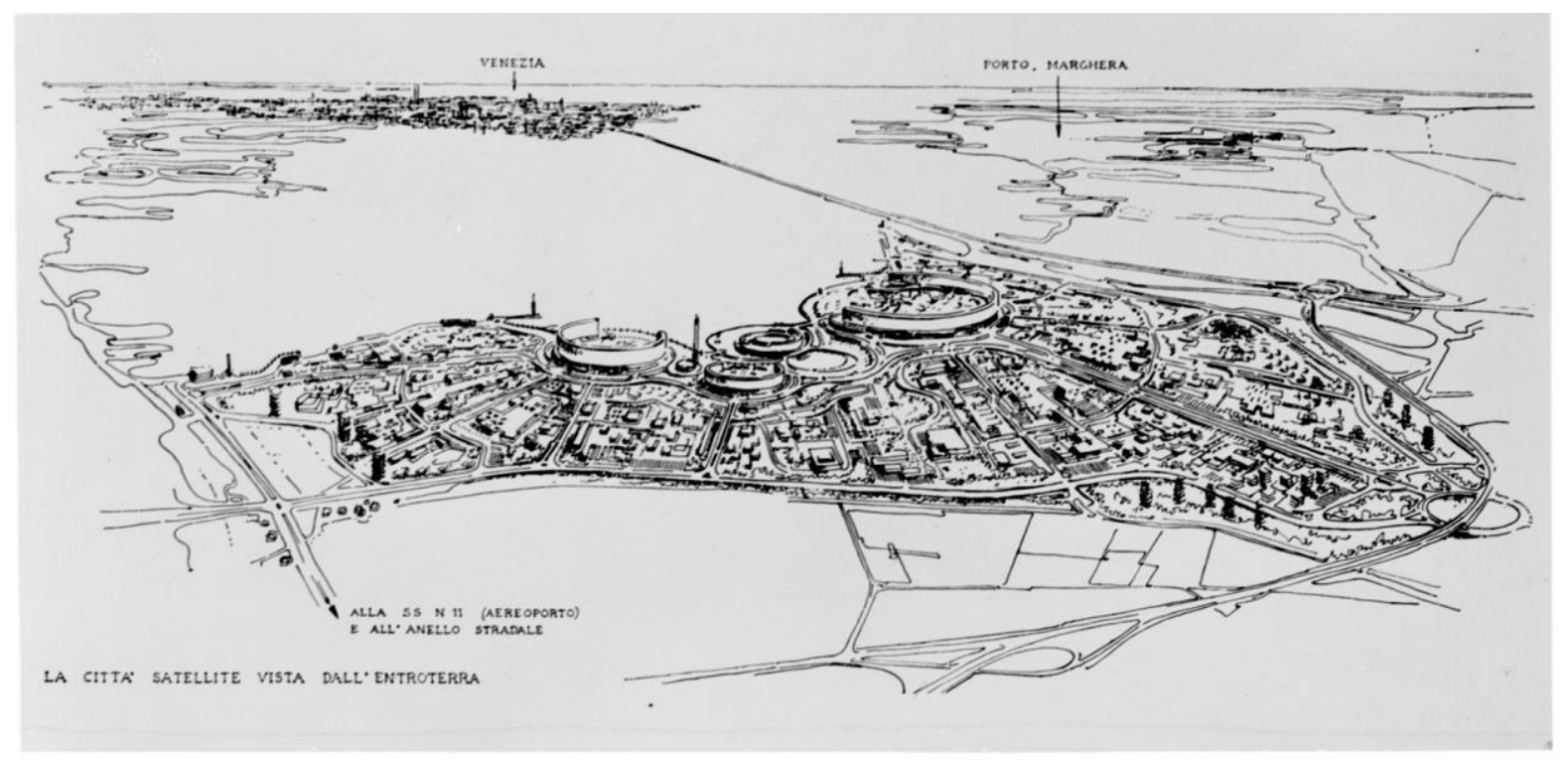

1. Ludovico Quaroni and collaborators, Project for the San Giuliano district (competition submission), 1959. Samonà 3.fot/1/080, Archivio Progetti Iuav, Venice.
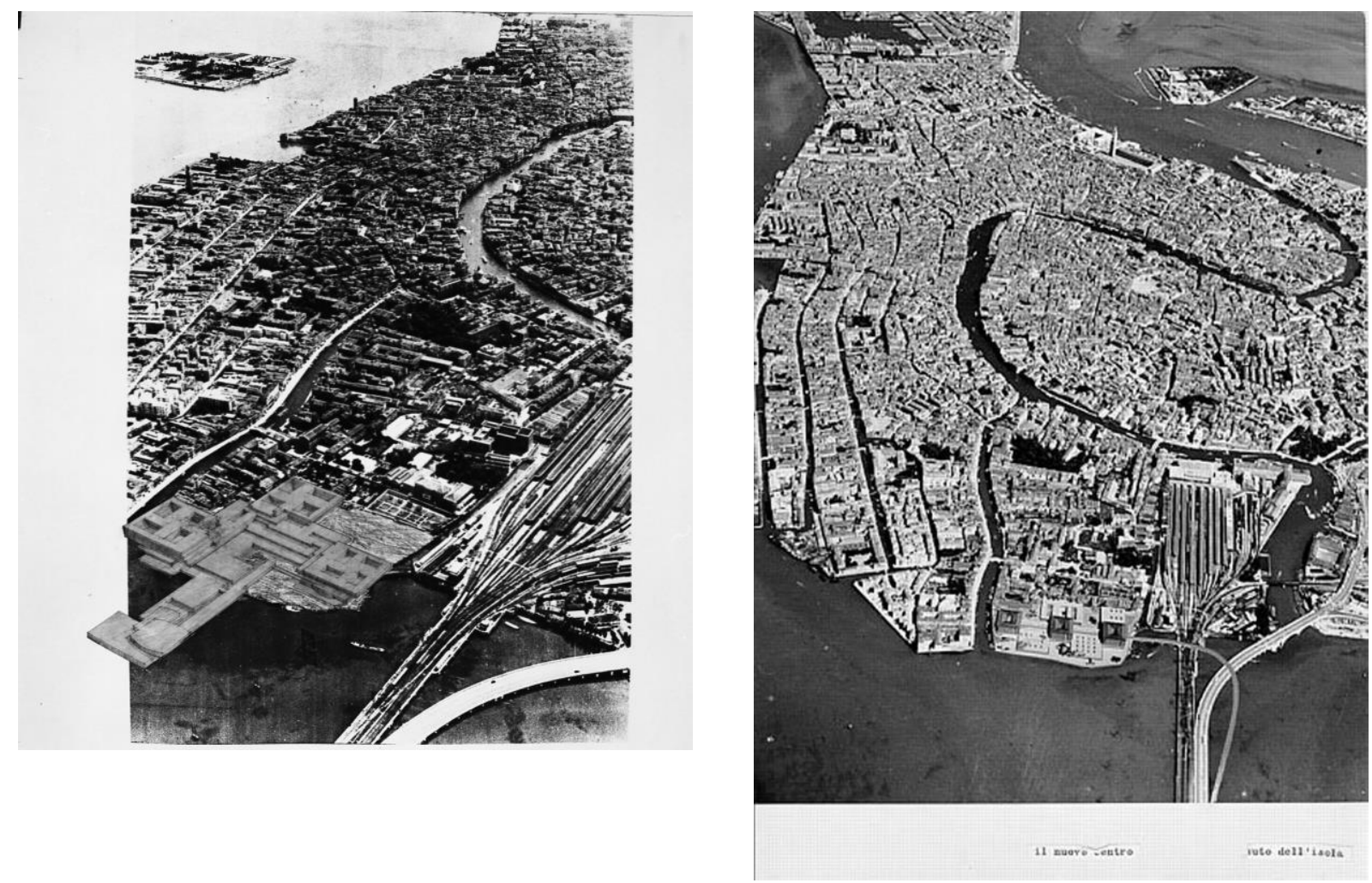

2. Romano Chirivi and collaborators, Project for the new Civic Hospital (competition submission), APriproduzioni/fot/015/12, Archivio Progetti Iuav, Venice.

3. Daniele Calabi and Mario Dalla Costa, Project for the new Civic Hospital (competition submission), APriproduzioni/fot/025/22, Archivio Progetti Iuav, Venice.

Another competition for Venice was held between May 20 and August 20,1963 ${ }^{45}$. The competition for the new Hospital was made mandatory by the impossibility of the existing one, located on San Zanipolo, to adequately satisfy the growing health care standards. The problem was as old as the hospital itself: in fact, it was since 1807, when Scuola Grande di San Marco and the Dominican convent of Santi Giovanni e Paolo as well as the

${ }^{45}$ Ospedali Civili Riuniti: I progetti preliminari per il nuovo ospedale di Venezia. Venezia: Stamperia di Venezia, 1964. s.p. 
Ospedale dei Mendicanti were transformed into hospitals, that the institution was fighting with the inadequacy of its buildings and a lack of space ${ }^{46}$. In 1962 Carlo Ottolenghi became the president of the Ospedali Civili Riuniti and engaged himself in the attempt to demonstrate that the new administration had "cultural openness and organizational skills, ${ }^{, 47}$ necessary to finally solve a century long problem. The competition produced an ambiguous result: out of a total of ten presented proposals, no first prize was assigned, two shared the second place and a special mention went to a third project. On one side, it can be assumed that the lack of a definitive result was due to the fact the at that time Hospital's administration had already established contacts with Le Corbusier inviting him to present a proposal. On the other, it is to be understand that at that moment at stake was not only the future of a single institution, but that of Venice as a whole ${ }^{48}$. Most of Jury's debates in fact focused not on the Hospital, but on the problem regarding the relationship between the historical center and modern architecture to be built not on terraferma, but within the city itself ${ }^{49}$.

The photo collages presented by the two second classified planners appear emblematic in exemplifying the impact that any new complex would have had for those arriving in Venice via the railway bridge. The first photo collage, presented by a group led by Romano Chirivi ${ }^{50}$, occupies the San Giobbe area with a cruciform shape. One of its wings stretches boldly towards the lagoon and would have produced an interesting dialogue with terraferma but in relation to Venice it did not present an "adequate scale" needed to be configured in relation to a regional health care system, thus reducing the number of beds and proposing to create other centers within the city and on terraferma. Services within the Hospital were organized in slabs, the highest of which were intended for hospitalization, while therapy and diagnostics occupied lower levels. The shape and the functional organization of this proposal have on some occasions even been indicated as elements Le Corbusier later used for his own project ${ }^{52}$.

The second proposal, designed by Daniele Calabi and Mario Dalla Costa, comprised two slabs hosting diagnostic and therapeutic functions, while concentrating hospitalization into three 20 meters high cubical volumes. The Jury considered it as an exceptionally good answer to Hospital's needs, but was unsatisfied with the architectural aspects of the proposal. As Bruno Zevi put it, "it hides a great organism [i.e., Venice] behind the facades of three irrelevant buildings ",53. Interpreting the results of this second competition, it might be said that although the competition offered some interesting proposals, it was the image of Venice that was not adequately taken in consideration neither in the first nor in the second project.

\footnotetext{
${ }^{46}$ Guidarelli, Gianmario; Tolic, Ines: "The history of the Civic Hospital in Venice (1797-2011) in the light of contemporary cultural and urban challenges". En Calabi, Donatella (Ed.): Built city, designed city, virtual city, the museum of the city. Rome: CROMA, 2013. pp. 233-253.

${ }^{47}$ Mattioni, Emilio: "La vicenda del concorso preliminare per il nuovo ospedale di Venezia". En Talamone, Marida (Ed.): L'Italia di Le Corbusier (exhibition catalogue: Rome, October 18, 2012 - February, 17, 2013). Milan: Electa, 2012. p. 377.

${ }^{48}$ Zevi, Bruno: “Un'ospedale per Venezia. La macchina per guarire chiede Le Corbusier". En Zevi, Bruno: Cronache e storia. Bari-Rome: Laterza, 1970. p. 303.

${ }^{49}$ Commissione giudicatrice concorso nuovo ospedale. Riunione 14-15 settembre 1963. Verbale 2. Nuovo Ospedale, M/41. Archivio Ospedale, Venezia.

${ }^{50}$ The group was formed by Romano Chirivi, Costantino Dardi, Emilio Mattioni, Valeriano Pastor and Luciano Semerani. Progetto per il Nuovo Ospedale Civile di Venezia (1963), AP-originali/pro/020, Archivio Progetti Iuav, Venezia.

${ }^{51}$ Zevi, Bruno: "Un'ospedale per Venezia. La macchina per guarire chiede Le Corbusier". En Zevi, Bruno: Cronache e storia. Bari-Rome: Laterza, 1970. p. 304.

${ }^{52}$ Tentori, Francesco: Imparare da Venezia: il ruolo futuribile di alcuni progetti architettonici veneziani dei primi anni Sessanta. Roma: Officina, 1994.

${ }^{53}$ Zevi, Bruno: “Un'ospedale per Venezia. La macchina per guarire chiede Le Corbusier”. En Zevi, Bruno: Cronache e storia. Bari-Rome: Laterza, 1970. p. 304.
} 
On October 29, 1963, the Municipality of Venice published a notice about another competition - an international one this time - for Tronchetto Island. The notice didn't conform to the rules for international architectural competitions inducing Pierre Vago, the secretary general of the International Union of Architects, to invite planners not to take part in it. Eventually, the notice was changed and the new international competition started on February 27, 1964. The competition notice asked planners "to pay attention to the habitat, to the landscape and to the quality of the view for those arriving to Venice from terraferma" "54. It seems that with competitions for a new Hospital on one side and for Tronchetto on the other, Venice was determined to refurbish its main facade in a modern fashion but, again, no clear or definitive result was achieved: five proposals were awarded and one special mention was assigned. Moreover, due to certain freedom of interpretation that the notice left to competitors, planners presented very different proposals thus creating difficulties during the judging phase $\mathrm{p}^{55}$.

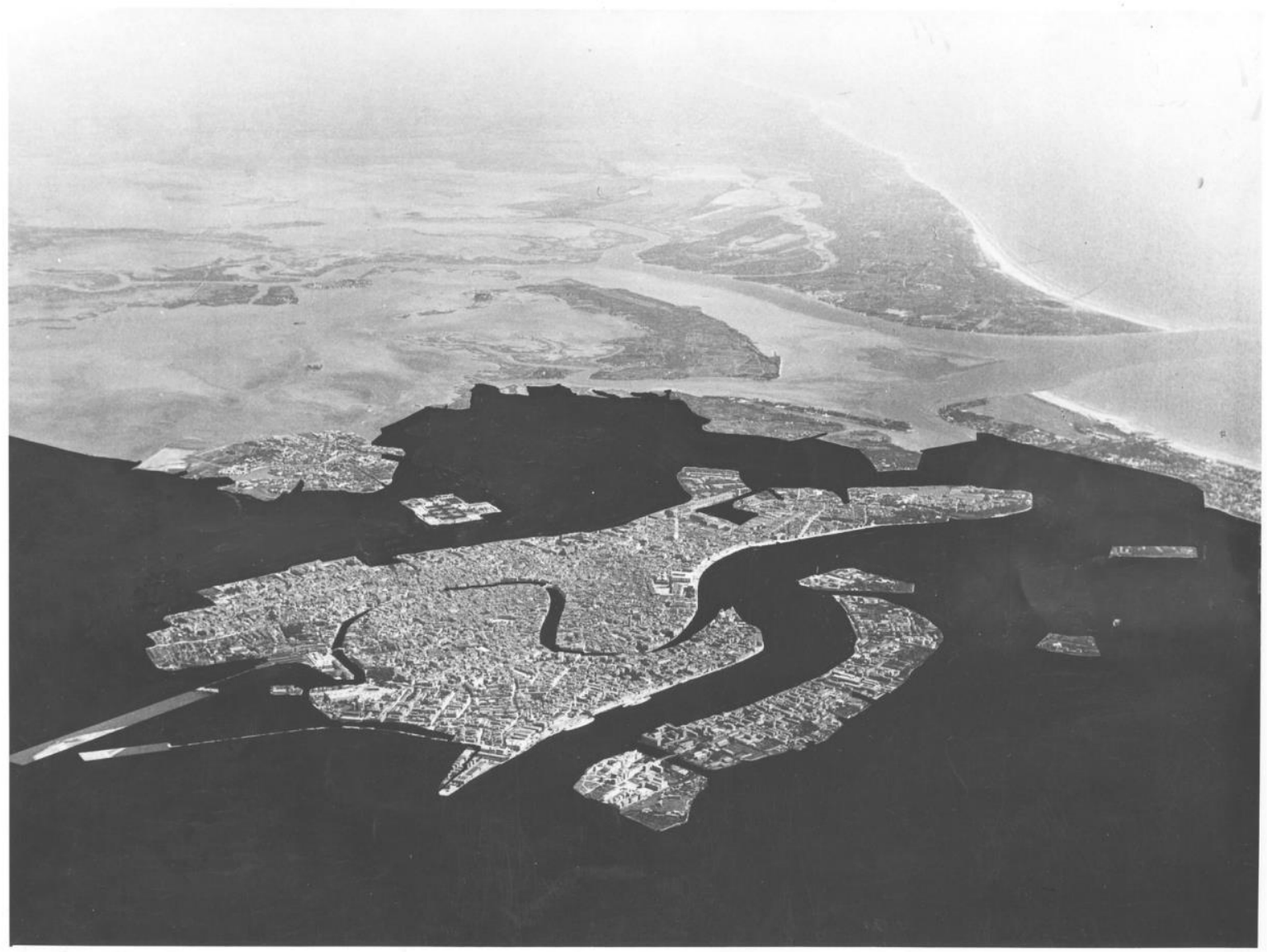

4. Giuseppe Samonà and collaborators, Project for the Tronchetto Island (competition submission), Trincanato 3. Attività professionale/1/049, Archivio Progetti Iuav, Venice.

Among the projects presented, one especially needs to be taken into consideration because of its radical answer to the problem of Venice. The proposal was presented with the name Novissime and was prepared by a group of

${ }^{54}$ Zevi, Bruno: "Lo sfregio di Venezia. Il Trinchetto istiga all'oscenità". En Zevi, Bruno: Cronache e storia. Bari-Rome: Laterza, 1970. p. 247.

${ }^{55}$ Concorso internazionale per il piano particolareggiato della nuova sacca del Tronchetto. Urbanistica. Rivista trimestrale dell'Istituto Nazionale di Urbanistica, nn. 42-43, February 1965, pp. 101-110. 
authors led by Giuseppe Samonà ${ }^{56}$. The project was based on the assumption that the most convenient choice for Venice would be to locate all the functions related to the commercial harbour not on Tronchetto Island (e.g. in Venice), but on terraferma. According to the planners, with this functional reorganization there would be no more need neither for the railway bridge nor for the highway which connect the city to mainland. Therefore, it was suggested to obliterate both, as well as the Tronchetto Island itself. The authors pushed the reasoning even further, suggesting that it was necessary to eliminate all the structures that were damaging the "true character" of Venice, bringing its form back to that that the city had in the 18 th Century ${ }^{57}$. Instead of being labeled as reactionary, the project was judged as one of "the most controversial, most radical, [and] culturally the most brilliant" ever proposed for the city ${ }^{58}$. Within this proposal, "Venice rediscover[ed] its form and [found] therein all that it needs [...]" while terraferma was to take over functions grown out of contemporary necessities. Obliging the historical center to stop its evolution, authors have affirmed the impossibility of Venice to satisfy modern needs, making it become mandatory to look for its future within the regional context.

Projects presented for Venice around the time Le Corbusier was involved in the debates about city's future are to be intended as attempts to guide the expansion on terraferma creating the premises for a balanced growth of the city center in modern fashion. During these debates, Le Corbusier was asked by the Hospital administration to present a proposal for San Giobbe. Slowly but steadily, the Hospital monopolized public opinion's attention reframing the problem of Venice as an insular matter. In fact, as thoroughly demonstrated by Mahnaz Shah ${ }^{60}$, Le Corbusier looked for inspiration in the historical center where he "discovered the expense of the city of Venice, its structure and its light ${ }^{, 61}$. As such, the project did not seek for a dialogue with terraferma but is to be understood in relation to the historical urban tissue and is to be intended as a modern counterpart of Saint Mark Square. Le Corbusier's Hospital was presented to the public opinion as a courageous and innovative project, but if a wider chronological frame is taken into consideration it seems that within the local administration a conservative front prevailed, thus renouncing to solve the "problem of Venice" within a wider regional frame.

\section{Conclusions}

Italian architecture and urban design went through an extraordinary period between 1950s and 1970s, as it is testified by the amount of competitions, buildings, publications and debates. Passionately discussed in those years was the relationship between historical centers and new peripheries, a topic that interested all Italian cities among which Venice represented an particularly delicate case. Within only a dozen of years, the city witnessed four major competitions, some of which - if buildings were accomplished - would have resulted in radical alterations of its character. The masterplan opened the city to a regional dimension which initiated the debates

\footnotetext{
${ }^{56}$ Other members of the team included: Costantino Dardi, Emilio Mattioni, Valeriano Pastor, Gian Ugo Polesello, Alberto Samonà. Gigot and Luciano Semerani, Egle Trincanato. Novissime, Trincanato 3.attività professionale/2/23, Archivio Progetti Iuav, Venezia.

${ }^{57}$ Il concorso per l'Isola del Tronchetto: si invertano i risultati. L'architettura. cronache e storia, n. 110, anno X, dicembre 1964, p. 507.

${ }^{58}$ Concorso internazionale per la sistemazione dell 'Isola del Trinchetto. L'architettura. Cronache e storia, n. 111, anno X, gennaio 1965, p. 596.

59 Rossi, Aldo: Considerazioni sul concorso internazionale per il piano urbanistico della Nuova Sacca del Trinchetto a Venezia. Casabella-Continuità, $\mathrm{N}^{\circ} 293$, November 1964. p. 17.

${ }^{60}$ Shah, Mahnaz: Le Corbusier's Venice Hospital Project. An Investigation into its Structural Formulation. Farnham: Ashgate, 2013.

${ }^{61}$ Allard, Pablo: "Bridge over Venice. Speculations on Cross-fertilization of Ideas between Team 10 and Le Corbusier (after a Conversation with Guillermo Jullian de la Fuente". En Sarkis, Hashim (Ed.), Le Corbusier. Venice hospital and the Mat building revival. Munich: Prestel, 2002. p. 30.
} 
about its future, and subsequent competitions tried to define it within the larger territorial context. Le Corbusier suggested terraferma as the location for the new Hospital ${ }^{62}$, but given administration's preferences for the center, he decided to assume the historical urban tissue as a generative element of his proposal. This decision, only partially retraceable in projects presented for the above mentioned competitions, framed the "problem of Venice" within its insular dimension. In other words, Le Corbusier reaffirmed the actuality of Venice within modernity, but to a certain degree also its self-sufficiency within the regional context. As such, the Hospital project is to be understood not in relation to terraferma, but as the counterpart of Saint Mark Square on the North-Western front, i.d. on the area that has become the new access point to the city since the railway bridge was built in 1831. In fact, being seen as "a meditation about the possibilities of architecture in relation to a city fragile and complex as Venice is ",63, Le Corbusier's project positioned itself in-between the conservative and the modernist front, satisfying the aspirations of both those for whom Venice was to be preserved and those for whom it was to be adapted to contemporary needs.

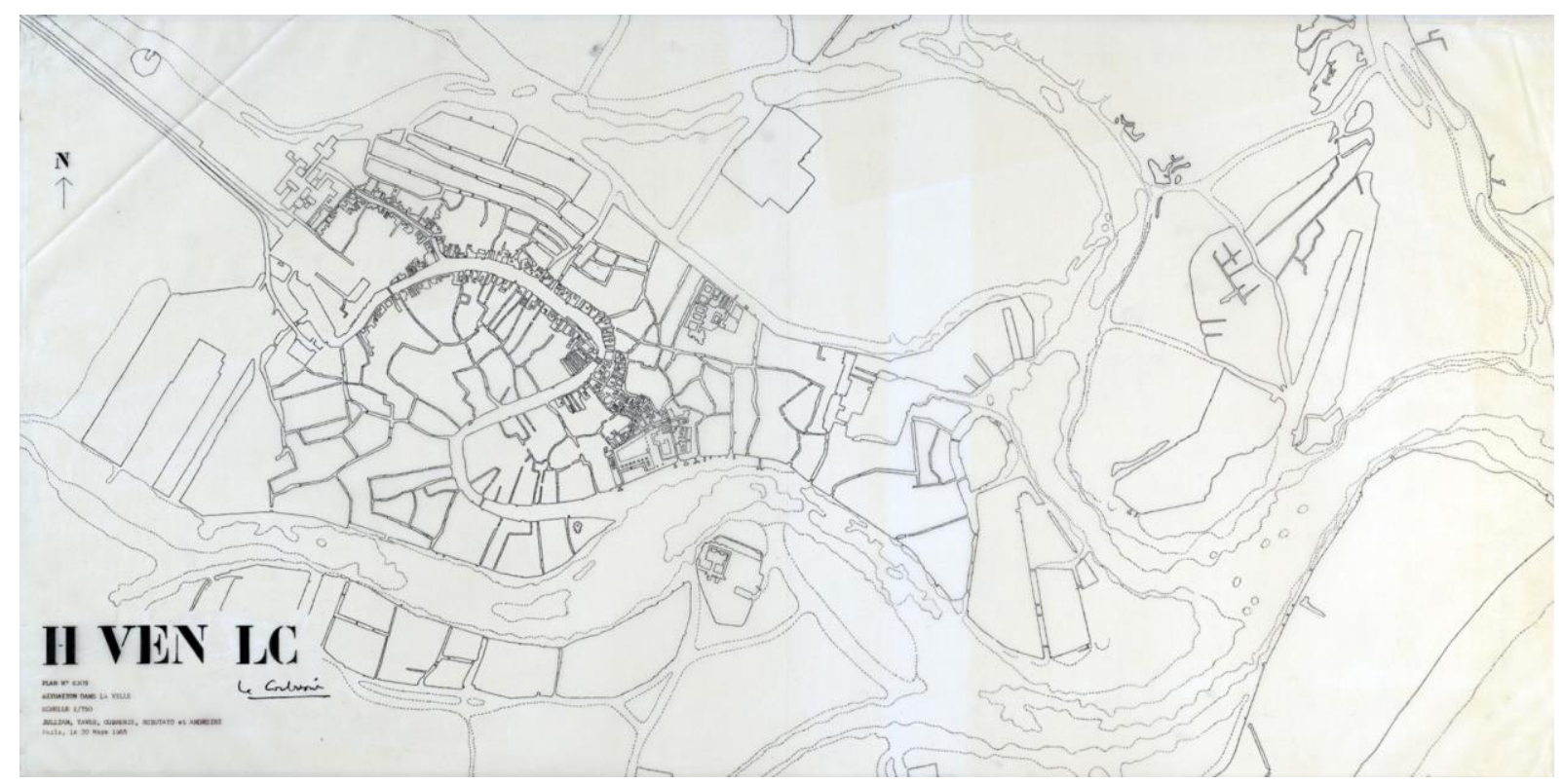

5. Le Corbusier, Situation dans la ville, Ospedale-pro/03/cartella 3/2, Archivio Progetti Iuav, Venice. @ FLC-ADAGP

Eventually however, the story got two dramatic turns with Le Corbusier's death on August 27, 1965 and with the extraordinary aqua alta on Novem ber 4, 1966. On the second date, water invaded the city of Venice causing damages that reaffirmed the fragile nature of the ecosystem within which the historical center is located. After that tragic episode, the debates about Venice assumed a much lower tone, being hijacked towards protection and preservation of the existing, instead of focusing on the integration with terraferma and the consequent modernization. However, the final coup de grace to the Hospital project arrived at the end of 1970s, when the national health care system was finally reorganized on regional bases - thus reconfiguring the very context for which the project was initially conceived. Prized back then because of its relationship to Venice, ironically, the unaccomplishment of Le Corbusier's project was eventually determined by its unfitness to the regional dimension. For however it might be, between 1954 and 1966 Venice witnessed an extraordinary period

\footnotetext{
${ }^{62}$ Farinati, Valeria: Introduzione. En Farinati, Valeria (ed): H VEN LC Hôpital de Venise Le Corbusier. Inventario analitico degli Atti Nuovo Ospedale. Venezia: IUAV - AP Archivio Progetti, 1999, p. 51.

${ }^{63}$ Dubbini, Renzo: Trentacinque anni dopo. En Farinati, Valeria: H VEN LC Hôpital de Venise Le Corbusier. Inventario analitico degli Atti Nuovo Ospedale. Venezia: IUAV - AP Archivio Progetti, 1999, p. 30.
} 
catalyzing the interest of national and international audience and Le Corbusier was there where he has always been: at the epicenter of architectural debates.

\section{Bibliography}

Approvazione del Piano Regolatore Generale del Comune di Venezia. March 20, 1965. Consiglio Comunale. Archivio Storico di Venezia, Venezia.

Approvazione del primo elenco dei Comuni obbligati a redigere il piano regolatore dei rispettivi territori. Gazzetta Ufficiale della Repubblica Italiana. No 120. May 26, 1954. Rome: Istituto Poligrafico dello Stato.

Barbiani, Elia (Ed.), Edilizia popolare a Venezia. Storia, politiche, realizzazioni dell'Istituto Autonomo per le Case Popolari della Provincia di Venezia. Milan: Electa, 1983.

Benevolo, Leonardo: Un consuntivo delle recenti esperienze urbanistiche italiane. Casabella-Continuità, $\mathrm{N}^{\circ} 242$. August 1960.

Bodei, Silvia: Le Corbusier e Olivetti. La Usine Verte per il Centro di calcolo elettronico. Macerata: Quodlibet, 2014.

Calabi, Donatella (Ed.): Built city, designed city, virtual city, the museum of the city. Rome: CROMA, 2013.

Chirivi, Romano and others: Progetto per il Nuovo Ospedale Civile di Venezia (1963), AP-originali/pro/020, Archivio Progetti Iuav, Venezia.

Ciacci, Leonardo (Ed.): Venezia è una città. Un secolo di interpretazioni del cinema documentario. Venice: Marsilio, 2004.

Colquhoun, Alan: Formal and Functional Interactions: A Study of Two Late Projects by Le Corbusier. Architectural Design. May 1966.

Commissione giudicatrice concorso nuovo ospedale. Riunione 14-15 settembre 1963. Verbale 2. Nuovo Ospedale, M/41. Archivio Ospedale, Venezia.

Comune di Venezia; Fondazione Giorgio Cini: Atti del Convegno internazionale "Il problema di Venezia". Venice: w/o.pub, 1964.

Comune di Venezia: Concorso nazionale di idee per la impostazione del piano regolatore generale del Comune di Venezia. June 9, 1956. 1948/X-1-2. Archivio Storico Comunale, Venezia.

Comune di Venezia: Piano Regolatore Generale. Relazione. Venezia: w/o, 1959.

Concorso internazionale per il piano particolareggiato della nuova sacca del Tronchetto. Urbanistica. Rivista trimestrale dell’'Istituto Nazionale di Urbanistica, NN42-43, February 1965.

Concorso internazionale per la sistemazione dell'Isola del Trinchetto. L'architettura. Cronache e storia, $\mathrm{N}^{\circ} 111$, X, January 1965.

Consiglio Comunale: Resoconto Stenografico della Seduta. Relazione Dorigo. February 14, 1958. Archivio Storico Comunale, Venezia.

Elementi per il concorso internazionale per il piano urbanistico. February 22, 1954. 1948/X-1-2. Archivio Storico Comunale, Venezia.

Farinati, Valeria (Ed.): H VEN LC Hôpital de Venise Le Corbusier. Inventario analitico degli Atti Nuovo Ospedale. Venezia: IUAV - AP Archivio Progetti, 1999.

Gresleri, Giuliano; Gresleri, Glauco: Le Corbusier. Il programma liturgico. Bologna: Compositori, 2001.

Il concorso per l'Isola del Tronchetto: si invertano $i$ risultati. L'architettura. cronache e storia, $\mathrm{N}^{\circ} 110, \mathrm{X}$, December 1964. 
L.S.: Il concorso per il quartiere residenziale alle Barene di S. Giuliano, Venezia-Mestre. Casabella-Continuità, $\mathrm{N}^{\circ} 242$, August 1960.

Ministero dei lavori pubblici: Quartieri coordinati. Rome: Editalia, 1960.

O’Byrne Orozco, María Cecilia. El proyecto para el hospital de Venecia de Le Corbusier. Director: Josep Quetglas. Universidad Politécnica de Cataluña, Escuela Superior de Arquitectura de Barcelona, 2007.

Ospedali Civili Riuniti: I progetti preliminari per il nuovo ospedale di Venezia. Venezia: Stamperia di Venezia, 1964.

Provvedimenti per la salvaguardia del carattere lagunare e monumentale di Venezia attraverso opere di risanamento civico e di interesse turistico. Gazzetta Ufficiale della Repubblica Italiana. No 103. April 28, 1956. Rome: Istituto Poligrafico dello Stato.

Puppi, Lionello; Romanelli, Giandomenico (Ed.): Le Venezie possibili: da Palladio a Le Corbusier. Milan: Electa, 1985.

Relazione del Sindaco Avv. Roberto Tognazzi nella seduta del 26 ottobre 1956 sul programma dell'Amministrazione Comunale per il quadriennio 1956-1960. Consiglio Comunale. Archivio Storico Comunale, Venezia.

Rossi, Aldo: Considerazioni sul concorso internazionale per il piano urbanistico della Nuova Sacca del Trinchetto a Venezia. Casabella-Continuità, N²93, November 1964.

Samonà, Giuseppe and others: Novissime, Trincanato 3.attività professionale/2/23, Archivio Progetti Iuav, Venezia.

Sarkis, Hashim (Ed.), Le Corbusier. Venice hospital and the Mat building revival. Munich: Prestel, 2002.

Settis, Salvatore: Se Venezia muore. Torino: Einaudi, 2014.

Shah, Mahnaz: Le Corbusier's Venice Hospital Project. An Investigation into its Structural Formulation. Farnham: Ashgate, 2013.

Talamone, Marida (Ed.): L'Italia di Le Corbusier (exhibition catalogue: Rome, October 18, 2012 - February, 17, 2013). Milan: Electa, 2012.

Tentori, Francesco: Imparare da Venezia: il ruolo futuribile di alcuni progetti architettonici veneziani dei primi anni Sessanta. Roma: Officina, 1994.

Zevi, Bruno: Cronache e storia. Bari-Rome: Laterza, 1970.

Zucconi, Guido (Ed.): La grande Venezia. Una metropoli incompiuta tra Otto e Novecento. Venice: Marsilio, 2002. 


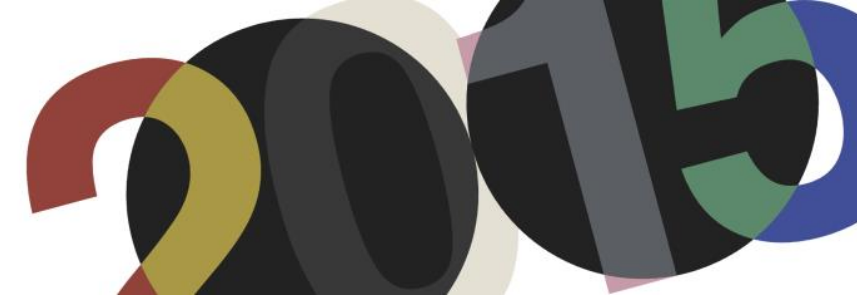

DOI: http://dx.doi.org/10.4995/LC2015.2015.792

\title{
Copy-Paste: Le Corbusier en OMA / Rem Koolhaas
}

\author{
R. del Valle González
}

Escuela Técnica Superior de Arquitectura de Madrid

\begin{abstract}
Resumen: La arquitectura que realiza OMA / Rem Koolhaas podría denominarse como un 'juego sabio de los volúmenes reunidos bajo la luz' disfrazados y entremezclados en la complejidad de los tiempos que vivimos, la de una arquitectura que debe reflejar nuestra sociedad. Para hacerlo posible, Rem parece 'calcar', paso a paso, la trayectoria lecorbuseriana, confundida y camuflada bajo hábiles mecanismos contemporáneos de 'Copy-Paste', vendiéndola al mejor postor como una 'nueva arquitectura' para los tiempos que están por venir. Pero el 'Copy-Paste' no es algo nuevo ni de ahora. Le Corbusier nos ha enseñado estos mecanismos de 'Copiar-Pegar' prácticamente en la totalidad de su obra, desde sus inicios hasta su madurez.
\end{abstract}

Abstract: The Architecture that OMA / Rem Koolhaas makes could be call like a the masterly interplay of masses brought together in light' disguised and interspersed with the complexity of the time that we are living, an architecture that must reflect our society. To make it possible, Rem appears to 'trace', step by step, the Le Corbusier's path, confused and camouflaged under skillful contemporary mechanisms of 'Copy-Paste', selling it to the highest bidder as a 'new architecture' for the times to come. However, the Copy-Paste' is not something new or now. Le Corbusier has taught us these mechanisms of "Copy-Paste" practically in all of his work, from his beginnings up to his maturity.

Palabras clave: Copy-Paste; Cita; Koolhaas; Estructura; Materia; Programas.

Keywords: Copy-Paste; Quote; Koolhaas; Structure; Materia; Programs.

\section{Introducción}

En el momento de revisar esta comunicación, leo un artículo en un diario de tirada nacional que lleva por título 'La guerra de las universidades contra el copy-paste' y que alerta del plagio, cada vez más recurrente por parte de los estudiantes, en los documentos académicos ${ }^{1}$, si bien la mayoría de las veces, éstos no son conscientes que la acción de copiar y pegar constituye una vulneración de la propiedad intelectual del autor del texto original.

Distinguir entre lo original y la copia, entre la interpretación de una realidad descrita por un autor -en forma de documento escrito, obra de arte o, en el terreno que nos ocupa, edificio o proyecto arquitectónico- y entre la imitación, alteración, manipulación o transformación que se somete al original por un segundo autor que haga que esta segunda obra goce de nueva autenticidad y, por tanto, no sea considerada una vulgar copia de la original, es una realidad que ha existido siempre, pero que hoy se encuentra sobre-intensificada gracias al potente desarrollo de las herramientas informáticas y la divulgación del conocimiento en una cultura global.

Sin duda, estudiando en profundidad la trayectoria de Koolhaas, podemos descubrir como su obra está claramente sustentada por la arquitectura lecorbuseriana, en forma y pensamiento. Koolhaas nunca lo dirá

\footnotetext{
${ }^{1}$ Otiniano Pulido, C: "La guerra de las universidades contra el copy-paste”. En Economía, El País. 8 de junio de 2015. No he podido evitar la inclusión de esta referencia a última hora, pues pone en evidencia los temas que aquí se tratan.
} 
expresamente, pero su obra está plagada de citas, referencias, homenajes o, si se quiere, copias disfrazadas de Le Corbusier. Aunque no sólo: figuras del constructivismo ruso, referencias cinematográficas, Leodinov, Constant, Archigram o Mies van der Rohe formarán parte de su ideario ${ }^{2}$, si bien no forma parte del interés de este texto, que se centrará, como desarrollaré a continuación, en el análisis de los mecanismos de copy-paste presentes en la obra de Le Corbusier y sus equivalentes en la producción de OMA / Rem Koolhaas, un nuevo remake del maestro franco-suizo ${ }^{3}$.

\section{Mecanismos de copy-paste en Le Corbusier}

Le Corbusier, en esencia, sustenta su trabajo y pensamiento con el empleo de tres herramientas fundamentales que pueden leerse como mecanismos primitivos de copy-paste. La acción proyectual no consistirá en tomar literalmente una referencia extraída de un contexto inicial para ser insertada en un nuevo contexto dotándola de un nuevo significado, será algo más complejo. Las investigaciones que Le Corbusier realiza a lo largo de los años generan soluciones que se ensayan una y otra vez en sucesivas ocasiones. Su obra se entiende pues como un reciclaje continuo, en el que las soluciones se retoman, transforman, manipulan y adaptan a cada nueva ocasión: Le Corbusier se copia a sí mismo, pero altera tanto el origen que llega a inventar un nuevo tipo, una nueva organización que en numerosas ocasiones, poco tiene que ver con la referencia inicial. En Le Corbusier, los mismos temas de siempre aparecen re-elaborados una y otra vez.

Reducir en este texto a tres herramientas -historia ${ }^{4}$, fotografía y pintura- el análisis del trabajo y pensamiento de Le Corbusier es un poco temerario tratándose de su personalidad compleja, inquieta e interesada por todo cuanto a su alrededor ocurre, pero si es una buena manera de acotar y entender las influencias más importantes que encontramos en su obra que nos puedan ayudar a entender a nuestros contemporáneos. Qué duda cabe: abordar con la profundidad necesaria estos aspectos conduciría en realidad a realizar prácticamente una monografía sobre los mismos, que no es el caso. Quisiéramos entonces enunciar aquí algunos de los ejemplos presentes en la arquitectura lecorbuseriana que nos permitan establecer el legado de su obra en un ejemplo significativo de la arquitectura contemporánea, la arquitectura de Rem Koolhaas.

\subsection{Las referencias a la Historia y la reinvención de los tipos}

Jeanneret descubrirá en sus viajes de juventud el paisaje y las relaciones geométricas presentes en la naturaleza;

\footnotetext{
2 “¿Qué influencia tiene la historia de la arquitectura en tu obra? Probablemente tenga una influencia totalmente inconsciente, pero en el momento en que me interesé por la arquitectura, también lo hice por los fenómenos de la modernidad y la modernización: me interesaban al mismo tiempo el constructivista ruso Ivan Leodinov, Mies van der Rohe y la arquitectura norteamericana de los años veinte y treinta. Ese interés me permitió apoyar mi propio trabajo y otorgarle una dimensión crítica" Koolhaas, Rem en "Seminario, 21 de enero de 1991". En Rem Koolhaas Conversaciones con estudiantes. Barcelona: Editorial Gustavo Gili, 2002. pp 54. Título original Rem Koolhaas: conversations with students. New York: Architecture at Rice Publications - Princenton University Press, 1996.

3 "No se puede explicar de otra manera; Koolhaas es el Le Corbusier de nuestros días" Kipnis, Jeffrey en "El último Koolhaas”. En OMA / Rem Koolhaas 1992-1996. Madrid: El Croquis nº 79, 1996 pp.26.

4 "Recién acabáis de ver que arrastrado por la defensa de los derechos a la invención, he tomado como testimonio el pasado, ese pasado que fue mi único maestro, que continúa siendo mi único amonestador. Todo hombre ponderado, lanzado hacia lo desconocido de la invención arquitectónica, sólo puede apoyar verdaderamente su esfuerzo en las lecciones dictadas por los siglos; los testigos respetados por los tiempos poseen un valor humano permanente" Le Corbusier en Mensaje a los Estudiantes de Arquitectura, 10ª ed. Buenos Aires: Ediciones Infinito, 2001. pp.39.
} 
el color, la luz y la sombra; el mundo clásico frente al mundo medieval; el valor de lo volumétrico frente a lo superficial, lo lineal frente al claroscuro; la arquitectura como volumen o la arquitectura como estructura. Referencias todas ellas almacenadas en su memoria gracias a sus cuadernos de notas y apuntes y usadas en sus proyectos una y otra vez de manera inagotable hasta su muerte. Episodios vividos se entremezclan con detalles de construcción, relaciones humanas conviven con la naturaleza y el territorio; toda una amalgama de formas, recursos e ideas puestas a disposición de su pensamiento arquitectónico.

Es sobradamente conocida y mucho se ha escrito ya de una tipología que captó de manera muy significativa su atención, el monasterio, por lo que sólo haremos una breve reseña en este texto a dos de ellos: el monasterio cartujo de Galuzzo en el valle de Ema, cerca de Florencia, y el monasterio cisterciense de Le Thoronet en la Provenza francesa.

Visitado por primera vez en 1907 en su viaje a Italia, donde observó, dibujó y estableció las bases de lo que iba a ser su arquitectura, Jeanneret encuentra en el monasterio de Galluzo las ideas que le permitirán combinar lo privado y lo público en un mismo tipo. El esquema de sección con celdas en forma de 'L' que generan un patio en doble altura precedidas por un corredor cubierto y una galería superior con vistas a la naturaleza se emplearían, con variaciones, en las villas Citrohan, los Inmuebles villas o en las Unités d'Habitation, por citar algunos ejemplos; incluso aquélla pequeña ventana en el muro exterior de la casa de sus padres junto al lago Léman se inspira en las vistas que las celdas de los monjes ofrecían. El segundo de ellos, el monasterio de Le Thoronet, será propuesto por el padre Coutouier como modelo para levantar el futuro Convento de la Tourette. Muchos de los aspectos que aparecen en el monasterio cisterciense se reflejan, adaptados y transformados en el nuevo convento. Así, Le Corbusier re-elabora y re-compone la planta del monasterio original convirtiendo la pirámide del lavatorio en oratorio, el claustro no horizontal, irregular y con circulación anular, en corredores en forma de cruz por su centro en vez de su perímetro trasladando además los desniveles existentes en el claustro del monasterio a las pendientes de los corredores que conducen a iglesia del convento; repite el acceso en puente a la iglesia e incorpora en los niveles superiores las celdas que descubrió en Galuzzo. (1)

Los mecanismos de copiar y pegar en le Corbusier incluyen un paso intermedio de análisis, manipulación y transformación tan intenso que el proceso bien podría denominarse entonces como una operación compleja de copiar-interpretar-pegar. Como ya indicaría Colin Rowe acerca de su obra 'objetos y episodios son importaciones entrometidas y, aunque conservan las matizaciones de su fuente y su origen, consiguen también un impacto totalmente nuevo a partir de su contexto cambiado,5, es decir, Le Corbusier busca el tipo en la historia para después transformarlo, distorsionarlo o invertirlo ${ }^{6}$. Incluso, como ya se ha indicado, alterará tanto los tipos que han surgido de diferentes contextos históricos, que creará unos nuevos a veces irreconocibles.

\footnotetext{
${ }^{5}$ Rowe, Colin; Koeter, Fred: Ciudad Collage, Barcelona: Editorial Gustavo Gili, 1981. pp 139.

6 "Lo que hace Le Corbusier al diseñar los espacios públicos no es más que volver a crear la espacialidad de los lugares públicos de la Antigüedad, los lugares de representación y glorificación del colectivo que se encuentran en el origen de nuestra cultura y que constituyen el amago de nuestra tradición. A través de un filtrado conocimiento histórico, pero también de un sentido de abstracción - que presupone una de las más admirables conquistas del pensamiento moderno, la suspensión voluntaria de la sucesión y compartimentación temporal, así como de las subsecuentes explicaciones evolutivas y catalogaciones-, Le Corbusier hace uso de una visión sincrónica de los espacios públicos de la Antigüedad, vinculando el pasado al presente, estableciendo entre ellos contactos, superposiciones" Sequeira, Marta: Para um Espaço Público. Le Corbusier e a Tradição Greco-Latina na Cidade Moderna. Lisboa: Fundação Calouste Gulbenkian. Fundação para a Ciência e a Tecnologia, 2012.
} 

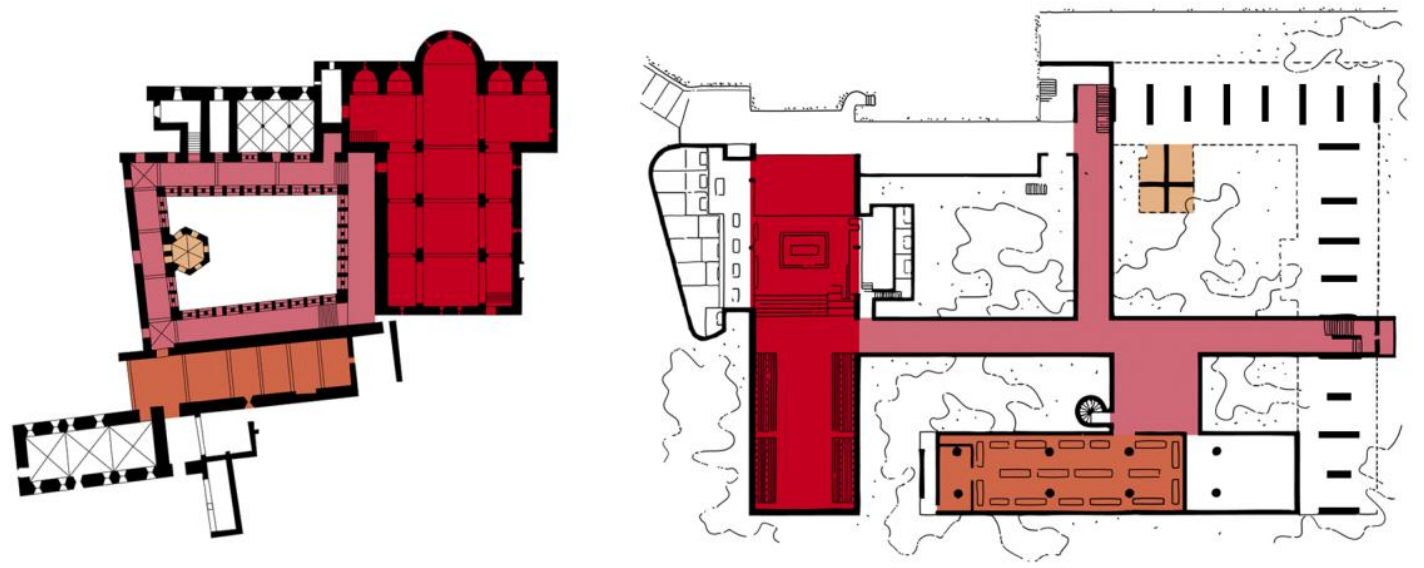

1. Plantas comparativas del Monasterio de Le Thoronet (izda) y del Convento de La Tourette, 1953-57 (dcha). Los colores identifican el cambio en la disposición de las diferentes partes del programa en ambos edificios.

Podemos ver, por ejemplo, como los pilotis blancos y delgados de sus villas de los años veinte se transforman en los rotundos soportes rugosos de hormigón de sus unidades de habitación. O como los brise-soleil que se emplean como elementos protectores de la fallida fachada de pan de verre empleada en la Cité de Refuge (París, 1929-33), se convierten en una verdadera pared perforada e independiente de la estructura, presente desde la primera idea del diseño, que introduce espacio en el borde y funde el exterior con el interior, en la Asociación de Hilanderos (Ahmedabab, 1951-54).

Pero Le Corbusier no sólo re-elabora elementos puntuales. Las mismas operaciones espaciales aparecen en su obra una y otra vez transformadas. Citamos como ejemplo la inserción de grandes vacíos en las fachadas. Estos vacíos rompen la simetría de la misma, estructuran su composición y, sobre todo, introducen ricos matices espaciales al incorporar sistemas de circulación en su interior. Son los casos de la villa Stein (Garches, 1927), el Palacio de Justicia (Chandigarh, 1951-55) y la Embajada de Francia en Brasilia (1964). Podríamos añadir el Pabellón L'Esprit Nouveau (París en 1925) que reproduce una de las células de vivienda de los Inmuebles villa de tres años antes o el Atelier Ozenfant (París, 1924) cuyo vacío en la fachada se muestra protegido por cerramientos de vidrio. (2)

Establecerá relaciones 'función-forma' y 'función-espacio' que no permiten disociar la una de la otra. Combinará los programas en un edificio, pero siempre los distinguirá de manera clara, o dicho de otro modo: no mezclará los programas en espacios únicos, aunque si los relacionará asociándolos cada uno a una forma determinada. De este modo Le Corbusier consigue una identificación 'función-volumen' en un mismo objeto. Buscar una forma idónea para cada función le conduce inevitablemente a inventar, crear 'inventos' que expresen 
con claridad esta relación 'función-forma" ${ }^{9}$. Una ventana, por ejemplo, podrá estar compuesta por dos elementos: los ondulatoires -sólo para iluminar, y los aérateurs -sólo para ventilar.
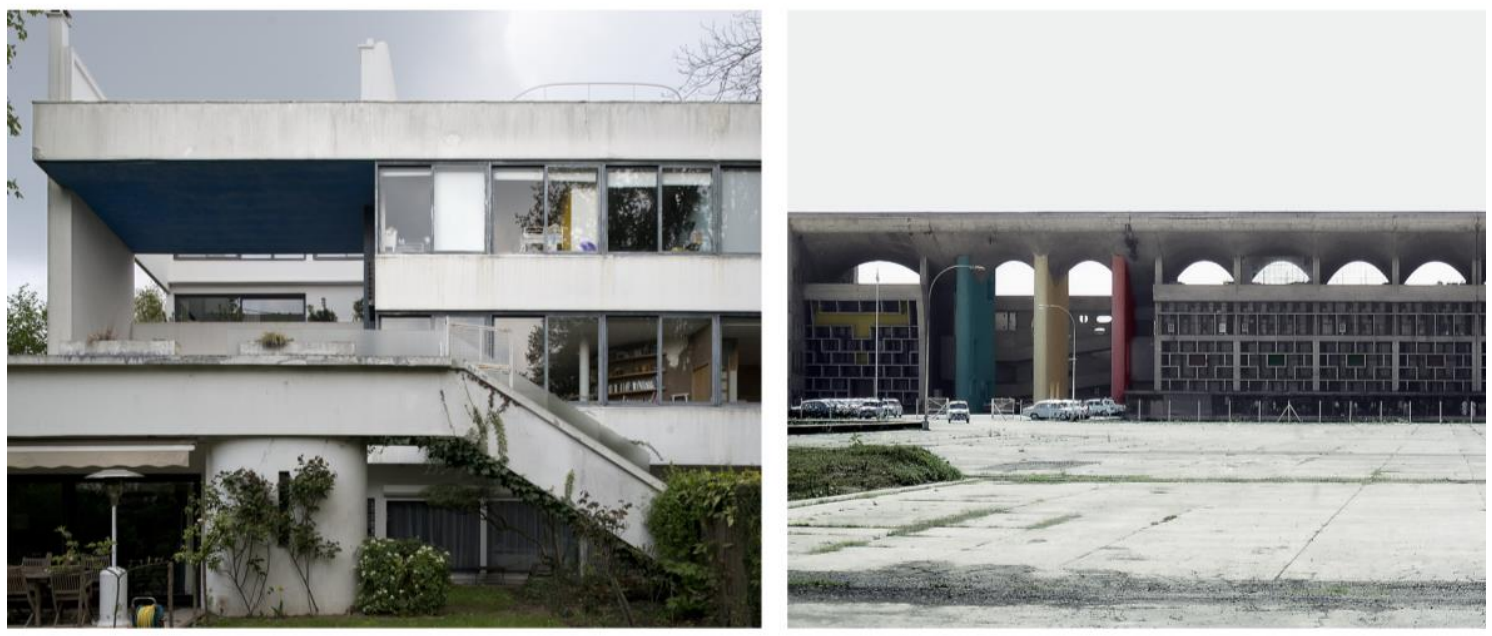

2. Fachadas comparadas con espacio vacío insertado en las mismas de la Villa Stein-de-Monzie "Les Terrasses", GarchesVaucresson 1926 (izda) y el Palacio de Justicia, Chandigarh 1952 (dcha).

\subsection{Las fotografías como divulgación de prototipos}

Le Corbusier separa los volúmenes para afirmarlos, para ser claros a la visión. Es decir, quiere que percibamos cada uno de los volúmenes completamente, separado de los otros, para poder descubrir y apreciar sus cualidades. Una vez el volumen, que adquiere cualidad de objeto gracias a su significación, se ha comprendido, se producirá un salto en la mirada hacia un nuevo volumen-objeto, con nuevas cualidades que introducirá nueva información, y así sucesivamente. Iremos recorriendo el espacio mediante las tensiones y las relaciones que los volúmenes y objetos crean entre sí, determinando nuestra posición y distancia a los mismos cada vez. Se entiende ahora mejor que una de las razones de separar el programa o la identificación de las funciones con objetos y volúmenes sea para lograr soluciones en las que una parte del programa no domine a la otra, para que cada objeto cuente con los significados que le son propios. Esta es una de las razones por las que Le Corbusier utiliza como mecanismo compositivo de manera preferente la fragmentación, la adición, sumar partes y añadir objetos, frente a la compacidad: copiar y pegar objetos en el espacio, pero cada uno de ellos con una intención y características que le son propias y que no se pierden cuando interactúa con sus vecinos. Los objetos contarán entonces en virtud de sus propiedades físicas, sus conflictos o sus acuerdos, algo que comprendieron bien los pintores $\operatorname{cubistas}^{8}$, usando sin embargo los objetos disociados.

Las cuidadas fotografías de su obra mostrarán estas relaciones, donde los objetos se irán sucediendo dentro de la composición fotográfica, estableciendo un recorrido en la mirada a través de ellos de la misma manera que recorreremos sus edificios. Así, Le Corbusier 'copia y pega' delante de cada uno de sus edificios su Voisin C7-

\footnotetext{
${ }^{7}$ Ver para más información Sáenz de Oíza, Francisco Javier: Le Corbusier, inventor de arquitecturas, Madrid: Colegio Oficial de Arquitectos de Madrid, 18 de diciembre de 1986. DVD (84m) Conferencia inaugural impartida por Oíza con motivo del ciclo de conferencias celebrando el centenario del maestro.

${ }^{8}$ Jeanneret, Ch. E.; Ozenfant, A: Después del Cubismo. Madrid: El Croquis Editorial, 1994. pp 12. Título original Jeanneret, Ch. E.; Ozenfant, A: Aprés le Cubisme. París: Edition des Commentaires, 1918.
} 
$10 \mathrm{HP}$ para tomar unas fotografías con las que pretende introducir en sus casas el rigor, la precisión y la economía que la industria del automóvil está desarrollando para los vehículos (3). Y es que las referencias a los logros técnicos de la época son constantes; en Vers une architecture podemos ver como paquebotes, aviones o automóviles se convierten en los estandartes con los que explicar la nueva arquitectura, y no existe reparo en mostrar el Partenón, en el que cada parte es decisiva, marca el máximo de precisión, de expresión ${ }^{9}$-dice Le Corbusier- junto a los prototipos del momento. La técnica aparece pues en Le Corbusier desde dos puntos de vista: como emblema y como prototipo. Rigor, precisión y economía se quieren trasladar a sus edificios. No existirán más piezas que las necesarias ni menos que las necesarias: se incluye justamente lo que hay que incluir. Así su definición de casa como machine à habiter no lo es tanto en el aspecto sino en la precisión, en el rigor con que una máquina está hecha. No le interesará a Le Corbusier la técnica por la técnica, como si se tratara de un recurso formal, sino todo lo contrario: es un instrumento para crear espacio. En este sentido, incorporar los automóviles en sus edificios no sólo como imágenes de propaganda, sino introducirlos físicamente en ellos, así como proponer nuevos trazados urbanos pensados desde el coche y la velocidad, tomará vital significación en su obra.
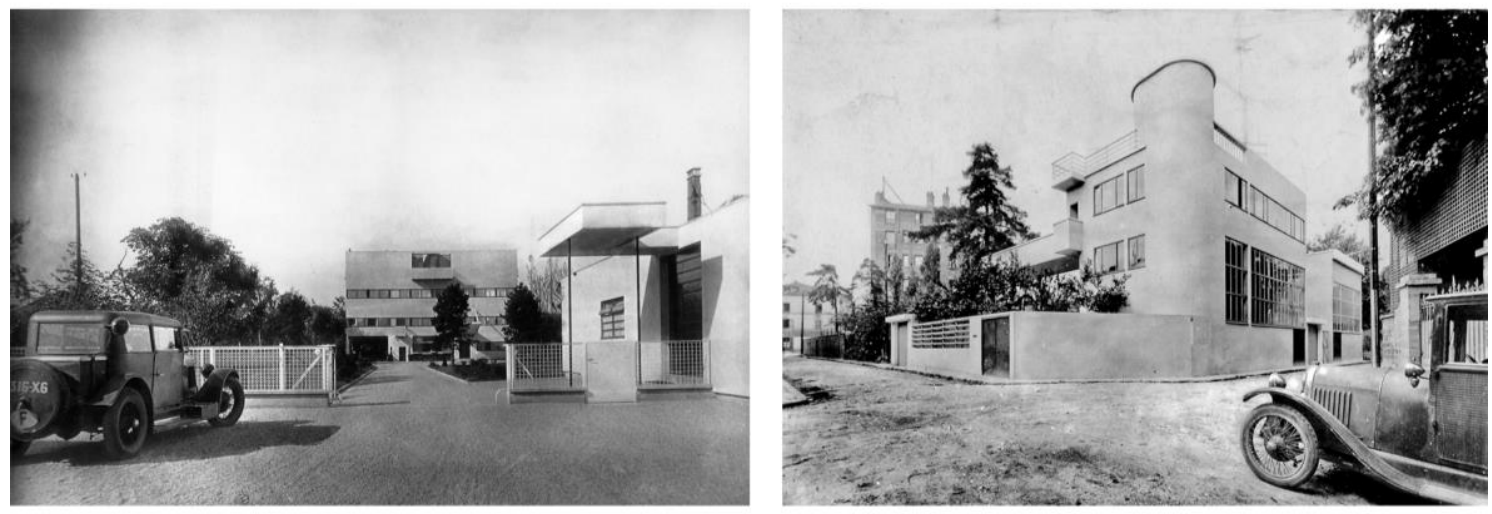

3. Copy-Paste del Voisin C7-10 HP propiedad de Le Corbusier en la Villa Stein-De Monzie "Les Terrasses", Garches 1927 (izda) y en las Maisons Lipchitz-Miestchaninoff, París 1923-24 (dcha).

\subsection{La pintura como laboratorio de arquitectura}

Yo soy conocido sólo como arquitecto; ninguno quiere reconocerme como pintor, aunque, incluso, es por el canal de la pintura por donde llego a la arquitectura ${ }^{10}$. Jeanneret entiende la pintura como pensamiento, como reflexión. Sus cuadros reflejan la importancia de los volúmenes, los huecos y la transparencia del espacio; reflejan el poder del objeto, el diálogo que se establece entre dicho objeto y el armazón que lo contiene. Su pintura es el verdadero laboratorio donde se ensayan las operaciones arquitectónicas que utilizará Le Corbusier en sus edificios: quien quiera conocer al Le Corbusier arquitecto no puede ignorar al Le Corbusier pintor. O dicho en los términos en los que este texto se escribe, Le Corbusier copia los descubrimientos que Jeanneret obtiene en sus cuadros y los pega en sus edificios.

\footnotetext{
${ }^{9}$ Le Corbusier: “Ojos que no ven” en Le Corbusier: Hacia una Arquitectura, 2ª ed. Buenos Aires: Editorial Poseidón, 1964. pp 111.

${ }^{10}$ Le Corbusier: Catálogo. Madrid: Museo Nacional Centro de Arte Reina Sofía, 1982. pp 112.
} 
En su etapa de formación (la Chaux-de-Fonds, viaje a Italia de 1907 y Viaje a Oriente de 1911) Jeanneret realiza acuarelas que capturan el paisaje, las relaciones entre la forma y el color, descubriendo la capacidad de éste de alterar la percepción de las cosas.

Instalado ya en París, Jeanneret crea junto al pintor Ozenfant y como respuesta crítica al Cubismo, el Purismo. Adoptará entonces el apodo de Le Corbusier para distinguir su trabajo arquitectónico del pictórico, si bien con el tiempo, terminará firmando los cuadros con el nuevo nombre adoptado. Los temas empleados son cotidianos, 'temas banales', que se irán convirtiendo con el tiempo en objetos de atracción poética. La línea concentra todo el valor formal: el contorno es el límite, un elemento muy denso; no es lo importante la forma que aglutina sino que tiene tanta importancia lo que incluye como lo que excluye. El color es rigurosamente 'encajado' en la línea y emplea una paleta sencilla de ocres, rojos y marrones $^{11}$.

El siguiente paso en su evolución será desligar el color de la línea: si primero se independizó el objeto, ahora se independizará el color, que es más fuerte, más unitario y opera por contraste. Plantea con el armazón simetrías que después rompe con la ayuda de los objetos. La retícula gobierna el orden del cuadro (las plantas en su arquitectura), aunque casi nunca está presente y se manifiesta de un modo parcial; los objetos serán capaces de crear espacio, de ahí que Jeanneret-Le Corbusier no sólo se interese por el objeto en sí mismo, sino por lo que alrededor del objeto se va creando. Los objetos se irán superponiendo, en grados que van desde la transparencia a la opacidad. Estos objetos tipo se asociarán generalmente a la introducción de curvas dentro de la planta. Definirán los cuartos de baño, cocinas, lavabos, las cajas de escalera y se tratarán como volúmenes-objetos aislados dentro del armazón. Estos volúmenes curvos moldearán de un modo fluido y dinámico el espacio, generando las circulaciones dentro de la planta, desplazando y distorsionando el resto de los espacios.

Quizás ahora comprendamos mejor los mecanismos con los que Le Corbusier opera, buscando los tipos en la historia, para tras alterarlos y modificarlos, insertarlos en un nuevo contexto, cuyo armazón compositivo oculto hay que buscarlo en la pintura. Y todo ello envuelto y cuidadosamente presentado con un potente discurso gráfico y verbal de divulgación y publicidad. Elementos fragmentados, sí, pero nada de juntos por azar. No se trata de una simple operación de copy-paste a la que podemos estar acostumbrados hoy en día. Se trata de una herramienta de composición arquitectónica y de organización programática y espacial compleja. No se tratan de copias sino de verdaderas citas a la historia o incluso a sí mismo; gracias a una 'lectura' atenta y cuidada de sus proyectos y edificios, podrán identificarse los elementos de origen, enriqueciendo con su descubrimiento el mensaje arquitectónico.

\section{Mecanismos de copy-paste en OMA / Rem Koolhaas}

La arquitectura que realiza OMA / Rem Koolhaas podría denominarse como un 'juego sabio de los volúmenes reunidos bajo la luz' disfrazados y entremezclados en la complejidad propia de los tiempos que vivimos, la de una arquitectura que debe reflejar nuestra sociedad. Para hacerlo posible, Rem parece 'calcar', paso a paso, la

\footnotetext{
${ }^{11}$ Ver para más información, Jeanneret, Ch. E.; Ozenfant, A: Después del Cubismo. Madrid: El Croquis Editorial, 1994. pp.12. Título original Jeanneret, Ch. E.; Ozenfant, A: Aprés le Cubisme. París: Edition des Commentaires, 1918. Sin duda en este manifiesto encontramos muchas de las claves de la pintura como campo de experimentación de la arquitectura. Desde la elección del tema, "un tema simple, un tema modesto" -leemos en el texto- hasta la subordinación del color a la forma "La idea de forma precede a la de color. La forma es preminente, el color no es más que uno de sus accesorios", pasando por la importancia de las proporciones, el uso claro de la geometría, concepción rigurosa o la admisión de ciertas deformaciones para restablecer la armonía.
} 
trayectoria lecorbuseriana, confundida y camuflada bajo hábiles mecanismos contemporáneos de "Copy-Paste".

Sin duda, si hay un arquitecto del que podamos aprender e investigar con profundidad es Le Corbusier: guardaba prácticamente todo, planos con facturas, objetos recogidos en la playa con libros, cuadros con pliegos de sus conferencias... una -irónicamente hablando- 'fuente de inspiración' inagotable para ser citado, homenajeado, imitado, re-interpretado, o sencillamente copiado por cualquiera de los arquitectos que le sucedieron.

La arquitectura de Koolhaas, como la de Le Corbusier, es una arquitectura de fragmentos, de suma de elementos para configurar un todo, una heterogeneidad en las partes que necesita, como en la arquitectura de Le Corbusier, de un mecanismo de unión arquitectónico. Copiar y pegar elementos -llámese citas, referencias o como quiera llamarse- produce en su arquitectura, inevitablemente, la decisión de eliminar el "detalle arquitectónico" entendido éste como el punto de unión entre una realidad copiada y una copia de otra realidad.

El Dios de Koolhaas no está en sus detalles, ni su menos es más.

Sencillamente el detalle se elimina de su arquitectura porque los fragmentos utilizados para lograr su arquitectura no concilian entre sí. En este sentido, preguntado por el papel que juegan las citas arquitectónicas, Rem Koolhaas contesta:

"Creo que estamos completamente inmersos en influencias. Y nunca he entendido el interés por identificar las citas en la arquitectura. Evolucionamos muy lentamente y estamos completamente influidos por el pasado, el remoto y el reciente. Siempre he sido incapaz de distinguir qué es una cita y qué es una simple influencia",12.

Curiosa respuesta, cuanto menos al comprobar que gran parte de su arquitectura está plagada de ¿citas? de la obra de Le Corbusier ${ }^{13}$. No se trata en este texto de desvelar todas, una por una, sólo indicaremos algunos ejemplos (4) que ayuden a explicar los argumentos que aquí se esbozan empleados por Rem Koolhaas para intentar la unión de los fragmentos, la integración de las partes: modificará la estructura (no sirve una estructura claramente miesiana de planos horizontales sustentados con columnas); confundirá los programas (huir de la identificación programa-forma tan propia de Le Corbusier); trabajará, investigará y alterará el tratamiento de ciertos materiales (como espejos y vidrios que contribuyan a romper el volumen de origen lecorbuseriano) y, finalmente, multiplicará los elementos de conexión (rampas, escaleras mecánicas, ascensores) para lograr un espacio en el que ninguna dirección sea predominante frente a otras (creará la que denomino 'multipromenade').

\footnotetext{
${ }^{12}$ Koolhaas, Rem: "Rem Koolhaas de la A a la Y". En El Croquis $n^{\circ}$ 134/135. Madrid: Editorial El Croquis, 2007. pp.384. Entrevista realizada por Beatriz Colomina.

${ }^{13}$ del Valle, Raúl. La Herencia de Le Corbusier en la Arquitectura de Rem Koolhaas. Composición y Adición de la Arquitectura Lecorbuseriana en la Arquitectura Contemporánea. Director: Alberto Campo Baeza. Universidad Politécnica de Madrid, Departamento de Proyectos Arquitectónicos. Madrid, 2006.
} 

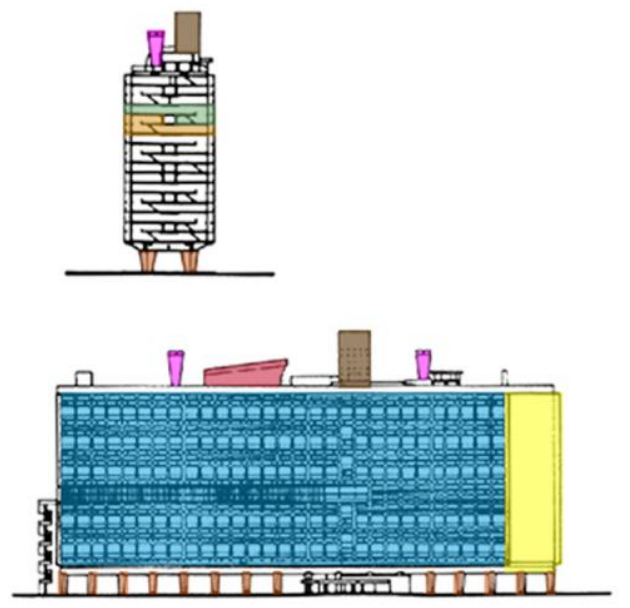
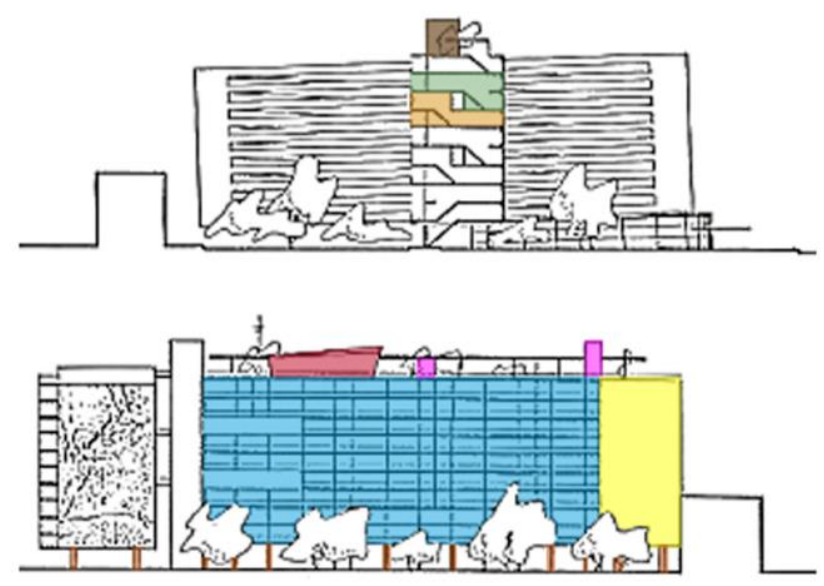

4. Copy-Paste de la Unité d'Habitation, Marsella 1946-1952, de Le Corbusier (izda) en el proyecto Torenstraat, La Haya 1985, de OMA / Rem Koolhaas (dcha). Los colores identifican la coincidencia de los diferentes elementos y partes del programa en ambos edificios.

\subsection{Destrucción de la Estructura}

Koolhaas irrumpe en el panorama arquitectónico a partir de una exhibición en el MoMA de Nueva York a finales de los años ochenta denominada 'La Deconstrucción'. Deconstruvist Architecture ${ }^{14}$ se mostró entonces acompañada de pintura y escultura perteneciente a las vanguardias rusas. Muchos de los aspectos que defiende la Deconstrucción y con los que se hace doctrina ya están presentes o, al menos presentados, en proyectos lecorbuserianos. Le Corbusier ya trabajó nuevos principios de desarrollo de la planta: en la Ciudad Contemporánea para tres millones de habitantes (1922) mantiene un esquema concéntrico, de jerarquías muy marcadas, de expansión del centro hacia el exterior; en la Ville Radieuse (1940) abandona el centro como generador y propone una ciudad organizada por bandas paralelas asociadas a diferentes usos, que pueden extenderse libremente; también encontramos en Le Corbusier a través de su fascinación y admiración por el plano horizontal de la Acrópolis (sobre el que se posan diferentes templos) o el plano de la Plaza de los Milagros de Pisa (sobre el que se sitúan el Campo Santo, el Baptisterio y la Torre inclinada) los ejemplos en la historia para poder establecer una disposición libre de objetos sobre una extensión determinada en sus arquitecturas; incluso el Hospital de Venecia (1965) se organiza en base a una trama, una malla, que puede extenderse por todos los lados si no hay dificultades de expansión.

\footnotetext{
${ }^{14}$ En ella, el trabajo de Koolhaas aparece junto al de Bernard Tshumi, Frank O. Gehry, Peter Eisenman, Daniel Libeskind y Coop Himmelblau entre otros. Con la Deconstrucción se pretende manifestar la no-estructura y poner en duda los modos de conexión habituales entre las partes. Los edificios son concebidos como estímulos para actividades humanas de índole imprevista e indeterminada.
} 

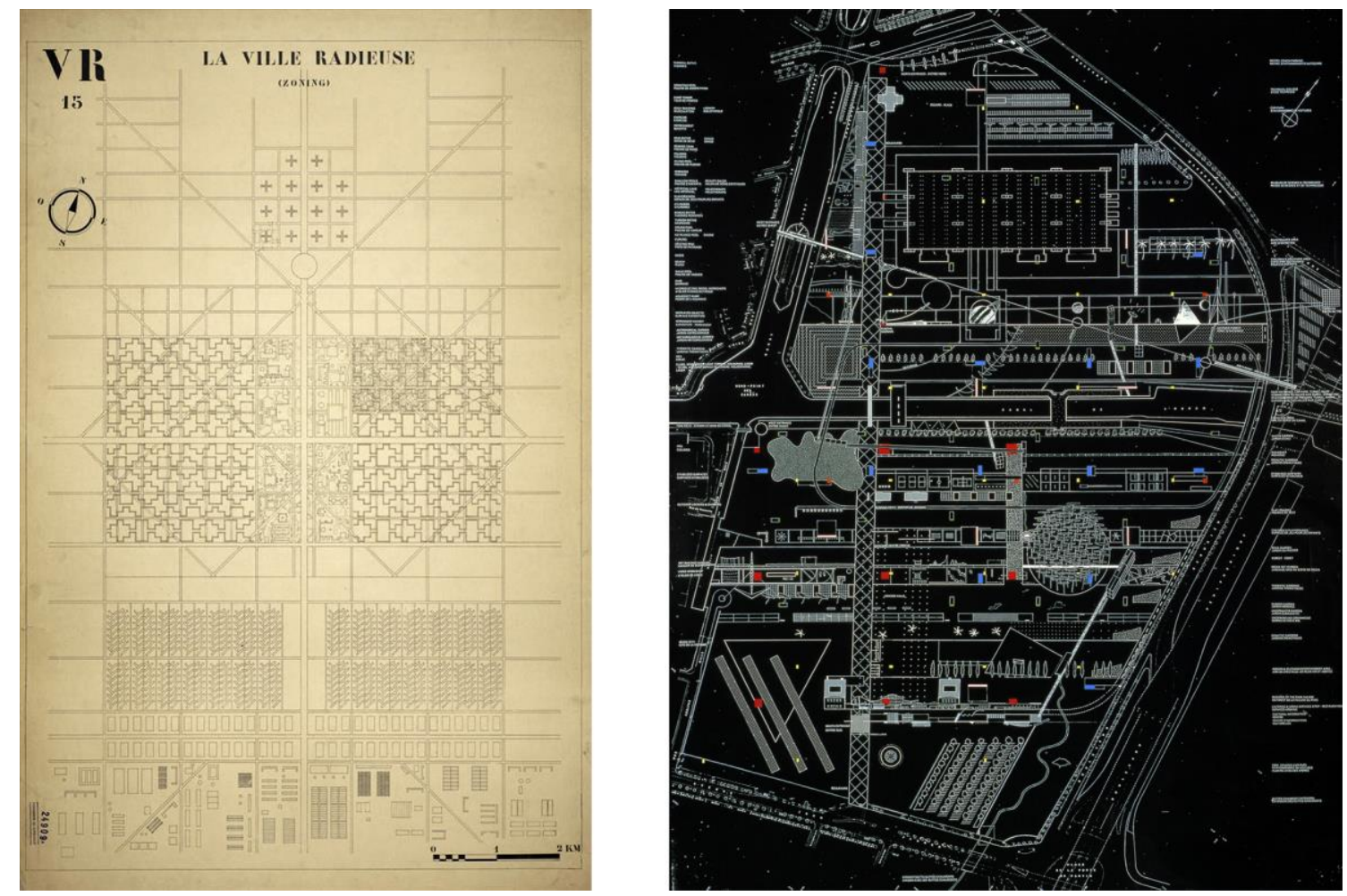

5. Le Corbusier, Villa Radiuse 1940, planta (izda) y OMA / Rem Koolhaas, Parc de La Villete, París 1982, planta (dcha).

Así pues, desarrollos tipo 'mat-building', con disposición libre de objetos sobre bandas, tramas o mallas, tan característicos del Deconstruvismo existen ya en Le Corbusier y son utilizados por Koolhaas en su proyecto del Parc de La Villette (París, 1982). Koolhaas nos dice que en el parque de La Villette profundiza en el tema de la congestión, ingrediente clave de cualquier proyecto o arquitectura metropolitanos. Es el primer proyecto en el que se investiga sobre este tema después de los estudios sobre Nueva York. (5) Para Koolhaas la arquitectura está muy ligada a la acción y al programa. Destruir la estructura es destruir la arquitectura misma, y la Deconstrucción no puede destruir aquella estructura que precisamente construye. Por esta razón Koolhaas intentará reducir al mínimo a la arquitectura.

La arquitectura de Koolhaas se conforma por tanto con la representación de la misma, no le interesa ni la construcción ni el empleo de los materiales más allá de su poder representativo de las ideas que detrás se esconden.

Si recurrimos de nuevo a la pintura elaborada en sus inicios por Jeanneret y evolucionada en la pintura de Le Corbusier recordamos que los elementos están ensamblados en una trama oculta, donde línea y color van asociados, para comenzar con el paso del tiempo a hacerse independientes, abandonando la trama reguladora e independizándose las líneas de los colores. En las naturalezas muertas, la composición de los objetos presenta sobre el mismo plano del cuadro dos visiones distintas y complementarias de los mismos: por un lado los alzados y por otro, las plantas dibujadas en continuidad con aquéllos. Se produce un cambio entre planos perpendiculares de manera continua. Le Corbusier no trasladará sin embargo esta idea a la arquitectura: el cambio de planos no se produce de manera continua, es decir, mantendrá la independencia de los planos horizontales y verticales, no estableciendo transformaciones de un elemento en otro como si hará Koolhaas.

Los suelos inclinados y, más aún, los suelos que se convierten en paredes verticales y quizás de nuevo en horizontales surgen no sólo por hacer "física" la continuidad espacial, en una extensión a una superficie mayor de la rampa lecorbuseriana, sino que surgen para representar conceptualmente y para disolver la estructura en una relación figura-fondo. 


\subsection{Simultaneidad de Programas}

Hubo un tiempo en que las funciones estaban asociadas a las estructuras que las permitían y dichas funciones determinaban a su vez esas estructuras. Existía una relación clara espacio-función: las cosas son lo que quieren ser, decía Kahn. Con el tiempo, podemos asignar a unos espacios pensados para una serie de actividades otras que en principio, no estaban destinadas allí: comienza a aparecer el espacio flexible. Y las cosas pueden ser lo que quieren ser, pero también algo más. Las estructuras se hacen más capaces para acoger diferentes usos. Pero claros y definidos: lo que antes era un hospital ahora puede ser un museo, y lo que antes era una fábrica ahora se convierte en un centro cultural. Pero no todos los usos permiten los cambios con la misma flexibilidad de igual modo que no todos los espacios son capaces de permitir todos los usos. El programa se convierte entonces para algunos arquitectos en un nuevo material para definir la arquitectura, que impone a ésta sus leyes y relaciones, dictando las decisiones del proyecto: estudiar los programas, con numerosos datos e infinitas relaciones posibles donde todo tiene cabida se convierte en un nuevo modo de afrontar el diseño del espacio desde el programa.

El Ayuntamiento de La Haya (1986) constituye el primer ejemplo en el que Koolhaas intenta resolver un proyecto desde la inestabilidad programática, de hacer arquitectura con programas y no con formas. Las plantas se componen de bandas paralelas que deslizan entre sí, manipulando una trama regular de pilares existente allí donde sea necesario gracias a la inserción de unos objetos-programa (llenos o vacíos), articulándose los diferentes espacios por medio de rampas, escaleras o ascensores. Plantas que recuerdan el modo organizativo de Le Corbusier de recintos enlazados por los espacios intermedios, o alterados por la manipulación que unos ejercen sobre los otros.

La libertad con la que Koolhaas pretende manejar los programas, con la excusa de reflejar cierta incertidumbre o inestabilidad, se traduce también en la casa Y2K de Rotterdam y la Casa da Música de Oporto, en las que un salón se convierte en una sala sinfónica, y diferentes estancias de la vivienda pueden ser diferentes espacios de un edificio público. Estamos quizá ante el ejemplo más evidente del copy-paste llevado al extremo: el de copiarse a si mismo. La traslación del proyecto existente es tan literal que el propio Koolhaas menciona el desconcierto de los miembros de su estudio 'no podían creer que fuésemos tan cínicos'15 ante el aparente oportunismo del cambio de escala de la casa para convertirla en auditorio.

Le Corbusier sin embargo, re-elaborará los programas buscando los tipos en la historia para después transformarlos, distorsionarlos o invertirlos como ya hemos expuesto y buscará una forma para cada función. La suma de elementos necesitará de varios mecanismos para unir y enlazar lo disperso, como son las calles creadas entre los edificios, el Modulor y los trazados reguladores como mecanismo de verificación, la división en estratos horizontales independientes que permiten ser intercambiados entre sí y que se conectan por un conjunto de escaleras y rampas, etc.

\subsection{Materialidad desmaterializada}

El empleo que los materiales hace Rem Koolhaas está lo más alejado posible de Le Corbusier, no haciendo gala de esa 'deshabillé' a la que se refería Sota ${ }^{16}$ ni, por asomo, al uso y empleo que de los materiales hace Mies van der Rohe. Tampoco el detalle constructivo, como ya hemos indicado, servirá para unir los fragmentos del copy-

\footnotetext{
${ }^{15}$ Koolhaas, Rem en Fernández-Galiano, Luís: “La vida de las formas”. En Arquitectura Viva no 73. Madrid, 2000. pp. 26

16 “Admiré siempre en la obra de Le Corbusier su deshabillé, esa perfección de dentro, esa elegancia imposible, tan ligada a esa imperfección aparente" De la Sota, Alejandro en "Le Corbusier". En Alejandro de La Sota. Madrid: Ed. Pronaos, 1989. pp. 223.
} 
paste. Sirva de ejemplo el Congrexpo de Lille (1990-1994) en el que Koolhaas recurre al empleo de un hormigón con un acabado que quiere ser una plementería, que se gira además cuarenta y cinco grados y que resuelve también pilares y pilastras indistintamente. Una falta de interés en los detalles que podemos apreciar también en el modo de marcar las juntas o incluso en la manera de diseñar la salida de los conductos: meros agujeros hechos con taladros allí donde es necesario, en la chapa o en el hormigón. (6)

Tampoco el empleo que de los materiales hace Rem Koolhaas en el McCormick Tribune Campus Center, ITT (Chicago, 2003) muestra un especial interés o respeto por el material y el modo de construir. Como escribe Javier Mozas: 'Koolhaas ha rebanado las mejillas de un Mies sonrojado y ha ensuciado el candor de la verdad agustiniana con materiales abyectos. El puritanismo miesiano sobre el acero, con esas esquinas bien perfiladas y dibujadas con primoroso candor, es transformado, por una carrera hacia lo genérico, en la construcción con un material mucho más trasgresor y abyecto como es el panel ligero de cerramiento. Un panel traslúcido de color naranja, un material chillón que recuerda a los restaurantes de comida rápida, resaltando aún más, en un juego perverso de contraposiciones, la nula utilización que Mies hacía del color. El panel barato que emplea Koolhaas en el Centro de Estudiantes del IIT, destroza el religioso puritanismo de Mies respecto a los materiales'17.
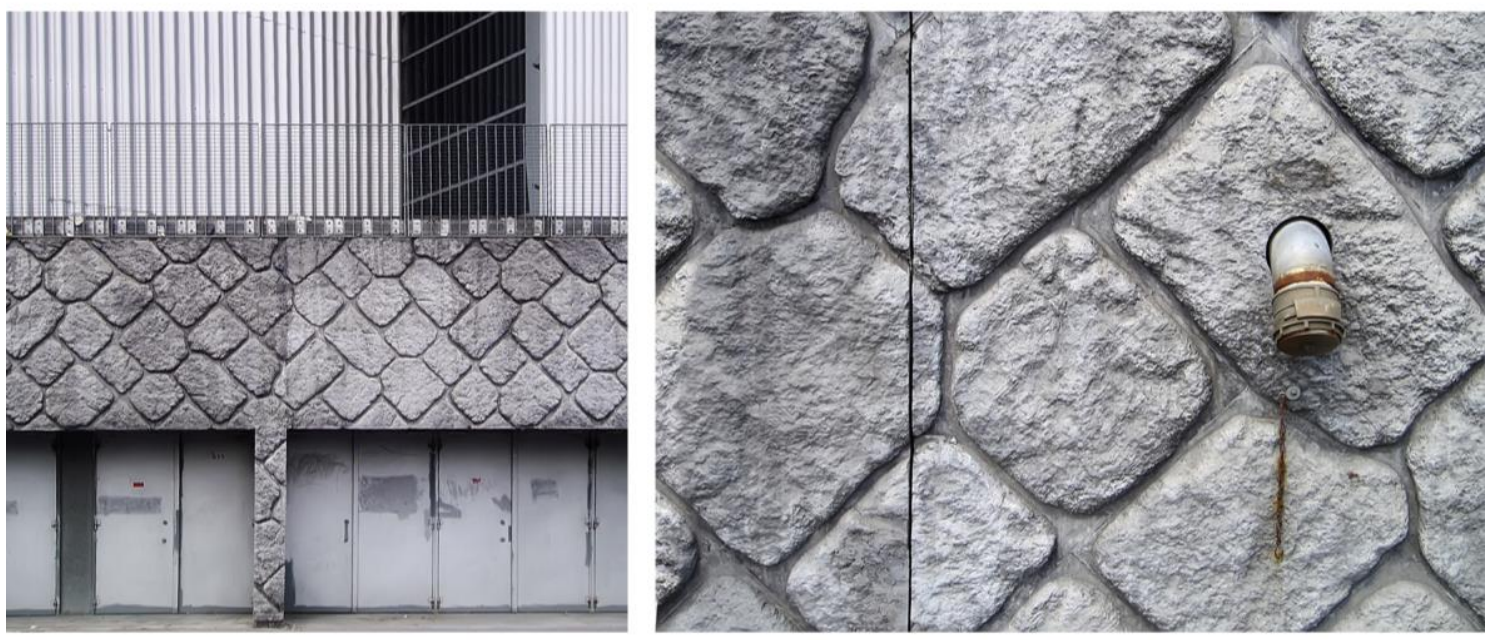

6. OMA / Rem Koolhaas, Congrexpo, Lille 1990-1994. Fachada y detalle.

\subsection{Multi-Promenade}

Le Corbusier estructura los diferentes espacios de sus edificios mediante la adición. Podrá quizás pensar y trabajar las diferentes piezas de manera aislada e independiente, pero al analizar el resultado comprobaremos que en verdad, esas piezas, no están ni tan aisladas en sus funciones ni son tan independientes en sus espacios. Utilizará el mecanismo arquitectónico de la rampa para unir y conectar, para establecer relaciones entre espacios y programas. Empleada en la mayoría de sus proyectos, las rampas no siempre se utilizarán del mismo modo y por tanto, no siempre adquieren las mismas connotaciones espaciales. Este mecanismo de conexión, vendrá muchas veces acompañado de escaleras y planos inclinados, y todos juntos, establecerán un complejo sistema que otorgara unidad al complejo armazón que constituye su idea de cómo debe ser la arquitectura.

\footnotetext{
${ }^{17}$ Mozas, Javier: "La condición moral de los materiales". En A+T Nueva Materialidad. Madrid, 2004. pp. 4.
} 
La promenade architecturale en definitiva, y dicho de manera sencilla, no es más que establecer una relación entre el hombre y el espacio a través del movimiento (la percepción, los itinerarios, las perspectivas) y toma con la rampa un protagonismo esencial. La visión lecorbuseriana no es focal, ni central, ni entendida de un modo clásico partiendo de un punto fijo en el espacio desde el que se percibe y entiende el mismo: con la incorporación de la rampa, transforma lo que antes era un recorrido horizontal en un recorrido mixto horizontalvertical.

Podríamos preguntarnos si la arquitectura se entiende, se asimila o se reconoce mejor en una posición fija o en movimiento. Caminamos por los espacios, pero nos detenemos cuando queremos observar algo con detenimiento e incluso nos sentamos. La arquitectura se transmite en la mayoría de las veces a través de una imagen fija, desde un punto de vista fijo, que es el de la cámara fotográfica, y a pesar de las nuevas tecnologías y nuevos medios de expresión y difusión pocas veces se recurre a imágenes en movimiento para transmitir los espacios creados, confiando en la fotografía para mejor expresar y transmitir sus intenciones en un determinado edificio.

En la obra de Rem Koolhaas, como en la de Le Corbusier, el movimiento es fundamental. Pero no lo es por el hecho de desplazarse de un sitio a otro, ni tampoco por pertenecer a una promenade pues el movimiento de Koolhaas no se entiende al modo lecorbuseriano como un movimiento que se apropie del espacio, sino todo lo contrario. Es importante el movimiento en Koolhaas por las conexiones que crea, por los puntos que une y enlaza. En movimiento por los espacios de sus edificios apreciamos y entendemos la fragmentación de cómo están hechos, las partes que se suman, independientes, puestas juntas, apreciamos las partes copiadas y pegadas. Suele ser un movimiento condicionado por la geometría impuesta. El equivalente a la rampa en la arquitectura de Le Corbusier en la arquitectura de Rem Koolhaas es la "escalera mecánica" que, en esta idea de establecer las relaciones y conexiones entre Koolhaas y Le Corbusier, hace que yo la denomine 'rampa mecánica': un mecanismo que permite el movimiento rápido por el espacio además de alcanzar dos puntos situados a diferentes alturas sin los desarrollos excesivos que el empleo de una rampa con pendientes admisibles requeriría. En el juego del despiste, Koolhaas multiplicará los elementos de conexión que se producen en sus edificios (como hace Le Corbusier), ofreciendo diversas alternativas a los recorridos, disolviendo el movimiento en el espacio en un intento de conseguir lo que Le Corbusier logra con su promenade architecturale: unir lo desunido, enlazar la disparidad de las partes y programas entremezclados en ellas.

\section{Conclusiones}

Le Corbusier inicia realmente su formación con los viajes de Jeanneret. Las enseñanzas de L’Éplattenier en La Chaux-de-Fonds fueron el punto de partida de un verdadero conocimiento adquirido al recorrer Europa, el Mediterráneo, y las grandes obras de la cultura clásica levantadas en torno a él. Inseparable de su cuaderno de viajes, anota, escribe y dibuja impresiones que le marcarán toda una vida. Con el dibujo como principal medio de expresión capta la esencia de todo cuanto ve, sintetiza complejas organizaciones en sencillos esquemas que interpreta una y otra vez en sus edificios. Hoy se viaja por Internet. Y el dibujo ha sido sustituido por la cámara fotográfica digital que atrapa lo que miramos, pero no nos permite ver. Vivimos un momento en el que predomina, frente a la esencia de las cosas, su imagen. Podemos ahora revisar algunas de influencias en el maestro tomadas de su verdadera fuente de inspiración, la Historia, y ver, con algunos ejemplos, cómo el proceso se repite en la obra de Rem Koolhaas, sin duda uno de los arquitectos más representativos de nuestro tiempo, al tomar las referencias, digamos 'prestadas' de la obra de Le Corbusier. Sobran las palabras. 
Podríamos leer toda la arquitectura de Le Corbusier como un copiar (de la historia) y pegar (las referencias intelectuales y complejas) operaciones que se repiten, una y otra vez en sus edificios. Y podemos ir más lejos: en toda la historia de la arquitectura existe un 'copy-paste' más o menos complejo, de unos estilos a otros (postmodern, neo-gótico, re-nacimiento), de unos arquitectos a otros, de unos edificios a otros. 'Copy-Paste' puede entenderse entonces como un proceso en el que un elemento específico es extraído de su ubicación original, transformando o no sus cualidades de escala, proporción y tamaño, y es insertado en un nuevo elemento del que comienza a formar parte, aportando sus cualidades a la formación de un 'todo' discontinuo, donde puede resultar reconocible o irreconocible, en función del grado de abstracción del proceso de inserción. (7)
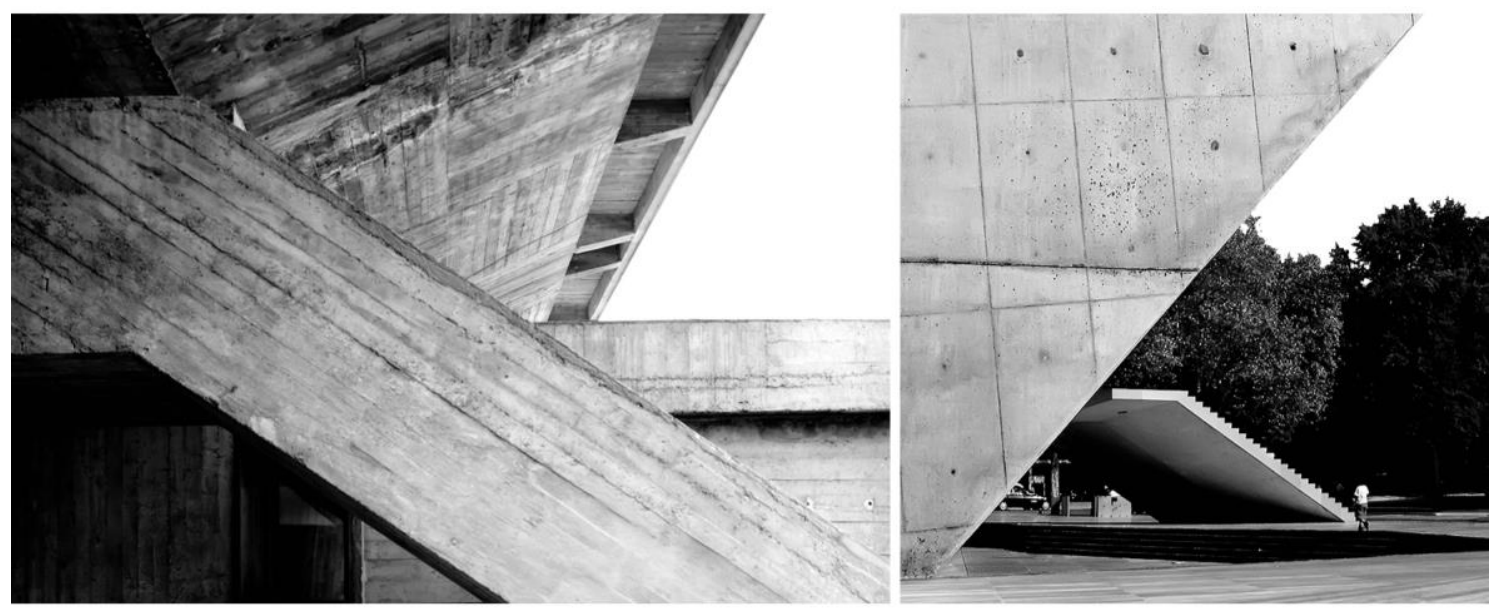

7. Copy-Paste de la Unité d'Habitation, Marsella 1946-1952, de Le Corbusier (izda) en la Casa da Música, Oporto 2001 2005, de OMA / Rem Koolhaas (dcha).

Esta idea, que no es nueva y que comúnmente se ha denominado por quien la practica 'referencia o cita histórica' aceptándose su uso, pues dotaba al resultado de cierta 'intelectualidad' en función del grado de complejidad de la referencia, hoy se ha convertido en un proceso más inmediato, donde no importa tanto lo intelectual sino la capacidad de resolución que dicha inserción pueda provocar. Este es el peligro que la acción de copiar y pegar introduce.

Si bien antes el proceso de 'copiar' (imitar, referenciar, homenajear, rememorar, citar) pretendía precisamente crear referencias con el pasado, con las grandes obras que se tomaban como modelos para proseguir el proceso de creación arquitectónica, hoy, el proceso de 'copiar' pierde las referencias del modelo: el contexto desaparece si es necesario, y en cierta media, se pretende 'esconder' el original dentro de un collage de elementos que se mezclan y confunden. Un último y aplastante ejemplo lo acabamos de ver en la reciente Biennale di Venezia de Arquitectura, dirigida por Rem Koolhaas. Bajo el título de Elements, la arquitectura se descompone, se divide, se fracciona, se desmorona, se destruye... puertas, ventanas y escaleras; fachadas, muros o suelos se estudian y tratan de manera independiente. Los elementos que forman la arquitectura pierden su contexto para crear un collage de partes, inconexas e independientes.

Ante este panorama del que la arquitectura no es ajeno, Le Corbusier puede entenderse, de nuevo, como una referencia a seguir. Porque su obra está llena de modelos y ejemplos que se copian y re-copian una y otra vez, pero siempre con un significado distinto, y siempre dejando la posibilidad de llegar a la fuente original de referencia que ha sido utilizada. Quizás entonces, tomando a Le Corbusier como modelo, el Copy-Paste se convertiría no en un peligro sino en un mecanismo eficaz para dar respuesta a la misma pregunta qué, siglo tras siglo, se han planteado los arquitectos una y otra vez: fabricar una visión propia de nuestro mundo, porque sólo en la medida que seamos capaces de interpretarlo, podremos cambiarlo. 


\section{Procedencia de las imágenes}

1. (izda) Extraída de 'Le Corbusier. Ideas y Formas’, p183. Policromía Raúl del Valle

(dcha) OC 1952-57 p45, extraída de 'Le Corbusier. Oeuvre Complète. Volumen 6. 1952-57' Edición Girsberger, 1957. CFLC-ADAGP. Policromía Raúl del Valle

2. (izda y dcha) @Raúl del Valle

3. (izda) L1(10)14 fotografía de Charles Gérard @FLC-ADAGP

(dcha) L1(6)31 fotografía de Charles Gérard CFLC-ADAGP

4. (izda) CFLC-ADAGP. Policromía Raúl del Valle

(dcha) Image courtesy OMA @OMA. Policromía Raúl del Valle

5. (izda) Plan FLC 24909A @FLC-ADAGP

(dcha) Image courtesy OMA @OMA.

6. (izda y dcha) @Raúl del Valle

7. (izda y dcha) @Raúl del Valle

\section{Bibliografía}

De la Sota, Alejandro: “Le Corbusier”. En Alejandro de La Sota. Madrid: Ed. Pronaos, 1989.

Del Valle, Raúl. La Herencia de Le Corbusier en la Arquitectura de Rem Koolhaas. Composición y Adición de la Arquitectura Lecorbuseriana en la Arquitectura Contemporánea. Director: Alberto Campo Baeza. Universidad Politécnica de Madrid, Departamento de proyectos Arquitectónicos. Madrid, 2006.

Fernández-Galiano, Luís: “La vida de las formas”. En Arquitectura Viva n 73. Madrid, 2000.

Jeanneret, Ch. E.; Ozenfant, A: Después del Cubismo. Madrid: El Croquis Editorial, 1994.

Koolhaas, Rem: Rem Koolhaas Conversaciones con estudiantes. Barcelona: Editorial Gustavo Gili, 2002.

Koolhaas, Rem: Rem Koolhaas 1992-1996. Madrid: El Croquis nº 79, 1996.

Koolhaas, Rem: El Croquis no 134/135. Madrid: Editorial El Croquis, 2007.

Le Corbusier: Mensaje a los Estudiantes de Arquitectura, 10ª ed. Buenos Aires: Ediciones Infinito, 2001.

Le Corbusier: Hacia una Arquitectura, 2ª ed. Buenos Aires: Editorial Poseidón, 1964.

Le Corbusier: Catálogo. Madrid: Museo Nacional Centro de Arte Reina Sofía, 1982.

Mozas, Javier: "La condición moral de los materiales". En A+T Nueva Materialidad. Madrid, 2004.

Otiniano Pulido, C: "La guerra de las universidades contra el copy-paste”. En Economía, El País. 8/06/2015.

Rowe, Colin; Koeter, Fred: Ciudad Collage, Barcelona: Editorial Gustavo Gili, 1981.

Sáenz de Oíza, Francisco Javier: Le Corbusier, inventor de arquitecturas, Madrid: Colegio Oficial de Arquitectos de Madrid, 18 de diciembre de 1986. DVD.

Sequeira, Marta: Para um Espaço Público. Le Corbusier e a Tradição Greco-Latina na Cidade Moderna, Lisboa: Fundação Calouste Gulbenkian. Fundação para a Ciência e a Tecnologia, 2012. 


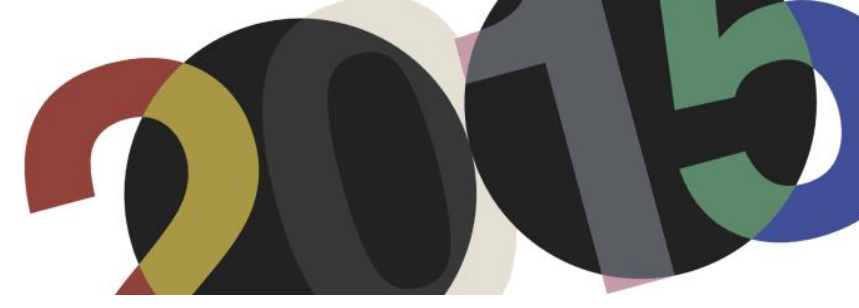

DOI: http://dx.doi.org/10.4995/LC2015.2015.723

\title{
Learning how to design architecture form the Villa Savoye design process
}

\author{
K. Vandenhende
}

KULeuven

\begin{abstract}
How to design architecture? And what makes a design process an interesting one? For non-experienced designers, it is difficult to understand typical aspects of exemplary design processes, like conflicting constraints, using mixed media, divergent thinking, working iteratively and in a non-lineair way, or integrating, many topics in one solution, balancing between a straightforward concept and ambiguïty, elaborating earlier concepts and learning from history. These characteristics were highlighted in various publications by several researchers during the past decades. And although the Villa Savoye was built before all that research, the extensive documentation of its design process by the Fondation Le Corbusier, makes it an excellent example to illustrate typical aspects of interesting design processes in a retroactive manner.
\end{abstract}

Keywords: Villa Savoye; design process; integrated; iteratively; concept; ambiguity.

\section{Introduction and methodology}

Most architecture students, at the beginning of their studies, have no experience at all in designing. It might help to explain them the typical aspects of interesting design processes, explored by many researches since the second half of the twentieth century. But it is difficult for students to understand these complexities without an interesting example.

Thanks to the 'Fondation Le Corbusier', the different phases of the design of the Villa Savoye are well documented. Le Corbusier's drawings and the story of the conception of the Villa Savoye, can thereby help to make the design process itself comprehensible.

This paper gives an overview of important aspects of design processes, highlighted by several authors during the past decades, each of these characteristics illustrated with the design process of the Villa Savoye.

\section{Typical aspects of the design process}

\subsection{Design proclems deal with many, often conflicting, constraints}

Architectural design is a form of problem solving in which designers have to deal with a lot of requirements. These can be very diverse, and they can be in conflict with each other. They range from constraints concerning the distribution of towns to constraints concerning the distribution of light fixtures ${ }^{1}$. In the case of the design of an Indian Village for example, Christopher Alexander stated that he worked with up to 140 requirements ${ }^{2}$.

\footnotetext{
${ }^{1}$ Alexander Christopher: A Pattern Language. New York: Oxford University Press, 1977

2 Jones J.C.: Design Methods. New York: John Wiley \& Sons, 1992
} 
When Le Corbusier was approached with the commission for the Villa Savoye in 1928, he had almost carte blanche and could set his own limits. At that time, he had reached a stage of extreme clarity in the formulation of his vocabulary, so he was well-armed with a priori ideas and constraints of his own, like purity of form on the one hand and the ideas summarized in his 'Les 5 points d'une architecture nouvelle' on the other: the pilotis, the roof garden, the free plan, the elongated window and the free façade ${ }^{3}$. All these aspects were part of the first project for the Villa Savoye, presented in October 10 1928, but came in conflict with economic reality. The first design was to too expensive and Le Corbusier and Pierre Jeanneret would have to rework the scheme in a way to meet all constraints.

\subsection{Mixed media}

In a drawing of that first design (1), Le Corbusier combined the three floor plans together with sketches that showed the interior and exterior of the villa.

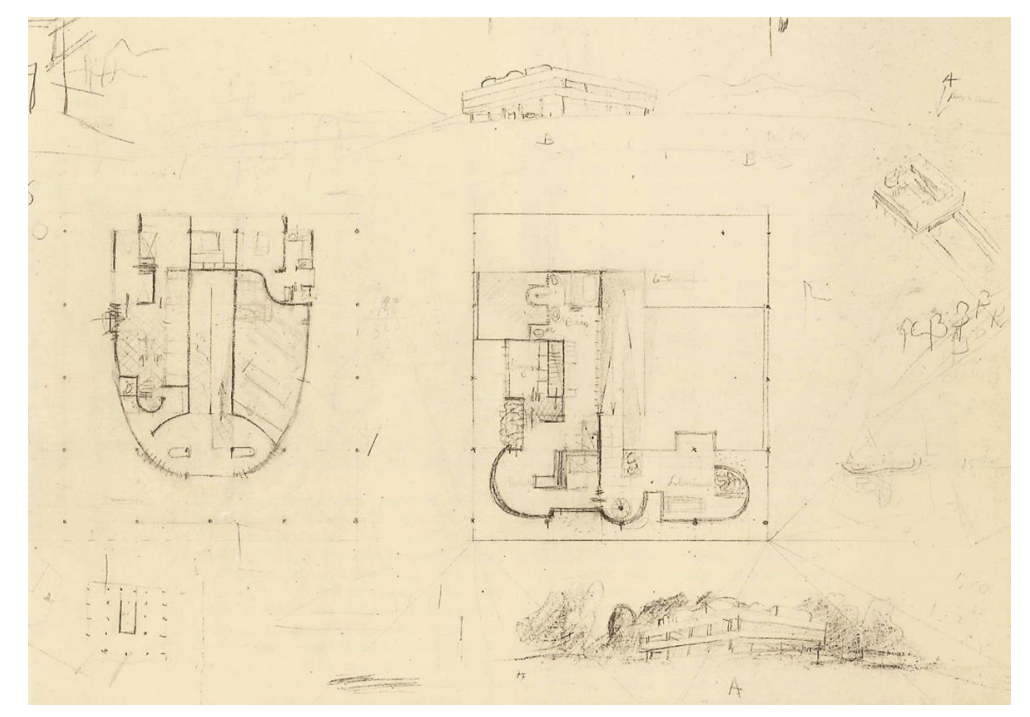

1. Part of the drawing of the first design, September 1928 (FLC 19583 OFLC-ADAGP)

Many theorists and architects wrote about this mixing of design media. Caruso ${ }^{4}$ stated that the diversity of constraints is often made visible in drawings that combine different media: schemes of overall concepts, perspective views and solutions for details. Each of these media medium or form of representation is used for a particular facet of the process. Lawson ${ }^{5}$ agreed that in architectural practices, design drawings are often overlaid and mixed together. Two-dimensional plans or sections can be seen with sketches and more diagrammatic marks all on the same piece of paper in what appears a confusing jumble. Neutelings ${ }^{6}$ stated that designers rely on various modes of representation to work their way through the design process, and the skill needed to design has a direct relationship with the various media available during the design process. The combination of text, image, sketch and/or draft can provoke among Heylighen ${ }^{7}$ new associations, which keep the design process going. An overview of all representations supports the architect in combining the different kinds of information.

\footnotetext{
${ }^{3}$ Curtis William J.R.: Le Corbusier Ideas and Forms. Oxford: Phaidon, 1986. pp. 93-99.

${ }^{4}$ Caruso Adam: "Over maquettes en beelden" in Oase: "Models/Maquettes". № 84. 2011, p.138-139.

${ }^{5}$ Lawson Bryan: Design in Mind. Oxford: Reed, 1997

${ }^{6}$ Neutelings Willem-Jan; Riedijk Michiel: At Work. Rotterdam: 010, 2005

${ }^{7}$ Heylighen Ann; Segers Nicole: "An architectural Shift+F7" in EAAE Transactions on Architectural Education. ํㅜ 14. Montreal: EAAE, 2004. p.134-143.
} 


\subsection{Divergent Thinking}

The importance of generating variations or alternatives cannot be overestimated. According to Liu ${ }^{8}$, designers have to test several alternatives, before finding a possible solution. They have to generate a wide range of concepts to prevent overlooking valuable ones. They have to evaluate and select these soon enough to restrict their number from getting too large to allow meaningful consideration. During the conceptual stage, in the formulation of McGown ${ }^{9}$, the number of what are called 'lateral' transformations shouldn't be exaggerated. In a lateral transformation, as Goel ${ }^{10}$ specified, movement is from one idea to a different idea. In a vertical transformation, movement is from one idea to a more detailed and exacting version of the same idea. Good design is a result of balance between lateral and vertical transformation. It is a result of a balance between divergent and convergent thinking. As written by Marples ${ }^{11}$, the nature of the problem can only be found by examining it through proposed solutions, and it seems likely that its examination through just one proposal leads to a very biased view. It seems probable that at least two radically different solutions need to be attempted in order to obtain a clear picture of the 'real nature' of the problem through comparisons of subproblems. Therefore, Lawson ${ }^{12}$ stated that it might be perhaps better for designers to use divergent thinking in excess rather than too sparingly.

How could the first project of the villa Savoye be made less expensive? As Benton ${ }^{13}$ analysed, the first project for this villa was based on a rigid 5-by-5-meter grid, and moreover, it used the dimension of the turning circle of a large car and the space required to bring a gently sloping ramp up through the house without dividing the plan in two. Just trying to reduce the dimensions a bit in all directions, would have made it impossible to maintain those important features. Therefore, Le Corbusier and Pierre Jeanneret tried in November 1928 several alternatives not maintaining all these typical characteristics of the first concept ${ }^{14}$. On November 26 , they made a completely new design; a juxtaposition of vertical volumes incorporating a vertical staircase block with a 'pan de verre' window (2).

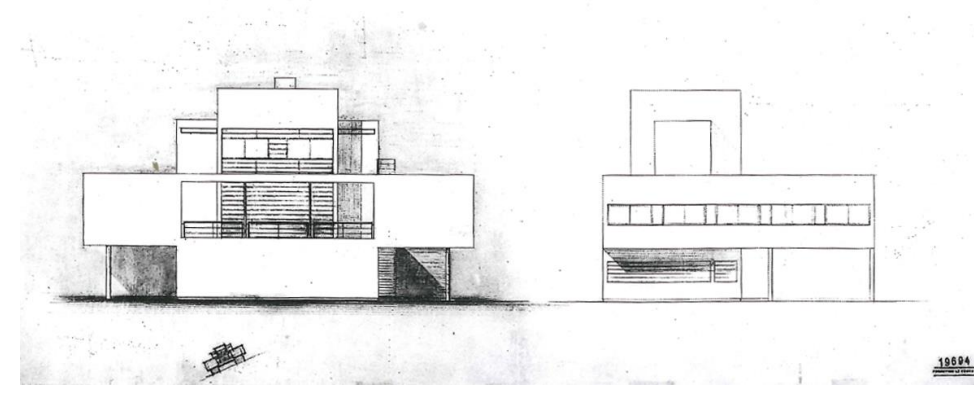

2. Façade of the scheme of November 26 (FLC 19694 OFLC-ADAGP)

\footnotetext{
${ }^{8}$ Liu Y.C.; Blight T.; Chakrabarti A.: "Towards an 'ideal' approach for concept generation” in Design Studies. No 4. 2003

${ }^{9}$ McGown Alistair: "Visible ideas: information patterns of conceptual sketch activity" in Design Studies. № 4. 1998

${ }^{10}$ Goel V.: Sketches of Thought. Cambridge: MIT Press, 1995

${ }^{11}$ Marples D.: The decisions of engineering design. London: Institute of Engineering Designers, 1960

${ }^{12}$ Lawson Bryan: How Designers Think. Oxford: The Architectural Press, 1980

${ }^{13}$ Benton Tim: Le Corbusier Architect of the Century. London: Arts Council of Great Britain, 1987

${ }^{14}$ Quetglas Joseph: Les heures Claires. Barcelona: Centre d'Investigacions estètiques, 2009
} 


\subsection{Iterative process}

After two months of research and several proposals, the architects still weren't satisfied with the newly developed concepts and looked back to their first drawings. However, the second and third projects were not useless at all. These alternative designs did help them to find saving solutions: by increasing the density of parts on the ground floor and the first floor, by reducing the terrace to a solarium, and by diminishing the range between posts. The new project of 21 December 1928, was in fact an adaptation of the first one, and costed much less ${ }^{15}$.

About this iterative process is also written by researchers. Levin ${ }^{16}$ said that with a first concept, it's almost impossible to propose an idea that meets all preconditions at once. Eventually, as Lawson ${ }^{17}$ stated, unless the design proves totally successful, one of two things happen to halt this phase. Either the general form of the solution reveals itself incapable of solving enough problems, or so many modifications have to be made that the idea behind the solution is lost and abandonded. In either case the designer is likely to choose the revolutionary step of starting a completely new train of thought. Ching ${ }^{18}$ noted that while the design process is typically presented as a linear series of steps, it is more truly a cyclical, iterative sequence of careful analysis of available information; intuitive synthesis of insights, and critical evaluation of possible solutions. An iterative process that is repeated until a successful fit between what exists and what is desired is achieved. The design process can be compressed into a short, intense period of time or extend over several months or even years, depending on the urgency or complexity of the design problem. Design can also be an untidy process in which moments of confusion are followed by instances of exquisite clarity, interspersed with periods of quiet reflection. Designing is in fact searching without really knowing what to look for ${ }^{19}$.

\subsection{Integrated architecture: merge and blend.}

In their final design, Le Corbusier and Pierre Jeanneret seemed to return to their first project, with only minor modifications. But in fact, in that last project, they managed to combine qualities of several of the previous designs, thereby adding the richness and complexity as Benton ${ }^{20}$ noticed. The contrast between horizontal and vertical, almost absent from the first project, but a main feature in the scheme of 26-27 November, was reintroduced in the final scheme in the form of the spiral staircase. Also the pan de verre modified the first project and made it possible to see down into the entrance hall and out onto the terrace as you move up or down the ramp.

From research about architectural design, we learn that combining multiple qualities in one solution gives satisfactory results. Jones ${ }^{21}$ clarified that ideas encompassing multiple topics are also called integrated or also composite. For architect Peter Zumthor ${ }^{22}$, architecture is at its most beautiful when things have come into their own -- when they are coherent. That is when everything refers to everything else, and it is impossible to remove a single thing without destroying the whole. Place, use, and form. The form reflects the place, the place is just

\footnotetext{
${ }^{15}$ Ragot Gilles; Dion Mathilde: Le Corbusier en France. Paris: Le Moniteur, 1997

${ }^{16}$ Levin P.H.: Decision making in urban design. Herts: Garston, 1966

${ }^{17}$ Lawson Bryan: How Designers Think. Oxford: The Architectural Press, 1980

${ }^{18}$ Ching Francis D.K.; Eckler James F.: Introduction to Architecture. New York: John Wiley \& Sons, 2012

${ }^{19}$ Neutelings Willem-Jan; Riedijk Michiel: At Work. Rotterdam: 010, 2005

${ }^{20}$ Benton Tim: The Villas of Le Corbusier and Pierre Jeanneret 1920-1930. Basel: Birkhauser, 2007, p. 183-201.

${ }^{21}$ Jones J.C.: Design Methods. New York: John Wiley \& Sons, 1992

${ }^{22}$ Zumthor Peter: Atmospheres: Architectural Environments - Surrounding Objects. Basel: Birkhauser, 2006
} 
so, and the use reflects this and that. Architectural qualities of the design must merge and blend with the constructional and formal structure of the finished building. Form and construction, appearance and function are then no longer separate. They belong together and form a whole.

Benton ${ }^{23}$ noted that the use for a standard window in the Villa Savoye can be read on numerous levels. First of all, the 'fenêtre en longueur' was made possible by the concrete structure and as such it served as an expression of that structure. Secondly, it was also an interior solution, being the most efficient way to distribute light. Thirdly, the 'fenêtre en longueur' was also a storage solution, whereby underneath the long windows built-in cupboards allowed for storage and concealed distribution channels for services. And finally, it was a technical solution, of which the architects tried to patent the sliding window.

Another example of integrated architecture in the Villa Savoye comes with the question of channelling and containing a route inside a regular volume, and linking that route to spaces of different size and intensity. Symmetry and asymmetry were both relevant, as were closure and transparency, a disciplining grid and fragmentation of that grid, the taut planes of the box and the sensuous spaces created by curves. All this resulted in a new combination for the 'Five Points'. At the end of the 1920s he drew a series of sketches comparing the house of the Maison La Roche/Jeanneret, to the final project for the Villa Baizeau at Carthage, and to the Villa Stein at Garches. The Villa Savoye fused together the asymmetry, spatial drama and promenade architecturale of the first, with the skeletal character of the second, and the geometrical clarity of the third (3). It combined the square, the grid, the axis, the frontal plane and a turbulent drama of interior and exterior spaces, volumes and surfaces; and it managed to play these together while maintaining unity, hierarchy and an appropriate level of detail $^{24}$.

1

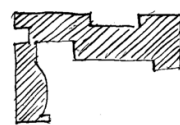

2

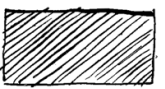

3

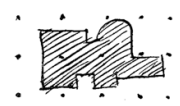

4

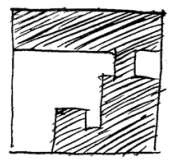

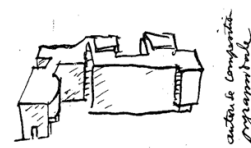
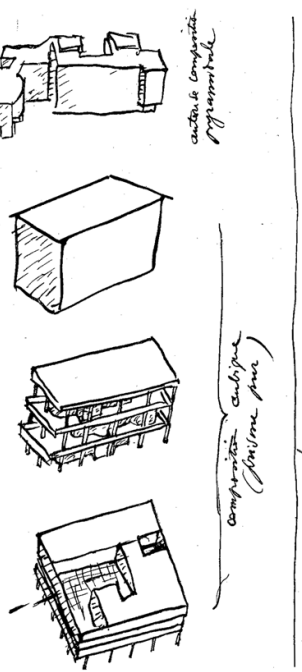

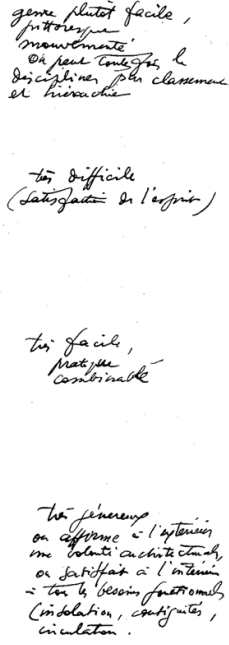

3. Sketches as published in Le Corbusier Pierre Jeanneret, Oeuvre Complète, volume 1.

\footnotetext{
${ }^{23}$ Benton Tim: Le Corbusier Architect of the Century. London: Arts Council of Great Britain, 1987

${ }^{24}$ Curtis William J.R.: Le Corbusier Ideas and Forms. Oxford: Phaidon, 1986. pp. 93-99.
} 


\subsection{Balancing a straightforward concept with ambiguïty.}

Winters $^{25}$ explained that variety or diversity is an important design consideration because "too much" visual activity may cause a chaotic effect. On the other hand, no variety or diversity results in monotony. The architectural designer must walk the tight rope between chaos and boredom to create a building or space of enticing interest. A balancing of complexity or detail on the one hand, and simplicity or plainness on the other, is necessary. When a building uses too many elements we say it is 'busy'. When a building uses no variety in elements we say it is uninteresting. The architect must have a balance of simplicity and restful visual areas with complex, more active forms. Venturi ${ }^{26}$ liked elements which are hybrid rather than "pure," compromising rather than "clean," distorted rather than "straightforward," ambiguous rather than "articulated," perverse as well as impersonal, boring as well as "interesting," conventional rather than "designed," accommodating rather than excluding, redundant rather than simple, vestigial as well as innovating, inconsistent and equivocal rather than direct and clear. He prefered messy vitality over obvious unity.

The architect Fujimoto ${ }^{27}$ declared that he wanted to make architecture that even a child can draw. A desire for lucidity. However, at the same time, he wanted this lucid architecture to contain an incomprehensible diversity. A place containing both the lucidity of the solution at the moment it appeared, and the experience of a profound diversity throughout.

We can find an example of this balance between concept and detail in the strip window bordering the terrace in the south façade of the Villa Savoye. This window was so broad that it had to be reinforced by two baby pilotis linking horizontal stiffeners. Seen from the outside these delicate cylinders hover in an ambiguous position (4). They seem part of the façade, which they are, but their diminutive size in comparison with the normal pilotis also forces a perspectival reading so that they are read simultaneously well within the building ${ }^{28}$.

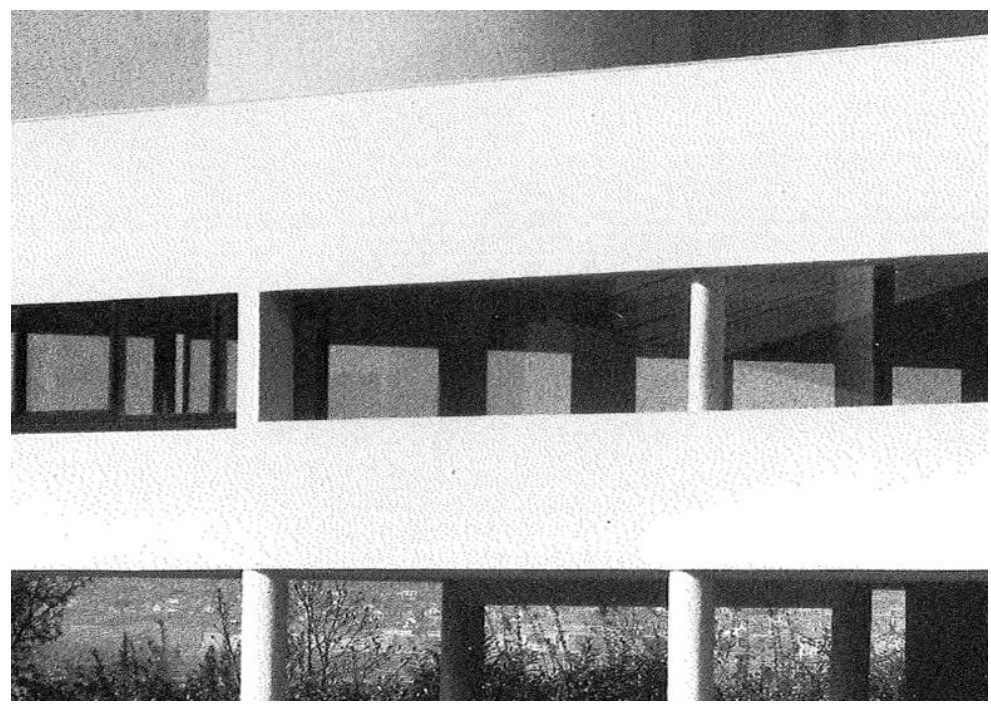

4. Photo of south façade showing the strip window pilotis having an ambiguous position.

\footnotetext{
${ }^{25}$ Winters Nathan B.: Architecture is Elementary. Salt Lake City: Gibbs M. Smith, 1986. p. 136.

${ }^{26}$ Venturi Robert: Complexity and Contradiction in Architecture. New York: Museum of Modern Art, 1966

${ }^{27}$ Fujimoto Sou: "Sou Fujimoto" in 2G. N50. 2009

${ }^{28}$ Curtis William J.R.: Le Corbusier Ideas and Forms. Oxford: Phaidon, 1986. pp. 93-99.
} 


\subsection{Elaborating earlier concepts.}

Many typical elements of the Villa Savoye, had all been worked out in earlier buildings. For example, already in 1925, Le Corbusier had developed a project which combined the stilt, the cube, and the sculptured roof, namely for the Villa Meyer, a project that was never realized ${ }^{29}$.

And Benton shows that the key features of the Villa Savoye design have emerged form the early design stages of the Villa Baizeau in Tunis. A house where Le Corbusier worked on when the Poissy project was at least still six months away ${ }^{30}(5)$.

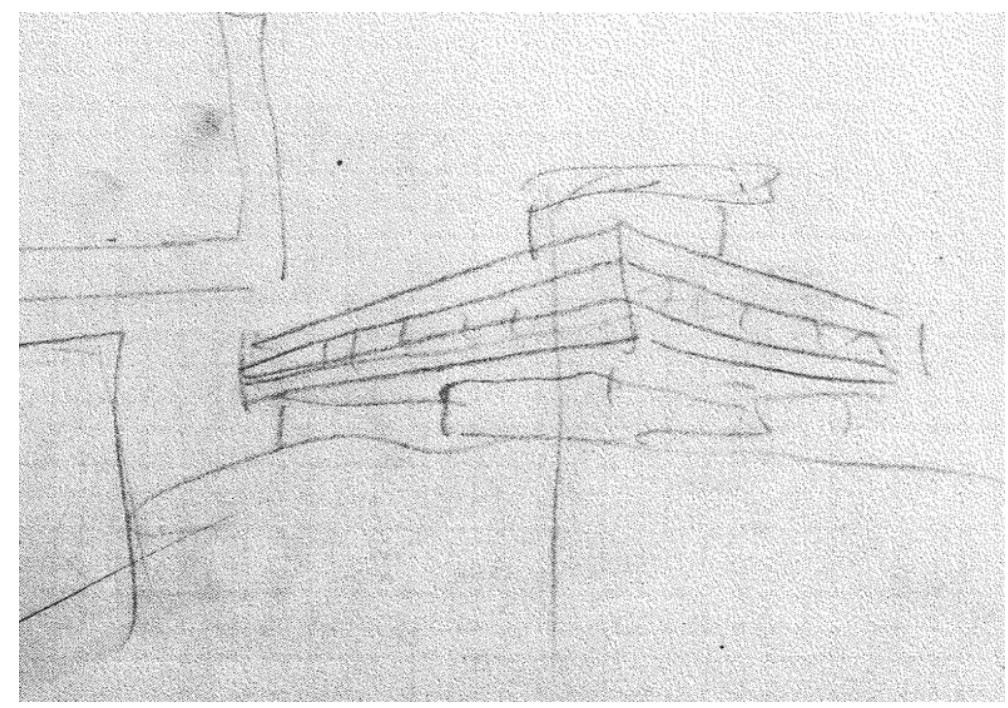

5. Part of sketch for the Villa Baizeau (FLC 24983 OFLC-ADAGP)

Architect Fujimoto ${ }^{31}$ stated that through heaps of models and by reusing, restacking and rethinking this heaps of models, they can generate a new model. These trashes and ruins give them inspiration to create something new. Being surrounded by models is important to get inspiration from different projects. This continuity of making and reusing models leads to evolution and eventually to new designs. Architect Ingels ${ }^{32}$ agreed that they also often sit in a design meeting and discover that there is this great idea, but that doesn't really work in that context. But for another client in another culture, it could really be the right answer to a different question. So as a result, they never throw anything out. They keep their office almost like an archive of architectural biodiversity.

\subsection{Learn from history.}

Starting from the existing to invent the new will thereby automatically facilitate cultural continuity. According to Caruso ${ }^{33}$, we are now working in a time that conspires to undervalue and dull our sensitivity to what has come before. Or as Ortega y Gasset ${ }^{34}$ mentioned that we cannot start afresh; that we must make use of what people have done before us. If we want to make progress, and this means that we must stand on the shoulders of our

\footnotetext{
${ }^{29}$ Benton Tim: The Villas of Le Corbusier and Pierre Jeanneret 1920-1930. Basel: Birkhauser, 2007, pp. 183-201.

${ }^{30}$ Benton Tim: "Villa Savoye and the Architect's Practice" in Allen Brooks H. (Ed.): Le Corbusier. Princeton: Princeton University Press,1987. Pp. 83-105.

${ }^{31}$ Fujimoto Sou: "Understanding abiguous spaces” in Architecture as a craft. Nijmegen: Sun, 2011 p. 161.

32 Ingels Bjarke: "3 warp-speed architecture tales" on www.TED.com, 2009

${ }^{33}$ Caruso Adam: Gardens of Experience, Amsterdam: Sun, 2010

${ }^{34}$ Rowe C. and Koetter F. : Collage Cit., Cambridge: MIT Press, 1978, p.86.
} 
predecessors, we must carry on a certain tradition. De Vylder ${ }^{35}$ stated that an architect should not always invent completely new concepts, but can start from an existing situation and bring that up to date. This will have the advantage of carrying the old in it. Part of the quality of the new lies in its comparison with the old. Or, as Perec $^{36}$ formulated for art paintings that a considerable number of, if not all, paintings only acquire their true significance in relation to the earlier works that are found in them, either simply reproduced whole or in part, or in a much more allusive manner, encrypted. Similarly, Geers ${ }^{37}$ wrote for architecture that the architect's project deals indirectly with everything that has happened before, both in the field of architecture and in the world. Architecture without acknowledging history is impossible. The project is not about inventions in order to bring something new into existence, but about formulating intentions to reassemble things already known in another way. In today's world, too much emphasis is put on the new, the fresh and the frenzy. Architecture is neither new nor old, architecture is always contemporary. Every new architecture reassembles chosen elements of a found reality.

Le Corbusier made several travels to study past architecture. In the villa Savoye, he was inspired by the earth ramps of Middle Eastern architecture for his promenade architectural. Among Le Corbusier, only on foot, in movement, can you see the developing articulation of the architecture ${ }^{38}$.

\section{Conclusion}

The making of the project for the Villa Savoye, seems to include all aspects of typical interesting design processes. As a frequently published that can also be visited and experienced in reality, it can help to explain the complexity of designing and make all these aspects of it more comprehensible.

\section{Bibliography/references}

Alexander Christopher: A Pattern Language. New York: Oxford University Press, 1977.

Benton Tim: Le Corbusier Architect of the Century. London: Arts Council of Great Britain, 1987.

Benton Tim: "Villa Savoye and the Architect's Practice" in Allen Brooks H. (Ed.): Le Corbusier. Princeton: Princeton University Press, 1987.

Benton Tim: The Villas of Le Corbusier and Pierre Jeanneret 1920-1930. Basel: Birkhauser, 2007.

Caruso Adam: Gardens of Experience, Amsterdam: Sun, 2010.

Caruso Adam: "Over maquettes en beelden" in Oase: "Models/Maquettes". № 84. 2011.

Ching Francis D.K.; Eckler James F.: Introduction to Architecture. New York: John Wiley \& Sons, 2012.

Curtis William J.R.: Le Corbusier Ideas and Forms. Oxford: Phaidon, 1986.

De Vylder J.: "Als een tekening” in 1 boek 2. Antwerpen: De Singel, 2011.

Jones J.C.: Design Methods. New York: John Wiley \& Sons, 1992.

Fujimoto Sou: "Sou Fujimoto" in 2G. N50. 2009.

\footnotetext{
${ }^{35}$ De Vylder J.: "Als een tekening” in 1 boek 2. Antwerpen: De Singel, 2011

${ }^{36}$ Perec G.: Le Cabinet d'amateur, La librairie du XXIème siècle ,1994

37 Geers K.: "Crafting architecture. In search of the architect's project" in Riedijk M. (Ed.) Architecture as a craft, Amsterdam: Sun, 2011

${ }^{38}$ Benton Tim: The Villas of Le Corbusier and Pierre Jeanneret 1920-1930. Basel: Birkhauser, 2007, pp. 183-201.
} 
Fujimoto Sou: "Understanding abiguous spaces” in Architecture as a craft. Nijmegen: Sun, 2011.

Geers K.: "Crafting architecture. In search of the architect's project" in Riedijk M. (Ed.) Architecture as a craft, Amsterdam: Sun, 2011.

Goel V.: Sketches of Thought. Cambridge: MIT Press, 1995.

Heylighen Ann; Segers Nicole: "An architectural Shift+F7" in EAAE Transactions on Architectural Education. $\mathrm{N}^{\mathrm{o}}$ 14. Montreal: EAAE, 2004.

Ingels Bjarke: "3 warp-speed architecture tales" on www.TED.com, 2009.

Jones J.C.: Design Methods. New York: John Wiley \& Sons, 1992.

Lawson Bryan: How Designers Think. Oxford: The Architectural Press, 1980.

Lawson Bryan: Design in Mind. Oxford: Reed, 1997.

Levin P.H.: Decision making in urban design. Herts: Garston, 1966.

Liu Y.C.; Blight T.; Chakrabarti A.: “Towards an 'ideal' approach for concept generation” in Design Studies. N 4. 2003.

Marples D.: The decisions of engineering design. London: Institute of Engineering Designers, 1960.

McGown Alistair: "Visible ideas: information patterns of conceptual sketch activity" in Design Studies. No 4. 1998.

Neutelings Willem-Jan; Riedijk Michiel: At Work. Rotterdam: 010, 2005.

Perec G.: Le Cabinet d'amateur, La librairie du XXIème siècle ,1994.

Quetglas Joseph: Les heures Claires. Barcelona: Centre d'Investigacions estètiques, 2009.

Ragot Gilles; Dion Mathilde: Le Corbusier en France. Paris: Le Moniteur, 1997.

Rowe C. and Koetter F. : Collage Cit., Cambridge: MIT Press, 1978.

Venturi Robert: Complexity and Contradiction in Architecture. New York: Museum of Modern Art, 1966

Winters Nathan B.: Architecture is Elementary. Salt Lake City: Gibbs M. Smith, 1986.

Zumthor Peter: Atmospheres: Architectural Environments - Surrounding Objects. Basel: Birkhauser, 2006. 


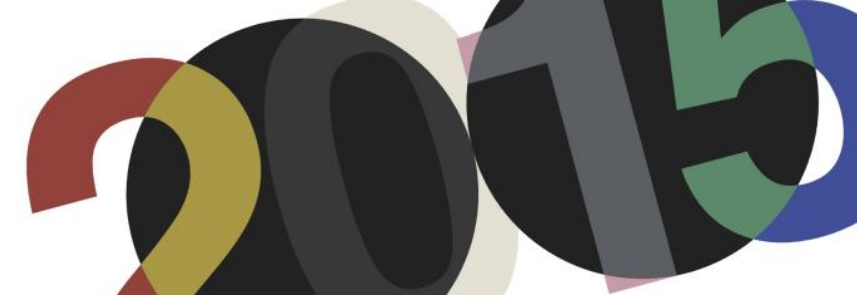

DOI: http://dx.doi.org/10.4995/LC2015.2015.678

\title{
Los dibujos para el Palacio
}

\author{
V. Velásquez Hernández
}

Universidad Nacional de Colombia

\begin{abstract}
Resumen: El concurso para la Sede del Palacio de Naciones en Ginebra, realizado en 1927, significa para Le Corbusier un momento crucial en su trabajo, entre otras cosas por la repercusión mediática que suscita, ayudando a proyectar su imagen a nivel internacional. La compleja propuesta del palacio sintetiza y aplica algunas de las principales preocupaciones de Le Corbusier, al tiempo que abre nuevos frentes de investigación para futuros proyectos. Un importante trabajo de dibujo acompaña el reto arquitectónico. La rica información proyectual, contenida en esos dibujos, documenta tanto los grandes planteamientos paisajísticos y de funcionamiento, como sutiles detalles constructivos. Los dibujos, en sus aspectos formales y técnicos, forman parte de una serie de pruebas en los sistemas de representación que Le Corbusier hace en estos años. Si bien la exploración en las técnicas gráficas pone en riesgo la posibilidad de ganar el concurso, le brinda la oportunidad de reutilizar los documentos para alimentar nuevas aventuras editoriales: "Une maison, un palais", "Vers une architecture" y "CEuvre Complète". El estudio de los dibujos ahonda en sus procedimientos de trabajo, tanto para la investigación en el proyecto arquitectónico como para su difusión en medios masivos. A la vez, reafirma una visión innovadora propia de su labor como agitador y divulgador de la arquitectura moderna.
\end{abstract}

Abstract: The 1927 "Palace of the league of Nations in Geneva" contest meant a crucial moment for Le Corbusier in his work, amongst other things due to the subsequent raising media repercussion, helping him scheme his image to an international level. The complex palace proposal synthetizes and applies some of Le Corbusier's main preoccupations, and opens at the same time new research fronts for future projects. An important drawing work ushers the architecture challenge. The rich design information, contained in those drawings, documents both the landscaping and the functioning proposal, as subtle constructive details. The drawings, in the formal and technical aspects, shape part of a series of proof on Le Corbusier's representation system for these years. Although the exploration on graphic techniques risks the possibility of him winning the contest, it also gives him the opportunity to reutilize such documents for new editorial adventures such as: "Une maison, un palais", "Vers une architecture" and "Euvre Complète". The study of the drawings deepens the work procedure, as well as the research he went through for an architecture project when is meant to be published in massive media. At the same time, it reasserts an innovation perspective unique of his work as an agitator and divulging person of modern architecture.

Palabras clave: Dibujos; Libros y escritos; Artes visuales; Técnica; Colaboradores; Palacio de Naciones. Keywords: Drawings; Books and writings; Visual Arts; Technique Partners; Palace of Nations.

\section{Introducción}

El presente es un estudio de los dibujos realizados para del concurso del Palacio de la Sociedad de Naciones en 1927. A excepción de la meticulosa publicación de algunos dibujos originales hecha por la universidad ETH de Zúrich en 1988, habitualmente los análisis que se han hecho sobre el proyecto tienden a destacar su indudable trascendencia dentro de la obra de Le Corbusier y las generalidades de su composición, pero suelen a pasar por alto el sustancioso trabajo que está contenido en los documentos de su representación. Se propone aquí examinar, con algo de atención, el contendido de los dibujos que configuran la imagen canónica del proyecto. Para ello se aborda, en primera instancia, el momento de su realización y sus autores, la enumeración y descripción de los documentos. A continuación se estudian algunos de de los procedimientos utilizados para su elaboración y finalmente, la forma en que son reutilizados por Le Corbusier para sus publicaciones. El estudio de 
los dibujos ahonda tanto en los detalles del proyecto, que de otro modo suelen pasar inadvertidos, como en los procedimientos de trabajo de Le Corbusier y en su propagación en medios masivos.

\section{El concurso y los dibujantes}

El concurso Internacional de arquitectura para la edificación del Palacio de la Sociedad de Naciones se abre oficialmente el 25 de julio de 1926, fijando la fecha de entrega para el 25 de enero de $1927^{1}$. Después de unos meses de silenciosa incubación, los trabajos de dibujo en el taller de Le Corbusier y Pierre Jeanneret comienzan a principios de noviembre. El taller funciona en esa época de una manera intermitente y sin empleados fijos ${ }^{2}$. A raíz de un par de conferencias dictadas en Zúrich el 24 y 25 de noviembre, Le Corbusier contacta con algunos alumnos del profesor Karl Mosser y les propone colaborar en su taller para el concurso. A principios de diciembre Ernst Schindler y Walter Schaad llegan a París. Unos días más tarde, Hans Neiße, J.J. DuPasquier y el yugoslavo Zvonimir Kavuric se suman a las labores de dibujo. A principios de enero se incorpora al grupo Alfred Roth para completar, junto a los patrones, siete dibujantes. Este reducido grupo elabora las dieciocho grandes láminas con los planos del proyecto. Antes de la llegada de los trabajadores la propuesta tiene ya un alto nivel de definición en cuanto a la ubicación, tamaño y tratamiento interno de las dos grandes partes en las que se divide el programa. Por un lado la gran sala de asambleas de forma trapezoidal, con unas dependencias adosadas en una barra perpendicular y, por otro, el conjunto de edificios del secretariado general en forma de " $H$ ", con la biblioteca acogida en un cuerpo bajo flanqueado, a su vez, por dos alas en forma de barras alargadas. Los dos componentes están unidos por unos puentes, estratégicamente ubicados entre la barra este de la secretaría y la barra adosada a la gran sala ${ }^{3}$. Gracias a la concreción en las grandes líneas del proyecto, los patronos pueden delegar, en los dibujantes contratados, las labores de producción de borradores más finos a lápiz antes del paso a limpio, y dedicarse a detallar aspectos más específicos del conjunto. En cualquier caso, es sorprendente la rapidez y eficiencia con que los arquitectos confeccionan los documentos, dadas las considerables dimensiones de las láminas y la premura del tiempo. El paquete de planos incluye once láminas para las plantas, tres de secciones, dos para elevaciones y dos más para las axonometrías. A este paquete de representación planimétrico hay que agregar otros tipos de dibujo: bocetos de vistas de diferentes ámbitos de la propuesta, perspectivas de una confección más detallada y montajes fotográficos. Las dieciocho láminas entregadas contienen una cuidada y rica información proyectual.

\footnotetext{
${ }^{1}$ La resolución oficial de La Sociedad de Naciones es del 17 de abril pero se fija 25 de julio como la fecha final de apertura. Programme et Règlement, Annexe V, p. 2.

${ }^{2}$ El 18 de septiembre de 1924 abre el taller de la rue de Sèvres. A partir de 1925 comienzan las colaboraciones temporales, pero la continuidad de los trabajadores es incierta. En el "Livre noir" sólo a partir de 1929 puede distinguirse la permanencia de los ayudantes y su responsabilidad en los proyectos.

${ }^{3}$ Ver FLC335405 y FLC23318 fechados el 7 de noviembre, FLC23368 (9 de noviembre), FLC23382 (sin fecha pero claramente vinculado a los anteriores), FLC23379 (10 de noviembre), FLC2345 (14 de noviembre), FLC23385 (19 de noviembre) y, finalmente, FLC23355 y FLC23346 (30 de noviembre). La secuencia muestra la toma de decisiones en la configuración de las piezas desde borradores vagos a dibujos cada vez más precisos.
} 


\section{Las láminas}

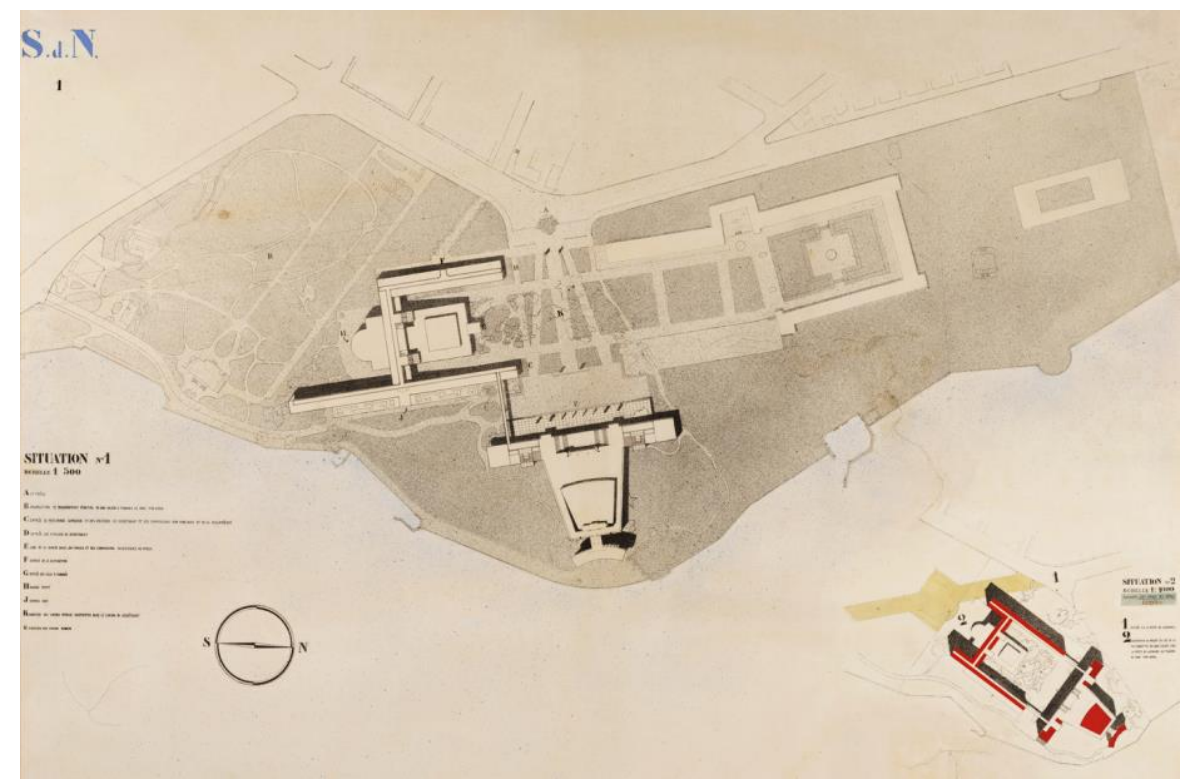

SdN1. 150x180. Fotograbado entintado y coloreado con gouache sobre papel Canson gta Archives / ETH Zurich (185-01-1, Le Corbusier, Völkerbundpalast), fragmento.

La primera lámina contiene la implantación del conjunto en el solar, a escala 1:500 ${ }^{4}$, definida por la orientación de las dos piezas principales que, interconectadas a través de dos ejes de simetría perpendiculares, parecen flotar en medio de un terreno muy alargado. Sin embargo, esta configuración está muy condicionada por el tamaño y los verdaderos linderos del solar adjudicado, así como por su entorno inmediato: en la parte superior de la lámina, costado oeste, el solar está delimitado por la vía que comunica Ginebra con Lausana, estableciendo el acceso principal del conjunto justo en el punto de inflexión de la vía; en la parte inferior, costado oriente, el solar se define por la línea litoral del lago Leman; en el costado sur, el dibujo incluye un parque municipal llamado Mon Repos, que en realidad no hace parte del solar; y finalmente, en el costado norte, la lámina abarca una partición del terreno contiguo (llamada propiedad Barton) que alberga, gráficamente matizada, la posible ampliación de las instalaciones, tal como lo exige el concurso. Uno de los aspectos más complejos del programa implicaba una profusa diversidad de dependencias que debían estar interconectadas. La accesibilidad a esta red programática es pues, uno de los aspectos álgidos de la propuesta. Así, el conjunto debe facilitar una entrada general y de allí distribuir, en accesos diferenciados, a varios tipos de usuario: el personal que trabaja en la secretaría, los comisionados, los visitantes, los periodistas, etc, y permitir el paso a la biblioteca, a los estacionamientos y a los depósitos de insumos para los servicios. Esta variedad de accesos a los diferentes estamentos del palacio, está indicada a través de letras mayúsculas referenciadas en un listado de convenciones. La lámina contiene además, en la esquina inferior derecha, un curioso apartado con una variante de ordenamiento del conjunto. Se trata, efectivamente, de los mismos componentes pero esta vez mirándose a sí mismos para configurar una composición simétrica y cerrada (dibujada esta vez a escala 1:1000) ${ }^{5}$. Corresponde, tal como lo indica el texto, a la "adaptación del proyecto en caso de la prolongación del Quai Wilson (vía y muelle sobre el lago) hacia la ruta de Lausana a través del parque Mon Repos".

\footnotetext{
${ }^{4}$ Después de los borradores mencionados ver lápices en FLC23391 y FLC23343; y entintado FLC23211.

${ }^{5}$ Borradores FLC23373 y FLC23416, y entintado FLC23215.
} 
Desde la lámina dos a la once se engloban todas las plantas en escala 1:200. Con excepción de la lámina cuatro, las dos partes de conjunto (secretariado y gran sala) están dibujadas de forma independiente, ocupando cada una un lugar en la plancha.

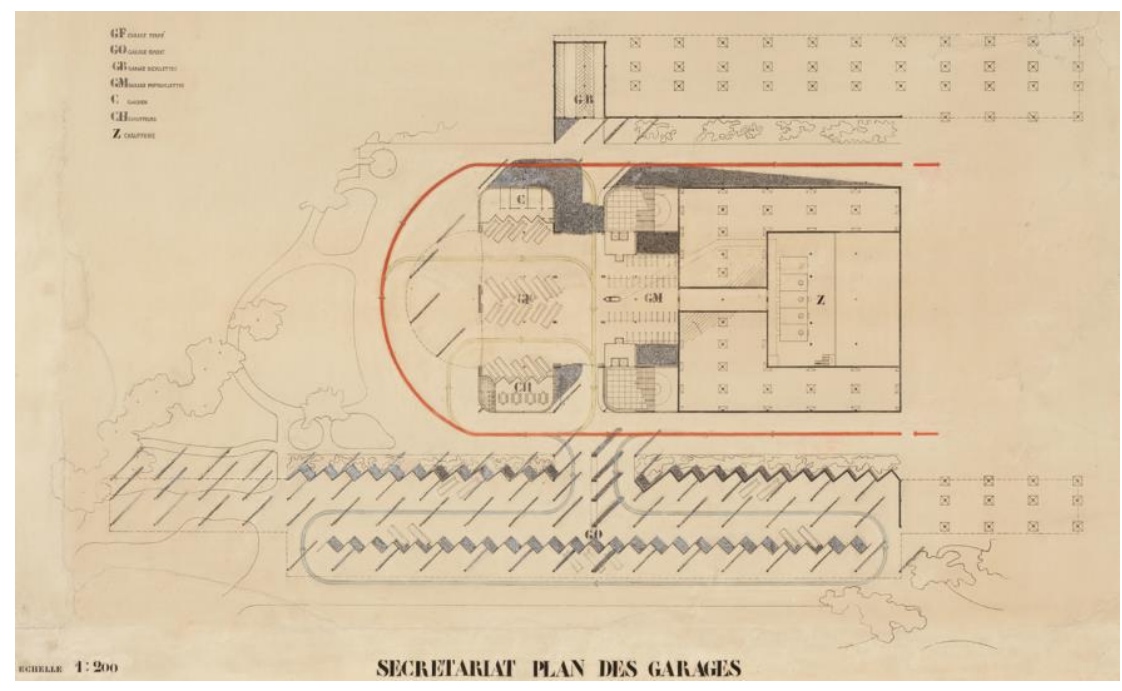

SdN2. 75x110 Fotograbado entintado y coloreado con gouache sobre papel Canson gta Archives / ETH Zurich (185-01-2, Le Corbusier, Völkerbundpalast), fragmento.

La segunda lámina recoge el planteamiento de los estacionamientos del conjunto nivelados en la cota $+376,5^{6}$ del terreno. Hay 20 plazas en los garajes cerrados, 38 plazas para motos y un espacio para bicicletas, mientras que los garajes "abiertos" albergan 74 plazas. La propuesta acoge muchas más plazas de las exigidas originalmente por el concurso ${ }^{7}$. La dirección de la circulación vehicular principal viene marcada por líneas continuas de color. El desnivel de terreno se representa a través de unas sombras proyectadas.

La tercera lámina $(75 \times 180 \mathrm{~cm})$ presenta la primera planta del edificio de la secretaría general y los bajos de la gran sala $\left(\operatorname{cota}+380\right.$ de terreno $\left.{ }^{8}\right)$. En ambos casos el mayor porcentaje del área está destinado al almacenaje, configurando una planta exclusivamente de servicios complementarios.

La cuarta lámina es de las más reveladoras sobre la distribución organizativa de los dos edificios. Este nivel (cota +383 de terreno ${ }^{9}$ ) establece la verdadera planta baja de acceso al conjunto. Aquí están contenidas las principales entradas tanto a la secretaría, en el extremo norte de las dos alas laterales, como a la sala de asambleas, a través de un gran porche que cobija siete puertas de acceso diferenciado: una central para los delegados, dos laterales para el personal de apoyo, una para los periodistas y otra para el público general.

\footnotetext{
${ }^{6}$ Borrador FLC23359, lápices FLC23258 y entintado FLC23172.

${ }^{7}$ Las bases del concurso especifican sólo 25 plazas para automóviles y un centenar de bicicletas, Programme et Réglement $\mathrm{p}$. 15.

${ }^{8}$ Lápices FLC23259 y FLC23261; entintado FLC23209 y FLC23182.

9 Para la secretaria borradores FLC23340 y FLC23341, lápices FLC23253 y entintado FLC23190; para la gran sala borradores FLC23237; lápices FLC23370 (18 de noviembre), FLC23348, FLC23363, FLC23334 y FLC23337 (en orden de definición) y entintado FLC23183.
} 


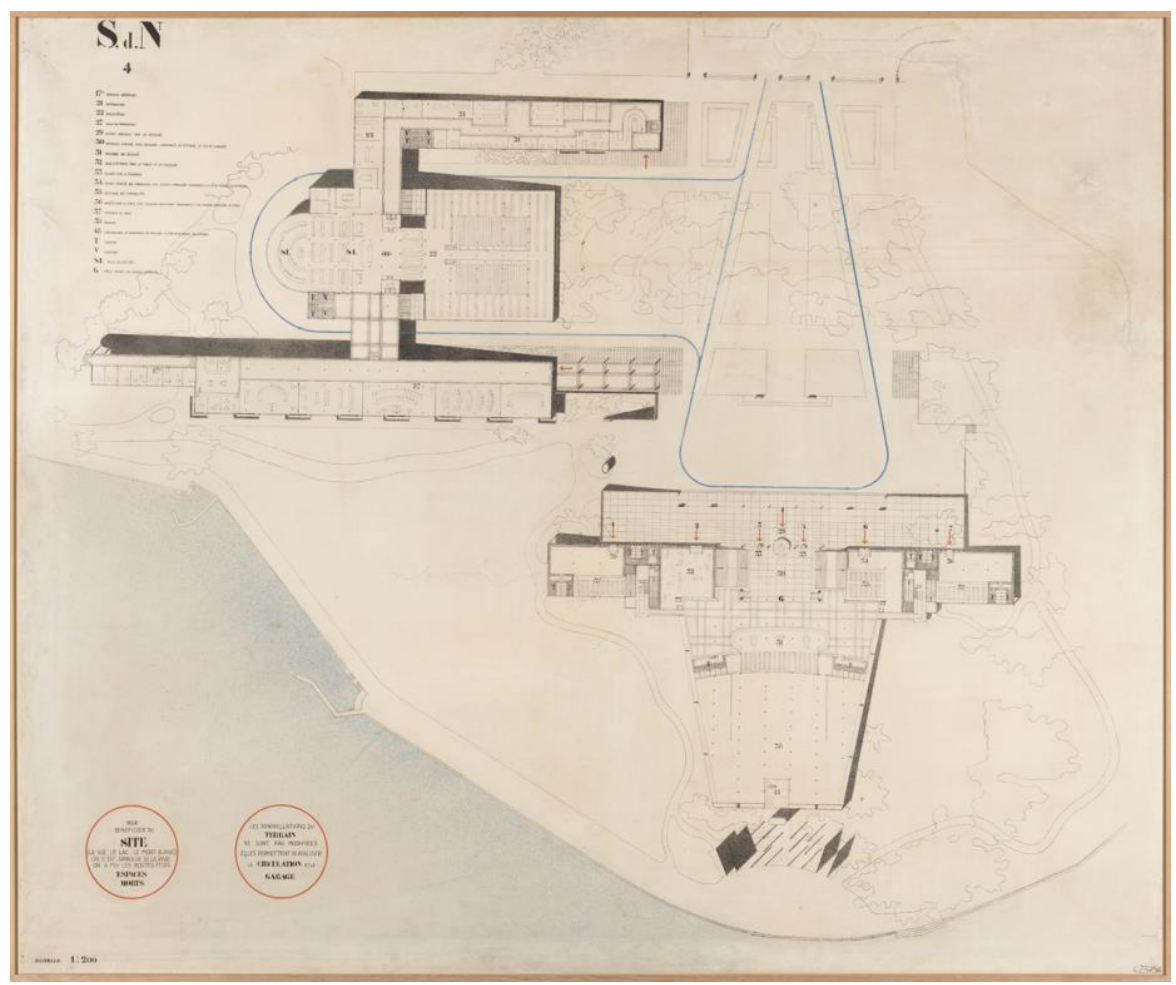

SdN4. 150x180 Fotograbado entintado y coloreado con gouache sobre papel Canson gta Archives / ETH Zurich (185-01-4, Le Corbusier, Völkerbundpalast)

Cada puerta está vinculada con vestíbulos particulares y sus correspondientes puntos de circulación vertical, que desembocan, a su vez, en áreas específicas dentro de la gran sala. De nuevo el funcionamiento de la circulación vehicular se marca con una línea continua a manera de flecha. Partiendo de una puerta de entrada y otra de salida, el circuito, que debe hacerse en un solo sentido, dibuja una "V" que recorre primero el muelle de acceso a la sala y después el frente a la biblioteca, tramo del que se desprende una derivación perpendicular que desciende bajo el edificio de la secretaría. De nuevo las sombras proyectadas dan perfecta cuenta de la relación del nivel de la planta con el terreno.

La quinta lámina contiene la planta correspondiente al nivel de las principales dependencias de la secretaría (cota $+387^{10}$ ). La oficina principal del secretario general y las de los subsecretarios tienen comunicación directa hacia unas generosas terrazas-jardín, con espléndidas vistas sobre el lago, mientras las alas transversal y posterior albergan las oficinas de consejerías jurídicas y administrativas. En cuanto al cuerpo de la gran sala, la lámina muestra la platea principal destinada a los delegados internacionales, a la que se accede una vez traspasado un amplio vestíbulo. Finalmente, en el costado opuesto, un pequeño cuerpo en forma semicircular corona el edificio sobre el lago, con las dependencias de apoyo y acceso del secretario general a la sala de asambleas ${ }^{11}$.

\footnotetext{
${ }^{10}$ Borradores FLC23234 y FLC23239; y entintados FLC23176 y FLC23181.

${ }^{11}$ Borradores FLC23344, FLC23288, FLC23383 y FLC23351.
} 
De la lámina sexta a la novena $(75 \times 180 \mathrm{~cm})$, la información tiende a ser repetitiva en el costado de la secretaría, pues su funcionamiento varía muy poco en esas cuatro plantas (niveles $+390.5,+394,+397.5,+401^{12}$ ): una crujía con pasillo lateral que alimenta una secuencia de oficinas para la barra oriental $(10 \mathrm{~m} \times 164 \mathrm{~m})$; la barra transversal (8m x 64m) funciona con una crujía de oficinas en el costado sur y pasillo central, que conecta con las dos grandes escaleras y baños en el costado norte, mientras que la barra occidental, más amplia (14m x 88m), alberga dos crujías de oficinas con pasillo central. En cuanto a la gran sala, la secuencia de las cuatro láminas va desglosando su funcionamiento estratificado. En la barra adosada, la zona de escaleras y ascensores va conectando los diferentes balcones del auditorio ${ }^{13}$.

La décima lámina está dedicada enteramente a la gran sala de asambleas, con una planta central que recoge la información diferenciada por niveles en las láminas anteriores, unificando así su actividad general ${ }^{14}$. La planta está acompañada de algunos esquemas sobre tres aspectos técnicos fundamentales para le Corbusier: el acústico $^{15}$, la iluminación y de acondicionamiento térmico de la sala ${ }^{16}$.

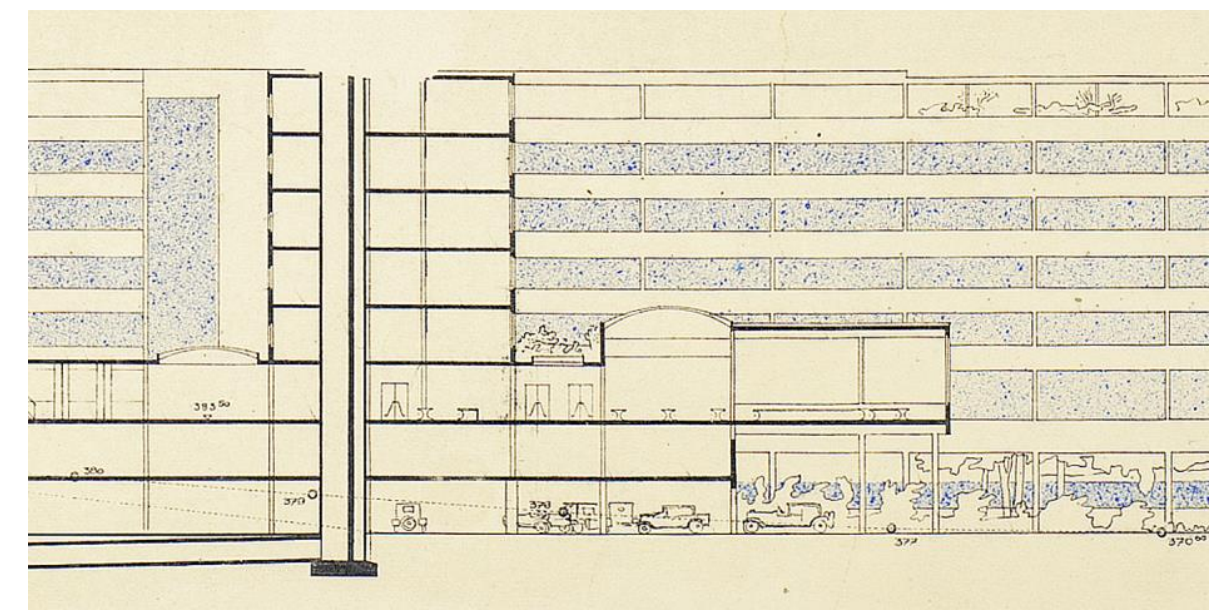

SdN 12. Sección de la biblioteca dirección este. Entintado y esgrafiado con gouache azul (fragmento FLC23226B @FLC-ADAGP)

La lámina once $(75 \times 90 \mathrm{~cm})$ describe la cubierta de la sala que actúa como una gran terraza-jardín, donde se instala una cafetería organizada en torno a los lucernarios y subdividida a través del remate de los pórticos estructurales $^{17}$. En todas estas plantas una sombra más escueta y en paralelo acompaña el perímetro del edificio.

La lámina doce contiene dos secciones generales hechas de forma perpendicular entre ellas y siguiendo las dos principales direcciones del conjunto ${ }^{18}$.

\footnotetext{
12 Borradores FLC23374 (piso 2, 21 de noviembre), FLC23375 (piso3, 22 de noviembre), FLC31988 (piso4, 22 de noviembre); lápices FLC23338 (piso2), FLC23235 (piso3), FLC23242 (piso4), FLC23241 (piso5); y entintados FLC23198 (piso 2), FLC23200 (piso 4), FLC23199 (piso5)

${ }^{13}$ Borradores FLC23254, FLC23256, FLC23257, FLC23238, FLC23240; y entintados FLC23196, FLC23179, FLC23197, FLC23208.

${ }^{14}$ Borradores FLC23367, FLC23262, FLC23249 y FLC23255, y entintado FLC23184.

15 Entintado FLC23216 y estudios de trazados acústicos de la sala definitiva FLC23187A y FLC23187B. Constan pruebas formales de la sala FLC12189A y FLC23189B como cúpula y FLC23188 de planta rectangular.

${ }^{16}$ FLC23178.

${ }^{17}$ Lápices FLC23236, FLC23371 y entintado FLC23191.

${ }^{18}$ Borradores FLC23289 y FLC23233; entintados FLC23170, FLC23175, FLC23226 y FLC23226b.
} 
Una hace el corte por las escaleras del secretariado en dirección norte, y la otra, por el eje de simetría del secretariado en dirección este. Otras dos secciones de la gran sala están contenidas en la lámina trece, una transversal, sobre su eje de simetría $^{19}$, en dirección sur con la fachada norte del secretariado, la otra en sentido longitudinal de la barra adosada a la sala ${ }^{20}$, revelando, a manera de diagrama, su movimiento interno y las diferentes conexiones de los grupos de escaleras. En todas las secciones el perfil del terreno está cuidadosamente indicado a través de líneas continuas o cortadas y puntos específicos con la indicación de la cota correspondiente. A estas dos secciones se suma la fachada oeste de la gran sala ${ }^{21}$.

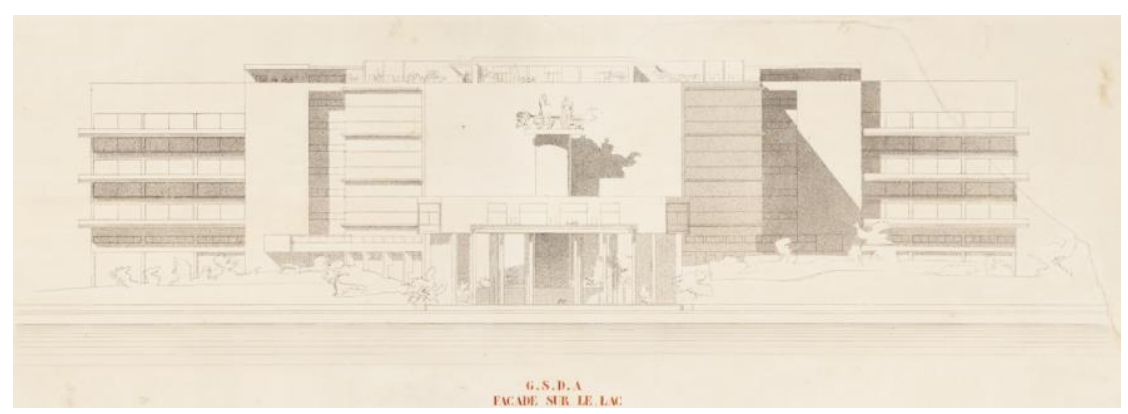

SdN17. Fachada de la gran sala. Fotograbado entintado y coloreado con gouache sobre papel Canson gta Archives / ETH Zurich (185-01-17, Le Corbusier, Völkerbundpalast), fragmento.

En las láminas dieciséis y diecisiete (ambas de $75 \times 225 \mathrm{~cm}$ ) se encuentran dos alzados. Uno recoge la fachada oriental de la secretaría ${ }^{22}$ y otro, la fachada de la gran sala ${ }^{23}$. Las dos fachadas conforman el costado oriental del conjunto, es decir, están dibujadas desde el lago.

Finalmente, la lámina dieciocho recoge una enorme sección longitudinal de la gran sala de asambleas, a escala $1: 100,{ }^{24}$ que viene acompañada de una sección constructiva de la doble membrana aislante del auditorio, en planta y sección a escala 1:50, y una pequeña axonometría de su sistema portante.

\section{Las imágenes del Palacio}

Además de la planimetría rigurosa de los edificios en plantas, alzados y cortes, es decir las proyecciones diédricas, en los sistemas de representación tridimensional, axonometrías y perspectivas, se focalizan algunas otras exploraciones concretas. El grupo de planos incluye dos axonometrías contrapuestas y una serie de imágenes en perspectiva de varios tipos.

\footnotetext{
${ }^{19}$ Borrador FLC23410 y entintado FLC23177.

${ }^{20}$ Borrador FLC23402 y entintado FLC23173.

${ }^{21}$ Borradores FLC23397, FLC23399 y FLC23320; entintado FLC23171.

${ }^{22}$ Borradores generales FLC23362, FLC23390, FLC23403 y FLC23405; tanteos de modulación FLC23401 y entintado FLC23180.

${ }^{23}$ Borrador FLC23319, lápices FLC23400, FLC23418; y entintado FLC23174.

${ }^{24}$ Proceso de ajuste y definición de componentes FLC23411, FLC23217, FLC23388, FLC23392 y FLC23412; borrador detallado del balcón FLC23413 y entintado FLC23168.
} 


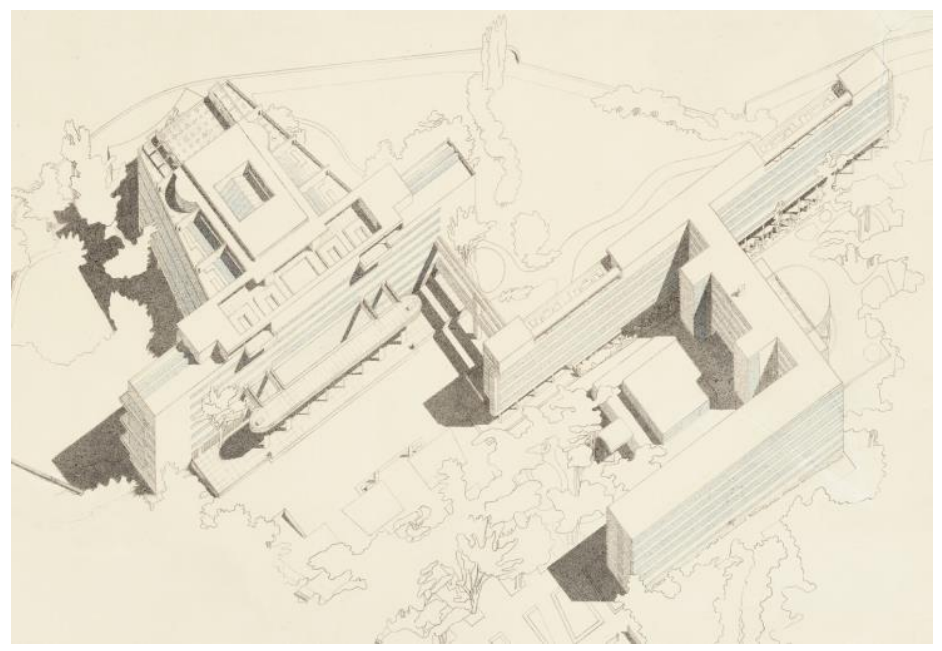

SdN15. Fotograbados entintados y esgrafiados sobre papel Canson gta Archives / ETH Zurich (185-01-15, Le Corbusier, Völkerbundpalast)

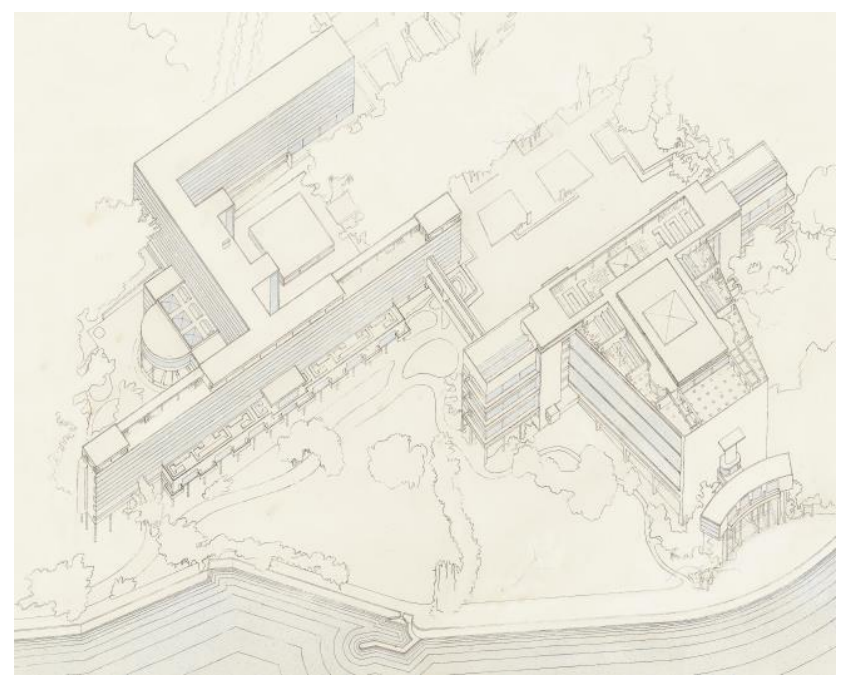

SdN14. Fotograbados entintados y esgrafiados sobre papel Canson gta Archives / ETH Zurich (185-01-14, Le Corbusier, Völkerbundpalast)

\subsection{Las axonometrías}

La primera axonometría construye la vista desde el costado suroriental, manifestando la relación del conjunto con los bordes del lago ${ }^{25}$. La segunda en el sentido opuesto, esta vez con sombras esgrafiadas, hace énfasis en la gran zona de acceso que interconecta en la planta baja los dos edificios ${ }^{26}$. Los dos dibujos, de exquisito trazo en el detalle, consiguen transmitir no solo la totalidad del conjunto y la interacción volumétrica de las partes, sino que de nuevo, buscan acentuar los atributos de su implantación y relación con el contexto. Si bien el grupo de jóvenes arquitectos, formados bajo la tutela de Karl Moser, aportan su pericia en el dibujo de las axonometrías ${ }^{27}$,

\footnotetext{
${ }^{25}$ Borradores LC23360 y FLC23247; lápices FLC23387 y FLC23378; entintado FLC23230.

${ }^{26}$ Borrador FLC23386 y entintado FLC23231 y FLC23185.

${ }^{27}$ Ver Benton, Tim, «Introduction », Le Corbusier, l'atelier 35 rue de Sevres, p. 2.
} 
ya era habitual el uso de este sistema de representación en el taller ${ }^{28}$. Por otra parte, el sistema axonométrico ha sido útil también para ir tomando decisiones durante el proceso de diseño. Basta verificar los borradores FLC23247 y FLC23360 (claramente elaborados por Le Corbusier), para deducir la utilidad de este tipo de representación para visualizar la distribución y proporción de los componentes simultáneamente con la definición de sus fachadas.

\subsection{Las perspectivas: grupo 1}

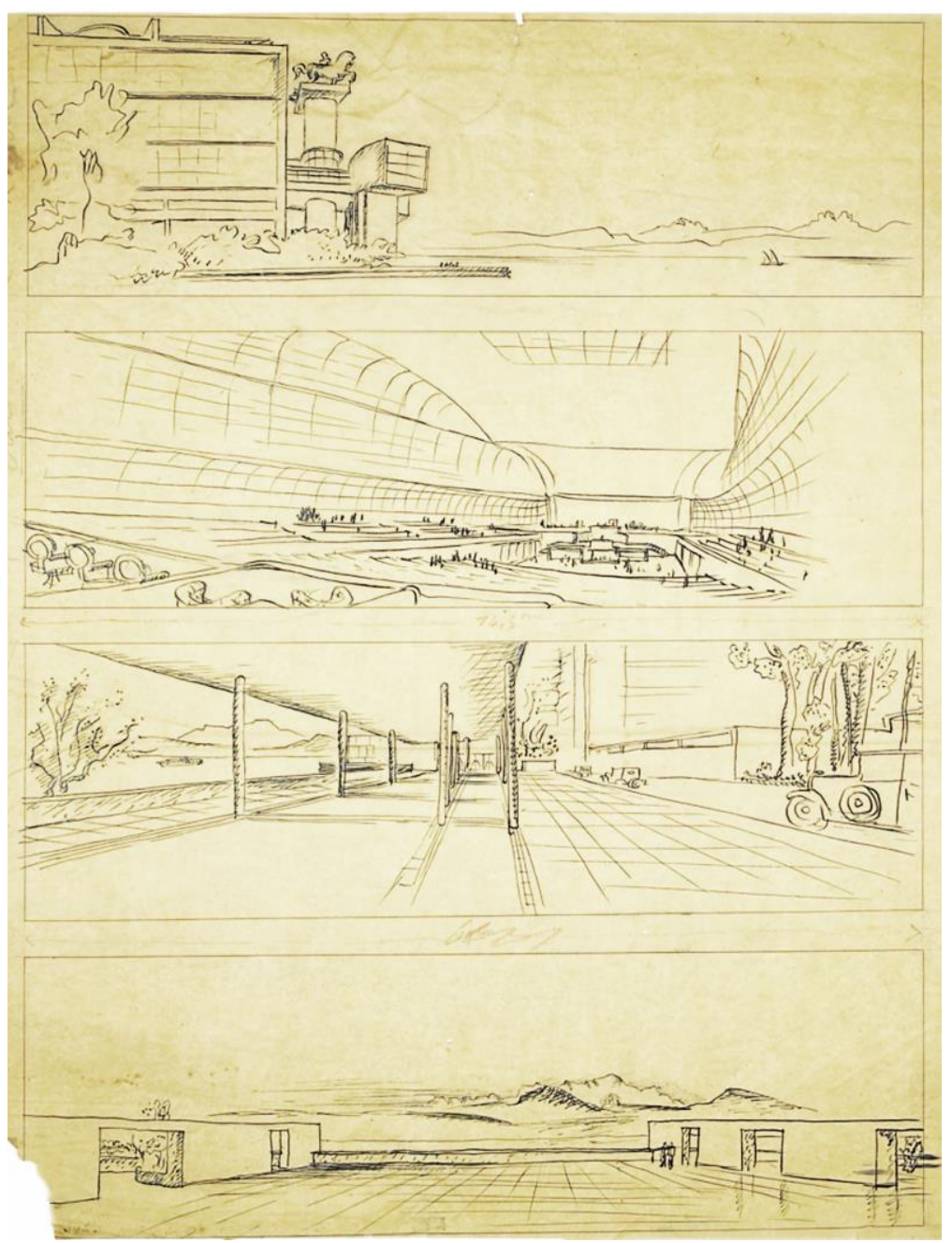

Serie de cuatro perspectivas. Lápiz y tinta negra sobre papel de calco (FLC23384@FLC-ADAGP)

Hay tres grupos de perspectivas, diferenciadas en sus características y acabados. El primer grupo consiste en cuatro vistas incluidas en la lámina $\mathrm{N}^{\mathbf{0}} 14$, claramente elaboradas a mano alzada, con el reconocible trazo desenvuelto y expresivo de Le Corbusier. La secuencia representa algunos de los puntos claves del proyecto y los títulos de cada dibujo buscan completar la idea sugerida en la imagen. El primer dibujo enseña una

${ }^{28}$ Proyectos “Abbatoires” de 1917, Pabellón de l'Esprit Nouveau, Immeubles-villas, Plan Voisin, villa Meyer, villa T (1925), Garage Raspail, Cite universitaire y Palais du Peuple (1926). Las axonometrías, influenciadas por Choisy, se hacen sistemáticas después de la exposición del grupo Stijl en la galería "L’Effort Moderne” en el otoño de 1923. Ver Velasquez, Victor, El libro abierto, p. 230. 
panorámica del lago en dirección norte, con un primer plano definido por el grupo escultural que corona la sala y se titula: "El FRENTE del palacio está en el corazón del sitio". La extensa vista del interior del salón de asambleas se acompaña de un texto que dice "La SALA es un garganta (gosier), un tímpano, una caja de luz". Por su parte la tercera vista se sitúa bajo el ala oriental del edificio del secretariado y el texto dice: "La ENTRADA del secretariado es un muelle". El último dibujo, titulado escuetamente "El TECHO de la sala SdN", es una vista desde la cubierta del salón, convertida en una gran terraza que domina el vasto paisaje hacia el lago y las montañas alpinas.

\subsection{Las perspectivas: grupo 2}

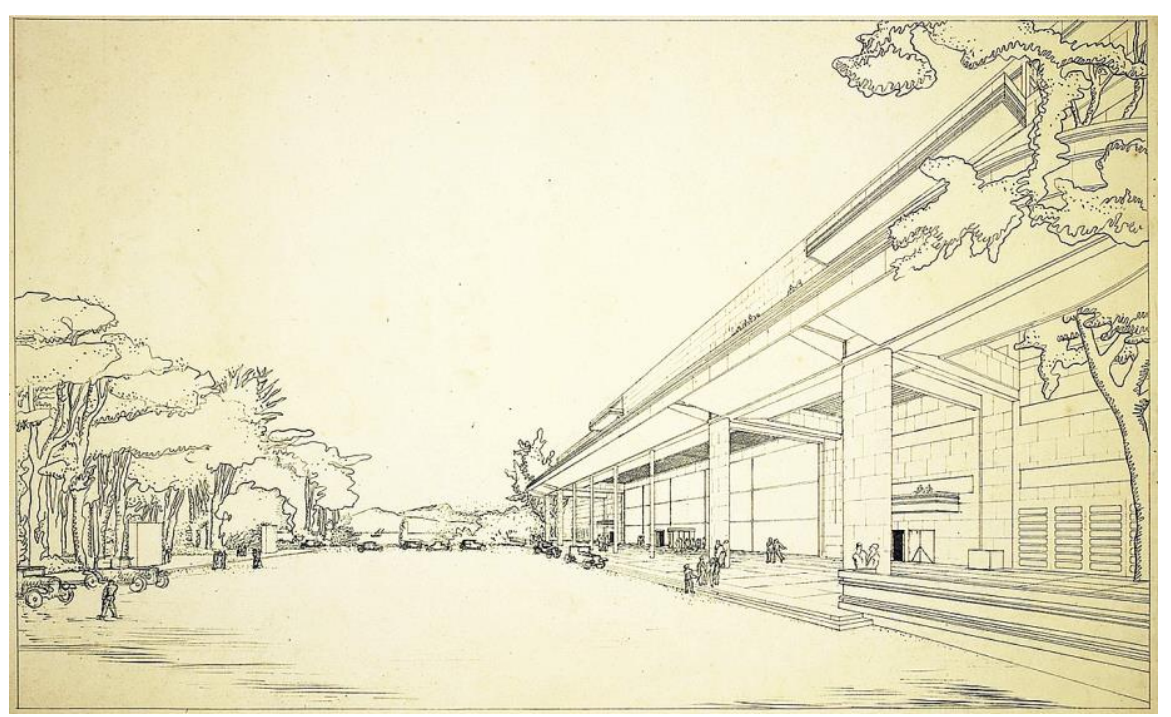

Vista sobre el muelle de la sala. Tinta negra sobre papel de calco (FLC23194A@FLC-ADAGP)

El segundo grupo de perspectivas contiene tres vistas exteriores del proyecto, elaboradas en láminas más reducidas e independientes. En este caso, las tres perspectivas denotan un trazado mucho más riguroso en su construcción geométrica, aunque los acabados se han hecho en el "estilo" Le Corbusier. El primero de ellos es la zona de acceso a la gran sala de la asamblea. En la imagen, la fachada aparece muy escorzada para dejar ver la amplitud de la vía frontal, al tiempo que se abarca el monumental. Una pequeña escalinata asciende a la plataforma de entrada cubierta con la gran marquesina que corre paralela al edificio y confiere al conjunto un aire institucional. La gran arboleda, que separa el edificio de la entrada principal, cierra la vista en el costado izquierdo. El gran porche está poblado de personajes que dan una idea clara de su escala. El dibujo es rico en detalles sobre aspectos constructivos sugiriendo, por ejemplo, el despiece del material de acabado para toda la fachada $^{29}$.

\footnotetext{
${ }^{29}$ Borrador FLC23246 y entintado FLC23194 (A y B). En FLC23224, enfoque similar descartado.
} 


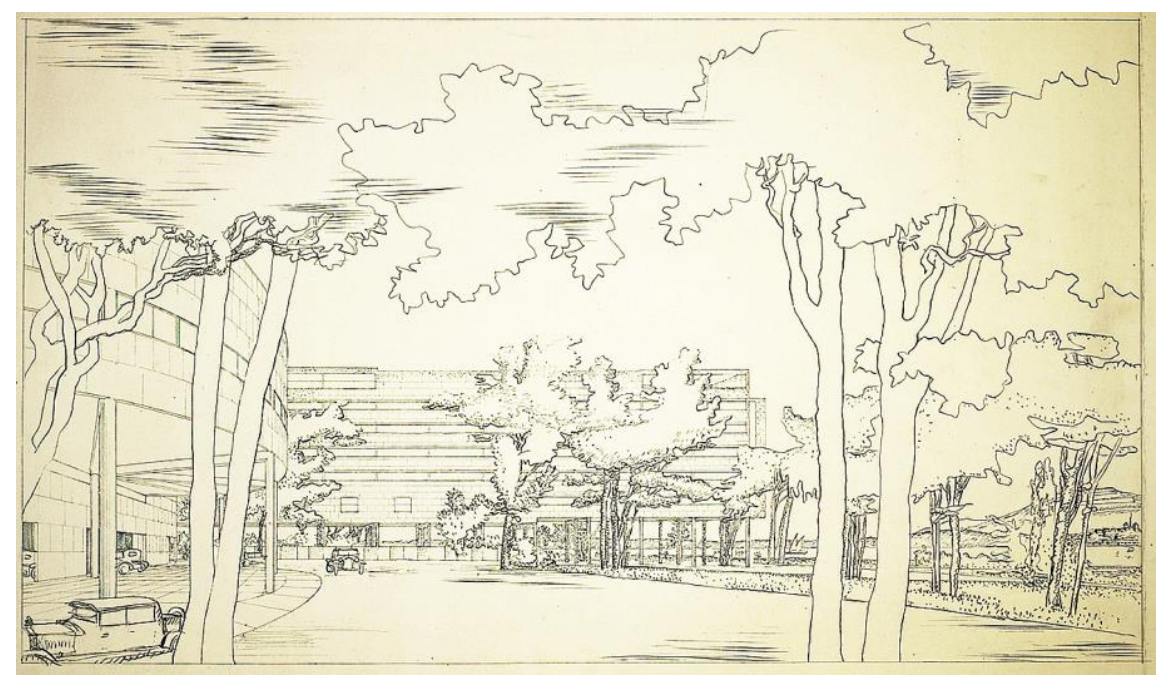

Vista sobre planta baja del secretariado. Tinta negra sobre papel de calco (FLC23195A@FLC-ADAGP)

La segunda perspectiva capta otro punto significativo. Se trata de la parte posterior del edificio del secretariado. El observador ha sido ubicado buscando ilustrar un aspecto del proyecto que Le Corbusier juzga estratégico: la circulación vehicular y los estacionamientos. Como se ha dicho, partiendo del nivel del acceso al conjunto, se desprende perpendicularmente un par vial que, aprovechando la pendiente del terreno, desciende para pasar bajo la biblioteca y, después de bordear una gran semicircunferencia, cambia de sentido. Los coches se han dibujado haciendo el recorrido en la dirección obligada de la propuesta. A la izquierda se alza el "ábside" de la biblioteca, una superficie curva que dibuja la semicircunferencia, bajo la cual, se encuentran los accesos a los estacionamientos cerrados. La vista se cierra con un fragmento del cuerpo alargado de oficinas, que se eleva sobre una multitud de pilares conformando, de esta manera, el estacionamiento abierto. Pero el dibujo enseña igualmente otro de los aspectos importantes para Le Corbusier. Está claro que las dependencias y las actividades habituales de trabajo se desarrollan arriba, flotando sobre el nivel representado. La imagen busca entonces reflejar la relación del edificio con el paisaje circundante. Al fondo, primero bajo el edificio de oficinas y después hacia el costado derecho, la vista se escapa de nuevo al lago y en medio de una arboleda, hacia la ciudad de Ginebra y el monte Salève ${ }^{30}$.

\footnotetext{
${ }^{30}$ Borrador FLC23322, lápices FLC23323, entintado FLC23195 A-B.
} 


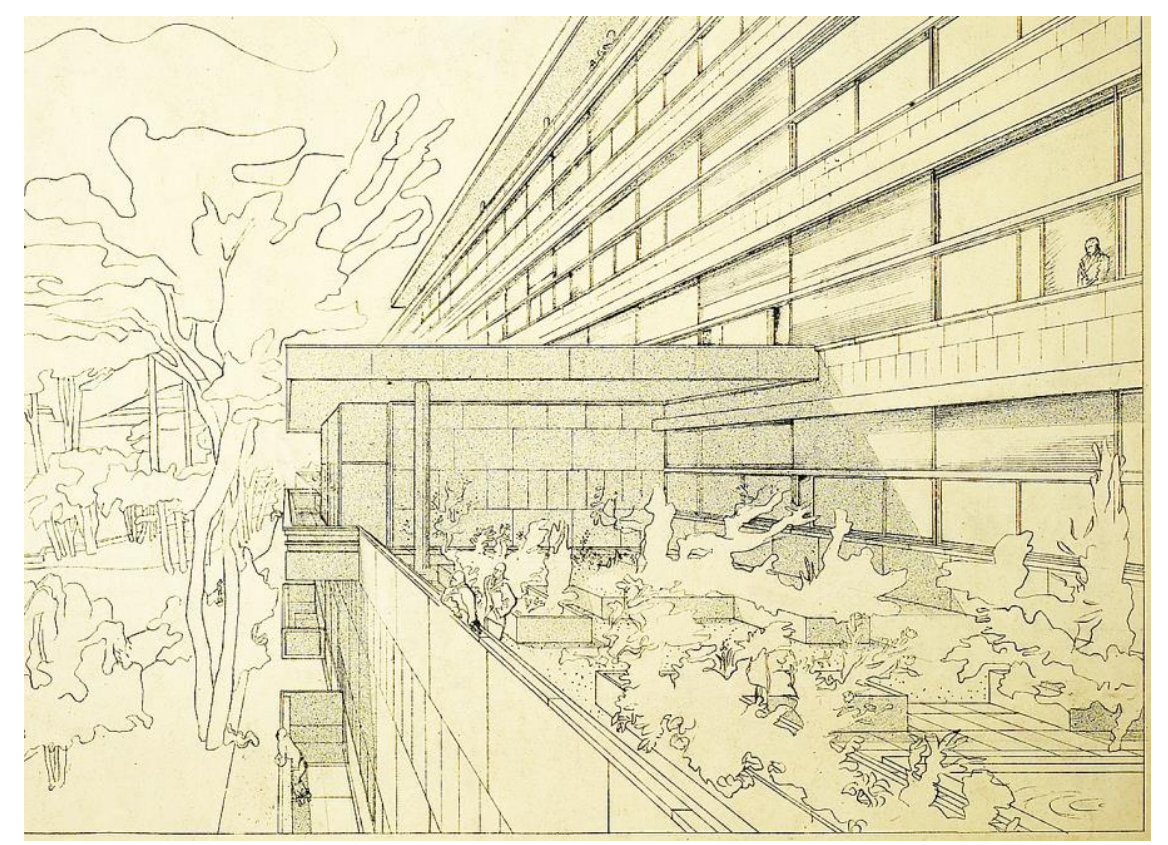

Vista de terrazas del secretariado. Tinta negra y esgrafiado sobre papel (FLC23193B@FLC-ADAGP)

El tercer dibujo representa una vista desde el costado opuesto del edificio de oficinas ${ }^{31}$. El dibujo captura la extensa fachada orientada hacia el lago, desde el nivel del conjunto de terrazas jardín de las oficinas del secretario general y sus principales subalternos ${ }^{32}$. En este enfoque, la terraza se visualiza perfectamente en primer plano, así como la interrupción de su continuidad con un pabellón que la parte en dos, mientras que la superficie vertical de la fachada se extiende sobre ella con tres niveles más de fenêtres en longueur. De la fachada del cuerpo bajo, sobresalen igualmente unos balcones alargados correspondientes a las salas de comisiones. Más abajo, una porción del terreno se extiende hasta un sendero peatonal y un antepecho, que dibujan claramente la orilla del lago, surcado por un yate. El paisaje se cierra de nuevo con el monte Salève.

\footnotetext{
${ }^{31}$ Lápices FLC23244, entintado FLC23193 (AyB).

${ }^{32}$ Existen dos borradores descartados que han servido para clarificar el enfoque ideal. En los dos, FLC2331 y FLC23245, el observador se ha ubicado detrás del doble puente.
} 


\subsection{Las perspectivas: grupo 3}

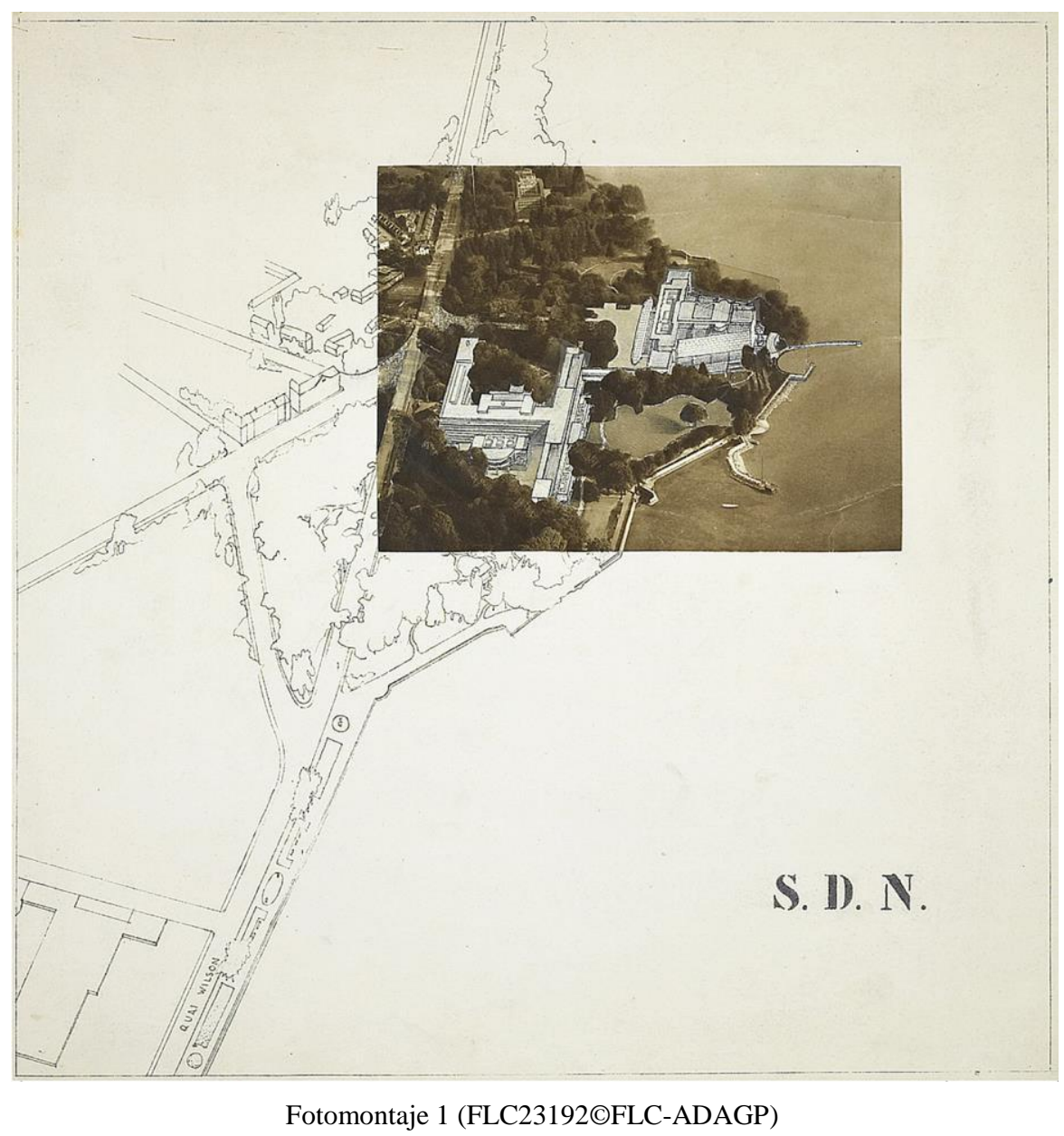

Finalmente, hay otro grupo de imágenes del conjunto. Se trata de dos fotomontajes y un carboncillo. En los dos primeros casos, Le Corbusier se ha servido del material entregado con la inscripción oficial como concursante. El documento de las bases del concurso anexaba un cuadernillo con una serie de diez fotografías del sitio, dos de ellas aéreas y ocho espléndidas vistas hechas por la agencia Boissonnas, con sede precisamente en Ginebra.

Le Corbusier ha utilizado dos de estas fotografías para implementar sendos montajes con sus propios dibujos. En el primer caso, se trata de una imagen aérea del terreno y sus alrededores ${ }^{33}$. El dibujante ha buscado, estratégicamente, una perspectiva del proyecto que simule el tamaño y el enfoque aproximado de la fotografía, ampliando el alcance de la vista, de tal manera que la imagen abarca una porción mucho mayor de la zona. El dibujo incluye la prolongación del Quai Wilson, que atravesando y dividiendo el Parque Mon Repos, se conecta con la carretera en dirección a Lausana ${ }^{34}$. Le Corbusier concibe la ubicación del palacio como el remate urbano de este largo muelle, un verdadero paseo urbano de aproximadamente 700 metros de recorrido lineal, que corre paralelo a la vía y configura el frente sobre el lago de ese sector de Ginebra. El ensamble de los dos documentos exige el retoque de algunas zonas en la fotografía original.

\footnotetext{
${ }^{33}$ Programme et Réglement, Annexe IV. p. 7.

${ }^{34}$ Entintado FLC23318.
} 


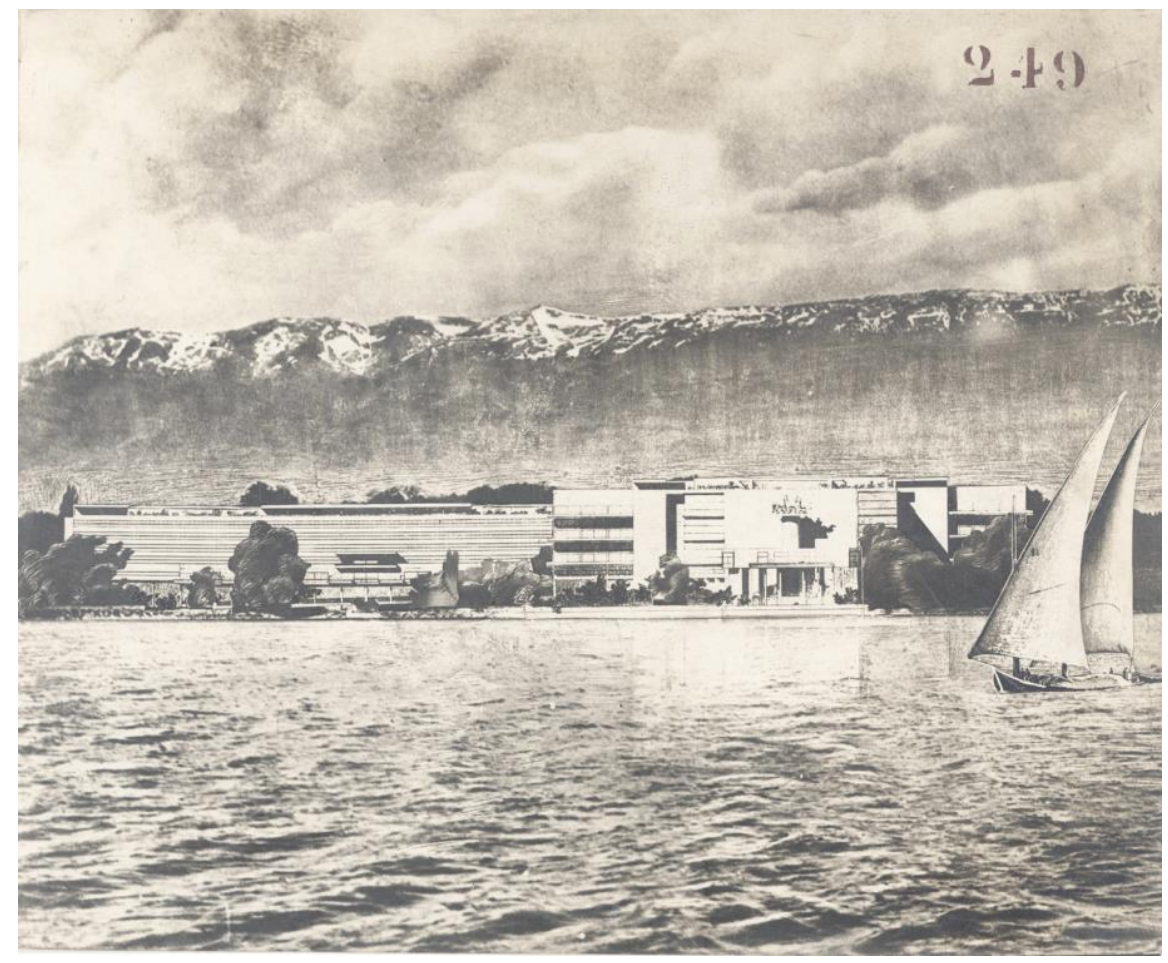

Fotomontaje 2 (L3(18)90@FLC-ADAGP)

El recurso del fotomontaje se repite para una segunda foto del anexo de las bases. Esta vez, se trata de una imagen lograda desde el lago hacia el terreno, a una distancia considerable, de tal manera que el observador puede captar como se destaca el macizo del Jura, imponente y nevado. El dibujo se corresponde al alzado oriental de todo el conjunto ${ }^{35}$. El empalme de los dos documentos ha usado sólo la parte superior de la fotografía, casi a manera de un telón de fondo, mientras la parte del lago ha sido extraído de otra imágen. Se configura un retrato del frente general del Palacio y su relación con el paisaje circundante.

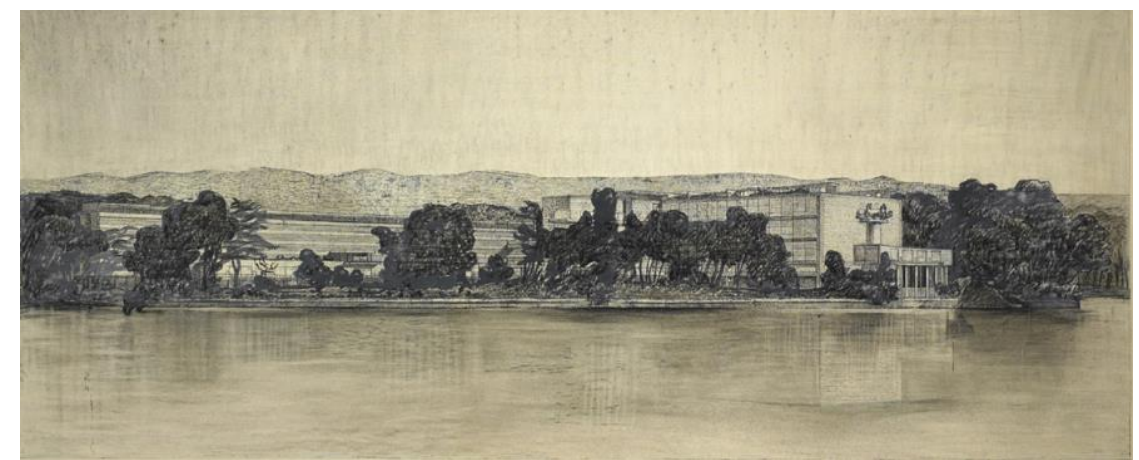

Carboncillo sobre papel (FLC23169@FLC-ADAGP)

La última imagen capta de nuevo el frente del palacio sobre el lago, pero esta vez con un enfoque diferente. El conjunto es representado desde un punto más cercano y con una orientación en la que los edificios aparecen ligeramente escorzados. Una perspectiva de los volúmenes, cuidadosamente trazada, es abruptamente interrumpida por los cuerpos oscuros de enormes y frondosos árboles ${ }^{36}$. El dibujo, gracias a la técnica del carboncillo, consigue acentuar la imagen de la interacción equilibrada entre una arquitectura de escala considerable con la naturaleza imponente del lago, los árboles y las montañas.

\footnotetext{
35 lápices del frente total FLC23362.

${ }^{36}$ Lápiz FLC23223.
} 


\section{Las técnicas gráficas}

El grupo de arquitectos logra una evidente sintonía en su trabajo al lograr finalizar en un tiempo récord y con un elevado nivel de calidad técnica. Igualmente asombroso resulta el hecho de que, a pesar del apuro en la entrega, los arquitectos no renuncian a realizar algunos experimentos en el campo de la representación, específicamente en el tratamiento de las sombras y las técnicas de acabado de los documentos.

El cuidadoso trazado de sombras proyectadas por los volúmenes puede apreciarse en las elevaciones, axonometrías y la planta de localización. Pero curiosamente, el cálculo de las sombras no se limita a este tipo de proyecciones, como es habitual. Se han proyectado sombras de la silueta de todas las plantas, consiguiendo una curiosa sensación de profundidad. Este experimento, muy poco usual, no es tan gratuito como pudiera parecer. El recurso de las sombras arrojadas en las plantas es especialmente eficaz en las láminas uno, dos y cuatro ${ }^{37}$, donde consigue simbolizar la discrepancia entre el plano de la planta y la pendiente del terreno donde se localiza. Esta táctica es fundamental para deducir el sistema de accesos, de circulación vehicular y la implantación del conjunto sobre un solar con diferencias de nivel de hasta ocho metros (desde la cota +383 en el acceso hasta la +375 al borde del lago).

En cuanto al tratamiento particular en los acabados, tanto de las sombras como de otras superficies, se recurre a la técnica del esgrafiado, ya sea con tinta china o con témpera. Este sistema permite producir áreas continuas de color plano y al mismo tiempo, controlar la densidad de su textura, que puede ir desde una capa ligera y semitransparente, a una mancha opaca. La sombra proyectada con esta técnica se convierte en una veladura de diferentes matices de gris, bajo la cual se alcanzan a percibir los trazos inferiores o en profundidad. La aplicación con témpera de color se hace en los alzados, los cortes y otros planos, para realzar los cristales en las fachadas, el cielo, el agua o aspectos técnicos y de funcionamiento ${ }^{38}$.

Ahora bien, estos acabados se han aplicado de acuerdo con una táctica específica de finalización de los planos. El propio Alfred Roth relata el proceso de ejecución: las láminas se dibujaron manualmente en tinta sobre un papel especial, después se hizo una copia reproducida en heliografía, las copias se enmarcaron en bastidores de madera y en último lugar, se aplicó la técnica del esgrafiado a las sombras proyectadas y a las témperas de color $^{39}$

Curiosamente, esta experimentación en las técnicas gráficas de representación tuvo una consecuencia inesperada para Le Corbusier. Terminó siendo la excusa para la descalificación del proyecto. Uno de jurados argumentó que la presentación contravenía una de las normas del concurso: los planos debían estar dibujados en tinta china de forma manual, es decir que, aparentemente, se prohibía la reproducción mecánica. Aunque dicha restricción no es explícita en el documento de las bases ${ }^{40}$, bastó para zanjar la decisión de no otorgar como ganador el proyecto de Le Corbusier (como parecía probable), y simplemente concederle, junto con otros ocho concursantes, la categoría de ex aequo. Evidentemente, se trataba más de una argucia por parte del ala conservadora del jurado.

\footnotetext{
${ }^{37}$ Borrador del nivel +383,5 con el estudio del trazado de las sombras a lápiz FLC23337.

${ }^{38}$ En la lámina uno: tratamiento de las sombras, el solar y los terrenos colindantes; en la cuatro y axonometría: la superficie del lago; en la cinco y la once : las plantas; en la diez: el color en los esquemas técnicos; en la segunda axonometría y los alzados : tratamiento de sombras y cristales en las fachadas y en la lámina dieciocho: color las zonas técnicas e interior de la gran sala.

${ }^{39}$ DasWettbewerbsprojekt p. 22.

${ }^{40} \mathrm{El}$ documento dice escuetamente: «Les plans doivent être dessinés et pochés à l'encre de Chine. Les coupes et façades dessinées au trait, ou au trait et simplement lavées à une seule teinte. Pour la présentation des perspectives, pleine et entière liberté est laissée aux concurrents. » Programme et Réglement p. 20.
} 
Es factible que Le Corbusier no fuera del todo consciente del riesgo que implicaba esta experimentación. Es explícito en argumentar esta decisión en términos puramente pragmáticos:

«... nous avions cru pouvoir, pour plus de netteté, et aussi pour faciliter l'exécution des plans sur les tables à dessin, nous servir de la presse d'imprimerie. ${ }^{41}$

Sin embargo, independientemente de la anécdota, es significativo su empeño en explorar las posibilidades de las herramientas modernas de reproducción. Por lo tanto, no se puede descartar que Le Corbusier tuviera en mente, desde antes de la elaboración final de las láminas, la opción de reproducir el fruto de un trabajo que podía intuir como trascendental para su carrera. El procedimiento respondería a un doble objetivo: asegurar una cierta celeridad en la producción de los documentos pero, al mismo tiempo, y gracias a las modernas técnicas de reproducción, reutilizar eventualmente los dibujos para alimentar su proyecto de difusión masiva.

\section{El palacio en los libros}

Después de un arduo proceso de deliberación, los resultados del concurso se hacen públicos el 5 de mayo de $1927^{42}$. Casi inmediatamente se desata una polémica internacional, alimentada desde diferentes tipos de prensa. Los dibujos son reproducidos inicialmente en la publicación oficial del concurso ${ }^{43}$, y a partir de ahí alimentarán otros medios. Entre ellos, los más significativos son aquellos en los que Le Corbusier tiene mayor injerencia, dadas la cercanía y afinidad con sus respectivos directores: L'Architecture Vivante de Jean Badovici ${ }^{44}$ y Cahiers d'Art de Christain Zervos ${ }^{45}$. Pero es en sus propias publicaciones donde Le Corbusier emprende la exposición y defensa del proyecto.

\subsection{Vers une architecture}

La tercera edición del libro, aparecido originalmente en 1923, contiene un somero relato de los principales componentes y condiciones del proyecto, en un preámbulo que titula «Température ${ }^{46}$. Le Corbusier escoge, para ilustrar sus argumentos, documentos de diferente procedencia. La planta de localización, los alzados, una axonometría y los fotomontajes son reimpresiones de las láminas acabadas, determinando un tipo de ilustración con muchos matices de grises. El resto de documentos, plantas del auditorio, esquemas y perspectivas en línea, tienen un carácter más técnico y provienen de los originales del taller.

El texto que acompaña los dibujos parte de una afirmación hecha en el prólogo de la segunda edición (1924):

«L'Architecture s'occupe de la maison, de la maison ordinaire et courante, pour hommes normaux et courants. Elle laisse tomber les palais. Voilà un signe des temps ». ${ }^{47}$

Le Corbusier es consciente de la aparente paradoja en la que ha caído en su anterior prólogo. En el libro se hace énfasis en la urgencia de encontrar el nuevo Plan de la casa. Insiste en abordar la vivienda como su objetivo primordial, en contra de un tipo de arquitectura más interesada en equipamientos públicos e institucionales. Sin

\footnotetext{
${ }^{41}$ Une maison un palais, p. 201.

${ }^{42}$ Ver Ricahrd Quincerot, en DasWettbewerbsprojekt, pp. 54-71.

${ }^{43}$ Concours d'architecture, 61.p.

${ }^{44}$ L'Architecture Vivante, otoño/invierno de 1927, pp. 21-25.

${ }^{45}$ Cahiers d'Art, números 6, 7-8 y 9 de 1927.

${ }^{46}$ Vers une architecture. Nouvelle édition revue et augmentée. Collection de L'Esprit Nouveau, Paris, Crés, 1928.

${ }^{47}$ Op. Cit . p. 12.
} 
embargo, ahora ha tenido que resolver un Palacio. Lejos de aceptar una hipotética contradicción, ahonda en la naturaleza de los dos términos, para encontrar un sentido arquitectónico común. El Palacio, el símbolo de la suntuosidad de tiempos superados, puede asumirse como un dispositivo capaz de generar "relaciones emotivas que revelen la grandeza y la nobleza de una intención". Se trata del mismo argumento desglosado para la casa en varios apartados del libro. El texto del nuevo prólogo discurre entonces, hacia la enunciación del conflicto generado por dos maneras de entender la arquitectura del momento. El choque de estas dos ópticas determina la verdadera "temperatura" de la época.

\subsection{Gesamntes Werk}

En este libro, que terminará siendo el primer tomo de la Obra Completa, la presentación del proyecto es mucho más detallada, haciendo acopio de buena parte del material elaborado para el concurso. El formato de la publicación muestra todas sus virtudes al permitir desplegar los documentos en un tamaño y orientación adecuados. La puesta en página consigue que imágenes y textos se relacionen de forma mucho más dinámica, acompañando varios dibujos con comentarios y aclaraciones adicionales. La exposición se inicia con dos alzados, provenientes de las láminas, compuestos en una doble página junto al texto introductorio. A ello le siguen cinco dobles-páginas con seis plantas (una general, dos de la sala y tres de la secretaría), dos secciones, (una general y otra de la gran sala) y las dos axonometrías. Todo este material viene directamente de los originales entintados del taller. A ellos se suman las tres perspectivas principales (dos de ellas a gran tamaño en doble-página), esquemas de funcionamiento estructural y acústico, un corte esquemático y los dos fotomontajes. La calidad de la edición permite que los dibujos con acabados en tinta pulverizada, se muestren en una gama amplia de grises. En cuanto al material original del taller, en algunos casos (perspectivas y axonometrías) el esgrafiado ha sido reemplazado por una trama homogénea de puntos "Letraset", mucho más apropiada en la edición impresa, para realzar los cuerpos vegetales ${ }^{48}$.

A toda esta información se suma una doble-página más, con el "segundo proyecto" para el palacio, y algunos esquemas que ilustran el supuesto plagio de sus ideas, por parte del equipo elegido para desarrollar el edificio construido $^{49}$.

\subsection{Une maison, un palais}

Si bien en los anteriores libros, Le Corbusier ha hecho una exposición general del proyecto valiéndose del material producido para el concurso, es en Une maison, un palais, donde puede desglosar la propuesta con mucha mayor precisión. Se trata de un libro prácticamente monográfico sobre el proyecto, con un periodo de incubación de un año y originalmente basado en unas conferencias dictadas durante $1928^{50}$.

El libro está estructurado en tres partes. La primera, a la que llama tesis, se trata en realidad del texto transcrito de las conferencias ${ }^{51}$. Es esta la ocasión para desarrollar las ideas escuetamente planteadas en el prólogo de Vers une architecure, es decir:

\footnotetext{
${ }^{48}$ Esta técnica aplicada a otros gráficos del mismo libro ha sido experimentada ya en Urbanisme.

${ }^{49}$ Ver. DasWettbewerbsprojekt p.p. 68-70. Le Corbusier documenta sus denuncias de plagio en l'Architecture d'Aujourd'hui de 1931 pp. 83-93. Constan 66 borradores de Le Corbusier para esta versión.

${ }^{50}$ Ver Una Casa- un Palacio, Le Corbusier, 1928 Madrid, p.25.

${ }^{51}$ Le Corbusier mismo aclara en la primera página que se trata, en realidad, de tres conferencias. Todas ellas fueron dadas durante 1928 en Zúrich, Madrid (mayo 9 y 11) y Barcelona (mayo 15 y 16).
} 
“... señalar que la acepción de palacio, reservada en la opinión pública a todo aquello que engloba el fasto y el boato, puede mudarse hoy en un concepto de excelencia, siendo [...], realmente, el resultado de una intención elevada y, mediante una vuelta a los orígenes, demostrar que el palacio [...] es, ciertamente, para empezar, una casa, una casa a escala humana ${ }^{52}$

El discurso es hilvanado a través de una estrategia particular de montaje: disponer textos y gráficos en páginas opuestas, permitiendo una lectura encadenada o de forma independiente. La particular estructura retórica de Le Corbusier ${ }^{53}$ conduce al lector, de forma casi natural, desde el planteamiento teórico de las ideas generales (terraza-jardín, la ventana corrida, el uso de pilares de hormigón etc.), a su ejemplificación visual, primero en sus obras anteriores antes de abordar el propio proyecto principal.

En la segunda parte, la propuesta se desglosa en siete aspectos específicos: el sitio, el conjunto, las oficinas, la sala para 2600 personas, la circulación, la estructura y la estética. Buena parte del libro ${ }^{54}$ está dedicado a exponer el problema de la gran sala, presentada como un "órgano de visibilidad, de audición y de circulación" cuya forma responde a rigurosos requerimientos técnicos y funcionales. Hasta este momento la explicación del proyecto se sirve de nueve plantas (seis de ellas impresiones directas de las láminas), y cinco secciones (dos de las láminas). A ellas se suma una serie de diagramas, esquemas y detalles constructivos.

Seguidamente Le Corbusier aborda el tema estético, entendido como una voluntad, una "fuerza creadora individual que expresa un todo coherente" (À la recherche d'une unité architecturale" es el subtítulo del libro). Es decir, una vez estudiados y resueltos a fondo los datos técnicos del programa, se puede pasar a explicar la intención. Va a hacer énfasis en: la horizontalidad del conjunto (que es llevada hasta la cubierta de la gran sala para observar el paisaje), el tratamiento de la luz en todo el proyecto, el recorte de los volúmenes puros que contrastan con el paisaje circundante, y en la honestidad como actitud de proyecto manifestada en la expresión exterior de un interior. Para esta parte de la argumentación se ayuda prioritariamente de los alzados, las axonometrías, las perspectivas y los fotomontajes, documentos ideales para expresar las intenciones estéticas.

La última parte del texto abre un apéndice que repasa los acontecimientos surgidos a raíz del concurso y el proceso posterior al dictado del veredicto.

El libro consigue explicar el proyecto del Palacio para la Sociedad de Naciones con un elevado nivel de precisión, abarcando toda una serie de aspectos fundamentales sobre su génesis y desarrollo. Logra además un equilibrado balance entre un marco teórico y su aplicación en el proyecto, estrategia que ha venido afinando con sus anteriores libros ${ }^{55}$.

\section{Conclusiones}

El estudio de los dibujos y su posterior manipulación para la edición de sus libros ha implicado una lectura más atenta sobre los pormenores del proyecto, así como sobre los procedimientos de diseño. El Palacio de Naciones contiene una serie de indicios sobre la manera como Le Corbusier aborda el complejo proceso que va de los planteamientos arquitectónicos generales a las particularidades del encargo. Los dibujos pueden revelar la forma en que esos planteamientos toman tierra, literalmente, en un lugar específico. En contra de algunos tópicos según

\footnotetext{
${ }^{52}$ Carta de Le Corbusier a Alberto Jimenez Fraud, Paris, 1 de enero de 1928, FLC C3 (5) 163-165.

${ }^{53}$ Ver Le Corbusier conférencier, p.26.

${ }^{54}$ De la pag 106 a la 133.

${ }^{55}$ Ver Velásquez, Victor, Estrategias gráficas, pp. 94-105.
} 
los cuales la arquitectura de Le Corbusier desconoce las singularidades del sitio, el estudio de los dibujos demuestra su esmerada preocupación por entender el solar, sus condiciones y valores paisajísticos. La respuesta al sitio del palacio no se limita exclusivamente a elevar buena parte del conjunto sobre un bosque de pilares de hormigón, preservando la topografía original y realzando la vista del lago, como lo reflejan eficazmente algunas perspectivas. Basta comprobar en las secciones como se cuida en perfilar la línea topográfica para adecuar a ella los estratos del edificio y la fluidez de las circulaciones, evitando de esta manera drásticas y costosas excavaciones. De ahí la obstinación en la proyección de las sombras en las plantas, para entender los niveles de asentamiento. Insiste igualmente en representar la vegetación existente en las axonometrías y, sobre todo, en los fotomontajes, buscando salvaguardar y armonizar al máximo los grandes árboles cercanos con los edificios y las vistas lejanas, para conseguir lo que más tarde llamaría un "acto de devoción” hacia la naturaleza. Le Corbusier se vanagloria de haber dibujado en las plantas, secciones y axonometrías "tanto los grandes árboles como las alamedas y los bosques" con "exactitud y sinceridad" 56 . Por otra parte hay que recordar, tanto en las plantas generales como en el fotomontaje 1 del grupo 3, el sentido que quiere darle al palacio como remate del gran paseo urbano del Quai Wilson, al punto de sacrificar para ello el parque Mon Repos, en una especie de concesión paisajística a la ciudad de Ginebra.

El cuidadoso trabajo de dibujo ha puesto a prueba algunas de las ideas desarrolladas hasta el momento en el taller, abriendo caminos sugerentes y potenciando su reflexión hacia campos aún no abordados. El edificio de la secretaría, por ejemplo, está concebido a la manera de un gran claustro de oficinas-tipo, iluminadas a través del sistema de fachada libre y ventana alargada de más de 100 de longitud exigiendo un dibujo detallado de la solución técnica. O la gran sala donde la definición y el detalle en los requerimientos específicos (acústica, circulación, iluminación y ventilación) desborda la experimentación llevada a cabo en proyectos anteriores. En últimas el Palacio ha obligado a Le Corbusier a cambiar de escala. Efectivamente, hasta ese momento el taller está consiguiendo consolidar una obra importante a nivel de la vivienda, tanto de villas burguesas como de células agrupadas. En cambio, son escasos y modestos los proyectos para equipamientos colectivos a escalas mayores. Le Corbusier está a punto de abordar una labor que le conducirá a lo que el mismo define como les Grands travaux.

\section{Bibliografía/referencias}

Benton, Tim, y otros : Le Corbusier, l'atelier 35 rue de Sevres, París : Bulletin d'Informations Architecturales, $1897, \mathrm{~N}^{\mathrm{o}} 114$

Benton, Tim: Le Corbusier conférencier. Paris: Moniteur, 2007.

Boesiger, Willy; Stonorov, Oscar : Le Corbusier und Pierre Jeanneret : ihr gesamtes Werk von 1910-1929. Zúrich: Girsberger, 1930.

Concours d'architecture : Concours d'architecture pour l'édification d'un palais de la Société des Nations, a Genève. Ginebra ; Rotogravure, 1927

Concours d'architecture : Programme et règlement du Concours d'architecture pour l'édification d'un Palais de la Société des Nations à Genève. Ginebra : A. Kunding, 1926.

Guerrero, Salvador (Ed): Le Corbusier : Madrid 1928 : una casa-un palacio. Madrid: Publicaciones de la Residencia de Estudiantes, 2010.

\footnotetext{
${ }^{56}$ Carta de Le Corbusier a Guillaume Fatio, 24 de octubre de 1927, DasWettbewerbsprojekt, p. 151.
} 
Institut für Geschichte und Theorie der Architektur, Eidgenössische Technische Hochschule (ETH), Le Corbusier \& Pierre Jeanneret : das Wettbewerbsprojekt für den Völkerbundspalast in Genf 1927 : à la recherche d'une unité architecturale. Zúrich : Gta/Amman ,1988

Le Corbusier, Une maison, un palais, à la recherche d'une unité architecturale. Paris : G. Crès, 1928.

Le Corbusier, Vers une architecture, Nouvelle édition revue et augmentée. $3^{\mathrm{a}}$ ed. Paris : G. Crès, 1928.

Le Corbusier: « À propos du palais de la Société des Nations »: L'Architecture d'Aujourd'hui. París, 1931, Nº 3, pp. 83-93.

Velásquez Hernández, Victor Hugo. EL LIBRO ABIERTO: Sistemas de representación arquitectónica en el libro Gesamtes Werk-Cuvre Complète, Le Corbusier-Pierre Jeanneret, 1910-1929. Director: Josep Quetglas. Universitat Politécnica de Catalunya, Departamento de Expresión Gráfica Arquitectónica, Barcelona, 2012.

Velásquez, Hernández, Victor Hugo: " Estrategias gráficas en el proyecto divulgativo de Le Corbusier durante los años veinte: el caso de Urbanisme”. De-Arq. Universidad de los Andes. Bogotá, 2013. № 12, pp. 94-105. 


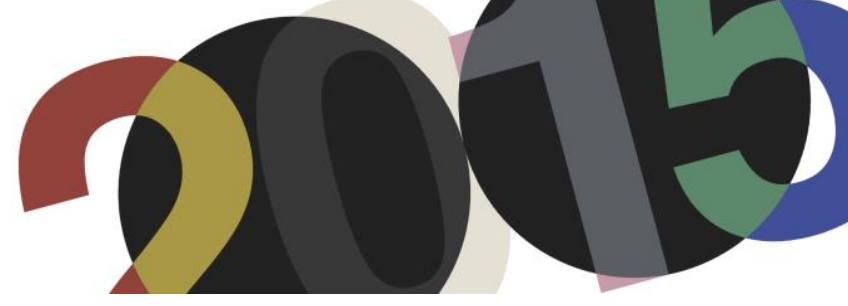

DOI: http://dx.doi.org/10.4995/LC2015.2015.610

\title{
Bajo la Luz. Buscando la luz
}

\author{
I. de Viar Fraile \\ Escuela Técnica Superior de Arquitectura de Donostia-San Sebastián
}

\begin{abstract}
Resumen: Le Corbusier fue un gran buscador. Un buscador de luz. Tras un primer periodo de búsqueda halló su arquitectura cúbica y blanca y luego, después de la Guerra y quince años sin construir, Le Corbusier inició un nuevo camino, una nueva búsqueda de la luz en su arquitectura; mucho más plena. En este segundo periodo el trabajo con la luz y con la sombra, sobre todo con la sombra, como mecanismo plástico, escultural, es muy intenso. Trabajó con la luz por medio de dos sistemas: la" interposición" y la "captación" (captura). El sistema de la "interposición" lo realizó mediante los Brise-Soleil, en un principio y luego, con mucha mayor contundencia, mediante los "edificios parasol" construidos como fachadas interpuestas. El sistema de la "captación”, más reducido, lo realizó por medio de lucernarios y grietas, buscando la luz, siempre con diferentes orientaciones. Por último decir que un arquitecto tan material como Le Corbusier construyó con lo inmaterial, con la luz, tejido de sus obras. Los edificios tratados son unos pocos, los principales, todos ellos de su segunda época.
\end{abstract}

\begin{abstract}
Le Corbusier was a great searcher. A light searcher. Afterwards a first period of searching he founded his cubic and white architecture and after the Word War II and fifteen years without erecting up a building, Le Corbusier restarted a new path, a new search for the light in his architecture, much broader. In this second age, the work with the light and with the shadow, mostly with the shadow, as plastic and sculptural mechanism is very deep. He worked with the light via two systems: "interposition" and "capture". The mechanism of "interposition" was developed by Le Corbusier by means of the BriseSoleil, at the beginning, and later, much more strongly, by means of the "parasol-sun shade buildings", erected like front façades. The "catching" system, done on a smaller scale, was made by the construction of several skylights and gaps, searching for the light and always with different orientations. Finally say that a material architect as Le Corbusier was, he constructed with the immaterial light, weave of his works. The buildings studied are a few, all of them part of second period and they are the core of Le Corbusier's buildings.
\end{abstract}

Palabras clave: Luz, Sombra, Buscar, Interposición, Captación, Silencio. Keywords: Light, Shadow, Search, Interposition, Capture, Silence.

\section{Buscar}

"El que encuentra ha buscado mal” Rutger Kopland ${ }^{1}$

Hay tanto en la obra de Le Corbusier; volumen, color, pintura, escultura, mediterráneo, arte moderno y mundo clásico, Turquía, Suiza o Grecia, máquina y paquebote, concha y naturaleza, cielo, blanco, negro, función, ángulo recto, curvas, ciudad, promenade, rampas y planos, espacio, recinto, pilotis, horizonte, hombre, proporción, medida y modulor, color y béton brut, periodismo y propaganda, moral, Italia, Alemania, África y Estados Unidos, textura; búsqueda, viaje, sol, luz, sombra y mar...tantas cosas.

Le Corbusier fue un perpetuo buscador. Buscó, como buen buscador, con el fin de no encontrar. Jordi Savall ${ }^{2}$ explica como el término recercada designa (en la obra de Diego Ortiz) la intención compositiva de recercar, es

\footnotetext{
${ }^{1}$ Pascal Quingard en su libro "Las escaleras de Chambord", mediante el protagonista Eduard, recita ese verso del poeta Holandés Rutger Kopland.

${ }^{2}$ Jordi Savall escribe sobre las recercadas en la introducción del disco sobre música de Diego Ortiz.
} 
decir, buscar de nuevo. Una de las principales búsquedas y preocupaciones de Le Corbusier fue el trabajo con la luz solar y la sombra, la búsqueda de la plástica. Buscó de nuevo, siguió buscando. Alan Le May escribió en 1954 su más famosa novela, The Searchers, que luego adaptó John Ford. En un momento, cuando Amos (Ethan/Wayne en la película) y Mart, llegan a la reserva de Fort Sill, el agente Hiran Appleby, un cuáquero de pelo canoso, les informa:

"Ningún grupo de comanches se mueve tan furtivamente como los Nawyecky. Uno de los nombres por los que les conocen el resto de los comanches es el de «Los-que-nunca-llegan-a-donde-se dirigen». No lo van a creer. Lo que les gusta es confundir y mentir acerca de su destino, y parten en una dirección, luego retroceden y se desvían. Lo hacen como hábito, sin ningún motivo aparente. "’

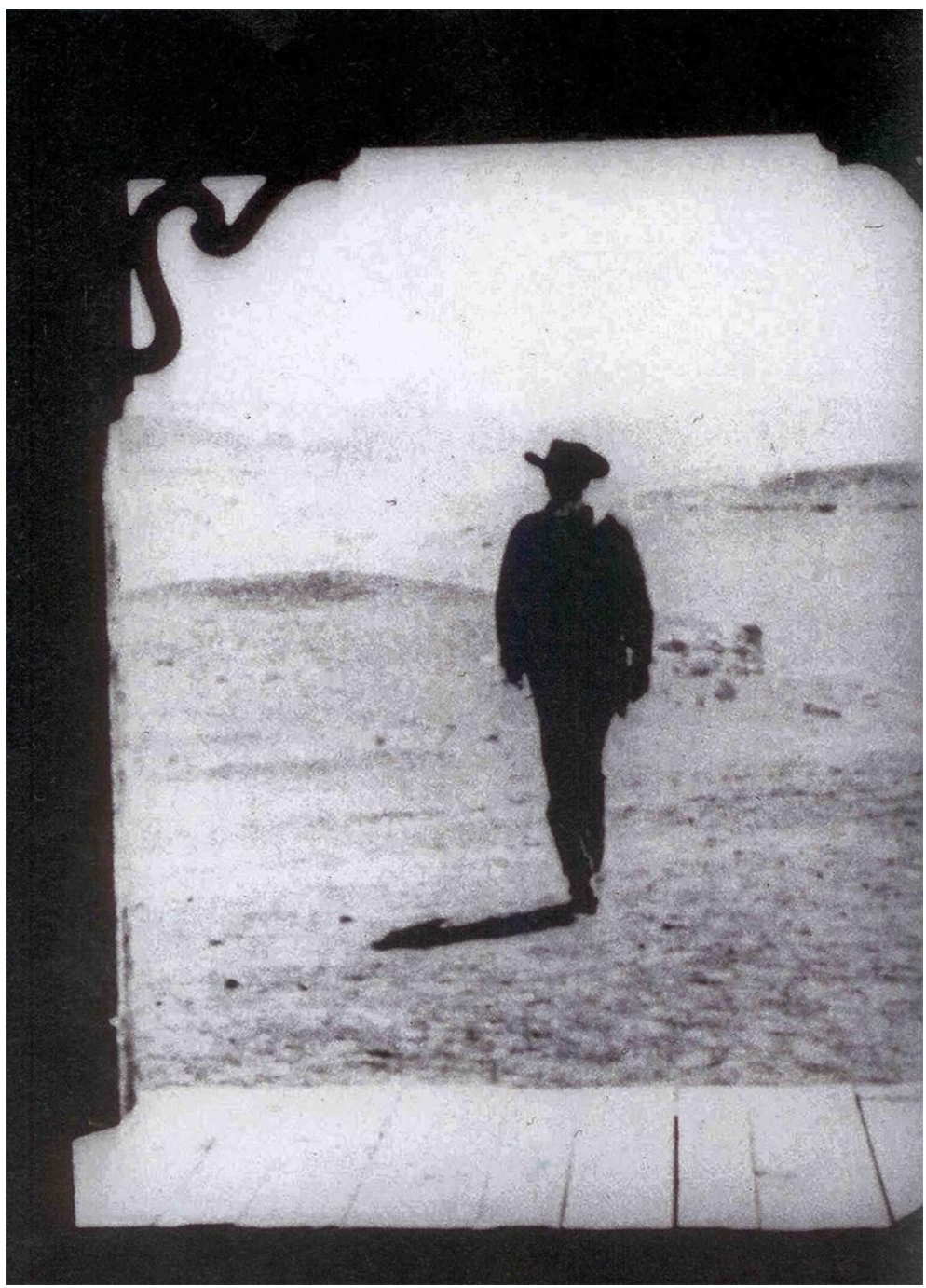

1. Imagen de "Centauros del desierto". John Ford. 1956. Años de Chandigarh, Ronchamp y La Tourette

\footnotetext{
${ }^{3}$ Alan Le May, Centauros del Desierto.
} 
Al final cuando Amos y Mart cabalgan, todavía sin encontrar a Debbie, de regreso a casa, escribe Le May:

"El hogar, para ellos, era más un rumbo que un lugar. Era como la marca de un topógrafo que está en el mapa pero no en la tierra: se está al sur de allí, y luego se cabalga hacia allí, y tras un tiempo estás al norte de allí, pero nunca se está exactamente allí, porque no existe tal cosa; el hogar tan sólo existe en la mente de uno.",

La búsqueda, la luz, el rumbo, más que el lugar guiaron a Le Corbusier. El trabajo de Le Corbusier nacido en la opaca suiza- no puede entenderse si no es bajo la luz del sol, en un mundo de luces y sombras.

Es difícil situar en el tiempo las obras de Le Corbusier. Sus obras se alargaron en el tiempo y sus libros son temáticos, alejándose de una cronología lineal. Sin embargo defino dos épocas básicas y diferenciadas, dos periodos de trabajo y búsqueda muy claros y definidos en su obra. Antes y después de la Segunda Guerra Mundial. Y los defino en su relación con el trabajo con la luz. Hay una primera preocupación, en el periodo anterior a la guerra, por la luz como definidora de volúmenes, en superficie, construyendo con planos y luces frías. Y un periodo de madurez, desarrollado tras la guerra, después de un largo periodo sin construir. Son años de madurez, cercano a los sesenta; son los años donde el trabajo plástico es más intenso, consciente y original.

\section{Fascinación (Tecnológica) y Volúmenes Bajo la Luz.}

El interés de Le Corbusier por el trabajo con la luz, sobre la relación de la arquitectura con la luz se manifiesta desde el principio de sus trabajos y escritos. En "Vers une Architecture", Le Corbusier lanza tres advertencias a los señores arquitectos. En la primera, donde aparece su famosa frase definiendo la arquitectura como el juego sabio de los volúmenes bajo la luz, dice también:

"Nuestros ojos están hechos para ver las formas bajo la luz"،

Le Corbusier forma parte de la larga línea que funda la modernidad, originada en la visión poética de Edgar Allan Poe, recibida en Europa por Charles Baudelaire y que llega a las vanguardias a través de Stéphané Mallarmé, Raymond Roussel o Marcel Duchamp. Fernand Leger explica muy bien la fascinación y el descubrimiento por las obras de la ingeniería del momento, por los avances y el diseño técnico, contaba:

"Fernad Léger cuenta que posiblemente en aquel mismo año de 1912 visitó una exposición de tecnología aeronáutica en compañía de Constantin Brancusi y Marcel Duchamp. Volviéndose hacia su amigo Brancusi, parece que Duchamp dijo: «La pintura ha muerto. ¿Quién podrá hacer algo mejor que esta hélice? Dime, serías capaz de hacerla?"

Esta seducción, este descubrimiento, esta nueva visón -comprensible, ya que la belleza de las máquinas, del mundo nuevo, es en aquellos años indiscutible-, es asumida por las vanguardias contaminando en poco tiempo a

\footnotetext{
${ }^{4}$ Alan Le May, Centauros del Desierto

${ }^{5}$ Le Corbusier, 1923, en "HACIA UNA ARQUITECTURA" lanza; TRES ADVERTENCIAS A LOS SEÑORES ARQUITECTOS, I, PRIMERA ADVERTENCIA: EL VOLUMEN

La arquitectura es el juego sabio, correcto y magnífico de los volúmenes reunidos bajo la luz. Nuestros ojos están hechos para ver las formas bajo la luz: las formas y los claros revelan las formas. Los cubos, los conos, las esferas, los cilindros o las pirámides son las grandes formas primarias que la luz revela bien; la imagen de ellas es clara y tangible, sin ambigüedad. Por esta razón son formas bellas, las más bellas. Todo el mundo está de acuerdo con esto: el niño, el salvaje y el metafísico. Es la condición esencial de las artes plásticas.

${ }^{6}$ Citado por Janis Mink en su libro sobre Duchamp
} 
todo el mundo del arte. Fascinación de las vanguardias también por el primitivismo, por el arte Africano. Dos descubrimientos -lo más primitivo y lo más tecnológico-, que fundamentaron buena parte del credo del arte de aquellos años. Le Corbusier, tras su viaje iniciático al primitivo oriente, buscaba, y encontró en estas dos sugerencias apoyos para su arquitectura. Por ejemplo, casi diez años después hacía suyas las revelaciones de Duchamp declarando su atracción por las máquinas ${ }^{7}$. También el cubismo, la pureza geométrica y las avanzadas ideas gestadas en la República de Weimar ayudaron en este cocktail para "fijar" la nueva arquitectura que Le Corbusier buscaba en esos primeros años de iniciación.

Sus ideas estaban claras ya desde su paso por Italia. En el camino de vuelta de su viaje a Oriente, a finales de 1911, escribió:

«Clamo por la geometría elemental; estoy poseído por el color blanco, el cubo, la esfera, el cilindro y la pirámide. Los prismas se elevan y se equilibran entre sí, estableciendo ritmos... bajo el sol del medio día los cubos se aplanan convirtiéndose en una superficie, en el crepúsculo un arco iris parece elevarse de las formas. Por la mañana son reales, arrojan luz y sombra y se perfilan claramente como un dibujo...». ${ }^{8}$

Y encontró sus primeras casas manifiesto, sus edificios de la primera época en París, cubistas, puristas, racionales, iniciando y propulsando la nueva arquitectura. Edificios blancos, exteriores, formados mediantes planos, volumétricos, fríos, casi gélidos; suizos. Esta primera arquitectura de Le Corbusier trabaja con la luz de una forma distante, exterior, creando volúmenes (puros bajo la luz).

\section{Viajes, Mediterráneo y Cambio.}

\section{“Todas las luces convergen al mar” Edmond Jabés ${ }^{9}$}

Los viajes fueron fundamentales en la vida y en la obra de Le Corbusier y como escribía Francis Bacon ${ }^{10}$, los viajes, en la época de la juventud, son parte de la educación; en la vejez, parte de la experiencia. La educación fue su viaje a oriente; la experiencia sus muchos viajes posteriores. Le Corbusier fue un gran viajero.

Le Corbusier había iniciado una carrera fulgurante y llena de éxitos y reconocimiento; en menos de diez años sus encargos como arquitecto fueron creciendo desde su primer proyecto "racionalista", el atelier de Ozenfant (1922) hasta los proyectos de los años 30; el Pabellón Suizo, el inmueble Clarté o la casa en la calle Nungesser et Coli (1930/32). Después de estos proyectos, cuyas obras se alargan hasta los primeros años treinta, Le Corbusier no vuelve a construir hasta el encargo de la Unidad de Habitación en Marsella en 1945, ya posicionado como gran figura internacional. En todo este tiempo, larguísimo periodo para cualquier arquitecto y más para una figura como Le Corbusier, no construye (salvo pequeños temas y la colaboración con Niemeyer y Costa en Brasil en 1936) y redirige sus energías a la pintura (en su estudio de su nueva casa), a un intenso trabajo explicando sus ideas, con conferencias y viajes y con múltiples propuestas urbanas (Barcelona, Ginebra, Estocolmo, Villa Radieuse y tantas otras). En estos años convulsos en Europa y en Francia, donde (ahora es fácil posicionarse) los extremos y excesos de la derecha y la izquierda estaban muy cerca, Le Corbusier busca grandes clientes en los diversos gobiernos. En 1928 recibe el encargo del edificio Centrosoyuz en Moscú, poco después

\footnotetext{
${ }^{7}$ En 1923 publicó Vers une Architecture y empezó las publicaciones de L`Esprit Nouveau en 1920.

${ }^{8}$ Juan Antonio Cortés en su artículo "La caja y el parasol, dos modelos recurrentes en la obra de Le Corbusier". Le Corbusier, Catalogo exposición, 1987. Le Corbusier adopta la seducción que Cezanne anticipaba a principios de siglo (cita33)

${ }^{9}$ Edmond Jabés, El libro de las preguntas.

${ }^{10}$ Francis Bacon, De la Sabiduría Egoísta.
} 
está cerca de afiliarse al Frente Popular, también intentó "vender" sus proyectos e ideas al régimen fascista de Mussolini, en 1937 fue nombrado Caballero de la Legión de Honor y finalmente, durante la ocupación se instaló en Vichy en 1941. En 1942 el régimen de Vichy le encargó realizar una serie de propuestas urbanísticas en Argelia pero en $1942^{11}$-al no conseguir trabajo del gobierno de Vichy- volvió a instalar su estudio en Paris, estableciendo lazos con la izquierda y fundando ASCORAL, un colectivo de Arquitectos e Ingenieros. Y es, en esa época oscura, convulsa, de vaivenes políticos, de difícil supervivencia y equilibrio, cuando Le Corbusier fragua su nueva arquitectura.

Durante este tiempo, casi quince años sin construir, Le Corbusier redescubre el sol, el mar y lo mediterráneo conoció y le impresionó la Kasbah de Argel- y realizó muchos viajes; Brasil y Argentina en 1929 y en 1935 Estados Unidos (visitando entre otros lugares Columbia, Yale, Princeton y Harvard). Años de búsqueda, una nueva y fructífera búsqueda. Buscar de nuevo, otro inicio. Dice George Steiner hablando de Incipit, incipiente:

"La inicial, en la cual el término significa comienzo y primacía, actúa como fanfarria; enuncia la máxima de Platón-de ninguna manera evidente-de que en todas las cosas, naturales y humanas, el origen es lo más excelso." 12

Esta nueva búsqueda, este nuevo inicio, diseña una nueva arquitectura, más interesante, personal y fructífera; ya no busca la rabiosa actualidad o el manifiesto, busca un mundo personal, una poética propia; sentida, humana, mediterránea y táctil.

Es el periodo bien conocido y descrito, por ejemplo Charles Jenks ${ }^{13}$ lo llamó "Other Languages of Architecture 1946-65”, que inicia a los cincuenta y ocho años, después de la Guerra.

\section{Más entero}

Juan Antonio Cortés explicaba muy bien las dos arquitecturas de Le Corbusier; caja y parasol.

"Se ha invertido en estos últimos edificios el planteamiento de los que consideramos en primer lugar. La estructura de losas y pilares - la estructura Dom-ino- no queda ya contenida dentro de un volumen geométrico regular y cerrado. Esa estructura sale al exterior como elemento abierto y destacado del edificio y bajo ella se sitúan los volúmenes que contienen los espacios habitables. Parece haberse cerrado así, en este recorrido desde las primeras casas de los años veinte hasta el Centro de Le Corbusier de Zúrich - completado en 1967 dos años después de la muerte del maestro_, el ciclo de la relación entre la estructura, que se ajusta al esquema Dom-ino, y el cerramiento, que sigue la idea de cuerpo platónico. De ser una superposición de losas sostenidas por una serie de pilares y estar contenida dentro del volumen ideal del cerramiento, la estructura ha pasado a exhibirse al exterior como gran marquesina o parasol que da sombra —real o figurada- a dicho cerramiento, descompuesto ahora en un conjunto de volúmenes y de superficies varias. Ha desaparecido con ello la pureza geométrica en que quedaban contenidas las casas de los años veinte, con su envolvente elemental, nítida, cerrada, que albergaba en su interior una gran complejidad plástica y espacial. Pero han aparecido en cambio las formas abiertas, exteriormente activas, de los parasoles, que pasan a dar una nueva escala y un nuevo orden simbólico al edificio ${ }^{, 14}$

\footnotetext{
${ }^{11}$ París es liberada en agosto de 1944

${ }^{12}$ George Steiner, Gramáticas de la Creación

${ }^{13}$ Charles Jenks fija cuatro periodos: Jeanneret's School for Le Corbusier 1887-1916, The Hero of the Heroic Period 191728, A War with reaction 1928-45 y por último, Other Languages of Architecture 1946-65.

${ }^{14}$ Juan Antonio Cortés en su artículo "La caja y el parasol, dos modelos recurrentes en la obra de Le Corbusier". Le Corbusier, Catalogo exposición, 1987.
} 
En la película de Víctor Erice, "El sol de membrillo", Antonio López conversando con Enrique Gran, pintor y amigo, recuerda como un profesor en la Academia de San Fernando al acercarse a sus pinturas y comentarle su trabajo, le decía:

-Más entero.

Y después explica Antonio López como -cuando era estudiante- no entendía aquello que su profesor quería significar, pero no se atrevía a preguntar. En 1992, él y Enrique Gran, lo entienden y no lo explican por obvio. Así es la obra de posguerra de Le Corbusier en su segundo periodo; "más entera". Mucho más entera. Más radiante, luminosa y también llena de sombras.

Hablaré y lo haré genéricamente, ya que forman un conjunto bastante compacto y coherente, de algunos edificios de la segunda época de Le Corbusier ${ }^{15}$, los más emblemáticos; 1'Unité en Marsella (1945-1952), la Casa Carrutchet (1949), los proyectos para la India (en 1951 empieza el plan Urbanístico de Chandigarh), Ronchamp (1951-1955), La Tourette (1953-1960). También incluyo la Fábrica Duval en Saint Dié (1946), terminada antes que la "l'Unité", por ser el edificio donde aparecen por primera vez los Brise-Soleil. Insisto, todos ellos iniciados después de los cincuenta y ocho años y después de tiempo sin construir. Edificios y proyectos desarrollados alternativamente, superpuestos en el tiempo, desarrollados durante veinte años, hasta la muerte de Le Corbusier en 1965 con setenta y ocho años.

Su arquitectura tiene ahora textura, es más cercana a lo táctil. Por un lado es más mediterránea, próxima a la artesanía, la cerámica o el esparto (vía en la que incidió Sert). Pero al mismo tiempo aparece el béton brut como material plástico que resuelve todo (mirando las grandes obras de la ingeniería, las presas o torres de refrigeración) y se aleja de la máquina de habitar. La luz es más vibrante, oblicua, temblorosa, curva, densa. Aleteante.

Escribía María Zambrano:

"Se muestra ahora el claro como espejo que tiembla, claridad aleteante que apenas deja dibujarse algo que al par se desdibuja. Y todo alude, todo es alusión y todo es oblicuo, la luz misma que se manifiesta como reflejo se da oblicuamente, más no lisa como espada. Ligeramente se curva la luz arrastrando consigo al tiempo ". ${ }^{16}$

\section{Luz y Arquitectura}

Escribía Le Corbusier para Ronchamp:

"La clave

es la luz

y la luz esclarece las formas

$Y$ estas formas tienen

una potencia emotiva

por el juego de las relaciones

inesperados, sorprendentes ${ }^{, 17}$

\footnotetext{
${ }^{15}$ Hay otra serie de edificios y proyectos sin realizar que considero un poco ajenos al discurso y que no incluyo por diversas razones; por la escala, la intensidad, etc. Tampoco incluyo o trato otras muchas propuestas construidas en la segunda época mencionada, como son: El cabanon (1950), la casa Jaoul (1951-55), la casa de Brasil (1957), el pabellón Philips (1958), el museo de Arte Occidental de Tokio (1959), el Carpenter Center (1959-1962), la Iglesia de Firminy (1960), la Casa del Hombre en Zurich (1963), las otras Unidades de Habitación o varios edificios en Chandigarh.

${ }^{16}$ Zambrano, María, Claros del Bosque.
} 
Para Le Corbusier la clave es la luz, sigue siendo la luz. En el largo camino entrelazado entre la arquitectura y la luz, entiendo que los arquitectos se han enfrentado a la lucha con la luz de dos formas básicamente; construyendo las arquitecturas que se protegen y las que la buscan la luz. Porque el mundo -y su arquitectura- se puede dividir de nuevo en dos; una parte tiene un exceso de luz y la otra déficit, lo que origina dos modelos de arquitectura; una se defiende de la luz (mediterránea), la otra, atrapa y condesa la escasa luz (nórdica), con todo lo que ello ha supuesto para la arquitectura y la manipulación de la luz. Le Corbusier participa de los dos mundos.

Podemos entonces decir que en la arquitectura (histórica) hay dos sistemas de trabajar con la luz. Los edificios escultura (exterior; templo griego), que funcionan hacia fuera, por medio de la interposición y trabajando las sombras y los edificios cofre (interior; Roma, románico, gótico), que funcionan como espacios con una determinante cualidad de luz, buscando atrapar, captar y manejar la luz en su interior y que utilizan el sistema de la captación. Curiosamente, cuando la pintura es más plana, los interiores son más ricos espacialmente; la luz tamizada, espesa y coloreada de las Iglesias y Catedrales medievales es el ejemplo. En el renacimiento la luz es racional (en la pintura y en la arquitectura). El barroco excava las posibilidades de la luz, en la pintura, la escultura y la arquitectura. ¿Que maravillosa la captación de la luz barroca en la arquitectura! Luego, la arquitectura se hace más racional, más clara, iluminada y tal vez, más plana y no es hasta el movimiento moderno (tardío) cuando la luz vuelve a ser voluntariamente captada y manipulada por los $\operatorname{arquitectos}^{18}$. Le Corbusier investigó y llevó hasta el límite muchas de las posibilidades. Por un lado trabajó el sistema tradicional de luz y sombra, la interposición y también trabajó el sistema de la captación. En 1960, definía la arquitectura como una secuencia de espacios "iluminados". Escribía como primero dibujaba un personaje, lo situaba en la casa y le hacía descubrir su volumen, tal forma de habitación y sobre todo tal cantidad de luz que entra por la ventana o el panel de cristales. Avanza: otro volumen, otra llegada de luz. Más lejos, otra fuente luminosa; más lejos aún, inundación de luz y penumbra a un lado. Habla en términos de luz natural, no hay mención a luz artificial, aunque también trabajó al final de su carrera, con la luz proyectada-eléctrica- la más nueva opción. En los mismos años desarrolló, quizás con demasiado adelanto, un trabajo experimental con luz artificial (proyecciones, música, espectáculo multimedia y poema electrónico de Edgar Varèse) en el pabellón Phillips de la Expo de Bruselas de 1958, que interesante sin duda, no es ahora objetivo.

\section{LUZ}

"Yo empleo, ya se habrán dado ustedes cuenta, abundantemente la luz; la luz es para mí base fundamental de la arquitectura. Yo compongo con la luz" Le Corbusier. ${ }^{19}$

Pensar sobre la luz en Le Corbusier es hablar de la luz natural, del sol, es hablar de la ausencia de luz. La descripción más interesante es la que define la luz como aquello que hace visibles los objetos.

Una definición técnica nos dice que la luz, es energía electromagnética radiante, que puede ser percibida por nuestros ojos. La luz presenta una naturaleza compleja: dependiendo como la observemos se manifestará como

\footnotetext{
${ }^{17}$ Le Corbusier: Textos y Dibujos para Ronchamp. Edición de Joan Petit, 1965, pocos meses antes de la desaparición de Le Corbusier.

${ }^{18}$ Con excepciones como Soane o Labrouste.

${ }^{19}$ Le Corbusier, hacia 1960. Citado por José Baltanás. Le Corbusier, "Précisions sur un état présent de lárchitecture et de l'urbanisme".
} 
una onda o como una partícula; tiene masa y se curva, y es atraída por la masa de los planetas. Veamos algunas fascinantes definiciones científicas, a las que es difícil escapar. Me interesa la luz como fenómeno poético, plástico, sin embargo la física también tiene una visión atractiva. Podemos hacer un glosario ${ }^{20}$ de los principales términos científicos:

Luz: El ojo humano sólo puede detectar una pequeña franja de todo el amplio espectro de ondas electromagnéticas. Las longitudes de onda visibles del espectro electromagnético, van desde los $400 \mathrm{~nm}$ (violeta) hasta los $700 \mathrm{~nm}$ (rojo). La luz esta compuesta de rojo, naranja, amarillo, verde, azul, añil y violeta. Cuando un rayo de luz atraviesa un prisma, se descomponen las franjas que lo constituyen y configuran un arcoíris de colores llamado continuo o espectro continuo.

Ondas electromagnéticas: Generadas por cargas eléctricas que oscilan, las ondas electromagnéticas difieren en su longitud de onda y en su frecuencia. Pero todas ellas, no obstante, se desplazan, en el vacío, a la misma velocidad, que gira en torno a los $300.000 \mathrm{Km} / \mathrm{s}$. Ésta es la velocidad de la luz y constituye la confirmación experimental de que la luz es una onda electromagnética.

Espectro electromagnético: Todo el rango de las ondas electromagnéticas, que va desde las ondas de radio, hasta la radiación infrarroja, la luz visible, la radiación ultravioleta, los rayos X y los rayos gamma.

La luz es roca (balín) y ola, roca y ola indistintamente:

"La publicación del artículo de Bohr (los electrones dan vueltas al rededor del núcleo del átomo en una serie de orbitas predeterminadas y al hacerlo no pierden energía, 1913) marcó el principio del fin de la visión clásica del mundo, pero lo peor estaba por venir. Einstein había demostrado que la luz presentaba dos naturalezas: corpuscular, como los balines disparados en una feria, y ondulatoria, como las olas de un estanque. En 1924 el francés Louis de Broglie, completó esta visión al afirmar que los balines no tenían que comportarse siempre como balines; también podían comportarse como olas de un estanque." Mark Kac ${ }^{21}$

Los receptores ${ }^{22}$ de estas ondas o balines son nuestros ojos (el ojo no lanza, recibe, es la mirada la que proyecta, la que lanza y ve, y mide y piensa y entiende, la mirada pensante). En nuestra retina existen unas células que transforman los impulsos eléctricos y mandan señales al cerebro, traduciendo la luz (y el color dependiendo de la longitud de onda) y definiendo así los objetos. De hecho nuestros ojos han evolucionado para hacer mejor uso de la radiación solar y hacer los objetos visibles a la luz. El cielo y el mar son azules por ser el espectro del azul el más amplio, el que más vemos. Los primeros primates desarrollaron en su evolución adaptaciones complejas ya que requerían nuevas habilidades cazadoras y recolectoras. Se vieron obligados a explotar fuentes de alimento por encima del nivel del suelo, lo que produjo cambios físicos de importancia; los ojos pasaran a una posición frontal, proporcionando una visión binocular que permitía navegar por un espacio tridimensional (mejor para atrapar presas) y desarrollaron la visión del color, que posibilitaba diferenciar las coloridas frutas del espeso verde y poder así consumir una amplia gama de alimentos.

Pero volvamos a lo realmente interesante; la capacidad de la luz de hacer visibles los objetos. El desocultamiento o la magia de la visibilidad son sus cualidades. Sin luz no hay nada. La verdad es aquello que se sitúa en la luz,

\footnotetext{
${ }^{20}$ Cita de Manjit Kumar sobre Niels Bohr.

${ }^{21}$ Miguel Ángel Sabadell cita a Mark Kac.

${ }^{22}$ Los objetos, nubes de electrones, protones y neutrones enlazados, absorben o reflejan la luz de un emisor con diversa intensidad. La luz rebota con distintas longitudes de onda y es interpretada por nosotros como formas, texturas y colores. Es nuestro cerebro, mediante los impulsos traducidos desde el ojo, quien es capaz de construir e interpretar -a partir de esas longitudes de onda y esos vacíos o sombras- un mundo tridimensional y en color.
} 
lo que se pone en escena; la antigüedad griega definía la verdad desvelada como aquello que se coloca a plena $1 u z^{23}$. La condición de la luz de hacer visibles las cosas, la verdad, se debe en gran medida a la sombra, que sitúa las cosas sobre un fondo, dando profundidad y volumen a los objetos (percepción tridimensional). Luz es Sombra.

\section{Sombra (y LUZ)}

"Bajo las bóvedas, miro

la oscuridad y no veo

la oscuridad: veo luz

en su negación”

Antonio Gamoneda ${ }^{24}$

Hablar de la luz en Le Corbusier es también hablar de su vaciado, de la sombra. Los arquitectos no creamos la luz, producimos sombras ${ }^{25}$, y Le Corbusier es el maestro moderno de la sombra.

La luz y la sombra son opuestos y complementarios, ya que sin sombra la luz nada desvelaría. La luz es todo, la sombra es la nada que la completa. Luz es presencia, aparición, consciencia; sombra es distancia, desaparición, ocultación, inversión. Pero no hay presencia sin ausencia, ser y no-ser se engendran el uno al otro ${ }^{26}$. Le Corbusier llama, en algún momento, luz enferma a la oscuridad.

La sombra es la oscuridad, la falta de luz, más o menos completa, como nos dice el diccionario (RAE). Nos dice también el diccionario que la sombra es la proyección oscura que un cuerpo lanza en el espacio en dirección opuesta a aquella por donde viene la luz; sugerente. Es, también, la imagen oscura que sobre una superficie cualquiera proyecta un cuerpo opaco, interceptando los rayos directos de la luz. En definitiva, la sombra es una zona donde la luz es bloqueada por un objeto interpuesto ${ }^{27}$, más o menos opaco, una imagen oscura proyectada. La sombra es también la alteración de la proyección de una figura, estirada o comprimida, es móvil y elástica, y es la sombra (solar), al alargarse o acortarse, al acentuarse o desvanecerse, al vibrar y girar, la que da movimiento a los objetos, siguiendo el recorrido del sol.

Pero la sombra en Le Corbusier es mucho más. Si la luz desvela la imagen, la sombra es la ficción, el fantasma, que suscita emoción, empatía y terror, más allá de los que provocan la percepción y empatía verdaderas. Es la puesta en escena de lo inauténtico, de lo fraudulento. Las sombras chinescas o el teatro de sombras contienen una doble ficción, ya que se interponen objetos sobre una pantalla, tras la fuente de luz, de manera que vemos la sombra de la sombra. Así son los edificios parasol. Escribe George Steiner

"Las sombras se alargan al atardecer, buscando el contacto con la tierra" "28,

\footnotetext{
${ }^{23}$ Michel Serres, Atlas.

${ }^{24}$ Antonio Gamoneda, Canción Errónea.

${ }^{25} \mathrm{O}$ captamos y tamizamos la luz.

${ }^{26}$ Lao Zi. Tao Te King.

${ }^{27} \mathrm{Si}$ lo que nuestro ojos ven son ondas electromagnéticas rebotadas en los objetos con diferente longitud (color), la interposición, la creación de sombras, se produce al impedir, negar, que la luz llegue y rebote.

${ }^{28}$ George Steiner, Gramáticas de la Creación, escribe también: "Hoy en día, las actitudes occidentales -nótese la muda presencia de la luz matutina en la palabra «occidental», los reflejos, los cambios de percepción pertenecen al mediodía y al atardecer."
} 
La sombra de le Corbusier (solar, negra) se estira y se comprime, es móvil y elástica, y, al alargarse o acortarse, al acentuarse o desvanecerse, al vibrar y girar, da movimiento a los edificios siguiendo el recorrido del sol.

La sombra en Le Corbusier tiene gran cantidad de matices. Hay sombras espesas, negrísimas, de gran densidad; hay sombras con un contorno muy definido o sin un límite claro, hay sombras verticales y sombras alargadas, hay sombras con vibración y sombras petrificadas, hay sombras matizadas y muy claras, hay sombras sobre blanco y sombras sobre negro, hay sombras mediterráneas o nórdicas. Las sombras puede ser opacas o veladuras.

Una peculiaridad de las sombras solares es que no son "en color", son, podríamos decir, en blanco y negro ${ }^{29}$ y si la sombra se produce por interposición de un objeto, es la luz la que es mutilada. No es extraño, por tanto, el atractivo del cine y la fotografía en blanco y negro, su reducción a la luz (blanca) y la sombra (negra), basta con recordar la sombra portentosa y crepitante del conde Orlok en Nosfertau ${ }^{30}$ (1922), en las sombras perfiladas de Ivan el Terrible ${ }^{31}(1945)$, las expresionistas luces y sombras de Orson Welles o las tamizadas de Josef Von Sternberg y, como no, los claroscuros del cine negro (negro por la temática, negro por la sombras) desde Jacques Tourneur hasta Fritz Lang. Recordar también la larga tradición de la fotografía en blanco y negro, iniciada con los primeros contactos de Fox-Talbot y la magia de su misterio hasta la actualidad. El color apareció en la fotografía muy pronto (color aditivo en 1861 o transparencias al carbón en tres colores en 1870), pero no se desarrollo hasta mucho más tarde, casi un siglo, quizás por la falta de interés. Tanizaki ${ }^{32}$ a principios de los años treinta era consciente de la cualidad de la sombra y de la perdida que la utilización indiscriminada de la plana luz eléctrica podía suponer. Algo parecido a lo que Marcel Schwob apreciaba unos años antes, disfrutando de la lectura y de la atractiva luz de una vela, artificial, finita y cambiante:

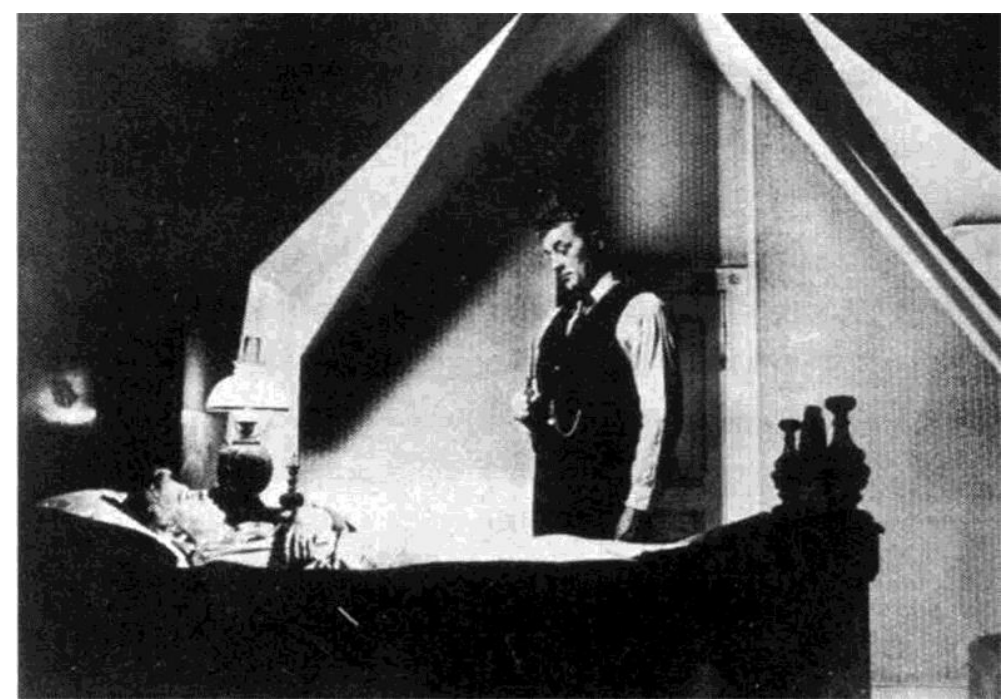

2. Imagen de "La noche del cazador". Charles Laughton. 1955.

\footnotetext{
${ }^{29}$ Luz blanca; suma de todas. Sombra negra; negación de todas.

${ }^{30}$ F.W. Murnau.

${ }^{31}$ Sergei Eisenstein.

${ }^{32}$ Junichiro Tanizaki, El elogio de la sombra (1933). En su conocido libro decía: Cuando sustituyeron la lámpara por un candelabro aún más oscuro y pude observar las bandejas y los cuencos a la luz vacilante de la llama, descubrí en los reflejos de las lacas, profundos y espesos como los de un estanque, un nuevo encanto totalmente diferente.
} 
"Leer en la cama es un placer de seguridad intelectual mezclado con bienestar... Recuerdo la página más interesante de la gran novela que devoraba antes de dormir, a la noche, hacia los quince años, en el momento en que se enturbia, se ensombrece, se borra, mientras la vela consumida hasta el final crepita, palpita azul en el candelabro y se apaga" Marcel Schwob ${ }^{33}$

Sentimiento de la vibración de las luces y las sombras, de cierta pérdida, que también compartía Cezanne:

"Vivimos bajo la férula de los capataces. Es el reino de los ingenieros, la república de las líneas rectas... ¿Hay acaso una sola línea recta en la naturaleza, dígame?... ¿Dónde esté Aix, mi Viejo Aix, las callejuelas del barrio viejo, la hierba entre las piedras de la calzada, las lámparas de petróleo...? Sí, la iluminación a petróleo, en lugar de vuestra cruda electricidad que viola el misterio, mientras que nuestras antiguas lámparas lo doraban, lo cocían, lo habitaban al estilo de Rembrandt..."34 Volviendo sobre el entrelazado necesario entre la luz y la sombra, Victor I. Stotchita habla de una fábula que sin duda nos suena familiar, "La maravillosa historia de Peter Schlemihl”, de Adelbert von Chamisso (1813). En la historia, Schlemihl, situado entre Fausto y Peter Pan, vende su sombra al diablo por una bolsa de oro inagotable. Descubre entonces que la sociedad -y la mujer a la que ama- rechazan a un hombre sin sombra, pasando el resto de su vida vagando por el mundo dedicado -curiosamente- a la exploración científica. El diablo convence a Schlemihl mediante las siguientes palabras:

“-Durante el corto tiempo que he tenido la suerte de encontrarme a su lado... si me permite decírselo, señor, he podido contemplar con auténtica e indecible admiración la bellísima sombra que da usted en el suelo, esa magnífica sombra que, sin darse cuenta, con un cierto noble descuido... arroja ahí a sus pies. Y ahora, perdóneme la atrevida pretensión: ¿No podría quizás sentirse inclinado a cedérmela? ",35

El diablo se fija en "la bellísima sombra que $d a$ usted en el suelo", y que con descuido arroja a sus pies. Algo tan natural se convierte en excepcional, como excepcional es perder la sombra y el consiguiente rechazo de la sociedad a un "hombre sin sombra". ¿Por qué? Quizás por que no exista, porque un hombre sin sombra representa la ignorancia de las reglas, un objeto sin sombra pertenece a lo imposible, a la ficción.

\section{Blanco y Negro Vs Color}

¿Y el color? Si las sombras solares son en blanco y negro, son ausencia. ¿Qué ocurre entonces con el color?

Para mi Le Corbusier es en blanco y negro, funciona muy bien. Quizá sea porque sus libros son básicamente en blanco y negro, por que la luz y la sombra son también en blanco y negro. Quizás porque el color, el color en planos, los colores suaves del principio, los colores fuertes del final, sean tan importantes en su obra. Quizás porque el color reacciona con el incoloro hormigón.

\footnotetext{
${ }^{33}$ Marcel Schwob en "El Terror y la piedad".

${ }^{34}$ Paul Cézanne, Leer la naturaleza. Palabras recogidas por Joachim Gasquet, Cézanne, 1921. Curiosamente Cezanne también anticipa, literalmente, la visión volumétrica de Le Corbusier. En un carta a Emile Bernard (Aix, 15 de abril de 1904) escribía: Permítame repetirle lo que le decía aquí: trate a la naturaleza mediante elcilindro, la esfera, el cono, todo puesto en perspectiva, de forma tal que cada lado de un objeto o de un plano se dirija hacia un punto central. Las líneas paralelas al horizonte dan la extensión, ya sea de una sección de la naturaleza...Las líneas perpendiculares a ese horizonte dan la profundidad. Ahora bien, la naturaleza, para nosotros los hombres, es más profundidad que superficie, de ahí la necesidad de introducir en nuestras vibraciones de luz, representadas por los rojos y los amarillos, una cantidad suficiente de azules, para hacer sentir el aire.

${ }^{35}$ Adelbert: Von Chamisso, La Maravillosa historia de Peter Schlemihl.
} 
Hay varios colores en la arquitectura de Le Corbusier. Los apagados y pálidos colores mediterráneos, colores del Monte Athos, los colores fuertes y planos de la etapa cúbica, los enérgicos colores y murales de posguerra y los colores de la luz; de la Tourette o Ronchamp. Y hay otros, como los colores de sus policromías arquitectónicas, de los catálogos y muestras para los papeles pintados Salubra (1931).

\section{Interposición y Captación. Brisa y Sonido}

Hay dos sistemas de los que ya he hablado previamente y que Le Corbusier utiliza trabajando con la luz. Uno exterior, la interposición y otro interior, la captación, que construyen edificios escultura y edificios cofre.

Pensar en el recorrido de la luz es pensar en el inicio. Desde su origen el mito de la pintura nos remite a la luz, a la sombra y al contorno (límite). El alfarero Butades, según una idea de su hija, perfiló sobre arcilla la sombra del rostro del amado de esta, proyectada a la luz de una vela, realizando así el primer dibujo a línea. Así del plano, de la superficie de la sombra, surge la línea. Pero también las más antiguas pinturas rupestres, el origen mítico de la pintura, nos remite al mecanismo de la sombra, más aún a la interposición. En el Panel de las Manos negativas (Galería de las Manos) de la cueva e Chauvet (30.000-10.000 a.C., las más antiguas pinturas rupestres conocidas) o la "Cueva de las Manos" (Patagonia, 9.300 a. C.) juegan con el contorno y el negativo, obtenido al soplar los pigmentos sobre una mano adherida a la pared. El primer gesto, la primera acción. El negativo.

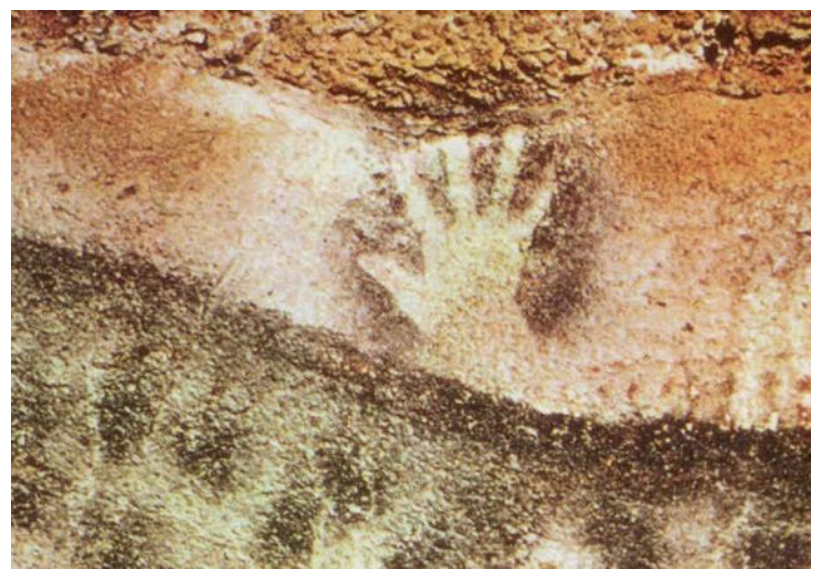

3. Imagen de la Cueva de Peche-Merle, Francia. Detalle Mano. Aproximadamente 25.000 a.C.

Este primer mecanismo es la interposición; lo utiliza Le Corbusier de dos formas. Primero (y quizás tímidamente), mediante el Brise-Soleil, después con absoluta rotundidad con los edificios parasol. Si la sombra es la proyección oscura que un cuerpo lanza en el espacio en dirección opuesta a aquella por donde viene la luz, Le Corbusier proyecta oscuridad sobre sus fachadas secundarias. La sombra, y esto es fundamental, se derrama, bien sobre el propio objeto - que la recibe-, modelándolo, bien sobre un fondo, el vacío de la fachada secundaria. Su sección eficaz es una silueta bidimensional; la inversión del objeto que bloquea la luz. El BriseSoliel, elementos creadores de sombras, pasa de ser un mecanismo adherido a la fachada a convertirse en edifico, llegando a constituirse como verdaderas construcciones autónomas superpuestas al volumen principal, los edificios parasol. Estos edificios parasol se construyen delante las fachadas secundarias, se interponen, entre la luz y el edificio y crean, además, una distancia infinita entre lo exterior y lo interior. El trabajo con la sombra es portentoso en Le Corbusier, es un trabajo griego. Es ahora cuando realmente aparece el mediterráneo en la arquitectura de Le Corbusier, el tacto del sol mediterráneo, la piedra, la rugosidad y la vibración: Grecia. Las 
luchas del sol y la sombra. El mármol se convierte en hormigón, las estrías de las columnas en planos. Las columnas, el peristilo, son los edificios parasol, la cella la fachada secundaria.

El Brise-Soleil ${ }^{36}$, aparece por primera vez como tal en el edificio para las Manufacturas Duval, Saint-Dié, en 1946-51. Experimentos anteriores son en la torre de alquiler en Argel (1933) o el Ministerio de Educación y Salud Pública en Brasil (1936). Realmente no importa. Pronto, paralelamente, aparecen los edificios parasol, el primero en Argentina, en la casa del Doctor Carruchet, en 1949.

Son edificios Brise-Soleil:

- $\quad$ La fábrica de manufacturas en Saint-Dié, Francia (1946/51)

- La Unité d’habitation de Marsella, Francia (1946/52)

- El convento de La Tourette, los “ondulatorios”, Francia (1957/60)

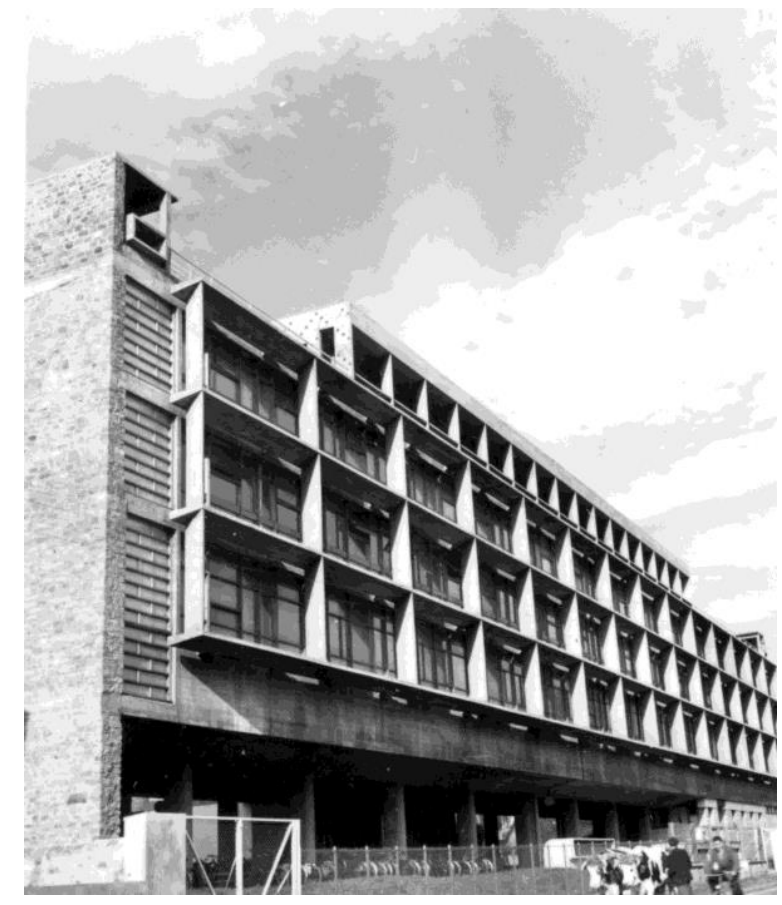

4. La fábrica de manufacturas en Saint-Dié. Fachada principal, Sudeste.

Son edificios parasol:

- La casa del Doctor Carrutchet en La Plata, Argentina (1949)

- $\quad$ El convento de La Tourette, las terrazas, Francia (1957/60)

- El Palacio de la Asociación de Hilanderos, Ahmedabad, India (1954)

- La Villa Shodan, Ahmedabad, India (1956)

- El Palacio de Justicia de Chandigarh, la fachada-pórtico-cajas noroeste, India (1956)

- El Secretariado de Chandigarh, las fachadas noroeste y sureste, India (1958)

- El Palacio de Asambleas de Chandigarh, fachadas pórtico suroeste y las otras, India (1956)

\footnotetext{
${ }^{36}$ El nombre de Brise-Soleil es sugerente. Deriva de Briser, romper y soleil, sol; romper el sol, briser soleil; rotura del sol. Pausa, interrupción o descanso del sol.
} 


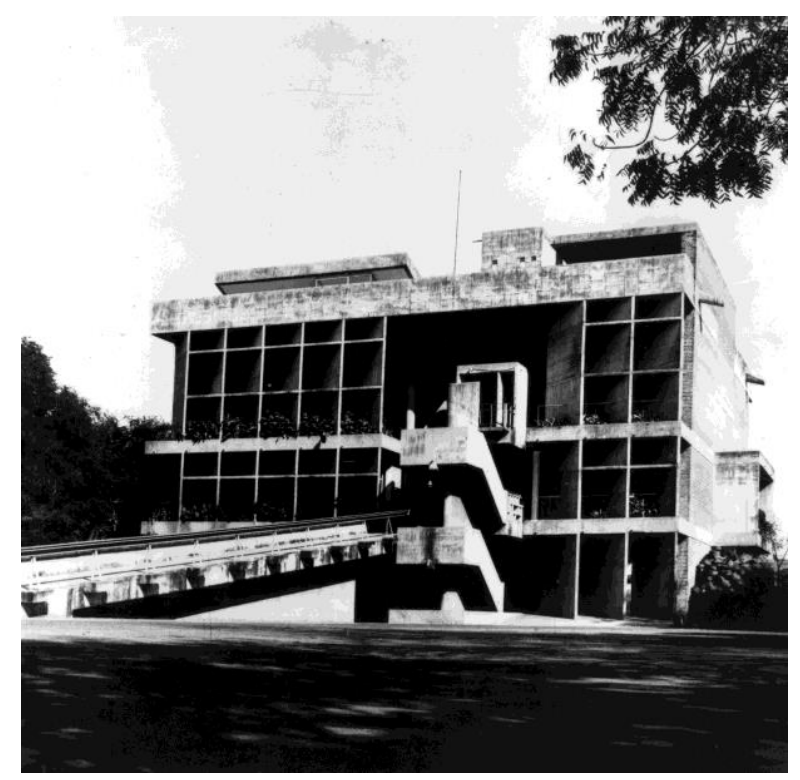

5. Palacio de la Asociación de Hilanderos. Fachada Oeste, “edificio parasol”. Buscando el Sur.

Considero esta parte de la obra de Le Corbusier básicamente griega, de interposición ${ }^{37}$, la sombra trabaja en las fachadas, en los planos-volúmenes exteriores creando una distancia entre el plano externo de luz (columnas o Brise-Soleil o edificios parasol) y la superficie proyectada (cella o fachada secundaria).

Hay también, y creo que es un tema trascedente e interesante que merece más desarrollo, unos fascinantes espacios intermedios en Le Corbusier; los interiores/exteriores o los exteriores/interiores que prolongan y descomponen los volúmenes y espacios. Las calles interiores de la Unité es un ejemplo. Pero también, y con otra trascendencia espacial, el vibrante espacio de la terraza de acogida, tras la rampa, en el Palacio de la Asociación de Hilanderos de Ahmedabad, el vacío bajo la cubierta unificadora en Palacio de Justicia de Chandigarh, la villa Shodan, el Museo de Chandigarh con el espacio patio interior-exterior o la Villa Carruchet son ejemplos de espacios exterior/interior, espacios peine, pasantes. El edificio parasol sirve también para crear distancia, alargar, aumentar la grieta, como el pórtico del palacio de la asamblea de Cahndigarh.

El segundo mecanismo es la captación. Los mecanismos de captación, los edificios cofre, son escasos en Le Corbusier, pero deslumbrantes.

Son edificios captadores:

- $\quad$ Ronchamp, la Iglesia y los tres captadores: norte, este y oeste (1950/54)

- $\quad$ El convento de La Tourette: la Iglesia y las capillas laterales inferiores (1957/60)

En La Tourette la Iglesia es un cubo de penumbra con grietas de luz y las capillas inferiores son un ejemplo de la captura de luz en diferentes orientaciones. Los captadores de Le Corbusier siguen al sol, son como heliotropos, la plantas que giran mirando al sol. En Ronchamp reutiliza sus ideas dibujadas en su viaje a Italia, del canopo de Villa Adriana, tantas veces citado. Con su vibrante luz coloreada sobre la granulada tirolesa, el trabajo con la luz es especial. Le Corbusier en este caso trabaja de forma diferente frente a la luz Suiza que frente a la continúa y uniforme luz de los trópicos o del mediterráneo, sin nubes. La luz es captada en diversas orientaciones, atrapando la vibrante luz Suiza, donde las nubes y el sol se alternan continuamente y mueven la luz de los

\footnotetext{
${ }^{37}$ El Palacio/templo griego de la Asamblea de Chandigarh es el ejemplo
} 
captadores, que vibran sobre la rugosa textura de los muros curvos. Parecen pinturas de Morandi. Le Corbusier en sus textos para Ronchamp escribe:

"Posiblemente, en la capilla de Ronchamp demostraré que la arquitectura no es problema de columnas sino de acontecimientos plásticos. Los acontecimientos plásticos no se rigen por formulas escolares o académicas, son libres e innúmeros $" 38$

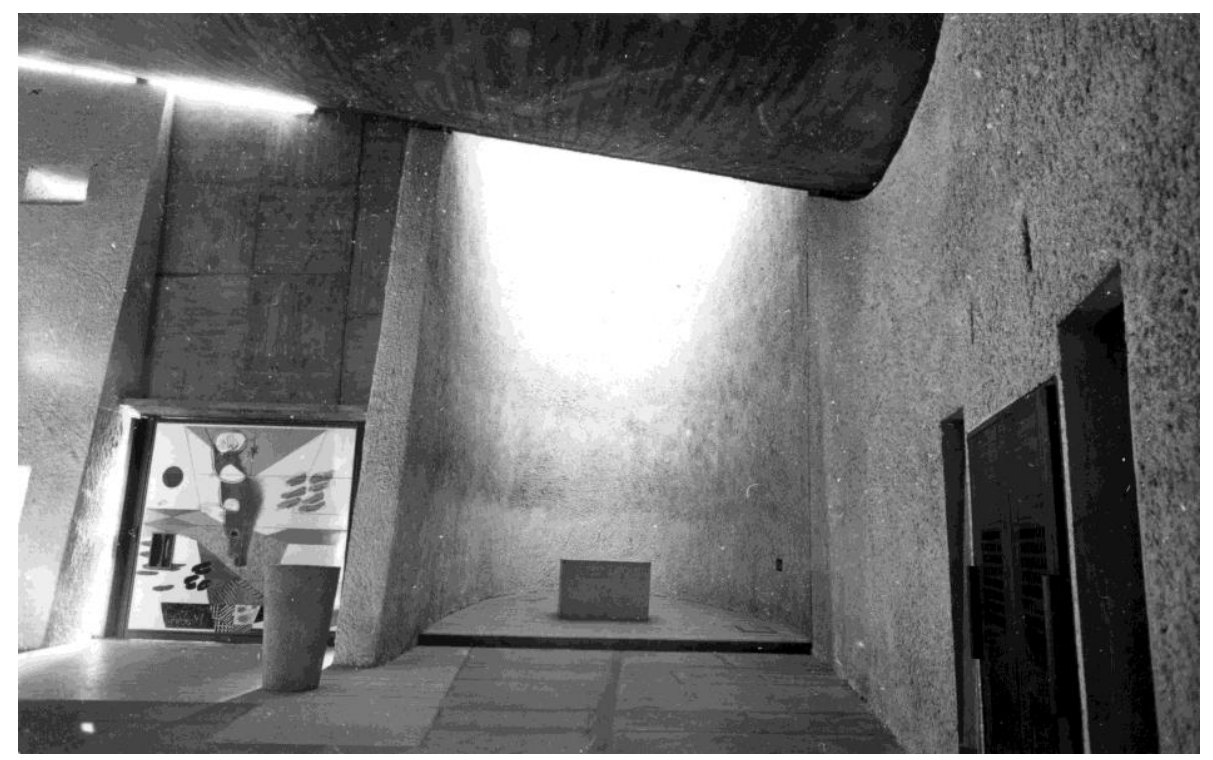

6. Capilla en Notre-Dame du Haut. Ronchamp. Capilla lateral.

Sombra y oscuridad no son lo mismo. La oscuridad es la negación, la ausencia de la luz, diferente de la sombra, su vaciado, que complementa la luz y se origina con ella. El pictograma chino 暗, Àn, significa oscuro y se forma mediante los pictogramas sonido y sol, significando "el sonido del sol". La luz emitida por el sol, que nos llega con siete minutos de retardo, puede ser entendida como un sonido, como música. La sombra es la pausa, la oscuridad el silencio.

La interposición es la brisa, el viento del sol que proyecta las sombras. La captación es el rumor del sol, que podemos levemente escuchar.

\section{Tejido y Silencio}

"Los parnasianos toman la cosa enteramente y la muestran: pero de este modo suprimen el misterio, sustraen a los espíritus el placer delicioso de creer que crean. Nombrar un objeto significa suprimir las tres cuartas partes del placer de la poesía, que consiste en adivinar poco a poco. Sugerir, este es el sueño. Y el uso perfecto de este misterio es lo que constituye el símbolo: evocar un objeto para mostrar un estado de ánimo, o bien elegir un objeto y hacer que irradie un estado de ánimo, mediante una serie de desciframientos." Stepháne Mallarmé ${ }^{39}$.

\footnotetext{
${ }^{38}$ Le Corbusier: Textos y Dibujos para Ronchamp.

${ }^{39}$ Cita Eco, en su libro "Historia de la Belleza", hablando de sugerir a Mallarmé, "Investigación sobre la evolución literaria" 1897.
} 


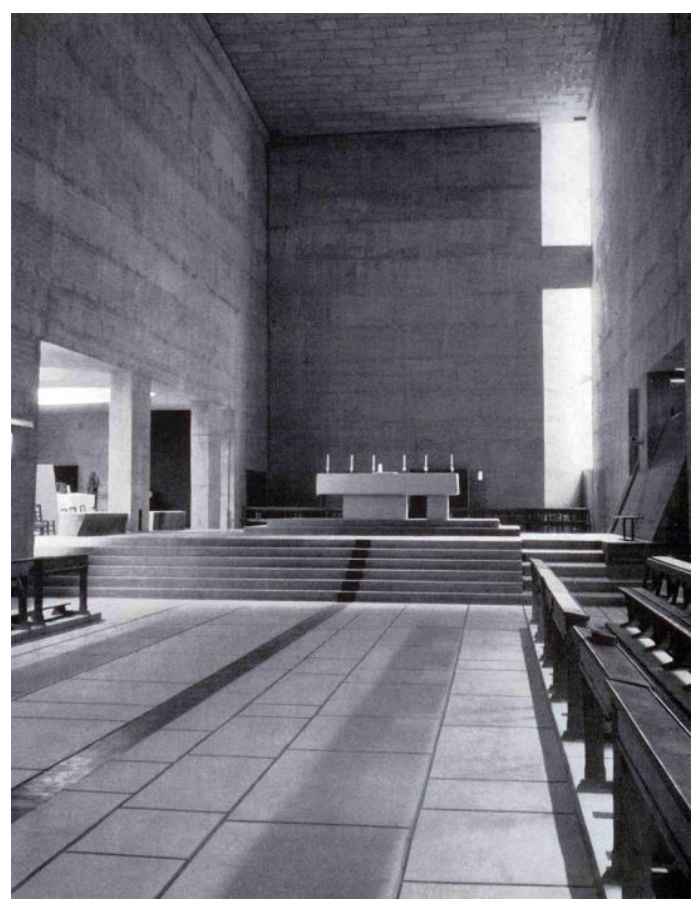

7. Convento de La Tourette. Interior de la Iglesia.

Le Corbusier heredero de la modernidad simbolista también encierra claves. Descifrar lo que significa la luz en Le Corbusier es sin duda interesante, quizás buscar lo que no dijo, sus sombras, sus silencios, escuchar su luz.

Le Corbusier utilizó el hormigón como material único, claro y diáfano, pero también utilizó la Luz (divina o humana, solar) y la sombra como material, explorando intensamente sus posibilidades. Porque la luz en Le Corbusier es arquitectura y la arquitectura de Le Corbusier es luz. Trabajó con la $L u z$ como algo físico, háptico, palpable y activo. Yo compongo con la luz, decía. La Luz y la Sombra (del mediterráneo, de los trópicos o de suiza) son palpables en Le Corbusier, densos, materiales, utilizados como un elemento (material) más de proyecto; como un muro, un cierre o un techo.

Aunque las posibilidades de trabajo con la luz son ilimitadas, su mayor hechizo, su cualidad extrema, es su intangibilidad. La seducción por lo intangible es difícil de resistir, por ello la luz, inmaterial y presencia, tiene tanto atractivo.

Construir con luz es, entonces, construir con lo intangible, sin materia. La luz es como el aire o el agua ${ }^{40}$, no tiene forma, es la superficie (el recipiente) el que le da la forma, es libre e innúmero. Tampoco tiene geometría, ni se somete al estricto control de la escuadra y cartabón; no tiene peso. La luz es materia inmaterial. Por ello lo intangible, lo que esta detrás, las presencias, sin límite o contorno definido se hacen, mediante la luz, objeto del trabajo de Le Corbusier. Sin forma, la luz es como o donde la proyectamos o recibamos. Michel Serres en su Atlas, hablando de los tejidos, decía:

"Ahora bien, entre la dureza llamada rigurosa del cristal, geométricamente ordenado, y la fluidez de las moléculas blandas y deslizantes, existe un material intermedio: velo, tela, tejido, trapo, paño, piel de cabra o de cordero, llamada pergamino, cuero despellejado de un becerro pelado o desollado, llamado vitela, papel flexible y frágil, lanas o sedas, todas las variedades planas o alabeadas en el espacio, envolturas del cuerpo o

\footnotetext{
${ }^{40}$ Como dice el Tao te King.
} 
soportes de la escritura, que pueden fluctuar como una cortina, ni líquido, ni sólido, claro, pero con algo de ambos estados. Plegable, desgarrable, extensible...topológico” Michel Serres ${ }^{41}$

La luz en la obra de Le Corbusier, es entonces, el tejido de su arquitectura. Y también el silencio. El padre Marie-Alain Couturier para expresar el origen del encargo a Le Corbusier del convento de la Tourette (1957-60), en el programa pedía Acoger cien corazones y cien cuerpos en el silencio.

Un constructor tan material como Le Corbusier, es, en sus últimos años, también un constructor de lo inmaterial, haciendo que lo invisible se torne visible, que lo ilimitado conforme los objetos, que lo ausente se haga presente, sin dimensión, sin límites y, en definitiva; que lo material surja de lo inmaterial. Construye con la luz -luz interior y luz exterior-, produce silencio; construye con el silencio. Charpentier anotaba la siguiente indicación para el Credo de la Misa de Monsieur de Mauroy.

"Producid aquí un gran silencio" 42

\section{Misterio y Búsqueda}

"Empujado por mi ávido deseo, anhelante por ver la gran mezcla de las variadas y extrañas formas hechas por la artificiosa naturaleza, dando muchos paseos entre los umbrosos acantilados, llegué a la entrada de una gran cueva, frente a la cual -al quedar muy estupefacto e ignorante de tal cosa-plegando mis riñones en arco, y quieta la cansada mano sobre la rodilla, con la derecha me hice sombra a las inclinadas y cerradas pestañas. $Y$, plegándome muchas veces aquí y allá para ver si podía discernir algo allá adentro, cosa que se me vetaba por la gran oscuridad que allí dentro había, -y después de mucho-enseguida se despertaron en mí dos cosas: miedo y deseo; miedo por la amenazadora oscura apertura, deseo de ver si allá adentro habría alguna milagrosa cosa" Leonardo da Vinci ${ }^{43}$

Para terminar el misterio, el deseo, la luz, la sombra y sobre todo, la búsqueda, de nuevo. ¿Cómo se puede entender Ronchamp ${ }^{44}$ si no es bajo una búsqueda permanente, insaciable? Le Corbusier, con su estilo perfectamente definido (La Unité o Chandigarh), se interesa por las formas naturales y cambia, para una obra, su arquitectura. ¿Y el Pabellón Philips, 1958? ¿Y su última obra, el pabellón en Zúrich, 1964? Le Corbusier, insaciable buscador, buscador de la luz, pedía a los estudiantes que mantengan los ojos abiertos, en clara actitud de permanente búsqueda. Escribía para los estudiantes:

“Y ahora, amigo mío, le ruego abra bien sus ojos. ¿Mantiene usted sus ojos abiertos? ¿Ha sido entrenado a abrir los ojos? ¿Los mantiene abiertos continuamente y útilmente? ¿Qué es lo que mira cuando va de paseo?"45

\footnotetext{
${ }^{41}$ Michel Serres, Atlas.

42 "Faites ici un grand silence", Marc-Antonie Charpentier, indicación para el Credo de la Misa de Monsieur de Mauroy. Cita de Jean Yves Patte, en su escrito "Marc Antoine Charpentier. Messe de Monsieur de Mauroy".

${ }^{43}$ Leonardo Da Vinci, Alegorías, Pensamientos, Profecías.

${ }^{44}$ Interpretada, entre otras muchas opciones, como dolmen, como cueva.

${ }^{45}$ Le Corbusier: Mensaje a los estudiantes de Arquitectura.
} 


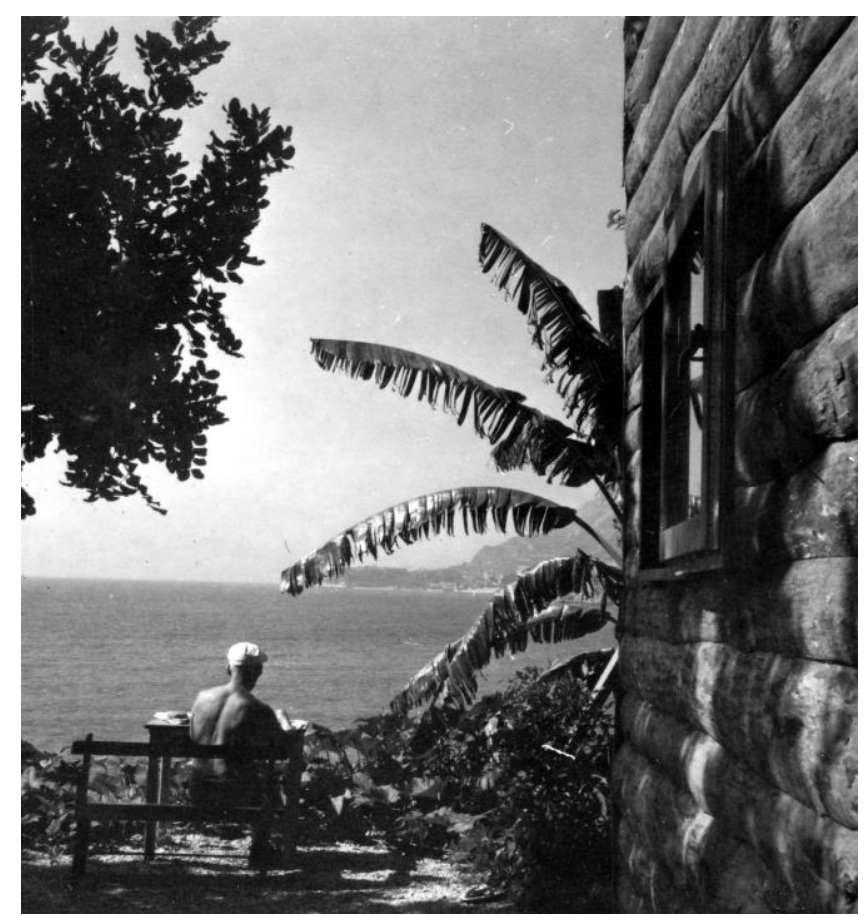

8. Le Corbusier, fuera de su cabanon en Roquebrune, Cap-Martin. Trabajando y mirando el mar.

\section{Conclusiones}

Le Corbusier, gran buscador, como el personaje doble de Stevenson, presenta -al menos- dos caras, ya que utilizó en su segunda etapa dos sistemas para trabajar con la luz: la interposición y la captación. La captación es medieval, nórdica, es la cueva, el misterio, y es también Le Corbusier barroco. La interposición es Grecia, es el mediterráneo, es la luz y la sombra, la sombra de la columna/edificio arrojada sobre el plano posterior de la cella o del edificio encerrado. Este sistema provoca, no sólo el juego de la luz y la sombra, crea también unos espacios intermedios y una "distancia" etérea entre la materialidad de sus edificios y la realidad. Y es precisamente la densidad de luz y la sombra, el material sin materia, doble, el principal elemento - de los muchos- en la obra de Le Corbusier.

Escribía Stevenson, buscador y viajero, en palabras de Henry Jekyll:

"Cada día, y desde ambos caras de mi inteligencia, la moral y la intelectual, yo me acercaba firmemente a esa verdad, por cuyo descubrimiento parcial he sido condenado a tan terrible naufragio: que el hombre no es verdaderamente uno, sino realmente dos. Digo dos, porque mi conocimiento no va más allá de ese punto." 46

\footnotetext{
${ }^{46}$ Robert Louis Stevenson en la edición original "The Strange Case of Dr Jekyll and Mr Hyde" de 1886, en el Capítulo10; la declaración o testamento del Dr. Jeckyll: "With every day, and from both side of my intelligence, the moral and the intelectual, I thus drew steadily nearer to that truth, by whose partial discovery I been doomed to such a dreadful shipwreck: That man is no truly one, but truly two. I say two, because the state of my own knowledge does not pass beyond that point."
} 


\section{Imágenes}

Imagen 1. Crsitóbal, Ramiro: Centauros del desierto. The searchers. 1956. John Ford. Madrid: El País, 2005. DVD.

Imagen 2. Font, Domenec: La noche del cazador. The night of the hunter. Barcelona: Paidós, 1998.

Imagen 3. Pijoan, Joan: Historia del arte, Tomo I. Barcelona: Salvat, 1973.

Imagen 4. L3(6)73-141, Photographer : Lucien Hervé. Fondation Le Corbusier.

Imagen 5. L3(8)3, Photographer : Lucien Hervé

Imagen 6. L3(3)113-656, Photographer : Lucien Hervé

Imagen 7. L1(7)92-410, Photographer : Lucien Hervé

Imagen 8. L4(11)11-17, Photographer : Lucien Hervé

\section{Referencias}

Savall, Jordi. Presentación. Diego Ortiz. Recercadas del tratado de glosas. Roma 1553. Disco: ALIAVOX Heritage vol.16.

Patte, Jean Yves. "Marc Antoine Charpentier. Messe de Monsieur de Mauroy" del disco del mismo nombre del Concert Spirituel, conducido por Hervé Niquet, Glossa Cabinet Discos. Marc-Antonie Charpentier, indicación para el Credo de la Misa de Monsieur de Mauroy.

\section{Bibliografía}

Bacon, Francis: De la Sabiduría Egoísta. Madrid: Great ideas, Taurus. Santillana Editores, 2012

Baltanás, José: Le Corbusier. Promenades. Barcelona: GG, 2005

Ceinos, Pedro: Manual de escritura de caracteres chinos. Madrid: Miranguano ediciones, 1998.

Cézanne, Paul: Leer la naturaleza. Madrid: Casimiro, 2014

Da Vinci, Leonardo: Alegorías, Pensamientos, Profecías. Pensamientos. Deseo insaciable de conocer. Madrid: Gadir Editorial S.L, 2014.

Eco, Umberto: Historia de la belleza. Barcelona: Lumen, 2004.

Gamoneda, Antonio: Canción Errónea. Barcelona: Tusquets, Nuevos textos sagrados, 2012.

Jabés, Edmond: El libro de las preguntas. Libros del tiempo. Madrid: Siruela, 2006.

Jenks, Charles: Le Corbusier and the Tragic View of Architecture. Massachusetts: Harvard University Pres, 1973.

Kumar, Manjit: Quántum. Einstein, Bohr y el debate sobre la naturaleza de la realidad. Barcelona: Kairós, 2011.

Lao Zi: Tao Te King. Libro del curso y de la virtud. Madrid: Sirulea, 1998.

Le Corbusier: Hacia una arquitectura. Barcelona: Poseidón, 1977.

Le Corbusier: Catalogo exposición, 1987, Ministerio de Cultura, Madrid.

Le Corbusier: Mensaje a los estudiantes de Arquitectura. Buenos Aires: Infinito, 2008.

Le Corbusier: Textos y Dibujos para Ronchamp. Suiza: edición Jean Petit. Association ouvre de N.D. du Haut, Ronchamp, 1965.

Le Corbusier: La casa del Hombre. Barcelona: Poseidón, 1999. 
Le Corbusier: Précisions sur un état présent de lárchitecture et de lúrbanisme. Vicent-Freal et Cie, París, 1960. Paris: Éditions Crès, Collection de "L'Esprit Nouveau", 1930. Ed; castellano, Precisiones respecto a un estado actual de la arquitectura y el urbanismo, Ed. Poseidón, Barcelona, 1978.

Le May, Alan: Centauros del Desierto. (The Serchers). Madrid: Valdemar, 2013.

Mink, Janis: Duchamp. Colonia: Taschen, 2004.

Quingard, Pascal: Las escaleras de Chambord. Barcelona: Círculo de Lectores, 2013

Sabadell, Miguel Ángel: Grandes Idas de la Ciencia. Barcelona: RBA, 2012.

Schwob, Marcel: El Terror y la piedad. Buenos Aires: Libros del Zorzal, 2006.

Serres, Michel: Atlas. Madrid: Cátedra, 1995.

Steiner, George: Gramáticas de la creación. Madrid: Siruela, 2011.

Stevenson, Robert Louis: El Dr. Jekyll y Mr. Hyde. Madrid: Biblioteca Stevenson. Alianza. 2008.

Stotchita, Victor I : Breve historia de la sombra. Madrid: Siruela, 1999.

Tanizaki, Junichiro: El elogio de la sombra. Madrid: Siruela, 1994

Von Chamisso, Adelbert: La Maravillosa historia de Peter Schlemihl. Madrid: Nórdica, 2009.

Zajonc, Arthur: Capturar la luz. Girona.:Atalanta, 2015.

Zambrano, María: Claros del Bosque. Madrid. Cátedra. Letras hispánicas, 2011. 
Manifesto; secondly which kind of structure they used and if it can be understood as belonging to the same kind of text; thirdly, how the tone of the Manifesto is changing along the years and why, as well as how this change is affecting the way they can communicate and the last point to be analyzed would be the relationship between theory and practice or how the Manifesto is translated, if so, to the architectonic design. The goal of the process will be to understand how the form of the Manifesto is used in both architects and, eventually, which kind of connections could be established between Le Corbusier, representing the Modernity, and Rem Koolhaas, as contemporary architect. Social, political, economical, philosophical and other aspects that can affect to the evolution in the architectonic ideas or design will be explained as part of those four main points, in order to understand them as a whole as well as for being the present paper focused on the roll of the architectonic Manifestoes.

Although the architectural work is shown as a product of a previous reflection that, in both cases, is also linked to the architects'social commitment, as solution for a given problem to get an important improvement for architecture regarding substantial social issues, the present research is willing to demonstrate how the process is actually the other way round: from an initial purely design idea all the texts are prepared to establish the appropriated theoretical frame for this first idea. In other words, we can say that theory (Manifesto), is used as a marketing tool to make more attractive the final architectonic product creating, eventually, a need in the population that did not exist before. As we will see this tendency does nothing but increase over the years and has served on many occasions to justify the expensive iconic architecture.

The conclusion of this line of thought is evident in the contemporary architecture: the building becomes an object, an icon, a Manifesto in itself. As we will see, this process was started, as many others, by who is considered the master between masters of Modernity: Le Corbusier. Going back to review their Manifestoes maybe we have the chance to come back also to the times when they were much more than marketing tools.

\section{Characteristics of the Manifestoes}

After its birth as a political tool the Manifesto is first use in art during the Avant-Garde era. Regarding the architectonic Manifestoes in architecture this period is not really important, as the lack of freedom of the discipline did not allow architects to "break the boundaries" as much as other Avant-Garde artist could do. However, there are some Manifestoes that deserve a special consideration, such as Futurist Architecture ${ }^{1}$, Manifesto $I^{2}$, Realistic Manifesto ${ }^{3}$ or Suprematist Manifesto ${ }^{4}$ to name some of the most important.

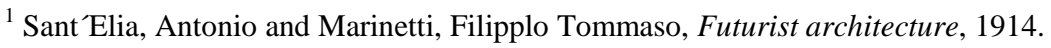

${ }^{2}$ D'Stjl, Manifesto I, 1918. Later this Dutch group will write other Manifestoes such as: Creative Demands in 1922 and Manifesto $V$ in 1923 among others.

${ }^{3}$ Gabo, Naum and Pevsner, Antoine, Realistic Manifesto, 1920.

${ }^{4}$ Malévich, Kazimir, Suprematist Manifesto, 1924.
} 


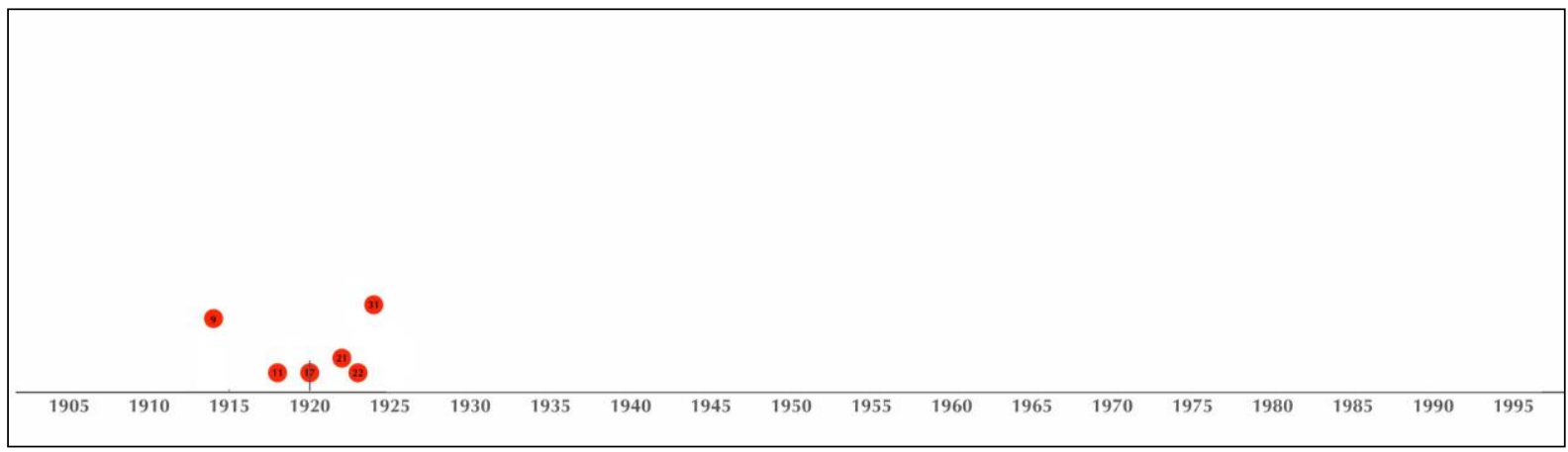

1. Chronological distribution of the Manifestoes written inside one of the Avant-Garde movements belonging to the discipline of Architecture.

Before those Manifestoes there were some others focused on architectonic concerns exclusively, that can be understood inside a context of the search for what was called the "new architectonic language", clearly influenced by the Industrial Revolution. The dialectic between the architect understood as an artist and the architect aligned with the new profession of engineer is clear in Thesis and Antithesis of the Werkbund ${ }^{5}$, a Manifesto from 1914 consistent in two antagonistic decalogues written by Herman Muthesius and Henry van de Velde.

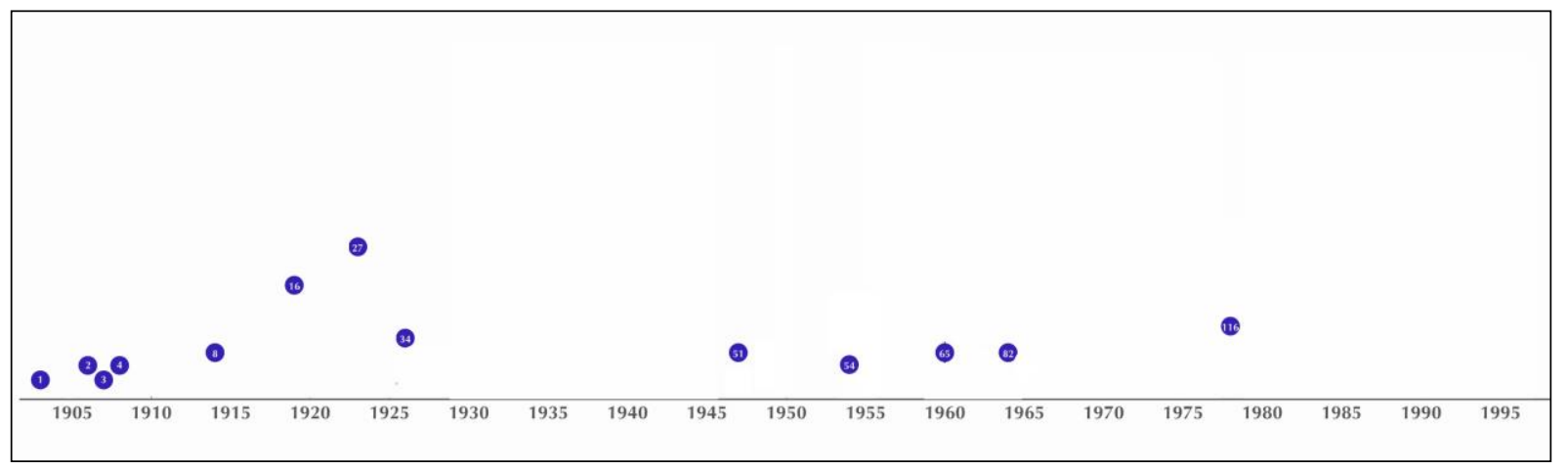

2. Manifestoes that are, in a way or another dealing with the relationship between art and industry, that started as a consequence of the changes introduced by the Industrial Revolution.

The 1920s are the years of the first peak in the production of the architectonic Manifesto when the previous issues, as well as the influence of the communist ideas coming from the Soviet Union through its Avant-Garde movements, started to create what is now understood as the Theoretical frame of the Modernity. Most of the socalled masters of the Modern Movement will write their own Manifestoes in those years. That is the case of Le Corbusier and the essays that will be collected in Towards an Architecture in 1923. Other examples are Organic architecture $^{6}$ or Working Thesis. ${ }^{7}$

\footnotetext{
${ }^{5}$ Muthesius, Hermann and van de Velde, Henry, Thesis and Antithesis of the Werkbund, written for the first exhibition and Conference of the Werbund, held in Cologne in 1914.

${ }^{6}$ Wright, Frank Lloyd, Organic Architecture, 1910.

${ }^{7}$ Mies van der Rohe, Ludwig, Working thesis, 1923.
} 


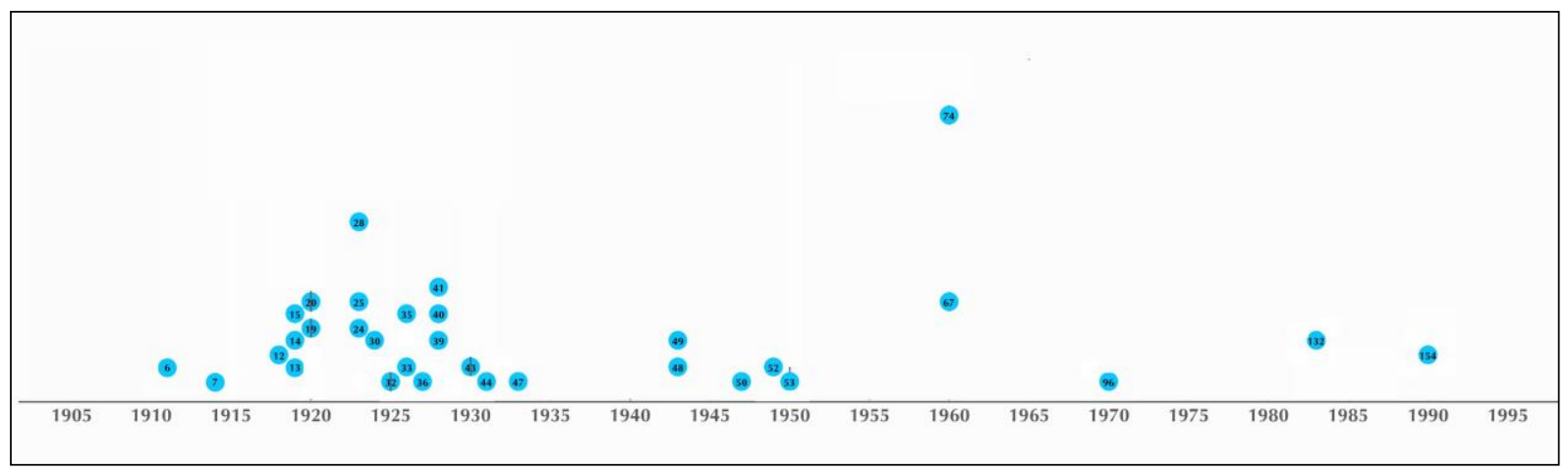

3. Group of Manifestoes that constitute the theoretical frame of the Modernity. Although they are mostly in the between wars period there are some echoes until the end of the past century

The unquestionability of the principles of the Modernity and the urban planning proposed in the Charte $d^{\prime}$ Athènes ${ }^{8}$ lasted until the Doorn Manifesto ${ }^{9}$, formulated by the new generations of the CIAM, THE TEAM 10, who were looking for more human cities: again looking for a new and better world.

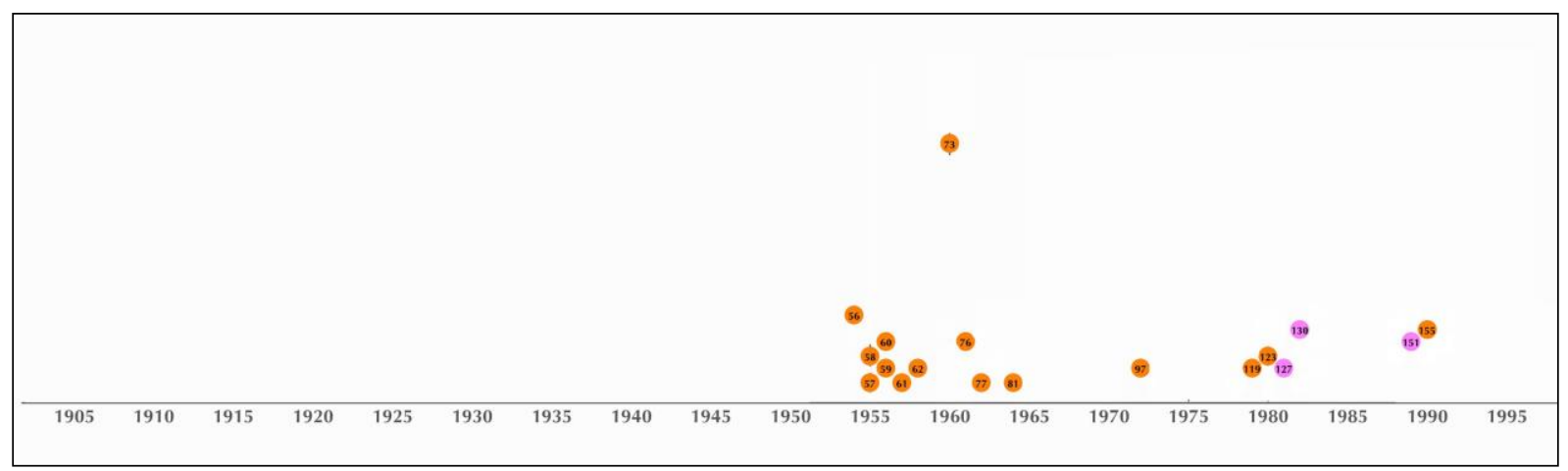

4. The review of the Modernity is a long outstanding issue that started around 1950s, as it could be seen in the graphic above and is still ongoing.

Until this era, the Manifesto was attached directly to the concept of Utopia, but around the 1950s, with the declaration of the death of the big Utopias, and after a last breath in the 1960s with the Manifestoes dedicated to imaging a new and perfect world based on the latest technologies, such as: The architect as world planner ${ }^{10}$, The ten principles of space town planning ${ }^{11}$, Universal Structure ${ }^{12}$ or No-plan ${ }^{13}$, a new era started to the architectonic Manifesto far from Utopian concepts. It will be also decisive the idea of "gentle Manifesto" formulated in the famous Complexity and Contradiction in Architecture by Robert Venturi.

\footnotetext{
${ }^{8}$ CIAM IV, 1933.

${ }^{9}$ TEAM 10, Doorn Manifesto, 1968.

${ }^{10}$ Buckminster Fuller, Richard, The architect as world planner, 1961.

${ }^{11}$ Friedman, Yona, The ten principles of space town planning, 1962.

${ }^{12}$ Archigram, Universal structure, 1964.

${ }^{13}$ Price, Cedric, No-plan, 1969.
} 


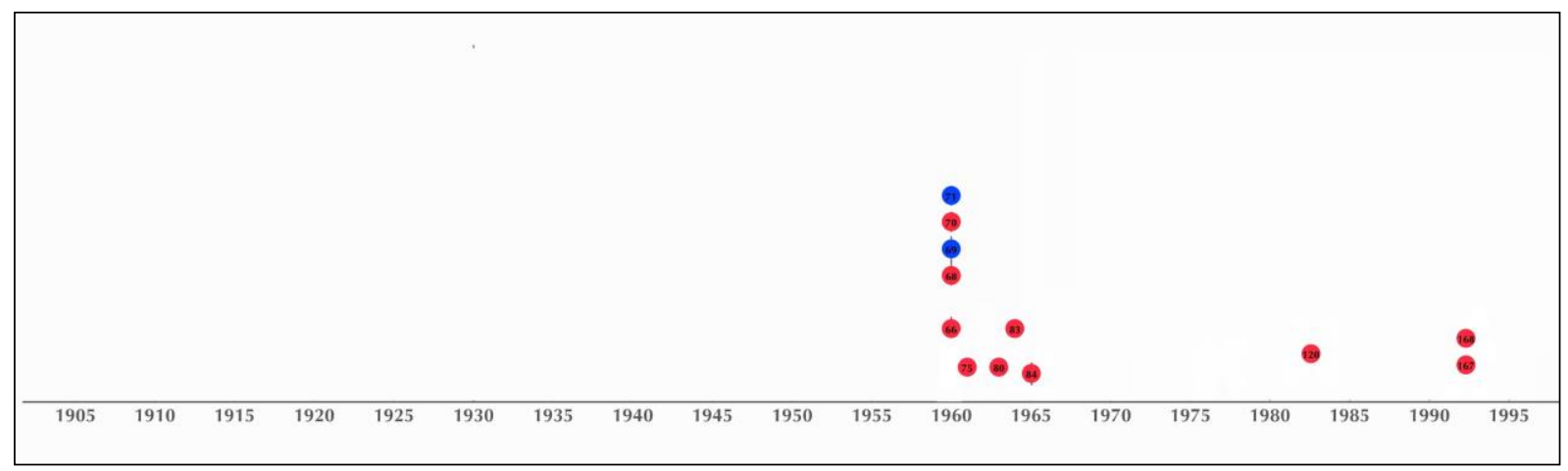

5. Last peak of the Utopian Manifestoes was during the 1960s with the Technological utopias, which are now coming back in the present century due to the review of those Manifestoes.

The contemporary Manifesto, disconnected from the concept of Utopia and using a tone not longer identifiable with the radical and angry one used by the first Manifestoes in Architecture, starts a complete transformation towards a new format. In this moment is when Rem Koolhaas wrote his "retroactive Manifesto for Manhattan": Delirious New York ${ }^{14}$, starting with a question in the introduction that shows his clear intention of using the specific format of the Manifesto for his book:

"How to write a manifesto - on a form of urbanism for what remains of the 20th century - in an age disgusted with them? The fatal weakness of manifestos is their inherent lack of evidence. Manhattan's problem is the opposite: it is a mountain range of evidence without manifesto. "Rem Koolhaas ${ }^{15}$

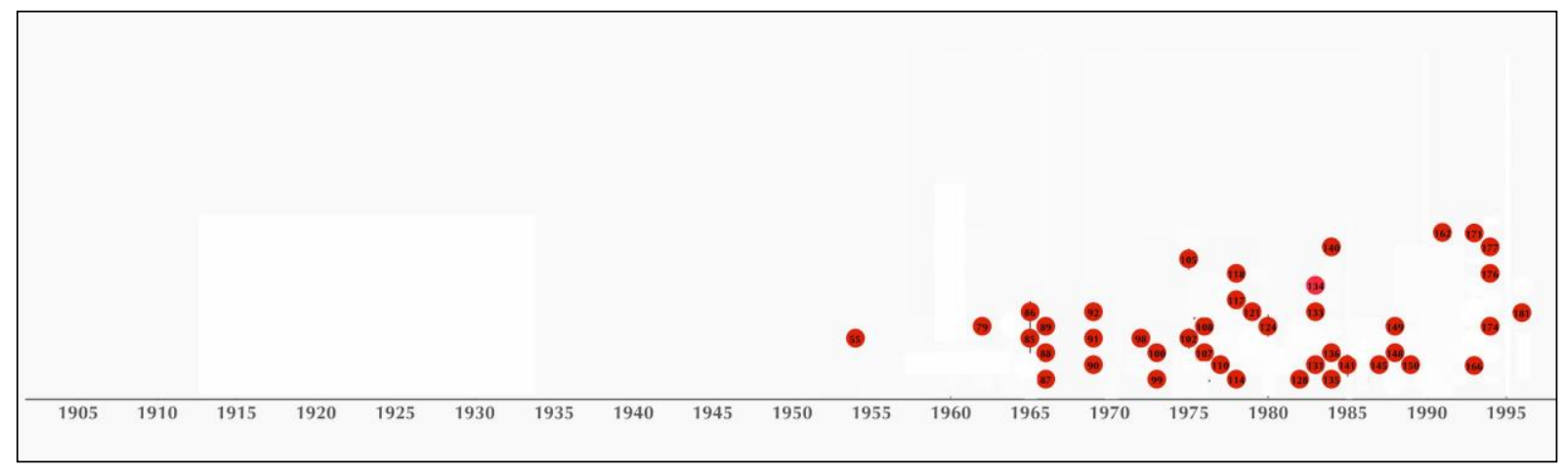

6. After the death of the Utopia started a new era for the Manifesto, which is used more as a marketing tool. Post modern and contemporary Manifestoes are multiplied in the second part of the last century and the first decade of the 21 st.

\footnotetext{
${ }^{14}$ Koolhaas, Rem, Delirious New York, A Retroactive Manifesto for Manhattan, 2nd. ed. New York: The Monacelli Press, 1994

${ }^{15}$ Op.cit., p. 9
} 


\subsection{Manifesto: Raison d'être}

"How would you like to live in the looking-glass house, kitty? You can see a peep of the hallway now, since the door to our drawing room is open. It looks like our hallway. But, you know, the area we can't see might be quite different. Oh, kitty! Let's pretend there's a way in. Let's pretend the glass is soft, so we can get through. Why, it's turning into a sort of mist now! It'll be easy enough to get through. "Alice ${ }^{16}$

However, Rem Koolhaas decided to use the format of the Manifesto despite its proliferation and the impossibility of being probed. The second problem is not important for him as Manhattan is already finished, but to consolidate his text as a Manifesto seems to be the only way he can use to theoretically dignify the island of Manhattan.

As it is established in the previous section, the situation in the year 1923, when Le Corbusier wrote Vers une architecture, is completely different. The Manifesto was the natural format to express new ideas as it had been settled before during the identity crisis architecture suffered after the Industrial Revolution and, mainly, with the birth of Engineering.

What remains clear comparing both Manifestoes is that, more than 50 years after, there is not other format as clear as the Manifesto to explain new ideas. The direct and radical language, even the simple word "Manifesto" seems to be the best way to indicate the intention of breaking with the status quo, to start from scratch.

When Le Corbusier wrote the essays collected in Towards an architecture his intention was to explain to the public what the changes he believed were necessary to get to this new order were exactly: the Modern Architecture. As it was said, in 1923 the Manifesto was the usual form to do that. So, in a way, he was doing nothing but following the normal way of communicating this kind of messages to the public.

On the contrary, the election of Koolhaas regarding the form of a Manifesto does not seem to be so logical, as himself has settled in the previous quote. However the author is sure that for Manhattan is mandatory to have a Manifesto, it needs it to make sense and, at the same time, to acquire the importance this part of the city of New York should have in the History of Architecture.

So, while in Le Corbusier's Manifesto we can perceive an evident dogmatic intention of explaining the changes to the uniformed society, in Koolhaas' the need of communicate is the same -or even more- but the intention is different. Koolhaas is using the Manifesto not to explain Manhattan but to dignify it. The difference between the raison d'être of the two Manifestoes is equivalent to the difference we can find between the Propaganda and the Marketing strategies: the difference between education and sale.

\subsection{Structure of a Manifesto}

"She turned her back to the house and set off down the path. She would just keep going straight until she reached the hill. Then the path gave a sudden twist and she was walking into the house again." 17

This difference is crucial in the understanding of contemporary Manifestoes, the ones written from the 1970s and is visible since the organization of the Manifesto itself, in their own structures.

\footnotetext{
${ }^{16}$ Mason, Eva (retold from Lewis Carroll) Alice in Wonderland \& Through the Looking-Glass. New York: Sterling Children's books, 2009, p. 73

17 Mason, Eva (retold from Lewis Carroll) Alice in Wonderland \& Through the Looking-Glass. New York: Sterling Children's books, 2009, p. 80
} 
As explained before, Towards an architecture is a collection of different essays written by Le Corbusier in Le Espirit Nouveau, the magazine that the author founded together with Ozenfant in 1920. The intention of those texts was clear and based on what was happening in other artistic disciplines since the beginning of the 20th century: to create a new architecture by destroying the formulas of the Academia. Although defending the same ideas, the ones that will be part of Le Corbusier's theoretical interests, each text was written separately, they were not conceived since the beginning to be part of a book. Actually, to collect all the texts signed by Le Corbusier was an idea of the director of the editorial La Sirène, Paul Laffite in 1922, as it is explained in the Preface of the Spanish version of the book. On the contrary, Delirious New York was conceived as a book since the beginning. The history of Manhattan, the main ideas, the explanation over the different skyscrapers and spaces of the city are situated in the right place for the message to be understood.

If Le Corbusier's statements are clear thanks to the consistency of their theoretical body, the ideas exposed in the Retroactive Manifesto for Manhattan are understood because they are consistent with the line of argument chosen by the author, like if it was a part of something that can be defined as a kind of Historiography of contemporary architecture. ${ }^{18}$

If we compare the index of the two books the difference is not that clear. Delirious New York, despite being actually written as a book, appears as an ensemble of texts dealing with different ideas, fragments of the complex reality of Manhattan itself. Each block -organized as the city blocks, like Koolhaas explained in the introductiondescribes a reality of Manhattan, and is named after each of these independent but coexistent realities: Coney Island, Skyscraper, Rockefeller Center and European. In the form of a Manifesto, the personal view of Koolhaas, mixed with some historical explanations are given to the reader to explain, not only their importance in the city, but also their importance for the city to be considered as a Manifesto itself.

The texts of the Manifesto Towards an architecture are organized by Le Corbusier according to the main idea they are dealing with. The engineer's Aesthetic and architecture, Three reminders to architects -subdivided, meaningfully, into mass, surface and plan-, Regulating lines, Eyes which do not see..., Architecture, Massproduction houses and Architecture or revolution. Written as a compilation of guide principles for the architects to design and build the new architecture, each Manifesto explains in a clear way the process they have to follow to achieve this goal or why they should do it. The consistency of the index is not showing a line of argument as Koolhaas shows in his Manifesto, but a natural order for the steps for Le Corbusier's personal recipe.

As conclusion we could say that, while Le Corbusier is using an structure in the Manifesto to explain his theories, Koolhaas is using Manhattan's structure to build his manifesto, and consequently, his theories about contemporary city and society.

\footnotetext{
${ }^{18}$ To illustrate the influence of the theories of the Historian of the Modernity, Panayotis Tournikiotis analyzed in The Historiography of Modern architecture nine essential books about Modernity written by nine historians: Sigfried Giedion and Reyner Banham together with Nikolaus Pevsner, Emil Kaufmann, Bruno Zevi, Leonardo Benevolo, Henry-Russell Hitchcock, Peter Collins, and Manfredo Tafuri.
} 


\subsection{Tone of the Manifesto}

"It's just like a chessboard!" Alice cried. She saw some men on the squares. "It's a huge game os chess!. What fun! How I wish I could play. I wouldn't mind being a pawn. Though of course I would like to be a queen best." Alice. ${ }^{19}$

The radical attack by Le Corbusier to what he describes as "Academia" is the essence of the Manifesto Towards an architecture itself. Precisely because of the need of breaking with everything that is consider as "good Architecture" in those years he wrote the essays, founded the magazine L'Espirit Nouveau and started signing as Le Corbusier. His affirmations does not admit any question, nor his proposals. The tone of the Manifesto is showing without discussion this character: Clear, radical, dogmatic and threatening. Le Corbusier express his contempt for the grievances he has received along his life in the preface of his book:

“Maybe I am lucky of being still aggrieved at 70!' Le Corbusier ${ }^{20}$

In a more conciliatory tone, Rem Koolhaas recite all the elements that, according to him, are essential to understand the importance of the city of Manhattan in the contemporary architecture. The text was written after and under the influence of Venturi's "gentle Manifesto" on one hand, and both the idea of a Retroactive Manifesto and, on the other hand, the moral value's changes in the society between the one from the beginning of the century -the public of Le Corbusier- and the society of the end of the century. These two ideas are also connected to the death of the Utopia, sign of the times that makes necessary for the manifesto to be "retroactive".

"I thought the twenty-first century would be, hopefully, more like a dialogue, more like conversation, and maybe than itself is a kind of manifestation or whatever. I am very careful in even using that word. I just think the twentieth century was so sure of itself, and I hope that the twenty-first century will be less sure. And part of that is to listen to what other people say and to enter into a dialogue, to not stand up and immediately declare one's intent. " Tino Sehgal. ${ }^{21}$

As the Manifesto is the expression of the culture of its era, these two examples, even having the same name and similar intentions are completely different in tone as they are trying to communicate them to two completely different societies. The tone used is, in both cases the one that is more suitable for the society of the moment, taking into account its sensibility, mood and cultural background. The "between wars" society from 1923 is less sophisticated and cynical than the peaceful society from 1978. If the architects wanted their message to be assumed for the correspondent society it is mandatory for them to take these aspects into account. A mistake in the tone of the Manifesto could have the message loss as a consequence. That is the reason why these two Manifestoes are so different in tone, and consequently, the reason for their success in their respective times.

\footnotetext{
${ }^{19}$ Mason, Eva (retold from Lewis Carroll) Alice in Wonderland \& Through the Looking-Glass. New York: Sterling Children's books, 2009 . p. 86

${ }^{20}$ Le Corbusier, Hacia una arquitectura, Barcelona: Ediciones Apóstrofe, 1998. Preface of the Spanish edition

${ }^{21}$ Sehgal, Tino, in the event Manifesto Marathon, curated by Hans Ulrich Obrist in October, 19th 2008, Serpentine Gallery, Londres.
} 


\subsection{Influences of the Manifesto in the architectonic works}

Until now, the differences between Rem Koolhaas and Le Corbusier are very clear. Both can be understood as products of their epochs that, as we have seen, were highly different. However, the points in common between the two architects are equally clear and have been developed along numerous essays and books.

As this work is focused in their capacity as Manifesto writers and, more specifically, in their two studied Manifestoes, the points in common to be described here would be also focused on this issue. Thus, one of the more important aspects to be highlighted regarding this is the relationship between the written Manifesto and the design work of Le Corbusier and Koolhaas respectively.

It is a tendency in the contemporary Manifesto to be used as a text capable of building the theoretical frame suitable for the architectonic work, specially if this work belongs to what can be described as "iconic architecture". The newness, seen as a virtue in itself is mandatory in those buildings so, as the society is not prepared to accept the iconic building easily, the Manifesto, with its direct and clear language, seems to be the ideal accomplice to achieve this acceptance.

"We might generalize by saying that form medium and small budgets the "right" supply-based demand would be to repeat what has worked in the past (...) For high budgets, on the other hand, the standard demand is for architecture to provide what is supposedly new (or exclusive, in the most repulsive and fascist sense of the word)" Eduard Sancho Pou ${ }^{22}$

Before this necessity, Le Corbusier, who was also proposing completely new ideas for the Modern Architecture, following the Avant-Garde artists as we saw before, used the Manifesto in its radical way as an instrument capable of waking up his coetaneous society and guide them to the new and better modern life.

In the same situation, 50 years after that, Rem Koolhaas will feel that the Modernity should be reviewed in a contemporary way. The city life, identified with Manhattan's, is not solved by the Modern urban planning, specially regarding what he described as the "culture of the congestion", a direct consequence of the megacities of our era.

The best example of this attempt of dealing with this "culture of congestion" is his project for the Parc de la Villete competition in 1982 in Paris. OMA's design is conceived conceptually as an American skyscraper understood a structure where a number of different activities are overlapped. By using this strategy, Koolhaas tries to solve the problem of how to combine the reality of the indetermination with the need of specificity that has the architectonic object, a problem that neither the Modernity nor its subsequent reviewers (such as the TEAM 10 for instance) could solve. This is also his first attempt of breaking the tandem form-function principle by introducing the idea of indetermination through the "activity areas", places with no specific shape. Those areas, the encounters between the users and the communication network, are the only elements in the Parc, that are conceived as a system of vectors which last definition relies on the user. The city of Manhattan understood as a system of relationships between the citizens and the skyscraper as a catalyst of the changes of the contemporary society. Both ideas, translated into concepts, will be repeated and developed along the work of the architect in the same way he did in this proposal for the park in Paris.

\footnotetext{
${ }^{22}$ Sancho Pou, Eduard, Architectural Strategies (Marketing, Icon, Politics, Masses, Developer, the N.1), Barcelona: Grup Editorial, 2012, p.9.
} 
If Rem Koolhaas will use the ideas explained in his Manifesto conceptually, as a way of understanding the contemporary society, influenced by the capitalism and translated it to a generative concept in all his projects even although there were not urban planning projects but assuming that all the buildings he design are affecting the city they belong to, as it does every skyscraper in Manhattan- the translation of the ideas explained in Towards an Architecture is more direct, so easier to understand.

As said before, Le Corbusier organized his previous Manifestoes in the book Towards an architecture in the form of a guideline for the contemporary architect being able to follow it and design modern architecture. The series of recipes mixed a change of attitude, a connection with the history of architecture -Roman architecture mostly- and proper examples on how to design. The book is clear about how Le Corbusier himself is using his statements. For example, after an explanation about the use of the regulating lines in the classic architecture, with a kind of affected shyness, he finds himself obliged to use his own buildings as examples:

"Here I excuse myself for mentioning my own examples, but, spite my researches, I did not have the pleasure of finding contemporary architects who have dealt with this question. "Le Corbusier ${ }^{23}$

To illustrate the use of this regulating lines he uses the design of the house for Ozenfant he did together with Pierre Jeanneret in 1923. The golden number is used here to make the composition of the façade, localizing every single element on it and, at the same time, to provide the small house with a sense of order, making it appear as something "monumental" between other buildings that have been build "with no rules" ${ }^{24}$ as he describes.

In both cases the design of the project itself is the ultimate goal they pursued with the Manifesto, that is just settling the basis for the new architecture to be designed -or dignified-. The main difference is the connection with this architecture. In the futuristic Manifesto Towards an architecture, Le Corbusier is facing a blank paper while Koolhaas is just writing a retroactive manifesto for Manhattan, that is already built. The connection between theory and building is inverted in the second case, so Koolhaas need to go more into conceptual concerns while Le Corbusier, paradoxically, is more realistic. Just the contrary as their Manifestoes were regarding their connection with the concept of Utopia.

\section{Conclusions. Rem Koolhass: Le Corbusier through the Looking-Glass}

"A house is a machine for living in. Baths, sun, hot-water, cold-water, warmth at will, conservation of food, hygiene, beauty in the sense of good proportion. "Le Corbusier ${ }^{25}$

The second part of Alice's adventures in Wonderland, Through the Looking-Glass and What Alice Found There, describes the world on the other side of the mirror, where Alice goes in a strange way. At first, the world seems to be quite similar to the one she is living in, later it seems to be all the contrary, but at the end, when she gets to understand its structure, it seems to be more complicated: a translation to the language of the mirror of her world.

More than often, the work of Le Corbusier and in general, of all the Modern architects, is understood as a translation of the classical architecture language to a new -modern- one. This affirmation is clear in the structure

\footnotetext{
${ }^{23}$ Le Corbusier, Towards an Architecture, New York: Holt, Rinehart and Winston, 1986, p. 62.

${ }^{24}$ Le Corbusier, Towards an Architecture, New York: Holt, Rinehart and Winston, 1986, p. 62.

${ }^{25}$ Le Corbusier, Towards an Architecture, New York: Holt, Rinehart and Winston, 1986, p. 89.
} 
of Le Corbusier Manifesto Towards an architecture. Despite being a collection of essays, written in different moments, the consistency of the ideas of the architect are extremely clear the same as is path that needs to be followed to get to this new order he describes and which constitutes the Modern Architecture. Path that starts with the classic architecture, saw as an stated point to learn from. In this sense, the translation of the classic architecture is evident, and so it is the rejection of the literal translation (imitation) proposed before by the Academy. As he explains in the Ozenfant's house façades, although the regulating lines are used like the Roman or Greek did before, the introduction of new modern elements, such as large ribbon windows and the geometrical abstraction, leads the house to what he describes as a new order. This process is the exact definition of translation and it could be the main reason for the success of the Modernity in the first place.

In the case of Koolhaas the translation is not that immediate, moreover, it is consciously complex. The use of Manhattan as a main example, as a generator of the change in the conception of the contemporary architecture is also an attempt to avoid any connection with history, using a city that he considers that has been started from scratch as a product of the desire of the capitalist contemporary society. He sees an example of that in Coney Island or the Rockefeller Center. The elements of the city are not explained here since their design, which remains as something unimportant, but since their capacity of canalizing the "congestion", main definition of the contemporary culture. Manhattan is a city made to satisfy our desires, what it is more interesting than its urban planning. Desires, on the other hand, that did not exist before, as they are directly connected to the contemporary way of living and understanding economics, politics or social relationships. But, although it locates Koolhaas in the antipodean from Le Corbusier the truth is that they are closer than it seems. In fact, Le Corbusier is for Koolhaas exactly the same as the classicism was for the master of the Modernity: the starting point from where to start the translation.

"Le Corbusier devouring ambition is invent and build a "new city" in accordance with the demand and potential splendour of the machine civilization.

His tragic bad luck is that this city already exist when he is developing his ambition: is, concretely, Manhattan'Rem Koolhaas ${ }^{26}$

So, despite the apparent differences between the two architects, forced by Koolhaas himself, they found a common point precisely in Manhattan, exemplary city for Koolhaas and, according also to him, the city Le Corbusier was, once and again, trying to create, without success. Thus Koolhaas is, at one time, the one responsible for the approach and distance of his own ideas from Le Corbusier's.

The lack of references to Le Corbusier, who is constantly present in Koolhaas work, could be nothing more but an attempt for the pupil to be released from the master. Like the characters in Lewis Carroll's books, Koolhaas is, absolutely aware of living in the world through the Looking-Glass. This fact is not making him, however, stop running away from this reality.

"-Well, this is what happens when you life upside down- said the Queen; and added complacently-: I have to admit that, at first, one get a little bit sick "Lewis Carroll ${ }^{27}$

\footnotetext{
${ }^{26}$ Koolhaas, Rem, Delirious New York, A Retroactive Manifesto for Manhattan, 2nd. ed. New York: The Monacelli Press, 1994, p. 249.

${ }^{27}$ Carroll, Lewis, Alicia en el País de las Maravillas, Madrid: Anaya, 2009, p. 202.
} 
The logical explanation could be that, the same as in Carroll's book, it could be possible that our reality is also taking place on top of a big chessboard from whose rules there is no escape.

Once Alicia got into the world inside the mirror she discovered that it was completely different form the one outside. She could not understand the rules, she was completely lost. But actually, as we see at the end of the book, she was the one who was creating this world, those rules and even the sensation of being lost, because all of this was part of her dream, her imagination. In other words, we can say that Alicia was doing nothing but transforming the world she knew into another invented one that was the result of the translation of her surrounding reality into another one built thanks to two main operations: symmetry and contrary. This strategy is broken with the introduction of the chessboard, representing an structure that is exactly the same in both sides of the mirror. Even the rules are the same. So she can only explain the world through the looking-glass by locate it in an intermediate state between being symmetrical and contrary to the world from Alice's side of the mirror.

The need for an old structure, something we can understand and, therefore break, is a common point of start at the beginning of a new era, specially in Arts and Architecture. The translation from the Classicism was the more criticised aspect of the "Revolution" Le Corbusier started with the Modernity. He was looking for a new language able to represent the new values of the Modern society, claiming against the Academia but using the same basis, how is it possible? his detractors said. Now we found out that Rem Koolhaas, like Alice, is creating a new world from Le Corbusier's Modern one like if it was looked through a looking-glass. The way he uses the small scale -Conney Island- to explain the big one -Manhattan-, the translation of the values of the new society from the social ones settled by Le Corbusier to the contemporary capitalism based ones, and even the structure of his manifesto explained in the index are just the translation of Le Corbusier theoretical strategies. Rem Koolhaas is playing in Le Corbusier's chessboard following his rules. If Le Corbusier was translating the Classic principles in Architecture to the Modern ones, Rem Koolhass, by translating Le Corbusier's, is retaking the Classicism, putting them into contemporary words but without changing their structure. By doing this, there is no other option that considering that, far from disappearing, the Modernity is being constantly reviewed and we can consider, in this way, that Rem Koolhaas is, in Charles Jencks words ${ }^{28}$, a Late Modern, which could led us to the conclusion than the Neo-Modernity and even the Post-Modernity are just punctual tendencies inside the process of building the Modern Movement, still ongoing.

\section{Source of images}

All images or tables accompanying this paper have been produced by the author herself. The Manifestoes included in the tables were found in the books Programs and Manifestoes on 20th century architecture, (Conrads, Ulrich Cambridge, Massachusetts: MIT Press, 1970) and Theories and Manifestoes of contemporary architecture, (Jencks, Charles and Kropf, Karl, Chichester: Academy, 1997)

\section{Acknowledgement}

The author acknowledge the support of Prince Sultan University in Riyadh, Saudi Arabia, during the research which has made it possible this paper and previous analysis.

\section{Bibliography/references}

\footnotetext{
${ }^{28}$ Jencks, Charles, The New Moderns. From Late to Neo-Modernism, Academy, Chichester, 1997.
} 
Carroll, Lewis, Alicia en el País de las Maravillas, Madrid: Anaya, 2009.

Conrads, Ulrich. Programs and Manifestoes on 20th century architecture, Cambridge, Massachusetts: MIT Press, 1970.

Jencks, Charles, The New Moderns. From Late to Neo-Modernism, Academy, Chichester, 1990.

Jencks, Charles and Kropf, Karl, Theories and Manifestoes of contemporary architecture, Chichester: Academy, 1997.

Koolhaas, Rem, Delirio de Nueva York, Barcelona: Editorial Gustavo Gili, 2007.

Koolhaas, Rem, Delirious New York: a retroactive manifesto for Manhattan, London: Thames and Hudson, 1978.

Le Corbusier, Hacia una arquitectura, Barcelona: Ediciones Apóstrofe, 1998.

Le Corbusier, Towards an Architecture, New York: Holt, Rinehart and Winston, 1986.

Mason, Eva (retold from Lewis Carroll) Alice in Wonderland \& Through the Looking-Glass. New York: Sterling Children's books, 2009.

Moneo, Rafael, Inquietud teórica y estrategia proyectual en la obra de ocho arquitectos contemporáneos, Barcelona, Editorial Actar, 2004.

Tournikiotis, Panayotis, The Historiography of Modern Architecture, Cambridge, Massachusetts: MIT Press, 1999.

Venturi, Robert, Complexity and Contradiction in Architecture, New York: Museum of Modern Art Press, 1966. 


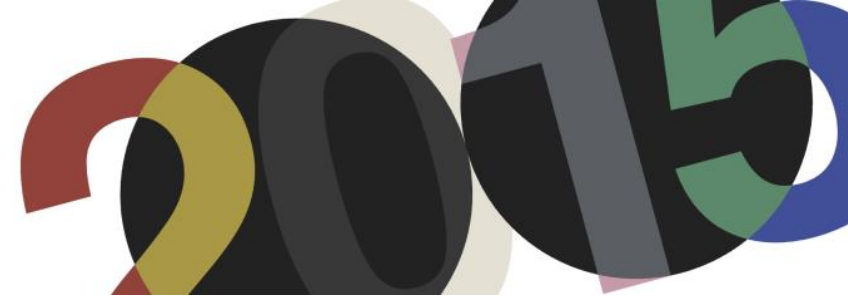

DOI: http://dx.doi.org/10.4995/LC2015.2015.569

\title{
Sobre una caracterización 'corbuseriana' del mobiliario moderno
}

\author{
M. Villanueva Fernández, H. García-Diego Villarías \\ Escuela de Arquitectura, Universidad de Navarra
}

\begin{abstract}
Resumen: A partir de 1920 Le Corbusier comenzó a elaborar un cuerpo teórico sobre el diseño de objetos que iría difundiendo a través de sus escritos y conferencias. Libros como Vers une architecture, L'art décoratif d'aujourd'hui o Précisions sur un état présent de l'architecture et de l'urbanisme han constituído un rico legado de ideas e imágenes interrelacionadas que permiten analizar la propuesta del arquitecto desde el plano de la teoría. Sin embargo, el poder de sus postulados fue continuamente experimentado y corroborado por su obra en materia de mobiliario, hasta el punto de establecerse relaciones directas entre teoría y obra. Esta evolución conjunta proporciona una completa visión del concepto de mobiliario moderno desarrollado por Le Corbusier. Por tanto, esta investigación persigue, por un lado, sacar a la luz un verdadero cuerpo teórico de cuño 'corbuseriano' y específico del equipamiento moderno, haciendo especial mención a los postulados y dibujos originales del arquitecto y, por otro, comprobar la correspondencia real entre sus teorías y sus obras mediante el análisis de una escogida selección de obras del arquitecto pertenecientes al periodo de entreguerras, para, finalmente, ofrecer una caracterización 'corbuseriana' del mobiliario moderno.
\end{abstract}

Abstract: From 1920 Le Corbusier began to develop a theoretical body on the objects design that went spreading through his writings and lectures. Books like Vers une architecture, L'art décoratif d'aujourd'hui or Précisions sur un état présent de l'architecture et de l'urbanisme have constituted a rich legacy of interlinked ideas and images to analyze the proposal of the architect from the level of theory. However, the power of its principles was continuously experienced and corroborated by his work in furniture, to the point of establishing direct relations between theory and work. This joint development provides a comprehensive overview of modern furniture concept developed by Le Corbusier. Therefore, this research aims on the one hand, to expose a 'Corbusian' and specific theoretical body of modern equipment, with special reference to the principles and original drawings by the architect; and, secondly, to check the real correspondence between his theories and works by analyzing a choice selection of works by the architect belonging to the interwar period, to finally offer a 'Corbusian' characterization of modern furniture.

Palabras clave: Teoría; mobiliario; moderno; escritos.

Keywords: Theory; furniture; modern; writings.

\section{Escritos, conferencias y mobiliario}

Le Corbusier dejó tras su muerte en 1965 un rico legado teórico que abarcó desde el urbanismo a gran escala hasta el diseño de objetos. Aunque su interés por este último campo comenzó en su periodo de formación en La Chaux-de-Fonds ${ }^{1}$, no fue hasta la década de 1920, en París, cuando formuló las ideas que fundamentaron la base de su teoría sobre el mueble moderno. Estos principios fueron difundidos no solo a través de su labor como arquitecto, sino también, y de manera más intensa, mediante su obra escrita y divulgación oral, lo que ha

\footnotetext{
${ }^{1}$ En 1912 Le Corbusier escribió Étude sur le mouvement d'art décoratif en Allemagne, resultante del estudio que la Escuela de Artes Aplicadas de La Chaux-de-Fonds le propuso realizar sobre las artes aplicadas en el país germano. Se trataba de su primer libro y el último que escribía en la ciudad suiza, ya que su posterior obra, Aprés le cubisme (1918), fue publicada junto con el pintor Amédée Ozenfant, ya en París, lugar donde estableció su residencia permanente.
} 
permitido profundizar en el pensamiento de Le Corbusier sobre la verdadera caracterización del mobiliario entendido moderno.

Ya en París, el maestro suizo difundió sus ideas sobre los objetos de uso a través de la conocida revista $L^{\prime} E s p r i t$ Nouveau, creada en 1920 por el pintor Amédée Ozenfant, el poeta Paul Dermée y el propio Le Corbusier, y que daría origen a otras conocidas publicaciones ${ }^{2}$. Entre ellas se encontraba Vers une architecture, publicada en 1923 como resultado de compendiar algunos de los artículos más destacados de la célebre revista. Aunque eran escasas las líneas dedicadas al estudio del mobiliario en este libro, el arquitecto presentó el germen de las ideas que se desarrollarían en textos posteriores.

Dos años después, con motivo de la Exposición de Artes Decorativas de París, Le Corbusier publicó L'art décoratif d'aujour'hui, un texto que, además de recoger algunas de las ideas que dieron forma al Pabellón de L'Esprit Nouveau, constituyó una suerte de manifiesto sobre el concepto de bienes útiles modernos y una de las piezas principales que sustentan el cuerpo de su teoría, abordando cuestiones como el ornamento, la belleza, la norma, la función, la máquina, el standard y el mueble moderno.

Estas ideas también fueron difundidas en algunas de sus ilustres conferencias, como la celebrada en Madrid en 1928 Arquitectura, mobiliario y obras de arte, o las llevadas a cabo un año después en Latinoamérica y que darían lugar en 1930 a la publicación Précisions sur un état présent de l'architecture et de l'urbanisme. Justamente, este texto incluía un capítulo, "La aventura del mobiliario", que confirmaba y complementaba las ideas publicadas con anterioridad, centrándose especialmente en la modulación y fabricación industrial de los objetos, así como en su utilización y su relación con el espacio.

En las reflexiones de Le Corbusier difundidas desde 1923 hasta 1930 es posible apreciar un intenso trabajo intelectual que se va puliendo y que en tan sólo siete años expone una clara postulación teórica sobre los objetos de uso, desde el inicio de sus primeras intuiciones hasta su maduración y posteriormente confirmación de sus ideas. No obstante, esa evolución no sólo se produce en el plano teórico sino también, y de forma paralela, en sus obras — desde el diseño del Pabellón de L'Esprit Nouveau hasta la creación de prototipos en 1928, producidos por Thonet en 1930 - que muestran un desarrollo considerable en la praxis llevada a cabo en el campo del diseño por el arquitecto suizo.

Todo este legado ha sido estudiado en profundidad por distintos investigadores a lo largo de la segunda mitad del siglo XX y comienzos del XXI. Entre ellos destaca Arthur Rüegg por la realización de una exhaustiva investigación que ha dado lugar al libro Le Corbusier: Meubles et Intérieurs 1905-1965. Sus aportaciones, junto con las de otros críticos como Banham, Frampton, Cohen, Von Moos o McLeod, y los escritos originales de Le Corbusier han constituido la fuente principal de esta investigación que pretende ofrecer una caracterización 'corbuseriana' del mobiliario moderno.

\section{Apuntes sobre una teoría del mueble moderno}

En 1923, con el libro Vers une architecture, Le Corbusier exponía buena parte del discurso en torno al cual iba a girar el conjunto de su obra. Por un lado, explicaba la necesidad de satisfacer las exigencias funcionales a través

\footnotetext{
${ }^{2}$ Cfr. Cohen, Jean-Louis: Le Corbusier 1887-1965. El lirismo de la arquitectura en la era mecánica. Köln: Taschen, 2004.
} 
de una forma empírica; y por otro, abogaba por la utilización de elementos abstractos para fascinar sensorialmente y fomentar la capacidad intelectual. En el capítulo "Ojos que no ven...", Le Corbusier abordó cuestiones sobre el mobiliario de la casa y los aspectos funcionales y estéticos de la arquitectura que más tarde, junto con otros conceptos como la proporción o la producción en serie de viviendas, presentadas en "Pura creación del espíritu" y "Casas en serie", se convertirían en un anticipo de la teoría acerca de los objetos de uso que desarrollaría Le Corbusier en 1925 en L'art décoratif d'aujourd hui.

\subsection{Arte decorativo de 'hoy'}

Precisamente, este libro fue publicado como respuesta al desconcertante panorama de las artes decorativas de la época, y junto con el Pabellón de L’Esprit Nouveau de la Exposición de Artes Decorativas de París de 1925 supuso una manifestación concluyente de las ideas desarrolladas por Le Corbusier sobre el diseño de objetos. Su postura contradecía firmemente las bases del estilo Art-Déco ${ }^{3}$, mayoritario en la exposición de París, que se convertiría en uno de los objetivos principales de crítica del arquitecto. En su libro L'art décoratif d'aujourd hui explicaba cómo el propio título, que hacía referencia a la muestra del 25, presentaba una paradoja: "el arte decorativo moderno no tiene decoración "4.

La paradoja radicaba no en el hecho, sino en las palabras, en la contradicción de hacer arte de herramientas: “ ¿Por qué deberíamos denominar todas estas cosas que nos ocupan en la actualidad, arte decorativo? Ahí reside la paradoja: ¿Por qué denominar arte decorativo a las sillas, las botellas, las cestas, los zapatos, todos los objetos útiles, los utensilios? Es una paradoja querer hacer arte con los utensilios „5. Por esta razón, la definición del término arte también se convertía en cardinal para comprender la base de sus teorías. Sólo si el arte era considerado la aplicación de conocimientos para la realización de una idea ${ }^{6}$, podía aplicarse a los objetos de uso. Por el contrario, el arte entendido como decoración o como "manifestación de la actividad humana mediante la cual se expresa una visión personal y desinteresada que interpreta lo real o imaginado con recursos plásticos, lingüísticos o sonoros”, no tenía sentido en la creación de bienes utilitarios.

"Y todos los sarcasmos emitidos acerca del objeto único, del mueble de arte, suenan a falso y prueban una incomprensión enfadosa de las necesidades de la hora presente: una silla no es una obra de arte; una silla no tiene alma; es una cosa para sentarse",7.

\subsection{Ausencia de ornamento}

Le Corbusier se hacía eco de las reflexiones expuestas por Adolf Loos años antes, afirmando que "cuanto más

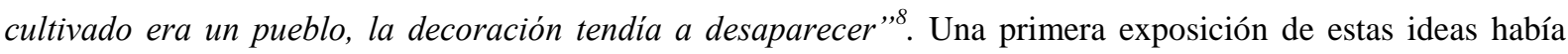

\footnotetext{
${ }^{3}$ Frampton, Kenneth: Le Corbusier. Madrid: Akal, 2002, p.22.

4 “'L'art dècoratif moderne n'a pas de décor". Le Corbusier: L'art décoratif d'aujourd'hui. Paris: G. Crès \& Cie., 1925, p.84.

${ }^{5}$ Idem."Pourquoi appeler ces choises qui nous occupent presentemente: art décoratif? Voilà le paradoxe; pourquoi appeler art décoratif des chaises, des bouteilles, des paniers, des chaussures, Tous objets utiles, des outils?" (Traducción al español extraída de Le Corbusier: El arte decorativo de hoy. Carlos Naya Villaverde e Inmaculada Jiménez Caballero (ed.) Maurici Pla Serra (trad.). Pamplona: EUNSA, 2013).

${ }^{6}$ Le Corbusier: L'art décoratif d'aujourd’hui, op.cit., p.84.

${ }^{7}$ Le Corbusier: Vers une architecture. Paris: G. Crès \& Cie., 1923, p.112. (Traducción al español extraída de Le Corbusier: Hacia una arquitectura. Barcelona: Ediciones Apóstrofe, 1998).

8 “Plus un peuple se cultive, plus le décor disparaît". Le Corbusier: L'art décoratif d'aujourd'hui, op.cit., p.85.
} 
tenido lugar en Vers une architecture en 1923, en donde el maestro suizo, por un lado, afirmaba que los objetos de uso tenían que mostrarse desprovistos de toda ornamentación; y, por otro, mantenía que toda expresión humana necesitaba "una cierta dosis de interés y sobre todo en el dominio estético",; y los objetos podían ser considerados como expresión del hombre, puesto que él los había creado.

Aquel interés se manifestaba de dos maneras distintas dependiendo del nivel cultural del individuo. Le Corbusier distinguía entre aquellos que calificaba como pueblos sencillos y la civilización culta. En los primeros se producía de manera sensorial y primaria mediante la 'decoración'; sin embargo, para los segundos, surgía motivado por el orden intelectual, a través de la "proporción' ${ }^{10}$. De este modo, la proporción era el único principio de captación del interés del hombre culto y la única manera de crear armonía; una armonía que se alcanzaba mediante la aplicación de la 'norma', es decir, "una necesidad de orden llevada al trabajo humano",11, que se establecía sobre bases funcionales, económicas y estéticas.

\subsection{Objetos-tipo}

La teoría formal de los bienes de uso de Le Corbusier estaba fundada, en parte, en la creencia de una correspondencia con el principio biológico de la selección natural. El arquitecto aplicó el concepto 'darwiniano' ${ }^{12}$ de la evolución al ámbito de las formas industriales, afectando así tanto al objeto como al usuario. Por un lado, se había producido un proceso de depuración de los objetos de uso en el cual se habían visto despojados de toda decoración alcanzando una mayor pureza y simplicidad formal. Por otro lado, el ser humano había experimentado un progreso debido a los objetos útiles, sus nuevas extensiones físicas, llamadas por Le Corbusier objets-membres humains.

Aunque el desarrollo de esta idea se llevó a cabo de un modo más amplio en L'art décoratif d'aujourd'hui, y más concretamente en el capítulo "Besoins-types, meubles-types", Le Corbusier ya había expuesto sus primeras reflexiones acerca de este tema en Vers une architecture ${ }^{13}$. Los objets-membres humains eran el resultado material de una búsqueda del hombre por satisfacer sus necesidades; unas necesidades comunes a las de todos los seres humanos: "Todos los hombres tienen el mismo organismo, las mismas funciones. Todos los hombres tienen las mismas necesidades" ${ }^{\prime 14}$. Sin embargo, el ser humano debía complementar sus capacidades naturales para adaptarse a su tiempo a través de la creación de las herramientas adecuadas y perfectas. Estos útiles eran objetos-tipo que respondían a unas necesidades-tipo de un hombre-tipo ${ }^{15}$.

\footnotetext{
9 “Toute manifestation humaine nécessite un certain quantum d'intérêt et surtout dans le domaine esthétique”. Le Corbusier: Vers une architecture, op.cit., p.112.

${ }^{10}$ Le Corbusier: Vers une architecture, op.cit., p.113.

${ }^{11}$ La palabra que utiliza Le Corbusier en Vers une architecture es standart. En la traducción española se sustituye por norma. Le Corbusier: Vers une architecture, op.cit., p.107.

${ }^{12}$ Le Corbusier explica el proceso de perfeccionamiento de los objetos a través de una terminología evolutiva que remite a Darwin. Estas reflexiones aparecen en varios párrafos del texto de L'art décoratif d'aujourd'hui; sin embargo, en la página 54 este procedimiento se aprecia especialmente. Frampton también hace referencia en su texto Le Corbusier a este modo de narrar el desarrollo de los objetos. Frampton, Kenneth: Le Corbusier, op.cit., p.21.

${ }^{13}$ Le Corbusier: Vers une architecture, op.cit., p.108.

${ }^{14}$ Idem. ("Tous les hommes ont même organisme, mêmes fonctions. Tous les hommes ont mêmes besoins"). Esta idea es expuesta en los tres textos, manteniéndose constante toda su vida. Finalmente, siguiendo estas ideas elaboraría en los $50 \mathrm{Le}$ Modulor, unidad de medida de su obra.

${ }^{15}$ Le Corbusier: L'art décoratif d'aujourd'hui, op.cit., p.76.
} 


\subsection{Standard}

Para ello, lo racional era crear objetos standard de dimensiones standard y que además se adecuasen a las medidas del cuerpo del hombre. El resultado de estas piezas debía caracterizarse por la precisión, lo cual obligaba a ejecutarlos con una máquina. Para ello se comenzaron a utilizar los nuevos materiales en campos que antes no se habían empleado, introduciéndose inevitablemente en las industrias de artes decorativas, lo que transformó desde el modo de producción hasta la forma de los objetos. Este progreso, caracterizado por la aportación de nuevas técnicas como el tubo de acero o la soldadura autógena, proporcionó unos medios de realización infinitamente más perfectos y más eficaces que los desarrollados anteriormente.

La clave para la óptima creación de estos objetos se encontraba en su correcto dimensionamiento. En la era maquinista esto ya no era considerado un problema, pues la industria de la madera y del metal podían construir objetos precisos de funcionamiento admirable y de una dimensión no aproximada, sino cierta. Le Corbusier proponía incorporar en las viviendas objetos standard que cumpliesen una función y cuya forma estética llenase el corazón y la sensibilidad de un hombre moderno. Tan sólo eran necesarios tres tipos de objetos para cubrir las necesidades del ser humano en materia de mobiliario doméstico: la mesa, el asiento y el casillero ${ }^{16}$.

\subsection{Mesa}

Le Corbusier proponía distribuir varias mesas standard en cada apartamento, con el propósito de satisfacer necesidades diferentes. Recomendaba la disposición de dos o tres piezas yuxtapuestas de tamaños diferentes de tal modo que el espacio se convirtiese en espacio polivalente, un espacio flexible que se adecuase a las distintas funciones del hombre: la mesa de mayor tamaño podría servir para comer, otra de ellas para trabajar y quizás las más pequeñas podían desempeñar una función de apoyo. Asimismo las mesas podían ser utilizadas como complementos las unas de las otras y no sólo como elementos independientes (1).

El proceso de fabricación de las mesas debía ser industrial. Además Le Corbusier apostaba por el empleo de los nuevos materiales; concretamente sugería que las mesas fueran construidas con tubos de acero. La unión de estas piezas debía producirse mediante una soldadura autógena ${ }^{17}$; de este modo, permitía fijar la bandeja por un sistema de ajuste automático, facilitando el transporte y la ubicación de las piezas para cualquier ocasión ${ }^{18}$. Con este sistema de mesas yuxtapuestas, Le Corbusier conseguía flexibilidad del espacio doméstico y comodidad para sus habitantes.

\footnotetext{
${ }^{16}$ Le Corbusier: Precisiones respecto a un estado actual de la arquitectura y del urbanismo. Johanna Givanel (trad.). Poseidón: Barcelona, 1978, p.131. ("Afirmoles a ustedes que exceptuando los asientos y las mesas, los muebles no son, a decir verdad, sino casilleros").

${ }^{17}$ Según la Real Academia de la Lengua Española, la soldadura autógena es una soldadura de metales, que se hace, sin intermedio de materia extraña, fundiendo con el soplete de oxígeno y acetileno las partes por donde ha de hacerse la unión.

${ }^{18}$ Le Corbusier: Precisiones respecto a un estado actual de la arquitectura y del urbanismo, op.cit., p.139.
} 


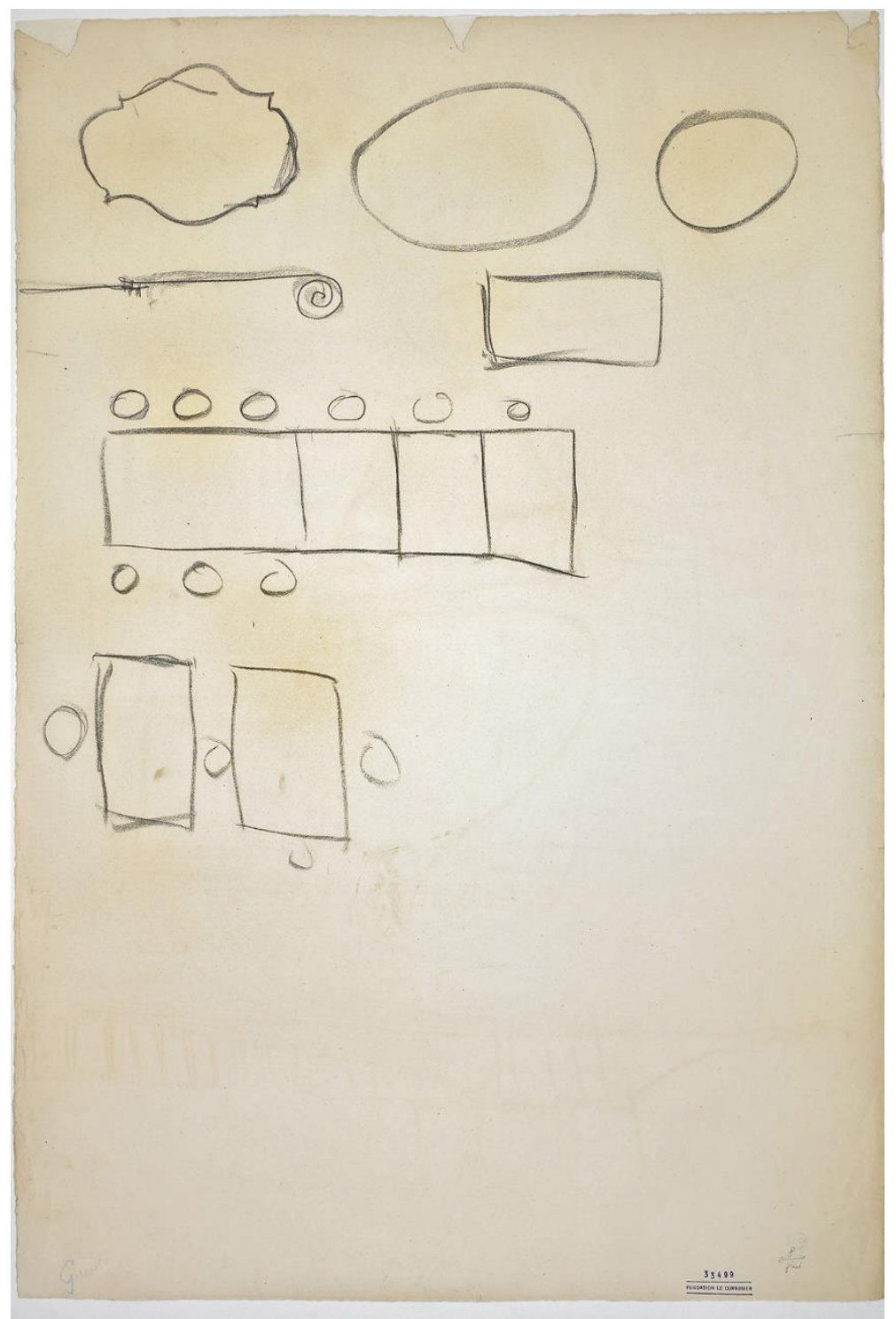

1. Dibujo de unas mesas en planta realizado por Le Corbusier. Plan FLC 33499

\subsection{Asiento}

Dependiendo del momento del día, de las preocupaciones de las personas y la actitud adoptada en un salón existían varias maneras de sentarse. Respondiendo a esta diversidad de posturas, Le Corbusier consideraba que debían utilizarse en cada situación las piezas de mobiliario adecuadas. Para trabajar se requería la silla, puesto que se trataba de un instrumento que por su morfología permitía al usuario mantenerse "en activo". Para demostrar una tesis, la pieza idónea era el taburete alto porque, además de mantener al orador activo, lo situaba en posición elevada frente a su público. Para charlar, el sillón era el asiento más adecuado pues dotaba al usuario de un porte decente y cortes. Para descansar, la opción más acertada era el taburete turco ${ }^{19}$ donde se conseguía un fabuloso estado de tranquilidad y relajación (2).

\footnotetext{
${ }^{19}$ Idem. Le Corbusier explicaba, asimismo las características del taburete turco de los "cavedjis" de Estambul, cuyas medidas eran 35 centímetros de alto y de 30 centímetros de diámetro.
} 
El mobiliario no sólo dependía de estos factores, vinculados en gran medida con las actividades del hombre, sino que también debía responder a cuestiones prácticas y funcionales, como por ejemplo, el número de asistentes o la menor ocupación del espacio en su almacenamiento. Para solventar ambas situaciones, la industria había creado sillas y taburetes apilables que resultaban de gran utilidad en momentos de gran concurrencia. Estas piezas de mobiliario podían encajarse unas en otras, de manera que su almacenamiento era rápido, situándolas en altura y ocupando menos espacio.

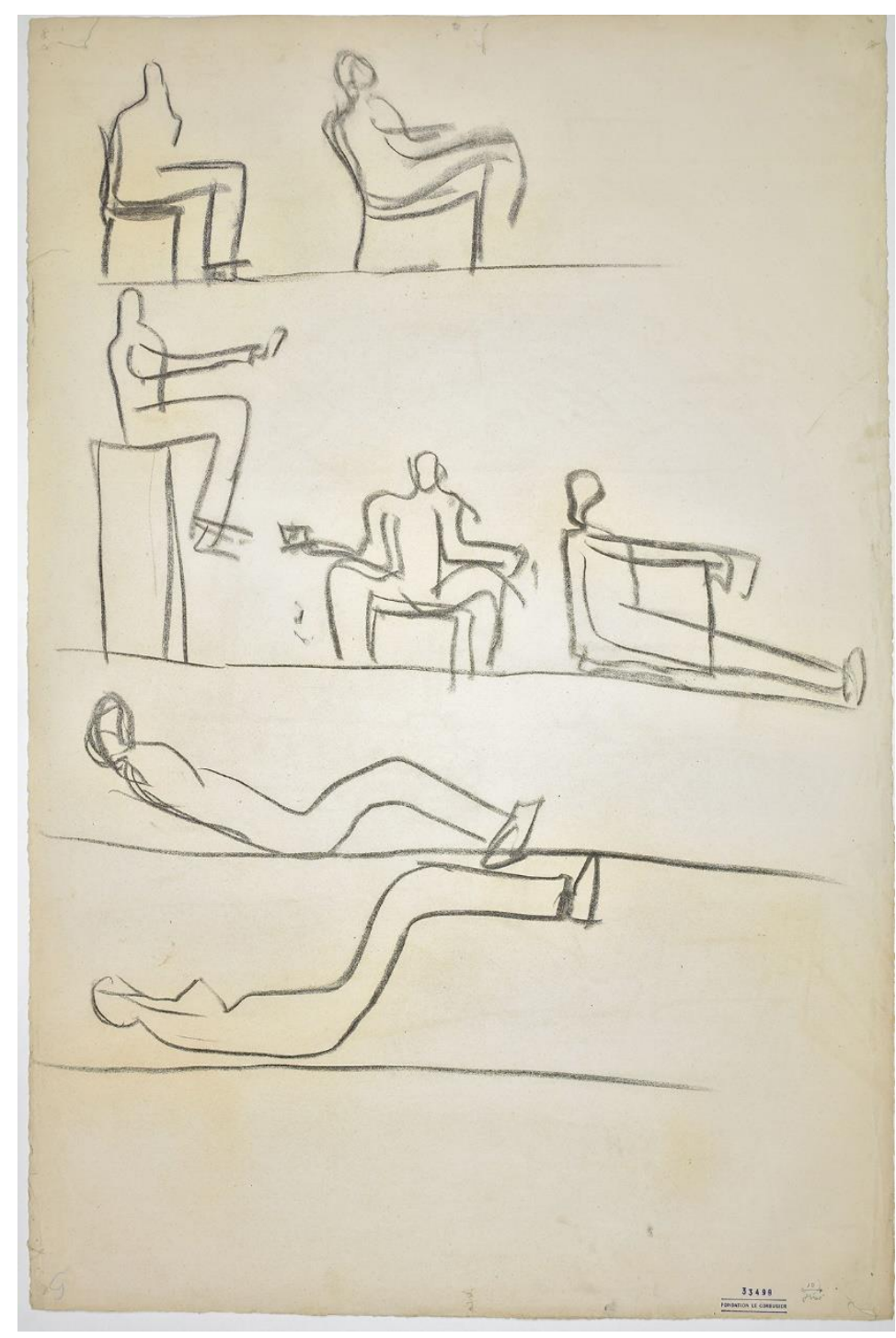

2. Dibujo realizado por Le Corbusier para mostrar las diferentes formas de sentarse. Plan FLC 33499

\subsection{Casillero}

Para Le Corbusier, el inventario de los objetos de uso diario del hombre se resumía en dos imágenes. En una de ellas mostraba los instrumentos para comer situados en un casillero: un estante con la cristalería, otro con la vajilla, otro con botellas y unos cajones con la cubertería. En la segunda, presentaba los elementos textiles necesarios, desde la ropa de cama, ropa interior, lencería, medias... hasta el traje y zapatos. Todos ellos habían sido diseñados según los miembros del cuerpo humano, por lo que almacenar eficazmente era necesario un mueble que también lo estuviera. Le Corbusier proponía para ello la utilización del casillero, y a través de otro de sus dibujos (3), las dimensiones exactas que debía tener: 

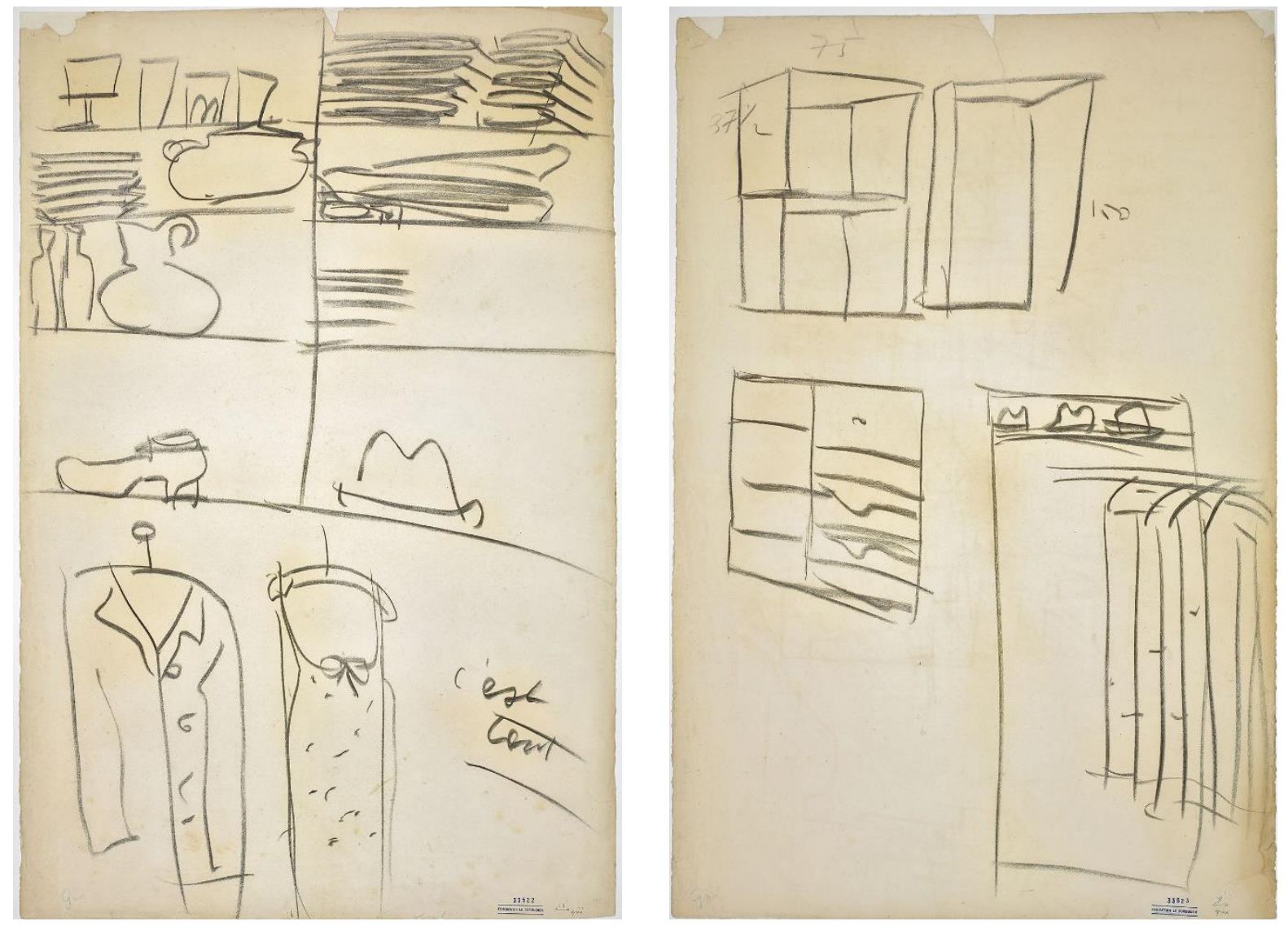

3. Dibujos realizados por Le Corbusier para ilustrar los objetos que hay que almacenar en una vivienda y la adecuación del casillero para este uso. Plan FLC 33522 (izda.), plan FLC 33523 (dcha.)

"Dibujo este casillero. Tiene 75 centímetros de lado y 37,50 a 50 centímetros de profundidad o $150 \times 75$ de frente y 37,50 a 75 de profundidad. La movilidad de la cota de profundidad resulta de los diversos métodos de arreglo interior de este casillero ${ }^{, 20}$.

Le Corbusier propuso una solución que afectaba a todos los órdenes: constructivo, económico e industrial: "Seria oportuno crear, industrialmente, unos casilleros, unos 'continentes', en gran serie, vendibles al particular que arregla su casa y al arquitecto que proyecta los planos ${ }^{21}$. De este modo, el propietario y habitante de la vivienda podría disponer los casilleros contra las paredes de sus habitaciones o construir con ellos unos tabiques nuevos a plena o a media altura, y por otro lado, el arquitecto podría incorporar en obra los

${ }^{20} \mathrm{Ibid}, \mathrm{p} .133$. Este conjunto de números no eran aleatorios, sino que respondían a unas necesidades estudiadas por el propio Le Corbusier, fruto de su reconocida experiencia en espacios expositivos e interiores. En el año 1913, realizó un proyecto para una exposición ambulante de arte decorativo, en el que debía dibujar un material desmontable que consistía en una batería de cocina que iba desde el office al salón y al "boudoir". En esta ocasión Le Corbusier halló un módulo de 75 centímetros y de 150 centímetros. Más tarde, en 1924, durante la preparación del Pabellón de L'Esprit Nouveau volvió a llegar a aquellas dimensiones tras un severo análisis, confirmándolas un año después, tras la inauguración del Pabellón. Finalmente, en 1928 Charlotte Perriand, asociada a Le Corbusier para la instalación de los interiores de las casas, llegó a la misma conclusión al realizar el proyecto para el Salón de Otoño de París en 1929. La instalación de dicha exposición pretendía demostrar de modo concluyente, el principio del "equipamiento de una habitación moderna", amueblada con sillas, mesas y casilleros standard.

${ }^{21}$ Ibid, p.135. 
casilleros introduciéndolos en el interior de las paredes. Así, casi todas las funciones del mobiliario del hogar estarían solucionadas. El único aspecto que quedaba por equipar era el interior de los casilleros, que se realizaría por medio de estantes y cajones ${ }^{22}$.

\subsection{Espacio}

Le Corbusier manifestó en distintas ocasiones que el interés en el mobiliario no se limitaba únicamente al propio objeto, sino que trascendía, influyendo de un modo directo en la arquitectura, en el "hombre y su ambiente",23. Con la llegada de nueva arquitectura, las viviendas se vaciaron de mobiliario obsoleto y se llenaron de luz, espacio y nuevos muebles adecuados a su tiempo. Para ilustrar de qué manera el mobiliario moderno era capaz de liberar espacio ${ }^{24}$, Le Corbusier analizó y comparó la planta y la sección de un dormitorio tradicional con las de uno moderno (4). A diferencia del primero, el segundo ofrecía un mayor aprovechamiento del espacio, mejora de las circulaciones, y un perfeccionamiento de las formas. El dormitorio tradicional, sin embargo, entorpecía la estancia por el gran tamaño y excesivo peso de sus muebles ${ }^{25}$.
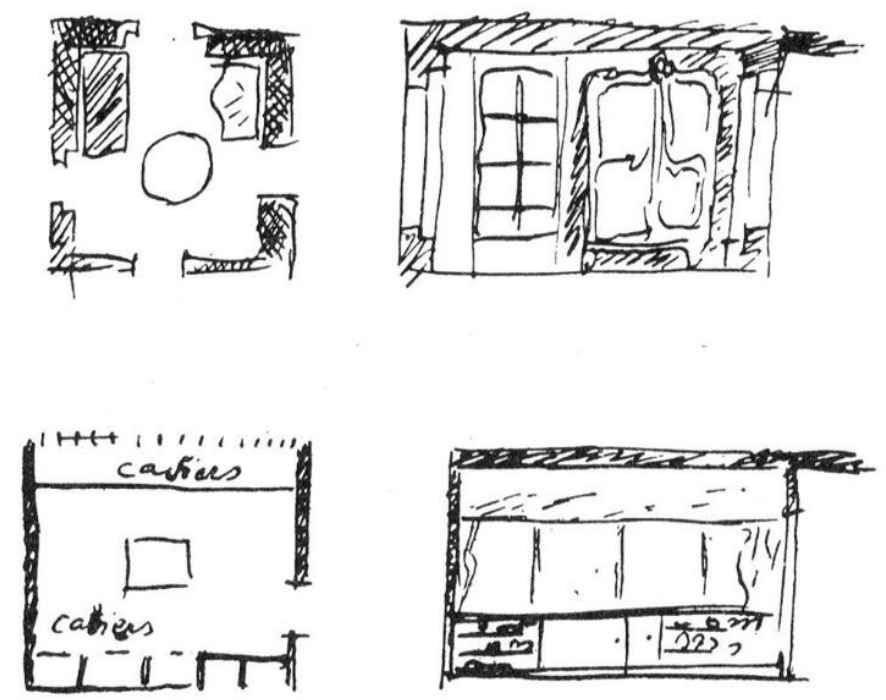

4. Dibujo realizado por Le Corbusier que compara el espacio de una habitación tradicional y otra moderna. Fuente: Le Corbusier: Precisiones respecto a un estado actual de la arquitectura y del urbanismo, p.132.

Le Corbusier estaba convencido de que no se enfocaría con eficacia la renovación del plano de la casa moderna sino después de haber puesto al desnudo la cuestión del mobiliario. "Aquí está el nudo gordiano. Hay que cortarlo, de lo contrario toda persecución de vida moderna es vana"26. Arquitectura y mobiliario estaban claramente vinculados hasta tal punto que dependían el uno del otro, cuestión que sería objeto de la experimentación del arquitecto a lo largo de toda su vida.

\footnotetext{
${ }^{22}$ Idem.

${ }^{23}$ Ibid, p. 10 .

${ }^{24}$ Las ilustraciones que aparecen en la publicación de Precisiones, según afirma su autor, son las mismas que dos años antes había empleado para explicar las características del mobiliario moderno en su conferencia "La aventura del mobiliario" celebrada en Argentina.

${ }^{25}$ Le Corbusier: Precisiones respecto a un estado actual de la arquitectura y del urbanismo, op.cit., p.135.

${ }^{26}$ Ibid, p. 127.
} 


\section{Hombre, objeto y ambiente}

Los proyectos desarrollados durante la segunda mitad de la década de 1920 por Le Corbusier, en colaboración con su primo Pierre Jeanneret, son manifiestos construidos a escala 1/1: la experimentación y corroboración de las ideas presentadas en sus escritos. Por esa razón, los cambios que experimentó su posición acerca de la relación establecida entre mueble y arquitectura se pueden apreciar tanto en su teoría como en su obra. Aunque la base de sus tesis, anteriormente expuesta, no sufre grandes modificaciones, se produce una importante transformación entre 1925 y 1928 que se tradujo en un mayor intervencionismo del arquitecto en el diseño de piezas standard.

La actitud adoptada en la Exposición de Artes Decorativas de París de 1925, ratificada tanto en el Pabellón de L'Esprit Nouveau como en su libro L'art décoratif d'aujourd 'hui, muestra su rechazo a la obra de arte total en la que el arquitecto lo diseña todo. Sin embargo, este posicionamiento se va flexibilizando a partir de la incorporación de Charlotte Perriand en 1927 al estudio de Le Corbusier y Pierre Jeanneret ${ }^{27}$. El Salón de Otoño de 1929 y su conferencia "La aventura del mobiliario" confirman esta evolución hacia una mayor participación del arquitecto en el diseño de objetos domésticos standard.

El punto de partida de este desarrollo es el Pabellón de 1925 (5), no sólo por la manera de amueblar la instalación - muy similar a la ya realizada en la casa La Roche/Jeanneret- sino también, y muy especialmente, por su carácter de manifiesto que complementaba a su libro L'art décoratif d'aujour'hui. En este proyecto, Le Corbusier, de nuevo influenciado por Adolf Loos - algo que el propio arquitecto suizo reconocía sin ambages, amuebló el espacio fundamentalmente con piezas ya existentes en el mercado. Su elección estaba claramente marcada por el carácter utilitario y casi anónimo de los objetos, que provenían tanto del mundo artesanal como industrial.

\footnotetext{
${ }^{27}$ A raíz de la exposición de su Bar bajo el tejado (Bar sous le toit) en el salón de la Sociedad de artistas decoradores, Charlotte Perriand logró llamar la atención de Le Corbusier quien le permitió incorporarse a su estudio. Perriand influida por la lectura de Vers une architecture y L'art décoratif d'aujourd'hui diría de estos textos que abrieron el muro que tenía ante sus ojos; además de servir de inspiración para la creación de sus piezas. McLeod, Mary: Charlotte Perriand. An Art of Living. New York: H.N. Abrams in association with the Architectural League of New York, 2003, p.36.
} 


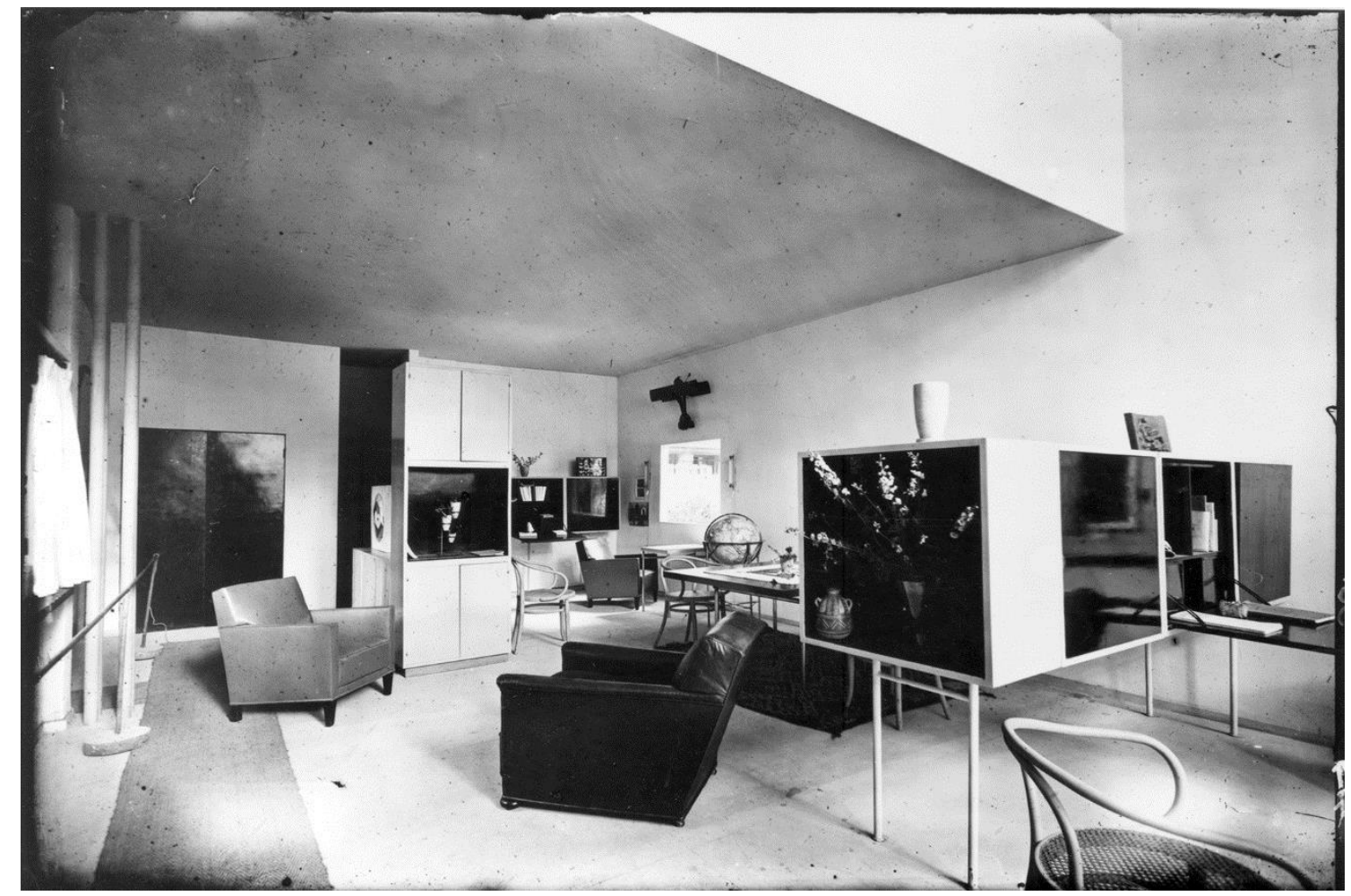

5. Fotografía del interior del Pabellón de L’Esprit Nouveau, París, 1925. Fuente: Fondation Le Corbusier. @ FLC-ADAGP

Según recoge Arthur Ruegg en su libro Le Corbusier: Meubles et intérieurs 1905-1965, se expusieron los siguientes objetos estándar: silla de oficina de Jacob \& Josef Kohn / Thonet Fréres (Viena-París) y Robert Mey (París), muebles de metal para jardín, tres sillas de cuero del club silla Abel Motte (París, ejecuciones según las indicaciones de Le Corbusier y Pierre Jeanneret), un baúl de viaje de la firma de Innovación (París) ${ }^{28}$. Entre estas piezas destaca el modelo 209 de Thonet que Le Corbusier utilizaría para amueblar, entre otras, la casa La Roche y las Weissenhofsiedlungen de Stuttgart, y que serviría de referencia para diseños propios como la silla pivotante.

Pero además fueron exhibidas en la muestra piezas diseñadas por Le Corbusier y Pierre Jeanneret: mesas ${ }^{29}$, camas y unos casilleros estándar, presentados por primera vez en la exposición (6). Estos últimos no sólo constituyeron un nuevo diseño de un mueble de almacenamiento, sino que presentaban una nueva manera de equipar la vivienda moderna, tal y como el arquitecto lo expondría en sus escritos. Por un lado, el casillero había sido ideado como un elemento standard que estaba equipado de manera diferente según las necesidades del usuario (con estantes, cajones, espacio para ropa...). Por otro, el mueble estaba estratégicamente situado para crear circulaciones y definir espacios, tal como lo expuso en su libro Précisions sur un état présent de l'architecture et de l'urbanisme.

\footnotetext{
${ }^{28}$ Rüegg, Arthur: Le Corbusier: Meubles et Intérieurs 1905-1965, Zurich: Scheidegger \& Spiess AG, 2012, p.252-254.

${ }^{29}$ Ibid, p.250.
} 


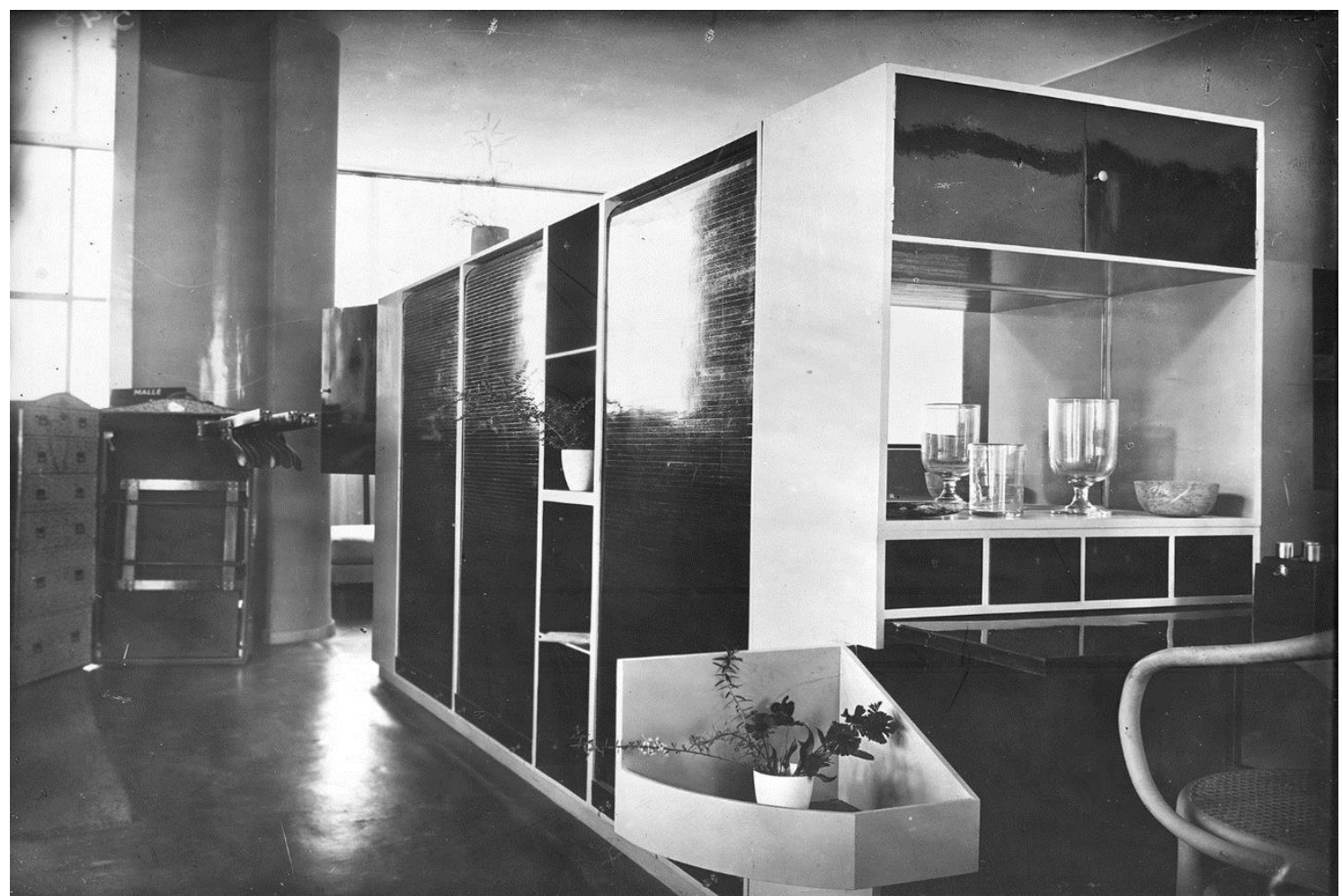

6. Fotografía de los casilleros instalados en el Pabellón de L’Esprit Nouveau, París, 1925. Fuente: Fondation Le Corbusier. (C) FLC-ADAGP

El pabellón era un espacio visualmente homogéneo "producto de una sola mentalidad creadora"30. Tal y como explicaba Frampton, la instalación mostraba un amueblamiento de acuerdo con el canon purista basado principalmente en objetos-tipo combinados con objetos-mesa; alfombras orientales y alfarería suramericana. El perfeccionamiento propio del mueble producido en serie, además de satisfacer funciones formales debido a su correcta ejecución, proporcionó una estética interior del pabellón que impactó tanto a organizadores como visitantes de la exposición. Se trataba, además de una protesta contra el Art Déco y sus seguidores, de una exposición pública de las propuestas espaciales de Le Corbusier para la modernidad ${ }^{31}$, que consistía principalmente en una actitud selectiva, basada en la elección de unos elementos standard disponibles en el mercado, y creando otros objetos-tipo con vocación de seriación.

A partir de entonces, la relación que Le Corbusier establecía entre mueble y arquitectura fue modificándose paulatinamente y experimentando un verdadero cambio que coincide con la entrada de Perriand en el estudio en 1927. Aunque a su llegada, el maestro suizo ya tenía un claro concepto de mobiliario moderno, su posición comenzó a tornarse más flexible hacia una postura normativa en la que el arquitecto también desarrollaba su propio mobiliario a través del lenguaje moderno. Una de las razones que motivaron este cambio, según apunta McLeod $^{32}$, fue la fascinación de Le Corbusier por los muebles de tubo de acero diseñados por Breuer y Mies van der Rohe. Al igual que ellos, y debido a su insatisfacción con los productos fabricados industrialmente, Le

\footnotetext{
${ }^{30}$ Banham, Reyner: Theory and Design in the first Machine Age. Londres: The Architectural Press, 1960, p.245.

${ }^{31}$ Frampton, Kenneth: Historia crítica de la arquitectura moderna. Barcelona: Gustavo Gili, 2002, p.157.

${ }^{32}$ McLeod, Mary: Charlotte Perriand. An Art of Living. New York: H.N. Abrams in association with the Architectural League of New York, 2003, pp.37-38.
} 
Corbusier contrató a Perriand para encargarse del mobiliario y poder diseñar prototipos de muebles en su propio taller.

Surgieron de este momento las piezas más famosas del estudio de Le Corbusier. Se trataba de la serie de muebles de tubo de acero y piel, creados entre 1927 y 1929, considerados hoy verdaderos clásicos del diseño del siglo XX. Entre ellos destacan el sillón de respaldo basculante, el gran confort, la Chaise longue - considerada por Le Corbusier "la verdadera máquina de reposo"33 _, la silla giratoria y la mesa-tubo de avión con tablero de vidrio. Resulta especialmente interesante destacar, tal y como lo explica Frampton, por una parte, que cada una de las piezas corresponde a una postura concreta del cuerpo humano y, por otra, que algunas derivaban de una tipología particular de mueble ya existente. La silla gran confort estaba inspirada en el sillón club inglés y exigía una postura frontal asociada a la silueta masculina. El sillón de respaldo basculante derivaba del tradicional sillón plegable de campaña británico. Las sillas giratorias estaban inspiradas en la clásica silla de mecanógrafa. La chaise longue, asociada a la forma femenina, era una pieza diseñada para el descanso ${ }^{34}$.

Todas estas piezas respondían a las características del mobiliario moderno expuestas por Le Corbusier en sus escritos previos - ausencia de ornamento, objetos-tipo para funciones-tipo, dimensiones standard, adecuación al espacio, entre otras - , por lo que eran ejemplos materiales de su teoría; algo que se reafirmaría cuando en 1930 la casa Thonet produjo varios modelos en pequeñas series ${ }^{35}$ que pasarían a formar parte de sus catálogos (7). La firma de muebles ofrecía estos modelos entre otros realizados por conocidos diseñadores del momento. Las obras de Marcel Breuer, Mart Stam, Ludwig Mies van der Rohe o André Lurçat, fueron recogidas en el catálogo, re-editado por Vitra Design Museum-Vitra Design Publications en 1989, que presentaba la primera colección completa de modelos de acero tubular alemanes y franceses comercializados en 1930-1931, entre los que también se encontraban las piezas de Le Corbusier, Jeanneret y Perriand ${ }^{36}$.

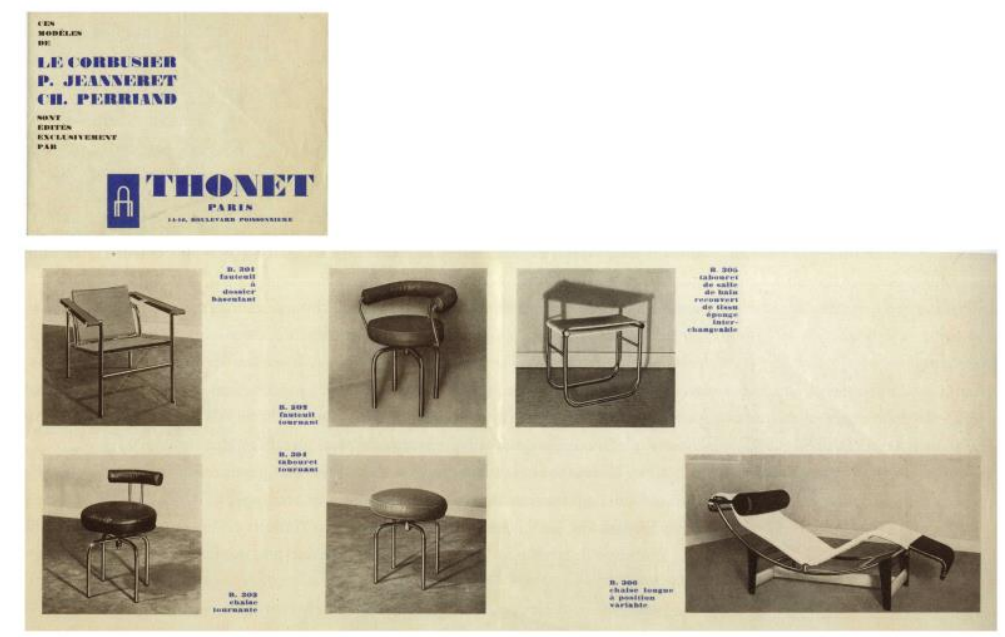

7. Folleto desplegable de la firma Thonet en París con los modelos de Le Corbusier, Jeanneret y Perriand, 1931. Fuente: Rüegg, Arthur: Le Corbusier: Meubles et Intérieurs 1905-1965, p.122 (Colección privada)

\footnotetext{
${ }^{33}$ Le Corbusier: Precisiones respecto a un estado actual de la arquitectura y del urbanismo, op.cit., p.142.

${ }^{34}$ Frampton, Kenneth: Le Corbusier, op.cit., p.51.

${ }^{35}$ A partir de 1965 sería la firma Cassina la encargada de producirlos, bajo licencia de la Fondation Le Corbusier.

${ }^{36}$ Gunther, Sonja: Thonet tubular steel furniture card catalogue. Well-Am-Rhein: Vitra Design Museum, 1989.
} 
Tan sólo un año antes, aquellas piezas — entonces prototipos- habían sido expuestas en el Salón de Otoño junto con unos casilleros modulares, modificables e intercambiables, similares a los ya presentados en el Pabellón de L'Esprit Nouveau. Desde 1925 el arquitecto fue transformando los casilleros y ajustando su diseño a las necesidades de un usuario-tipo, tratando de producir modelos standard adecuados a la vivienda moderna. Estas unidades de almacenamiento fueron claves en el desarrollo de la obra de Le Corbusier, convirtiéndose en objeto de estudio del arquitecto y pieza indispensable en muchas de sus obras.

En enero de 1929 ya se había realizado una primera versión de los casilleros metálicos que iban a ser expuestos en el Salón de Artistas Decoradores de ese mismo año. Finalmente, aquella presentación pública no se llevó a cabo y aquel primer prototipo realizado por la casa Blanc de París no prosperó debido a cuestiones técnicas elementos de chapa inestables o desperdicio de material innecesario-, tal y como lo explica Rüegg ${ }^{37}$. La segunda versión fabricada por Thonet Frères se expuso en el Salón de Otoño de 1929 (8). Le Corbusier, Jeanneret y Perriand proyectaron un modelo íntegramente equipado, en el que todos los casilleros constaban de estantes desmontables y ligeros que permitían modular y distribuir el espacio interior. Tras este diseño se realizaron proyectos de simplificación de los casilleros, algunos sin trascender más allá del papel y otros llegando a construirse como el casillero Rivier de 1930 o Lakarmé de 1931.

El objetivo de la propuesta realizada para el Salón de Otoño de 1929 era diseñar un apartamento transformable, con piezas móviles y ligeras que, por una parte, colaborasen en la distribución y modulación de la arquitectura y, por otra, permitieran percibir y disfrutar el espacio proyectado. El conjunto de estos objetos fue presentado al público como 'Equipamiento de la vivienda', como parte de una instalación que mostrase al público un nuevo modo de habitar "en el espacio" y no "entre muebles"38. El Salón de Otoño del 29 supuso la confirmación de sus ideas divulgadas en sus conferencias por Argentina y de sus escritos, al tiempo que sirvió como medio para publicitar el mobiliario producido en el atelier que utilizaría en muchas de sus obras posteriores, incluida su vivienda, el Inmueble Molitor.

\footnotetext{
${ }^{37}$ Rüegg, Arthur: Le Corbusier: Meubles et Intérieurs 1905-1965, op.cit. p.286.

${ }^{38}$ Mang, Karl: History of modern furniture. John William Gabriel (trad.). Londres: Academy Edition, 1979, p.119.
} 


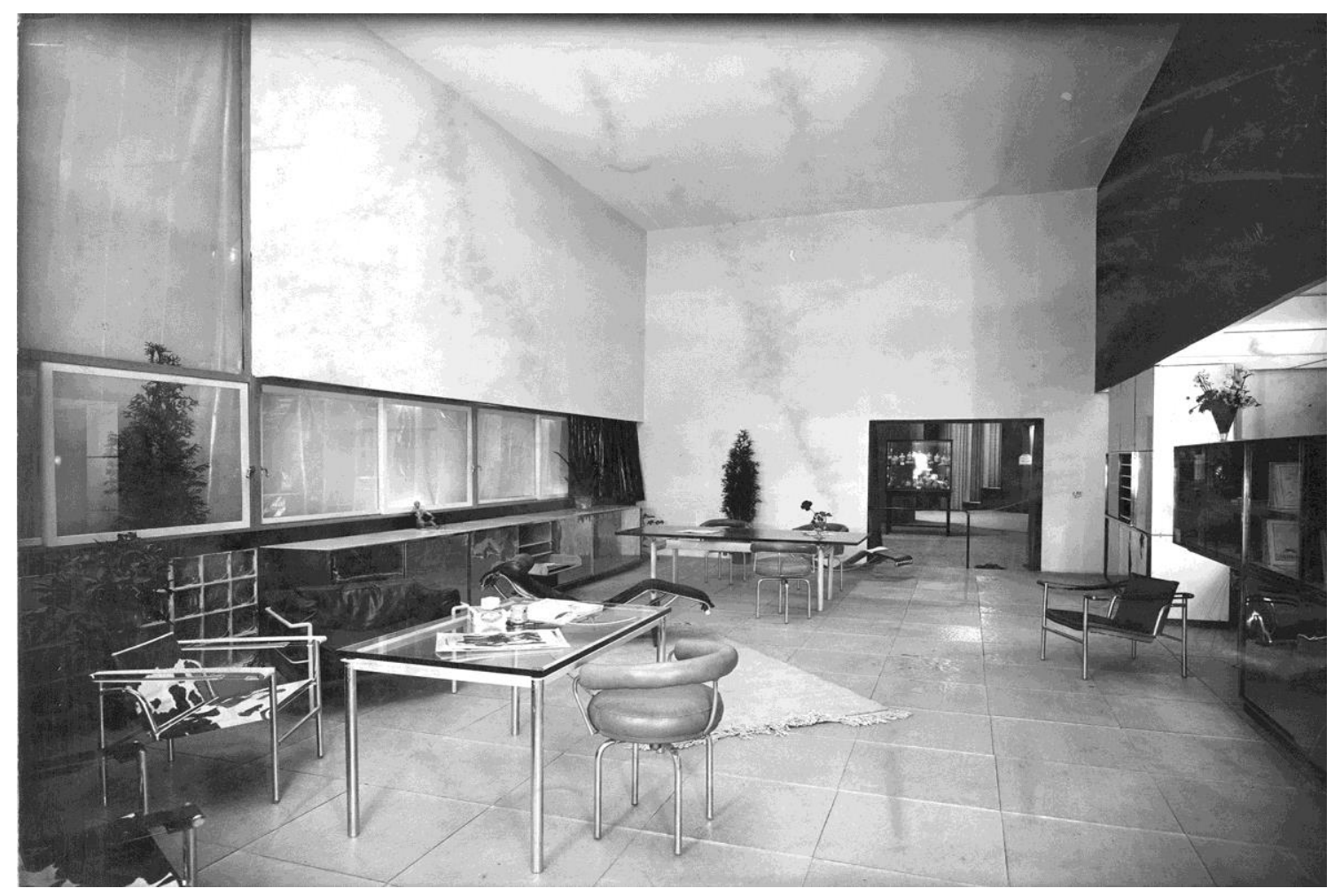

8. Fotografía de la instalación del Salón de Otoño de 1929 de Le Corbusier, Jenneret y Perriand. Fuente: Fondation Le Corbusier. (C) FLC-ADAGP

\section{Teoría y obra: argumentos sobre una caracterización 'corbuseriana' del mobiliario moderno}

Tras el análisis del legado de Le Corbusier en el campo del diseño, es posible apreciar una estrecha relación entre su obra escrita y construida. Las primeras intuiciones divulgadas en Vers une architecture y los posteriores postulados publicados en L'art décoratif d'aujour 'hui son puestos en práctica en proyectos como la maison La Roche/Jeanneret o en el Pabellón de L’Esprit Nouveau en el que, además, son públicamente expuestos. Estos manifiestos teórico-prácticos ofrecen las claves para conocer la caracterización del mueble moderno según Le Corbusier; un verdadero cuerpo teórico, coherente, que se materializa en objetos concretos, sin ornamento, ligeros y standard -objetos-tipo que cumplen unas funciones-tipo para unas necesidades-tipo de un hombretipo $^{39}$ - y que en el Pabellón se evidencia con una actitud fundamentalmente selectiva del autor.

De aquellas ideas que establecen la base de su teoría, se desarrollan otras que Le Corbusier expone en conferencias como las de Madrid y Argentina, y en su libro Précisions sur un état présent de l'architecture et de l'urbanisme. Se centran especialmente en la modulación y fabricación industrial de los objetos, así como en su utilización y su relación con el espacio. Algo que no sorprende al analizar sus obras entre 1927 y 1930, ya que se vuelven a ratificar las reflexiones enunciadas por Le Corbusier pero en este caso de forma más activa, gracias a la colaboración de Charlotte Perriand. Los prototipos diseñados para el interior de la villa Church, expuestos en el pabellón de Otoño del 29 y producido en serie por Thonet a partir de 1930, son la conclusión de sus ideas en tanto en cuanto se trata de unos objetos standard diseñados según unas medidas también standard, industrializados y por tanto, repetibles para un nuevo espacio: la vivienda moderna.

\footnotetext{
${ }^{39}$ Le Corbusier: L'art décoratif d'aujourd'hui, op.cit., p.76.
} 
En ese sentido, una de las principales aportaciones de Le Corbusier fue su innovadora concepción del espacio, en la que la arquitectura albergaba muebles, distribuidos como cuerpos independientes sobre el plano. Se trataba de elementos añadidos caracterizados por su cualidad móvil y materialidad ligera; por unas piezas que cumplían una función como objetos y una función espacial. No eran por tanto muebles sino objetos-tipo que al entrar en contacto con el espacio, lo dotaban de las funciones necesarias, es decir, lo equipaban. Lo que llevó a Le Corbusier a proponer una nueva definición 'corbuseriana' sobre el mobiliario moderno, ya que "la noción del mobiliario ha desaparecido. Se ha substituido por un vocablo nuevo: 'el equipo domestico, ${ }^{\text {,,40 }}$.

\section{Agradecimientos}

Los autores agradecen a la Fondation Le Corbusier su colaboración y ayuda para la realización de la presente investigación.

\section{Procedencia de las imágenes}

1. Dibujo de unas mesas en planta realizado por Le Corbusier. Plan FLC 33499

2. Dibujo realizado por Le Corbusier para mostrar las diferentes formas de sentarse. Plan FLC 33499

3. Dibujos realizados por Le Corbusier para ilustrar los objetos que hay que almacenar en una vivienda y la adecuación del casillero para este uso. Plan FLC 33522 (izda.), plan FLC 33523 (dcha.)

4. Dibujo realizado por Le Corbusier que compara el espacio de una habitación tradicional y otra moderna. Fuente: Le Corbusier: Precisiones respecto a un estado actual de la arquitectura y del urbanismo. Johanna Givanel (trad.). Poseidón: Barcelona, 1978, p.132.

5. Fotografía del interior del Pabellón de L’Esprit Nouveau, París, 1925. Fuente: Fondation Le Corbusier. () FLC-ADAGP

6. Fotografía de los casilleros instalados en el Pabellón de L’Esprit Nouveau, París, 1925. Fuente: Fondation Le Corbusier. ( FLC-ADAGP

7. Folleto desplegable de la firma Thonet en París con los modelos de Le Corbusier, Jeanneret y Perriand, 1931. Fuente: Rüegg, Arthur: Le Corbusier: Meubles et Intérieurs 1905-1965, p.122 (Colección privada)

8. Fotografía de la instalación del Salón de Otoño de 1929 de Le Corbusier, Jenneret y Perriand. Fuente: Fondation Le Corbusier. @ ( FLC-ADAGP

\section{Bibliografía/Referencias}

Banham, Reyner: Theory and Design in the first Machine Age. Londres: The Architectural Press, 1960.

Cohen, Jean-Louis: Le Corbusier 1887-1965. El lirismo de la arquitectura en la era mecánica. Köln: Taschen, 2004.

Frampton, Kenneth: Le Corbusier. Madrid: Akal, 2002.

Frampton, Kenneth: Historia crítica de la arquitectura moderna. Barcelona: Gustavo Gili, 2002.

Le Corbusier: El arte decorativo de hoy. Carlos Naya Villaverde e Inmaculada Jiménez Caballero (ed.) Maurici Pla Serra (trad.). Pamplona: EUNSA, 2013.

\footnotetext{
${ }^{40}$ Le Corbusier: Precisiones respecto a un estado actual de la arquitectura y del urbanismo, op.cit., p.143.
} 
Le Corbusier: L'art décoratif d'aujourd hui. Paris: G. Crès \& Cie., 1925.

Le Corbusier: Précisions sur un état présent de l'architecture et de l'urbanisme. París: Les Editions G. Crès et Cie., 1930.

Le Corbusier: Vers une architecture. Paris: G. Crès \& Cie., 1923.

Mang, Karl: History of modern furniture. John William Gabriel (trd.). Londres: Academy Edition, 1979.

McLeod, Mary: Charlotte Perriand. An Art of Living. New York: H.N. Abrams in association with the Architectural League of New York, 2003.

Rüegg, Arthur: Le Corbusier: Meubles et Intérieurs 1905-1965. Zurich: Scheidegger \& Spiess AG, 2012.

Gunther, Sonja: Thonet tubular steel furniture card catalogue. Well-Am-Rhein: Vitra Design Museum, 1989. 


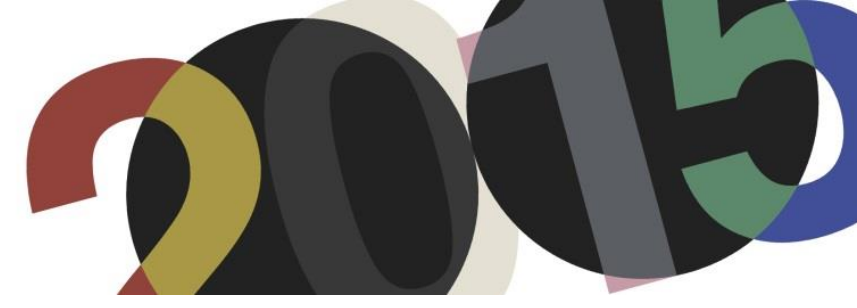

DOI: http://dx.doi.org/10.4995/LC2015.2015.1251

\title{
"EL PROYECTO DEL CONVENTO DE SAINTE MARIE DE LA TOURETTE. DE LA CELDA AL ESPACIO INEFABLE"
}

\author{
A. Vírseda Aizpún \\ Escuela Superior de Arquitectura de Madrid
}

\begin{abstract}
Resumen: En la década de los años 50 Le Corbusier realiza el convento de Sainte Marie de la Tourette reconocido por la propia Oeuvre complète como su "producción más significativa" ya que supone "una confrontación y una síntesis de su evolución desde la Cartuja de Ema, que descubriera y dibujara en Italia en 1911..."

El artículo trata de revelar el sentido de esta afirmación, centrando su foco de atención en la fase de proyecto que comprende un periodo de 5 años, entre 1953 y 1957. Es en este periodo de elaboración, y desarrollo de las ideas en el Atelier de LC, previa a la acción de construir, donde se encuentran las verdaderas claves, para poder entenderla y explicarla.

Los apartados del escrito se ordenan según la cronología del proyecto, y en cada uno de ellos se analizan dos conceptos característicos de la producción de LC presentes en el convento. Este procedimiento binario, es utilizado muy frecuentemente por el arquitecto para lograr que los conceptos e ideas estallen, se hagan transparentes o muestren su estructura íntima con una mayor intensidad que si se presentaran de un modo aislado, ofreciendo a la reflexión una superficie lisa imposible de morder.
\end{abstract}

Abstract: In the 1950s Le Corbusier brings into being the convent of Sainte Marie de la Tourette which was recognised by the Oeuvre complète as his "most significant work" as it was "a confrontation and a synthesis of its evolution from Cartuja de Ema, that he discovered and drew in Italy in $1911 \ldots$...

This article attempts to reveal the meaning of this affirmation, centring the focus of its attention on the 5 year fase of the project between 1953 and 1957. It is in this period of design and development of ideas at the Atelier de LC, prior to construction, that we discover the keys to understand and explain the work.

The following sections are arranged in the project's chronological order and in each one two characteristic concepts are analysed. This binary procedure is frequently used by the architect so that the concepts and ideas explode, become transparent or show their intimate structure with a higher intensity than if they were presented in isolation, providing a deliberation like a flat surface that is impossible to bite.

Palabras clave: Le Corbusier, convento; Tourette; celda; inefable.

Keywords: Le Corbusier, convent; Tourette; cell; ineffable.

\section{Desde el primer dibujo del lugar. NATURALEZA- BETON BRUT.}

El 4 de mayo de 1953, en su primera visita a la parcela de 70 Has que la Comunidad Dominica poseía al norte de Lyon $^{1}$, LC elige inmediatamente el lugar en el que situará el futuro convento.

\footnotetext{
${ }^{1}$ El terreno debe el nombre a su propietario en el siglo XVIII, el botánico Marc Antoine-Louis Claret de Fleurieu de la Tourette (1729-1776). Éste desarrolló en él una escuela forestal con un gran parque botánico de trazado pintoresco en el que crecían más de 3000 especies provenientes de todos los lugares del mundo. En la actualidad aún se pueden reconocer muchas de ellas (el tilo que se enfrenta al acceso al convento es un ejemplo), así como los vestigios de pintorescas intervenciones que también realizó (el templo del amor, el bélvèdere de la Tourette, el pozo de nieve...).

Para más información ver Monfalcon, J.B: Histoire Monumentale de la Ville de Lyon. Tomo III. París, 1866. pp. 34-35.
} 
Se trata de un claro en la ladera, junto al bosque, en el punto más alejado de la edificación existente. Sus características principales son las privilegiadas vistas del valle del Turdine, hacia la orientación oeste, y el telón de fondo del frente boscoso que se extiende tras él.

Con esta decisión, busca accionar la particular tensión de opuestos, entre arquitectura y naturaleza, tan presente en su trabajo, recuperando un pensamiento geométrico que había abandonado en la capilla de Ronchamp. Como ha reconocido la crítica $^{2}$, en la mayoría de las fotografías que el arquitecto elige para la publicación de sus edificios en la Oeuvre Complète, rehúye los primeros planos, recurriendo siempre, a visiones lejanas en las que los volúmenes netos, y rotundos de su arquitectura, y la naturaleza, comparten protagonismo.

Para LC, arquitectura y naturaleza, han sido siempre dos fenómenos indisociables. Concibe la arquitectura no como el edificio construido sino como la tensión entre dos mundos antagónicos, el del edificio construido y el de su entorno natural.

Durante una visita de obra explica a los monjes el modo en que comenzó el proyecto, con las siguientes palabras:

"Llegué aquí. Tomé mi carnet como hago habitualmente. Dibujé la carretera, dibujé el horizonte, tomé conciencia de la orientación del sol, "olfateé" la topografía. Decidí el emplazamiento, ya que no estaba fijado. Al elegirlo cometí el acto criminal, o válido. El primer gesto realizado, fue la elección, la naturaleza del emplazamiento, y a continuación, la naturaleza de la composición, que iba a realizar en esas condiciones..."3

El primer croquis que realiza en el terreno elegido, representa la "bella vista" del valle del Turdine. El arquitecto dibuja cada uno de sus elementos, las "sequoias", "el castillo", "la pradera", "el bosque" (1).

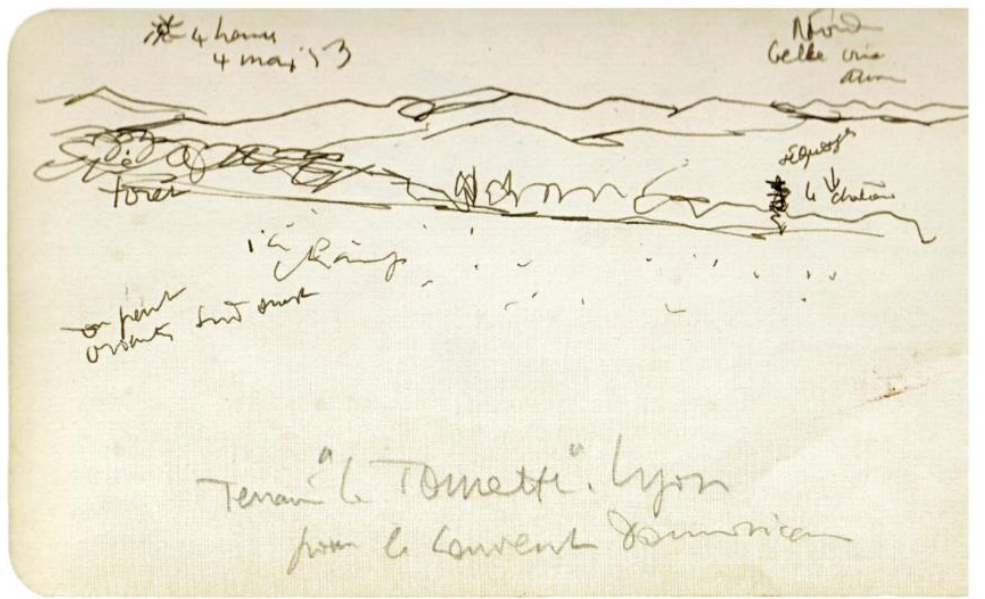

1. Croquis realizado por LC desde el punto de la ladera del valle del Turdine elegido para levantar el nuevo convento. OFLCADAGP.

Como había advertido en el capítulo, "Lo exterior es siempre un interior", de Vers une Architecture, junto a su famoso croquis del Pecile de Villa Adriana, “... Habia que componer con los elementos del lugar..."“. La anotación que escribe al pie del dibujo, "podemos orientarnos", demuestra su intención, de que el futuro edificio, no interactuara, exclusivamente, con el entorno cercano y sus elementos, sino con otra naturaleza, la del paisaje.

\footnotetext{
${ }^{2}$ Quetglas, Josep. Les Heures Claires. Barcelona: Massilia. 2008. pp. 479-483.

${ }^{3}$ Le Corbusier: "On venu ici”. En Petit, Jean: Un couvent de Le Corbusier. París: Éditions Minuit. 1961. pp 28. Traducción del autor.

${ }^{4}$ Le Corbusier. Hacia una Arquitectura. Barcelona: Editorial Poseidón. 1998. pp. 156.
} 
Ya, en otras ocasiones, había representado el paisaje lejano en su primera visita al lugar. En Argel, había dibujado "los cuatro horizontes" que iban a ordenar su Plan Director, y lo mismo había hecho, en todos los proyectos religiosos anteriores al del convento, en su primera visita al lugar de la basílica de Sainte-Baume, o sobre la colina de Bourlémont, donde posteriormente construiría Ronchamp. En ellos, busca establecer una particular relación con el paisaje que se puede explicar con el enigmático dibujo de L'Poème del angle droit, publicación que está realizando en esta época (2).

\section{ne se touchant pas mais ä des oritances en chaque}

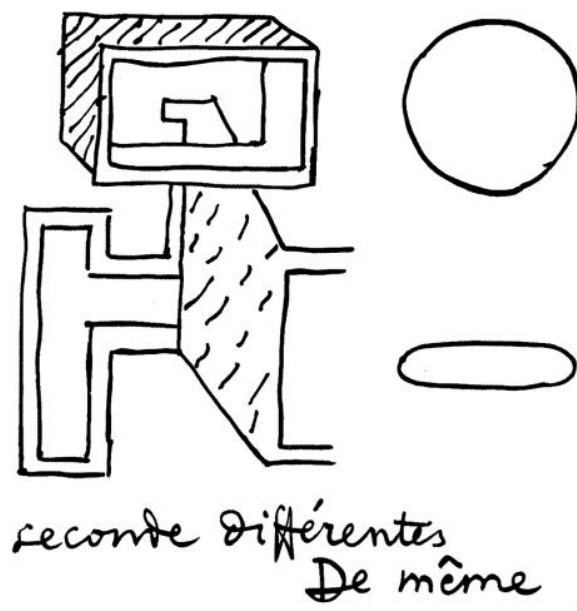

2. Dibujo publicado en L'Poème de l'angle droit.

En él, representa en axonometría el campanario del convento de la Tourette, y junto a él, una silueta semejante a la de un pabellón auditivo, que bien podría ser el volumen de capillas de la fachada norte. Esta silueta nos da la clave sobre la relación que el edificio tratará de establecer con el paisaje lejano. Esta relación irá más allá de lo puramente visual siendo también una cuestión auditiva. La armonía con la naturaleza entendida en su sentido musical más estricto. Una vibración que emana del edificio hacia el paisaje y del paisaje al edificio y que no puede medirse mediante fórmulas racionales, ya que es una variable espacial, no solamente física o intelectual, sino también emocional. Para LC, esta relación, es solo perceptible "para unos pocos" a los que denomina "monjes".

Ya en el ámbito cercano, la geometría cartesiana utilizada desde el inicio, va estableciendo otras sutiles relaciones con la naturaleza, que también contribuyen a lograr la armonía entre las dos realidades: arquitectura y naturaleza.

La primera fotografía, que LC publica del edificio en la Oeuvre Complète (1957-65), muestra una vista del edificio desde el camino del acceso. Entre las dos partes, en que se presenta el Convento, pasa casi desapercibida la presencia de un álamo solitario. Este árbol se publica, intencionadamente, despoblado de hojas con el objetivo

\footnotetext{
5 "La capacidad de sensibilidad aquí evocada y correspondiente al animal humano es lo que ya suscitó en Cézanne, en los grandes cubistas de antes de 1914, después en un "monje" del tipo Mondrian (durante treinta años de su vida), una potencia auditiva marcando una cumbre, no solamente de sensibilidad y de concentración sino de voluntad, del espíritu de claridad, del espíritu de exactitud, únicos soportes eficaces de la poesía, cuya razón es la de poner en juego los recursos más elevados del pensamiento". Le Corbusier. El Modulor II. Barcelona. Editorial Poseidón. 1980. pp. 149.
} 
de ceder la totalidad del protagonismo a la arquitectura situada tras él, sin embargo, su importancia no debe ser ignorada.

Una fotografía similar de la FLC, en la que se puede ver dicho árbol con su copa repleta de hojas, pone de manifiesto, claramente, su relación dimensional con el convento (3).

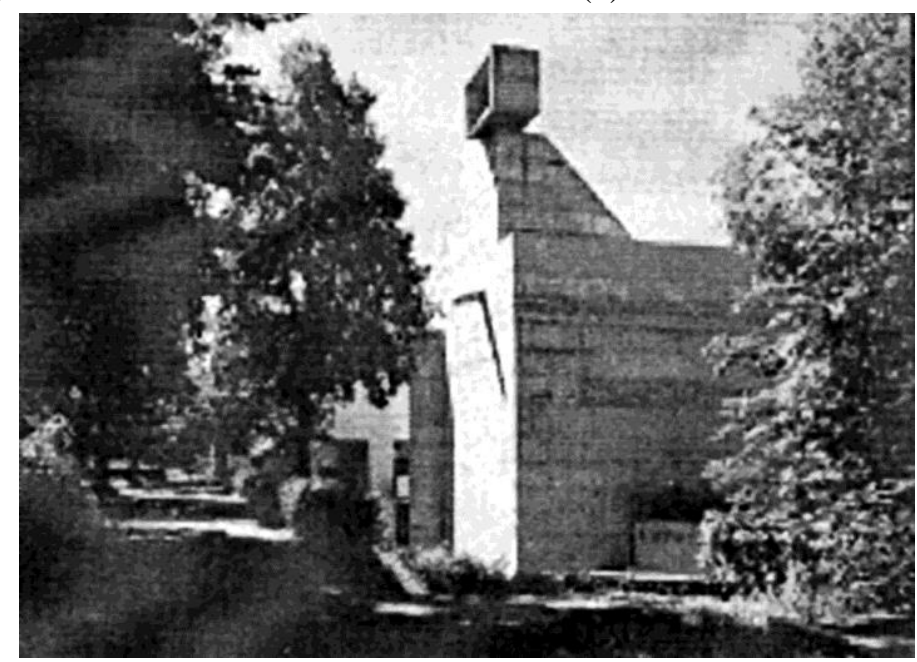

3. Imagen de la serie de fotografías de la FLC denominadas "Perutz", número 9,19. CFLC-ADAGP.

Así, lo reconoce LC, en otra fotografía, en la que la iglesia y el árbol se enfrentan. En el negativo, al lado de ella, escribirá "Enfrentado a la naturaleza, el campanario del convento en negativo. El árbol da la medida de su altura"6.

El volumen ondulado de las capillas, en la fachada norte de la iglesia, también tiene como objetivo establecer una relación dimensional. En este caso con los árboles frutales que crecían en la superficie existente entre los dos edificios. Así, este volumen, realiza la transición de escala con la naturaleza cultivada por el hombre, y en definitiva con el hombre mismo. Hay que recordar, que el camino más directo entre el edificio antiguo y el nuevo, discurría a lo largo de la cota baja de la parcela, por lo que el monje que camina desde uno a otro asciende hasta el acceso del nuevo convento, tangente al gran plano de la fachada norte.

En planta, el Atelier prepara un plano para el topógrafo encargado de realizar el levantamiento del lugar. En él, entre los ejes ortogonales de replanteo del proyecto, y junto al camino, señalan un punto que debe ser fijado exactamente (4).

\footnotetext{
${ }^{6}$ Negativo de la fotografía FLC X2-2.
} 


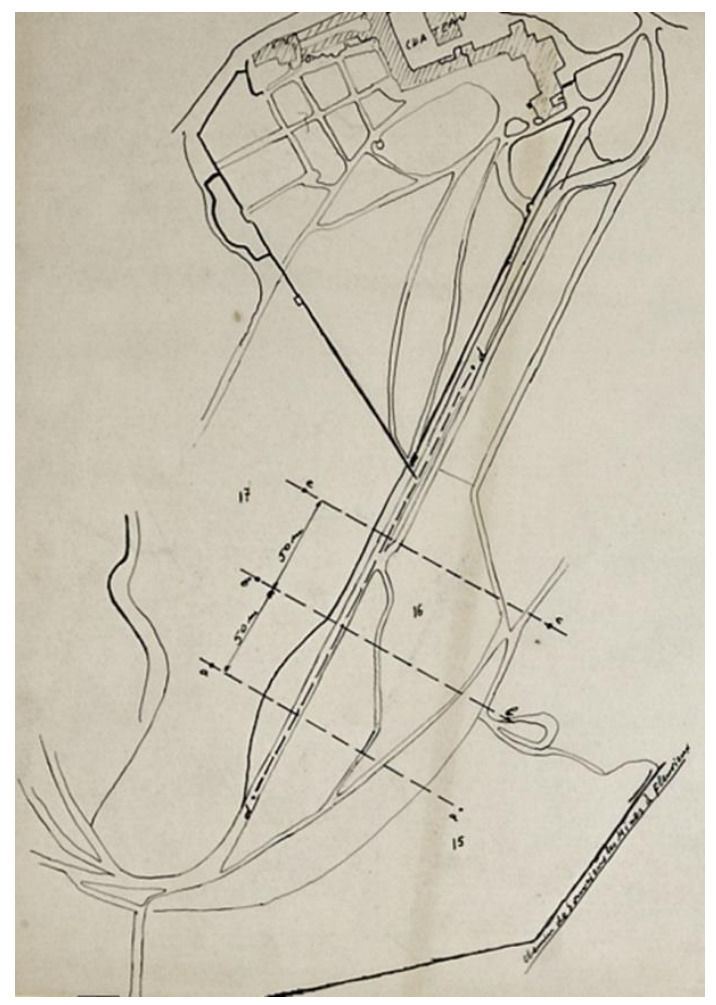

4. FLC 1029. CFLC-ADAGP. Plano con indicación de las secciones cuyo levantamiento topográfico debía realizarse.

De nuevo, se trata de un árbol. En este caso, un tilo ligeramente adelantado de la gran masa del bosque, que constituirá el punto de replanteo del futuro convento. Este árbol, construirá virtualmente el eje central del arco de acceso, fijando así su posición exacta ${ }^{7}$. A partir de él, se desarrolla el resto del edificio bajo el preciso dictado de las medidas de El Modulor.

Otra relación de la arquitectura con la naturaleza, presente ya en el proyecto desde el principio, será su materialidad.

En la abadía de Thoronet, a la que LC viaja dos meses después de visitar el lugar donde se construirá el convento, escribirá, refiriéndose a la Iglesia: "La iluminación es un 10\%" y "Todo es Piedra" . La conmoción que le produce esta austera arquitectura, se pone de manifiesto en la introducción que escribe dos años después en la publicación de fotografías de Lucien Hervé sobre el edificio. En ella realiza una auténtica oda a la piedra y

\footnotetext{
${ }^{7}$ Ver la fotografía YP-1-75 que representa al tilo enfrentado al eje central del arco de acceso. En muchas ocasiones anteriores LC había utilizado la presencia de un árbol para fijar la disposición del acceso a sus edificios, e incluso les había otorgado un papel activo en la solución formal del edificio. La maison La Roche-Jeanneret, la maison Lipchitz-Miestschninoff, la villa Saboya o la villa Stein-de Monzie [22,23,24,25] son ejemplos ilustrativos de las sutiles conexiones que sus volúmenes platónicos siempre habían intentado establecer con la naturaleza próxima.

Para más información ver, Martínez Santamaría, Luis: El árbol, el camino y el estanque. Barcelona: Colección Arquithesis núm.15. Fundación Caja de Arquitectos. 2004. pp. 59-63.

Quetglas, Josep: Les Heures Claires. Barcelona: Massilia. 2008. pp. 502-503.

${ }^{8}$ Croquis realizado en la abadía de Thoronet publicado en Le Corbusier: Le Corbusier Sketchbooks. Volumen 2, 1950-54. Carnet G-29. Cambridge-Massachusetts: The MIT Press. 1981.

En él escribe "Thoronet/26 juillet 53/ tout est éclairage 10\% / [tout est] pierre unique / Abbaye du Thoronet (Var)".
} 
a la "arquitectura de la verdad", dirá, construida únicamente con un material. Sin embargo finaliza el texto advirtiendo "es la hora del betón brut"".

El betón brut, un material con claras afinidades al universo natural lecorbusireriano, se encuentra presente ya, desde el primer instante en la mente del arquitecto. En el convento de la Tourette hará uso, ante todo, de este material de los tiempos nuevos, del que, al igual que ocurre con la piedra en Thoronet, explotará al límite todas sus posibilidades constructivas y expresivas. Lo usará, no tanto por sus propiedades estructurales, de hecho pensó al principio la Iglesia con estructura metálica, como por su capacidad plástica y su cualidad de acabado. Como reconoce, lo utilizará por "su textura ruda e imperfecta, y su ductilidad y adaptabilidad a un molde, para lograr cualquier forma" ${ }^{\prime 10}$.

Por otro lado, su acabado, ofrecía a LC la posibilidad de lograr en su arquitectura una presencia atávica, brutalista, que estableciera con el hombre, relaciones similares a las de sus objets à réaction poétique.

LC, presenta a menudo estos objetos en sus edificios, como en la Unité d'Habitation de Marsella, y como es sabido, en el plano-puente de acceso al convento de la Tourette ${ }^{11}$. Se trata, de objetos de la naturaleza moldeados por el tiempo, y a los que éste, les confiere unas propiedades, que establecen relaciones poéticas muy particulares, con el "corazón del hombre"12, según las propias palabras del arquitecto.

Pero, no solamente es importante la componente poética proporcionada por el particular acabado del Betón brut.

Iannis Xenakis, ingeniero y compositor griego, nombrado por LC su principal colaborador en el convento, y que, como veremos, tiene un papel muy importante en el proyecto, será el responsable, de que el edificio establezca una nueva relación con la naturaleza.

Los pan de verre y los ondulatoires, que proyecta para las fachadas, y en los que lleva al límite las propiedades estructurales de este material, buscan establecer una nueva relación con la naturaleza. En estos cerramientos, Xenakis aplica su particular visión de la música, que le gustaba explicar con la fotografía aérea del damero de un paisaje. Los compondrá, del mismo modo que componía su música, a partir de la combinación, mediante precisas leyes matemáticas, de un mínimo número de elementos. En el caso de su música estos eran frecuentemente sonidos de la naturaleza. Así, la continuidad y el ritmo del paisaje, o las aleatorias discontinuidades de su presencia cercana, vibrarán en las fachadas del convento. Por eso, no es casual que el joven ingeniero utilizara el color verde para concebir estos cerramientos (5).

\footnotetext{
${ }^{9}$ Introducción de Le Corbusier en Cali, Francois: La Plus Grande Aventure du Monde. Photographies de Lucien Hervé. París: Editorial Arthaud. 1956. Traducción del autor. El escrito original fue realizado por LC el 12 de junio de 1955. FLC U3-08-33.

${ }^{10}$ Le Corbusier: “Cinq questions à Le Corbusier”. En Zodiac no 7. Roma. 1960. Pag 50. Traduccción del autor.

${ }^{11}$ Ver la fotografía FLC L1-15-122, publicada en la Oeuvre complète 1946-52 (pp. 222) que representa la pareja cilindro fuente-roca en la cubierta de la Unité d'habitation de Nantes-Rezé.

${ }^{12}$ Le Corbusier: "Objects à réaction poétique". En Petit, Jean: Le Corbusier lui-Même. Ginebra: Collection Panorama Forces Vives. Rousseau Éditeur. 1969. pp 178. Traducción del autor.
} 


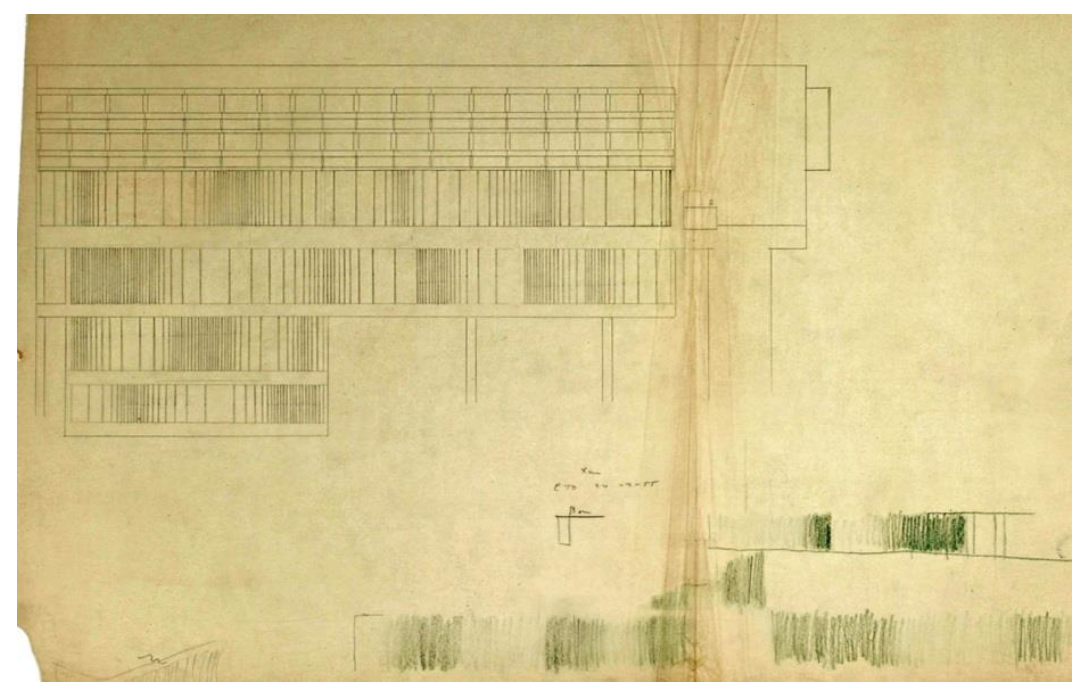

5. FLC 02557. (FLC-ADAGP. Alzado oeste dibujado por Iannis Xenakis durante la fase del Projet pour l'appel d'offre.

Las relaciones explicadas, harán que, como se ha reconocido, “...el edificio final, no reproduzca tan radicalmente la oposición naturaleza-artificio. Sino, que en el proceso se va desarrollando una especie de contaminación progresiva, un efecto de regreso a lo "natural", que caracteriza la evolución de la arquitectura de LC, y la conduce a la madurez...".13.

La ilustración de las manos entrelazadas que LC publicará en L'Poème del angle droit, dos años después de su primera visita al valle del convento, representa bien la relación que he tratado de explicar. Una relación de encuentro y acuerdo mutuo, pero a la vez, de afirmación de la esencia individual, de dos realidades opuestas, arquitectura y naturaleza.

\footnotetext{
${ }^{13}$ Simonnet, Cyrille: "Le couvent de la Tourette face aux éléments". En Le Corbusier Fondation (ed.): Le Corbusier. La nature. París: Éditions de la Villette \& Fondation Le Corbusier. 2004. pp 174. Traducción del autor.
} 


\section{Desde el primer croquis de Le Corbusier. COMPOSICIÓN- CIRCULACIÓN.}

El día 19 de septiembre de 1953, dos meses después de su visita al emplazamiento, LC realiza el primer croquis del convento (6).
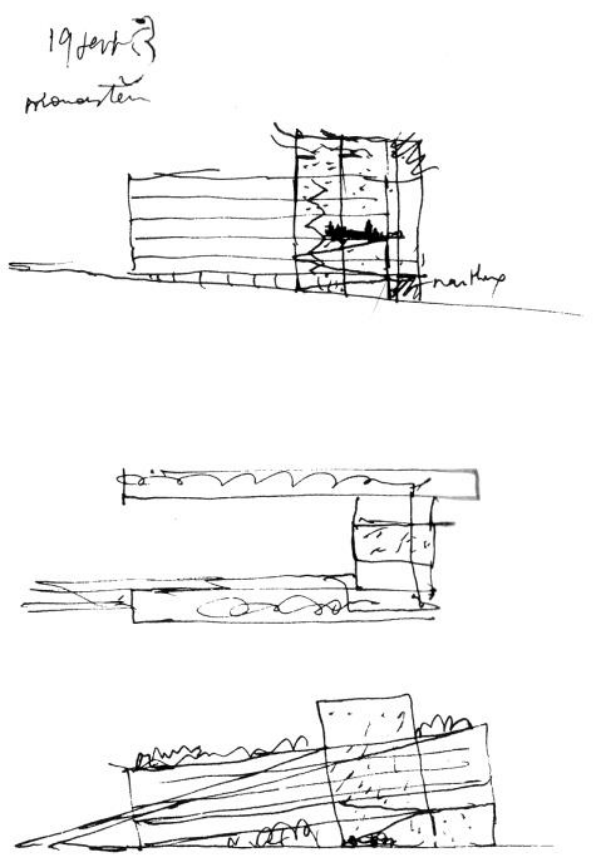

6. Primeros croquis del convento realizados por Le Corbusier.

Se trata, del rápido esbozo de una planta, un alzado y una sección, que quieren introducir algunas de las características genéricas del futuro edificio.

Lo primero que llama la atención de estos tres dibujos, compuestos por dos volúmenes, es la aparente falta de acuerdo entre la solución insinuada, y el emplazamiento y programa. La geometría de la planta, en forma de "U", abierta hacia el paisaje, no evoca el carácter, hermético y cerrado, de la tipología monacal, e igualmente, en sección, el edificio se levanta sobre un terreno horizontal, que ignora la inclinación de la ladera del valle. Desde el terreno, arrancan unas rampas que ascienden hasta la cubierta. Solamente, la palabra nártex, desvela el tipo de edificio proyectado.

Parece, por tanto, que fiel a su modo de proceder, LC no atiende, en un principio, a las constantes propias del programa o el lugar sino que, como analizaremos a continuación, recurre, de modo casi automático, a una serie de invariantes propias de su arquitectura.

En efecto, esta composición, claramente dual y elemental, de un volumen-tejido, lineal, modular, flexible y adaptable, y un volumen-caja, platónico, cerrado, y unitario espacialmente, que nos trae a la memoria el campo Santo de Pisa visitado por el joven Jeanneret en 1911, no es ni mucho menos novedosa. Todos los Grands Travaux del periodo de entreguerras, de las décadas de los 20 y 30, responden al patrón de composición elemental descrito. Incluso algunos, como el Palacio de la Sociedad de Naciones de Ginebra, o el Centrosoyus de Moscú, reproducen en sus fases iniciales la misma geometría en "U” esbozada por LC para el convento.

Sin embargo, como demuestran el Parlamento del Capitolio de Chandigarh, y otros ejemplos de los años 50 y 60 , estos edificios de gran escala, evolucionarán progresivamente, a lo largo de la carrera del arquitecto, hacia una presencia claramente unitaria, que enfatizará su representatividad. Pero en ella siempre permanecerá presente la realidad dual inicial. 
Y en esta evolución el convento de la Tourette representa un hito muy particular.

En efecto, el convento, constituye, un verdadero punto de inflexión, en el que se encuentra todavía, la composición elemental del pasado, esbozada por LC en el primer croquis, y presente también en la primera maqueta del proyecto (7), pero además se produce la presencia unitaria de sus futuros trabajos de gran escala.

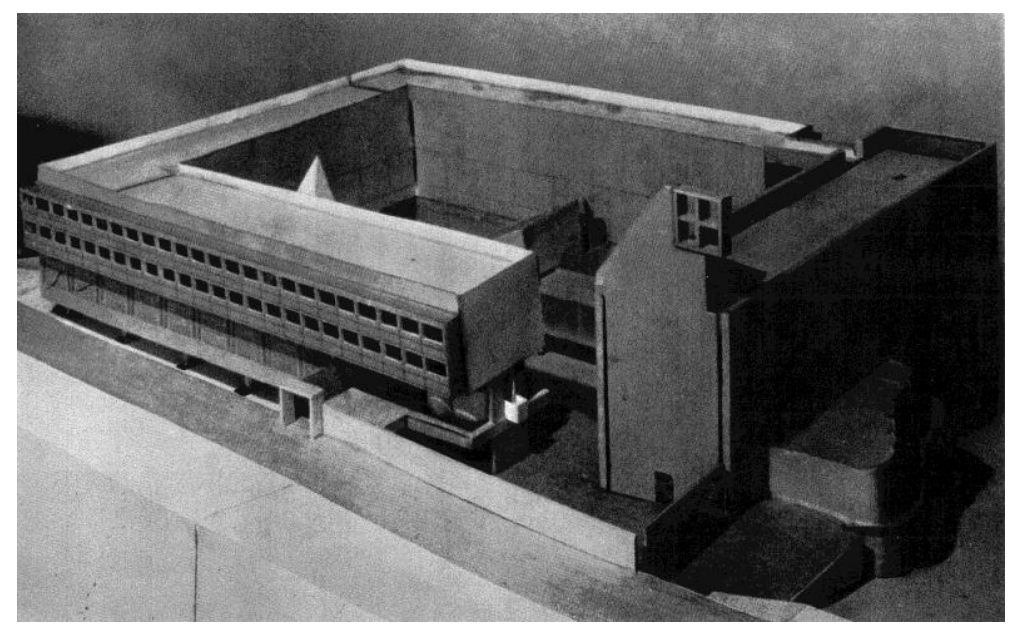

7. Fotografía de la primera maqueta publicada en la Oeuvre complète. 1952-57. OFLC-ADAGP.

Por tanto uno de los objetivos primordiales, (por no decir el principal), que dirige el proceso de proyecto, será lograr la tensión, y la unidad física y perceptiva, de un proyecto, en definitiva compuesto por partes.

Para ello, el arquitecto recurre a diversas estrategias, aunque la que sustenta todas ellas, como había sucedido ya en otros proyectos, será la confianza en la circulación como elemento articulador, y de unión, de unos fragmentos, que sin su presencia aparecerían "dispersos" $"$. Desde el inicio, comienza a tejerse, una red intermedia de circulaciones en promenade, que contribuirá a vincularlos (a soldarlos) aportando unidad a la composición.

"Todo y también la arquitectura es cuestión de circulación" $" 15$ solía afirmar LC.

Como se observa en este plano (8), Xenakis comienza a trabajar en el proyecto con la función, a partir de una volumetría unitaria y cerrada, según la lógica del tipo monacal tradicional, y completamente opuesta, a la esbozada por LC en el primer croquis.

\footnotetext{
${ }^{14}$ Ver cita posterior de A. Wogensky.

${ }^{15}$ Le Corbusier: Une Maison- un palais. París: Éditions Connivences. 1989. pp. 78. O también "Es una gran palabra moderna. Traducción del autor. Todo es circulación en la arquitectura y en el urbanismo". Le Corbusier: Precisiones. Barcelona: Ediciones Apóstrofe. 1999. pp. 151.
} 


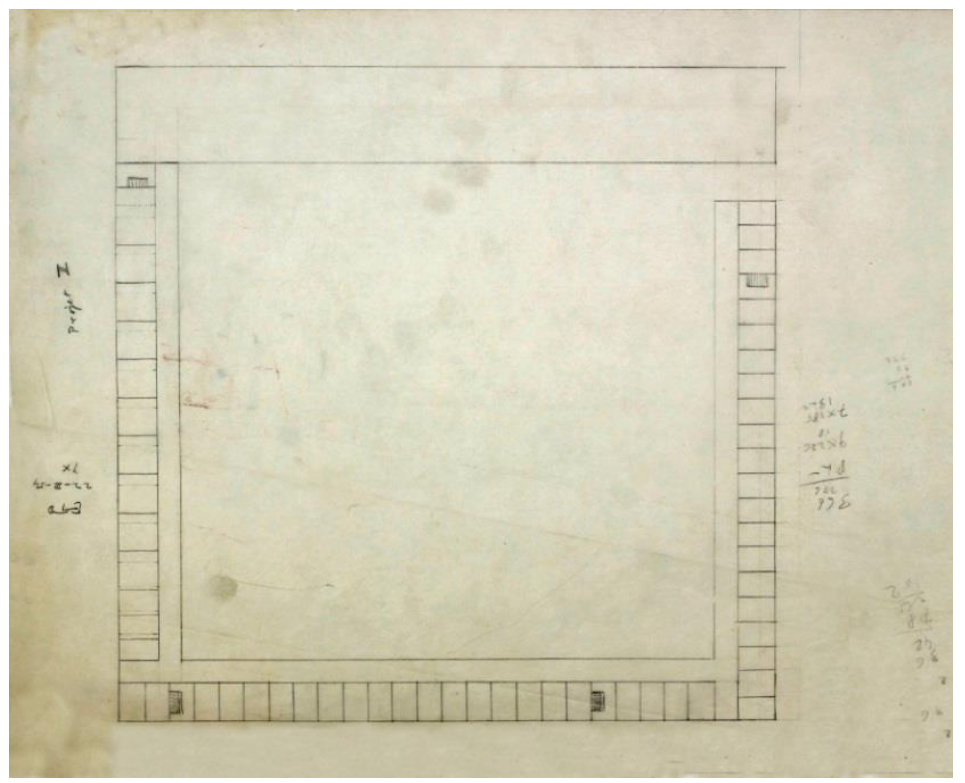

8. FLC 01230. CFLC-ADAGP. Primera planta dibujada por Iannis Xenakis en el avant-projet.

En ella, eso sí, están presentes los dos volúmenes descritos.

Simultáneamente, LC dedica ya su tiempo a realizar diversos esbozos sobre la circulación, que acabará plasmando sobre este primer croquis del avant-projet (9). Esta labor se extenderá durante las primeras fases del proyecto. Así lo ha reconocido su colaborador Wogensky: “...desde el principio, LC, estuvo particularmente concentrado en la circulación del claustro. Cuando esté se desarrolla, en torno a un jardín cuadrado, situado en el centro, se produce una cierta dispersión -igual la palabra “dispersión” es un poco fuerte (añade y continua...)- NO la reunión alrededor de un centro, como ocurre en la Tourette, con la solución propuesta por Le Corbusier..."16

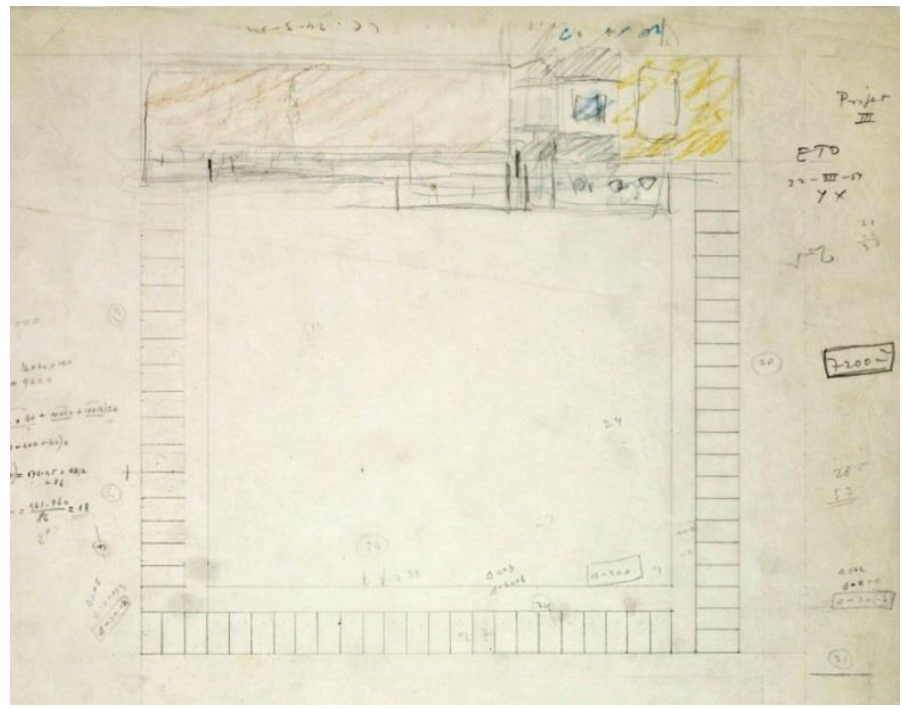

9. FLC 01146. OFLC-ADAGP. Primeros esbozos de LC sobre la planta delineada por Iannis Xenakis en el avant-projet.

\footnotetext{
${ }^{16}$ Casali, Valerio: “Conversazione con André Wogensky”. En Gresleri, Giuliano, Gresleri, Glauco: Le Corbusier: il programa litúrgico. Bolonia: Editrice Compositori. 2001. pp. 149. Traducción del autor.
} 
Se ha dicho, "Entrar en un edificio de LC, es subir, tanto de forma literal, como figurada" ${ }^{17}$. Por ello, todas las circulaciones que LC propone en el CONVENTO, arrancan en continuidad con el espacio exterior, ascendiendo hacia la cubierta, donde sitúa el claustro. Sin embargo la posición de este sistema de circulaciones, entre los dos volúmenes, y la situación del claustro en cubierta, provocan por ahora la unión física y perceptiva del edificio conventual en U y la Iglesia.

Mientras atiende a esta circulación, la labor con la función de Xenakis termina por concretar los tanteos que el arquitecto ya había realizado en el corazón del edificio, y propone el claustro en cruz, que también une los dos edificios en el nivel inferior (10).

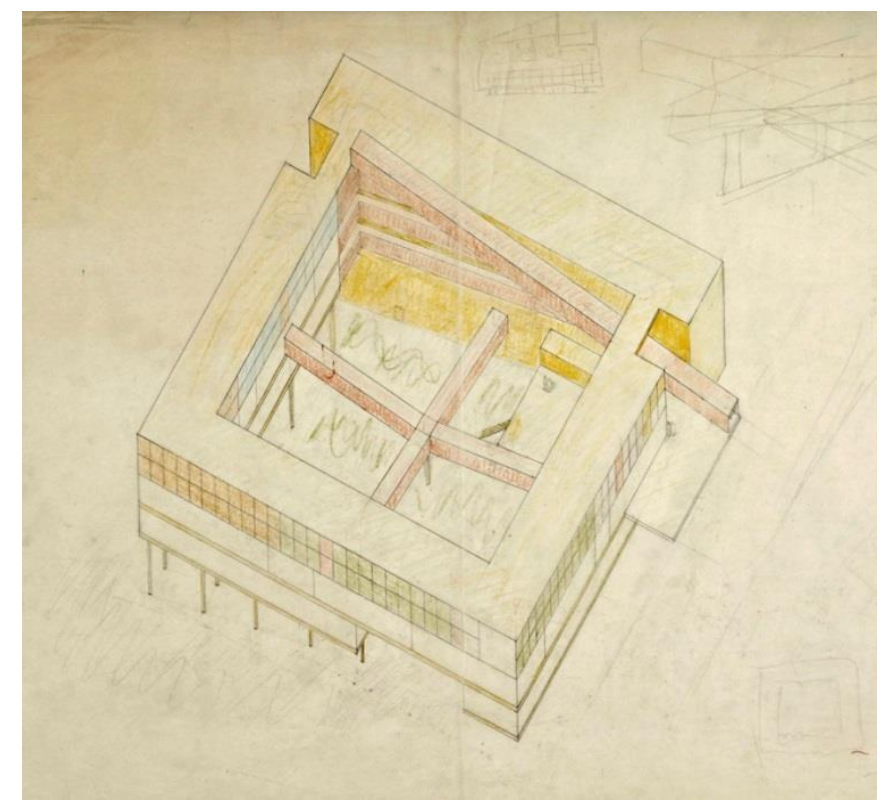

10. FLC 01244. OFLC-ADAGP. Axonometría dibujada por Iannis Xenakis en el avant-projet (30/03/1954).

Ambas circulaciones se mantendrán hasta una avanzada fase del proyecto. Solo cuando LC acepte prescindir de la circulación ascendente como le exigían los dominicos, y entienda que en un convento "todo debe desarrollarse no hacia el valle sino hacia el centro del altar"18 como le habían escrito, el claustro en cruz, comenzará a adquirir su verdadera importancia, y a desarrollarse plenamente, funcionando como un auténtico vertebrador de la composición dual. Entonces, también las dos partes del convento comenzarán a evolucionar de un modo independiente hacia una presencia arquitectónica dual más equilibrada.

En la primera planta, dibujada por Xenakis para el avant-projet (11), la circulación ascendente ya ha desaparecido y el claustro en cruz se ha desarrollado considerablemente.

\footnotetext{
${ }^{17}$ Quetglas, Josep: "Viajes alrededor de mi alcoba”. En COAM (ed.): Arquitectura C.O.A.M. $n^{o}$ 264, 265. Madrid: C.O.A.M. 1987. pp. 103-113.

18 FLC K3-20-188 y 189. Correspondencia del padre Belaud de 12 de mayo de 1954 tras consultar con el Padre Provincial y el Padre Prisset los temas tratados en el Atelier de la rue Sèvres el 21-04-1954 y reflejados en el escrito de A. Wogensky denominado "Conclusions tirées de la visite du Pére Belaud a l'Atelier Le Corbusier 21-04-1954". Traducción del autor.
} 


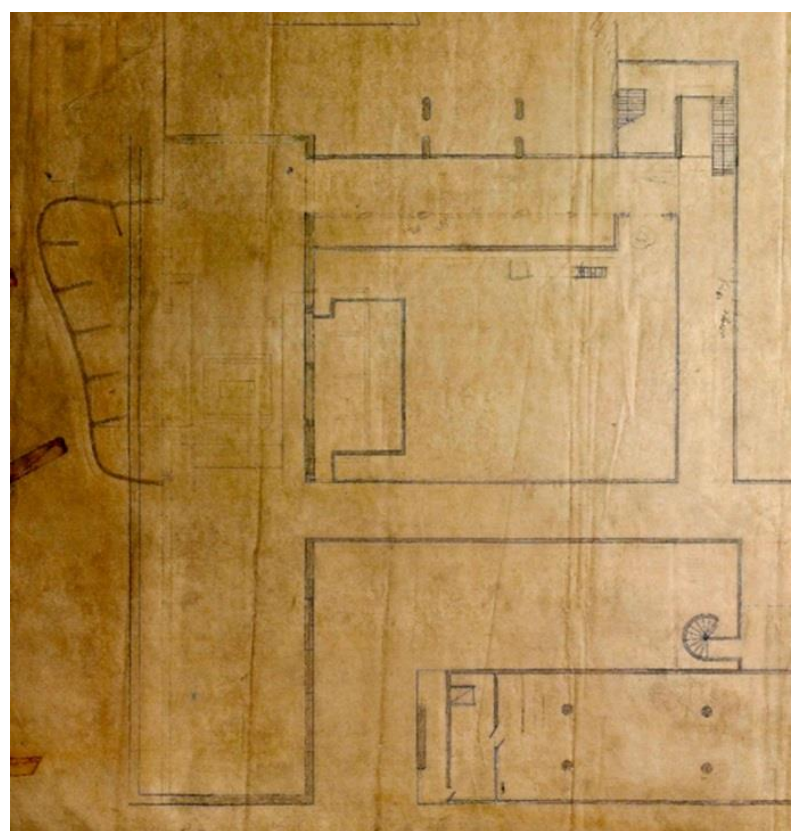

11. FLC 01038A. OFLC-ADAGP. Fragmento de la planta del refectorio entregada en el avant-projet (22/11/1954).

Sobre la iglesia, a la izquierda en la imagen, unas líneas borradas, pero todavía visibles, nos muestran como este volumen, que en un principio tenía la misma anchura que el edificio en U anexo, ha aumentado su dimensión. En efecto el claustro en cruz garantiza la unidad del conjunto permitiendo a cada fragmento desarrollarse con mayor independencia.

Analizando la progresiva evolución del proyecto en planta, y aquí solo se muestra uno de los planos finales del complejo proceso, descubrimos, cómo el desarrollo del claustro interior y su importancia, será directamente proporcional a la independencia que van adquiriendo los volúmenes perimetrales entre los que media. En este plano del projet d'exécution (12) la independencia de las dos partes, ha aumentado definitivamente, no solo a nivel dimensional.

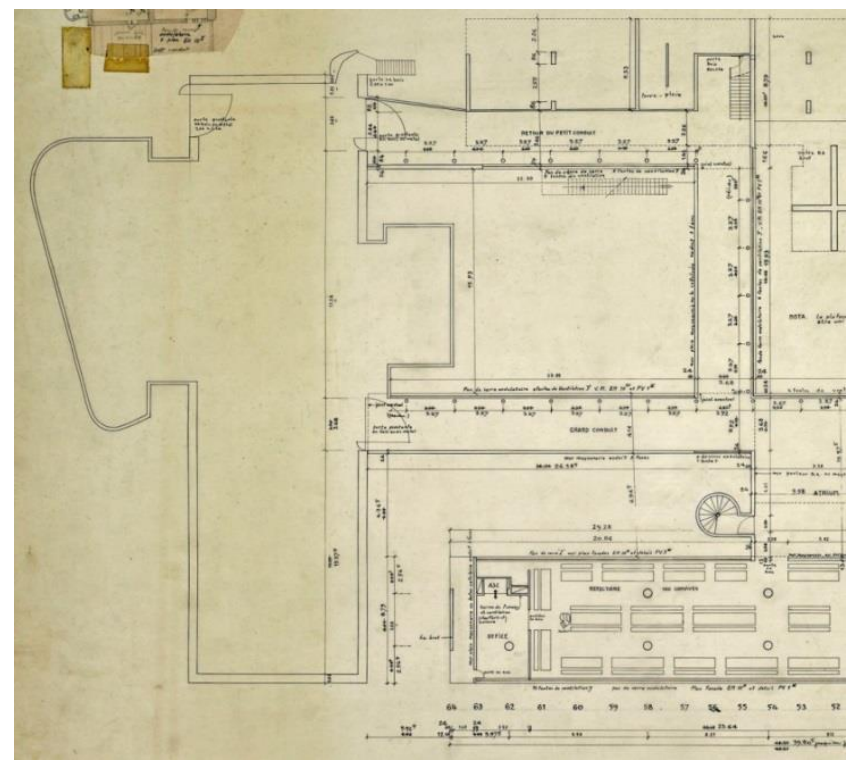

12. FLC 01047A. CFLC-ADAGP. Plano “E.TO-LC. En.12VII. Refectoire. Etage 2" del projet d'exécution (15/06/1956).

La iglesia se representa ya en un plano aparte lo cual afirma su independencia y la diferencia de las dos partes. El grueso cerramiento, y el espacio único y esculpido por los volúmenes laterales, contrastan con la longitudinalidad, fragmentación, y apertura del edificio conventual. El paramento del claustro en cruz, se 
prolonga, doblándose, para conformar el volumen interior de las capillas del patio, pero ante todo, para mediar de un modo más adecuado e intenso, del que hubiera proporcionado una simple unión puntual.

Pero también en sección (13), la eliminación de la circulación ascendente a cubierta, provoca un aumento de la complejidad del claustro en cruz, y de su importancia en el conjunto, ya que comienza articular la progresiva independencia altimétrica de las dos partes. La circulación se invierte, y desciende desde las celdas, desde la vida en soledad del monje, multiplicándose en los niveles inferiores para conformar una trama horizontal de gran riqueza espacial, que conecta todos los usos comunes y cuyo final se encuentra en la iglesia.

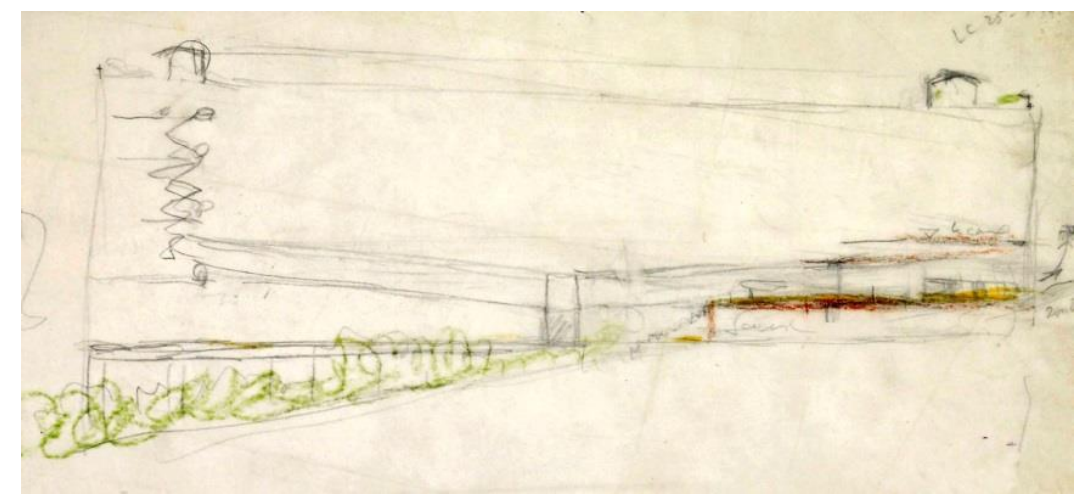

13. FLC 01212. CFLC-ADAGP. Esbozo de sección realizado por LC en el avant-projet. (25/03/1954).

En esta obra ya "no se entra", y "no se sube", ahora "se baja". El convento de la Tourette, no vibra en su contacto con el cielo, como ocurre con otros edificios de LC, sino en el contacto con el suelo, pero en vez de "dispersarse", el claustro en cruz, mantiene unidos, físicamente, dos fragmentos, que en su coronación, son unificados, solo perceptivamente, por la horizontal.

Al respecto el arquitecto afirma: "Aquí en este paraje tan móvil, tan fluido, tan cambiante, descendente, me dije: "No voy a determinar la posición desde el suelo porque se escapa... La determinamos a partir de la horizontal, de lo alto del edificio, para que esté alineada con el horizonte. Y vamos a medirlo todo a partir de esa horizontal, de lo alto, y ya pensaremos en el suelo cuando lleguemos abajo... “19.

Así, conforme la circulación, va construyendo esa realidad móvil, con entidad propia, que recorre y articula los dos volúmenes independientes de la iglesia y el edificio conventual, otros mecanismos formales, o más conceptuales, continuarán desarrollándose, para lograr que el convento de la Tourette, constituya, la perfecta unidad en la composición de los edificios de gran escala lecorbusierianos.

Una unidad, tantas veces reproducida por el arquitecto en sus pinturas, mediante la balanza de brazos desiguales, y que definirá en El Modulor II, publicado en 1954, en el instante que estamos analizando "no como la falsa acepción de igualdad, mantenida por un academicismo siempre vivaz, sino como la de equilibrio entre contrarios" 20 .

\footnotetext{
${ }^{19}$ Le Corbusier: “On venu ici”. En Petit, Jean: Un couvent de Le Corbusier. París: Éditions Minuit. 1961. pp 28. Traducción del autor.

${ }^{20}$ Le Corbusier: El Modulor II. $3^{\text {a }}$ ed. Barcelona: Editorial Poseidón. 1980. pp. 155.
} 


\section{Desde el avant-projet. TEXTÚRICA- FUNCIÓN.}

El primer dibujo que LC entrega a Xenakis para comenzar el avant-projet, es un croquis, de la habitación del hotel de la Unidad de Marsella, que permanece en los fondos documentales del convento en la FLC (14).

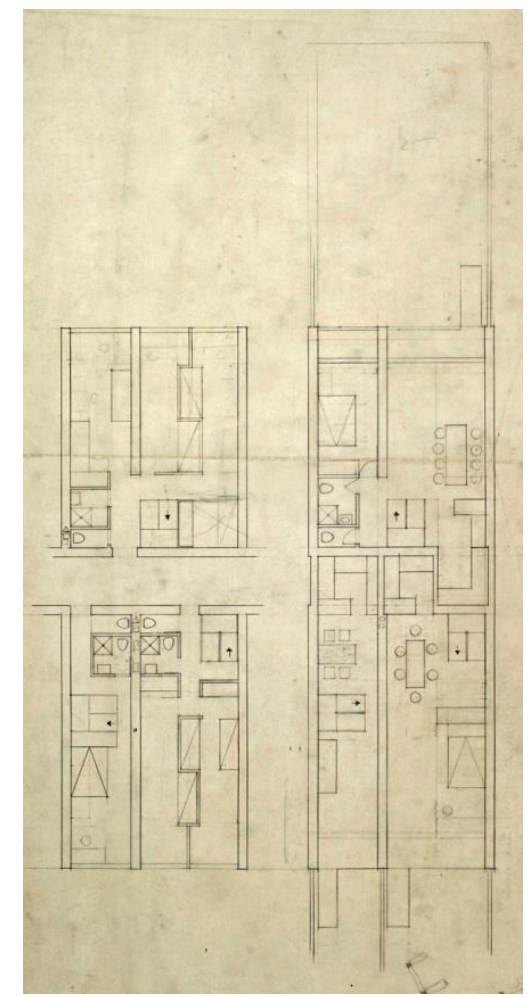

14. FLC 01296. OFLC-ADAGP. Croquis de la habitación de hotel de la Unité d,habitation de Marsella encontrado en el archivo de la Tourette de la FLC.

Como le habían dibujado los dominicos, en la carta del encargo ${ }^{21}$, el tipo monacal tradicional se genera mediante la agrupación de los usos comunitarios de gran tamaño alrededor de vacío del patio. La iglesia, situada en uno de los lados, es el volumen que dirige la composición.

Sin embargo, en el convento de la Tourette, Xenakis, atendiendo a las indicaciones de LC, comienza el proyecto a partir del replanteo y dimensionado de la unidad mínima de la celda, situándola en tres de los lados del rectángulo. El espacio eclesial, será ignorado, variando de dimensiones, según el dictado del resto de la planta, llegando a adquirir, en algunos momentos, proporciones casi imposibles.

Este comienzo, contrario a lo convencional, es de nuevo propio de la arquitectura de LC.

En múltiples conferencias, como la impartida en 1929, "Un hombre=una célula; unas células=la ciudad", y en publicaciones, como Urbanismo, había descrito, como sus ciudades y sus grandes edificios, se generaban, como los organismos, a partir de un sumatorio de "células". Diluía, así, la tradicional frontera entre urbanismo y arquitectura. Este proceso, que en El Modulor denomina con el neologismo, "Textúrica", garantizaba "la unidad en la base, y el tumulto en el conjunto" ${ }^{22}$. El arquitecto utilizará la textúrica para aportar, el orden y la unidad, de los grandes edificios clásicos, a la libre composición por elementos, propia de su forma de hacer. Además, frente

\footnotetext{
${ }^{21}$ FLC K3-20-163. Carta de 14 de marzo de 1953 del padre Belaud a Le Corbusier.

${ }^{22}$ Le Corbusier: El Modulor II. $3^{\text {a }}$ ed. Barcelona: Editorial Poseidón. 1980. pp. 148-149.
} 
a las "rígidas composiciones de patrones y mallas academicistas",23, este método proporciona, la presencia, de la escala humana, en la solución finalmente construida.

En el convento, la celda generada, con las medidas de este sistema métrico, será la unidad de la trama tridimensional Dom-ino, a partir de la cual comenzará a desarrollarse, toda la arquitectura. (no hay que olvidar que el propio LC advertía, a menudo, que este sistema Dom-ino no era arquitectura, sino un "un sistema de estructura" o "sistema de construcción"24).

Pero la utilización de la habitación del hotel de la Unité d'Habitation de Marsella no es solo importante desde este punto de vista modular o métrico. Junto al croquis anteriormente expuesto, en la FLC, se encuentra también una fotografía de la Unité de Nantes. Su presencia en los fondos documentales del convento, demuestra, que Xenakis utilizó no solo el módulo, sino el prototipo arquitectónico completo, como referente para del proyecto de la Tourette.

Y para la iglesia también recurrirá a otro prototipo de LC, la Boîte à miracles. Así lo evidencia el primer plano del proyecto publicado en la Obra Completa. En él la iglesia se presenta con el frente abierto.

Pero si nos detenemos, y analizamos este punto desde otra perspectiva, es sorprendente que en estos momentos iniciales, LC y Xenakis, solo recurran a prototipos arquitectónicos propios, en un encargo que por su particular tipología se prestaba claramente al uso de modelos, o ejemplos, ya construidos. En efecto, al recibir el encargo, LC, no solicita a los monjes ejemplos de modelos conventuales, sino toda la información que pudieran, "sobre la vida monástica y sobre cómo esos planos de conventos manifestaban la particular forma de vida de los monjes..."25 según solicita a la comunidad.

Ya durante sus múltiples viajes de juventud, como el realizado a Athos en 1911, el joven Jeanneret había demostrado, tanto o más interés por el modo de vida de los monjes que por la arquitectura de los conventos o los monasterios. Es consciente de que las soluciones formales de los modelos del pasado, son contingentes, y es el particular modo de vida del monje, la constante generadora del tipo arquitectónico ${ }^{26}$. Es en definitiva el funcionamiento, la función, la que debe ser respetada por el nuevo modelo conventual que conciba.

Esta función, responde a una rutina, a un rito diario, y a una tradición secular milenaria, existente antes incluso que la propia forma arquitectónica, y que se encuentra recogida en las Reglas de cada orden, en el caso de la Comunidad Dominica las de San Agustín ${ }^{27}$. Dicho rito diario introduce un tiempo sagrado, muy distinto al profano. Éste, despojado de significación religiosa, es lineal, y evoluciona indefectiblemente hacia un final, mientras aquel no "transcurre", es reversible, indefinidamente recuperable. Es un tiempo mítico, primordial,

\footnotetext{
${ }^{23}$ Le Corbusier: El Modulor II. $3^{\text {a }}$ ed. Barcelona: Editorial Poseidón. 1980. pp. 149.

${ }^{24}$ Como ejemplo sirvan las palabra que escribe sobre el sistema Dom-ino en su Oeuvre complète: "He aquí la concepción pura y total de un sistema de construcción, considerando todos los problemas que ha aparecido a raíz de la guerra y son de actualidad en este momento... Hemos concebido un sistema de estructura -esqueleto- completamente independiente de las funciones del plano de la casa: esta estructura aporta simplemente los forjados y la escalera...”. Boesiger, W, Stonorov, O (eds): Oeuvre complète Le Corbusier. Volume 1. 1910-29. Berlin: Birkhäuser. 1999. pp. 23. Traducción del autor.

${ }^{25}$ Carta enviada por A. Wogensky al padre Couturier (con copia al padre Belaud) el 11 de mayo de 1953. FLC K3-7-776 y FLC K3-20-167. Traducción del autor.

${ }^{26}$ Ver sobre el tipo Martí Arís, Carlos: Las variaciones de la identidad. Ensayo sobre el tipo en arquitectura. Barcelona: Ediciones del Serbal. Demarcación de Barcelona del Colegio de Arquitectos de Cataluña. 1993.

${ }^{27}$ Regla y Constituciones de la orden de San Agustín. Madrid: Ediciones Escurialenses. 2002.
} 
hecho presente. Por tanto, es la existencia del monje lo que constituye un acto sagrado, y es lo que el nuevo convento debe respetar ${ }^{28}$.

Como desvela el análisis de la documentación gráfica del proyecto, todas las decisiones de proyecto son resultado de un profundo conocimiento y respeto a dicho ritual. Desde las primeras etapas del avant-projet, Xenakis, realiza un arduo trabajo con la función, mientras LC, como se ha dicho, dedica su atención sobre todo a la circulación.

Como era costumbre en los grandes proyectos, confecciona un collage con las distintas partes del programa, disponiéndolas unas junto a otras, hasta conseguir un perfecto funcionamiento del conjunto. A continuación, realiza múltiples propuestas, que nombra con una numeración correlativa del 1 al 5 (Projet I, II, III, IV, V), y en las que va introduciendo ya los espacios solicitados, en la trama tridimensional generada a partir de la celda.

Como veremos, el respeto del perfecto engranaje concebido sobre el plano será en muchos momentos el catalizador de importantes decisiones que llegarán a producir la solución definitiva del convento. El esquematismo de los planos, casi como si fuesen organigramas, demuestra como la atención a la función, predomina, en un principio, sobre consideraciones contextuales, constructivas o de cualquier otra índole.

Evidentemente, no voy a describir detalladamente este largo proceso, pero sí que me interesa, detenerme brevemente en él, para demostrar la importancia que tiene en el resultado final, a pesar de que LC apenas se implica.

Según dicta la Regla de San Agustín, la comunidad dominica se compone de dos grupos principales de religiosos, los "Padres", monjes más veteranos, y los "Hermanos", monjes jóvenes que son el mayor número, y que a su vez se dividen en múltiples grupos, ya que el Convento de la Tourette, no es un modelo convencional, sino una casa de estudios.

En los alzados, el joven ingeniero va situando estos grupos ayudándose del color. En el proyecto inicial todavía aparecen reminiscencias de las Unités d'Habitation, como la distribución aleatoria de los usos comunes sobre una trama de celdas. En las sucesivas propuestas irá apareciendo la estratigrafía horizontal propia de la solución final del convento, comenzando desde arriba "y llegando al terreno como se podía"29, según había descrito LC.

En la primera sección transversal que Xenakis dibuja (15), situada a la izquierda del dibujo, se percibe cómo la presencia de los espacios comunes en los niveles inferiores, obliga a aumentar su dimensión. Por ello, su circulación perimetral, rellena en rojo como la de los niveles superiores, se desplaza hacia la derecha, obligando a realizar un quiebro en sección inadecuado formal y estructuralmente.

\footnotetext{
${ }^{28}$ Eliade, Mircea: Lo Sagrado y lo Profano. Barcelona: Editorial Paidós Orientalia., 1998. Capitulo II "El tiempo Sagrado y los mitos". Pags 53-85.

${ }^{29}$ Le Corbusier: “On venu ici”. En Petit, Jean: Un couvent de Le Corbusier. París: Éditions Minuit. 1961. pp 28. Traducción del autor.
} 


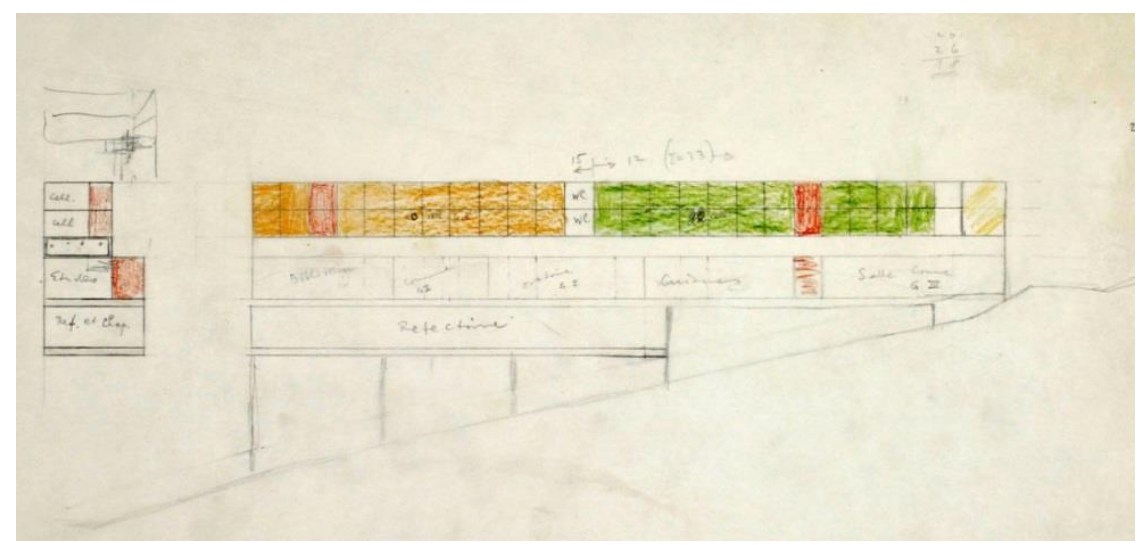

15. FLC 01243. OFLC-ADAGP. Sección del Projet II dibujado por Xenakis en las primeras fases del avant-projet. (22/03/1954).

Así, el claustro en cruz (16), surge de la necesidad de eliminar esta circulación perimetral de los niveles inferiores, y generar un tránsito independiente a la iglesia, que en ningún momento atravesara los usos comunes situados en las tres alas conventuales.

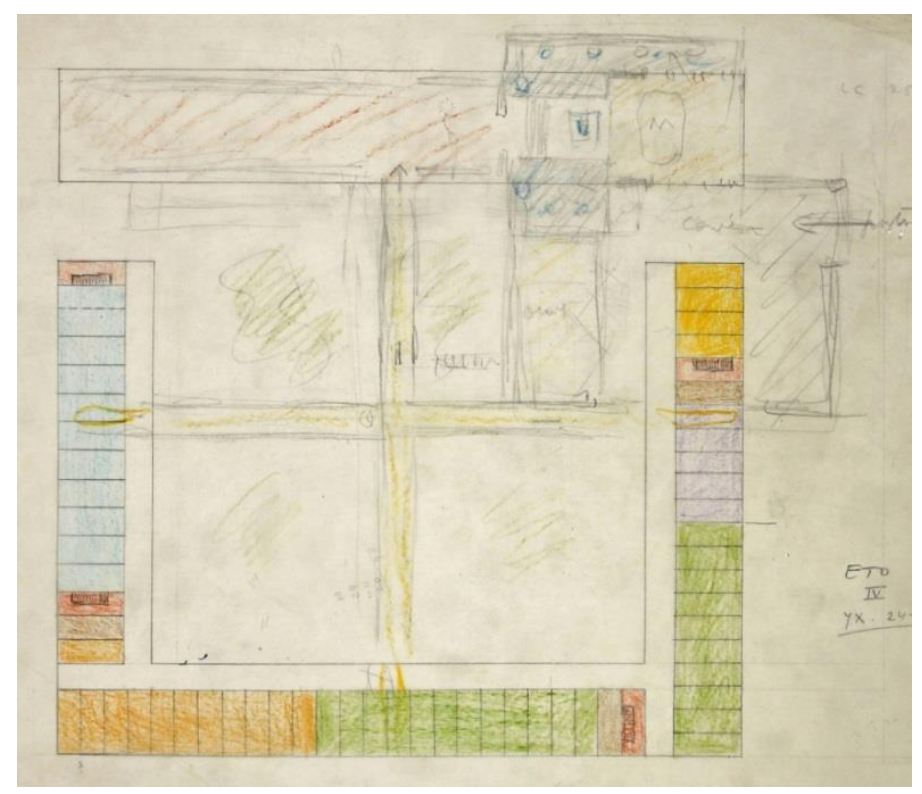

16. FLC 01200. CFLC-ADAGP. Planta del Projet III dibujado por Xenakis en las primeras fases del avant-projet. (24/03/1954).

Además, la Regla de San Agustín obliga a mantener la máxima independencia entre los distintos grupos de monjes alojados en los tres lados del edificio conventual, por lo que este claustro en cruz los reúne, sólo en un punto central, y equidistante de las tres, que conecta con la Iglesia. Por ello, esta particular geometría del nuevo claustro, surgida ante todo de una exigencia funcional, será aceptada por la Comunidad Dominica a pesar de traicionar la solución tradicional, algo, que no había sucedido con las propuestas en promenade a cubierta, y el claustro en ella, dibujadas por LC. 
Ya en su primera visita a la cartuja de Ema, en 1911, LC admitirá: “la primera impresión es de armonía, lo esencial y profundo, me aparece más tarde:.... Y es.... la presencia de la ecuación a resolver confiada a la perspicacia de los hombres, el binomio individuo-colectividad..."30

Y en todo convento el espacio que articula esa perfecta ecuación es el atrio. En él finaliza la existencia en soledad del monje y comienza la vida en comunidad. En él, los monjes se reúnen tres veces al día, para dirigirse, a las celebraciones de la Iglesia que precederán otros actos comunitarios como el alimento en el Refectorio o las reuniones en la Sala Capitular.

Lógicamente, como se ve en el plano, Xenakis situará el atrio en el punto de encuentro de los brazos en cruz, pero además lo desplazará hacia el ala oeste donde ya había situado los usos descritos, el refectorio y la sala capitular.

Y ya en sección, la cubierta inclinada del atrio, situada en el centro de la imagen, también es dibujada para cumplir un requerimiento funcional. Los Padres, los monjes con mayores privilegios de la comunidad, se sitúan en los niveles superiores del ala oeste, frente a las vistas del valle. Desde sus celdas debían poder bajar directamente al espacio del atrio. Sin embargo la situación del refectorio, junto a él, impedía continuar el desarrollo de la escalera de dicho ala. Por ello, el joven ingeniero se ve obligado a introducir una nueva escalera en el atrio, como se aprecia en el plano bajo el color amarillo (17). A continuación proyecta la cubierta inclinada. Ésta se mantendrá ya hasta la obra construida.

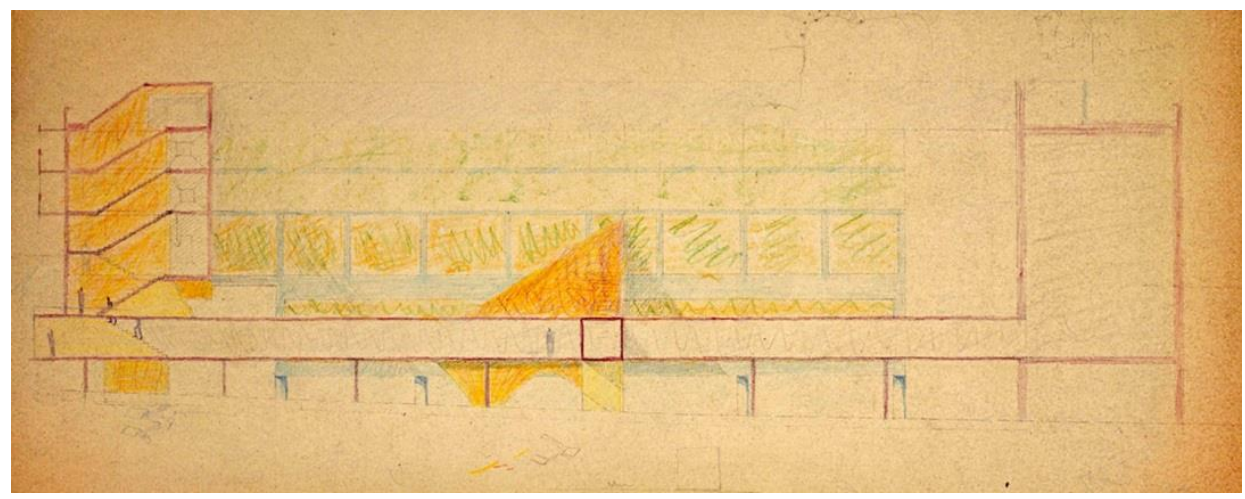

17. FLC 01322. CFLC-ADAGP. Sección por el deambulatorio dibujada por Xenakis (22/06/1954).

Quizá no sea una coincidencia el hecho de que el mismo día que propone esta cubierta, Xenakis, se encuentre trabajando con geometrías piramidales que debían recubrir los paramentos de la iglesia para evitar problemas acústicos.

Este mismo análisis, podría realizarse con cada una de las partes del programa, la biblioteca, el locutorio, el volumen ondulado de las capillas de la iglesia, o tantas otras, en las que el joven ingeniero trabaja concienzudamente hasta aportar la solución definitiva, o al menos, hasta acotar al máximo un problema, que la comunidad o el propio LC, acabarán por resolver. Así, su labor con la función, va ordenando y dirigiendo el proceso de proyecto, siendo el germen de muchas de las soluciones formales que lo caracterizan.

Por ello, el convento de la Tourette, es primeramente una máquina de habitar perfecta, que responde al ritual de vida de una casa de estudios para cien monjes. Un auténtico organismo en el que como explicó LC en su conferencia El Plano de la Casa Moderna, el "fenómeno biológico" es decir "el problema planteado", la

\footnotetext{
${ }^{30}$ Carta de C.E. Jeanneret en Petit, Jean: Le Corbusier lui-même. Ginebra: Collection Panoramas Forces Vives. Ediciones Rousseau. 1969. pp. 44. Traducción del autor.
} 
"utilidad de la empresa", anticipa el fenómeno plástico, "la sensación fisiológica, la "impresión”, la presión por los sentidos... Y ambos indisolublemente unidos provocan el objetivo final de toda arquitectura, la emoción arquitectónica" ${ }^{, 31}$.

\section{Hasta el projet d'exécution. CELDA- ESPACIO INEFABLE.}

Desde el comienzo del proyecto, Xenakis, dibuja múltiples propuestas de la celda. Aunque la primera que puede considerarse definitiva será la del avant-projet entregado sin la supervisión de LC, que se encuentra en su séptimo viaje a India ${ }^{32}$ (18 izda).

Observamos, cómo la mesa, en la que el monje debía pasar una gran número de horas de estudio, se encuentra, pegada a la pared, generando, además, una circulación diagonal en la pequeña estancia, o cómo la posición del lavabo impide el adecuado uso del armario.

Esta torpe propuesta inicial, y todas las siguientes, serán cuidadosamente corregidas por LC, hasta la propuesta definitiva del projet d'exécution (18 dcha). En ella, se produce ya, una modificación de la distribución, para lograr un correcto funcionamiento de la estancia, pero lo que es más importante, para adecuarse a la direccionalidad espacial centrífuga propia del sistema Citroham, o como también como se ha descrito, Megarón, que genera la celda. La mesa, retrasa ya su posición, al igual que el pequeño ropero, liberando el muro, y permitiendo a la vista resbalar, a lo largo de éste, hasta fundirse con el paisaje. El acabado exageradamente rugoso, descrito como "cemento proyectado de grano grueso"33, también parece negar el reposo del monje, proyectándolo hacia el escritorio y la loggia. El lavabo, cambia su posición, quedando suspendido del testero, enfatizando así la oclusión de este plano, y por tanto, el sentido de la fuga espacial.
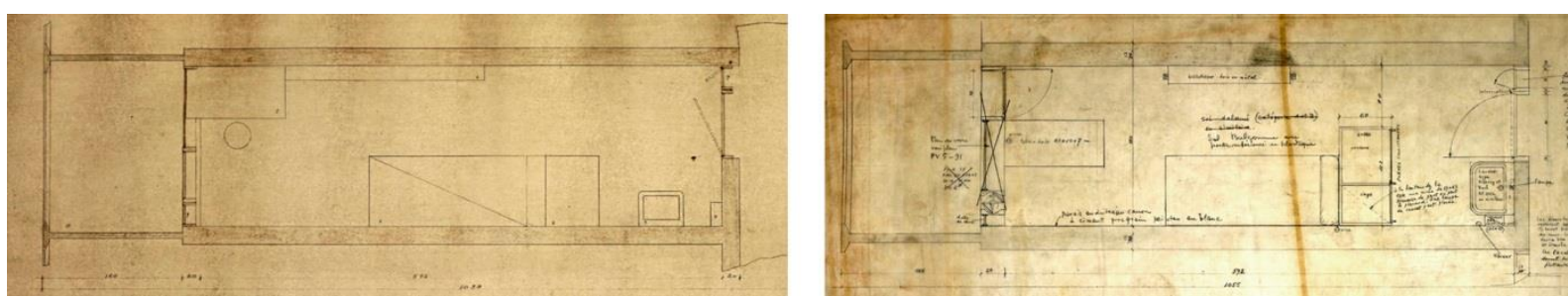

18. FLC 01014. OFLC-ADAGP. Fragmento del plano "E.TO.LC.Cel.I. Plan de cellules" del avant-projet. (22/11/1954). FLC 01015. OFLC-ADAGP. Fragmento del plano "E.TO.LC.Cel.II. Plan de cellules (183 et 226)" del projet d'exécution. (27/07/1955).

Esta operación, ya había sido realizada en el prototipo doméstico Citrohan, de los años 20. En él, el pequeño habitáculo del inodoro, se sitúa, contrariamente a la convención, y a las primeras propuestas, en el punto medio de uno de los testeros, cualificando la direccionalidad del espacio hacia el plano principal opuesto.

En la iglesia, el órgano, un instrumento conformado también por tubos, recorridos por aire, también se suspende del testero para enfatizar su cierre.

\footnotetext{
${ }^{31}$ Precisiones respecto a un estado actual de la arquitectura y el urbanismo. Le Corbusier. Editorial Apóstrofe. Colección Poseidón. Barcelona, 1999. Pag 148.

${ }^{32}$ Le Corbusier viaja en 23 ocasiones a la India. El séptimo viaje lo realiza entre el 9 de noviembre y el 12 de diciembre de 1954.

33 "Parois enduites en canon à ciment gros grain". Leyenda del plano "E.TO.LC.Cel.II. Plan de cellules (183 et 226)" del projet d'exécution.
} 
Evidentemente, ésta, no es más que una relación superficial, entre los dos espacios extremos de la promenade del convento. Como se ha reconocido, "las celdas, son como cien recapitulaciones parciales de la iglesia" ${ }^{34}$. Ambas, comparten el mismo prototipo germinal Megaron.

Pero esta relación no se cimenta exclusivamente en sus semejanzas, sino además y sobre todo en sus oposiciones; el pequeño espacio de la celda, frente al gran espacio de la iglesia, el espacio centrífugo en la celda, frente al centrípeto hacia el altar en la iglesia; la repetición en la celda, frente a la unidad del espacio eclesial, o en el plano social, de gran importancia, la existencia en soledad, frente a la vida comunitaria. Esta fecunda relación dual, enfatiza las características propias de ambos, y a su vez, constituye otra estrategia, para generar un vínculo más, entre los dos grandes volúmenes, del edificio conventual y la iglesia, que conforman el proyecto del convento de la Tourette.

Un vínculo, que provoca, que el tránsito ritual que el monje recorre diariamente, DE LA CELDA AL ESPACIO INEFABLE DE LA IGLESIA, no sea sólo, una unión física o un acontecimiento fenoménico, sino que, como en todas las promenades lecorbusierianas, esconda, significados "ocultos" muy precisos, que contribuyen a unir aún "más profundamente" estos espacios, y sin los cuales no llegaremos a un total entendimiento de la obra ${ }^{35}$.

Y para descubrir uno de los significados ocultos de esta promenade, y concluir el escrito, recurriré a la vivienda de la rue Nungesser et Coli en París. Este apartamento, junto con el Cabanon, serán las viviendas en las que LC reside durante el proyecto del convento, y hasta su muerte.

Junto a su escalera curva, reposa la enigmática escultura de un toro sobre un ladrillo (19). Éste quizá sea uno los objetos que mejor explique y condense no solo la arquitectura doméstica de LC, sino, toda su arquitectura, y universo artístico y personal. Sobre un ladrillo cerámico, LC coloca la talla de un toro micénico. Sobre el objeto de geometrías cúbicas, puras, generado mediante un proceso industrial, standarizado, y símbolo de la modernidad, el arquitecto, sitúa el objeto de formas curvas, orgánicas, único, moldeado por la mano del hombre, y evocador de un tiempo clásico, mítico. Una relación binaria que condensa la esencia de su particular universo artístico, y una dualidad presente en el convento de la Tourette.

\footnotetext{
${ }^{34}$ Rowe, Colin: "La Tourette". En Rowe, Colin: Manierismo y arquitectura moderna y otros ensayos. Barcelona: Editorial Gustavo Gili. 1980. pp. 192.

${ }^{35}$ Ver Benton, Tim. "Le Corbusier y la promenade architecturale". En Arquitectura COAM n ${ }^{\circ}$ 264-265. Madrid: enero, 1987. pp. 38-47.
} 


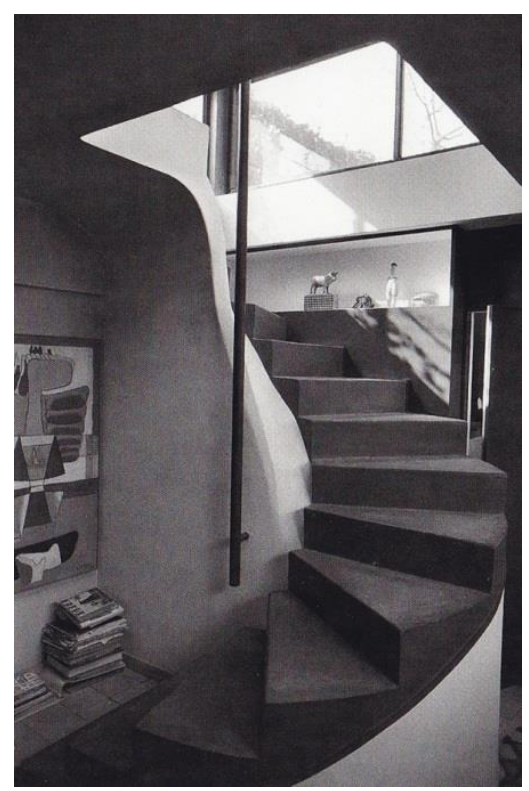

19. Escalera del apartamento de LC en la rue Nungesser et Coli de París.

Pero este objeto, también condensa la esencia de su particular universo doméstico, de su concepto de vivienda. Un concepto que llegó a reproducir en este apartamento de la calle Nungesser et Coli. En él, la escalera no solo une dos niveles, sino que también sirve de puente entre dos mundos, la perfecta máquina de habitar en la que habitaba, destinada a procurar alimento, higiene, descanso, comodidad del cuerpo, aire puro, vistas... ("un regalo de las técnicas ${ }^{\$ 36}$ escribirá también) y su estudio, el lugar que aporta al espíritu la calma indispensable, el santuario cerrado, atávico, el lugar del alma, de la meditación, de la expresión ${ }^{37}$.

Pero esta dualidad, solamente adquiría vida a través del tránsito, que LC realizaba diariamente entre ambos lugares; a través del rito generado entre el taller y el santuario ${ }^{38}$, un rito que como el brazo de la balanza de sus pinturas, alimenta esa polaridad que se sostiene en el equilibrio. Un tránsito entre dos realidades opuestas, pero nunca contradictorias, sino complementarias, ambas necesarias para la vida. Como escribe el propio LC “...la vida mana en el medio, en el justo medio. El equilibrio es el signo del movimiento imperecedero. El equilibrio es el lugar en que se conjugan todas las fuerzas...”39.

\footnotetext{
${ }^{36}$ Le Corbusier: “Urbanisme. La Règle de 7V (Voies de circulation)”. En Boesiger. W (ed.): Le Cobusier Oeuvre Complète. Vol 5. 1946-52. Berlin: Birkhäuser Publishers. 1999. pp. 90-94. Traducción del autor.

${ }^{37}$ El espacio doméstico lecorbusieriano basculará entre las dos acepciones con que el arquitecto definió la vivienda en los años 20. La primera de ellas, la más conocida, la considera una "machine à habiter destinada a procurarnos una ayuda eficaz para la rapidez y exactitud en el trabajo, una máquina diligente y atenta para satisfacer las exigencias del cuerpo: comodidad". Pero esta primera definición, la más reproducida, es secundada por un enunciado de carácter opuesto cuya consecución según las palabras del propio LC, es el verdadero cometido de todo arquitecto (frente al ingeniero) "proporcionar un lugar útil para la meditación y finalmente un lugar donde la belleza exista y aporte al espíritu la calma indispensable".

Ver Le Corbusier: El Espíritu Nuevo en la Arquitectura, En defensa de la Arquitectua. Murcia: Colección de Arquitectura. Colegio Oficial de Aparejadores y Arquitectos Técnicos. 1993. pp 25.

${ }^{38}$ Quetglas, Josep: "El taller y el santuario". En Calatrava, Juan (ed.): Doblando el ángulo recto. 7 ensayos en torno a Le Corbusier. Madrid: Ediciones Arte y Estética. 2009. Pag 117.

${ }^{39}$ Le Corbusier: Cuando las catedrales eran blancas. Barcelona: Ediciones Apóstrofe. 1999. pp. 239.

Le Cobusier: "Le Grand gaspillage". En Boesiger. W (ed.): Le Cobusier Oeuvre Complète. Vol 3. 1934-38. Basilea: Birkhäuser Publishers. 1999. pp. 19. Traducción del autor.
} 
Y el rito diario de LC encuentra su eco en la promenade diaria que el monje del convento de la Tourette recorre de la celda al espacio inefable de la iglesia.

Y esa repetición diaria, rememora un tiempo mítico primordial, por lo que en ella adquiere sentido más que nunca el verdadero objetivo de la vivienda de LC, desvelado en Vers une architecture, “...recuperar las bases humanas, la escala humana, la necesidad tipo, la función tipo, la emoción-tipo... „40

Por ello, en esta gran máquina de habitar para 100 monjes, el convento de la Tourette, la casa se convierte en lugar para la vida, y el espacio doméstico lecorbusieriano alcanza más que nunca su furor sagrado.

Y la promenade acaba en la Iglesia, o aún más abajo en las capillas (20), santuario de esta gran casa, o de este gran palacio, donde el arquitecto como se reconoce en su obra completa..... "nunca antes tuvo la posibilidad de expresar su total maestría con la luz y el espacio - espacio inefable-cumpliendo con los requerimientos, no solo materiales, sino espirituales, y de respeto a la tradición monástica",41

20. Espacio de las capillas individuales de la Iglesia.

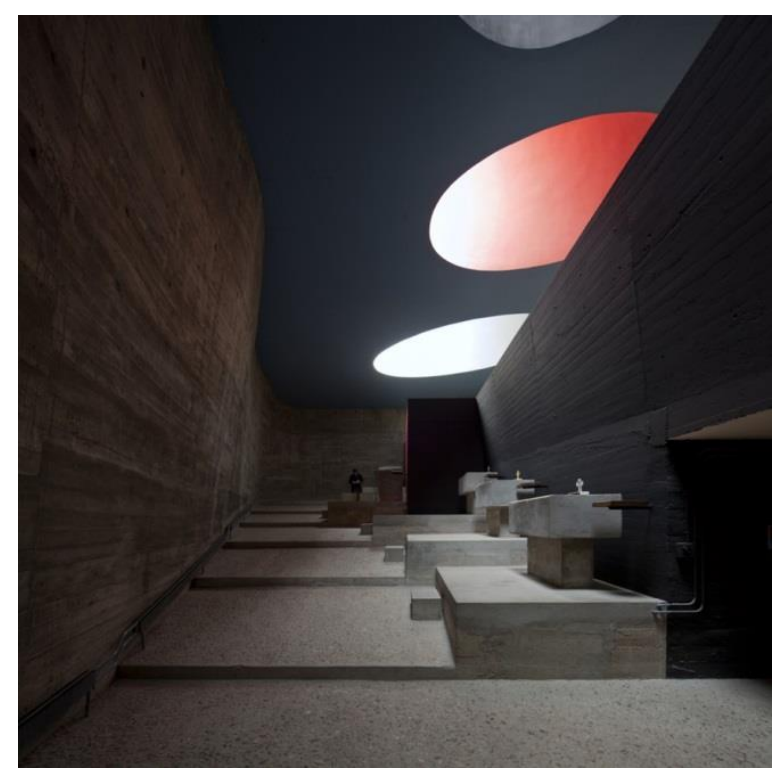

\section{Agradecimientos.}

El autor agradece a la Fundación Le Corbusier la diligencia y generosidad con la que siempre han atendido su solicitud de información sobre la producción del arquitecto. Es todo un ejemplo de inteligencia a la hora de honrar y hacer perdurar su legado.

\section{Procedencia de las imágenes.}

1. FLC y Petit, Jean: Un couvent de Le Corbusier. París: Éditions Minuit. 1961.

2. Le Corbusier: Le Poème de l'angle droit. París: Fondation Le Corbusier, Editions Connivences. 1989. pp.65.

3. Fotografía de la FLC denominada "Perutz", número 9,19.

4. FLC 1029.

5. FLC 02557.

\footnotetext{
${ }^{40}$ Le Corbusier. Hacia una Arquitectura. Barcelona: Editorial Poseidón. 1998. pp. 16.

${ }^{41}$ En Boesiger. W (ed.): Le Cobusier Oeuvre Complète. Vol 7. 1957-65. Basilea: Birkhäuser Publishers. 1999. pp. 32. Traducción del autor.
} 
6. Petit, Jean: Un couvent de Le Corbusier. París: Éditions Minuit. 1961.

7. Boesiger. W (ed.): Le Cobusier Oeuvre Complète. Vol 6. 1952-57. Berlin: Birkhäuser Publishers. 1999. pp. 43.

8. FLC 01230.

9. FLC 01146.

10. FLC 01244.

11. FLC 01038A.

12. FLC 01047A.

13. FLC 01212.

14. FLC 01296.

15. FLC 01243.

16. FLC 01200.

17. FLC 01322.

18. FLC 01014. FLC 01015.

19. Rüegg, Arthur: Le Corbusier, René Burri, Magnum Photos. Berlin: Birkhäuser Publishers. pp.167.

20. Fotografía realizada por Montserrat Zamorano.

\section{Bibliografía/referencias.}

Boesiger. W (ed.): Le Cobusier Oeuvre Complète. Vol 5. 1946-52. Berlin: Birkhäuser Publishers. 1999.

Boesiger. W (ed.): Le Cobusier Oeuvre Complète. Vol 7. 1957-65. Basilea: Birkhäuser Publishers. 1999.

Calatrava, Juan (ed.): Doblando el ángulo recto. 7 ensayos en torno a Le Corbusier. Madrid: Ediciones Arte y Estética. 2009.

Cali, Francois. La Plus Grande Aventure du Monde. Photographies de Lucien Hervé. París: Editorial Arthaud. 1956.

COAM (ed.): Arquitectura C.O.A.M. $n^{\circ}$ 264, 265. Madrid: C.O.A.M. 1987.

Eliade, Mircea: Lo Sagrado y lo Profano. Barcelona: Editorial Paidós Orientalia. 1998.

Gresleri, Giuliano, Gresleri, Glauco: Le Corbusier: il programa litúrgico. Bolonia: Editrice Compositori. 2001.

Le Corbusier: Cuando las catedrales eran blancas. Barcelona: Ediciones Apóstrofe. 1999.

Le Corbusier: El Espíritu Nuevo en la Arquitectura, En defensa de la Arquitectua. Murcia: Colección de Arquitectura. Colegio Oficial de Aparejadores y Arquitectos Técnicos. 1993.

Le Corbusier. El Modulor II. Barcelona. Editorial Poseidón. 1980.

Le Corbusier Fondation (ed.): Le Corbusier. La nature. París: Éditions de la Villette \& Fondation Le Corbusier. 2004.

Le Corbusier: Precisione. Respecto a un estado actual de la arquitectura y el urbanismo. Barcelona: Ediciones Apóstrofe. 1999.

Le Corbusier: Le Corbusier Sketchbooks. Volumen 2, 1950-54. Carnet G-29. Cambridge-Massachusetts: The MIT Press. 1981.

Le Corbusier. Hacia una Arquitectura. Barcelona: Editorial Poseidón. 1998.

Le Corbusier: Une Maison- un palais. París: Éditions Connivences. 1989. 
Martí Arís, Carlos: Las variaciones de la identidad. Ensayo sobre el tipo en arquitectura. Barcelona: Ediciones del Serbal. Demarcación de Barcelona del Colegio de Arquitectos de Cataluña. 1993.

Martínez Santamaría, Luis: El árbol, el camino y el estanque. Barcelona: Colección Arquithesis núm.15. Fundación Caja de Arquitectos. 2004.

Monfalcon, J.B: Histoire Monumentale de la Ville de Lyon. Tomo III. París, 1866.

Petit, Jean: Le Corbusier lui-Même. Ginebra: Collection Panorama Forces Vives. Rousseau Éditeur. 1969.

Petit, Jean: Un couvent de Le Corbusier. París: Éditions Minuit. 1961.

Quetglas, Josep. Les Heures Claires. Barcelona: Massilia. 2008.

Regla y Constituciones de la orden de San Agustín. Madrid: Ediciones Escurialenses. 2002.

Rowe, Colin: Manierismo y arquitectura moderna y otros ensayos. Barcelona: Editorial Gustavo Gili. 1980. 


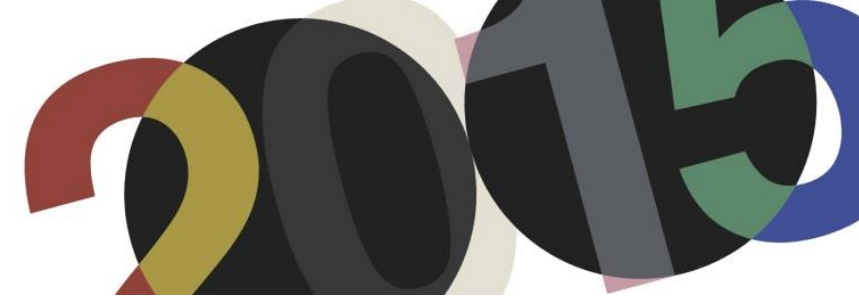

DOI: http://dx.doi.org/10.4995/LC2015.2015.926

\title{
Le Corbusier's Secret Geometry: Speculations on Regulating Lines Hidden in Ronchamp
}

\author{
P. Wood
}

Victoria University of Wellington, New Zealand

\begin{abstract}
Despite the prominence of Ronchamp in the work of Le Corbusier we remain largely ignorant of the geometric approach the architect applied to determine the specific relationship of the building's plan to its liturgical responsibilities. It is assumed that the Modulor was the principle proportional system used to determine the chapels plan. In this paper it is contented that the Modulor played a minor role in finding the principle geometric relationships, at least in plan. With reference to two formal explorations, the research presents two findings. Firstly, that in exploring primary relationships Le Corbusier was more likely to have made geometric reference to attributes of the extant site. A second part of this argument goes on to show that once the plan of Ronchamp was established it was used to provide geometric coordinates for other parts of the site development.
\end{abstract}

Resumen: A pesar de la prominencia de Ronchamp, en la obra de Le Corbusier que permanecen gran parte ignorante del enfoque geométrico el arquitecto aplicó para determinar la relación específica del plan del edificio para sus responsabilidades litúrgicas. Se supone que el Modulor fue el sistema proporcional principio utilizado para determinar el plan capillas. En este trabajo se está contento de que el Modulor jugó un papel de menor importancia en la búsqueda de las relaciones geométricas principales, por lo menos en el plan. Con referencia a las dos exploraciones formales, la investigación presenta dos conclusiones. En primer lugar, que en la exploración de las relaciones primarias Le Corbusier era más probable que hayan hecho referencia geométrica a los atributos del sitio existente. Una segunda parte de este argumento pasa a mostrar que una vez que se estableció el plan de Ronchamp se utiliza para proporcionar coordenadas geométricas de otras partes del desarrollo del sitio

Keywords: Ronchamp; geometry; proportion.

Palabras clave: Ronchamp; la geometría; proporción.

\section{Introduction}

Ronchamp is rightfully regarded as a masterpiece in Le Corbusier's oeuvre, and as such it has attracted continual attention from historians, critics and architects alike. It has been pointed out that archival information on Ronchamp is remarkable for the coverage it offers on his methodological design approach. ${ }^{1}$ And yet we remain largely ignorant of the geometric strategies Le Corbusier utilised to determine the specific relationship of the building's plan to its liturgical responsibilities. Indeed, many interpretations of Ronchamp tend to position it as an organic sculptural work somewhat apart from his other buildings ${ }^{2}$. It may well be that we prefer the image of Ronchamp as an act of pure creative expression. However romantic views are difficult to sustain if we consider the role the Modulor played in organising a plan so wilful in rejecting Cartesian coordination. That the Modulor underlies the complexity of Ronchamp is not in doubt. Corbusier went so far as to challenge visitors to discover it, calling it a game of proportions. In his petit monograph on Ronchamp Le Corbusier describes the Modulor as

\footnotetext{
${ }^{1}$ Pauly, D. (1985). "The Chapel of Ronchamp." Architectural Design 55(7/8): 30-37.

${ }^{2}$ See Jencks, C. (1987). Le Corbusier and the Tragic View of Architecture. Middlesex, England, Penguin Books.
} 
being 'everywhere', but he then writes: "I defy a visitor to give, offhand, the dimensions of the different parts of the building"3. In a similar vein elsewhere in this marvellous small book, Le Corbusier emphasis 'play' where he writes on the play of proportions, and the play of relationships. ${ }^{4}$ A third example of how Le Corbusier conceptualised Ronchamp as a geometric conundrum can be found in this rather melodramatic paragraph from The Modulor II:

"It was a pleasure, here, to allow free play to the resources of the Modulor, keeping a corner of one's eye on the game to avoid blunders, for blunders lie in wait for you, beckon you on, tug at your sleeve, drag you down into the abyss. $" 5$

In each of these descriptions Le Corbusier offers Ronchamp a kind of enigmatic game, a puzzle to be understood, if not solved. But it is not at all obvious who this riddle serves. Whether there is in Ronchamp a genuine intellectual challenge to those who experience the building, or if the building served a more internal creative dialogue for Le Corbusier's development of Modulor geometries?

\section{Methodological Approach}

In particular it is in the extraordinary plan of Ronchamp that we can observe a contestable territory between agreed accounts of the project's genesis (the disciplinary account) and diverse expositions on the chapel's symbolic iconography (Le Corbusier's personal narrative). Critiques of the plan have tended to operate on the assumption that the Modulor was a grand proportional determinant without ever testing this claim consistently or in detail. In a revealing passage in Modulor II Le Corbusier writes, in advance of Ronchamp's completion, that 'all will be coherent' and 'released by free invention' based on the 'faultless mathematics of the combinations'. But other than the proportional detailing of the flagstone floor the plan of Ronchamp defies simple explanation. Finding the Modulor in the chapel plans requires an act of faith in Le Corbusier's assertions that it is, indeed, integral, and in that moment it is demanded of us that we trust without evidence. As Robin Evans has put it, while it is difficult to see how the Modulor and Ronchamp are connected, it is easier to see how they are alike. ${ }^{6}$ Or perhaps we should say 'if we want to see how them as alike' as the issue here might be one of recognition rather than realisation?

In this paper I will be attempting to explain some part of Le Corbusier's Ronchamp riddle. Immediately this work is then defined by problems of translation as formal 'meaning' is retrieved from a language of building. This is fraught but it is in no way new to Corbusier scholarship. Ivan Zaknic has observed that literary translators of Le Corbusier have sometimes taken minute liberties with his words with significant consequences. ${ }^{7}$ But in the discipline of architecture translation is not limited to the written text. As Robin Evans continues elsewhere, translation is an instrumentation that underpins our entire disciplinary authority as architectural ideas move

\footnotetext{
${ }^{3}$ Le Corbusier (1957). The Chapel of Ronchamp. London, Architectural Press. Page 118.

${ }^{4}$ Le Corbusier (1957). The Chapel of Ronchamp. London, Architectural Press. Page 27.

${ }^{5}$ Le Corbusier (1958). Modulor 21955 (Let the User Speak Next) Continuation of 'The Modulor' 1948. Cambridge, Massachusetts, and London England, The M.I.T. Press. Page 254.

${ }^{6}$ Evans, R. (1995). The Projective Cast. Cambridge, Mass., The MIT Press. Page 279.

${ }^{7}$ The best example of this was when Frederick Etchells inserted the word 'new' into the title of Vers une architecture. Le Corbusier (1995). The Final Testament of Pere Corbu: A Translation and Interpretation of Mise au point by Ivan Zaknic. New Haven and London, Yale University Press. Page ix.
} 
between fields of representation, presentation and realisation. ${ }^{8}$ For Evans, Ronchamp offered a particularly acute problem of architectural translation concerned with revealing the chapels 'secrets'.

Utilising a series of graphic studies I wish to tease out some version - a translation - of these 'secrets'. Remembering Zaknic's salient warning on translation, here I will be taking some very great liberties with Ronchamp. It is inevitable that many of these will be, if not outright wrongs, then definitely unstable positions. But maybe this is as it should be. The most powerful puzzle of Ronchamp is that we puzzle over it at all. That an extraordinarily "odd ${ }^{10}$ piece of architecture should demand our continued interrogation is what marks it out as exceptional. In one of Ronchamp's first reviews James Stirling wrote with transparent suspicion of the dominant poetic expressiveness of the building, describing it in a Mannerist tradition as being a personal interpretation of rationalist architecture. ${ }^{11}$ Yet in a personal correspondence he went further into the anxiety presented by Ronchamp: "there is something about it (the idea in Corb's mind, I think) which I have failed to grasp. With considerable on the spot study I feel it might eventually communicate something of great importance - what?"12 The short answer to Stirling's rhetorical question is 'geometry'. The Modulor is the much longer answer but not, necessarily, the right one.

\section{Developing Argument}

To begin in on a contrary position, I will start by showing the extent to which mathematics latent in Ronchamp do not relate to the Modulor at all but instead turn to geometries of reflection, tangency and - as we might expect - the right angle. To set this stage I will give a detailed account of Ronchamp's geometric relationship to its surroundings. In making this case two linked themes are apparent. One is concerned with the way in which Ronchamp subsumed reference information from the site. The other details the degree to which Le Corbusier acted on the reverse principle and externalised the geometry of his chapel. In demonstrating this a case is made for an extent of creative invention in Le Corbusier's design for Ronchamp that is not concerned with the Modulor. The second part of this paper is then obliged to explain where we do find the Modulor. My proposition is that we find it in the most obvious of places but not in a lead role organisational as we might expect.

Le Corbusier's generally arrangement sketches for Ronchamp, especially the earliest examples, typically show a common organisation of architectural features. The most obvious of these is the extraordinary plan, with its highly distinctive relationship of curves readily traceable to the extant building. However there are a number of other features in the early project drawings that did not survive in any obvious way through the construction process. The disappearance of these elements, I suggest, represent the beginning of Ronchamp's secret geometry. I will address each in turn but to begin it is important to note that these elements fall into two distinction that can be simply differentiated as the 'external' and 'internal' spatial parameters. The latter category is very much concerned with the specific question of how Le Corbusier utilised the Modulor as a planimetric device. Here I wish to discuss a pair of factors that have acted about the plan of Ronchamp. This deals with two sets of conditions evident on the site plans.

\footnotetext{
${ }^{8}$ Evans, R. (1986). "Translations from Drawing to Building." AA Files(12): 3-18.

${ }^{9}$ Evans, R. (1995). The Projective Cast. Cambridge, Mass., The MIT Press. Page 315.

${ }^{10}$ Evans, R. (1995). The Projective Cast. Cambridge, Mass., The MIT Press. Page 315.

${ }^{11}$ Stirling, J. (1956). "Ronchamp: Le Corbusier's Chapel and the Crisis of Rationalism." The Architectural Review 119 (March 1956): 155-161.

12 James Stirling quotes in Girouard, M. (1998). Big Jim: The Life and Work of James Stirling. London, Chatto \& Windus. Page 83.
} 
The first of these concerns is the footprint of auxiliary buildings to the west of Ronchamp. The second addresses Le Corbusier's original campanile proposal. In both examples I will suggest that the Modulor is a minor organisational element at best, and that the principle geometric features in play have more in common with classical alignments and tangencies.

In making my case I will make each exegesis will be based on a series of diagrammes in which I overlay possible geometries onto Le Corbusier's drawings. The limits of reproduction, supposition, accuracy and assumption mean that this is inevitable a problematic approach. To any methodological criticism I think it important to say that I am not defending this approach as the 'correct' one. My point is more broadly concern with inviting into our understanding of Ronchamp a possible case for geometric certainties that has otherwise been overlooked.

\section{Case-study a) the significance of auxiliary buildings.}

In all of Le Corbusier's early site plans he records the footprints of auxiliary buildings to the immediate west of the chapel. It is possible in some photographs to discern the nearest of these as probably domestic, but today there is little left to suggest that these buildings existed let alone held any influence(1).

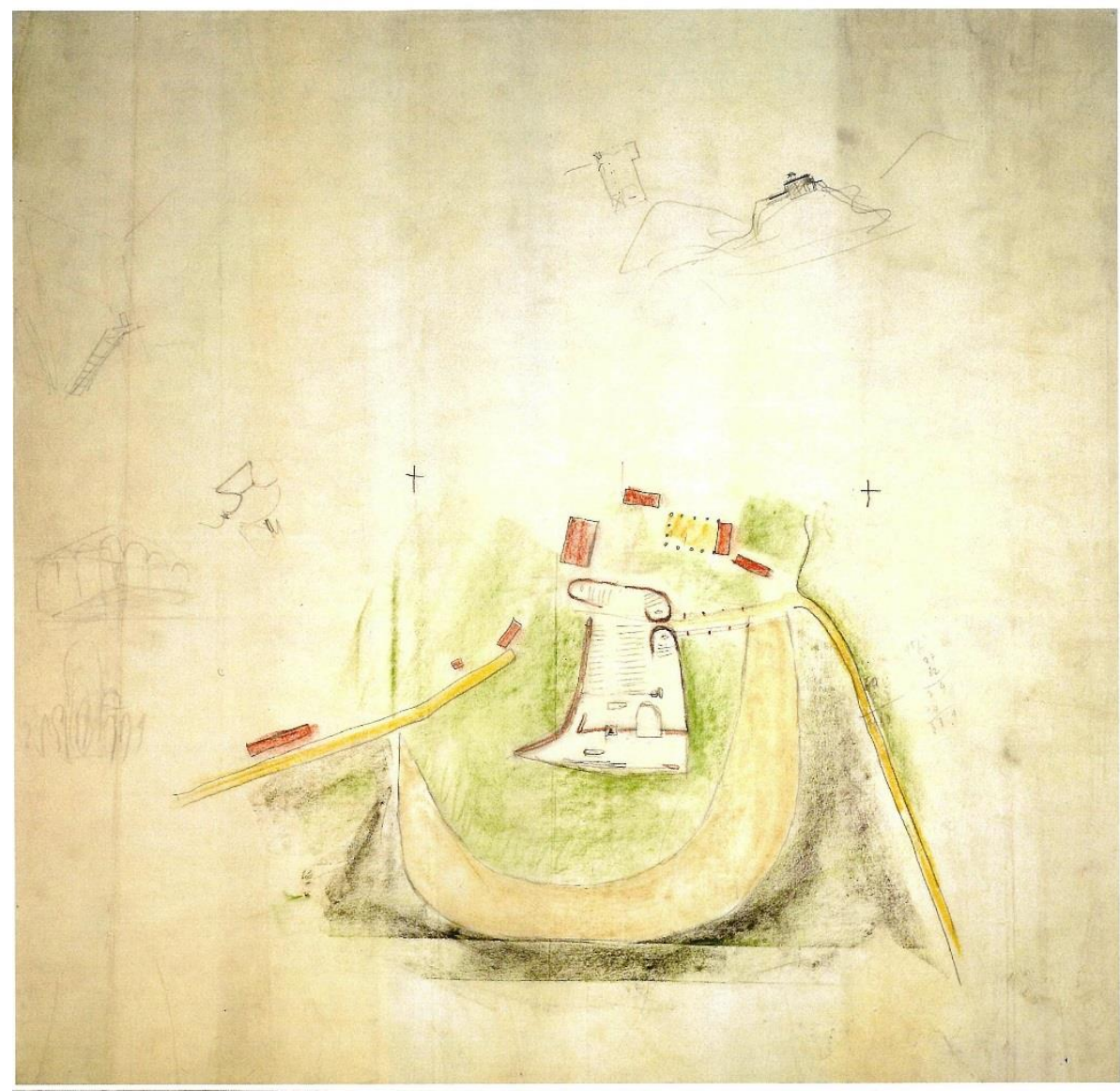

1. Ronchamp: Schematic Site Plan

There is a tentativeness towards the drawings of these buildings that they may have been somewhat less than complete when Le Corbusier's visited. The house to the south west that can be found in period photographs, is shaded in brown, adding to it an air of substantiality. But the patterns to the west are depicted in hesitant lines broken at regular intervals with columns or posts. In other places the post/column markers appear without the 
support of a wall. The curious suggestion in these drawings is that these might be temple-like buildings. The association I am making here is to the Acropolis, and I suggest that it is not accidental that Le Corbusier begins The Chapel at Ronchamp by describing his architectural epiphany of six weeks experiencing the 'soliloquies amongst the ruins' of the Acropolis. ${ }^{13}$ In this view Ronchamp is to the hill of Bourlémont as the Parthenon is to the Acropolis. In itself this is not a new position on Le Corbusier. Colin Rowe saw the same parallel in La Tourette. ${ }^{14}$ But in my view what is happening here is more than just analogy based on landscape or type but rather a serious attempt by Le Corbusier to apply geometric lessons to create a new Acropolis. To achieve this Le Corbusier the hill of Bourlémont as a field of existing points of coordination form which he extracted specific information (2).

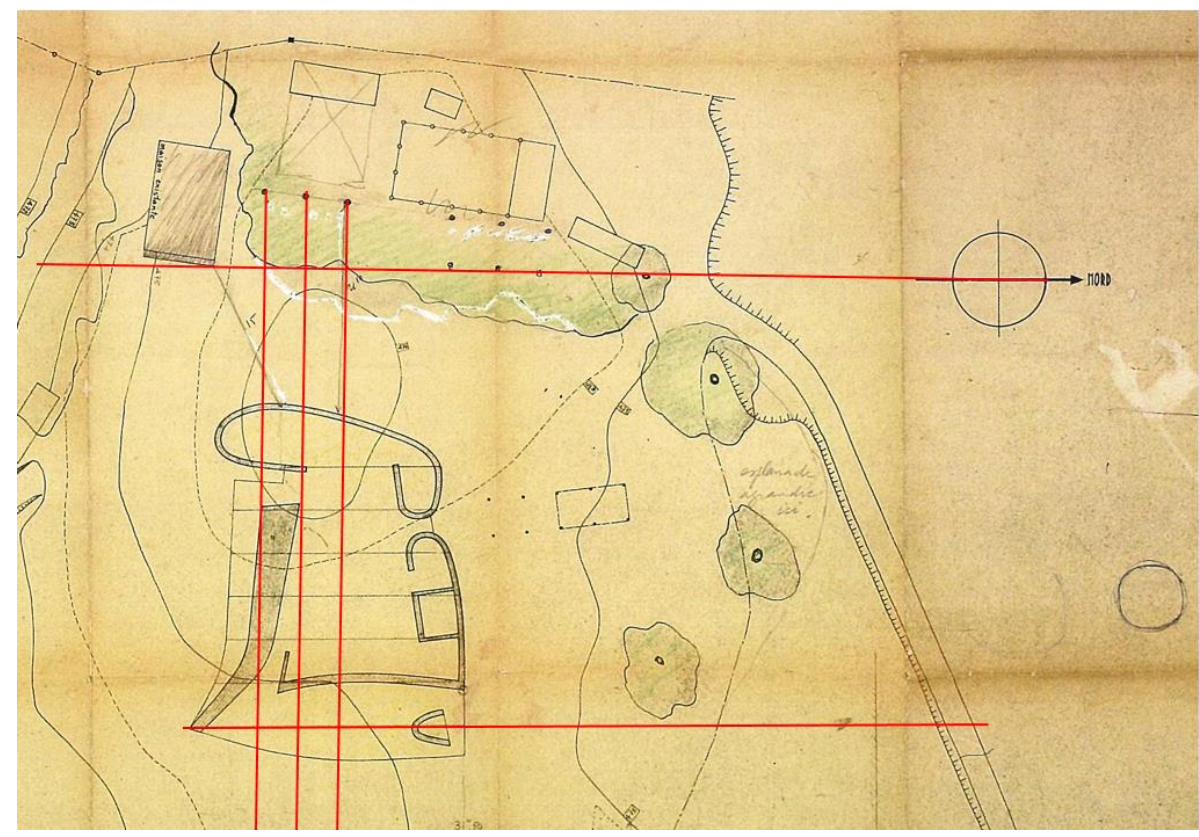

2. Ronchamp site plan (cropped), 13 December 1952, showing vertical alignments

Turning to the western outlines this influence begins with a grid set in place by three free columns depicted directly above Ronchamp. These can be found to drop vertically to cross perpendicular to an axis through the pilgrimage chapel. This produces a bipartite division to the plan that aligns with the footprint of the south wall. However the greater curiosity of this drawing is a second perpendicular crossing that simultaneously clips the east corner of the shaded dwelling, a fourth column, and a tree truck to arrive, most tellingly, on a direct alignment with the compass rose of the drawing. To appreciate that this is not just a convenience of draughting regulating lines are introduced that use the compass points as a datum (3).

\footnotetext{
${ }^{13}$ Le Corbusier (1957). The Chapel at Ronchamp. London, Architectural Press. Page 6.

${ }^{14}$ Rowe, C. (1982). The Mathematics of the Ideal Villa and Other Essays. Massachusetts, The MIT Press.
} 


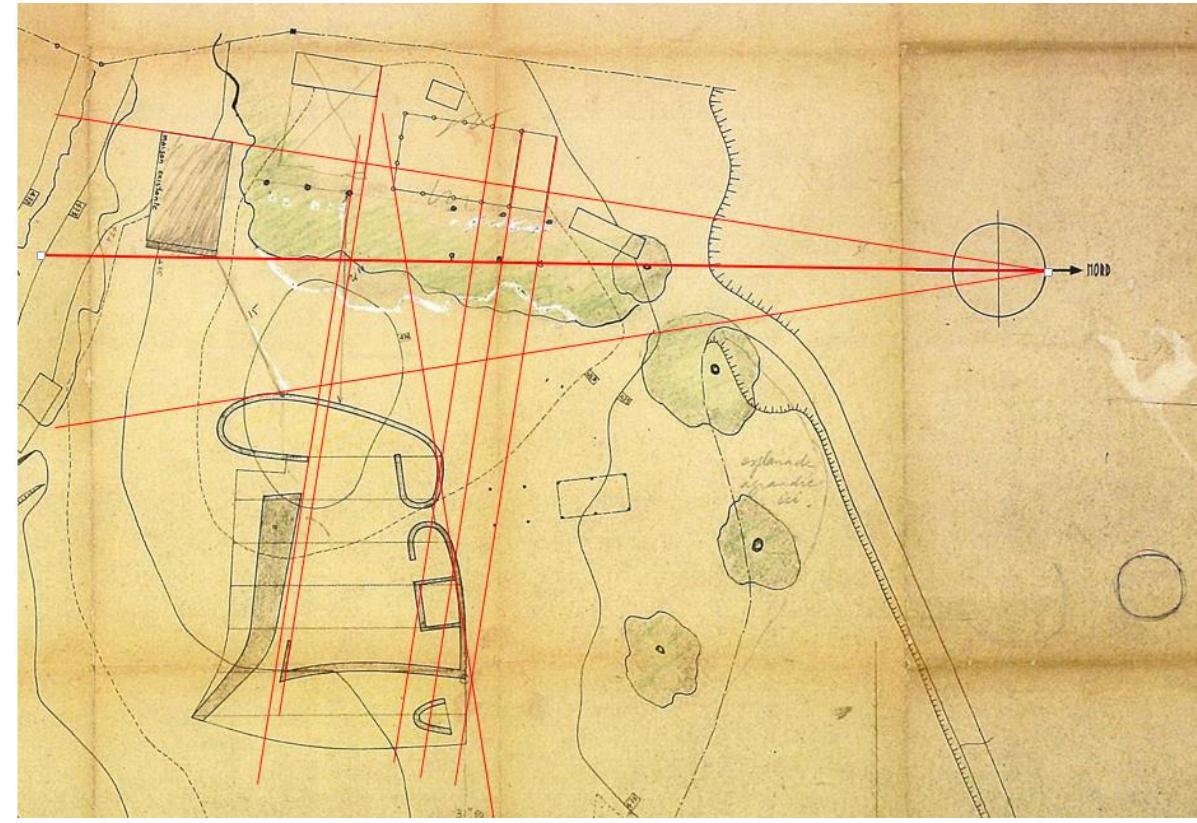

3. Ronchamp site plan (cropped), 13 December 1952, showing compass rose alignment

Demonstrated this way a second alignment to the shaded dwelling is realised, this time aligning directly to its west wall. The reflection vector that corresponds finds an equally pertinent tangency to the west most part of Ronchamp's west wall. However it is when perpendicular intersections are generated off the upper compass vector that a more compelling set of relationships occurs. In particular the temple-like figures produces alignments to the northeast corner of the chapel, but similarly spacings appear for the division between the southeast intersection (4).

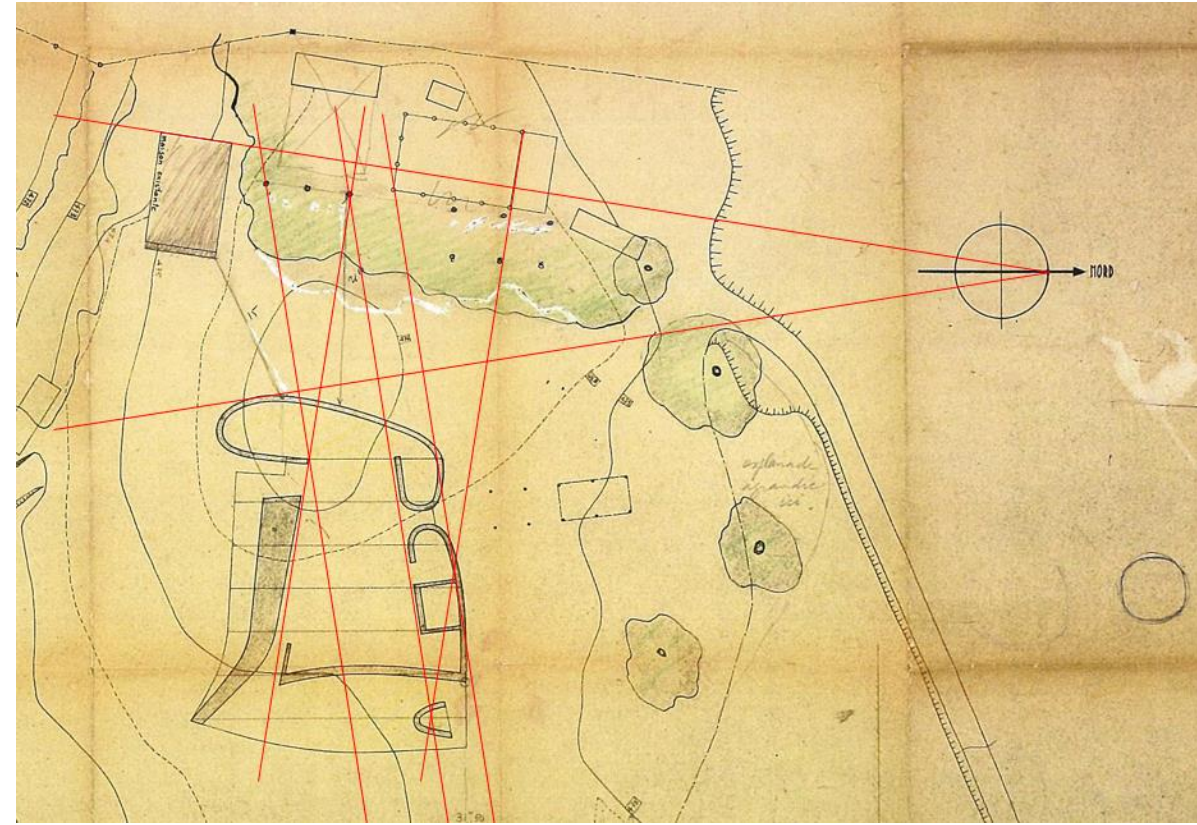

4. Ronchamp site plan (cropped), 13 December 1952, showing compass rose alignment

Introducing perpendicular crossings to the lower compass line produces similar alignments, this time to the intervals of the northern spaces and the nave. These alignments do not significantly account for the design of Ronchamp, but they do suggest the importance of external alignments as being necessary for the refinement of the design, and its placement in its physical context. But even more importantly, if we are to take as a serious 
intention the placement of the compass rose as a part of the geometric instrumentation of Ronchamp it demands of us a much richer understanding of how Le Corbusier used drawing as a methodological process. To show this I have a further variation on the western alignment for consideration (5).

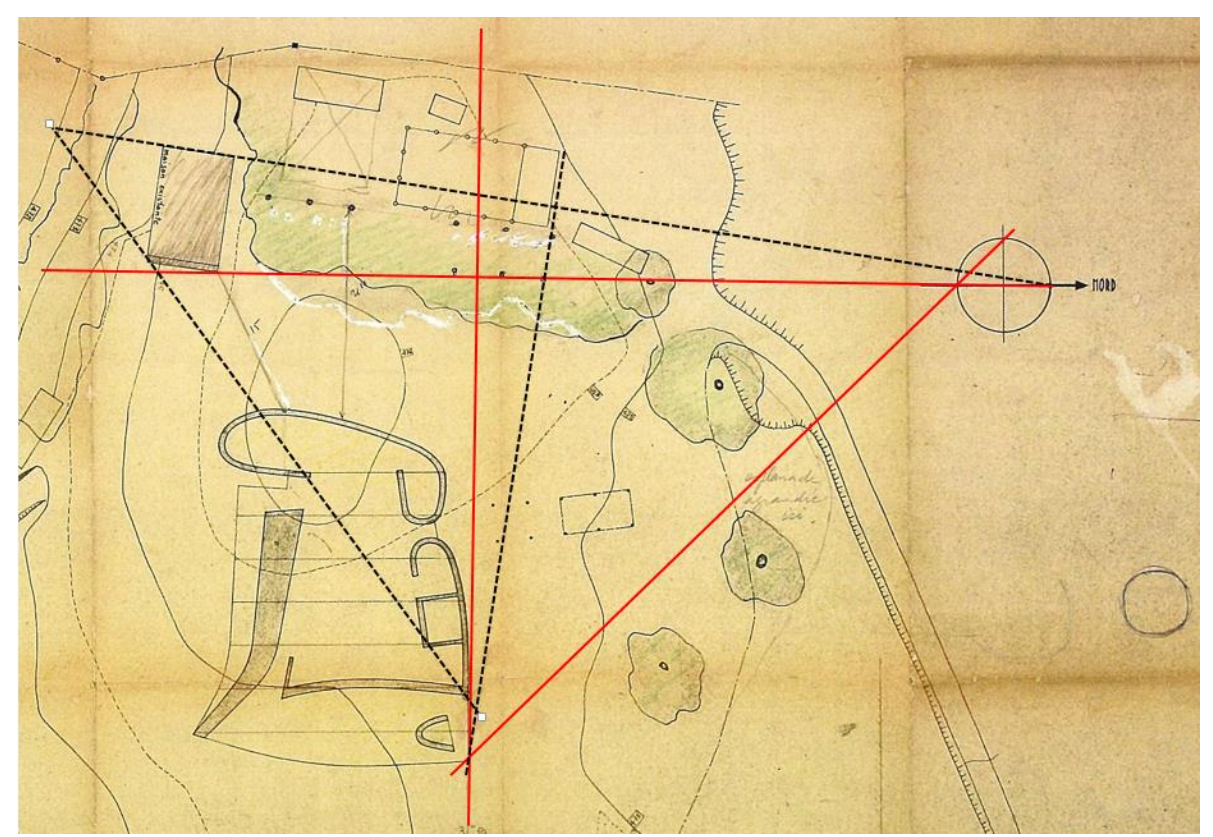

5. Ronchamp site plan (cropped), 13 December 1952, showing compass rose ancillary alignment

Taking the compass axis as a datum a right angle triangle can be generated off the south point that aligns with the northeast time of Ronchamp. In turn a second line can be drawn back from this point to produce a perpendicular intersect with the vector of the upper rose point. Now a second right angle triangle can be generated back via the southeast corner of the shaded dwelling to produce tangencies with three key points In Ronchamp's plan.

At this point it is worth considering that these studies might be little more than the manipulative products of a fertile imagination coupled to the extraordinarily rich possibilities offered by Le Corbusier. They are, at best, examples of circumstantial evidence that is not easily proved. If there is a 'proof' here it one revealed by the insistent occurrence of geometric alignments rather than any one example. To that end I wish to examine the artefacts to the south to suggest that LE Corbusier also drew geometries out of Ronchamp to make decision concerning the dormitory accommodation (6). 


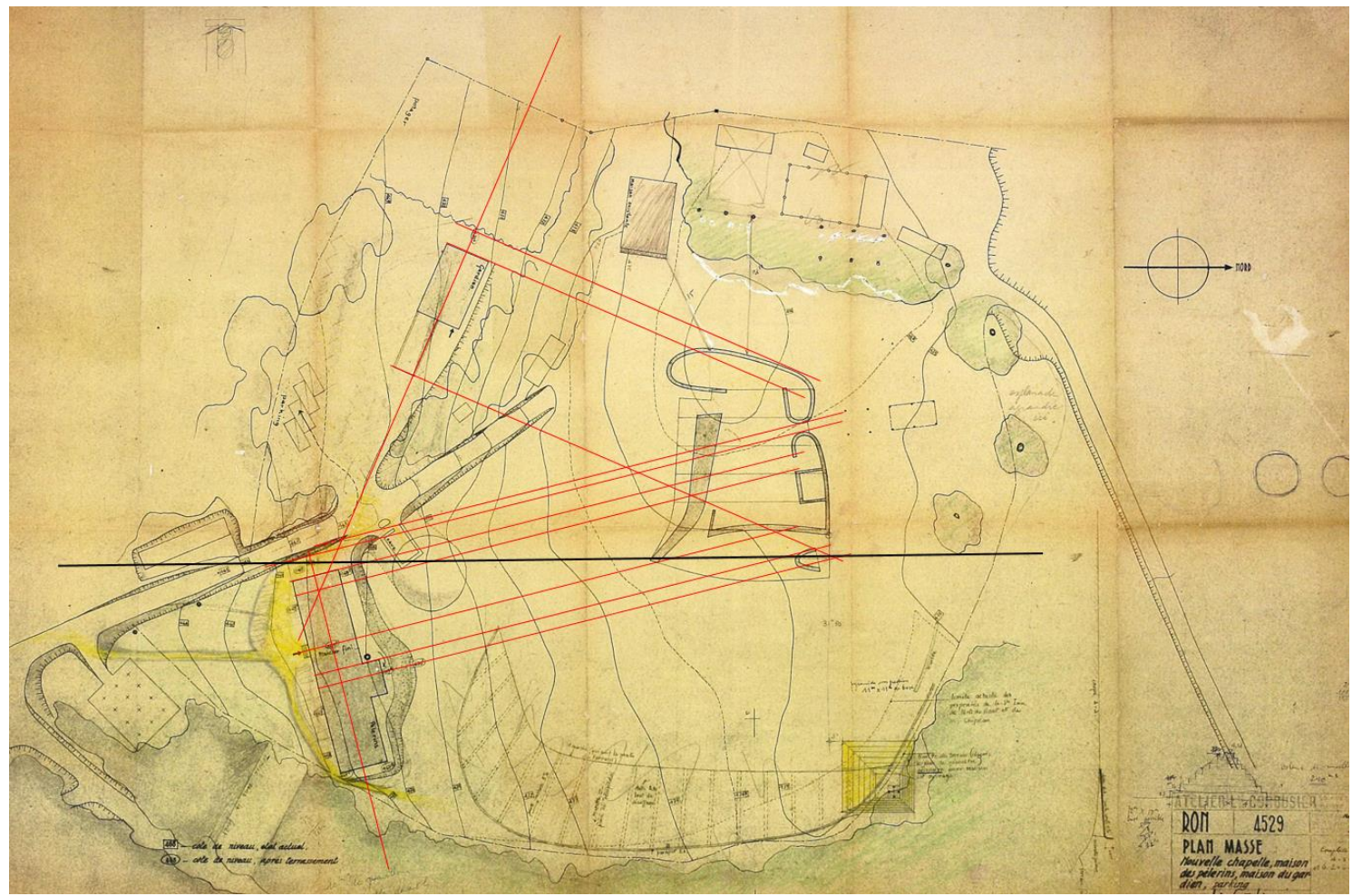

6. Ronchamp site plan (cropped), 13 December 1952, alignment to dormitory

In the first of these I have identified the centreline of the dormitory block, from which perpendicular projections have been taken form points of demonstrable significance (walls, changes in direction, elements highlighted on the drawing, and so on). In this model Ronchamp provides the frame of geometric reference from which the dormitory placement and dimensions can be determined. Similarly the extent of the western accommodation block can be determined Working backwards perpendicular alignments can once more be found to the major intervals in the chapel, and with the introduction of an axial datum through the pilgrimage chapel a reflection line is located.

I would like to turn one final example of ancillary alignments. Despite its prominence the monument de la Paix receives remarkable little attention from scholars. One reason for this is that the simplicity of the regular stepped pyramidal form is so at odds with the complex curves of the chapel. But if anything we should look at the monument even more closely for the way in which its design and construction presents a versions of Le Corbusier's preference for dialectical elements. Against the obviousness of the monument early plans show, to the south of the dormitory, provision for a formal grove (7). 


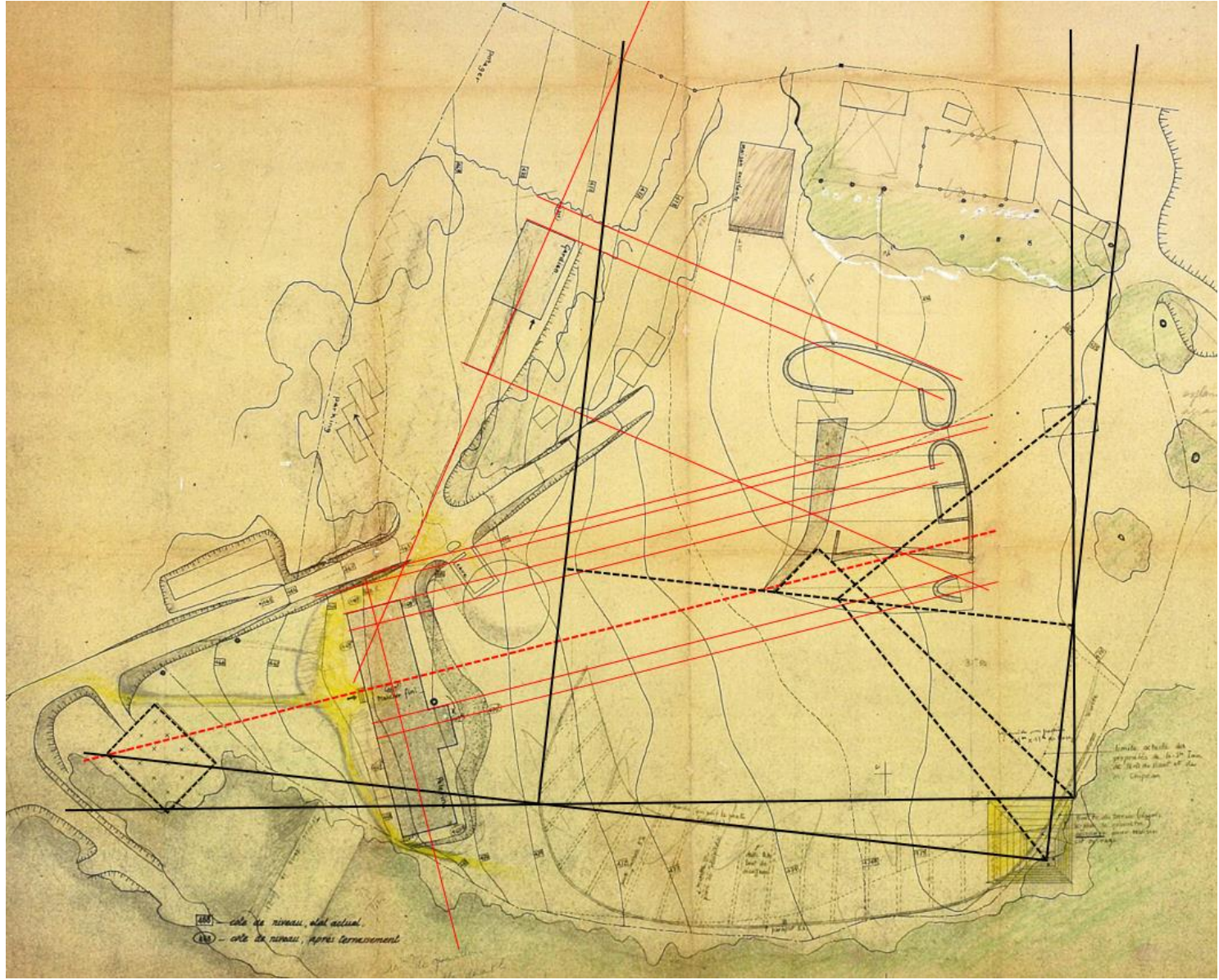

7. Ronchamp site plan (cropped), 13 December 1952, alignment to dormitory

Together these two elements take their datum points from the chapels plan. A parallel line taken from the northwest corner of the monument provides a tangency for the grove, and when taken westwards intersects with the enclosed component of the proposed campanile. At the same time a diagonal bisection of the grove aligns to the peak of the monument, and a perpendicular extraction of this point intersects with the first posts of the original campanile. The significance of this can be found where the two skewed right angles intersect on the vertical axis. By taking a perpendicular projections off at this point a secondary axis is found that passes though the southeast tip of the chapel. Finally, by splitting both right angles against the southeast tip alignments back to the campanile and south wall vector can be found.

In discussing the role of ancillary elements to the geometry of Ronchamp two quite different principles are apparent. In the first I have suggested that latent architectural information to the north of Ronchamp was used as an early generator of reference points. However, once the plan of Ronchamp was resolved Le Corbusier then found point of alignment and tangency which could be projected out into the surrounding landscape to locate additional architectural elements. In the next part I will look more closely at how the original campanile proposal had a more intimate role.

\section{Case-study b) the significance of the original campanile.}

From the his earliest sketches for Ronchamp Le Corbusier had proposed a simple scaffold-like campanile organised on an axial alignment with the northern entrance. That this was a serious part of Ronchamp's conception and development cannot be doubted and it appears in all the developmental workings leading right to 
the formal scheme. In both the elevation and the model photo-montage reproduced in his oeuvre complete the campanile is a visually dominant element in the composition (8).

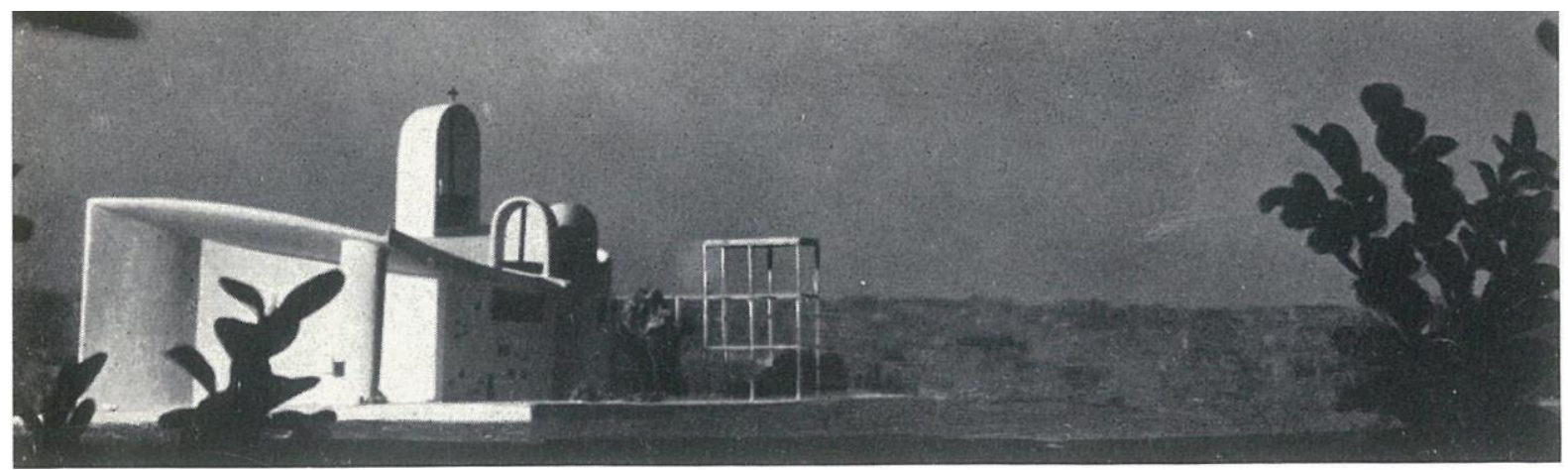

8. Maquette de la chapelle

To speculate on the meaningfulness that this might hold I suggest that the purpose of the campanile's dominance is as a parallel symbolic element to the three towers. I broadly concur with interpretations that find in Ronchamp's three towering light-wells associations to the female figures of greatest influence in Le Corbusier's life. ${ }^{15}$ Against this triadic "cult of Mary' ${ }^{16}$ the campanile is, I suggest, a biographical manifestation of Le Corbsuier's masculinity. This substantially accounts for the opposition of compositional elements: the solid curves of the towers against the open post and beams of the campanile. It could also be read as a very literal manifestation of Le Corbusier's meant when he mentions the 'phenomonon of visual acoustics' of Ronchamp ${ }^{17}$. Evans and Scully ${ }^{18}$, amongst others, have tended to interpret this as spatial metaphor, but had the campanile been constructed as Le Corbusier first intended he would have achieved something far more directly acoustic. The proximity and placement of the bells so close to Ronchamp would have created unique acoustic properties as the sound was reflected around the curved forms. The two northern towers, directly in line with the campanile, would have 'funnelled' the sound across Ronchamp's roof. By contrast the larger southern tower, facing as it does toward the north, would have become an acoustic trap, directing any sound it received down into the altar space beneath in a most direct version of the acoustic detection apparatus he reproduced in his 1935 publication, Aircraft ${ }^{19}$

If the campanile was such an important biographical and acoustic component to Ronchamp then losing it from the final outcome might look like a failure of sorts of Le Corbusier to realise a complete scheme? That so little attention has been given to the first campanile suggests that this is not the case. Indeed, viewing it now the gridded scaffold form is a glaring intrusion on the curves of the chapel. However I don't think we should accept that the influence of the campanile is negligible because its physical presence is missing. To show what this means we need to examine the geometric influence of the campanile. The drawing numbered RON. 4457 is particular helpful for this analysis as it is one of the few in which we find an organisational grid imposed on Ronchamp, with an axis through the chapel made clear (9).

\footnotetext{
${ }^{15}$ Samuel, F. (2004). Le Corbusier: Architect and Feminist. Great Britain, Willey-Academy.

${ }^{16}$ Flora, S. and I. Linder-Gaillard (2013). Sacred Concrete: The Churches of Le Corbusier. Basel, Birkhäuser. Page 108.

${ }^{17}$ Le Corbusier (1957). The Chapel at Ronchamp. London, Architectural Press. Page 89.

${ }^{18}$ Evans, R. (1995). The Projective Cast. Cambridge, Mass., The MIT Press. Scully Scully, V. (1961). Modern Architecture. New York, Braziller.

${ }^{19}$ Le Corbusier (1988). Aircraft. New York, Universe Books.
} 


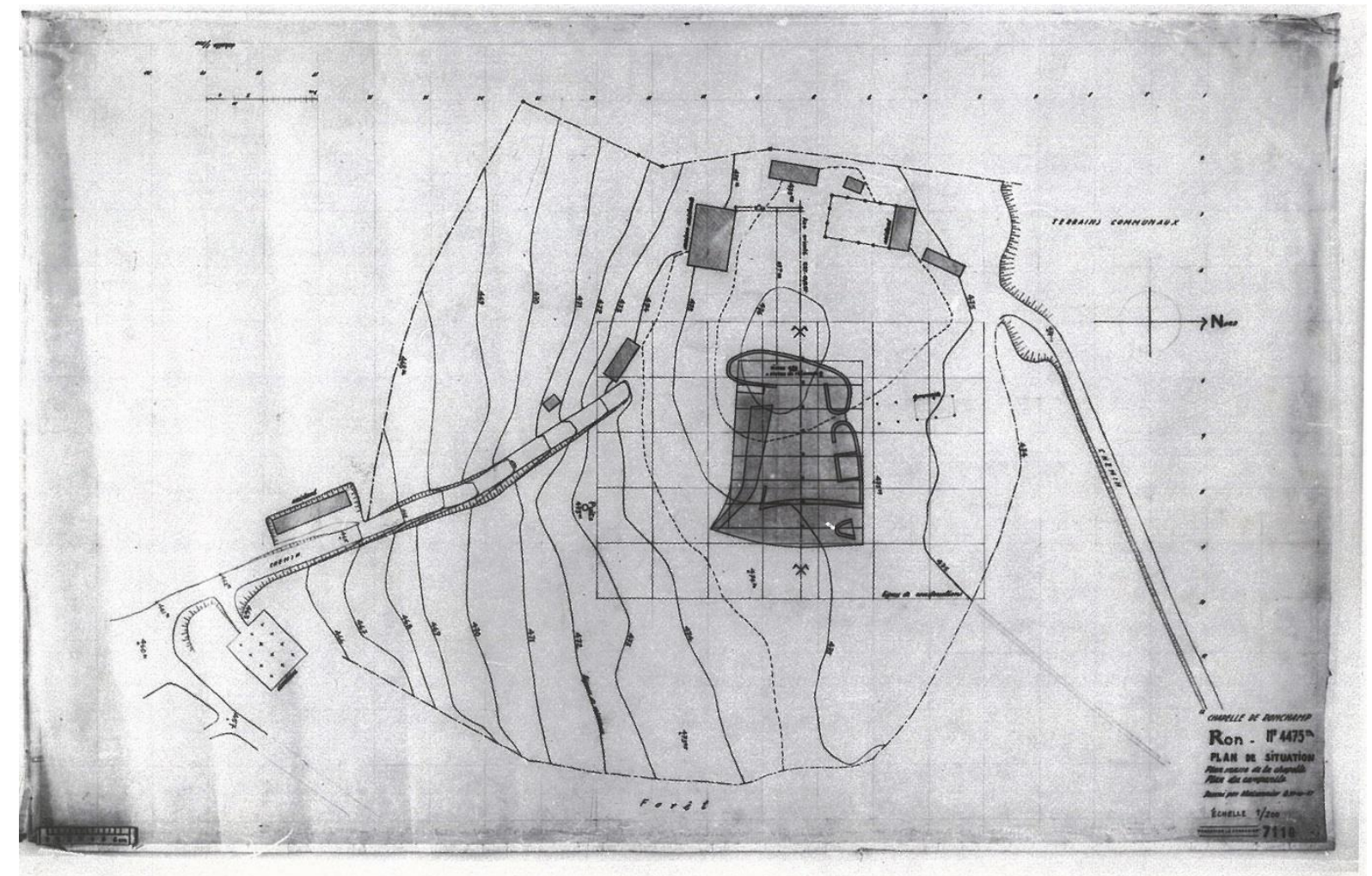

9. Ronchamp Plan de situation, 1952

The first observation to be made about this drawing is that we find here an alignment between the grid and the compass rose, suggesting once more the significance of the compass as a geometric reference point. The second observation concerns the divergence between the overlaid gird and the axis of the campanile. That said the preliminary alignments are immediately apparent. Using the grid/compass axis as the horizontal datum, 45 degree vectors can be taken off the centreline icons on the vertical axis to coincide with both the obvious overgrid of the plan and the campanile grid. Recognising that these two grids are not aligned adds significance to this configuration (10). 


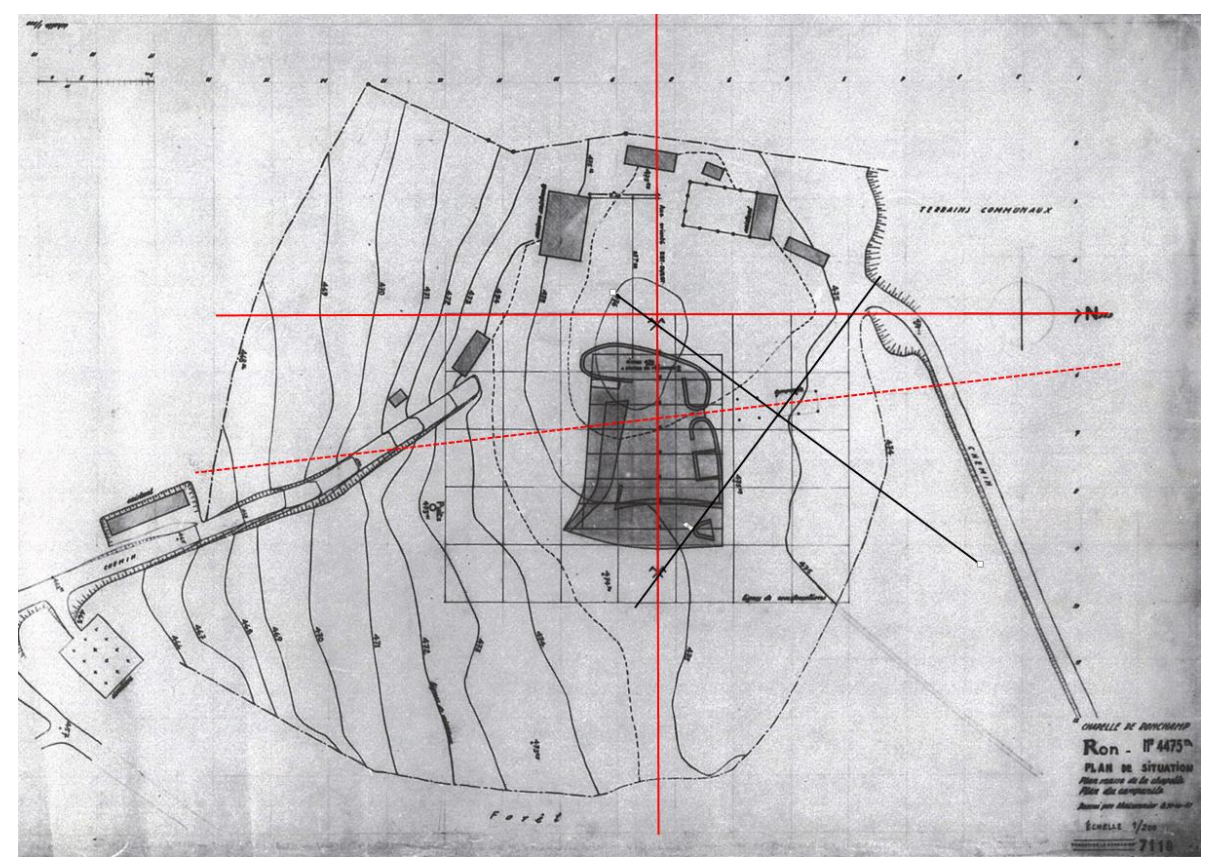

10. Ronchamp with campanile alignment

In the next move I will return to the geometry of the compass point to find a vector between the tip of the compass and the point where the central axis finds the bottom of the plan grid. In turn this line if reflected across the horizontal datum of the grid/compass to find a mirroring intersection at the top of the central axis. Reflecting both these lines across the vertical axis then locates two important points. The first is a tangency with the southeast corner of Ronchamp. The second, tellingly, is an aligned intersection between the axis of the campanile and the left-hand margin of the plan grid (11).

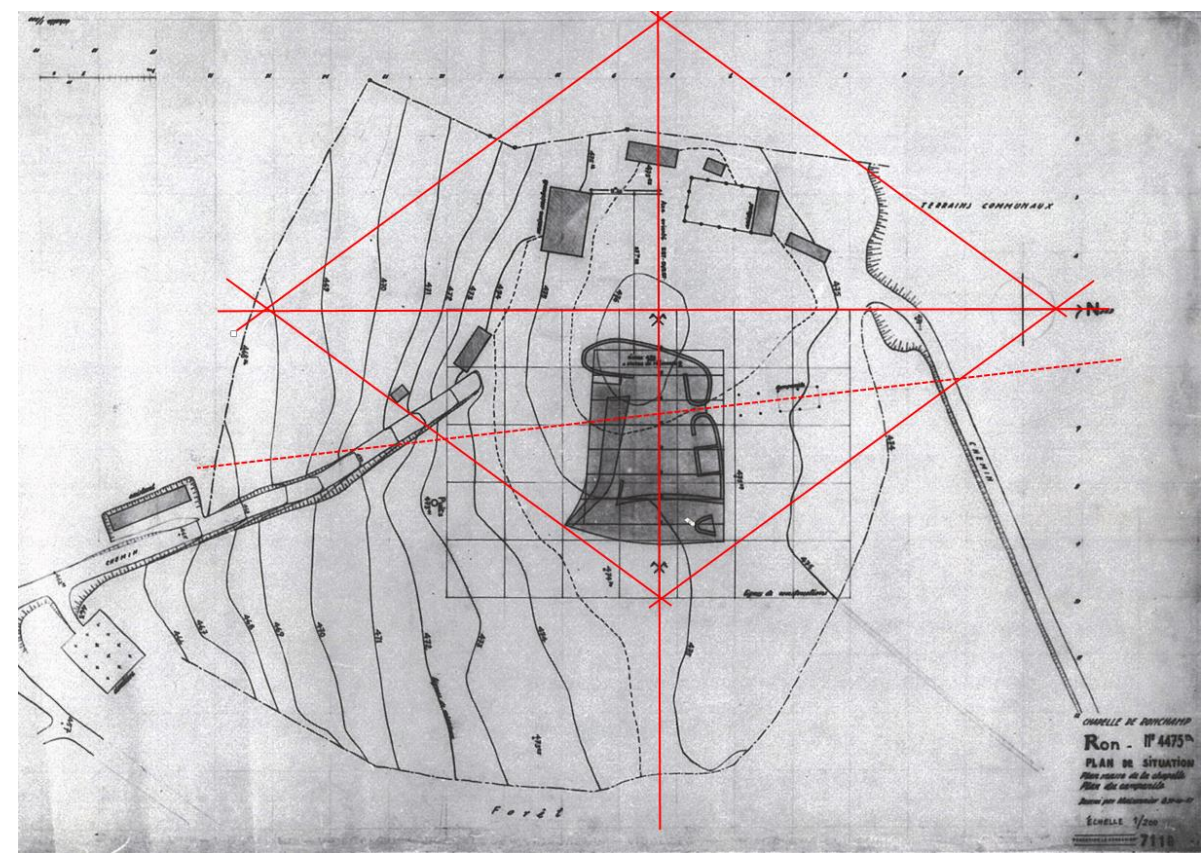

11. Ronchamp with campanile triangulation

These alignments become more convincing when perpendicular versions of the campanile axis are introduced. The most important of these takes the upper point of intersection and find a centreline through the northern altars and entrance. When reflected to the other side of the axis this vector runs parallel to the external south wall. In a 
third move, if the campanile axis line is reflected across the grid/compass axis an alignment occurs with the western structures (12).

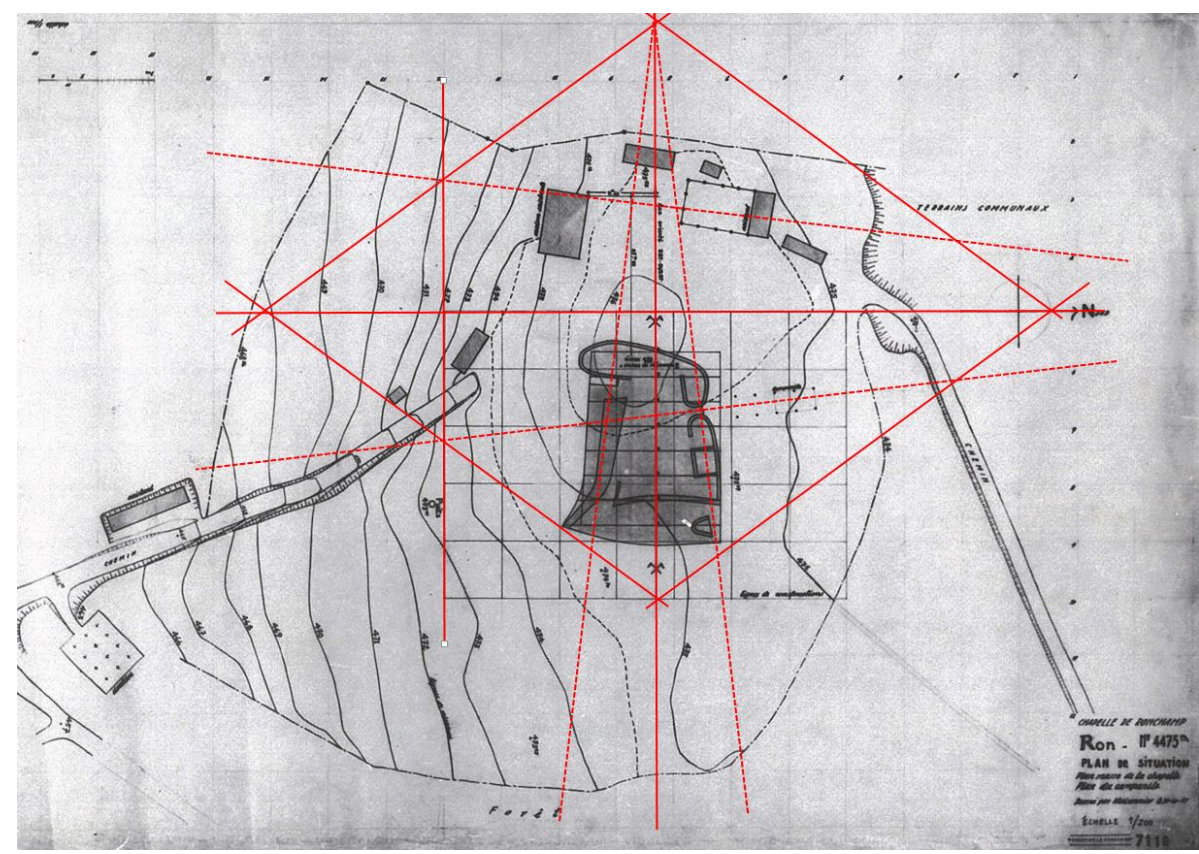

12. Ronchamp with campanile triangulation

In the next development I have added a crossing vector derived from a campanile diagonal that, by reflecting through the vertical axis, creates a chevron and the beginning of a pentagram. Once more inverting this form across the grid/compass line produces alignments with the western ancillary forms (13).

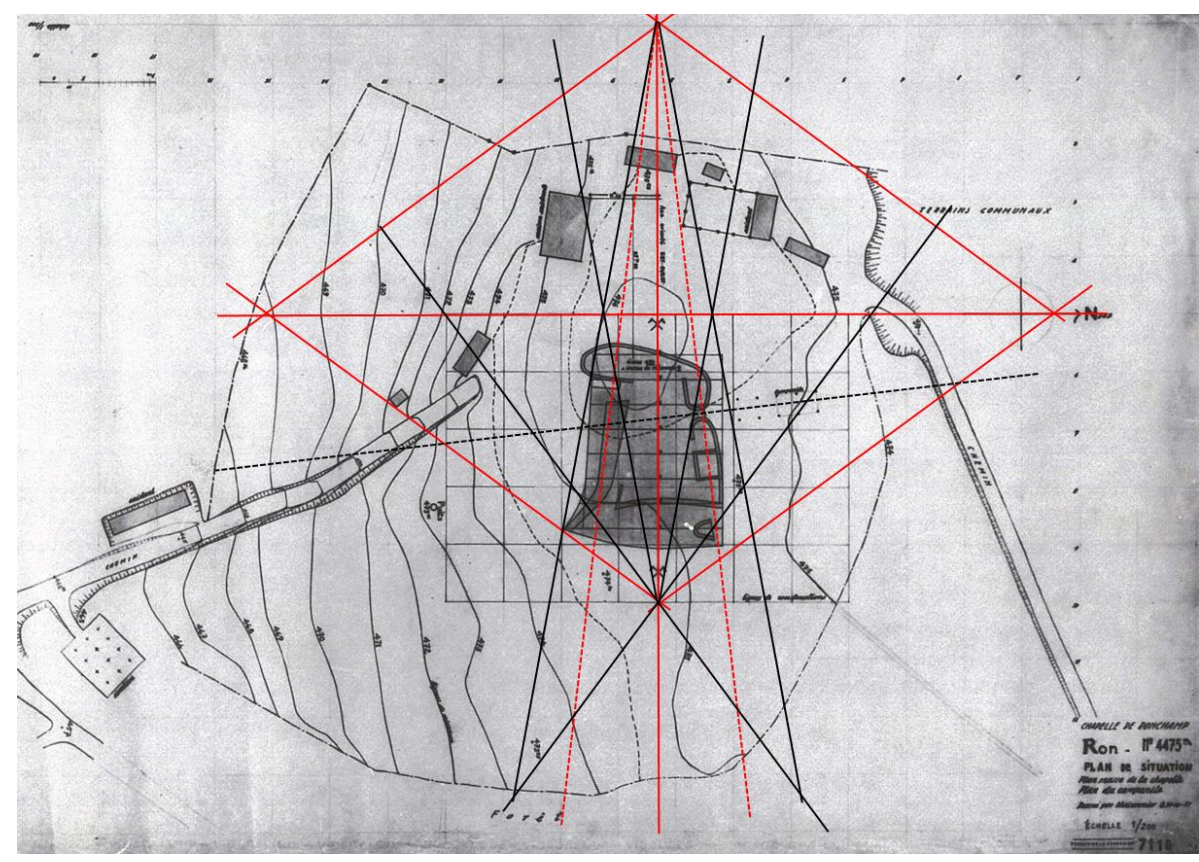

13. Ronchamp with campanile triangulation

It should be of interest that the asymmetry of Ronchamp should start to fall into the kind of symmetrical figuration that underpins the organisational structure of his paintings, and especially his enamel on the door of 
Ronchamp. ${ }^{20}$ However the real impact of the campanile can be found if a more universal grid generated by it is expanded over the entire plan (14).

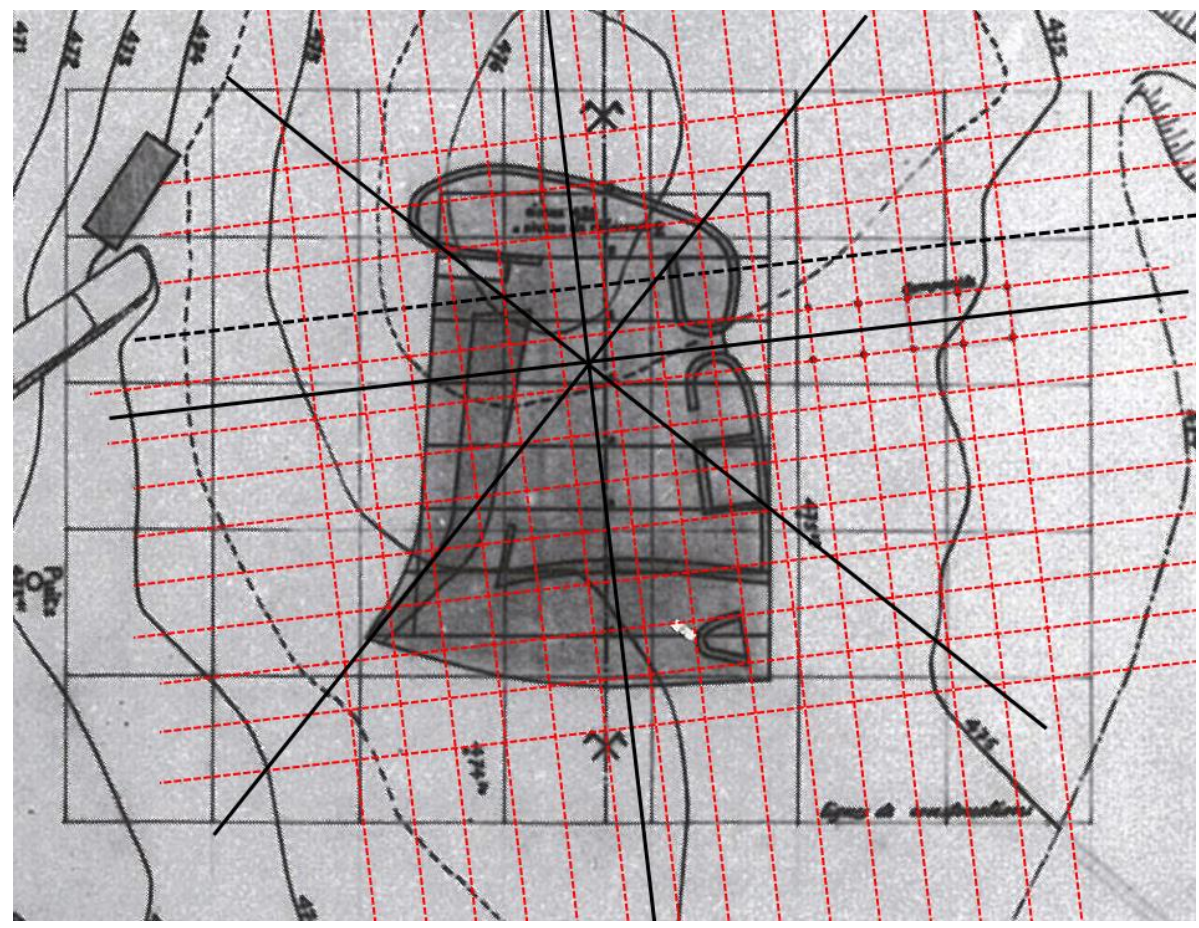

14. Ronchamp with campanile grid (detail)

Alignments here are not dramatic but they are significant. Of particular note is the fact that the eastern pulpit occupies the proportions of the campanile perfectly. Returning to the centre axis of the campanile, the plan can be dissected into quadrants which produce tangencies with many key components including the south entrance, southeast corner, secondary chapel limits and main altar.

\section{Conclusion}

Le Corbusier first visited the site for what would become the Chapel of Notre-Dame-du-Haut at Ronchamp on June $4^{\text {th }}, 1950$. In the company of Canon Ledeur he climbed the processional path of the hill Bourlémont to the remains of a pilgrimage chapel destroyed in the recent war. As Le Corbusier recalls it, at that time he carefully drew a response to the site based upon the four horizons and a resultant volume which "architecturally triggered the acoustic response - acoustics in the realm of forms" ${ }^{21}$. It is now a part of Ronchamp's enigmatic legend that the graphic documentary of its 'spontaneous birth' ${ }^{22}$ are long gone, 'misplaced or lost', as Le Corbusier put it ${ }^{23}$. But if we are left with some question of Ronchamp's genesis Le Corbusier seems as surprised of its outcome as us. Revisiting Ronchamp several years after its completion he expressed this creative uncertainty when he asked, "But where did I get all that?"24. By 'all that' we should not think that Le Corbusier did not have a singular sense of why or how Ronchamp came to be. Indeed, I plan to show here that the actuality of Ronchamp was quite the product of singular certainty. That we could take from Le Corbusier's comment is a more universal truth of

${ }^{20}$ Reichlin, B. (1997). Jeanneret-Le Corbusier, Painter-Architect. Architecture and Cubism. E. Blau and N. J. Troy. Cambridge, Massachusetts, The MIT Press: 195-218.

${ }^{21}$ Le Corbusier, Textes et dessins pour Ronchamp, unpaginated.

${ }^{22}$ Le Corbusier, Textes et dessins pour Ronchamp, unpaginated.

${ }^{23}$ Le Corbusier, Textes et dessins pour Ronchamp, unpaginated.

${ }^{24}$ Pauly the chapel of ronchamp in brooks ed. Page xiv. 
architectural design in which a separation can be made between the 'that' of a building (a complex entity of myriad decisions) and the 'this' of a design procedure that directs the buildings architecture. When facing Ronchamp we can, in common with Le Corbusier, marvel at the 'that-ness' of it, but we should be in no doubt that he knew exactly what he did to get from 'this' to 'that'.

Any vagueness Le Corbusier might imply about the creative derivation of Ronchamp is missing where he hints at the execution of the design. In Texts and Sketches for Ronchamp he writes of ". . the clarity of the relations, everything being based on the faultless mathematics of the combinations." ${ }^{25}$ Guessing the origin of Ronchamp has become an opening gambit for Corbusian scholars. For James Stirling it presented itself like a large thumb emerging form the hill ${ }^{26}$. Charles Jenck's found a cornette, clasped hands and a duck, and more. ${ }^{27}$ There are many other suggestions but the 'truth' (if we can ever use such a word with Le Corbusier) is probably far too inclusive to identify one reading as correct. However, for the sake of the argument I am presenting here I think it useful to look to the most obvious and familiar comparison as a guide. That is, that Ronchamp was principally conceived with a boat in mind. The usefulness in this bias is that it paces its conceptual emphasis an 'outside' element: the ship-shape of the western outdoor pilgrimage chapel. I think we can be even more specific about this source. In his work on Le Corbusier's 'secret photography' Tim Benton reproduces a series of photographs captured by the architect in September, 1936. In these images of the small fishing boats of Arcachon Bay, Le Piquey, it is impossible not to see in their rising bows a prototype of Ronchamp (15). But more than that, each boat is numbered, and each number is prefaced with the boats port of origin: 'ARC'. We should think of Ronchamp as more than boat-like, but as an actual boat. Grounded on the crest of Bourlémont it is simultaneously evokes Noah's Ark, the architecture of the Acropolis, and the arcs of tangency present through geometry. The sharp relevance of this is found in the different axis of movement between buildings and boats where the latter adds to the stable Cartesian coordinates of $\mathrm{x}, \mathrm{y}$ and $\mathrm{z}$ the dynamic attributes of roll, yaw and pitch. The Modulor, it should be apparent, operates best when applied to predictable surfaces. Ronchamp, on the other hand, is an extraordinary exploration in form where the traditional stabilities of top/bottom, near/far and left/right have been superseded by dynamic relationships. As Le Corbusier teased in a caption from The chapel at Ronchamp, "try to look at the picture upside-down or sideways. You will discover the game." 28

\footnotetext{
${ }^{25}$ Texts and Sketches for Ronchamp, unpaginated.

${ }^{26}$ Stirling, J. (1956). "Ronchamp: Le Corbusier's Chapel and the Crisis of Rationalism." The Architectural Review 119 (March 1956): 155-161.

${ }^{27}$ Jencks, C. (2000). Le Corbusier: And the Continual Revolution in Architecture. New York, The Monacelli Press.

${ }^{28}$ Le Corbusier (1957). The Chapel at Ronchamp. London, Architectural Press. Page 46.
} 


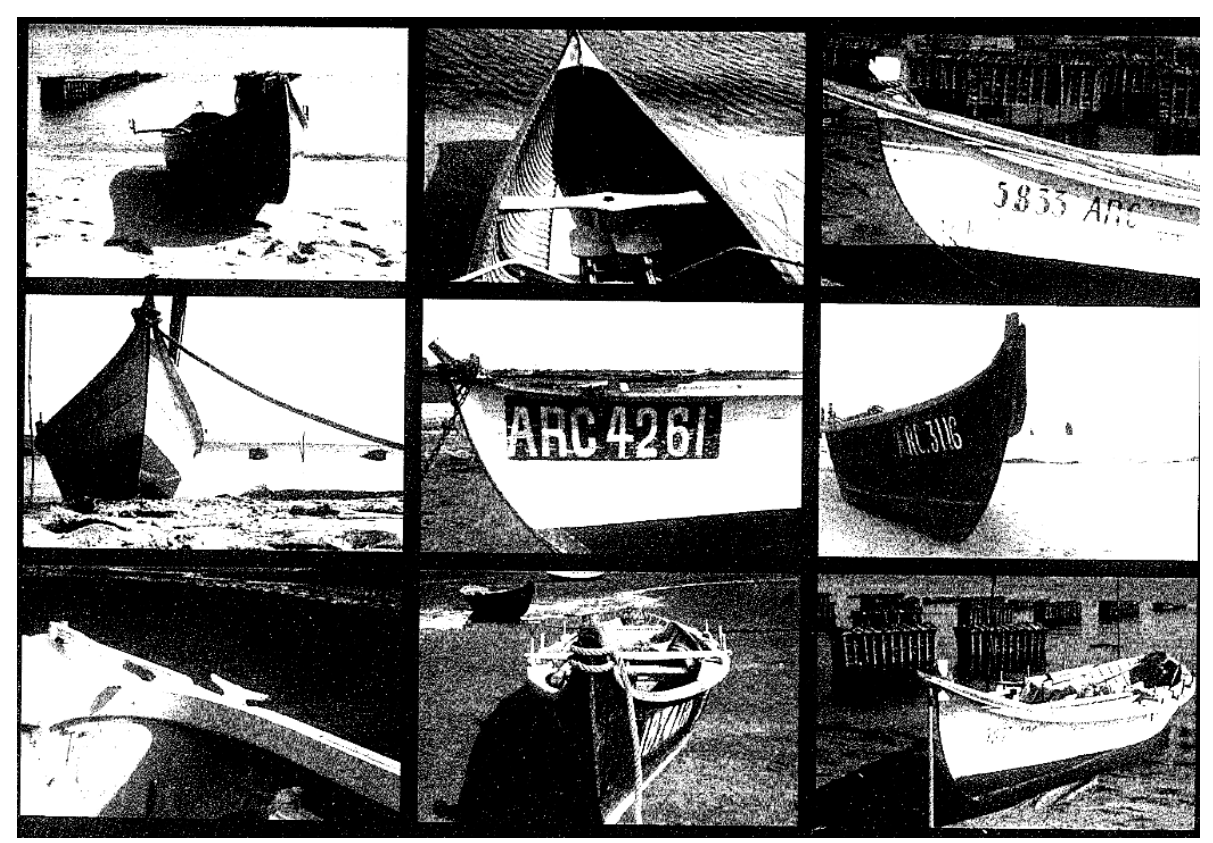

15. Pinasses, Le Piquey, Bassin d'Arcachon, September 1936

\section{Figures}

1: Ronchamp, schematic site plan Le Corbusier Le Grand page 559. OFLC-ADAGP

2, 3, 4, 5, 6, 7: Site plan of Notre-Dame-du-Haut and associated buildings. 13 December 1952. FLC Ron. 4529. CFLC-ADAGP

8: Marquette de la chapelle Le Corbusier The Complete Works Vol. V, page 72. OFLC-ADAGP

9, 10, 11, 12, 13,14: Plan de situation, plan de la chapelle et du campanille FLC 7.118. OFLC-ADAGP

15: Pinasse FLC Sequence 31346, 31351, 32384, 32389, 16455, 31112, 31408, 31404, 32385. OFLC-ADAGP

\section{Bibliography}

Evans, R. The Projective Cast. Cambridge, Mass.: The MIT Press, 1995

Evans, R. "Translations from Drawing to Building" AA Files (12), 1986: 3-18.

Girouard, M. Big Jim: The Life and Work of James Stirling. London: Chatto \& Windus, 1998

Jencks, C. Le Corbusier: And the Continual Revolution in Architecture. New York: The Monacelli Press, 2000

Jencks, C. Le Corbusier and the Tragic View of Architecture. Middlesex, England: Penguin Books, 1987

Le Corbusier. Aircraft. New York: Universe Books, 1988

Le Corbusier. The Final Testament of Pere Corbu: A Translation and Interpretation of Mise au point by Ivan Zaknic. New Haven and London: Yale University Press, 1995

Le Corbusier Modulor 21955 (Let the User Speak Next) Continuation of 'The Modulor' 1948. Cambridge, Massachusetts, and London England: The M.I.T. Press, 1958

Le Corbusier. The Chapel at Ronchamp. London: Architectural Press, 1957

Le Corbusier, Textes et dessins pour Ronchamp, Paris: Éditions Forces vives Impr. I.L.C., 1965.

Pauly, D. "Chapelle Notre-Dame-du-Haut" in The Le Corbusier Archive, vol. 20. Ed. H. A. Brooks, Garland Publishing and Fondation Le Corbusier: Paris, 1983 
Pauly, D. “The Chapel of Ronchamp” Architectural Design 55 (7/8), 1985: 30-37.

Reichlin, B. "Jeanneret-Le Corbusier, Painter-Architect" Architecture and Cubism. E. Blau and N. J. Troy. Cambridge, Massachusetts: The MIT Press, 1997.

Rowe, C. The Mathematics of the Ideal Villa and Other Essays. Massachusetts: The MIT Press, 1982

Samuel, F. Le Corbusier: Architect and Feminist. Great Britain: Willey-Academy, 2004

Samuel, F. and I. Linder-Gaillard Sacred Concrete: The Churches of Le Corbusier. Basel: Birkhäuser, 2013

Scully, V. Modern Architecture. New York, Braziller, 1961

Stirling, J. "Ronchamp: Le Corbusier's Chapel and the Crisis of Rationalism" The Architectural Review 119, 1956 


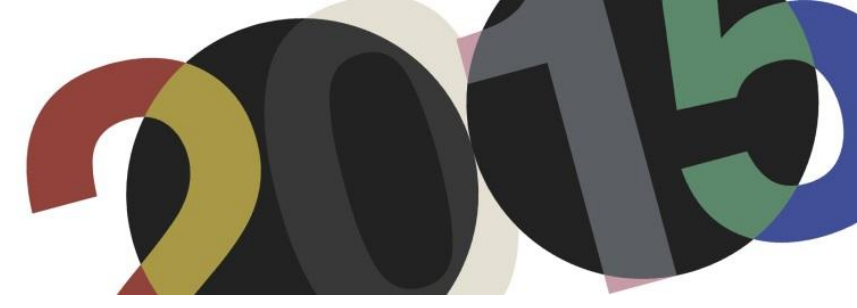

DOI: http://dx.doi.org/10.4995/LC2015.2015.949

\title{
MONUMENTALIZING MODERN MOBILITY
}

\author{
C.E. Comas
}

Universidade Federal do Rio Grande do Sul, Porto Alegre, Brasil

\begin{abstract}
The inhabitable viaduct is one of the most intriguing design proposals of Le Corbusier. Scholarly attention has focused upon the curvilinear megastructures designed for Rio de Janeiro and Algiers and their connection to the Ville Radieuse, downplaying the introduction of the inhabitable viaduct in São Paulo, and its connection with earlier proposals for Montevideo and Buenos Aires, the Plan Voisin and Ville Contemporaine, when Le Corbusier himself suggested that all these designs make up a sequence. The inhabitable viaduct has been understood as a reaction to non-European landscape and the airplane view, standing for a new sense of the organic in Le Corbusier's work. A closer inspection of these designs along with Le Corbusier's pertinent texts and imagery suggests that his architecture from 1929 onwards changes in degree rather than nature. The genesis of the inhabitable viaduct is seen as part of a sequence of topological transformations, informed by specific but generalizable site conditions and a host of precedents, but also, and primarily, as an alternative in Le Corbusier's controversial quest for monumentalizing the modern metropolis.
\end{abstract}

Resumen: El viaducto habitable es una de las propuestas más intrigantes de Le Corbusier. Los estudiosos han concentrado su atención en las mega-estructuras curvilíneas proyectadas para Río de Janeiro y Argelia y en sus conexiones con la Ville Radieuse, menospreciando la introducción del viaducto habitable en São Paulo, y su conexión con las propuestas anteriores para Montevideo y Buenos Aires, el Plan Voisin y Ville Contemporaine, cuando Le Corbusier mismo sugirió que todos eses proyectos forman una secuencia. El viaducto habitable ha sido entendido como una reacción al paisaje no-europeo y a la vista del avión, indicando un sentido nuevo de lo orgánico en la obra de Le Corbusier. Una inspección mas detenida de eses proyectos a la luz de textos e imágenes pertinentes del arquitecto sugiere que su arquitectura del 1929 en adelante sufre un cambio de énfasis y no de naturaleza. La génesis del viaducto habitable se ve aquí como parte de una secuencia de transformaciones topológica, que son informadas tanto por condiciones de situación a la vez específicas y susceptible de generalización cuanto por un conjunto de precedentes, pero también, y primariamente, como una alternativa en la búsqueda controvertida de Le Corbusier por monumentalizar la metrópolis moderna.

Keywords: Inhabitable viaduct/South America/ Algiers/ Monumentality/ Landscape/ Urbanism.

Palabras clave: Viaducto habitable/ Suramerica/ Argelia/ Monumentalidad/ Paisaje/ Urbanismo.

\section{Practical applications and ideal schemes}

Images of the Fiat Lingotto factory (1916-1922) in Turin illustrate the last chapter of Vers une architecture, ${ }^{1}$ but it was not until 1934 that Le Corbusier visited the building designed by engineer Giacomo Mattè-Trucco, and drove a car in the test track on its roof. Later, he said:

"The Fiat factory is more advanced than urbanism in our mechanized age. The freeway on the roof, for example, offers evidence of the modern technical possibilities. It is no longer a dream but a fact that certain cities, such as Genoa, Algiers, and Rio de Janeiro, could be saved from the disaster that threats them by constructing large

\footnotetext{
${ }^{1}$ Le Corbusier. Vers une architecture (Paris: Crès, 1923), p. 242.
} 
freeways at great height (like the Fiat track) on standard structures, allowing the cities to provide housing for a large population in optimal conditions.",2

The factory validated the inhabitable viaducts in his designs for two of those cities. He submitted his Plan Obus for Algiers ${ }^{3}$ after a first visit for conferences in 1931. It was an attempt both to get and enlarge the commission for redesigning the Quartier de la Marine, scheduled for demolition. His first design for Rio followed proposals for Buenos Aires, Montevideo and São Paulo, all done during a three-month long trip for conferences in 1929 and published immediately ${ }^{4}$. A second design for Rio was worked out in Paris in 1930 but published later ${ }^{5}$. Le Corbusier hoped to get commissions in South America too. Both suburbanization and vertical redevelopment were increasing in the cities he visited. Mario Palanti had designed Palacio Barolo (1919-1923), the tallest building in Buenos Aires, and Palacio Salvo (1923-1928), the tallest building in Montevideo ${ }^{6}$. Le Corbusier called the latter a "young skyscraper wrapped up in twisted decorative trimmings", despising its bodywork, but not its chassis. FIG 1 . He sought a "unity of system":

"I will implicate in the same consequence Buenos Aires, Montevideo d'Uruguay, São Paulo and Rio. Same principle, but deep diversity in the application of the principle. " 8

The ideal scheme for the Ville Contemporaine of 1922 is implied in that statement, along with its corollary, the 1925 Plan Voisin for Paris, and its variant, the Ville Radieuse of 1930. The diversity in the application of the principle paralleled the diversity of situations. Buenos Aires and Montevideo faced the River Plate on Spanish grids, with wide, straight streets fit for motor traffic. São Paulo and Rio mixed grids and winding, narrow streets in Portuguese style. São Paulo was a radio-concentric city built inland upon the "sinuosities" of a "nipplelike plateau," while Rio was a linear city stretched between mountains that "advanced toward the sea like the fingers of a hand". Built on slopes, Algiers faced the Mediterranean with the Kabylie Hills and Atlas Mountains behind. The boulevards of the French colonial city contrasted with the Casbah and its dense maze of narrow alleys.

The sequence of sites makes up a typology. Ville Contemporaine, Plan Voisin and Ville Radieuse deal with a square plain. Buenos Aires features a square plateau, one side raised along water. Montevideo features an elongated trapezoidal promontory prolonging a square plateau, a ridge establishing their common axis. São

\footnotetext{
${ }^{2}$ Willy Boesiger. Le Corbusier et Pierre Jeanneret. Oeuvre complète de 1929-1934. $13^{\text {th }}$ ed (Zurich: Editions d'Architecture/ Edition Girsberger, 1995), p. 202. All translations from the French are from the author, unless otherwise noted.

${ }^{3}$ Le Corbusier, "Plan d'aménagement de la ville d'Alger, 1931-1932”. L'Architecture Vivante (Automne-Hiver 1932), pp. 59, 15-21.

${ }^{4}$ Le Corbusier, Précisions sur un état present de l'architecture et de l'urbanisme (Paris: Vincent, Fréal, 1930). See also Cecilia Rodrigues dos Santos, and others. Le Corbusier e o Brasil (São Paulo: Projeto/Tessela, 1987); Fernando Pérez Oyarzun (ed.) Le Corbusier y Suramérica (Santiago: Ediciones ARQ, 1999); Jorge Francisco Liernur and Pablo Pschepiurca. La red austral. Obras y proyectos de Le Corbusier y sus discípulos en Argentina 1924-1965. Buenos Aires: Universidad Nacional de Quilmes, 2008; Ramon Gutierrez (ed.). Le Corbusier en el Río de la Plata, 1929 (Buenos Aires: Cedodal; Montevideo: FARQ Universidad de la Republica, 2009).

${ }^{5}$ Le Corbusier, La ville radieuse: Éléments d'une doctrine d'urbanisme pour l'équipement de la civilisation machiniste (Boulogne-sur-Seine, France: Éditions de L'Architecture d'aujourd'hui, 1935), p. 225.

${ }^{6}$ Leonel Contreras. Rascacielos porteños (Buenos Aires: Gobierno de la Ciudad de Buenos Aires, 2005), pp. 67-78 for Palacio Barolo, pp. 79-92 for Salvo. See also Sebastián Alonso, and others. 5 narrativas, 5 edificios (Montevideo: Ministerio de Educación y Cultura, 2010), p. 14-59.

${ }^{7}$ Le Corbusier. Précisions, p. 238.

${ }^{8}$ Idem.

${ }^{9}$ Le Corbusier, Précisions, pp. 234-241.
} 
Paulo presents a surface rather regularly embossed in low relief in a gridlike pattern. A mix of lowlands and fingerlike distribution of promontories, Rio presents a surface rather irregularly embossed in high relief with a radial pattern. Algiers features a flattened promontory approximating an oval truncated cone cut in half lengthwise. In Buenos Aires, Le Corbusier said his 1915 Maison Dom-ino updated the seventeenth-century Flemish béguinage ${ }^{10}$, and proposed a Plan Voisin for the Argentine capital ${ }^{11}$, aware that its flat ground echoed that of the Low Countries and Paris. Comparing the Carioca to the Alpine landscape, he later counted among "the balconies of the world" the Valais, "in front of the Lake Geneva and the mountains," and Rio, "between disheveled spurs". ${ }^{12}$

The cruciform skyscrapers suggested for Buenos Aires replicate those in Ville Contemporaine and Plan Voisin, but they rise from a boxy two-story base advancing into the river. The roof of this artificial promontory prolongs the level ground of the existing city and the surrounding pampas, which extend westward as far as the Andes. The axis of the composition runs next and parallel to the avenue connecting the presidential palace by the river to the Congress close to Palacio Barolo. The coastal boulevard and its branches insinuate a handwritten X, bringing to mind the diagonal avenues of Ville Contemporaine. FIG. 2 The seascrapers suggested for Montevideo came in two versions. The bolder one shows a T-shaped office building that touches the sea at one extremity and both seizes and prolongs the natural promontory. Its roof slab abuts the city's leveled main avenue generating a Latin cross. Palacio Salvo appears misplaced at one end of that avenue, which extends into the road to the hinterland. FIG. 3 The tamer version shows a single slab building advancing into the water. FIG. 4

The Brazilian proposals accentuated the engagement with the landscape at the scale of the whole city and the articulation of movement in a regional basis. The first inhabitable viaducts stand straight on São Paulo's curvaceous ground. They are multiuse structures, earthscrapers, to be filled with housing or offices. One meets the road to the port of Santos; another, the road to Rio. They are rulers that intersect generating a Greek cross like the cardo and decumanus of Roman camps. Near the crossing, they backdrop São Paulo's brand-new skyscrapers, retooling the city's business core. In the first Rio design, two curved earthscrapers share an intermediary segment, resembling a handwritten X, akin to the coastal boulevard and its branches in Buenos Aires. The longest connects Copacabana with the road to São Paulo. The shortest faces the shoreline, in the form of an expanded Lorraine cross whose triple bars shelter business at the Calabouço Point landfill and balance Sugarloaf Mountain at the other end. An extension of this branch becomes a bridge to Niterói across Guanabara Bay. FIG. 5, 6 The 1930 variant features an inhabitable viaduct parallel to the beaches. The 20 meters wide freeway runs 100 meters above sea level, with garages underneath; fifteen floors of infill housing start at 40 meters. FIG. 7

The first Plan Obus for Algiers suggests an expanded Lorraine cross with quadruple bars. Slightly deviated from a radial generator of the slope, a standard viaduct 160 meters above sea level joins the plateau of Fortl'Empereur to the rooftop of the 31-story office building at the Quartier de la Marine, condensing the city's new business core and connecting it to the hinterland. Two straight slab buildings cross that man-made axis at the plateau, anchoring a loop of curving rédents on each side of the viaduct, superimposed earthscrapers and 14story skyscrapers. The intermediary, covered vehicular streets are level with the deck of the standard viaduct. Another curving earthscraper runs parallel to the coast with a roof freeway 100 meters above sea level. That 28 kilometers long, 26 meters wide inhabitable viaduct connects Saint-Eugène to the north and Hussein-Dey to the south passing under the standard viaduct. It bends at its two extremities, descending to join the parallel coastal

\footnotetext{
${ }^{10}$ Le Corbusier. Précisions, p. 94.

${ }^{11}$ Le Corbusier. Précisions, pp. 167-213.

${ }^{12}$ Le Corbusier. Sur les quatre routes. (Paris: Gallimard, 1941), p. 38.
} 
corniche 10 meters above sea level, which gives access by below to the office building. The vehicular connection between Fort l'Empereur and the Quartier de la Marine- and hence, that between the city and its territory- is made through banks of elevators; as Antoine Picon observed ${ }^{13}$, Le Corbusier borrows from both garage managers and engineers. FIG. 8

The covered vehicular streets in the Fort l'Empereur rédents are branch roads. The structure is of the standard Dom-ino type both there and in the coastal highway, at times replaced by huge arches giving way to existing streets. The floor slabs of the inhabitable viaducts were termed artificial sites. Termed interior streets, doubleloaded corridors give access to internal plots of differing widths. Balconies appear in the coastal inhabitable viaduct planned for a low-income population, but only at the upscale rédents the plots are wide enough to allow for both balconies and lateral setbacks of varying dimensions, resulting in picturesque facades that validate Le Corbusier's claim to these buildings being vertical garden cities, offering absolute diversity within unity.

"Every architect will build his villa as he likes; what matters to the whole if a Moorish-style villa flanks another in Louis XVI or in Italian renaissance?",14

The decorative trimmings favored by Palanti are ordered by the serial succession of columns and the sharp slab borders. The ground at Fort l'Empereur is rather untouched. FIG. 9

\section{Topological transformations}

In Buenos Aires, the urban composition features vertical terminal elements, the parallel skyscrapers and the mountain chain. In Montevideo, the terminal elements undergo figural inversion: Palacio Salvo resembles a giraffe or an obelisk over a box; the T-shaped business core uses the same figure upside down. Rio has the business core and a mountain culminating one inhabitable viaduct. With the business core as the head of the city, the so-called Plan Voisin for Buenos Aires suggests either halving Ville Contemporaine because of the river, or prefiguring the Ville Radieuse. The Algiers plan illustrates the new ideal scheme, all components able to develop individually. ${ }^{15}$ But the new does not render the old obsolete. It is simply added to the repertory, applying to all cities that are ports. São Paulo's downtown remains at the heart of the city, as in the Ville Contemporaine.

The sequence is one of topological transformations. Unconcerned with shape or extension, already a major branch of mathematics in the 1920s, topology makes no distinction between curves and straight lines. The rédents that bridge streets in the ideal schemes are topologically identical to the straight rulers and curvilinear ribbons rising as inhabitable viaducts in Brazil and Algeria. Pleated, straight or bent slab buildings, they can be transformed into each other without cutting or tearing, and so do the surfaces making up the typology of sites earlier described. Including the ideal schemes, all the designs are variations on a cruciform structure, except for Montevideo's straight design. The Ville Radieuse is a kind of Lorraine cross with multiple arms. The Ville Contemporaine is both cruciform and $\mathrm{X}$-shaped; given its diagonals, it features both a straight and a rotated Greek cross. Other than a handwritten $\mathrm{X}$ distorting a rotated Greek cross, the Rio inhabitable viaducts may be seen as superposed back-to-back C's, which could be taken apart and pleated or straightened defining parallel strips of slab buildings, thus reinforcing the link between practical applications and unitary principle.

\footnotetext{
${ }^{13}$ Antoine Picon. "Les projets d'Alger et la dimension de l'infrastructure." In Fondation Le Corbusier. Le Corbusier: visions d'Alger (Paris: Editions de la Villette, 2012), pp. 131-145.

${ }^{14}$ Le Corbusier. La ville radieuse, p. 247.

15 Mary McLeod. "Le Corbusier and Algiers." Oppositions 19/20. (Winter-Spring 1980), pp. 55-85. See also Zeynep Çelik. Urban Forms and Colonial Confrontations: Algiers Under French Rule. (Berkeley: University of California Press, 1997), pp. 13-58.
} 
Topological transformations might have started in Montevideo after condensing the multiple towers of Buenos Aires into a single tower, by shortening one arm of that Greek cross until it became a T-shaped Tau cross, and then turning the single tower upside down. The condensation might have been triggered by the small size and greater topographical irregularity of the city, along with the correspondence between the promontory and the boxy base designed for the Buenos Aires towers given not only the different levels of the port and the city, but also the width of the port area, as well as the correspondence between the ridge and the avenue punctuated by the singular figure of Palacio Salvo. Inverting the young skyscraper ensued. Rooftops became parking streets, open to low-speed vehicular traffic. The seascraper was born. By shortening the branch arms, the seascraper roof became one with the avenue. An increase in height, extension, and speed limits on hilly ground followed. The earthscraper was born, a true inhabitable viaduct.

The duplication and intersection of inhabitable viaducts in São Paulo re-enacted a foundational gesture, the horizontal lines at their top counterpointing the sinuous lines at their bottom. The next step was a further increase in height and some bending in Rio, alluding to the Buenos Aires coastal boulevard in the process. The buildable area of Rio is flat ground, and the horizontal lines of the inhabitable viaducts at their bottom and top counterpointed the irregular profile of the surrounding mountains. Bending the buildings adjusted them to the irregular footprint of the mountains. Algiers features slopes with mountains in the backdrop. The inhabitable viaducts bent following the contours or straddled the slopes. Rio- and São Paulo-type earthscrapers accompany a variant of Montevideo-type earthscrapers with curvilinear parking streets at their top, in turn topped by skyscrapers.

Le Corbusier reacted to the Carioca and Algerian sites with the right amounts of contrast and similarity. If domination of the surrounding mountains was impossible, total subordination was avoided. But domination was the obvious choice in flat Paris, or Buenos Aires- whose relationship with the Andes was ideal rather than perceptual, and a reasonable strategy in São Paulo- whose hills were not of striking height. Subordination suited the Montevideo situation- where Palacio Salvo had come first ${ }^{16}$. Architecture reigns in business-minded, tough, workaholic São Paulo and Buenos Aires. Nature shines in beautiful, playful Rio, "a resort", and "charming, tiny" Montevideo. ${ }^{17}$ Architecture and nature recast each other in Algiers. The practical applications were both sitespecific and generalizable, adding to a typology of solutions. While the existing circulation network was tacitly accepted in Buenos Aires and Montevideo, its redefinition was a major problem in São Paulo, Rio and Algiers, providing conceptual and physical grounds for the idea of the inhabitable viaduct. The geometric order of columns anchors the freedom of walls between floor slabs in Le Corbusier's Four Compositions ${ }^{18}$, showing alternatives offered by the standard Dom-ino structure. In Ville Contemporaine, the geometric order of roads anchors the freedom of constant height rédents, strips of pleated slab buildings bridging a directional, hierarchical grid of collector streets, arterial thoroughfares and intercity freeways. The inhabitable viaduct conflated architectural and urban ordering devices. It mixed the primary axes and/or loops of urban circulation with straight or curved slab buildings that were topologically equivalent to rédents bridging existing streets and landscape. In its own way, it is as much an ideal scheme as the Ville Contemporaine or the Ville Radieuse.

\footnotetext{
${ }^{16}$ The Architectural History Foundation; Fondation Le Corbusier. (Eds.) Le Corbusier Sketchbooks - Vol. 1, 1914-1948. (New York: The MIT Press, 1981), B4 drawing 238.

${ }^{17}$ Le Corbusier, Précisions, p. 244.

${ }^{18}$ Willy Boesiger and Oscar Stonorov. Le Corbusier et Pierre Jeanneret. Oeuvre complète de 1910-1929, 14th ed, (Zurich: Editions d'Architecture/ Edition Girsberger), p. 189.
} 


\section{Precedents}

Le Corbusier did not shun making comparisons that doubled as statements of inspiration, as the béguinage example shows. If he maligned the styles rendered obsolete by the machine age in the first Buenos Aires conference, he quickly added, "people label me today a revolutionary, but I have not had other master than the past, other discipline than the study of the past."19 Despite broken alignments, the exaggerated building continuity of the rédents paved the way for the inhabitable viaduct. Rédents were indebted to Eugène Hénard, who first proposed broken alignments in boulevards à redans (1903). Inhabitable viaducts are therefore indirectly relatable to Parisian hôtels particuliers, Versailles, phalanstères, or Auguste Perret's apartment building at rue Franklin (1902-1904). Le Corbusier preferred to rhapsodize when presenting the São Paulo earthscrapers to his public:

"What bigger Segovia aqueduct, what giant Pont du Gard! Is there anything more elegant than the pure line of a viaduct in an uneven terrain, and more diverse than their substructures piercing the undulations to meet the ground?" 20

Earthscrapers were wittily compared to water-bringing devices in the only city in the sequence that was not a port. The comparison reinforced the allusions to Roman urbanism, and hence to the foundational character of inhabitable viaducts. Le Corbusier had published images of the two aqueducts in the same page as Gustave Eiffel's 1545 meters long Cubzac Bridge (1883) and the Marseille Transporter Bridge (1905), whose 239 meters long movable platform rose 50 meters. ${ }^{21}$ FIG. 10 These benchmarks went unmentioned, as did another steel structure, Eiffel's 554 meters long, 122 meters high Garabit Bridge (1888), the opening image of Vers une architecture. Otherwise, Le Corbusier recalled neither massive and straight railway viaducts like the reinforced concrete, 152 meters long, 65 meters high Day (1925) in Switzerland, and the brick masonry, 574 meters long, 78 meters high Goltzschtal (1851) in Germany, nor massive and curvilinear railway viaducts in limestone masonry like the 136 meters long, 65 meters high Landwasser (1902), and the spiral 110 meters long Brusio (1908), both Swiss-made.

Curvilinear inhabitable viaducts have been likened to mid-eighteenth-century one-sided streets such as the serpentine, 500 meters long John Palmer's Lansdown Crescent at Bath, ${ }^{22}$ and straight inhabitable viaducts could have been likened to early nineteenth-century one-sided streets such as Charles Percier and Pierre Fontaine's Rue de Rivoli extending its arcades for 1100 meters in Paris. More to the point, the Rio and Algiers designs suggest the crossing of crescents with scenic American parkways (such as Long Island) ${ }^{23}$ or a touristic road from Milan to Varese (Autostrada dei Laghi), whereas the São Paulo proposals combine a racing track in suburban Berlin (AVUS) with Parisian croisées. Besides the 800 meters long Fiat Lingotto factory, hybrid objects considered as precedents include medieval inhabited bridges or Edgar Chambles's 1910 Roadtown also involve a standard lasting structure designed to withstand public vehicular mobility mixed with an ordinary, transient infill intended for private occupation and slower rhythms. ${ }^{24}$ An offspring of that factory must have been at least mentioned to Le Corbusier in Buenos Aires. Close to his hostess Victoria Ocampo's property, Palanti's Palacio

\footnotetext{
${ }^{19}$ Le Corbusier. Précisions, p. 34.

${ }^{20}$ Le Corbusier. Précisions, p. 242.

${ }^{21}$ Le Corbusier. Une maison - un palais. À la recherche d'une unité architecturale. (Paris: Crès, 1928), p. 20.

${ }^{22}$ Siegfried Giedion. Space, time and architecture. The growth of a new tradition. (Cambridge, Mass.: The Harvard University Press, 1941), pp. 81-84, 91-94.

${ }^{23}$ Carlos Eduardo Comas. "Le Corbusier and the Brazilian Landscape", in Jean-Louis Cohen and Barry Bergdoll (eds.). Le Corbusier: an Atlas of Modern Landscapes (New York: The Museum of Modern Art, 2013), pp. 324-331.

${ }^{24}$ Stanislaus von Moos. Le Corbusier. Elements of a synthesis. ${ }^{\text {nd }}$. Ed. (Rotterdam: 010 Publishers 2009), pp. 198-99.
} 
Chrysler (1927-1928) was a car dealership and repair workshop with an oval test track as rooftop, less of a wedding cake than Palacio Barolo or Salvo. ${ }^{25}$ FIG. 11

Le Corbusier noted himself in Algiers that "the viaduct level 100, it is built at the port!",26 FIGS. 12, 13 Charles-Frédéric Chassériau had designed the 1500 meters long Arcades des Anglais (1860-66) as a kind of engaged viaduct, or hollow retaining wall fronting the sea. They featured a giant order and were roofed by Boulevard de la République and the ramps and staircases leading to it. Shops were inserted at the level of the port, and dwelling for fishermen served by galleries at the intermediary level. Le Corbusier's note was not without reservations, as he added, "nothing was conceived with particular efficiency for the housing of families." Le Corbusier's inhabitable viaducts were disengaged, bridge-like, so he could say he was correcting the deficiencies of the Arcades des Anglais, and providing an optimal condition for housing. Next to the sketch of the Arcades in La Ville Radieuse, he placed a photo of the Lingotto factory, which he claimed he had forgotten prior to the 1934 visit, so that the idea of a roof road had come to him spontaneously. ${ }^{27}$ Le Corbusier's reference to the Arcades confirms that he recognized the power of the proper, meaningful precedent as a tool for understanding and persuasion, as well as an object of topological transformations inasmuch as the Arcades were straight, and the Algerian inhabitable viaducts curvilinear. His claim of spontaneity would be more convincing if there were no Palacio Chrysler to remind him of the Lingotto factory. But he might be telling the truth from a certain point of view, as topological transformations may be undertaken subliminally.

\section{Monumental issues}

Le Corbusier invoked no precedent whatsoever for Rio, not even its eighteenth-century Lapa Aqueduct, and at first sight he likened urbanizing the city to filling the tub of the Danaides, an eternal punishment ${ }^{28}$. Flights increased his grasp of the Carioca and Algerian sites. ${ }^{29}$ Allowing for bird's eye views, they confirmed rather than revealed that the roof plan was a fifth façade. Surveys had been done before the airplane was invented, maps drawn, and models made. He did not need airplanes to design the 1927 Palace of League of Nations in Geneva with the Alps in the background. He commented:

"We have led the development of our buildings towards a single, smooth and pure horizontal crowning, that pure horizontal high up, sometimes profiled against the sky, sometimes giving their measure to the mountains that surpass them, that horizontal was a conclusion of lyrical order. ",30

The horizontality of the Rio and Algiers viaducts from the water mattered as much as their curves from the air. Curves were not alien to Le Corbusier's vocabulary. Rio brought about their emphatic application to an urban and bigger scale. Algiers, a similar type of site, amplified it. This sense of the organic was not prompted only by uneven terrain. Aerodynamics was changing the appearances of cars and airplanes, and Aircraft shows that Le

\footnotetext{
${ }^{25}$ For similar comment, Liernur. La red austral, pp. 144-45; Gutierrez, Le Corbusier y el Río de la Plata, p. 47.

${ }^{26}$ The Architectural History Foundation: Fondation Le Corbusier, Le Corbusier Sketchbooks- Vol. 1, 1914-1948. C10, drawing 660.

${ }^{27}$ Le Corbusier. La Ville Radieuse, p. 241.

${ }^{28}$ Le Corbusier. Précisions, p. 244.

${ }^{29}$ Yannis Tsiomis, 'Rio-Alger-Rio, 1929-1936, Transferts'. In Fondation Le Corbusier 2012, Le Corbusier. Visions d'Alger, (Paris: Editions de la Villette: 2012), pp. 84-101. See also Yannis Tsiomis (ed.). Le Corbusier. Rio de Janeiro 1929-1936 (Rio de Janeiro: Centro de Arquitetura e Urbanismo, 1998).

${ }^{30}$ Le Corbusier. Une maison - un palais, pp. 152, 163.
} 
Corbusier was aware of $\mathrm{it}^{31}$. Curved surfaces were replacing the straight surfaces and boxy volumes so emblematic of movement technology in the first half of the 1920s. In the second half of the 1920s the old biplane shape gave way to the streamlined monoplane configuration of the racing seaplanes that won the Schneider Trophy from 1913 to $1931^{32}$. Although not as dramatic, the transformation also showed in cars ${ }^{33}$. The machine was becoming biomorphic, and Le Corbusier had anticipated it by publishing an early image of the "airplane of the future" ${ }^{34}$. FIG. 14

In short, Rio and Algiers brought no fundamental change in Le Corbusier's architecture and urbanism: he just expanded his vocabulary. He reacted to both ideal and actual sites, spectacular and plain landscapes, with a similar monumental impulse, long operative in his work, and duly disapproved by left leaning critics when he first presented Ville Contemporaine. Le Corbusier wanted to build both houses and palaces. He certainly subscribed to Charles Baudelaire's understanding of modernity as "the fleeting, the transient, the contingent, the half of art of which the other half is the eternal and the immovable" ${ }^{, 35}$. Garabit Bridge features again in "Perennité," a chapter of Urbanisme ${ }^{36}$. FIG. 15 Moreover, despite his diatribes against academicism, Le Corbusier made full and inventive use of the whole Beaux-Arts mental equipment. ${ }^{37}$ His entry for the Palace of the League of Nations and subsequent project for a Mundaneum had been chastised by El Lissistky and Karel Teige under those terms ${ }^{38}$.

The designs for São Paulo, Rio or Algiers have obvious monumental qualities. Formal simplicity, size, visibility at distant range, symmetry and axiality make the overall composition and its elements highly memorable. The contrast with irregular, picturesque, and lower urban fabric would be striking: differences in scale and figural attributes like isolation and dominance would make the overall composition and its elements look exceptional. Although the durability of unbuilt projects cannot be gauged, Le Corbusier acknowledged the different potential duration of different urban or architectural elements, and emphasized accordingly the role of the standard structure and the circulation grid in his designs. He understood that ordering devices were lasting devices, and vice-versa ${ }^{39}$. Order, he insinuated, can turn a house into a palace. Le Corbusier adhered to height uniformity as strict as that regulating Haussmann's Paris. The picturesque and the irregular might find another place in the artificial sites at the floor slabs, and create a kind of latter-day Diocletian's Palace.

References are an aid regarding representation, and Le Corbusier understood how essential representation was for the memorability of built or unbuilt designs, in drawings, models, photographs, and print. Most of his work has endured in paper. Victor Hugo prophesized: the book would kill the cathedral as the privileged means of social bonding. ${ }^{40}$ Yet drawings or prints promoted architecture even in medieval times. Figural resemblances and associations mattered: the image of the cruciform church plan reinforced in bi-dimensional terms the building's

\footnotetext{
${ }^{31}$ Le Corbusier. Aircraft (London: The Studio, 1935).

${ }^{32}$ John David Anderson, Jr. A history of aerodynamics and its impact on flying machines. (Cambridge: Cambridge University Press, 1997), pp. 355-358.

${ }^{33}$ Antonio Amado. Voiture minimum. Le Corbusier and the automobile. (Cambridge, Mass.: The MIT Pres, 2011).

${ }^{34}$ Le Corbusier. Vers une architecture, p. 239: cover of Louis Charles Bréguet. L'aviation d'hier et de demain (Paris: Draeger 1921).

${ }^{35}$ Charles Baudelaire. "La modernité", a chapter of Le peintre de la vie moderne (1863).

${ }^{36}$ Le Corbusier. Urbanisme, pp. 41-50.

${ }^{37}$ Reyner Banham. Theory and Design in the first machine age. (London: The Architectural Press, 1960), pp. 14-22. Colin Rowe. The architecture of good intentions. (London: Academy Editions, 1994), pp. 101-102.

${ }^{38}$ Le Corbusier. Précisions, p. 225

${ }^{39}$ Le Corbusier was anticipating the Japanese Metabolist thinking and ideas on mass housing of the 1960s, not to mention his own Unité d'Habitation in Marseille (1945-52).

${ }^{40}$ Victor Hugo. "Ceci tuera cela", second chapter, fifth book. Notre Dame de Paris (1831).
} 
connection with the Crucifixion. An appropriate evocation adds to the intelligibility of the design. The cross recalls Roman urbanism in São Paulo, the pairs of divergent curves at the opposite sides of a straight stem suggest a dancer in Rio, bent rédents in Algiers relate both to the anatomy of Arab women and Arabic calligraphy ${ }^{41}$.

Aqueducts were particularly apt references given their persistence through centuries and their suggestive massiveness. It was not difficult to imagine their bays filled with diverse and changeable dwellings, standing on "artificial sites" provided by floor slabs, and standing for ephemerality in comparison to the timelessness of the structure. The contrast between the Segovia Aqueduct and more recent buildings in its vicinity provided additional information for the public. They were of the adequate height too: Segovia was 28 meters high and 813 meters long, Pont du Gard was 48,8 meters high and 275 meters long. Viaducts are bridge-like structures, and the bridges Le Corbusier published admiringly would give a better idea of the proposed horizontal lines in Rio, but Garabit was too light against the landscape or the Marseille transporter high up in the sky too light over the roofs, and they lacked substance. The Arcades des Anglais was a better reference for functional hybridism, but not tall enough, and unknown to Le Corbusier before his 1931 trip to Algiers.

Le Corbusier made formal qualities suggest distinction of purpose. Prominence of place, verticality and cruciform plan combine to emphasize the real and symbolical importance of a new business core. The very idea of a vertical business core was not that old: Rockefeller Center would not be completed until 1939. An intersection, it orders the São Paulo downtown. It sits on artificial headland in Rio. It stands as an artificial cliff close to the water in Algiers. Le Corbusier presents business cores as towering bastions. Inhabitable viaducts are ramparts, condensing three basic objectives into a single element: adequate provision for fast automobile traffic connecting city and territory, adequate provision for high-density housing, and minimum occupation and disturbance of the ground. Megastructures of imposing length, they are also backdrops against which the business core is deployed, along with cultural facilities, historic monuments, parks, a sizable portion of the existing urban fabric, and natural topography. New building not only straddles green fields as in the ideal schemes, but also fields filled with the remains of bygone eras and the recent past. An example is the volume of the Municipal Theater recognizable in the three published drawings of the São Paulo proposal. Urban renewal was not predicated on razing all but the outstanding historical monuments of a district as in Plan Voisin. Razing was one strategy among others for dealing with underused, overcrowded or obsolete areas. Business, housing and traffic were the key urban problems. As in Paris, Buenos Aires and Montevideo, there was no shortage of cultural facilities in São Paulo, Rio and Algiers. Although the new business cores and inhabitable viaducts would alter these cities, they would not cancel their polycentrism, they would add to their multiple foci. These were not villages where public spaces were restricted to the main street and the city square.

The hybridism of the inhabitable viaduct had further resonances. The modern viaduct, the result of an engineering esthetics, would rather look like Garabit than a Roman aqueduct. But for Le Corbusier, engineers made tools, and in time tools are discarded, like the old locomotive that is "thrown for scrap" ${ }^{42}$. He did not object to bridges, dams, tunnels, viaducts, and other big structures of public utility being called in French ouvrages d'art since the late nineteenth century, made to last even if lacy. At the same time, he claimed that the difference between the house and the palace was one of degree, but he recognized that the house belongs to the private realm, and the palace to the public realm: "a palace is a house that impresses by the dignity of its aspect ${ }^{43}$. The modern viaduct lacked gravitas but had public status, and could endow ordinary housing with a

\footnotetext{
${ }^{41}$ Kenneth Frampton, “Mariage des contours.” Oppositions 19/20, p. 87.

${ }^{42}$ Le Corbusier. Vers une architecture, p. 5.

${ }^{43}$ Le Corbusier. Une maison - un palais, p. 52.
} 
public aura. In turn, ordinary, ephemeral housing would paradoxically lend substance, solidity and stability to the transparent but enduring viaduct dedicated to speed.

"A city made for speed is a city made for success" $"$, said Le Corbusier, but his emphasis on mobility was restricted to cars, buses and trucks: "the tramway has no longer rights in the heart of the modern city" published Garabit Bridge at least thrice, never mentioning that it was a railway viaduct. Rio, São Paulo and Algiers were cities without subways. He thought that the inhabitable viaduct would obviate the need for a subway in Algiers. Reference to rail transportation in his texts is hasty. As seen, he was at best ambivalent about the role of railway viaducts in the genesis of his inhabitable viaduct. Rails were nineteenth-century, while the automobile and the airplane were contemporary. Freeways in the 1920 s were a novelty. Autobahnen, autostradas and carreteras only became conspicuous after 1930, in countries not as rail-rich as England or France. For Le Corbusier,

"The civilization of the road will re-establish the harmonious and regular relations between town and country, relations broken by the railway that, working contrariwise, had emptied the country in favor of the town and had drawn men away from nature, their natural milieu. "46

Motorized mobility was more than a means of transport. Le Corbusier celebrated the pleasure the inhabitable viaduct would afford for the driver and passengers alike, confined high up in the sky, conscious of acceleration, propulsion, gravity and of the landscape unfolding before them. Curves would augment the exhilaration in Rio and Algiers, but there, as in São Paulo, the experience would resemble racing instead of cruising. Exhilaration was to rely upon the restraining limits of guardrails, the tokens of bondage in the controlled access public space of the freeway. Freedom characterized the opposite end of the urban movement hierarchy. Le Corbusier despised the pedestrian flânerie in the Grands Boulevards described by Baudelaire, although allotting space for it at the feet of the great skyscrapers in Ville Contemporaine's business core. He preferred casual encounters happening amid greenery. He did not rule out completely the frontal alignments that characterize the hated, congested multifunctional corridor street of the railroad city, as well as the square: both re-appear sometimes in the Ville Radieuse superblocks as the chance meeting of rédents, but their width is grossly expanded, as if fearing enclosure by architecture itself. And the lone pedestrian looks pitiful in the drawing illustrating an Algiers rooftop freeway.

\section{Crashes}

The inhabitable viaducts were alternatives to contemporary plans for São Paulo (by Prestes Maia), Rio (by Alfred-Donat Agache) and Algiers (by Henri Prost, René Danger and Maurice Rotival). But Le Corbusier shared many ideas with his opponents from the Société Française des Urbanistes (of which Hénard had been a founder). Diagnostics were often similar, and solutions too. Le Corbusier did not invent zoning, street hierarchy, grade separation between pedestrians and cars, urban parks, differentiation of residential neighborhoods by income level, or razing slums, for instance. Le Corbusier built upon Rotival's ideas for Algiers ${ }^{47}$, which included skyscrapers au Quartier de la Marine, coastal boulevards at different levels atop parking garages, car elevators and a viaduct connecting Boulevard de la République with a proposed boulevard 100 meters above sea level.

\footnotetext{
${ }^{44}$ Le Corbusier. Urbanisme, p. 190.

${ }^{45}$ Le Corbusier. Urbanisme, p. 162.

${ }^{46}$ Le Corbusier. "Les besoins collectifs et le génie civil." In Anatole de Monzie, Pierre Abraham (eds.). L'Encyclopédie Française, Tome XVI (Paris: Societé de l'Encyclopédie Française, 1935).

${ }^{47}$ Maurice Rotival, "Veut-on faire d'Alger une capitale?” Chantiers nord-africains (Jan 1931), pp. 27-37.
} 
FIG. 16 Rotival took New York's Wall Street area as an example. Preservation of the Casbah was then French policy, and both Rotival and Le Corbusier agreed with it. Still, in comparison, Le Corbusier's enthusiasm for both the freeway and greenery verged on fetish, his publicly controlled automotive city plans matched only by their polar opposite, Frank Lloyd Wright's contemporary Broadacre City (1932).

In its day, the inhabitable viaduct did not interest Brazilian and Algerian decision-makers. Its practicality was open to question in engineering, financial and political terms. The hybrid solution might look like synthesis for his author. Far from being worked out in all details, it did not conform to either engineering or development logic. Many people, irrespectively of income bracket, might find it psychologically disturbing. Workers in Algiers might accept a road over their heads, since their dwellings would be close to working quarters, and fourteen square meters per person was a rather decent provision, but low-income housing was not a priority for either government or private enterprise in any of these cities. The upper classes preferred villas to apartments. Le Corbusier's appeal to authority fueled charges of authoritarianism. ${ }^{48}$

Authoritarian has two meanings: one is aristocratic (favoring, denoting, or relating to government by a small elite with wide powers); the other, behavioral (telling other people what to do in a peremptory or arrogant manner). Authority is basically either the power to make decisions, or the power to influence and persuade resulting from knowledge and experience. After receiving Plan Obus, Mayor Charles Brunel replied to Le Corbusier, ${ }^{49}$ saying it was too costly, and would lead to the complete destruction over time of the existing city. To implement the Plan, a French mayor would need dictator powers with the property, and even lives of his subjects. Le Corbusier did not take human needs into account. Apartments were awful, and small, and no one would want to live in them, given the possibility of a house in the hills. No need to work close to dwelling.

Le Corbusier might believe and behave in authoritarian ways, but he had no authority other than his expertise, and his authority as an expert was lost on the political authority of the mayor. Whether as apolitical or affiliated professional, Le Corbusier dazzled without persuading, and dominated without convincing. ${ }^{50}$ The mayor might reasonably think that Le Corbusier's plan was too costly, and would have no political support, as landowners would oppose it, rejecting low-income public housing and going for suburbanization; fears of destruction might be justified, but could the mayor stop the growth of Algiers, and piecemeal destruction of the present city?

Nothing in principle prevented democracies to build large pieces of public urban infrastructure and low-income high-density public housing. A large aggregate of small-scale transformations over time disrupts cities as much as any large-scale intervention, including subway construction going on in Paris, London and New York. Le Corbusier was not alone in criticizing the disorderly and fragmentary expansion of cities through lot-by-lot vertical redevelopment and suburbanization, or in advocating planning instead of laissez-faire. But he posited unconventional change, reacting to the problems and opportunities of the modern city first and foremost as visionary architect. The inhabitable viaduct transposed the Fiat Lingotto factory for the sake of reconciling increased physical mobility with dwelling and landscape, recreating the physical immobility of the land in its structure along with an immemorial, elementary and enduring urban layout with its artificial sites, interior streets, and transient houses. It also celebrated, in the Algerian coast, the feasibility, from an architectural standpoint, of extending to the many environmental advantages hitherto reserved to the few. Low-income

\footnotetext{
48 Jean-Pierre Giordani. "Le Plan-Obus 1932-3: du sublime aux réalités”. In Fondation Le Corbusier 2012, Le Corbusier. Visions d'Alger, pp. 102-129; Simone Brott. "Architecture et Révolution: Le Corbusier and the Fascist Revolution." Thresholds 41 (Spring 2013), pp. 146-157.

${ }^{49}$ Letter from December 26, 1932, apud Mary McLeod, note 16. Oppositions 19/20, pp. 82-83.

${ }^{50}$ Tim Benton. "La rhétorique de la vérité: Le Corbusier à Alger. In Fondation Le Corbusier, Le Corbusier. Visions d'Alger, p. 186.
} 
housing was not only close to the workplace. It enjoyed all too visibly some of the best views in town, comparable to those from the upscale rédents at Fort-l'Empereur. Class differences in the Plan reminded this was not utopia, but a historical possibility depending on public policy. Tellingly, no coastal inhabitable viaduct featured in the second and also unasked for Plan Obus, submitted in 1933. As Le Corbusier well knew, architecture depends upon power. And yet, even granted that architecture is the dependent variable in its relationship with society, to know what is theoretically possible in any field is to allow wider scope for decisions, objectives, choices ${ }^{51}$. For all its flaws, assertive, provocative, monumental, the inhabitable viaduct still frightens, and enlightens.

\footnotetext{
${ }^{51}$ Leslie Martin \& Lionel March. Urban space and structures. (Cambridge: Cambridge University Press, 1972), p. 26.
} 


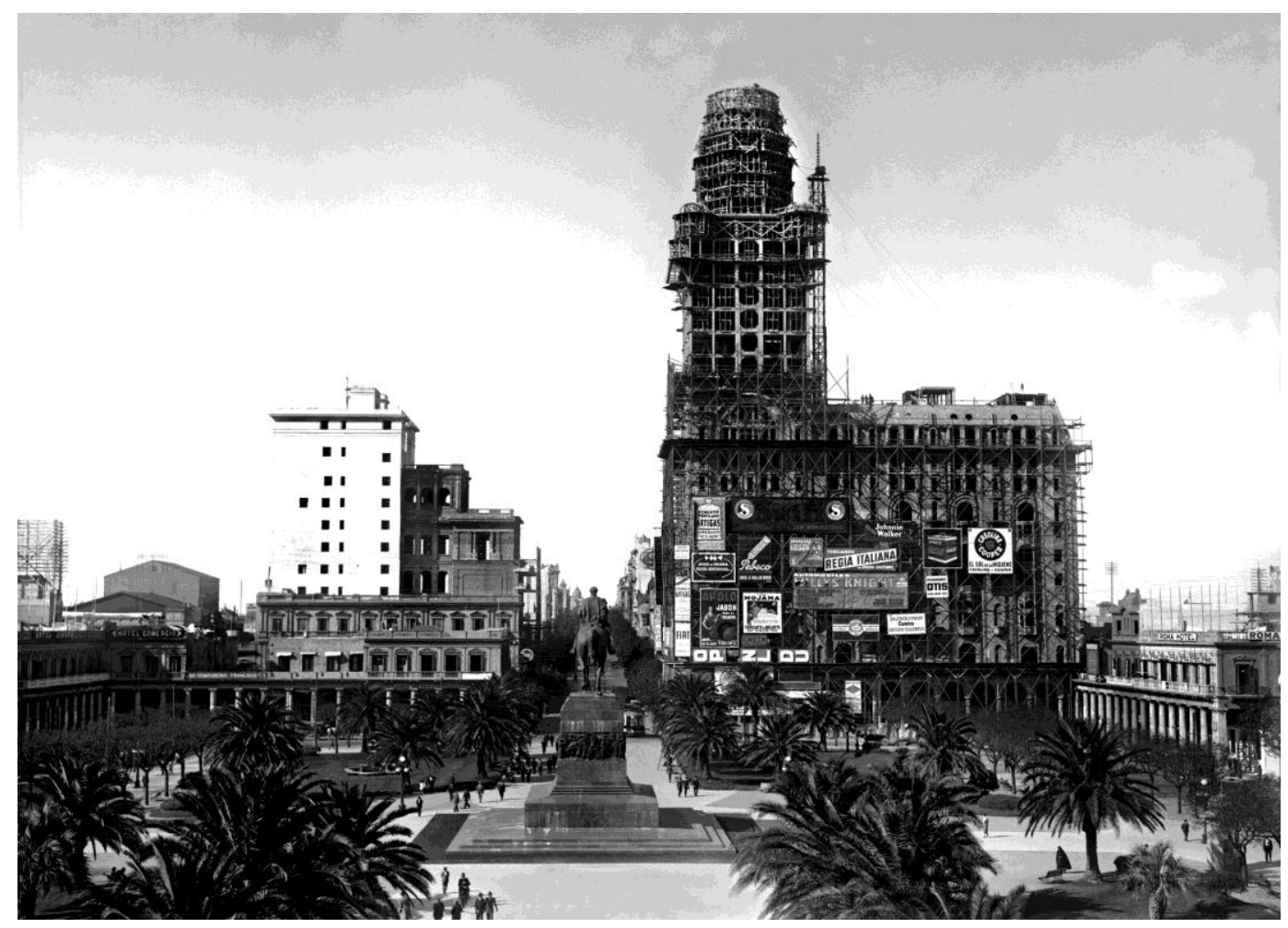

1. Postcard showing Palacio Salvo under construction from Plaza Independencia. 1926.

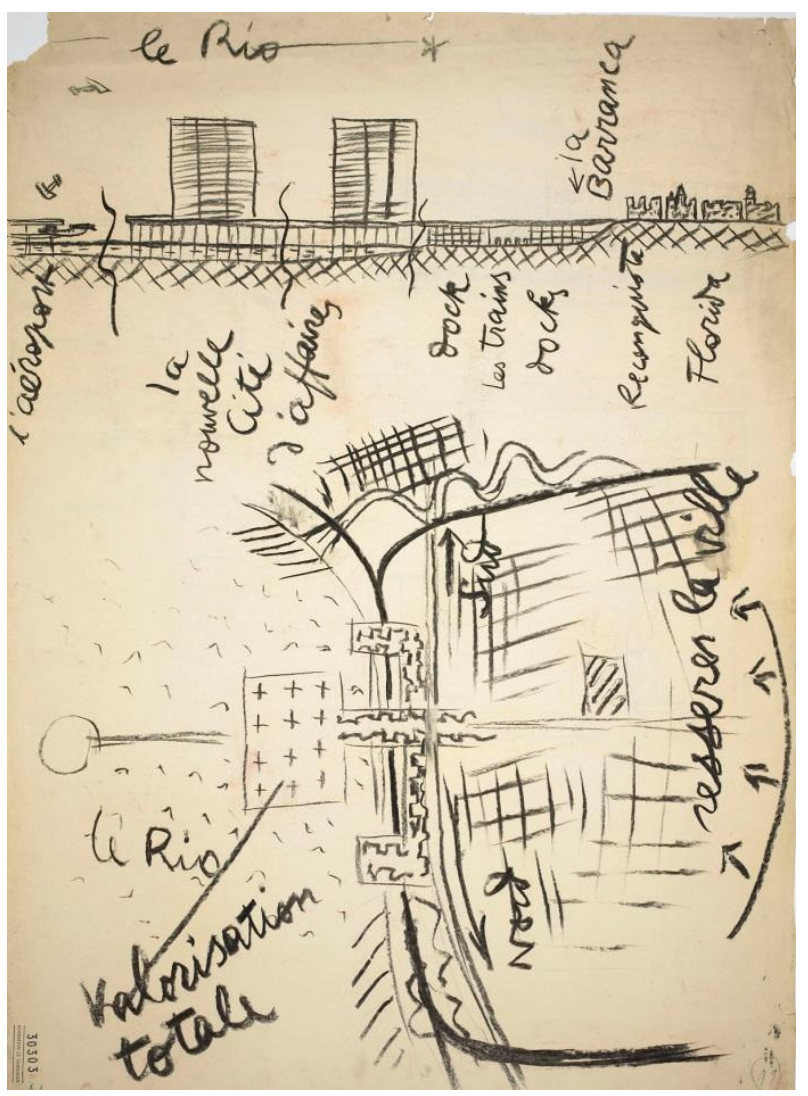

2. Le Corbusier. Plan for Buenos Aires. 1929. From "Précisions sur un état présent de l'architecture et de l'urbanisme“, (Paris: Crès, 1930), p. 206. 


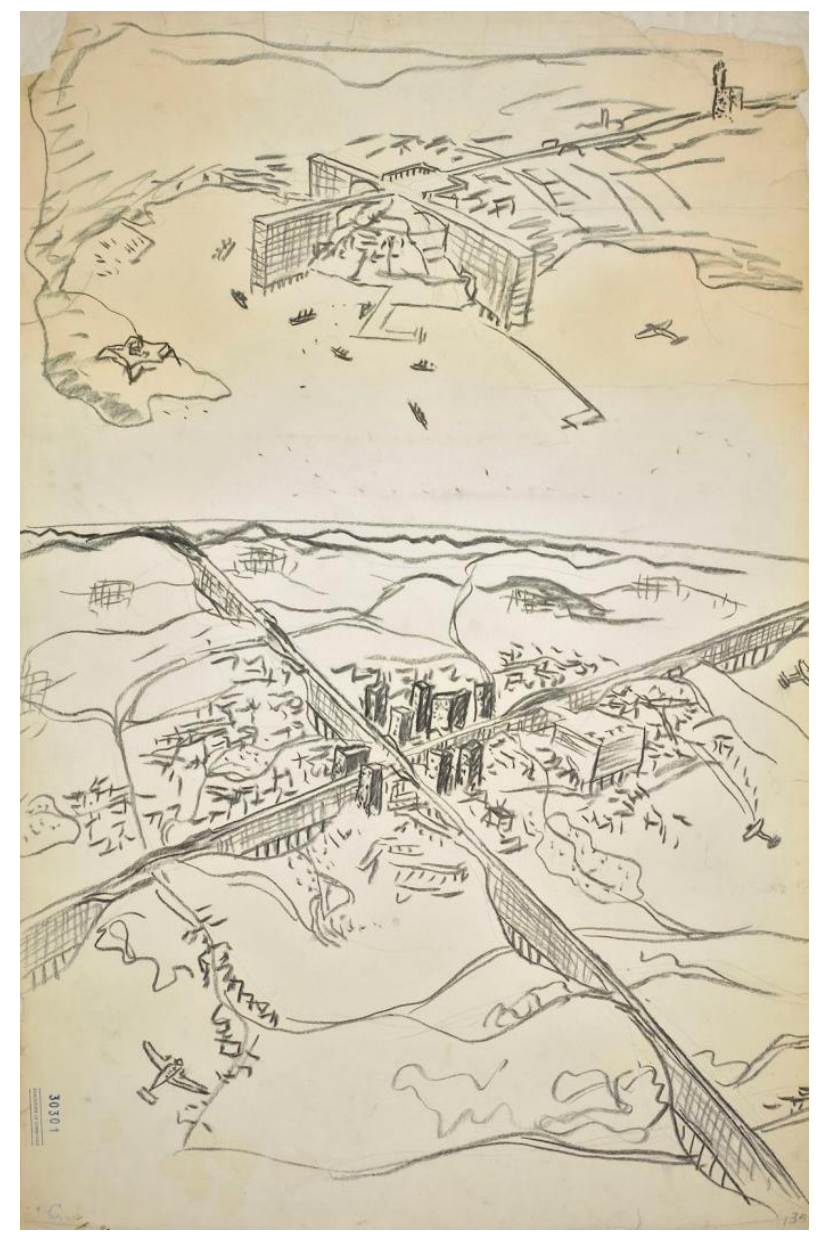

3. Le Corbusier. Plans for Montevideo and São Paulo. 1929. Fondation Le Corbisoer, Paris FLC 30301

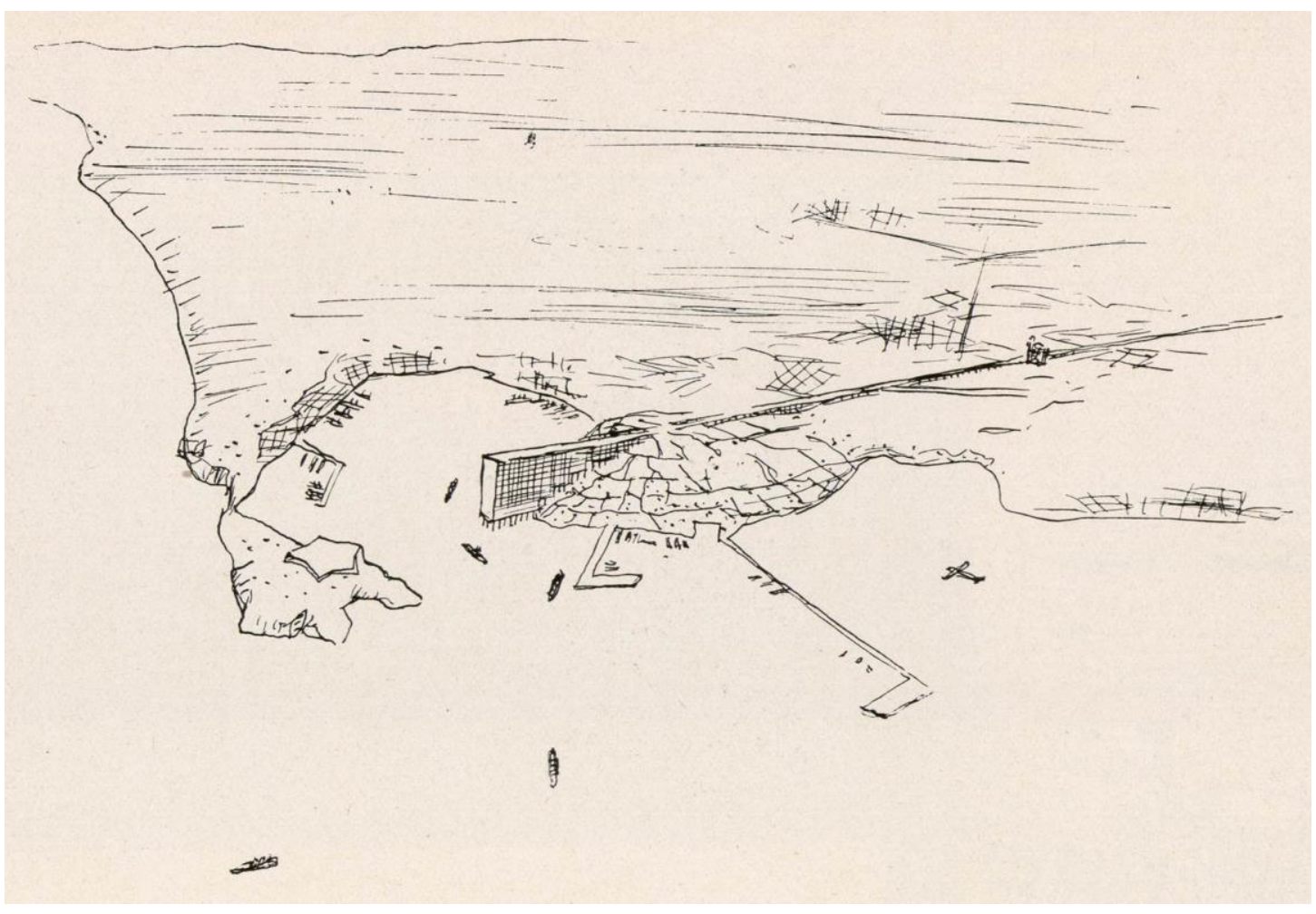

4. Le Corbusier. Plans for Montevideo. 1929. From La Ville Radieuse, p. 222. 


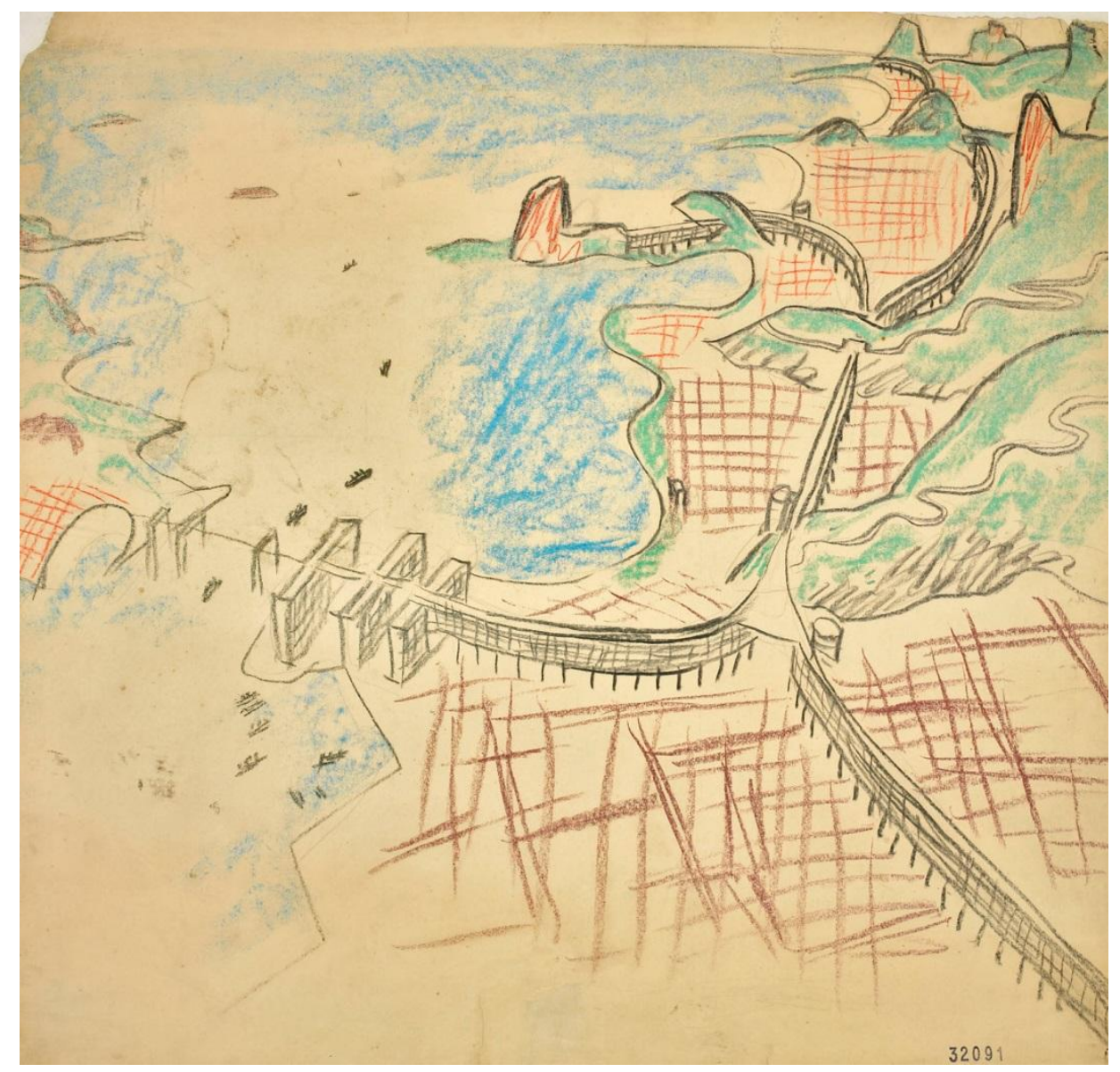

5. Le Corbusier. Plan for Rio de Janeiro. Fondation Le Corbusier, Paris FLC 32091

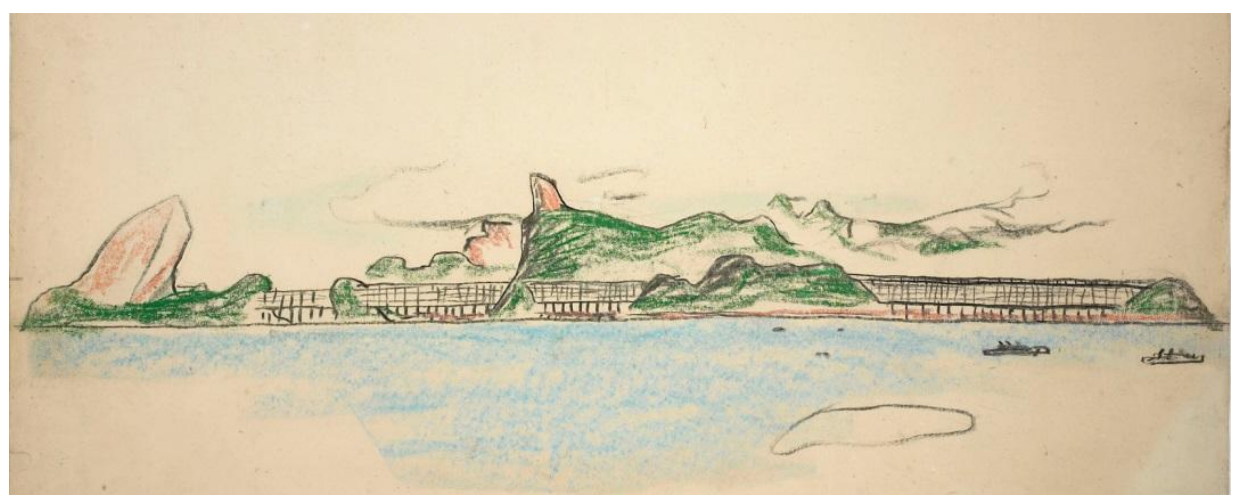

6. Le Corbusier. Plan for Rio de Janeiro. 1929. Fondation Le Corbusier, Paris. FLC 33425

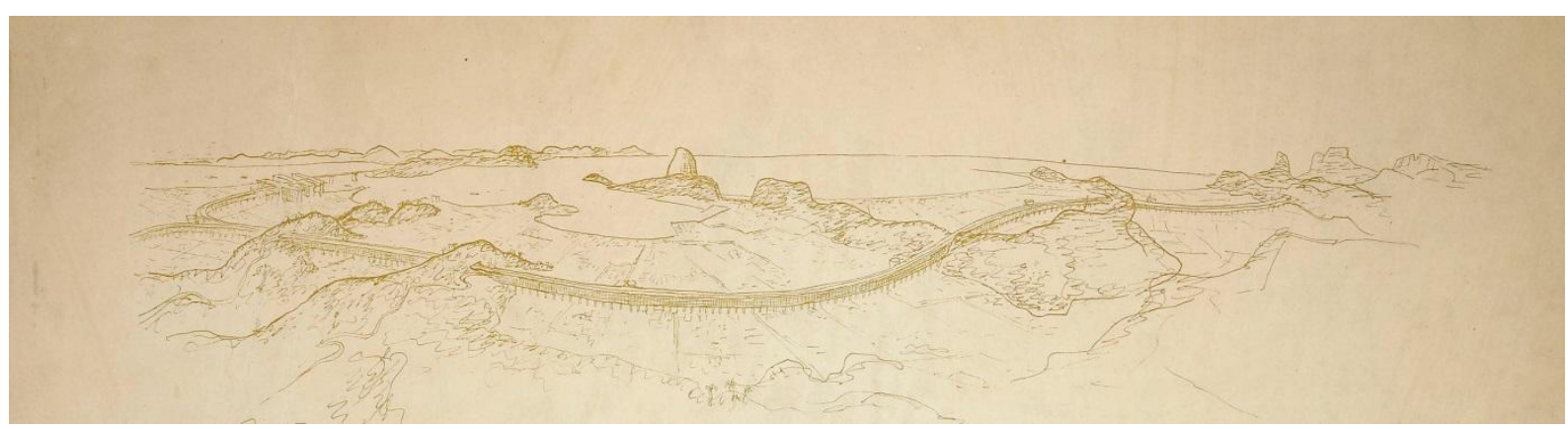

7. Le Corbusier. Variant of plan for Rio de Janeiro. 1930. Fondation Le Corbusier, Paris. FLC 31878 


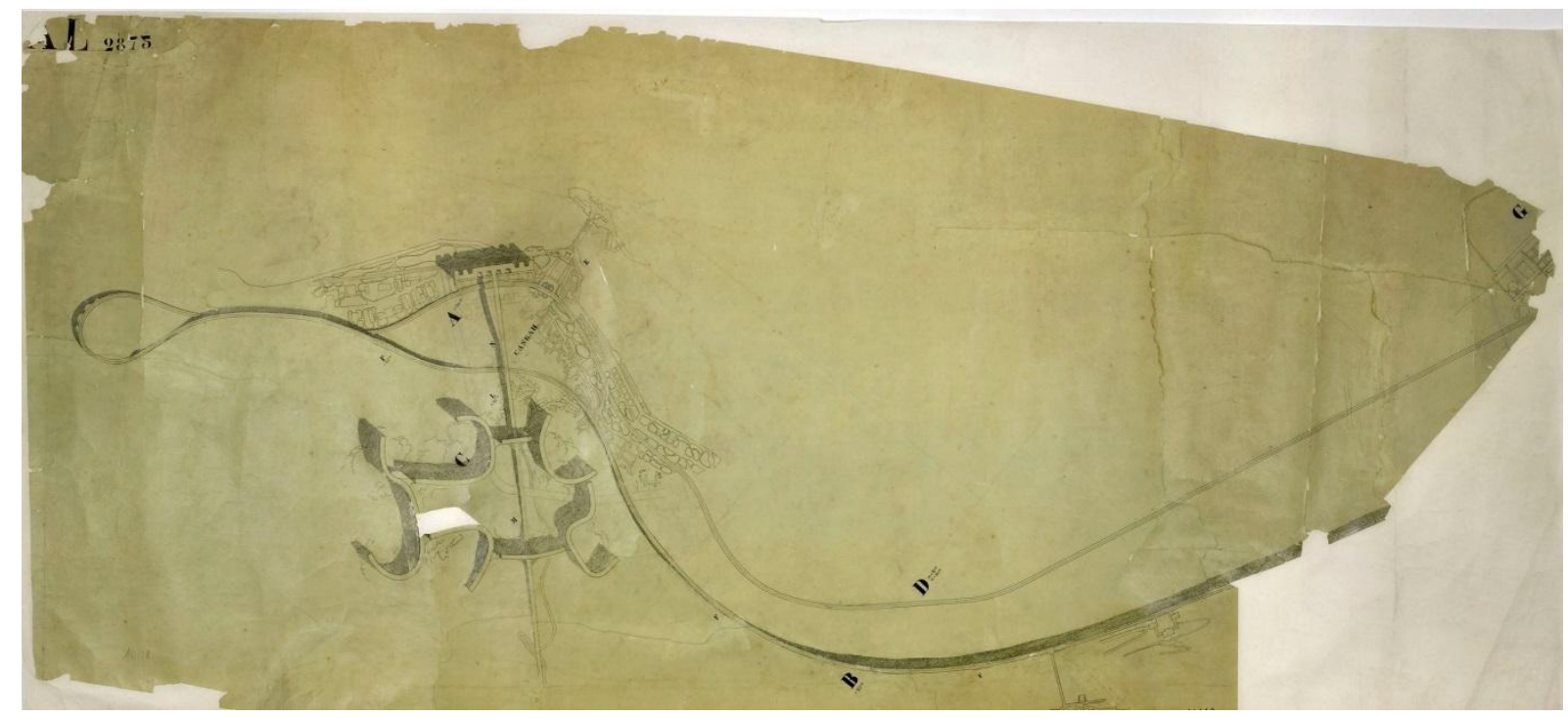

8. Le Corbusier. Plan Obus for Algiers. 1932. Fondation Le Corbusier, Paris. FLC 14118

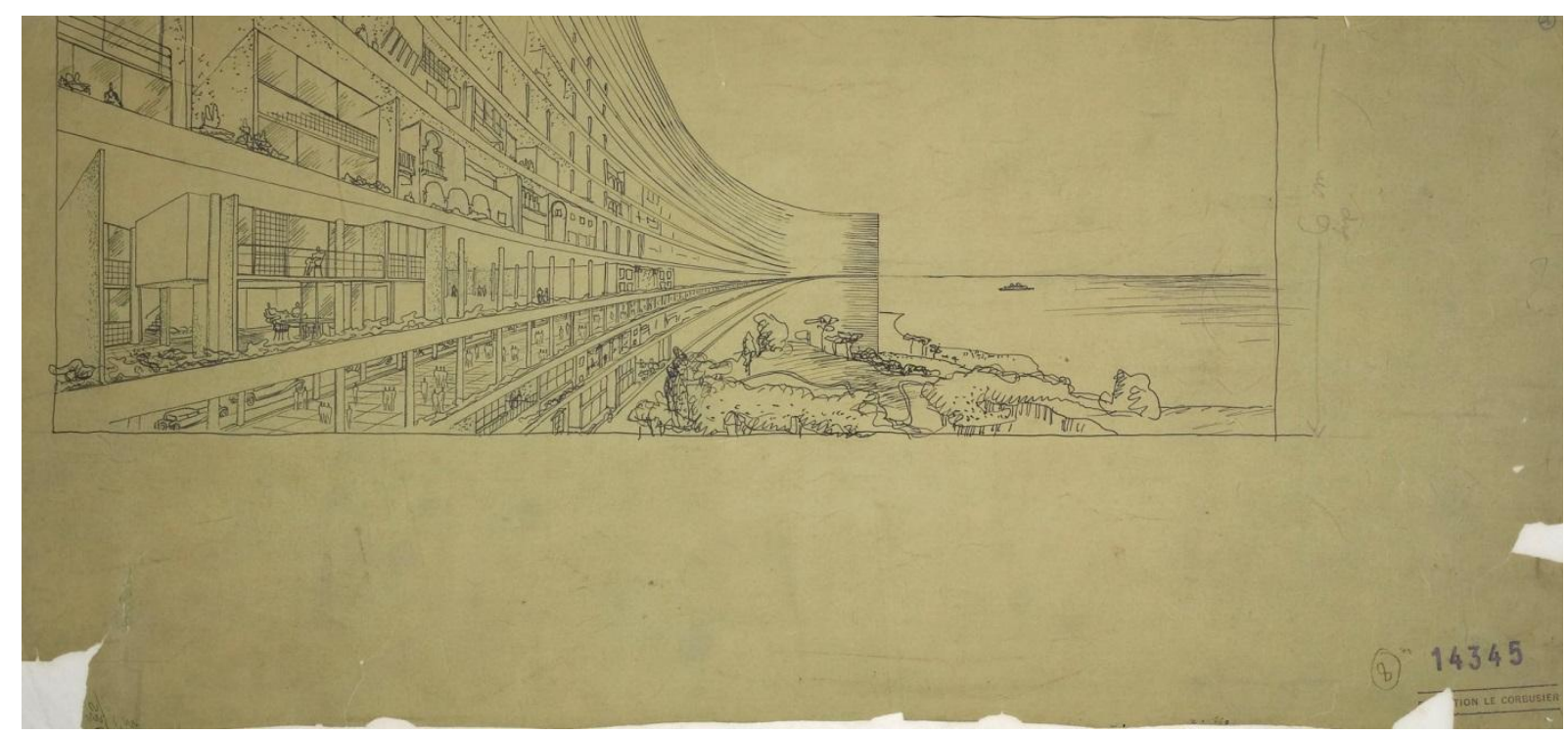

9. Le Corbusier. Plan Obus for Algiers. Perspective. 1932. Fondation Le Corbusier, Paris. FLC 14345 


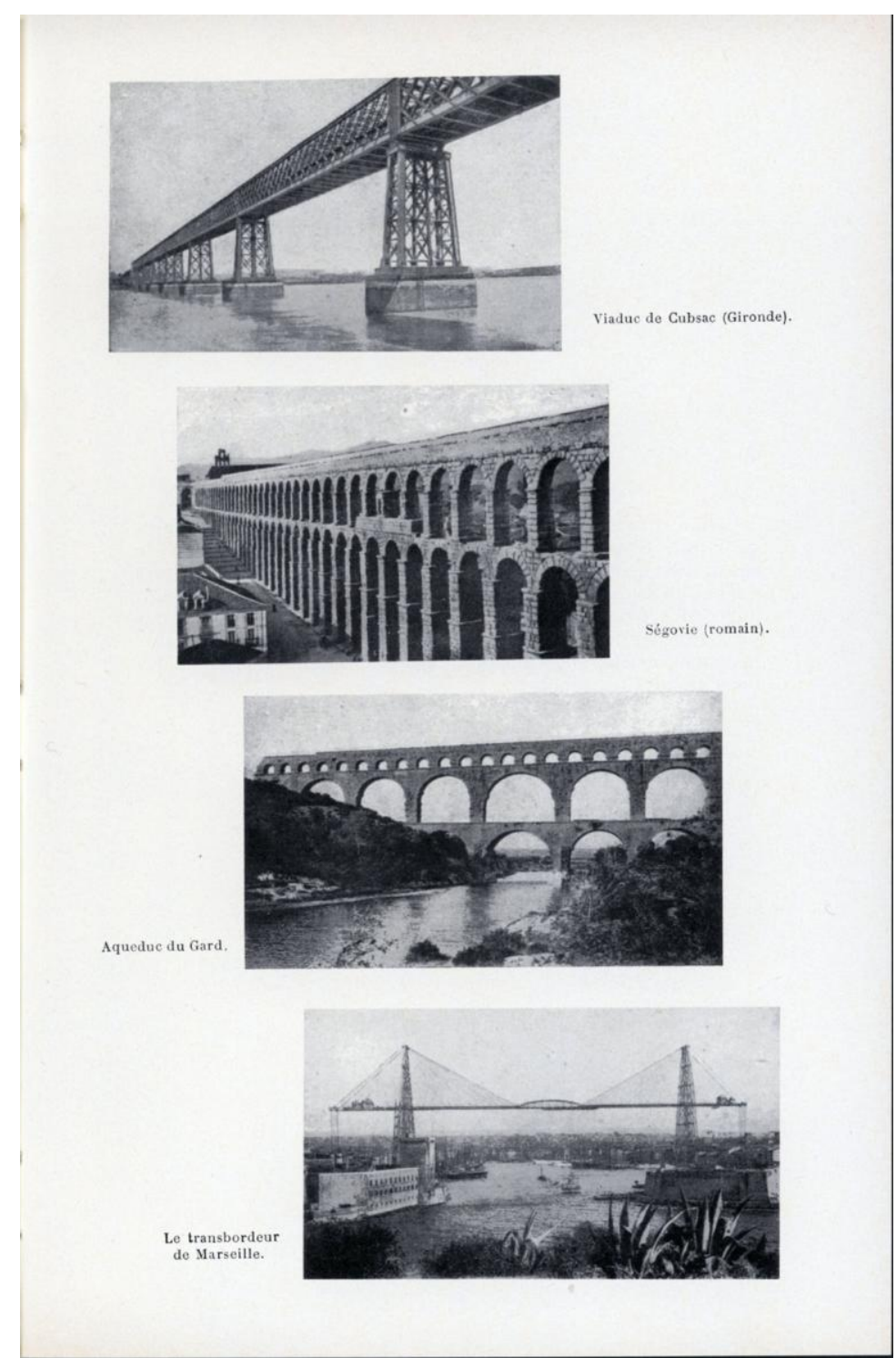

10. Cubzac Viaduct, Segovia Aqueduct, Pont du Gard and Marseille Transporter Bridge. From Le Corbusier, "Une Maison, Un Palais", (Paris: Crès, 1928), p. 21 


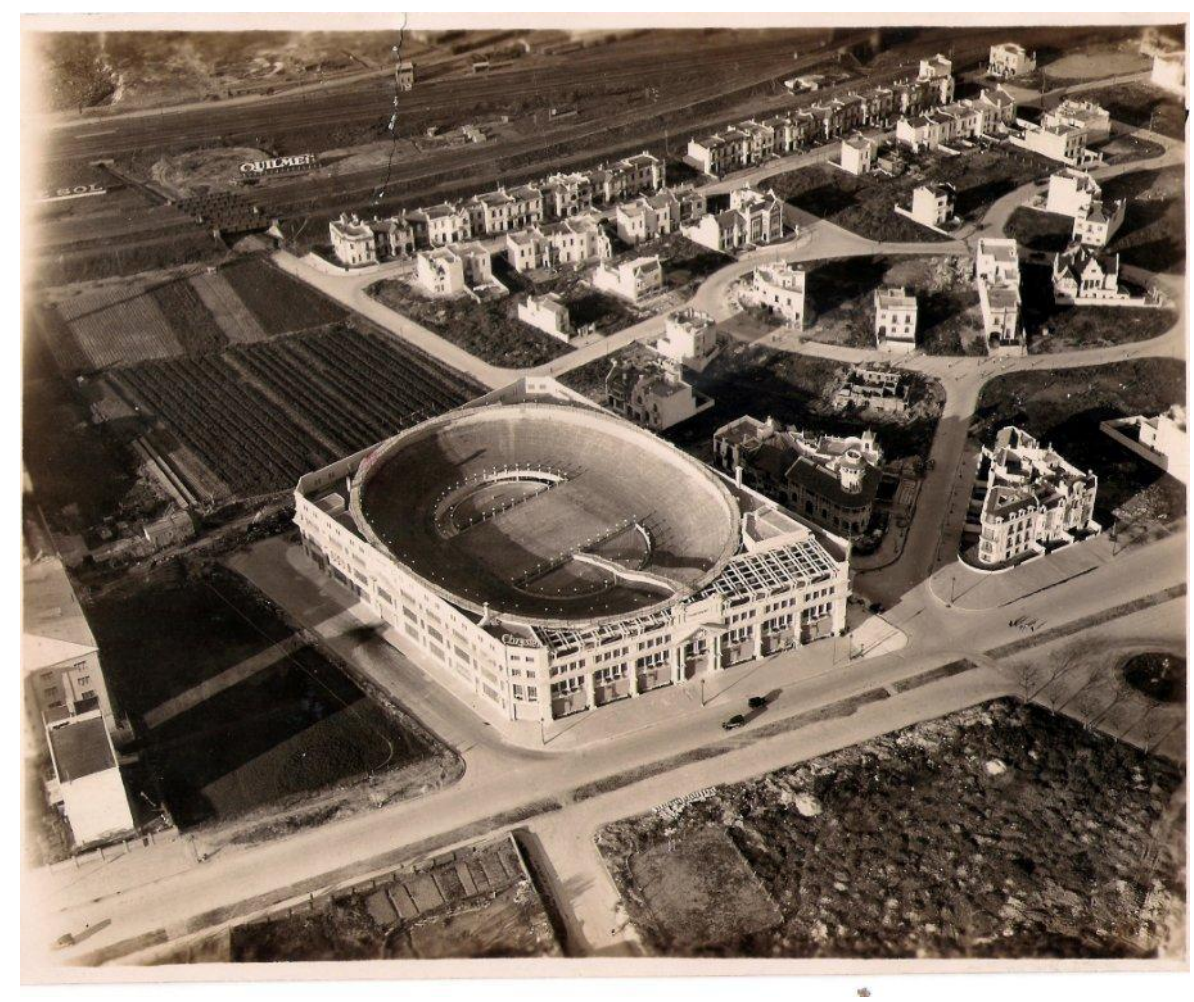

11. Postcard showing Palácio Chrysler, 1928.

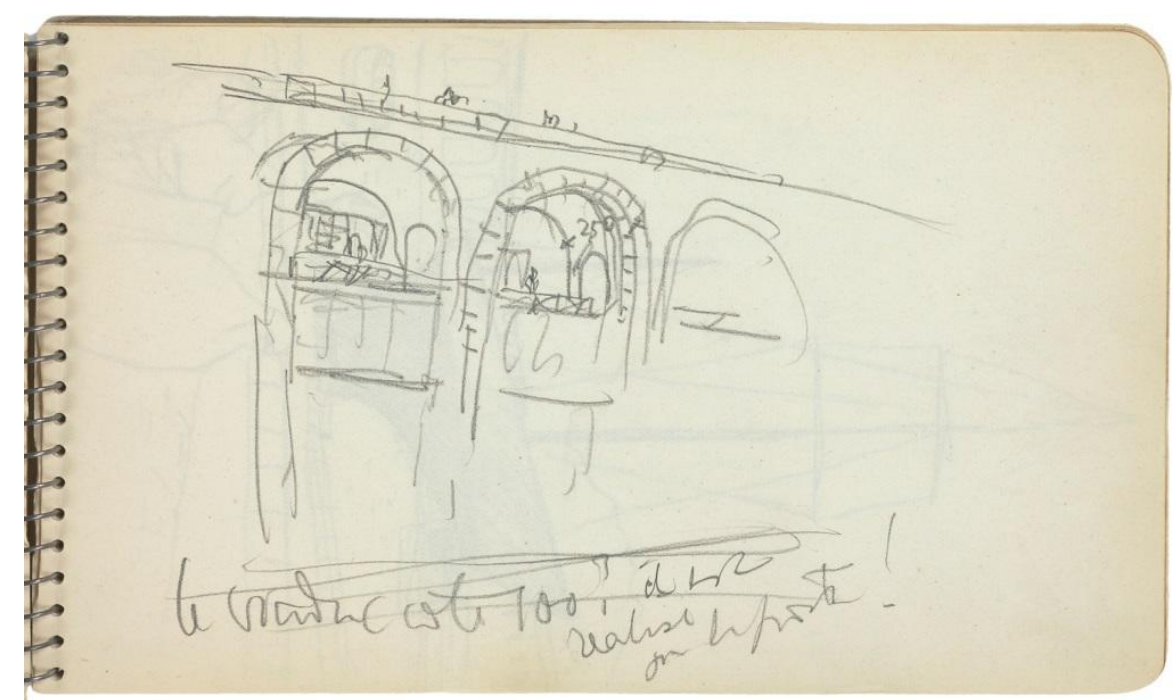

12. Le Corbusier. Arcades des Anglais. 1931. Carnet C10-660. Fondation Le Corbusier, Paris. 


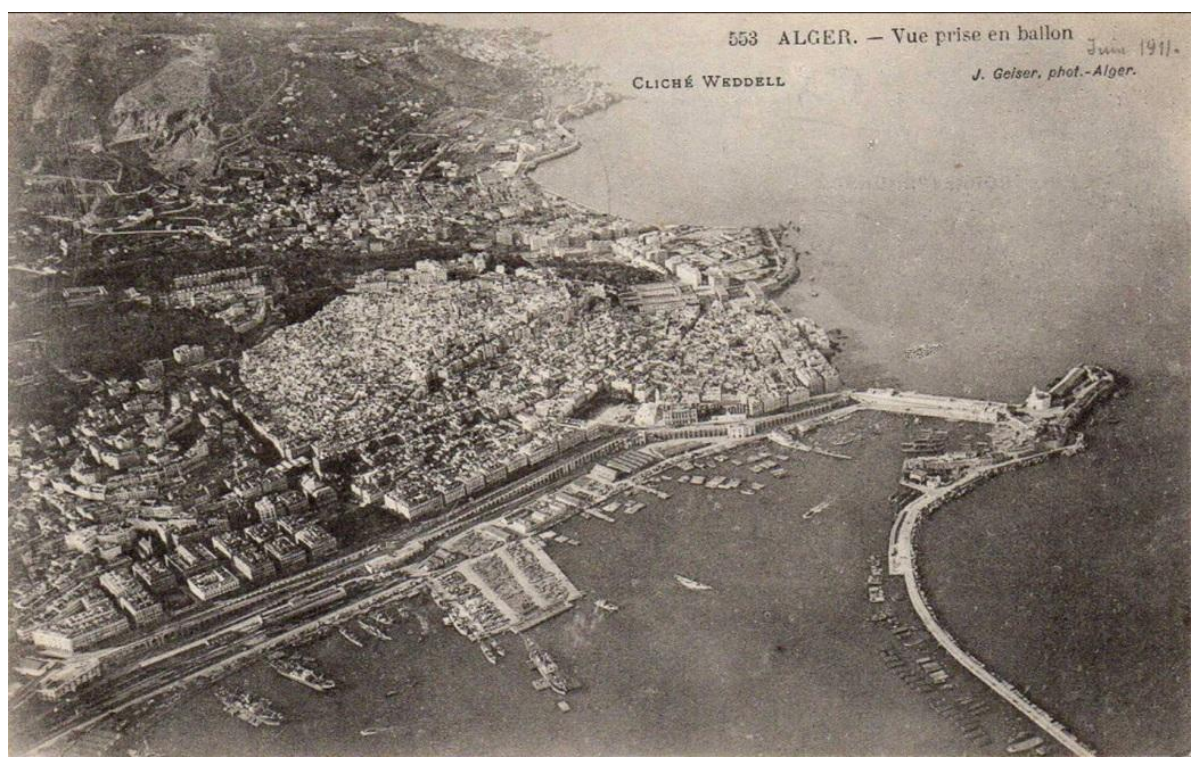

13. Postcard showing Boulevard de la Republique, Algiers.

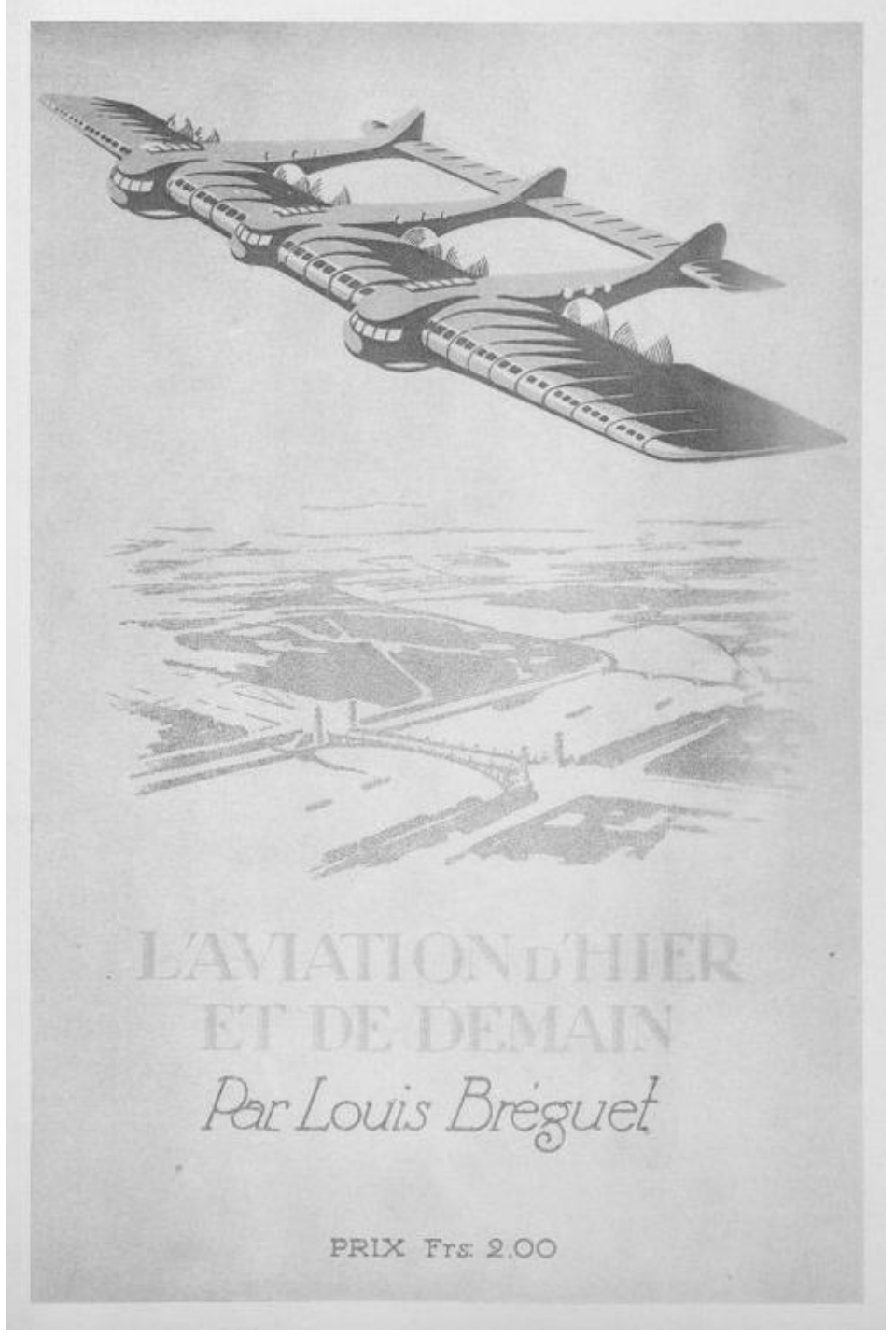

14. Cover of "L'aviation d'hier et de demain", 1922. Bibliothèque Nationale de France. 


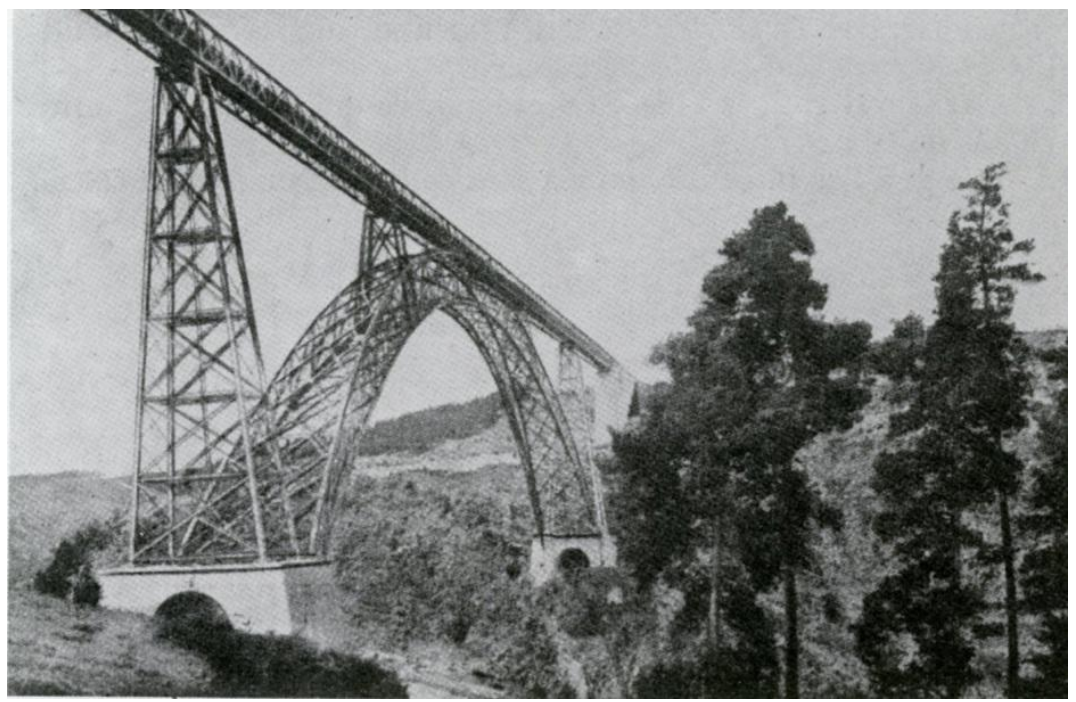

15. Garabit Bridge. From Le Corbusier, "Urbanisme”, (Paris: Crès, 1925), p. 49.

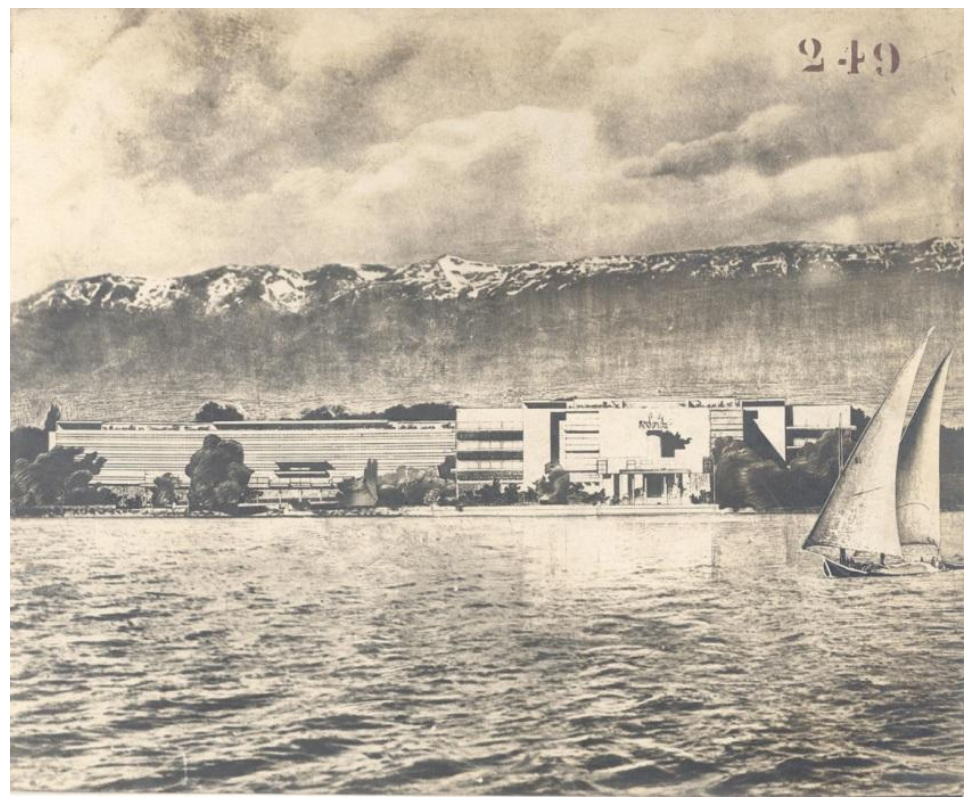

16. Palace of the League of Nations. From Le Corbusier, "Une Maison - Un Palais”, (Paris: Crès, 1928), p. 163.

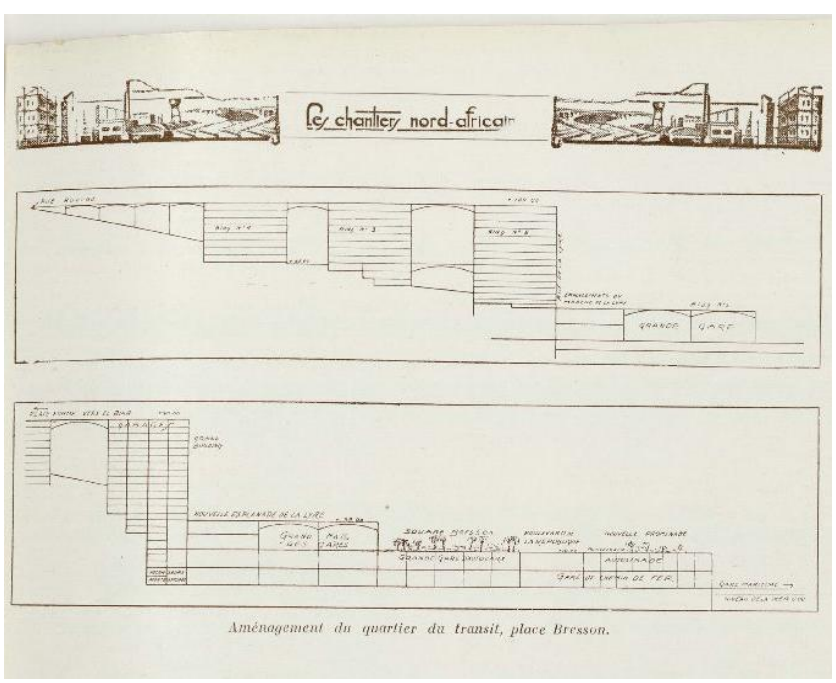

17. Maurice Rotival. Plan for Algiers. Section. From “Chantiers Nord-Africains”, January 1931, p. 35. 


\section{Acknowledgements}

The research for this paper was partly funded by CNPq- Conselho Nacional de Desenvolvimento Científico, Brasil. Victor Tessler, Vanessa Renck and Carlos Eduardo Binato de Castro collaborated in the iconographical research

\section{Source of images}

Carlos Eduardo Comas collection $(1,11,13)$.

Fondation Le Corbusier @FLC-ADAGP $(2,3,4,5,6,8,9,10,12,14,15)$.

Bibliothèque Nationale de France (17).

\section{Bibliography/references}

Alonso, Sebastián and others. 5 narrativas, 5 edificios. Montevideo: Ministerio de Educación y Cultura, 2010.

Amado, Antonio. Voiture minimum. Le Corbusier and the automobile. Cambridge, Mass.: The MIT Pres, 2011.

Anderson Jr., John David. A history of aerodynamics and its impact on flying machines. Cambridge: Cambridge University Press, 1997.

Architectural History Foundation; Fondation Le Corbusier. (Eds.) Le Corbusier. Sketchbooks - Vol.1, 19141948. Cambridge, Mass.: MIT Press, 1981.

Banham, Reyner. Theory and Design in the first machine age. London: The Architectural Press, 1960.

Baudelaire, Charles. Le peintre de la vie moderne. Paris: 1863. http://baudelaire.litteratura.com/\#

Boesiger, Willy. Le Corbusier et Pierre Jeanneret. Oeuvre complète de 1929-1934. 13th ed. Zurich: Editions d'Architecture/ Edition Girsberger, 1995.

Boesiger, Willy; Stonorov, Oscar. Le Corbusier et Pierre Jeanneret. Oeuvre complète de 1910-1929. 14th ed. Zurich: Editions d'Architecture/ Edition Girsberger, 1995.

Carlos, Rute Alexandra. A Ville Verte de Le Corbusier como sistema: uma perspectiva centrada no parque . Directorship: Xavier Monteys Roig, Paulo Jorge Souza Cruz. Ph.D. Thesis. Braga, Universidade do Minho, 2013.

Çelik, Zeynep. Urban Forms and Colonial Confrontations: Algiers Under French Rule. Berkeley: University of California Press, 1997.

Cohen, Jean-Louis; Bergdoll, Barry. (Eds.) Le Corbusier. An atlas of modern landscapes New York: MoMA, 2013.

Contreras, Leonel. Rascacielos porteños. Buenos Aires: Gobierno de la Ciudad de Buenos Aires, 2005.

Fondation Le Corbusier. Le Corbusier. Visions d'Alger. Paris: Editions de la Villette, 2012.

Giedion, Sigfried. Space, time and architecture. The growth of a new tradition. Cambridge, Mass.: Harvard University Press, 1941.

Gutierrez, Ramon. (Ed.) Le Corbusier en el Río de la Plata, 1929. Buenos Aires: Cedodal; Montevideo: FARQ Universidad de la Republica, 2009.

Hénard, Eugène. Etudes sur l'architecture et les transformations de Paris \& autres écrits sur l'architecture et l'urbanisme. Preface by Jean-Louis Cohen. Paris: Editions de la Villette, 2013

http://librairie.immateriel.fr/fr/ebook/9782814500396

Hugo, Victor. Notre Dame de Paris. Paris: 1831. 
Le Corbusier, Sur les quatre routes. Paris: Gallimard, 1941.

Le Corbusier. Aircraft. London: The Studio, 1935.

Le Corbusier. La ville radieuse. Éléments d'une doctrine d'urbanisme pour l'équipement de la civilisation machiniste. Boulogne-sur-Seine, France: Éditions de L'Architecture d'aujourd'hui, 1935.

Le Corbusier. Précisions sur un état present de l'architecture et de l'urbanisme. Paris: Vincent, Fréal, 1930.

Le Corbusier. Une maison - un palais. À la recherche d'une unité architecturale. Paris: Crès, 1928.

Le Corbusier. Urbanisme. Paris: Crès, 1925.

Le Corbusier. Vers une architecture. Paris: Crès, 1923.

Liernur, Jorge Francisco; Pschepiurca Pablo. La red austral. Obras y proyectos de Le Corbusier y sus discípulos en la Argetina 1924-1965. Buenos Aires: Universidad Nacional de Quilmes, 2008/

Martin, Leslie; March, Lionel. Urban space and structures. Cambridge: Cambridge University Press, 1972.

Oppositions. 19-20. Winter-Spring 1980.

Paris: publie.net 2010-10-22

Perez Oyarzun, Fernando. (Ed.) Le Corbusier y Suramerica. Santiago: Ediciones ARQ, 1999.

Rodrigues dos Santos, Cecilia, and others. Le Corbusier e o Brasil. São Paulo: Projeto/Tessela, 1987.

Rowe, Colin. The architecture of good intentions. London: Academy Editions, 1994.

Thresholds. 41, Spring 2013.

Tsiomis, Yannis. (Ed.) Le Corbusier. Rio de Janeiro 1929-1936. Rio: Centro de Arquitetura e Urbanismo, 1998. von Moos, Stanislaus. Le Corbusier. Elements of a synthesis. $2^{\text {nd }}$ ed. Rotterdam: 010 Publishers, 2009. 




\section{0}

LC2015. Congreso internacional

En agosto de 1965 se produjo en las aguas del Mediterráneo el fallecimiento de Le Corbusier, reconocido como el arquitecto más importante del siglo XX. Con este motivo, el Departamento de Proyectos Arquitectónicos de la Universidad Politécnica de Valencia, con el apoyo de diversos organismos, promueve la realización de este congreso internacional en Valencia.

Le Corbusier fue uno de los arquitectos más fecundos en producir interrelaciones entre ideas e imágenes, entre disciplinas plásticas y arquitectura, entre historia y modernidad. El poder de sus ideas estaba continuamente siendo experimentado y corroborado por su obra arquitectónica. En sus proyectos, escritos, pinturas y esculturas va desgranando diferentes visiones de lo que debía corresponderse con la modernidad arquitectónica, que, en su persona, se nutrió de referencias ideológicas también heterogéneas.

Si hay algo que se destaca en su trayectoria es la transversalidad en su labor creativa. Esta idea de transversalidad permite la apertura del congreso a artistas plásticos, historiadores, editores de libros, fotógrafos, pensadores y, por supuesto, arquitectos.

El congreso LC2015 se celebró del 18 al 20 de noviembre 2015 en la Escuela Técnica Superior de Arquitectura de la Universidad Politécnica de Valencia. 